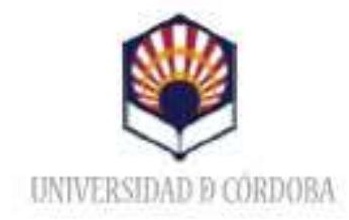

DPTO. DE INGENIERIA GRAFICA Y GEOMATTICA

TESIS DOCTORAL

DESARROLLO DE UNA APLICACIÓN INFORMÁTICA

PARA EL CÁLCULO DEL SOSTENIMIENTO DE

TALUDES MEDIANTE REVEGETACIÓN 
TITULO: Desarrollo de una aplicación informática para el cálculo de sostenimiento de taludes mediante revegetación.

\author{
AUTOR: José Luis Barros Ruiz
}

(c) Edita: Servicio de Publicaciones de la Universidad de Córdoba. 2016 Campus de Rabanales

Ctra. Nacional IV, Km. 396 A

14071 Córdoba

www.uco.es/publicaciones

publicaciones@uco.es 

TESIS DOCTORAL

\section{DESARROLLO DE UNA APLICACIÓN INFORMÁTICA PARA EL CÁLCULO DEL SOSTENIMIENTO DE TALUDES MEDIANTE REVEGETACIÓN}

MEMORIA PRESENTADA POR JOSÉ LUIS BARROS RUÍZ PARA ASPIRAR AL GRADO DE DOCTOR.

\section{DIRECTOR}

Dr. D. FRANCISCO DE PAULA MONTES TUBío

Catedrático de Expresión Gráfica en la Ingeniería UNIVERSIDAD DE CÓRDOBA

CODIRECTOR

Dr. D. GASPAR FERNÁNDEZ SAN ELÍAS

Profesor Titular de Expresión Gráfica en la Ingeniería UNIVERSIDAD DE LEÓN 


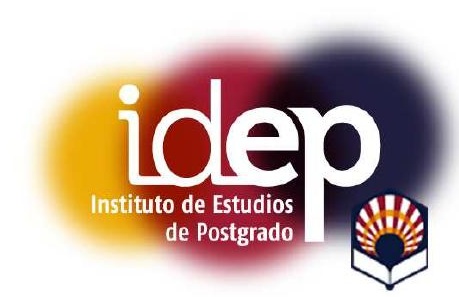

\section{TÍTULO DE LA TESIS: DESARROLLO DE UNA APLICACIÓN INFORMÁTICA PARA EL CÁLCULO DE SOSTENIMIENTO DE TALUDES MEDIANTE REVEGETACIÓN}

\section{DOCTORANDOIA: JOSÉ LUIS BARROS RUÍZ}

\section{INFORME RAZONADO DEL/DE LOS DIRECTOR/ES DE LA TESIS}

La tesis doctoral presentada por D. José Luis Barros Ruiz se centra en una intensa investigación que evalúa la influencia que ejercen las plantas en el refuerzo y estabilización del suelo. Se obtiene un modelo matemático para el cálculo de la estabilización de taludes integrando en el mismo algunos de los efectos que ejercen las plantas sobre dichos taludes. Con objeto de facilitar el cálculo de estabilidad de taludes el modelo se implementa a través de un programa informático para su cálculo.

El efecto mecánico generado a partir de la presencia de vegetación está compuesto por una serie de fenómenos físicos involucrados que, a partir de las características propias del tipo de vegetación y suelo, e interactúan, otorgando, un efecto total de variación en la resistencia al deslizamiento. Todos estos mecanismos han sido investigados como una combinación de especies vegetales y características del talud.

El desarrollo de la tesis ha supuesto un ambicioso trabajo de recopilación de información, estudios preliminares y creación del modelo matemático. Debe añadirse el desarrollo de un programa informático para determinar los parámetros finales de forma inmediata.

El trabajo ha dado lugar a diversas publicaciones, unas que ya han visto la luz y otras aceptadas, pendientes de publicación, en revistas de investigación.

Por todo ello, se autoriza la presentación de la tesis doctoral.

\section{Córdoba, 30 de Octubre de 2015}

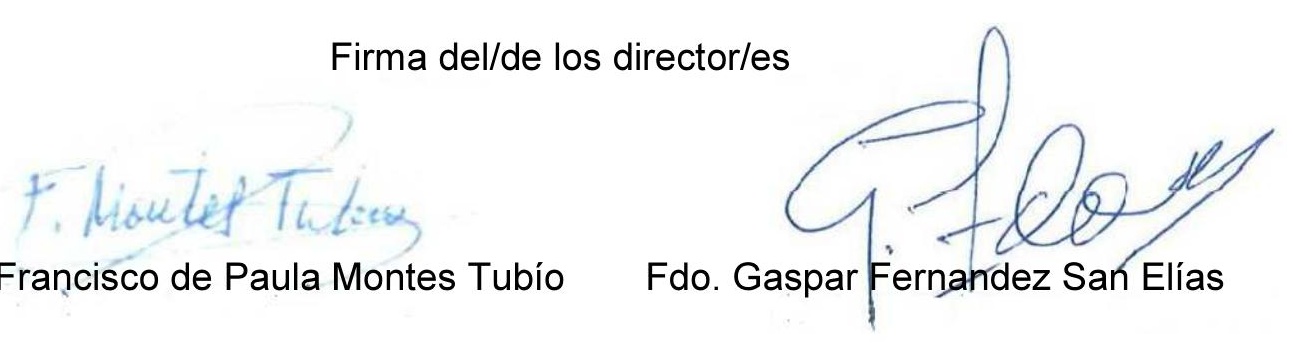

Fdo.: Francisco de Paula Montes Tubío

Fdo. Gaspar Fernandez San Elías 

A toda mi familia, por su apoyo, especialmente mis padres, mi mujer y a mi hijo Adrián 



\section{AGRADECIMIENTOS}

Quiero dejar constancia de mi agradecimiento, al Dr. D. Francisco de Paula Montes Tubío, director y propulsor de este trabajo, por la confianza demostrada en mí, así como por sus consejos e interés.

AI Dr. D. Gaspar Fernandez, San Elías por su aporte y experiencia.

Al equipo de INCASLE INGENIEROS S.L, por su contribución y experiencia aportada especialmente a $D^{\mathrm{a}}$. Raquel Fernandez y Sergio González.

Agradecer hoy y siempre a mi familia.

Finalmente, gracias por la colaboración incondicional de todos los amigos que me han ofrecido su tiempo y medios. 



\section{DESARROLLO DE UNA APLICACIÓN INFORMÁTICA PARA EL CÁLCULO DE SOSTENIMIENTO DE TALUDES MEDIANTE REVEGETACIÓN}

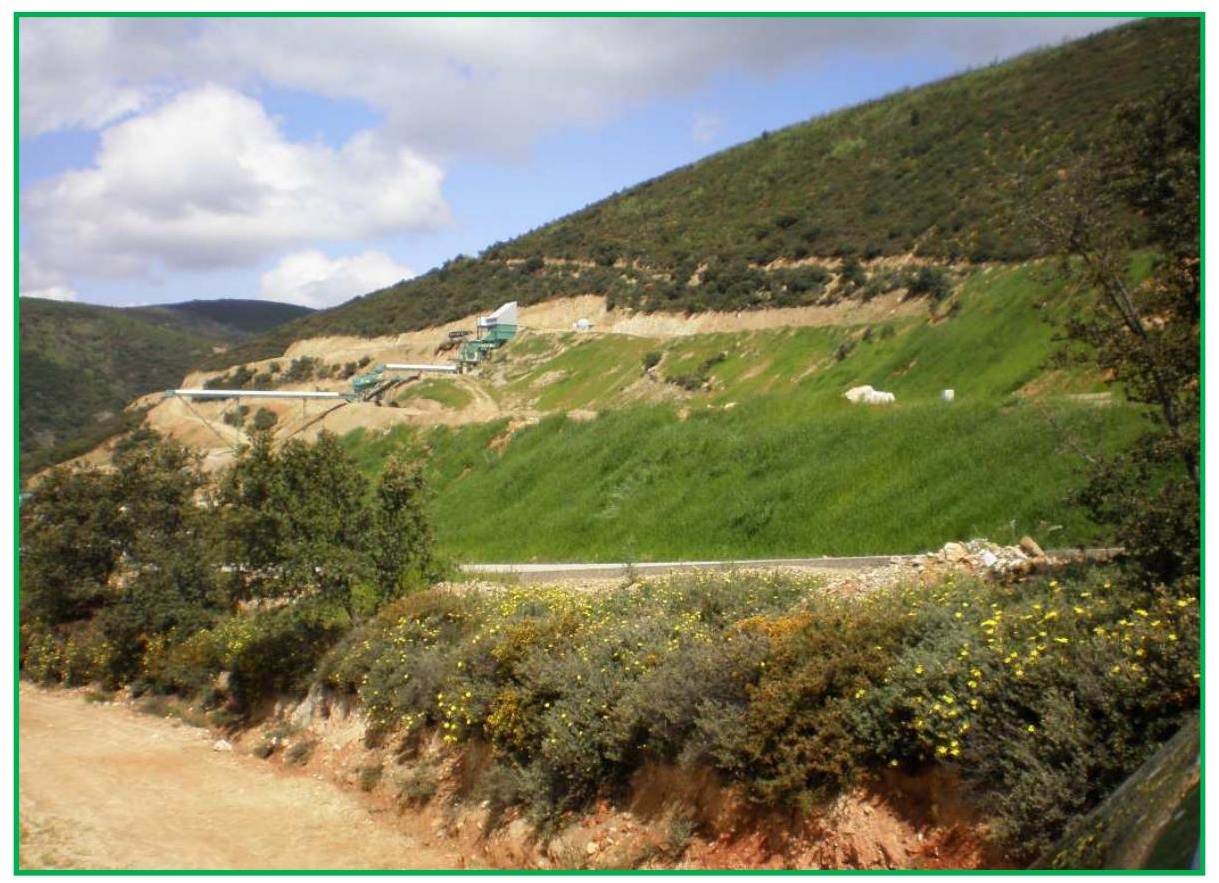

ALUMNO: JOSÉ LUÍS BARROS RUÍZ

FECHA: JUNIO 2015 


\section{ÍNDICE GENERAL}

\section{MEMORIA}

1.- INTRODUCCIÓN

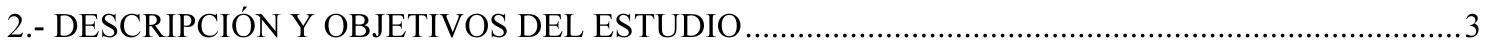

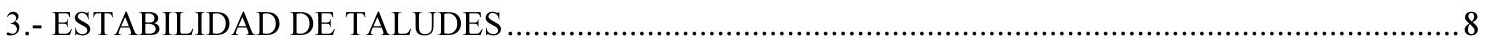

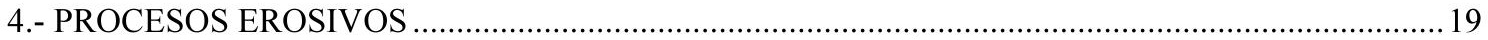

5.- EFECTOS DE LA VEGETACIÓN EN LA ESTABILIZACIÓN DE TALUDES.................................22

6.- SELECCIÓN DE ESPECIES VEGETALES PARA SU UTILIZACIÓN EN LA REVEGETACIÓN

DE TALUDES ....

7.- MODELO MATEMÁTICO PARA LA DEFINICIÓN DEL EFECTO DE LA VEGETACIÓN

SOBRE LA ESTABILIDAD DE TALUDES

8.- IMPLEMENTACIÓN DEL MODELO MATEMÁTICO DE REFUERZO DE TALUDES CON

VEGETACIÓN EN UN PROGRAMA INFORMÁTICO

9. - MEMORIA DE DESARROLLO DEL PROYECTO

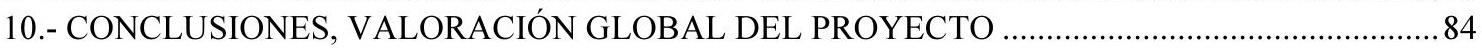

ANEXO I.- TÉCNICAS DE IMPLANTACIÓN UTILIZADAS EN REVEGETACIÓN DE TALUDES

1.- TÉCNICAS DE IMPLANTACIÓN UTILIZADAS EN LA REVEGETACIÓN DE TALUDES ........98

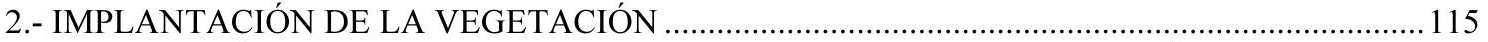

3.- CARACTERÍSTICAS DE LAS ESPECIES UTILIZADAS EN REVEGETACIÓN ..........................149

ANEXO II.- INVENTARIO FORESTAL

1.- CARACTERÍSTICAS DE LAS ESPECIES UTILIZADAS EN REVEGETACIÓN 160

ANEXO III.- MÉTODOS DE CÁLCULO DE ESTABILIDAD DE TALUDES

1.- INTRODUCCIÓN

2.- SUPERFICIES DE DESLIZAMIENTO PLANA-CIRCULAR ….....................................................2.

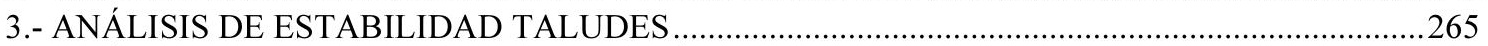

4.- ANÁLISIS DE ESTABILIDAD POR EL MÉTODO TSYTOVICH .............................................273

5.- DESLIZAMIENTOS TRASLACIONALES: MÉTODO DE MASLOV ……….............................28

6.- EQUILIBRIO DE MOMENTOS: MÉTODO DE JAMBU ……...........................................................2.

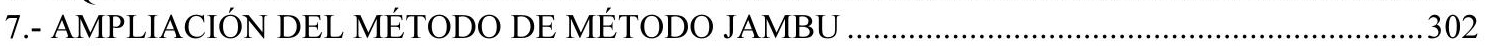

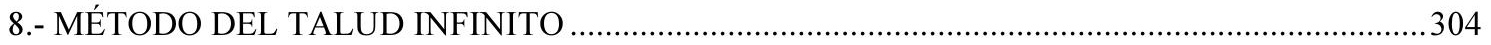

ANEXO IV.- EFECTOS DE LA VEGETACIÓN EN LA ESTABILIDAD DE TALUDES

1.- INTRODUCCIÓN

2.- EFECTOS DE LA VEGETACIÓN SOBRE EL TERRENO ……………………………………......... 314

3.- EFECTOS DE LA VEGETACIÓN SOBRE EL TERRENO A CONSIDERAR Y MODELIZACIÓN

A

4.- INFLUENCIA DE LA MEZCLA DE ESPECIES EN EL CÁLCULO DEL FACTOR DE

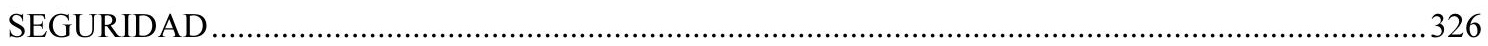

5.- INFLUENCIA DE LA DENSIDAD DE PLANTACIÓN EN EL CÁLCULO DEL FACTOR DE

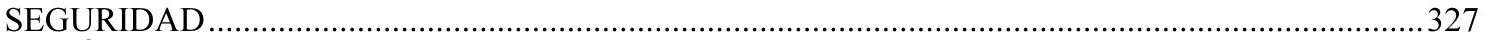

6.- CÁLCULO DE LA PROFUNDIDAD DEL PLANO DE DESLIZAMIENTO EN UN TALUD CON

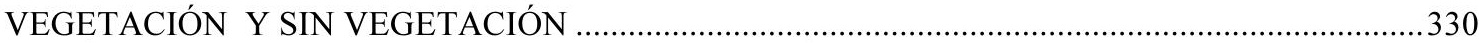

7.- CÁLCULO DE LA ALTURA VERTICAL DE LA LÁMINA DE AGUA SOBRE EL PLANO DE

DESLIZAMIENTO 
DESARROLLO DE UNA APLICACIÓN IMFORMÁTICA PARA EL CÁLCULO DE SOSTENIMIENTO DE TALUDES MEDIANTE REVEGETACIÓN

8.- CÁLCULO DEL FACTOR DE SEGURIDAD DE UN TALUD CONSIDERANDO EL EFECTO DE LA VEGETACIÓN.

ANEXO V.- DESARROLLO DE LA APLICACIÓN INFORMÁTICA: ANÁLISIS INTEGRAL DE RESTAURACIÓN Y ESTABILIZACIÓN DE LADERAS

1.- INTRODUCCIÓN 341

2.- REQUISITOS Y CARACTERÍSTICAS DEL PROGRAGRAMA ...................................................... 342

3.- ESTRUCTURA Y FUNCIONAMIENTO GENERAL DEL PROGRAMA ......................................343

4.- DESCRIPCIÓN DEL FUNCIONAMIENTO Y PARÁMETROS DE ENTRADA ….........................345

ANEXO VI.- MANUAL DEL PROGRAMA: ANÁLISIS INTEGRAL DE RESTAURACIÓN Y ESTABILIZACIÓN DE LADERAS 1.0

1.- INTRODUCCIÓN 366

2.- INSTALACIÓN. 369

3.- UTILIZACIÓN DEL PROGRAMA

371

4.- EJEMPLOS PRÁCTICOS DE UTILIZACIÓN DEL PROGRAMA 391

\section{BIBLIOGRAFÍA}

DOCUMENTOS ADJUNTOS AL PROYECTO:

1.- Resultados de análisis de laboratorio de caracterización y composición de suelos.

2.- Pruebas del modelo matemático para el cálculo de estabilidad de taludes. 


\section{INDICE DE FIGURAS}

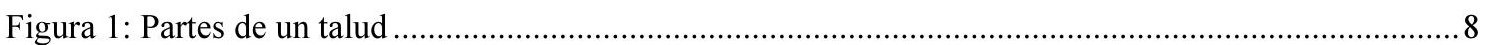

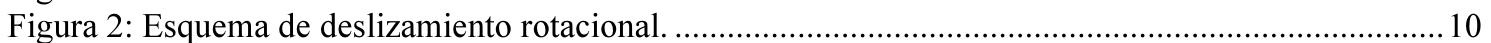

Figura 3: Representación gráfica del Criterio de rotura de Mohr-Coulomb....................................... 11

Figura 4: Rotura plana, con aplicación de la hipótesis del talud infinito.............................................. 14

Figura 5: Esquema de equilibrio de fuerzas sobre la sección unitaria del talud. ...................................15

Figura 6: Succión del suelo en función de la precipitación, Gray. 1978.............................................. 19

Figura 7: Gráfico para estimación del coeficiente K (Goldman et al, 1986).......................................21

Figura 8: Disminución del contenido de humedad debido a la acción de las plantas en suelos arcillosos .24

Figura 9: Efectos Mecánicos proporcionados por la vegetación sobre una Ladera....................................33

Figura 10: Tipos de reforzamiento radicular y anclaje del terreno en pendientes. Tsukamoto y Kusakabe,

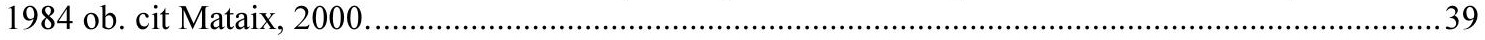

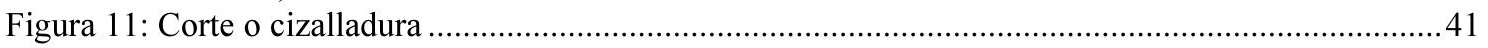

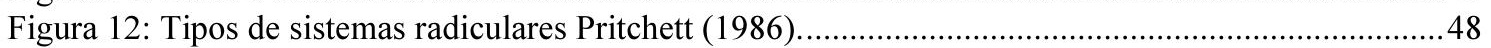

Figura 13: Efecto de sobrecarga de la vegetación sobre la parte inferior de una superficie de

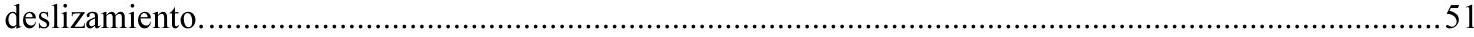

Figura 14: Representación esquemática del efecto del viento sobre el talud........................................53

Figura 15: Fuerza de anclaje de arbustos y de hierbas de raíz profunda (Bache y Mackaskill, 1984). ......67

Figura 16: Componentes del peso que actúan sobre un talud con vegetación: terreno $\left(\mathrm{W}_{\mathrm{T}}\right)$, agua $\left(\mathrm{W}_{\mathrm{W}}\right)$, y

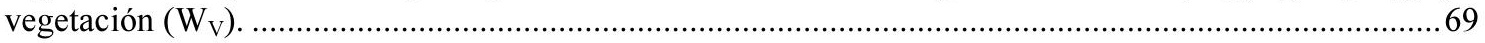

Figura 17: Diagramas indicando los parámetros que intervienen ......................................................74

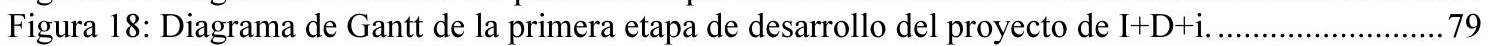

Figura 19: Diagrama de Gantt de la segunda etapa de desarrollo del proyecto de $\mathrm{I}+\mathrm{D}+\mathrm{i}$......................81

Figura 20: Evolución del F.S. por efecto de la densidad de plantación. .................................................91

Figura 21: Evolución del incremento del F.S. (\%), por efecto combinado de la densidad de plantación y

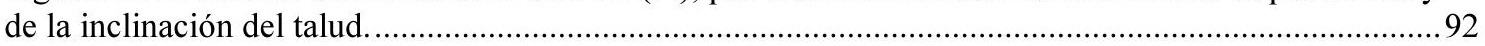

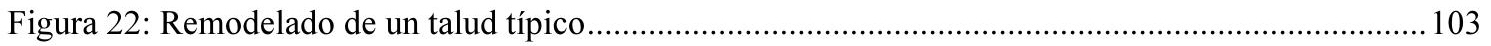

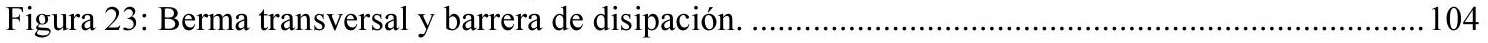

Figura 24: Tipos de drenajes. ................................................................................................. 105

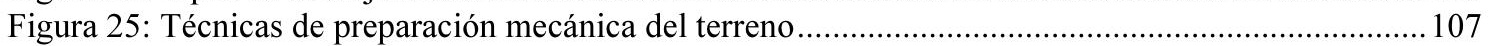

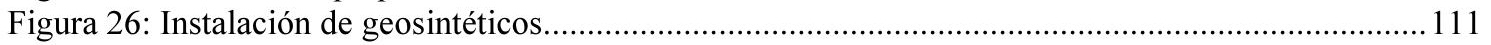

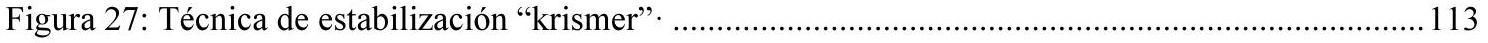

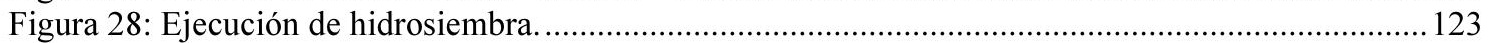

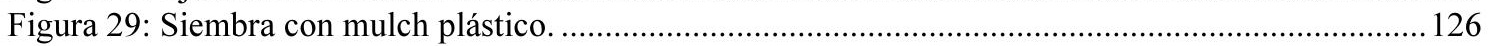

Figura 30: Plantación de árboles en zonas de alta exposición eólica................................................... 135

Figura 31: Fajinas elaboradas "in situ”" con material vegetal. ....................................................... 139

Figura 32: Superficies planas $\quad$ Figura 33: Superficies circulares ................................................2245

Figura 34: Envolventes de Mohr-Coulomb en términos de esfuerzos tangenciales y normales..............246

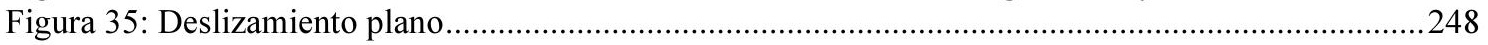

Figura 36: Gráfico de diseño del Talud (Deslizamiento plano) ....................................................249

Figura 37: Cálculo de las funciones x e y (Deslizamiento plano) ........................................................250

Figura 38: Cálculo de las funciones x e y (Deslizamiento circular) ....................................................251

Figura 39: Funciones x e y para distintos coeficientes de seguridad ...................................................252

Figura 40: Procedimiento para determinar el coeficiente de seguridad de un talud (Hoek y Bray) .........253

Figura 41: Deslizamiento por rotura de cuña de pie ..........................................................................260

Figura 42: Rotura de Pandeo ..........................................................................................................261

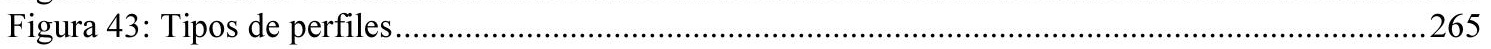

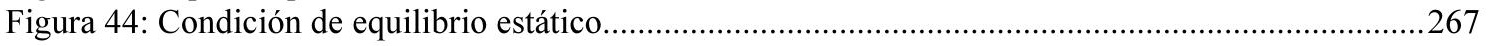

Figura 45: Deslizamiento según un plano en terrenos coherentes. ....................................................268

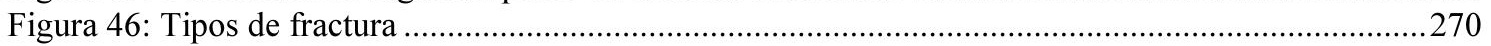

Figura 47: Ensayo: diagrama de tensiones en la zona superior del talud. .............................................2271

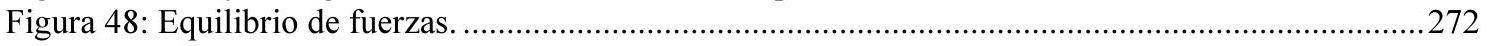

Figura 49: Método gráfico para determinar el Factor de seguridad de una superficie de deslizamiento

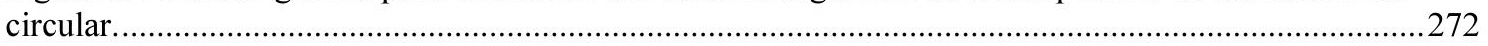

Figura 50: Fuerzas sobre una partícula, en pendiente del terreno suelto ..........................................2275 


\section{DESARROLLO DE UNA APLICACIÓN IMFORMÁTICA PARA EL CÁLCULO DE SOSTENIMIENTO DE TALUDES MEDIANTE REVEGETACIÓN}

Figura 51: Pendiente vertical en un terreno coherente .................................................................2276

Figura 52: Última presión sobre la superficie de una "pendiente" horizontal. .....................................278

Figura 53: Forma del contorno de pendientes equiestables ...........................................................279

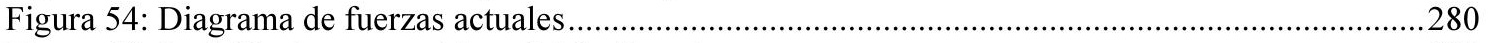

Figura 55: Posición de arcos críticos del deslizamiento...................................................................282

Figura 56: Fuerzas actuando a lo largo de la superficie de deslizamiento.............................................283

Figura 57: Ilustración del método "Fuerzas horizontales". ...........................................................286

Figura 58: Relación entre la resistencia al corte de un suelo arcilloso Sp, el coeficiente Fp y el ángulo de

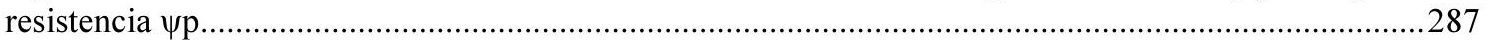

Figura 59: Principio del método. Fuerzas horizontales ..................................................................28

Figura 60: Talud estable de resistencia uniforme (método Fp) ......................................................2292

Figura 61: Comparación entre perfiles por el método Fp..........................................................294

Figura 62: Diagrama para el cálculo de la estabilidad, referido al método de superficie circular - cilíndrica

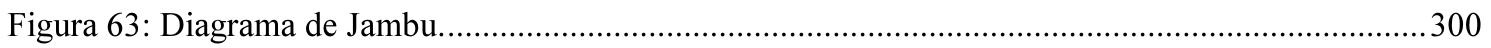

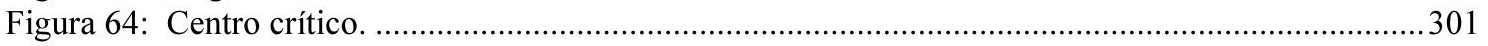

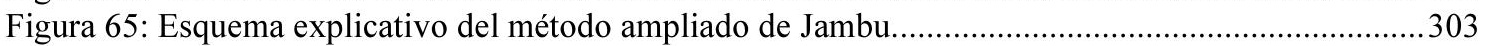

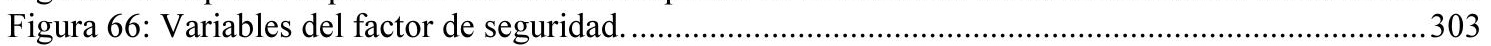

Figura 67: Rotura plana, con aplicación de la hipótesis del talud infinito..........................................304

Figura 68: Esquema de equilibrio de fuerzas sobre la sección unitaria del talud. ..............................305

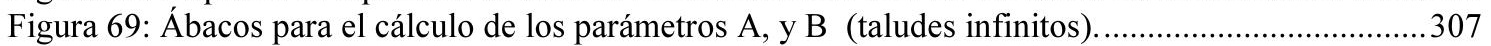

Figura 70: Factores de la vegetación que influyen sobre la estabilidad del terreno. ..............................313

Figura 71: Efectos hidrológicos de la vegetación sobre la estabilidad del terreno................................314

Figura 72: Efecto de refuerzo del terreno por las raíces. ..................................................................317

Figura 73: Tipos de anclaje de las raíces (Tsukamoto y Kusakube 1984)...........................................318

Figura 74: Fuerza de anclaje de arbustos y de hierbas de raíz profunda (Bache y Mackaskill, 1984). ....322

Figura 75: Modelo de raíces elásticas y flexibles atravesando verticalmente una zona de falla o rotura

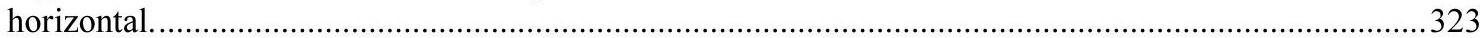

Figura 76: Distribución espacial de la vegetación en el talud, condiciones más favorables.....................324

Figura 77: Componentes del peso que actúan sobre un talud con vegetación: terreno $\left(\mathrm{W}_{\mathrm{T}}\right)$, agua $\left(\mathrm{W}_{\mathrm{W}}\right)$, y

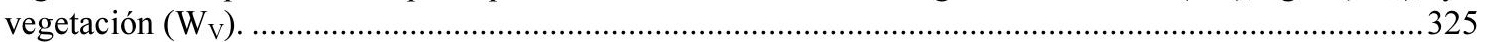

Figura 78: Representación esquemática del efecto del viento sobre el talud.......................................326

Figura 79: Representación esquemática del efecto arco producido por la distribución de la vegetación

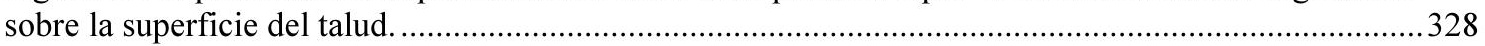

Figura 80: Representación de la profundidad de influencia de las raíces de la vegetación. .....................332

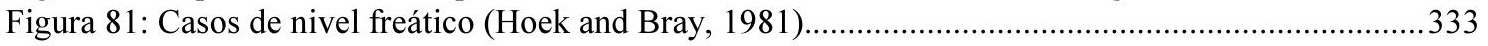

Figura 82: Diagramas indicando los parámetros que intervienen en el cálculo de Fs (sin vegetación), y

distribución de las fuerzas que actúan sobre la masa de terreno deslizante............................................335

Figura 83: Diagramas indicando los parámetros que intervienen en el cálculo de Fsv (con vegetación), y

distribución de las fuerzas que actúan sobre la masa de terreno deslizante........................................336

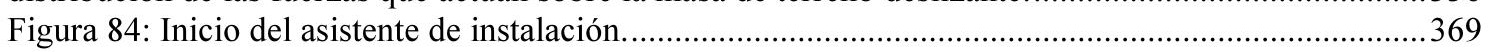

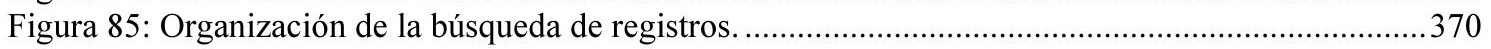

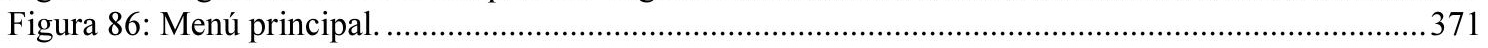

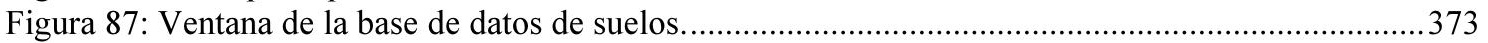

Figura 88: Ventana de la base de datos de especies vegetales................................................................374

Figura 89: Ventana de la base de datos de localizaciones. ...................................................................375

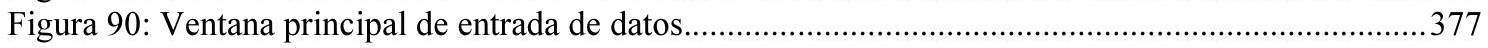

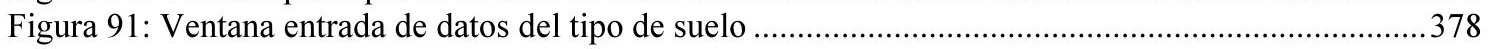

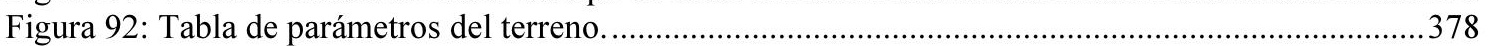

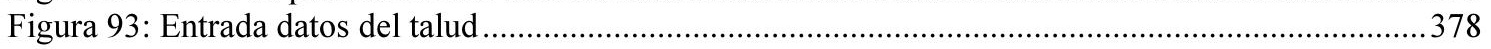

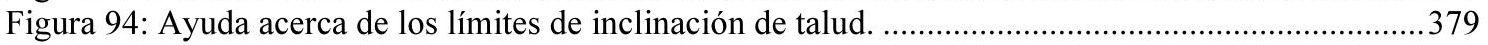

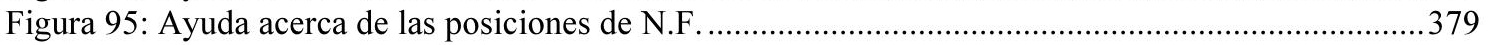

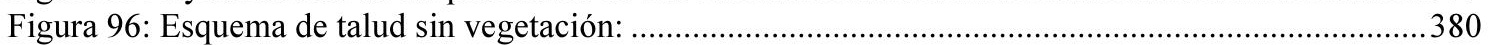

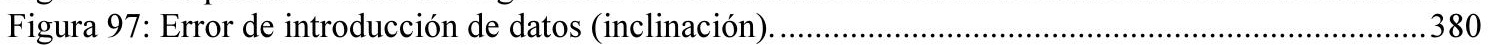

Figura 98: ventana de cálculo de la profundidad del plano de deslizamiento (z) y altura vertical de la

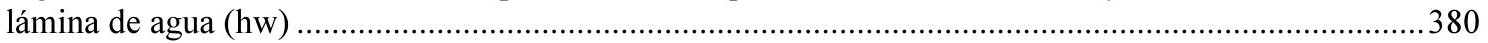

Figura 99: Botón de cálculo del Factor de Seguridad sin vegetación (FS) .............................................381

Figura 100: Botón de introducción de parámetros de la vegetación.......................................................381

Figura 101: Ventana de introducción de datos de la vegetación............................................................381 


\section{DESARROLLO DE UNA APLICACIÓN IMFORMÁTICA PARA EL CÁLCULO DE SOSTENIMIENTO DE TALUDES MEDIANTE REVEGETACIÓN}

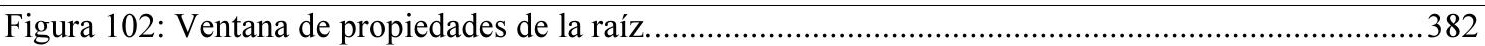

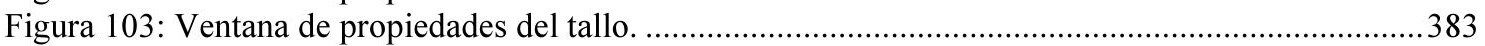

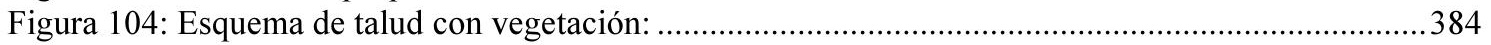

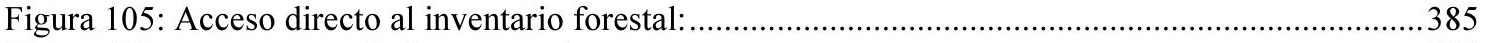

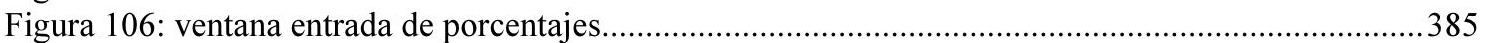

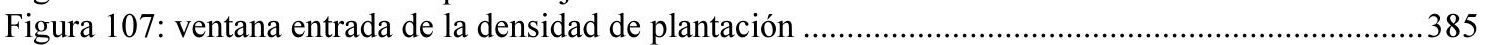

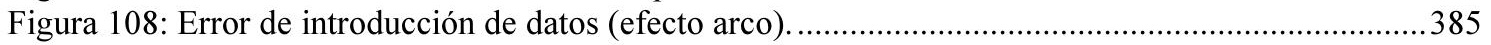

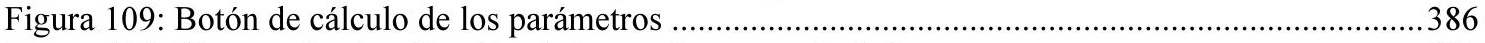

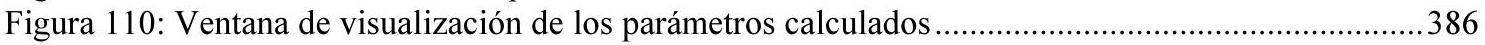

Figura 111: ventana de cálculo de la profundidad del plano de deslizamiento con vegetación ( $\mathrm{z}^{\prime}$ ) y la

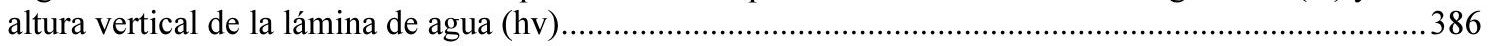

Figura 112: Botón de cálculo del Factor de Seguridad con vegetación (FSv)....................................387

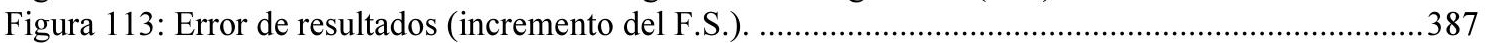

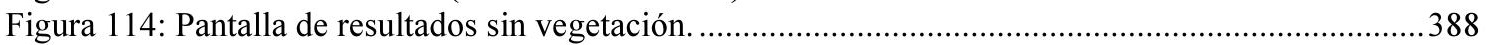

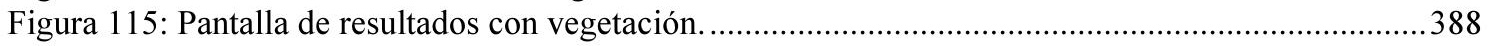

Figura 116: Presentación de resultados $\Sigma$ FR, $\Sigma$ FM, y factor de seguridad........................................390

Figura 117: Presentación de resultados: incremento del factor de seguridad, indicación de la estabilidad

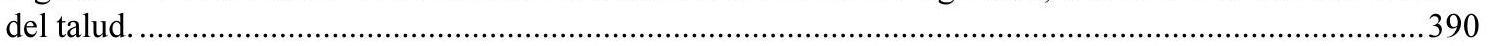

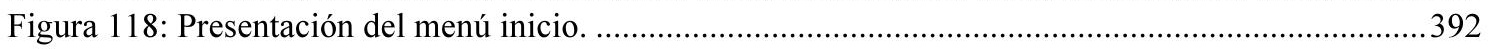

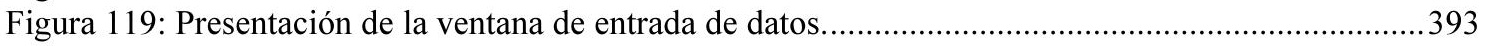

Figura 120: Presentación de la ventana de resultados sin vegetación.....................................................394

Figura 121: Presentación de la ventana de entrada de parámetros de la vegetación.................................395

Figura 122: Presentación de la ventana de entrada de parámetros de la raíz y tallo...............................395

Figura 123: Presentación de la ventana de entrada de datos con los parámetros de vegetación...............397

Figura 124: Presentación de la ventana de resultados con vegetación. ..................................................398

Figura 125: Presentación del informe de resultados con vegetación. ....................................................399 


\section{INDICE MEMORIA}

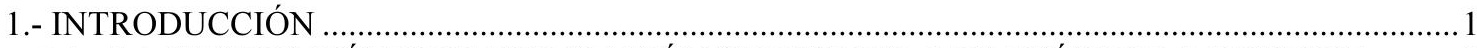
1.1.- LA VEGETACIÓN Y SU UTILIZACIÓN INGENIERIL A TRAVÉS DE LA HISTORIA..........2

2.- DESCRIPCIÓN Y OBJETIVOS DEL ESTUDIO

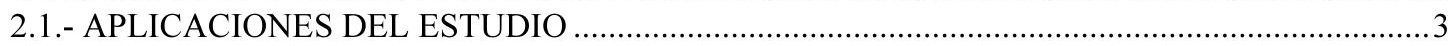

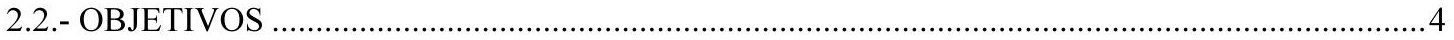

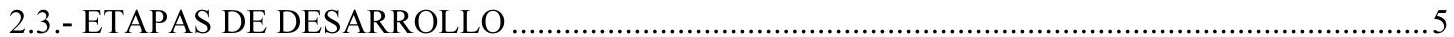

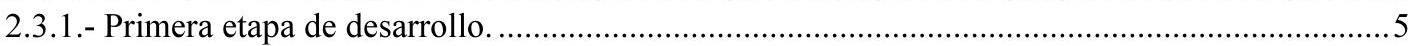

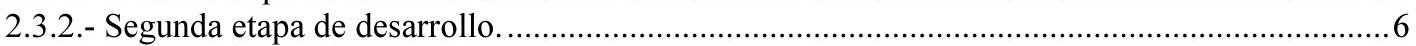

2.4.- CARACTERÍSTICAS DE LA HERRAMIENTA A DESARROLLAR .................................... 7

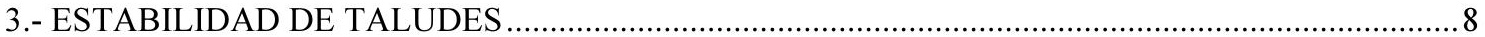

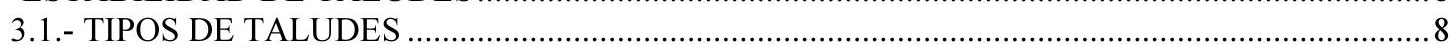

3.2.- DEFINICIÓN DE LA ESTABILIDAD DE UN TALUD ........................................................

3.3.- MÉTODOS DE ANÁLISIS DE ESTABILIDAD DE TALUDES ......................................... 10

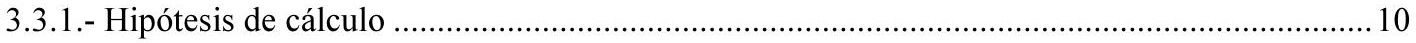

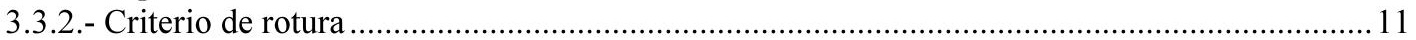

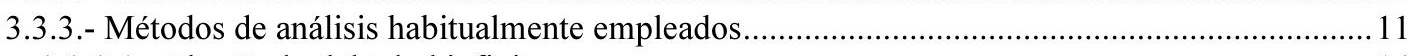

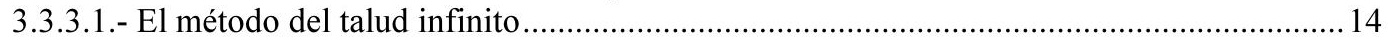

3.3.4.- Ecuación final de cálculo basada en el método del talud infinito....................................... 15

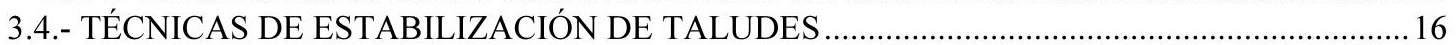

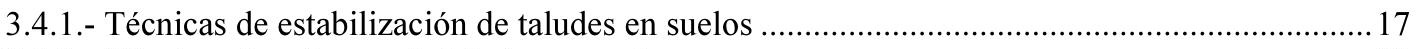

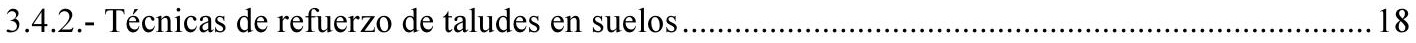

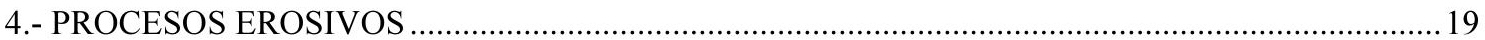

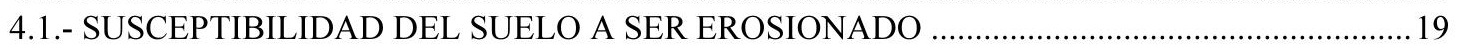

4.2.- ECUACIÓN UNIVERSAL DE PÉRDIDA DE SUELOS .........................................................20

5.- EFECTOS DE LA VEGETACIÓN EN LA ESTABILIZACIÓN DE TALUDES............................22

5.1.- EFECTOS FÍSICOS DE LA VEGETACIÓN .........................................................................22

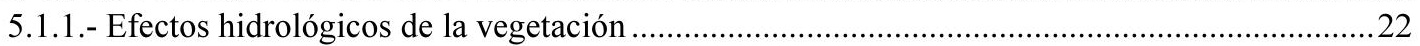

5.1.1.1.- Intercepción del agua de lluvia.............................................................................22

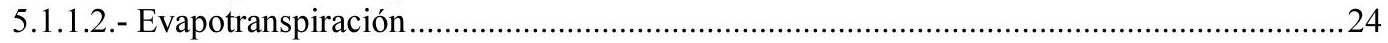

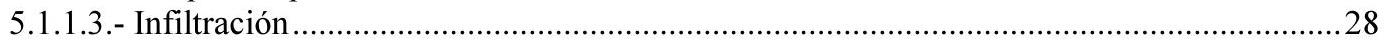

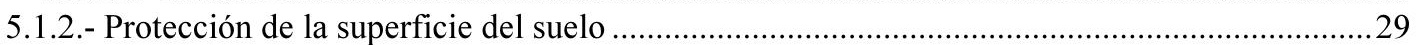

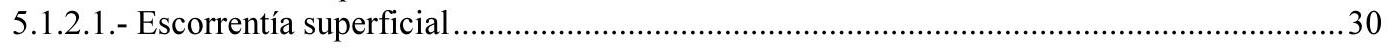

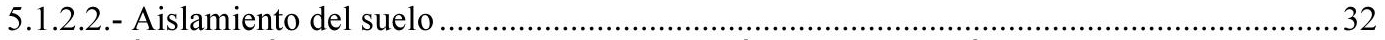

5.2.- SUJECIÓN MECÁNICA DEL SUELO POR ACCIÓN DE LAS RAÍCES ..................................33

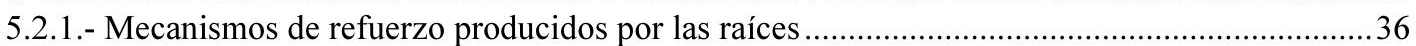

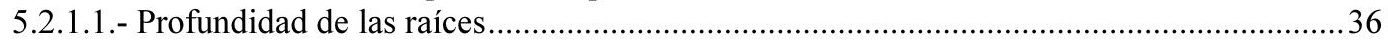

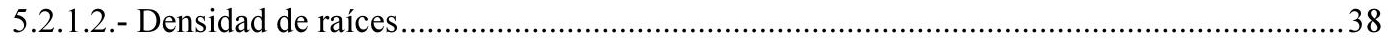

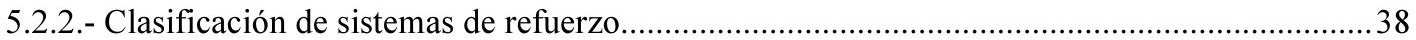

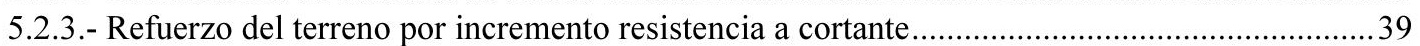

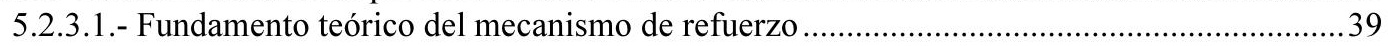

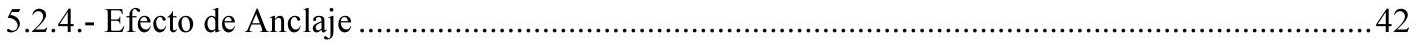

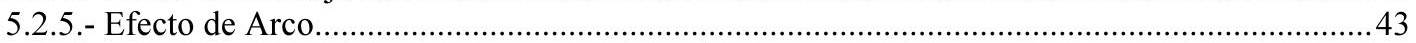

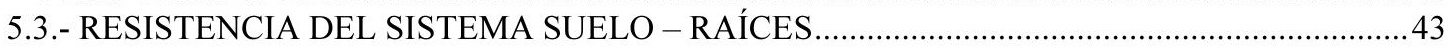

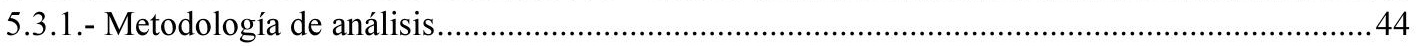

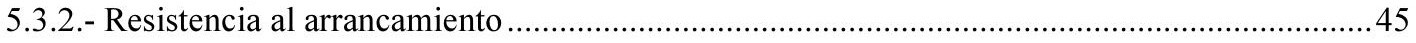

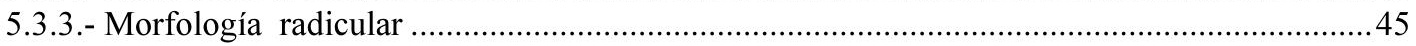

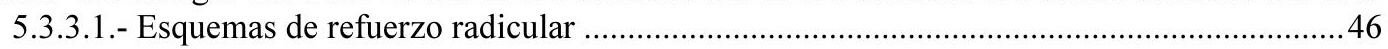

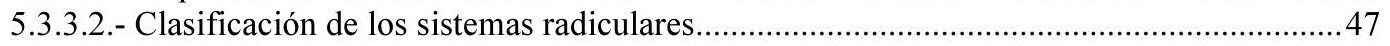

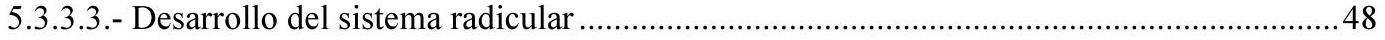

5.3.3.4.- Tipos de crecimiento de las raíces en el suelo .................................................................48

5.3.3.5.- Descripción de algunos sistemas radiculares de especies arbóreas y arbustivas ...............49 
DESARROLLO DE UNA APLICACIÓN INFORMÁTICA PARA EL CÁLCULO DE SOSTENIMIENTO DE TALUDES MEDIANTE REVEGETACIÓN

MEMORIA

5.4.- SOBRECARGAS PRODUCIDAS POR LA VEGETACIÓN ....................................................50

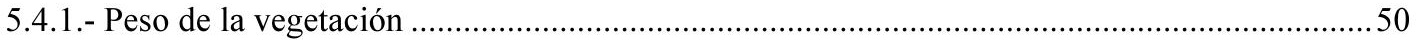

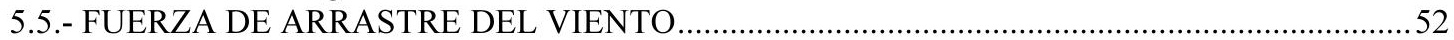

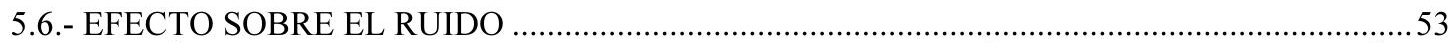

6.- SELECCIÓN DE ESPECIES VEGETALES PARA SU UTILIZACIÓN EN LA REVEGETACIÓN

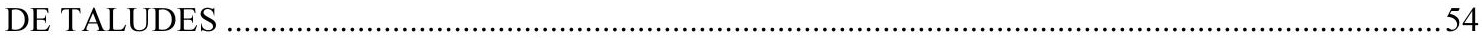

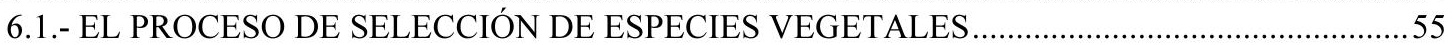

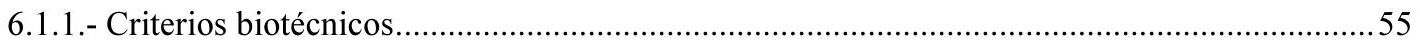

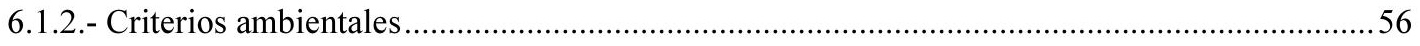

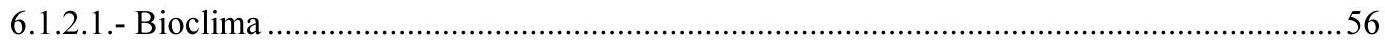

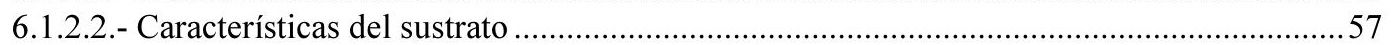

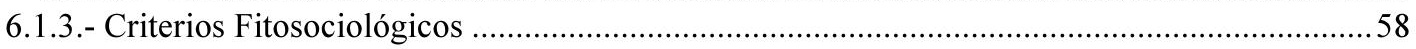

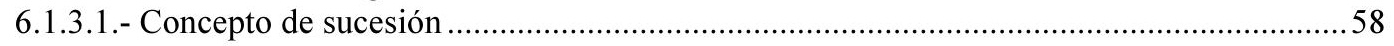

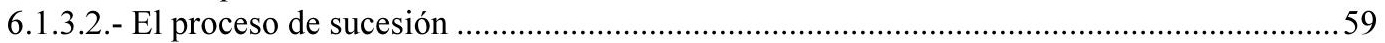

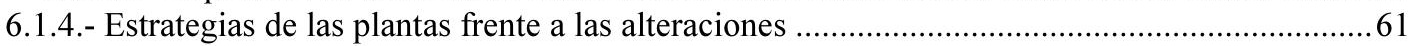

6.1.4.1.- Estrategias de la fase juvenil (regenerativa) ..............................................................6 61

6.1.4.2.- Estrategias para la fase madura (establecida).......................................................... 62

7.- MODELO MATEMÁTICO PARA LA DEFINICIÓN DEL EFECTO DE LA VEGETACIÓN

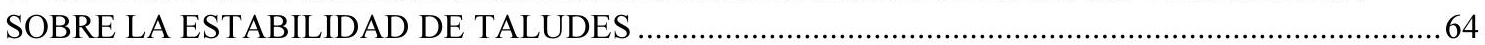

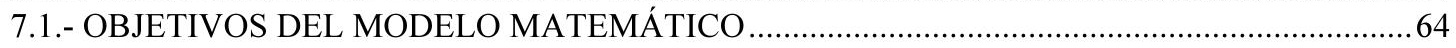

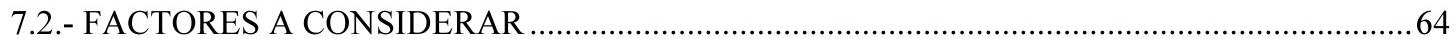

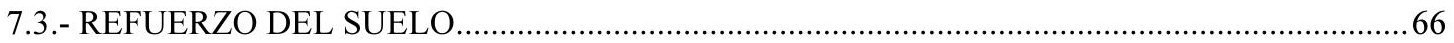

7.3.1.- Aumento de resistencia a cortante: cohesión mejorada ......................................................66

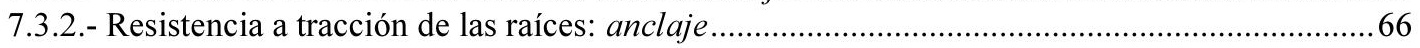

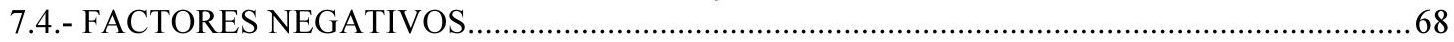

7.4.1.- Incremento del peso sobre el talud: sobrecarga ..................................................................68

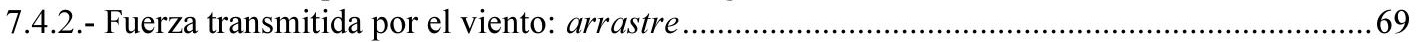

7.5.- INFLUENCIA DE LA COMBINACIÓN DE ESPECIES RESPECTO A ESPECIES

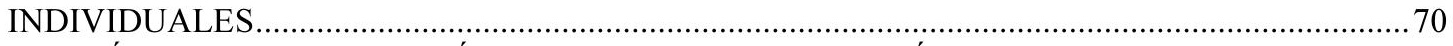

7.6.- CÁLCULO DE LOS PARÁMETROS DE LA VEGETACIÓN EN UNA MEZCLA DE

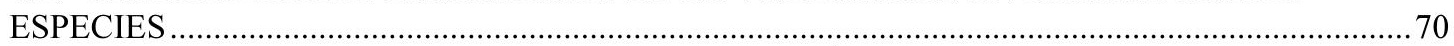

7.7.- INFLUENCIA DE LA DENSIDAD DE PLANTACIÓN Y EFECTO ARCO ............................71

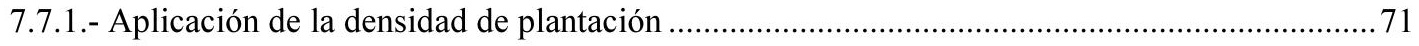

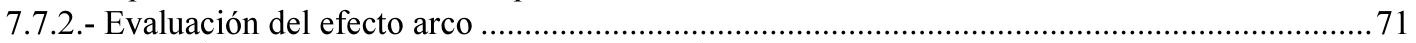

7.8.- DEFINICIÓN DE LAS ECUACIONES DE CÁLCULO DEL FACTOR DE SEGURIDAD ......72

7.8.1.- Cálculo de la profundidad del plano de deslizamiento .......................................................72

7.8.1.1.- Profundidad del plano de deslizamiento..................................................................... 72

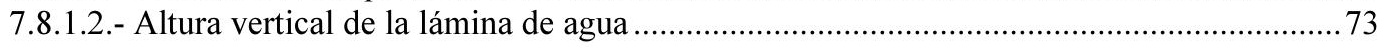

7.8.2.- Ecuación para el cálculo del factor de seguridad sin vegetación.............................................73

8.- IMPLEMENTACIÓN DEL MODELO MATEMÁTICO DE REFUERZO DE TALUDES CON

VEGETACIÓN EN UN PROGRAMA INFORMÁTICO .............................................................75

8.1.- APLICACIÓN Y REQUISITOS DEL PROGRAMA ............................................................. 75

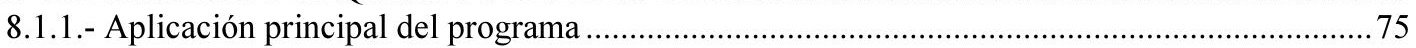

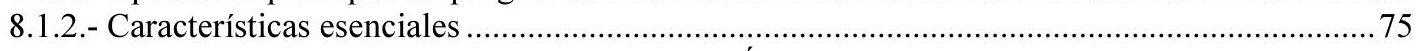

8.2.- FUNCIONAMIENTO DEL PROGRAMA- "ANÁLISIS DE ESTABILIDAD DE TALUDES"

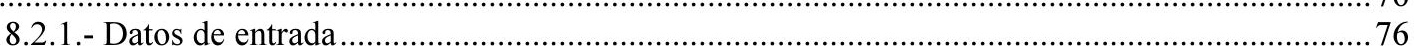

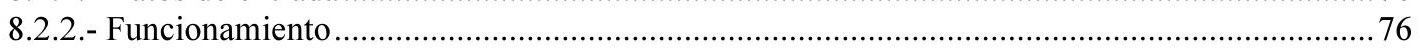

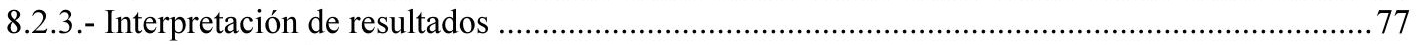

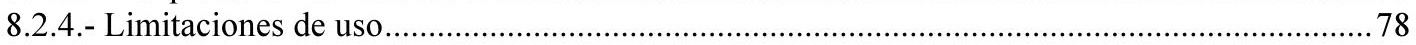

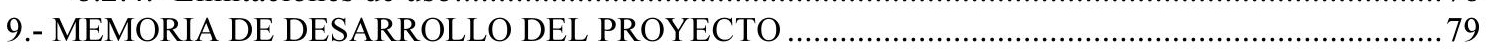

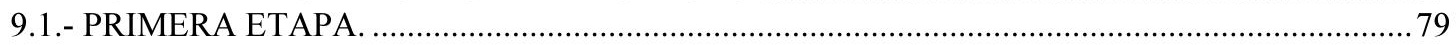

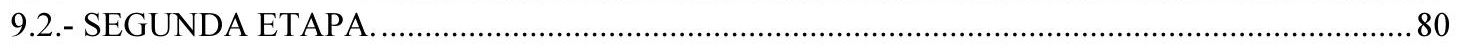

9.3.- INCIDENCIAS Y OBSERVACIONES RELATIVAS AL PROCESO DE DESARROLLO.......82

10.- CONCLUSIONES, VALORACIÓN GLOBAL DEL PROYECTO …..........................................8

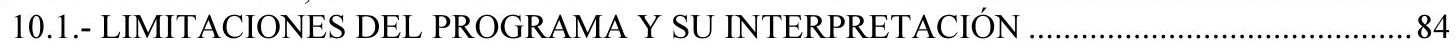

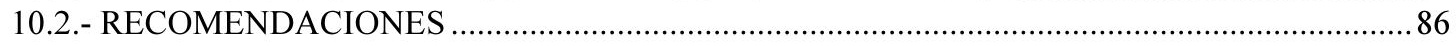


DESARROLLO DE UNA APLICACIÓN INFORMÁTICA PARA EL CÁLCULO DE SOSTENIMIENTO

DE TALUDES MEDIANTE REVEGETACIÓN

MEMORIA

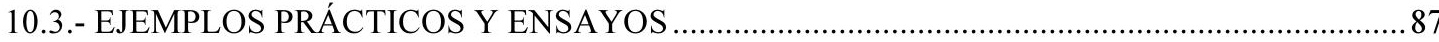

10.3.1.- Aplicación: Restauración de explotaciones mineras o escombreras ..................................87

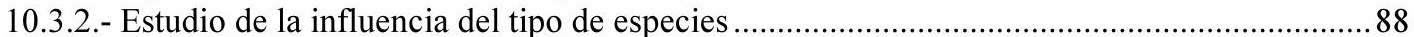

10.3.3.- Estudio de la influencia de la densidad de plantación ....................................................... 90 
DESARROLLO DE UNA APLICACIÓN INFORMÁTICA PARA EL CÁLCULO DE SOSTENIMIENTO DE TALUDES MEDIANTE REVEGETACIÓN 


\section{1.- INTRODUCCIÓN}

Con el presente estudio, se pretende desarrollar una aplicación informática mediante la cual y a través de una serie de datos relativos al tipo de terreno, clima y ubicación de una zona, podamos determinar la composición óptima de la cubierta vegetal, realizando posteriormente una simulación, en la que se incluyan otras variables como pendiente, nivel freático, etc., para obtener de esta forma una solución de sostenimiento del terreno a través del enraizado de diferentes plantas, bajo la influencia del tipo de especies, representación en la mezcla y densidad de plantación.

Normalmente la vegetación es utilizada en las obras de ingeniería como reductor de impacto visual ocasionado por la intervención de las obras en el medio, mejorando la calidad paisajística de las zonas afectadas. Sin embargo, la vegetación también puede jugar un papel importante en los siguientes aspectos:

- Ejerce un control de los procesos erosivos, protegiendo el suelo en superficie.

- Aumenta la resistencia y cohesión de los terrenos en profundidad.

- Influye de forma significativa en la humedad y capacidad de retención de agua.

Los efectos proporcionados por la vegetación pueden ser benéficos como adversos dependiendo de las condiciones en las que se utilice, aunque en la mayoría de los casos de aplicación, existe un predominio de los efectos positivos. Es así como actualmente se ha venido desarrollando una rama de la ingeniería en la que se utilizan plantas vivas como materiales de construcción, en contraste con la ingeniería convencional, en la cual se utilizan materiales inertes e inorgánicos.

La metodología para la utilización de vegetación debe centrarse en definir las características comparativas de unas especies respecto a otras en relación a sus propiedades bioingenieriles, como solución, o bien como complemento de otras soluciones tradicionales.

Los estudios de las propiedades relativas a resistencia al esfuerzo cortante de un suelo en el que se han desarrollado raíces, y la resistencia a tracción de las mismas, para diversas especies, nutren científicamente los postulados relacionados con el refuerzo de terrenos que estas originan, especialmente en terrenos con pendiente.

En la mecánica de suelos tradicional, el análisis de estabilidad de taludes normalmente considera parámetros relacionados con el tipo de material involucrado y sus características 
geomecánicas, métricas o geométricas y, en algunos casos, modelos que incluyen dentro de su análisis, la presencia de mapas. "Urbano y U.L. de Meneses, 1997".

\section{1.- LA VEGETACIÓN Y SU UTILIZACIÓN INGENIERIL A TRAVÉS DE LA HISTORIA.}

Existen registros que datan de tiempos antiguos en que la vegetación, ya fuera viva o muerta, era utilizada como medio para mejorar la estabilidad de pendientes.

- Utilización de la caña alrededor de la gran muralla china.

- Utilización de la caña en los Zigurats de Bagdad.

- Utilización de sauces para la estabilización de diques.

- Utilización para la estabilización de terraplenes y las riberas de los ríos.

Los orígenes de la bioingeniería se sitúan en los países alpinos de Europa (Suiza y Austria), con obras escritas ya en el siglo XVIII. El desarrollo moderno de la disciplina tuvo lugar en los años 30 en Austria. La razón de que esta disciplina surgiera en los Alpes fue la necesidad de controlar los desprendimientos de tierra, torrenteras, avalanchas de montaña unidos a la recesión económica de los años 30 que obligó a utilizar técnicas artesanales baratas disponibles in situ de manera inmediata. Estos fenómenos de erosión intensa aparecen años después en la ingeniería civil, por lo que la técnica se extiende.

El argumento de partida de la bioingeniería es que para el control de la erosión y la restauración paisajística, las técnicas tradicionales de la ingeniería civil no son sostenibles a largo plazo debido a lo caro que resulta la inversión inicial y (más importante) a las crecientes necesidades de mantenimiento a lo largo del tiempo. Las técnicas de bioingeniería son más sostenibles a lo largo del tiempo ya que la vegetación tiene capacidad de auto-regeneración y es capaz de responder de forma dinámica y natural a condiciones cambiantes, sin perder sus propiedades ingenieriles.

En general la utilización de vegetación para estabilización de pendientes dependerá en gran medida de las condiciones climáticas, así por ejemplo los países mediterráneos son menos vulnerables que los tropicales húmedos, puesto que en los últimos, las precipitaciones son intensas y prolongadas, aumentando los riesgos de deslizamientos masivos, inclusive cuando las pendientes hayan sido bien diseñadas construidas con factores de seguridad apropiados. Los campos de aplicación de las técnicas de bioingeniería son muy variados, y con ellas se obtienen resultados altamente satisfactorios. 


\section{2.- DESCRIPCIÓN Y OBJETIVOS DEL ESTUDIO}

El movimiento de tierras que se produce en las laderas, ya sea por causas naturales o como efecto de las obras llevadas a cabo por el hombre, conlleva una serie de riesgos.

Definir dichos riesgos, así como la estabilidad de los taludes, la restauración, rehabilitación y recuperación de los mismos, es una tarea de gran importancia, tanto a nivel medioambiental, como a nivel paisajístico.

El presente trabajo tiene la intención de ser una herramienta, que permita desarrollar una aplicación capaz de calcular y determinar posibles soluciones y obras necesarias para garantizar la estabilidad de los taludes, principalmente, usando la vegetación.

El objetivo principal es elaborar una aplicación informática para calcular el sostenimiento de taludes estableciendo la vegetación más idónea para determinadas zonas que cuentan con problemática de incendios forestales, abandono de explotaciones, infraestructuras, etc. en las que se presenta el problema de la inestabilidad de taludes.

\section{1.- APLICACIONES DEL ESTUDIO}

Los estudios hacia los que se encaminará este proyecto, tendrán el fin de paliar los riesgos ocasionados por inestabilidad del terreno, ya sean de erosión, deslizamientos, desprendimientos...etc., planteándose las siguientes aplicaciones:

- Recuperación de las cuencas mineras tanto del carbón como de la pizarra y piedra natural, ya sean pozos de explotación como escombreras.

- Reforestación de montes, que han sufrido deterioro por incendios, por tala o por intento de explotación de monte.

- Implantación de nuevos cultivos para un aprovechamiento máximo del monte.

- Conservación del medio ambiente, teniendo en cuenta para todos los resultados, el impacto ambiental.

- Estabilización de taludes con riesgos de desprendimientos, deslizamientos,...etc.

- Estabilización de taludes en obras lineales de nueva construcción. 
Para un estudio exhaustivo de la posible revegetación de zonas con riesgos, se lleva a cabo una recopilación de datos de tipo cartográfico, morfológico, medioambiental, composición de suelo, parámetros geotécnicos, parámetros de vegetación, estudio de materiales, así como estudios llevados a cabo en temas relacionados con la revegetación con el fin de crear una aplicación informática. Esta herramienta supondrá una gran ventaja, dado que para cualquier aplicación del estudio real, el programa será capaz de proporcionar una solución tanto científica como técnicamente viable, con una cantidad mínima de datos respecto a la restauración y estabilización de una zona.

La utilidad de la aplicación estará justificada para arquitectura del paisaje o paisajismo, estabilidad de taludes, empujes de tierras, control de erosión, biología, climatología, edafología, conservación de suelos, geografía, topografía, catastro, ingeniería ambiental, agronomía, etc.

\section{2.- OBJETIVOS}

El objetivo principal de este proyecto es el desarrollo de una aplicación informática para el cálculo del sostenimiento de taludes, estableciendo la vegetación más idónea en determinadas zonas con problemas debido a la recurrencia de los incendios, el abandono de explotaciones mineras, la ejecución de infraestructuras, etc. y en las que se presenta un problema de inestabilidad en los taludes.

Se obtendrá como resultado una solución integral para la restauración y estabilización de terrenos con cierta pendiente:

- Estableciendo la propuesta de revegetación más idónea para una zona determinada, en función de las características del clima, vegetación existente y terreno.

- Calculando el incremento de seguridad de un talud frente fenómenos de inestabilidad aportado por la implantación de vegetación.

Además de incrementar la estabilidad de la ladera, también se quieren alcanzar otros objetivos como son:

- La restauración o integración paisajística del espacio degradado por las intervenciones humanas o los incendios.

- Evitar la pérdida de suelo por efecto de la erosión laminar y la escorrentía. 
En esta investigación, se pretende desarrollar una aplicación informática mediante la cual y a través de una serie de datos, podamos simular las diferentes condiciones del terreno que se presenten en cuanto a sustrato, profundidad e inclinación, y obtener como solución un indicador del sostenimiento del terreno a través de la influencia que ejerce el enraizado de diferentes especies arbóreas, arbustivas y herbáceas sobre el mismo, teniendo en cuenta variables como especie vegetal, densidad de plantación, porcentaje de representación de cada especie en la plantación y disposición de las mismas.

Como resultado final se obtendrá una aplicación de cómodo y sencillo manejo, mediante la cual, el usuario podrá analizar cada uno de los aspectos más relevantes para recuperar una zona.

\section{3.- ETAPAS DE DESARROLLO}

Dentro del programa de trabajo para el desarrollo de la aplicación, diferenciaremos dos etapas de desarrollo:

1. Una primera dedicada a la recopilación de información y al desarrollo de procedimientos que permitan determinar cuál es la vegetación más idónea para implantar en una zona, y para evaluar cuál es su contribución a la mejora de las propiedades resistentes del terreno.

2. Una segunda, que tendrá por objeto el desarrollo de un modelo que permita evaluar la estabilidad de taludes con influencia de la vegetación, incluyendo las pruebas necesarias y el proceso de desarrollo del programa.

\subsection{1.- Primera etapa de desarrollo.}

En esta primera etapa se llevan a cabo los estudios bibliográficos, la toma de muestras y trabajos de campo para la elaboración de una guía de parámetros, que permitirá avanzar los siguientes pasos dentro de la investigación:

- Estudio bibliográfico, que incluya una revisión de las técnicas de implantación de vegetación, parámetros de especies vegetales, y estudios previos relacionados con este proyecto de investigación.

- Estudios cartográficos de las zonas en las que se pretende establecer propuestas para la restauración. 
- Toma de muestras del terreno recogidas mediante calicatas, y análisis de laboratorio para la comparación y contraste de los resultados.

- Análisis de las plantas y muestreo de raíces, para evaluar el tipo y consistencia del enraizamiento, el aporte de sujeción, el número de unidades, densidad y volumen a utilizar, así como la superficie de sujeción delimitada.

- Recopilación de los datos obtenidos mediante el trabajo de campo, los resultados del laboratorio, y las fuentes bibliográficas.

- Definición del tipo de vegetación que va a incluirse en la evaluación.

- Definición de los modelos matemáticos utilizados para evaluar la estabilidad de taludes, conjunto de hipótesis, y evaluación del efecto de la vegetación.

\subsection{2.- Segunda etapa de desarrollo.}

A partir de la información recopilada en el apartado anterior, se estará en condiciones de calcular el aporte a la resistencia del terreno debido a la malla formada por el enraizamiento, dando finalmente lugar al tipo de sostenimiento que tendremos en cada caso.

Una vez que el modelo analítico haya sido sometido a las pruebas de cálculo necesarias, se desarrollará la aplicación informática, introduciendo los datos y modelos anteriormente estudiados. La aplicación integrará los siguientes parámetros y funciones:

- Datos de localización, clima y precipitaciones.

- Datos de campo, entre los que se incluirán la altitud, la pendiente, la vegetación existente, y otros.

- Datos obtenidos de análisis de muestras de calicatas, relativos a propiedades y composición del suelo.

- Parámetros geotécnicos de los terrenos, pendientes, y efectos del agua subterránea.

- Análisis de las raíces, densidad, formación de mallas, desarrollo en profundidad.

- Análisis de los efectos de la fracción aérea de la planta.

- Determinación del factor de seguridad inicial y con efecto de la vegetación.

- Cálculo de progresión del sostenimiento vegetal según el número de unidades, especie vegetal, tipo, etc. 
El resultado será una herramienta completa que permita calcular las mejoras de sostenimiento aportadas por medio de la vegetación.

\section{4.- CARACTERÍSTICAS DE LA HERRAMIENTA A DESARROLLAR}

La aplicación informática cuenta con tres características esenciales:

1. Una interfaz gráfica o ventanas gráficas de usuario completo y fácil de utilizar para una introducción de datos sencilla.

2. Una base de datos dinámica, en las que existen datos generales de la zona, otros referentes al terreno, a la vegetación para el cálculo del factor de seguridad y en la que se pueden introducir y almacenar otros nuevos.

3. Herramienta gráfica mediante la cual se pueden visualizar los resultados obtenidos en las simulaciones.

La aplicación además permite obtener una o varias soluciones en función de los datos que se introduzcan.

Así para una determinada propuesta de revegetación, la aplicación permite modificar los valores de densidad y porcentaje de las especies empleadas en la mezcla con el objetivo de conseguir la mejor solución a la estabilidad del terreno con las especies vegetales propuestas. 


\section{3.- ESTABILIDAD DE TALUDES}

\section{1.- TIPOS DE TALUDES}

Se define talud como la inclinación de un terreno o del paramento de un muro. En función de su permanencia, se distinguen:

Taludes Permanentes.

- Se diseñan para ser estables alargo plazo, se construyen con fines de edificación.

- Priman en el diseño criterios de seguridad.

Taludes Temporales.

- Se proyectan para ser estables a corto y mediano plazo.

- Se utilizan principalmente en la minería.

- Priman en el diseño criterios de carácter económico.

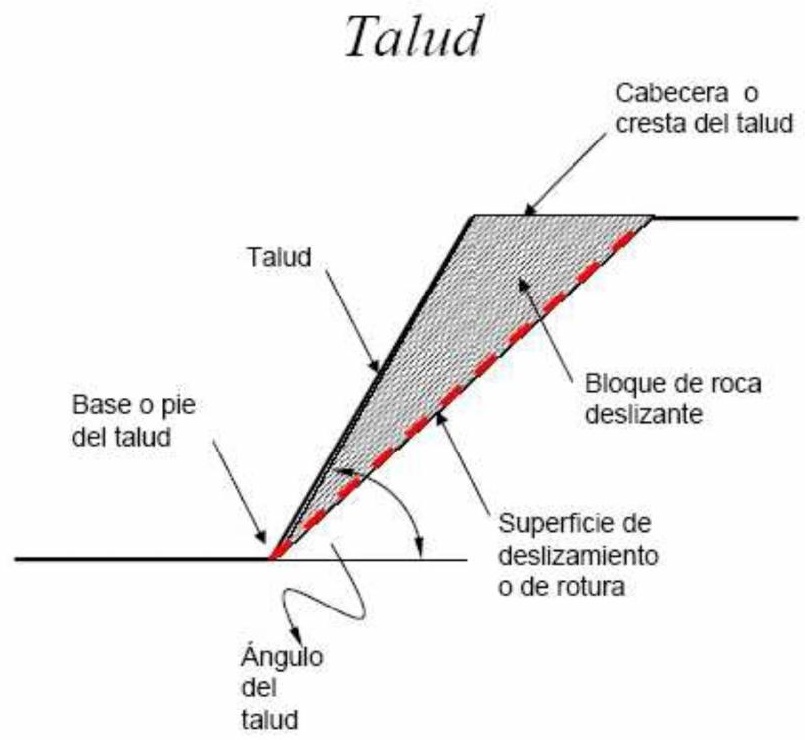

Figura 1: Partes de un talud

En función de los riesgos asociados a posibles fenómenos de inestabilidad también se pueden distinguir varias clases de taludes: 
Clase de riesgo 1.

- Pérdidas económicas potenciales bajas.

- Daños potenciales a personas leves.

\section{Clase de riesgo 2.}

- Pérdidas económicas potenciales importantes.

- Daños potenciales a personas moderados.

Clase de riesgo 3.

- Pérdidas económicas potenciales importantes.

- Daños potenciales a personas graves.

\section{2.- DEFINICIÓN DE LA ESTABILIDAD DE UN TALUD}

Para realizar una cuantificación de la estabilidad de un talud es necesario, en primer lugar establecer un valor del factor de seguridad.

El factor de seguridad se define como el cociente entre las fuerzas resistentes y las fuerzas motoras, que actúan sobre una determinada masa de terreno potencialmente inestable, delimitada por la superficie de deslizamiento.

$$
F=\frac{S}{\tau}=\frac{S \cdot A}{\tau \cdot A}=\frac{R}{W_{T}}
$$

- Fuerzas resistentes $(\boldsymbol{R})$ : Se oponen al deslizamiento. Son básicamente la cohesión y el ángulo de rozamiento interno del terreno.

- Fuerzas motoras $\left(\boldsymbol{W}_{T}\right)$ : Tienden a desestabilizar el terreno. Tienen su origen en la componente tangencial del peso de la masa de terreno potencialmente inestable.

El coeficiente de seguridad es un valor numérico próximo a la unidad, si el valor supera la unidad, el talud es estable, pero debe exigirse un valor mínimo algo mayor, para que exista un margen de seguridad. 
El factor de seguridad mínimo exigible se selecciona teniendo en cuenta el tiempo de servicio de los taludes y el riesgo que llevan asociado.

\section{3.- MÉTODOS DE ANÁLISIS DE ESTABILIDAD DE TALUDES}

\subsection{1.- Hipótesis de cálculo}

Para el análisis de estabilidad de taludes, determinado un valor de factor de seguridad, para unas condiciones del mismo, no existe un procedimiento único.

Deben adoptarse una serie de hipótesis, con objeto de simplificar los procedimientos de cálculo, en muchos casos basados en la aplicación de tablas, ábacos y gráficos. Cada hipótesis tendrá una serie de limitaciones.

Se consideran las siguientes hipótesis relativas a la rotura del talud:

- Superficies planas.- Aplicables a estructuras muy definidas.

- Superficies circulares.- Son aplicables en el caso de materiales sueltos, y rocas blandas, donde las propiedades mecánicas no están dominadas por las características estructurales.

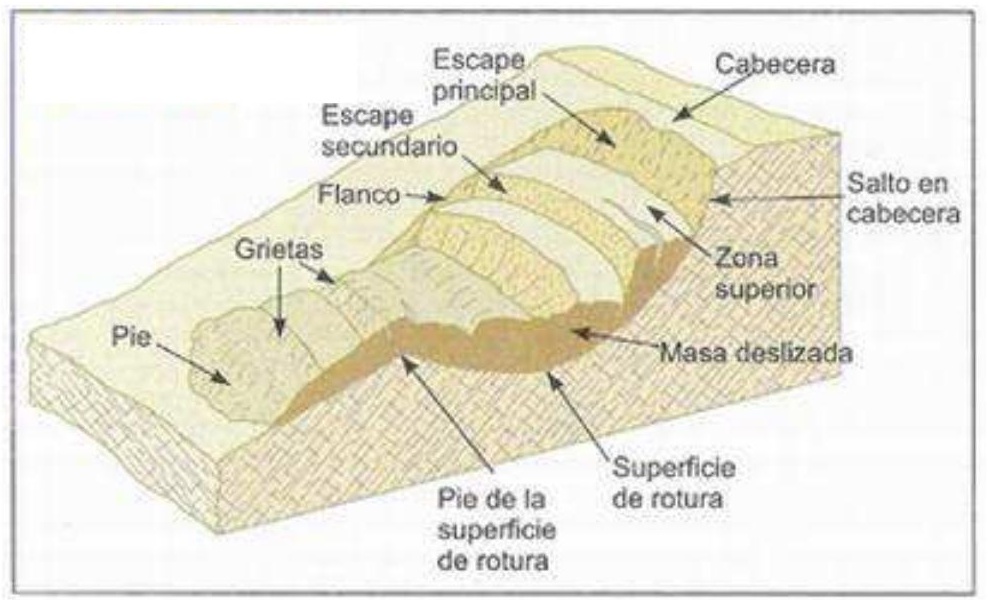

Figura 2: Esquema de deslizamiento rotacional. 


\subsection{2.- Criterio de rotura}

El criterio de rotura empleado se basa en el de Mohr-Coulomb, de tipo lineal, que representa la resistencia al corte mediante una expresión que integra los parámetros: cohesión del terreno $(c)$, ángulo de rozamiento interno $(\boldsymbol{\varphi})$, tensión normal al plano de rotura $(\sigma)$, para proporcionar el valor de la tensión tangencia máxima que soporta un terreno $(\tau)$ :

$$
\tau=c+\sigma \tan \varphi
$$

Figura 3: Representación gráfica del Criterio de rotura de Mohr-Coulomb.

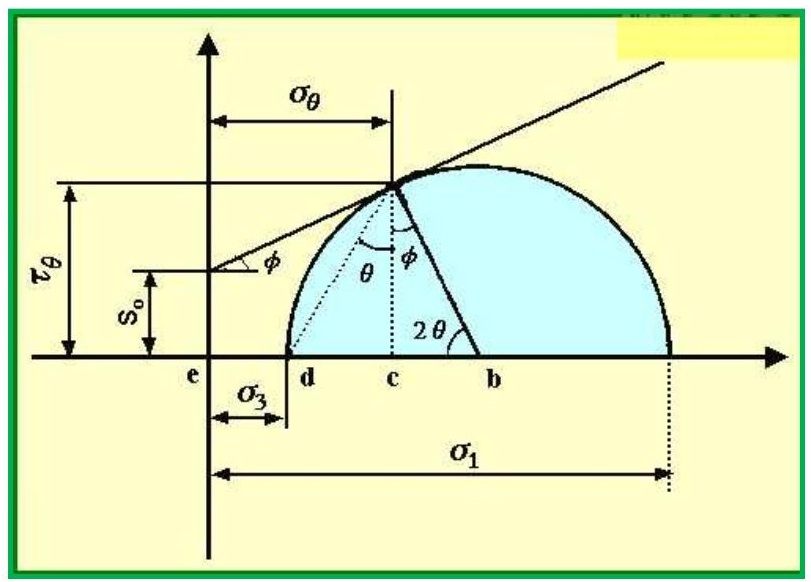

\subsection{3.- Métodos de análisis habitualmente empleados}

Es aconsejable el empleo de métodos de equilibrio límite para el cálculo del factor de seguridad. Este tipo de métodos analizan el equilibrio de fuerzas a lo largo de una superficie de deslizamiento, y se basan en lo siguiente:

- La selección de una superficie teórica de rotura en el talud.

- El criterio de rotura de Mohr-Coulomb.

- La definición de Coeficiente de seguridad.

Integrando todo lo anterior, se llega a la expresión que permite calcular el factor de seguridad del talud $(\boldsymbol{F})$ :

$$
F=\frac{\mathrm{cA}+(\mathrm{W} \cos \alpha-\mathrm{U}) \operatorname{tg} \varphi}{\mathrm{Wsen} \alpha}
$$

Siendo:

- $\quad \boldsymbol{C A}=$ Fuerza debida a la cohesión en el plano de deslizamiento. 
- $\quad(W \cos \alpha-U) \operatorname{tg} \varphi=$ Fuerza debida al rozamiento en el plano.

- $\boldsymbol{W} \cos \alpha=$ Componente estabilizadora del peso (normal a la superficie de deslizamiento).

- $\boldsymbol{U}=$ Fuerza total debida a la presión de agua sobre la superficie de deslizamiento.

- Wsen $\alpha=$ componente del peso tendente al deslizamiento (paralela a la superficie de deslizamiento).

- $\quad \boldsymbol{A}=$ Área del plano de rotura.

A partir de ésta definición de factor se seguridad, se aplica cada una de las hipótesis y fórmulas que define cada método de cálculo de estabilidad de taludes, desde los más sencillos, basados en la aplicación de ábacos, a los más complejos, que proporciona una mayor precisión. Se señala en este sentido que:

- Los métodos de cálculo complejos proporcionan resultados más precisos, pero por otro lado, requieren que los datos de partida sean a su vez muy precisos.

- Los métodos simplificados tienen la ventaja de la rapidez y de requerir una cantidad mínima de datos, sin embargo la precisión del resultado aconseja asegurar un margen adicional de seguridad.

En la siguiente tabla, se presenta un resumen de los métodos de cálculo de estabilidad de taludes habitualmente empleados, con las particularidades que los definen: 
Tabla 1.- resumen de los métodos de cálculo de estabilidad de taludes.

\begin{tabular}{|c|c|}
\hline $\begin{array}{lr}\text { Superficies } & \text { de } \\
\text { deslizamiento } & \text { plana- } \\
\text { circular } & \end{array}$ & $\begin{array}{l}\text { - Hipótesis de rotura plana } \\
\text { - Hipótesis de rotura circular } \\
\text { - Gráficos para determinar varios parámetros de las } \\
\text { fórmulas de cálculo }\end{array}$ \\
\hline $\begin{array}{l}\text { Rotura circular: método } \\
\text { de Hoek y Bray }\end{array}$ & $\begin{array}{l}\text { - Rotura circular } \\
\text { - Se basa en una serie de ábacos para cada posición del } \\
\text { nivel freático. }\end{array}$ \\
\hline $\begin{array}{l}\text { Estabilidad de taludes de } \\
\text { muro }\end{array}$ & $\begin{array}{l}\text { - Aplicable a rotura plana con bajo ángulo de } \\
\text { deslizamiento. } \\
\text { - Se basa en una serie de gráficos y ecuaciones. }\end{array}$ \\
\hline $\begin{array}{l}\text { Caso general de análisis } \\
\text { de estabilidad de taludes }\end{array}$ & $\begin{array}{l}\text { - Hipótesis de Rankine.- para terrenos incoherentes } \\
\text { - } \quad \text { Fórmula de Resalt.- para terrenos coherentes } \\
\text { - } \quad \text { Se basa en un conjunto de fórmulas }\end{array}$ \\
\hline Método de TSYTOVICH & $\begin{array}{ll}\text { - } & \text { Equilibro límite de fuerzas } \\
\text { - } & \text { Hipótesis de deslizamiento plano } \\
\text { - } & \text { En terrenos cohesivos } \\
\text { - } & \text { En terrenos sueltos } \\
\text { - } & \text { Hipótesis de rotura circular } \\
\text { - } & \text { Hipótesis de desplazamiento circular-cilíndrico } \\
\text { - } & \text { Aplica tablas y gráficos }\end{array}$ \\
\hline $\begin{array}{l}\text { Deslizamientos } \\
\text { traslacionales MASLOV }\end{array}$ & $\begin{array}{l}\text { - Equilibrio límite de fuerzas } \\
\text { - } \quad \text { Aplicable a deslizamientos traslacionales } \\
\text { - } \quad \text { Utiliza soluciones gráficas } \\
\text { - } \quad \text { Aplica una modelización de la humedad del terreno }\end{array}$ \\
\hline $\begin{array}{l}\text { Equilibrio de momentos } \\
\text { JAMBU }\end{array}$ & $\begin{array}{l}\text { - } \quad \text { Equilibrio límite de momentos } \\
\text { - } \quad \text { Aplicable a rotura circular } \\
\text { - } \quad \text { Conjunto de fórmulas, admite representación gráfica. }\end{array}$ \\
\hline $\begin{array}{l}\text { Ampliación del método } \\
\text { de Jambu }\end{array}$ & $\begin{array}{l}\text { - Aplica las condiciones de equilibrio a elementos finitos del } \\
\text { talud, evaluando las condiciones de equilibrio de cada uno } \\
\text { de éstos. }\end{array}$ \\
\hline Método del talud infinito & - Aplica condiciones de equilibrio a la masa inestable \\
\hline
\end{tabular}




\begin{tabular}{|l|l|}
\hline & $\begin{array}{l}\text { suponiendo que la superficie de deslizamiento es infinita } \\
\text { en longitud. }\end{array}$ \\
\hline
\end{tabular}

Todos estos métodos se encuentran ampliamente desarrollados en el Anexo III.Métodos de cálculo de estabilidad de taludes.

\subsubsection{1.- El método del talud infinito}

Este método se basa en la hipótesis de que la franja de terreno delimitada por una superficie de deslizamiento paralela a la superficie del talud, puede considerarse infinita, con respecto al espesor de la masa deslizada, aplicándose a la misma, las condiciones de equilibrio de fuerzas.

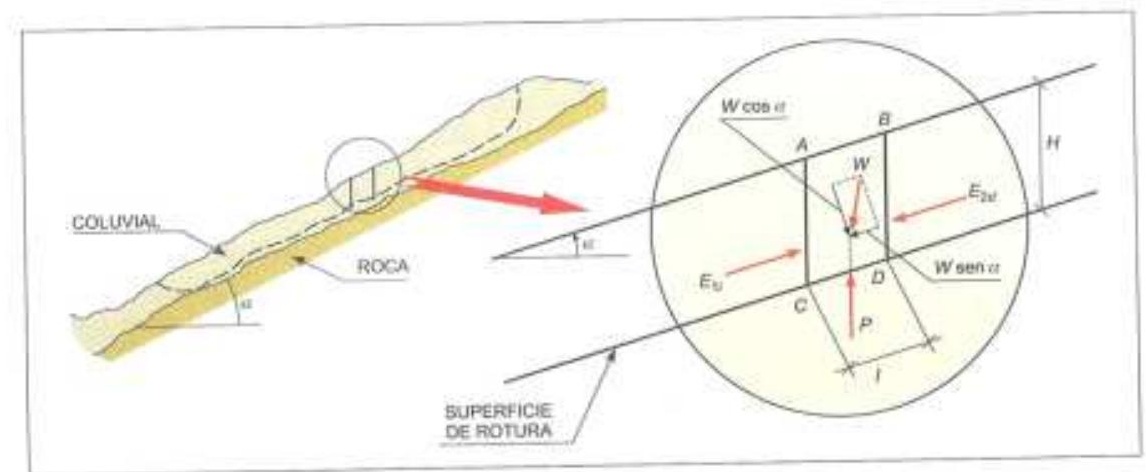

Figura 4: Rotura plana, con aplicación de la hipótesis del talud infinito.

Intervienen las fuerzas: componente tangencial del peso (desestabilizadora), rozamiento y cohesiva (estabilizadoras).

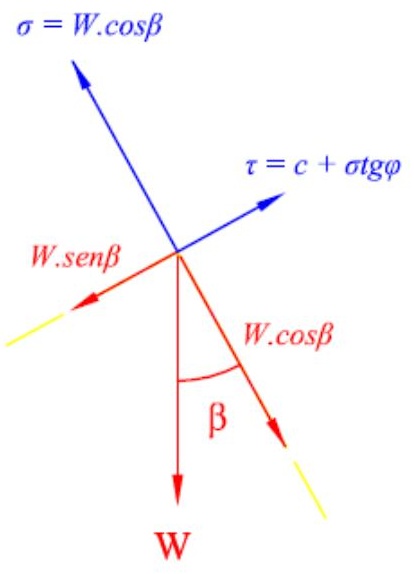

Para las condiciones generales: terreno cohesivo, con influencia de nivel freático, la fórmula de cálculo que define el factor de seguridad según este método es la siguiente:

$$
F=\frac{\left(\sigma_{n}-u\right) \operatorname{tg} \varphi+c}{S}
$$


Figura 5: Esquema de equilibrio de fuerzas sobre la sección unitaria del talud.

\subsection{4.- Ecuación final de cálculo basada en el método del talud infinito}

En el presente trabajo, se presenta como la ecuación más idónea para la evaluación de la estabilidad de taludes, una fórmula de cálculo basada en el método del talud infinito:

$$
F_{S}=\frac{\left(c+\left(\gamma z-\gamma_{w} h_{w}\right) \cos ^{2} \beta \operatorname{tang} \emptyset\right)}{(\gamma z \operatorname{sen} \beta \cos \beta)}
$$

- Hipótesis simplificativa (método del talud infinito).- En el caso simple de una falla traslacional a lo largo de una superficie de deslizamiento paralela al suelo sobre un talud uniforme relativamente largo, puede ser examinado por el análisis del talud infinito. En este caso, un solo elemento o segmento de la pendiente, puede ser considerada como representativa de toda la ladera y una porción de la cabeza y pie de talud son ignorados, siendo minimizados en extensión (Morgan y Rickson, 1995).

Siendo los parámetros de cálculo, los siguientes:

Tabla 2: Parámetros que intervienen en la ecuación de cálculo del factor de seguridad.

\begin{tabular}{|c|l|l|}
\hline Parámetro & Definición & Unidades \\
\hline $\mathbf{c}$ & Cohesión del terreno & $\mathrm{kN} / \mathrm{m}^{3}$ \\
\hline$\gamma$ & Peso específico del terreno & $\mathrm{kN} / \mathrm{m}^{3}$ \\
\hline $\mathbf{z}$ & Profundidad del plano de deslizamiento & $\mathrm{m}$ \\
\hline$\gamma_{\mathbf{w}}$ & Peso específico del agua & $\mathrm{kN} / \mathrm{m}^{3}$ \\
\hline $\mathbf{h}_{\mathbf{w}}$ & Altura de la lámina de agua sobre el plano de deslizamiento & $\mathrm{m}$ \\
\hline $\boldsymbol{\beta}$ & Ángulo de inclinación del talud & grados (ㅇ) \\
\hline$\varnothing$ & Ángulo de rozamiento interno del terreno & grados (ㅇ) \\
\hline
\end{tabular}




\section{4.- TÉCNICAS DE ESTABILIZACIÓN DE TALUDES}

La estabilización de un talud comprende las siguientes acciones:

- Determinar el sistema o combinación de sistemas de estabilización más apropiados, teniendo en cuenta todas las circunstancias del talud estudiado.

- Diseñar en detalle el sistema a emplear, incluyendo planos y especificaciones de diseño.

- Instrumentación y control durante y después de la estabilización. Debe tenerse en cuenta que en taludes, nunca existen diseños detallados inmodificables y que las observaciones que se hacen durante el proceso de construcción tienden generalmente, a introducir modificaciones al diseño inicial y esto debe preverse en las cláusulas contractuales de construcción.

Los sistemas de estabilización se pueden clasificar en:

- Conformación del talud o ladera: Sistemas que tienden a lograr un equilibrio de masas, reduciendo las fuerzas que producen el movimiento.

- Recubrimiento de la superficie: Métodos que tratan de impedir la infiltración o la ocurrencia de fenómenos superficiales de erosión, o refuerzan el suelo más subsuperficial. El recubrimiento puede consistir en elementos impermeabilizantes como el concreto o elementos que refuercen la estructura superficial del suelo como la cobertura vegetal.

- Control de agua superficial y subterránea: Sistemas tendientes a controlar el agua y sus efectos, disminuyendo fuerzas que producen movimiento y / o aumentando las fuerzas resistentes.

- Estructuras de contención: Métodos en los cuales se van a colocar fuerzas externas al movimiento aumentando las fuerzas resistentes, sin disminuir las actuantes. Las estructuras de contención son obras generalmente masivas, en las cuales el peso de la estructura es un factor importante y es común colocar estructuras ancladas en las cuales la fuerza se transmite al deslizamiento por medio de un cable o varilla de acero. Cada tipo de estructura tiene un sistema diferente de trabajo y se deben diseñar de acuerdo a su comportamiento particular. 


\subsection{1.- Técnicas de estabilización de taludes en suelos}

En este caso las condiciones de pendiente y sustrato resultan mucho más favorables para el desarrollo de la vegetación.

Es fundamental que la superficie del talud quede lo más tendida posible sobre el terreno, de forma que se reduzca su inestabilidad y los efectos erosivos del agua, y aumente la posibilidad de introducción de forma natural de las especies vegetales de la zona. Sin embargo es habitual que el talud presente una fuerte pendiente que hace necesario la aplicación de distintos métodos de estabilización.

Siempre que sea posible, se debe procurar remodelar geométricamente el terreno con el objeto de alcanzar unas condiciones que permitan garantizar la estabilidad de la nueva forma adoptada.

\section{Descarga del talud.}

Consiste en reducir las fuerzas que provocan que una masa de terreno se deslice, es decir, reducir las fuerzas que favorecen el movimiento. Algunos inconvenientes asociados con la excavación son los costes si el volumen es grande, unidos a la accesibilidad, ya que los taludes en la mayoría de los casos deben ser excavados desde la parte más alta a la más baja.

Existen distintos tipos de actuaciones para descargar el talud:

- Descabezamiento del talud, que consiste en eliminar la masa inestable o el material de la parte superior, ya que su peso contribuye más al deslizamiento y menos a la resistencia.

- Tendido del talud, que consiste en la disminución del ángulo del talud para aumentar la estabilidad del mismo y el banqueado del talud.

- Rellenos de baja densidad, que consiste en la utilización de materiales ligeros, algunos de ellos objeto incluso de desecho, con cierta impermeabilidad, y que en definitiva aportan una mayor estabilidad al talud. 


\subsection{2.- Técnicas de refuerzo de taludes en suelos}

\section{$\underline{\text { Muros }}$}

Técnica basada en contrarrestar las fuerzas desestabilizadoras mediante la aplicación de una fuerza externa que incrementa las fuerzas resistentes. Existen tres tipos de muro en función de su finalidad: Recubrimiento, sostenimiento y contención.

Según el tipo de material con el que se ejecutan, podemos tener: muros de hormigón ejecutados in situ, muros de fábrica, muros jaula, muros de escollera, muros de tierra armada, muros de gaviones, etc.

\section{$\underline{\text { Mallas }}$}

La fijación de mallas y redes metálicas a la superficie del talud inmoviliza o amortigua el deslizamiento de materiales procedentes de la descomposición del sustrato y contribuye a la consolidación definitiva de dicho talud. Precisan igualmente de una serie de anclajes en el terreno.

\section{Drenajes}

La técnica de drenaje aplicada en taludes en suelo es prácticamente similar a la utilizada en taludes en roca. Los objetivos que persigue el drenaje son: Control del agua en superficie, control del agua infiltrada, reducción de la presión en profundidad y del peso del talud.

\section{Tratamientos sobre el terreno}

Para mejorar las condiciones de estabilidad, entre ellos los tratamientos químicos presentan muchas posibilidades, siendo las inyecciones de cementos Portland, cloruros cálcicos e inyecciones de cal los más utilizados. 


\section{4.- PROCESOS EROSIVOS}

\section{1.- SUSCEPTIBILIDAD DEL SUELO A SER EROSIONADO}

Ante la actuación de los mismos agentes erosivos no todos los suelos se ven alterados en la misma manera, por tanto, interesa conocer la susceptibilidad del suelo a sufrir erosión. Con respecto a este tema, es de gran importancia caracterizar los suelos según su susceptibilidad a ser erosionados como consecuencia del efecto de la lluvia y las corrientes de agua, y sufrir por tanto fenómenos de separación y transporte de sus partículas.

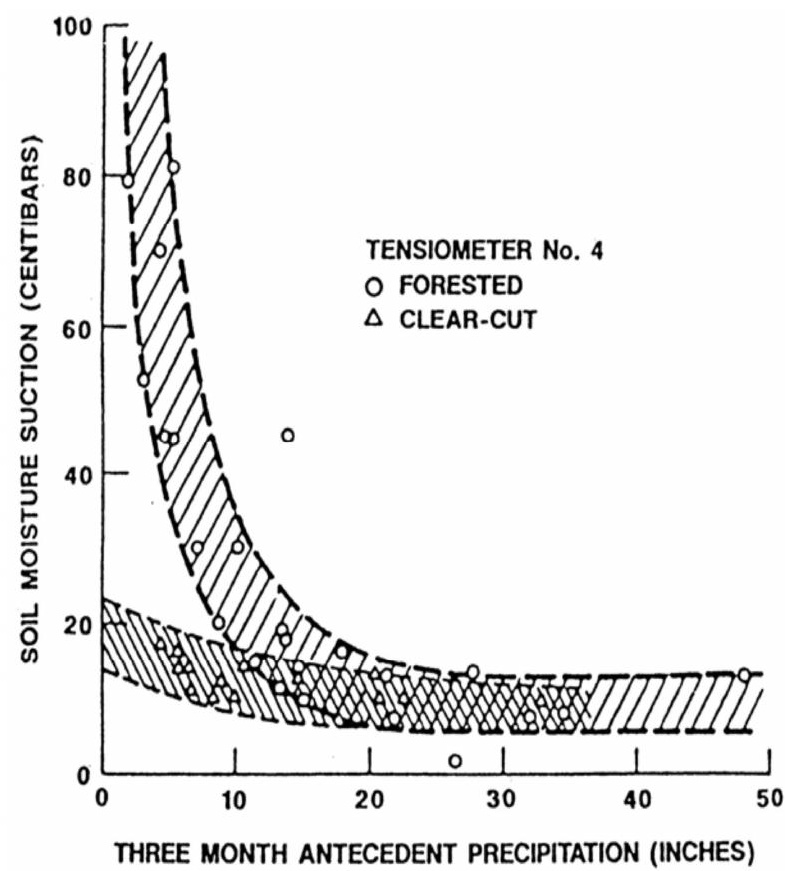

Figura 6: Succión del suelo en función de la precipitación, Gray. 1978.

La susceptibilidad de un suelo a sufrir erosión se mide a través de un coeficiente que depende de la textura del suelo y la longitud e inclinación del talud. Sobre el efecto de la longitud e inclinación del talud en el transporte de las partículas de suelo una vez se han visto disgregadas por el impacto de la lluvia o por la acción de una corriente de agua, el análisis se suele realizar por medio de un factor denominado factor de longitud-inclinación del talud. 


\section{2.- ECUACIÓN UNIVERSAL DE PÉRDIDA DE SUELOS}

USLE es un método que utiliza seis factores: erosividad de la lluvia $(\boldsymbol{R})$, susceptibilidad de erosión del suelo $(\boldsymbol{K})$, largo de la pendiente $(\boldsymbol{L})$, magnitud de la pendiente $(\boldsymbol{S})$, cubierta y manejo de cultivos y residuos $(\boldsymbol{C})$, y prácticas de conservación $(\boldsymbol{P})$, para estimar la pérdida de suelos promedio $(\boldsymbol{A})$ por el periodo de tiempo representado por $\mathrm{R}$, generalmente un año.

\section{$A=R \times K \times L \times S \times C \times P$}

- $\boldsymbol{A}$ - Es la pérdida de suelos calculada por unidad de superficie, expresada en las unidades seleccionadas para $\mathrm{K}$ y el período seleccionado para $\mathrm{R}$, generalmente toneladas ( $\mathrm{t}$ ) hectárea $(\mathrm{ha})^{-1} \mathrm{año}{ }^{-1}$.

- $\quad \boldsymbol{R}$ - El factor lluvia y escurrimiento, es el número de unidades de índice de erosión pluvial (EI), más un factor para escurrimiento por derretimiento de nieve o aplicación de agua. El El para una tormenta es el producto de la energía total de la tormenta (E) y su máxima intensidad en 30 minutos (I).

- $\boldsymbol{K}$ - El factor susceptibilidad de erosión del suelo, es la tasa de pérdida de suelos por unidad El para un suelo específico, medido en una porción de terreno estándar (22.13 $\mathrm{m}$ de largo, $9 \%$ pendiente, en barbecho y labranza continua).

- $\quad$ - El factor de largo de la pendiente, es la proporción de pérdida de suelos en el largo de la pendiente específica con respecto a un largo de pendiente estándar (22,13 m).

- $\quad \boldsymbol{S}$ - El factor de magnitud de la pendiente, es la proporción de pérdida de suelos de una superficie con una pendiente específica con respecto a aquella en la pendiente estándar de $9 \%$, con todos los otros factores idénticos.

- $\quad \boldsymbol{C}$ - El factor cubierta y manejo, es la proporción de pérdida de suelo en una superficie con cubierta y manejo específico con respecto a una superficie idéntica en barbecho, con labranza continua.

- $\quad \boldsymbol{P}$ - El factor de prácticas de apoyo de conservación, es la proporción de pérdida de suelo con una práctica de apoyo como cultivo en contorno, barreras vivas, o cultivo en terrazas, con respecto a aquella labranza en el sentido de la pendiente. 
Existen también otros índices relacionados con la susceptibilidad a la erosión como son el coeficiente de dispersión $\left(\boldsymbol{C}_{\boldsymbol{d}}\right)$, la relación entre coloides y equivalente de humedad $\left(\boldsymbol{C}_{\boldsymbol{r}}\right)$, coeficiente de erosión $\left(\boldsymbol{C}_{e}\right)$, coeficiente $\boldsymbol{C}_{s}$, etc. Estos coeficientes se encuentran definidos en distintas bibliografías relacionadas con la erosión en suelo, y permiten establecer, en función de su valor, la facilidad de un suelo a ser erosionado.

$$
\begin{aligned}
& -C_{d}=\frac{\%(\text { limo }+ \text { arcilla }) \text { sin dispersante }}{\%(\text { limo }+ \text { arcilla }) \text { con dispersante }} * 100 ;>15 \text { Fácilmente erosionable } \\
& -C_{r}=\frac{\% \text { coloides }}{\text { equivalente humedad }} ;>1,5 \text { Fácilmente erosionable } \\
& -C_{e}=\frac{C_{d}}{C_{r}} ;>10 \text { Erosionable } \\
& -C_{s}=\frac{\text { sup.específica en cm } 2 / \text { gr de partículas } \phi \text { entre } 0,05 \mathrm{y} 2 \mathrm{~mm}}{\% \text { limo y arcilla en suelo dispersado menos en suelo no dispersado }}
\end{aligned}
$$

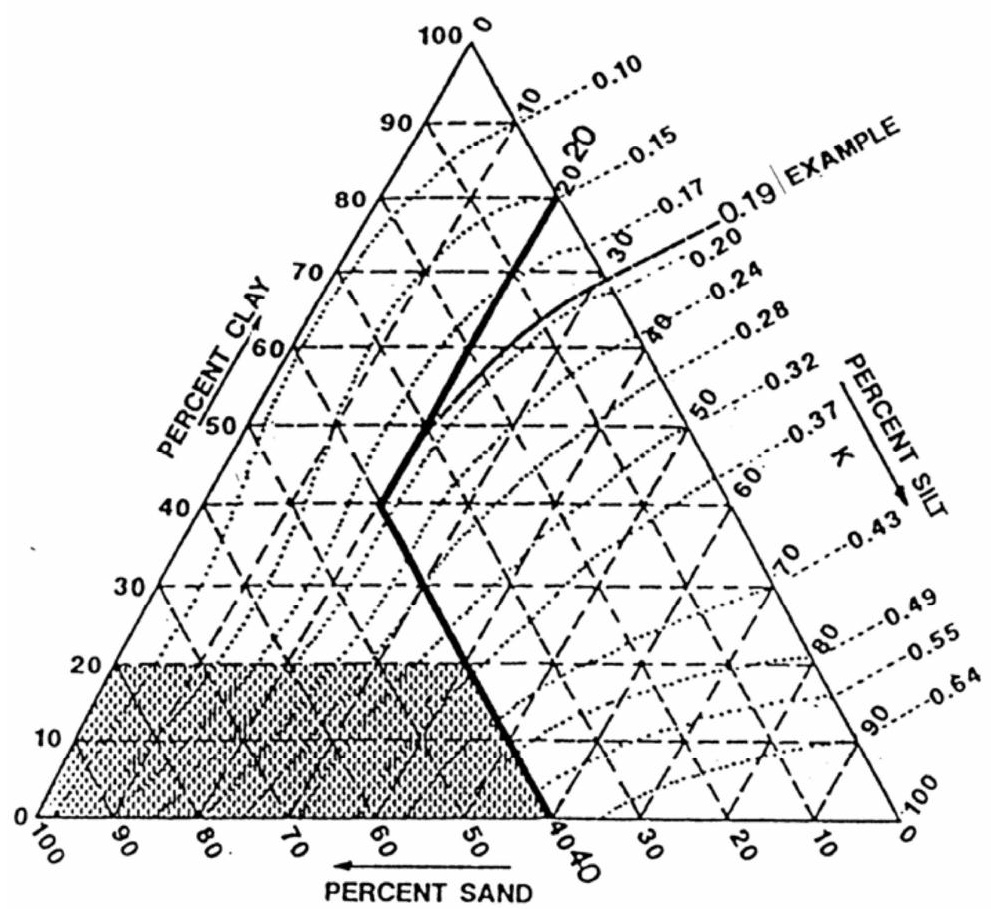

Figura 7: Gráfico para estimación del coeficiente K (Goldman et al, 1986). 


\section{5.- EFECTOS DE LA VEGETACIÓN EN LA ESTABILIZACIÓN DE TALUDES}

\section{1.- EFECTOS FÍSICOS DE LA VEGETACIÓN}

La vegetación constituye una interfase de interacción entre el suelo y la atmósfera que se manifiesta a través de una serie de efectos hidrológicos y mecánicos.

Influye en la forma de transferencia del agua de la atmósfera al suelo, y modifica en cierta medida los sistemas de drenaje superficial y profundo de éste. La existencia de una cubierta vegetal incrementa la capacidad de almacenamiento de agua del suelo y su tasa de infiltración. Como consecuencia se produce una reducción del volumen de escorrentía generado y de su velocidad, con el consiguiente efecto sobre la intensidad y extensión de los procesos erosivos.

Como efectos mecánicos, la vegetación aumenta la resistencia al deslizamiento y la estabilidad del suelo, al tiempo que protege la superficie del terreno ante la acción de algunos agentes externos, como el viento.

\subsection{1.- Efectos hidrológicos de la vegetación}

\subsubsection{1.- Intercepción del agua de lluvia}

La cubierta vegetal intercepta y retiene una proporción variable del volumen de agua de precipitación. Parte se almacena en las hojas y tallos y desde allí regresa a la atmósfera por evaporación, el resto, que se denomina precipitación temporalmente interceptada (P.T.I.), pasa al suelo escurriendo por tallos, ramas y troncos, o goteando desde la superficie de las hojas.

De este efecto de intercepción se derivan interesantes consecuencias para la conservación y protección del suelo y la estabilización de laderas:

- Se reduce el volumen de precipitación que alcanza la superficie del terreno y, por tanto, la cantidad de agua capaz de producir remoción y movilización de las partículas del suelo.

- Se retrasa la llegada de la lluvia al suelo, disminuyéndose así la intensidad de la precipitación. 
- Se evita el impacto directo de las gotas de lluvia sobre el suelo y se disipa su energía erosiva al frenar su caída.

En principio y suponiendo que la lluvia cae verticalmente, el volumen de agua de intercepción es directamente proporcional al grado de cubierta vegetal, aunque las condiciones de la precipitación influyen directamente sobre este fenómeno, así como las características morfológicas de las plantas.

Por ejemplo, con lluvias de intensidad moderada, el volumen de agua interceptada puede alcanzar el $100 \%$ de la precipitación recibida, mientras que con aguaceros tormentosos no supera el $25 \%$. Respecto al tipo de vegetación, las cubiertas herbáceas continuas tienen una capacidad de intercepción máxima superior a las formaciones leñosas, y dentro de estas, las masas arbóreas de hoja perenne, interceptan un volumen de precipitación mayor que las de hoja caduca.

La parte de la precipitación interceptada que no se evapora alcanza el suelo bajo la cubierta vegetal por escurrimiento a lo largo de tallo, ramas y troncos, o por goteo desde las hojas y otras estructuras vegetales.

El escurrimiento reduce la energía cinética del agua de lluvia y con ello su capacidad erosiva, aunque en las cubiertas arbóreas y arbustivas puede producirse una concentración del agua en líneas de flujo preferente.

En estos casos, la intensidad efectiva de la lluvia en los puntos de llegada del agua al suelo puede alcanzar valores de hasta el 150-200 \% de la precipitación recibida, provocando la disgregación y arrastre de las partículas del suelo y la generación de escorrentía. En las superficies herbáceas, por el contrario, el agua que llega al suelo tiene una distribución más regular y no se produce este fenómeno.

El potencial erosivo del agua interceptada que alcanza el suelo por goteo es función del tamaño de las gotas que se forman por coalescencia en las estructuras vegetales, y de la altura de caída, aunque, en general, su capacidad erosiva por salpicadura es notablemente inferior a la de la lluvia directa dentro de un orden de altura. Al igual que sucede con el agua de escurrimiento, la concentración de agua de goteo puede generar grandes intensidades de 
precipitación en puntos concretos. Aunque esto solo sucede en situaciones de calma, ya que el viento, al mover las ramas y hojas, evita la concentración del goteo.

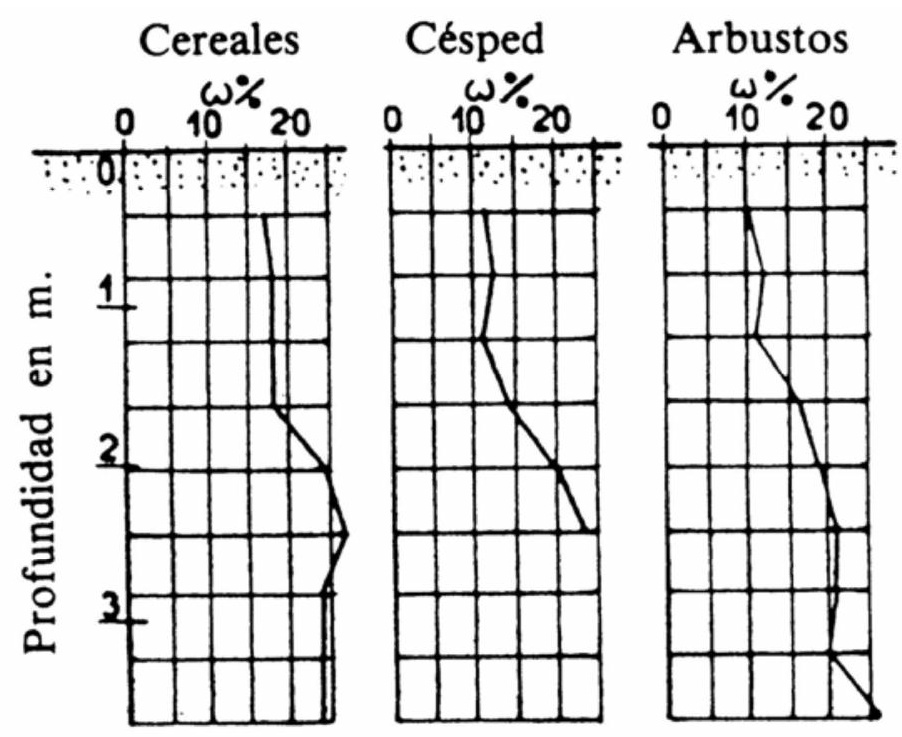

Figura 8: Disminución del contenido de humedad debido a la acción de las plantas en suelos arcillosos

A modo de ejemplo, la reducción del volumen de escorrentía por efecto de la vegetación puede llegar a ser en zonas urbanas de hasta un $60-70 \%$ de la precipitación total recibida, mientras que en zonas de cultivos, esta cantidad se reduce hasta un 30-40\%. En terrenos provistos de una cubierta vegetal densa y continua, ya sea arbórea o herbácea, el volumen de escorrentía tan solo supone de un 10 a un $20 \%$ de la precipitación total recibida.

\subsubsection{2.- Evapotranspiración}

El término evapotranspiración (E.T.P.) se utiliza para describir el conjunto de pérdidas de agua en forma de vapor debidas a la evaporación de la lluvia interceptada por la vegetación y a la transpiración de las plantas. Esta vaporización tiene lugar en un espacio tridimensional que se extiende desde las capas superficiales del suelo hasta la altura extrema alcanzada por la vegetación, denominada superficie evaporante.

Uno de sus principales efectos sobre el suelo es que disminuye su contenido en humedad respecto a su máximo potencial, de manera que, en condiciones similares, el contenido de agua de los suelos desnudos suele ser mayor al de los suelos vegetados. Este efecto tiene importantes consecuencias, positivas y negativas, en la estabilidad y el régimen 
hidrológico superficial de los suelos. Uno de los más interesantes es que incrementa su resistencia al corte. Esto se debe fundamentalmente a que la depresión del contenido en humedad del suelo reduce la presión de poros del agua e incrementa la succión del suelo.

Además, la disminución del contenido de agua del suelo implica un menor peso, lo que tiene un efecto beneficioso claro en laderas con riesgo de inestabilidad y de movimientos en masa. Supone una reducción en la componente tangencial de las fuerzas de corte y, por tanto, en la magnitud total de estas fuerzas que inducen inestabilidad. También influye en el régimen hidrológico superficial, en cuanto a que disminuye el volumen total de escorrentía y retrasa su momento de generación.

El bombeo de agua provoca un incremento de la conductividad hidráulica del suelo y de su capacidad de almacenamiento. Así, la frecuencia con que quedan saturados y comienza el encharcamiento en suelos desnudos, es mayor que en suelos vegetados. Las plantas freatofitas, plantas que extienden sus raíces por debajo del nivel freático y extraen sus requerimientos de humedad directamente de la zona saturada, tienen altas tasas de transpiración, por lo que su capacidad para extraer agua del suelo es muy grande. Este tipo de plantas son muy útiles para el tratamiento de zonas con alta presión de poros del agua, aprovechando este efecto, aunque tienen la desventaja de que no aguantan condiciones de sequedad.

\section{Influencia de la evapotranspiración sobre la estabilidad de los suelos.}

Uno de los principales efectos de la Evapotranspiración de las plantas sobre el suelo es que disminuye su contenido de humedad respecto al de su máximo potencial.

Las plantas succionan el agua a través de las raíces, y la devuelven a la atmósfera en forma de vapor, de tal manera que, en condiciones similares, los suelos vegetados suelen tener un contenido menor de agua que los suelos desnudos.

Esta disminución de humedad tiene importantes efectos negativos y positivos sobre la estabilidad y resistencia de los suelos y en el régimen hidrológico superficial.

El esfuerzo cortante es una medida de la cohesión del suelo y de su resistencia a los esfuerzos ejercidos por: 
- Gravedad.

- Movimiento de fluidos.

- Cargas mecánicas.

Su fuerza deriva de la resistencia a la fricción que presentan las partículas que forman el suelo cuando son forzadas a deslizarse unas sobre otras o a moverse, desplazándose de sus posiciones internas, de la absorción de las tensiones o esfuerzos por los contactos sólido-sólido entre partículas, de las fuerzas de cohesión relacionadas con los enlaces de las arcillas y de las fuerzas de tensión superficial entre las películas de agua en suelos no saturados.

Todos estos factores se conocen solo cualitativamente, es por eso que en la práctica se expresa a través de la ecuación empírica (Criterio de Mohr-Coulomb):

\section{$T=c+\sigma \tan \varphi$}

Donde:

- $\quad \boldsymbol{T}=$ esfuerzo cortante requerido para producir la falla o ruptura.

- $\quad c=$ la medida de cohesión producto del tamaño de las partículas.

- $\boldsymbol{\sigma}$ =esfuerzo normal al plano cortante (todos en unidades de fuerza por unidad de superficie).

- $\boldsymbol{\varphi}=$ ángulo de rozamiento interno.

Ambos, c y $\boldsymbol{\varphi}$ deben considerarse como parámetros empíricos más que propiedades físicas del suelo.

El esfuerzo cortante disminuye al aumentar el contenido de humedad en el suelo, produciéndose en consecuencia, cambios en su comportamiento de acuerdo a la estacionalidad (estación seca y húmeda), y el comportamiento pluvial durante los eventos de precipitaciones. Con bajos contenidos de humedad, el suelo se comporta como un sólido y se fractura como respuesta a un esfuerzo, pero al aumentar el contenido de humedad se vuelve plástico y se deforma sin fracturarse.

El punto de cambio de comportamiento se denomina límite plástico. Humedeciendo aún más el suelo se alcanza el límite líquido, y este comienza a fluir por su propio peso. Si el drenaje del suelo saturado no es posible, este es sometido a más carga, la presión aumenta, la 
carga de compactación no es soportada por las partículas y el suelo se deforma comportándose como material plástico.

Por el contrario, si el drenaje es posible, el suelo soportará más carga y es probable que permanezca bajo el límite plástico y soporte un esfuerzo cortante mayor. El incremento de la resistencia al corte proporcionado por la E.T.P. se suma al refuerzo proporcionado por las raíces. Tal efecto se debe a que la depresión del contenido de humedad del suelo, reduce la presión de poros del agua e incrementa la succión del suelo:

- Al bajar la presión de poros, aumenta el contacto interpartículas, haciendo al suelo más resistente a la deformación por una eventual fuerza que actúe sobre él.

- La mayor succión también incrementa la atracción entre partículas, a través de los efectos del agua capilar residual, en suelos parcialmente saturados, ya que el efecto sostenido desarrollado por la succión en la resistencia al suelo, es debido a un incremento en la cohesión.

El grado de influencia que la disminución del contenido de humedad en el suelo tiene sobre su resistencia no se conoce a ciencia cierta con datos cuantitativos, aunque debe ser menor que la proporcionada por las raíces de las capas superficiales del suelo.

Pero si se sabe que la intensidad de este efecto depende de las características edáficas, climáticas locales y del tipo de vegetación. Por otro lado, la disminución en el contenido de agua del suelo, implica directamente una disminución del peso, lo que tiene un efecto benéfico en laderas inestables. Esta disminución de peso supone una reducción en la componente tangencial de las fuerzas de corte $y$, por tanto, en la magnitud total de estas fuerzas que inducen inestabilidad.

La disminución del contenido de humedad del suelo debida a la vegetación, también influye en el régimen hidrológico superficial, por cuanto reduce el volumen de escorrentía y retrasa su aparición. Junto a los efectos benéficos, la E.T.P. también puede provocar efectos adversos.

Es así como en ciertos suelos la extracción prolongada de agua por las raíces puede conducir a la desecación y agrietamiento del suelo. Una vez formadas estas grietas, la permeabilidad y la capacidad de infiltración del suelo, se incrementan en forma permanente 
respecto a sus condiciones originales y con ello aumenta el riesgo de deslizamiento en las capas superficiales.

\subsubsection{3.- Infiltración}

La permeabilidad y la tasa de infiltración del suelo es mayor en los que están provistos de vegetación que en los suelos desnudos, debido a una serie de efectos que interactúan entre sí (intercepción, transpiración de las plantas, mayor contacto agua-suelo en suelos vegetados, etc.).

Esto determina que, bajo las mismas condiciones edáficas, de precipitación y de pendiente, los volúmenes de escorrentía generados durante un aguacero sean menores en suelos con vegetación que en suelos desnudos, y que el momento de su generación se retrase.

Es decir, para que se genere el mismo volumen de escorrentía en un suelo provisto de vegetación se requiere mayor volumen total y mayor intensidad de precipitación. El efecto que tiene la vegetación sobre la capacidad de infiltración del suelo es muy variable y depende de ciertas características de este (textura, estructura, etc.), de la topografía del terreno y de determinadas cualidades de la vegetación, como grado de cubierta, tipo morfológico, etc.

Los fenómenos que determinan la permeabilidad del suelo y su tasa de infiltración están asociados a los siguientes procesos provocados por la presencia de vegetación.

- Retraso de la llegada al suelo del agua precipitada, y disminución de su intensidad, evitando la saturación prematura del suelo.

- Disipación de la energía cinética que contienen las gotas de lluvia, debido a la intercepción, reduciendo con esto la capacidad erosiva y por ende también la obstrucción de poros por el material disgregado, conservando de esta manera la capacidad de infiltración.

- Regulación de las tasas de humedad del suelo a través de la transpiración de las plantas, conservando su capacidad de almacenamiento y, ayudando a recuperar la capacidad de infiltración con mayor rapidez.

- Retraso del punto de encharcamiento proporcionado por la absorción de agua por la cubierta húmica y restos vegetales, con lo que se retrasa también la aparición de escorrentía superficial. 
- Disminución de velocidad de escorrentía por la presencia de vegetación que aumenta la rugosidad y el tiempo de contacto agua-suelo, con lo que aumenta la infiltración.

- Apertura de vías de entrada de agua al interior del suelo por penetración profunda de las raíces, que al morir dejan redes de canalículos por donde circula el agua con facilidad.

- Aumento de la porosidad por incorporación de materia orgánica que favorece la formación de agregados y con ello, también el equilibrio en la distribución en los tamaños de poros, aumentando la capacidad de almacenamiento y su permeabilidad.

\subsection{2.- Protección de la superficie del suelo}

El efecto debido al impacto directo de las gotas de lluvia sobre la superficie del suelo se denomina erosión por salpicadura. En ausencia de obstáculos, las gotas de lluvia golpean el suelo disgregando las partículas terrosas y proyectándolas en el aire.

La capacidad erosiva de este mecanismo es muy notable: en experiencias de laboratorio se ha observado que una gota de agua de $6 \mathrm{~mm}$ de diámetro, caída desde $2 \mathrm{~m}$ de altura, al golpear el suelo proyecta partículas a $0,6 \mathrm{~m}$ de altura y a $1,5 \mathrm{~m}$ de distancia.

Las cubiertas vegetales modifican algunos de los aspectos de la precipitación que definen su poder erosivo por salpicadura, y reducen la intensidad de este efecto:

- La vegetación forma una cubierta protectora que evita el impacto directo de la lluvia en el suelo. Es decir, actúa reduciendo el volumen de precipitación potencialmente erosivo.

- Disminuye localmente la intensidad de la precipitación al retrasar la llegada del agua al suelo.

- La intercepción disipa, o reduce, la energía cinética de las gotas de lluvia al frenar su caída.

- La capacidad erosiva de la salpicadura en un suelo es función de:

- Intensidad de precipitación

- La fracción de precipitación que alcanza el suelo, ya sea directamente o por goteo. 
- Energía cinética de la lluvia $\left(E=m \cdot v^{2}\right)$ que a su vez es función de la velocidad con que alcanza el suelo y, el tamaño de las gotas.

El grado de cubierta determina la superficie de suelo que queda protegida por la vegetación, del impacto directo de la lluvia. La máxima protección la proporcionan cubiertas del $70 \%$, o superiores.

El mantillo y los restos vegetales cumplen la misma función: debajo de doseles arbóreos altos, la capa de restos vegetales puede reducir la disgregación de las partículas de suelo un 93 $\%$ respecto a la tasa que se alcanzaría en condiciones de suelo desnudo.

Si la cubierta está pegada al suelo, o tiene una altura inferior a 0,3 m, el volumen de agua de goteo suele ser pequeño y no alcanza velocidades suficientes para que la erosión por salpicadura sea significativa. En estos casos, la pérdida de suelo decrece exponencialmente al incrementarse el grado de cubierta.

En cubiertas vegetales de menos de $0,5 \mathrm{~m}$ de altura, la pérdida de suelo decrece linealmente con el incremento del grado de cubierta. En las de más de 0,5 m de altura, si no se generan cantidades significativas de agua de goteo o las gotas resultantes son de pequeño tamaño, la pérdida decrece al incrementarse la cubierta y aumenta linealmente con la altura.

En las cubiertas de más de 0,5 $\mathrm{m}$ de altura en las que sí se generan grandes gotas de agua, la pérdida de suelo se incrementa con el grado de cubierta y puede llegar a ser superior que en el suelo desnudo. Con estas mismas condiciones de goteo y alturas de más de 2,5 m, la pérdida de suelo sigue incrementándose con la altura aunque más lentamente, hasta el límite de $6 \mathrm{~m}$, cuando el incremento del efecto erosivo por la altura de caída se hace inapreciable.

\subsubsection{1.- Escorrentía superficial}

El agua de lluvia que cae sobre la fracción expuesta de la superficie de suelo, se denomina lluvia directa, a diferencia del agua que filtra a través de una capa vegetal que se llama drenaje foliar.

Esta lluvia directa puede tomar diferentes rutas en su camino, dependiendo de las características de infiltración que presente el suelo sobre el que se precipita, de tal forma que puede ingresar al subsuelo o desplazarse a través de la superficie de la ladera, en tal caso se 
genera un flujo laminar con todas las características hidráulicas asociadas al comportamiento de fluidos, tales como el número de Reynolds:

$$
\operatorname{Re}=v r / V
$$

Donde:

- $\quad \mathbf{v}=$ velocidad del fluido

- $\quad r=$ radio hidráulico o profundidad del flujo

- $\quad \mathbf{V}=$ viscosidad cinemática del agua que nos indica el nivel de turbulencia a través de la relación de las fuerzas inerciales que actúan.

El proceso de transporte producido por la escorrentía superficial está relacionado entonces al flujo laminar que avanza hacia los pies del talud o ladera arrastrando el material susceptible de ser trasladado.

Es así como también, el agua de escorrentía actúa como agente de transporte de las partículas disgregadas por salpicadura y, a su vez, provocando disgregación sobre las partículas que permanecen inalteradas.

La capacidad de disgregación y de transporte de la escorrentía es función de:

- Volumen.

- Velocidad y nivel de turbulencia.

- Cantidad y naturaleza de los materiales arrastrados.

La disminución del volumen de escorrentía es consecuencia de la combinación de varios factores: la intercepción y evaporación del agua de lluvia; la transpiración de las plantas; la gran capacidad de absorción de las cubiertas húmicas y de los restos vegetales, que retrasa el punto de encharcamiento; la mejora de la estructura del suelo por la vegetación; y la mayor rugosidad de las superficies vegetadas que disminuye la velocidad de circulación de la escorrentía favoreciendo su infiltración.

Respecto al movimiento de la escorrentía, las cubiertas vegetales actúan como un obstáculo físico que se opone al paso de la escorrentía reduciendo su velocidad, y crean una microtopografía que diversifica las líneas de circulación del agua evitando su concentración en trazas definidas, cuyo potencial erosivo es muy superior al de los flujos laminares.

Cuando la vegetación no presenta una distribución ni un grado de cubierta uniformes, puede producirse un incremento localizado de la erosión. Cuando el flujo de agua se divide 
para sobrepasar un grupo de plantas, se produce una diferencia de presión entre la zona de aguas arriba (zona de alta presión de flujo) y la de aguas abajo (zona de baja presión de flujo), lo que origina tensiones que pueden conducir a la formación de remolinos, turbulencias y vórtices.

Es así como se aprecia que la disminución de la escorrentía es resultado de la combinación de varios factores:

- La transpiración de las plantas que bombea el agua a la atmósfera y regula las cantidades de humedad del suelo, incrementando con ello su capacidad de almacenamiento.

- La intercepción y evaporación de una fracción de la precipitación recibida, disminuyendo la cantidad de agua que alcanza el suelo. Con esto también se provoca una disminución de la intensidad de los eventos de precipitación y se retarda su llegada al suelo.

- Las cubiertas húmicas proveen al igual que los restos vegetales de una gran capacidad de absorción de agua, retrasando el punto de encharcamiento y, con ello el punto de aparición del flujo superficial.

- Mejora de la estructura del suelo a partir de la presencia de vegetación, aumentando la capacidad de infiltración.

\subsubsection{2.- Aislamiento del suelo}

La cubierta vegetal proporciona al suelo un efecto de aislamiento, al provocar un microclima en las zonas próximas, reduciendo de esta forma las variaciones de temperatura y humedad.

Esto disminuye la agresividad de los procesos de meteorización mecánica que actúan por ruptura de los agregados del suelo. Particularmente, se reducen los daños causados por los ciclos de congelación y deshielo, y de humectación y desecación del suelo. 


\section{2.- SUJECIÓN MECÁNICA DEL SUELO POR ACCIÓN DE LAS RAÍCES}

El efecto mecánico generado a partir de la presencia de vegetación está compuesto por una serie de fenómenos físicos involucrados que, a partir de las características propias del tipo de vegetación y suelo, interactúan otorgando un efecto total de variación en la resistencia al deslizamiento.

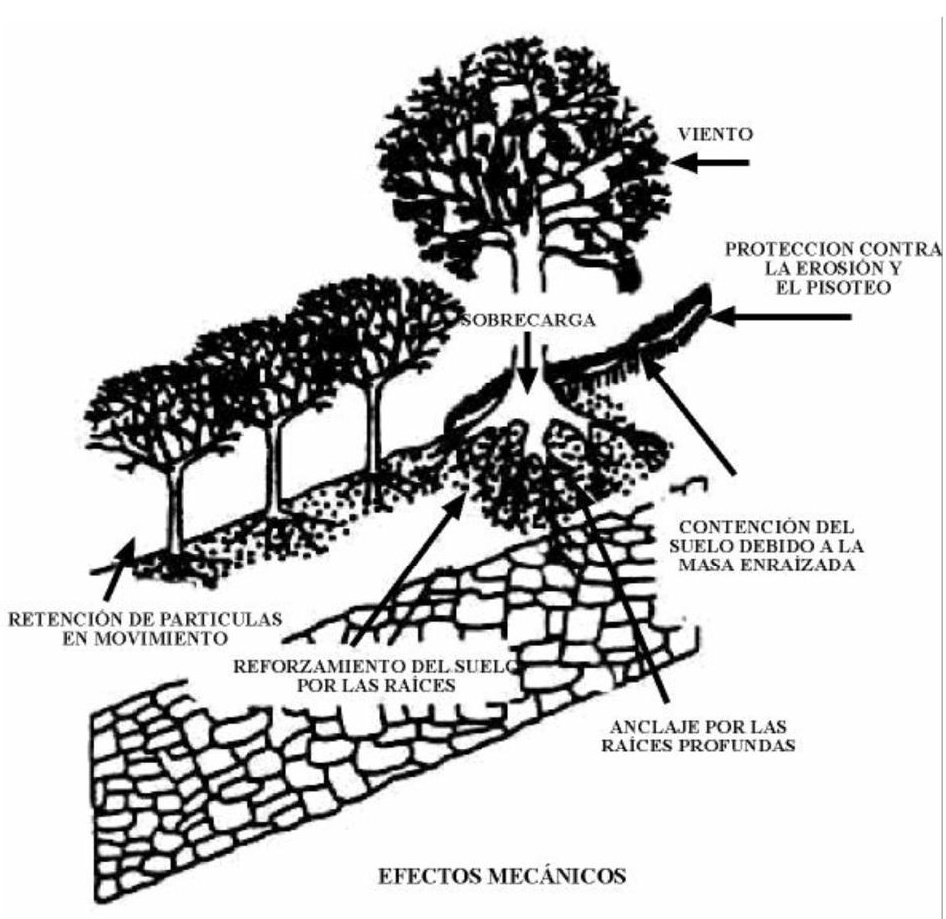

Figura 9: Efectos Mecánicos proporcionados por la vegetación sobre una Ladera.

El papel desempeñado por las raíces en términos del refuerzo del suelo no es tan simple como lo es el de las estructuras artificiales; si bien las raíces no tienen la resistencia mecánica de las bandas de acero, en el suelo se comportan de una manera más compleja, ya que ejercen fuerzas de tensión además de transferencia de tracción a lo largo y ancho del refuerzo.

Las raíces de las plantas que miden normalmente entre 1 y $12 \mathrm{~mm}$ de diámetro, retienen las partículas del suelo evitando los desplazamientos inducidos por la gravedad, el impacto de las gotas de lluvia, la escorrentía y/o el viento. Para esta función, son más efectivas las plantas que tienen un sistema radical somero y extendido, a diferencia de los que poseen una estructura radical vertical y pivotante.

Los árboles, los arbustos y los matorrales de tamaño grande son útiles para sujetar superficies inestables en las que se producen desprendimientos de material rocoso, ya que evitan que este ruede ladera abajo 
Las plantas más eficaces para esta función son las que reúnen las siguientes cualidades:

- Resistencia, entendida como capacidad para soportar el impacto de caída de los materiales sin daño, y flexibilidad, para que su ramaje y troncos se doblen sin romperse.

- Ramificación desarrollada desde la base, para ofrecer más superficie normal a la trayectoria de caída de los materiales, maximizando de esta manera el efecto de retención.

- Tolerancia al enterramiento, es decir, que sean capaces de producir nuevas raíces desde los tallos enterrados, y así desarrollar un nuevo sistema radical sobre una superficie de suelo nueva.

Puntos a favor del carácter propio a las raíces se tienen en la capacidad de recuperación y regeneración frente a daños físicos, así como en la bioadaptación, a través de la cual responden una vez se presentan condiciones desfavorables de topografía y disponibilidad de agua, entre otros (edafoecotropismo). En general, al eliminarse la vegetación de las laderas, tiende a incrementarse la inestabilidad y la frecuencia de movimientos en masa; esto es señalado por O'Loughlin y Pearce (1976) citados por Hawley y Dymond (1988), quienes exponen que hay buena evidencia de que en muchas litologías la desaparición de bosques de ladera, produce un incremento en la ocurrencia de deslizamientos.

El refuerzo de las raíces es el mecanismo más obvio de influencia de la vegetación en la estabilización de vertientes; la entremezcla de raíces laterales tiende a unir el suelo en una masa única (Gray y Leiser, 1982). En las vertientes, la raíz principal puede penetrar deslizándose.

González (1995) con relación a la resistencia que confieren las raíces al suelo, expone que el incremento en la resistencia al corte por la acción de las mismas puede alcanzar el doble de su valor cuando éstas no están presentes.

Sin embargo, el refuerzo debido a la vegetación puede ser limitado por la conformación y distribución de los sistemas radiculares, ya que no se puede garantizar en un posible movimiento en masa que las raíces atraviesen la superficie de falla, donde se da el efecto de 
refuerzo; si las raíces no la cruzan, sus efectos en la estabilidad del talud se limitan al control de la humedad del suelo y a la sobrecarga, pudiendo ser esta última desfavorable.

Gray y Leiser (1982), exponen que un suelo reforzado por raíces o fibras se comporta como un material compuesto en el cual las fibras relativamente elásticas con fuertes tensiones, se encuentran embebidas en una matriz de suelo relativamente plástico; los esfuerzos se movilizan entre la matriz y el material fibroso (raíces). Esto significa que esfuerzos de tensión en el suelo generan resistencia a la tensión en las fibras, las cuales imparten una mayor resistencia al suelo.

Sin embargo, el papel que la vegetación puede cumplir en la prevención de movimientos en masa, está centrado principalmente en movimientos someros a medianamente profundos; a este respecto, Hawley y Dymond (1988) anotan que los árboles que crecen sobre laderas inhiben los deslizamientos superficiales en su vecindad; estos autores desarrollaron un método para medir el efecto de estabilización impartido por los árboles en las laderas, especialmente válido para amplios espaciamientos entre ejemplares. Sus resultados mostraron que las pérdidas de suelo eran reducidas por concepto de los árboles en un $13,8 \%$, resaltándose que si estos hubiesen sido plantados en arreglo al cuadro de $10 \mathrm{~m}$ (malla de 10x10 m), los daños se habrían disminuido como mínimo en un $70 \%$.

En las gramíneas y leguminosas herbáceas y los arbustos de pequeño tamaño, la acción reforzadora se extiende a profundidades de entre 0,75 y $1,5 \mathrm{~m}$, y en árboles alcanza hasta $3 \mathrm{~m}$ de profundidad y se extiende alrededor de la planta.

La magnitud del refuerzo mecánico es función de los siguientes factores:

- Densidad de enraizamiento.

- Resistencia a la tracción.

- Módulo de tracción.

- Relación Longitud-Diámetro

- Rugosidad superficial.

- Índice de alineamiento de las raíces, por Ej. Rectitud / angulosidad.

- Orientación respecto a la dirección del esfuerzo principal.

Respecto a la resistencia a la tracción de las raíces, es necesario señalar las siguientes consideraciones: 
- En una misma especie, puede producirse un rango de variación de muy amplio espectro de su resistencia, dependiendo de circunstancias tales como tamaño, edad, estado de las raíces, estación del año, etc.

- Los árboles y arbustos pueden tener en raíces individuales, resistencias muy altas superiores a los $60\left(\mathrm{~N} / \mathrm{mm}^{2}\right.$ ), como sucede en el Avellano (Coryllus avellana).

- El grosor de las raíces, responde a cargas asimétricas, como las que se experimentan en los taludes.

- Las raíces de las herbáceas poseen también una resistencia alta, especialmente las especies perennes.

\subsection{1.- Mecanismos de refuerzo producidos por las raíces}

Los principales factores que determinan el desarrollo de las raíces son:

- Disponibilidad de nutrientes en el suelo.

- Disponibilidad de oxígeno.

- Contenido de humedad.

- Succión o presión osmótica.

- Temperatura del suelo.

- Niveles de toxinas y elementos patogénicos.

- Sistema de poros.

Las características de las raíces dependen de la especie vegetal, la edad, las propiedades del perfil de suelo y el medio ambiente.

\subsubsection{1.- Profundidad de las raíces}

La profundidad de las raíces generalmente no supera los cuatro metros en árboles grandes, 70 centímetros en los arbustos y 30 centímetros en los pastos; aunque se han dado casos de raíces de árboles de más de 30 metros de profundidad (Macgregor y Macmanus, 1992).

La extensión lateral del sistema radicular generalmente es mayor que su profundidad y en algunos casos supera los 50 metros de longitud. 
La longitud de las raíces y su profundidad deben evaluarse para determinar su efecto sobre la estabilidad de un talud. Watson y O'Loughlin (1990) midieron el tamaño de las raíces de un pino Monterrey de 25 años y encontraron que mientras la raíz se extendía lateralmente 10,4 metros, alcanzaba una profundidad máxima de solamente 3,10 metros y un promedio de 2,4 metros.

Se ha encontrado que la longitud de las raíces es mayor cuando el árbol se encuentra en un suelo bien drenado granular, que cuando se encuentra en un suelo arcilloso. Aparentemente, este efecto se debe a la necesidad que el árbol tiene de buscar agua en el caso de que el drenaje sea bueno.

Ante la dificultad de poder determinar con precisión la longitud de raíz debido a la poca información existente sobre las características radiculares de las diversas especies, se puede tomar como regla general que la raíz se extiende lateralmente 1,5 veces el radio de la corona del follaje, aunque debe tenerse en cuenta que en algunos casos, las raíces pueden extenderse hasta 22 veces el radio de la corona (Kozlowski, 1971).

La profundidad de refuerzo de las raíces de los pastos es de solo 20 centímetros comúnmente, pero algunas especies tienen profundidades que permiten el anclaje a mantos de roca relativamente profundos.

Se conoce algún individuo de Eucaliptus con raíces de hasta 27 metros y raíces de bosque tropical hasta de 30 metros de profundidad, pero la mayoría de los árboles tienen raíces de profundidad hasta de tres metros (Greenway, 1987), y esta es la profundidad hasta la que puede confiarse un refuerzo con raíces.

Algunas plantas (Greenway, 1987) poseen un sistema de raíz "extensivo", en el cual las raíces alcanzan profundidades o extensiones grandes, mientras otras forman un sistema "intensivo" con raíces más cortas y finas.

Leventhal y Mostyn (1987) indican que las raíces de diámetro menor a 20 milímetros, son las más importantes para la estabilidad de un talud que las raíces de mayor diámetro. 


\subsubsection{2.- Densidad de raíces}

Otro factor que contribuye a la resistencia del sistema suelo - raíces es la densidad de raíces por volumen de suelo. El número de raíces por unidad de área y su diámetro, puede evaluarse como una relación de áreas raíz-suelo en un plano determinado de falla.

Un sistema de recolección de información consiste en tomar muestras de suelo con raíces, por un sistema de tamizado separar las raíces de suelo, y con la comparación de los volúmenes determinar la relación raíz-suelo.

\subsection{2.- Clasificación de sistemas de refuerzo}

Una clasificación del refuerzo de taludes con las raíces de los árboles fue propuesta por Tsukamoto y Kusakabe (1984).

- TIPO A.- Taludes que poseen una capa muy delgada de suelo sobre roca masiva y sin defectos que permitan puntos de anclaje para las raíces y una superficie de falla potencial entre el suelo y la roca.

- TIPO B.- Una capa delgada de suelo sobre una roca con fracturas o defectos que permiten la entrada y anclaje de las raíces.

- TIPO C.- Varias capas de suelo y las raíces penetran normalmente las interfaces, reforzando los contactos entre las diversas capas.

- TIPO D.- Taludes con una capa gruesa de suelo y raíces a profundidades superiores a las de las superficies potenciales de falla. 
MEMORIA

\begin{tabular}{|l|l|l|}
\hline Tipo de Talud & Descripción & Efecto Estabilizador de Raíces \\
\cline { 2 - 4 } & $\begin{array}{l}\text { Una capa de suelo relativamente delgada } \\
\text { totalmente reforzado por las raices, sobre una } \\
\text { masa rocosa impenetrable para las raíces }\end{array}$ & $\begin{array}{l}\text { Pequeño, El plano de rotura esta } \\
\text { en contacto con la roca }\end{array}$ \\
\cline { 2 - 4 } & $\begin{array}{l}\text { Similar al tipo anterior, a expeción de que la masa } \\
\text { rocosa es discontinua y las raíces han penetrado } \\
\text { en ella. Los troncos y raíces actúan como puntales } \\
\text { de contención }\end{array}$ & Alto \\
\cline { 2 - 4 } & $\begin{array}{l}\text { Capa de suelo mas gruesa, con una capa de } \\
\text { transiciónen la que la densidad y la resistencia al } \\
\text { corte se incrementa con la profundidad. La } \\
\text { penetración de raíces en esta capa proporciona }\end{array}$ & Sustancial \\
\cline { 2 - 4 } & $\begin{array}{l}\text { Gruesa capa de suelo por debajo de la zona de } \\
\text { enraízamiento, en la que los árboles flotan. }\end{array}$ & $\begin{array}{l}\text { Pequeño efecto de inestabilidad } \\
\text { asentamiento }\end{array}$ \\
\hline
\end{tabular}

Figura 10: Tipos de reforzamiento radicular y anclaje del terreno en pendientes. Tsukamoto y Kusakabe, 1984 ob. cit Mataix, 2000.

\subsection{3.- Refuerzo del terreno por incremento resistencia a cortante}

\subsubsection{1.- Fundamento teórico del mecanismo de refuerzo}

En las laderas se tienen dos tipos de agentes que explican los movimientos según la forma en que actúan:

- Factores condicionantes.- Se refieren a aquellos que establecen las características de resistencia de las vertientes y los esfuerzos que se generan en ellas.

- Factores desencadenantes.- Tienen que ver con la producción de variaciones en tales características de resistencia y esfuerzos, rompiéndose con ello el equilibrio estático existente entre ellos.

El equilibrio más precario en las laderas es aquel existente entre la resistencia y el esfuerzo cortante; como ya se comentó, la resistencia al corte queda determinada por el criterio de Mohr-Coulomb, que combina la cohesión y el ángulo de rozamiento interno:

$$
T=c+\sigma \tan \varphi
$$


En esta expresión $\boldsymbol{T}$ es la resistencia al corte; $\boldsymbol{c}$ es la cohesión efectiva; $\boldsymbol{\sigma}$ es el esfuerzo efectivo; y $\boldsymbol{\varphi}$ el ángulo efectivo de rozamiento interno. Las raíces incrementan la resistencia al corte del suelo en un término $\boldsymbol{\Delta} \mathrm{T}$ o $\boldsymbol{\Delta} \mathrm{c}$; este último, producto de la creación de una falsa cohesión (pseudo cohesión).

La cohesión y el ángulo de rozamiento interno, son función del material, la estructura, la vegetación que sustenta, y las condiciones hídricas de la ladera. Por su parte, el esfuerzo cortante depende del peso del material que integra y sustenta la ladera y de su pendiente.

En teoría, cuando ocurre una falla, la raíz se deforma para actuar como refuerzo, desarrollando resistencia a la tracción, evitando de tal forma no sólo su rotura, sino además retardando la falla del suelo. Han sido desarrollados modelos teóricos para explicar el comportamiento de las raíces cuando el suelo es sometido a esfuerzos cortantes. Algunos de ellos sugieren que las fuerzas de tensión que se desarrollan en las raíces cuando el suelo es sometido al esfuerzo cortante, son resueltas en una componente tangencial que resiste directamente la cizalladura, y una componente normal o perpendicular que incrementa la concentración del esfuerzo en el plano de cizalladura, y que tiene que ver con la unión que favorecen las raíces del conjunto de suelo, entre capas.

La cohesión y el ángulo de rozamiento interno, se incrementan por la acción de las raíces, así, cuando una raíz cruza la zona de cizalladura, se somete a una fuerza de tensión (tr), y la tensión se descompone en una parte perpendicular y otra paralela a la zona de cizalladura ( $\sigma r$ y $\boldsymbol{\tau r}$ ), tales que $\boldsymbol{\tau}_{r}=\operatorname{tr} \operatorname{sen} \beta, \sigma_{r}=\operatorname{tr} \cos \beta$. Se dice que $\sigma r$ incrementa el esfuerzo normal, el cual es proporcional a la componente friccional, y tr es la fuerza de tensión de la raíz. El ángulo $\boldsymbol{\beta}$, es la inclinación del plano de deslizamiento.

En general, el incremento en la resistencia al corte debido a las raíces, es función de la resistencia a la tracción de las raíces o fuerza promedio de las raíces a la tensión $\left(\mathbf{t}_{\mathrm{r}}\right)$ y una relación de áreas: Área efectiva de las raíces cruzada por la superficie de rotura $\left(A_{r}\right)$ y Área de superficie potencial de falla o área total de la superficie de rotura $(A)$, las cuales tienen que ver con la densidad de raíces en la superficie de rotura y la inclinación de las mismas con respecto a la superficie de rotura $(\boldsymbol{\beta})$, tal que:

$$
\begin{aligned}
& \Delta T=1,2 \tau r \\
& r=t_{r}\left(A_{r} / A\right)
\end{aligned}
$$


Si el esfuerzo cortante en el suelo excede cierto valor crítico, el suelo falla; dicho valor crítico depende de las propiedades del suelo (cohesión c y ángulo de rozamiento interno $\boldsymbol{\phi}$ ) y de las condiciones ambientales.

Los factores condicionantes son prácticamente constantes (tipo de material y estructuración del mismo); los modificables son la pendiente, el contenido de humedad, la vegetación y las cargas que sustenta la ladera, así, es sobre éstos que actúan los factores desencadenantes.

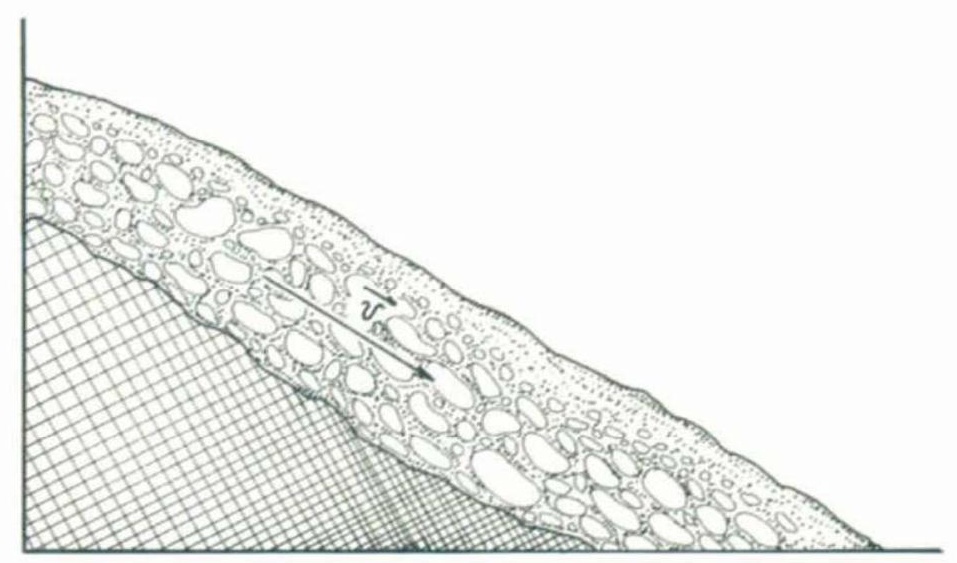

Figura 11: Corte o cizalladura

Dentro de los factores condicionantes se destaca la cobertura vegetal, en especial el papel cumplido por los sistemas radiculares dando un armazón cohesivo al conjunto del suelo, sin embargo, la vegetación puede hacer las veces de factor desencadenante, al penetrar las raíces sustratos rocosos, abriendo grietas

en laderas propensas a desprendimientos y deslizamientos traslacionales, ya que en éstos la superficie de rotura se produce a favor de tales discontinuidades.

Asimismo, con el crecimiento de la vegetación se aumenta el peso por concepto de biomasa, actuando como fuerza motora, por el contrario, la liberación brusca de tales sobrecargas por talas masivas (modalidad de tala rasa en el aprovechamiento del bosque), es negativa por el esponjamiento que se produce del suelo y la elevada carga hídrica que éste adquiere en épocas o en zonas lluviosas.

Por otra parte, un factor condicionante de gran importancia es la carga hídrica, ya que su presencia reduce la estabilidad de las laderas, entre otras, por las siguientes razones: 
- Lubricación de superficies potenciales de movilización.

- Aumento del peso del terreno, generación de esfuerzos desestabilizadores.

- Reducción de los estabilizadores.

La resistencia a la tracción de las raíces no es constante, ya que depende de lo maderables que sean, esto es que hayan desarrollado la albura, el durámen y la médula, que componen el xilema. Las raíces jóvenes son muy flexibles, ya que se acomodan a las condiciones de suelo, y las raíces maduras se comportan como madera, presentando una mayor rigidez.

Se han encontrado valores de resistencia máxima del suelo sin refuerzo del orden de $0,22 \mathrm{~kg} / \mathrm{cm}^{2}$, valor que con raíces de eucaliptos se incrementa en un $65 \%$. Por otra parte, con raíces de pino se han obtenido incrementos del $111 \%$, siendo los mayores valores de refuerzo obtenidos cuando se tiene un alto número de raicillas de diámetros pequeños; asimismo la resistencia al corte de un suelo reforzado con raíces es del orden del $100 \%$ de la resistencia aportada por el suelo sin refuerzo, pudiendo ser incluso mayor (González, 1995).

\subsection{4.- Efecto de Anclaje}

Un efecto positivo muy importante es el "anclaje" de masas de suelo por las raíces. Las características físicas de las raíces determinan el efecto de anclaje o refuerzo del suelo, y la densidad del sistema radicular mejora la retención de las partículas o masas de suelo, aumentando la resistencia a la erosión.

El fenómeno del efecto de refuerzo de las raíces debe estudiarse en una forma global, analizando la superficie de falla al cortante de un talud, pudiéndose observar dos elementos principales:

- La movilización de la resistencia a la tensión de las raíces por efecto de anclaje de las raíces a materiales más resistentes. Este efecto es muy importante en perfiles de poco espesor de suelos residuales, en los cuales las raíces se anclan en la roca o en los materiales menos meteorizados.

- La profundización de la superficie crítica de falla en profundidades por debajo del volumen de presencia densa de raíces. Este efecto es importante en perfiles de suelo de gran espesor. 


\subsection{5.- Efecto de Arco}

Para reducir el riesgo de movimientos, el espaciamiento de los árboles debe ser lo más cercano posible. Un árbol junto a otro puede generar un efecto de arco.

Sin embargo, no se requiere que las raíces se entrelacen y el efecto de arco puede lograrse con separaciones de raíces entre 3 y $10 \mathrm{~m}$ dependiendo de las características del material del talud y del tipo de árbol (Gray, 1978). Una separación de $10 \mathrm{~m}$ entre árboles de grandes raíces produce soporte sustancial en la mayoría de los casos.

\section{3.- RESISTENCIA DEL SISTEMA SUELO - RAÍCES}

En la literatura se encuentran informes contradictorios relacionados con el efecto de las raíces sobre la resistencia al cortante de los suelos.

Gray (1974) observa que las raíces aumentan la resistencia al cortante por incremento de la cohesión aparente del suelo, reportando incrementos de resistencia hasta de 3 a 4 veces.

Yagi y otros (1994) encontraron en pruebas de laboratorio que no existe prácticamente ninguna variación en el ángulo de fricción interna efectivo del material del suelo por la presencia de raíces o el aumento del porcentaje volumétrico de raíces en el suelo.

Gray y Ohashi (1983) indicaron que la orientación de las raíces en un ángulo de 60 grados con la superficie de cortante, aumenta a un máximo la resistencia al cortante equivalente a la dirección principal de tensión, lo cual se entiende como una resistencia generada por la tensión en las raíces.

La resistencia a la tensión de las raíces puede ser hasta el 30\% de la del acero según Schiechtl (1980) y pueden extenderse varios metros por debajo de la superficie del talud.

La resistencia promedio a la tensión de las raíces depende de las características y estructura de la planta y puede variar desde 1300 psi (Pounds per Square Inch - unidad de presión cuyo valor equivale a 1 libra por pulgada cuadrada), hasta 7000 psi (Burroughs y Thomas, 1976; Gray, 1978 y Turmanina, 1965). 
Las raíces de árboles y arbustos poseen un comportamiento a la tensión con un bajo módulo de elasticidad y según Gray y Ohashi (1983), no se rompen durante el proceso de corte del suelo. Sin embargo, ensayos realizados con raíces en Colombia muestran deformaciones a rotura muy compatibles con el comportamiento al cortante de los suelos en la mayoría de las raíces ensayadas, especialmente en raíces con diámetro superior a $1 \mathrm{~mm}$.

Las raíces de mayor diámetro dan generalmente, menores valores de resistencia a la tensión en las mismas condiciones, sin embargo, al realizar pruebas con raíces de diferente árbol pero del mismo tipo o variedad, los resultados de resistencia a la tensión pueden variar hasta en un $500 \%$, lo cual dificulta la asignación de una resistencia específica para elaborar un modelo matemático.

La relación entre la resistencia a la tensión de la raíz y su diámetro puede expresarse en la forma de una simple ecuación logarítmica:

$$
T_{r}=n \times D^{m}
$$

Donde:

- $\quad T_{r}=$ Resistencia a la tensión de la raíz.

- $\quad \mathrm{D}=$ Diámetro.

- $\quad \mathrm{n}$ y $\mathrm{m}=$ Constantes empíricas que se deben determinar para cada especie de árbol.

La edad del árbol y sus condiciones ambientales (clima, humedad, suelo, etc.) producen un cambio importante en la resistencia a la tensión de las raíces. Suyama (1992), informa de que las raíces individuales aumentan su resistencia a medida que ellas son más largas.

Los ensayos de resistencia a la tensión en raíces han sido difíciles debido a que se tienen problemas con las mordazas, en razón de que la piel de las raíces o las fibras exteriores tienden a deformarse, independientemente de las fibras interiores y las mordazas tienden a soltarse.

\subsection{1.- Metodología de análisis}

Para facilidad en el empleo de modelos sistematizados de análisis se utiliza la siguiente metodología:

- Se determina el espesor de la capa de suelo con raíces. 
- Se hace un análisis de número de raíces por unidad de área, diámetros y resistencia, y se obtiene la resistencia a la tensión de las raíces por unidad de área de suelo.

- Se realizan ensayos de tensión y de deformación de raíces para determinar qué diámetros de raíces no se deben tener en cuenta en el análisis (de acuerdo a su porcentaje de deformación a rotura).

- Se calcula la fuerza a la tensión de las raíces por unidad de área de suelo.

$$
F_{r}=\sum a_{r} \times f_{r}
$$

Donde:

- $\quad a_{r}=$ Area neta de raíces (tomada de la relación de áreas raíz-suelo).

$\mathrm{f}_{\mathrm{r}}=$ Resistencia a la tensión de la raíz (de acuerdo a la variedad vegetal).

- La fuerza de tensión puede analizarse como una fuerza de anclaje horizontal o puede convertirse en cohesión aparente $(\mathrm{Cr})$, adicionándose a la cohesión del suelo.

\subsection{2.- Resistencia al arrancamiento}

Otro elemento importante es la resistencia de la raíz al arrancamiento. En pruebas de arrancamiento en campo generalmente, la raíz se rompe y no se deja arrancar y al observar fallas de arrancamiento por fuerza del viento en la mayoría de los casos, el suelo es arrancado conjuntamente con la mayor parte del sistema radicular y la falla a rotura de las raíces ocurre sobre una superficie en la cual la densidad de raíces es menor, solo en algunas ocasiones las raíces profundas son arrancadas.

\subsection{3.- Morfología radicular}

El desarrollo y la estructura de los sistemas radiculares son controlados en general por caracteres genéticos e influenciados por el medio que los rodea (Gray y Leiser, 1982).

Así como son analizados factores del orden edáfico, climático, social, económico y cultural, la profundidad y la extensión del sistema radicular deben ser asimismo considerados para la elección de plantas a incluir en programas de estabilización de suelos y para el cubrimiento de vertientes de montañas. A tal respecto, especies de raíces profundas son 
preferibles para estabilizar suelos e incrementar la resistencia en zonas de ladera; esto puede ser tomado como premisa general pero dicho tipo de vegetación podría no ser la más conveniente. En general se recomiendan especies con raíces largas, flexibles y de una alta concentración por volumen.

El sistema radicular de arbustivas y arbóreas consiste de una parte radicular lateral y una radicular central vertical; las raíces laterales unen el suelo en una masa unitaria, en tanto que las verticales evitan el deslizamiento en las laderas al hacer las veces de elementos de anclaje.

En general, se dice que en razón de los requerimientos de oxígeno, la mayoría de las raíces se concentran cerca de la superficie. Por otra parte, algunos autores exponen que las herbáceas no son tan efectivas como las leñosas para el restablecimiento de las laderas dada la mayor debilidad de sus raíces y menor profundidad, sin embargo, su efecto protector contra el impacto directo de las gotas de lluvia es indiscutible.

\subsubsection{1.- Esquemas de refuerzo radicular}

Existen distintos tipos de esquemas de refuerzo radicular, los cuales han sido tratados en el capítulo 5.2.2.- Clasificación de sistemas de refuerzo, propuesta por Tsukamoto y Kusakabe (1984).

El esquema de refuerzo radicular tipo $\boldsymbol{A}$ describe taludes con un manto de suelo relativamente delgado que puede ser plenamente reforzado por las raíces, pero el lecho rocoso subyacente no alcanza a ser penetrado por las mismas; un plano de debilidad podría formarse en la interfase, a raíz de la falta de anclaje y el aumento en la concentración del peso.

El tipo B está representado por taludes semejantes a los anteriores, a diferencia de presentar el lecho rocoso discontinuidades que pueden ser penetradas por las raíces; la presencia de raíces de vegetación arbórea dará el mayor soporte estabilizador en estos taludes, en razón del anclaje del suelo a la roca.

Los taludes con esquema de refuerzo tipo $\boldsymbol{C}$ tienen capas delgadas de suelo que aumentan su densidad y su resistencia con la profundidad; las raíces penetran hasta encontrar un estrato competente, dándose un anclaje entre las diferentes capas del suelo.

Los taludes tipo $\boldsymbol{D}$ presentan un estrato competente en el cual las raíces pueden anclarse, sin embargo, éste se encuentra a una gran profundidad; en este caso, la acción de 
refuerzo de las raíces se extiende hasta el límite de éstas, es decir, hasta donde alcanzan a llegar.

\subsubsection{2.- Clasificación de los sistemas radiculares}

Los sistemas radiculares han sido clasificados desde diferentes ópticas. Una de ellas, la más común y de mayor relevancia para el entendimiento del papel que cumplen desde el punto de vista mecánico en las laderas, es la que se establece con base en su forma. Así, los sistemas radiculares pueden ser agrupados en dos amplias categorías (Gutiérrez, 1974):

- Fibrosas, difusas o fasciculadas: sólo para absorción, son delgadas y filiformes, la raíz principal se desarrolla poco, las secundarias y adventicias la sobrepasan en crecimiento. Estas raíces forman un manojo a manera de cabellera en la cual todas las raíces tienen las mismas dimensiones; crecen sobre los estratos superiores del suelo, logrando más extensión que profundidad.

- Pivotantes, fusiformes o axonomorfas: tienen una gran raíz principal; es común en plantas dicotiledóneas y árboles. Debido a su configuración pueden profundizarse en el suelo, teniendo lugar una mayor fijación de la planta a éste.

Por otra parte, Pritchett (1986) propone su clasificación de acuerdo al hábito de arraigamiento (dirección morfológica y distribución de las raíces estructurales más grandes) y por la intensidad de la raíz (forma, distribución y número de raíces pequeñas). Aunque el hábito o forma es influenciado por las condiciones locales, éste tiende a estar bajo control genético; se exponen tres tipos de sistemas:

- Sistema axonomorfo: caracterizado por presentar una raíz principal con fuerte crecimiento hacia abajo, la cual puede ramificarse. Este es el caso de algunas especies de leguminosas y otras como Juglans $s p$ y Quercus $s p$, Taxus $s p$, etc.

- Sistema fibroso: presenta muchas raíces ramificadas diagonalmente desde la base del árbol, sin ninguna raíz principal definida. Se citan entre otras especies, las siguientes: Larix sp, Betula sp, Tilia $s p$, y especies de gramíneas. 
- Sistema radiado: sistema radicular poco profundo con fuertes ramificaciones laterales a partir de las cuales hay ramificaciones verticales. Se citan los géneros Populus, Fraxinus, Pinus y la especie leguminosa Gliricidia sepium.

\subsubsection{3.- Desarrollo del sistema radicular}

El desarrollo de las raíces exhibe diferentes respuestas en función de las condiciones del medio, aún cuando se afirma que su crecimiento está bajo control genético.

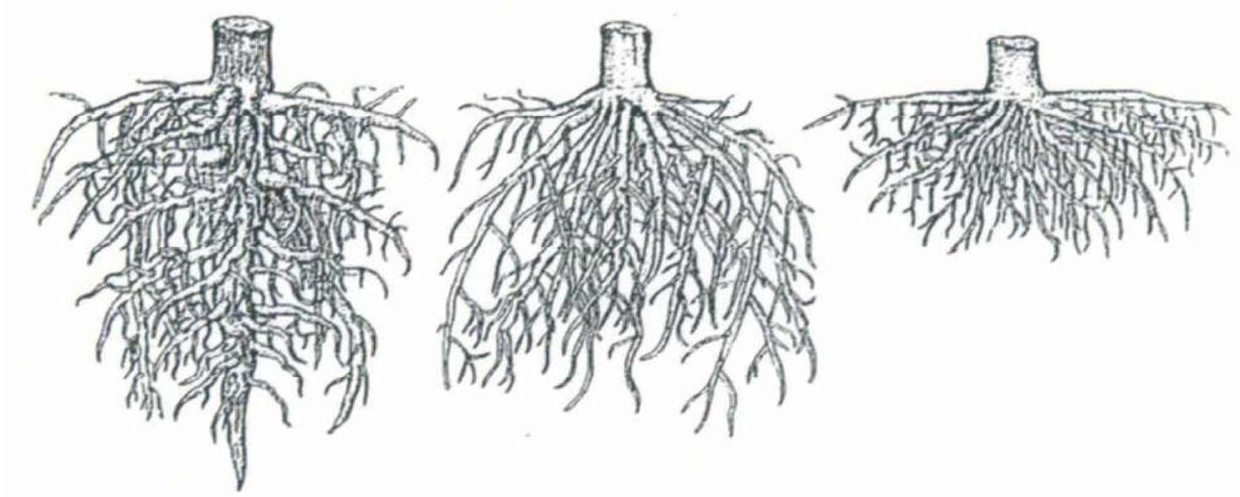

Figura 12: Tipos de sistemas radiculares Pritchett (1986).

\subsubsection{4.- Tipos de crecimiento de las raíces en el suelo}

- En suelos densos, de texturas pesadas, las raíces tienden a seguir roturas y fisuras $\sin$ necesariamente penetrar los agregados.

- El desarrollo de la raíz es más rápido en suelos arenosos, sueltos.

- Las raíces tienen un mayor desarrollo donde hay mayor cantidad de nutrientes (K, Ca, $\mathrm{Mg}, \mathrm{NH}_{4}$ ); al respecto, Piedrahíta (1987) menciona que la incapacidad de muchas raíces para penetrar suelos se relaciona más estrechamente con la carencia de alimentos que con la resistencia mecánica o la aireación deficiente.

- En suelos sueltos, las raíces tienden a ramificarse para compensar el tamaño del grano en la rata de absorción de nutrientes.

- Los ejes radiculares tienden a crecer en línea recta, así, cuando tienen que desviarse por el encuentro con un agregado, si éste es muy duro, lo rodean y tratan de tomar la dirección original. 
- La profundidad y extensión de la masa radicular es en parte resultado de la estructura genética y ambiental.

- Un alto nivel freático o un estrato impermeable cerca a la superficie tiende a inhibir el desarrollo de la raíz principal.

- El área radicular está en función del tamaño de copa, de la calidad del sitio y de la densidad del suelo.

- Si las condiciones edáficas lo permiten, la profundidad de los sistemas radiculares puede alcanzar valores del orden de 10, 3 y 1 metro para vegetación de tipo arbórea, arbustiva y herbácea respectivamente.

Es clara la importancia que reviste el conocimiento detallado de los sistemas radiculares de las especies vegetales de cara a su inclusión en programas de repoblación para la estabilización de laderas y taludes. De dicho conocimiento dependerá en buena medida el éxito alcanzado por tales programas, en la medida que las especies incluidas contribuyan efectivamente a controlar y recuperar la estabilidad, y no por el contrario, actúen como agentes desestabilizantes.

Dado el bajo conocimiento que de tales sistemas se tiene, en buen número de ocasiones se han elegido especies vegetales de manera inapropiada, en contra de los objetivos de estabilización.

\subsubsection{5.- Descripción de algunos sistemas radiculares de especies arbóreas y arbustivas}

A modo de ejemplo se describen los sistemas radiculares de algunas especies vegetales. En el Anexo II.- Inventario Forestal, se describe el sistema radicular de las especies consideradas en el presente estudio.

\section{- Pino (Pinus sp.)}

Sistema radicular radiado; Se adapta a condiciones muy precarias de fertilidad. El $85 \%$ de las raíces se ha encontrado en los primeros $30 \mathrm{~cm}$ de suelo; las raíces verticales, que se desarrollan de las laterales producen brazos lejos del tallo que logran penetrar casi la misma distancia que la raíz principal. Se tienen longitudes radiculares mayores de $2 \mathrm{~m}$ con diámetros superiores a los $10 \mathrm{~cm}$. Ashton (1975). 


\section{- Eucalipto (Eucalyptus sp.)}

Especies de crecimiento muy rápido con vida relativamente corta. Se dice que su sistema radicular es superficial, pero hay raíces pivotantes a profundidades mayores de $2 \mathrm{~m}$. Se adaptan a condiciones adversas en forma similar a los pinos. Su evapotranspiración es muy alta, razón por la cual se emplea para el secado de pantanos en algunos lugares del mundo. Durante la primera estación desarrollan una fuerte raíz principal, para luego desarrollar el sistema de raíces laterales; de estas últimas crecen las raíces "chupadoras" que son verticales y que darán el anclaje necesario después de la desaparición de la raíz principal; esta raíz principal sirve de anclaje en los primeros años de vida, pero aproximadamente a los quince años se pudre. El mayor desarrollo radicular está entre los $15-45 \mathrm{~cm}$ de suelo, y cerca del $96 \%$ de las raíces se concentra en los primeros $60 \mathrm{~cm}$. Se han encontrado raíces principales hasta de $8 \mathrm{~m}$, con diámetros promedios de $20 \mathrm{~cm}$, y pocas raíces secundarias. Ashton (1975).

\section{- Sauce (Salix sp.)}

Sistema radicular con buena capacidad de amarre y desarrollo en suelos húmedos o sometidos a períodos de inundación (especie hidrófila); sistema denso, grueso y de amplia distribución. (González, 1995).

\section{4.- SOBRECARGAS PRODUCIDAS POR LA VEGETACIÓN}

\subsection{1.- Peso de la vegetación}

Se denomina sobrecarga al incremento del peso que sufren las laderas debido a la presencia de vegetación. Este efecto solo se produce con vegetación arbórea, ya que el incremento de peso que suponen las cubiertas arbustivas o herbáceas no resulta significativo con el peso total de la masa del suelo.

La componente horizontal del peso añadido se suma a las fuerzas desestabilizadoras que inducen el movimiento del suelo pendiente abajo, y su componente vertical incrementa la fricción entre el suelo y la superficie de deslizamiento, con ello la magnitud de las fuerzas que se oponen al desplazamiento de la masa del suelo. Así pues, la sobrecarga puede afectar a la estabilidad de las laderas tanto positiva como negativamente dependiendo de cuál de los componentes sea dominante. 
En condiciones de pendiente moderada, suele predominar el efecto positivo, y la existencia de sobrecarga, debida a la vegetación, tiene un efecto beneficioso sobre la estabilidad de las pendientes.

Una cubierta vegetal formada por árboles de gran tamaño puede incrementar la fuerza normal ejercida sobre la pendiente en más de $5 \mathrm{kN} / \mathrm{m}^{2}$, aunque no más de la mitad de esta fuerza contribuye a incrementar la resistencia al corte.

La geometría de un talud, la distribución espacial de la vegetación y las propiedades del suelo, son algunos de los factores determinantes del efecto. Si la vegetación se concentra en la cabecera del talud se incrementa el riesgo de inestabilidad, ya que la resistencia cohesiva del suelo disminuye.

Por el contrario, si la sobrecarga se aplica en la parte baja del talud, se incrementa la estabilidad. En este caso, cuando la mayoría de los árboles se concentra en el pie del talud, el centro de gravedad de la masa arbórea está localizado de forma que el momento resultante se sitúa sobre el centro de rotación.

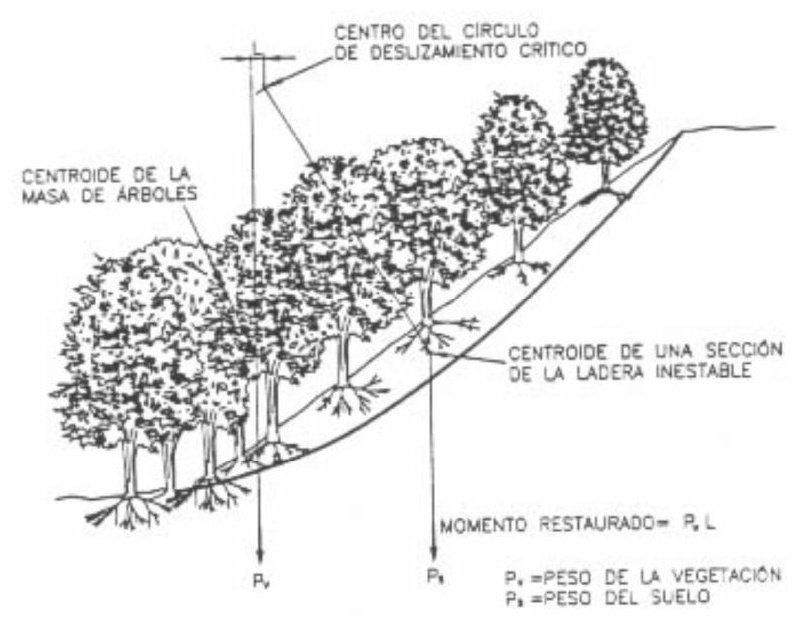

Figura 13: Efecto de sobrecarga de la vegetación sobre la parte inferior de una superficie de deslizamiento.

Esta sobrecarga, se transmite al terreno como un incremento de carga que puede afectar a las capas superiores del terreno, provocando el inicio de deslizamientos. 


\section{5.- FUERZA DE ARRASTRE DEL VIENTO}

A partir de ensayos realizados en túneles aerodinámicos, se han desarrollado diversos modelos que cuantifican la fuerza de empuje del viento. El modelo de Brown y Sheu, 1975, expresa la fuerza de arrastre de cada árbol transmitida al talud, suponiendo un viento que sopla paralelamente a la superficie del suelo, a través de la siguiente ecuación:

$$
\begin{array}{ll}
i=h 1 & \mathrm{D}=\Sigma\left(0.5^{*} \rho \mathrm{a}^{*} \mathrm{u} 2^{*} \mathrm{CA} A^{*} \cos 2 \beta * \mathrm{~b}\right) * \mathrm{i} \\
i=h 2 & \mathrm{D}=\Sigma\left(0.5^{*} \rho \mathrm{a}^{*} \mathrm{u} 2^{*} \mathrm{CA} A^{*} \cos 2 \beta^{*} \mathrm{~b}\right) * \mathrm{i}
\end{array}
$$

Donde:

- $\boldsymbol{A}=$ Fuerza de arrastre transmitida a la ladera del talud $(\mathrm{kg})$.

- $\quad \boldsymbol{h 1}$ = Altura del tronco desde la superficie del terreno hasta el comienzo de la copa, (m).

- $\quad \boldsymbol{h} \mathbf{2}=$ Altura total del árbol desde la superficie del suelo hasta el extremo superior de la copa $(\mathrm{m})$.

- $\boldsymbol{\rho} \boldsymbol{a}=$ Densidad del aire $\left(\mathrm{kg} / \mathrm{m}^{3}\right)$.

- $\quad \boldsymbol{u}=$ Velocidad del viento $(\mathrm{m} / \mathrm{s})$.

- $\quad C A=$ Coeficiente adimensional de arrastre.

- $\quad \boldsymbol{\beta}=$ Inclinación del talud (grados).

- $\quad \boldsymbol{b}=$ Anchura transversal de las copas con cada incremento de i $(\mathrm{m})$.

Según el mismo modelo, la fuerza de arrastre de cada árbol transmitida al talud, bajo las mismas hipótesis, se calcula de la siguiente manera:

$$
\mathrm{D}=\mathrm{Cdx}\left(1 / 2 \rho \mathrm{V}^{2}\right)
$$

Donde:

- $\quad \mathbf{D}=$ Empuje del viento transmitida a la ladera del talud $\left(\mathrm{kN} / \mathrm{m}^{2}\right)$.

- $\quad \mathbf{P}=$ Densidad del aire $\left(\mathrm{kg} / \mathrm{m}^{3}\right)$.

- $\quad \mathbf{V}=$ Velocidad del viento $(\mathrm{m} / \mathrm{s})$.

- $\quad \mathbf{C d}=$ Coeficiente adimensional de arrastre.

$\mathbf{C d}=0,7$ para secciones circulares con superficie lisa.

La sobrecarga debida al viento solo es significativa cuando su velocidad es superior a 11 $\mathrm{m} / \mathrm{s}$, y cuando su dirección es paralela a la línea de máxima pendiente. El empuje del viento 
sobre los árboles también puede producir una desestabilización del talud y de los propios árboles.

La fuerza que el viento ejerce sobre las plantas es transferida al interior del terreno, interviniendo en el sistema de fuerzas que operan y desestabilizándolo. Si el viento sopla con suficiente fuerza o el árbol no está bien enraizado, puede producirse la rotación y vuelco del árbol, con ello además de desestabilizarse el sistema de fuerzas del talud, se incrementa el nivel de infiltración en la cicatriz producida, efecto que es aun más crítico.

Figura 14: Representación esquemática del efecto del viento sobre el talud.

La magnitud de la fuerza de arrastre ejercida por el viento en los árboles es función de los siguientes factores:

- Velocidad del viento.

- Altura de los árboles.

- Extensión de la cubierta.

- Pendiente del talud.

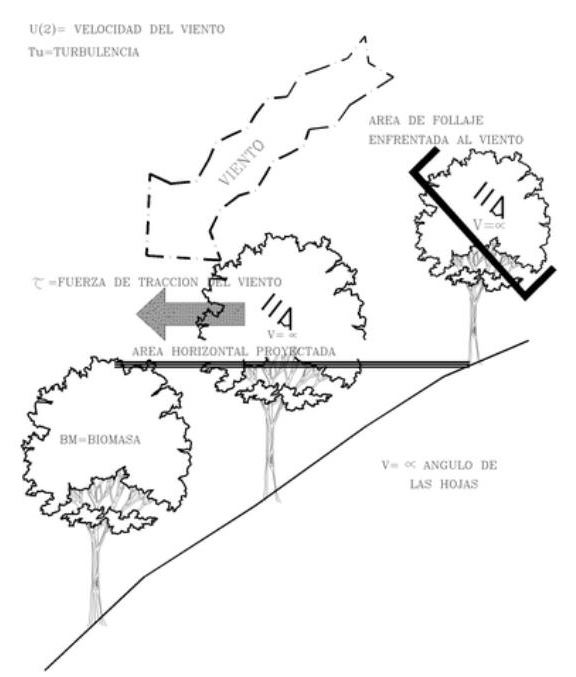

\section{6.- EFECTO SOBRE EL RUIDO}

La vegetación proporciona un efecto de atenuación del ruido, actuando como barrera que se interpone en el camino de propagación de las ondas sonoras impidiendo su transmisión y creando zonas de sombra acústica.

El mencionado efecto de atenuación del ruido es resultado de la reflexión, difracción y absorción de las ondas sonoras. Su magnitud depende de la frecuencia del sonido y de las características morfológicas y estructurales de la vegetación.

Las plantas absorben de mejor forma los sonidos de altas frecuencias que los de media y baja. Exceptuando cuando se trata de franjas anchas de vegetación arbórea, que otorgan resultados similares en toda la banda de frecuencias. 
Respecto a la morfología de las plantas, teóricamente las más efectivas son las que tienen un follaje denso formado por hojas anchas, carnosas y tallos finos, ya que permiten un mayor grado de vibración, y son más flexibles, lo que se traduce en mayores niveles de difracción y reflexión.

Prácticamente, no existe gran diferenciación entre las capacidades de atenuación del ruido de unas y otras especies, sin embargo se sabe que las especies caducifolias otorgan un efecto estacional a diferencia de las perennifolias que otorgan un efecto constante en el tiempo.

\section{6.- SELECCIÓN DE ESPECIES VEGETALES PARA SU UTILIZACIÓN EN LA REVEGETACIÓN DE TALUDES}

Para restaurar áreas degradadas por efecto de construcción de obras civiles, actividades extractivas, etc., es absolutamente necesario generar una cobertura vegetal que lo proteja y lo integre progresivamente al paisaje, cuestión que por cierto no es fácil, puesto que este proceso debe hacerse con rapidez con el objetivo de evitar la erosión hídrica y eólica que naturalmente afectan en gran medida a las superficies con fuerte inclinación.

En este sentido, surge la necesidad de investigar cuales son las especies vegetales susceptibles de utilizarse para conseguir estos efectos, es decir aquellas especies que tengan la característica de ser rústicas y que puedan iniciar el proceso de sucesión ecológica con el consiguiente proceso de generación de suelo.

Por otra parte es absolutamente imprescindible para efectos prácticos, que se cuente con una entidad que proporcione el material vegetal necesario para implementar cualquier plan de restauración, como también el estudio a gran escala de las condiciones climáticas y la planificación territorial asociada a este tipo de proyectos.

El éxito de la revegetación dependerá de variados factores que condicionan e influyen en el desarrollo de la vegetación, como de igual forma, la aplicación correcta de las técnicas adecuadas para corregir los problemas. 


\section{1.- EL PROCESO DE SELECCIÓN DE ESPECIES VEGETALES}

Este proceso metodológico tiene por objetivo central la búsqueda e identificación de los vegetales que cumplan con las condiciones de estabilización de taludes y que a la vez posean la capacidad de adaptabilidad necesaria para su uso de acuerdo a las condiciones ambientales existentes en la zona de trabajo.

Los criterios que deben ser tenidos en cuenta, son los siguientes:

- Criterios biotécnicos.

- Criterios ambientales.

- Criterios fitosociológicos.

\subsection{1.- Criterios biotécnicos}

La vegetación a utilizar debe cumplir su función como elemento estructural estabilizador o protector. Se deben entonces tener en cuenta estos requerimientos a la hora de seleccionar una u otra acción, ya que dependiendo de estos se recurre a la función de recubrimiento y protección de plantas fibrosas, superficiales muy extendidas, capaces de crear cubiertas densas y continuas, por ejemplo, en el caso del control de la erosión.

Por el contrario, si el efecto que quiere lograrse es de estabilización frente a procesos de remoción en masa, lo más adecuado sería buscar en la vegetación el efecto de anclaje y refuerzo de terreno, en plantas con sistemas radiculares fuertes, profundos y de rápido desarrollo, que además presenten tallos de gran resistencia y una alta relación entre biomasa del sistema radical y la biomasa de la parte aérea.

La morfología de las plantas y su ciclo vital son factores determinantes en la adecuación a las diferentes funciones asociadas a la vegetación.

Tanto las especies herbáceas como las leñosas pueden usarse para la estabilización de taludes, aunque generalmente la herbácea es utilizada en mayor medida para el control de la erosión superficial. Para prevenir procesos de deslizamiento en masa, y de inestabilidad superficial, resultan más adecuadas, las especies leñosas: árboles y arbustos. 
Tabla 3. Características más convenientes según las funciones de la vegetación:

\begin{tabular}{|ll|}
\hline Función & Características deseables \\
\hline Contención y captura & Ramificación desde la base \\
\hline & Tallos fuertes y flexibles \\
\hline Rápido crecimiento de la parte aérea \\
\hline Capacidad de rebrote \\
\hline Propagación rápida por esquejes y brotes de raíz \\
\hline Revestimiento y cubierta & Superficie de crecimiento extensiva y densa \\
\hline Refuerzo y soporte & Raíces profundas fuertes y extendidas \\
\hline Rápido crecimiento del sistema radical \\
\hline Alta relación entre biomasa de la raíz y la de la parte aérea \\
\hline Alta tasa de transpiración a través de las hojas \\
\hline
\end{tabular}

\subsection{2.- Criterios ambientales}

La capacidad de adaptación y tolerancia de los vegetales es diferente según la especie, cuestión por lo que las especies seleccionadas deben cumplir estos condicionantes, expresando su capacidad para prosperar en el medio de actuación.

Los factores ambientales se pueden agrupar de la siguiente forma:

- Bioclima.

- Características del sustrato.

- Consideraciones fitosociológicas.

\subsubsection{1.- Bioclima}

Comprende la combinación de los factores climáticos que determinan el crecimiento de la vegetación y la supervivencia de las especies que forman una comunidad ecológica.

Este factor ambiental no es modificable, y el éxito de la revegetación está en seleccionar adecuadamente la combinación de vegetales a emplear, para que se adapten perfectamente a las condiciones de la zona de actuación. 
Sin embargo, el diseño y gestión de la revegetación puede moderar su influencia. Para un estudio adecuado de este factor, es necesario distinguir dos escalas de trabajo:

- Nivel regional.- En esta escala los factores que determinan el tipo de bioclima son:

- Altitud.

- Latitud.

- Distancia del mar.

- Nivel local.- Llamado también microclima, definido evidentemente por las condiciones locales que modifican las características climáticas generales. En este nivel, las condiciones microclimáticas están determinadas por:

- Exposición y orientación de las superficies a revegetar.

- Naturaleza del suelo y tipo de cubierta.

- Características fisiográficas locales.

- Régimen de humedad.

- Circulación atmosférica y régimen de vientos.

- Cercanía a cursos de agua.

\subsubsection{2.- $\underline{\text { Características del sustrato }}$}

El medio edáfico es un sistema que actúa con y sobre la vegetación de manera dinámica e interdependiente. Es el que proporciona de nutrientes y agua a las plantas, además del oxigeno para el proceso de respiración de los sistemas radiculares.

En situación contrapuesta al bioclima, este factor es modificable a través del uso de técnicas de preparación y tratamiento del suelo, adecuando las propiedades de este a los requerimientos de los vegetales. Los elementos del suelo que actúan sobre la vegetación, y que deben considerarse en el proceso de selección de especies son los siguientes:

- Textura y densidad: Determinan las posibilidades y el tipo de enraizamiento como a su vez la capacidad de almacenamiento e intercambio de agua con las plantas. De esta forma cabe esperar que las propuestas para suelos altamente arcillosos requieren el uso de plantas adaptadas a esas condiciones edáficas, tanto en sus sistemas radicales como en su fisiología. 
- Fertilidad: Referida a la presencia de macro nutrientes (N, P, K) y micronutrientes (Ca, $\mathrm{Ma}, \mathrm{S}, \mathrm{Na}$, metales traza). En el caso de sistemas edáficos muy pobres, es conveniente incluir dentro de la selección de especies, elegir plantas leguminosas que son capaces de fijar el nitrógeno propio; además de ser capaces de sobrevivir y prosperar en suelos adversos, su actividad mejora las características de estos suelos.

- $\quad$ pH: Las condiciones extremas de este parámetro resultan tóxicas para la gran mayoría de las plantas, además de determinar el grado de asimilabilidad de determinados nutrientes. Si se da el caso de estas condiciones extremas, será indicado el uso de especies especialmente adaptadas (especies acidófilas y basófilas).

\subsection{3.- Criterios Fitosociológicos}

La vegetación no es un elemento estático, esto debe tenerse en consideración a la hora de la decisión que se está haciendo uso de un sistema dinámico que establece una compleja red de interrelaciones entre las distintas especies de individuos y su entorno medioambiental, sujetos a continuos cambios y evoluciones.

El estudio de los procesos de sucesión vegetal arroja elementos que pueden acercarse a la predicción de la evolución de la composición específica y de la estructura de la vegetación implantada $y$, en función de ellos, se puede decidir que especies se van a utilizar, su proporción, y especificar una gestión del espacio tratado que asegure la permanencia de las plantas sobre las que recaen las funciones de estabilización y/o protección de los taludes tratados.

La dinámica de la vegetación posee dos conceptos claves: la Sucesión y el Clímax.

\subsubsection{1.- Concepto de sucesión}

Sucesión es aquella que se produce tras una alteración. Cuando la alteración es radical, por ejemplo el fuego, inundaciones, o nuestro caso de estudio, los taludes, el concepto de sucesión se asocia a la recuperación, y este proceso se pone en paralelo con las técnicas artificiales de recuperación. De aquí es que surgen los dos conceptos constitutivos de la recuperación o revegetación artificial. 
- Sucesión primaria: Se refiere al proceso de estructuración gradual del ecosistema. Asociado a esto está el desarrollo de los suelos y la vegetación a la par, interrelacionados e interdependientes entre sí.

- Sucesión secundaria: Una vez que se ha formado el suelo maduro. Una perturbación como la eliminación de la vegetación debida a cualquier $(\mathrm{x})$ causa, da como resultado cambios secuenciales graduales en los organismos que forman la comunidad. Esta secuencia se denomina Sucesión secundaria.

\subsubsection{2.- El proceso de sucesión}

Al observar una comunidad de plantas emplazada en un territorio en dos tiempos diferentes, los datos obtenidos muestran la tendencia de cambio en la composición de especies.

\section{Colección $A \quad \longrightarrow \quad$ Colección $B$}

Este hecho constatado reiteradamente engloba otros tres:

- Cuanto más largo es el tiempo transcurrido entre observaciones, las colecciones A y B son más diferentes.

- Cuando se hacen series de observaciones en lugares semejantes, estas tienden a poner de manifiesto una secuencia:

\section{Colección $R \quad \longrightarrow$ Colección $S \longrightarrow$ Colección $T \ldots$}

Donde $\mathrm{R}, \mathrm{S}$, T reciben el nombre de Comunidades seriales o etapas seriales. En este caso $\mathrm{R}, \mathrm{S}, \mathrm{T}$ se suponen diferentes entre sí. La diferencia estriba en unas pocas especies habitualmente escogidas por el observador de modo subjetivo con la finalidad de describirlas y clasificarlas.

Hay una colección de especies W, después de la cual no parecen darse más cambios en la composición de especies, de modo que la secuencia temporal se hace:

... colección $V \longrightarrow$ colección $W \longrightarrow$ colección $W \ldots$ 
- Escala de tiempo: Es la escala humana, por tanto no más cambios quiere decir décadas, o a lo más un par de siglos, es decir periodos fuera de la influencia de los grandes cambios climáticos.

- Rango espacial: Se refiere a terrenos relativamente extensos, mucho más amplio que el espacio cubierto por la planta.

La palabra pionero se usa como palabra estándar para describir la etapa inicial de una serie y sus especies propias.

Estas especies pioneras presentan las siguientes propiedades:

- Gran producción de semillas.

- Alta movilidad de semillas.

- Alta exigencia de luz.

- Capacidad para tolerar medios alterados.

Pueden encontrarse así otras palabras que en definitiva apuntan al mismo concepto, tales como colonizadora, oportunista, fugitiva, etc. Las plantas pioneras forman una comunidad herbácea dominada generalmente por gramíneas de carácter ruderal.

Este tipo de especies crece rápidamente y tiene una alta tasa de reproducción, aunque solo son competitivas en condiciones ambientales muy desfavorables. Una vez que las condiciones de implantación de la zona mejoran, propiciadas precisamente por éstas, son sustituidas por especies de crecimiento más lento pero de mayor longevidad, pertenecientes a las etapas superiores de la sucesión vegetal, cuya estrategia de crecimiento les permite competir con ventaja cuando no existen condiciones de estrés ambiental.

En general, las plantas utilizadas por la bioingeniería son pioneras y/o pertenecientes a las primeras etapas de la sucesión vegetal, debido a que las áreas que se pretenden revegetar presentan condiciones adversas para el desarrollo de especies pertenecientes a etapas superiores de dicha sucesión. Junto a lo anterior, se presenta el hecho de que las plantas pioneras son de mucho más rápido crecimiento, tanto de sus sistemas radiculares como de la parte aérea. 
Es adecuado para asegurar el establecimiento de los vegetales a largo plazo, y su función estabilizadora, que se utilicen mezclas de vegetales pioneros con otros de crecimiento más lento, para proveer de una cubierta protectora de los procesos erosivos a corto plazo, para las plantas que permanecerán allí más tiempo.

El uso de especies pioneras en alta proporción en conjunto con árboles y arbustos, asegura la creación de una cubierta leñosa a corto plazo, pero se incurre en mayores costos por concepto de mantenimiento, ya que se hace necesario el control de crecimiento de las especies pioneras para favorecer el desarrollo de las especies competidoras.

\subsection{4.- Estrategias de las plantas frente a las alteraciones}

Frente a las alteraciones naturales o artificiales que suceden en los ecosistemas, los organismos que habitan cambian sus pautas de comportamiento para defenderse, tanto a nivel fisiológico como morfológico.

- Estrategia: “Agrupamiento de características genéticas semejantes o análogas que ocurren entre las especies o poblaciones y hacen que las mismas exhiban sus semejanzas ecológicas" - Grime, 1982 ob cit Morgan, 1995.

Claro está que estas estrategias variarán de una planta a otra, como para una comunidad a lo largo de las diferentes fases de su evolución, es decir su fase juvenil o inmadura (regenerativa), y fase madura (establecida).

\subsubsection{1.- Estrategias de la fase juvenil (regenerativa)}

Existe la regeneración por brotes vegetativos y por semillas. Cuando no existen procesos sexuales de reproducción (herbáceas, perenne, helechos, briofitas, algunos árboles y arbustos): esquejes, yemas, bulbos, tubérculos,..., la regeneración se asocia con la consolidación local de poblaciones y tiene el efecto de producir comunidades de plantas genéticamente uniformes. Consecuencia negativa de esto, es la tendencia de las poblaciones a responder catastróficamente a cambios en el hábitat, inducidos por factores como el clima, depredación y manejo de la vegetación.

La reproducción sexuada se traduce en que la variedad genotípica resultante favorece la respuesta de poblaciones y especies a la selección natural. Los tipos de estrategias son:

- Expansión vegetativa. 
- Regeneración a través de un banco permanente de semillas.

- Regeneración a través de distintos tipos de semilla o esporas diseminadas por el viento.

- Regeneración a través de un banco permanente de plántulas.

\subsubsection{2.- Estrategias para la fase madura (establecida)}

Los factores que limitan la cantidad de materia vegetal viva o muerta presente en cualquier hábitat, pueden clasificarse en dos categorías:

- Restricciones: Fenómenos que limitan la producción fotosintética (falta de luz, agua, nutrientes minerales, temperaturas no óptimas).

- Alteraciones: Se asocia con la destrucción total o parcial de la biomasa vegetal y es el resultado de herbívoros, agentes patógenos, acciones antropogénicas (pisoteo, fuego, segado, arado, etc.), viento, heladas, sequías, erosión del suelo. Las plantas juegan un papel dentro del proceso de sucesión vegetal y este será función de la estrategia de establecimiento y desarrollo que presenten.

De esta manera es que se distinguen tres grupos de vegetales de acuerdo a las estrategias básicas de respuesta y adaptación a intensidades variables de estrés ambiental o restricciones (disponibilidad de luz, de nutrientes, agua, etc.) y el grado de perturbación atribuible o alteraciones (actividad antrópica, herbívoros, agentes patógenos, erosión, fuego, etc.):

- Plantas competidoras: Explotan condiciones de bajo estrés ambiental y bajo nivel de perturbación, pero donde muchas especies están compitiendo por los recursos disponibles. La competencia se refiere exclusivamente a la adquisición de recursos y constituye solo una parte del mecanismo por medio del cual una planta puede suprimir la adecuación de su vecina al modificar su medio ambiente (no incluye alelopatías).

- Plantas tolerantes: Explotan condiciones de alto estrés, pero bajo nivel de perturbación. La producción de materia vegetal seca está sujeta a una alta variedad de restricciones ambientales. De éstas las más frecuentes están relacionadas con los excesos y déficit de suministro de: 
- Energía solar.

- Agua.

- Nutrientes minerales.

- Plantas ruderales: Toleran un alto nivel de perturbación, pero no condiciones de estrés ambiental.

No existen plantas que presenten estrategias de resistencia al estrés y a la perturbación, que son las condiciones más frecuentes en el tratamiento de taludes. Para que la revegetación tenga éxito es necesario entonces intervenir en uno de los dos condicionantes.

Para el caso de operar sobre la resistencia al estrés se deben mejorar las características del suelo, la pendiente, exposición, etc. Mientras que para hacerlo sobre la perturbación, se deben controlar sus agentes asociados.

En general, las zonas de suelo desnudo que sean sometidas a procesos de sucesión vegetal, lo harán a través de plantas ruderales, y la dirección en la que progresará posteriormente la vegetación implantada será de acuerdo a las condiciones de estrés relativo por clima y suelo.

En las zonas donde se presenten condiciones de estrés moderado, las comunidades ruderales serán sustituidas por plantas competidoras. Por el contrario, si las condiciones ambientales son muy desfavorables, debido a la pobreza del suelo y/o a la dureza del clima, la vegetación se desarrollara en el sentido de la sustitución por vegetales tolerantes al estrés.

Los taludes a estabilizar y/o controlar su erosión, generalmente presentan las últimas condiciones. Para su tratamiento es adecuado seleccionar plantas que presenten tolerancia a condiciones ambientales desfavorables, a menos que se pretendan desarrollar labores de mantenimiento continuadas, que actúen sobre estos condicionantes para corregirlos.

Es importante también conocer las estrategias de propagación de las plantas, puesto que este factor determina la capacidad para regenerarse, en caso de sufrir daños. Los vegetales de propagación vegetativa como los estolones, rizomas o brotes de raíz, presentan características más vigorosas y rápidas en la colonización de nuevas zonas, a diferencia de las que se propagan a través de semillas. 
Las interrelaciones ambientales en las que se trabaja tienen directa relación con la favorabilidad ambiental que se espera. Este nivel de análisis determina los requerimientos que deben cumplir las especies a seleccionar, al menos en gran medida, lo que permite reducir las medidas de mantenimiento posterior, reduciendo tiempo y costes.

\section{7.- MODELO MATEMÁTICO PARA LA DEFINICIÓN DEL EFECTO DE LA VEGETACIÓN SOBRE LA ESTABILIDAD DE TALUDES}

\section{1.- OBJETIVOS DEL MODELO MATEMÁTICO}

Una vez que han sido estudiados los efectos de la vegetación sobre la estabilidad de taludes, descritos a lo largo del capítulo 5.- Efectos de la vegetación en la estabilización de taludes, son necesarios los siguientes pasos.

- Por un lado, determinar cuáles de estos factores deben ser considerados para la evaluación de la influencia de la vegetación sobre la estabilidad de terrenos en pendiente.

- Posteriormente, para cada factor deben desarrollarse un modelo que permita cuantificar el efecto sobre el valor numérico final que define la estabilidad del talud: el factor de seguridad.

El objetivo del presente capítulo es definir en líneas generales el procedimiento seguido para obtener los modelos matemáticos que definen cada uno de los efectos de la vegetación considerados, sobre el valor del factor de seguridad. El Anexo IV.- Efectos de la vegetación sobre la estabilidad de taludes, trata con mayor grado de detalle el contenido de este capítulo.

\section{2.- FACTORES A CONSIDERAR}

En una primera aproximación, se pueden clasificar los factores que actúan sobre la estabilidad de taludes en las siguientes categorías:

- Efectos hidrológicos.- Son los siguientes:

- Intercepción del agua de lluvia. 
- Retención del agua.

- Extracción del agua del suelo por ETP (evapotranspiración).

- Acumulación de agua.

- Drenaje por el follaje.

- Aumento de la infiltración.

- Efectos hidráulicos.- Se traducen en modificaciones en la velocidad de escorrentía, con la consiguiente disminución en la capacidad erosiva de una corriente de agua.

- Efectos de refuerzo del suelo.- Son los siguientes:

- Aumento de resistencia al corte.

- Efecto de anclaje.

- Efecto arco.

- Efectos negativos de la vegetación.- Oponiéndose a los anteriores, se distinguen una serie de factores que contribuyen a la inestabilidad, relacionados directamente con la vegetación:

- La desecación de suelos expansivos por absorción de agua.

- La sobrecarga inducida por el peso de la vegetación.

- La fuerza de arrastre del viento.

- El deterioro de estructuras artificiales por acción del crecimiento de las raíces.

- La formación de turbulencias y erosión concentrada en zonas con distribución no homogénea de la cubierta vegetal.

De estos factores, no se tendrán en cuenta los efectos hidráulicos e hidrológicos: intercepción, evapotranspiración, infiltración, etc. sobre la vegetación, anteriormente descritos, en base a los siguientes motivos:

- La complejidad del cálculo y cuantificación de estos factores.

- La baja influencia que tienen sobre los resultados respecto a los demás factores.

- Los modelos habitualmente utilizados no los consideran, proporcionado sin embargo, resultados fiables.

Igualmente, no son considerados los efectos negativos desecación y turbulencia, por tratarse de efectos relacionados con los hidrológicos e hidráulicos, así como tampoco se considera el efecto del deterioro de estructuras, al no ser objetivo del presente estudio. 


\section{3.- REFUERZO DEL SUELO}

Los mecanismos de refuerzo, a efectos de desarrollar el modelo, se resumen en los siguientes:

- Incremento de la cohesión del terreno.

- Efecto anclaje de las raíces.

\subsection{1.- Aumento de resistencia a cortante: cohesión mejorada}

El incremento de la resistencia a cortante es debido al refuerzo del terreno por la malla que forman las raíces entrelazadas.

- En suelos cohesivos actúa incrementando el valor de la cohesión inicial del terreno

- En suelos granulares, proporciona cohesión a un terreno carente de ésta.

Este factor se cuantifica como un aumento de la cohesión inicial del terreno, o cohesión efectiva $(\boldsymbol{c})$, proporcionando un valor de cohesión efectiva mejorada $\left(\boldsymbol{c}^{\prime}\right)$, aplicable al conjunto terreno + vegetación.

$$
c^{\prime}=c+c R
$$

El aporte de las raíces al valor de la cohesión $(\boldsymbol{c R})$, al igual que la cohesión efectiva de un suelo, debe determinarse a partir de ensayos. Se utilizan una serie de valores de referencia para el parámetro $\boldsymbol{C R}$, que permiten definirlo para las especies consideradas en el inventario.

\subsection{2.- Resistencia a tracción de las raíces: anclaje}

Este mecanismo actúa en el caso de que las raíces sean capaces de penetrar en un estrato inferior estable y anclar al mismo la masa de terreno potencialmente inestable.

Se asume que este efecto no puede ser considerado en el caso de que las raíces se desarrollen por encima del plano de deslizamiento, o bien aunque consigan alcanzarlo no tengan una longitud de anclaje suficiente por debajo de este plano de deslizamiento.

Este efecto se considera en el resto de los casos, (profundidad de deslizamiento inferior a profundidad de raíces + longitud de anclaje). 
Este efecto se traduce en un anclaje ejercido por las propias raíces oponiéndose al deslizamiento por acción de su resistencia a tracción la cual depende de:

- La resistencia media a la tracción de las raíces o fibras (Tr)

- La sección media de las raíces $\left(\boldsymbol{S}_{\text {raiz }}\right)$.

- La relación Raíces / Superficie de suelo, o fracción de superficie de una sección tipo de suelo que es atravesada por raíces $\left(\boldsymbol{A}_{R} / \boldsymbol{A}\right)$.

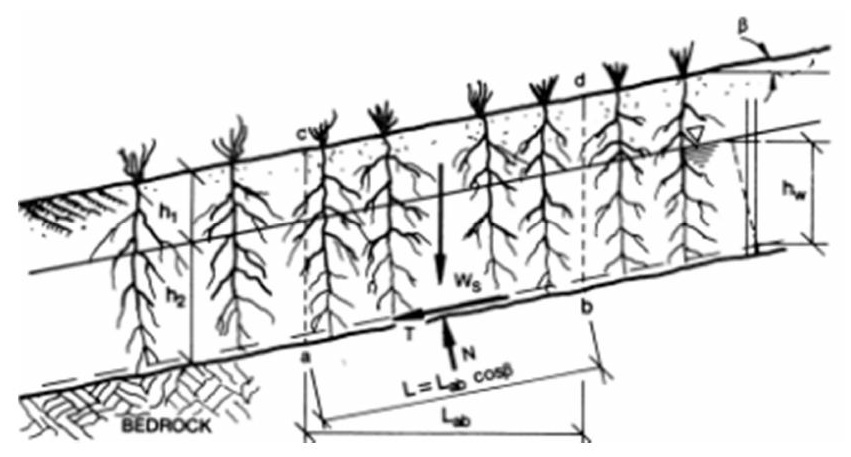

Figura 15: Fuerza de anclaje de arbustos y de hierbas de raíz profunda (Bache y Mackaskill, 1984).

Como resultado, se tiene una fuerza de tracción $(T)$, cuyas dos componentes (normal y tangencial) aporta resistencia frente al deslizamiento de la masa de terreno. Esta fuerza queda definida por la siguiente expresión:

$$
\operatorname{T}=\operatorname{Tr} x S_{\text {raiz }}\left(A_{R} / A\right)
$$

Los parámetros que utiliza quedan definidos anteriormente.

Existe una dependencia del ángulo de corte $(\boldsymbol{\theta})$ entre las raíces y la superficie de deslizamiento, la cual se puede asumir constante, en función de ensayos realizados, en un valor de entre 45 y 50 grados. Este ángulo determina la magnitud de las componentes de la fuerza de tracción. 


\section{4.- FACTORES NEGATIVOS}

Los factores considerados que generan inestabilidad inducida por la vegetación son los siguientes:

- Incremento del peso sobre el talud.

- Fuerza del viento transmitida por la vegetación.

\subsection{1.- Incremento del peso sobre el talud: sobrecarga}

Se debe al incremento del peso de la masa de terreno potencialmente inestable debido a la sobrecarga que supone el peso de la vegetación. Se tienen en cuenta las siguientes particularidades:

En especies arbóreas se considera, mientras que en especies herbáceas este factor es despreciable.

El peso de la vegetación sobre el talud actúa de dos maneras:

- Su componente tangencial desestabiliza el talud.

- Su componente normal, tiende a estabilizarlo, por aumento del rozamiento interno.

El modelo matemático desarrollado para el cálculo del factor de seguridad considera los dos efectos.

Por otra parte, los aumentos de ángulo de talud incrementan de forma progresiva la componente tangencial respecto a la normal, incrementando con ello el efecto negativo.

No conviene en ningún caso sobrecargar las zonas de cabecera de talud con especies vegetales que aporten un peso elevado.

La fórmula desarrollada para el cálculo del peso de vegetación arbórea, considera los siguientes parámetros:

- Peso de la vegetación (Wv).

- Diámetro del árbol medido a 1,30 m (Dt). 
- Densidad de la madera $(\boldsymbol{\gamma} \boldsymbol{v})$.

- Altura del árbol (ht).

- Aceleración de la gravedad $(\boldsymbol{g})$.

- Factor de forma (f.f. $)^{1}$.

Figura 16: Componentes del peso que actúan sobre un talud con vegetación: terreno $\left(W_{T}\right)$, agua $\left(W_{W}\right), y$ vegetación $\left(W_{v}\right)$.

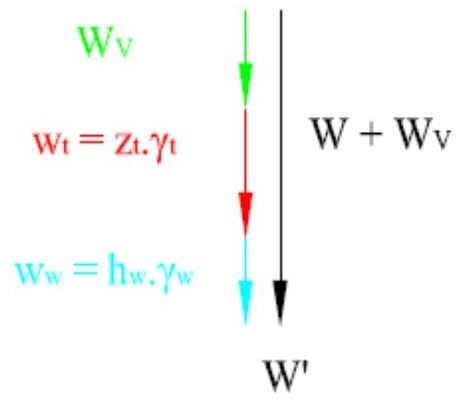

La expresión matemática del peso de la vegetación $(\boldsymbol{W} \boldsymbol{v})$ es la siguiente:

$$
W_{v}=\gamma_{v} \times \pi / 4 \times D_{t}^{2} \times h_{t} x(f: f) \times g
$$

\subsection{2.- Fuerza transmitida por el viento: arrastre}

La fuerza que el viento ejerce sobre las plantas es transferida al interior del terreno desestabilizándolo.

La magnitud y fuerza de arrastre ejercida, depende de la velocidad del viento, la altura de los árboles, la extensión de la cubierta y la pendiente del talud.

El modelo empleado para evaluar la fuerza de empuje del viento es el de Brown y Sheu, 1975 que expresa la fuerza de arrastre de cada árbol transmitida al talud, suponiendo que el viento sopla de forma paralela a la superficie del terreno. Este modelo considera los factores:

- Densidad del aire $(\boldsymbol{P})$.

- Velocidad del viento (V).

- Coeficiente adimensional de arrastre $(\boldsymbol{C d})$, que puede considerarse 0,7 para secciones circulares con superficie lisa.

El empuje transmitido por el viento se calcula con la fórmula:

$$
D=C d x\left(1 / 2 \rho V^{2}\right)=C d x q
$$

\footnotetext{
${ }^{I}$ El factor de forma representa la influencia en el cálculo del peso de la diferencia entre la forma real del tronco y una forma cilíndrica ideal con el diámetro medio, se puede considerar constante $(0,65)$.
} 
Con objeto de simplificar los cálculos, se puede determinar el parámetro presión del viento $(\boldsymbol{q})$, directamente, a partir de las normas tecnológicas de la edificación (NTE), para la zona eólica correspondiente y en función de la altura del árbol (ht).

\section{5.- INFLUENCIA DE LA COMBINACIÓN DE ESPECIES RESPECTO A ESPECIES INDIVIDUALES}

El caso más frecuente de propuesta para la restauración de un talud con vegetación es la que se compone de una mezcla de dos o más especies que pueden ser de varios tipos: árboles, arbustos y herbáceas. Cada especie estará representada en la superficie total en un porcentaje que será como máximo del 100\%. La representación o porcentaje de mezcla será considerado en los parámetros calculados para cada especie de forma individual, de manera que se pueda obtener una media ponderada de cada parámetro en la mezcla.

\section{6.- CÁLCULO DE LOS PARÁMETROS DE LA VEGETACIÓN EN UNA MEZCLA DE ESPECIES}

Los parámetros de cálculo de la mezcla de especies vegetales, se hallan aplicando a cada parámetro correspondiente a la especie, el porcentaje en que esta se encuentra representada. De esta forma, se calcula la media ponderada de los parámetros del conjunto de la mezcla.

Ejemplo de cálculo de un parámetro para la mezcla de especies:

Parámetro mezcla $=$ Parámetro esp. $1 * \%$ esp. $1+$ Parámetro esp. $2 * \%$ esp. 2

$+\ldots+$ Parámetro esp. $N * \%$ esp. $N$

- Para aplicar esta fórmula el porcentaje deberá estar expresado en tanto por uno.

Los parámetros medios de la mezcla que deben ser determinados son los siguientes: Cohesión mejorada del suelo (cR); Fuerza de tracción de las raíces (T); Peso debido a la vegetación (Wv); Empuje del viento sobre la vegetación (D); Profundidad de las raíces (p.r). 


\section{7.- INFLUENCIA DE LA DENSIDAD DE PLANTACIÓN Y EFECTO ARCO}

\subsection{1.- Aplicación de la densidad de plantación}

La densidad de plantación se refiere al número de unidades de especie vegetal por cada unidad de superficie de terreno.

Los parámetros básicos de cálculo, que definen el efecto de la vegetación, para la mezcla se determinan con la fórmula del capítulo anterior. Estos parámetros solo pueden ser utilizados directamente en el caso de que la densidad de plantación fuera de 1 unidad por $\mathrm{m}^{2}$, hipótesis que no suele cumplirse.

Para la determinación de los parámetros básicos de cálculo finales, es necesario aplicar la densidad de plantación, según el ejemplo:

\section{Parámetro (unidades $\left./ m^{2}\right)=$ Parámetro $($ ud/planta) * Densidad de plantación (plantas $/ \mathrm{m}^{2}$ )}

Esta expresión se aplica a los parámetros de la mezcla: Cohesión mejorada del suelo (CR); Fuerza de tracción de las raíces (T); Peso debido a la vegetación (Wv); Empuje del viento sobre la vegetación $(\boldsymbol{D})$.

- No se aplicaría al parámetro: Profundidad de las raíces (p.r), porque no está bajo la influencia de la densidad de plantación.

\subsection{2.- Evaluación del efecto arco}

Las raíces individuales actúan como anclajes que estabilizan los arcos de suelo que se extienden a través del talud. El efecto arco está directamente relacionado con la densidad de plantación, y para que este tenga lugar, el espaciamiento de los árboles debe ser el menor posible. Se considera que se produce efecto arco para espaciamientos entre árboles menores a $10 \mathrm{~m}$.

El espaciado (e) o marco de plantación se puede calcular según la fórmula siguiente:

$$
e=\sqrt{\frac{10000}{\text { densidad de plantacion }\left(\frac{u d}{h a}\right)}}
$$


El efecto arco, garantiza una distribución homogénea de las fuerzas que contribuyen a estabilizar el talud sobre la totalidad de la superficie. En caso de no haber efecto arco aparecerían zonas de debilidad, no protegidas por el efecto de la vegetación, en las que podría ser inducido un fenómeno de inestabilidad.

\section{8.- DEFINICIÓN DE LAS ECUACIONES DE CÁLCULO DEL FACTOR DE SEGURIDAD}

\subsection{1.- Cálculo de la profundidad del plano de deslizamiento}

El cálculo del factor de seguridad requiere que previamente se hayan determinado los parámetros:

- Profundidad del plano de deslizamiento (z).

- Altura de la lámina de agua sobre el plano de deslizamiento $\left(\mathbf{h}_{\mathrm{w}}\right)$.

Ambos parámetros se verán modificados respecto a los iniciales por la presencia de la vegetación. Por ello se distingue en primer lugar, el cálculo sin considerar la vegetación, y en segundo lugar con vegetación.

\subsubsection{1.- Profundidad del plano de deslizamiento}

El cálculo de z, o z' (con vegetación), se efectúa considerando la hipótesis de equilibrio entre fuerzas resistentes y fuerzas motoras, para la cual el valor del factor de seguridad es la unidad. A partir de esta relación, se determina el valor de $\mathbf{z}$.

\section{Cálculo sin vegetación $(z)$ :}

$$
\frac{c+\tan \emptyset W \operatorname{sen} \beta}{W \cos \beta} F S=\square \quad \mathrm{Z}=\frac{\mathrm{c}}{(\cos \beta-\operatorname{sen} \beta \tan \emptyset) \gamma}
$$

\section{Cálculo con vegetación $\left(z^{\prime}\right)$ :}

$$
\frac{c^{\prime}+\tan \emptyset W \operatorname{sen} \beta}{W \cos \beta} F S=\quad \longrightarrow \quad \mathrm{z}^{\prime}=\left[\mathrm{c}^{\prime}(\cos \beta-\operatorname{sen} \beta \tan \varnothing)-W\right] \times \frac{1}{(\gamma \mathrm{t}+\gamma \mathrm{w})}
$$

- En ambos casos F.S. = 1, en situación de equilibrio límite. 
Los parámetros que intervienen en la fórmula son:

- $\boldsymbol{\gamma}=$ Peso específico del terreno.

- $\quad c=$ Cohesión del terreno, o la cohesión mejorada $\left(\boldsymbol{c}^{\prime}\right)$

- $\quad \boldsymbol{\beta}=$ Ángulo inclinación del talud.

- $\quad \varnothing=$ Ángulo de rozamiento interno interna del material del suelo.

- $\quad \boldsymbol{W}_{\boldsymbol{v}}=$ Peso de la vegetación

- $\boldsymbol{V}_{\boldsymbol{w}}=$ Peso unitario del agua $\left(9,8 \mathrm{kN} / \mathrm{m}^{3}\right)$.

\subsubsection{2.- Altura vertical de la lámina de agua}

La altura de la lámina de agua sobre el plano de deslizamiento incluye en el modelo la influencia del agua subterránea. Se calcula a partir de la profundidad del plano de deslizamiento y la del nivel freático, en función de la situación del mismo.

Según Hoek and Bray, la posición del nivel freático puede clasificarse en cinco clases, situándose de 1 a 5 a: 0 (talud seco), 1/8, 1/4, 1/2, y 1 (talud saturado) veces la profundidad del plano de deslizamiento.

La forma de calcular $\boldsymbol{h}_{\boldsymbol{w}}$, es multiplicar por el factor correspondiente a cada clase de nivel freático, el valor calculado de $\boldsymbol{z}$. En el caso de taludes con vegetación se calcula el valor de $\boldsymbol{h}_{v}$, (altura de la lámina de agua sobre el plano de deslizamiento con vegetación), a partir del valor de $z^{\prime}$.

\subsection{2.- Ecuación para el cálculo del factor de seguridad sin vegetación}

La ecuación de cálculo del factor de seguridad se fundamenta en el método del talud infinito, basado en la hipótesis que se basa en la hipótesis de que la longitud de una rotura plana superficial al talud puede considerarse infinita con respecto al espesor deslizado.

El método se desarrolla en el Anexo III - Métodos de cálculo de Estabilidad.

Se parte de la fórmula que define el factor de seguridad $\boldsymbol{F s}$, sin considerar el efecto de la vegetación: 


$$
F S=\frac{c+\left(\gamma z-\gamma_{w} h_{w}\right) \cos ^{2} \beta \tan \emptyset}{\gamma z \sin \beta \cos \beta}
$$

La cual se modifica introduciendo los parámetros de la vegetación, según la expresión propuesta por Coppin y Richards, 1990 citados por Morgan y Rickson, 1995, manteniéndose como válida la hipótesis del talud infinito.

$$
F s_{v}=\frac{(c+c R)+\left[\left(\left(\gamma z^{\prime}-\gamma_{w} h_{v}\right)+W_{v}\right) \cos ^{2} \beta+T \sin \theta\right] \tan \emptyset+T \cos \theta}{\left[\left(\gamma z^{\prime}+W_{v}\right) \sin \beta+D\right] \cos \beta}
$$

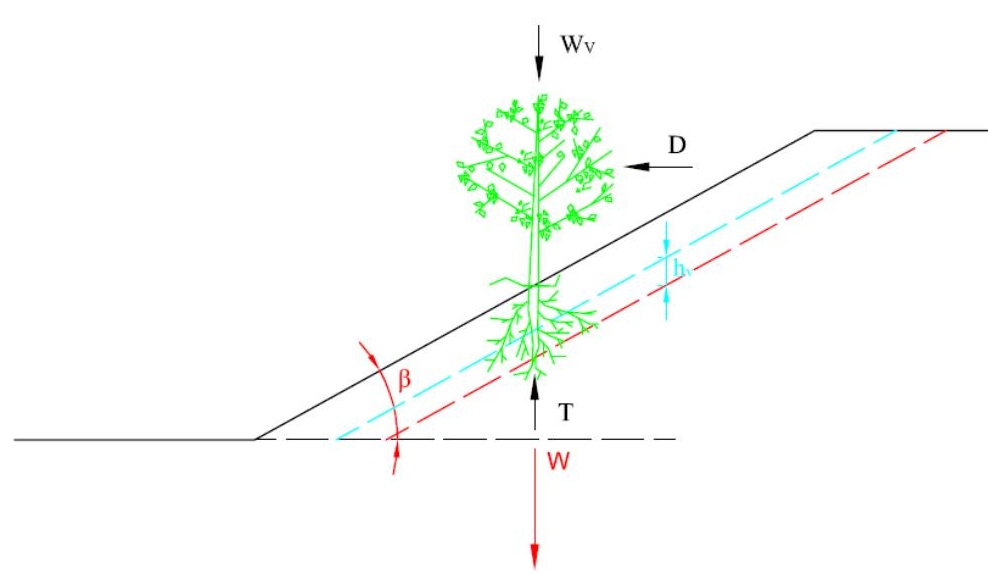

Figura 17: Diagramas indicando los parámetros que intervienen

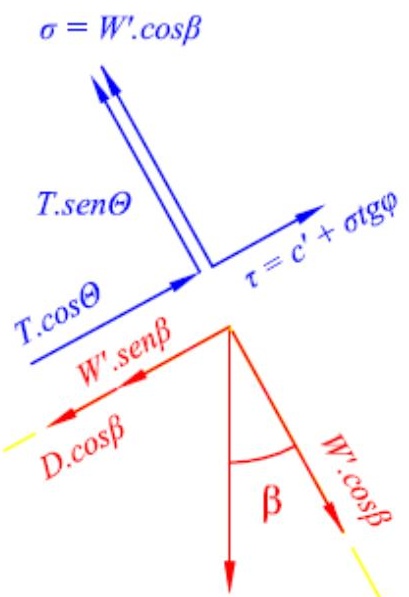

$\mathrm{W}^{\prime}$

en el cálculo de Fsv (con vegetación), y distribución de las fuerzas

que actúan sobre la masa de terreno deslizante.

Según la fórmula anterior, el valor del factor de seguridad con vegetación $\left(\boldsymbol{F} \boldsymbol{s}_{v}\right)$, se calcula en función de los siguientes parámetros:

- $\quad c=$ Cohesión efectiva del suelo.

- $\quad \boldsymbol{C R}=$ Cohesión efectiva del suelo mejorada debido al refuerzo por raíces.

- $\quad \boldsymbol{V}=$ Peso específico del suelo.

- $\quad \boldsymbol{z}^{\prime}=$ Profundidad del plano de deslizamiento con vegetación.

- $\quad W_{v}=$ Sobrecarga debido al peso de la vegetación.

- $\quad \boldsymbol{\beta}=$ Ángulo de la pendiente.

- $\quad \boldsymbol{V}_{w}=$ Peso unitario del agua.

- $\boldsymbol{h}_{V}=$ Altura vertical de la lámina de agua por encima del plano de deslizamiento con la vegetación.

- $\boldsymbol{T}=$ Fuerza de tracción de las raíces actuando en la base del plano de deslizamiento. 
- $\quad \boldsymbol{\theta}=$ Ángulo entre las raíces y el plano de deslizamiento.

- $\varnothing=$ Ángulo de fricción interna del material del suelo.

- $\quad \boldsymbol{D}=$ Fuerza de carga del viento paralela a la ladera.

Después de calcular el factor de seguridad con vegetación es conveniente efectuar una comparación del resultado con respecto al obtenido sin vegetación, calculando el incremento, o en su caso disminución del factor de seguridad debido a la influencia de un tipo determinado de vegetación sobre el talud objeto de estudio.

\section{8.- IMPLEMENTACIÓN DEL MODELO MATEMÁTICO DE REFUERZO DE TALUDES CON VEGETACIÓN EN UN PROGRAMA INFORMÁTICO}

\section{1.- APLICACIÓN Y REQUISITOS DEL PROGRAMA}

\subsection{1.- Aplicación principal del programa}

La aplicación para la cual se diseña el programa es la siguiente:

- Evaluación de la estabilidad de taludes, para determinar el incremento de estabilidad atribuido a la presencia de vegetación.

\subsection{2.- Características esenciales}

La aplicación informática cuenta con tres características esenciales:

1. Una interfaz gráfica de usuario completa, de intuitiva y de fácil manejo.

2. Una base de datos dinámica, en las que se incluyen datos generales de la zona, del terreno, y de la vegetación.

3. Funciones de cálculo que permitan establecer una propuesta de vegetación y calcular el factor de seguridad de taludes.

4. Herramienta gráfica mediante la cual se pueden visualizar los resultados obtenidos. 


\section{2.- FUNCIONAMIENTO DEL PROGRAMA- "ANÁLISIS DE ESTABILIDAD DE TALUDES"}

\subsection{1.- Datos de entrada}

Los parámetros necesarios para el cálculo del factor de seguridad de taludes, se clasifican en tres tipos: talud, el terreno y de la vegetación.

En el caso de los parámetros de vegetación, si es de aplicación la propuesta obtenida en el primer módulo, esta será tenida en cuenta como dato de entrada.

Tabla 1.- Parámetros empleados para el análisis de estabilidad.

\begin{tabular}{|c|c|c|}
\hline Datos de talud & & $\begin{array}{l}\text { Ángulo de inclinación del talud. } \boldsymbol{\beta} \\
\text { Posición del nivel freático. NF }\end{array}$ \\
\hline Datos de terreno & $\begin{array}{l}- \\
- \\
-\end{array}$ & $\begin{array}{l}\text { Tipo o clasificación de suelo } \\
\text { Cohesión. c } \\
\text { Ángulo de rozamiento interno. } \varnothing \\
\text { Peso específico del suelo. y }\end{array}$ \\
\hline Datos de vegetación & $\begin{array}{l}- \\
- \\
- \\
- \\
- \\
- \\
- \\
-\end{array}$ & $\begin{array}{l}\text { Especie vegetal } n \\
\text { Tipo de vegetación (especie } n \text { ) } \\
\text { Porcentaje de vegetación } \\
\text { Diámetro medio del tallo (especie } n \text { ). DtN } \\
\text { Densidad de la madera (especie } n \text { ). YvN } \\
\text { Altura de la planta (especie } n \text { ). htN } \\
\text { Factor de forma del tronco (especie n). f.f.N } \\
\text { Fuerza del viento (especie n). DN } \\
\text { Diámetro medio de las raíces (especie n). DrN } \\
\text { Densidad estimada de las raíces (especie n). drN (Ar/As) } \\
\text { Profundidad media de las raíces (especie n). prN } \\
\text { Resistencia a la tracción (especie n). TN } \\
\text { Cohesión raíces (especie } n \text { ). cRN } \\
\text { Densidad de la plantación }\end{array}$ \\
\hline
\end{tabular}

\subsection{2.- Funcionamiento}

El funcionamiento de esta aplicación se basa en la utilización de una serie de secuencias lógicas y ecuaciones internas que permiten obtener como resultado final valores del factor de seguridad de taludes.

Se resume en la siguiente secuencia:

1. Introducción de los datos correspondientes a: talud, propiedades del terreno y propuesta de vegetación. 
2. El programa calcula los parámetros finales que define la acción sobre el terreno de la combinación de especies vegetales:

- Cohesión de las raíces (cR), fuerza de tracción de las raíces (T), sobrecarga de la vegetación (Wv), fuerza del viento (D), profundidad media de las raíces (p.r), espaciado, cohesión mejorada del suelo $\left(c^{\prime}\right)$, peso total sobre el talud ( $\left.w^{\prime}\right)$.

3. El programa ejecuta la función de cálculo de la profundidad del plano de deslizamiento, en ambos supuestos: sin vegetación ( $z$ ) y con vegetación ( $\left.z^{\prime}\right)$.

4. Se realiza el cálculo de la altura vertical de la lámina de agua a partir de la profundidad de deslizamiento.

5. Se efectúa el cálculo de las fuerzas motoras (desestabilizadoras) y las fuerzas resistentes (estabilizadoras), que actúan sobre la masa de terreno potencialmente inestable.

6. Se determina el valor del coeficiente de seguridad del talud.

El cálculo se realiza en dos etapas, siendo la primera la determinación del factor de seguridad sin vegetación, y la segunda, con vegetación. Una vez se disponga de los dos resultados se procede a:

7. Comparar los resultados: incremento del F.S., absoluto y en porcentaje.

Opcionalmente, se verían los resultados y se repite el proceso, con el fin de evaluar el comportamiento de diferentes soluciones de revegetación.

\subsection{3.- Interpretación de resultados}

Los resultados finales obtenidos son: el factor de seguridad inicial del talud ( $\sin$ la vegetación), el factor de seguridad modificado por la vegetación, y la diferencia entre ambos.

Como ha sido expuesto a lo largo del proyecto, debe exigirse que para un talud, se cumpla la siguiente condición:

- F.S. > 1 + Margen adicional de seguridad.

Por otra parte, el programa también proporciona una serie de resultados intermedios que son necesarios para al cálculo final del factor de seguridad, y que aportan información adicional muy útil, acerca de las condiciones del talud.

Tabla 2.- Resultados (parciales y finales) del cálculo de estabilidad de taludes.

\begin{tabular}{|c|c|}
\hline Resultados parciales & $\begin{array}{ll}\text { - } & \text { Sobrecarga de vegetación (especie } \mathrm{n} \text { ). } \mathbf{W} \mathbf{V} \\
\text { - } & \text { Fuerza tracción raíces (especie } \mathrm{n} \text { ). TN } \\
\text { - } & \text { Sobrecarga de la vegetación (mezcla). Wv0 } \\
\text { - } & \text { Fuerza del viento (mezcla). D0 } \\
\text { - } & \text { Profundidad media de raíces (final). pr }\end{array}$ \\
\hline
\end{tabular}




\begin{tabular}{|c|c|}
\hline & 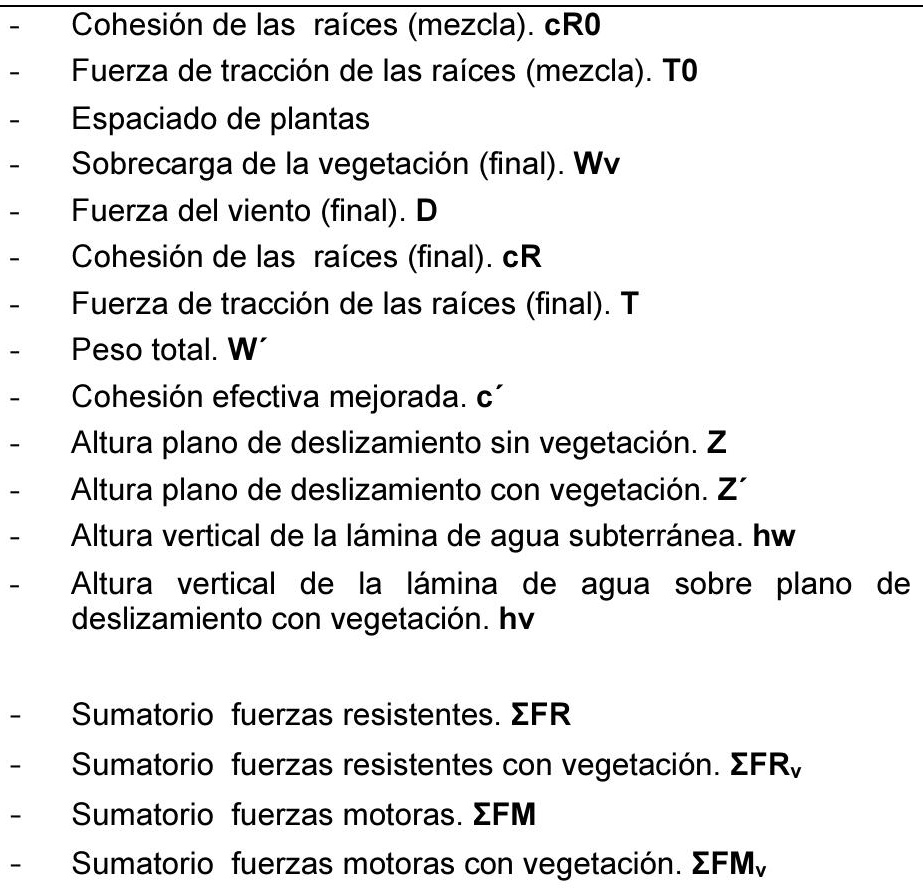 \\
\hline Resultados finales & $\begin{array}{ll}- & \text { Factor de Seguridad. FS } \\
\text { - } & \text { Factor de Seguridad con vegetación. FS } \\
\text { - } & \text { Diferencias del F.S. con vegetación respecto a inicial }\end{array}$ \\
\hline
\end{tabular}

\subsection{4.- Limitaciones de uso}

Se ha podido comprobar que existen algunas limitaciones en el cálculo del factor de seguridad, derivadas del modelo matemático:

1. Se establece un límite inferior para el ángulo de inclinación del talud $(\beta)$ de 6 ㅇ.

2. El límite superior de inclinación del talud ( $\beta$ ), es:

- $35 \%$ para suelos granulares,

- $\quad 70$ o para suelos cohesivos.

3. La profundidad del plano de deslizamiento ( $\mathrm{z})$, deberá estar comprendida entre:

- 5 m (límite inferior).

- $60 \mathrm{~m}$ (límite superior). 


\section{9.- MEMORIA DE DESARROLLO DEL PROYECTO}

El proyecto ha sido desarrollado en líneas generales, según las etapas establecidas en el capítulo 2.3.- Etapas de desarrollo.

\section{1.- PRIMERA ETAPA.}

En una primera etapa se llevaron a cabo los estudios necesarios para la selección de las especies vegetales, se recopilaron e integraron los datos necesarios para el proyecto y se comenzó a desarrollar el modelo matemático que define la influencia de la vegetación en la estabilidad de laderas.

DESGLOSE DE LA PRIMERA ETAPA DE DESARROLLO DEL PROYECTO:

\begin{tabular}{|c|c|c|c|c|c|}
\hline ID & (1) & Task Name & Duration & Start & Finish \\
\hline 1 & 国 & ESTUDIOS PRE VIOS & 65 days & Tue 01/06/10 & Mon 30/08/10 \\
\hline 2 & 国 & TRABAJOS DE CAMPO & 87 days & Thu $02 / 09 / 10$ & Fri $31 / 12 / 10$ \\
\hline 3 & 国 & ANÁLISIS DE LABORATORIO & 65 days & Fri $31 / 12 / 10$ & Thu 31/03/11 \\
\hline 4 & 国 & ESTUDIOS BIBLIOGRÁFICOS & 108 days & Fri 01/04/11 & Tue $30 / 08 M 1$ \\
\hline 5 & 国 & INTEGRACIÓN DE INFORMACIÓN & 87 days & Thu 01/09/1 & Fri $30 / 12 / 11$ \\
\hline 6 & 国 & INVENTARIO DE ESPECIES & 108 days & Mon 02/01/12 & Wed 30/05/12 \\
\hline 7 & 国 & MODELOMATEMÁTICO & 131 days & Fri $01 / 06 / 12$ & Fri $30 / 11 / 12$ \\
\hline
\end{tabular}

\begin{tabular}{|c|c|c|c|c|c|c|c|c|c|c|c|c|c|}
\hline \multirow[t]{2}{*}{ ID } & \multirow{2}{*}{ (9) } & \multirow{2}{*}{ Task Name } & \multicolumn{7}{|c|}{2011} & \multicolumn{4}{|l|}{2012} \\
\hline & & & Q2 & Q3 & Q4 & Q1 & Q2 & Q3 & Q4 & Q1 & Q2 & Q3 & Q4 \\
\hline 1 & 亚 & ESTUDIOS PREVIOS & & & & & & & & & & & \\
\hline 2 & 国 & TRABAJOS DE CAMPO & & & & & & & & & & & \\
\hline 3 & 国 & ANÁLISIS DE LABORATORIO & & & & & & & & & & & \\
\hline 4 & 国 & ESTUDIOS BIBLIOGRÁFICOS & & & & & & & & & & & \\
\hline 5 & 国 & INTEGRACIÓN DE INFORMACIÓN & & & & & & & & & & & \\
\hline 6 & 国 & INVENTARIO DE ESPECIES & & & & & & & & & & & \\
\hline 7 & 国 & MODELO MATEMÁTICO & & & & & & & & & & & \\
\hline
\end{tabular}

Figura 18: Diagrama de Gantt de la primera etapa de desarrollo del proyecto de I+D+i. 
1. ESTUDIOS PREVIOS

2. TRABAJOS DE CAMPO

- Estudios cartográficos.

- Toma de muestras.

- Análisis de plantas y muestreos.

3. ANÁLISIS DE LABORATORIO

- Análisis de propiedades y composición de suelos.

4. ESTUDIOS BIBLIOGRÁFICOS

- Revisión de las técnicas de implantación de vegetación.

- Parámetros de especies vegetales.

- Estudios previos.

5. RECOPILACIÓN E INTEGRACIÓN DE DATOS

6. DEFINICIÓN DEL INVENTARIO DE ESPECIES

- Definición del tipo de vegetación que va a incluirse en la evaluación.

7. MODELO MATEMÁTICO DE EVALUACIÓN DE ESTABILIDAD

- Definición de los modelos matemáticos de evaluación de estabilidad.

- Modelización del efecto de la vegetación sobre la estabilidad de taludes.

\section{2.- SEGUNDA ETAPA.}

En la segunda etapa, se procedió, en primer lugar, al desarrollo y prueba del modelo matemático definido al final de la etapa anterior, el cual posteriormente fue implementado en una aplicación informática. 
DESARROLLO DE UNA APLICACIÓN INFORMÁTICA PARA EL CÁLCULO DE SOSTENIMIENTO DE TALUDES MEDIANTE REVEGETACIÓN

MEMORIA

DESGLOSE DE LA SEGUNDA ETAPA DE DESARROLLO DEL PROYECTO:

\begin{tabular}{|c|c|c|c|c|c|}
\hline ID & & Task Name & Duration & Start & Finish \\
\hline 1 & E- & PRUEBAS DE CÁLCULO & 43 days & Mon $03 / 12 / 12$ & Wed $30 / 01 / 13$ \\
\hline 2 & & $\mathrm{Pr}$. Especies individuales & 22 days & Mon $03 / 12 / 12$ & Tue $01 / 01 / 13$ \\
\hline 3 & 阵 & Pr. Combinaciones especies & 21 days & Wed $02,01 / 13$ & Wed $30 / 01 / 13$ \\
\hline 4 & Fe & DESARROLLO PROGRAMA & 57 days & Fri $01 / 02 / 3$ & Mon $22 / 04 / 13$ \\
\hline 5 & 㸧 & Integración de datos & 10 days & Fri $01 / 02 / 3$ & Thu $14 / 02 / 13$ \\
\hline 6 & E- & Interfaz gráfica & 10 days & Fri $15 / 02 / 13$ & Thu $28 / 02 / 13$ \\
\hline 7 & 可 & Definición funcionam iento & 22 days & Fri $01 / 03 / 13$ & Mon $01,04 / 13$ \\
\hline 8 & 㸧 & Programación & 15 days & Tue $02 / 04 / 13$ & Mon $22 / 04 / 13$ \\
\hline 9 & 可 & PRUE BAS FUNCIONAMIENTO & 15 days & Wed $10 / 04 / 13$ & Tue $30 / 04 / 13$ \\
\hline 10 & 可 & REDACCIÓN MANUAL & 14 days & Tue $23 / 04 / 13$ & Fri $10 / 05 / 13$ \\
\hline 11 & 圃 & DOCUMENTACIÓN & 74 days & Fri $01 / 02 / 13$ & Wed $15 / 05 / 13$ \\
\hline
\end{tabular}

\begin{tabular}{|c|c|c|c|c|c|c|c|c|c|c|c|c|c|c|c|c|c|c|c|c|}
\hline \multirow[t]{2}{*}{ ID } & \multirow[b]{2}{*}{ (9) } & \multirow[t]{2}{*}{ Task Name } & \multirow[t]{2}{*}{ Duration } & \multicolumn{2}{|r|}{ Dec 12} & $\operatorname{Jan} 13$ & \multicolumn{3}{|c|}{ Feb'13 } & \multicolumn{4}{|c|}{ Mar'13 } & \multicolumn{4}{|c|}{ Apr'13 } & \multicolumn{3}{|c|}{ May'13 } \\
\hline & & & & \begin{tabular}{|l|l|l|l}
19 & 26 \\
\end{tabular} & \begin{tabular}{|l|l|l|l|}
03 & 10 & 17 & 24 \\
\end{tabular} & \begin{tabular}{|l|l|l|l|l}
31 & 07 & 14 & 21 & \\
\end{tabular} & 28 & \begin{tabular}{l|l}
04 & 11 \\
\end{tabular} & \begin{tabular}{l|l|l|l|l|l|l}
11 & 18 \\
\end{tabular} & 25 & 04 & \begin{tabular}{|l|l|}
11 & 18 \\
\end{tabular} & 25 & 01 & 08 & 15 & 22 & 29 & 06 & 13 \\
\hline 1 & 胆 & PRUE BAS DE CÁLCULO & 43 days & & & & & & & & & & & & & & & & & \\
\hline 2 & & Pr. Especies individuales & 22 days & & & & & & & & & & & & & & & & & \\
\hline 3 & 国 & $\mathrm{Pr}$. Combinaciones especies & 21 days & & & & & & & & & & & & & & & & & \\
\hline 4 & 国 & DESARROLLO PROGRAMA & 57 days & & & & & & & & & & & & & & & & & \\
\hline 5 & 国 & Integración de datos & 10 days & & & & & & & & & & & & & & & & & \\
\hline 6 & 四 & Interfaz gráfica & 10 days & & & & & & & & & & & & & & & & & \\
\hline 7 & 国 & Definición funcionam iento & 22 days & & & & & & & & & & & & & & & & & \\
\hline 8 & 国 & Programación & 15 days & & & & & & & & & & & & & & & & & \\
\hline 9 & 国 & PRUE BAS FUNCIONAMIENTO & 15 days & & & & & & & & & & & & & & & & & \\
\hline 10 & 周 & REDACCIÓN MANUAL & 14 days & & & & & & & & & & & & & & & & & \\
\hline 11 & 酯 & DOCUMENTACIÓN & 74 days & & & & & & & & & & & & & & & & & \\
\hline
\end{tabular}

Figura 19: Diagrama de Gantt de la segunda etapa de desarrollo del proyecto de I+D+i.

1. PRUEBAS DE CÁLCULO DEL MODELO MATEMÁTICO

- Pruebas de cálculo considerando especies vegetales individuales.

- Intervalos de inclinación de talud: de 10 grados.

- Posiciones de nivel freático: las 5 posibles.

- Densidades de plantación: 600-1200-2500 ud/ha.

- Pruebas de cálculo considerando combinaciones de especies vegetales.

- Intervalos de inclinación de talud: de 10 grados.

- Posiciones de nivel freático: las 5 posibles.

- Densidades de plantación: 600-1200-2500 ud/ha.

- Definición de los límites de aplicación del modelo. 


\section{DESARROLLO DEL PROGRAMA}

- Definición de requerimientos y planificación.

- Integración de datos, definición de entradas.

- Desarrollo de la interfaz gráfica.

- Definición del funcionamiento:

- Elaboración de diagramas de flujo.

- Creación del pseudocódigo.

- Programación.

- Traducción del pseudocódigo al lenguaje de programación.

- Enlace interfaz gráfica - código.

\section{PRUEBAS DE FUNCIONAMIENTO DEL PROGRAMA}

- Comprobación del funcionamiento y coherencia de resultados.

4. REDACCIÓN DEL MANUAL DE USUARIO

5. REDACCIÓN DE DOCUMENTOS DEL PROYECTO, CONCLUSIONES

\section{3.- INCIDENCIAS Y OBSERVACIONES RELATIVAS AL PROCESO DE DESARROLLO.}

En primer lugar, es necesario hacer mención a la escasez de estudios previos relacionados con el objeto del proyecto, siendo en ocasiones difícil la obtención de datos, en la mayor parte de los casos restringidos a estudios concretos. Ha sido necesario por ello, unificar todas las teorías, criterios y variables, con objeto de establecer un método de evaluación de la influencia de la vegetación en la estabilidad de taludes.

En segundo lugar, ha sido necesario seleccionar de entre los disponibles, un modelo matemático que incluya las características: sencillez de aplicación, precisión y facilidad de implementación en un programa, y que a su vez permita incluir los parámetros que definen el comportamiento de la vegetación, resumido en los siguientes aspectos:

- La cohesión mejorada, cuyo valor numérico se basa en datos empíricos, disponibles para tipos de especies.

- La fuerza de tracción, calculada a partir de su resistencia mecánica y de las características de las raíces. Se encuentran ciertas dificultades en la estimación de los 
parámetros: densidad de raíces, y diámetro medio de las raíces, extrapolando los datos disponibles de tipos de especie a otras del mismo grupo.

- El peso de la vegetación se determinó a partir de los parámetros de la densidad de la madera y las dimensiones de la planta, según la fórmula expuesta.

- El arrastre del viento, para el cual ha sido necesario introducir directamente en la fórmula de cálculo empleada, un parámetro que define la presión ejercida por el viento, según criterios de las normas tecnológicas de la edificación.

- Se ha estudiado además la influencia de la profundidad de las raíces, respecto a la profundidad del plano de deslizamiento, según el modelo de refuerzo, siendo necesario en ocasiones no considerar algunos de los parámetros de refuerzo.

- Han sido descartados una serie de parámetros, por su escasa influencia en el modelo, por ser demasiado complejos de evaluar o simplemente por ser irrelevantes.

- Se estudia por último la influencia del efecto arco, debiendo calcularse el espaciado entre unidades vegetales a partir de la densidad, y con este especiado comprobando si se produce o no el efecto arco.

- Se pudo comprobar la necesidad de plantear una fórmula para determinar la profundidad del plano de deslizamiento, en los casos en que este fuese inicialmente desconocido, dicha fórmula se basa en determinar la profundidad de deslizamiento para las condiciones de equilibrio límite.

Durante las pruebas a que fue sometido el modelo matemático, ha sido ocasional la obtención de resultados anómalos, que en ocasiones se debieron a errores en la introducción de parámetros o de definición de las funciones matemáticas. En gran medida se pudo solventar este problema definiendo por partes, u operaciones sencillas, fórmulas matemáticas complejas, como por ejemplo la división en factores de la fórmula de cálculo del factor de seguridad: término cohesivo, término que define el rozamiento interno, etc.

En caso de detectar un error en un resultado final, se continúa analizando los resultados parciales inmediatamente anteriores al resultado final, reduciendo de forma progresiva la escala de trabajo hasta detectar el problema y solventarlo. 
Las pruebas de cálculo permitieron definir los límites de aplicación de la fórmula, debido a la generación sistemática de errores fuera de estos límites, lo cual permitió identificarlos con cierta precisión.

Por último, habría que mencionar que el proceso de programación requirió de la realización de numerosos ajustes, a medida que se avanzaba en su desarrollo, algo normal en este tipo de trabajos. Fue necesaria la realización de pruebas diarias y correcciones, con objeto de asegurar el funcionamiento de una función previa, antes de pasar a programar la siguiente.

\section{0.- CONCLUSIONES, VALORACIÓN GLOBAL DEL PROYECTO}

Han sido desarrollados a lo largo del presente documento, y sus anexos, cada una de los pasos necesarios, desde el planteamiento del proyecto, hasta la programación y prueba de funcionamiento, tratando aspectos clave como la recopilación de información, desarrollo de modelos matemáticos, pruebas de cálculo, definición de funciones y operación del programa, hasta la fase de programación

Como resultado final, se ha puesto en funcionamiento una aplicación informática de fácil manejo y altamente versátil, que permite estudiar las mejores opciones de restauración de un entorno alterado, tanto desde el punto de vista de la adaptación a las condiciones de la zona como de la contribución a la estabilidad de taludes o laderas naturales.

Es igualmente importante destacar que junto al programa, se ha desarrollado una serie de documentación de elevado valor práctico, en la que se detallan entre otros aspectos, cada una de las fases de desarrollo, procedimiento de utilización del programa e interpretación de resultados.

\section{1.- LIMITACIONES DEL PROGRAMA Y SU INTERPRETACIÓN}

Como ha sido comentado en anteriores apartados, debido a límites de aplicabilidad del método, el programa va a permitir la realización de análisis de estabilidad entre los intervalos de pendiente de 60 a $70 \circ$, con las siguientes particularidades:

- Por debajo de los 6 de inclinación, el terreno puede considerarse llano, y por lo tanto no tendría sentido evaluar la estabilidad del mismo. 
- En suelos granulares (suelos arenosos, gravas), se establece un límite superior de inclinación de 35을 debido a que se trata de suelos sin cohesión inicial, los cuales solamente serían estables con inclinaciones inferiores al ángulo de talud natural, o ángulo de rozamiento interno, situado en 35‥ Aunque con la implantación de vegetación se lograra dotar al suelo de la cohesión necesaria para soportar inclinaciones superiores a 35으, teóricamente ya se habría producido un fenómeno de inestabilidad antes de que la vegetación llegase a desarrollarse, a menos que fueran aplicadas técnicas de estabilización auxiliares.

- En suelos dotados de cohesión (suelos con fracciones finas: arcillas y limos), se permite evaluar la estabilidad de taludes para inclinaciones de hasta 70 . A partir de este máximo, es preferible aplicar técnicas de estabilización tradicionales. En este punto también es preciso establecer un límite adicional de 55 de inclinación, aplicable a especies arbóreas, basado en el hecho de que para inclinaciones elevadas, la componente tangencial del peso de la vegetación, que tiende a desestabilizar el talud, registra un aumento importante, actuando de forma negativa. Los casos de especies herbáceas, implantadas sobre taludes con inclinaciones mayores 55으, hasta el límite máximo de 70 o, pueden ser evaluados, debido a que este tipo de vegetación prácticamente no ejerce sobrecarga en el talud debida al peso.

Las mejoras en el factor de seguridad considerando la vegetación, se establecen teniendo en cuanta una fase avanzada de desarrollo de la misma, por lo que conviene tener en cuenta que inicialmente no se van a registrar los aumentos señalados por el programa. En cierta medida, el programa permite estudiar la evolución del factor de seguridad en función del desarrollo de la vegetación, siempre y cuando los parámetros de entrada utilizados correspondan a la fase de desarrollo estudiada. Los parámetros de la base de datos inicial corresponden a una fase avanzada de desarrollo.

Al definir una propuesta de vegetación, hay que tener en cuenta que solamente han sido estudiadas las comarcas del Bierzo, Laciana y varias zonas del norte de Zamora, por lo que existe una restricción geográfica respecto a esta parte de la aplicación. En el caso de ser necesario aportar una propuesta de vegetación fuera de las zonas definidas sería conveniente recurrir a otros métodos para definir la propuesta más idónea. 
En suelos granulares puros, el valor calculado para la profundidad del plano de deslizamiento es en ocasiones demasiado bajo, por lo que el programa debe asignar un mínimo. Se señala que los suelos granulares puros son poco frecuentes.

En la mayor parte de los casos, el suelo tiene un valor de cohesión inicial c $>0$, desapareciendo el problema de los suelos cohesivos puros, sin embargo, para inclinaciones altas (> 57으), se alcanza al valor máximo considerado.

- Teniendo en cuenta lo anterior, los resultados obtenidos por el programa presentan una mayor exactitud en las condiciones: suelo cohesivo, con inclinación de talud de 6oㅡ a 57ㅇ.

Debido al propio fundamento teórico del método del talud infinito, implementado en el programa, no es posible evaluar el efecto que una vegetación de tipo arbóreo ejerce al estar plantada en la cabecera de un talud, sobrecargándolo en esta zona.

La densidad máxima de plantación contemplada es de 2.500 unidades por hectárea en todos los casos de especies arbóreas y arbustivas.

\section{2.- RECOMENDACIONES}

Es conveniente asegurar que el talud inicialmente cumple la condición F.S. > 1, pudiendo lograr un margen adicional a este valor mediante la vegetación.

Es importante señalar que debido a las propiedades poco homogéneas de la vegetación, la variabilidad de las mismas en función de su etapa de desarrollo, así como otros factores, los resultados del programa no deben tomarse como valores definitivos, especialmente en el caso de que puedan existir riesgos importantes asociados a la inestabilidad del talud.

Se señala en este sentido que es conveniente en primer lugar:

- Asegurarse de que la inclinación del talud es compatible con la seguridad mínima requerida por la normativa.

- Plantear un programa de restauración, teniendo como objetivos principales la integración paisajística, evitar problemas de erosión, mejorar el entorno, etc. 
- Evaluar finalmente, el incremento en la seguridad del talud aportado por el refuerzo de la vegetación, o bien detectar si se produjese el efecto contrario.

En suelos cohesivos, a partir de los 55으, conviene plantear solamente la restauración a base de especies herbáceas, ya que las arbóreas pueden tener un efecto negativo en la estabilidad sobre terrenos con pendiente elevada.

Como ha sido expuesto, fuera de las condiciones identificadas, en las cuales la exactitud del programa es mayor, debe exigirse un factor de seguridad ligeramente mayor.

Si se conoce a priori la profundidad del plano de deslizamiento $(z)$, por existencia de algún tipo de plano de discontinuidad, es conveniente introducirla directamente en el programa.

A la hora de plantear la restauración de una zona, para el desarrollo de una vegetación arbórea en un suelo totalmente alterado, sin una cohesión inicial ni una estructura definida, es aconsejable proceder de la siguiente forma:

- Aplicación de técnicas de reconstrucción del suelo.

- Plantación de herbáceas, aplicando hidrosiembra, o métodos alternativos para estabilización del suelo.

- Las herbáceas generarán las condiciones de suelo que permitirán el desarrollo futuro de las especies arbóreas.

\section{3.- EJEMPLOS PRÁCTICOS Y ENSAYOS}

\subsection{1.- Aplicación: Restauración de explotaciones mineras o escombreras}

El programa permite analizar la estabilidad en cada una de las fases de restauración: Un ejemplo práctico sería el siguiente: Restauración de una escombrera.

Tabla 8. Ejemplo práctico de cálculo para la restauración de una escombrera en dos etapas.

\begin{tabular}{|c|c|c|}
\hline Condiciones de terreno & GP: Gravas mal graduadas, mezclas de grava y arena \\
\hline $\mathbf{c}=0$ & $\varnothing=35^{\circ}$ & $\gamma=19,2 \mathrm{kN} / \mathrm{m}^{3}$ \\
\hline \multicolumn{2}{|c|}{ Condiciones de talud } & \\
\hline
\end{tabular}


MEMORIA

\begin{tabular}{|l|l|l|}
\hline \multicolumn{1}{|c|}{$\beta=35^{\circ}$} & \multicolumn{1}{|c|}{ N.F. clase 1 } & \multicolumn{1}{c|}{ F.S.0 $=1,03$} \\
\hline Restauración & 1.- Hidrosiembra de herbáceas & 2.- Plantación de árboles \\
\hline Mezcla de especies & $\begin{array}{l}\text { Lodium peremne --- 25\% } \\
\text { Agropyrum desertorum --- 20\% } \\
\text { Festuca arrundinacea --- 20\% } \\
\text { Dactylis glomerata --- 15\% } \\
\text { Medicago sativa --- 05\% } \\
\text { Trifolium subterraneum --- 05\% } \\
\text { Lotus cormiculatus --- 05\% } \\
\text { Onobrychis sativa --- 05\% }\end{array}$ & $\begin{array}{l}\text { Quercus ilex --- 20\% } \\
\text { Sorbus aucuparia --- 10\% }\end{array}$ \\
\hline Densidad plantación & \multicolumn{1}{|c|}{5.000 ud/ha } & 2.500 ud/ha \\
\hline Período & 1 año & $>2-3$ años \\
\hline F.S. & $\mathbf{1 , 3 7 5}$ & $\mathbf{1 , 4 9 9}$ \\
\hline
\end{tabular}

En la primera etapa se produce el desarrollo de las herbáceas, proporcionando un factor de seguridad de 1,37 a un talud prácticamente en el límite de equilibrio, posteriormente, la implantación de las especies arbóreas eleva el F.S. a 1,49. Para las condiciones de talud existentes, se exige un F.S. mínimo de 1,3 (clase de riesgos C2), en el caso de que fuera temporal (aplicable en la fase de desarrollo de las herbáceas), y de 1,5 (clase de riesgo (5), en el caso de que fuese permanente (valor que deberá superar cuando sea considerado definitivo, esto es, cuando se desarrolle la vegetación arbórea).

Se puede comprobar con el ejemplo la posibilidad que ofrece el programa de evaluar la incidencia de le vegetación en situaciones como la expuesta, justificando las soluciones adoptadas.

\subsection{2.- Estudio de la influencia del tipo de especies}

Se estudia en este apartado la variabilidad del incremento del F.S., en función de las condiciones de talud, terreno y especies vegetales, con objeto de determinar cuáles son las más idóneas, según los resultados del programa, para aumentar el valor del factor de seguridad. 
Hasta 55으 de inclinación de taludes (35으, si se trata de suelos granulares), los mayores aumentos se producen con especies arbóreas y arbustivas que presentan las siguientes propiedades:

- Elevada resistencia del sistema radicular.

- Profundidad de raíces alta.

- Bajo desarrollo de la parte aérea.

- Peso relativamente reducido.

$\checkmark$ Especies vegetales: Juglans regia, Quercus sp, Pinus nigra, Pinus sylvestrys, Ilex aquifolium, Salix alba, Taxus bacata.

Tabla 9. Algunos ejemplos de aumento del F.S. con especies arbóreas y arbustivas.

\begin{tabular}{|l|c|c|c|}
\hline \multirow{2}{*}{$\begin{array}{c}\text { Condiciones de terreno } \\
\mathbf{c}=13,2 \mathrm{kN} / \mathrm{m}^{2}\end{array}$} & \multicolumn{3}{|c|}{ CL: Arcillas inorgánicas poco plásticas o de plasticidad mediana } \\
\hline Condiciones de talud & \multicolumn{2}{|c|}{$\gamma=30^{\circ}$} & \multicolumn{2}{c|}{$\gamma=14,0 \mathrm{kN} / \mathrm{m}^{3}$} \\
\hline Especies & F.S. & N.F. clase 1 \\
\hline Juglans regia & 1,86 & 2,66 & Incremento \\
\hline Pinus nigra & 1,86 & 2,67 & $42,93 \%$ \\
\hline Pinus sylvestrys & 1,86 & 2,60 & $43,79 \%$ \\
\hline Ilex aquifolium & 1,86 & 2,69 & $40,00 \%$ \\
\hline Salix alba & 1,86 & 2,64 & $44,87 \%$ \\
\hline Taxus bacata & 1,86 & 2,66 & $42,17 \%$ \\
\hline Quercus sp. & 1,86 & $2,70-2,74$ & $45,17 \%-47,58 \%$ \\
\hline
\end{tabular}

A partir de los 550 de inclinación de taludes, y en general, en suelos no cohesivos, se recomienda plantear restauraciones a base de especies herbáceas, debido a que:

- La elevada densidad del sistema radicular aporta una elevada cohesión.

- Los efectos del peso y arrastre del viento son irrelevantes.

$\checkmark$ Especies vegetales: Lolium peremne, Festuca arundinacea, Trifolium subterraneum, Lotus corniculatus, Medicago sativa, etc.

Tabla 10. Algunos ejemplos de aumento del F.S. con especies herbáceas. 
DESARROLLO DE UNA APLICACIÓN INFORMÁTICA PARA EL CÁLCULO DE SOSTENIMIENTO DE TALUDES MEDIANTE REVEGETACIÓN

MEMORIA

\begin{tabular}{|l|c|c|c|}
\hline \multicolumn{1}{|c|}{ Condiciones de terreno } & \multicolumn{2}{|c|}{ CL: Arcillas inorgánicas poco plásticas o de plasticidad mediana } \\
\hline Condiciones de talud & \multicolumn{2}{|c|}{$\varnothing=30^{\circ}$} & \multicolumn{2}{|c|}{$\gamma=14,0 \mathrm{kN} / \mathrm{m}^{3}$} \\
\hline Especies & F.S. & \multicolumn{2}{|c|}{ N.F. clase 1} \\
\hline Lodium peremne & 1,86 & F.S.V & Incremento \\
\hline Festuca arrundinacea & 1,86 & 2,59 & $39,06 \%$ \\
\hline
\end{tabular}

\begin{tabular}{|l|c|c|c|}
\hline \multicolumn{1}{|c|}{ Condiciones de terreno } & \multicolumn{3}{|c|}{ GC: Gravas arcillosas, mezclas de grava, arena y arcilla } \\
\hline $\mathbf{c}=0$ & $\varnothing=32,6^{\circ}$ & \multicolumn{2}{|c|}{$\gamma=17,0 \mathrm{kN} / \mathrm{m}^{3}$} \\
\hline Condiciones de talud & $\beta=35^{\circ}$ & \multicolumn{2}{|c|}{ N.F. clase 1} \\
\hline Especies & F.S. & F.S.V & Incremento \\
\hline Lodium peremne & 0,64 & 1,32 & $104,06 \%$ \\
\hline Festuca arrundinacea & 0,64 & 1,32 & $104,06 \%$ \\
\hline
\end{tabular}

Se detectan aumentos de F.S. $>100 \%$, en algunos casos de suelos granulares, debido a que la vegetación aporta una cohesión al terreno inexistente anteriormente, lo que justifica los resultados. En cualquier caso la restauración de este tipo de suelos requiere añadir algún tipo de estabilizante, que aporte algo de cohesión previa al crecimiento de la vegetación.

\subsection{3.- Estudio de la influencia de la densidad de plantación}

Se ha podido verificar que densidades de plantación elevadas sobrecargan de forma excesiva los taludes de elevada pendiente, lo que contrarresta los efectos positivos de refuerzo producido por las raíces. Este efecto no es aplicable a herbáceas.

Tabla 11. Algunos ejemplos de la influencia de la densidad de plantación en el F.S.

\begin{tabular}{|c|c|c|c|}
\hline \multirow{2}{*}{$\begin{array}{c}\text { Condiciones de terreno } \\
\mathbf{c}=20,5 \mathrm{kN} / \mathrm{m}^{2}\end{array}$} & \multicolumn{3}{|c|}{ SM: Arenas limosas, mezclas de arena-limo mal graduadas } \\
\hline Condiciones de talud & \multicolumn{2}{|c|}{$\beta=32^{\circ}$} & \multicolumn{2}{c|}{$\gamma=15,5 \mathrm{kN} / \mathrm{m}^{3}$} \\
\hline \multirow{2}{*}{ Especies } & \multicolumn{2}{|c|}{ N.F. clase 2} \\
\cline { 2 - 4 } & Crataegus migra & \multicolumn{2}{c|}{$90 \%$} \\
\hline Densidad [ud./ha] & F.S. & F.S.v & $10 \%$ \\
\hline 2500 & 1,64 & 2,162 & $31,57 \%$ \\
\hline 1600 & 1,64 & 2,175 & $32,36 \%$ \\
\hline 1100 & 1,64 & 2,182 & $32,82 \%$ \\
\hline
\end{tabular}


DESARROLLO DE UNA APLICACIÓN INFORMÁTICA PARA EL CÁLCULO DE SOSTENIMIENTO DE TALUDES MEDIANTE REVEGETACIÓN

MEMORIA

\begin{tabular}{|c|c|c|c|}
\hline 600 & 1,64 & 2,190 & $33,29 \%$ \\
\hline 300 & 1,64 & 2,194 & $33,58 \%$ \\
\hline 100 & 1,64 & 2,198 & $33,77 \%$ \\
\hline
\end{tabular}

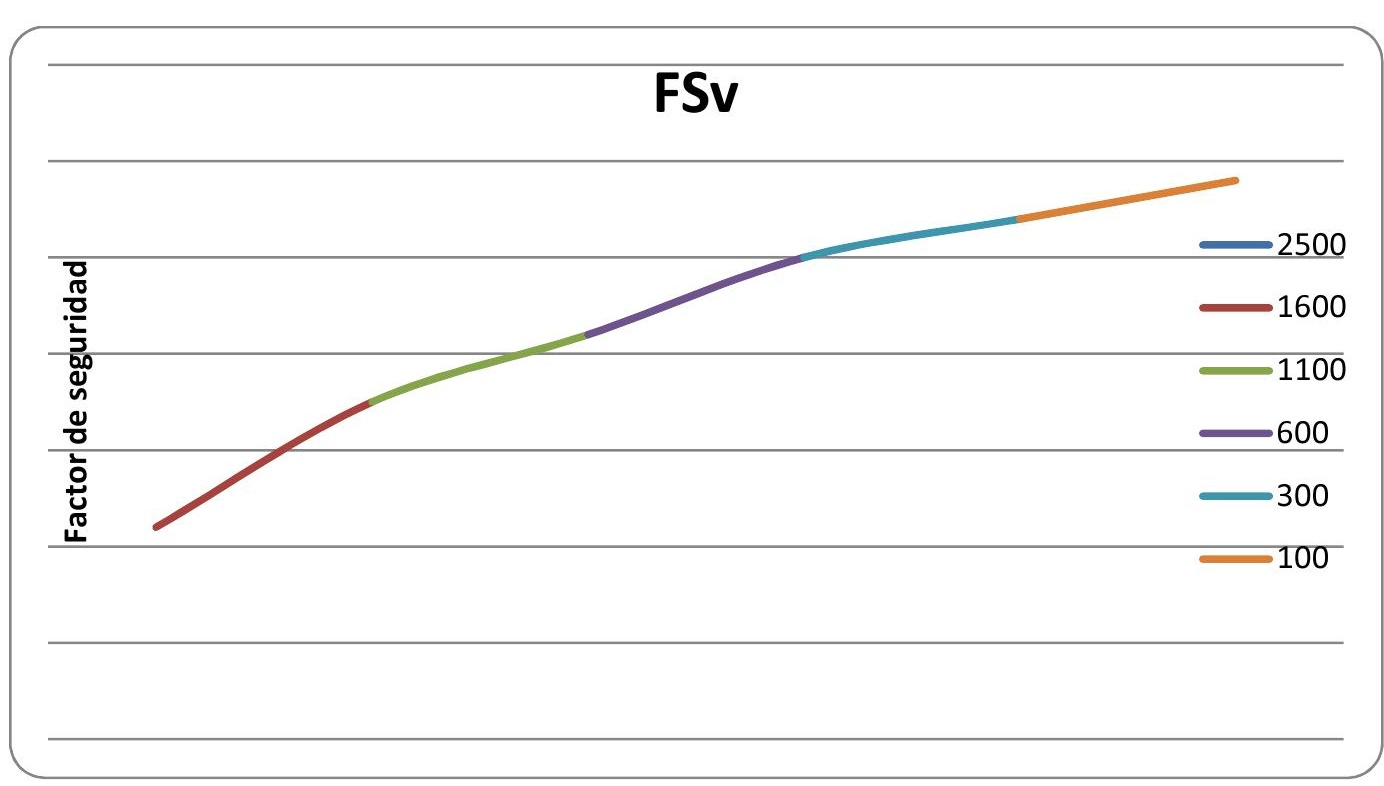

Figura 20: Evolución del F.S. por efecto de la densidad de plantación.

Como puede observarse en los ejemplos, a medida que se reduce la densidad de plantación, aumenta el F.S., hasta un aumento máximo situado en 100 unidades / ha. Por otra parte, debe tenerse en cuenta la variable espaciado, debido a que densidades bajas podrían ocasionar la pérdida del efecto arco, dejando zonas del talud desprotegidas. Por ello, no se consideran viables densidades inferiores a 100 unidades/ha.

Efecto combinado de las variables densidad - inclinación del talud.

Lo anteriormente expuesto se cumple para taludes en los que la pendiente empieza a ser elevada, es conveniente por ello, estudiar cual es el efecto combinado de la densidad y la inclinación del talud.

Tabla 12. Algunos ejemplos de la influencia de la densidad de plantación, combinada con la inclinación del talud sobre el F.S.

\begin{tabular}{|l|c|c|}
\hline Condiciones de terreno & \multicolumn{2}{|c|}{ SM: Arenas limosas, mezclas de arena-limo mal graduadas } \\
\hline \multicolumn{1}{|c|}{$\boldsymbol{c}=20,5 \mathrm{kN} / \mathrm{m}^{2}$} & $\varnothing=32^{\circ}$ & $\gamma=15,5 \mathrm{kN} / \mathrm{m}^{3}$ \\
\hline Condiciones de talud & $\beta$ Variable & N.F. clase 2 \\
\hline Especies & Pinus nigra & $90 \%$ \\
\hline
\end{tabular}


DESARROLLO DE UNA APLICACIÓN INFORMÁTICA PARA EL CÁLCULO DE SOSTENIMIENTO DE TALUDES MEDIANTE REVEGETACIÓN

MEMORIA

\begin{tabular}{|c|c|c|}
\hline & Crataegus monogyna & $10 \%$ \\
\hline \multirow{3}{*}{ Inclinación $\beta$} & \multicolumn{2}{|c|}{ Incremento de F.S. } \\
\cline { 2 - 3 } & Densidad: 2500 ud./ha & Densidad: 100 ud./ha \\
\hline $10^{\circ}$ & $38,52 \%$ & $35,46 \%$ \\
\hline $30^{\circ}$ & $38,89 \%$ & $35,70 \%$ \\
\hline $35^{\circ}$ & $38,38 \%$ & $34,60 \%$ \\
\hline $36^{\circ}$ & $31,72 \%$ & $34,05 \%$ \\
\hline $37^{\circ}$ & $31,57 \%$ & $33,77 \%$ \\
\hline $40^{\circ}$ & $32,72 \%$ & $32,76 \%$ \\
\hline $50^{\circ}$ & $-28,33 \%$ & $-27,98 \%$ \\
\hline
\end{tabular}

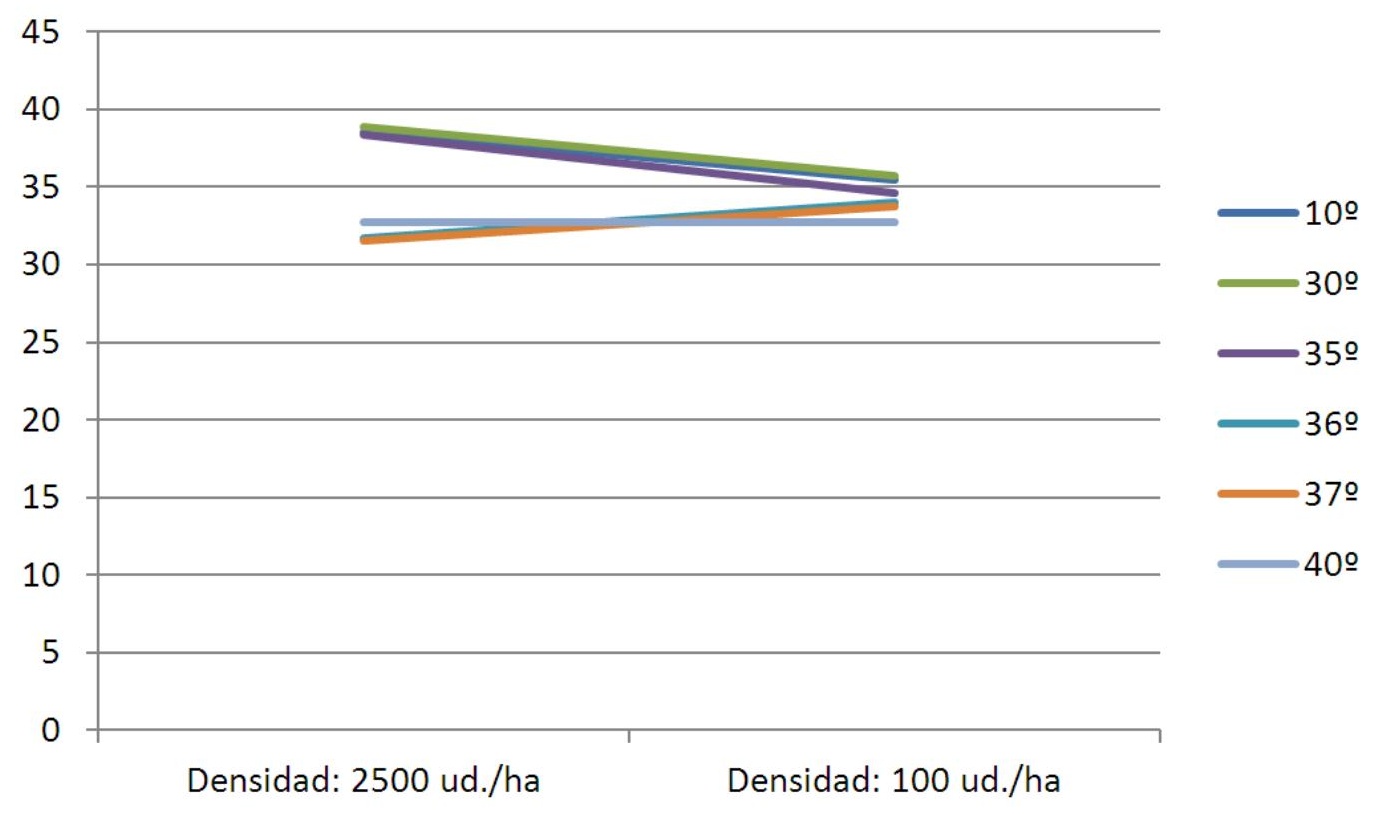

Figura 21: Evolución del incremento del F.S. (\%), por efecto combinado de la densidad de plantación y de la inclinación del talud.

Se observa que es necesario tener en cuenta la inclinación del talud para evaluar la influencia de la densidad sobre el aumento del factor de seguridad, en el sentido que se indica:

- Para inclinaciones elevadas $(>36 \%)$ el incremento del factor de seguridad es mayor cuanto menor es la densidad de plantación, debido a la reducción de sobrecarga. 
- En el caso de pendientes bajas (<35), se produce un mayor aumento del factor de seguridad por efecto de la vegetación, a medida que aumenta su densidad, debido a la contribución del peso sobre la resistencia a cortante.

- Para pendientes entorno a 40ㅇ, la diferencia es poco apreciable, apareciendo, en 50ㅇ disminuciones de factor de seguridad por aumento excesivo de la componente tangencial del peso de la vegetación.

- Entre los valores de inclinación de talud $35^{\circ}-36^{\circ}$, se produce una inversión de la tendencia al aumento del F.S. con la densidad, apreciándose que a partir de esta inclinación se produce el efecto opuesto. 
DESARROLLO DE UNA APLICACIÓN INFORMÁTICA PARA EL CÁLCULO DE SOSTENIMIENTO DE TALUDES MEDIANTE REVEGETACIÓN

\section{-}




\section{ANEXO I \\ TÉCNICAS DE IMPLANTACIÓN UTILIZADAS EN REVEGETACIÓN DE TALUDES}

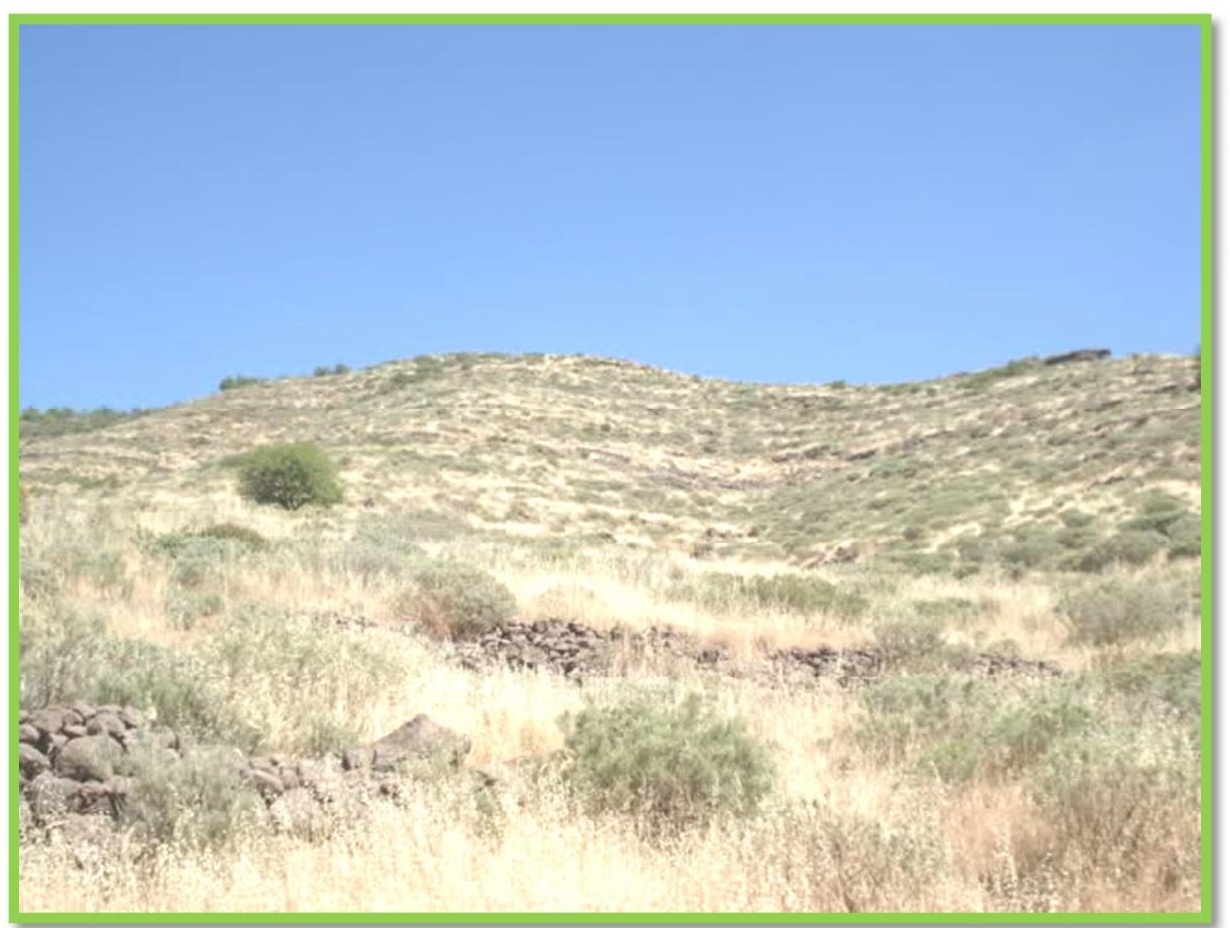




\section{ÍNDICE}

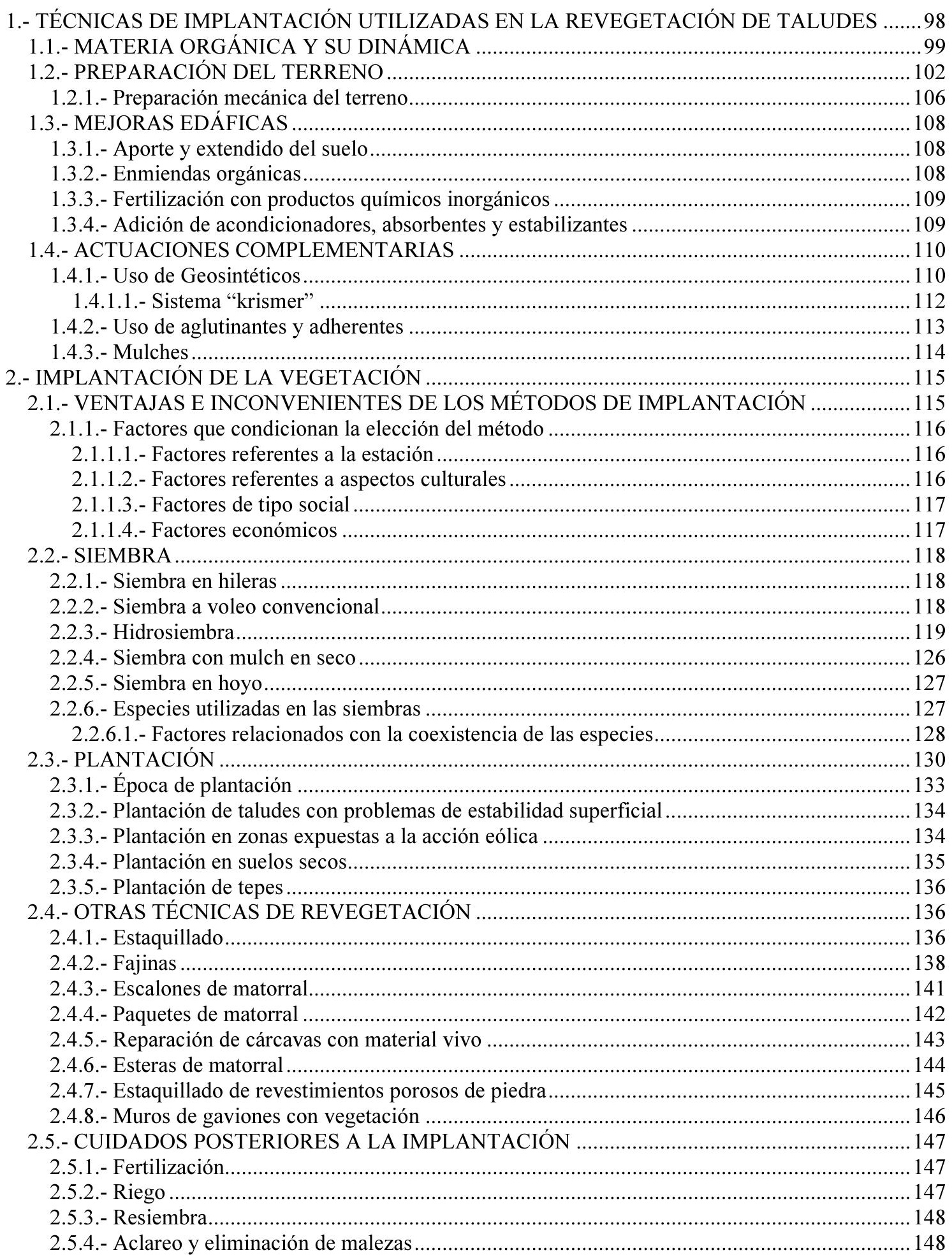


DESARROLLO DE UNA APLICACIÓN INFORMÁTICA PARA EL CÁLCULO DE SOSTENIMIENTO

DE TALUDES MEDIANTE REVEGETACIÓN

ANEXO I.- TÉCNICAS DE IMPLANTACIÓN UTILIZADAS EN LA REVEGETACIÓN DE TALUDES

3.- CARACTERÍSTICAS DE LAS ESPECIES UTILIZADAS EN REVEGETACIÓN 149

3.1.- ESPECIES HERBÁCEAS

150

3.2.- ESPECIES LEÑOSAS

154 


\section{1.- TÉCNICAS DE IMPLANTACIÓN UTILIZADAS EN LA REVEGETACIÓN DE TALUDES}

Las características del medio que determinarán la selección de especies, la técnica de implantación y la viabilidad de la revegetación son, junto a las condiciones de humedad y temperatura del sustrato, las características físicas, químicas y estructurales, en casi todos los casos muy distintas a las de los suelos naturales.

El sustento vegetal proporcionado por el suelo depende de las interrelaciones entre las propiedades físicas, químicas y biológicas que pueda presentar y, a su vez estas quedan definidas por los distintos constituyentes del medio edáfico; sin embargo, la fracción orgánica del suelo y la biomasa microbiana asociada cumplen un rol determinante en la dinámica el sistema edáfico.

Es particularmente conocido el papel que desempeña la materia orgánica en la génesis y evolución de los suelos, constituyendo la única fuente de reserva de nitrógeno en el suelo, Además de su participación para la estructuración de la mayoría de los materiales que componen los suelos, particularmente los de textura fina.

La cantidad y calidad de materia orgánica incide sobre los diversos procesos bioquímicos y químicos en el sistema edáfico y representa la base de la fertilidad de los suelos, expresada a través de los efectos directos o indirectos que ejercen estas fracciones orgánicas en el crecimiento y desarrollo de las plantas.

La disminución de los niveles de materia orgánica está asociada a la pérdida de la capacidad de sustentación del suelo, conllevando lentamente a la desagregación y por ende colaborando con el proceso de degradación de los suelos.

Debe entonces tenerse en cuenta que los balances asociados a la materia orgánica son fundamentales a la hora de hablar de planes de manejo que conserven o aumenten las cantidades de esta presentes en el suelo. Sin embargo, la práctica de incorporar materia orgánica directamente al suelo, no resulta recomendable, pues requieren de tiempo para lograr la condición de ser asimilables por los vegetales a través de los procesos de humificación y mineralización. 
Una alternativa interesante la constituyen los bioprocesos, tales como el compostaje u oxidación biológica y la fermentación o reducción biológica.

El material procedente de estos procesos, contiene un cierto grado de nutrientes disponibles para las plantas, tiene mejor calidad sanitaria, además del aporte de materia orgánica estabilizada o humus, principal responsable de la mayoría de los procesos fisicoquímicos y biológicos presentes en el suelo.

\section{1.- MATERIA ORGÁNICA Y SU DINÁMICA}

La materia orgánica es una mezcla heterogénea de diversos residuos animales, vegetales y microbianos en diferentes estados de descomposición por la acción catabólica de la biomasa edáfica que sustenta. Dentro de este sistema, la biomasa edáfica o parte biótica, conformada por la fauna macro, meso y micro, y la microflora, representa menos de un $5 \%$ del total de la materia orgánica del suelo.

En la materia orgánica abiótica, que resulta de los aportes orgánicos, se distinguen: una fracción orgánica disponible como fuente de energía y de nutrientes, del orden de un $10 \%$ del total y una fracción compleja y biológicamente más estable denominada humus. La acumulación de humus en el suelo constituye el reservorio de substancias orgánicas y representa aprox. el $85 \%$ del total de la materia orgánica del suelo. Este material es de naturaleza química polimérica, de color oscuro, hidrófilo, ácido, asociado a la materia mineral más fina del suelo. Se puede fraccionar en base a solubilidad decreciente y en pesos moleculares y estabilidad creciente, en:

- Ácidos fúlvicos.

- Ácidos húmicos.

- Huminas.

Lo anterior cobra importancia en relación a los efectos directos e indirectos que se ejercen en el crecimiento de las plantas. La influencia sobre el metabolismo vegetal está relacionada con compuestos orgánicos de bajo peso molecular, Flaig et al, 1978 ob.cit Faundez, 2000. 
En cambio los efectos indirectos, que tienen relación con las propiedades físicas y químicas del suelo, se atribuyen principalmente a las fracciones húmicas de alto peso molecular, interactuando con arcillas, cationes polivalentes y formando complejos coloidales humus-arcilla. Este complejo permite mantener al suelo con una buena estructura, a través de la agregación de partículas, mejorando la circulación del aire y del agua.

Las fracciones de ácidos fúlvicos participan activamente en procesos relacionados con movimientos iónicos y, por lo tanto con la génesis, fertilidad y dinámica del suelo, Rosell 1990 ob cit Faundez, 2000.

Las transformaciones químicas y biológicas de los aportes frescos de residuos orgánicos generan las diferentes fracciones del suelo, en donde ocurren al unísono dos procesos:

- Descomposición biológica o mineralización de fracciones orgánicas lábiles.

- Síntesis de compuestos orgánicos estables.

El balance determinado por estos dos procesos es acusado por los coeficientes de humificación o isohúmico y de descomposición del humus estable, y permite establecer la dinámica entre estos dos estados de la materia orgánica que dependen de la temperatura, humedad, nivel de oxígeno, textura del suelo, tipo de vegetación, entre otros.

La degradación biológica de las fracciones orgánicas lábiles, es decir, las menos resistentes a la actividad de la biomasa microbiana, se conoce como mineralización primaria. La descomposición rápida de estas fracciones conduce a un enriquecimiento relativo de sustancias orgánicas menos degradables como la lignina, la hemicelulosa y la celulosa. La mineralización primaria ocurre relativamente rápido y concluye con el proceso de humificación, es decir, con la formación de humus estable en pocos años, dependiendo del clima:

- Climas húmedos y templados con suelos bien aireados: 1 a 2 años.

- Climas templados y semiáridos: 2 a 3 años.

- Climas tropicales húmedos: menos de un año.

El humus a su vez, es susceptible de oxidarse al aire, pero sobretodo es descompuesto lentamente por los microorganismos, mediante la Mineralización secundaria. Esta degradación se produce con una media del orden de 0.5 a $2 \%$ del total en el término de un año, según sean las características del medio que lo origina y las condiciones del clima. Así por ejemplo bajo 
labranzas convencionales se puede mineralizar anualmente entre un 1 y $3 \%$ del humus estable; en cambio bajo labranza mínima y cero labranza, se pierde menos del $0.5 \%$ Rosell 1990 ob. cit Faundez, 2000.

Ambos tipos de mineralización poseen características comunes, como la liberación de nutrientes fácilmente absorbibles por las raíces en las plantas; sin embargo las tasas de mineralización primaria son más altas que las de mineralización secundaria. Comúnmente en suelos sin intervención, se alcanza un estado de equilibrio, donde el nivel de materia orgánica abiótica es una función de los aportes orgánicos frescos de las transformaciones bioquímicas microbiológicas de estos residuos.

En el caso de suelos sometidos a diversas prácticas de manejo, como la quema de rastrojos y residuos, este equilibrio se altera. Se destruye el nivel superficial de materia orgánica, acompañado de una esterilización microbiológica, especialmente en el caso de cepas termolábiles (susceptibles a las temperaturas). Las altas temperaturas desnaturalizan las proteínas, aceleran la oxidación química de la materia orgánica, con una gran producción de $\mathrm{CO}_{2}$, junto con las pérdidas de Nitrógeno (N) y Azufre (S) asociadas a la materia orgánica (Aguilera, 2000).

Luego, esta disminución de la fracción orgánica determina la eventual pérdida de la estructura y el peligro de erosión del suelo. Si se considera el cuantioso desecho orgánico animal y vegetal que se produce anualmente por la actividad antrópica y natural, no puede desestimarse la utilización e incorporación de estos al suelo, aprovechando su potencial energético y nutricional.

Los diferentes tratamientos de estos desechos, implican un uso más adecuado de estos recursos, reciclando las materias primas, estabilizándolas mediante bioprocesos, obteniendo productos con valor agregado para utilizarlos como acondicionadores y/o abonos orgánicos de suelo. 


\section{2.- PREPARACIÓN DEL TERRENO}

En general, los taludes presentan condiciones inadecuadas para el desarrollo de vegetación, estas son producto del proceso de construcción de estos, tales como la pobreza edáfica y la compactación de los materiales que lo conforman.

Es frecuente también en taludes antiguos, la presencia de regueros y cárcavas e incluso problemas puntuales de inestabilidad y socavamiento de la base del talud provocados fundamentalmente por deficiencias en el control de escorrentías superficiales y subsuperficiales. Para implantar la vegetación es necesario realizar una serie de acciones de preparación con el objetivo de corregir las deficiencias mencionadas, creando en la zona de actuación condiciones topográficas, de drenaje y calidad del sustrato adecuadas.

Se proponen tres tipos de medidas:

- Remodelado y control del drenaje.

- Preparación mecánica del sustrato.

- Mejoras edáficas.

Es adecuado para las labores de preparación e implantación, que estas se desarrollen en lo posible durante la construcción del talud, puesto que de lo contrario se crean condiciones de accesibilidad bastante deficientes que obligan al uso de maquinaria no convencional que encarece los costos y dificulta la realización de las operaciones, llegando incluso a la imposibilidad de actuar sobre el terreno.

Comúnmente, la cabecera del talud, pie y bordes laterales, presentan perfiles de alta pendiente, que ofrecen condiciones adversas a la revegetación y mayor exposición de la estructura a los efectos de la erosión provocada por la escorrentía superficial, la acción eólica y el desecamiento. 


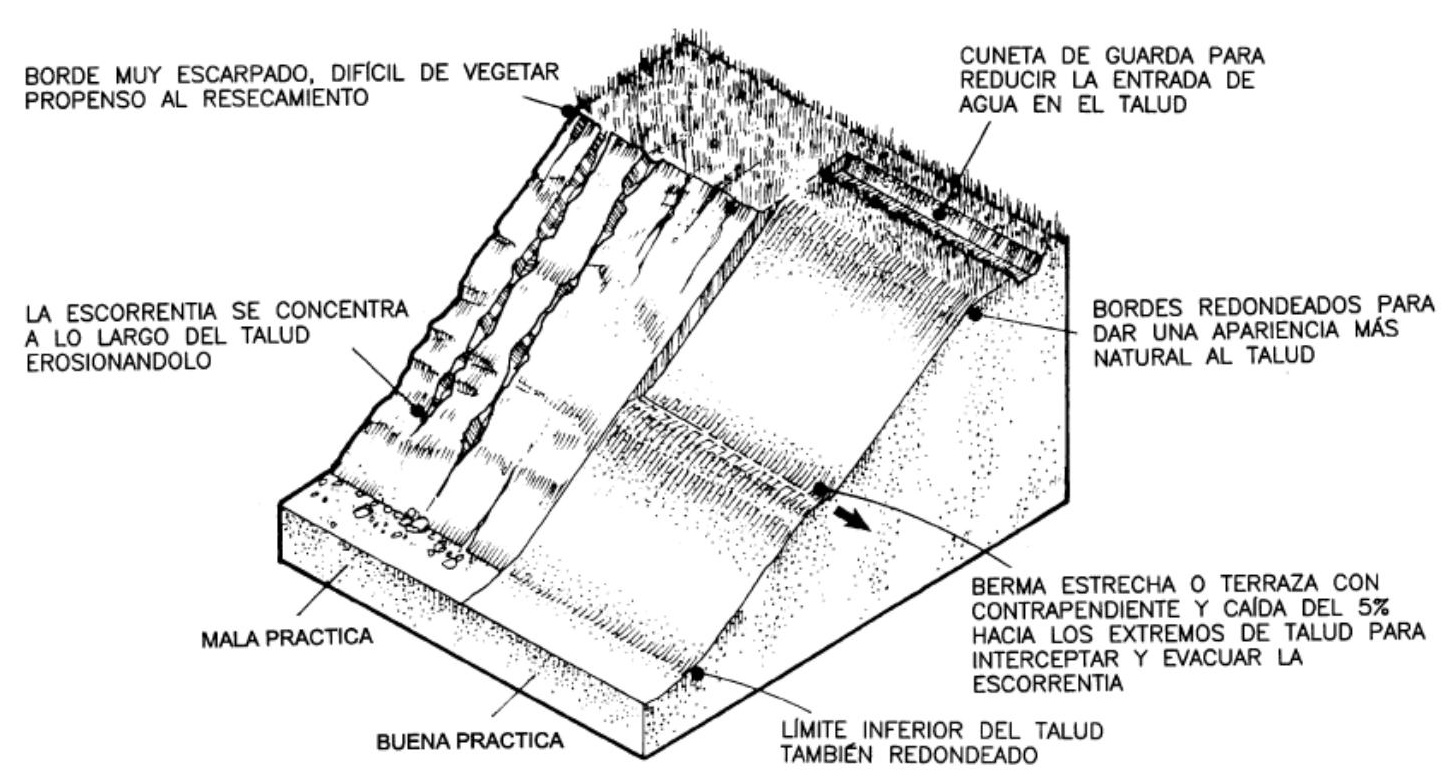

Figura 22: Remodelado de un talud típico

Por esta razón los perfiles deben ser redondeados, facilitando de esta forma el enraizamiento de la vegetación, disminuyendo y eliminando los efectos de la erosión. De presentarse taludes con superficies afectadas por la erosión, tales como líneas de erosión laminar, regueros, cárcavas y zonas de abarrancamiento, deben ser tratados para su desaparición, creando una superficie lisa y perfilada. Las irregularidades menos profundas pueden tratarse con el uso de arado o niveladoras, que deben aplicarse según la línea de máxima pendiente (Figura 1)

Si el talud presenta pendientes inferiores a $1 \mathrm{H}$ : $3 \mathrm{~V}$, y es accesible, la operación de remodelado deberá hacerse a través del empleo de máquinas especiales o modificadas para estas condiciones.

Para el caso de taludes antiguos, puede darse el caso de que presenten bolos, los que deberán retirarse empujándolos pendiente abajo y dando un uso de muro de contrafuerte en el pie del talud.

En caso de que los materiales sean, muy erosionables, la longitud de la pendiente muy extensa, o los eventos de precipitación sean de una intensidad alta, el rol de la vegetación frente a los procesos asociados será limitado, debiendo de esta manera actuar sobre éstos para minimizar la intensidad y/o prevenir los procesos erosivos y sus efectos. 
Las medidas a tomar en esta dirección deben apuntar hacia los dos factores que determinan estos procesos erosivos:

- Volumen de escorrentía, reduciendo el ingreso de agua al interior del talud.

- Velocidad de escorrentía, disminuyendo la longitud efectiva de la pendiente.

La reducción del volumen de escorrentía a través de la disminución del ingreso de agua, se hace a través de la construcción de cunetas en la cabecera del talud, interceptando estas las aguas de escorrentía generadas en el entorno del talud $y$, conduciéndolas hacia fuera de la estructura a través de la pendiente dada a la canaleta en los bordes del talud.

Por su parte, la reducción de la velocidad de escorrentía a través de la reducción efectiva de la pendiente, se hace mediante la construcción de una serie de bermas o banquetas, transversales a la línea de máxima pendiente y con contrapendiente de $0.5-1 \%$, las que deben tener una zanja en su interior que conduzca el agua interceptada a través de una caída transversal a la línea de máxima pendiente hacia los bordes del talud.

Las bajadas o drenes laterales del talud serán las vías de evacuación final. No existen recetas para determinar el ancho óptimo de las banquetas, sin embargo, se ha visto que no debe ser inferior a 1 - $1.5 \mathrm{~m}$. de ancho, siendo variables hasta terrazas por donde puede pasar maquinaria utilizada para operaciones de implantación de vegetación.

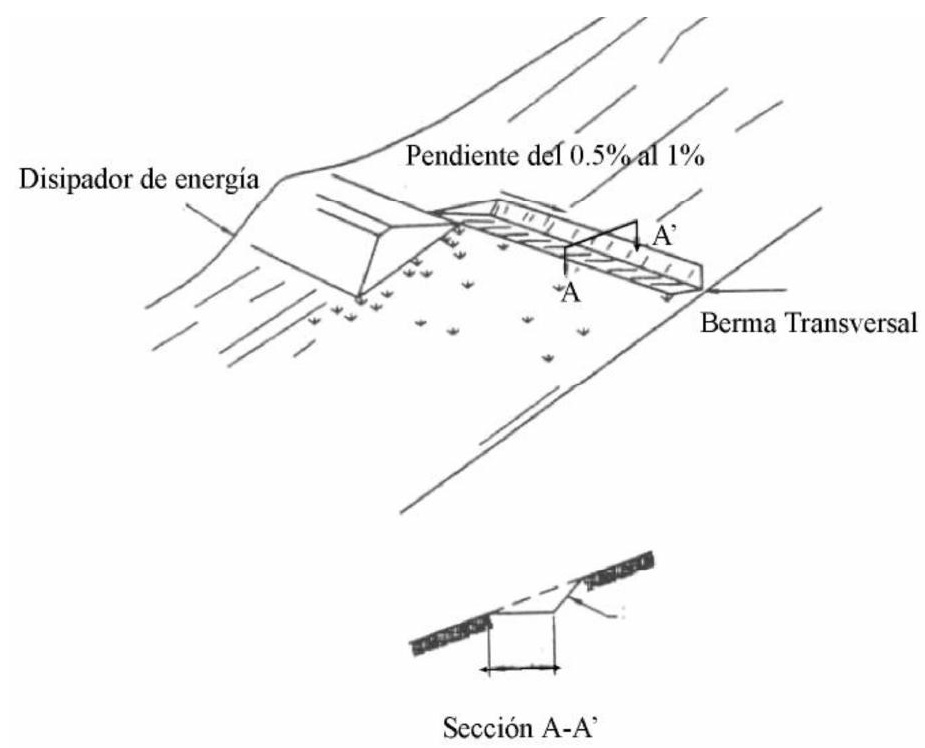

Figura 23: Berma transversal y barrera de disipación. 
La construcción de barreras de disipación se hace para reducir la velocidad del agua de escorrentía que discurre por la superficie del talud y con ello sus efectos erosivos. Estas construcciones son barreras transversales a la pendiente formadas por piedras, ramajes, matojos de paja etc., que frenan el paso del agua disipando su energía cinética y la erosividad asociada aguas abajo.

Las filtraciones de agua pueden ser causa de deslizamientos y de desencadenamiento de procesos de erosión superficial. Estas pueden proceder de las capas inferiores del subsuelo, o de la infiltración en la cabecera del talud que se moviliza por su interior buscando una zona de material de menor conductividad hidráulica. Las filtraciones de origen superficial pueden controlarse a través de la construcción de zanjas de drenaje en las zonas críticas, como sería la cabecera del talud. Por su parte las filtraciones profundas se controlan con la construcción de drenes horizontales o la instalación de tuberías perforadas introducidas en el talud, que interceptan y reconducen el agua hacia los extremos para su evacuación.

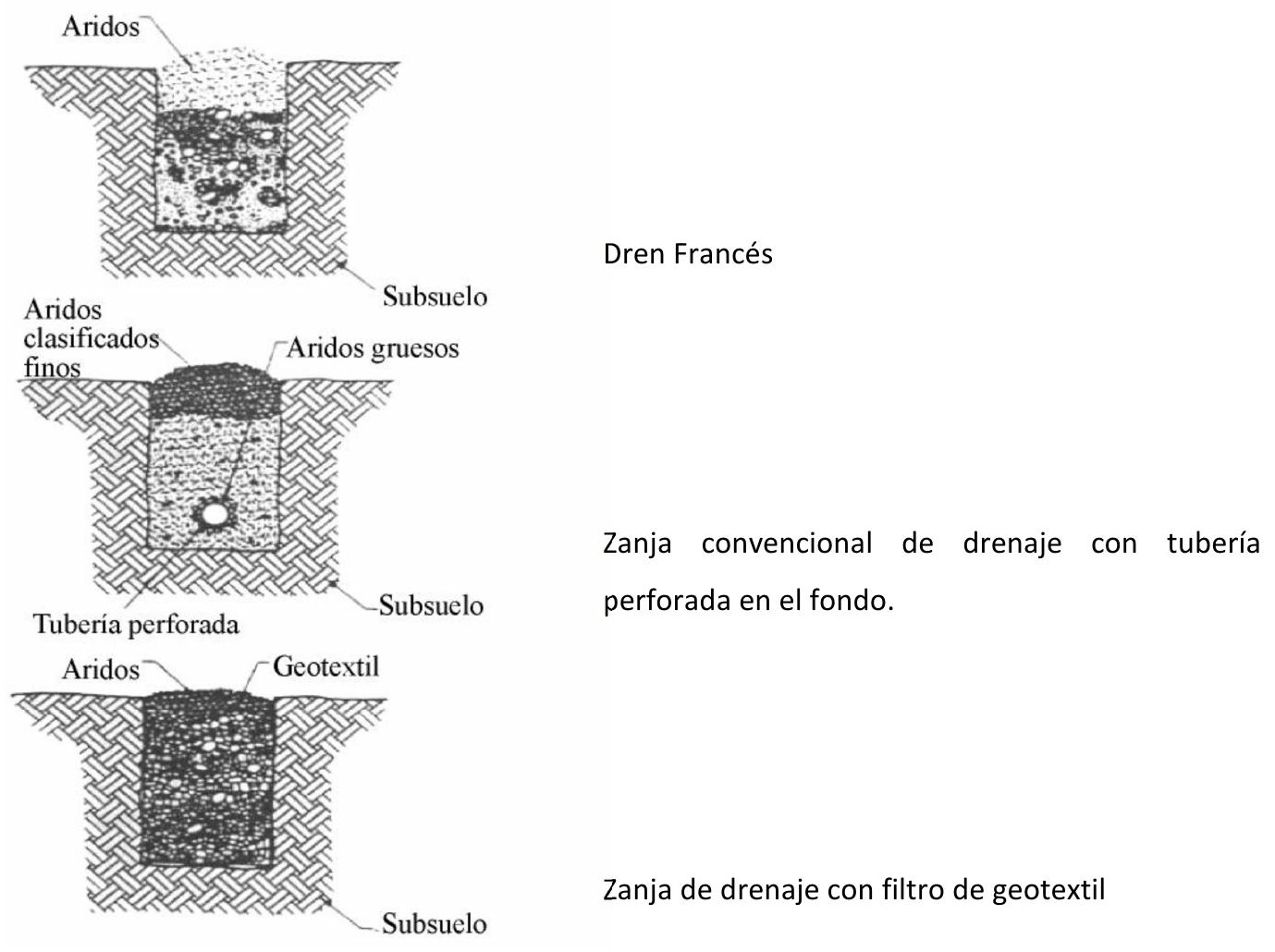

Figura 24: Tipos de drenajes. 


\subsection{1.- Preparación mecánica del terreno}

El proceso fundamental será el descompactado del terreno, que proporciona los siguientes efectos:

- Reducción del volumen de escorrentía por efecto de la creación de caminos de drenaje e incremento de la velocidad de infiltración.

- Aumento de la capacidad de almacenamiento de agua y, por ende, de la profundidad potencial de enraizamiento debido a la reducción de la densidad del suelo.

Esta técnica se realiza utilizando un riper, un subsolador o un arado de vertedera, dependiendo del nivel de volteo y mezcla del sustrato que se pretenda.

Junto con la aplicación del descompactado, se proponen también una serie de actuaciones englobadas dentro de lo que se denomina preparación de la cama de siembra, que están ligadas a lo que es la implantación de la vegetación propiamente tal, y que están destinadas a la correcta implantación y a asegurar que la germinación y el arraigo de la vegetación se desarrolle en los niveles óptimos.

La preparación de la cama de siembra se compone de las siguientes actuaciones:

- Pases de rodillo.

- Rastrillado profundo.

- Nivelación.

- Despedregado.

- Mullido.

- Gradeo.

- Arado.

El método a usar será determinado por la forma de implantación a utilizar, la accesibilidad de la superficie del talud, tipo de suelo y niveles de humedad. No existen reglas rígidas para establecer las condiciones idóneas de un terreno, por lo que esta dependerá del método de implantación a usar. Así entonces, para la plantación es casi irrelevante el estado de la superficie del terreno, ya que su preparación se hace con la apertura y relleno de los 
hoyos de cada planta individual, mientras que en la siembra no solo es básica para la obtención de buenos resultados, sino que la condiciona directamente.

Es así como podemos esperar que para el uso de siembra, es necesario que la superficie del terreno este razonablemente nivelada, despedregada y mullida. Por el contrario, en el uso de la técnica de la hidrosiembra o siembra a voleo sin enterramiento de las semillas es necesario que la superficie posea una estructura rugosa, con grietas y hendiduras, protegiendo los niveles de humedad y proporcionando protección contra los ciclos de humedad desecación.

Para taludes con pendiente inferior a $1 \mathrm{~V}: 3 \mathrm{H}$ es posible utilizar para las labores mencionadas maquinaria del tipo agrícola convencional. De no poderse dada la pendiente y condiciones de accesibilidad adversas, se deberán ocupar maquinarias adaptadas especialmente.

Por razones de seguridad, normalmente es preferible que la maquinaria trabaje según la línea de máxima pendiente, pero esta manera crea surcos longitudinales que podrían favorecer los procesos erosivos, razón por la que se prefiere que los trabajos se realicen en forma transversal.

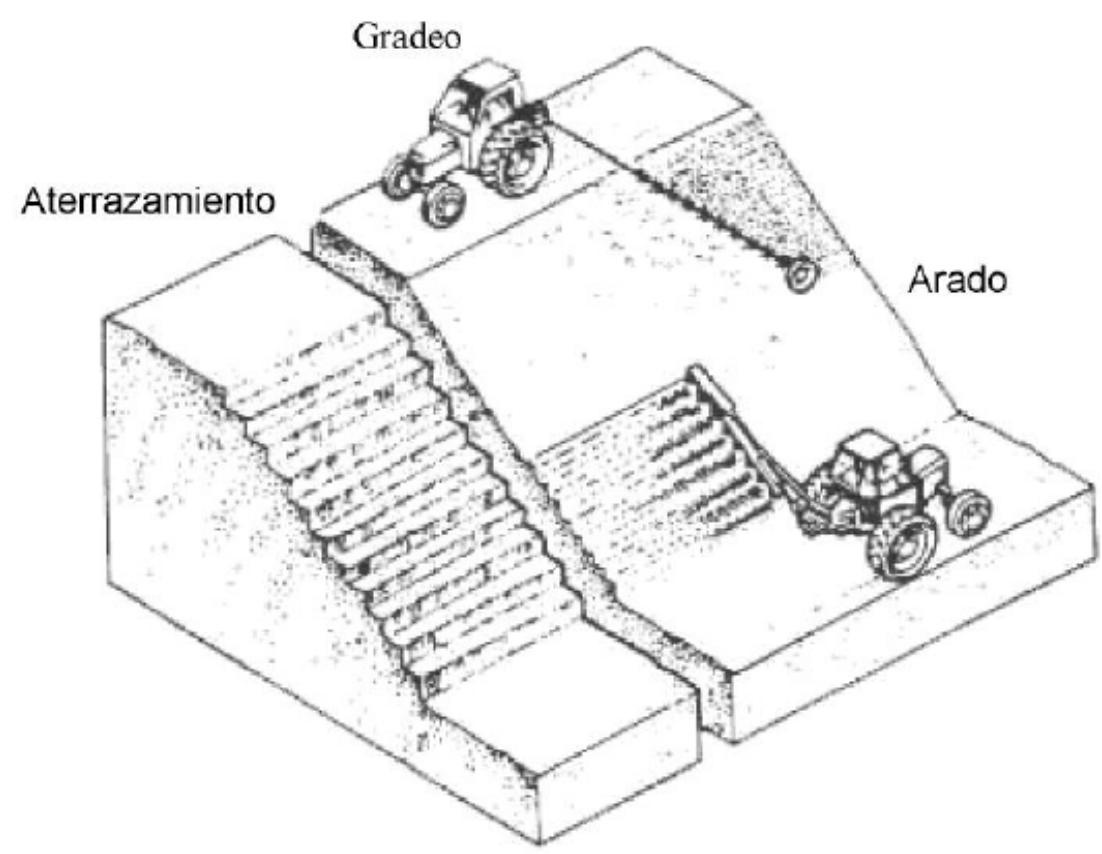

Figura 25: Técnicas de preparación mecánica del terreno 


\section{3.- MEJORAS EDÁFICAS}

En general, los taludes no presentan buenas condiciones físicas, químicas ni biológicas para el establecimiento de vegetación y su desarrollo. Los problemas más frecuentes están relacionados con la ausencia de materia orgánica, nutrientes, bajo nivel de agregación y texturas extremas. Todos estos derivados de la tendencia a la excesiva retención de agua o encharcamiento, o bien insuficiencia en esta. Caso típico de esto serian los taludes de corte en roca, que presentan directamente una inexistencia de suelo.

Existen diversas técnicas destinadas a mejorar las características del sustrato, sin embargo, se pueden distinguir cuatro tipos:

- Aporte y extendido del suelo.

- Enmiendas orgánicas.

- Fertilización con productos químicos inorgánicos.

- Adición de acondicionadores, estabilizantes y absorbentes.

\subsection{1.- Aporte y extendido del suelo}

Su objetivo es crear una superficie con características fisicoquímicas y espesor suficientes que permitan el arraigo y desarrollo de la vegetación a implantar. Puede ser constituido por tierras naturales, de préstamo u obtenidas del mismo suelo. En el caso de no hacer una retirada previa del suelo para su posterior uso, la utilización de tierra vegetal de mejor calidad, hará probablemente incurrir en costos y esfuerzos adicionales.

\subsection{2.- Enmiendas orgánicas}

Estas son aplicadas para incrementar los niveles de fertilidad del sustrato y mejorar las propiedades físicas (estructura, capacidad de retención, aireación, etc.). La forma química en que se hallan los nutrientes en la materia orgánica, permite su lenta absorción, manteniendo a largo plazo los niveles de fertilidad. 
El uso de las enmiendas orgánicas se hace aplicando estiércol, aunque en la actualidad hay materiales de otro tipo como el compost de residuos sólidos urbanos o lodos de plantas de tratamiento de aguas, que proporcionan mejores rendimientos y que a veces resultan más baratos.

\subsection{3.- Fertilización con productos químicos inorgánicos}

Estos productos generalmente poseen contenidos de nitrógeno, fósforo, potasio en diferentes proporciones, incluyendo entre ellos también el magnesio. La forma química en la que se encuentran los hace rápidamente asimilables por las plantas, o bien en formas lentas de liberación, proporcionando nutrientes en forma continua y a través del tiempo.

\subsection{4.- Adición de acondicionadores, absorbentes y estabilizantes}

Se aplican con el objetivo de mejorar la estructura del suelo y su capacidad de retención del agua, e incluyen:

- Alginatos: Extractos naturales de algas que mejoran la estructura, resistencia a la erosión, retención de humedad.

- Polímeros sintéticos: Su acción puede ser de tipo floculante, en cuyo caso actúa como creador de una película que une las partículas de tierra mediante la unión fisicoquímica, aportando a la desagregación; o actuar también como absorbente, caso en el que el producto retiene al agua a tensiones suficientes para evitar la evaporación, evitando perdidas por este concepto, pero lo suficientemente baja para que las raíces puedan absorber agua sin dificultad. 


\section{4.- ACTUACIONES COMPLEMENTARIAS}

A partir de la imposibilidad de realizar una buena preparación del terreno o de la susceptibilidad que este puede presentar ante los procesos erosivos, particularmente en el periodo comprendido entre la finalización de la preparación de terreno y el implante y arraigo de la vegetación, es que se han creado una serie de técnicas destinadas a obtener buenos resultados en las condiciones mencionadas.

Estos son de tres categorías:

- Geosinteticos.

- Productos aglutinantes y adherentes.

- Mulches.

\subsection{1.- Uso de Geosintéticos}

Son comúnmente utilizados para obtener protección de la superficie frente a los procesos erosivos y sujeción de las capas superficiales del terreno, aunque también cumplen una función en el arraigo de la vegetación. Los más usados son:

- Redes o mallas tridimensionales.

- Mantas orgánicas.

- Georedes celulares.

- Mantas volumétricas.

El efecto proporcionado por estas técnicas es semejante al de la vegetación en cuanto a la modificación del régimen de escorrentía superficial (intercepción, infiltración, drenaje subsuperficial, etc.), protección frente a la erosión por golpeteo, refuerzo y sujeción mecánica de las capas superficiales del suelo, etc.

Los materiales de fabricación de las mallas tridimensionales son fibras de polietileno de alta densidad, fibras de nylon u otros materiales no fotodegradables, tejidas en una o más capas. 
Una vez instaladas se rellenan con tierra y se siembran. Las raíces se introducen en los espacios del tejido, entrelazándose con el geosintético, formando una masa compacta y resistente que liga el estrato vegetal a la superficie del talud, proporcionando una protección ante la erosión permanente y continua.

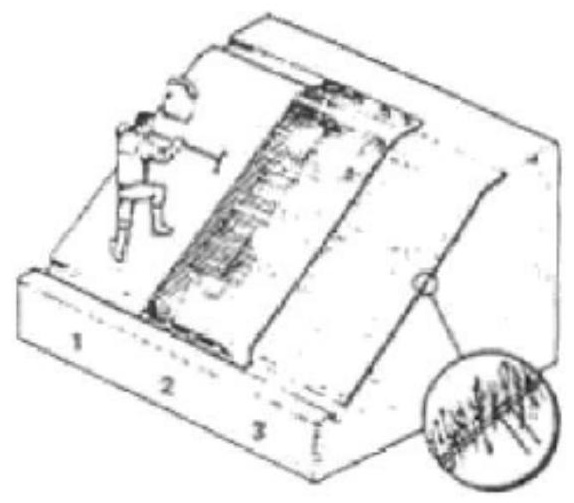

MALLA ORGÁNICA BIDIMENSIONAL PARA EL CONTROL DE LA EROSION

1.-Superficie alisada, limpia y fertilizada.

2.-Geotextil desenrrollado y clavado

3.-Siembra sobre el geotextil.

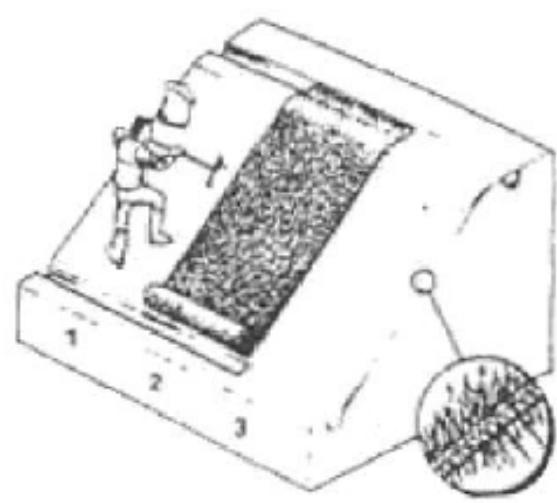

MALLA SINTETICA TRIDIMENSIONAL PARA EL CONTROL DE LA EROSION Y EL REFORZAMIENTO SUPERFICIAL.

1.-Superficie alisada, limpia y fertilizada. 2.-estera desenrrollada y clvada y asegurada en la cabecera y el pié con una zanja. 3.-Siembra.

\section{Nota:}

1.-Es importante asegurarse de que el geotextil está en intimo contacto con la superficie para el control de la erosión y el reforzamiento superficial del terreno en todo el área. 2.-Debe cuidarse no crear superficies de rotura al excavar la zanja.

Figura 26: Instalación de geosintéticos.

Para condiciones de erosión severa o las condiciones de arraigo de la vegetación son muy adversas, se recomienda utilizar mallas que contienen grava y alquitrán, césped natural precultivado, o tierra vegetal con semillas de especies de rápido crecimiento.

Cuando la erosión requiere de un control temporal solo hasta que la vegetación arraigue es suficiente con la utilización de mantas orgánicas. Estas se fabrican a partir de materiales naturales de origen vegetal (paja de cereales, fibras de coco, etc.), aunque también se usan residuos de papel y forestales. Estas mallas tienen la capacidad de ser biodegradables, razón por la que su papel es solo durante el periodo de arraigo. Se instalan sobre la superficie del talud, cubriendo con ella el suelo junto a las semillas. 
Las mantas cumplen la función de colchón amortiguador de la energía cinética de las gotas de lluvia, evitando la erosión por golpeteo, hacen continua y minimizada la evaporación, evitando también el desecamiento del suelo y las semillas.

En las redes, las fibras con las que están fabricadas cumplen la función de pequeños diques evitando que las semillas y las partículas del suelo sean arrastradas. Ambas aportan materia orgánica al suelo al descomponerse.

Las georedes (geoweb), mantas volumétricas y mallas de confinamiento celular se utilizan especialmente en el tratamiento de taludes de gran pendiente. El efecto proporcionado por este tipo de geosintéticos es a través de la formación de estructuras de contención, celdas o alvéolos, que quedan rellenos con el sustrato aportado impidiendo que este se deslice pendiente abajo. Los materiales de fabricación pueden ser sintéticos (fibras de nylon, poliéster, o laminas de polietileno de alta densidad) o naturales (fibras vegetales tejidas).

\subsubsection{1.- Sistema "krismer"}

Es una técnica de estabilización de taludes ya sean naturales de corte o terraplén, que consiste en una rejilla tridimensional de $80 \mathrm{~mm}$ de profundidad de acero galvanizado de 1.7 $\mathrm{mm}$ de espesor, denominada JKS, fabricada en paneles de $3 \times 1.2 \mathrm{~m}$.

Estos paneles se anclan a la superficie del talud con clavos cuya cabeza lleva incorporado un gancho para sostener a los demás componentes del sistema. A continuación se rellenan, primero con una capa de grava y luego con una de tierra vegetal para después proceder a la siembra.

Las cantidades de relleno aproximado son: $3-4 \mathrm{~m}^{3} / 100 \mathrm{~m}^{2}$ de grava de $45-65 \mathrm{~mm}$ y 3 $5 \mathrm{~m}^{3} / 100 \mathrm{~m}^{2}$ de tierra vegetal. Es necesario recalcar que la superficie debe quedar llana y limpia de elementos que pudieran entorpecer las labores. Se sugiere la instalación de canales de drenaje por debajo de la instalación de los paneles en el caso de que el talud este muy afectado por surgencias y escorrentías elevadas. 

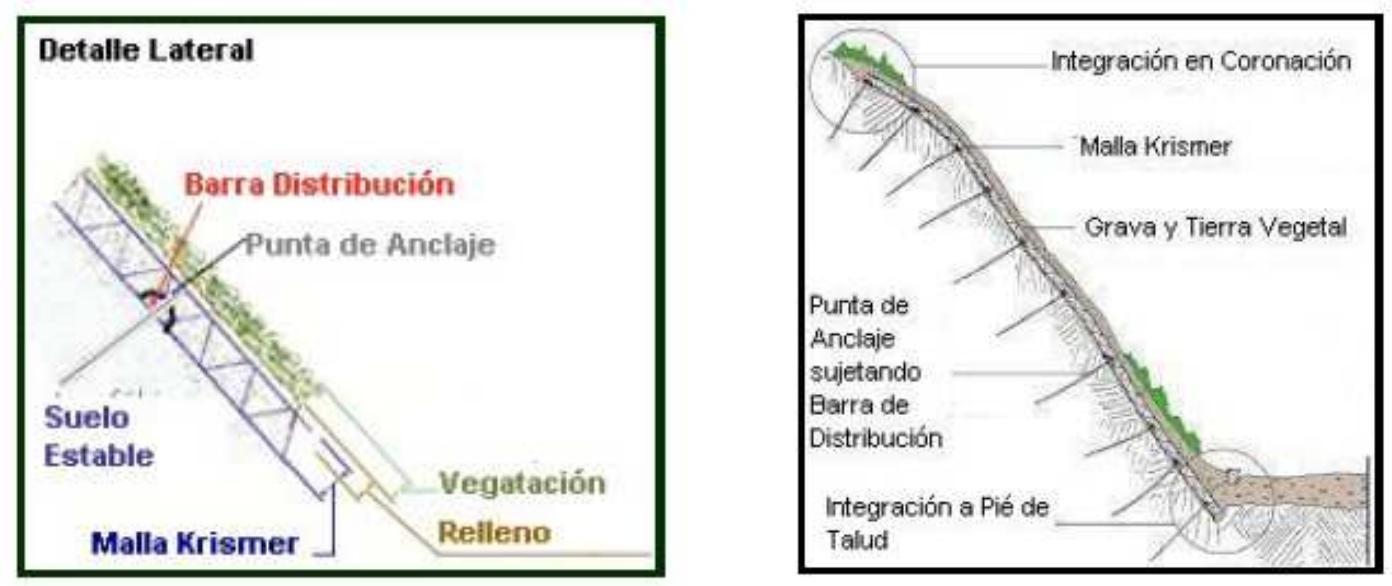

Figura 27: Técnica de estabilización "krismer".

\subsection{2.- Uso de aglutinantes y adherentes}

Son aquellos que se disponen en solución acuosa sobre la superficie del talud y una vez secos forman una película protectora que actúa en contra de la desagregación del suelo.

Se utilizan comúnmente:

- Emulsiones bituminosas.

- Plásticos líquidos.

- Emulsiones naturales derivados de productos lignocelulósicos

- Emulsiones de aceite de butadieno.

Otorgan protección frente a la erosión, pero no proporcionan por si solas, ayuda al proceso de revegetación. Su acción es temporal, desapareciendo a corto plazo. Sin embargo proporciona disminución en la infiltración, razón por la que no es recomendable su uso para situaciones en que se pronostican niveles altos de escorrentía, ya que puede generar el efecto contrario al requerido.

Se debe ser cuidadoso al seleccionar el tipo de producto, considerando dentro de la decisión:

- Capacidad de penetración en el suelo.

- Grado de toxicidad para las plantas. 
- Resistencia de la película protectora.

\subsection{3.- Mulches}

Se define como mulch toda cubierta orgánica que tiene un efecto protector hecha de materiales orgánicos desmenuzados. Se acostumbra utilizar residuos agrícolas como la paja de cebada o trigo, residuos forestales como el serrín, astillas, corteza, pasta triturada de papel etc.; fibras naturales etc.

Se utilizan fundamentalmente para proteger la superficie del talud frente a la erosión hídrica y eólica, aunque también aportan a la conservación del microclima haciéndolo más favorable al desarrollo de vegetación y evitando el arrastre de semillas pendiente abajo. 


\section{2.- IMPLANTACIÓN DE LA VEGETACIÓN}

En cada caso habrá que decidir razonadamente la elección del método, después de evaluar las ventajas e inconvenientes de cada uno de estos métodos, y teniendo en cuenta sus condicionantes.

\section{1.- VENTAJAS E INCONVENIENTES DE LOS MÉTODOS DE IMPLANTACIÓN}

Ventajas de la siembra:

- Se obtiene una elevada densidad en la masa creada.

- La poda natural será más precoz y eficaz, con mayor libertad en la ejecución de claras.

- Las masas están mejor adaptadas a las variaciones de calidad del suelo, por la distribución aleatoria de los pies.

Inconvenientes de la siembra:

- Mayores costos de las operaciones silvícolas (riesgo de decaimiento vegetativo).

- La preparación del suelo ha de ser cuidadosa, asegurando el contacto de la semilla con el terreno.

- Es necesario disponer de una gran cantidad de semillas.

- Las plántulas están expuestas a mayor cantidad de riesgos, (heladas tardías, sequias estivales, daños por animales, etc.).

- Se obtiene una distribución superficial irregular, con dificultad para la reposición de marras.

Ventajas de la plantación:

- Las plantas de 1, 2 ó 3 savias son más resistentes, con mayor probabilidad de éxito.

- La ocupación se hace más rápido y de forma más regular en el terreno.

- Es más fácil la mezcla de especies. 
- Menor costo de los cuidados culturales (pueden retrasarse las primeras claras).

- Menor riesgo de plagas y enfermedades.

Inconvenientes de la plantación:

- Es difícil de aplicar en determinadas especies por su complicada producción.

- Mayor gasto en podas.

- Necesario disponer de mano de obra especializada y en mayor cantidad.

\subsection{1.- Factores que condicionan la elección del método}

Para decidir lo más conveniente en cada caso, se deben analizar los factores y condicionantes de cada uno de los métodos: factores estacionales, culturales, sociales y económicos.

\subsubsection{1.- Factores referentes a la estación}

Siembra:

- No deben existir riesgos de daños meteorológicos como heladas tardías, sequias estivales, etc. La estación debe ser adecuada a la especie.

- Las condiciones edáficas deben ser favorables al desarrollo de la radícula.

- La predación sobre la semilla debe ser reducida.

\section{Plantación:}

- Es el método más adecuado para estaciones climáticas difíciles y el que mejor aprovecha las labores de corrección.

\subsubsection{2.- Factores referentes a aspectos culturales}

Siembra:

- Deberán usarse especies con semillas de tamaño grande que facilite su manejo y la vida de la plántula tras la germinación.

- Debe haber poca competencia con el matorral. Si no existe nada de vegetación, debe ser una especie robusta. 
- Las altas espesuras serán ventajosas en relación a la poda natural y no serán inconveniente por riesgo de incendio.

\section{Plantación:}

- No existen limitaciones, salvo que la producción de la planta sea difícil.

- Las espesuras iniciales se garantizan con seguridad, la masa tendrá poda natural tardía.

\subsubsection{3.- Factores de tipo social}

Siembra:

- Requiere poca mano de obra y no especializada.

\section{Plantación:}

- Requiere mano de obra abundante y especializada.

\subsubsection{4.- Factores económicos}

Siembra:

- Es más barato aunque con resultados inciertos.

- Requiere grandes cantidades de semilla, pudiendo repercutir en su calidad.

- Necesita mayores cuidados culturales durante el primer turno.

\section{Plantación:}

- La ejecución es más cara, aunque con resultados más seguros.

- La cantidad de plantas puede ser menor y garantizar su calidad y procedencia.

- Es necesario disponer de infraestructuras de viveros.

- El coste de los cuidados culturales iniciales se abarata en función de la densidad inicial. 


\section{2.- SIEMBRA}

Es un proceso que consiste en la deposición de semillas sobre el terreno preparado. En general se utilizan semillas de herbáceas vivaces, aunque también pueden usarse semillas de árboles y/o arbustos. Permite crear a corto plazo una cubierta vegetal de bajo crecimiento pero densa, con capacidad protectora ante la erosión y deslizamientos superficiales, aportando también a la formación de suelo.

Los métodos de siembra básicos son:

- Siembra en hileras.

- Siembra a voleo.

De la siembra a voleo se deriva la técnica de hidrosiembra, que es la más utilizada para las condiciones de pobreza, inaccesibilidad y pendiente que presentan los taludes.

\subsection{1.- Siembra en hileras}

Consiste en depositar las semillas en surcos previamente abiertos con arado de discos. Una vez depositadas las semillas se entierran por acción del propio apero que abre el surco, o mediante el paso de rastras y rodillos, etc.

Se compacta el suelo alrededor de las semillas con un rodillo compresor. Esta técnica puede utilizarse en taludes que permiten el uso de maquinaria agrícola convencional y suelos fértiles libres de piedras. Dadas las condiciones que normalmente presentan los taludes no suele ser un método muy utilizado.

\subsection{2.- Siembra a voleo convencional}

La distribución de semillas se hace directamente sobre el suelo, manualmente o con ayuda de un compresor neumático dependiendo de las condiciones de accesibilidad, goza de gran aceptación pues es fácil de utilizar y adecuado para terrenos difíciles. 
Las semillas quedan depositadas en la superficie del suelo, razón por la que si el suelo posee una textura fina será necesario recubrir con una capa de mulch o bien enterrarlas para evitar su desecación y arrastre. Por el contrario, si la textura del material es gruesa, las semillas pueden introducirse en las hendiduras y grietas donde existen condiciones microclimáticas más favorables a la germinación.

La distribución de semillas en esta técnica es irregular, por lo que se recomienda realizar el proceso en dos direcciones perpendiculares entre si, en sentido ascendente y distribuyendo mayor cantidad de semillas en la parte alta y en los bordes.

\subsection{3.- Hidrosiembra}

Es la disposición de una suspensión homogénea de agua y semillas a gran presión sobre la superficie del terreno, con otros productos como fertilizantes, mulches y estabilizadores químicos, que tienen el objetivo de fijar las semillas al terreno, evitando perdidas por escorrentía, gravedad o por efecto del viento.

Las semillas son seleccionadas para el terreno específico, lo cual minimiza el riesgo de sembrar semillas inadecuadas para el terreno, y los aditivos que se utilizan fomentan una recuperación óptima. La siembra se realiza mediante una mezcla de agua, semilla, fertilizantes, fijadores, aditivos, y mulch con colorante:

- Agua: Actúa como un portador y acelerador del proceso de germinación de la semilla.

- Semilla: Puede utilizarse casi cualquier semilla, de césped, flores silvestres, forraje, etc. en la misma proporción de otros métodos de siembra.

- Mulch: Puede estar compuesto de fibras de celulosa, madera, o por mezcla de estos dos, y tiene la capacidad de absorber 10 veces su peso en agua, es un producto reciclado y biodegradable. Se le agrega colorante verde (orgánico y biodegradable) para indicar las áreas aplicadas y las densidades, asegurando una aplicación uniforme. Sus funciones son proteger contra el impacto de las gotas de lluvia o riego, reduce la velocidad de evaporación, manteniendo más tiempo la humedad necesaria para la germinación, protege a la semilla contra aves y otros depredadores, aporta materia orgánica, prolonga el periodo vegetativo y 
de siembra, conserva la estructura superficial del suelo y modera la temperatura.

- Fertilizantes: Generalmente se utilizan en la mezcla. El más común es un fertilizante con alto contenido en fosforo que estimulara el crecimiento de las raíces.

- Fijadores (tackifier): Productos solubles y biodegradables que forman una película homogénea, elástica y permeable sobre el terreno, que ayudan a mantener la tierra y el mulch para prevenir erosión.

- Otros aditivos: Se pueden emplear bioestimulantes, cal (para regular el pH), copolímeros (HYGEL) que tienen capacidad de retener 400 veces su peso en agua con entrega lenta de humedad. Especialmente para control de erosión se aplica HYNET, compuesto de fibras sintéticas que se entrelazan con el mulch, formando una verdadera red en el suelo fijando la aplicación para proteger el terreno de la erosión causada por la lluvia, el viento, etc.

La hidrosiembra de taludes de corte o desmonte producidos durante la construcción de una obra lineal es la técnica más eficaz y rápida para la instalación de una cubierta vegetal. Las dosis de aplicación varían de $2-4 \mathrm{l} / \mathrm{m}^{2}$. Generalmente la cantidad de sólidos que las maquinas hidrosembradoras aceptan en la mezcla, admiten entre el $10-15 \%$, pero en las zonas de pendiente $>35^{\circ}$ o con problemas de estabilidad graves, es necesario aumentar la dosis de estabilizador y mulch por encima de este rango.

Si se produce una concentración excesiva de fertilizante en la mezcla podría dañar las semillas, por lo que se puede optar por fertilizantes insolubles o de liberación lenta, reduciendo la cantidad de fertilizante soluble incorporada, o bien retrasando la aplicación de la mayor parte de los fertilizantes hasta la germinación de las plantas.

Si el sustrato presenta problemas de acidez será necesario aplicar a la mezcla de hidrosiembra una cantidad de piedra caliza molida, cal viva u otro tipo de estabilizante. La germinación, nascencia y fructificación son mejores en los taludes orientados a umbría y naciente.

También debe evitarse el paso de maquinaria que pudiera compactar el sustrato, así como la aplicación de materiales como gunita u hormigón, cuando éstos no son necesarios 
para la estabilidad geotécnica del talud. A este respecto, se recomienda el uso de tierra vegetal siempre que sea posible, ya que ésta cumple la misión de favorecer las condiciones edafológicas del suelo, crear una matriz que retiene físicamente las semillas, así como la aportación suplementaria de semillas para la colonización vegetal.

Ha quedado demostrado que con la aportación de tierra vegetal aumenta la variedad de especies vegetales, así como la eficiencia en la creación de biomasa en los primeros estadios de la comunidad. Este aspecto es particularmente importante, dada su función de prevención de las pérdidas de suelo por escorrentía. Los resultados experimentales demuestran mejores comportamientos en taludes en los que se extendió tierra vegetal. Las diferencias son especialmente significativas en el caso de los desmontes.

En zonas con climas áridos del sudeste de la Península Ibérica, con precipitaciones menores de $300 \mathrm{~mm}$ año (Almería, Murcia, etc.), es muy improbable que las plantas de la hidrosiembra que lleguen a germinar sobrevivan. Una parte de la Península Ibérica se encuentra en esta situación y por ello, además de la precipitación media anual es preciso tener en cuenta la periodicidad y el régimen de esta precipitación.

El índice de torrencialidad, definido como el porcentaje que la precipitación máxima en 24 horas, para un periodo de retorno de 100 años, supone respecto a la precipitación total del año, puede ser útil para descartar la hidrosiembra en ciertas zonas, en particular cuando el valor del índice supera el 50\%. En estos casos la fuerza de las lluvias provocará el arrastre de suelo y semillas, y hará inútil la inversión en el proceso de revegetación.

Los resultados indican que en el caso de terraplenes estos valores pueden incluso superarse debido a ciertas características del sustrato, tales como el grado de formación del suelo o la aireación.

Por ello es necesario controlar, siempre que sea posible, otros parámetros más informativos sobre el agua disponible para las plantas, bien con medidas puntuales del contenido hídrico del suelo o bien por estimación del tiempo que el suelo permanece por debajo de valores críticos. Uno de estos valores es el punto de marchitez del suelo, definido como el umbral hídrico por debajo del cual las plantas no pueden extraer el agua del suelo y se marchitan. 
La cantidad de agua del suelo ha de mantenerse siempre por encima de este punto, para asegurar la supervivencia de la vegetación. En sustratos que, o bien no retienen el agua (muy arenosos), o bien es difícil que la cedan a las plantas (muy arcillosos), la germinación de las semillas y la posterior supervivencia de las plántulas se ve comprometida. En estos casos es importante alterar las características del suelo ( $\%$ de arena), considerar distintos riegos y diversas combinaciones de especies o densidades de plantas que permitan el asentamiento de la vegetación bajo las condiciones hídricas locales.

El éxito de la revegetación también está determinado por las temperaturas del lugar en que se va a realizar. El rendimiento será bajo cuando las temperaturas sean muy extremas o presenten grandes oscilaciones diurnas o estacionales. En general, no es recomendable realizar hidrosiembras inespecíficas (p.e. con mezclas de especies comerciales) en zonas en las

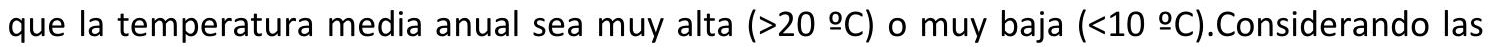
condiciones termopluviométricas del clima mediterráneo, se puede considerar que la época ideal para ejecutar las hidrosiembras sería el otoño para aprovechar las primeras lluvias y facilitar la germinación de las semillas, Una vez germinada, la plántula tendría tiempo de desarrollarse adecuadamente hasta la llegada del verano.

Por el contrario, si la hidrosiembra se realiza en primavera las plántulas tendrán humedad para germinar pero es probable que no sobrevivan al estrés hídrico del verano. Es preciso estudiar previamente el régimen local de tormentas y episodios de lluvias torrenciales que puedan desplazar las semillas o enterrarlas a profundidades en las que su germinación resulta inviable.

Para mejorar las actividades encaminadas a la restauración de la cubierta vegetal es más útil conocer las especies y comunidades ruderales de la zona e intentar su asentamiento en el talud, que concentrar el esfuerzo y los medios económicos en unas pocas especies "emblemáticas", generalmente propias de comunidades y tipos de vegetación poco viables en taludes. 


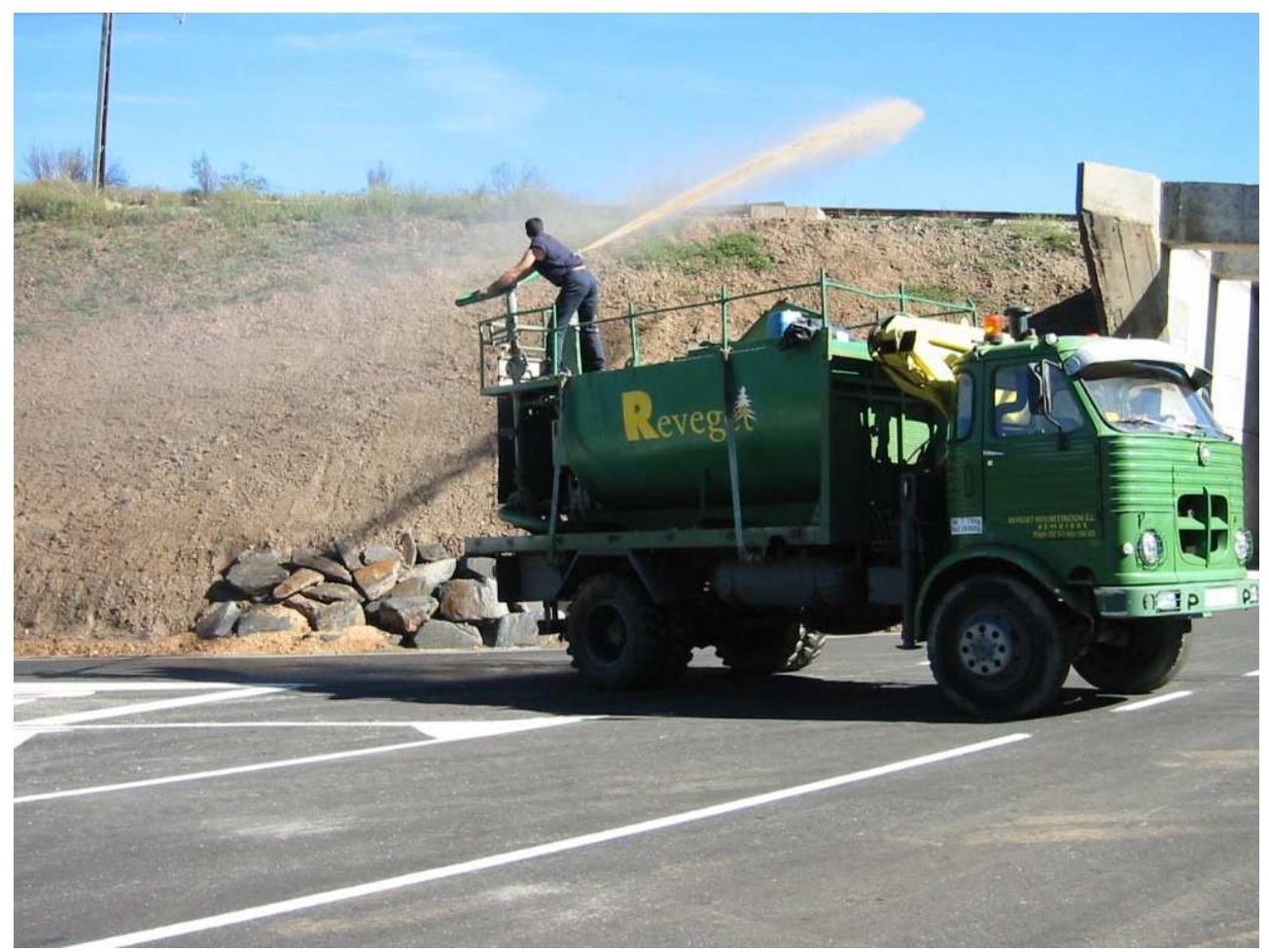

Figura 28: Ejecución de hidrosiembra.

En este sentido, la definición de "vegetación autóctona" (referencia obligada para la restauración ecológica de la zona afectada por las obras) debe basarse en aquellas especies y comunidades asociadas a entornos y condiciones ecológicas similares al de los taludes de infraestructuras lineales, y no a las formaciones forestales o de máximo nivel de desarrollo características de la región.

Asimismo, en todas las situaciones es muy recomendable la conservación de vegetación adyacente como fuente de propágulos para el proceso de revegetación. En particular, es útil conservar, en la medida de lo posible, las franjas verdes que quedarían entre la cabecera de desmonte y la cuneta de guarda o caminos de servicio.

Las mezclas habitualmente contempladas en los proyectos, que podríamos llamar "comerciales" o inespecíficas de las condiciones ecológicas donde se van a sembrar, tienen escaso éxito en áreas de clima mediterráneo, especialmente cuando confluyen otras circunstancias limitantes para el desarrollo de la vegetación (p.e. sustratos yesíferos o termopluviometrías particularmente adversas). 
De hecho, los resultados demuestran que las mezclas comerciales no dan buenos resultados cuando se cumplen una o varias de las siguientes condiciones en el entorno a restaurar:

- Estrés hídrico y/o temperaturas extremas.

- Superficies muy rocosas (p.e. desmontes).

- Pendientes superiores a 270 .

- Sustrato con bajo contenido en nutrientes y/o de alta compactación.

La hidrosiembra comercial se recomienda principalmente cuando se verifiquen simultáneamente las siguientes condiciones:

1. Que la zona a restaurar esté lejos de la flora adyacente y/o existan barreras que impidan la llegada de propágulos. De hecho algunas de las especies comerciales hidrosembradas con más frecuencia en ocasiones no desaparecen con rapidez de zonas de clima y suelo benignos, y no ayudan significativamente al progreso de la vegetación cuando hay propágulos en el suelo o en zonas próximas. Por el contrario llegan a constituir una amenaza para la biodiversidad natural de la zona.

2. Que el clima (precipitación, temperaturas) y el tipo de suelo (nutrientes, pH, compactación) sean intermedios en una escala relativa de adversidad.

La hidrosiembra con mezclas de semillas inespecíficas del lugar donde se ejecuta el proyecto, fracasa en condiciones extremas y no es necesaria en condiciones muy favorables. Para el establecimiento de una cubierta vegetal que favorezca la sucesión ecológica, resultaría útil una mezcla de semillas con suficiente diversidad específica (10-15 especies distintas). Una mayor diversidad en la mezcla de semillas acelera el proceso de sucesión, lo que incide en una mayor estabilidad estructural y funcional del sistema, cumpliendo así el principal objetivo funcional de la restauración, que es el de estabilizar el talud.

Asimismo, los resultados indican que la práctica habitual de mezclar semillas de crecimiento rápido (conocidas normalmente como "starters") con especies autóctonas no siempre favorece el proceso de revegetación, en particular en situaciones limitantes. No es recomendable hidrosembrar con mezclas que contengan especies autóctonas, en general de 
crecimiento lento, y especies comerciales de crecimiento rápido como Lolium rigidum, las cuales sofocan a las primeras y luego sucumben ante la sequía estival.

Sin embargo, no debe menospreciarse el papel estabilizador de los "starters". Una posible solución, probablemente difícil de implementar a corto plazo, pasaría por la realización de hidrosiembras en dos épocas distintas, utilizando primero especies pioneras de crecimiento rápido y posteriormente (antes de la sequía estival) volver a hidrosembrar con especies autóctonas de crecimiento lento.

En las trincheras y desmontes los taludes que se apoyan en la ladera presentan mejores resultados que su par, independientemente de su posición. En las embocaduras de túneles y en los taludes de fuerte pendiente, superior a 1:2, la solución más eficaz es la instalación de una geomalla y posterior hidrosiembra, dando excelentes resultados al mejorar la integración visual y limitar los procesos erosivos de estas estructuras.

El éxito estará asegurado si se seleccionan y estudian la composición y dosis de los componentes. La hidrosiembra no es la panacea para todo tipo de situaciones. Exige, antes de aplicarla, el estudio y clasificación de las posibles zonas de actuación. Variables como la pendiente, altura, composición del sustrato, riesgo de inestabilidad, procesos erosivos, drenaje, microexposición y accesibilidad visual, determinaran la necesidad, previamente a su ejecución, de instalar geomallas o labores de preparación de superficie.

Muchos de los comentarios que se imputan a esta técnica tienen su origen en defectos de ejecución, ausencia de estudios previos en las zonas de actuación y desconocimiento de las condicionantes técnicas de sus componentes. La hidrosiembra es algo más que una mezcla de agua y semillas lanzada por un cañón sobre un talud. Es una solución técnica complementaria que puede corregir situaciones no deseadas y con menor costo que otras soluciones más duras. Su objetivo final, alcanzable a medio plazo es, conseguir la entrada de las especies características del lugar.

Es una medida correctora y protectora contra procesos erosivos. En las vías tratadas con hidrosiembra, el mantenimiento del sistema de drenaje es mejor, se detectan antes los problemas de inestabilidad o drenaje en los taludes cubiertos de vegetación. En la situación de movimientos de tierras, estos son más lentos, y los volúmenes de material involucrado son menores. 
La época más favorable para su ejecución es al final del verano o principios de otoño, y las resiembras deben hacerse pasado un periodo vegetativo completo.

Las siembras en invierno con precipitaciones medias inferiores a $600 \mathrm{~mm}$ están muy condicionadas por las precipitaciones de primavera.

\subsection{4.- Siembra con mulch en seco}

Es utilizada cuando es necesario aplicar una gran cantidad de mulch, y es una variante de la siembra a voleo, que se diferencia de esta en el extendido del mulch que se hace en seco mediante aire comprimido después que las semillas han sido distribuidas según la técnica más adecuada (hidrosiembra, voleo o sembradora convencional).

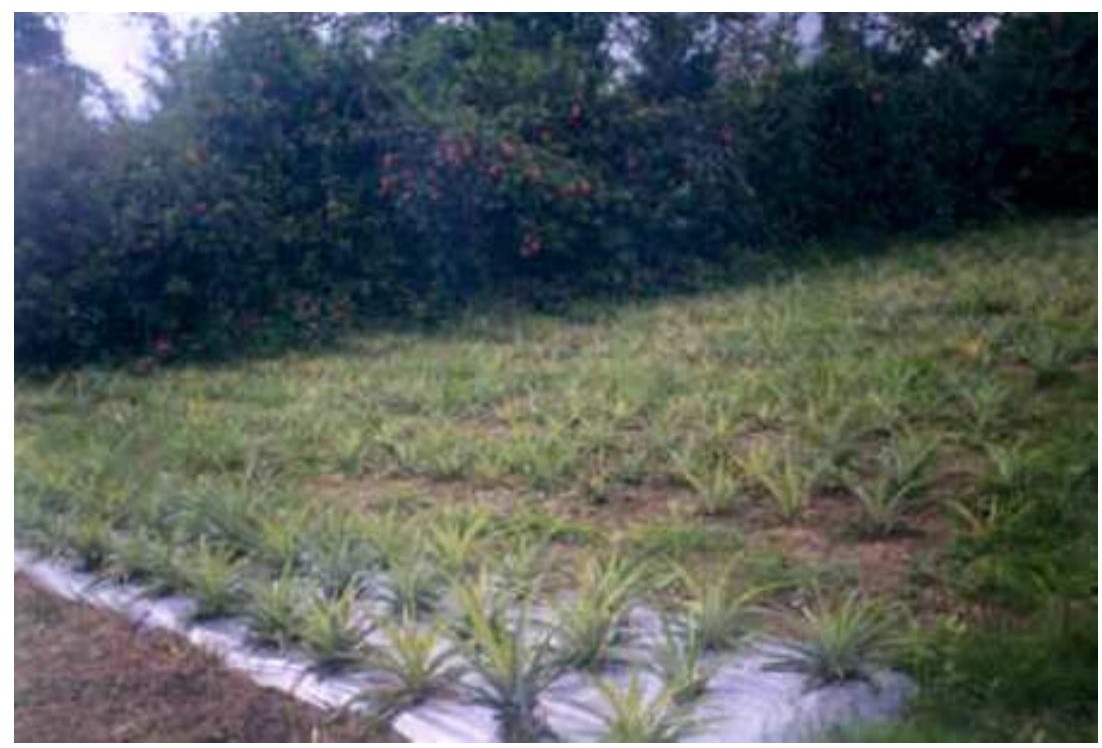

Figura 29: Siembra con mulch plástico.

Como mulch, se usa normalmente paja de cereal picada en cantidades que oscilan entre 4.5 - $6 \mathrm{tn} / \mathrm{ha}$. Las ventajas comparativas que presenta esta técnica sobre la hidrosiembra, se manifiestan en zonas donde las características de clima y suelo son especialmente desfavorables, el riesgo de erosión es elevado, o bien, las semillas a emplear son altamente susceptibles a la desecación, ya que la capa de mulch aplicada será más gruesa que en la hidrosiembra y, en consecuencia más efectiva. 


\subsection{5.- Siembra en hoyo}

Es una técnica de siembra manual en que las semillas son introducidas en un hoyo previamente dispuesto para este efecto. El número de semillas por hoyo será función del tamaño de estas, por ejemplo en el caso de las semillas de quercineas (Encinas, Roble) se usan 3 - 5 semillas por hoyo. Los hoyos se construyen de $10-15 \mathrm{~cm}$ de diámetro y $10-20 \mathrm{~cm}$ de profundidad.

La distancia entre hoyos es variable dependiendo de la densidad final de cubrimiento que se pretenda, aunque se usa normalmente una distancia entre $1-5 \mathrm{~m}$. Se recomienda el uso de esta técnica para casos en que no sea viable realizar una siembra extensiva del talud, en los casos en que ya exista una cubierta herbácea y se pretenda introducir especies leñosas dentro de la sucesión, o en general cuando no es necesaria la creación de una cubierta vegetal a corto plazo. Se usa para la implantación de árboles y arbustos.

Es recomendable disponer en el fondo de cada hoyo un fertilizante de liberación lenta y, una vez cubierto, la aplicación de una capa de mulch para otorgar humedad al suelo.

\subsection{6.- Especies utilizadas en las siembras}

Seleccionar adecuadamente las especies utilizadas en la revegetación es un buen método para minimizar los efectos negativos del clima o de las malas condiciones edáficas, de hecho ya en los años 70 se planteaba el uso de leguminosas en zonas pobres en nutrientes (Dudeck \& Young 1970).

En general después de la siembra se establecen solo unas pocas de las especies sembradas. Pero junto a estas se establece un número variable de especies provenientes de la lluvia de semillas y del banco de semillas. La presencia de estas últimas y el escaso éxito de las especies sembradas demuestran que existen lugares disponibles para la colonización y que las condiciones pueden ser adecuadas, pero solo para determinadas especies. Por lo que se hace necesario seleccionar las especies que se van a sembrar, como han propuesto algunos autores (Ash et al. 1994). 
Aunque anteriormente otros autores (Wright et al. 1978; Ash et al. 1994; Jusaitis \& Pillman 1997; Sharma et al. 1997) ya habían planteado la necesidad de seleccionar especies que estuvieran adaptadas a las condiciones especiales de los sustratos producidos en minería, Le Floc'h et al. (1999) plantearon por primera vez el tema de la selección de especies adaptadas al clima local en trabajos de restauración. Dicho trabajo, junto con los de Aronson et al. (1993a; 1993b; 1999), supusieron un cambio importante en la concepción de los trabajos de restauración.

En algunos casos la introducción sin más de semillas de especies adaptadas a las condiciones del área restaurada produce buenos resultados (Ash et al. 1994; Jusaitis \& Pillman 1997). Pero no hay que perder de vista que factores como el tamaño de la semilla o la biología de la germinación han demostrado su importancia al determinar los diferentes resultados obtenidos por cada especie en el establecimiento y la colonización posterior. En este sentido, Montalbo et al. (2002) mostraron que en las hidrosiembras se ven favorecidas las especies con semillas de menor tamaño.

\subsubsection{1.- Factores relacionados con la coexistencia de las especies}

Una vez las especies se han establecido en las zonas restauradas, las relaciones entre ellas pueden determinar el éxito relativo de cada una de ellas. Está ampliamente demostrado que la coexistencia entre las especies produce cambios en la abundancia relativa de las mismas (Davis et al. 1998; Goldberg et al. 2001). De hecho, la competencia y/o la facilitación son factores muy importantes a la hora de determinar las dinámicas poblacionales de las plantas (Crawley 1990; Lortie et al. 2004) por lo que debería tenerse en cuenta también en la restauración de zonas degradadas.

Esta competencia o facilitación puede producirse entre las propias especies sembradas, entre las especies sembradas y las que están presentes en la zona a restaurar o entre las especies sembradas y las que llegan a ella posteriormente por dispersión desde los alrededores. En zonas mineras, se ha observado que la presencia de un competidor vigoroso puede cambiar la composición específica de las zonas restauradas. Jochimsen (2001) demostró que las oscilaciones interanuales de especies del género Melilotus producían cambios en la diversidad de las zonas restauradas disminuyendo ésta al aumentar la cobertura de Melilotus $s p$. 
De hecho, las diferencias en la capacidad para establecerse, crecer y competir entre las especies sembradas pueden hacer que la composición específica de las zonas revegetadas no refleje la composición específica de las siembras (Jefferson 2004). Se ha descrito que estas interacciones entre las plantas sembradas se hacen más intensas en ambientes ricos en nutrientes, donde determinadas especies se ven más beneficiadas que otras y pueden convertirse en dominantes (Baer et al. 2004; Fraser \& Keddy 2005). Este factor es muy importante, ya que un tratamiento común en restauración es la aplicación de fertilizantes.

Por otro lado en condiciones de baja disponibilidad de agua las interacciones negativas entre plantas se ven incrementadas (Davis et al. 1998) además en condiciones adversas pueden aumentar las relaciones de facilitación (Tirado \& Pugnaire 2005; Pugnaire \& Padilla 2006). Estos resultados actualmente están siendo debatidos por diversos autores (Maestre et al. 2005; Lortie \& Callaway 2006; Maestre et al. 2006b). En todo caso, el estrés hídrico en relación a las relaciones de convivencia entre las especies es un factor muy a tener en cuenta.

La presencia o ausencia de competencia entre las especies sembradas puede afectar incluso a la estructura de la comunidad. Schuman (2005) demostró que al sembrar menores densidades de semillas, la falta de interacción entre las plantas sembradas producía plantas de mayor tamaño con mayor probabilidad de supervivencia y que daban mayor diversidad estructural a la comunidad.

Como se ha dicho, la competencia puede darse entre las especies sembradas y las especies ya presentes anteriormente a las siembras. Determinadas especies pueden impedir la colonización natural deteniendo la sucesión en etapas tempranas o manteniendo comunidades poco diversas (Wiegleb \& Felinks 2001).

De hecho, en algunos casos puede ser necesario eliminar las plantas que compiten con las que han sido sembradas para lograr que éstas se establezcan (Iverson \& Wali 1987) o sembrar mayores cantidades de las especies que interesan para desplazar a las que estaban presentes anteriormente. Stevenson (1995) demostró que aunque no existían diferencias en cuanto al incremento de la diversidad en función de la dosis de siembra aplicada, a dosis mayores las especies sembradas lograban desplazar a las ya establecidas espontáneamente. 


\section{3.- PLANTACIÓN}

Las plantas forestales pueden encontrarse en los viveros en una gran variedad de tipos y tamaños y en un amplio rango de precios. Es importante hacer la elección de la planta de forma adecuada, teniendo en cuenta el lugar de plantación y la relación coste-calidad. La elección de la planta nunca debe guiarse por criterios de mínimo coste salvo en condiciones de igualdad de calidad. Básicamente se suministran dos tipos de planta para repoblación:

- Planta a raíz desnuda.- Son plantas producidas directamente en las eras de cultivo del vivero, en general con una o dos savias (numero de periodos vegetativos que ha pasado en el vivero), o en algunos casos más de dos savias. Este sistema favorece un desarrollo adecuado de la raíz con numerosas raíces secundarias y en equilibrio con la parte aérea.

- Planta en contenedor.- Este tipo de plantas se refiere a aquellas que han crecido en contenedores especiales, los cuales se llenan de una mezcla adecuada que forma un cepellón alrededor de la raíz. Este sistema se utiliza con un gran número de especies y tamaños de planta, aunque en el caso de los envases más frecuentes (bandejas de alveolos), por el volumen de los alveolos y la densidad de plantación, no debe superarse más de dos savias. Actualmente se están utilizando una gran variedad de envases, pero en general pueden agruparse en dos grandes grupos: los envases reutilizables (bandejas plásticas rígidas de alveolos individuales) y los no reutilizables (bandejas plásticas de un solo uso, paper-pot, root-traines, etc.).

Por las condiciones climáticas de la zona mediterránea, se tiende a utilizar principalmente envases, pero eso no quiere decir que todas las especies respondan mejor a este sistema de producción, siendo recomendable en algunos casos la producción de planta a raíz desnuda.

Ambos sistemas presentan ventajas e inconvenientes, por lo que deben definirse criterios mínimos de calidad:

- Desechar plantas con heridas no cicatrizadas, daños en las yemas, rotura de guías y cualquier tipo de daño mecánico que pueda comprometer su viabilidad.

- Desechar plantas que presentan pudriciones, sobre todo si afectan al cuello de la raíz. 
- Desechar plantas que presenten desecaciones totales o parciales.

- Desechar plantas que estén malformadas, tanto por fuertes curvaturas como por excesiva ramificación, falta de ramificación en especies que deberían tenerla o presencia de tallos múltiples.

- Desechar plantas que aparentemente puedan estar atacadas por enfermedades.

- Desechar plantas que presenten enrollamiento o fuertes torceduras en las raíces principales.

- Desechar plantas que no tengan un abundante desarrollo de raíces secundarias.

- Desechar plantas pequeñas o excesivamente grandes.

- Desconfiar de plantas que presenten poca elasticidad ya que podría deberse al comienzo de un proceso de desecación.

- Una planta correctamente lignificada debería de recuperar su forma rápidamente si es doblada. De lo contrario puede presentar un deficiente grado de lignificación debido a un crecimiento anormal por exceso de fertilización.

- Tallo y ramas con parada invernal incompleta.

- Tallo desprovisto de una yema terminal sana.

- Cuello de la raíz dañado.

- Si la especie o especies de planta que se van a comprar tienen alguna finalidad reproductiva como objetivo principal o secundario (pino piñonero, chopos, eucalipto, etc.), el comprador debe asegurarse de que las plantas proceden de una semilla certificada o semillas de progenie controlada, pidiendo documentos acreditativos al viverista.

\section{$\underline{\text { Recomendaciones específicas para plantas a raíz desnuda: }}$}

Las plantas producidas a raíz desnuda deben haber sufrido al menos uno o dos repiques en función del número de savias o edad de los plantones. El repique consiste en la corta de las raíces principales a la profundidad deseada para inducir la formación de raíces secundarias. 
Estas raíces secundarias son mucho más eficaces en la absorción de agua y minerales y por tanto a mayor número de ellas mayor probabilidad tendrá la planta de establecerse con éxito.

En las plantas a raíz desnuda el periodo de tiempo transcurrido desde su levantamiento en vivero hasta su llegada al campo ha de ser el menor posible.

\section{$\underline{\text { Recomendaciones especificas para plantas producidas en envase: }}$}

Los envases han de garantizar que no se produzca espiralización o reviramiento de las raíces. La espiralización consiste en que las raíces al tocar las paredes del envase se desarrollan siguiendo círculos mientras profundizan en el envase hasta llegar al fondo del mismo, donde se enrollan en forma de espiral o giran remontando hasta la parte superior.

Esto tiene como consecuencia una escasa ramificación secundaria de la raíz, que pueden terminar estrangulando el árbol. Esta ha sido la causa de la muerte repentina de repoblaciones que se desarrollaron correctamente hasta los 10 ó 15 años de edad. Para evitar esto los envases no deben tener sección circular a menos que presenten estrías o costillas que obliguen a las raíces mediante aperturas inferiores, induciendo la formación de raíces secundarias.

Debe vigilarse especialmente la calidad de la planta producida en maceta o bolsa, al tratarse de técnicas de producción inadecuadas para la mayor parte de las especies forestales.

En situación en que las condiciones de la zona de actuación no sean adecuadas para la germinación de semillas y las plántulas se desarrollen, será entonces recomendable utilizar esta técnica. En el hoyo de plantación suelen aplicarse una serie de elementos que tienen por objetivo mejorar las condiciones nutricionales y el incremento de la retención de agua.

- Compost.

- Estiércol.

- Turba.

- Fertilizantes de liberación lenta.

- Polímeros absorbentes. 
En caso de extrema pobreza edáfica será recomendable rellenar los hoyos con tierra vegetal. Pueden ser plantados prácticamente todo tipo de árboles y arbustos e incluso herbáceas, de diverso grado de desarrollo y formas de presentación. El tamaño y forma de presentación debe ser electo considerando cuidadosamente:

- Condiciones edáficas.

- Clima.

- Características morfológicas.

- Características fisiológicas.

- Función asignada a la vegetación de estabilización y/o protección.

- Efecto deseado.

La plantación de esquejes (fragmento de cualquier parte del vegetal que tiene la capacidad de emitir raíces y desarrollarse) es muy usada para la estabilización de taludes. Para su plantación de ciertas especies cuyas yemas y brotes se encuentran situados en los órganos subterráneos y que se propagan muy activamente de forma vegetativa a través de la raíz como Phalaris, Thypa, Juncus, Acorus, Iris o Glyceria, se usan bulbos, rizomas y tubérculos. La plantación de estaquillas se utiliza con especies de rápido enraizamiento, generalmente sauces.

Las plantaciones de frondosas de porte arbóreo a raíz desnuda tienen importantes bajas en los primeros seis meses. Para tratar de reducir las fallas en las plantaciones de ejemplares arbóreos, con precipitaciones medias anuales inferiores a $600 \mathrm{~mm}$., se recomienda seleccionar especies vegetales que broten de cepa, suministradas en cepellón.

\subsection{1.- Época de plantación}

La plantación debe realizarse entre finales de otoño y principio de invierno. Preferentemente se localizaran en las cabeceras o pies de los taludes. El tamaño recomendado es el que corresponde a la clase $10-12 \mathrm{~cm}$. de circunferencia. La colocación de tutores, realización de alcorques y al menos ocho riegos de mantenimiento, con una dosis de un tercio del volumen del hoyo de plantación durante los dos primeros periodos vegetativos, son condiciones necesarias para conseguir resultados aceptables en la instalación definitiva del vegetal. 
Las pérdidas en las plantaciones de arbustos y matas no son tan importantes, aun con precipitaciones por debajo de las esperadas en los meses siguientes a la plantación. Las causas de la menor mortandad en las especies con porte arbustivo y subarbustivo tienen su justificación en un mayor equilibrio del sistema radical y el tamaño de la planta por su cultivo en envase.

En cuanto al diseño se debe procurar la formación de grupos pluriespecíficos, con una densidad media de 5 plantas por metro cuadrado en la parte superior, y de 3 por metro cuadrado en la inferior, localizando las especies que alcanzan mas desarrollo en la parte inferior del talud. Las especies tapizantes se localizaran preferentemente en la parte superior del talud.

\subsection{2.- Plantación de taludes con problemas de estabilidad superficial}

El principal problema que presentan estos taludes es que las plantas que se disponen en ellos pueden quedar cubiertas por tierra o materiales deslizados pendiente abajo incluso por los mismos operarios que a su paso por la plantación pueden provocar estos pequeños pero significativos desprendimientos.

Lo recomendable es la estabilización previa de la superficie mediante una siembra con especies que no sean competidoras de las que vayan a usarse en la plantación. La forma en que se deben desarrollar las operaciones de plantación debe ser desde la cabecera del talud hacia la base por líneas ortogonales a la de máxima pendiente.

\subsection{3.- Plantación en zonas expuestas a la acción eólica}

Para estos casos deben tomarse en consideración:

- Instalación de pantallas cortavientos prefabricadas o construidas con arbustos. Estas deben disponerse perpendicularmente a la dirección del viento dominante, y la plantación a sotavento de la pantalla.

- Plantación inicial con especies resistentes al viento, para que una vez desarrolladas plantar especies no tolerantes al abrigo de las primeras. 
- Podas y/o instalación de vientos y tutores para evitar el balanceo de la planta por el viento.

- Uso de plantas de pequeño tamaño.

- Instalación de protectores plásticos individuales para dar refugio a las plantas.

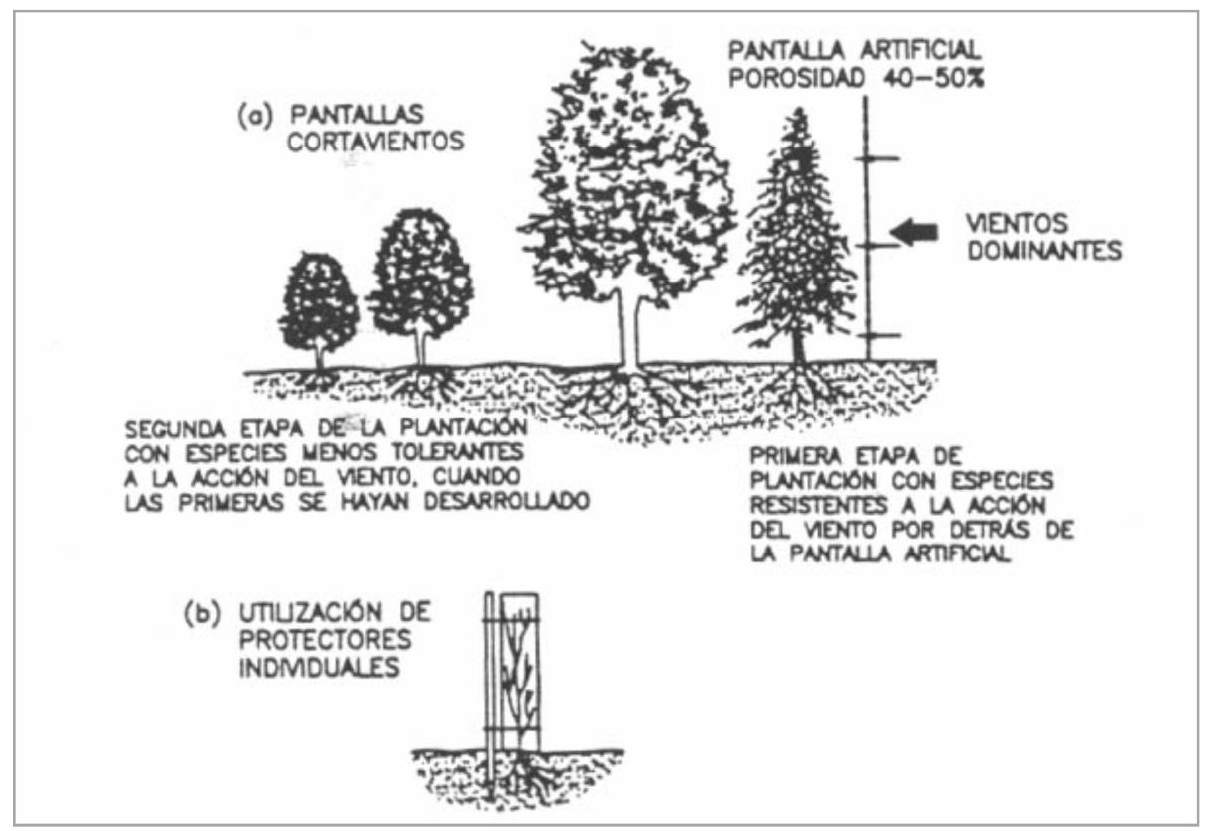

Figura 30: Plantación de árboles en zonas de alta exposición eólica.

\subsection{4.- Plantación en suelos secos}

Para estos casos es necesario maximizar en el suelo la tasa de infiltración e incrementar la capacidad de retención de agua, para lo que se adoptan las siguientes medidas:

- Aportando productos absorbentes para retención de humedad al hoyo de plantación.

- Cubrimiento de los alrededores de la planta con mulches o protectores de base para reducir la evaporación de agua.

- Riegos periódicos de mantención hasta la estabilización.

- Plantación con terrazas con contrapendiente, recogiendo y concentrando la escorrentía en un área accesible para las plantas. 
- Rellenar hoyos de plantación con una mezcla de turba húmeda, suelo y fertilizante.

\subsection{5.- Plantación de tepes}

Los tepes son porciones de tierra cubiertas de césped, y la vegetación herbácea puede también introducirse a través de estos. Estas porciones están muy trabadas por las esteras de raíces, o se cortan para disponerlas en otro lugar. Es una técnica de alta efectividad, pero su costo es alto, razón por la que se usa en situaciones muy puntuales tales como:

- Donde es imprescindible el recubrimiento instantáneo del talud, como zonas de altos índices de erosión, orillas sometidas a la acción directa de corrientes.

- En taludes con gran longitud de pendiente, plantando franjas de tepes en líneas transversales o formando un enrejado, para que actúen como núcleo estabilizado de vegetación desde el cual esta pueda propagarse y colonizar el resto del talud.

Los tepes cultivados en viveros generalmente se sirven en pequeños bloques o tiras de 0.3 - $0.4 \mathrm{~m}$, de ancho y $0.5-1 \mathrm{~m}$. de largo. También pueden obtenerse tepes de forma natural retirando previamente las tiras de césped de las zonas que van a ser alteradas por la construcción del talud. Este tipo de tepes presenta menor calidad en cuanto a consistencia, pero presentan la ventaja de adaptación al medio. La superficie donde vayan a instalarse los tepes debe ser des-compactada y nivelada para la penetración de las raíces y asegurar un contacto íntimo entre estos y la superficie del talud.

\section{4.- OTRAS TÉCNICAS DE REVEGETACIÓN}

\subsection{1.- Estaquillado}

Consiste en introducir en el suelo estaquillas de plantas leñosas, capaces de arraigar y desarrollar una planta adulta, de longitud y grosor suficiente para que puedan ser clavadas en el suelo como estacas. 
Cuando las estaquillas arraigan crean una matriz de raíces que estabilizan el suelo por refuerzo y cohesión de sus partículas, y reducen el exceso de humedad. Generalmente se utilizan estaquillas de sauce (Salix $s p$.) o chopo (Populus sp.). Este tipo de plantas enraízan rápidamente y comienzan a drenar el talud al poco tiempo de ser instaladas, y además son capaces de desarrollarse en sustratos carentes totalmente de suelo.

Esta técnica está especialmente recomendada para reparar pequeños deslizamientos y asentamientos originados por un exceso de humedad en el suelo, en sitios en los que las condiciones de inestabilidad no sean graves. Su aplicación es muy sencilla y es muy adecuada cuando se dispone de poco tiempo para ejecutar las obras de estabilización y es necesario además utilizar un método barato.

El estaquillado puede utilizarse también para fijar a la superficie del talud materiales de control de la erosión, como redes y mantas orgánicas, geotextiles, etc., en combinación con otras técnicas de bioingeniería, como por ejemplo las fajinas, y para revegetar estructuras porosas de retención (gaviones, escolleras, sistemas de confinamiento celular, muros de bloque de hormigón, etc.).

Cuando las estaquillas han desarrollado plantas adultas, la cubierta vegetal resultante mejora las características del suelo y crea condiciones adecuadas para que el espacio tratado pueda ser colonizado por otras especies procedentes del entorno natural. Las estaquillas deben provenir de ejemplares de más de dos años de edad, vigorosos y sin enfermedades. Los más adecuados son aquellos de entre 2 y 5 años, que tengan la corteza fina y sin muchas estrías.

Su tamaño oscila entre 20 y $75 \mathrm{~mm}$ de diámetro y 0,5 - $1 \mathrm{~m}$ de longitud. Si se van a insertar en el interior de gaviones o escolleras su diámetro debe ser mayor para que sean suficientemente resistentes y no se quiebren al ser introducidas. En el caso de que la zona de tratamiento tenga un nivel freático estable, es conveniente utilizar estaquillas con longitud suficiente para que lleguen hasta el nivel de estiaje de dicho nivel freático.

Al preparar las estaquillas deben eliminarse las ramas laterales y dejar la corteza intacta. El extremo inferior se corta en ángulo, para facilitar su inserción en el suelo. Es conveniente sumergirlas en agua durante 24 horas e instalarlas el mismo día en que se concluya su preparación. Se clavan en el suelo en ángulo recto con un golpe seco de martillo, siempre 
disponiéndolas con las yemas de crecimiento hacia arriba. Para facilitar esta labor puede abrirse un hoyo con un plantamón o una barra de hierro. Las cuatro quintas partes de la estaquilla deben quedar enterradas y el suelo firmemente compactado a su alrededor. Se disponen al tresbolillo con una separación de entre 0,3 y $1 \mathrm{~m}$. La densidad de plantación recomendada es de 3 - 5 estaquillas $/ \mathrm{m}^{2}$.

\subsection{2.- Fajinas}

Son manojos de ramas y tallos atados en forma de huso que se colocan en el fondo de zanjas poco profundas, excavadas transversalmente siguiendo el contorno del talud, recubriéndolas después parcialmente de tierra. Para evitar que se muevan pueden fijarse con estacas de madera o con estaquillas de la misma especie empleada en la construcción de las fajinas.

Si el talud no presenta problemas de exceso de agua, las zanjas donde se instalan las fajinas se excavan en ángulo recto con la línea de máxima pendiente. Si hay problemas derivados de un exceso de humedad, es conveniente darles una ligera pendiente hacia los laterales del talud para evacuar el exceso de agua.

Las fajinas constituyen una técnica de estabilización muy efectiva que protege los taludes frente a deslizamientos superficiales $(0,25-0,75 \mathrm{~m}$ de profundidad) y que permite escalonar o banquear la pendiente cuando la excavación es difícil.

La matriz de raíces que se desarrolla a partir de las fajinas proporciona efectos de contención y retención de las capas superficiales del suelo, evita la formación de cárcavas y barrancos y protege el talud frente a la erosión superficial, ya que se reduce la longitud efectiva de la pendiente al quedar está dividida en tramos más cortos por las sucesivas fajinas.

En las terrazas que se forman entre filas sucesivas de fajinas quedan, además, retenidas las partículas que arrastra la escorrentía superficial, con lo que se reducen así las necesidades de conservación de las cunetas. 


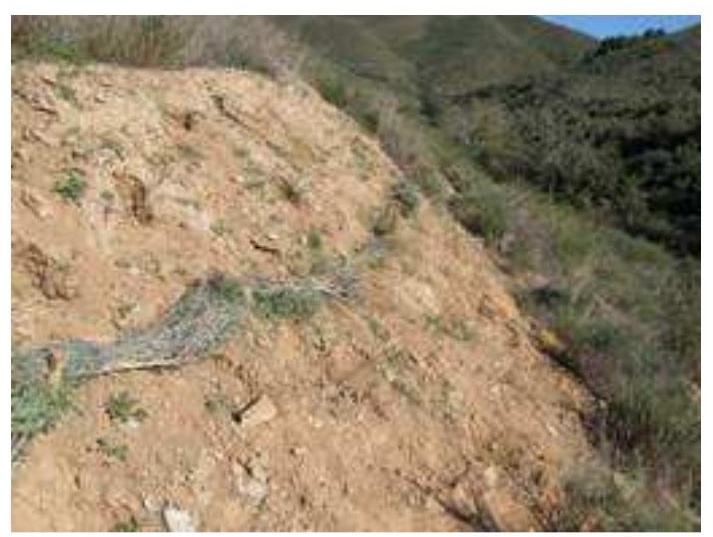

Figura 31: Fajinas elaboradas "in situ" con material vegetal.

Para construir las fajinas se utilizan ramas y tallos de plantas leñosas con alta capacidad de enraizamiento. Las ramas deben ser largas, rectas y flexibles y estar provistas de yemas de crecimiento activas. Los sauces (Salix $s p$ ) son los que mejor resultado dan, pero también pueden utilizarse algunas especies del género Cornus, abedules (Betula $s p$ ), alisos (Alnus $s p$ ) y chopos (Populus sp).

Al elegir el material vegetal conviene tener en cuenta que los sauces jóvenes, menores de 1 año, desarrollan las yemas de crecimiento con mucha facilidad, los ejemplares adultos tienen mayores reservas vegetativas y los de mayor edad son más resistentes. Conviene, por tanto, mezclar material de todas las edades, procurando que la mayoría corresponda a ejemplares de entre 1 y 4 años.

Para construir la fajina se emplean ramas de entre 1 y $9 \mathrm{~m}$ de longitud y entre 15 y 30 $\mathrm{mm}$ de diámetro. Las ramas se agrupan para formar un haz y se atan cada $30-50 \mathrm{~cm}$ con bramante o cuerda fina hecha con fibras vegetales. Las dimensiones recomendadas para la fajina completa son de 15 a $30 \mathrm{~cm}$ de diámetro y de 2 a $10 \mathrm{~m}$ de longitud, aunque estas dimensiones pueden variar dependiendo de las condiciones particulares de la zona de actuación.

Las yemas apicales de crecimiento deben quedar orientadas en la misma dirección y los extremos de las ramas y tallos uniformemente distribuidos a lo largo de la fajina.

Para anclar las fajinas pueden utilizarse estaquillas o estacas de madera maciza. Las estaquillas deben tener unos $0,5 \mathrm{~m}$ de longitud como mínimo si el talud es en desmonte, y 
0,75 m si está construido en terraplén. Las estacas de madera maciza deben tener entre 0,6 y 1 $\mathrm{m}$ de longitud. Su madera debe estar sana y todas las estacas que se rompan o se astillen durante la instalación deben ser desechadas.

La instalación comienza por la base del talud excavando una zanja transversal a la pendiente de longitud igual o ligeramente superior a la de la fajina y anchura variable, dependiendo del ángulo de pendiente del talud $(0,3-0,5 \mathrm{~m})$. La profundidad de la zanja debe ser aproximadamente la mitad del diámetro de la fajina.

Después se coloca la fajina en el fondo de la zanja y se la fija al talud introduciendo entre las ramas estacas de madera cada 0,75 - $1 \mathrm{~m}$ y clavándolas en el suelo. En los tramos donde las fajinas se solapan es conveniente colocar estacas extra. La parte superior de las estacas debe quedar a ras con la cara externa de la fajina.

Las estaquillas se instalan generalmente en la cara inferior de las fajinas. Se clavan por debajo y contra la fajina al tresbolillo con las estacas de madera que han sido clavadas anteriormente. Las estaquillas deben sobresalir entre $5-10 \mathrm{~cm}$ por encima de la parte superior de las fajinas.

Los laterales de las fajinas se recubren de tierra húmeda de manera que su parte superior sea claramente visible una vez concluida la instalación. Desde la base del talud hacia su parte alta se van instalando sucesivas filas de fajinas hasta completar el tratamiento. Siempre que sea posible es conveniente instalar una o dos filas de fajinas sobre la parte superior del talud. La distancia entre las sucesivas filas de fajinas varía en función de la pendiente y la longitud del talud

Es conveniente completar el tratamiento sembrando el espacio existente entre filas consecutivas de fajinas $y / o$ instalando en él materiales de recubrimiento para prevenir la erosión. Si la pendiente es de 2,5 H : 1V o inferior es suficiente con extender paja o cualquier otro tipo de mulch. Si el talud tiene más pendiente debería recubrirse este espacio con mantas o redes orgánicas en lugar de con mulch. 


\subsection{3.- Escalones de matorral}

Esta técnica consiste en situar ramas de especies leñosas con capacidad para enraizar en pequeñas zanjas o entre capas sucesivas de tierra a lo largo de la pendiente de los taludes, de manera que formen una especie de terrazas o escalones.

Esta técnica difiere de las fajinas en la orientación de las ramas y la profundidad a la que éstas se sitúan. En los escalones de matorral las ramas se orientan más o menos perpendicularmente al perfil del talud y se introducen hasta dos metros dentro de él, mientras que las fajinas se sitúan paralelas al perfil del talud y se entierran muy someramente.

La orientación perpendicular es más efectiva desde el punto de vista del refuerzo del suelo y la estabilidad del talud frente a movimientos de masas. Las ramas actúan como elementos de tensión que refuerzan el talud y las porciones de las ramas que sobresalen sobre la superficie actúan frenando la escorrentía y disipando su potencial erosivo. Los escalones de matorral proporcionan de forma inmediata varios efectos positivos en cuanto al control de la erosión, el refuerzo del suelo y la estabilidad de los taludes frente a movimientos en masa.

La pendiente queda dividida en una serie de escalones separados por las filas de matorral, lo que disminuye la longitud efectiva de la pendiente y con ello la capacidad erosiva de la escorrentía.

- Las ramas introducidas en el talud refuerzan el suelo ya antes de que se desarrollen las raíces, e incrementan de forma significativa su resistencia al deslizamiento y a los movimientos rotacionales.

- La vegetación desarrollada a partir de las ramas retiene los sedimentos y mejora las condiciones de infiltración en los suelos secos, y drena los suelos excesivamente húmedos.

- Mejoran las condiciones microclimáticas y facilitan el desarrollo de la vegetación y la regeneración natural.

- Los escalones de matorral redireccionan y mitigan los efectos del drenaje interno del talud al actuar como drenajes horizontales. 
Se utilizan ramas de sauce (Salix sp), aliso (Alnus sp) o chopo (Populus sp) de $20-50 \mathrm{~mm}$ de diámetro y longitud suficiente para que lleguen al final de la zanja (1 -2,5 m), los laterales de las ramas deben permanecer intactos.

La excavación de las zanjas se inicia al pie del talud y se va avanzando hacia la cabecera, de forma que el material excavado en cada zanja superior sirva para el relleno de la que está situada inmediatamente por debajo.

Las zanjas deben tener contrapendiente de entre 10 y 20 hacia el talud. Su anchura suele ser de entre 0,5 y $1 \mathrm{~m}$. Si existen problemas de drenaje debe dárseles una ligera pendiente hacia el borde del talud, de forma que las aguas de las zanjas recojan puedan circular y no queden retenidas.

Las ramas se introducen en la zanja perpendicularmente a la superficie del talud, con las yemas de crecimiento hacia afuera, y de manera que sobresalgan al menos $15-30 \mathrm{~cm}$ fuera de la zanja ( $1 / 4$ de su longitud total). Las ramas se colocan de forma entrecruzada para formar una especie de estera de entre 75 y $200 \mathrm{~mm}$ de espesor.

Una vez que las ramas han sido colocadas en el interior de las zanjas, se cubren con tierra. Este relleno debe compactarse para eliminar las bolsas de aire. Las yemas de crecimiento deben quedar situadas ligeramente por fuera del relleno. Cuando se concluye la instalación de un escalón de matorral, se procede a la instalación del siguiente por arriba. La distancia entre zanjas sucesivas varía dependiendo de la pendiente del talud y de sus condiciones previas de estabilidad. Una distancia media recomendada es entre 1 y $2,5 \mathrm{~m}$.

Es conveniente tratar la superficie comprendida entre zanjas adyacentes para protegerla frente a la erosión. Si entre las filas de zanjas consecutivas la pendiente es $3 \mathrm{H}$ : $1 \mathrm{~V}$ o inferior, es suficiente con sembrar el espacio y extender una capa de mulch de fibra larga. Si la pendiente es superior a este valor, en lugar de mulch, es conveniente utilizar una red o una manta orgánica.

\subsection{4.- Paquetes de matorral}

Es una técnica que se utiliza para reparar las depresiones ocasionadas por pequeños deslizamientos. Consiste en rellenar la depresión que se quiere reparar con capas alternas de 
ramas de matorral y tierras de relleno compactadas. Sólo puede utilizarse en áreas de deslizamiento menores de $1 \mathrm{~m}$ de profundidad y/o $2 \mathrm{~m}$ de anchura.

Esta técnica es efectiva para el refuerzo y la estabilidad frente a movimientos en masa en taludes de pequeño tamaño. Recién instaladas Las ramas actúan como tirantes que refuerzan el suelo. Cuando comienzan a crecer y desarrollan follaje, frenan la escorrentía y disipan su energía erosiva, y las raíces enlazan el material de relleno y lo anclan al sustrato de suelo natural, formando una masa unificada.

Los materiales que se emplean son ramas con capacidad de enraizamiento de 10 a 50 $\mathrm{mm}$ de diámetro y longitud suficiente para que alcancen el fondo de la depresión que se está reparando y sobresalgan ligeramente por su borde superior.

También se usan estacas de madera maciza de 1,5 a 2,5 m de largo y 75 a $100 \mathrm{~mm}$ de diámetro. También la longitud de las estacas varía dependiendo de la profundidad del deslizamiento que se está reparando.

La instalación comienza por el punto más bajo de la zona a reparar, hincando las estacas de madera verticalmente a una profundidad de entre 1 y $1,25 \mathrm{~m}$, distanciadas entre 15 y 30 $\mathrm{cm}$. Se sitúa una capa de ramas de entre 10 y $15 \mathrm{~cm}$ de espesor en el fondo del deslizamiento, entre las estacas verticales, perpendicularmente a la cara del talud. Las ramas deben entrelazarse y disponerse con los extremos de las yemas de crecimiento orientadas hacia la superficie del talud. Algunas de ellas deben tocar el fondo del deslizamiento.

Las siguientes capas de ramas se colocan con el extremo final más bajo que el extremo que tiene las yemas de crecimiento. Cada capa de ramas se cubre con otra de tierra compactada para asegurar un íntimo contacto con el suelo. Una vez concluida la instalación, el perfil final del relleno de ramas y tierra debe enrasar con la superficie del talud y las ramas sólo deben sobresalir ligeramente sobre las de tierra.

\subsection{5.- Reparación de cárcavas con material vivo}

Es una técnica muy parecida a la de los paquetes de matorral, pero más adecuada para reparar depresiones ocasionadas por erosión superficial, como regueros profundos y cárcavas. 
Consiste en rellenar el reguero o la cárcava que se pretende reparar con capas alternas de ramas y tierras compactadas.

Las ramas proporcionan un efecto inmediato de refuerzo del suelo tras su instalación, disminuyen la velocidad de circulación del agua de escorrentía y actúan como una barrerafiltro que retiene el material arrastrado.

Se utilizan ramas de 10 - $50 \mathrm{~mm}$ de diámetro, lo suficientemente largas para tocar el terreno no alterado en el fondo del reguero o de la cárcava y sobresalir ligeramente fuera del perfil de la pendiente reconstruida.

La instalación se comienza por el punto más bajo de la zona de actuación colocando las ramas perpendicularmente a la pendiente, de manera que formen capas de 70 a $100 \mathrm{~mm}$ de espesor. Las ramas deben entrecruzarse, orientando los extremos con las yemas de crecimiento hacia la cara del talud y con el extremo basal situado más bajo que el de crecimiento. Cada conjunto de ramas se cubre con una capa de tierras de $150-200 \mathrm{~mm}$ de espesor que posteriormente se compacta.

\subsection{6.- Esteras de matorral}

Consiste en recubrir la superficie del talud con una capa gruesa de ramas atadas y entrelazadas de manera que formen una especie de colchón o estera, o simplemente extendidas sobre el terreno y ancladas a él por medio de estacas de madera o estaquillas y alambre. Esta técnica está especialmente indicada para el tratamiento de las orillas de ríos y arroyos, donde la pendiente no sobrepasa $3 \mathrm{H}: 1 \mathrm{~V}$ o 4H: $1 \mathrm{~V}$.

Las esteras protegen el talud de forma inmediata frente a la acción de la corriente y desarrollan en una o dos estaciones una espesa franja de vegetación arbustiva. Por otro lado, crean una superficie de fricción que reduce la velocidad de la corriente en la franja de contacto con el talud, y con ello su energía erosiva.

Las ramas retienen los sedimentos y materiales que arrastra la corriente y crean un colchón protector que aísla la superficie de la orilla de la acción directa del agua y la protege del golpeteo de las olas. 
Se utilizan ramas de sauce, aliso u otras especies de carácter ribereño que enraícen con facilidad y estén adaptadas a condiciones de encharcamiento periódico. Para el anclaje de las ramas se utilizan estaquillas de la misma especie, estacas de madera maciza o clavos metálicos y alambre galvanizado de doble torsión.

La zona donde se va a instalar la estera de matorral debe ser despedregada, limpiada de ramas y otros elementos y ligeramente taluzada, para lograr una superficie más o menos uniforme que permita un buen contacto entre las ramas y el suelo.

A continuación, se excava una zanja de $20-30 \mathrm{~cm}$ de profundidad justo por debajo del nivel mínimo estacional de la lámina de agua. Las ramas se sitúan dentro de la zanja con el extremo inferior orientado hacia la cara del talud y perpendicularmente al perfil de la orilla.

La capa de ramas deberá tener un espesor tal que cuando sea comprimida por los alambres de sujeción y anclaje su grosor sea de al menos $10 \mathrm{~cm}$. El extremo inferior de las ramas se sujeta con troncos, piedra de escollera o fajinas. Posteriormente, se clavan una serie de estaquillas o estacas de madera maciza (5 - $10 \mathrm{~cm}$ de diámetro) atravesando la capa de ramas, y se ata a ellas alambre galvanizado de $3 \mathrm{~mm}$ de grosor, de manera que se forme una red romboidal por encima de las ramas. Este alambre debe quedar bien tensado para que sujete firmemente la capa de ramas.

Las estacas o estaquillas deben ser de longitud suficiente para atravesar la capa de ramas, introducirse firmemente en el talud y sobresalir por encima de ella. Una vez instalada y sujeta convenientemente, la capa de ramas se recubre parcialmente con una capa de tierra de entre 3 y $5 \mathrm{~cm}$ de espesor.

\subsection{7.- Estaquillado de revestimientos porosos de piedra}

Esta técnica consiste en introducir estaquillas de matorral a través de las juntas y huecos que dejan las piedras que recubren el talud, hasta clavarlas firmemente en el mismo. El estaquillado puede realizarse una vez concluido el revestimiento de la superficie o de forma simultánea con su ejecución.

Las raíces de las plantas desarrolladas a partir de la estaquillas drenan el exceso de agua del talud y crean una densa matriz en el suelo sobre el que se asienta el revestimiento rocoso, 
que refuerza el efecto de protección superficial de éste y evita el arrastre de finos por debajo y entre las piedras que lo forman.

Se utilizan estaquillas de especies arbustivas de 10 a $40 \mathrm{~mm}$ de diámetro y longitud suficiente para atravesar el recubrimiento, quedar firmemente clavadas en el suelo y sobresalir por encima de aquel.

Las estaquillas se introducen entre los huecos que dejan las rocas y se clavan en el talud con un golpe seco de martillo. Deben quedar situadas en ángulo recto con la superficie del talud y sobresalir ligeramente sobre el revestimiento. Conviene distribuirlas aleatoriamente por la superficie de tratamiento, con una densidad de 2 a 5 estaquillas por $\mathrm{m}^{2}$.

\subsection{8.- Muros de gaviones con vegetación}

Para revegetar los muros construidos con gaviones, se colocan capas de ramas de matorral entre los sucesivos gaviones que componen el muro. Opcionalmente, pueden introducirse algunas ramas dentro de los propios gaviones.

Las raíces que desarrollan las ramas se introducen entre el relleno de los gaviones y alcanzan el talud arraigando en él y consolidando así la estructura. La vegetación, por tanto, refuerza la estructura del muro de gaviones y la hace más resistente, al tiempo que le da una apariencia más natural, aunque es el muro de gaviones quien asume la función de estabilización. Es una técnica adecuada cuando es necesario cuidar estéticamente el acabado de las obras.

Los gaviones se construyen de la forma convencional. Para su revegetación se utilizan ramas de 10 a $25 \mathrm{~mm}$ de diámetro y longitud suficiente para que lleguen, atravesando los gaviones, hasta el talud y sobresalgan de la cara frontal del muro.

Al finalizar la colocación de cada piso de gaviones, se sitúa sobre ellos una capa de ramas, orientadas perpendicularmente al talud. Las ramas se cubren con una capa de tierras de relleno de buena calidad, y el conjunto se compacta ligeramente para conseguir un buen contacto. Sobre la capa de tierra y ramas se instala el siguiente piso de gaviones y se repite la secuencia de construcción hasta alcanzar la altura de muro deseada. 


\section{5.- CUIDADOS POSTERIORES A LA IMPLANTACIÓN}

El implante de la vegetación debe contemplar labores posteriores que aseguren el desarrollo adecuado de esta hasta que pueda auto mantenerse. Estas labores pueden ser:

- Fertilización.

- Riego.

- Resiembra.

- Aclareo y eliminación de malezas.

- Siegas.

\subsection{1.- Fertilización}

La fertilización debe hacerse a partir de inspecciones anuales de los posibles déficits nutricionales, que son identificados a partir del amarilleamiento del follaje y aparición de claros en el follaje. Los productos fertilizantes pueden añadirse en forma de abonado foliar 0 diluidos en el agua de riego.

Como dosis de mantención anual en las superficies sembradas se debe realizar un abonado de fondo al mes de iniciado el otoño con fertilizantes químicos disueltos en agua de riego, y otro de cementera a finales de invierno con compuestos orgánicos nitrogenados (urea, nitrato amoniaco, etc.).

\subsection{2.- Riego}

Debe asegurarse el suministro de agua hasta el momento de arraigo de las plantas. Para superficies hidrosembradas deberá efectuarse con máximo cuidado para evitar el arrastre de tierras y semillas. Los momentos del día adecuados para esta operación son la mañana temprano o la tarde, evitando hacerlo durante periodos de vientos fuertes. En las zonas de clima continental deben realizarse como mínimo, riegos mensuales en los meses de verano. 


\subsection{3.- Resiembra}

En caso de que la nascencia sea irregular y las semillas no germinen homogéneamente, deberá proceder a la resiembra de las superficies con las mismas especies y dosis que en la primera siembra.

\subsection{4.- Aclareo y eliminación de malezas}

En caso de que una vez logrado el arraigo de la vegetación, la densidad de la plantación sea mayor que la deseada para cubrir los objetivos de estabilización y/o protección, será apropiado efectuar labores de aclareo con el objeto de obtener la densidad adecuada.

En general las zonas en que se hayan efectuado plantaciones no será necesario efectuar aclareos, más bien es común usar este cuidado en superficies implantadas a voleo en donde la distribución espacial se hace más azarosamente.

Una operación esencial es la eliminación de la vegetación que crece en forma silvestre en las proximidades del sistema radical de los ejemplares plantados, que compite con estos por los nutrientes y la humedad. Esta operación se efectúa manualmente o con aplicación de herbicidas una o dos veces durante la estación de crecimiento en el primer año, en plantación de especies jóvenes puede ser necesario prolongar esta actuación a los dos o tres primeros años. 
DESARROLLO DE UNA APLICACIÓN INFORMÁTICA PARA EL CÁLCULO DE SOSTENIMIENTO DE TALUDES MEDIANTE REVEGETACIÓN

\section{3.- CARACTERÍSTICAS DE LAS ESPECIES UTILIZADAS EN REVEGETACIÓN}

A continuación se describen las características más relevantes de las especies vegetales utilizadas en la revegetación de taludes. Se diferenciara en especies herbáceas y especies leñosas. 


\section{1.- ESPECIES HERBÁCEAS}

\begin{tabular}{|c|c|c|c|c|c|c|c|c|c|}
\hline Especie & Familia & Altitud & $\begin{array}{l}\text { Exigencias } \\
\text { hídricas }\end{array}$ & $\begin{array}{l}\text { Exigencias } \\
\text { climáticas }\end{array}$ & Tipo suelo & $\begin{array}{l}\text { Sistema } \\
\text { radicular }\end{array}$ & $\begin{array}{l}\text { Porte de la } \\
\text { planta }\end{array}$ & Utilidad & Características \\
\hline $\begin{array}{l}\text { Elymus } \\
\text { hispidus }\end{array}$ & Gramínea & $\begin{array}{l}200 \mathrm{a} \\
1.000 \mathrm{~m}\end{array}$ & $\mathrm{P}>350 \mathrm{~mm}$ & $\begin{array}{l}\text { Clima } \\
\text { mediterráneo }\end{array}$ & $\begin{array}{l}\text { Rico en } \\
\text { bases }\end{array}$ & $\begin{array}{l}\text { Fibroso, acción } \\
\text { reforzadora } \\
\text { entre } 0.75 \text { y } 1.5 \\
\mathrm{~m}\end{array}$ & $\begin{array}{l}\text { Mide entre } \\
40 \text { y } 90 \mathrm{~cm}\end{array}$ & $\begin{array}{l}\text { Usada en } \\
\text { sujeción de } \\
\text { taludes }\end{array}$ & $\begin{array}{l}\text { No tolera } \\
\text { encharcamiento. } \\
\text { Freatismo } \\
\text { estacional }\end{array}$ \\
\hline $\begin{array}{l}\text { Agropirum } \\
\text { desertorum }\end{array}$ & Gramínea & $\begin{array}{l}225 \mathrm{a} \\
1.600 \mathrm{~m}\end{array}$ & $\mathrm{P}>350 \mathrm{~mm}$ & $\begin{array}{l}\text { Clima semiárido y } \\
\text { continental }\end{array}$ & $\begin{array}{l}\text { Suelo } \\
\text { Yesífero } \\
\text { calizo }\end{array}$ & $\begin{array}{l}\text { Potente planta } \\
\text { rízomatosa, } \\
\text { productiva y } \\
\text { fácil de } \\
\text { implantar }\end{array}$ & $\begin{array}{l}\text { Mide entre } \\
25 \mathrm{y} 40 \mathrm{~cm}\end{array}$ & $\begin{array}{l}\text { Muy usada en } \\
\text { revegetación }\end{array}$ & $\begin{array}{l}\text { Rizoma muy } \\
\text { ramificado a flor } \\
\text { de tierra, a partir } \\
\text { del cual nacen los } \\
\text { brotes. }\end{array}$ \\
\hline $\begin{array}{l}\text { Bromus } \\
\text { erectus }\end{array}$ & Gramínea & $\begin{array}{l}500 \mathrm{a} \\
2.100 \mathrm{~m}\end{array}$ & $\mathrm{P}>350 \mathrm{~mm}$ & $\begin{array}{l}\text { Clima } \\
\text { semimediterráneo }\end{array}$ & $\begin{array}{l}\text { Pasto } \\
\text { húmedos } \\
\text { soleados, } \\
\text { bien } \\
\text { drenados, } \\
\text { alcalino }\end{array}$ & $\begin{array}{l}\text { Proporciona } \\
\text { sujeción entre } \\
0.75 \text { y } 1 \mathrm{~m} \mathrm{de} \\
\text { raíz }\end{array}$ & $\begin{array}{l}\text { Mide entre } \\
20 \text { y } 90 \mathrm{~cm}\end{array}$ & $\begin{array}{l}\text { Restauración } \\
\text { laderas } \\
\text { erosionables o } \\
\text { pedregosas }\end{array}$ & \\
\hline $\begin{array}{l}\text { Festuca } \\
\text { arundinacea }\end{array}$ & Gramínea & $\begin{array}{l}250 \mathrm{a} \\
2.000 \mathrm{n}\end{array}$ & $\mathrm{P}>600 \mathrm{~mm}$ & $\begin{array}{l}\text { Clima } \\
\text { mediterráneo }\end{array}$ & $\begin{array}{l}\text { Suelos } \\
\text { ricos en } \\
\text { nutrientes }\end{array}$ & $\begin{array}{l}\text { Fibroso y } \\
\text { potente, de } 30 \text { a } \\
35 \mathrm{~cm} \mathrm{de} \\
\text { profundidad }\end{array}$ & $\begin{array}{l}\text { Mide entre } \\
50 \text { y } 150 \mathrm{~cm}\end{array}$ & $\begin{array}{l}\text { Proporciona un } \\
\text { césped } \\
\text { resistente, } \\
\text { usada en } \\
\text { taludes para } \\
\text { controlar la } \\
\text { erosión. }\end{array}$ & $\begin{array}{l}\text { Gran resistencia al } \\
\text { encharcamiento, } \\
\text { crecimiento inicial } \\
\text { lento }\end{array}$ \\
\hline
\end{tabular}




\begin{tabular}{|c|c|c|c|c|c|c|c|c|c|}
\hline Especie & Familia & Altitud & $\begin{array}{l}\text { Exigencias } \\
\text { hídricas }\end{array}$ & $\begin{array}{l}\text { Exigencias } \\
\text { climáticas }\end{array}$ & Tipo suelo & $\begin{array}{l}\text { Sistema } \\
\text { radicular }\end{array}$ & $\begin{array}{l}\text { Porte de la } \\
\text { planta }\end{array}$ & Utilidad & Características \\
\hline Festuca ovina & Gramínea & $\begin{array}{l}0 \mathrm{a} \\
2.000 \mathrm{~m}\end{array}$ & $\begin{array}{l}\text { Resistente a } \\
\text { la sequia P> } \\
350 \mathrm{~mm}\end{array}$ & $\begin{array}{l}\text { Climas } \\
\text { mesofíticos- } \\
\text { mediterráneos } \\
\text { subnemorales }\end{array}$ & $\begin{array}{l}\text { Se } \\
\text { desarrolla } \\
\text { bien en } \\
\text { suelos muy } \\
\text { pobres }\end{array}$ & $\begin{array}{l}\text { Sistema } \\
\text { radicular } \\
\text { extenso que la } \\
\text { hace más } \\
\text { tolerante a la } \\
\text { sequía que las } \\
\text { festucas rubras }\end{array}$ & $\begin{array}{l}\text { Mide entre } \\
20 \text { y } 45 \mathrm{~cm}\end{array}$ & $\begin{array}{l}\text { Revegetaciones } \\
\text { en clima seco y } \\
\text { frío }\end{array}$ & $\begin{array}{l}\text { Se cultiva donde } \\
\text { las siegas, el agua } \\
\text { y la fertilización } \\
\text { son escasos o } \\
\text { inexistentes. Usada } \\
\text { en revegetación } \\
\text { paisajística }\end{array}$ \\
\hline $\begin{array}{l}\text { Onobrychis } \\
\text { sativa }\end{array}$ & Fabácea & $\begin{array}{l}400 \mathrm{a} \\
2.500 \mathrm{~m}\end{array}$ & $\mathrm{P}>500 \mathrm{~mm}$ & $\begin{array}{l}\text { climas } \\
\text { mediterráneos } \\
\text { fríos, subhúmedos } \\
\text { o semiáridos }\end{array}$ & $\begin{array}{l}\text { Calcícola. } \\
\text { Mejor seco } \\
\text { profundo }\end{array}$ & $\begin{array}{l}\text { Raíz pivotante } \\
\text { muy } \\
\text { desarrollada, } \\
\text { puede llegar a } 2 \\
\text { metros de } \\
\text { profundidad }\end{array}$ & $\begin{array}{l}\text { Mide de } 20 \text { a } \\
80 \mathrm{~cm} \mathrm{de} \\
\text { altura }\end{array}$ & & $\begin{array}{l}\text { No soporta bien el } \\
\text { calor, lo que } \\
\text { supone una bajada } \\
\text { del rendimiento así } \\
\text { como de la } \\
\text { actividad } \\
\text { metabólica. }\end{array}$ \\
\hline $\begin{array}{l}\text { Trifolium } \\
\text { pratense }\end{array}$ & Fabácea & $\begin{array}{l}0 \mathrm{a} \\
2.500 \mathrm{~m}\end{array}$ & $\mathrm{P}>650 \mathrm{~mm}$ & $\begin{array}{l}\text { Climas } \\
\text { mediterráneos, } \\
\text { eurosiberianos, } \\
\text { incluso montaña }\end{array}$ & $\begin{array}{l}\text { Suelos } \\
\text { fértiles, } \\
\text { profundos y } \\
\text { compactos }\end{array}$ & $\begin{array}{l}\text { Numerosas } \\
\text { raíces } \\
\text { adventicias que } \\
\text { arrancan del } \\
\text { cuello. }\end{array}$ & $\begin{array}{l}\text { Mide entre } \\
10 \text { y } 60 \mathrm{~cm}\end{array}$ & & $\begin{array}{l}\text { Resiste mal el } \\
\text { encharcamiento y } \\
\text { tiene problemas de } \\
\text { perdurabilidad a } \\
\text { partir del tercer } \\
\text { año. }\end{array}$ \\
\hline $\begin{array}{l}\text { Trifolium } \\
\text { repens }\end{array}$ & Fabácea & $\begin{array}{l}0 \mathrm{a} \\
2.500 \mathrm{~m}\end{array}$ & $\mathrm{P}>850 \mathrm{~mm}$ & $\begin{array}{l}\text { Clima húmedo, } \\
\text { Zonas atlánticas, } \\
\text { tolera } \\
\text { encharcamiento }\end{array}$ & $\begin{array}{l}\text { Todo tipo, } \\
\text { mejor } \\
\text { profundos y } \\
\text { con buen } \\
\text { contenido } \\
\text { de bases }\end{array}$ & $\begin{array}{l}\text { Una raíz } \\
\text { pivotante, y } \\
\text { numerosas } \\
\text { raíces } \\
\text { adventicias que } \\
\text { arrancan del } \\
\text { cuello. }\end{array}$ & $\begin{array}{l}\text { Mide entre } \\
10 \text { y } 50 \mathrm{~cm}\end{array}$ & $\begin{array}{l}\text { Se implanta con } \\
\text { facilidad y su } \\
\text { vida productiva } \\
\text { es de } 2-3 \text { años }\end{array}$ & \\
\hline
\end{tabular}




\begin{tabular}{|c|c|c|c|c|c|c|c|c|c|}
\hline Especie & Familia & Altitud & $\begin{array}{l}\text { Exigencias } \\
\text { hídricas }\end{array}$ & $\begin{array}{l}\text { Exigencias } \\
\text { climáticas }\end{array}$ & Tipo suelo & $\begin{array}{l}\text { Sistema } \\
\text { radicular }\end{array}$ & $\begin{array}{l}\text { Porte de la } \\
\text { planta }\end{array}$ & Utilidad & Características \\
\hline $\begin{array}{l}\text { Trifolium } \\
\text { subterraneu } \\
\text { m }\end{array}$ & Fabácea & $\begin{array}{l}0 \mathrm{a} \\
1.100 \mathrm{~m}\end{array}$ & $\mathrm{P}>450 \mathrm{~mm}$ & $\begin{array}{l}\text { Climas } \\
\text { mediterráneos. } \\
\text { Necesita frío } \\
\text { invernal. }\end{array}$ & $\begin{array}{l}\text { Silíceo o } \\
\text { calizo } \\
\text { descarbonat } \\
\text { ado } \\
\text { Tolera } \\
\text { suelos } \\
\text { pobres }\end{array}$ & $\begin{array}{l}\text { Presenta raíz } \\
\text { pivotante muy } \\
\text { desarrollada. }\end{array}$ & $\begin{array}{l}\text { Mide entre } \\
20 \text { y } 30 \mathrm{~cm}\end{array}$ & $\begin{array}{l}\text { Se implanta con } \\
\text { cierta dificultad } \\
\text { y su } \\
\text { crecimiento } \\
\text { otoñal es escaso }\end{array}$ & $\begin{array}{l}\text { En zonas con } \\
\text { pluviometría } \\
\text { superior a } 400 \\
\text { mm/año se utilizan } \\
\text { variedades de ciclo } \\
\text { largo, capaces de } \\
\text { producir durante } \\
\text { más tiempo. }\end{array}$ \\
\hline $\begin{array}{l}\text { Cynodon } \\
\text { dactylon }\end{array}$ & Gramínea & $\begin{array}{l}0 \mathrm{a} \\
2.200 \mathrm{~m}\end{array}$ & $\mathrm{P}>350 \mathrm{~mm}$ & $\begin{array}{l}\text { Climas cálidos y } \\
\text { templados }\end{array}$ & $\begin{array}{l}\text { Todo tipo } \\
\text { de suelo }\end{array}$ & $\begin{array}{l}\text { Muy profundo, } \\
\text { pudiendo llegar } \\
\text { a } 2 \mathrm{~m} \text {, la } \\
\text { mayoría } 60 \mathrm{~cm} \\
\text { de profundidad }\end{array}$ & $\begin{array}{l}\text { Mide entre } \\
10 \text { y } 30 \mathrm{~cm}\end{array}$ & $\begin{array}{l}\text { Revegetaciones } \\
\text { gran capacidad } \\
\text { de } \\
\text { regeneración, } \\
\text { Semilla } \\
\text { pequeña, difícil } \\
\text { implantar }\end{array}$ & $\begin{array}{l}\text { Los tallos reptan } \\
\text { por el suelo y de } \\
\text { los nódulos salen } \\
\text { nuevas raíces } \\
\text { formando matas } \\
\text { densas. }\end{array}$ \\
\hline $\begin{array}{l}\text { Dactylis } \\
\text { glomerata }\end{array}$ & Gramínea & $\begin{array}{l}0 \mathrm{a} \\
2.000 \mathrm{~m}\end{array}$ & $\mathrm{P}>300 \mathrm{~mm}$ & $\begin{array}{l}\text { Clina templado } \\
\text { No crece a } \\
\text { temperaturas } \\
\text { menores de } 5^{\circ} \mathrm{C} \mathrm{y} \\
\text { en primavera tiene } \\
\text { un gran desarrollo } \\
\text { pero lento al } \\
\text { principio }\end{array}$ & $\begin{array}{l}\text { calizos y } \\
\text { ricos en } \\
\text { materia } \\
\text { orgánica, } \\
\text { vive bien } \\
\text { en los } \\
\text { silíceos (pH } \\
\text { entre 6-8) }\end{array}$ & $\begin{array}{l}\text { Superficial y } \\
\text { sensible a la } \\
\text { sequía }\end{array}$ & $\begin{array}{l}\text { Mide entre } \\
30 \text { y } 150 \mathrm{~cm}\end{array}$ & $\begin{array}{l}\text { Enorme valor } \\
\text { en restauración }\end{array}$ & $\begin{array}{l}\text { Rápido desarrollo } \\
\text { y entrada en } \\
\text { producción. }\end{array}$ \\
\hline
\end{tabular}




\begin{tabular}{|c|c|c|c|c|c|c|c|c|c|}
\hline Especie & Familia & Altitud & $\begin{array}{l}\text { Exigencias } \\
\text { hídricas }\end{array}$ & $\begin{array}{l}\text { Exigencias } \\
\text { climáticas }\end{array}$ & Tipo suelo & $\begin{array}{l}\text { Sistema } \\
\text { radicular }\end{array}$ & $\begin{array}{l}\text { Porte de la } \\
\text { planta }\end{array}$ & Utilidad & Características \\
\hline $\begin{array}{l}\text { Lolium } \\
\text { perenne }\end{array}$ & Gramínea & $\begin{array}{l}0 \mathrm{a} \\
1.500 \mathrm{~m}\end{array}$ & $\mathrm{P}>600 \mathrm{~mm}$ & $\begin{array}{l}\text { Clima } \\
\text { mesofítico o } \\
\text { nemoromediterr } \\
\text { áneo }\end{array}$ & $\begin{array}{l}\text { Suelos de } \\
\text { mediana a } \\
\text { alta } \\
\text { fertilidad, } \\
\text { francos/fra } \\
\text { ncoarcillos } \\
\text { os. }\end{array}$ & $\begin{array}{l}\text { La raíz en } \\
\text { cabellera } \\
\text { abundante y } \\
\text { superficial, el } 90 \\
\% \text { se encuentra } \\
\text { en los primeros } \\
30 \mathrm{~cm} \text { de suelo. }\end{array}$ & $\begin{array}{l}\text { Mide entre } 8 \\
\text { y } 90 \mathrm{~cm}\end{array}$ & $\begin{array}{l}\text { importancia en } \\
\text { la creación de } \\
\text { céspedes }\end{array}$ & $\begin{array}{l}\text { Rápida } \\
\text { germinación no } \\
\text { tiene resistencia a } \\
\text { la sequía, cuando } \\
\text { se seca la capa } \\
\text { superficial por el } \\
\text { calor y los vientos. }\end{array}$ \\
\hline $\begin{array}{l}\text { Lolium } \\
\text { multiflorum }\end{array}$ & Gramínea & $\begin{array}{l}0 \text { a } 800 \\
\mathrm{~m}\end{array}$ & $\mathrm{P}>700 \mathrm{~mm}$ & $\begin{array}{l}\text { Más exigente en } \\
\text { humedad y } \\
\text { menos con frio y } \\
\text { calor }\end{array}$ & $\begin{array}{l}\text { No tolera el } \\
\text { encharcami } \\
\text { ento. En } \\
\text { suelos } \\
\text { fértiles } \\
\text { desarrolla } \\
\text { un elevado } \\
\text { potencial } \\
\text { productivo. }\end{array}$ & $\begin{array}{l}\text { Fibrosa, en } \\
\text { cabellera y } \\
\text { relativamente } \\
\text { superficial. }\end{array}$ & $\begin{array}{l}\text { Mide entre } \\
40 \text { y } 120 \mathrm{~cm}\end{array}$ & $\begin{array}{l}\text { Especie } \\
\text { agresiva con un } \\
\text { alto porcentaje } \\
\text { de germinación }\end{array}$ & $\begin{array}{l}\text { Similares al lolium } \\
\text { perenne }\end{array}$ \\
\hline $\begin{array}{l}\text { Medicago } \\
\text { sativa }\end{array}$ & Fabáceas & $\begin{array}{l}0 \mathrm{a} \\
1.200 \mathrm{~m}\end{array}$ & $\mathrm{P}>450 \mathrm{~mm}$ & $\begin{array}{l}\text { Amplio rango } \\
\text { climático. } \\
\text { Tolera el calor y } \\
\text { es bastante } \\
\text { resistente a la } \\
\text { sequía. Puede } \\
\text { soportar bajas } \\
\text { temperaturas }\end{array}$ & $\begin{array}{l}\text { Suelos } \\
\text { calizos } \\
\text { profundos, } \\
\text { no } \\
\text { compactad } \\
\text { o ni } \\
\text { encharcado }\end{array}$ & $\begin{array}{l}\text { Sus raíces } \\
\text { suelen ser muy } \\
\text { profundas, } \\
\text { pudiendo medir } \\
\text { hasta } 4,5 \text { metros }\end{array}$ & $\begin{array}{l}\text { Mide entre } \\
10 \text { y } 80 \mathrm{~cm}\end{array}$ & $\begin{array}{l}\text { Utilizada en } \\
\text { revegetación } \\
\text { por su fácil } \\
\text { implantación, y } \\
\text { rápido } \\
\text { desarrollo }\end{array}$ & $\begin{array}{l}\text { Sus raíces poseen } \\
\text { nódulos } \\
\text { conteniendo las } \\
\text { bacterias } \\
\text { Sinorhizobium } \\
\text { meliloti, fijadoras } \\
\text { de nitrógeno que } \\
\text { favorecen el } \\
\text { crecimiento de las } \\
\text { plantas adyacentes. }\end{array}$ \\
\hline
\end{tabular}




\section{2.- ESPECIES LEÑOSAS}

\begin{tabular}{|c|c|c|c|c|c|c|c|c|c|}
\hline Especie & Familia & Altitud & $\begin{array}{l}\text { Exigencias } \\
\text { hídricas }\end{array}$ & $\begin{array}{l}\text { Exigencias } \\
\text { climáticas }\end{array}$ & Tipo suelo & $\begin{array}{l}\text { Sistema } \\
\text { radicular }\end{array}$ & $\begin{array}{l}\text { Porte de la } \\
\text { planta }\end{array}$ & Utilidad & Características \\
\hline Salix alba & Salicáceas & $\begin{array}{l}0 \mathrm{a} \\
1.800 \mathrm{~m}\end{array}$ & $\begin{array}{l}\text { Necesita } \\
\text { humedad } \\
\text { permanente en } \\
\text { el suelo }\end{array}$ & $\begin{array}{l}\text { Clima con } \\
\text { humedad } \\
\text { permanente }\end{array}$ & $\begin{array}{l}\text { Suelos } \\
\text { ricos en } \\
\text { bases con } \\
\text { pH } 5.5 \text { y } 8\end{array}$ & $\begin{array}{l}\text { Sistema } \\
\text { radicular con } \\
\text { buena capacidad } \\
\text { de amarre y } \\
\text { desarrollo en } \\
\text { suelos húmedos }\end{array}$ & $\begin{array}{l}\text { Hasta } 25 \text { m } \\
\text { de altura }\end{array}$ & $\begin{array}{l}\text { Se usa para } \\
\text { consolidar ríos } \\
\text { y arroyos y } \\
\text { bosques de } \\
\text { ribera }\end{array}$ & $\begin{array}{l}\text { No soporta } \\
\text { temperaturas } \\
\text { extremas. Se da en } \\
\text { casi todas las } \\
\text { provincias,(especie } \\
\text { hidrófila) sistema } \\
\text { radicular denso, } \\
\text { grueso de amplia } \\
\text { distribución }\end{array}$ \\
\hline Populus alba & Salicáceas & $\begin{array}{l}0 \mathrm{a} \\
1.000 \mathrm{~m}\end{array}$ & $\begin{array}{l}\text { Soporta bien el } \\
\text { frío y los } \\
\text { calores } \\
\text { excesivos con } \\
\text { tal de tener } \\
\text { aprovisionami } \\
\text { ento de agua. }\end{array}$ & $\begin{array}{l}\text { Clima } \\
\text { continental }\end{array}$ & $\begin{array}{l}\text { Frescos, } \\
\text { ricos y } \\
\text { húmedos en } \\
\text { las } \\
\text { proximidad } \\
\text { es de los } \\
\text { ríos. Sin } \\
\text { gran } \\
\text { exigencia. }\end{array}$ & $\begin{array}{l}\text { Muy fuerte con } \\
\text { multitud de de } \\
\text { raíces } \\
\text { hidrotrópicas, } \\
\text { geníferas que se } \\
\text { reproducen por } \\
\text { retoños }\end{array}$ & $\begin{array}{l}\text { Hasta } 30 \mathrm{~m} \\
\text { de altura }\end{array}$ & $\begin{array}{l}\text { Sus raíces son } \\
\text { agresivas, por } \\
\text { lo que debe } \\
\text { descartarse su } \\
\text { plantación } \\
\text { cerca de } \\
\text { instalaciones o } \\
\text { construcciones }\end{array}$ & $\begin{array}{l}\text { Temperamento } \\
\text { muy robusto. } \\
\text { Puede resistir } \\
\text { mucho frío. Todas } \\
\text { las provincias. } \\
\text { Crecimiento rápido }\end{array}$ \\
\hline Populus nigra & Salicáceas & $\begin{array}{l}0 \mathrm{a} \\
1.800 \mathrm{~m}\end{array}$ & $\begin{array}{l}\text { Zonas de } \\
\text { ribera con } \\
\text { suelos fértiles } \\
\text { y alto grado de } \\
\text { humedad }\end{array}$ & $\begin{array}{l}\text { Cualquier tipo } \\
\text { de clina } \\
\text { siempre que se } \\
\text { cumplan sus } \\
\text { exigencias } \\
\text { hidricas }\end{array}$ & $\begin{array}{l}\text { Rehúye los } \\
\text { suelos } \\
\text { excesivame } \\
\text { nte salinos }\end{array}$ & $\begin{array}{l}\text { Sistema radical } \\
\text { potente, con } \\
\text { raíces agresivas }\end{array}$ & $\begin{array}{l}\text { Hasta } 30 \mathrm{~m} \\
\text { de altura }\end{array}$ & $\begin{array}{l}\text { Se usa para } \\
\text { consolidar } \\
\text { zonas de ribera } \\
\text { por su potente } \\
\text { sistema radical. }\end{array}$ & $\begin{array}{l}\text { Bastante exigente } \\
\text { en principios } \\
\text { nutritivos y en } \\
\text { cuanto a la luz, no } \\
\text { tolera bien la } \\
\text { cubierta. }\end{array}$ \\
\hline
\end{tabular}




\begin{tabular}{|c|c|c|c|c|c|c|c|c|c|}
\hline Especie & Familia & Altitud & $\begin{array}{l}\text { Exigencias } \\
\text { hídricas }\end{array}$ & $\begin{array}{l}\text { Exigencias } \\
\text { climáticas }\end{array}$ & Tipo suelo & $\begin{array}{l}\text { Sistema } \\
\text { radicular }\end{array}$ & $\begin{array}{l}\text { Porte de la } \\
\text { planta }\end{array}$ & Utilidad & Características \\
\hline $\begin{array}{l}\text { Fraxinus } \\
\text { excelsior }\end{array}$ & Oleáceas & $\begin{array}{l}0 \mathrm{a} \\
1.500 \mathrm{~m}\end{array}$ & $\begin{array}{l}\text { Soporta la } \\
\text { humedad, } \\
\text { incluso el agua } \\
\text { estancada. }\end{array}$ & $\begin{array}{l}\text { No tolera los } \\
\text { climas secos y } \\
\text { calurosos }\end{array}$ & $\begin{array}{l}\text { Indiferente } \\
\text { al pH. } \\
\text { Frescos, } \\
\text { ricos y } \\
\text { profundos }\end{array}$ & $\begin{array}{l}\text { Potente sistema } \\
\text { radicular, con } \\
\text { raíces agresivas. }\end{array}$ & $\begin{array}{l}\text { Mide entre } \\
20 \text { y } 35 \mathrm{~m}\end{array}$ & $\begin{array}{l}\text { Se utiliza como } \\
\text { árbol de } \\
\text { alineación o } \\
\text { formando } \\
\text { grupos }\end{array}$ & $\begin{array}{l}\text { En general ocupa } \\
\text { posiciones } \\
\text { topográficas de } \\
\text { vaguada o partes } \\
\text { bajas de ladera en } \\
\text { umbría. }\end{array}$ \\
\hline $\begin{array}{l}\text { Fraxinus } \\
\text { angustifolia }\end{array}$ & Oleáceas & $\begin{array}{l}300 \mathrm{a} \\
1.500 \mathrm{~m}\end{array}$ & $\begin{array}{l}\text { Soporta muy } \\
\text { bien alta } \\
\text { humedad en el } \\
\text { terreno, ya que } \\
\text { es una especie } \\
\text { muy exigente } \\
\text { en agua. }\end{array}$ & $\begin{array}{l}\text { Clima } \\
\text { mediterráneo. } \\
\text { Tolera muy } \\
\text { bien tanto el } \\
\text { frio como el } \\
\text { calor. }\end{array}$ & $\begin{array}{l}\text { Indiferente } \\
\text { al pH } \\
\text { siempre } \\
\text { que sean } \\
\text { frescos } \\
\text { ricos y } \\
\text { profundos. }\end{array}$ & $\begin{array}{l}\text { Profundo y bien } \\
\text { desarrollado. } \\
\text { Raíces } \\
\text { pivotantes }\end{array}$ & $\begin{array}{l}\text { Puede } \\
\text { alcanzar los } \\
18 \mathrm{~m} \text { de } \\
\text { altura. }\end{array}$ & $\begin{array}{l}\text { Se usa en } \\
\text { revegetación } \\
\text { zonas de ribera } \\
\text { y fondos de } \\
\text { valle. }\end{array}$ & $\begin{array}{l}\text { Crecimiento de } \\
\text { medio a rápido, } \\
\text { necesita insolación } \\
\text { abundante. }\end{array}$ \\
\hline Betula alba & Betuláceas & $\begin{array}{l}0 \mathrm{a} \\
1.800 \mathrm{~m}\end{array}$ & $\begin{array}{l}\text { Requiere } \\
\text { elevada } \\
\text { humedad } \\
\text { ambiental } \\
\text { durante todo el } \\
\text { año }\end{array}$ & $\begin{array}{l}\text { Resiste bien } \\
\text { los fríos } \\
\text { invernales } \\
\text { intensos, } \\
\text { pudiendo } \\
\text { soportar } \\
\text { temperaturas } \\
\text { muy bajas }\end{array}$ & $\begin{array}{l}\text { Se } \\
\text { desarrolla } \\
\text { muy mal en } \\
\text { suelos } \\
\text { calizos, } \\
\text { prefiere los } \\
\text { ácidos } \\
\text { frescos y } \\
\text { sueltos }\end{array}$ & $\begin{array}{l}\text { Las raíces son } \\
\text { someras (Casi } \\
\text { encima o muy } \\
\text { inmediato a la } \\
\text { superficie) y } \\
\text { extendidas }\end{array}$ & $\begin{array}{l}\text { Mide hasta } \\
20 \mathrm{~m} \mathrm{de} \\
\text { altura }\end{array}$ & $\begin{array}{l}\text { Abundan en } \\
\text { riberas de ríos, } \\
\text { arroyos y } \\
\text { laderas } \\
\text { húmedas, en } \\
\text { suelos ácidos y } \\
\text { sueltos, aguanta } \\
\text { intensos fríos. }\end{array}$ & $\begin{array}{l}\text { Crecimiento inicial } \\
\text { rápido, más } \\
\text { adelante es más } \\
\text { lento. }\end{array}$ \\
\hline $\begin{array}{l}\text { Quercus } \\
\text { suber }\end{array}$ & Fagáceas & $\begin{array}{l}0 \mathrm{a} \\
1.000 \mathrm{~m}\end{array}$ & $\mathrm{P}>400 \mathrm{~mm}$ & $\begin{array}{l}\text { Clima } \\
\text { continental } \\
\text { invierno suave } \\
\text { y húmedo }\end{array}$ & $\begin{array}{l}\text { Calcífugo, } \\
\text { suelo fresco } \\
\text { y húmedo, } \\
\text { sin } \\
\text { encharcar }\end{array}$ & $\begin{array}{l}\text { Potente raíz } \\
\text { principal de la } \\
\text { que crecen } \\
\text { numerosas } \\
\text { raíces laterales } \\
\text { próximas a la } \\
\text { superficie. }\end{array}$ & $\begin{array}{l}\text { Mide hasta } \\
20 \mathrm{~m} \mathrm{de} \\
\text { altura }\end{array}$ & $\begin{array}{l}\text { Se utiliza en } \\
\text { mezclas con } \\
\text { encina, castaño, } \\
\text { quejigo y } \\
\text { pinaster. }\end{array}$ & $\begin{array}{l}\text { Es una especie de } \\
\text { luz con un } \\
\text { crecimiento } \\
\text { relativamente } \\
\text { rápido. }\end{array}$ \\
\hline
\end{tabular}




\begin{tabular}{|c|c|c|c|c|c|c|c|c|c|}
\hline Especie & Familia & Altitud & $\begin{array}{l}\text { Exigencias } \\
\text { hídricas }\end{array}$ & $\begin{array}{l}\text { Exigencias } \\
\text { climáticas }\end{array}$ & Tipo suelo & $\begin{array}{l}\text { Sistema } \\
\text { radicular }\end{array}$ & $\begin{array}{l}\text { Porte de la } \\
\text { planta }\end{array}$ & Utilidad & Características \\
\hline Quercus ilex & Fagáceas & $\begin{array}{l}200 \mathrm{a} \\
1.200 \mathrm{~m}\end{array}$ & $\begin{array}{l}\text { Bajas } \\
\text { necesidades } \\
\text { hídricas. }\end{array}$ & $\begin{array}{l}\text { Clima } \\
\text { mediterráneo }\end{array}$ & $\begin{array}{l}\text { Indiferente, } \\
\text { mejor } \\
\text { sueltos, ricos } \\
\text { y profundos. } \\
\text { No } \\
\text { encharcados }\end{array}$ & $\begin{array}{l}\text { Sistema } \\
\text { radicular } \\
\text { extenso y poco } \\
\text { profundo. }\end{array}$ & $\begin{array}{l}\text { Mide entre } \\
16 \text { y } 25 \mathrm{~m} \mathrm{de} \\
\text { altura }\end{array}$ & $\begin{array}{l}\text { Se pueden } \\
\text { plantar muy } \\
\text { cerca unas de } \\
\text { otras, creciendo } \\
\text { altas y robustas, } \\
\text { sin perder hojas } \\
\text { ni ramas bajas }\end{array}$ & $\begin{array}{l}\text { Temperamento } \\
\text { robusto. Gran } \\
\text { resistencia a } \\
\text { continentalidad, a } \\
\text { fuertes calores y } \\
\text { fríos }\end{array}$ \\
\hline $\begin{array}{l}\text { Acer } \\
\text { campestre }\end{array}$ & Sapindáceas & $\begin{array}{l}0 \mathrm{a} \\
1.200 \mathrm{~m}\end{array}$ & $\begin{array}{l}\text { Precipitacion } \\
\text { es medias- } \\
\text { abundantes }\end{array}$ & $\begin{array}{l}\text { Prefiere zonas } \\
\text { templadas } \\
\text { aunque soporta } \\
\text { bien el frío }\end{array}$ & $\begin{array}{l}\text { Se adapta a } \\
\text { cualquier } \\
\text { suelo pero } \\
\text { prefiere los } \\
\text { calizos }\end{array}$ & $\begin{array}{l}\text { Muy } \\
\text { ramificado y } \\
\text { superficial. }\end{array}$ & $\begin{array}{l}\text { Mide entre } 7 \\
\text { y } 15 \mathrm{~m} \mathrm{de} \\
\text { altura }\end{array}$ & $\begin{array}{l}\text { Suele verse } \\
\text { como árbol de } \\
\text { alineación en } \\
\text { las calles de las } \\
\text { ciudades. }\end{array}$ & $\begin{array}{l}\text { Se planta junto con } \\
\text { quejigos, abetos. } \\
\text { Exposición de } \\
\text { media sombra. }\end{array}$ \\
\hline $\begin{array}{l}\text { Alnus } \\
\text { glutinosa }\end{array}$ & Betuláceas & $\begin{array}{l}0 \mathrm{a} \\
1.300 \mathrm{~m}\end{array}$ & $\begin{array}{l}\text { Precisa } \\
\text { disponibilida } \\
\text { d permanente } \\
\text { de agua en el } \\
\text { suelo }\end{array}$ & $\begin{array}{l}\text { Climas de tipo } \\
\text { templado- } \\
\text { cálido o } \\
\text { templado-frío, } \\
\text { tolerando fríos } \\
\text { invernales de } \\
\text { cierta } \\
\text { intensidad. }\end{array}$ & $\begin{array}{l}\text { Preferencia } \\
\text { sobre los de } \\
\text { naturaleza } \\
\text { silícea, } \\
\text { soportando } \\
\text { los arcillosos } \\
\text { y pesados. }\end{array}$ & $\begin{array}{l}\text { No muy } \\
\text { profundo, } \\
\text { ramificado. } \\
\text { Sin raíz } \\
\text { principal } \\
\text { diferenciada. }\end{array}$ & $\begin{array}{l}\text { Hasta } 22 \mathrm{~m} \\
\text { de altura }\end{array}$ & $\begin{array}{l}\text { Repoblaciones } \\
\text { de cauces o } \\
\text { humedales }\end{array}$ & $\begin{array}{l}\text { Las raíces } \\
\text { secundarias son } \\
\text { horizontales y las } \\
\text { terciarias } \\
\text { verticales, tienen } \\
\text { función de anclaje }\end{array}$ \\
\hline $\begin{array}{l}\text { Pinus } \\
\text { sylvestris }\end{array}$ & Pináceas & $\begin{array}{l}1.000 \mathrm{a} \\
2.000 \mathrm{~m}\end{array}$ & $\begin{array}{l}\text { No es } \\
\text { exigente en } \\
\text { cuanto a } \\
\text { humedad } \\
\text { relativa, si lo } \\
\text { es a humedad } \\
\text { del suelo }\end{array}$ & $\begin{array}{l}\text { Resiste el frio } \\
\text { y las heladas } \\
\text { primaverales. } \\
\text { Adaptado al } \\
\text { clima } \\
\text { continental. }\end{array}$ & $\begin{array}{l}\text { Se adapta a } \\
\text { todo tipo de } \\
\text { suelo, } \\
\text { siempre que } \\
\text { exista } \\
\text { humedad } \\
\text { suficiente }\end{array}$ & $\begin{array}{l}\text { Muy potente } \\
\text { con una raíz } \\
\text { principal, larga } \\
\text { y gruesa y con } \\
\text { muchas raíces } \\
\text { secundarias. }\end{array}$ & $\begin{array}{l}\text { Hasta } 30 \mathrm{~m} \\
\text { de altura }\end{array}$ & & \\
\hline
\end{tabular}




\section{ANEXO II}

\section{INVENTARIO FORESTAL}

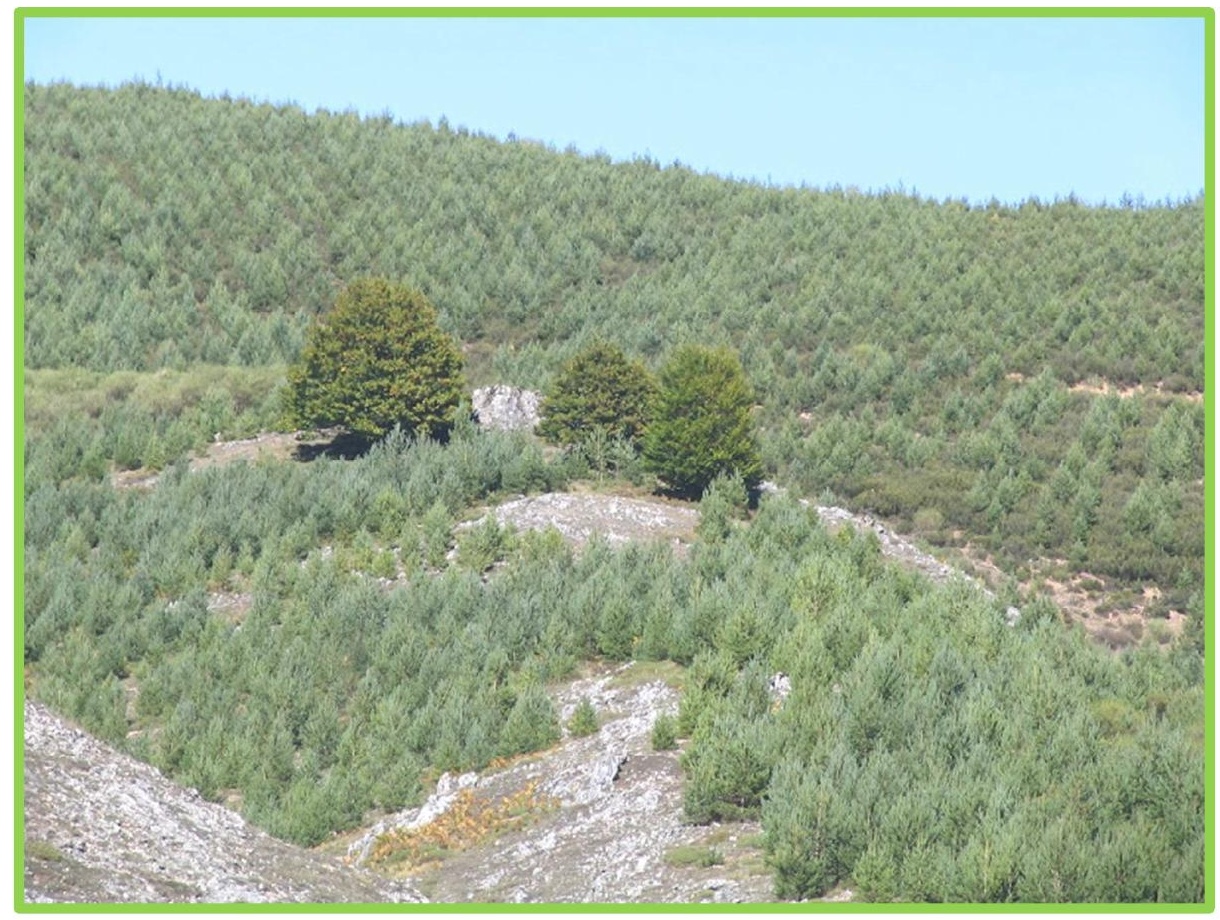




\section{ÍNDICE}

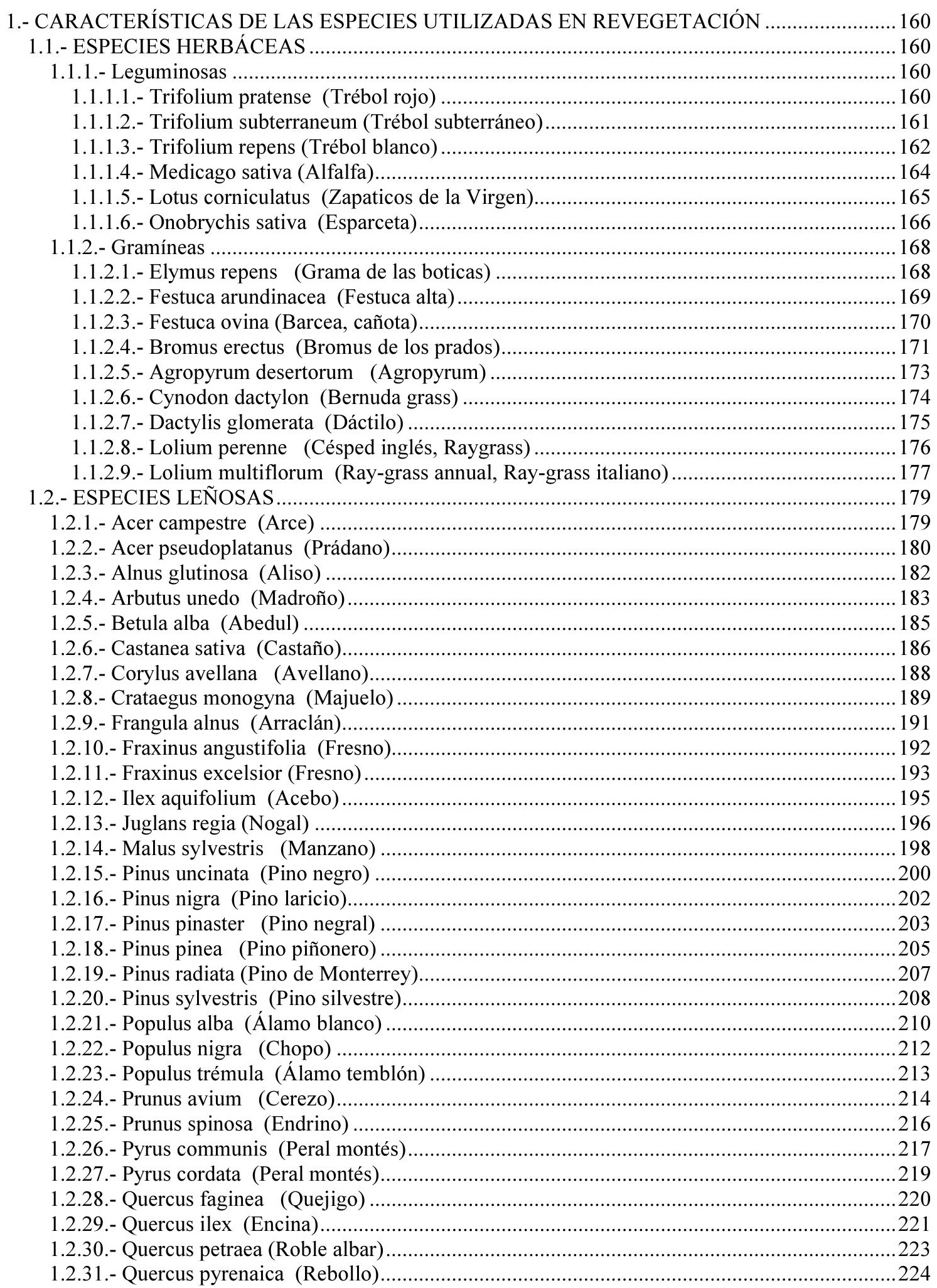


DESARROLLO DE UNA APLICACIÓN INFORMÁTICA PARA EL CÁLCULO DE SOSTENIMIENTO DE TALUDES MEDIANTE REVEGETACIÓN

1.2.32.- Quercus robur (Roble carballo) 226

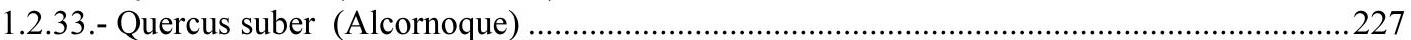

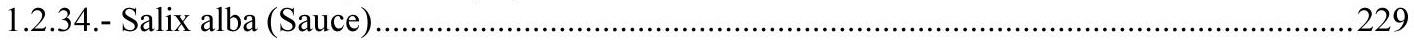

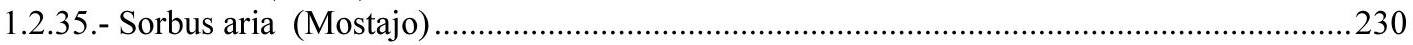

1.2.36.- Sorbus aucuparia (Serbal de cazadores) ....................................................................2232

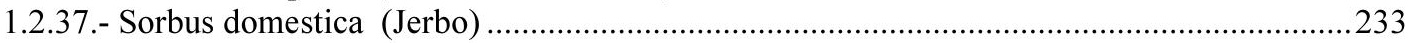

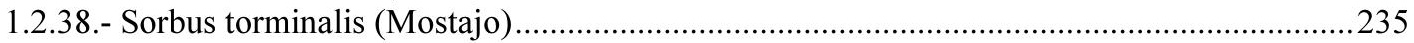

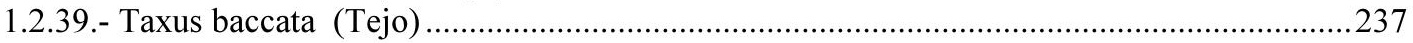

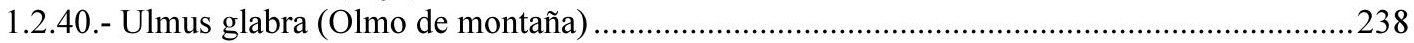




\section{1.- CARACTERÍSTICAS DE LAS ESPECIES UTILIZADAS EN REVEGETACIÓN}

A continuación se describen las características más relevantes de las especies vegetales utilizadas en la revegetación de taludes. Se diferenciará en especies herbáceas y especies leñosas.

\section{1.- ESPECIES HERBÁCEAS}

\subsection{1.- Leguminosas}

\subsubsection{1.- Trifolium pratense (Trébol rojo)}

$\begin{array}{ll}\text { REINO } & \text { Plantae } \\ \text { DIVISIÓN } & \text { Magnoliophyta } \\ \text { CLASE } & \text { Magnoliopsida } \\ \text { ORDEN } & \text { Fabales } \\ \text { FAMILIA } & \text { Fabaceae } \\ \text { GENERO } & \text { Trifolium } \\ \text { ESPECIE } & \text { T.pratense }\end{array}$

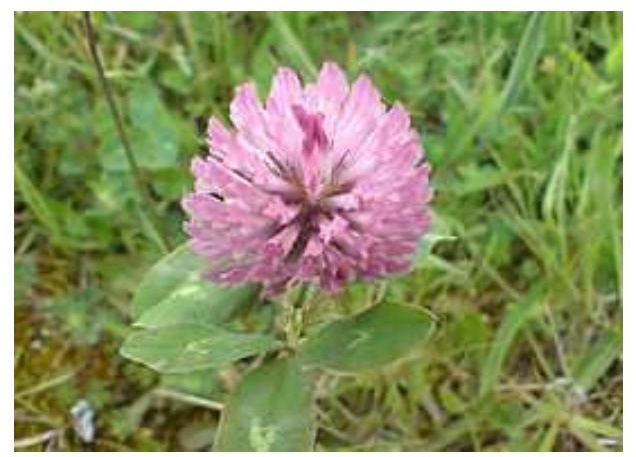

Hábitat - El trébol rojo o trébol violeta es una herbácea perenne que se distribuye por toda Europa, oeste de Asia, noroeste de África y región macaronésica (Azores, Madeira y Canarias), desde el nivel del mar hasta $2500 \mathrm{~m}$ de altitud. Crece de forma espontánea a lo largo de todo el territorio en cultivos abandonados, bordes de caminos, riberas de ríos, etc. Vive en pastos y prados húmedos, pero no soporta los encharcamientos prolongados ni la sequía. Crece bien a temperaturas medias, tolerando mejor las bajas que las altas temperaturas, siendo este el factor que influye de manera definitiva en el desarrollo del cultivo. También aguanta la sombra, no muy intensa, en riberas arboladas. Vegeta en todo tipo de suelos aunque prefiere los profundos ricos en bases, y un buen nivel de arcilla mejora el cultivo. Puede ir en suelos más ácidos y más húmicos que la alfalfa, y responde muy bien a los aportes de fósforo y potasio.

Utilización - Es una especie forrajera, que proporciona pasto abundante y de muy buena calidad para el ganado (es muy nutritivo). También suele cultivarse en praderas de siega asociado a una gramínea pratense. 

$\operatorname{los} 110 \mathrm{~cm})$.

Altura - Se trata de una herbácea perenne de $10-60 \mathrm{~cm}$ de altura (puede alcanzar hasta

Inflorescencia - Inflorescencias de color rosa violáceo con forma de capítulo, ovoides o subglobosas de 17-40 $\mathrm{mm}$ de longitud.

Fruto - El fruto es una legumbre sentada, incluida en el cáliz, indehiscente, de forma ovoide y contiene una sola semilla.

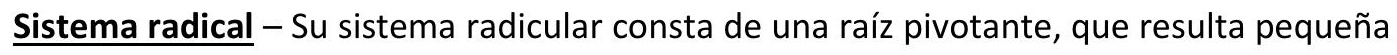
en comparación con las numerosas raíces adventicias que arrancan del cuello, y no es muy profundo. En sus raíces se produce una simbiosis con bacterias del género Rhizobium, que son capaces de fijar nitrógeno atmosférico en nitratos y nitritos, que son los que pueden ser usados por el metabolismo vegetal. A partir de la raíz crecen numerosos tallos.

\section{Parámetros medios}

\begin{tabular}{|c|c|c|c|c|c|c|c|}
\hline \multirow{2}{*}{ Especie } & \multicolumn{5}{|c|}{ RAÍCES } & \multicolumn{2}{c|}{ TRONCO } \\
\cline { 2 - 7 } & $\begin{array}{c}\text { Cohesión } \\
\mathrm{cR}\left(\mathrm{kN} / \mathrm{m}^{2}\right)\end{array}$ & $\begin{array}{c}\text { Resist. } \\
\text { Tracción } \\
\mathrm{T}\left(\mathrm{N} / \mathrm{mm}^{2}\right)\end{array}$ & $\begin{array}{c}\text { Diámetro } \\
\text { D.r }(\mathrm{mm})\end{array}$ & $\begin{array}{c}\text { Densidad } \\
\text { d.r }[\mathrm{Ar} / \mathrm{As}]\end{array}$ & $\begin{array}{c}\text { Profundidad } \\
\mathrm{p} . \mathrm{r}(\mathrm{m})\end{array}$ & $\begin{array}{c}\text { Diámetro } \\
\text { D.t }(\mathrm{cm})\end{array}$ & $\begin{array}{c}\text { Densidad } \\
\gamma \mathbf{v}\left(\mathrm{kg} / \mathrm{m}^{3}\right)\end{array}$ \\
$\begin{array}{c}\text { Altura } \\
\mathrm{h} . \mathrm{t}(\mathrm{m})\end{array}$ & $\begin{array}{c}\text { Fac. } \\
\text { forma } \\
(\mathrm{f} . \mathrm{f})\end{array}$ \\
\hline $\begin{array}{c}\text { Trifolium } \\
\text { pratense }\end{array}$ & 3 & 10,9 & 3,7 & 0,6 & 0,6 & 0 & 0 \\
\hline
\end{tabular}

\subsubsection{2.- Trifolium subterraneum (Trébol subterráneo)}

$\begin{array}{ll}\text { REINO } & \text { Plantae } \\ \text { DIVISIÓN } & \text { Magnoliophyta } \\ \text { CLASE } & \text { Magnoliopsida } \\ \text { ORDEN } & \text { Fabales } \\ \text { FAMILIA } & \text { Fabaceae } \\ \text { GENERO } & \text { Trifolium } \\ \text { ESPECIE } & \text { T. subterraneum }\end{array}$

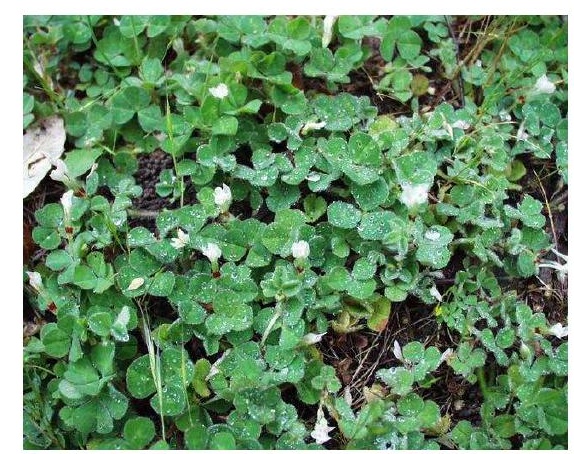

Hábitat - El trébol subterráneo es una planta anual, de hábito rastrero, originaria del sur de Europa y de la Cuenca Mediterránea hasta $1100 \mathrm{~m}$ de altitud. Su cultivo se ha extendido a otros países y regiones con clima mediterráneo como Nueva Zelanda, Australia, Argentina y EEUU. Presente en toda la Península Ibérica aunque en mayor proporción en el sudoeste, donde se considera la leguminosa pratense más importante. Tolera la sombra así como no 
soporta la sequía. Existen dos subespecies: T. subterraneum subsp. subterraneum y $T$. subterraneum subsp. oxaloides, que se adaptan a distintas condiciones de suelo. Crecen en majadales silíceos y la segunda la podemos encontrar con frecuencia en depresiones húmedas.

Utilización - Utilizada como planta forrajera para alimentar el ganado. Puede ensilarse u henificarse.

Altura - Su altura está comprendida entre 20 y $30 \mathrm{~cm}$ aproximadamente.

Inflorescencia - Inflorescencias capituliformes, ovoides, axilares, agrupadas en cabezuelas con pocas flores: $2-6$ flores fértiles sentadas y varias flores estériles, todas ellas de un color blanquecino.

Fruto - El fruto es un glomérulo sentado e indehiscente, que contiene 2 ó 3 semillas.

Sistema radical - Presenta una raíz principal pivotante muy desarrollada, poco profunda y con numerosas ramificaciones secundarias superficiales, que no suelen superar los $20 \mathrm{~cm}$ de profundidad. Como todas las leguminosas, posee nódulos de Rhizobium, por lo que se trata de una especie mejoradora del suelo.

\section{Parámetros medios}

\begin{tabular}{|c|c|c|c|c|c|c|c|c|c|}
\hline \multirow{2}{*}{ Especie } & \multicolumn{5}{|c|}{ RAÍCES } & \multicolumn{4}{|c|}{ TRONCO } \\
\hline & $\begin{array}{l}\text { Cohesión } \\
\mathrm{cR}\left(\mathrm{kN} / \mathrm{m}^{2}\right)\end{array}$ & $\begin{array}{c}\text { Resist. } \\
\text { Tracción } \\
\mathrm{T}\left(\mathrm{N} / \mathrm{mm}^{2}\right)\end{array}$ & $\begin{array}{l}\text { Diámetro } \\
\text { D.r }(\mathrm{mm})\end{array}$ & $\begin{array}{l}\text { Densidad } \\
\text { d.r [Ar/As] }\end{array}$ & $\begin{array}{l}\text { Profundidad } \\
\text { p.r (m) }\end{array}$ & $\begin{array}{l}\text { Diámetro } \\
\text { D.t }(\mathrm{cm})\end{array}$ & $\begin{array}{c}\text { Densidad } \\
\gamma \mathbf{v}\left(\mathrm{kg} / \mathrm{m}^{3}\right)\end{array}$ & $\begin{array}{l}\text { Altura } \\
\text { h.t (m) }\end{array}$ & $\begin{array}{l}\text { Fac. } \\
\text { forma } \\
\text { (f.f) }\end{array}$ \\
\hline $\begin{array}{c}\text { Trifolium } \\
\text { subterraneum }\end{array}$ & 3 & 10 & 3,7 & 0,6 & 0,6 & 0 & 0 & 0 & 0 \\
\hline
\end{tabular}

1.1.1.3.- Trifolium repens (Trébol blanco)

$\begin{array}{ll}\text { REINO } & \text { Plantae } \\ \text { DIVISIÓN } & \text { Magnoliophyta } \\ \text { CLASE } & \text { Magnoliopsida } \\ \text { ORDEN } & \text { Fabales } \\ \text { FAMILIA } & \text { Fabaceae } \\ \text { GENERO } & \text { Trifolium } \\ \text { ESPECIE } & \text { T. repens }\end{array}$

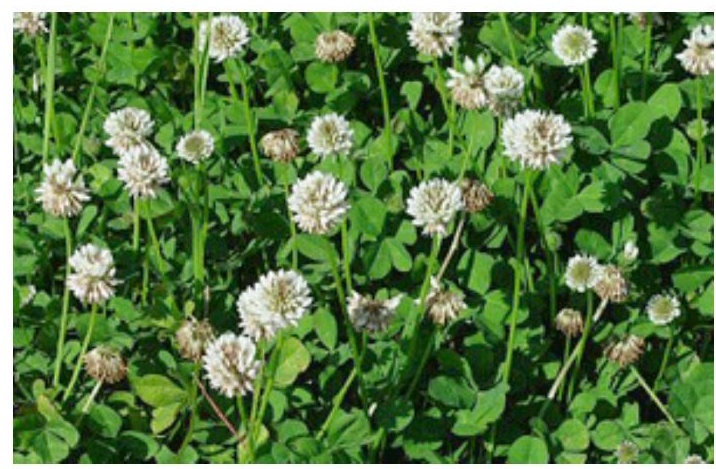


Hábitat - El trébol blanco es una herbácea perenne nativa de Europa, de la región mediterránea y de macaronesia (Azores, Madeira y Canarias). Crece en prados de siega y en bordes de arroyos y fuentes desde el nivel del mar hasta los $2400 \mathrm{~m}$. El trébol blanco es exigente en luz y sensible a la sequía, lo que obliga a cultivarlo bajo riego en veranos secos. Sin embargo, puede vegetar en los suelos pobres, ácidos o arenosos, necesitando fuertes abonados fosfóricos. Tanto en verano como en invierno, se reduce mucho el crecimiento. Es poco tolerante a la salinidad, pero soporta encharcamientos.

Utilización - Se trata de una planta forrajera, cuya mejor forma de aprovechamiento es mediante pastoreo en mezcla con gramíneas. Ocasionalmente se siega y se henifica. Se utiliza también para formar céspedes en jardinería, en suelos pobres donde otras especies no se desarrollan o tienen dificultades para hacerlo. No es muy apreciado para formar césped en campos deportivos.

Altura - Alcanza una altura entre 10 y $50 \mathrm{~cm}$.

Inflorescencia - Son capítulos globulares de 1.5 a $2 \mathrm{~cm}$ de ancho, conteniendo de 50 a 200 flores blancas o blanco-rosadas. Estos capítulos se encuentran sobre un pedúnculo de 7 $\mathrm{cm}$. Las flores son de tipo papilionáceo.

Fruto - Sentado, indehiscente que contiene de 1 a 4 semillas.

Sistema radical - Muy superficial, ramificado a partir de su raíz principal, además presenta raíces adventicias de carácter estolonífero. Desarrolla en sus raíces nódulos formados por bacterias nitrificantes del género Rhizobium, que fijan importantes cantidades de nitrógeno de la atmósfera en condiciones de suelo, temperatura y humedad adecuadas.

\section{Parámetros medios}

\begin{tabular}{|c|c|c|c|c|c|c|c|c|c|}
\hline \multirow{2}{*}{ Especie } & \multicolumn{5}{|c|}{ RAÍCES } & \multicolumn{4}{|c|}{ TRONCO } \\
\hline & $\begin{array}{l}\text { Cohesión } \\
\mathrm{cR}\left(\mathrm{kN} / \mathrm{m}^{2}\right)\end{array}$ & $\begin{array}{c}\text { Resist. } \\
\text { Tracción } \\
\mathrm{T}\left(\mathrm{N} / \mathrm{mm}^{2}\right)\end{array}$ & $\begin{array}{l}\text { Diámetro } \\
\text { D.r }(\mathrm{mm})\end{array}$ & $\begin{array}{l}\text { Densidad } \\
\text { d.r }[\mathrm{Ar} / \mathrm{As}]\end{array}$ & $\begin{array}{l}\text { Profundidad } \\
\text { p.r (m) }\end{array}$ & $\begin{array}{l}\text { Diámetro } \\
\text { D.t }(\mathrm{cm})\end{array}$ & $\begin{array}{c}\text { Densidad } \\
\gamma \mathbf{v}\left(\mathrm{kg} / \mathrm{m}^{3}\right)\end{array}$ & $\begin{array}{l}\text { Altura } \\
\text { h.t (m) }\end{array}$ & $\begin{array}{c}\text { Fac. } \\
\text { forma } \\
\text { (f.f) }\end{array}$ \\
\hline $\begin{array}{c}\text { Trifolium } \\
\text { repens }\end{array}$ & 3 & 16 & 0,9 & 0,6 & 0,2 & 0 & 0 & 0 & 0 \\
\hline
\end{tabular}




\subsubsection{4.- Medicago sativa (Alfalfa)}

$\begin{array}{ll}\text { REINO } & \text { Plantae } \\ \text { DIVISIÓN } & \text { Magnoliophyta } \\ \text { CLASE } & \text { Magnoliopsida } \\ \text { ORDEN } & \text { Fabales } \\ \text { FAMILIA } & \text { Fabaceae } \\ \text { GENERO } & \text { Medicago } \\ \text { ESPECIE } & \text { M. sativa }\end{array}$

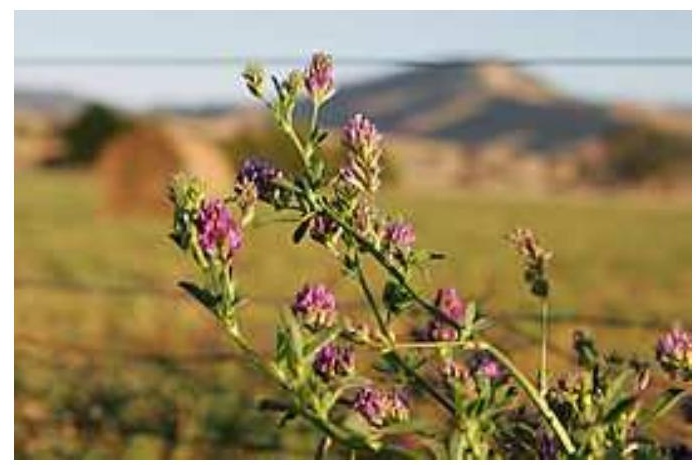

Hábitat - La alfalfa es natural de Asia Menor, de la cuenca mediterránea (Medicago sativa subsp. sativa) y del norte de Eurasia ( $M$. sativa subsp. falcata). Se encuentra cultivada y naturalizada en casi todo el globo. En la Península Ibérica está presente en todas las provincias. La encontramos habitualmente en campos de cultivo y ocasionalmente adventicia o naturalizada en barbechos, taludes y márgenes de caminos. Posee un amplio rango climático; tolera el calor y es resistente a la sequía, a la vez que puede soportar bajas temperaturas. Necesita suelos profundos y permeables, no compactados ni encharcados, y los prefiere neutros o básicos. Tolera la salinidad, pero no el encharcamiento.

Utilización - Se trata de una planta forrajera. La principal forma de aprovechamiento de la alfalfa es la siega. El forraje puede consumirse en verde o conservarse mediante henificado o deshidratado. También es utilizada en revegetación por su fácil implantación y rápido desarrollo.

Altura - Presenta una altura comprendida entre 30 y $90 \mathrm{~cm}$.

Inflorescencia-Flores de color violeta o púrpura, dispuestas en racimos densos terminales, con pedúnculo más largo que la hoja adyacente. Cada uno de los racimos contiene 10-30 flores.

Fruto - Legumbre de 4-8 mm de diámetro, pardo o negruzco en la maduración con 2-3 espiras en espiral abierta y con pelos no glandulíferos.

Sistema radical - Sus raíces suelen ser profundas; de esta manera, la planta es especialmente resistente a la sequía. Como todas las leguminosas, sus raíces poseen nódulos conteniendo las bacterias Sinorhizobium meliloti, con habilidad de fijar nitrógeno, produciendo 
alimento alto-proteico, sin importar el nitrógeno disponible en el suelo. Su habilidad fijadora de nitrógeno, incrementando su contenido en el suelo, favorece el crecimiento de las plantas adyacentes.

\section{Parámetros medios}

\begin{tabular}{|c|c|c|c|c|c|c|c|c|c|}
\hline \multirow{2}{*}{ Especie } & \multicolumn{5}{|c|}{ RAÍCES } & \multicolumn{4}{|c|}{ TRONCO } \\
\hline & $\begin{array}{l}\text { Cohesión } \\
\mathrm{cR}\left(\mathrm{kN} / \mathrm{m}^{2}\right)\end{array}$ & $\begin{array}{c}\text { Resist. } \\
\text { Tracción } \\
\mathrm{T}\left(\mathrm{N} / \mathrm{mm}^{2}\right)\end{array}$ & $\begin{array}{l}\text { Diámetro } \\
\text { D.r (mm) }\end{array}$ & $\begin{array}{c}\text { Densidad } \\
\text { d.r [Ar/As] }\end{array}$ & $\begin{array}{l}\text { Profundidad } \\
\text { p.r (m) }\end{array}$ & $\begin{array}{l}\text { Diámetro } \\
\text { D.t }(\mathrm{cm})\end{array}$ & $\begin{array}{c}\text { Densidad } \\
\gamma \mathbf{v}\left(\mathrm{kg} / \mathrm{m}^{3}\right)\end{array}$ & $\begin{array}{l}\text { Altura } \\
\text { h.t (m) }\end{array}$ & $\begin{array}{l}\text { Fac. } \\
\text { forma } \\
\text { (f.f) }\end{array}$ \\
\hline Medicago sativa & 3 & 25 & 3,0 & 0,6 & 0,4 & 0 & 0 & 0 & 0 \\
\hline
\end{tabular}

\subsubsection{5.- Lotus corniculatus (Zapaticos de la Virgen)}

$\begin{array}{ll}\text { REINO } & \text { Plantae } \\ \text { DIVISIÓN } & \text { Magnoliophyta } \\ \text { CLASE } & \text { Magnoliopsida } \\ \text { ORDEN } & \text { Fabales } \\ \text { FAMILIA } & \text { Fagaceae } \\ \text { GENERO } & \text { Lotus } \\ \text { ESPECIE } & \text { L.corniculatus }\end{array}$

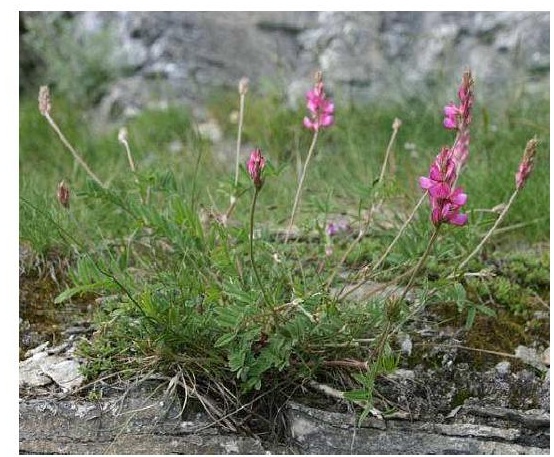

Hábitat - Adaptada a condiciones ambientales muy diversas. Tolera el frío y el calor y, de forma moderada, la sequía estival. Se desarrolla mejor en climas fríos y húmedos. Se adapta a suelos de distinto $\mathrm{pH}(5,5-7,5)$. Tolera la salinidad pero no soporta el encharcamiento ni los suelos arenosos. Persiste bien en condiciones de baja fertilidad.

Utilización - Además de su uso forrajero para ganado ovino, también se ha utilizado como planta apícola y como abono verde rotaciones cerealistas, así como en jardinería.

Altura - Se trata de una planta de talla variable, que puede medir hasta $40 \mathrm{~cm}$ de altura aunque habitualmente no suele sobrepasar los $20 \mathrm{~cm}$.

Inflorescencia - El pedúnculo en el que se inserta la inflorescencia en umbela es de origen axilar. Su corola es amarilla, con la forma típica que presentan las leguminosas: de 
simetría zigomorfa con cinco pétalos (estandarte, quilla y dos alas). El cáliz presenta sépalos de igual longitud y derechos. El androceo no cuenta con más de 11 estambres.

Fruto - El fruto es una legumbre de dehiscencia longitudinal, de menos de $4 \mathrm{~mm}$ de grosor. Tiene la forma característica de una pata de pájaro (carácter del cual toma su nombre común en inglés: "birdsfoot trefoil"). La legumbre contiene de 10 a 30 semillas y tiene un alto grado de dehiscencia en la madurez, retorciéndose en forma de espiral, especialmente cuando su humedad es inferior al $40 \%$.

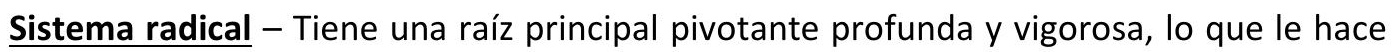
resistente a la sequía.

\section{Parámetros medios}

\begin{tabular}{|c|c|c|c|c|c|c|c|c|c|}
\hline \multirow{2}{*}{ Especie } & \multicolumn{3}{|c|}{ RAÍCES } & \multicolumn{3}{|c|}{ TRONCO } \\
\cline { 2 - 9 } & $\begin{array}{c}\text { Cohesión } \\
\mathrm{cR}\left(\mathrm{kN} / \mathrm{m}^{2}\right)\end{array}$ & $\begin{array}{c}\text { Resist. } \\
\text { Tracción } \\
\mathrm{T}\left(\mathrm{N} / \mathrm{mm}^{2}\right)\end{array}$ & $\begin{array}{c}\text { Diámetro } \\
\text { D.r }(\mathrm{mm})\end{array}$ & $\begin{array}{c}\text { Densidad } \\
\mathrm{d} . \mathrm{r}[\mathrm{Ar} / \mathrm{As}]\end{array}$ & $\begin{array}{c}\text { Profundidad } \\
\text { p.r }(\mathrm{m})\end{array}$ & $\begin{array}{c}\text { Diámetro } \\
\text { D.t }(\mathrm{cm})\end{array}$ & $\begin{array}{c}\text { Densidad } \\
\gamma \mathrm{v}\left(\mathrm{kg} / \mathrm{m}^{3}\right)\end{array}$ & $\begin{array}{c}\text { Altura } \\
\text { h.t }(\mathrm{m})\end{array}$ & $\begin{array}{c}\text { Fac. } \\
\text { forma } \\
(\mathrm{f} . \mathrm{f})\end{array}$ \\
\hline $\begin{array}{c}\text { Lotus } \\
\text { corniculatus }\end{array}$ & 3 & 14 & 3,6 & 0,6 & 1,0 & 0 & 0 & 0 & 0 \\
\hline
\end{tabular}

\subsubsection{6.- Onobrychis sativa (Esparceta)}

$\begin{array}{ll}\text { REINO } & \text { Plantae } \\ \text { DIVISIÓN } & \text { Magnoliophyta } \\ \text { CLASE } & \text { Magnoliopsida } \\ \text { ORDEN } & \text { Fagales } \\ \text { FAMILIA } & \text { Fagaceae } \\ \text { GENERO } & \text { Onobrychis } \\ \text { ESPECIE } & \text { O. sativa }\end{array}$

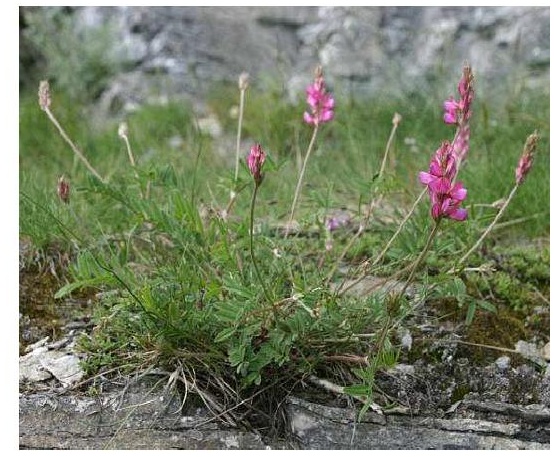

Hábitat - La esparceta o pipirigallo se distribuye de forma natural en el sureste de Europa y el oeste de Asia. En cuanto a altitud, esta planta se desarrolla entre 1300-2800 m. Debido a que se ha cultivado ampliamente, se encuentra naturalizada en la mayor parte de Europa, norte de África y Norteamérica. Habita en cultivos irrigados y en cunetas y taludes de caminos y carreteras, casi siempre en zonas frías de clima mediterráneo o con influencia 
mediterránea. Resiste bien el frío y soporta también el calor estival. Es una especie basófila, colonizadora en suelos calizos y pedregosos. No soporta los encharcamientos ni los suelos demasiado compactos, aunque tolera la salinidad.

Utilización - Además de su uso como forraje, también se ha utilizado como planta apícola y como abono verde rotaciones cerealistas, así como en jardinería. Es una excelente regeneradora de la fertilidad en suelos abandonados o en los que reiteradamente se han cultivado cereales.

Altura - Se trata de una planta de talla media, que mide entre 20 y $80 \mathrm{~cm}$ de altura.

Inflorescencia - Las flores se agrupan formando apretados y largos racimos terminales, con brácteas lanceoladas y un elevado número de flores, que son de color rosado-rojizo.

Fruto - El fruto es una legumbre pequeña indehiscente y que contiene únicamente una semilla, es decir, es monosperma.

Sistema radical - Tiene una raíz pivotante muy desarrollada. De la raíz principal parten numerosas raíces finas laterales en las que se encuentran la mayoría de los nódulos de Rhizobium.

\section{Parámetros medios}

\begin{tabular}{|c|c|c|c|c|c|c|c|c|c|}
\hline \multirow{2}{*}{ Especie } & \multicolumn{5}{|c|}{ RAÍCES } & \multicolumn{4}{|c|}{ TRONCO } \\
\hline & $\begin{array}{l}\text { Cohesión } \\
\mathrm{cR}\left(\mathrm{kN} / \mathrm{m}^{2}\right)\end{array}$ & $\begin{array}{c}\text { Resist. } \\
\text { Tracción } \\
\mathrm{T}\left(\mathrm{N} / \mathrm{mm}^{2}\right)\end{array}$ & $\begin{array}{l}\text { Diámetro } \\
\text { D.r }(\mathrm{mm})\end{array}$ & $\begin{array}{l}\text { Densidad } \\
\text { d.r [Ar/As] }\end{array}$ & $\begin{array}{l}\text { Profundidad } \\
\text { p.r (m) }\end{array}$ & $\begin{array}{l}\text { Diámetro } \\
\text { D.t }(\mathrm{cm})\end{array}$ & $\begin{array}{c}\text { Densidad } \\
\gamma \vee\left(\mathrm{kg} / \mathrm{m}^{3}\right)\end{array}$ & $\begin{array}{l}\text { Altura } \\
\text { h.t (m) }\end{array}$ & $\begin{array}{l}\text { Fac. } \\
\text { forma } \\
\text { (f.f) }\end{array}$ \\
\hline $\begin{array}{c}\text { Onobrychis } \\
\text { sativa }\end{array}$ & 3 & 21 & 2,5 & 0,6 & 0,4 & 0 & 0 & 0 & 0 \\
\hline
\end{tabular}




\subsection{2.- Gramíneas}

\subsubsection{1.- Elymus repens (Grama de las boticas)}

$\begin{array}{ll}\text { REINO } & \text { Plantae } \\ \text { DIVISIÓN } & \text { Magnoliophyta } \\ \text { CLASE } & \text { Liliopsida } \\ \text { ORDEN } & \text { Poales } \\ \text { FAMILIA } & \text { Poaceae } \\ \text { GENERO } & \text { Elymus } \\ \text { ESPECIE } & \text { E. repens }\end{array}$

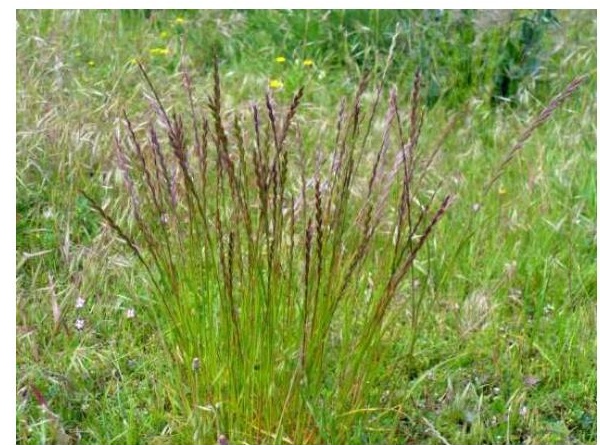

Hábitat - La grama es una planta perenne que crece en los ribazos de los caminos, bordes y campos de cultivo descuidados, una herbácea que crece en cultivos y campos incultos de Europa, América, Asia y el norte de África desde los 200 hasta los $1000 \mathrm{~m}$ de altitud. En general se le considera una mala hierba. Se le conoce como grama de las boticas, grama del norte, gramilla y trigo rastrero. Prefiere los suelos ricos en bases y no tolera el encharcamiento.

Utilización - Se utiliza como planta herbácea estabilizadora de taludes.

Altura - Alcanza 60-90 cm de altura.

Inflorescencia - Inflorescencias tipo espiga, terminales y divididas en dos partes, conteniendo de 4 a 8 flores cada una. Estas son muy pequeñas y de color morado.

Fruto - Cariopsis linear fusiforme, con hilo linear largo.

Sistema radical - Posee un sistema radicular somero formado por numerosas raicillas que se extienden a gran distancia y poca profundidad. Crece de forma invasiva y resulta muy difícil de eliminar, ya que la planta puede regenerarse a partir de la raíz aunque haya sido cortada a ras de tierra. 


\section{Parámetros medios}

\begin{tabular}{|c|c|c|c|c|c|c|c|c|c|}
\hline \multirow{2}{*}{ Especie } & \multicolumn{5}{|c|}{ RAÍCES } & \multicolumn{4}{|c|}{ TRONCO } \\
\hline & $\begin{array}{l}\text { Cohesión } \\
\mathrm{cR}\left(\mathrm{kN} / \mathrm{m}^{2}\right)\end{array}$ & $\begin{array}{c}\text { Resist. } \\
\text { Tracción } \\
\mathrm{T}\left(\mathrm{N} / \mathrm{mm}^{2}\right)\end{array}$ & $\begin{array}{l}\text { Diámetro } \\
\text { D.r (mm) }\end{array}$ & $\begin{array}{c}\text { Densidad } \\
\text { d.r [Ar/As] }\end{array}$ & $\begin{array}{l}\text { Profundidad } \\
\text { p.r }(\mathrm{m})\end{array}$ & $\begin{array}{l}\text { Diámetro } \\
\text { D.t }(\mathrm{cm})\end{array}$ & $\begin{array}{c}\text { Densidad } \\
\gamma \mathbf{v}\left(\mathrm{kg} / \mathrm{m}^{3}\right)\end{array}$ & $\begin{array}{l}\text { Altura } \\
\text { h.t (m) }\end{array}$ & $\begin{array}{l}\text { Fac. } \\
\text { forma } \\
\text { (f.f) }\end{array}$ \\
\hline Elymus repens & 3 & 7,5 & 0,9 & 0,6 & 0,30 & 0 & 0 & 0 & 0 \\
\hline
\end{tabular}

\subsubsection{2.- Festuca arundinacea (Festuca alta)}

$\begin{array}{ll}\text { REINO } & \text { Plantae } \\ \text { DIVISIÓN } & \text { Magnoliophyta } \\ \text { CLASE } & \text { Apogonia } \\ \text { ORDEN } & \text { Poales } \\ \text { FAMILIA } & \text { Poaceae } \\ \text { GENERO } & \text { Festuca } \\ \text { ESPECIE } & \text { F. arundinacea }\end{array}$

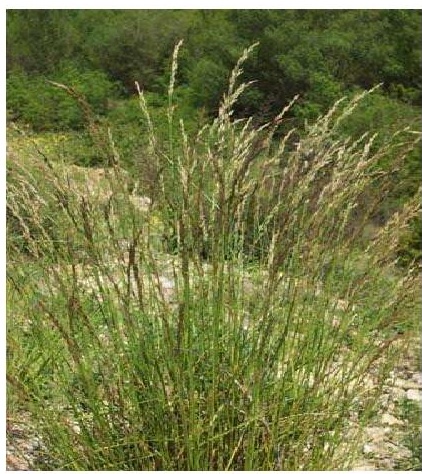

Hábitat - La festuca alta o cañuela alta es nativa de Europa y del norte de África. Se cultiva en varios lugares del mundo como EE.UU., Argentina, Uruguay y Australia. Tiene una excelente tolerancia al calor y altas temperaturas así como a la sequía, y una tolerancia media a las bajas temperaturas. Estas características hacen que tenga una buena adaptación a zonas de clima mediterráneo y de transición. Prefiere suelos fértiles y ligeramente ácidos, y admite ciertos niveles de sombra. No es muy resistente a la salinidad. Soporta los suelos secos y posee gran resistencia a los suelos encharcados, característica que la hace muy interesante a la hora de utilizarla en revegetación.

Utilización - Es una gramínea que posee una gran polivalencia de uso. Además de tratarse de una planta forrajera muy importante dentro de los sistemas de producción extensivos de ganado, se utiliza en praderas combinadas con leguminosas y gramíneas, así como en céspedes ornamentales y deportivos. Se utiliza también en sistemas de rotación de suelos en agricultura, pues al final de la rotación, deja un suelo con una materia orgánica mejorada y una mejor estructura. Es ideal para controlar la erosión en taludes y para revegetaciones. Permite la hidrosiembra.

Altura - Su altura está comprendida entre 50 y $150 \mathrm{~cm}$ aproximadamente. 
Inflorescencia - La inflorescencia es una panoja hasta de 1 a $3 \mathrm{dm}$, aunque puede llegar a $5 \mathrm{dm}$. Las panojas o panículas varían de abiertas y ramificadas sin orden a muy angostas. Las ramificaciones cortas tienen varias espiguillas. Las espiguillas son desde elípticas a oblongas, de 1 a $2 \mathrm{~cm}$. Cada espiguilla tiene de 3 a 10 flósculos. Sin embargo, aproximadamente solo la mitad de los flósculos produce semilla.

Fruto - Cariopsis con una sola semilla fusionada a la pared del fruto.

Sistema radical - Su sistema radicular es fibroso y potente, denso en superficie, alcanzando una profundidad de 60 a $70 \mathrm{~cm}$. Esto le permite ser una especie muy resistente a la aridez, requiriendo aportes de agua muy inferiores a otras especies. Además, algunas raíces pueden descender muy profundas, lo que hace que sea utilizable en la conservación de suelos, pues fija bien el terreno frente a la erosión.

\section{Parámetros medios}

\begin{tabular}{|c|c|c|c|c|c|c|c|c|c|}
\hline \multirow{2}{*}{ Especie } & \multicolumn{3}{|c|}{ RAÍCES } & \multicolumn{3}{|c|}{ TRONCO } \\
\cline { 2 - 9 } & $\begin{array}{c}\text { Cohesión } \\
\mathrm{cR}\left(\mathrm{kN} / \mathrm{m}^{2}\right)\end{array}$ & $\begin{array}{c}\text { Resist. } \\
\text { Tracción } \\
\mathrm{T}\left(\mathrm{N} / \mathrm{mm}^{2}\right)\end{array}$ & $\begin{array}{c}\text { Diámetro } \\
\text { D.r }(\mathrm{mm})\end{array}$ & $\begin{array}{c}\text { Densidad } \\
\text { d.r }[\mathrm{Ar} / \mathrm{As}]\end{array}$ & $\begin{array}{c}\text { Profundidad } \\
\mathrm{p} . \mathrm{r}(\mathrm{m})\end{array}$ & $\begin{array}{c}\text { Diámetro } \\
\text { D.t }(\mathrm{cm})\end{array}$ & $\begin{array}{c}\text { Densidad } \\
\gamma \mathrm{v}\left(\mathrm{kg} / \mathrm{m}^{3}\right)\end{array}$ & $\begin{array}{c}\text { Altura } \\
\text { h.t }(\mathrm{m})\end{array}$ & $\begin{array}{c}\text { Fac. } \\
\text { forma } \\
(\mathrm{f} . \mathrm{f})\end{array}$ \\
\hline $\begin{array}{c}\text { Festuca } \\
\text { arundinaceae }\end{array}$ & 3 & 19 & 1,7 & 0,6 & 0,7 & 0 & 0 & 0 & 0 \\
\hline
\end{tabular}

\subsubsection{3.- Festuca ovina (Barcea, cañota)}

$\begin{array}{ll}\text { REINO } & \text { Plantae } \\ \text { DIVISIÓN } & \text { Magnoliophyta } \\ \text { CLASE } & \text { Magnoliopsida } \\ \text { ORDEN } & \text { Poales } \\ \text { FAMILIA } & \text { Poaceae } \\ \text { GENERO } & \text { Festuca } \\ \text { ESPECIE } & \text { F. ovina }\end{array}$

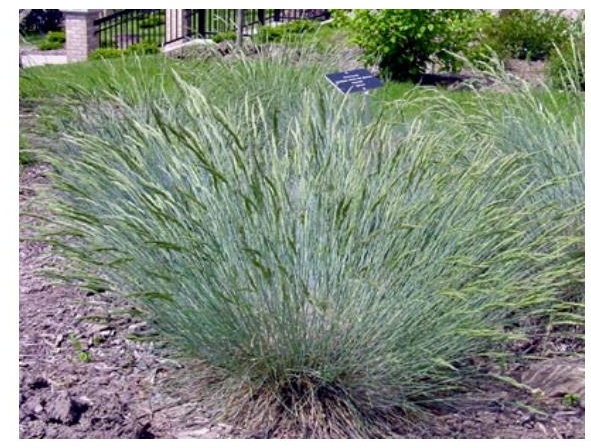

Hábitat - La cañuela ovina o festuca de las ovejas es una gramínea nativa de Europa. Vive en regiones templadas y frías, y la encontramos con facilidad en regiones montañosas, ya 
que además de ser muy resistente a la sequía, también lo es a las bajas temperaturas. Resiste bien en suelos pobres y tolera perfectamente la sombra.

Utilización - Muy utilizada en obras de revegetación paisajística y, en menor medida, en jardines. Suele utilizarse muy a menudo en zonas de difícil acceso, ya que no necesita siega ni mantenimiento, y no resiste el pisoteo.

Altura - Alcanza un tamaño de 20 a 45 centímetros.

Inflorescencia - En forma de panícula.

Fruto - Cariopsis oblongoidea.

Sistema radical - Sistema radicular superficial, potente y extenso.

\section{Parámetros medios}

\begin{tabular}{|c|c|c|c|c|c|c|c|c|}
\hline \multirow{2}{*}{ Especie } & \multicolumn{3}{|c|}{ RAÍCES } & \multicolumn{2}{c|}{ TRONCO } \\
\cline { 2 - 8 } & $\begin{array}{c}\text { Cohesión } \\
\mathrm{cR}\left(\mathrm{kN} / \mathrm{m}^{2}\right)\end{array}$ & $\begin{array}{c}\text { Resist. } \\
\text { Tracción } \\
\mathrm{T}\left(\mathrm{N} / \mathrm{mm}^{2}\right)\end{array}$ & $\begin{array}{c}\text { Diámetro } \\
\text { D.r }(\mathrm{mm})\end{array}$ & $\begin{array}{c}\text { Densidad } \\
\text { d.r [Ar/As] }\end{array}$ & $\begin{array}{c}\text { Profundidad } \\
\text { p.r }(\mathrm{m})\end{array}$ & $\begin{array}{c}\text { Diámetro } \\
\text { D.t }(\mathrm{cm})\end{array}$ & $\begin{array}{c}\text { Densidad } \\
\gamma \mathbf{v}\left(\mathrm{kg} / \mathrm{m}^{3}\right)\end{array}$ & $\begin{array}{c}\text { Altura } \\
\text { h.t }(\mathrm{m})\end{array}$ \\
$\begin{array}{c}\text { Fac. } \\
\text { forma } \\
(\mathrm{f} . \mathrm{f})\end{array}$ \\
\hline Festuca ovina & 3 & 15 & 2,5 & 0,6 & 0,20 & 0 & 0 \\
\hline
\end{tabular}

1.1.2.4.- Bromus erectus (Bromus de los prados)

$\begin{array}{ll}\text { REINO } & \text { Plantae } \\ \text { DIVISIÓN } & \text { Magnoliophyta } \\ \text { CLASE } & \text { Apogonia } \\ \text { ORDEN } & \text { Poales } \\ \text { FAMILIA } & \text { Poaceae } \\ \text { GENERO } & \text { Bromus } \\ \text { ESPECIE } & \text { B. erectus }\end{array}$

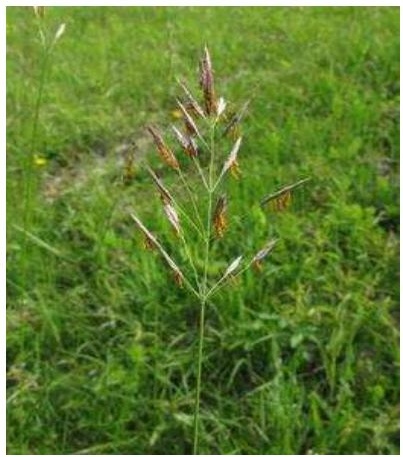

Hábitat - El bromo erecto es una gramínea nativa de Europa, Asia y norte de África. Es frecuente en prados y pastos de montaña, y ocasionalmente entra también en bosques desde los 500 hasta los $2100 \mathrm{~m}$. Soporta climas mediterráneos, incluso con periodos de sequía estival 
relativamente larga, y tolera también el frío. Es una gramínea perenne cuyas preferencias edáficas la sitúan en terrenos ricos en bases, aunque es poco exigente en calidad, llegando a vegetar bien sobre terrenos pedregosos o arcillosos.

Utilización - Se utiliza como planta forrajera para alimentar al ganado. También posee cierto interés para la implantación de pastos de monte y para la restauración de laderas erosionables o pedregosas.

Altura - Hasta $1 \mathrm{~m}$ de altura.

Inflorescencia - Panícula contraída. Espiguillas hermafroditas, pediceladas, con más de 10 flores. Flores con dos glumas.

Fruto - Cariópside elipsoide con pelos en el ápice y acanalado longitudinalmente por un largo hilo.

Sistema radical - Raíces adventicias, sin raíz principal. Posee un rizoma fuerte que proporciona sujeción entre 0.75 y $1 \mathrm{~m}$ de la raíz.

\section{Parámetros medios}

\begin{tabular}{|c|c|c|c|c|c|c|c|c|c|}
\hline \multirow{2}{*}{ Especie } & \multicolumn{4}{|c|}{ RAÍCES } & \multicolumn{4}{|c|}{ TRONCO } \\
\cline { 2 - 9 } & $\begin{array}{c}\text { Cohesión } \\
\mathrm{cR}\left(\mathrm{kN} / \mathrm{m}^{2}\right)\end{array}$ & $\begin{array}{c}\text { Resist. } \\
\text { Tracción } \\
\mathrm{T}\left(\mathrm{N} / \mathrm{mm}^{2}\right)\end{array}$ & $\begin{array}{c}\text { Diámetro } \\
\text { D.r }(\mathrm{mm})\end{array}$ & $\begin{array}{c}\text { Densidad } \\
\mathrm{d} . \mathrm{r}[\mathrm{Ar} / \mathrm{As}]\end{array}$ & $\begin{array}{c}\text { Profundidad } \\
\mathrm{p} . \mathrm{r}(\mathrm{m})\end{array}$ & $\begin{array}{c}\text { Diámetro } \\
\text { D.t }(\mathrm{cm})\end{array}$ & $\begin{array}{c}\text { Densidad } \\
\gamma \mathrm{v}\left(\mathrm{kg} / \mathrm{m}^{3}\right)\end{array}$ & $\begin{array}{c}\text { Altura } \\
\text { h.t }(\mathrm{m})\end{array}$ & $\begin{array}{c}\text { Fac. } \\
\text { forma } \\
(\mathrm{f} . \mathrm{f})\end{array}$ \\
\hline $\begin{array}{c}\text { Bromus } \\
\text { erectus }\end{array}$ & 3 & 8 & 1,9 & 0,6 & 0,5 & 0 & 0 & 0 & 0 \\
\hline
\end{tabular}




\subsubsection{5.- Agropyrum desertorum (Agropyrum)}

$\begin{array}{ll}\text { REINO } & \text { Plantae } \\ \text { DIVISIÓN } & \text { Magnoliophyta } \\ \text { CLASE } & \text { Magnoliopsida } \\ \text { ORDEN } & \text { Poales } \\ \text { FAMILIA } & \text { Poaceae } \\ \text { GENERO } & \text { Agropyron } \\ \text { ESPECIE } & \text { A. desertorum }\end{array}$

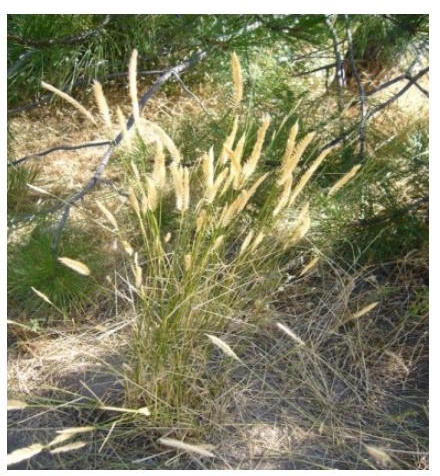

Hábitat - Especie procedente de las estepas del este Europeo, que ha sido introducida en el resto de Europa y Norteamérica para pastos (en España sin éxito) y para revegetación. Vive habitualmente en climas mediterráneos y sobre suelos arcillosos y pesados, generalmente ricos en bases aunque no es muy exigente en este aspecto, y sometidos a fenómenos de freatismo estacional. Tolera los suelos arenosos.

Utilización - Su principal interés se centra en la fijación de taludes y la restauración de terrenos y minas a cielo abierto, sobre todo en difíciles condiciones climáticas y edáficas (clima seco o semiárido y continental), aunque por su carácter alóctono y su no probado éxito, no se suele recomendar su empleo.

Altura - Mide entre 25 y $40 \mathrm{~cm}$ de altura, aunque puede llegar a sobrepasar $1 \mathrm{~m}$.

Inflorescencia - Es una espiga compuesta por espiguillas dísticas y con raquis articulado y tenaz. Las espiguillas son plurifloras y están sentadas de a una en cada diente.

Fruto-Cariopside linear fusiforme, con hilo linear largo.

Sistema radical - Posee un rizoma muy ramificado, La raíz es fibrosa, en cabellera y puede alcanzar cierto desarrollo y profundidad en terrenos bien preparados.

\section{Parámetros medios}

\begin{tabular}{|c|c|c|c|c|c|c|c|c|c|}
\hline \multirow{3}{*}{ Especie } & \multicolumn{4}{|c|}{ RAÍCES } & \multicolumn{4}{c|}{ TRONCO } \\
\cline { 2 - 9 } & $\begin{array}{c}\text { Cohesión } \\
\mathrm{cR}\left(\mathrm{kN} / \mathrm{m}^{2}\right)\end{array}$ & $\begin{array}{c}\text { Resist. } \\
\text { Tracción } \\
\mathrm{T}\left(\mathrm{N} / \mathrm{mm}^{2}\right)\end{array}$ & $\begin{array}{c}\text { Diámetro } \\
\text { D.r }(\mathrm{mm})\end{array}$ & $\begin{array}{c}\text { Densidad } \\
\text { d.r }[\mathrm{Ar} / \mathrm{As}]\end{array}$ & $\begin{array}{c}\text { Profundidad } \\
\text { p.r }(\mathrm{m})\end{array}$ & $\begin{array}{c}\text { Diámetro } \\
\text { D.t }(\mathrm{cm})\end{array}$ & $\begin{array}{c}\text { Densidad } \\
\gamma \mathrm{v}\left(\mathrm{kg} / \mathrm{m}^{3}\right)\end{array}$ & $\begin{array}{c}\text { Altura } \\
\text { h.t (m) }\end{array}$ & $\begin{array}{c}\text { Fac. } \\
\text { forma } \\
(\mathrm{f} . \mathrm{f})\end{array}$ \\
\hline
\end{tabular}




\begin{tabular}{|c|c|c|c|c|c|c|c|c|c|}
\hline & & & & & & & \\
\hline $\begin{array}{c}\text { Trifolium } \\
\text { pratense }\end{array}$ & 3 & 3 & 2,7 & 0,6 & 0,5 & 0 & 0 & 0 & 0 \\
\hline
\end{tabular}

\subsubsection{6.- Cynodon dactylon (Bernuda grass)}

$\begin{array}{ll}\text { REINO } & \text { Plantae } \\ \text { DIVISIÓN } & \text { Magnoliophyta } \\ \text { CLASE } & \text { Magnoliopsida } \\ \text { ORDEN } & \text { Poales } \\ \text { FAMILIA } & \text { Poaceae } \\ \text { GENERO } & \text { Cynodon } \\ \text { ESPECIE } & \text { C.dactylon }\end{array}$

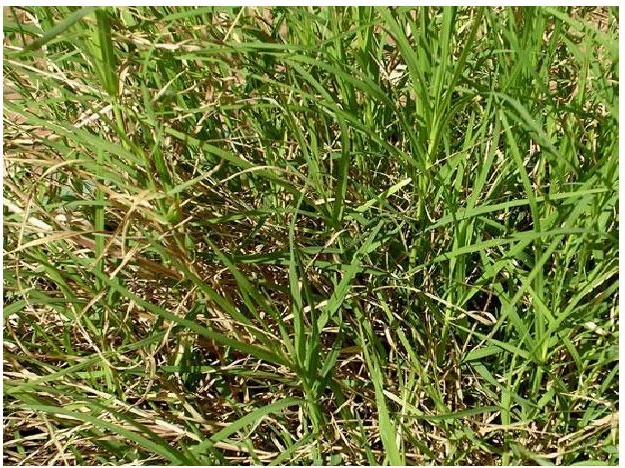

Hábitat - La bermuda o grama es una gramínea nativa del norte de África y el sur de Europa, que la podemos encontrar desde el nivel del mar hasta los 2200m de altitud. Se trata de una planta viaria, ruderal y arvense. Es una especie de sol, necesita luz y calor ( ${ }^{\mathrm{T}}>15^{\circ}$ ). Tolera muy mal la sombra y resiste las sequías. No soporta las heladas. Es muy tolerante a salinidades elevadas y a aguas de baja calidad. Tolera inundaciones temporales. Es capaz de colonizar todo tipo de suelos, incluso los más pobres, excepto los ácidos.

Utilización - Especie ampliamente cultivada como pasto y en campos de deportes. Como tolera muy bien la salinidad, es muy útil en la recuperación de terrenos salinos. Se utiliza también en revegetaciones.

Altura - De 10 a $30 \mathrm{~cm}$ de altura.

Inflorescencia - Flores agrupadas en inflorescencias tipo espiga (4 a 6), de 1,5 a $6 \mathrm{~cm}$ de diámetro de largo, distribuidas en un verticilo y formadas por espiguillas (flores), de 2-3 mm de largo, verde-violáceas y densamente dispuestas.

Fruto-Cariopsis oblonga y de color oscuro.

Sistema radical - Posee un sistema radicular muy profundo; en condiciones de sequía y con perfil de suelo penetrable, las raíces pueden crecer a más de $2 \mathrm{~m}$ de profundidad, aunque 
la mayoría de la masa radicular está a menos de $60 \mathrm{~cm}$ bajo la superficie. Los tallos reptan por

el suelo, y de nódulos salen nuevas raíces, formando densas matas.

\section{Parámetros medios}

\begin{tabular}{|c|c|c|c|c|c|c|c|c|c|}
\hline \multirow[b]{2}{*}{ Especie } & \multicolumn{5}{|c|}{ RAÍCES } & \multicolumn{4}{|c|}{ TRONCO } \\
\hline & $\begin{array}{l}\text { Cohesión } \\
\mathrm{cR}\left(\mathrm{kN} / \mathrm{m}^{2}\right)\end{array}$ & $\begin{array}{c}\text { Resist. } \\
\text { Tracción } \\
\mathrm{T}\left(\mathrm{N} / \mathrm{mm}^{2}\right)\end{array}$ & $\begin{array}{l}\text { Diámetro } \\
\text { D.r (mm) }\end{array}$ & $\begin{array}{c}\text { Densidad } \\
\text { d.r [Ar/As] }\end{array}$ & $\begin{array}{l}\text { Profundidad } \\
\text { p.r }(\mathrm{m})\end{array}$ & $\begin{array}{l}\text { Diámetro } \\
\text { D.t }(\mathrm{cm})\end{array}$ & $\begin{array}{c}\text { Densidad } \\
\gamma \mathbf{v}\left(\mathrm{kg} / \mathrm{m}^{3}\right)\end{array}$ & $\begin{array}{l}\text { Altura } \\
\text { h.t (m) }\end{array}$ & $\begin{array}{c}\text { Fac. } \\
\text { forma } \\
\text { (f.f) }\end{array}$ \\
\hline $\begin{array}{l}\text { Cynodum } \\
\text { dactylon }\end{array}$ & 3 & 24 & 2,5 & 0,6 & 0,4 & 0 & 0 & 0 & 0 \\
\hline
\end{tabular}

\subsubsection{7.- Dactylis glomerata (Dáctilo)}

$\begin{array}{ll}\text { REINO } & \text { Plantae } \\ \text { DIVISIÓN } & \text { Magnoliophyta } \\ \text { CLASE } & \text { Magnoliopsida } \\ \text { ORDEN } & \text { Poales } \\ \text { FAMILIA } & \text { Poaceae } \\ \text { GENERO } & \text { Dactylis } \\ \text { ESPECIE } & \text { D.glomerata }\end{array}$

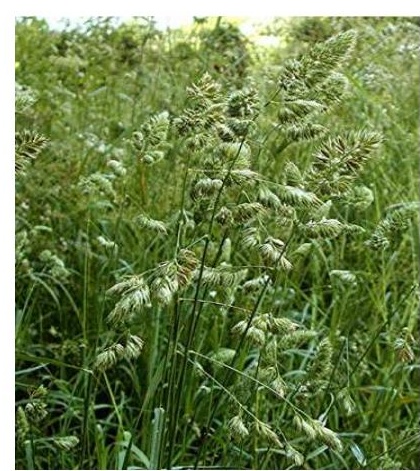

Hábitat - El dáctilo es una gramínea nativa de Europa, tanto de la parte atlántica como de la mediterránea. Vive en prados de siega, setos y orlas de bosques, desde el nivel del mar hasta los $1700 \mathrm{~m}$. Tolera la sequía, el calor y la sombra, aunque crece a plena luz. Está adaptado a suelos de fertilidad media-alta $y$, aunque no soporta los suelos pesados que tienden a encharcarse, tolera cierta salinidad.

Utilización - Esta planta tiene gran importancia como planta forrajera. Produce un buen forraje cuando es joven pero pierde enseguida su calidad y digestibilidad al florecer. Es por eso que debe segarse o ser pastoreado pronto para aprovecharlo antes de que madure demasiado. Suele ensilarse o henificarse. Posee un enorme valor en restauración por su rápido desarrollo.

Altura - Tiene una altura de 60 a $120 \mathrm{~cm}$. 
Inflorescencia - La inflorescencia es una panícula de 1-15 cm, con espiguillas aglomeradas en ramas. Estas espiguillas, de 5-9 mm, están comprimidas lateralmente y poseen de 2 a 5 flores cada una.

Fruto - El fruto es una cariópside.

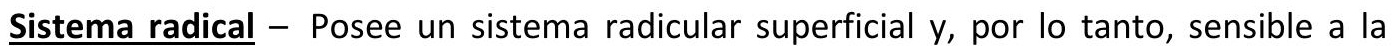
sequía.

\section{Parámetros medios}

\begin{tabular}{|c|c|c|c|c|c|c|c|c|}
\hline \multirow{2}{*}{ Especie } & \multicolumn{4}{|c|}{ RAÍCES } & \multicolumn{2}{|c|}{ TRONCO } \\
\cline { 2 - 7 } & $\begin{array}{c}\text { Cohesión } \\
\mathrm{cR}\left(\mathrm{kN} / \mathrm{m}^{2}\right)\end{array}$ & $\begin{array}{c}\text { Resist. } \\
\text { Tracción } \\
\mathrm{T}\left(\mathrm{N} / \mathrm{mm}^{2}\right)\end{array}$ & $\begin{array}{c}\text { Diámetro } \\
\text { D.r }(\mathrm{mm})\end{array}$ & $\begin{array}{c}\text { Densidad } \\
\text { d.r [Ar/As] }\end{array}$ & $\begin{array}{c}\text { Profundidad } \\
\text { p.r }(\mathrm{m})\end{array}$ & $\begin{array}{c}\text { Diámetro } \\
\text { D.t }(\mathrm{cm})\end{array}$ & $\begin{array}{c}\text { Densidad } \\
\gamma \mathrm{v}\left(\mathrm{kg} / \mathrm{m}^{3}\right)\end{array}$ & $\begin{array}{c}\text { Altura } \\
\mathrm{h} . \mathrm{t}(\mathrm{m})\end{array}$ \\
$\begin{array}{c}\text { Factylis } \\
\text { forma } \\
(\mathrm{f} . \mathrm{f})\end{array}$ & 11 & 2,5 & 0,6 & 0,20 & 0 & 0 \\
\hline
\end{tabular}

1.1.2.8.- Lolium perenne (Césped inglés, Raygrass)

$\begin{array}{ll}\text { REINO } & \text { Plantae } \\ \text { DIVISIÓN } & \text { Magnoliophyta } \\ \text { CLASE } & \text { Magnoliopsida } \\ \text { ORDEN } & \text { Poales } \\ \text { FAMILIA } & \text { Poaceae } \\ \text { GENERO } & \text { Lolium } \\ \text { ESPECIE } & \text { L.perenne }\end{array}$

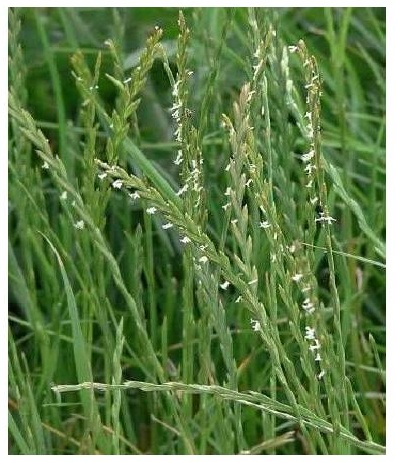

Hábitat - El ray-grass inglés es una gramínea originaria de Europa y norte de África, que la encontramos desde el nivel del mar hasta $1500 \mathrm{~m}$. Ha sido introducida en Sudamérica, Australia y Nueva Zelanda. Vive en climas templados en prados, pastizales y bordes de caminos. Es resistente al frío, pero sensible a las heladas así como al calor y a la sequía. Poco tolerante a la sombra. Prefiere suelos húmedos pero no encharcados, y es muy exigente en cuanto a fertilidad, especialmente nitrogenada.

Utilización - Tiene gran importancia como especie forrajera en praderas de larga duración, pues tiene una elevada productividad y calidad nutritiva. Es una gramínea perenne cespitosa, que se usa en campos de fútbol, de golf y jardines. 
Altura - Entre 8 y $90 \mathrm{~cm}$ de altura.

Inflorescencia - Las flores se reúnen en una espiga de 3 a $31 \mathrm{~cm}$, lateralmente comprimida. Las espiguillas tienen 10 flores y miden 5-23 x 1-7 mm.

Fruto - Es una cariópside tres veces más larga que ancha.

Sistema radical - Posee un sistema radicular denso, el 90\% del cual se encuentra en los primeros $30 \mathrm{~cm}$ del suelo. Raíz en cabellera, abundante y superficial. El diámetro de sus raíces es pequeño, por lo que tiene una mayor capacidad de exploración de la tierra y de nutrición, a la vez que realiza una labor mejoradora de la estructura del suelo, que es superior a la de otras gramíneas.

\section{Parámetros medios}

\begin{tabular}{|c|c|c|c|c|c|c|c|c|c|}
\hline \multirow{2}{*}{ Especie } & \multicolumn{3}{|c|}{ RAÍCES } & \multicolumn{3}{|c|}{ TRONCO } \\
\cline { 2 - 9 } & $\begin{array}{c}\text { Cohesión } \\
\mathrm{cR}\left(\mathrm{kN} / \mathrm{m}^{2}\right)\end{array}$ & $\begin{array}{c}\text { Resist. } \\
\text { Tracción } \\
\mathrm{T}\left(\mathrm{N} / \mathrm{mm}^{2}\right)\end{array}$ & $\begin{array}{c}\text { Diámetro } \\
\text { D.r }(\mathrm{mm})\end{array}$ & $\begin{array}{c}\text { Densidad } \\
\mathrm{d} . \mathrm{r}[\mathrm{Ar} / \mathrm{As}]\end{array}$ & $\begin{array}{c}\text { Profundidad } \\
\mathrm{p} . \mathrm{r}(\mathrm{m})\end{array}$ & $\begin{array}{c}\text { Diámetro } \\
\text { D.t }(\mathrm{cm})\end{array}$ & $\begin{array}{c}\text { Densidad } \\
\gamma \mathrm{v}\left(\mathrm{kg} / \mathrm{m}^{3}\right)\end{array}$ & $\begin{array}{c}\text { Altura } \\
\text { h.t (m) }\end{array}$ & $\begin{array}{c}\text { Fac. } \\
\text { forma } \\
(\mathrm{f} . \mathrm{f})\end{array}$ \\
\hline $\begin{array}{c}\text { Lolium } \\
\text { perenne }\end{array}$ & 3 & 6 & 1,5 & 0,6 & 0,3 & 0 & 0 & 0 & 0 \\
\hline
\end{tabular}

\subsubsection{9.- Lolium multiflorum (Ray-grass annual, Ray-grass italiano)}

$\begin{array}{ll}\text { REINO } & \text { Plantae } \\ \text { DIVISIÓN } & \text { Magnoliophyta } \\ \text { CLASE } & \text { Magnoliopsida } \\ \text { ORDEN } & \text { Poales } \\ \text { FAMILIA } & \text { Poaceae } \\ \text { GENERO } & \text { Lolium } \\ \text { ESPECIE } & \text { L. multiflorum }\end{array}$

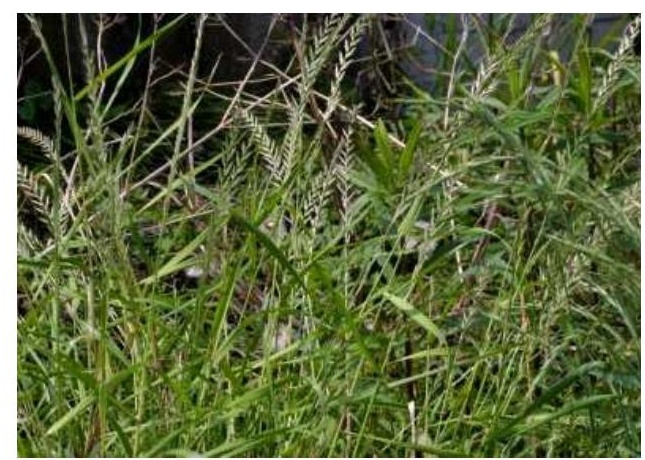

Hábitat - El ray-grass italiano se distribuye generalmente por el oeste, centro y sur de Europa, norte de África, suroeste de Asia y Macaronesia (excepto Cabo Verde); y ha sido introducida en diversas partes del globo. Vive hasta $800 \mathrm{~m}$ de altitud en las orillas de cultivos y caminos, más bien húmedos. Necesita suelos fértiles, sobre todo nitrogenados, aunque tolera 
los suelos pesados. Tolera la salinidad y es resistente al pisoteo. Se adapta muy bien a los climas fríos. Desaparece cuando suben mucho las temperaturas y es poco tolerante a la sombra.

Utilización - Se utiliza como especie forrajera en praderas de corta duración, tanto para siega como para pasto. Suele ensilarse o henificarse. Tiene una elevada productividad y calidad nutritiva.

Altura - Tallos de 30 a $130 \mathrm{~cm}$.

Inflorescencia - Las flores se agrupan en inflorescencias de tipo espiga, de 10 a $30 \mathrm{~cm}$, delgadas, erectas, comprimidas y de color verde. Esta inflorescencia está formada a su vez por espiguillas de 8 a $25 \mathrm{~mm}$, alternas en lados opuestos del raquis, con 11 - 22 flores sésiles cada una.

Fruto - Es una cariópside más de 3 veces larga que ancha.

Sistema radical - Sistema radicular fibroso, en cabellera y superficial, lo que lo hace sensible a los efectos de la sequía.

\section{Parámetros medios}

\begin{tabular}{|c|c|c|c|c|c|c|c|c|c|}
\hline \multirow{2}{*}{ Especie } & \multicolumn{4}{|c|}{ RAÍCES } & \multicolumn{4}{|c|}{ TRONCO } \\
\cline { 2 - 9 } & $\begin{array}{c}\text { Cohesión } \\
\mathrm{cR}\left(\mathrm{kN} / \mathrm{m}^{2}\right)\end{array}$ & $\begin{array}{c}\text { Resist. } \\
\text { Tracción } \\
\mathrm{T}\left(\mathrm{N} / \mathrm{mm}^{2}\right)\end{array}$ & $\begin{array}{c}\text { Diámetro } \\
\text { D.r }(\mathrm{mm})\end{array}$ & $\begin{array}{c}\text { Densidad } \\
\mathrm{d} . \mathrm{r}[\mathrm{Ar} / \mathrm{As}]\end{array}$ & $\begin{array}{c}\text { Profundidad } \\
\mathrm{p} . \mathrm{r}(\mathrm{m})\end{array}$ & $\begin{array}{c}\text { Diámetro } \\
\text { D.t }(\mathrm{cm})\end{array}$ & $\begin{array}{c}\text { Densidad } \\
\gamma \mathrm{v}\left(\mathrm{kg} / \mathrm{m}^{3}\right)\end{array}$ & $\begin{array}{c}\text { Altura } \\
\text { h.t }(\mathrm{m})\end{array}$ & $\begin{array}{c}\text { Fac. } \\
\text { forma } \\
(\mathrm{f} . \mathrm{f})\end{array}$ \\
\hline $\begin{array}{c}\text { Lolium } \\
\text { multiflorum }\end{array}$ & 3 & 14 & 2,5 & 0,6 & 0,20 & 0 & 0 & 0 & 0 \\
\hline
\end{tabular}




\section{2.- ESPECIES LEÑOSAS}

\subsection{1.- Acer campestre (Arce)}

$\begin{array}{ll}\text { REINO : } & \text { Plantae } \\ \text { DIVISIÓN: } & \text { Magnoliophyta } \\ \text { CLASE: } & \text { Magnoliopsida } \\ \text { ORDEN: } & \text { Sapindales } \\ \text { FAMILIA: } & \text { Sapindaceae } \\ \text { GENERO: } & \text { Acer } \\ \text { ESPECIE: } & \text { Acer campestre }\end{array}$

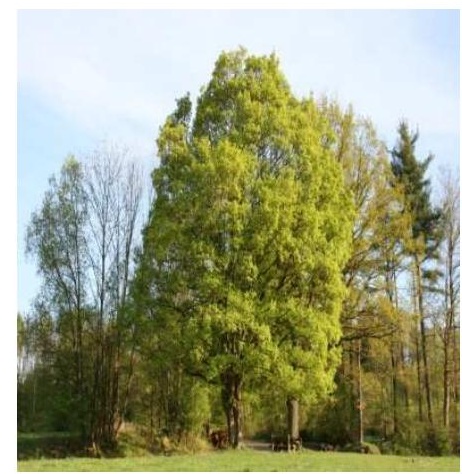

Hábitat - El arce menor o acerón se distribuye por Europa y oeste de Asia; también en algunas zonas del norte de África. En España se extiende en la porción septentrional. Prefiere zonas templadas, aunque soporta bien el frío. En cuanto a altitud, lo encontramos desde el nivel del mar hasta los $1200 \mathrm{~m}$ de altitud. Es un árbol de sol o de media sombra. Es muy resistente a la sequedad. Es indiferente respecto al tipo de suelo, aunque prefiere los calizos.

Utilización - Alto interés ornamental, sobre todo en zonas urbanas ya que soporta la contaminación del aire. Semilla muy germinadora y, una vez germinada, es fácilmente trasplantable, por lo que podría usarse en revegetaciones, aunque da una sombra densa que provoca la muerte a las especies intolerantes a la sombra que viven bajo él.

Altura - Es un árbol de talla media, que puede llegar a alcanzar de 15 a 25 metros de altura.

Inflorescencia - Flores en inflorescencias erguidas corimbosas, con las ramillas algo pelosas; son de color verdoso, con cáliz y corola bien desarrollados, pelosos y filamentos de estambres lampiños; son casi siempre unisexuales, pero también polígamas.

Floración - Florece en abril o mayo.

Fruto - Fruto provisto de dos alas membranosas que se estrechan poco en la base y son muy divergentes, formando un ángulo próximo a los 180 ㅇ․ 
Fructificación - En los meses de julio y agosto.

Sistema radical - El sistema radicular está muy ramificado y es muy superficial.

\section{Parámetros medios}

\begin{tabular}{|c|c|c|c|c|c|c|c|c|c|}
\hline \multirow{2}{*}{ Especie } & \multicolumn{5}{|c|}{ RAÍCES } & \multicolumn{4}{|c|}{ TRONCO } \\
\hline & $\begin{array}{c}\text { Cohesión } \\
\mathrm{cR}\left(\mathrm{kN} / \mathrm{m}^{2}\right)\end{array}$ & $\begin{array}{c}\text { Resist. } \\
\text { Tracción } \\
\mathrm{T}\left(\mathrm{N} / \mathrm{mm}^{2}\right)\end{array}$ & $\begin{array}{l}\text { Diámetro } \\
\text { D.r (mm) }\end{array}$ & $\begin{array}{c}\text { Densidad } \\
\text { d.r [Ar/As] }\end{array}$ & $\begin{array}{c}\text { Profundidad } \\
\text { p.r }(\mathrm{m})\end{array}$ & $\begin{array}{l}\text { Diámetro } \\
\text { D.t (cm) }\end{array}$ & $\begin{array}{c}\text { Densidad } \\
\gamma \mathrm{v}\left(\mathrm{kg} / \mathrm{m}^{3}\right)\end{array}$ & $\begin{array}{l}\text { Altura } \\
\text { h.t (m) }\end{array}$ & $\begin{array}{c}\text { Fac. } \\
\text { forma } \\
\text { (f.f) }\end{array}$ \\
\hline Acer campestre & 4,56 & 7 & 28 & 0,3 & 0,5 & 45 & 700 & 15 & 0,65 \\
\hline
\end{tabular}

\subsection{2.- Acer pseudoplatanus (Prádano)}

$\begin{array}{ll}\text { REINO : } & \text { Plantae } \\ \text { DIVISIÓN: } & \text { Magnoliophyta } \\ \text { CLASE: } & \text { Magnoliopsida } \\ \text { ORDEN: } & \text { Sapindales } \\ \text { FAMILIA: } & \text { Sapindaceae } \\ \text { GENERO: } & \text { Acer } \\ \text { ESPECIE: } & \text { Acer pseudoplatanus }\end{array}$

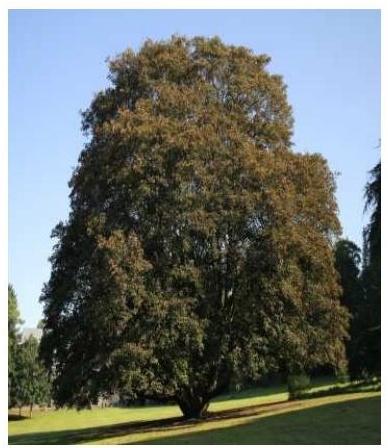

Hábitat - Este arce también llamado prádano crece en terrenos frescos, tanto calizos como silíceos desde el nivel del mar hasta los $1800 \mathrm{~m}$ de altitud en suelos profundos y fértiles. En Castilla y León se distribuye por áreas montañosas y húmedas de León sobre pizarras y esquistos donde se mezcla con acebos, roble albar, tilos, fresnos y hayas, así como con álamos y alisos cuando crece en las riberas como se observa por toda la cuenca del río Sil. Es una especie con gran capacidad de adaptación a condiciones adversas, encontrándonos estos árboles en ambientes más secos de los alrededores de ciudades de Castilla y León como Segovia y Palencia y también las riberas de los ríos Tirón, Carrión, Duero, etc.

Utilización - La madera de este árbol es muy apreciada en carpintería, ebanistería, parquet, tornería y pasta de papel. Tradicionalmente se ha utilizado en la fabricación de moldes de fundición en fraguas y ferrerías, así como para hacer escaleras, instrumentos de medida, rodillos de imprentas y útiles agrícolas. Se usa para la fabricación de instrumentos 
musicales como violines. Sus hojas se emplean tradicionalmente para envolver los quesos de Cabrales y Valdeón en la cornisa cantábrica. Así como sus ramas como forraje para ovejas y cabras. Tiene también valor como ornamental y para conseguir pantallas cortavientos y aislantes acústicos frente a autovías, ferrocarriles, etc, por la resistencia y opacidad de su densa copa, así como por su resistencia a los ambientes contaminados y vientos huracanados.

Altura - Es un árbol de copa densa y amplia que puede alcanzar los $30 \mathrm{~m}$ de altura.

Inflorescencia - Las flores son hermafroditas o unisexuales, regulares (de simetría radial), de color amarillo-verdoso dispuestas en cimas o racimos colgantes que aparecen con las hojas o poco después; tienen largos cabillos, una envuelta floral doble, formada por 5 sépalos libres inicialmente imbricados y 5 pétalos alargados libres que alternan con los sépalos y se insertan, junto con los 8 estambres, en un disco anular carnoso situado debajo del ovario.

Fruto - Los frutos son disámaras que se dispersan girando como una hélice, estrechas por la base y anchas por el extremo.

Sistema radical - El prádano no presenta raíz pivotante importante, sin embargo las raíces secundarias son abundantes, superficiales y penetran oblicuamente.

\section{Parámetros medios}

\begin{tabular}{|c|c|c|c|c|c|c|c|c|c|}
\hline \multirow[b]{2}{*}{ Especie } & \multicolumn{5}{|c|}{ RAÍCES } & \multicolumn{4}{|c|}{ TRONCO } \\
\hline & $\begin{array}{l}\text { Cohesión } \\
\mathrm{cR}\left(\mathrm{kN} / \mathrm{m}^{2}\right)\end{array}$ & $\begin{array}{c}\text { Resist. } \\
\text { Tracción } \\
\mathrm{T}\left(\mathrm{N} / \mathrm{mm}^{2}\right)\end{array}$ & $\begin{array}{l}\text { Diámetro } \\
\text { D.r (mm) }\end{array}$ & $\begin{array}{l}\text { Densidad } \\
\text { d.r [Ar/As] }\end{array}$ & $\begin{array}{l}\text { Profundidad } \\
\text { p.r }(\mathrm{m})\end{array}$ & $\begin{array}{l}\text { Diámetro } \\
\text { D.t }(\mathrm{cm})\end{array}$ & $\begin{array}{c}\text { Densidad } \\
\gamma \mathbf{v}\left(\mathrm{kg} / \mathrm{m}^{3}\right)\end{array}$ & $\begin{array}{l}\text { Altura } \\
\text { h.t (m) }\end{array}$ & $\begin{array}{l}\text { Fac. } \\
\text { forma } \\
\text { (f.f) }\end{array}$ \\
\hline $\begin{array}{c}\text { Acer } \\
\text { pseudoplatanus }\end{array}$ & 4,56 & 16 & 28 & 0,3 & 0,5 & 38 & 610 & 22 & 0,65 \\
\hline
\end{tabular}




\subsection{3.- Alnus glutinosa (Aliso)}

$\begin{array}{ll}\text { REINO : } & \text { Plantae } \\ \text { DIVISIÓN: } & \text { Magnoliophyta } \\ \text { CLASE: } & \text { Magnoliopsida } \\ \text { ORDEN: } & \text { Fagales } \\ \text { FAMILIA: } & \text { Betulaceae } \\ \text { GENERO: } & \text { Alnus } \\ \text { ESPECIE: } & \text { Alnus glutinosa }\end{array}$

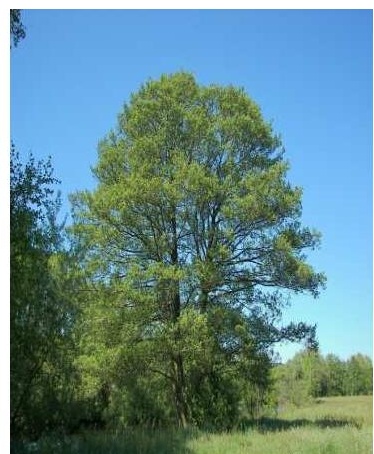

Hábitat - El aliso es un árbol de la familia de las betuláceas, que se distribuye por Europa y el sudeste de Asia. En la Península Ibérica lo podemos ver especialmente en la mitad norte y occidental, faltando sin embargo en Baleares. Es una especie de ribera, que necesita un suelo con humedad y tolera muy mal la sequía estival. Sus raíces son capaces de fijar nitrógeno, por lo que puede vivir en suelos muy pobres. Lo podemos ver asociado a fresnos, sauces y chopos o formando alisedas.

Utilización - Es de crecimiento rápido y se utiliza para repoblar zonas pobres y encharcadas, ya que la madera es muy resistente al agua. Es por eso que nuestros antepasados la utilizaban para construir palafitos.

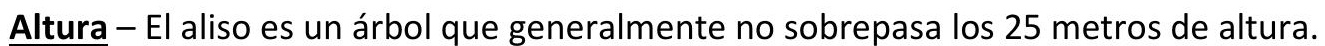

Inflorescencia - Las flores masculinas están dispuestas en amentos cilíndricos de 3 a 7 $\mathrm{cm}$ de longitud y de 2 a $6 \mathrm{~mm}$ de diámetro, de color rojizo. Las inflorescencias femeninas se agrupan en amentos globosos de menor tamaño.

Floración - Florece desde febrero hasta abril.

Fruto - Las inflorescencias femeninas lignifican y originan infrutescencias llamadas pseudoestróbilos, que se parecen a una piña. Estas infrutescencias son verdes de jóvenes y negras en la madurez, pedunculadas y se reúnen en grupos de 2 a 5 . Además alojan a los aquenios, que son pequeños y comprimidos lateralmente. 
Fructificación - Los frutos maduran desde el verano al otoño.

Sistema radical - El aliso emite abundantes chupones de la raíz y posee unas raíces muy extendidas en superficie. Pierde la raíz primaria prematuramente, desarrollando numerosas raíces secundarias oblicuas y raíces terciarias verticales, más profundas y de fuerte anclaje, que le permite resistir riadas y avenidas. Necesita tener las raíces embebidas en agua permanentemente. Si el encharcamiento es periódico, lo tolera siempre y cuando haya renovación de agua corriente. Cuando las inundaciones son continuas, produce raíces adventicias en el tronco que son blandas y ramificadas. Posee nódulos fijadores de nitrógeno atmosférico en las raíces más superficiales, asociado a la bacteria Actinomyces alni.

\section{$\underline{\text { Parámetros medios }}$}

\begin{tabular}{|c|c|c|c|c|c|c|c|c|c|}
\hline \multirow{2}{*}{ Especie } & \multicolumn{3}{|c|}{ RAÍCES } & \multicolumn{3}{|c|}{ TRONCO } \\
\cline { 2 - 9 } & $\begin{array}{c}\text { Cohesión } \\
\mathrm{cR}\left(\mathrm{kN} / \mathrm{m}^{2}\right)\end{array}$ & $\begin{array}{c}\text { Resist. } \\
\text { Tracción } \\
\mathrm{T}\left(\mathrm{N} / \mathrm{mm}^{2}\right)\end{array}$ & $\begin{array}{c}\text { Diámetro } \\
\text { D.r }(\mathrm{mm})\end{array}$ & $\begin{array}{c}\text { Densidad } \\
\text { d.r }[\mathrm{Ar} / \mathrm{As}]\end{array}$ & $\begin{array}{c}\text { Profundidad } \\
\mathrm{p} . \mathrm{r}(\mathrm{m})\end{array}$ & $\begin{array}{c}\text { Diámetro } \\
\text { D.t }(\mathrm{cm})\end{array}$ & $\begin{array}{c}\text { Densidad } \\
\gamma \mathrm{v}\left(\mathrm{kg} / \mathrm{m}^{3}\right)\end{array}$ & $\begin{array}{c}\text { Altura } \\
\text { h.t (m) }\end{array}$ & $\begin{array}{c}\text { Fac. } \\
\text { forma } \\
(\mathrm{f} . \mathrm{f})\end{array}$ \\
\hline $\begin{array}{c}\text { Alnus } \\
\text { glutinosa }\end{array}$ & 9,6 & 32 & 18 & 0,3 & 0,6 & 60 & 510 & 20 & 0,65 \\
\hline
\end{tabular}

\subsection{4.- Arbutus unedo (Madroño)}

$\begin{array}{ll}\text { REINO : } & \text { Plantae } \\ \text { DIVISIÓN: } & \text { Magnoliophyta } \\ \text { CLASE: } & \text { Magnoliopsida } \\ \text { ORDEN: } & \text { Ericales } \\ \text { FAMILIA: } & \text { Ericaceae } \\ \text { GENERO: } & \text { Arbutus } \\ \text { ESPECIE: } & \text { Arbutus unedo }\end{array}$

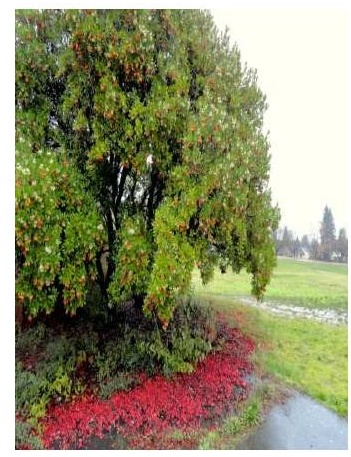

Hábitat - El madroño es un árbol de la familia de las ericáceas, que se distribuye por la región Mediterránea y la Europa occidental. Es frecuente en las Islas Baleares, especialmente en las provincias litorales y regiones de clima suave. Crece zonas de encinares, alcornocales y 
en los matorrales que resultan de su degradación, sobre todo tipo de terrenos, calizos o silíceos, ascendiendo hasta altitudes de 1200 , prefiere suelos algo frescos y profundos y requiere un clima suave, sin fuertes heladas.

Utilización - Como planta ornamental en parques y jardines.

Altura - El madroño es un arbolillo o arbusto de 6 a $10 \mathrm{~m}$ de altura de copa densa y redondeada. Generalmente no sobrepasa los $10 \mathrm{~m}$ de altura.

Inflorescencia - Las flores aparecen agrupadas en ramilletes colgantes en número de 15 a 20. Son de corola blanco-verdosa, a veces rosada y de forma urceolada (en forma de olla).

Floración - En el otoño o principios del invierno, a la vez que maduran sus frutos, pudiendo ver al tiempo las flores y los frutos.

Fruto - El fruto es de tipo baya, de 2 a $2,5 \mathrm{~cm}$ de diámetro, forma esférica y superficie verrugosa o con púas, al principio de color verde amarillento y en la madurez rojo como una fresa. La carne del interior es amarillenta y contiene gran número de semillas pequeñas, pardas y angulosas.

Fructificación - Los frutos maduran en el otoño y principios del invierno a al vez de la floración.

Sistema radical - El madroño tiene un sistema radical muy fuerte y potente, provisto de gruesas cepas. Se reproduce por semilla y por brotes de cepa.

\section{Parámetros medios}

\begin{tabular}{|c|c|c|c|c|c|c|c|c|c|}
\hline \multirow{2}{*}{ Especie } & \multicolumn{5}{|c|}{ RAÍCES } & \multicolumn{4}{|c|}{ TRONCO } \\
\hline & $\begin{array}{c}\text { Cohesión } \\
\mathrm{cR}\left(\mathrm{kN} / \mathrm{m}^{2}\right)\end{array}$ & $\begin{array}{c}\text { Resist. } \\
\text { Tracción } \\
\mathrm{T}\left(\mathrm{N} / \mathrm{mm}^{2}\right)\end{array}$ & $\begin{array}{l}\text { Diámetro } \\
\text { D.r (mm) }\end{array}$ & $\begin{array}{c}\text { Densidad } \\
\text { d.r [Ar/As] }\end{array}$ & $\begin{array}{l}\text { Profundidad } \\
\text { p.r (m) }\end{array}$ & $\begin{array}{l}\text { Diámetro } \\
\text { D.t }(\mathrm{cm})\end{array}$ & $\begin{array}{c}\text { Densidad } \\
\gamma \mathbf{v}\left(\mathrm{kg} / \mathrm{m}^{3}\right)\end{array}$ & $\begin{array}{l}\text { Altura } \\
\text { h.t (m) }\end{array}$ & $\begin{array}{l}\text { Fac. } \\
\text { forma } \\
\text { (f.f) }\end{array}$ \\
\hline Arbutus unedo & 2,64 & 40 & 21,9 & 0,3 & 0,5 & 20 & 820 & 8 & 0,65 \\
\hline
\end{tabular}




\subsection{5.- Betula alba (Abedul)}

$\begin{array}{lll}\text { REINO } & \text { Plantae } \\ \text { DIVISIÓN } & \text { Magnoliophyta } \\ \text { CLASE } & \text { Magnoliopsida } \\ \text { ORDEN } & \text { Fagales } \\ \text { FAMILIA } & \text { Betulaceae } \\ \text { GENERO } & \text { Betula } \\ \text { ESPECIE } & \text { B. alba }\end{array}$

Hábitat-El abedul se distribuye por casi toda Europa y noroeste de Asia. En la Península presente solo en la mitad norte. Podemos encontrarlo desde 0 hasta $1800 \mathrm{~m}$ de altitud, incluso a $2000 \mathrm{~m}$. Se trata de un árbol típico de zonas frescas y húmedas de las montañas, descendiendo por los ríos a menores altitudes a lo largo de los sotos ribereños hacia las llanuras. Vive en turberas o humedales de bosques y bordes de cursos de agua. No tolera los suelos secos ni compactos, y prefiere los suelos silíceos frente a los calizos. Resiste muy bien los fríos inviernos intensos.

Utilización - Es de crecimiento muy rápido y elevado valor protector. Son utilizados para restaurar terrenos desnudos, pobres, e incluso tóxicos en ambientes contaminados.

Altura - Árbol que puede alcanzar alturas de 20-30 m.

Inflorescencia - Inflorescencias en gatillos colgantes que se deshacen en la madurez. Flores masculinas en amentos cilíndricos de color verde pálido. Las flores femeninas son de color verde oscuro y poseen escamas.

Floración - Florece de Abril a Mayo. Las flores masculinas agrupadas en amentos pasan el invierno sobre el árbol completando su desarrollo en primavera, estación en que aparecen las flores femeninas reunidas en amentos cilíndricos más cortos, de color amarillo verdosos. Las flores masculinas están amparadas por una bráctea grande y dos laterales pequeñas. 
Fruto - Los frutos son aquenios con dos alas laterales de color pardo llamadas sámaras, formando una infrutescencia cilíndrica colgante, de 1 a $4 \mathrm{~cm}$ de longitud y de 5 a 7 de diámetro.

Fructificación - El fruto madura de julio a septiembre.

Sistema radical - Posee unas raíces someras y extendidas. Forma micorrizas con hongos simbiontes específicos de los abedules como Leccinum scabrum, Boletus edulis, Lactarius pubescens, Russula sp.,etc.

\section{Parámetros medios}

\begin{tabular}{|c|c|c|c|c|c|c|c|c|c|}
\hline \multirow{2}{*}{ Especie } & \multicolumn{5}{|c|}{ RAÍCES } & \multicolumn{4}{|c|}{ TRONCO } \\
\hline & $\begin{array}{l}\text { Cohesión } \\
\mathrm{cR}\left(\mathrm{kN} / \mathrm{m}^{2}\right)\end{array}$ & $\begin{array}{c}\text { Resist. } \\
\text { Tracción } \\
\mathrm{T}\left(\mathrm{N} / \mathrm{mm}^{2}\right)\end{array}$ & $\begin{array}{l}\text { Diámetro } \\
\text { D.r (mm) }\end{array}$ & $\begin{array}{l}\text { Densidad } \\
\text { d.r [Ar/As] }\end{array}$ & $\begin{array}{c}\text { Profundidad } \\
\text { p.r }(\mathrm{m})\end{array}$ & $\begin{array}{c}\text { Diámetro } \\
\text { D.t }(\mathrm{cm})\end{array}$ & $\begin{array}{c}\text { Densidad } \\
\gamma \mathrm{v}\left(\mathrm{kg} / \mathrm{m}^{3}\right)\end{array}$ & $\begin{array}{l}\text { Altura } \\
\text { h.t (m) }\end{array}$ & $\begin{array}{l}\text { Fac. } \\
\text { forma } \\
\text { (f.f) }\end{array}$ \\
\hline Betula alba & 2,64 & 23 & 30 & 0,3 & 0,3 & 26 & 680 & 25 & 0,65 \\
\hline
\end{tabular}

\subsection{6.- Castanea sativa (Castaño)}

$\begin{array}{ll}\text { REINO } & \text { Plantae } \\ \text { DIVISIÓN } & \text { Magnoliophyta } \\ \text { CLASE } & \text { Magnoliopsida } \\ \text { ORDEN } & \text { Fagales } \\ \text { FAMILIA } & \text { Fagaceae } \\ \text { GENERO } & \text { Castanea } \\ \text { ESPECIE } & \text { Castanea sativa }\end{array}$

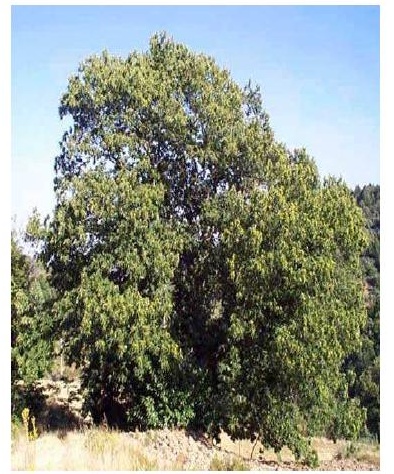

Hábitat - El castaño es una planta mesoterma e higrófila que prefiere sustratos silíceos como son los granitos y cuarcitas aunque también aparece sobre calizas cuando las condiciones climáticas permiten un lavado de las mismas eliminando las bases. Crece sobre suelos sueltos, frescos, profundos, sin acumulación excesiva de sales, como tierras pardas, evitando suelos compactos y muy húmedos. El castaño crece en zonas umbrías y frescas hasta altitudes de $1500 \mathrm{~m}$. A menudo ocupa extensos bosques que vienen a ocupar antiguos robledales naturales. 
Utilización - Su madera se ha utilizado en el pasado para la fabricación de toneles. Hoy en día su uso es casi exclusivo para la fabricación de muebles. Las hojas suelen utilizarse como forraje y la corteza y el leño se emplean como astringentes. Los frutos son considerados de gran valor culinario en Europa central y meridional, usado para harina, para hacer pan y cocinar. También se emplea para el engorde de animales. Las hojas se emplean para infusiones contra afecciones respiratorias, siendo un remedio popular para la tos ferina. Muy utilizado en homeopatía.

Altura - Árbol caducifolio que puede alcanzar alturas de hasta $30 \mathrm{~m}$.

Inflorescencia - Las flores masculinas aparecen en amentos colgantes de $13-30 \mathrm{~cm}$ de longitud y 5-7 mm de diámetro; al principio son de color verde y se vuelven amarillos durante la floración; aparecen 6-7 flores en la axila de las brácteas del amento, que son ligeramente trilobadas; tienen el perianto formado por 6 piezas de lóbulos ovados y obtusos, con 10-20 estambres y un ovario rudimentario.

Las flores femeninas aparecen en un amento más pequeño situado en la base del masculino, que está formado por 3 a 6 carpelos y los estilos aparecen soldados a un perigonio de 7 lóbulos.

Floración - La floración se produce en los meses de mayo y junio.

Fruto - Los frutos son aquenios con dos alas laterales de color pardo llamadas sámaras, formando una infrutescencia cilíndrica colgante, de 1 a $4 \mathrm{~cm}$ de longitud y de 5 a 7 de diámetro.

Fructificación - El fruto madura de julio a septiembre.

Sistema radical - Raíz principal pivotante medianamente profunda, secundarias se ramifican con marcada tendencia a profundizar en suelos sueltos. No admite limitación de profundidad edáfica. 


\section{Parámetros medios}

\begin{tabular}{|c|c|c|c|c|c|c|c|c|c|}
\hline \multirow{2}{*}{ Especie } & \multicolumn{5}{|c|}{ RAÍCES } & \multicolumn{4}{|c|}{ TRONCO } \\
\hline & $\begin{array}{l}\text { Cohesión } \\
\mathrm{cR}\left(\mathrm{kN} / \mathrm{m}^{2}\right)\end{array}$ & $\begin{array}{c}\text { Resist. } \\
\text { Tracción } \\
\mathrm{T}\left(\mathrm{N} / \mathrm{mm}^{2}\right)\end{array}$ & $\begin{array}{l}\text { Diámetro } \\
\text { D.r (mm) }\end{array}$ & $\begin{array}{c}\text { Densidad } \\
\text { d.r [Ar/As] }\end{array}$ & $\begin{array}{l}\text { Profundidad } \\
\text { p.r }(\mathrm{m})\end{array}$ & $\begin{array}{l}\text { Diámetro } \\
\text { D.t }(\mathrm{cm})\end{array}$ & $\begin{array}{c}\text { Densidad } \\
\gamma \mathbf{v}\left(\mathrm{kg} / \mathrm{m}^{3}\right)\end{array}$ & $\begin{array}{l}\text { Altura } \\
\text { h.t (m) }\end{array}$ & $\begin{array}{l}\text { Fac. } \\
\text { forma } \\
\text { (f.f) }\end{array}$ \\
\hline $\begin{array}{c}\text { Castanea } \\
\text { sativa }\end{array}$ & 4,0 & 40 & 25 & 0,3 & 0,5 & 30 & 590 & 25 & 0,65 \\
\hline
\end{tabular}

\subsection{7.- Corylus avellana (Avellano)}

$\begin{array}{ll}\text { REINO } & \text { Plantae } \\ \text { DIVISIÓN } & \text { Magnoliophyta } \\ \text { CLASE } & \text { Magnoliopsida } \\ \text { ORDEN } & \text { Fagales } \\ \text { FAMILIA } & \text { Betulaceae } \\ \text { GENERO } & \text { Corylus } \\ \text { ESPECIE } & \text { Corylus avellana }\end{array}$

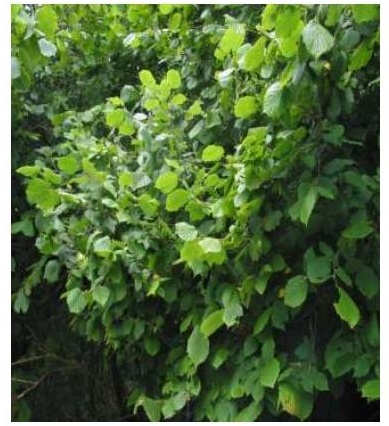

Hábitat - Sin ser muy exigente, el avellano requiere un terreno profundo, fresco, blando, de naturaleza silíceo-calcáreo-arcillosa o calcáreo-silíceo-arcillosa y de subsuelo permeable, con pH entre 5,5 y 7,8 . El avellano es muy sensible a la sequía, y si las tierras son excesivamente calcáreas y de naturaleza seca puede resentirse por la falta de humedad. Se cría en las laderas, fondo de los valles fluviales, hoces y barrancos, preferentemente en sitios umbrosos y frescos, no asciende generalmente por encima de los $1500 \mathrm{~m}$; requiere climas sin sequías estivales muy acusadas; se asocia frecuentemente a tilos, arces, fresnos, robles, etc. Se cultiva como planta ornamental.

Utilización - Sus ramas flexibles se emplean para la fabricación de aros de toneles, cestos, bastones, cuévanos, etc. La leña es bastante estimable para combustible. Su fruto es comestible.

Altura - Es un árbol que alcanza normalmente entre 3 a $8 \mathrm{~m}$ de alto, aunque en ocasiones puede llegar a los $15 \mathrm{~m}$ con una copa muy extendida de forma irregular, generalmente ramificado desde la base.

Inflorescencia - Las flores nacen antes que las hojas, a principios de la primavera. Son monoicas y con amentos de sexo diferenciado; los masculinos de color amarillo pálido y entre 
5 a $12 \mathrm{~cm}$ de largo, los femeninos muy pequeños y prácticamente ocultos en las yemas de las que surgen los estilos rojo brillante, en número de 1 a 3 . Las flores masculinas se reúnen en espigas colgantes ya visibles antes del invierno. Las flores femeninas se agrupan generalmente de dos en dos sobre ramillos hojosos.

Floración - La floración se produce de enero a abril.

Fruto - El fruto es la avellana, que se produce en grupos de 1 a 5 , cada una contenida en un pequeño y hojoso involucro que encierra alrededor de las 3/4 partes de la nuez.

Fructificación - El fruto madura de agosto a octubre.

Sistema radical - Posee raíces poco profundas, largas, nudosas. Durante los primeros cuatro o cinco primeros años de vida de la planta se desarrollan abundantes raíces secundarias, de las que algunas alcanzan gran longitud; brota muy bien de cepa y sus raíces pueden dar numerosos renuevos.

\section{Parámetros medios}

\begin{tabular}{|c|c|c|c|c|c|c|c|c|c|}
\hline \multirow{2}{*}{ Especie } & \multicolumn{5}{|c|}{ RAÍCES } & \multicolumn{4}{|c|}{ TRONCO } \\
\hline & $\begin{array}{c}\text { Cohesión } \\
\mathrm{cR}\left(\mathrm{kN} / \mathrm{m}^{2}\right)\end{array}$ & $\begin{array}{c}\text { Resist. } \\
\text { Tracción } \\
\mathrm{T}\left(\mathrm{N} / \mathrm{mm}^{2}\right)\end{array}$ & $\begin{array}{l}\text { Diámetro } \\
\text { D.r (mm) }\end{array}$ & $\begin{array}{c}\text { Densidad } \\
\text { d.r [Ar/As] }\end{array}$ & $\begin{array}{l}\text { Profundidad } \\
\text { p.r }(\mathrm{m})\end{array}$ & $\begin{array}{l}\text { Diámetro } \\
\text { D.t }(\mathrm{cm})\end{array}$ & $\begin{array}{c}\text { Densidad } \\
\gamma \mathbf{v}\left(\mathrm{kg} / \mathrm{m}^{3}\right)\end{array}$ & $\begin{array}{l}\text { Altura } \\
\text { h.t (m) }\end{array}$ & $\begin{array}{l}\text { Fac. } \\
\text { forma } \\
\text { (f.f) }\end{array}$ \\
\hline $\begin{array}{l}\text { Corylus } \\
\text { avellana }\end{array}$ & 2,64 & 66 & 15 & 0,3 & 0,5 & 15 & 670 & 12 & 0,65 \\
\hline
\end{tabular}

\subsection{8.- Crataegus monogyna (Majuelo)}

$\begin{array}{ll}\text { REINO } & \text { Plantae } \\ \text { DIVISIÓN } & \text { Magnoliophyta } \\ \text { CLASE } & \text { Magnoliopsida } \\ \text { ORDEN } & \text { Rosales } \\ \text { FAMILIA } & \text { Rosaceae } \\ \text { GENERO } & \text { Crataegus }\end{array}$

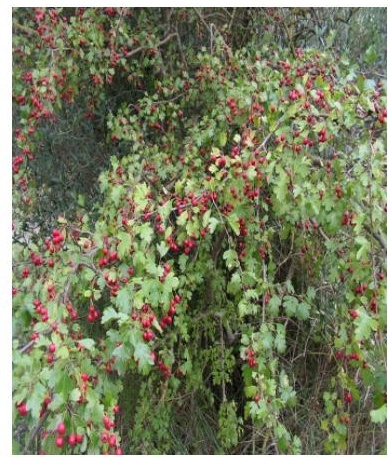




\section{ESPECIE Crataegus monogyna}

Hábitat - Se desarrolla en diferentes zonas tantos costeras como del interior y desde el nivel del mar hasta los $1800 \mathrm{~m}$. Es muy corriente encontrarlo en los linderos de los caminos y zonas agrestes y pedregosas del Bierzo. Indiferente a la naturaleza del suelo.

Utilización - Es una planta naturalizada para su cultivo ornamental. La madera por ser muy dura puede utilizarse en ebanistería. Suele utilizarse como seto de defensa. Sus espinas y ramaje cerrado lo convierten en una buena barrera para encerrar ganado e impedir el paso de personas. Los frutos dan un tinte verde y un pigmento de color parecido.

Altura - Alcanza una altura entre 3 a $8 \mathrm{~m}$.

Inflorescencia - Las flores se disponen en corimbos de cinco a veinticinco juntas; cada flor tiene aproximadamente un $\mathrm{cm}$. de diámetro, con cinco pétalos blancos, numerosos estambres rojos, y un singular estilo; son moderadamente fragantes.

Floración - La floración se produce durante el mes de marzo.

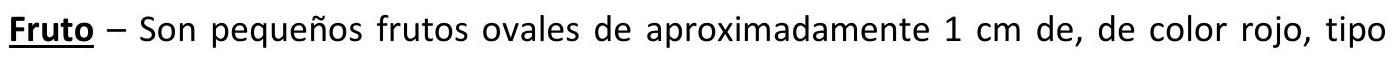
cereza, llamadas majuelas.

Fructificación - Durante el mes de mayo.

Sistema radical - Sistema radicular uniforme, ramificado, con forma semiesférica cuyas raíces exploran hacia abajo.

\section{Parámetros medios}

\begin{tabular}{|c|c|c|c|c|c|c|c|c|c|}
\hline \multirow{2}{*}{ Especie } & \multicolumn{5}{|c|}{ RAÍCES } & \multicolumn{4}{|c|}{ TRONCO } \\
\hline & $\begin{array}{l}\text { Cohesión } \\
\mathrm{cR}\left(\mathrm{kN} / \mathrm{m}^{2}\right)\end{array}$ & $\begin{array}{c}\text { Resist. } \\
\text { Tracción } \\
\mathrm{T}\left(\mathrm{N} / \mathrm{mm}^{2}\right)\end{array}$ & $\begin{array}{l}\text { Diámetro } \\
\text { D.r (mm) }\end{array}$ & $\begin{array}{l}\text { Densidad } \\
\text { d.r }[\mathrm{Ar} / \mathrm{As}]\end{array}$ & $\begin{array}{l}\text { Profundidad } \\
\text { p.r (m) }\end{array}$ & $\begin{array}{l}\text { Diámetro } \\
\text { D.t }(\mathrm{cm})\end{array}$ & $\begin{array}{c}\text { Densidad } \\
\gamma \mathbf{v}\left(\mathrm{kg} / \mathrm{m}^{3}\right)\end{array}$ & $\begin{array}{l}\text { Altura } \\
\text { h.t (m) }\end{array}$ & $\begin{array}{l}\text { Fac. } \\
\text { forma } \\
\text { (f.f) }\end{array}$ \\
\hline $\begin{array}{l}\text { Crataegus } \\
\text { monogyna }\end{array}$ & 2,64 & 50 & 21,9 & 0,3 & 0,5 & 15 & 800 & 7 & 0,65 \\
\hline
\end{tabular}




\subsection{9.- Frangula alnus (Arraclán)}

$\begin{array}{ll}\text { REINO } & \text { Plantae } \\ \text { DIVISIÓN } & \text { Magnoliophyta } \\ \text { CLASE } & \text { Magnoliopsida } \\ \text { ORDEN } & \text { Rosales } \\ \text { FAMILIA } & \text { Rhamnaceae } \\ \text { GENERO } & \text { Frangula } \\ \text { ESPECIE } & \text { Frangula alnus }\end{array}$

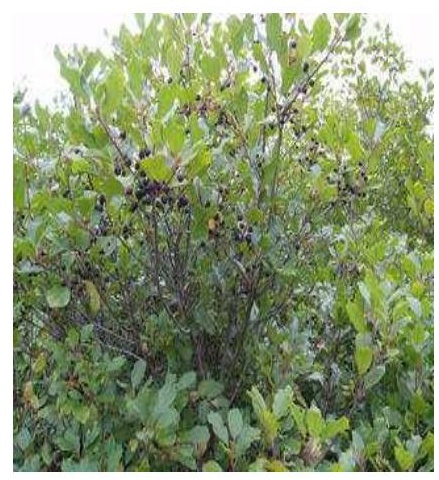

Hábitat - Se trata de un arbusto típico de suelos frescos y húmedos en sustratos silíceos, pero también en los calizos, desde el nivel del mar hasta zonas de montaña, barrancos umbrosos y húmedos, ampliamente extendidos por Europa, Asia y norte de África. En la Península es más frecuente en la mitad septentrional y occidental, haciéndose rara hacia el sur pero alcanzando las provincias de Cádiz y Huelva. No es una planta abundante ni forma grandes masas arbustivas o arbóreas.

Utilización - Es una planta naturalizada para su cultivo ornamental.

Altura - Alcanza una altura entre 3 y $6 \mathrm{~m}$.

Inflorescencia - Las flores son muy pequeñas y hermafroditas y nacen en grupitos, cimas, poco numerosos de la axila de las hojas tienen un cáliz verdoso y amarillento, con 5 sépalos y cinco pétalos ovalados, éstos algo menores.

Floración - La floración se produce de abril a junio.

Fruto - Es globoso, del tamaño de un guisante, al principio verdoso, después rojizo y finalmente negro, tiene poca carne y dos o tres huesecillos.

Fructificación-Madura a partir de agosto. 
Sistema radical - Posee raíces poco profundas con abundantes raíces secundarias que alcanzan gran longitud; brota muy bien de cepa y sus raíces pueden dar numerosos renuevos.

\section{Parámetros medios}

\begin{tabular}{|c|c|c|c|c|c|c|c|c|c|}
\hline \multirow[b]{2}{*}{ Especie } & \multicolumn{5}{|c|}{ RAÍCES } & \multicolumn{4}{|c|}{ TRONCO } \\
\hline & $\begin{array}{l}\text { Cohesión } \\
\mathrm{cR}\left(\mathrm{kN} / \mathrm{m}^{2}\right)\end{array}$ & $\begin{array}{c}\text { Resist. } \\
\text { Tracción } \\
\mathrm{T}\left(\mathrm{N} / \mathrm{mm}^{2}\right)\end{array}$ & $\begin{array}{l}\text { Diámetro } \\
\text { D.r (mm) }\end{array}$ & $\begin{array}{c}\text { Densidad } \\
\text { d.r [Ar/As] }\end{array}$ & $\begin{array}{l}\text { Profundidad } \\
\text { p.r }(\mathrm{m})\end{array}$ & $\begin{array}{l}\text { Diámetro } \\
\text { D.t }(\mathrm{cm})\end{array}$ & $\begin{array}{c}\text { Densidad } \\
\gamma \mathbf{v}\left(\mathrm{kg} / \mathrm{m}^{3}\right)\end{array}$ & $\begin{array}{l}\text { Altura } \\
\text { h.t (m) }\end{array}$ & $\begin{array}{l}\text { Fac. } \\
\text { forma } \\
\text { (f.f) }\end{array}$ \\
\hline $\begin{array}{l}\text { Frangula } \\
\text { alnus }\end{array}$ & 2,64 & 30 & 21,9 & 0,3 & 0,3 & 10 & 790 & 6 & 0,65 \\
\hline
\end{tabular}

\subsubsection{0.- Fraxinus angustifolia (Fresno)}

$\begin{array}{ll}\text { REINO } & \text { Plantae } \\ \text { DIVISIÓN } & \text { Magnoliophyta } \\ \text { CLASE } & \text { Magnoliopsida } \\ \text { ORDEN } & \text { Lamiales } \\ \text { FAMILIA } & \text { Oleaceae } \\ \text { GENERO } & \text { Fraxinus } \\ \text { ESPECIE } & \text { F.angustifolia }\end{array}$

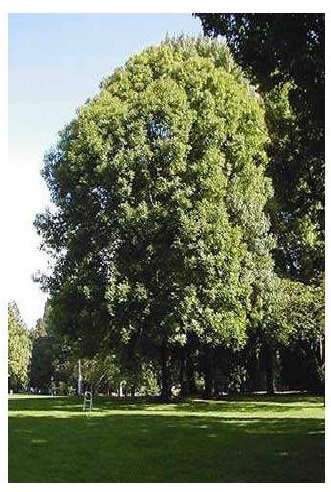

Hábitat - El fresno de hojas estrechas habita en el sur de Europa, suroeste de Asia y noroeste de África. En la Península Ibérica se encuentra en casi todas las provincias, aunque escasea en el norte, donde es sustituido por Fraxinus excelsior. De clima mediterráneo, vive desde el nivel del mar hasta los $1600 \mathrm{~m}$ de altitud. Vive casi siempre en riberas, preferentemente silíceas, y sotos. A veces también en bosques frescos y umbrosos. Sobre suelos fértiles, sueltos, profundos y sin sequía estival, pues es muy exigente en cuanto a humedad del suelo. Tolera bien tanto el frío como el calor, pero no soporta las heladas.

Utilización - Las fresnedas han sido utilizadas históricamente como dehesas. Pueden utilizarse en revegetación de zonas de ribera y fondos de valle. 
Altura - Es un árbol de crecimiento relativamente rápido pudiendo alcanzar entre 25 y $30 \mathrm{~m}$ de altura.

Inflorescencia - Las flores son muy precoces y se disponen formando ramilletes opuestos; carecen de sépalos y pétalos teniendo sólo 2 ó 3 estambres y el pistilo.

Floración - Florece en el mes de marzo.

Fruto - El fruto es aplastado y en forma de lengüeta con un ala que facilita su diseminación; mide de 2 a $4 \mathrm{~cm}$ y tiene un color amarillento; se trata de un aquenio alado o sámara. Los frutos se encuentran donde empieza la ramita del último año.

Fructificación - Los frutos maduran en el mes de septiembre.

Sistema radical - Tiene un sistema radical potente, profundo y es de crecimiento rápido.

\section{Parámetros medios}

\begin{tabular}{|c|c|c|c|c|c|c|c|}
\hline \multirow{2}{*}{ Especie } & \multicolumn{9}{|c|}{ RAÍCES } & \multicolumn{2}{c|}{ TRONCO } \\
\cline { 2 - 7 } & $\begin{array}{c}\text { Cohesión } \\
\mathrm{cR}\left(\mathrm{kN} / \mathrm{m}^{2}\right)\end{array}$ & $\begin{array}{c}\text { Resist. } \\
\text { Tración } \\
\mathrm{T}\left(\mathrm{N} / \mathrm{mm}^{2}\right)\end{array}$ & $\begin{array}{c}\text { Diámetro } \\
\text { D.r }(\mathrm{mm})\end{array}$ & $\begin{array}{c}\text { Densidad } \\
\text { d.r }[\mathrm{Ar} / \mathrm{As}]\end{array}$ & $\begin{array}{c}\text { Profundidad } \\
\mathrm{p} . \mathrm{r}(\mathrm{m})\end{array}$ & $\begin{array}{c}\text { Diámetro } \\
\text { D.t }(\mathrm{cm})\end{array}$ & $\begin{array}{c}\text { Densidad } \\
\gamma \mathrm{v}\left(\mathrm{kg} / \mathrm{m}^{3}\right)\end{array}$ \\
$\begin{array}{c}\text { Altura } \\
\mathrm{h} . \mathrm{t}(\mathrm{m})\end{array}$ & $\begin{array}{c}\text { Fac. } \\
\text { forma } \\
(\mathrm{f} . \mathrm{f})\end{array}$ \\
\hline $\begin{array}{c}\text { Fraxinus } \\
\text { angustifolia }\end{array}$ & 2,64 & 27 & 30 & 0,3 & 1,5 & 25 & 680 \\
\hline
\end{tabular}

\subsubsection{1.- Fraxinus excelsior (Fresno)}

$\begin{array}{ll}\text { REINO } & \text { Plantae } \\ \text { DIVISIÓN } & \text { Magnoliophyta } \\ \text { CLASE } & \text { Magnoliopsida } \\ \text { ORDEN } & \text { Lamiales } \\ \text { FAMILIA } & \text { Oleaceae } \\ \text { GENERO } & \text { Fraxinus } \\ \text { ESPECIE } & \text { F. excelsior }\end{array}$

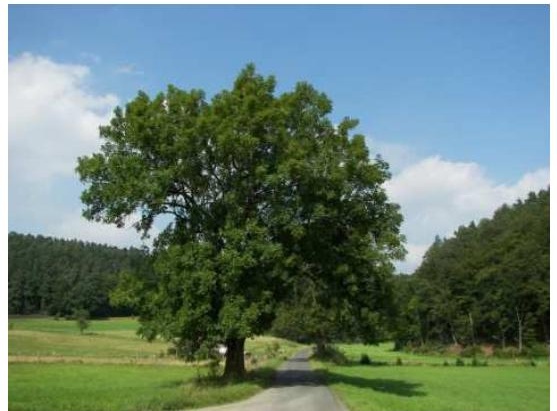


Hábitat - El fresno común está presente en Europa y Asia menor, solo está ausente en la región mediterránea y el noreste de Escandinavia. En la Península Ibérica solo está presente en la mitad norte. Crece en bosques mixtos, orillas de ríos, sebes, en suelos frescos de mediana a elevada humedad, desde el nivel del mar hasta los $1400 \mathrm{~m}$ de altitud. Prefiere los suelos profundos y ricos en bases. Soporta la humedad, incluso el agua estancada y resiste grandes fríos, pero no tolera los climas secos y calurosos.

Utilización - Es una especie de gran crecimiento y valor económico y ecológico, especialmente indicada por su valor múltiple en la repoblación forestal en terrenos frescos de montaña.

Altura - Árbol de entre 20 y $30 \mathrm{~m}$ de altura.

Inflorescencia - Las flores, que carecen de cáliz y corola, salen antes que las hojas y aparecen en racimos axilares cortos sobre ramas del año anterior. Las flores femeninas son más largas que las masculinas, y son de un color púrpura oscuro. Pueden ser unisexuales o hermafroditas, y en un mismo árbol puede variar de un año a otro.

Floración - Florece entre febrero y marzo.

Fruto - Se trata de una sámara oblongo-lanceolada de unos 3,5 cm, glabra, con el ápice oblicuamente truncado o escotado, que tiene en su interior una semilla oblonga.

Fructificación - El fruto madura en septiembre.

Sistema radical - Posee un sistema radical profundo, potente, bien desarrollado y extendido.

\section{Parámetros medios}

\begin{tabular}{|c|c|c|c|c|c|c|c|c|c|}
\hline \multirow{2}{*}{ Especie } & \multicolumn{5}{|c|}{ RAÍCES } & \multicolumn{4}{|c|}{ TRONCO } \\
\hline & $\begin{array}{l}\text { Cohesión } \\
\mathrm{cR}\left(\mathrm{kN} / \mathrm{m}^{2}\right)\end{array}$ & $\begin{array}{c}\text { Resist. } \\
\text { Tracción } \\
\mathrm{T}\left(\mathrm{N} / \mathrm{mm}^{2}\right)\end{array}$ & $\begin{array}{l}\text { Diámetro } \\
\text { D.r }(\mathrm{mm})\end{array}$ & $\begin{array}{l}\text { Densidad } \\
\text { d.r }[\mathrm{Ar} / \mathrm{As}]\end{array}$ & $\begin{array}{l}\text { Profundidad } \\
\text { p.r (m) }\end{array}$ & $\begin{array}{l}\text { Diámetro } \\
\text { D.t }(\mathrm{cm})\end{array}$ & $\begin{array}{c}\text { Densidad } \\
\gamma \mathbf{v}\left(\mathrm{kg} / \mathrm{m}^{3}\right)\end{array}$ & $\begin{array}{l}\text { Altura } \\
\text { h.t (m) }\end{array}$ & $\begin{array}{c}\text { Fac. } \\
\text { forma } \\
\text { (f.f) }\end{array}$ \\
\hline $\begin{array}{l}\text { Fraxinus } \\
\text { excelsior }\end{array}$ & 2,64 & 28 & 30 & 0,3 & 1,5 & 26 & 680 & 25 & 0,65 \\
\hline
\end{tabular}




\subsubsection{2.- Ilex aquifolium (Acebo)}

$\begin{array}{ll}\text { REINO } & \text { Plantae } \\ \text { DIVISIÓN } & \text { Magnoliophyta } \\ \text { CLASE } & \text { Magnoliopsida } \\ \text { ORDEN } & \text { Aquifoliales } \\ \text { FAMILIA } & \text { Aquifoliaceae } \\ \text { GENERO } & \text { Ilex } \\ \text { ESPECIE } & \text { Ilex aquifolium }\end{array}$

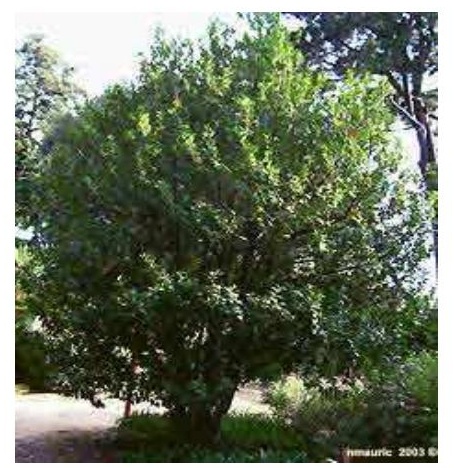

Hábitat - Como requiere siempre de ambientes húmedos y umbríos, se cría en el interior de los bosques o en las laderas de umbría, tajos y hoces de montaña. Asciende hasta poco más de los 1600 metros y siempre en suelos frescos y sueltos, preferentemente silíceos. Se distribuye por toda la región mediterránea; en las Islas Baleares se encuentra únicamente en Mallorca y en la península es una especie abundante en la mitad norte, alcanzando también las montañas del sur, Montes de Toledo, Cáceres, etc.

Utilización - Es una especie de uso ornamental principalmente y es muy apreciada también en ebanistería al tener una madera muy dura. El acebo tiene desde antiguo un gran uso en jardinería por su especial belleza en las hojas y frutos, además de ser un excelente seto ya que tolera bien la poda, por lo que existen gran cantidad de variedades o "cultivares".

Altura - Alcanza hasta los 8-10 m de altura.

Inflorescencia - Es planta dioica y en los ejemplares masculinos, las flores aparecen en grupos axilares de color amarillento. En los femeninos, aisladas o en grupos de tres y son pequeñas y de color blanco o levemente rosado, y se componen de cuatro pétalos y cuatro sépalos parcialmente fusionados en la base.

Floración - La floración se produce desde abril a junio o julio.

Fruto - Producen los ejemplares femeninos un fruto carnoso (drupa), de un color rojo brillante o amarillo vivo. Contiene en su interior 4 ó 5 "huesecillos" (semillas), que no germinan hasta el segundo año, en caso de ser ingerida por algún ave como el mirlo. 
Fructificación - La maduración del fruto se produce en el mes de octubre y se mantiene durante mucho tiempo en el árbol.

Sistema radical - Posee un sistema radical más bien profundo pero extendido. Brota bien de cepa.

\section{Parámetros medios}

\begin{tabular}{|c|c|c|c|c|c|c|c|c|c|}
\hline \multirow[b]{2}{*}{ Especie } & \multicolumn{5}{|c|}{ RAÍCES } & \multicolumn{4}{|c|}{ TRONCO } \\
\hline & $\begin{array}{l}\text { Cohesión } \\
\mathrm{cR}\left(\mathrm{kN} / \mathrm{m}^{2}\right)\end{array}$ & $\begin{array}{c}\text { Resist. } \\
\text { Tracción } \\
\mathrm{T}\left(\mathrm{N} / \mathrm{mm}^{2}\right)\end{array}$ & $\begin{array}{l}\text { Diámetro } \\
\text { D.r (mm) }\end{array}$ & $\begin{array}{c}\text { Densidad } \\
\text { d.r [Ar/As] }\end{array}$ & $\begin{array}{l}\text { Profundidad } \\
\text { p.r }(\mathrm{m})\end{array}$ & $\begin{array}{l}\text { Diámetro } \\
\text { D.t }(\mathrm{cm})\end{array}$ & $\begin{array}{c}\text { Densidad } \\
\gamma \mathrm{v}\left(\mathrm{kg} / \mathrm{m}^{3}\right)\end{array}$ & $\begin{array}{l}\text { Altura } \\
\text { h.t (m) }\end{array}$ & $\begin{array}{l}\text { Fac. } \\
\text { forma } \\
\text { (f.f) }\end{array}$ \\
\hline $\begin{array}{c}\text { Ilex } \\
\text { aquifolium }\end{array}$ & 2,64 & 40 & 21,9 & 0,3 & 2,6 & 20 & 870 & 10 & 0,65 \\
\hline
\end{tabular}

\subsubsection{3.- Juglans regia (Nogal)}

$\begin{array}{ll}\text { REINO } & \text { Plantae } \\ \text { DIVISIÓN } & \text { Magnoliophyta } \\ \text { CLASE } & \text { Magnoliopsida } \\ \text { ORDEN } & \text { Fagales } \\ \text { FAMILIA } & \text { Juglandaceae } \\ \text { GENERO } & \text { Juglans } \\ \text { ESPECIE } & \text { Juglans regia }\end{array}$

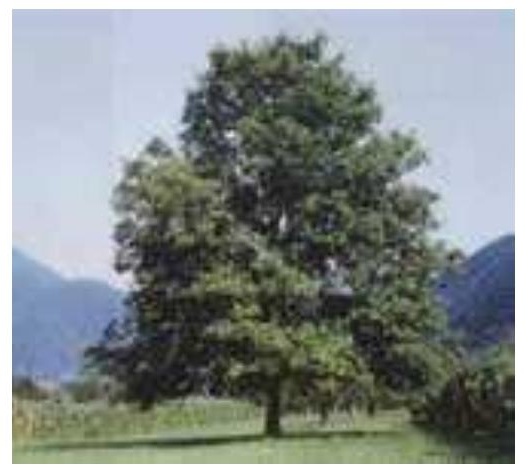

Hábitat - El nogal es una especie que requiere suelos ricos y profundos, ya sean calizos o silíceos. Especie termófila, sufre en zonas de altitudes elevadas y heladas tardías. Crece en altitudes comprendidas entre los 400 y $800 \mathrm{~m}$ de altitud. Es de temperamento de media sombra. Necesita protección cuando es pequeño, sobre todo del viento y las heladas tardías; pero los ejemplares adultos requieren bastante luz para desarrollarse y fructificar abundantemente. El nogal está ampliamente distribuido en Europa como árbol, frutal especialmente en vegas y valles de la región mediterránea. En la península se encuentra ampliamente distribuido tanto en el norte, centro y sur. 
Utilización - Sus semillas son un importante artículo alimenticio; se consumen frescas o se usan para cocinar y condimentar. De las semillas se extrae un delicado aceite comestible, de aplicación también en pinturas y jabones. Las hojas son estimulantes y astringentes y las infusiones se empleaban antiguamente en el tratamiento de afecciones cutáneas. El fruto y la cáscara producen un colorante pardo usado para teñir los suelos. Su madera es homogénea, veteada, de color oscuro y de gran valor en ebanistería y fabricación de muebles, también se emplea para tornear y para tallar chapas y culatas de armas.

Altura - Puede alcanzar alturas de hasta 30-35 m de altura y superar diámetros de tronco de $2 \mathrm{~m}$.

Inflorescencia - Flores masculinas dispuestas en amentos largos, de 6 a $8 \mathrm{~cm}$. casi siempre solitarios, de color verde parduzco e insertas en la parte superior de las ramillas nacidas el año anterior, que en la floración están desprovistas de hojas. Las flores femeninas son solitarias o agrupadas en un número de una a cinco, en espigas terminales encima de los ramillos del año, y son llevadas por un pedúnculo corto y grueso. El receptáculo floral lleva un pequeño perigonio con tres o cuatro dientecitos; ovario ínfero adherente, con un óvulo, terminado por dos estilos muy cortos.

Floración - La floración se produce entre abril y mayo.

Fruto - El fruto es una drupa subglobosa, de unos 4-5 cm, con la piel lisa, provista de glándulas blanquecinas, y muy poca carne. La cubierta externa termina secándose y tomando color negro. En su interior se encuentra el hueso, formado por 2 valvas leñosas de superficie rugosa que está dividido interiormente por dos o cuatro falsos tabiques. Contiene una sola semilla cerebriforme, hendida en cuatro lóbulos. El hueso de la drupa de nogal se conoce popularmente como nuez.

Fructificación - La maduración del fruto se produce entre septiembre y octubre.

Sistema radical - Sistema radicular muy desarrollado, formado por una raíz principal pivotante y un sistema secundario de raíces someras y robustas. Raíces notablemente extendidas, tanto en sentido horizontal como vertical.

\section{Parámetros medios}




\begin{tabular}{|c|c|c|c|c|c|c|c|c|c|}
\hline \multirow{2}{*}{ Especie } & \multicolumn{5}{|c|}{ RAÍCES } & \multicolumn{4}{|c|}{ TRONCO } \\
\hline & $\begin{array}{l}\text { Cohesión } \\
\mathrm{cR}\left(\mathrm{kN} / \mathrm{m}^{2)}\right.\end{array}$ & $\begin{array}{c}\text { Resist. } \\
\text { Tracción } \\
\mathrm{T}\left(\mathrm{N} / \mathrm{mm}^{2}\right)\end{array}$ & $\begin{array}{l}\text { Diámetro } \\
\text { D.r }(\mathrm{mm})\end{array}$ & $\begin{array}{l}\text { Densidad } \\
\text { d.r [Ar/As] }\end{array}$ & $\begin{array}{l}\text { Profundidad } \\
\text { p.r }(\mathrm{m})\end{array}$ & $\begin{array}{l}\text { Diámetro } \\
\text { D.t }(\mathrm{cm})\end{array}$ & $\begin{array}{c}\text { Densidad } \\
\gamma \vee\left(\mathrm{kg} / \mathrm{m}^{3}\right)\end{array}$ & $\begin{array}{l}\text { Altura } \\
\text { h.t (m) }\end{array}$ & $\begin{array}{l}\text { Fac. } \\
\text { forma } \\
\text { (f.f) }\end{array}$ \\
\hline Juglans regia & 4,0 & 40 & 25 & 0,3 & 3,0 & 30 & 720 & 25 & 0,65 \\
\hline
\end{tabular}

\subsubsection{4.- Malus sylvestris (Manzano)}

$\begin{array}{ll}\text { REINO } & \text { Plantae } \\ \text { DIVISIÓN } & \text { Magnoliophyta } \\ \text { CLASE } & \text { Magnoliopsida } \\ \text { ORDEN } & \text { Rosales } \\ \text { FAMILIA } & \text { Rosaceae } \\ \text { GENERO } & \text { Malus } \\ \text { ESPECIE } & \text { Malus sylvestris }\end{array}$

Hábitat - El manzano silvestre es una especie que puede crecer en condiciones ambientales muy diversas. En general es propio de regiones forestales con suelos frescos y ricos, silíceos, arcillosos y más raramente calizos. Crece especialmente en suelos de tipo ranker, pardos forestales y rendzinas, donde el ph puede ser muy variable. El manzano silvestre se distribuye por toda Europa y Asia occidental excepto en el norte de Escandinavia y Rusia. En España es frecuente en montañas de la mitad septentrional, desde Galicia a Cataluña y se enrarece en la mitad sur, en donde se acantona en montañas elevadas. En nuestra región abunda, esparcido, en las montañas y páramos silíceos septentrionales (León, Palencia, Burgos y Zamora) y por las sierras de la Demanda, Urbión y estribaciones, como también en el Sistema Central en claros de robledales y de pinares, sobre todo en las vertientes de umbría.

Utilización - El manzano silvestre presenta una madera dura muy apreciada en trabajos de ebanistería y artesanía. Es una madera que se utiliza para la fabricación de muchos utensilios como palos de golf, telares, lanzaderas y mangos de herramientas de carpintería como cepillos, garlopas y empuñaduras de martillos, sierras y muy especialmente de hachas. Es buen combustible con elevado poder calorífico. 
En la actualidad uno de los productos más destacados que se obtienen de este árbol es el licor de maíllas o pacharán de maíllas que se obtiene a partir de la maceración de los frutos en orujo o anís. También se utilizan para la elaboración de sidra.

Altura - El manzano silvestre es un arbolillo que alcanza alturas entre 4 y $12 \mathrm{~m}$.

Inflorescencia - Las inflorescencias, en cimas poco nutridas, contienen de 4 a 8 flores regulares, blancas, manchadas de rosa, de 3 a $4 \mathrm{~cm}$ de diámetro con estambres de antera amarilla y en número de 15 a 50. Los pedúnculos miden de 1 a $3 \mathrm{~cm}$.

Floración - La floración se produce entre abril y mayo.

Fruto - El fruto se conoce con el nombre de "maílla", "maguilla", es una pequeña manzana amarillenta o, en parte rojiza, de 2,5 a $4 \mathrm{~cm}$ de diámetro de sabor agrio.

Fructificación - La maduración del fruto se produce entre septiembre y diciembre.

Sistema radical - Posee un sistema radical penetrante y poco ramificado brotando poco de cepa.

\section{Parámetros medios}

\begin{tabular}{|c|c|c|c|c|c|c|c|c|c|}
\hline \multirow{2}{*}{ Especie } & \multicolumn{5}{|c|}{ RAÍCES } & \multicolumn{4}{|c|}{ TRONCO } \\
\hline & $\begin{array}{l}\text { Cohesión } \\
\mathrm{cR}\left(\mathrm{kN} / \mathrm{m}^{2}\right)\end{array}$ & $\begin{array}{c}\text { Resist. } \\
\text { Tracción } \\
\mathrm{T}\left(\mathrm{N} / \mathrm{mm}^{2}\right)\end{array}$ & $\begin{array}{l}\text { Diámetro } \\
\text { D.r (mm) }\end{array}$ & $\begin{array}{l}\text { Densidad } \\
\text { d.r }[\mathrm{Ar} / \mathrm{As}]\end{array}$ & $\begin{array}{l}\text { Profundidad } \\
\text { p.r }(\mathrm{m})\end{array}$ & $\begin{array}{l}\text { Diámetro } \\
\text { D.t }(\mathrm{cm})\end{array}$ & $\begin{array}{c}\text { Densidad } \\
\gamma \mathbf{v}\left(\mathrm{kg} / \mathrm{m}^{3}\right)\end{array}$ & $\begin{array}{l}\text { Altura } \\
\text { h.t (m) }\end{array}$ & $\begin{array}{l}\text { Fac. } \\
\text { forma } \\
\text { (f.f) }\end{array}$ \\
\hline Malus sylvestris & 2,64 & 25 & 21,9 & 0,3 & 0,5 & 30 & 670 & 10 & 0,65 \\
\hline
\end{tabular}




\subsubsection{5.- Pinus uncinata (Pino negro)}

$\begin{array}{ll}\text { REINO } & \text { Plantae } \\ \text { DIVISIÓN } & \text { Pinophyta } \\ \text { CLASE } & \text { Pinopsida } \\ \text { ORDEN } & \text { Pinales } \\ \text { FAMILIA } & \text { Pinaceae } \\ \text { GENERO } & \text { Pinus } \\ \text { ESPECIE } & \text { Pinus uncinata }\end{array}$

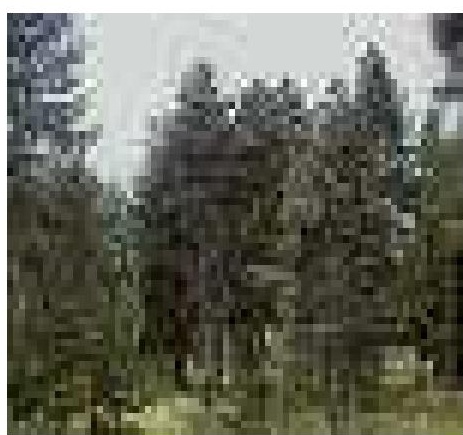

Hábitat - Especie de alta montaña, crece en altitudes elevadas principalmente entre los 1.600 y 2.400 metros y en zonas de mucha precipitación, buena parte de las cuales caen en forma de nieve. Es el árbol que alcanza mayor altitud en la Península Ibérica, colonizando todo tipo de terrenos y substratos, incluso los canchales y grietas de las rocas; soporta muy bien los fríos intensos y prolongados y crece tantos en suelos calizos como silíceos algo húmedos, no aguantando las sequías estivales. Su temperamento es de media sombra, necesitando protección lateral cuando es joven. Se mezcla en su nivel inferior con el pino albar y con abetos y hayas; convive frecuentemente con arándanos (Vaccinium myrtillus), rododendros (Rhododendron ferrugineum), sauce pirenaico (Salix pyrenaica) y otros arbustos del piso subalpino. Asociado a este pino encontramos algunas especies de setas como los boletus especialmente Boletus pinicola.

Utilización - La madera es blanda, poco resinosa, a menudo torcida y nudosa, en general poco estimada. Se utilizaba antiguamente para construir chozos en las majadas. El valor principal de este árbol es el de protector del suelo frente a aludes, avalanchas, etc.

Altura - El pino negro alcanza alturas entre 10 y $20 \mathrm{~m}$.

Inflorescencia - Conos masculinos de 8 a $15 \mathrm{~mm}$, ovoides o subcilíndricos de color amarillo claro o amarillo dorado; escamas con laminilla terminal redondeada y con borde denticulado. 
Floración - Florece de Junio a Julio.

Fruto - El fruto es una piña de 5 a $7 \mathrm{~cm}$ de largo, aovada, de forma muy característica con el vértice de las escamas exteriores ganchudas hacia la base de la piña.

Fructificación - Las piñas maduran al final del segundo verano y se diseminan al tercer año.

Sistema radical - Raíz principal potente poco desarrollada, secundarias gruesas, extendidas y asimétricas, proporcionando gran anclaje.

\section{Parámetros medios}

\begin{tabular}{|c|c|c|c|c|c|c|c|c|c|}
\hline \multirow{2}{*}{ Especie } & \multicolumn{5}{|c|}{ RAÍCES } & \multicolumn{4}{|c|}{ TRONCO } \\
\hline & $\begin{array}{l}\text { Cohesión } \\
\mathrm{cR}\left(\mathrm{kN} / \mathrm{m}^{2)}\right.\end{array}$ & $\begin{array}{c}\text { Resist. } \\
\text { Tracción } \\
\mathrm{T}\left(\mathrm{N} / \mathrm{mm}^{2}\right)\end{array}$ & $\begin{array}{l}\text { Diámetro } \\
\text { D.r (mm) }\end{array}$ & $\begin{array}{l}\text { Densidad } \\
\text { d.r [Ar/As] }\end{array}$ & $\begin{array}{l}\text { Profundidad } \\
\text { p.r }(\mathrm{m})\end{array}$ & $\begin{array}{l}\text { Diámetro } \\
\text { D.t }(\mathrm{cm})\end{array}$ & $\begin{array}{c}\text { Densidad } \\
\gamma \mathbf{v}\left(\mathrm{kg} / \mathrm{m}^{3}\right)\end{array}$ & $\begin{array}{l}\text { Altura } \\
\text { h.t (m) }\end{array}$ & $\begin{array}{l}\text { Fac. } \\
\text { forma } \\
\text { (f.f) }\end{array}$ \\
\hline $\begin{array}{c}\text { Pinus } \\
\text { uncinata }\end{array}$ & 1,4 & 14 & 20 & 0,3 & 2,6 & 25 & 650 & 15 & 0,65 \\
\hline
\end{tabular}




\subsubsection{6.- Pinus nigra (Pino laricio)}

$\begin{array}{ll}\text { REINO } & \text { Plantae } \\ \text { DIVISIÓN } & \text { Pinophyta } \\ \text { CLASE } & \text { Pinopsida } \\ \text { ORDEN } & \text { Pinales } \\ \text { FAMILIA } & \text { Pinaceae } \\ \text { GENERO } & \text { Pinus } \\ \text { ESPECIE } & \text { Pinus nigra }\end{array}$

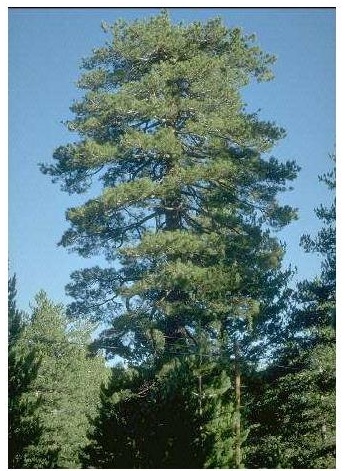

Hábitat - Especie de media montaña, crece en altitudes comprendidas entre 800 y 2000 $\mathrm{m}$ sobre suelos calizos principalmente pero también silíceos mezclado con quejigos y sabinas. Se desarrolla en zonas de precipitaciones poco abundantes; los requerimientos hídricos de esta especie oscilan entre 100 y 500 mm/año, colonizando zonas donde la sequedad impide el desarrollo de otros pinos como Pinus sylvestris. Temperamento de media sombra, al menos en las primeras edades, requiriendo posteriormente una puesta en luz para crecer. En España habita la subespecie Pinus nigra subsp. Salzmanni, que se subdivide en dos variedades: hispanica y pyrenica. En Castilla y León existe de forma natural la variedad hispanica, adaptada a climas más secos y continentales y a situaciones de ladera.

Utilización - La madera de este pino es de las más apreciadas de los pinos españoles, empleada en construcción, carpintería y ebanistería. La resina es muy utilizada en la industria y antiguamente tenía un uso medicinal, cicatrizante y desinfectante de heridas. Tiene también un gran interés faunístico pues estos árboles son un gran soporte para las distintas especies de aves que utilizan la copa para la construcción de sus nidos.

Altura - El pino laricio puede alcanzar una altura de hasta $40 \mathrm{~m}$.

Inflorescencia - Las flores son unisexuales, las masculinas reunidas en conos de $15-20 \mathrm{x}$ 5-7 mm, oblongo-cilíndricas, obtusos, de color amarillo, agrupadas en la base de los brotes anuales. Las femeninas reunidas en conos ovoides de $10-15 \mathrm{~mm}$, rojos, erectos y pedunculados, solitarios o agrupados en verticilos, situados en el ápice de los brotes.

Floración - Florece de Marzo a Mayo. 
Fruto - El fruto es un estróbilo (piña) de 4-6 x 2-4 cm, alargado, ovoide-cónico, color entre castaño amarillo y castaño claro en la madurez, que forma un ángulo muy abierto con la rama que lo sustenta.

Fructificación - Las piñas maduran en el otoño del año siguiente. La madurez sexual se alcanza en 15 a 40 años; las cosechas grandes de la semilla se producen en intervalos de 2 a 5 años.

Sistema radical - La raíz principal está poco desarrollada pero las secundarias están muy desarrolladas.

\section{Parámetros medios}

\begin{tabular}{|c|c|c|c|c|c|c|c|c|c|}
\hline \multirow{2}{*}{ Especie } & \multicolumn{5}{|c|}{ RAÍCES } & \multicolumn{4}{|c|}{ TRONCO } \\
\hline & $\begin{array}{l}\text { Cohesión } \\
\mathrm{cR}\left(\mathrm{kN} / \mathrm{m}^{2}\right)\end{array}$ & $\begin{array}{c}\text { Resist. } \\
\text { Tracción } \\
\mathrm{T}\left(\mathrm{N} / \mathrm{mm}^{2}\right)\end{array}$ & $\begin{array}{l}\text { Diámetro } \\
\text { D.r (mm) }\end{array}$ & $\begin{array}{l}\text { Densidad } \\
\text { d.r [Ar/As] }\end{array}$ & $\begin{array}{l}\text { Profundidad } \\
\text { p.r (m) }\end{array}$ & $\begin{array}{c}\text { Diámetro } \\
\text { D.t }(\mathrm{cm})\end{array}$ & $\begin{array}{c}\text { Densidad } \\
\gamma \mathbf{v}\left(\mathrm{kg} / \mathrm{m}^{3}\right)\end{array}$ & $\begin{array}{l}\text { Altura } \\
\text { h.t (m) }\end{array}$ & $\begin{array}{l}\text { Fac. } \\
\text { forma } \\
\text { (f.f) }\end{array}$ \\
\hline Pinus nigra & 4 & 15 & 40 & 0,3 & 2,6 & 25 & 620 & 30 & 0,65 \\
\hline
\end{tabular}

\subsubsection{7.- Pinus pinaster (Pino negral)}

$\begin{array}{ll}\text { REINO } & \text { Plantae } \\ \text { DIVISIÓN } & \text { Pinophyta } \\ \text { CLASE } & \text { Pinopsida } \\ \text { ORDEN } & \text { Pinales } \\ \text { FAMILIA } & \text { Pinaceae } \\ \text { GENERO } & \text { Pinus } \\ \text { ESPECIE } & \text { Pinus pinaster }\end{array}$

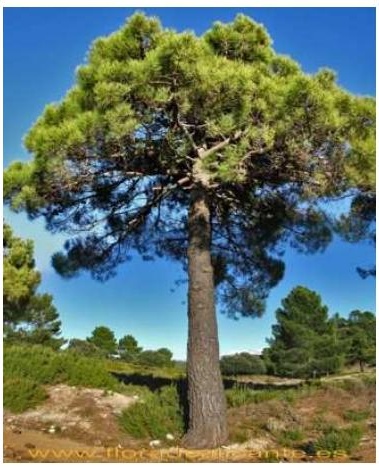

Hábitat - Este pino crece desde el nivel del mar hasta los $1500 \mathrm{~m}$ de altitud, principalmente sobre suelos desprovistos de cal, prefiriendo los suelos sueltos y arenosos pero soporta la caliza (dolomías cristalinas); Es una especie heliófila y resistente a la sequía (necesita una precipitación media anual de $300 \mathrm{~mm}$ ) y las heladas aunque no tanto como otros pinos, necesitando una temperatura media, en e invierno, entre 0 y $12 \stackrel{\circ}{\circ}$, mientras que en verano la 
temperatura debe oscilar entre 15 y $26 \stackrel{\circ}{\circ}$. Se asocia frecuentemente a jaras y brezos. Habita en la mitad occidental de la región mediterránea y su contorno. Falta en las Islas Baleares y se encuentra en casi toda la Península, aunque no es natural ni en Galicia ni en la mayor parte de la zona norte.

Utilización - Esta conífera se ha aprovechado, desde siempre por su madera, leña y la resina. Entre los muchos usos de la madera de Pinus pinaster está la fabricación de cajas, pasta para papel, traviesas para vías férreas, postes telefónicos y de luz, paneles de madera, muebles, parqués, artesanado, revestimientos de paredes, contrachapeado, también es utilizada en el sector de la construcción para enconfrados etc. Los productos fabricados a partir de la resina son muchos. La miera se lleva en toneles a las fábricas donde se separa en dos componentes principales: el aguarrás (trementina) y la colofonia. El aguarrás es objeto de aprovechamiento en la industria de las pinturas y barnices mientras la colofonia lo es en perfumería, adhesivos, esparadrapos, tintas de imprenta, etc. En la actualidad se emplean los barrascos o mieras bastas de final de temporada en la elaboración del asfalto antideslizante de gran aplicación. Todos estos productos son naturales y renovables, a diferencia de la industria del petróleo. De sus hojas se extrae un aceite esencial balsámico utilizado en medicina y perfumería. Pinus pinaster también tiene un gran interés ecológico y paisajístico, utilizado para la fijación de dunas y suelos arenosos, así como de forma ornamental en parques y jardines.

Altura - Pinus pinaster es un árbol, que alcanza una altura de 20 a 30 metros, aunque en condiciones excepcionales se han medido pinos que rondan los 40 metros ( la talla media no suele pasar los 35 metros).

Inflorescencia - Es una especie monoica: cada pie produce conos masculinos y femeninos separados. Los masculinos aparecen en grupos hacia el extremo de las ramas, son amarillos y producen una gran cantidad de polen, cayendo cuando se ha dispersado éste (ayudado por el viento). Los conos femeninos, de color violáceo, se encuentran casi en el extremo de las ramas más altas.

Floración - Florece a partir de finales de marzo hasta principios de mayo.

Fruto - Las piñas son aovado-cónicas, revueltas, de 8 a $22 \mathrm{~cm}$., casi sentadas sobre las ramas, con escamas provistas en el dorso de un escudete piramidal rómbico, muy prominente y punzante; cada una lleva dos piñones de 6 a $8 \mathrm{~mm}$, largamente alados y de color pardo- 
cenizos. Yemas ovoides, fusiformes, con escamas revueltas, algo blanquecinas, no resinosas. Escudetes piramidales con ombligo punzante, de color marrón rojizo reluciente o mate, bastante cubiertas de resina.

Fructificación - las piñas maduran a finales del verano del año siguiente. La caída del piñón se da en la primavera o verano del tercer año.

Sistema radical - El Sistema radical está bastante desarrollado y profundo con raíz principal penetrante, y secundarias muy desarrolladas y horizontales.

\section{Parámetros medios}

\begin{tabular}{|c|c|c|c|c|c|c|c|c|c|}
\hline \multirow{2}{*}{ Especie } & \multicolumn{5}{|c|}{ RAÍCES } & \multicolumn{4}{|c|}{ TRONCO } \\
\hline & $\begin{array}{l}\text { Cohesión } \\
\mathrm{cR}\left(\mathrm{kN} / \mathrm{m}^{2}\right)\end{array}$ & $\begin{array}{c}\text { Resist. } \\
\text { Tracción } \\
\mathrm{T}\left(\mathrm{N} / \mathrm{mm}^{2}\right)\end{array}$ & $\begin{array}{l}\text { Diámetro } \\
\text { D.r (mm) }\end{array}$ & $\begin{array}{c}\text { Densidad } \\
\text { d.r [Ar/As] }\end{array}$ & $\begin{array}{l}\text { Profundidad } \\
\text { p.r }(\mathrm{m})\end{array}$ & $\begin{array}{l}\text { Diámetro } \\
\text { D.t }(\mathrm{cm})\end{array}$ & $\begin{array}{c}\text { Densidad } \\
\gamma \mathrm{v}\left(\mathrm{kg} / \mathrm{m}^{3}\right)\end{array}$ & $\begin{array}{l}\text { Altura } \\
\text { h.t (m) }\end{array}$ & $\begin{array}{l}\text { Fac. } \\
\text { forma } \\
\text { (f.f) }\end{array}$ \\
\hline $\begin{array}{c}\text { Pinus } \\
\text { pinaster }\end{array}$ & 4 & 15 & 30 & 0,3 & 2,6 & 25 & 540 & 30 & 0,65 \\
\hline
\end{tabular}

\subsubsection{8.- Pinus pinea (Pino piñonero)}

$\begin{array}{ll}\text { REINO } & \text { Plantae } \\ \text { DIVISIÓN } & \text { Pinophyta } \\ \text { CLASE } & \text { Pinopsida } \\ \text { ORDEN } & \text { Pinales } \\ \text { FAMILIA } & \text { Pinaceae } \\ \text { GENERO } & \text { Pinus } \\ \text { ESPECIE } & \text { Pinus pinea }\end{array}$

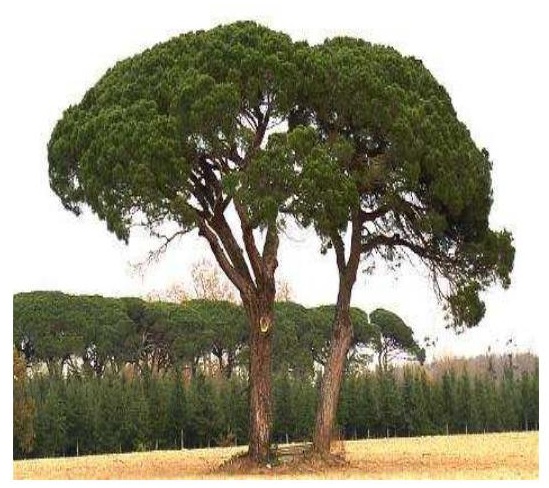

Hábitat - Pinus pinea, también llamado pino piñonero se distribuye de forma natural por toda la franja mediterránea, siendo en la Península Ibérica más habitual en la zona centro y sur. Se desarrolla normalmente en un rango de alturas que van desde el nivel del mar hasta los 1000 ó $1200 \mathrm{~m}$, formando bosques monoespecíficos preferentemente en suelos silíceos principalmente. Es una especie heliófila y requiere luz para desarrollarse cuando es joven, resiste bien la sequía estival aunque requiere una precipitación media anual superior a 250 $\mathrm{mm}$; el rango de precipitaciones medio se sitúa entre 400 y $800 \mathrm{~mm}$. Soporta temperaturas mínimas de hasta -12 o -13드 y máximas de hasta 40․ En Castilla y León, se distribuye sobre 
todo por las Ilanuras castellanas de Valladolid, Segovia, Ávila y Zamora, así como en la ribera del Duero por Berlanga de Duero (Soria) y Aranda. También en zonas de Zamora, Ávila, Segovia y Valladolid, siendo en ésta última donde se encuentra la mayor extensión de pino piñonero de la región.

Utilización - El aprovechamiento principal de esta especie es el piñón, de gran valor económico para las zonas donde se produce. La madera del pino piñonero es ligera y flexible. Se la puede utilizar en carpintería y en estructuras, en particular, en la construcción marítima. También se puede utilizar ésta para hacer carbón vegetal; igualmente se utiliza la madera de este pino para la fabricación de pasta de papel o para obtener resina. La corteza en la actualidad es muy apreciada como sustrato en viveros y jardinería previa trituración, debido a su peso ligero.

Altura-Pinus pinea es un árbol que alcanza alturas de hasta $35 \mathrm{~m}$.

Inflorescencia - Flores masculinas en espigas alargadas, oblongo-cilíndricas.

Floración - Florece a partir de marzo a mayo.

Fruto - Las piñas son grandes ( 8 a $14 \mathrm{~cm}$ de largo por 7 a $10 \mathrm{~cm}$ de ancho), aovadas o globosas, solitarias o formando grupos de 2-3 piñas; son de color pardo rojizo y lustrosas. Poseen escamas ensanchadas hacia el ápice, con escudete ancho, romboidal, algo prominente, de color grisáceo en el centro; cada una lleva dos grandes piñones de 15 a $20 \mathrm{~mm}$ de largo, aovado-oblongos, aplanados en su cara inferior, de color pardo-oscuro o negruzcos, con una ala ancha muy corta que se desprende con mucha facilidad.

Fructificación - Las piñas maduran al tercer año dando unos piñones cubiertos de una dura corteza, de $1 \mathrm{~cm}$ de longitud, carnosos y sabrosos, pudiendo haber piñas en su primer año de maduración junto con otras listas para ser recogidas en la copa de un mismo pino piñonero.

Sistema radical - Raíz principal potente y gruesa, penetrante que aborta pronto y secundarias inclinadas que, en ocasiones, llegan a penetrar mucho.

\section{Parámetros medios}




\begin{tabular}{|c|c|c|c|c|c|c|c|c|c|}
\hline \multirow{2}{*}{ Especie } & \multicolumn{5}{|c|}{ RAÍCES } & \multicolumn{4}{|c|}{ TRONCO } \\
\hline & $\begin{array}{c}\text { Cohesión } \\
\mathrm{cR}\left(\mathrm{kN} / \mathrm{m}^{2}\right)\end{array}$ & $\begin{array}{l}\text { Resist. } \\
\text { Tracción } \\
\mathrm{T}\left(\mathrm{N} / \mathrm{mm}^{2}\right)\end{array}$ & $\begin{array}{l}\text { Diámetro } \\
\text { D.r (mm) }\end{array}$ & $\begin{array}{l}\text { Densidad } \\
\text { d.r }[\mathrm{Ar} / \mathrm{As}]\end{array}$ & $\begin{array}{l}\text { Profundidad } \\
\text { p.r (m) }\end{array}$ & $\begin{array}{l}\text { Diámetro } \\
\text { D.t }(\mathrm{cm})\end{array}$ & $\begin{array}{c}\text { Densidad } \\
\gamma \mathrm{v}\left(\mathrm{kg} / \mathrm{m}^{3}\right)\end{array}$ & $\begin{array}{l}\text { Altura } \\
\text { h.t (m) }\end{array}$ & $\begin{array}{l}\text { Fac. } \\
\text { forma } \\
\text { (f.f) }\end{array}$ \\
\hline Pinus pinea & 8,24 & 15 & 30 & 0,3 & 2,6 & 30 & 740 & 30 & 0,65 \\
\hline
\end{tabular}

\subsubsection{9.- Pinus radiata (Pino de Monterrey)}

$\begin{array}{ll}\text { REINO } & \text { Plantae } \\ \text { DIVISIÓN } & \text { Pinophyta } \\ \text { CLASE } & \text { Pinopsida } \\ \text { ORDEN } & \text { Pinales } \\ \text { FAMILIA } & \text { Pinaceae } \\ \text { GENERO } & \text { Pinus } \\ \text { ESPECIE } & \text { Pinus radiata }\end{array}$

Hábitat - Pinus radiata es una especie originaria de California. Se desarrolla mejor en suelos silíceos y muy profundos. Prefiere climas templados o cálidos, puesto que no soporta las temperaturas muy bajas ni las heladas, y necesita bastante humedad, aunque tolera algo de sequía estival.

Utilización - Es una especie de gran interés para la industria por la calidad de su madera y su rápido crecimiento, que hace que su cultivo comience a dar beneficios en pocos años. Su madera se aprovecha para diferentes fines, entre las que destacan la pasta de papel y la fabricación de tableros de partículas. Se cultiva en muchos países para hacer repoblaciones, principalmente por la rapidez de su crecimiento.

Altura - Pinus radiata puede alcanzar alturas de hasta 30-35 m.

Inflorescencia - Flores unisexuales, las masculinas reunidas en conos de $2 \mathrm{~cm}$, color pardo amarillentas, con tinte rosado, muy abundantes, y agrupadas en la base de los brotes anuales. Las femeninas reunidas en conos color púrpura violeta, agrupados por pares o en verticilos de 3-5, situados en el ápice de los brotes. 
Floración - Florece a partir de marzo a mayo.

Fruto - Las piñas tienen entre 7 y $14 \mathrm{~cm}$ de longitud y 5 a $8 \mathrm{~cm}$ de ancho; aparecen en verticilos de 3-5 ó apareadas, subsentadas, muy simétricas, con la apófisis de las escamas externas muy prominentes; el piñón es negruzco, de 5 a 8 mm de longitud.

Fructificación - las piñas se abren en el segundo otoño, aunque a veces permanecen cerradas varios años sin que sufra alteraciones la capacidad germinativa del piñón.

Sistema radical - El sistema radicular de Pinus radiata se caracteriza por unas raíces que pueden extenderse lateralmente hasta distancias de $12 \mathrm{~m}$, entremezclándose e injertándose con las de otros pies.

\section{Parámetros medios}

\begin{tabular}{|c|c|c|c|c|c|c|c|c|c|}
\hline \multirow{2}{*}{ Especie } & \multicolumn{4}{|c|}{ RAÍCES } & \multicolumn{3}{|c|}{ TRONCO } \\
\cline { 2 - 9 } & $\begin{array}{c}\text { Cohesión } \\
\mathrm{cR}\left(\mathrm{kN} / \mathrm{m}^{2}\right)\end{array}$ & $\begin{array}{c}\text { Resist. } \\
\text { Tracción } \\
\mathrm{T}\left(\mathrm{N} / \mathrm{mm}^{2}\right)\end{array}$ & $\begin{array}{c}\text { Diámetro } \\
\text { D.r }(\mathrm{mm})\end{array}$ & $\begin{array}{c}\text { Densidad } \\
\text { d.r }[\mathrm{Ar} / \mathrm{As}]\end{array}$ & $\begin{array}{c}\text { Profundidad } \\
\mathrm{p} . \mathrm{r}(\mathrm{m})\end{array}$ & $\begin{array}{c}\text { Diámetro } \\
\text { D.t }(\mathrm{cm})\end{array}$ & $\begin{array}{c}\text { Densidad } \\
\gamma \mathrm{v}\left(\mathrm{kg} / \mathrm{m}^{3}\right)\end{array}$ & $\begin{array}{c}\text { Altura } \\
\text { h.t }(\mathrm{m})\end{array}$ & $\begin{array}{c}\text { Fac. } \\
\text { forma } \\
(\mathrm{f.f})\end{array}$ \\
\hline $\begin{array}{c}\text { Pinus } \\
\text { radiata }\end{array}$ & 4 & 18 & 30 & 0,3 & 2,6 & 25 & 480 & 30 & 0,65 \\
\hline
\end{tabular}

\subsubsection{0.- Pinus sylvestris (Pino silvestre)}

$\begin{array}{ll}\text { REINO } & \text { Plantae } \\ \text { DIVISIÓN } & \text { Pinophyta } \\ \text { CLASE } & \text { Pinopsida } \\ \text { ORDEN } & \text { Pinales } \\ \text { FAMILIA } & \text { Pinaceae } \\ \text { GENERO } & \text { Pinus } \\ \text { ESPECIE } & \text { P. sylvestris }\end{array}$

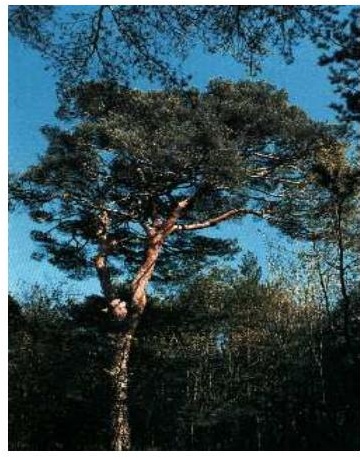

Hábitat - El pino silvestre o pino albar es un árbol muy común en el hemisferio norte, formando bosques en Eurasia, desde Siberia hasta la Península Ibérica, donde se encuentran sus poblaciones más meridionales. En el norte de su distribución se expande desde el nivel del mar hasta los $1.000 \mathrm{~m}$, mientras que en el sur se desarrolla en montañas en altitudes 
comprendidas entre los 800 y los $2.400 \mathrm{~m}$. Lo podemos encontrar cultivado En Nueva Zelanda o en algunas zonas de Norteamérica, donde está considerada una especie invasora.

Es indiferente al sustrato y se adapta a todo tipo de suelo menos a los inundados, pero si a los húmedos. Cuanto más fértiles y profundos sean los suelos, mayor es el desarrollo. Se trata de una especie pionera que ocupa los terrenos de montaña desarbolados, ocupando también los claros de los robledales y hayedos, aunque con el tiempo pueden verse desplazados, ya que no vive mucho tiempo en competencia con especies que lo superen en altura porque es heliófila, es decir, que necesita suficiente luz. No tolera la contaminación. Es una especie muy resistente, tanto a la sequía como a los inviernos muy fríos.

Utilización - Se utiliza en repoblaciones. Es bueno para repoblar en suelos ácidos, sueltos, en brezales y humedales, pero no en suelos mal drenados o de influencia costera. Sirve de protección, no solamente contra la erosión, sino también contra los aludes de nieve y piedras.

Altura - Árbol de hasta 40 metros de altura.

Inflorescencia - Es monoica. Posee numerosas flores masculinas en espigas de unos 3 $\mathrm{cm}$ de longitud formadas por flores individuales de $1 \mathrm{~cm}$ de largo muy apretadas., que son de color amarillento y producen gran cantidad de polen. Las flores femeninas están dispuestas en conos normalmente en grupos de dos, de menos de $1 \mathrm{~cm}$ de largo por 4-5 $\mathrm{mm}$ de ancho.

Floración - Florece en abril y mayo.

Fruto - Son conos de forma oblonga, "piñas", de $3-6 \mathrm{~cm}$ de longitud, de color pardoamarillento, mates y de escamas poco prominentes. Están reunidos de a 2 a 3 y son caedizos ya que apenas maduran, caen.

Fructificación - la piña madura en el otoño del año siguiente, si bien puede permanecer en el árbol uno o dos años.

Sistema radical - Especie de crecimiento rápido, cuyo sistema radical es muy potente, con una raíz principal, que en suelos profundos y sueltos puede ser larga y gruesa, y con muchas raíces secundarias. En zonas rocosas la raíz principal se atrofia y se desarrollan 
únicamente las secundarias. Asociado a él crecen numerosos hongos de interés como Lactarius deliciosus.

\section{Parámetros medios}

\begin{tabular}{|c|c|c|c|c|c|c|c|c|c|}
\hline \multirow{2}{*}{ Especie } & \multicolumn{5}{|c|}{ RAÍCES } & \multicolumn{4}{|c|}{ TRONCO } \\
\hline & $\begin{array}{l}\text { Cohesión } \\
\mathrm{cR}\left(\mathrm{kN} / \mathrm{m}^{2}\right)\end{array}$ & $\begin{array}{c}\text { Resist. } \\
\text { Tracción } \\
\mathrm{T}\left(\mathrm{N} / \mathrm{mm}^{2}\right)\end{array}$ & $\begin{array}{l}\text { Diámetro } \\
\text { D.r (mm) }\end{array}$ & $\begin{array}{c}\text { Densidad } \\
\text { d.r [Ar/As] }\end{array}$ & $\begin{array}{l}\text { Profundidad } \\
\text { p.r }(\mathrm{m})\end{array}$ & $\begin{array}{l}\text { Diámetro } \\
\text { D.t }(\mathrm{cm})\end{array}$ & $\begin{array}{c}\text { Densidad } \\
\gamma \mathbf{v}\left(\mathrm{kg} / \mathrm{m}^{3}\right)\end{array}$ & $\begin{array}{l}\text { Altura } \\
\text { h.t (m) }\end{array}$ & $\begin{array}{l}\text { Fac. } \\
\text { forma } \\
\text { (f.f) }\end{array}$ \\
\hline $\begin{array}{c}\text { Pinus } \\
\text { sylvestris }\end{array}$ & 1,4 & 16 & 25 & 0,3 & 2,6 & 20 & 550 & 20 & 0,65 \\
\hline
\end{tabular}

\subsubsection{1.- Populus alba (Álamo blanco)}

$\begin{array}{ll}\text { REINO } & \text { Plantae } \\ \text { DIVISIÓN } & \text { Magnoliophyta } \\ \text { CLASE } & \text { Magnoliopsida } \\ \text { ORDEN } & \text { Malpighiales } \\ \text { FAMILIA } & \text { Salicaceae } \\ \text { GENERO } & \text { Populus } \\ \text { ESPECIE } & \text { P.alba }\end{array}$

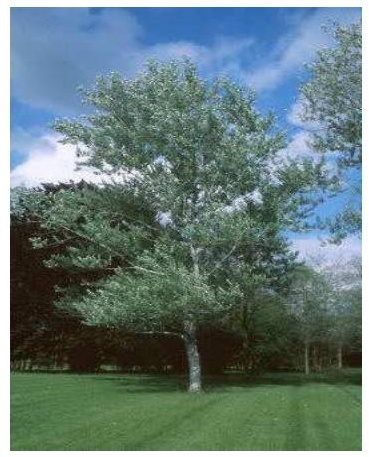

Hábitat - El álamo o chopo blanco se distribuye por el sur y centro de Europa y por el norte de África. En la Península, cultivado o de forma natural, en casi todas las provincias. Su área de distribución es difícil de establecer de forma precisa por haberse cultivado desde antiguo. Se desarrolla en suelos frescos y húmedos, casi siempre en las proximidades de los cursos de agua, formando parte de los sotos y bosques ribereños; asociado a fresnos, sauces y olmos. Soporta bien los climas cálidos y no suele ascender por encima de los $1000 \mathrm{~m}$ de altitud.

Utilización - Es muy utilizado como cortavientos y en caminos cerca del mar. También se utiliza para consolidar ríos y arroyos y bosques de ribera.

Altura - Árbol de hasta $30 \mathrm{~m}$ de altura y $1 \mathrm{~m}$ de diámetro. 
Inflorescencia - Las flores se reúnen en inflorescencias de tipo amento, cilíndricas y colgantes. Los amentos masculinos son lanosos y miden de 3 a $6 \mathrm{~cm}$. Son de color rojizo y poseen unas escamas oblongas, festoneadas o dentadas con el margen ciliado, además de 8 10 estambres. Los amentos femeninos, más alargados y delgados, son de color amarilloverdoso, tienen las flores más separadas y las escamas festoneadas, apenas pelosas.

Floración - Florece de febrero a abril.

Fruto - El fruto es una cápsula de unos $4 \mathrm{~mm}$ oblonga, cónica, lampiña y algo rugosa, verde al principio y después se vuelve parda.

Fructificación - La maduración del fruto se produce en mayo.

Sistema radical - Posee unas raíces fuertes y muy ramificadas, cuyo eje principal profundiza rápidamente, a la vez que crecen raíces secundarias largas y someras que pueden emitir renuevos. Es por esto que es una gran competidora con las especies próximas. Leccinum duriusculum vive formando micorrizas exclusivamente con las raíces del álamo blanco. Puede crecer en un suelo arenoso costero soportando eventuales encharcamientos por agua de mar en su sistema radicular.

\section{Parámetros medios}

\begin{tabular}{|c|c|c|c|c|c|c|c|c|c|}
\hline \multirow{2}{*}{ Especie } & \multicolumn{5}{|c|}{ RAÍCES } & \multicolumn{4}{|c|}{ TRONCO } \\
\hline & $\begin{array}{l}\text { Cohesión } \\
\mathrm{cR}\left(\mathrm{kN} / \mathrm{m}^{2}\right)\end{array}$ & $\begin{array}{c}\text { Resist. } \\
\text { Tracción } \\
\mathrm{T}\left(\mathrm{N} / \mathrm{mm}^{2}\right)\end{array}$ & $\begin{array}{l}\text { Diámetro } \\
\text { D.r (mm) }\end{array}$ & $\begin{array}{c}\text { Densidad } \\
\text { d.r [Ar/As] }\end{array}$ & $\begin{array}{l}\text { Profundidad } \\
\text { p.r }(\mathrm{m})\end{array}$ & $\begin{array}{l}\text { Diámetro } \\
\text { D.t }(\mathrm{cm})\end{array}$ & $\begin{array}{c}\text { Densidad } \\
\gamma \mathrm{v}\left(\mathrm{kg} / \mathrm{m}^{3}\right)\end{array}$ & $\begin{array}{l}\text { Altura } \\
\text { h.t (m) }\end{array}$ & $\begin{array}{l}\text { Fac. } \\
\text { forma } \\
\text { (f.f) }\end{array}$ \\
\hline Populus alba & 2,64 & 6 & 38 & 0,3 & 0,3 & 30 & 450 & 30 & 0,65 \\
\hline
\end{tabular}




\subsubsection{2.- Populus nigra (Chopo)}

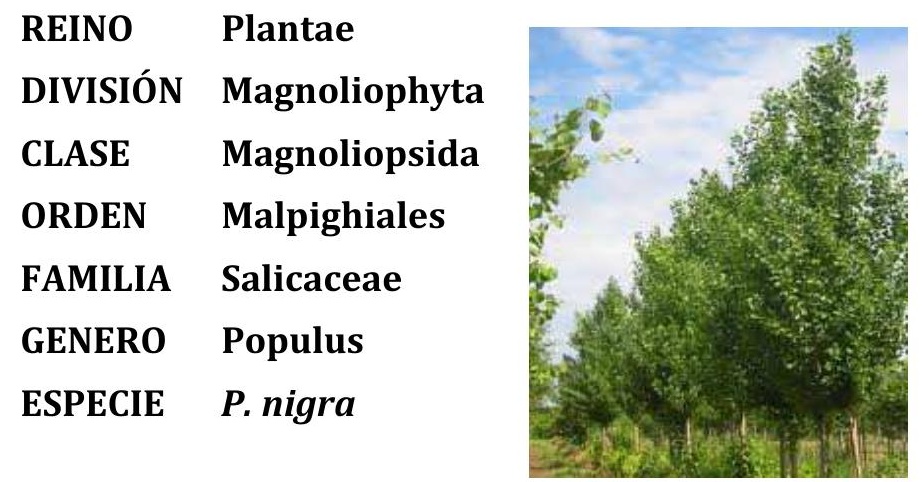

Hábitat - El álamo o chopo negro se extiende por el sur, centro y este de Europa, centro y oeste de Asia y norte de África. En la Península aparece en todas las provincias desde el nivel del mar hasta los $1800 \mathrm{~m}$ de altitud. Forma parte de la vegetación de sotos y riberas de los ríos, asociado con frecuencia a olmos, sauces y fresnos; también en terrenos de suelo profundo y fresco, con capa freática accesible; prefiere los suelos sueltos y ligeros y necesita mucha luz, no tolerando la sombra.

Utilización - Se utiliza como ornamental, en la protección de laderas y como cortavientos. También es utilizado en la restauración de zonas húmedas y riberas debido a su rápido desarrollo y facilidad de multiplicación.

Altura - Árbol de hasta $35 \mathrm{~m}$ de altura.

Inflorescencia - Las flores son muy pequeñas, unisexuales, y se agrupan en amentos colgantes, separados en árboles machos y hembras; los masculinos llevan cada flor con una escama lampiña y 6 a 25 estambres insertos en un disco acopado reflejo; los femeninos llevan la misma escama y un pistilo aovado y lampiño.

Floración - Florece de febrero a marzo.

Fruto - Es una cápsula entre $7-9 \mathrm{~cm}$, elipsoidal, algo granulosa y con cuatro surcos longitudinales. 
Fructificación - La maduración del fruto se produce en abril.

Sistema radical - El sistema radical de esta especie es somero.

\section{Parámetros medios}

\begin{tabular}{|c|c|c|c|c|c|c|c|c|c|}
\hline \multirow[b]{2}{*}{ Especie } & \multicolumn{5}{|c|}{ RAÍCES } & \multicolumn{4}{|c|}{ TRONCO } \\
\hline & $\begin{array}{l}\text { Cohesión } \\
\mathrm{cR}\left(\mathrm{kN} / \mathrm{m}^{2}\right)\end{array}$ & $\begin{array}{c}\text { Resist. } \\
\text { Tracción } \\
\mathrm{T}\left(\mathrm{N} / \mathrm{mm}^{2}\right)\end{array}$ & $\begin{array}{l}\text { Diámetro } \\
\text { D.r (mm) }\end{array}$ & $\begin{array}{c}\text { Densidad } \\
\text { d.r [Ar/As] }\end{array}$ & $\begin{array}{l}\text { Profundidad } \\
\text { p.r }(\mathrm{m})\end{array}$ & $\begin{array}{l}\text { Diámetro } \\
\text { D.t }(\mathrm{cm})\end{array}$ & $\begin{array}{c}\text { Densidad } \\
\gamma \mathbf{v}\left(\mathrm{kg} / \mathrm{m}^{3}\right)\end{array}$ & $\begin{array}{l}\text { Altura } \\
\text { h.t (m) }\end{array}$ & $\begin{array}{l}\text { Fac. } \\
\text { forma } \\
\text { (f.f) }\end{array}$ \\
\hline $\begin{array}{l}\text { Populus } \\
\text { nigra }\end{array}$ & 2,64 & 5 & 38 & 0,3 & 0,3 & 30 & 450 & 30 & 0,65 \\
\hline
\end{tabular}

\subsubsection{3.- Populus trémula (Álamo temblón)}

$\begin{array}{ll}\text { REINO } & \text { Plantae } \\ \text { DIVISIÓN } & \text { Magnoliophyta } \\ \text { CLASE } & \text { Magnoliopsida } \\ \text { ORDEN } & \text { Malpighiales } \\ \text { FAMILIA } & \text { Salicaceae } \\ \text { GENERO } & \text { Populus } \\ \text { ESPECIE } & \text { P.tremula }\end{array}$

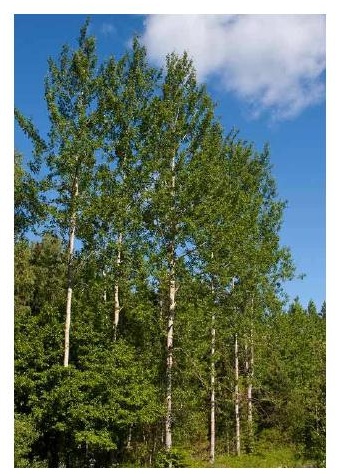

Hábitat - El álamo temblón es una especie heliófila, de crecimiento rápido. Se la considera una especie pionera que ocupa los claros o zonas desarboladas de los bosques sobre suelos húmedos. Se mezcla con espinos cervales (Rhamnus catharticus), rabiacanes (Frangula alnus) y cerezos (Prunus padus). En Castilla y león se encuentra en zonas montañosas en altitudes comprendidas entre los $900 \mathrm{~m}$ y los $1900 \mathrm{~m}$ siendo poco abundante en las llanuras de la meseta. También crece a lo largo de los cursos de los ríos descendiendo hasta altitudes de $300 \mathrm{~m}$. Prefiere los suelos neutros y silíceos y escasea sobre los calizos.

Utilización - Tiene un gran valor ornamental, las hojas antes de la caída toman colores muy diferentes. Su nombre se debe a que sus hojas se mueblen temblorosas al menor movimiento de aire. Es una madera blanca y ligera, empleada en la elaboración de cajas y embalajes, cerillas y palillos de dientes. Se ha empleado también para la fabricación de muebles, construcción de vigas y fabricación de utensilios como escaleras, cribas o cedazos y 
mangos de herramientas. Se utiliza para la elaboración de pasta de papel y la corteza tiene propiedades medicinales.

Altura - Árbol de tronco erguido y cilíndrico que alcanza alturas entre 15 y $25 \mathrm{~m}$.

Inflorescencia - Las flores se reúnen en inflorescencias de tipo amento. Son colgantes y presentan escamas glabras. Los masculinos, más pequeños (de hasta $9 \times 1 \mathrm{~cm}$ ), son sésiles y los femeninos (de hasta $15 \times 08 \mathrm{~cm}$ ), pedunculados.

Fruto - Es una cápsula entre 3-4 mm, ovoidea, abridera en dos valvas, con numerosas semilla cubiertas de largos pelos blanquecinos.

Fructificación - La maduración del fruto se produce de abril a junio; las semillas se dispersan por el viento.

Sistema radical - El sistema de radicular del álamo temblón se caracteriza por ser superficial y extenso dando lugar a numerosos retoños.

\section{Parámetros medios}

\begin{tabular}{|c|c|c|c|c|c|c|c|c|c|}
\hline \multirow{2}{*}{ Especie } & \multicolumn{5}{|c|}{ RAÍCES } & \multicolumn{4}{|c|}{ TRONCO } \\
\hline & $\begin{array}{c}\text { Cohesión } \\
\mathrm{cR}\left(\mathrm{kN} / \mathrm{m}^{2}\right)\end{array}$ & $\begin{array}{c}\text { Resist. } \\
\text { Tracción } \\
\mathrm{T}\left(\mathrm{N} / \mathrm{mm}^{2}\right)\end{array}$ & $\begin{array}{l}\text { Diámetro } \\
\text { D.r (mm) }\end{array}$ & $\begin{array}{c}\text { Densidad } \\
\text { d.r [Ar/As] }\end{array}$ & $\begin{array}{l}\text { Profundidad } \\
\text { p.r }(\mathrm{m})\end{array}$ & $\begin{array}{l}\text { Diámetro } \\
\text { D.t }(\mathrm{cm})\end{array}$ & $\begin{array}{c}\text { Densidad } \\
\gamma \mathbf{V}\left(\mathrm{kg} / \mathrm{m}^{3}\right)\end{array}$ & $\begin{array}{l}\text { Altura } \\
\text { h.t (m) }\end{array}$ & $\begin{array}{l}\text { Fac. } \\
\text { forma } \\
\text { (f.f) }\end{array}$ \\
\hline Populus tremula & 2,64 & 10 & 38 & 0,3 & 0,3 & 30 & 560 & 25 & 0,65 \\
\hline
\end{tabular}

\subsubsection{4.- Prunus avium (Cerezo)}

$\begin{array}{ll}\text { REINO } & \text { Plantae } \\ \text { DIVISIÓN } & \text { Magnoliophyta } \\ \text { CLASE } & \text { Magnoliopsida } \\ \text { ORDEN } & \text { Rosales } \\ \text { FAMILIA } & \text { Rosaceae } \\ \text { GENERO } & \text { Prunus } \\ \text { ESPECIE } & \text { P. avium }\end{array}$

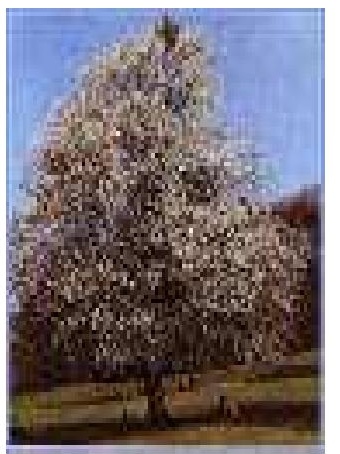


Hábitat - El cerezo se desarrolla en altitudes comprendidas entre 800 y 1500 m, sobre terrenos silíceos, sueltos profundos y frescos. Prefiere climas templados a fríos y no resiste temperaturas por debajo de (-10/-20) grados. El cerezo habita en la mayor parte de Europa, Asia occidental y norte de África. En la península aparece sobre todo en la mitad septentrional, enrareciéndose hacia el sur.

Utilización -La madera es muy apreciada en trabajos de ebanistería y tornería; es buen combustible y con la corteza se obtiene un tinte amarillo. Los frutos o cerezas son comestibles y con ellos también se elaboran licores o bebidas alcohólicas como el kirch y aguardiente de guindas. Además de un gran valor económico, el cerezo tiene también un gran valor ecológico pues sus frutos y el néctar de sus flores sirven de alimento a pájaros e insectos y también ornamental debido a su profusa floración primaveral y a los brillantes colores dorados y púrpuras del follaje en otoño.

Altura - Árbol que puede alcanzar los $25 \mathrm{~m}$ de altura.

Inflorescencia - Las flores son blancas, de entre 2 y $3 \mathrm{~cm}$ de diámetro; muestran cinco sépalos y otros tantos pétalos blancos obovados. Los estambres son múltiples. Las flores forman haces (umbelas), formados por 2 a 6 unidades, en cuya base hay una corona de brácteas.

Floración - Florece de abril a mayo.

Fruto - El fruto es una drupa de color rojo negruzco, más o menos claro, o excepcionalmente amarillo. Es globosa o ligeramente oblonga; Madura tempranamente en el año; de sabor ligeramente ácido, es apreciadísimo fresco y en conserva.

Fructificación - A comienzos del verano.

Sistema radical - No presenta raíz pivotante; La raíz principal es fasciculada y ramificada.

\section{Parámetros medios}

\begin{tabular}{|c|c|c|c|c|c|c|c|c|c|}
\hline \multirow{3}{*}{ Especie } & \multicolumn{4}{|c|}{ RAÍCES } & \multicolumn{3}{c|}{ TRONCO } \\
\cline { 2 - 8 } & $\begin{array}{c}\text { Cohesión } \\
\mathrm{cR}\left(\mathrm{kN} / \mathrm{m}^{2}\right)\end{array}$ & $\begin{array}{c}\text { Resist. } \\
\text { Tracción } \\
\mathrm{T}\left(\mathrm{N} / \mathrm{mm}^{2}\right)\end{array}$ & $\begin{array}{c}\text { Diámetro } \\
\text { D.r }(\mathrm{mm})\end{array}$ & $\begin{array}{c}\text { Densidad } \\
\text { d.r }[\mathrm{Ar} / \mathrm{As}]\end{array}$ & $\begin{array}{c}\text { Profundidad } \\
\text { p.r }(\mathrm{m})\end{array}$ & $\begin{array}{c}\text { Diámetro } \\
\text { D.t }(\mathrm{cm})\end{array}$ & $\begin{array}{c}\text { Densidad } \\
\gamma \mathrm{v}\left(\mathrm{kg} / \mathrm{m}^{3}\right)\end{array}$ & $\begin{array}{c}\text { Altura } \\
\text { h.t }(\mathrm{m})\end{array}$ & $\begin{array}{c}\text { Fac. } \\
\text { forma } \\
(\mathrm{f} . \mathrm{f})\end{array}$ \\
\hline
\end{tabular}




\begin{tabular}{|c|c|c|c|c|c|c|c|c|}
\hline & & & & & & & & \\
\hline Prunus avium & 4 & 45 & 21.9 & 0,3 & 0,5 & 30 & 620 & 25 \\
\hline
\end{tabular}

\subsubsection{5.- Prunus spinosa (Endrino)}

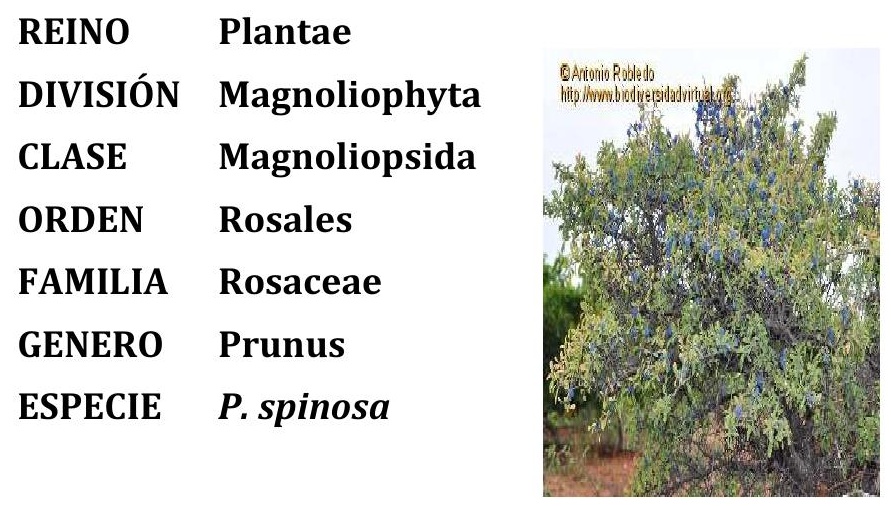

Hábitat - El endrino forma parte del estrato arbustivo en bordes de robledales, encinares, hayedos y bosques de ribera, desde el nivel del mar hasta los $1500 \mathrm{~m}$ de altitud. Especie característica del piso montano prefiere los suelos calizos aunque crece también sobre los silíceos. Especie heliófila, se desarrolla sobre suelos húmedos y poco ácidos con pH entre 4,5 y 7,5 .

Utilización - Se ha utilizado, desde la antigüedad, como planta medicinal y alimenticia. Las endrinas se utilizan en la elaboración de mermeladas y jaleas, así como para la preparación del pacharán. Tiene valor ornamental y paisajístico utilizado en jardinería para formar setos.

Altura - Arbusto espinoso e intrincado de ramas entrecruzadas que mide entre 2,5 y 5 $\mathrm{m}$ de altura.

Inflorescencia - Las flores son muy numerosas, de 1 a 1,5 cm, blancas y nacen antes que las hojas, solitarias o en grupos de 2-3- en las ramas del año anterior; su rabillo es corto, de no más de $1 \mathrm{~cm}$, y lampiño. Corola con 5 pétalos alargados, libres, insertos con los estambres en la garganta de una corta envuelta sepaloidea que remata en 5 lóbulos aovados y rodea al pistilo.

Floración - Florece desde marzo hasta mayo, según la localidad. 
Fruto - El fruto llamado endrinas, es una drupa globosa, azul oscura o negra, cubierta de una fina película azulada que se desprende al frotar, mide unos $10-15 \mathrm{~mm}$ y su pulpa tiene un sabor ácido y muy áspero.

Fructificación - La maduración tiene lugar entre agosto y septiembre.

Sistema radical - El sistema radicular de esta especie se caracteriza por presentar en los primeros años de desarrollo una raíz principal fuerte. A partir de ésta se extienden raíces primarias laterales con diferente grado de fuerza. A partir de las primarias se extienden las secundarias. A lo largo de los años, el crecimiento de la raíz principal disminuye favoreciendo el desarrollo de las raíces laterales.

\section{Parámetros medios}

\begin{tabular}{|c|c|c|c|c|c|c|c|c|c|}
\hline \multirow{2}{*}{ Especie } & \multicolumn{5}{|c|}{ RAÍCES } & \multicolumn{4}{|c|}{ TRONCO } \\
\hline & $\begin{array}{c}\text { Cohesión } \\
\mathrm{cR}\left(\mathrm{kN} / \mathrm{m}^{2}\right)\end{array}$ & $\begin{array}{c}\text { Resist. } \\
\text { Tracción } \\
\mathrm{T}\left(\mathrm{N} / \mathrm{mm}^{2}\right)\end{array}$ & $\begin{array}{l}\text { Diámetro } \\
\text { D.r (mm) }\end{array}$ & $\begin{array}{l}\text { Densidad } \\
\text { d.r [Ar/As] }\end{array}$ & $\begin{array}{c}\text { Profundidad } \\
\text { p.r (m) }\end{array}$ & $\begin{array}{l}\text { Diámetro } \\
\text { D.t }(\mathrm{cm})\end{array}$ & $\begin{array}{c}\text { Densidad } \\
\gamma \mathrm{v}\left(\mathrm{kg} / \mathrm{m}^{3}\right)\end{array}$ & $\begin{array}{l}\text { Altura } \\
\text { h.t (m) }\end{array}$ & $\begin{array}{l}\text { Fac. } \\
\text { forma } \\
\text { (f.f) }\end{array}$ \\
\hline Prunus spinosa & 4 & 25 & 21,9 & 0,3 & 0,5 & 5 & 700 & 5 & 0,65 \\
\hline
\end{tabular}

\subsubsection{6.- Pyrus communis (Peral montés)}

$\begin{array}{ll}\text { REINO } & \text { Plantae } \\ \text { DIVISIÓN } & \text { Magnoliophyta } \\ \text { CLASE } & \text { Magnoliopsida } \\ \text { ORDEN } & \text { Rosales } \\ \text { FAMILIA } & \text { Rosaceae } \\ \text { GENERO } & \text { Pyrus } \\ \text { ESPECIE } & \text { P.communis }\end{array}$

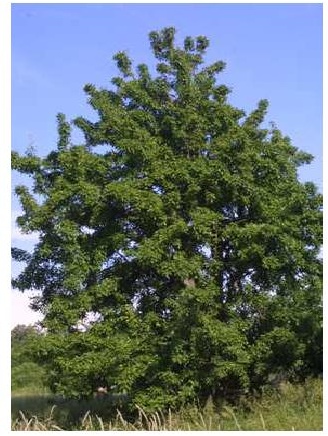

Hábitat - El peral silvestre es una especie de media luz, muy exigente en precipitación y requiere suelos profundos, permeables, bien drenados y sueltos; en altitudes que llegan hasta los $1200 \mathrm{~m}$. Prospera en climas templados y algo húmedos. Resiste más el frío que el calor. El clima más adecuado se caracteriza por inviernos con suficiente frío invernal, pocas heladas tardías y primaveras y veranos soleados con temperaturas no muy elevadas. Florece a $70 \mathrm{C}$ y 
resiste temperaturas de -18 ㅇ $\mathrm{C}$ a -20 으 y hasta -40 으. El área de distribución de esta especie se extiende por las estribaciones de las montañas cantábricas y valles de León (Bierzo a Sajambre), mitad norte de Palencia y norte de Burgos asociado a robles carballos y albares, castaños y setos entre prados de siega.

Utilización - Se ha utilizado, desde la antigüedad, como planta medicinal y alimenticia. Las endrinas se utilizan en la elaboración de mermeladas y jaleas, así como para la preparación del pacharán. Tiene valor ornamental y paisajístico utilizado en jardinería para formar setos

Altura - Arbolillo espinoso de 3 a $10 \mathrm{~m}$ de altura.

Inflorescencia -Las flores son blancas con largos pedicelos, formando corimbos umbeliformes en la terminación de las ramillas; son de buen tamaño, con ovario inferior y de color blanco o blanco rosado; el cáliz está formado por 5 sépalos lanceolados, estrechados en punta; los pétalos miden generalmente de 12 a $14 \mathrm{~mm}$ y son abovados y libres.

Floración - Florece desde abril a mayo.

Fruto - Los frutos o peras son de color verde, pueden medir hasta $5 \mathrm{~cm}$ de largo y viran a hacia el color amarillo al madurar.

Fructificación - La maduración de los frutos en septiembre y octubre.

Sistema radical - La raíz principal es profunda con el eje central muy desarrollado por lo que permite un buen anclaje y es resistente a la sequía.

\section{Parámetros medios}

\begin{tabular}{|c|c|c|c|c|c|c|c|c|c|}
\hline \multirow{2}{*}{ Especie } & \multicolumn{5}{|c|}{ RAÍCES } & \multicolumn{4}{|c|}{ TRONCO } \\
\hline & $\begin{array}{l}\text { Cohesión } \\
\mathrm{cR}\left(\mathrm{kN} / \mathrm{m}^{2}\right)\end{array}$ & $\begin{array}{c}\text { Resist. } \\
\text { Tracción } \\
\mathrm{T}\left(\mathrm{N} / \mathrm{mm}^{2}\right)\end{array}$ & $\begin{array}{l}\text { Diámetro } \\
\text { D.r }(\mathrm{mm})\end{array}$ & $\begin{array}{c}\text { Densidad } \\
\text { d.r }[\mathrm{Ar} / \mathrm{As}]\end{array}$ & $\begin{array}{c}\text { Profundidad } \\
\text { p.r }(\mathrm{m})\end{array}$ & $\begin{array}{c}\text { Diámetro } \\
\text { D.t (cm) }\end{array}$ & $\begin{array}{c}\text { Densidad } \\
\gamma \mathbf{V}\left(\mathrm{kg} / \mathrm{m}^{3}\right)\end{array}$ & $\begin{array}{l}\text { Altura } \\
\text { h.t (m) }\end{array}$ & $\begin{array}{l}\text { Fac. } \\
\text { forma } \\
\text { (f.f) }\end{array}$ \\
\hline $\begin{array}{c}\text { Pyrus } \\
\text { communis }\end{array}$ & 2,64 & 25 & 21,9 & 0,3 & 0,5 & 40 & 745 & 10 & 0,65 \\
\hline
\end{tabular}




\subsubsection{7.- Pyrus cordata (Peral montés)}

$\begin{array}{ll}\text { REINO } & \text { Plantae } \\ \text { DIVISIÓN } & \text { Magnoliophyta } \\ \text { CLASE } & \text { Magnoliopsida } \\ \text { ORDEN } & \text { Rosales } \\ \text { FAMILIA } & \text { Rosaceae } \\ \text { GENERO } & \text { Pyrus } \\ \text { ESPECIE } & \text { P. cordata }\end{array}$

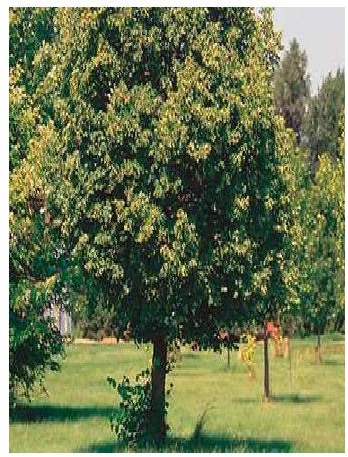

Hábitat - Esta especie de peral es característico de la orla arbustiva de los bosques caducifolios silicícolas con influencia oceánica. Se trata de una especie que habita sobre sustratos ácidos, requiere un tipo de clima templado y con precipitaciones abundantes. Su óptimo biogeográfico se localiza en las estribaciones montañosas de Cantabria y el centro oriental de Asturias, especial-mente asociado a robledales (Quercus petraea y Quercus robur) y melojares (Quercus pyrenaica).

Utilización - Su madera se utiliza para la fabricación de instrumentos musicales debido a su dureza, grano y peso. También se utiliza como planta ornamental en parques y jardines y como patrón de injerto de frutales.

Altura - Arbolillo espinoso de 2 a $3 \mathrm{~m}$ que puede llegar hasta $8 \mathrm{~m}$ de altura.

Inflorescencia - Las flores son blancas, melíferas, en inflorescencias corimbosas, con cinco pétalos, y sus estambres le dan un aspecto rosáceo.

Floración - Florece de abril a junio.

Fruto - Los frutos es una pera de pequeño tamaño, mide unos $15 \mathrm{~mm}$, globosa, que toma un color verdoso a rojizo al madurar y es poco carnoso; de sabor amargo.

Fructificación - La maduración de los frutos en septiembre y octubre.

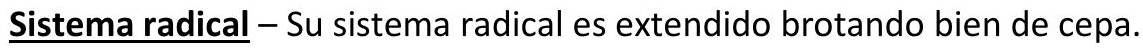




\section{Parámetros medios}

\begin{tabular}{|c|c|c|c|c|c|c|c|c|c|}
\hline \multirow{2}{*}{ Especie } & \multicolumn{5}{|c|}{ RAÍCES } & \multicolumn{4}{|c|}{ TRONCO } \\
\hline & $\begin{array}{l}\text { Cohesión } \\
\mathrm{cR}\left(\mathrm{kN} / \mathrm{m}^{2)}\right.\end{array}$ & $\begin{array}{c}\text { Resist. } \\
\text { Tracción } \\
\mathrm{T}\left(\mathrm{N} / \mathrm{mm}^{2}\right)\end{array}$ & $\begin{array}{l}\text { Diámetro } \\
\text { D.r (mm) }\end{array}$ & $\begin{array}{l}\text { Densidad } \\
\text { d.r [Ar/As] }\end{array}$ & $\begin{array}{l}\text { Profundidad } \\
\text { p.r (m) }\end{array}$ & $\begin{array}{l}\text { Diámetro } \\
\text { D.t }(\mathrm{cm})\end{array}$ & $\begin{array}{c}\text { Densidad } \\
\gamma \mathbf{v}\left(\mathrm{kg} / \mathrm{m}^{3}\right)\end{array}$ & $\begin{array}{l}\text { Altura } \\
\text { h.t (m) }\end{array}$ & $\begin{array}{l}\text { Fac. } \\
\text { forma } \\
\text { (f.f) }\end{array}$ \\
\hline $\begin{array}{c}\text { Pyrus } \\
\text { cordata }\end{array}$ & 2,64 & 25 & 21,9 & 0,3 & 0,5 & 20 & 775 & 8 & 0,65 \\
\hline
\end{tabular}

\subsubsection{8.- Quercus faginea (Quejigo)}

$\begin{array}{ll}\text { REINO } & \text { Plantae } \\ \text { DIVISIÓN } & \text { Magnoliophyta } \\ \text { CLASE } & \text { Magnoliopsida } \\ \text { ORDEN } & \text { Fagales } \\ \text { FAMILIA } & \text { Fagaceae } \\ \text { GENERO } & \text { Quercus } \\ \text { ESPECIE } & \text { Q.faginea }\end{array}$

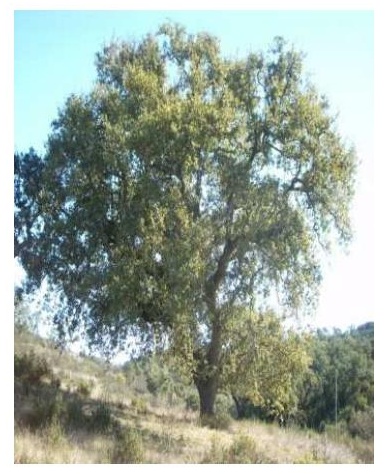

Hábitat - El quejigo es una especie xerófila presente en países del Mediterráneo occidental y muy extendida por toda España, especialmente en áreas montañosas situadas entre 500 y 1000 m de altitud. Adaptada a los ambientes continentales secos, requiriendo unos $400 \mathrm{~mm}$ de lluvia anual y soportando sequías prolongadas. Ocupa sobre todo terrenos calizos o con margas, soportando también los yesos; aunque crece también sobre suelos silíceos. Prefiere terrenos umbrosos y secos, con mayor capacidad de retención de la humedad que la encina. El quejigo es abundante en toda la comunidad de Castilla y León.

Utilización - El quejigo es apreciado sobre todo por su leña como combustible y para la obtención de carbón vegetal que se considera de muy buena calidad. La bellota se emplea como alimento para el ganado y su corteza como curtiente.

Altura - El quejigo es un árbol de tamaño medio, que puede alcanzar los $20 \mathrm{~m}$ de altura, aunque a menudo se encuentra desmochado o bien formando tallares o montes bajos de escasa altura. 
Inflorescencia - Las inflorescencias masculinas se disponen en grupitos, sobre amentos colgantes, alargados con envuelta dividida en 5 - 6 sépalos alargados y un número variable de estambres. Las femeninas sentadas o con pedicelos muy cortos.

Floración - El quejigo florece de abril a mayo.

Fruto - El fruto es una bellota que nace sobre un corto pedúnculo, con cúpula de escamas ovadas, algo prominentes en el dorso.

Fructificación - Las bellotas maduran y se diseminan entre septiembre y octubre.

Sistema radical - El quejigo tiene un sistema radical bastante profundo con raíz principal pivotante y raíces laterales más o menos profundas. El sistema radicular no profundiza tanto como el de los robles común y albar, ni tiene tampoco las raíces superficiales del rebollo.

\section{Parámetros medios}

\begin{tabular}{|c|c|c|c|c|c|c|c|c|}
\hline \multirow{2}{*}{ Especie } & \multicolumn{3}{|c|}{ RAÍCES } & \multicolumn{2}{|c|}{ TRONCO } \\
\cline { 2 - 7 } & $\begin{array}{c}\text { Cohesión } \\
\mathrm{cR}\left(\mathrm{kN} / \mathrm{m}^{2}\right)\end{array}$ & $\begin{array}{c}\text { Resist. } \\
\text { Tracción } \\
\mathrm{T}\left(\mathrm{N} / \mathrm{mm}^{2}\right)\end{array}$ & $\begin{array}{c}\text { Diámetro } \\
\text { D.r }(\mathrm{mm})\end{array}$ & $\begin{array}{c}\text { Densidad } \\
\text { d.r [Ar/As] }\end{array}$ & $\begin{array}{c}\text { Profundidad } \\
\text { p.r }(\mathrm{m})\end{array}$ & $\begin{array}{c}\text { Diámetro } \\
\text { D.t }(\mathrm{cm})\end{array}$ & $\begin{array}{c}\text { Densidad } \\
\gamma \mathbf{v}\left(\mathrm{kg} / \mathrm{m}^{3}\right)\end{array}$ & $\begin{array}{c}\text { Altura } \\
\mathrm{h} . \mathrm{t}(\mathrm{m})\end{array}$ \\
$\begin{array}{c}\text { Quercus } \\
\text { faginea }\end{array}$ & 2,64 & 30 & 30 & 0,3 & 2 & 27 & 790 \\
$\begin{array}{c}\text { Fac. } \\
(\mathrm{f} . \mathrm{f})\end{array}$ \\
0
\end{tabular}

\subsubsection{9.- Quercus ilex (Encina)}

$\begin{array}{ll}\text { REINO } & \text { Plantae } \\ \text { DIVISIÓN } & \text { Magnoliophyta } \\ \text { CLASE } & \text { Magnoliopsida } \\ \text { ORDEN } & \text { Fagales } \\ \text { FAMILIA } & \text { Fagaceae } \\ \text { GENERO } & \text { Quercus } \\ \text { ESPECIE } & \text { Q.ilex }\end{array}$

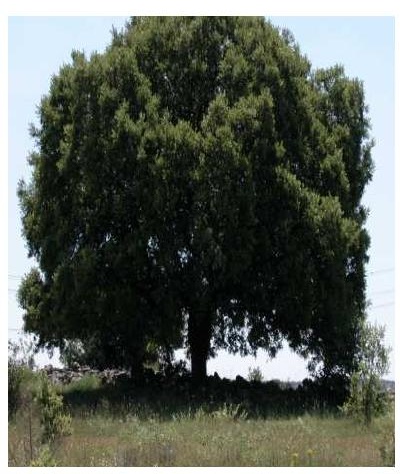

Hábitat - El área de distribución natural de la encina es la región mediterránea. En las Islas Baleares se encuentra en las islas de Mallorca, Menorca e Ibiza. En la península alcanza 
todas las regiones siendo más o menos frecuente según la zona. Crece en todo tipo de suelos, desde el nivel del mar hasta los 1400 m., pero en ejemplares aislados y arbustivos puede ascender en las solanas hasta los $1900 \mathrm{~m}$; es una especie muy adaptada a soportar fuertes sequías estivales y los climas duros continentales; es el árbol dominante en gran parte de las regiones de clima mediterráneo seco, siendo desplazada en los suelos más profundos y frescos o en climas más oceánicos por robles, quejigos y alcornoques.

Utilización - La encina es uno de los árboles que se utilizan para producir trufas. Sus bellotas, además, se utilizan para alimentar el ganado y su madera como combustible. Puede utilizarse como árbol ornamental en parques y jardines. Se puede sujetar para formar un seto alto, siendo adecuado como cortavientos costero en algunos suelos bien drenados.

Altura - Es un árbol de talla media, que puede llegar a alcanzar de 15 a 250 metros de altura.

Inflorescencia - Flores masculinas en amentos colgantes y flores femeninas en pequeños grupos.

Floración - La floración se produce entre abril y mayo.

Fruto - Es una bellota largamente ovoide que nace sobre un pedúnculo muy corto y tiene en su base una cúpula hemisférica en forma de dedal, de color ceniciento, con escamas casi planas.

Fructificación - las bellotas maduran desde septiembre hasta diciembre.

Sistema radical - Está compuesto por una raíz principal potente y penetrante que en las primeras edades se desarrolla mucho. Más tarde se ramifica mucho para asegurar el anclaje y el aprovisionamiento de nutrientes y agua, desarrollándose también muchas secundarias de gran vigor. Sus raíces forman micorrizas con las tan apreciadas trufas.

\section{Parámetros medios}

\begin{tabular}{|c|c|c|c|c|c|c|c|c|c|}
\hline \multirow{2}{*}{ Especie } & \multicolumn{4}{|c|}{ RAÍCES } & \multicolumn{4}{c|}{ TRONCO } \\
\cline { 2 - 9 } & $\begin{array}{c}\text { Cohesión } \\
\mathrm{cR}\left(\mathrm{kN} / \mathrm{m}^{2}\right)\end{array}$ & $\begin{array}{c}\text { Resist. } \\
\text { Tracción } \\
\mathrm{T}\left(\mathrm{N} / \mathrm{mm}^{2}\right)\end{array}$ & $\begin{array}{c}\text { Diámetro } \\
\text { D.r }(\mathrm{mm})\end{array}$ & $\begin{array}{c}\text { Densidad } \\
\mathrm{d} . \mathrm{r}[\mathrm{Ar} / \mathrm{As}]\end{array}$ & $\begin{array}{c}\text { Profundidad } \\
\mathrm{p} . \mathrm{r}(\mathrm{m})\end{array}$ & $\begin{array}{c}\text { Diámetro } \\
\text { D.t }(\mathrm{cm})\end{array}$ & $\begin{array}{c}\text { Densidad } \\
\gamma \mathrm{v}\left(\mathrm{kg} / \mathrm{m}^{3}\right)\end{array}$ & $\begin{array}{c}\text { Altura } \\
\text { h.t (m) }\end{array}$ & $\begin{array}{c}\text { Fac. } \\
\text { forma } \\
(\mathrm{f} . \mathrm{f})\end{array}$ \\
\hline Quercus ilex & 2,64 & 37 & 25 & 0,3 & 2 & 20 & 900 & 15 & 0,65 \\
\hline
\end{tabular}




\subsubsection{0.- Quercus petraea (Roble albar)}

$\begin{array}{ll}\text { REINO } & \text { Plantae } \\ \text { DIVISIÓN } & \text { Magnoliophyta } \\ \text { CLASE } & \text { Magnoliopsida } \\ \text { ORDEN } & \text { Fagales } \\ \text { FAMILIA } & \text { Fagaceae } \\ \text { GENERO } & \text { Quercus } \\ \text { ESPECIE } & \text { Q.petraea }\end{array}$

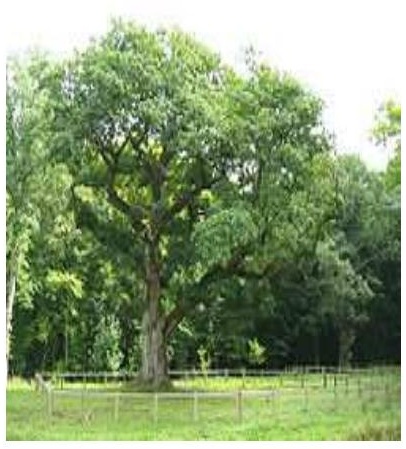

Hábitat - Es una especie subatlántica que se distribuye por gran parte de Europa occidental y central, incluyendo Irlanda y Gran Bretaña. En España habita principalmente en las montañas septentrionales, desde Galicia, Asturias y León, hasta Palencia, Cantabria y norte de Burgos, así como también en los montes vascos y del entorno pirenaico. El roble albar crece en las laderas y faldas de las montañas, soportando suelos más secos y menos profundos que el carballo (Q.robur) ya que a veces vive incluso entre rocas. Sube a mayor altitud que Quercus robur, hasta los $1800 \mathrm{~m}$; prefiere los suelos sueltos, algo profundos, y se desarrolla tanto en suelos calizos como en los silíceos. Se mezcla con el haya (Fagus sylvatica), abedul (Betula $a l b a$ ) y otros roble (Q.robur y Q.pyrenaica) con los que forma fácilmente híbridos.

Utilización -La madera de roble albar es muy empleada en la construcción, fabricación de muebles, barricas, cajas, escaleras, traviesas de ferrocarril, tableros de partículas y fibras contrachapados; también para apeas de minas. La corteza se ha utilizado como curtiente por su abundante contenido en tanino. De la corteza se extrae la quercitina, componente amargo y astrigente utilizado como medicina en las enfermedades del aparato digestivo y respiratorio. Las bellotas sirven como alimento para el ganado y para la fauna silvestre como el jabalí.

Altura - El roble albar es un árbol de gran tamaño que puede llegar a medir $30 \mathrm{~m}$ de altura.

Inflorescencia - Las flores masculinas se disponen en amentos. Las flores femeninas nacen sentadas sobre las ramillas o sobre pedúnculos muy cortos y no son nunca colgantes. 
Floración - La floración se produce en abril o mayo.

Fruto - El fruto es una bellota largamente ovoide y tiene el cascabillo con escamas numerosas, empizarradas, de forma triangular-ovada, casi planas o convexas y algo nudosas.

Fructificación - La maduración de las bellotas se produce entre septiembre y octubre.

Sistema radical - El roble albar presenta una raíz principal pivotante y profunda. Al año suele tener una raíz central relativamente desarrollada y puede llegar a penetrar a una profundidad de metro y medio en el suelo; de 6 a 8 años, emite raíces laterales y en conjunto emite un sistema radical penetrante y profundo.

\section{Parámetros medios}

\begin{tabular}{|c|c|c|c|c|c|c|c|c|c|}
\hline \multirow{2}{*}{ Especie } & \multicolumn{5}{|c|}{ RAÍCES } & \multicolumn{4}{|c|}{ TRONCO } \\
\hline & $\begin{array}{l}\text { Cohesión } \\
\mathrm{cR}\left(\mathrm{kN} / \mathrm{m}^{2}\right)\end{array}$ & $\begin{array}{c}\text { Resist. } \\
\text { Tracción } \\
\mathrm{T}\left(\mathrm{N} / \mathrm{mm}^{2}\right)\end{array}$ & $\begin{array}{l}\text { Diámetro } \\
\text { D.r (mm) }\end{array}$ & $\begin{array}{l}\text { Densidad } \\
\text { d.r [Ar/As] }\end{array}$ & $\begin{array}{l}\text { Profundidad } \\
\text { p.r }(\mathrm{m})\end{array}$ & $\begin{array}{l}\text { Diámetro } \\
\text { D.t }(\mathrm{cm})\end{array}$ & $\begin{array}{c}\text { Densidad } \\
\gamma \mathbf{v}\left(\mathrm{kg} / \mathrm{m}^{3}\right)\end{array}$ & $\begin{array}{l}\text { Altura } \\
\text { h.t (m) }\end{array}$ & $\begin{array}{l}\text { Fac. } \\
\text { forma } \\
\text { (f.f) }\end{array}$ \\
\hline $\begin{array}{l}\text { Quercus } \\
\text { petraea }\end{array}$ & 2,64 & 30 & 30 & 0,3 & 2,0 & 28 & 730 & 20 & 0,65 \\
\hline
\end{tabular}

\subsubsection{1.- Quercus pyrenaica (Rebollo)}

$\begin{array}{ll}\text { REINO } & \text { Plantae } \\ \text { DIVISIÓN } & \text { Magnoliophyta } \\ \text { CLASE } & \text { Magnoliopsida } \\ \text { ORDEN } & \text { Fagales } \\ \text { FAMILIA } & \text { Fagaceae } \\ \text { GENERO } & \text { Quercus } \\ \text { ESPECIE } & \text { Q.pyrenaica }\end{array}$

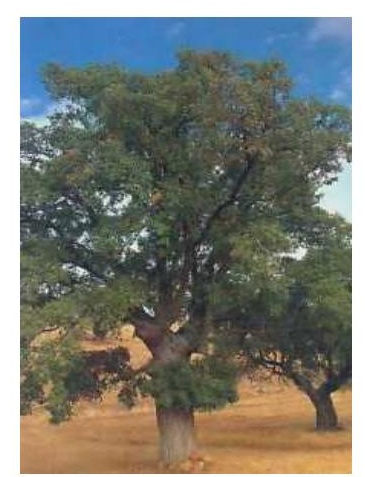

Hábitat - Especie de media luz y temperamento robusto, se cría en las laderas y faldas de las montañas del centro y cuadrante noroccidental sobre suelos silíceos, raramente sobre calizas o dolomías cristalinas, desde los 400 a los 1500 m de altitud y algo más en Andalucía (2000 m en Sierra Nevada). Prefiere los suelos sueltos y de textura arenosa y está muy bien adaptado a los climas continentales, soportando las heladas, por su corto periodo de desarrollo vegetativo y condiciones más xerofíticas que las de Q.robur y Q.petraea. 
Utilización - El aprovechamiento principal del rebollar es la obtención de leña y carbón vegetal. La bellota es utilizada como alimento para el ganado en montanera y para la fauna silvestre como el jabalí.

Altura - El rebollo es un árbol de gran tamaño que puede llegar a medir $25 \mathrm{~m}$ de altura.

Inflorescencia -Las flores masculinas son amarillentas y menudas, con envuelta dividida en 5-8 lacinias pelosas, número variable de estambres y agrupadas en amentos alargados y flojos que cuelgan en número variable de las ramillas, y las femeninas solitarias o en grupos de tres o cuatro en las axilas de las ramillas del último año.

Floración - La floración se produce en mayo o principios de junio.

Fruto - Sus frutos, igual que en el resto de especies del género Quercus, son bellotas, en este caso gruesas, de pedúnculo corto y rechoncho, de hasta $3-4 \mathrm{~cm}$ de longitud, con $1 / 3-1 / 2$ cubierto por una cúpula hemisférica, con forma de dedal, vellosa, con numerosas escamas lacias. Nacen solas o en grupos de 2-3.

Fructificación - Las bellotas maduran entre octubre y noviembre.

Sistema radical - El rebollo presenta un sistema radical potente, la raíz principal es bastante profunda y desarrollada de la cual nacen numerosas raíces secundarias horizontales y próximas a la superficie del suelo.

\section{Parámetros medios}

\begin{tabular}{|c|c|c|c|c|c|c|c|c|c|}
\hline \multirow{2}{*}{ Especie } & \multicolumn{5}{|c|}{ RAÍCES } & \multicolumn{4}{|c|}{ TRONCO } \\
\hline & $\begin{array}{l}\text { Cohesión } \\
\text { cR }\left(\mathrm{kN} / \mathrm{m}^{2}\right)\end{array}$ & $\begin{array}{c}\text { Resist. } \\
\text { Tracción } \\
\mathrm{T}\left(\mathrm{N} / \mathrm{mm}^{2}\right)\end{array}$ & $\begin{array}{l}\text { Diámetro } \\
\text { D.r (mm) }\end{array}$ & $\begin{array}{c}\text { Densidad } \\
\text { d.r [Ar/As] }\end{array}$ & $\begin{array}{l}\text { Profundidad } \\
\text { p.r (m) }\end{array}$ & $\begin{array}{c}\text { Diámetro } \\
\text { D.t }(\mathrm{cm})\end{array}$ & $\begin{array}{c}\text { Densidad } \\
\gamma \mathbf{v}\left(\mathrm{kg} / \mathrm{m}^{3}\right)\end{array}$ & $\begin{array}{l}\text { Altura } \\
\text { h.t (m) }\end{array}$ & $\begin{array}{l}\text { Fac. } \\
\text { forma } \\
\text { (f.f) }\end{array}$ \\
\hline $\begin{array}{c}\text { Quercus } \\
\text { pyrenaica }\end{array}$ & 2,64 & 30 & 30 & 0,3 & 2,0 & 30 & 760 & 15 & 0,65 \\
\hline
\end{tabular}




\subsubsection{2.- Quercus robur (Roble carballo)}

$\begin{array}{ll}\text { REINO } & \text { Plantae } \\ \text { DIVISIÓN } & \text { Magnoliophyta } \\ \text { CLASE } & \text { Magnoliopsida } \\ \text { ORDEN } & \text { Fagales } \\ \text { FAMILIA } & \text { Fagaceae } \\ \text { GENERO } & \text { Quercus } \\ \text { ESPECIE } & \text { Q.robur }\end{array}$

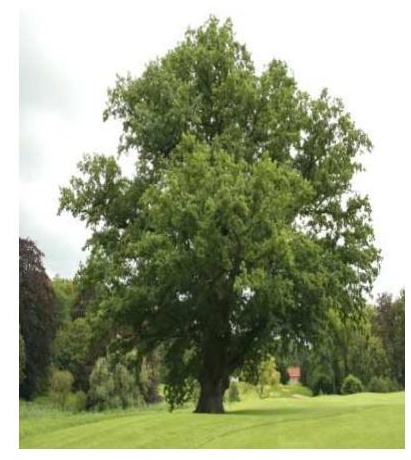

Hábitat - El roble carballo es propio de suelos húmedos y profundos; prefiere suelos silíceos y se desarrolla en altitudes desde el nivel hasta los $1000 \mathrm{~m}$. En Castilla y León debido a la sequedad estival puede llegar a los $1800 \mathrm{~m}$ de altitud para contrarrestar esta falta de humedad. Se trata de una especie heliófila que necesita luz para desarrollarse. Este roble tiene unos requerimientos hídricos superiores a $600 \mathrm{~mm}$ de precipitación anual y más de $200 \mathrm{~mm}$ de precipitación en la época estival. Necesita también humedad ambiental. Se mezcla con otros robles ( $Q$. petraea y $Q$. pyrenaica) con los que forma híbridos con facilidad. El roble carballo es un árbol típico de las regiones lluviosas europeas. En España se desarrolla en la cornisa cantábrica desde Galicia y Asturias hasta Cantabria y País Vasco. En Castilla y León solo es frecuente en los valles del norte de León y Burgos.

Utilización - El principal aprovechamiento del roble carballo es la madera. Se trata de una madera pesada y fuerte muy parecida a la del roble albar y que es también muy apreciada y valorada en trabajos de ebanistería y carpintería. Al igual que otras especies del gn Quercus, el roble carballo tiene también un valor ecológico y paisajístico importante, sirviendo de refugio y alimento para la fauna silvestre de la zona.

Altura - El roble carballo es un árbol robusto de porte majestuoso que puede alcanza los $40 \mathrm{~m}$ de altura.

Inflorescencia - El roble produce flores masculinas en largos amentos colgantes y lampiños, de 3 a $6 \mathrm{~cm}$ en longitud con flores de 5 a 8 estambres y perigonio de 5-6 divisiones. Las flores femeninas en grupos de $2-3$, insertadas en el extremo de un largo y lampiño pedúnculo entre las hojas superiores desarrolladas en el año. Tienen 3 estilos soldados en su base, cortos y rojos. 
Floración - La floración se produce entre abril y mayo.

Fruto - Los frutos son bellotas colgantes sobre un largo pedúnculo, aovado-oblongas, con caperuza o cascabillo de escamas casi planas, empizarradas.

Fructificación - las bellotas maduran en septiembre y caen en octubre.

Sistema radical - Sistema radical fuertemente pivotante y profundo; las raíces secundarias son vigorosas y extendidas a partir de los 6 u 8 años.

\section{Parámetros medios}

\begin{tabular}{|c|c|c|c|c|c|c|c|c|c|}
\hline \multirow{2}{*}{ Especie } & \multicolumn{3}{|c|}{ RAÍCES } & \multicolumn{3}{|c|}{ TRONCO } \\
\cline { 2 - 9 } & $\begin{array}{c}\text { Cohesión } \\
\mathrm{cR}\left(\mathrm{kN} / \mathrm{m}^{2}\right)\end{array}$ & $\begin{array}{c}\text { Resist. } \\
\text { Tracción } \\
\mathrm{T}\left(\mathrm{N} / \mathrm{mm}^{2}\right)\end{array}$ & $\begin{array}{c}\text { Diámetro } \\
\text { D.r }(\mathrm{mm})\end{array}$ & $\begin{array}{c}\text { Densidad } \\
\text { d.r }[\mathrm{Ar} / \mathrm{As}]\end{array}$ & $\begin{array}{c}\text { Profundidad } \\
\text { p.r }(\mathrm{m})\end{array}$ & $\begin{array}{c}\text { Diámetro } \\
\text { D.t }(\mathrm{cm})\end{array}$ & $\begin{array}{c}\text { Densidad } \\
\gamma \mathrm{v}\left(\mathrm{kg} / \mathrm{m}^{3}\right)\end{array}$ & $\begin{array}{c}\text { Altura } \\
\text { h.t }(\mathrm{m})\end{array}$ & $\begin{array}{c}\text { Fac. } \\
\text { forma } \\
(\mathrm{f} . \mathrm{f})\end{array}$ \\
\hline $\begin{array}{c}\text { Quercus } \\
\text { robur }\end{array}$ & 2,64 & 32 & 30 & 0,3 & 2,0 & 25 & 750 & 25 & 0,65 \\
\hline
\end{tabular}

\subsubsection{3.- Quercus suber (Alcornoque)}

$\begin{array}{ll}\text { REINO } & \text { Plantae } \\ \text { DIVISIÓN } & \text { Magnoliophyta } \\ \text { CLASE } & \text { Magnoliopsida } \\ \text { ORDEN } & \text { Fagales } \\ \text { FAMILIA } & \text { Fagaceae } \\ \text { GENERO } & \text { Quercus } \\ \text { ESPECIE } & \text { Q.suber }\end{array}$

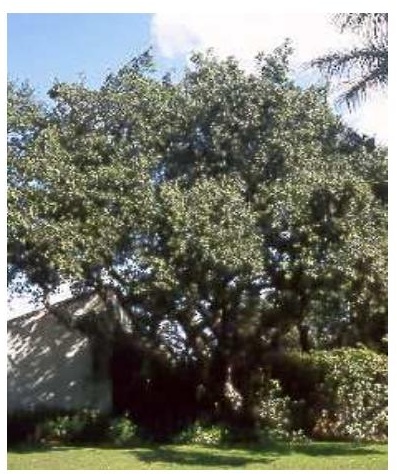

Hábitat - El área de distribución del alcornoque es la región mediterránea occidental: sur de Europa y Norte de África. En la Península Ibérica presente en el cuadrante suroeste, Cataluña, Castellón y dispersa por otros puntos. Forma bosques, a menudo de extensión considerable, en substrato silíceo, preferentemente suelto y permeable, raramente sobre dolomías, sobre todo en zonas abrigadas de los vientos dl norte, desde el nivel del mar hasta los $1000 \mathrm{~m}$. Prefiere climas cálidos y soporta bien la sequía estival, siempre y cuando se 
compense con precipitaciones más abundantes el resto del año. Requiere una buena aireación del suelo para sus raíces, por lo que crece en suelos arenosos, poco pedregosos, con pocas arcillas y sin encharcamientos. Se asocia frecuentemente con encinas (Q.ilex) y quejigos (Q.faginea).

Utilización - Los alcornocales se pueden utilizar de dos maneras: la primera es utilizarlos combinados con otros aprovechamientos agrarios, como el pastoreo; y la segunda es tratarlos como bosque sin otros usos agrarios, esto es, por ejemplo, aprovechar los alcornocales como productores de corcho, que es el principal aprovechamiento del alcornoque y tiene múltiples aplicaciones. Para revegetaciones no es muy aconsejable ya que no es un árbol muy colonizador y, muy a menudo, la semilla germina únicamente bajo su cubierta.

Altura - El alcornoque es un árbol de tamaño medio, llegando a medir 20 ó $25 \mathrm{~m}$ de altura como mucho.

Inflorescencia - Las flores son unisexuales. Las masculinas aparecen en amentos de 4-8 $\mathrm{cm}$ de raquis velloso, amarillentos y colgantes, en grupos de 5 ó 6 . Las flores femeninas se encuentran solitarias o en pequeños grupos.

Floración - La floración se produce entre marzo y junio.

Fruto - El fruto es una bellota de tamaño variable, con más de $40 \mathrm{~mm}$ de longitud y hasta unos $20 \mathrm{~mm}$ de anchura, con pedúnculo de hasta $4 \mathrm{~cm}$; castaño rojizo en la madurez, que está cubierta en su parte inferior por una cúpula de 1-2 cm de color gris.

Fructificación - las bellotas maduran desde septiembre hasta febrero.

Sistema radical - El alcornoque posee un sistema radical fuerte, profundo y muy desarrollado. Presentan un eje central flexible, que puede profundizar varios metros si el terreno lo permite, unas raíces secundarias oblicuas y superficiales, a veces sinuosas, que le permiten progresar hasta en suelos rocosos, y que muchas veces provocan brotes de raíz en torno al árbol. Estas raíces permiten establecer competencia radical directa con casi todas las especies de su sotobosque. El sistema radical del alcornoque se asocia con micorrizas diversas, pertenecientes principalmente a los géneros Boletus, Russula, Armillaria y Lactarius. Estos hongos entran en simbiosis con el sistema radical del alcornoque, aumentando su poder de absorción y la solubilidad de algunos compuestos de fósforo y potasio. 


\section{Parámetros medios}

\begin{tabular}{|c|c|c|c|c|c|c|c|c|c|}
\hline \multirow{2}{*}{ Especie } & \multicolumn{5}{|c|}{ RAÍCES } & \multicolumn{4}{|c|}{ TRONCO } \\
\hline & $\begin{array}{c}\text { Cohesión } \\
\mathrm{cR}\left(\mathrm{kN} / \mathrm{m}^{2}\right)\end{array}$ & $\begin{array}{c}\text { Resist. } \\
\text { Tracción } \\
\mathrm{T}\left(\mathrm{N} / \mathrm{mm}^{2}\right)\end{array}$ & $\begin{array}{l}\text { Diámetro } \\
\text { D.r }(\mathrm{mm})\end{array}$ & $\begin{array}{l}\text { Densidad } \\
\text { d.r [Ar/As] }\end{array}$ & $\begin{array}{c}\text { Profundidad } \\
\text { p.r }(\mathrm{m})\end{array}$ & $\begin{array}{c}\text { Diámetro } \\
\text { D.t (cm) }\end{array}$ & $\begin{array}{c}\text { Densidad } \\
\gamma \mathrm{v}\left(\mathrm{kg} / \mathrm{m}^{3}\right)\end{array}$ & $\begin{array}{l}\text { Altura } \\
\text { h.t (m) }\end{array}$ & $\begin{array}{l}\text { Fac. } \\
\text { forma } \\
\text { (f.f) }\end{array}$ \\
\hline Quercus suber & 2,64 & 32 & 30 & 0,3 & 2,0 & 25 & 830 & 17 & 0,65 \\
\hline
\end{tabular}

\subsubsection{4.- Salix alba (Sauce)}

$\begin{array}{ll}\text { REINO } & \text { Plantae } \\ \text { DIVISIÓN } & \text { Magnoliophyta } \\ \text { CLASE } & \text { Magnoliopsida } \\ \text { ORDEN } & \text { Malpighiales } \\ \text { FAMILIA } & \text { Salicaceae } \\ \text { GENERO } & \text { Salix } \\ \text { ESPECIE } & \text { S. alba }\end{array}$

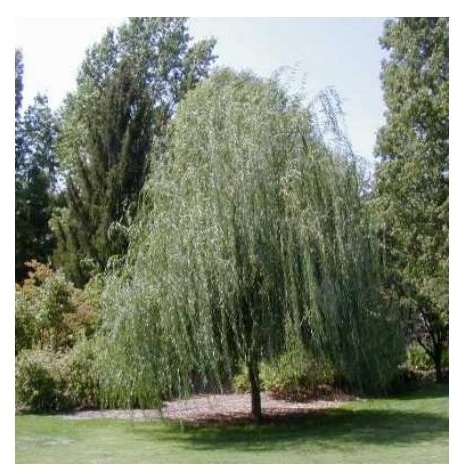

Hábitat - El sauce blanco se distribuye por toda Europa, norte y centro de Asia y el norte de África. En la península habita por todas o casi todas las regiones y provincias. Crece en lugares húmedos con nivel freático elevado, cerca de ríos en sotos y riberas y no soporta las temperaturas extremas. Vive en suelos arenosos o arcillo- arenosos ricos en nutrientes desde el nivel del mar hasta unos $1500 \mathrm{~m}$ de altitud.

Utilización - Es imprescindible en la restauración de humedales y se está empezando a usar en la restauración de cauces, pues el entramado de sus raíces ayuda protegiendo el suelo evitando así la pérdida por las crecidas de los ríos. Sus ramas se emplean para trabajos de cestería y como ramón para alimento del ganado en invierno.

Altura - Alcanza hasta $25 \mathrm{~m}$ de altura. Debido a su rápido crecimiento, está expuesto a enfermedades que acortan su vida, lo que puede suponer un grave problema en replantaciones de una gran cantidad de ejemplares de sauce blanco. 
Inflorescencia - Las flores están dispuestas en amentos de 2 a $7 \mathrm{~cm}$ de longitud y $1 \mathrm{~cm}$ de grosor, cilíndricos y delgados que crecen sobre pedúnculos. La flor masculina tiene dos nectarios: uno externo y otro interno y dos estambres de filamentos libres y pelosos. La flor femenina tiene un único nectario y su pistilo es glabro.

Floración - Florece entre marzo y abril.

Fruto - El fruto es una cápsula ovoidea, obtusa y lampiña. En la madurez se abre en dos valvas y libera las semillas, rodeadas de finos pelos algodonosos.

Fructificación - La madurez del fruto se produce en mayo.

Sistema radical - Raíces principales dominantes, con desarrollo lateral importante que exploran las capas superficiales del suelo. Tiene buena capacidad de amarre y desarrollo en suelos húmedos.

\section{Parámetros medios}

\begin{tabular}{|c|c|c|c|c|c|c|c|c|c|}
\hline \multirow{2}{*}{ Especie } & \multicolumn{5}{|c|}{ RAÍCES } & \multicolumn{4}{|c|}{ TRONCO } \\
\hline & $\begin{array}{c}\text { Cohesión } \\
\mathrm{cR}\left(\mathrm{kN} / \mathrm{m}^{2}\right)\end{array}$ & $\begin{array}{c}\text { Resist. } \\
\text { Tracción } \\
\mathrm{T}\left(\mathrm{N} / \mathrm{mm}^{2}\right)\end{array}$ & $\begin{array}{l}\text { Diámetro } \\
\text { D.r (mm) }\end{array}$ & $\begin{array}{c}\text { Densidad } \\
\text { d.r [Ar/As] }\end{array}$ & $\begin{array}{l}\text { Profundidad } \\
\text { p.r }(\mathrm{m})\end{array}$ & $\begin{array}{l}\text { Diámetro } \\
\text { D.t }(\mathrm{cm})\end{array}$ & $\begin{array}{c}\text { Densidad } \\
\gamma \mathbf{v}\left(\mathrm{kg} / \mathrm{m}^{3}\right)\end{array}$ & $\begin{array}{l}\text { Altura } \\
\text { h.t (m) }\end{array}$ & $\begin{array}{l}\text { Fac. } \\
\text { forma } \\
\text { (f.f) }\end{array}$ \\
\hline Salix alba & 2,64 & 11 & 40 & 0,3 & 3,0 & 30 & 490 & 20 & 0,65 \\
\hline
\end{tabular}

\subsubsection{5.- Sorbus aria (Mostajo)}

$\begin{array}{ll}\text { REINO } & \text { Plantae } \\ \text { DIVISIÓN } & \text { Magnoliophyta } \\ \text { CLASE } & \text { Magnoliopsida } \\ \text { ORDEN } & \text { Rosales } \\ \text { FAMILIA } & \text { Rosaceae } \\ \text { GENERO } & \text { Sorbus } \\ \text { ESPECIE } & \text { S. aria }\end{array}$

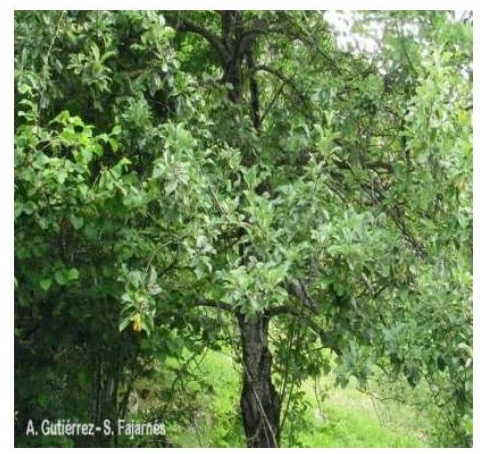


Hábitat - El mostajo es originario del suroeste de Europa y norte de África. En Castilla y León se extiende por toda la orla montañosa del norte de Palencia, León, Zamora, Burgos, norte de Soria y Segovia. Crece en las laderas pedregosas de las montañas y aún entre las mismas rocas, de preferencia en los suelos calizos, pero también crece sobre suelos silíceos en altitudes comprendidas entre 600 y $2200 \mathrm{~m}$ de altitud. Se mezcla con robles, hayas, abedules, quejigos, etc en bosques frescos con más de $600 \mathrm{~mm}$ de precipitación. Especie heliófila, propia de claros y bordes de los bosques, así como en roquedales y canchales.

Utilización - La madera de esta especie es dura y muy apreciada para trabajos de ebanistería y tornería. Se utiliza también como combustible pues la leña y el carbón vegetal que se obtienen son de buena calidad. Tiene también un gran valor como especie fijadora del terreno en laderas de fuerte pendiente. Se utiliza también como planta ornamental en parques y jardines. Se planta también en zonas oseras para suministro de alimento en estas zonas.

Altura - Árbol de tamaño medio, con una talla que puede llegar a los $20 \mathrm{~m}$ de altura.

Inflorescencia - Las flores son blancas, de unos 10-15 mm de diámetro, agrupadas en corimbos terminales, con el cáliz y pedicelos cubiertos de borra blanca. Tienen 5 pétalos redondeados, abiertos en estrella, estambres numerosos y ovario ínfero, en forma de copa, estilos algo pelosos en la base.

Floración - Florece entre abril y junio, en ocasiones hasta julio.

Fruto - El fruto es un pomo carnoso, globoso u ovoide, de unos 6-15 mm de diámetro, rojo-anaranjado, de pulpa dulce, algo ácida y harinosa.

Fructificación - Los frutos maduran entre septiembre y octubre.

Sistema radical - Posee una raíz central con raíces extendidas alrededor del árbol que es muy útil para la estabilización de laderas con fuerte pendiente. Tiene facilidad para rebrotar de cepa o de raíz.

\section{Parámetros medios}

\begin{tabular}{|c|c|c|c|c|c|c|c|c|c|}
\hline \multirow{3}{*}{ Especie } & \multicolumn{4}{|c|}{ RAÍCES } & \multicolumn{4}{c|}{ TRONCO } \\
\cline { 2 - 8 } & $\begin{array}{c}\text { Cohesión } \\
\mathrm{cR}\left(\mathrm{kN} / \mathrm{m}^{2}\right)\end{array}$ & $\begin{array}{c}\text { Resist. } \\
\text { Tracción } \\
\mathrm{T}\left(\mathrm{N} / \mathrm{mm}^{2}\right)\end{array}$ & $\begin{array}{c}\text { Diámetro } \\
\text { D.r }(\mathrm{mm})\end{array}$ & $\begin{array}{c}\text { Densidad } \\
\text { d.r }[\mathrm{Ar} / \mathrm{As}]\end{array}$ & $\begin{array}{c}\text { Profundidad } \\
\text { p.r }(\mathrm{m})\end{array}$ & $\begin{array}{c}\text { Diámetro } \\
\text { D.t }(\mathrm{cm})\end{array}$ & $\begin{array}{c}\text { Densidad } \\
\gamma \mathrm{v}\left(\mathrm{kg} / \mathrm{m}^{3}\right)\end{array}$ & $\begin{array}{c}\text { Altura } \\
\text { h.t }(\mathrm{m})\end{array}$ & $\begin{array}{c}\text { Fac. } \\
\text { forma } \\
(\mathrm{f} . \mathrm{f})\end{array}$ \\
\hline
\end{tabular}




\begin{tabular}{|c|c|c|c|c|c|c|c|c|c|}
\hline & & & & & & & & \\
\hline Sorbus aria & 2,64 & 22 & 28 & 0,3 & 0,3 & 30 & 700 & 15 & 0,65 \\
\hline
\end{tabular}

\subsubsection{6.- Sorbus aucuparia (Serbal de cazadores)}

$\begin{array}{ll}\text { REINO } & \text { Plantae } \\ \text { DIVISIÓN } & \text { Magnoliophyta } \\ \text { CLASE } & \text { Magnoliopsida } \\ \text { ORDEN } & \text { Rosales } \\ \text { FAMILIA } & \text { Rosaceae } \\ \text { GENERO } & \text { Sorbus } \\ \text { ESPECIE } & \text { S. aucuparia }\end{array}$

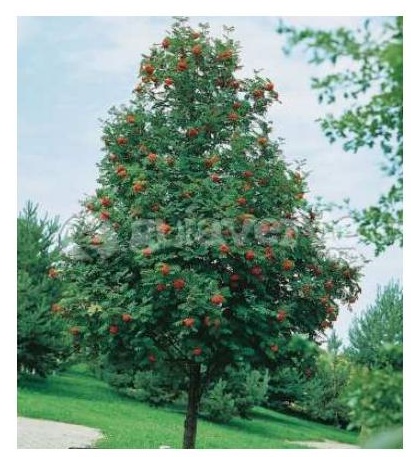

Hábitat - El serbal de cazadores es un árbol propio de las regiones boreales de Eurasia que en España crece en montañas sobre terreno silíceo y abundantes precipitaciones desde los 200 hasta los 2000 m de altitud. En Castilla y León se haya ampliamente distribuido y abunda en las montañas cantábricas y leonesas, también en el Sistema Ibérico y Central. Es una especie heliófila o de media sombra y se desarrolla en un rango de temperatura media de entre 6 y 10 ㄷ. Se mezcla con robles, hayas, álamos temblones y sobre todo con pinos albares, tejos, abedules y acebos.

Utilización - Es un árbol muy apreciado como ornamental en parques y jardines por su floración y fructificación, especialmente en pueblos y caminos de montaña, además de suministrar alimento a las especies de fauna. Sus frutos se utilizan en la fabricación de vodka, licores y para la obtención de sorbosa que es un endulzante para diabéticos. Los frutos son una fuente importante de alimentos para las aves que posteriormente dispersan las semillas y también para los osos de las zonas de León y Palencia durante el otoño y el invierno.

Altura - Árbol de tamaño medio que puede alcanzar los 15-20 m de altura.

Inflorescencia - Las inflorescencias son hermafroditas y se producen en grandes corimbos terminales de 8 a $15 \mathrm{~cm}$ de diámetro con más de 250 flores, cada una de alrededor de $1 \mathrm{~cm}$ de diámetro con cinco pétalo blanco-cremosos, que polinizan los insectos.

Floración - Florece entre mayo y julio. 
Fruto - El fruto es un pomo pequeño de entre 4 a $8 \mathrm{~mm}$ de diámetro, carnoso y de forma globosa de color anaranjado brillante o rojo coral. Forman ramilletes bajo cuyo peso se curvan las ramas y tienen un sabor áspero y ácido.

Fructificación - Los frutos maduran entre septiembre y octubre.

Sistema radical - Raíces principales dominantes, con desarrollo lateral, poco profundas que exploran las capas superficiales del suelo.

\section{Parámetros medios}

\begin{tabular}{|c|c|c|c|c|c|c|c|c|c|}
\hline \multirow{2}{*}{ Especie } & \multicolumn{5}{|c|}{ RAÍCES } & \multicolumn{4}{|c|}{ TRONCO } \\
\hline & $\begin{array}{c}\text { Cohesión } \\
\mathrm{cR}\left(\mathrm{kN} / \mathrm{m}^{2}\right)\end{array}$ & $\begin{array}{c}\text { Resist. } \\
\text { Tracción } \\
\mathrm{T}\left(\mathrm{N} / \mathrm{mm}^{2}\right)\end{array}$ & $\begin{array}{l}\text { Diámetro } \\
\text { D.r (mm) }\end{array}$ & $\begin{array}{c}\text { Densidad } \\
\text { d.r [Ar/As] }\end{array}$ & $\begin{array}{l}\text { Profundidad } \\
\text { p.r (m) }\end{array}$ & $\begin{array}{l}\text { Diámetro } \\
\text { D.t }(\mathrm{cm})\end{array}$ & $\begin{array}{c}\text { Densidad } \\
\gamma \mathbf{v}\left(\mathrm{kg} / \mathrm{m}^{3}\right)\end{array}$ & $\begin{array}{l}\text { Altura } \\
\text { h.t (m) }\end{array}$ & $\begin{array}{l}\text { Fac. } \\
\text { forma } \\
\text { (f.f) }\end{array}$ \\
\hline $\begin{array}{c}\text { Sorbus } \\
\text { aucuparia }\end{array}$ & 2,64 & 25 & 28 & 0,3 & 0,3 & 30 & 710 & 15 & 0,65 \\
\hline
\end{tabular}

\subsubsection{7.- Sorbus domestica (Jerbo)}

$\begin{array}{ll}\text { REINO } & \text { Plantae } \\ \text { DIVISIÓN } & \text { Magnoliophyta } \\ \text { CLASE } & \text { Magnoliopsida } \\ \text { ORDEN } & \text { Rosales } \\ \text { FAMILIA } & \text { Rosaceae } \\ \text { GENERO } & \text { Sorbus } \\ \text { ESPECIE } & \text { S. doméstica }\end{array}$

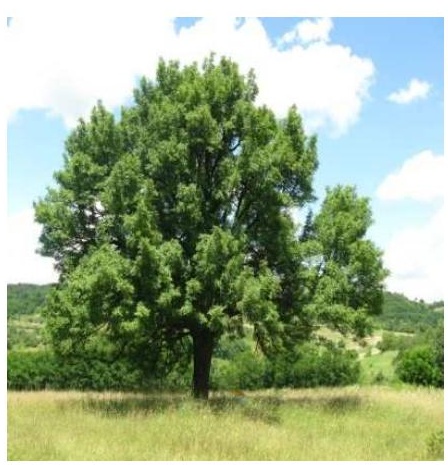

Hábitat - El Jerbo es una especie de tendencia termófila, propia de zonas bajas y medias, situándose en altitudes desde los 300 a los 1200 m. Aunque de tendencia termófila, esta especie es capaz de resistir fríos invernales hasta mínimas absolutas de 25 ㄷ $\mathrm{C}$ negativos. Resiste bien e frío y el hielo pero mal el calor y las sequías fuertes. Prefiere terrenos calizos (aunque soporta también los silíceos), profundos y frescos, orientados al este y oeste. El jerbo es una especie de heliófila o de media luz. En climas cálidos y secos puede comportarse como de media sombra. La temperatura óptima de desarrollo está entre 6 y $10^{\circ} \mathrm{C}$. El jerbo se considera originario de las áreas montañosas de Europa mediterránea (incluyendo las islas), sur de Rusia, norte de África (Argelia y Túnez) y mitad norte de Asia menor. En España se 
distribuye principalmente por la mitad oriental, especialmente en la Rioja, Álava y Mallorca. En Castilla y León es abundante en las provincias de Zamora, León, Palencia, Burgos y Soria. Crece esparcido por las márgenes y claros de bosques de xerófilos, esclerófilos mediterráneos y matorrales de encina (Quercus ilex), quejigo (Quercus faginea), roble melojo (Quercus pyrenaica) así como pinares de de pino negral (Pinus pinaster) y pino carrasco (Pinus halepensis).

Utilización - Es un árbol muy apreciado por la calidad de su madera para trabajos de ebanistería y carpintería con el que se fabrica una gran cantidad de utensilios como peines, mangos de cuchillos y herramientas agrícolas, castañuelas, etc. Es una de las maderas con mayor valor económico, alcanzándose precios de $4500 € / \mathrm{m} 3$. La corteza y las hojas se han empleado como curtientes. Hoy en día se utiliza en la industria de los bronceadores. La leña y el carbón son combustibles de muy buena calidad.

Altura - Este árbol puede alcanzar los $30 \mathrm{~m}$ de altura.

Inflorescencia - Inflorescencias en característicos racimos cónicos, piramidales y corimbiformes de $10 \mathrm{~cm}$ de altura y unos $12-15 \mathrm{~cm}$ de diámetro, con flores hermafroditas, regulares, blancas y pequeñas, de $1,5 \mathrm{~cm}$ de diámetro con 5 estilos.

Floración- Florece entre abril y mayo.

Fruto - Los frutos son en pomo carnoso, piriforme redondeado de unos $2,5 \mathrm{~cm}$; de jóvenes son verdes pero al madurar adquieren un color rojo-castaño.

Fructificación - Los frutos maduran entre septiembre y octubre.

Sistema radical - Raíz central pivotante poco profunda, con raíces laterales de distinta importancia, aunque con desarrollo menor que Sorbus aucuparia.

\section{Parámetros medios}

\begin{tabular}{|c|c|c|c|c|c|c|c|c|c|}
\hline \multirow{2}{*}{ Especie } & \multicolumn{5}{|c|}{ RAÍCES } & \multicolumn{4}{|c|}{ TRONCO } \\
\hline & $\begin{array}{c}\text { Cohesión } \\
\mathrm{cR}\left(\mathrm{kN} / \mathrm{m}^{2}\right)\end{array}$ & $\begin{array}{c}\text { Resist. } \\
\text { Tracción } \\
\mathrm{T}\left(\mathrm{N} / \mathrm{mm}^{2}\right)\end{array}$ & $\begin{array}{l}\text { Diámetro } \\
\text { D.r (mm) }\end{array}$ & $\begin{array}{c}\text { Densidad } \\
\text { d.r [Ar/As] }\end{array}$ & $\begin{array}{l}\text { Profundidad } \\
\text { p.r }(\mathrm{m})\end{array}$ & $\begin{array}{l}\text { Diámetro } \\
\text { D.t }(\mathrm{cm})\end{array}$ & $\begin{array}{c}\text { Densidad } \\
\gamma \mathbf{v}\left(\mathrm{kg} / \mathrm{m}^{3}\right)\end{array}$ & $\begin{array}{l}\text { Altura } \\
\text { h.t (m) }\end{array}$ & $\begin{array}{l}\text { Fac. } \\
\text { forma } \\
\text { (f.f) }\end{array}$ \\
\hline $\begin{array}{c}\text { Sorbus } \\
\text { domestica }\end{array}$ & 4 & 20 & 28 & 0,3 & 0,3 & 25 & 870 & 30 & 0,65 \\
\hline
\end{tabular}




\subsubsection{8.- Sorbus torminalis (Mostajo)}

$\begin{array}{ll}\text { REINO } & \text { Plantae } \\ \text { DIVISIÓN } & \text { Magnoliophyta } \\ \text { CLASE } & \text { Magnoliopsida } \\ \text { ORDEN } & \text { Rosales } \\ \text { FAMILIA } & \text { Rosaceae } \\ \text { GENERO } & \text { Sorbus } \\ \text { ESPECIE } & \text { S. torminalis }\end{array}$

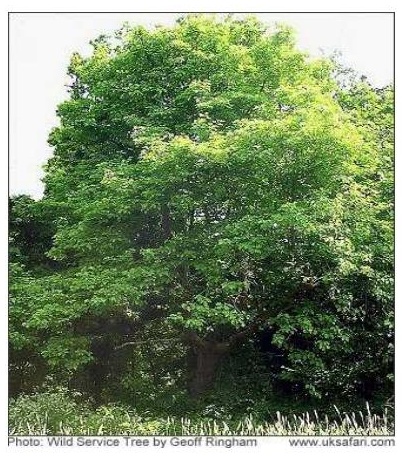

Hábitat - El mostajo es una especie submediterránea y orófila que aparece en zonas montañosas asociado a bosques caducifolios marcescentes de Quercus pyrenaica, Quercus humilis, Quercus faginea, Quercus cerroides y también pero en menor medida en hayedos y pinares de montaña. Aún considerándose una especie orófila, no asciende a gran altura, situándose generalmente entre los 800 y 1200 m, aunque en la cornisa cantábrica puede descender en altitud hasta el nivel del mar. Esta especie es frecuente en laderas rocosas con elevada pendiente; crece tanto en suelos silíceos como calizos, siendo más exigente en nutrientes que otros serbales como es el caso de Sorbus domestica. El temperamento de la especie es de media luz aunque en las zonas de montaña más septentrionales y húmedas se comporta como especie heliófila. Se trata de una especie nativa de Europa, norte de África y sureste de Asia. En España se extiende desde el Pirineo y montañas cantábricas hasta los Montes de Toledo, Sierra Nevada y montañas levantinas. En Castilla y León aparece disperso por robledales, encinares y claros de hayedos en zonas de montaña del norte de Burgos, Sanabria en Zamora, León, Palencia, Soria, Ávila y Salamanca.

Utilización - Es un árbol muy apreciado por la calidad de su madera para trabajos de ebanistería y carpintería con el que se fabrica una gran cantidad de utensilios como mangos de herramientas y piezas de instrumentos de medida instrumentos musicales de viento, en particular de los tubos y piezas de órganos, pianos y clavicordios etc. La leña y el carbón son combustibles de muy buena calidad. Los frutos tienen propiedades astringentes y febrífugos, se utilizaban antiguamente contra la diarrea y contra el dolor de oídos. En Centroeuropa elaboran un licor denominado aliziergeist. Además de su gran valor económico, el mostajo tiene también un gran valor ecológico frente a la protección de los suelos frente a la erosión y como alimento de numerosas aves y mamíferos como el oso pardo y un valor paisajístico y 
ornamental debido a su porte elegante y a la bella tonalidad que adquieren estos árboles en otoño.

Altura - Se trata de un árbol de gran porte que alcanzan alturas de 25-30m.

Inflorescencia - Las flores son blancas de unos $12 \mathrm{~mm}$ de diámetro, agrupadas en corimbos terminales poco nutridos de 7,5 a $10 \mathrm{~cm}$ de anchura. Tienen 5 pétalos abiertos en estrella, 2 estilos soldados en la base y numerosos estambres.

\section{Floración - Florece en mayo.}

Fruto - Los frutos son ovoides o redondeados de unos $12 \mathrm{~mm}$ de diámetro, carnosos, de color pardo verdoso que pasan a tener un color marrón, moteados por puntitos más claros. Su sabor es áspero y al madurar algo más dulce.

Fructificación - Los frutos maduran entre septiembre y octubre.

Sistema radical - Raíz principal y raíces laterales poco profundas que exploran las capas superficiales del suelo. Tiene buena capacidad de amarre y desarrollo en suelos húmedos.

\section{Parámetros medios}

\begin{tabular}{|c|c|c|c|c|c|c|c|c|c|}
\hline \multirow{2}{*}{ Especie } & \multicolumn{5}{|c|}{ RAÍCES } & \multicolumn{4}{|c|}{ TRONCO } \\
\hline & $\begin{array}{c}\text { Cohesión } \\
\mathrm{cR}\left(\mathrm{kN} / \mathrm{m}^{2}\right)\end{array}$ & $\begin{array}{c}\text { Resist. } \\
\text { Tracción } \\
\mathrm{T}\left(\mathrm{N} / \mathrm{mm}^{2}\right)\end{array}$ & $\begin{array}{l}\text { Diámetro } \\
\text { D.r (mm) }\end{array}$ & $\begin{array}{c}\text { Densidad } \\
\text { d.r [Ar/As] }\end{array}$ & $\begin{array}{l}\text { Profundidad } \\
\text { p.r (m) }\end{array}$ & $\begin{array}{l}\text { Diámetro } \\
\text { D.t }(\mathrm{cm})\end{array}$ & $\begin{array}{c}\text { Densidad } \\
\gamma \mathbf{v}\left(\mathrm{kg} / \mathrm{m}^{3}\right)\end{array}$ & $\begin{array}{l}\text { Altura } \\
\text { h.t (m) }\end{array}$ & $\begin{array}{l}\text { Fac. } \\
\text { forma } \\
\text { (f.f) }\end{array}$ \\
\hline $\begin{array}{c}\text { Sorbus } \\
\text { torminalis }\end{array}$ & 2,64 & 18 & 28 & 0,3 & 0,3 & 22 & 850 & 25 & 0,65 \\
\hline
\end{tabular}




\subsubsection{9.- Taxus baccata (Tejo)}

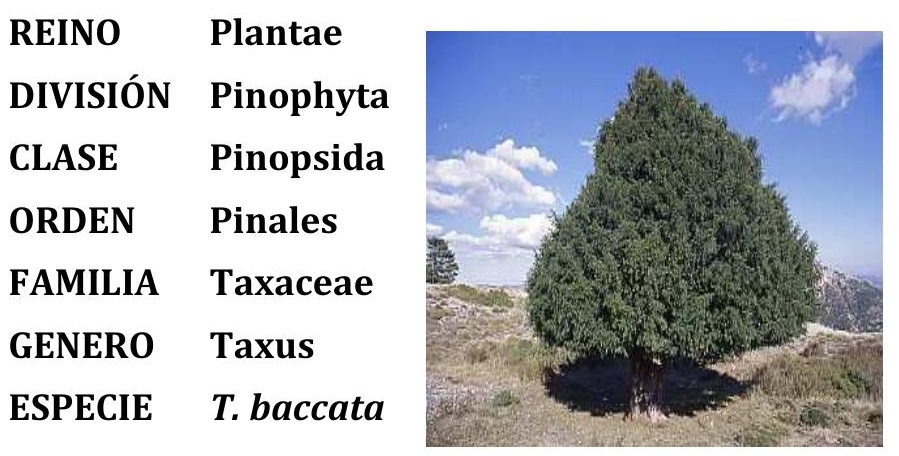

Hábitat - El tejo crece en zonas de umbría o laderas orientadas al norte o este, donde la frescura y la humedad ambiental están aseguradas. El temperamento es de sombra e higrófilo. Se desarrolla sobre todo en las faldas y áreas pedregosas y ásperas de las montañas desde los 100 a los $1400 \mathrm{~m}$ de altitud, aunque pueden llegar a los $1800 \mathrm{~m}$ en zonas del Sistema Central y descender a cotas de unos $40 \mathrm{~m}$ en zonas de Guipúzcoa o Asturias. El tejo prefiere los suelos calizos pero tolera bien los silíceos. Es resistente al frío pero no soporta bien las heladas tardías. Se mezcla con gran cantidad de especies sobre todo robles y hayas pero también con acebos, abedules, mostajos, fresnos, etc.

Utilización - Es un árbol muy apreciado por su valor ecológico, ornamental, forrajero (para vacas y cabras), por su madera de alta calidad para trabajos de carpintería y ebanistería y más actualmente por su aplicación en medicina contra el cáncer. La madera de tejo por sus características tecnológicas de elasticidad y dureza es de las más apreciadas en Europa para la elaboración de tarimas, sillas, mesas, instrumentos musicales y escultura.

Altura - Se trata de un árbol o arbolillo que mide entre 6 y $15 \mathrm{~m}$ de altura, pudiendo llegar a superar los $25 \mathrm{~m}$ de altura.

Inflorescencia - Las flores son unisexuales, apareciendo las masculinas y las femeninas en distintos árboles, son pequeñas y verdosas. Las masculinas aparecen formando conos en las axilas de las hojas, en la cara inferior de las ramas; son solitarias, globosas, con 6-14 escamas, cada una con 4-8 sacos polínicos. Las flores femeninas constan de 1 ó 2 rudimentos seminales; cada uno con una escama estéril o varias imbricadas.

Floración - Florece entre marzo y abril. 
Fruto - El fruto es una semilla ovalada y está cubierta en su parte por un disco carnoso, el arilo, que se abre en la parte superior; de color verde que pasa a ser rojo cuando madura. EI arilo es la única parte de la planta que no resulta tóxica para el hombre.

Fructificación - Los frutos se forman a finales de verano o en el otoño del mismo año.

Sistema radical - Sistema radicular profundo y fuerte.

\section{Parámetros medios}

\begin{tabular}{|c|c|c|c|c|c|c|c|c|}
\hline \multirow{2}{*}{ Especie } & \multicolumn{3}{|c|}{ RAÍCES } & \multicolumn{2}{c|}{ TRONCO } \\
\cline { 2 - 8 } & $\begin{array}{c}\text { Cohesión } \\
\mathrm{cR}\left(\mathrm{kN} / \mathrm{m}^{2}\right)\end{array}$ & $\begin{array}{c}\text { Resist. } \\
\text { Tracción } \\
\mathrm{T}\left(\mathrm{N} / \mathrm{mm}^{2}\right)\end{array}$ & $\begin{array}{c}\text { Diámetro } \\
\text { D.r }(\mathrm{mm})\end{array}$ & $\begin{array}{c}\text { Densidad } \\
\text { d.r [Ar/As] }\end{array}$ & $\begin{array}{c}\text { Profundidad } \\
\text { p.r }(\mathrm{m})\end{array}$ & $\begin{array}{c}\text { Diámetro } \\
\text { D.t }(\mathrm{cm})\end{array}$ & $\begin{array}{c}\text { Densidad } \\
\gamma \mathrm{v}\left(\mathrm{kg} / \mathrm{m}^{3}\right)\end{array}$ & $\begin{array}{c}\text { Altura } \\
\mathrm{h} . \mathrm{t}(\mathrm{m})\end{array}$ \\
$\begin{array}{c}\text { Taxus } \\
\text { baccata }\end{array}$ & 2,64 & 45 & 20 & 0,3 & 2,0 & 30 & 700 \\
$\begin{array}{c}\text { Fac. } \\
(\mathrm{f} . \mathrm{f})\end{array}$ \\
\hline
\end{tabular}

\subsubsection{0.- Ulmus glabra (Olmo de montaña)}

$\begin{array}{ll}\text { REINO } & \text { Plantae } \\ \text { DIVISIÓN } & \text { Magnoliophyta } \\ \text { CLASE } & \text { Magnoliopsida } \\ \text { ORDEN } & \text { Urticales } \\ \text { FAMILIA } & \text { Ulmaceae } \\ \text { GENERO } & \text { Ulmus } \\ \text { ESPECIE } & \text { U.glabra }\end{array}$

Hábitat - El olmo de montaña se encuentra esparcido en zonas de montaña de climas lluviosos has los $1500 \mathrm{~m}$ de altitud. Crece en suelos fértiles, frescos y ligeros; prefiere los suelos calizos pero crece también en los silíceos. Requiere más de $600 \mathrm{~mm}$ de precipitación anual, soporta los fríos intensos con temperaturas inferiores a $3 \stackrel{\circ}{C}$ y los veranos calurosos con temperaturas que pueden llegar a los $40^{\circ} \mathrm{C}$. El olmo se distribuye por gran parte de Europa hasta Asia occidental. En la Península ocupa áreas montañosas de la mitad septentrional y en Castilla y León se instala en ambientes boscosos de montaña de la cornisa cantábrica, del 
sistema Ibérico y Central. En estás áreas el olmo crece en los claros de robledales, y de hayedos; a menudo entre rocas y terrenos pedregosos junto a tilos, fresnos, avellanos, cerezos silvestres, etc.

Utilización - Debido a la dureza de la madera y su resistencia a la putrefacción, la madera de olmo se ha utilizado en la construcción naval y en la fabricación de pilotes para minas. Sirve también para la fabricación de muebles, entarimados y objetos sometidos a golpes continuos como son las prensas y antiguamente para la fabricación de carros. La corteza del olmo se ha empleado en medicina por sus propiedades astringentes y antiinflamatorias, así como las hojas son utilizadas como forraje para el ganado en época de escasez de pastos. Los frutos y las hojas también suponen una fuente de alimento para multitud de aves y caza como corzos, ciervos, etc. Los árboles viejos albergan a numerosos animales que se esconden en los troncos como gatos monteses, martas, cárabos, lechuzas, etc.

Altura - Árbol de porte elevado y robusto de talla hasta $35 \mathrm{~m}$.

Inflorescencia - Las flores se agrupan en ramilletes apretados o glomérulos globosos sentados sobre las ramillas, de color verdoso o pardo-rojizo, casi sin pedicelos; cada una lleva una envuelta con un número variable de sépalos, entre 4 y 6 , y el mismo número de estambres salientes, con anteras de color purpúreo, opuestos a los sépalos.

Floración - Florece entre febrero y marzo.

Fruto - El fruto es alado y de tipo sámara, ovalado o circular y mide de 2 a $3 \mathrm{~cm}$ de diámetro con la semilla centrada y escotadura poco marcada.

Fructificación - Los frutos se forman a comienzos de primavera.

Sistema radical - Sistema radical somero con potentes raíces secundarias, sin echar renuevos.

\section{Parámetros medios}

\begin{tabular}{|c|c|c|c|c|c|c|c|c|c|}
\hline \multirow{2}{*}{ Especie } & \multicolumn{5}{|c|}{ RAÍCES } & \multicolumn{4}{|c|}{ TRONCO } \\
\hline & $\begin{array}{l}\text { Cohesión } \\
\mathrm{cR}\left(\mathrm{kN} / \mathrm{m}^{2}\right)\end{array}$ & $\begin{array}{c}\text { Resist. } \\
\text { Tracción } \\
\mathrm{T}\left(\mathrm{N} / \mathrm{mm}^{2}\right)\end{array}$ & $\begin{array}{l}\text { Diámetro } \\
\text { D.r (mm) }\end{array}$ & $\begin{array}{c}\text { Densidad } \\
\text { d.r }[\mathrm{Ar} / \mathrm{As}]\end{array}$ & $\begin{array}{l}\text { Profundidad } \\
\text { p.r }(\mathrm{m})\end{array}$ & $\begin{array}{l}\text { Diámetro } \\
\text { D.t (cm) }\end{array}$ & $\begin{array}{c}\text { Densidad } \\
\gamma \mathbf{v}\left(\mathrm{kg} / \mathrm{m}^{3}\right)\end{array}$ & $\begin{array}{l}\text { Altura } \\
\text { h.t (m) }\end{array}$ & $\begin{array}{l}\text { Fac. } \\
\text { forma } \\
\text { (f.f) }\end{array}$ \\
\hline Ulmus glabra & 2,64 & 25 & 20 & 0,3 & 0,6 & 35 & 690 & 15 & 0,65 \\
\hline
\end{tabular}


DESARROLLO DE UNA APLICACIÓN INFORMÁTICA PARA EL CÁLCULO DE SOSTENIMIENTO DE TALUDES MEDIANTE REVEGETACIÓN 


\section{ANEXO III \\ MÉTODOS DE CÁLCULO DE ESTABILIDAD DE TALUDES}

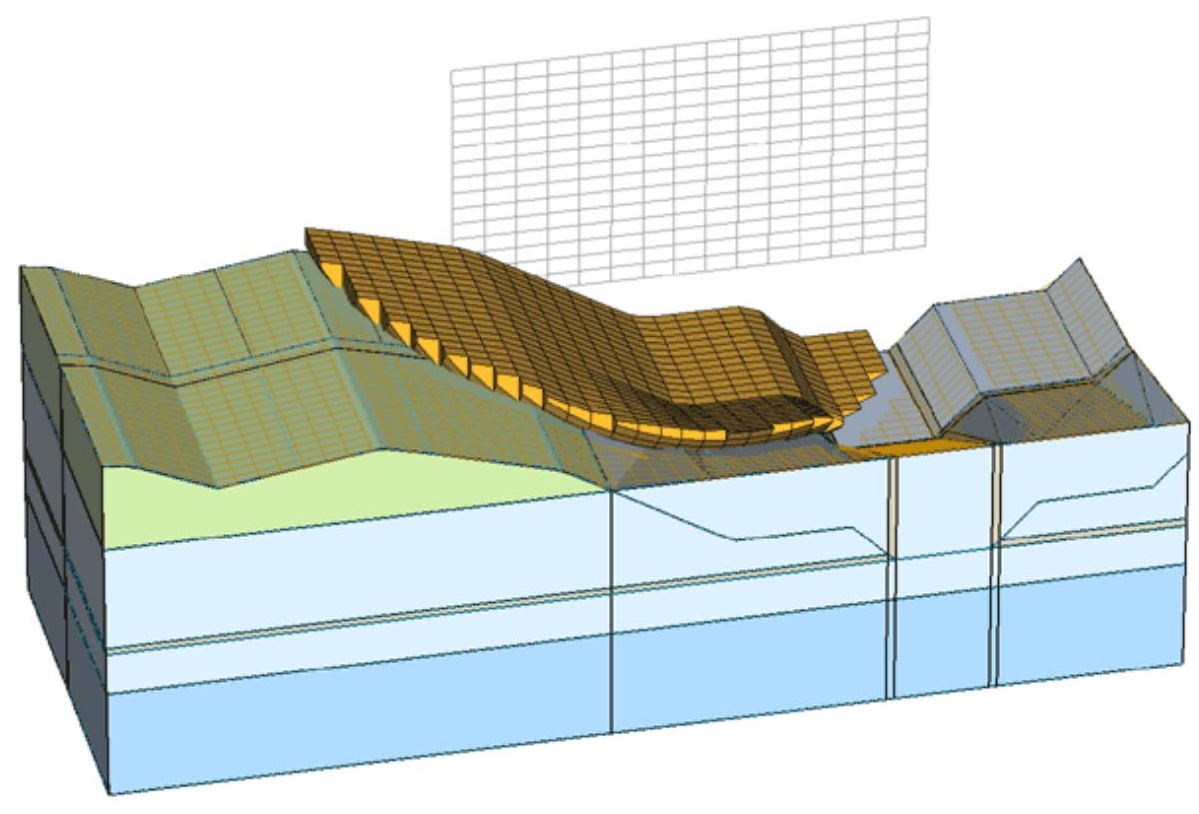




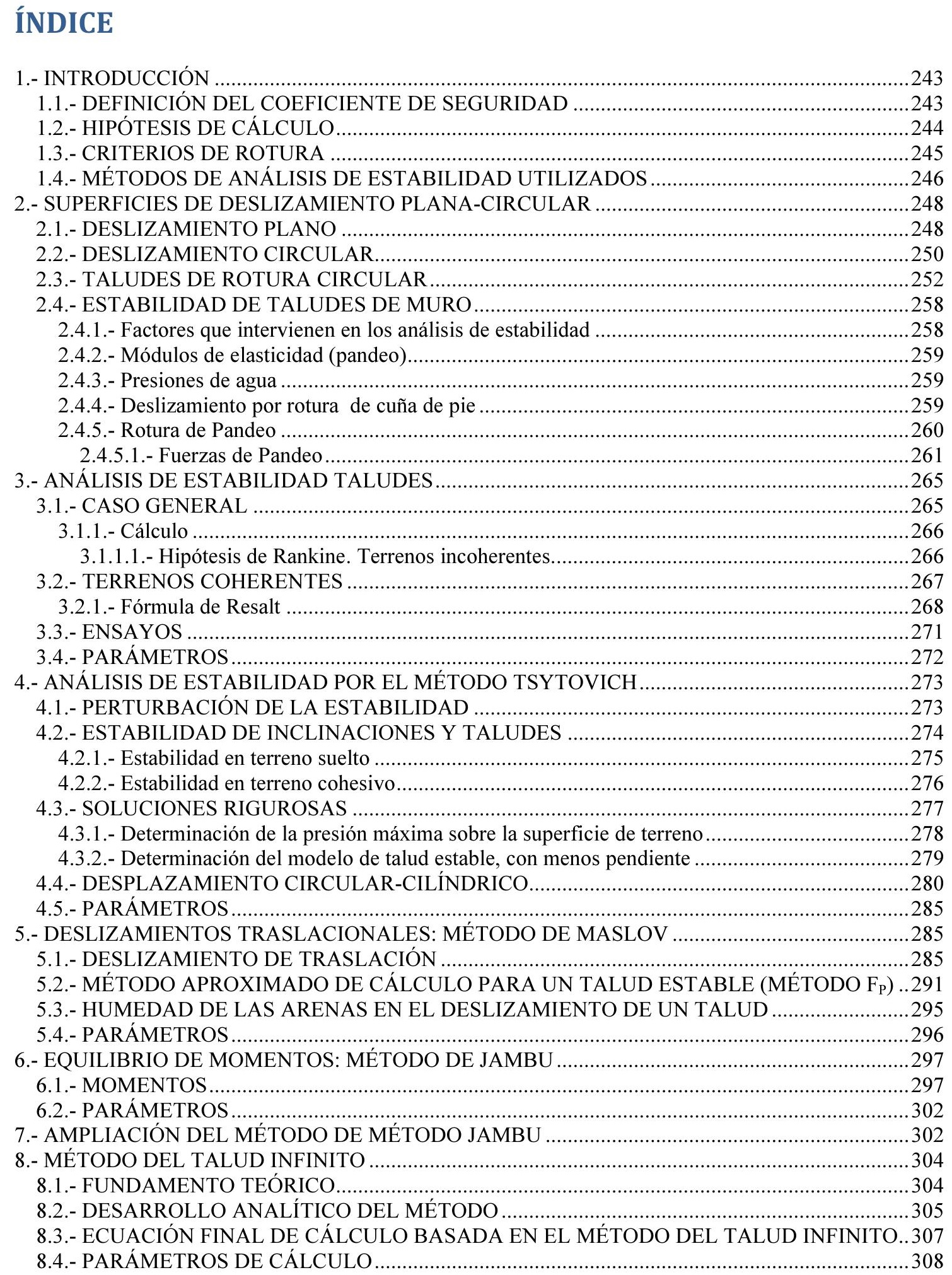




\section{1.- INTRODUCCIÓN}

\section{1.- DEFINICIÓN DEL COEFICIENTE DE SEGURIDAD}

Para realizar una cuantificación de la estabilidad de un talud es necesario, en primer lugar establecer un valor del factor de seguridad.

El factor de seguridad se define como el cociente entre las fuerzas resistentes y las fuerzas motoras, que actúan sobre una determinada masa de terreno potencialmente inestable, delimitada por la superficie de deslizamiento.

$$
F=\frac{S}{\tau}=\frac{S \cdot A}{\tau \cdot A}=\frac{R}{W_{T}}
$$

1. Fuerzas resistentes (R): Se oponen al deslizamiento. Son básicamente la cohesión y el ángulo de rozamiento interno del terreno.

2. Fuerzas motoras (WT): Tienden a desestabilizar el terreno. Tienen su origen en la componente tangencial del peso de la masa de terreno potencialmente inestable.

El coeficiente de seguridad es un valor numérico próximo a la unidad, si el valor supera la unidad, el talud es estable, pero debe exigirse un valor mínimo algo mayor, para que exista un margen de seguridad.

El factor de seguridad mínimo exigible se selecciona teniendo en cuenta el tiempo de servicio de los taludes y el riesgo que llevan asociado.

\section{Tiempo de servicio}

Se distinguen dos categorías en función del tiempo de servicio.

- Temporales.- Su vida útil prevista es inferior a 9 meses.

- Permanentes.- Su vida útil prevista es superior a 9 meses.

\section{Riesgo asociado}

Se analiza de forma cualitativa desde el punto de vista social y económico, estableciéndose las tres categorías que se muestran en la tabla. 
Tabla 1: Tipos de riesgo asociados al talud, en función de posibles pérdidas económicas o daños a las personas.

\begin{tabular}{|l|l|}
\hline Riesgo & Descripción \\
\hline Riesgo 1 & $\begin{array}{l}\text { Pérdidas económicas bajas. } \\
\text { Daños leves a personas. }\end{array}$ \\
\hline Riesgo 2 & $\begin{array}{l}\text { Pérdidas económicas importantes. } \\
\text { Daños moderados a personas. }\end{array}$ \\
\hline Riesgo 3 & $\begin{array}{l}\text { Pérdidas económicas importantes. } \\
\text { Daños graves a personas. }\end{array}$ \\
\hline
\end{tabular}

A partir de los dos anteriores factores, se determina la clase de riesgo, la cual va a determinar el factor de seguridad mínimo exigible.

Tabla 2: Determinación de la clase de riesgo en función del tiempo de servicio y el riesgo asociado.

\begin{tabular}{|l|l|l|}
\hline & Talud Temporal & Talud Permanente \\
\hline Riesgo 1 & C1 & C4 \\
\hline Riesgo 2 & C2 & C5 \\
\hline Riesgo 3 & C3 & C6 \\
\hline
\end{tabular}

Tabla 3: Determinación del factor de seguridad a partir de la clase de riesgo.

\begin{tabular}{|l|l|l|l|l|l|l|}
\hline Categoría & C1 & C2 & C3 & C4 & C5 & C6 \\
\hline $\begin{array}{l}\text { Factor de } \\
\text { Mayoración }\end{array}$ & 1,4 & 1,5 & 1,8 & 1,6 & 1,8 & 2,0 \\
\hline $\begin{array}{l}\text { Factor de } \\
\text { Seguridad }\end{array}$ & 1,3 & 1,3 & 1,4 & 1,4 & 1,5 & 1,5 \\
\hline
\end{tabular}

\section{2.- HIPÓTESIS DE CÁLCULO}

Para el cálculo del ángulo de estabilidad de taludes, con un factor de seguridad preestablecido, no existe un procedimiento de análisis único que permita realizar el cálculo sean cuales fueren las características del macizo rocoso.

Por lo anterior, los métodos de cálculo empleados, están basados en la sencillez de la formulación, aplicación lo más general posible, y la utilización de tablas, ábacos y gráficos.

La derivación de un gráfico universal de cálculo, que tenga en cuenta todas las posibles combinaciones de materiales geológicos, geometrías de superficies de caída y condiciones de aguas freáticas, no se considera factible. 
Por lo tanto, para realizar un trabajo de valor práctico para los técnicos, es preciso simplificar con algunas hipótesis, e imponer algunas limitaciones.

Se consideraran solamente:

- Superficies planas, de estructuras muy definidas, (Fig. 32).

- Superficies circulares, que se presentan en materiales sueltos, y rocas blandas, donde las propiedades mecánicas no están dominadas por las características estructurales, (Fig. 33).

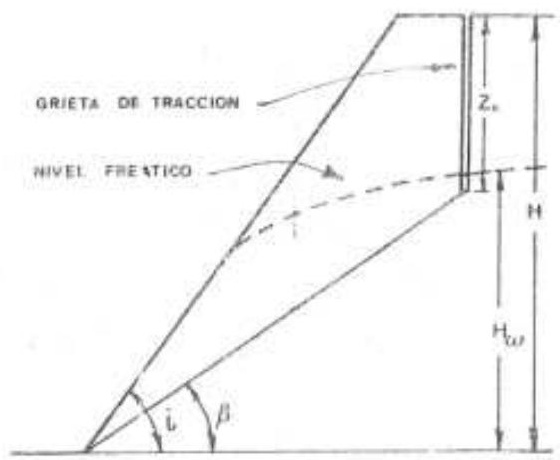

Figura 32: Superficies planas

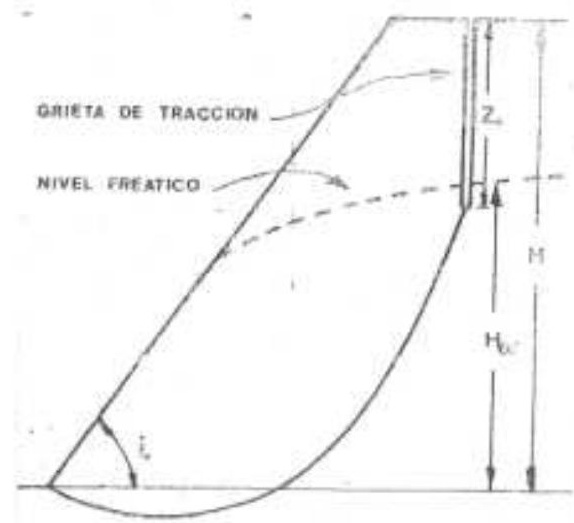

Figura 33: Superficies circulares

\section{3.- CRITERIOS DE ROTURA}

De forma simplificada, se puede utilizar la ecuación de Mohr- Coulomb para establecer una relación entre las fuerzas resistentes y las fuerzas que tienden a desestabilizar el talud.

El criterio de rotura de Mohr- Coulomb es un criterio de rotura lineal, esto significa que la ecuación que la define es una línea recta.

Este criterio expresa la resistencia al corte a lo largo de un plano en un estado triaxial de tensiones, obteniéndose la relación entre los esfuerzos normal y tangencial actuantes en el momento de la rotura mediante la expresión matemática:

$$
\tau=c+\sigma \tan \varphi
$$

En la cual: 
- $\quad \boldsymbol{c}$ : Es la cohesión, una constante que representa la tensión cortante que puede soportar un terreno sin romperse, por adherencia de las partículas.

- $\phi$ : Es el ángulo de fricción.

- $\sigma$ : Es la tensión normal sobre el plano de rotura.

- $\tau$ : Es la tensión tangencial que actúa en el plano de rotura.

A continuación (Figura 34), se representa el criterio de Mohr-Coulomb en el espacio de tensiones normal y tangencial. Se puede apreciar que la ecuación de la superficie de rotura es la ecuación de la recta tangente a todos los círculos de falla. Para un estado tensional por debajo de la recta, no se producirá la rotura.

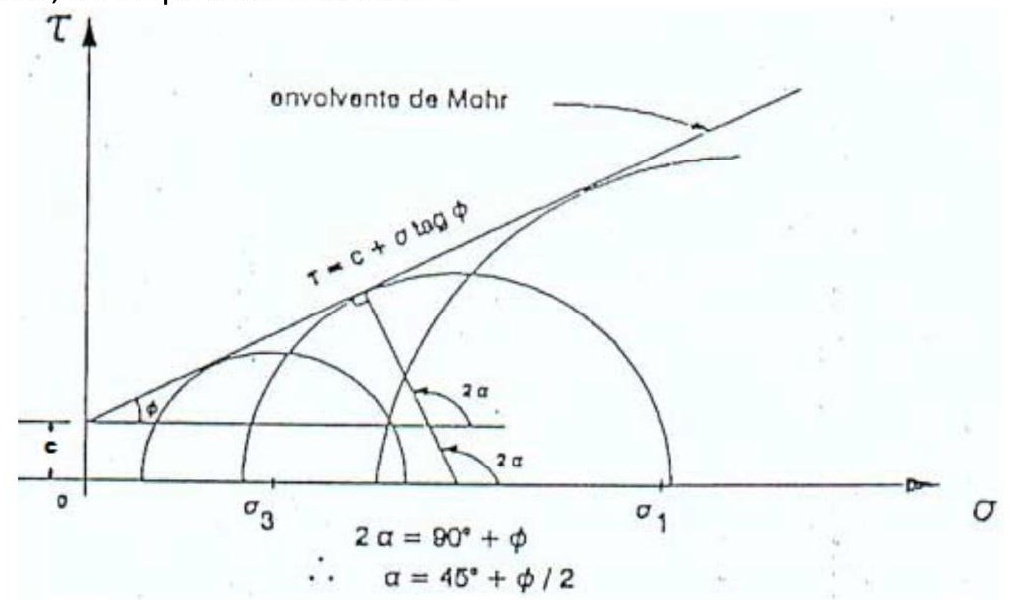

Figura 34: Envolventes de Mohr-Coulomb en términos de esfuerzos tangenciales y normales.

\section{4.- MÉTODOS DE ANÁLISIS DE ESTABILIDAD UTILIZADOS}

Para el cálculo del factor de seguridad se recomienda el empleo de métodos de equilibrio límite, que analizan el equilibrio de una masa potencialmente inestable y consisten en comparar las fuerzas tendentes al movimiento con las fuerzas resistentes que se oponen al mismo a lo largo de una determinada superficie de rotura. Estos métodos se basan en:

- La selección de una superficie teórica de rotura en el talud.

- El criterio de rotura de Mohr-Coulomb.

- La definición de Coeficiente de seguridad.

Para poder aplicar los Métodos de equilibrio límite se deben asumir las siguientes condiciones:

- La superficie de rotura debe ser postulada con una geometría tal que permita que ocurra el deslizamiento.

- La distribución de las fuerzas actuando en la superficie de rotura podrá ser computada utilizando datos conocidos (peso específico del material, presión de agua, etc). 
- La resistencia se moviliza simultáneamente a lo largo de todo el plano de rotura.

Con estas condiciones se establecen las condiciones de equilibrio entre las fuerzas que inducen al deslizamiento y las resistentes obteniendo el coeficiente de seguridad del talud.

$$
\mathrm{F}=\frac{\text { Fuerzas estabilizadoras }}{\text { Fuerzas desestabilizadoras }}
$$

O expresado en términos de tensiones:

$$
F=\frac{\text { Tensiones tangenciales resistentes }}{\text { Tensiones tangenciales deslizantes }}
$$

Las fuerzas que actúan sobre el plano de rotura suponiendo que no existen fuerzas externas sobre el talud son las debidas al peso del terreno, $\mathbf{W}$, a la cohesión, $\mathbf{c}$, y al ángulo de rozamiento interno, $\boldsymbol{\phi}$ del plano.

El coeficiente de seguridad viene dado por:

$$
F=\frac{c A+(W \cos \alpha-U) \operatorname{tg} \varphi}{W \operatorname{sen} \alpha}
$$

Siendo:

- $\quad \mathbf{A} \mathbf{A}=$ Fuerza debida a la cohesión en el plano de deslizamiento.

- $\quad(\mathbf{W} \cos \alpha-U) \operatorname{tg} \phi=$ Fuerza debida al rozamiento en el plano

- Wos $\alpha=$ Componente estabilizadora del peso (normal a la superficie de deslizamiento)

- $\mathbf{U}=$ Fuerza total debida a la presión de agua sobre la superficie de deslizamiento.

- Wsen $\alpha$ = componente del peso tendente al deslizamiento (paralela a la superficie de deslizamiento).

- $\quad A=$ Área del plano de rotura. 


\section{2.- SUPERFICIES DE DESLIZAMIENTO PLANA-CIRCULAR}

\section{1.- DESLIZAMIENTO PLANO}

La hipótesis de deslizamiento plano (Fig. 35), es válida cuando se cumple:

$$
\mathrm{i}>\beta>\varnothing\left[10^{\circ}<\varnothing<40^{\circ}\right]
$$

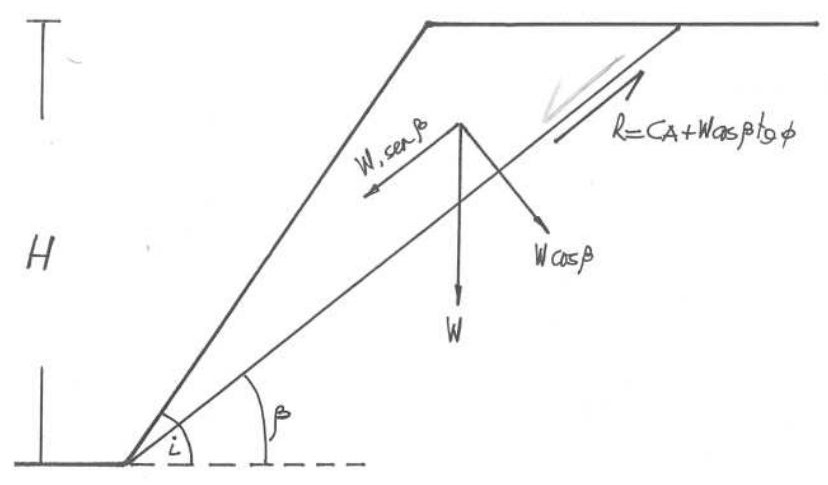

Figura 35: Deslizamiento plano

El factor de seguridad viene dado por la siguiente ecuación:

$$
\mathrm{F}=\frac{2 \mathrm{CSen} \mathrm{i}}{\gamma \mathrm{HSen}(\mathrm{i}-\beta) \times \operatorname{Sen} \beta}+\frac{\operatorname{tg} \varnothing}{\operatorname{tg} \beta} \quad(\text { ecuación } 1)
$$

Pudiendo expresarse:

$$
\frac{\gamma \mathrm{H}}{\mathrm{C}}=\frac{2 \operatorname{Sen} \mathrm{i} \times \operatorname{Cos} \emptyset}{\operatorname{Sen}(\mathrm{i}-\beta)(\mathrm{F} \operatorname{Sen} \beta \operatorname{Cos} \emptyset-\operatorname{Sen} \emptyset \operatorname{Cos} \beta)}(\text { ecuación } 2)
$$

- $\quad$ Si F = 1 (situación de equilibrio límite)

$$
\frac{\gamma \mathrm{H}}{\mathrm{C}}=\frac{2 \operatorname{Sen} \mathrm{i} \times \operatorname{Cos} \emptyset}{\operatorname{Sen}(\mathrm{i}-\beta) \times \operatorname{Sen}(\beta-\emptyset)}(\text { ecuación } 3)
$$

Las ecuaciones 2 y 3 muestran que la altura $\mathrm{H}$, puede combinarse con la densidad $\gamma$ y la cohesión C, para producir un grupo adimensional: $\gamma \mathrm{H} / \mathrm{C}$ 
Sus dimensiones son las siguientes:

$$
\gamma-\frac{\mathrm{T}}{\mathrm{m}^{3}} ; \mathrm{H}-\mathrm{m} \quad ; \quad \mathrm{C}-\frac{\mathrm{T}}{\mathrm{m}^{2}} \quad ; \quad \frac{\gamma \mathrm{H}}{\mathrm{C}} \rightarrow \frac{\mathrm{T} / \mathrm{m}^{3} \times \mathrm{m}}{\mathrm{T} / \mathrm{m}^{2}}
$$

La combinación ideal de I, $\beta$, y $\varnothing$; “función $X$ del ángulo del talud", reducirá la relación crítica de talud dada por la ecuación 3 , a una curva simple.

La función elegida es:

$$
X=2 \times \sqrt{(i-\beta) \times(\beta-\emptyset)}
$$

El estudio se realiza según el gráfico (Fig. 36), donde las abscisas son la función:

$$
X=2 \times \sqrt{(i-\beta) \times(\beta-\emptyset)}
$$

Y las ordenadas, son la denominada "función altura del talud":

$$
\mathrm{y}=\frac{\gamma H}{C}
$$

Figura 36: Gráfico de diseño del Talud (Deslizamiento plano)

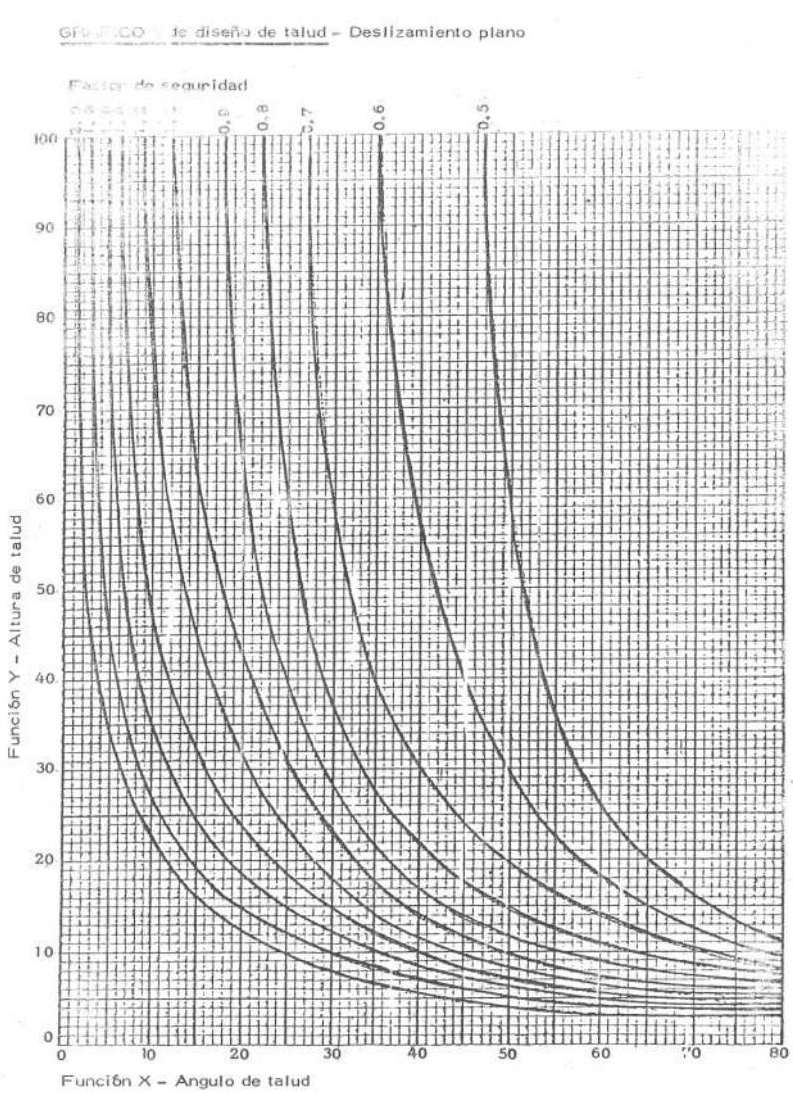

En el caso de un talud rocoso, con un plano de deslizamiento potencial, inclinado un ángulo $\beta$, con una grieta de tracción de profundidad [Z0] y agua subterránea a un nivel [Hw] 
sobre la parte alta del talud (Fig. 33), el factor de seguridad se puede expresar como función de los parámetros adimensionales:

$$
\mathrm{F}>\mathrm{f}\left(\frac{\gamma \mathrm{H}}{\mathrm{C}}, \mathrm{i}, \beta, \varnothing, \frac{[\mathrm{Z} 0]}{\mathrm{H}}, \frac{[\mathrm{Hw}]}{\mathrm{H}}\right)
$$

Valores de las funciones $x$ e y, que corrigen dichas funciones, adecuándolas a los casos presentados en la Figura 37.
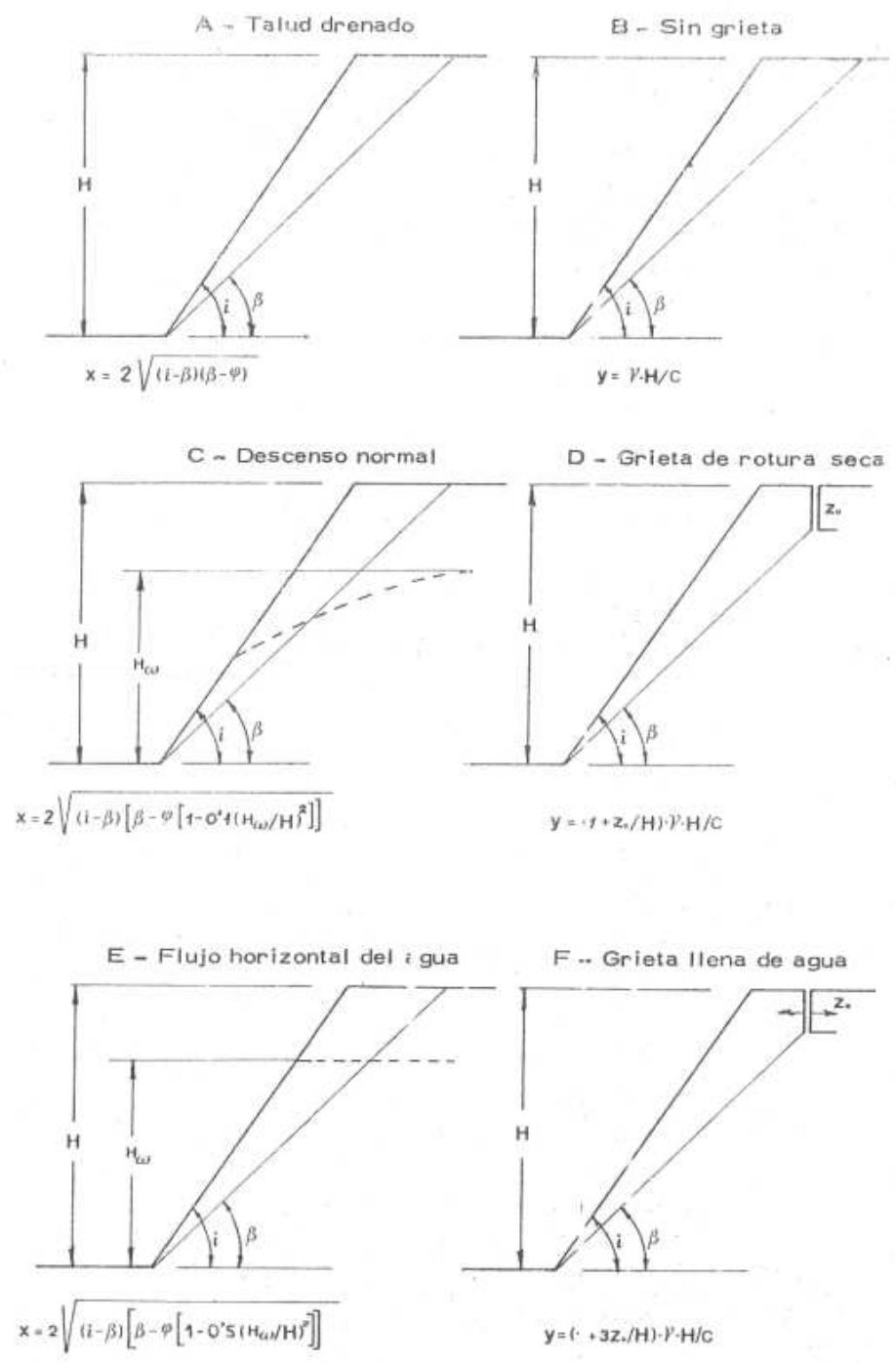

Figura 37: Cálculo de las funciones x e y (Deslizamiento plano)

\section{2.- DESLIZAMIENTO CIRCULAR}

El método es adecuado para terrenos sueltos y rocas blandas. Se pueden utilizar como funciones $x$ e $y$ :

- Función $\mathrm{x}$ de ángulo de talud $=\mathrm{i}-1,2 \varnothing$ 
- Función y de altura de talud $=\frac{\gamma \mathrm{H}}{\mathrm{C}}$

Se establecen correcciones para la influencia del agua subterránea y para las grietas de rotura en la parte alta del talud, según la Figura 38.
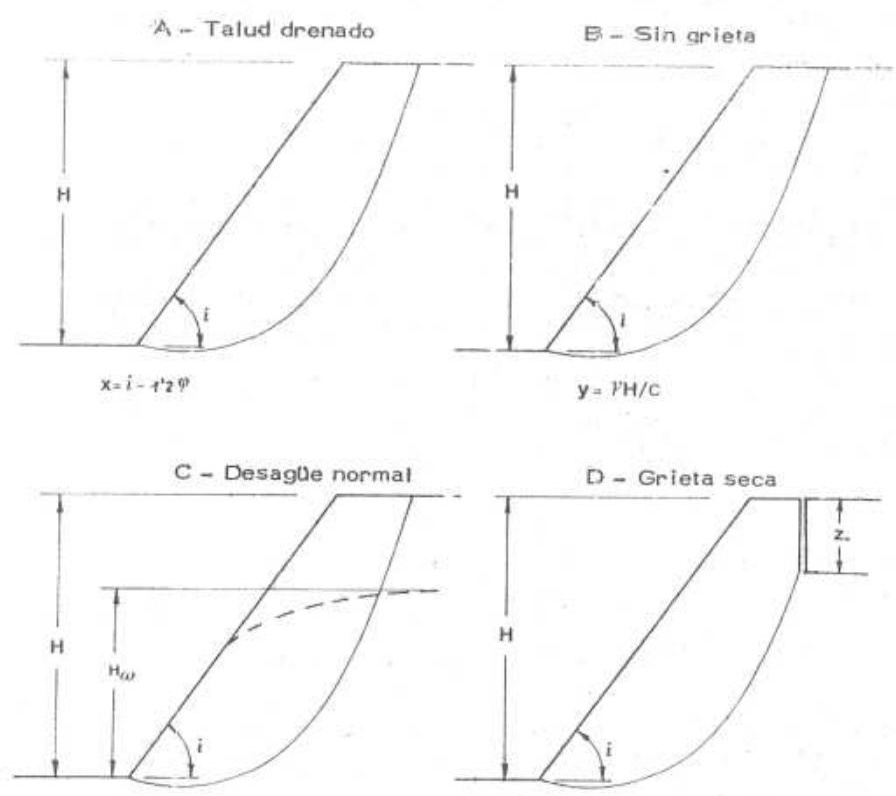

$x=i-p\left(12-0^{\prime}+H_{w} / H\right)$

$\mathbf{y}=\left[1+\left(\frac{1-2 S}{100}\right) z_{0} / H\right] \gamma H / C$
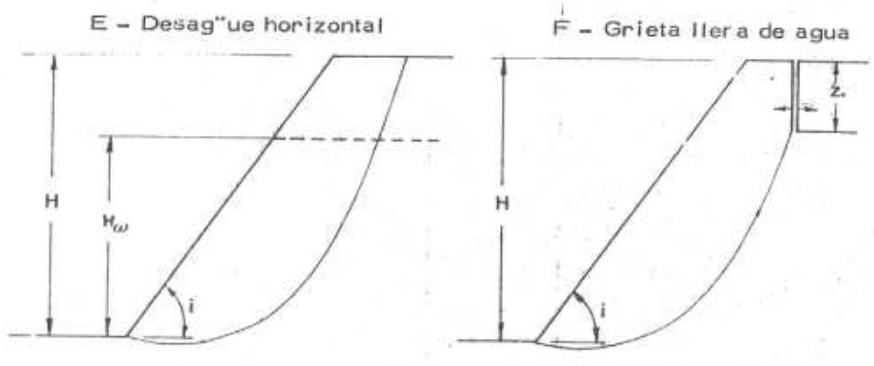

$\left.x=i-\varphi\left(1^{\prime} Z-0^{\prime}\right) H_{\omega} / H\right)$

$y=\left[1+\left(\frac{1-10}{100}\right) z / 1 H\right]$ r H /

Figura 38: Cálculo de las funciones x e y (Deslizamiento circular) 
El gráfico (Fig. 39), representa las funciones de $\mathrm{x}$ del ángulo de talud e y de altura del mismo, para distintos coeficientes de seguridad.

Figura 39: Funciones x e y para distintos coeficientes de seguridad

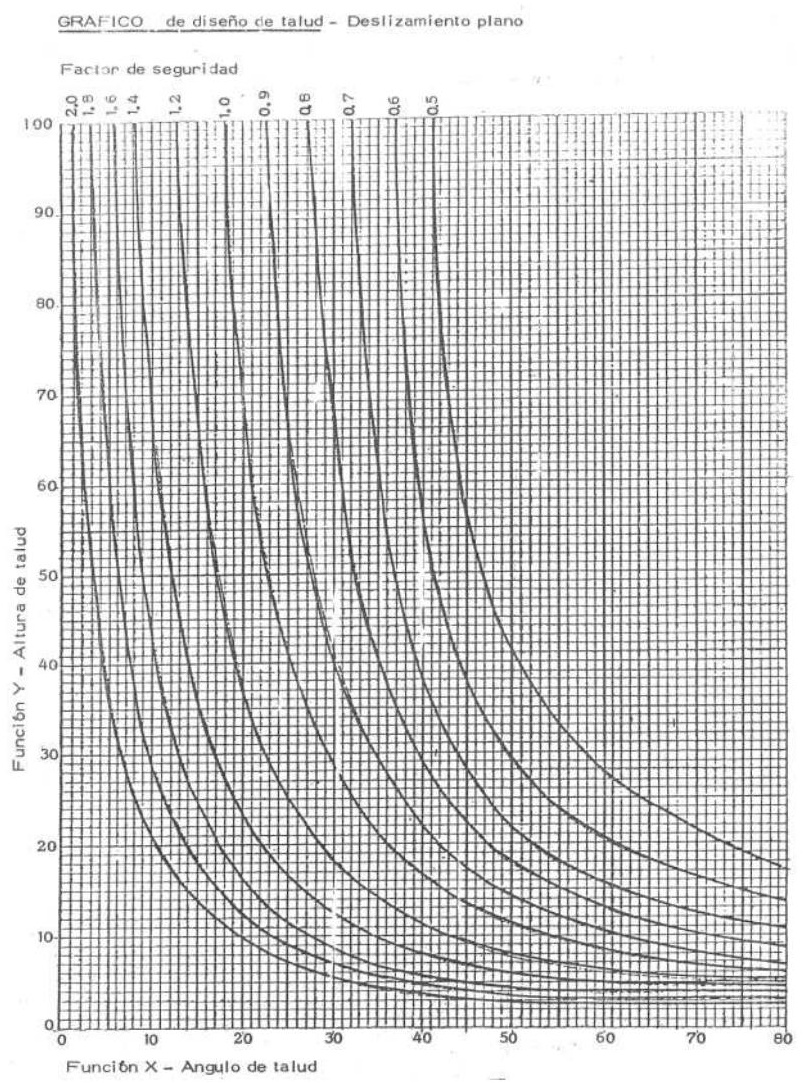

\section{3.- TALUDES DE ROTURA CIRCULAR}

$\underline{\text { Ábacos }}$

Se emplearan en materiales blandos o flojos, especialmente indicados para el análisis de estabilidad de escombreras y zonas de relleno.

\section{Hipótesis básicas}

- Se supone que el material de talud es homogéneo, es decir, que sus propiedades mecánicas no varían con la dirección de la carga.

- La resistencia al corte está caracterizada por una cohesión C y un ángulo de rozamiento interno $\varnothing$, relacionados según la siguiente fórmula (Mohr-Coulomb):

$$
\tau=C+\sigma \times \operatorname{tg} \varnothing
$$

- La rotura pasa por el pie del talud.

- Hay una grieta vertical de tracción en la superficie superior o en la cara del talud.

- La localización de la grieta de tracción y de la superficie de rotura, son tales que el factor de seguridad del talud es mínimo para la geometría del mismo y las condiciones de agua subterránea considerados. 
- Se consideran en el análisis una gama de condiciones de agua subterránea, que va del talud seco al talud totalmente saturado.

\section{Factor de seguridad}

Es igual a:

$$
F=\frac{\text { Resitencia al corte necesaria para resistir el deslizamiento }}{\text { Resistencia al corte movilizada en la superficie de rotura }}
$$

Transponiendo términos, tenemos:

$$
\tau_{\mathrm{mb}}=\frac{\mathrm{C}}{\mathrm{F}}+\frac{\tau \operatorname{tg} \emptyset}{\mathrm{F}}
$$

- Donde tmb, es la tensión de corte movilizada a lo largo de la superficie de rotura.

Los ábacos que definen una situación correspondiente a las condiciones de agua subterránea, son los de la Tabla 4.

Para su utilización, con el fin de determinar un factor de seguridad particular, deberán seguirse las etapas mostradas en la Fig. 40.

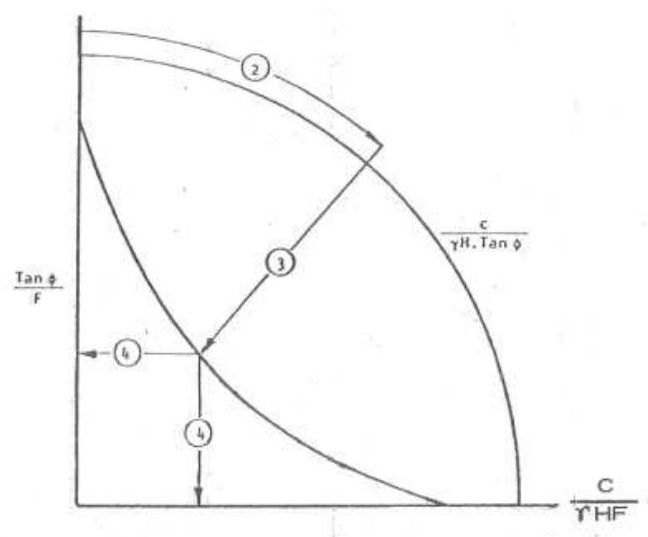

Figura 40: Procedimiento para determinar el coeficiente de seguridad de un talud (Hoek y Bray) 


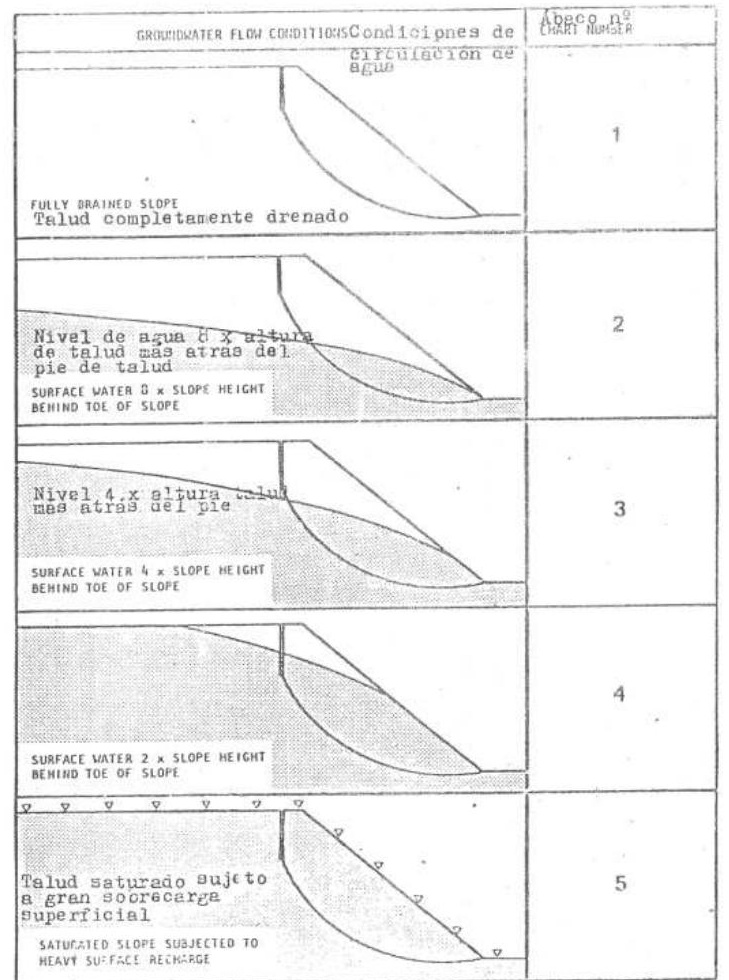

- Tabla 4.- Condiciones de saturación del agua.

- Decidir las condiciones de agua subterránea que se cree existan en el talud y elegir el ábaco que se acerque más a estas condiciones utilizando los datos de la Tabla 4.

- Calcular el valor de la relación adimensional $\frac{\mathrm{C}}{\gamma \pi \operatorname{tg} \emptyset}$, y llevar este valor a la escala circular exterior del ábaco.

- Seguir la línea radial desde el valor hallado en la etapa 2, hasta su intersección con la curva que corresponde al ángulo del talud considerado.

- Hallar el valor correspondiente de $\frac{\operatorname{tg} \emptyset}{\mathrm{F}} \circ$ bien $\frac{\mathrm{C}}{\gamma \mathrm{HF}}$, según sea el más conveniente y calcular el factor de seguridad $F$.

- NOTA.- En principio y supuesta ausencia de datos reales referentes a cohesiones y fricción se pueden hacer uso de las tablas 5 y 6 . 
DESARROLLO DE UNA APLICACIÓN INFORMÁTICA PARA EL CÁLCULO DE SOSTENIMIENTO

DE TALUDES MEDIANTE REVEGETACIÓN

ANEXO III.- METODOS DE CÁLCULO DE ESTABILIDAD DE TALUDES

Tabla 5: Densidad aparente $(\rho)$ y cohesión $(C)$ de diversos materiales

\begin{tabular}{|c|c|c|c|c|}
\hline MATERIALES & $\rho$ en $\mathrm{gr} / \mathrm{cm}^{\mathbf{3}}$ & C mínima en MPA & C máxima en MPA * & C media en MPA \\
\hline Carbón & 1,5 & 0,05 & 0,035 & 0,01 \\
\hline Pizarra & 2,7 & 0,05 & 1,00 & 0,35 \\
\hline Arenisca & 2,7 & 1,00 & 1,80 & 1,35 \\
\hline Caliza & 2,68 & 0,80 & 1,3 & 1,15 \\
\hline Cuarcita & 2,6 & 2,00 & 2,8 & 2,6 \\
\hline
\end{tabular}

- $10 \mathrm{~kg} / \mathrm{cm}^{2}=1 M P A$

Tabla 6: Ángulos aproximados de fricción para rocas típicas

\begin{tabular}{|c|c|c|c|}
\hline TIPO DE ROCA & $\emptyset\left({ }^{\circ}\right)$ roca no alterada & $\emptyset\left({ }^{\circ}\right)$ roca agrietada & $\emptyset\left({ }^{\circ}\right)$ residual \\
\hline Andesita & 45 & $31-35$ & $28-30$ \\
\hline Arenisca & $45 \cdot 50$ & $27-38$ & $25-34$ \\
\hline Basalto & $48-50$ & 47 & - \\
\hline Caliza & $30-60$ & - & $33-37$ \\
\hline Creta & - & $35-41$ & - \\
\hline Cuarcita & 64 & 44 & $26-34$ \\
\hline Diorita & $53-55$ & - & - \\
\hline Esquisto & $26 \cdot 70$ & - & - \\
\hline Grauvaca & $45-50$ & - & - \\
\hline Granito & $50 \cdot 64$ & - & - \\
\hline Monzonita & $48-65$ & - & $28-32$ \\
\hline Pizarra & $45-64$ & 37 & $27 \cdot 32$ \\
\hline Pórfido & - & 40 & $30-34$ \\
\hline Pudinga & 50 & \multirow[t]{2}{*}{43} & - \\
\hline \multicolumn{2}{|r|}{ OTROS MATERIALES } & & Valores aproximados de $\emptyset\left(^{\circ}\right)$ \\
\hline \multicolumn{3}{|c|}{ Salbanda de arcilla } & $10 \cdot 20$ \\
\hline \multicolumn{3}{|c|}{ Material calizo de la zona de deslizamiento } & $20-27$ \\
\hline \multicolumn{3}{|c|}{ Material de deslizamiento de pizarra } & $14-22$ \\
\hline \multicolumn{3}{|c|}{ Brecha de roca dura } & $22 \cdot 30$ \\
\hline \multicolumn{3}{|c|}{ Agregado de roca dura compacto } & 40 \\
\hline \multicolumn{3}{|c|}{ Relleno de roca dura } & 38 \\
\hline
\end{tabular}


DESARROLLO DE UNA APLICACIÓN INFORMÁTICA PARA EL CÁLCULO DE SOSTENIMIENTO

DE TALUDES MEDIANTE REVEGETACIÓN

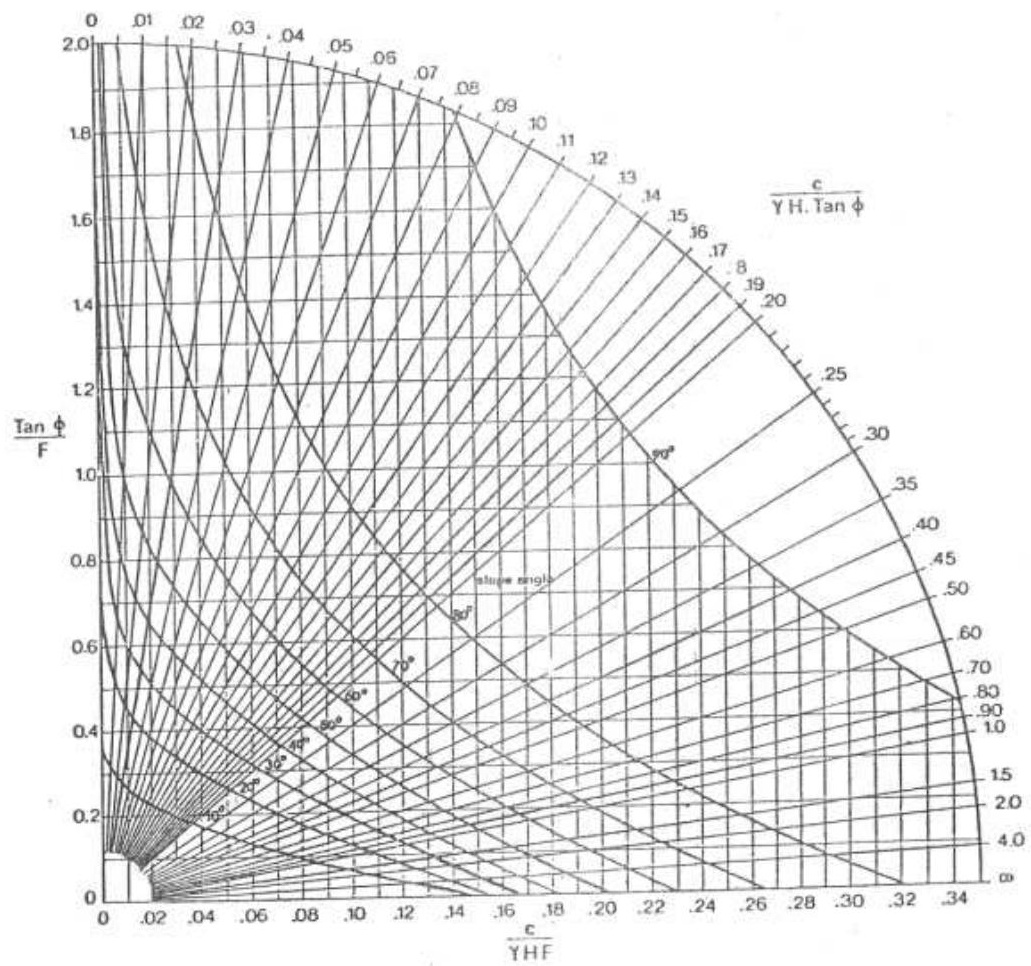

Ábaco 2: De rotura circular

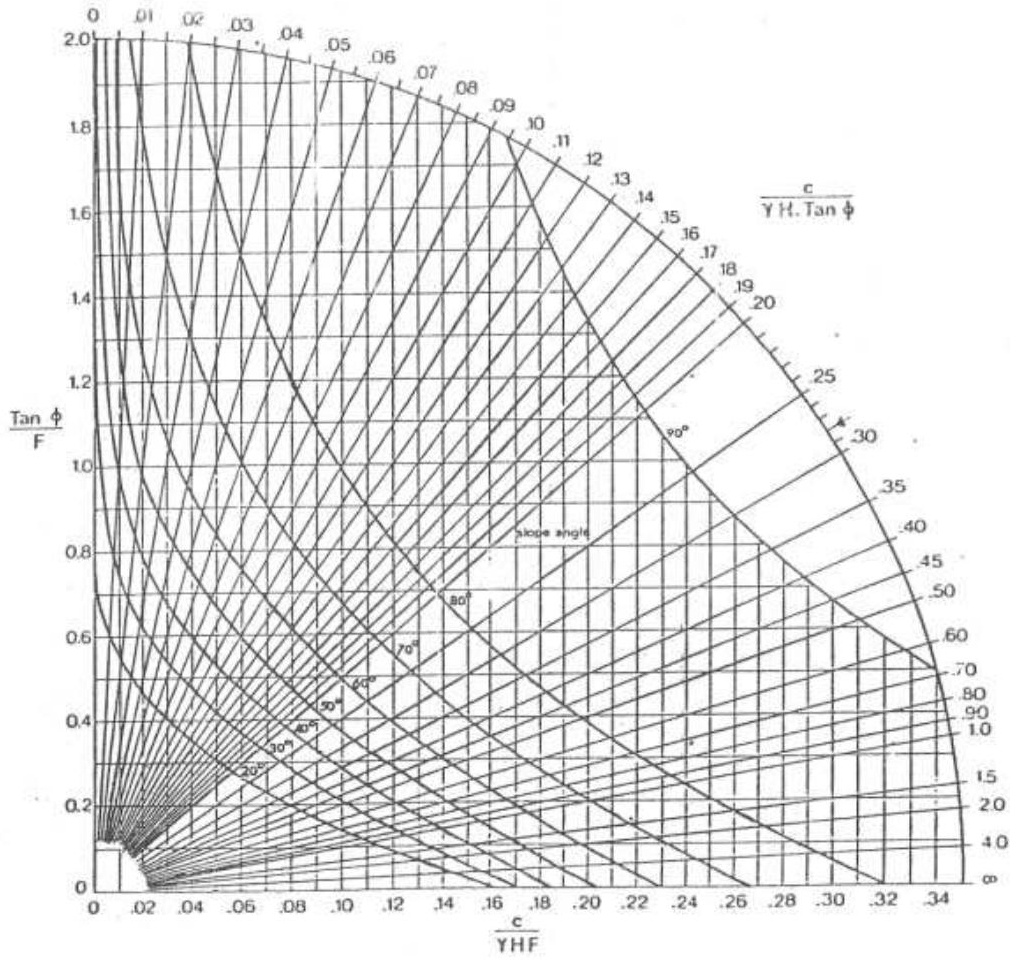


DESARROLLO DE UNA APLICACIÓN INFORMÁTICA PARA EL CÁLCULO DE SOSTENIMIENTO

DE TALUDES MEDIANTE REVEGETACIÓN

Ábaco 3: De rotura circular

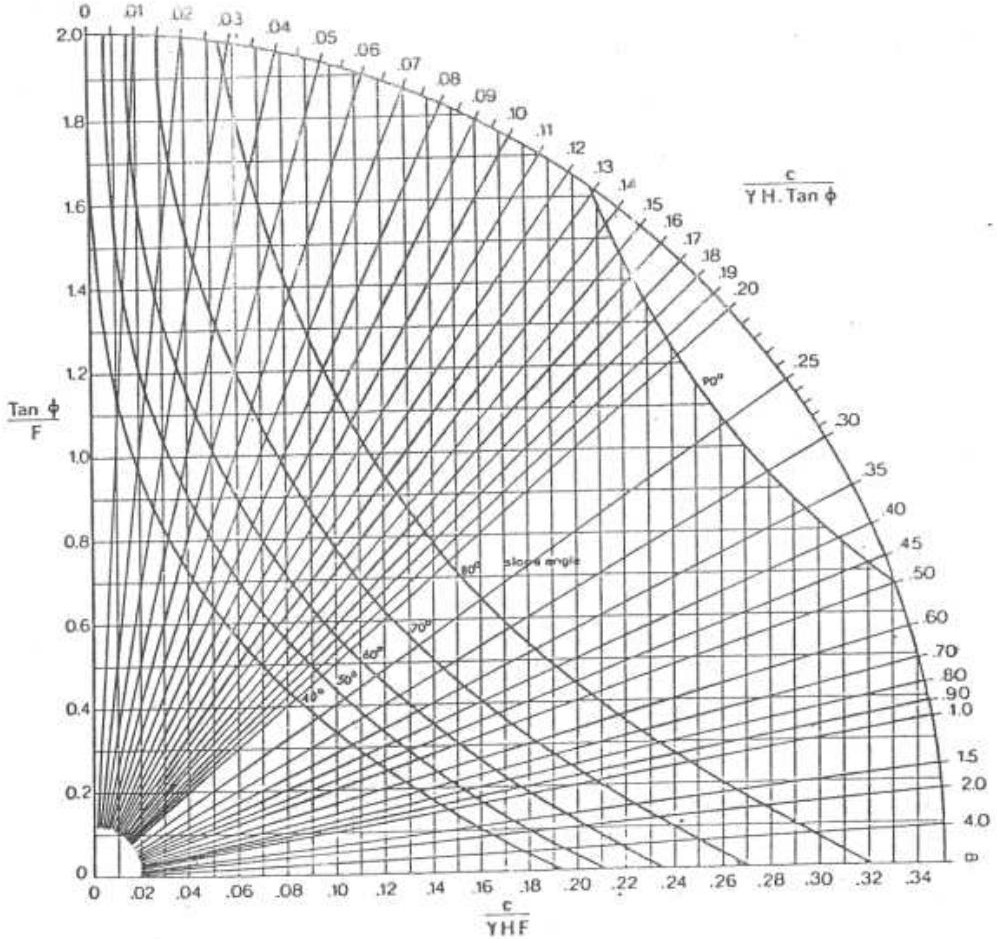

Ábaco 4: De rotura circular

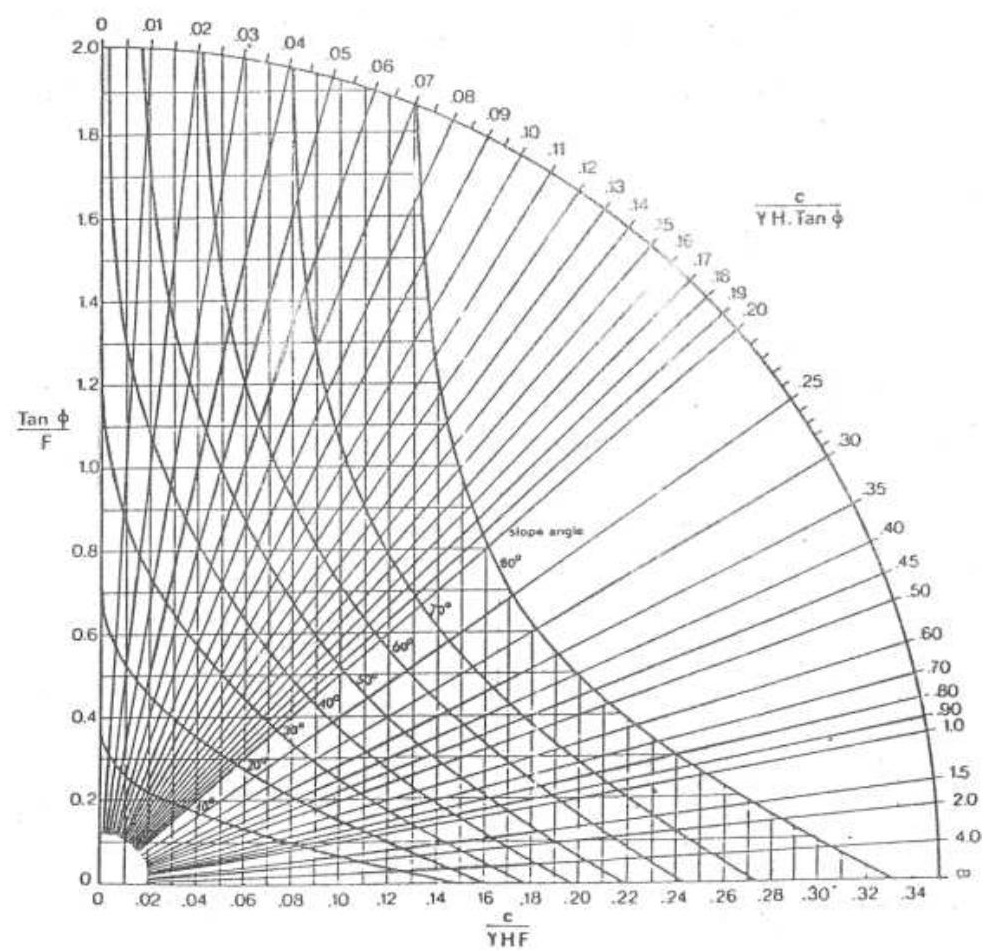




\section{4.- ESTABILIDAD DE TALUDES DE MURO}

Se trata de un método aplicable en explotaciones de carbón a cielo abierto.

Altura de talud

- Capas de buzamiento $<45$ 은

Según las causas de inestabilidad en el pie, las roturas podrían ser:

- Rotura por descalces de pie y/o laterales: Se producen normalmente durante la excavación.

- Rotura por diaclasas o fracturas más tendidas que la estratificación: Se produce a través de fracturas con rumbo próximo a la estratificación y buzamiento más suave, rotura peligrosa que se presente con frecuencia.

- Rotura por cuña de pie: La rotura tiene lugar por levantamiento de una cuña en el pie, limitado por las fallas de rumbo similar a la estratificación y buzamiento más fuerte.

- Rotura por pandeo: Se trata del pandeo del pie del banco o de la placa sometida a una fuerte compresión, siendo factores decisivos, la cuantía y excentricidad de la compresión, la longitud y potencia de la placa y la resistencia y deformabilidad de la roca.

\subsection{1.- Factores que intervienen en los análisis de estabilidad}

- Resistencia a corte en los planos de estratificación

- Pizarras: Cohesión nula o de $4 \frac{\mathrm{T}}{\mathrm{m}^{2}}$, rozamiento de 30 .

- Areniscas: Cohesión nula o de $4 \frac{\mathrm{T}}{\mathrm{m}^{2}}$, rozamiento de 35 .

- Caliza: Cohesión nula o de $4 \frac{\mathrm{T}}{\mathrm{m}^{2}}$, rozamiento de $32 \circ$.

- Resistencia a corte en planos de cizallamiento con relleno arcilloso

- Arcilla de consistencia firme a dura: cohesión nula y rozamiento de 15․

- Resistencia a corte del conjunto de la roca matriz - Fracturas en el modelo de rotura de pie

- Arenisca buena (sana): cohesión $20 \frac{\mathrm{T}}{\mathrm{m}^{2}}$, rozamiento de 44 .

- Arenisca media / Pizarra buena: cohesión $15 \frac{\mathrm{T}}{\mathrm{m}^{2}}$, rozamiento de 39o.

- Arenisca /pizarra mala: cohesión $10 \frac{\mathrm{T}}{\mathrm{m}^{2}}$, rozamiento de 35․ 


\subsection{2.- Módulos de elasticidad (pandeo)}

Tabla 7: Módulos de elasticidad (rotura por pandeo).

\begin{tabular}{|l|c|}
\hline ROCA & MÓDULO $\mathbf{~ k g} / \mathbf{m}^{\mathbf{2}}$ \\
\hline Arenisca buena & 50.000 \\
\hline Arenisca media & 37.500 \\
\cline { 1 - 1 } Pizarra buena & \\
\cline { 1 - 1 } Arenisca mala & 25.000 \\
\hline Pizarra mala & \\
\hline
\end{tabular}

\subsection{3.- Presiones de agua}

Se han considerado las distribuciones tipo, de presiones de agua en forma triangular. Adoptándose dos hipótesis:

1. Modelo drenado.- La presión máxima es un décimo de la altura del talud, a = 0,1 (en las cercanías de vaguadas o con drenaje en los taludes).

2. Modelo no drenado.- La presión máxima está "sobre" un tercio de la altura del talud, $a=0,4$ (si no hay medidas utilizar este caso).

\subsection{4.- Deslizamiento por rotura de cuña de pie}

Ante las dificultades en su estudio, este caso de rotura, se ha optado por asimilarlo a una rotura de pie, por una fractura a través de la roca con $25 \cong$ de buzamiento (Fig. 9). Las ecuaciones que definen el factor de seguridad son:

$$
\mathrm{F}=\frac{3,24 \times \mathrm{b} \times C_{\mathrm{b}} \mathrm{x}[1]+\tan \emptyset_{\mathrm{b}} \mathrm{x}[3]}{0,95 \mathrm{x}[2]+1,63 \mathrm{xb}^{2}}
$$

Siendo:

$$
\begin{aligned}
& \text { (1) }=2,69 \times \mathrm{b} \times \mathrm{H}-5,63 \times \mathrm{b}^{2}-0,74 \times \mathrm{aH}^{2}+1,54 \times \mathrm{a} \times \mathrm{b} \times \mathrm{H} \\
& (2)=2,5 \times \mathrm{b} \times \mathrm{H}-5,25 \times \mathrm{b}^{2}-\mathrm{C}_{\mathrm{a}}[1,47 \times \mathrm{H}-3,08 \times \mathrm{b}]-\operatorname{tg} \varnothing_{\mathrm{a}} \times(1) \\
& \text { (3) }=0,31 \times(2)+3,49 \times \mathrm{b}^{2}-1,62 \times \mathrm{a} \times \mathrm{b} \times \mathrm{H}
\end{aligned}
$$

En donde las variables son:

- $\quad H=$ Altura del talud

- $\quad B=$ Potencia del estrato 


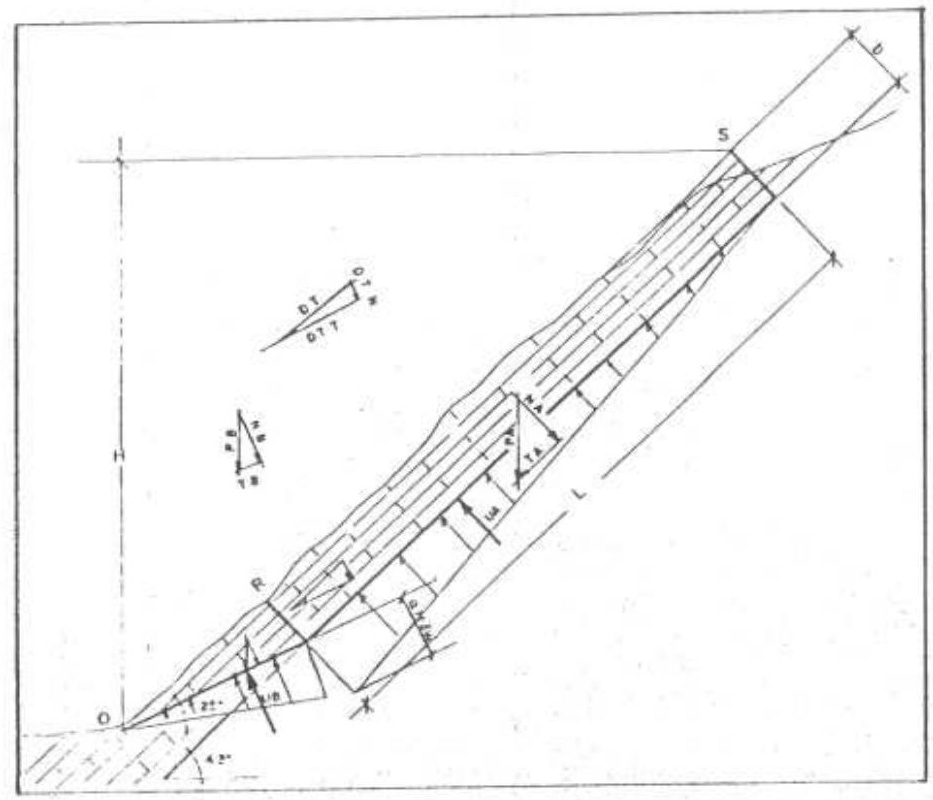

Figura 41: Deslizamiento por rotura de cuña de pie

- $\quad A=$ Coeficiente de presión del agua:

$$
\begin{aligned}
& 0,1 \text { para placas drenadas. } \\
& 0,4 \text { para placas no drenadas. }
\end{aligned}
$$

- $\quad \mathrm{C}_{\mathrm{a}}=$ Cohesión de la cuña.

- $\quad \varnothing_{\mathrm{a}}=$ Ángulo de rozamiento de la cuña.

- $\quad \mathrm{C}_{\mathrm{b}}=$ Cohesión de la placa.

- $\varnothing_{\mathrm{b}}=$ Ángulo de rozamiento en la placa.

- $\quad \mathrm{L}=$ Longitud de la placa.

- Cálculos válidos para $\mathrm{L}>4 \mathrm{~b}$

\subsection{5.- Rotura de Pandeo}

En la estabilidad frente al pandeo, son fundamentales la excentricidad de la compresión y la relación longitud de pandeo / potencia de la placa. El estudio es válido para L' $>10 \mathrm{~b}$.

Se considera una excentricidad $15 \%$ y una relación longitud de pandeo potencia de la placa de 5.

Según BRAY:

$$
[\mathrm{FP}]=\frac{K \times \pi^{2} \times E \times b^{3}}{12 \times L^{2}}
$$


Donde:

$F P=$ Fuerza de pandeo.

$K=$ Factor función de la excentricidad y la potencia aproximada igual a 0,2.

$B=$ Potencia de la placa.

$L=$ Longitud de pandeo $=5 \mathrm{~b}$

- $\quad H=$ Altura vertical de la placa.

- $\quad E=$ Módulo de elasticidad medio de la placa.

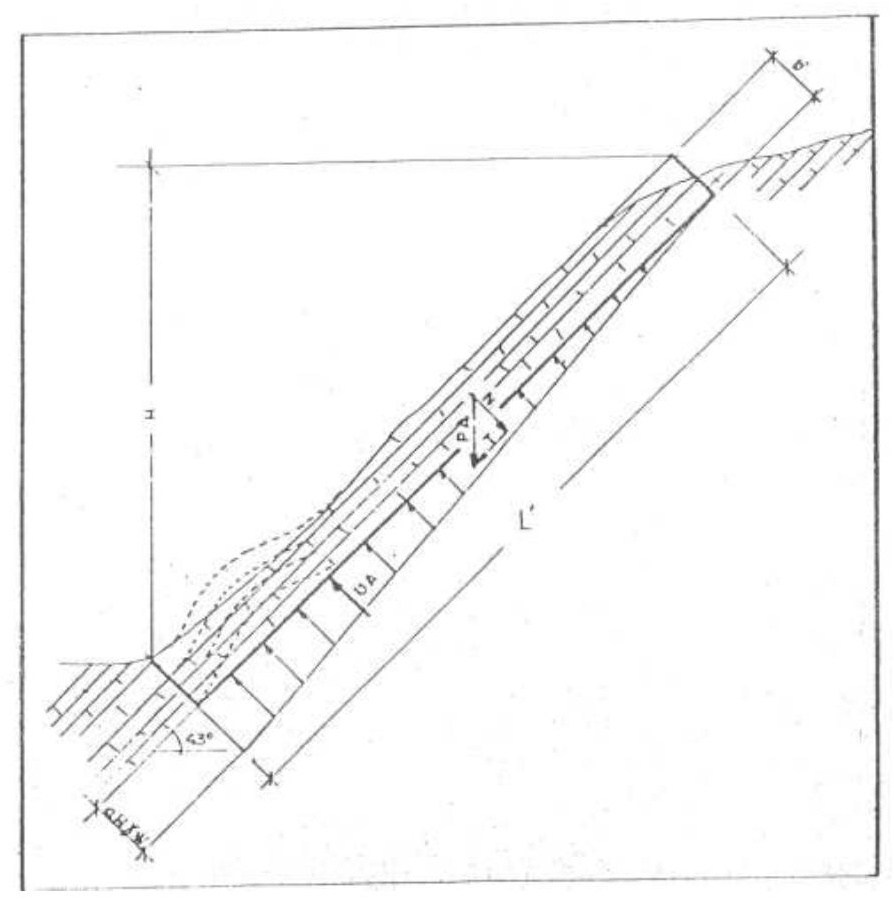

Figura 42: Rotura de Pandeo

\subsubsection{1.- Fuerzas de Pandeo}

Tabla 8: Fuerzas de pandeo para cada tipo de material.

\begin{tabular}{|c|c|}
\hline Arenisca sana & \multirow{2}{*}{$\mathrm{FP}=224 \times \mathrm{x} \mathrm{d} / \mathrm{m}^{2}$} \\
\cline { 1 - 2 } Arenisca & \multirow{2}{*}{$\mathrm{FP}=168 \times \mathrm{x} \mathrm{t} / \mathrm{m}^{2}$} \\
\cline { 1 - 1 } Pizarra buena & \multirow{2}{*}{$\mathrm{FP}=112 \times \mathrm{x} \mathrm{t} / \mathrm{m}^{2}$} \\
\cline { 1 - 2 } Arenisca & \\
\cline { 1 - 2 } Pizarra mala &
\end{tabular}

La fuerza desestabilizadora que actúa en cada caso es:

$$
\mathrm{DT}=\mathrm{T}-\mathrm{C} \mathrm{L}-(\mathrm{N}-\mathrm{UA}) \operatorname{tg} \varnothing
$$


Dónde:

- $\quad T=1,71 \mathrm{Hd}$

- $\quad N=1,83 \mathrm{Hd}$

- $\quad U A=0,73 H 2 * a$

El factor de seguridad frente al pandeo es:

$$
\mathrm{F}=\frac{\mathrm{FP}}{\mathrm{DT}}
$$

- $\quad \mathrm{a}=0,1 \rightarrow$ Placas drenadas

- $\quad \mathrm{a}=0,4 \rightarrow$ Placas no drenadas

Las alturas máximas en los taludes para un coeficiente de seguridad de 1,3, en función de la potencia de los estratos, tomando como cálculo la expresión de F, se pueden obtener los ábacos $5,6,7^{2}$.

${ }^{2}$ NOTA.- En principio, y supuesta una ausencia de datos reales, referentes a cohesiones y fricciones, se puede hacer uso de las tablas 2 y 3 . 
DESARROLLO DE UNA APLICACIÓN INFORMÁTICA PARA EL CÁLCULO DE SOSTENIMIENTO DE TALUDES MEDIANTE REVEGETACIÓN

Ábaco 5, para el cálculo del factor de seguridad, rotura por pandeo.
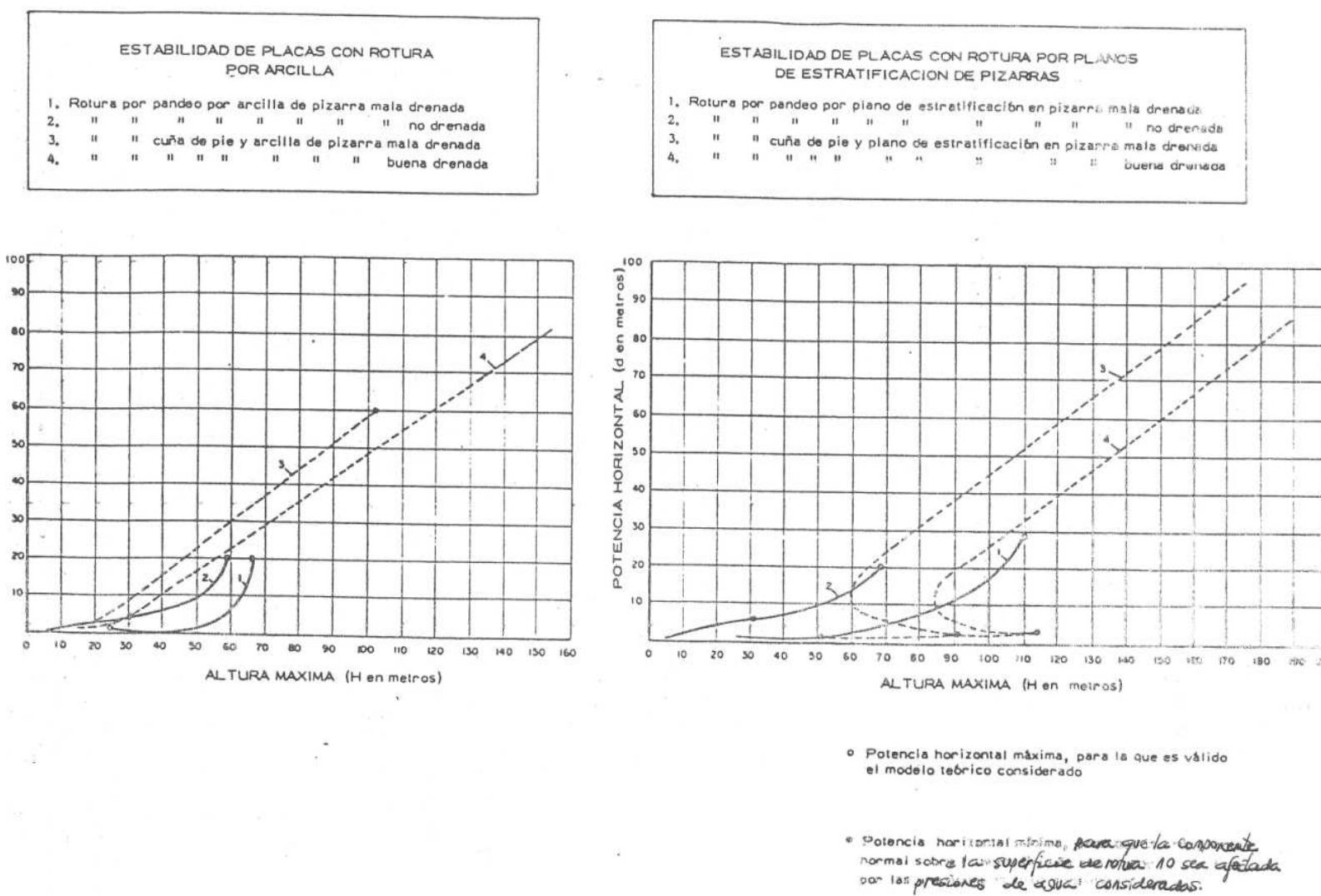

Ábaco 6, para el cálculo del factor de seguridad, rotura por pandeo. 
DESARROLLO DE UNA APLICACIÓN INFORMÁTICA PARA EL CÁLCULO DE SOSTENIMIENTO

DE TALUDES MEDIANTE REVEGETACIÓN
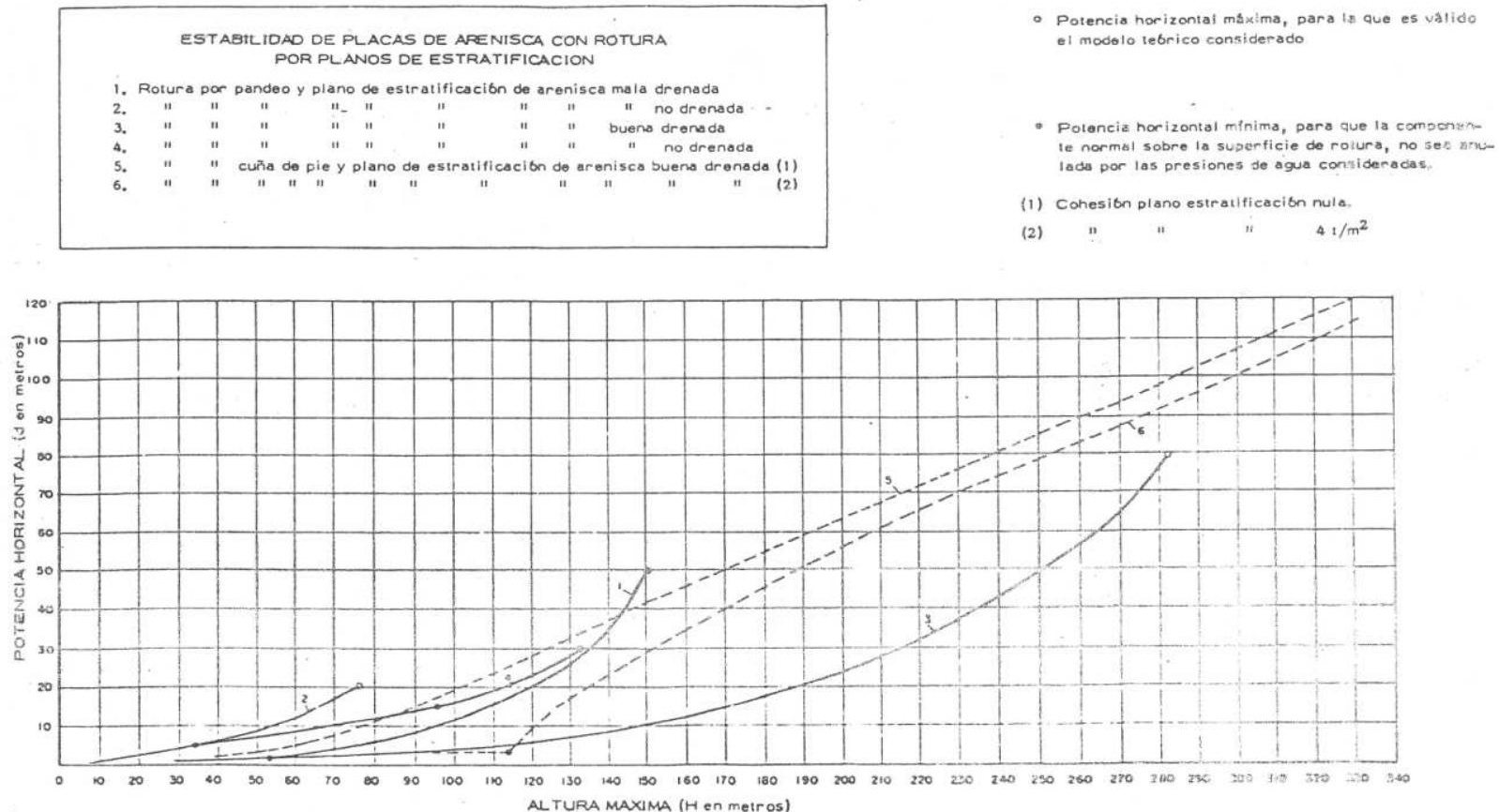

Ábaco 7, para el cálculo del factor de seguridad, rotura por pandeo.

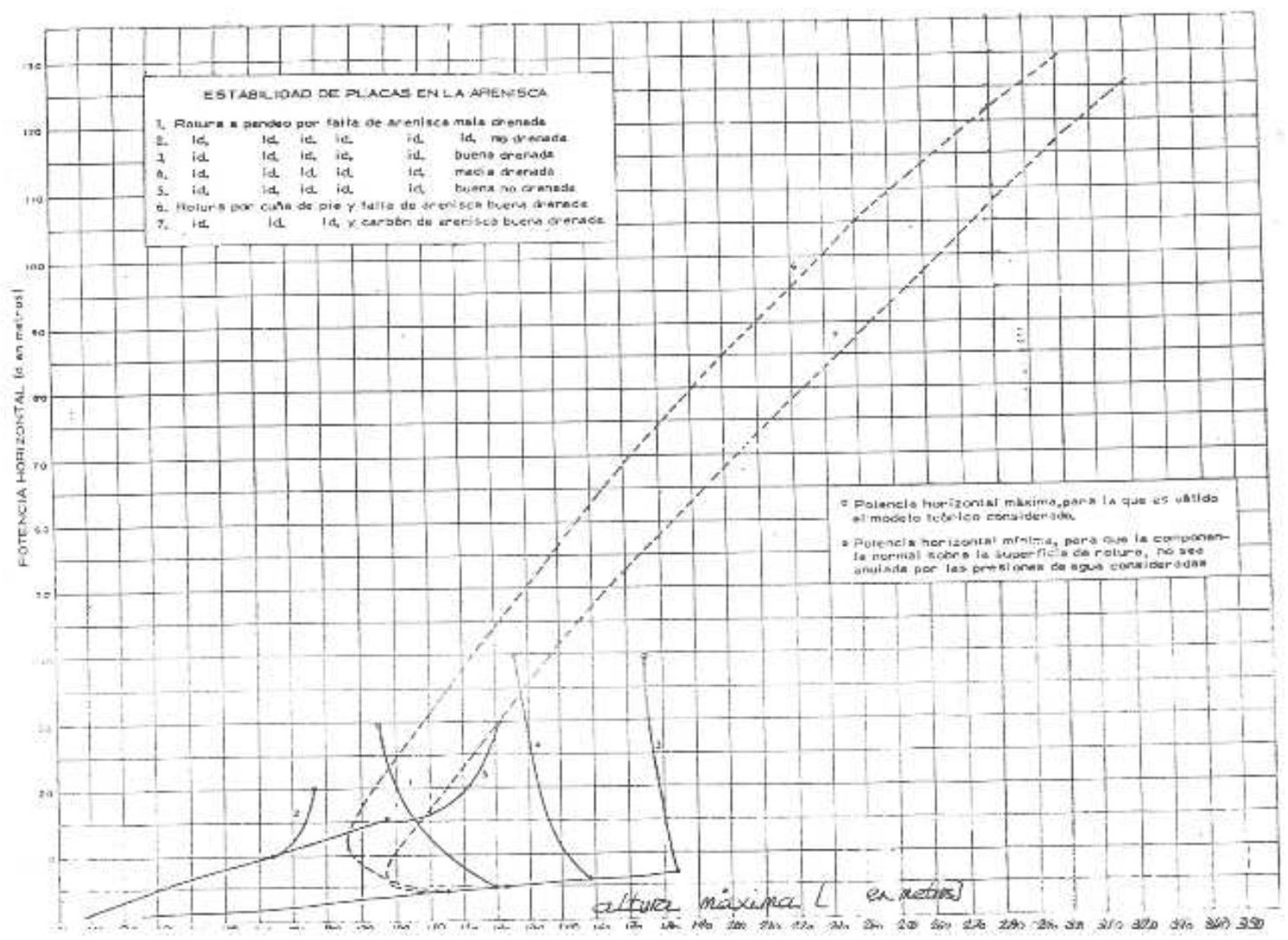




\section{3.- ANÁLISIS DE ESTABILIDAD TALUDES}

\section{1.- CASO GENERAL}

En las cortas mineras, el equilibrio del terreno se perturba, al faltar la contrapresión de la parte extraída, debiendo mantenerse frentes de los taludes firmes, sin derrumbarse, gracias a sus características internas:

- $\mathrm{c}=$ cohesión.

- $\varnothing=$ ángulo de rozamiento interno.

Estas condiciones iniciales pueden verse afectadas por agentes atmosféricos, ondas de presión de las voladuras,... que originan diaclasas, grietas y desprendimientos en los frentes y zonas adyacentes.

En los taludes de explotación, hay dos tipos de perfiles (Fig. 43):

- Perfil del talud.

- Perfil de cresta.

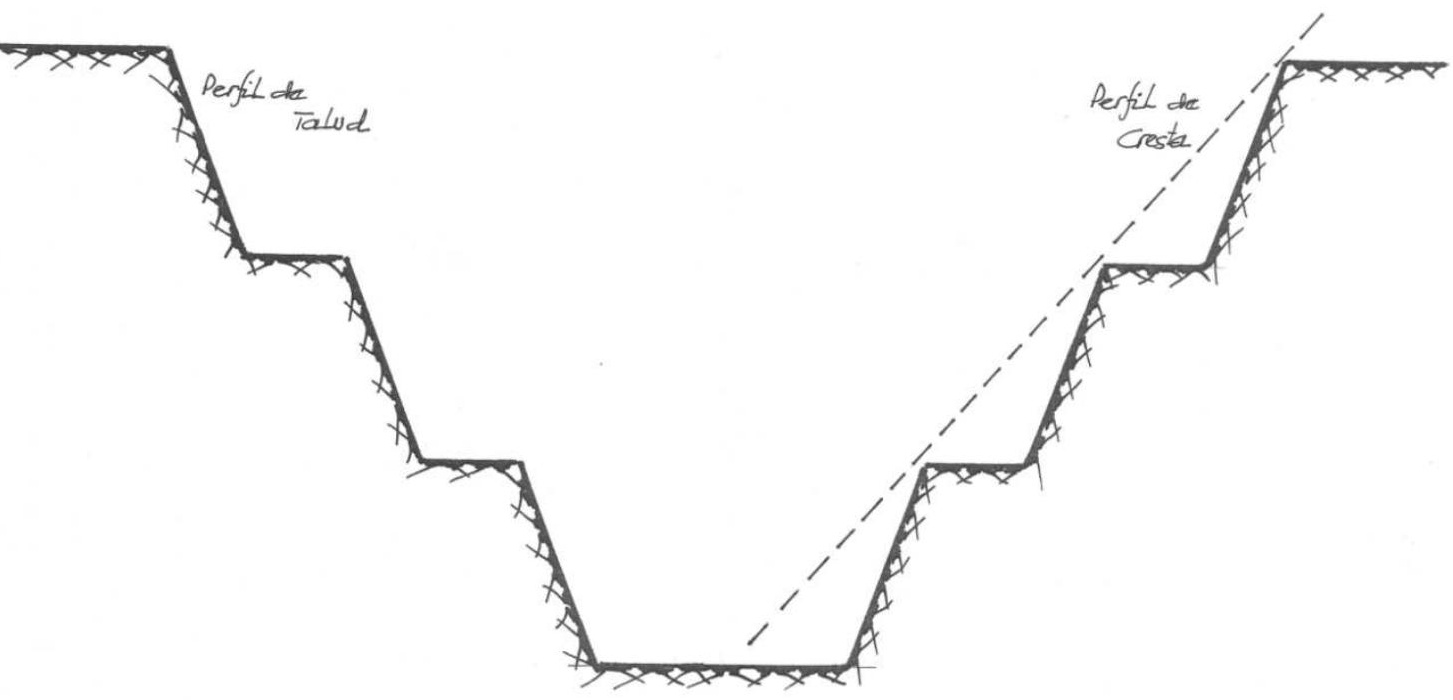

Figura 43: Tipos de perfiles

Las variables que condicionan la estabilidad de un talud son:

- Ángulo de talud.

- Altura de talud.

Existiendo una altura crítica $(h c)$, función de la calidad del terreno, valor que no se ha de sobrepasar. 


\subsection{1.- Cálculo}

\section{Hipótesis general}

Dado un talud, del que se conoce,

- Densidad

- Sobrecargas

- Cohesión

- Ángulo de rozamiento interno

Hallar:

- La superficie de deslizamiento (rotura) más favorable (superficie crítica)

- La altura crítica

Se considera válida la fórmula de Mohr-Coulomb.

Existen dos hipótesis sobre la superficie crítica de rotura:

1. Hipótesis "simplista de Rankine", supone que la superficie de deslizamiento es plana.

2. Hipótesis perfeccionada. La superficie crítica es cilíndrica y de directriz circular (primera aproximación válida para muchos casos).

\subsubsection{1.- Hipótesis de Rankine. Terrenos incoherentes.}

Para terrenos sueltos como arenas, escombreras, etc. (Fig. 12), se plantea la condición de equilibrio estático:

Fuerza resistente (rozamiento interno) > Fuerza solicitante (peso propio)

$$
\begin{gathered}
\rho \cos \alpha \operatorname{tg} \varnothing \geq \rho \operatorname{sen} \alpha \\
k=\frac{\operatorname{tg} \emptyset}{\operatorname{tg} \alpha} \geq 1
\end{gathered}
$$

En estas expresiones no interviene la altura (h) del talud, lo que hace solamente:

- La pendiente del talud.

- Ángulo de rozamiento interno. 
Si $\mathbf{k}>\mathbf{1}$, puede darse al talud cualquier altura (resistiendo el suelo base), que no sobrevendrá el deslizamiento.

Si $\mathbf{k}<\mathbf{1}$, independientemente de la altura, se derrumbará.

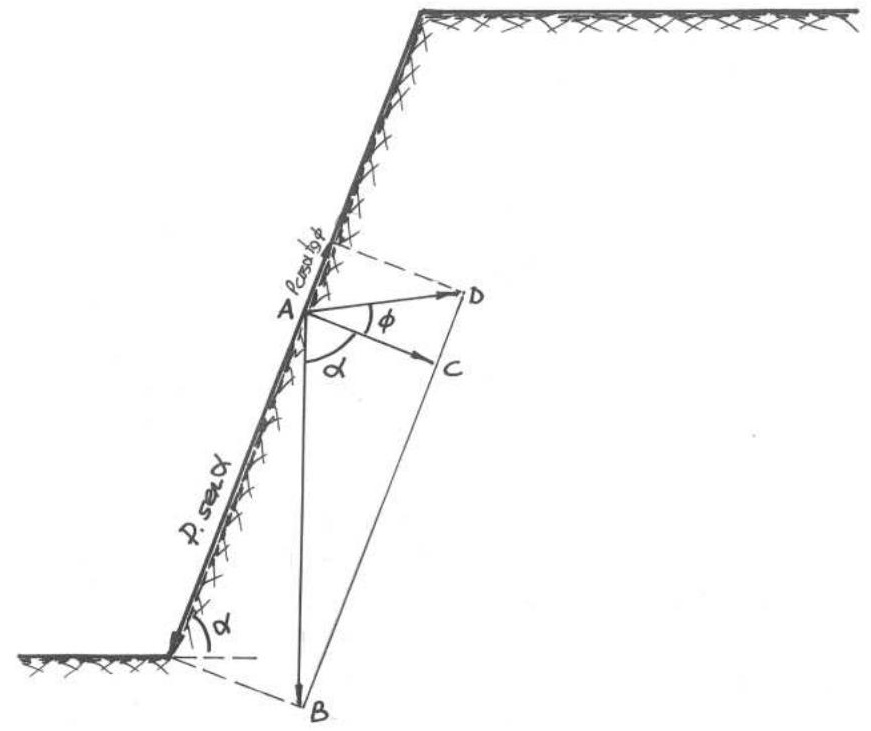

Figura 44: Condición de equilibrio estático.

Se pueden considerar como estables los taludes que tengan valores de $\boldsymbol{k}$ algo superiores a la unidad, considerando el ángulo de rozamiento interno mínimo, para la expresión del coeficiente $\boldsymbol{k}$.

El ángulo de rozamiento interno del suelo o escombrera varía con la humedad. Un terreno empapado puede disminuir $\boldsymbol{k}$ por debajo de 1.

Se pueden considerar como equivalentes, en los terrenos sueltos y escombreras, el ángulo de rozamiento y el talud natural.

En resumen, un talud en rocas no coherentes será estable siempre que el ángulo $\alpha$ no sobrepase el ángulo de talud natural.

\section{2.- TERRENOS COHERENTES}

En este tipo de terreno, cada elemento del mismo está sometido a una fuerza (peso que gravita sobre él) y dos de reacción, cohesión y rozamiento interno. 
Los movimientos de los taludes son numerosos:

- desprendimiento parcial por auto saneamiento del frente.

- por reptación tectónica

- hundimiento vertical (pérdida de consistencia)

Pero el movimiento verdaderamente grave por sus posibilidades catastróficas, es de deslizamiento o rotura con desplazamiento, según un plano, de una masa de talud, hacia abajo y hacia fuera.

Si se admite la existencia de un momento de vuelco y la producción de unas grietas de tracción en la parte superior del talud, (se está en la hipótesis n2).

\subsection{1.- Fórmula de Resalt}

Deslizamiento según un plano en terrenos coherentes. Se considera un talud (Fig. 45), cuyo frente forma un ángulo $\alpha$ con la horizontal, y que el deslizamiento se produzca según el plano MB.

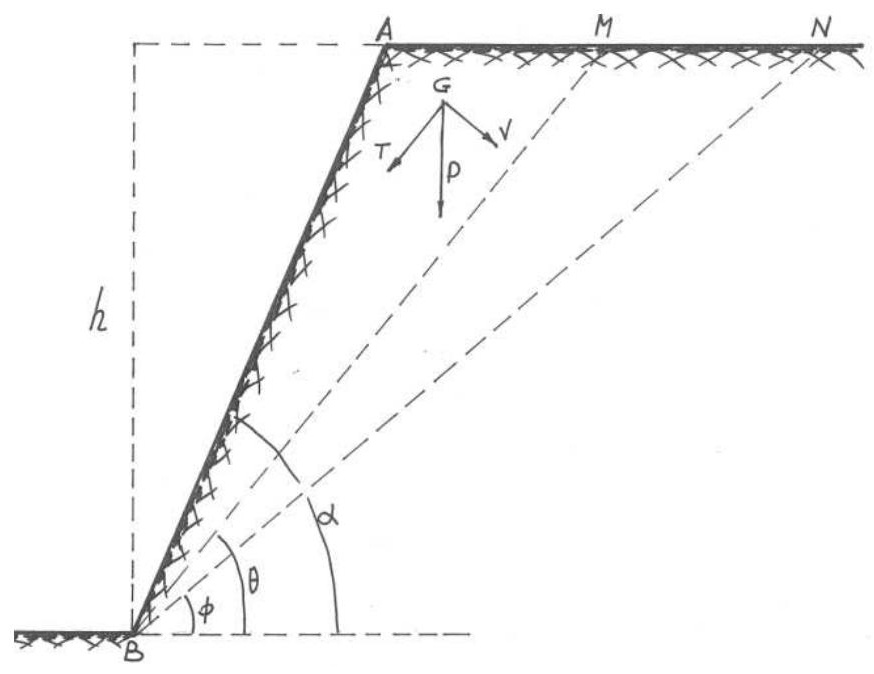

Figura 45: Deslizamiento según un plano en terrenos coherentes.

La cuña deslizante será el macizo AMB, cuyo peso es:

$$
\frac{A M * h}{2} * \rho
$$

Siendo: $p=$ peso unitario del terreno, y sus componentes: 
- Tangencial al plano de deslizamiento.

- Normal al plano de deslizamiento.

Peso macizo AMB: $\quad G p=\frac{A M * h}{2} * \rho$

Esfuerzo tangencial (cortante). Plano BM: $\quad G t=\frac{\rho * h^{2}}{2} * \operatorname{sen} \theta *(\operatorname{ctg} \theta-\operatorname{ctg} \alpha)$

Presión normal. Plano BM: $\quad G r=\frac{\rho * h^{2}}{2} * \cos \theta *(\operatorname{ctg} \theta-\operatorname{ctg} \alpha)$

El valor de la fuerza de cohesión (fuerza unitaria), que actúa a lo largo de todo el plano $M B$, es $c * h / \operatorname{sen} \theta$.

En el equilibrio límite, el esfuerzo cortante será igual a la fuerza de cohesión del terreno, más la fuerza de rozamiento interno, opuesta al deslizamiento, o sea:

$$
\frac{p * h^{2}}{2} *(\operatorname{ctg} \theta-\operatorname{ctg} \alpha) * \operatorname{sen} \theta=\frac{c * h}{\operatorname{sen} \theta}+\frac{p * h^{2}}{2} *(\operatorname{ctg} \theta-\operatorname{ctg} \alpha) * \cos \theta * \operatorname{tg} \theta
$$

Donde:

$$
h=\frac{2 * c}{\rho} * \frac{1}{(\operatorname{sen} \theta-\cos \theta * \operatorname{tg} \emptyset) * \operatorname{sen} \theta *(\operatorname{ctg} \theta-\operatorname{ctg} \alpha)}
$$

La altura crítica se calcula, hallando el valor de $\Theta$, que haga máximo h. Esto equivale a hallar el mínimo del denominador de la expresión anterior.

Se trata de elegir la posición más favorable del plano de deslizamiento $(\theta)$, es decir, aquella que nos da el valor mínimo de la altura, que no debería sobrepasarse sin que haya grave riesgo de rotura.

El mencionado máximo de $h$ resulta para:

$$
\theta=\frac{\emptyset+\alpha}{2}
$$

Sustituyendo:

$$
h_{c}=\frac{c}{\rho} * \frac{2 * \operatorname{sen} \alpha * \cos \emptyset}{\left(\operatorname{sen}^{2}(\alpha-\emptyset) / 2\right.}
$$

Como se ve:

$\boldsymbol{h}=\boldsymbol{f}\left\{\begin{array}{l}\text { Cohesión } \\ \text { Pendiente del talud } \\ \text { Peso específico (variable con la humedad) } \\ \text { Ángulo de rozamiento interno } \\ \quad \text { LOy }\end{array}\right.$


La fórmula de Resalt, es muy útil en la primera aproximación, ya que el equilibrio de un talud ha de conservarse a través del tiempo, siendo el terreno algo "vivo", que admite cambios en las variables, habrá que cuidar la elección de h y $\alpha$.

La hipótesis de Rankine sobre el equilibrio de la cuña deslizante puede ser considerada defectuosa en base a los siguientes motivos:

- Por falta de homogeneidad del terreno, la superficie de fractura es necesariamente un plano. Se han propuesto varias curvas (como la espiral logarítmica) para el perfil de deslizamiento, pero la que más práctica resulta es la circunferencia cilíndrica con directriz circular.

- La superficie crítica no tiene que pasar necesariamente por el pie del talud. En la práctica se dan tres tipos de fractura (Fig. 14) en las que aquella incide por encima, en o por debajo de la arista del pie del talud.

- Existe un momento de vuelco debido a que las fuerzas consideradas (peso, cohesión, rozamiento) no son concurrentes. Es la causa de la aparición de las grietas de tracción en la parte superior del talud.

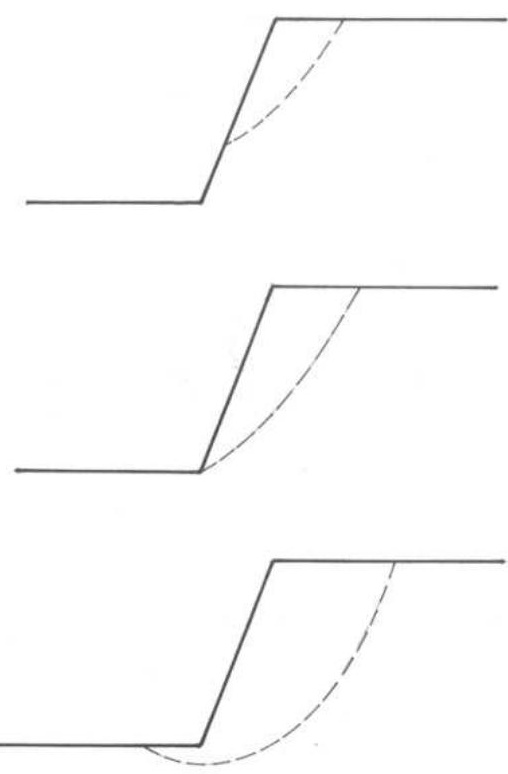

Figura 46: Tipos de fractura 


\section{3.- ENSAYOS}

La Figura 15, esquematiza el diagrama de tensiones a tracción (debidas al momento de vuelco) en la zona superior del talud.

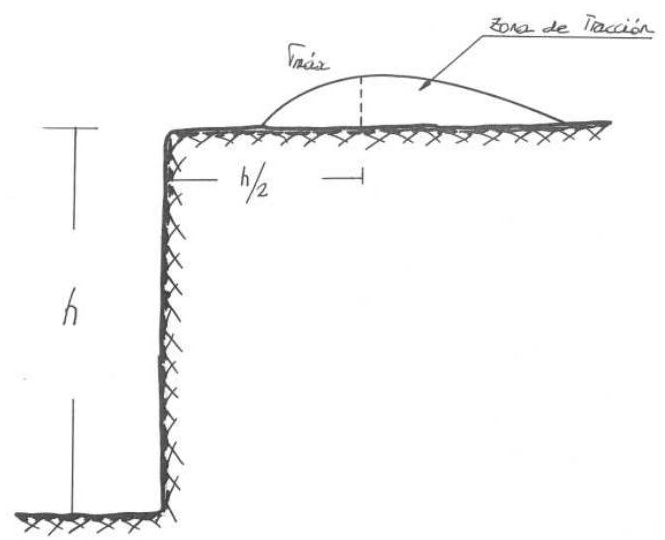

Figura 47: Ensayo: diagrama de tensiones en la zona superior del talud.

La experiencia de los derrumbes producidos y del laboratorio, confirman la validez de la superficie crítica cilíndrica como base de cálculo.

Un cálculo simplificado y directo es suponer las tres fuerzas concurrentes (no hay $\boldsymbol{M}_{\boldsymbol{f}}-$ momento flector de vuelco):

- Peso propio $=$ Resultante de cohesión + Resultante de fricción. Fig. 17

- Peso P-Área ABE * $\rho$. Pasa por el centro de gravedad de la masa deslizante.

- Cohesión $R c$ - Tiene la dirección de la cuerda $\overline{\mathrm{EB}}$ y por valor; $\mathrm{C} * \overline{\mathrm{EB}}$. Para hallar el punto de aplicación de la misma, se toman momentos respecto de $\mathrm{O}$, centro del círculo de arco BE:

Fricción $R F$ - Tiene que pasar por la intersección de las otras dos y además ser tangente a la circunferencia de centro 0 y radio $r=R^{*} \operatorname{sen} \varnothing$, construyendo el triángulo de fuerzas.

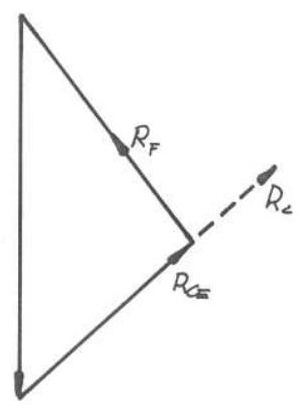

$R F$ cortará a $R C$ y si el equilibrio es estable, cerrará el triángulo de fuerzas (Fig. 48). 
Figura 48: Equilibrio de fuerzas.

$C * \overline{E B} * x=C * R * \overline{E B}$

$$
x=R * \frac{\overline{E B}}{\overline{E B}}
$$

Figura 49: Método gráfico para determinar el Factor de seguridad de una superficie de deslizamiento circular.

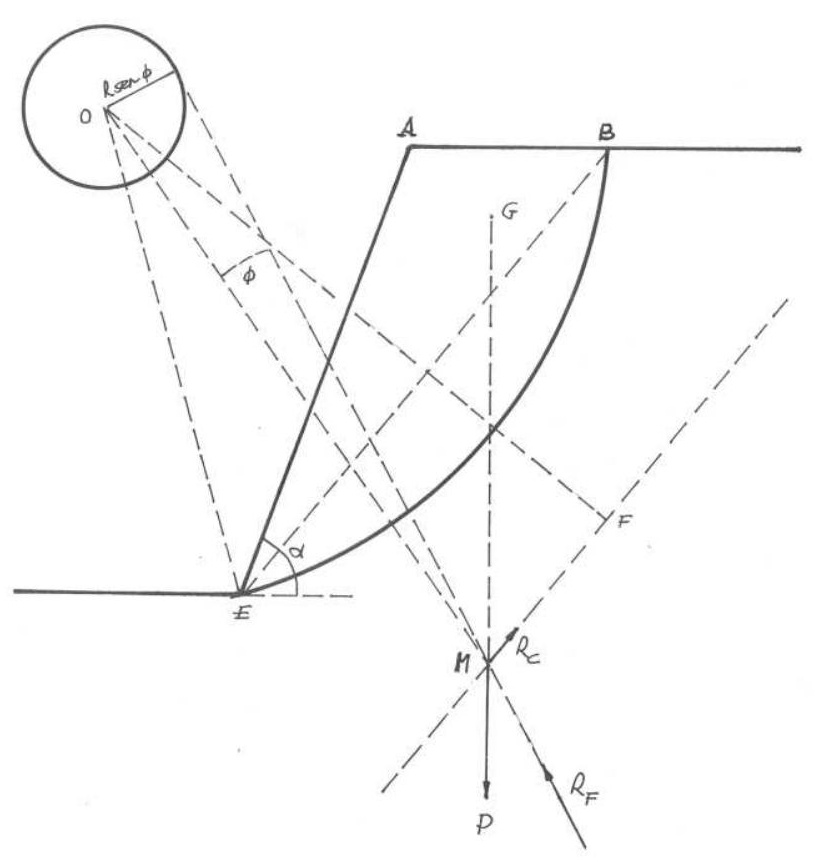

Si $\mathbf{R}_{\mathbf{F}}$ corta a $\mathbf{R}_{\mathbf{C}}$ en un punto interior a este, el talud está dimensionado con un factor de seguridad:

$$
K=\frac{R_{C}}{R_{C E}}=\frac{C}{C_{E}}
$$

O sea que un terreno con una cohesión $\mathrm{C}_{\mathrm{E}}$, menor que $\mathrm{C}$, admitirá un talud estable de las mismas características.

En el caso en que $\mathbf{R}_{\mathbf{F}}$ cortara a $\mathbf{R}_{\mathbf{C}}$ en un punto exterior a la derecha del origen de fuerzas, habría deslizamiento de la masa.

\section{4.- PARÁMETROS}

Los parámetros que intervienen en el cálculo de la estabilidad de taludes, aplicando el caso general, son los siguientes:

- C.- cohesión

- Ø.-fricción (ángulo)

- $\boldsymbol{h}_{c}$.- altura crítica

- $\quad \alpha .-$ ángulo del talud

- $\quad k$.- coeficiente 
- $\quad$ p.- peso unitario del terreno

- $G_{t}$.- efecto tangencial cortante

- $\boldsymbol{G}_{r}$. - presión normal

- $\boldsymbol{G}_{p}$. - peso macizo

- $\quad \boldsymbol{\theta}$.- ángulo plano MB (deslizamiento)

\section{4.- ANÁLISIS DE ESTABILIDAD POR EL MÉTODO TSYTOVICH}

\section{1.- PERTURBACIÓN DE LA ESTABILIDAD}

El análisis de la estabilidad de los terrenos es de vital importancia para diseñar estructuras en los mismos:

- Terraplenes.

- Desmontes.

- Tranques (embalsamientos).

- Labores que pueden alcanzar 100 m ó más.

- Estructuras similares.

El problema de la estabilidad del terreno es un problema particular de la teoría general del último estado tensional de aquel, teniendo particularidades esenciales causadas por el movimiento del terreno cuando se altera su estabilidad.

El cálculo de esta forma parte de la estática de estructuras.

Se estudiarán solamente alguna de las relaciones, las cuales pueden ilustrar la esencia del problema, definiendo los métodos más importantes para su solución, ampliamente empleados en la práctica.

Las causas más importantes de la perturbación de la estabilidad de las masas del terreno son:

- Procesos erosivos.

- Trastorno del equilibrio.

Los procesos erosivos siguen una regla: ocurren despacio e imperceptiblemente. Dependen de la meteorología externa y de condiciones físico-geológicas y también de las propiedades de la superficie del terreno (normalmente no se consideran en la mecánica del suelo). 
Sin embargo, el estudio de las condiciones de estabilidad del terreno y sus cambios, es el objetivo directo de la citada mecánica.

La rotura de la estabilidad del terreno puede ocurrir abruptamente, con un "deslizamiento" de gran cantidad de terreno.

La clase de perturbación del equilibrio es de lo más variado: ocurre en distintas pendientes, en una vertiente natural, cuando la carga que actúa en el terreno se incrementa, decrece la resistencia interna.

Se puede producir un incremento del peso cuando la presión de la estructura diseñada respecto a la pendiente y declive excede cierto límite, y también cuando el peso del terreno incrementa su saturación natural de agua después de un periodo prolongado de lluvias, grandes inundaciones o retención capilar de la humedad.

El decrecimiento de la resistencia interna puede ocurrir en el caso de una destrucción de los soportes naturales del terreno y también con la reducción del rozamiento efectivo (presencia de agua en los poros), y fuerzas de cohesión (humedad e hinchamiento del terreno).

Los deslizamientos principales pueden ser ocasionados por lo siguiente:

- Deslizamiento rotacional (formación de superficies de rotura curvilíneas).

- Deslizamiento por derrumbe (deslizamiento a lo largo de superficies fijas).

- Deslizamiento por licuefacción (flujo de terrenos supersaturados a lo largo del lecho de los ríos y líneas de máxima pendiente.

\section{2.- ESTABILIDAD DE INCLINACIONES Y TALUDES}

Para resolver dos problemas elementales, se establecen ciertos conceptos:

1. Estabilidad de un talud. Terreno suelto.

2. Estabilidad de un talud. Terreno cohesivo. 


\subsection{1.- Estabilidad en terreno suelto}

En este primer caso, se tiene una partícula sólida M colocada sobre un talud de terreno suelto (Fig. 50). El peso $\mathrm{p}$ de la misma tiene dos componentes: la componente normal $\mathrm{N}$ a la línea del talud ab y la componente tangencial $T$. La fuerza $T$, tiende a mover la partícula hasta la base del talud, si no es contrarrestada por la fuerza de fricción $\mathrm{T}$, la cual es proporcional a la presión normal, $\mathrm{T}=f(\mathrm{~N})$, donde $f$ es el coeficiente de fricción.

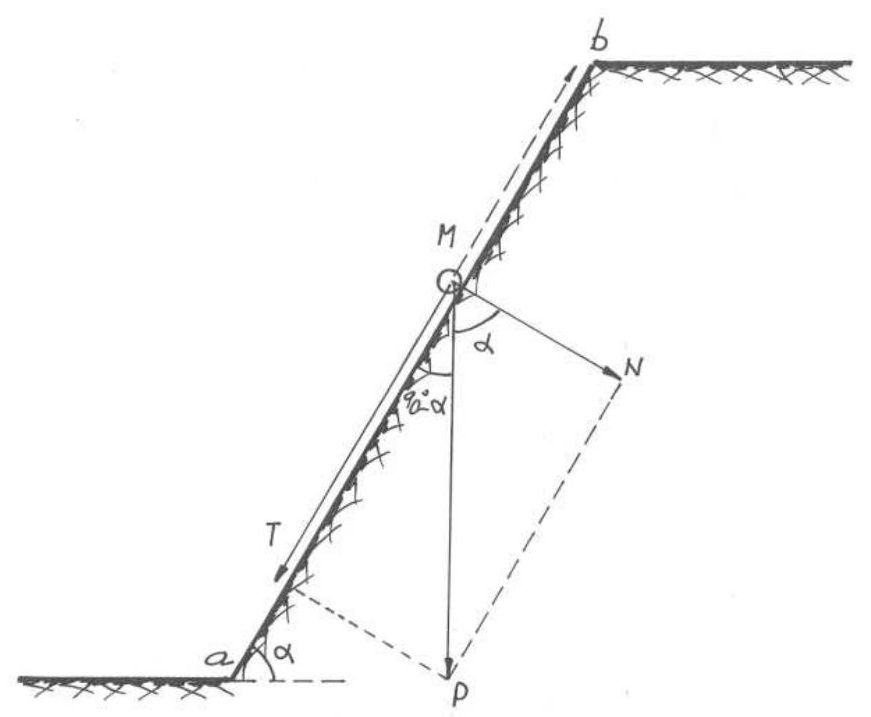

Figura 50: Fuerzas sobre una partícula, en pendiente del terreno suelto

Proyectando todas las fuerzas sobre el plano del talud, se tiene:

$$
p * \operatorname{sen} \alpha-f * p * \cos \alpha=0
$$

De donde $\operatorname{tg} \alpha=f$, y ya que el coeficiente de fricción es $f=\operatorname{tg} \emptyset$, queda finalmente que:

$$
\alpha=\varnothing
$$

De este modo el ángulo final del talud de tierras sueltas $(\alpha)$ es igual al ángulo de fricción interna del terreno $(\varnothing)$. Esta se llama "ángulo de reposo".

Este concepto es solamente aplicable a terreno suelto y seco, siendo menos significativo para suelos cohesivos arcillosos, el ángulo del talud de estos puede variar desde 0 a 90 , dependiendo de la humedad del terreno y de la altura del talud. 


\subsection{2.- Estabilidad en terreno cohesivo}

En este segundo caso, terreno con una perfecta cohesión ( $\varnothing=0 ; c=0)$, se asume que aproximadamente la pérdida de equilibrio se produce a una determinada altura $h$ y a lo largo de la superficie total del talud ac, inclinada un ángulo $\alpha$ respecto a la horizontal. Fig. 51.

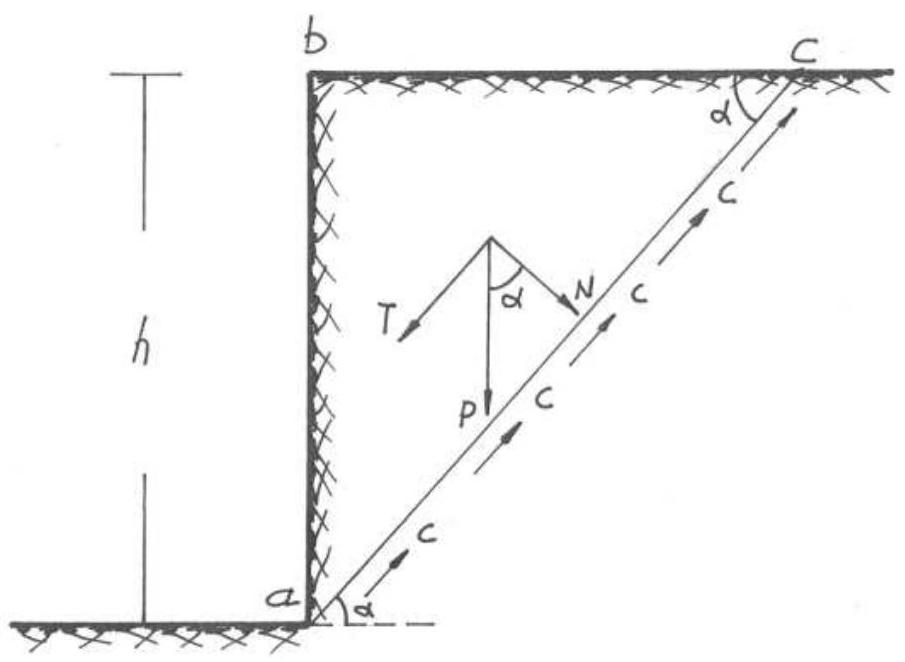

Figura 51: Pendiente vertical en un terreno coherente

La fuerza activa es el peso $p$ del prisma abc.

Según la Figura 51:

$b c=h * \operatorname{ctg} \alpha$

$$
p=\frac{\gamma * h^{2}}{2} \operatorname{ctg} \alpha
$$

(1)

La fuerza $p$ se resuelve en una fuerza normal y en otra tangencial a la superficie ac del perfil del talud.

Las fuerzas que contrarrestan el desprendimiento, son solamente las de cohesión c sobre el plano ac.

$$
a c=\frac{h}{\operatorname{sen} \alpha}
$$

Ya que la presión en el punto superior c del prisma abc es cero, y en el punto inferior a es máxima, se puede tomar el promedio (la mitad de la fuerza de cohesión). 
Se llega a una solución rigurosa por la teoría del "equilibrio último".

Tomando la suma de las proyecciones de todas las fuerzas, en la dirección ac, e igualando a cero, se obtiene la ecuación de equilibrio siguiente:

$$
\frac{\gamma * h^{2}}{2} * \operatorname{ctg} \alpha * \operatorname{sen} \alpha-\frac{c}{2} * \frac{h}{\operatorname{sen} \alpha}=0
$$

De donde:

$$
c=\frac{\gamma^{h}}{2} * \operatorname{sen} 2 \alpha
$$

Si la altura $h=h_{90}$, que corresponde a la máxima eficacia de las fuerzas de cohesión, entonces se tiene:

$$
h_{90 \mathrm{o}}=\frac{2 c}{\gamma}
$$

Así, la cohesión de la masa del talud puede tener una pendiente vertical, solamente en el límite de $\left(h_{900}\right)$.

Con una altura mayor, el prisma abc deslizará hacia abajo.

Se recuerda que un terreno natural tiene no solamente cohesión, sino también fricción, y el problema de estabilidad del buzamiento, llega a complicarse sustancialmente si se precisa una solución rigurosa.

\section{3.- SOLUCIONES RIGUROSAS}

Para proporcionar una solución rigurosa al problema de estabilidad de terrenos, teniendo:

- Ángulo de rozamiento interno.

- Cohesión.

Se han de resolver dos problemas:

1. Determinación de la presión máxima sobre la superficie horizontal del terreno, en el cual el talud tiene un contorno estable.

2. Determinación del modelo de talud estable, con menos pendiente. 


\subsection{1.- Determinación de la presión máxima sobre la superficie de terreno}

El resultado con una solución rigurosa al primer problema, se ha obtenido por numerosas integraciones de raíces diferenciales del último equilibrio, con varios ángulos de fricción interna $(\varnothing)$ y varios ángulos de pendiente del talud ( $\alpha$ ) (Fig. 52).

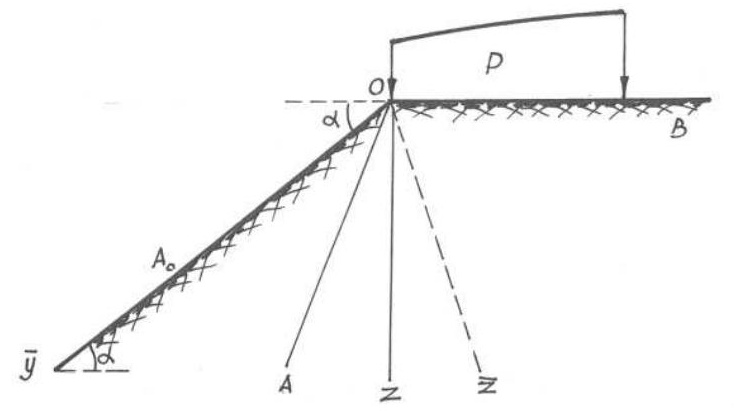

Figura 52: Última presión sobre la superficie de una "pendiente" horizontal.

La última presión es:

$$
P=\overline{\sigma_{z}} * c+P_{e}
$$

Y la coordenada correspondiente:

$$
y=\bar{y} * \frac{c}{\gamma}
$$

Donde:

- $\quad \sigma_{\mathrm{z}}=$ menor valor de la última presión (Tabla 4)

- $\quad P_{e}=c * \operatorname{tg} \varnothing=$ presión de cohesión

- $\quad y=$ coordenada relativa (Tabla 4), cuyo valor actual es:

$$
\bar{y}=y * \frac{\gamma}{c}
$$

Usando los datos de la tabla 9, se puede calcular el diagrama de las últimas presiones, sobre una superficie horizontal del plano de un talud para varios valores de $\alpha, \emptyset$, c y $\boldsymbol{\gamma}$.

Tabla 4: Últimas dimensiones de la presión $\bar{\sigma}_{z}$ sobre la superficie horizontal de un talud. 
DESARROLLO DE UNA APLICACIÓN INFORMÁTICA PARA EL CÁLCULO DE SOSTENIMIENTO DE TALUDES MEDIANTE REVEGETACIÓN

ANEXO III.- METODOS DE CÁLCULO DE ESTABILIDAD DE TALUDES

\begin{tabular}{|c|c|c|c|c|c|c|c|c|c|c|c|c|c|c|}
\hline \multirow{3}{*}{$\bar{y}$} & \multicolumn{14}{|c|}{ Valores de $\overline{\sigma_{z}}$ según $\varnothing$} \\
\hline & \multicolumn{3}{|c|}{10} & \multicolumn{3}{|r|}{20} & & \multicolumn{3}{|c|}{30} & & \multicolumn{3}{|c|}{40} \\
\hline & \multicolumn{14}{|c|}{$Y$ según $\alpha$} \\
\hline 2,0 & 8,34 & 7,51 & 14,8 & 12,7 & 10,9 & 30,1 & 24,3 & 19,6 & 15,7 & 75,3 & 55,9 & 41,4 & 30,6 & 22,5 \\
\hline 2,5 & 9,02 & 7,90 & 17,9 & 14,8 & 12,0 & 43,0 & 32,6 & 24,4 & 18,1 & 139,0 & 94,0 & 62,6 & 41,3 & 27,1 \\
\hline 1,0 & 9,64 & 8,26 & 20,6 & 16,6 & 13,1 & 53,9 & 39,8 & 28,8 & 20,3 & 193,0 & 126,0 & 81,1 & 50,9 & 31,0 \\
\hline 2,0 & 10,8 & 8,95 & 25,4 & 19,9 & 15,0 & 73,6 & 52,9 & 36,7 & 24,2 & 292,0 & 186,0 & 115,0 & 68,4 & 38,1 \\
\hline 2,5 & 11,3 & 9,28 & 27,7 & 21,4 & 15,8 & 82,9 & 59,0 & 40,4 & 26,0 & 339,0 & 215,0 & 132,0 & 76,7 & 41,3 \\
\hline 3,0 & 11,8 & 9,59 & 29,8 & 23,0 & 16,7 & 91,8 & 65,1 & 44,1 & 27,8 & 386,0 & 243,0 & 148,0 & 84,9 & 44,4 \\
\hline 3,5 & 12,3 & 9,89 & 31,9 & 24,4 & 17,5 & 101,0 & 71,0 & 47,6 & 29,4 & 432,0 & 271,0 & 164,0 & 93,0 & 47,5 \\
\hline 4,0 & 12,8 & 10,2 & 34,0 & 25,8 & 18,3 & 109,0 & 76,8 & 51,2 & 31,1 & 478,0 & 299,0 & 179,0 & 101,0 & 50,4 \\
\hline
\end{tabular}

\subsection{2.- Determinación del modelo de talud estable, con menos pendiente}

El modelo del último talud estable, para un caso donde el terreno tenga fricción y cohesión, se muestra en la Figura 53.

Figura 53: Forma del contorno de pendientes equiestables

Las coordenadas de este talud vienen dadas en función de sus unidades menores:

$$
x=\bar{x} * \frac{c}{\gamma} \quad y=\bar{y} * \frac{c}{\gamma}
$$

Donde $\boldsymbol{x}$ e $\boldsymbol{y}$ son las coordenadas de menor

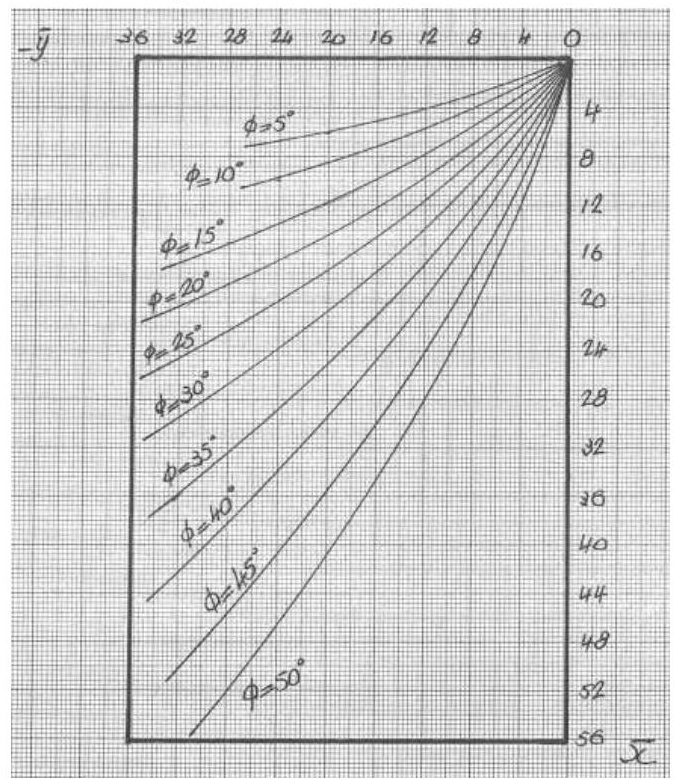
valor.

La forma de un talud estable, se construye empleando desde el corte superior.

La superficie horizontal de un talud estable, puede llevar un peso distribuido uniformemente, determinado por:

$$
P_{0}=\frac{2 * c * \cos \alpha}{1-\operatorname{sen} \varnothing}
$$

Si este peso se considera como una "presión" del suelo, se tiene: 


$$
P_{0}=\gamma * h
$$

Obteniendo:

$$
h=\frac{2 c * \cos \emptyset}{\gamma *(1-\operatorname{sen} \varnothing)}
$$

Para una cohesión perfecta del terreno $(\varnothing=0)$, se obtiene:

$$
h=\frac{2 c}{\gamma}
$$

\section{4.- DESPLAZAMIENTO CIRCULAR-CILÍNDRICO}

Este método se emplea ampliamente, en la práctica garantiza una "cierta" estabilidad, basado en datos experimentales.

Su posición más crítica se determina mediante el cálculo.

Se supone que el centro de la superficie de deslizamiento (circular- cilíndrico) del prisma, es el punto 0 (Fig. 54).

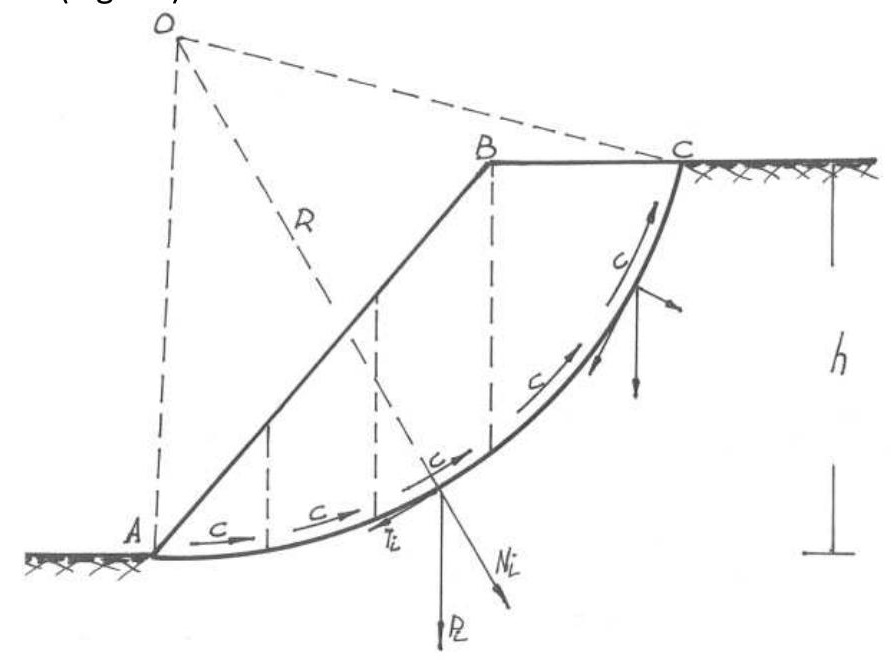

Figura 54: Diagrama de fuerzas actuales

La ecuación de equilibrio es:

$$
\sum M_{0}=0
$$


Para encontrar las ecuaciones de los momentos relativos al punto 0 , el prisma de deslizamiento $A B C$ se divide en planos verticales, dando un número de secciones, el peso $\mathbf{P i}$ de cada sección, se aplica en el punto de intersección de la línea de aplicación con el arco de deslizamiento.

Las fuerzas de interacción sobre los planos verticales de una sección, están afectadas por las presiones de secciones "vecinas", iguales en magnitud y de dirección opuesta. Después de proyectar los pesos $\mathrm{Pi}$ en los radios de rotación y su dirección perpendicular, se puede escribir la ecuación de equilibrio, igualando a cero, el momento de todas las fuerzas relativas al punto de rotación.

$$
\sum T_{i} * R-\sum N_{i} * \operatorname{tg} \emptyset * R-c * L * R=0
$$

Eliminando $\boldsymbol{R}$ :

$$
\sum T_{i}-\sum N_{i} * \operatorname{tg} \emptyset-c * L=0
$$

Donde $L$ es la longitud del desplazamiento arco AC; $\varnothing$ у c son respectivamente el ángulo de fricción interno y la cohesión del terreno; y $\mathbf{T i}$ y $\mathbf{N i}$ son componentes de la presión de los pesos de las secciones, las cuales se pueden determinar gráficamente o calcularlas según medidas de los ángulos $\boldsymbol{\alpha}_{i}$.

$$
\begin{aligned}
& T i=P i * \operatorname{sen} \alpha_{i} \\
& N i=P i * \cos \alpha_{i}
\end{aligned}
$$

El coeficiente de seguridad de un talud está expresado como la razón del momento de las fuerzas resistentes a las fuerzas de rotura.

$$
\begin{gathered}
y=\frac{M_{r e t}}{M_{s h}}=\frac{\left(\sum_{i=1}^{i=1} N i * \operatorname{tg} \emptyset+c * L\right) * R}{\sum T_{i} * R} \\
y=\frac{\sum_{i=1}^{i=1} N i * f+c * L}{\sum T_{i}}
\end{gathered}
$$

Habiendo encontrado el coeficiente de seguridad para un arco de deslizamiento cualquiera, aun no se ha resuelto el problema de todos los arcos posibles de deslizamiento, se debe de optar por el más crítico o desfavorable. El último se encuentra por el proceso y método, asumiendo diferentes posiciones de los puntos 0 al rotar. El primero de los pasos puede reducirse usando ciertas técnicas, por ejemplo las dadas en la Figura 55, donde está indicada la posición de los arcos críticos de deslizamiento. 


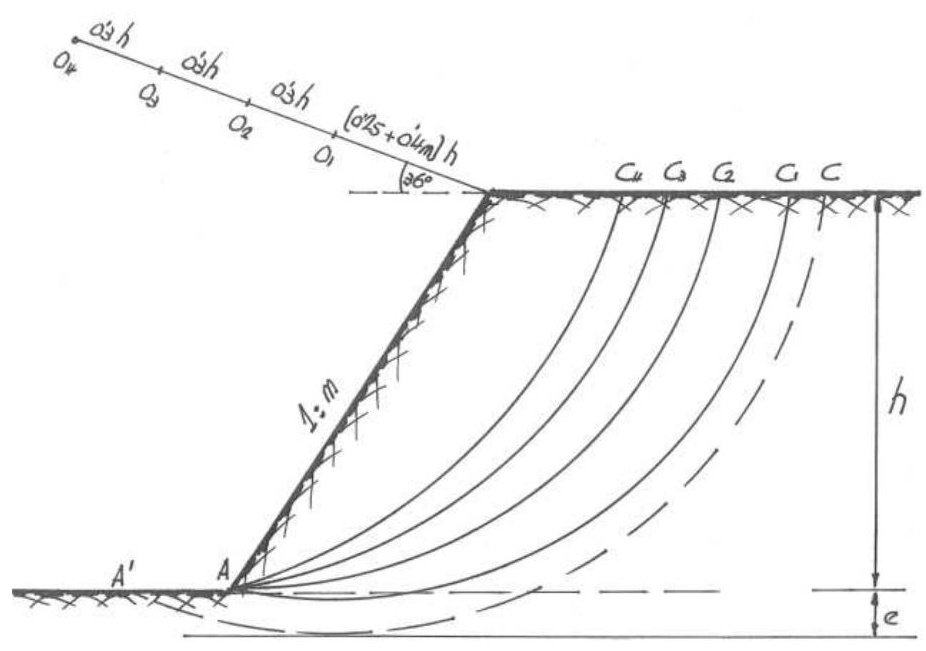

Figura 55: Posición de arcos críticos del deslizamiento.

Para un número de centros seleccionados de arcos de la superficie de deslizamiento $(01,02,03)$ (Fig. 55), se determina la cohesión necesaria para las condiciones de estabilidad y correspondiendo al último equilibrio, se ha dado a la pendiente de acuerdo con la expresión siguiente, la relación:

$$
c=\sum \mathrm{Ti}-\sum \mathrm{Ni} * \operatorname{tg} \varnothing
$$

De todos los centros posibles de deslizamiento, se elegirá el que precise mayor fuerza de cohesión. Este centro es el más crítico y el coeficiente de seguridad y, se calcula por la fórmula dada:

$$
y=\frac{\sum_{i=1}^{i=1} N i * f+c * L}{\sum T i}
$$

Se acepta usualmente que un talud es estable cuando:

$$
\mathrm{y} \geq 1,1-1,5
$$

La fórmula de y solo será cierta para casos en que el arco de toda la superficie de deslizamiento, en todas sus partes, decae hacia el posible desplazamiento del declive o pendiente o (para un caso de deslizamiento sobre una superficie cilíndrica) cuando todas las secciones de la curva de deslizamiento están localizadas a un lado de la dirección del radio vertical OA (Fig. 56). 


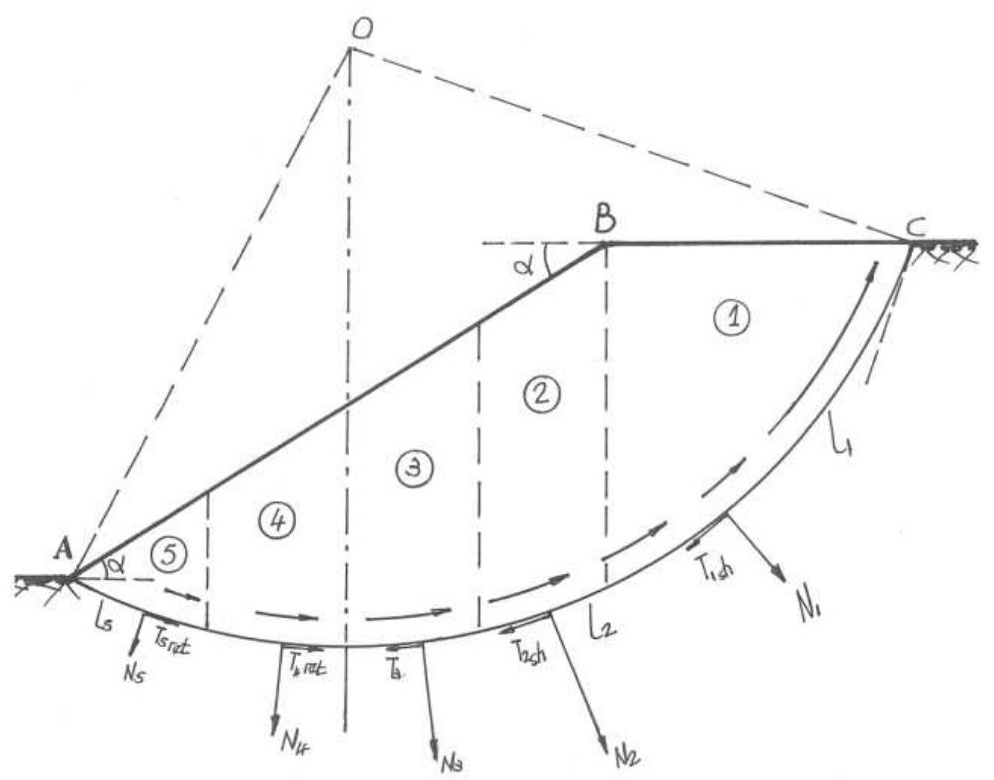

Figura 56: Fuerzas actuando a lo largo de la superficie de deslizamiento.

Llamando a las fuerzas de "corte", dirigidas hacia el deslizamiento, Tish, y a la acción en la dirección opuesta (T4 y T5 en la Figura 56), como Tiret (reteniendo el talud del deslizamiento), tenemos:

$$
\mathrm{y}=\frac{\sum_{\mathrm{i}=1}^{\mathrm{i}=1} \mathrm{Ni} * \mathrm{f}_{\mathrm{i}}+\sum_{\mathrm{i}=1}^{\mathrm{i}=1} \mathrm{c} * \mathrm{~L}_{1} \sum_{\mathrm{i}=1}^{\mathrm{i}=1} \mathrm{~T}_{\mathrm{i}_{\text {ret }}}}{\sum_{\mathrm{i}=1}^{\mathrm{i}=1} \mathrm{~T}_{\mathrm{i} h}}
$$

Esta expresión debe ser usada para determinar el coeficiente de seguridad de pendientes y taludes en cálculos, por el método de superficie en deslizamiento circularcilíndrico.

Este método puede dar en algunas ocasiones un margen excesivo, y lo que es más importante, no tiene en cuenta las fuerzas verticales actuando sobre las superficies de la sección; el método hace el cálculo por aproximación.

Se ha hecho una cierta simplificación para este método de cálculo. La fórmula recomendada por Goldstein para el coeficiente de seguridad es:

$$
y=f * A+\frac{c}{\gamma * h} * B
$$


Donde A y B son coeficientes dependiendo de las dimensiones geométricas de la cuña de deslizamiento expresadas como fracciones de la altura $\mathrm{h}$ del talud. En la tabla 5 se dan sus valores.

Tabla 5: Coeficientes A y B para una aproximación de la estabilidad de los taludes

\begin{tabular}{|c|c|c|c|c|c|c|c|c|c|c|}
\hline \multirow{3}{*}{$\begin{array}{c}\text { Razón del } \\
\text { talud } \\
1: \eta\end{array}$} & \multirow{2}{*}{\multicolumn{2}{|c|}{$\begin{array}{l}\text { Superficie del } \\
\text { deslizamiento que } \\
\text { pasa por el borde } \\
\text { inferior del talud }\end{array}$}} & \multicolumn{8}{|c|}{$\begin{array}{c}\text { Superficie del deslizamiento, que pasa por la base y tiene una tangente horizontal a la } \\
\text { profundidad de: }\end{array}$} \\
\hline & & & \multicolumn{2}{|c|}{$e=1 / 4 h$} & \multicolumn{2}{|c|}{$e=1 / 2 h$} & \multicolumn{2}{|c|}{$e=h$} & \multicolumn{2}{|c|}{$e=1 / 2 h$} \\
\hline & A & $B$ & A & $B$ & A & $B$ & A & $B$ & A & $B$ \\
\hline $1: 1,00$ & 2,34 & 5,79 & 2,56 & 6,10 & 317 & 5,92 & 4,32 & 5,80 & 5,78 & 5,75 \\
\hline $1: 1,25$ & 2,64 & 6,05 & 2,66 & 6,32 & 3,24 & 6,62 & 4,43 & 5,86 & 5,86 & 5,80 \\
\hline $1: 1,50$ & 2,64 & 6,50 & 2,80 & 6,53 & 3,32 & 6,13 & 4,54 & 5,93 & 5,94 & 5,85 \\
\hline $1: 1,75$ & 2,87 & 6,58 & 2,93 & 6,72 & 3,41 & 6,26 & 4,66 & 6,00 & 6,02 & 5,90 \\
\hline $1: 2,00$ & 3,13 & 6,70 & 3,10 & 6,87 & 3,53 & 6,40 & 4,78 & 6,08 & 6,10 & 5,95 \\
\hline $1: 2,25$ & 3,19 & 7,27 & 3,26 & 7,23 & 3,66 & 6,56 & 4,90 & 6,16 & 6,18 & 5,98 \\
\hline $1: 2,75$ & 3,59 & 8,02 & 3,68 & 8,00 & 4,02 & 6,95 & 5,17 & 6,36 & 6,34 & 6,05 \\
\hline $1: 3,00$ & 3,59 & 8,81 & 3,93 & 8,40 & 4,24 & 7,20 & 5,31 & 6,47 & 6,44 & 6,09 \\
\hline
\end{tabular}

La altura $\boldsymbol{h}$ se halla según:

$$
h=\frac{c * B}{\gamma *(y-f * A)}
$$

Usando las últimas fórmulas y la tabla 5, es fácil encontrar el coeficiente de seguridad $y$ de un talud, o la última altura $\mathbf{h}$, función del $\eta$.

Para suelos cohesivos con un pequeño ángulo de fricción interna $(\varnothing<5-7$ 으), con un terreno denso, localizado a la profundidad e (Fig. 26), para el área de la superficie de deslizamiento $A C$, el cálculo se realiza bajo la suposición de que la base del pandeo, cae más "allá" del contorno del talud.

Ejemplo: Cálculo de la última altura de un talud de gradiente (pendiente) 1:2, para:

- $\quad \mathrm{N}=2$

- $\varnothing=22$ 은

- $\quad C=1.2 \mathrm{t} / \mathrm{m}^{2}$

- $\quad \Gamma=1.8 \mathrm{t} / \mathrm{m}^{3}$

Buscando los valores de A y B en la tabla, se obtiene:

$$
h=\frac{c * B}{\gamma(\eta-f * A)}=\frac{1.2 * 6.7}{1.8 *(2-0.0404 * 3.23)}=6.4 \mathrm{~m}
$$

Donde:

$$
f=\operatorname{tg} \alpha
$$




\section{5.- PARÁMETROS}

Los parámetros que intervienen en el cálculo de la estabilidad, por el método descrito a lo largo del capítulo, son los siguientes:

- $\quad$ M .- partícula sólida

- $\quad \boldsymbol{P}$.- peso de la partícula

- $\quad \boldsymbol{N}$.- componente normal de la P

- $\quad a b .-$ línea talud

- $\quad \boldsymbol{T}$.- componente tangencial

- $\quad T^{\prime}$.- fuerza de fricción

- $\quad$ f.- coeficiente de fricción

- $\quad \boldsymbol{\alpha} .-$ ángulo del talud

- $\varnothing$.- ángulo de fricción interna del terreno

- $\quad \boldsymbol{h}$.- altura de equilibrio del talud

- $\quad$ P .- peso del prisma

- $\quad \boldsymbol{\gamma}$.- densidad terreno

- c.-cohesión

- $\sqrt{z}$.- valor de la presión mínima

- $\quad \boldsymbol{X} \boldsymbol{y}$.- coordenadas

- $\quad$ M.- momento

- $\quad \boldsymbol{R}$.- radio

- L .- longitud desplazamiento arco AC

- $\boldsymbol{M}_{\text {ret }}$.- momento fuerzas resistentes

- $\boldsymbol{M}_{s h} .-$ momento fuerzas rotura

- $\quad y .-$ coeficiente de seguridad

\section{5.- DESLIZAMIENTOS TRASLACIONALES: MÉTODO DE MASLOV}

\section{1.- DESLIZAMIENTO DE TRASLACIÓN}

El carácter de una superficie de deslizamiento, está regido no solamente por el estado tensional del suelo, sino también por las condiciones naturales del mismo y por la estructura de su masa. 
Juega un papel muy importante la interacción entre los estratos, pudiendo reducirse la resistencia a la rotura (deslizamiento), y la forma de la superficie de los estratos subyacentes, a lo largo de los cuales, la masa del talud se desliza (desplazamiento de suelo "incrustado").

En un caso bidimensional, estas superficies de deslizamiento pueden aproximarse al plano de la Figura 57, por una serie de líneas de fuerza.

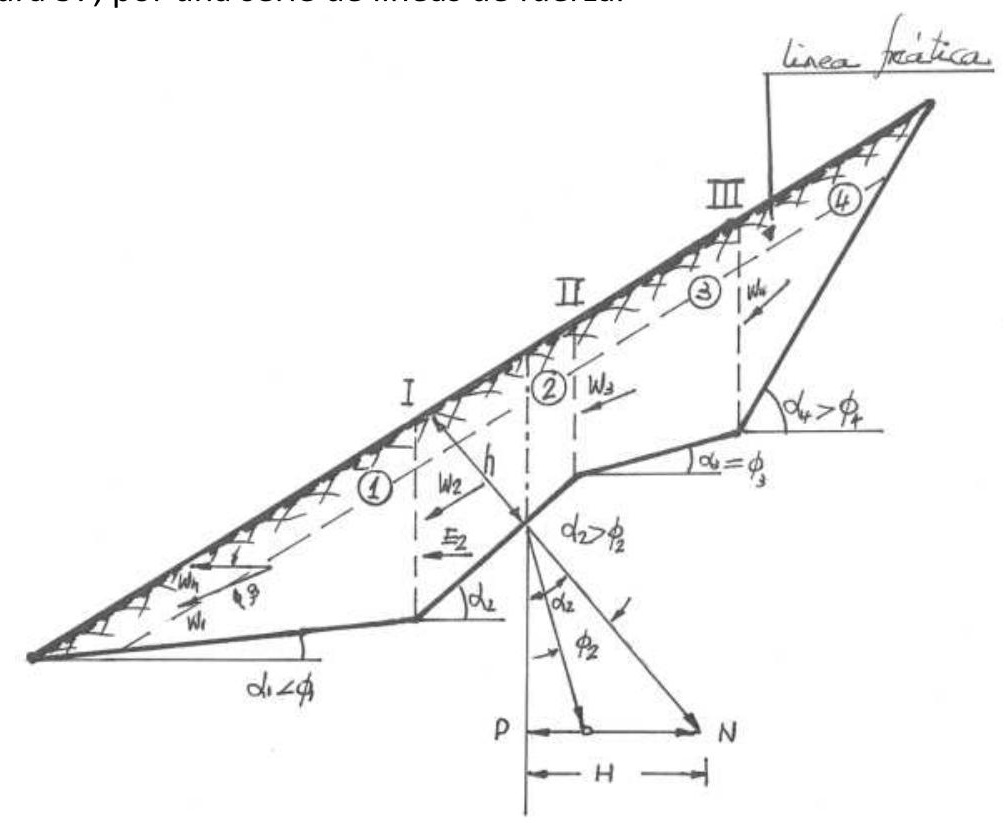

Figura 57: Ilustración del método "Fuerzas horizontales".

- $\quad n=\Sigma\left[H_{i}-E_{i}\right] / \Sigma H_{i}$

- $\quad n=\Sigma p_{i l}\left[\operatorname{tg} \alpha_{i}-\operatorname{tg}\left(\alpha_{i}-\emptyset_{i}\right)\right] / \Sigma p_{i}+\operatorname{tg} \alpha_{i}$

- $\varnothing_{i}=\operatorname{arctg}\left[\operatorname{tg} \emptyset_{w}+C_{w} / p\right]$

El método de fuerzas horizontales se puede usar con cierta ventaja para evaluar la estabilidad de una masa del terreno bajo aquellas condiciones, tal como se ha demostrado en la práctica.

La resistencia a la rotura del suelo $S_{p}$, además de expresarse en los términos comunes de:

- $\varnothing .-$ ángulo de rozamiento interno.

- c.- cohesión. 
Puede ser expresada a través del coeficiente $\boldsymbol{F}_{p}$ y del ángulo de resistencia a la rotura $\psi$, (Fig. 58). En el último caso no es necesaria la subdivisión del total de la resistencia a la rotura en la fuerza de fricción interna $p * \operatorname{tg} \varnothing$ y la cohesión $c$.

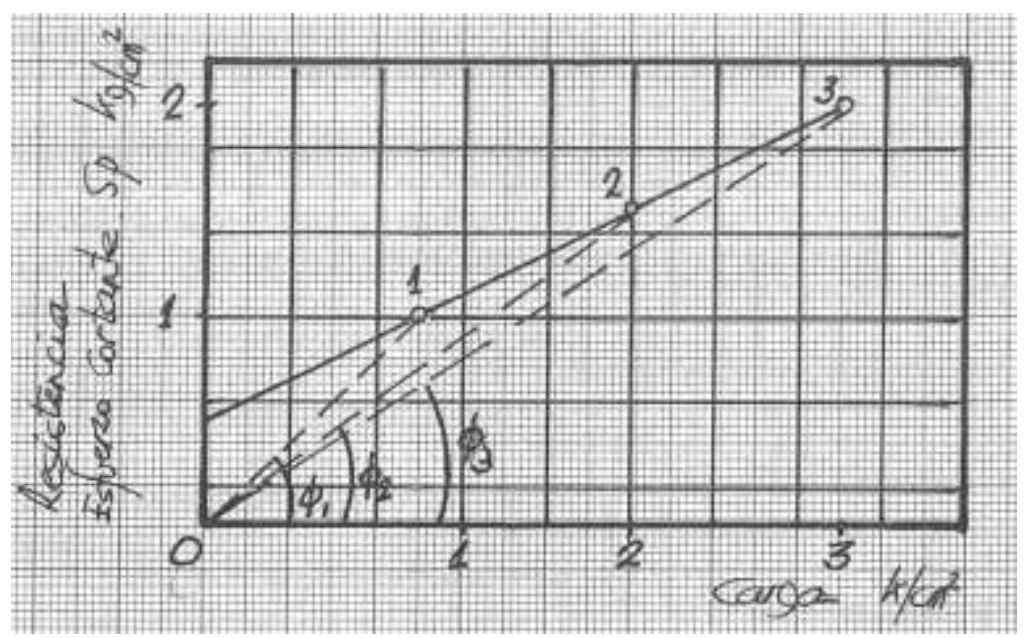

Figura 58: Relación entre la resistencia al corte de un suelo arcilloso Sp, el coeficiente Fp y el ángulo de resistencia $\psi p$

Estos índices característicos están interconectados por la relación:

$$
F_{p}=\operatorname{tg} \psi_{p} \quad \text { y } \quad \psi_{p}=\operatorname{arctg} F_{p}
$$

Al mismo tiempo,

$$
F_{p}=\frac{s_{p}}{p}
$$

Donde:

$$
S_{p}=p * \operatorname{tg} \emptyset+c
$$

Entonces,

$$
F_{p}=\operatorname{tg} \varnothing+\frac{c}{p} \quad \text { y } \quad S_{p}=p * F_{p}
$$

Como se puede ver, el coeficiente $\boldsymbol{F}_{p}$ y el ángulo de resistencia a la rotura $\psi_{p}$, están relacionados por la carga (Fig. 59). 


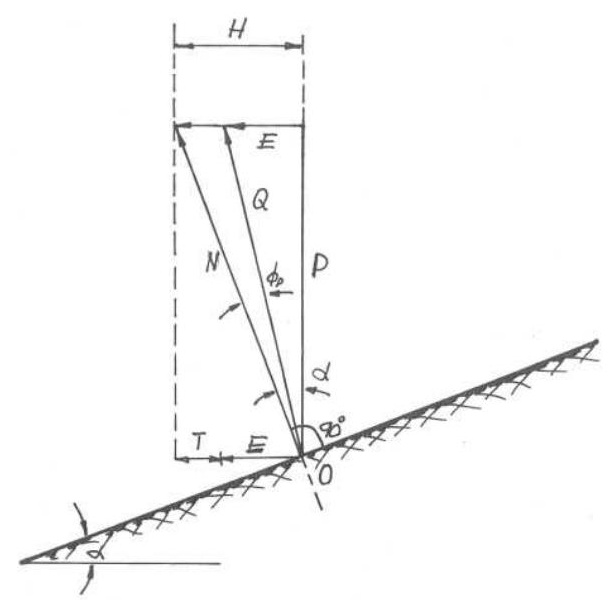

Figura 59: Principio del método. Fuerzas horizontales

En particular, si $p=0$, el coeficiente $F_{p}$ y el ángulo $\psi_{p}$ son respectivamente igual a infinito y a 90 ㅇ.

Por otra parte, si la carga $\boldsymbol{p}$ es infinita,

$$
F_{p}=\operatorname{tg} \emptyset \quad \text { y } \quad \psi_{p}=\emptyset
$$

Los análisis muestran que el ángulo crítico del talud iguala al ángulo de resistencia a la rotura del terreno $\psi_{p}$, si la tensión normal p corresponde a la condición específica:

$$
\psi_{p}=\alpha_{c r}
$$

Se recuerda que el ángulo de resistencia a la rotura $\psi_{p}$, en un terreno suelto cuya cohesión es $0(c=0)$, es igual al ángulo de fricción interna $\varnothing$.

Consecuentemente, el ángulo crítico del talud $\alpha_{c r}$, formado por terreno suelto, es igual al ángulo de rozamiento interno,

$$
\alpha_{c r}=\varnothing
$$

Se puede considerar (Fig. 59), donde $\boldsymbol{N}$ es la componente normal de la reacción de la masa $\boldsymbol{p}$, un diseño definitivo de un bloque (zona) (Fig. 58), en la superficie del deslizamiento, con la condición de que,

$$
\psi_{p}=0
$$


- Que es cuando $\varnothing=0$ y $c=0$.

La fuerza $\boldsymbol{Q}$, es la reacción a $\boldsymbol{p}$ bajo las condiciones de fricción y cohesión de un terreno activo en la superficie de deslizamiento.

La dirección de esta fuerza está regida por el ángulo de fricción interna $\varnothing$, o por el ángulo de resistencia a la rotura $\psi_{p}$, si el terreno tiene cohesión $(c \neq 0)$.

La fuerza $\boldsymbol{H}$, es una proyección de la fuerza $\boldsymbol{N}$ sobre un eje horizontal representando un empuje externo, que es la presión ejercida sobre una pared vertical por el bloque del terreno (rebajado) elegido (Fig. 61) si el terreno no tiene fricción de cohesión.

La fuerza $\boldsymbol{T}$ es una porción del empuje externo $\mathrm{H}$, soportado por fuerzas de fricción y cohesión, E, es una porción de $H$.

Siendo así, se tiene:

$$
\begin{aligned}
& H=p * \operatorname{tg} \alpha \\
& E=p * \operatorname{tg}\left(\alpha-\psi_{p}\right) \\
& T=H-E=P *\left[\operatorname{tg} \alpha-\operatorname{tg}\left(\alpha-\psi_{p}\right)\right]
\end{aligned}
$$

La ecuación (1) hace posible, en principio, establecer la estabilidad de cada bloque de terreno seleccionado. (Fig. 58).

- Si $\alpha=\boldsymbol{\Psi}_{\varnothing p}$, el bloque 3 está en equilibrio; si $\alpha>\psi_{\varnothing p}$, la estabilidad de los bloques 2 y 4 no está garantizada.

- Si $\boldsymbol{\alpha}=\boldsymbol{\psi}_{\emptyset p}$, el bloque 1 es estable, proporcionando un apoyo a los bloques superiores.

Conociendo los valores de:

$$
\sum\left( \pm H_{i}\right) \quad \text { y } \quad \sum T_{i}
$$

Para cada bloque y para todo el talud sujeto a deslizamiento, se puede calcular el factor de seguridad:

$$
K_{s a f}=\frac{\sum T_{i}}{\sum\left( \pm H_{i}\right)}
$$


Si hay filtraciones de agua a través del talud, se transmite una presión adicional $\boldsymbol{W}_{\mathbf{s}}$ al terreno deslizante.

La magnitud de $\boldsymbol{W}_{\boldsymbol{s i}}$ transmitida a cada bloque individual, se calcula mediante:

$$
\mathrm{W}_{\mathrm{si}}=\rho_{\mathrm{w}} * \mathrm{~W}_{\mathrm{i}} * \mathrm{I}_{\mathrm{i}}
$$

La dirección de la presión de infiltración $\boldsymbol{W}_{\boldsymbol{s i}}$ puede ser asumida en cada bloque si es paralela a la curva de presión en los mismos.

Así, es posible establecer el ángulo $\boldsymbol{B}_{\boldsymbol{s i}}$ entre la dirección de $\boldsymbol{W}_{\boldsymbol{i}}$ y la horizontal.

El factor de seguridad de un terreno deslizante, teniendo en cuenta la presión de filtración, es:

$$
k_{s a f}=\frac{\sum T_{i}}{\sum\left( \pm H_{i}\right)+\sum W_{i}^{*} \cos \beta_{s i}}
$$

La presión principal $\mathbf{h}_{\mathbf{w}}$, se "activa" en el contacto entre estratos, en función del "espesor" del estrato incrustado $\mathbf{h}_{\mathbf{s}}$.

Cuando existe equilibrio, según el valor crítico del ángulo del talud, $\boldsymbol{\alpha}_{c r} ; \boldsymbol{K}_{s a f}=1$, entonces:

$$
\operatorname{tg} \alpha_{c r}=\left[1-\frac{1}{2} * \frac{h_{w}}{h_{s}}\right] * \operatorname{tg} \emptyset_{w}+\frac{C_{w}}{\rho_{s} * h_{s}}
$$

Si el terreno en contacto con un estrato no tiene cohesión, $c=0$, se tiene:

$$
\operatorname{tg} \alpha_{c r}=\left[1-\frac{1}{2} * \frac{h_{w}}{h_{s}}\right] * \operatorname{tg} \emptyset_{w}
$$

Si $\boldsymbol{h}_{\boldsymbol{w}}=\boldsymbol{h}_{\boldsymbol{s}}$ (podría ser mayor $h_{w}>h_{s}$ ), y para un caso dado, el ángulo crítico del talud es:

$$
\alpha_{c r}=\frac{\emptyset_{w}}{2}
$$

Como se puede ver, la presencia de una presión horizontal, en el contacto con el estrato. Reduce apreciablemente la estabilidad de la masa del terreno sobre la superficie de deslizamiento. Si la presión principal, $\boldsymbol{h}_{w}$ es notable y excede al espesor del terreno del estrato deslizante, el ángulo crítico del talud puede resultar muy pequeño, y la masa se moverá uniformemente. 


\section{2.- MÉTODO APROXIMADO DE CÁLCULO PARA UN TALUD ESTABLE (MÉTODO FP)}

El método "presume" que el límite de equilibrio en un talud estable, en cada uno de sus puntos a profundidad $\mathbf{z}$, desde la superficie libre, satisface la condición:

$$
\alpha_{z}=\psi_{p z}
$$

Donde:

- $\quad \alpha_{z}$.- ángulo de inclinación del talud con la horizontal a profundidad $z$.

- $\quad \psi_{p z}$.- ángulo de resistencia a la rotura, característico de un "horizonte" particular.

La relación existente entre $\psi_{p z}$ y el valor del coeficiente de resistencia a la rotura $F_{p z}$ es:

$$
\begin{aligned}
& F_{p z}=\operatorname{tg} \psi_{p z} \\
& \psi_{p z}=\operatorname{arctg} F_{p z}
\end{aligned}
$$

Siendo el coeficiente de rotura:

$$
F_{p z}=\operatorname{tg} \emptyset+\frac{c}{p}
$$

El peso $\boldsymbol{p}$, a una profundidad $\boldsymbol{z}$, es el terreno de recubierto:

$$
p=\rho * Z
$$

Pudiendo escribir:

$$
F_{p Z}=\operatorname{tg} \psi_{p z}=\operatorname{tg} \emptyset+\frac{c}{\rho * z}
$$

Si hay una distribución uniforme de la carga $P_{0}$, más allá de la cresta del talud, tendremos:

$$
F_{p z}=\operatorname{tg} \psi_{p z}=\operatorname{tg} \emptyset+\frac{c}{\left(p_{0}+p_{z}\right)}
$$

Si la cohesión c es cero, el ángulo de resistencia a la rotura es:

$$
\psi_{p z}=0
$$

- Valor típico para arenas sueltas con poca cohesión. 
Para otros terrenos que tengan cohesión, el perfil de un talud estable está curvado, siendo escarpado en la parte superior y llano en la inferior.

En un estado subcrítico, caracterizado por el valor de $\left(K_{\text {saf }}\right)$, en cada horizonte $\boldsymbol{z}$ se tendrá:

$$
\operatorname{tg} \alpha_{z}=\frac{1}{K_{s a f}} * \operatorname{tg} \psi_{p z}
$$

El grado de estabilidad de todo el talud está regido por la condición, a profundidad $\mathbf{z}$ :

$$
K_{\text {saf }}=\frac{\operatorname{tg} \psi_{p z}}{\operatorname{tg} \alpha_{z}}>1
$$

Existen métodos gráficos y analíticos para trazar el perfil de un talud estable, con valor específico de $K_{\text {saf, }}$ usando las ecuaciones anteriores.

El método analítico parece más seguro en comparación con el gráfico. Sin embargo, si la masa de terreno del talud está compuesta de varios estratos con diferentes propiedades mecánicas, el método analítico es demasiado complicado y se opta entonces por el gráfico.

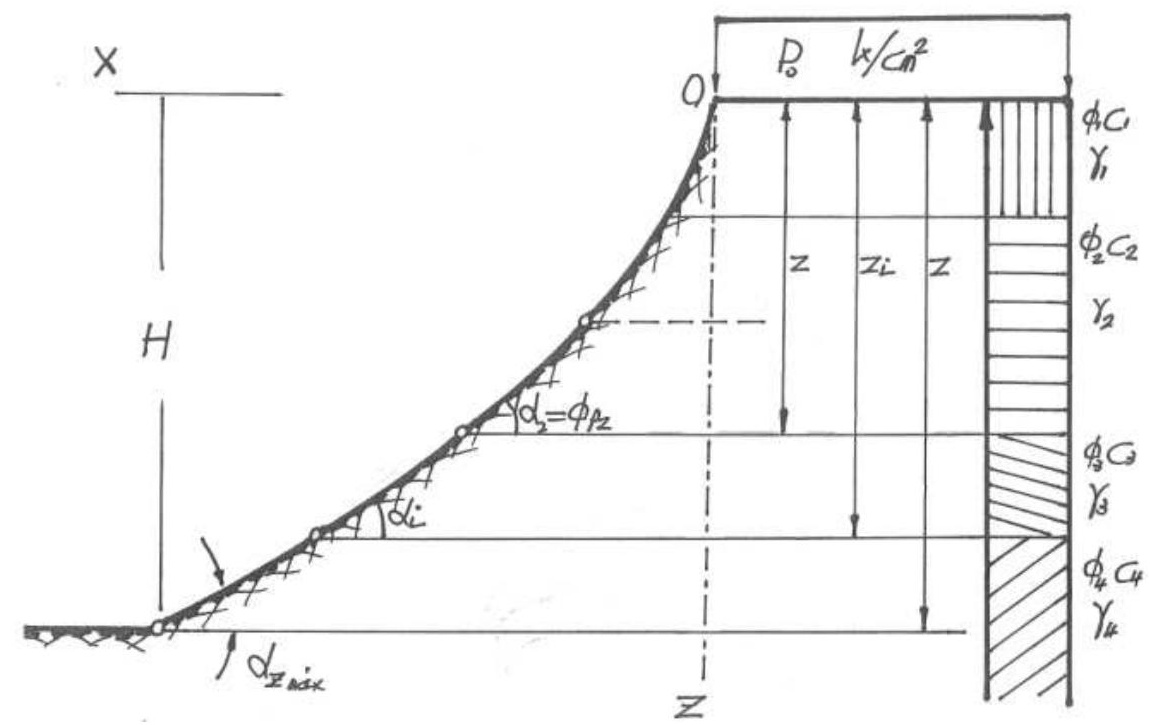

Figura 60: Talud estable de resistencia uniforme (método Fp)

El método gráfico de $F_{p}$, (Fig. 60), ecuaciones 9 y 15 , el talud se divide en series de capas, con la parte inferior a profundidades $z_{1}, z_{2}, z_{3}, \ldots$ de la parte superior.

Un gran número de subdivisiones proporcionan mayor exactitud. 
$\mathrm{Si}$ el terreno debajo del talud tiene juntas de materiales distintos, el horizonte correspondiente al diseño de las capas, debe de conformar los contactos de las juntas.

Se encuentra el valor del ángulo de resistencia a rotura $\boldsymbol{\psi}_{p z}$ para cada capa, a profundidad $z_{i}$, en función de la magnitud del coeficiente de resistencia a la rotura $\boldsymbol{F}_{p}$, según las ecuaciones 12 ó 13.

Después de esto, se usan las expresiones 9 ó 15, para establecer la magnitud de los ángulos del talud $\left(\boldsymbol{\alpha}_{z}\right)$, correspondiendo a los valores establecidos de los ángulos de resistencia a la rotura $\psi_{p z}$, dar un valor del factor de seguridad $K_{s a f}$, alcanzando el equilibrio para $K_{s a f}=1$.

Si $\boldsymbol{K}_{\text {saf }}$ tiene este valor, el talud es generalmente trazado según la ecuación 9.

Se comienza el trazado del punto más bajo del talud para:

$$
z_{\text {max }}=H
$$

La medida del ángulo $\boldsymbol{\alpha}_{\boldsymbol{z}}$ corresponde al horizonte particular siguiendo la determinación de la línea hasta la intersección con el horizonte próximo, de profundidad z. EI punto de intersección mide otra vez el ángulo $\boldsymbol{\alpha}$, correspondiente a este horizonte. Encontrando así un nuevo punto de intersección de una línea con la adyacente del horizonte superior, etc, hasta que el talud llegue a la superficie.

Conectando por una curva suave los puntos obtenidos de intersección del diseño del horizonte determinando los ángulos del talud $\boldsymbol{\alpha}$. Como se demuestra en la práctica, este método refleja adecuadamente las condiciones actuales (Fig. 61). 


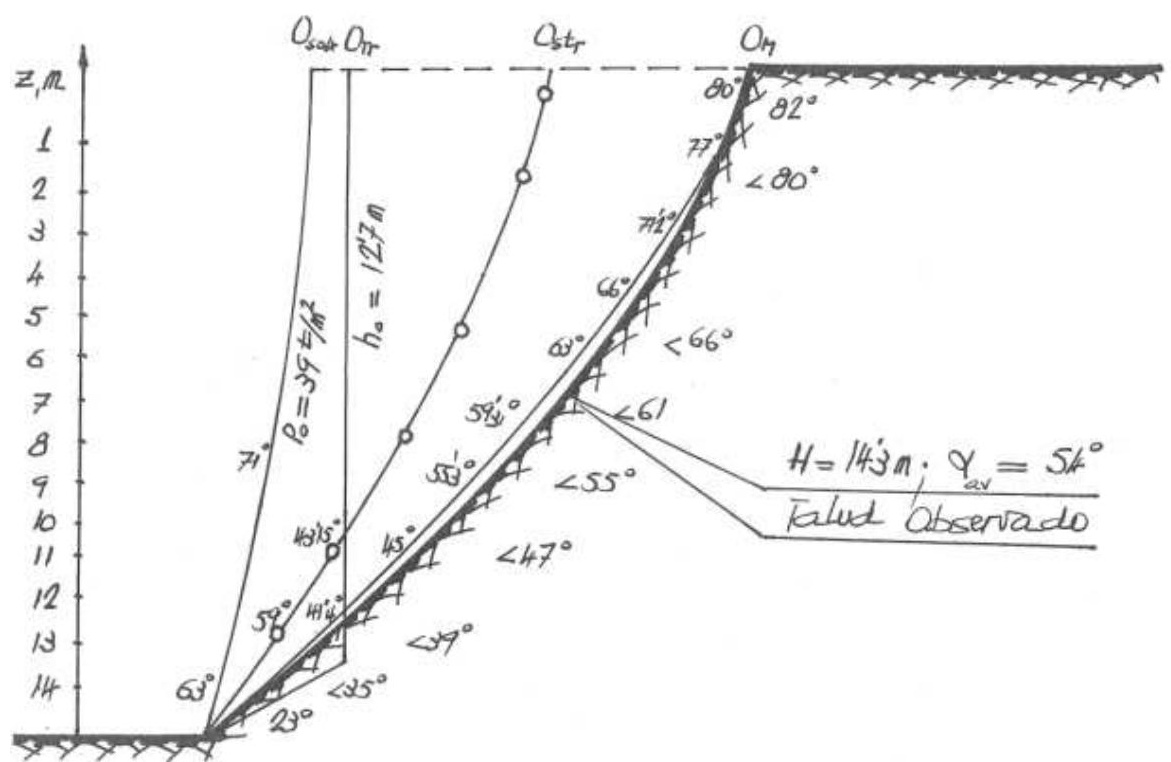

Figura 61: Comparación entre perfiles por el método Fp.

Comparación entre el perfil actual de deslizamiento de un talud $\left(K_{\text {saf }}=1\right)$ y el perfil de referencia por el método Fp.

- $0_{\text {sok }}$ : Línea de V.V. Sokolovsky

- $\quad 0_{\text {Tr: }}$ Línea de M.N. Troitskaya

- $\quad 0_{\text {STr }}$ Línea de A.S. Strogarvu

- $0_{M}$ : Línea de N.N. Maslov

Si no existe una carga en la superficie del terreno, más allá de la cima del talud:

$p_{o}=0$

Y si el terreno es uniforme en la cohesión $c$, el ángulo del talud en la superficie de la masa del terreno llega a ser igual a $90 \circ$ y $z=0$.

Valores según la fórmula 12.

A menudo es necesario determinar la altura $H_{x}$ de un talud vertical, según los parámetros: $\rho, \emptyset, c$; según la ecuación:

$$
E_{a c}=\frac{1}{2} * \rho * H^{2} * \operatorname{tg}^{2}\left[45^{\circ}-\frac{\emptyset}{2}\right]-2 * c\left[H * \operatorname{tg}\left(45^{\circ}-\frac{\emptyset}{2}\right)-\frac{\mathrm{c}}{\rho}\right]
$$

En un talud vertical, la presión activa de la masa del terreno es:

$$
E_{a c}=0
$$


Descartando el segundo término, debido a su pequeñez, se reduce la ecuación en $H^{*} \operatorname{tg}\left(45^{\circ}-\alpha / 2\right)$, la altura de un talud, en equilibrio, sin ningún soporte:

$$
H_{x}=\frac{4 * c}{\rho * \operatorname{tg}\left[45^{\circ}-\frac{\emptyset}{2}\right]}
$$

\section{3.- HUMEDAD DE LAS ARENAS EN EL DESLIZAMIENTO DE UN TALUD}

El desplazamiento de la arena de un estrato, o de un talud, está causado por licuefacción de la arena, o su saturación, la cual poco a poco permite una fluencia del agua del subsuelo con un gradiente definitivo (I, fluencia) de su arrastre.

Analizando las condiciones de estabilidad de estratos superiores de una masa de arena en un talud, actuando la presión por filtraciones hace posible esta relación:

$$
\mathrm{K}_{\mathrm{saf}}=\frac{1}{2} * \frac{\operatorname{tg} \emptyset}{\operatorname{tg} \alpha}
$$

Consecuentemente, el ángulo crítico del talud $(K s a f=1)$ en el cual, el terreno puede deslizar hasta la parte inferior del talud, será:

$$
\alpha=\frac{\emptyset}{2}
$$

El ángulo de fricción interna $\varnothing$, para materiales arenosos está cercano a los 30 .

Si la razón del talud es $\alpha=150$ o su escarpadura

$$
\frac{1}{m}=\frac{1}{3.75}
$$

El movimiento de la arena húmeda puede "ocurrir".

En los cálculos anteriores se ha hecho uso, entre otros, de los índices más característicos en la estabilidad de un talud:

- $\varnothing w$-Ángulo de rozamiento interno.

- C $\mathbf{w}$-Cohesión. 


\section{4.- PARÁMETROS}

Los parámetros que intervienen en el cálculo de la estabilidad frente a deslizamientos traslacionales, son los siguientes:

- $s_{p}$. - resistencia a rotura del suelo

- $\varnothing$.- ángulo de resistencia interna

- C.- cohesión

- $\boldsymbol{\psi}_{p}$.- ángulo de resistencia a la rotura

- $\quad$ p.- peso del terreno

- $\boldsymbol{F}_{p}$.- coeficiente de resistencia a rotura

- $\boldsymbol{\alpha}_{c r}$.- ángulo crítico del talud

- $\quad \boldsymbol{N}$.- componente normal

- $\quad$ Q.- reacción de $p$

- $\quad \boldsymbol{H}$.- proyección de la fuerza $\mathrm{N}$

- $\quad \boldsymbol{T}$.- fracción del empuje $\mathrm{H}$

- $\quad \boldsymbol{E}$.- fracción del empuje $\mathrm{H}$

- $\boldsymbol{W}_{s}$.- presión adicional del agua

$\boldsymbol{B}_{s i}$. ángulo: Horizontal $-\mathrm{W}_{\mathrm{i}}$

- $\boldsymbol{k}_{\text {saf }}$. - factor de seguridad cuerpo deslizante

- $\boldsymbol{h}_{w}$.- presión principal

- $\boldsymbol{h}_{\boldsymbol{s}}$.- espesor estrato

- $\quad \boldsymbol{z}$.- profundidad talud

- $\quad$ o.- densidad terreno

- I.- fluencia (gradiente)

- $\boldsymbol{m}$.- escarpadura 


\section{6.- EQUILIBRIO DE MOMENTOS: MÉTODO DE JAMBU}

\section{1.- MOMENTOS}

El sistema más simple, en principio, y más popular en la antigua U.R.S.S., es el conocido como "método de los momentos".

Asume que un talud puede deslizarse solamente si la masa deslizante lo hace alrededor del centro 0 (Fig. 62).

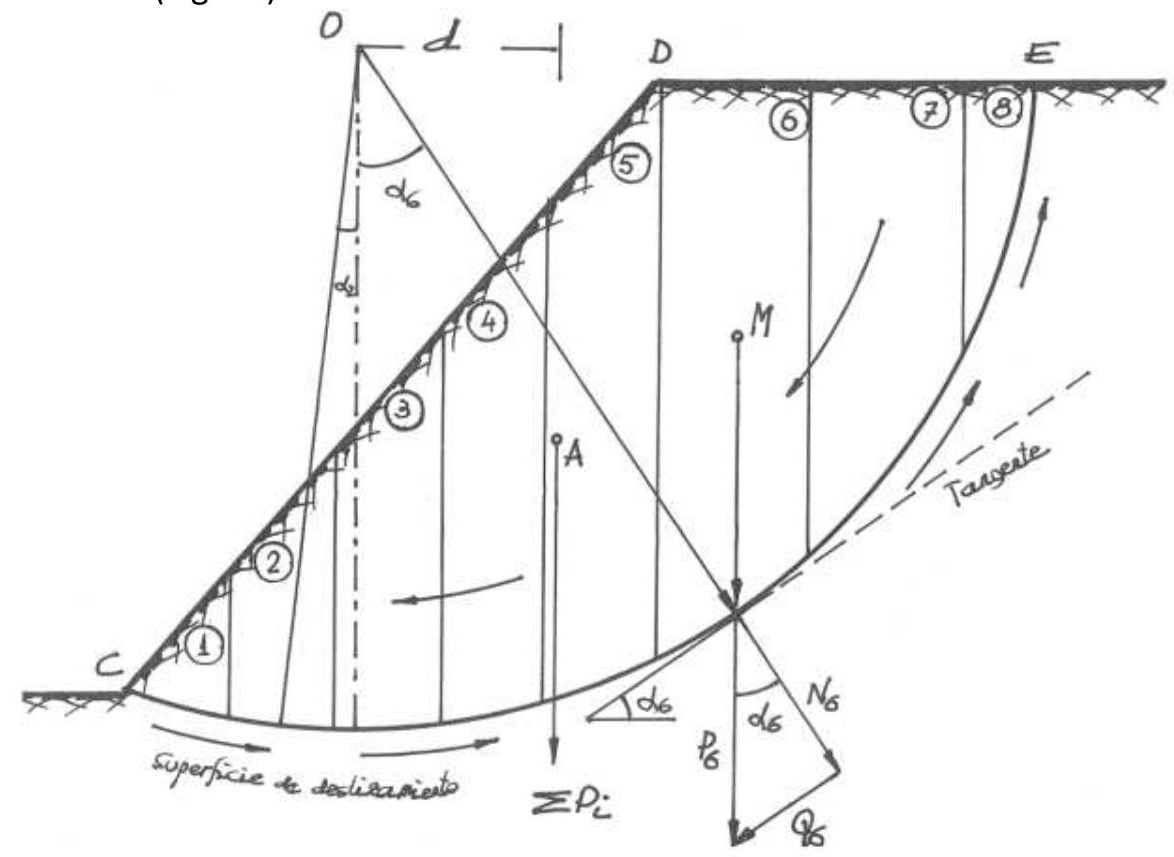

Figura 62: Diagrama para el cálculo de la estabilidad, referido al método de superficie circular cilíndrica

Consecuentemente, la superficie de desplazamiento BD, puede ser representada por un arco de círculo, cuyo radio tiene como centro 0.

La masa deslizante, se supone que es un bloque sólido, en el que todas las partes participan en el movimiento. Esto, naturalmente, es una mera aproximación.

En la masa del terreno deslizante actúan dos momentos:

- $\quad M_{\text {rot }}$ - momento de rotación del bloque.

- $M_{\text {res }}$ - momento resistente.

Siendo el factor de seguridad: 


$$
k_{\text {saf }}=\frac{M_{\text {res }}}{M_{\text {rot }}}
$$

Complica el método la necesidad de tener en cuenta valores variables de las fuerzas de fricción $T$, que aparecen en los diferentes puntos de la superficie del deslizamiento durante la rotura, siendo:

$$
T=N * \operatorname{tg} \emptyset
$$

Donde $\boldsymbol{N}$ es la componente normal del peso $P$, de una porción definida del bloque del terreno tangente a la superficie de deslizamiento, en este caso, bloque no6 (Fig. 62).

Como puede verse en el diagrama:

$$
N_{i}=P_{i} * \cos \alpha_{i}
$$

Donde $\boldsymbol{\alpha}_{i}$ es el ángulo de inclinación de la tangente a la superficie de deslizamiento, con la horizontal como punto especifico, cuya medida numérica es el ángulo entre la vertical y un radio vector $R$, a este punto.

Así, en este caso, la dirección de la fuerza normal $\boldsymbol{N}$, coincide con la del radio vector $\boldsymbol{R}$.

La fuerza de rotura $Q \mathbf{i}$, sobre el punto, inducida por el peso $\boldsymbol{p i}$, es:

$$
Q_{i}=P_{i} * \operatorname{sen} \alpha_{i}
$$

Hay que tener presente que $\boldsymbol{Q}_{i}$ puede tener diferentes signos según sean las zonas descendentes o ascendentes sobre la línea de deslizamiento.

Sustituyendo en la ecuación (2) el valor de $\boldsymbol{N}$, ecuación (3), se obtiene la fuerza de fricción:

$$
T_{i}=P_{i} * \cos \alpha_{i} * \operatorname{tg} \varnothing
$$

Según el ángulo de $\boldsymbol{\alpha}_{\boldsymbol{i}}$, el valor de $\boldsymbol{P}_{\boldsymbol{i}}$, puede cambiar en varios puntos a lo largo de la línea de deslizamiento. Estos factores, tomados juntos, proporcionan el factor de seguridad del talud:

$$
K_{\text {saf }}=\frac{\sum M_{\text {res }}}{\sum M_{\text {rot }}}
$$


Sería necesario dividir en zonas la masa hipotética de deslizamiento, determinando para cada una las fuerzas resistentes a la rotura.

La resistencia total $S_{i}$ de la superficie de deslizamiento, es la suma de las fuerzas de fricción $T_{i}$ y de cohesión $C_{i}$ :

$$
S_{i}=T_{i}+C_{i}
$$

Para cada zona i, se tiene:

$$
S_{i}=P_{i} * \cos \alpha_{i} * \operatorname{tg} \emptyset+C_{i} * L_{i}
$$

- Siendo:

$$
\begin{gathered}
M_{\text {rot }}=\sum P_{i} * \operatorname{sen}_{i} * R \\
M_{\text {res }}=\sum\left[P_{i} * \cos \alpha_{i} * \operatorname{tg} \emptyset_{i}+C_{i} * L_{i}\right] * R
\end{gathered}
$$

Proporcionando el factor de seguridad:

$$
K_{\text {Saf }}=\frac{\sum\left[P_{i} \cos \alpha_{i} * \tan \alpha_{i}+C_{i} * L_{i}\right]}{\sum P_{i} * \sin \alpha_{i}}
$$

Los valores de $\varnothing\left(\varnothing_{w}\right)$ y $C\left(C_{w}\right)$ proporcionarían una correspondencia más real con valores naturales respecto a la densidad-humedad del terreno.

El terreno es homogéneo, cuando:

- $\varnothing_{w}$ - constante

- $C_{w}$. - constante

- $\rho_{w}$. - constante

Según lo anterior, el factor de seguridad, se puede expresar:

$$
K_{S a f}=\frac{\Sigma N_{i} * \tan \emptyset_{w}+C * L}{\Sigma Q_{i}}
$$


Cuando un talud tiene una parte sumergida en agua (rivera de un río), es necesario establecer la presión de cada bloque independientemente $\boldsymbol{P}_{\boldsymbol{i}}$, teniendo en cuenta la capacidad de flotación efectuada por el agua.

El método, es a menudo complicado en la práctica actual por la indeterminación del centro de rotación 0 .

Sus coordenadas y el valor del radio $R$, deben ser determinados con los valores más desfavorables, el centro 0 , se puede establecer para hallar el valor más bajo posible del factor de seguridad $\boldsymbol{k}_{\text {saf }}$ en un talud determinado.

La posición de 0 se halla por cálculos consecutivos.

Existen varios métodos, uno de los más empleados, el Jambu. (Figs. 63 y 64).

Figura 63: Diagrama de Jambu.

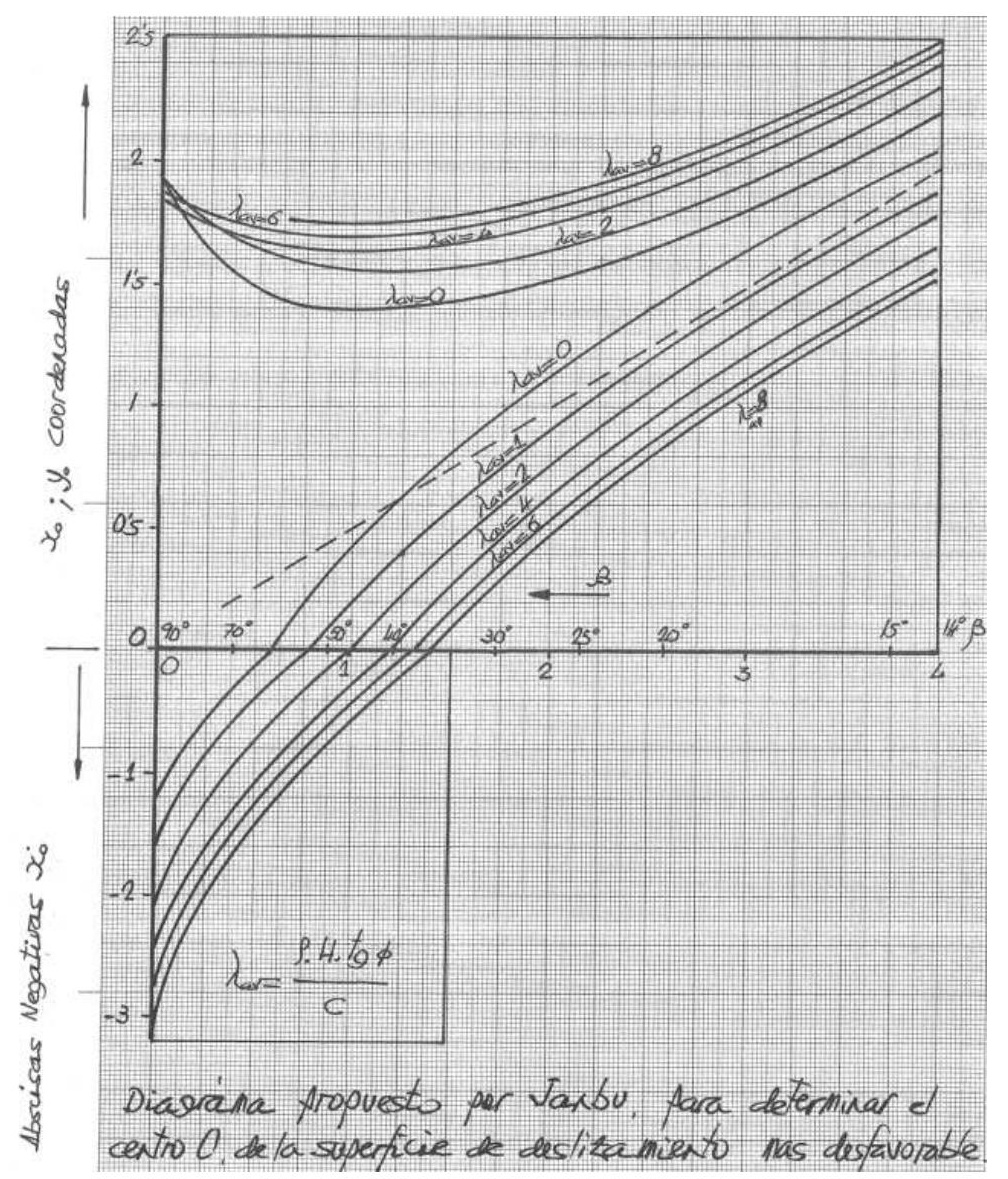




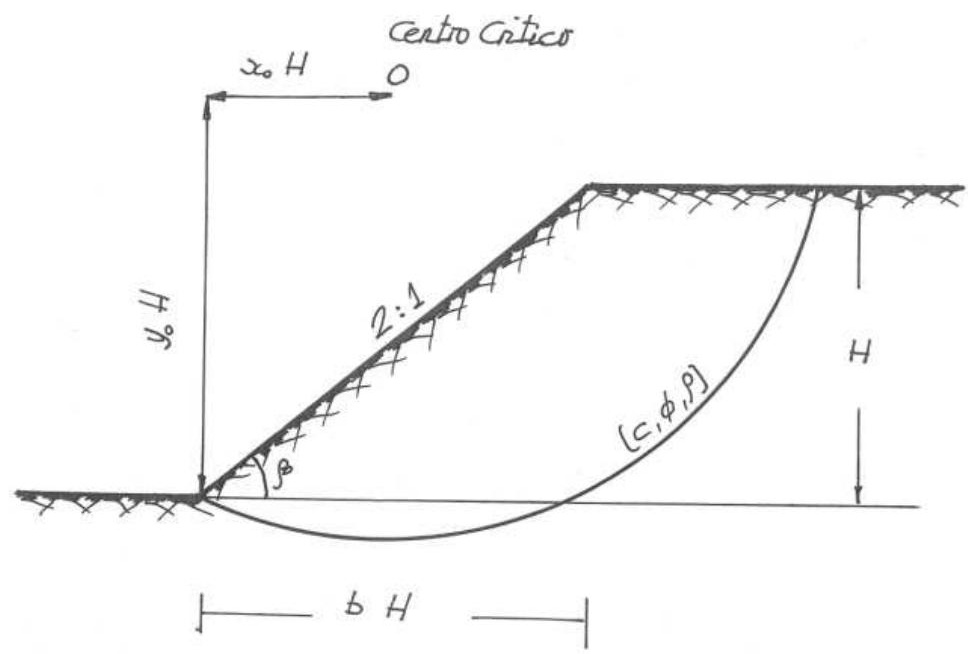

Figura 64: Centro crítico.

Es fácil que un deslizamiento ocurra si el factor de seguridad es menor que la unidad. Es imperativo que $k_{\text {saf }}>1$.

En teoría, la estabilidad de un talud o pendiente estará garantizada si el factor de seguridad excede solamente un pequeño margen sobre la unidad.

El problema mayor está en determinar el valor de $K_{\text {saf. }}$.

Cuando un talud tiene la estabilidad indeterminada y no pudiendo determinar el esfuerzo de rotura, de manera correcta se debe usar:

$$
k_{\text {saf }}=1,25-1,30
$$

- simplemente 1,5.

- En un deslizamiento progresivo, se puede tomar, $k_{s a f}=1$.

- Si se controlan los parámetros de la resistencia a rotura del terreno, se puede adoptar,

$$
k_{\text {saf }}=1,05-1,1
$$




\section{2.- PARÁMETROS}

Los parámetros que intervienen en el cálculo de la estabilidad de taludes, aplicando el método de Jambu, son los siguientes:

- $\quad \boldsymbol{T}$.- fuerza de fricción

- C.- fuerza de cohesión

- $\quad \boldsymbol{N}$.- componente normal

- $\quad \boldsymbol{P}$.- peso interviniente

- $\varnothing$.- ángulo de rozamiento interno

- $\quad \boldsymbol{\alpha}$.- ángulo de tangente horizontal

- $\quad$ Q .- fuerza de rotura

- $\boldsymbol{M}_{\text {res }}$-.- momento resistente

- $M_{\text {rot }}$.- momento de rotura

- $\quad$ L .- longitud de cada zona (adimensional)

- $\quad \boldsymbol{P}$.- densidad del terreno

- $\quad$ 0 .- centro superficie de deslizamiento

- $\quad \boldsymbol{x}, \boldsymbol{y} .-$ coordenadas

- $\quad$ B.- ángulo del talud

- $\quad$ H.- altura del talud

\section{7.- AMPLIACIÓN DEL MÉTODO DE MÉTODO JAMBU}

El estudio sobre la estabilidad de taludes que precisen métodos rigurosos de cálculo, el método Jambu, permite trabajar con superficies de deslizamiento cuales-quiera incluyendo las irregulares, muy apropiadas a la forma típica de escombreras de ladera.

Para el cálculo del coeficiente de seguridad, se divide la masa deslizante en franjas limitadas por: dos planos verticales, la superficie libre del talud y la superficie hipotética de rotura (Fig. 65), siendo el espesor de cada franja perpendicular al plano de la figura, igual a la unidad. 


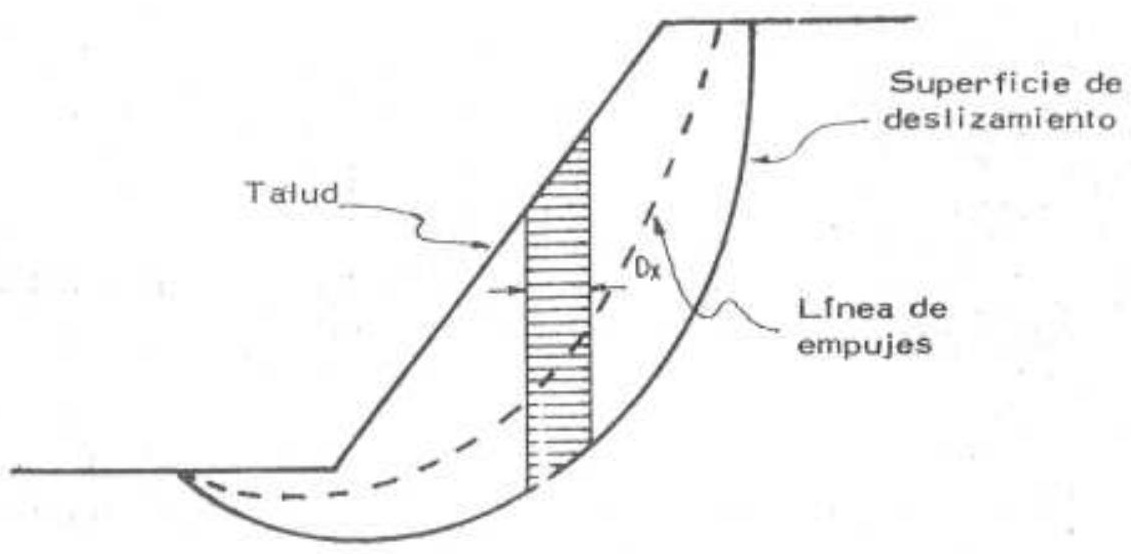

Figura 65: Esquema explicativo del método ampliado de Jambu.

La fórmula del factor de seguridad es:

$$
F=\frac{\sum \frac{1}{a} *[C * D X+(D W+D T-U * D X) * \operatorname{tg} \varnothing]}{Q+\sum(D W+D T) * \operatorname{tg} \alpha}
$$

Siendo:

$$
a=\cos ^{2} \alpha *\left[1+\frac{\operatorname{tg} \alpha * \operatorname{tg} \emptyset}{F}\right]
$$

El significado de las variables que integran estas expresiones es el que se expone a continuación, de acuerdo con la Figura 66:

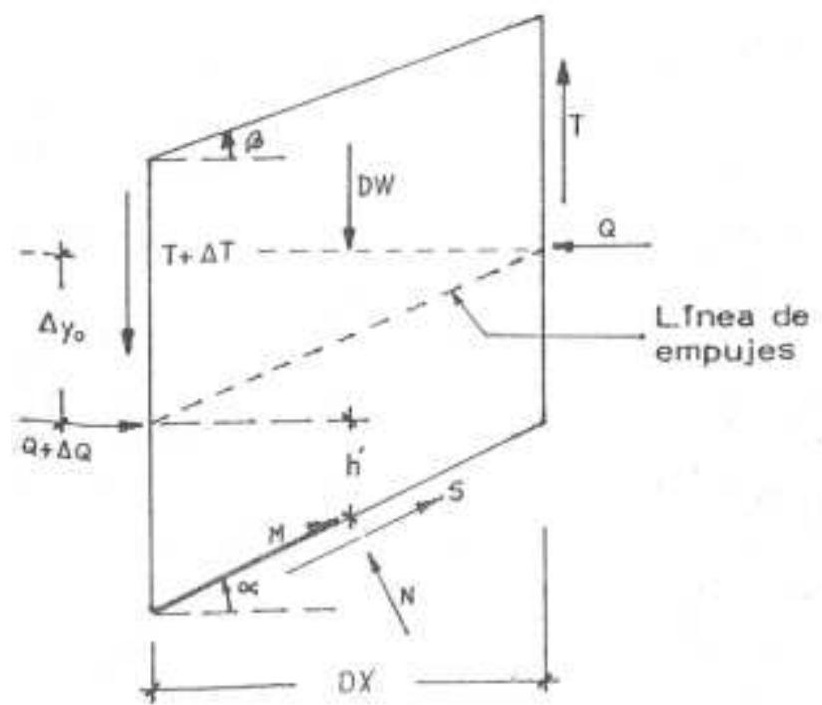

Figura 66: Variables del factor de seguridad. 
- $\quad \boldsymbol{C}$.- cohesión efectiva del material en la superficie de deslizamiento

- $\varnothing$.- ángulo de rozamiento interno efectivo del material en la superficie de deslizamiento.

- $\quad D X$.- anchura de la franja

- DW.- peso de la franja

- $\quad \boldsymbol{\alpha}$.- ángulo de la superficie de deslizamiento con la horizontal

- $\quad \boldsymbol{U}$.- presión intersticial

- $\quad \boldsymbol{T}$.- Esfuerzos tangenciales totales en los costados de las franjas

- $\quad \boldsymbol{N}$.- Esfuerzos normales totales en los costados de las franjas

- $\quad \boldsymbol{F}$.- cociente de seguridad del talud

- $\quad$ Q.- empuje horizontal aportado por el talud

\section{8.- MÉTODO DEL TALUD INFINITO}

\section{1.- FUNDAMENTO TEÓRICO}

Este método se basa en la hipótesis de que la franja de terreno delimitada por una superficie de deslizamiento paralela a la superficie del talud, puede considerarse infinita, con respecto al espesor de la masa deslizada (Figura 67).

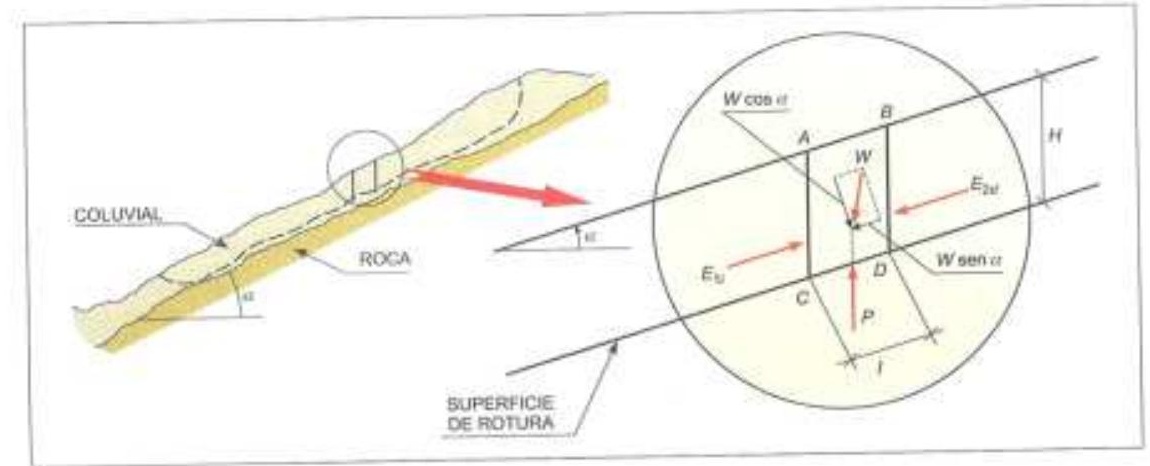

Figura 67: Rotura plana, con aplicación de la hipótesis del talud infinito.

Se considera una sección unitaria del talud (Figura 67), la cual está sometida lateralmente a los empujes tangenciales $E_{1 i}$ y $E_{2 d}$, además de a su propio peso $W$, actuando en la base. El peso produce: 
- Una fuerza tangencial deslizante (componente de W paralela al talud).

- Un mecanismo de rozamiento, en dicha base (debida a la componente normal del peso), y función del rozamiento interno del terreno. A esta componente resistente hay que añadir, en su caso, la posible existencia de una fuerza debida a la cohesión.

Figura 68: Esquema de equilibrio de fuerzas sobre la sección unitaria del talud. .

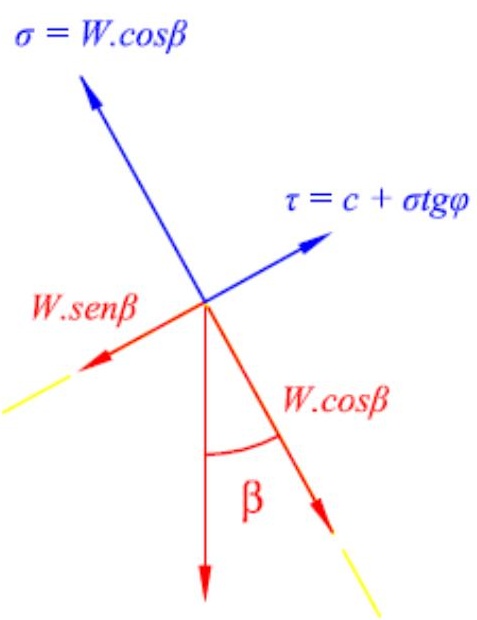

W

Este método es el más apropiado puesto que es el que más se utiliza para el análisis de estabilidad en laderas naturales.

\section{2.- DESARROLLO ANALÍTICO DEL MÉTODO}

Se describen a continuación las ecuaciones correspondientes a cada una de las hipótesis de cálculo consideradas:

- Terrenos sin cohesión.

- Presión intersticial permanente.

- Filtración paralela al talud.

- Terreno con cohesión.

\section{Terrenos sin cohesión.}

Si no hay cohesión (suelos granulares), el coeficiente de seguridad viene dado por la siguiente expresión:

$$
F=\frac{\tau}{S}=\frac{\sigma_{n} \operatorname{tg} \varphi}{S}=\frac{\operatorname{tg} \varphi}{\operatorname{tg} \alpha}
$$

- Siendo:

$$
\begin{gathered}
\sigma_{n}=\frac{W \cos \alpha}{l}=\gamma H \cos ^{2} \alpha \\
S=\frac{W \operatorname{sen} \alpha}{l}=\gamma H \operatorname{sen} \alpha \cos \alpha
\end{gathered}
$$


Donde $I$ es la longitud de la base de la sección, $\varphi$ es el rozamiento efectivo y $\gamma$ es el peso específico aparente del terreno.

\section{Presión intersticial permanente.}

Si existe una presión intersticial permanente, $\boldsymbol{u}$, y constante a lo largo del plano de rotura, la fórmula de cálculo del factor de seguridad varía:

$$
F=\frac{\left(\sigma_{n}-u\right) \operatorname{tg} \varphi}{S}=\frac{\left(\gamma H \cos ^{2} \alpha-u\right) \operatorname{tg} \varphi}{\gamma H \operatorname{sen} \alpha \cos \alpha}=\left(1-\frac{r_{u}}{\cos ^{2} \alpha}\right) \frac{\operatorname{tg} \varphi}{\operatorname{tg} \alpha}
$$

- Donde:

$$
r_{u}=\frac{u}{\gamma H} \text {.- es el coeficiente de presión intersticial. }
$$

\section{Filtración paralela al talud.}

Si existe una filtración paralela al talud, se utiliza la misma fórmula que en el caso anterior para el cálculo del factor de seguridad. En este caso, el coeficiente de presión intersticial, $r_{u}$ resulta:

$$
r_{u}=\frac{h}{H} \frac{\gamma_{w}}{\gamma} \cos ^{2} \alpha
$$

- Siendo $\boldsymbol{h}$ la altura de agua sobre la superficie de deslizamiento.

Con esta notación, el coeficiente de seguridad se puede escribir:

$$
F=A \frac{\operatorname{tg} \varphi}{\operatorname{tg} \alpha}
$$

- Siendo $\boldsymbol{A}$, un parámetro que depende de $r_{u}$ y de $\alpha$ (Figura 37)

\section{Terreno con cohesión.}

Si existe cohesión en el terreno, el proceso de análisis es similar, modificándose la fórmula de cálculo del factor de seguridad de la siguiente manera:

$$
F=\frac{\left(\sigma_{n}-u\right) \operatorname{tg} \varphi+c}{S}
$$

Con lo que la expresión final puede escribirse: 


$$
F=A \frac{\operatorname{tg} \varphi}{\operatorname{tg} \alpha}+B \frac{c}{\gamma H}
$$

- Siendo $\boldsymbol{B}$, un parámetro que depende de la inclinación del talud $\alpha$ (Figura 68)

$$
B=\frac{1}{(\cos \alpha \operatorname{sen} \alpha)}
$$
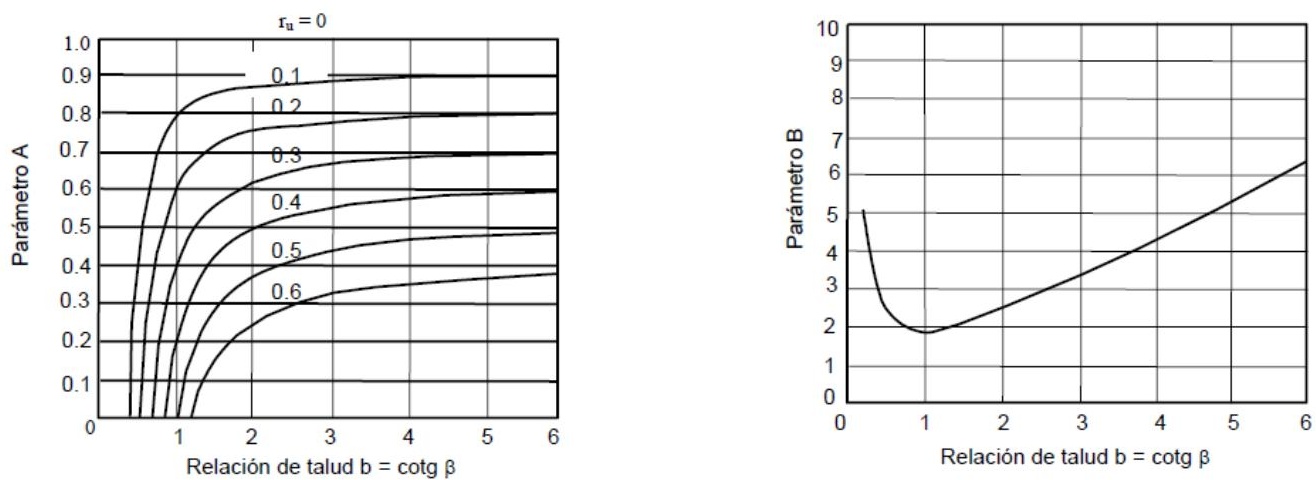

Figura 69: Ábacos para el cálculo de los parámetros A, y B (taludes infinitos).

\section{3.- ECUACIÓN FINAL DE CÁLCULO BASADA EN EL MÉTODO DEL TALUD INFINITO}

En el presente trabajo, se presenta como la ecuación más idónea para la evaluación de la estabilidad de taludes, una fórmula de cálculo basada en el método del talud infinito:

$$
F s=\frac{\left(c+\left(\gamma z-\gamma_{w} h_{w}\right) \cos ^{2} \beta \operatorname{tang} \emptyset\right)}{(\gamma z \operatorname{sen} \beta \cos \beta)}
$$

- Hipótesis simplificativa (método del talud infinito).- En el caso simple de una falla traslacional a lo largo de una superficie de deslizamiento paralela al suelo sobre un talud uniforme relativamente largo, puede ser examinado por el análisis del talud infinito. En este caso, un solo elemento o segmento de la pendiente, puede ser considerada como representativa de toda la ladera y una porción de la cabeza y pie de talud son ignorados, siendo minimizados en extensión (Morgan y Rickson, 1995). 


\section{4.- PARÁMETROS DE CÁLCULO}

Los parámetros que intervienen en el cálculo de la estabilidad de taludes, la fórmula anterior basada en el método del talud infinito, son los siguientes:

Tabla 6: Parámetros que intervienen en la ecuación de cálculo del factor de seguridad

\begin{tabular}{|c|l|l|}
\hline Parámetro & Definición & Unidades \\
\hline $\mathbf{c}$ & Cohesión del terreno & $\mathrm{kN} / \mathrm{m}^{3}$ \\
\hline$\gamma$ & Peso específico del terreno & $\mathrm{kN} / \mathrm{m}^{3}$ \\
\hline $\mathbf{z}$ & Profundidad del plano de deslizamiento & $\mathrm{m}$ \\
\hline$\gamma_{\mathbf{w}}$ & Peso específico del agua & $\mathrm{kN} / \mathrm{m}^{3}$ \\
\hline $\mathbf{h}_{\mathbf{w}}$ & Altura de la lámina de agua sobre el plano de deslizamiento & $\mathrm{m}$ \\
\hline $\boldsymbol{\beta}$ & Ángulo de inclinación del talud & grados $\left(^{\circ}\right)$ \\
\hline$\varnothing$ & Ángulo de rozamiento interno del terreno & grados $\left(^{\circ}\right)$ \\
\hline
\end{tabular}

En la siguiente tabla, se muestra una relación de los parámetros del terreno característicos para cada clasificación del mismo.

Tabla 7: Valores característicos de propiedades geotécnicas del terreno: cohesión (saturado). c; Ángulo de rozamiento interno. $\Phi$; Peso específico (v).

\begin{tabular}{|c|l|c|c|c|}
\hline $\begin{array}{l}\text { Clase de } \\
\text { suelo }\end{array}$ & Descripción & $\begin{array}{c}\mathbf{c} \\
\mathbf{k N} / \mathbf{m}^{2}\end{array}$ & $\begin{array}{c}\boldsymbol{\Phi} \\
\left.\mathbf{(}^{\mathbf{}}\right)\end{array}$ & $\begin{array}{c}\boldsymbol{\gamma} \\
\mathbf{k} / \mathbf{m}^{\mathbf{3}}\end{array}$ \\
\hline GW & Gravas bien graduadas, mezclas de grava y de arena & 0 & 36 & 20,8 \\
\hline GP & Gravas mal graduadas, mezclas de grava y arena & 0 & 35 & 19,2 \\
\hline GM & Gravas limosas, mezclas de grava, arena y limo mal graduadas & 0 & 36 & 20,8 \\
\hline GC & $\begin{array}{l}\text { Gravas arcillosas, mezclas de grava, arena y arcilla mal } \\
\text { graduadas }\end{array}$ & 0 & 32,6 & 17 \\
\hline SW & Arenas bien graduadas, arenas con grava & 0 & 34 & 17,9 \\
\hline SP & Arenas mal graduadas, arenas con grava & 0 & 33 & 16,7 \\
\hline SM & Arenas limosas, mezclas de arena-limo mal graduadas & 20,5 & 32 & 15,5 \\
\hline SM-SC & Mezclas de arena-limo-arcilla con finos poco plásticos & 14,6 & 32 & 15,5 \\
\hline SC & Arenas arcillosas, mezclas de arena-arcilla & 11,2 & 32 & 15,5 \\
\hline ML & Limos orgánicos y limos arcillosos & 9,3 & 31 & 14,1 \\
\hline ML-CL & Mezcla de limo inorgánico y arcilla & 22,4 & 31 & 14,1 \\
\hline
\end{tabular}


DESARROLLO DE UNA APLICACIÓN INFORMÁTICA PARA EL CÁLCULO DE SOSTENIMIENTO DE TALUDES MEDIANTE REVEGETACIÓN

ANEXO III.- METODOS DE CÁLCULO DE ESTABILIDAD DE TALUDES

\begin{tabular}{|c|l|c|c|c|}
\hline $\mathrm{CL}$ & Arcillas inorgánicas poco plásticas o de plasticidad mediana & 13,2 & 30 & 14,0 \\
\hline $\mathrm{MH}$ & Limos arcillosos inorgánicos, suelos limosos & 20,5 & 27 & 13,5 \\
\hline $\mathrm{CH}$ & Arcillas inorgánicas muy plásticas & 11,2 & 25 & 12,9 \\
\hline
\end{tabular}


DESARROLLO DE UNA APLICACIÓN INFORMÁTICA PARA EL CÁLCULO DE SOSTENIMIENTO DE TALUDES MEDIANTE REVEGETACIÓN 


\section{ANEXO IV}

\section{EFECTOS DE LA VEGETACIÓN SOBRE LA ESTABILIDAD DE TALUDES}

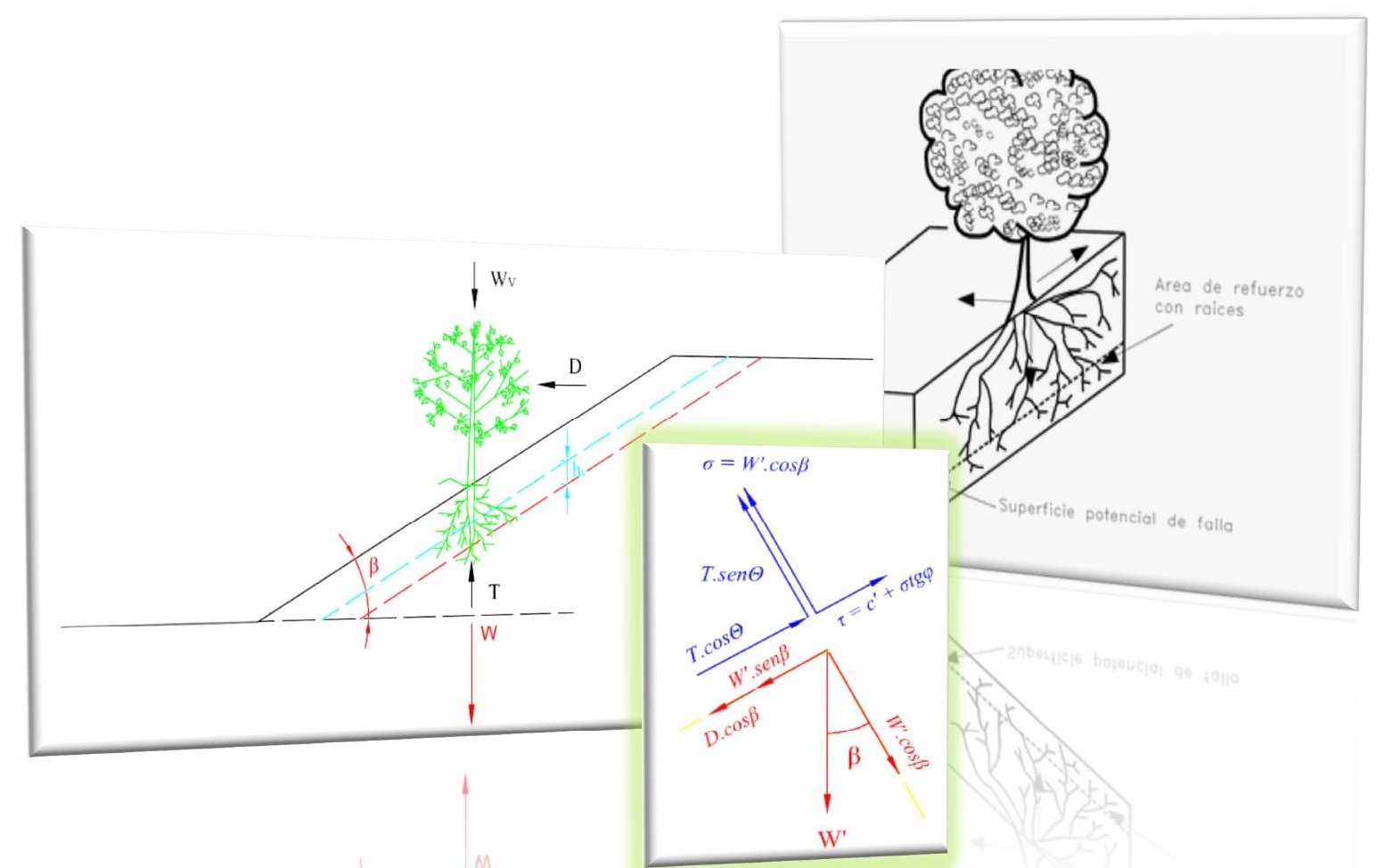


DESARROLLO DE UNA APLICACIÓN INFORMÁTICA PARA EL CÁLCULO DE SOSTENIMIENTO

DE TALUDES MEDIANTE REVEGETACIÓN

ANEXO IV.- EFECTOS DE LA REVEGETACIÓN SOBRE LA ESTABILIDAD DE TALUDES

\section{ÍNDICE}

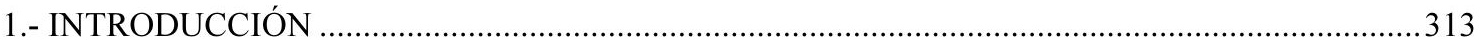

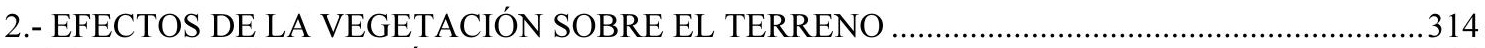

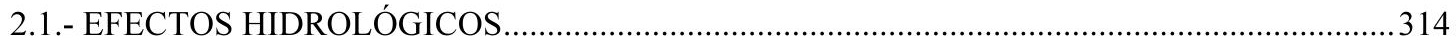

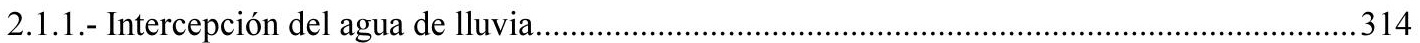

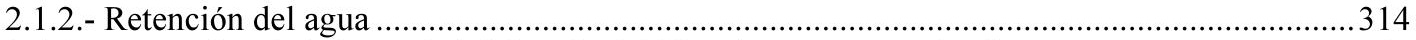

2.1.3.- Extracción de la humedad del suelo debido a la evapotranspiración .....................................315

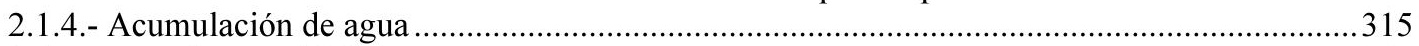

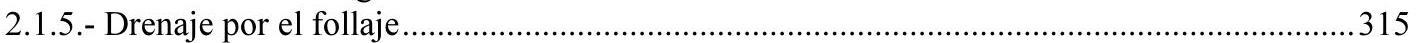

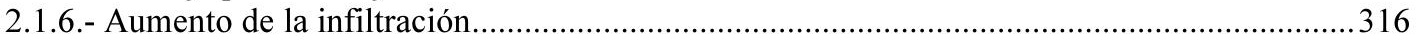

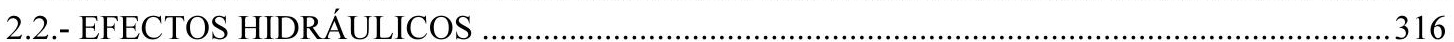

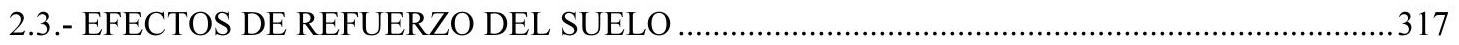

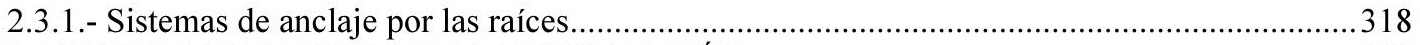

2.4.- EFECTOS NEGATIVOS DE LA VEGETACIÓN...............................................................319

3.- EFECTOS DE LA VEGETACIÓN SOBRE EL TERRENO A CONSIDERAR Y MODELIZACIÓN

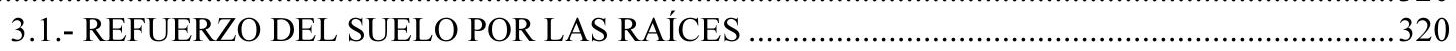

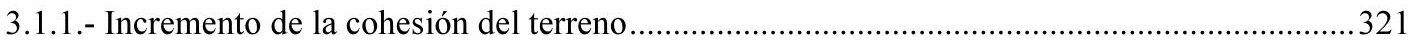

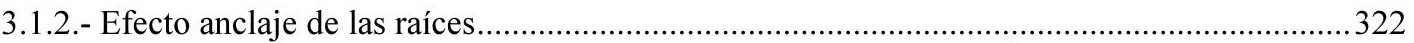

3.2.- SOBRECARGA PRODUCIDA POR EL PESO DE LA VEGETACIÓN ………….......................324

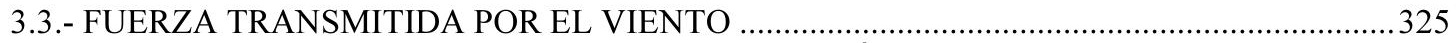

4.- INFLUENCIA DE LA MEZCLA DE ESPECIES EN EL CÁLCULO DEL FACTOR DE

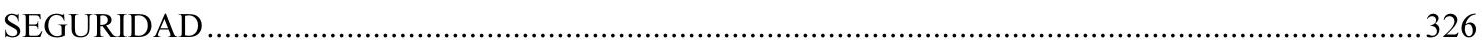

4.1.- CÁLCULO DE LOS PARÁMETROS DE LA VEGETACIÓN EN UNA MEZCLA DE

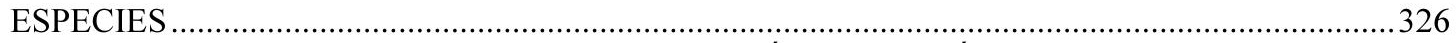

5.- INFLUENCIA DE LA DENSIDAD DE PLANTACIÓN EN EL CÁLCULO DEL FACTOR DE

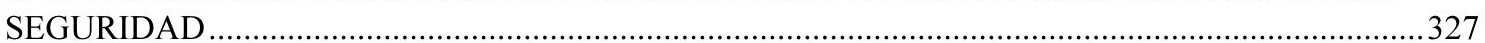

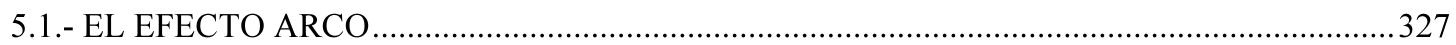

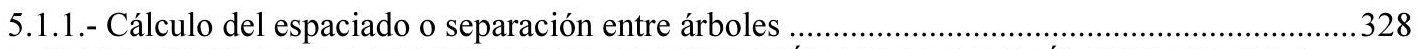

5.2.- INFLUENCIA DE LA DENSIDAD DE PLANTACIÓN EN LOS PARÁMETROS DE LA

VEGETACIÓN EN UNA MEZCLA DE ESPECIES ………………………………………………….......

6.- CÁLCULO DE LA PROFUNDIDAD DEL PLANO DE DESLIZAMIENTO EN UN TALUD CON

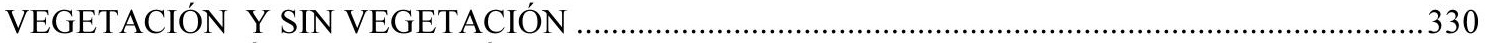

6.1.- ECUACIÓN PARA EL CÁLCULO DE LA PROFUNDIDAD DEL PLANO DE

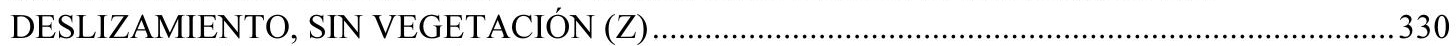

6.2.- ECUACIÓN PARA EL CÁLCULO DE LA PROFUNDIDAD DEL PLANO DE

DESLIZAMIENTO (Z') …………………………………………………………………..... 331

6.3.- INFLUENCIA DE LA PROFUNDIDAD DE DESLIZAMIENTO EN EL CÁLCULO DEL

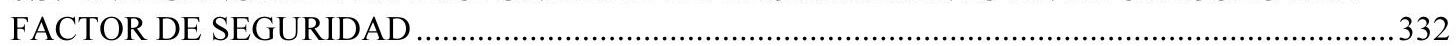

7.- CÁLCULO DE LA ALTURA VERTICAL DE LA LÁMINA DE AGUA SOBRE EL PLANO DE

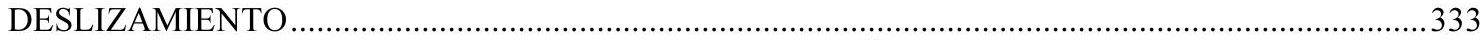

7.1.- CÁLCULO DE LA ALTURA VERTICAL DE LA LÁMINA DE AGUA …………....................334

8.- CÁLCULO DEL FACTOR DE SEGURIDAD DE UN TALUD CONSIDERANDO EL EFECTO DE

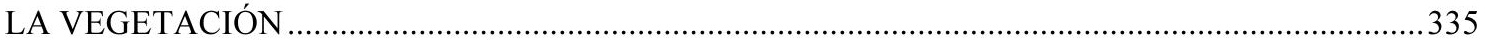

8.1.- ECUACIÓN PARA EL CÁLCULO DEL FACTOR DE SEGURIDAD SIN VEGETACIÓN ..335

8.2.- ECUACIÓN PARA EL CÁLCULO DEL FACTOR DE SEGURIDAD CON VEGETACIÓN 336

8.3.- ANÁLISIS COMPARATIVO DE RESULTADOS ENTRE LOS VALORES OBTENIDOS DEL

FACTOR DE SEGURIDAD CON VEGETACIÓN Y SIN VEGETACIÓN .. 


\section{1.- INTRODUCCIÓN}

Los efectos de la vegetación sobre los taludes han sido muy debatidos en los últimos años. La experiencia ha demostrado el efecto positivo de la vegetación para evitar problemas de erosión, reptación y fallas subsuperficiales.

Para analizar los fenómenos del efecto de la vegetación sobre el suelo, se requiere analizar las características específicas de la vegetación en el entorno natural que se esté estudiando.

La vegetación cumple dos funciones principales:

- Determina el contenido de agua en la superficie.

- Proporciona consistencia al suelo debido al entramado mecánico de sus raíces.

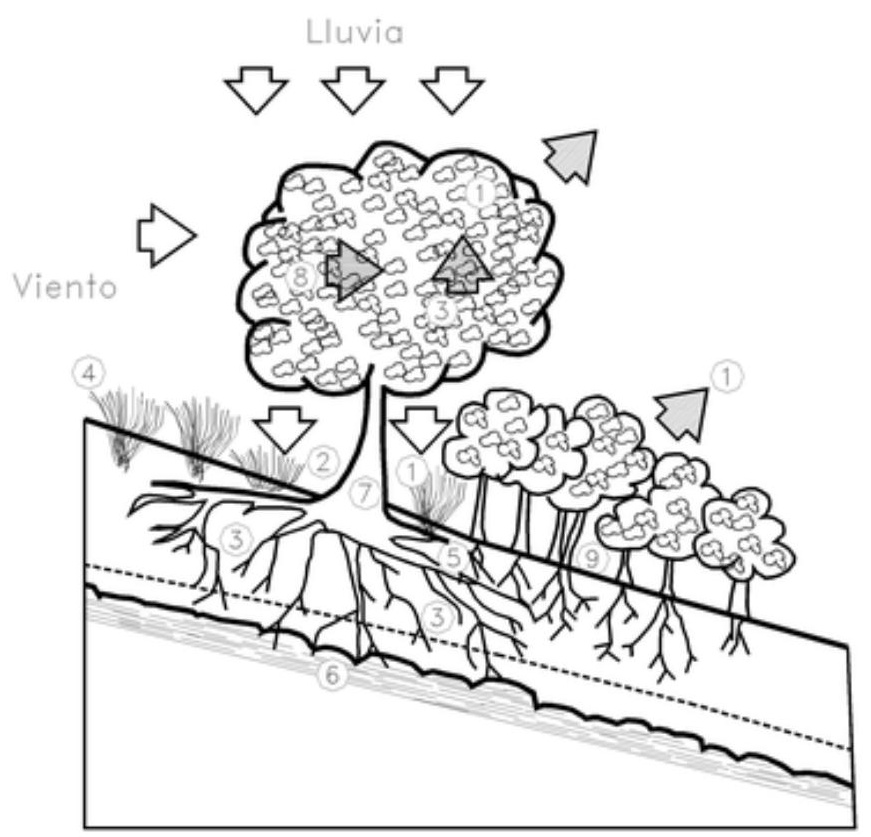

1. Intercepta la lluvia.

2. Aumenta la capacidad de infiltración.

3. Extrae la humedad del suelo.

4. Grietas por desecación.

5. Raíces refuerzan el suelo, aumentando resistencia al cortante.

6. Anclan el suelo superficial a mantos más profundos.

7. Aumentan el peso sobre el talud.

8. Transmiten al suelo fuerza del viento.

9. Retienen las partículas del suelo disminuyendo susceptibilidad a la erosión.

Figura 70: Factores de la vegetación que influyen sobre la estabilidad del terreno. 


\section{2.- EFECTOS DE LA VEGETACIÓN SOBRE EL TERRENO}

\section{1.- EFECTOS HIDROLÓGICOS}

\subsection{1.- Intercepción del agua de lluvia}

El follaje intercepta la lluvia impidiendo el impacto directo sobre el suelo y amortiguando la energía de las gotas. La intercepción varía dependiendo del tipo de vegetación y la intensidad de la lluvia de acuerdo a la siguiente expresión:

$$
\text { IC = Lluvia .CF }
$$

Donde:

- $\quad$ CF = Porcentaje de área cubierta por el follaje.

Parte de la lluvia interceptada es retenida y evaporada y parte alcanza finalmente la tierra por goteo o por flujo sobre las hojas y troncos.

Figura 71: Efectos hidrológicos de la vegetación sobre la estabilidad del terreno.

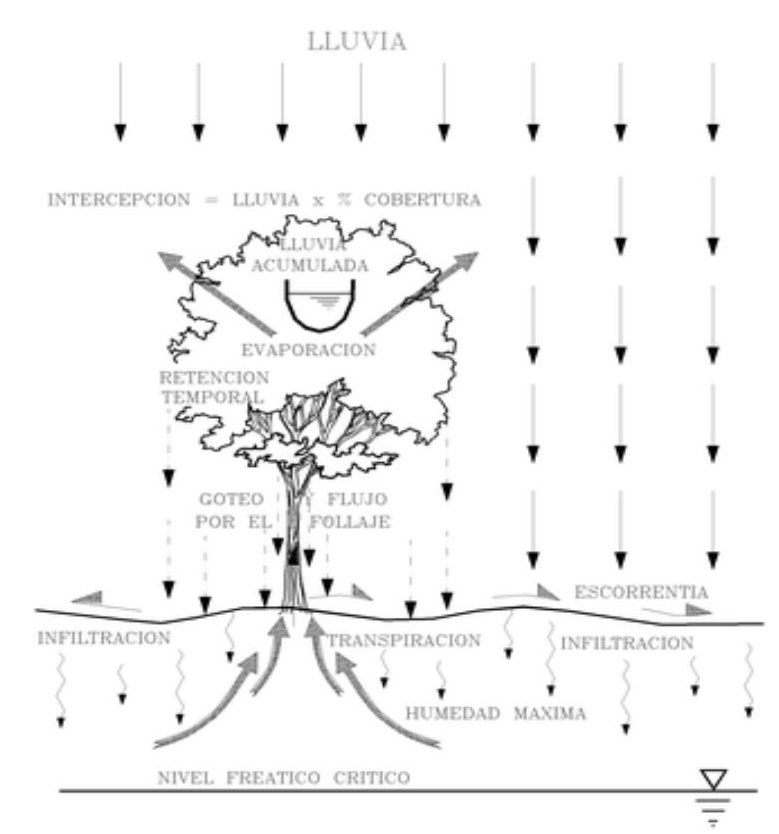

\subsection{2.- Retención del agua}

La retención de agua en el follaje demora o modifica el ciclo hidrológico en el momento de una lluvia. Este fenómeno disminuye la rata de agua de escorrentía, disminuyendo su poder erosivo pero puede aumentar la rata de infiltración. La retención de agua en el follaje depende del tipo de vegetación, sus características y la intensidad de la lluvia. 
Los árboles de mayor volumen o densidad de follaje, retrasan más el ciclo hidrológico en razón a que retienen por mayor tiempo las gotas de lluvia. En el caso de las lluvias muy intensas la retención de agua es mínima, pero en el caso de lluvias moderadas a ligeras, la retención puede ser hasta de un $30 \%$.

\subsection{3.- Extracción de la humedad del suelo debido a la evapotranspiración}

La evapotranspiración es un efecto combinado de evaporación y transpiración. Su efecto es una disminución de la humedad en el suelo. Cada tipo de vegetación en un determinado tipo de suelo, tiene un determinado potencial de evapotranspiración, y se obtiene generalmente una humedad de equilibrio, dependiendo de la disponibilidad de agua de lluvia y nivel freático.

La evapotranspiración es un efecto importante en cuanto a la estabilidad del terreno puesto que ayuda a mantener la humedad por debajo del límite de saturación mejorando la estabilidad del talud.

\subsection{4.- Acumulación de agua}

El agua acumulada en el follaje retrasa el flujo y disminuye el potencial de avenidas torrenciales. La cantidad de lluvia acumulada por la vegetación depende especialmente de la densidad interna del follaje medida por el total de área de hojas por área nominal. Generalmente el volumen de agua acumulada llega a un máximo y a partir de ese momento el follaje no tiene capacidad para acumular más agua. En lluvias intensas el porcentaje acumulado es relativamente pequeño comparado con el volumen total de la lluvia pero en lluvias cortas de poca intensidad este porcentaje puede ser alto.

\subsection{5.- Drenaje por el follaje}

Parcialmente la lluvia interceptada es transportada hasta el suelo por el follaje especialmente en los pastos de hoja ancha. El agua interceptada se transporta a lo largo de las hojas concentrándose en el pie de la planta. Para que este flujo ocurra se requiere que las hojas tengan una pendiente entre 30 y y 70 situación muy común en los pastos de alturas 
medianas. Se deben esperar grandes caudales de drenaje por el follaje en las plantas con una arquitectura de follaje con hojas que parten directamente desde el pie de la planta.

Este drenaje disminuye la energía de impacto de la lluvia sobre el suelo, reduciendo la erosión. Las plantas altas y los pastos de hoja muy delgada tienen una menor capacidad de drenaje por el follaje.

\subsection{6.- $\quad$ Aumento de la infiltración}

Las raíces y los residuos de las plantas ayudan a mantener la porosidad y permeabilidad del suelo.

La permeabilidad y la tasa de infiltración del suelo es mayor en los casos de taludes provistos de vegetación que en los suelos desnudos, debido a la actuación combinada de otros efectos como son: la intercepción, la transpiración de las plantas, el mayor contacto aguasuelos en suelos provistos de cobertura vegetal, etc).

\section{2.- EFECTOS HIDRÁULICOS}

La velocidad de la escorrentía depende en buena parte de la rugosidad del terreno y la vegetación aumenta considerablemente esta rugosidad como se indicó en el capítulo 3. El coeficiente de Manning puede variar de 0,005 para vegetación baja hasta 0,1 para vegetación alta. Al aumentar la rugosidad disminuyen las velocidades y de esta forma, disminuye la erosión. La rugosidad depende además de la morfología de la planta y de la densidad del follaje junto a la superficie del terreno. Se pueden presentar grandes reducciones de velocidad de flujo utilizando una cobertura densa y espacialmente uniforme.

El efecto de la vegetación sobre la rugosidad puede medirse de acuerdo al índice de retardanza $\mathrm{Cl}$ (Temple, 1982).

$$
\mathrm{Cl}=2,5 \mathrm{~h}(\mathrm{~h} \sqrt{\mathrm{M}})^{1 / 3}
$$

\section{Donde:}

- $\quad \mathrm{Cl}=$ Indice de retardanza. 
- $\quad h=$ Altura de los tallos $u$ hojas en metros.

- $\quad M=$ Densidad de los tallos (número de tallos $/ \mathrm{m}^{2}$ ).

- Un pasto puede tener entre 500 y 5500 tallos $/ \mathrm{m}^{2}$.

\section{3.- EFECTOS DE REFUERZO DEL SUELO}

Las raíces y el follaje aíslan el suelo de las fuerzas de tracción directa, ocasionadas por el flujo del agua de escorrentía.

Las raíces refuerzan el suelo aumentando la resistencia al corte (principalmente cohesión) y la resistencia a las fuerzas de erosión.

Las raíces profundas, de árboles, anclan el suelo a estratos más profundos, creando fuerzas resistentes al deslizamiento.

Entre el sistema de raíces de cada árbol y los contiguos se forma el efecto de arco, que contribuye a la estabilidad de toda la masa de terreno.

Las raíces forman una red densa entretejida en los primeros 30 a 50 centímetros de suelo, y esta red forma una membrana lateral que tiende a reforzar la masa de suelo más superficial y sostenerla en el sitio.

Figura 72: Efecto de refuerzo del terreno por las raíces.

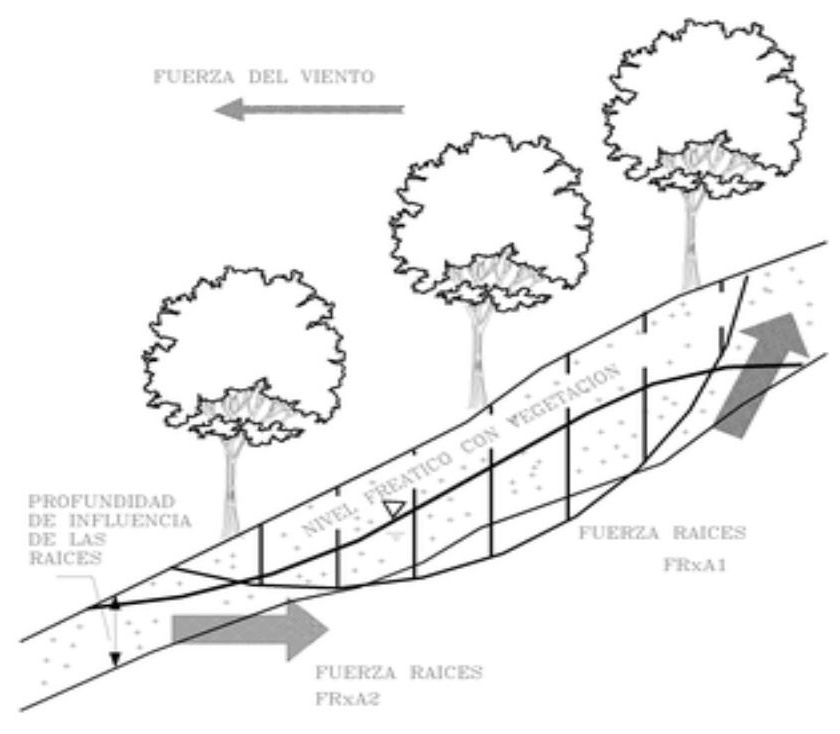




\subsection{1.- Sistemas de anclaje por las raíces}

Tsukamoto y Kusakabe (1984), presentaron una clasificación de refuerzo de taludes con las raíces de los árboles que se resume en la tabla (Tabla 1) y esquema (Figura 73) siguientes:

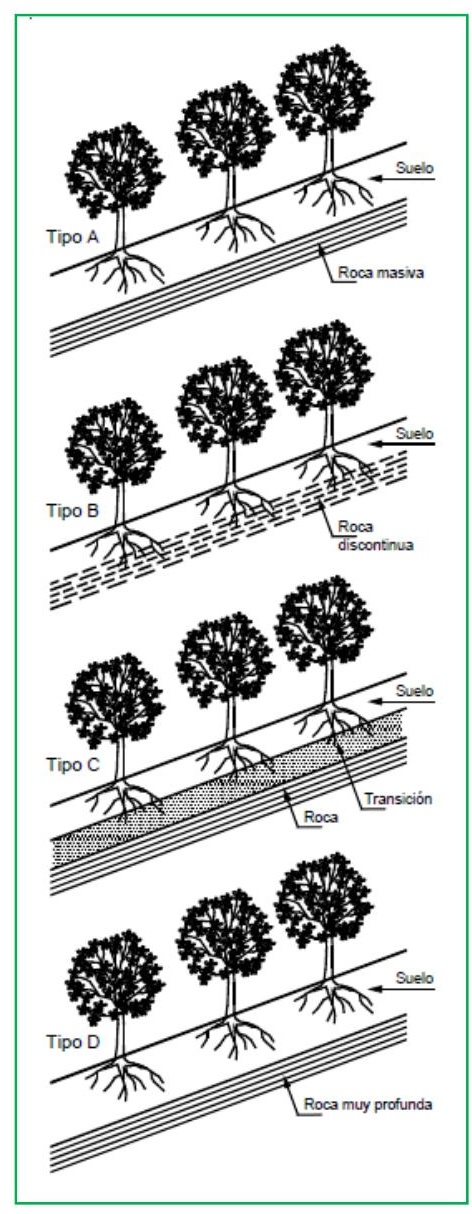

Tabla1: Descripción de los tipos de anclaje de las raíces.

\begin{tabular}{|c|c|c|}
\hline TIPO & DESCRIPCIÓN & $\begin{array}{c}\text { EFECTO } \\
\text { ESTABILIZANTE }\end{array}$ \\
\hline A & $\begin{array}{l}\text { Manto delgado de suelo } \\
\text { sobre roca masiva no } \\
\text { penetrable porlas raíces }\end{array}$ & Muy pequeño \\
\hline B & $\begin{array}{l}\text { Manto delgado de suelo } \\
\text { sobre roca discontinua o } \\
\text { fracturada penetrable por las } \\
\text { raíces }\end{array}$ & Grande \\
\hline C & $\begin{array}{l}\text { Manto delgado de suelo } \\
\text { sobre zona de transición o } \\
\text { saprolito }\end{array}$ & Grande \\
\hline D & Manto muy grueso de suelo & Pequeño \\
\hline
\end{tabular}

Figura 73: Tipos de anclaje de las raíces (Tsukamoto y Kusakube 1984). 


\section{4.- EFECTOS NEGATIVOS DE LA VEGETACIÓN}

Algunos efectos de la vegetación pueden generar inestabilidad. Entre estos efectos se pueden mencionar los siguientes:

1. La desecación del suelo por especies ávidas de agua puede producir agrietamiento especialmente en suelos expansivos.

2. El peso de la vegetación aumenta las fuerzas motoras de deslizamiento. Este efecto sólo es importante en el caso de vegetación arbórea, puesto que el incremento de peso que suponen la vegetación herbácea y arbustiva no es muy significativa. En condiciones normales el peso de la vegetación se le considera como un efecto positivo o beneficioso sobre la estabilidad de los taludes.

3. Las fuerzas del viento producen fuerzas sobre las masas de suelo que podrían activar deslizamientos. La fuerza que el viento ejerce sobre las plantas es transferida al interior del terreno, interviniendo en el sistema de fuerzas que operan $y$ desestabilizándolo. Si el viento sopla con suficiente fuerza o el árbol no está bien enraizado, puede producirse la rotación y vuelco del árbol.

4. Las raíces pueden levantar las estructuras livianas cimentadas subsuperficialmente, como canales, revestimientos, etc.

5. Una cobertura vegetal no homogénea produce una distribución irregular en el flujo de agua que circula sobre una ladera, concentrándose en zonas más débiles, no protegidas por la vegetación. Sobre estas zonas se generan turbulencias en el flujo, aumentando de forma intensa la erosión. 


\section{3.- EFECTOS DE LA VEGETACIÓN SOBRE EL TERRENO A CONSIDERAR Y MODELIZACIÓN}

Todos los efectos descritos en el apartado anterior influyen en la estabilidad del terreno; Sin embargo en el desarrollo del modelo de cálculo del Factor de Seguridad indicativo del grado de estabilidad de un talud se considera lo siguiente:

1. No se tendrán en cuenta los efectos hidráulicos e hidrológicos: intercepción, evapotranspiración, infiltración, etc. sobre la vegetación anteriormente descritos, por los siguientes motivos:

- La complejidad del cálculo de estos factores, siendo los efectos producidos por los mismos, difíciles de cuantificar.

- La influencia que tienen sobre los resultados finales de estabilidad, es baja en comparación con los factores que si se consideran.

- Los modelos habitualmente utilizados, no consideran los efectos hidráulicos e hidrológicos, proporcionando sin embargo, resultados fiables.

2. A efectos del desarrollo del modelo de cálculo del factor de seguridad se tendrán en cuenta los efectos mecánicos proporcionados por la vegetación:

- El refuerzo del suelo por las raíces: aumento de resistencia a cortante y anclaje.

- La sobrecarga producida por el peso de la vegetación.

- La fuerza transmitida debido al empuje del viento.

Estos efectos, además de ser los que mayor influencia en el mecanismo de refuerzo del terreno, permiten ser cuantificados mediante un modelo matemático.

\section{1.- REFUERZO DEL SUELO POR LAS RAÍCES}

La presencia de raíces implica un aumento del sostenimiento del talud, debido a los efectos que se describen a continuación:

- Incremento de la cohesión del terreno.

- Efecto anclaje de las raíces. 


\subsection{1.- Incremento de la cohesión del terreno}

El Incremento de la cohesión del suelo (cohesión mejorada: $\boldsymbol{c}+\boldsymbol{c} \boldsymbol{R}$, se produce de tres formas:

- Por la unión de materiales de los suelos inestables a mantos más estables.

- Por la formación de una red densa entretejida en los primeros 30 a $50 \mathrm{~cm}$ de suelo; esta red forma una membrana lateral que tiende a reforzar la masa de suelo más superficial y sostenerla en el sitio.

- Por la unión de grupos de partículas impidiendo la ocurrencia de pequeños deslizamientos.

Existen datos sobre el refuerzo proporcionado por las raíces al suelo (Tabla 2), basados en resultados de laboratorio. Estos datos serán tomados como referencia para la cuantificación del aumento de cohesión de un terreno debida a la malla formada por las raíces de la vegetación

Tabla 2: Valores típicos del incremento en la cohesión del suelo, debida a la acción de las raíces (cohesión de raíces: $c R$ ).

\begin{tabular}{|c|c|c|}
\hline Autor & Suelo/Vegetación & $c R\left(k N / m^{2}\right)$ \\
\hline Swantson, 1970 & Coníferas de montaña sobre morrenas & $3,4-4,4$ \\
\hline O Loughlin, 1974 & Coníferas de montaña sobre morrenas & 3,0 \\
\hline Endo Tsuruta, 1969 & Alisos de Vivero en suelos de Aluvión & $2,0-12$ \\
\hline Wu, et al 1979 & Coníferas de montaña sobre morrenas & 5,9 \\
\hline Waldron et al., 1981 & $\begin{array}{l}\text { Pinos de semillero cultivados en macetas sobre } \\
\text { arcillas }\end{array}$ & 5 \\
\hline $\begin{array}{l}\text { O Loughlin y Ziemer, } \\
1982\end{array}$ & $\begin{array}{l}\text { Bosque perenne mixto sobre suelos someros } \\
\text { desarrollados en morrenas }\end{array}$ & 3,3 \\
\hline $\begin{array}{l}\text { Gray y Megaham, } \\
1981\end{array}$ & Coníferas en suelos arenosos & 10,3 \\
\hline $\begin{array}{l}\text { Riestemberg, } \\
\text { Savonick y Dunford, } \\
1983\end{array}$ & Arces en suelos de coluvión arcillosos & 5,7 \\
\hline $\begin{array}{l}\text { Burroughs y Thomas, } \\
1977\end{array}$ & Coníferas en suelos de montaña & $3-17,5$ \\
\hline $\begin{array}{l}\text { Barker y Hewlett, } \\
1986\end{array}$ & $\begin{array}{l}\text { Pastizal sembrado en bloques de hormigón rellenos } \\
\text { de suelo arcilloso reforzado con estructura celular. }\end{array}$ & $3-5$ \\
\hline
\end{tabular}




\subsection{2.- Efecto anclaje de las raíces}

Este efecto se debe a la fuerza de tensión de las raíces que puede considerarse como una fuerza de anclaje, actuando las raíces como pilas de refuerzo.

El efecto de anclaje de las masas de suelo por las raíces se considera un efecto positivo que depende de las características físicas de las raíces y de la densidad del sistema radicular (Figura 74).

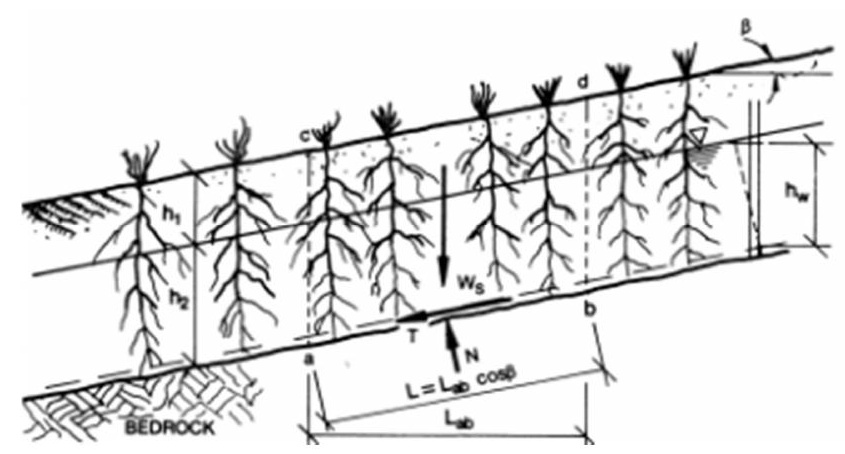

Figura 74: Fuerza de anclaje de arbustos y de hierbas de raíz profunda (Bache y Mackaskill, 1984).

Existen distintos modelos para cuantificar la fuerza de anclaje proporcionada por las raíces al suelo.

En este estudio se va utilizar el modelo simplificado de raíces perpendiculares que considera a las raíces como elementos que cortan perpendicularmente el plano de deslizamiento.

Utiliza el análisis geotécnico de equilibrio límite, que determina que el suelo es estable mientras que la resistencia final de los materiales a ser deslizados a lo largo del plano de rotura inducido en el suelo, esté en equilibrio con las fuerzas que tienden a producir el movimiento.

El supuesto básico de este modelo es el que las raíces cruzan el plano de falla en ángulo recto, cuestión que se sabe que no es cierta al 100\%.

En varios estudios se ha demostrado que las raíces tienden a crecer pendiente arriba. Es decir, tienden a incrementar el ángulo de intercepción de las raíces con el plano de falla.

A partir del modelo citado se han desarrollado algunos modelos más complejos en el que el supuesto de ortogonalidad de las raíces es modificado, para trabajar con la inclinación de las raíces. 
El modelo simplificado de raíces perpendiculares permite cuantificar el incremento en la resistencia al corte del suelo producido por las raíces. Este incremento, debido a la elasticidad de las raíces verticales que atraviesan perpendicularmente el plano de deslizamiento, se produce al aumentarse el esfuerzo máximo admisible, y la resistencia al corte en el comienzo del movimiento.

La fuerza desarrollada sobre las raíces cuando el suelo se desplaza, se resuelve con una componente tangencial de resistencia al corte, y una componente normal que incrementa el esfuerzo máximo admisible, y por tanto, la resistencia a la tracción a lo largo del plano de deslizamiento. (Figura 75)

Figura 75: Modelo de raíces elásticas y flexibles atravesando verticalmente una zona de falla o rotura horizontal.

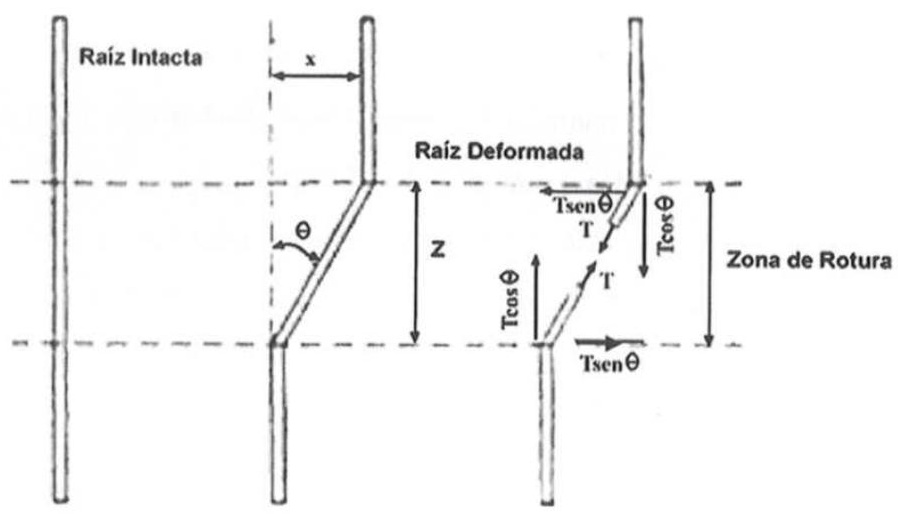

El valor medio de la resistencia a la tracción, $\boldsymbol{t} \boldsymbol{R}$, se obtiene aplicando la siguiente ecuación:

$$
\operatorname{T}=\operatorname{Tr} \times S_{\text {raiz }}\left(A_{R} / A\right)
$$

Donde:

- $\quad T$ = Fuerza de tracción ejercida por las raíces $\left(\mathrm{kN} / \mathrm{m}^{2}\right)$

- $\operatorname{Tr}=$ Resistencia media a la tracción de las raíces o fibras $\left(\mathrm{N} / \mathrm{mm}^{2}\right)$

- $\mathrm{S}_{\text {raíz }}=$ Sección media de las raíces para la especie considerada $\left(\mathrm{mm}^{2}\right)$.

$$
\mathrm{S}_{\text {raiz }}=\pi(\mathrm{Dr} / 2)^{2}
$$

$A_{R} / A=$ Relación Raíces / Superficie de suelo, o fracción de superficie de una sección tipo de suelo que es atravesada por raíces.

- Mediante la realización de diferentes ensayos se ha determinado que el ángulo de corte $(\theta)$ varía entre 45 y 50 grados. Otros autores como $W u$ et al (1979), señalan que, basándose en experiencias realizadas en campo, el ángulo $\theta$ varía más comúnmente entre $45 \mathrm{y}$ 
70 grados. En este caso se ha considerado en todos los casos un ángulo $\theta$ de 45 으 para el cálculo posterior del factor de seguridad.

Los valores de resistencia a tracción (Tr) y Diámetro de la raíz (Dr), relativos a las raíces de cada una de las especies, han sido recopilados a partir de ensayos realizados sobre estos parámetros. En el caso de especies donde no existían valores de estos parámetros, estos han sido estimados a partir de otros correspondientes a especies similares, o pertenecientes a la misma familia aplicando un coeficiente de reducción.

\section{2.- SOBRECARGA PRODUCIDA POR EL PESO DE LA VEGETACIÓN}

Este efecto solo es importante en el caso de que el suelo esté cubierto con vegetación arbórea, siendo despreciable este incremento para el caso de vegetación herbácea.

La sobrecarga puede afectar a la estabilidad de las laderas de manera positiva o negativa dependiendo de cuál de las dos componentes sea predominante. El incremento de la estabilidad del talud por efecto del peso de la vegetación tiene relación con la distribución espacial de la vegetación en el talud, y con las propiedades del suelo. Si la vegetación se concentra en la parte baja del talud se incrementa la estabilidad, en cambio si la sobrecarga del talud se concentra en la cabecera la estabilidad del suelo disminuye al reducirse la resistencia al esfuerzo cortante que actúa sobre el terreno.

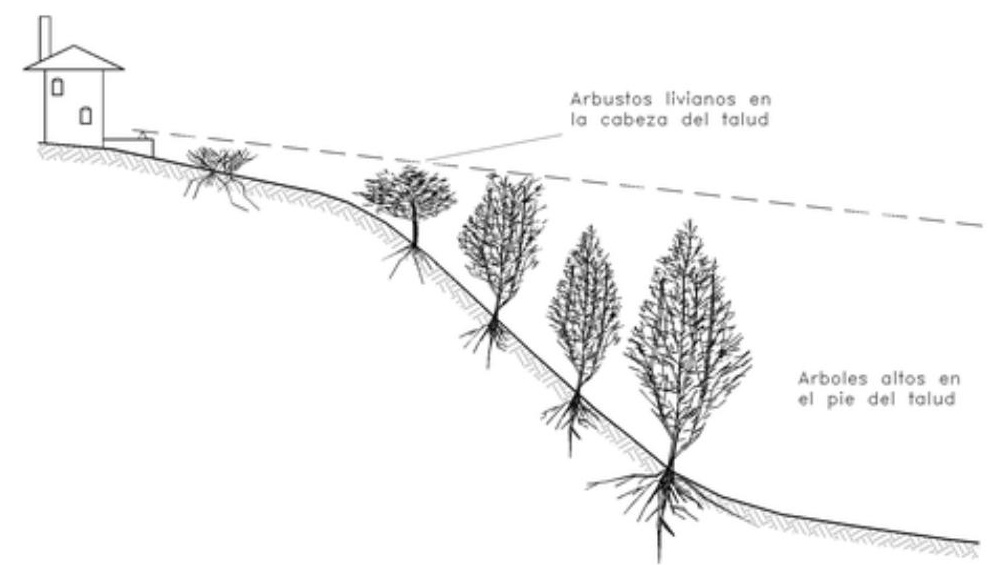

Figura 76: Distribución espacial de la vegetación en el talud, condiciones más favorables.

La ecuación para el cálculo de la sobrecarga producida por la vegetación se resume en la siguiente expresión: 


$$
W_{v}=\nu_{v} \times \pi / 4 \times D_{t}^{2} \times h_{t} \times(f . f) \times g
$$

Donde:

- $\quad W v=$ Peso de la vegetación $\left(\mathrm{kN} / \mathrm{m}^{2}\right)$

- $\quad \mathrm{Dt}=$ Diámetro del árbol medido a 1,30 m

- $\quad \gamma v=$ Densidad de la madera $\left(\mathrm{kg} / \mathrm{m}^{3}\right)$

- $\quad h t=$ Altura del árbol $(m)$

- $g$ = Aceleración de la gravedad $\left(9,8 \mathrm{~m} / \mathrm{s}^{2}\right)$

- f.f. =Factor de forma $(0,65)$

Figura 77: Componentes del peso que actúan sobre un talud con

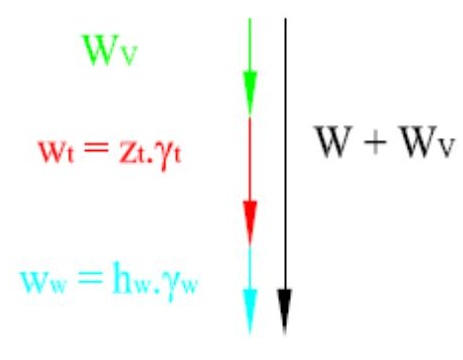

$W^{\prime}$

$\left(W_{w}\right)$, y vegetación $\left(W_{v}\right)$.

\section{3.- FUERZA TRANSMITIDA POR EL VIENTO}

La fuerza que el viento ejerce sobre las plantas es transferida al interior del terreno desestabilizándolo.

La magnitud y fuerza de arrastre ejercida por el viento en los árboles es función de los siguientes factores:

- Velocidad del viento.

- Altura de los árboles.

- Extensión de la cubierta.

- Pendiente del talud.

Existen diversos modelos que cuantifican la fuerza de empuje del viento. En este proyecto se va a utilizar para su cálculo el modelo de Brown y Sheu, 1975 que expresa la fuerza de arrastre de cada árbol transmitida al talud, suponiendo que el viento sopla de forma paralela a la superficie del terreno.

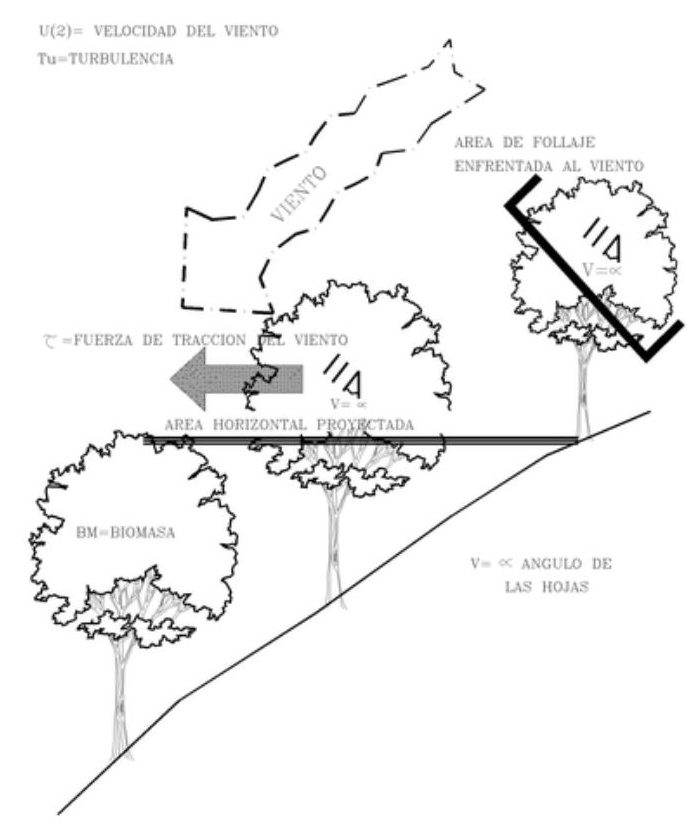

$D=C d \times\left(1 / 2 \rho V^{2}\right)=C d \times q$

Donde: 
- $\quad D=$ Empuje del viento transmitida a la ladera del talud $\left(\mathrm{kN} / \mathrm{m}^{2}\right)$.

- $\quad P=$ Densidad del aire $\left(\mathrm{kg} / \mathrm{m}^{3}\right)$.

- $\quad \mathrm{V}=$ Velocidad del viento $(\mathrm{m} / \mathrm{s})$.

- $\quad C d=$ Coeficiente adimensional de arrastre.

$C d=0,7$ para secciones circulares con superficie lisa.

Figura 78: Representación esquemática del efecto del viento sobre el talud

- $\quad \mathrm{q}$ = Carga o presión de viento $\left(\mathrm{kg} / \mathrm{m}^{2}\right)$. El valor de $\mathrm{q}$ se ha tomado de las normas tecnológicas de la edificación (NTE), correspondiente al capítulo del cálculo de cargas del viento sobre edificios para cada zona eólica. Los valores de $q$, son los correspondientes a la zona eólica W, con situación topográfica Normal. Los valores de q calculados están referidos a cada altura media del árbol, q (ht).

\section{4.- INFLUENCIA DE LA MEZCLA DE ESPECIES EN EL CÁLCULO DEL FACTOR DE SEGURIDAD}

El caso más frecuente de propuesta para la restauración de un talud con vegetación es la que se compone de una mezcla de dos o más especies que pueden ser de varios tipos: árboles, arbustos y herbáceas. Cada especie estará representada en la superficie total en un porcentaje que será como máximo del 100\%. La representación o porcentaje de mezcla será considerado en los parámetros calculados para cada especie de forma individual, de manera que se pueda obtener una media ponderada de cada parámetro en la mezcla.

\section{1.- CÁLCULO DE LOS PARÁMETROS DE LA VEGETACIÓN EN UNA MEZCLA DE ESPECIES}

Los parámetros de la vegetación considerados en el cálculo del factor de seguridad son:

- $\quad \boldsymbol{C} \boldsymbol{R}=$ Cohesión mejorada del suelo $\left(\mathrm{kN} / \mathrm{m}^{2}\right)$.

- $\quad \boldsymbol{T}=$ Fuerza de tracción de las raíces $\left(\mathrm{kN} / \mathrm{m}^{2}\right)$.

- $\boldsymbol{W} \boldsymbol{v}=$ Peso debido a la vegetación $\left(\mathrm{kN} / \mathrm{m}^{2}\right)$.

- $\boldsymbol{D}=$ Empuje del viento sobre la vegetación $\left(\mathrm{kN} / \mathrm{m}^{2}\right)$.

- $\quad p . r=$ Profundidad de las raíces $(m)$.

Los parámetros de cálculo de la mezcla de especies vegetales, se hallan aplicando a cada parámetro correspondiente a la especie, el porcentaje en que esta se encuentra 
representada. De esta forma, se calcula la media ponderada de los parámetros del conjunto de la mezcla.

De este modo los parámetros considerados se calculan de la siguiente manera:

$$
\begin{aligned}
& c R_{0}=c R_{1 *} \% 1+c R_{2 *} \% 2+c R_{3 *} \% 3+\ldots+c R_{N^{*}} \% N \\
& T_{0}=T_{1 *} \% 1+T_{2 *} \% 2+T_{3 *} \% 3+\ldots+T_{N^{*}} \% N \\
& W_{v 0}=W_{v 1 *} \% 1+W_{v 2} \% 2+W_{v 3 *} \% 3+\ldots+W_{v N^{*}} \% N \\
& D_{0}=D_{1 *} \% 1+D_{2 *} \% 2+D_{3 *} \% 3+\ldots+D_{N^{*}} \% N \\
& \text { p.r } r_{0}=p . r_{1 *} \% 1+p . r_{2 *} \% 2+p . r_{3 *} \% 3+\ldots+p . r_{N^{*}} \% N
\end{aligned}
$$

\section{5.- INFLUENCIA DE LA DENSIDAD DE PLANTACIÓN EN EL CÁLCULO DEL FACTOR DE SEGURIDAD}

\section{1.- EL EFECTO ARCO}

Las raíces individuales actúan como anclajes que estabilizan los arcos de suelo que se extienden a través del talud. El efecto arco está directamente relacionado con la densidad de plantación, y para que este tenga lugar, el espaciamiento de los árboles debe ser el menor posible. Se considera que se produce efecto arco para espaciamientos entre arboles menores a $10 \mathrm{~m}$. 


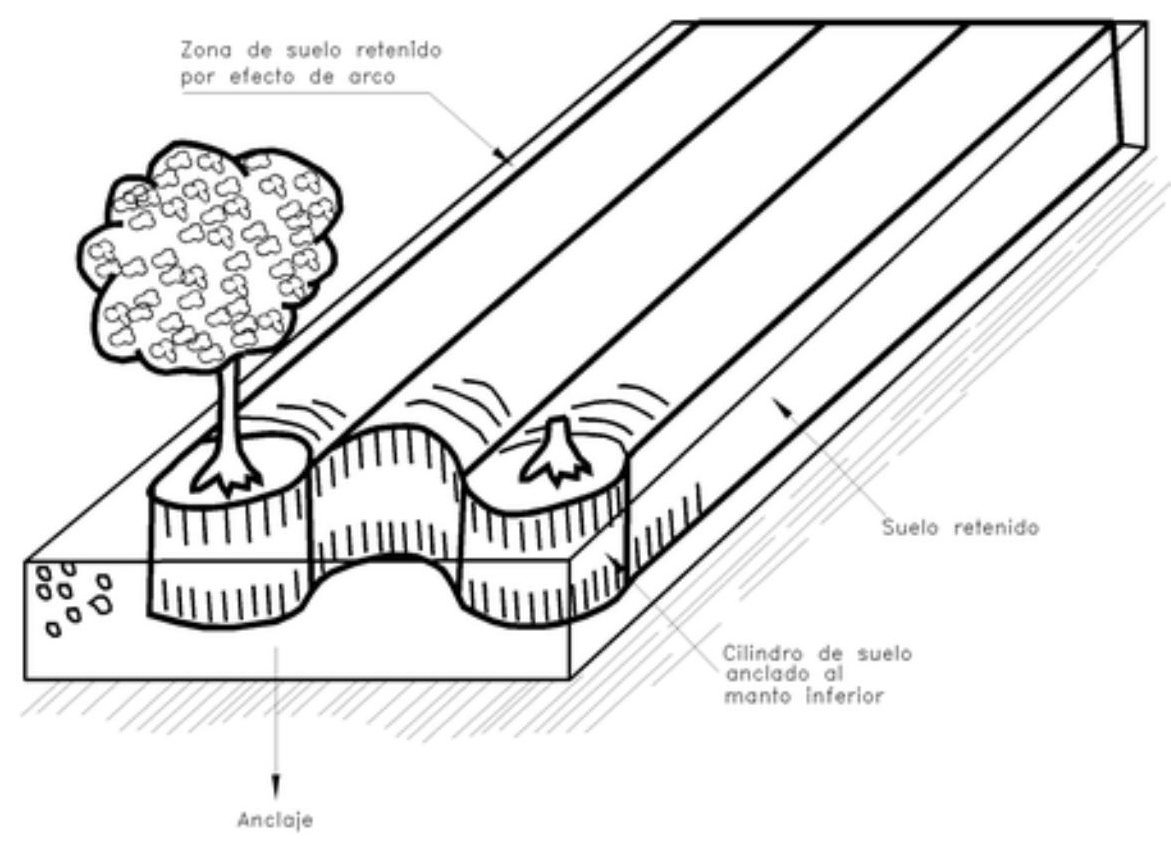

Figura 79: Representación esquemática del efecto arco producido por la distribución de la vegetación sobre la superficie del talud.

\subsection{1.- Cálculo del espaciado o separación entre árboles}

El espaciado (e) o marco de plantación se puede calcular según la fórmula siguiente:

$$
e=\sqrt{\frac{10000}{\text { densidad de plantacion }\left(\frac{u d}{h a}\right)}}
$$

En la tabla 11: se muestra la densidad (plantas / hectárea) según el marco de plantación elegido:

\begin{tabular}{|l|l|l|l|l|l|l|l|l|l|}
\hline \multirow{2}{*}{$\begin{array}{l}\text { Distancia } \\
\text { entre } \\
\text { plantas }(\mathrm{m})\end{array}$} & \multicolumn{6}{|l|}{ Distancia entre líneas de plantación $(\mathrm{m})$} \\
\cline { 2 - 12 } & 2 & 2,5 & 3 & 3,5 & 4 & 4,5 & 5 & 5,5 & 6 \\
\hline 2 & 2500 & 2000 & 1667 & 1429 & 1250 & 1111 & 1000 & 909 & 833 \\
\hline 2,5 & 2000 & 600 & 1333 & 1143 & 1000 & 889 & 800 & 727 & 667 \\
\hline 3 & 1667 & 333 & 1111 & 952 & 833 & 741 & 667 & 606 & 556 \\
\hline 3,5 & 1429 & 143 & 952 & 816 & 714 & 635 & 571 & 519 & 476 \\
\hline 4 & 1250 & 1000 & 833 & 714 & 625 & 556 & 500 & 455 & 417 \\
\hline 4,5 & 1111 & 889 & 741 & 635 & 556 & 494 & 444 & 404 & 370 \\
\hline 5 & 1000 & 800 & 667 & 571 & 500 & 444 & 400 & 364 & 333 \\
\hline 5,5 & 909 & 727 & 606 & 519 & 455 & 404 & 364 & 331 & 303 \\
\hline
\end{tabular}


DESARROLLO DE UNA APLICACIÓN INFORMÁTICA PARA EL CÁLCULO DE SOSTENIMIENTO

DE TALUDES MEDIANTE REVEGETACIÓN

ANEXO IV.- EFECTOS DE LA REVEGETACIÓN SOBRE LA ESTABILIDAD DE TALUDES

\begin{tabular}{|l|l|l|l|l|l|l|l|l|l|}
\hline 6 & 833 & 667 & 556 & 476 & 417 & 370 & 333 & 303 & 278 \\
\hline
\end{tabular}

Tabla de Densidad (plantas/ha) en función del marco.

Las celdas sombreadas corresponden a las densidades empleadas con mayor frecuencia.

\section{2.- INFLUENCIA DE LA DENSIDAD DE PLANTACIÓN EN LOS PARÁMETROS DE LA VEGETACIÓN EN UNA MEZCLA DE ESPECIES}

La densidad de plantación se considera en todos los parámetros anteriores, menos en la profundidad de las raíces, para la cual no se considera que este factor tenga alguna influencia.

El cálculo consiste en multiplicar la densidad en (unidades $/ \mathrm{m}^{2}$ ) a los distintos parámetros de la vegetación considerados en la mezcla de especies:

$$
\begin{aligned}
& c R\left(\mathrm{kN} / \mathrm{m}^{2}\right)=c R_{0} \times \text { Densidad de plantación }\left(\mathrm{ud} / \mathrm{m}^{2}\right) \\
& T\left(\mathrm{kN} / \mathrm{m}^{2}\right)=T_{0} \times \text { Densidad de plantación }\left(\mathrm{ud} / \mathrm{m}^{2}\right) \\
& W_{v}\left(\mathrm{kN} / \mathrm{m}^{2}\right)=W_{v 0} \times \text { Densidad de plantación }\left(\mathrm{ud} / \mathrm{m}^{2}\right) \\
& D\left(\mathrm{kN} / \mathrm{m}^{2}\right)=D_{0} \times \text { Densidad de plantación }\left(\mathrm{ud} / \mathrm{m}^{2}\right)
\end{aligned}
$$

Desarrollando cada una de las fórmulas los parámetros se calculan según las siguientes expresiones:

$$
\begin{aligned}
& c R\left(\mathrm{kN} / \mathrm{m}^{2}\right)=\left(c R_{1^{*}} \% 1+c R_{2^{*}} \% 2+c R_{3^{*}} \% 3+\ldots+c R_{N^{*}} \% N\right) \times \text { Densidad plantación }\left(\mathrm{ud} / \mathrm{m}^{2}\right) \\
& T\left(\mathrm{kN} / \mathrm{m}^{2}\right)=\left(T_{1^{*}} \% 1+T_{2^{*}} \% 2+T_{3^{*}} \% 3+\ldots+T_{N^{*}} \% N\right) \times \text { Densidad plantación }\left(\mathrm{ud} / \mathrm{m}^{2}\right) \\
& W_{v}\left(\mathrm{kN} / \mathrm{m}^{2}\right)=\left(W_{v 1} \% 1+W_{v 2 *} \% 2+W_{v 3^{*}} \% 3+\ldots+W_{v N^{*}} \% N\right) \times \text { Densidad plantación }\left(\mathrm{ud} / \mathrm{m}^{2}\right) \\
& D\left(\mathrm{kN} / \mathrm{m}^{2}\right)=\left(D_{1 *} \% 1+D_{2^{*}} \% 2+D_{3^{*}} \% 3+\ldots+D_{N^{*}} \% N\right) \times \text { Densidad plantación }\left(\mathrm{ud} / \mathrm{m}^{2}\right) \\
& \text { p.r }(\mathrm{m})=\text { p. } r_{1 *} \% 1+p . r_{2^{*}} \% 2+p . r_{3 *} \% 3+\ldots+p . r_{N^{*}} \% N
\end{aligned}
$$




\section{6.- CÁLCULO DE LA PROFUNDIDAD DEL PLANO DE DESLIZAMIENTO EN UN TALUD CON VEGETACIÓN Y SIN VEGETACIÓN}

Inicialmente se suponía el valor de $\mathbf{z}$ como un dato de entrada en el cálculo del factor de seguridad, pero se ha comprobado que no es posible, en la inmensa mayoría de los casos, conocer a priori este dato, por lo que es necesario desarrollar las fórmulas que calculen inicialmente cual será la profundidad del plano de deslizamiento, tanto si hay vegetación ( $\left.\mathbf{z}^{\prime}\right)$, como si no la hay (z).

\section{1.- ECUACIÓN PARA EL CÁLCULO DE LA PROFUNDIDAD DEL PLANO DE DESLIZAMIENTO, SIN VEGETACIÓN (Z)}

Para el cálculo de $\mathbf{z}$ se ha considerado el equilibrio entre Fuerzas motoras y Fuerzas resistentes, de la fórmula que define el Factor de seguridad, es decir, se despeja la z para la situación en la que F.S. =1, tal y como se indica a continuación:

$$
\begin{gathered}
\mathrm{FS}=\frac{c+\tan \emptyset W \operatorname{sen} \beta}{W \cos \beta} \\
-\quad \text { Si } F . S .=1 \\
\frac{c+\tan \emptyset W \operatorname{sen} \beta}{W \cos \beta}=1 \longrightarrow W \cos \beta=c+\tan \emptyset W \operatorname{sen} \beta \\
W(\cos \beta-\operatorname{sen} \beta \cdot \tan \varnothing)=c \longrightarrow \mathrm{W}=\frac{\mathrm{c}}{(\cos \beta-\operatorname{sen} \beta \tan \varnothing)} \\
\mathrm{z}=\frac{\mathrm{c}}{(\cos \beta-\operatorname{sen} \beta \tan \varnothing) \gamma}
\end{gathered}
$$

Donde:

- $\quad c=$ Cohesión efectiva del suelo $\left(\mathrm{kN} / \mathrm{m}^{2}\right)$.

- $\quad \beta=$ Ángulo de la pendiente (grados).

- $\varnothing=$ Ángulo de fricción interna del material del suelo (grados).

- $\boldsymbol{\gamma}=$ Peso específico del suelo $\left(\mathrm{kN} / \mathrm{m}^{3}\right)$.

- $\quad \boldsymbol{z}=$ Altura del plano de deslizamiento sin vegetación $(\mathrm{m})$. 


\section{2.- ECUACIÓN PARA EL CÁLCULO DE LA PROFUNDIDAD DEL PLANO DE DESLIZAMIENTO (Z')}

En el cálculo de $z^{\prime}$, o altura del plano de deslizamiento con vegetación el procedimiento es el mismo que en $\boldsymbol{z}$, pero en el caso de $\boldsymbol{z}^{\prime}$, es preciso tener en cuenta los parámetros de la vegetación que intervienen en el desarrollo de la fórmula.

Se parte de la fórmula anterior, considerando el equilibrio entre fuerzas motoras y fuerzas resistentes:

$$
\begin{aligned}
& F \boldsymbol{S}=\frac{c^{\prime}+\tan \emptyset W \operatorname{sen} \beta}{W \cos \beta} \quad ; \quad c^{\prime}=c+c R \\
& \text { - Si F.S. }=1 \\
& \frac{c^{\prime}+\tan \emptyset W \operatorname{sen} \beta}{W \cos \beta}=1 \Longrightarrow W \cos \beta=c^{\prime}+\tan \emptyset W \operatorname{sen} \beta \\
& W(\cos \beta-\operatorname{sen} \beta \cdot \tan \varnothing)=c^{\prime} \quad \square \quad W=\frac{c^{\prime}}{(\cos \beta-\operatorname{sen} \beta \tan \varnothing)} \square \\
& W=W_{t}+W_{w}+W_{v}=\left(\gamma_{t}+\gamma_{w}\right) z^{\prime}+\left[\gamma_{v} \times \pi / 4 \times D_{t}^{2} \times h t \times(f . f) \times g\right] \\
& \frac{c^{\prime}}{(\cos \beta-\operatorname{sen} \beta \tan \varnothing)}=(\nu t+\gamma w) z^{\prime}+\left[\gamma_{v} \times \pi / 4 \times D t 2 \times h t \times(f . f) \times g\right] \\
& z^{\prime}=\left[\frac{c^{\prime}}{(\cos \beta-\operatorname{sen} \beta \tan \emptyset)}-\left(\gamma_{\mathrm{v}} \times \pi / 4 \times D_{t^{2}} \times h_{t} \times(f . f) \times g\right)\right] \times \frac{1}{(\gamma t+\gamma w)}
\end{aligned}
$$

Donde:

- $\quad \mathbf{z}^{\prime}=$ Altura del plano de deslizamiento con vegetación $(\mathrm{m})$.

- $\quad \boldsymbol{v}=$ Peso específico del suelo $\left(\mathrm{kN} / \mathrm{m}^{3}\right)$.

- $\quad c^{\prime}=$ Cohesión mejorada del suelo $\left(\mathrm{kN} / \mathrm{m}^{2}\right)$.

- $\boldsymbol{c}=$ Cohesión efectiva del suelo $\left(\mathrm{kN} / \mathrm{m}^{2}\right)$.

- $\quad \boldsymbol{C} \boldsymbol{R}=$ Cohesión efectiva del suelo mejorada debido al refuerzo por raíces $\left(\mathrm{kN} / \mathrm{m}^{2}\right)$

- $\boldsymbol{\beta}=$ Ángulo de la pendiente (grados).

- $\varnothing=$ Ángulo de rozamiento interno del material del suelo (grados).

- $\boldsymbol{W}_{v}=$ Peso de la vegetación $\left(\mathrm{kN} / \mathrm{m}^{2}\right)$. 
- $\quad \boldsymbol{D}_{\boldsymbol{t}}=$ Diámetro del árbol medido a 1,30 m (cm).

- $\quad \quad_{v}=$ Densidad de la madera $\left(\mathrm{kg} / \mathrm{m}^{3}\right)$.

- $\quad \boldsymbol{h}_{\boldsymbol{t}}=$ Altura del árbol $(\mathrm{m})$.

- $\boldsymbol{g}=$ Aceleración de la gravedad $\left(9,8 \mathrm{~m} / \mathrm{s}^{2}\right)$.

- f.f. = Factor mórfico $(0,65)$.

- $\quad \boldsymbol{V}_{w}=$ Peso unitario del agua $\left(9,8 \mathrm{kN} / \mathrm{m}^{3}\right)$.

\section{3.- INFLUENCIA DE LA PROFUNDIDAD DE DESLIZAMIENTO EN EL CÁLCULO DEL}

\section{FACTOR DE SEGURIDAD}

Se consideran como valores de $\mathbf{z}^{\prime}$ (o $\mathbf{z}$ ), válidos aquellos que se encuentren en el rango $(0,5-60 \mathrm{~m})$ ambos inclusive, Fuera de esta rango los valores de $\mathbf{z}^{\prime}$ no son admisibles para el cálculo del factor de seguridad.

El cálculo de la profundidad del plano de deslizamiento tiene una gran importancia a la hora de establecer el tipo de vegetación más adecuada que sirva para el refuerzo del terreno. Así se establece que si $\mathbf{z}^{\prime}<=$ (profundidad raíz - 0,6) se considera que las raíces ejercen una fuerza de anclaje en el suelo, teniendo en cuenta un margen de longitud de anclaje.

- En caso de que se dé esta condición, se tendrá en cuenta el valor de $\boldsymbol{T}$ (Fuerza de tracción de las raíces), en el cálculo del factor de seguridad.

- Si por el contrario, $\mathbf{z}^{\prime}>$ (profundidad raíz - 0,6), no se tiene en cuenta el valor de $T$, debido a que no se considera que las raíces alcancen la profundidad total de deslizamiento y puedan anclar el terreno.

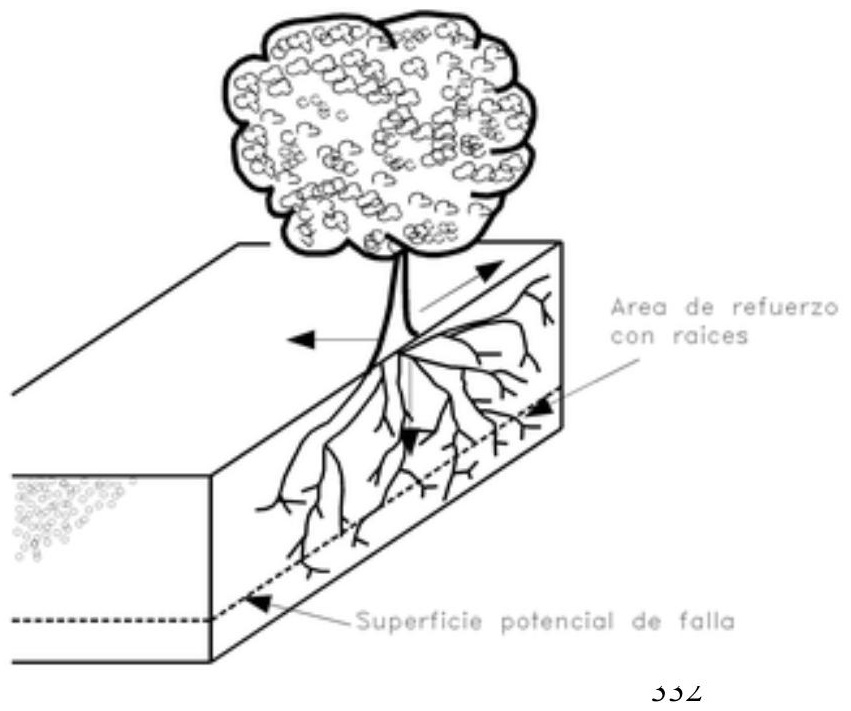

Figura 80: Representación de la profundidad de influencia de las raíces de la vegetación. 


\section{7.- CÁlCULO DE LA ALTURA VERTICAL DE LA LÁMINA DE AGUA SOBRE EL PLANO DE DESLIZAMIENTO}

La altura de la lámina de agua sobre el plano de deslizamiento con vegetación y sin vegetación se calcula teniendo en cuenta los casos de situación del nivel freático definidos por Hoek and Bray (Figura 81).

Los casos de nivel freático considerados en el cálculo del factor de seguridad se resumen en la siguiente tabla:

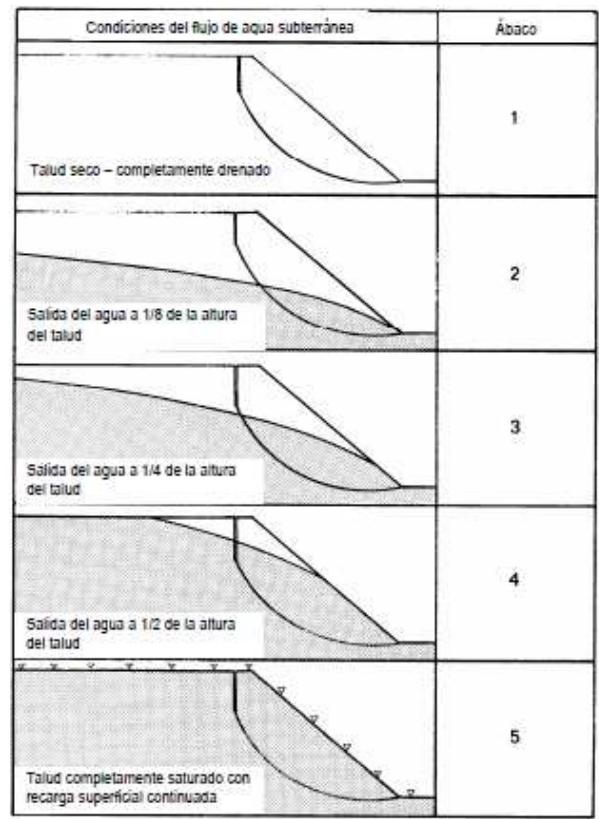

Figura 81: Casos de nivel freático (Hoek and Bray, 1981). 


\section{1.- CÁLCULO DE LA ALTURA VERTICAL DE LA LÁMINA DE AGUA}

El valor de la altura de la lámina de agua $\boldsymbol{h}_{v}$ se calcula teniendo en cuenta la clase de nivel freático de la tabla anterior según las fórmulas siguientes:

$$
\begin{array}{ll}
\text { NF1; } & h_{\mathrm{v} 1}=0 * z \text { (Talud seco) } \\
\text { NF2; } & h_{\mathrm{v} 2=1 / 8 * z} \\
\text { NF3; } & h_{\mathrm{v} 3}=1 / 4 * z \\
\text { NF4; } & h_{\mathrm{v} 4=1 / 2 * z} \\
\text { NF5; } & h_{\mathrm{v} 5}=1 * z \text { (Talud saturado) }
\end{array}
$$

El valor calculado del Factor de Seguridad será diferente en función de la clase de nivel freático considerado.

La altura vertical de la lámina de agua sobre el plano de deslizamiento con vegetación, $\boldsymbol{h}_{\boldsymbol{w}}$ se calcula teniendo en cuenta, como en el caso anterior, las clases de nivel freático y en este caso el valor de z' (con vegetación).

Las expresiones de cálculo de $\boldsymbol{h}_{\boldsymbol{w}}$ son las siguientes:

$$
\begin{array}{ll}
\text { NF1; } & h_{w 1}=0 * z^{\prime} \text { (Talud seco) } \\
\text { NF2; } & h_{w 2}=1 / 8 * z^{\prime} \\
\text { NF3; } & h_{w 3}=1 / 4 * z^{\prime} \\
\text { NF4; } & h_{w 4}=1 / 2 * z^{\prime} \\
\text { NF5; } & h_{w 5}=1 * z^{\prime} \text { (Talud saturado) }
\end{array}
$$




\section{8.- CÁLCULO DEL FACTOR DE SEGURIDAD DE UN TALUD CONSIDERANDO EL EFECTO DE LA VEGETACIÓN}

Para el cálculo del factor de seguridad se van a emplear el método del talud infinito que se basa en la hipótesis de que la longitud de una rotura plana superficial al talud puede considerarse infinita con respecto al espesor deslizado.

Este método es el más apropiado puesto que es el que más se utiliza para el análisis de estabilidad en laderas naturales (Ver Anexo III - Métodos de cálculo de Estabilidad).

\section{1.- ECUACIÓN PARA EL CÁLCULO DEL FACTOR DE SEGURIDAD SIN VEGETACIÓN}

Usando el análisis del esfuerzo efectivo convencional, el factor de seguridad sin efecto de la vegetación puede ser definido por:

$$
F S=\frac{c+\left(\gamma z-\gamma_{w} h_{w}\right) \cos ^{2} \beta \tan \emptyset}{\gamma z \sin \beta \cos \beta}
$$
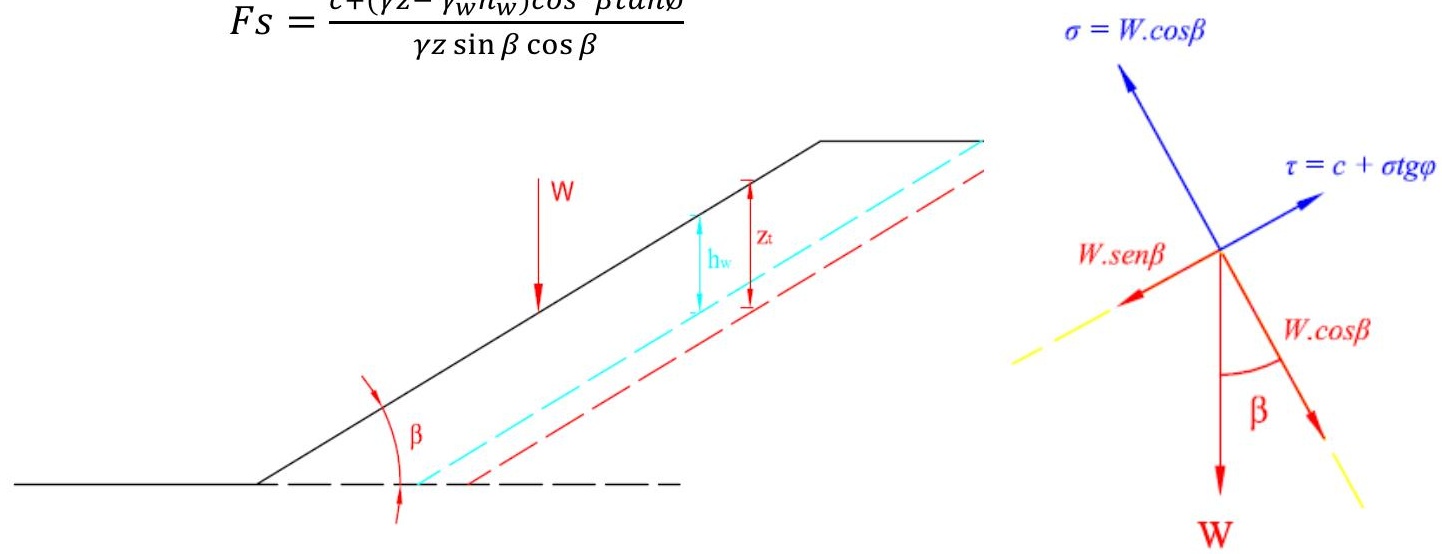

Figura 82: Diagramas indicando los parámetros que intervienen en el cálculo de Fs (sin vegetación), y distribución de las fuerzas que actúan sobre la masa de terreno deslizante.

Donde:

- $\quad \boldsymbol{F} \boldsymbol{s}=$ Factor de seguridad sin vegetación.

- $\quad c=$ Cohesión efectiva del suelo $\left(\mathrm{kN} / \mathrm{m}^{2}\right)$.

- $\boldsymbol{\gamma}=$ Peso específico del suelo $\left(\mathrm{kN} / \mathrm{m}^{3}\right)$.

- $\quad \boldsymbol{z}=$ Profundidad del plano de deslizamiento sin vegetación $(\mathrm{m})$.

- $\boldsymbol{\gamma}_{w}=$ Peso unitario del agua $\left(9,8 \mathrm{kN} / \mathrm{m}^{3}\right)$.

- $\quad \boldsymbol{h}_{W}=$ Altura vertical de la lámina de agua subterránea $(\mathrm{m})$.

- $\boldsymbol{\beta}=$ Ángulo de la pendiente (grados).

- $\quad \varnothing=$ Ángulo de fricción interna del material del suelo (grados). 


\section{2.- ECUACIÓN PARA EL CÁLCULO DEL FACTOR DE SEGURIDAD CON VEGETACIÓN}

Coppin y Richards, 1990 citados por Morgan y Rickson, 1995 muestran las influencias principales de la vegetación sobre la estabilidad de un segmento de ladera.

Estas pueden ser incluidas en el cálculo del factor de seguridad como sigue:

$$
F s_{v}=\frac{(c+c R)+\left[\left(\left(\gamma z^{\prime}-\gamma_{w} h_{v}\right)+W_{v}\right) \cos ^{2} \beta+T \sin \theta\right] \tan \emptyset+T \cos \theta}{\left[\left(\gamma z^{\prime}+W_{v}\right) \sin \beta+D\right] \cos \beta}
$$
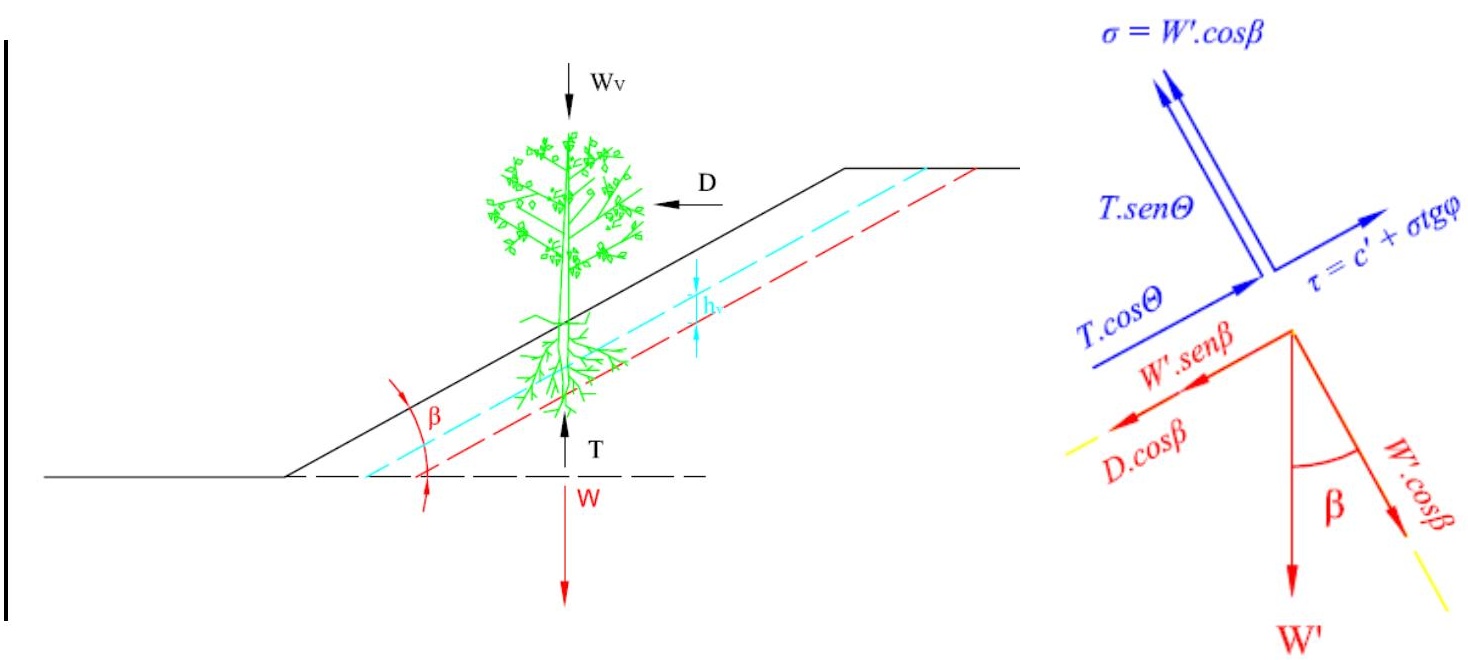

Figura 83: Diagramas indicando los parámetros que intervienen en el cálculo de Fsv (con vegetación), y distribución de las fuerzas que actúan sobre la masa de terreno deslizante.

Donde:

- $\quad \boldsymbol{F s} \boldsymbol{v}=$ Factor de seguridad con vegetación

- $\quad c=$ Cohesión efectiva del suelo $\left(\mathrm{kN} / \mathrm{m}^{2}\right)$.

- $\quad \boldsymbol{C R}=$ Cohesión efectiva del suelo mejorada debido al refuerzo por raíces $\left(\mathrm{kN} / \mathrm{m}^{2}\right)$.

- $\boldsymbol{\gamma}=$ Peso específico del suelo $\left(\mathrm{kN} / \mathrm{m}^{3}\right)$.

- $\quad \boldsymbol{z}^{\prime}=$ Profundidad del plano de deslizamiento con vegetación (m).

- $\boldsymbol{W}_{v}=$ Sobrecarga debido al peso de la vegetación $\left(\mathrm{kN} / \mathrm{m}^{2}\right)$.

- $\boldsymbol{\beta}=$ Ángulo de la pendiente (grados).

- $\boldsymbol{\gamma}_{w}=$ Peso unitario del agua $\left(9,8 \mathrm{kN} / \mathrm{m}^{3}\right)$.

- $\boldsymbol{h}_{V}=$ Altura vertical de la lámina de agua por encima del plano de deslizamiento con la vegetación $(m)$. 
- $\quad \boldsymbol{T}=$ Fuerza de tracción de las raíces actuando en la base del plano de deslizamiento $\left(\mathrm{kN} / \mathrm{m}^{2}\right)$.

- $\quad \boldsymbol{\theta}=$ Ángulo entre las raíces y el plano de deslizamiento (grados).

- $\varnothing=$ Ángulo de fricción interna del material del suelo (grados).

- $\quad \boldsymbol{D}=$ Fuerza de carga del viento paralela a la ladera $\left(\mathrm{kN} / \mathrm{m}^{2}\right)$.

\section{3.- ANÁLISIS COMPARATIVO DE RESULTADOS ENTRE LOS VALORES OBTENIDOS DEL FACTOR DE SEGURIDAD CON VEGETACIÓN Y SIN VEGETACIÓN}

Después de calcular el factor de seguridad con vegetación se compara el resultado con respecto al obtenido sin vegetación, y se calcula el incremento en el valor del factor de seguridad en porcentaje. Se consideran incrementos válidos los comprendidos entre 0 y $100 \%$. Incrementos negativos o mayores a 100 no se tendrán en cuenta, al no ser fiables, hecho que no suele ser habitual. 
DESARROLLO DE UNA APLICACIÓN INFORMÁTICA PARA EL CÁLCULO DE SOSTENIMIENTO DE TALUDES MEDIANTE REVEGETACIÓN 


\section{ANEXO V \\ DESARROLLO DE LA APLICACIÓN INFORMÁTICA: \\ ANÁLISIS INTEGRAL DE RESTAURACIÓN Y ESTABILIZACIÓN DE LADERAS}
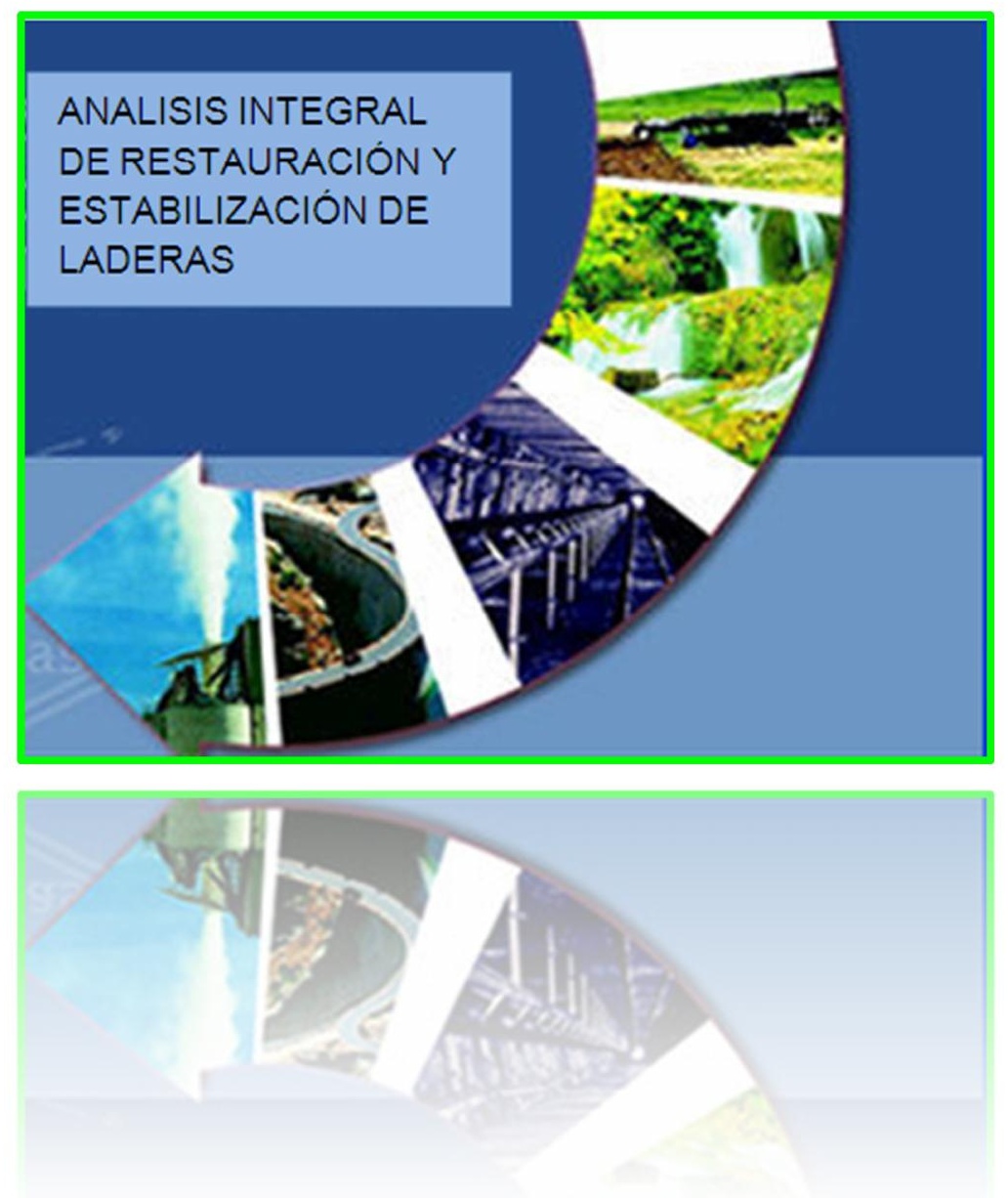


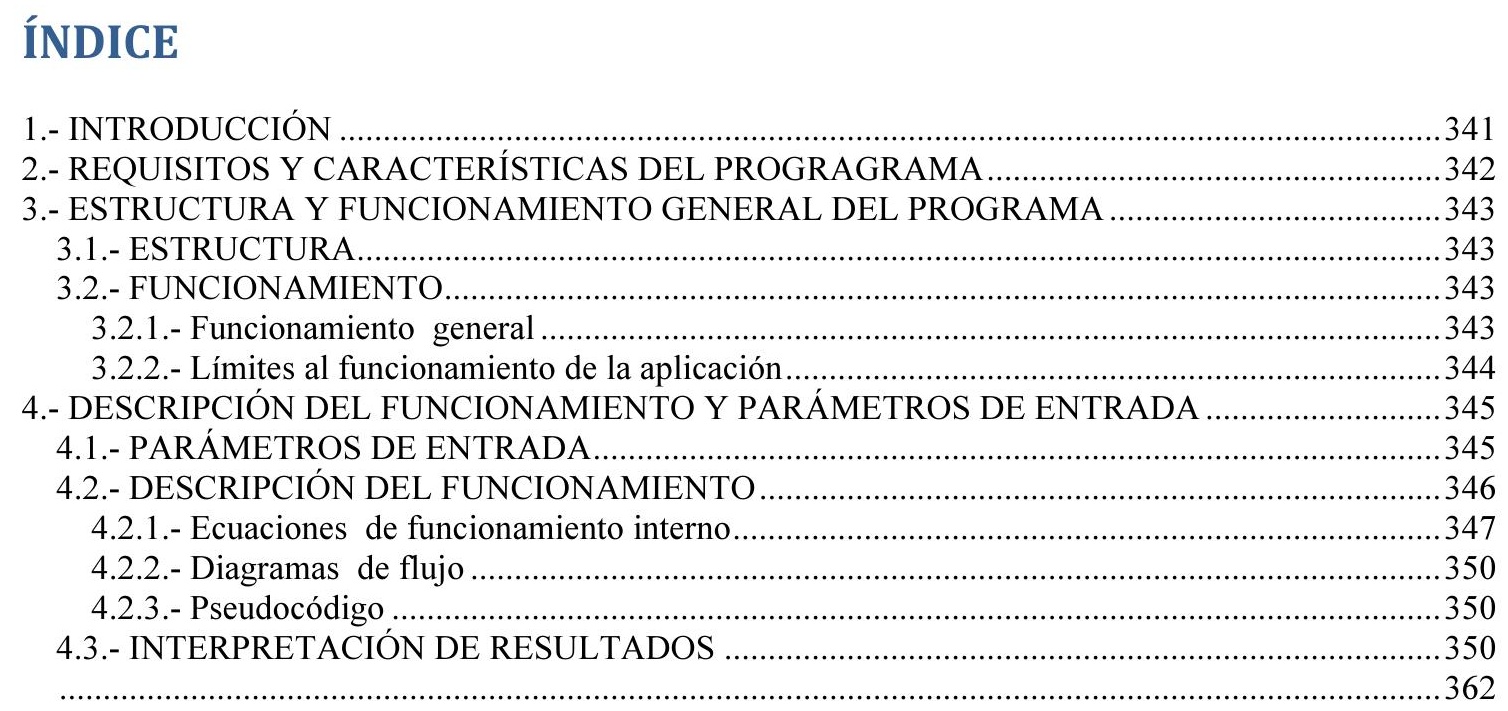

DOCUMENTO 1.- PSEUDOCÓDIGO

DOCUMENTO 2.- DIAGRAMAS DE FLUJO 


\section{1.- INTRODUCCIÓN}

El objetivo principal del proyecto, como ha sido descrito en los documentos precedentes, es el desarrollo de una aplicación informática que permita el cálculo del sostenimiento de taludes, estableciendo la vegetación más idónea en determinadas zonas con problemas debido a la recurrencia de los incendios, el abandono de explotaciones mineras, la ejecución de infraestructuras, etc. y en las que pudieran presentarse problemas de inestabilidad de taludes.

Además de incrementar la estabilidad de la ladera, también se quieren alcanzar otros objetivos como son:

- La restauración o integración paisajística del espacio degradado por las intervenciones humanas o los incendios.

- Evitar la pérdida de suelo por efecto de la erosión laminar y la escorrentía.

La aplicación informática desarrollada, a través de una serie de datos, permitirá realizar una simulación de las diferentes condiciones del terreno que se presenten en cuanto a sustrato, profundidad e inclinación, y obtener como solución un indicador del sostenimiento del terreno a través de la influencia que ejerce el enraizado de diferentes especies arbóreas, arbustivas y herbáceas sobre el mismo, teniendo en cuenta variables como especie vegetal, densidad de plantación, porcentaje de representación de cada especie en la plantación y disposición de las mismas. 


\section{2.- REQUISITOS Y CARACTERÍSTICAS DEL PROGRAGRAMA}

La aplicación informática cuenta con tres características esenciales:

1. Una interfaz gráfica de usuario completa, de intuitiva y de fácil manejo, para una introducción e interpretación de datos sencilla.

2. Una base de datos dinámica, en las que se incluyen datos generales de la zona, del terreno, y de la vegetación, en la que se pueden introducir y almacenar otros nuevos.

3. Funciones de cálculo que permitan establecer una propuesta de vegetación y calcular el factor de seguridad de taludes, pudiendo estudiar variaciones en función de las entradas.

4. Herramienta gráfica mediante la cual se pueden visualizar los resultados obtenidos en las simulaciones, y almacenarlos. 


\section{3.- ESTRUCTURA Y FUNCIONAMIENTO GENERAL DEL PROGRAMA}

\section{1.- ESTRUCTURA}

La aplicación tiene como objetivo la evaluación de estabilidad de taludes, calculando para ello el factor de seguridad que se obtiene bajo la influencia de una propuesta de revegetación concreta.

Se divide en dos partes:

1. Base de datos: La base de datos almacena datos geotécnicos y de vegetación para una zona concreta. Cada parámetro está compuesto por un nombre o un símbolo y la unidad de medida.

2. Herramienta de cálculo: La herramienta de cálculo se basa en diversas ecuaciones internas en las que se introducen los diferentes parámetros del talud, geotécnicos y de vegetación, obteniendo como resultado el cálculo del factor de seguridad del talud, en dos variantes: sin vegetación y con vegetación, comparando después los resultados.

\section{2.- FUNCIONAMIENTO}

\subsection{1.- Funcionamiento general}

Si ya se dispone de una vegetación concreta en una zona, o bien se ha determinado de antemano cual va a ser la composición y los parámetros de las especies vegetales a implantar en una restauración, se puede utilizar la herramienta desarrollada para evaluar la contribución, o no contribución, a la estabilidad de taludes.

El funcionamiento general del programa se basa en la aplicación de una serie de secuencias lógicas y ecuaciones internas que permiten obtener como resultado final valores del factor de seguridad de taludes.

El funcionamiento del programa de estabilización de taludes se resume en la siguiente secuencia:

1. Introducción de los datos correspondientes a: talud, propiedades del terreno y propuesta de vegetación.

2. El programa calcula los parámetros finales que define la acción sobre el terreno de la combinación de especies vegetales: 
DESARROLLO DE UNA APLICACIÓN INFORMÁTICA PARA EL CÁLCULO DE SOSTENIMIENTO

DE TALUDES MEDIANTE REVEGETACIÓN

ANEXO V.- DESARROLLO DE LA APLICACIÓN INFORMÁTICA:

ANÁLISIS INTEGRAL DE RESTAURACIÓN Y ESTABILIZACIÓN DE LADERAS

- Cohesión de las raíces ( $C R$ ), fuerza de tracción de las raíces $(T)$, sobrecarga de la vegetación $(W v)$, fuerza del viento $(D)$, profundidad media de las raíces (p.r), espaciado, cohesión mejorada del suelo $\left(c^{\prime}\right)$, peso total sobre el talud ( $\left.w^{\prime}\right)$.

3. El programa ejecuta la función de cálculo de la profundidad del plano de deslizamiento, en ambos supuestos: sin vegetación y con vegetación.

4. Se realiza el cálculo de la altura vertical de la lámina de agua a partir de la profundidad de deslizamiento.

5. Se efectúa el cálculo de las fuerzas motoras (desestabilizadoras) y las fuerzas resistentes (estabilizadoras), que actúan sobre la masa de terreno potencialmente inestable.

6. Se determina el valor del coeficiente de seguridad del talud.

El cálculo se realiza en dos etapas, siendo la primera la determinación del factor de seguridad sin vegetación, y la segunda, con vegetación. Una vez se disponga de los dos resultados se procede a:

7. Comparar los resultados: incremento del F.S., absoluto y en porcentaje.

Opcionalmente, se verían los resultados y se repite el proceso, con el fin de evaluar el comportamiento de diferentes soluciones de revegetación.

\subsection{2.- Límites al funcionamiento de la aplicación}

Durante la realización de pruebas de funcionamiento de las funciones matemáticas en las que se basa el programa (Metodología del "talud infinito"), para los diferentes:

- Tipos de suelos (granulares y cohesivos);

- Las distintas posiciones del nivel freático;

- Y las distintas inclinaciones del talud.

Se ha podido comprobar que existen algunas limitaciones en el cálculo del factor de seguridad:

1. En suelos cohesivos (suelos con cohesión), el funcionamiento del programa es óptimo para inclinaciones del talud $(\beta)$ entre 60 y $70 \circ$, para cualquier tipo de vegetación; sin embargo, a partir de 55이 los resultados obtenidos para vegetación no herbácea no deben ser considerados como fiables, ya que este tipo de vegetación puede tener un comportamiento contrario al que se busca (generando inestabilidad).

2. En suelos no cohesivos o granulares (suelos sin cohesión), El rango de aplicación del programa de cálculo corresponde a inclinaciones del talud $(\beta)$ comprendidas entre 60 y 35 o para cualquier tipo de vegetación. A partir de este valor, el talud siempre sería inestable. 
3. La aplicación encuentra problemas de funcionamiento, debidos a las ecuaciones internas, en taludes con un valor de la profundidad del plano de deslizamiento (z), tanto demasiado bajas como demasiado elevadas, por lo que se establece el criterio de limitar dichas profundidades a un intervalo comprendido entre los valores $0,5 \mathrm{~m}$ (mínimo), y 60 m (máximo).

\section{4.- DESCRIPCIÓN DEL FUNCIONAMIENTO Y PARÁMETROS DE ENTRADA}

\section{1.- PARÁMETROS DE ENTRADA}

En las tablas siguientes (Tabla 3, Tabla 4 y Tabla 5), se detallan los parámetros necesarios para el cálculo del factor de seguridad de taludes. Se distinguen parámetros de entrada del talud, el terreno y de la vegetación.

Parámetros del talud:

Tabla 3.- Parámetros de talud empleados para el análisis de estabilidad

\begin{tabular}{|l|c|c|}
\hline \multicolumn{1}{|c|}{ PARÁMETRO } & Símbolo & Unidades \\
\hline Ángulo del talud & $\boldsymbol{\beta}$ & Grados, sexagesimal \\
\hline Posición del nivel freático & NF & \\
& & \\
\hline
\end{tabular}

Parámetros del terreno:

Tabla 4.- Parámetros de terreno empleados para el análisis de estabilidad

\begin{tabular}{|l|c|c|}
\hline \multicolumn{1}{|c|}{ PARÁMETRO } & Símbolo & Unidades \\
\hline Tipo de suelo & & $\begin{array}{c}\mathrm{GW} \ldots \mathrm{CH} \\
(14 \mathrm{clases})\end{array}$ \\
\hline Cohesión & $\mathbf{c}$ & $\mathrm{kN} / \mathrm{m}^{2}$ \\
\hline Ángulo de rozamiento interno & $\emptyset$ & grados sexagesimal \\
\hline Peso específico del suelo & $\mathbf{~ Y N} / \mathrm{m}^{3}$ \\
\hline
\end{tabular}

Parámetros de la vegetación

Tabla 5.- Parámetros de vegetación empleados para el análisis de estabilidad

\begin{tabular}{|c|c|c|}
\hline PARÁMETRO & Símbolo & Unidades \\
\hline Especie vegetal $\mathrm{n}$ & & $\begin{array}{c}\text { Acer campestre...Trifolium } \\
\text { subterraneum }\end{array}$ \\
\hline
\end{tabular}


DESARROLLO DE UNA APLICACIÓN INFORMÁTICA PARA EL CÁLCULO DE SOSTENIMIENTO DE TALUDES MEDIANTE REVEGETACIÓN

ANEXO V.- DESARROLLO DE LA APLICACIÓN INFORMÁTICA:

ANÁLISIS INTEGRAL DE RESTAURACIÓN Y ESTABILIZACIÓN DE LADERAS

\begin{tabular}{|c|c|c|}
\hline & & (55 clases) \\
\hline Tipo de vegetación (especie n) & & (arbórea- arbustiva-herbácea) \\
\hline $\begin{array}{l}\text { Porcentaje de vegetación } \\
\text { (especie } n \text { ) }\end{array}$ & & $\%$ \\
\hline Diámetro medio del tallo (especie $\mathrm{n}$ ) & DtN & $\mathrm{cm}$ \\
\hline Densidad de la madera (especie $n$ ) & $\mathrm{Yv}_{\mathrm{v}} \mathbf{N}$ & $\mathrm{kg} / \mathrm{m}^{3}$ \\
\hline $\begin{array}{l}\text { Altura de la planta } \\
\text { (especie } n \text { ) }\end{array}$ & htN & $\mathrm{m}$ \\
\hline Factor de forma del tronco (especie $n$ ) & f.f.N & \\
\hline $\begin{array}{l}\text { Fuerza del viento } \\
\text { (especie } n \text { ) }\end{array}$ & DN & $\mathrm{kN} / \mathrm{m}^{2}$ \\
\hline Diámetro medio de las raíces (especie n) & DrN & $\mathrm{mm}$ \\
\hline Densidad estimada de las raíces (especie n) & $\begin{array}{c}\mathrm{drN} \\
(\mathrm{Ar} / \mathrm{As})\end{array}$ & \\
\hline Profundidad media de las raíces (especie $n$ ) & prN & $\mathrm{m}$ \\
\hline Resistencia a la tracción (especie $\mathrm{n}$ ) & TN & $\mathrm{N} / \mathrm{mm}^{2}$ \\
\hline $\begin{array}{l}\text { Cohesión raíces } \\
\text { (especie } n)\end{array}$ & cRN & $\mathrm{kN} / \mathrm{m}^{2}$ \\
\hline Densidad de la vegetación & & $\mathrm{ud} / \mathrm{ha}$ \\
\hline
\end{tabular}

\section{2.- DESCRIPCIÓN DEL FUNCIONAMIENTO}

El funcionamiento está basado en la aplicación de una serie de secuencias lógicas y ecuaciones internas que permiten obtener, a partir de los datos introducidos, los resultados finales del factor de seguridad.

Para la obtención de este resultado, el programa sigue el procedimiento descrito, de forma más o menos detallada.

1. Se introducen los datos correspondientes al talud: inclinación, clase de NF.

2. Se indica el tipo de suelo, o bien, se introducen los datos correspondientes al terreno: cohesión, rozamiento interno y peso específico. En caso de indicar solamente el tipo de suelo, los parámetros del mismo se carga automáticamente.

3. El programa ejecuta la función de cálculo de profundidad del plano de deslizamiento $(z)$, por el momento, sin vegetación.

4. Se calcula automáticamente la altura vertical de la lámina de agua sobre el plano de deslizamiento, en función de z y la posición del nivel freático $\left(\boldsymbol{h}_{w}\right)$.

5. El programa procede a calcular la suma de fuerzas motoras y de fuerzas resistentes.

6. Se procede al cálculo del Factor de Seguridad (FS).

7. Se añade la vegetación, definida de la siguiente manera: especies vegetales, porcentaje, y densidad de plantación. El programa asigna de forma automática los 
DESARROLLO DE UNA APLICACIÓN INFORMÁTICA PARA EL CÁLCULO DE SOSTENIMIENTO

DE TALUDES MEDIANTE REVEGETACIÓN

ANEXO V.- DESARROLLO DE LA APLICACIÓN INFORMÁTICA:

ANÁLISIS INTEGRAL DE RESTAURACIÓN Y ESTABILIZACIÓN DE LADERAS

parámetros básicos de cálculo para cada especie vegetal, aunque admiten ser modificados.

8. De forma automática son calculados, para cada especie:

- Fuerza de tracción de las raíces (T), a partir de las propiedades de la raíz.

- Sobrecarga de la vegetación (Wv), a partir de las propiedades del tallo.

9. El programa determina el espaciado entre plantas (e), y evalúa si este es compatible con la existencia de efecto arco.

10. Son determinados en función de la composición de la mezcla, y de la densidad de plantación los parámetros finales de cálculo del factor de seguridad con vegetación:

- Cohesión de las raíces ( $C R$ ), fuerza de tracción de las raíces $(T)$, sobrecarga de la vegetación $(W v)$, fuerza del viento (D), profundidad media de las raíces (p.r), espaciado, cohesión mejorada del suelo ( $\left.c^{\prime}\right)$, peso total sobre el talud ( $\left.w^{\prime}\right)$.

11. El programa ejecuta la función de cálculo de profundidad del plano de deslizamiento con vegetación $\left(z^{\prime}\right)$.

12. Se calcula automáticamente la altura vertical de la lámina de agua sobre el plano de deslizamiento con vegetación, en función de $z^{\prime}$ y la posición del nivel freático $\left(\boldsymbol{h}_{v}\right)$.

13. El programa procede a calcular la suma de fuerzas motoras y de fuerzas resistentes.

14. Se procede al cálculo del Factor de Seguridad con vegetación $\left(\boldsymbol{F S}_{\mathbf{V}}\right)$.

15. Finalmente se efectúa una comparación de resultados entre $\boldsymbol{F S}$ y $\boldsymbol{F} \boldsymbol{S}_{\boldsymbol{V}}$, determinando el incremento tanto en valor absoluto como en porcentaje.

Es útil posteriormente variar los parámetros de la vegetación (especies, porcentajes, densidad), y estudiar su influencia sobre el factor de seguridad.

El programa incorpora dos bases de datos que permiten almacenar grupos de parámetros, y cargarlos en la aplicación de cálculo de forma instantánea:

- Base de datos de parámetros geotécnicos del terreno.

- Base de datos de especies vegetales.

\subsection{1.- Ecuaciones de funcionamiento interno}

Para el desarrollo del algoritmo que permite el cálculo del factor de seguridad en taludes se han utilizado las siguientes ecuaciones de funcionamiento interno: 


\section{A) Ecuaciones para el caso de talud sin vegetación:}

Las ecuaciones fundamentales utilizadas en el cálculo del factor de seguridad sin vegetación, se han desarrollado en el orden siguiente:

1) Cálculo de la profundidad del plano de deslizamiento $\mathbf{z}$ :

$$
Z=\frac{c}{[\cos \beta-\operatorname{sen} \beta \operatorname{tag} \emptyset] \gamma}
$$

2) Cálculo de Fuerzas resistentes $(\Sigma F R)$ :

$$
\mathrm{FR}=\mathrm{c}+(\gamma \mathrm{z}-\gamma \mathrm{whw}) * \cos 2 \beta * \operatorname{tang} \varnothing
$$

3) Cálculo de las Fuerzas motoras $(\Sigma F R)$ :

\section{$\mathrm{FM}=\gamma \mathrm{z}^{*} \operatorname{sen} \beta * \cos \beta$}

4) Calculo del Factor de Seguridad (FS):

$$
F S=\frac{F R}{F M}=\frac{\mathrm{c}+(\gamma \mathrm{z}-\gamma \mathrm{whw}) * \cos ^{2} \beta * \operatorname{tang} \emptyset}{\gamma \mathrm{z} * \operatorname{sen} \beta * \cos \beta}
$$

\section{B) Ecuaciones para el caso de talud con vegetación:}

Las ecuaciones fundamentales utilizadas en el cálculo del factor de seguridad con vegetación, se han desarrollado en el orden siguiente:

1) Previamente se definen las ecuaciones que permiten calcular los parámetros de la mezcla de especies.

- Cohesión de las raíces:

$c R=[c R 1 * \% 1+c R 2 * \% 2 \ldots+c R N * \% N] *$ densidad plantación

- Fuerza de tracción de las raíces:

$T=\left[T 1 * \% 1+T 2 * \% 2 \ldots+T N^{*} \% N\right] *$ densidad plantación

- Sobrecarga de la vegetación:

$W_{v}=\left[W_{v} 1 * \% 1+W_{v} 2 * \% 2 \ldots+W_{v} N^{*} \% N\right] *$ densidad plantación 
- Empuje del viento:

$D=[D 1 * \% 1+D 2 * \% 2 \ldots+D N * \% N] *$ densidad plantación

- Profundidad de las raíces:

$\operatorname{Pr}=[\operatorname{Pr} 1 * \% 1+\operatorname{Pr} 2 * \% 2 \ldots+\operatorname{PrN} * \% N]$

2) Cálculo de la cohesión efectiva mejorada:

$$
c^{\prime}=c+c R
$$

3) Cálculo del peso de la vegetación:

$$
W v\left(k N / m^{2}\right)=\text { Densidad_madera } * \pi / 4 *(D t)^{2} * h t * f . f * g
$$

4) Cálculo de la profundidad del plano de deslizamiento del terreno con la vegetación $z^{\prime}$ :

- Cálculo del factor A:

$A=\cos \beta-\operatorname{sen} \beta * \operatorname{tang} \varnothing$

- Cálculo del factor B: $\mathrm{B}=\mathrm{WV}^{*}$ Densidad plantación

- Cálculo del factor:

$C^{\prime} / A$

- Cálculo del factor: $C^{\prime} / A-B$

$$
z^{\prime}=\left[c^{\prime} / A-B\right]^{*} 1 /\left(\gamma_{t}+\gamma_{w}\right)
$$

5) Cálculo de las fuerzas resistentes ( $\boldsymbol{\Sigma} \boldsymbol{F} \boldsymbol{R})$ :

- Cálculo del factor $E: \quad E=\left[\left(\gamma z^{\prime}-\gamma w h v\right)+w v\right]^{*} \cos 2 \beta$

- Cálculo del factor $F: \quad F=T^{*} \operatorname{sen} \theta$

- Cálculo del factor: $\quad(E+F) * \operatorname{tang} \varnothing$

- Cálculo del factor $\mathrm{G}: \quad \mathrm{G}=\mathrm{T}^{*} \cos \theta$

$$
\Sigma F R=c^{\prime}+(E+F) * \operatorname{tang} \varnothing+G
$$

6) Cálculo de las fuerzas motoras ( $\Sigma$ FM):

- $\quad$ Cálculo del Factor $H: \quad H=\left(\gamma z^{\prime}+W v\right)^{*} \operatorname{sen} \beta$

- Factor D: Fuerza de empuje del viento. 


\section{$\Sigma \mathrm{FM}=(\mathrm{H}+\mathrm{D}) * \cos \beta$}

7) Cálculo del Factor de Seguridad (F.S.v):

$$
\mathrm{FSv}=\frac{F R}{F M}=\frac{\mathrm{c}^{\prime}+(\mathrm{E}+\mathrm{F}) * \operatorname{tang} \varnothing+\mathrm{G}}{(\mathrm{H}+\mathrm{D}) * \cos \beta}
$$

8) Cálculo del espaciado de la plantación (e):

$$
e=\sqrt{\frac{10000}{\text { densidad de plantación }\left(\frac{u d}{h a}\right)}}
$$

Los ángulos deben operar siempre en radianes.

La altura vertical de la lámina de agua hv y hw, se calcula aplicando el \% correspondiente según la posición del N.F. al valor de $z$ o z', respectivamente.

\subsection{2.- Diagramas de flujo}

La aplicación informática para el cálculo de la estabilidad se ha diseñado teniendo en cuenta los diagramas de flujo correspondientes al análisis de estabilidad del terreno sin vegetación y con vegetación.

- DIAGRAMA DE FLUjo 01- [CÁlCULO fS SIN VEgetACIÓN].

- DIAGRAMA DE FLUJO 02- [CÁlCULO FS CON VEGETACIÓN].

Los diagramas de flujo quedan representados en el Documento adjunto 1.- Diagramas de Flujo, del presente anexo.

\subsection{3.- $\quad$ Pseudocódigo}

El funcionamiento de la aplicación informática se explica según el pseudocódigo que se detalla en el Documento adjunto 2.- Pseudocódigo, del presente anexo.

\section{3.- INTERPRETACIÓN DE RESULTADOS}

Los resultados finales obtenidos son: el factor de seguridad inicial del talud ( $\sin$ la vegetación), el factor de seguridad modificado por la vegetación, y la diferencia entre ambos. 
- Como ha sido expuesto a lo largo del proyecto, un F.S. inferior a la unidad implica que el talud no es estable.

- Si por el contrario, el F.S. es superior a 1, el talud será estable. Debe tenerse en cuenta que un talud con F.S. = 1 se encuentra en situación de equilibrio límite, siendo necesario un cierto margen sobre la unidad para garantizar la seguridad del talud, y que varía según la aplicación del talud.

Es conveniente asegurar que el talud inicialmente cumple la condición F.S. $>1$, pudiendo lograr un margen adicional a este valor mediante la vegetación.

Tabla 6.- Resultados finales del cálculo de estabilidad de taludes:

\begin{tabular}{|l|c|c|}
\hline \multicolumn{1}{|c|}{ PARÁMETRO } & Símbolo & Unidades \\
\hline Factor de Seguridad & FS & \\
\hline Factor de Seguridad con vegetación & FS $_{\mathrm{v}}$ & \\
\hline Diferencia del F.S. con vegetación respecto a inicial & & \\
\hline Incremento del F.S. con vegetación respecto a inicial & & $\%$ \\
\hline
\end{tabular}

Por otra parte, el programa también proporciona una serie de resultados intermedios que son necesarios para al cálculo final del factor de seguridad, y que aportan información adicional muy útil, acerca de las condiciones del talud. Tales resultados se muestran en la Tabla 7, destacándose los siguientes:

- Parámetros finales que definen los efectos de la vegetación.

- Espaciado entre unidades de plantas.

- Profundidad del plano de deslizamiento.

- Altura de la lámina de agua subterránea sobre el plano de deslizamiento.

- Suma de fuerzas resistentes.

- Suma de fuerzas motoras.

Tabla 7.- Resultados intermedios del cálculo de estabilidad de taludes:

\begin{tabular}{|l|c|c|}
\hline \multicolumn{1}{|c|}{ PARÁMETRO } & Símbolo & Unidades \\
\hline Altura plano de deslizamiento sin vegetación & $\mathbf{Z}$ & $\mathrm{m}$ \\
\hline Altura plano de deslizamiento con vegetación & $\mathbf{Z}^{\prime}$ & $\mathrm{m}$ \\
\hline Altura vertical de la lámina de agua subterránea & $\mathbf{h w}$ & $\mathrm{m}$ \\
\hline
\end{tabular}


DESARROLLO DE UNA APLICACIÓN INFORMÁTICA PARA EL CÁLCULO DE SOSTENIMIENTO DE TALUDES MEDIANTE REVEGETACIÓN

ANEXO V.- DESARROLLO DE LA APLICACIÓN INFORMÁTICA:

ANÁLISIS INTEGRAL DE RESTAURACIÓN Y ESTABILIZACIÓN DE LADERAS

\begin{tabular}{|l|c|c|}
\hline $\begin{array}{l}\text { Altura vertical de la lámina de agua sobre plano de } \\
\text { deslizamiento con vegetación }\end{array}$ & hv & $\mathrm{m}$ \\
\hline & $\mathbf{E R}$ & $\mathrm{kN} / \mathrm{m}^{2}$ \\
\hline Sumatorio fuerzas resistentes & $\mathbf{\Sigma F R}$ & $\mathrm{kN} / \mathrm{m}^{2}$ \\
\hline Sumatorio fuerzas resistentes con vegetación & $\mathbf{\Sigma F M}$ & $\mathrm{kN} / \mathrm{m}^{2}$ \\
\hline Sumatorio fuerzas motoras & $\mathbf{\Sigma F M} \mathbf{v}$ & $\mathrm{kN} / \mathrm{m}^{2}$ \\
\hline Sumatorio fuerzas motoras con vegetación & & $\mathrm{kN} / \mathrm{m}^{2}$ \\
\hline & $\mathbf{W} \mathbf{N}$ & $\mathrm{kN} / \mathrm{m}^{2}$ \\
\hline $\begin{array}{l}\text { Sobrecarga de vegetación } \\
\text { (especie n) }\end{array}$ & $\mathbf{T N}$ & \\
\hline Fuerza tracción raíces (especie $\mathrm{n})$ & & \\
\hline
\end{tabular}

Tabla 7 (continuación).- Resultados intermedios del cálculo de estabilidad de taludes:

\begin{tabular}{|l|c|c|}
\hline \multicolumn{1}{|c|}{ PARÁMETRO } & Símbolo & Unidades \\
\hline Sobrecarga de la vegetación (mezcla) & Wv0 & $\mathrm{kN} / \mathrm{m}^{2}$ \\
\hline Fuerza del viento (mezcla) & D0 & $\mathrm{kN} / \mathrm{m}^{2}$ \\
\hline Profundidad media de raíces (final) & pr & $\mathrm{m}$ \\
\hline Cohesión de las raíces (mezcla) & $\mathbf{c R 0}$ & $\mathrm{kN} / \mathrm{m}^{2}$ \\
\hline Fuerza de tracción de las raíces (mezcla) & T0 & $\mathrm{kN} / \mathrm{m}^{2}$ \\
\hline & & $\mathrm{m}$ \\
\hline Espaciado de plantas & & $\mathrm{kN} / \mathrm{m}^{2}$ \\
\hline Sobrecarga de la vegetación (final) & $\mathbf{W v}$ & $\mathrm{kN} / \mathrm{m}^{2}$ \\
\hline Fuerza del viento (final) & $\mathbf{D}$ & $\mathrm{kN} / \mathrm{m}^{2}$ \\
\hline Cohesión de las raíces (final) & $\mathbf{c R}$ & $\mathrm{kN} / \mathrm{m}^{2}$ \\
\hline Fuerza de tracción de las raíces (final) & $\mathbf{T}$ & \\
\hline & & $\mathrm{kN} / \mathrm{m}^{2}$ \\
\hline Peso total & $\mathbf{W}$ & $\mathrm{kN} / \mathrm{m}^{2}$ \\
\hline Cohesión efectiva mejorada & $\mathbf{c}^{\prime}$ & \\
\hline
\end{tabular}




\section{DOCUMENTO 1.- PSEUDOCódIGO}

El funcionamiento de la aplicación informática se explica según el siguiente pseudocódigo:

ANÁLISIS INTEGRAL DE RESTAURACIÓN Y ESTABILIZACIÓN DE LADERAS V 1.0

>Inicio del programa

¿Talud con vegetación?

NO talud_tipo $=0$

$>$ Iniciar CALCULO DE ESTABILIDAD SIN VEGETACIÓN

SI talud_tipo $=1$

>Iniciar CALCULO DE ESTABILIDAD CON VEGETACIÓN

>CALCULO DE ESTABILIDAD SIN VEGETACIÓN

¿Disponibilidad de parámetros de suelo?

NO param_suelo $=0$

$>$ ¿Tipo de suelo?

tipo_suelo $=G W, G P \ldots[14$ clases $]$

>Asignar valores de parámetros para GW, GP ...

cohesión

roz interno

$>$ Pasar a radianes

peso_esp

SI param_suelo $=1$

$>$ Indicar valores de parámetros

tipo_suelo

cohesión

roz_interno

$>$ Pasar a radianes

peso_esp

$>$ Asignar valores.

¿Parámetros del talud?

$>$ Indicar $\boldsymbol{\beta}$ (inclinación)

incl_talud

$>$ Pasar a radianes

¿Inclinación del talud $<6^{\circ}$ ?

Sl incl_talud $<6$

$>$ Error - inclinación no admisible.

SI incl_talud >= 6 --- comprobar:

¿Tipo de suelo?

SI tipo-suelo = GW, GP...SP

¿Inclinación del talud?

SI incl_talud $>35$

>Error - inclinación no admisible para este tipo de suelo. SI tipo-suelo $=\mathrm{SM}, \ldots \mathrm{CH}$ (resto de tipos)
¿Inclinación del talud?

¿Inclinación del talud?
SI incl_talud $>70$

$>$ Error - inclinación no admisible

para este tipo de suelo.

SI incl_talud > =6; (tipo-suelo = granulares y incl_talud $\left.<35^{\circ}\right)$

(tipo-suelo $=$ cohesivos $y$ incl_talud $<70^{\circ}$ )

>continuar... 
DESARROLLO DE UNA APLICACIÓN INFORMÁTICA PARA EL CÁLCULO DE SOSTENIMIENTO DE TALUDES MEDIANTE REVEGETACIÓN

ANEXO V.- DESARROLLO DE LA APLICACIÓN INFORMÁTICA: ANÁLISIS INTEGRAL DE RESTAURACIÓN Y ESTABILIZACIÓN DE LADERAS

>PRECALCULAR z (z0) profundidad plano deslizamiento.

FUNCIÓN:

$$
Z=\frac{c}{[\cos \beta-\operatorname{sen} \beta \operatorname{tag} \varnothing] \gamma}
$$

Resultado: z_deslizamiento 0

SI ż_deslizamiento $0<0,5$

$>$ Asignar z_deslizamiento $=0,5(z=0,5 \mathrm{~m})$

SI z_deslizamiento $\overline{0}>60$

$>$ Asignar z_deslizamiento $=60(z=60 \mathrm{~m})$

NO (z_deslizamientoo entre 0,5 y $60 \mathrm{~m}$ )

>Asignar z_deslizamiento $=$ z_deslizamiento0 (calculado)

>Indicar posición N.F --- Calcular altura vertical de la lámina de agua

SI posición_nf $=1$

$>$ Calcular: $h w \_$agua $=0{ }^{*} z$ deslizamiento

SI posición_nf $=2$

$>$ Calcular: $h w \_$agua $=1 / 8{ }^{*} z$ _deslizamiento

SI posición_nf $=3$

$>$ Calcular: $h w \_$agua $=1 / 4{ }^{*} z$ deslizamiento

SI posición_nf $=4$

$>$ Calcular: $h w \_a g u a=1 / 2{ }^{*} z$ deslizamiento

SI posición_nf $=5$

$>$ Calcular: $h w \_a g u a=1 * z$ deslizamiento

>CALCULAR Fuerzas resistentes

FUNCIÓN: $F R=c+\left(y z-y_{w} h_{w}\right){ }^{*} \cos ^{2} \beta^{*} \operatorname{tang} \varnothing$

$>$ Asignar el resultado a parámetro: fuerzas_resistentes

>CALCULAR Fuerzas motoras

FUNCIÓN: $F M=y z^{*} \operatorname{sen} \beta^{*} \cos \beta$

$>$ Asignar el resultado a parámetro: fuerzas_motoras

\section{>CALCULAR FACTOR DE SEGURIDAD}

FUNCIÓN: FS = FR $/$ FM

>Asignar el resultado a parámetro: factor_seguridad

¿Estabilidad del talud?

SI factor seguridad $>1$

$>$ talud estable

NO factor_seguridad $<=1$

$>$ talud inestable 


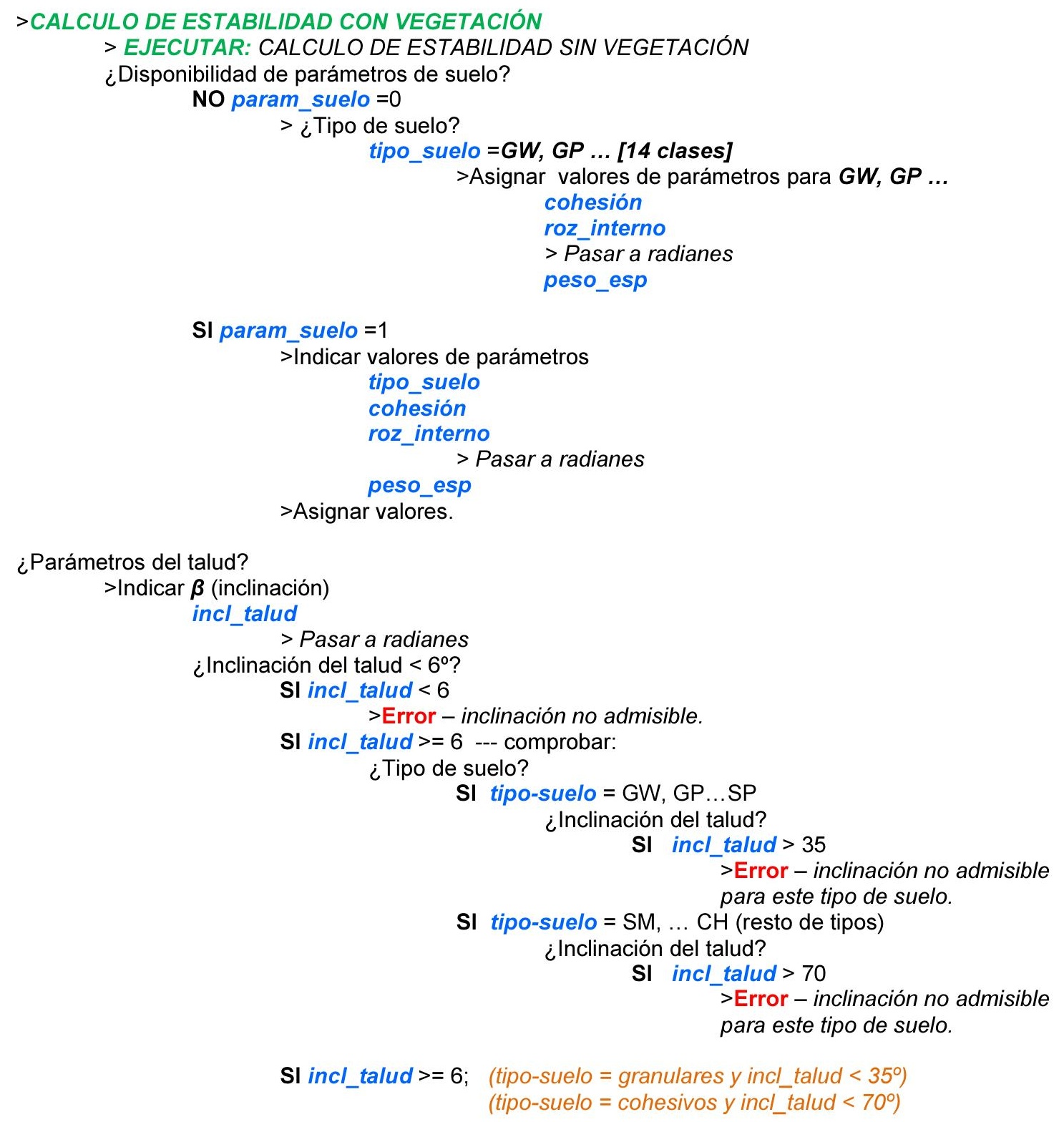

>PRECALCULAR z (z0) profundidad plano deslizamiento.

FUNCIÓN

$$
Z=\frac{c}{[\cos \beta-\operatorname{sen} \beta \operatorname{tag} \varnothing] \gamma}
$$

Resultado: z_deslizamiento0

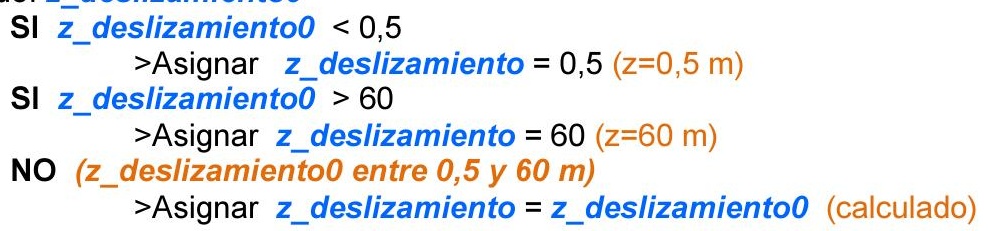


>Indicar posición N.F --- Calcular altura vertical de la lámina de agua

SI posición_nf $=1$

$>$ Calcular: $h w \_a g u a=0 * z$ deslizamiento

SI posición_nf $=2$

$>$ Calcular: $h w \_$agua $=1 / 8{ }^{*} z$ _deslizamiento

SI posición_nf $=3$

$>$ Calcular: $h w \_$agua $=1 / 4{ }^{*} z$ _deslizamiento

SI posición_nf $=4$

$>$ Calcular: $h w$ agua $=1 / 2{ }^{*} z$ _deslizamiento

SI posición_nf $=5$

$>$ Calcular: $h w \_a g u a=1{ }^{*} z$ _deslizamiento

>CALCULAR Fuerzas resistentes

FUNCIÓN: FR= c + $\left(y z-\gamma_{w} h_{w}\right){ }^{*} \cos ^{2} \beta^{*} \operatorname{tang} \varnothing$

$>$ Asignar el resultado a parámetro: fuerzas_resistentes

>CALCULAR Fuerzas motoras

FUNCIÓN: $F M=y z^{*} \operatorname{sen} \beta^{*} \cos \beta$

$>$ Asignar el resultado a parámetro: fuerzas motoras

\section{>CALCULAR FACTOR DE SEGURIDAD}

\section{FUNCIÓN: FS = FR / FM}

>Asignar el resultado a parámetro: factor seguridad

¿Estabilidad del talud?

SI factor seguridad $>1$

NO factor_seguridad $<=1$

$>$ talud estable

$>$ talud inestable

>continuar con cálculo de estabilidad con vegetación

> EJECUTAR: CALCULO DE ESTABILIDAD CON VEGETACIÓN

¿Disponibilidad de parámetros de vegetación?

NO param_vegetacion $=0$

¿Especie vegetal?

PRIMERA ESPECIE VEGETAL

especie_vegetal_1 = Acer campestre, Arbutus unedo, ... [55 clases]

>Asignar valores de parámetros para tipo: Acer campestre, ...

tipo_vegetación_1

herbácea

arbustiva

arbórea

diámetro_tallo_1

densidad_madera_1

altura_plānta_1

factor forma 1

fuerza viento 1

diámetro_raiz_1

densidad raiz 1

profund_raiz_ 1

resist_traccion_1

$>$ Asignar valores

cohesion_raiz_ 1 
>CALCULAR parámetros derivados: vegetación 1 (sobrecarga, f. tracción). ¿Vegetación herbácea?

SI tipo_vegetación_1 = herbácea

$>$ peso_vegetación_1 = 0 (sobrecarga)

$>$ fuerza_viento_1 = 0

NO tipo_vegetación_1 = arbórea o arbustiva

$>$ Calcular sobrecarga. vegetación 1

FUNCIÓN: $W_{v}\left(k N / m^{2}\right)=$ Dens.madera ${ }^{*} \pi / 4^{*}(D t)^{2}{ }^{*} h_{t}{ }^{*} f . f * g$ $>$ Resultado: peso_vegetación_1

>Asignar valor calculado del parámetro

>Calcular fuerza de tracción. vegetación 1

FUNCIÓN: $\operatorname{Tr}\left(k N / \mathrm{m}^{2}\right)=\mathrm{TO}\left(\mathrm{N} / \mathrm{mm}^{2}\right){ }^{*} \pi^{*}(\mathrm{D} . \mathrm{r} / 2)^{2}{ }^{*}$ d.r/1000

$>$ Resultado: fuerza_tracción_1

$>$ Asignar valor calculado del parámetro

SEGUNDA ESPECIE VEGETAL

especie_vegetal_2 = Acer campestre, Arbutus unedo, ... [55 clases]

>Asignar valores de parámetros para tipo : Acer campestre, ... tipo_vegetación_2

herbácea

arbustiva

arbórea

diámetro_tallo_2

densidad_madera_2

altura planta 2

factor_forma_2

fuerza viento 2

diámetro_raiz_2

densidad_raiz_2

profund_raiz_ $\overline{2}$

resist_traccion_2

cohesion raiz $\overline{2}$

>Asignar valores

>CALCULAR parámetros derivados: vegetación 2 (sobrecarga, f. tracción). ¿Vegetación herbácea?

SI tipo_vegetación_2 = herbácea

$>$ peso_vegetación_2 = 0 (sobrecarga)

$>$ fuerza_viento_2 $=0$

NO tipo_vegetación_2 = arbórea o arbustiva

>Calcular sobrecarga. vegetación 2

FUNCIÓN: $W_{v}\left(k N / m^{2}\right)=$ Dens.madera ${ }^{*} \pi / 4^{*}(D t)^{2}{ }^{*} h_{t}{ }^{*} f . f * g$ >Resultado: peso_vegetación_2

>Asignar valor calculado del parámetro

$>$ Calcular fuerza de tracción. vegetación 2

FUNCIÓN: $\operatorname{Tr}\left(\mathrm{kN} / \mathrm{m}^{2}\right)=$ T0 $\left(\mathrm{N} / \mathrm{mm}^{2}\right){ }^{*} \pi^{*}(\mathrm{D} . \mathrm{r} / 2)^{2}{ }^{*}$ d.r/1000

$>$ Resultado: fuerza_tracción_2

$>$ Asignar valor calculado del parámetro 


\section{>repeticiones que sean necesarias}

ÚLTIMA ESPECIE VEGETAL

especie_vegetal_N = Acer campestre, Arbutus unedo, ... [55 clases]

>Asignar valores de parámetros para tipo : Acer campestre, ... tipo_vegetación_N

herbácea

arbustiva

arbórea

diámetro_tallo_N

densidad_madera_N

altura_planta_N

factor_forma_ $N$

fuerza_viento_N

diámetro raiz $N$

densidad_raiz_N

profund_raiz_N

resist_traccion_N

cohesion_raiz_N

>Asignar valores

>CALCULAR parámetros derivados: vegetación $\mathbf{N}$ (sobrecarga, f. tracción). ¿Vegetación herbácea?

SI tipo_vegetación_N = herbácea

$>$ peso_vegetación_ $N=0$ (sobrecarga)

$>$ fuerza_viento_N $=0$

NO tipo_vegetación_N = arbórea o arbustiva

$>$ Calcular sobrecarga. vegetación $\mathbf{N}$

FUNCIÓN: $W_{v}\left(k N / m^{2}\right)=$ Dens.madera * $\pi / 4^{*}(D t)^{2}{ }^{*} h_{t}{ }^{*} f . f * g$

$>$ Resultado: peso_vegetación_N

>Asignar valor calculado del parámetro

>Calcular fuerza de tracción. vegetación $\mathbf{N}$

FUNCIÓN: $\operatorname{Tr}\left(k N / m^{2}\right)=$ T0 $\left(\mathrm{N} / \mathrm{mm}^{2}\right)^{*} \pi^{*}(\mathrm{D} . \mathrm{r} / 2)^{2}{ }^{*}$ d.r/1000

$>$ Resultado: fuerza_tracción_N

>Asignar valor calculado del parámetro

(Parámetros básicos:

cohesion raiz $N$; fuerza tracción $N$;

peso_vegetación_N; fuerza_viento__N; profund_raiz)

¿Distribución de especies?

>INDICAR distribución de especies

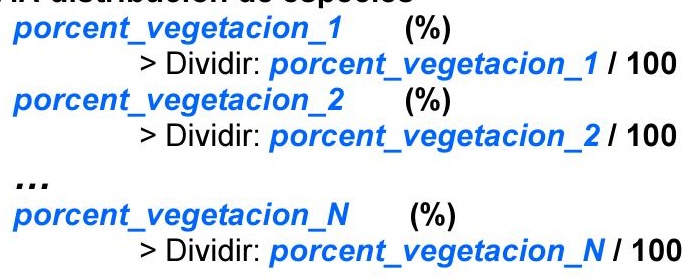

>Asignar \% especies vegetales. 
>Calcular parámetros MEZCLA

Cohesión de las raíces.

>FUNCIÓN: $c R 0=\left[c R 1 * \% 1+c R 2 * \% 2 \ldots+c R N^{*} \% N\right]$

$>$ Asignar resultado: cohesion_raiz_O

Fuerza de tracción de las raíces.

$>$ FUNCIÓN: $T 0=\left[T r 1 * \% 1+T r 2 * \% 2 \ldots+T r N^{*} \% N\right]$

$>$ Asignar resultado: fuerza_tracción_0

Sobrecarga de la vegetación.

>FUNCIÓN: $W_{v} 0=\left[W_{v} 1 * \%+W_{v} 2 * \% 2 \ldots+W_{v} N * N \%\right]$

Fuerza del viento.

$>$ Asignar resultado: peso_vegetación_o

>FUNCIÓN: $D 0=[D 1 * \% 1+D 2 * \% 2 \ldots+D N * \% N]$

$>$ Asignar resultado: fuerza_viento_o

Profundidad de las raíces.

$>$ FUNCIÓN: $p . r=[p . r 1 * \% 1+p . r 2 * \% 2 \ldots+p . r N * \% N]$

$>$ Asignar resultado: profund_raiz

$>$ Calcular parámetros FINALES

¿Densidad de plantación?

>INDICAR densidad de plantación

dens_vegetacion (unidades / ha)

$>$ Calcular espaciado

> Dividir 1/10.000 -- Pasar a ud. / $\mathbf{m}^{2}$

$>$ Calcular espaciado

>FUNCIÓN: $100 / \sqrt{ }$ dens_vegetacion (unidades / ha)

$>$ Asignar resultado: espaciado

SI espaciado $>10$

$>$ Error - zonas sin cubrir

NO espaciado $<=10$

(no hay efecto arco)

>continuar... (hay efecto arco)

Cohesión de las raíces.

>FUNCIÓN: cRO* dens_vegetacion ud. / $\mathbf{m}^{2}$

$>$ Asignar resultado: cohesion_raiz

Fuerza de tracción de las raíces.

>FUNCIÓN: T0* dens_vegetacion ud. $/ \mathrm{m}^{2}$ $>$ Asignar resultado: fuerza_tracción

Sobrecarga de la vegetación.

>FUNCIÓN: $W_{v} 0^{*}$ dens_vegetacion ud. $/ \mathrm{m}^{2}$

Fuerza del viento.

>Asignar resultado: peso_vegetación

$>$ FUNCIÓN: D0* dens_vegetacion ud. $/ \mathrm{m}^{2}$ >Asignar resultado: fuerza_viento

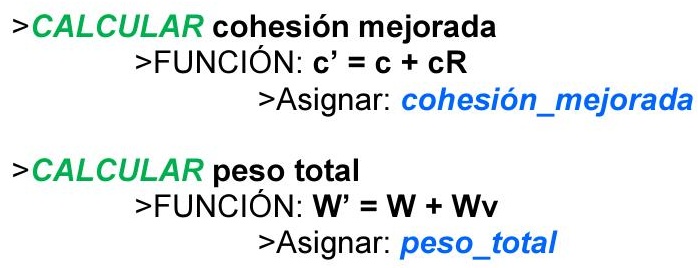

Traer parámetros desde: cálculo de estabilidad sin vegetación: cohesion roz_interno peso_esp incl.,talud clasēnf 
DESARROLLO DE UNA APLICACIÓN INFORMÁTICA PARA EL CÁLCULO DE SOSTENIMIENTO DE TALUDES MEDIANTE REVEGETACIÓN

ANEXO V.- DESARROLLO DE LA APLICACIÓN INFORMÁTICA:

ANÁLISIS INTEGRAL DE RESTAURACIÓN Y ESTABILIZACIÓN DE LADERAS

>PRECALCULAR z' (z'0) profundidad plano deslizamiento con vegetación

FUNCIÓN: $A=\cos \beta-\operatorname{sen} \beta^{*} \operatorname{tang} \varnothing--B=W_{v}---c^{\prime} I A$

$$
z^{\prime}=\left[c^{\prime} / A-B\right]^{*} 1 /\left(Y_{t}+Y_{w}\right)
$$

Resultado: z_deslizamiento_prima0

SI $\bar{z}$ _deslizamiento_prima0 $<0,5$

$>$ Asignar z_deslizamiento_prima $=0,5(z=0,5 \mathrm{~m})$

SI z_deslizamiento prima0 $>60$

>Asignar z_deslizamiento_prima $=60(\mathrm{z}=60 \mathrm{~m})$

NO (z_deslizamiento 0 entre 0,5 y $\overline{60} \mathrm{~m}$ )

>Asignar z_deslizamiento_prima = z_deslizamiento_prima0 (calc.)

¿Acción de las raíces?

>Comprobar acción de las raíces

SI z_deslizamiento_prima $>$ [profund_raiz - 0,6]

$>$ fuerza_tracción $=0 \quad(T=0)$

NO z_deslizamiento_prima $<=[$ profund_raiz - 0,6]

>continuar ... (fuerza_tracción =valor asignado)

>Indicar posición N.F --- Calcular altura vertical de la lámina de agua con vegetación

SI posición_nf $=1$

$>$ Calcular: $h v \_a g u a=0 * z$ deslizamiento_prima

SI posición_nf $=2$

$>$ Calcular: $h v \_$agua $=1 / 8^{*} z$ deslizamiento_prima

SI posición_nf $=3$

$>$ Calcular: $h v \_$agua $=1 / 4{ }^{*} z$ deslizamiento_prima

SI posición_nf $=4$

$>$ Calcular: $h v \_$agua $=1 / 2{ }^{*} z$ _deslizamiento_prima

SI posición_nf $=5$

$>$ Calcular: $h v \_a g u a=1 * z$ deslizamiento_prima

>CALCULAR Fuerzas resistentes con vegetación

FUNCIÓN:

$$
\begin{aligned}
& E=\left[\left(y z^{*}-\gamma_{w} h_{v}\right)+w_{v}\right]^{*} \cos ^{2} \beta \\
& F=T^{*} \operatorname{sen} \theta \\
& (E+F){ }^{*} \operatorname{tang} \varnothing \\
& G=T^{*} \cos \theta
\end{aligned}
$$

$F R=c^{\prime}+(E+F)^{*} \operatorname{tang} \varnothing+G$

$>$ Asignar el resultado a parámetro: fuerzas_resistentes_v

>CALCULAR Fuerzas motoras con vegetación

FUNCIÓN:

$H=\left(y z^{\prime}+W v\right)^{*} \operatorname{sen} \beta$

$F M=(H+D)^{*} \cos \beta$

$>$ Asignar el resultado a parámetro: fuerzas_motoras_v

>CALCULAR FACTOR DE SEGURIDAD con vegetación

FUNCIÓN: FSv $=$ FRv $/$ FMv 
DESARROLLO DE UNA APLICACIÓN INFORMÁTICA PARA EL CÁLCULO DE SOSTENIMIENTO DE TALUDES MEDIANTE REVEGETACIÓN

ANEXO V.- DESARROLLO DE LA APLICACIÓN INFORMÁTICA:

ANÁLISIS INTEGRAL DE RESTAURACIÓN Y ESTABILIZACIÓN DE LADERAS

>Asignar el resultado a parámetro: factor_seguridad_v

¿Estabilidad del talud?

SI factor_seguridad_v $>1$

>talud estable

NO factor_seguridad_v $<=1$

>talud inestable

¿Efecto arco?

SI espaciado > 10

$>$ no hay efecto arco

NO espaciado <= 10

>efecto arco

>COMPARAR RESULTADOS

$>$ CALCULAR diferencia de factores de seguridad

>Restar: factor_seguridad_v - factor_seguridad

Resultādo = diferencia_fs

$>$ CALCULAR incremento (\%)

>Dividir: diferencia_fs / factor_seguridad

Resultado = incremento_fs $\times 100$--- \%

SI incremento_fs $>100 \%$

>Error - variación anómala o disminución de F.S.

$>$ Limitar incremento.

SI incremento_fs $<0$ (negativo)

>Error - variación anómala o disminución de F.S.

NO incremento_fs de 0 a $100 \%$

$>$ Mostrar resultados

¿Repetir cálculos?

SI

NO

$>$ Volver a Inicio del programa

>FINALIZAR 


\section{DOCUMENTO 2.- DIAGRAMAS DE FLUJO}

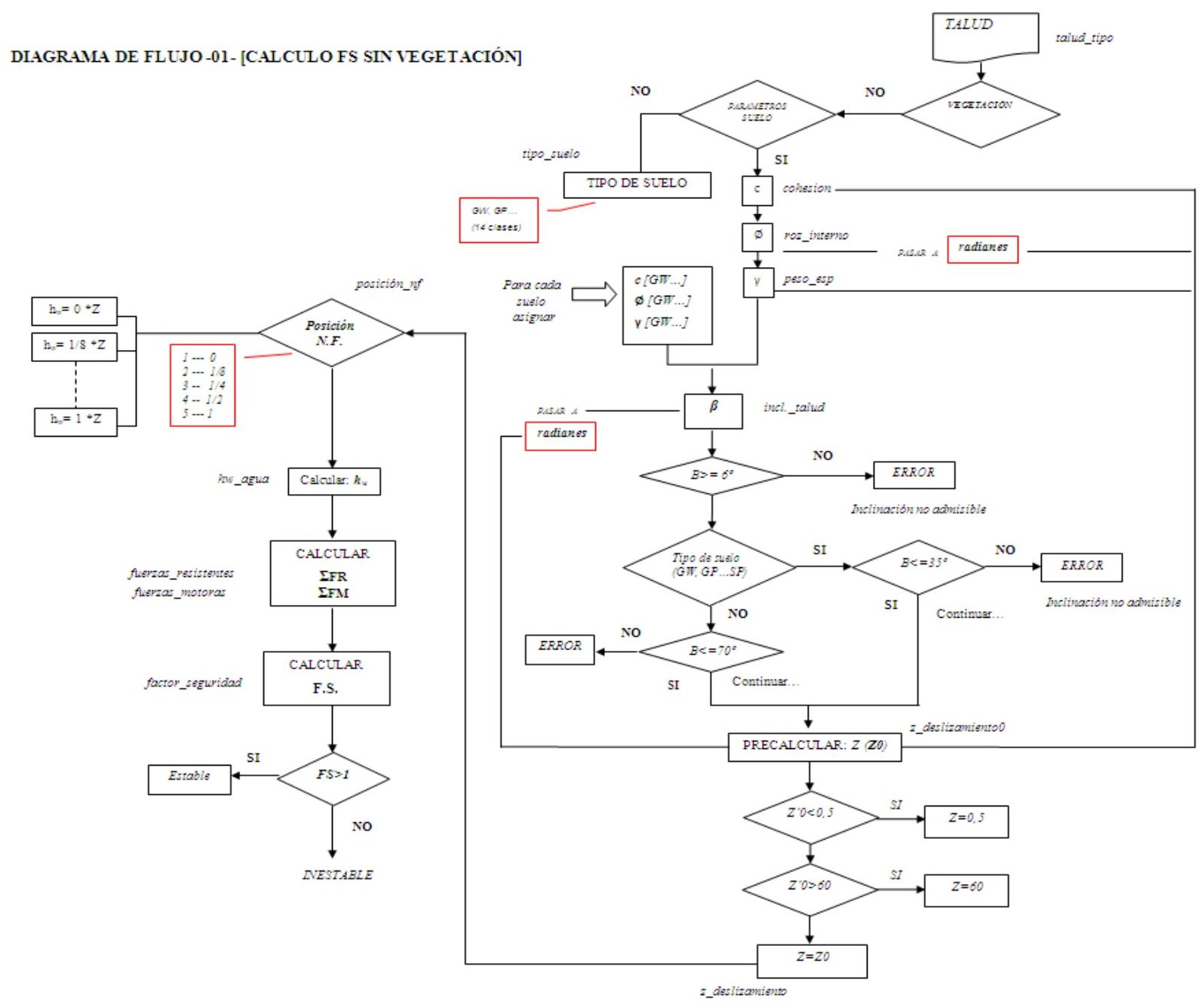




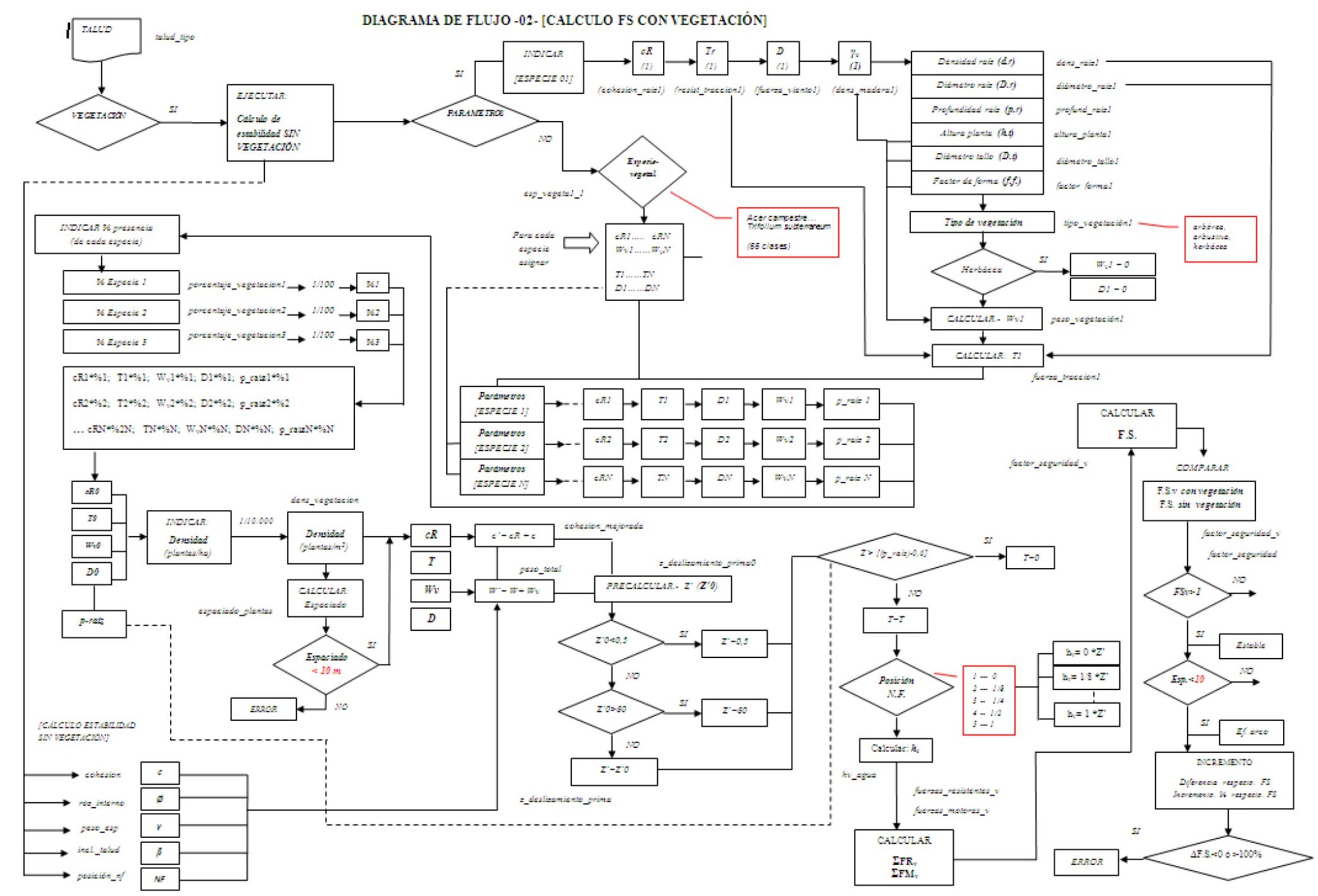




\section{ANEXO VI \\ MANUAL DEL PROGRAMA \\ ANÁLISIS INTEGRAL DE RESTAURACIÓN Y ESTABILIZACIÓN DE LADERAS 1.0}

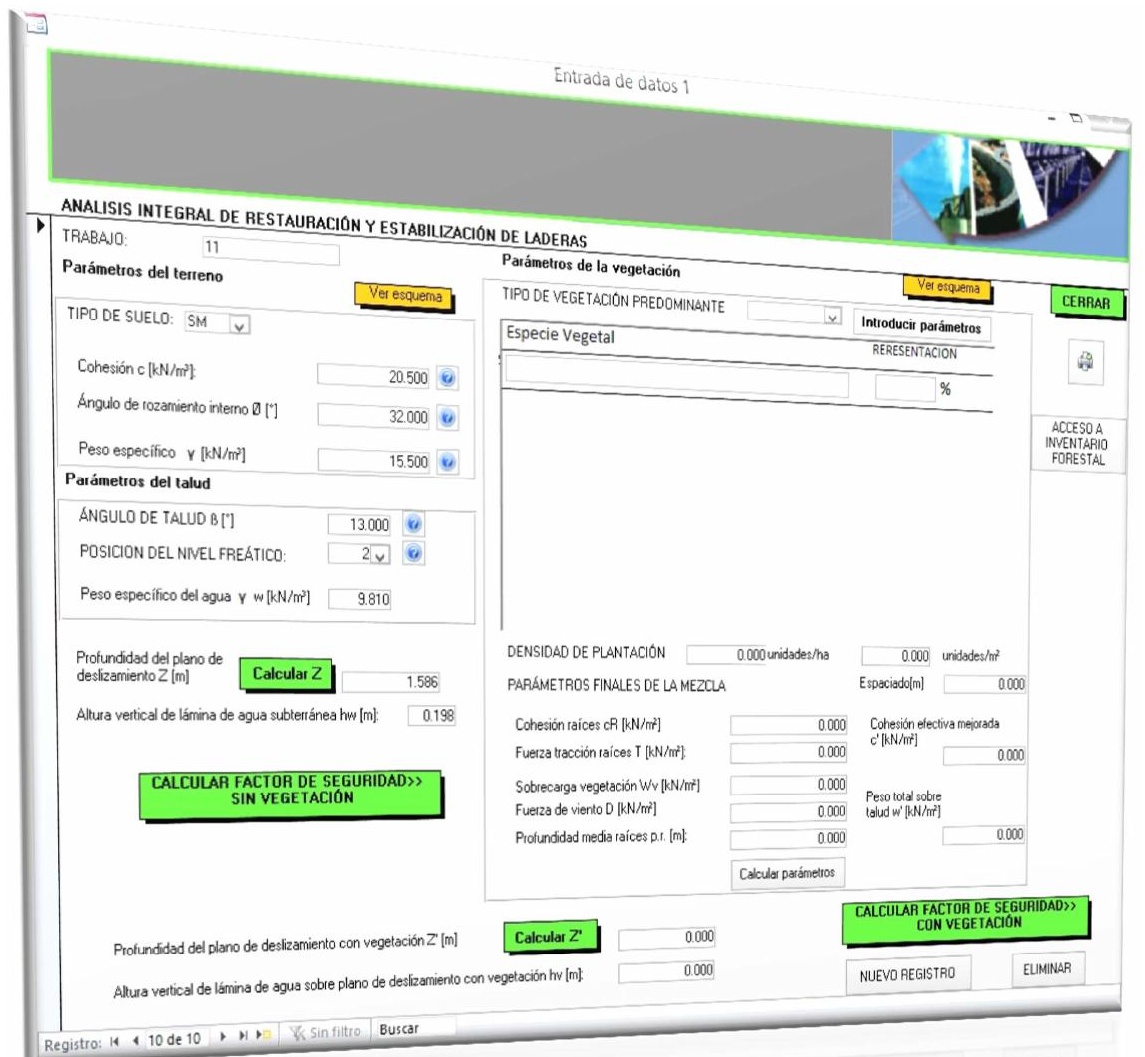




\section{ÍNDICE}

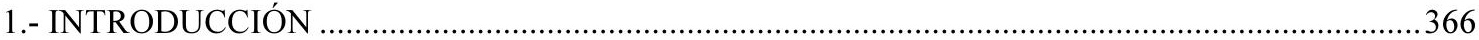

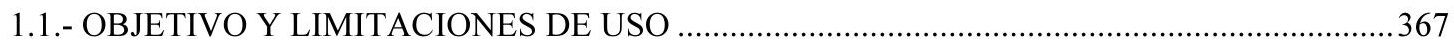

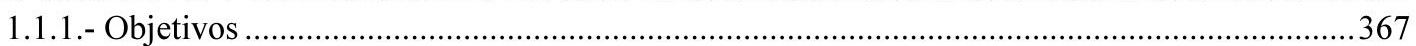

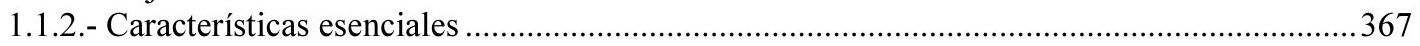

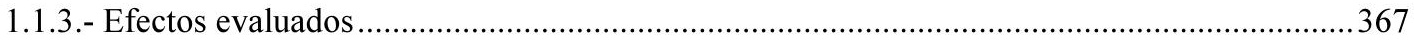

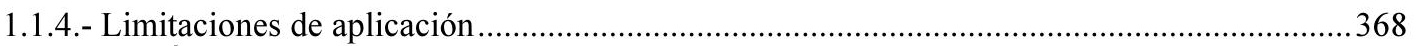

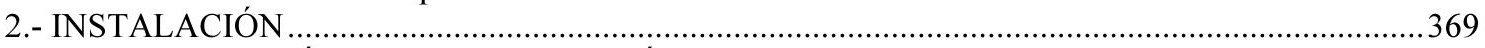

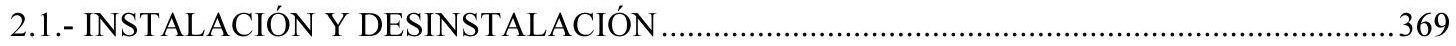

2.1.1.- Procedimiento de instalación...............................................................................................369

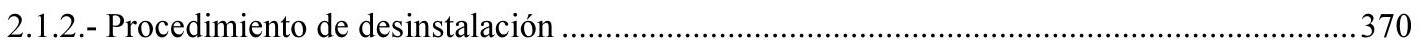

2.2.- SISTEMA DE FICHEROS Y REGISTROS......................................................................... 370

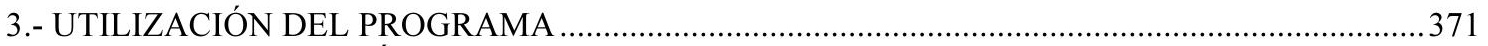

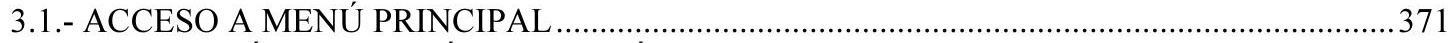

3.2.- APLICACIÓN INFORMÁTICA: "ANÁLISIS DE ESTABILIDAD DE TALUDES” ................372

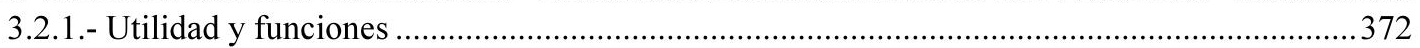

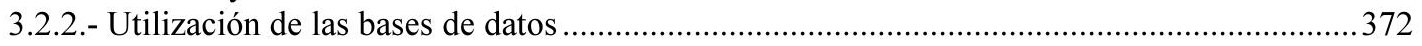

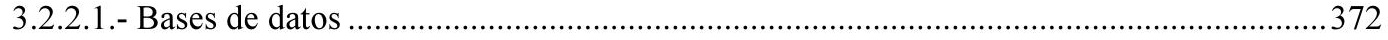

3.2.2.2.- Operativa de trabajo con las bases de datos ...................................................................... 376

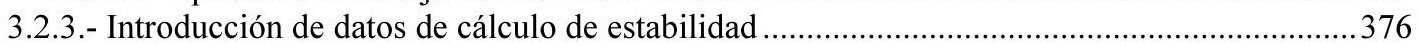

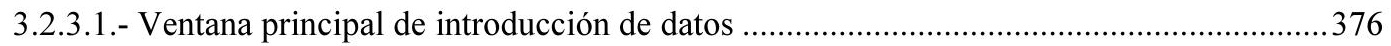

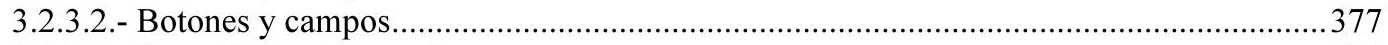

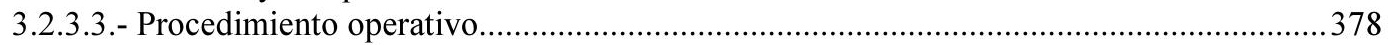

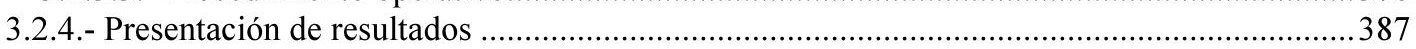

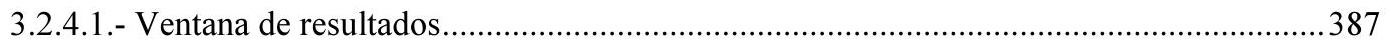

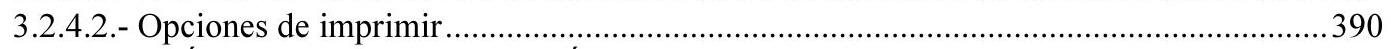

4.- EJEMPLOS PRÁCTICOS DE UTILIZACIÓN DEL PROGRAMA …………......................................391

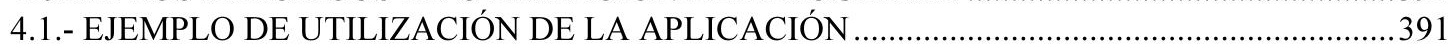

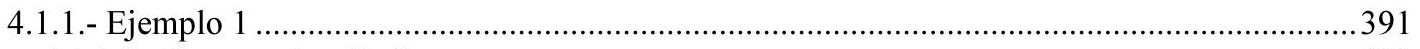

4.1.1.1.- Proceso de cálculo ..................................................................................................... 391 


\section{1.- INTRODUCCIÓN}

El programa Análisis Integral de Restauración y Estabilización de Laderas, es una herramienta informática de fácil manejo, altamente versátil, que permite estudiar las mejores opciones de restauración de un entorno alterado, tanto desde el punto de vista de la adaptación a las condiciones de la zona, como de la contribución a la estabilidad de taludes o laderas naturales.

El programa ofrece las herramientas básicas para evaluar y mitigar los riesgos producidos por inestabilidad del terreno, planteándose las siguientes aplicaciones:

$\checkmark$ Recuperación de las cuencas mineras tanto del carbón como de la pizarra y piedra natural, ya sean pozos de explotación como escombreras.

$\checkmark$ Reforestación de montes, que han sufrido deterioro por incendios, por tala o por intento de explotación de monte.

$\checkmark$ Implantación de nuevos cultivos para un aprovechamiento máximo del monte.

$\checkmark$ Conservación del medio ambiente, teniendo en cuenta para todos los resultados, el impacto ambiental.

$\checkmark$ Estabilización de taludes con riesgos de desprendimientos, deslizamientos,...etc.

$\checkmark$ Estabilización de taludes en obras lineales de nueva construcción. 


\section{1.- OBJETIVO Y LIMITACIONES DE USO}

\subsection{1.- Objetivos}

La aplicación, ha sido desarrollada con objeto de evaluar las opciones de restauración en una zona desde dos puntos de vista:

$\checkmark$ Adaptabilidad al entorno, en función de la ubicación, terreno, clima, y otras variables.

$\checkmark$ Efecto sobre la estabilidad de taludes o laderas, en función de las condiciones del terreno y la vegetación.

\subsection{2.- Características esenciales}

La aplicación dispone de las siguientes características esenciales:

5. Una interfaz gráfica de usuario completa, intuitiva y de fácil manejo.

6. Una base de datos dinámica, en la que se incluyen datos generales de la zona, del terreno, y de la vegetación.

7. Funciones de cálculo que permitan establecer una propuesta de vegetación y calcular el factor de seguridad de taludes.

8. Herramienta gráfica mediante la cual se pueden visualizar los resultados obtenidos.

\subsection{3.- Efectos evaluados}

Los efectos que tiene en cuenta el programa, relacionados con la estabilidad de taludes y con la influencia de la vegetación, son los siguientes:

Tabla 1.- Efectos sobre la estabilidad del talud, evaluados por el programa (terreno).

\begin{tabular}{|l|c|}
\hline Equilibrio límite de fuerzas & $\mathrm{SI}$ \\
\hline Curvatura del plano de deslizamiento & $\mathrm{NO}$ \\
\hline Fuerzas cohesivas & $\mathrm{SI}$ \\
\hline Mecanismo de rozamiento interno & $\mathrm{SI}$ \\
\hline Peso del terreno & $\mathrm{SI}$ \\
\hline Agua subterránea & $\mathrm{SI}$ \\
\hline
\end{tabular}


Tabla 2.- Efectos sobre la estabilidad del talud, evaluados por el programa (vegetación).

\begin{tabular}{|l|c|}
\hline Cohesión efectiva mejorada & $\mathrm{SI}$ \\
\hline Anclaje de las raíces & $\mathrm{SI}$ \\
\hline Sobrecarga de la vegetación & $\mathrm{SI}$ \\
\hline Arrastre del viento & $\mathrm{SI}$ \\
\hline Profundidad raíces / profundidad deslizamiento & $\mathrm{SI}$ \\
\hline Composición de mezcla de especies & $\mathrm{SI}$ \\
\hline Densidad de plantación & $\mathrm{SI}$ \\
\hline Efecto arco & $\mathrm{SI}$ \\
\hline
\end{tabular}

\subsection{4.- Limitaciones de aplicación}

Se establecen los siguientes límites de funcionamiento del programa:

$\checkmark$ Limites de inclinación de talud:

- Inclinación mínima.- 60

- Inclinación máxima para suelo granular (cohesión = 0).- 350

- Inclinación máxima para suelo cohesivo (cohesión >0).- 70은

- Límite de aplicación de plantación de especies arbóreas y arbustivas.- 550

$\checkmark$ Base de datos inicial limitada a fases avanzadas de desarrollo de la vegetación.

$\checkmark$ Propuesta de vegetación, según adaptabilidad al entorno, definidas para las regiones geográficas:

- Provincia de León.- comarca del Bierzo, comarca de Laciana.

- Provincia de Zamora.- norte de Zamora.

$\checkmark$ Resultados óptimos en las condiciones: suelo cohesivo, inclinación de talud de 60 - 57ㅇ․

$\checkmark \quad$ No se evalúa sobrecarga localizada en la cabecera del talud.

$\checkmark \quad$ No se recomiendan densidades de plantación superiores a 2.500 unidades/ha (para arbóreas y arbustivas). 


\section{2.- INSTALACIÓN}

\section{1.- INSTALACIÓN Y DESINSTALACIÓN}

El programa se suministra en un CD-ROM, con una carpeta, con el siguiente contenido:

- Carpeta FILES

- $\quad$ Archivo ejecutable (Setup.exe), para la instalación de este módulo.

- Archivo ejecutable (AccessRuntime.exe), para ordenadores sin Access instalado.

- Base de datos inicial (suelos + especies vegetales).- fichero: 001COLAD.accdb

- Fotografías de especies vegetales.-Archivo: fotos_especies_vegetales.

\subsection{1.- Procedimiento de instalación}

Para la instalación se siguen los pasos que se indican:

1.-Ejecución del CD-ROM:\ESTABILIZACION_LADERAS\INSTALADOR

LADERAS\LADERAS_PROG\setup.exe

2.- Marcar la ruta de instalación: recomendable dejar la ruta marcada por defecto:

C:IESTABILIZACION_LADERAS

Figura 84: Inicio del asistente de instalación.

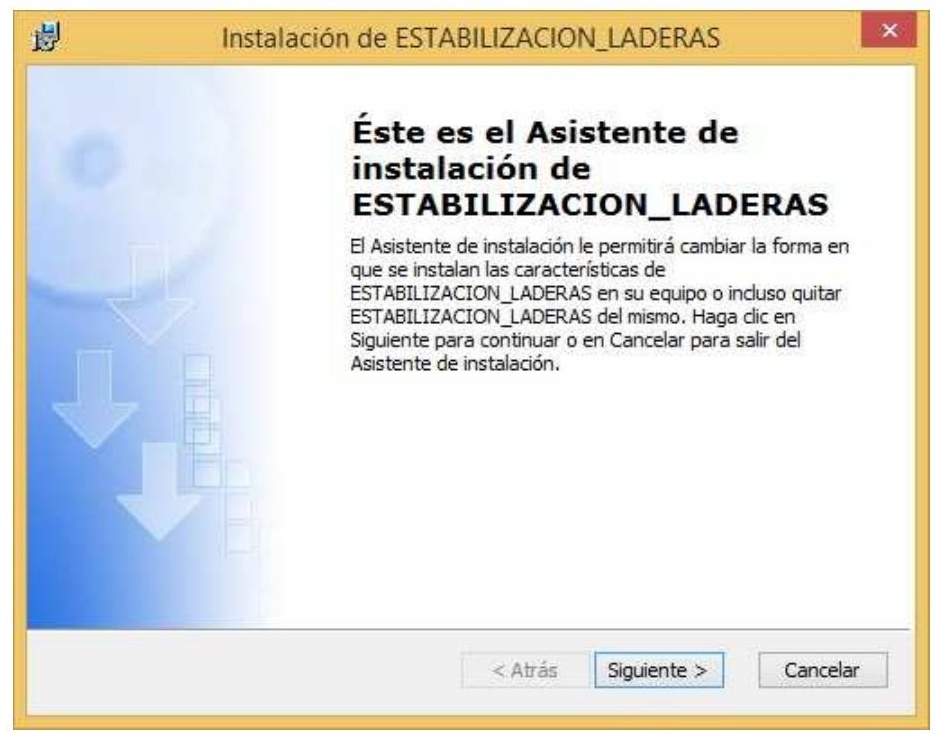


3. Seguir los pasos marcados por el asistente de instalación.

4. Copiar la base de datos inicial (001COLAD.accdb), en la ruta:

\section{C:\ESTABILIZACION_LADERAS}

5. Copiar la carpeta de fotografías de especies vegetales (carpeta), en la ruta:

C:\ESTABLIZACION_LADERAS

6. Para ordenadores sin Microsoft Office Access instalado es necesaria la instalación de la aplicación AccessRuntime.exe.

\subsection{2.- Procedimiento de desinstalación}

Para desinstalar Buscar en el menú: Inicio>Programas>Estabilizacion_Laderas, el fichero de desinstalación de la aplicación o bien utilizar el panel de control, opción aplicaciones, para desinstalar.

A partir de este punto seguir los pasos indicados por el asistente de desinstalación de la aplicación.

\section{2.- SISTEMA DE FICHEROS Y REGISTROS}

El programa utiliza un sistema de registros que permite almacenar y localizar cada uno de los registros almacenados en las bases de datos.

La aplicación informática permite almacenar los registros de las tres bases de datos de que dispone: suelos, especies vegetales y localizaciones, y además los datos de los trabajos (cálculos de estabilidad de taludes). Incluye las herramientas:

- La barra de desplazamiento permite pasar de un registro a otro.

- La opción buscar localiza un registro por el nombre.

Tabla 1.- Opciones de registros.

\begin{tabular}{|c|l|}
\hline NUEVO REGISTRO & $\begin{array}{l}\text { Crea un nuevo registro de la base de datos. } \\
\text { Guarda el anterior. }\end{array}$ \\
\hline ELIMINAR & $\begin{array}{l}\text { Borra un registro. } \\
\text { Se pide confirmación de borrado. }\end{array}$ \\
\hline
\end{tabular}

Figura 85: Organización de la búsqueda de registros.

\begin{tabular}{|l|l|l|l}
\hline Registro: $14<1$ de 1 & $\nabla+1$ Sin filtro & Buscar
\end{tabular}


Las bases de datos pueden ser ampliadas, quedando guardadas en el archivo (001COLAD.accdb). Las bases de datos de cálculo (suelos, especies vegetales), permiten ser actualizadas.

\section{3.- UTILIZACIÓN DEL PROGRAMA}

\section{1.- ACCESO A MENÚ PRINCIPAL}

El programa arranca mediante la ruta de acceso:

Inicio>programas > Estabilización de laderas.exe, o bien mediante el acceso directo del escritorio.

\section{Acceso directo >}

El programa muestra el menú principal:

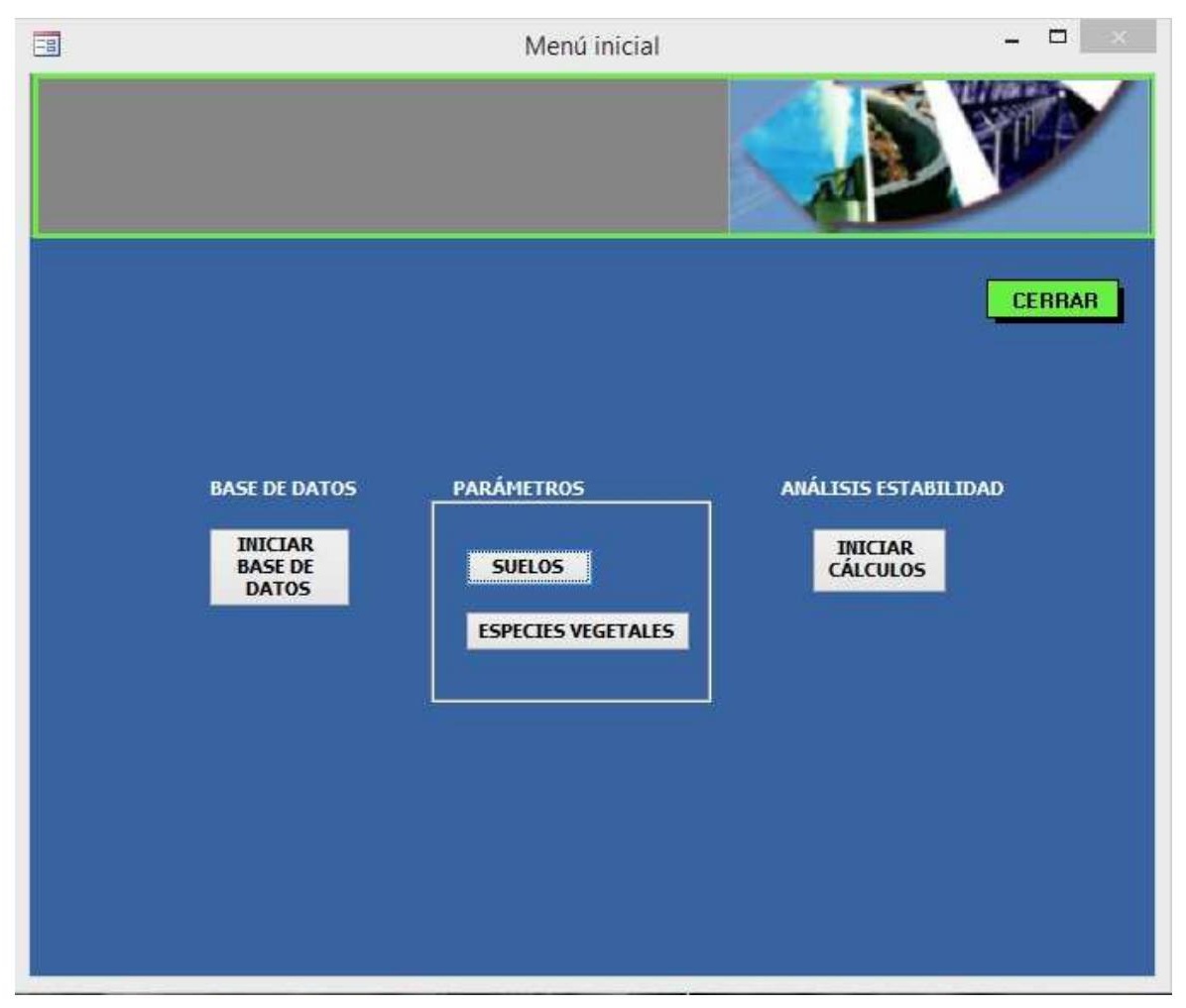

Figura 86: Menú principal.

Es la ventana por la cual se accede por una parte a la base de datos y por otra parte a la herramienta de cálculo del factor de estabilidad. 
El menú principal ofrece las siguientes opciones:

Tabla 2.- Opciones de menú principal.

\begin{tabular}{|c|c|}
\hline $\begin{array}{c}\text { INICIAR } \\
\text { BASE DE } \\
\text { DATOS }\end{array}$ & Accede a la base de datos de localizaciones \\
\hline SUELOS & Actualizar la base de datos de cálculo: suelos \\
\hline ESPECIES VEGETALES & Actualizar la base de datos de cálculo: especies vegetales \\
\hline $\begin{array}{c}\text { INICIAR } \\
\text { CÁLCULOS }\end{array}$ & Inicia la herramienta de cálculo de estabilidad de taludes \\
\hline
\end{tabular}

\section{2.- APLICACIÓN INFORMÁTICA: “ANÁLISIS DE ESTABILIDAD DE TALUDES”}

\subsection{1.- Utilidad y funciones}

Aplicación:

$\checkmark$ Evaluación de la estabilidad de taludes, para determinar el incremento de estabilidad atribuido a la presencia de vegetación.

Presenta las funciones:

- Base de datos de localizaciones.

- Base de datos de cálculo:

$\checkmark$ Suelos.

$\checkmark$ Especies vegetales.

- Herramienta de cálculo de factor de seguridad.

$\checkmark$ Talud en su estado inicial.

$\checkmark$ Talud restaurado, y comparativa.

\subsection{2.- Utilización de las bases de datos}

\subsubsection{1.- Bases de datos}

\section{BASE DE DATOS DE SUELOS}

En esta ventana se introducen los tipos de suelos conocidos y sus características (denominación, cohesión, ángulo de rozamiento interno y peso específico). 
Figura 87: Ventana de la base de datos de suelos.

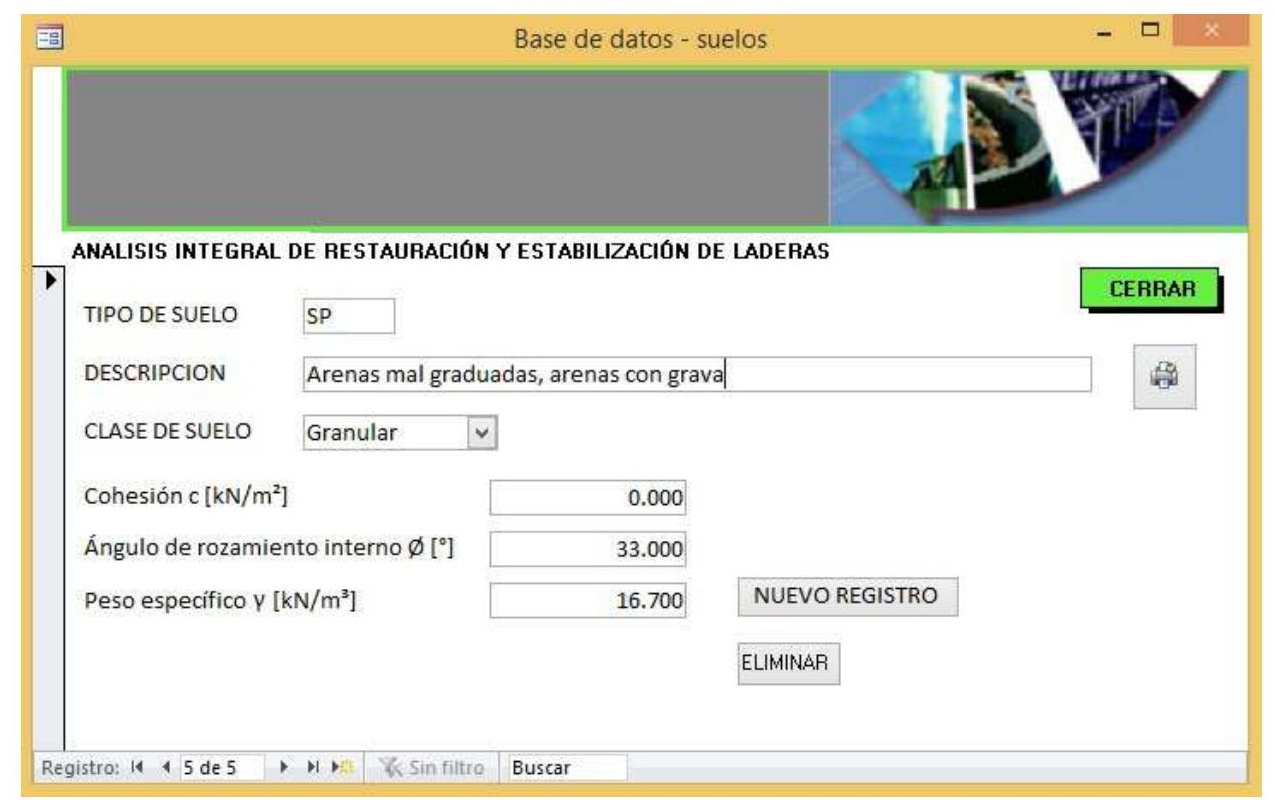

Tabla 3.- Parámetros de la base de datos de suelos.

\begin{tabular}{|l|c|c|}
\hline \multicolumn{1}{|c|}{ PARÁMETRO } & Símbolo & Unidades \\
\hline Tipo de suelo & & $\begin{array}{c}\mathrm{GW} \ldots \mathrm{CH} \\
(14 \mathrm{clases})\end{array}$ \\
\hline Cohesión & $\mathrm{c}$ & $\mathrm{kN} / \mathrm{m}^{2}$ \\
\hline Ángulo de rozamiento interno & $\emptyset$ & grados sexagesimal \\
\hline Peso específico del suelo & $\mathrm{Y}$ & $\mathrm{kN} / \mathrm{m}^{3}$ \\
\hline
\end{tabular}

\section{BASE DE DATOS DE ESPECIES VEGETALES}

En esta ventana se introducen los parámetros de la raíz y tallo, correspondiente a cada especie vegetal necesarios para el cálculo de dos parámetros fundamentales en la determinación posterior del factor de seguridad que son la fuerza de tracción de las raíces $\boldsymbol{T}$ $\left(\mathrm{kN} / \mathrm{m}^{2}\right)$ y la sobrecarga de la vegetación $\boldsymbol{W v}\left(\mathrm{kN} / \mathrm{m}^{2}\right)$. También tiene la opción de insertar foto o imagen descriptiva de la especie arbórea, arbustiva o herbácea que designemos. 
DESARROLLO DE UNA APLICACIÓN INFORMÁTICA PARA EL CÁLCULO DE SOSTENIMIENTO

DE TALUDES MEDIANTE VEGETACIÓN

ANEXO VI.- MANUAL DEL PROGRAMA: ANÁLISIS INTEGRAL DE RESTAURACIÓN Y ESTABILIZACIÓN DE LADERAS

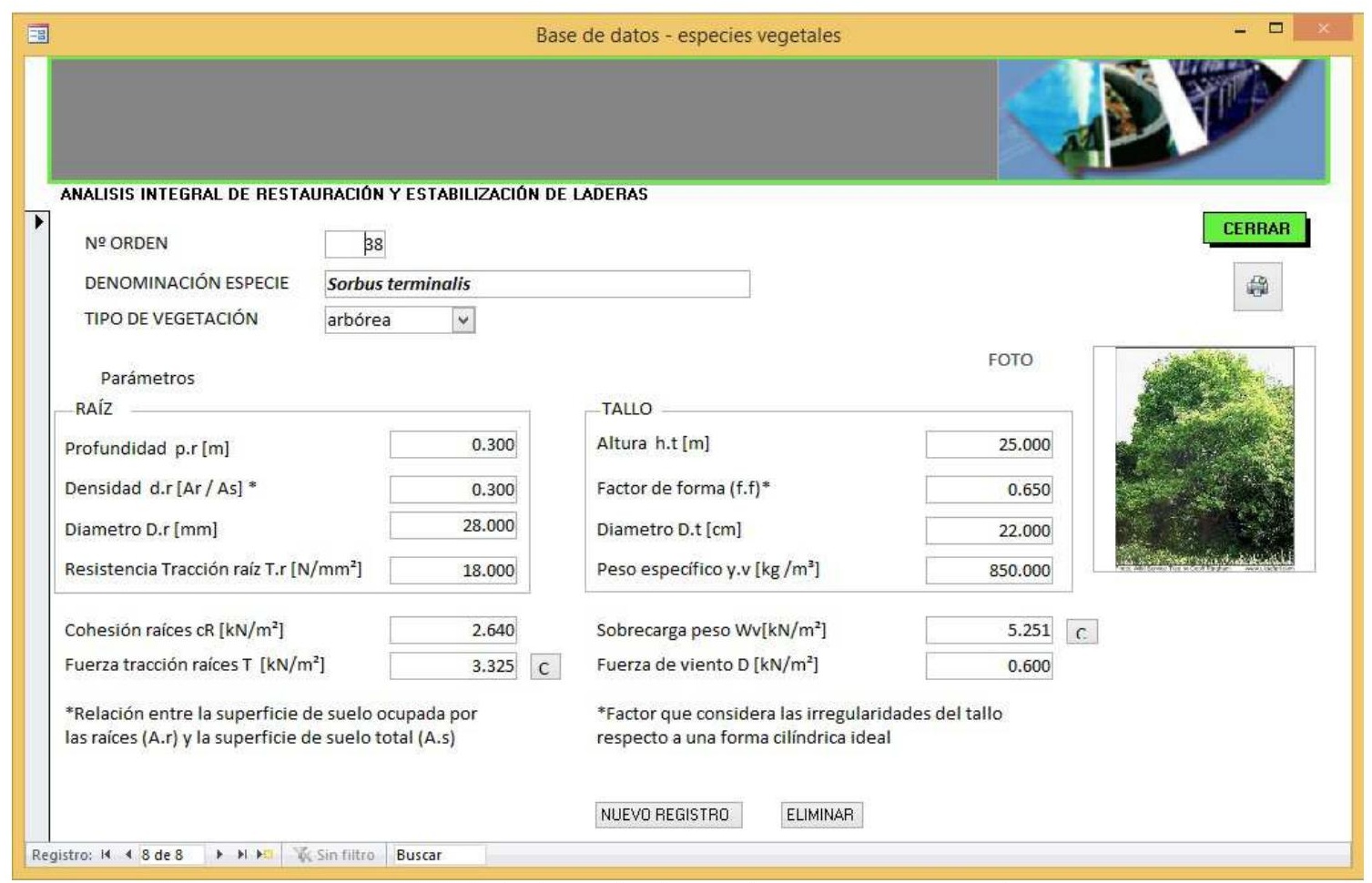

Figura 88: Ventana de la base de datos de especies vegetales.

Tabla 4.- Parámetros de la base de datos de especies vegetales.

\begin{tabular}{|c|c|c|}
\hline PARÁMETRO & Símbolo & Unidades \\
\hline Número de orden & & - \\
\hline Especie vegetal $n$ & & $\begin{array}{c}\text { Acer campestre...Trifolium } \\
\text { subterraneum } \\
\text { (55 clases) }\end{array}$ \\
\hline Tipo de vegetación (especie $n$ ) & & (arbórea- arbustiva-herbácea) \\
\hline Diámetro medio del tallo (especie $n$ ) & DtN & $\mathrm{cm}$ \\
\hline Densidad de la madera (especie $n$ ) & $\mathrm{V} v \mathrm{v}_{\mathrm{v}} \mathrm{N}$ & $\mathrm{kg} / \mathrm{m}^{3}$ \\
\hline Altura de la planta (especie $n$ ) & htN & $\mathrm{m}$ \\
\hline Factor de forma del tronco (especie $n$ ) & f.f.N & \\
\hline Fuerza del viento (especie $n$ ) & DN & $\mathrm{kN} / \mathrm{m}^{2}$ \\
\hline Diámetro medio de las raíces (especie $n$ ) & DrN & $\mathrm{mm}$ \\
\hline Densidad estimada de las raíces (especie n) & $\mathrm{drN}$ & (Ar/As) \\
\hline Profundidad media de las raíces (especie $\mathrm{n}$ ) & prN & $\mathrm{m}$ \\
\hline Resistencia a la tracción (especie $\mathrm{n}$ ) & TN & $\mathrm{N} / \mathrm{mm}^{2}$ \\
\hline Cohesión raíces (especie $n$ ) & cRN & $\mathrm{kN} / \mathrm{m}^{2}$ \\
\hline
\end{tabular}

El botón $\mathrm{C}$, permite calcular el valor de los parámetros derivados:

- A partir de las raíces.- Fuerza de tracción de las raíces. $T\left[\mathrm{kN} / \mathrm{m}^{2}\right]$.

- A partir del tallo.- Sobrecarga. $\mathrm{W}_{\mathrm{V}}\left[\mathrm{kN} / \mathrm{m}^{2}\right]$. 
Fotografía de la vegetación.- se introduce cargando un archivo de imagen. Basta con pinchar sobre el espacio reservado para la foto y pulsar el icono de adjuntar:

\section{BASE DE DATOS DE LOCALIZACIONES}

En esta ventana se introducen los parámetros de suelo y vegetación, referidos a unas coordenadas y altitud determinadas.

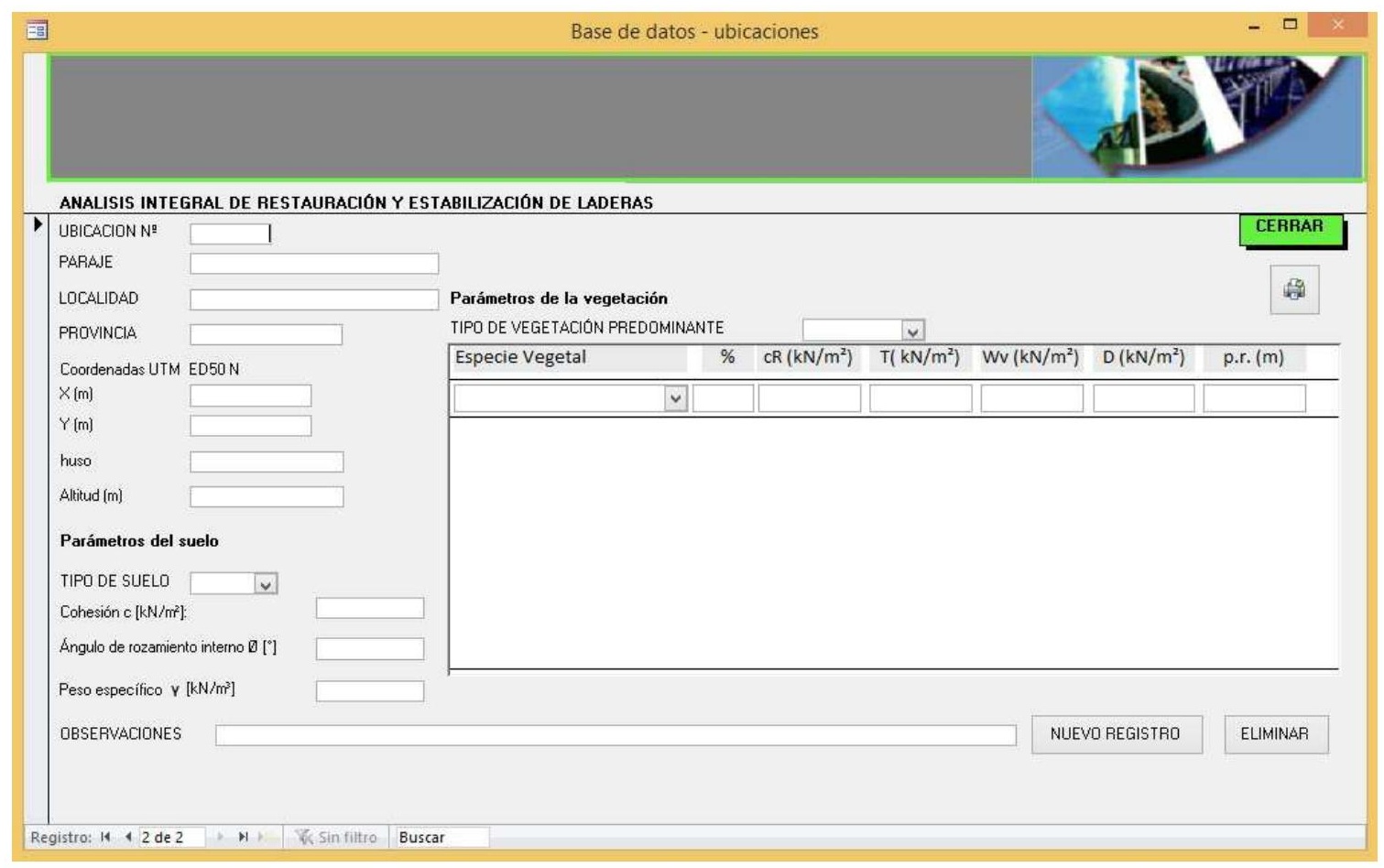

Figura 89: Ventana de la base de datos de localizaciones.

Los parámetros mostrados son los mismos que los correspondientes a las bases de datos de suelos y de especies vegetales, con la particularidad de que en este caso, se indica el porcentaje de representación de cada especie vegetal.

Quedan recogidos además los datos identificativos de la ubicación:

- Número de ubicación, paraje, localidad y provincia.

- Coordenadas UTM (ED.50 N), X e Y, en metros, huso UTM.

- Atura sobre el nivel el mar (m). 
DESARROLLO DE UNA APLICACIÓN INFORMÁTICA PARA EL CÁLCULO DE SOSTENIMIENTO

DE TALUDES MEDIANTE VEGETACIÓN

ANEXO VI.- MANUAL DEL PROGRAMA: ANÁLISIS INTEGRAL DE RESTAURACIÓN Y ESTABILIZACIÓN DE LADERAS

Se muestra además una tabla resumen de los parámetros básicos de cálculo de cada especie vegetal: Fuerza de tracción de las raíces $(\boldsymbol{T})$; Cohesión raíces $(\boldsymbol{c} \boldsymbol{R})$; Sobrecarga $\left(\boldsymbol{W}_{\boldsymbol{V}}\right)$; Fuerza de arrastre del viento $(\boldsymbol{D})$, expresados en $\mathrm{kN} / \mathrm{m}^{2}$., y profundidad de las raíces $\boldsymbol{p} . \boldsymbol{r}(\mathrm{m})$.

\subsubsection{2.- Operativa de trabajo con las bases de datos}

Se introducen los datos correspondientes a cada registro en las unidades indicadas, una vez finalizado, se guarda el registro, y se pasa a introducir los datos del siguiente.

Las bases de datos de cálculo: Suelos y especies vegetales, recogen todos los parámetros de cálculo. Inicialmente el programa instala las bases de datos de:

$\checkmark$ Suelos. 14 registros.

$\checkmark$ Especies vegetales. 55 registros.

Si fuese necesario introducir datos disponibles de una zona, distintos de los genéricos, que carga el programa, se debe:

1. Acceder a la base de datos correspondiente.

2. Añadir un registro nuevo.

3. Indicar en el nombre la identificación del registro, evitando que el nombre coincida con uno preexistente.

4. Introducir los datos.

5. Indicar la opción nuevo registro y salir de la base de datos.

El nuevo registro estará disponible en las ventanas de introducción de datos de cálculo del programa.

Para obtener detalles acerca de la gestión de los registros, ver capítulo FICHEROS Y REGISTROS.

\subsection{3.- Introducción de datos de cálculo de estabilidad}

\subsubsection{1.- Ventana principal de introducción de datos}

Esta ventana constituye la herramienta de cálculo del factor de estabilidad del talud. En esta ventana se distinguen dos partes:

La parte de la izquierda de la ventana incluye las casillas de introducción de los parámetros del terreno y del suelo y dos botones de cálculo del parámetro z, y del cálculo del factor de seguridad sin vegetación. 
DESARROLLO DE UNA APLICACIÓN INFORMÁTICA PARA EL CÁLCULO DE SOSTENIMIENTO

DE TALUDES MEDIANTE VEGETACIÓN

ANEXO VI.- MANUAL DEL PROGRAMA: ANÁLISIS INTEGRAL DE RESTAURACIÓN Y ESTABILIZACIÓN DE LADERAS

La parte de la derecha incluye las casillas de introducción de las especies vegetales con sus porcentajes de representación así como la densidad de plantación elegida. Incluye unos botones de cálculo de los parámetros finales de la mezcla, de $z^{\prime}$ y del factor de seguridad con vegetación.

Figura 90: Ventana principal de entrada de datos.

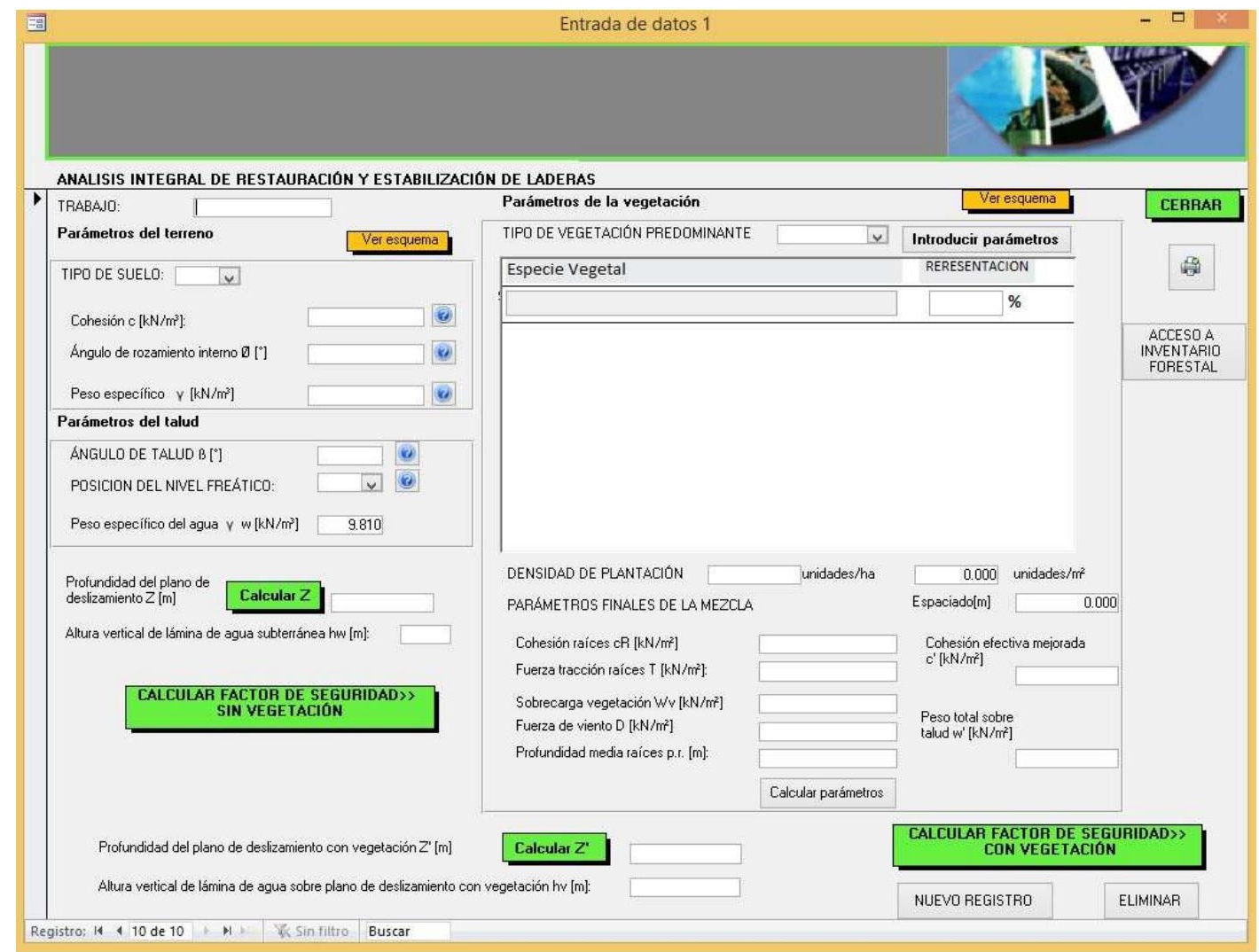

\subsubsection{2.- Botones y campos}

Tabla 5.- Botones y campos de introducción de datos de cálculo.

\begin{tabular}{|c|c|}
\hline Ver esquema & $\begin{array}{l}\text { Permite visualizar la representación gráfica de los } \\
\text { parámetros que intervienen en el cálculo sobre un } \\
\text { esquema del talud. }\end{array}$ \\
\hline (2) & Activa los menús emergentes de ayuda. \\
\hline $\begin{array}{l}\text { ACCESO A } \\
\text { INVENTARIO } \\
\text { FORESTAL }\end{array}$ & $\begin{array}{l}\text { Despliega la base de datos de especies vegetales, con } \\
\text { todos los parámetros almacenados correspondientes a } \\
\text { cada especie vegetal. }\end{array}$ \\
\hline Introducir parámetros & Activa el menú de introducción de datos de vegetación. \\
\hline Calcular parámetros & $\begin{array}{l}\text { Calcula los parámetros finales de cálculo para la mezcla } \\
\text { de especies vegetales a la densidad propuesta. }\end{array}$ \\
\hline
\end{tabular}


DESARROLLO DE UNA APLICACIÓN INFORMÁTICA PARA EL CÁLCULO DE SOSTENIMIENTO

DE TALUDES MEDIANTE VEGETACIÓN

ANEXO VI.- MANUAL DEL PROGRAMA: ANÁLISIS INTEGRAL DE RESTAURACIÓN Y ESTABILIZACIÓN DE LADERAS

\begin{tabular}{|l|l|}
\hline Calcular Z & $\begin{array}{l}\text { Calcula la profundidad del plano de } \\
\text { deslizamiento sin la vegetación. }\end{array}$ \\
\hline Calcular Z' & $\begin{array}{l}\text { Calcula la profundidad del plano de } \\
\text { deslizamiento con la vegetación. }\end{array}$ \\
\hline $\begin{array}{r}\text { CALCULAR FACTOR DE SEGURIDAD>> } \\
\text { SIN VEGETACIÓN }\end{array}$ & $\begin{array}{l}\text { Calcula el F.S. sin vegetación. } \\
\text { Despliega pantalla de resultados. }\end{array}$ \\
\hline $\begin{array}{r}\text { CALCULAR FACTOR DE SEGURIDAD>> } \\
\text { CON VEGETACIÓN }\end{array}$ & $\begin{array}{l}\text { Calcula el F.S. con vegetación. } \\
\text { Despliega pantalla de resultados. }\end{array}$ \\
\hline CERRAR & Sale de la aplicación. \\
\hline
\end{tabular}

\subsubsection{3.- Procedimiento operativo}

Para la introducción de datos, obtención progresiva de resultados parciales y cálculo final, previa identificación del trabajo, debe seguirse el procedimiento descrito.

Se indica el tipo de suelo, los parámetros del mismo: cohesión, rozamiento interno y peso específico, se cargan automáticamente desde la base de datos.

Figura 91: Ventana entrada de datos del tipo de suelo

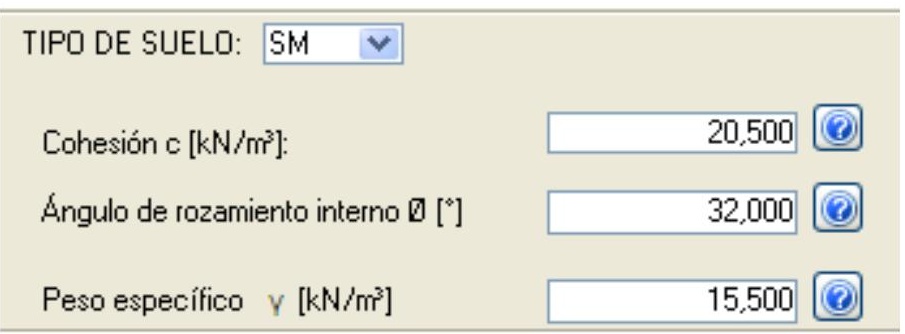

En todo momento, puede accederse a los parámetros almacenados en la base de datos, basta con pinchar sobre el botón de ayuda (2), que se sitúa al lado de cada parámetro.

Figura 92: Tabla de parámetros del terreno.

\begin{tabular}{|l|r|r|}
\hline 圆 Peso especifico del suelo & - & \multicolumn{1}{c|}{ Tipo de suelo } \\
\hline Símbolo & & Peso específico y $\left(\mathrm{kN} / \mathrm{m}^{3}\right.$; \\
\hline & Gravas bien graduadas, mezclas de grava y de arena & 0,000 \\
\hline GW & Arenas limosas & 20,800 \\
\hline SM & & 15,500 \\
\hline
\end{tabular}

Se introducen los datos correspondientes al talud: inclinación, clase de NF.

Figura 93: Entrada datos del talud

\begin{tabular}{lr} 
ANGULO DE TALUD B [ [ ] & 20,000 \\
POSICION DEL NIVEL FREATICO: & $2 \checkmark$ \\
\hline
\end{tabular}


La inclinación del talud queda limitada en función del tipo de terreno, activando el botón de ayuda (2), se pueden consultar los límites de inclinación.

Figura 94: Ayuda acerca de los límites de inclinación de talud.

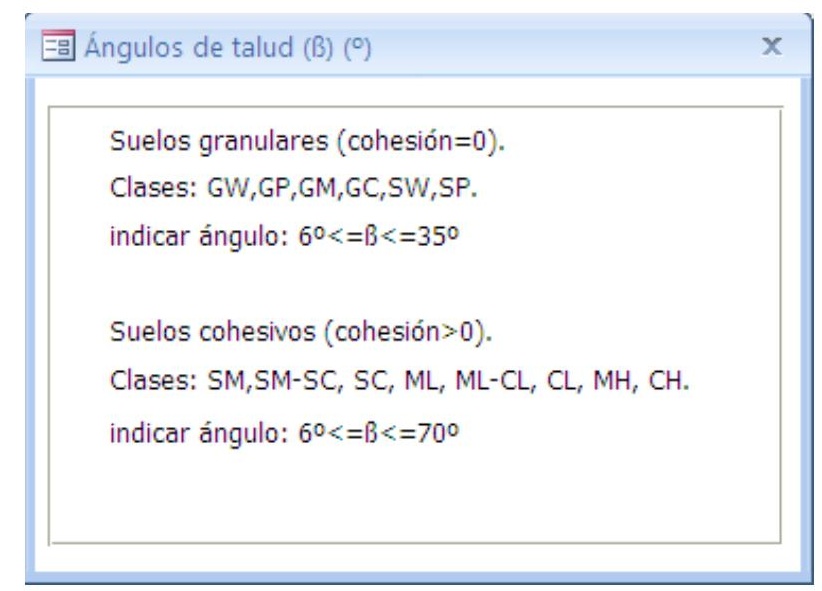

Otro desplegable de ayuda indica las posibilidades respecto a la posición del nivel freático (2), presentando 5 opciones: $1(0), 2(1 / 8), 3(1 / 4), 4(1 / 2), 5(1)$, relativas a la profundidad del plano de deslizamiento.

Figura 95: Ayuda acerca de las posiciones de N.F.

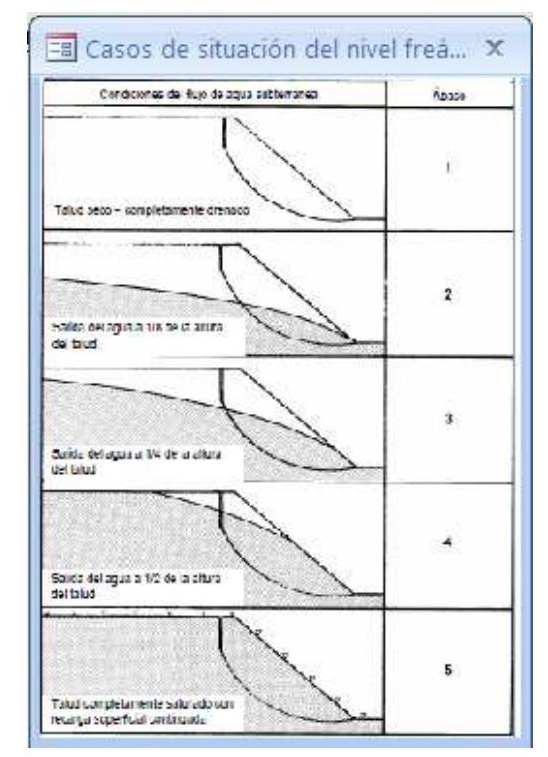

Puede efectuarse una consulta del esquema de talud, en el que se representan los parámetros que interviene en el cálculo de estabilidad, mediante el botón Ver esquema 
Figura 96: Esquema de talud sin vegetación:

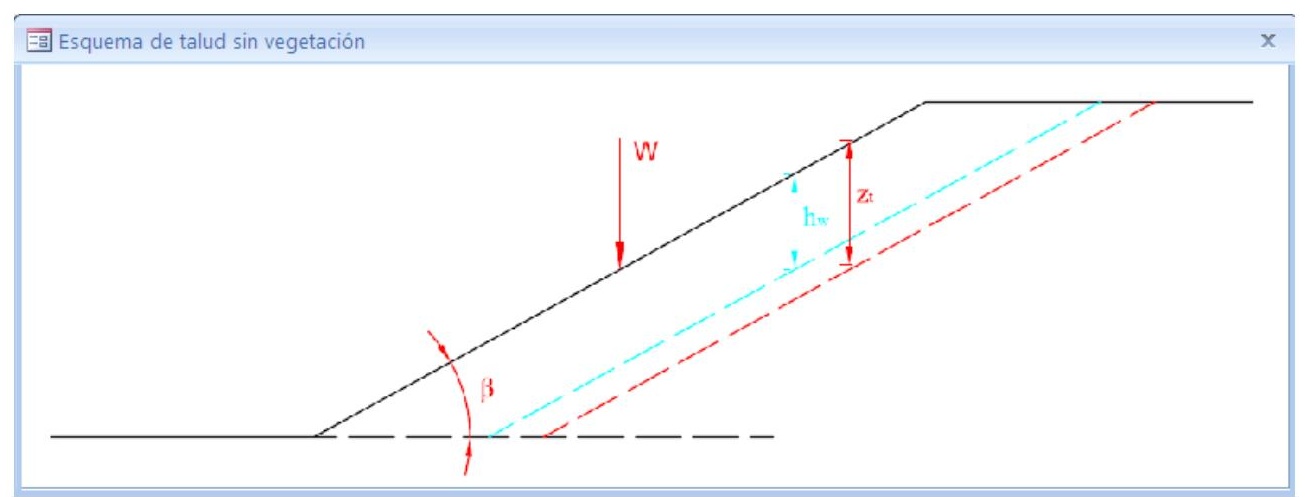

Si fuera marcada una inclinación de talud fuera del rango de aplicación para un tipo determinado de suelo, el programa lo detectaría y presentaría un mensaje de error.

Figura 97: Error de introducción de datos (inclinación).

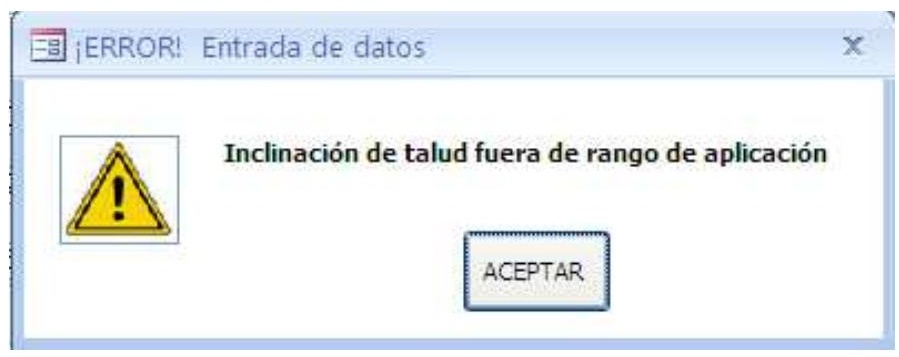

El programa ejecuta la función de cálculo de profundidad del plano de deslizamiento (z), por el momento, sin vegetación.

Figura 98: ventana de cálculo de la profundidad del plano de deslizamiento (z) y altura vertical de la lámina de agua ( $h w)$

\begin{tabular}{|c|c|c|}
\hline $\begin{array}{l}\text { Profundidad del plano de } \\
\text { deslizamiento } Z \text { [m] }\end{array}$ & Calcular Z & 1.822 \\
\hline Altura vertical de lámina d & h & 0,228 \\
\hline
\end{tabular}

Se calcula automáticamente la altura vertical de la lámina de agua sobre el plano de deslizamiento, en función de z y la posición del nivel freático $\left(\boldsymbol{h}_{\boldsymbol{w}}\right)$.

El programa procede a calcular la suma de fuerzas motoras y de fuerzas resistentes.

Se procede al cálculo del Factor de Seguridad (FS), desplegando la pantalla de resultados para el caso: talud sin vegetación. 
DESARROLLO DE UNA APLICACIÓN INFORMÁTICA PARA EL CÁLCULO DE SOSTENIMIENTO

DE TALUDES MEDIANTE VEGETACIÓN

ANEXO VI.- MANUAL DEL PROGRAMA: ANÁLISIS INTEGRAL DE RESTAURACIÓN Y ESTABILIZACIÓN DE LADERAS

Figura 99: Botón de cálculo del Factor de Seguridad sin vegetación (FS)

CALCULAR FACTOR DE SEGURIDAD〉>

SIN VEGETACIÓN

Se añade la vegetación, definida de la siguiente manera: especies vegetales, porcentaje, y densidad de plantación. El programa asigna de forma automática los parámetros básicos de cálculo para cada especie vegetal, aunque admiten ser modificados.

Para ello, previamente es necesario desplegar la ventana de introducción de datos de la vegetación.

Figura 100: Botón de introducción de parámetros de la vegetación

\section{Introducir parámetros}

Figura 101: Ventana de introducción de datos de la vegetación.

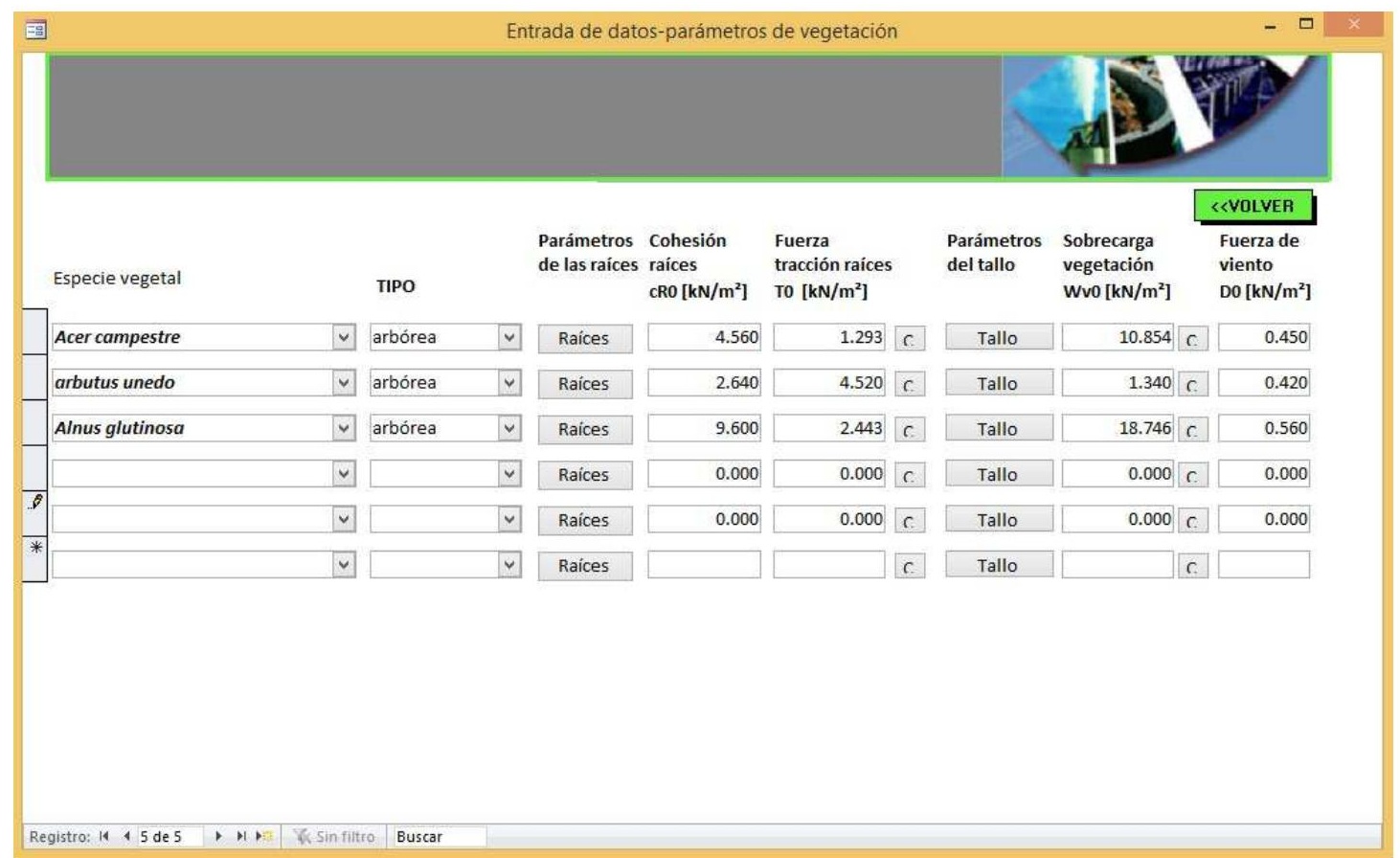

Debe indicarse: Nombre especies vegetales que componen la mezcla. El programa completa automáticamente el resto de los campos.

Si fuese necesario variar alguno de estos parámetros, se activarían dos ventanas secundarias:

Raíces > Activa la ventana de propiedades de las raíces: 
Figura 102: Ventana de propiedades de la raíz.

Entrada de datos-vegetación raíces
ANALISIS INTEGRAL DE RESTAURACION
Y ESTABILIZACION DE LADERAS
PARAMETROS DE VEGETACIÓN
PARAMETROS DE LAS RAícES
Especie vegetal $\quad$ Acer campestre
Diametro medio de las raices D.r [mm]
Densidad estimada de raíces d.r [Ar / As] *
Profundidad media raíces p.r [m]
Resistencia a tracción raices T.r [N/mm ${ }^{2}$ ]
*Relación entre la superficie de suelo ocupada por las
raices (A.r) y la superficie de suelo total (A.s)

Serían introducidos los parámetros indicados, en las unidades que figuran en la tabla siguiente:

Tabla 6.- Parámetros de especies vegetales: raíz.

\begin{tabular}{|l|c|c|}
\hline \multicolumn{1}{|c|}{ PARÁMETRO } & Símbolo & Unidades \\
\hline Diámetro medio de las raíces & $\mathbf{D r}$ & $\mathrm{mm}$ \\
\hline Densidad estimada de las raíces & $\mathbf{d r}$ & $(\mathrm{Ar} / \mathrm{As})$ \\
\hline Profundidad media de las raíces & $\mathbf{p r}$ & $\mathrm{m}$ \\
\hline Resistencia a la tracción & $\mathbf{T}$ & $\mathrm{N} / \mathrm{mm}^{2}$ \\
\hline
\end{tabular}

Tallo $>$ Activa la ventana de propiedades del tallo: 
Figura 103: Ventana de propiedades del tallo.

Entrada de datos-vegetación [tallo]
ANALISIS INTEGRAL DE RESTAURACION
Y ESTABILIZACION DE LADERAS
PARAMETROS DE VEGETACIÓN
PARAMETROS DEL TALLO
Especie vegetal Acer campestre
Diametro medio del tronco o tronco D.t [cm]
Densidad de la madera y.v $\left[\mathrm{kg} / \mathrm{m}^{3}\right.$ ]
Altura de la planta h.t [m]
Factor de forma del tallo (f.ff)
*Factor que considera las irregularidades del tallo
respecto a una forma cilindrica ideal

Serían introducidos los parámetros indicados, en las unidades que figuran en la tabla siguiente:

Tabla 7.- Parámetros de especies vegetales: tallo.

\begin{tabular}{|l|c|c|}
\hline \multicolumn{1}{|c|}{ PARÁMETRO } & Símbolo & Unidades \\
\hline Diámetro medio del tallo & Dt & $\mathrm{cm}$ \\
\hline Densidad de la madera & $\mathbf{Y v}$ & $\mathrm{kg} / \mathrm{m}^{3}$ \\
\hline Altura de la planta & ht & $\mathrm{m}$ \\
\hline Factor de forma del tronco & f.f. & \\
\hline
\end{tabular}

Una vez finalizada la introducción de los datos anteriores, se utiliza el botón volver a la ventana principal de introducción de parámetros de la vegetación.

Para cada especie están definidos los parámetros básicos necesarios para el cálculo de estabilidad.

- Los parámetros $\boldsymbol{C R}$, y $\boldsymbol{D}$, pueden actualizarse directamente en este menú.

- Los parámetros $T$, y $W v$, son derivados de otros, se calculan con el botón C 
De forma automática son calculados, para cada especie:

- Fuerza de tracción de las raíces (T), a partir de las propiedades de la raíz.

- Sobrecarga de la vegetación (Wv), a partir de las propiedades del tallo.

Tabla 8.- Parámetros básicos de cálculo que definen la influencia de la vegetación.

\begin{tabular}{|l|c|c|}
\hline \multicolumn{1}{|c|}{ PARÁMETRO } & Símbolo & Unidades \\
\hline Cohesión de las raíces & $\mathbf{c R}$ & $\mathrm{kN} / \mathrm{m}^{2}$ \\
\hline Fuerza de tracción de las raíces & $\mathbf{T}$ & $\mathrm{kN} / \mathrm{m}^{2}$ \\
\hline Profundidad media de las raíces & $\mathbf{p . r}$ & $\mathrm{m}$ \\
\hline Peso de la vegetación & $\mathbf{W v}$ & $\mathrm{kN} / \mathrm{m}^{2}$ \\
\hline Fuerza de arrastre del viento & $\mathbf{D}$ & $\mathrm{kN} / \mathrm{m}^{2}$ \\
\hline
\end{tabular}

Finalizadas las operaciones de introducción de especies vegetales, se pulsa

\section{< VOLVER}

Puede efectuarse una consulta del esquema de talud, en el que se representan los parámetros que interviene en el cálculo de estabilidad, en este caso con vegetación, mediante el botón Ver esquema

Figura 104: Esquema de talud con vegetación:

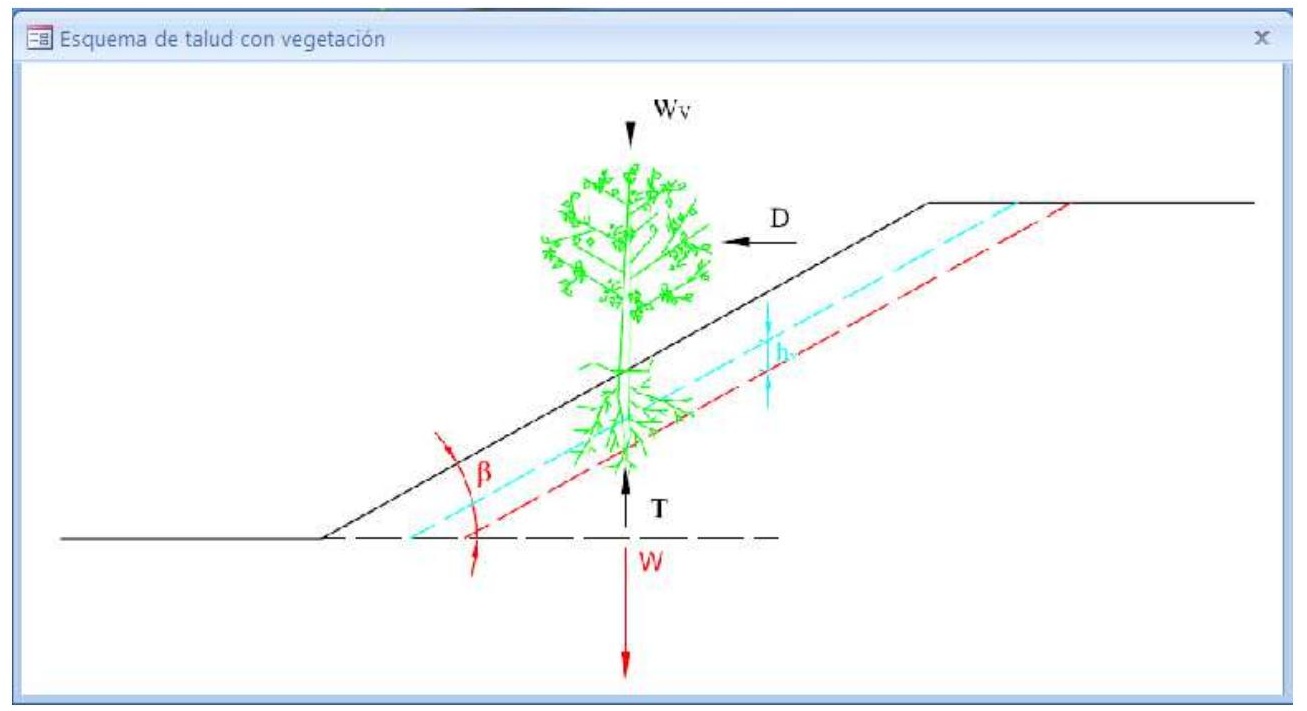

En el botón de acceso al inventario se despliega la tabla del inventario forestal donde se puede consultar cualquiera de los parámetros de cada una de las especies vegetales introducidas en la base de datos. 
Figura 105: Acceso directo al inventario forestal:

$$
\begin{gathered}
\text { ACCESO A } \\
\text { INVENTARIO } \\
\text { FORESTAL }
\end{gathered}
$$

En la ventana principal de introducción de datos, se introduce el porcentaje de cada especie vegetal, en la tabla de especies, y se determina el tipo predominante (árboles, arbustos o herbáceas). Previamente pichar sobre la tabla.

Figura 106: ventana entrada de porcentajes

\begin{tabular}{l|c|}
\hline Especie Vegetal & RERESENTACION \\
\hline Alnus glutinosa & $80,00 \%$ \\
\hline \hline Acer campestre & $20,00 \%$ \\
\hline \hline & \\
\hline
\end{tabular}

Posteriormente, se indica la densidad de plantación, en unidades/ha. Tras pulsar Intro, el programa calcula la densidad en las unidades de trabajo (unidades $/ \mathrm{m}^{2}$ ).

Figura 107: ventana entrada de la densidad de plantación

\begin{tabular}{l|l|r|} 
DENSIDAD DE PLANTACIÓN & 1600,000 unidades/ha & 0,160 \\
unidades $/ \mathrm{m}^{2}$
\end{tabular}

El programa determina el espaciado entre plantas (e), y evalúa si este es compatible con la existencia de efecto arco. En caso contrario muestra una alerta.

Figura 108: Error de introducción de datos (efecto arco).

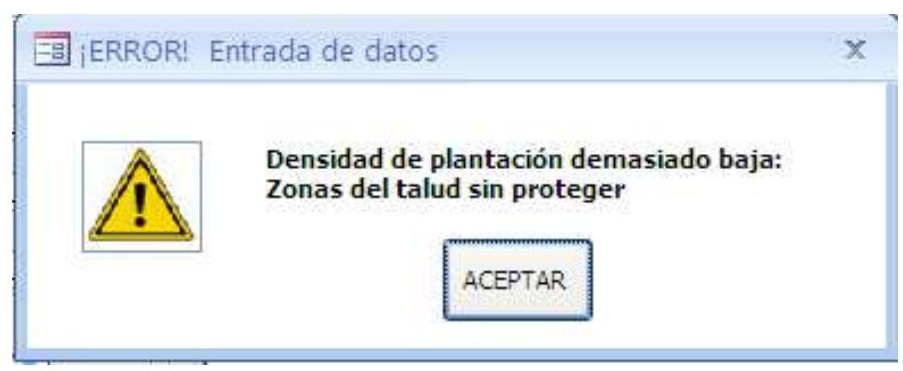

Son determinados en función de la composición de la mezcla, y de la densidad de plantación los parámetros finales de cálculo del factor de seguridad con vegetación:

- Cohesión de las raíces (cR), fuerza de tracción de las raíces (T), sobrecarga de la vegetación $(W v)$, fuerza del viento $(D)$, profundidad media de las raíces (p.r), espaciado, cohesión mejorada del suelo ( $\left.c^{\prime}\right)$, peso total sobre el talud ( $\left.w^{\prime}\right)$. 
Estos parámetros se calculan automáticamente al pulsar el botón "Parámetros"

Figura 109: Botón de cálculo de los parámetros

\section{Calcular parámetros}

Figura 110: Ventana de visualización de los parámetros calculados

\begin{tabular}{|c|c|c|c|}
\hline PARAMETROS FINALES DE LA MEZ & & Espaciado[m] & 2,500 \\
\hline Cohesión raíces cR $\left[\mathrm{kN} / \mathrm{m}^{2}\right]$ & 1,375 & \multirow{2}{*}{\multicolumn{2}{|c|}{$\begin{array}{l}\text { Cohesión efectiva mejorada } \\
\mathrm{c}^{\prime}\left[\mathrm{kN} / \mathrm{m}^{2}\right] \\
\qquad 21,875\end{array}$}} \\
\hline Fuerza tracción raíces $\mathrm{T}\left[\mathrm{kN} / \mathrm{m}^{2}\right]$ : & 0,354 & & \\
\hline Sobrecarga vegetación $W v\left[\mathrm{kN} / \mathrm{m}^{2}\right]$ & 2,747 & \multirow{3}{*}{$\begin{array}{l}\text { Peso total sobr } \\
\text { talud } w^{\prime}\left[\mathrm{kN} / \mathrm{m}^{2}\right.\end{array}$} & \\
\hline Fuerza de viento $D\left[\mathrm{kN} / \mathrm{m}^{2}\right]$ & 0,086 & & \\
\hline Profundidad media raíces p.r. [m]: & 0,580 & & 20,844 \\
\hline
\end{tabular}

El programa ejecuta la función de cálculo de profundidad del plano de deslizamiento con vegetación $\left(z^{\prime}\right)$.

Figura 111: ventana de cálculo de la profundidad del plano de deslizamiento con vegetación $\left(z^{\prime}\right)$ y la altura vertical de la lámina de agua (hv)

\begin{tabular}{|c|c|c|}
\hline Profundidad del plano de deslizamiento con vegetación Z' [m] & Calcular Z' & 1,082 \\
\hline Altura vertical de lámina de agua sobre plano de deslizamiento & tación $\mathrm{h}$ & 0,135 \\
\hline
\end{tabular}

Se calcula automáticamente la altura vertical de la lámina de agua sobre el plano de deslizamiento con vegetación, en función de z’ y la posición del nivel freático $\left(\boldsymbol{h}_{\boldsymbol{v}}\right)$.

El programa procede a calcular la suma de fuerzas motoras y de fuerzas resistentes.

Se procede al cálculo del Factor de Seguridad con vegetación $\left(\boldsymbol{F S}_{V}\right)$.

Finalmente se efectúa una comparación de resultados entre $\boldsymbol{F S}$ y $\boldsymbol{F S}_{\boldsymbol{V}}$, desplegando la pantalla de resultados para el caso: talud con vegetación; y determinando el incremento tanto en valor absoluto como en porcentaje. 
Figura 112: Botón de cálculo del Factor de Seguridad con vegetación (FSv)

CALCULAR FACTOR DE SEGURIDAD〉> CON VEGETACIÓN

Si el resultado presenta un aumento anómalo de F.S. con vegetación respecto al inicial, entendiéndose por tal un incremento de $+100 \%$, o bien si se produjese una disminución del mismo, el programa activaría un aviso, ya que en algunos casos puede ser debido a errores en la introducción de datos.

Figura 113: Error de resultados (incremento del F.S.).

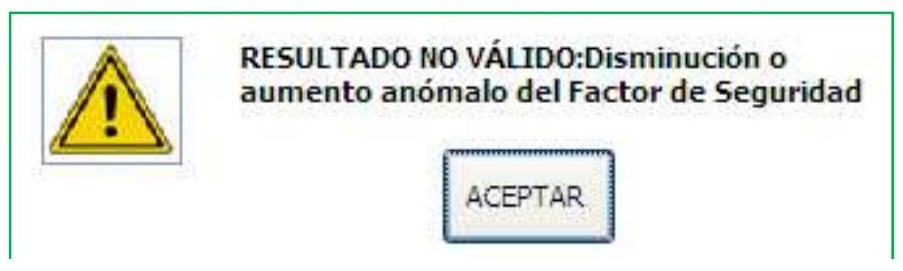

Es útil posteriormente variar los parámetros de la vegetación (especies, porcentajes, densidad), y estudiar su influencia sobre el factor de seguridad.

\subsection{4.- Presentación de resultados}

\subsubsection{1.- Ventana de resultados}


Figura 114: Pantalla de resultados sin vegetación.

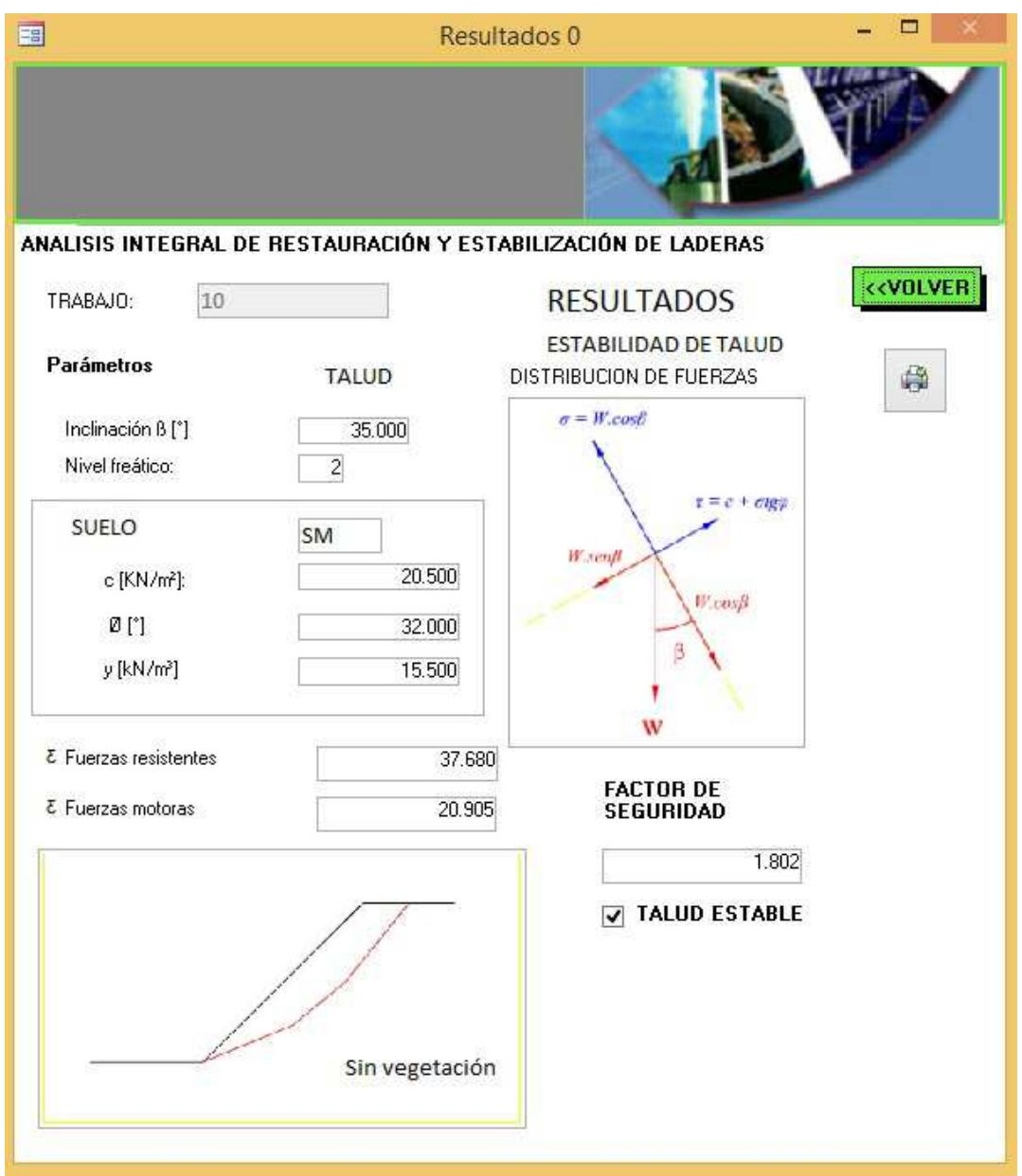

Se muestra en la pantalla de resultados, la siguiente información:

Tabla 9.- Presentación de resultados (sin vegetación).

\begin{tabular}{|c|c|}
\hline Trabajo & Identificación del trabajo. \\
\hline $\begin{array}{l}\text { Datos } \\
\text { introducidos }\end{array}$ & $\begin{array}{l}\text { - Resumen de los parámetros del talud. } \\
\text { - Resumen de los parámetros del suelo. }\end{array}$ \\
\hline $\begin{array}{l}\text { Fuerzas } \\
\text { resultantes }\end{array}$ & $\begin{array}{l}\text { - Sumatorio de fuerzas resistentes. } \boldsymbol{\Sigma} \mathbf{F R}\left(\mathrm{kN} / \mathrm{m}^{2}\right) \\
\text { - Sumatorio de fuerzas motoras. } \mathbf{\Sigma} \mathbf{F M}\left(\mathrm{kN} / \mathrm{m}^{2}\right)\end{array}$ \\
\hline Resultado & $\begin{array}{l}\text { - } \quad \text { Factor de seguridad } \boldsymbol{F} . \boldsymbol{S} . \\
\text { - } \quad \text { Indicación de condición de estabilidad. }\end{array}$ \\
\hline Otros & $\begin{array}{l}\text { - } \quad \text { Diagrama de distribución de fuerzas actuantes. } \\
\text { - } \quad \text { Representación esquemática del deslizamiento. }\end{array}$ \\
\hline
\end{tabular}

Figura 115: Pantalla de resultados con vegetación. 


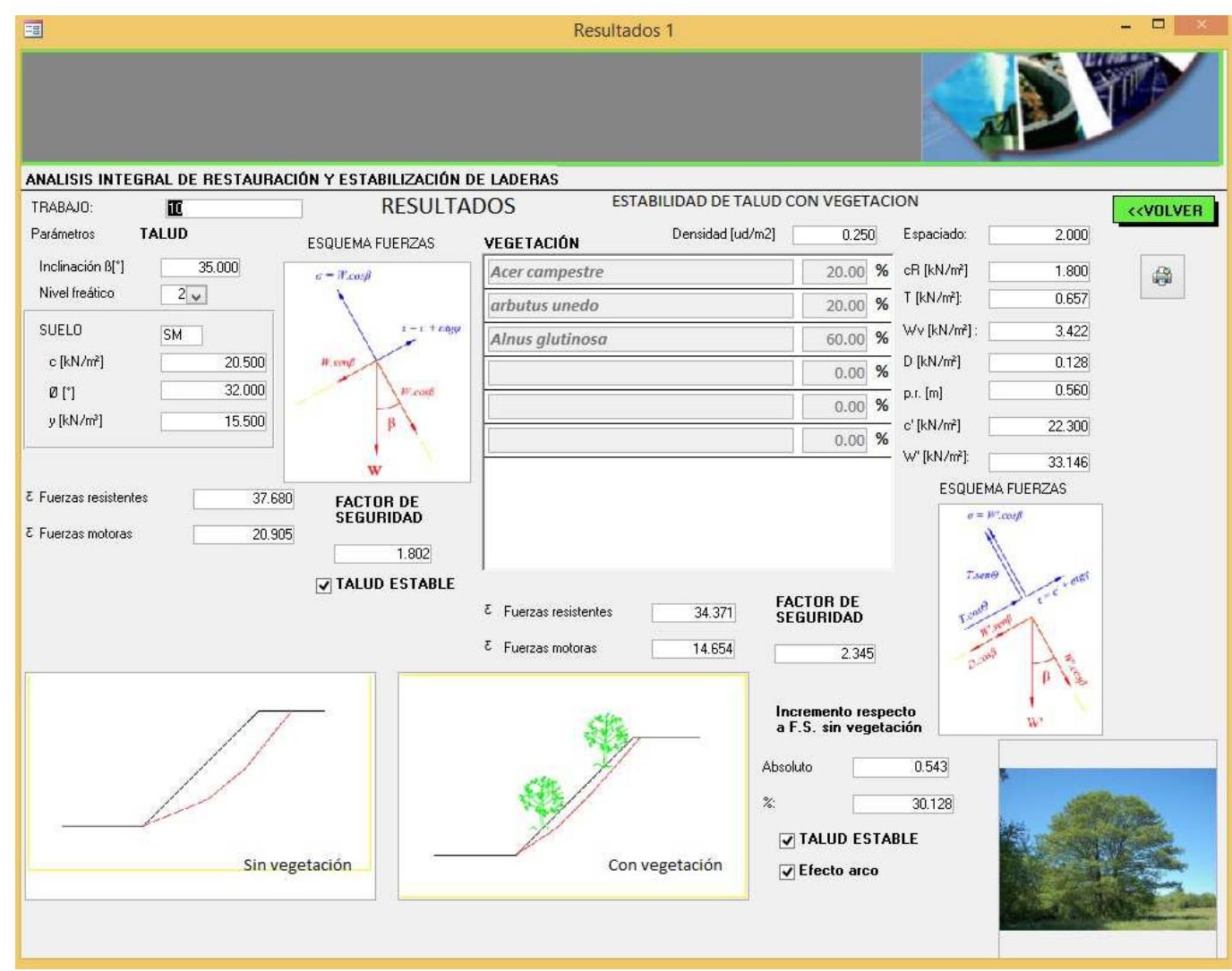

Se muestra en la pantalla de resultados, la siguiente información:

Tabla 10.- Presentación de resultados (con vegetación).

\begin{tabular}{|c|c|}
\hline Trabajo & Identificación del trabajo. \\
\hline $\begin{array}{l}\text { Datos } \\
\text { introducidos }\end{array}$ & $\begin{array}{l}\text { - Resumen de los parámetros del talud. } \\
\text { - Resumen de los parámetros del suelo. } \\
\text { - Densidad de la vegetación. } \\
\text { - Tabla de composición de la mezcla vegetal. } \\
\text { - Resumen de los parámetros de la vegetación. }\end{array}$ \\
\hline $\begin{array}{l}\text { Fuerzas } \\
\text { resultantes }\end{array}$ & $\begin{array}{l}\text { - Sumatorio de fueras resistentes. } \mathbf{\Sigma} \mathbf{F R}\left(\mathrm{kN} / \mathrm{m}^{2}\right) \\
\text { - Sumatorio de fuerzas motoras. } \mathbf{\Sigma} \mathbf{F M}\left(\mathrm{kN} / \mathrm{m}^{2}\right) \\
\text { - Sumatorio de fueras resistentes con vegetación. } \\
\mathbf{\Sigma} \mathbf{F R v}\left(\mathrm{kN} / \mathrm{m}^{2}\right) \\
\text { - Sumatorio de fuerzas motoras con vegetación. } \\
\mathbf{\Sigma} \mathbf{F M v}\left(\mathrm{kN} / \mathrm{m}^{2}\right)\end{array}$ \\
\hline Resultado & $\begin{array}{l}\text { - } \quad \text { Factor de seguridad } \boldsymbol{F . S .} \\
\text { - } \quad \text { Factor de seguridad con vegetación F.S.v } \\
\text { - } \quad \text { Indicación de condición de estabilidad. }\end{array}$ \\
\hline
\end{tabular}


DESARROLLO DE UNA APLICACIÓN INFORMÁTICA PARA EL CÁLCULO DE SOSTENIMIENTO DE TALUDES MEDIANTE VEGETACIÓN

ANEXO VI.- MANUAL DEL PROGRAMA: ANÁLISIS INTEGRAL DE RESTAURACIÓN Y ESTABILIZACIÓN DE LADERAS

\begin{tabular}{|l|l|l|}
\hline & - Indicación de que se produce efecto arco. \\
& - Diferencia: F.S.v - F.S. \\
\hline Otros & - Incremento (\%) de F.S.v respecto a F.S. \\
\hline & - Diagrama de distribución de fuerzas actuantes. \\
&
\end{tabular}

Figura 116: Presentación de resultados $\Sigma F R, \Sigma F M$, y factor de seguridad.

\begin{tabular}{l|r|r|}
$\bar{\varepsilon}$ Fuerzas resistentes & \multicolumn{1}{c}{ FACTOR DE } \\
SEGURIDAD
\end{tabular}

Figura 117: Presentación de resultados: incremento del factor de seguridad, indicación de la estabilidad del talud.

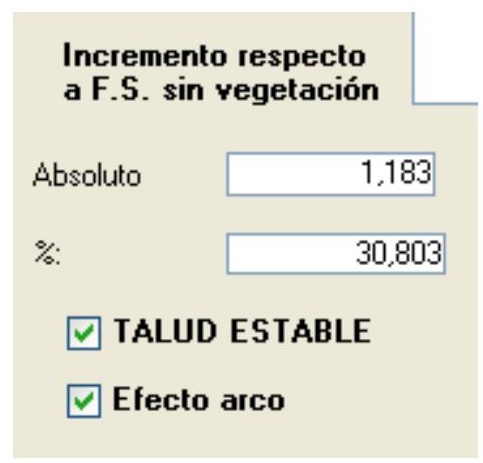

\subsubsection{2.- Opciones de imprimir}

Los botones de imprimir, repartidos a lo largo de las ventanas, permiten imprimir cualquiera de las pantallas de base de datos, introducción de datos o resultados, presentando en una hoja toda la información contenida en la ventana que corresponda. 


\section{4.- EJEMPLOS PRÁCTICOS DE UTILIZACIÓN DEL PROGRAMA}

\section{1.- EJEMPLO DE UTILIZACIÓN DE LA APLICACIÓN}

En este apartado se explica un ejemplo del cálculo del factor de estabilidad sin vegetación y con vegetación.

En este caso la revegetación se realiza con especies arbóreas y arbustivas autóctonas.

\subsection{1.- Ejemplo 1}

"Se tiene la propuesta de revegetación anterior situada en el término municipal de Sanabria sobre una parcela con pendiente media del $22 \%$ (o ángulo del talud aproximado $\beta$ $=13^{\circ}$ ) y sobre un suelo del tipo arenoso-limoso arcilloso (tipo SM). La clase de nivel freático es la 2 (la altura de la lámina de agua se sitúa a 1/8 de la altura del talud".

La propuesta de revegetación anterior está formada por la combinación de las especies arbóreas siguientes:

Tabla 11.- Propuesta de revegetación del talud.

\begin{tabular}{|c|c|c|}
\hline $\begin{array}{c}\text { PROPUESTA DE REVEGETACIÓN DEL } \\
\text { TALUD O LADERA }\end{array}$ & $\%$ & $\begin{array}{c}\text { Densidad final } \\
\text { (pl/ha) }\end{array}$ \\
\hline Quercus pyrenaica & 40 & \multirow{2}{*}{2000} \\
\hline Pinus nigra & 40 & \\
\hline Quercus ilex & 10 & \\
\hline Prunus avium & 10 & \\
\hline
\end{tabular}

4.1.1.1.- Proceso de cálculo

En la ventana "Menú inicial" entramos directamente en el menú Análisis de estabilidad - Iniciar cálculos. 
Figura 118: Presentación del menú inicio.

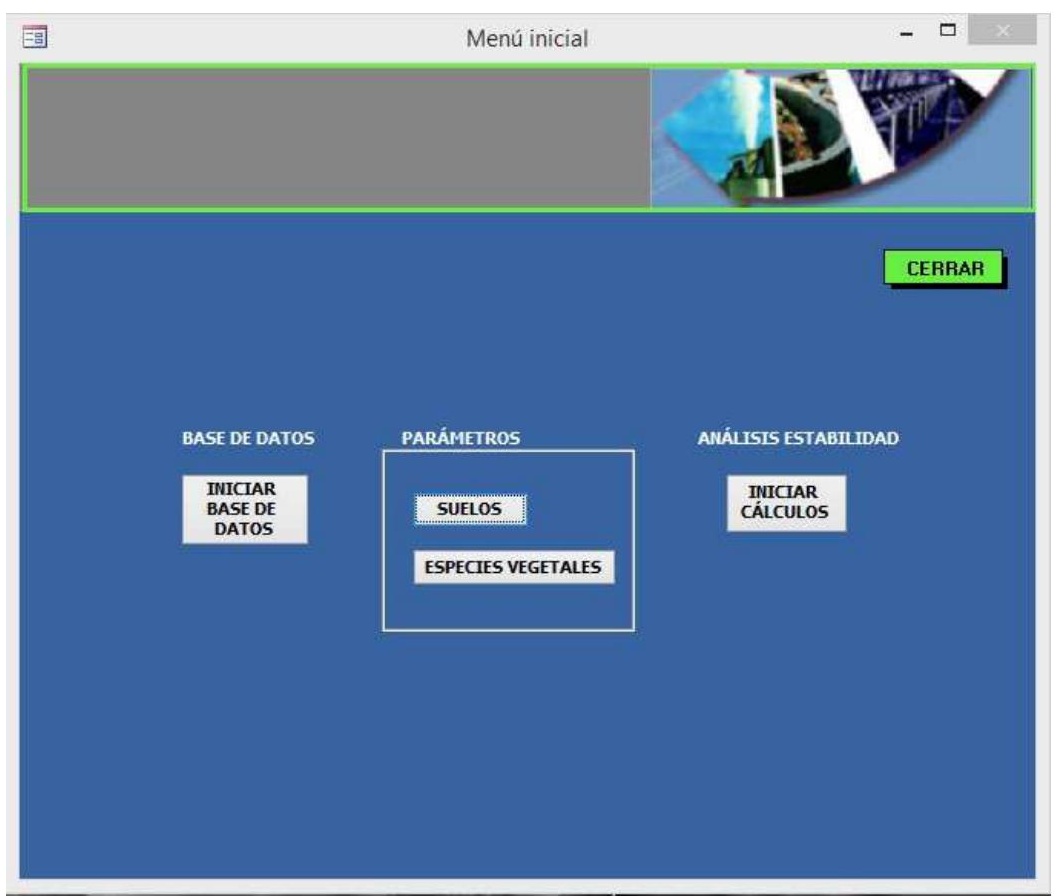

En la ventana "Entrada de datos 1":

1. Se introduce un número o un título para designar el trabajo a realizar.

2. Se introduce el tipo de suelo y los parámetros del talud (ángulo del talud y posición del nivel freático).

3. Se presiona el botón del cálculo de $z$ o profundidad del plano de deslizamiento sin vegetación.

4. Se calcula el factor de seguridad presionando el botón del cálculo de factor de seguridad sin vegetación. 
DESARROLLO DE UNA APLICACIÓN INFORMÁTICA PARA EL CÁLCULO DE SOSTENIMIENTO

DE TALUDES MEDIANTE VEGETACIÓN

ANEXO VI.- MANUAL DEL PROGRAMA: ANÁLISIS INTEGRAL DE RESTAURACIÓN Y ESTABILIZACIÓN DE LADERAS

Figura 119: Presentación de la ventana de entrada de datos.

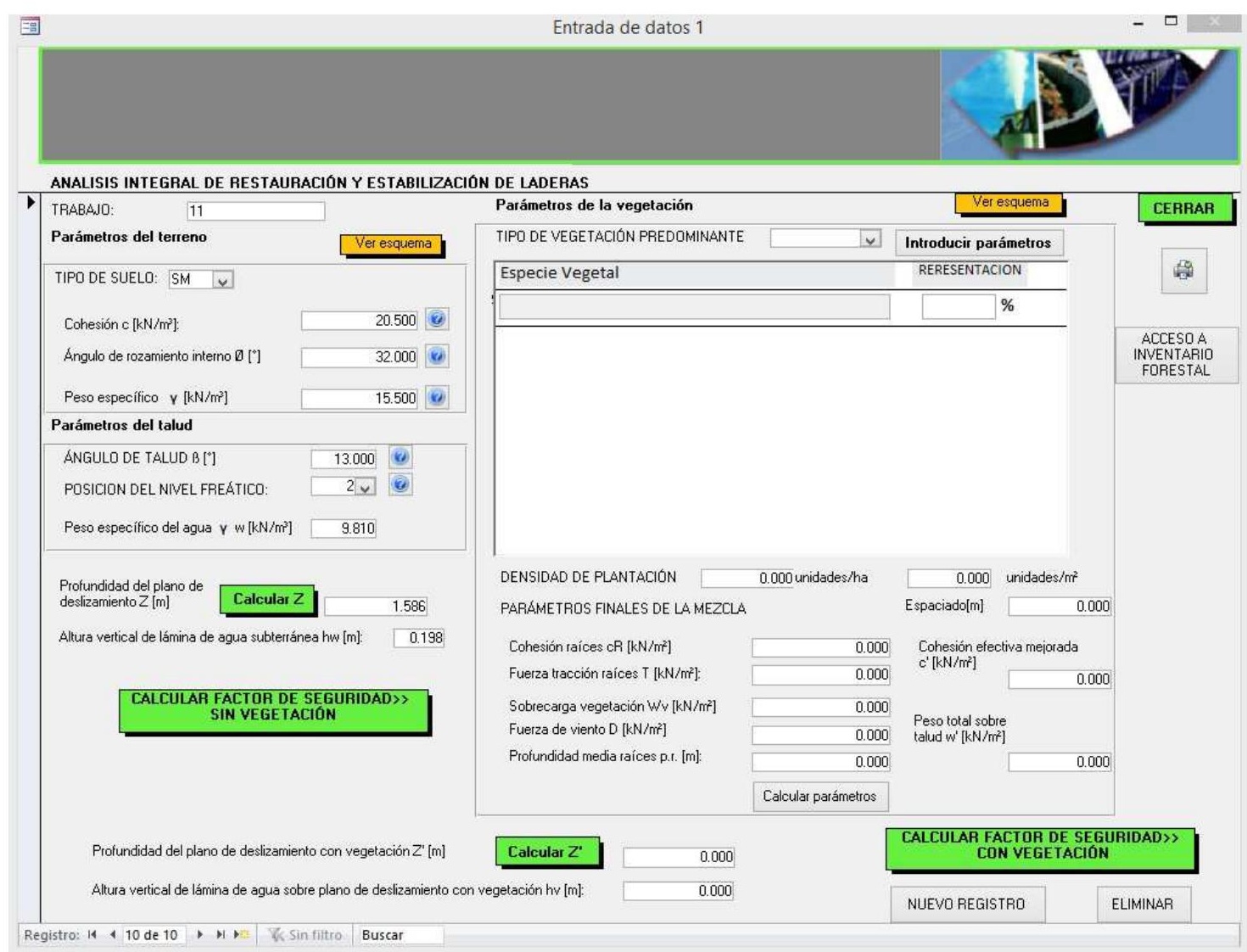

Obtención del resultado del factor de estabilidad sin vegetación en la ventana de resultados: 
Figura 120: Presentación de la ventana de resultados sin vegetación.

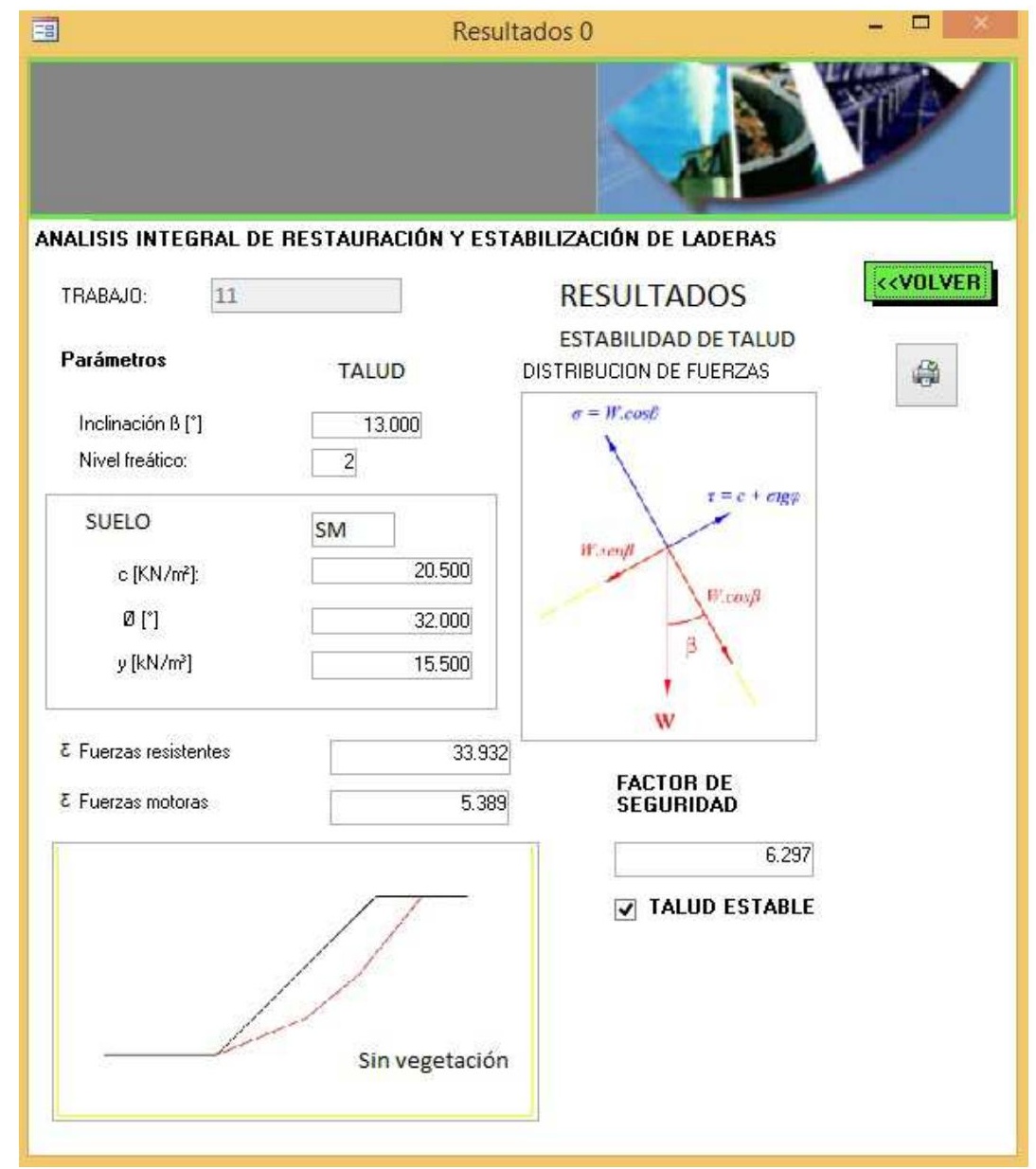

Desde esta ventana se vuelve a la ventana principal de entrada de datos pulsando el botón "volver". Se puede prescindir de esta ventana de resultados si la finalidad es calcular el factor de seguridad teniendo en cuenta la vegetación.

Se introducen los parámetros correspondientes a la vegetación indicando el tipo de vegetación predominante en la mezcla y a continuación se introducen las especies que intervienen en la muestra pulsando el botón "Introducir parámetros". Los parámetros de la raíz y el tronco que aparecen por defecto en las casillas corresponden a un árbol o arbusto adulto de tipo medio, por lo que éstos parámetros pueden ser modificados pulsando en los botones "raíces" y "tallo", calculando posteriormente nuevos valores de peso y fuerza de tracción por $\mathrm{m}^{2}$. 
DESARROLLO DE UNA APLICACIÓN INFORMÁTICA PARA EL CÁLCULO DE SOSTENIMIENTO

DE TALUDES MEDIANTE VEGETACIÓN

ANEXO VI.- MANUAL DEL PROGRAMA: ANÁLISIS INTEGRAL DE RESTAURACIÓN Y ESTABILIZACIÓN DE LADERAS

Figura 121: Presentación de la ventana de entrada de parámetros de la vegetación.

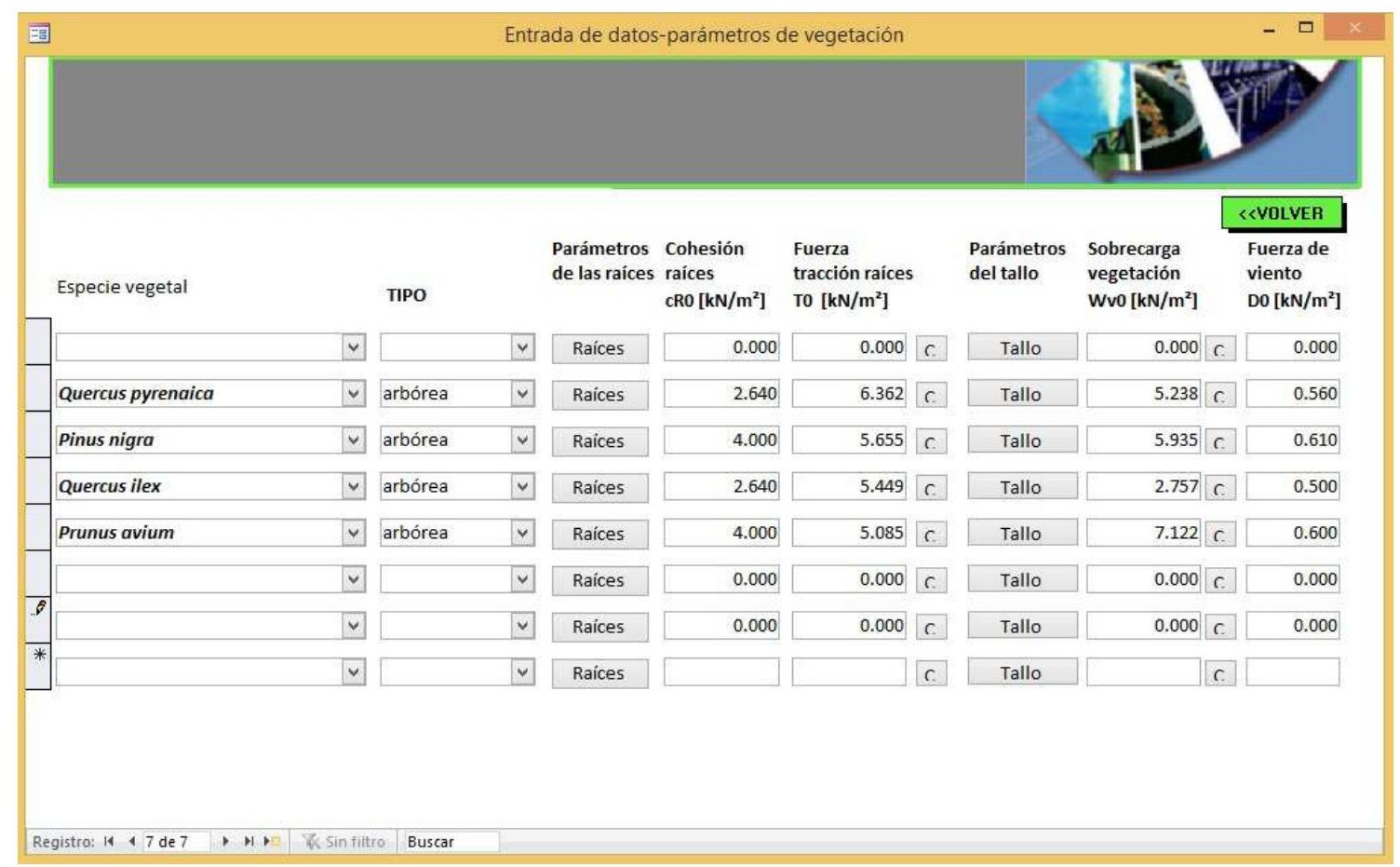

Figura 122: Presentación de la ventana de entrada de parámetros de la raíz y tallo.
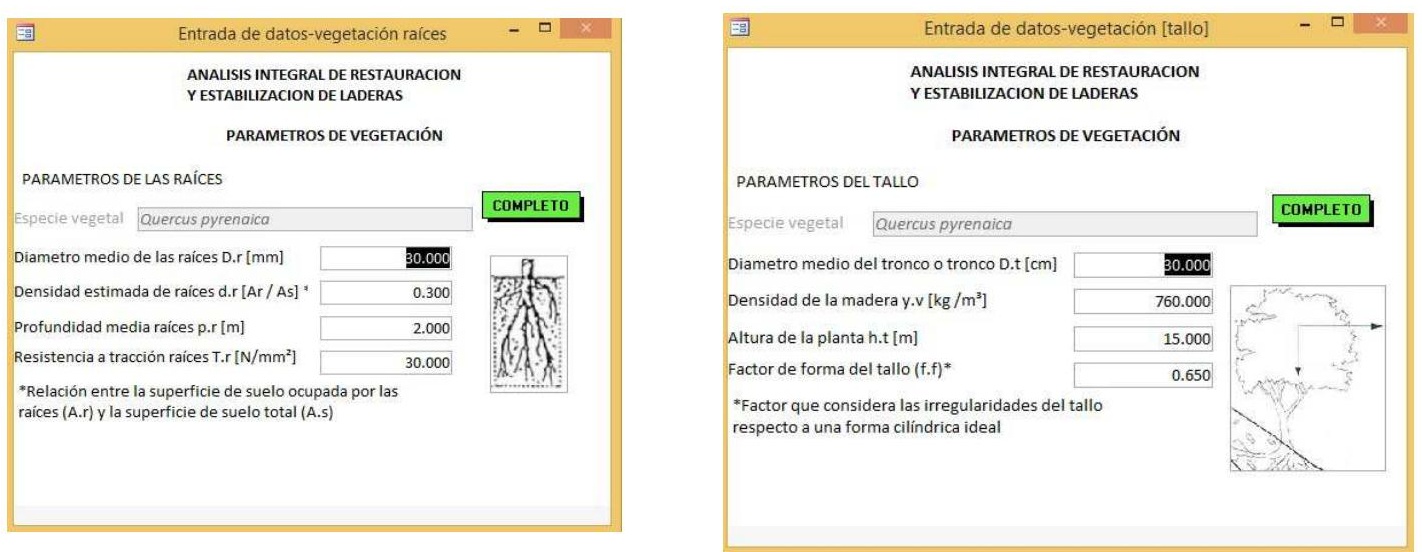
Se retorna a la ventana principal de entrada de datos pulsando "volver".

Pulsando en una de las casillas de especies vegetales aparecen automáticamente el grupo de especies seleccionadas de la ventana anterior, introduciendo a continuación los porcentajes de representación de cada especie en la mezcla.

Se introduce el valor de la densidad de plantación y se pulsa "INTRO" cubriéndose automáticamente las casillas de densidad en $\mathrm{ud} / \mathrm{m}^{2}$ y el espaciamiento o distancia entre árboles.

Se calculan los parámetros finales de la mezcla pulsando el botón "calcular parámetros" obteniendo la cohesión de las raíces y la cohesión efectiva mejorada, tensión de tracción, peso de la vegetación y empuje del viento una vez aplicados los porcentajes de cada especie y la densidad. En el caso de la profundidad de las raíces no se tiene en cuenta la densidad en el cálculo de la profundidad media.

Se calcula a continuación la profundidad del plano de deslizamiento $z^{\prime}$ con vegetación y la altura de la lámina de agua sobre el plano de deslizamiento con vegetación $\boldsymbol{h} \boldsymbol{v}$ rellenándose automáticamente la casilla del peso total sobre el talud.

Finalmente se calcula el factor de estabilidad con vegetación pulsando en el botón "calcular el factor de seguridad con vegetación".

Obtención del valor del factor de seguridad para tipo de talud y propuesta de especies designada en la ventana de resultados 1.

En esta ventana de resultados se muestra a la izquierda los resultados obtenidos del cálculo del factor de seguridad sin vegetación, así como un esquema descriptivo del talud y diagrama de fuerzas que actúan sobre el mismo. En la parte centro derecha se muestra un resumen de los parámetros que intervienen en el cálculo del factor de seguridad teniendo en cuenta en primer lugar la mezcla de especies empleada en el cálculo con sus porcentajes de representación y densidad, así como el resto de parámetros calculados como son cohesión, 
DESARROLLO DE UNA APLICACIÓN INFORMÁTICA PARA EL CÁLCULO DE SOSTENIMIENTO DE TALUDES MEDIANTE VEGETACIÓN

ANEXO VI.- MANUAL DEL PROGRAMA: ANÁLISIS INTEGRAL DE RESTAURACIÓN Y ESTABILIZACIÓN DE LADERAS

fuerza de tracción de las raíces, etc. También se muestra el esquema del talud con vegetación y el diagrama de fuerzas.

En la parte posterior aparecen los sumatorios de las fuerzas resistentes y motoras que actúan sobre el talud con vegetación y finalmente el valor calculado del factor de seguridad.

En la ventana de resultados podemos observar también cuanto se incrementa el factor de seguridad empleando dicha mezcla en valor absoluto y en porcentaje. Las dos últimas casillas marcadas indican que el talud es estable y que existe efecto arco.

Figura 123: Presentación de la ventana de entrada de datos con los parámetros de vegetación.

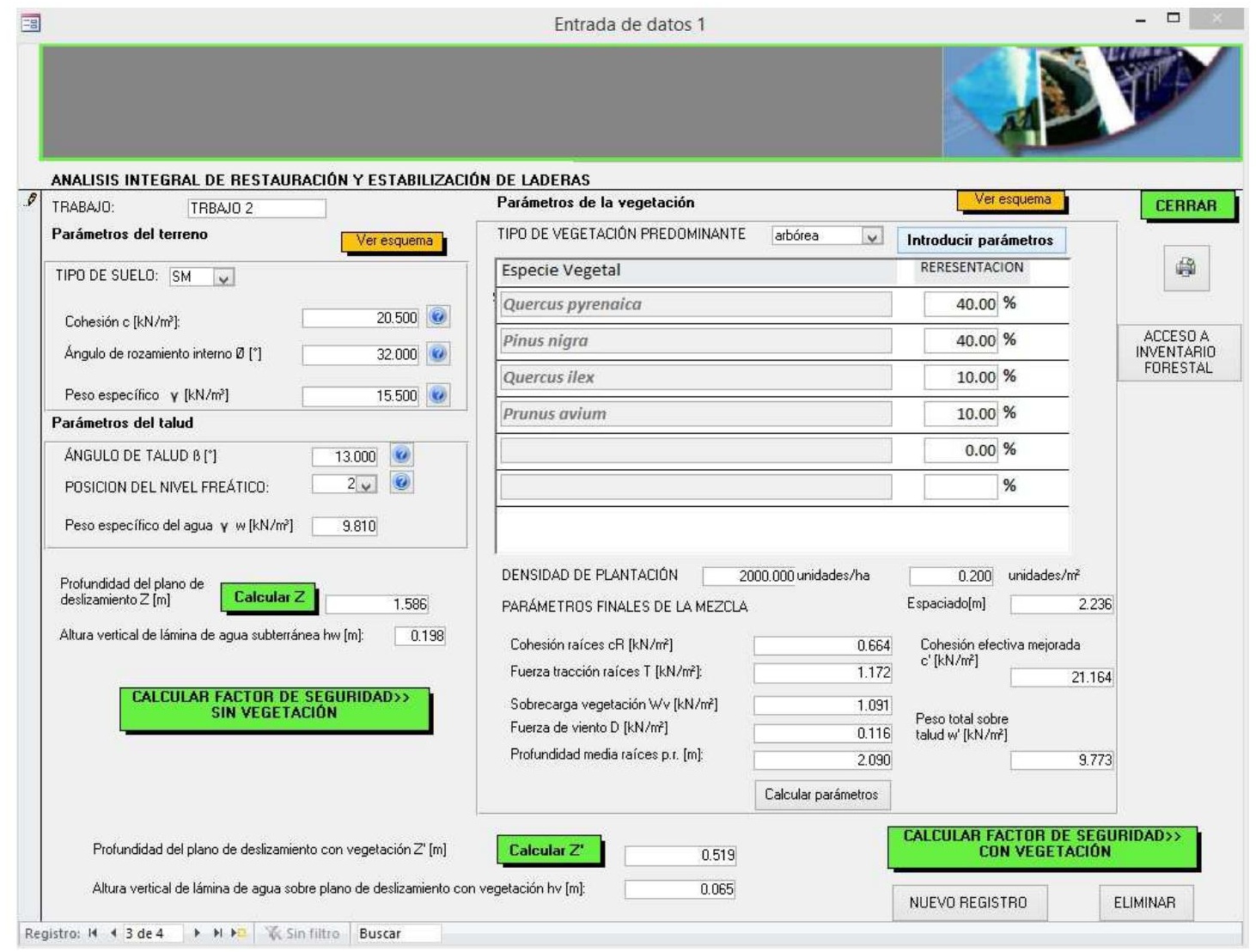


Figura 124: Presentación de la ventana de resultados con vegetación.

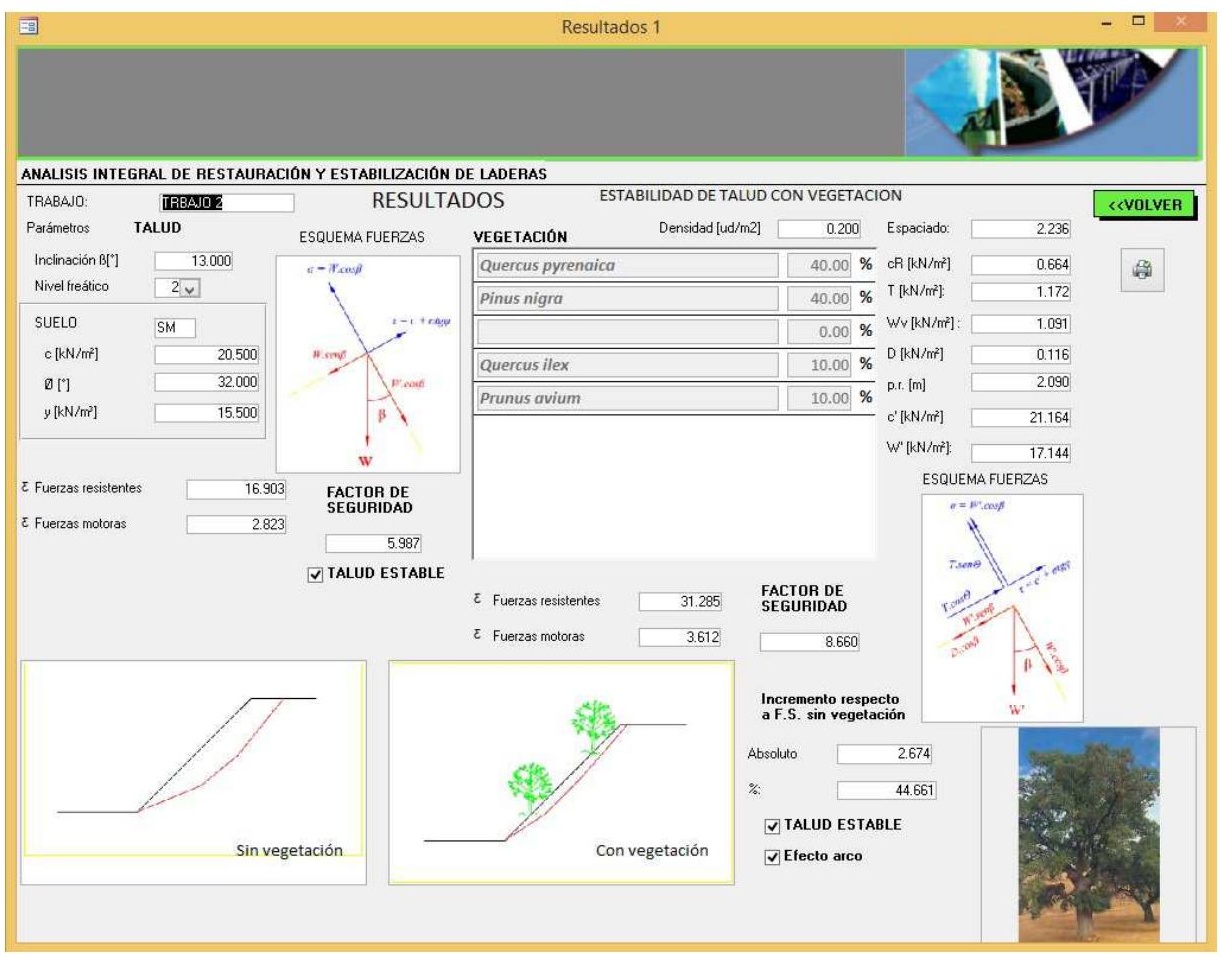

Una vez concluido el cálculo del factor de seguridad se retorna a la ventana principal de entrada de datos si se considera conveniente modificar la propuesta, variando el tipo de especie, densidad y porcentaje de representación en la mezcla con el fin de obtener un resultado del factor de estabilidad que se aproxime a las necesidades del promotor y que implique una mejora de la estabilidad del terreno.

Si el cálculo del factor de estabilidad es el adecuado se termina el proceso imprimiendo el informe de resultados en el botón "imprimir" 
DESARROLLO DE UNA APLICACIÓN INFORMÁTICA PARA EL CÁLCULO DE SOSTENIMIENTO DE TALUDES MEDIANTE VEGETACIÓN

ANEXO VI.- MANUAL DEL PROGRAMA: ANÁLISIS INTEGRAL DE RESTAURACIÓN Y ESTABILIZACIÓN DE LADERAS

Figura 125: Presentación del informe de resultados con vegetación.

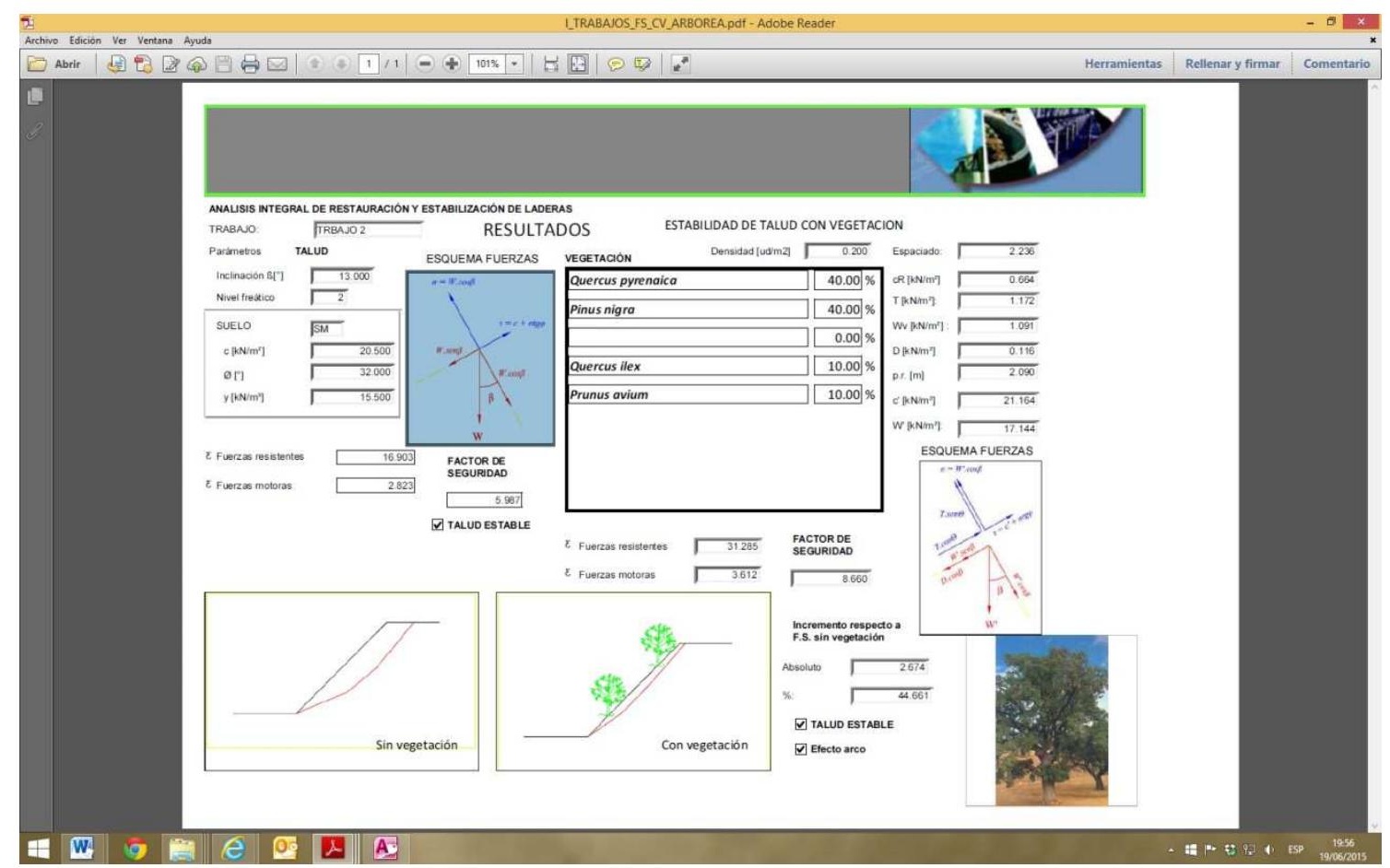




\section{Bibliografía.}

DESARROLLO DE UNA APLICACIÓN IMFORMÁTICA PARA EL CÁLCULO DE SOSTENIMIENTO DE TALUDES MEDIANTE REVEGETACIÓN

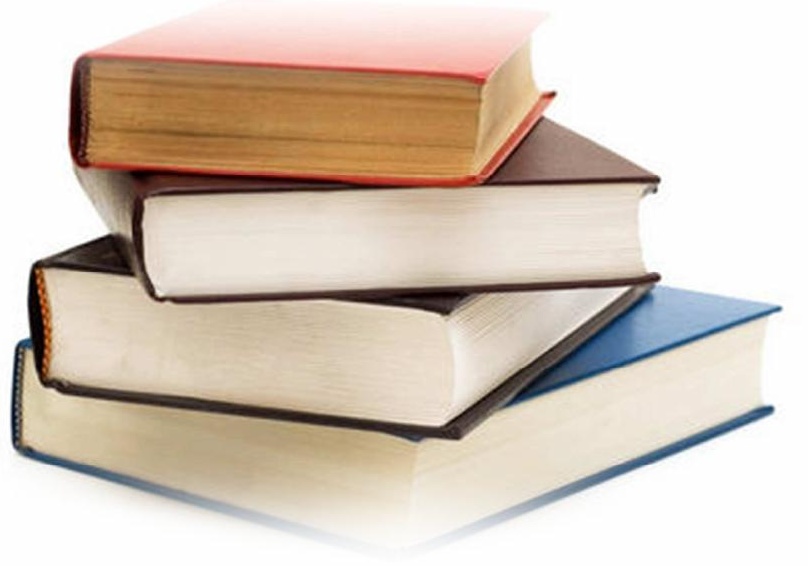


ABRAMSON, L. W., (1996), «Slope Stabilization methods». Slope stability and stabilization methods. John Wiley \& Sons, Inc. New York.

Anon (1960) "How far apart should hedges be planted". Vetiver newsletter 4.

BARKER D.H. (1995) "The way ahead - continuing and future developments in vegetative slope engineering or ecoengineering".Vegetation and slopes. Stabilization, protection and ecology. D.H. Barker Editor. Institution of Civil Engineers. Thomas Telford. London.

BACHE D.H., MacAskill I.A., (1984). “Vegetation in civil and landscape engineering” Granada Technical books, London.

BAYFIELD N.G. (1995) "Species selecton and management for slope revegetation projects". Vegetation and slopes. Stabilization,protection and ecology. D.H. Barker Editor. Institution of Civil Engineers. Thomas Telford. Londres.

BERLIJN, J. - BERNANDON A. (1987) “Pastizales naturales” Editorial Trillas - México.

BLUNT S.M. , Dorken T.C. (1995) "Erosion of Highway slopes in upland wales: Problems and solutions". Vegetation and slopes.Stabilization, protection and ecology. D.H. Barker Editor. Institution of Civil Engineers. Thomas Telford. Londres.

BROOKER K. (2001). "Fertilizers and soil amendments". IECA. Soil stabilization series volume 14. Revegetation materials, equipment and techniques.

BROWN F., CLARK J., (1995). "The west coast road in St Lucia, an approach to slope stabilization". Vegetation and slopes. Stabilization, protection and ecology. D.H. Barker Editor. Institution of Civil Engineers. Thomas Telford. Londres.

COOPIN N , STILES R. “ Ecological principles for vegetation establishment and maintenance. Slope Stabilization and Erosion Control. A Bioengineering Approach. Editors R.P.C. Morgan y R.J. Rickson. E y FN Spon. Cambridge Inglaterra.

DICKERSON J.A., MILLER C.F., BURGDOF D.W., GRINTER M.V.D. “A critical analysis of plant materials needed for soil bioengineering”. Ieca soil stabilization series volumen 5. Methods and techniques for using bioengineering to control erosion.

DOORENBOS, J., PRUITT, W.O. (1977). “Guidelines for predicting crop water requirements”. FAO Irrigation and Drainage.

ESCOBAR C.E. (1998) “Especies vegetales” Manual para el control de la erosión. CorpocaldasInvias.

GOFF K. (2001). “Amending the soil”. IECA. Soil stabilization series volume 14. Revegetation materials, equipment and techniques.

GONZÁLEZ DE VALLEJO, Luis. (2002); “Ingeniería Geeológica”. PEARSON.

GRAY, D.H. y SOTIR, R.B. (1996).: "Biotechnical and Soil Bioengineering Slope Stabilization. A Practical Guide for Erosion Control”. John Wiley \& Sons, INC.

GRAY D.H., OHASHI H. (1983) Mechanics of Fiber reinforcement in sand. J. Geotechnical Engineering. ASCE.

GREENWAY D.R. (1987) «Vegetation and Slope Stability» Slope Stability (Ed. Anderson MG. y Richards Kis). John Wiley and Sons Ltda.

GREENWAY D.R. (1998) “Biotechnical slope protection in Hong Kong. Ieca soil stabilization series volumen 5. Methods and techniques for using bioengineering to control erosion. 
GRIMSHAW R.G. (1995) “Vetiver Grass - Its use for slope and structure stabilization under tropical and semi tropical conditions".Vegetation and slopes. Thomas Telford, London.

HAILE M. (2001). "Which type of fertlizer should you choose". IECA. Soil stabilization series volume 14. Revegetation materials, equipment and techniques.

HELLIWELL D.R. (1995). "Rooting habits and moisture requirements of trees and other vegetation". Vegetation and slopes. Stabilization, protection and ecology. D.H. Barker Editor. Institution of Civil Engineers. Thomas Telford. Londres.

HEWLETT, H.M. , BOORMAN L.A,, BRAMLEY M.E., (1987). “Design of reinforced grass waterways. CIRIA report 116. CIRIA, London.

HURNI - H. (1982) "Soil Erosion in Huai Thung choa - Northern Thailand concerns and Constraints". Mountain research and Development.

INCASLE INGENIEROS S.L (1999): “Jornada práctica de restauración de taludes”. Colegio Oficial de la Ingeniería Técnica Minera.

INCASLE INGENIEROS S.L (2002): “Estudio para la recuperación de suelo y reforestación en las comarcas del Bierzo y Laciana".

INCASLE INGENIEROS S.L (2004): “Restauración y recuperación del suelo en el oeste de León y norte de Zamora".

I.T.G.E. (1989):: “Manual de restauración de terrenos y evaluación de impactos ambientales en minería". Serie: Ingeniería Geoambiental.

I.T.G.E. (1986).: "Manual de restauración de ingeniería de taludes". Serie: Ingeniería Geoambiental.

JANBÚ , N. (1973). "Slope Stability Computations". Embankment Dam Engineering. Edited by Hirshfield R.C.-Poulos S.J., John Wiley and Sons, p 47-86, New York.

JOHNSON K. (1982) "Environmental Knowledge and Response to natural hazard in Mountainous Nepal. Mountain Research and Development, Vol. 2, No. 2.

JUNTA DE CASTILLA Y LEÓN (2007); “Cuadernos de zona y requerimientos técnicos para la realización de trabajos de forestación de tierras agrícolas (2007-2013).

JUNTA DE CASTILLA Y LEÓN, INIA y CESEFOR (2008); “Plantaciones de frondosas en castilla y León. Cuaderno de campo".

LANCASTER T., NELSEN R., CROKE T. (1999) "Combining FHWA and USDA channel lining design methodologies: A more accurate, computerized approach to vegetative lining analysis". ". IECA Conference 30, Nashville, Tennessee.

LÓPEZ GONZÁLEZ., Ginés. (1982); “ La guía de los árboles y arbustos de la Península Ibérica. Editorial Incafo.

LÓPEZ GONZÁLEZ., Ginés. (2004); “ Guía de los árboles y arbustos de la Península Ibérica y Baleares. Mundiprensa.

McCULLAH J. (2001). "Biotechnical Soil Stabilization for Slopes and Streambanks”. IECA Professional Development Course. Training Manual. Las Vegas. 
DESARROLLO DE UNA APLICACIÓN INFORMÁTICA PARA EL CÁLCULO DE SOSTENIMIENTO DE TALUDES MEDIANTE VEGETACIÓN

ANEXO VI.- MANUAL DEL PROGRAMA: ANÁLISIS INTEGRAL DE RESTAURACIÓN Y ESTABILIZACIÓN DE LADERAS

MATAIX, C. et al (1999): “Manual de estabilización y revegetación de taludes”. Editor

Carlos López Jimeno.

MATAIX, C. (2003): Técnicas de revegetación de taludes. Inc: Restauración de ecosistemas mediterráneos, Colección Aula Abierta no 20. Universidad de Alcalá.

MINISTERIO DE FOMENTO (1973); “Normas técnicas de la edificación (NTE); cargas de viento).

MORGAN, R.P.C. y RICKSON, R.J. (Ed.) (1995).: “Slope Stabilization and Erosion

Control: A Bioengineering Approach". Chapman and Hall.

MOSES T. (1998) “Channel rehabilitation at the brookside enhancement project, Oregon". IECA Soil stabilization series: Vol. 1. Methods and techniques for stabilizing channels and streambanks.

OGASAWARA T.A. (1996) "Waikakalaua stream realignment project: Saprolitic soil stabilization and vegetation of severely cut slopes". IECA Conference 27, Seattle, Washington, pp117-127.

ORIA DE RUEDA, J.A y Díez, J (2003). “Guía de árboles y arbustos de Castilla y León. Cálamo, 2 edición.

PAWAR P.B. (1999) “Vetiver: A miracle grass for watershed management”. IECA Conference 30, Nashville, Tennessee.

REGIONE DI LAZIO (2006);" Manuale di Ingegnería Naturalistica”. Editoriale Emilmarc.

RICE R.M., KRAMES J.S. (1970). "Mass-Wasting Process in Watershed Management". Proceedings on Interdisciplinary Aspects of Watershed Management, ASCE, pp. 231-260.

SERRADA, R; MONTERO, M y REQUE, J (2008); “ Compendio de selvicultura aplicada en España. INIA y FUCOVASA.

SERRADA, R. (2008). "Apuntes de Selvicultura”. Servicio de Publicaciones. EUIT Forestal. Madrid.

SCHIECHTL .M., (1980), “ Bioengineering for land Reclamation and Conservation”. University of Alberta Press.

STEINBACHER J. (2001). "Revegetating with native plants at drastically disturbed sites". IECA. Soil stabilization series volume 14. Revegetation materials, equipment and techniques.

STYCZEN M.E., MORGAN R.P.C. (1995) “Engineering Properties of Vegetation”. Slope Stabilization and Erosion Control. A Bioengineering Approach. Editors R.P.C. Morgan y R.J. Rickson. E y FN Spon. Cambridge Inglaterra.

STOKES, Alexia; MICKOVSKI Slobodan and CAMMERAAT, erik (2008); "Slope stability and erosion control: Ecotechnological solutions. Springer.

SUAREZ, Jaime; “Deslizamientos: Técnicas de Remediación.; capítulo 9: La vegetación y los deslizamientos". www.erosión.com.co.

TEMPLE D.M. (1982). "Flow retardance of submerged grass channel linings". Trans. Am. Soc. Agric. Engnrs., 25, 1300-3.

WATSON A. , MARDEN M., ROWAN D. (1995) "Tree species performance and slope stability". Vegetation and slopes. Stabilization, protection and ecology. D.H. Barker Editor. Institution of Civil Engineers. Thomas Telford. Londres. 
DESARROLLO DE UNA APLICACIÓN INFORMÁTICA PARA EL CÁLCULO DE SOSTENIMIENTO DE TALUDES MEDIANTE VEGETACIÓN

ANEXO VI.- MANUAL DEL PROGRAMA: ANÁLISIS INTEGRAL DE RESTAURACIÓN Y ESTABILIZACIÓN DE LADERAS

WHITERS, B., VIPOND, S. (1974). “Irrigation: Design and Practice”. Batsford, London.

YOON P.K. (1995). "Important biological considerations in use of Vetiver grass hedgerows" (Vghr) for slope protection and stabilization. Vegetation and slopes. Stabilization, protection and ecology. D.H. Barker Editor. Institution of Civil Engineers. Thomas Telford. Londres. 


\section{Documento adjunto 1}

RESULTADOS DE ANÁLISIS DE LABORATORIO DE CARACTERIZACIÓN Y COMPOSICIÓN DE SUELOS.

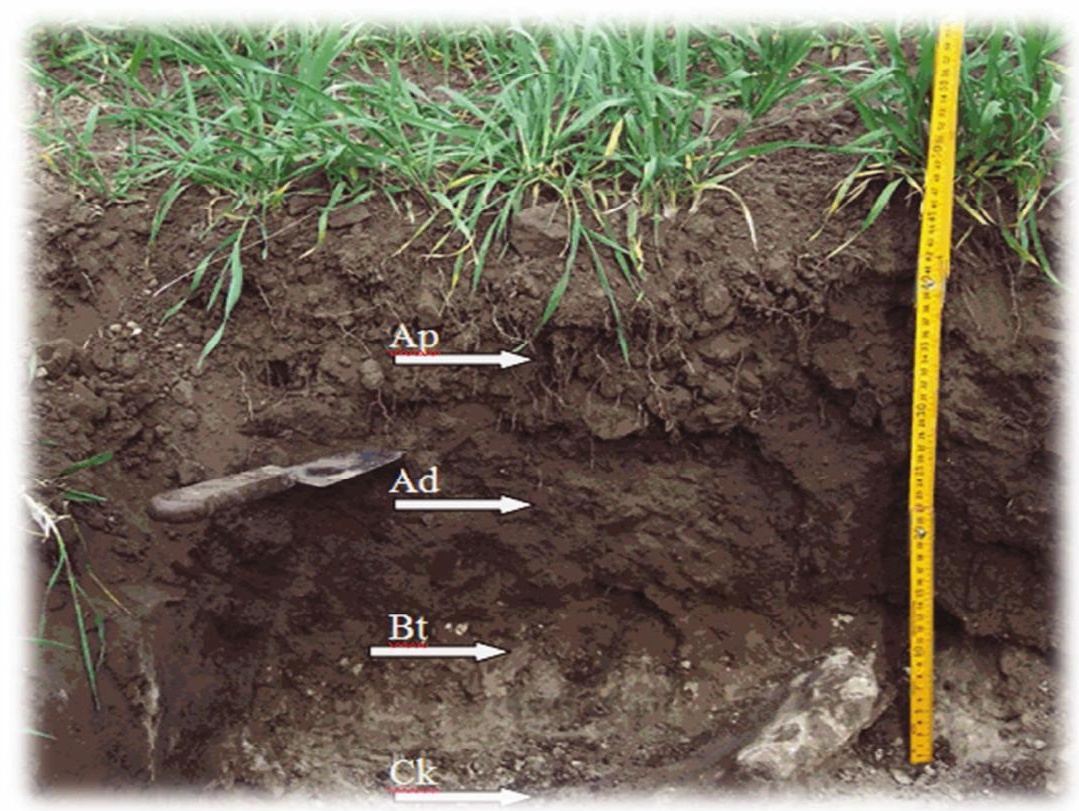


DESARROLLO DE UNA APLICACIÓN IMFORMÁTICA PARA EL CÁLCULO DE SOSTENIMIENTO DE TALUDES MEDIANTE VEGETACIÓN

RESULTADOS DE ANÁLISIS DE LABORATORIO DE CARACTERIZACIÓN Y COMPOSICIÓN DE SUELOS.

1.- RESULTADOS DE ANÁLISIS DE CARACTERIZACIÓN DE SUELOS. 


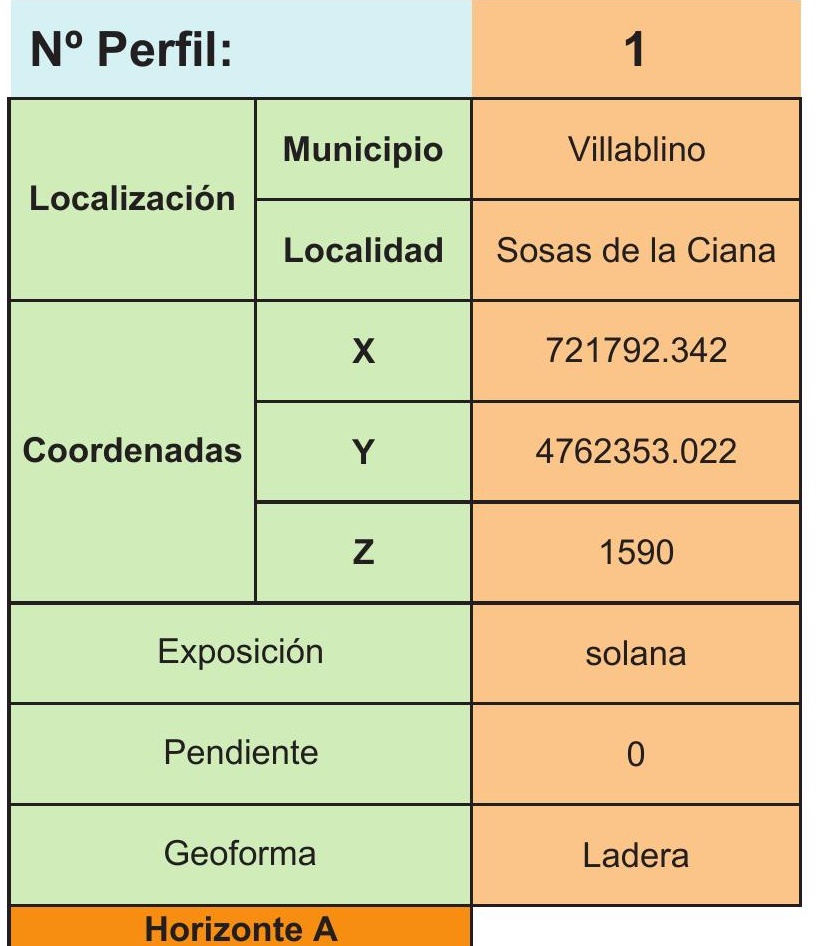

\begin{tabular}{|c|c|}
\hline Erosión & No hay manifestación \\
\hline Vegetación & Monte bajo robles y ericas \\
\hline Usos terreno & Grupo C, calse VII \\
\hline Roca Madre & Pizarras y areniscas \\
\hline Terren. Circu. & Igual características \\
\hline Aflor. Rocosos & Numerosos puntos \\
\hline Pedreg. Super. & Abundante \\
\hline Tiempo Atmosf. & Soleado y frío \\
\hline Profundidad & 0 - 10 cm \\
\hline
\end{tabular}

Abundante pedregosidad, constituida por piedras y cascajos. Consistencia blanda en seco y, color pardo en seco y en humedo pardo grisáceo oscuro, siendo la separación con el horizonte inferior difusa. Abundante raíces y actividad microbiana normal.

\section{Horizonte B}

\section{Profundidad}

$15-30 \mathrm{~cm}$

De características analogas al horizonte anterior en cuanto a las caracteristicas mineralogicas, con estruztura en bloques subangulares, moderada. Color en seco rojo debil y en huemdo rojo debil a pardo-rojizo. Baja ligeramente el contenido de elementos activos y de reserva. Raices frecuentes y poca actividad biologica.

\begin{tabular}{|c|l|l|}
\cline { 3 - 3 } Horizonte C & Profundidad & \multicolumn{1}{c|}{$>30 \mathrm{~cm}$} \\
\hline Roca madre de pizarras y cuarcitas. & \multicolumn{2}{l|}{} \\
\hline Horizonte & Profundidad & \\
\hline \multicolumn{3}{|l}{} \\
\hline
\end{tabular}


ANÁLISIS DE CARACTERIZACIÓN DE SUELOS

Desarrollo de una aplicación informática para el cálculo de sostenimiento de taludes mediante vegetación

$N^{\circ}$ Perfil:

\begin{tabular}{|c|c|c|}
\hline \multirow{2}{*}{ Localización } & Municipio & Villablino \\
\cline { 2 - 3 } & Localidad & Orallo \\
\hline \multirow{2}{*}{ Coordenadas } & $\mathbf{X}$ & 715692.8832 \\
\cline { 2 - 3 } & $\mathbf{Y}$ & 4760213.722 \\
\cline { 2 - 3 } & $\mathbf{Z}$ & 1452 \\
\hline Exposición & solana \\
\hline \multicolumn{2}{|c|}{ Pendiente \% } & 55 \\
\hline \multicolumn{2}{|c|}{ Geoforma } & Intermerdia \\
\hline \multicolumn{2}{|c|}{ Horizonte A } & \\
\hline
\end{tabular}

2

\begin{tabular}{|c|c|}
\hline Erosión & $\begin{array}{c}\text { Se manifiesta claramente } \\
\text { en gran parte de la zona. }\end{array}$ \\
\hline Vegetación & $\begin{array}{c}\text { Monte de robles y } \\
\text { carrascas. }\end{array}$ \\
\hline Usos terreno & Grupo C, calse VII \\
\hline Roca Madre & Pizarras y carbon \\
\hline Terren. Circu. & Igual caracteristicas \\
\hline Aflor. Rocosos & Numeros puntos \\
\hline Pedreg. Super. & Abundante \\
\hline Tiempo Atmosf. & Soleado y frio \\
\hline Profundidad & 0 - 20 cm \\
\hline
\end{tabular}

Horizonte constituido por gran cantidad de elementeos gruesos, piedras y cascajo anguloso. La separación con el horizonte inferior esta claramente definida. Color en seco pardo grisaceo y en humedo pardo oscuro. Consistencua blanda y estructura migajosa moderada, con raices abuandantes y activa vida biológica.

\begin{tabular}{|c|c|c|}
\hline Horizonte C & Profundidad & $>20 \mathrm{~cm}$ \\
\hline \multicolumn{3}{|l|}{ Pizarras } \\
\hline Horizonte & Profundidad & \\
\hline Horizonte & Profundidad & \\
\hline & & \\
\hline & & \\
\hline & & \\
\hline
\end{tabular}




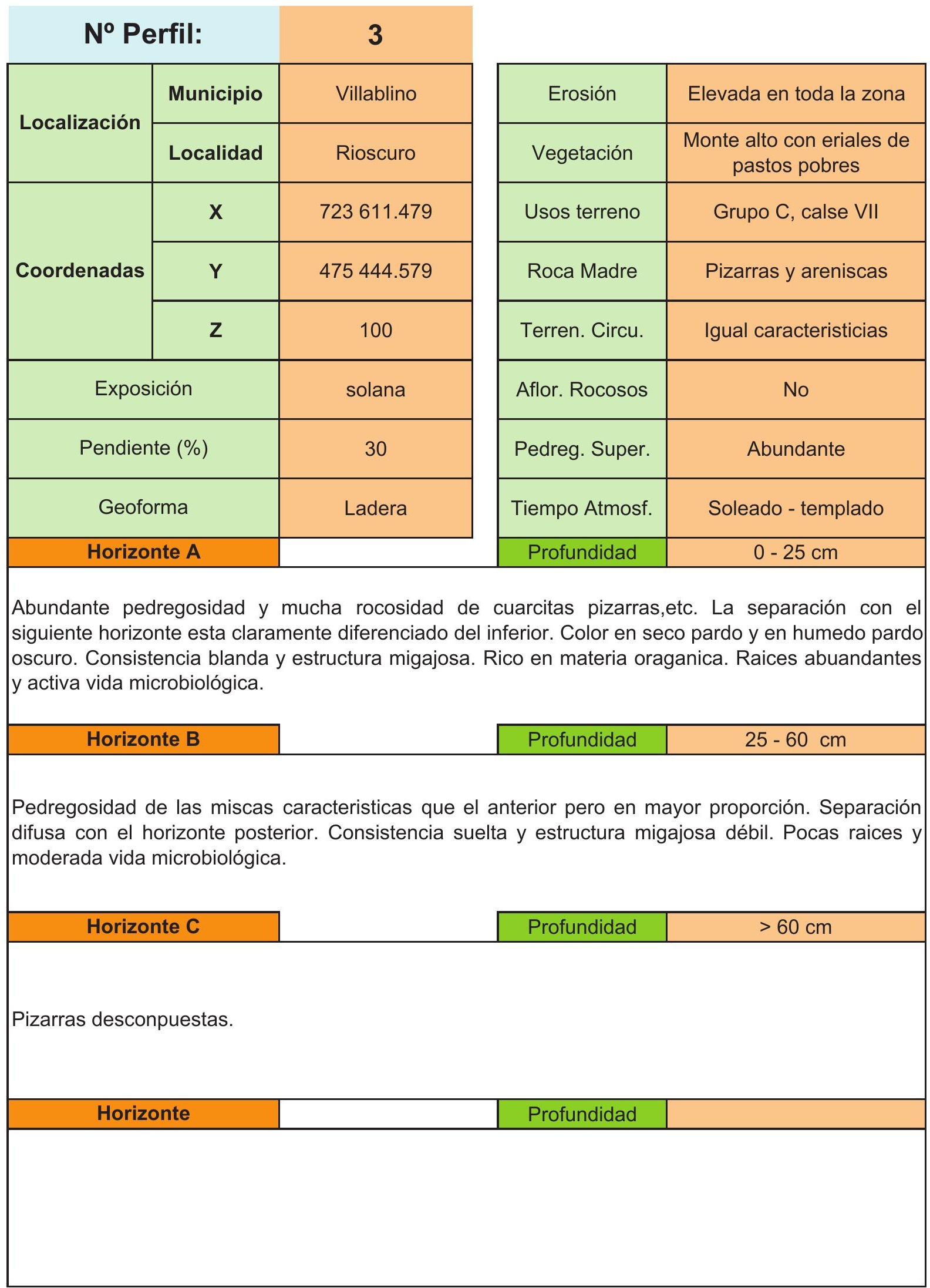




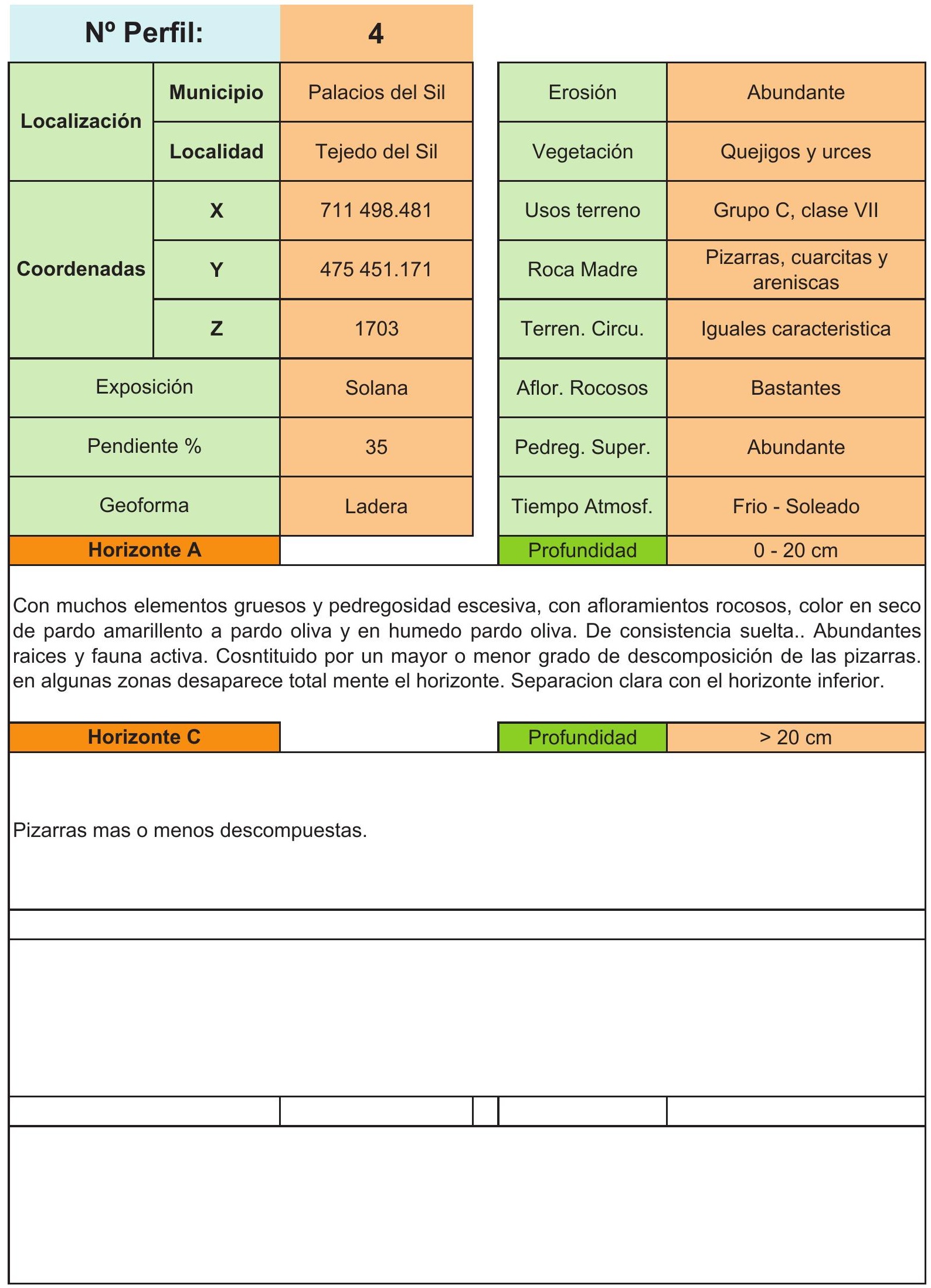


ANÁLISIS DE CARACTERIZACIÓN DE SUELOS

Desarrollo de una aplicación informática para el cálculo de sostenimiento de taludes mediante vegetación

No Perfil:

\begin{tabular}{|c|c|c|}
\hline \multirow{2}{*}{ Localización } & Municipio & Palacios del Sil \\
\cline { 2 - 3 } & Localidad & Valdeprado \\
\hline \multirow{2}{*}{ Coordenadas } & $\mathbf{X}$ & 708202.321 \\
\cline { 2 - 3 } & $\mathbf{Y}$ & 4750372.954 \\
\cline { 2 - 3 } & & 1301 \\
\hline Exposición & solana \\
\hline \multicolumn{2}{|c|}{ Pendiente \% } & 50 \\
\hline \multicolumn{2}{|c|}{ Geoforma } & Ladera \\
\hline \multicolumn{2}{|c|}{ Horizonte A } & \\
\hline
\end{tabular}

\section{5}

\begin{tabular}{|c|c|}
\hline Erosión & Poca \\
\hline Vegetación & Monte alto y bajo. \\
\hline Usos terreno & Grupo C, clase VII \\
\hline Roca Madre & $\begin{array}{c}\text { Pizarra, cuarcitas y } \\
\text { areniscas }\end{array}$ \\
\hline Terren. Circu. & Igual carracteristica \\
\hline Aflor. Rocosos & Abundante \\
\hline Pedreg. Super. & Poca \\
\hline Tiempo Atmosf. & Frio y humedo \\
\hline Profundidad & 0 - 20 cm \\
\hline
\end{tabular}

Horizonte con grandes afloramientos rocosos, pero sin gran pedregosidad, siendo estas del tipo planiforme. Terreno de consistencia blanda y estructura en bloques. Color pardo grisaceo. Abunadantes raices y activa vida microbiana.

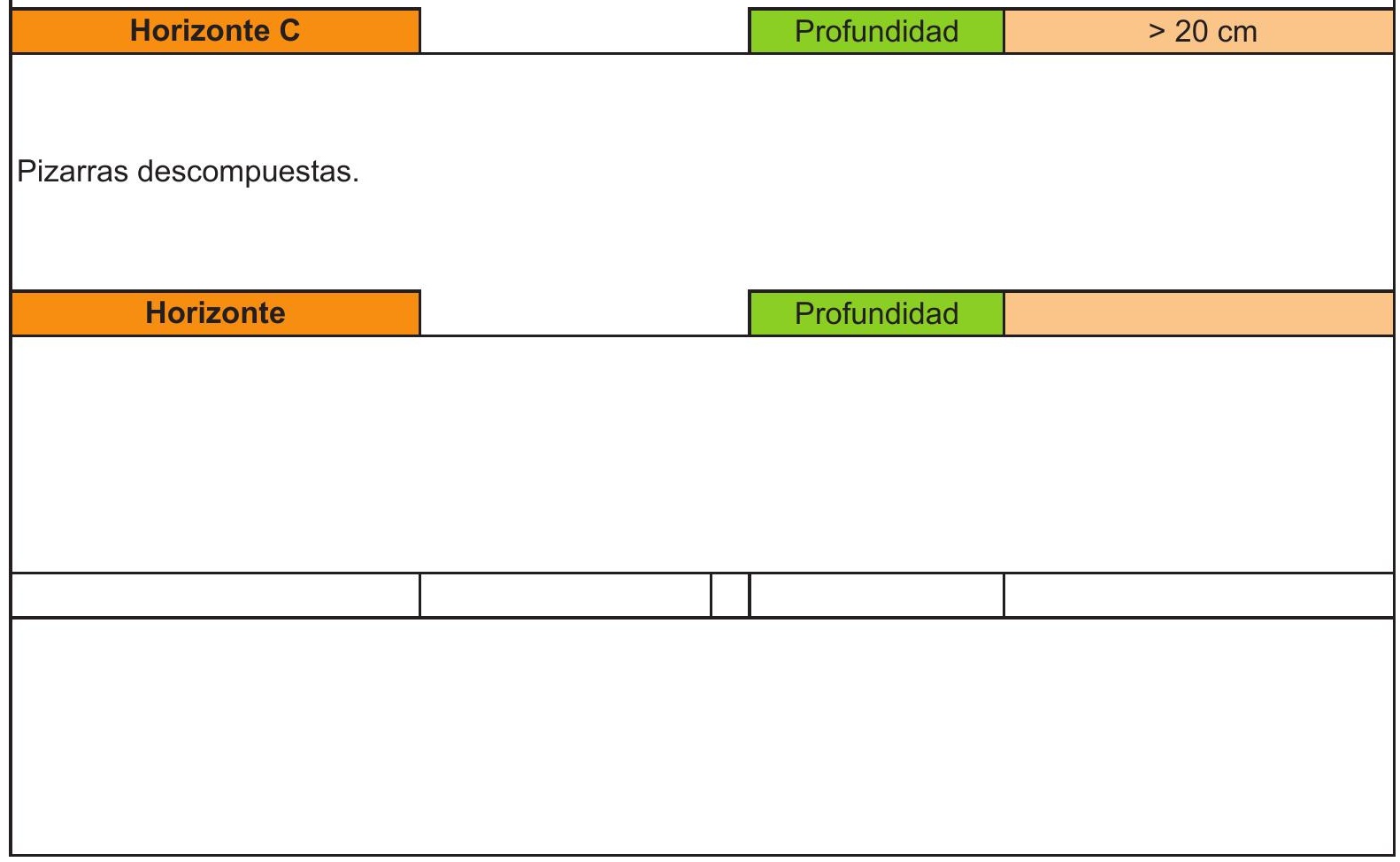




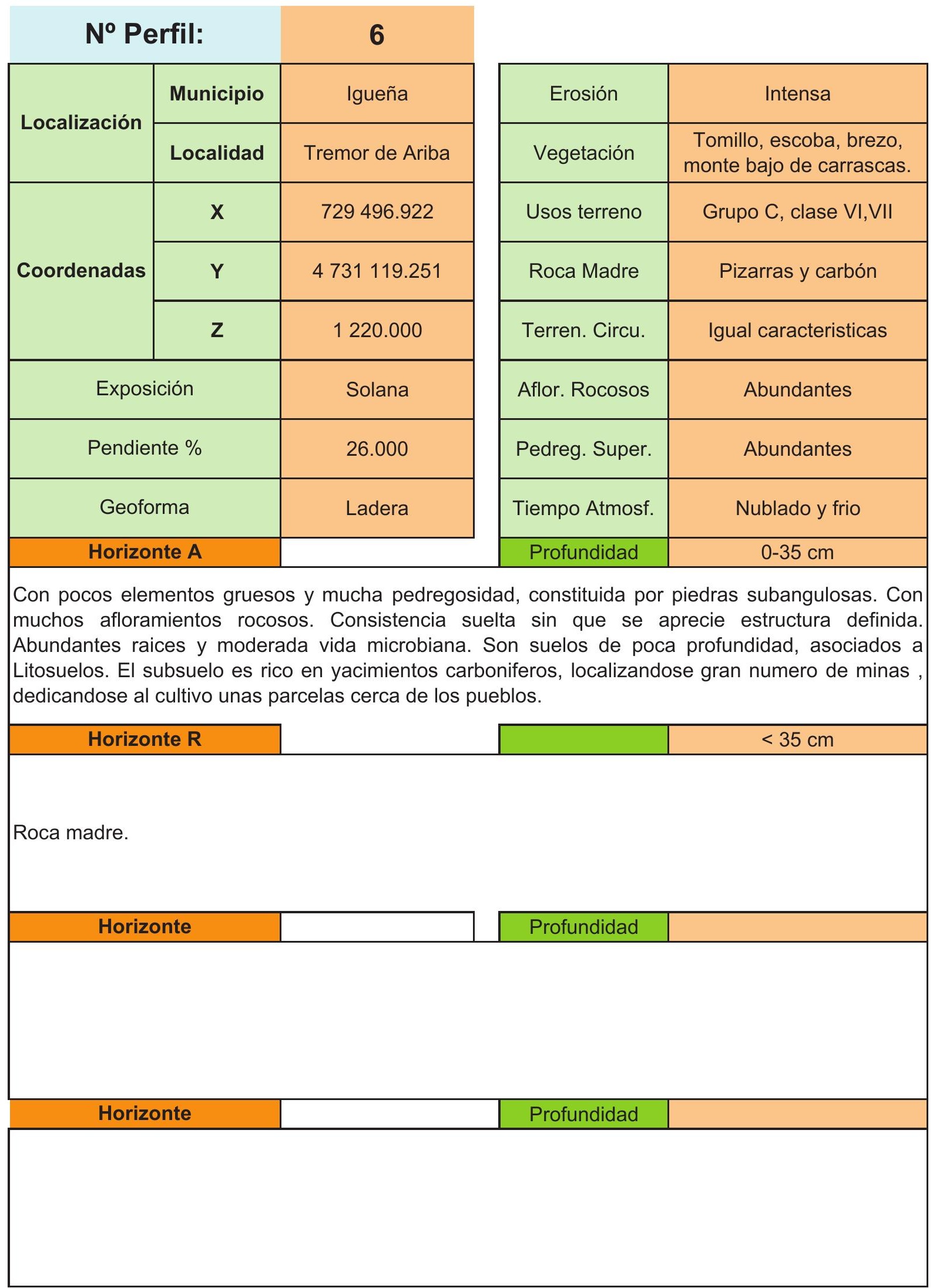




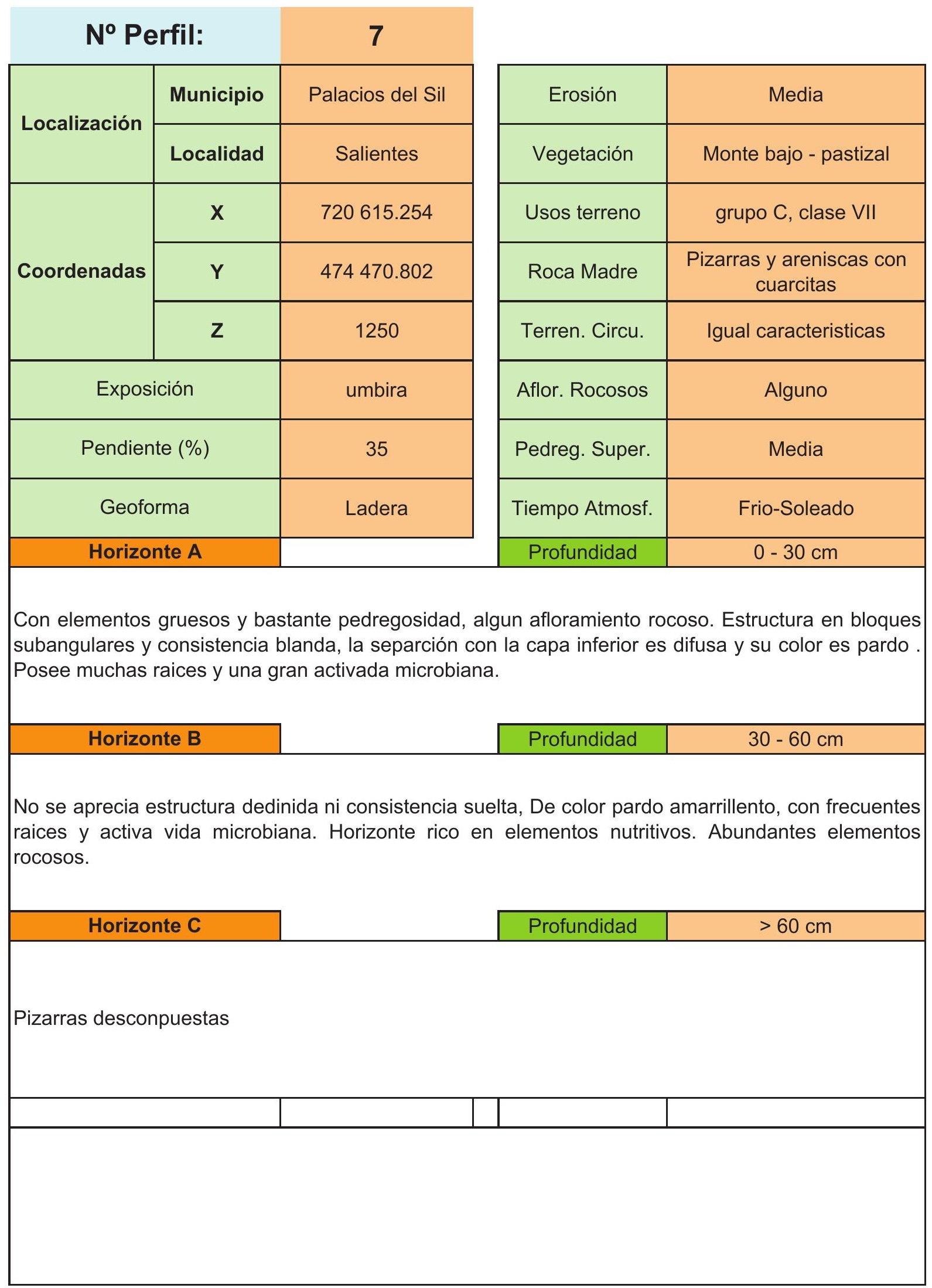


ANÁLISIS DE CARACTERIZACIÓN DE SUELOS

Desarrollo de una aplicación informática para el cálculo de sostenimiento de taludes mediante vegetación

No Perfil:

\begin{tabular}{|c|c|c|}
\hline \multirow{2}{*}{ Localización } & Municipio & Paramo del Sil \\
\cline { 2 - 3 } & Localidad & Anllares \\
\hline \multirow{2}{*}{ Coordenadas } & $\mathbf{X}$ & 702958.926 \\
\cline { 2 - 3 } & $\mathbf{Y}$ & 4747377.926 \\
\cline { 2 - 3 } & $\mathbf{Z}$ & 1310 \\
\hline Exposición & Solana \\
\hline Pendiente \% & 25 \\
\hline \multicolumn{2}{|c|}{ Geoforma } & Ladera \\
\hline \multicolumn{2}{|c|}{ Horizonte A } & \\
\hline
\end{tabular}

\section{8}

\begin{tabular}{|c|c|}
\hline Erosión & Fuerte \\
\hline Vegetación & Praderas y monte bajo \\
\hline Usos terreno & Grupo B, Clase IV \\
\hline Roca Madre & Pizarras \\
\hline Terren. Circu. & iguales caracteristicas \\
\hline Aflor. Rocosos & Bastantes \\
\hline Pedreg. Super. & Abunadantes \\
\hline Tiempo Atmosf. & Soleado y fresco \\
\hline Profundidad & 25 cm \\
\hline
\end{tabular}

Con elmentos grueso u bastante pedregosidad de piedras y cascajos angulosos y subangulosos. Mucha rocosidad. Color en seco pardo amarillento y en humedo pardo oscuro.Cosistencia blanda y estructura migajosa. Abunadantes raices y actividad microbiana normal.

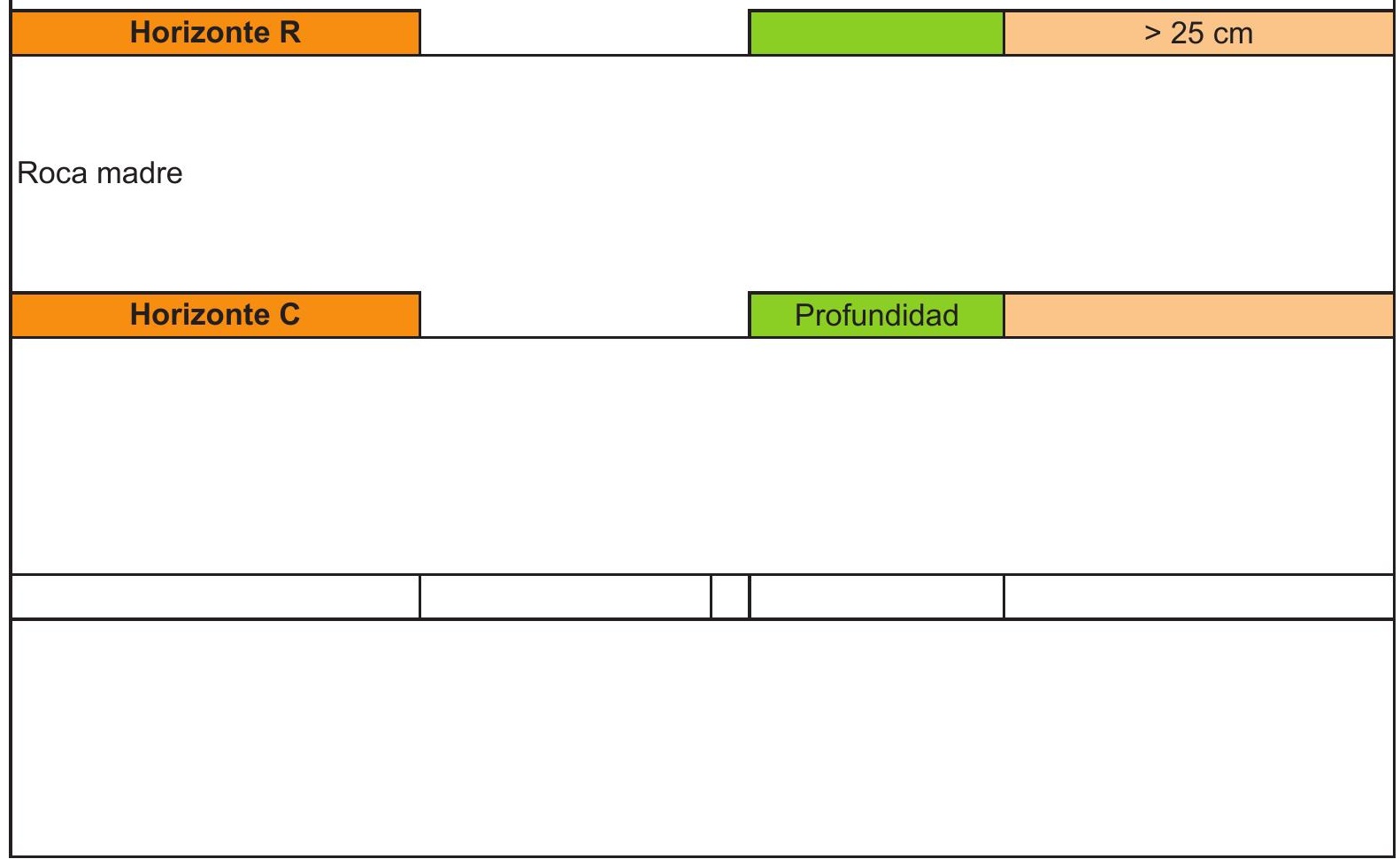


No Perfil:

\begin{tabular}{|c|c|c|}
\hline \multirow{2}{*}{ Localización } & Municipio & Parramo del Sil \\
\cline { 2 - 3 } & Localidad & Sorbeda \\
\hline \multirow{2}{*}{ Coordenadas } & $\mathbf{X}$ & 700178.716 \\
\cline { 2 - 3 } & $\mathbf{Y}$ & 474096.028 \\
\cline { 2 - 3 } & $\mathbf{Z}$ & 985 \\
\hline Exposición & Solana \\
\hline \multicolumn{2}{|c|}{ Pendiente } & 0.6 \\
\hline \multicolumn{2}{|c|}{ Geoforma } & Loma \\
\hline \multicolumn{2}{|c|}{ Horizonte A } & \\
\hline
\end{tabular}

\begin{tabular}{|c|c|}
\hline Erosión & Grande \\
\hline Vegetación & $\begin{array}{c}\text { Cereales y pasto, con algo } \\
\text { de monte bajo. }\end{array}$ \\
\hline Usos terreno & Grupo A, clase III \\
\hline Roca Madre & Arcillas y margas \\
\hline Terren. Circu. & Igual caracteristicas \\
\hline Aflor. Rocosos & Ninguno \\
\hline Pedreg. Super. & Poca \\
\hline Tiempo Atmosf. & Niebla \\
\hline Profundidad & 0 - $25 \mathrm{~cm}$ \\
\hline
\end{tabular}

Abundante pedregosidad formada por cascajo procedente de la descomposición de las pizarras y cuarcitas. Estructura en bloques subangulares de poca estabilidad y consistencia blanda. Corlor en huemdo pardo oscuro amarillento y en seco pardo amarillento. Separación definida con el horizonte inferior. con abundante raices y acitva vida microbiana.

Con pocos elementos gruesos y poca pedregosida constituida por piedras de cascajo redondeado. Color en humedo pardo rojizo y en seco pardo fuerte. Separción con el horizonte inferior es difusa, disminullendo la activiad biologica y pocas raices.

\section{Horizonte B2}

\section{$70-150 \mathrm{~cm}$}

Con pocos elementos gruesos y pedregosidad constituida por piedras de cascajo redondeado en mayor canticad que el horizonte anterior. Color en humedo pardo rojizo y en seco pardo fuerte. Separción con el horizonte inferior es difusa, sin activiad biologica y sin raices.

Horizonte C

$>150 \mathrm{~cm}$

Roca madre descompuesta. 
ANÁLISIS DE CARACTERIZACIÓN DE SUELOS

Desarrollo de una aplicación informática para el cálculo de sostenimiento de taludes mediante vegetación

No Perfil:

\begin{tabular}{|c|c|c|}
\hline \multirow{2}{*}{ Localización } & Municipio & Páramo del Sil \\
\cline { 2 - 3 } & Localidad & Santa Cruz del Sil \\
\hline \multirow{2}{*}{ Coordenadas } & $\mathbf{X}$ & 708568.008 \\
\cline { 2 - 3 } & $\mathbf{Y}$ & 4737250.975 \\
\cline { 2 - 3 } & $\mathbf{Z}$ & 1005 \\
\hline Exposición & Media luz \\
\hline \multicolumn{2}{|c|}{ Pendiente \% } & 15 \\
\hline \multicolumn{2}{|c|}{ Geoforma } & Ladera \\
\hline \multicolumn{2}{|c|}{ Horizonte A } & \\
\hline
\end{tabular}

10

\begin{tabular}{|c|c|}
\hline Erosión & Bastante \\
\hline Vegetación & Ericas y quejigos \\
\hline Usos terreno & Grupo C, clase IV \\
\hline Roca Madre & Pizarras \\
\hline Terren. Circu. & Iguales características \\
\hline Aflor. Rocosos & Abundantes \\
\hline Pedreg. Super. & Abundantes \\
\hline Tiempo Atmosf. & Nublado y frío \\
\hline Profundidad & $40 \mathrm{~cm}$ \\
\hline
\end{tabular}

Elementos grueso y abundante pedregosidad formada por piedras angulosas. Estructura en bloque débil y fina y de consistencia blanda, el color es amarillo rojizo. Con escasas raíces y poca vida microbiana.

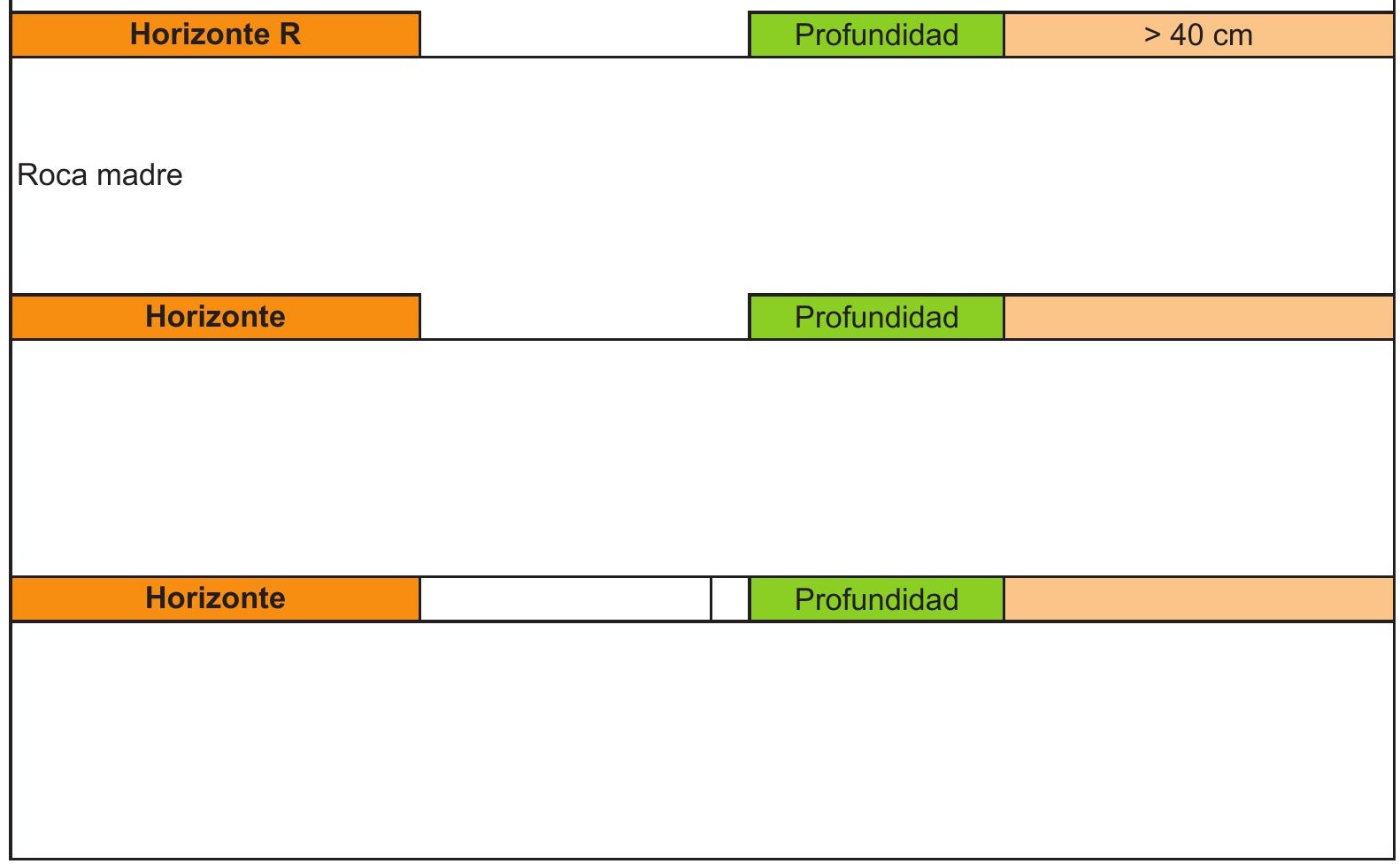


ANÁLISIS DE CARACTERIZACIÓN DE SUELOS

Desarrollo de una aplicación informática para el cálculo de sostenimiento de taludes mediante vegetación

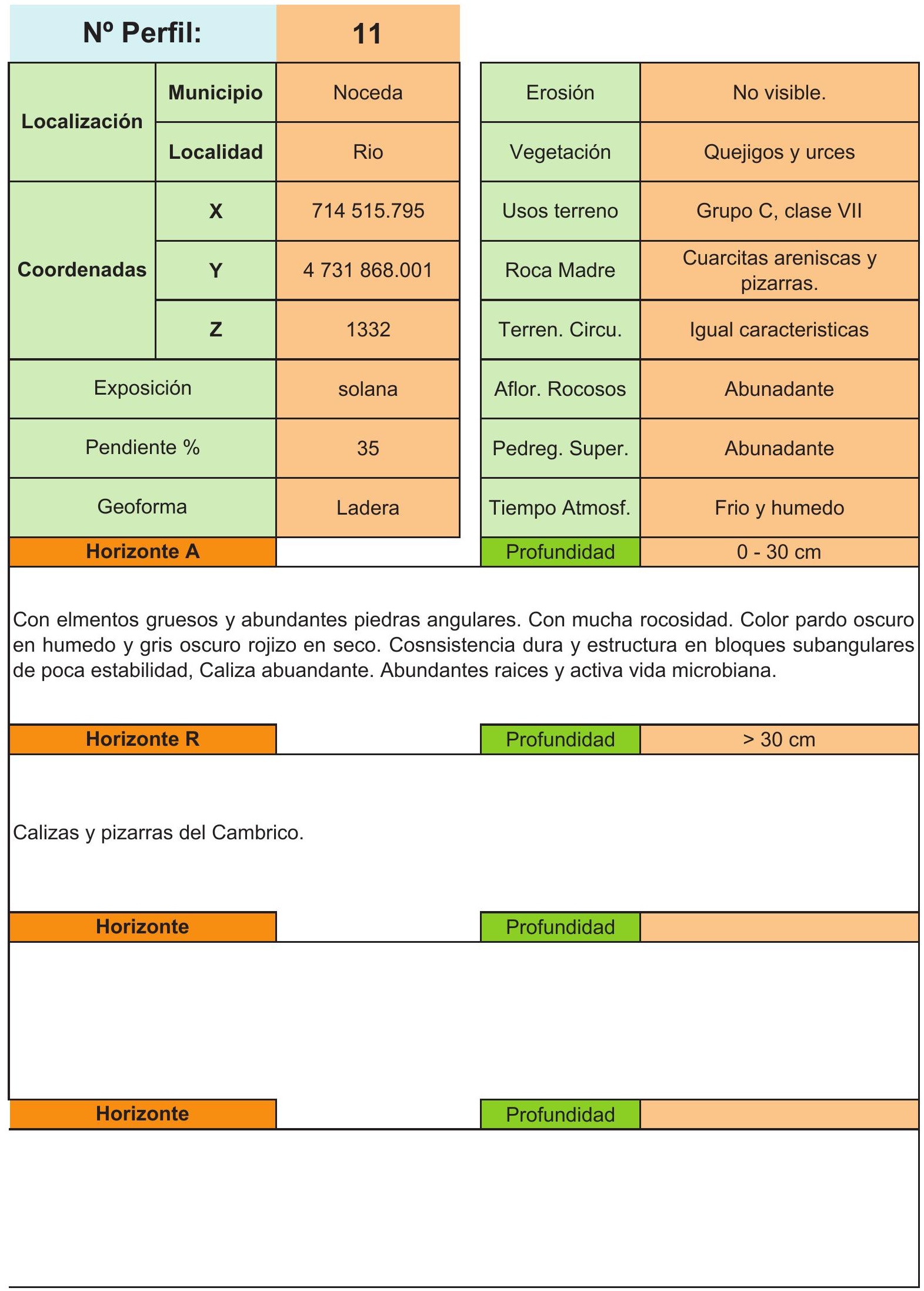




No Perfil:
\begin{tabular}{|c|c|c|}
\hline \multirow{2}{*}{ Localización } & Municipio & 12 \\
\cline { 2 - 3 } & Localidad & $\begin{array}{c}\text { Urdiales de la } \\
\text { Colina }\end{array}$ \\
\hline \multirow{2}{*}{ Coordenadas } & $\mathbf{X}$ & 718689.109 \\
\cline { 2 - 3 } & $\mathbf{Y}$ & 4735852.710 \\
\cline { 2 - 3 } & $\mathbf{Z}$ & 1325 \\
\hline Exposición & Solana \\
\hline Pendiente \% & 44 \\
\hline \multicolumn{2}{|c|}{ Geoforma } & Ladera \\
\hline \multicolumn{2}{|c|}{ Horizonte A } & \\
\hline
\end{tabular}

Con elementos gruesos y mucha pedregosidad formada por grava planiforme. Con mucha rocosidad. Estructura débil en bloques. Consistencia blanda. Escasas raices y moderada actividad microbiana. Con frecuencia el suelo desaparece, constituyendo verdaderos litosulos.

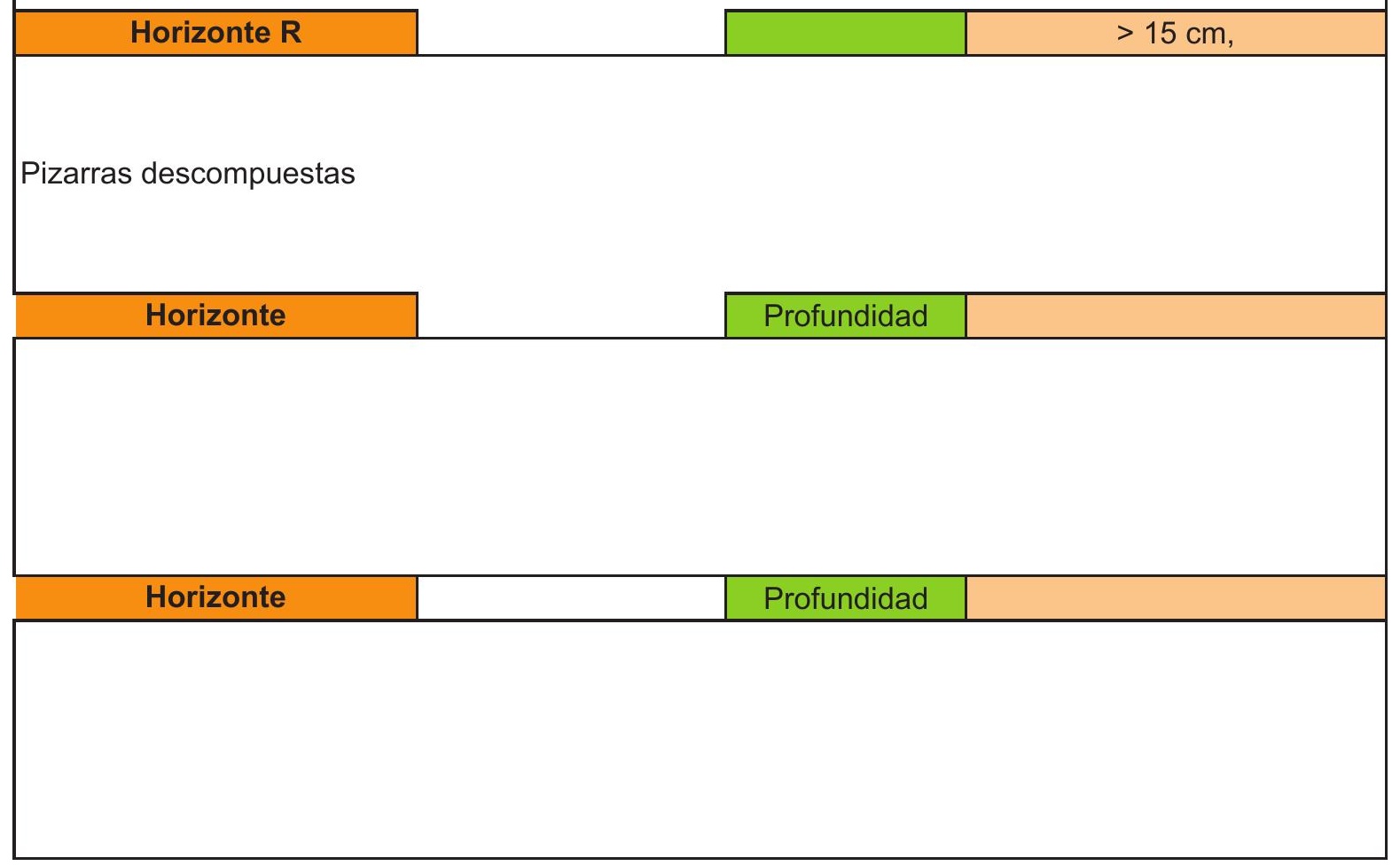




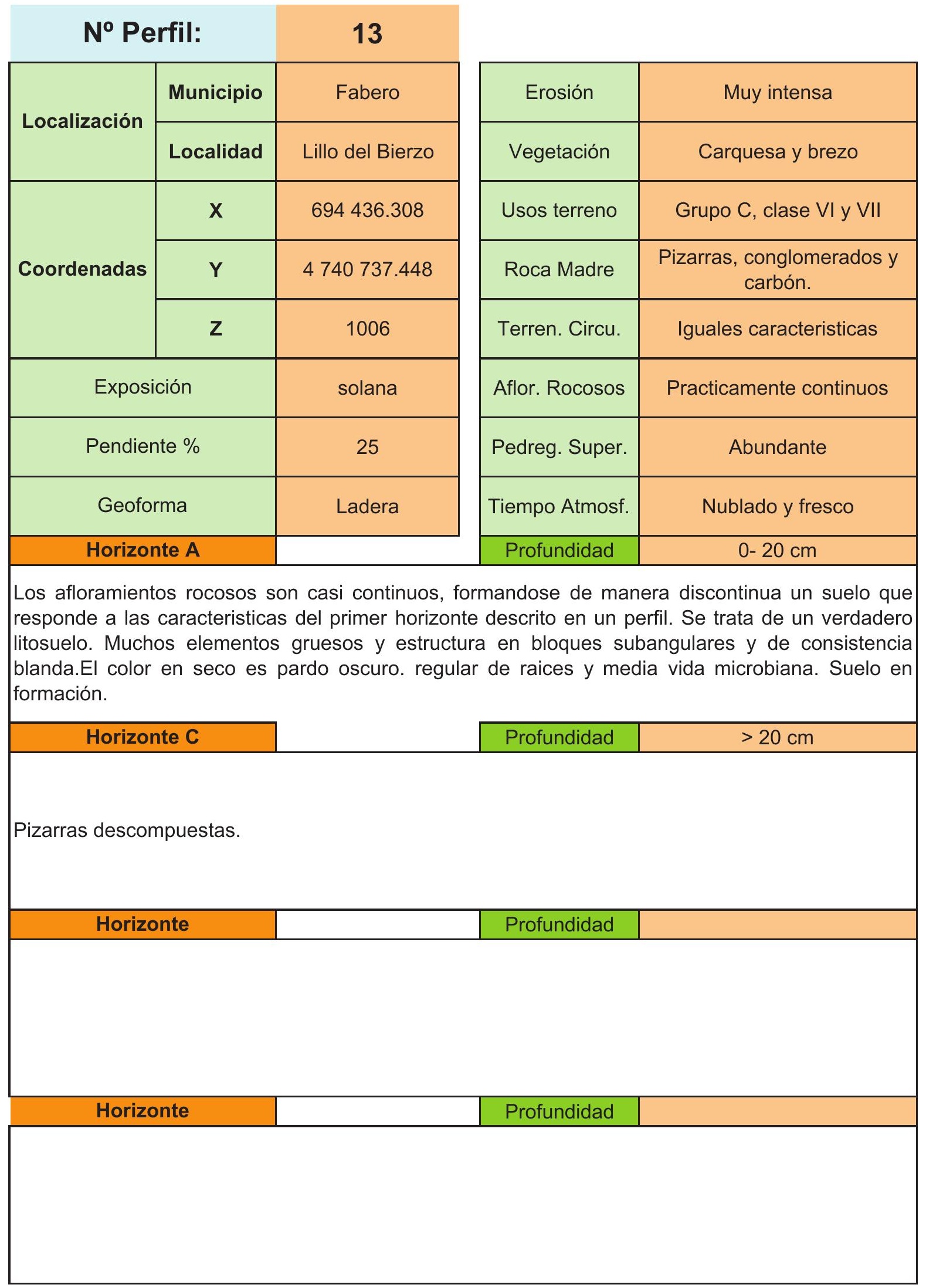


ANÁLISIS DE CARACTERIZACIÓN DE SUELOS

Desarrollo de una aplicación informática para el cálculo de sostenimiento de taludes mediante vegetación

\begin{tabular}{|c|c|c|c|c|}
\hline \multicolumn{2}{|c|}{ No Perfil: } & \multirow{2}{*}{14} & \multirow[b]{2}{*}{ Erosión } & \multirow[b]{2}{*}{ No hay manifestación } \\
\hline & Municipio & & & \\
\hline & Localidad & Villar de Trabiesas & Vegetación & Momte bajo robles y ericas \\
\hline \multirow{3}{*}{ Coordenadas } & $x$ & 707132.240 & Usos terreno & Forestal \\
\hline & $\mathbf{Y}$ & 4731119.251 & Roca Madre & Pizarras con conglomerados \\
\hline & $\mathbf{z}$ & 960 & Terren. Circu. & Igual carzteristicas \\
\hline \multicolumn{2}{|c|}{ Exposición } & solana & Aflor. Rocosos & Numeros puntos \\
\hline \multicolumn{2}{|c|}{ Pendiente } & 0 & Pedreg. Super. & Abundante \\
\hline \multicolumn{2}{|c|}{ Geoforma } & Ladera & Tiempo Atmosf. & Soleado y frio \\
\hline \multicolumn{2}{|c|}{ Horizonte A } & & Profundidad & $0-20 \mathrm{~cm}$ \\
\hline \multicolumn{5}{|c|}{$\begin{array}{l}\text { Elementos gruesos y mucha pedregosidad, estremadamente rocoso. Color en seco pardo oscuro y } \\
\text { en humedo pardo amarillento. Estando claramente definaida la separción con el horizonte inferior, } \\
\text { la consistencia en seco es blanda y la estructura migajosa débil. Abundante raices y moderada } \\
\text { acitividad microbiana. }\end{array}$} \\
\hline \multicolumn{2}{|c|}{ Horizonte $\mathbf{R}$} & & Profundidad & $>20 \mathrm{~cm}$ \\
\hline \multicolumn{5}{|l|}{ Roca Madre } \\
\hline \multicolumn{2}{|c|}{ Horizonte } & & Profundidad & \\
\hline \multicolumn{2}{|c|}{ Horizonte } & & Profundidad & \\
\hline
\end{tabular}


ANÁLISIS DE CARACTERIZACIÓN DE SUELOS

Desarrollo de una aplicación informática para el cálculo de sostenimiento de taludes mediante vegetación

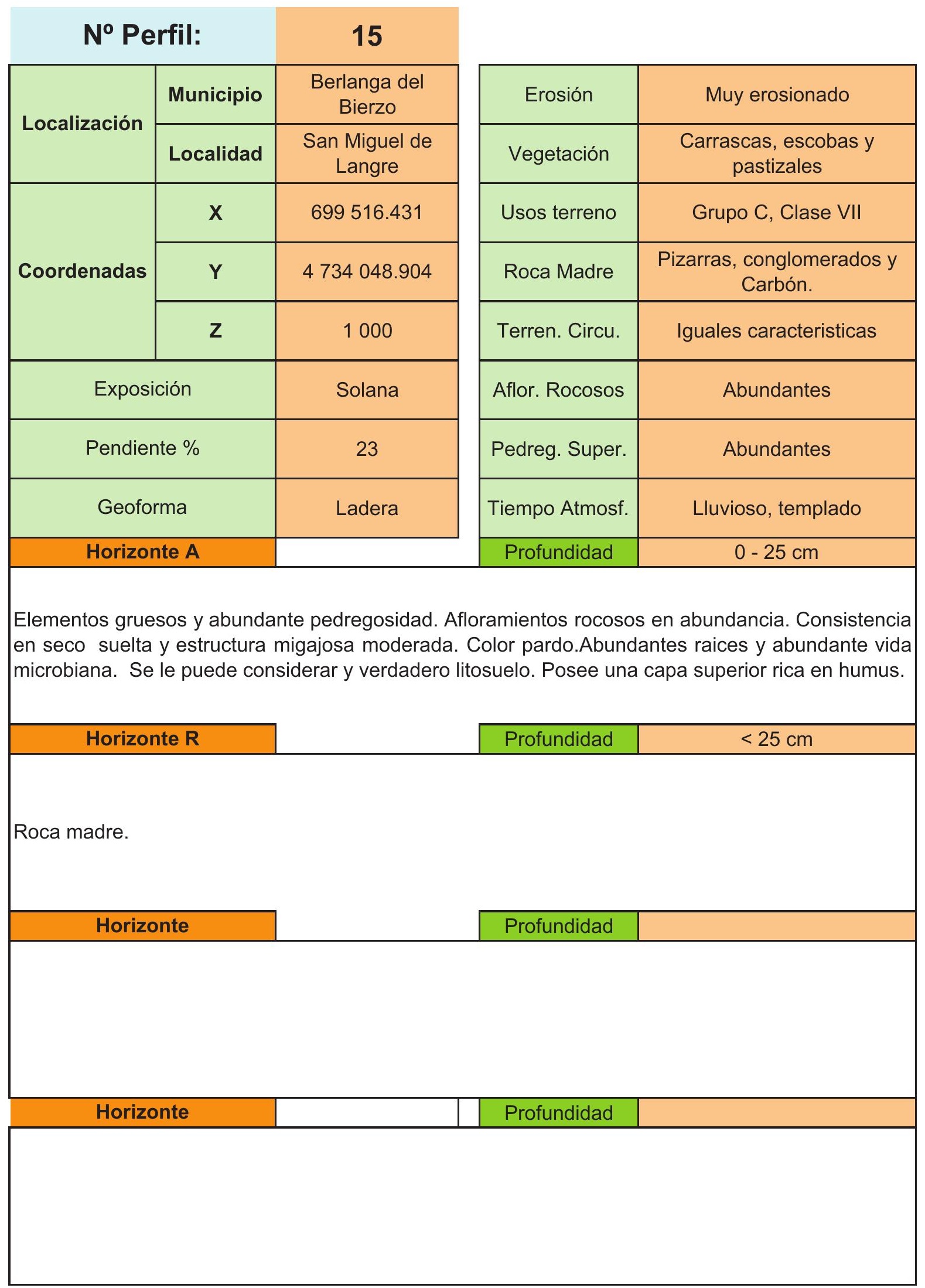




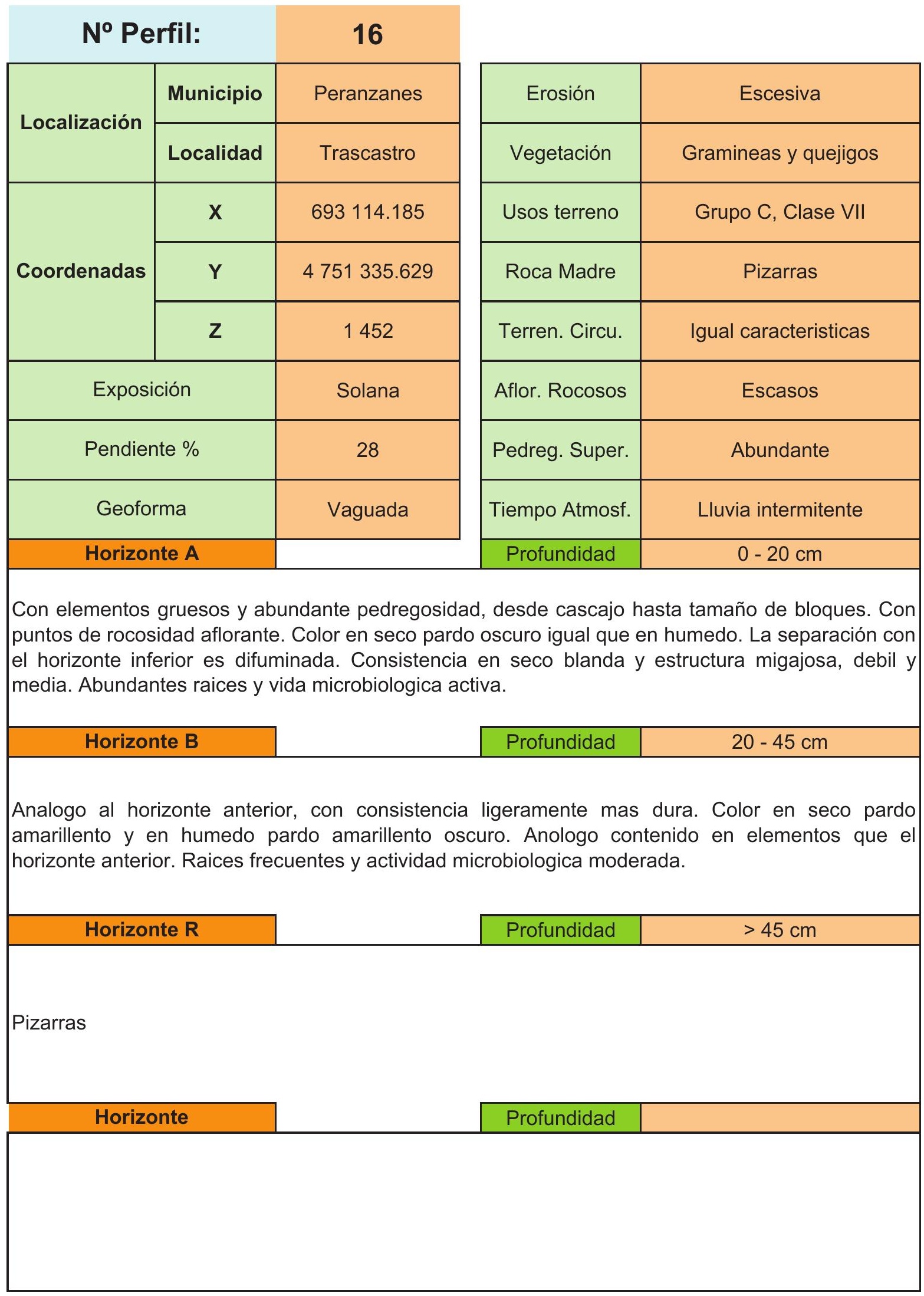




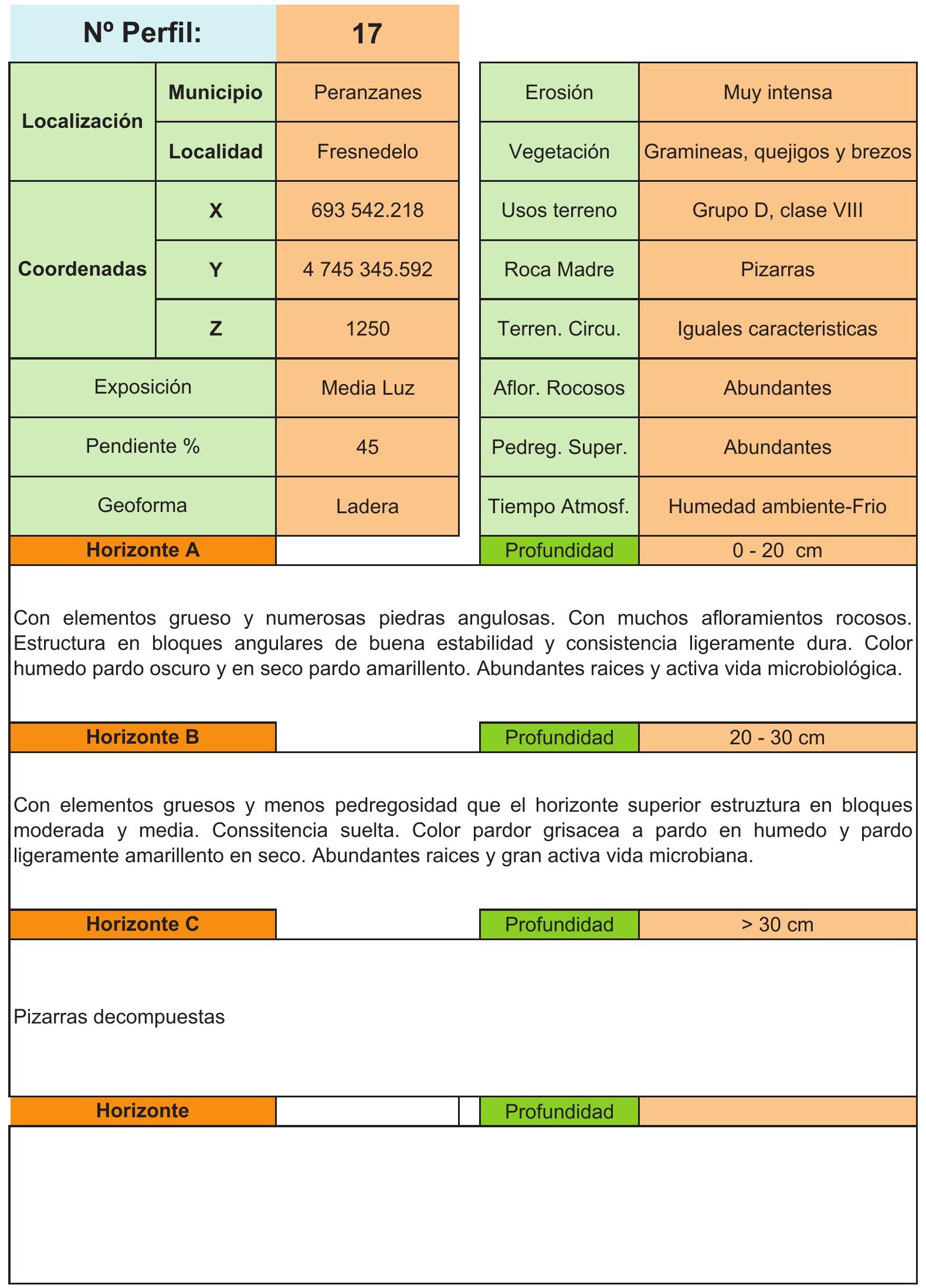


ANÁLISIS DE CARACTERIZACIÓN DE SUELOS

Desarrollo de una aplicación informática para el cálculo de sostenimiento de taludes mediante vegetación

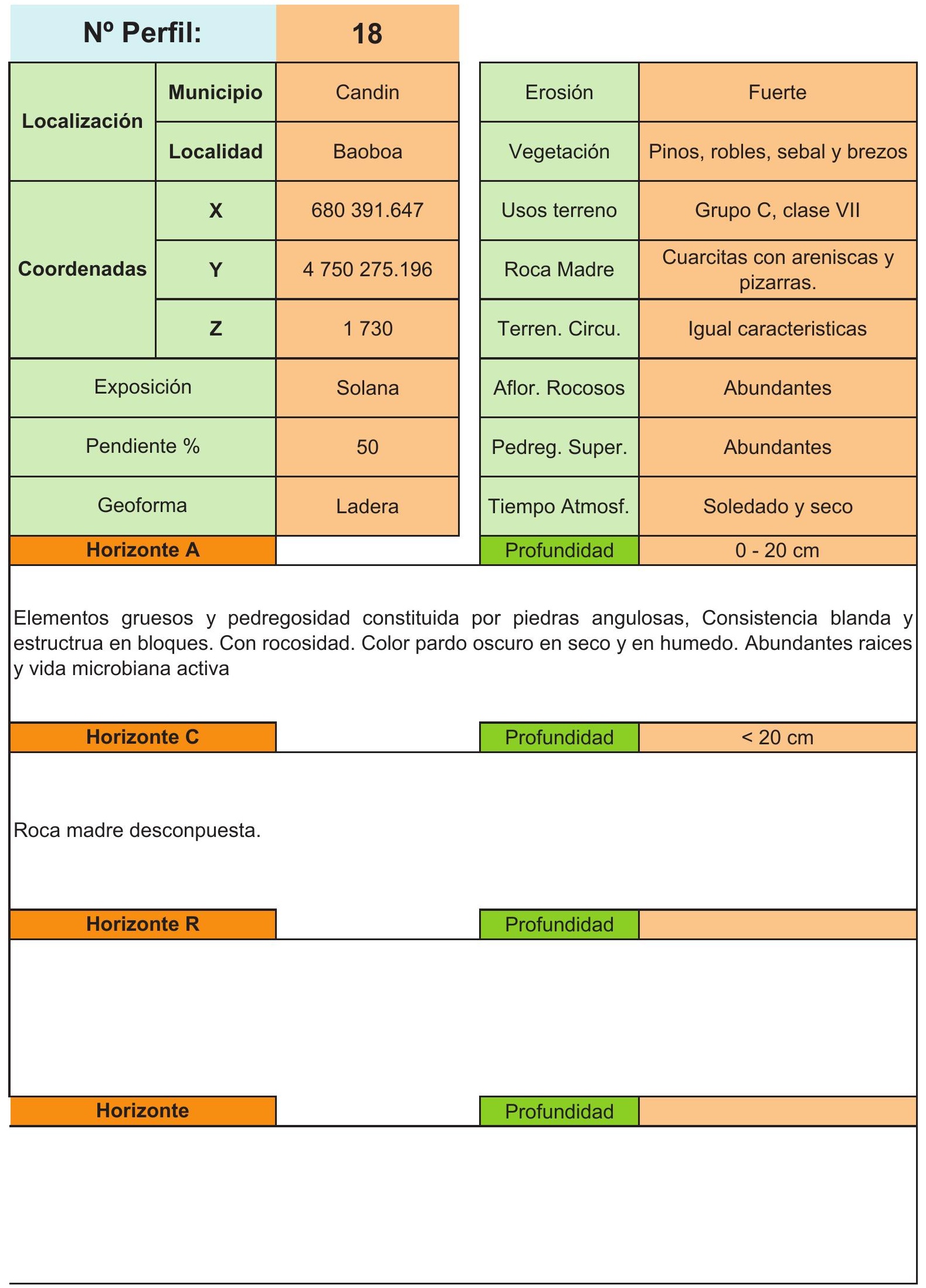


ANÁLISIS DE CARACTERIZACIÓN DE SUELOS

Desarrollo de una aplicación informática para el cálculo de sostenimiento de taludes mediante vegetación

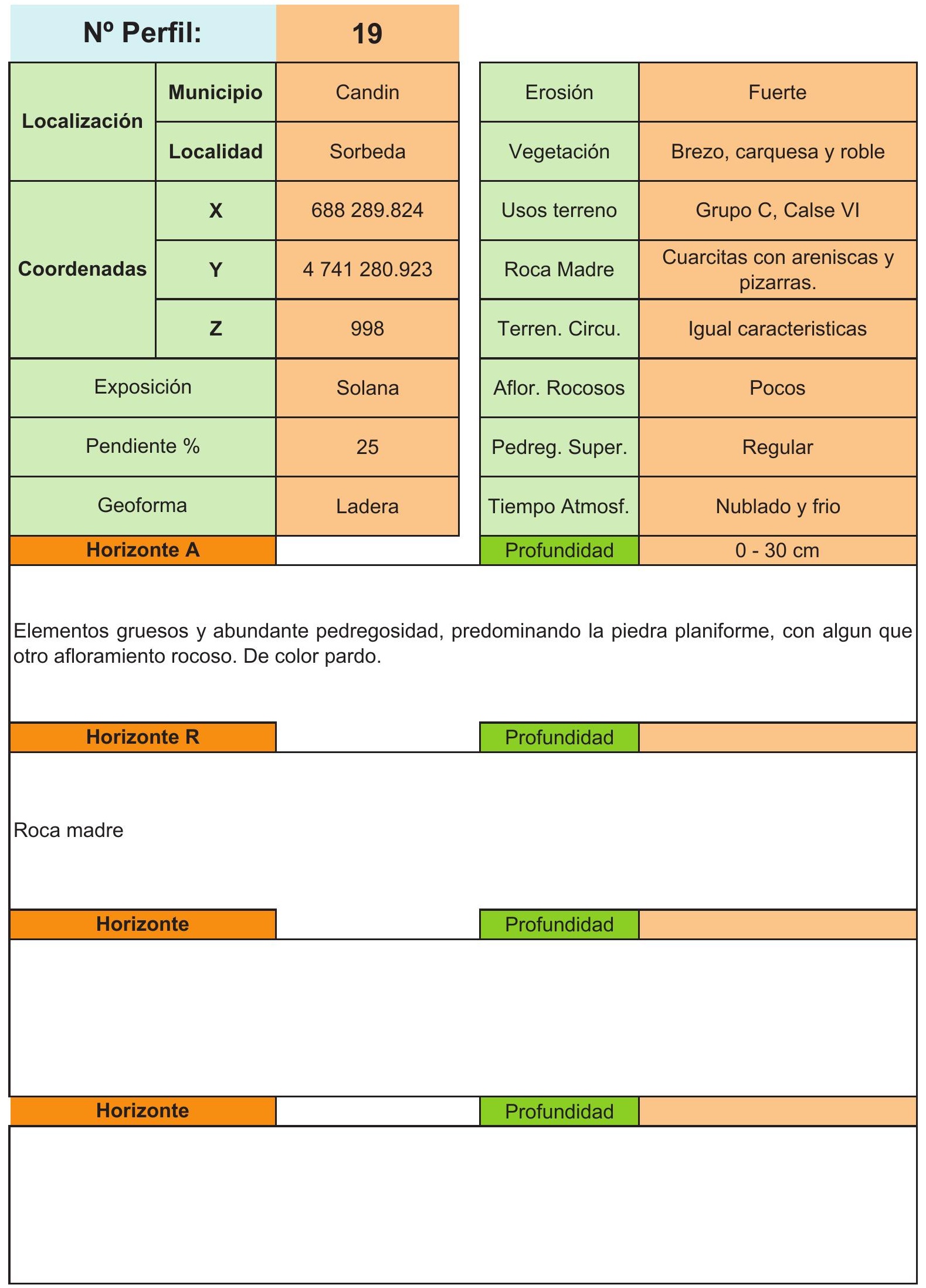


ANÁLISIS DE CARACTERIZACIÓN DE SUELOS

Desarrollo de una aplicación informática para el cálculo de sostenimiento de taludes mediante vegetación

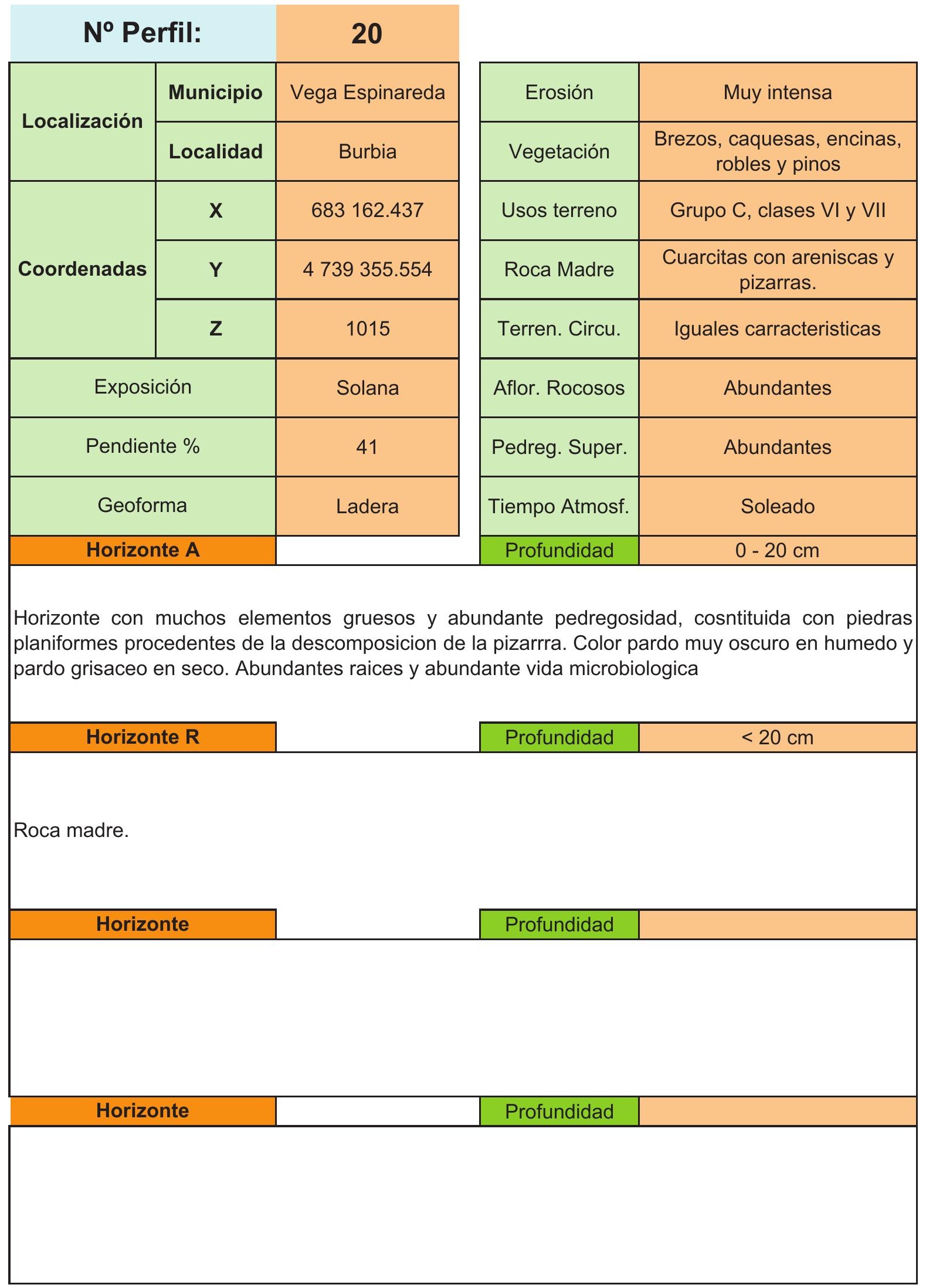




\begin{tabular}{|c|c|c|c|c|}
\hline \multicolumn{2}{|c|}{ No Perfil: } & \multirow{2}{*}{$\frac{21}{\text { Vega Espinareda }}$} & & \\
\hline \multirow{2}{*}{ Localización } & Municipio & & Erosión & Poco erosionado \\
\hline & Localidad & Moreda & Vegetación & Cereales, viña y monte bajo \\
\hline \multirow{3}{*}{ Coordenadas } & $x$ & 687228.743 & Usos terreno & $\begin{array}{c}\text { Grupo A, Clase II y Grupo B, } \\
\text { clase IV }\end{array}$ \\
\hline & $\mathbf{Y}$ & 4733258.550 & Roca Madre & Pizarras y cuarcitas \\
\hline & $\mathbf{z}$ & 720 & Terren. Circu. & Iguales características \\
\hline \multicolumn{2}{|c|}{ Exposición } & Media Luz & Aflor. Rocosos & Ninguno \\
\hline \multicolumn{2}{|c|}{ Pendiente \% } & 10 & Pedreg. Super. & Poca o nula \\
\hline \multicolumn{2}{|c|}{ Geoforma } & Vaguada & Tiempo Atmosf. & Soleado y seco \\
\hline \multicolumn{2}{|c|}{ Horizonte A } & & Profundidad & $0-40 \mathrm{~cm}$ \\
\hline \multicolumn{5}{|c|}{$\begin{array}{l}\text { Elementos gruesos y regular pedregosidad constituidos por piedra y cascajo, generalmente } \\
\text { cuarcitas. Estructura en bloque de débil estado de agregación y consistencia blanda. Color pardo en } \\
\text { húmedo y amarillo rojizo en seco. Sin rocosidad. Abundantes raices y buena actividad } \\
\text { microbiologica. La separación con el horizonte inferior esta bien definida. }\end{array}$} \\
\hline \multicolumn{2}{|c|}{ Horizonte B1 } & & & $40-110 \mathrm{~cm}$ \\
\hline \multicolumn{5}{|c|}{$\begin{array}{l}\text { Con pocos elementos gruesos y poca pedregosida constituida por piedras de cascajo redondeado } \\
\text { Color en humedo pardo rojizo y en seco pardo fuerte. Separción con el horizonte inferior es difusa, } \\
\text { disminullendo la activiad biologica y pocas raices. }\end{array}$} \\
\hline \multicolumn{2}{|c|}{ Horizonte B2 } & & & $110-200 \mathrm{~cm}$ \\
\hline \multicolumn{5}{|c|}{$\begin{array}{l}\text { Con pocos elementos gruesos y pedregosidad constituida por piedras de cascajo redondeado en } \\
\text { mayor canticad que el horizonte anterior. Color en humedo pardo rojizo y en seco pardo fuerte. } \\
\text { Separción con el horizonte inferior es difusa, sin activiad biologica y sin raices. }\end{array}$} \\
\hline \multicolumn{2}{|c|}{ Horizonte C } & & & $>200 \mathrm{~cm}$ \\
\hline \multicolumn{5}{|c|}{ Pizarras descompuestas y cuarcitas } \\
\hline
\end{tabular}


No Perfil:

\begin{tabular}{|c|c|c|}
\hline \multirow{2}{*}{ Localización } & Municipio & Vega Espinareda \\
\cline { 2 - 3 } & Localidad & Sésamo \\
\hline \multirow{2}{*}{ Coordenadas } & $\mathbf{X}$ & 692017.0025 \\
\cline { 2 - 3 } & $\mathbf{Z}$ & 4734163.981 \\
\hline Exposición & 652 \\
\hline \multicolumn{2}{|c|}{ Pendiente \% } & Solana \\
\hline \multicolumn{2}{|c|}{ Geoforma } & 6 \\
\hline Horizonte A & Vaguada \\
\hline
\end{tabular}

\section{2}

\begin{tabular}{|c|c|}
\hline Erosión & Intensa \\
\hline Vegetación & Vid, cerales y pinos \\
\hline Usos terreno & Grupo A, Clase II y III \\
\hline Roca Madre & Margas y comglomerado \\
\hline Terren. Circu. & Iguales caracteristicas \\
\hline Aflor. Rocosos & Ninguno \\
\hline Pedreg. Super. & Poca o nula \\
\hline Tiempo Atmosf. & Soledado y seco \\
\hline Profundidad & 0 - $40 \mathrm{~cm}$ \\
\hline
\end{tabular}

Elementos gruesos y regular pedregosidad. Sin rocosidad. Color en seco pardo y en humedo pardo rojizo. Consistencia en seco dura. Estructura en bloques débil y media. Abundantes raices y vida microbiana activa. La separación con el horizonte inferior esta bien definida.

\section{Horizonte B}

Profundidad

$40-86 \mathrm{~cm}$

Elementos gruesos y regular pedregosidad. Sin rocosidad. Color en seco pardo oscuro y en humedo pardo rojizo. Consistencia dura. Estructura en bloques subangulares, moderada y media. Abundantes raices y vida microbiana activa. La separación con el horizonte inferior esta definida.

\section{Horizonte B}

\section{Profundidad}

$86-152 \mathrm{~cm}$

Pocos elementos gruesos y abundantes piedres subangulares, Consistencia muy dura y estructura en bloque subangulares, fuerte y gruesa. Color en humedo de rojo a rojo oscuroy en seco rojo amarillento. Separado de la siguiente capa por una linea definida. Aumento del contenido en arcilla. Escasas raices y y regular actividad microbiana

\section{Horizonte C}

\section{Profundidad}

$>152 \mathrm{~cm}$

Horizonte de transición hacia la roca madre formadora. Sin raices ni vida microbiana. Consistencia dura y estructura fuerte. 


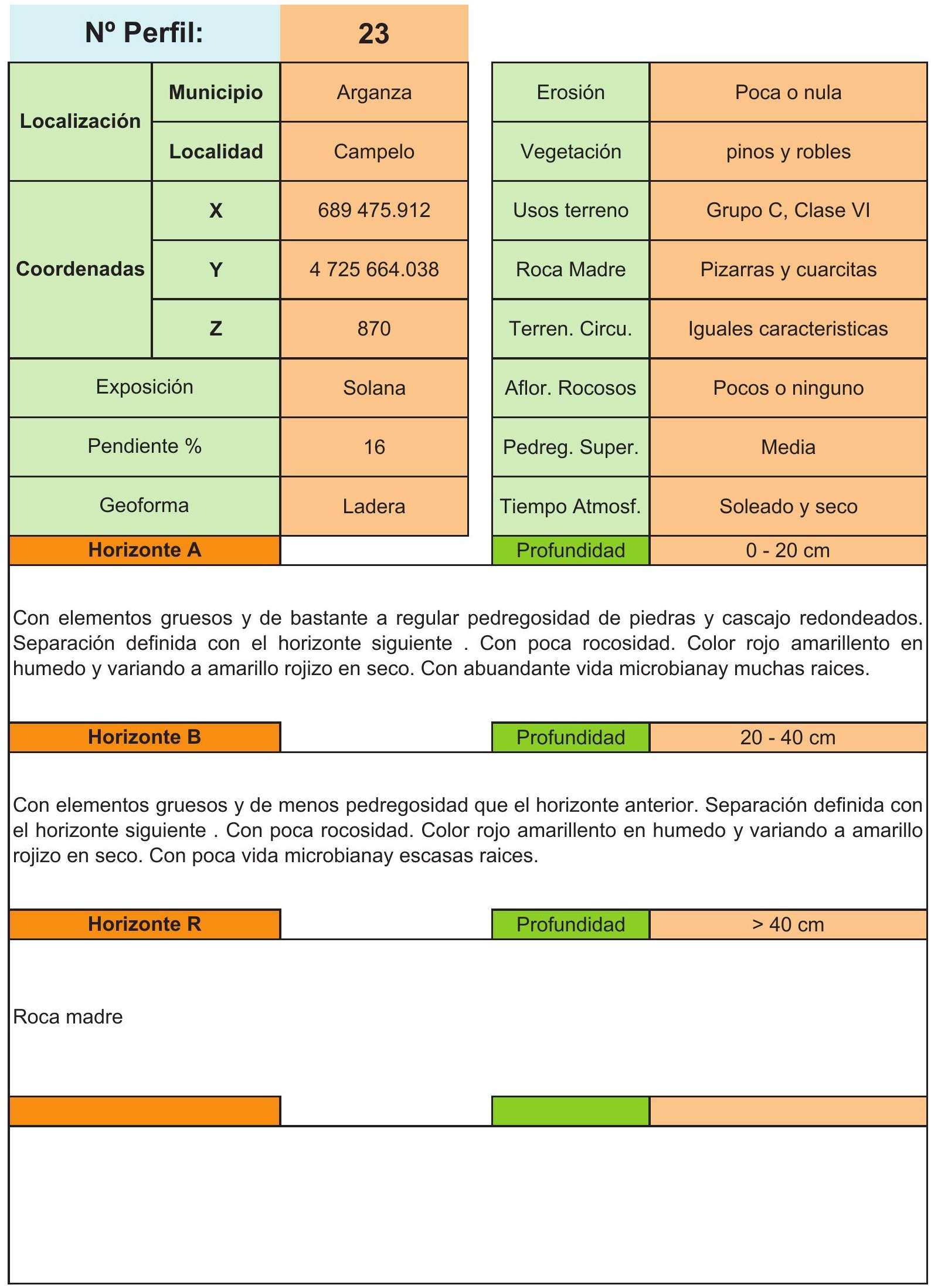




\begin{tabular}{|c|c|c|c|c|}
\hline \multicolumn{2}{|c|}{ No Perfil: } & \multirow{2}{*}{24} & & \\
\hline \multirow{2}{*}{ Localización } & Municipio & & Erosión & Fuerte \\
\hline & Localidad & Sancedo & Vegetación & $\begin{array}{c}\text { Encinares, viñas, cereales y } \\
\text { grupos de castaños }\end{array}$ \\
\hline \multirow{3}{*}{ Coordenadas } & $x$ & 6939335.025 & Usos terreno & Grupo C, clase VI \\
\hline & $\mathbf{Y}$ & 4725945.011 & Roca Madre & Margas y conglomerados \\
\hline & $\mathbf{z}$ & 670 & Terren. Circu. & Iguales caracteristicas \\
\hline \multicolumn{2}{|c|}{ Exposición } & Solana & Aflor. Rocosos & Ninguno \\
\hline \multicolumn{2}{|c|}{ Pendiente \% } & 12 & Pedreg. Super. & Poca o nula \\
\hline \multicolumn{2}{|c|}{ Geoforma } & Ladera & Tiempo Atmosf. & Soleado \\
\hline \multicolumn{2}{|c|}{ Horizonte A } & & Profundidad & $0-20 \mathrm{~cm}$ \\
\hline \multicolumn{5}{|c|}{$\begin{array}{l}\text { Horizonte con abundantes raices y actividad microbiana. Con elementos gruesos y abundante } \\
\text { pedregosidad del tamaño de piedra y forma redondeada. Separación difusa con la capa inferior. } \\
\text { Estructura en bloque angulares y consistencia en seco dura. Color amarillo rojizo. }\end{array}$} \\
\hline \multicolumn{3}{|c|}{ Horizonte B } & & $20-110 \mathrm{~cm}$ \\
\hline \multicolumn{5}{|c|}{$\begin{array}{l}\text { Con elementos gruesos y mucha pedregosidad constituidas por cuarcitas redondeadas. Estructura } \\
\text { en bloques subangulares de moderado grado de agregación y consistencia dura, la separación con } \\
\text { el siguiente horizonte sigue siendo difusa. El color es rojo amarrillento en humedo variando en seco. } \\
\text { Todavia posee abundantes raices y vida microbiana. }\end{array}$} \\
\hline \multicolumn{3}{|c|}{ Horizonte C } & & $110-145 \mathrm{~cm}$ \\
\hline \multicolumn{5}{|c|}{$\begin{array}{l}\text { Horizonte sin acitvidad microbiologica, ni raices, de color rojo a rojo oscuro en humedo y rojo } \\
\text { amarillento en seco. Con pocos elementos gruesos y menos pedregosidad que el horizonte superior } \\
\text { Con una estructura en bloques subangulares moderada. }\end{array}$} \\
\hline \multicolumn{2}{|c|}{ Horizonte $\mathbf{R}$} & & & $>145 \mathrm{~cm}$ \\
\hline \multicolumn{5}{|c|}{ Roca madre. } \\
\hline
\end{tabular}




\begin{tabular}{|c|c|c|c|c|}
\hline \multicolumn{2}{|c|}{ No Perfil: } & \multirow{2}{*}{25} & \multirow[b]{2}{*}{ Erosión } & \multirow[b]{2}{*}{ Baja } \\
\hline \multirow{2}{*}{ Localización } & Municipio & & & \\
\hline & Localidad & Villabuena & Vegetación & Cultivos de regadio \\
\hline \multirow{3}{*}{ Coordenadas } & $x$ & 684971.464 & Usos terreno & Grupo A, clase I \\
\hline & $\mathbf{Y}$ & 4723770.885 & Roca Madre & $\begin{array}{c}\text { Conglomerados, arcillas y } \\
\text { limos }\end{array}$ \\
\hline & $\mathbf{z}$ & 820 & Terren. Circu. & Iguales caracteristicas \\
\hline \multicolumn{2}{|c|}{ Exposición } & Solana & Aflor. Rocosos & Ninguno \\
\hline \multicolumn{2}{|c|}{ Pendiente \% } & 2 & Pedreg. Super. & Ninguno \\
\hline \multicolumn{2}{|c|}{ Geoforma } & Fondo de valle & Tiempo Atmosf. & Soleado \\
\hline \multicolumn{2}{|c|}{ Horizonte A } & & Profundidad & $0-30 \mathrm{~cm}$ \\
\hline \multicolumn{5}{|c|}{$\begin{array}{l}\text { Sin elementos gruesos y poca pedregosidad de forma redondeada y forma de piedra. Sin rocosidad } \\
\text { Estructura moderadamente fuerte, en bloque subangulares. Consistencia dura. Posee una } \\
\text { separación con el siguiente horizonte definida. Color pardo negruzco en humedo y pardo ligeramente } \\
\text { amarillo en seco. Abundantes racices y buena actividad microbiana. }\end{array}$} \\
\hline \multicolumn{2}{|c|}{ Horizonte B } & & & $30-60 \mathrm{~cm}$ \\
\hline \multicolumn{5}{|c|}{$\begin{array}{l}\text { Al igual que el anterior este tambien posee pocos elementos gruesos y poca pedregosidad. Colo } \\
\text { pardo negruzco en humedo y pardo amarillento en seco. Frecuentes raices y vida microbiologica } \\
\text { Estructura prismatica y consistencia dura. }\end{array}$} \\
\hline \multicolumn{2}{|c|}{ Horizonte B } & & & $60-110 \mathrm{~cm}$ \\
\hline \multicolumn{5}{|c|}{$\begin{array}{l}\text { Este horizonte presenta ya mas elementos gruesos y mucha pedregosidad sin que aparezca } \\
\text { estructura definida. Con una separación clara con el siguiente horizonte. Color pardo amarillento, y } \\
\text { ya con escasas raices y moderada vida microbiológica. }\end{array}$} \\
\hline \multicolumn{2}{|c|}{ Horizonte B } & & & $>110 \mathrm{~cm}$ \\
\hline \multicolumn{5}{|c|}{ Consistencia suelta, y sin estructura definida. Sin racices ni acitivida microbiológica. } \\
\hline
\end{tabular}




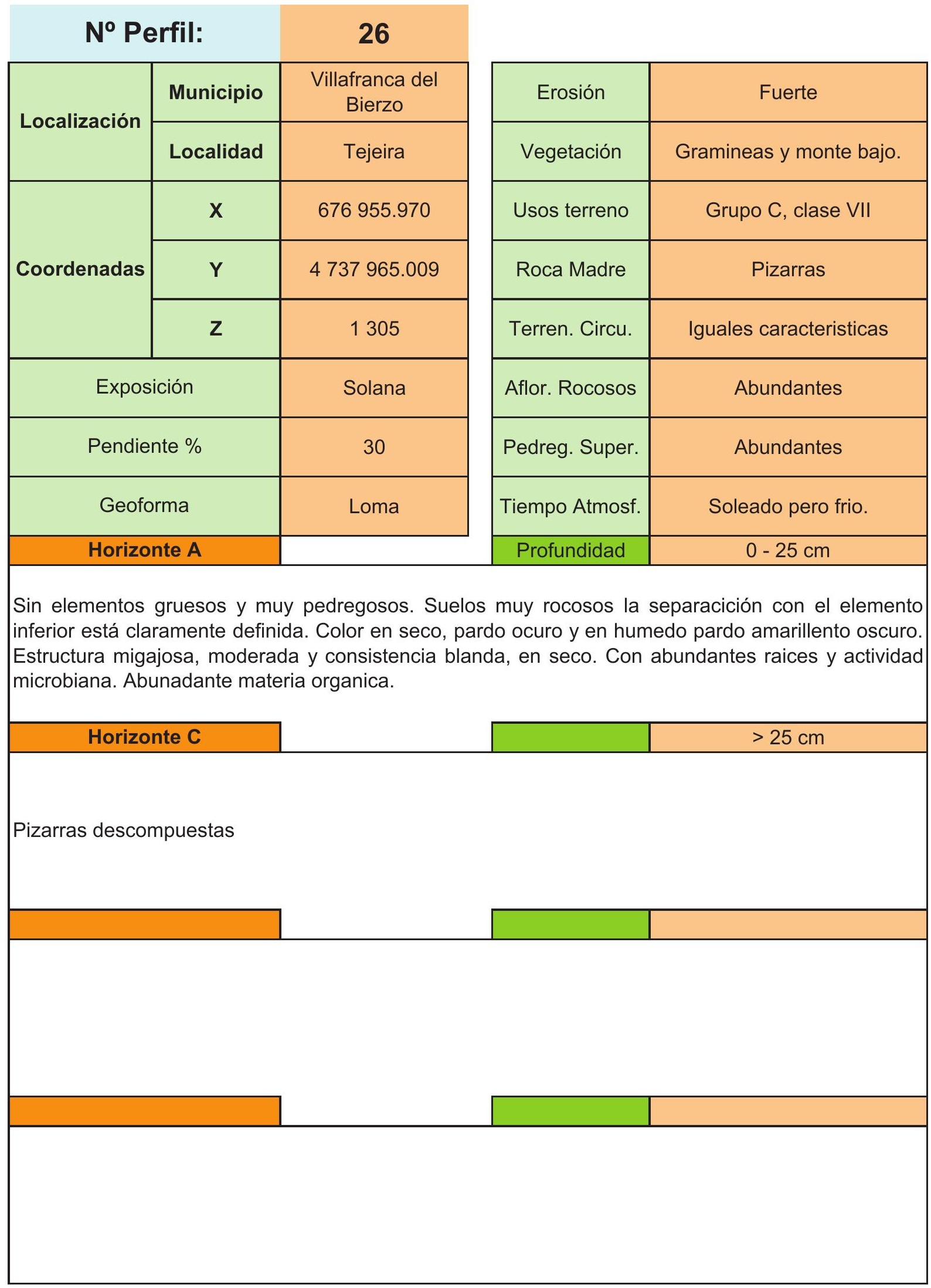




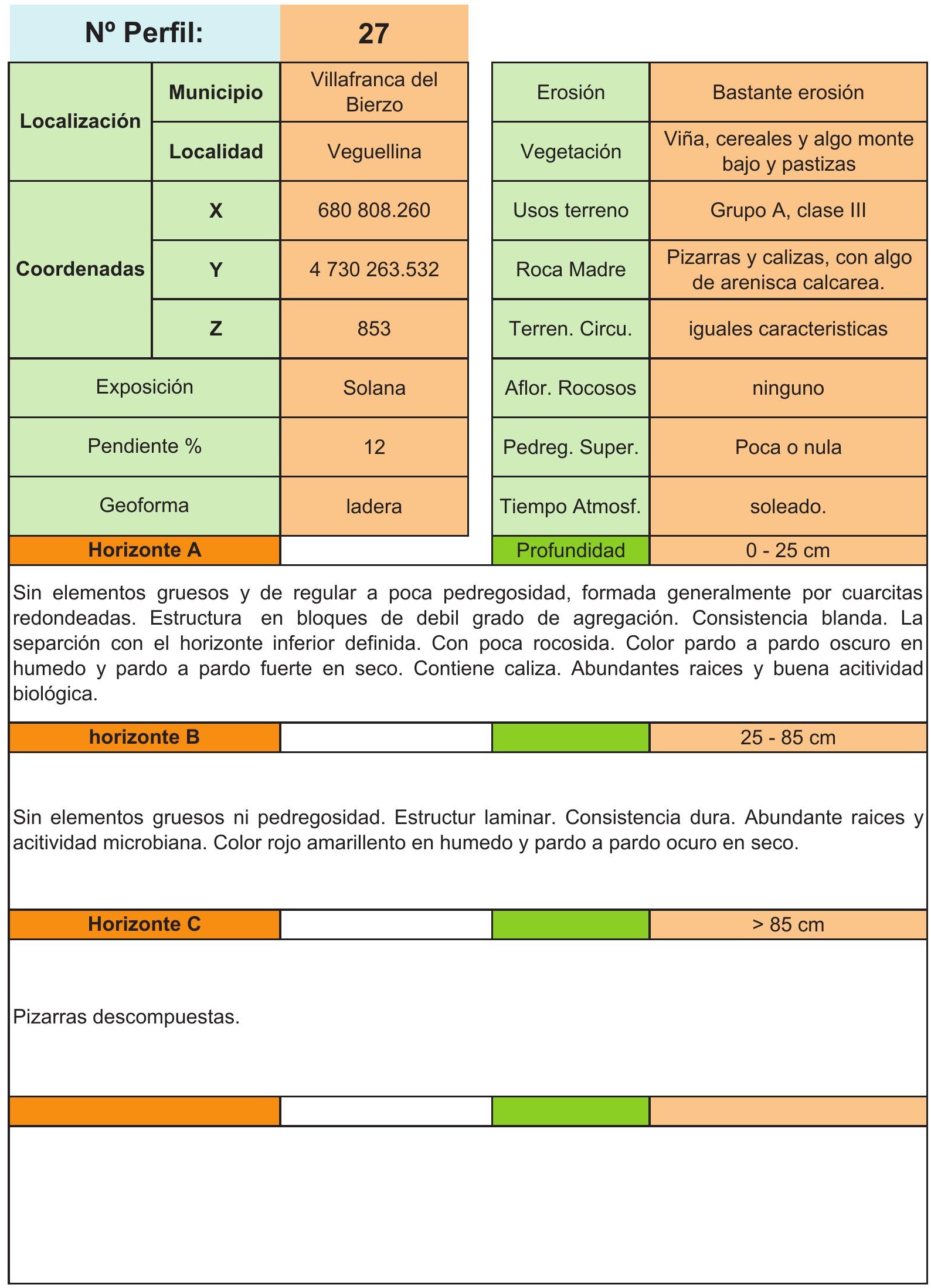


No Perfil:

\begin{tabular}{|c|c|c|}
\hline \multirow{2}{*}{ Localización } & Municipio & $\begin{array}{c}\text { Villafranca del } \\
\text { Biezo }\end{array}$ \\
\cline { 2 - 3 } & Localidad & $\begin{array}{c}\text { Villafranca del } \\
\text { Biezo }\end{array}$ \\
\hline \multirow{2}{*}{ Coordenadas } & $\mathbf{Y}$ & 679917.003 \\
\cline { 2 - 3 } & $\mathbf{Z}$ & 6479 \\
\hline Exposición & Solana \\
\hline Pendiente \% & 3 \\
\hline Geoforma & Fondo de valle \\
\hline Horizonte A & \\
\hline \multicolumn{2}{|c|}{} \\
\hline
\end{tabular}

\section{8}

\begin{tabular}{|c|c|}
\hline Erosión & Poca \\
\hline Vegetación & Viñedo y cultivos de huerta \\
\hline Usos terreno & Grupo A, clase II \\
\hline Roca Madre & $\begin{array}{c}\text { Arcilas con margas y } \\
\text { comglomerados }\end{array}$ \\
\hline Terren. Circu. & $\begin{array}{r}\text { Igual características } \\
\hline \text { Aflor. Rocosos }\end{array}$ \\
\hline Pedreg. Super. & No \\
\hline Tiempo Atmosf. & Humedo y frio \\
\hline Profundidad & $0-30 \mathrm{~cm}$ \\
\hline
\end{tabular}

Sin elementos gruesos y poca pedregosidad de forma redondeada y forma de piedra. Sin rocosidad. Estructura moderadamente fuerte, en bloque subangulares. Consistencia dura. Posee una separación con el siguiente horizonte definida. Color pardo negruzco en humedo y pardo ligeramente amarillo en seco. Abundantes racices y buena actividad microbiana.

\section{Horizonte B}

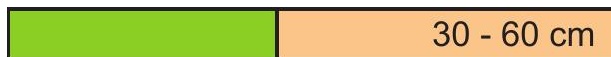

Al igual que el anterior este tambien posee pocos elementos gruesos y poca pedregosidad. Color pardo negruzco en humedo y pardo amarillento en seco. Frecuentes raices y vida microbiologica. Estructura prismatica y consistencia dura.

Horizonte B

\begin{tabular}{|r|r}
\hline & $60-110 \mathrm{~cm}$ \\
\hline
\end{tabular}

Este horizonte presenta ya mas elementos gruesos y mucha pedregosidad sin que aparezca estructura definida. Con una separación clara con el siguiente horizonte. Color pardo amarillento, y ya con escasas raices y moderada vida microbiológica.

Horizonte B

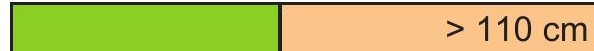

Cons+M193istencia suelta, y sin estructura definida. Sin racices ni acitivida microbiológica. 
ANÁLISIS DE CARACTERIZACIÓN DE SUELOS

Desarrollo de una aplicación informática para el cálculo de sostenimiento de taludes mediante vegetación

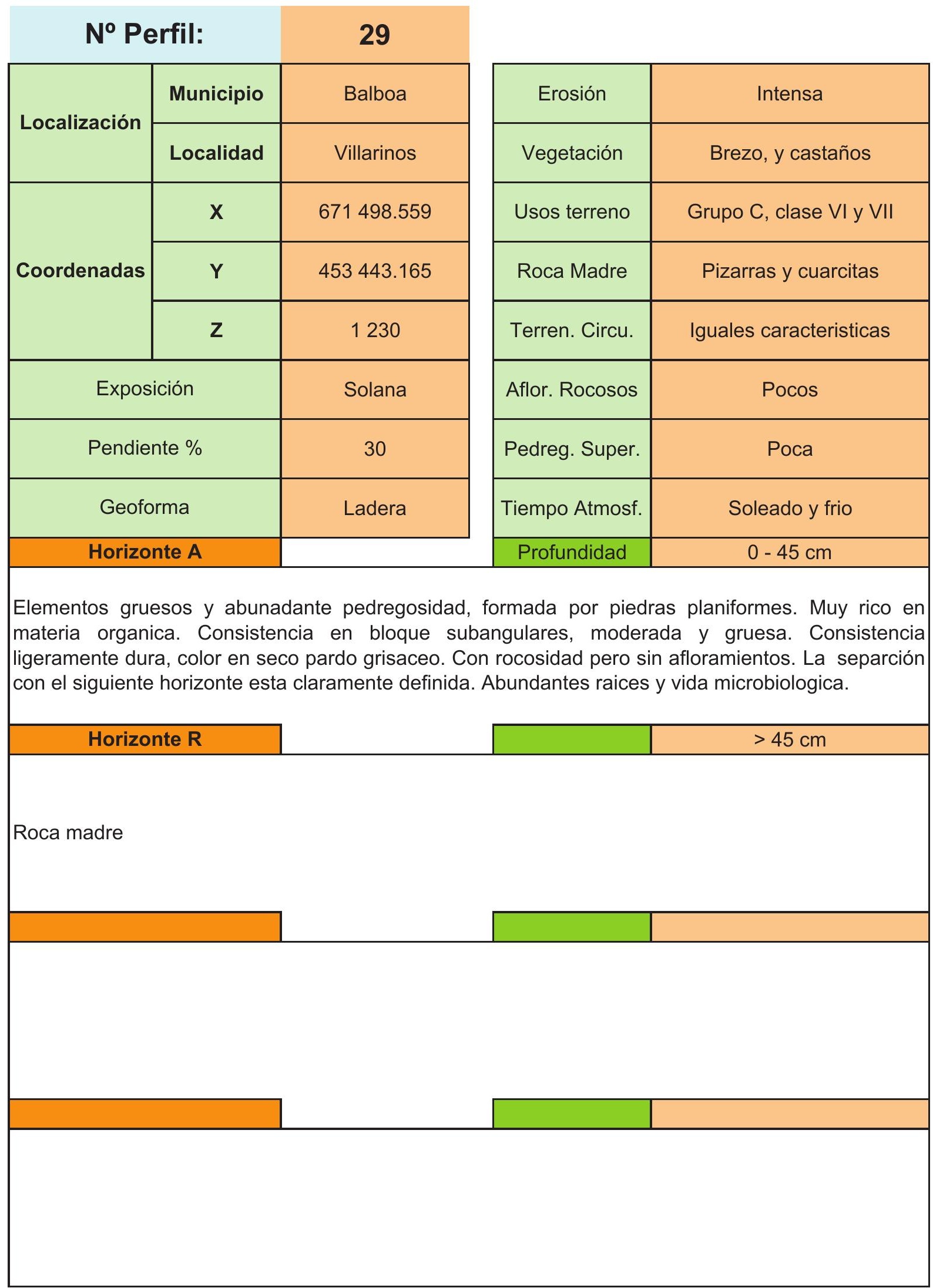


ANÁLISIS DE CARACTERIZACIÓN DE SUELOS

Desarrollo de una aplicación informática para el cálculo de sostenimiento de taludes mediante vegetación

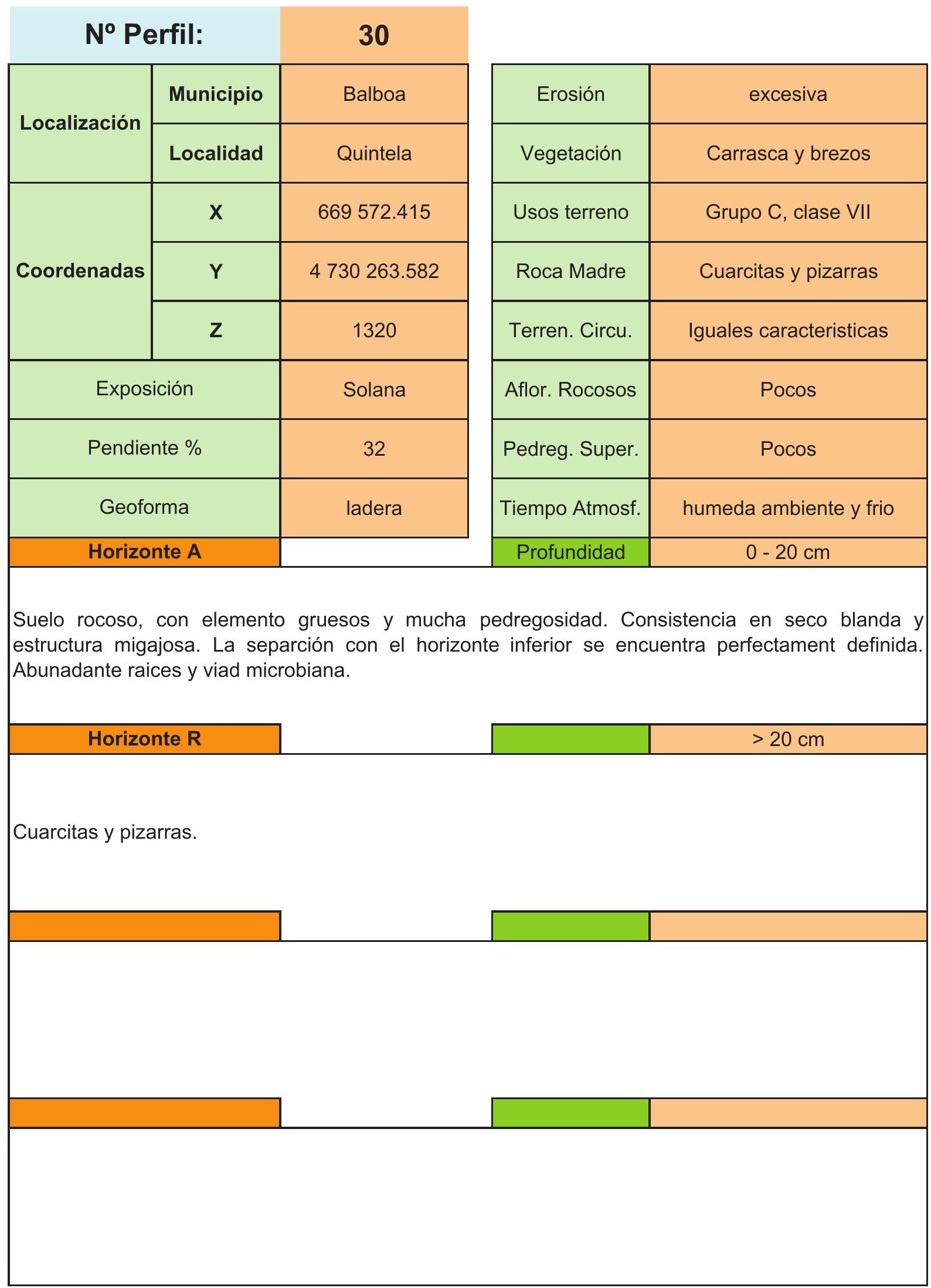


ANÁLISIS DE CARACTERIZACIÓN DE SUELOS

Desarrollo de una aplicación informática para el cálculo de sostenimiento de taludes mediante vegetación

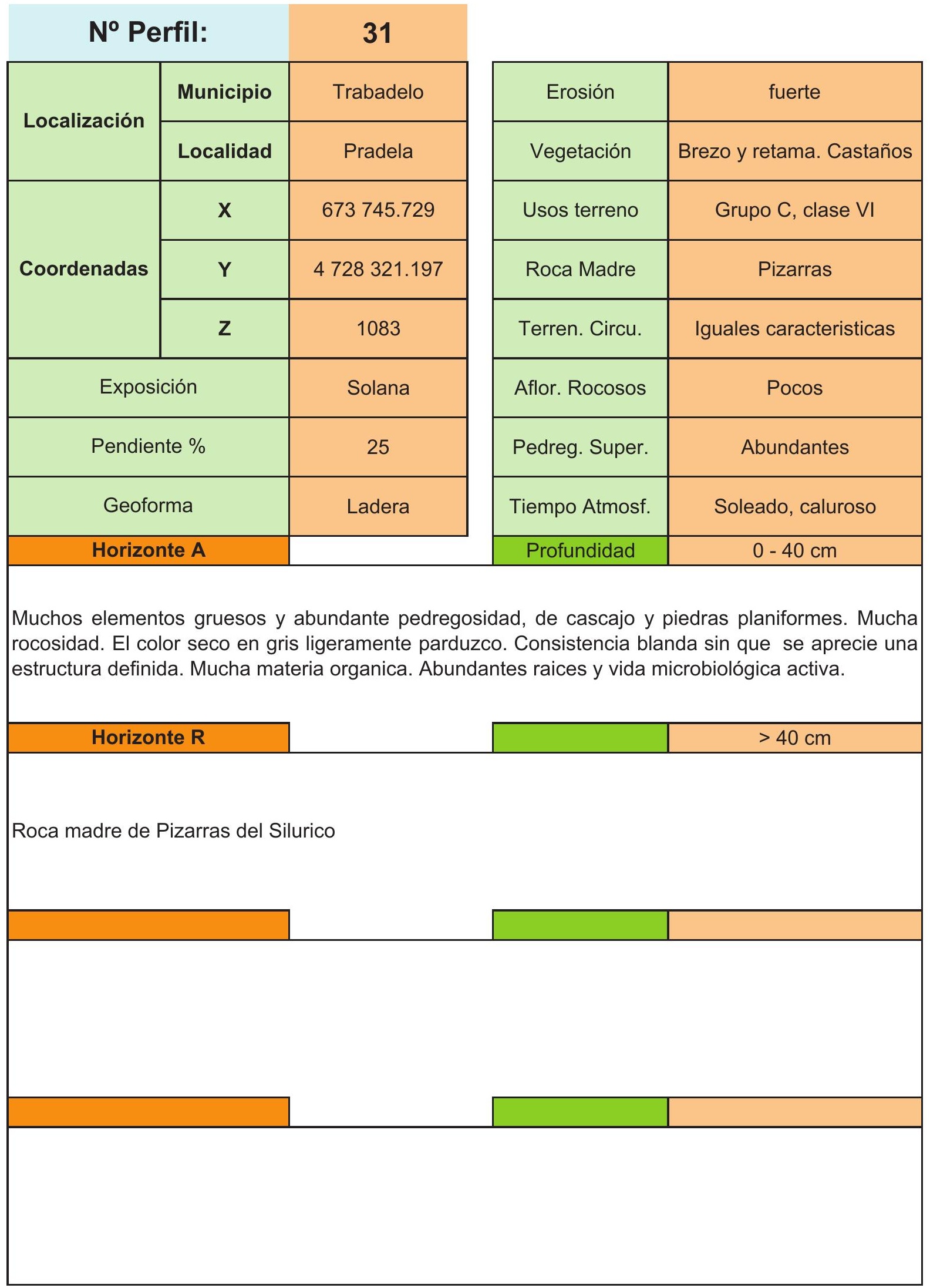


ANÁLISIS DE CARACTERIZACIÓN DE SUELOS

Desarrollo de una aplicación informática para el cálculo de sostenimiento de taludes mediante vegetación

No Perfil:
\begin{tabular}{|c|c|c|}
\hline \multirow{2}{*}{ Localización } & Municipio & Trabadelo \\
\cline { 2 - 3 } & Localidad & Sotoparada \\
\hline \multirow{2}{*}{ Coordenadas } & $\mathbf{X}$ & 671284.5436 \\
\cline { 2 - 3 } & $\mathbf{Y}$ & 4722348.124 \\
\cline { 2 - 3 } & $\mathbf{Z}$ & 891 \\
\hline Exposición & Solana \\
\hline Pendiente \% & 26 \\
\hline \multicolumn{2}{|c|}{ Geoforma } & Ladera \\
\hline \multicolumn{2}{|c|}{ Horizonte A } & \\
\hline
\end{tabular}

\begin{tabular}{|c|c|}
\hline Erosión & Intensa \\
\hline Vegetación & $\begin{array}{c}\text { Brezo y retama, con algo } \\
\text { de repoblación de pinos. }\end{array}$ \\
\hline Usos terreno & Grupo C, clase VII \\
\hline Roca Madre & Pizarras \\
\hline Terren. Circu. & Iguales caracteristicas \\
\hline Aflor. Rocosos & Abundantes \\
\hline Pedreg. Super. & Abundantes \\
\hline Tiempo Atmosf. & Soleado, caluroso \\
\hline Profundidad & $0-40 \mathrm{~cm}$ \\
\hline
\end{tabular}

Muchos elementos gruesos y abundante pedregosidad, de cascajo y piedras planiformes. Mucha rocosidad. El color seco en gris ligeramente parduzco. Consistencia blanda sin que se aprecie una estructura definida. Mucha materia organica. Abundantes raices y vida microbiológica activa.

Horizonte $\mathbf{R}$

$>40 \mathrm{~cm}$

Pizarras

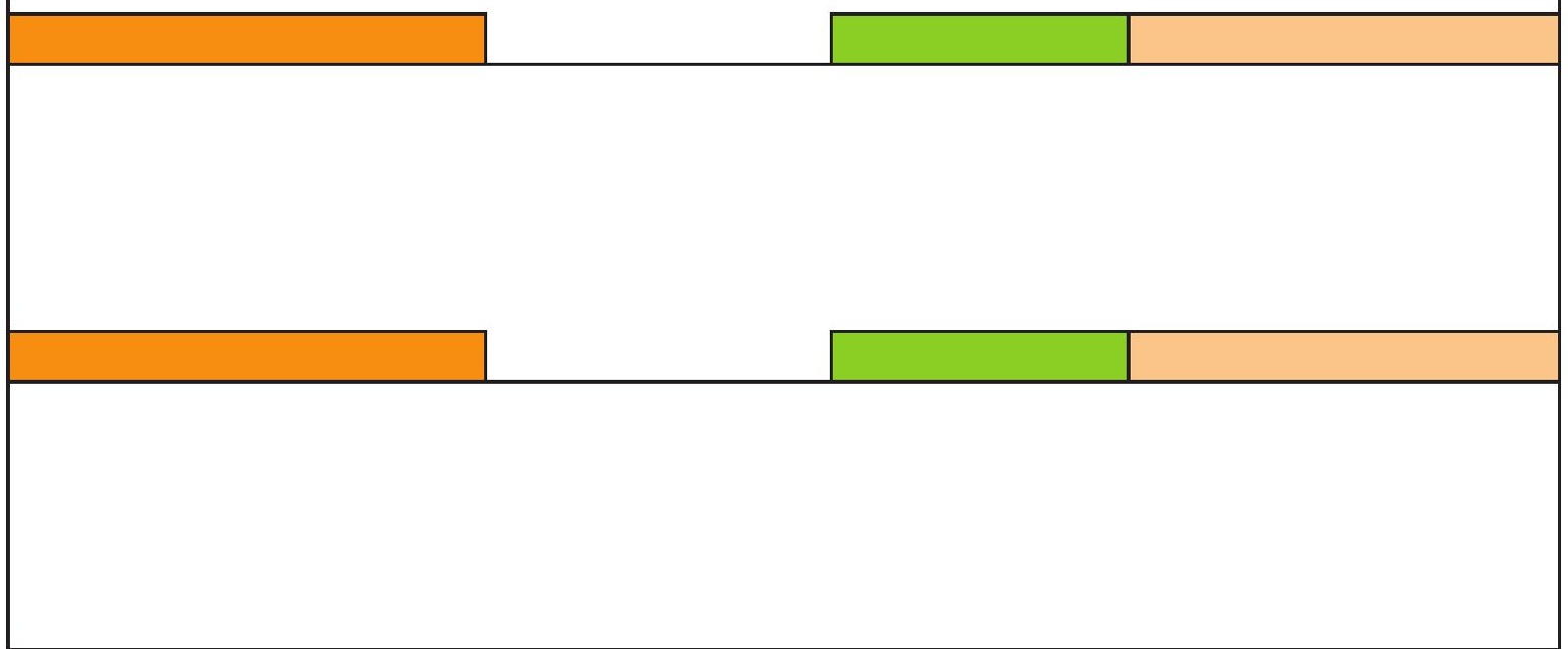


ANÁLISIS DE CARACTERIZACIÓN DE SUELOS

Desarrollo de una aplicación informática para el cálculo de sostenimiento de taludes mediante vegetación

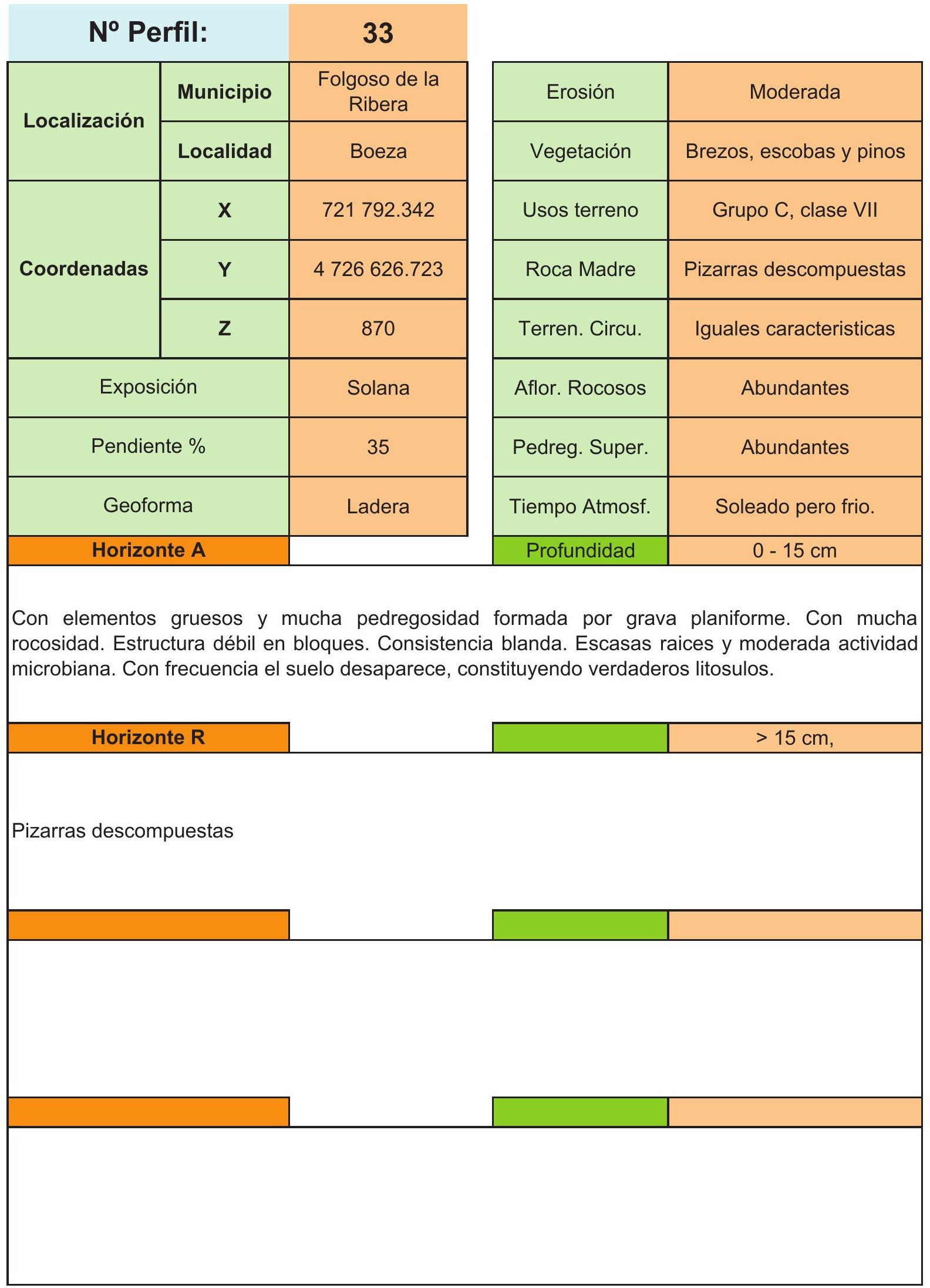


ANÁLISIS DE CARACTERIZACIÓN DE SUELOS

Desarrollo de una aplicación informática para el cálculo de sostenimiento de taludes mediante vegetación

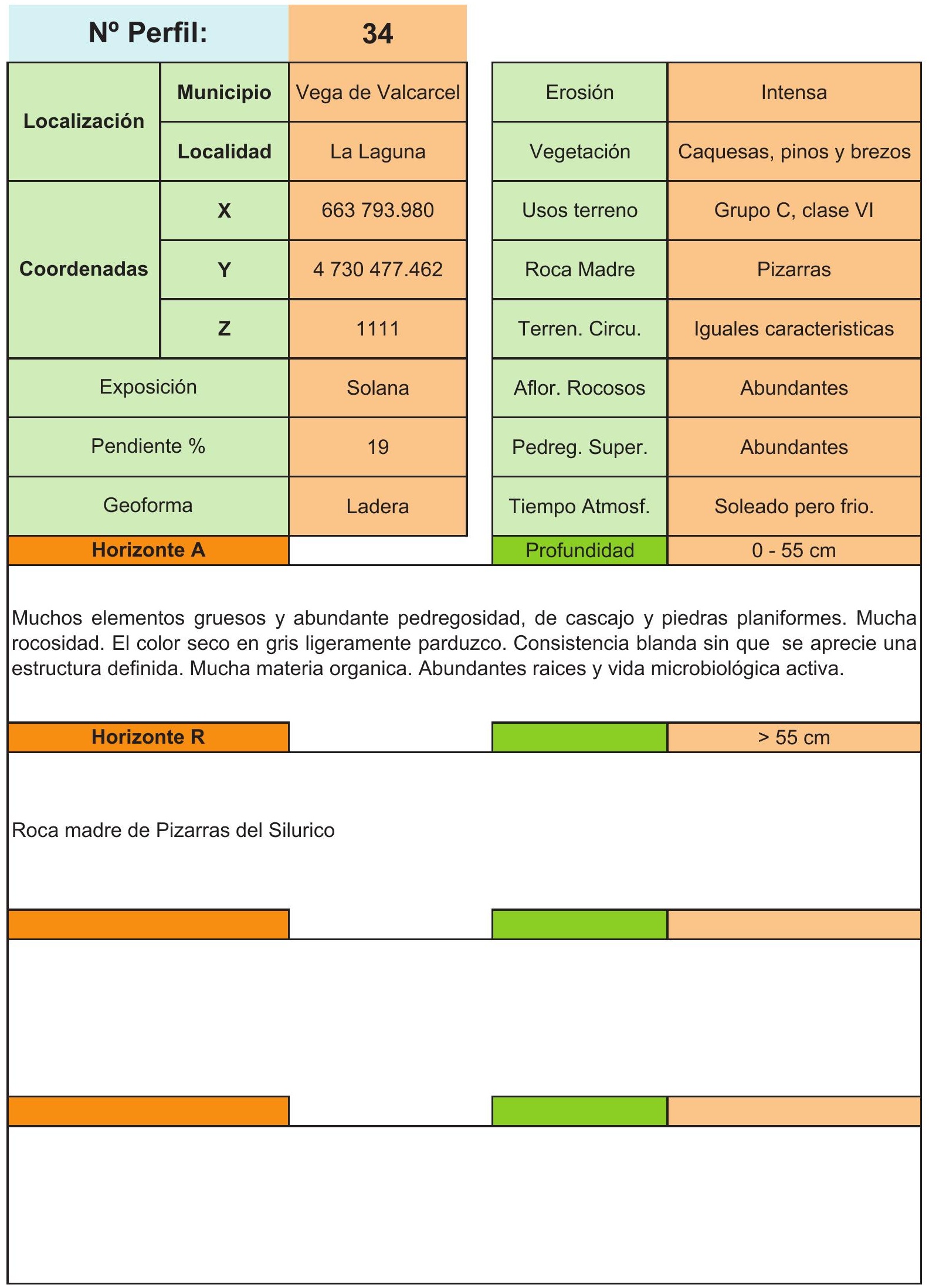




\begin{tabular}{|c|c|c|c|c|}
\hline \multicolumn{2}{|c|}{ No Perfil: } & \multirow{2}{*}{35} & \multirow[b]{2}{*}{ Erosión } & \multirow[b]{2}{*}{ Moderada } \\
\hline \multirow{2}{*}{ Localización } & Municipio & & & \\
\hline & Localidad & Corrales & Vegetación & Cultivos de huerta \\
\hline \multirow{3}{*}{ Coordenadas } & $\mathbf{x}$ & 667218.238 & Usos terreno & Grupo A, Clase I \\
\hline & $\mathbf{Y}$ & 4719994.895 & Roca Madre & $\begin{array}{c}\text { Sedimentos del } \\
\text { cuaternario }\end{array}$ \\
\hline & $\mathbf{z}$ & 530 & Terren. Circu. & Iguales caracteristicas \\
\hline \multicolumn{2}{|c|}{ Exposición } & Media luz & Aflor. Rocosos & Ninguno \\
\hline \multicolumn{2}{|c|}{ Pendiente \% } & 9 & Pedreg. Super. & Ninguna \\
\hline \multicolumn{2}{|c|}{ Geoforma } & Vaguada & Tiempo Atmosf. & Lluvioso \\
\hline \multicolumn{2}{|c|}{ Horizonte A } & & Profundidad & $0-30 \mathrm{~cm}$ \\
\hline \multicolumn{5}{|c|}{$\begin{array}{l}\text { Sin elementos gruesos y poca pedregosidad de forma redondeada y forma de piedra. Sin rocosidad } \\
\text { Estructura moderadamente fuerte, en bloque subangulares. Consistencia dura. Posee una } \\
\text { separación con el siguiente horizonte definida. Color pardo negruzco en humedo y pardd } \\
\text { ligeramente amarillo en seco. Abundantes racices y buena actividad microbiana. }\end{array}$} \\
\hline \multicolumn{2}{|c|}{ Horizonte B } & & & $30-60 \mathrm{~cm}$ \\
\hline \multicolumn{5}{|c|}{$\begin{array}{l}\text { Al igual que el anterior este tambien posee pocos elementos gruesos y poca pedregosidad. Colo } \\
\text { pardo negruzco en humedo y pardo amarillento en seco. Frecuentes raices y vida microbiologica } \\
\text { Estructura prismatica y consistencia dura. }\end{array}$} \\
\hline \multicolumn{3}{|c|}{ Horizonte B } & & $60-110 \mathrm{~cm}$ \\
\hline \multicolumn{5}{|c|}{$\begin{array}{l}\text { Este horizonte presenta ya mas elementos gruesos y mucha pedregosidad sin que aparezc } \\
\text { estructura definida. Con una separación clara con el siguiente horizonte. Color pardo amarillento, } \\
\text { ya con escasas raices y moderada vida microbiológica. }\end{array}$} \\
\hline \multicolumn{2}{|c|}{ Horizonte B } & & & $>110 \mathrm{~cm}$ \\
\hline \multicolumn{5}{|c|}{ Consistencia suelta, y sin estructura definida. Sin racices ni acitivida microbiológica. } \\
\hline
\end{tabular}


ANÁLISIS DE CARACTERIZACIÓN DE SUELOS

Desarrollo de una aplicación informática para el cálculo de sostenimiento de taludes mediante vegetación

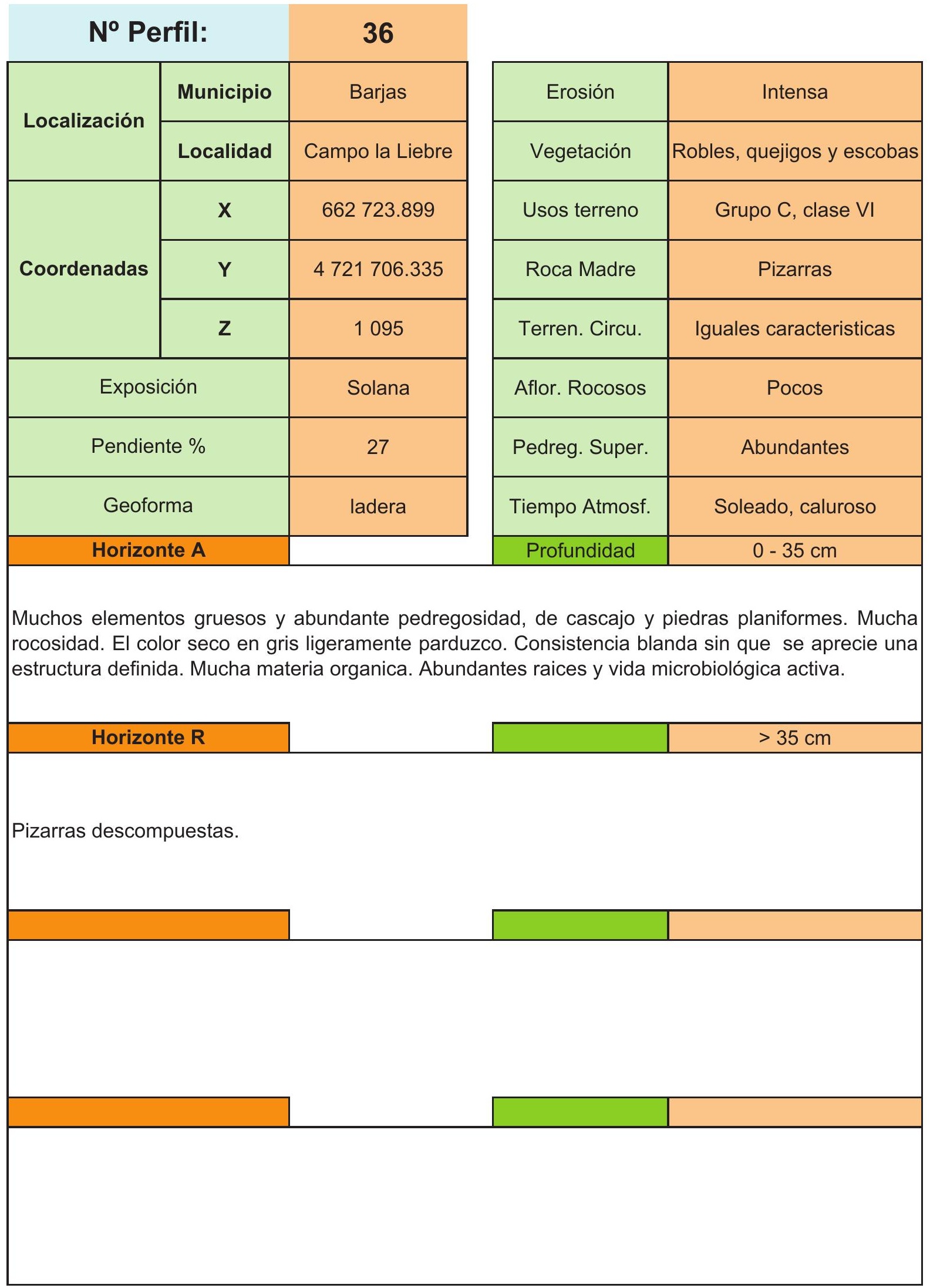


ANÁLISIS DE CARACTERIZACIÓN DE SUELOS

Desarrollo de una aplicación informática para el cálculo de sostenimiento de taludes mediante vegetación

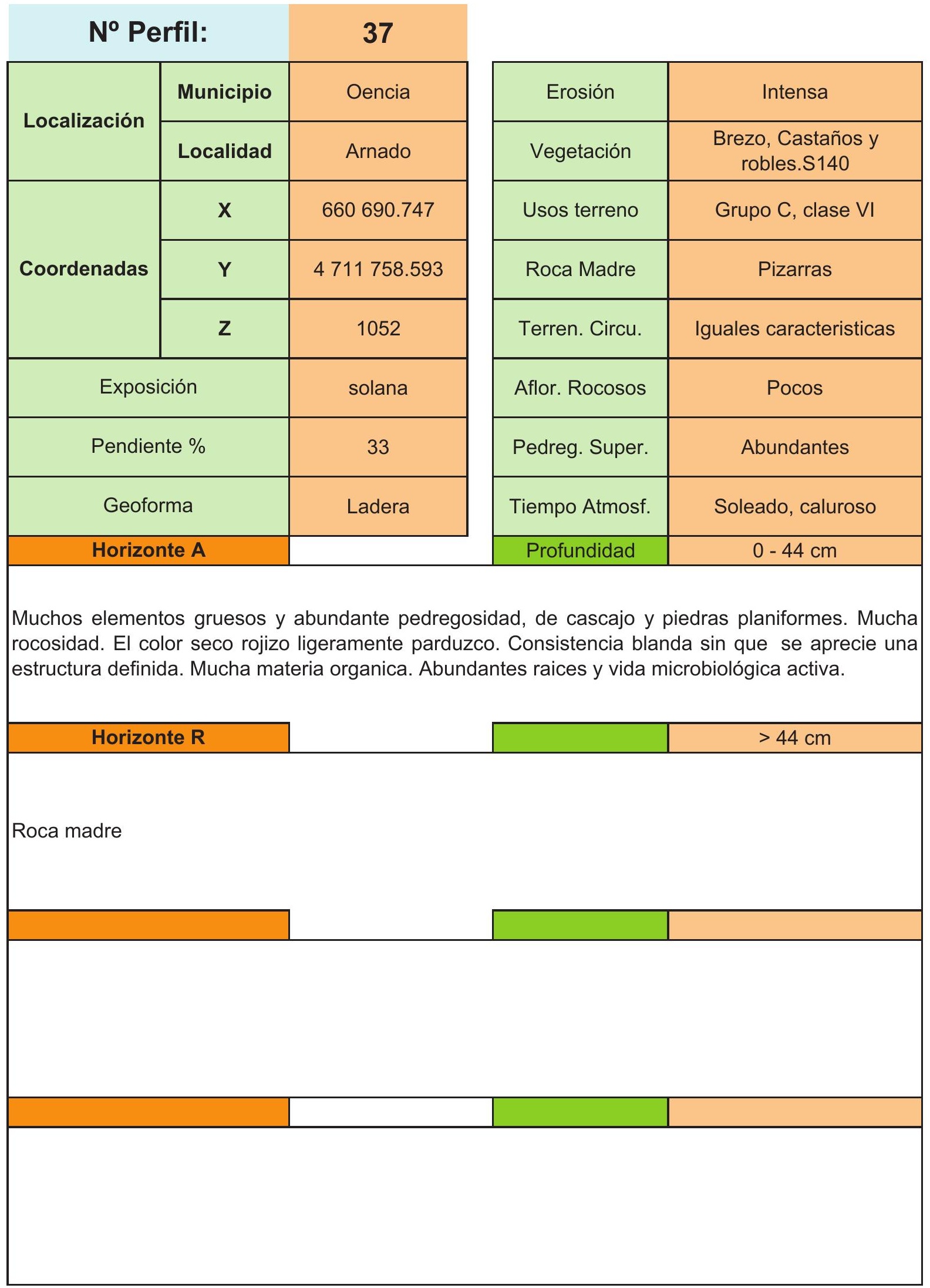


ANÁLISIS DE CARACTERIZACIÓN DE SUELOS

Desarrollo de una aplicación informática para el cálculo de sostenimiento de taludes mediante vegetación

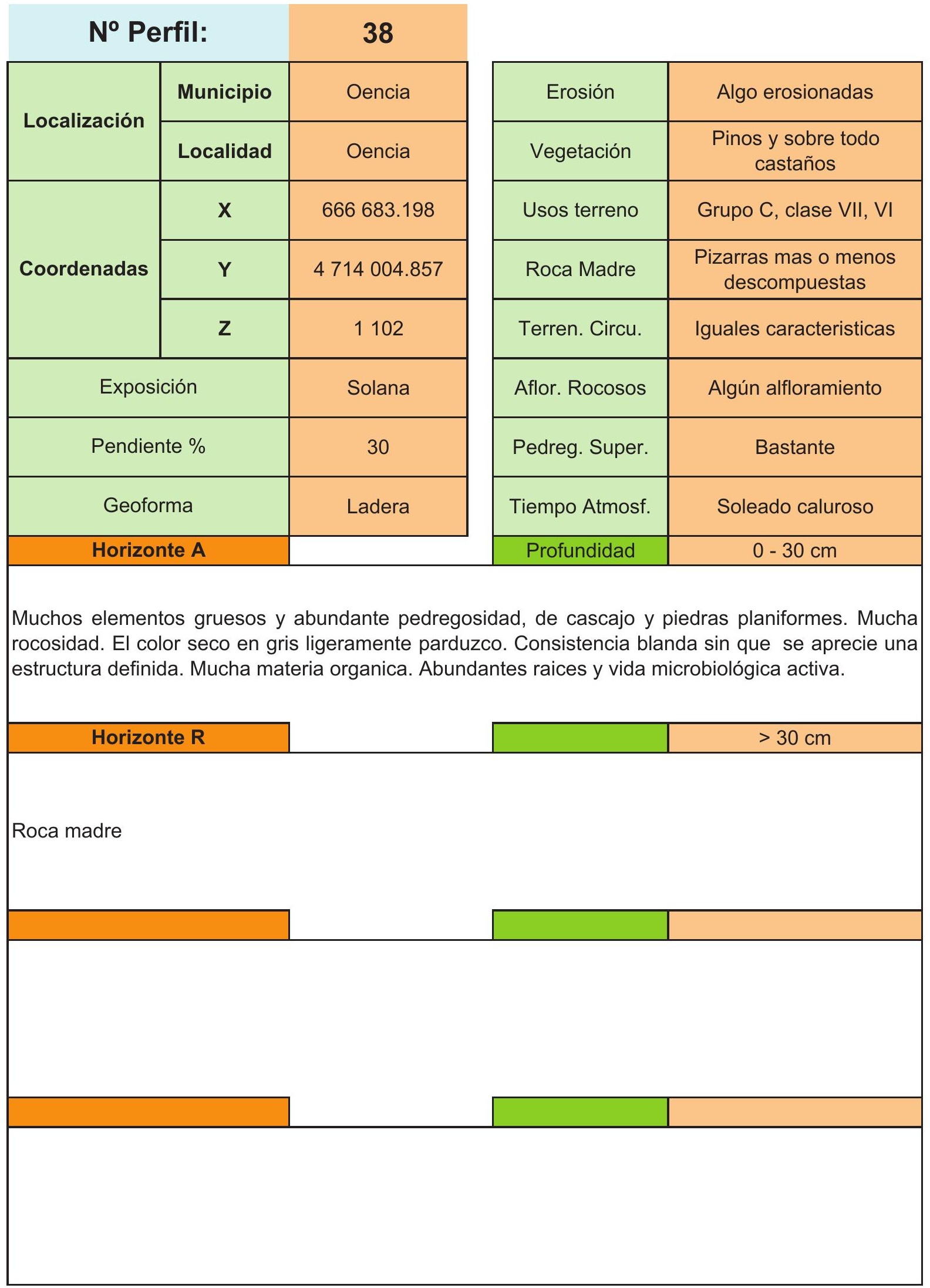


ANÁLISIS DE CARACTERIZACIÓN DE SUELOS

Desarrollo de una aplicación informática para el cálculo de sostenimiento de taludes mediante vegetación

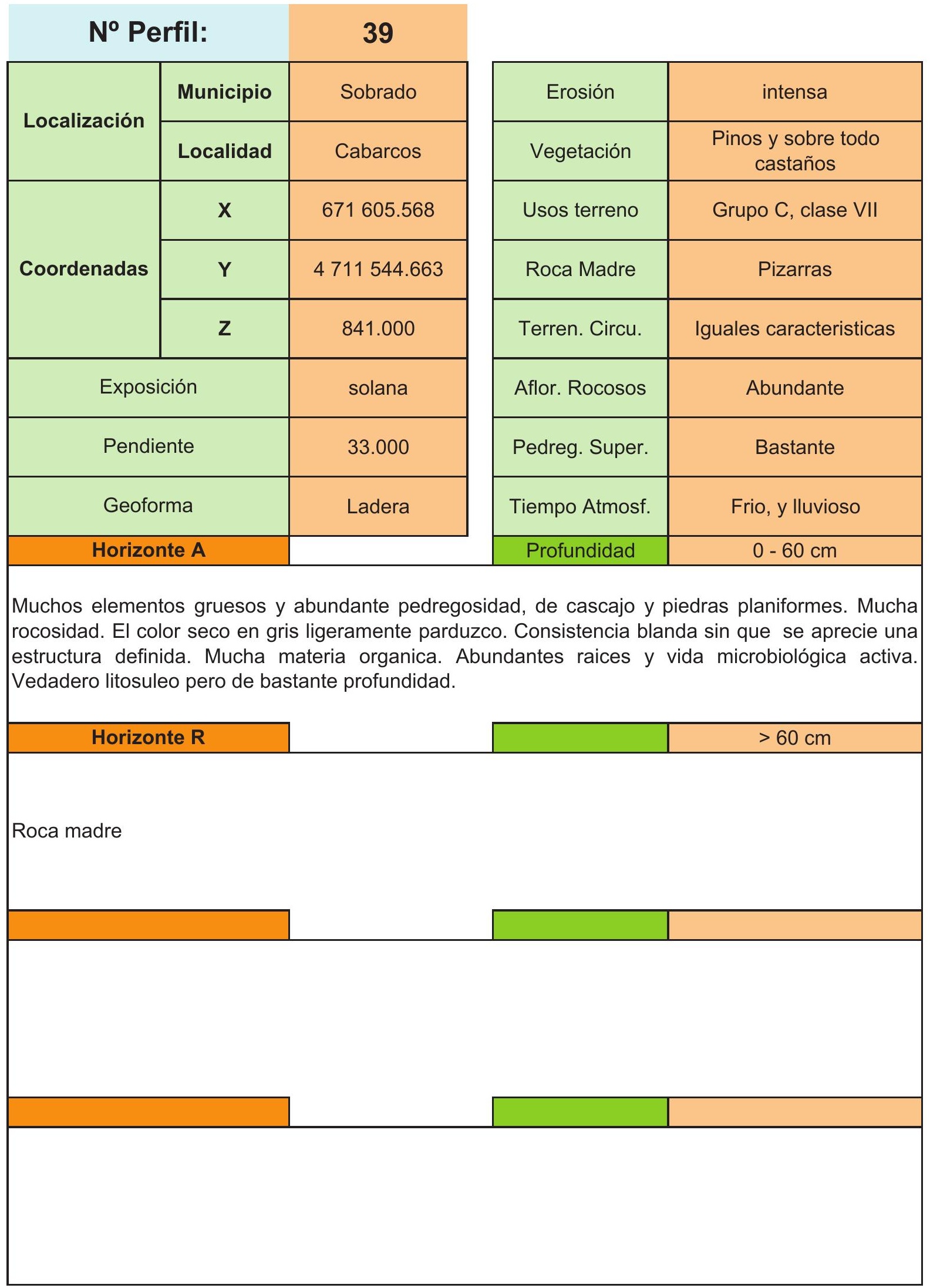




\begin{tabular}{|c|c|c|c|c|}
\hline \multicolumn{2}{|c|}{ No Perfil: } & \multirow{2}{*}{40} & \multirow[b]{2}{*}{ Erosión } & \multirow[b]{2}{*}{ Moderada } \\
\hline \multirow{2}{*}{ Localización } & Municipio & & & \\
\hline & Localidad & El Carril & Vegetación & Cultivos de huerta \\
\hline \multirow{3}{*}{ Coordenadas } & $\mathbf{x}$ & 675029.825 & Usos terreno & Grupo A, Clase I \\
\hline & $\mathbf{Y}$ & 4708763.574 & Roca Madre & $\begin{array}{c}\text { Sedimentos del } \\
\text { cuaternario }\end{array}$ \\
\hline & $\mathbf{z}$ & 370 & Terren. Circu. & Iguales caracteristicas \\
\hline \multicolumn{2}{|c|}{ Exposición } & Solana & Aflor. Rocosos & Ninguno \\
\hline \multicolumn{2}{|c|}{ Pendiente \% } & 5 & Pedreg. Super. & Ninguna \\
\hline \multicolumn{2}{|c|}{ Geoforma } & Vaguada & Tiempo Atmosf. & Lluvioso \\
\hline \multicolumn{2}{|c|}{ Horizonte A } & & Profundidad & $0-20 \mathrm{~cm}$ \\
\hline \multicolumn{5}{|c|}{$\begin{array}{l}\text { Sin elementos gruesos y poca pedregosidad de forma redondeada y forma de piedra. Sin rocosidad } \\
\text { Estructura moderadamente fuerte, en bloque subangulares. Consistencia dura. Posee una } \\
\text { separación con el siguiente horizonte definida. Color pardo negruzco en humedo y pardd } \\
\text { ligeramente amarillo en seco. Abundantes racices y buena actividad microbiana. }\end{array}$} \\
\hline \multicolumn{2}{|c|}{ Horizonte B } & & & $20-50 m$ \\
\hline \multicolumn{5}{|c|}{$\begin{array}{l}\text { Al igual que el anterior este tambien posee pocos elementos gruesos y poca pedregosidad. Colo } \\
\text { pardo negruzco en humedo y pardo amarillento en seco. Frecuentes raices y vida microbiologica } \\
\text { Estructura prismatica y consistencia dura. }\end{array}$} \\
\hline \multicolumn{3}{|c|}{ Horizonte B } & & $50-100 \mathrm{~cm}$ \\
\hline \multicolumn{5}{|c|}{$\begin{array}{l}\text { Este horizonte presenta ya mas elementos gruesos y mucha pedregosidad sin que aparezc } \\
\text { estructura definida. Con una separación clara con el siguiente horizonte. Color pardo amarillento, } \\
\text { ya con escasas raices y moderada vida microbiológica. }\end{array}$} \\
\hline \multicolumn{2}{|c|}{ Horizonte B } & & & $>100 \mathrm{~cm}$ \\
\hline \multicolumn{5}{|c|}{ Cosnistencia suelta, y sin estructura definida. Sin racices ni acitivida microbiológica. } \\
\hline
\end{tabular}




\begin{tabular}{|c|c|c|c|c|}
\hline $\mathrm{N}^{0} \mathrm{Pe}$ & rfil: & 41 & & \\
\hline & Municipio & Corullón & Erosión & Baja \\
\hline & Localidad & Melezna & Vegetación & Frutales \\
\hline & $\mathbf{x}$ & 672140.608 & Usos terreno & Grupo A, Clase II \\
\hline Coordenadas & $\mathbf{Y}$ & 4717213.806 & Roca Madre & Pizarras y cuarcitas \\
\hline & $\mathbf{Z}$ & 540 & Terren. Circu. & Iguales caracteristicas. \\
\hline Expos & ción & Solana & Aflor. Rocosos & Ninguno \\
\hline Pendie & te $\%$ & 6 & Pedreg. Super. & Escasa o nula \\
\hline Geofo & & Loma & Tiempo Atmosf. & Soleado pero fresco. \\
\hline Horizo & te $A$ & & Profundidad & $0-25 \mathrm{~cm}$ \\
\hline $\begin{array}{l}\text { Con elementos } \\
\text { moderada en bl } \\
\text { raices y moder } \\
\text { comienza a dist }\end{array}$ & $\begin{array}{l}\text { gruesos y pc } \\
\text { ques. Muy } r \\
\text { da actividac } \\
\text { gguirse difere }\end{array}$ & $\begin{array}{l}\text { o nula pedregc } \\
\text { en materia orga } \\
\text { icrobiana. Sepa } \\
\text { ias de color. }\end{array}$ & $\begin{array}{l}\text { d, esta es de ca } \\
\text { El color es pard } \\
\text { ón con el horizol }\end{array}$ & $\begin{array}{l}\text { ajo redondeado. Estructur } \\
\text { n seco. Posee abundante } \\
\text { inferior difusa, aunque }\end{array}$ \\
\hline Horizon & te B1 & & Profundidad & $25-50 \mathrm{~cm}$ \\
\hline $\begin{array}{l}\text { Mas elementos } \\
\text { redondeadas. } N \\
\text { horizonte inferic } \\
\text { amarillento a an }\end{array}$ & $\begin{array}{l}\text { gruesos y } \mathrm{m} \\
\text { o se aprecia } \\
\text { sigue sienc } \\
\text { arillo parduz }\end{array}$ & $\begin{array}{l}\text { pedregosidad } \\
\text { tructura definida } \\
\text { difusa. El color } \\
\text { en seco. Escasa }\end{array}$ & $\begin{array}{l}\text { el horizonte supe } \\
\text { a consistencia es } \\
\text { pardo oscuro am } \\
\text { ces y moderada a }\end{array}$ & $\begin{array}{l}\text { r, constituidas por piedra } \\
\text { anda.La separación con } \\
\text { lento en humedo y paro } \\
\text { jidad microbiana. }\end{array}$ \\
\hline Horizon & te $B 2$ & & Profundidad & $50-80 \mathrm{~cm}$ \\
\hline $\begin{array}{l}\text { Con abundantes } \\
\text { aveces se apros } \\
\text { Color como el h }\end{array}$ & $\begin{array}{l}\text { elementos } \mathrm{g} \\
\text { iman al tama } \\
\text { rizonte anter }\end{array}$ & $\begin{array}{l}\text { esos y mucha pe } \\
\text { de bloques. Sin } \\
\text { Sin raices y sin }\end{array}$ & $\begin{array}{l}\text { gosidad, formada } \\
\text { se aprecie estruc } \\
\text { jidad microbiana. }\end{array}$ & $\begin{array}{l}\text { piedras redondeadas qu } \\
\text { a y de consistencia suelt }\end{array}$ \\
\hline Horizo & te $\mathbf{R}$ & & Profundidad & $>80 \mathrm{~cm}$ \\
\hline Roca madre & & & & \\
\hline
\end{tabular}


ANÁLISIS DE CARACTERIZACIÓN DE SUELOS

Desarrollo de una aplicación informática para el cálculo de sostenimiento de taludes mediante vegetación

\begin{tabular}{|c|c|c|c|c|}
\hline \multicolumn{2}{|c|}{ No Perfil: } & 42 & & \\
\hline \multirow{2}{*}{ Localización } & Municipio & Corullón & Erosión & Intensa \\
\hline & Localidad & Corullón & Vegetación & Cereales, castaños, pastos.. \\
\hline \multirow{3}{*}{ Coordenadas } & $\mathbf{x}$ & 677491.011 & Usos terreno & Grupo C, Clases VI y VII \\
\hline & $\mathbf{Y}$ & 4714860.577 & Roca Madre & Pizarras, cuarcitas y calizas \\
\hline & $\mathbf{z}$ & 906 & Terren. Circu. & Iguales caracteristicas. \\
\hline \multicolumn{2}{|c|}{ Exposición } & Solana & Aflor. Rocosos & Abundantes \\
\hline \multicolumn{2}{|c|}{ Pendiente \% } & 24 & Pedreg. Super. & Abundantes \\
\hline \multicolumn{2}{|c|}{ Geoforma } & Ladera & Tiempo Atmosf. & Lluvioso \\
\hline \multicolumn{2}{|c|}{ Horizonte A } & & Profundidad & $0-25 \mathrm{~cm}$ \\
\hline \multicolumn{5}{|c|}{$\begin{array}{l}\text { Con elementos gruesos y mucha pedregosidad, esta es de cascajo, piedras y blques. Rocosidad } \\
\text { abunadante que da lugar a litosuelos. Muy rico en materia organica. El color es pardo en seco. } \\
\text { Posee abundantes raices y moderada actividad microbiana. Separación con el horizonte inferior } \\
\text { clara. }\end{array}$} \\
\hline \multicolumn{2}{|c|}{ Horizonte C } & & & $>25 \mathrm{~cm}$ \\
\hline \multicolumn{5}{|c|}{ Roca madre descompuesta } \\
\hline
\end{tabular}


No Perfil:

\begin{tabular}{|c|c|c|}
\hline \multirow{2}{*}{ Localización } & Municipio & Castropodame \\
\cline { 2 - 3 } & Localidad & Matanza \\
\hline \multirow{2}{*}{ Coordenadas } & $\mathbf{X}$ & 710128.465 \\
\cline { 2 - 3 } & $\mathbf{Y}$ & 4714004.857 \\
\cline { 2 - 3 } & $\mathbf{Z}$ & 1095 \\
\hline Exposición & Solana \\
\hline Pendiente \% & Ladera \\
\hline Geoforma & \\
\hline Honte A & \\
\hline
\end{tabular}

43

\begin{tabular}{|c|c|}
\hline Erosión & Media \\
\hline Vegetación & Vid, cerales y castaños \\
\hline Usos terreno & Grupo A, clase II \\
\hline Roca Madre & Pizarras. \\
\hline Terren. Circu. & Iguales caracteristicas \\
\hline Aflor. Rocosos & Ninguno \\
\hline Pedreg. Super. & Alguna \\
\hline Tiempo Atmosf. & Soleado \\
\hline Profundidad & $0-50 \mathrm{~cm}$ \\
\hline
\end{tabular}

Sin elementos gruesos y poca pedregosidad formadas por cuarcitas subangulosas y redondeadas. Color pardo muy oscuro grisaceo en humedo y en seco pardo. Con abundante materia organica pero sin llegar a se un horizonte $\mathrm{H}$. Limite difuso con el horizonte inferior. Abundantes raices y activa vida microviana.

\section{Horizonte B}

Profundidad

$50-120 \mathrm{~cm}$

Sin elementos gruesos ni pedregosidad escesiva. Estructura en bloques subangulares de regularar estabilidad. Consistencia ligeramente dura. Color pardo oscuro amarillento en humedo y pardo amarillento o amarillento parduzco en seco. Pocas raices y escasa actividad microbiana. Separación difuda con el horizonte inferior.

\section{Horizonte C}

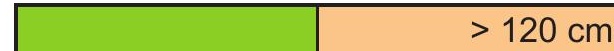

Roca madre descompuesta. 
ANÁLISIS DE CARACTERIZACIÓN DE SUELOS

Desarrollo de una aplicación informática para el cálculo de sostenimiento de taludes mediante vegetación

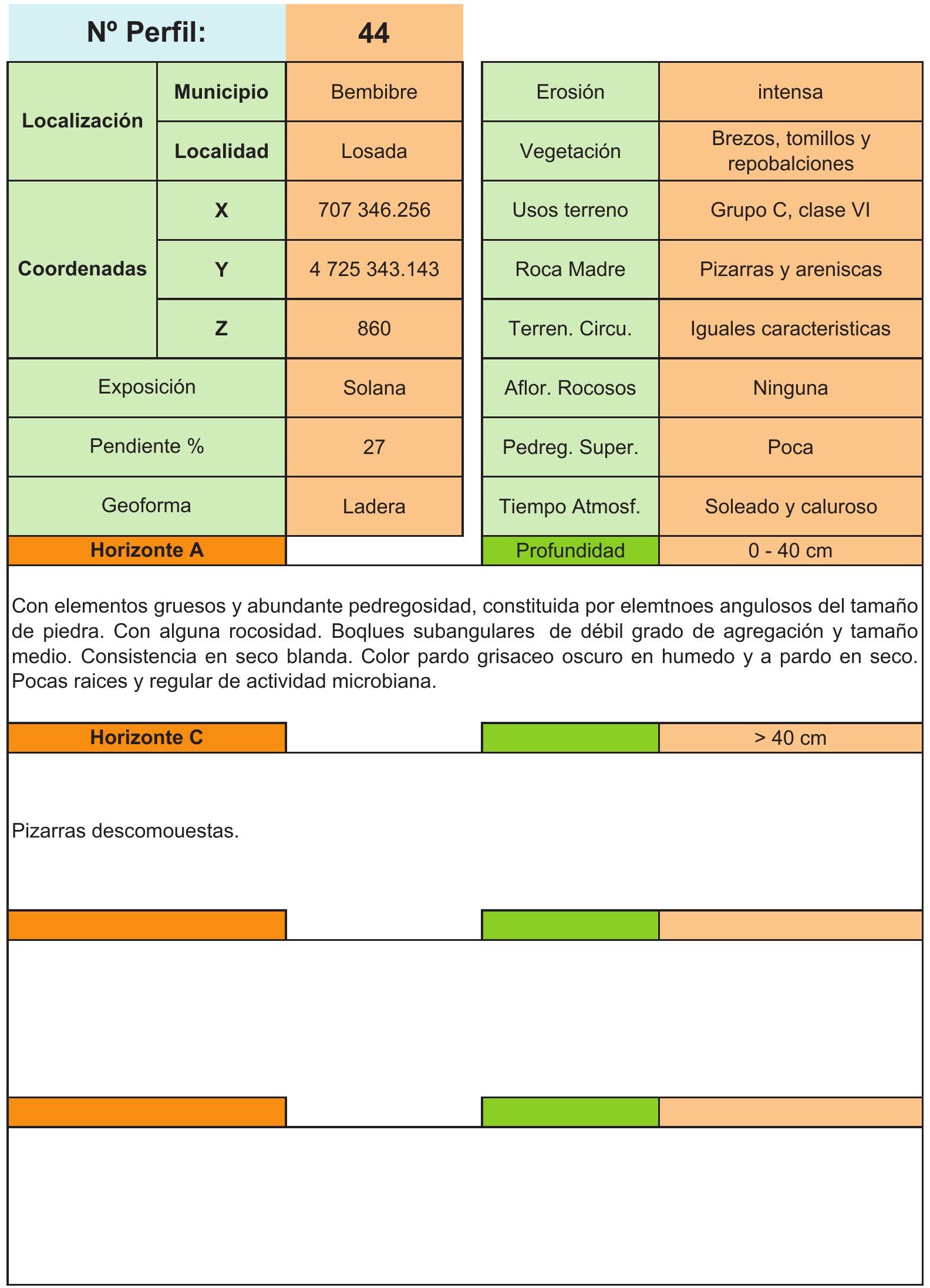


No Perfil:

\begin{tabular}{|c|c|c|}
\hline \multirow{2}{*}{ Localización } & Municipio & Carracedelo \\
\cline { 2 - 3 } & Localidad & Carracedelo \\
\hline \multirow{2}{*}{ Coordenadas } & $\mathbf{X}$ & 685302.598 \\
\cline { 2 - 3 } & $\mathbf{Y}$ & 4713790.928 \\
\hline Exposición & 423.000 \\
\hline \multicolumn{2}{|c|}{ Pendiente \% } & Solana \\
\hline \multicolumn{2}{|c|}{ Geoforma } & Fondo de valle \\
\hline Horizonte A & \\
\hline
\end{tabular}

\begin{tabular}{|c|c|}
\hline Erosión & Poca o ninguna \\
\hline Vegetación & $\begin{array}{c}\text { Castaños y monte bajo, con } \\
\text { alguna zona repoblada. }\end{array}$ \\
\hline Usos terreno & Grupo A, clase II \\
\hline Roca Madre & pizarras siluricas. \\
\hline Terren. Circu. & Iguales caracteristicas \\
\hline Aflor. Rocosos & Ninguno \\
\hline Pedreg. Super. & Ninguno \\
\hline Tiempo Atmosf. & Soleado y caluroso \\
\hline Profundidad & 0 - 40 \\
\hline
\end{tabular}

Pocos elementos gruesos y piedras redondeadas. Sin rocosidad. Estructura en bloque, moderada y media. Consistencia ligeramente dura. Color en humedo rojo amarillento y en seco amarillo rojizo. La separación con el siguiente horizonte esta claramente definida. De raices abundantes y activa vida microbiana.

\section{Horizonte B}

$40-100 \mathrm{~cm}$

Pocos elementos gruesos y piedras redondeadas. Sin rocosidad. Estructura en bloque, de buena estabilidad. Consistencia dura en seco. Color en humedo rojo amarillento y en seco amarillo rojizo. La separación con el siguiente horizonte esta claramente definida.Sin raices y escasa vida microbiana.

\section{Horizonte C}

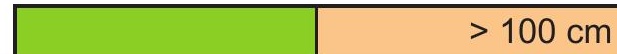

Estructura prismatica fuerte y media. Consistencia muy dura. Aumento de arcilla con respecto a las capas superiores. Con pocos elementos gruesos y poca pedregosidad, si afloramientos rocosos.

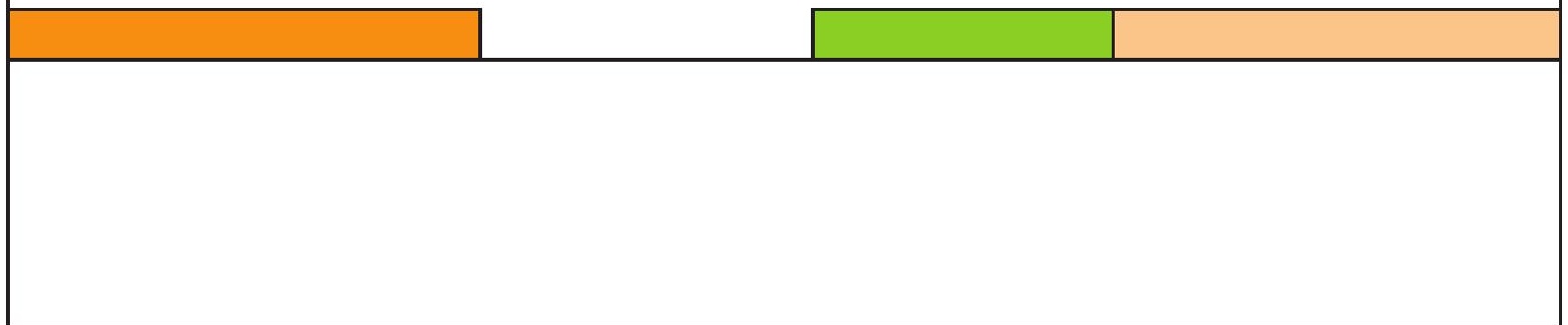


No Perfil:

\begin{tabular}{|c|c|c|}
\hline \multirow{2}{*}{ Localización } & Municipio & Molinaseca \\
\cline { 2 - 3 } & Localidad & Acebo \\
\hline \multirow{2}{*}{ Coordenadas } & $\mathbf{X}$ & 707873.809 \\
\cline { 2 - 3 } & $\mathbf{Y}$ & 4708100.483 \\
\cline { 2 - 3 } & $\mathbf{Z}$ & 322.000 \\
\hline Exposición & Solana \\
\hline Pendiente & 33.000 \\
\hline \multicolumn{2}{|c|}{ Geoforma } & Ladera \\
\hline Horizonte A & \\
\hline
\end{tabular}

46

\begin{tabular}{|c|c|}
\hline Erosión & Moderada \\
\hline Vegetación & Pastos, brezos, pinos \\
\hline Usos terreno & Grupo C, clase VI \\
\hline Roca Madre & cuarcitas y pizarras \\
\hline Terren. Circu. & Iguales caracteristicas \\
\hline Aflor. Rocosos & Escaos o ninguno \\
\hline Pedreg. Super. & Abundante \\
\hline Tiempo Atmosf. & Soleado y caluroso \\
\hline Profundidad & 0 - 40 \\
\hline
\end{tabular}

Pocos elementos gruesos y piedras redondeadas. Sin rocosidad. Estructura en bloque, moderada y media. Consistencia ligeramente dura. Color en humedo pardo amarillento y en seco pardo. La separación con el siguiente horizonte esta claramente definida. De raices abundantes y activa vida microbiana.

\section{Horizonte B}

$40-100 \mathrm{~cm}$

Pocos elementos gruesos y piedras redondeadas. Sin rocosidad. Estructura en bloque, de buena estabilidad. Consistencia blanda. Color en humedo rojo amarillento y en seco pardo rojizo. La separación con el siguiente horizonte esta claramente definida.Sin raices y escasa vida microbiana.

\section{Horizonte C}

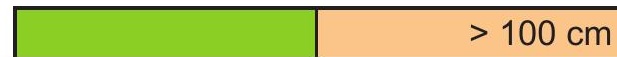

Roca madre descompuesta.

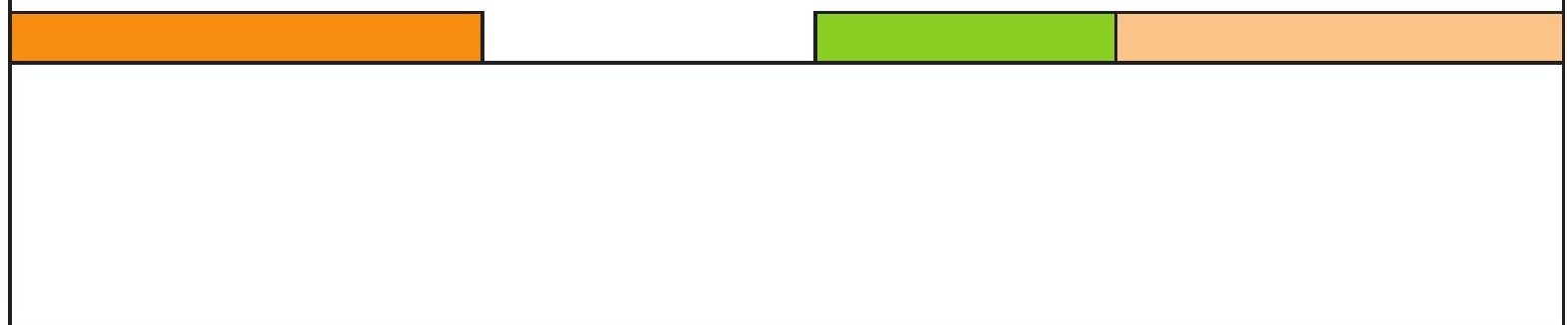




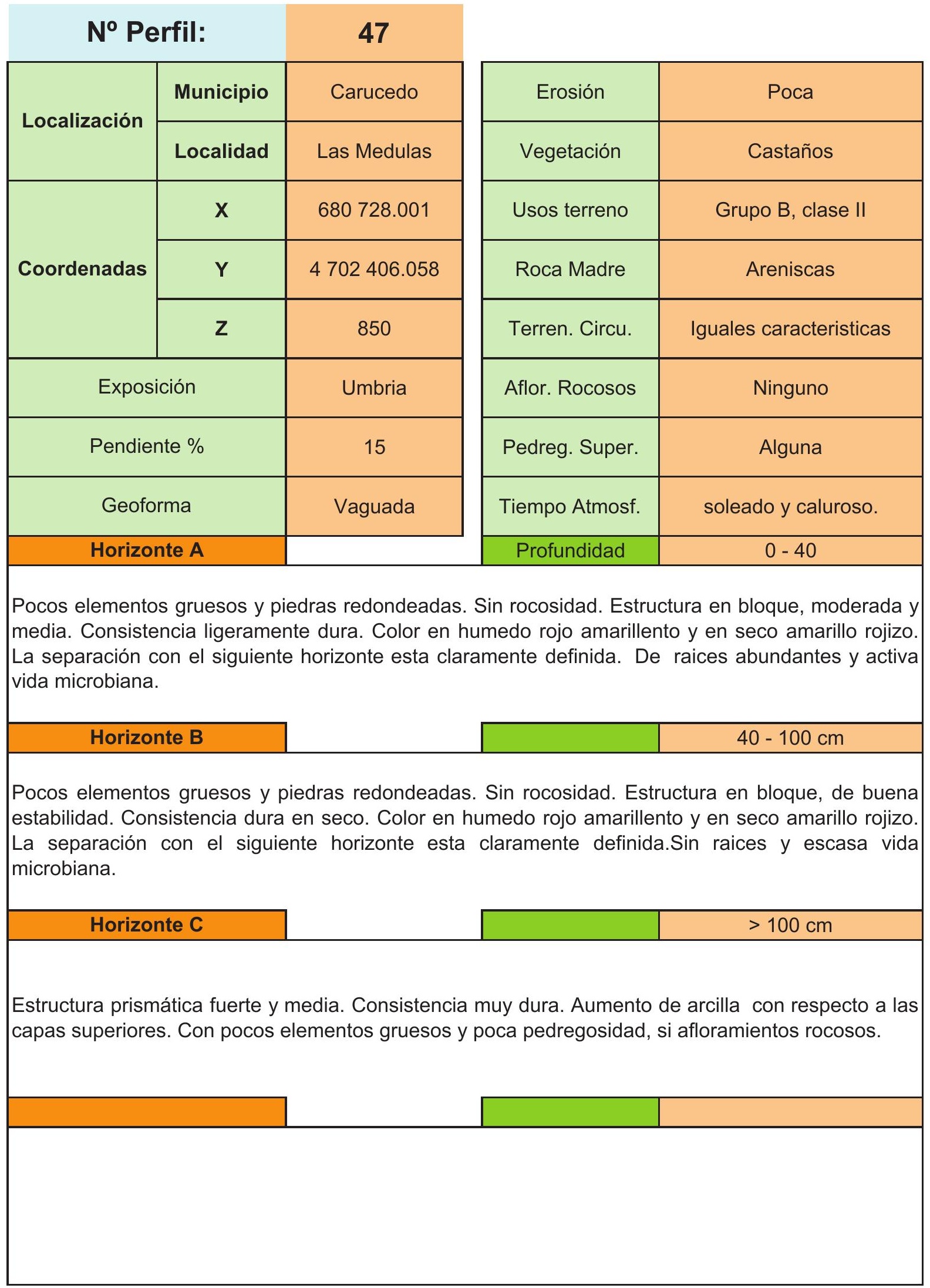


ANÁLISIS DE CARACTERIZACIÓN DE SUELOS

Desarrollo de una aplicación informática para el cálculo de sostenimiento de taludes mediante vegetación

No Perfil:

\begin{tabular}{|c|c|c|}
\hline \multirow{2}{*}{ Localización } & Municipio & Torre Bierzo \\
\cline { 2 - 3 } & Localidad & Polvobueno \\
\hline \multirow{2}{*}{ Coordenadas } & $\mathbf{X}$ & 716227.923 \\
\cline { 2 - 3 } & $\mathbf{Y}$ & 4710581.978 \\
\cline { 2 - 3 } & $\mathbf{Z}$ & 1115 \\
\hline Exposición & Solana \\
\hline \multicolumn{2}{|c|}{ Pendiente \% } & 41.000 \\
\hline \multicolumn{2}{|c|}{ Geoforma } & Ladera \\
\hline \multicolumn{2}{|c|}{ Horizonte A } & \\
\hline
\end{tabular}

48

\begin{tabular}{|c|c|}
\hline Erosión & Intensa \\
\hline Vegetación & Robles, pasto, escobas. \\
\hline Usos terreno & Grupo C, clase VII \\
\hline Roca Madre & Pizarras \\
\hline Terren. Circu. & Iguales caracteristicas \\
\hline Aflor. Rocosos & Abundantes \\
\hline Pedreg. Super. & Abundantes \\
\hline Tiempo Atmosf. & Niebla. \\
\hline Profundidad & 0 - 34 cm \\
\hline
\end{tabular}

Sin elementos gruesos pero con abundante pedregosidad del tamaño de piedra y cascajo y estremadamente rocoso. De estructura migajosa. Limite bien definido con la roca madre. Abundantes afloramientos rocosos

Horizonte R

$>34 \mathrm{~cm}$

Roca Madre 
No Perfil:

\begin{tabular}{|c|c|c|}
\hline \multirow{2}{*}{ Localización } & Municipio & Camponaraya \\
\hline & Localidad & La Valgona \\
\hline \multirow{3}{*}{ Coordenadas } & $x$ & 690224.968 \\
\hline & $\mathbf{Y}$ & 4717641.666 \\
\hline & $\mathbf{Z}$ & 465.000 \\
\hline \multicolumn{2}{|c|}{ Exposición } & Solana \\
\hline \multicolumn{2}{|c|}{ Pendiente \% } & 6.200 \\
\hline \multicolumn{2}{|c|}{ Geoforma } & Fondo de valle \\
\hline \multicolumn{2}{|c|}{ Horizonte A } & \\
\hline
\end{tabular}

49

\begin{tabular}{|c|c|}
\hline Erosión & Moderada \\
\hline Vegetación & $\begin{array}{c}\text { Castaños, cereales, Vid y } \\
\text { cultivos de huerta }\end{array}$ \\
\hline Usos terreno & Grupo A, clase II \\
\hline Roca Madre & $\begin{array}{c}\text { Arcillas con margas y } \\
\text { conglomerados }\end{array}$ \\
\hline Terren. Circu. & Iguales caracteristicas \\
\hline Aflor. Rocosos & Ninguno \\
\hline Pedreg. Super. & Ninguno \\
\hline Tiempo Atmosf. & Soleado y caluroso \\
\hline Profundidad & $0-30 \mathrm{~cm}$ \\
\hline
\end{tabular}

Pocos elementos gruesos y piedras redondeadas. Sin rocosidad. Estructura en bloque, moderada y media. Consistencia ligeramente dura. Color en humedo rojo amarillento y en seco amarillo rojizo. La separación con el siguiente horizonte esta claramente definida. De raices abundantes y activa vida microbiana.

\section{Horizonte B}

\section{$30-90 \mathrm{~cm}$}

Pocos elementos gruesos y piedras redondeadas. Sin rocosidad. Estructura en bloque, de buena estabilidad. Consistencia dura en seco. Color en humedo rojo amarillento y en seco amarillo rojizo. La separación con el siguiente horizonte esta claramente definida.Sin raices y escasa vida microbiana.

\section{Horizonte C}

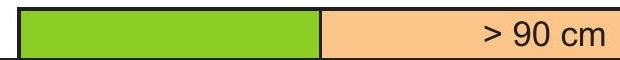

Estructura prismática fuerte y media. Consistencia muy dura. Aumento de arcilla con respecto a las capas superiores. Con pocos elementos gruesos y poca pedregosidad, si afloramientos rocosos.

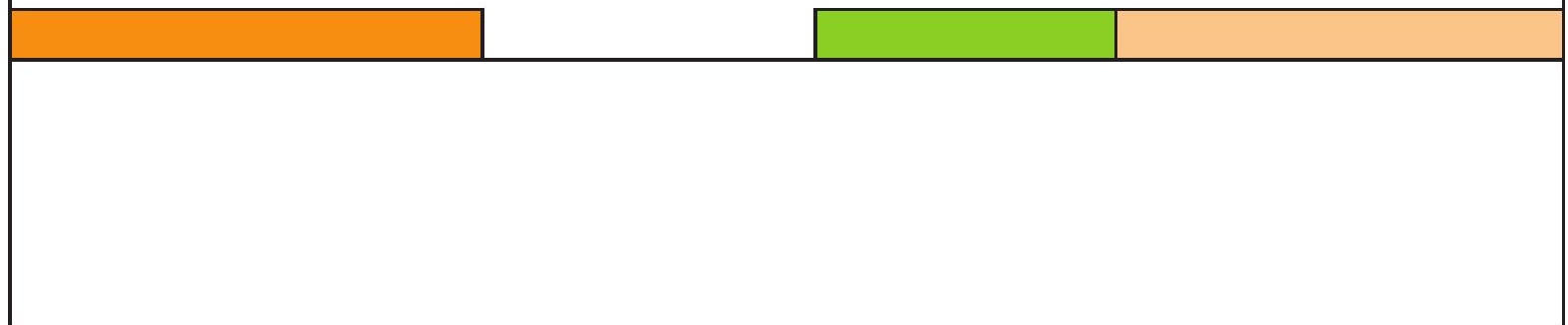


ANÁLISIS DE CARACTERIZACIÓN DE SUELOS

Desarrollo de una aplicación informática para el cálculo de sostenimiento de taludes mediante vegetación

No Perfil:

\begin{tabular}{|c|c|c|}
\hline \multirow{2}{*}{ Localización } & Municipio & $\begin{array}{c}\text { Priaranza del } \\
\text { Bierzo }\end{array}$ \\
\cline { 2 - 3 } & Localidad & Villavieja \\
\hline \multirow{2}{*}{ Coordenadas } & $\mathbf{X}$ & 689227.213 \\
\cline { 2 - 3 } & $\mathbf{Y}$ & 4706087.601 \\
\cline { 2 - 3 } & $\mathbf{Z}$ & 785 \\
\hline Exposición & Solana \\
\hline \multicolumn{2}{|c|}{ Pendiente } & 22 \\
\hline \multicolumn{2}{|c|}{ Geoforma } & Loma \\
\hline \multicolumn{2}{|c|}{ Horizonte A } & \\
\hline
\end{tabular}

\section{0}

\begin{tabular}{|c|c|}
\hline Erosión & Intensa \\
\hline Vegetación & Castaños, robles, escobas \\
\hline Usos terreno & Grupo C, clase VI \\
\hline Roca Madre & $\begin{array}{c}\text { Cuarcitas areniscas y } \\
\text { pizarras }\end{array}$ \\
\hline Terren. Circu. & Iguales caracteristicas \\
\hline Aflor. Rocosos & Abundantes \\
\hline Pedreg. Super. & Abundantes \\
\hline Tiempo Atmosf. & Soleado \\
\hline Profundidad & 0 - 45 cm \\
\hline
\end{tabular}

Con elementos gruesos y abundante pedregosidad, constituida por elementos angulosos del tamaño de piedra. Con alguna rocosidad. Boqlues subangulares de débil grado de agregación y tamaño medio. Consistencia en seco blanda. Color pardo grisaceo oscuro en humedo y a pardo en seco. Pocas raices y regular de actividad microbiana.

\section{Horizonte C}

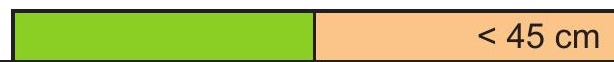

Roca madre descompuesta

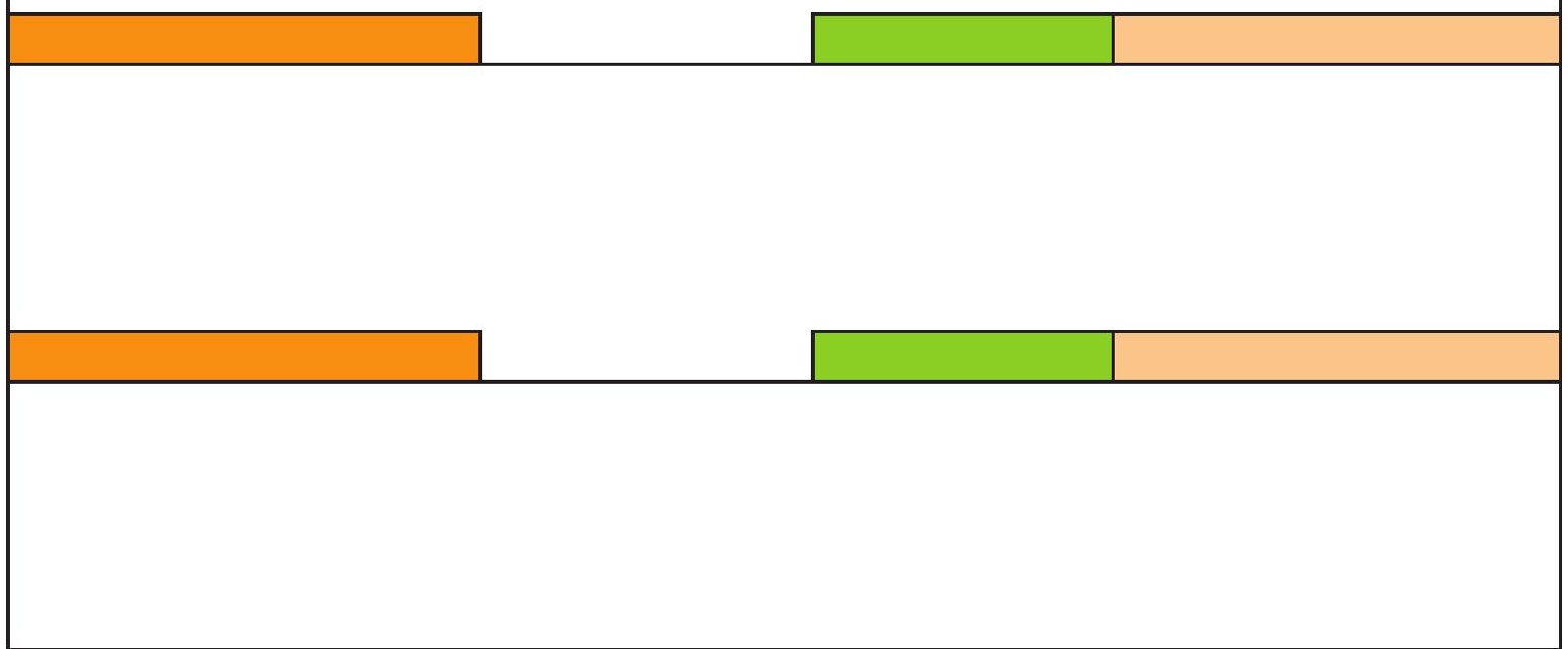


ANÁLISIS DE CARACTERIZACIÓN DE SUELOS

Desarrollo de una aplicación informática para el cálculo de sostenimiento de taludes mediante vegetación

No Perfil:

\begin{tabular}{|c|c|c|}
\hline \multirow{2}{*}{ Localización } & Municipio & $\begin{array}{c}\text { Pte. Domingo } \\
\text { Flórez }\end{array}$ \\
\cline { 2 - 3 } & Localidad & Vega de Yeres \\
\hline \multirow{2}{*}{ Coordenadas } & $\mathbf{X}$ & 680134.875 \\
\cline { 2 - 3 } & $\mathbf{Y}$ & 4697999.459 \\
\hline Exposición & 868 \\
\hline \multicolumn{2}{|c|}{ Pendiente } & Solana \\
\hline \multicolumn{2}{|c|}{ Geoforma } & 37 \\
\hline \multicolumn{2}{|c|}{ Horizonte A } & Ladera \\
\hline
\end{tabular}

\section{1}

\begin{tabular}{|c|c|}
\hline Erosión & Intensa \\
\hline Vegetación & Carracas, retamas, robles.... \\
\hline Usos terreno & Grupo C, clase VII \\
\hline Roca Madre & Pizarras con cuarcitas \\
\hline Terren. Circu. & Iguales caracteristicas \\
\hline Aflor. Rocosos & Abundantes \\
\hline Pedreg. Super. & Abundantes \\
\hline Tiempo Atmosf. & Soleado pero frio. \\
\hline Profundidad & 0 - 25 cm \\
\hline
\end{tabular}

Consistencia dura. Estructura en bloque subangulares moderada y media. Horizonte con pocos elementos gruesos y abundantes piedras angulares. Abundantes raices y vida microbiologica.

\section{Horizonte C}

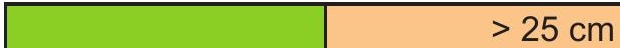

Roca madre en descomposición.

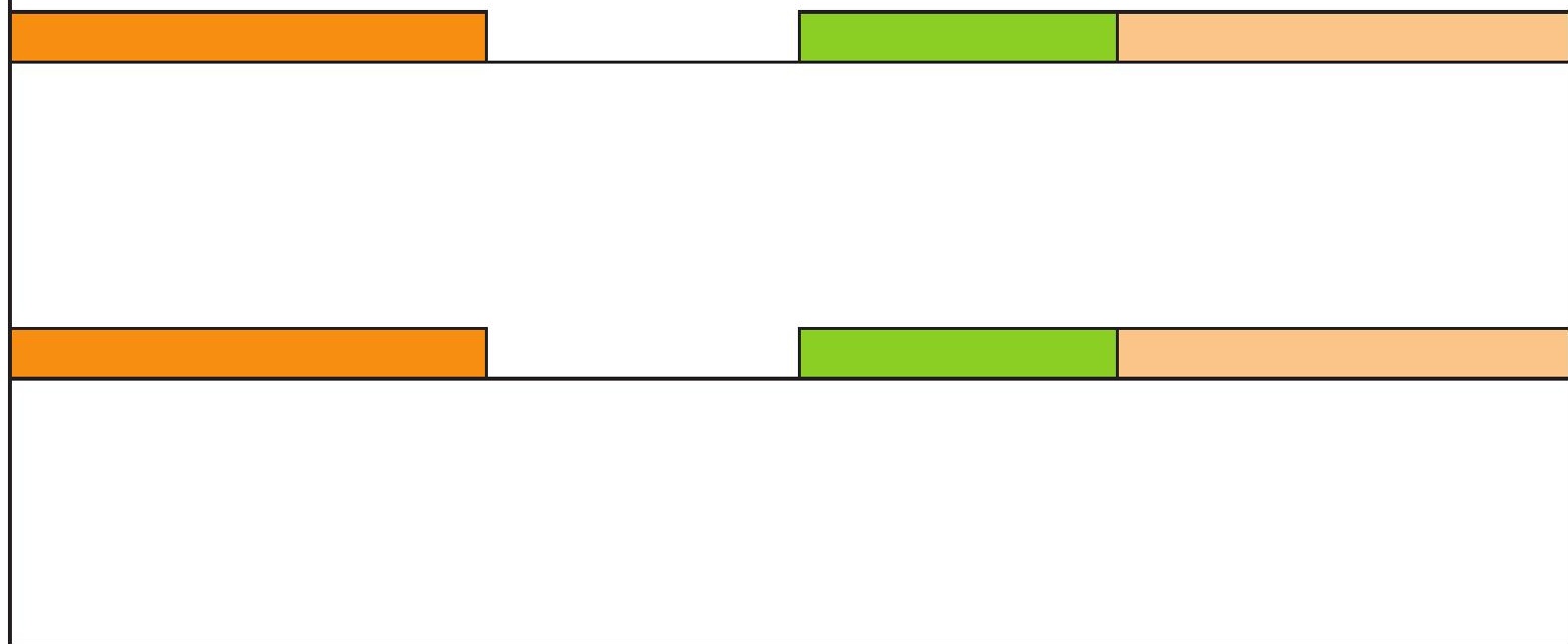


ANÁLISIS DE CARACTERIZACIÓN DE SUELOS

Desarrollo de una aplicación informática para el cálculo de sostenimiento de taludes mediante vegetación

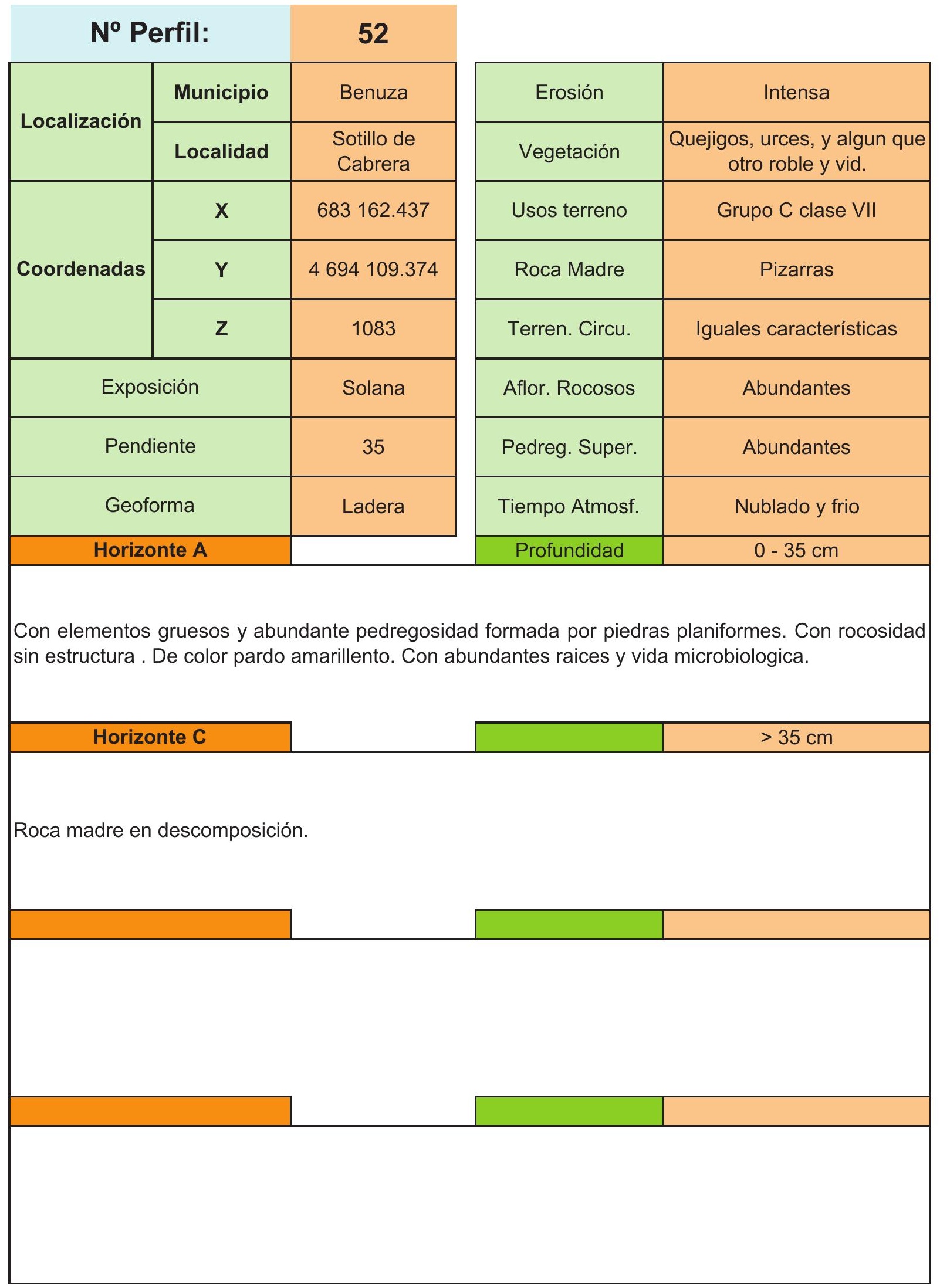


ANÁLISIS DE CARACTERIZACIÓN DE SUELOS

Desarrollo de una aplicación informática para el cálculo de sostenimiento de taludes mediante vegetación

No Perfil:

\begin{tabular}{|c|c|c|}
\hline \multirow{2}{*}{ Localización } & Municipio & Benuza \\
\cline { 2 - 3 } & Localidad & Lomba \\
\hline \multirow{2}{*}{ Coordenadas } & $\mathbf{X}$ & 690007.002 \\
\cline { 2 - 3 } & $\mathbf{Z}$ & 4691608.952 \\
\hline Exposición & 1023 \\
\hline Pendiente & Solana \\
\hline Geoforma & 33 \\
\hline Horizonte A & Ladera \\
\hline
\end{tabular}

\section{3}

\begin{tabular}{|c|c|}
\hline Erosión & Intensa \\
\hline Vegetación & $\begin{array}{c}\text { Quejigos, urces, y algun que } \\
\text { otro roble y vid. }\end{array}$ \\
\hline Usos terreno & Grupo C clase VII \\
\hline Roca Madre & Pizarras \\
\hline Terren. Circu. & Iguales características \\
\hline Aflor. Rocosos & Abundantes \\
\hline Pedreg. Super. & Abundantes \\
\hline Tiempo Atmosf. & Nublado y frio \\
\hline Profundidad & 0 - 38 cm \\
\hline
\end{tabular}

Con elementos gruesos y abundante pedregosidad formada por piedras planiformes. Con rocosidad sin estructura . De color pardo amarillento. Con abundantes raices y vida microbiologica.

Horizonte C

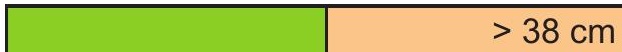

Roca madre en descomposición.

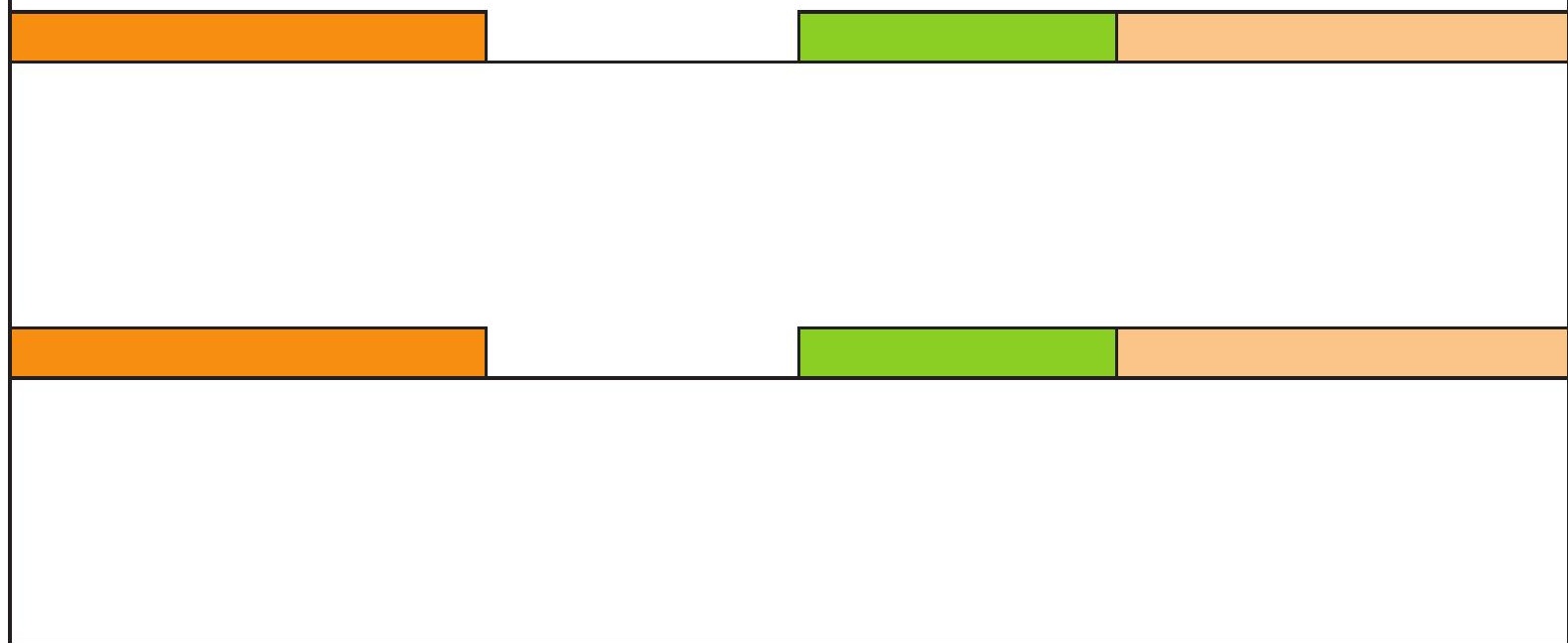


ANÁLISIS DE CARACTERIZACIÓN DE SUELOS

Desarrollo de una aplicación informática para el cálculo de sostenimiento de taludes mediante vegetación

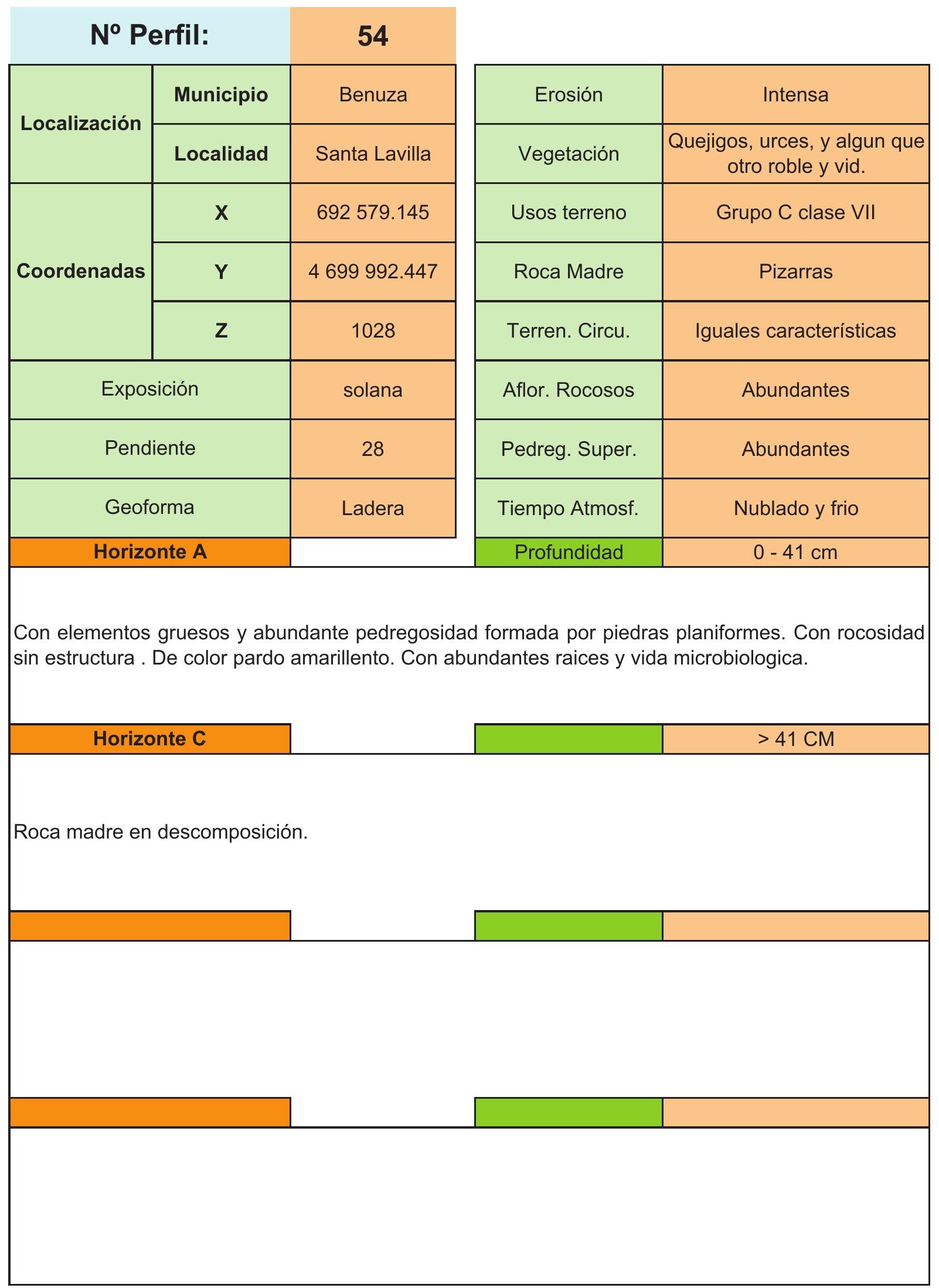




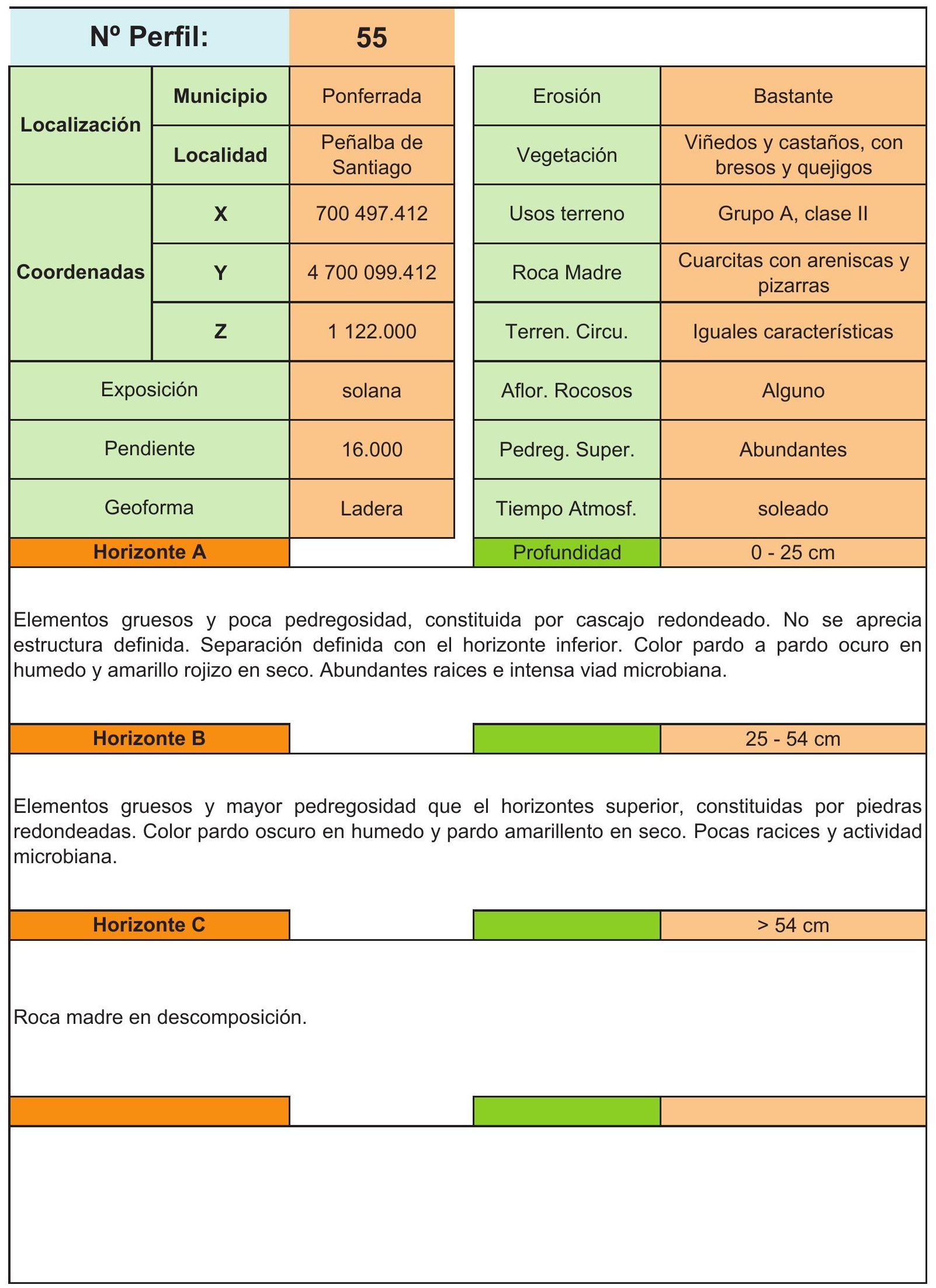


ANÁLISIS DE CARACTERIZACIÓN DE SUELOS

Desarrollo de una aplicación informática para el cálculo de sostenimiento de taludes mediante vegetación

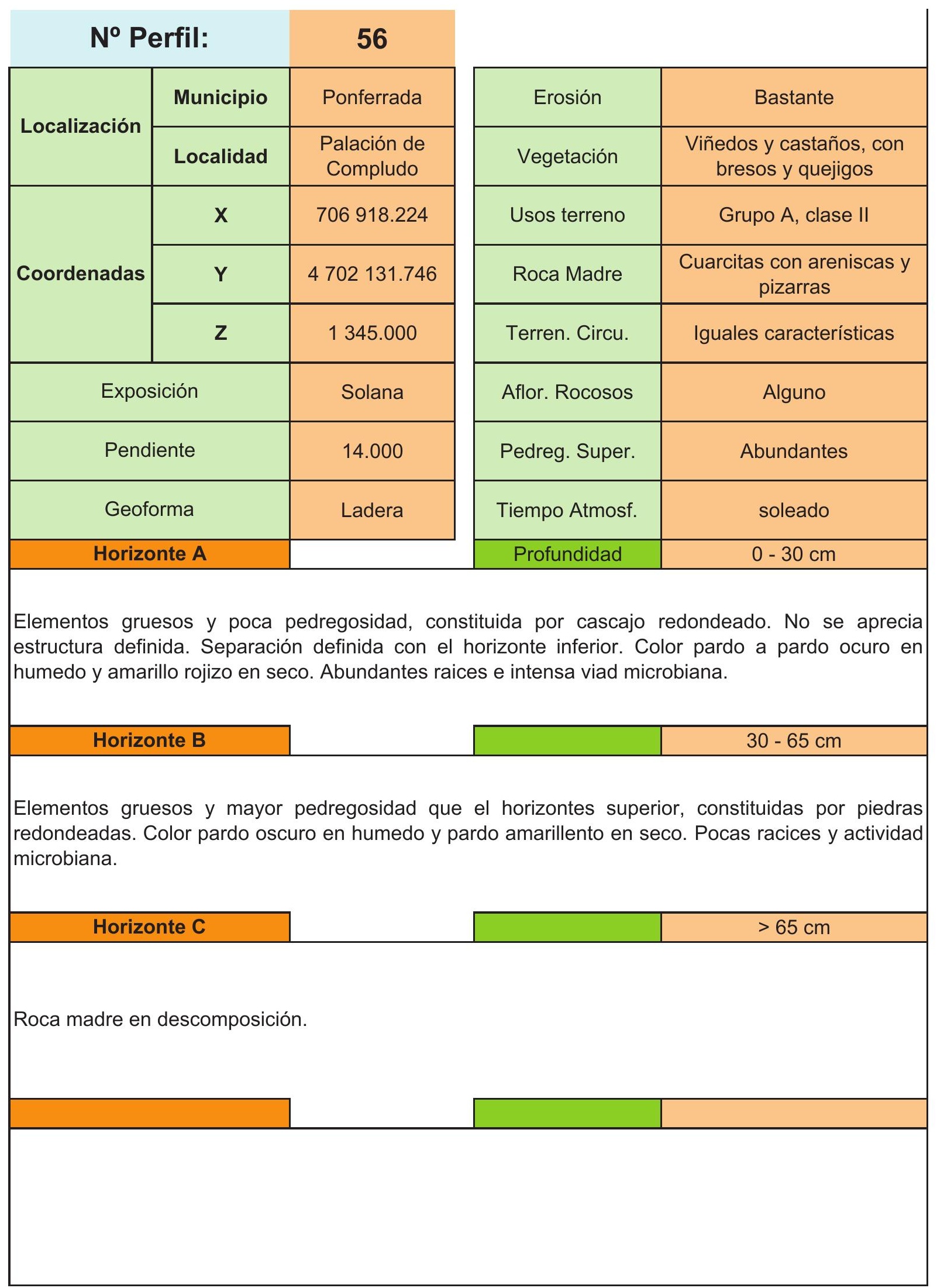




\begin{tabular}{|c|c|c|c|c|}
\hline \multicolumn{2}{|c|}{ No Perfil: } & \multirow{2}{*}{57} & & \\
\hline \multirow{2}{*}{ Localización } & Municipio & & Erosión & Baja \\
\hline & Localidad & Molinaseca & Vegetación & cultivos agricolas \\
\hline \multirow{3}{*}{ Coordenadas } & $x$ & 701754.976 & Usos terreno & Grupo A, clase I \\
\hline & $\mathbf{Y}$ & 4712584.755 & Roca Madre & $\begin{array}{l}\text { Arcillas con margas y } \\
\text { conglomerados }\end{array}$ \\
\hline & $\mathbf{z}$ & 488 & Terren. Circu. & iguales caracteristicas \\
\hline \multicolumn{2}{|c|}{ Exposición } & Solana & Aflor. Rocosos & Ninguno \\
\hline \multicolumn{2}{|c|}{ Pendiente \% } & 2 & Pedreg. Super. & Ninguno \\
\hline \multicolumn{2}{|c|}{ Geoforma } & Fondo de valle & Tiempo Atmosf. & Soleado \\
\hline \multicolumn{2}{|c|}{ Horizonte A } & & Profundidad & $0-25 \mathrm{~cm}$ \\
\hline \multicolumn{5}{|c|}{$\begin{array}{l}\text { Sin elementos gruesos y poca pedregosidad de forma redondeada y forma de piedra. Sin rocosidad } \\
\text { Estructura moderadamente fuerte, en bloque subangulares. Consistencia dura. Posee una } \\
\text { separación con el siguiente horizonte definida. Color pardo negruzco en humedo y pardo ligeramente } \\
\text { amarillo en seco. Abundantes racices y buena actividad microbiana. }\end{array}$} \\
\hline \multicolumn{2}{|c|}{ Horizonte B } & & & $25-55 \mathrm{~cm}$ \\
\hline \multicolumn{5}{|c|}{$\begin{array}{l}\text { Al igual que el anterior este tambien posee pocos elementos gruesos y poca pedregosidad. Colo } \\
\text { pardo negruzco en humedo y pardo amarillento en seco. Frecuentes raices y vida microbiologica } \\
\text { Estructura prismatica y consistencia dura. }\end{array}$} \\
\hline \multicolumn{2}{|c|}{ Horizonte B } & & & $55-120 \mathrm{~cm}$ \\
\hline \multicolumn{5}{|c|}{$\begin{array}{l}\text { Este horizonte presenta ya mas elementos gruesos y mucha pedregosidad sin que aparezc } \\
\text { estructura definida. Con una separación clara con el siguiente horizonte. Color pardo amarillento, y y } \\
\text { con escasas raices y moderada vida microbiológica. }\end{array}$} \\
\hline \multicolumn{2}{|c|}{ Horizonte B } & & & $>120 \mathrm{~cm}$ \\
\hline \multicolumn{5}{|c|}{ Cosnistencia suelta, y sin estructura definida. Sin racices ni acitivida microbiológica. } \\
\hline
\end{tabular}


ANÁLISIS DE CARACTERIZACIÓN DE SUELOS

Desarrollo de una aplicación informática para el cálculo de sostenimiento de taludes mediante vegetación

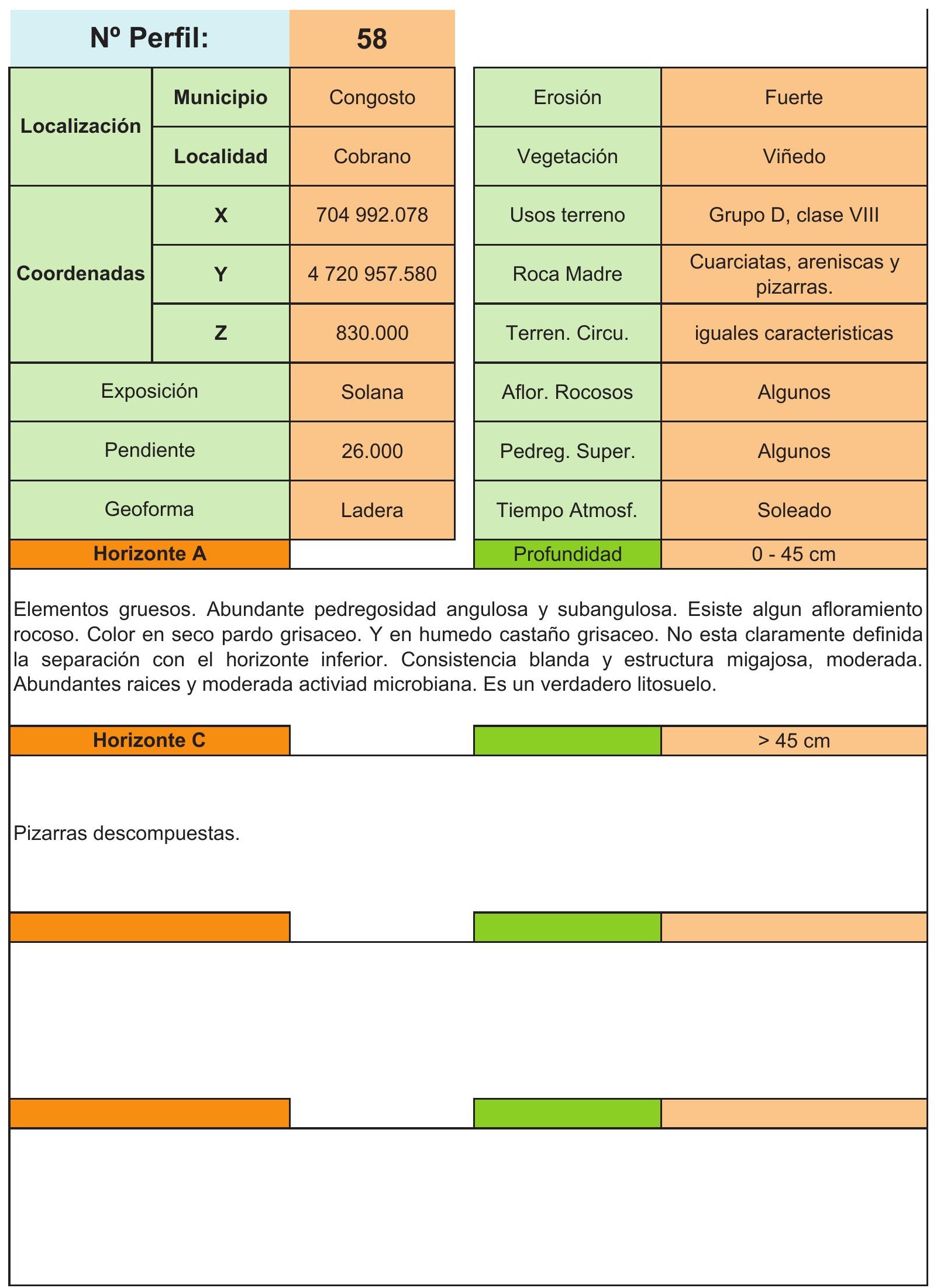




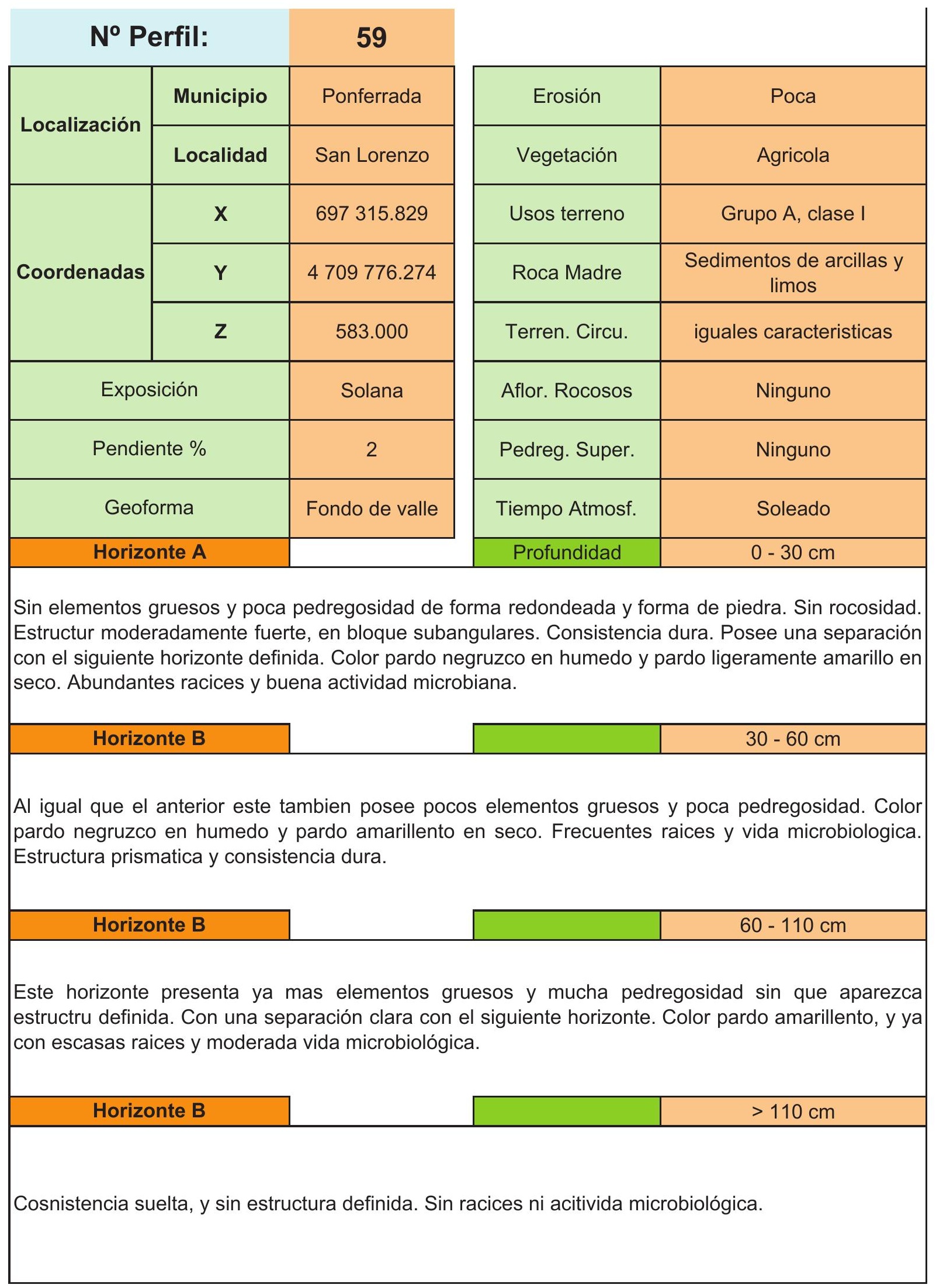




\begin{tabular}{|c|c|c|c|c|}
\hline \multicolumn{2}{|c|}{ No Perfil: } & \multirow{2}{*}{$\frac{60}{\text { Cabañas Raras }}$} & & \\
\hline \multirow{2}{*}{ Localización } & Municipio & & Erosión & Moderada \\
\hline & Localidad & Cabañas Raras & Vegetación & Agricola, sobre todo vid \\
\hline \multirow{3}{*}{ Coordenadas } & $x$ & 693863.242 & Usos terreno & Grupo A, clase I \\
\hline & $\mathbf{Y}$ & 4719567.035 & Roca Madre & $\begin{array}{l}\text { Arcillas con margas y } \\
\text { conglomerados }\end{array}$ \\
\hline & $\mathbf{z}$ & 511 & Terren. Circu. & iguales caracteristicas \\
\hline \multicolumn{2}{|c|}{ Exposición } & Solana & Aflor. Rocosos & Ninguno \\
\hline \multicolumn{2}{|c|}{ Pendiente \% } & 10 & Pedreg. Super. & Poca o nula \\
\hline \multicolumn{2}{|c|}{ Geoforma } & Ladera & Tiempo Atmosf. & Soleado \\
\hline \multicolumn{2}{|c|}{ Horizonte A } & & Profundidad & $0-20 \mathrm{~cm}$ \\
\hline \multicolumn{5}{|c|}{$\begin{array}{l}\text { Horizonte con abundantes raices y actividad microbiana. Con elementos gruesos y abundante } \\
\text { pedregosidad del tamaño de piedra y forma redondeada. Separación difusa con la capa inferior } \\
\text { Estructura en bloque angulares y consistencia en seco dura. Color amarillo rojizo. }\end{array}$} \\
\hline \multicolumn{3}{|c|}{ Horizonte B } & & $20-110 \mathrm{~cm}$ \\
\hline \multicolumn{5}{|c|}{$\begin{array}{l}\text { Con elementos gruesos y mucha pedregosidad constituidas por cuarcitas redondeadas. Estructura } \\
\text { en bloques subangulares de moderado grado de agregación y consistencia dura, la separación con e } \\
\text { siguiente horizonte sigue siendo difusa. El color es rojo amarrillento en humedo variando en seco. } \\
\text { Todavia posoe abundantes raices y vida microbiana. }\end{array}$} \\
\hline \multicolumn{3}{|c|}{ Horizonte C } & & $110-145 \mathrm{~cm}$ \\
\hline \multicolumn{5}{|c|}{$\begin{array}{l}\text { Horizonte sin acitvidad microbiologica, ni raices, de color rojo a rojo oscuro en humedo y rojc } \\
\text { amarillento en seco. Con pocos elementos gruesos y menos pedregosidad que el horizonte superior } \\
\text { Con una estructura en bloques subangulares moderada. }\end{array}$} \\
\hline \multicolumn{2}{|c|}{ Horizonte R } & & & $>145 \mathrm{~cm}$ \\
\hline \multicolumn{5}{|c|}{ Roca madre. } \\
\hline
\end{tabular}


$N^{\circ}$ Perfil:

\begin{tabular}{|c|c|c|}
\hline \multirow{2}{*}{ Localización } & Municipio & Cubillos del Sil \\
\cline { 2 - 3 } & Localidad & Finolledo \\
\hline \multirow{2}{*}{ Coordenadas } & $\mathbf{X}$ & 698357.580 \\
\cline { 2 - 3 } & $\mathbf{Z}$ & 4724915.283 \\
\cline { 2 - 3 } & & 783 \\
\hline Exposición & Solana \\
\hline Pendiente \% & 22 \\
\hline Geoforma & Ladera \\
\hline Horizonte A & \\
\hline
\end{tabular}

\section{1}

\begin{tabular}{|c|c|}
\hline Erosión & Media \\
\hline Vegetación & $\begin{array}{c}\text { Robles, encinas, pinos, } \\
\text { algo de cultivos agricolas. }\end{array}$ \\
\hline Usos terreno & Grupo B,C y clase VI \\
\hline Roca Madre & Pizarras y areniscas \\
\hline Terren. Circu. & Iguales caracteristicas \\
\hline Aflor. Rocosos & ninguno \\
\hline Pedreg. Super. & ninguna \\
\hline Tiempo Atmosf. & soledado y frio. \\
\hline Profundidad & 0 - 60 cm \\
\hline
\end{tabular}

Abundantes raices y activa vida microbiana, con pocos elementos gruesos y regular de pedregosidad, constituida por elementos subangulosos del tamaño de piedra . Sin rocosidad. De color pardo pálido en seco y ligeramente amarillo en humedo. Separación definida con el horizonte inferior.

Horizonte B

$>60 \mathrm{~cm}$

Estructura en bloques, Consistencia ligeramente dura. De color pardo. Sin raices ni vida microbiana activa. Abundante pedregosidad

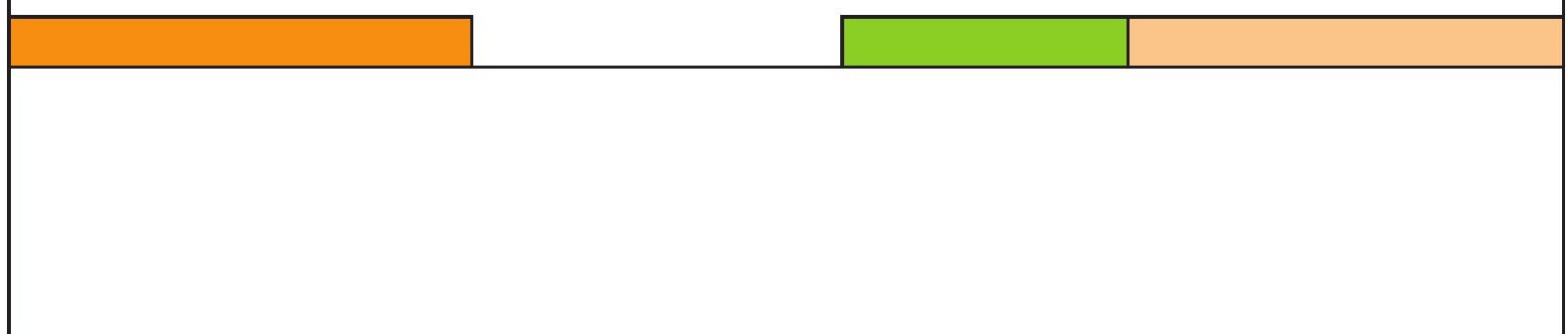


ANÁLISIS DE CARACTERIZACIÓN DE SUELOS

Desarrollo de una aplicación informática para el cálculo de sostenimiento de taludes mediante vegetación

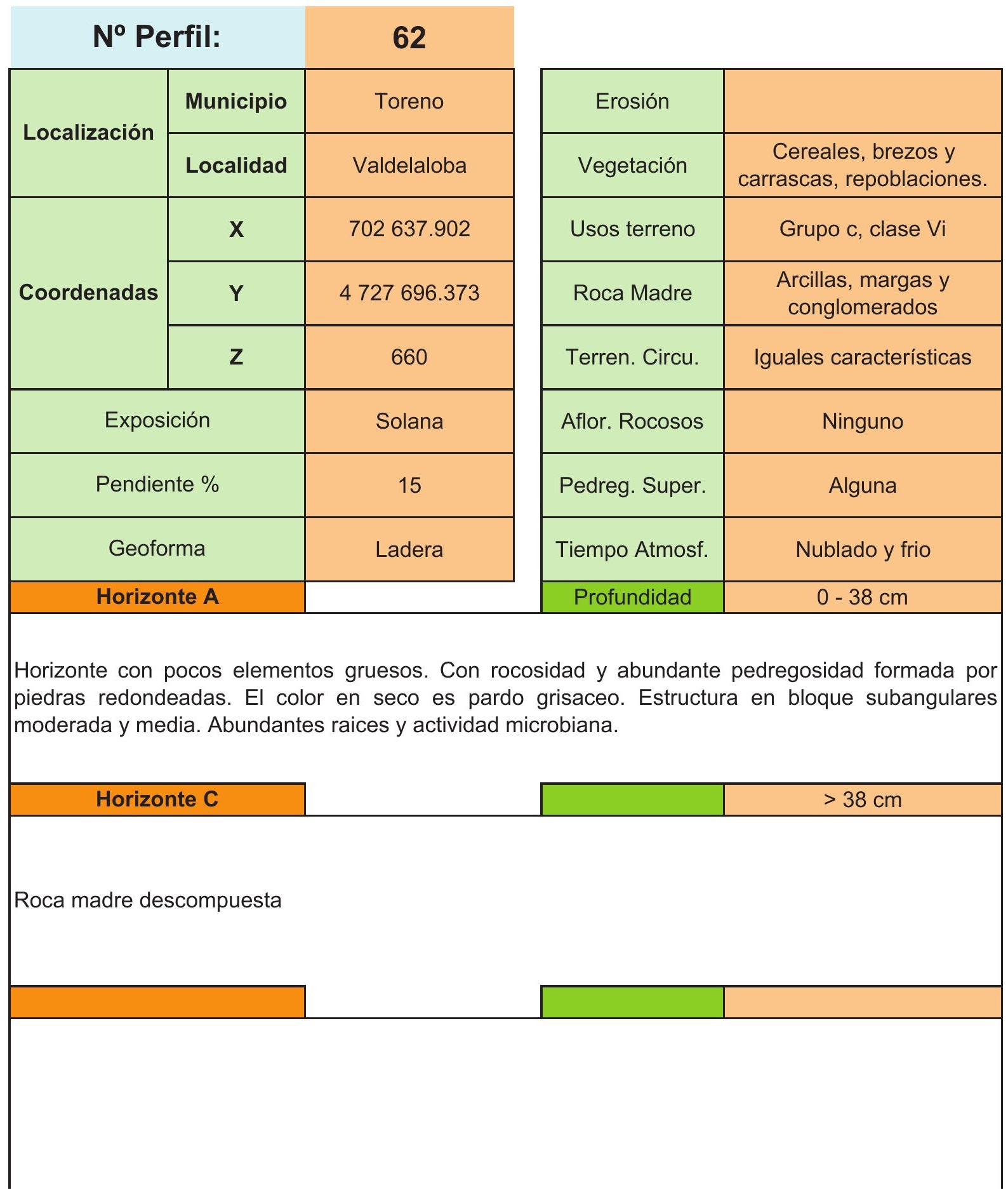


No Perfil:

\begin{tabular}{|c|c|c|}
\hline \multirow{2}{*}{ Localización } & Municipio & Torre Biezo \\
\cline { 2 - 3 } & Localidad & $\begin{array}{c}\text { San Andres de las } \\
\text { Fuentes }\end{array}$ \\
\hline \multirow{2}{*}{ Coordenadas } & $\mathbf{X}$ & 715906.891 \\
\cline { 2 - 3 } & $\mathbf{Z}$ & 4715716.297 \\
\hline Exposición & 963 \\
\hline Pendiente \% & Solana \\
\hline \multicolumn{2}{|c|}{ Geoforma } & 23 \\
\hline Horizonte A & Ladera \\
\hline
\end{tabular}

\section{3}

\begin{tabular}{|c|c|}
\hline Erosión & Intensa \\
\hline Vegetación & $\begin{array}{c}\text { Brezo y carrasas con } \\
\text { quejigos }\end{array}$ \\
\hline Usos terreno & Grupo C, clase VII \\
\hline Roca Madre & Pizarras con cuarcitas \\
\hline Terren. Circu. & Iguales características \\
\hline Aflor. Rocosos & Alguno \\
\hline Pedreg. Super. & Abundante \\
\hline Tiempo Atmosf. & humedad ambiente \\
\hline Profundidad & 0 - 36 cm \\
\hline
\end{tabular}

Con pocos elementos gruesos y abundante pedregosidad, de tamaño de piedra y cascajo subangulares. Con abuandante rocosidad. Consistencia ligermente dura en seco. Adherente y ligeramente plastico en humedo. Separación claramente diferenciada con la capa inferior. Color pardo en seco y pardo oscuro en humedo. Raices abundantes y normal actividad microbiana.

Horizonte C

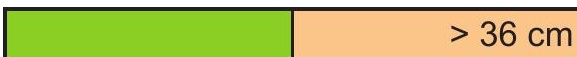

Roca madre descompuesta 
No Perfil:

\begin{tabular}{|c|c|c|}
\hline \multirow{2}{*}{ Localización } & Municipio & $\begin{array}{c}\text { Folgoso de la } \\
\text { Ribera }\end{array}$ \\
\cline { 2 - 3 } & Localidad & Villavicioso \\
\hline \multirow{2}{*}{ Coordenadas } & $\mathbf{X}$ & 717619.029 \\
\cline { 2 - 3 } & $\mathbf{Z}$ & 4721492.404 \\
\hline Exposición & 760 \\
\hline Pendiente \% & Solana \\
\hline \multicolumn{2}{|c|}{ Geoforma } & 19 \\
\hline Horizonte A & Ladera \\
\hline
\end{tabular}

\section{4}

\begin{tabular}{|c|c|}
\hline Erosión & Intensa \\
\hline Vegetación & $\begin{array}{c}\text { Brezo y carquesas, } \\
\text { repoblaciones de pinos }\end{array}$ \\
\hline Usos terreno & Grupo C clase VI \\
\hline Roca Madre & Pizarras \\
\hline Terren. Circu. & Iguales caracteristicas \\
\hline Aflor. Rocosos & Ninguno \\
\hline Pedreg. Super. & Alguna \\
\hline Tiempo Atmosf. & Frio \\
\hline Profundidad & 0 - 45 cm \\
\hline
\end{tabular}

Con elementos gruesos y abundante pedregosidad, constituida por piedras angulosas y planiformes. Sin que aprecie estructura definida y con consistencia blanda. En la parte inferior existe mucha rocosidad. Separado del horizonte inferior por una linea definida e irregular, Abundante raices y actividad microbiana. Se puede considerar un verdadero litosuelo..

Horizonte C

Roca madre descompuesta
$>45 \mathrm{~cm}$ 
DESARROLLO DE UNA APLICACIÓN IMFORMÁTICA PARA EL CÁLCULO DE SOSTENIMIENTO DE TALUDES MEDIANTE VEGETACIÓN

RESULTADOS DE ANÁLISIS DE LABORATORIO DE CARACTERIZACIÓN Y COMPOSICIÓN DE SUELOS.

2.- RESULTADOS DE ANÁLISIS DE COMPOSICIÓN DE SUELOS. 
ANÁLISIS DE COMPOSICIÓN DE SUELOS

Desarrollo de una aplicación informática para el cálculo de sostenimiento de taludes mediante vegetación

\begin{tabular}{|c|c|c|c|c|c|}
\hline \multirow[t]{2}{*}{ Perfil $n^{\circ}$} & \multirow[t]{2}{*}{1} & & & & \\
\hline & & Horizonte A & Horizonte B & Horizonte C & Horizonte \\
\hline \multirow{3}{*}{ Textura } & Arena (\%) & 64 & 59 & & \\
\hline & Limo (\%) & 27 & 30 & & \\
\hline & Arcilla (\%) & 9 & 11 & & \\
\hline \multicolumn{2}{|c|}{ Clase textural } & Fraco arenoso & Franca arenoso & & \\
\hline \multicolumn{2}{|l|}{ pH } & 5 & 5.1 & & \\
\hline \multicolumn{2}{|c|}{ Carbonatos (\% caliza) } & ip & ip & & \\
\hline \multicolumn{2}{|c|}{ Materia orgánica (\%) } & 4.2 & 0.5 & & \\
\hline \multicolumn{2}{|c|}{ Nitrogeno total (\%) } & 0.48 & 0.2 & & \\
\hline \multicolumn{2}{|c|}{ Relación C/N } & 4.375 & 1 & & \\
\hline \multicolumn{2}{|c|}{ Fosforo (olssen ppm) } & 8 & 11 & & \\
\hline \multicolumn{2}{|c|}{ Calcio (ppm) } & 68 & 79 & & \\
\hline \multicolumn{2}{|c|}{ Potasio (ppm) } & 50 & 60 & & \\
\hline \multicolumn{2}{|c|}{ Magnesio (ppm) } & 28 & 33 & & \\
\hline \multicolumn{2}{|l|}{$\mathrm{Ca} / \mathrm{Mg}$} & 2.429 & 2.394 & & \\
\hline \multicolumn{2}{|c|}{ Sodio (ppm) } & 0.6 & 1 & & \\
\hline \multicolumn{2}{|c|}{ C.I.C. Meq/100g } & 6.5 & 7.4 & & \\
\hline \multicolumn{2}{|c|}{ Manganeso (ppm) } & 45 & 50 & & \\
\hline \multicolumn{2}{|c|}{ Hierro (ppm) } & 3 & 1 & & \\
\hline \multicolumn{2}{|c|}{ Cobre (ppm) } & 0.2 & 2 & & \\
\hline \multicolumn{2}{|l|}{ Zinc (ppm) } & 2.5 & 2.5 & & \\
\hline \multicolumn{2}{|l|}{ Boro (ppm) } & 0.7 & 1 & & \\
\hline \multicolumn{2}{|c|}{ Conductividad (dS/m) } & 0.05 & 0.04 & & \\
\hline \multicolumn{2}{|c|}{ Observaciones } & & & & \\
\hline
\end{tabular}


ANÁLISIS DE COMPOSICIÓN DE SUELOS

Desarrollo de una aplicación informática para el cálculo de sostenimiento de taludes mediante vegetación

\begin{tabular}{|c|c|c|c|c|c|}
\hline \multirow[t]{2}{*}{ Perfil $n^{\circ}$} & \multirow[t]{2}{*}{2} & & & & \\
\hline & & Horizonte A & Horizonte C & Horizonte & Horizonte \\
\hline \multirow{3}{*}{ Textura } & Arena (\%) & 57 & & & \\
\hline & $\operatorname{Limo}(\%)$ & 32 & & & \\
\hline & Arcilla (\%) & 11 & & & \\
\hline \multicolumn{2}{|c|}{ Clase textural } & F. - Arenosa & & & \\
\hline \multicolumn{2}{|l|}{ pH } & 5.4 & & & \\
\hline \multicolumn{2}{|c|}{ Carbonatos (\% caliza) } & 2 & & & \\
\hline \multicolumn{2}{|c|}{ Materia orgánica (\%) } & 6 & & & \\
\hline \multicolumn{2}{|c|}{ Nitrogeno total (\%) } & 0.12 & & & \\
\hline \multicolumn{2}{|c|}{ Relación C/N } & 28.5 & & & \\
\hline \multicolumn{2}{|c|}{ Fosforo (olssen ppm) } & 0.8 & & & \\
\hline \multicolumn{2}{|c|}{ Calcio (ppm) } & 126 & & & \\
\hline \multicolumn{2}{|c|}{ Potasio (ppm) } & 2.5 & & & \\
\hline \multicolumn{2}{|c|}{ Magnesio (ppm) } & 37 & & & \\
\hline \multicolumn{2}{|l|}{$\mathrm{Ca} / \mathrm{Mg}$} & 3.405 & & & \\
\hline \multicolumn{2}{|c|}{ Sodio (ppm) } & 15 & & & \\
\hline \multicolumn{2}{|c|}{ C.I.C. Meq/100g } & 9.5 & & & \\
\hline \multicolumn{2}{|c|}{ Manganeso (ppm) } & 5 & & & \\
\hline \multicolumn{2}{|c|}{ Hierro (ppm) } & 1 & & & \\
\hline \multicolumn{2}{|c|}{ Cobre (ppm) } & 1.5 & & & \\
\hline \multicolumn{2}{|l|}{ Zinc (ppm) } & 1.5 & & & \\
\hline \multicolumn{2}{|l|}{ Boro (ppm) } & 0.7 & & & \\
\hline \multicolumn{2}{|c|}{ Conductividad (dS/m) } & 1.8 & & & \\
\hline \multicolumn{2}{|c|}{ Observaciones } & & & & \\
\hline & Suelo & pobre y poco $\mathrm{pt}$ & rofundo.Muy 1 & vado. & \\
\hline
\end{tabular}


ANÁLISIS DE COMPOSICIÓN DE SUELOS

Desarrollo de una aplicación informática para el cálculo de sostenimiento de taludes mediante vegetación

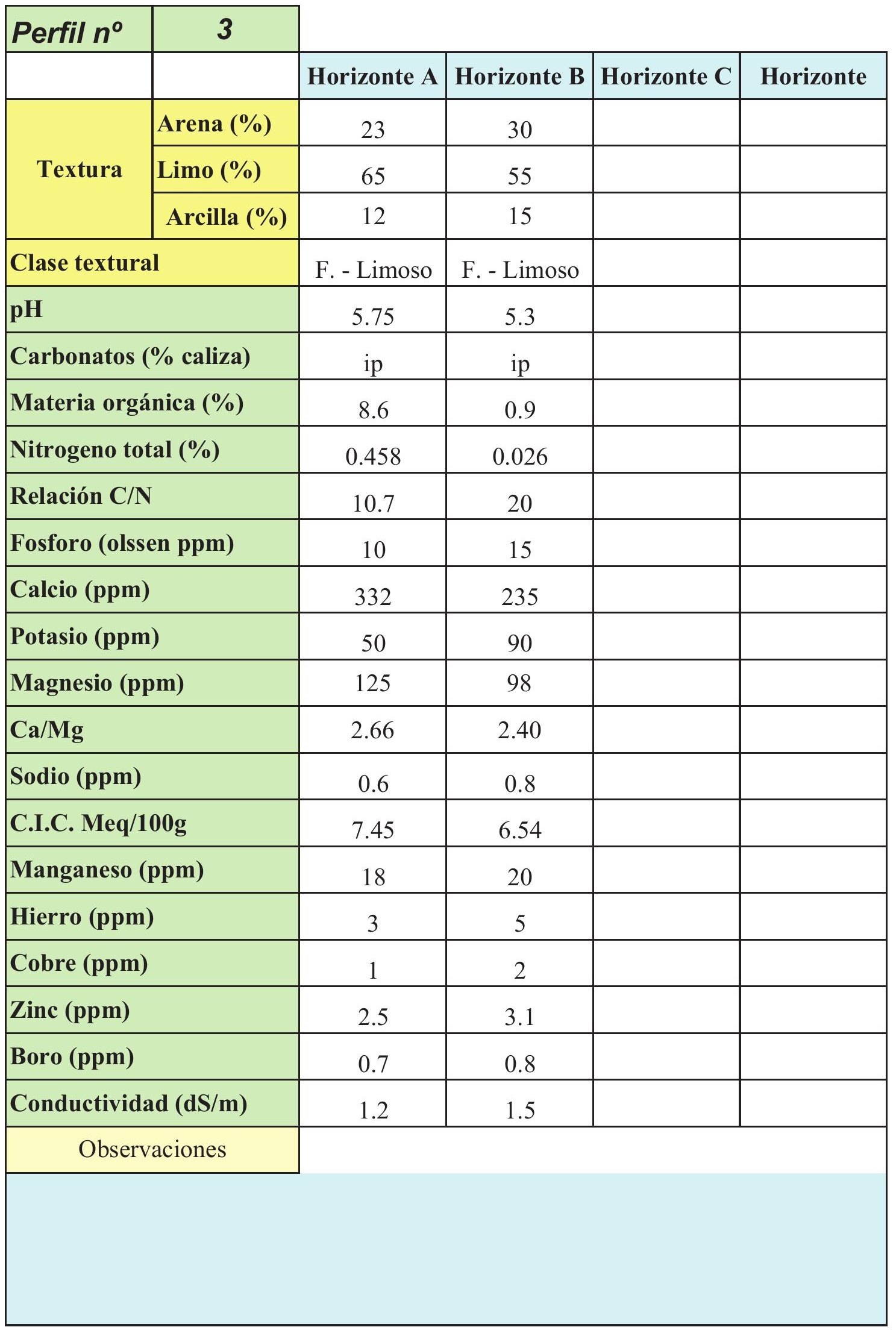


ANÁLISIS DE COMPOSICIÓN DE SUELOS

Desarrollo de una aplicación informática para el cálculo de sostenimiento de taludes mediante vegetación

\begin{tabular}{|c|c|c|c|c|c|}
\hline \multirow[t]{2}{*}{ Perfil $n^{\circ}$} & \multirow[t]{2}{*}{4} & \multirow[b]{2}{*}{ Horizonte A } & \multirow[b]{2}{*}{ Horizonte C } & \multirow[b]{2}{*}{ Horizonte } & \multirow[b]{2}{*}{ Horizonte } \\
\hline & & & & & \\
\hline \multirow{3}{*}{ Textura } & Arena (\%) & 68 & & & \\
\hline & $\operatorname{Limo}(\%)$ & 30 & & & \\
\hline & Arcilla (\%) & 2 & & & \\
\hline \multicolumn{2}{|c|}{ Clase texstural } & Franca-Areno & & & \\
\hline \multicolumn{2}{|l|}{ pH } & 5.5 & & & \\
\hline \multicolumn{2}{|c|}{ Carbonatos ( $\%$ caliza) } & ip & & & \\
\hline \multicolumn{2}{|c|}{ Materia orgánica (\%) } & 2.75 & & & \\
\hline \multicolumn{2}{|c|}{ Nitrogeno total (\%) } & 0.165 & & & \\
\hline \multicolumn{2}{|c|}{ Relación C/N } & 9.5 & & & \\
\hline \multicolumn{2}{|c|}{ Fosforo (olssen ppm) } & 4 & & & \\
\hline \multicolumn{2}{|c|}{ Calcio (ppm) } & 98 & & & \\
\hline \multicolumn{2}{|c|}{ Potasio (ppm) } & 60 & & & \\
\hline \multicolumn{2}{|c|}{ Magnesio (ppm) } & 25 & & & \\
\hline \multicolumn{2}{|l|}{$\mathrm{Ca} / \mathrm{Mg}$} & 3.92 & & & \\
\hline \multicolumn{2}{|c|}{ Sodio (ppm) } & 0.1 & & & \\
\hline \multicolumn{2}{|c|}{ C.I.C. Meq/100g } & 6 & & & \\
\hline \multicolumn{2}{|c|}{ Manganeso (ppm) } & 21 & & & \\
\hline \multicolumn{2}{|c|}{ Hierro (ppm) } & 1.5 & & & \\
\hline \multicolumn{2}{|c|}{ Cobre (ppm) } & 0.7 & & & \\
\hline \multicolumn{2}{|l|}{ Zinc (ppm) } & 2.3 & & & \\
\hline \multicolumn{2}{|l|}{ Boro (ppm) } & 0.2 & & & \\
\hline \multicolumn{2}{|c|}{ Conductividad (dS/m) } & 0.4 & & & \\
\hline \multicolumn{2}{|c|}{ Observaciones } & & & & \\
\hline
\end{tabular}


ANÁLISIS DE COMPOSICIÓN DE SUELOS

Desarrollo de una aplicación informática para el cálculo de sostenimiento de taludes mediante vegetación

\begin{tabular}{|c|c|c|c|c|c|}
\hline \multirow[t]{2}{*}{ Perfil $n^{\circ}$} & \multirow[t]{2}{*}{5} & \multirow[b]{2}{*}{ Horizonte A } & \multirow[b]{2}{*}{ Horizonte C } & \multirow[b]{2}{*}{ Horizonte } & \multirow[b]{2}{*}{ Horizonte } \\
\hline & & & & & \\
\hline \multirow{3}{*}{ Textura } & Arena (\%) & 25 & & & \\
\hline & Limo (\%) & 58 & & & \\
\hline & Arcilla (\%) & 17 & & & \\
\hline \multicolumn{2}{|c|}{ Clase textural } & Franca-limos & & & \\
\hline \multicolumn{2}{|l|}{ pH } & 5.5 & & & \\
\hline \multicolumn{2}{|c|}{ Carbonatos (\% caliza) } & ip & & & \\
\hline \multicolumn{2}{|c|}{ Materia orgánica (\%) } & 7.9 & & & \\
\hline \multicolumn{2}{|c|}{ Nitrogeno total (\%) } & 0.500 & & & \\
\hline \multicolumn{2}{|c|}{ Relación C/N } & 9 & & & \\
\hline \multicolumn{2}{|c|}{ Fosforo (olssen ppm) } & 2 & & & \\
\hline \multicolumn{2}{|c|}{ Calcio (ppm) } & 22 & & & \\
\hline \multicolumn{2}{|c|}{ Magnesio (ppm) } & 1.25 & & & \\
\hline \multicolumn{2}{|l|}{$\mathrm{Ca} / \mathrm{Mg}$} & 1.60 & & & \\
\hline \multicolumn{2}{|c|}{ Potasio (ppm) } & 10 & & & \\
\hline \multicolumn{2}{|c|}{ Sodio (ppm) } & 0.01 & & & \\
\hline \multicolumn{2}{|c|}{ C.I.C. Meq/100g } & 10 & & & \\
\hline \multicolumn{2}{|c|}{ Manganeso (ppm) } & 18 & & & \\
\hline \multicolumn{2}{|c|}{ Hierro (ppm) } & 1.4 & & & \\
\hline \multicolumn{2}{|c|}{ Cobre (ppm) } & 0.1 & & & \\
\hline \multicolumn{2}{|l|}{ Zinc (ppm) } & 1.3 & & & \\
\hline \multicolumn{2}{|l|}{ Boro (ppm) } & 0.26 & & & \\
\hline \multicolumn{2}{|c|}{ Conductividad (dS/m) } & 1.2 & & & \\
\hline \multicolumn{2}{|c|}{ Observaciones } & & & & \\
\hline
\end{tabular}


ANÁLISIS DE COMPOSICIÓN DE SUELOS

Desarrollo de una aplicación informática para el cálculo de sostenimiento de taludes mediante vegetación

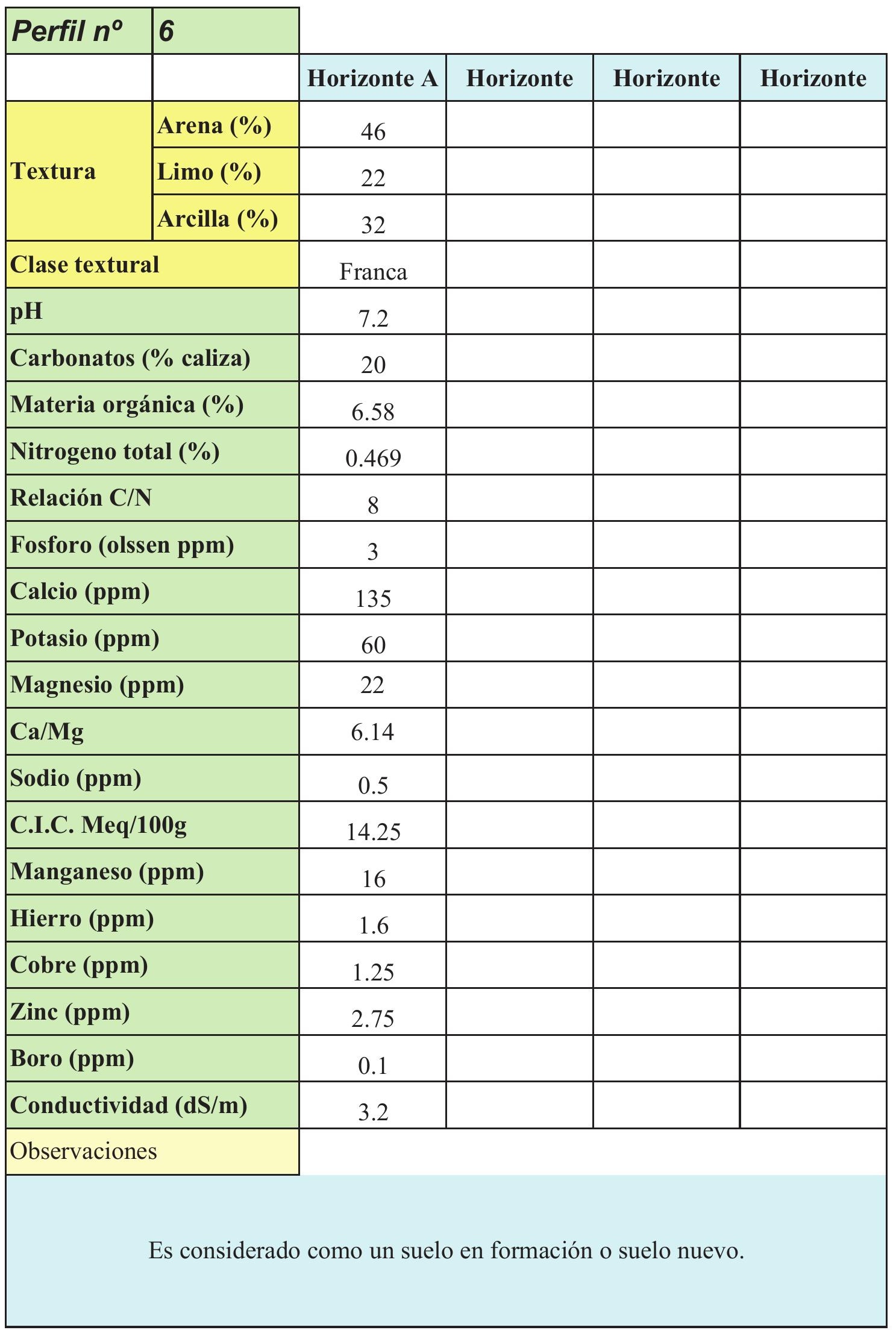


ANÁLISIS DE COMPOSICIÓN DE SUELOS

Desarrollo de una aplicación informática para el cálculo de sostenimiento de taludes mediante vegetación

\begin{tabular}{|c|c|c|c|c|c|}
\hline \multirow[t]{2}{*}{ Perfil $n^{\circ}$} & \multirow[t]{2}{*}{7} & \multirow[b]{2}{*}{ Horizonte A } & \multirow[b]{2}{*}{ Horizonte B } & \multirow[b]{2}{*}{ Horizonte C } & \multirow[b]{2}{*}{ Horizonte D } \\
\hline & & & & & \\
\hline \multirow{3}{*}{ Textura } & Arena (\%) & 33 & 28 & & \\
\hline & Limo (\%) & 54 & 61 & & \\
\hline & Arcilla (\%) & 13 & 11 & & \\
\hline \multicolumn{2}{|c|}{ Clase textural } & Fran - limo & Fran - limo & & \\
\hline \multicolumn{2}{|l|}{ pH } & 6.5 & 6.2 & & \\
\hline \multicolumn{2}{|c|}{ Carbonatos (\% caliza) } & ip & ip & & \\
\hline \multicolumn{2}{|c|}{ Materia orgánica (\%) } & 5.6 & 5.3 & & \\
\hline \multicolumn{2}{|c|}{ Nitrogeno total (\%) } & 0.355 & 0.325 & & \\
\hline \multicolumn{2}{|c|}{ Relación C/N } & 9 & 9.3 & & \\
\hline \multicolumn{2}{|c|}{ Fosforo (olssen ppm) } & 6 & 6 & & \\
\hline \multicolumn{2}{|c|}{ Calcio (ppm) } & 251 & 254 & & \\
\hline \multicolumn{2}{|c|}{ Potasio (ppm) } & 84 & 85 & & \\
\hline \multicolumn{2}{|c|}{ Magnesio (ppm) } & 90 & 88 & & \\
\hline \multicolumn{2}{|l|}{$\mathrm{Ca} / \mathrm{Mg}$} & 2.79 & 2.89 & & \\
\hline \multicolumn{2}{|c|}{ Sodio (ppm) } & 15 & 10 & & \\
\hline \multicolumn{2}{|c|}{ C.I.C. Meq/100g } & 12 & 11 & & \\
\hline \multicolumn{2}{|c|}{ Manganeso (ppm) } & 17 & 18 & & \\
\hline \multicolumn{2}{|c|}{ Hierro (ppm) } & 1.58 & 1.6 & & \\
\hline \multicolumn{2}{|c|}{ Cobre (ppm) } & 0.2 & 0.2 & & \\
\hline \multicolumn{2}{|l|}{ Zinc (ppm) } & 1.25 & 1.3 & & \\
\hline \multicolumn{2}{|l|}{ Boro (ppm) } & 0.35 & 0.24 & & \\
\hline \multicolumn{2}{|c|}{ Conductividad (dS/m) } & 1.5 & 1.6 & & \\
\hline \multicolumn{2}{|c|}{ Observaciones } & & & & \\
\hline
\end{tabular}


ANÁLISIS DE COMPOSICIÓN DE SUELOS

Desarrollo de una aplicación informática para el cálculo de sostenimiento de taludes mediante vegetación

\begin{tabular}{|c|c|c|c|c|c|}
\hline \multirow[t]{2}{*}{ Perfil $n^{\circ}$} & \multirow[t]{2}{*}{8} & \multirow[b]{2}{*}{ Horizonte A } & \multirow[b]{2}{*}{ Horizonte B } & \multirow[b]{2}{*}{ Horizonte C } & \multirow[b]{2}{*}{ Horizonte D } \\
\hline & & & & & \\
\hline \multirow{3}{*}{ Textura } & Arena (\%) & 70 & & & \\
\hline & Limo (\%) & 22 & & & \\
\hline & Arcilla (\%) & 8 & & & \\
\hline \multicolumn{2}{|c|}{ Clase textural } & Franca-Aren & & & \\
\hline \multicolumn{2}{|l|}{ pH } & 5.7 & & & \\
\hline \multicolumn{2}{|c|}{ Carbonatos ( $\%$ caliza) } & 0.1 & & & \\
\hline \multicolumn{2}{|c|}{ Materia orgánica (\%) } & 1.2 & & & \\
\hline \multicolumn{2}{|c|}{ Nitrogeno total (\%) } & 0.068 & & & \\
\hline \multicolumn{2}{|c|}{ Relación C/N } & 10 & & & \\
\hline \multicolumn{2}{|c|}{ Fosforo (olssen ppm) } & 4.2 & & & \\
\hline \multicolumn{2}{|c|}{ Calcio (ppm) } & 40 & & & \\
\hline \multicolumn{2}{|c|}{ Potasio (ppm) } & 30 & & & \\
\hline \multicolumn{2}{|c|}{ Magnesio (ppm) } & 75 & & & \\
\hline \multicolumn{2}{|l|}{$\mathrm{Ca} / \mathrm{Mg}$} & 0.53 & & & \\
\hline \multicolumn{2}{|c|}{ Sodio (ppm) } & 23 & & & \\
\hline \multicolumn{2}{|c|}{ C.I.C. Meq/100g } & 4 & & & \\
\hline \multicolumn{2}{|c|}{ Manganeso (ppm) } & 12 & & & \\
\hline \multicolumn{2}{|c|}{ Hierro (ppm) } & 1.53 & & & \\
\hline \multicolumn{2}{|c|}{ Cobre (ppm) } & 0.02 & & & \\
\hline \multicolumn{2}{|l|}{ Zinc (ppm) } & ip & & & \\
\hline \multicolumn{2}{|l|}{ Boro (ppm) } & 0.03 & & & \\
\hline \multicolumn{2}{|c|}{ Conductividad (dS/m) } & 0.03 & & & \\
\hline \multicolumn{2}{|c|}{ Observaciones } & & & & \\
\hline
\end{tabular}


ANÁLISIS DE COMPOSICIÓN DE SUELOS

Desarrollo de una aplicación informática para el cálculo de sostenimiento de taludes mediante vegetación

\begin{tabular}{|c|c|c|c|c|c|}
\hline \multirow[t]{2}{*}{ Perfil $n^{\circ}$} & \multirow[t]{2}{*}{9} & \multirow[b]{2}{*}{ Horizonte A } & \multirow[b]{2}{*}{ Horizonte B } & \multirow[b]{2}{*}{ Horizonte C } & \multirow[b]{2}{*}{ Horizonte D } \\
\hline & & & & & \\
\hline \multirow{3}{*}{ Textura } & Arena (\%) & 38 & 30 & 10 & \\
\hline & Limo (\%) & 42 & 35 & 55 & \\
\hline & Arcilla (\%) & 20 & 35 & 35 & \\
\hline \multicolumn{2}{|c|}{ Clase textural } & Franca & Franca-Arcil & Fran-Arc-Lim & \\
\hline \multicolumn{2}{|l|}{ pH } & 5.4 & 5.5 & 5.6 & \\
\hline \multicolumn{2}{|c|}{ Carbonatos ( $\%$ caliza) } & 5.2 & 4 & --- & \\
\hline \multicolumn{2}{|c|}{ Materia orgánica (\%) } & 2.8 & 0.5 & --- & \\
\hline \multicolumn{2}{|c|}{ Nitrogeno total $(\%)$} & 0.177 & 0.057 & --- & \\
\hline \multicolumn{2}{|c|}{ Relación C/N } & 9 & 5 & --- & \\
\hline \multicolumn{2}{|c|}{ Fosforo (olssen ppm) } & 10 & 20 & 8 & \\
\hline \multicolumn{2}{|c|}{ Calcio (ppm) } & 823 & 942 & 1121 & \\
\hline \multicolumn{2}{|c|}{ Potasio (ppm) } & 144 & 210 & 153 & \\
\hline \multicolumn{2}{|c|}{ Magnesio (ppm) } & 38 & 44 & 53 & \\
\hline \multicolumn{2}{|l|}{$\mathrm{Ca} / \mathrm{Mg}$} & 21.66 & 21.41 & 21.15 & \\
\hline \multicolumn{2}{|c|}{ Sodio (ppm) } & 30 & 35 & 43 & \\
\hline \multicolumn{2}{|c|}{ C.I.C. Meq/100g } & 18 & 19 & 20 & \\
\hline \multicolumn{2}{|c|}{ Manganeso (ppm) } & 30 & 35 & 10 & \\
\hline \multicolumn{2}{|c|}{ Hierro (ppm) } & 3 & 3.5 & 4 & \\
\hline \multicolumn{2}{|c|}{ Cobre (ppm) } & ip & ip & ip & \\
\hline \multicolumn{2}{|l|}{ Zinc (ppm) } & ip & ip & ip & \\
\hline \multicolumn{2}{|l|}{ Boro (ppm) } & 0.2 & 0.3 & 0.1 & \\
\hline \multicolumn{2}{|c|}{ Conductividad (dS/m) } & 1 & 1.1 & 1.4 & \\
\hline \multicolumn{2}{|c|}{ Observaciones } & & & & \\
\hline
\end{tabular}


ANÁLISIS DE COMPOSICIÓN DE SUELOS

Desarrollo de una aplicación informática para el cálculo de sostenimiento de taludes mediante vegetación

\begin{tabular}{|c|c|c|c|c|c|}
\hline \multirow[t]{2}{*}{ Perfil $n^{\circ}$} & \multirow[t]{2}{*}{10} & \multirow[b]{2}{*}{ Horizonte A } & \multirow[b]{2}{*}{ Horizonte B } & \multirow[b]{2}{*}{ Horizonte C } & \multirow[b]{2}{*}{ Horizonte D } \\
\hline & & & & & \\
\hline \multirow{3}{*}{ Textura } & Arena (\%) & 28 & & & \\
\hline & Limo (\%) & 9 & & & \\
\hline & Arcilla (\%) & 15 & & & \\
\hline \multicolumn{2}{|c|}{ Clase textural } & Franc-Lim & & & \\
\hline \multicolumn{2}{|l|}{ pH } & 6.6 & & & \\
\hline \multicolumn{2}{|c|}{ Carbonatos (\% caliza) } & 6.01 & & & \\
\hline \multicolumn{2}{|c|}{ Materia orgánica (\%) } & 3.1 & & & \\
\hline \multicolumn{2}{|c|}{ Nitrogeno total (\%) } & 0.177 & & & \\
\hline \multicolumn{2}{|c|}{ Relación C/N } & 10 & & & \\
\hline \multicolumn{2}{|c|}{ Fosforo (olssen ppm) } & 14.5 & & & \\
\hline \multicolumn{2}{|c|}{ Calcio (ppm) } & 811 & & & \\
\hline \multicolumn{2}{|c|}{ Potasio (ppm) } & 183 & & & \\
\hline \multicolumn{2}{|c|}{ Magnesio (ppm) } & 133 & & & \\
\hline \multicolumn{2}{|l|}{$\mathrm{Ca} / \mathrm{Mg}$} & 6.10 & & & \\
\hline \multicolumn{2}{|c|}{ Sodio (ppm) } & 40 & & & \\
\hline \multicolumn{2}{|c|}{ C.I.C. Meq/100g } & 10 & & & \\
\hline \multicolumn{2}{|c|}{ Manganeso (ppm) } & 15 & & & \\
\hline \multicolumn{2}{|c|}{ Hierro (ppm) } & 0.2 & & & \\
\hline \multicolumn{2}{|c|}{ Cobre (ppm) } & 0.3 & & & \\
\hline \multicolumn{2}{|l|}{ Zinc (ppm) } & 0.22 & & & \\
\hline \multicolumn{2}{|l|}{ Boro (ppm) } & 0.8 & & & \\
\hline \multicolumn{2}{|c|}{ Conductividad (dS/m) } & 1.1 & & & \\
\hline \multicolumn{2}{|c|}{ Observaciones } & & & & \\
\hline
\end{tabular}


ANÁLISIS DE COMPOSICIÓN DE SUELOS

Desarrollo de una aplicación informática para el cálculo de sostenimiento de taludes mediante vegetación

\begin{tabular}{|c|c|c|c|c|c|}
\hline \multirow[t]{2}{*}{ Perfil $n^{\circ}$} & \multirow[t]{2}{*}{11} & & & & \\
\hline & & Horizonte A & Horizonte $\mathrm{C}$ & Horizonte & Horizonte \\
\hline \multirow{3}{*}{ Textura } & Arena (\%) & 26 & & & \\
\hline & $\operatorname{Limo}(\%)$ & 58 & & & \\
\hline & Arcilla (\%) & 16 & & & \\
\hline \multicolumn{2}{|c|}{ Clase textural } & Franc-Limo & & & \\
\hline \multicolumn{2}{|l|}{ pH } & 6.2 & & & \\
\hline \multicolumn{2}{|c|}{ Carbonatos ( $\%$ caliza) } & 2.25 & & & \\
\hline \multicolumn{2}{|c|}{ Materia orgánica (\%) } & 1.3 & & & \\
\hline \multicolumn{2}{|c|}{ Nitrogeno total (\%) } & 0.05 & & & \\
\hline \multicolumn{2}{|c|}{ Relación C/N } & 14.82 & & & \\
\hline \multicolumn{2}{|c|}{ Fosforo (olssen ppm) } & 3.01 & & & \\
\hline \multicolumn{2}{|c|}{ Calcio (ppm) } & 685 & & & \\
\hline \multicolumn{2}{|c|}{ Potasio (ppm) } & 35 & & & \\
\hline \multicolumn{2}{|c|}{ Magnesio (ppm) } & 251 & & & \\
\hline \multicolumn{2}{|l|}{$\mathrm{Ca} / \mathrm{Mg}$} & 2.729 & & & \\
\hline \multicolumn{2}{|c|}{ Sodio (ppm) } & 10 & & & \\
\hline \multicolumn{2}{|c|}{ C.I.C. Meq/100g } & 3 & & & \\
\hline \multicolumn{2}{|c|}{ Manganeso (ppm) } & 9.75 & & & \\
\hline \multicolumn{2}{|c|}{ Hierro (ppm) } & 0.5 & & & \\
\hline \multicolumn{2}{|c|}{ Cobre (ppm) } & ip & & & \\
\hline \multicolumn{2}{|l|}{ Zinc (ppm) } & ip & & & \\
\hline \multicolumn{2}{|l|}{ Boro (ppm) } & ip & & & \\
\hline \multicolumn{2}{|c|}{ Conductividad (dS/m) } & 1.1 & & & \\
\hline \multicolumn{2}{|c|}{ Observaciones } & & & & \\
\hline \multicolumn{6}{|c|}{ Pobre en microelementos y macroelementos estudiados } \\
\hline
\end{tabular}


ANÁLISIS DE COMPOSICIÓN DE SUELOS

Desarrollo de una aplicación informática para el cálculo de sostenimiento de taludes mediante vegetación

\begin{tabular}{|c|c|c|c|c|c|}
\hline \multirow[t]{2}{*}{ Perfil $n^{\circ}$} & \multirow[t]{2}{*}{12} & & & & \\
\hline & & Horizonte A & $\begin{array}{l}\text { Horizonte } \\
\text { Cures }\end{array}$ & Horizonte & Horizonte \\
\hline \multirow{3}{*}{ Textura } & Arena (\%) & 63 & & & \\
\hline & Limo (\%) & 24 & & & \\
\hline & Arcilla (\%) & 13 & & & \\
\hline \multicolumn{2}{|c|}{ Clase textural } & Fran-Aren & & & \\
\hline \multicolumn{2}{|l|}{ pH } & 5.5 & & & \\
\hline \multicolumn{2}{|c|}{ Carbonatos (\% caliza) } & 3.5 & & & \\
\hline \multicolumn{2}{|c|}{ Materia orgánica (\%) } & 3.26 & & & \\
\hline \multicolumn{2}{|c|}{ Nitrogeno total (\%) } & 0.09 & & & \\
\hline \multicolumn{2}{|c|}{ Relación C/N } & 11 & & & \\
\hline \multicolumn{2}{|c|}{ Fosforo (olssen ppm) } & 2.5 & & & \\
\hline \multicolumn{2}{|c|}{ Calcio (ppm) } & 234 & & & \\
\hline \multicolumn{2}{|c|}{ Potasio (ppm) } & 35 & & & \\
\hline \multicolumn{2}{|c|}{ Magnesio (ppm) } & 101 & & & \\
\hline \multicolumn{2}{|l|}{$\mathrm{Ca} / \mathrm{Mg}$} & 2.317 & & & \\
\hline \multicolumn{2}{|l|}{ Sodio (ppm) } & 16 & & & \\
\hline \multicolumn{2}{|c|}{ C.I.C. Meq/100g } & 18 & & & \\
\hline \multicolumn{2}{|c|}{ Manganeso (ppm) } & 105 & & & \\
\hline \multicolumn{2}{|c|}{ Hierro (ppm) } & ip & & & \\
\hline \multicolumn{2}{|c|}{ Cobre (ppm) } & ip & & & \\
\hline \multicolumn{2}{|l|}{ Zinc (ppm) } & ip & & & \\
\hline \multicolumn{2}{|l|}{ Boro (ppm) } & ip & & & \\
\hline \multicolumn{2}{|c|}{ Conductividad (dS/m) } & 0.25 & & & \\
\hline \multicolumn{2}{|c|}{ Observaciones } & & & & \\
\hline
\end{tabular}


ANÁLISIS DE COMPOSICIÓN DE SUELOS

Desarrollo de una aplicación informática para el cálculo de sostenimiento de taludes mediante vegetación

\begin{tabular}{|c|c|c|c|c|c|}
\hline \multirow[t]{2}{*}{ Perfil $n^{\circ}$} & \multirow[t]{2}{*}{13} & & & & \\
\hline & & Horizonte A & Horizonte C & Horizonte & Horizonte \\
\hline \multirow{3}{*}{ Textura } & Arena (\%) & 62 & & & \\
\hline & Limo (\%) & 27 & & & \\
\hline & Arcilla (\%) & 11 & & & \\
\hline \multicolumn{2}{|c|}{ Clase textural } & Aren-Limo & & & \\
\hline \multicolumn{2}{|l|}{$\mathrm{pH}$} & 5.5 & & & \\
\hline \multicolumn{2}{|c|}{ Carbonatos (\% caliza) } & 1.1 & & & \\
\hline \multicolumn{2}{|c|}{ Materia orgánica (\%) } & 4.6 & & & \\
\hline \multicolumn{2}{|c|}{ Nitrogeno total (\%) } & 0.291 & & & \\
\hline \multicolumn{2}{|c|}{ Relación C/N } & 9 & & & \\
\hline \multicolumn{2}{|c|}{ Fosforo (olssen ppm) } & 12 & & & \\
\hline \multicolumn{2}{|c|}{ Calcio (ppm) } & 250 & & & \\
\hline \multicolumn{2}{|c|}{ Potasio (ppm) } & 60 & & & \\
\hline \multicolumn{2}{|c|}{ Magnesio (ppm) } & 100 & & & \\
\hline \multicolumn{2}{|l|}{$\mathrm{Ca} / \mathrm{Mg}$} & 2.50 & & & \\
\hline \multicolumn{2}{|c|}{ Sodio (ppm) } & 20 & & & \\
\hline \multicolumn{2}{|c|}{ C.I.C. Meq/100g } & 6 & & & \\
\hline \multicolumn{2}{|c|}{ Manganeso (ppm) } & 13 & & & \\
\hline \multicolumn{2}{|c|}{ Hierro (ppm) } & ip & & & \\
\hline \multicolumn{2}{|c|}{ Cobre (ppm) } & ip & & & \\
\hline \multicolumn{2}{|l|}{ Zinc (ppm) } & ip & & & \\
\hline \multicolumn{2}{|l|}{ Boro (ppm) } & ip & & & \\
\hline \multicolumn{2}{|c|}{ Conductividad (dS/m) } & 0.8 & & & \\
\hline \multicolumn{2}{|c|}{ Observaciones } & & & & \\
\hline
\end{tabular}


ANÁLISIS DE COMPOSICIÓN DE SUELOS

Desarrollo de una aplicación informática para el cálculo de sostenimiento de taludes mediante vegetación

\begin{tabular}{|c|c|c|c|c|c|}
\hline \multirow[t]{2}{*}{ Perfil $n^{\circ}$} & \multirow[t]{2}{*}{14} & \multirow[b]{2}{*}{ Horizonte A } & \multirow[b]{2}{*}{ Horizonte C } & \multirow[b]{2}{*}{ Horizonte } & \multirow[b]{2}{*}{ Horizonte } \\
\hline & & & & & \\
\hline \multirow{3}{*}{ Textura } & Arena (\%) & 35 & & & \\
\hline & Limo (\%) & 40 & & & \\
\hline & Arcilla (\%) & 25 & & & \\
\hline \multicolumn{2}{|c|}{ Clase texstural } & Franca & & & \\
\hline \multicolumn{2}{|l|}{ pH } & 5.5 & & & \\
\hline \multicolumn{2}{|c|}{ Carbonatos (\% caliza) } & 20 & & & \\
\hline \multicolumn{2}{|c|}{ Materia orgánica (\%) } & 3 & & & \\
\hline \multicolumn{2}{|c|}{ Nitrogeno total (\%) } & 0.155 & & & \\
\hline \multicolumn{2}{|c|}{ Relación C/N } & 11 & & & \\
\hline \multicolumn{2}{|c|}{ Fosforo (olssen ppm) } & 25 & & & \\
\hline \multicolumn{2}{|c|}{ Calcio (ppm) } & 275 & & & \\
\hline \multicolumn{2}{|c|}{ Potasio (ppm) } & 35 & & & \\
\hline \multicolumn{2}{|c|}{ Magnesio (ppm) } & 36 & & & \\
\hline \multicolumn{2}{|l|}{$\mathrm{Ca} / \mathrm{Mg}$} & 7.64 & & & \\
\hline \multicolumn{2}{|c|}{ Sodio (ppm) } & 65 & & & \\
\hline \multicolumn{2}{|c|}{ C.I.C. Meq/100g } & 12 & & & \\
\hline \multicolumn{2}{|c|}{ Manganeso (ppm) } & 25 & & & \\
\hline \multicolumn{2}{|c|}{ Hierro (ppm) } & 0.5 & & & \\
\hline \multicolumn{2}{|c|}{ Cobre (ppm) } & 0.02 & & & \\
\hline \multicolumn{2}{|l|}{ Zinc (ppm) } & 0.2 & & & \\
\hline \multicolumn{2}{|l|}{ Boro (ppm) } & 0.9 & & & \\
\hline \multicolumn{2}{|c|}{ Conductividad (dS/m) } & 1.1 & & & \\
\hline \multicolumn{2}{|c|}{ Observaciones } & & & & \\
\hline
\end{tabular}


ANÁLISIS DE COMPOSICIÓN DE SUELOS

Desarrollo de una aplicación informática para el cálculo de sostenimiento de taludes mediante vegetación

\begin{tabular}{|c|c|c|c|c|c|}
\hline \multirow[t]{2}{*}{ Perfil $n^{\circ}$} & \multirow[t]{2}{*}{15} & & & & \\
\hline & & Horizonte A & Horizonte B & Horizonte C & Horizonte D \\
\hline \multirow{3}{*}{ Textura } & Arena (\%) & 55 & & & \\
\hline & Limo (\%) & 29 & & & \\
\hline & Arcilla (\%) & 16 & & & \\
\hline \multicolumn{2}{|c|}{ Clase textural } & Fran-Aren & & & \\
\hline \multicolumn{2}{|l|}{ pH } & 5.2 & & & \\
\hline \multicolumn{2}{|c|}{ Carbonatos ( $\%$ caliza) } & 0.9 & & & \\
\hline \multicolumn{2}{|c|}{ Materia orgánica (\%) } & 2.55 & & & \\
\hline \multicolumn{2}{|c|}{ Nitrogeno total (\%) } & 0.162 & & & \\
\hline \multicolumn{2}{|c|}{ Relación C/N } & 9 & & & \\
\hline \multicolumn{2}{|c|}{ Fosforo (olssen ppm) } & 3 & & & \\
\hline \multicolumn{2}{|c|}{ Calcio (ppm) } & 321 & & & \\
\hline \multicolumn{2}{|c|}{ Magnesio (ppm) } & 95 & & & \\
\hline \multicolumn{2}{|l|}{$\mathrm{Ca} / \mathrm{Mg}$} & 3.38 & & & \\
\hline \multicolumn{2}{|c|}{ Potasio (ppm) } & 30 & & & \\
\hline \multicolumn{2}{|l|}{ Sodio (ppm) } & 10 & & & \\
\hline \multicolumn{2}{|c|}{ C.I.C. Meq/100g } & ip & & & \\
\hline \multicolumn{2}{|c|}{ Manganeso (ppm) } & ip & & & \\
\hline \multicolumn{2}{|c|}{ Hierro (ppm) } & ip & & & \\
\hline \multicolumn{2}{|c|}{ Cobre (ppm) } & ip & & & \\
\hline \multicolumn{2}{|l|}{ Zinc (ppm) } & ip & & & \\
\hline \multicolumn{2}{|l|}{ Boro (ppm) } & ip & & & \\
\hline \multicolumn{2}{|c|}{ Conductividad (dS/m) } & 0.9 & & & \\
\hline \multicolumn{2}{|c|}{ Observaciones } & & & & \\
\hline \multicolumn{6}{|c|}{ Pobre en elementos y oligoelementos esenciales. } \\
\hline
\end{tabular}


ANÁLISIS DE COMPOSICIÓN DE SUELOS

Desarrollo de una aplicación informática para el cálculo de sostenimiento de taludes mediante vegetación

\begin{tabular}{|c|c|c|c|c|c|}
\hline \multirow[t]{2}{*}{ Perfil $n^{\circ}$} & \multirow[t]{2}{*}{16} & \multirow[b]{2}{*}{ Horizonte A } & \multirow[b]{2}{*}{ Horizonte B } & \multirow[b]{2}{*}{ Horizonte C } & \multirow[b]{2}{*}{ Horizonte D } \\
\hline & & & & & \\
\hline \multirow{3}{*}{ Textura } & Arena (\%) & 41 & 35 & & \\
\hline & Limo (\%) & 34 & 28 & & \\
\hline & Arcilla (\%) & 25 & 37 & & \\
\hline \multicolumn{2}{|c|}{ Clase textural } & Franca & Fran-Arci & & \\
\hline \multicolumn{2}{|l|}{ pH } & 6 & 5 & & \\
\hline \multicolumn{2}{|c|}{ Carbonatos (\% caliza) } & 0.03 & 0.01 & & \\
\hline \multicolumn{2}{|c|}{ Materia orgánica (\%) } & 3 & 0.9 & & \\
\hline \multicolumn{2}{|c|}{ Nitrogeno total (\%) } & 0.171 & 0.064 & & \\
\hline \multicolumn{2}{|c|}{ Relación C/N } & 10 & 8 & & \\
\hline \multicolumn{2}{|c|}{ Fosforo (olssen ppm) } & 5.4 & 6.3 & & \\
\hline \multicolumn{2}{|c|}{ Calcio (ppm) } & 92 & 89 & & \\
\hline \multicolumn{2}{|c|}{ Potasio (ppm) } & 80 & 101 & & \\
\hline \multicolumn{2}{|c|}{ Magnesio (ppm) } & 23 & 34 & & \\
\hline \multicolumn{2}{|l|}{$\mathrm{Ca} / \mathrm{Mg}$} & 4.00 & 2.62 & & \\
\hline \multicolumn{2}{|c|}{ Sodio (ppm) } & 13 & 11 & & \\
\hline \multicolumn{2}{|c|}{ C.I.C. Meq/100g } & 6 & 6 & & \\
\hline \multicolumn{2}{|c|}{ Manganeso (ppm) } & 10 & 9 & & \\
\hline \multicolumn{2}{|c|}{ Hierro (ppm) } & 0.5 & 0.52 & & \\
\hline \multicolumn{2}{|c|}{ Cobre (ppm) } & 0.02 & 0.06 & & \\
\hline \multicolumn{2}{|l|}{ Zinc (ppm) } & 1.05 & 1.1 & & \\
\hline \multicolumn{2}{|l|}{ Boro (ppm) } & 0.01 & 0.02 & & \\
\hline \multicolumn{2}{|c|}{ Conductividad (dS/m) } & 0.9 & 0.9 & & \\
\hline \multicolumn{2}{|c|}{ Observaciones } & & & & \\
\hline
\end{tabular}


ANÁLISIS DE COMPOSICIÓN DE SUELOS

Desarrollo de una aplicación informática para el cálculo de sostenimiento de taludes mediante vegetación

\begin{tabular}{|c|c|c|c|c|c|}
\hline \multirow[t]{2}{*}{ Perfil $n^{\circ}$} & \multirow[t]{2}{*}{17} & \multirow[b]{2}{*}{ Horizonte A } & \multirow[b]{2}{*}{ Horizonte B } & \multirow[b]{2}{*}{ Horizonte C } & \multirow[b]{2}{*}{ Horizonte D } \\
\hline & & & & & \\
\hline \multirow{3}{*}{ Textura } & Arena (\%) & 56 & 38 & & \\
\hline & Limo (\%) & 26 & 39 & & \\
\hline & Arcilla (\%) & 18 & 23 & & \\
\hline \multicolumn{2}{|c|}{ Clase textural } & Fran-Aren & Fran-Arci & & \\
\hline \multicolumn{2}{|l|}{ pH } & 5.5 & 6 & & \\
\hline \multicolumn{2}{|c|}{ Carbonatos (\% caliza) } & 1.2 & 1.4 & & \\
\hline \multicolumn{2}{|c|}{ Materia orgánica (\%) } & 7.25 & 1.3 & & \\
\hline \multicolumn{2}{|c|}{ Nitrogeno total $(\%)$} & 0.376 & 0.057 & & \\
\hline \multicolumn{2}{|c|}{ Relación C/N } & 11 & 13 & & \\
\hline \multicolumn{2}{|c|}{ Fosforo (olssen ppm) } & 18 & 22 & & \\
\hline \multicolumn{2}{|c|}{ Calcio (ppm) } & 350 & 425 & & \\
\hline \multicolumn{2}{|c|}{ Potasio (ppm) } & 156 & 185 & & \\
\hline \multicolumn{2}{|c|}{ Magnesio (ppm) } & 75 & 86 & & \\
\hline \multicolumn{2}{|l|}{$\mathrm{Ca} / \mathrm{Mg}$} & 4.67 & 4.94 & & \\
\hline \multicolumn{2}{|c|}{ Sodio (ppm) } & 25 & 20 & & \\
\hline \multicolumn{2}{|c|}{ C.I.C. Meq/100g } & 9 & 5 & & \\
\hline \multicolumn{2}{|c|}{ Manganeso (ppm) } & 18 & 23 & & \\
\hline \multicolumn{2}{|c|}{ Hierro (ppm) } & 0.2 & 0.8 & & \\
\hline \multicolumn{2}{|c|}{ Cobre (ppm) } & 0.05 & 0.1 & & \\
\hline \multicolumn{2}{|l|}{ Zinc (ppm) } & 0.9 & 0.6 & & \\
\hline \multicolumn{2}{|l|}{ Boro (ppm) } & 0.6 & 0.8 & & \\
\hline \multicolumn{2}{|c|}{ Conductividad (dS/m) } & 0.5 & 0.6 & & \\
\hline \multicolumn{2}{|c|}{ Observaciones } & & & & \\
\hline
\end{tabular}


ANÁLISIS DE COMPOSICIÓN DE SUELOS

Desarrollo de una aplicación informática para el cálculo de sostenimiento de taludes mediante vegetación

\begin{tabular}{|c|c|c|c|c|c|}
\hline \multirow[t]{2}{*}{ Perfil $n^{\circ}$} & \multirow[t]{2}{*}{18} & \multirow[b]{2}{*}{ Horizonte A } & \multirow[b]{2}{*}{ Horizonte B } & \multirow[b]{2}{*}{ Horizonte C } & \multirow[b]{2}{*}{ Horizonte D } \\
\hline & & & & & \\
\hline \multirow{3}{*}{ Textura } & Arena (\%) & 43 & & & \\
\hline & Limo (\%) & 46 & & & \\
\hline & Arcilla (\%) & 11 & & & \\
\hline \multicolumn{2}{|c|}{ Clase textural } & Franca & & & \\
\hline \multicolumn{2}{|l|}{ pH } & 5.7 & & & \\
\hline \multicolumn{2}{|c|}{ Carbonatos ( $\%$ caliza) } & 2.3 & & & \\
\hline \multicolumn{2}{|c|}{ Materia orgánica (\%) } & 1.9 & & & \\
\hline \multicolumn{2}{|c|}{ Nitrogeno total (\%) } & 0.07 & & & \\
\hline \multicolumn{2}{|c|}{ Relación C/N } & 6 & & & \\
\hline \multicolumn{2}{|c|}{ Fosforo (olssen ppm) } & 18 & & & \\
\hline \multicolumn{2}{|c|}{ Calcio (ppm) } & 122 & & & \\
\hline \multicolumn{2}{|c|}{ Potasio (ppm) } & 101 & & & \\
\hline \multicolumn{2}{|c|}{ Magnesio (ppm) } & 35 & & & \\
\hline \multicolumn{2}{|l|}{$\mathrm{Ca} / \mathrm{Mg}$} & 3.49 & & & \\
\hline \multicolumn{2}{|c|}{ Sodio (ppm) } & 23 & & & \\
\hline \multicolumn{2}{|c|}{ C.I.C. Meq/100g } & 6 & & & \\
\hline \multicolumn{2}{|c|}{ Manganeso (ppm) } & 22 & & & \\
\hline \multicolumn{2}{|c|}{ Hierro (ppm) } & 0.8 & & & \\
\hline \multicolumn{2}{|c|}{ Cobre (ppm) } & 0.09 & & & \\
\hline \multicolumn{2}{|l|}{ Zinc (ppm) } & 1.3 & & & \\
\hline \multicolumn{2}{|l|}{ Boro (ppm) } & 0.6 & & & \\
\hline \multicolumn{2}{|c|}{ Conductividad (dS/m) } & 1.2 & & & \\
\hline \multicolumn{2}{|c|}{ Observaciones } & & & & \\
\hline
\end{tabular}


ANÁLISIS DE COMPOSICIÓN DE SUELOS

Desarrollo de una aplicación informática para el cálculo de sostenimiento de taludes mediante vegetación

\begin{tabular}{|c|c|c|c|c|c|}
\hline \multirow[t]{2}{*}{ Perfil $n^{0}$} & \multirow[t]{2}{*}{19} & \multirow[b]{2}{*}{ Horizonte A } & \multirow[b]{2}{*}{ Horizonte B } & \multirow[b]{2}{*}{ Horizonte C } & \multirow[b]{2}{*}{ Horizonte D } \\
\hline & & & & & \\
\hline \multirow{3}{*}{ Textura } & Arena (\%) & 55 & & & \\
\hline & Limo (\%) & 23 & & & \\
\hline & Arcilla (\%) & 22 & & & \\
\hline \multicolumn{2}{|c|}{ Clase textural } & Fran-Aren & & & \\
\hline \multicolumn{2}{|l|}{ pH } & 5.2 & & & \\
\hline \multicolumn{2}{|c|}{ Carbonatos ( $\%$ caliza) } & 2.3 & & & \\
\hline \multicolumn{2}{|c|}{ Materia orgánica (\%) } & 1.2 & & & \\
\hline \multicolumn{2}{|c|}{ Nitrogeno total (\%) } & 0.08 & & & \\
\hline \multicolumn{2}{|c|}{ Relación C/N } & 8 & & & \\
\hline \multicolumn{2}{|c|}{ Fosforo (olssen ppm) } & 11 & & & \\
\hline \multicolumn{2}{|c|}{ Calcio (ppm) } & 123 & & & \\
\hline \multicolumn{2}{|c|}{ Potasio (ppm) } & 83 & & & \\
\hline \multicolumn{2}{|c|}{ Magnesio (ppm) } & 54 & & & \\
\hline \multicolumn{2}{|l|}{$\mathrm{Ca} / \mathrm{Mg}$} & 2.28 & & & \\
\hline \multicolumn{2}{|c|}{ Sodio (ppm) } & 33 & & & \\
\hline \multicolumn{2}{|c|}{ C.I.C. Meq/100g } & 9 & & & \\
\hline \multicolumn{2}{|c|}{ Manganeso (ppm) } & 15 & & & \\
\hline \multicolumn{2}{|c|}{ Hierro (ppm) } & 1.2 & & & \\
\hline \multicolumn{2}{|c|}{ Cobre (ppm) } & 0.7 & & & \\
\hline \multicolumn{2}{|l|}{ Zinc (ppm) } & 0.4 & & & \\
\hline \multicolumn{2}{|l|}{ Boro (ppm) } & 0.03 & & & \\
\hline \multicolumn{2}{|c|}{ Conductividad (dS/m) } & 0.9 & & & \\
\hline \multicolumn{2}{|c|}{ Observaciones } & & & & \\
\hline
\end{tabular}


ANÁLISIS DE COMPOSICIÓN DE SUELOS

Desarrollo de una aplicación informática para el cálculo de sostenimiento de taludes mediante vegetación

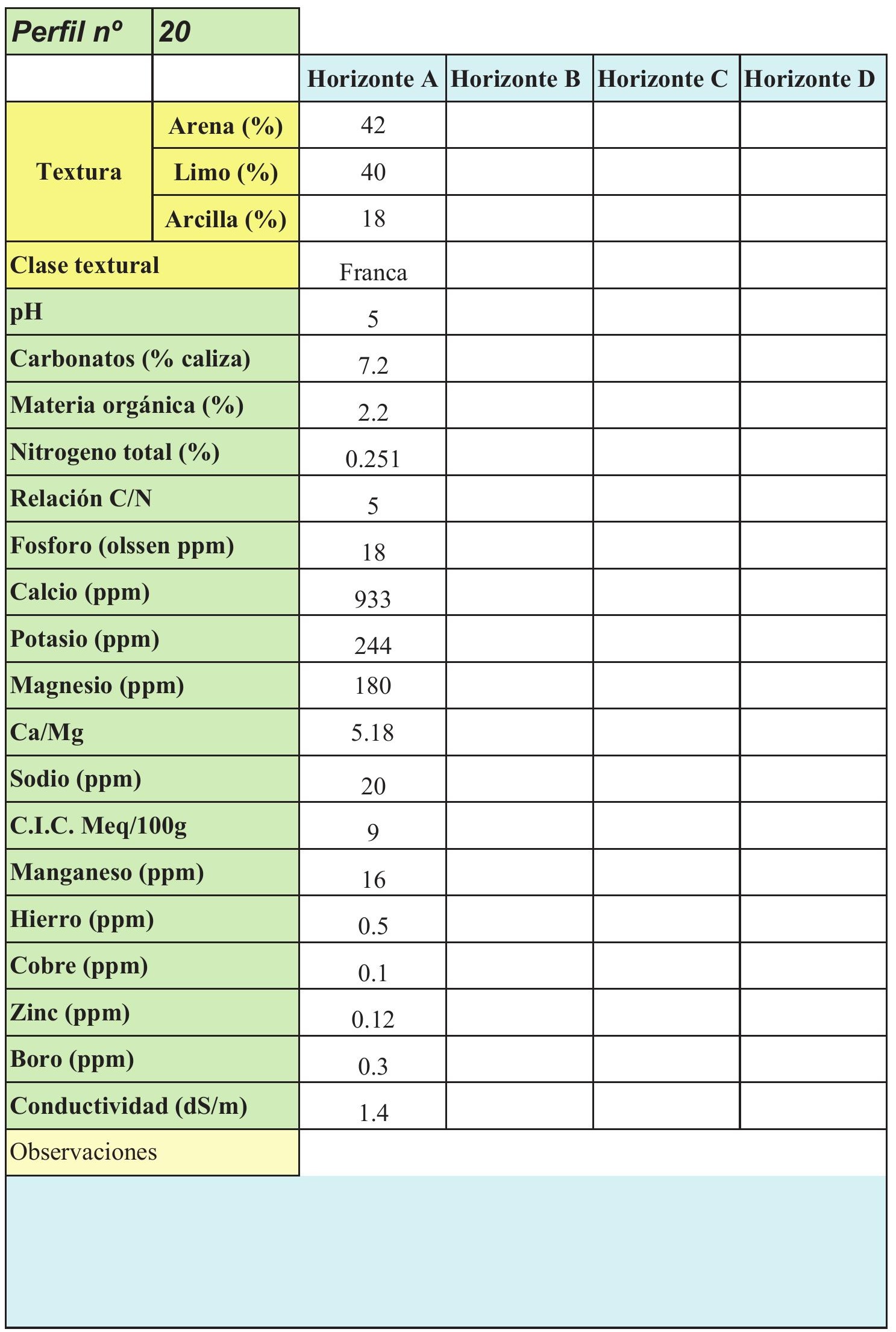


ANÁLISIS DE COMPOSICIÓN DE SUELOS

Desarrollo de una aplicación informática para el cálculo de sostenimiento de taludes mediante vegetación

\begin{tabular}{|c|c|c|c|c|c|}
\hline \multirow[t]{2}{*}{ Perfil $n^{\circ}$} & \multirow[t]{2}{*}{21} & & & & \\
\hline & & Horizonte A & Horizonte B & Horizonte C & Horizonte D \\
\hline \multirow{3}{*}{ Textura } & Arena (\%) & 39 & 42 & 63 & \\
\hline & Limo (\%) & 37 & 40 & 19 & \\
\hline & Arcilla (\%) & 24 & 18 & 18 & \\
\hline \multicolumn{2}{|c|}{ Clase textural } & Franca & Franca & Fran-Are-Arc & \\
\hline \multicolumn{2}{|l|}{ pH } & 5.1 & 5 & 4.09 & \\
\hline \multicolumn{2}{|c|}{ Carbonatos (\% caliza) } & 19 & 7.2 & ---- & \\
\hline \multicolumn{2}{|c|}{ Materia orgánica (\%) } & 3.2 & 2.2 & ---- & \\
\hline \multicolumn{2}{|c|}{ Nitrogeno total (\%) } & 1.5 & 0.251 & ---- & \\
\hline \multicolumn{2}{|c|}{ Relación C/N } & 15 & 5 & ---- & \\
\hline \multicolumn{2}{|c|}{ Fosforo (olssen ppm) } & 27 & 18 & 9 & \\
\hline \multicolumn{2}{|c|}{ Calcio (ppm) } & 281 & 933 & 1111 & \\
\hline \multicolumn{2}{|c|}{ Potasio (ppm) } & 354 & 244 & 135 & \\
\hline \multicolumn{2}{|c|}{ Magnesio (ppm) } & 80 & 180 & 92 & \\
\hline \multicolumn{2}{|l|}{$\mathrm{Ca} / \mathrm{Mg}$} & 3.513 & 5.18 & 12.08 & \\
\hline \multicolumn{2}{|c|}{ Sodio (ppm) } & 32 & 20 & 30 & \\
\hline \multicolumn{2}{|c|}{ C.I.C. Meq/100g } & 10.5 & 9 & 8 & \\
\hline \multicolumn{2}{|c|}{ Manganeso (ppm) } & 26 & 16 & 21 & \\
\hline \multicolumn{2}{|c|}{ Hierro (ppm) } & 0.6 & 0.5 & 0.8 & \\
\hline \multicolumn{2}{|c|}{ Cobre (ppm) } & 0.03 & 0.1 & 0.02 & \\
\hline \multicolumn{2}{|l|}{ Zinc (ppm) } & 0.3 & 0.12 & 0.09 & \\
\hline \multicolumn{2}{|l|}{ Boro (ppm) } & 1.1 & 0.3 & 0.2 & \\
\hline \multicolumn{2}{|c|}{ Conductividad (dS/m) } & 1.1 & 1.4 & 2.1 & \\
\hline \multicolumn{2}{|c|}{ Observaciones } & & & & \\
\hline
\end{tabular}


ANÁLISIS DE COMPOSICIÓN DE SUELOS

Desarrollo de una aplicación informática para el cálculo de sostenimiento de taludes mediante vegetación

\begin{tabular}{|c|c|c|c|c|c|}
\hline \multirow[t]{2}{*}{ Perfil $n^{\circ}$} & \multirow[t]{2}{*}{22} & & & & \\
\hline & & Horizonte A & Horizonte B & Horizonte C & Horizonte D \\
\hline \multirow{3}{*}{ Textura } & Arena (\%) & 25 & 41 & 23 & \\
\hline & Limo (\%) & 66 & 37 & 37 & \\
\hline & Arcilla (\%) & 9 & 22 & 40 & \\
\hline \multicolumn{2}{|c|}{ Clase textural } & Franc-Lim & Franca & Fran-Are-Arc & \\
\hline \multicolumn{2}{|l|}{ pH } & 6.2 & 5.3 & 4.09 & \\
\hline \multicolumn{2}{|c|}{ Carbonatos ( $\%$ caliza) } & 5.8 & 6.5 & ---- & \\
\hline \multicolumn{2}{|c|}{ Materia orgánica (\%) } & 2.8 & 0.84 & ---- & \\
\hline \multicolumn{2}{|c|}{ Nitrogeno total (\%) } & 0.25 & 0.2 & ---- & \\
\hline \multicolumn{2}{|c|}{ Relación C/N } & 13 & 6 & ---- & \\
\hline \multicolumn{2}{|c|}{ Fosforo (olssen ppm) } & 19 & 15 & 5 & \\
\hline \multicolumn{2}{|c|}{ Calcio (ppm) } & 958 & 758 & 598 & \\
\hline \multicolumn{2}{|c|}{ Potasio (ppm) } & 182 & 154 & 135 & \\
\hline \multicolumn{2}{|c|}{ Magnesio (ppm) } & 98 & 58 & 92 & \\
\hline \multicolumn{2}{|l|}{$\mathrm{Ca} / \mathrm{Mg}$} & 1.857 & 2.655 & 6.50 & \\
\hline \multicolumn{2}{|c|}{ Sodio (ppm) } & 36 & 21 & 19 & \\
\hline \multicolumn{2}{|c|}{ C.I.C. Meq/100g } & 15 & 17 & 8 & \\
\hline \multicolumn{2}{|c|}{ Manganeso (ppm) } & 17 & 18 & 21 & \\
\hline \multicolumn{2}{|c|}{ Hierro (ppm) } & 0.5 & 0.6 & 0.8 & \\
\hline \multicolumn{2}{|c|}{ Cobre (ppm) } & 0.25 & 0.4 & 0.02 & \\
\hline \multicolumn{2}{|l|}{ Zinc (ppm) } & 0.15 & 0.14 & 0.09 & \\
\hline \multicolumn{2}{|l|}{ Boro (ppm) } & 0.7 & 0.5 & 0.2 & \\
\hline \multicolumn{2}{|c|}{ Conductividad (dS/m) } & 1.1 & 1.4 & 2.1 & \\
\hline \multicolumn{2}{|c|}{ Observaciones } & & & & \\
\hline
\end{tabular}


ANÁLISIS DE COMPOSICIÓN DE SUELOS

Desarrollo de una aplicación informática para el cálculo de sostenimiento de taludes mediante vegetación

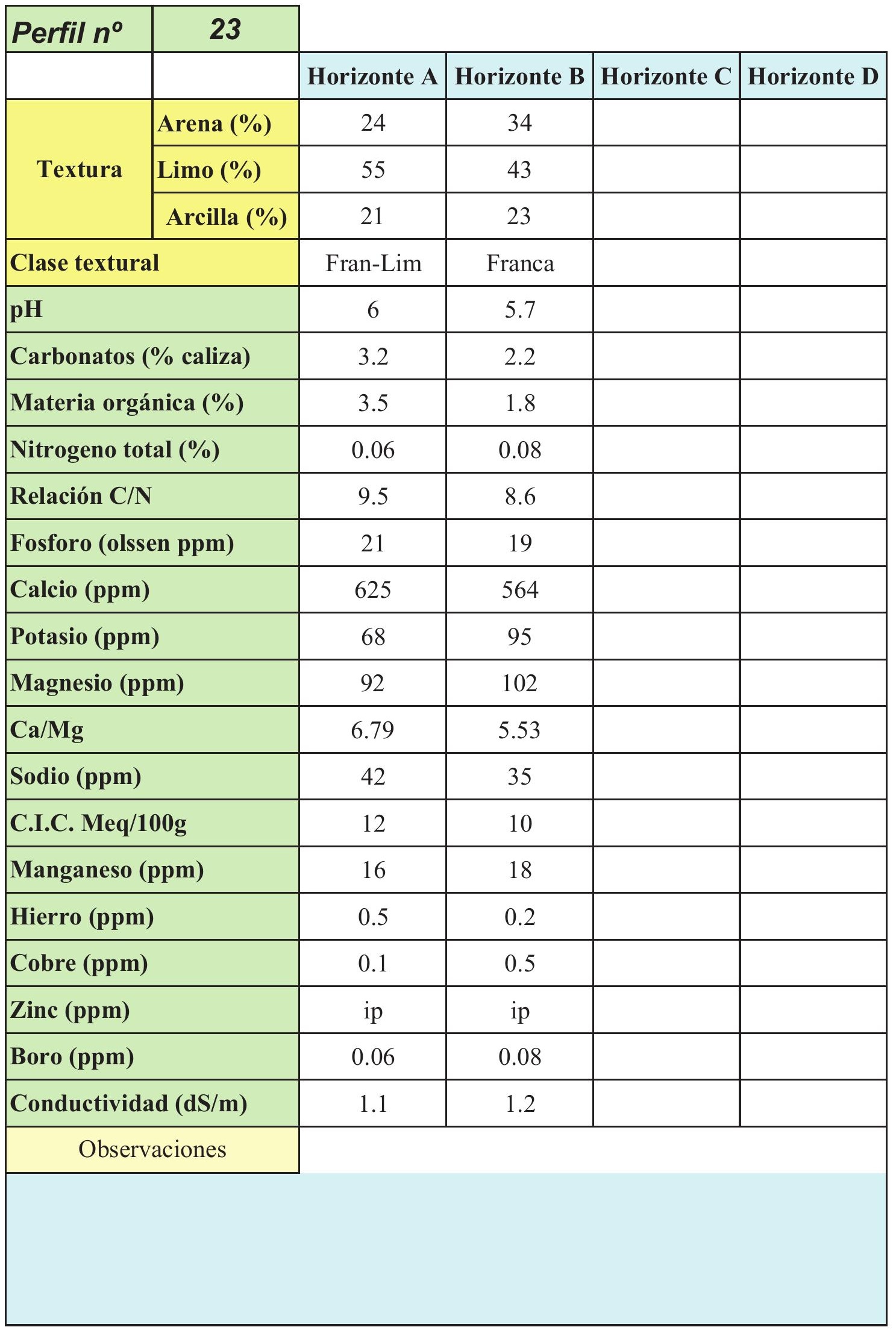


ANÁLISIS DE COMPOSICIÓN DE SUELOS

Desarrollo de una aplicación informática para el cálculo de sostenimiento de taludes mediante vegetación

\begin{tabular}{|c|c|c|c|c|c|}
\hline \multirow[t]{2}{*}{ Perfil $n^{\circ}$} & \multirow[t]{2}{*}{24} & & & & \\
\hline & & Horizonte A & Horizonte B & Horizonte C & Horizonte D \\
\hline \multirow{3}{*}{ Textura } & Arena (\%) & 46 & 38 & 41 & \\
\hline & Limo (\%) & 33 & 42 & 44 & \\
\hline & Arcilla (\%) & 21 & 20 & 15 & \\
\hline \multicolumn{2}{|c|}{ Clase textural } & Franca & Franca & Franca & \\
\hline \multicolumn{2}{|l|}{ pH } & 6.5 & 5 & 5 & \\
\hline \multicolumn{2}{|c|}{ Carbonatos (\% caliza) } & 7.3 & 15 & --- & \\
\hline \multicolumn{2}{|c|}{ Materia orgánica (\%) } & 2.8 & 1.5 & --- & \\
\hline \multicolumn{2}{|c|}{ Nitrogeno total (\%) } & 0.9 & 0.076 & --- & \\
\hline \multicolumn{2}{|c|}{ Relación C/N } & 10 & 11.2 & --- & \\
\hline \multicolumn{2}{|c|}{ Fosforo (olssen ppm) } & 9 & 29 & 22 & \\
\hline \multicolumn{2}{|c|}{ Calcio (ppm) } & 795 & 222 & 255 & \\
\hline \multicolumn{2}{|c|}{ Potasio (ppm) } & 135 & 29.3 & 32 & \\
\hline \multicolumn{2}{|c|}{ Magnesio (ppm) } & 98 & 49 & 125 & \\
\hline \multicolumn{2}{|l|}{$\mathrm{Ca} / \mathrm{Mg}$} & 8.11 & 4.53 & 2.04 & \\
\hline \multicolumn{2}{|c|}{ Sodio (ppm) } & 26 & 30 & 20 & \\
\hline \multicolumn{2}{|c|}{ C.I.C. Meq/100g } & 10 & 10 & 7 & \\
\hline \multicolumn{2}{|c|}{ Manganeso (ppm) } & 0.5 & 10 & 8 & \\
\hline \multicolumn{2}{|c|}{ Hierro (ppm) } & 1.2 & 0.9 & 1 & \\
\hline \multicolumn{2}{|c|}{ Cobre (ppm) } & 0.9 & 0.04 & 0.3 & \\
\hline \multicolumn{2}{|l|}{ Zinc (ppm) } & 0.8 & 0.1 & 0.3 & \\
\hline \multicolumn{2}{|l|}{ Boro (ppm) } & 0.35 & 0.7 & 0.2 & \\
\hline \multicolumn{2}{|c|}{ Conductividad (dS/m) } & 0.03 & 0.7 & 0.3 & \\
\hline \multicolumn{2}{|c|}{ Observaciones } & & & & \\
\hline
\end{tabular}


ANÁLISIS DE COMPOSICIÓN DE SUELOS

Desarrollo de una aplicación informática para el cálculo de sostenimiento de taludes mediante vegetación

\begin{tabular}{|c|c|c|c|c|c|}
\hline \multirow[t]{2}{*}{ Perfil $n^{\circ}$} & \multirow[t]{2}{*}{25} & & & & \\
\hline & & Horizonte A & Horizonte B & Horizonte $\mathrm{C}$ & Horizonte D \\
\hline \multirow{3}{*}{ Textura } & Arena (\%) & 25 & 33 & 54 & \\
\hline & Limo (\%) & 66 & 44 & 33 & \\
\hline & Arcilla (\%) & 9 & 23 & 13 & \\
\hline \multicolumn{2}{|c|}{ Clase textural } & Fran-Lim & Franca & Fran-Aren & \\
\hline \multicolumn{2}{|l|}{ pH } & 5.6 & 5.9 & 6 & \\
\hline \multicolumn{2}{|c|}{ Carbonatos (\% caliza) } & 12 & 10 & 0.6 & \\
\hline \multicolumn{2}{|c|}{ Materia orgánica (\%) } & 3.2 & 2.5 & 0.6 & \\
\hline \multicolumn{2}{|c|}{ Nitrogeno total $(\%)$} & 0.39 & 0.5 & 0.02 & \\
\hline \multicolumn{2}{|c|}{ Relación C/N } & 3 & 10 & 9 & \\
\hline \multicolumn{2}{|c|}{ Fosforo (olssen ppm) } & 15 & 13 & 14 & \\
\hline \multicolumn{2}{|c|}{ Calcio (ppm) } & 930 & 852 & 705 & \\
\hline \multicolumn{2}{|c|}{ Magnesio (ppm) } & 235 & 203 & 88 & \\
\hline \multicolumn{2}{|l|}{$\mathrm{Ca} / \mathrm{Mg}$} & 3.96 & 4.20 & 8.01 & \\
\hline \multicolumn{2}{|c|}{ Potasio (ppm) } & 220 & 175 & 136 & \\
\hline \multicolumn{2}{|c|}{ Sodio (ppm) } & 23 & 33 & 44 & \\
\hline \multicolumn{2}{|c|}{ C.I.C. Meq/100g } & 13 & 11 & 9 & \\
\hline \multicolumn{2}{|c|}{ Manganeso (ppm) } & 15 & 16 & 22 & \\
\hline \multicolumn{2}{|c|}{ Hierro (ppm) } & 0.2 & 0.9 & 2.3 & \\
\hline \multicolumn{2}{|c|}{ Cobre (ppm) } & 0.1 & 0.3 & 0.2 & \\
\hline \multicolumn{2}{|l|}{ Zinc (ppm) } & 1.5 & 1.3 & 1.2 & \\
\hline \multicolumn{2}{|l|}{ Boro (ppm) } & ip & ip & ip & \\
\hline \multicolumn{2}{|c|}{ Conductividad (dS/m) } & 1.1 & 0.9 & 0.78 & \\
\hline \multicolumn{2}{|c|}{ Observaciones } & & & & \\
\hline
\end{tabular}


ANÁLISIS DE COMPOSICIÓN DE SUELOS

Desarrollo de una aplicación informática para el cálculo de sostenimiento de taludes mediante vegetación

\begin{tabular}{|c|c|c|c|c|c|}
\hline \multirow[t]{2}{*}{ Perfil $n^{\circ}$} & \multirow[t]{2}{*}{26} & & & & \\
\hline & & Horizonte A & Horizonte B & Horizonte $\mathrm{C}$ & Horizonte D \\
\hline \multirow{3}{*}{ Textura } & Arena (\%) & 55 & & & \\
\hline & Limo (\%) & 25 & & & \\
\hline & Arcilla (\%) & 20 & & & \\
\hline \multicolumn{2}{|c|}{ Clase textural } & Fran-Aren & & & \\
\hline \multicolumn{2}{|l|}{ pH } & 5.4 & & & \\
\hline \multicolumn{2}{|c|}{ Carbonatos ( $\%$ caliza) } & 0.9 & & & \\
\hline \multicolumn{2}{|c|}{ Materia orgánica (\%) } & 3.2 & & & \\
\hline \multicolumn{2}{|c|}{ Nitrogeno total (\%) } & 0.02 & & & \\
\hline \multicolumn{2}{|c|}{ Relación C/N } & 3 & & & \\
\hline \multicolumn{2}{|c|}{ Fosforo (olssen ppm) } & 7 & & & \\
\hline \multicolumn{2}{|c|}{ Calcio (ppm) } & 88 & & & \\
\hline \multicolumn{2}{|c|}{ Potasio (ppm) } & 83 & & & \\
\hline \multicolumn{2}{|c|}{ Magnesio (ppm) } & 73 & & & \\
\hline \multicolumn{2}{|l|}{$\mathrm{Ca} / \mathrm{Mg}$} & 1.21 & & & \\
\hline \multicolumn{2}{|c|}{ Sodio (ppm) } & 11 & & & \\
\hline \multicolumn{2}{|c|}{ C.I.C. Meq/100g } & 6 & & & \\
\hline \multicolumn{2}{|c|}{ Manganeso (ppm) } & ip & & & \\
\hline \multicolumn{2}{|c|}{ Hierro (ppm) } & ip & & & \\
\hline \multicolumn{2}{|c|}{ Cobre (ppm) } & ip & & & \\
\hline \multicolumn{2}{|l|}{ Zinc (ppm) } & ip & & & \\
\hline \multicolumn{2}{|l|}{ Boro (ppm) } & ip & & & \\
\hline \multicolumn{2}{|c|}{ Conductividad (dS/m) } & 1.05 & & & \\
\hline \multicolumn{2}{|c|}{ Observaciones } & & & & \\
\hline
\end{tabular}


ANÁLISIS DE COMPOSICIÓN DE SUELOS

Desarrollo de una aplicación informática para el cálculo de sostenimiento de taludes mediante vegetación

\begin{tabular}{|c|c|c|c|c|c|}
\hline \multirow[t]{2}{*}{ Perfil $n^{\circ}$} & \multirow[t]{2}{*}{27} & \multirow[b]{2}{*}{ Horizonte A } & \multirow[b]{2}{*}{ Horizonte B } & \multirow[b]{2}{*}{ Horizonte C } & \multirow[b]{2}{*}{ Horizonte D } \\
\hline & & & & & \\
\hline \multirow{3}{*}{ Textura } & Arena (\%) & 44 & 61 & & \\
\hline & Limo (\%) & 33 & 27 & & \\
\hline & Arcilla (\%) & 23 & 12 & & \\
\hline \multicolumn{2}{|c|}{ Clase textural } & Franca & fran-Aren & & \\
\hline \multicolumn{2}{|l|}{ pH } & 6.2 & 5.9 & & \\
\hline \multicolumn{2}{|c|}{ Carbonatos ( $\%$ caliza) } & 1.1 & 1.3 & & \\
\hline \multicolumn{2}{|c|}{ Materia orgánica (\%) } & 4.3 & 2.1 & & \\
\hline \multicolumn{2}{|c|}{ Nitrogeno total (\%) } & 0.35 & 0.44 & & \\
\hline \multicolumn{2}{|c|}{ Relación C/N } & 4 & 3 & & \\
\hline \multicolumn{2}{|c|}{ Fosforo (olssen ppm) } & 8 & 9 & & \\
\hline \multicolumn{2}{|c|}{ Calcio (ppm) } & 90 & 102 & & \\
\hline \multicolumn{2}{|c|}{ Potasio (ppm) } & 30 & 44 & & \\
\hline \multicolumn{2}{|c|}{ Magnesio (ppm) } & 27 & 33 & & \\
\hline \multicolumn{2}{|l|}{$\mathrm{Ca} / \mathrm{Mg}$} & 3.33 & 3.09 & & \\
\hline \multicolumn{2}{|c|}{ Sodio (ppm) } & 5 & 6 & & \\
\hline \multicolumn{2}{|c|}{ C.I.C. Meq/100g } & 3 & 4 & & \\
\hline \multicolumn{2}{|c|}{ Manganeso (ppm) } & ip & ip & & \\
\hline \multicolumn{2}{|c|}{ Hierro (ppm) } & ip & ip & & \\
\hline \multicolumn{2}{|c|}{ Cobre (ppm) } & ip & ip & & \\
\hline \multicolumn{2}{|l|}{ Zinc (ppm) } & ip & ip & & \\
\hline \multicolumn{2}{|l|}{ Boro (ppm) } & ip & ip & & \\
\hline \multicolumn{2}{|c|}{ Conductividad (dS/m) } & 0.9 & 0.7 & & \\
\hline \multicolumn{2}{|c|}{ Observaciones } & & & & \\
\hline
\end{tabular}


ANÁLISIS DE COMPOSICIÓN DE SUELOS

Desarrollo de una aplicación informática para el cálculo de sostenimiento de taludes mediante vegetación

\begin{tabular}{|c|c|c|c|c|c|}
\hline \multirow[t]{2}{*}{ Perfil $n^{\circ}$} & \multirow[t]{2}{*}{28} & & & & \\
\hline & & Horizonte A & Horizonte B & Horizonte C & Horizonte D \\
\hline \multirow{3}{*}{ Textura } & Arena (\%) & 25 & 27 & 38 & \\
\hline & Limo (\%) & 66 & 57 & 41 & \\
\hline & Arcilla (\%) & 7 & 5 & 59 & \\
\hline \multicolumn{2}{|c|}{ Clase textural } & Fran-Lim & Fran-Lim & Franca & \\
\hline \multicolumn{2}{|l|}{ pH } & 6.1 & 5.8 & 5.2 & \\
\hline \multicolumn{2}{|c|}{ Carbonatos (\% caliza) } & 10 & 8 & 1 & \\
\hline \multicolumn{2}{|c|}{ Materia orgánica (\%) } & 3.2 & 1.1 & ---- & \\
\hline \multicolumn{2}{|c|}{ Nitrogeno total (\%) } & 0.29 & 0.15 & 0.7 & \\
\hline \multicolumn{2}{|c|}{ Relación C/N } & 20 & 10 & ----- & \\
\hline \multicolumn{2}{|c|}{ Fosforo (olssen ppm) } & 32 & 25 & 12 & \\
\hline \multicolumn{2}{|c|}{ Calcio (ppm) } & 1025 & 821 & 935 & \\
\hline \multicolumn{2}{|c|}{ Potasio (ppm) } & 265 & 168 & 154 & \\
\hline \multicolumn{2}{|c|}{ Magnesio (ppm) } & 220 & 156 & 89 & \\
\hline \multicolumn{2}{|l|}{$\mathrm{Ca} / \mathrm{Mg}$} & 4.66 & 5.26 & 10.51 & \\
\hline \multicolumn{2}{|c|}{ Sodio (ppm) } & 24 & 12 & 16 & \\
\hline \multicolumn{2}{|c|}{ C.I.C. Meq/100g } & 26 & 14 & 2 & \\
\hline \multicolumn{2}{|c|}{ Manganeso (ppm) } & 31 & 28 & 26 & \\
\hline \multicolumn{2}{|c|}{ Hierro (ppm) } & 0.8 & 0.6 & 0.9 & \\
\hline \multicolumn{2}{|c|}{ Cobre (ppm) } & 0.2 & 0.6 & 0.4 & \\
\hline \multicolumn{2}{|l|}{ Zinc (ppm) } & ip & ip & ip & \\
\hline \multicolumn{2}{|l|}{ Boro (ppm) } & 0.9 & 0.5 & 0.7 & \\
\hline \multicolumn{2}{|c|}{ Conductividad (dS/m) } & 1.1 & 0.9 & 1.3 & \\
\hline \multicolumn{2}{|c|}{ Observaciones } & & & & \\
\hline
\end{tabular}


ANÁLISIS DE COMPOSICIÓN DE SUELOS

Desarrollo de una aplicación informática para el cálculo de sostenimiento de taludes mediante vegetación

\begin{tabular}{|c|c|c|c|c|c|}
\hline \multirow[t]{2}{*}{ Perfil $n^{\circ}$} & \multirow[t]{2}{*}{29} & & & & \\
\hline & & Horizonte A & Horizonte B & Horizonte $\mathrm{C}$ & Horizonte D \\
\hline \multirow{3}{*}{ Textura } & Arena (\%) & 49 & & & \\
\hline & Limo (\%) & 31 & & & \\
\hline & Arcilla (\%) & 20 & & & \\
\hline \multicolumn{2}{|c|}{ Clase textural } & Franca & & & \\
\hline \multicolumn{2}{|l|}{ pH } & 5.6 & & & \\
\hline \multicolumn{2}{|c|}{ Carbonatos ( $\%$ caliza) } & 3 & & & \\
\hline \multicolumn{2}{|c|}{ Materia orgánica (\%) } & 1.9 & & & \\
\hline \multicolumn{2}{|c|}{ Nitrogeno total (\%) } & 0.05 & & & \\
\hline \multicolumn{2}{|c|}{ Relación C/N } & 6 & & & \\
\hline \multicolumn{2}{|c|}{ Fosforo (olssen ppm) } & 29 & & & \\
\hline \multicolumn{2}{|c|}{ Calcio (ppm) } & 258 & & & \\
\hline \multicolumn{2}{|c|}{ Potasio (ppm) } & 69 & & & \\
\hline \multicolumn{2}{|c|}{ Magnesio (ppm) } & 42 & & & \\
\hline \multicolumn{2}{|l|}{$\mathrm{Ca} / \mathrm{Mg}$} & 6.14 & & & \\
\hline \multicolumn{2}{|c|}{ Sodio (ppm) } & 13 & & & \\
\hline \multicolumn{2}{|c|}{ C.I.C. Meq/100g } & 3 & & & \\
\hline \multicolumn{2}{|c|}{ Manganeso (ppm) } & ip & & & \\
\hline \multicolumn{2}{|c|}{ Hierro (ppm) } & ip & & & \\
\hline \multicolumn{2}{|c|}{ Cobre (ppm) } & ip & & & \\
\hline \multicolumn{2}{|l|}{ Zinc (ppm) } & ip & & & \\
\hline \multicolumn{2}{|l|}{ Boro (ppm) } & ip & & & \\
\hline \multicolumn{2}{|c|}{ Conductividad (dS/m) } & 0.6 & & & \\
\hline \multicolumn{2}{|c|}{ Observaciones } & & & & \\
\hline
\end{tabular}


ANÁLISIS DE COMPOSICIÓN DE SUELOS

Desarrollo de una aplicación informática para el cálculo de sostenimiento de taludes mediante vegetación

\begin{tabular}{|c|c|c|c|c|c|}
\hline \multirow[t]{2}{*}{ Perfil $n^{\circ}$} & \multirow[t]{2}{*}{30} & & & & \\
\hline & & Horizonte A & Horizonte B & Horizonte $\mathrm{C}$ & Horizonte D \\
\hline \multirow{3}{*}{ Textura } & Arena (\%) & 56 & & & \\
\hline & Limo (\%) & 24 & & & \\
\hline & Arcilla (\%) & 20 & & & \\
\hline \multicolumn{2}{|c|}{ Clase textural } & Fran-Aren & & & \\
\hline \multicolumn{2}{|l|}{ pH } & 4.9 & & & \\
\hline \multicolumn{2}{|c|}{ Carbonatos ( $\%$ caliza) } & 1.2 & & & \\
\hline \multicolumn{2}{|c|}{ Materia orgánica (\%) } & 8.1 & & & \\
\hline \multicolumn{2}{|c|}{ Nitrogeno total (\%) } & 0.06 & & & \\
\hline \multicolumn{2}{|c|}{ Relación C/N } & 18 & & & \\
\hline \multicolumn{2}{|c|}{ Fosforo (olssen ppm) } & 6 & & & \\
\hline \multicolumn{2}{|c|}{ Calcio (ppm) } & 125 & & & \\
\hline \multicolumn{2}{|c|}{ Potasio (ppm) } & 69 & & & \\
\hline \multicolumn{2}{|c|}{ Magnesio (ppm) } & 20 & & & \\
\hline \multicolumn{2}{|l|}{$\mathrm{Ca} / \mathrm{Mg}$} & 6.25 & & & \\
\hline \multicolumn{2}{|c|}{ Sodio (ppm) } & 11 & & & \\
\hline \multicolumn{2}{|c|}{ C.I.C. Meq/100g } & 7 & & & \\
\hline \multicolumn{2}{|c|}{ Manganeso (ppm) } & ip & & & \\
\hline \multicolumn{2}{|c|}{ Hierro (ppm) } & ip & & & \\
\hline \multicolumn{2}{|c|}{ Cobre (ppm) } & ip & & & \\
\hline \multicolumn{2}{|l|}{ Zinc (ppm) } & ip & & & \\
\hline \multicolumn{2}{|l|}{ Boro (ppm) } & ip & & & \\
\hline \multicolumn{2}{|c|}{ Conductividad (dS/m) } & 0.67 & & & \\
\hline \multicolumn{2}{|c|}{ Observaciones } & & & & \\
\hline
\end{tabular}


ANÁLISIS DE COMPOSICIÓN DE SUELOS

Desarrollo de una aplicación informática para el cálculo de sostenimiento de taludes mediante vegetación

\begin{tabular}{|c|c|c|c|c|c|}
\hline \multirow[t]{2}{*}{ Perfil $n^{\circ}$} & \multirow[t]{2}{*}{31} & & & & \\
\hline & & Horizonte A & Horizonte B & Horizonte C & Horizonte D \\
\hline \multirow{3}{*}{ Textura } & Arena (\%) & 38 & & & \\
\hline & Limo (\%) & 38 & & & \\
\hline & Arcilla (\%) & 24 & & & \\
\hline \multicolumn{2}{|c|}{ Clase textural } & Franca & & & \\
\hline \multicolumn{2}{|l|}{ pH } & 5.5 & & & \\
\hline \multicolumn{2}{|c|}{ Carbonatos ( $\%$ caliza) } & 3.2 & & & \\
\hline \multicolumn{2}{|c|}{ Materia orgánica (\%) } & 3.7 & & & \\
\hline \multicolumn{2}{|c|}{ Nitrogeno total (\%) } & 0.12 & & & \\
\hline \multicolumn{2}{|c|}{ Relación C/N } & 8 & & & \\
\hline \multicolumn{2}{|c|}{ Fosforo (olssen ppm) } & 19 & & & \\
\hline \multicolumn{2}{|c|}{ Calcio (ppm) } & 365 & & & \\
\hline \multicolumn{2}{|c|}{ Potasio (ppm) } & 69 & & & \\
\hline \multicolumn{2}{|c|}{ Magnesio (ppm) } & 59 & & & \\
\hline \multicolumn{2}{|l|}{$\mathrm{Ca} / \mathrm{Mg}$} & 6.186 & & & \\
\hline \multicolumn{2}{|c|}{ Sodio (ppm) } & 15 & & & \\
\hline \multicolumn{2}{|c|}{ C.I.C. Meq/100g } & 4 & & & \\
\hline \multicolumn{2}{|c|}{ Manganeso (ppm) } & ip & & & \\
\hline \multicolumn{2}{|c|}{ Hierro (ppm) } & ip & & & \\
\hline \multicolumn{2}{|c|}{ Cobre (ppm) } & ip & & & \\
\hline \multicolumn{2}{|l|}{ Zinc (ppm) } & ip & & & \\
\hline \multicolumn{2}{|l|}{ Boro (ppm) } & ip & & & \\
\hline \multicolumn{2}{|c|}{ Conductividad (dS/m) } & 0.09 & & & \\
\hline \multicolumn{2}{|c|}{ Observaciones } & & & & \\
\hline
\end{tabular}


ANÁLISIS DE COMPOSICIÓN DE SUELOS

Desarrollo de una aplicación informática para el cálculo de sostenimiento de taludes mediante vegetación

\begin{tabular}{|c|c|c|c|c|c|}
\hline \multirow[t]{2}{*}{ Perfil $n^{\circ}$} & \multirow[t]{2}{*}{32} & & & & \\
\hline & & Horizonte A & Horizonte B & Horizonte C & Horizonte D \\
\hline \multirow{3}{*}{ Textura } & Arena (\%) & 32 & & & \\
\hline & Limo (\%) & 44 & & & \\
\hline & Arcilla (\%) & 24 & & & \\
\hline \multicolumn{2}{|c|}{ Clase textural } & Franca & & & \\
\hline \multicolumn{2}{|l|}{ pH } & 5.3 & & & \\
\hline \multicolumn{2}{|c|}{ Carbonatos (\% caliza) } & ip & & & \\
\hline \multicolumn{2}{|c|}{ Materia orgánica (\%) } & 0.9 & & & \\
\hline \multicolumn{2}{|c|}{ Nitrogeno total $(\%)$} & 0.026 & & & \\
\hline \multicolumn{2}{|c|}{ Relación C/N } & 20 & & & \\
\hline \multicolumn{2}{|c|}{ Fosforo (olssen ppm) } & 15 & & & \\
\hline \multicolumn{2}{|c|}{ Calcio (ppm) } & 235 & & & \\
\hline \multicolumn{2}{|c|}{ Potasio (ppm) } & 90 & & & \\
\hline \multicolumn{2}{|c|}{ Magnesio (ppm) } & 98 & & & \\
\hline \multicolumn{2}{|l|}{$\mathrm{Ca} / \mathrm{Mg}$} & 2.40 & & & \\
\hline \multicolumn{2}{|c|}{ Sodio (ppm) } & 0.8 & & & \\
\hline \multicolumn{2}{|c|}{ C.I.C. Meq/100g } & 6.54 & & & \\
\hline \multicolumn{2}{|c|}{ Manganeso (ppm) } & 20 & & & \\
\hline \multicolumn{2}{|c|}{ Hierro (ppm) } & 5 & & & \\
\hline \multicolumn{2}{|c|}{ Cobre (ppm) } & 2 & & & \\
\hline \multicolumn{2}{|l|}{ Zinc (ppm) } & 3.1 & & & \\
\hline \multicolumn{2}{|l|}{ Boro (ppm) } & 0.8 & & & \\
\hline \multicolumn{2}{|c|}{ Conductividad (dS/m) } & 1.5 & & & \\
\hline \multicolumn{2}{|c|}{ Observaciones } & & & & \\
\hline
\end{tabular}


ANÁLISIS DE COMPOSICIÓN DE SUELOS

Desarrollo de una aplicación informática para el cálculo de sostenimiento de taludes mediante vegetación

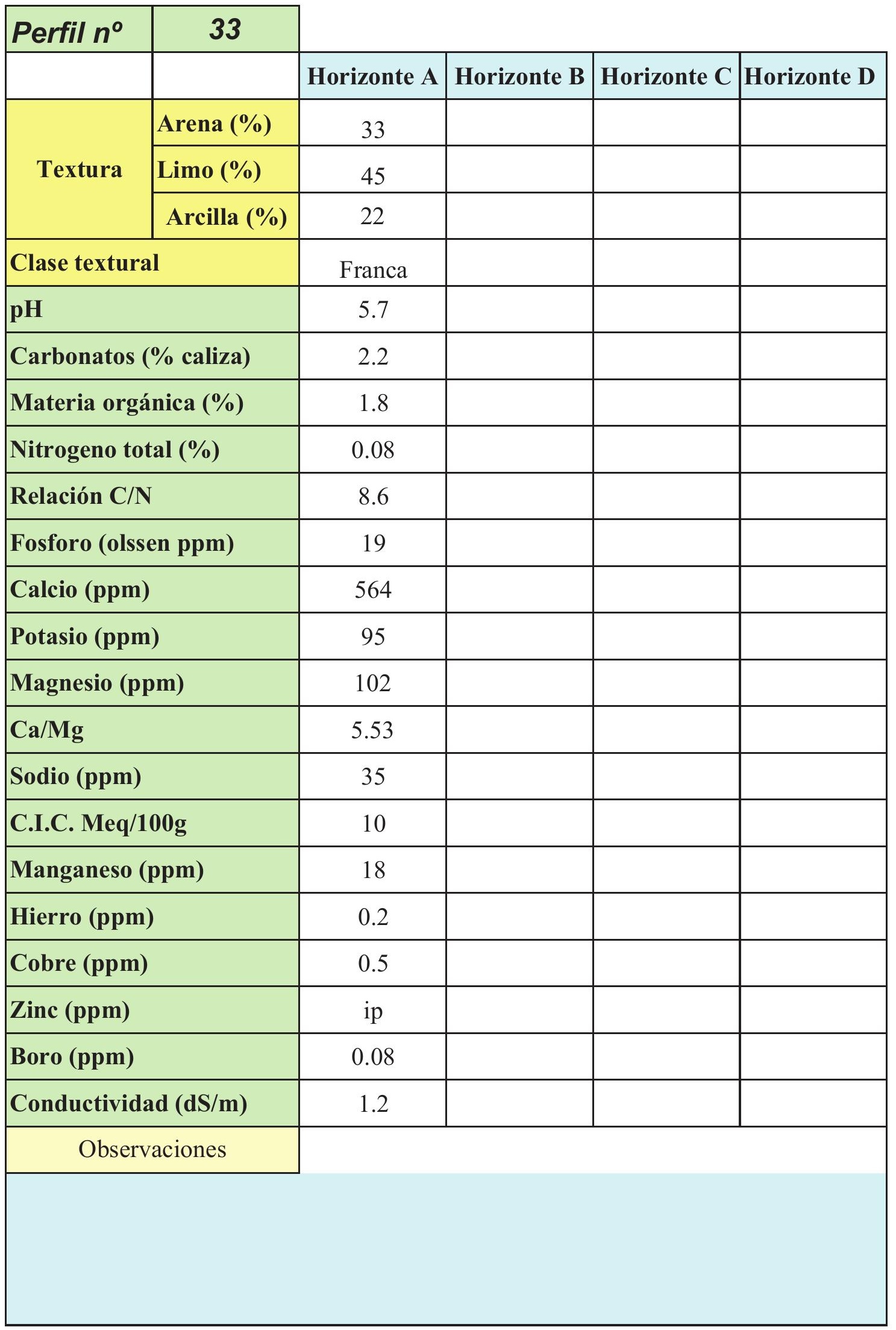


ANÁLISIS DE COMPOSICIÓN DE SUELOS

Desarrollo de una aplicación informática para el cálculo de sostenimiento de taludes mediante vegetación

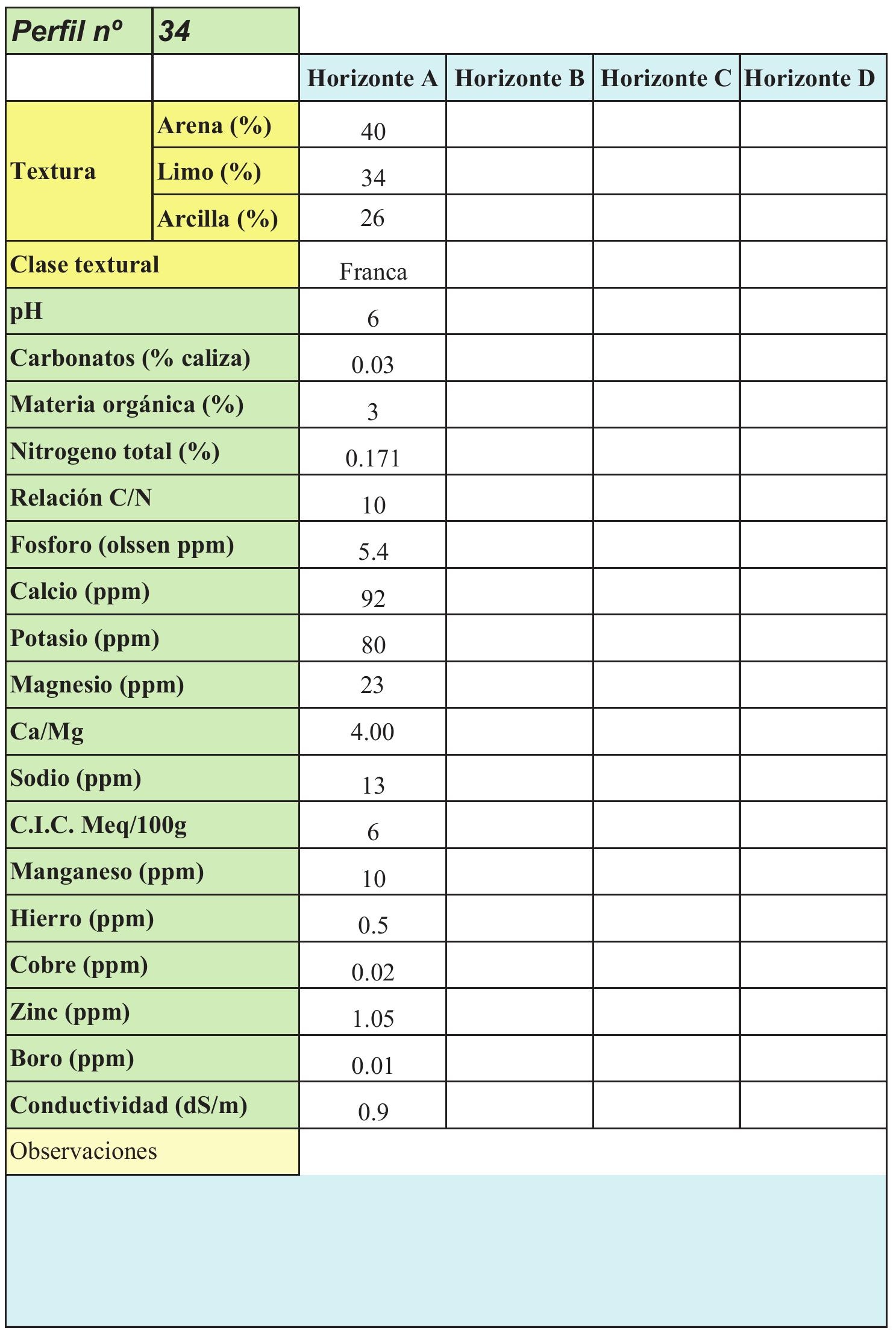




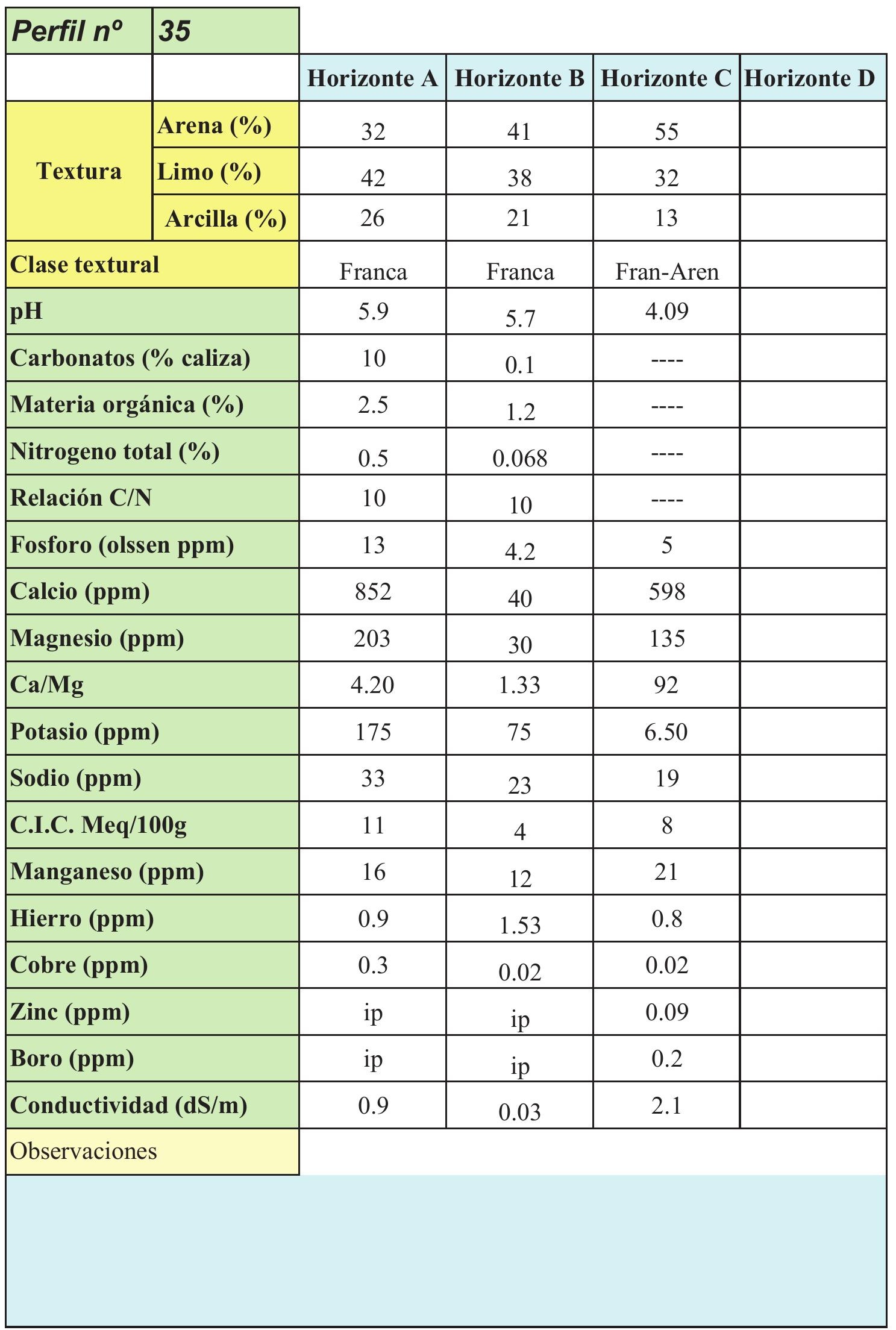


ANÁLISIS DE COMPOSICIÓN DE SUELOS

Desarrollo de una aplicación informática para el cálculo de sostenimiento de taludes mediante vegetación

\begin{tabular}{|c|c|c|c|c|c|}
\hline \multirow[t]{2}{*}{ Perfil $n^{\circ}$} & \multirow[t]{2}{*}{36} & \multirow[b]{2}{*}{ Horizonte A } & \multirow[b]{2}{*}{ Horizonte B } & \multirow[b]{2}{*}{ Horizonte C } & \multirow[b]{2}{*}{ Horizonte D } \\
\hline & & & & & \\
\hline \multirow{3}{*}{ Textura } & Arena (\%) & 39 & & & \\
\hline & Limo (\%) & 35 & & & \\
\hline & Arcilla (\%) & 26 & & & \\
\hline \multicolumn{2}{|c|}{ Clase textural } & Franca & & & \\
\hline \multicolumn{2}{|l|}{ pH } & 5.9 & & & \\
\hline \multicolumn{2}{|c|}{ Carbonatos ( $\%$ caliza) } & 10 & & & \\
\hline \multicolumn{2}{|c|}{ Materia orgánica (\%) } & 2.5 & & & \\
\hline \multicolumn{2}{|c|}{ Nitrogeno total (\%) } & 0.5 & & & \\
\hline \multicolumn{2}{|c|}{ Relación C/N } & 10 & & & \\
\hline \multicolumn{2}{|c|}{ Fosforo (olssen ppm) } & 13 & & & \\
\hline \multicolumn{2}{|c|}{ Calcio (ppm) } & 852 & & & \\
\hline \multicolumn{2}{|c|}{ Potasio (ppm) } & 203 & & & \\
\hline \multicolumn{2}{|c|}{ Magnesio (ppm) } & 4.20 & & & \\
\hline \multicolumn{2}{|l|}{$\mathrm{Ca} / \mathrm{Mg}$} & 175 & & & \\
\hline \multicolumn{2}{|c|}{ Sodio (ppm) } & 33 & & & \\
\hline \multicolumn{2}{|c|}{ C.I.C. Meq/100g } & 11 & & & \\
\hline \multicolumn{2}{|c|}{ Manganeso (ppm) } & 16 & & & \\
\hline \multicolumn{2}{|c|}{ Hierro (ppm) } & 0.9 & & & \\
\hline \multicolumn{2}{|c|}{ Cobre (ppm) } & 0.3 & & & \\
\hline \multicolumn{2}{|l|}{ Zinc (ppm) } & 1.3 & & & \\
\hline \multicolumn{2}{|l|}{ Boro (ppm) } & ip & & & \\
\hline \multicolumn{2}{|c|}{ Conductividad (dS/m) } & 0.9 & & & \\
\hline \multicolumn{2}{|c|}{ Observaciones } & & & & \\
\hline
\end{tabular}


ANÁLISIS DE COMPOSICIÓN DE SUELOS

Desarrollo de una aplicación informática para el cálculo de sostenimiento de taludes mediante vegetación

\begin{tabular}{|c|c|c|c|c|c|}
\hline \multirow[t]{2}{*}{ Perfil $n^{\circ}$} & \multirow[t]{2}{*}{37} & \multirow[b]{2}{*}{ Horizonte A } & \multirow[b]{2}{*}{ Horizonte B } & \multirow[b]{2}{*}{ Horizonte C } & \multirow[b]{2}{*}{ Horizonte D } \\
\hline & & & & & \\
\hline \multirow{3}{*}{ Textura } & Arena (\%) & 55 & & & \\
\hline & Limo (\%) & 36 & & & \\
\hline & Arcilla (\%) & 9 & & & \\
\hline \multicolumn{2}{|c|}{ Clase textural } & Fran-Aren & & & \\
\hline \multicolumn{2}{|l|}{ pH } & 5.3 & & & \\
\hline \multicolumn{2}{|c|}{ Carbonatos ( $\%$ caliza) } & 2.5 & & & \\
\hline \multicolumn{2}{|c|}{ Materia orgánica (\%) } & 2.6 & & & \\
\hline \multicolumn{2}{|c|}{ Nitrogeno total (\%) } & 0.06 & & & \\
\hline \multicolumn{2}{|c|}{ Relación C/N } & 6 & & & \\
\hline \multicolumn{2}{|c|}{ Fosforo (olssen ppm) } & 10 & & & \\
\hline \multicolumn{2}{|c|}{ Calcio (ppm) } & 152 & & & \\
\hline \multicolumn{2}{|c|}{ Potasio (ppm) } & 50 & & & \\
\hline \multicolumn{2}{|c|}{ Magnesio (ppm) } & 35 & & & \\
\hline \multicolumn{2}{|l|}{$\mathrm{Ca} / \mathrm{Mg}$} & 4.34 & & & \\
\hline \multicolumn{2}{|c|}{ Sodio (ppm) } & 11 & & & \\
\hline \multicolumn{2}{|c|}{ C.I.C. Meq/100g } & 5.2 & & & \\
\hline \multicolumn{2}{|c|}{ Manganeso (ppm) } & ip & & & \\
\hline \multicolumn{2}{|c|}{ Hierro (ppm) } & ip & & & \\
\hline \multicolumn{2}{|c|}{ Cobre (ppm) } & ip & & & \\
\hline \multicolumn{2}{|l|}{ Zinc (ppm) } & ip & & & \\
\hline \multicolumn{2}{|l|}{ Boro (ppm) } & ip & & & \\
\hline \multicolumn{2}{|c|}{ Conductividad (dS/m) } & 0.68 & & & \\
\hline \multicolumn{2}{|c|}{ Observaciones } & & & & \\
\hline
\end{tabular}


ANÁLISIS DE COMPOSICIÓN DE SUELOS

Desarrollo de una aplicación informática para el cálculo de sostenimiento de taludes mediante vegetación

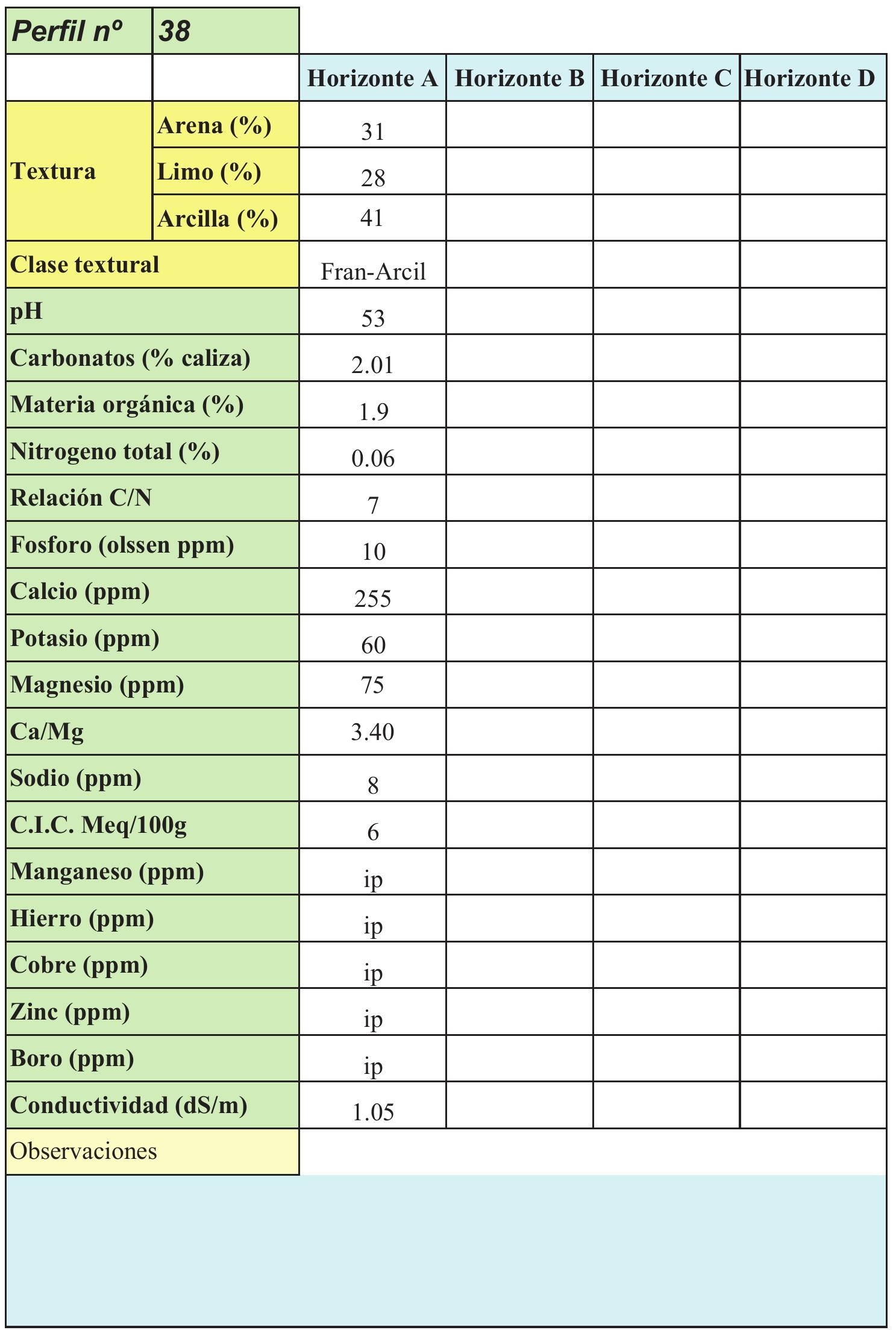


ANÁLISIS DE COMPOSICIÓN DE SUELOS

Desarrollo de una aplicación informática para el cálculo de sostenimiento de taludes mediante vegetación

\begin{tabular}{|c|c|c|c|c|c|}
\hline \multirow[t]{2}{*}{ Perfil $n^{\circ}$} & \multirow[t]{2}{*}{39} & \multirow[b]{2}{*}{ Horizonte A } & \multirow[b]{2}{*}{ Horizonte B } & \multirow[b]{2}{*}{ Horizonte C } & \multirow[b]{2}{*}{ Horizonte D } \\
\hline & & & & & \\
\hline \multirow{3}{*}{ Textura } & Arena (\%) & 38 & & & \\
\hline & Limo (\%) & 42 & & & \\
\hline & Arcilla (\%) & 20 & & & \\
\hline \multicolumn{2}{|c|}{ Clase textural } & Franca & & & \\
\hline \multicolumn{2}{|l|}{ pH } & 6.1 & & & \\
\hline \multicolumn{2}{|c|}{ Carbonatos ( $\%$ caliza) } & 1.3 & & & \\
\hline \multicolumn{2}{|c|}{ Materia orgánica (\%) } & 2.2 & & & \\
\hline \multicolumn{2}{|c|}{ Nitrogeno total (\%) } & 0.08 & & & \\
\hline \multicolumn{2}{|c|}{ Relación C/N } & 6 & & & \\
\hline \multicolumn{2}{|c|}{ Fosforo (olssen ppm) } & 15 & & & \\
\hline \multicolumn{2}{|c|}{ Calcio (ppm) } & 332 & & & \\
\hline \multicolumn{2}{|c|}{ Potasio (ppm) } & 75 & & & \\
\hline \multicolumn{2}{|c|}{ Magnesio (ppm) } & 83 & & & \\
\hline \multicolumn{2}{|l|}{$\mathrm{Ca} / \mathrm{Mg}$} & 4.00 & & & \\
\hline \multicolumn{2}{|c|}{ Sodio (ppm) } & 9 & & & \\
\hline \multicolumn{2}{|c|}{ C.I.C. Meq/100g } & 5 & & & \\
\hline \multicolumn{2}{|c|}{ Manganeso (ppm) } & ip & & & \\
\hline \multicolumn{2}{|c|}{ Hierro (ppm) } & ip & & & \\
\hline \multicolumn{2}{|c|}{ Cobre (ppm) } & ip & & & \\
\hline \multicolumn{2}{|l|}{ Zinc (ppm) } & ip & & & \\
\hline \multicolumn{2}{|l|}{ Boro (ppm) } & ip & & & \\
\hline \multicolumn{2}{|c|}{ Conductividad (dS/m) } & 0.9 & & & \\
\hline \multicolumn{2}{|c|}{ Observaciones } & & & & \\
\hline
\end{tabular}


ANÁLISIS DE COMPOSICIÓN DE SUELOS

Desarrollo de una aplicación informática para el cálculo de sostenimiento de taludes mediante vegetación

\begin{tabular}{|c|c|c|c|c|c|}
\hline \multirow[t]{2}{*}{ Perfil $n^{\circ}$} & \multirow[t]{2}{*}{40} & \multirow[b]{2}{*}{ Horizonte A } & \multirow[b]{2}{*}{ Horizonte B } & \multirow[b]{2}{*}{ Horizonte C } & \multirow[b]{2}{*}{ Horizonte D } \\
\hline & & & & & \\
\hline \multirow{3}{*}{ Textura } & Arena (\%) & 41 & 48 & 54 & \\
\hline & Limo (\%) & 37 & 32 & 22 & \\
\hline & Arcilla (\%) & 22 & 20 & 24 & \\
\hline \multicolumn{2}{|c|}{ Clase textural } & Franca & Franca & Fran-Are & \\
\hline \multicolumn{2}{|l|}{ pH } & 6.1 & 5.9 & 5.2 & \\
\hline \multicolumn{2}{|c|}{ Carbonatos (\% caliza) } & 1.12 & 0.68 & ---- & \\
\hline \multicolumn{2}{|c|}{ Materia orgánica (\%) } & 3.25 & 2.58 & ---- & \\
\hline \multicolumn{2}{|c|}{ Nitrogeno total (\%) } & 1.05 & 0.86 & ---- & \\
\hline \multicolumn{2}{|c|}{ Relación C/N } & 13 & 9 & ---- & \\
\hline \multicolumn{2}{|c|}{ Fosforo (olssen ppm) } & 25 & 19 & 24 & \\
\hline \multicolumn{2}{|c|}{ Calcio (ppm) } & 958 & 856 & 789 & \\
\hline \multicolumn{2}{|c|}{ Potasio (ppm) } & 169 & 158 & 45 & \\
\hline \multicolumn{2}{|c|}{ Magnesio (ppm) } & 125 & 145 & 98 & \\
\hline \multicolumn{2}{|l|}{$\mathrm{Ca} / \mathrm{Mg}$} & 7.66 & 5.90 & 8.05 & \\
\hline \multicolumn{2}{|c|}{ Sodio (ppm) } & 15 & 13 & 12 & \\
\hline \multicolumn{2}{|c|}{ C.I.C. Meq/100g } & 6 & 5 & 4 & \\
\hline \multicolumn{2}{|c|}{ Manganeso (ppm) } & 12 & 14 & 10 & \\
\hline \multicolumn{2}{|c|}{ Hierro (ppm) } & ip & ip & ip & \\
\hline \multicolumn{2}{|c|}{ Cobre (ppm) } & ip & ip & ip & \\
\hline \multicolumn{2}{|l|}{ Zinc (ppm) } & ip & ip & ip & \\
\hline \multicolumn{2}{|l|}{ Boro (ppm) } & ip & ip & ip & \\
\hline \multicolumn{2}{|c|}{ Conductividad (dS/m) } & 1.2 & 0.9 & 0.85 & \\
\hline \multicolumn{2}{|c|}{ Observaciones } & & & & \\
\hline
\end{tabular}


ANÁLISIS DE COMPOSICIÓN DE SUELOS

Desarrollo de una aplicación informática para el cálculo de sostenimiento de taludes mediante vegetación

\begin{tabular}{|c|c|c|c|c|c|}
\hline \multirow[t]{2}{*}{ Perfil $n^{\circ}$} & \multirow[t]{2}{*}{41} & & & & \\
\hline & & Horizonte A & Horizonte B & Horizonte C & Horizonte D \\
\hline \multirow{3}{*}{ Textura } & Arena (\%) & 38 & 43 & 63 & \\
\hline & Limo (\%) & 35 & 39 & 21 & \\
\hline & Arcilla (\%) & 27 & 18 & 16 & \\
\hline \multicolumn{2}{|c|}{ Clase textural } & Franca & Franca & Fran-Are-Arc & \\
\hline \multicolumn{2}{|l|}{ pH } & 6.2 & 5.8 & 5.1 & \\
\hline \multicolumn{2}{|c|}{ Carbonatos (\% caliza) } & 2.25 & 1.56 & ---- & \\
\hline \multicolumn{2}{|c|}{ Materia orgánica (\%) } & 3.1 & 2.2 & ---- & \\
\hline \multicolumn{2}{|c|}{ Nitrogeno total (\%) } & 0.9 & 0.800 & ---- & \\
\hline \multicolumn{2}{|c|}{ Relación C/N } & 2.0 & 1.6 & ---- & \\
\hline \multicolumn{2}{|c|}{ Fosforo (olssen ppm) } & 22 & 18 & 25 & \\
\hline \multicolumn{2}{|c|}{ Calcio (ppm) } & 685 & 933 & 315 & \\
\hline \multicolumn{2}{|c|}{ Potasio (ppm) } & 154 & 144 & 98 & \\
\hline \multicolumn{2}{|c|}{ Magnesio (ppm) } & 251 & 180 & 48 & \\
\hline \multicolumn{2}{|l|}{$\mathrm{Ca} / \mathrm{Mg}$} & 2.729 & 5.18 & 6.563 & \\
\hline \multicolumn{2}{|c|}{ Sodio (ppm) } & 10 & 20 & 16 & \\
\hline \multicolumn{2}{|c|}{ C.I.C. Meq/100g } & 8 & 6 & 5 & \\
\hline \multicolumn{2}{|c|}{ Manganeso (ppm) } & 9.75 & 6.5 & 8.9 & \\
\hline \multicolumn{2}{|c|}{ Hierro (ppm) } & 0.5 & 0.3 & 0.2 & \\
\hline \multicolumn{2}{|c|}{ Cobre (ppm) } & ip & ip & ip & \\
\hline \multicolumn{2}{|l|}{ Zinc (ppm) } & ip & ip & ip & \\
\hline \multicolumn{2}{|l|}{ Boro (ppm) } & ip & ip & ip & \\
\hline \multicolumn{2}{|c|}{ Conductividad (dS/m) } & 1.1 & 1.4 & 1.3 & \\
\hline \multicolumn{2}{|c|}{ Observaciones } & & & & \\
\hline
\end{tabular}


ANÁLISIS DE COMPOSICIÓN DE SUELOS

Desarrollo de una aplicación informática para el cálculo de sostenimiento de taludes mediante vegetación

\begin{tabular}{|c|c|c|c|c|c|}
\hline \multirow[t]{2}{*}{ Perfil $n^{\circ}$} & \multirow[t]{2}{*}{42} & \multirow[b]{2}{*}{ Horizonte A } & \multirow[b]{2}{*}{ Horizonte B } & \multirow[b]{2}{*}{ Horizonte C } & \multirow[b]{2}{*}{ Horizonte D } \\
\hline & & & & & \\
\hline \multirow{3}{*}{ Textura } & Arena (\%) & 31 & & & \\
\hline & Limo (\%) & 48 & & & \\
\hline & Arcilla (\%) & 21 & & & \\
\hline \multicolumn{2}{|c|}{ Clase textural } & Franca & & & \\
\hline \multicolumn{2}{|l|}{ pH } & 5.4 & & & \\
\hline \multicolumn{2}{|c|}{ Carbonatos (\% caliza) } & 1.4 & & & \\
\hline \multicolumn{2}{|c|}{ Materia orgánica (\%) } & 2.9 & & & \\
\hline \multicolumn{2}{|c|}{ Nitrogeno total (\%) } & 0.25 & & & \\
\hline \multicolumn{2}{|c|}{ Relación C/N } & 11 & & & \\
\hline \multicolumn{2}{|c|}{ Fosforo (olssen ppm) } & 15 & & & \\
\hline \multicolumn{2}{|c|}{ Calcio (ppm) } & 422 & & & \\
\hline \multicolumn{2}{|c|}{ Potasio (ppm) } & 80 & & & \\
\hline \multicolumn{2}{|c|}{ Magnesio (ppm) } & 92 & & & \\
\hline \multicolumn{2}{|l|}{$\mathrm{Ca} / \mathrm{Mg}$} & 4.587 & & & \\
\hline \multicolumn{2}{|l|}{ Sodio (ppm) } & 11 & & & \\
\hline \multicolumn{2}{|c|}{ C.I.C. Meq/100g } & 10 & & & \\
\hline \multicolumn{2}{|c|}{ Manganeso (ppm) } & ip & & & \\
\hline \multicolumn{2}{|c|}{ Hierro (ppm) } & ip & & & \\
\hline \multicolumn{2}{|c|}{ Cobre (ppm) } & ip & & & \\
\hline \multicolumn{2}{|l|}{ Zinc (ppm) } & ip & & & \\
\hline \multicolumn{2}{|l|}{ Boro (ppm) } & ip & & & \\
\hline \multicolumn{2}{|c|}{ Conductividad (dS/m) } & 1.1 & & & \\
\hline \multicolumn{2}{|c|}{ Observaciones } & & & & \\
\hline
\end{tabular}


ANÁLISIS DE COMPOSICIÓN DE SUELOS

Desarrollo de una aplicación informática para el cálculo de sostenimiento de taludes mediante vegetación

\begin{tabular}{|c|c|c|c|c|c|}
\hline \multirow[t]{2}{*}{ Perfil $n^{\circ}$} & \multirow[t]{2}{*}{43} & & & & \\
\hline & & Horizonte A & Horizonte B & Horizonte C & Horizonte D \\
\hline \multirow{3}{*}{ Textura } & Arena (\%) & 50 & 62 & & \\
\hline & Limo (\%) & 33 & 27 & & \\
\hline & Arcilla (\%) & 17 & 11 & & \\
\hline \multicolumn{2}{|c|}{ Clase textural } & Franca & Fran-Aren & & \\
\hline \multicolumn{2}{|l|}{ pH } & 5.8 & 5.5 & & \\
\hline \multicolumn{2}{|c|}{ Carbonatos (\% caliza) } & 1.6 & 1.1 & & \\
\hline \multicolumn{2}{|c|}{ Materia orgánica (\%) } & 2.8 & 4.6 & & \\
\hline \multicolumn{2}{|c|}{ Nitrogeno total $(\%)$} & 0.04 & 0.291 & & \\
\hline \multicolumn{2}{|c|}{ Relación C/N } & 6 & 9 & & \\
\hline \multicolumn{2}{|c|}{ Fosforo (olssen ppm) } & 14 & 12 & & \\
\hline \multicolumn{2}{|c|}{ Calcio (ppm) } & 735 & 250 & & \\
\hline \multicolumn{2}{|c|}{ Potasio (ppm) } & 70 & 60 & & \\
\hline \multicolumn{2}{|c|}{ Magnesio (ppm) } & 88 & 100 & & \\
\hline \multicolumn{2}{|l|}{$\mathrm{Ca} / \mathrm{Mg}$} & 8.35 & 2.50 & & \\
\hline \multicolumn{2}{|c|}{ Sodio (ppm) } & 27 & 20 & & \\
\hline \multicolumn{2}{|c|}{ C.I.C. Meq/100g } & 7 & 6 & & \\
\hline \multicolumn{2}{|c|}{ Manganeso (ppm) } & ip & 13 & & \\
\hline \multicolumn{2}{|c|}{ Hierro (ppm) } & ip & ip & & \\
\hline \multicolumn{2}{|c|}{ Cobre (ppm) } & ip & ip & & \\
\hline \multicolumn{2}{|l|}{ Zinc (ppm) } & ip & ip & & \\
\hline \multicolumn{2}{|l|}{ Boro (ppm) } & ip & ip & & \\
\hline \multicolumn{2}{|c|}{ Conductividad (dS/m) } & 0.95 & 0.8 & & \\
\hline \multicolumn{2}{|c|}{ Observaciones } & & & & \\
\hline
\end{tabular}


ANÁLISIS DE COMPOSICIÓN DE SUELOS

Desarrollo de una aplicación informática para el cálculo de sostenimiento de taludes mediante vegetación

\begin{tabular}{|c|c|c|c|c|c|}
\hline \multirow[t]{2}{*}{ Perfil $n^{\circ}$} & \multirow[t]{2}{*}{44} & \multirow[b]{2}{*}{ Horizonte A } & \multirow[b]{2}{*}{ Horizonte B } & \multirow[b]{2}{*}{ Horizonte C } & \multirow[b]{2}{*}{ Horizonte D } \\
\hline & & & & & \\
\hline \multirow{3}{*}{ Textura } & Arena (\%) & 28 & & & \\
\hline & Limo (\%) & 52 & & & \\
\hline & Arcilla (\%) & 20 & & & \\
\hline \multicolumn{2}{|c|}{ Clase textural } & Fran-lim & & & \\
\hline \multicolumn{2}{|l|}{ pH } & 5.85 & & & \\
\hline \multicolumn{2}{|c|}{ Carbonatos ( $\%$ caliza) } & 0.8 & & & \\
\hline \multicolumn{2}{|c|}{ Materia orgánica (\%) } & 1.8 & & & \\
\hline \multicolumn{2}{|c|}{ Nitrogeno total (\%) } & 0.08 & & & \\
\hline \multicolumn{2}{|c|}{ Relación C/N } & 6 & & & \\
\hline \multicolumn{2}{|c|}{ Fosforo (olssen ppm) } & 10 & & & \\
\hline \multicolumn{2}{|c|}{ Calcio (ppm) } & 525 & & & \\
\hline \multicolumn{2}{|c|}{ Potasio (ppm) } & 72 & & & \\
\hline \multicolumn{2}{|c|}{ Magnesio (ppm) } & 85 & & & \\
\hline \multicolumn{2}{|l|}{$\mathrm{Ca} / \mathrm{Mg}$} & 6.18 & & & \\
\hline \multicolumn{2}{|c|}{ Sodio (ppm) } & 22 & & & \\
\hline \multicolumn{2}{|c|}{ C.I.C. Meq/100g } & 7 & & & \\
\hline \multicolumn{2}{|c|}{ Manganeso (ppm) } & 9 & & & \\
\hline \multicolumn{2}{|c|}{ Hierro (ppm) } & ip & & & \\
\hline \multicolumn{2}{|c|}{ Cobre (ppm) } & ip & & & \\
\hline \multicolumn{2}{|l|}{ Zinc (ppm) } & ip & & & \\
\hline \multicolumn{2}{|l|}{ Boro (ppm) } & ip & & & \\
\hline \multicolumn{2}{|c|}{ Conductividad (dS/m) } & 2.05 & & & \\
\hline \multicolumn{2}{|c|}{ Observaciones } & & & & \\
\hline
\end{tabular}


ANÁLISIS DE COMPOSICIÓN DE SUELOS

Desarrollo de una aplicación informática para el cálculo de sostenimiento de taludes mediante vegetación

\begin{tabular}{|c|c|c|c|c|c|}
\hline \multirow[t]{2}{*}{ Perfil $n^{\circ}$} & \multirow[t]{2}{*}{45} & \multirow[b]{2}{*}{ Horizonte A } & \multirow[b]{2}{*}{ Horizonte B } & \multirow[b]{2}{*}{ Horizonte C } & \multirow[b]{2}{*}{ Horizonte D } \\
\hline & & & & & \\
\hline \multirow{3}{*}{ Textura } & Arena (\%) & 33 & 41 & 55 & \\
\hline & Limo (\%) & 45 & 38 & 32 & \\
\hline & Arcilla (\%) & 22 & 21 & 13 & 100 \\
\hline \multicolumn{2}{|c|}{ Clase textural } & Franca & Franca & Fran-Aren & \\
\hline \multicolumn{2}{|l|}{ pH } & 5.8 & 5.7 & 4.09 & \\
\hline \multicolumn{2}{|c|}{ Carbonatos ( $\%$ caliza) } & 4.2 & 0.1 & ---- & \\
\hline \multicolumn{2}{|c|}{ Materia orgánica (\%) } & 1.2 & 1.2 & --- & \\
\hline \multicolumn{2}{|c|}{ Nitrogeno total (\%) } & 0.03 & 0.068 & ---- & \\
\hline \multicolumn{2}{|c|}{ Relación C/N } & 5 & 10 & --- & \\
\hline \multicolumn{2}{|c|}{ Fosforo (olssen ppm) } & 10 & 4.2 & 5 & \\
\hline \multicolumn{2}{|c|}{ Calcio (ppm) } & 322 & 40 & 598 & \\
\hline \multicolumn{2}{|c|}{ Magnesio (ppm) } & 128 & 30 & 135 & \\
\hline \multicolumn{2}{|l|}{$\mathrm{Ca} / \mathrm{Mg}$} & 75 & 1.33 & 92 & \\
\hline \multicolumn{2}{|c|}{ Potasio (ppm) } & 4.29 & 75 & 6.50 & \\
\hline \multicolumn{2}{|c|}{ Sodio (ppm) } & 22 & 23 & 19 & \\
\hline \multicolumn{2}{|c|}{ C.I.C. Meq/100g } & 11 & 4 & 8 & \\
\hline \multicolumn{2}{|c|}{ Manganeso (ppm) } & 19 & 12 & 21 & \\
\hline \multicolumn{2}{|c|}{ Hierro (ppm) } & 1.1 & 1.53 & 0.8 & \\
\hline \multicolumn{2}{|c|}{ Cobre (ppm) } & 0.5 & 0.02 & 0.02 & \\
\hline \multicolumn{2}{|l|}{ Zinc (ppm) } & 1.1 & ip & 0.09 & \\
\hline \multicolumn{2}{|l|}{ Boro (ppm) } & 0.07 & ip & 0.2 & \\
\hline \multicolumn{2}{|c|}{ Conductividad (dS/m) } & 0.9 & 0.03 & 2.1 & \\
\hline \multicolumn{2}{|c|}{ Observaciones } & & & & \\
\hline
\end{tabular}


ANÁLISIS DE COMPOSICIÓN DE SUELOS

Desarrollo de una aplicación informática para el cálculo de sostenimiento de taludes mediante vegetación

\begin{tabular}{|c|c|c|c|c|c|}
\hline \multirow[t]{2}{*}{ Perfil $n^{\circ}$} & \multirow[t]{2}{*}{46} & \multirow[b]{2}{*}{ Horizonte A } & \multirow[b]{2}{*}{ Horizonte B } & \multirow[b]{2}{*}{ Horizonte C } & \multirow[b]{2}{*}{ Horizonte D } \\
\hline & & & & & \\
\hline \multirow{3}{*}{ Textura } & Arena (\%) & 46 & 48 & & \\
\hline & Limo (\%) & 22 & 18 & & \\
\hline & Arcilla (\%) & 32 & 34 & & \\
\hline \multicolumn{2}{|c|}{ Clase textural } & Franca & Fra-Aren-Lim & & \\
\hline \multicolumn{2}{|l|}{ pH } & 7.2 & 6.2 & & \\
\hline \multicolumn{2}{|c|}{ Carbonatos (\% caliza) } & 20 & 12 & & \\
\hline \multicolumn{2}{|c|}{ Materia orgánica (\%) } & 6.58 & 1.3 & & \\
\hline \multicolumn{2}{|c|}{ Nitrogeno total (\%) } & 0.469 & 0.05 & & \\
\hline \multicolumn{2}{|c|}{ Relación C/N } & 8 & 6 & & \\
\hline \multicolumn{2}{|c|}{ Fosforo (olssen ppm) } & 15 & 3 & & \\
\hline \multicolumn{2}{|c|}{ Calcio (ppm) } & 135 & 99 & & \\
\hline \multicolumn{2}{|c|}{ Potasio (ppm) } & 60 & 65 & & \\
\hline \multicolumn{2}{|c|}{ Magnesio (ppm) } & 22 & 25 & & \\
\hline \multicolumn{2}{|l|}{$\mathrm{Ca} / \mathrm{Mg}$} & 6.14 & 3.96 & & \\
\hline \multicolumn{2}{|c|}{ Sodio (ppm) } & 0.5 & 0.06 & & \\
\hline \multicolumn{2}{|c|}{ C.I.C. Meq/100g } & 14.25 & 11 & & \\
\hline \multicolumn{2}{|c|}{ Manganeso (ppm) } & 16 & 11 & & \\
\hline \multicolumn{2}{|c|}{ Hierro (ppm) } & 1.6 & ip & & \\
\hline \multicolumn{2}{|c|}{ Cobre (ppm) } & 1.25 & ip & & \\
\hline \multicolumn{2}{|l|}{ Zinc (ppm) } & 2.75 & ip & & \\
\hline \multicolumn{2}{|l|}{ Boro (ppm) } & 0.1 & ip & & \\
\hline \multicolumn{2}{|c|}{ Conductividad (dS/m) } & 3.2 & 2.1 & & \\
\hline \multicolumn{2}{|c|}{ Observaciones } & & & & \\
\hline
\end{tabular}


ANÁLISIS DE COMPOSICIÓN DE SUELOS

Desarrollo de una aplicación informática para el cálculo de sostenimiento de taludes mediante vegetación

\begin{tabular}{|c|c|c|c|c|c|}
\hline \multirow[t]{2}{*}{ Perfil $n^{\circ}$} & \multirow[t]{2}{*}{47} & \multirow[b]{2}{*}{ Horizonte A } & \multirow[b]{2}{*}{ Horizonte B } & \multirow[b]{2}{*}{ Horizonte C } & \multirow[b]{2}{*}{ Horizonte D } \\
\hline & & & & & \\
\hline \multirow{3}{*}{ Textura } & Arena (\%) & 27 & 41 & 38 & \\
\hline & Limo (\%) & 66 & 41 & 45 & \\
\hline & Arcilla (\%) & 7 & 18 & 17 & \\
\hline \multicolumn{2}{|c|}{ Clase textural } & Fran-Lim & Franca & Franca & \\
\hline \multicolumn{2}{|l|}{ pH } & 5.8 & 5.2 & 5 & \\
\hline \multicolumn{2}{|c|}{ Carbonatos ( $\%$ caliza) } & 6.01 & 5 & 4.9 & \\
\hline \multicolumn{2}{|c|}{ Materia orgánica (\%) } & 3.2 & 2.1 & ---- & \\
\hline \multicolumn{2}{|c|}{ Nitrogeno total $(\%)$} & 0.18 & 0.25 & ---- & \\
\hline \multicolumn{2}{|c|}{ Relación C/N } & 10 & 5 & & \\
\hline \multicolumn{2}{|c|}{ Fosforo (olssen ppm) } & 15 & 19 & 6 & \\
\hline \multicolumn{2}{|c|}{ Calcio (ppm) } & 825 & 921 & 125 & \\
\hline \multicolumn{2}{|c|}{ Potasio (ppm) } & 22 & 25 & 13 & \\
\hline \multicolumn{2}{|c|}{ Magnesio (ppm) } & 135 & 159 & 56 & \\
\hline \multicolumn{2}{|l|}{$\mathrm{Ca} / \mathrm{Mg}$} & 6.11 & 5.79 & 2.23 & \\
\hline \multicolumn{2}{|c|}{ Sodio (ppm) } & 38 & 22 & 25 & \\
\hline \multicolumn{2}{|c|}{ C.I.C. Meq/100g } & 14 & 16 & 20 & \\
\hline \multicolumn{2}{|c|}{ Manganeso (ppm) } & ip & ip & ip & \\
\hline \multicolumn{2}{|c|}{ Hierro (ppm) } & ip & ip & ip & \\
\hline \multicolumn{2}{|c|}{ Cobre (ppm) } & ip & ip & ip & \\
\hline \multicolumn{2}{|l|}{ Zinc (ppm) } & ip & ip & ip & \\
\hline \multicolumn{2}{|l|}{ Boro (ppm) } & ip & ip & ip & \\
\hline \multicolumn{2}{|c|}{ Conductividad (dS/m) } & 1.1 & 1.5 & 1.6 & \\
\hline \multicolumn{2}{|c|}{ Observaciones } & & & & \\
\hline
\end{tabular}


ANÁLISIS DE COMPOSICIÓN DE SUELOS

Desarrollo de una aplicación informática para el cálculo de sostenimiento de taludes mediante vegetación

\begin{tabular}{|c|c|c|c|c|c|}
\hline \multirow[t]{2}{*}{ Perfil $n^{\circ}$} & \multirow[t]{2}{*}{48} & \multirow[b]{2}{*}{ Horizonte A } & \multirow[b]{2}{*}{ Horizonte B } & \multirow[b]{2}{*}{ Horizonte C } & \multirow[b]{2}{*}{ Horizonte D } \\
\hline & & & & & \\
\hline \multirow{3}{*}{ Textura } & Arena (\%) & 41 & & & \\
\hline & Limo (\%) & 42 & & & \\
\hline & Arcilla (\%) & 17 & & & \\
\hline \multicolumn{2}{|c|}{ Clase textural } & Franca & & & \\
\hline \multicolumn{2}{|l|}{ pH } & 5.6 & & & \\
\hline \multicolumn{2}{|c|}{ Carbonatos ( $\%$ caliza) } & 1.3 & & & \\
\hline \multicolumn{2}{|c|}{ Materia orgánica (\%) } & 2.35 & & & \\
\hline \multicolumn{2}{|c|}{ Nitrogeno total (\%) } & 0.12 & & & \\
\hline \multicolumn{2}{|c|}{ Relación C/N } & 7 & & & \\
\hline \multicolumn{2}{|c|}{ Fosforo (olssen ppm) } & 12 & & & \\
\hline \multicolumn{2}{|c|}{ Calcio (ppm) } & 475 & & & \\
\hline \multicolumn{2}{|c|}{ Potasio (ppm) } & 83 & & & \\
\hline \multicolumn{2}{|c|}{ Magnesio (ppm) } & 69 & & & \\
\hline \multicolumn{2}{|l|}{$\mathrm{Ca} / \mathrm{Mg}$} & 6.88 & & & \\
\hline \multicolumn{2}{|c|}{ Sodio (ppm) } & 15 & & & \\
\hline \multicolumn{2}{|c|}{ C.I.C. Meq/100g } & 6 & & & \\
\hline \multicolumn{2}{|c|}{ Manganeso (ppm) } & 8 & & & \\
\hline \multicolumn{2}{|c|}{ Hierro (ppm) } & ip & & & \\
\hline \multicolumn{2}{|c|}{ Cobre (ppm) } & ip & & & \\
\hline \multicolumn{2}{|l|}{ Zinc (ppm) } & ip & & & \\
\hline \multicolumn{2}{|l|}{ Boro (ppm) } & 0.2 & & & \\
\hline \multicolumn{2}{|c|}{ Conductividad (dS/m) } & 1.83 & & & \\
\hline \multicolumn{2}{|c|}{ Observaciones } & & & & \\
\hline
\end{tabular}


ANÁLISIS DE COMPOSICIÓN DE SUELOS

Desarrollo de una aplicación informática para el cálculo de sostenimiento de taludes mediante vegetación

\begin{tabular}{|c|c|c|c|c|c|}
\hline \multirow[t]{2}{*}{ Perfil $n^{\circ}$} & \multirow[t]{2}{*}{49} & & & & \\
\hline & & Horizonte A & Horizonte B & Horizonte C & Horizonte D \\
\hline \multirow{3}{*}{ Textura } & Arena (\%) & 55 & 39 & 10 & \\
\hline & Limo (\%) & 23 & 35 & 55 & \\
\hline & Arcilla (\%) & 22 & 26 & 35 & \\
\hline \multicolumn{2}{|c|}{ Clase textural } & Fran-Aren & Franca & Fran-Arc-Lim & \\
\hline \multicolumn{2}{|l|}{ pH } & 5.2 & 5.9 & 5.6 & \\
\hline \multicolumn{2}{|c|}{ Carbonatos ( $\%$ caliza) } & 2.3 & 10 & --- & \\
\hline \multicolumn{2}{|c|}{ Materia orgánica (\%) } & 1.2 & 2.5 & --- & \\
\hline \multicolumn{2}{|c|}{ Nitrogeno total $(\%)$} & 0.08 & 0.5 & --- & \\
\hline \multicolumn{2}{|c|}{ Relación C/N } & 8 & 10 & --- & \\
\hline \multicolumn{2}{|c|}{ Fosforo (olssen ppm) } & 11 & 13 & 8 & \\
\hline \multicolumn{2}{|c|}{ Calcio (ppm) } & 858 & 852 & 369 & \\
\hline \multicolumn{2}{|c|}{ Potasio (ppm) } & 83 & 203 & 153 & \\
\hline \multicolumn{2}{|c|}{ Magnesio (ppm) } & 105 & 89.00 & 53 & \\
\hline \multicolumn{2}{|l|}{$\mathrm{Ca} / \mathrm{Mg}$} & 8.17 & 9.57 & 6.96 & \\
\hline \multicolumn{2}{|c|}{ Sodio (ppm) } & 33 & 33 & 43 & \\
\hline \multicolumn{2}{|c|}{ C.I.C. Meq/100g } & 9 & 11 & 20 & \\
\hline \multicolumn{2}{|c|}{ Manganeso (ppm) } & 15 & 16 & 10 & \\
\hline \multicolumn{2}{|c|}{ Hierro (ppm) } & 1.2 & 0.9 & 4 & \\
\hline \multicolumn{2}{|c|}{ Cobre (ppm) } & 0.7 & 0.3 & ip & \\
\hline \multicolumn{2}{|l|}{ Zinc (ppm) } & 0.4 & 1.3 & ip & \\
\hline \multicolumn{2}{|l|}{ Boro (ppm) } & 0.03 & ip & 0.1 & \\
\hline \multicolumn{2}{|c|}{ Conductividad (dS/m) } & 0.9 & 0.9 & 1.4 & \\
\hline \multicolumn{2}{|c|}{ Observaciones } & & & & \\
\hline
\end{tabular}


ANÁLISIS DE COMPOSICIÓN DE SUELOS

Desarrollo de una aplicación informática para el cálculo de sostenimiento de taludes mediante vegetación

\begin{tabular}{|c|c|c|c|c|c|}
\hline \multirow[t]{2}{*}{ Perfil $n^{\circ}$} & \multirow[t]{2}{*}{50} & \multirow[b]{2}{*}{ Horizonte A } & \multirow[b]{2}{*}{ Horizonte B } & \multirow[b]{2}{*}{ Horizonte C } & \multirow[b]{2}{*}{ Horizonte D } \\
\hline & & & & & \\
\hline \multirow{3}{*}{ Textura } & Arena (\%) & 44 & & & \\
\hline & Limo (\%) & 38 & & & \\
\hline & Arcilla (\%) & 18 & & & \\
\hline \multicolumn{2}{|c|}{ Clase textural } & Franca & & & \\
\hline \multicolumn{2}{|l|}{ pH } & 5.1 & & & \\
\hline \multicolumn{2}{|c|}{ Carbonatos (\% caliza) } & 0.95 & & & \\
\hline \multicolumn{2}{|c|}{ Materia orgánica (\%) } & 2.93 & & & \\
\hline \multicolumn{2}{|c|}{ Nitrogeno total (\%) } & 0.09 & & & \\
\hline \multicolumn{2}{|c|}{ Relación C/N } & 5.8 & & & \\
\hline \multicolumn{2}{|c|}{ Fosforo (olssen ppm) } & 9 & & & \\
\hline \multicolumn{2}{|c|}{ Calcio (ppm) } & 495 & & & \\
\hline \multicolumn{2}{|c|}{ Potasio (ppm) } & 88 & & & \\
\hline \multicolumn{2}{|c|}{ Magnesio (ppm) } & 79 & & & \\
\hline \multicolumn{2}{|l|}{$\mathrm{Ca} / \mathrm{Mg}$} & 6.27 & & & \\
\hline \multicolumn{2}{|c|}{ Sodio (ppm) } & 35 & & & \\
\hline \multicolumn{2}{|c|}{ C.I.C. Meq/100g } & 8 & & & \\
\hline \multicolumn{2}{|c|}{ Manganeso (ppm) } & 11 & & & \\
\hline \multicolumn{2}{|c|}{ Hierro (ppm) } & ip & & & \\
\hline \multicolumn{2}{|c|}{ Cobre (ppm) } & ip & & & \\
\hline \multicolumn{2}{|l|}{ Zinc (ppm) } & ip & & & \\
\hline \multicolumn{2}{|l|}{ Boro (ppm) } & 0.3 & & & \\
\hline \multicolumn{2}{|c|}{ Conductividad (dS/m) } & 1.35 & & & \\
\hline \multicolumn{2}{|c|}{ Observaciones } & & & & \\
\hline
\end{tabular}


ANÁLISIS DE COMPOSICIÓN DE SUELOS

Desarrollo de una aplicación informática para el cálculo de sostenimiento de taludes mediante vegetación

\begin{tabular}{|c|c|c|c|c|c|}
\hline \multirow[t]{2}{*}{ Perfil $n^{\circ}$} & \multirow[t]{2}{*}{51} & & & & \\
\hline & & Horizonte A & Horizonte B & Horizonte $\mathrm{C}$ & Horizonte D \\
\hline \multirow{3}{*}{ Textura } & Arena (\%) & 43 & & & \\
\hline & Limo (\%) & 33 & & & \\
\hline & Arcilla (\%) & 24 & & & \\
\hline \multicolumn{2}{|c|}{ Clase textural } & Franca & & & \\
\hline \multicolumn{2}{|l|}{ pH } & 5.7 & & & \\
\hline \multicolumn{2}{|c|}{ Carbonatos ( $\%$ caliza) } & 1.3 & & & \\
\hline \multicolumn{2}{|c|}{ Materia orgánica (\%) } & 2.6 & & & \\
\hline \multicolumn{2}{|c|}{ Nitrogeno total (\%) } & 0.05 & & & \\
\hline \multicolumn{2}{|c|}{ Relación C/N } & 6 & & & \\
\hline \multicolumn{2}{|c|}{ Fosforo (olssen ppm) } & 10 & & & \\
\hline \multicolumn{2}{|c|}{ Calcio (ppm) } & 623 & & & \\
\hline \multicolumn{2}{|c|}{ Potasio (ppm) } & 69 & & & \\
\hline \multicolumn{2}{|c|}{ Magnesio (ppm) } & 102 & & & \\
\hline \multicolumn{2}{|l|}{$\mathrm{Ca} / \mathrm{Mg}$} & 6.108 & & & \\
\hline \multicolumn{2}{|c|}{ Sodio (ppm) } & 23 & & & \\
\hline \multicolumn{2}{|c|}{ C.I.C. Meq/100g } & 12 & & & \\
\hline \multicolumn{2}{|c|}{ Manganeso (ppm) } & ip & & & \\
\hline \multicolumn{2}{|c|}{ Hierro (ppm) } & ip & & & \\
\hline \multicolumn{2}{|c|}{ Cobre (ppm) } & ip & & & \\
\hline \multicolumn{2}{|l|}{ Zinc (ppm) } & ip & & & \\
\hline \multicolumn{2}{|l|}{ Boro (ppm) } & ip & & & \\
\hline \multicolumn{2}{|c|}{ Conductividad (dS/m) } & 1 & & & \\
\hline \multicolumn{2}{|c|}{ Observaciones } & & & & \\
\hline
\end{tabular}


ANÁLISIS DE COMPOSICIÓN DE SUELOS

Desarrollo de una aplicación informática para el cálculo de sostenimiento de taludes mediante vegetación

\begin{tabular}{|c|c|c|c|c|c|}
\hline \multirow[t]{2}{*}{ Perfil $n^{\circ}$} & \multirow[t]{2}{*}{52} & & & & \\
\hline & & Horizonte A & Horizonte B & Horizonte C & Horizonte D \\
\hline \multirow{3}{*}{ Textura } & Arena (\%) & 43 & & & \\
\hline & Limo (\%) & 31 & & & \\
\hline & Arcilla (\%) & 26 & & & \\
\hline \multicolumn{2}{|c|}{ Clase textural } & Franca & & & \\
\hline \multicolumn{2}{|l|}{ pH } & 5.2 & & & \\
\hline \multicolumn{2}{|c|}{ Carbonatos (\% caliza) } & 1.5 & & & \\
\hline \multicolumn{2}{|c|}{ Materia orgánica (\%) } & 309 & & & \\
\hline \multicolumn{2}{|c|}{ Nitrogeno total (\%) } & 0.06 & & & \\
\hline \multicolumn{2}{|c|}{ Relación C/N } & 7 & & & \\
\hline \multicolumn{2}{|c|}{ Fosforo (olssen ppm) } & 12 & & & \\
\hline \multicolumn{2}{|c|}{ Calcio (ppm) } & 584 & & & \\
\hline \multicolumn{2}{|c|}{ Potasio (ppm) } & 73 & & & \\
\hline \multicolumn{2}{|c|}{ Magnesio (ppm) } & 98 & & & \\
\hline \multicolumn{2}{|l|}{$\mathrm{Ca} / \mathrm{Mg}$} & 0.745 & & & \\
\hline \multicolumn{2}{|l|}{ Sodio (ppm) } & 29 & & & \\
\hline \multicolumn{2}{|c|}{ C.I.C. Meq/100g } & 15 & & & \\
\hline \multicolumn{2}{|c|}{ Manganeso (ppm) } & 12 & & & \\
\hline \multicolumn{2}{|c|}{ Hierro (ppm) } & ip & & & \\
\hline \multicolumn{2}{|c|}{ Cobre (ppm) } & ip & & & \\
\hline \multicolumn{2}{|l|}{ Zinc (ppm) } & ip & & & \\
\hline \multicolumn{2}{|l|}{ Boro (ppm) } & ip & & & \\
\hline \multicolumn{2}{|c|}{ Conductividad (dS/m) } & 1.05 & & & \\
\hline \multicolumn{2}{|c|}{ Observaciones } & & & & \\
\hline
\end{tabular}


ANÁLISIS DE COMPOSICIÓN DE SUELOS

Desarrollo de una aplicación informática para el cálculo de sostenimiento de taludes mediante vegetación

\begin{tabular}{|c|c|c|c|c|c|}
\hline \multirow[t]{2}{*}{ Perfil $n^{\circ}$} & \multirow[t]{2}{*}{53} & \multirow[b]{2}{*}{ Horizonte A } & \multirow[b]{2}{*}{ Horizonte B } & \multirow[b]{2}{*}{ Horizonte C } & \multirow[b]{2}{*}{ Horizonte D } \\
\hline & & & & & \\
\hline \multirow{3}{*}{ Textura } & Arena (\%) & 50 & & & \\
\hline & Limo (\%) & 33 & & & \\
\hline & Arcilla (\%) & 17 & & & \\
\hline \multicolumn{2}{|c|}{ Clase textural } & Franca & & & \\
\hline \multicolumn{2}{|l|}{ pH } & 5.8 & & & \\
\hline \multicolumn{2}{|c|}{ Carbonatos (\% caliza) } & 1.6 & & & \\
\hline \multicolumn{2}{|c|}{ Materia orgánica (\%) } & 2.8 & & & \\
\hline \multicolumn{2}{|c|}{ Nitrogeno total (\%) } & 0.04 & & & \\
\hline \multicolumn{2}{|c|}{ Relación C/N } & 6 & & & \\
\hline \multicolumn{2}{|c|}{ Fosforo (olssen ppm) } & 14 & & & \\
\hline \multicolumn{2}{|c|}{ Calcio (ppm) } & 735 & & & \\
\hline \multicolumn{2}{|c|}{ Potasio (ppm) } & 70 & & & \\
\hline \multicolumn{2}{|c|}{ Magnesio (ppm) } & 88 & & & \\
\hline \multicolumn{2}{|l|}{$\mathrm{Ca} / \mathrm{Mg}$} & 8.35 & & & \\
\hline \multicolumn{2}{|c|}{ Sodio (ppm) } & 27 & & & \\
\hline \multicolumn{2}{|c|}{ C.I.C. Meq/100g } & 7 & & & \\
\hline \multicolumn{2}{|c|}{ Manganeso (ppm) } & ip & & & \\
\hline \multicolumn{2}{|c|}{ Hierro (ppm) } & ip & & & \\
\hline \multicolumn{2}{|c|}{ Cobre (ppm) } & ip & & & \\
\hline \multicolumn{2}{|l|}{ Zinc (ppm) } & ip & & & \\
\hline \multicolumn{2}{|l|}{ Boro (ppm) } & ip & & & \\
\hline \multicolumn{2}{|c|}{ Conductividad (dS/m) } & 0.95 & & & \\
\hline \multicolumn{2}{|c|}{ Observaciones } & & & & \\
\hline
\end{tabular}


ANÁLISIS DE COMPOSICIÓN DE SUELOS

Desarrollo de una aplicación informática para el cálculo de sostenimiento de taludes mediante vegetación

\begin{tabular}{|c|c|c|c|c|c|}
\hline \multirow[t]{2}{*}{ Perfil $n^{\circ}$} & \multirow[t]{2}{*}{54} & & & & \\
\hline & & Horizonte A & Horizonte B & Horizonte C & Horizonte D \\
\hline \multirow{3}{*}{ Textura } & Arena (\%) & 44 & & & \\
\hline & Limo (\%) & 33 & & & \\
\hline & Arcilla (\%) & 23 & & & \\
\hline \multicolumn{2}{|c|}{ Clase textural } & Franca & & & \\
\hline \multicolumn{2}{|l|}{ pH } & 5.3 & & & \\
\hline \multicolumn{2}{|c|}{ Carbonatos (\% caliza) } & 0.9 & & & \\
\hline \multicolumn{2}{|c|}{ Materia orgánica (\%) } & 1.7 & & & \\
\hline \multicolumn{2}{|c|}{ Nitrogeno total (\%) } & 0.08 & & & \\
\hline \multicolumn{2}{|c|}{ Relación C/N } & 7 & & & \\
\hline \multicolumn{2}{|c|}{ Fosforo (olssen ppm) } & 12 & & & \\
\hline \multicolumn{2}{|c|}{ Calcio (ppm) } & 823 & & & \\
\hline \multicolumn{2}{|c|}{ Potasio (ppm) } & 81 & & & \\
\hline \multicolumn{2}{|c|}{ Magnesio (ppm) } & 105 & & & \\
\hline \multicolumn{2}{|l|}{$\mathrm{Ca} / \mathrm{Mg}$} & 7.84 & & & \\
\hline \multicolumn{2}{|c|}{ Sodio (ppm) } & 25 & & & \\
\hline \multicolumn{2}{|c|}{ C.I.C. Meq/100g } & 8 & & & \\
\hline \multicolumn{2}{|c|}{ Manganeso (ppm) } & ip & & & \\
\hline \multicolumn{2}{|c|}{ Hierro (ppm) } & ip & & & \\
\hline \multicolumn{2}{|c|}{ Cobre (ppm) } & ip & & & \\
\hline \multicolumn{2}{|l|}{ Zinc (ppm) } & ip & & & \\
\hline \multicolumn{2}{|l|}{ Boro (ppm) } & ip & & & \\
\hline \multicolumn{2}{|c|}{ Conductividad (dS/m) } & 0.88 & & & \\
\hline \multicolumn{2}{|c|}{ Observaciones } & & & & \\
\hline
\end{tabular}


ANÁLISIS DE COMPOSICIÓN DE SUELOS

Desarrollo de una aplicación informática para el cálculo de sostenimiento de taludes mediante vegetación

\begin{tabular}{|c|c|c|c|c|c|}
\hline \multirow[t]{2}{*}{ Perfil $n^{\circ}$} & \multirow[t]{2}{*}{55} & \multirow[b]{2}{*}{ Horizonte A } & \multirow[b]{2}{*}{ Horizonte B } & \multirow[b]{2}{*}{ Horizonte C } & \multirow[b]{2}{*}{ Horizonte D } \\
\hline & & & & & \\
\hline \multirow{3}{*}{ Textura } & Arena (\%) & 55 & & & \\
\hline & Limo (\%) & 29 & & & \\
\hline & Arcilla (\%) & 16 & 100 & 100 & 100 \\
\hline \multicolumn{2}{|c|}{ Clase textural } & Fran-Aren & & & \\
\hline \multicolumn{2}{|l|}{ pH } & 5.8 & 5.7 & 4.5 & \\
\hline \multicolumn{2}{|c|}{ Carbonatos ( $\%$ caliza) } & 0.9 & 0.1 & --- & \\
\hline \multicolumn{2}{|c|}{ Materia orgánica (\%) } & 2.55 & 1.2 & ---- & \\
\hline \multicolumn{2}{|c|}{ Nitrogeno total $(\%)$} & 0.162 & 0.068 & --- & \\
\hline \multicolumn{2}{|c|}{ Relación C/N } & 9 & 10 & ---- & \\
\hline \multicolumn{2}{|c|}{ Fosforo (olssen ppm) } & 12 & 4.2 & 2.3 & \\
\hline \multicolumn{2}{|c|}{ Calcio (ppm) } & 321 & 322 & 152 & \\
\hline \multicolumn{2}{|c|}{ Magnesio (ppm) } & 95 & 128 & 69 & \\
\hline \multicolumn{2}{|l|}{$\mathrm{Ca} / \mathrm{Mg}$} & 3.38 & 2.52 & 2.20 & \\
\hline \multicolumn{2}{|c|}{ Potasio (ppm) } & 30 & 75 & 21 & \\
\hline \multicolumn{2}{|c|}{ Sodio (ppm) } & 10 & 22 & 11 & \\
\hline \multicolumn{2}{|c|}{ C.I.C. Meq/100g } & ip & ip & ip & \\
\hline \multicolumn{2}{|c|}{ Manganeso (ppm) } & ip & ip & ip & \\
\hline \multicolumn{2}{|c|}{ Hierro (ppm) } & ip & ip & ip & \\
\hline \multicolumn{2}{|c|}{ Cobre (ppm) } & ip & ip & ip & \\
\hline \multicolumn{2}{|l|}{ Zinc (ppm) } & ip & ip & ip & \\
\hline \multicolumn{2}{|l|}{ Boro (ppm) } & ip & ip & ip & \\
\hline \multicolumn{2}{|c|}{ Conductividad (dS/m) } & 0.8 & 1.5 & 1.2 & \\
\hline \multicolumn{2}{|c|}{ Observaciones } & & & & \\
\hline
\end{tabular}


ANÁLISIS DE COMPOSICIÓN DE SUELOS

Desarrollo de una aplicación informática para el cálculo de sostenimiento de taludes mediante vegetación

\begin{tabular}{|c|c|c|c|c|c|}
\hline \multirow[t]{2}{*}{ Perfil $n^{\circ}$} & \multirow[t]{2}{*}{56} & & & & \\
\hline & & Horizonte A & Horizonte B & Horizonte $\mathrm{C}$ & Horizonte D \\
\hline \multirow{3}{*}{ Textura } & Arena (\%) & 44 & 54 & & \\
\hline & Limo (\%) & 42 & 33 & & \\
\hline & Arcilla (\%) & 14 & 13 & & \\
\hline \multicolumn{2}{|c|}{ Clase textural } & Franca & Fran-Aren & & \\
\hline \multicolumn{2}{|l|}{ pH } & 6.1 & 6 & & \\
\hline \multicolumn{2}{|c|}{ Carbonatos ( $\%$ caliza) } & 1.2 & 0.6 & & \\
\hline \multicolumn{2}{|c|}{ Materia orgánica (\%) } & 2.9 & 0.6 & & \\
\hline \multicolumn{2}{|c|}{ Nitrogeno total $(\%)$} & 0.3 & 0.02 & & \\
\hline \multicolumn{2}{|c|}{ Relación C/N } & 11 & 9 & & \\
\hline \multicolumn{2}{|c|}{ Fosforo (olssen ppm) } & 20 & 14 & & \\
\hline \multicolumn{2}{|c|}{ Calcio (ppm) } & 954 & 705 & & \\
\hline \multicolumn{2}{|c|}{ Potasio (ppm) } & 58 & 88 & & \\
\hline \multicolumn{2}{|c|}{ Magnesio (ppm) } & 125 & 80.10 & & \\
\hline \multicolumn{2}{|l|}{$\mathrm{Ca} / \mathrm{Mg}$} & 7.63 & 8.80 & & \\
\hline \multicolumn{2}{|c|}{ Sodio (ppm) } & 14 & 44 & & \\
\hline \multicolumn{2}{|c|}{ C.I.C. Meq/100g } & 10 & 9 & & \\
\hline \multicolumn{2}{|c|}{ Manganeso (ppm) } & 22 & 12 & & \\
\hline \multicolumn{2}{|c|}{ Hierro (ppm) } & 2.3 & 0.5 & & \\
\hline \multicolumn{2}{|c|}{ Cobre (ppm) } & 0.2 & ip & & \\
\hline \multicolumn{2}{|l|}{ Zinc (ppm) } & 1.2 & ip & & \\
\hline \multicolumn{2}{|l|}{ Boro (ppm) } & ip & ip & & \\
\hline \multicolumn{2}{|c|}{ Conductividad (dS/m) } & 1.8 & 0.78 & & \\
\hline \multicolumn{2}{|c|}{ Observaciones } & & & & \\
\hline
\end{tabular}


ANÁLISIS DE COMPOSICIÓN DE SUELOS

Desarrollo de una aplicación informática para el cálculo de sostenimiento de taludes mediante vegetación

\begin{tabular}{|c|c|c|c|c|c|}
\hline \multirow[t]{2}{*}{ Perfil $n^{\circ}$} & \multirow[t]{2}{*}{57} & & & & \\
\hline & & Horizonte A & Horizonte B & Horizonte C & Horizonte D \\
\hline \multirow{3}{*}{ Textura } & Arena (\%) & 36 & & & \\
\hline & Limo (\%) & 41 & & & \\
\hline & Arcilla (\%) & 23 & 100 & 100 & \\
\hline \multicolumn{2}{|c|}{ Clase textural } & Franca & Franca & Franca & \\
\hline \multicolumn{2}{|l|}{ pH } & 5.5 & 5.1 & 5.8 & \\
\hline \multicolumn{2}{|c|}{ Carbonatos (\% caliza) } & ip & ip & ip & \\
\hline \multicolumn{2}{|c|}{ Materia orgánica (\%) } & 1.5 & 0.5 & ----- & \\
\hline \multicolumn{2}{|c|}{ Nitrogeno total (\%) } & 0.5 & 0.2 & ---- & \\
\hline \multicolumn{2}{|c|}{ Relación C/N } & 6 & 1 & ----- & \\
\hline \multicolumn{2}{|c|}{ Fosforo (olssen ppm) } & 25 & 11 & 15 & \\
\hline \multicolumn{2}{|c|}{ Calcio (ppm) } & 89 & 79 & 56 & \\
\hline \multicolumn{2}{|c|}{ Potasio (ppm) } & 71 & 60 & 22 & \\
\hline \multicolumn{2}{|c|}{ Magnesio (ppm) } & 41 & 33 & 25 & \\
\hline \multicolumn{2}{|l|}{$\mathrm{Ca} / \mathrm{Mg}$} & 2.17 & 2.394 & 2.24 & \\
\hline \multicolumn{2}{|c|}{ Sodio (ppm) } & 15 & 25 & 38 & \\
\hline \multicolumn{2}{|c|}{ C.I.C. Meq/100g } & 10 & 7.4 & 9 & \\
\hline \multicolumn{2}{|c|}{ Manganeso (ppm) } & 45 & 50 & ip & \\
\hline \multicolumn{2}{|c|}{ Hierro (ppm) } & 0.5 & 1 & ip & \\
\hline \multicolumn{2}{|c|}{ Cobre (ppm) } & 0.66 & 0.5 & ip & \\
\hline \multicolumn{2}{|l|}{ Zinc (ppm) } & ip & ip & ip & \\
\hline \multicolumn{2}{|l|}{ Boro (ppm) } & ip & ip & ip & \\
\hline \multicolumn{2}{|c|}{ Conductividad (dS/m) } & 1.5 & 1.2 & 1.1 & \\
\hline \multicolumn{2}{|c|}{ Observaciones } & & & & \\
\hline
\end{tabular}


ANÁLISIS DE COMPOSICIÓN DE SUELOS

Desarrollo de una aplicación informática para el cálculo de sostenimiento de taludes mediante vegetación

\begin{tabular}{|c|c|c|c|c|c|}
\hline \multirow[t]{2}{*}{ Perfil $n^{\circ}$} & \multirow[t]{2}{*}{58} & \multirow[b]{2}{*}{ Horizonte A } & \multirow[b]{2}{*}{ Horizonte B } & \multirow[b]{2}{*}{ Horizonte C } & \multirow[b]{2}{*}{ Horizonte D } \\
\hline & & & & & \\
\hline \multirow{3}{*}{ Textura } & Arena (\%) & 39 & & & \\
\hline & Limo (\%) & 43 & & & \\
\hline & Arcilla (\%) & 18 & & & \\
\hline \multicolumn{2}{|c|}{ Clase textural } & Franca & & & \\
\hline \multicolumn{2}{|l|}{ pH } & 5.5 & & & \\
\hline \multicolumn{2}{|c|}{ Carbonatos ( $\%$ caliza) } & 1.5 & & & \\
\hline \multicolumn{2}{|c|}{ Materia orgánica (\%) } & 2.5 & & & \\
\hline \multicolumn{2}{|c|}{ Nitrogeno total (\%) } & 0.07 & & & \\
\hline \multicolumn{2}{|c|}{ Relación C/N } & 5 & & & \\
\hline \multicolumn{2}{|c|}{ Fosforo (olssen ppm) } & 10 & & & \\
\hline \multicolumn{2}{|c|}{ Calcio (ppm) } & 699 & & & \\
\hline \multicolumn{2}{|c|}{ Potasio (ppm) } & 92 & & & \\
\hline \multicolumn{2}{|c|}{ Magnesio (ppm) } & 201 & & & \\
\hline \multicolumn{2}{|l|}{$\mathrm{Ca} / \mathrm{Mg}$} & 3.48 & & & \\
\hline \multicolumn{2}{|c|}{ Sodio (ppm) } & 23 & & & \\
\hline \multicolumn{2}{|c|}{ C.I.C. Meq/100g } & 6 & & & \\
\hline \multicolumn{2}{|c|}{ Manganeso (ppm) } & 14 & & & \\
\hline \multicolumn{2}{|c|}{ Hierro (ppm) } & 0.25 & & & \\
\hline \multicolumn{2}{|c|}{ Cobre (ppm) } & ip & & & \\
\hline \multicolumn{2}{|l|}{ Zinc (ppm) } & ip & & & \\
\hline \multicolumn{2}{|l|}{ Boro (ppm) } & 0.15 & & & \\
\hline \multicolumn{2}{|c|}{ Conductividad (dS/m) } & 1.22 & & & \\
\hline \multicolumn{2}{|c|}{ Observaciones } & & & & \\
\hline
\end{tabular}




\begin{tabular}{|c|c|c|c|c|c|}
\hline \multirow[t]{2}{*}{ Perfil $n^{\circ}$} & \multirow[t]{2}{*}{59} & \multirow[b]{2}{*}{ Horizonte A } & \multirow[b]{2}{*}{ Horizonte B } & \multirow[b]{2}{*}{ Horizonte C } & \multirow[b]{2}{*}{ Horizonte D } \\
\hline & & & & & \\
\hline \multirow{3}{*}{ Textura } & Arena (\%) & 38 & 30 & 10 & \\
\hline & Limo (\%) & 42 & 35 & 55 & \\
\hline & Arcilla (\%) & 20 & 35 & 35 & \\
\hline \multicolumn{2}{|c|}{ Clase textural } & Franca & Fran-Arci & Fra-Arc-Limo & \\
\hline \multicolumn{2}{|l|}{ pH } & 5.6 & 5.4 & 5.7 & \\
\hline \multicolumn{2}{|c|}{ Carbonatos (\% caliza) } & 5.1 & 4.2 & ---- & \\
\hline \multicolumn{2}{|c|}{ Materia orgánica (\%) } & 2.7 & 0.5 & ---- & \\
\hline \multicolumn{2}{|c|}{ Nitrogeno total (\%) } & 0.16 & ----- & ---- & \\
\hline \multicolumn{2}{|c|}{ Relación C/N } & 9.5 & ---- & ---- & \\
\hline \multicolumn{2}{|c|}{ Fosforo (olssen ppm) } & 10 & 19 & 8 & \\
\hline \multicolumn{2}{|c|}{ Calcio (ppm) } & 832 & 965 & 269 & \\
\hline \multicolumn{2}{|c|}{ Potasio (ppm) } & 154 & 215 & 96 & \\
\hline \multicolumn{2}{|c|}{ Magnesio (ppm) } & 265 & 158 & 64 & \\
\hline \multicolumn{2}{|l|}{$\mathrm{Ca} / \mathrm{Mg}$} & 3.14 & 6.11 & 4.20 & \\
\hline \multicolumn{2}{|c|}{ Sodio (ppm) } & 28 & 27 & 42 & \\
\hline \multicolumn{2}{|c|}{ C.I.C. Meq/100g } & 15 & 14 & 10 & \\
\hline \multicolumn{2}{|c|}{ Manganeso (ppm) } & 2 & 2.5 & ip & \\
\hline \multicolumn{2}{|c|}{ Hierro (ppm) } & ip & ip & ip & \\
\hline \multicolumn{2}{|c|}{ Cobre (ppm) } & ip & ip & ip & \\
\hline \multicolumn{2}{|l|}{ Zinc (ppm) } & 0.2 & ip & ip & \\
\hline \multicolumn{2}{|l|}{ Boro (ppm) } & 1.1 & 0.3 & ip & \\
\hline \multicolumn{2}{|c|}{ Conductividad (dS/m) } & 1.1 & 1.2 & 2.6 & \\
\hline \multicolumn{2}{|c|}{ Observaciones } & & & & \\
\hline
\end{tabular}


ANÁLISIS DE COMPOSICIÓN DE SUELOS

Desarrollo de una aplicación informática para el cálculo de sostenimiento de taludes mediante vegetación

\begin{tabular}{|c|c|c|c|c|c|}
\hline \multirow[t]{2}{*}{ Perfil no } & \multirow[t]{2}{*}{60} & & & & \\
\hline & & Horizonte A & Horizonte B & Horizonte C & Horizonte D \\
\hline \multirow{3}{*}{ Textura } & Arena (\%) & 27 & 44 & 58 & \\
\hline & Limo (\%) & 62 & 38 & 10 & \\
\hline & Arcilla (\%) & 11 & 18 & 32 & \\
\hline \multicolumn{2}{|c|}{ Clase textural } & Franc-Lim & Franca & Fra-Are-Arc & \\
\hline \multicolumn{2}{|l|}{ pH } & 5.8 & 5.7 & 5.6 & \\
\hline \multicolumn{2}{|c|}{ Carbonatos (\% caliza) } & 5.6 & 5.2 & 4.1 & \\
\hline \multicolumn{2}{|c|}{ Materia orgánica (\%) } & 3.4 & 1.1 & ----- & \\
\hline \multicolumn{2}{|c|}{ Nitrogeno total (\%) } & 0.18 & 0.256 & ----- & \\
\hline \multicolumn{2}{|c|}{ Relación C/N } & 10 & 5 & ----- & \\
\hline \multicolumn{2}{|c|}{ Fosforo (olssen ppm) } & 14.5 & 18 & 6 & \\
\hline \multicolumn{2}{|c|}{ Calcio (ppm) } & 825 & 921 & 573 & \\
\hline \multicolumn{2}{|c|}{ Potasio (ppm) } & 133 & 244 & 132 & \\
\hline \multicolumn{2}{|c|}{ Magnesio (ppm) } & 201 & 123 & 94 & \\
\hline \multicolumn{2}{|l|}{$\mathrm{Ca} / \mathrm{Mg}$} & 4.10 & 7.49 & 6.10 & \\
\hline \multicolumn{2}{|c|}{ Sodio (ppm) } & 21 & 26 & 31 & \\
\hline \multicolumn{2}{|c|}{ C.I.C. Meq/100g } & 13 & 10 & 9 & \\
\hline \multicolumn{2}{|c|}{ Manganeso (ppm) } & 19 & 17 & 22 & \\
\hline \multicolumn{2}{|c|}{ Hierro (ppm) } & 0.1 & 0.4 & 0.7 & \\
\hline \multicolumn{2}{|c|}{ Cobre (ppm) } & 0.2 & 0.15 & 0.05 & \\
\hline \multicolumn{2}{|l|}{ Zinc (ppm) } & 0.18 & 0.2 & 0.04 & \\
\hline \multicolumn{2}{|l|}{ Boro (ppm) } & 0.9 & 0.4 & 0.15 & \\
\hline \multicolumn{2}{|c|}{ Conductividad (dS/m) } & 1.1 & 1.4 & 2.1 & \\
\hline \multicolumn{2}{|c|}{ Observaciones } & & & & \\
\hline
\end{tabular}


ANÁLISIS DE COMPOSICIÓN DE SUELOS

Desarrollo de una aplicación informática para el cálculo de sostenimiento de taludes mediante vegetación

\begin{tabular}{|c|c|c|c|c|c|}
\hline \multirow[t]{2}{*}{ Perfil no } & \multirow[t]{2}{*}{61} & & & & \\
\hline & & Horizonte A & Horizonte B & Horizonte C & Horizonte D \\
\hline \multirow{3}{*}{ Textura } & Arena (\%) & 62 & 38 & & \\
\hline & Limo (\%) & 21 & 38 & & \\
\hline & Arcilla (\%) & 17 & 24 & & \\
\hline \multicolumn{2}{|c|}{ Clase textural } & Franc-Aren & Franca & & \\
\hline \multicolumn{2}{|l|}{ pH } & 6.7 & 5.5 & & \\
\hline \multicolumn{2}{|c|}{ Carbonatos (\% caliza) } & 4.5 & 3.2 & & \\
\hline \multicolumn{2}{|c|}{ Materia orgánica (\%) } & 1.05 & 3.7 & & \\
\hline \multicolumn{2}{|c|}{ Nitrogeno total (\%) } & 0.08 & 0.12 & & \\
\hline \multicolumn{2}{|c|}{ Relación C/N } & 7 & 8 & & \\
\hline \multicolumn{2}{|c|}{ Fosforo (olssen ppm) } & 22 & 19 & & \\
\hline \multicolumn{2}{|c|}{ Calcio (ppm) } & 305 & 365 & & \\
\hline \multicolumn{2}{|c|}{ Potasio (ppm) } & 186 & 69 & & \\
\hline \multicolumn{2}{|c|}{ Magnesio (ppm) } & 165 & 59 & & \\
\hline \multicolumn{2}{|l|}{$\mathrm{Ca} / \mathrm{Mg}$} & 1.848 & 6.186 & & \\
\hline \multicolumn{2}{|c|}{ Sodio (ppm) } & 15 & 15 & & \\
\hline \multicolumn{2}{|c|}{ C.I.C. Meq/100g } & 14 & 4 & & \\
\hline \multicolumn{2}{|c|}{ Manganeso (ppm) } & 0.2 & ip & & \\
\hline \multicolumn{2}{|c|}{ Hierro (ppm) } & 0.05 & ip & & \\
\hline \multicolumn{2}{|c|}{ Cobre (ppm) } & 1.5 & ip & & \\
\hline \multicolumn{2}{|c|}{ Zinc (ppm) } & 0.03 & ip & & \\
\hline \multicolumn{2}{|c|}{ Boro (ppm) } & 0.07 & ip & & \\
\hline \multicolumn{2}{|c|}{ Conductividad (dS/m) } & 1.02 & 0.09 & & \\
\hline \multicolumn{2}{|c|}{ Observaciones } & & & & \\
\hline
\end{tabular}


ANÁLISIS DE COMPOSICIÓN DE SUELOS

Desarrollo de una aplicación informática para el cálculo de sostenimiento de taludes mediante vegetación

\begin{tabular}{|c|c|c|c|c|c|}
\hline Perfil $n^{o}$ & 62 & & & & \\
\hline & & Horizonte A & Horizonte B & Horizonte C & Horizonte D \\
\hline & Arena (\%) & 43 & & & \\
\hline Textura & Limo (\%) & 38 & & & \\
\hline & Arcilla (\%) & 19 & & & \\
\hline Clase textu & & Franc & & & \\
\hline pH & & 5.3 & & & \\
\hline Carbonatos & (\% caliza) & 6.5 & & & \\
\hline Materia or & ́́nica (\%) & 2.2 & & & \\
\hline Nitrogeno $t$ & tal (\%) & 0.11 & & & \\
\hline Relación C/ & & 11 & & & \\
\hline Fosforo (ols & en ppm) & 19 & & & \\
\hline Calcio (ppn & & 455 & & & \\
\hline Potasio (pp & & 174 & & & \\
\hline Magnesio ( & pm) & 86 & & & \\
\hline $\mathrm{Ca} / \mathrm{Mg}$ & & 2.023 & & & \\
\hline Sodio (ppm & & 12 & & & \\
\hline C.I.C. Meq & $00 \mathrm{~g}$ & 10 & & & \\
\hline Manganeso & ppm) & 22 & & & \\
\hline Hierro (ppr & & 3 & & & \\
\hline Cobre (ppn & & 0.2 & & & \\
\hline Zinc (ppm) & & 0.01 & & & \\
\hline Boro (ppm) & & 1.1 & & & \\
\hline Conductivi & ad $(\mathrm{dS} / \mathrm{m})$ & 0.09 & & & \\
\hline Observacion & & & & & \\
\hline
\end{tabular}


ANÁLISIS DE COMPOSICIÓN DE SUELOS

Desarrollo de una aplicación informática para el cálculo de sostenimiento de taludes mediante vegetación

\begin{tabular}{|c|c|c|c|c|c|}
\hline Perfil $n^{o}$ & 63 & & & & \\
\hline & & Horizonte A & Horizonte B & Horizonte C & Horizonte D \\
\hline & Arena $(\%)$ & 31 & & & \\
\hline Textura & Limo (\%) & 52 & & & \\
\hline & Arcilla (\%) & 17 & & & \\
\hline Clase textu & & Franc-Limo & & & \\
\hline pH & & 6 & & & \\
\hline Carbonatos & \% caliza) & 6.2 & & & \\
\hline Materia or & inica (\%) & 0.98 & & & \\
\hline Nitrogeno t & tal (\%) & 0.08 & & & \\
\hline Relación C/ & & 10 & & & \\
\hline Fosforo (ols & en ppm) & 11 & & & \\
\hline Calcio (ppn & & 435 & & & \\
\hline Potasio (pp & & 101 & & & \\
\hline Magnesio (I & m) & 103 & & & \\
\hline $\mathrm{Ca} / \mathrm{Mg}$ & & 4.22 & & & \\
\hline \begin{tabular}{|l|} 
Sodio (ppm \\
\end{tabular} & & 36 & & & \\
\hline C.I.C. Meq & $00 \mathrm{~g}$ & 9 & & & \\
\hline Manganeso & ppm) & 13 & & & \\
\hline Hierro (ppr & & 0.5 & & & \\
\hline Cobre (ppn & & 0.02 & & & \\
\hline Zinc (ppm) & & 0.05 & & & \\
\hline Boro (ppm) & & 0.03 & & & \\
\hline Conductivi & $\mathrm{d}(\mathrm{dS} / \mathrm{m})$ & 1.1 & & & \\
\hline Observacion & & & & & \\
\hline
\end{tabular}


ANÁLISIS DE COMPOSICIÓN DE SUELOS

Desarrollo de una aplicación informática para el cálculo de sostenimiento de taludes mediante vegetación

\begin{tabular}{|c|c|c|c|c|c|}
\hline Perfil no & 64 & & & & \\
\hline & & Horizonte A & Horizonte B & Horizonte C & Horizonte D \\
\hline & Arena (\%) & 33 & & & \\
\hline Textura & Limo (\%) & 56 & & & \\
\hline & Arcilla (\%) & 11 & & & \\
\hline Clase text & & Franc-Limo & & & \\
\hline pH & & 5.8 & & & \\
\hline Carbonato & (\% caliza) & 4.2 & & & \\
\hline Materia or & ́́nica (\%) & 1.2 & & & \\
\hline Nitrogeno & tal (\%) & 0.03 & & & \\
\hline Relación C & & 5 & & & \\
\hline Fosforo (o & en ppm) & 10 & & & \\
\hline Calcio (pp & & 322 & & & \\
\hline Potasio (pI & & 128 & & & \\
\hline Magnesio & pm) & 75 & & & \\
\hline $\mathrm{Ca} / \mathrm{Mg}$ & & 4.29 & & & \\
\hline Sodio (ppn & & 22 & & & \\
\hline C.I.C. Mec & $00 \mathrm{~g}$ & 11 & & & \\
\hline Manganes & ppm) & 19 & & & \\
\hline Hierro (pp & & 1.1 & & & \\
\hline Cobre (pp & & 0.5 & & & \\
\hline Zinc (ppm & & 1.1 & & & \\
\hline Boro (ppm & & 0.07 & & & \\
\hline Conductiv & $\operatorname{ad}(\mathrm{dS} / \mathrm{m})$ & 0.9 & & & \\
\hline Observacio & & & & & \\
\hline
\end{tabular}




\section{Documento adjunto 2}

\section{PRUEBAS DEL MODELO MATEMÁTICO PARA EL CÁLCULO DE}

ESTABILIDAD DE TALUDES.

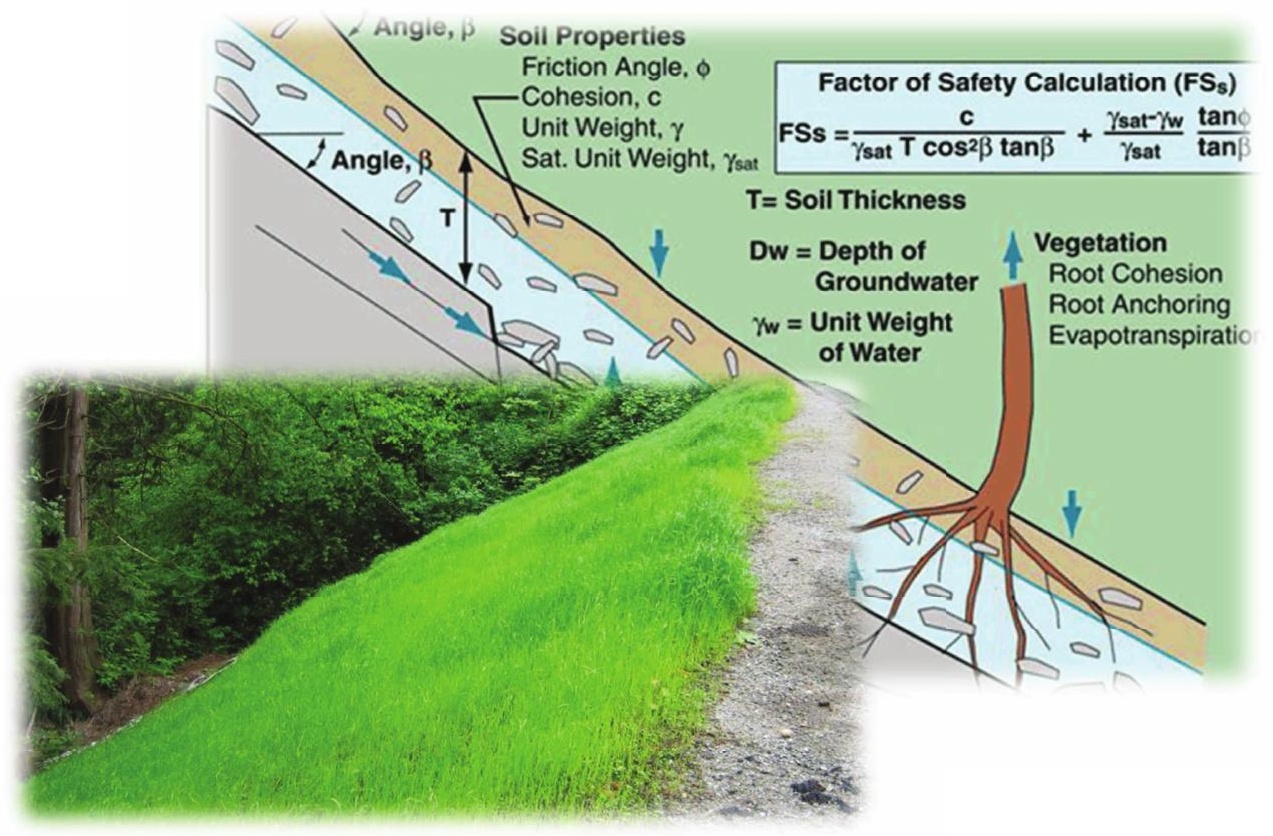


DESARROLLO DE UNA APLICACIÓN IMFORMÁTICA PARA EL CÁLCULO DE SOSTENIMIENTO DE TALUDES MEDIANTE VEGETACIÓN

\section{PRUEBA A: ESPECIES INDIVIDUALES}

A01. DENSIDAD DE PLANTACIÓN: 600 plantas/ha. A02. DENSIDAD DE PLANTACIÓN: 1600 plantas/ha. A03. DENSIDAD DE PLANTACIÓN: 2500 plantas/ha.

\section{PRUEBA B: COMBINACIONES DE ESPECIES}

B01. DENSIDAD DE PLANTACIÓN: 600 plantas/ha.

B02. DENSIDAD DE PLANTACIÓN: 1600 plantas/ha.

B03. DENSIDAD DE PLANTACIÓN: 2500 plantas/ha. 
DESARROLLO DE UNA APLICACIÓN IMFORMÁTICA PARA EL CÁLCULO DE SOSTENIMIENTO DE TALUDES MEDIANTE VEGETACIÓN

PRUEBAS DEL MODELO MATEMÁTICO PARA EL CÁLCULO DE ESTABILIDAD DE TALUDES.

\section{PRUEBA A: ESPECIES INDIVIDUALES}

A01. DENSIDAD DE PLANTACIÓN: 600 plantas/ha.

A01-1.POSICIÓN N.F. 1

A01-2.POSICIÓN N.F. 2

A01-3.POSICIÓN N.F. 3

A01-4.POSICIÓN N.F. 4

A01-5.POSICIÓN N.F. 5 
DESARROLLO DE UNA APLICACIÓN IMFORMÁTICA PARA EL CÁLCULO DE SOSTENIMIENTO DE TALUDES MEDIANTE VEGETACIÓN

A01. DENSIDAD DE PLANTACIÓN: 600 plantas/ha.

\section{A01-1.POSICIÓN N.F. 1}

INCLINACIÓN DE TALUD 6-100

INCLINACIÓN DE TALUD 10-200

INCLINACIÓN DE TALUD 20-30

INCLINACIÓN DE TALUD 30-40

INCLINACIÓN DE TALUD $35^{\circ}$

INCLINACIÓN DE TALUD 40-50

INCLINACIÓN DE TALUD 50-550

INCLINACIÓN DE TALUD 55-60

INCLINACIÓN DE TALUD 60-700

INCLINACIÓN DE TALUD 70-80 

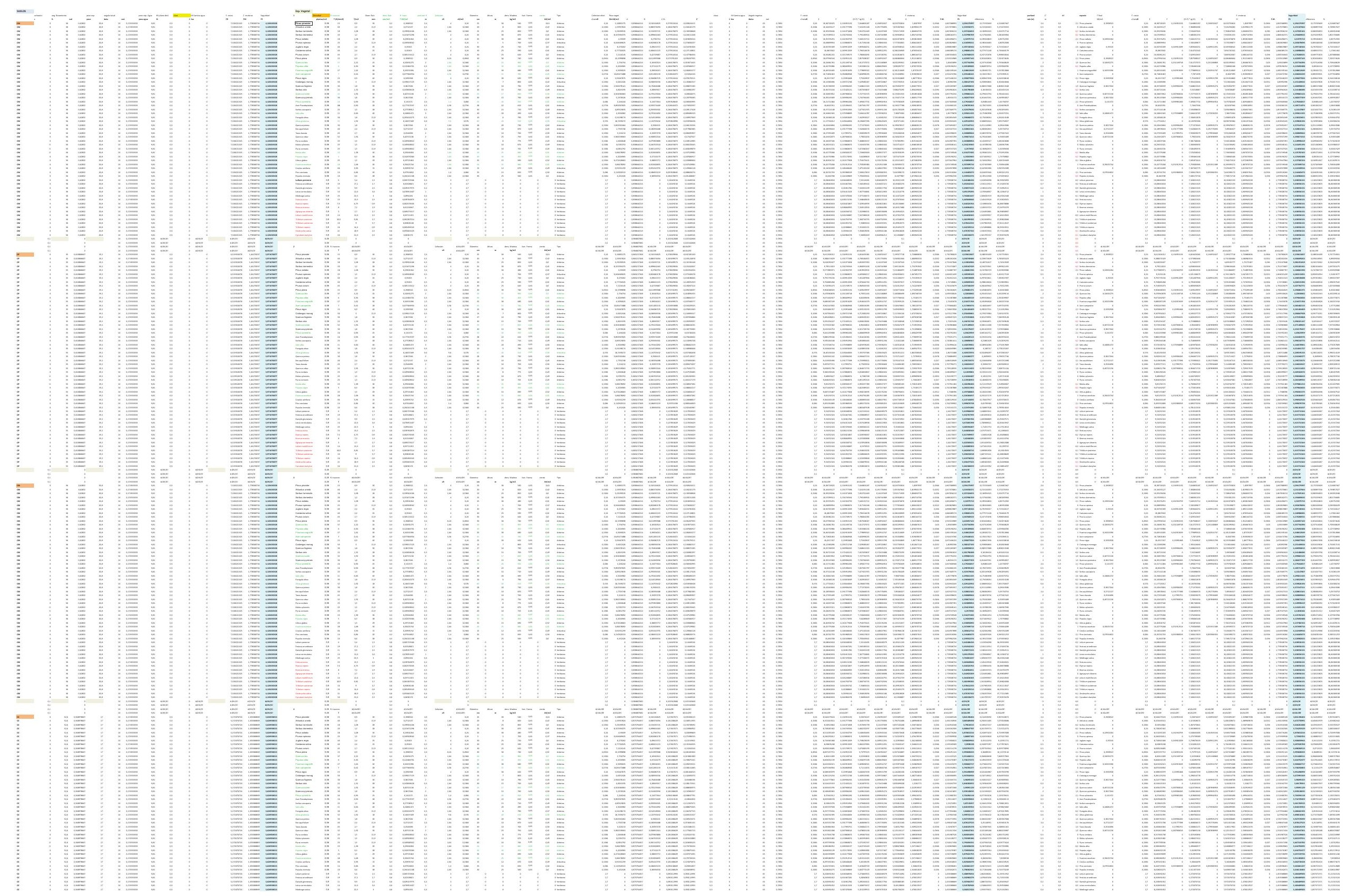


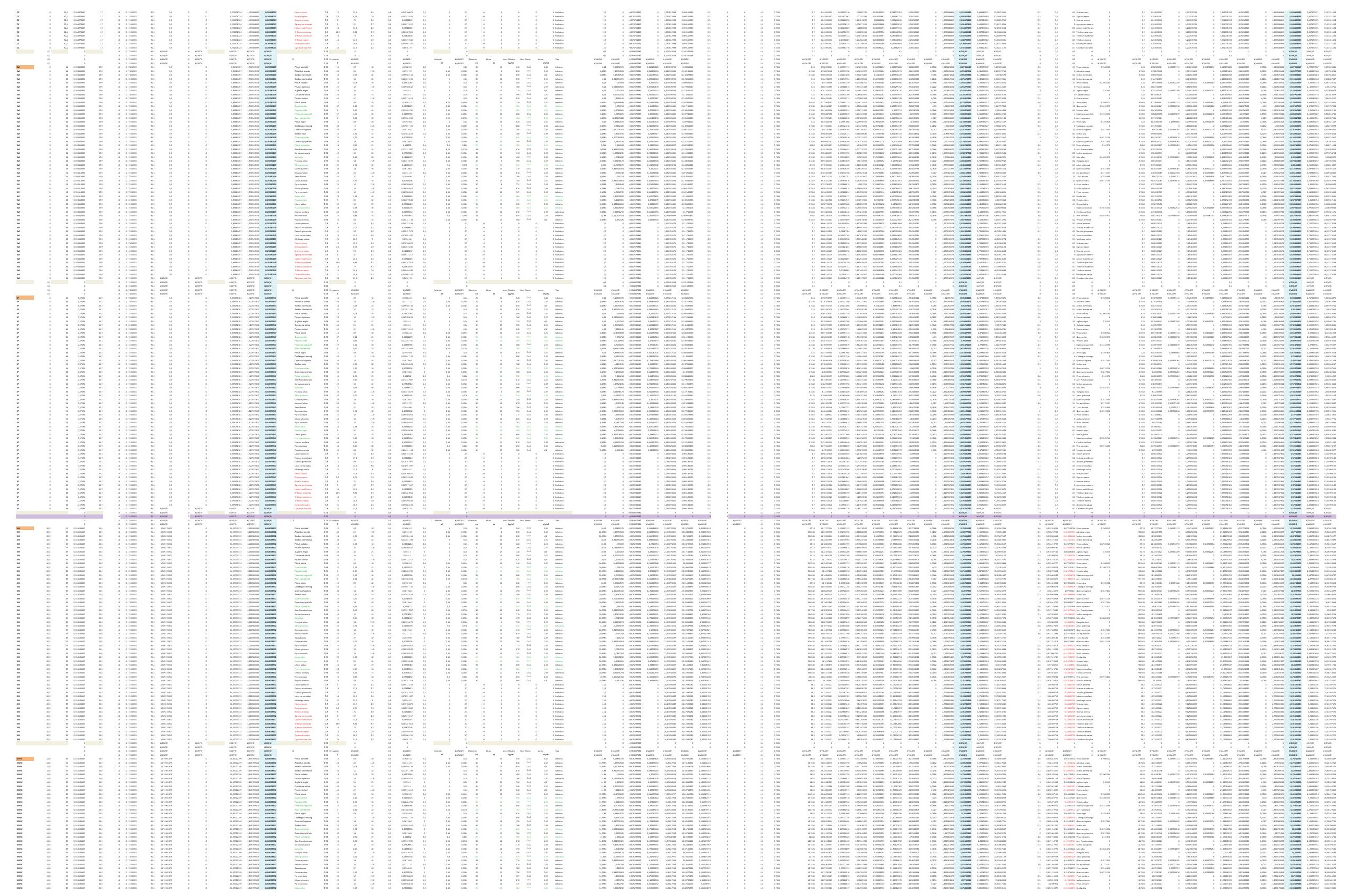



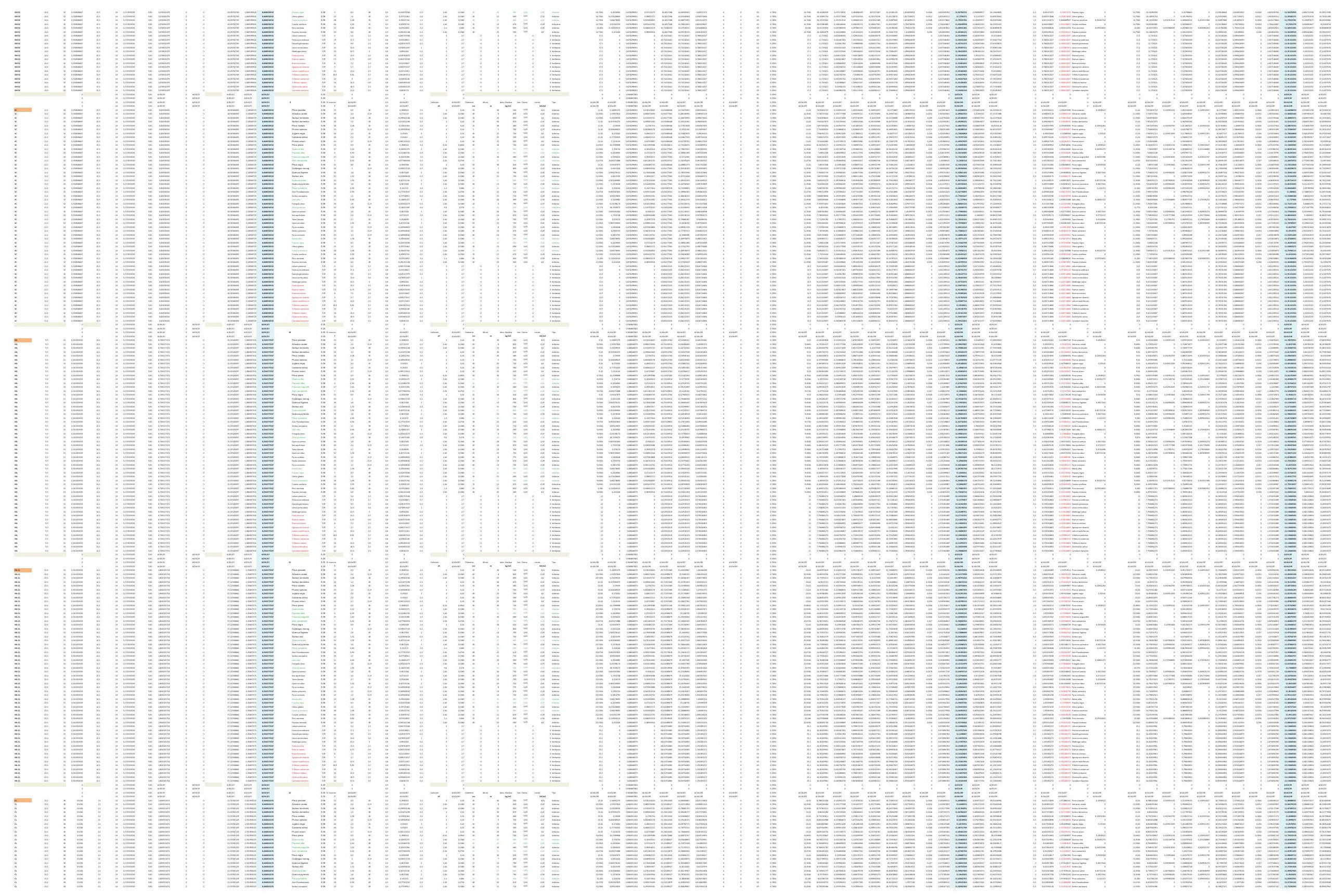


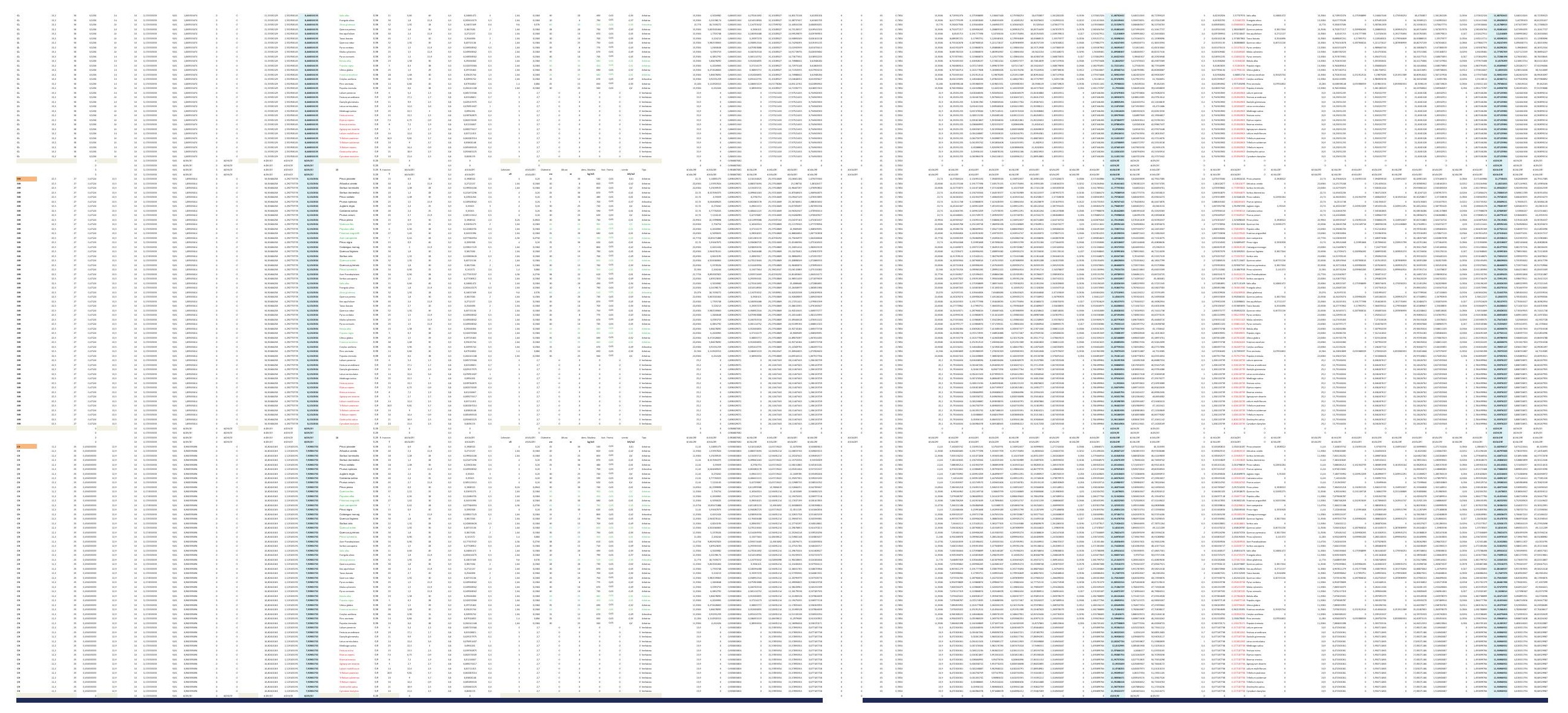



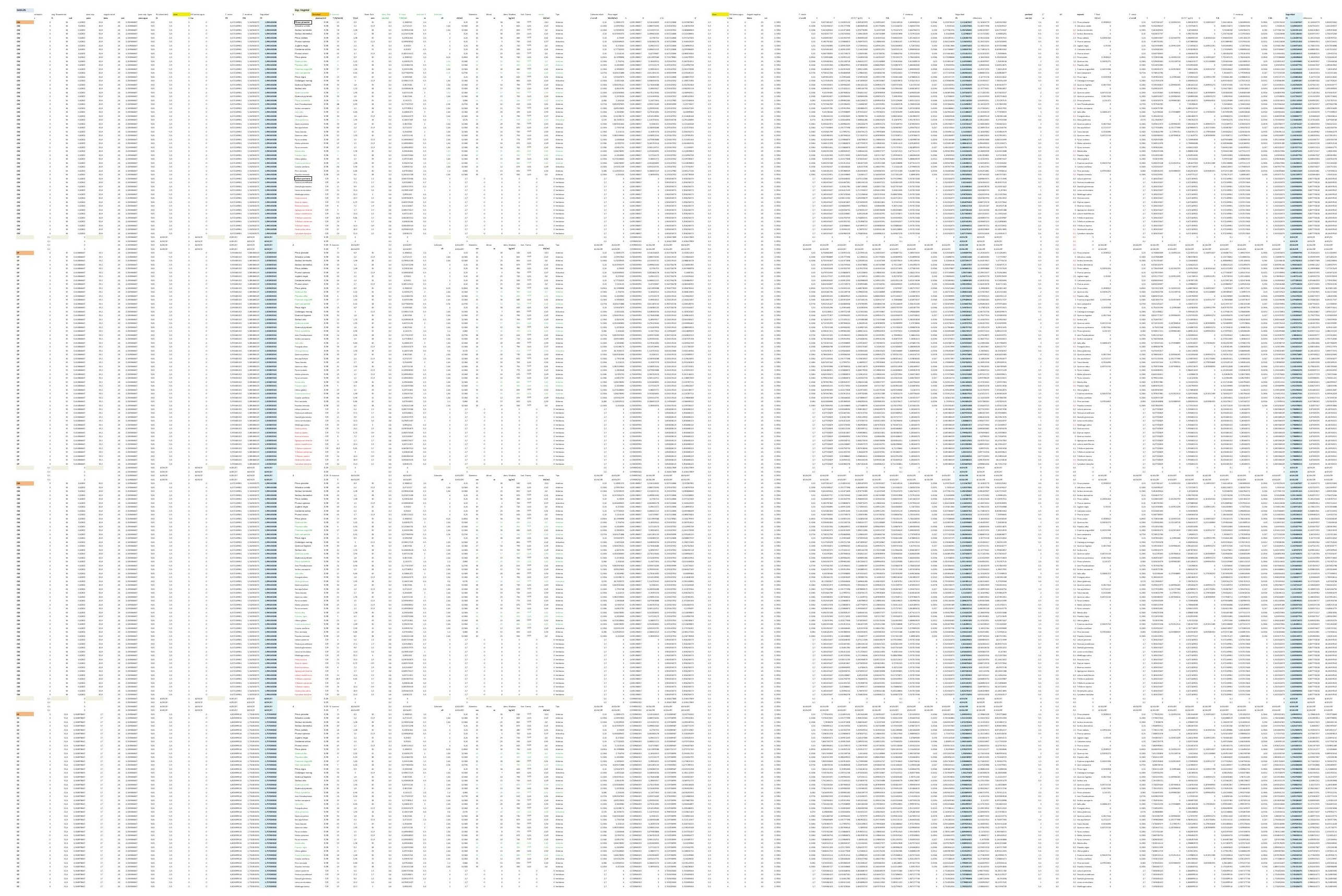


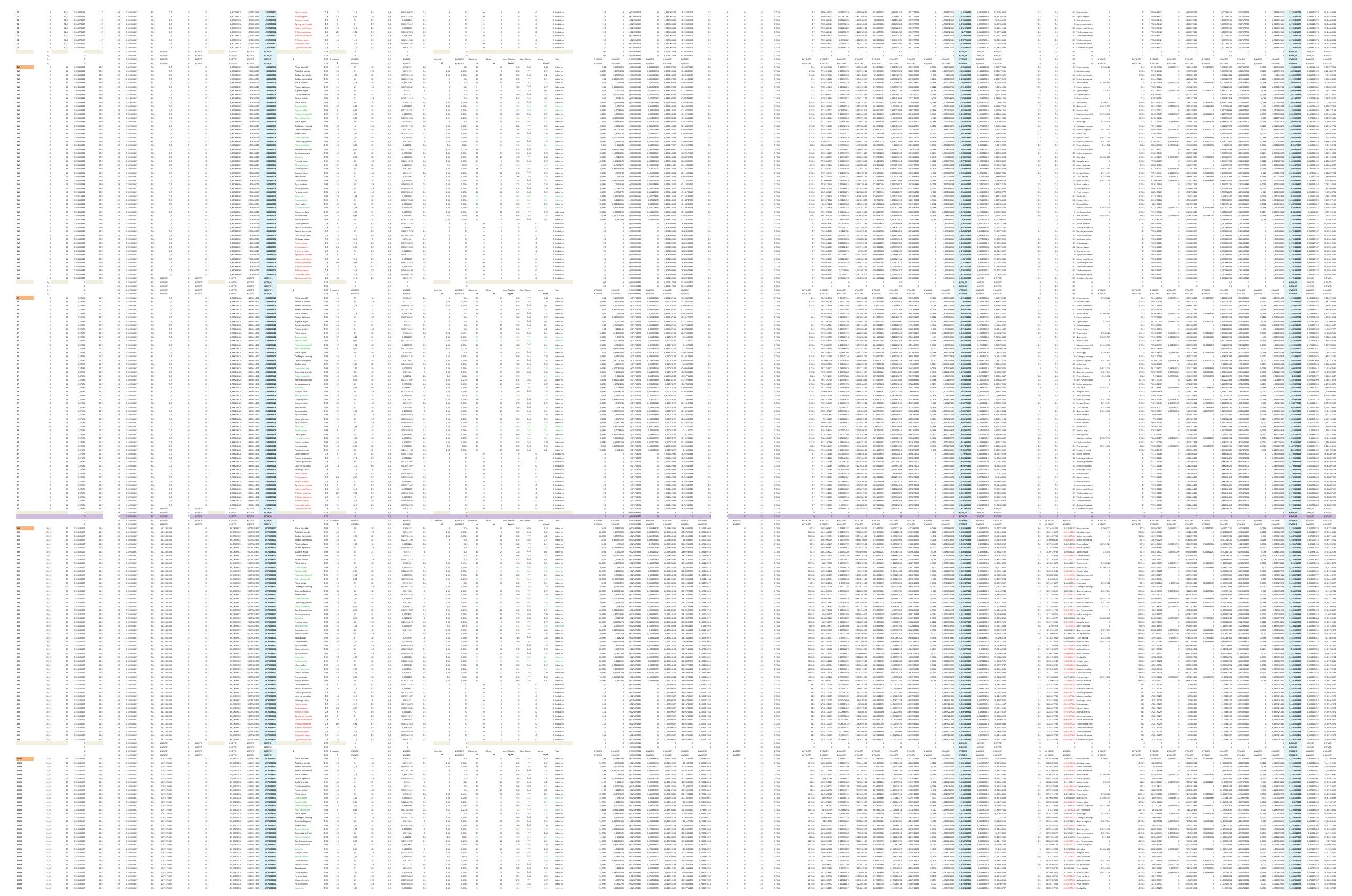



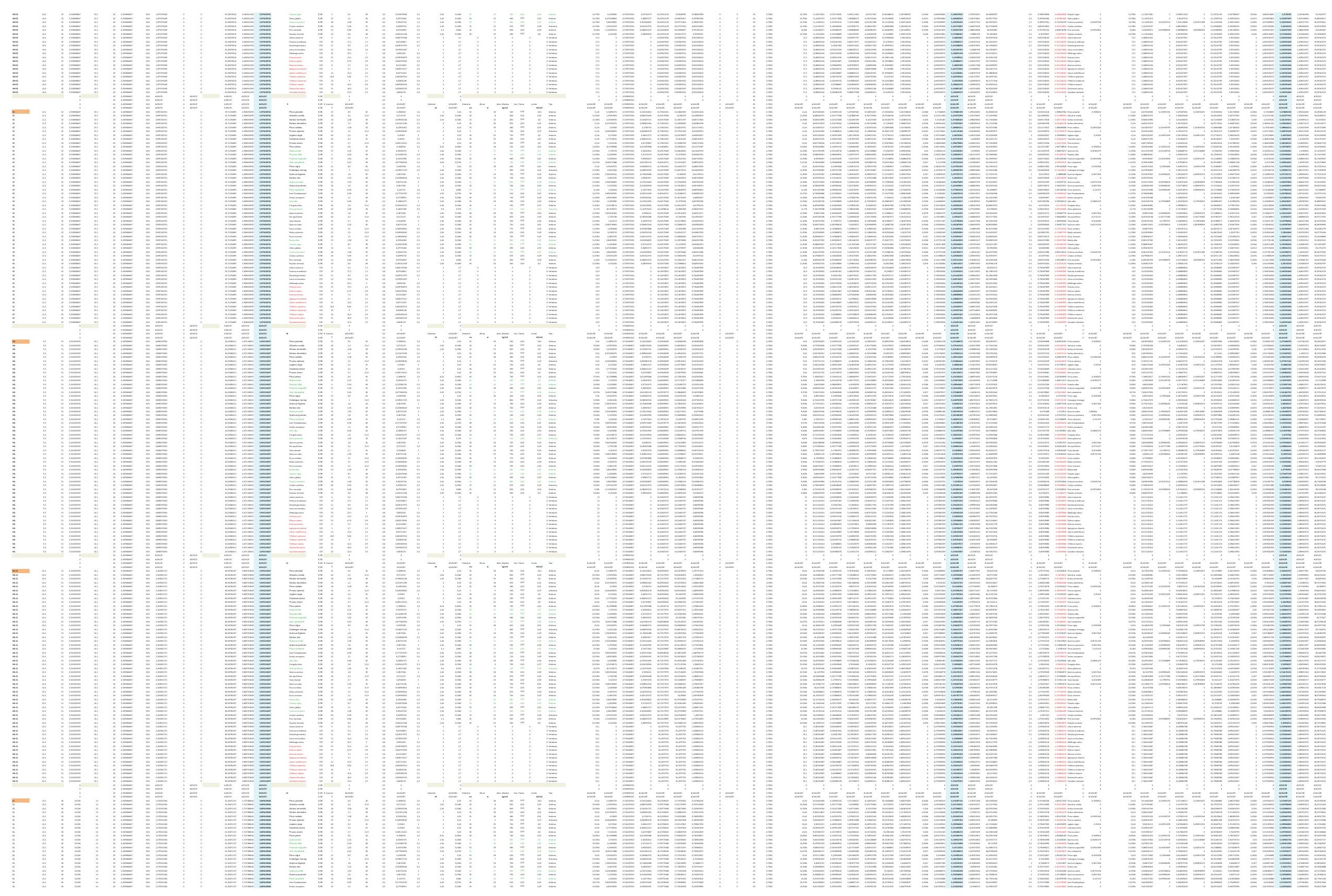


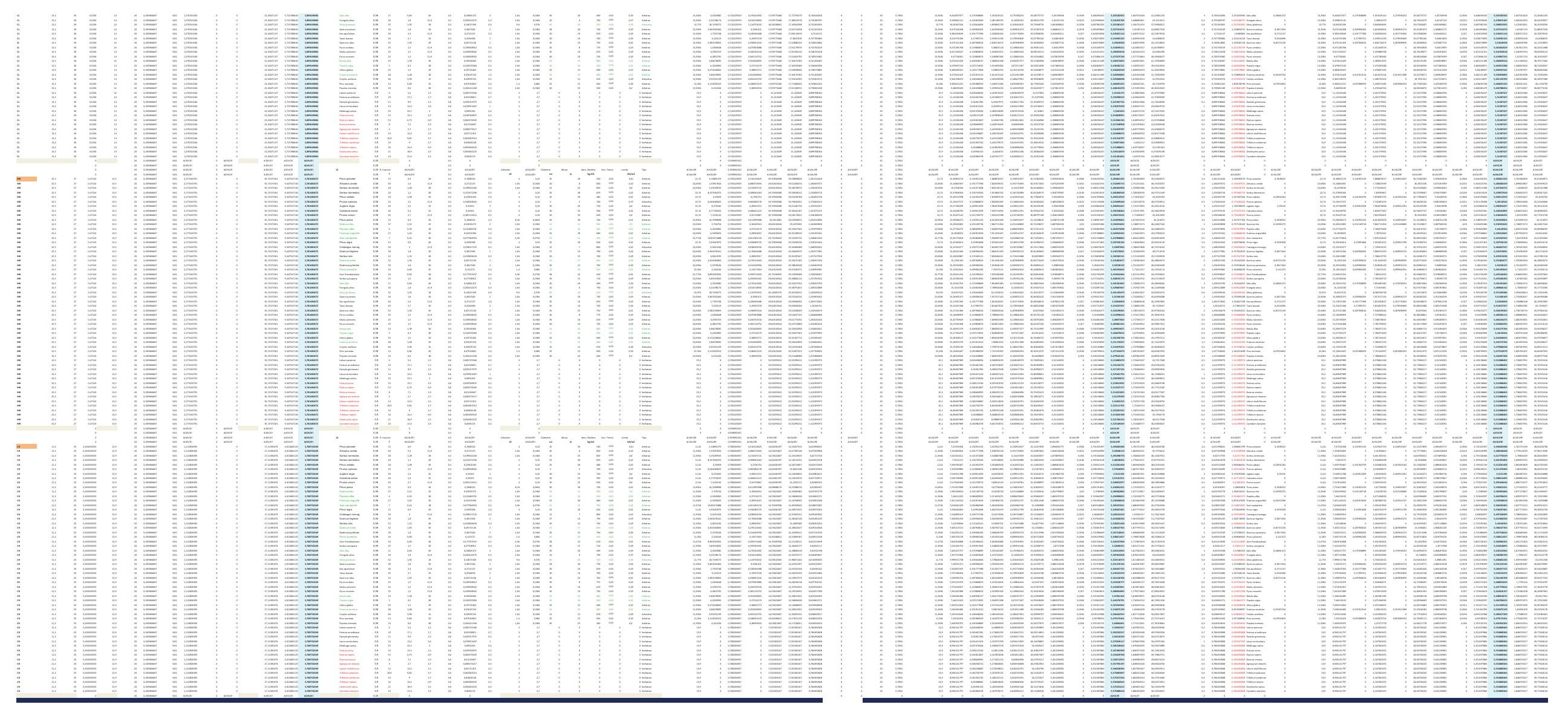



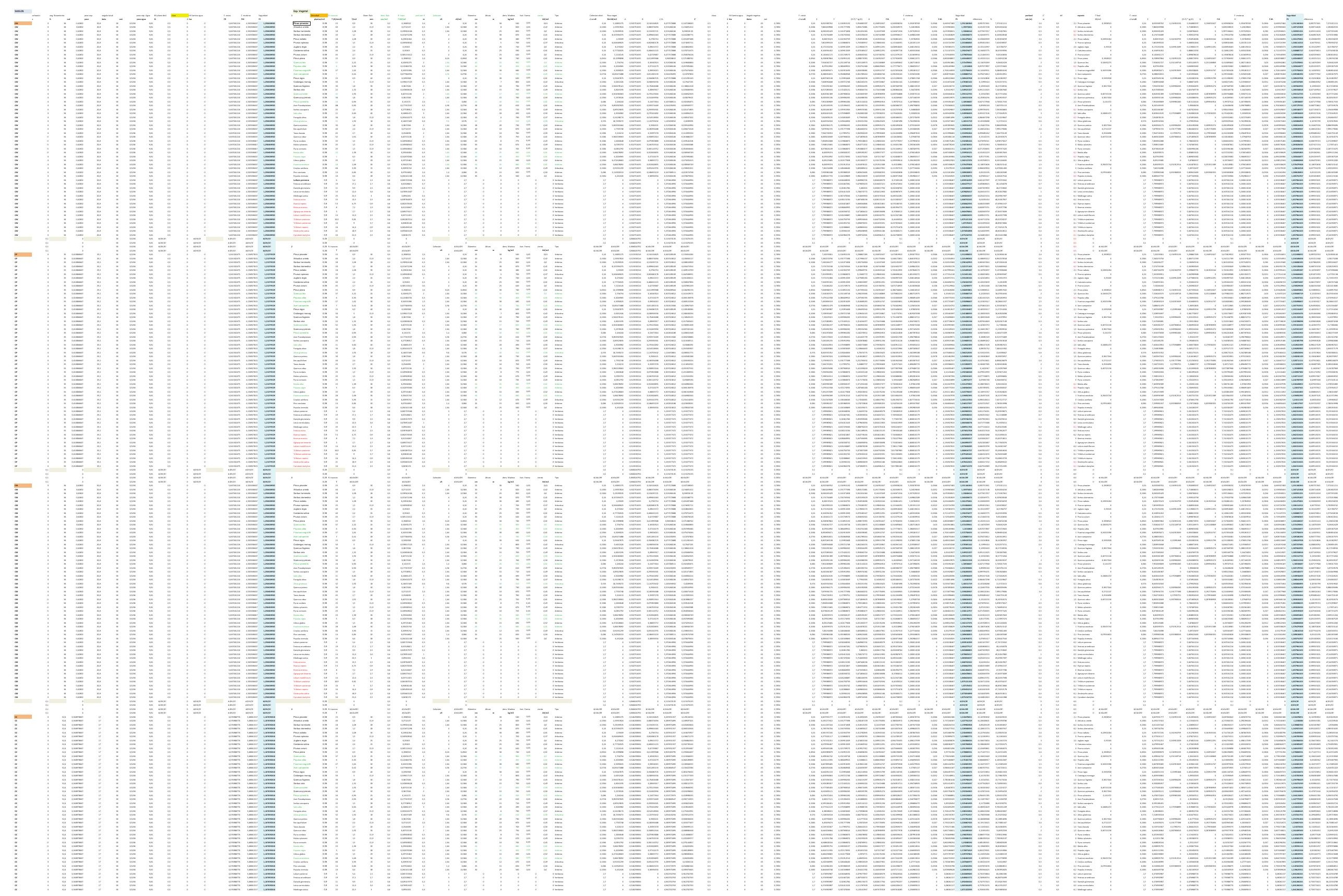


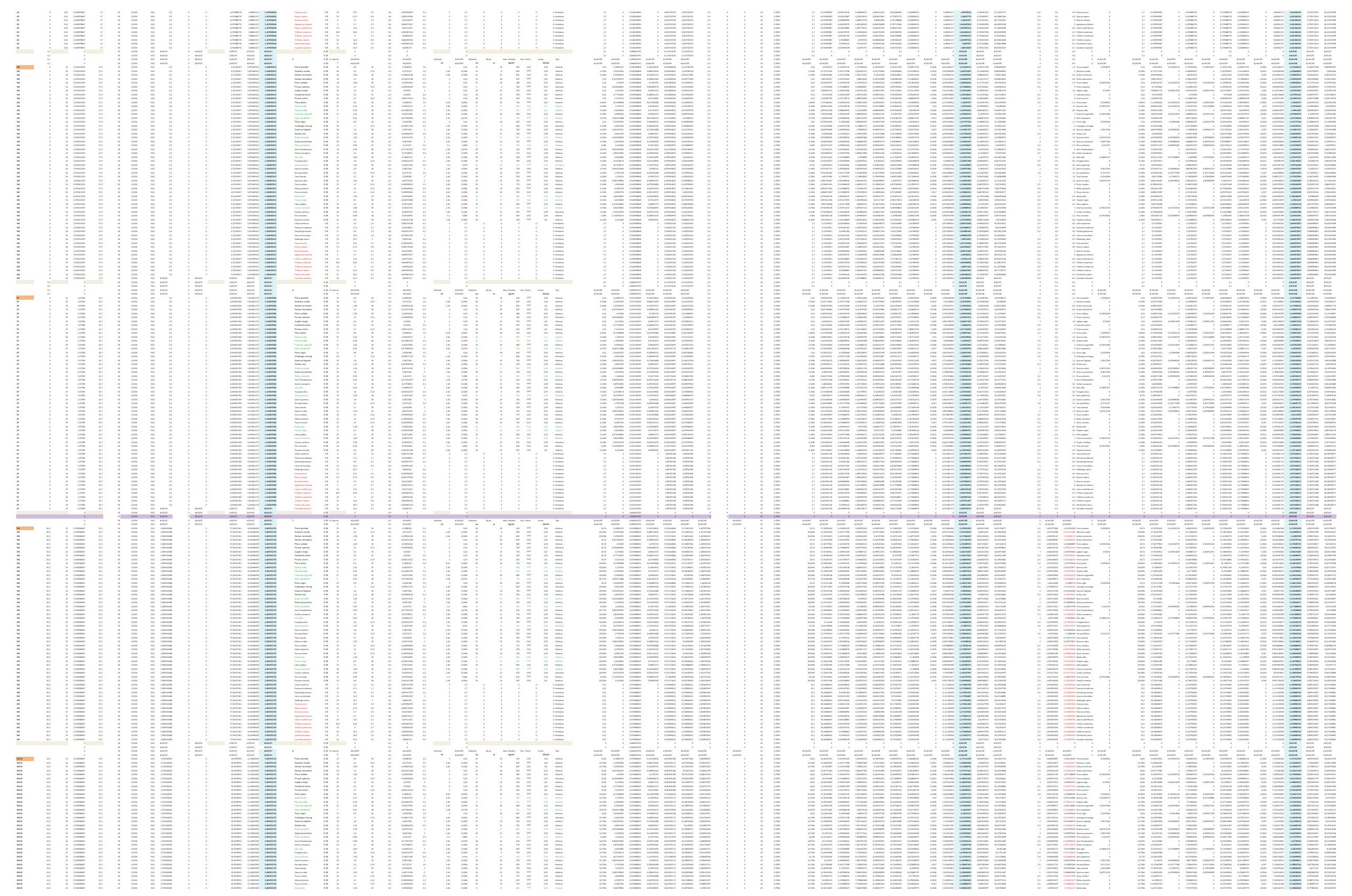



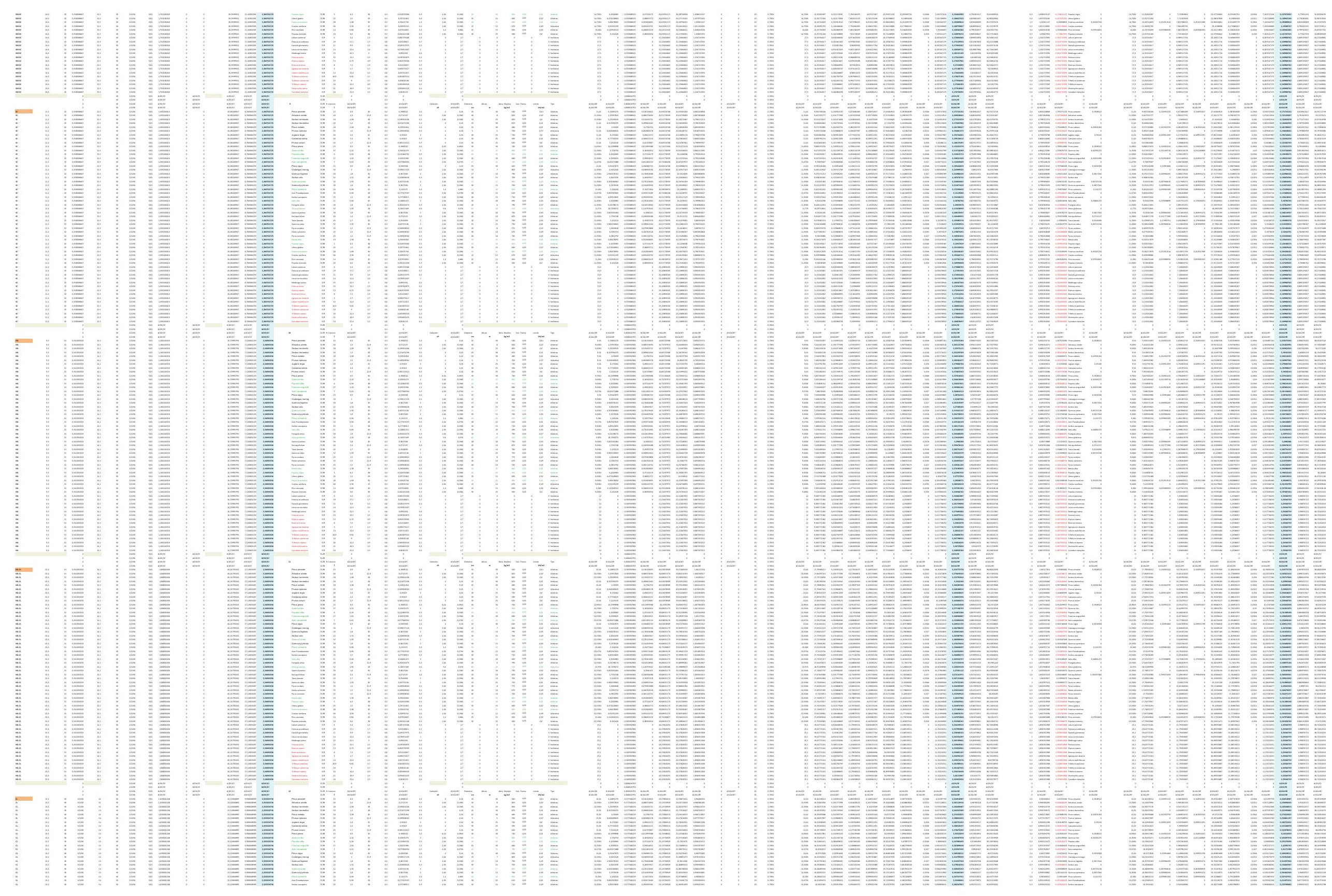


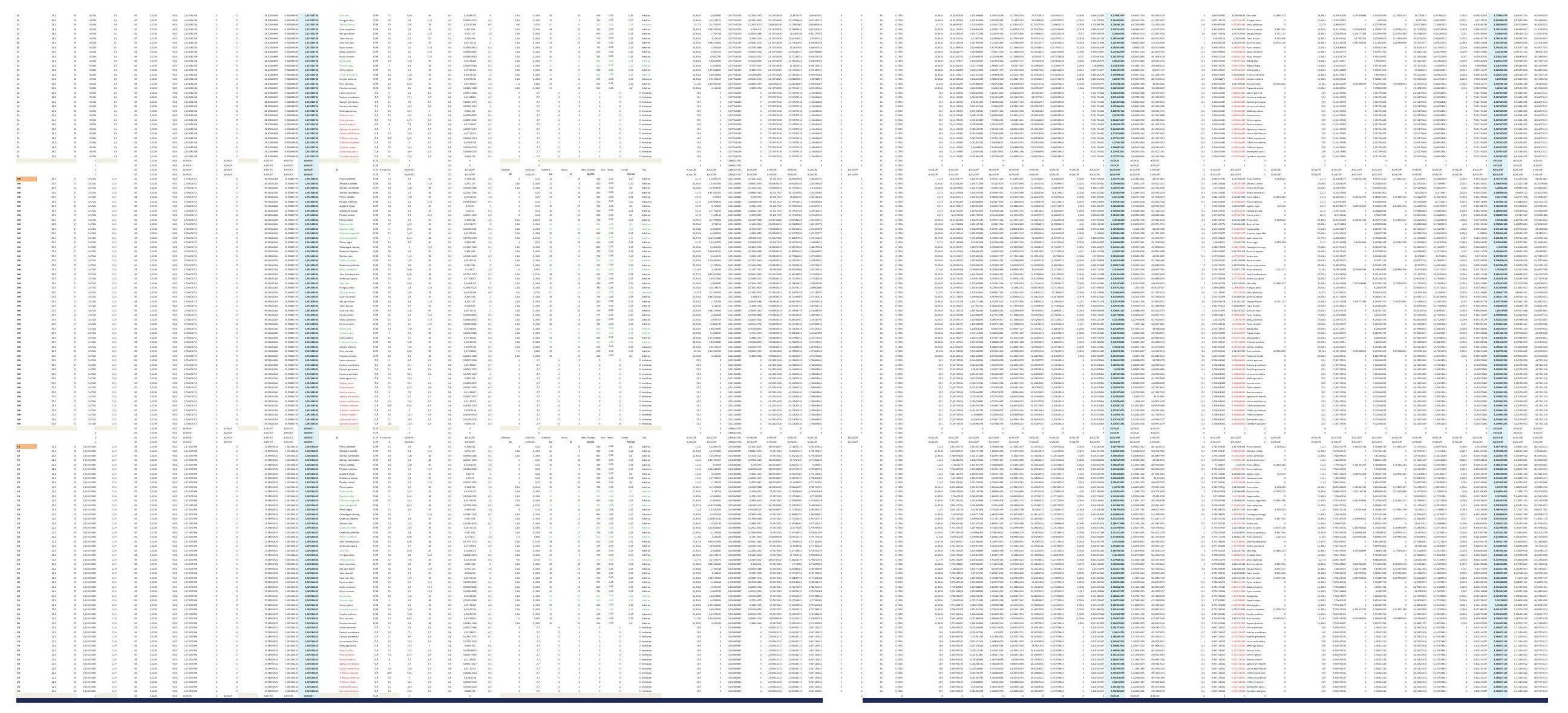



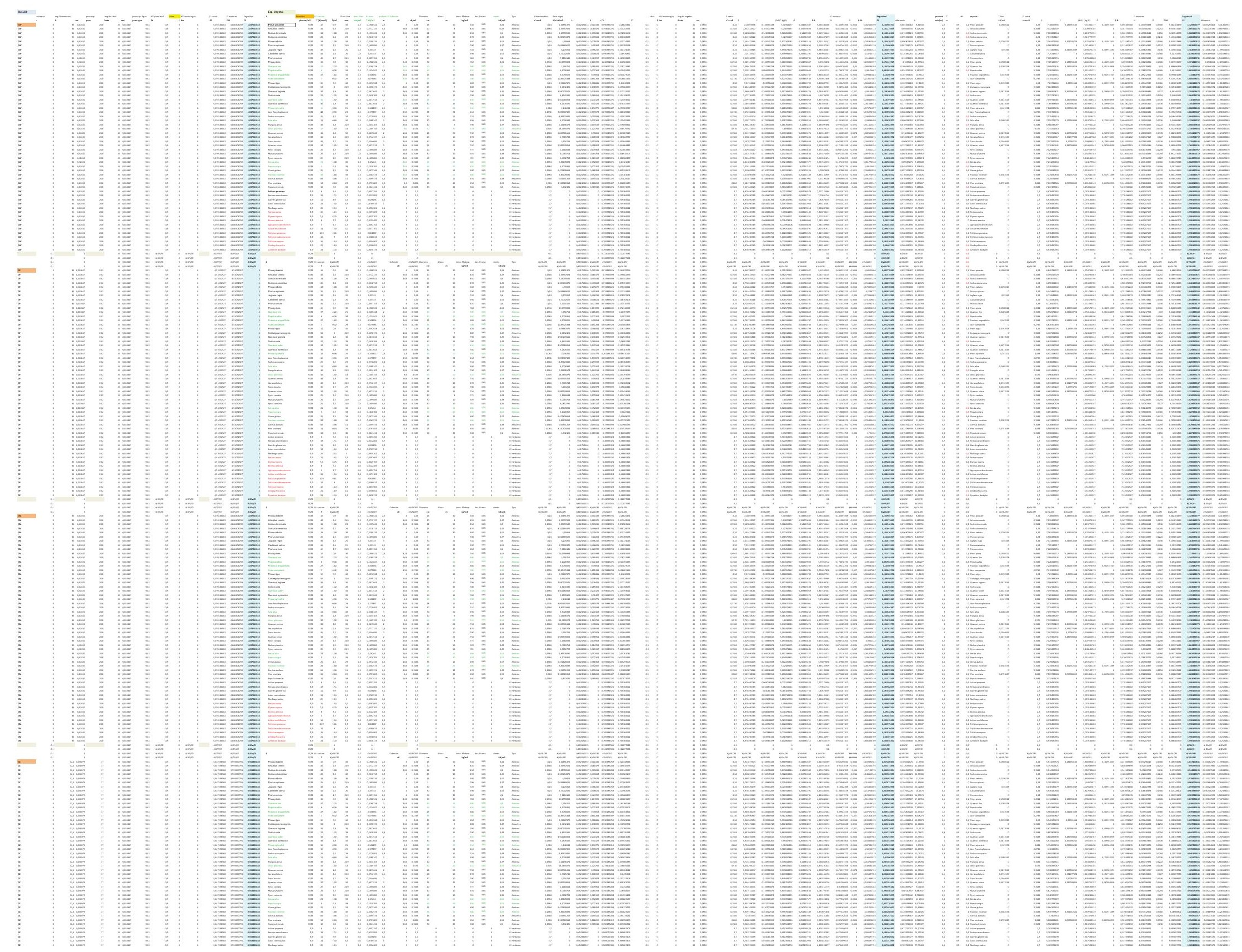


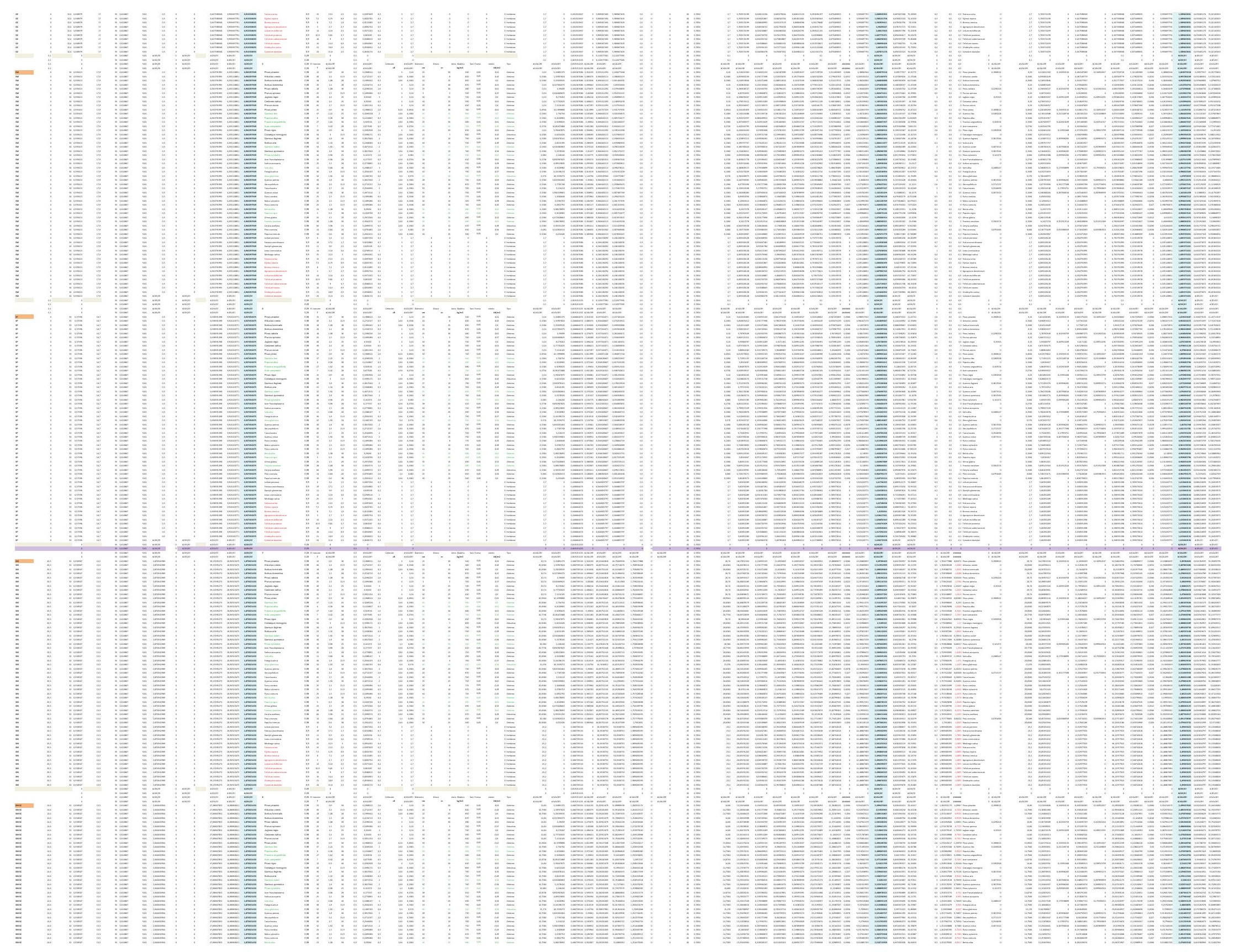



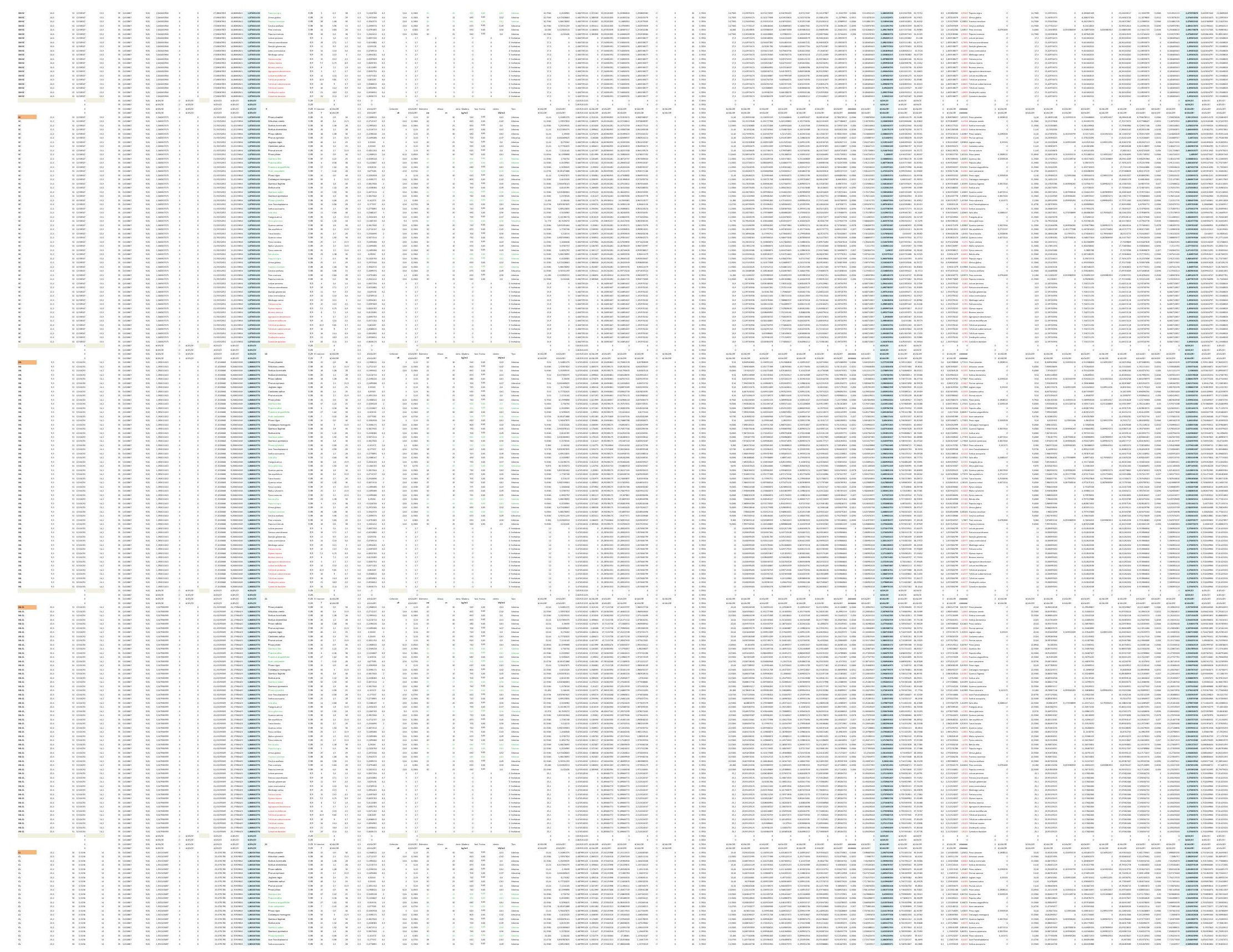


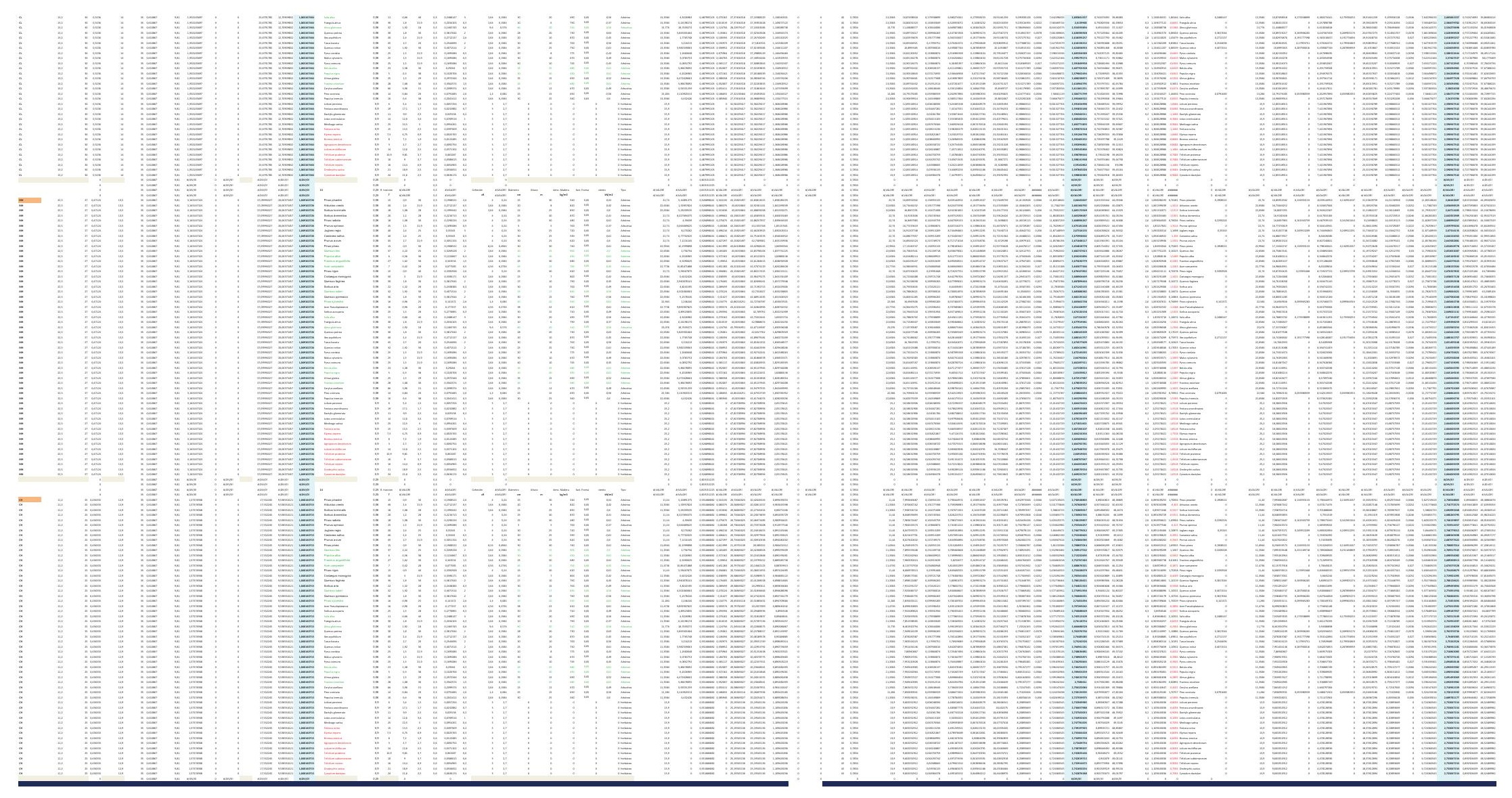



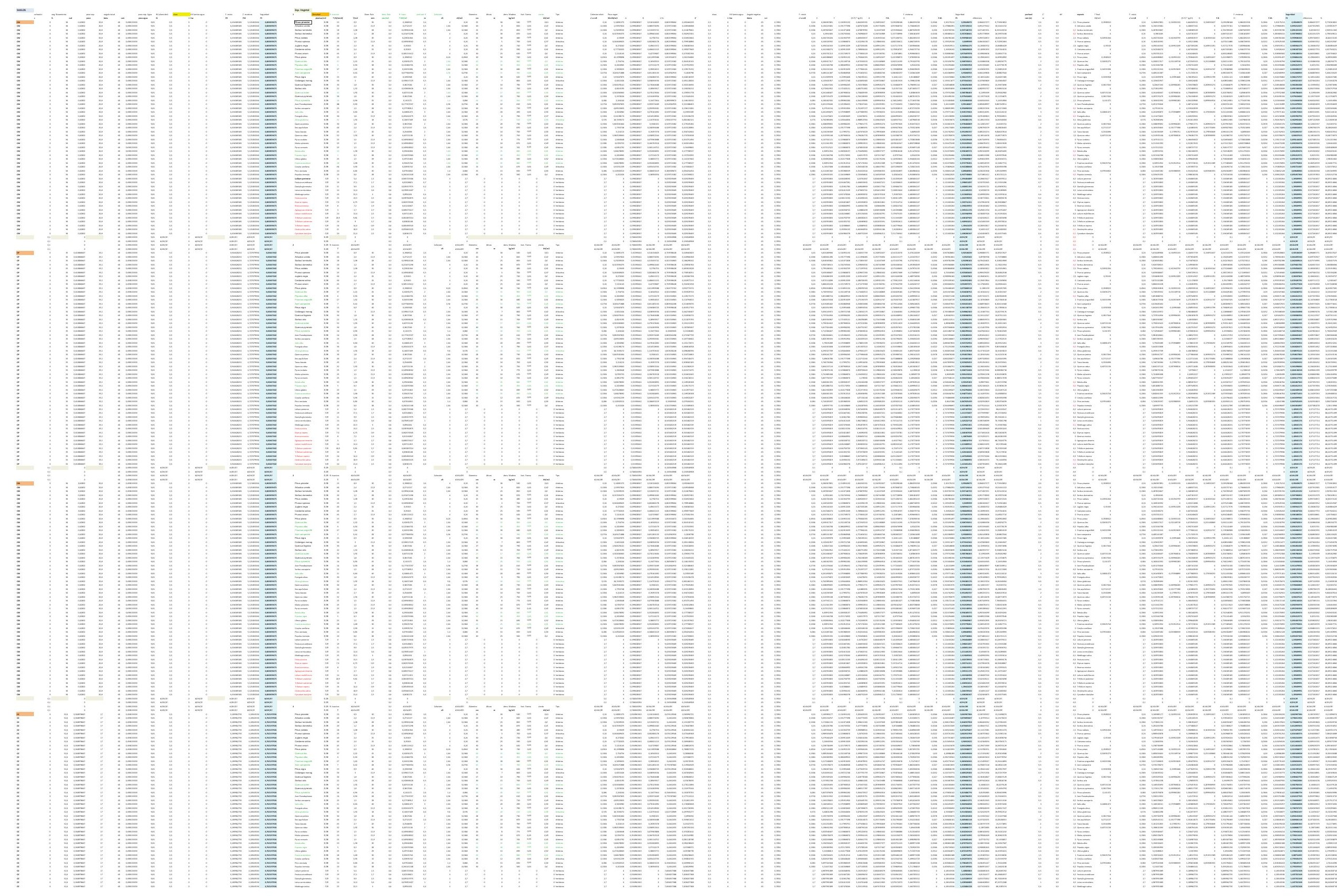


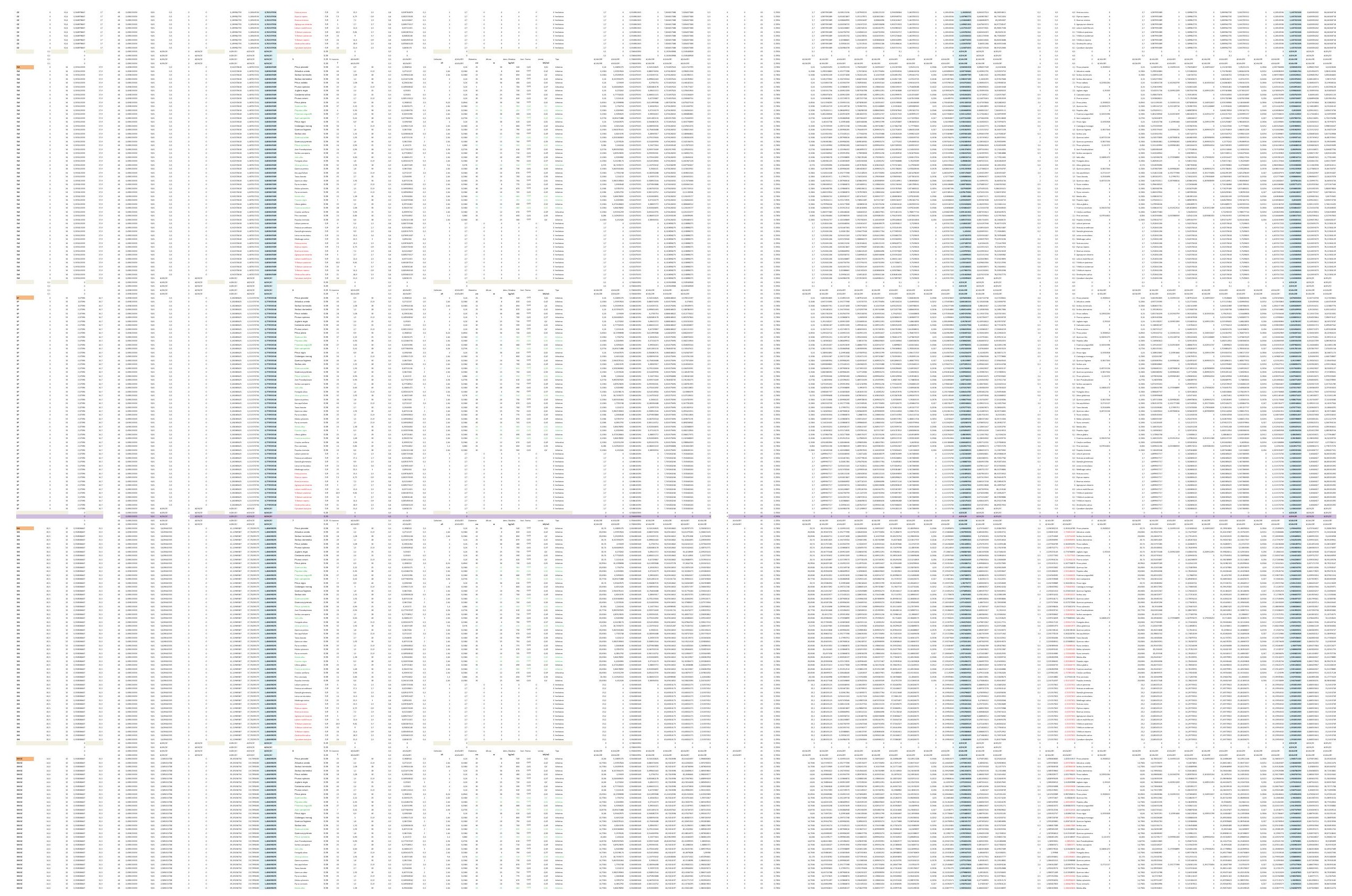



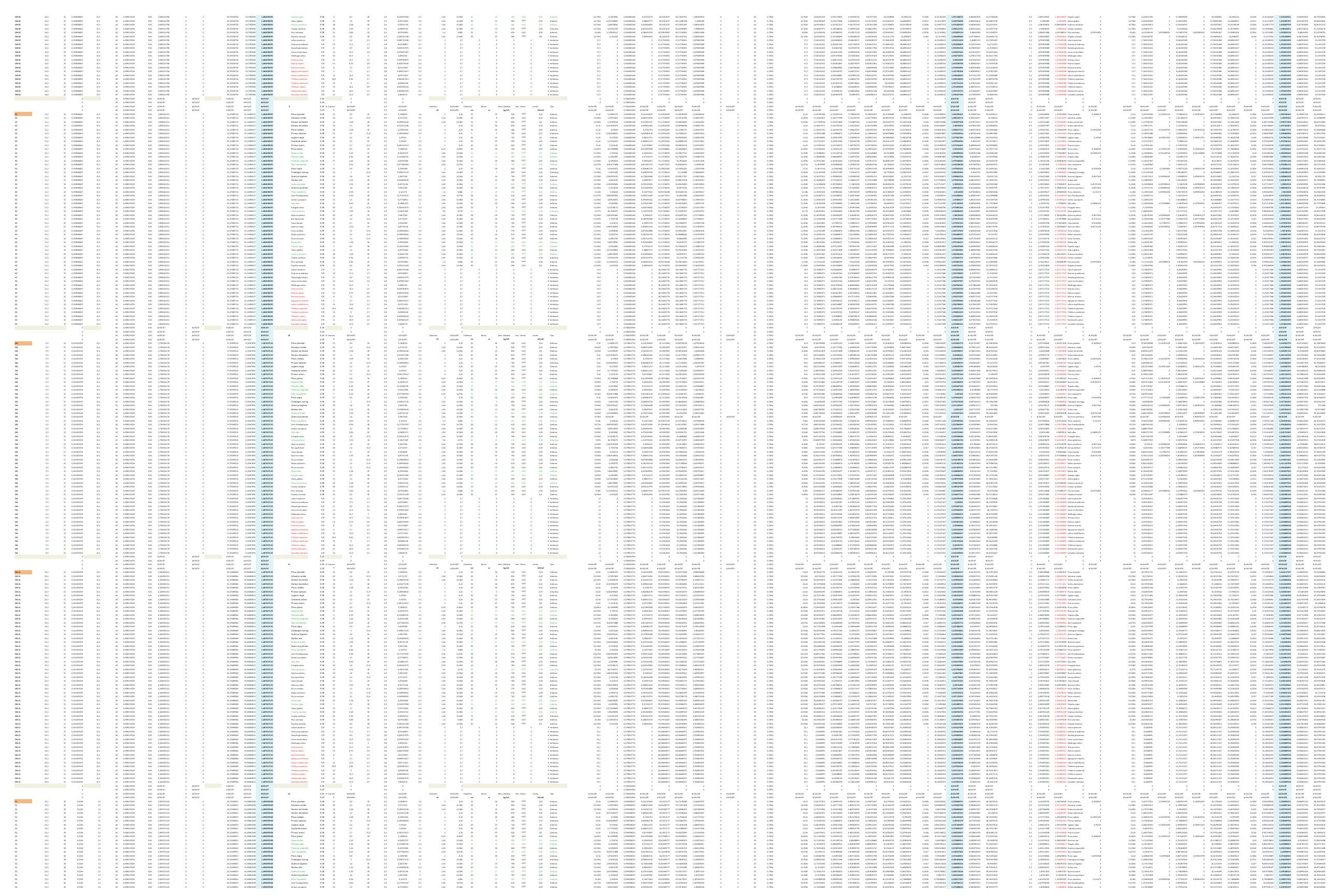


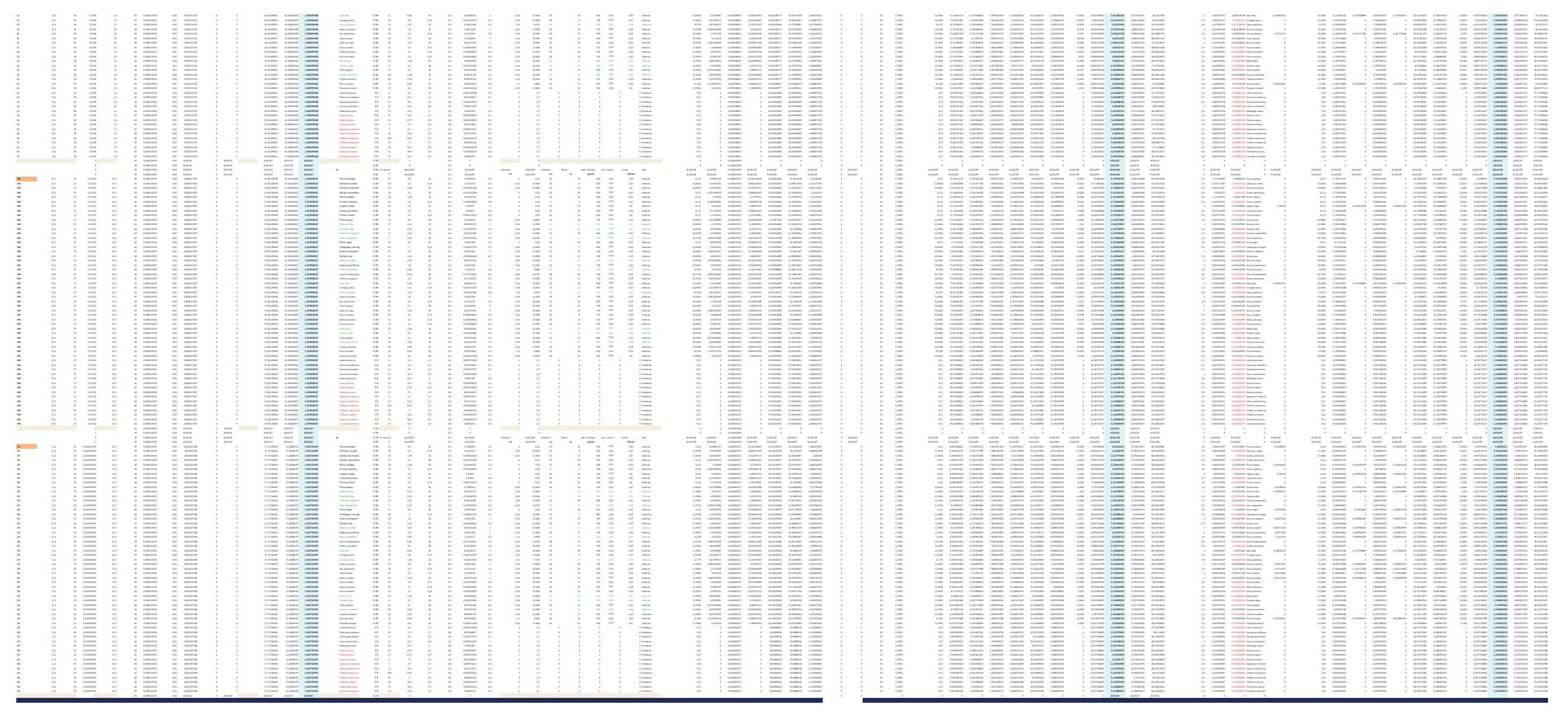



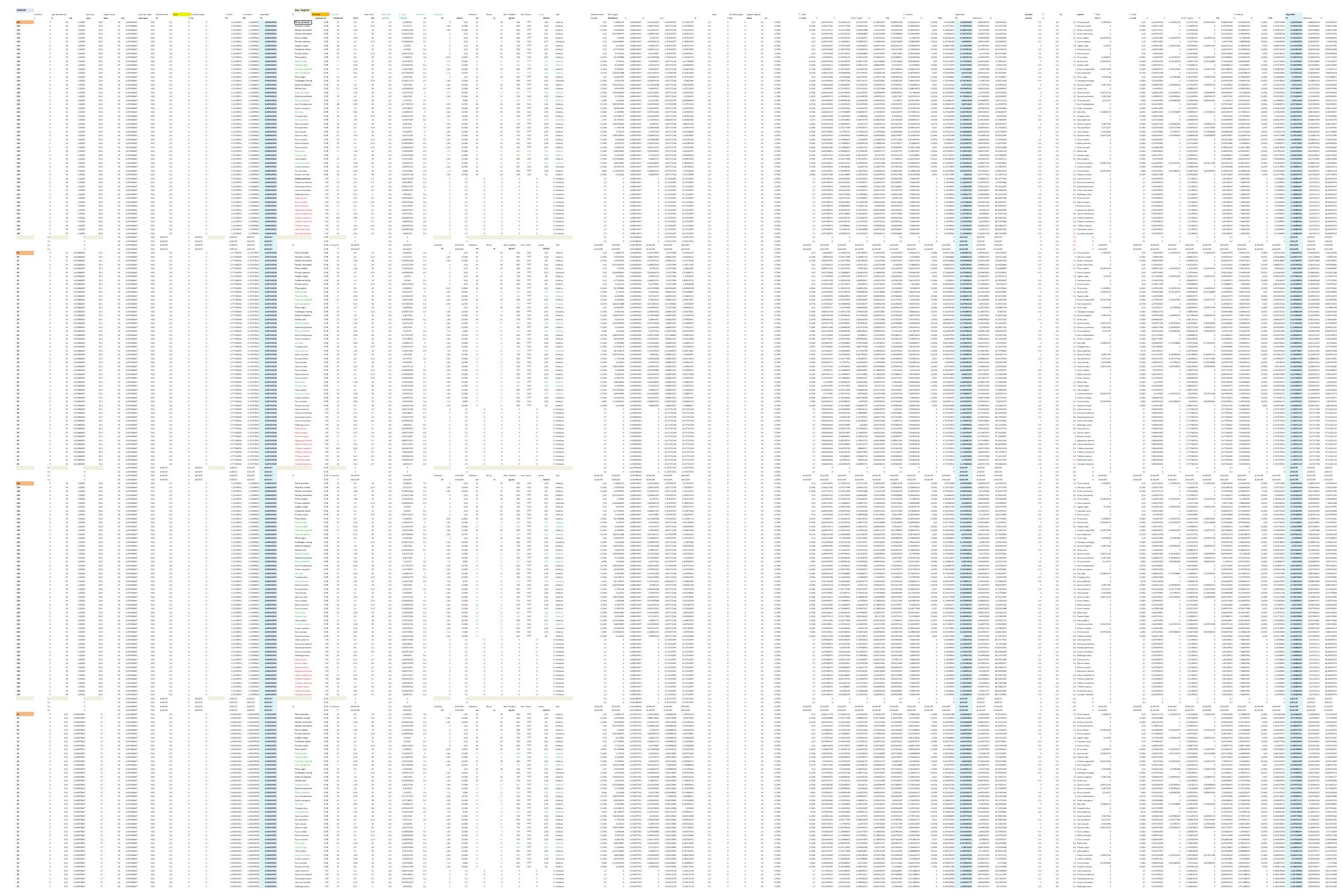


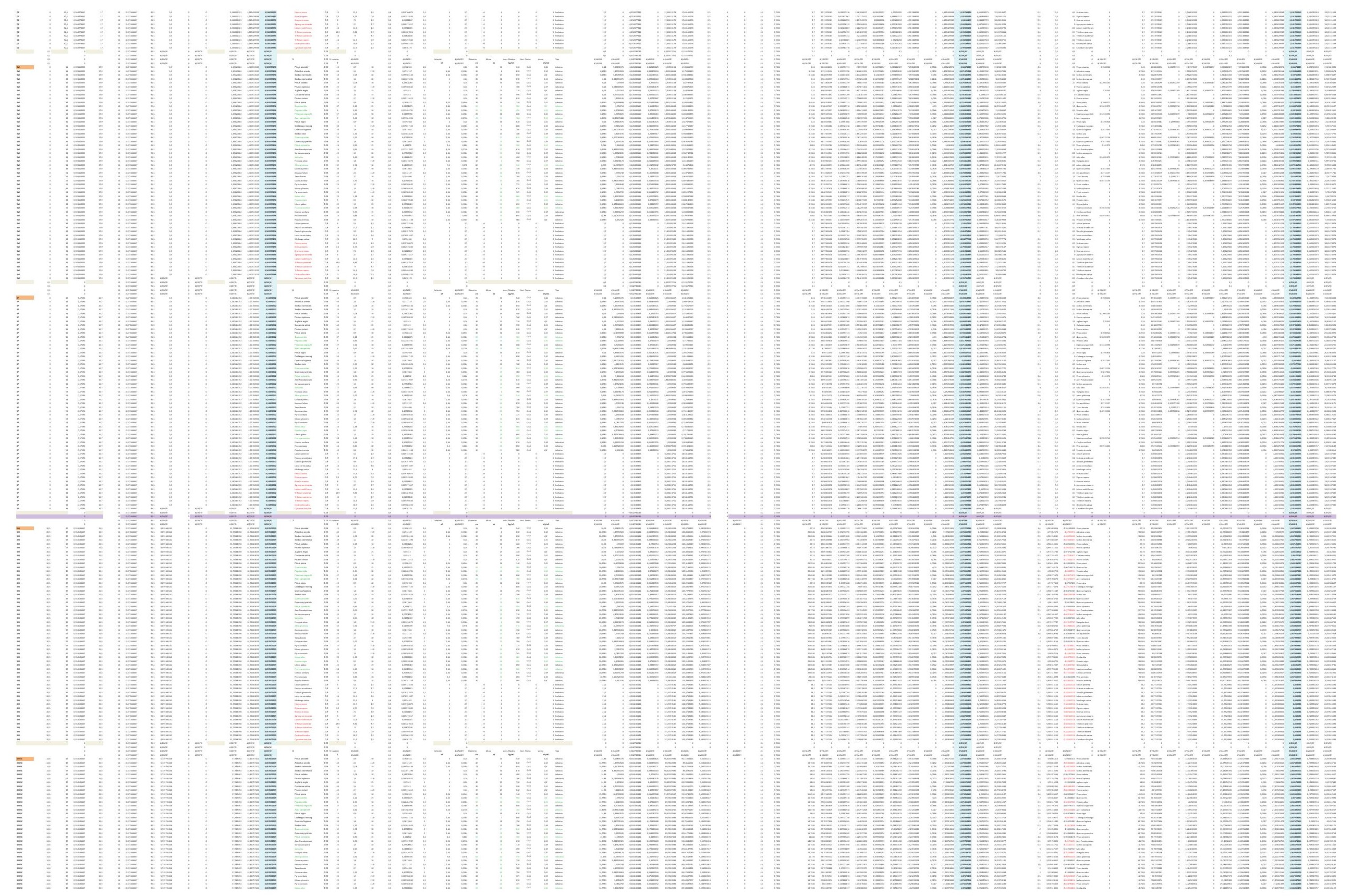



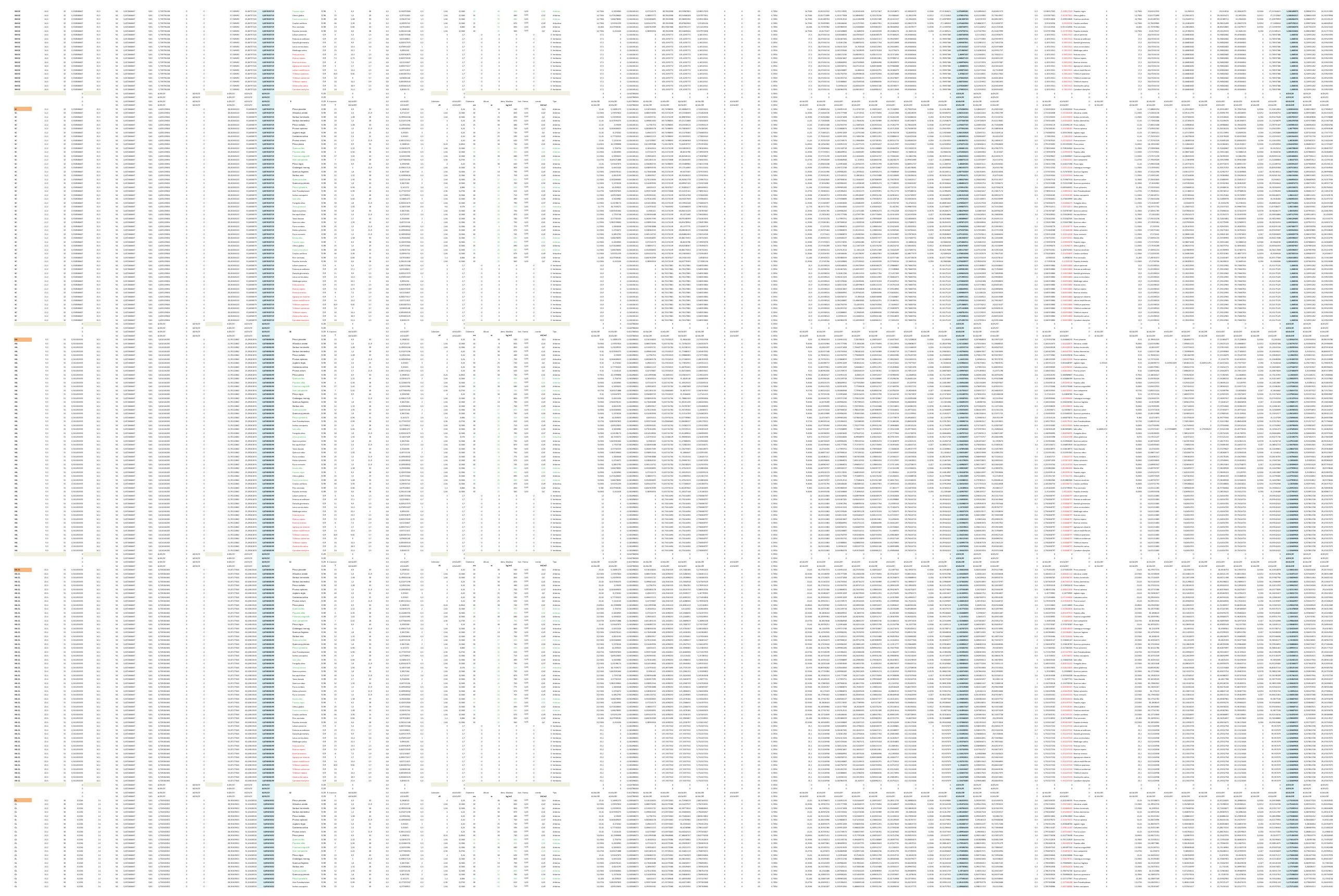


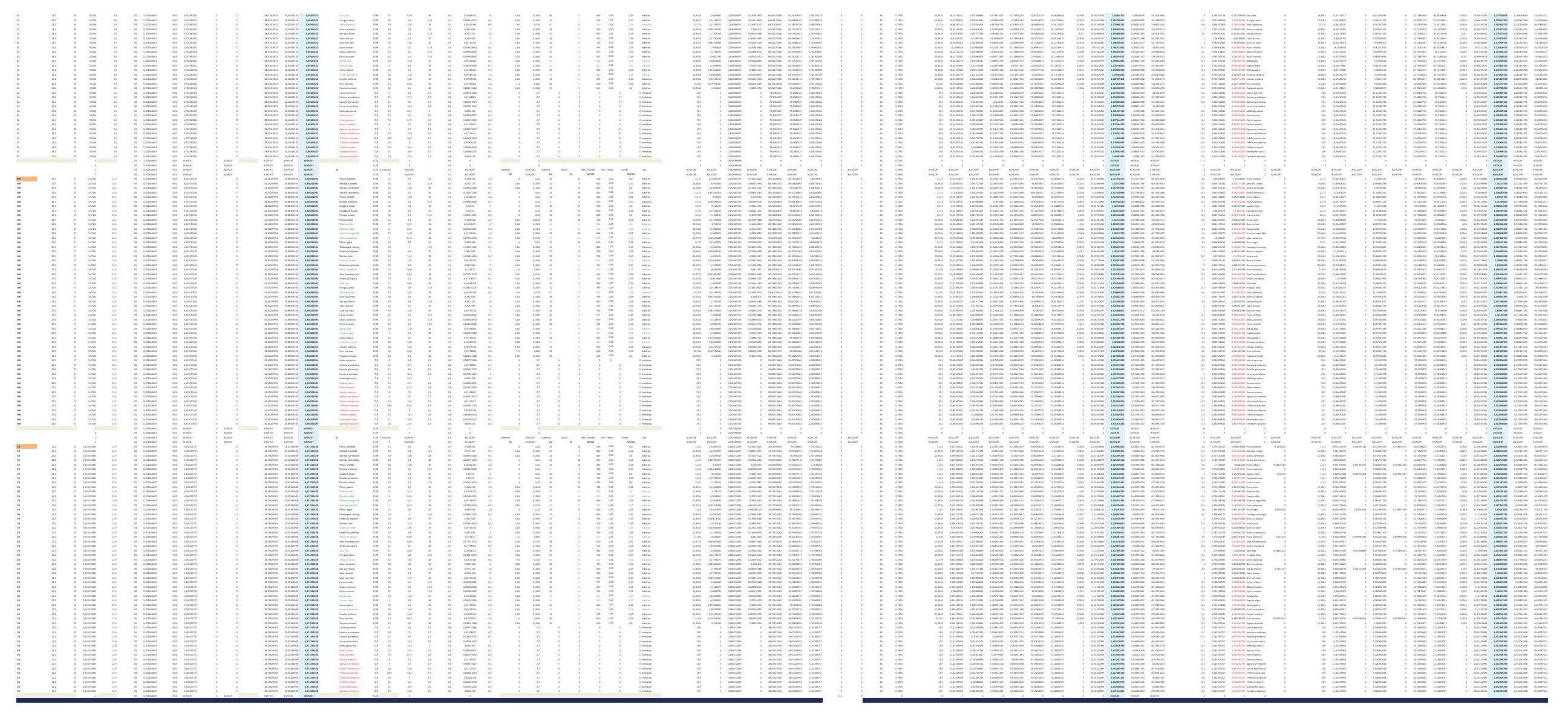



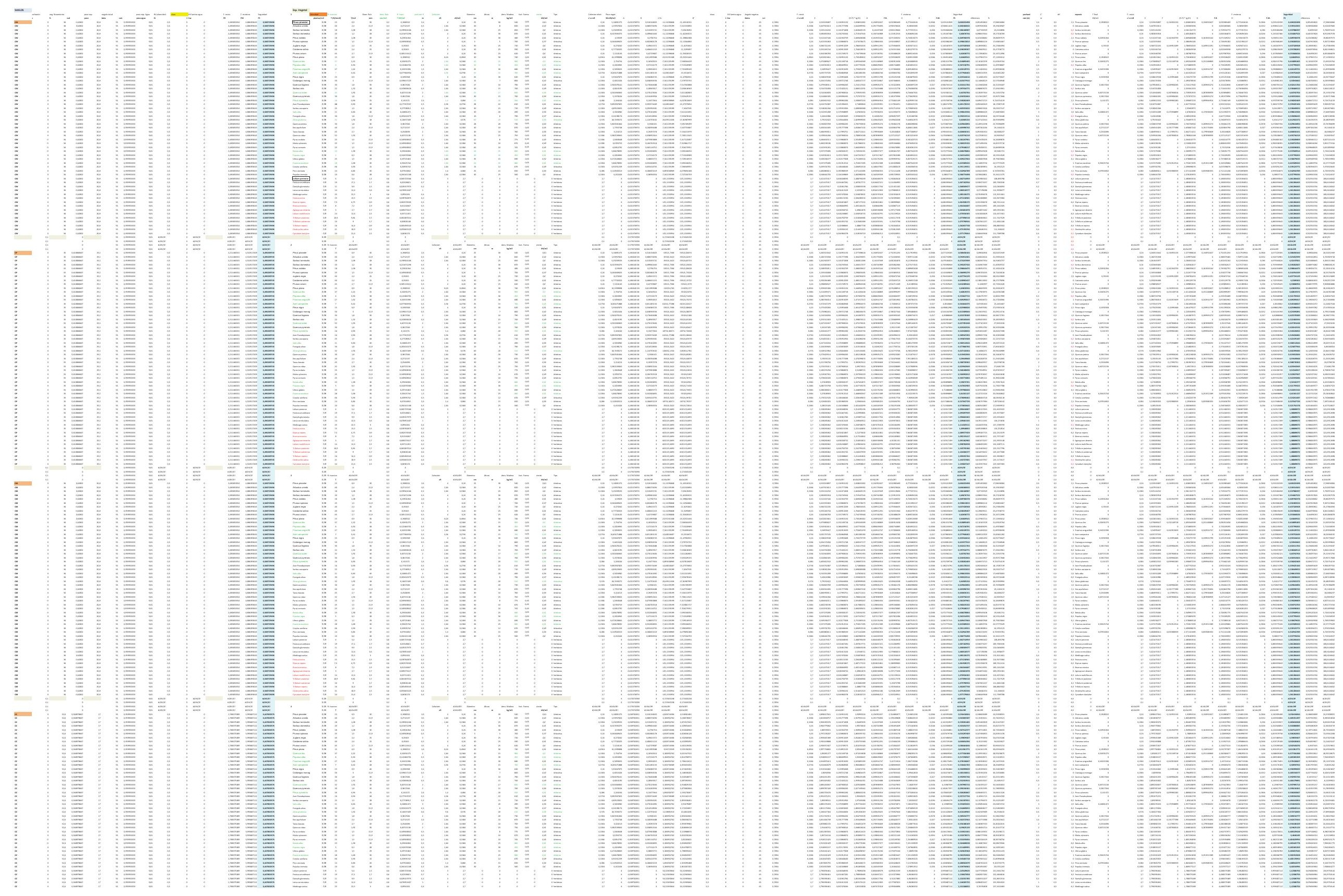


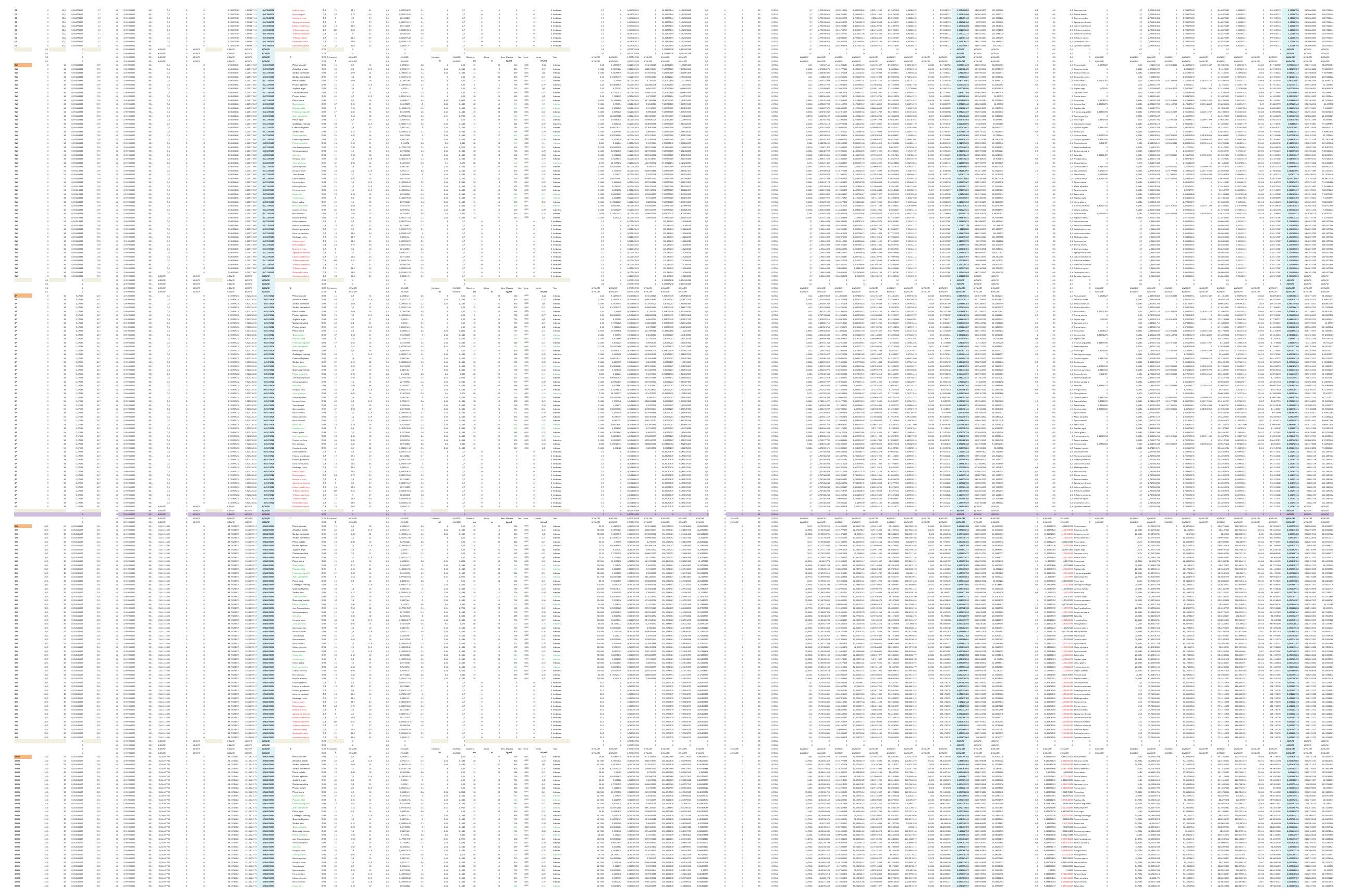



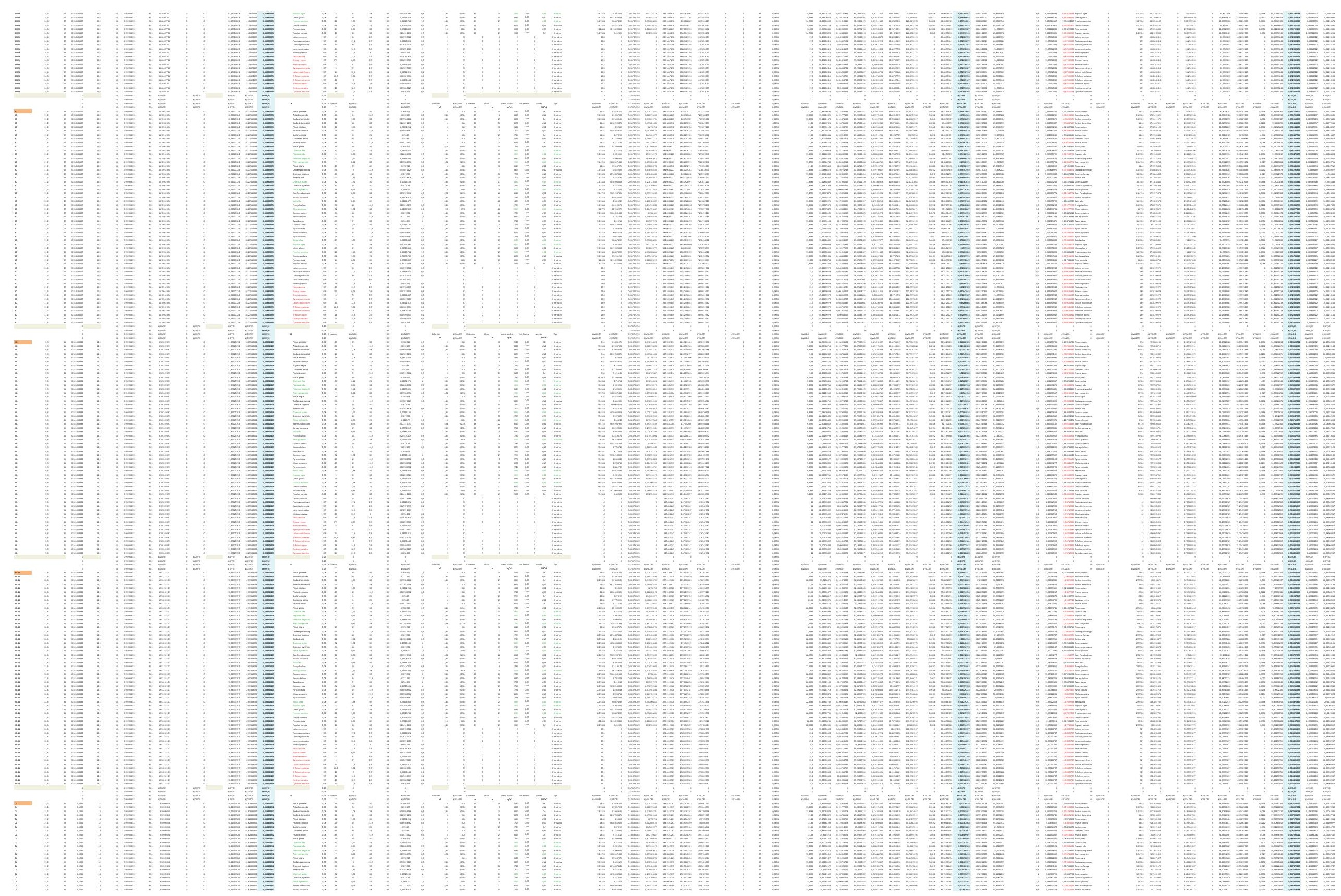


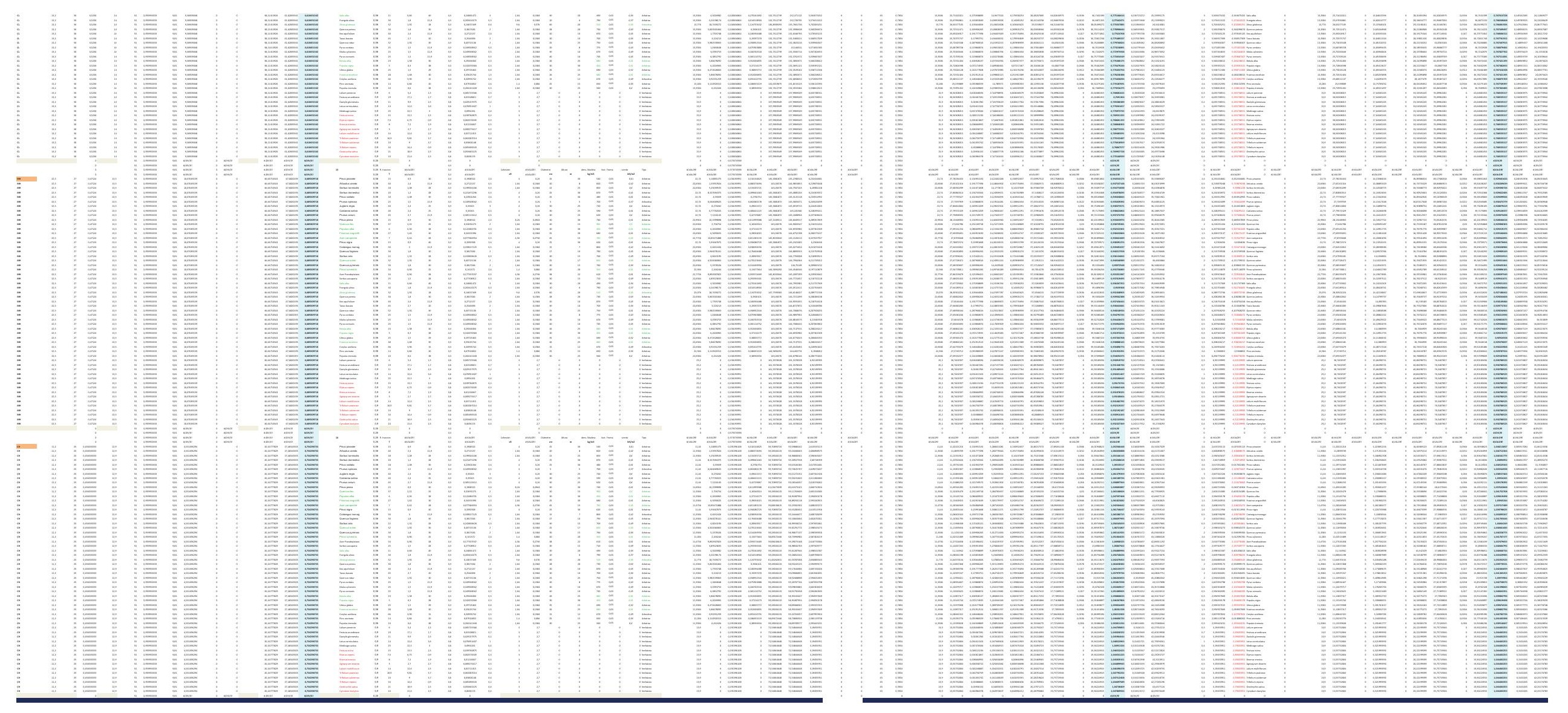



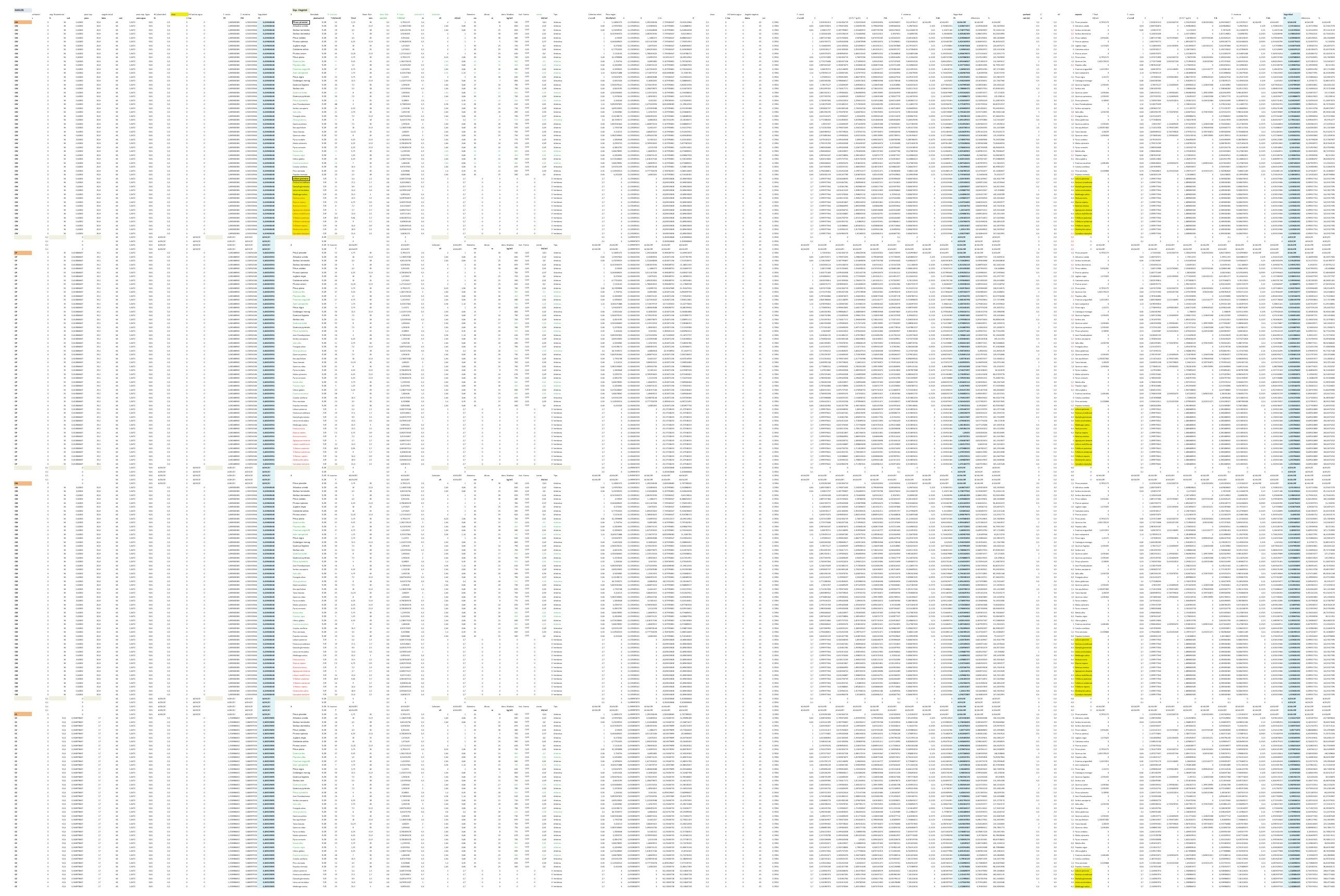


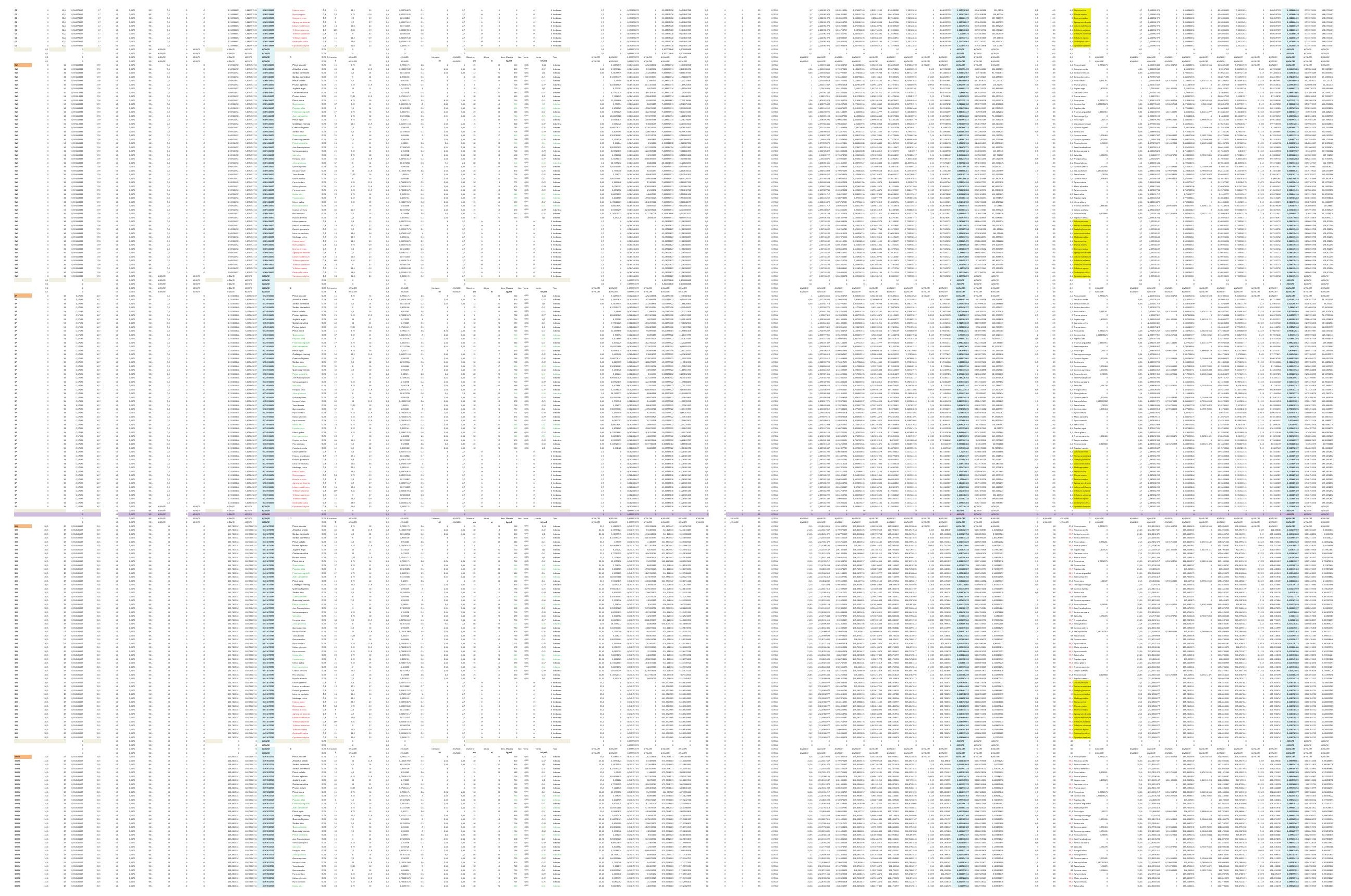



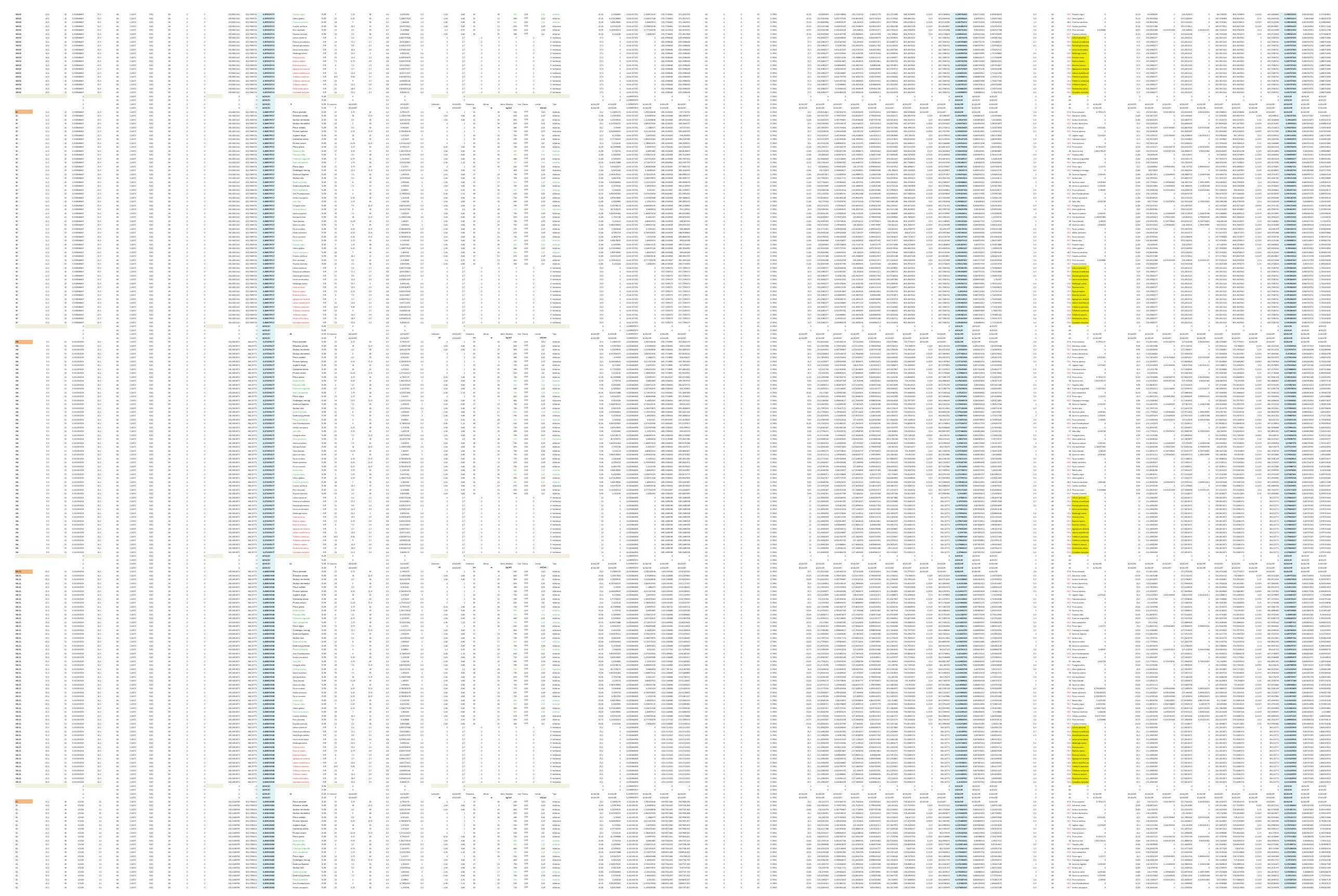


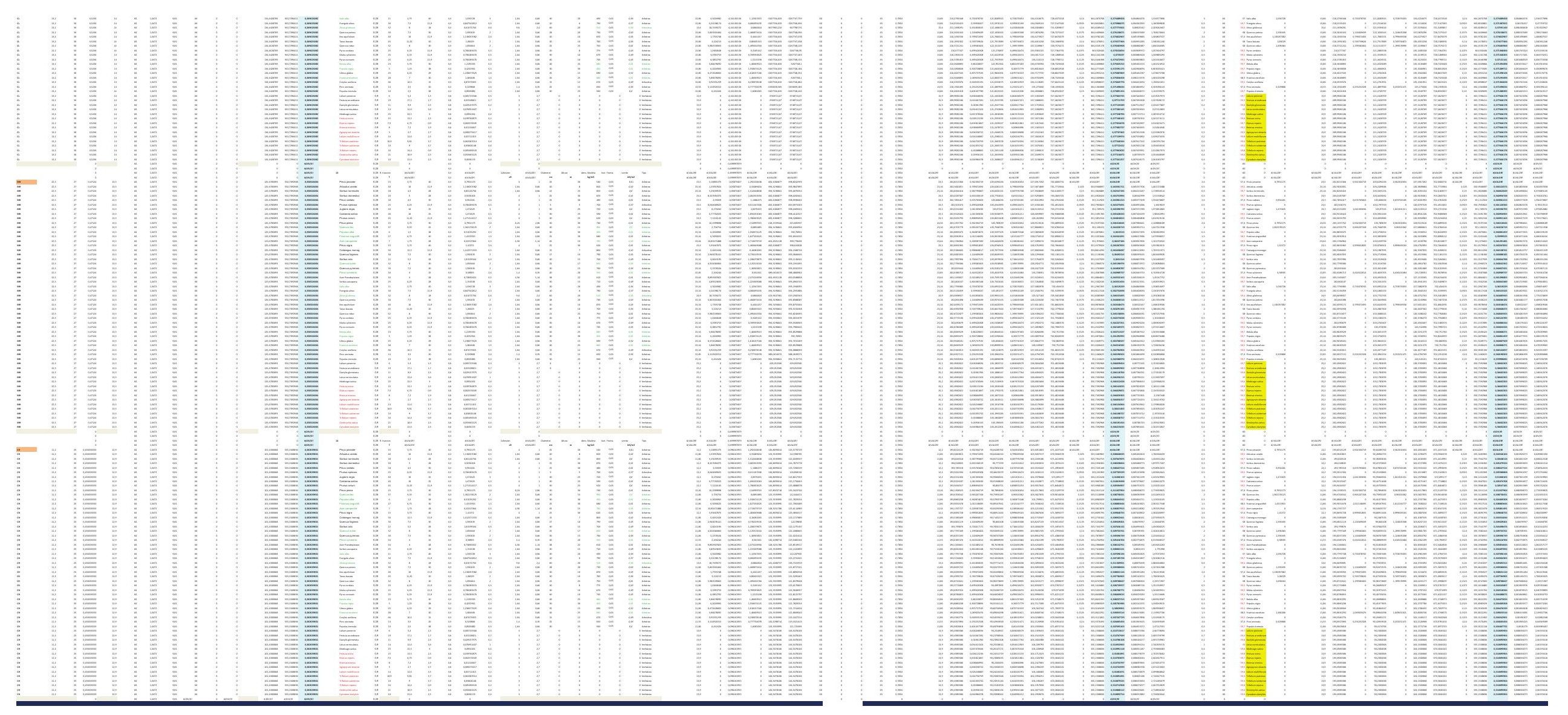



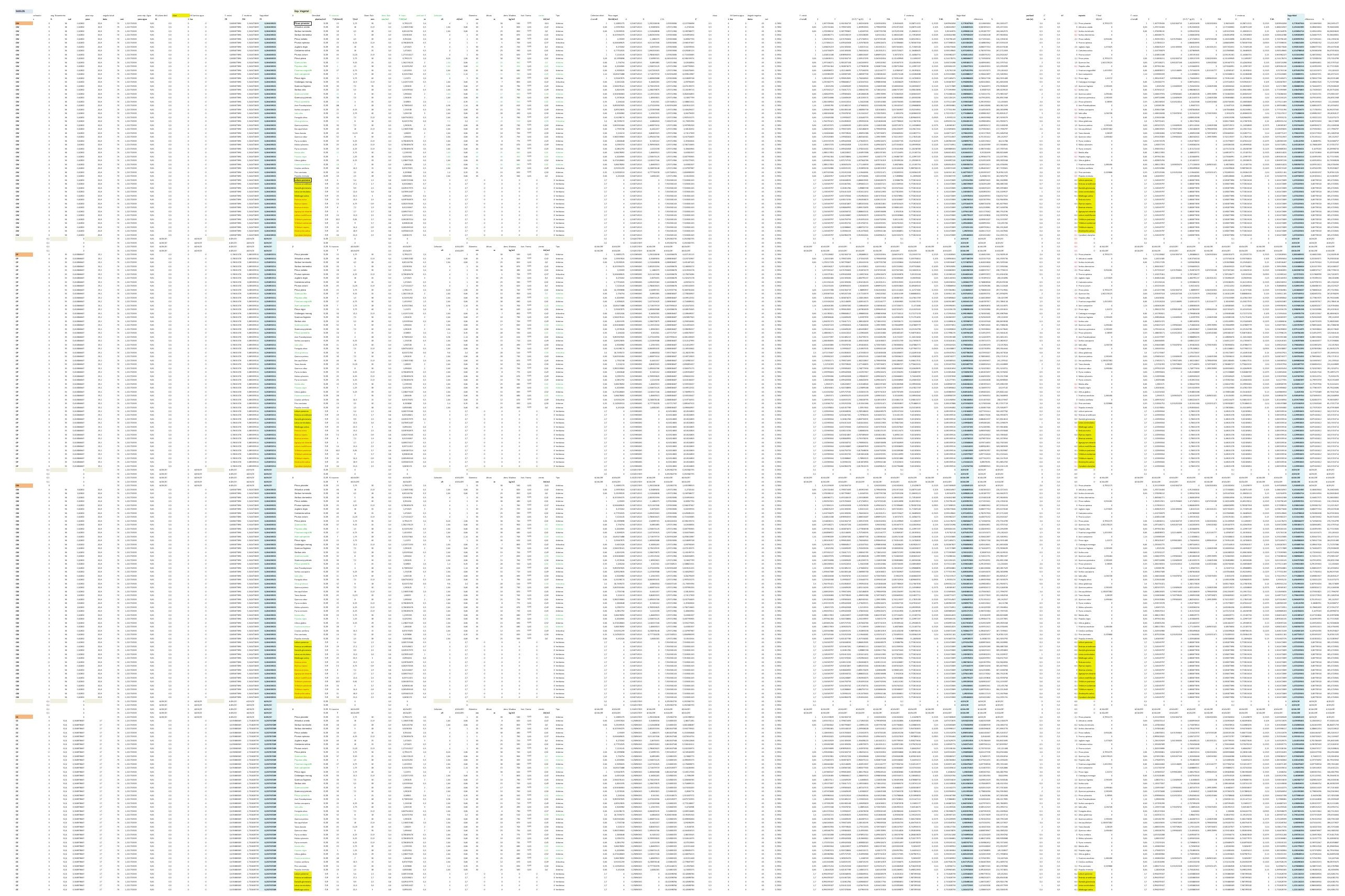


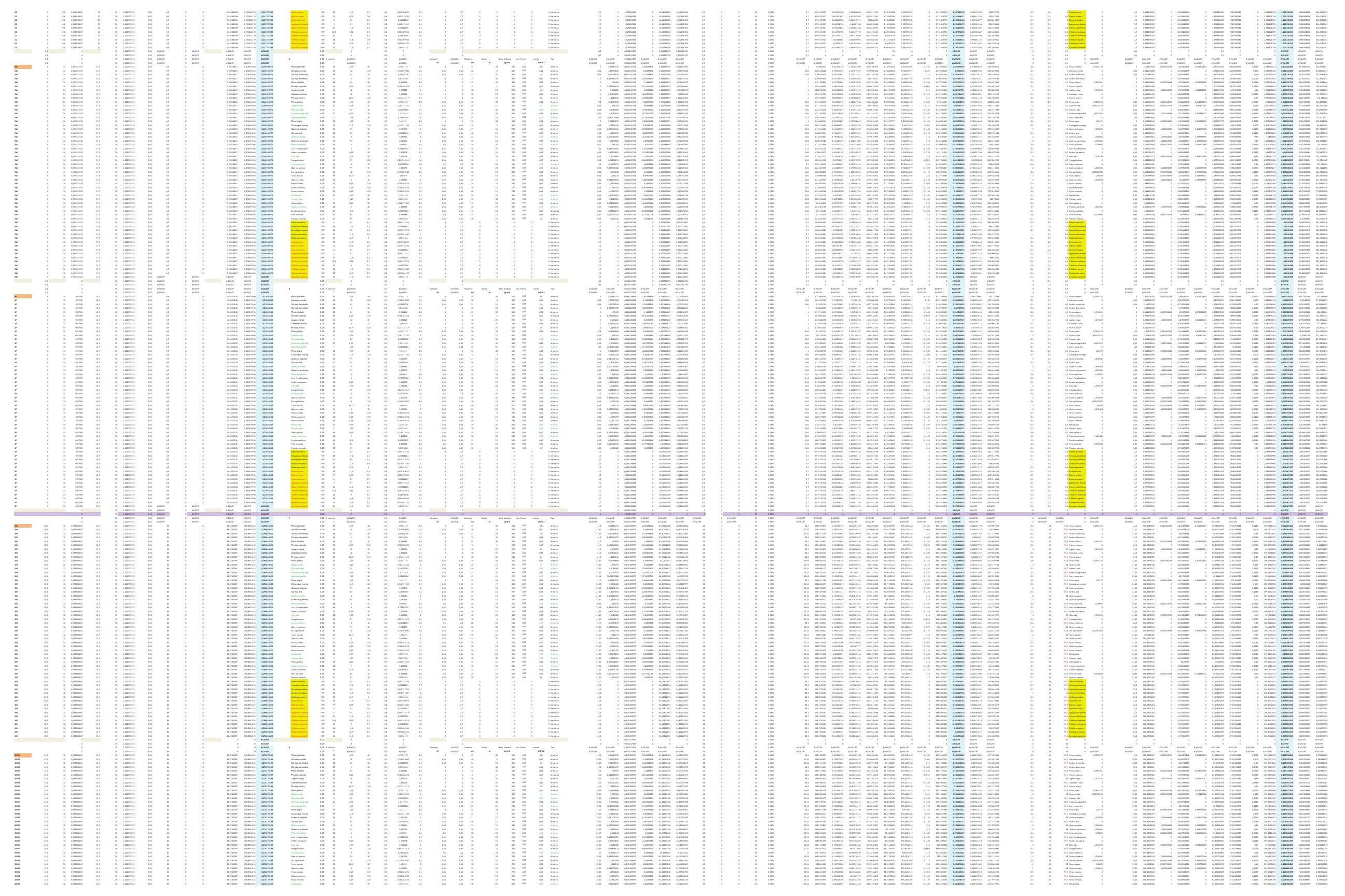



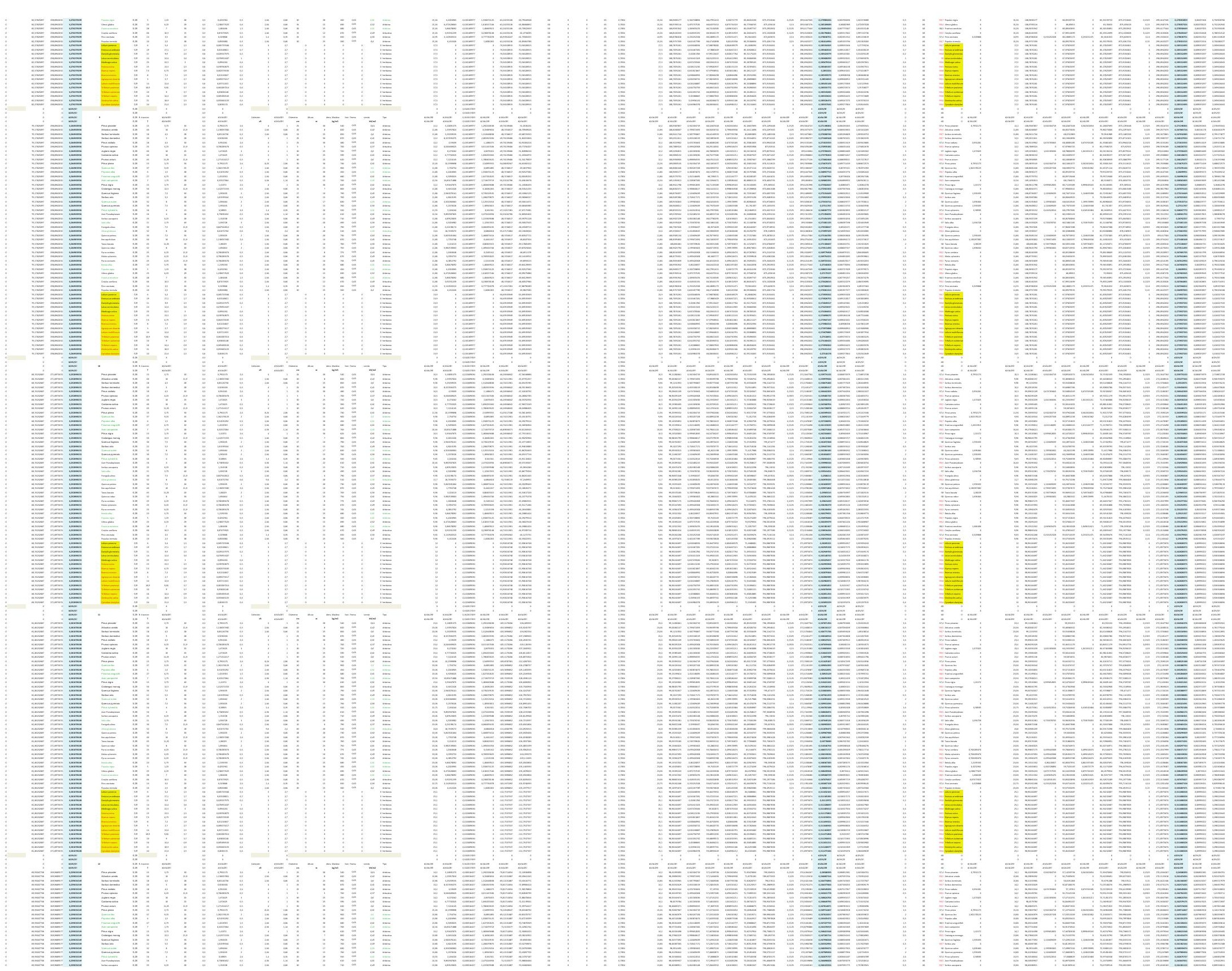


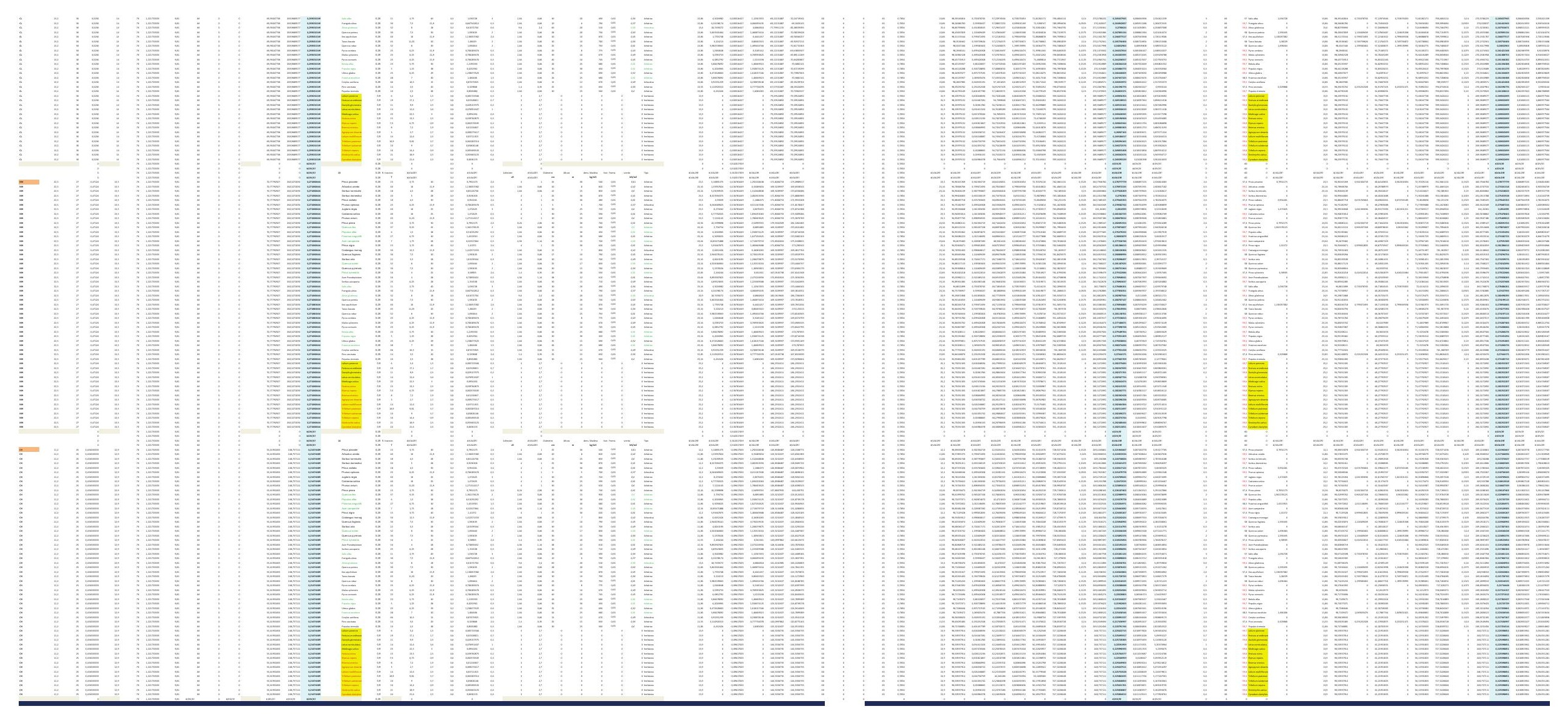



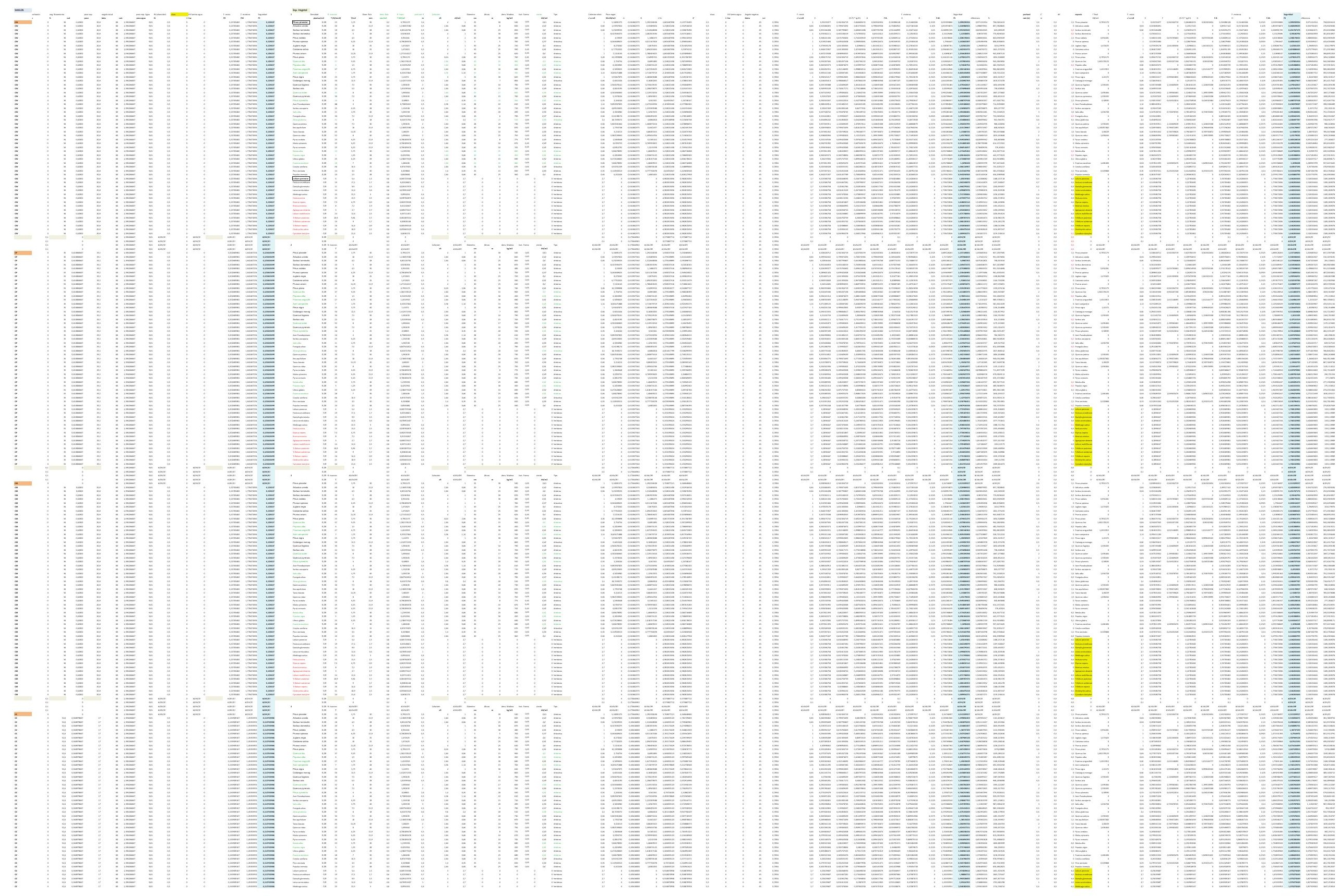


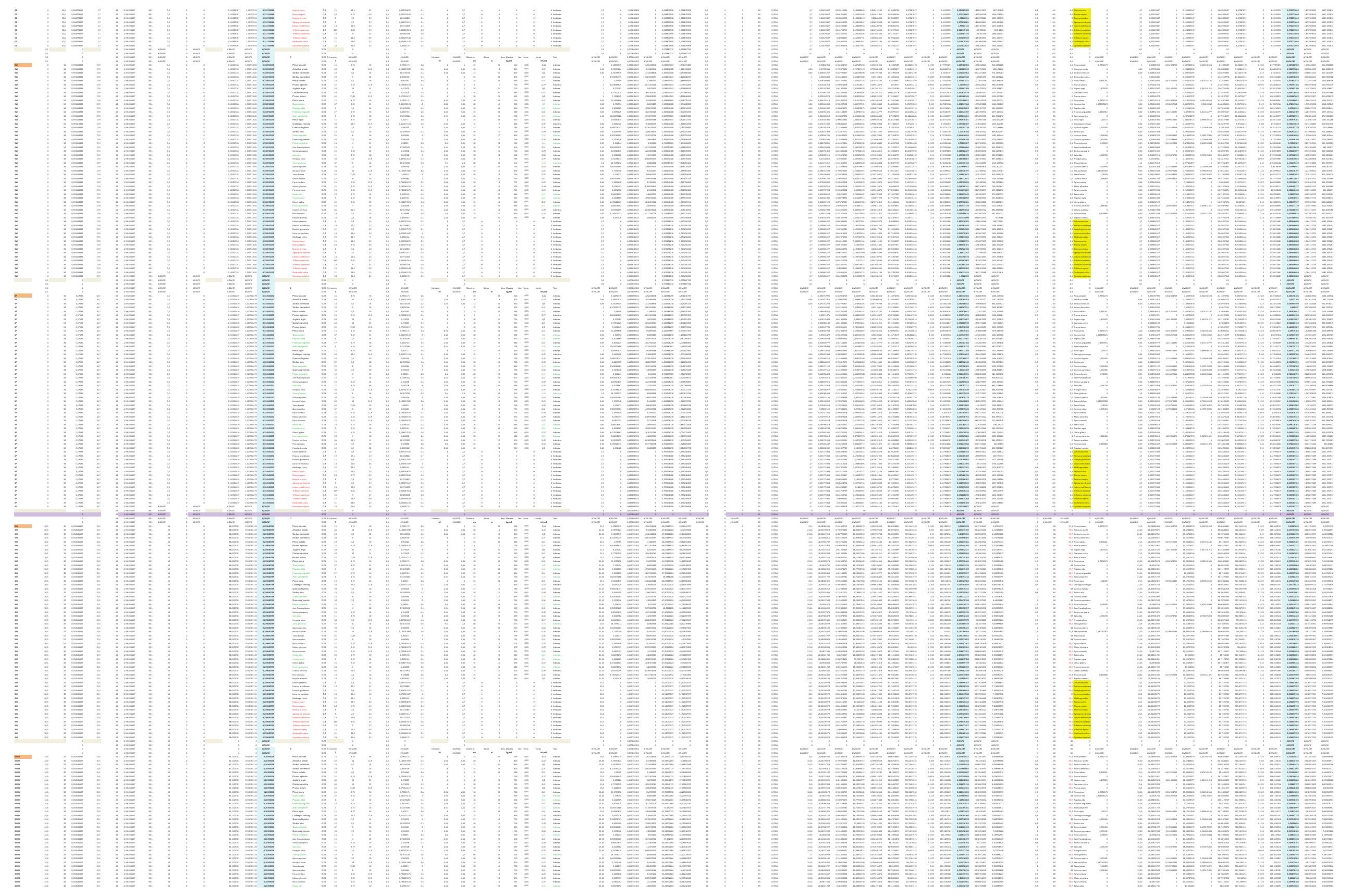



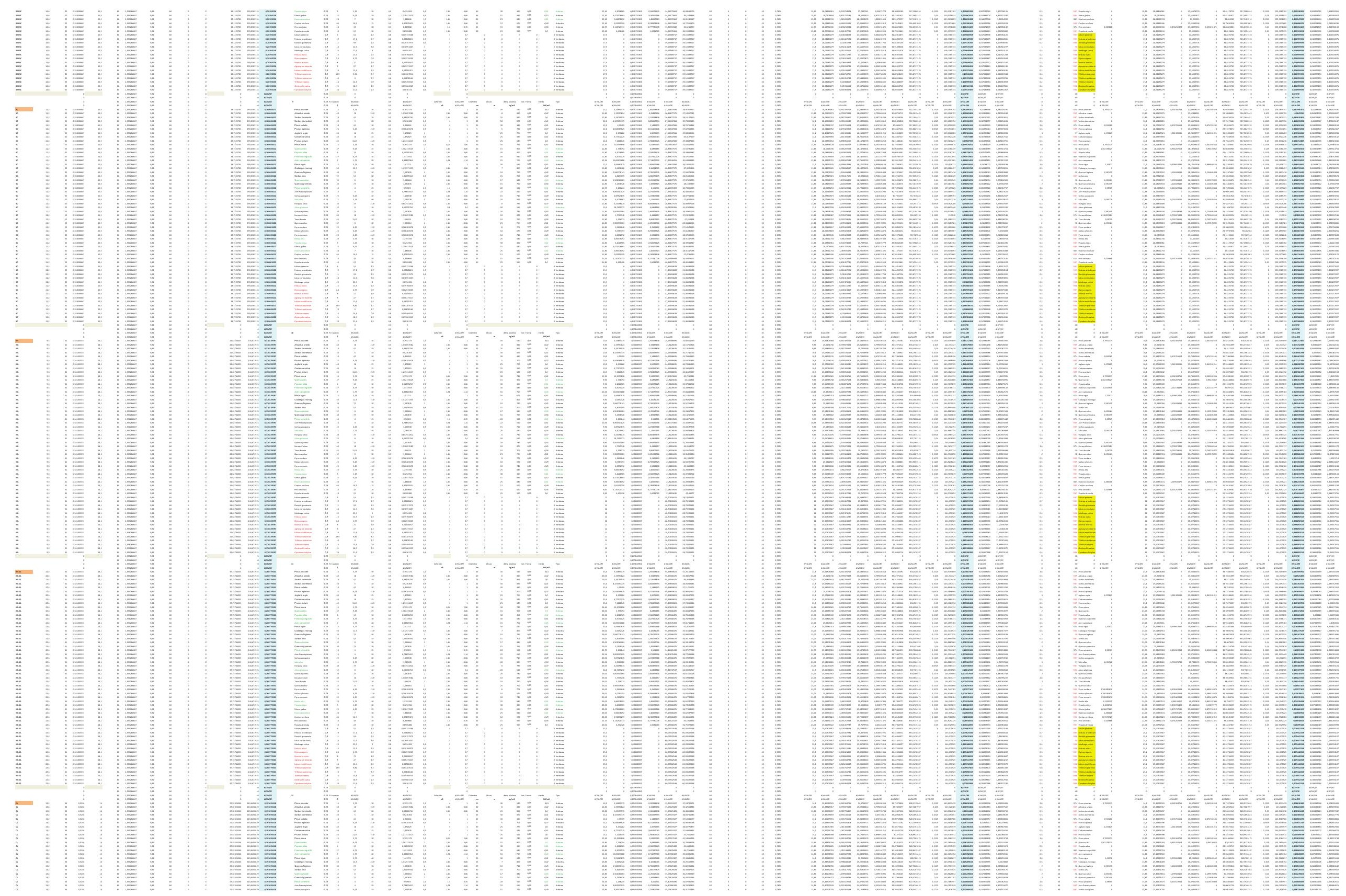


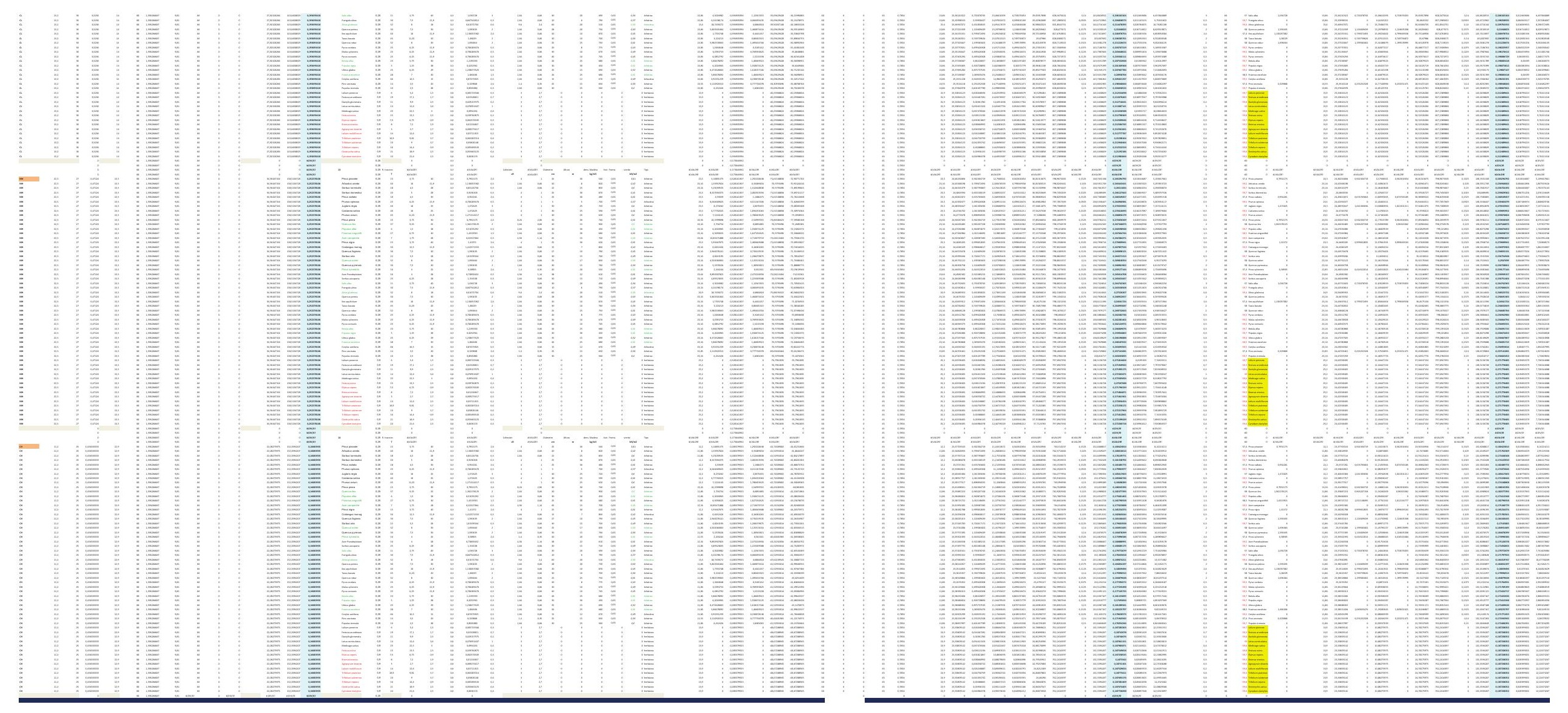


DESARROLLO DE UNA APLICACIÓN IMFORMÁTICA PARA EL CÁLCULO DE SOSTENIMIENTO DE TALUDES MEDIANTE VEGETACIÓN

A01. DENSIDAD DE PLANTACIÓN: 600 plantas/ha.

\section{A01-2.POSICIÓN N.F. 2}

INCLINACIÓN DE TALUD 6-100

INCLINACIÓN DE TALUD 10-200

INCLINACIÓN DE TALUD 20-30

INCLINACIÓN DE TALUD 30-40

INCLINACIÓN DE TALUD $35^{\circ}$

INCLINACIÓN DE TALUD 40-50

INCLINACIÓN DE TALUD 50-550

INCLINACIÓN DE TALUD 55-60

INCLINACIÓN DE TALUD 60-700

INCLINACIÓN DE TALUD 70-80 

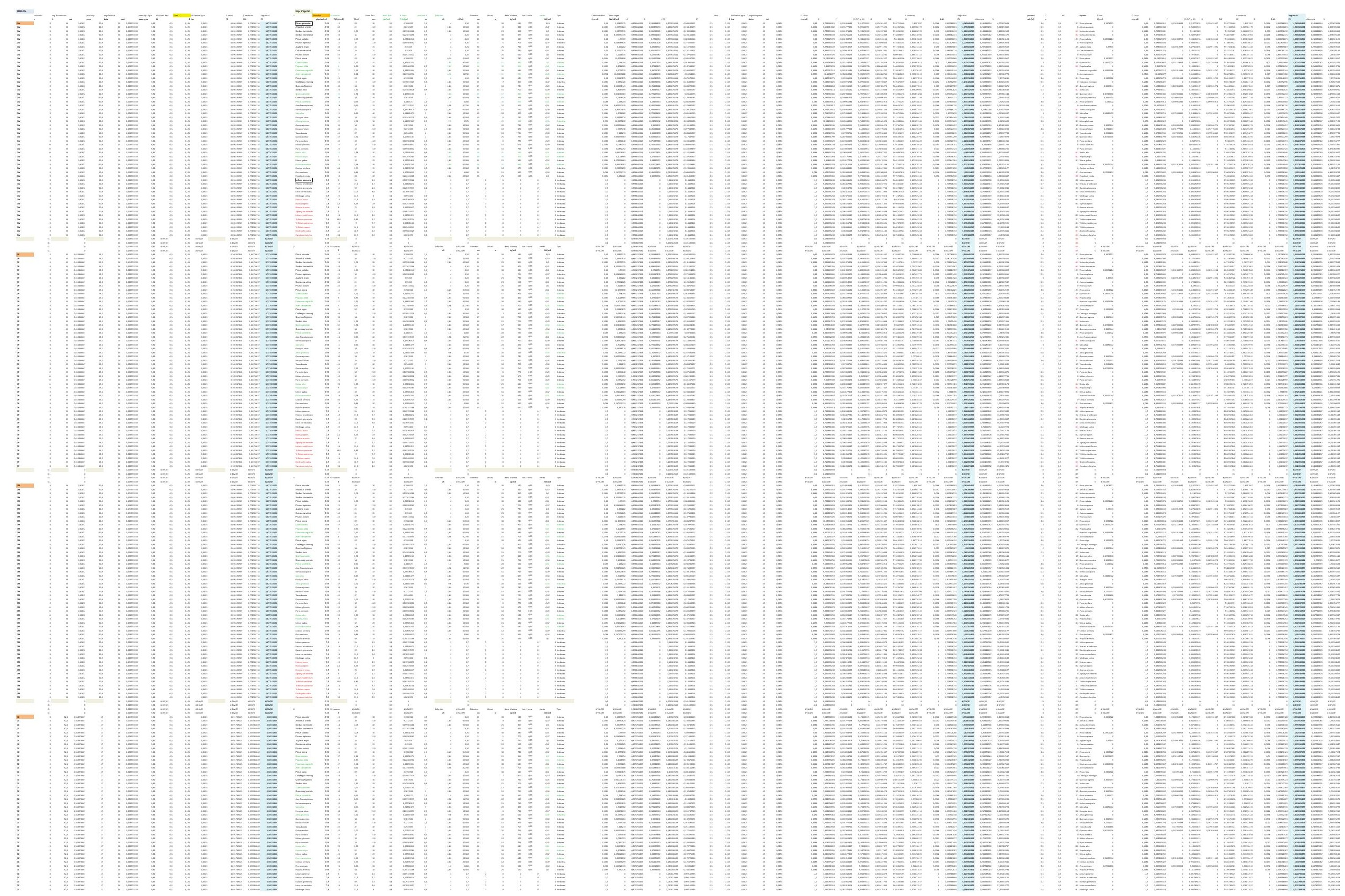


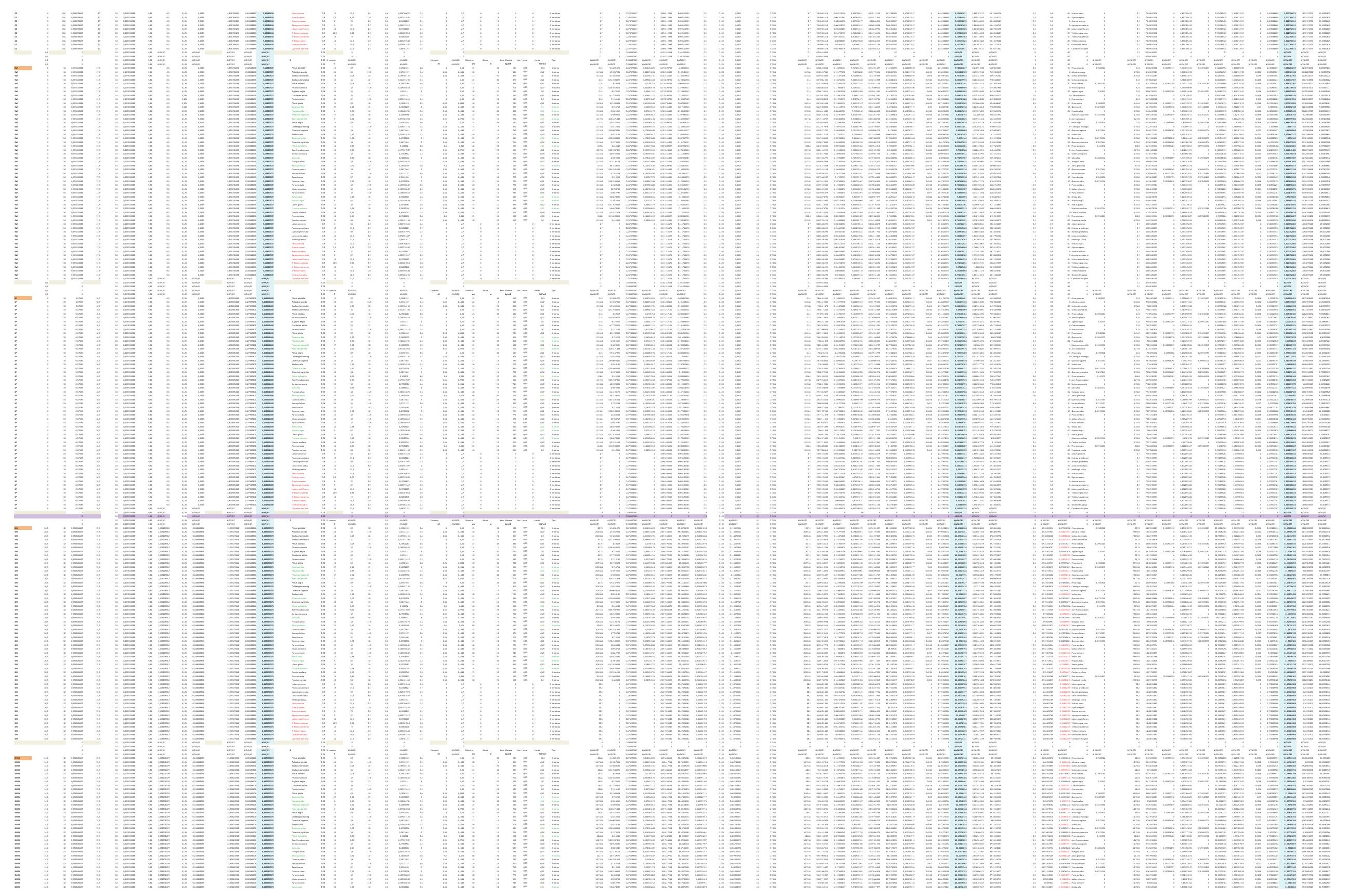



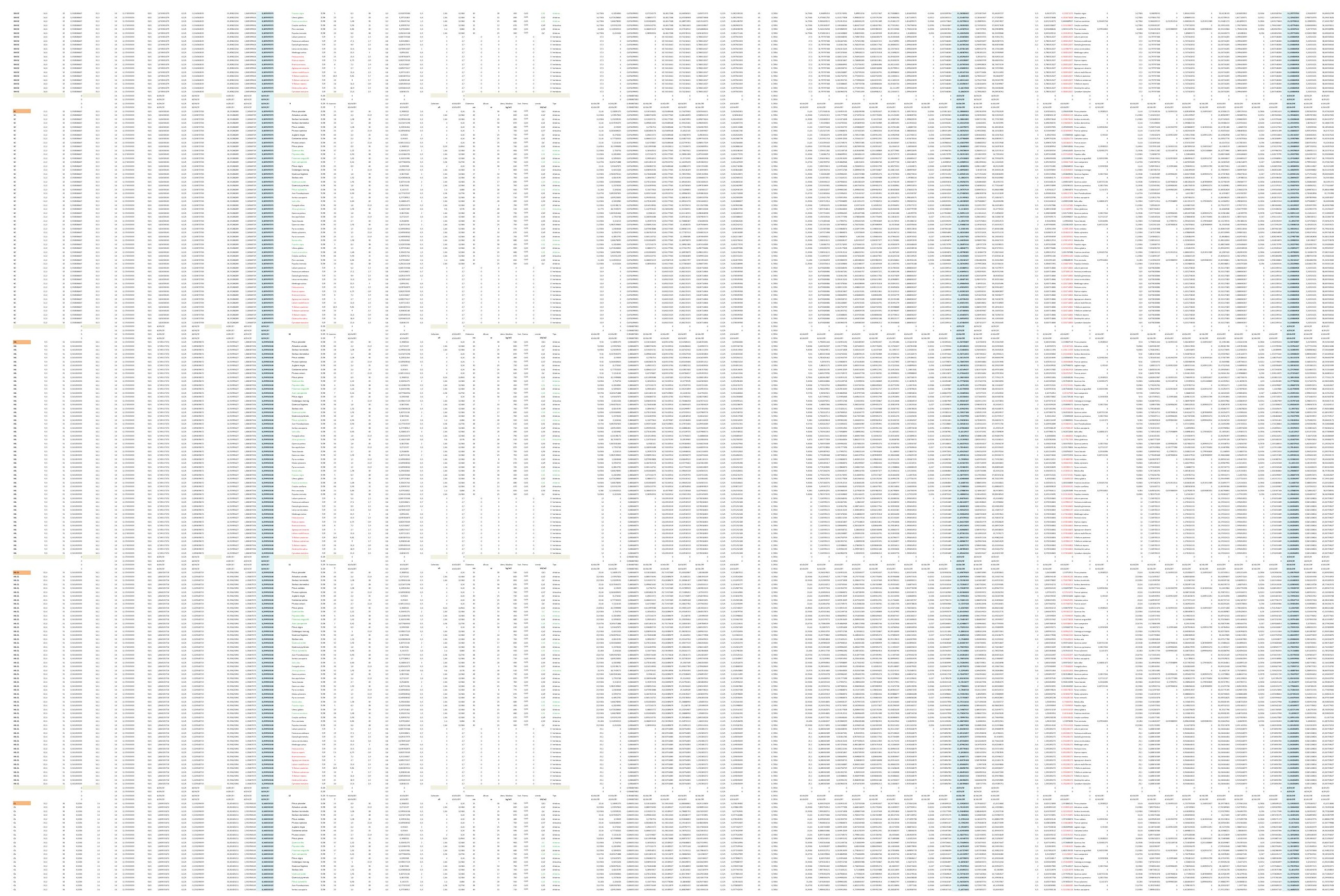


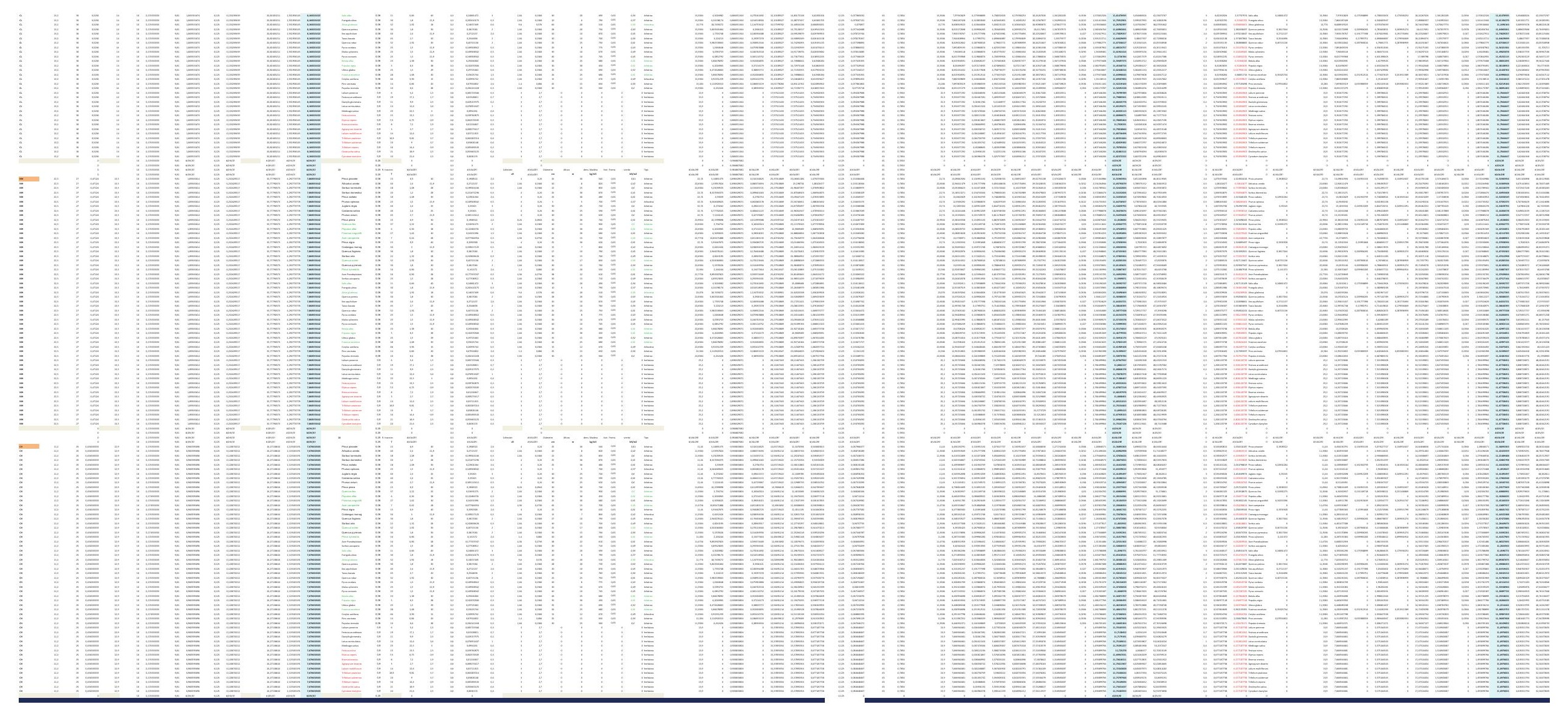



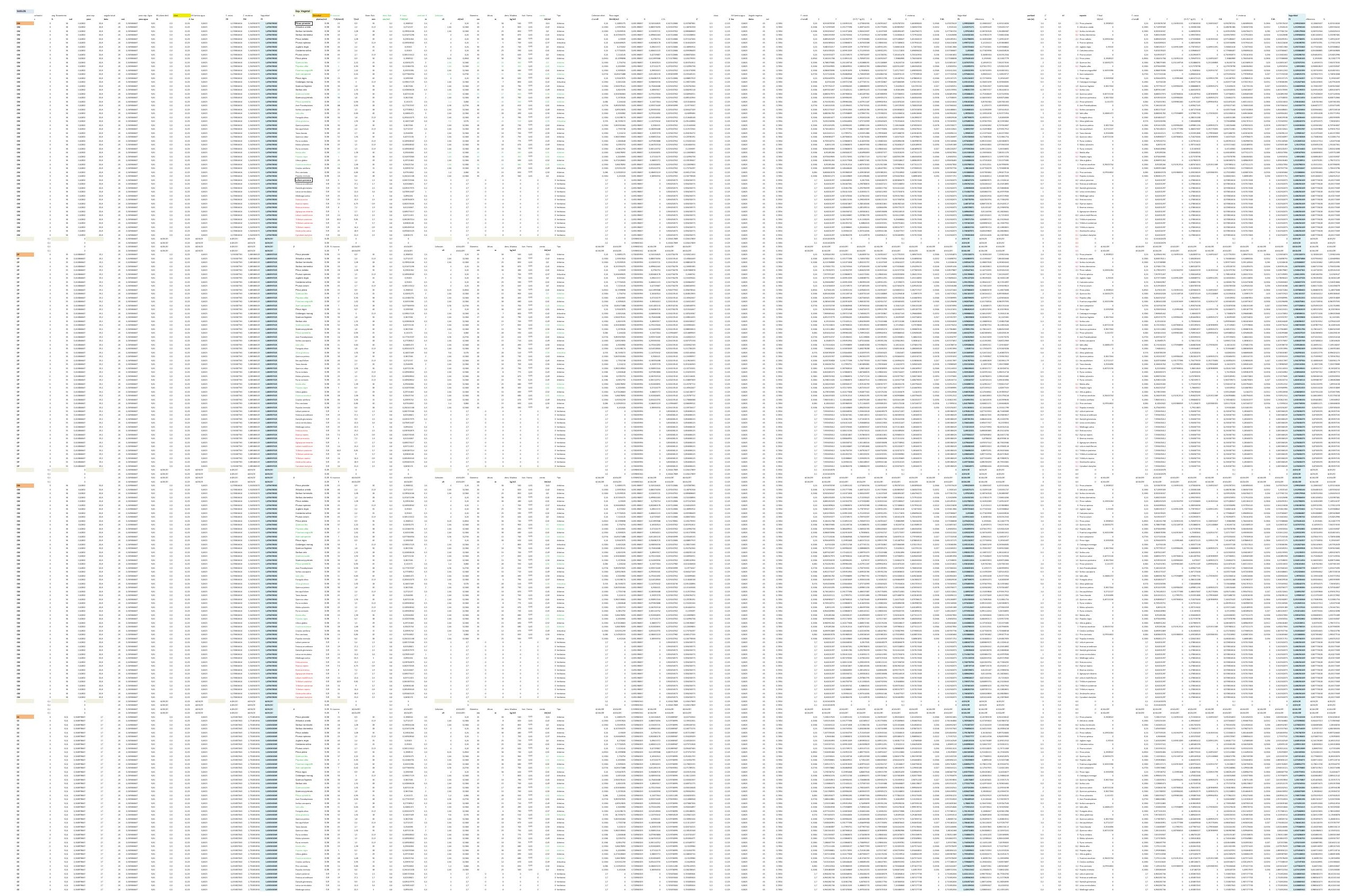


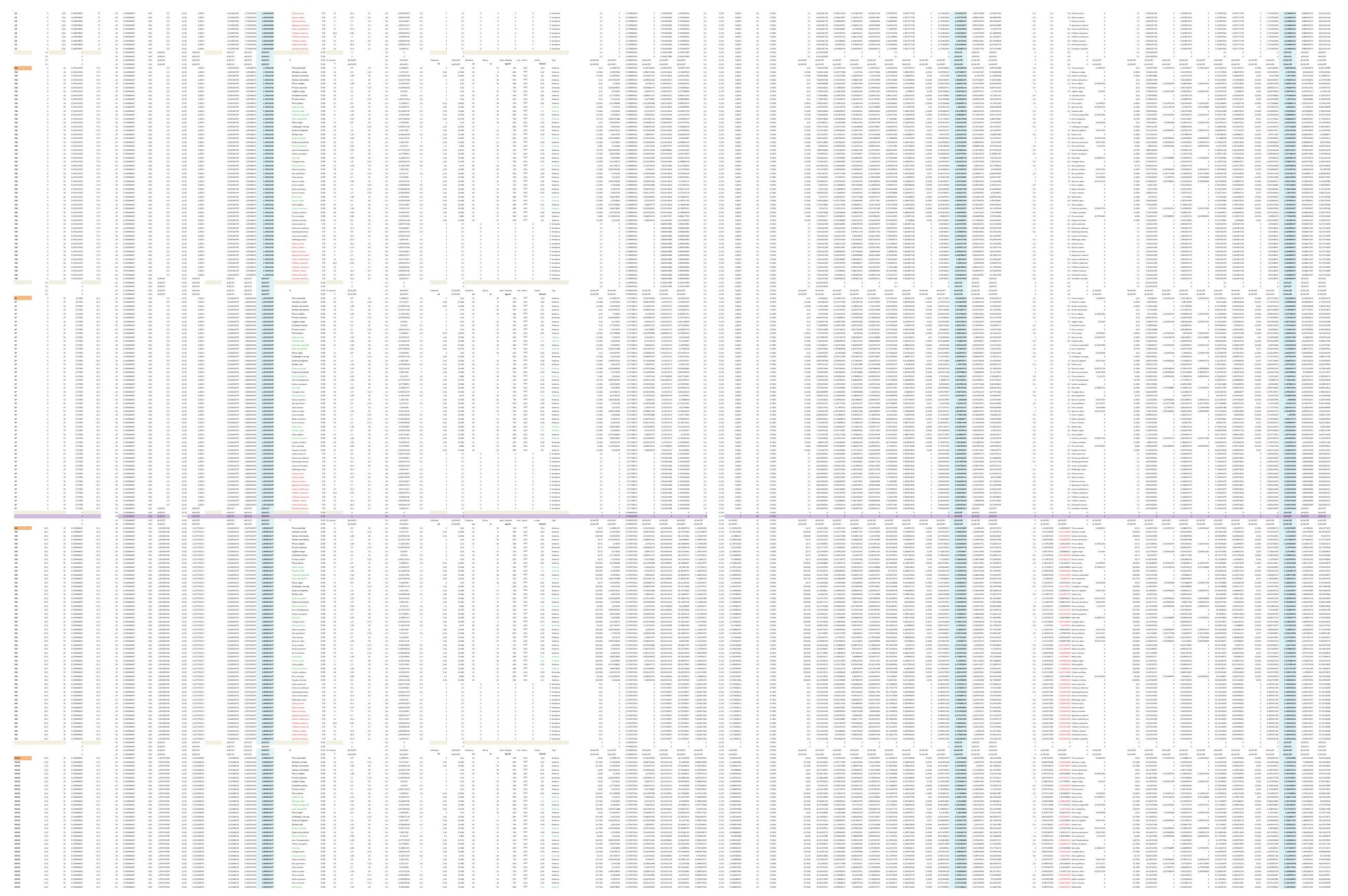



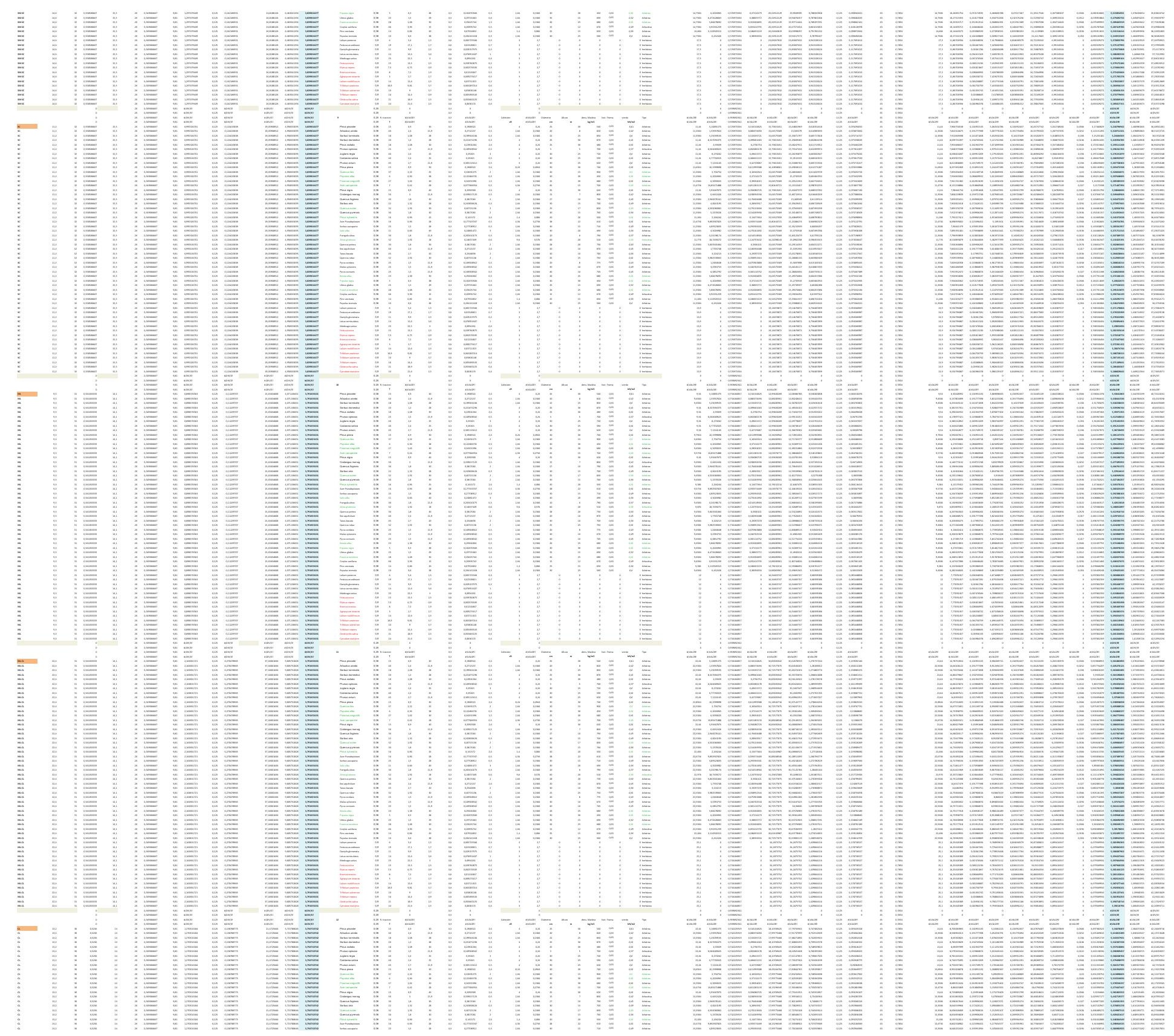

:
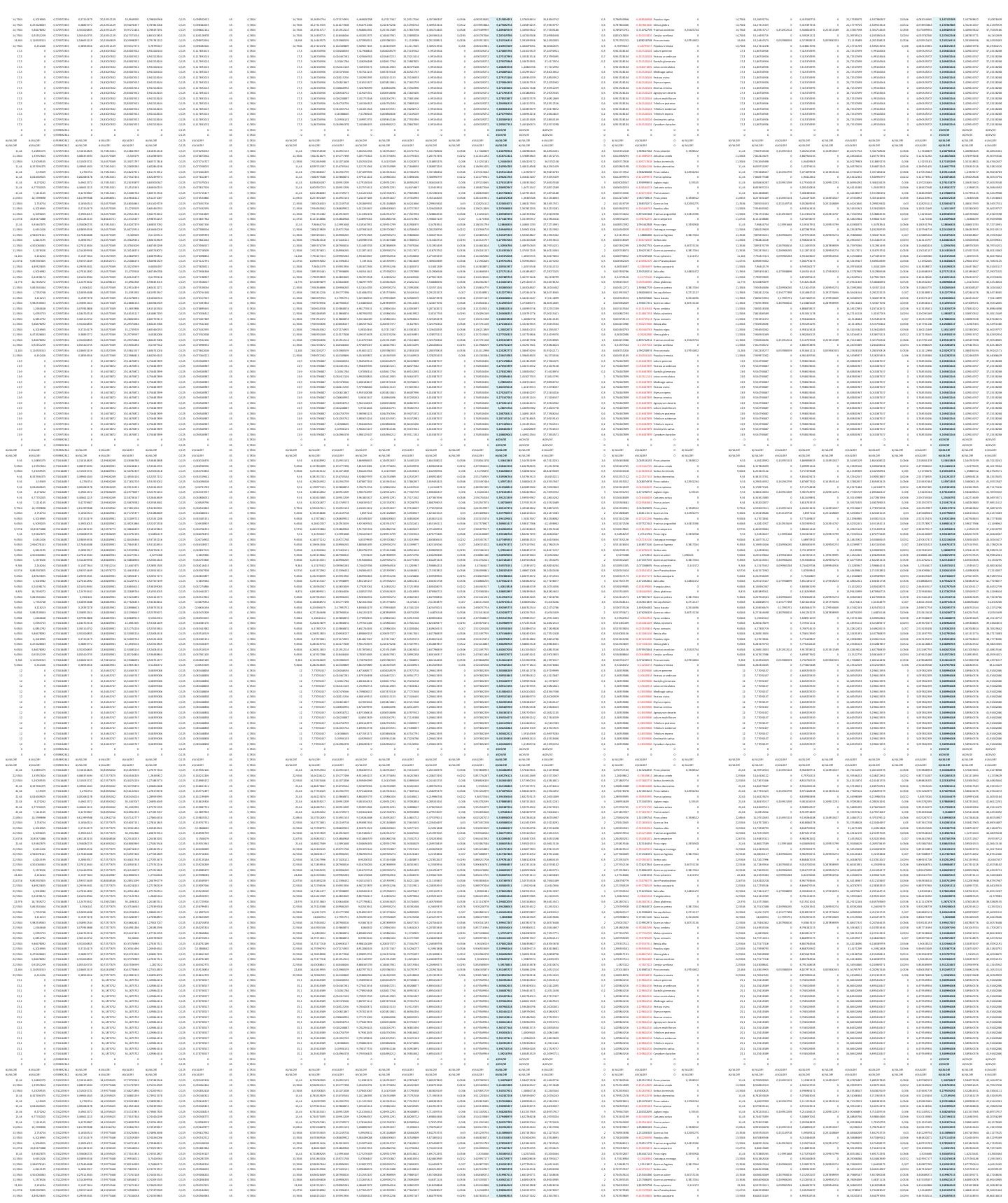


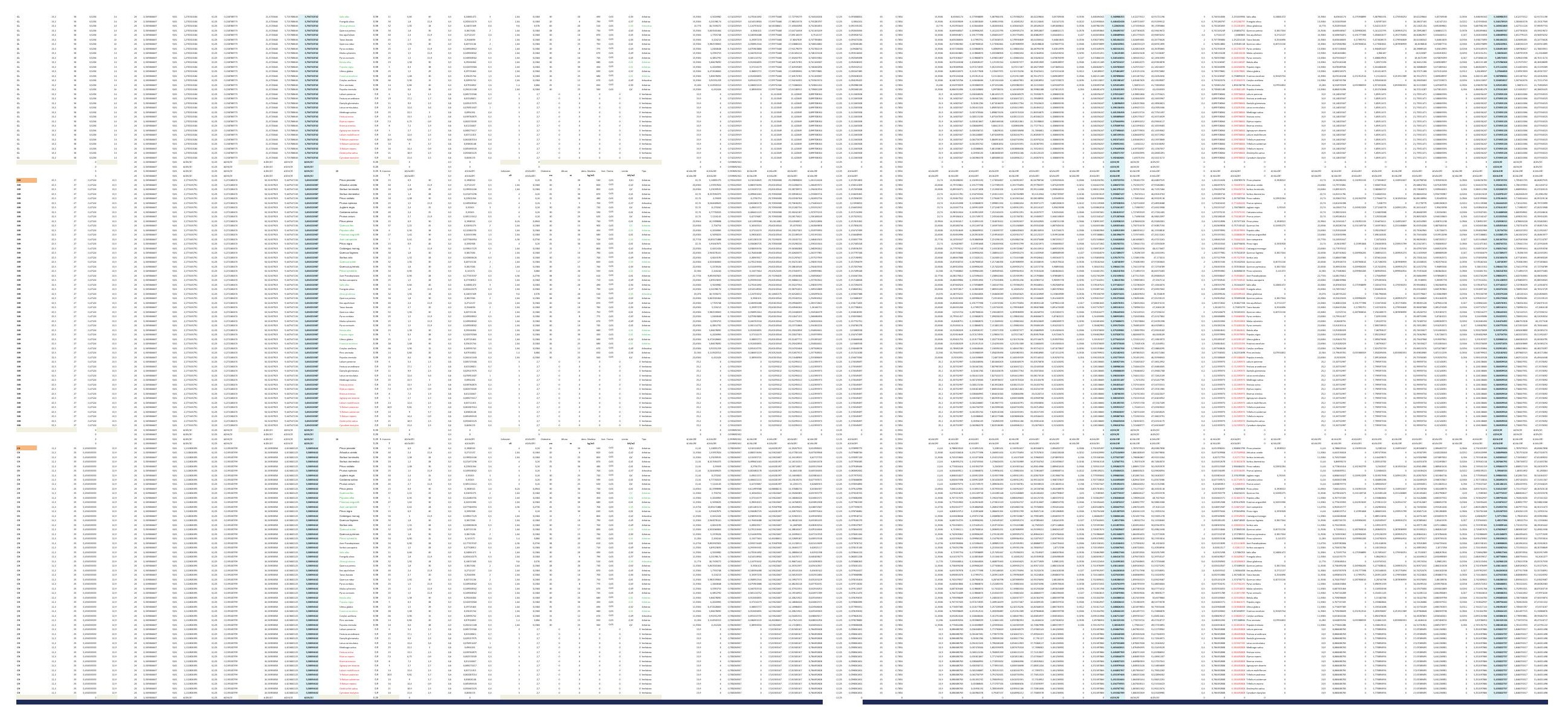



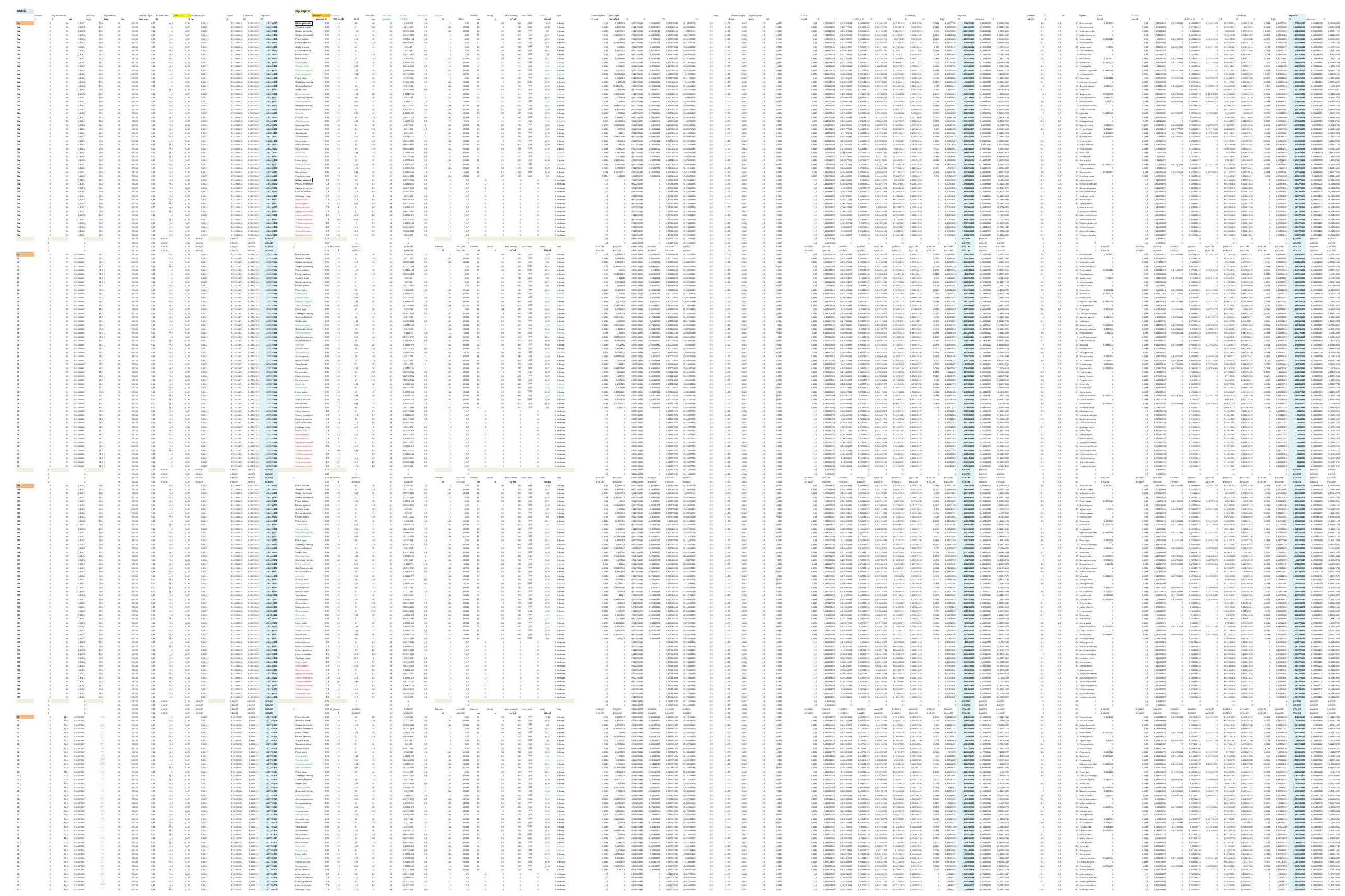


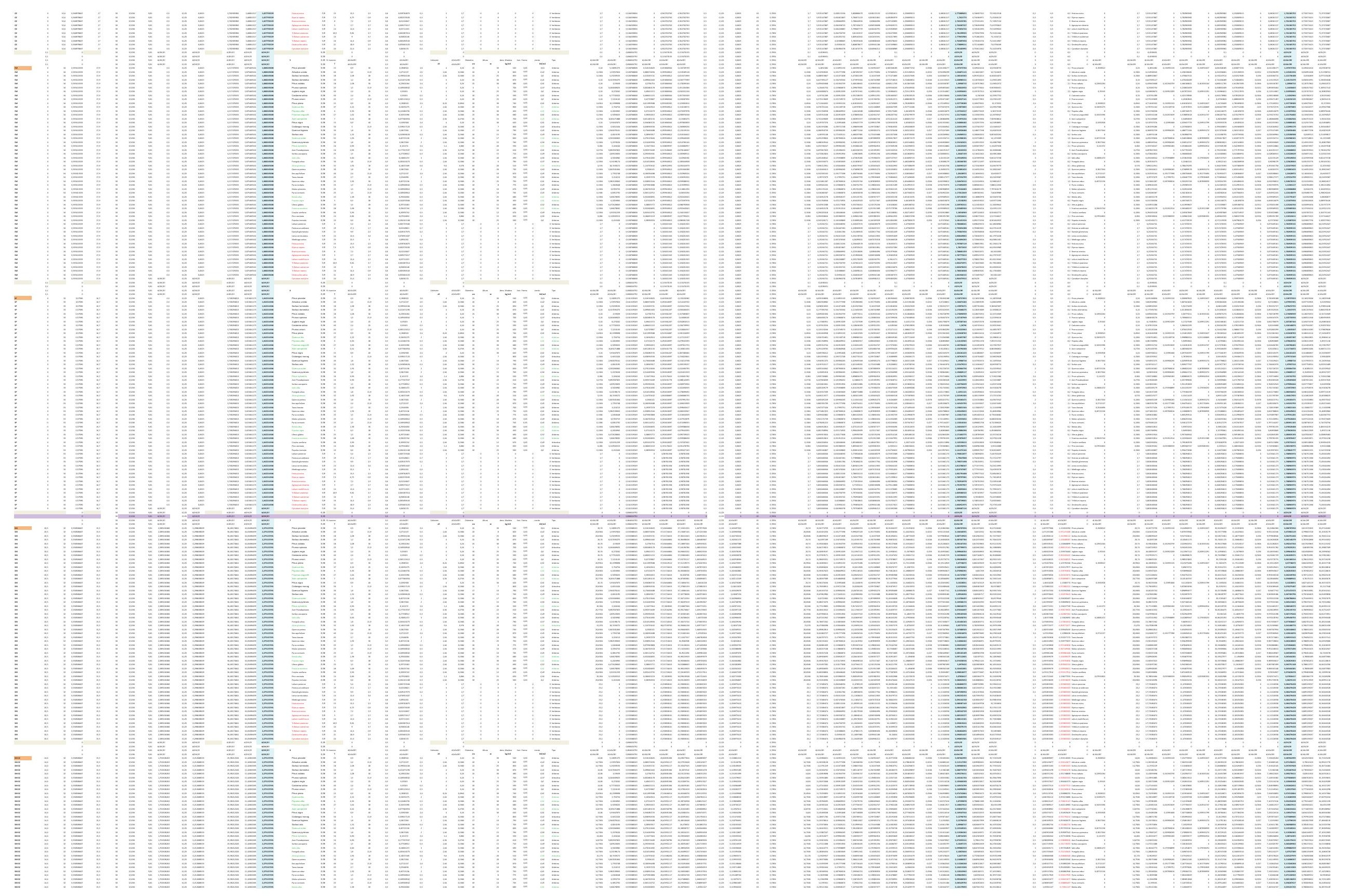



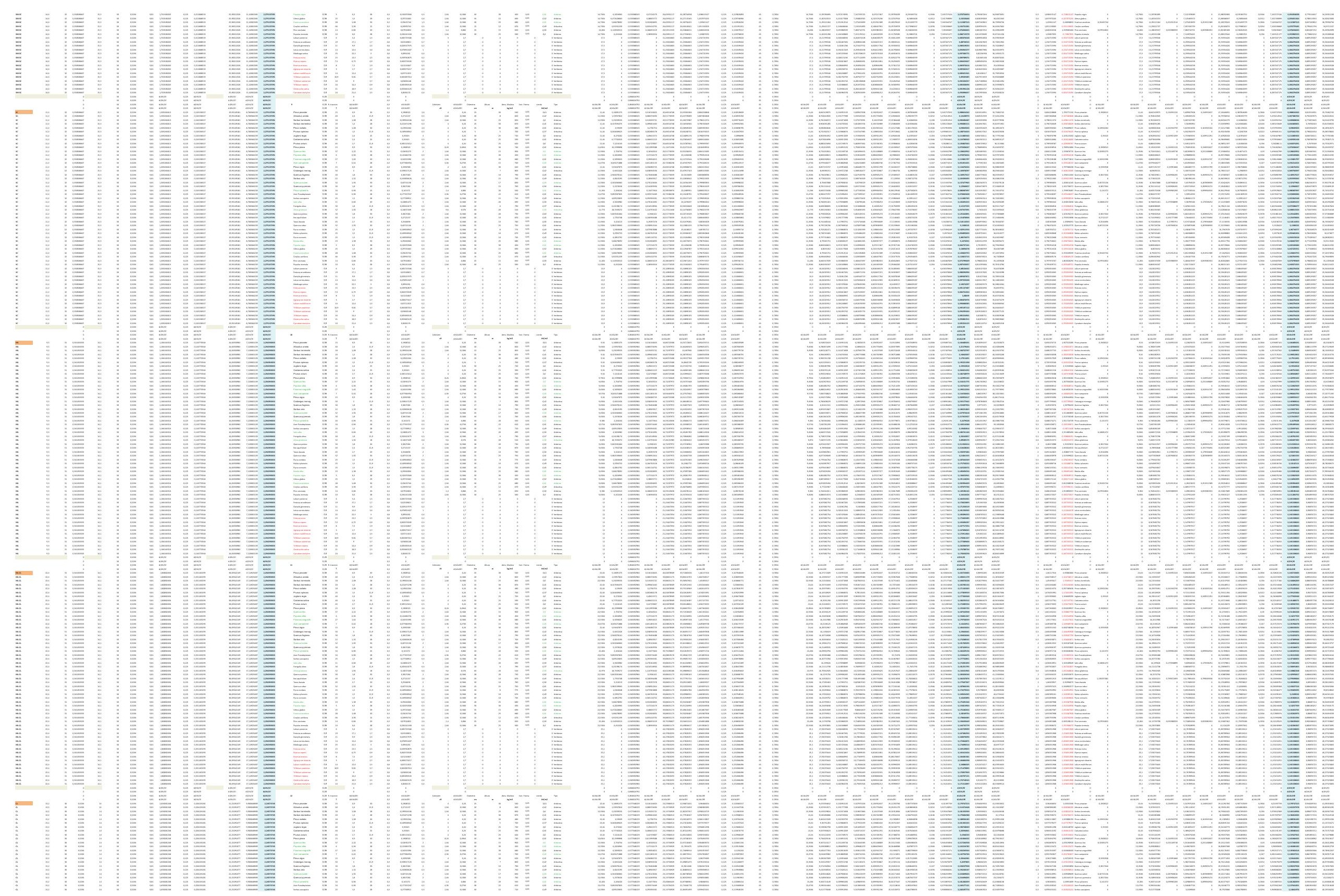


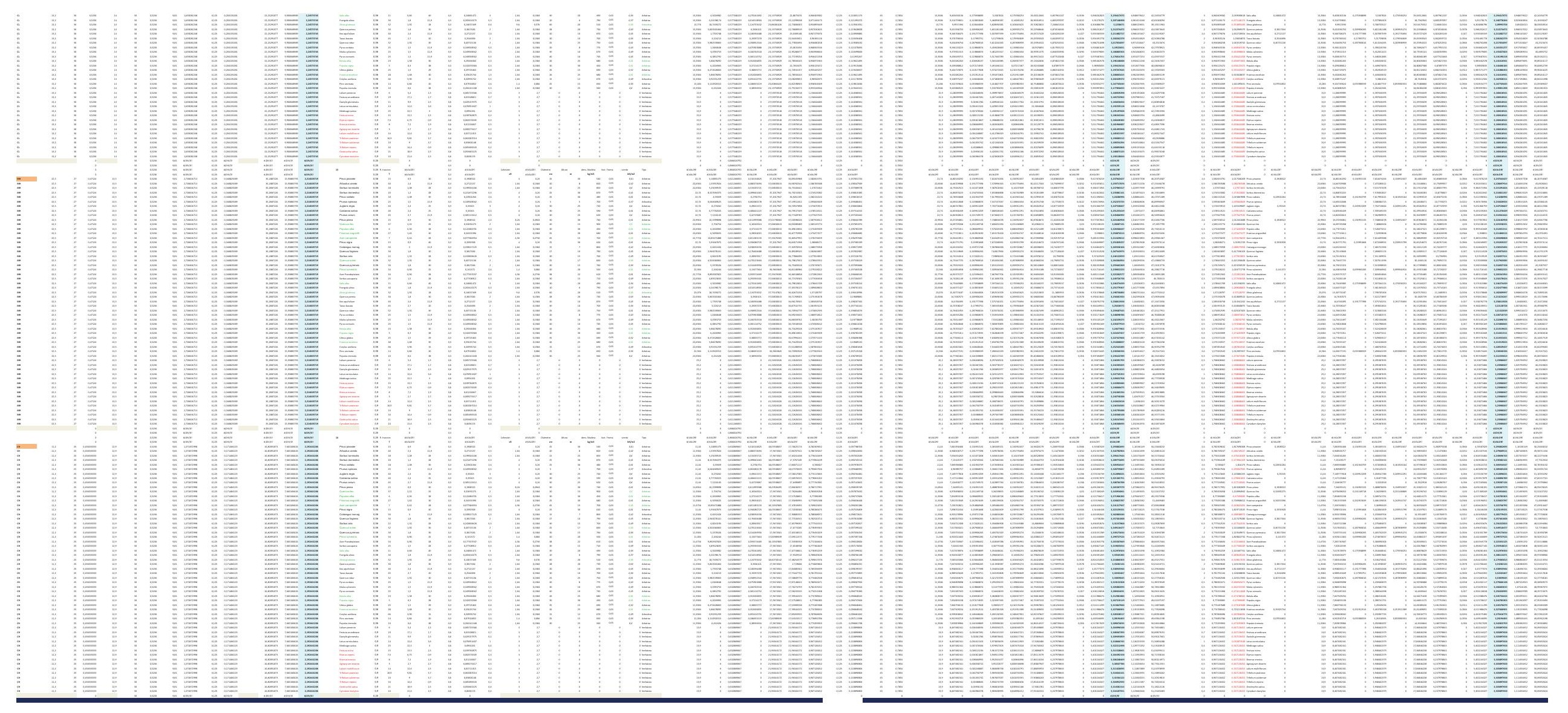



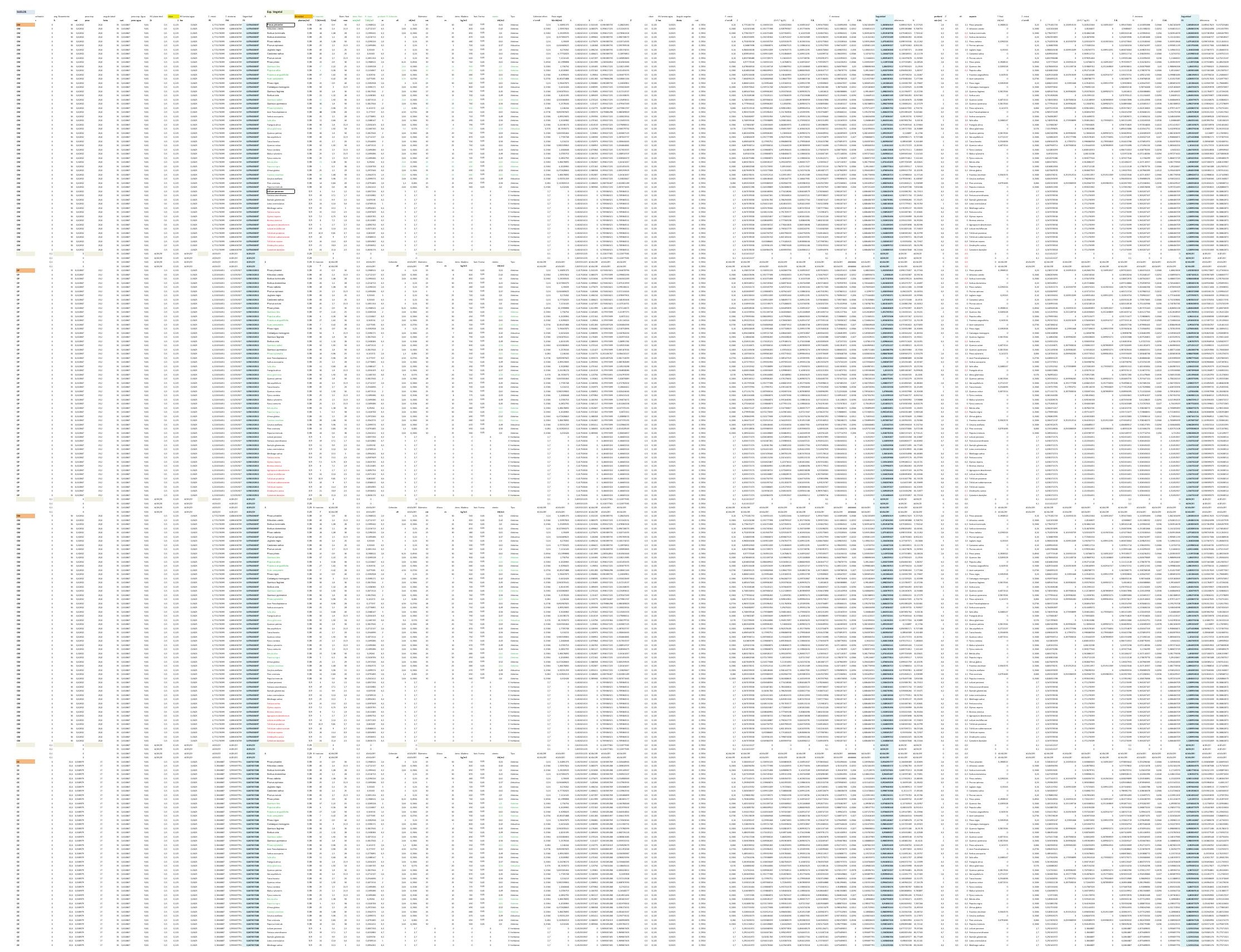


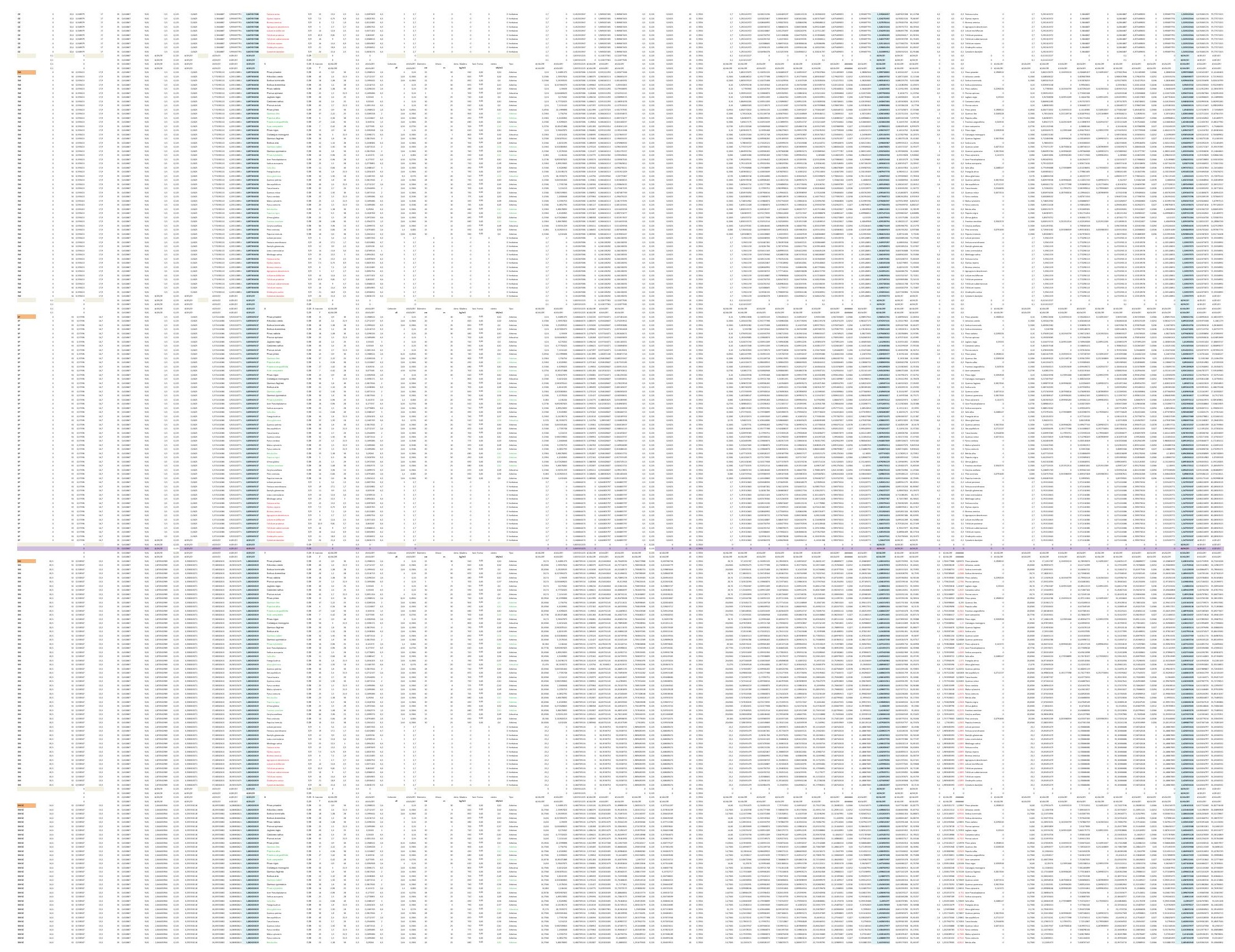



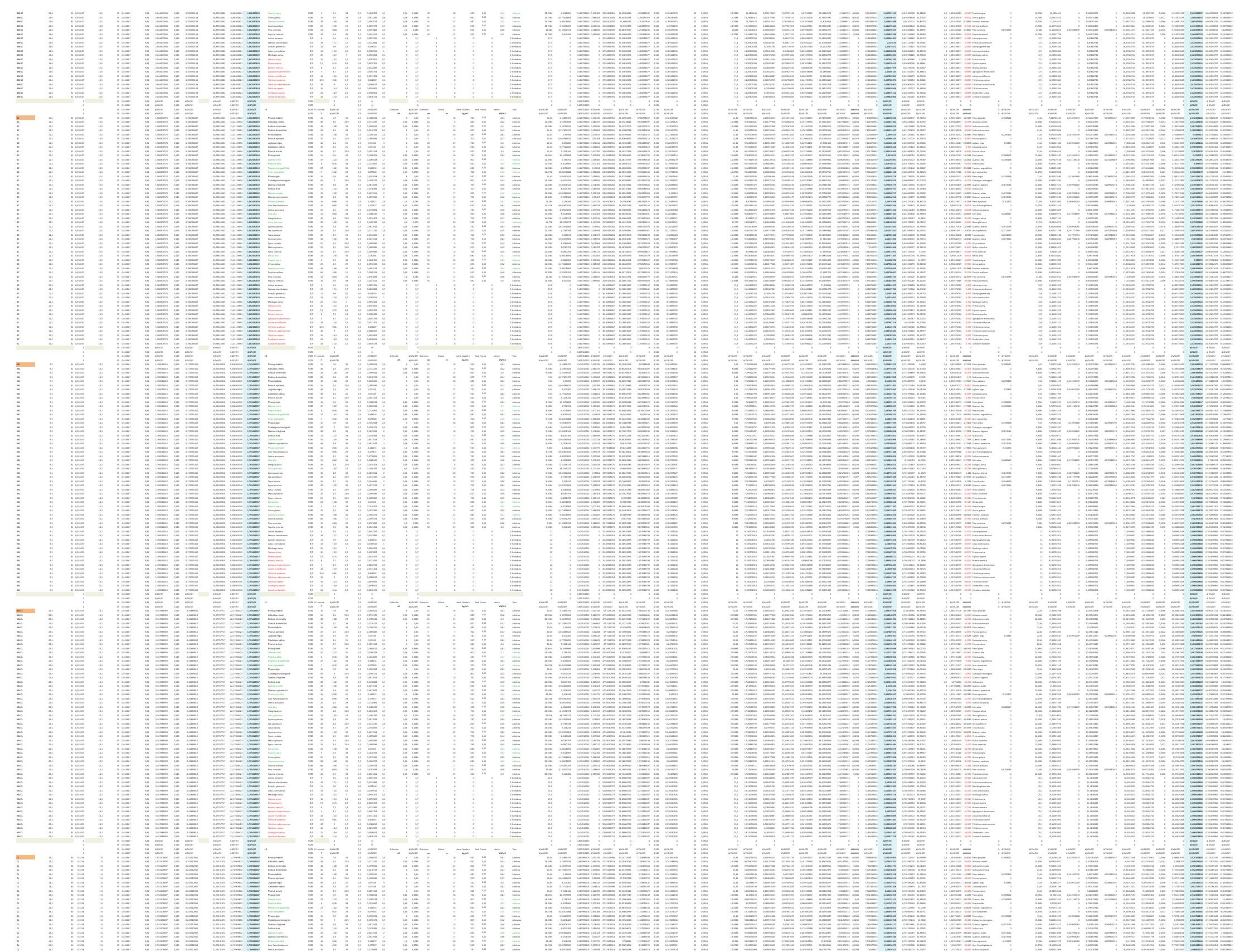


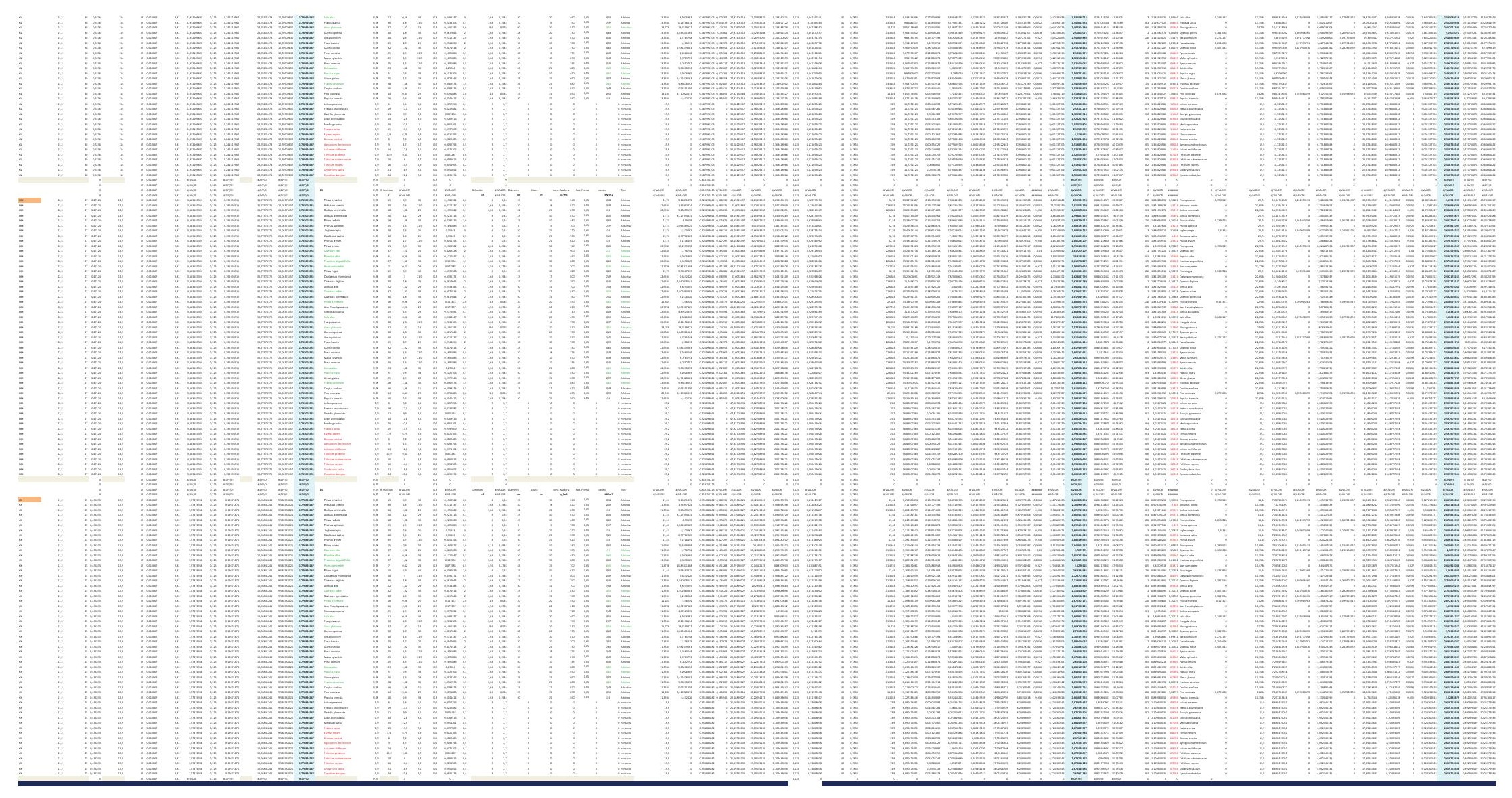



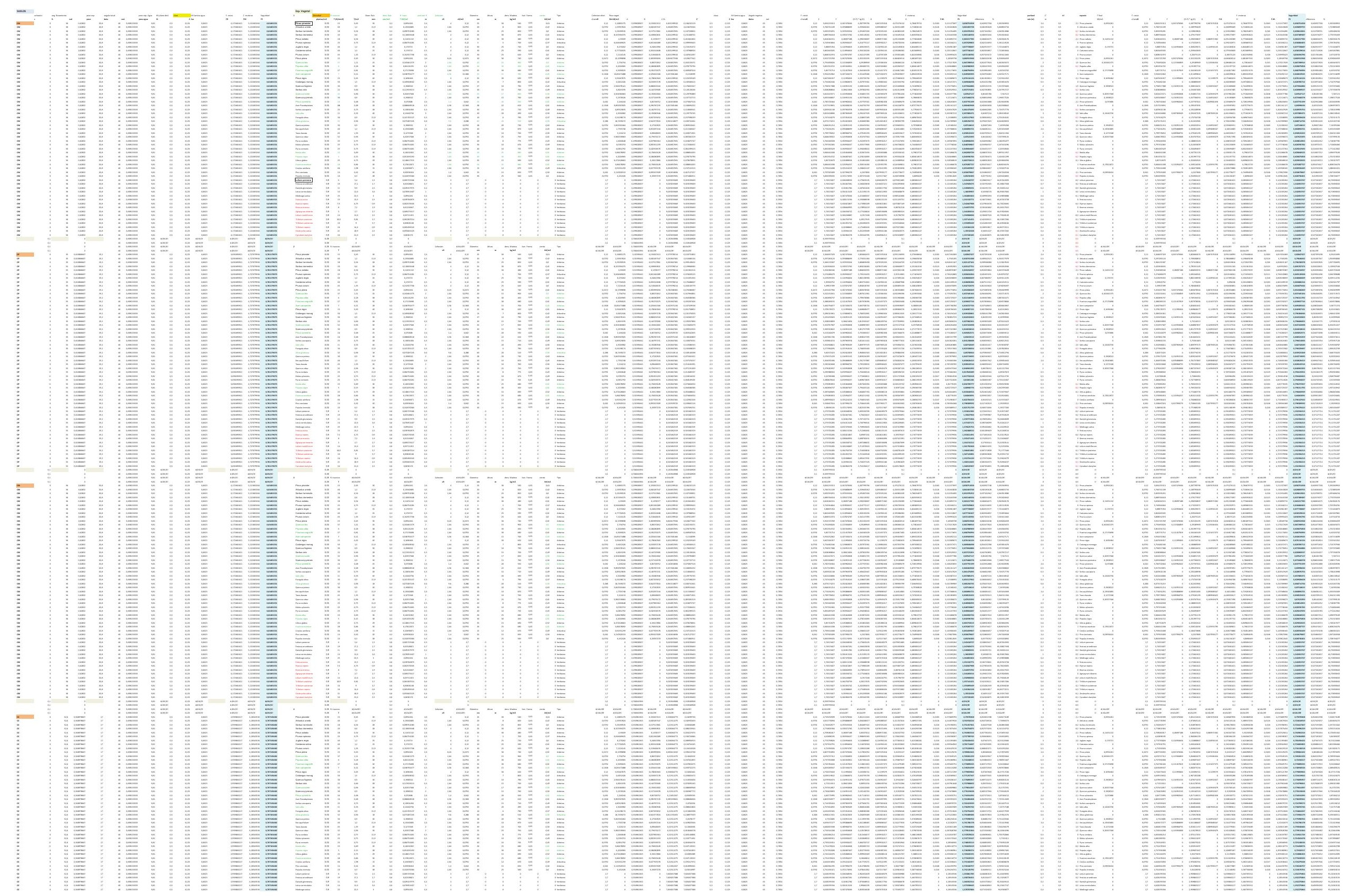


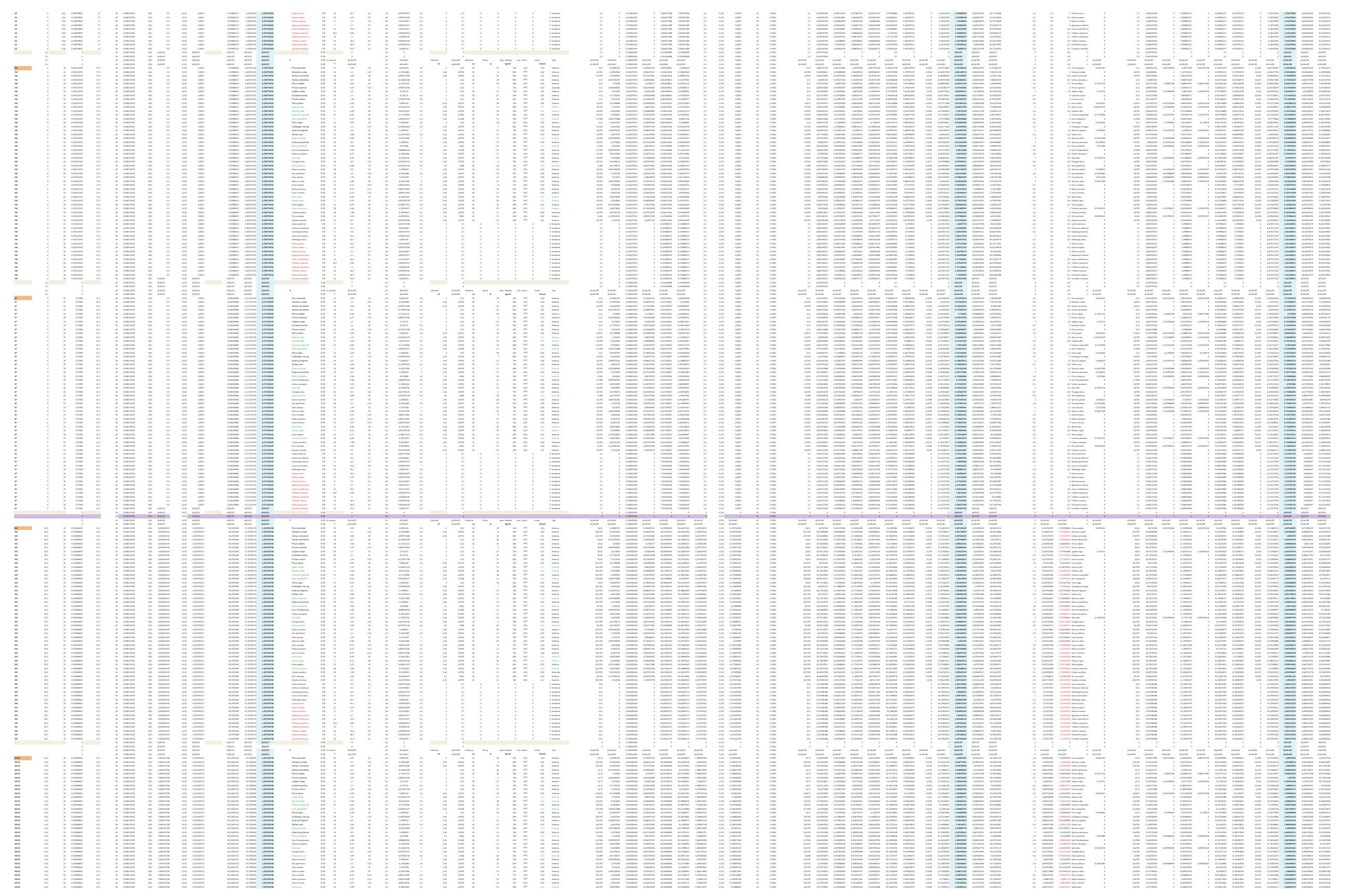



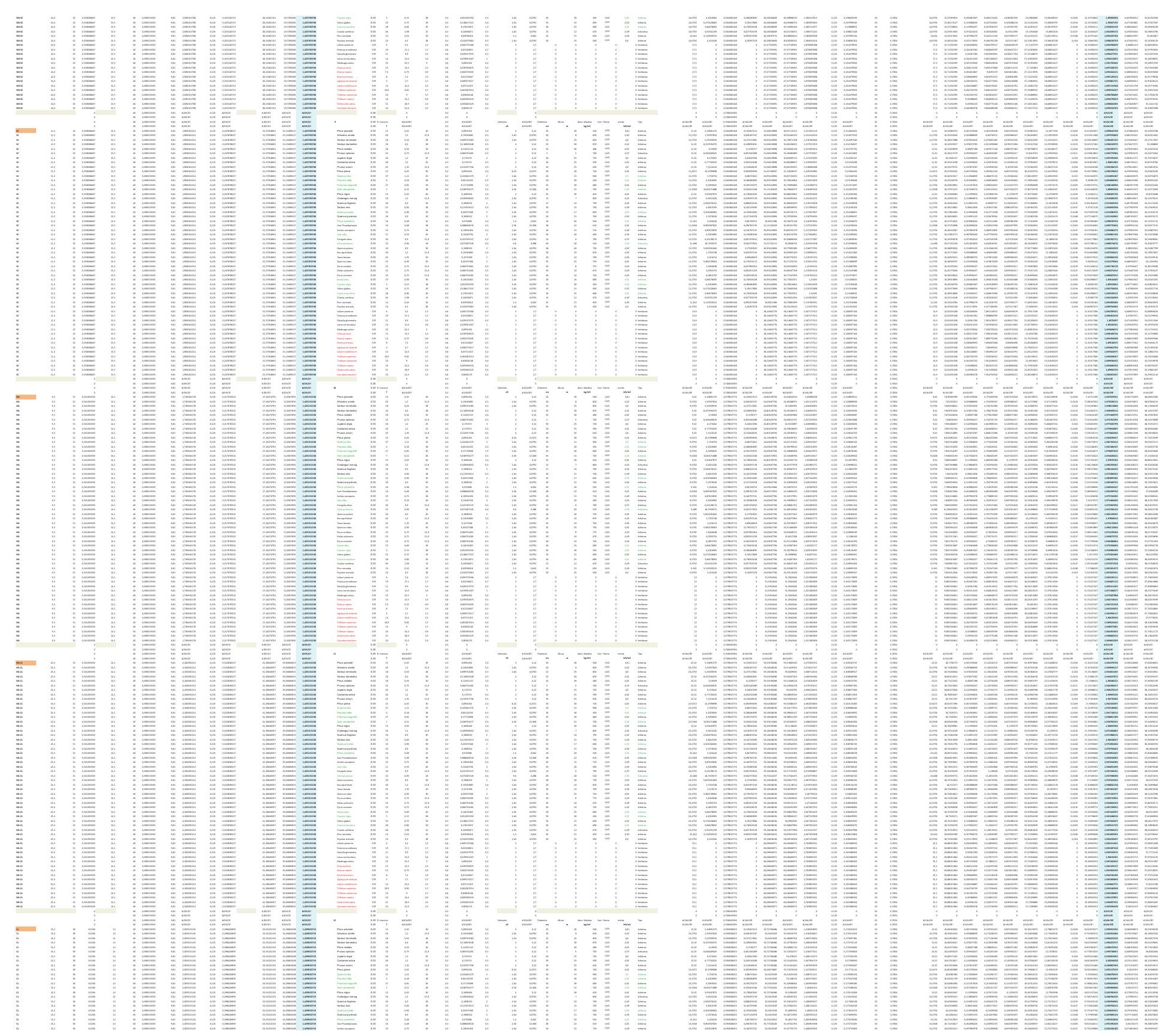

II
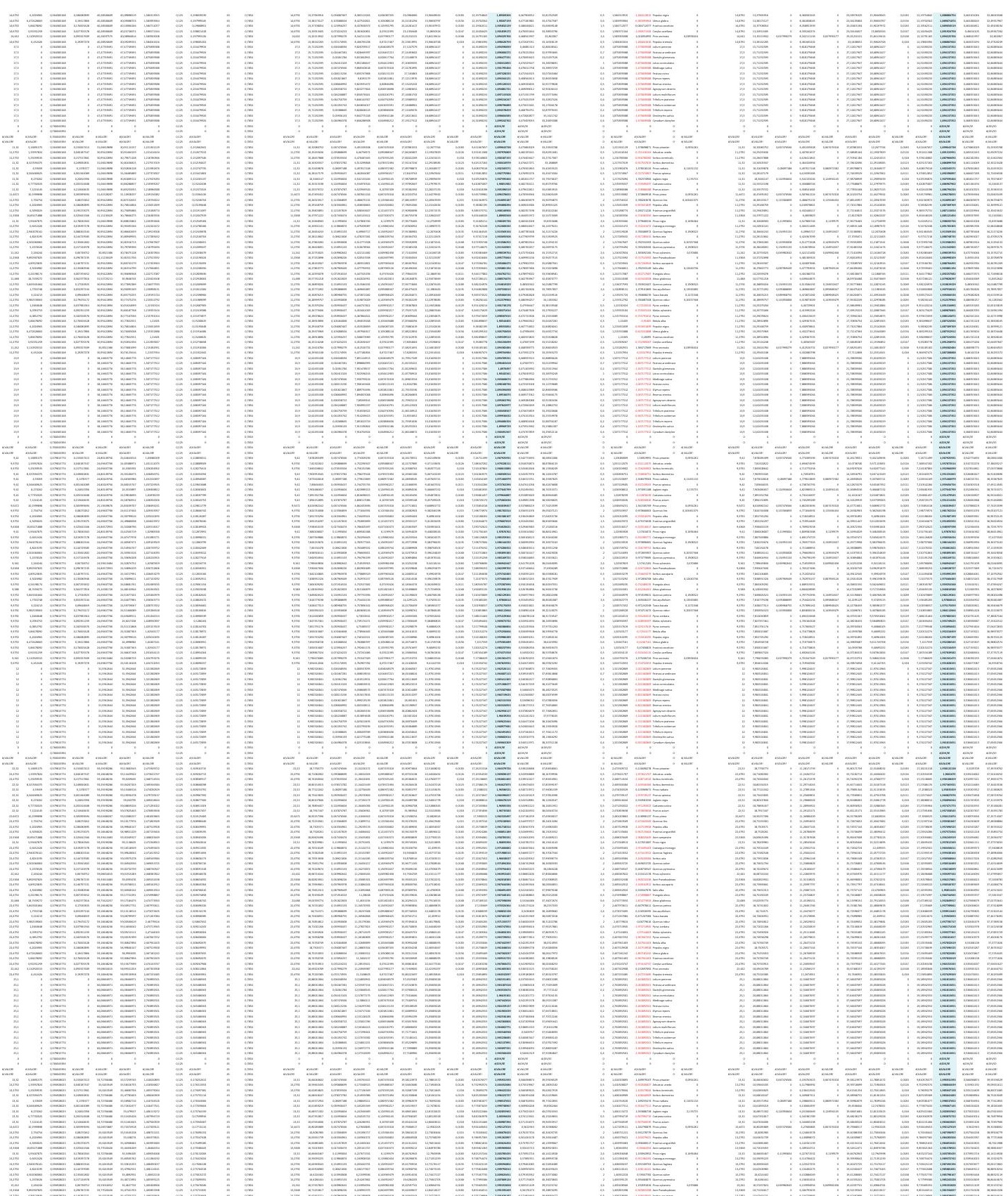


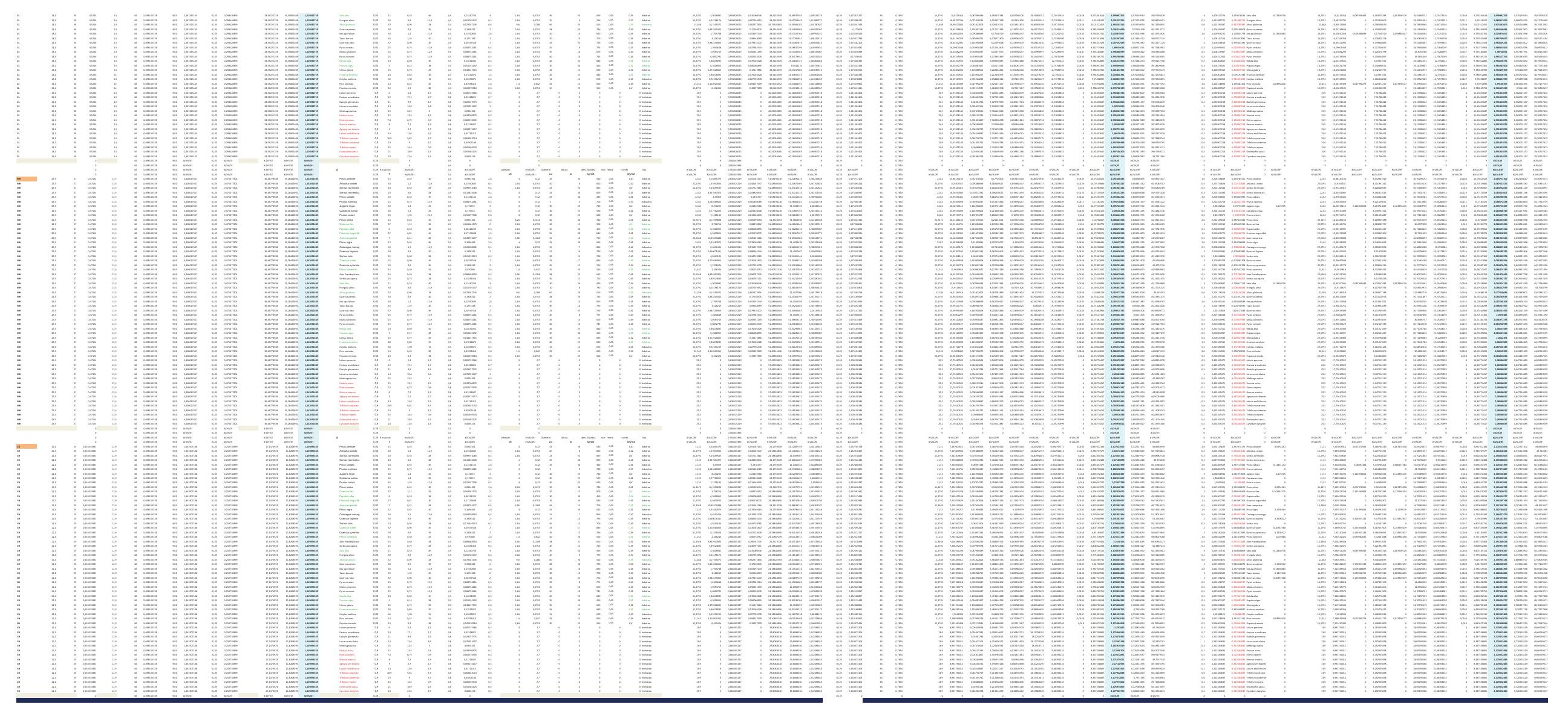



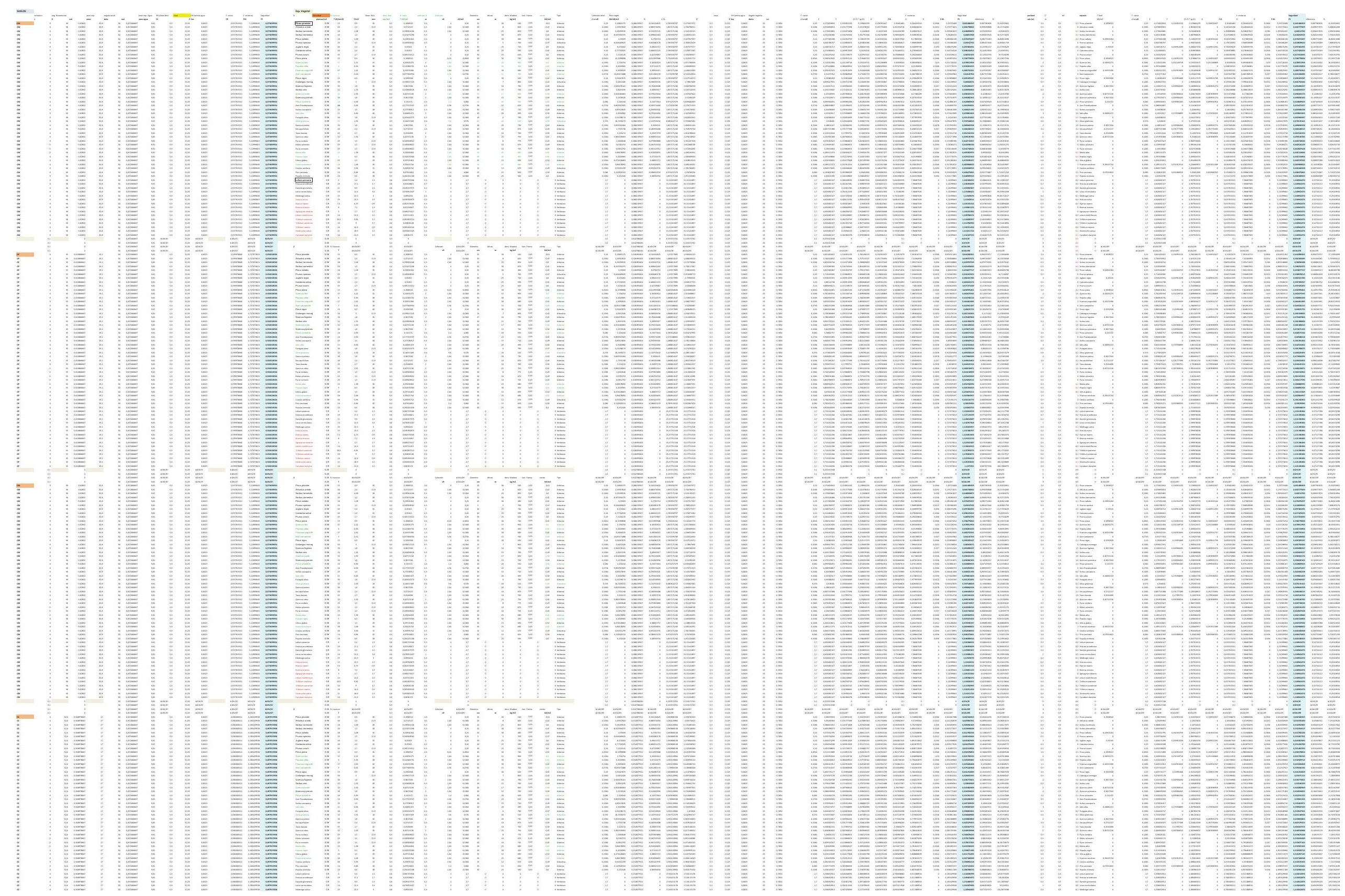


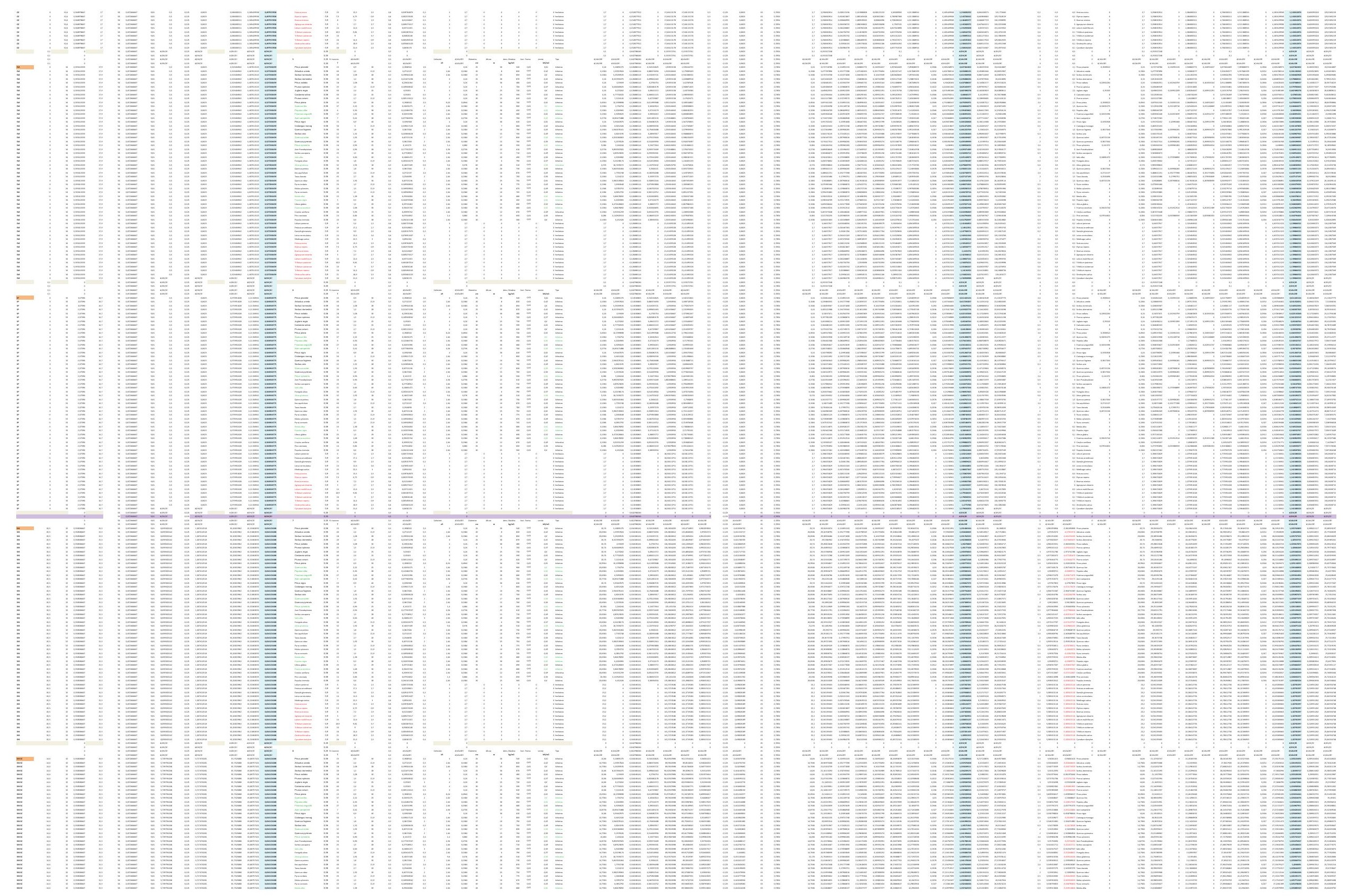




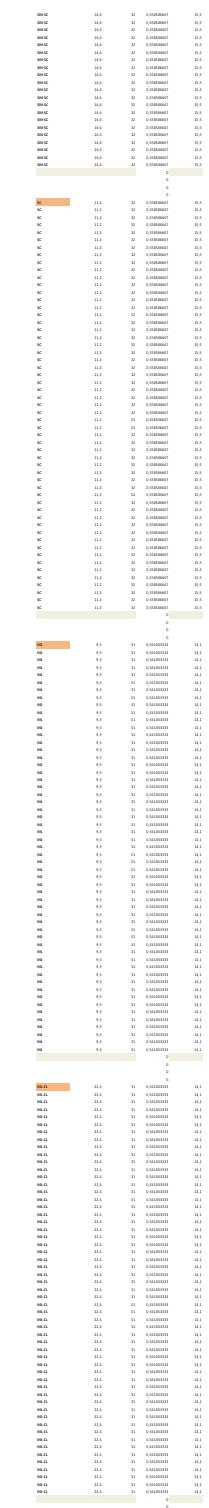

؛

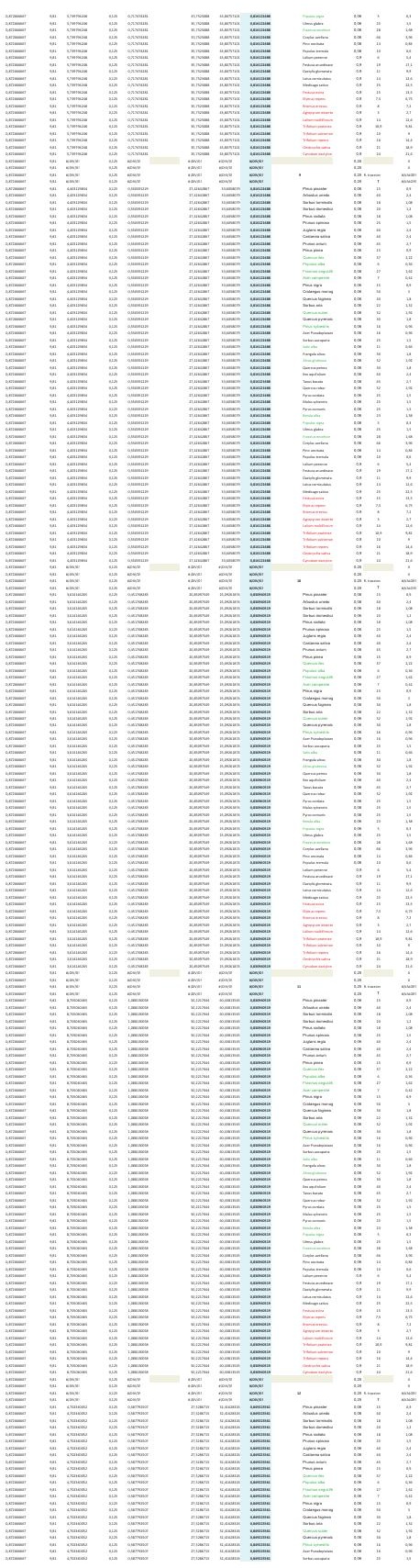

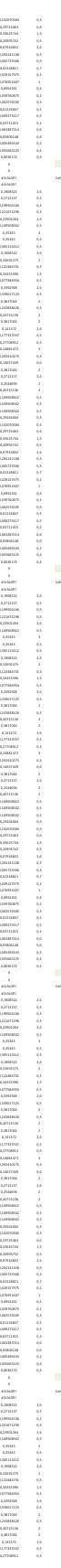
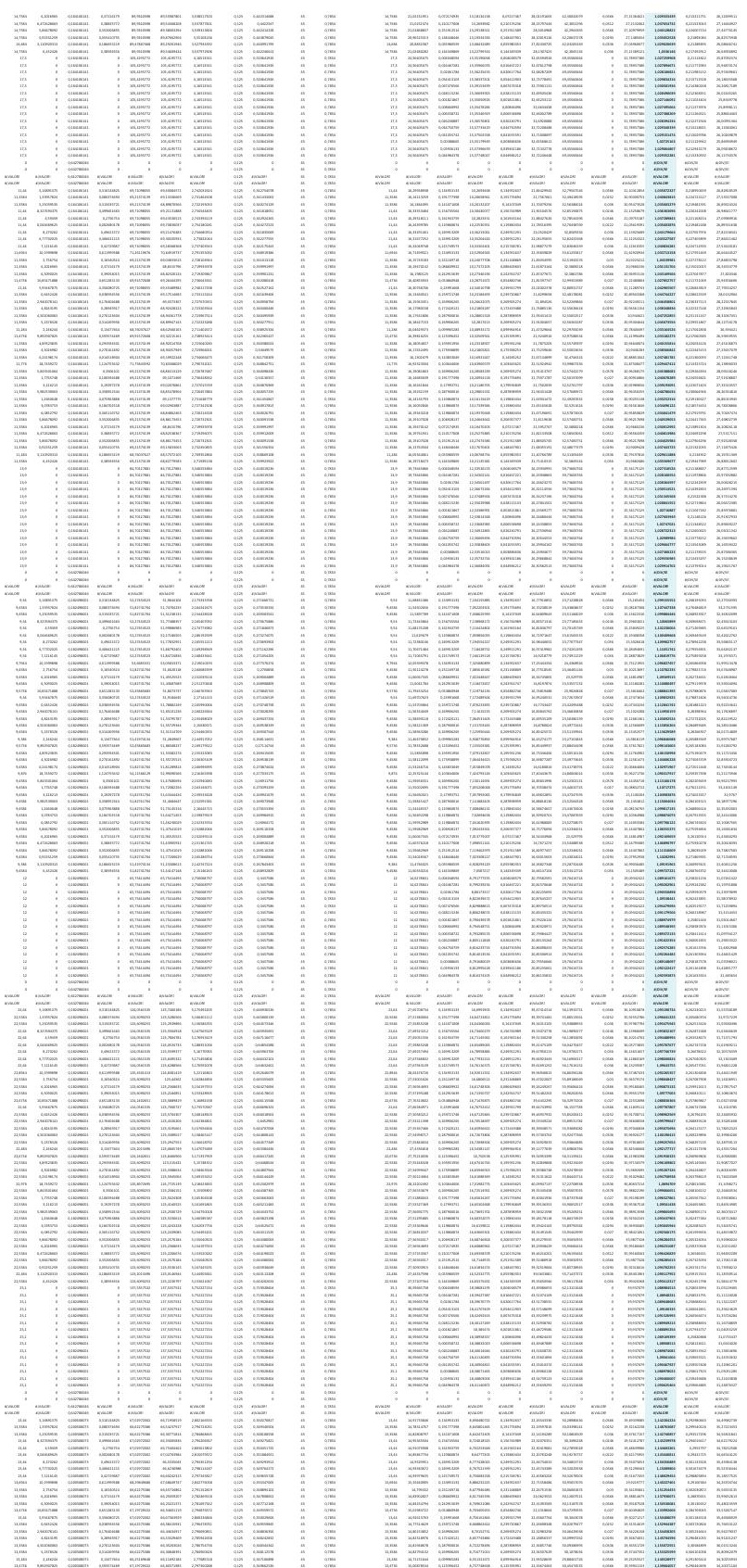
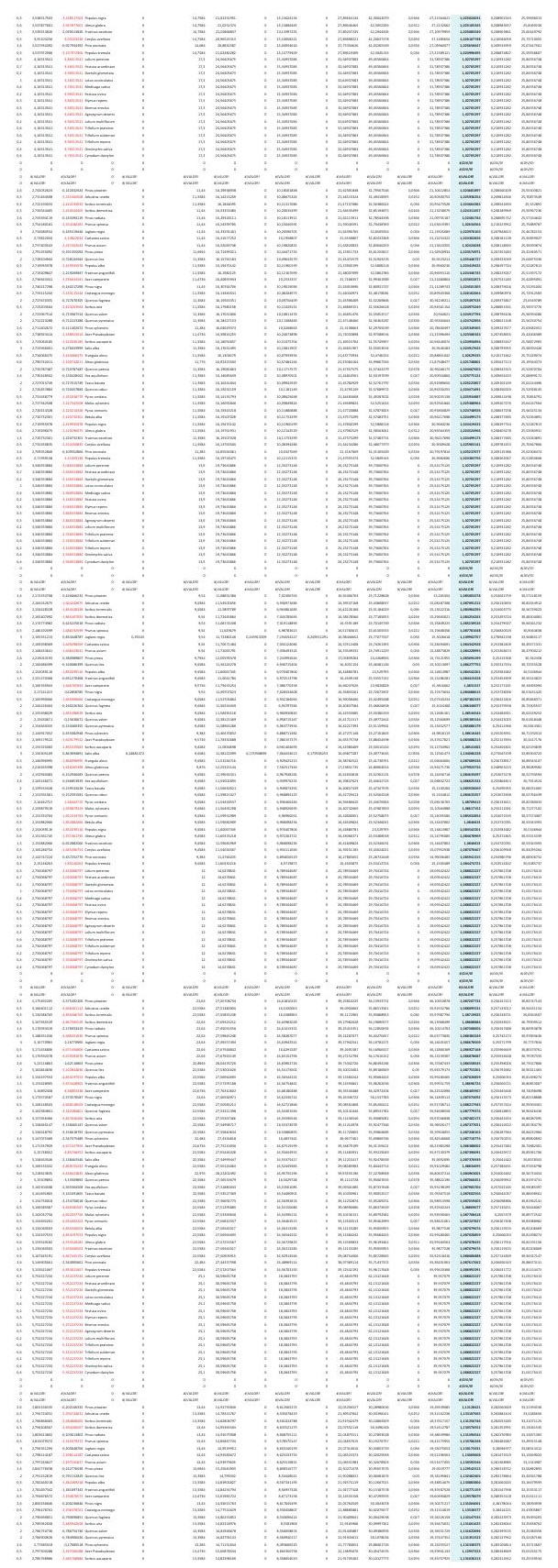


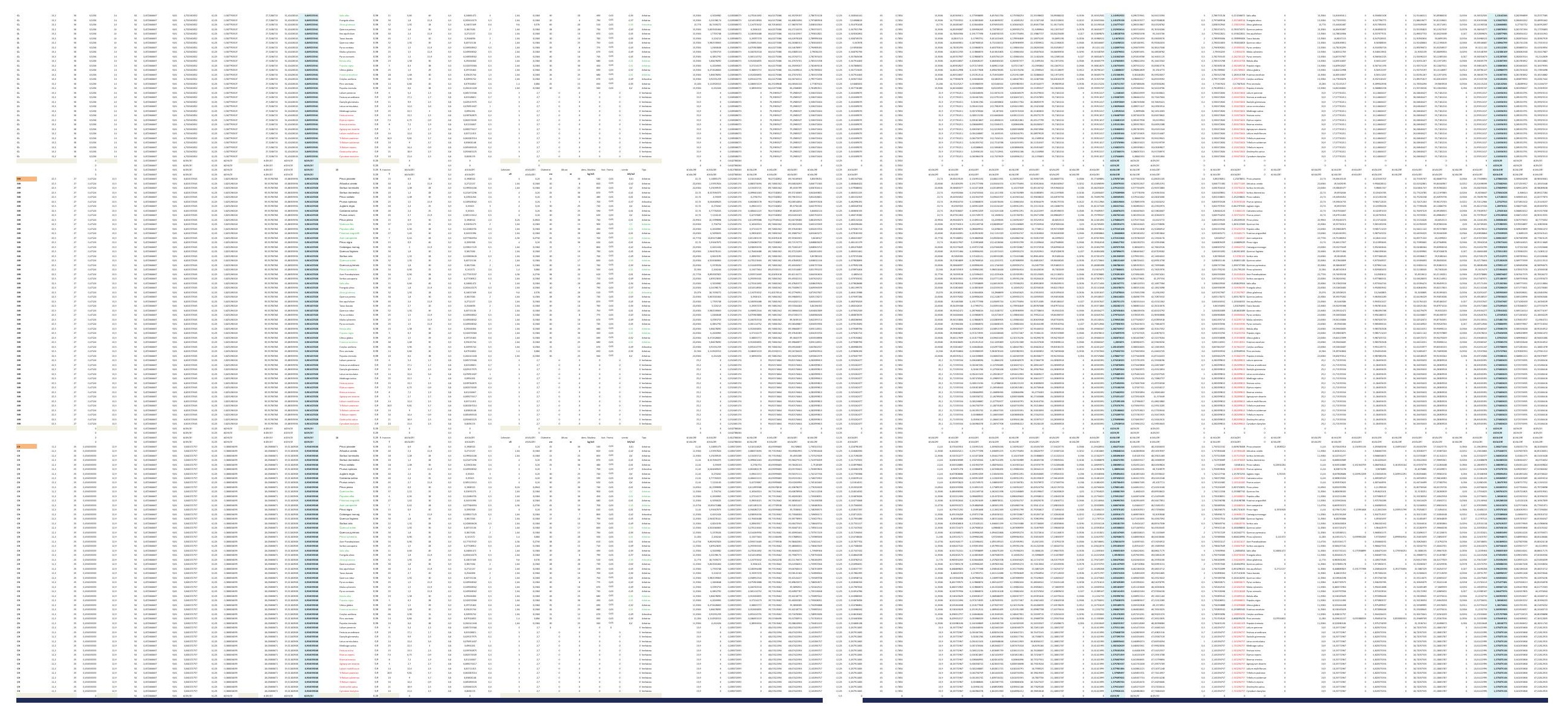



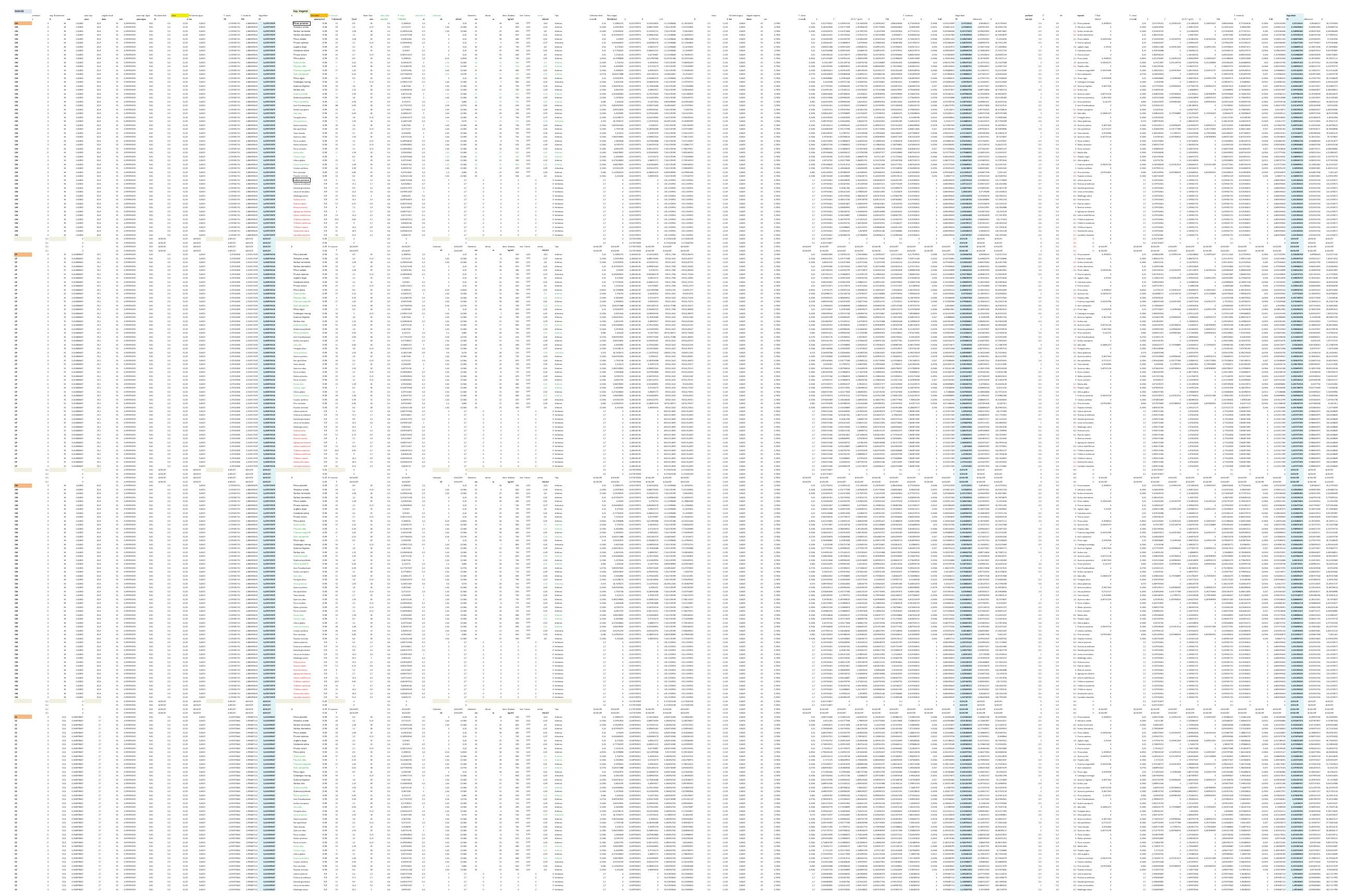


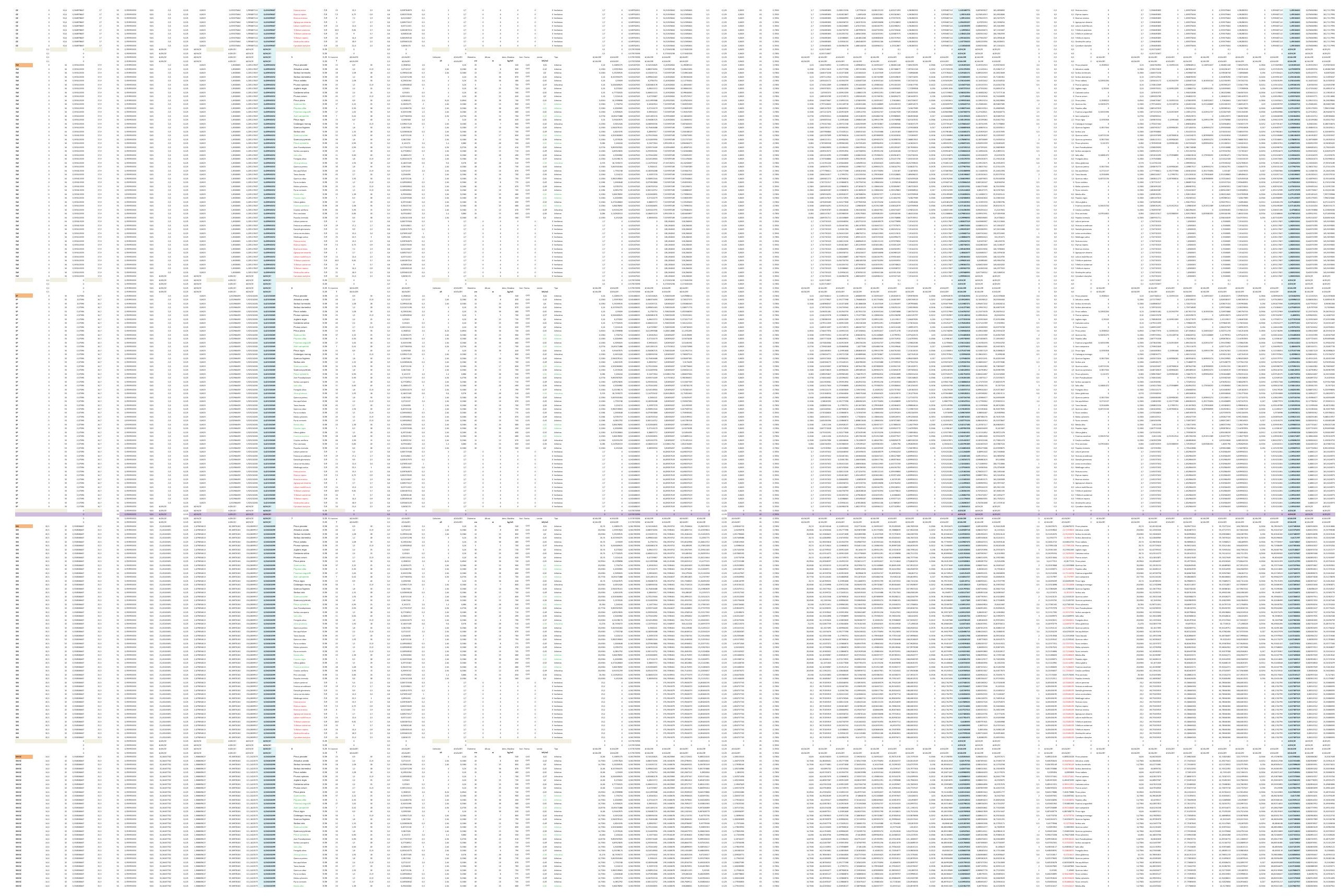



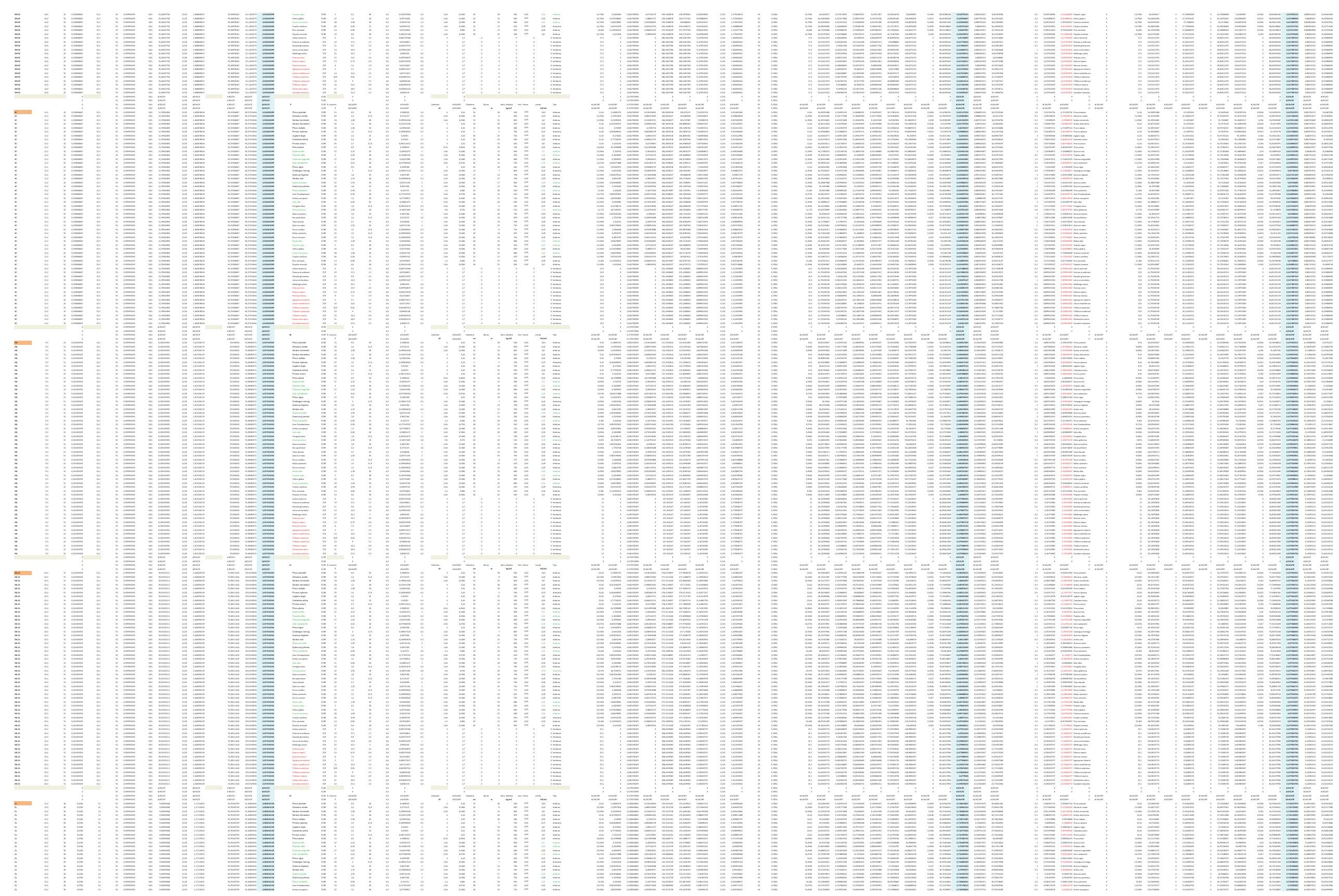


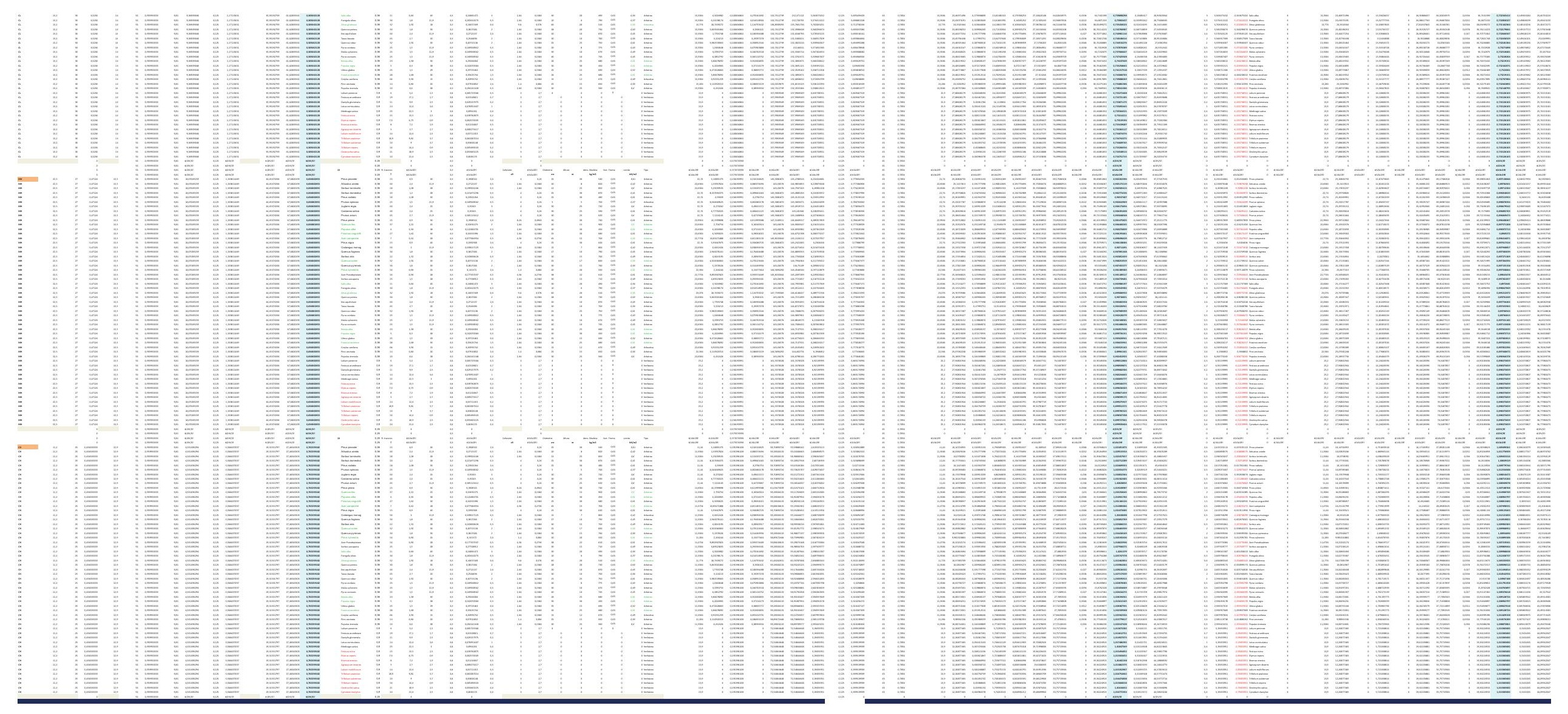



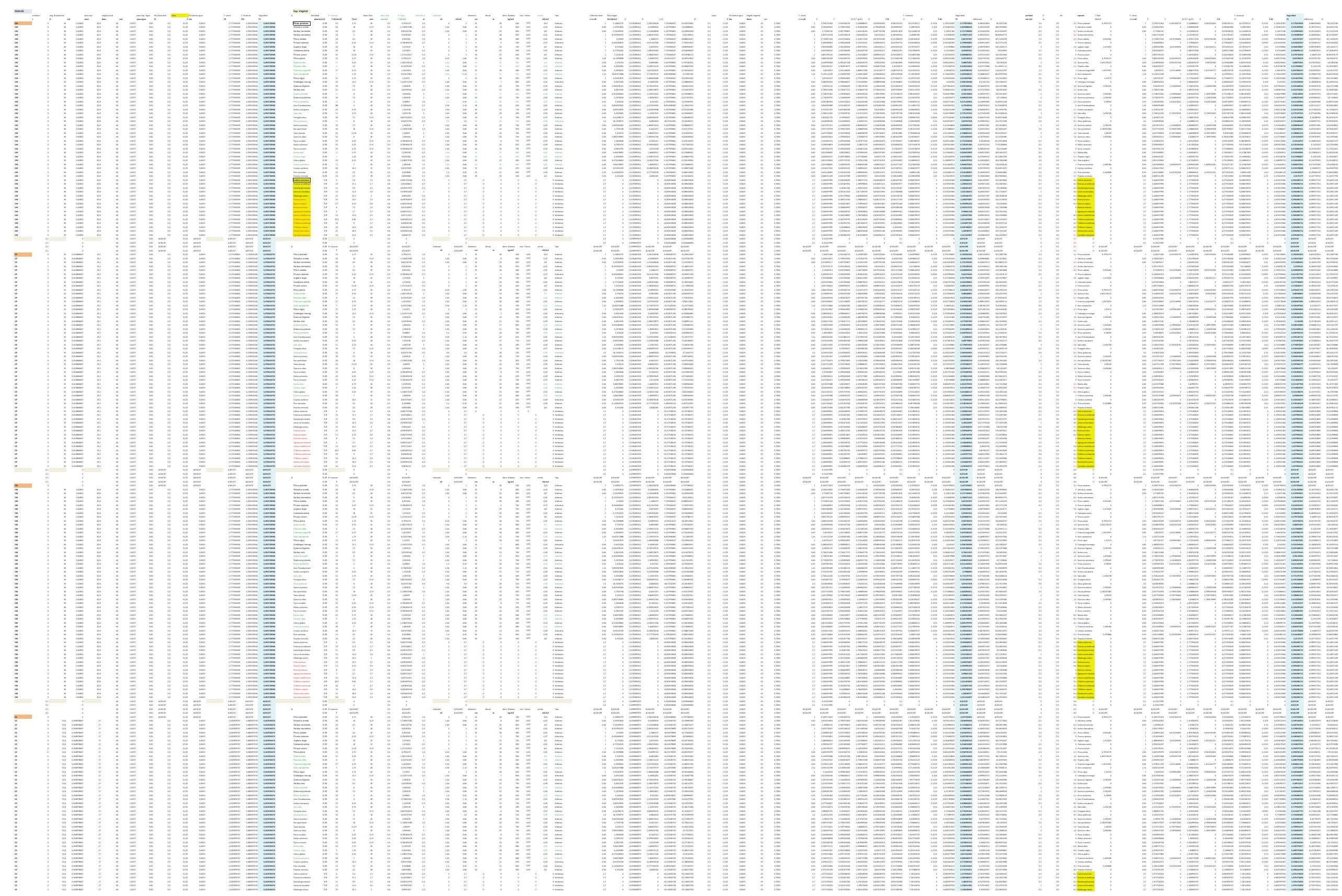


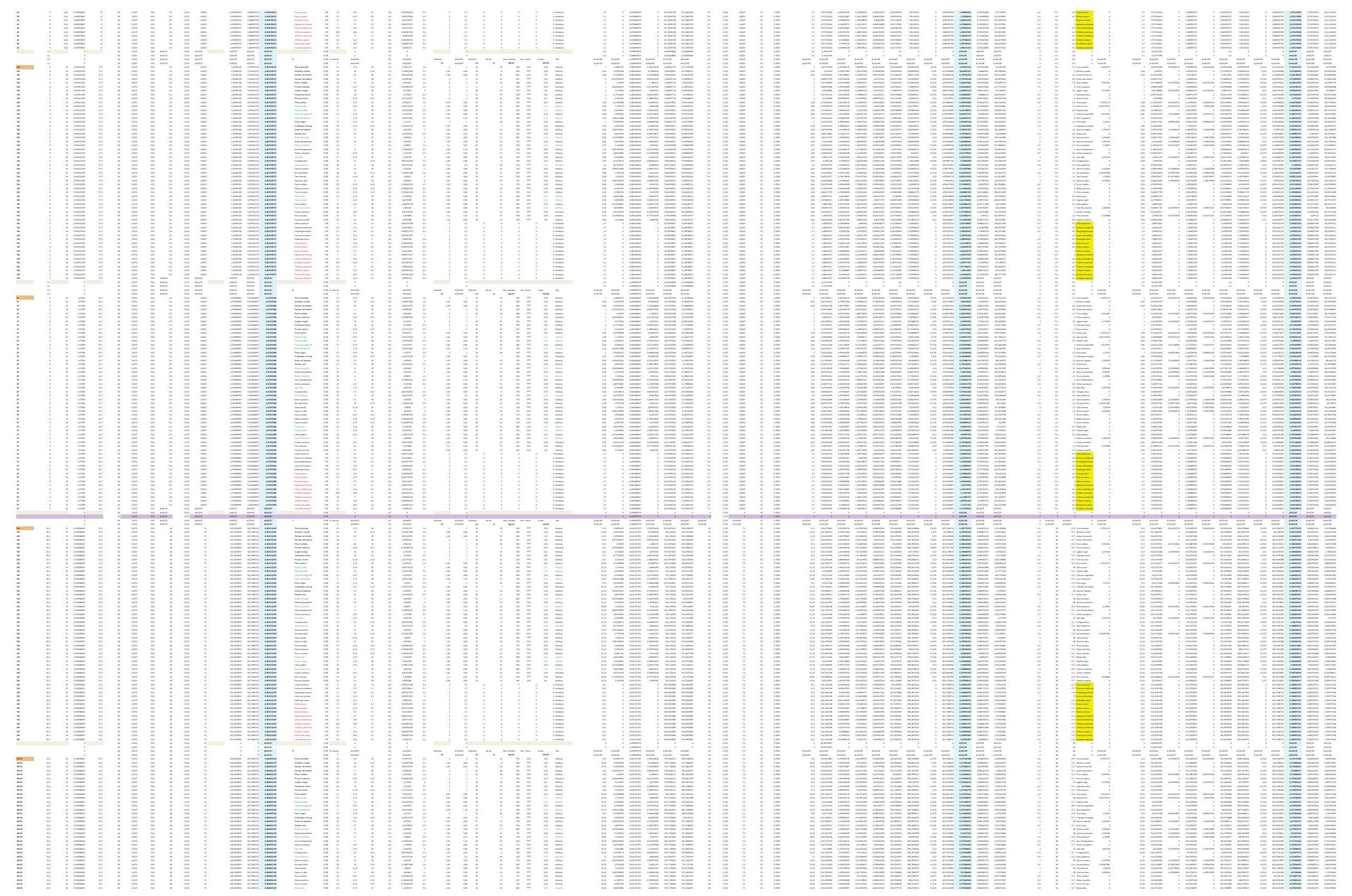



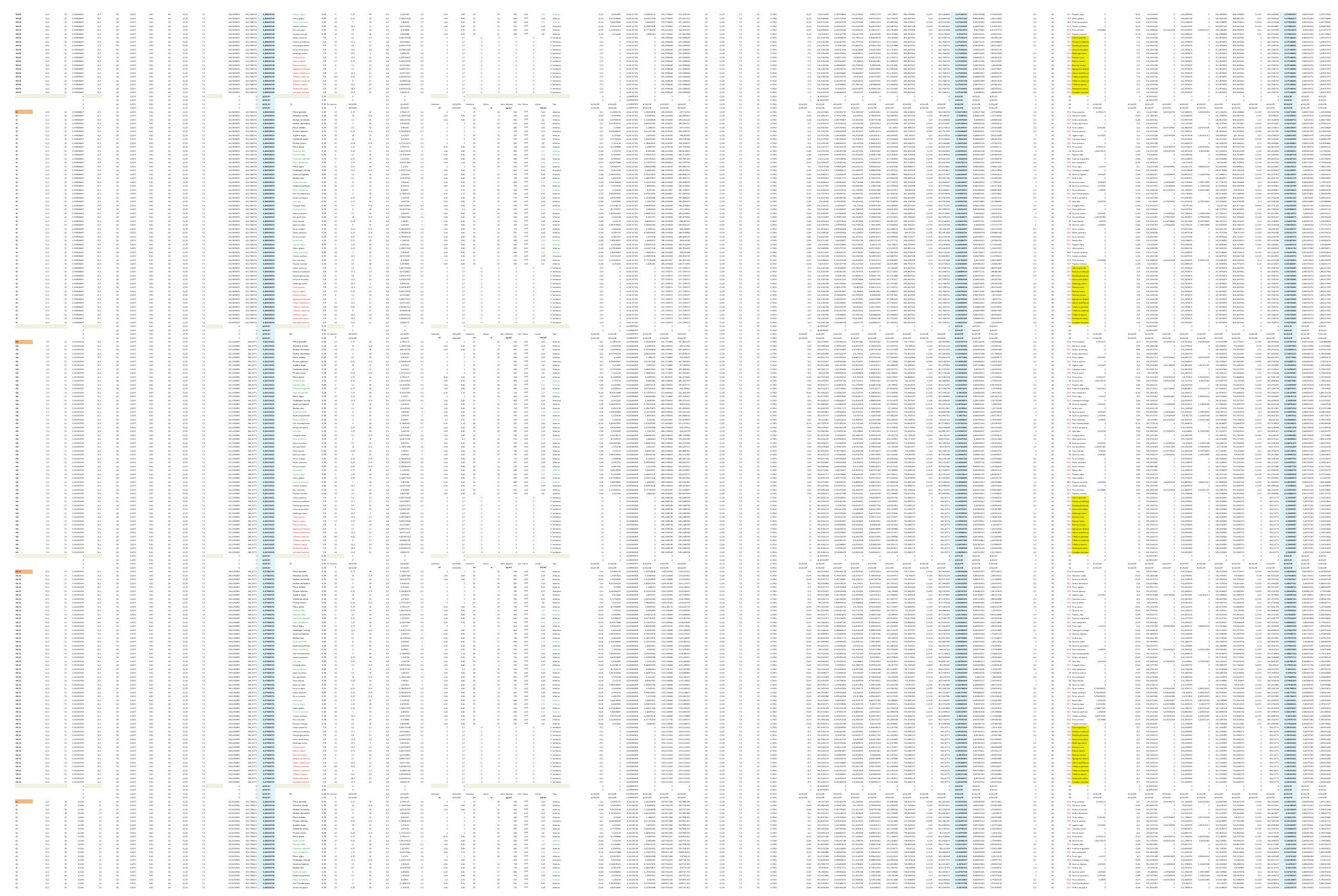


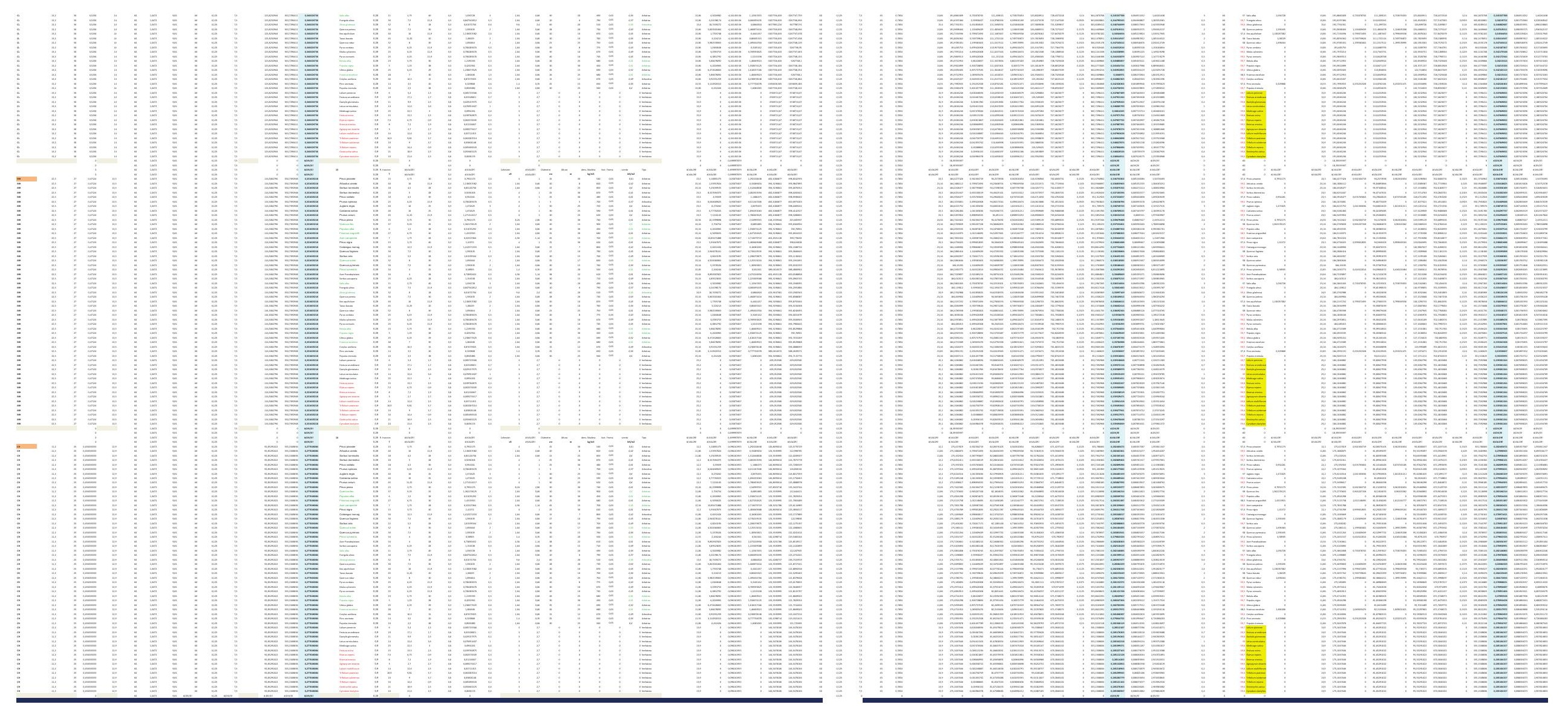



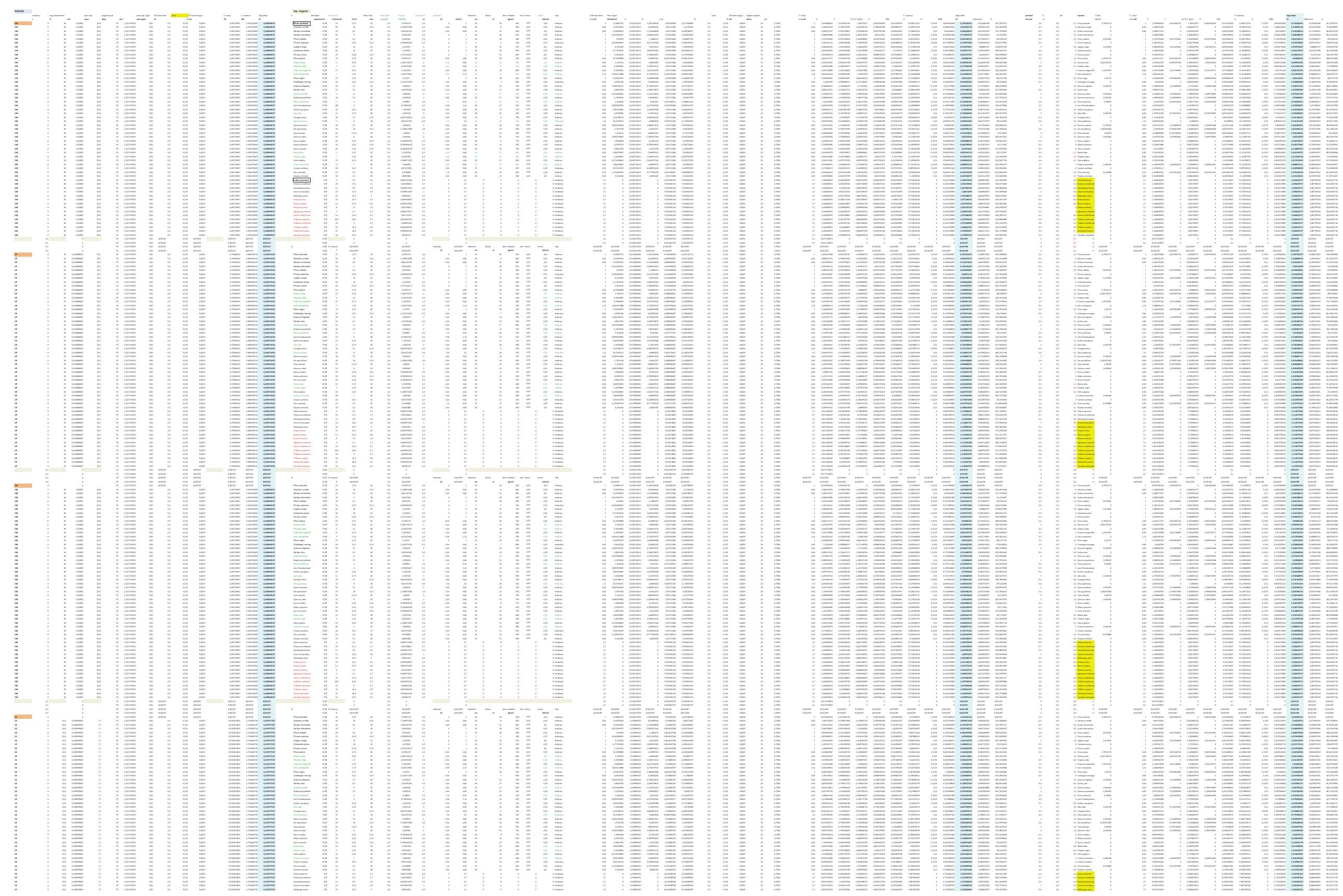


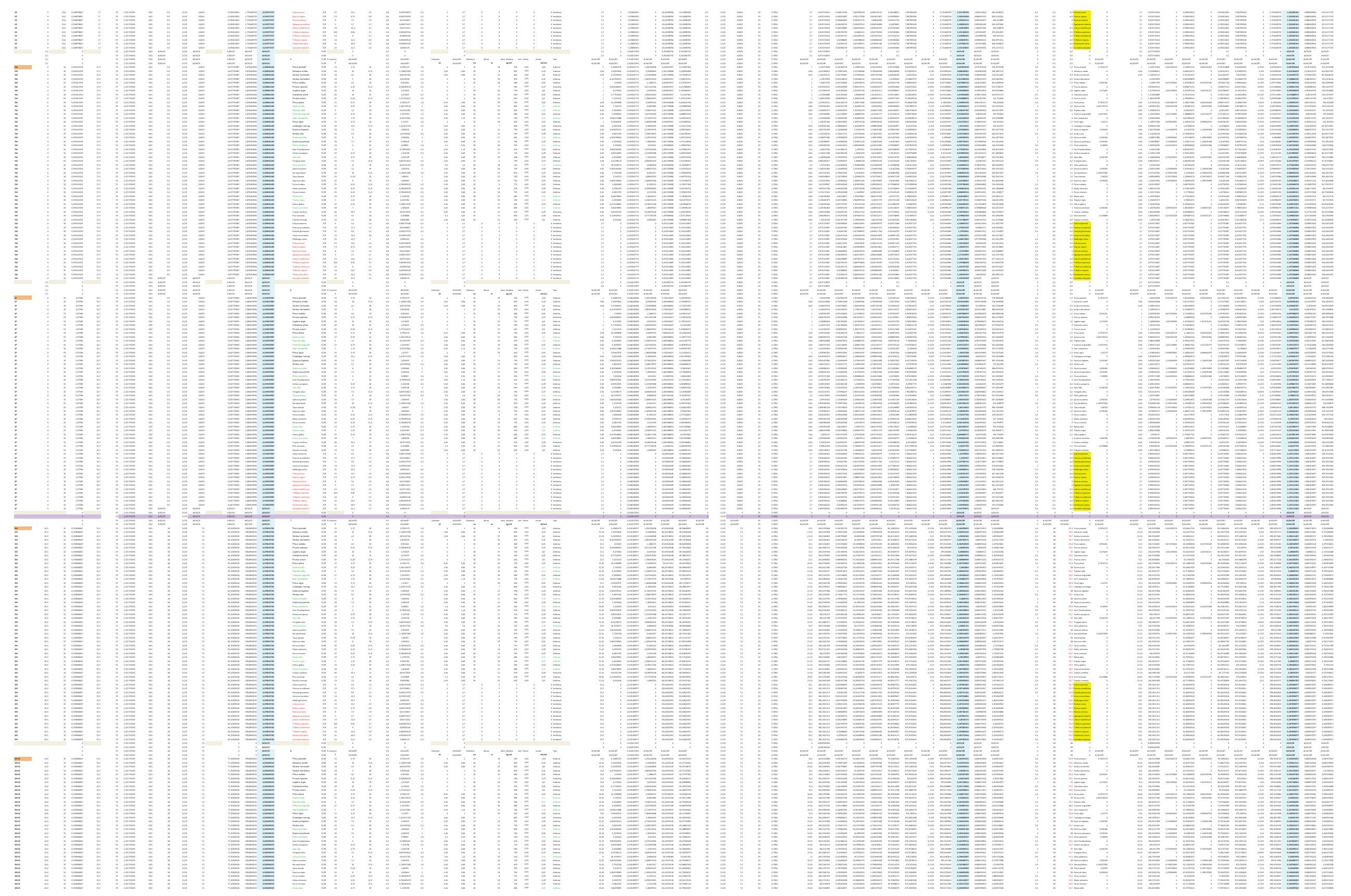




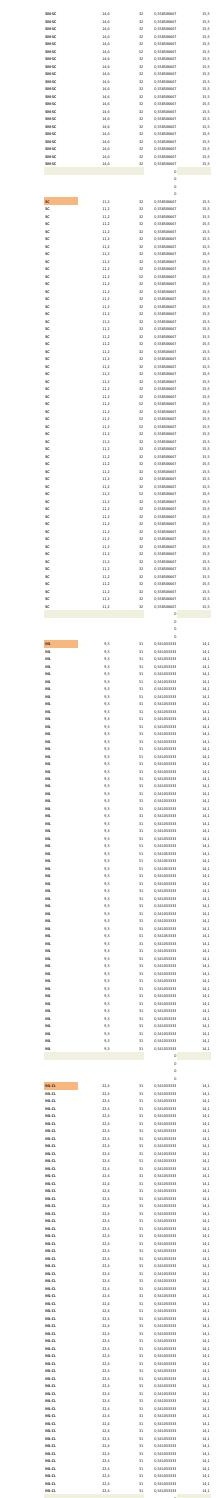

$-$

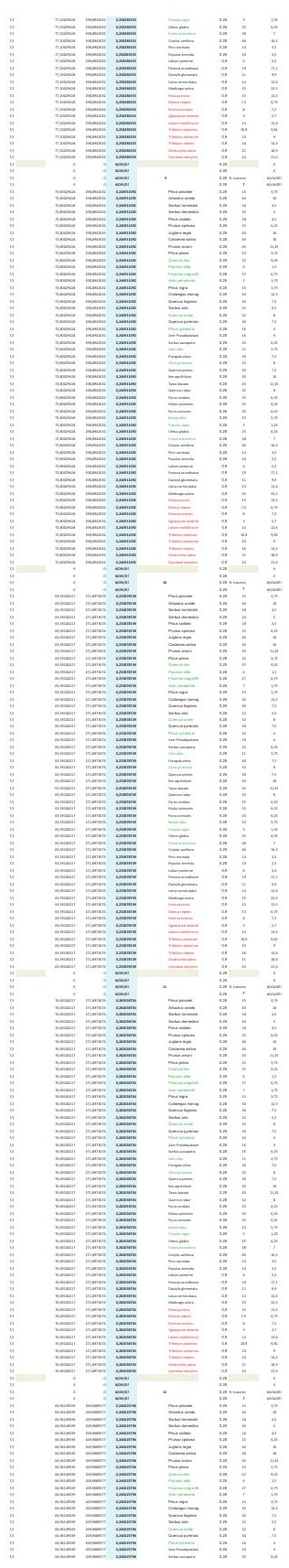

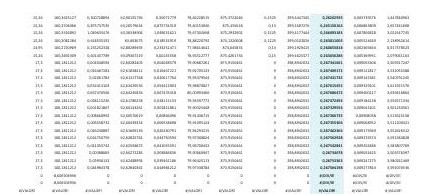
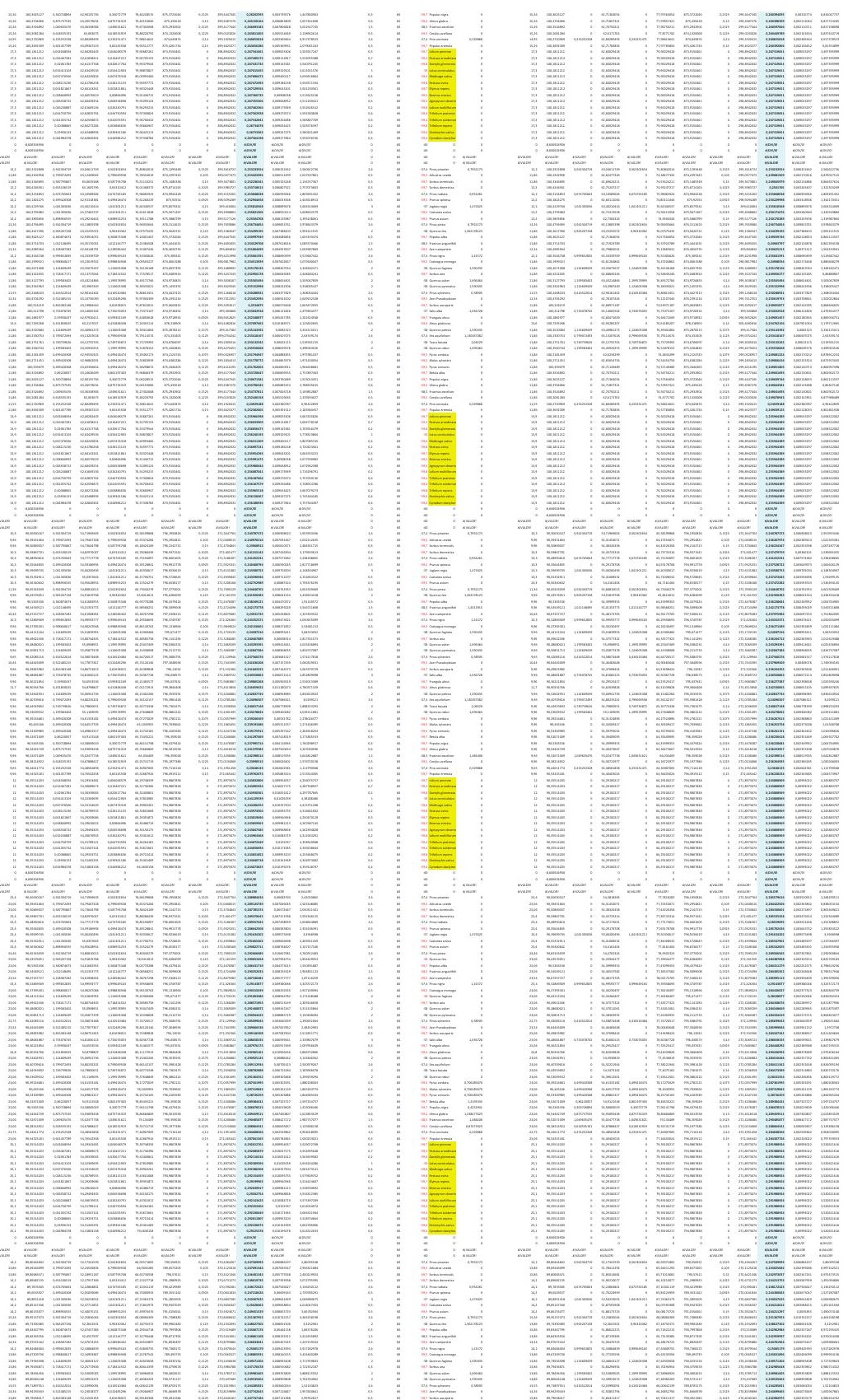


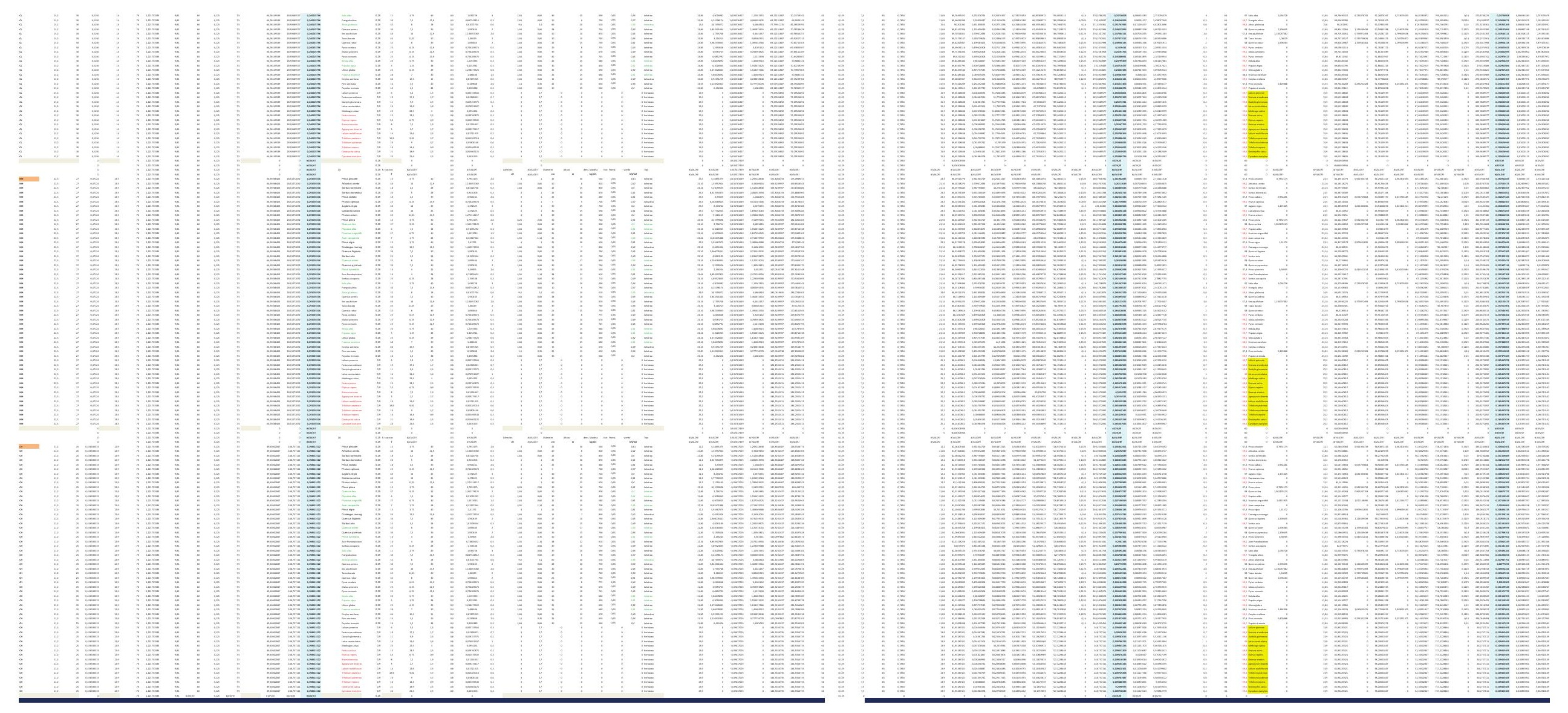



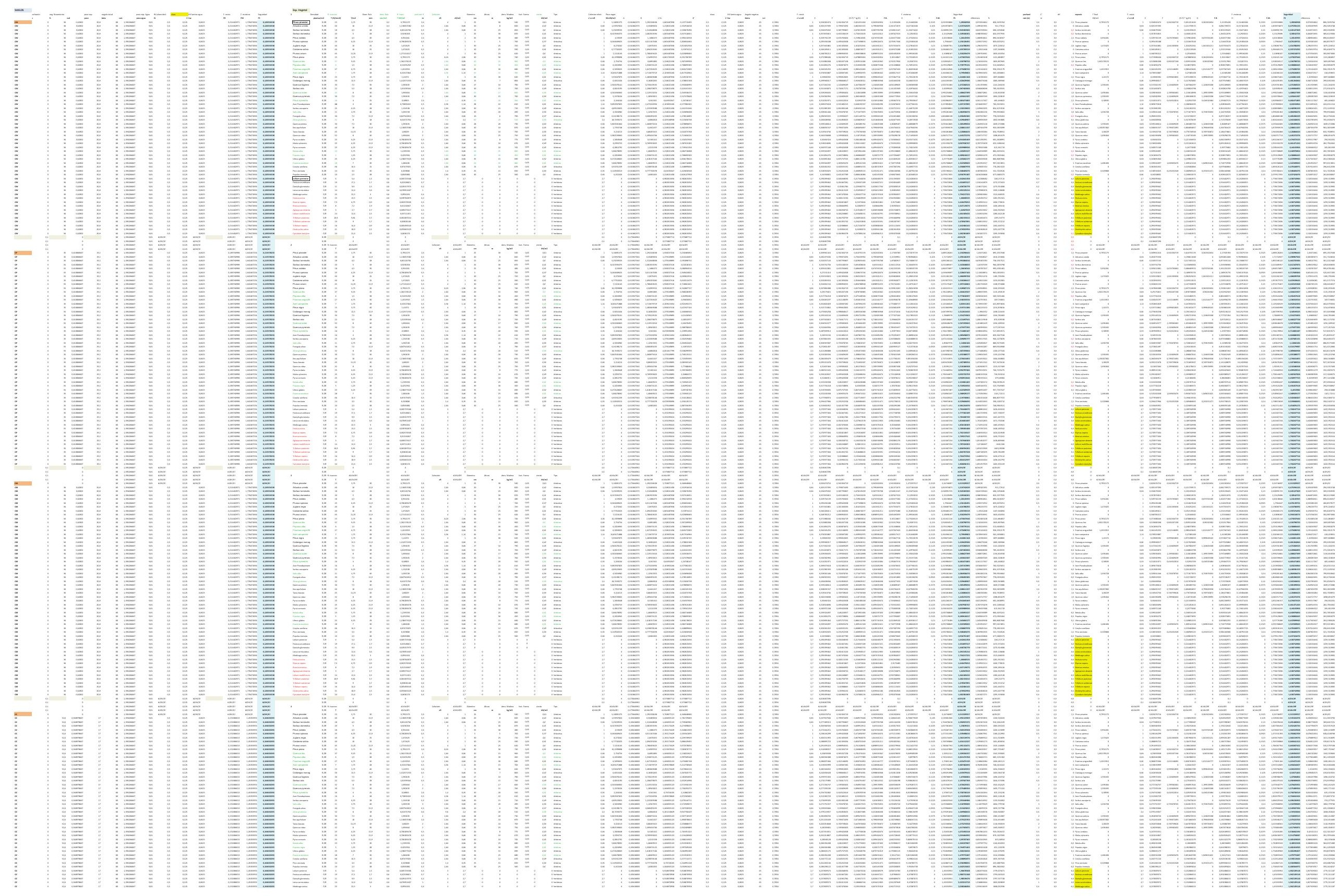


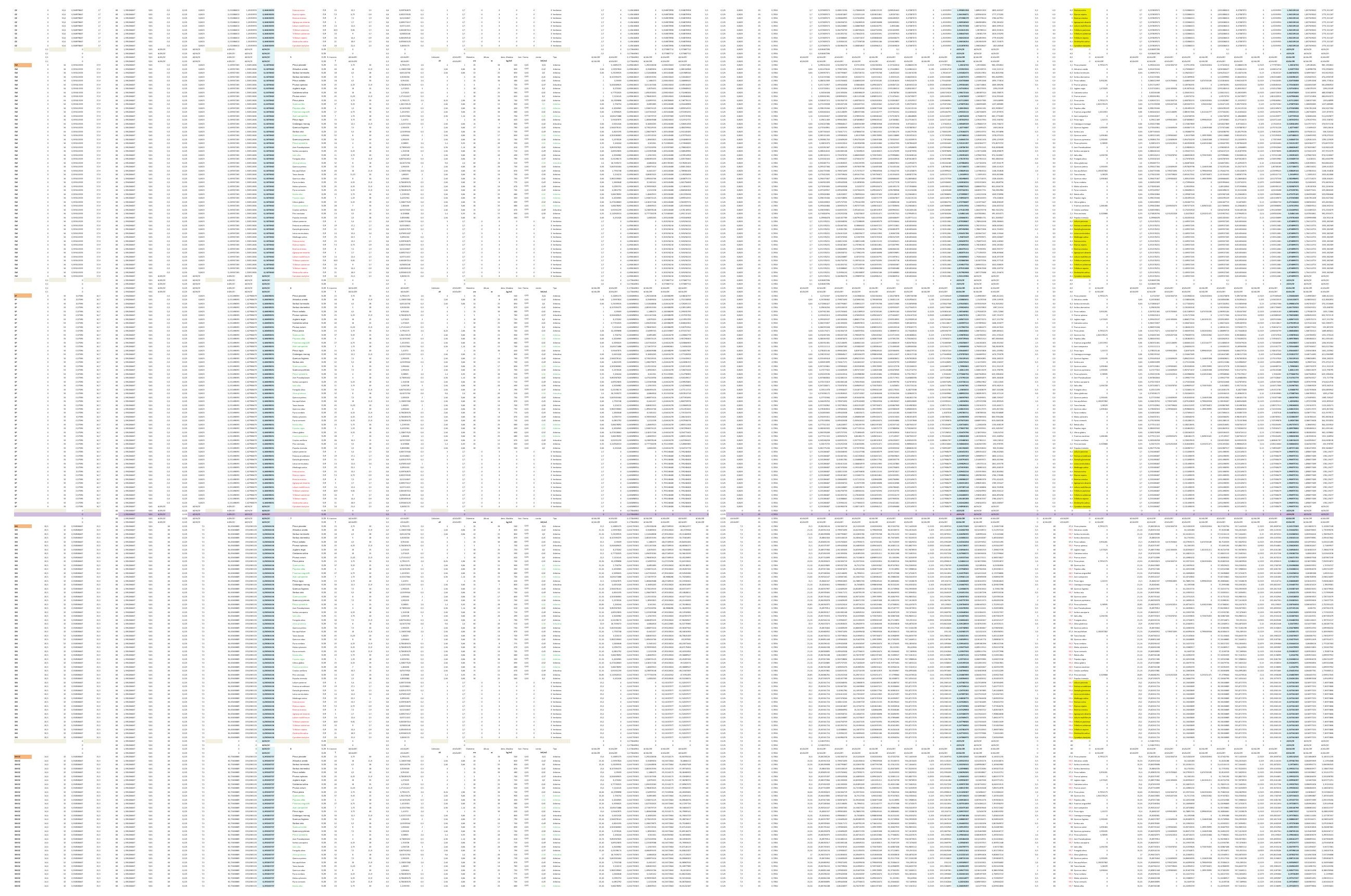




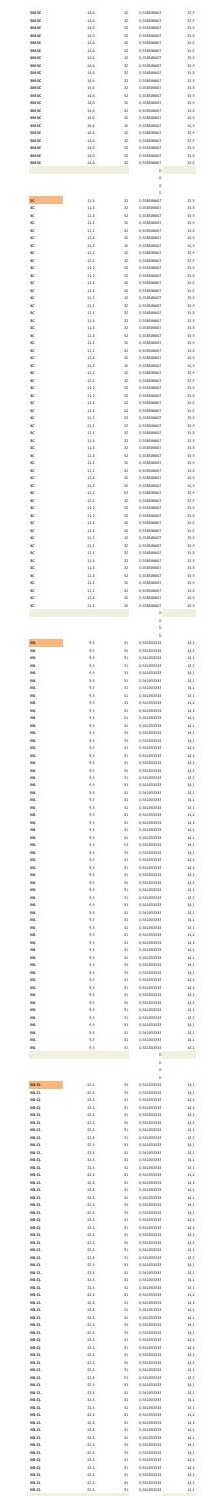

ำ
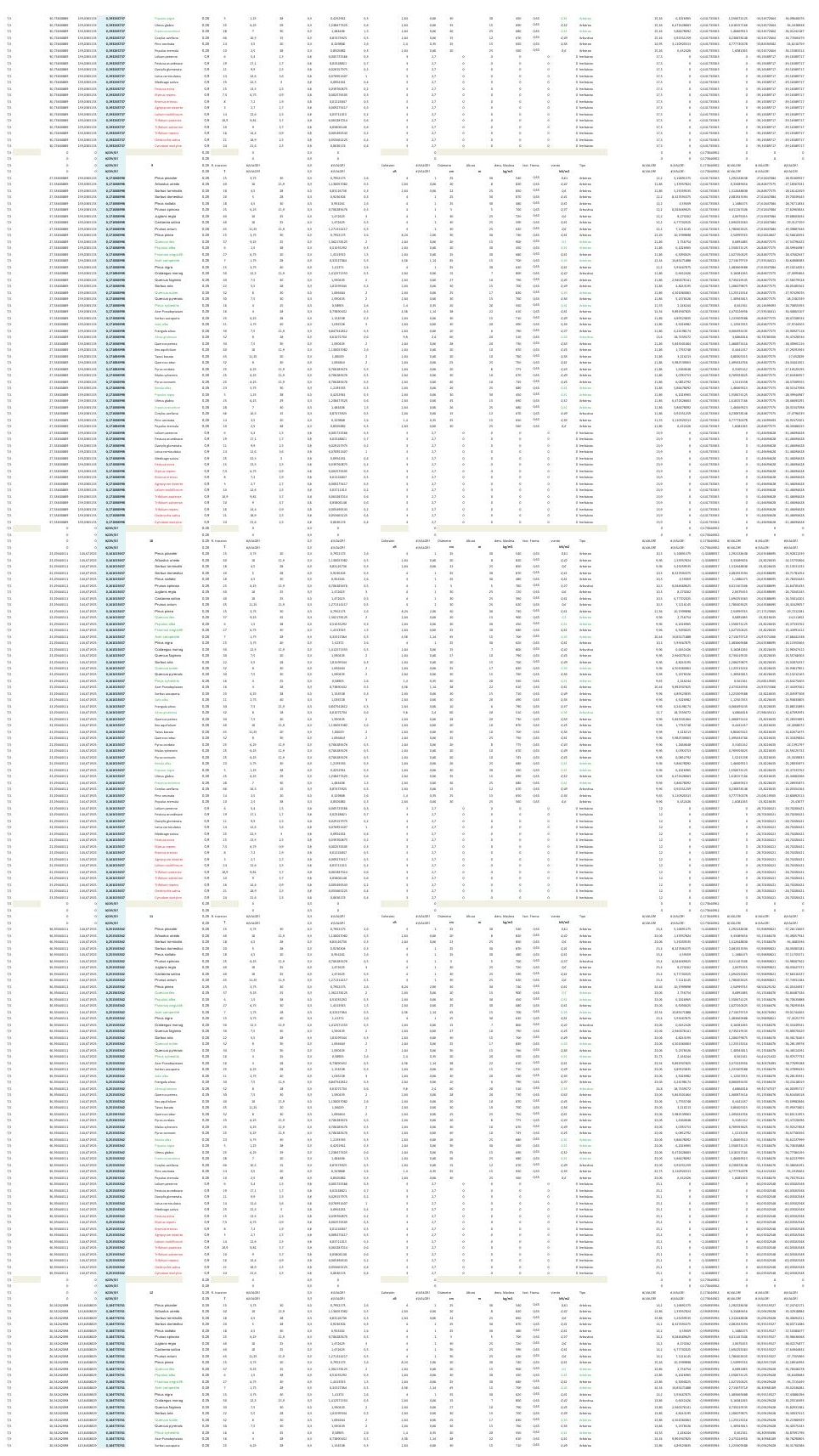
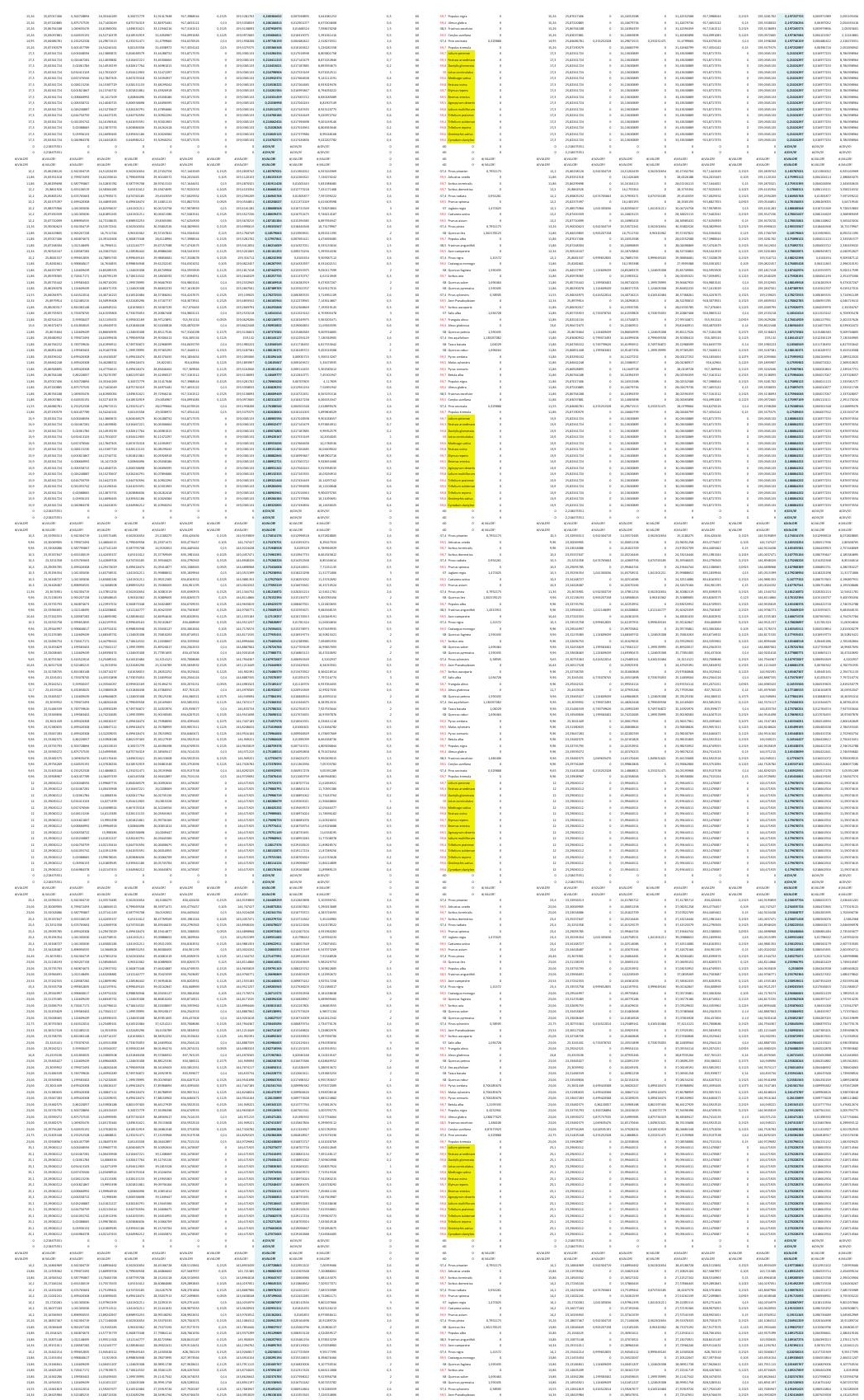

E
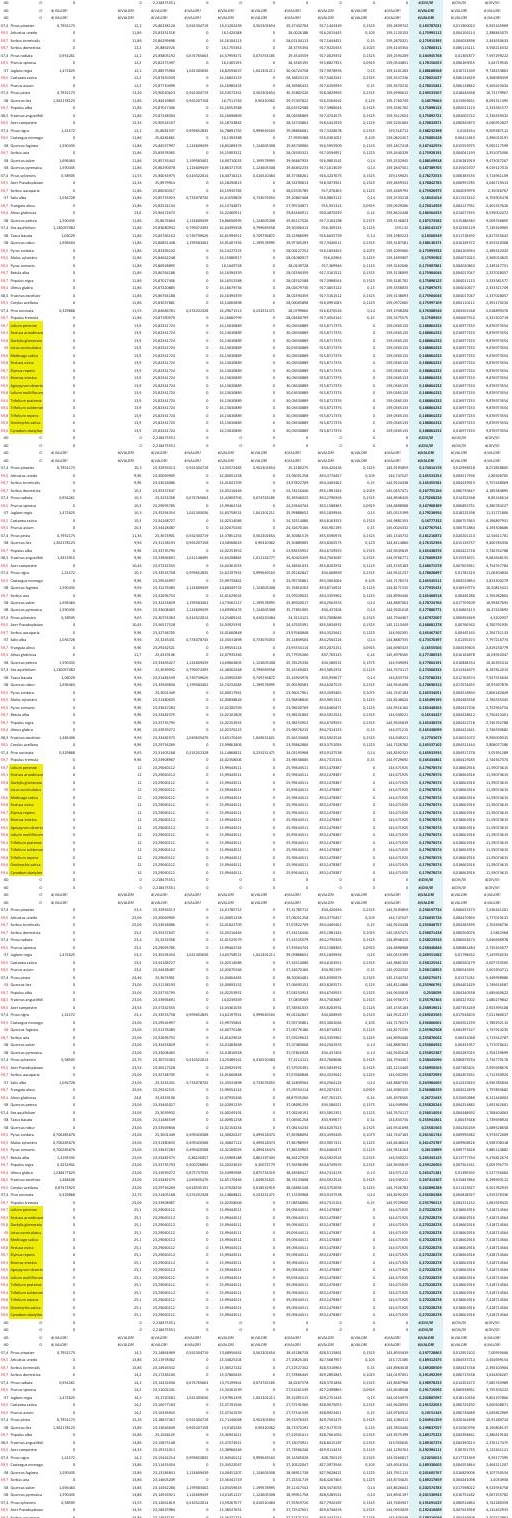


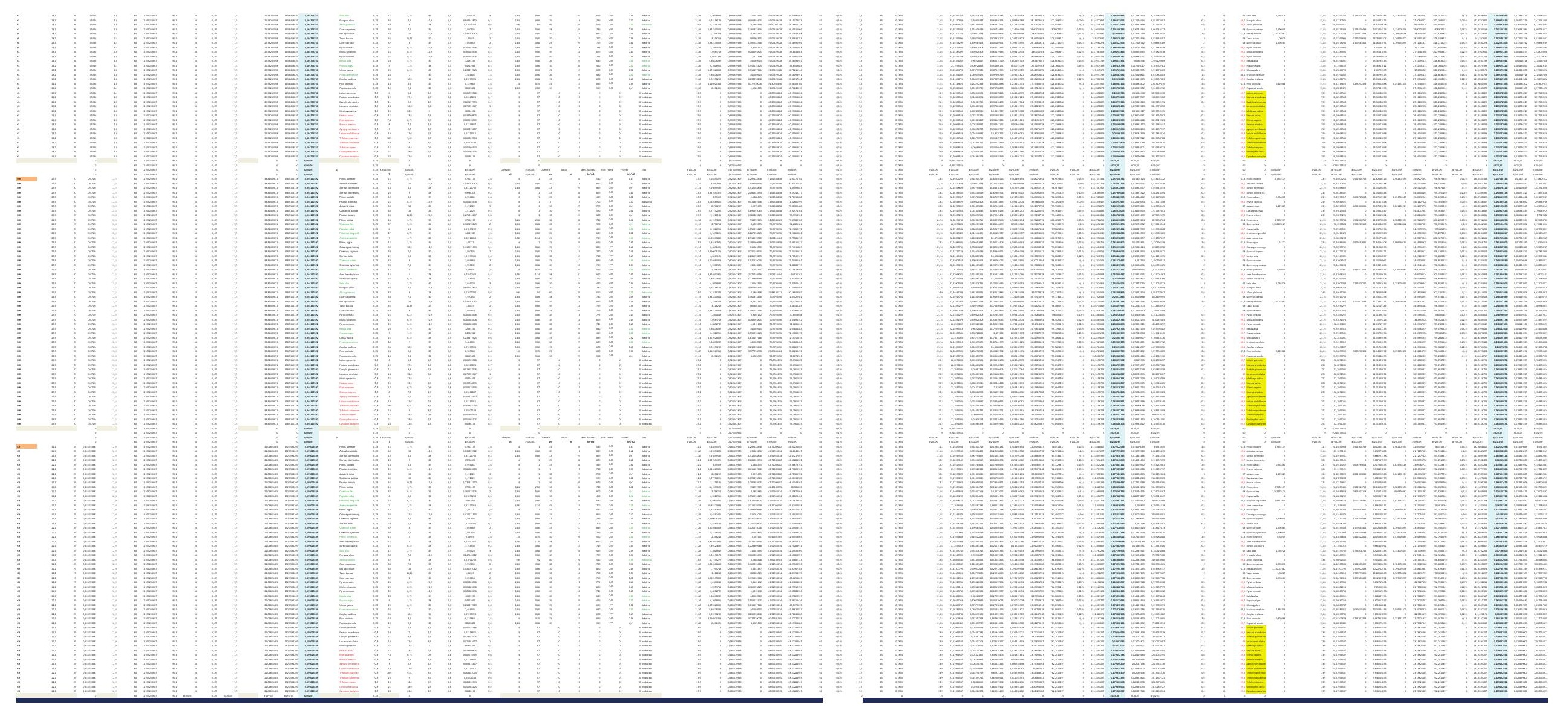


DESARROLLO DE UNA APLICACIÓN IMFORMÁTICA PARA EL CÁLCULO DE SOSTENIMIENTO DE TALUDES MEDIANTE VEGETACIÓN

A01. DENSIDAD DE PLANTACIÓN: 600 plantas/ha.

\section{A01-3.POSICIÓN N.F. 3}

INCLINACIÓN DE TALUD 6-100

INCLINACIÓN DE TALUD 10-200

INCLINACIÓN DE TALUD 20-30

INCLINACIÓN DE TALUD 30-40

INCLINACIÓN DE TALUD $35^{\circ}$

INCLINACIÓN DE TALUD 40-50

INCLINACIÓN DE TALUD 50-550

INCLINACIÓN DE TALUD 55-60

INCLINACIÓN DE TALUD 60-700

INCLINACIÓN DE TALUD 70-80 

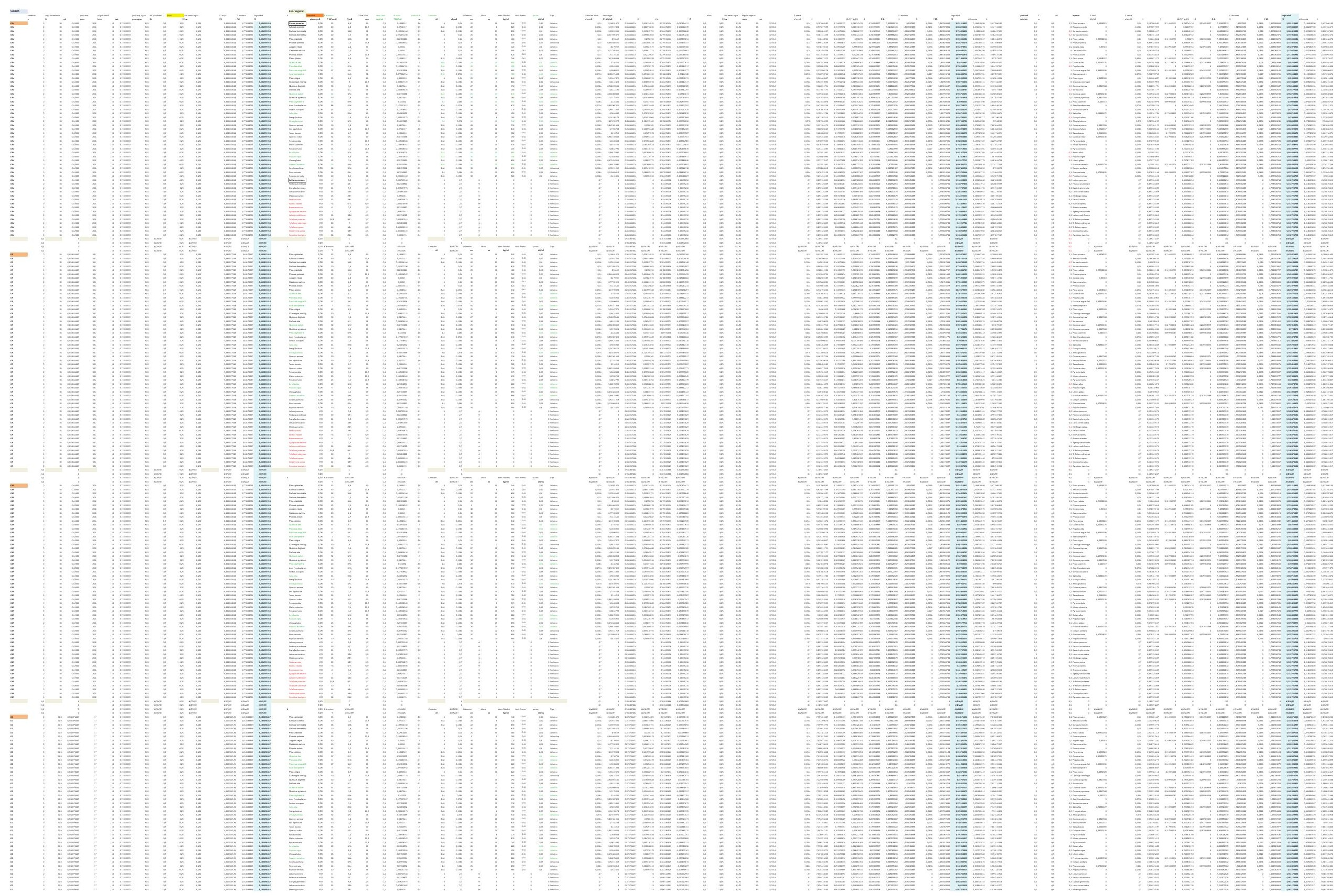


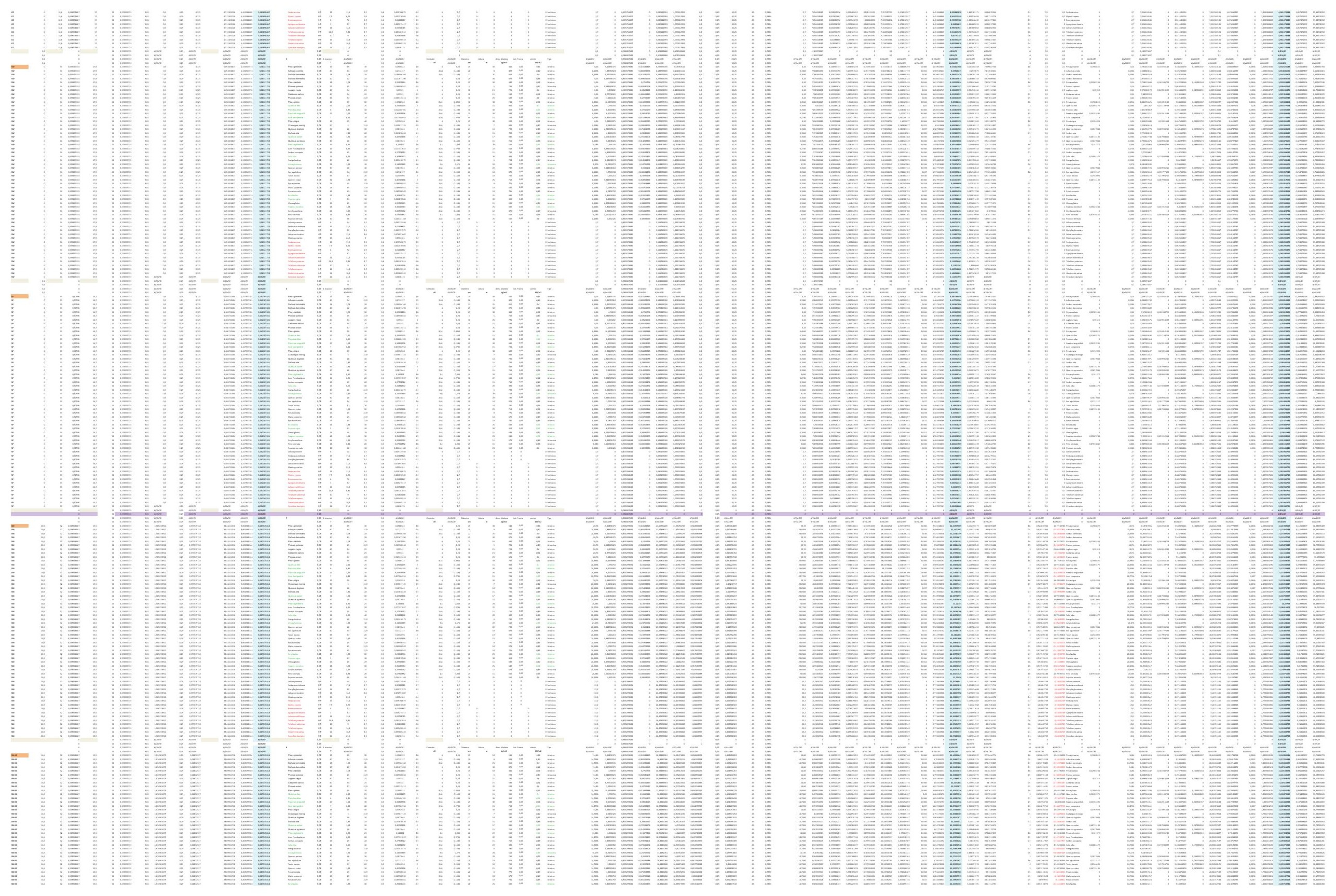



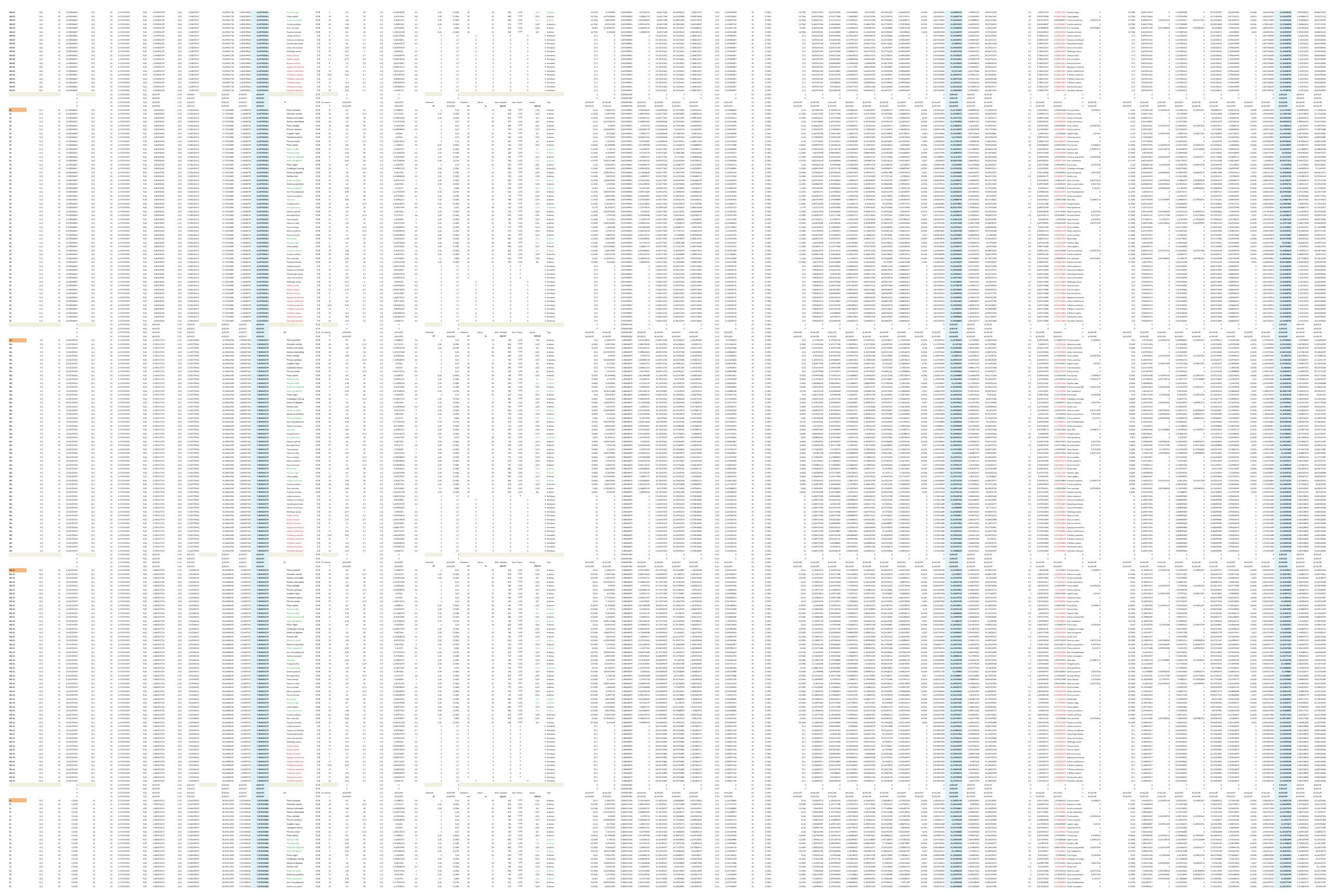

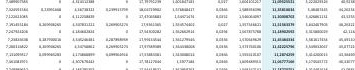




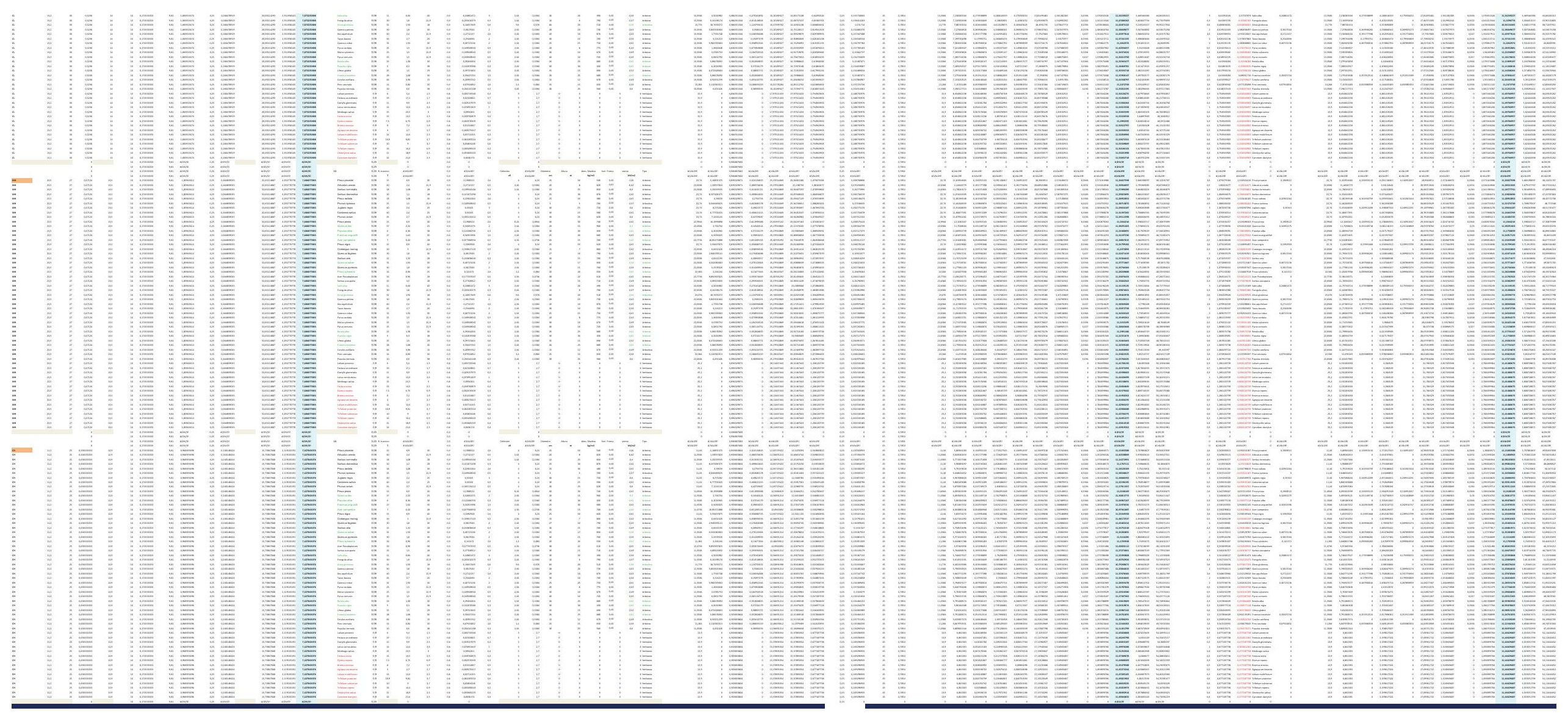



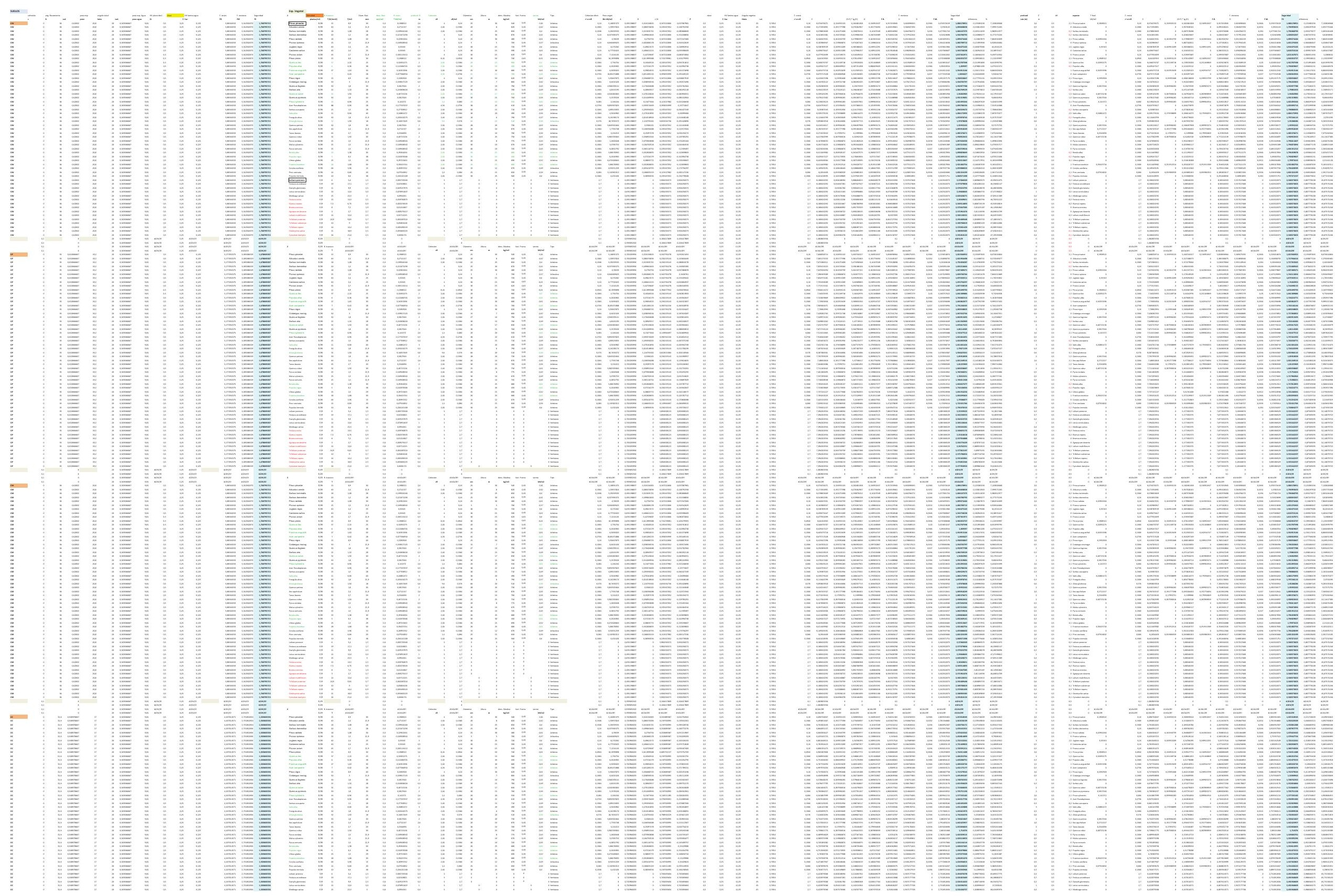

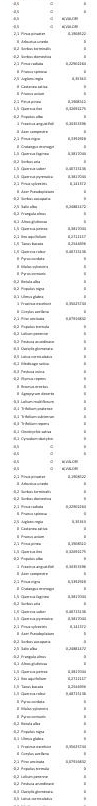

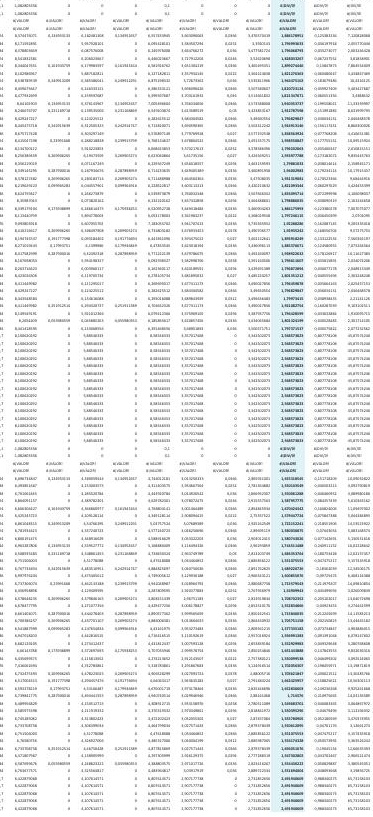




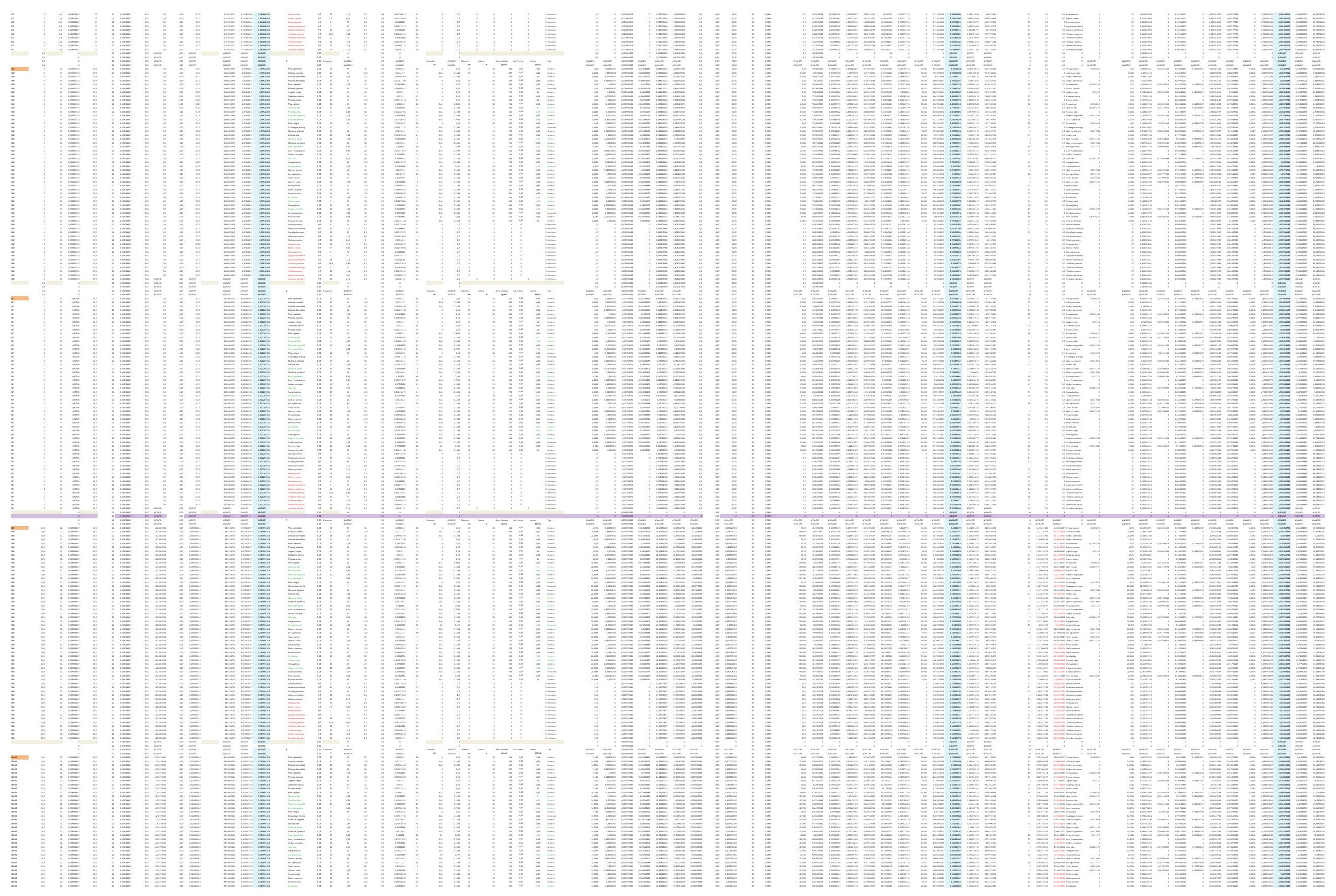



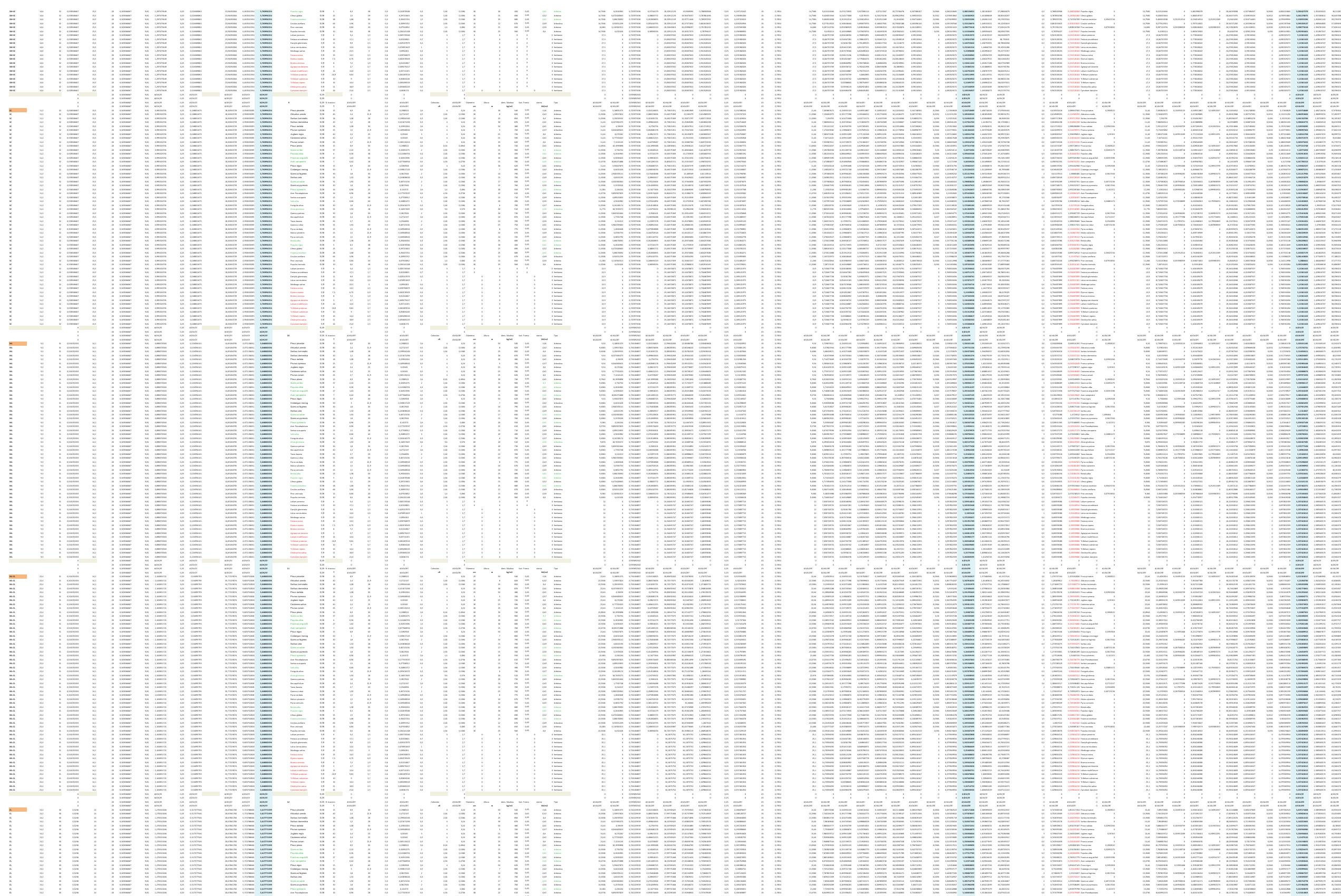

=
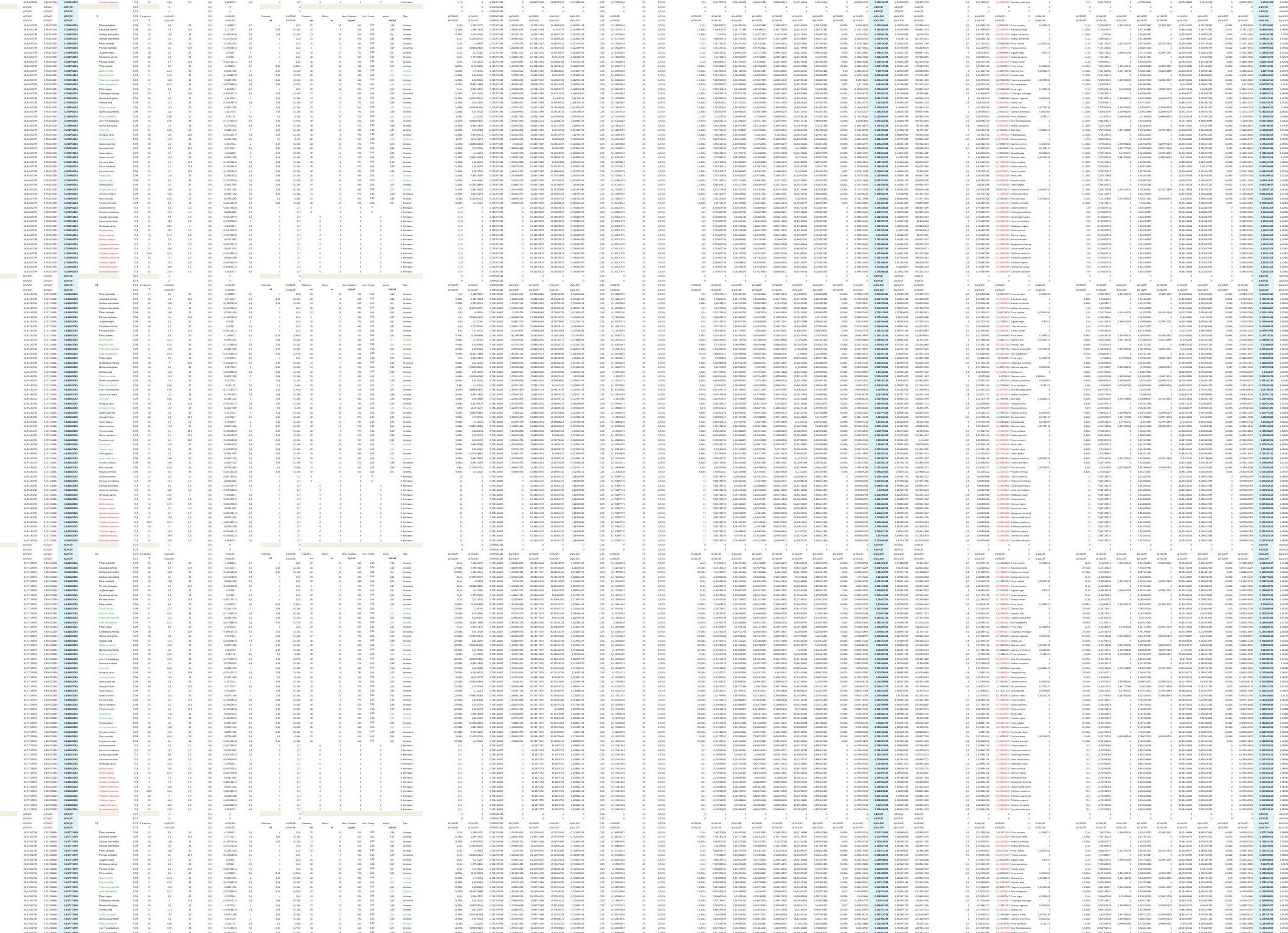

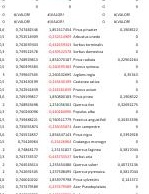

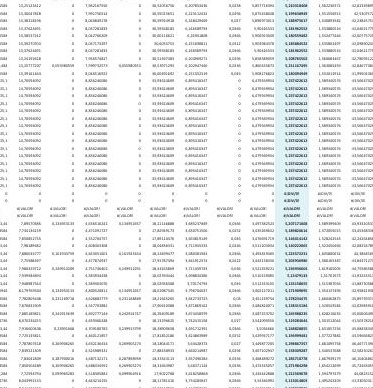




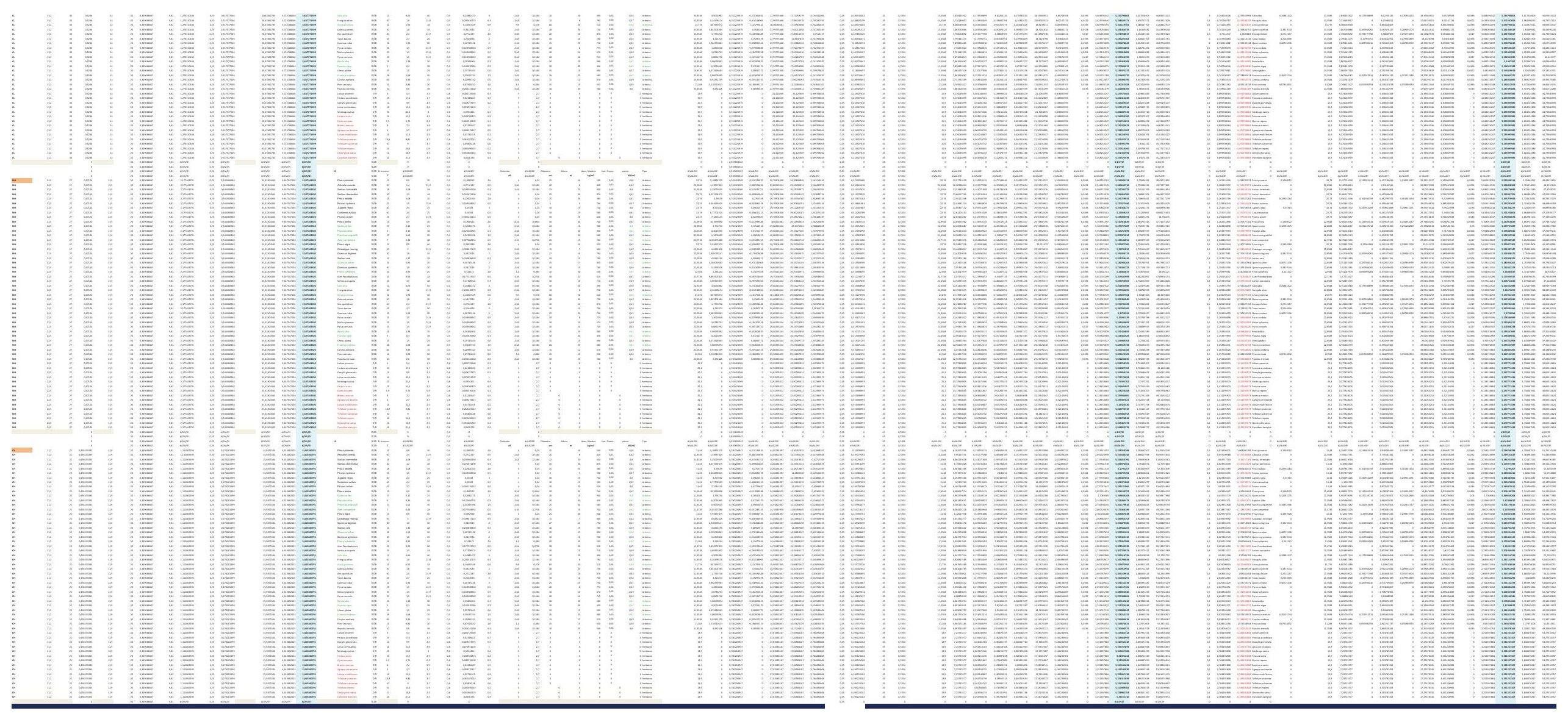



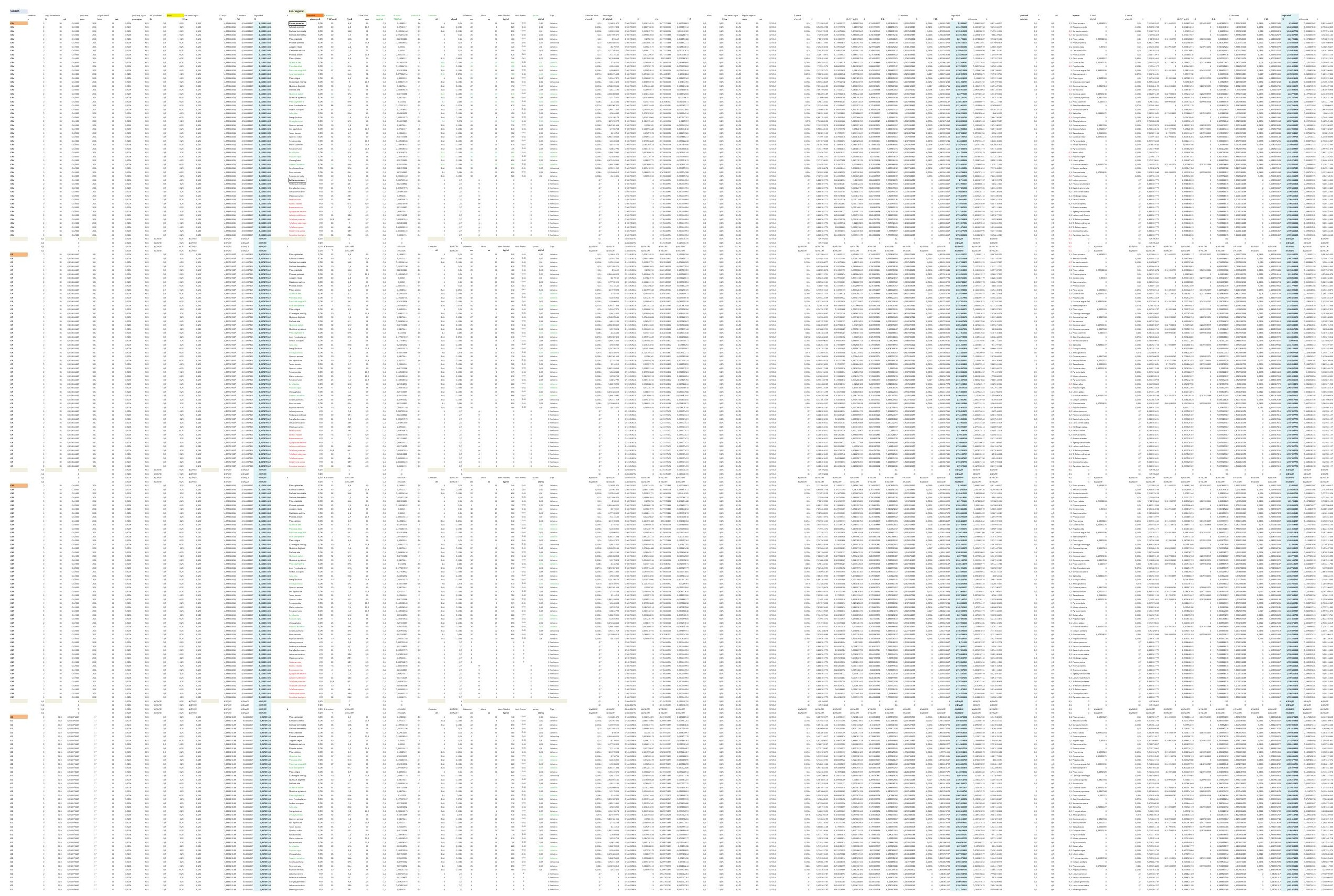

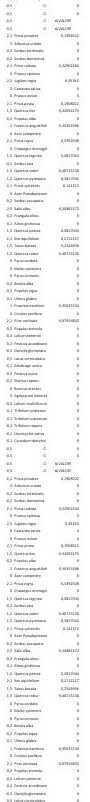

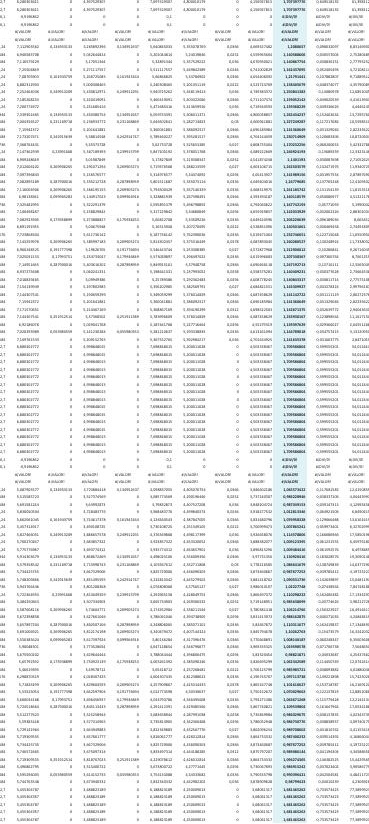




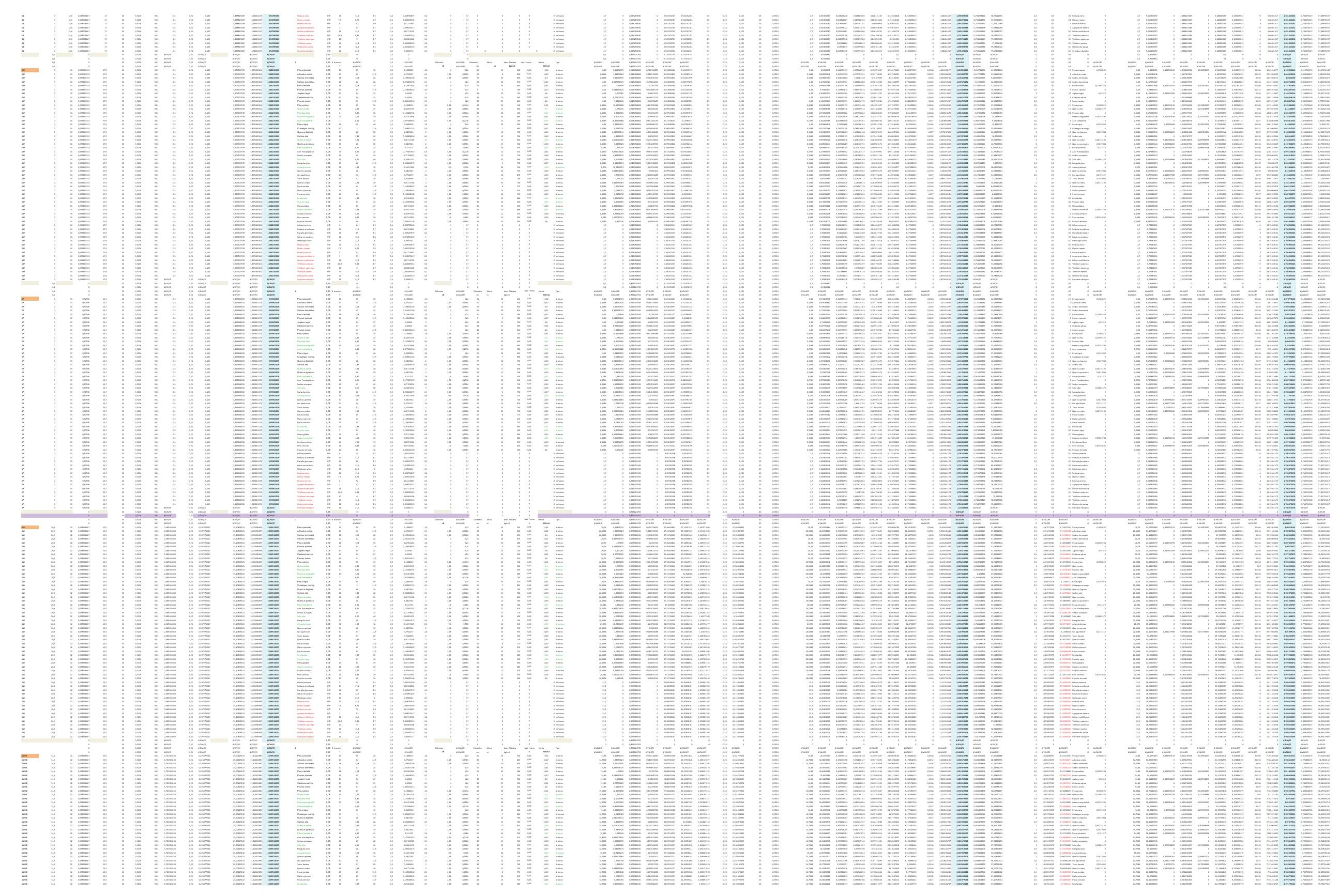



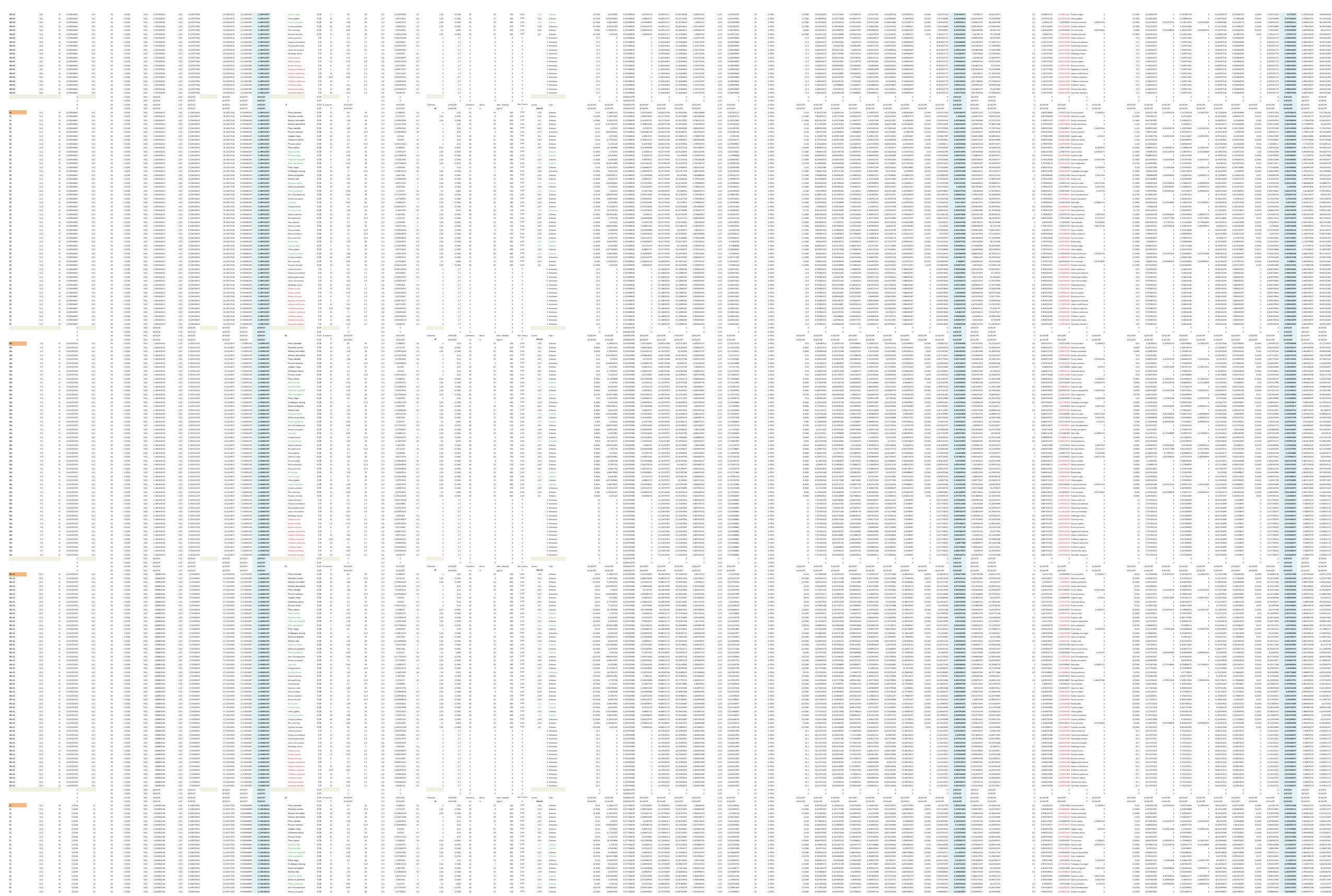

$=$
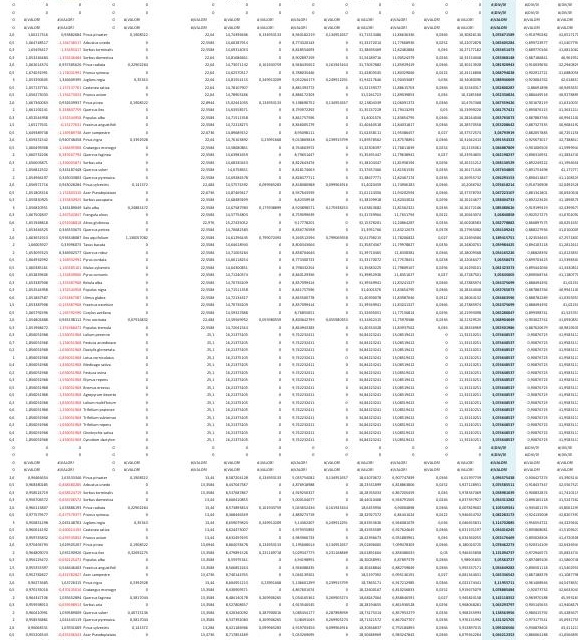


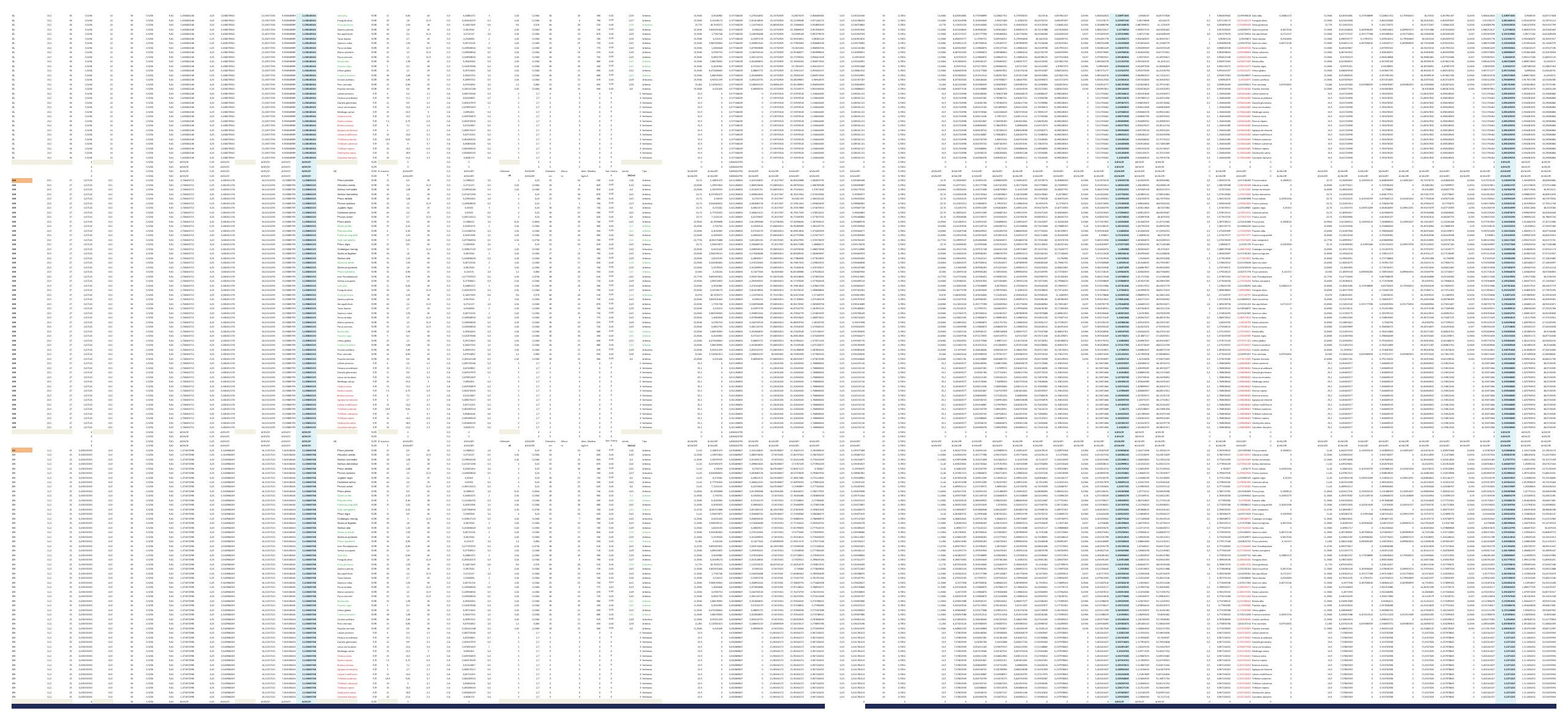



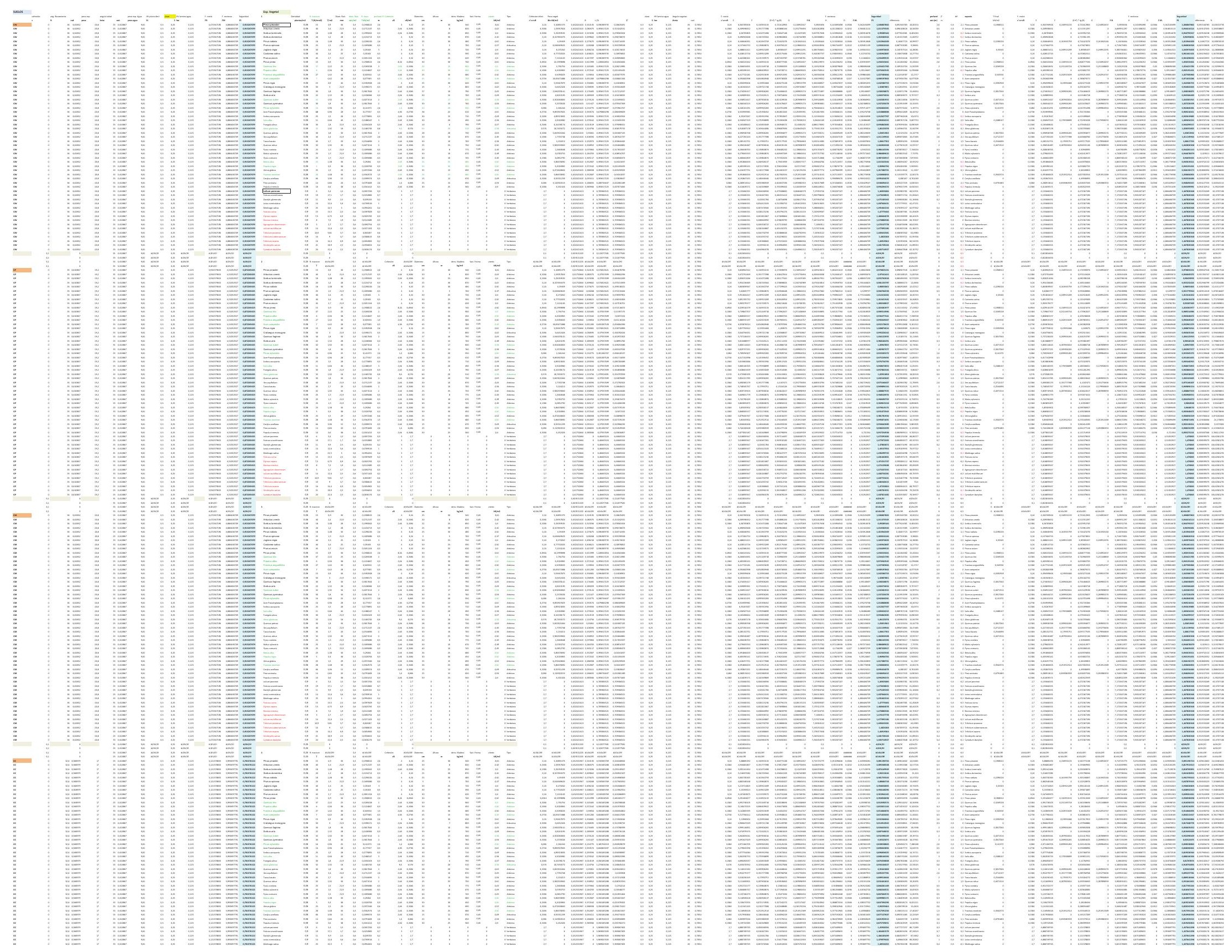


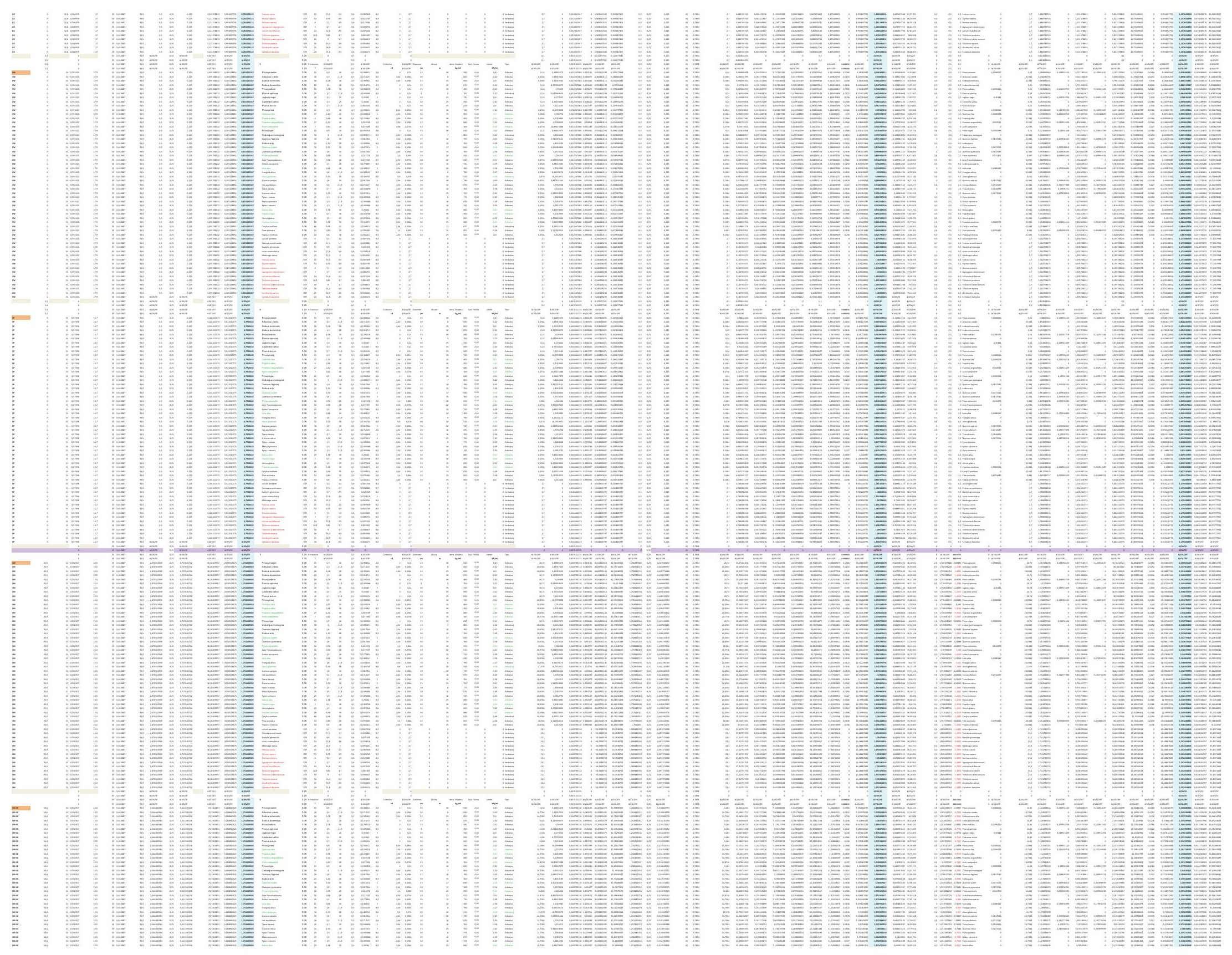



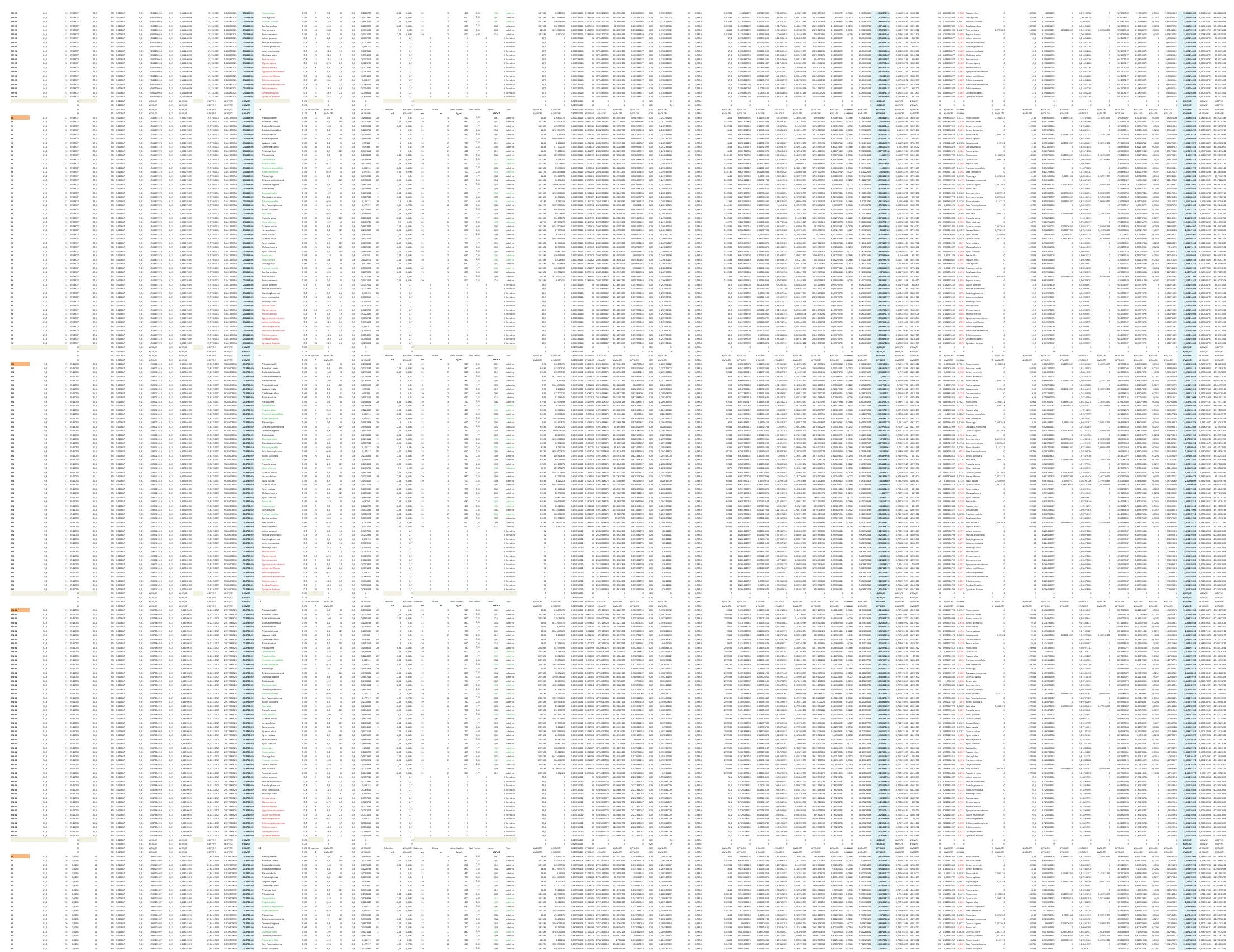

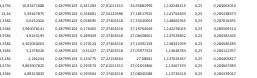

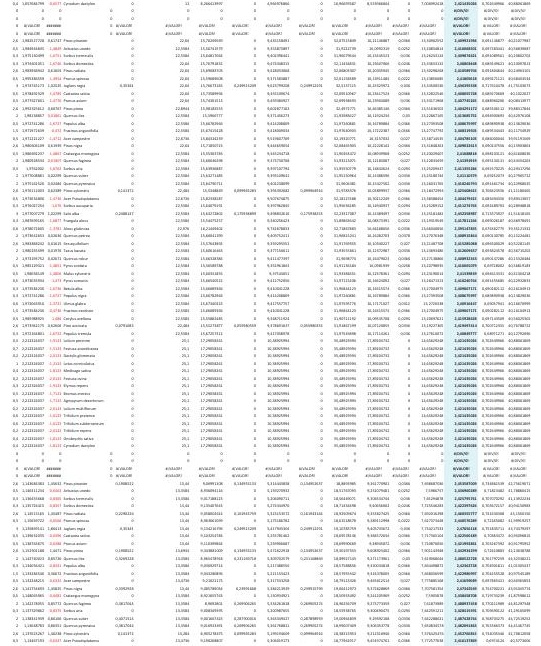




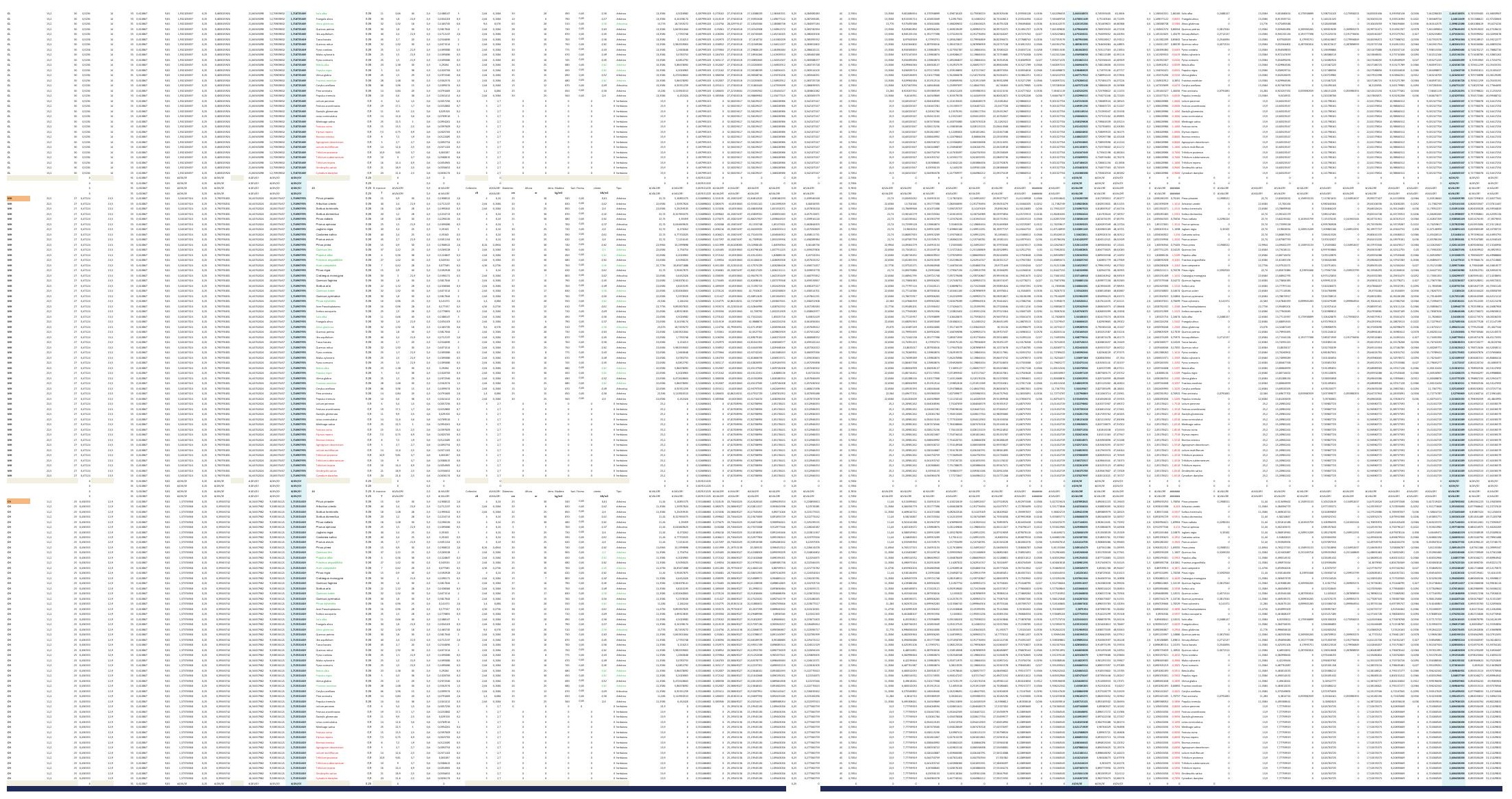



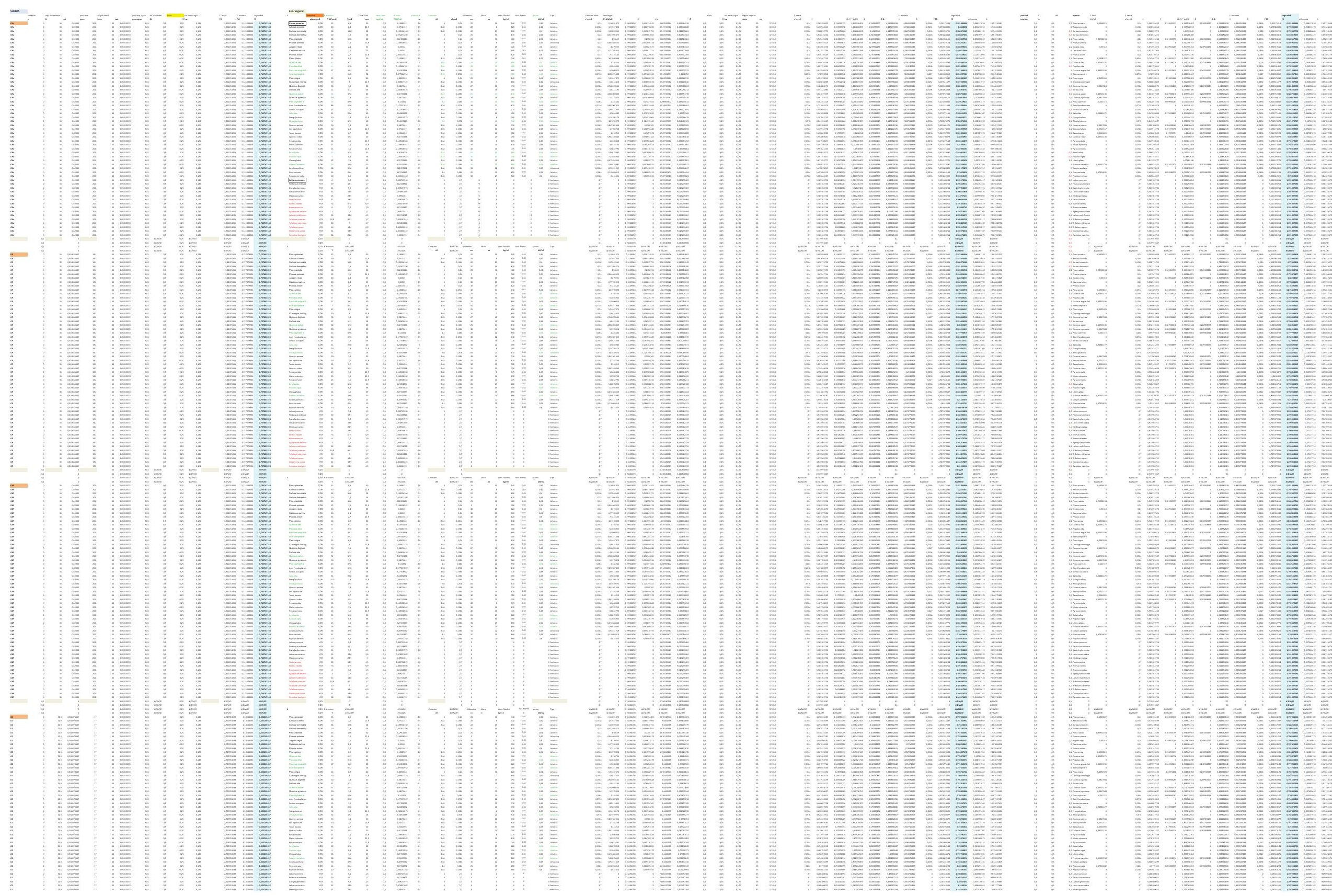


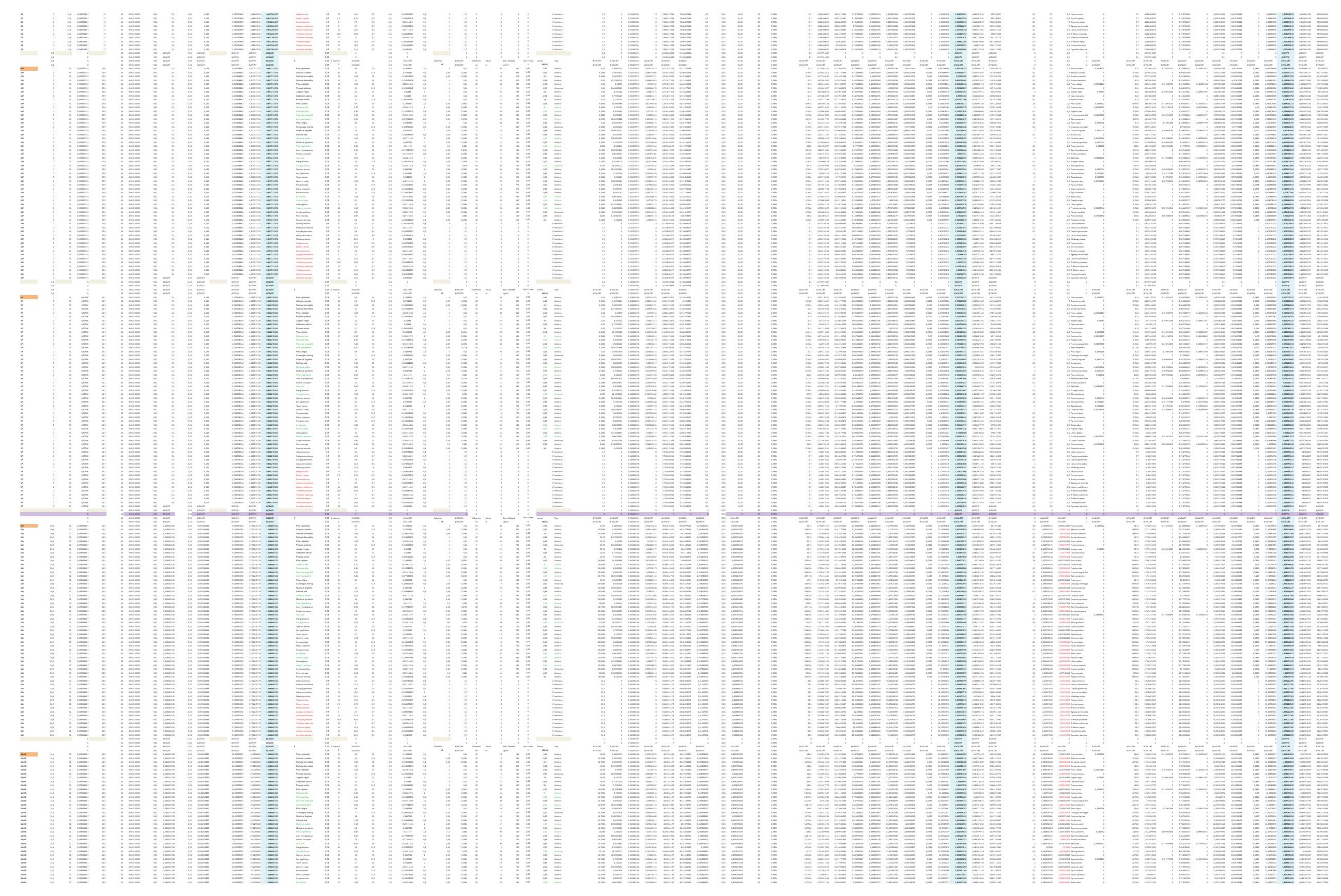



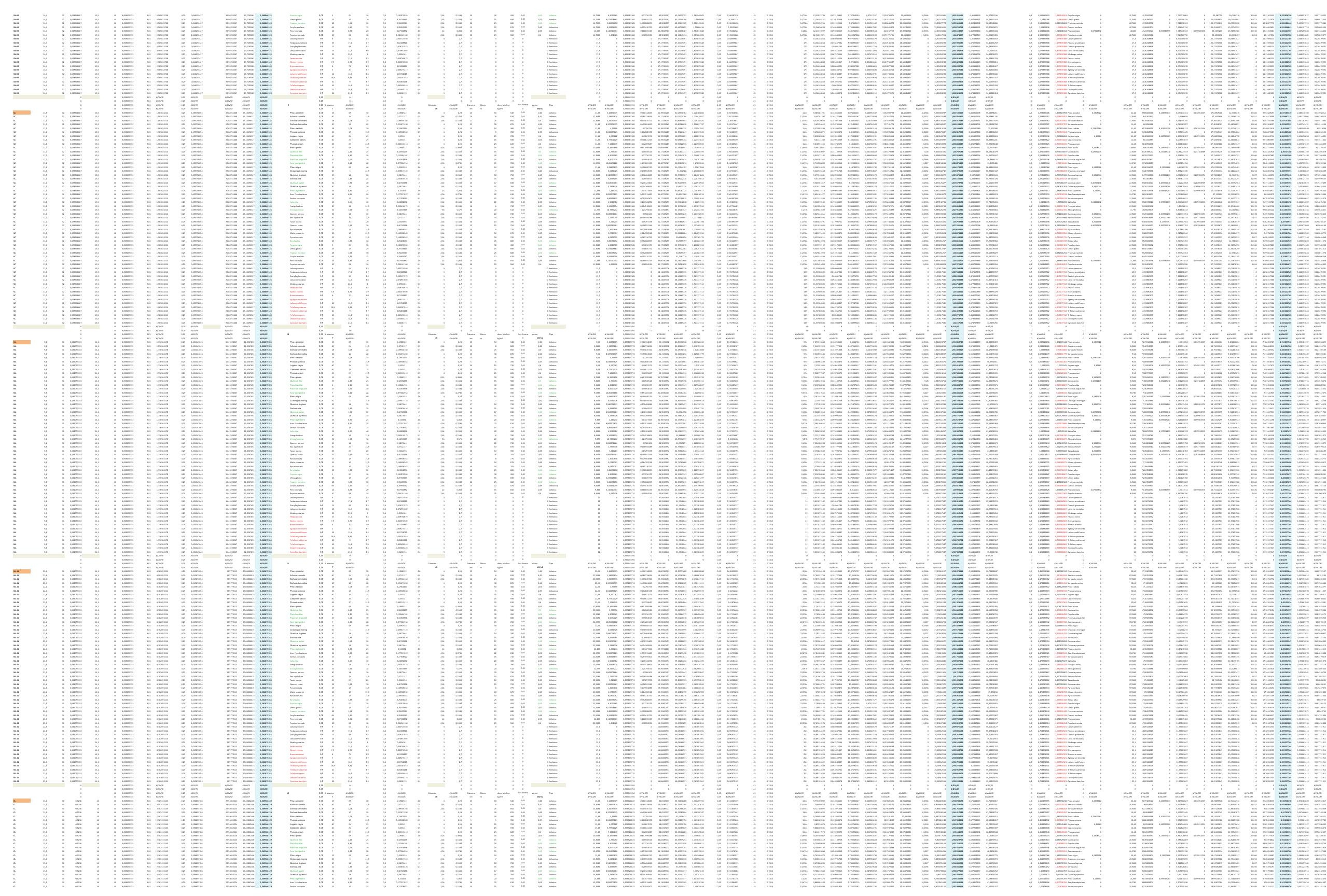


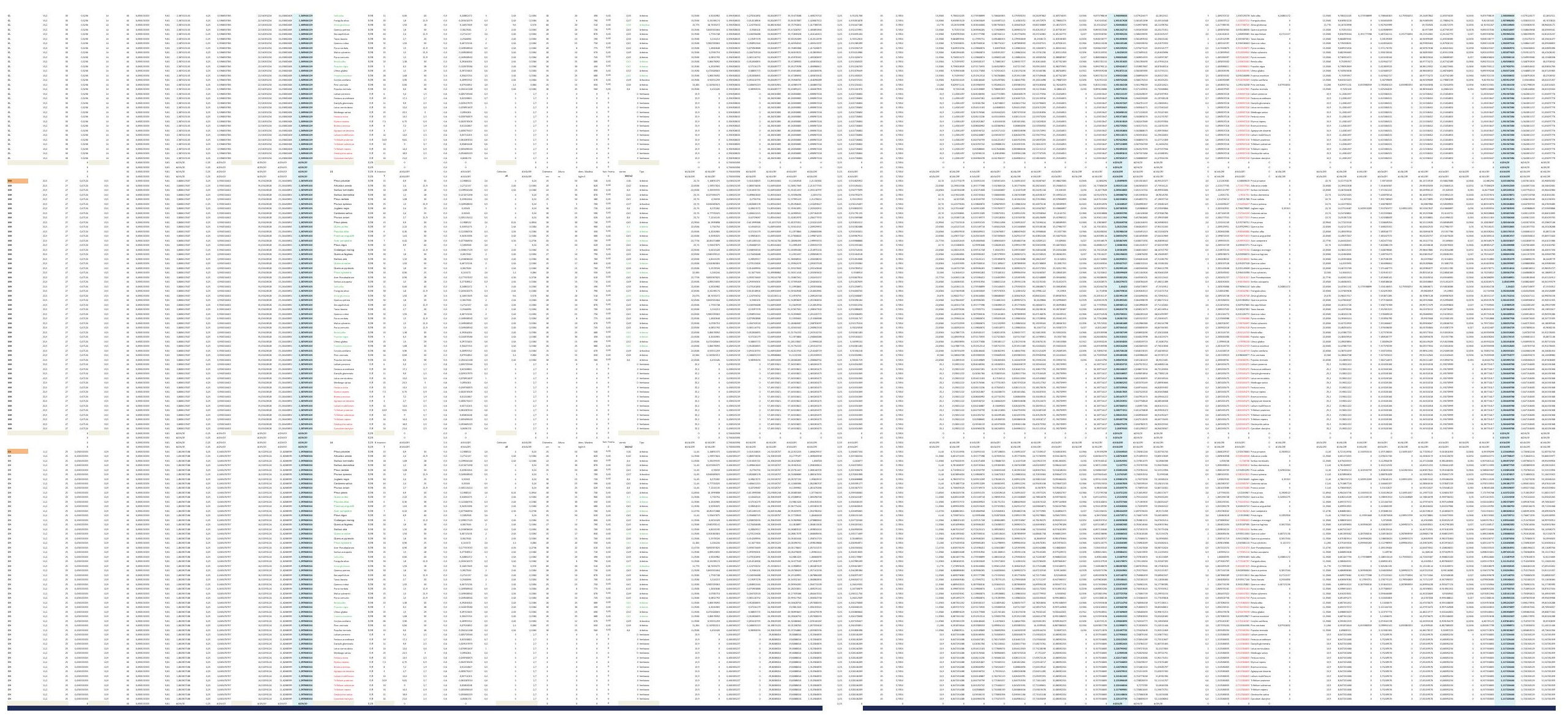



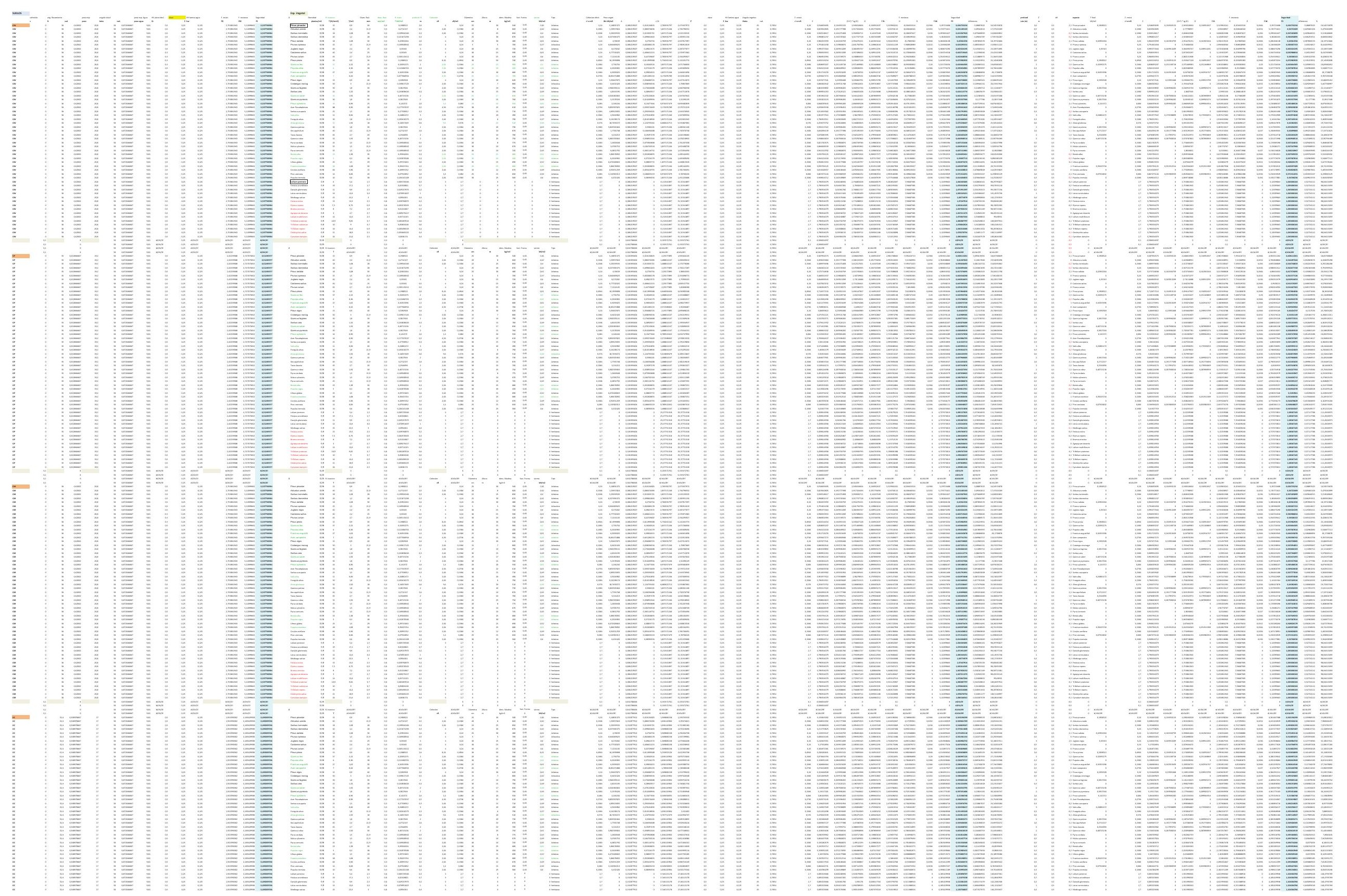


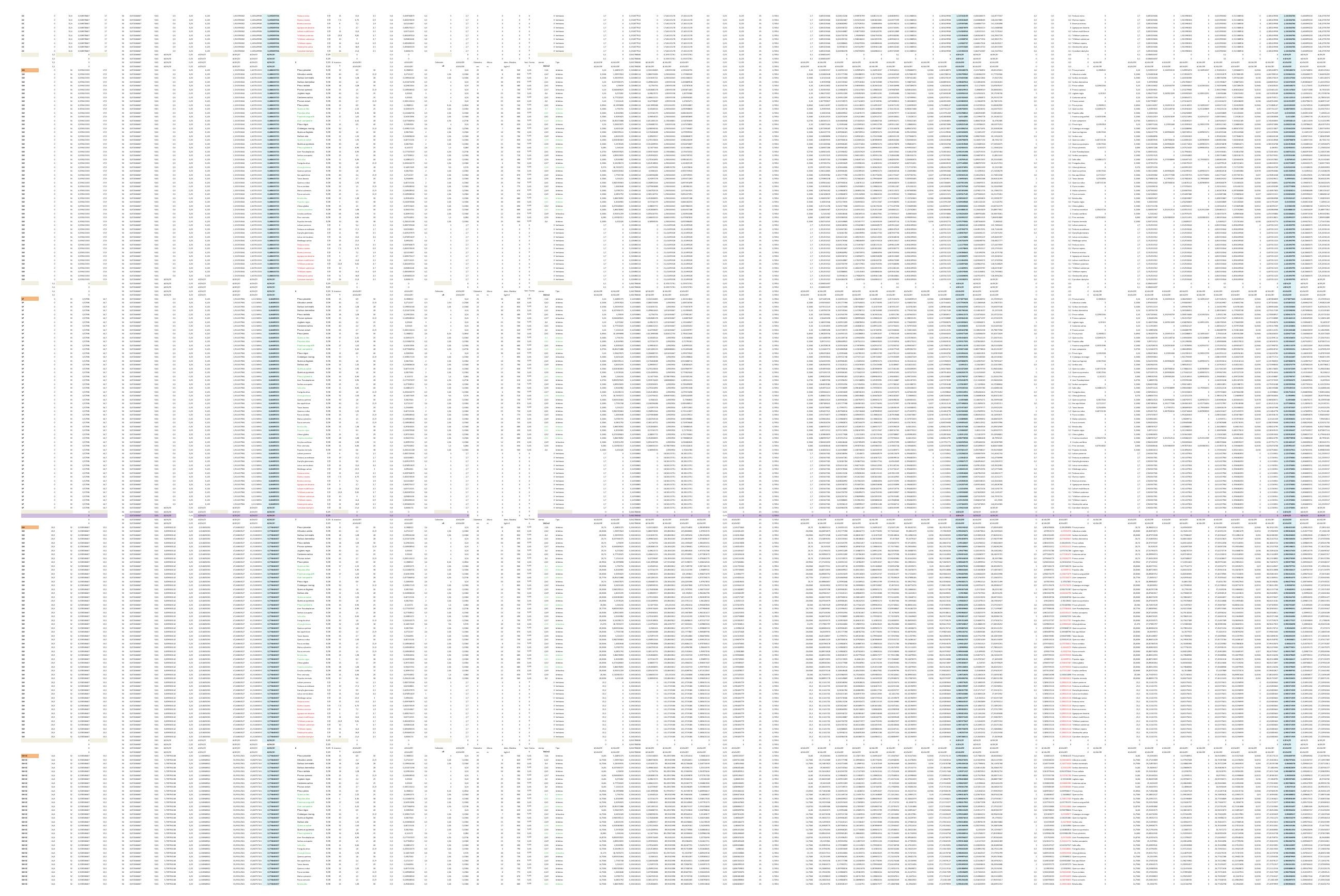



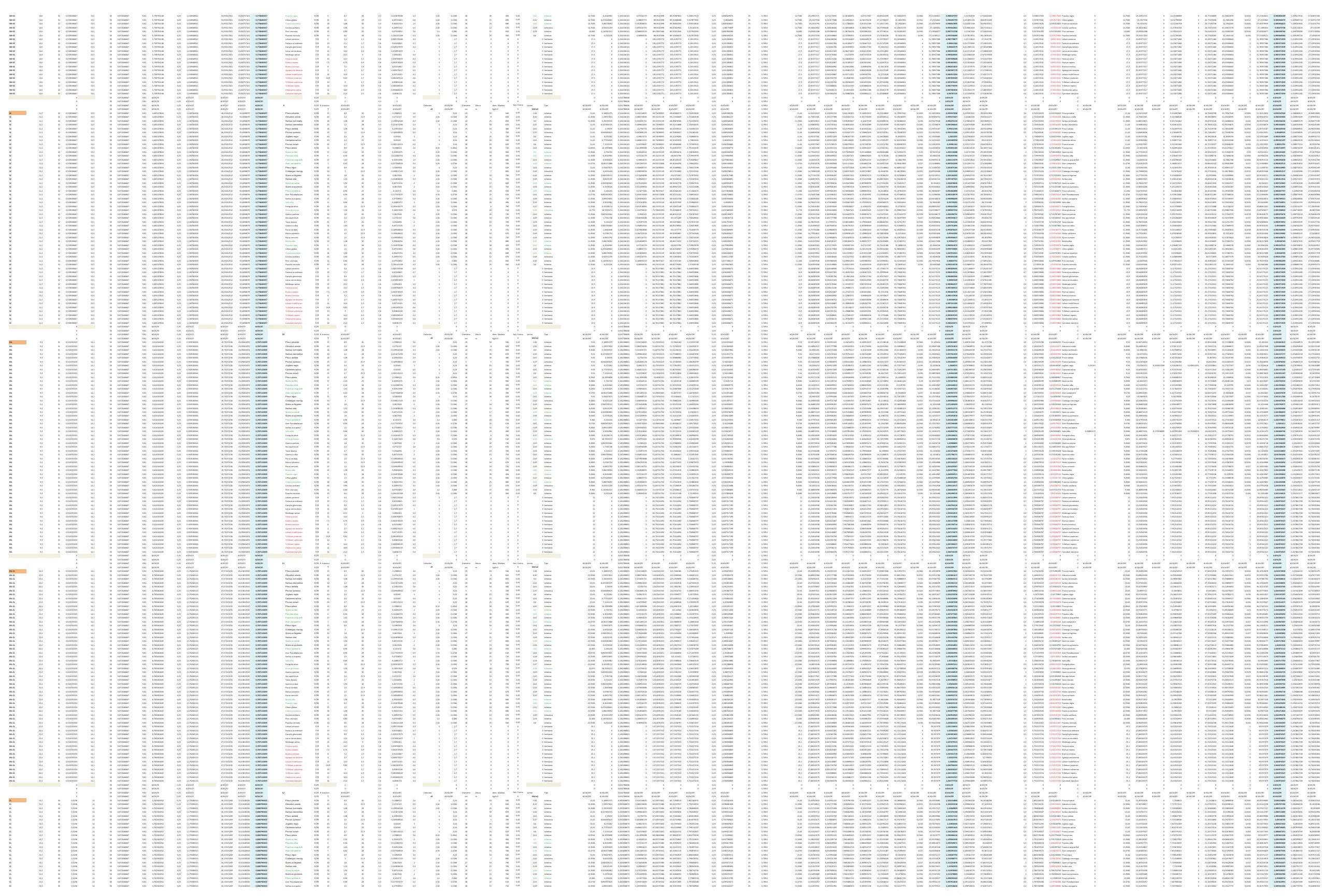


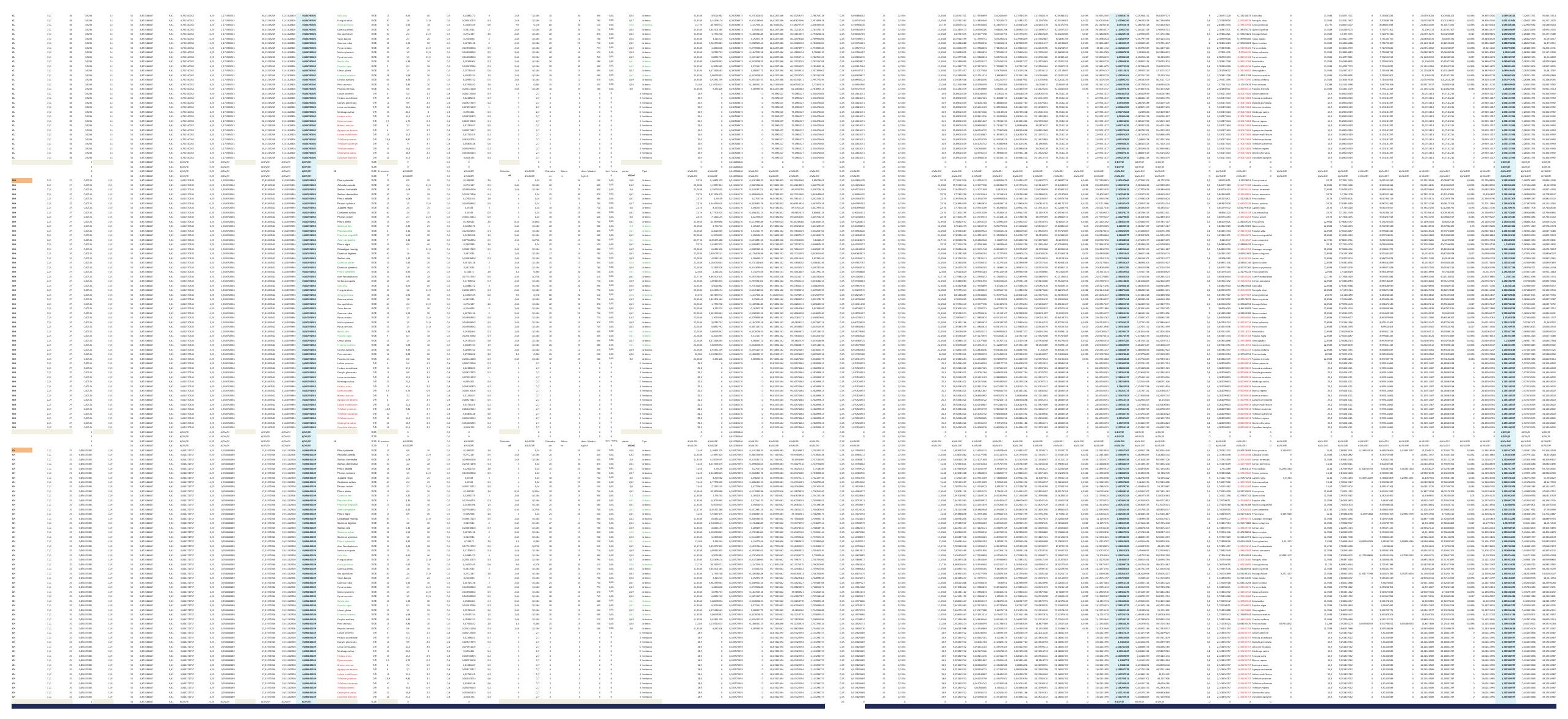



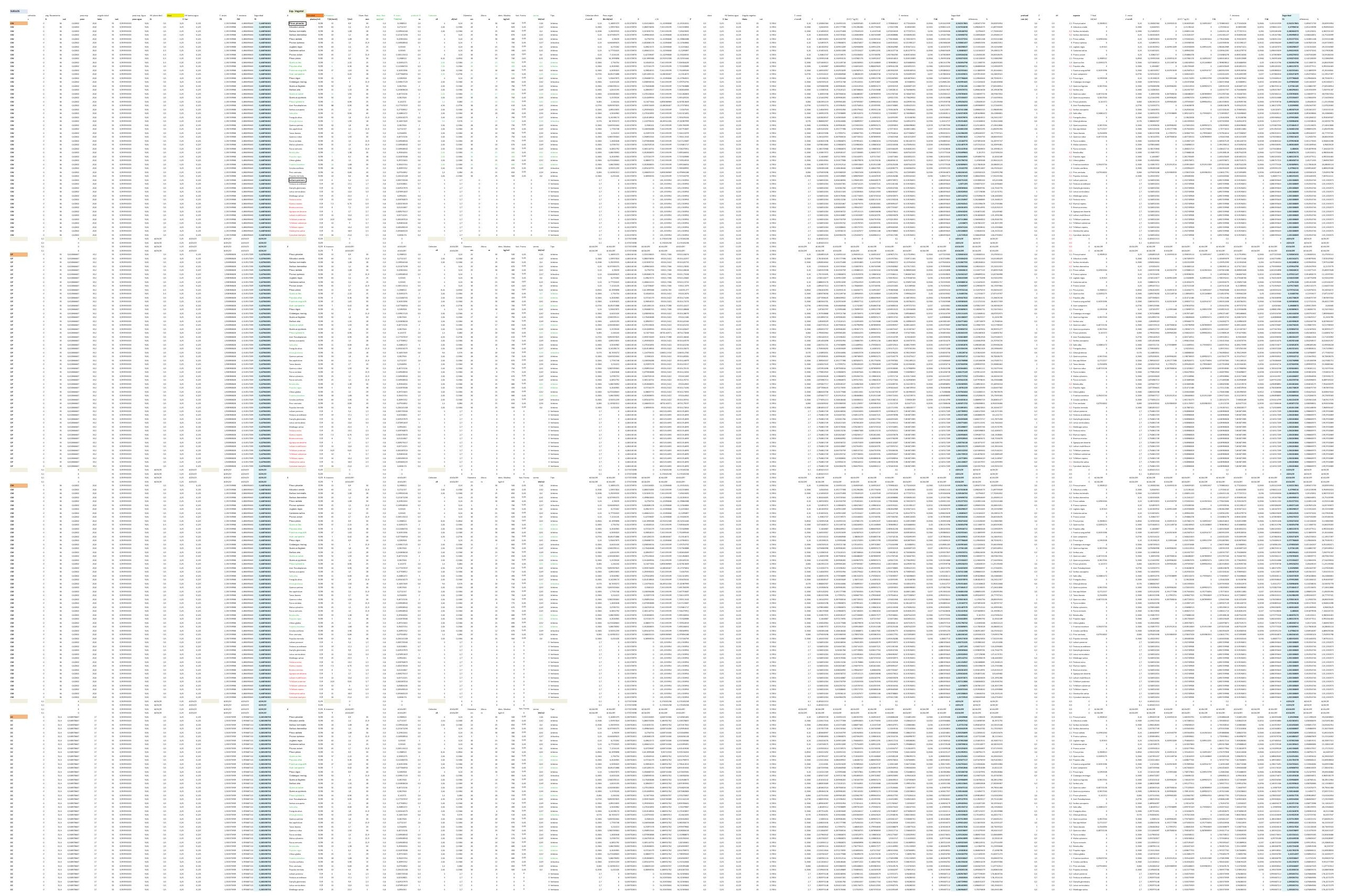

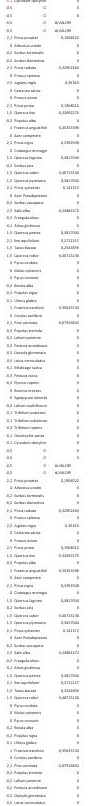

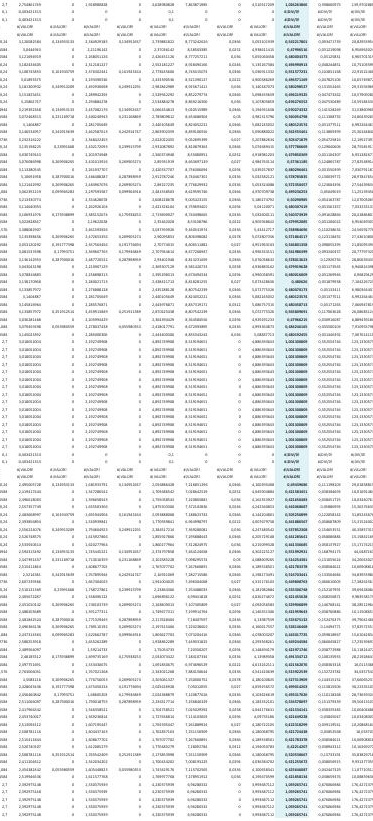




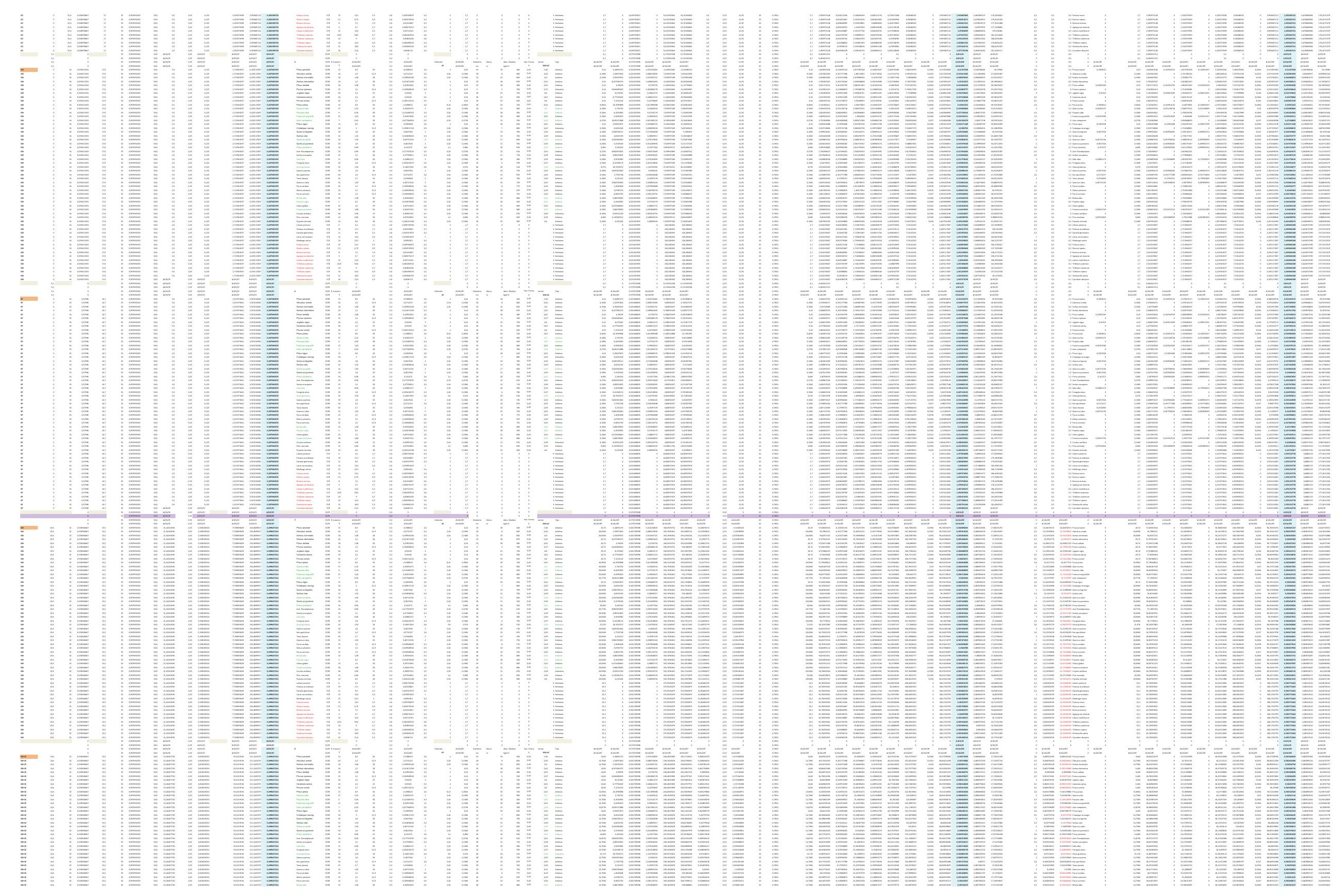



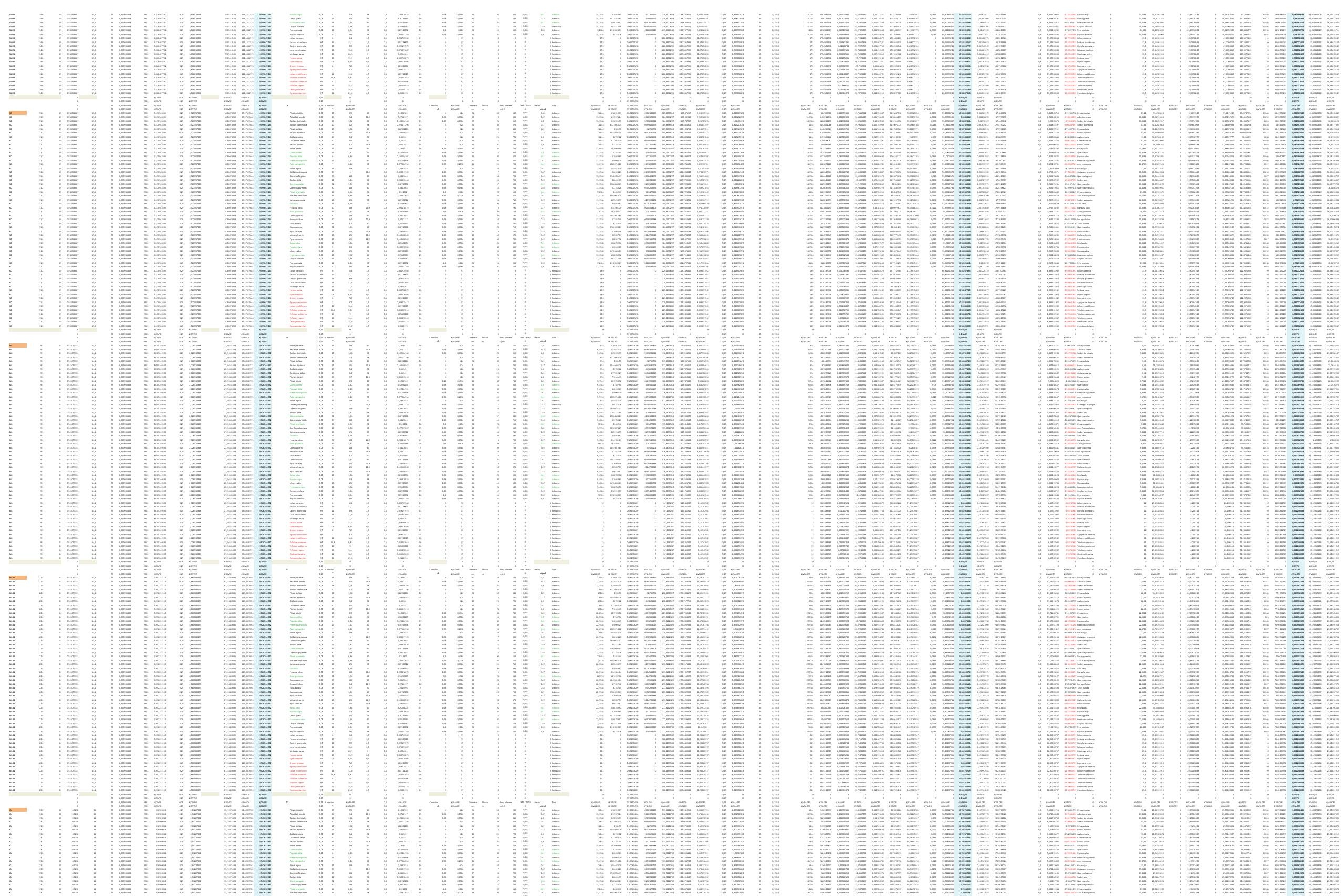

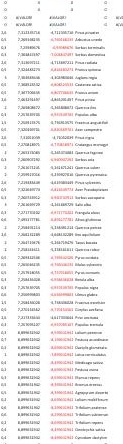
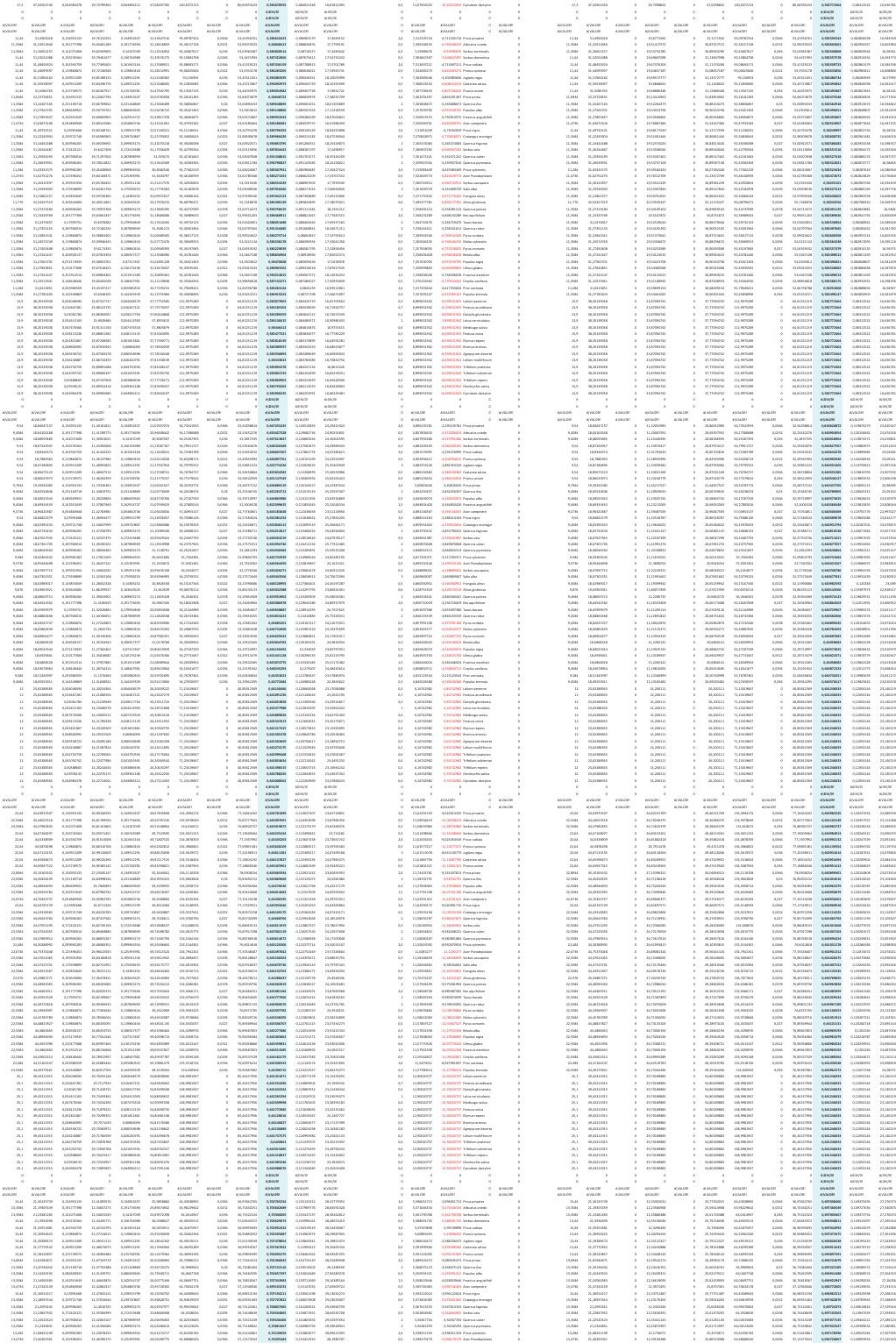

II 


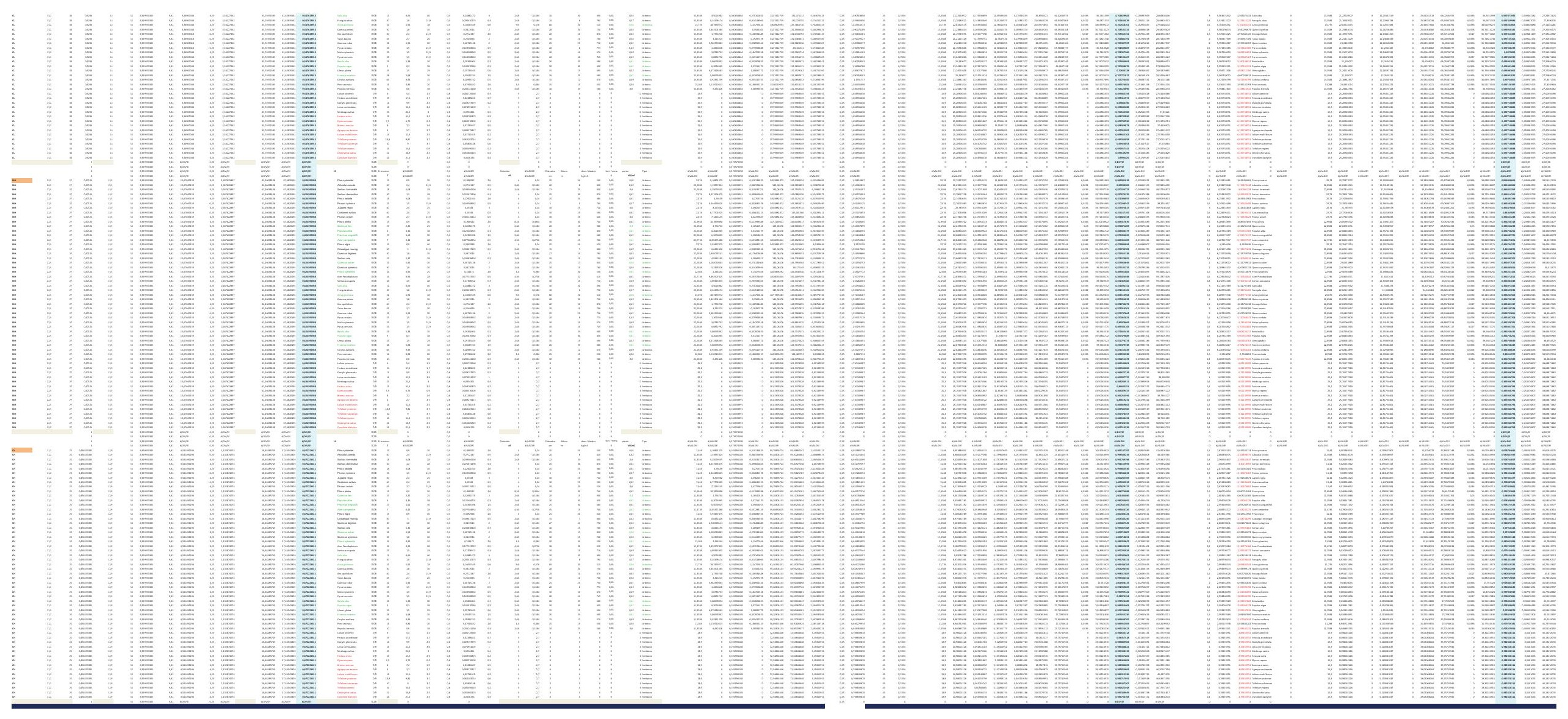



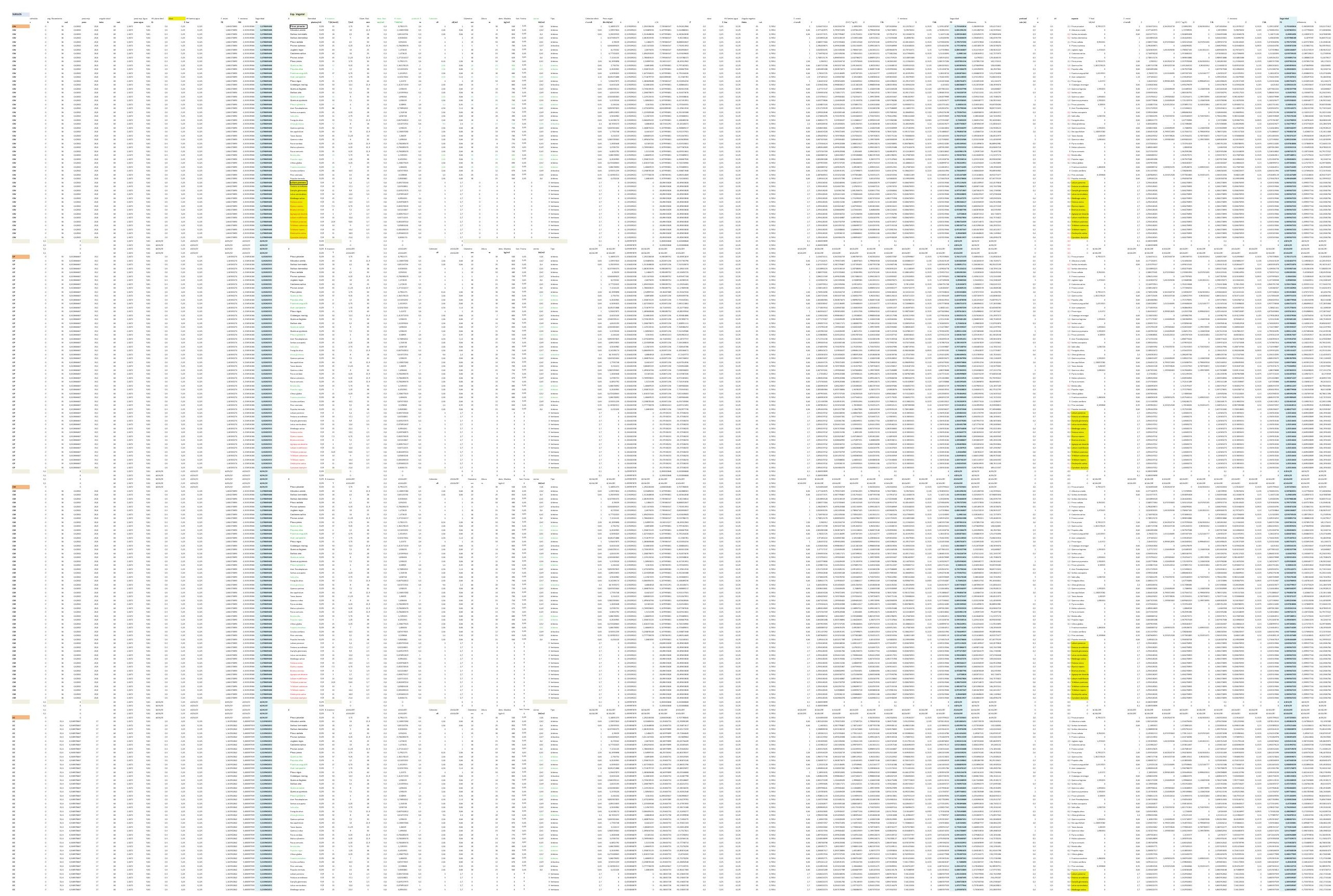


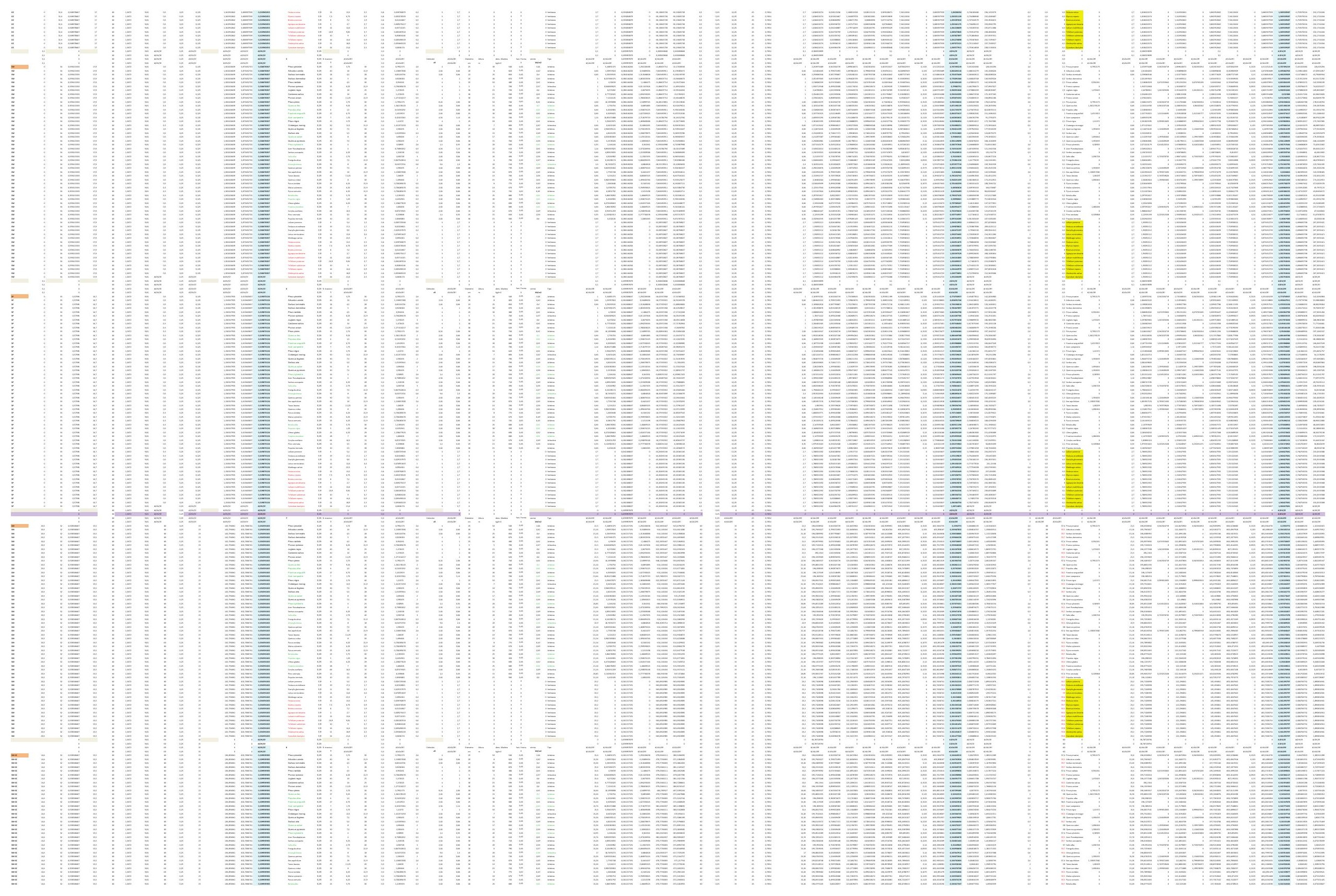



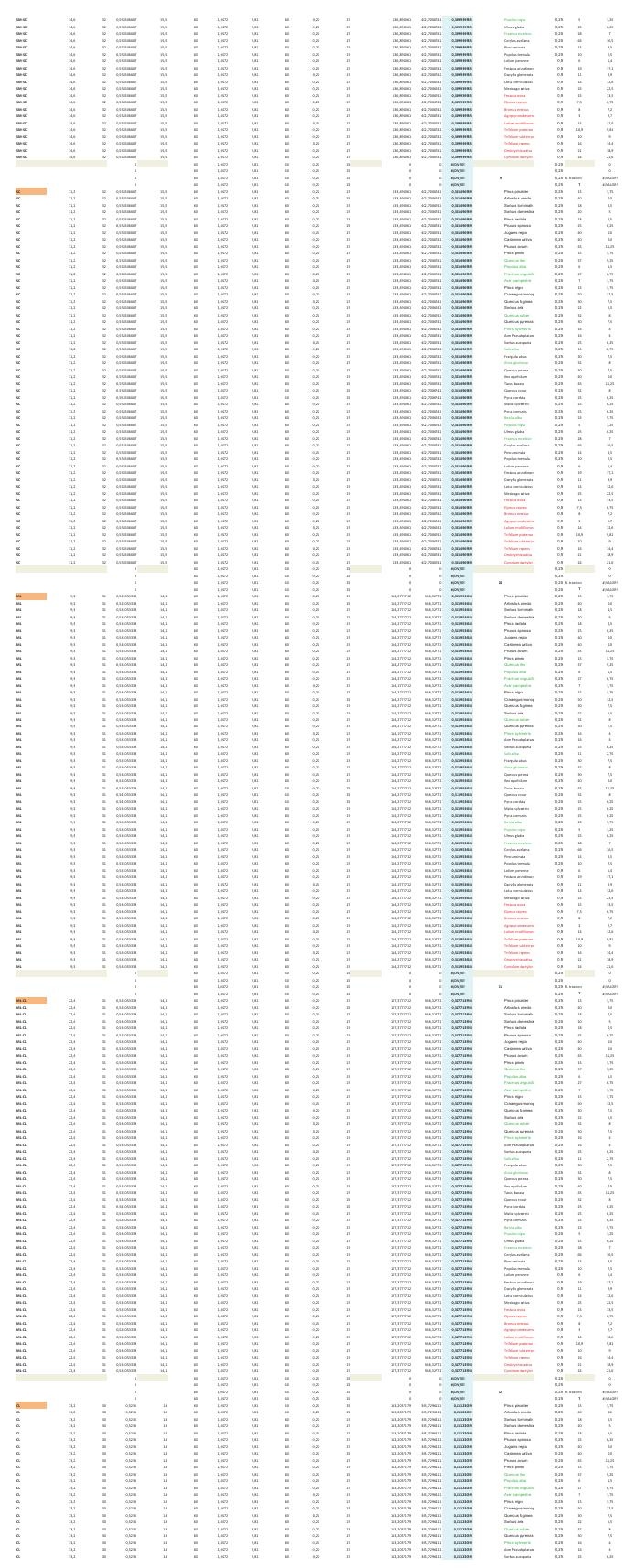

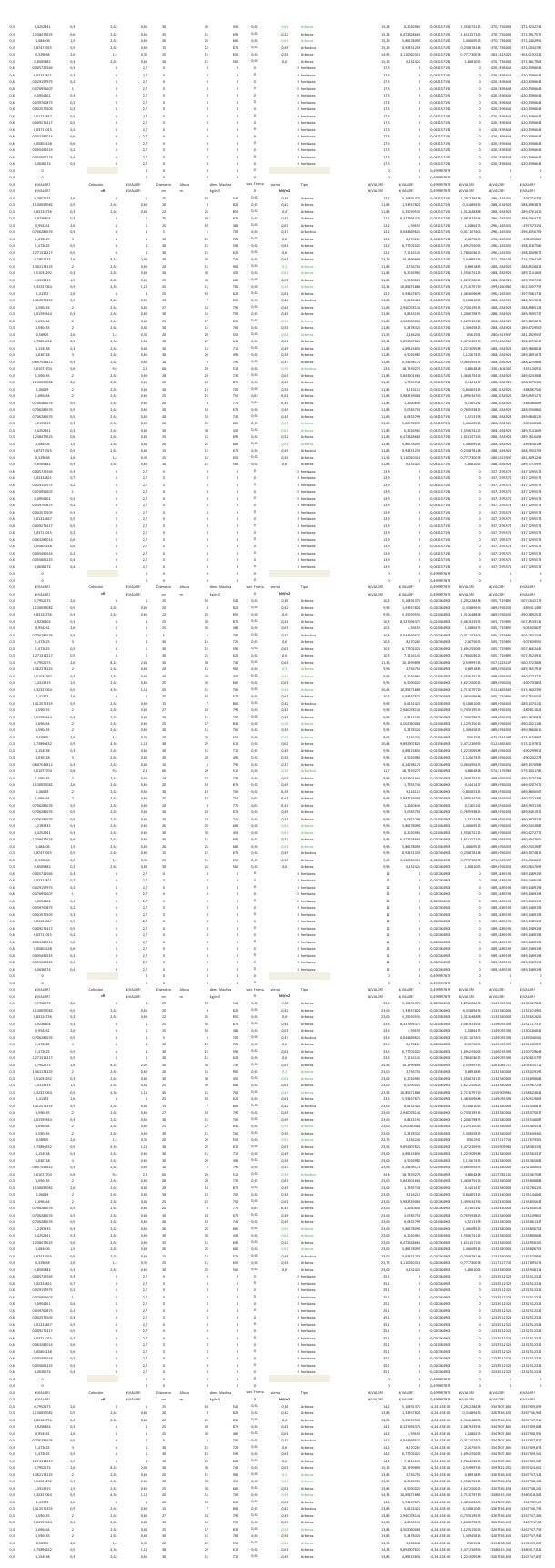

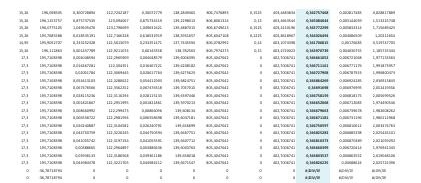
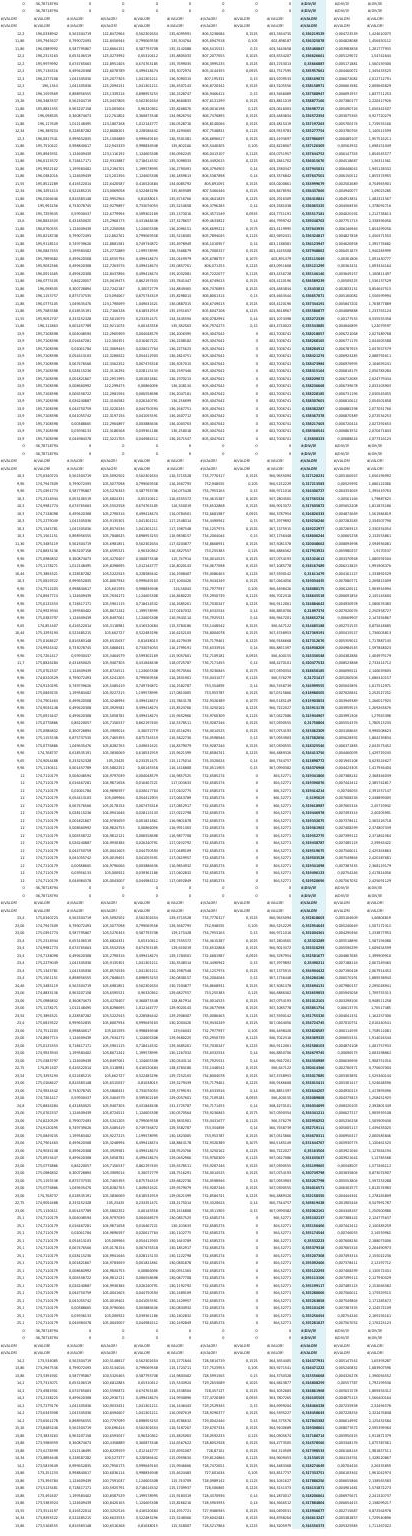

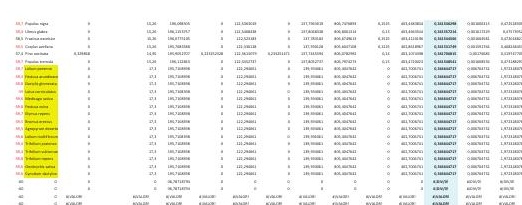

毫

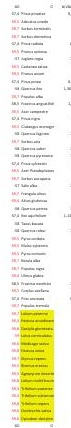

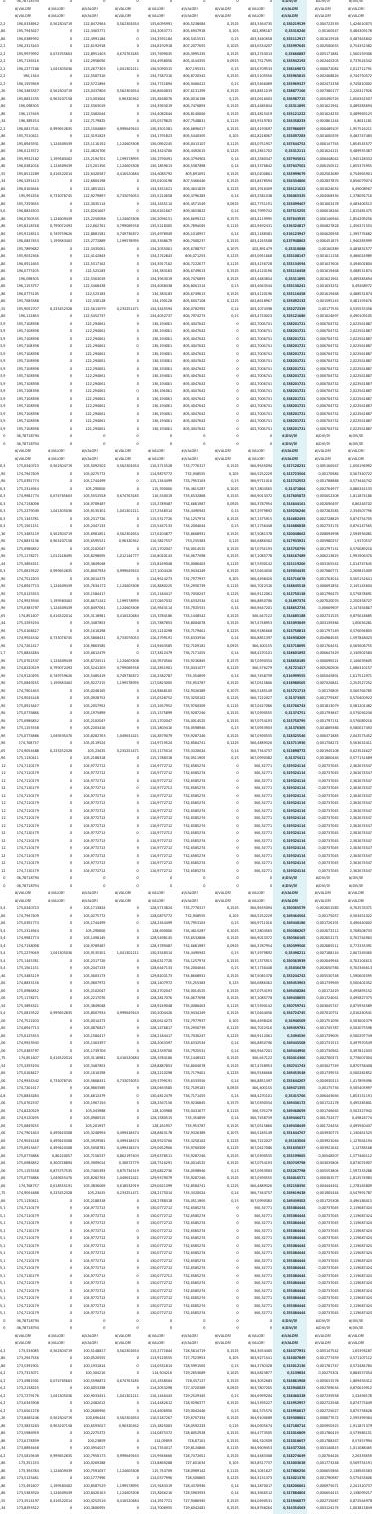

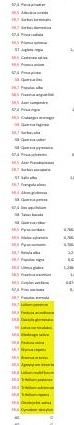

咅 


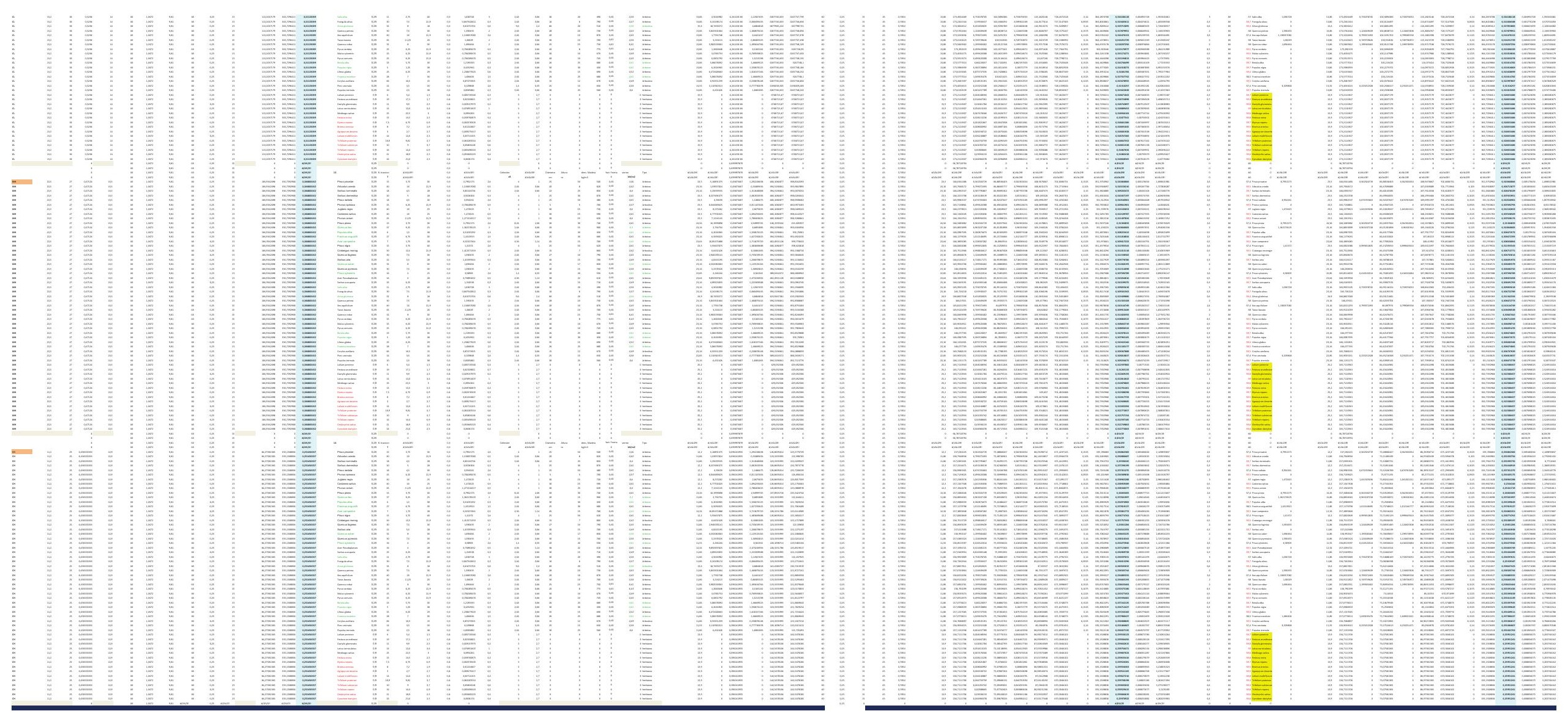



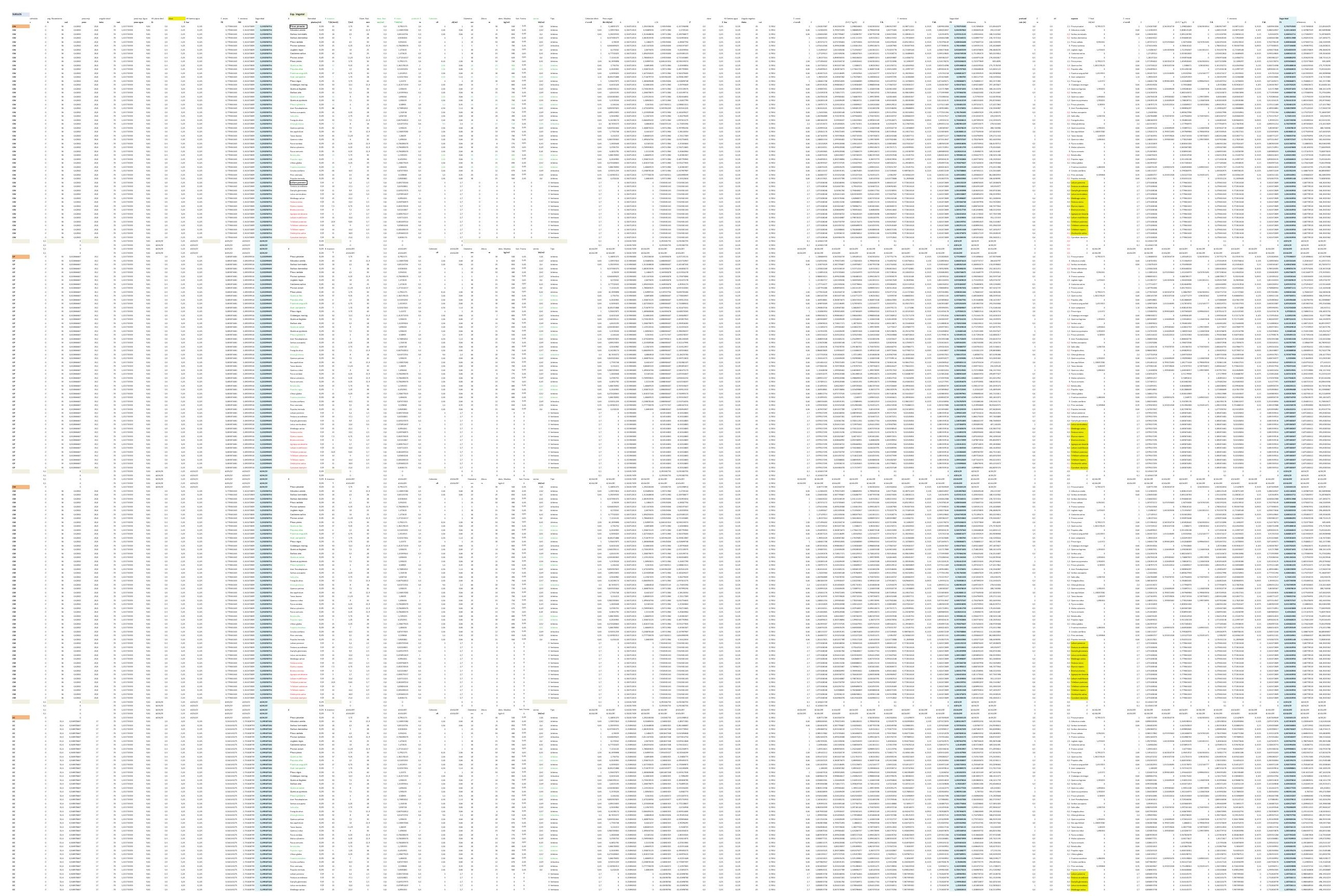

翌

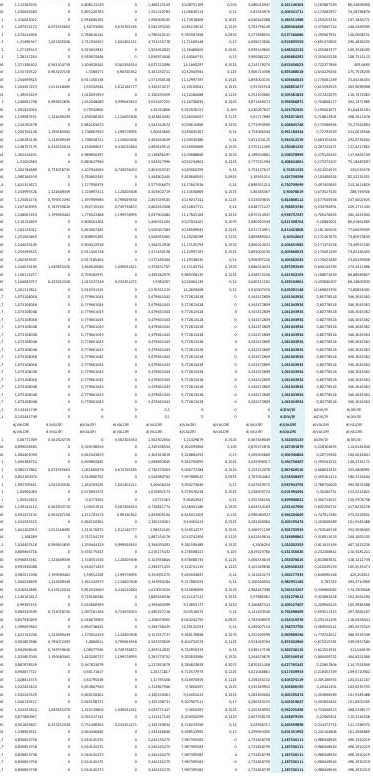




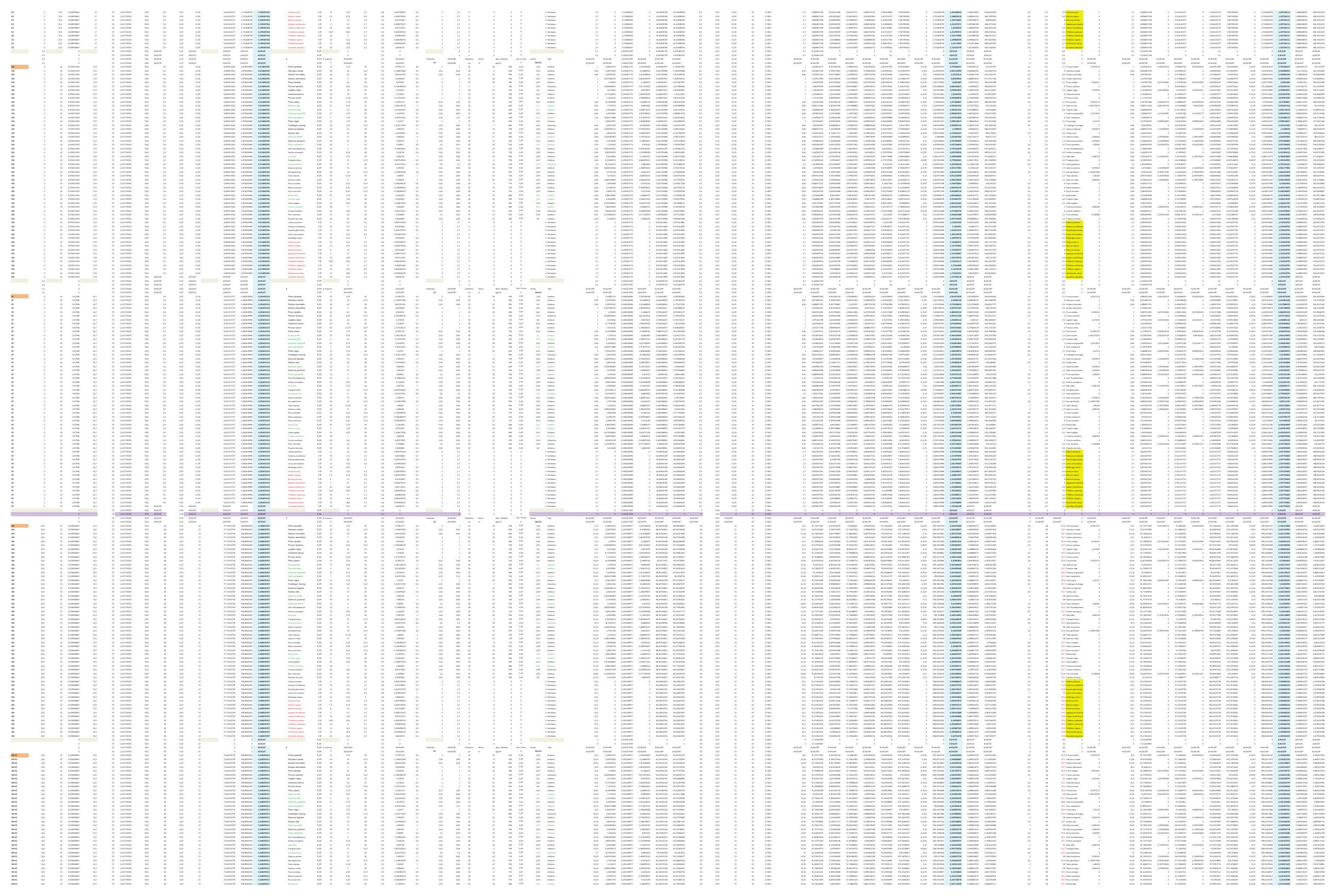




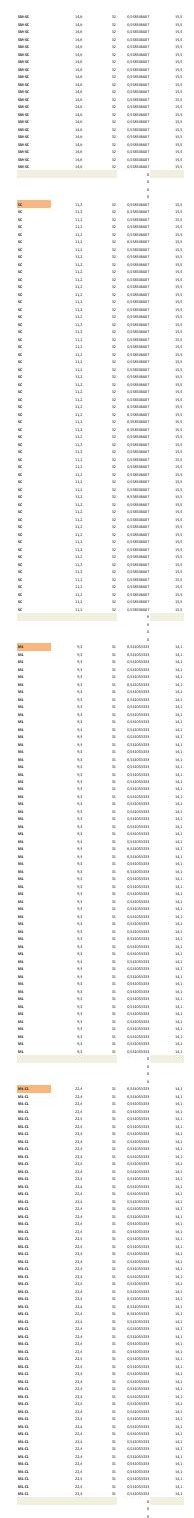

$-$

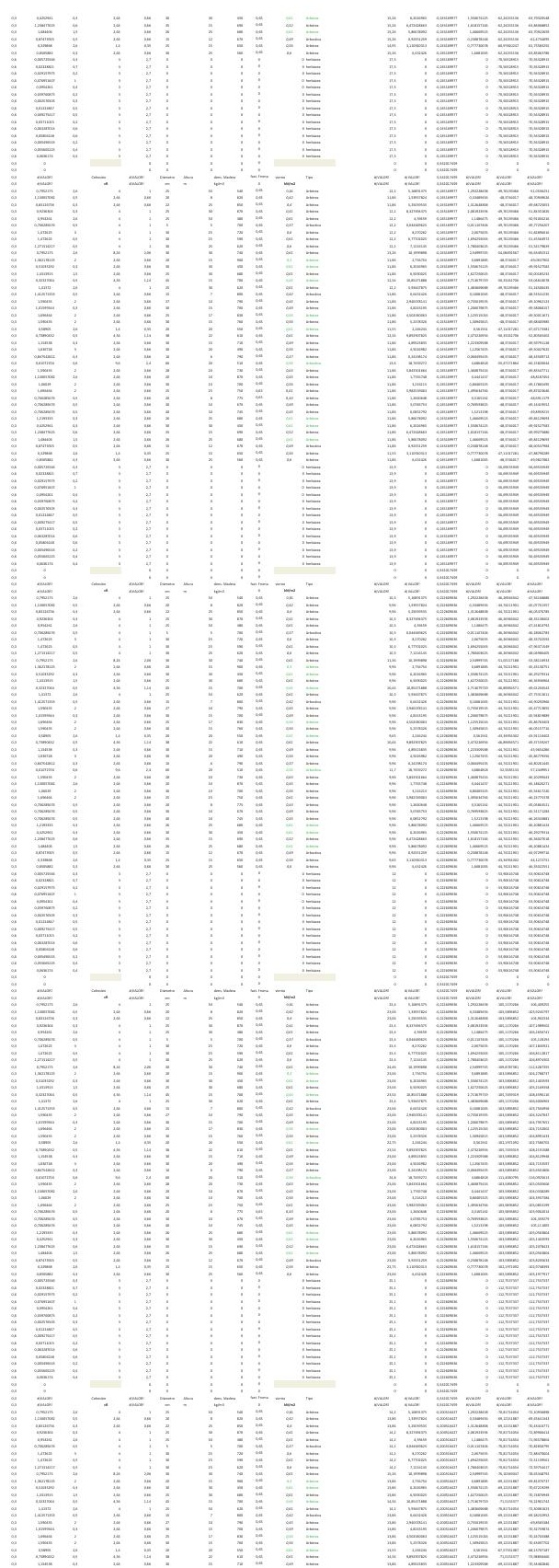

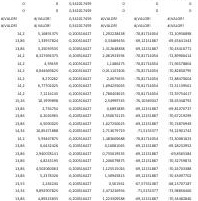
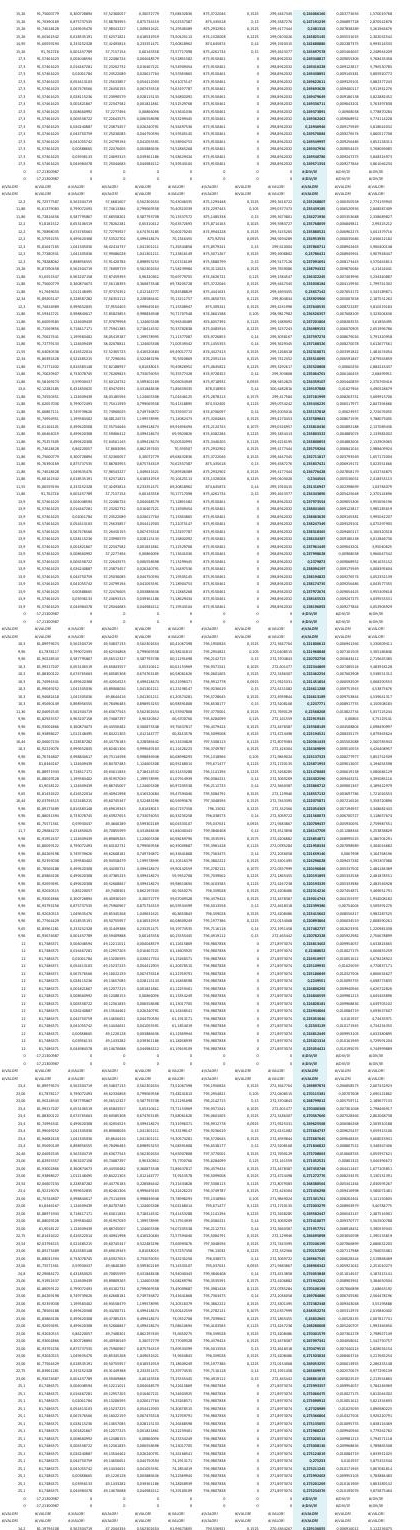

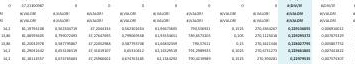

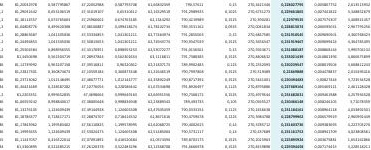

झ

=

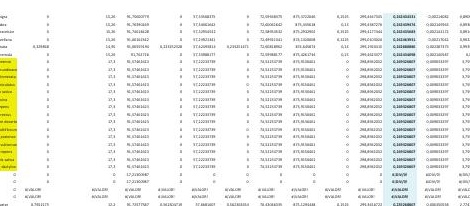

离

$\mid$
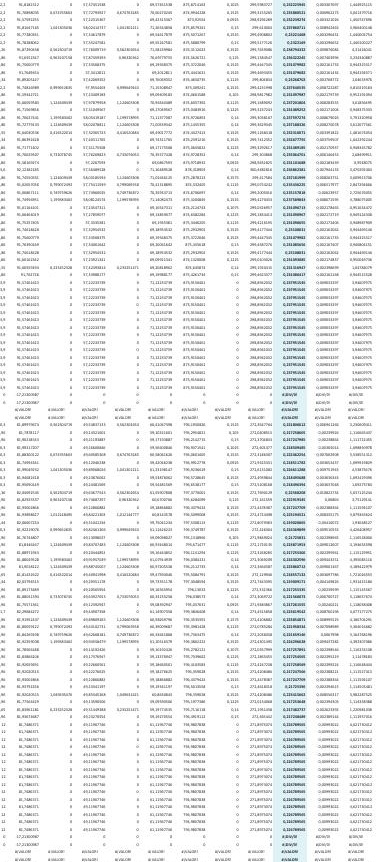

$\equiv$
$\equiv$
$\equiv$
$\equiv$
$\equiv$
$\equiv$
$\equiv$
$\equiv$
$\equiv$

$\vdots$
$\equiv$
$\equiv$
$\equiv$
$\equiv$

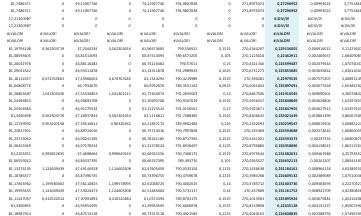




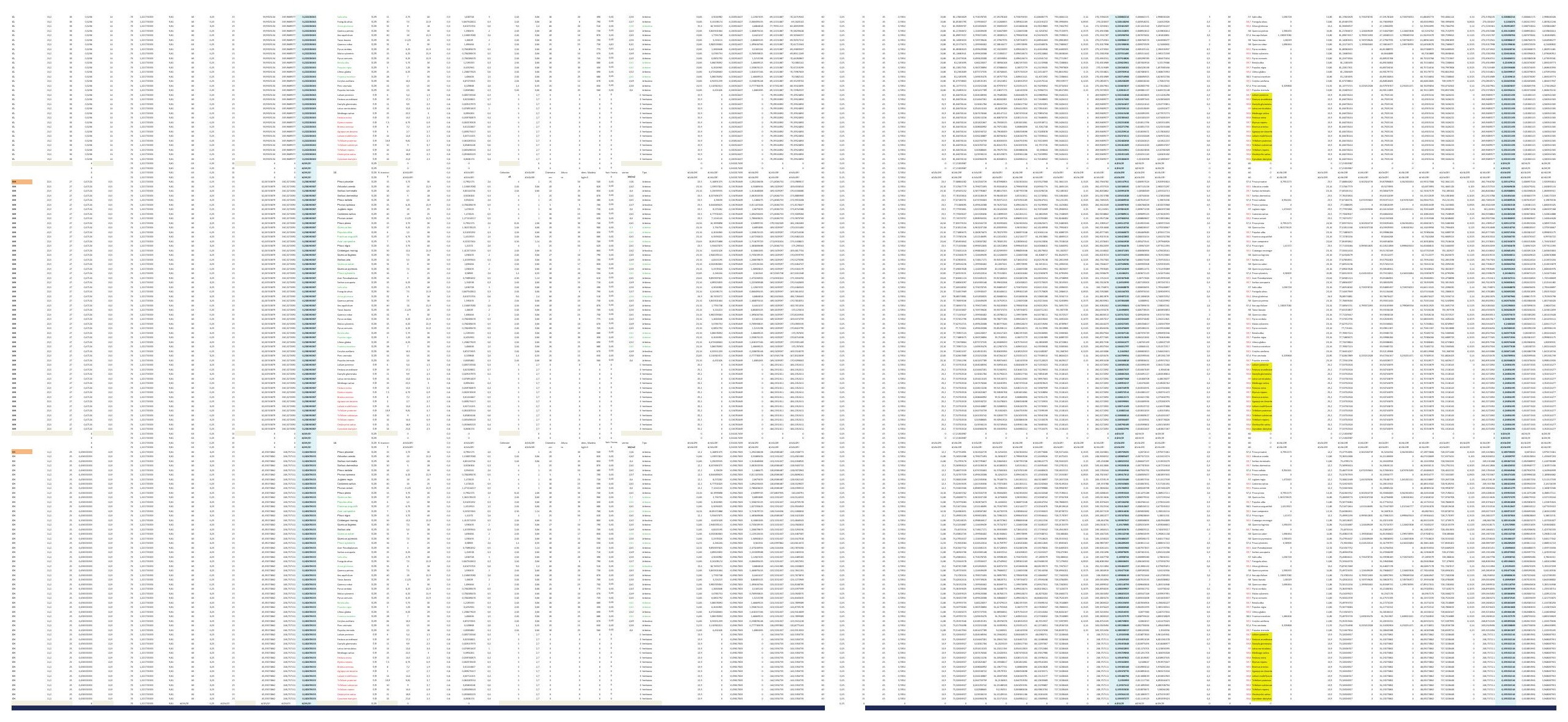



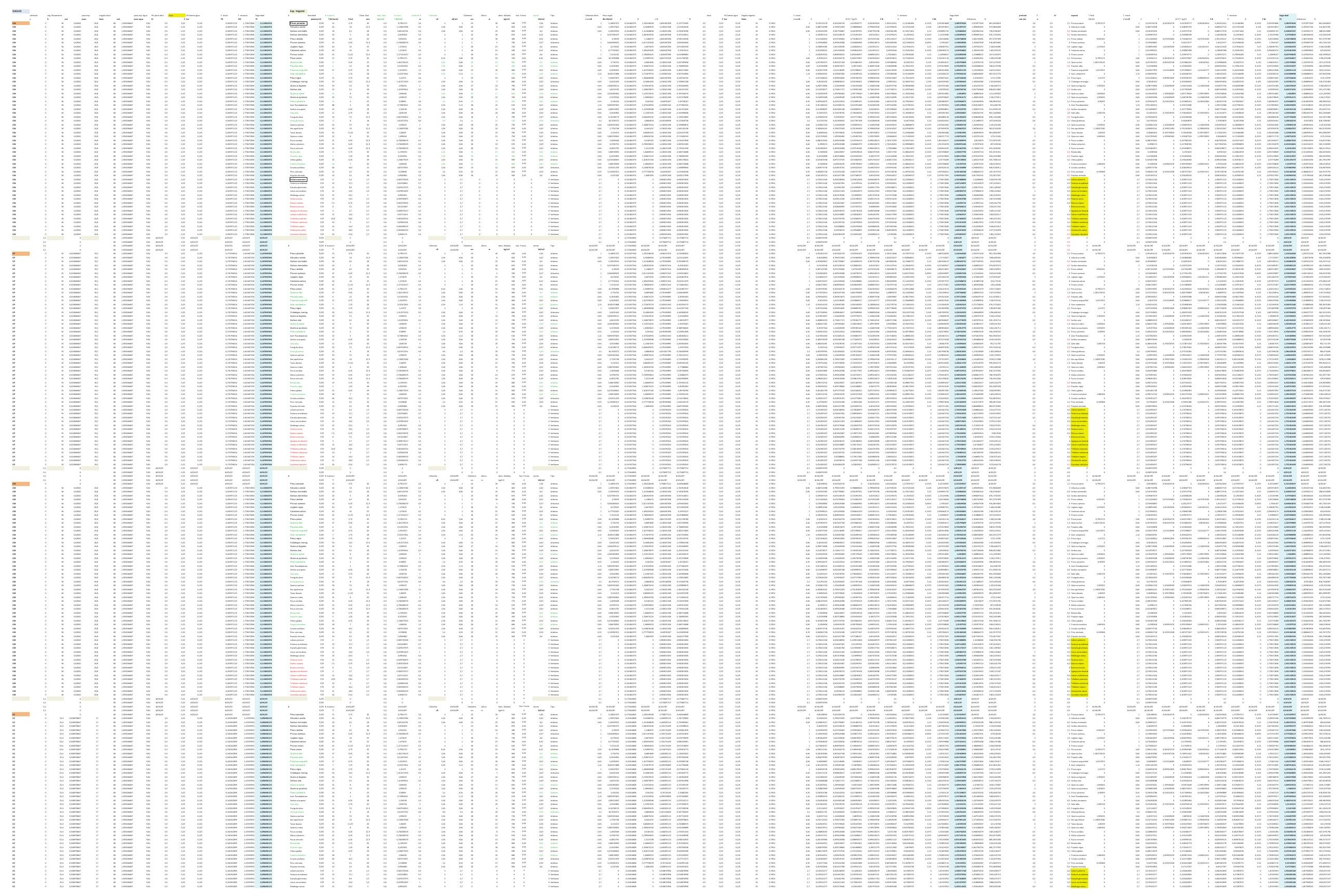


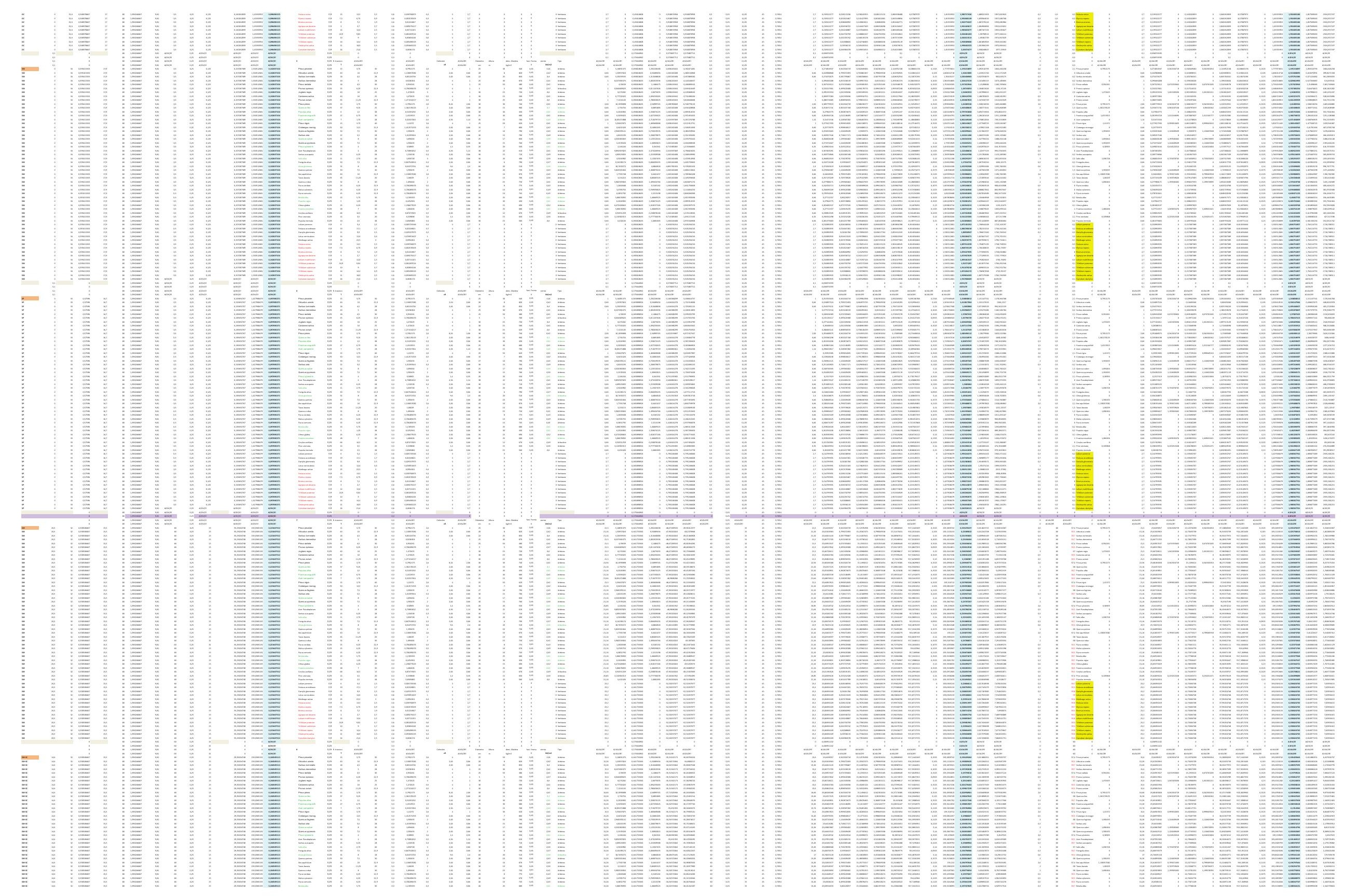



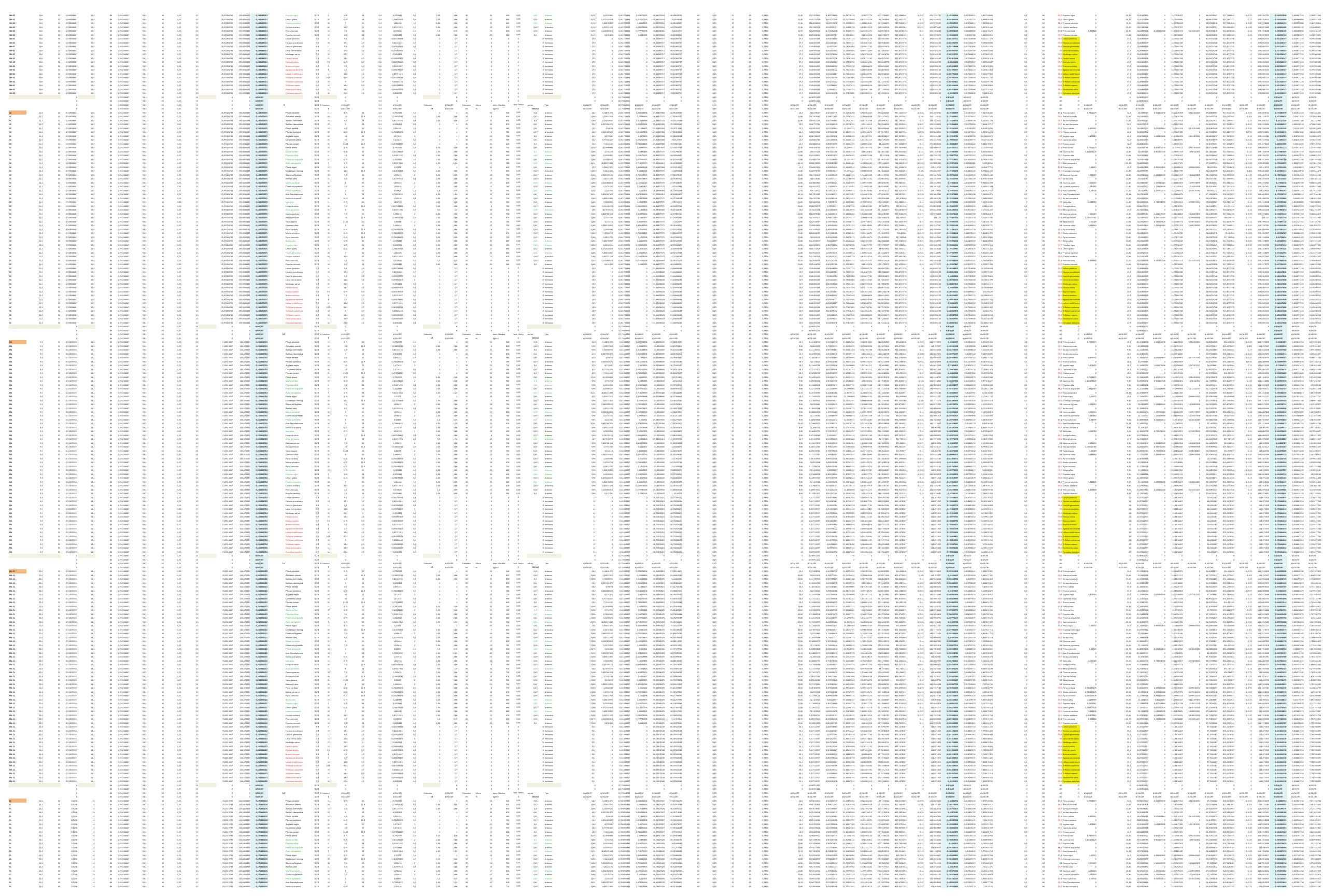

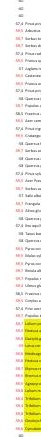
$\equiv \equiv \equiv \equiv \equiv \equiv \equiv$

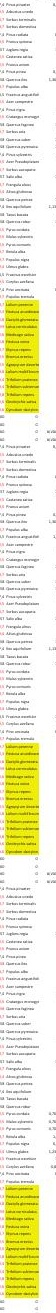
$\equiv \equiv \equiv \equiv \equiv \equiv$

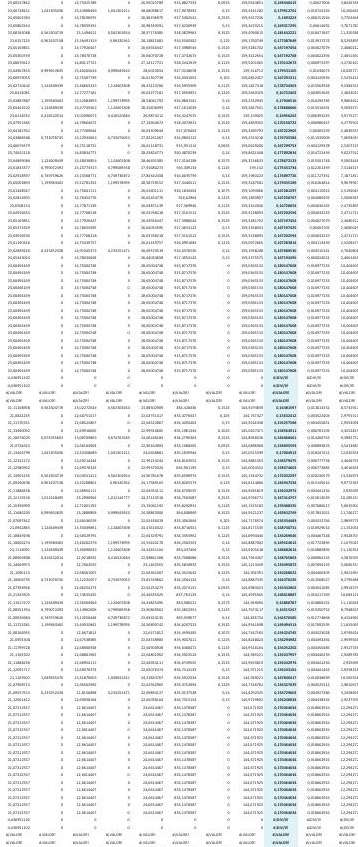

$=\equiv$
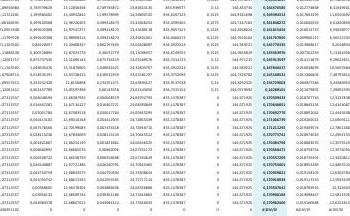

E
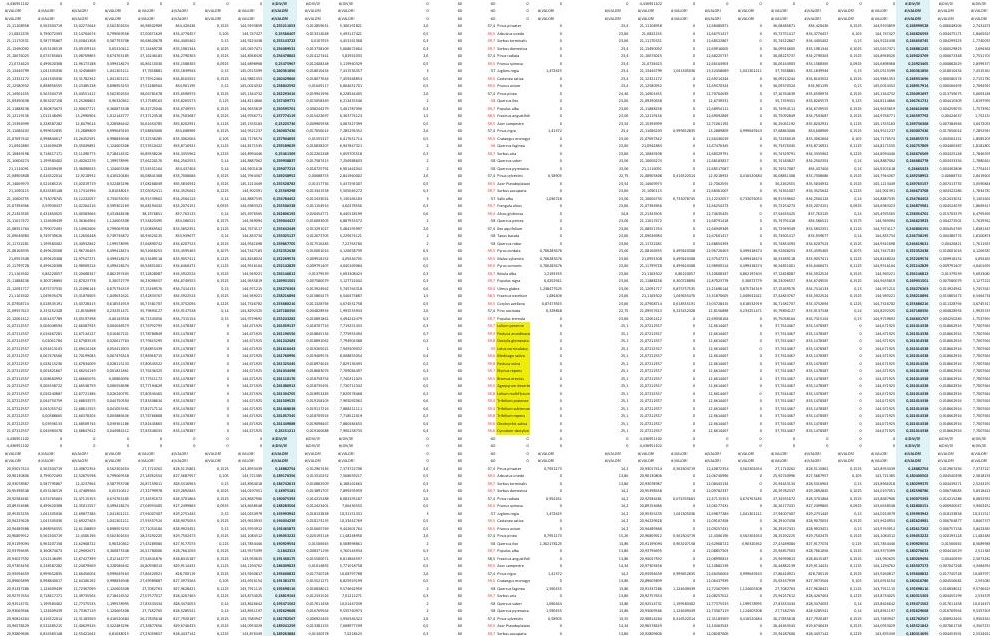


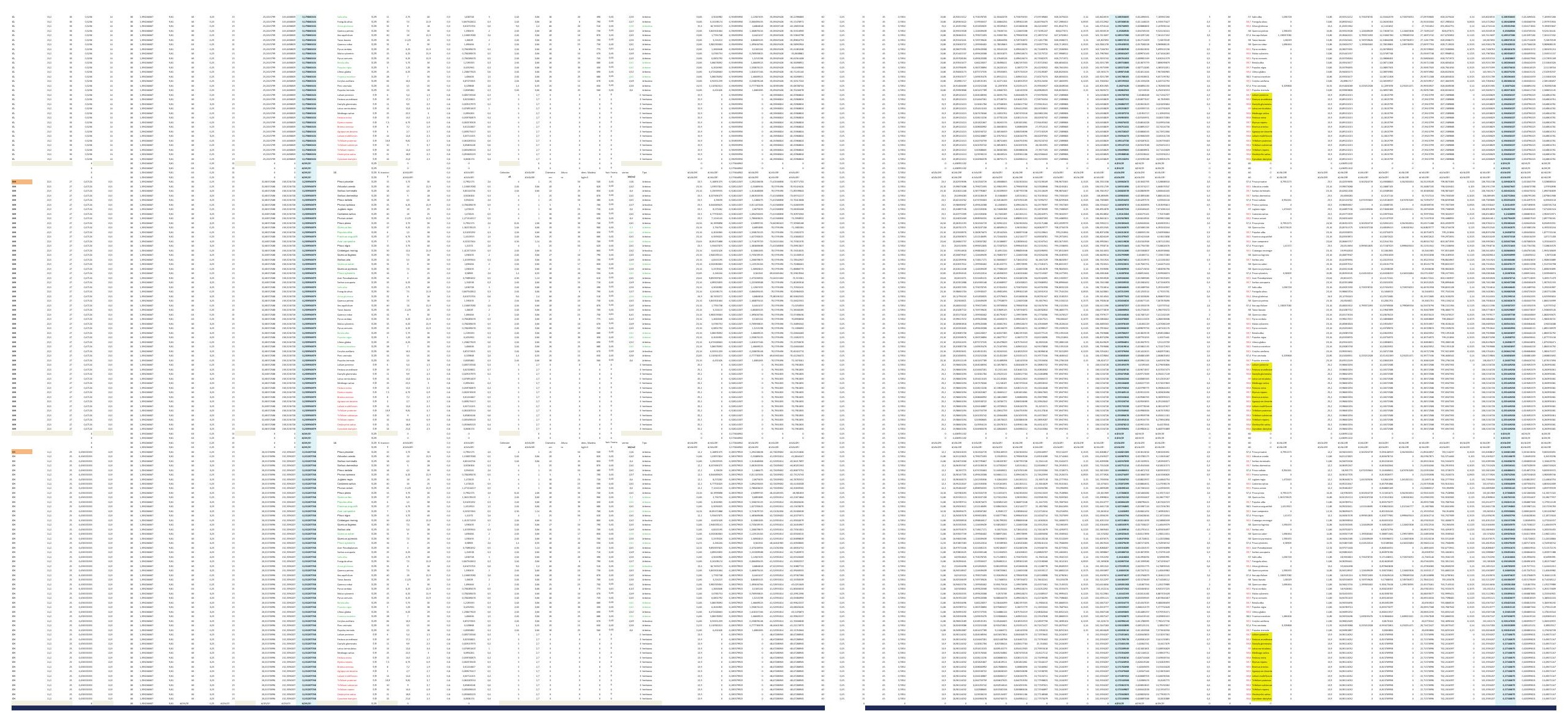


DESARROLLO DE UNA APLICACIÓN IMFORMÁTICA PARA EL CÁLCULO DE SOSTENIMIENTO DE TALUDES MEDIANTE VEGETACIÓN

A01. DENSIDAD DE PLANTACIÓN: 600 plantas/ha.

\section{A01-4.POSICIÓN N.F. 4}

INCLINACIÓN DE TALUD 6-100

INCLINACIÓN DE TALUD 10-200

INCLINACIÓN DE TALUD 20-30

INCLINACIÓN DE TALUD 30-40

INCLINACIÓN DE TALUD $35^{\circ}$

INCLINACIÓN DE TALUD 40-50

INCLINACIÓN DE TALUD 50-550

INCLINACIÓN DE TALUD 55-60

INCLINACIÓN DE TALUD 60-700

INCLINACIÓN DE TALUD 70-80 

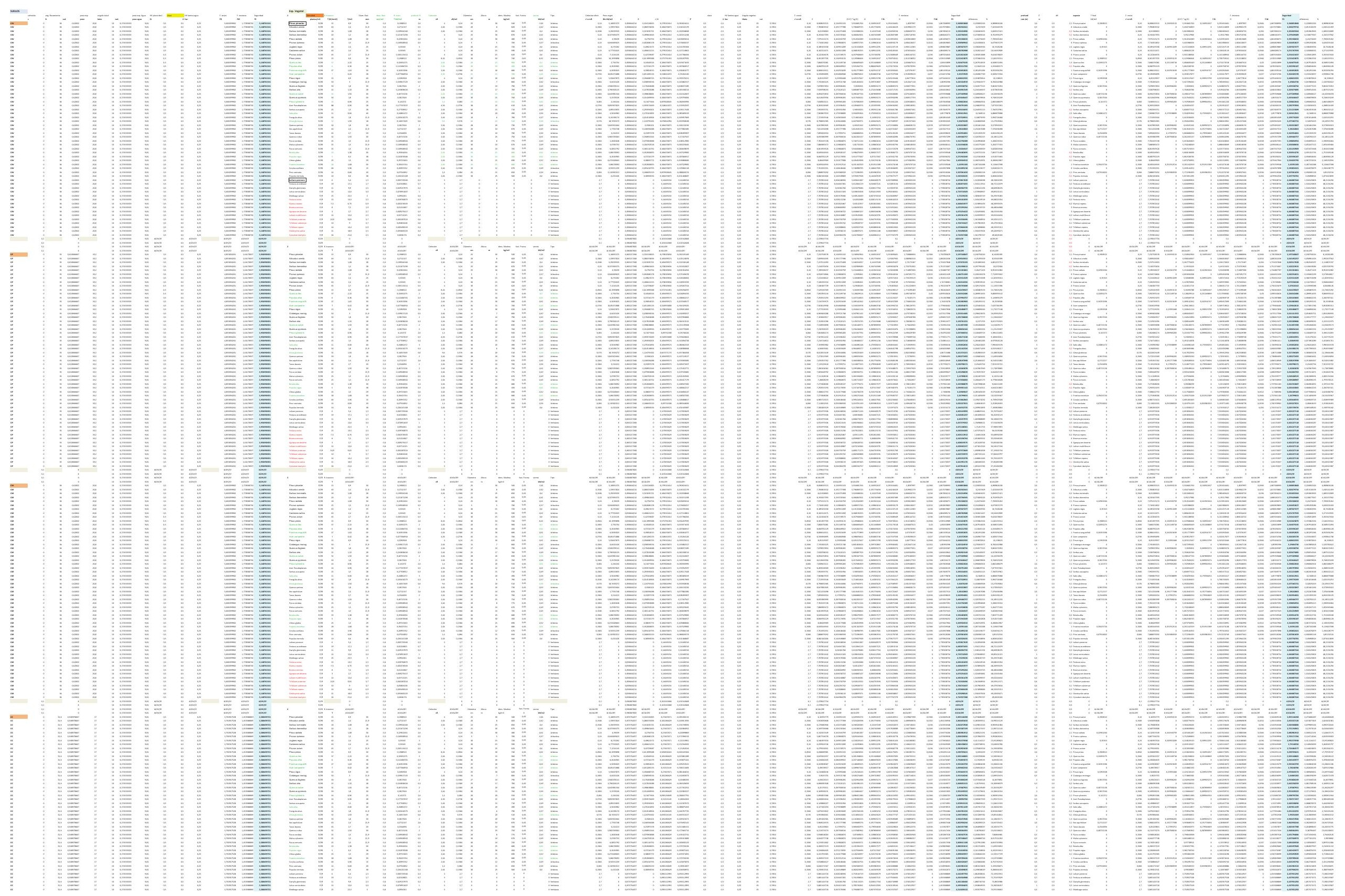


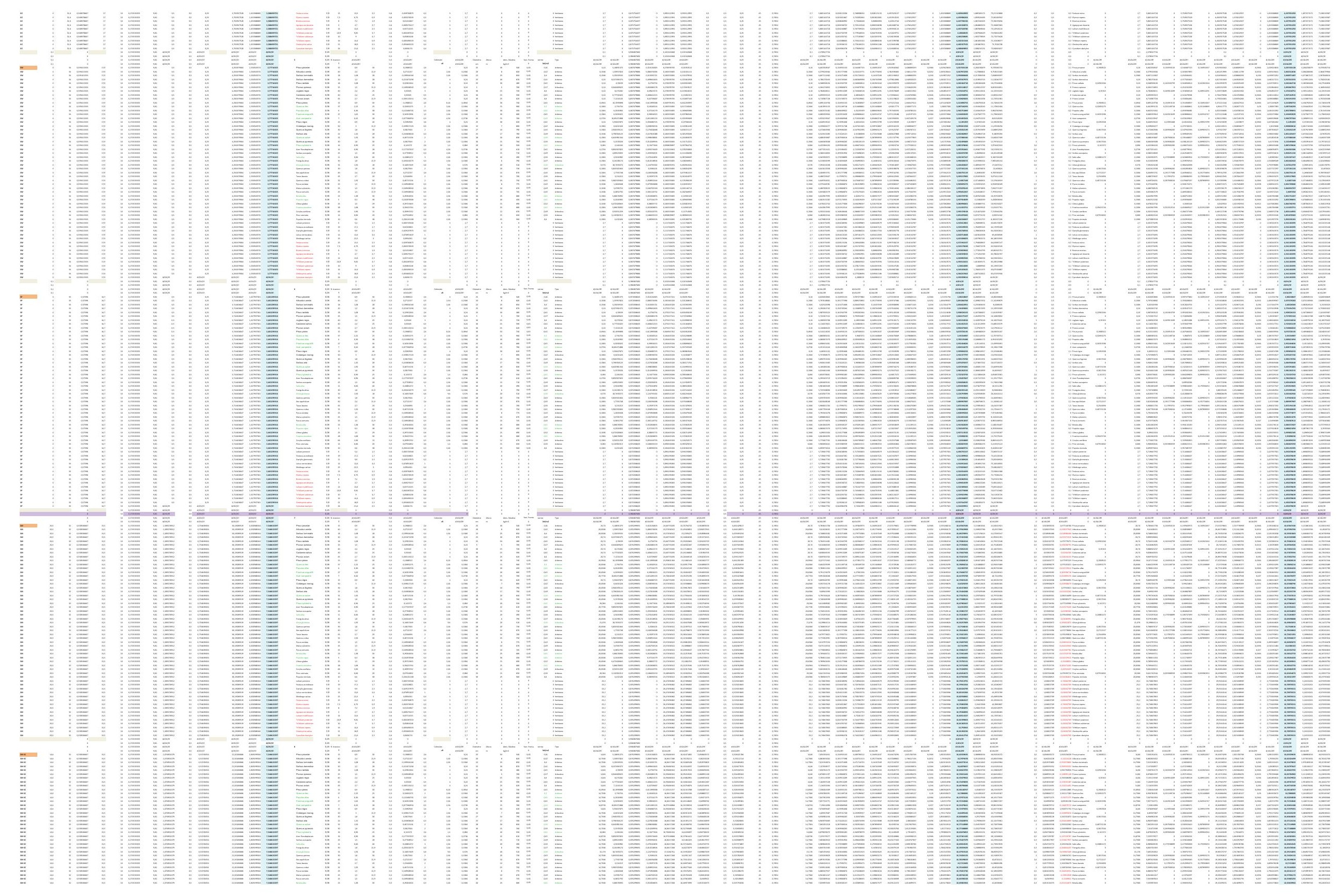



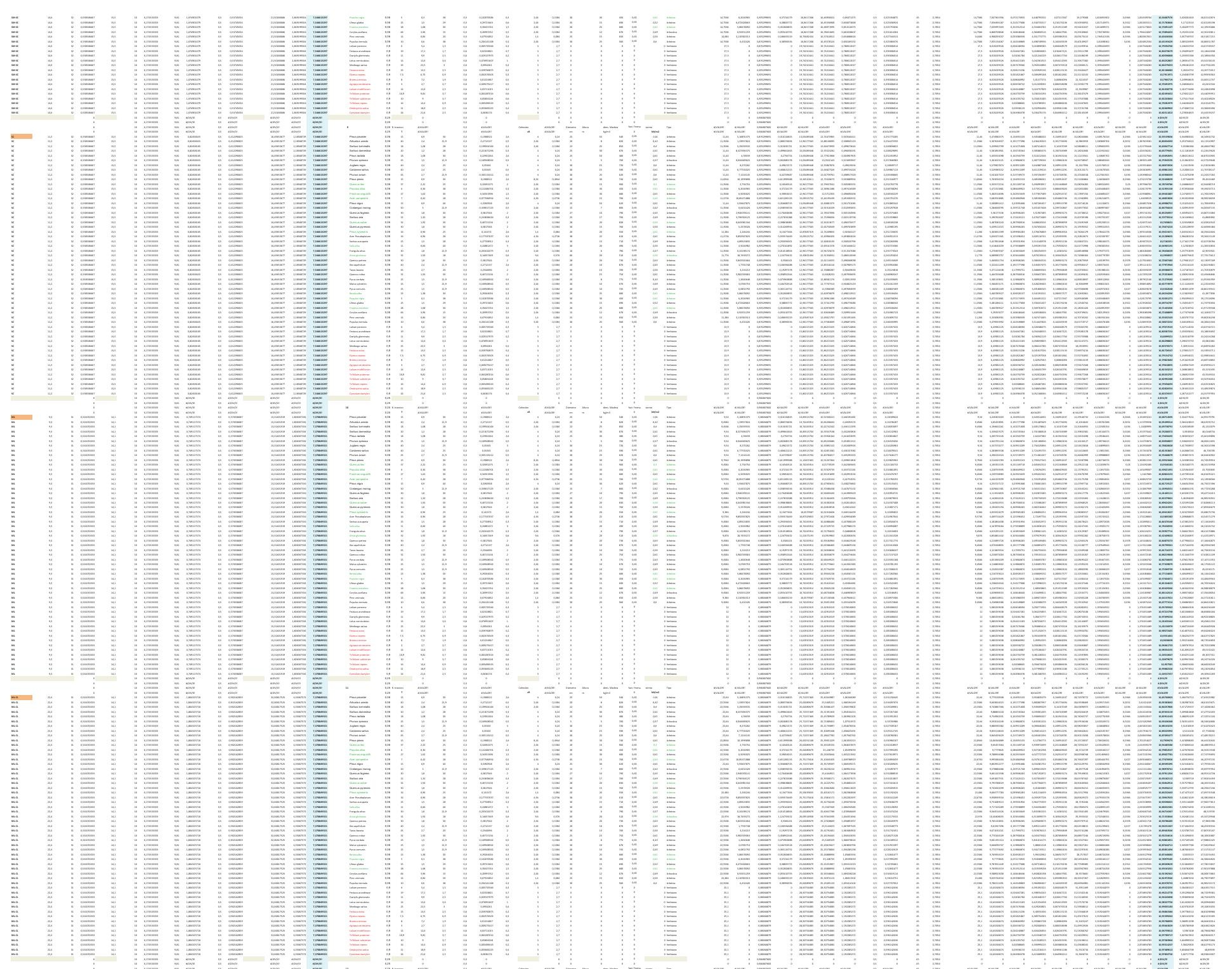

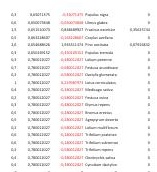
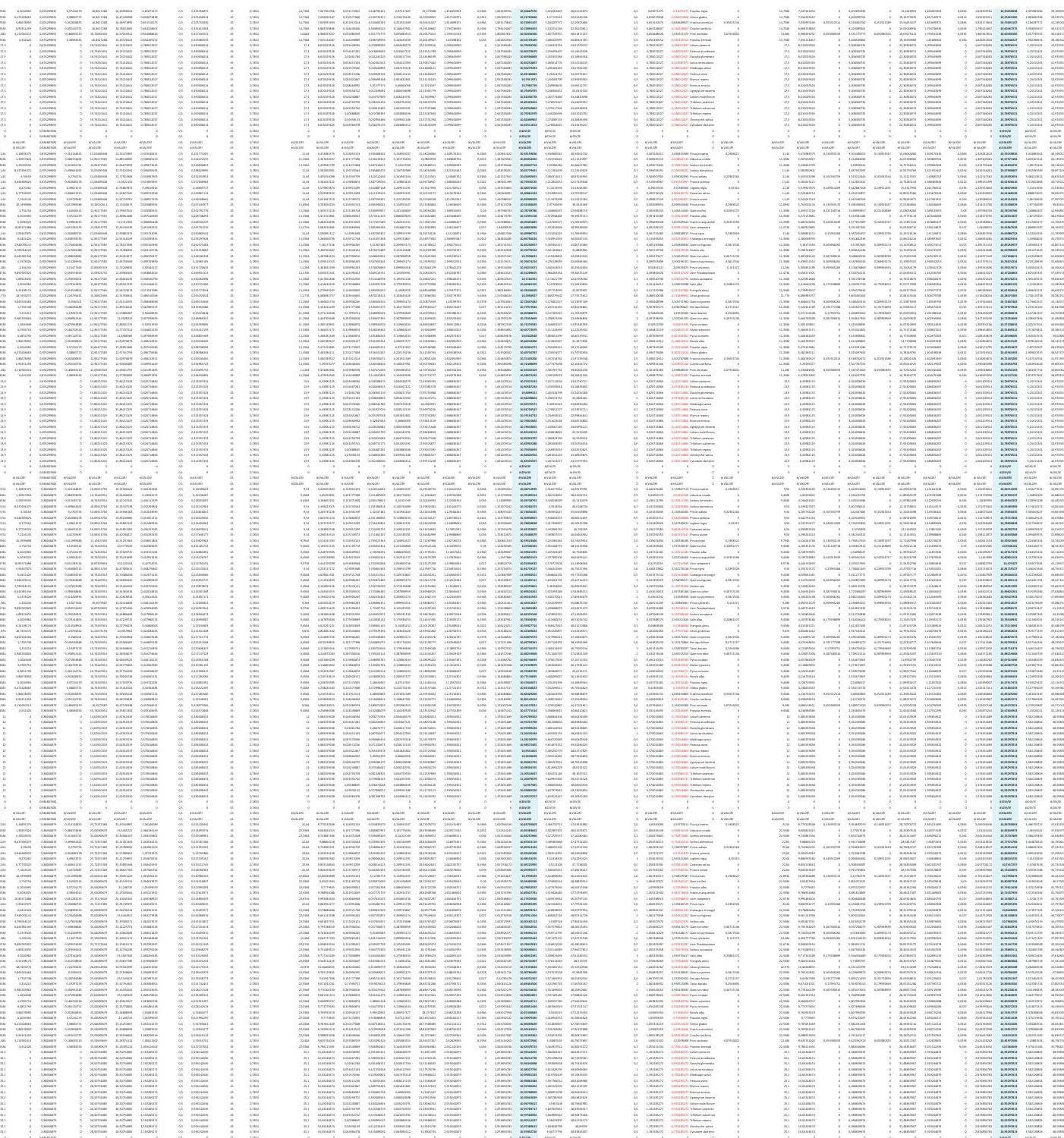

$\equiv \equiv$
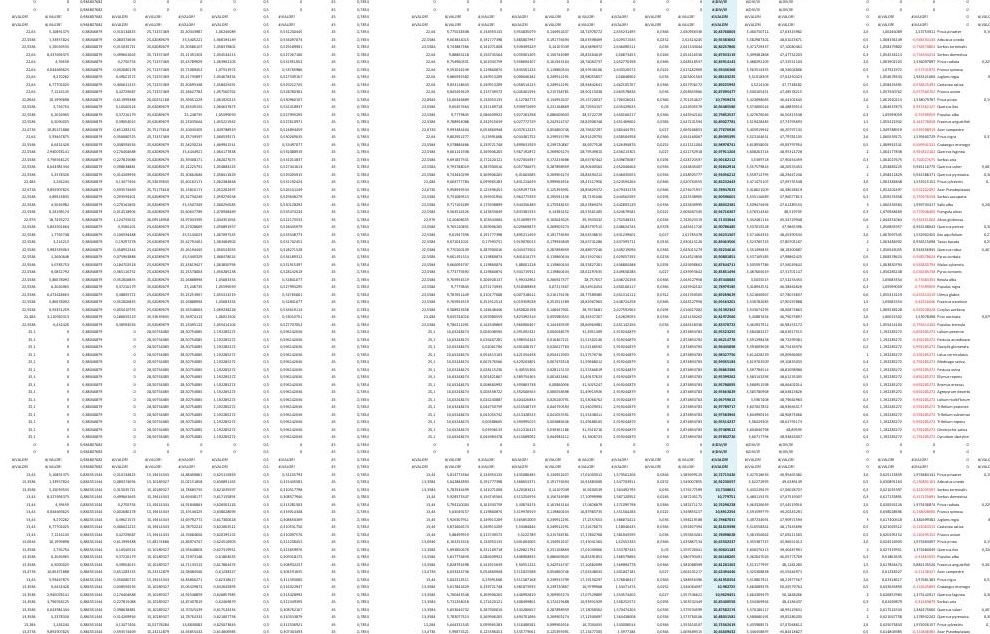

$\sqrt{E^{E}}=$

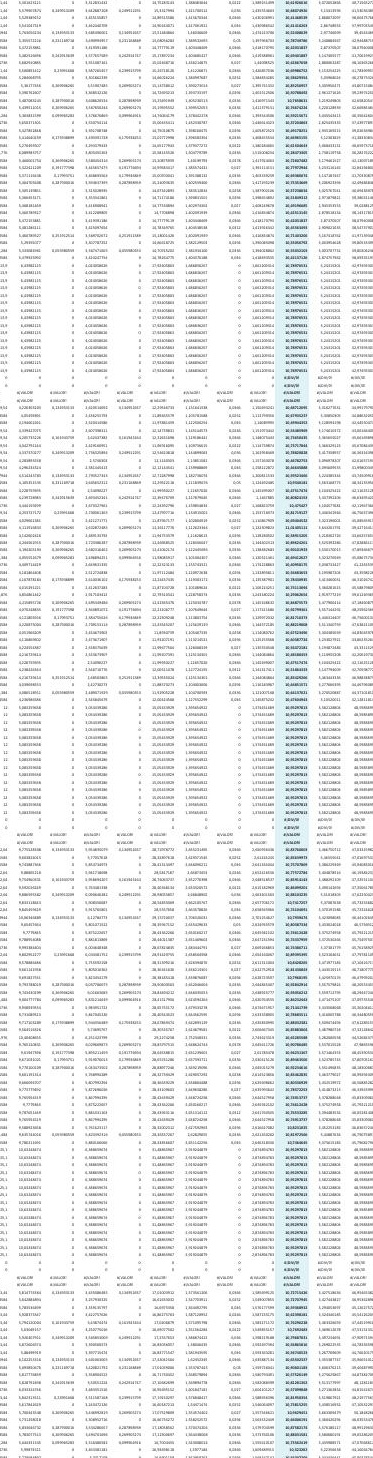




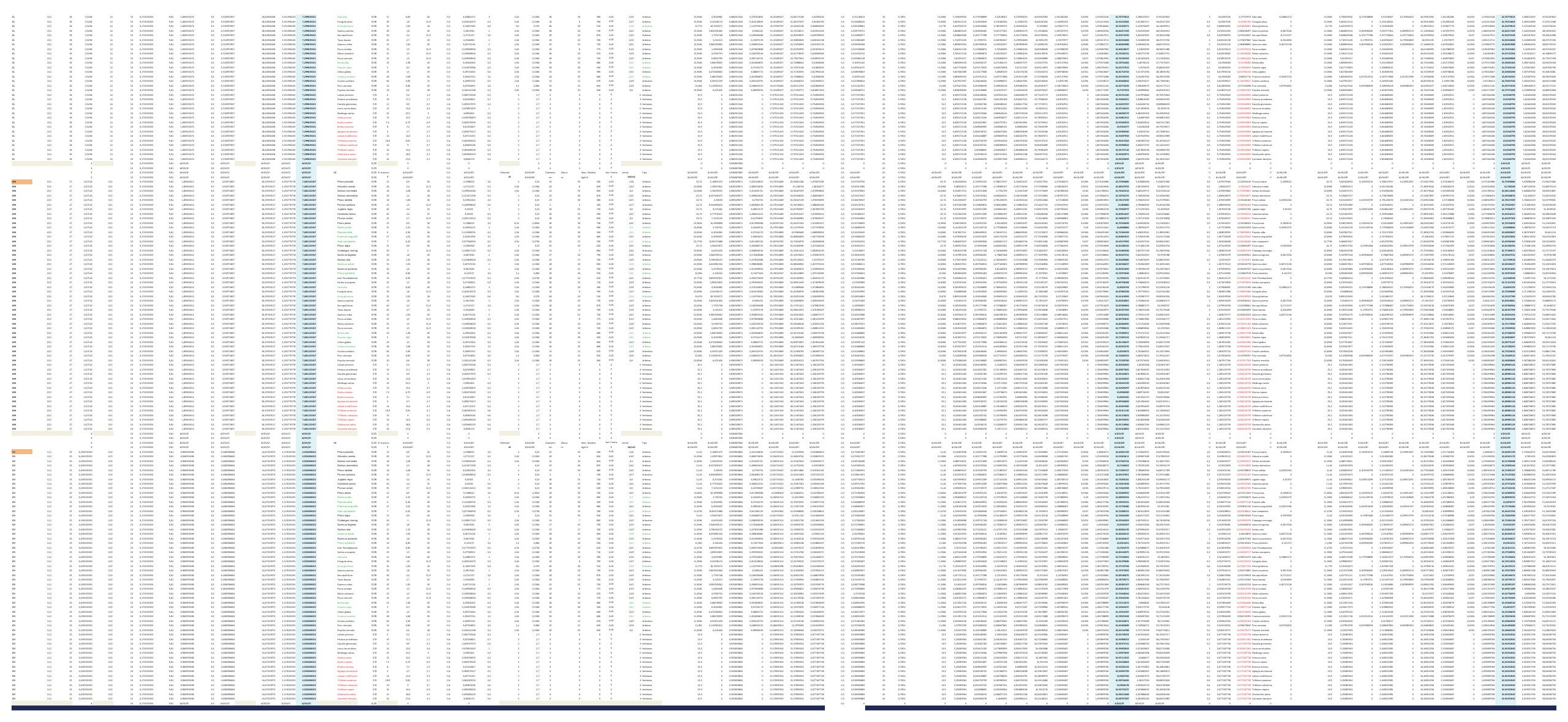



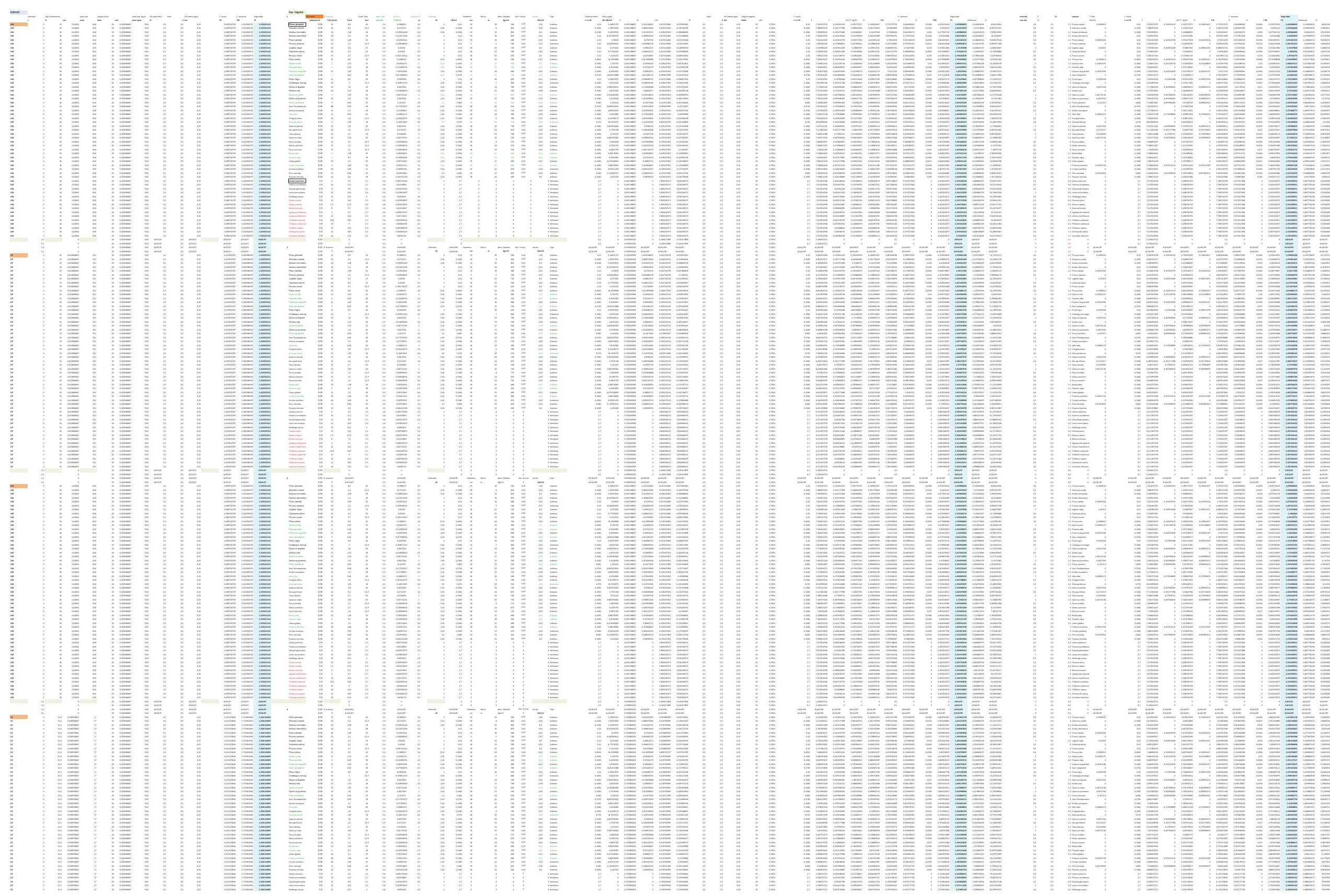

准

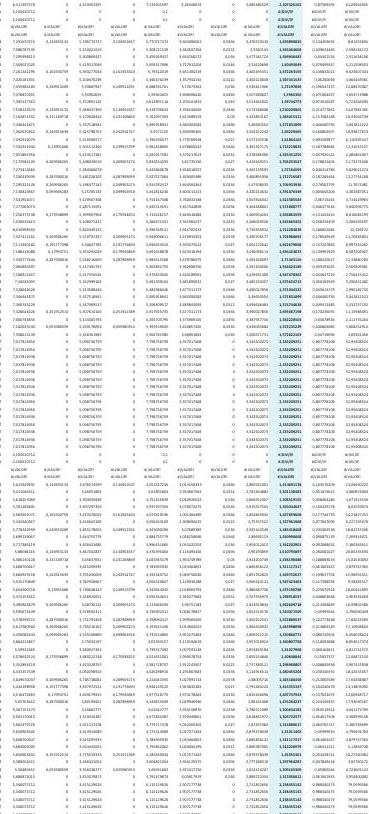




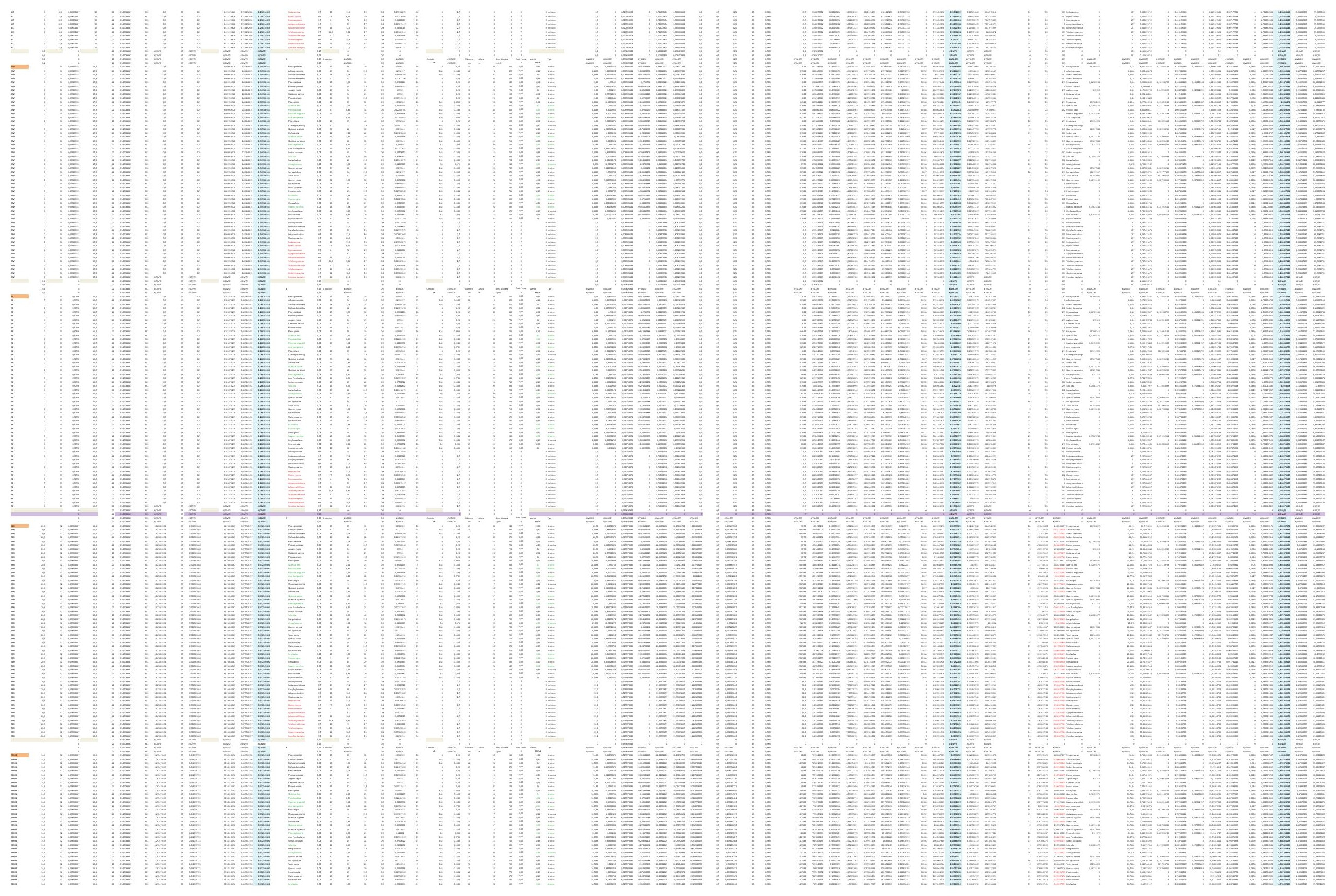



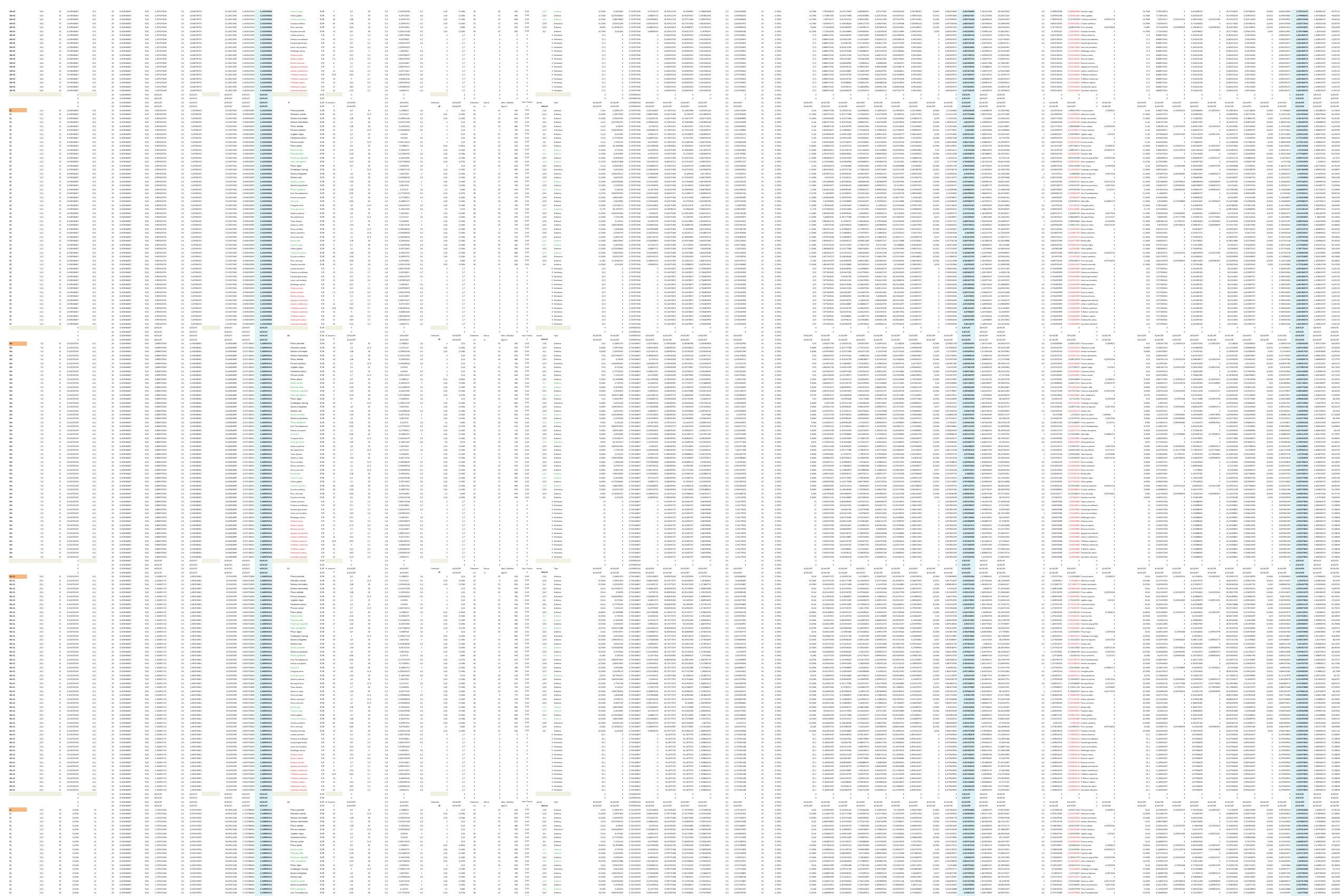

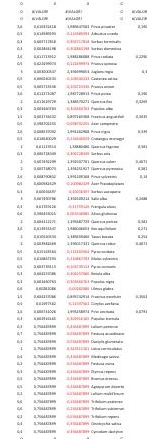
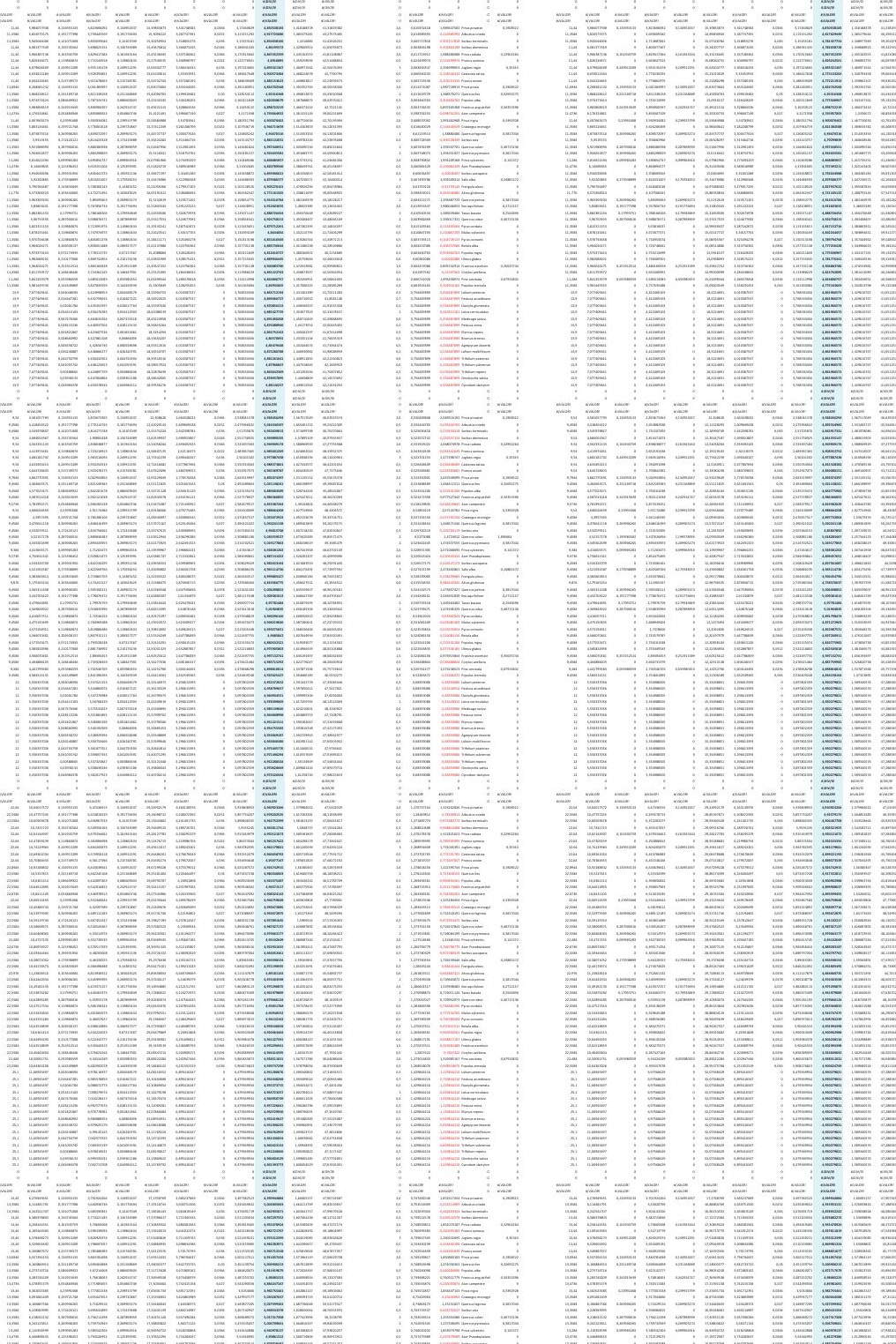

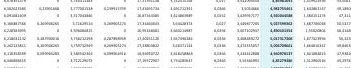




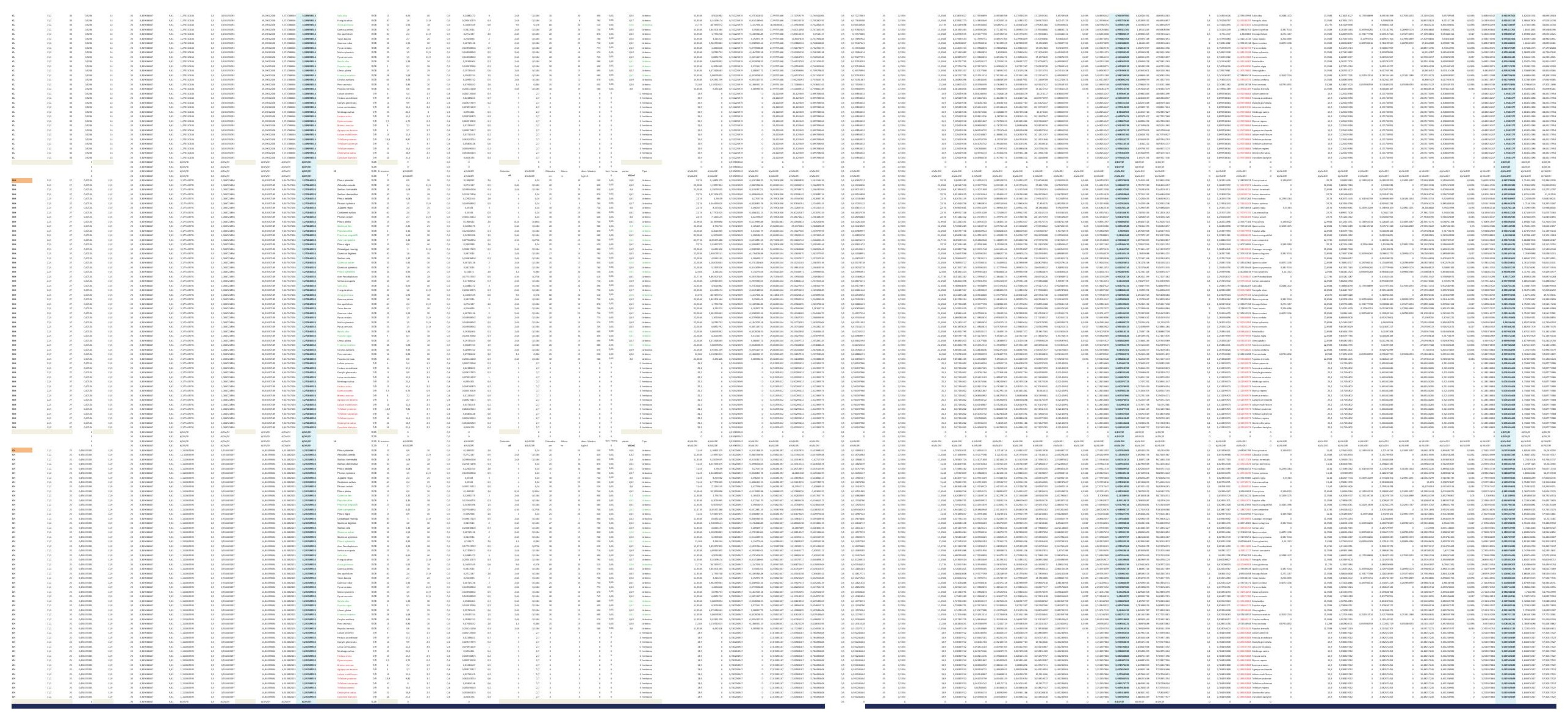



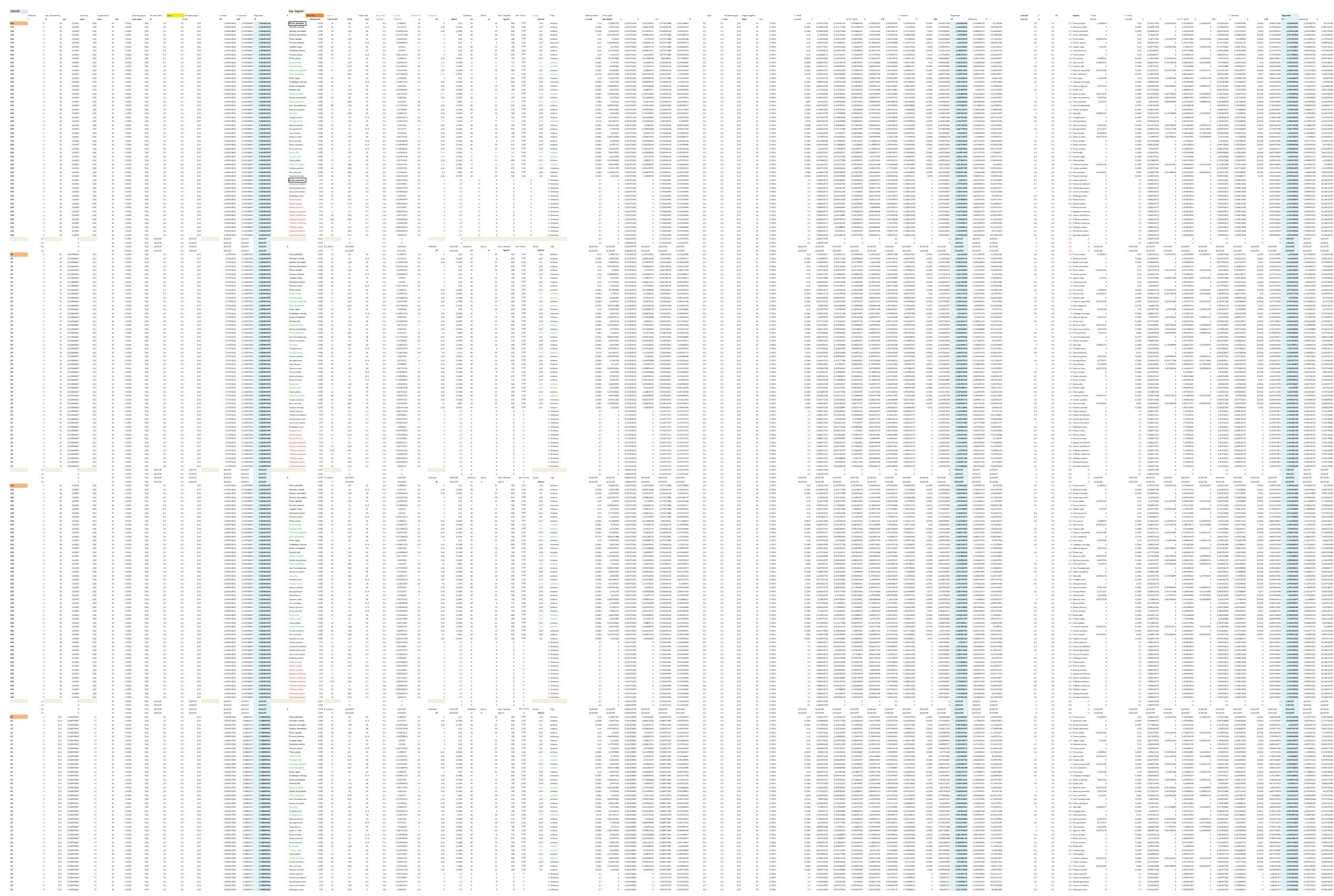


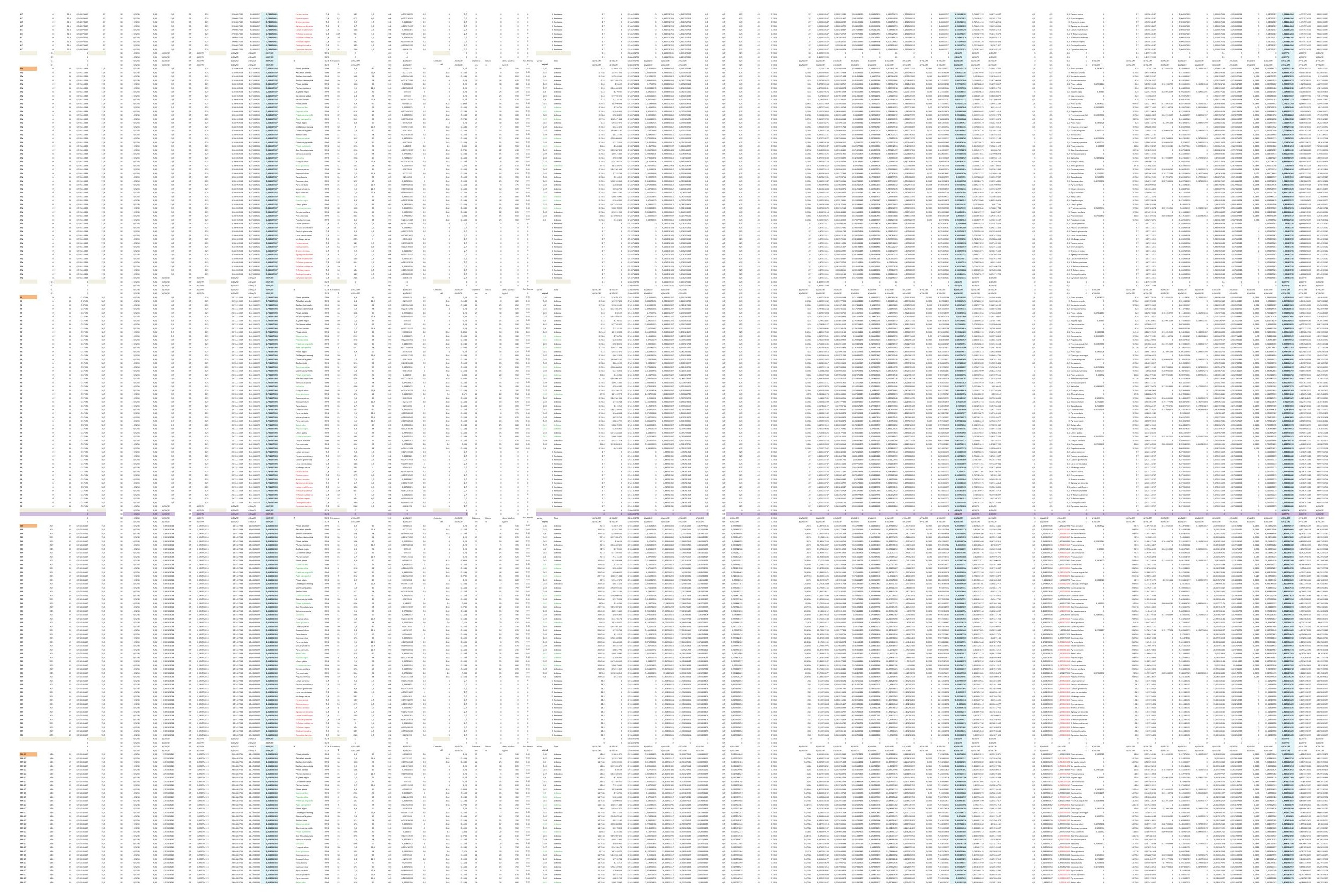



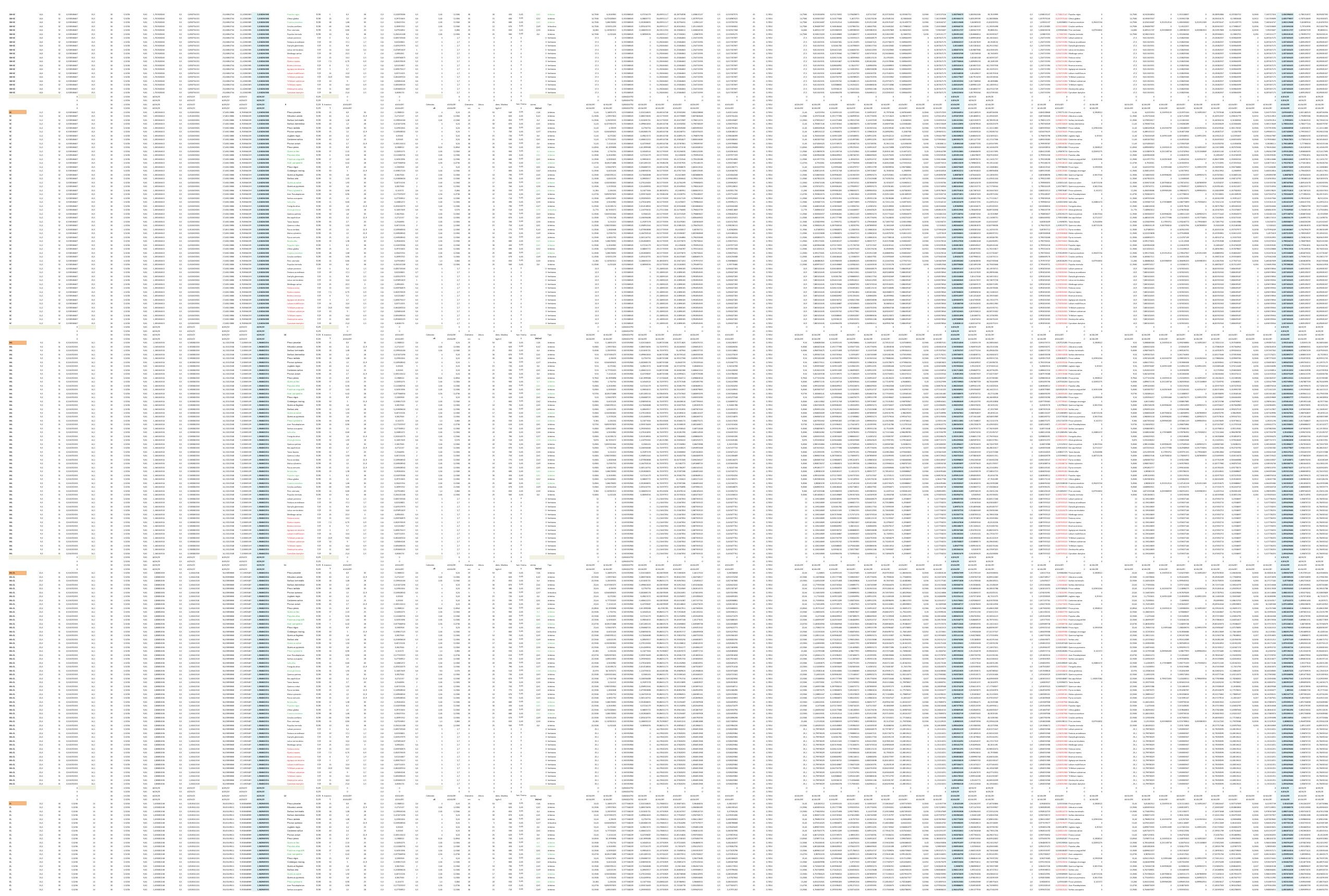

,
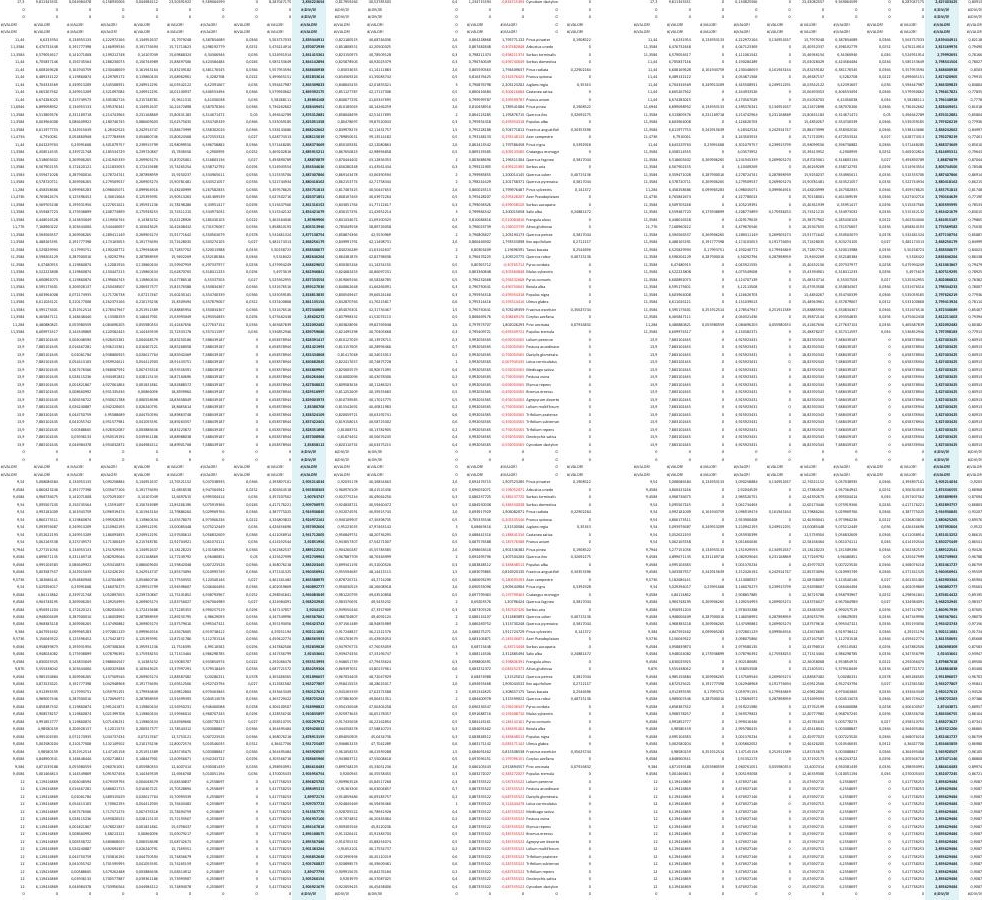

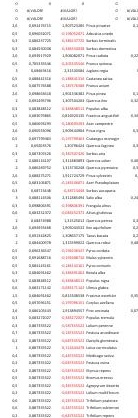
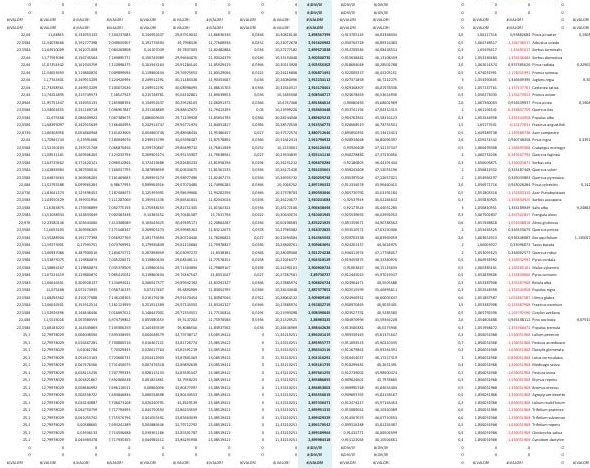

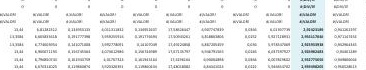

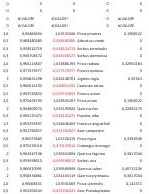

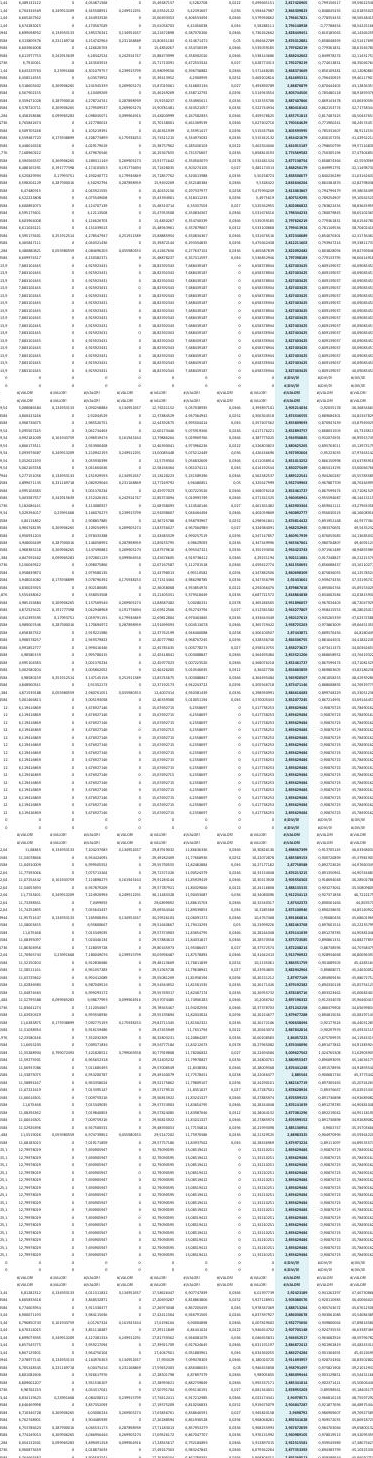




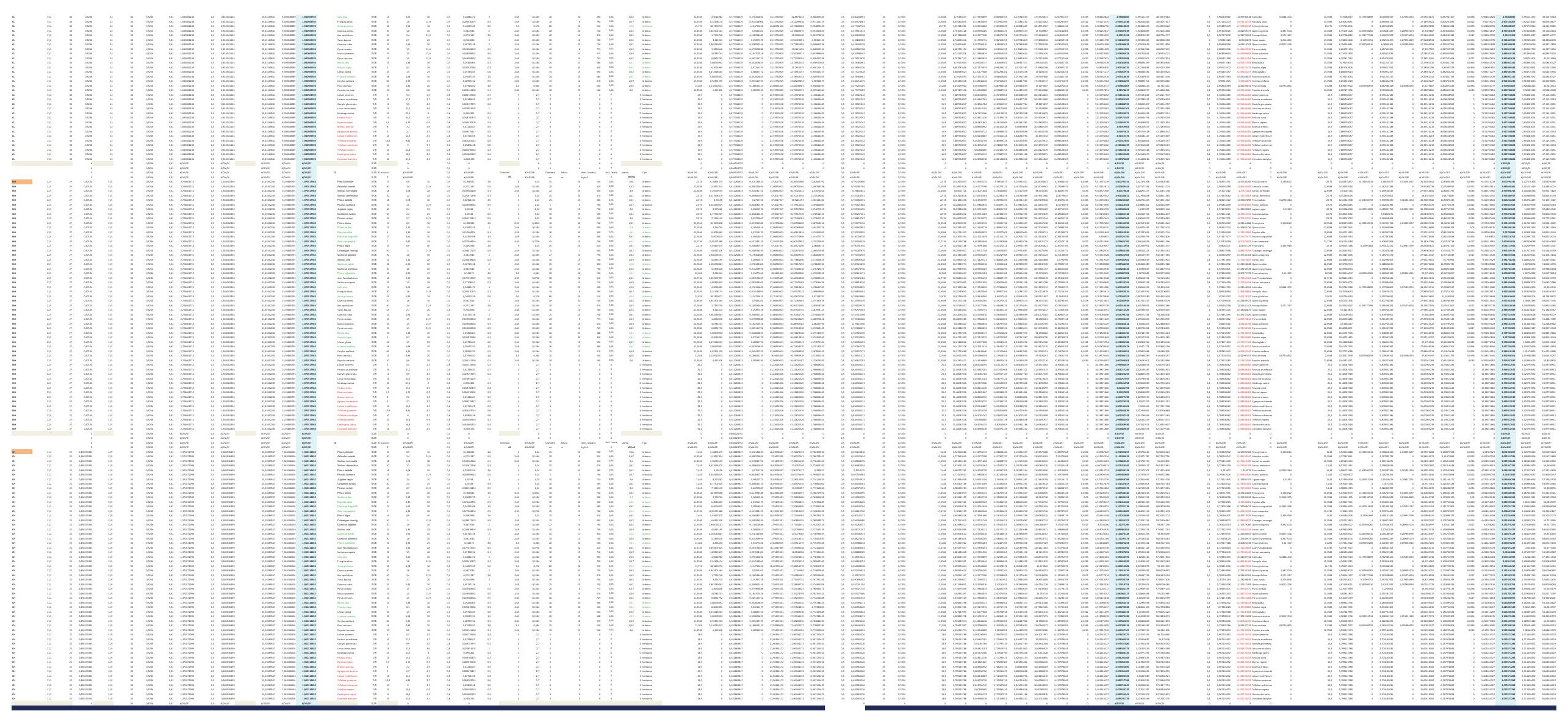



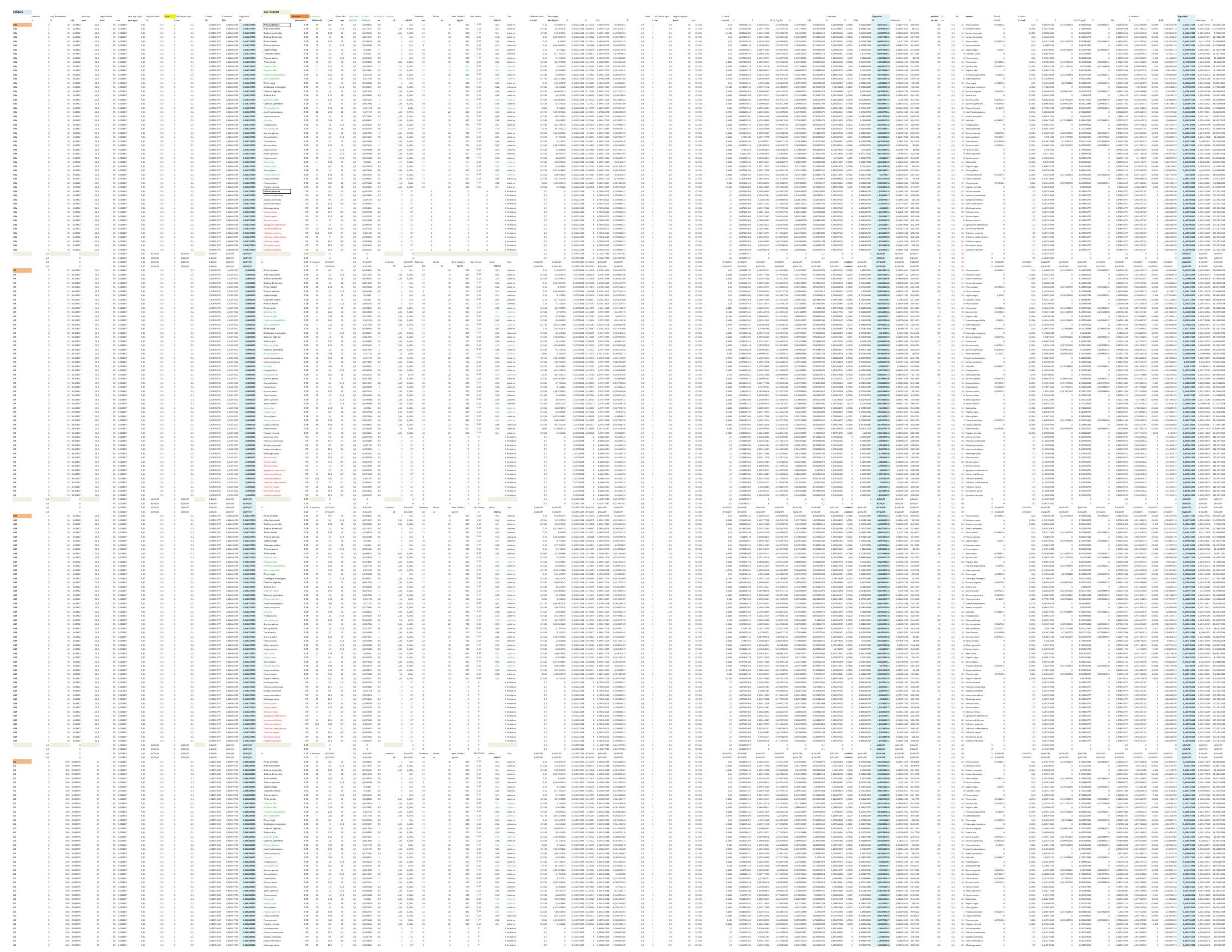


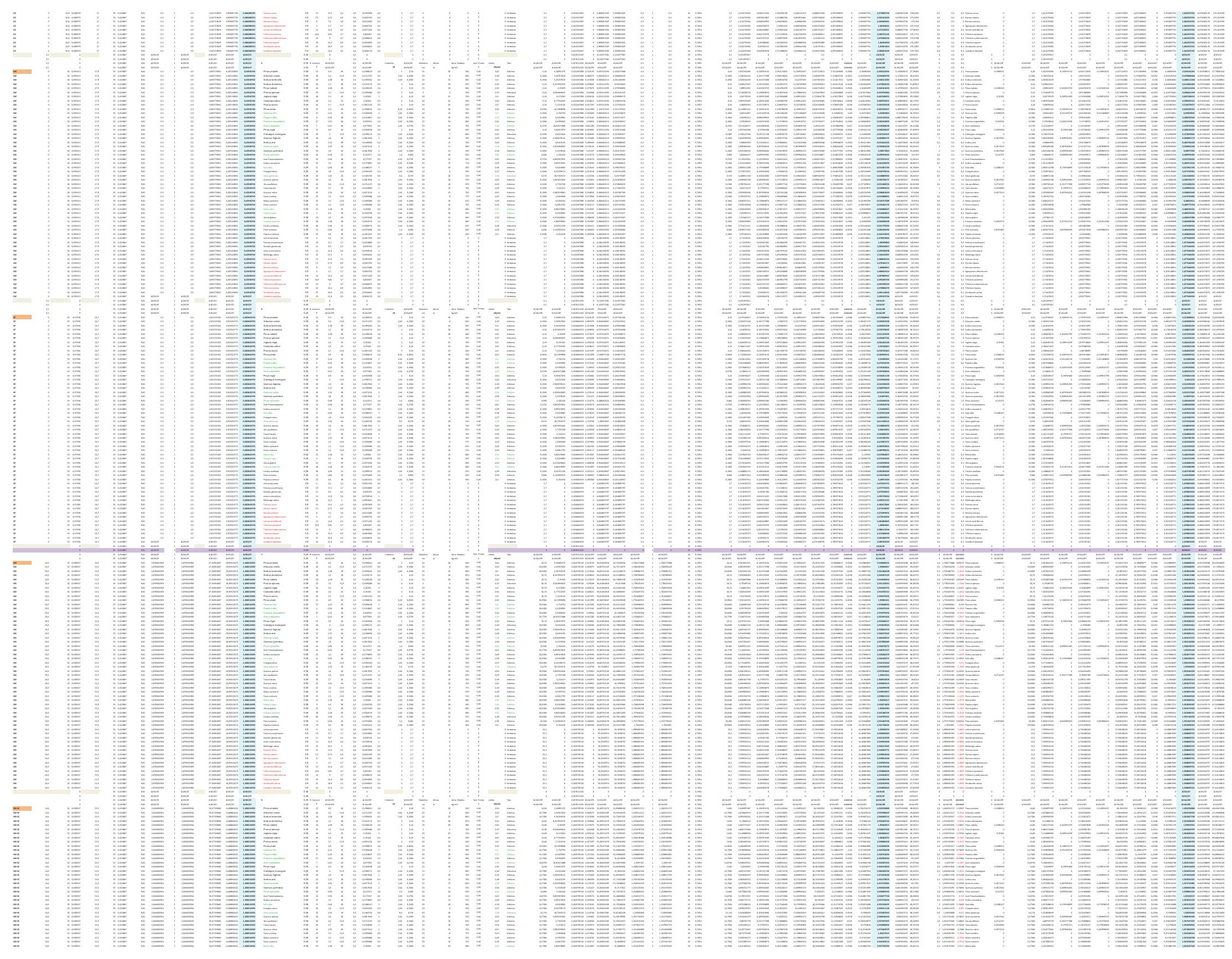



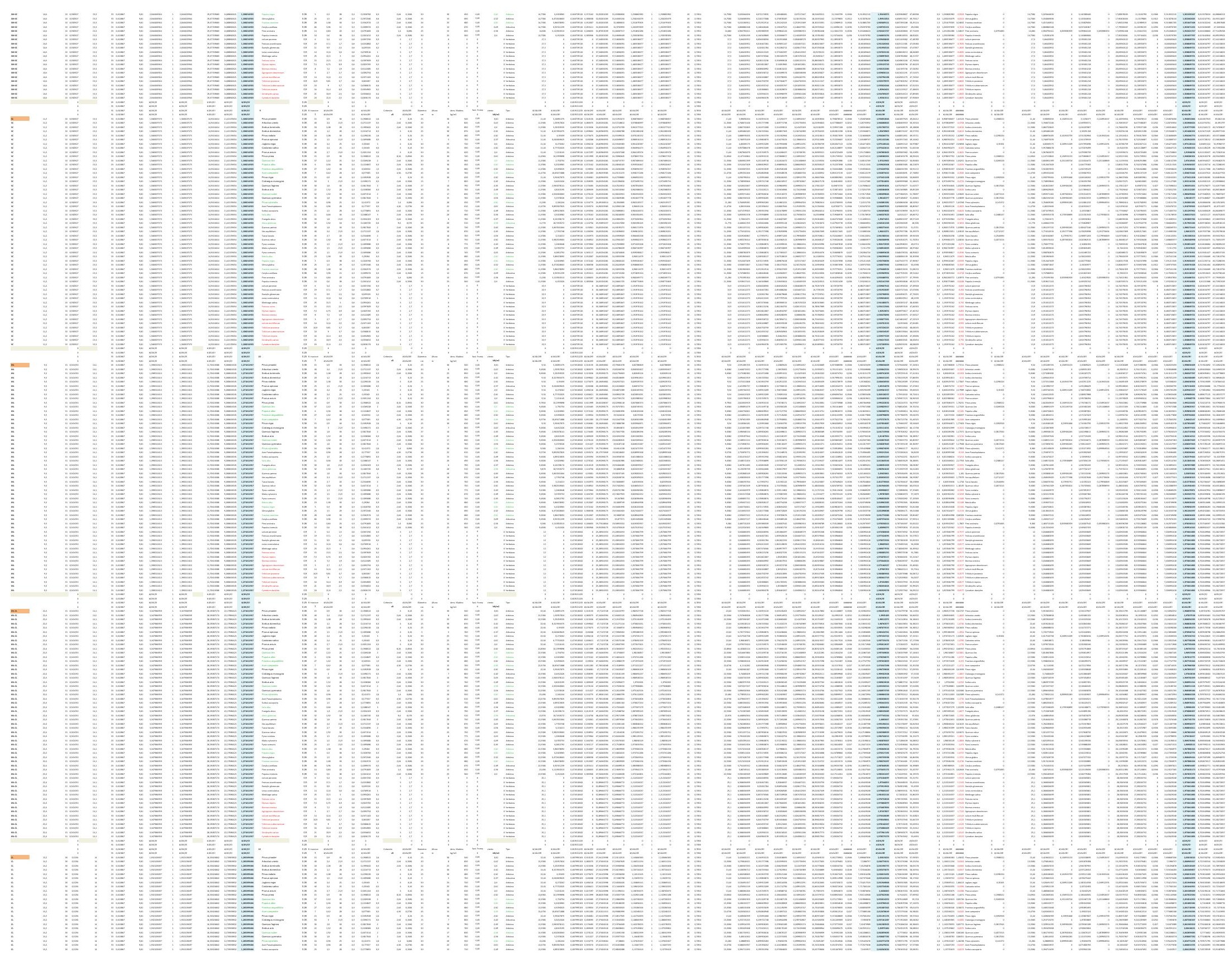

$-$
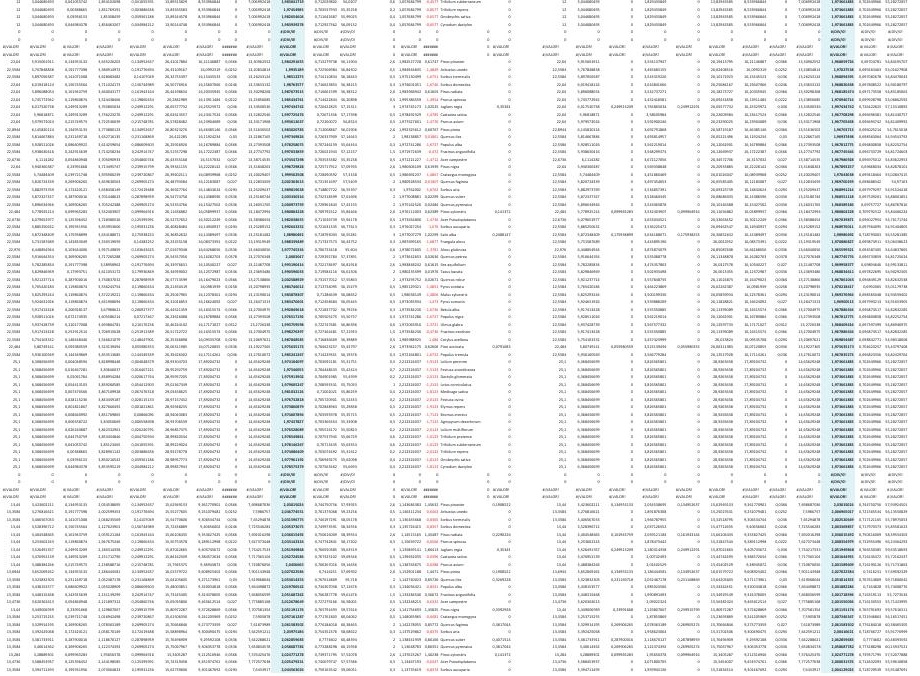


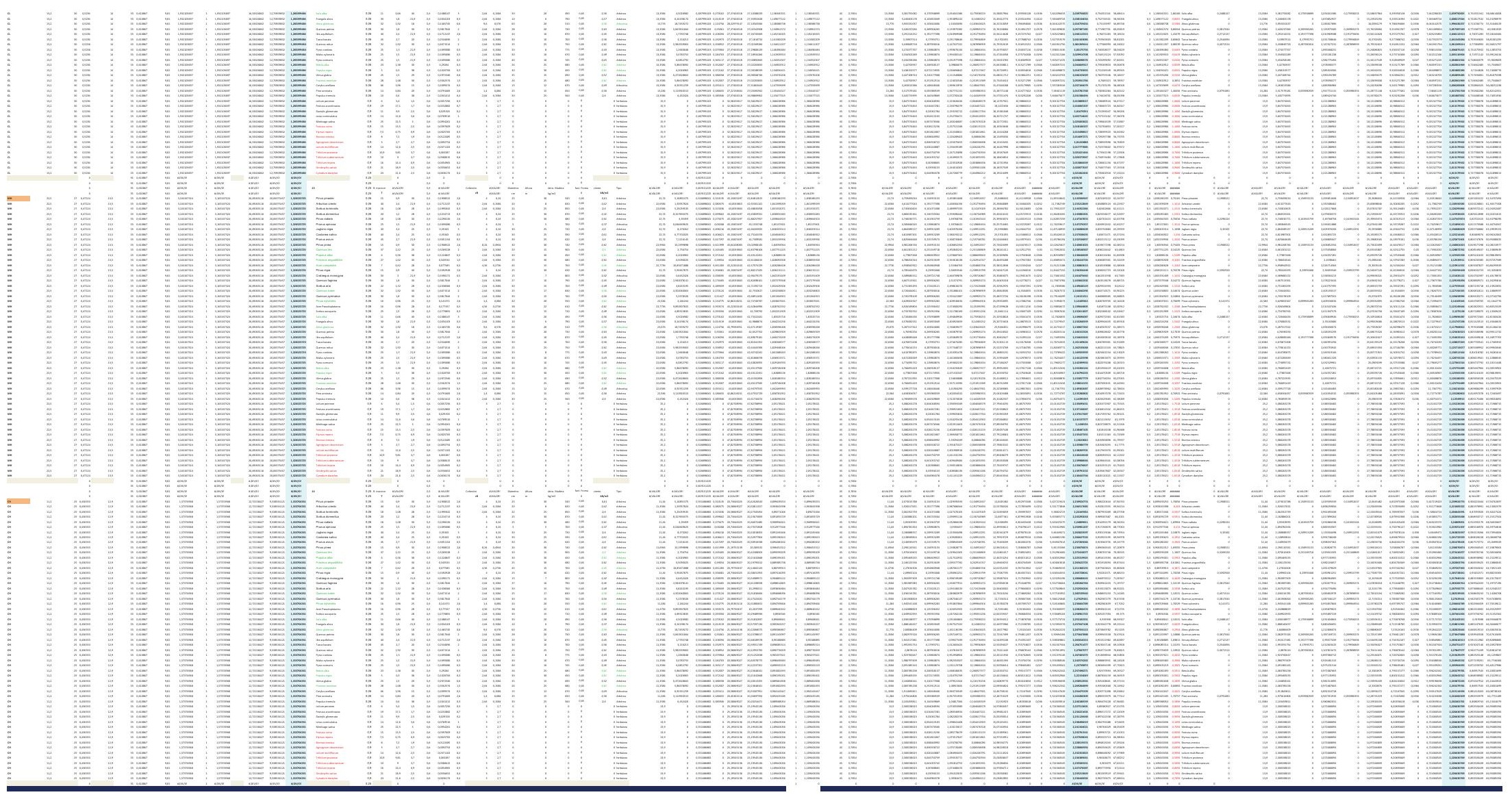



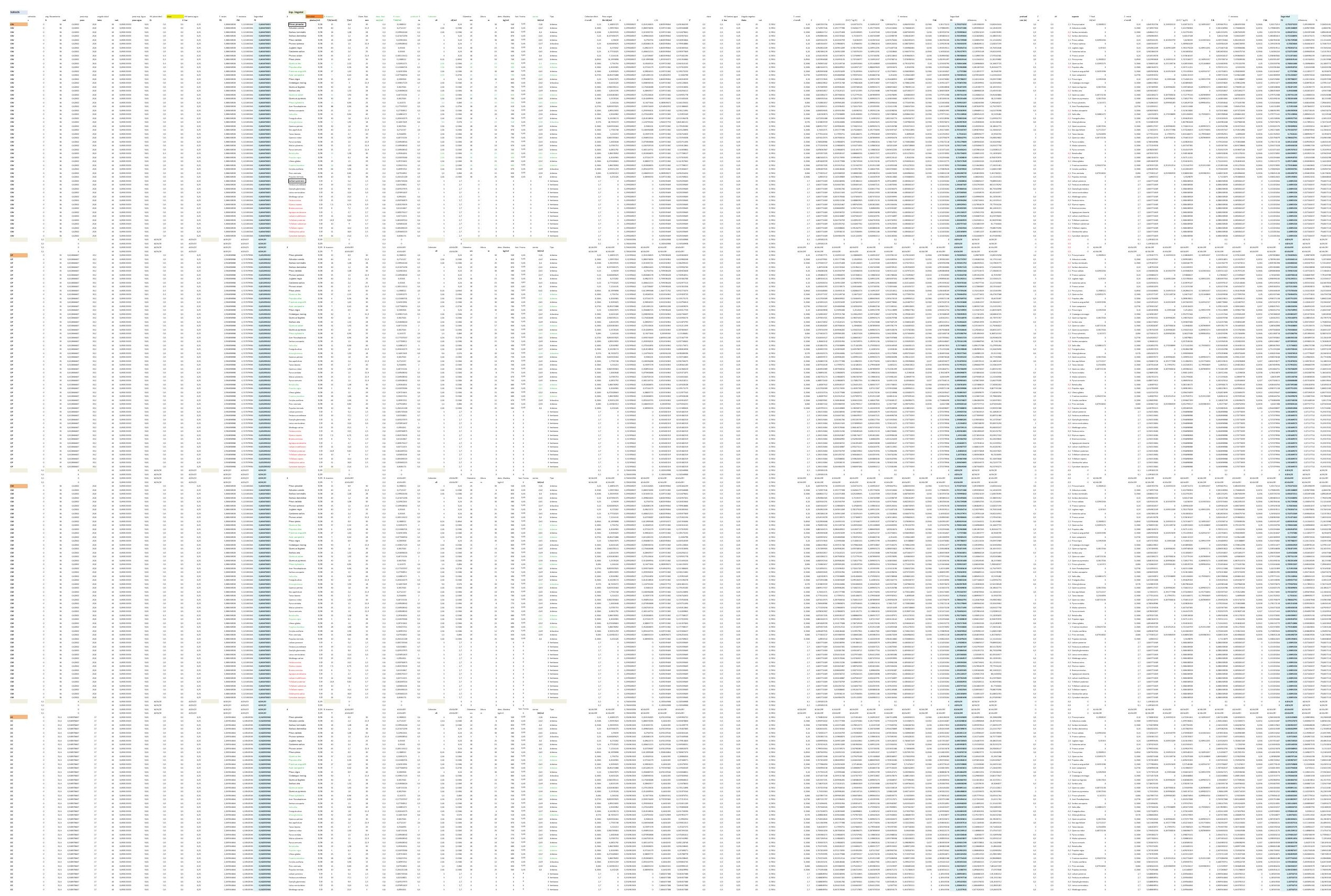


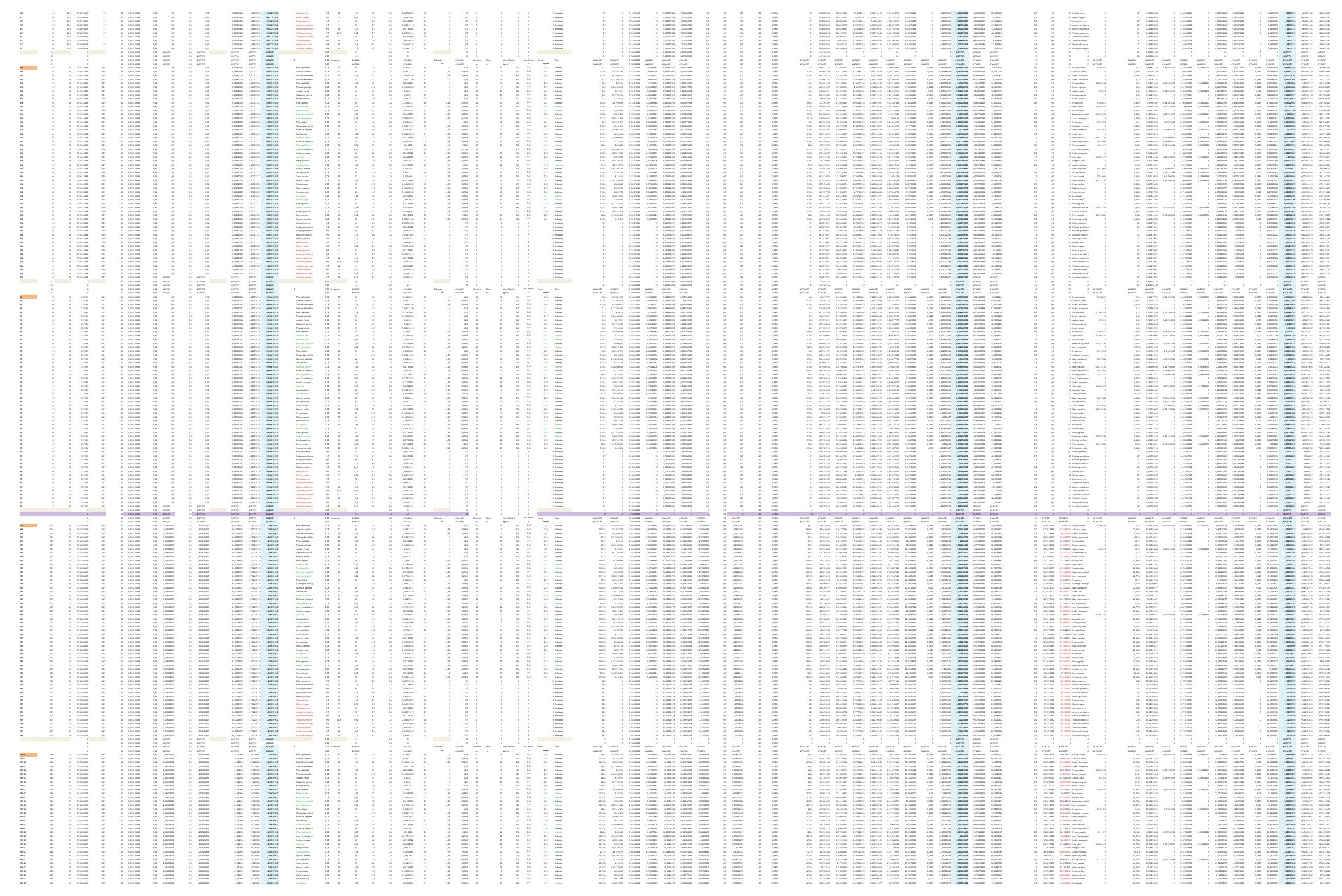



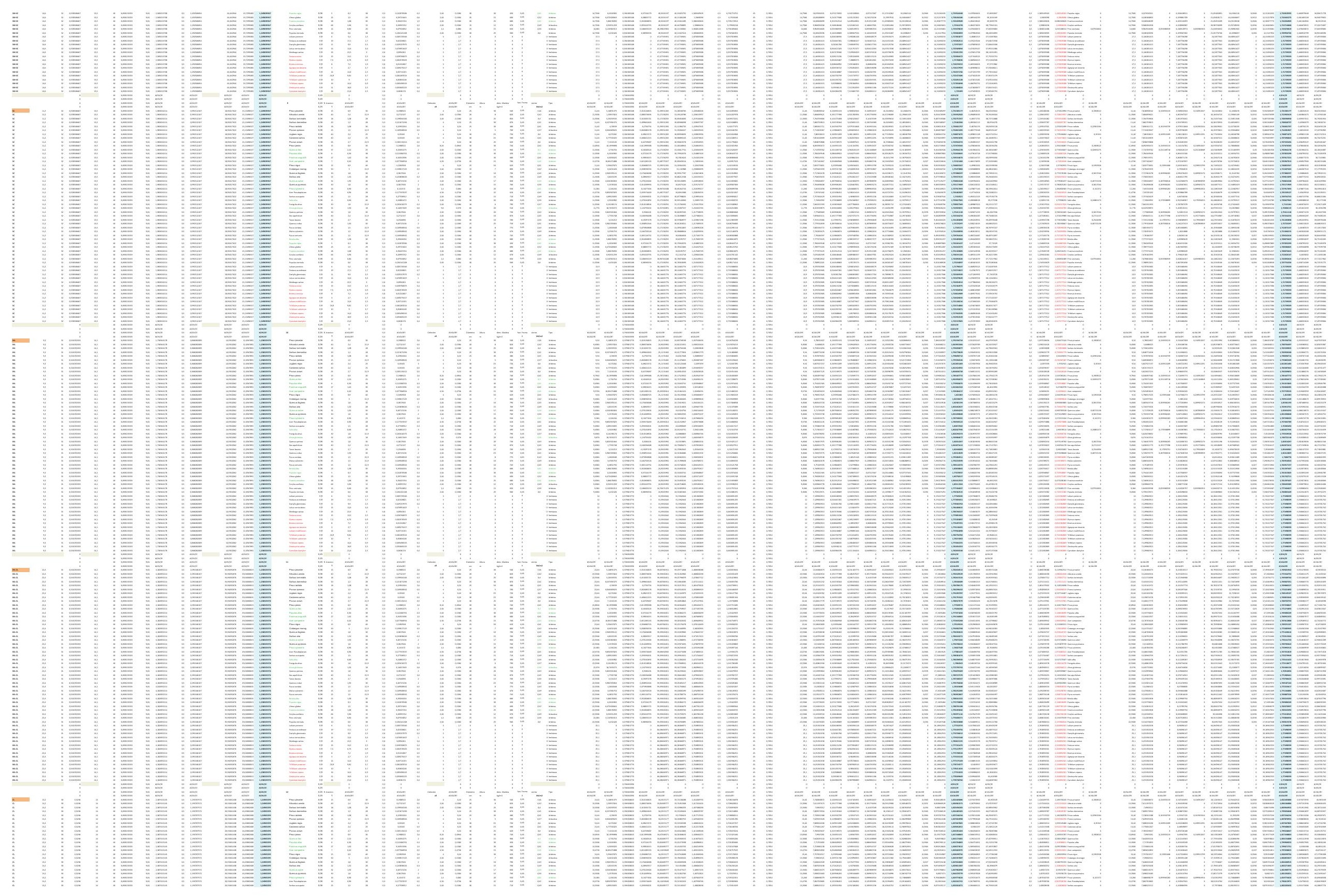


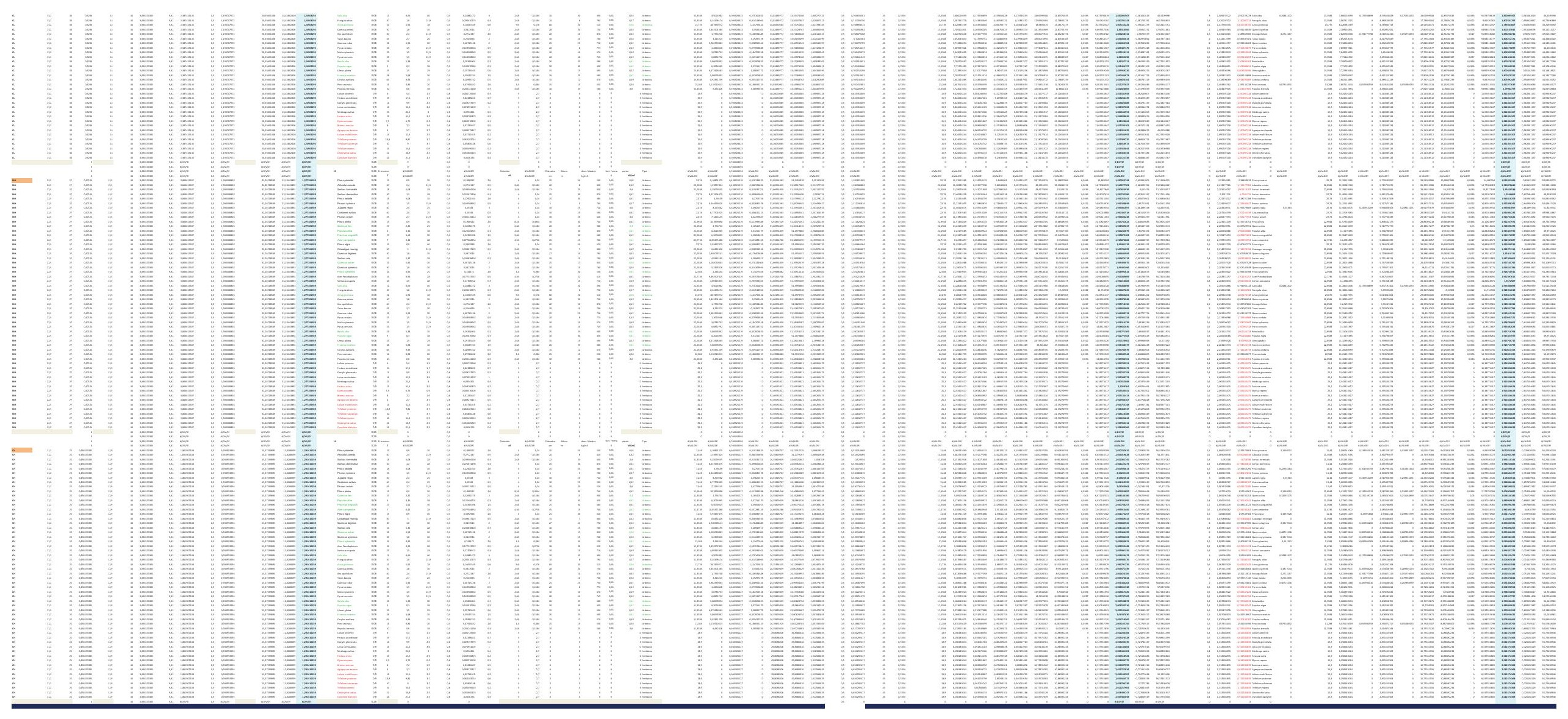



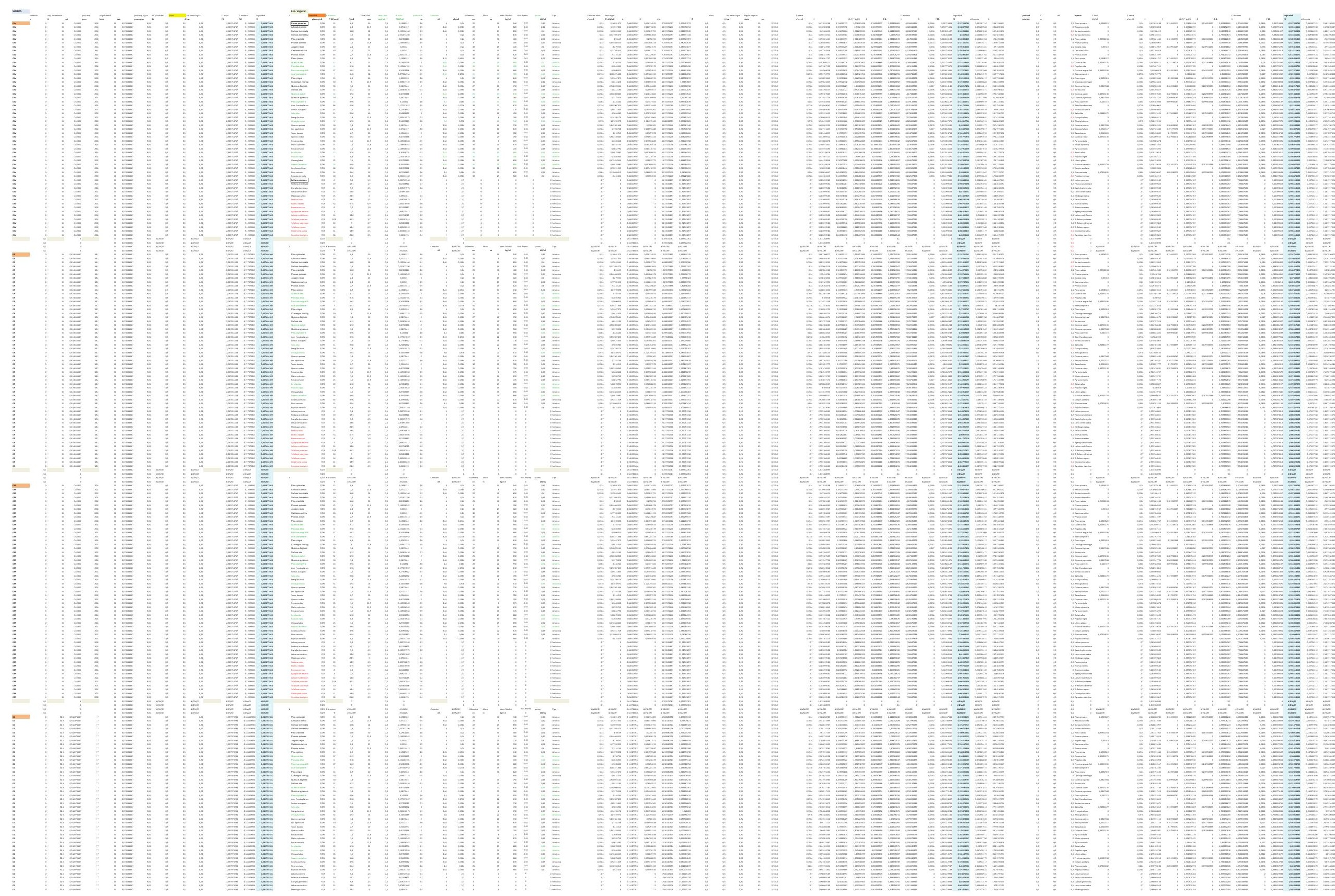


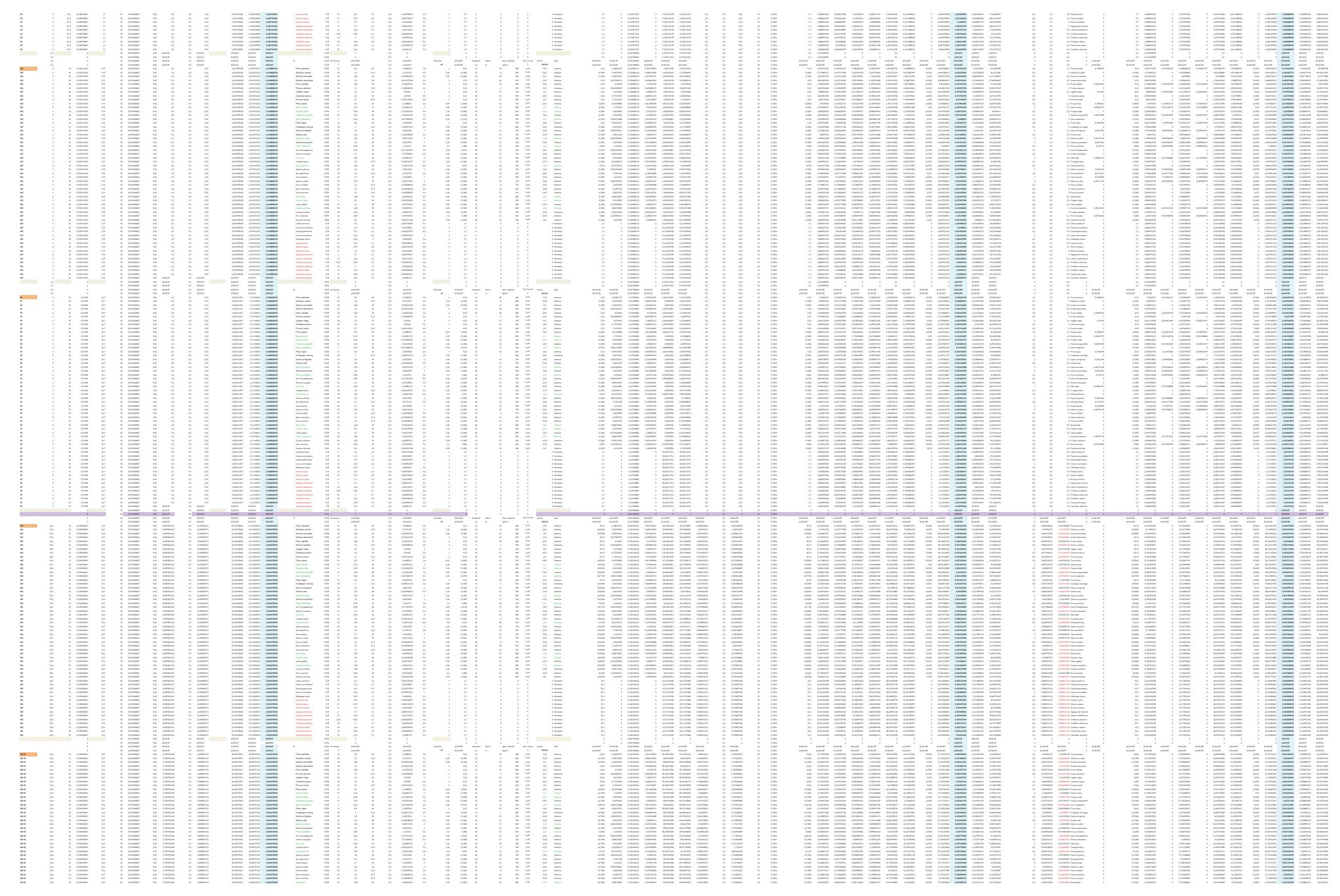



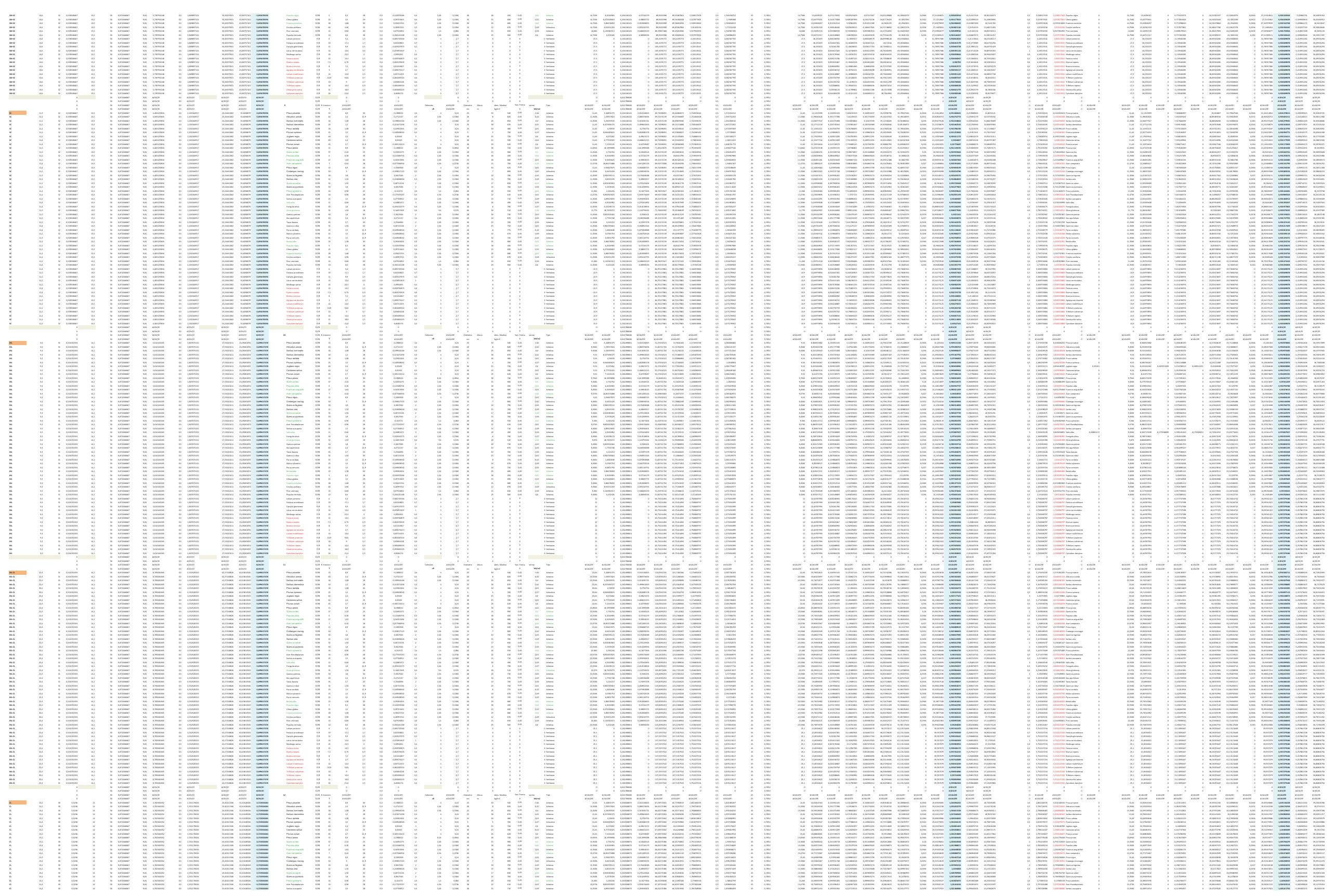


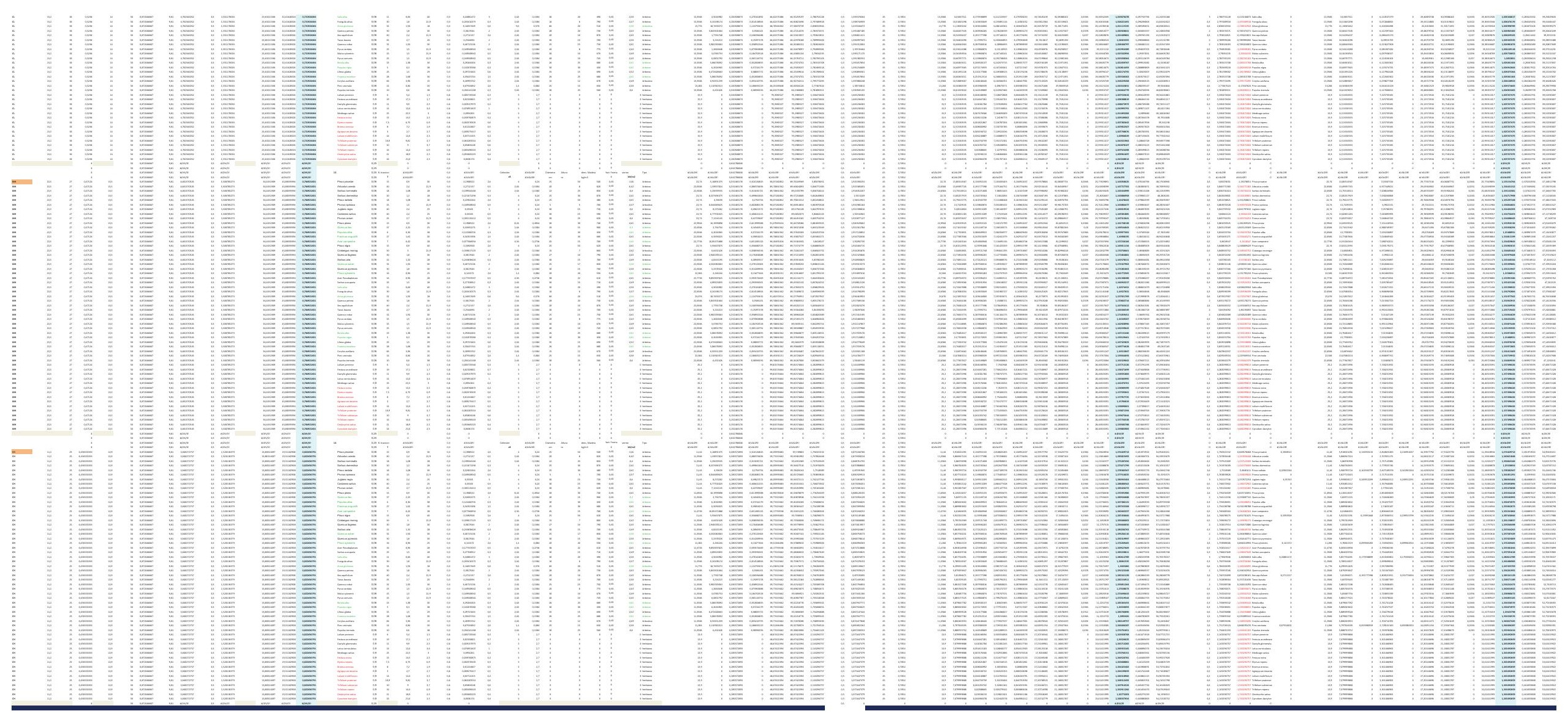



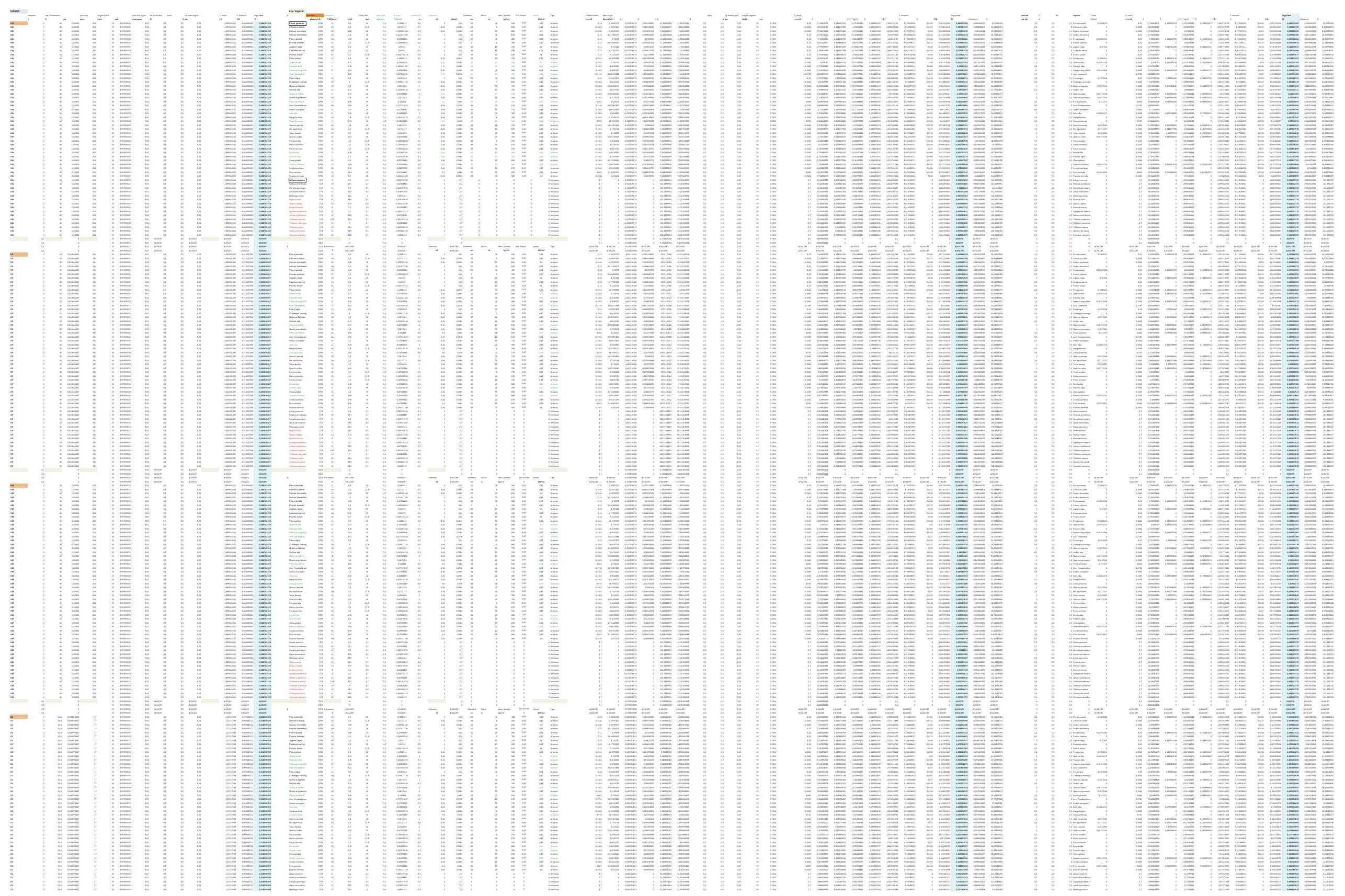


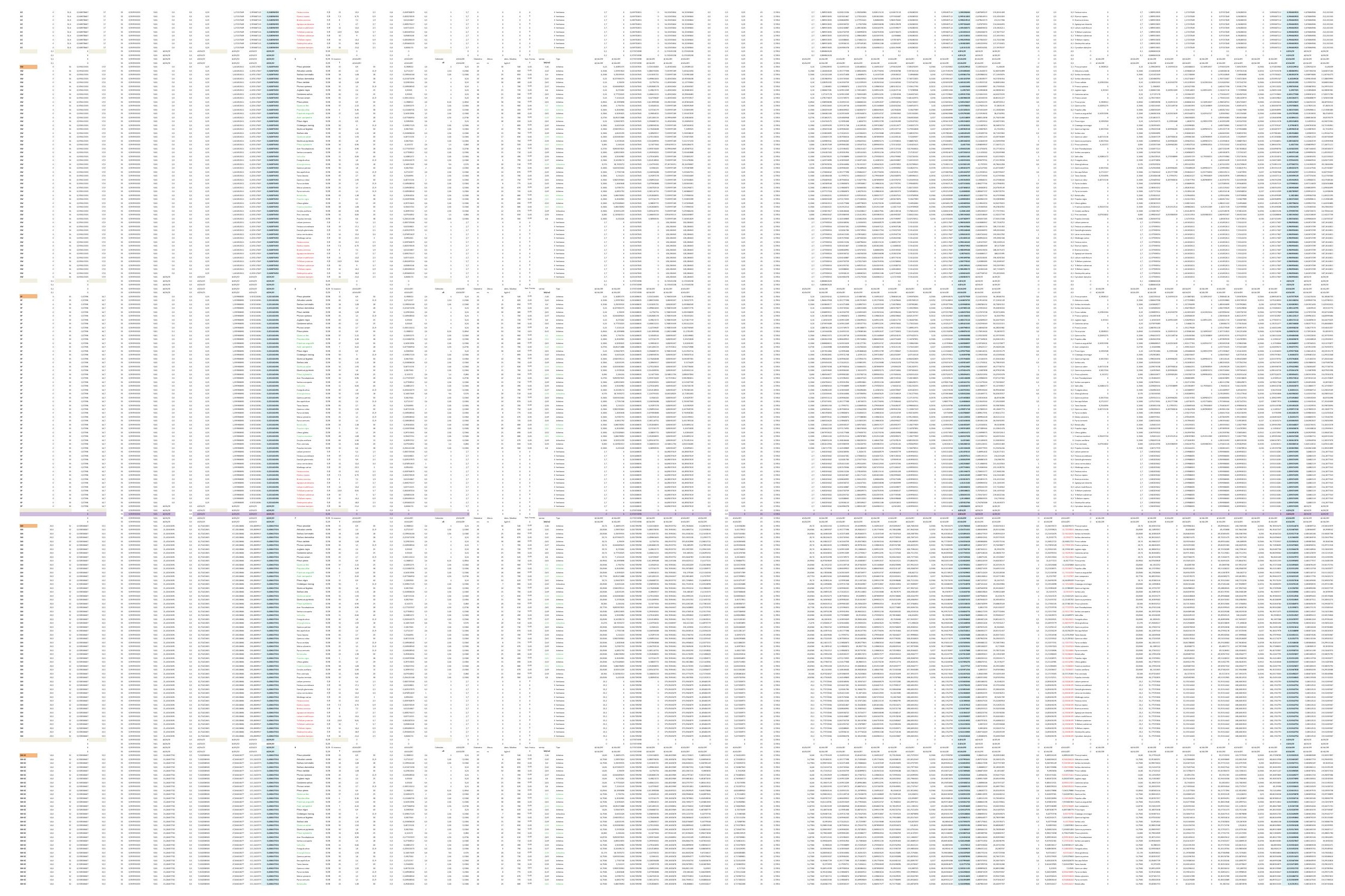



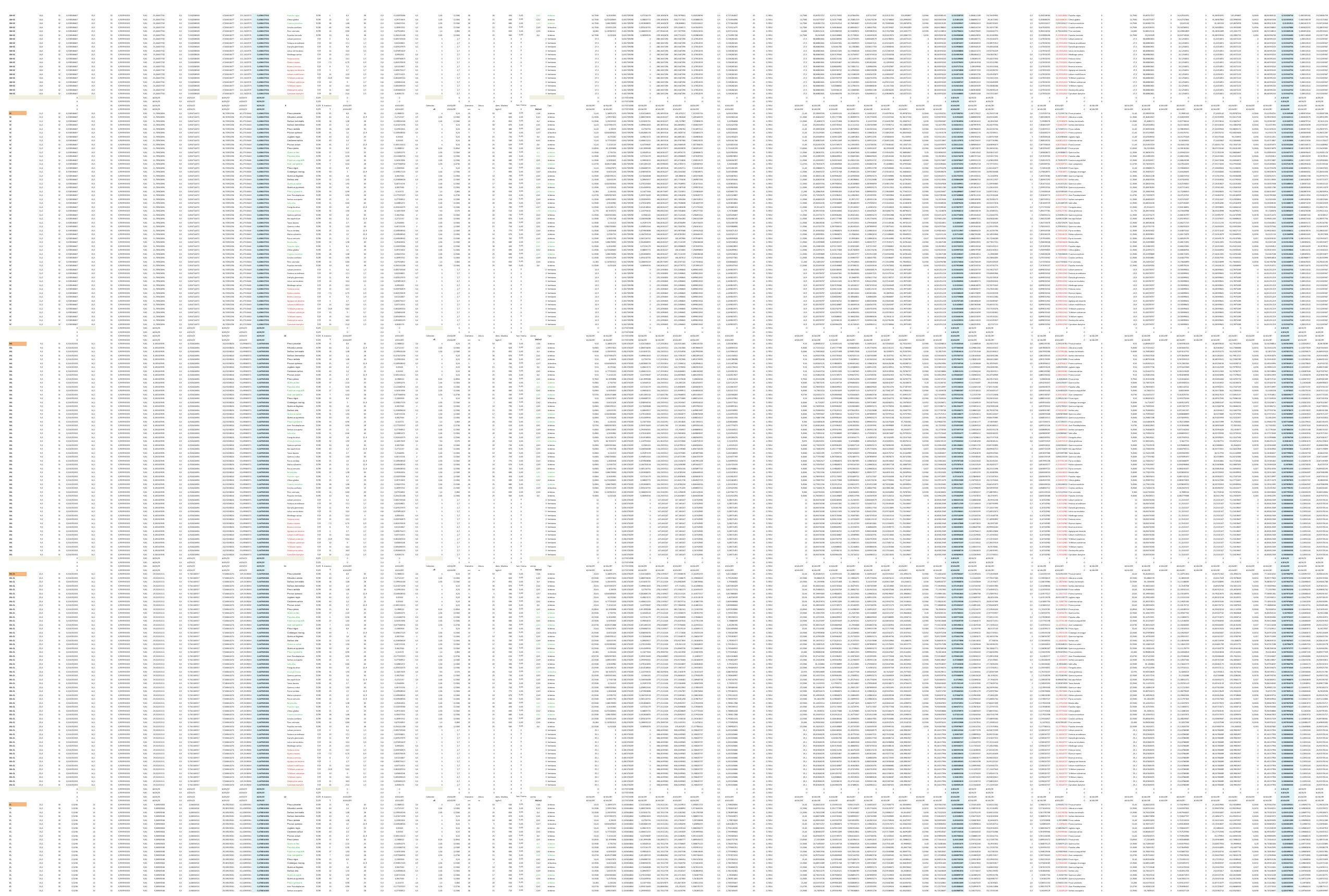


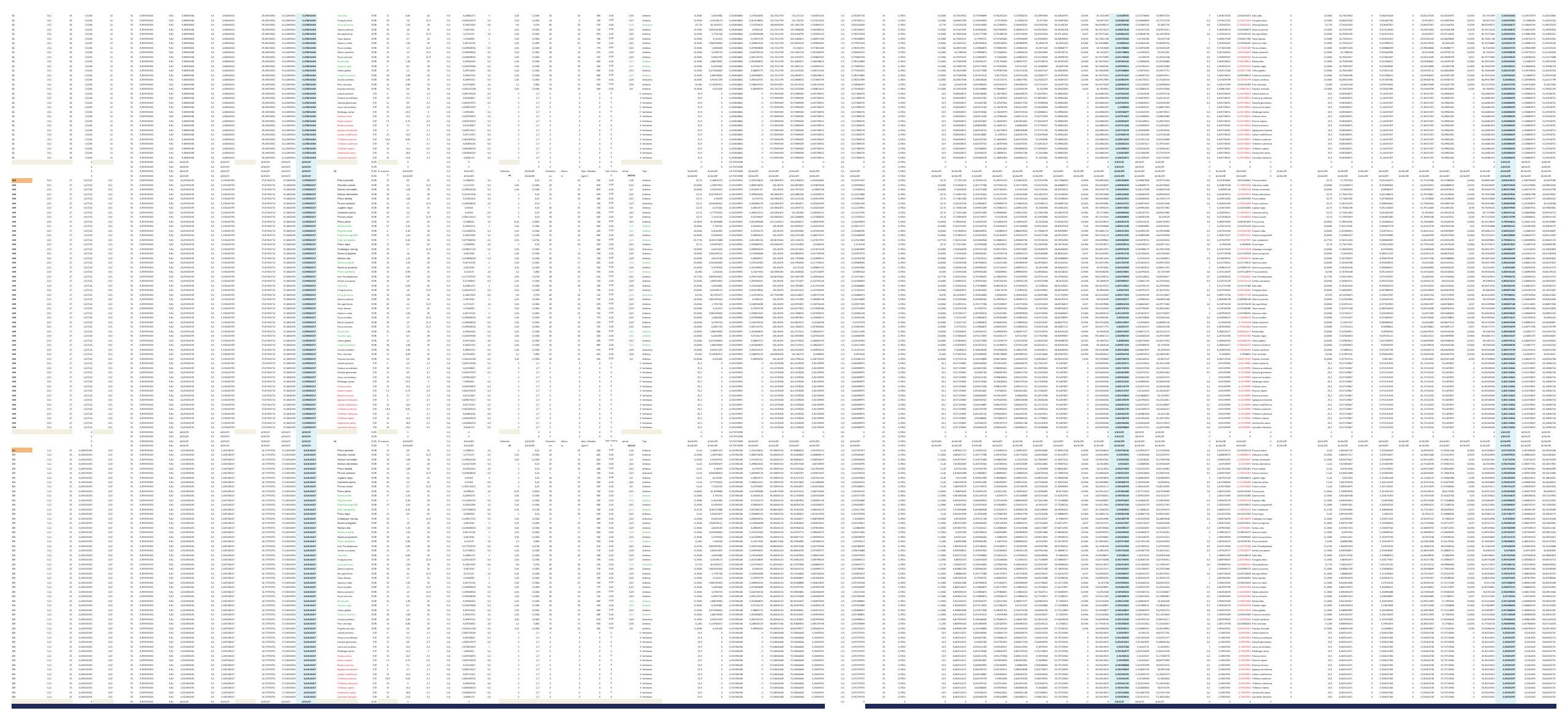



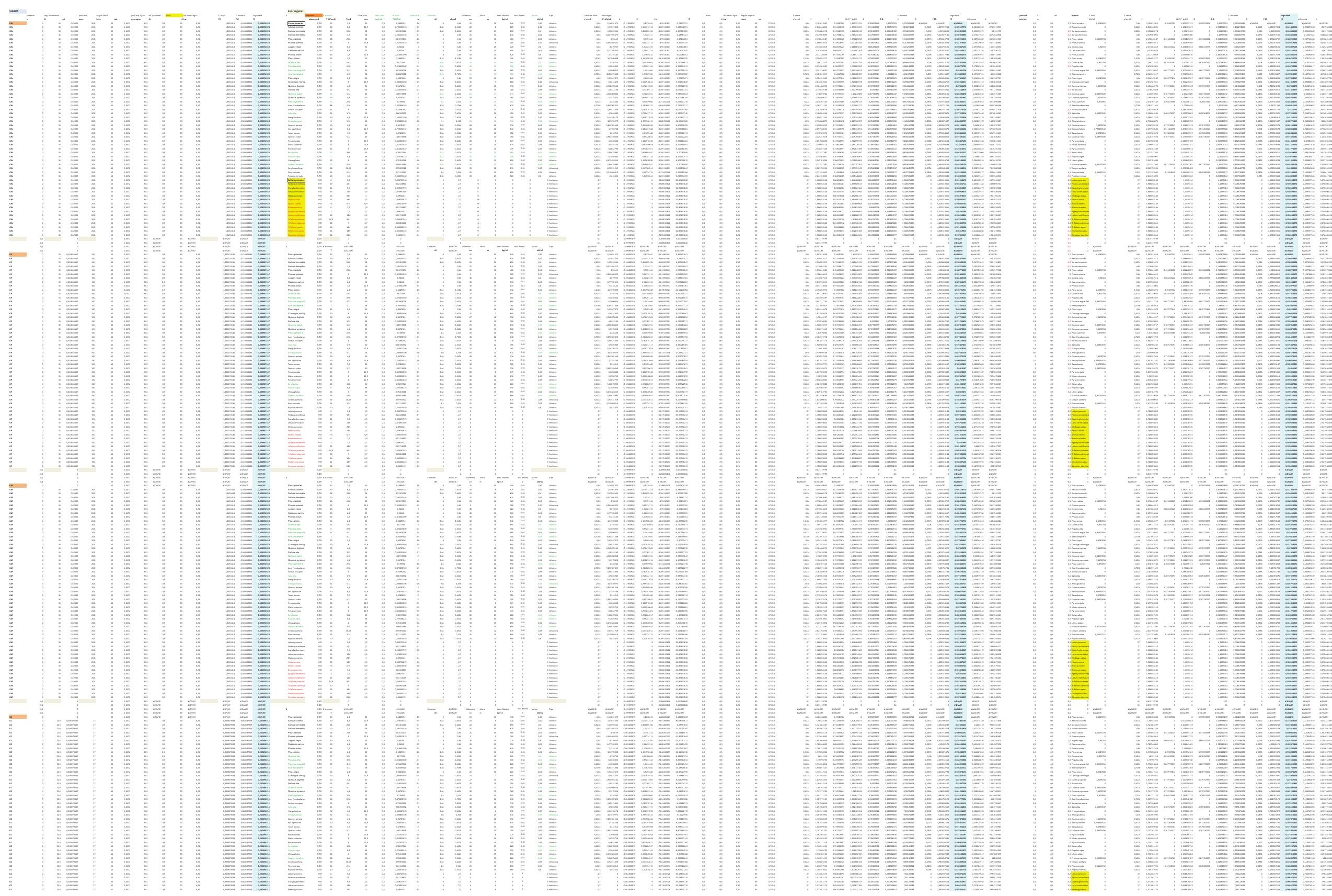

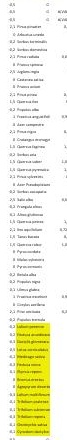

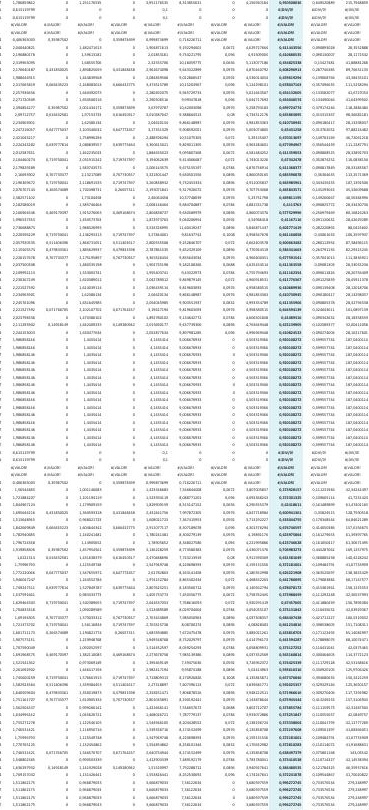




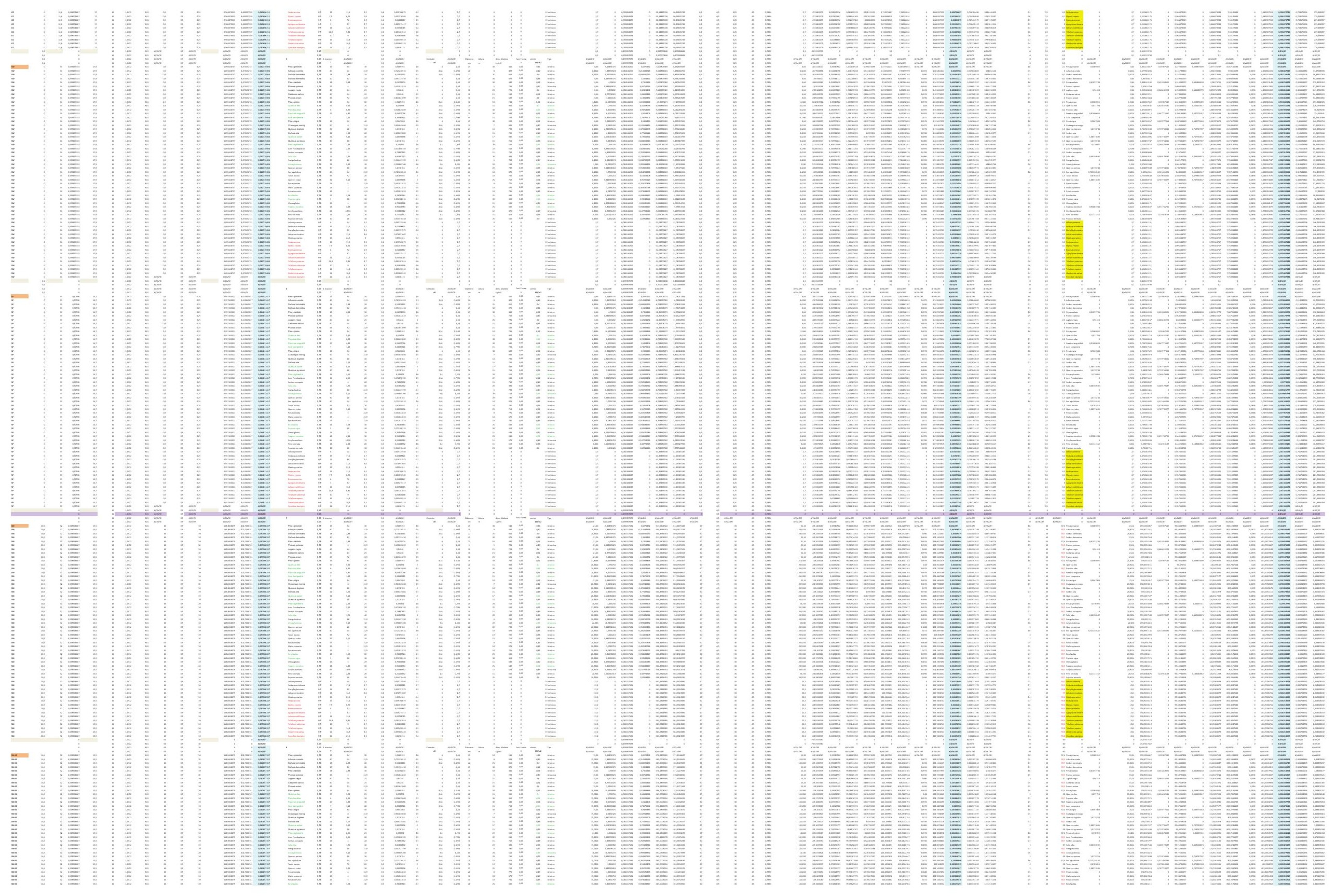



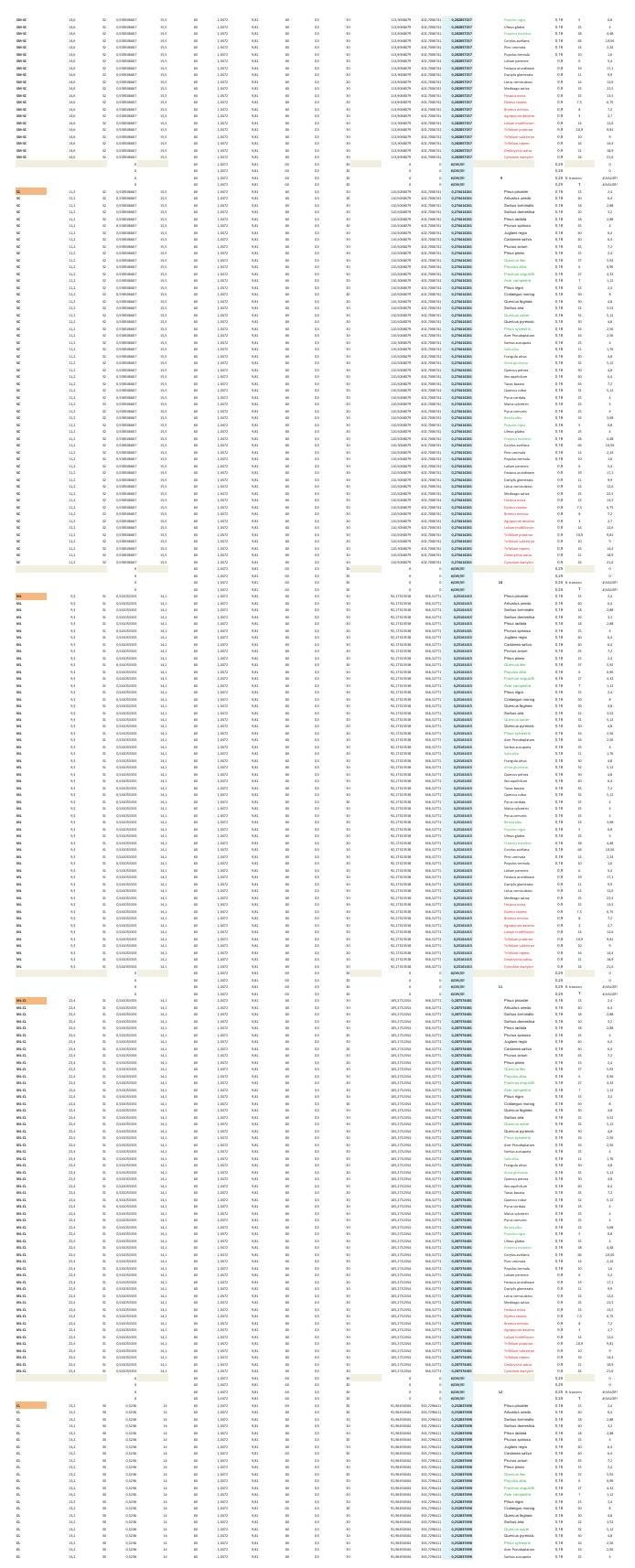

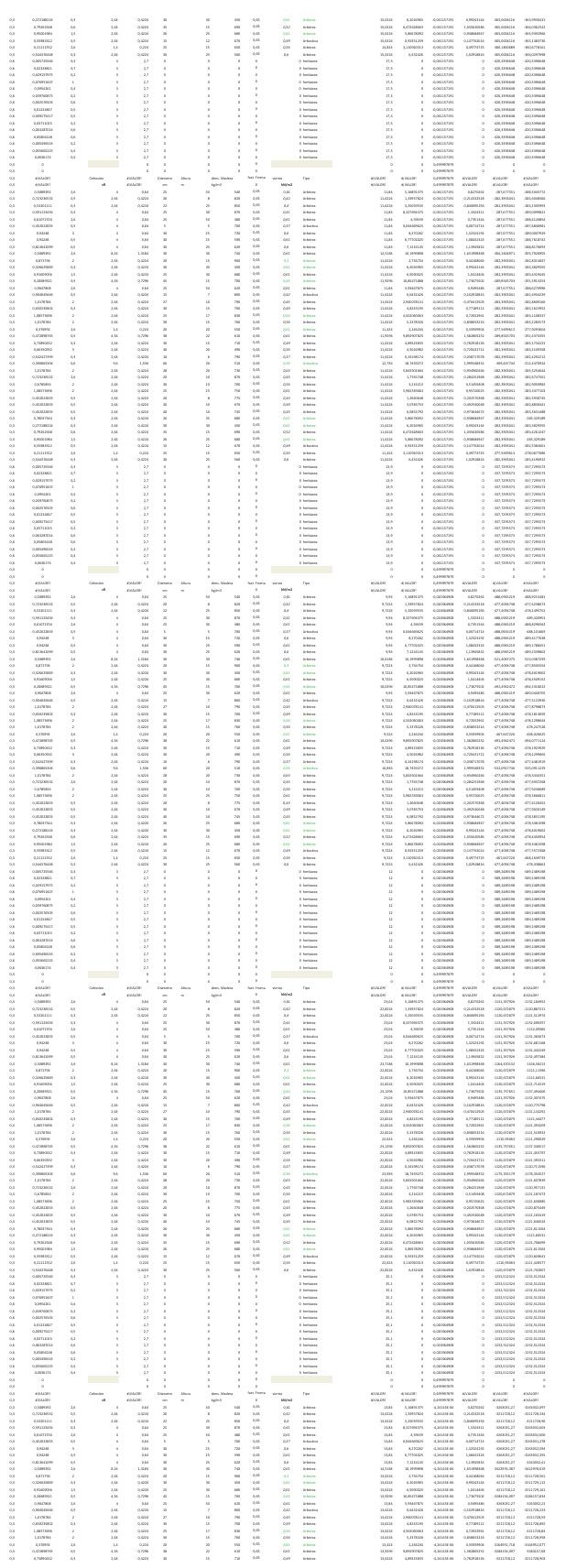

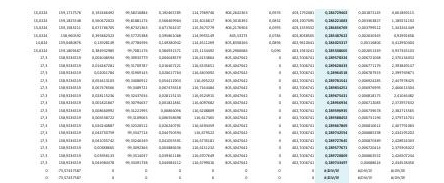
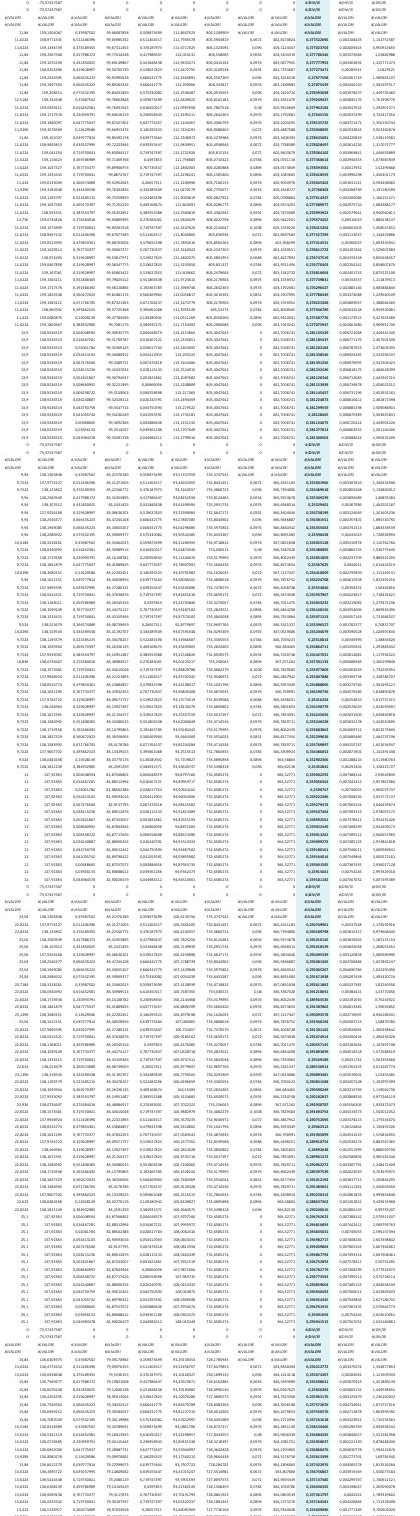

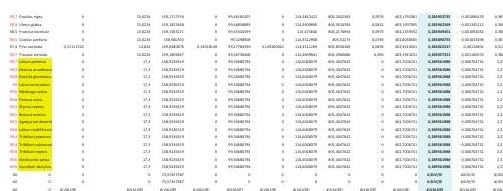

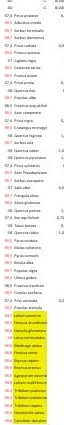

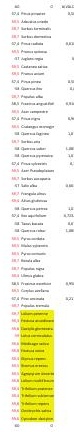

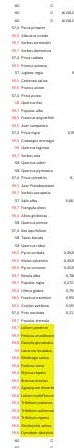

雍

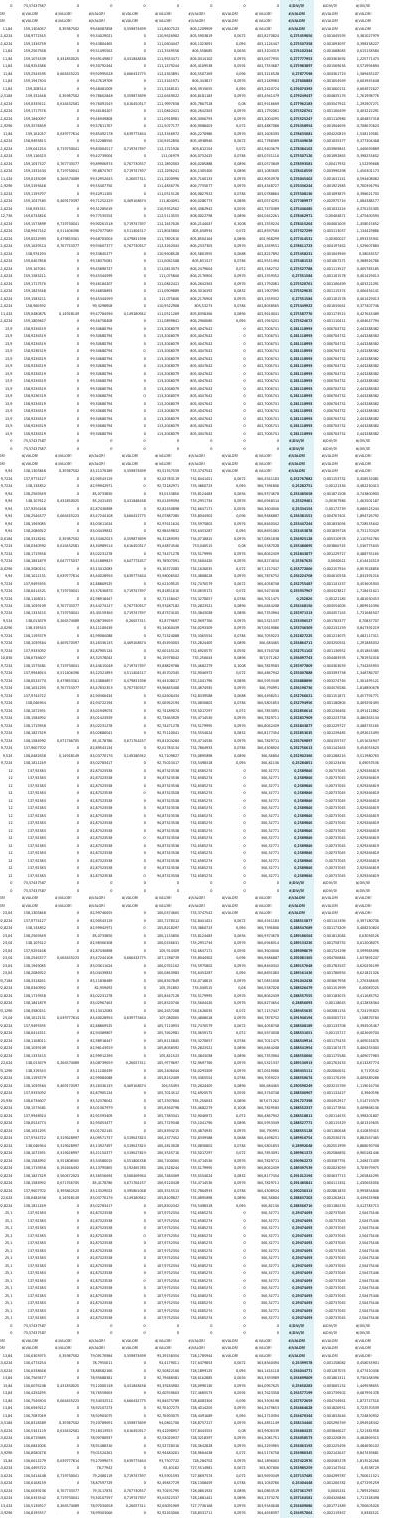




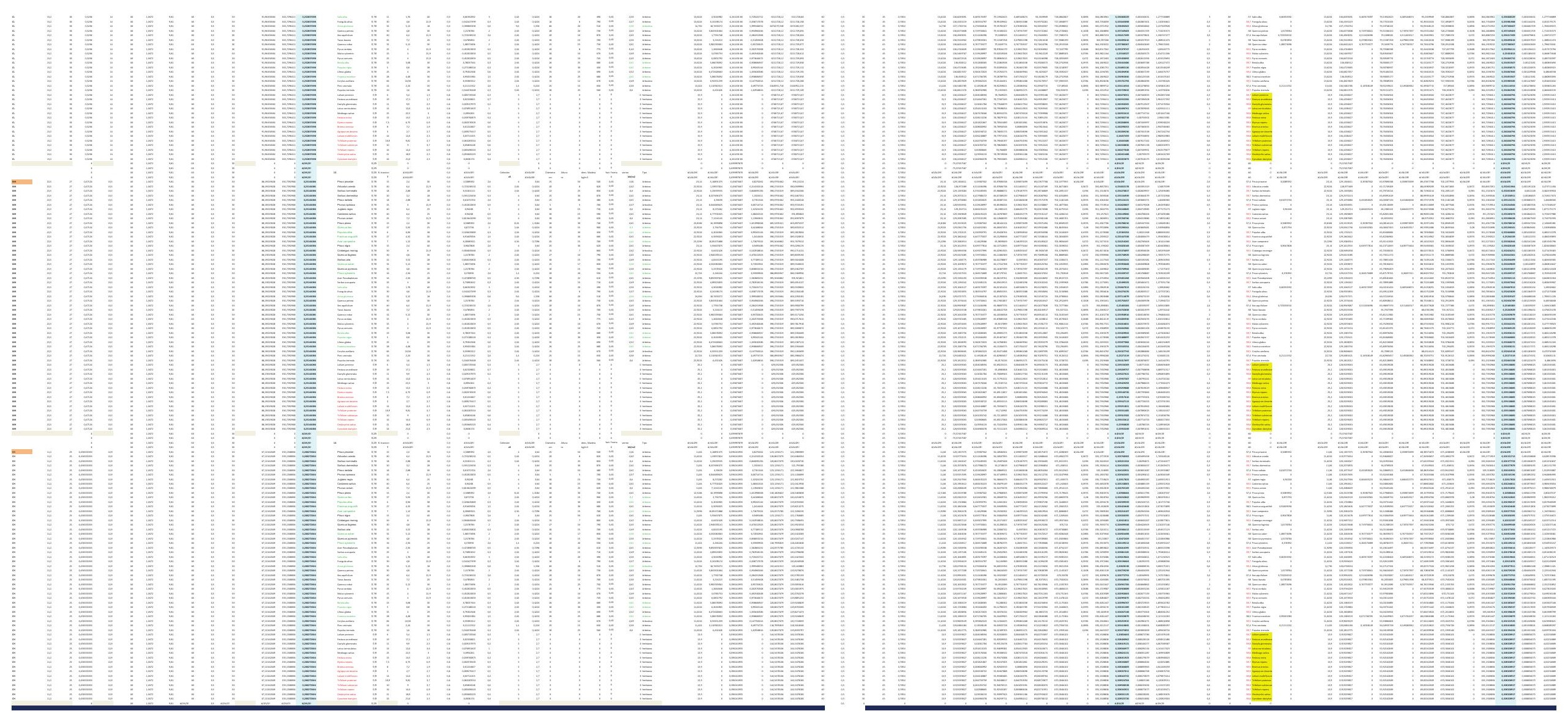



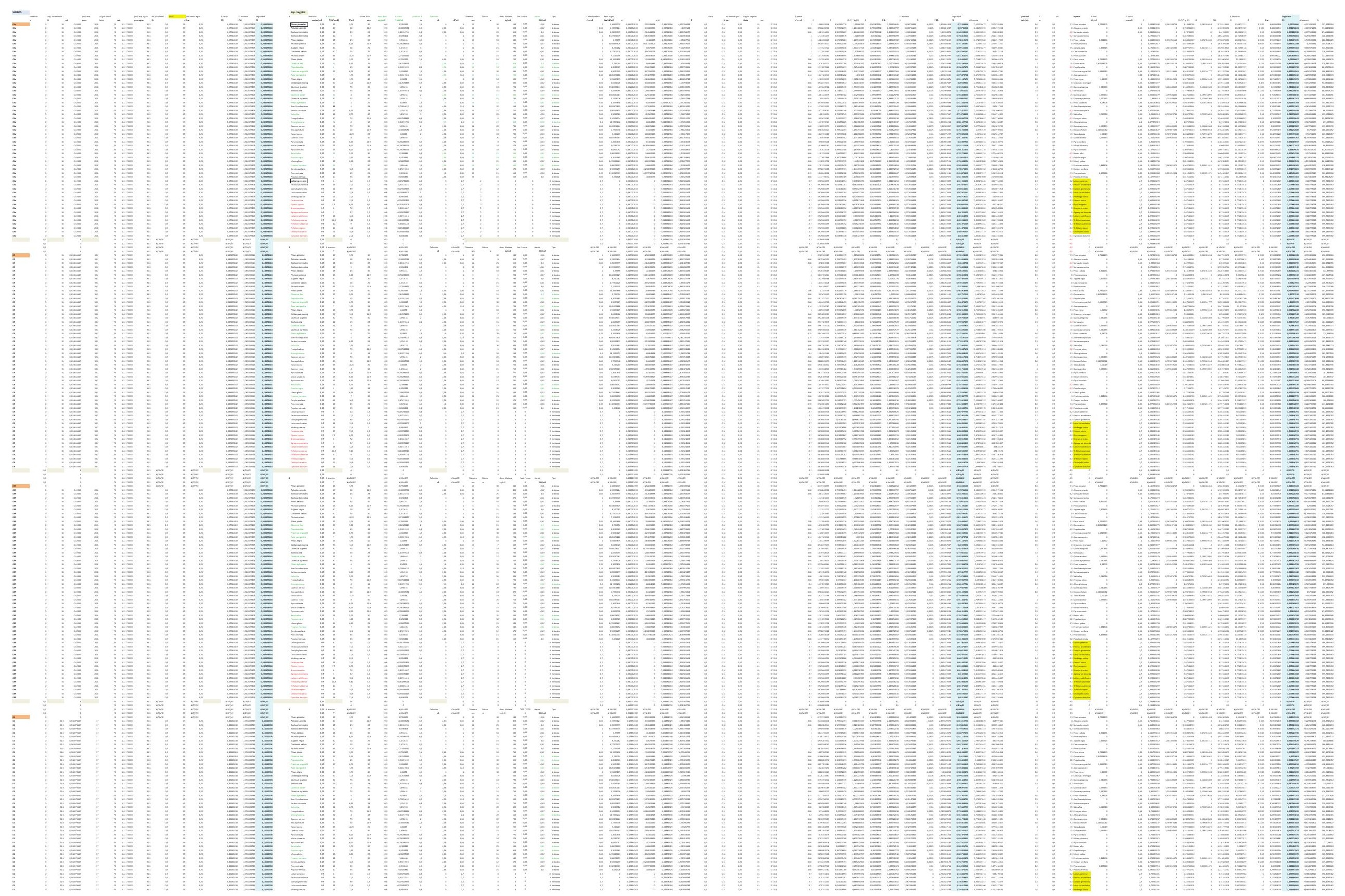

佰

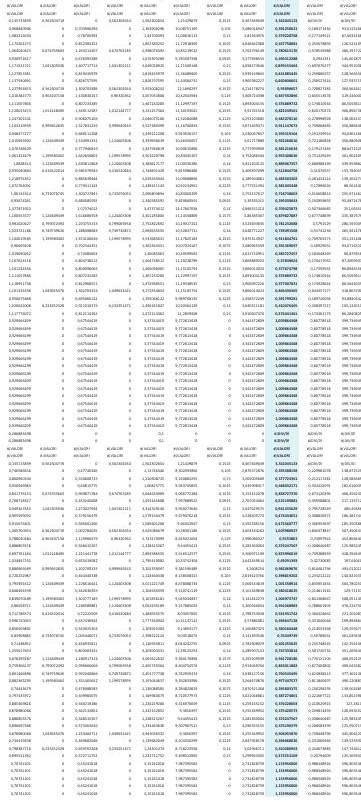




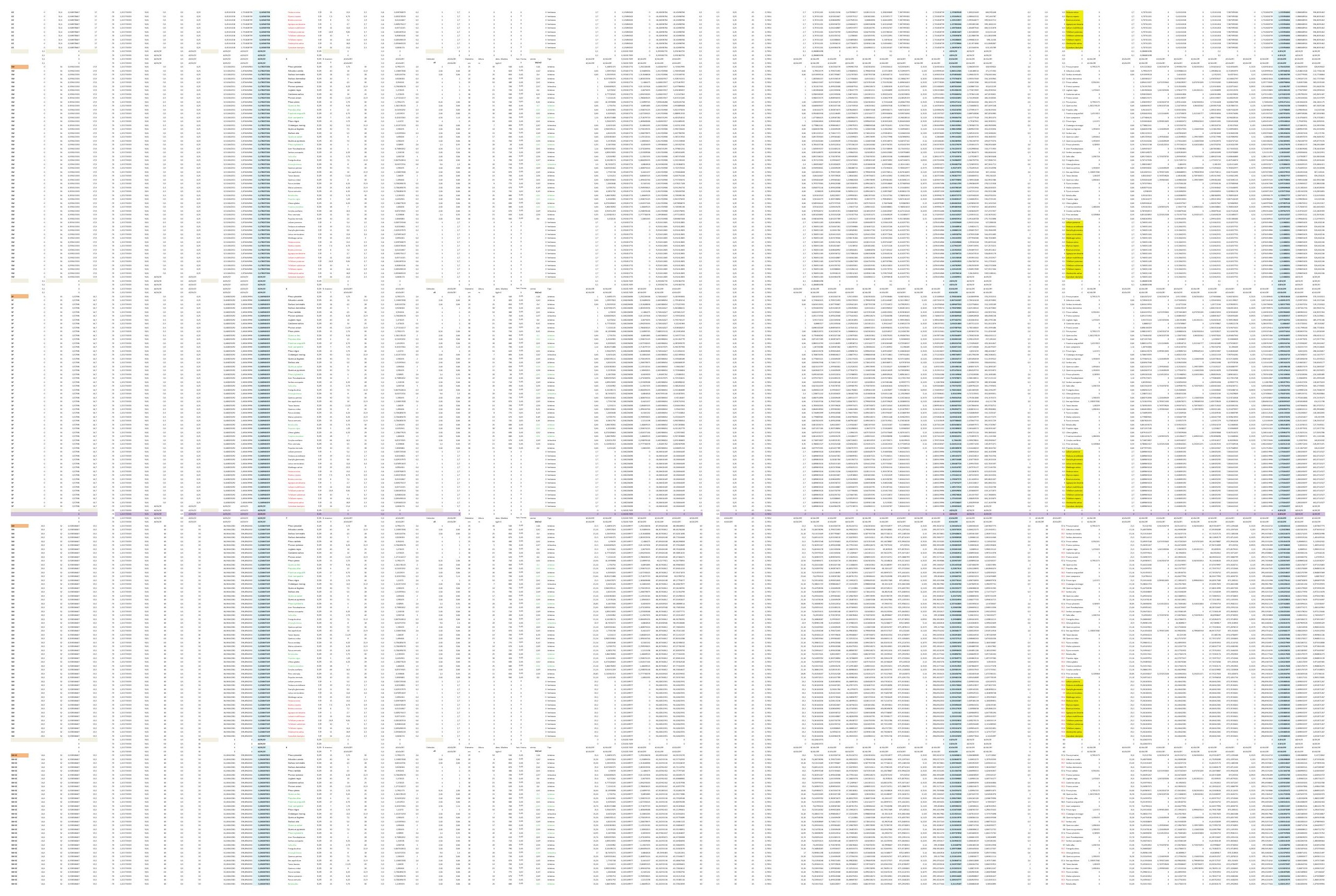




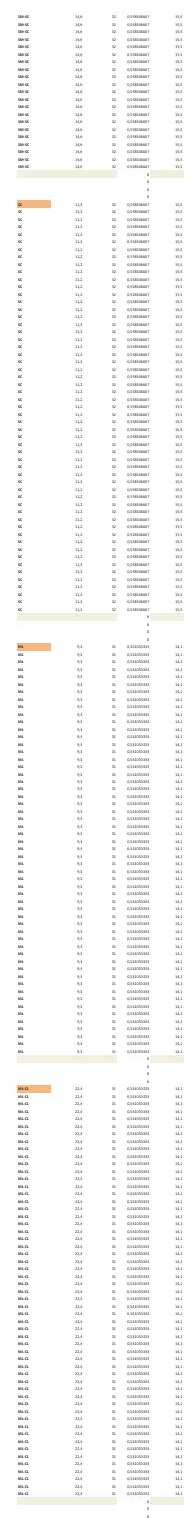

$-$
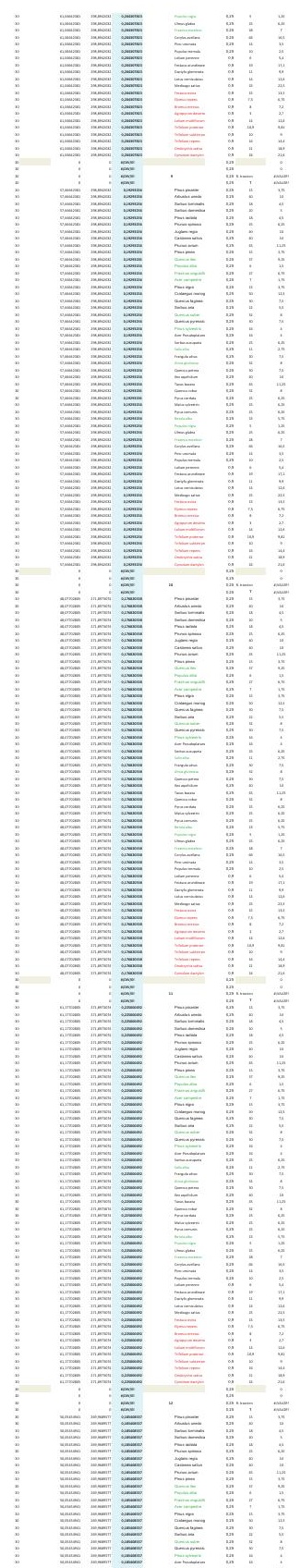

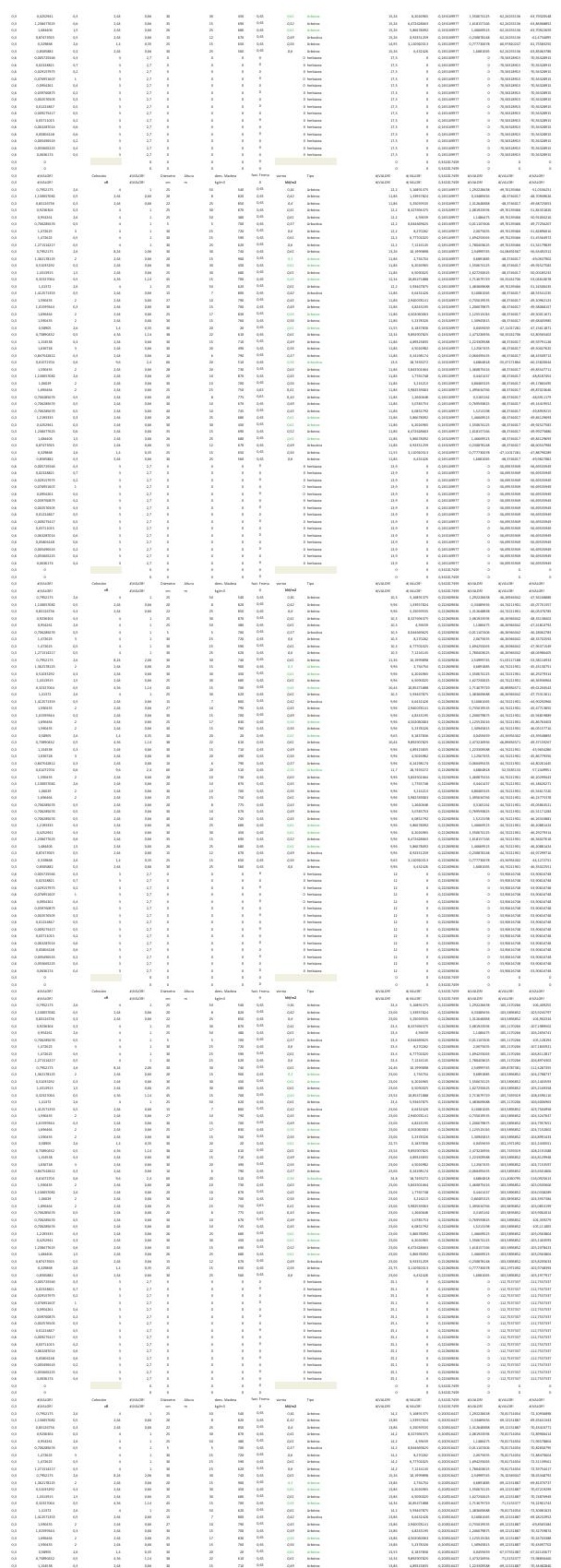

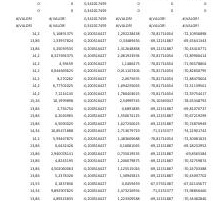

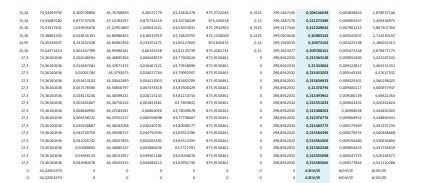

$\equiv$
$\equiv$
$\equiv$
$\equiv$

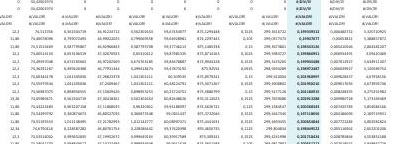

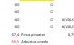

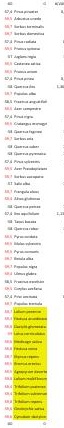
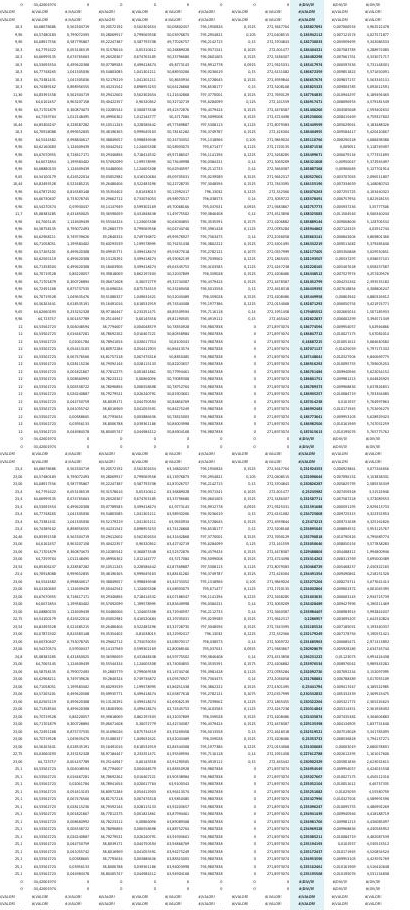

$-\equiv \equiv \equiv \equiv \equiv \equiv \equiv$

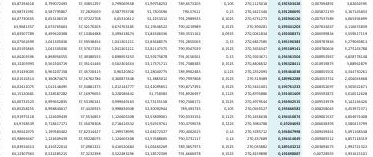

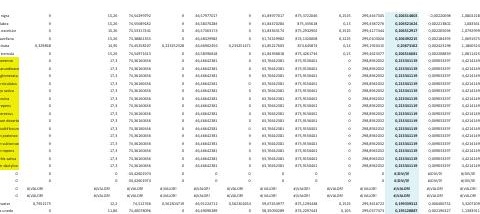
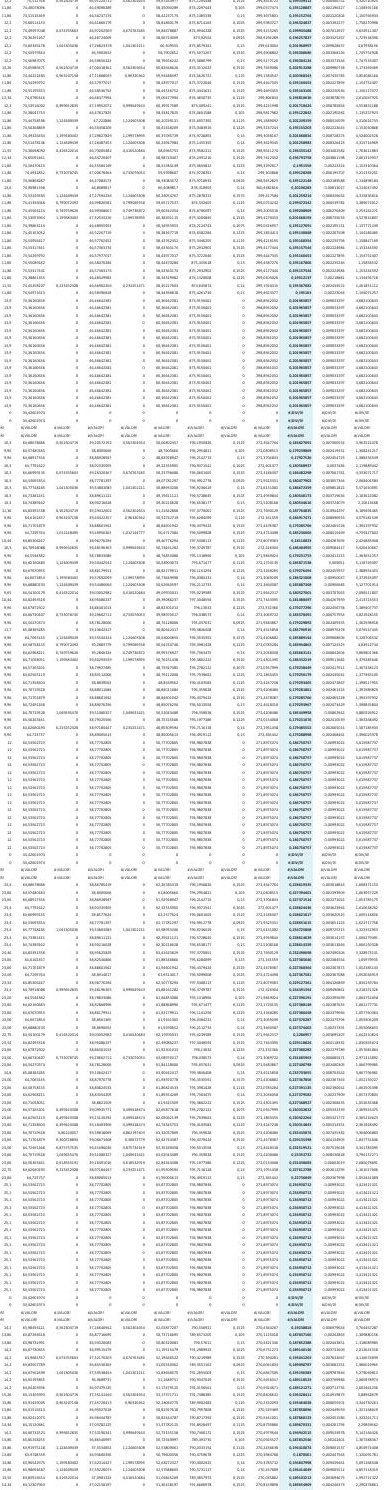


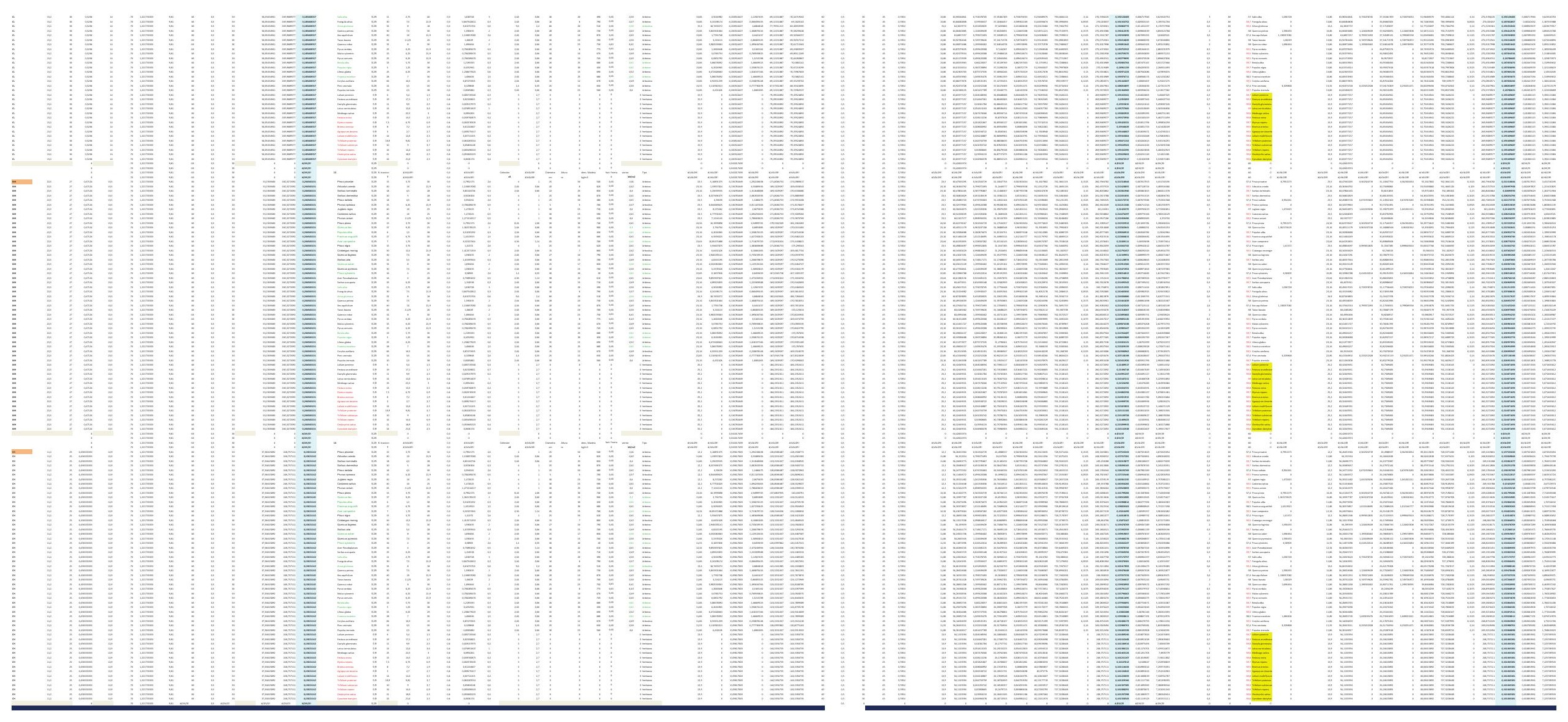



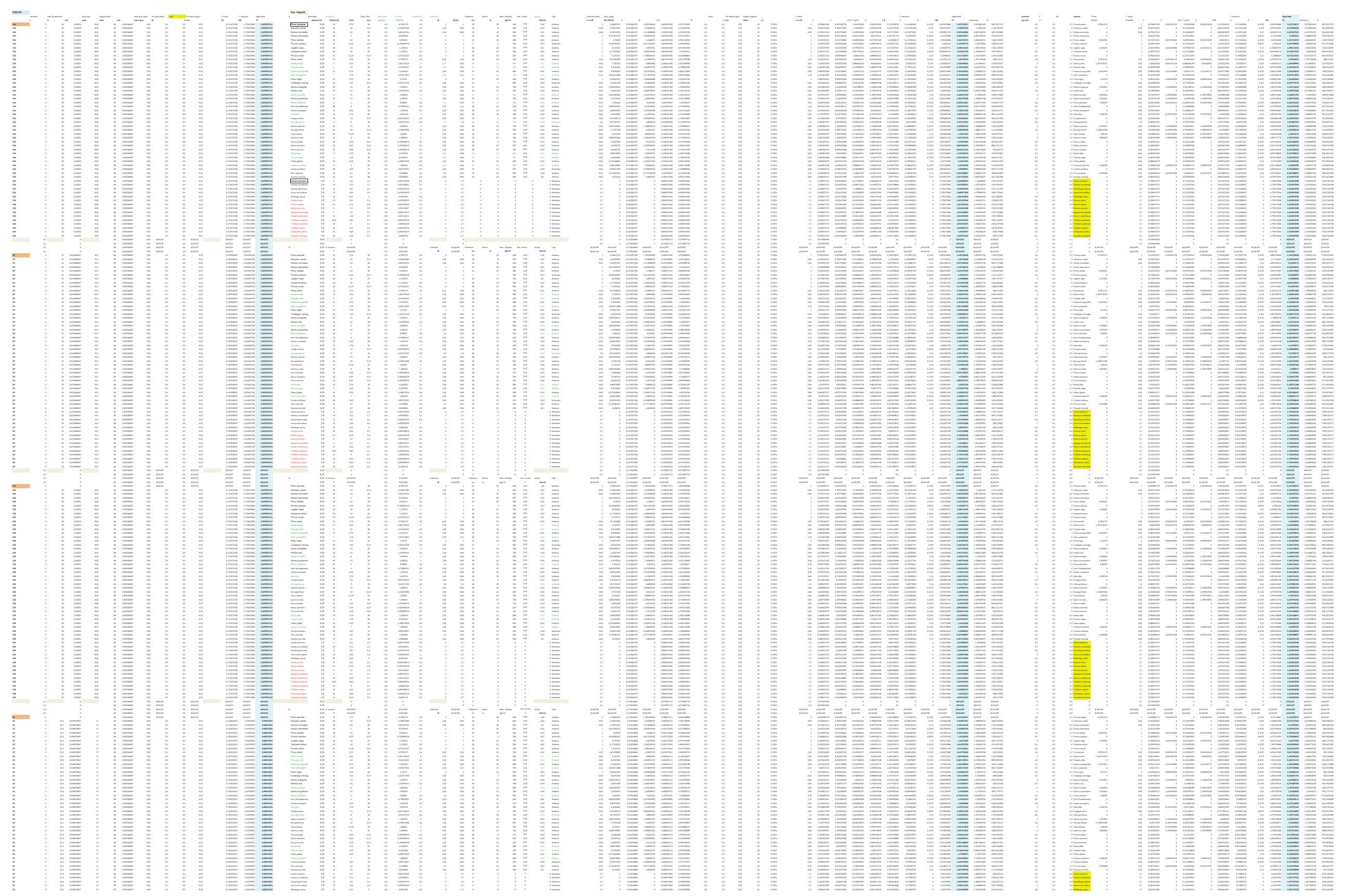

䎑

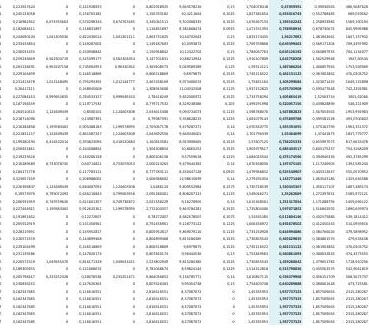




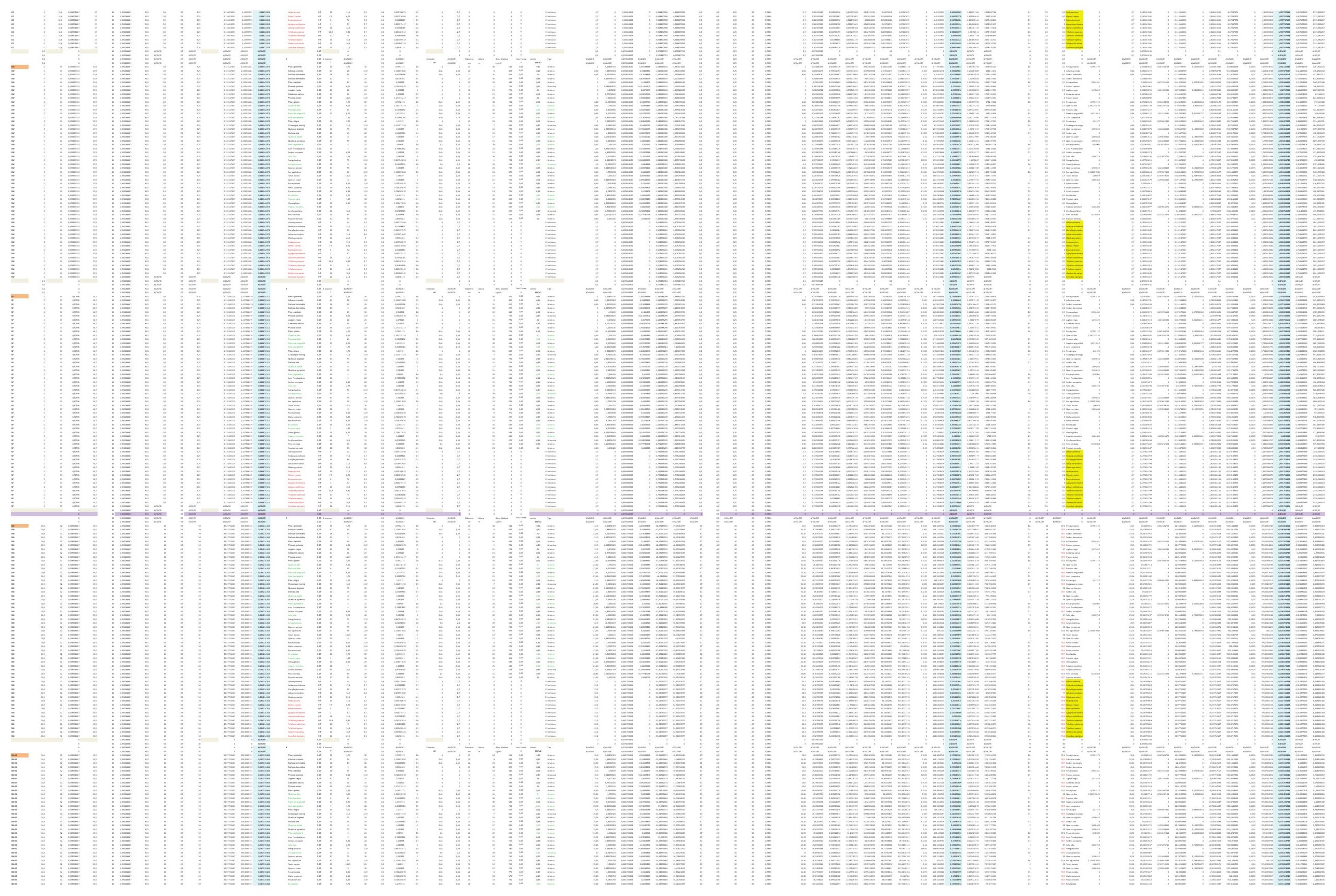



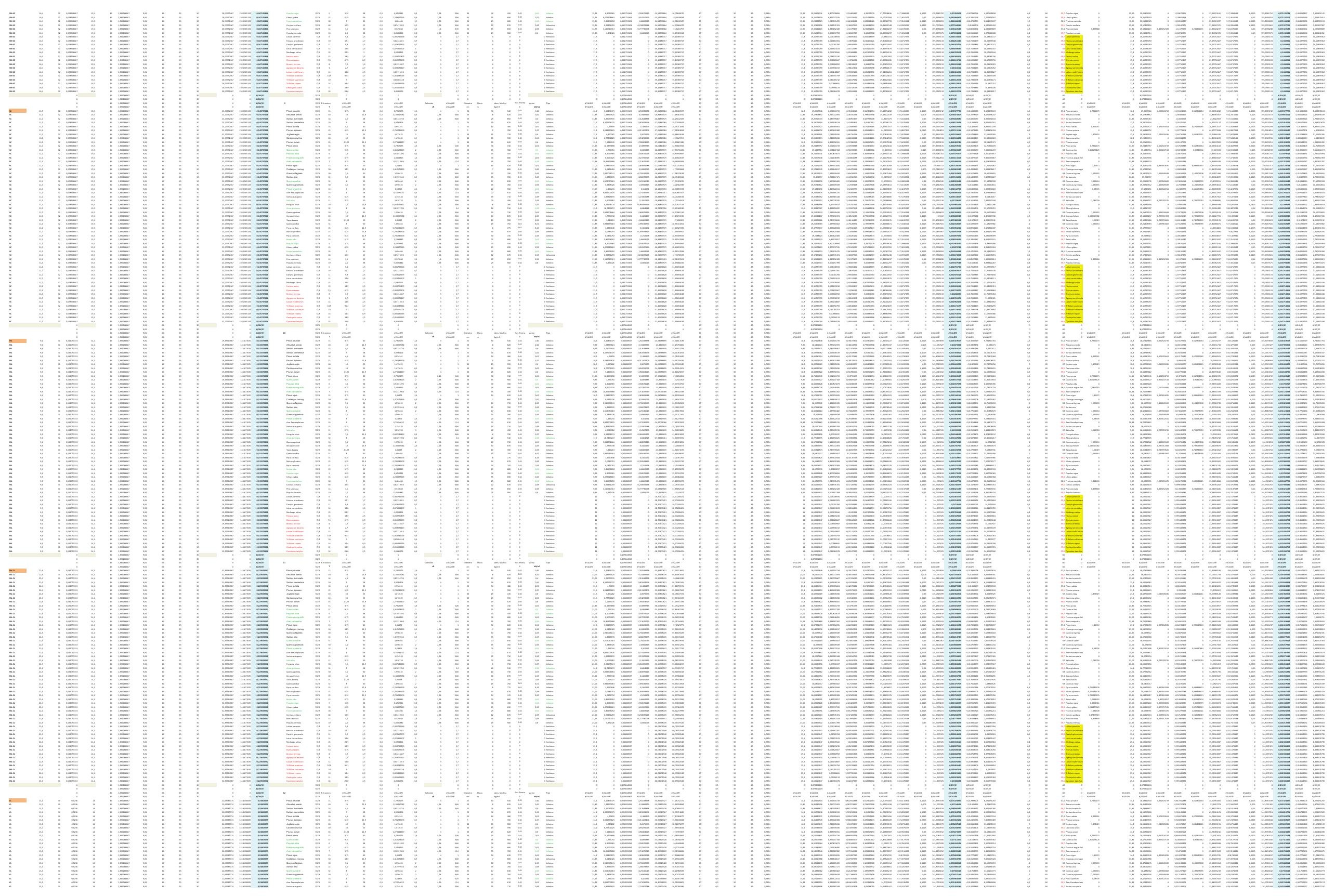


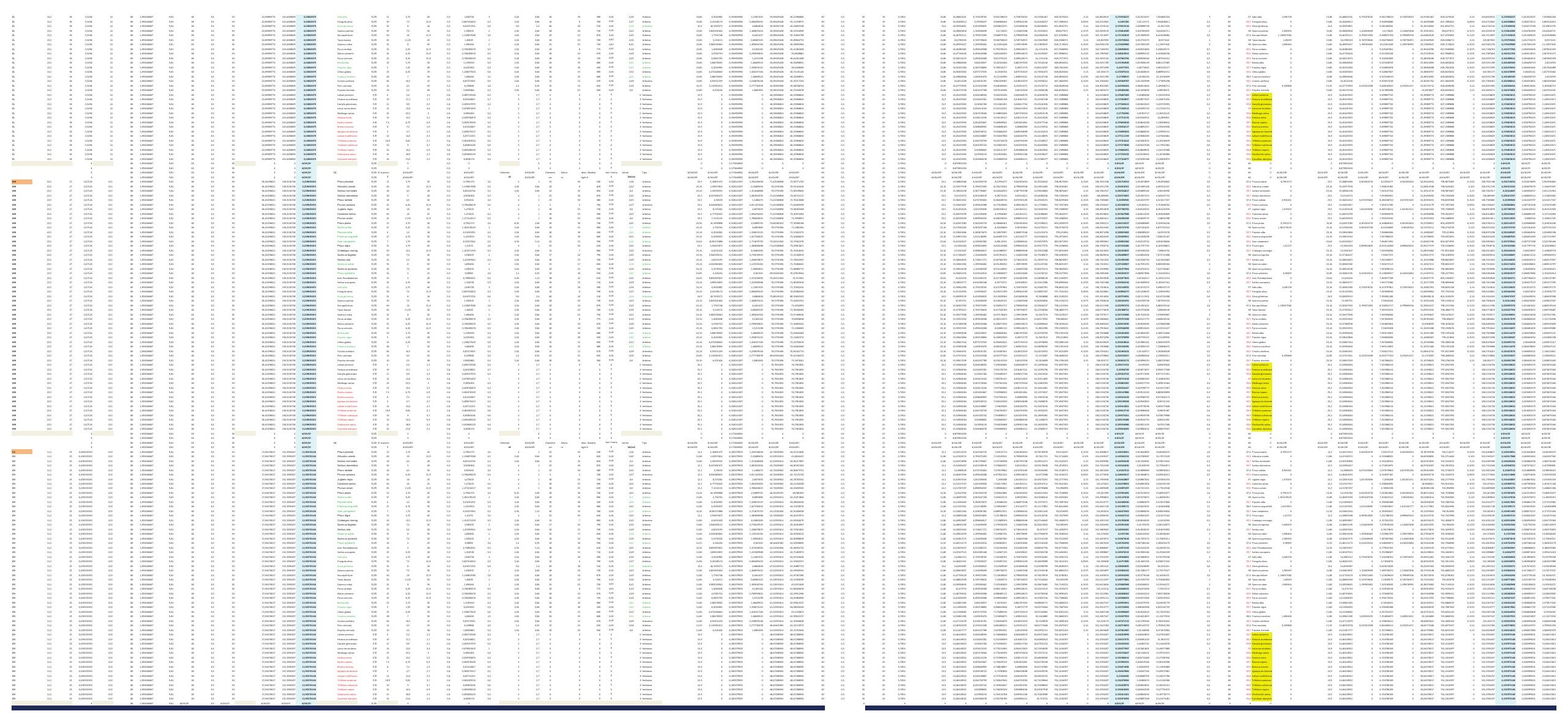


DESARROLLO DE UNA APLICACIÓN IMFORMÁTICA PARA EL CÁLCULO DE SOSTENIMIENTO DE TALUDES MEDIANTE VEGETACIÓN

A01. DENSIDAD DE PLANTACIÓN: 600 plantas/ha.

\section{A01-5.POSICIÓN N.F. 5}

INCLINACIÓN DE TALUD 6-100

INCLINACIÓN DE TALUD 10-200

INCLINACIÓN DE TALUD 20-30

INCLINACIÓN DE TALUD 30-40

INCLINACIÓN DE TALUD $35^{\circ}$

INCLINACIÓN DE TALUD 40-50

INCLINACIÓN DE TALUD 50-550

INCLINACIÓN DE TALUD 55-60

INCLINACIÓN DE TALUD 60-700

INCLINACIÓN DE TALUD 70-80 

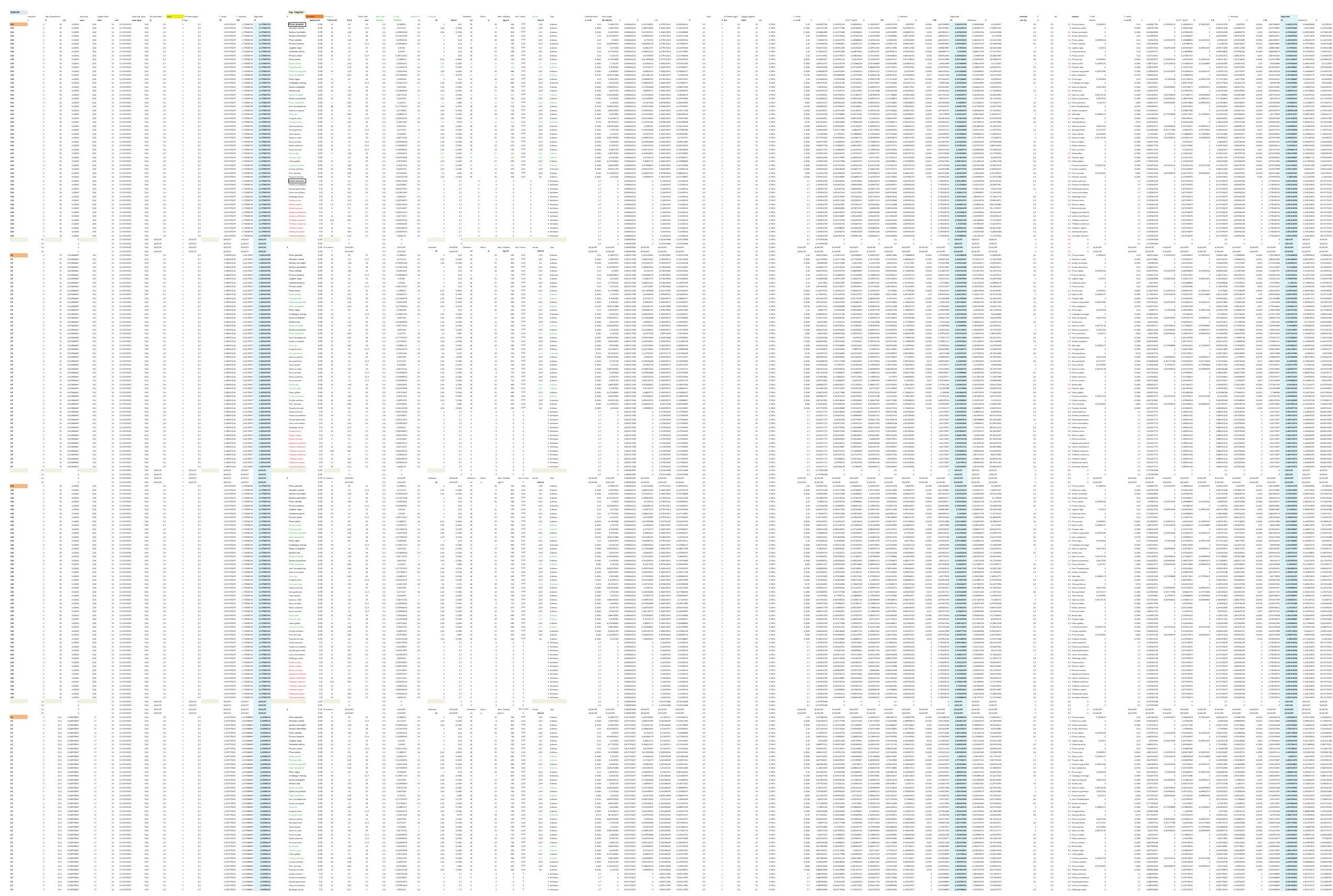

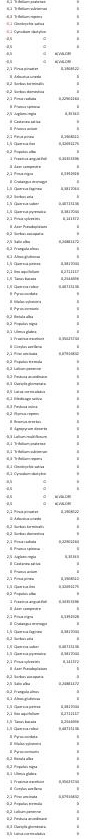

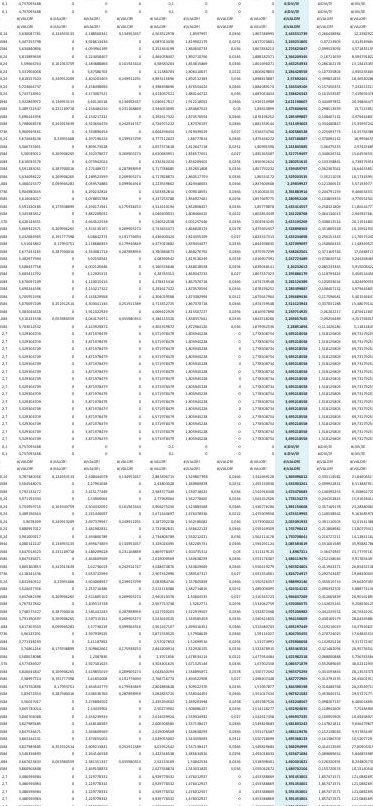




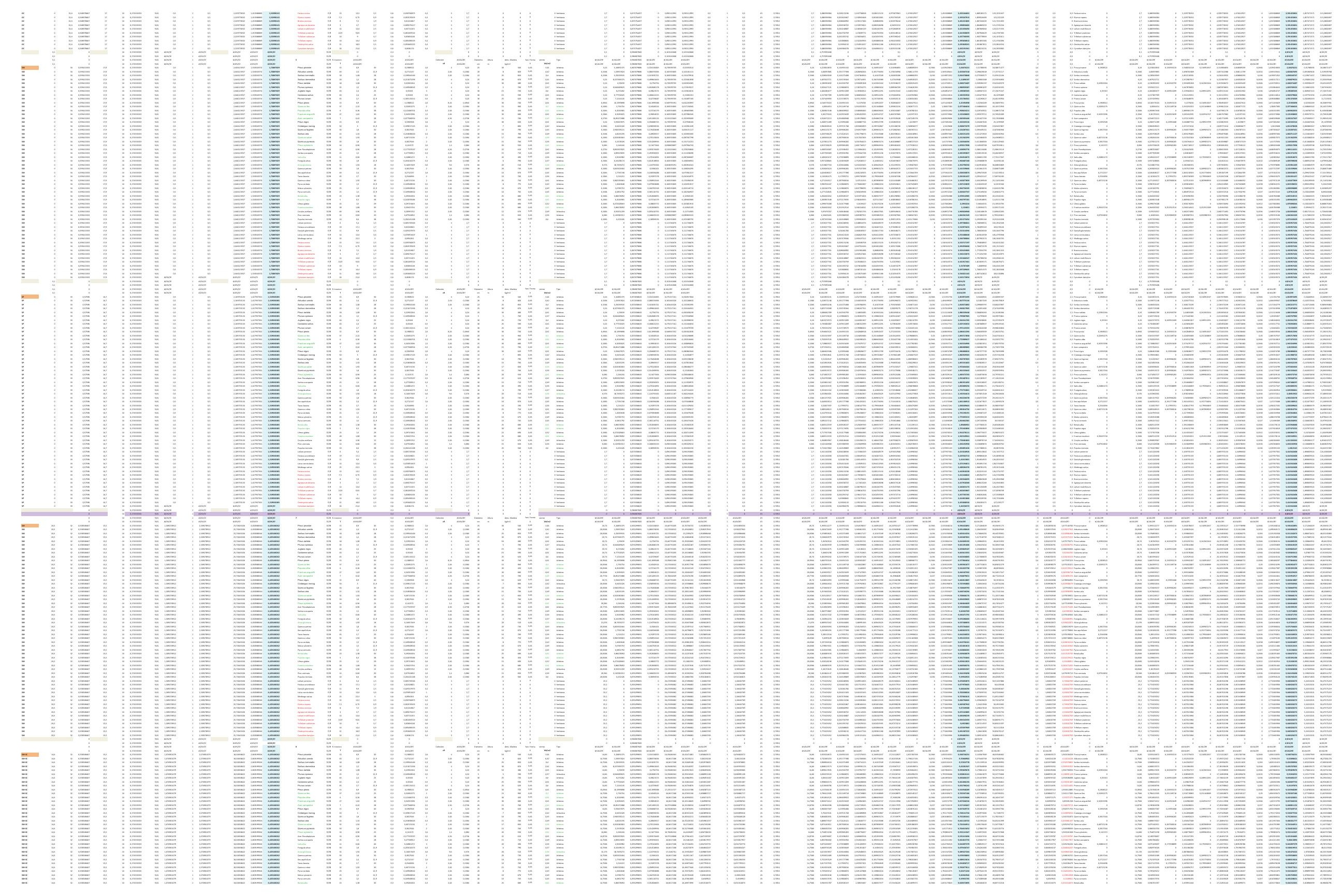



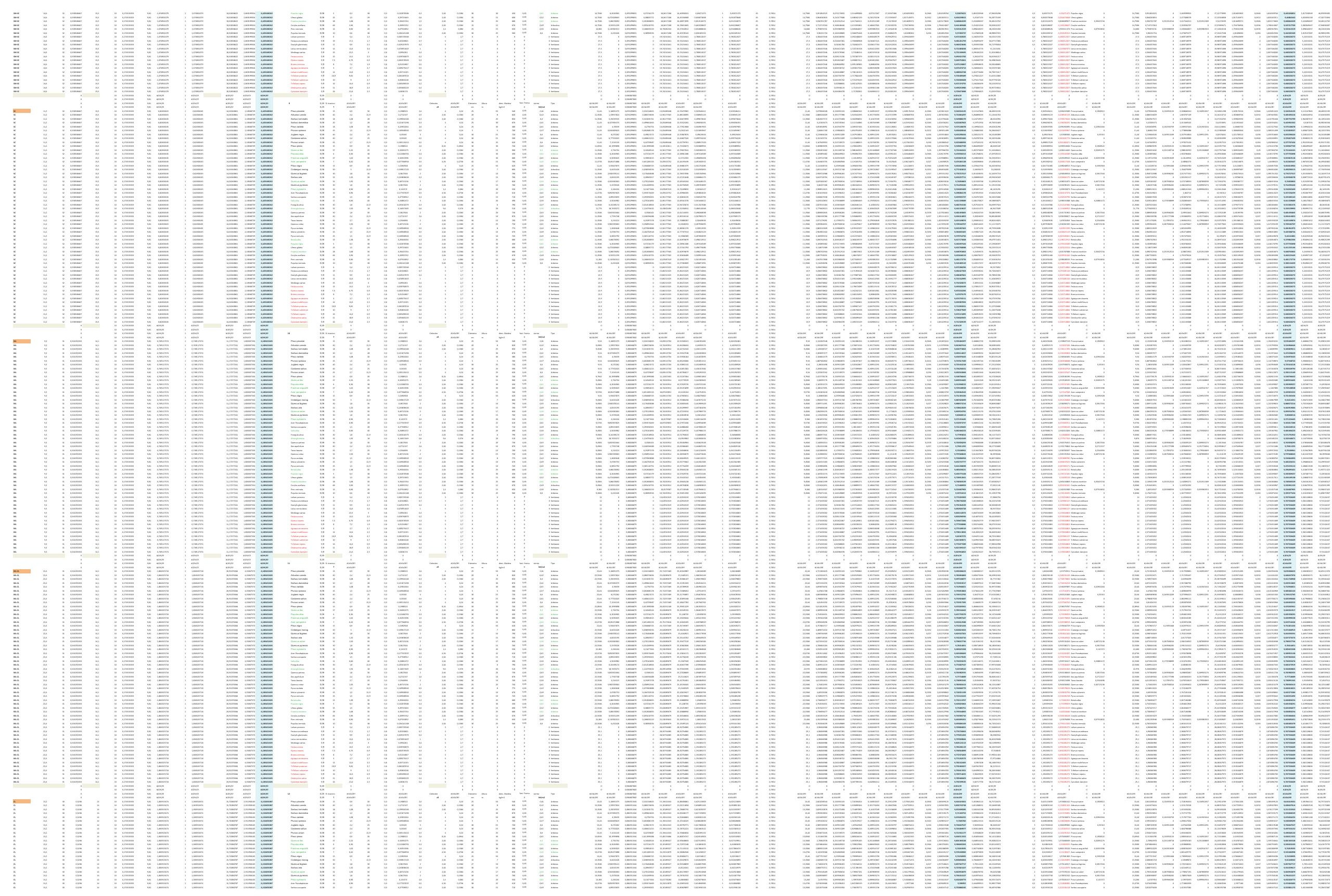

敃=
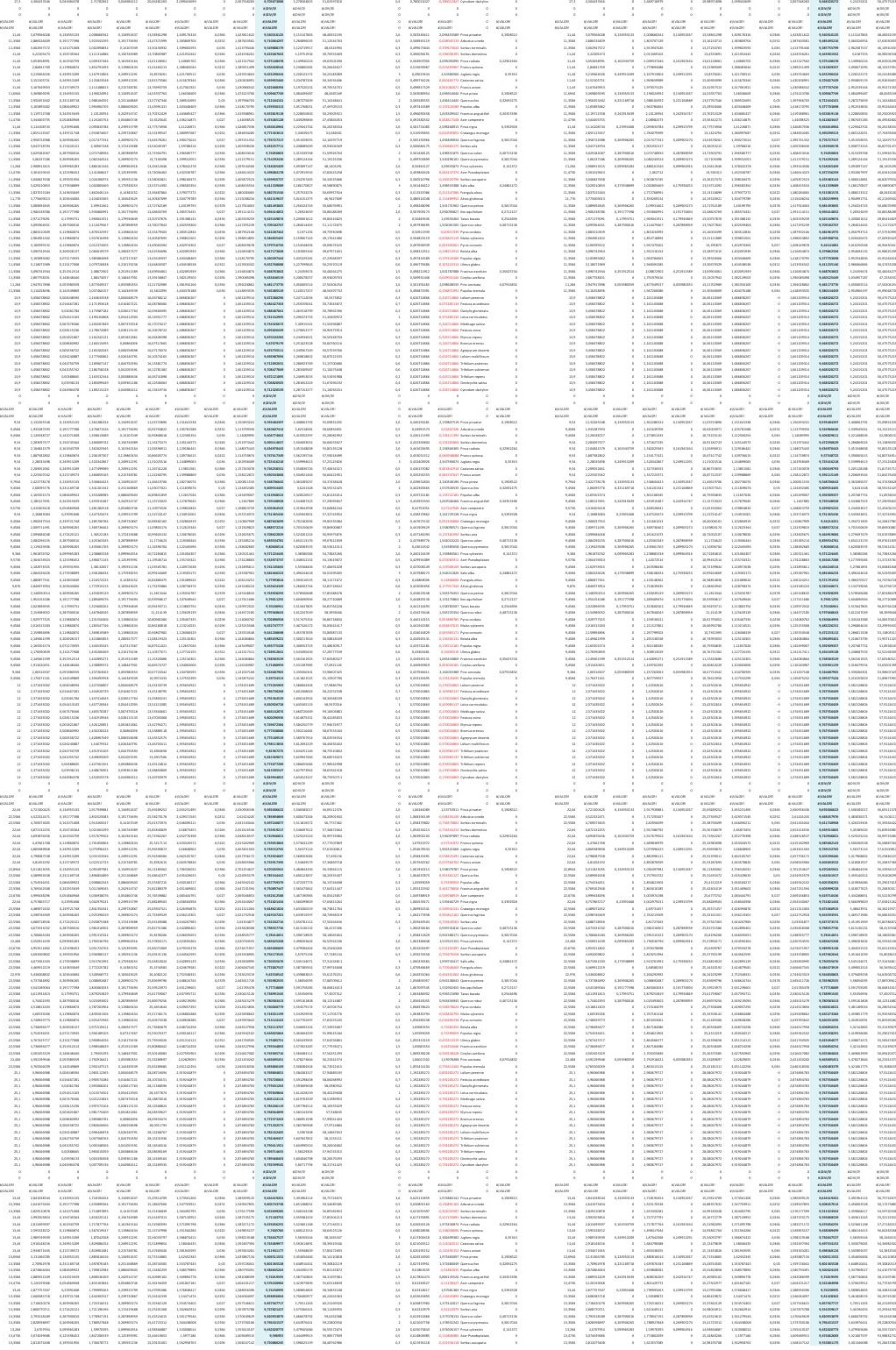

$=\equiv \equiv \equiv \equiv \equiv \equiv$

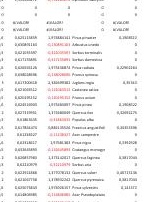




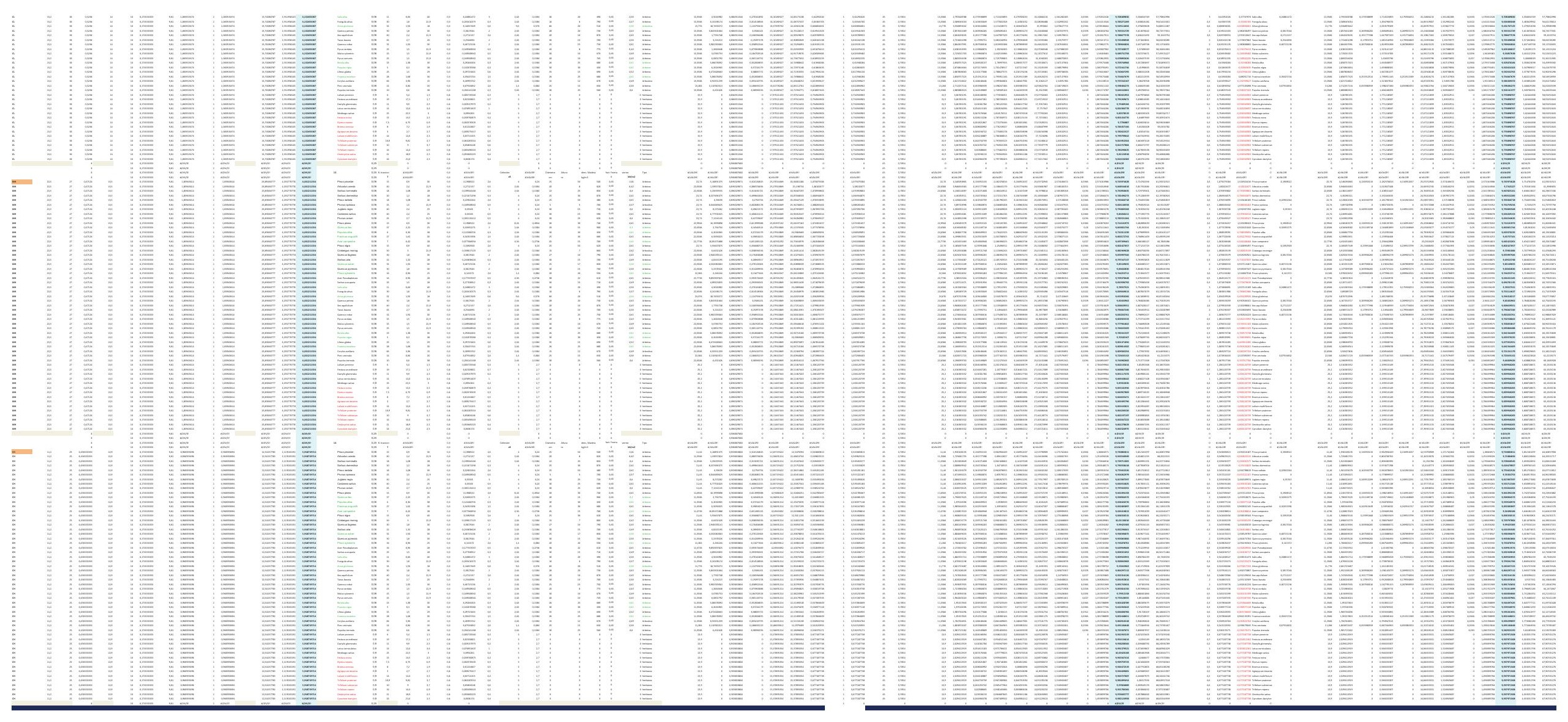



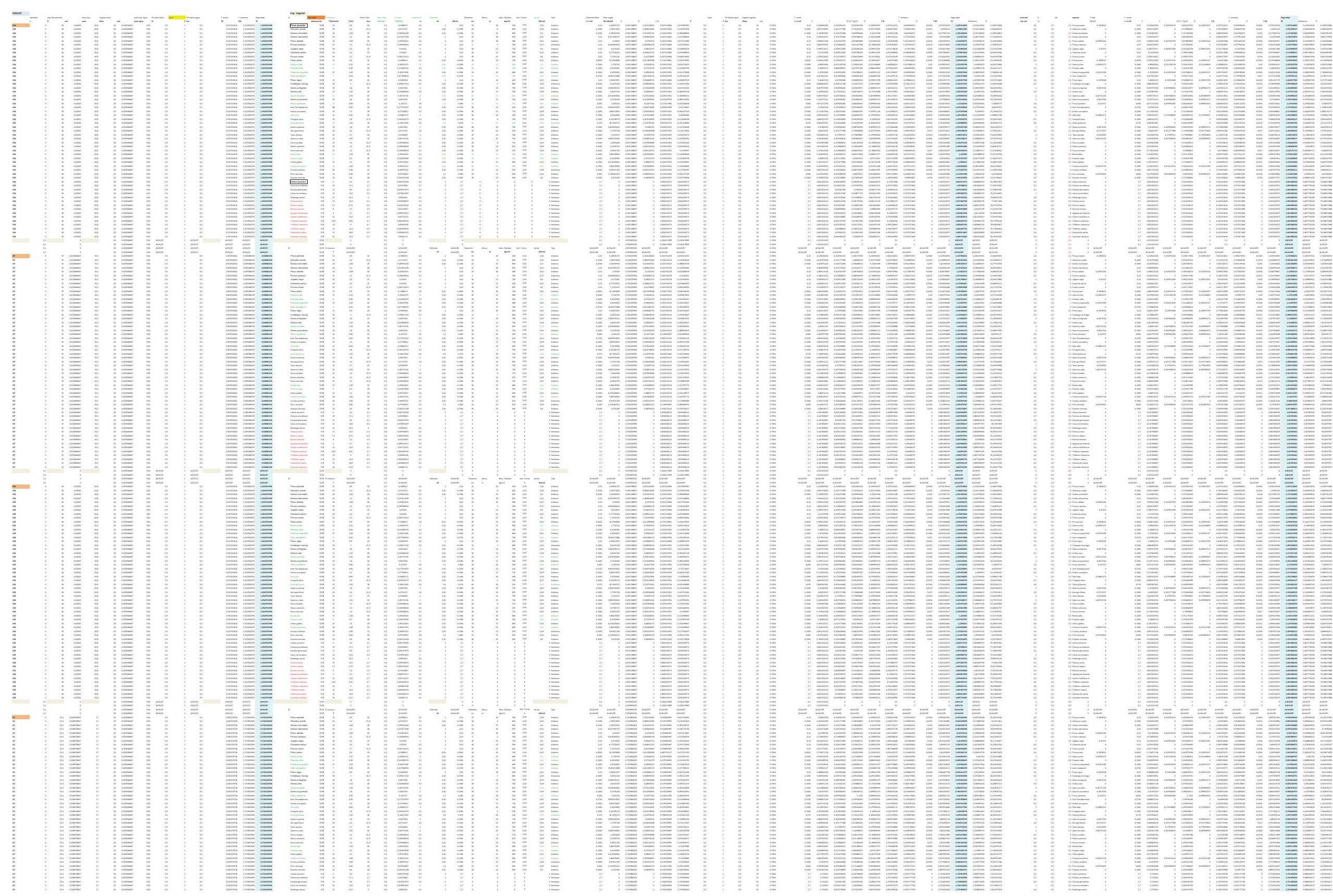


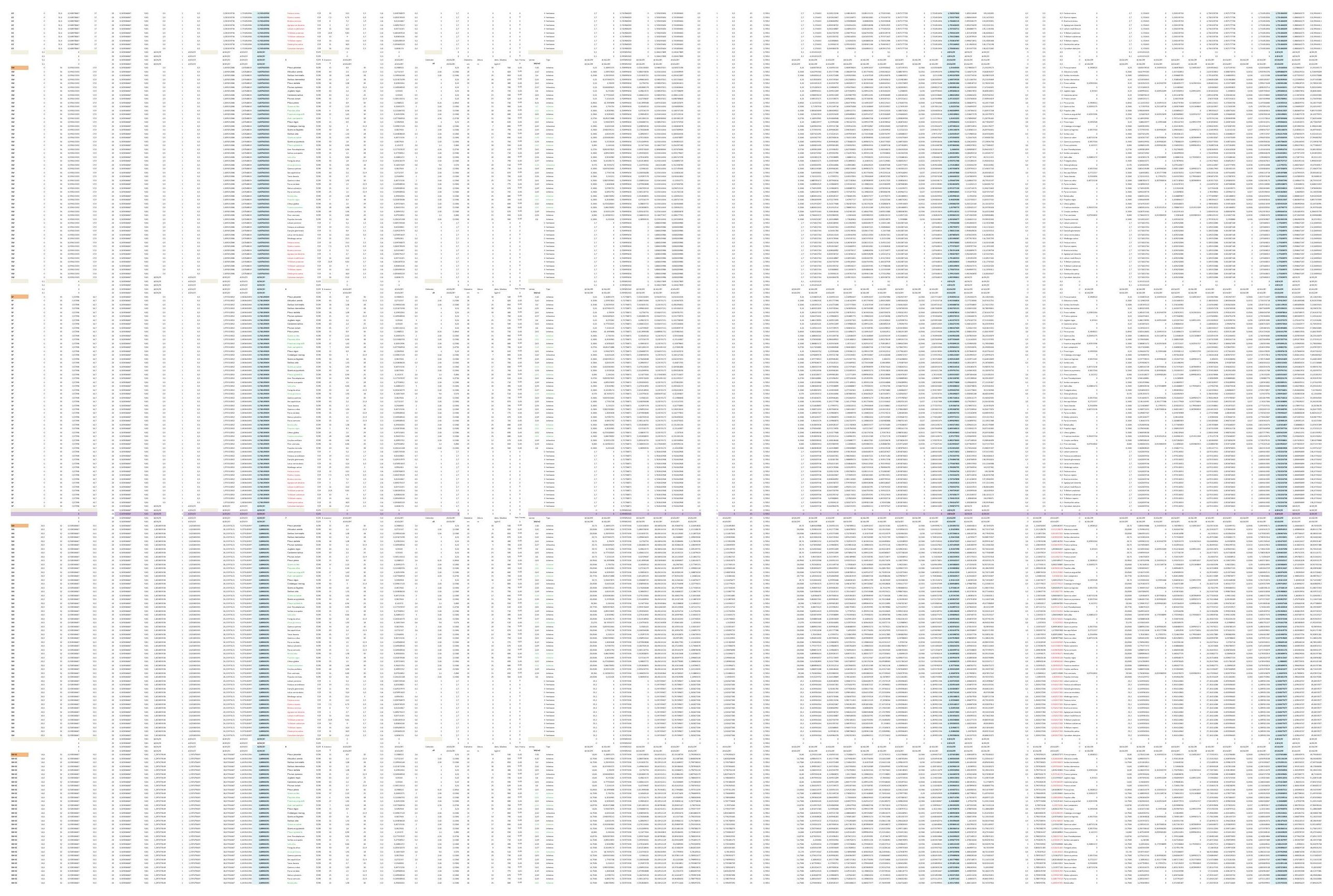



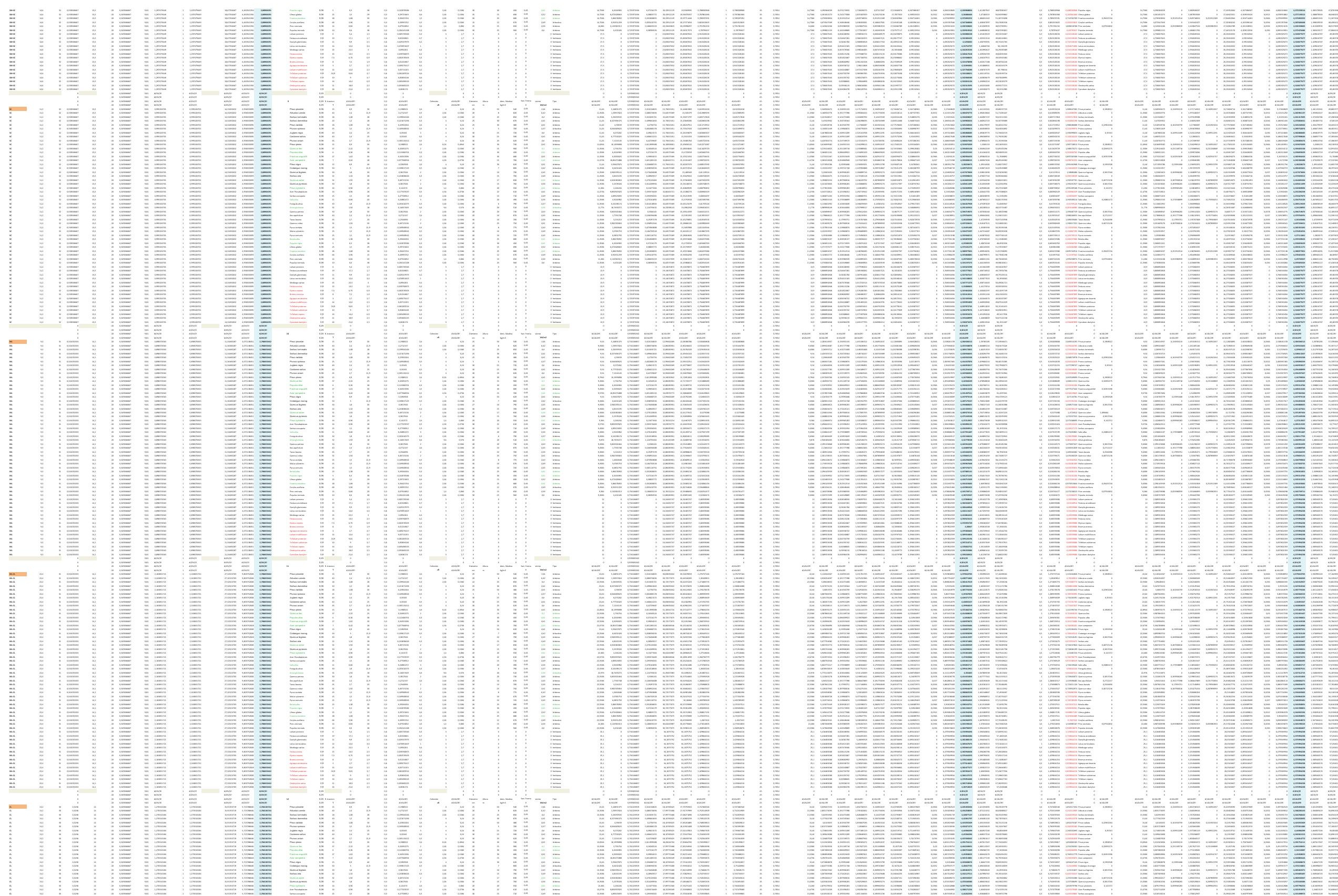

$\equiv \equiv$
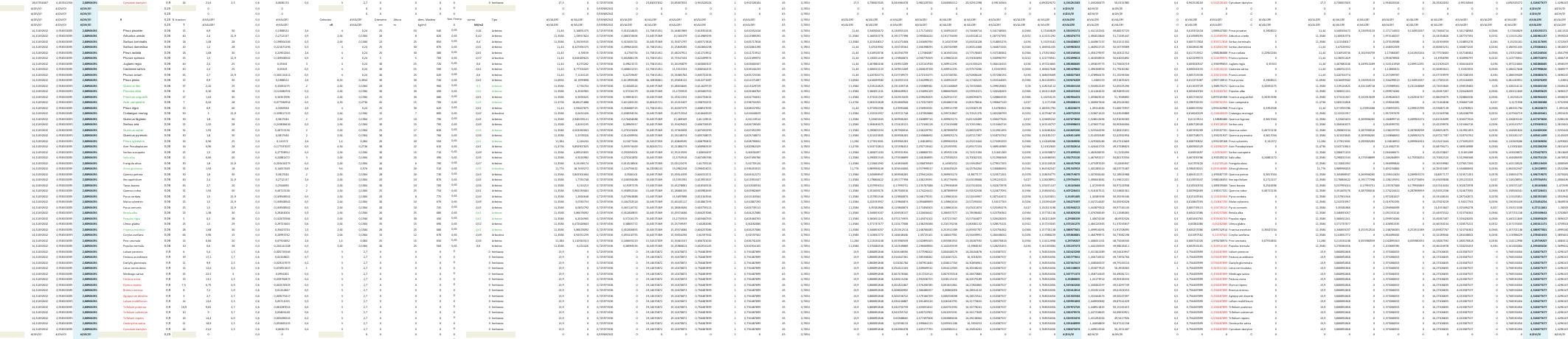

$=$

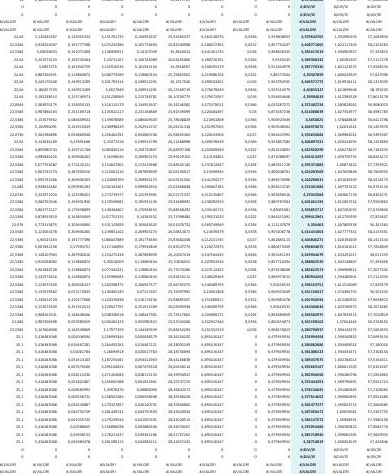

$=$

$=\equiv \equiv \equiv \equiv \equiv \equiv \equiv \equiv$

$\equiv \equiv$
$\equiv \equiv$
$\equiv \equiv$

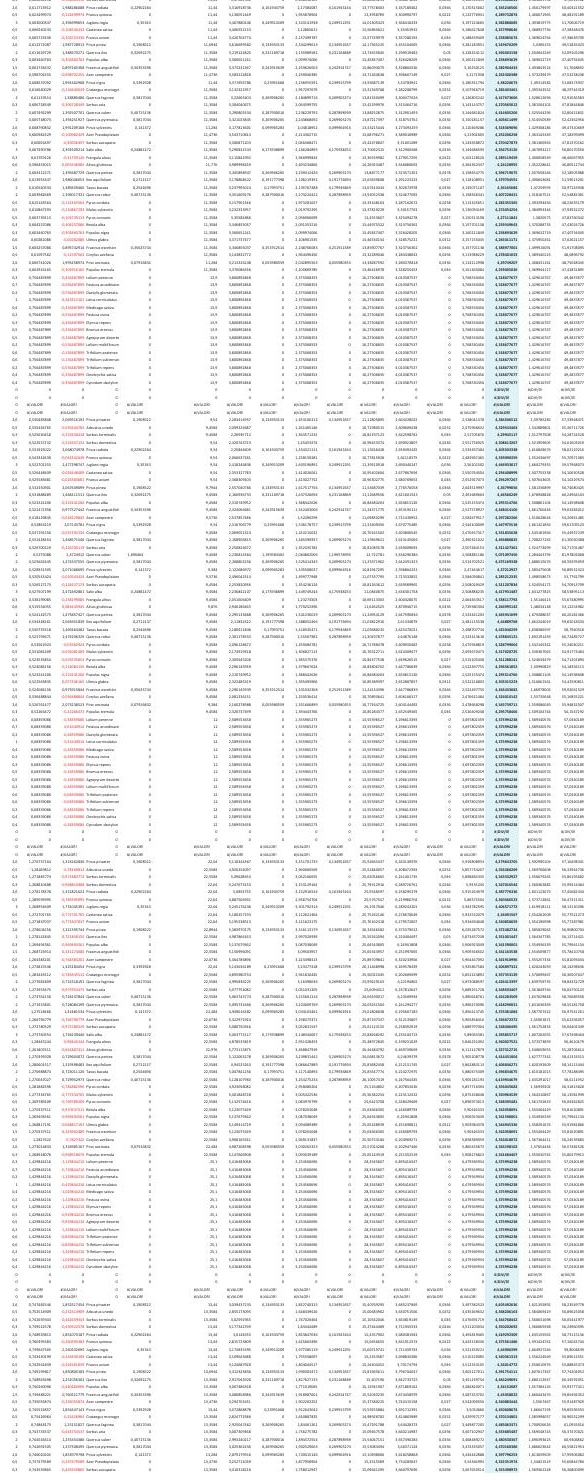

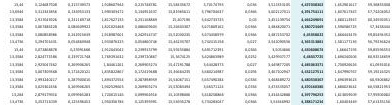




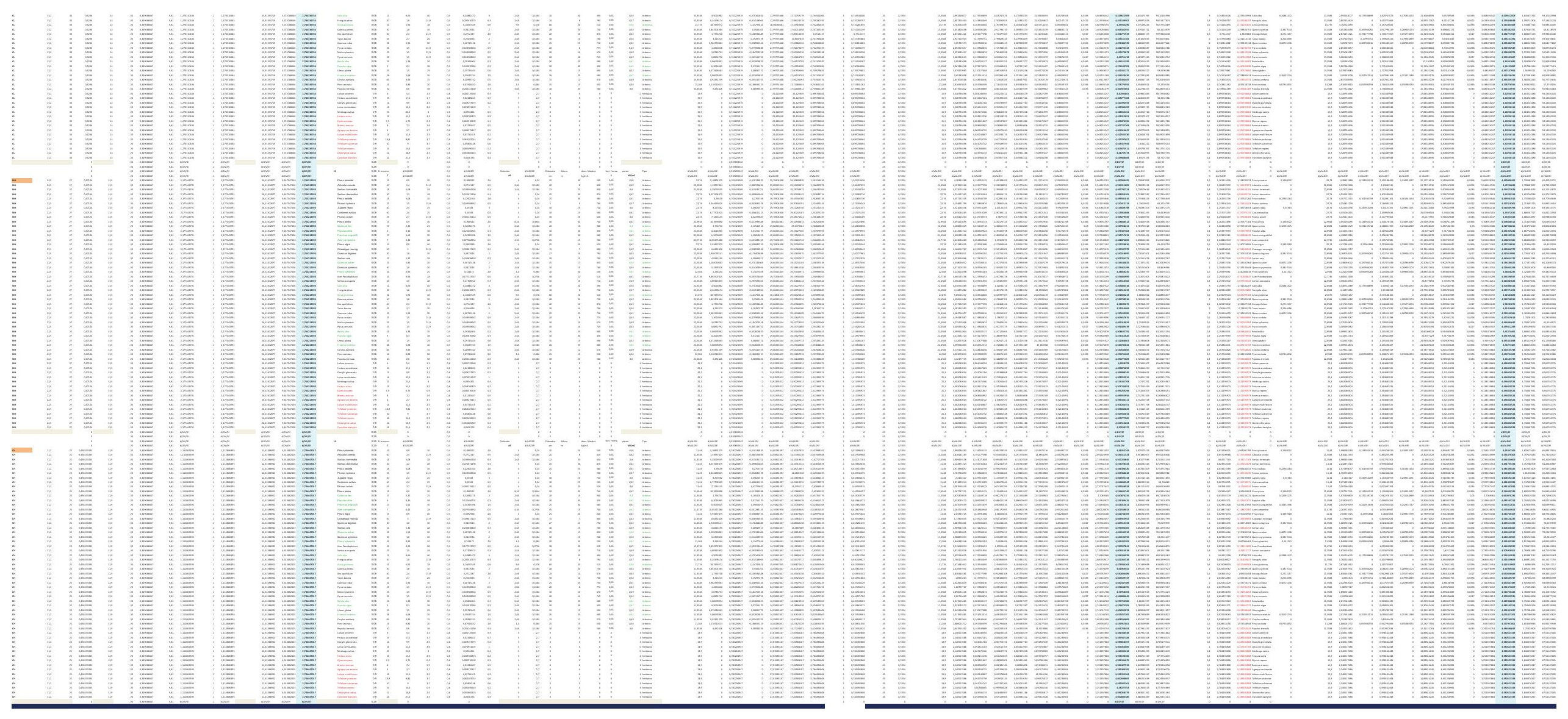



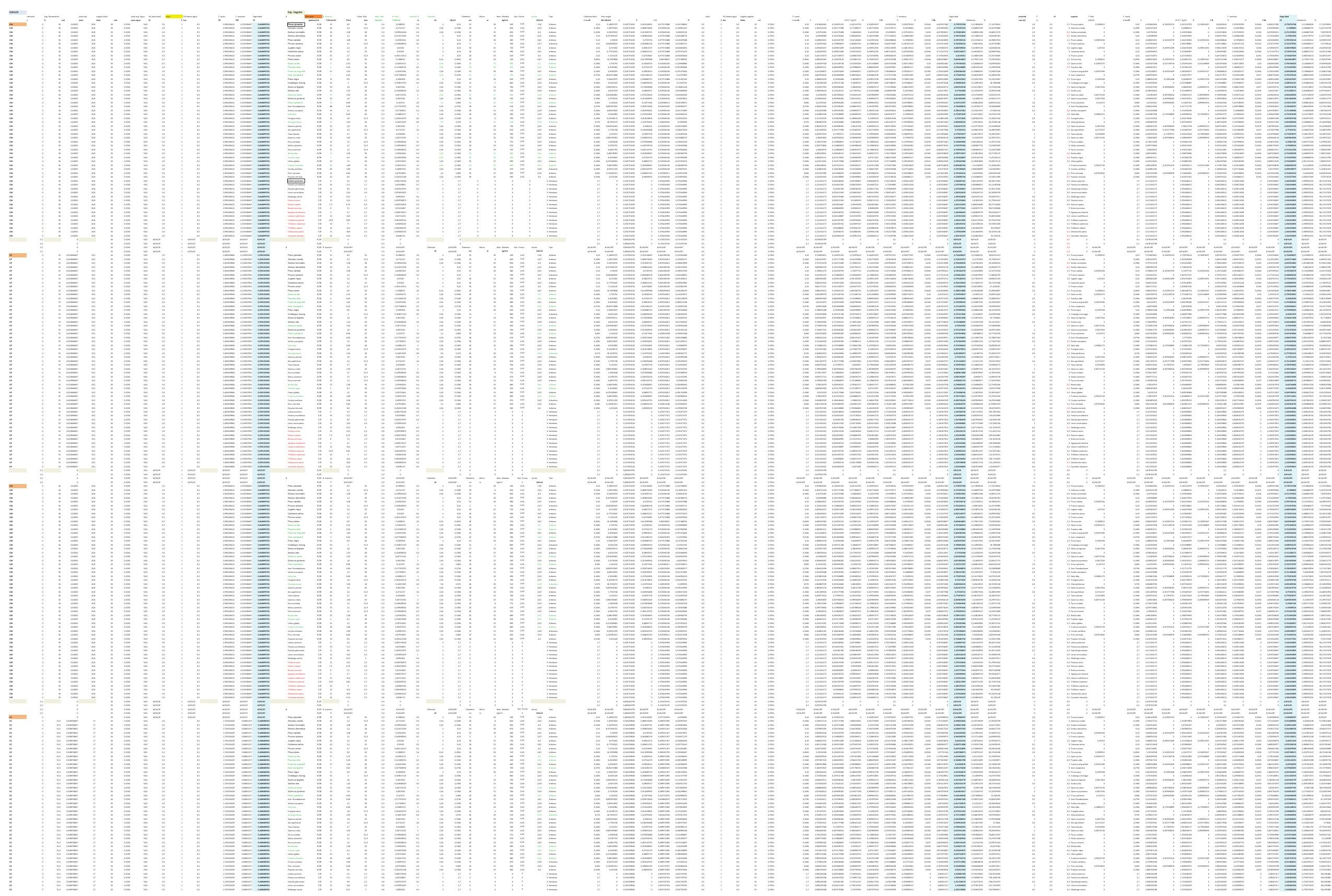

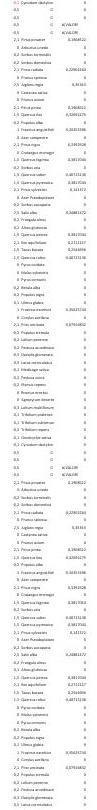

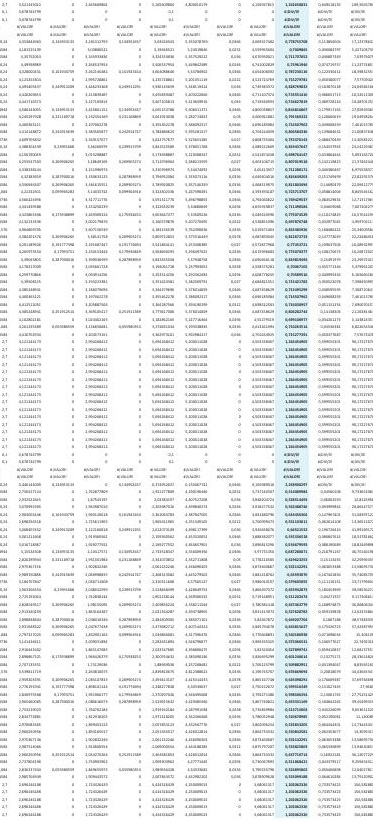




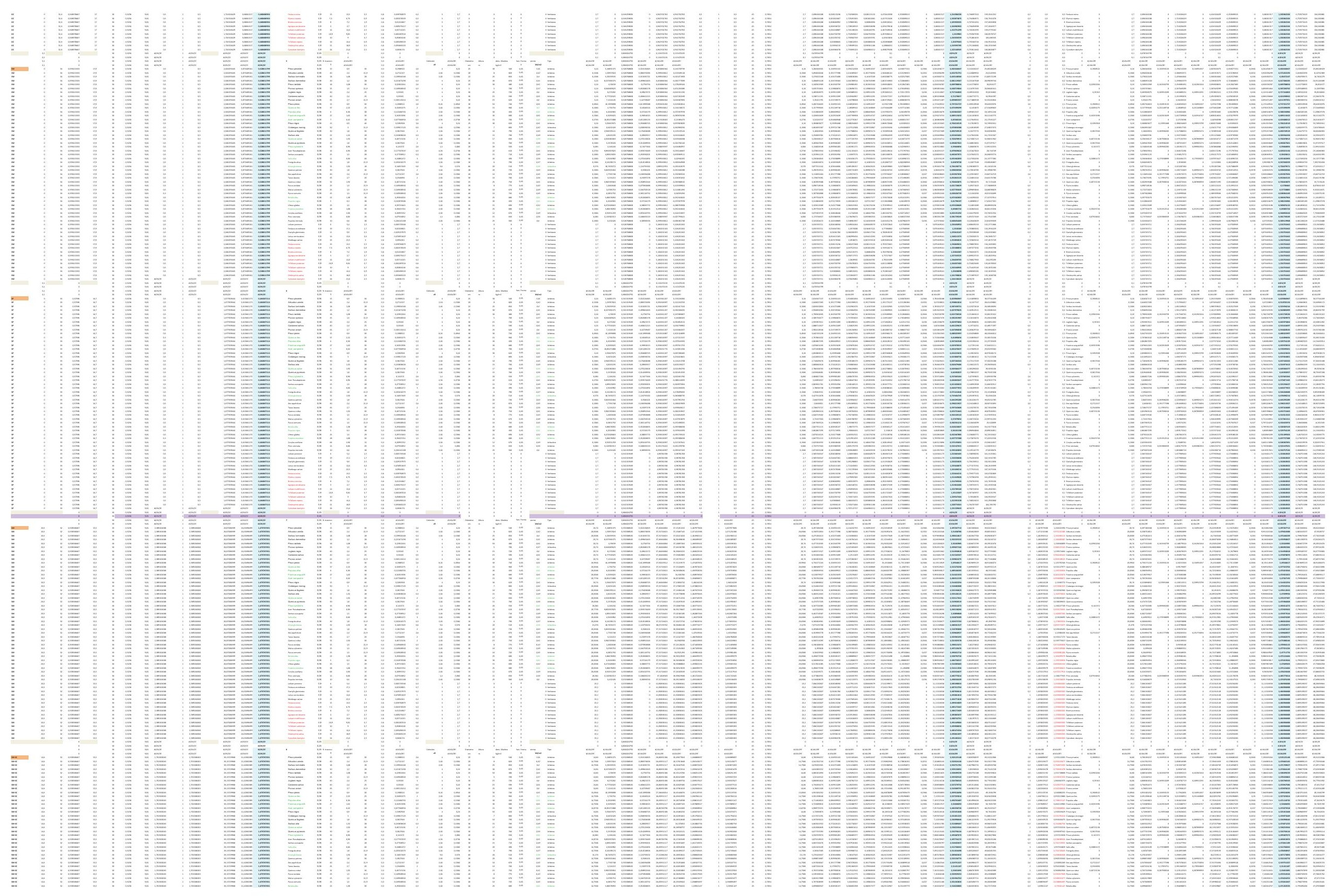



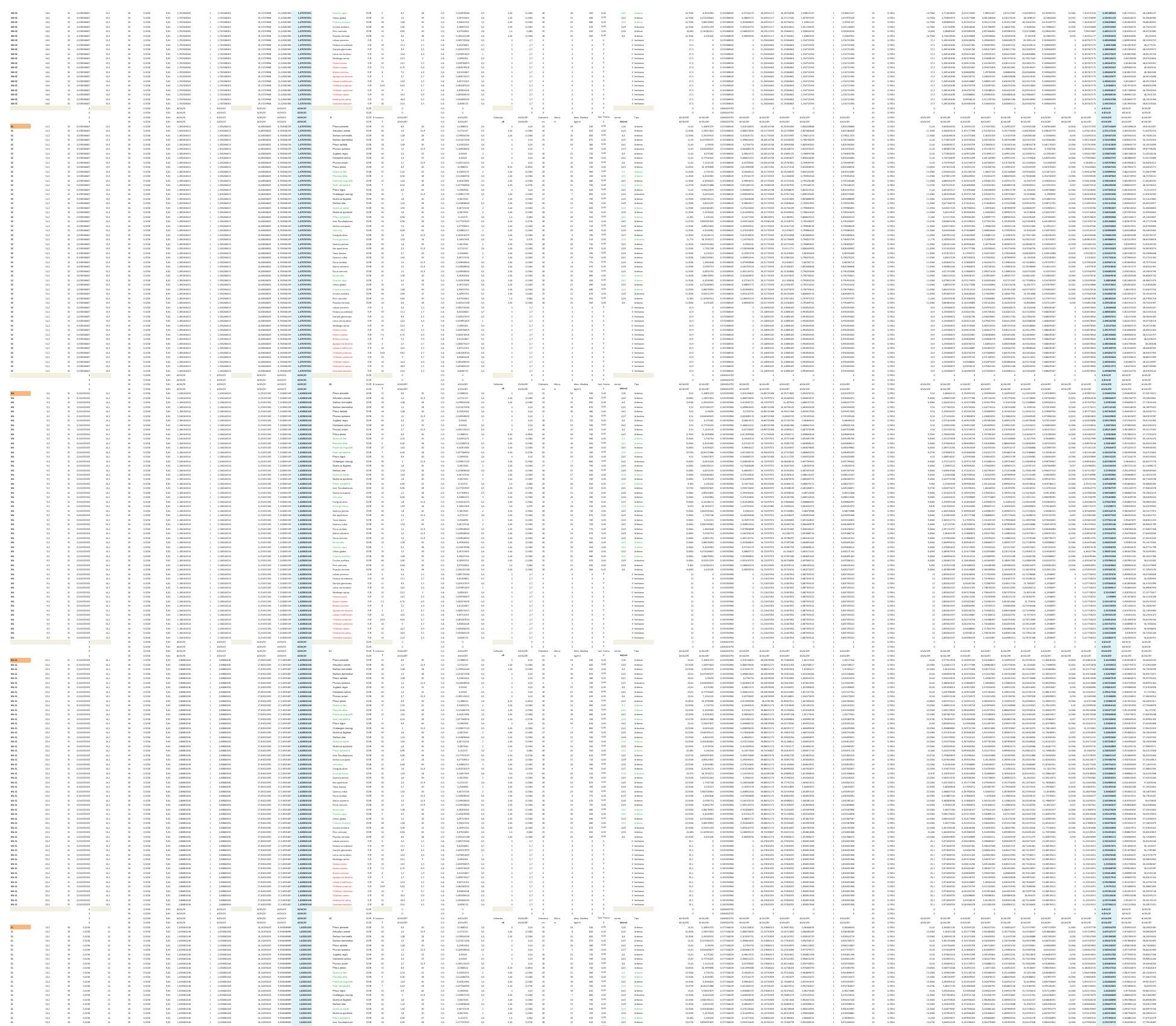

${ }^{\circ}{ }^{\circ} \equiv \equiv$
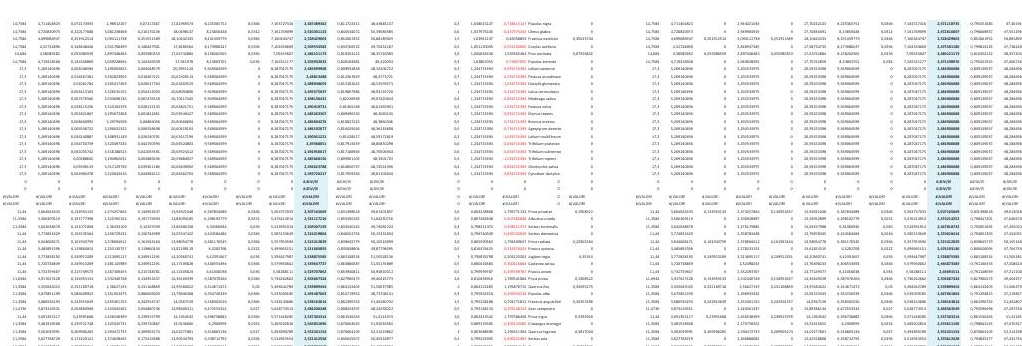

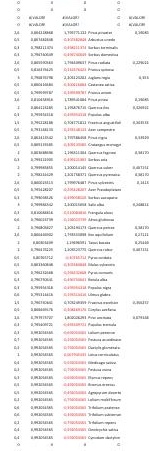
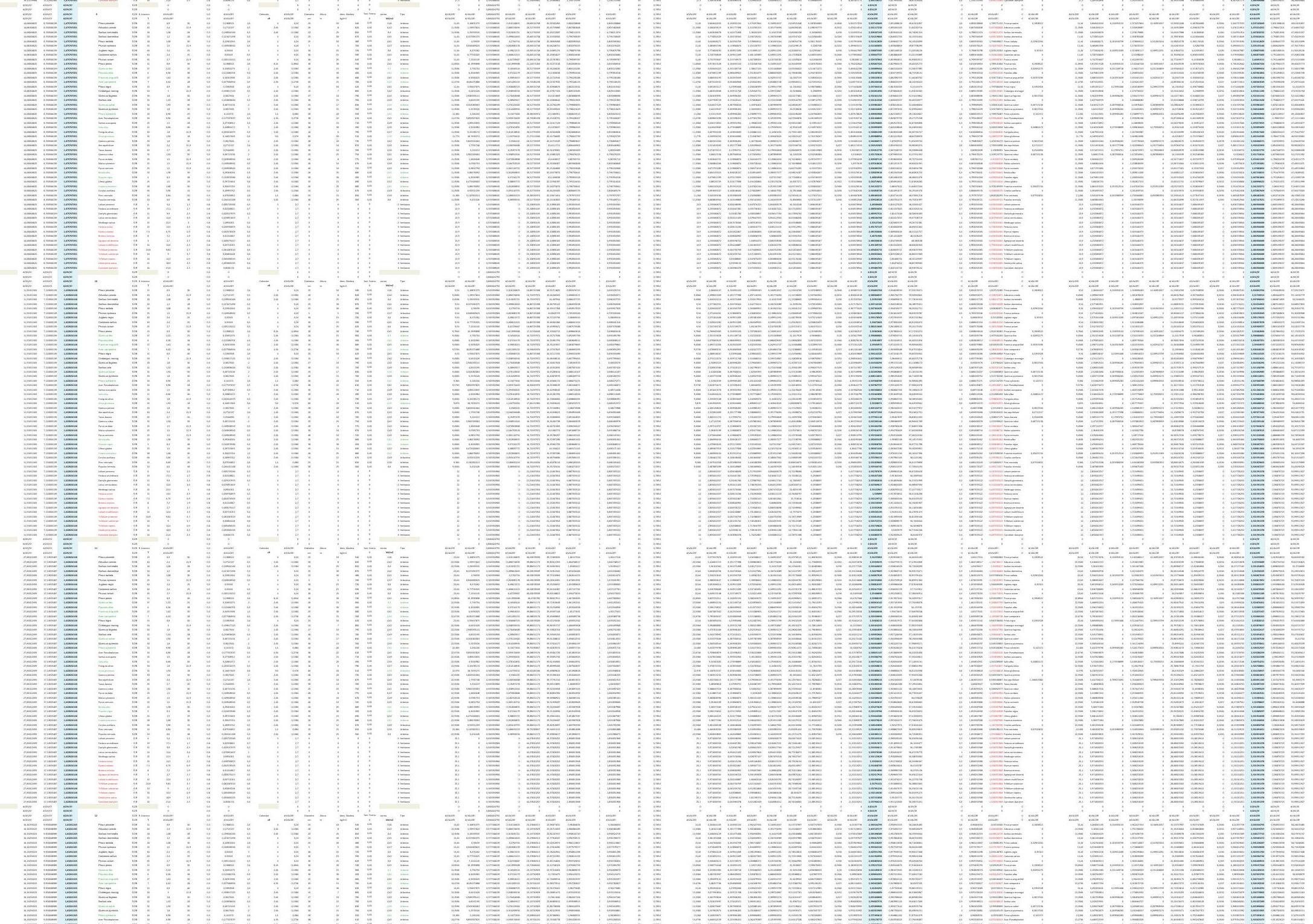


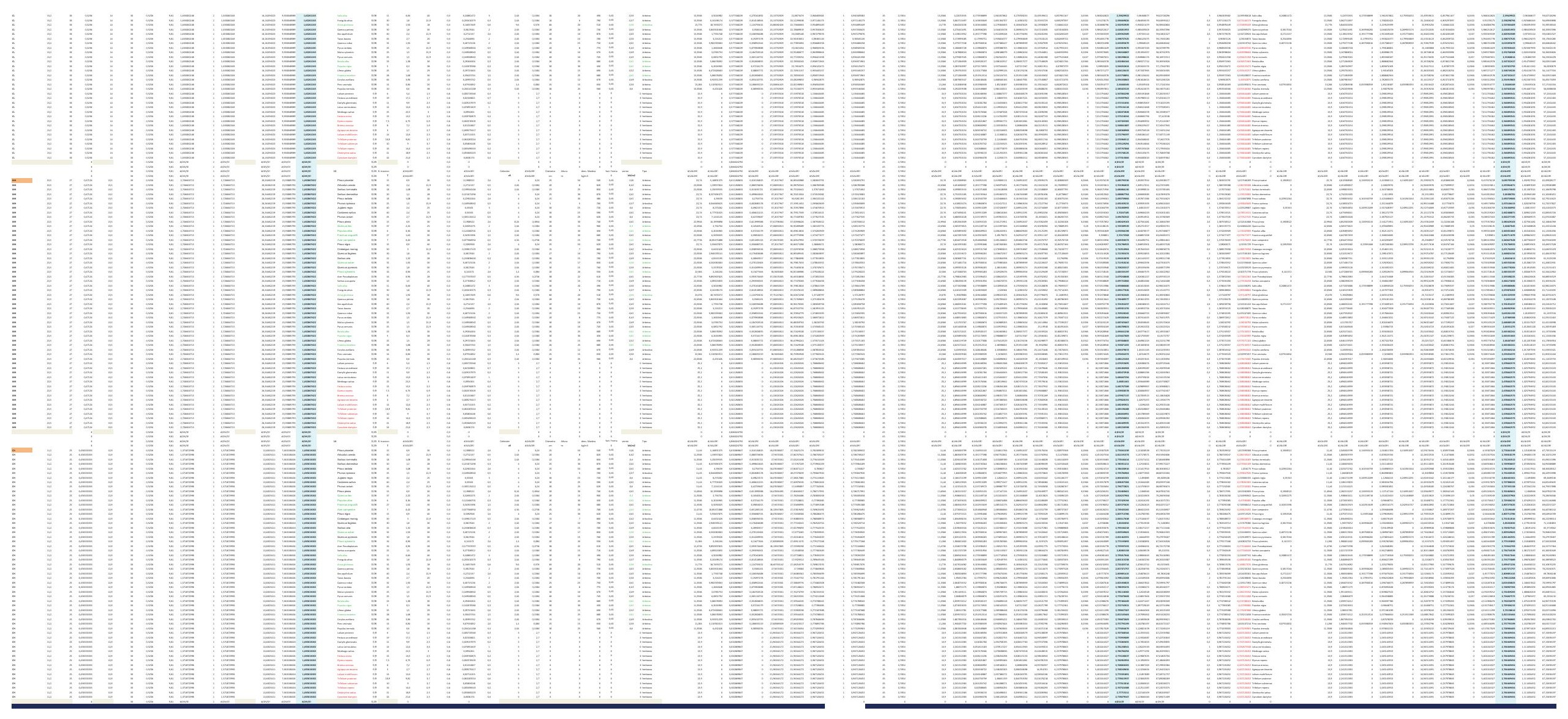



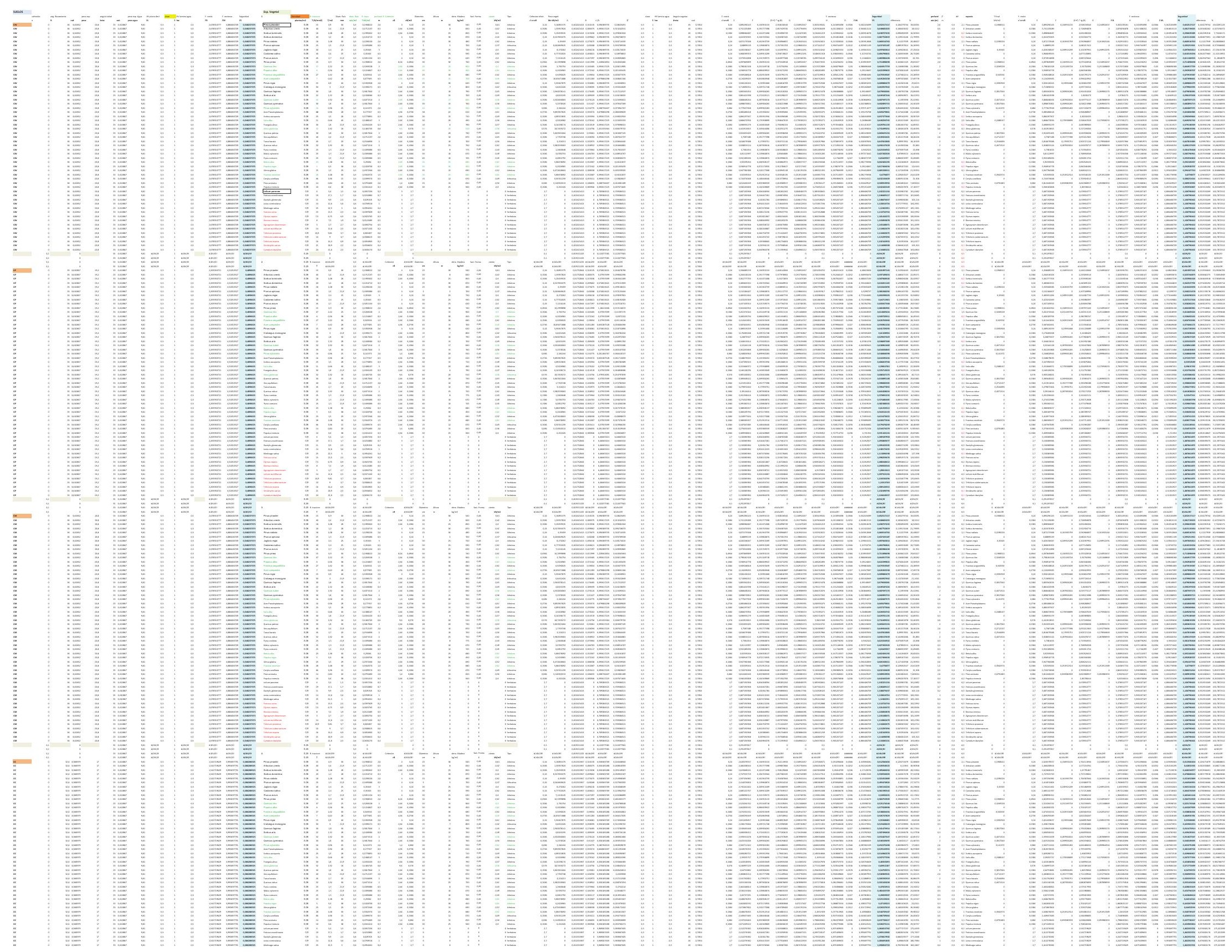


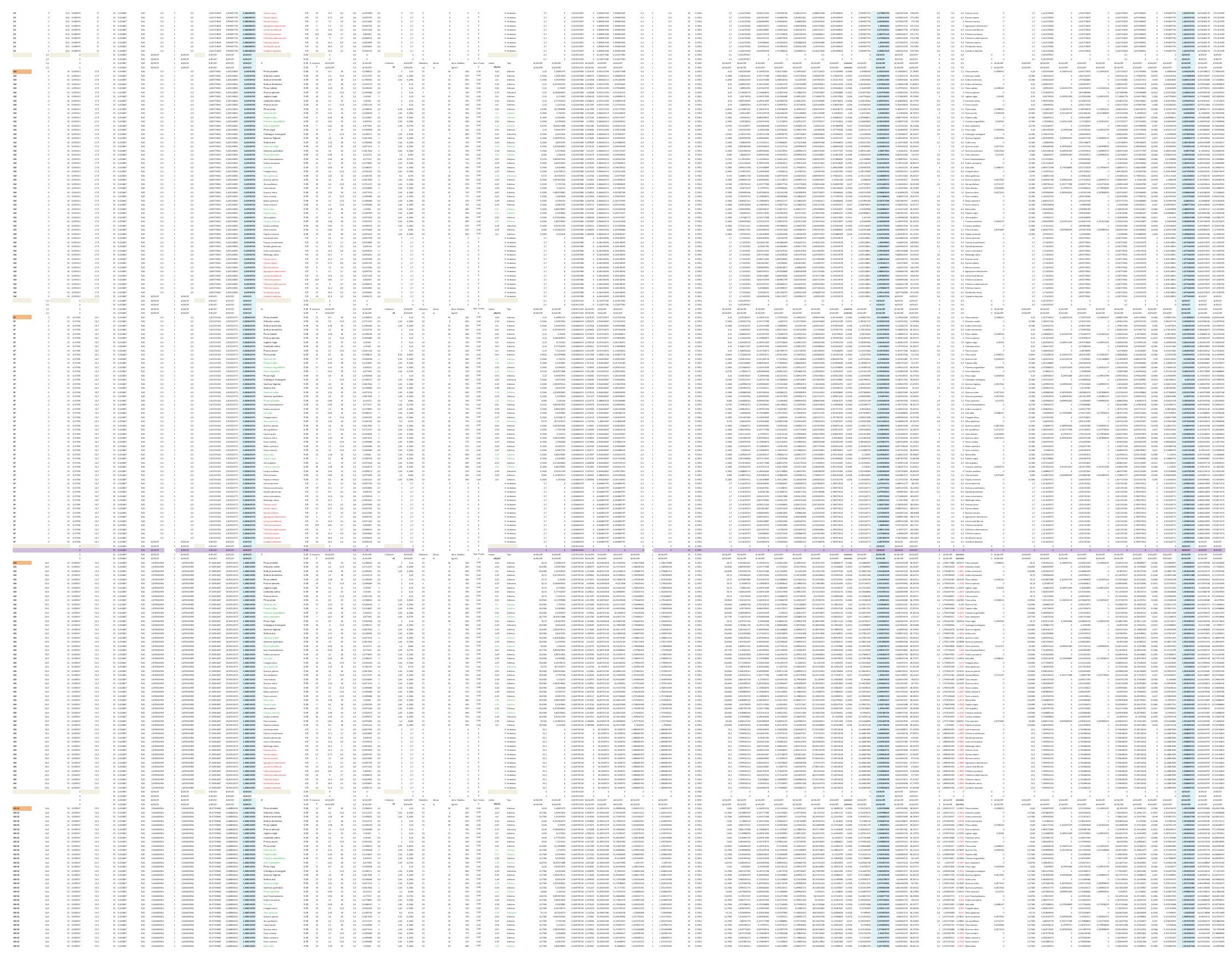



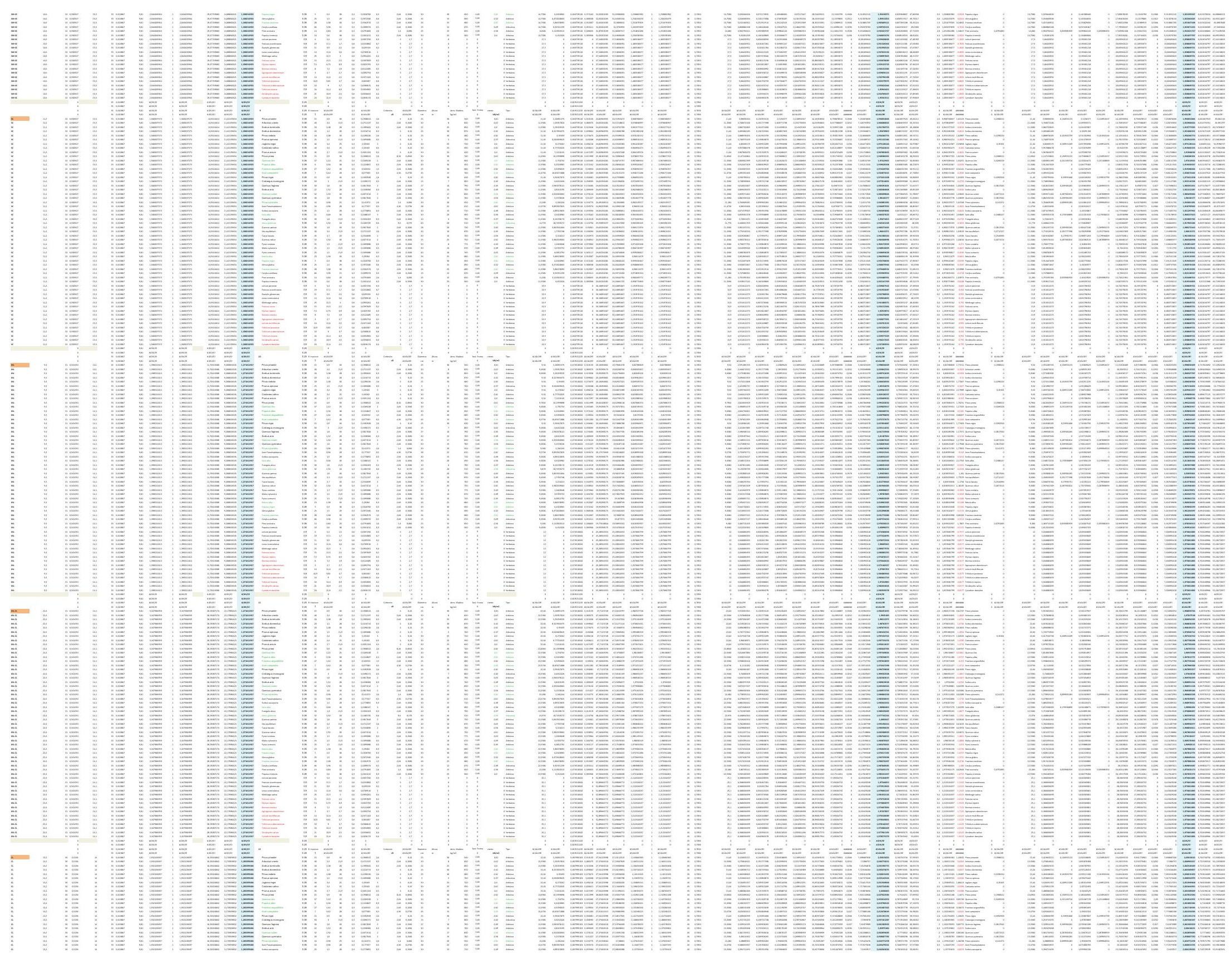

$-$
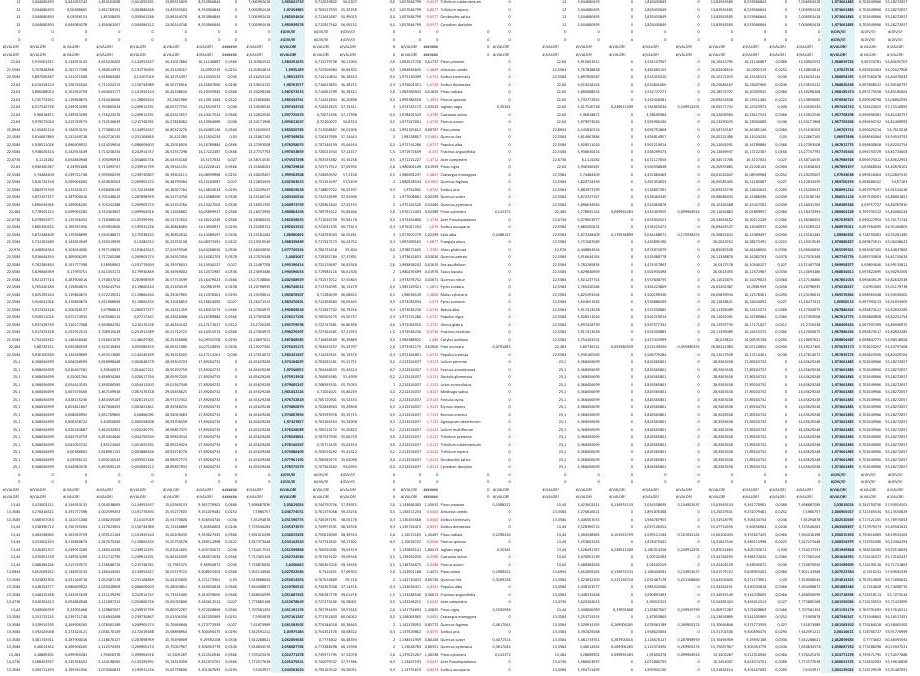


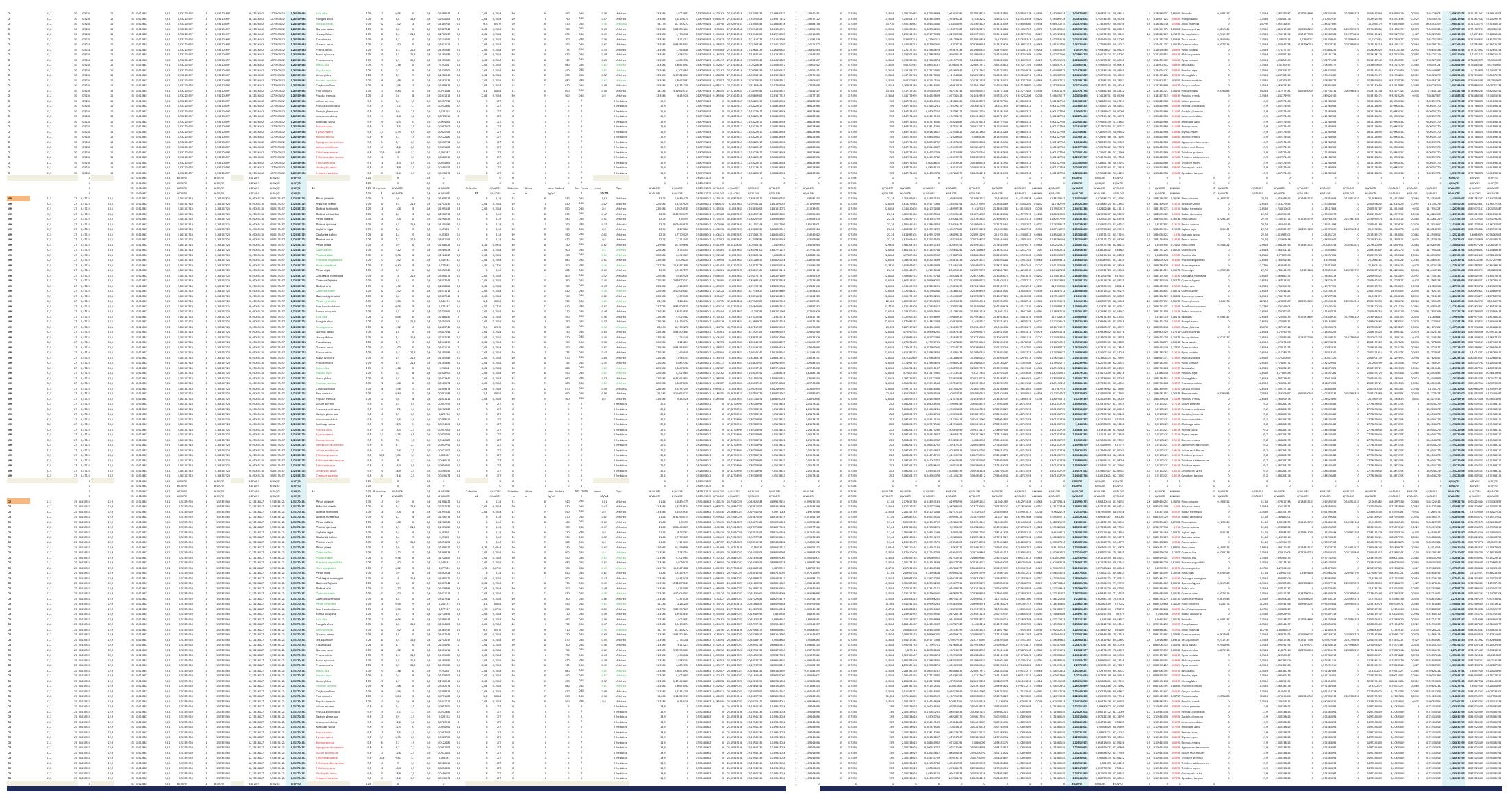



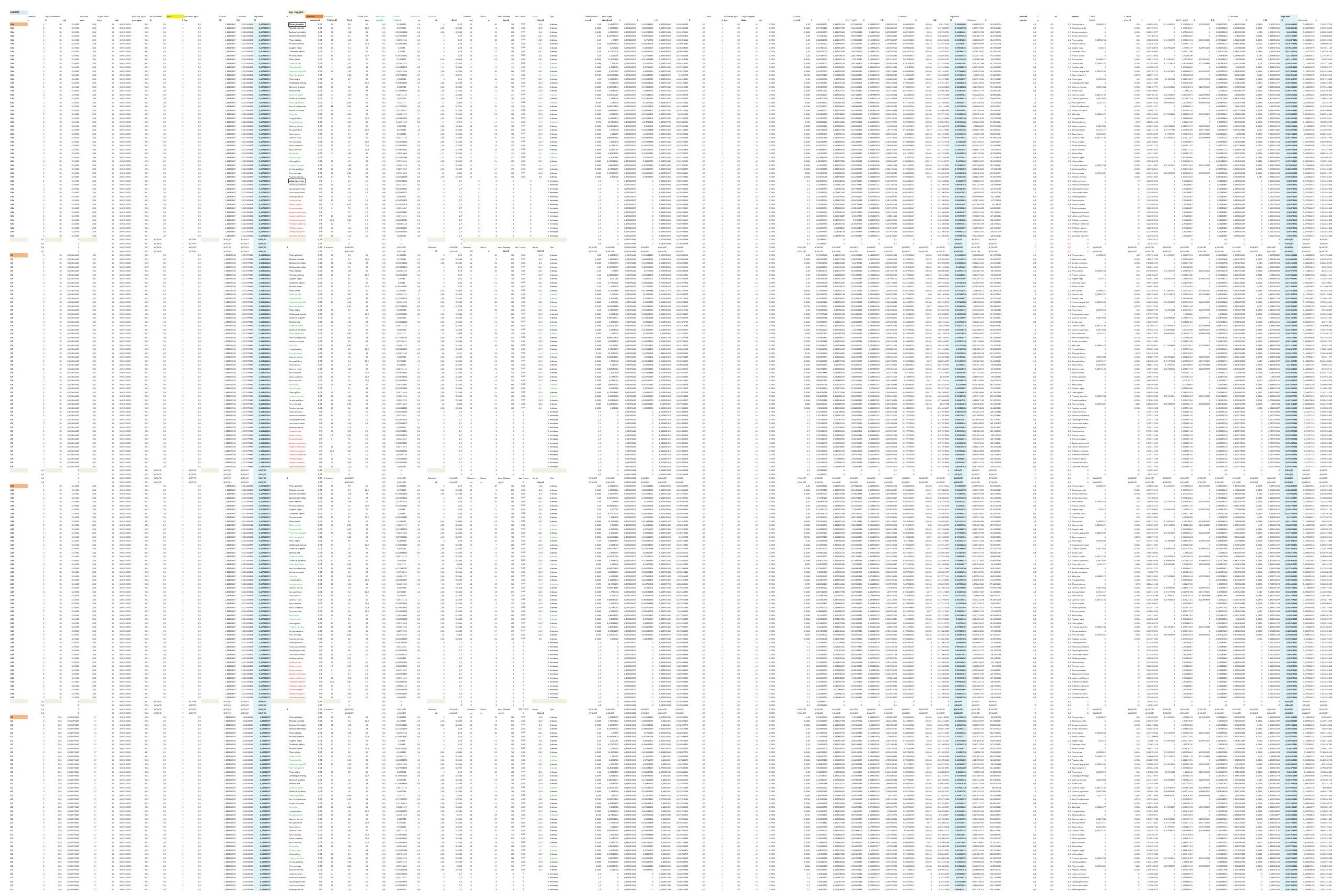


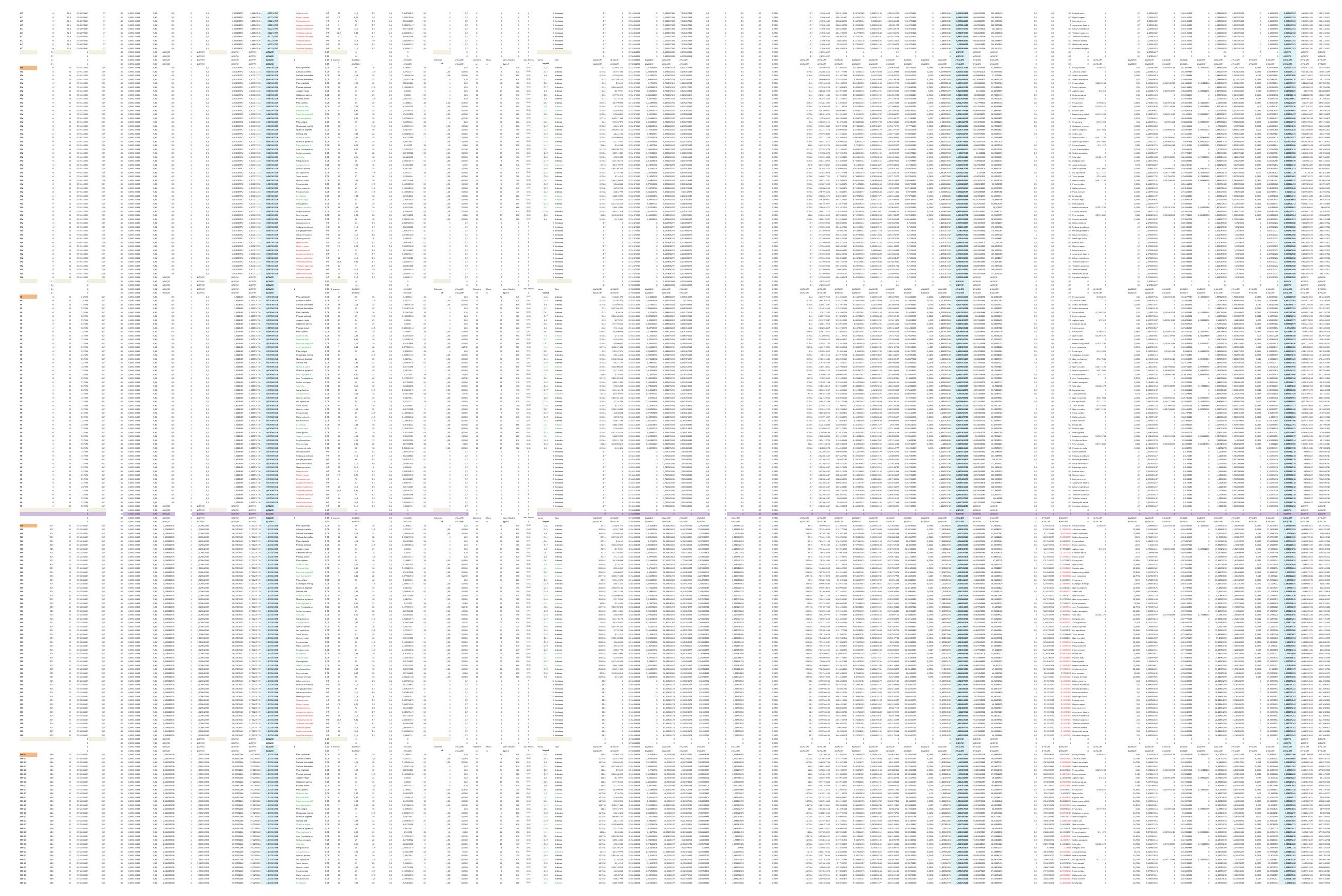



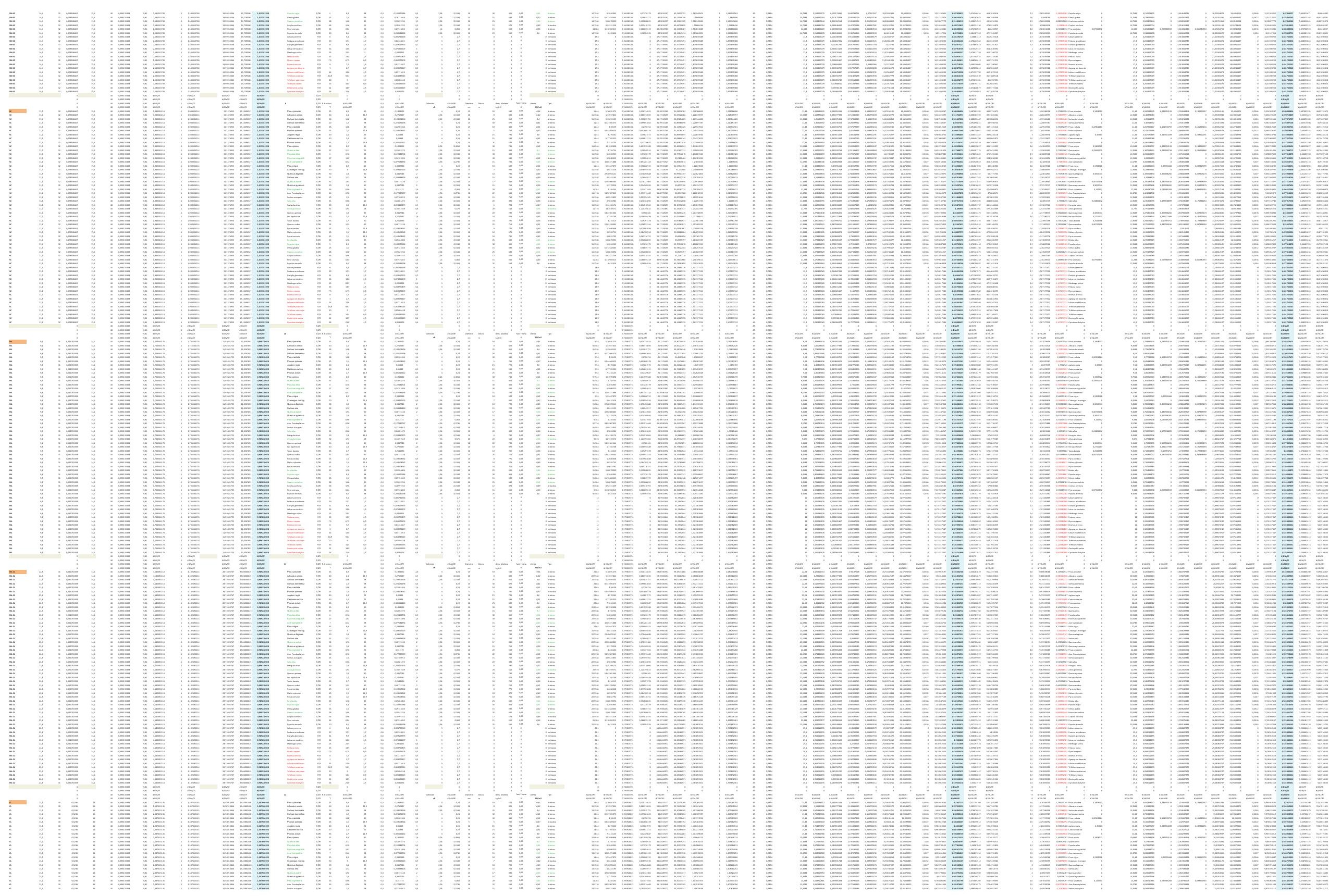


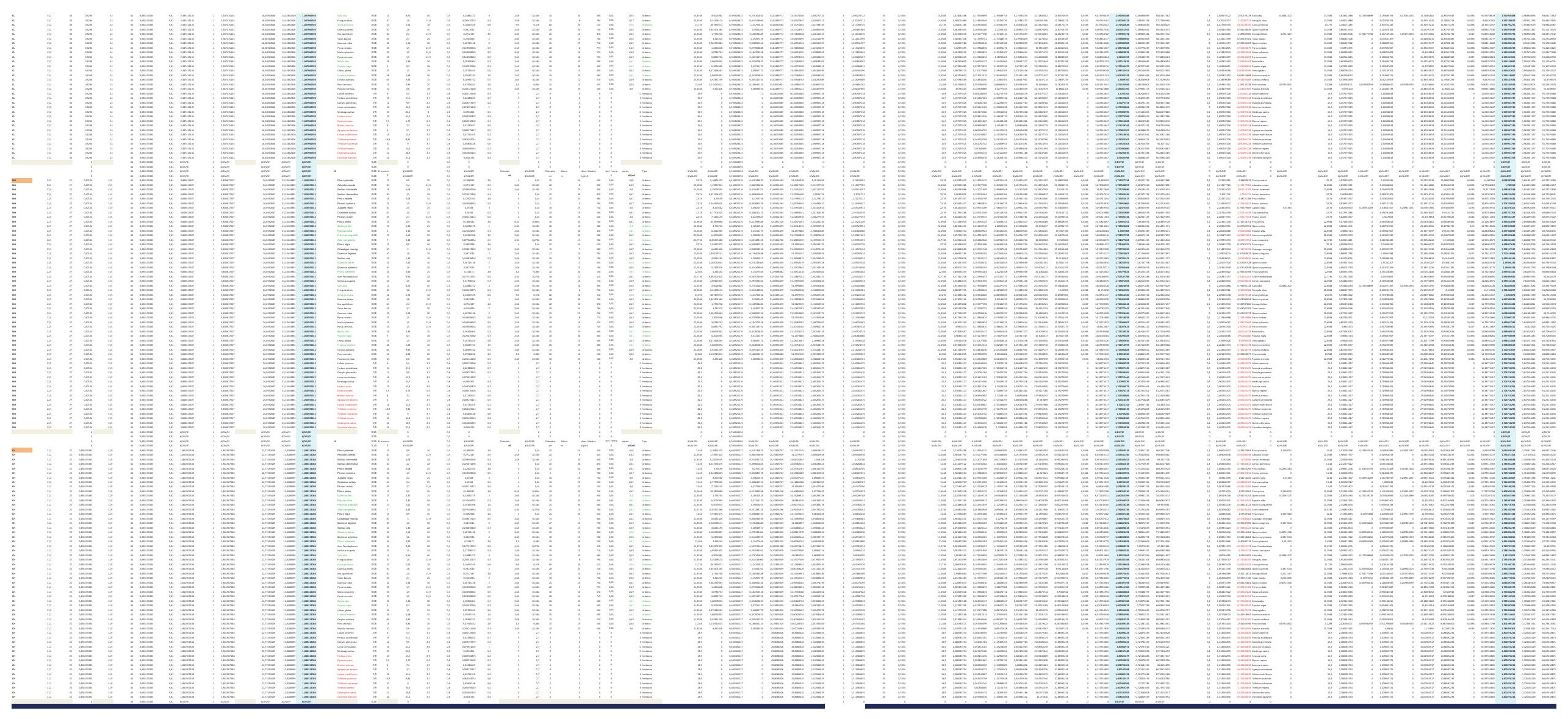



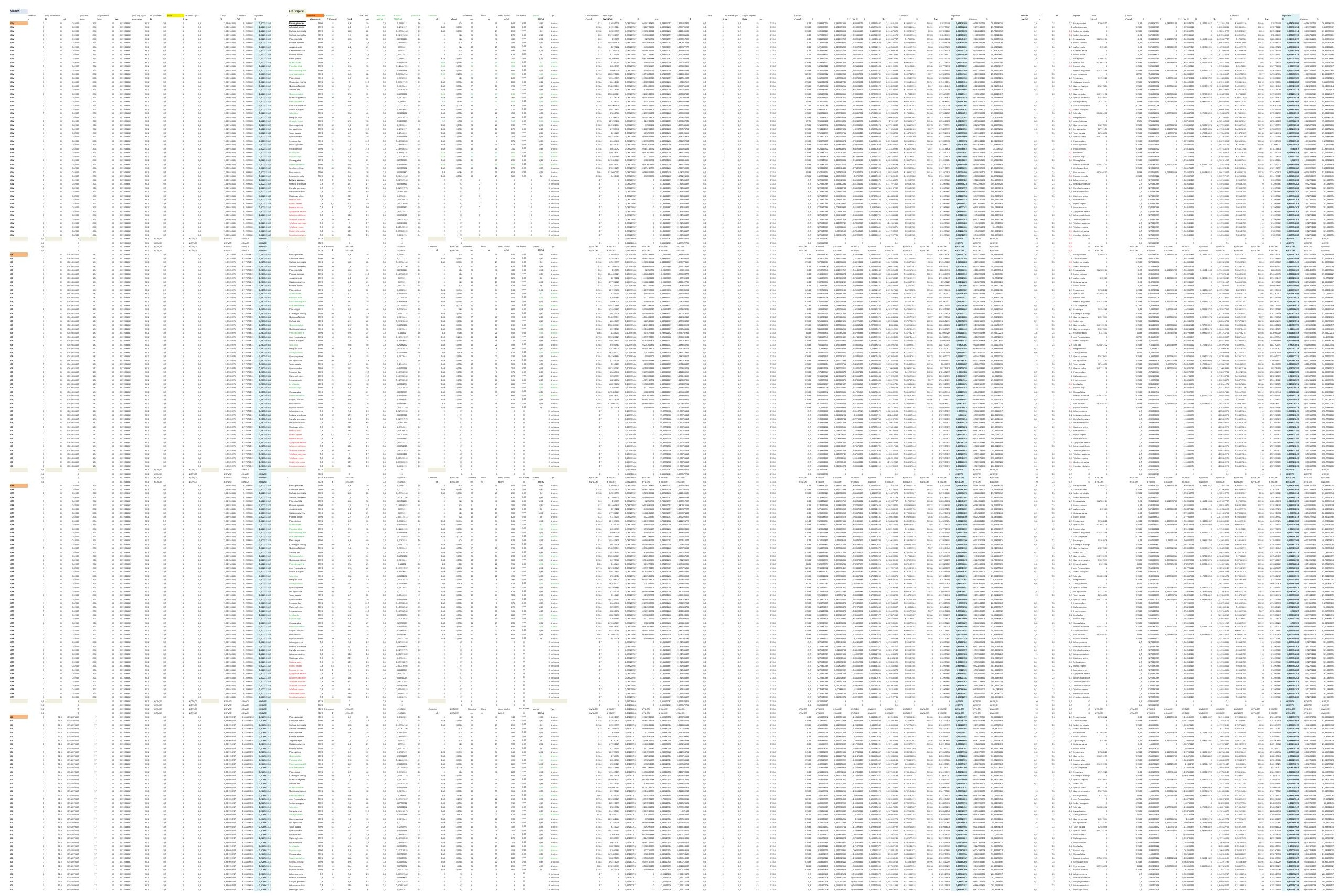


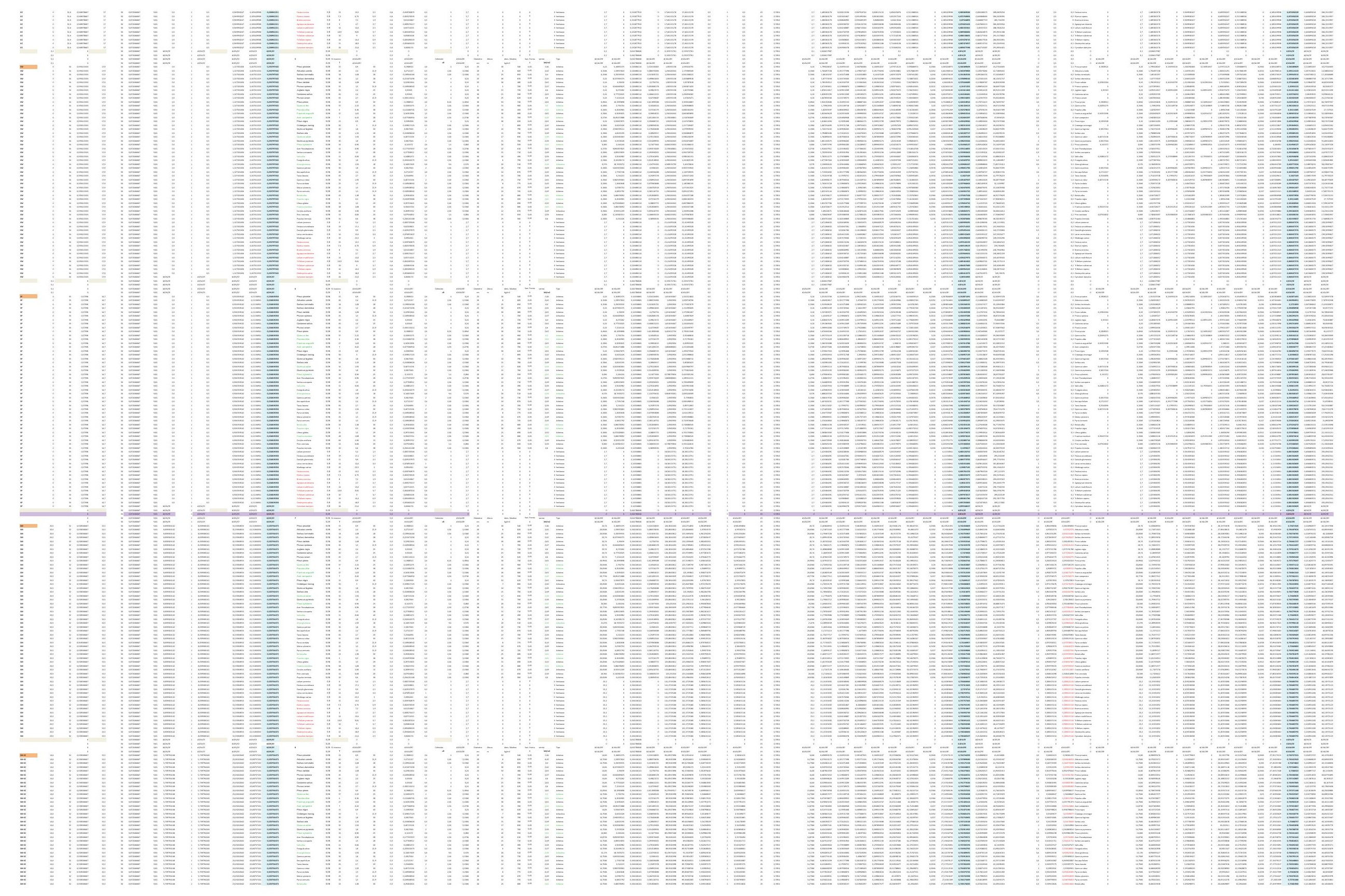



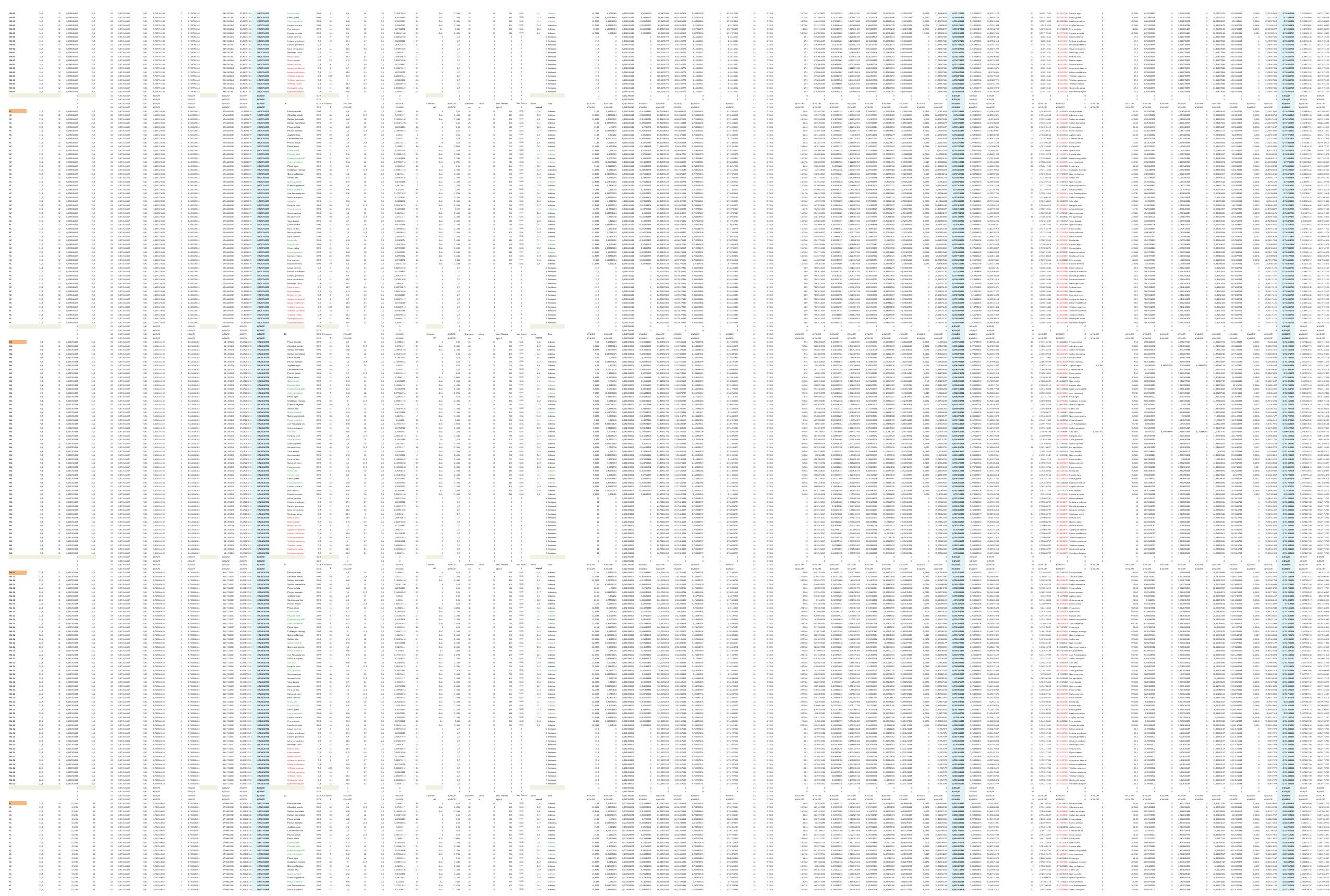


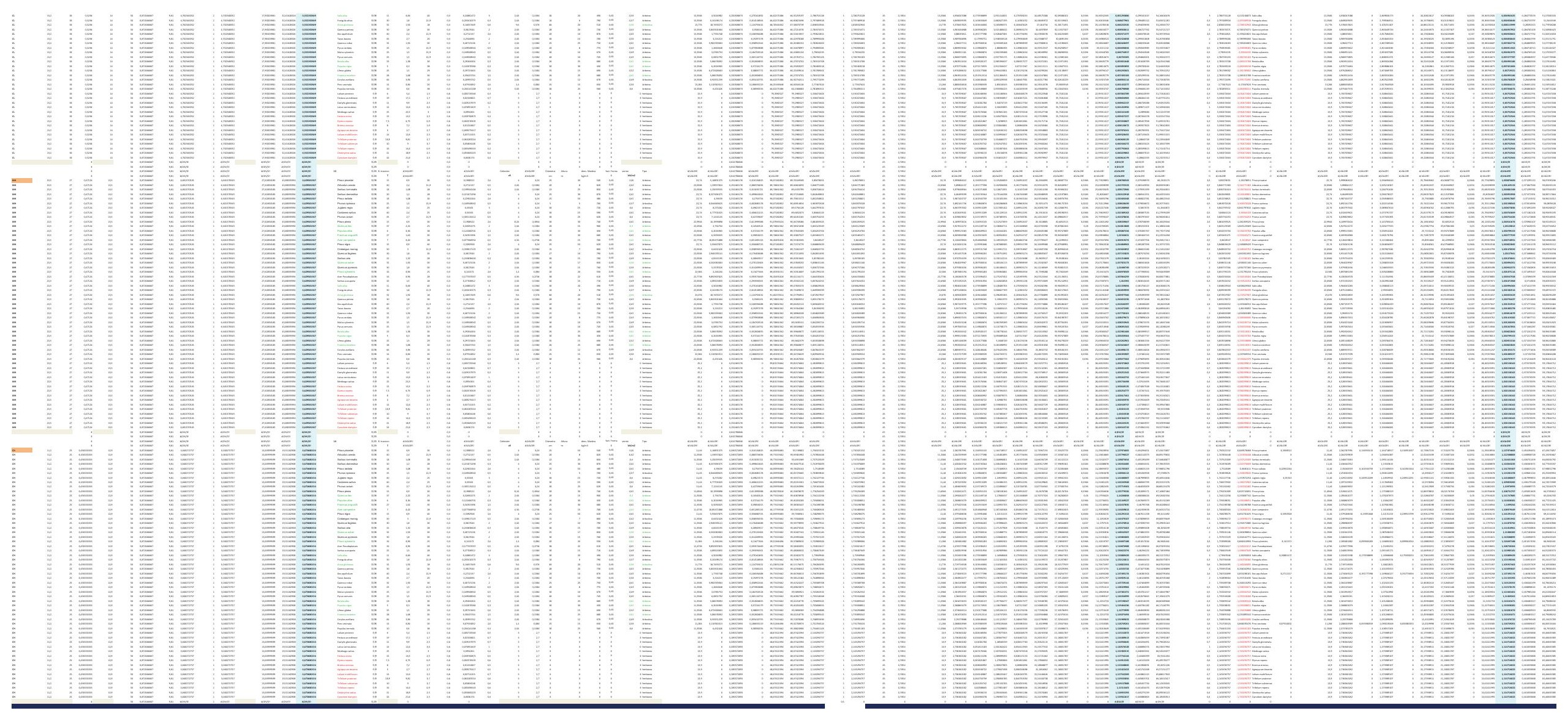



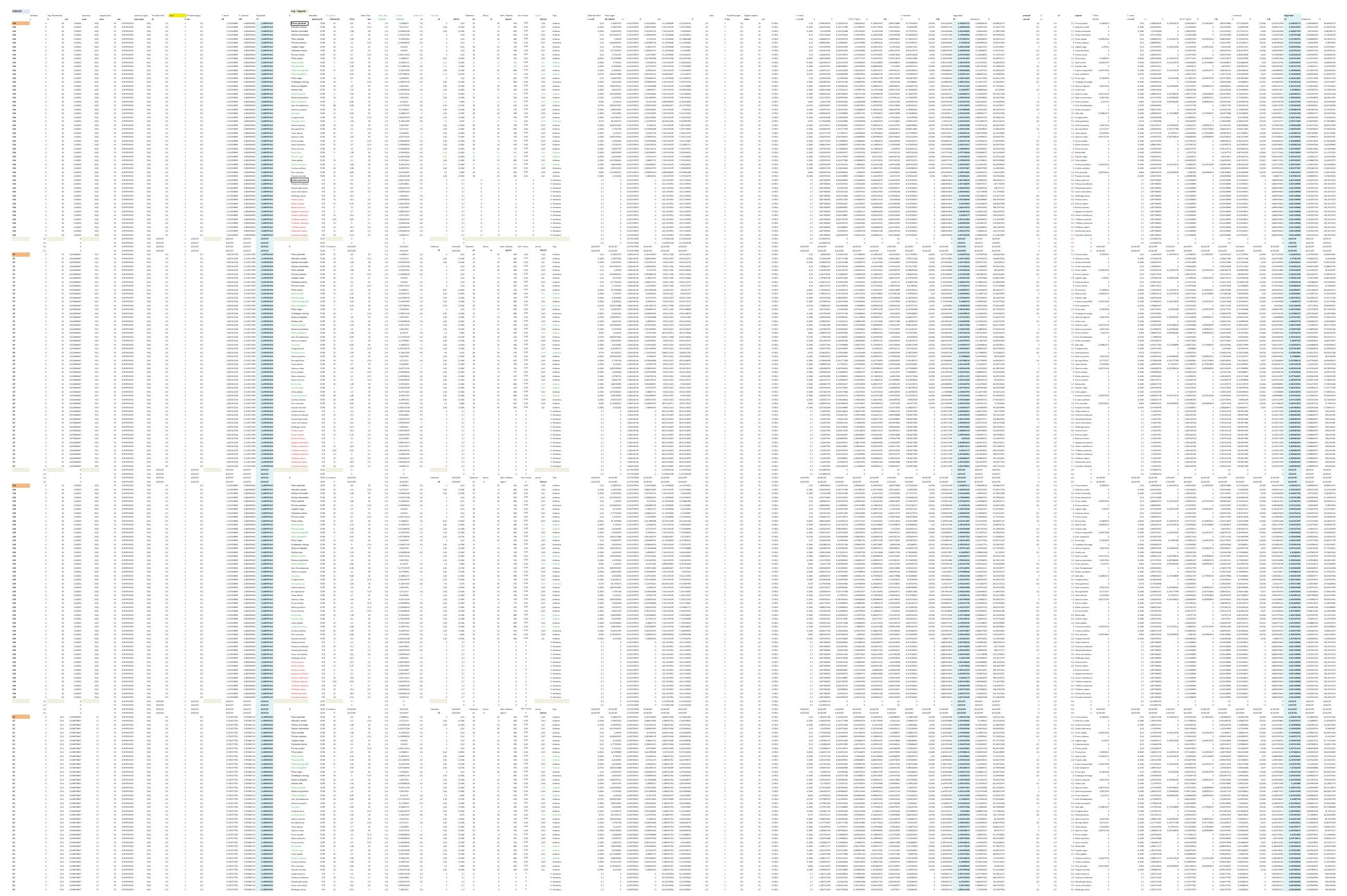


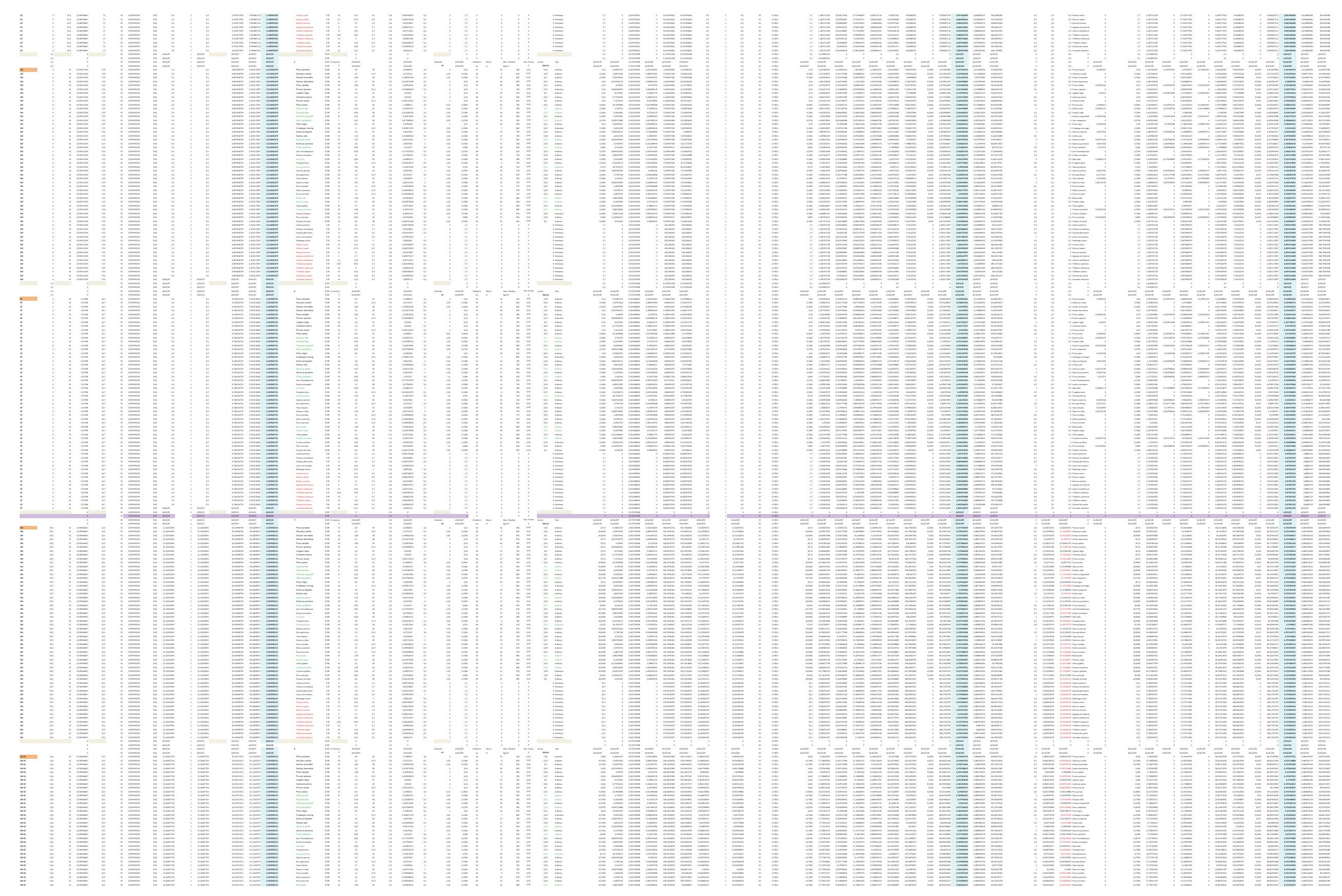



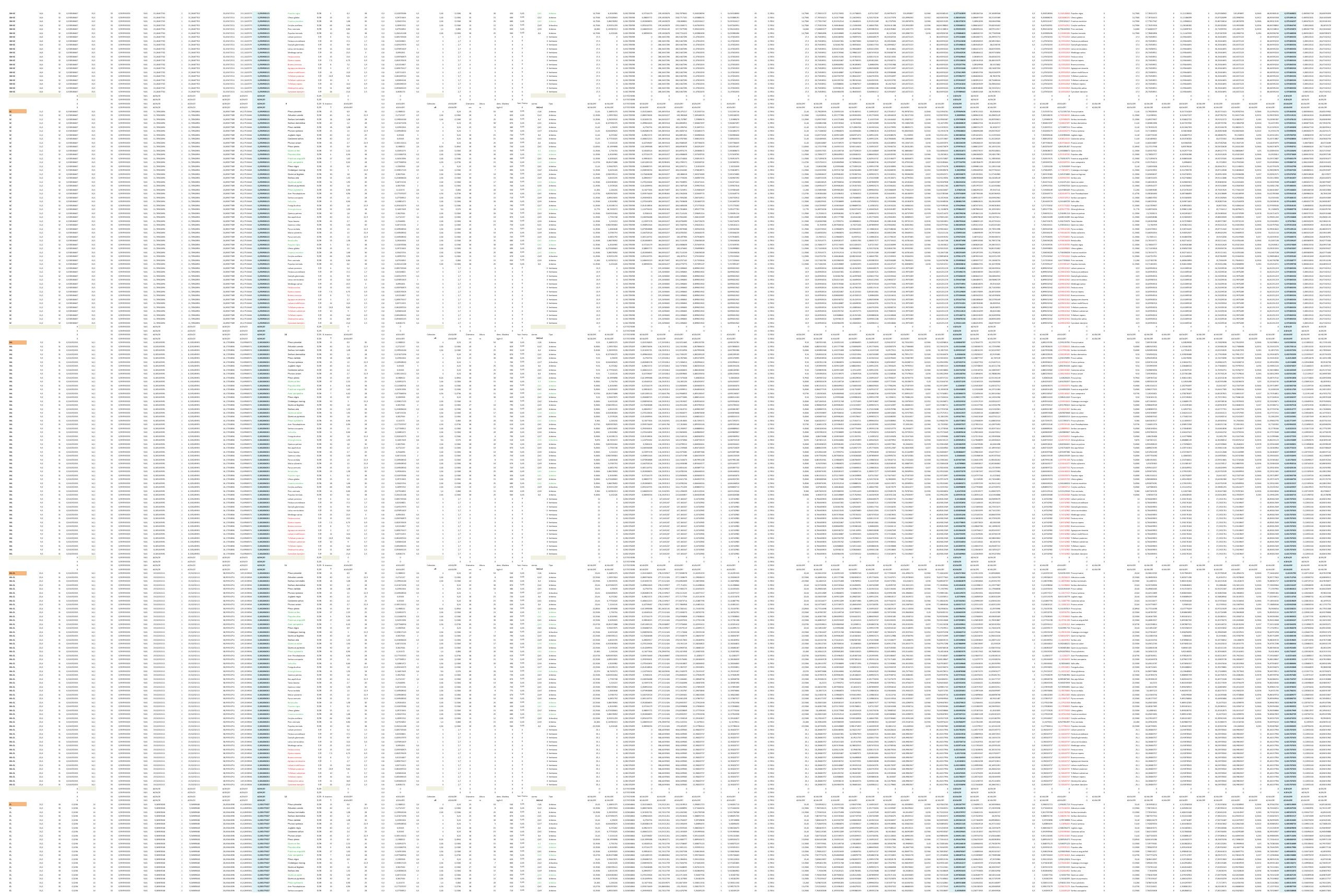


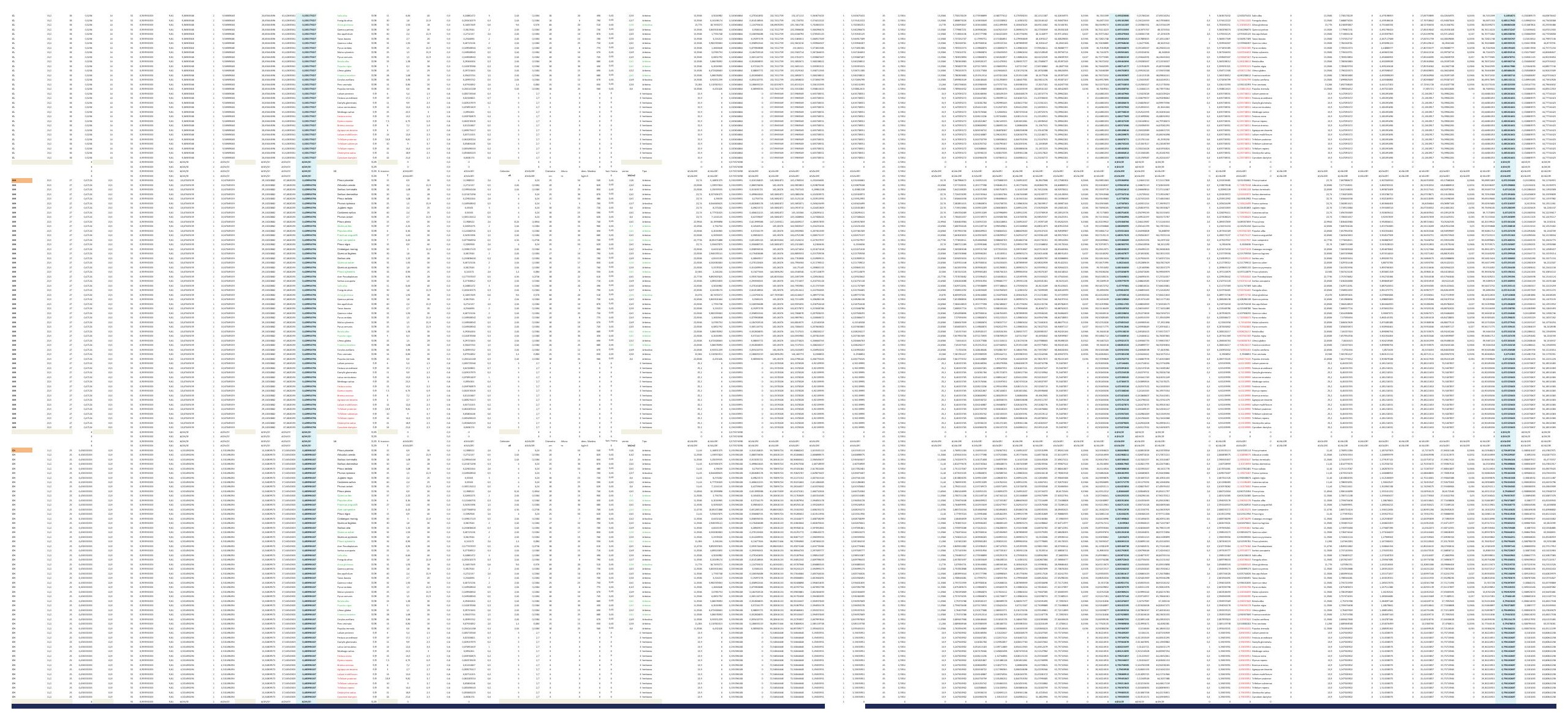



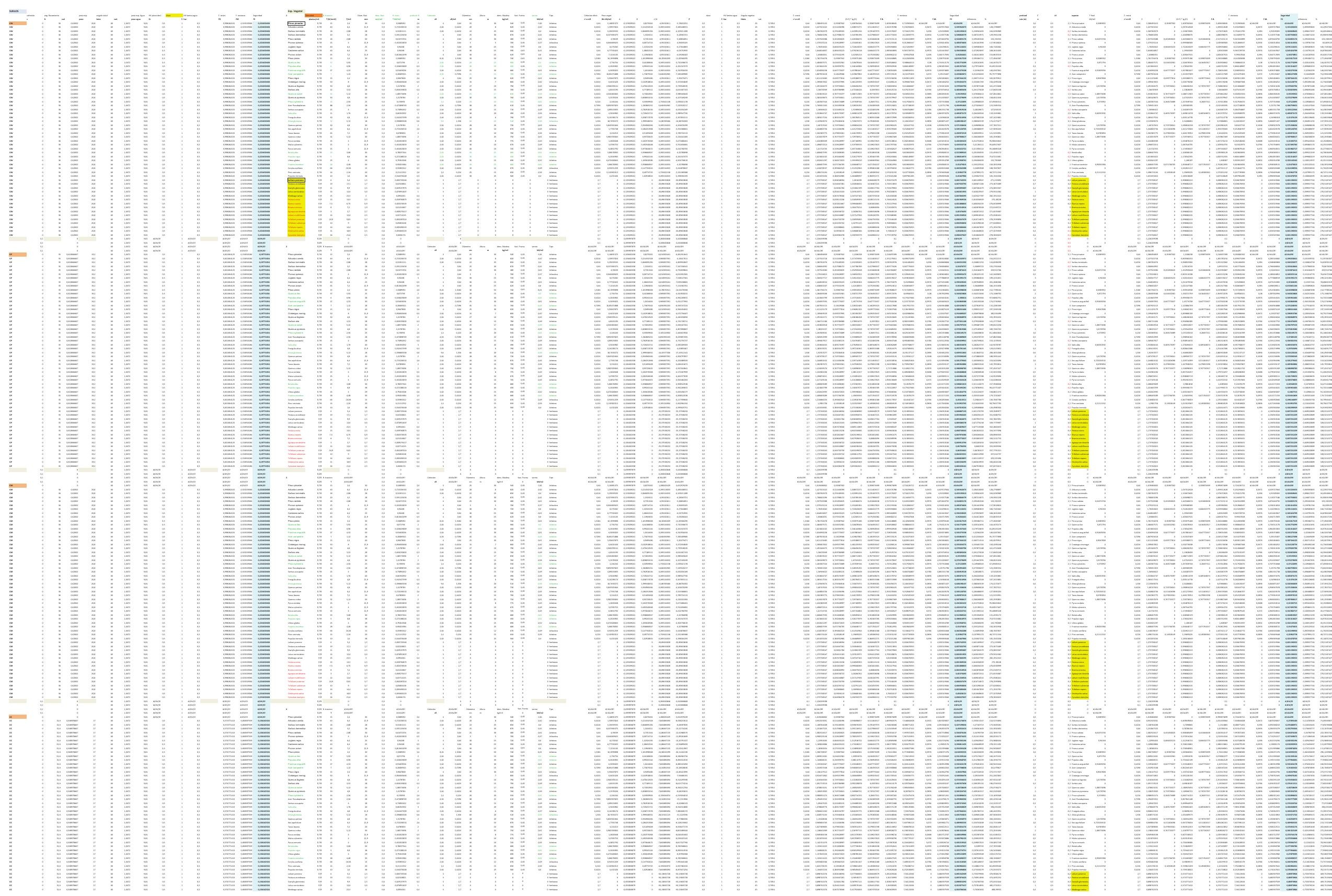

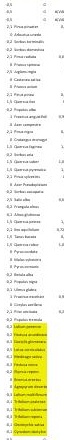
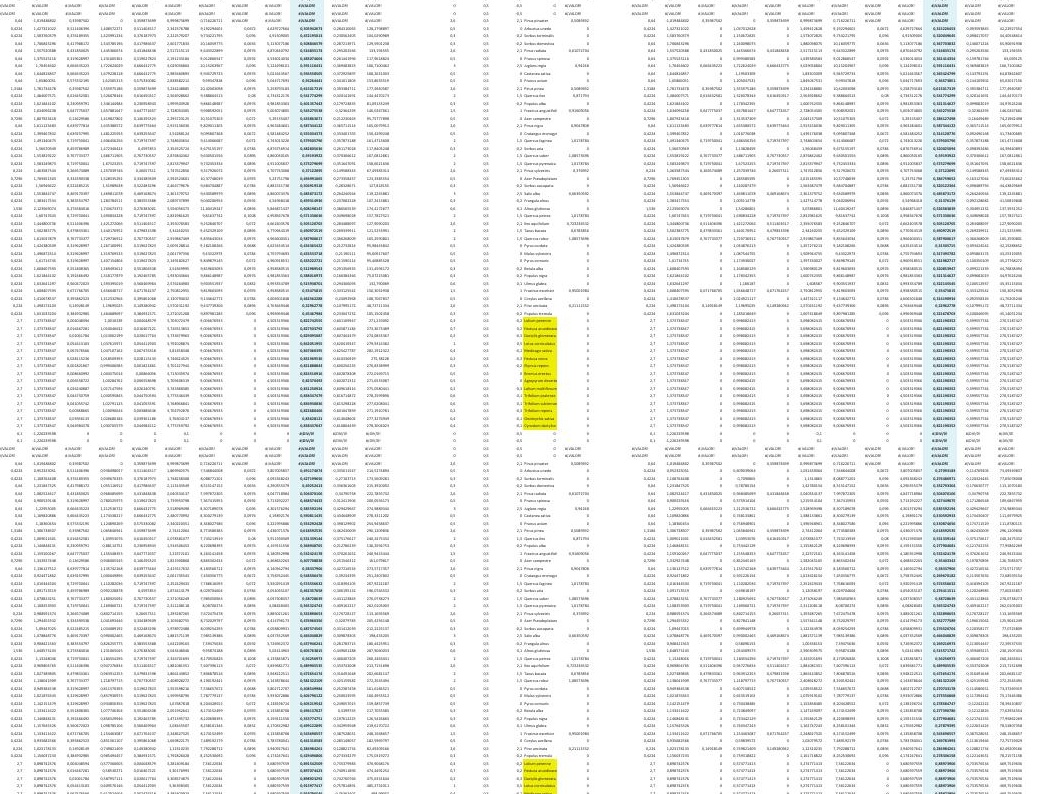

俸

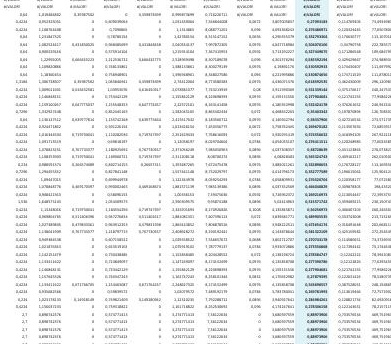




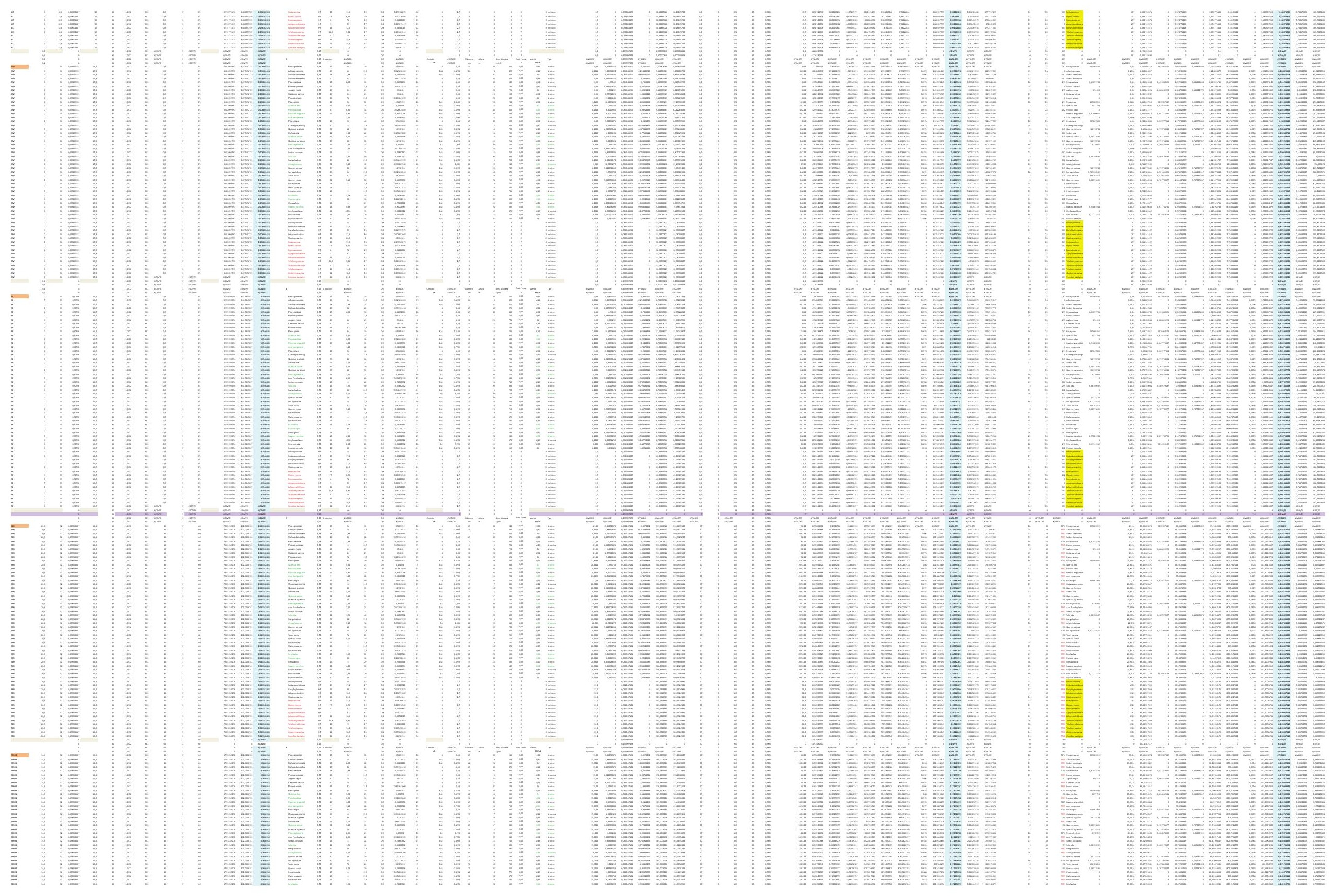



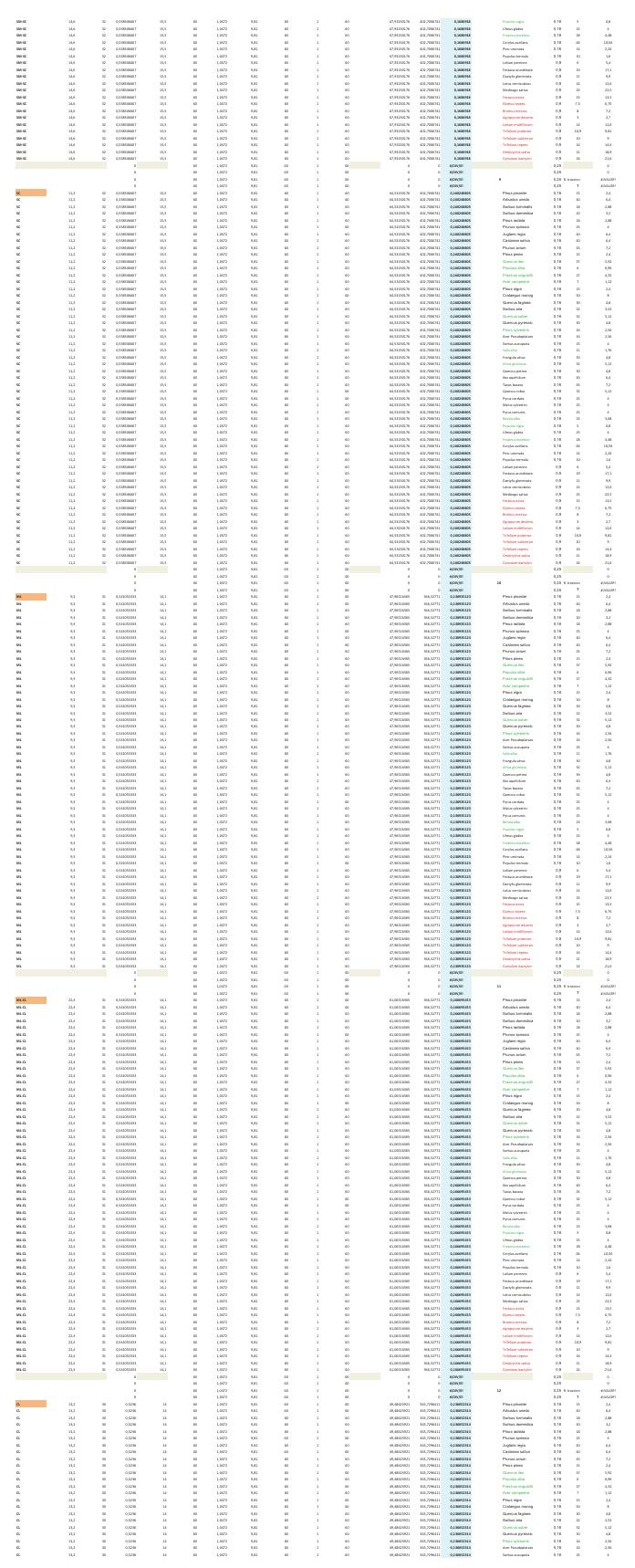

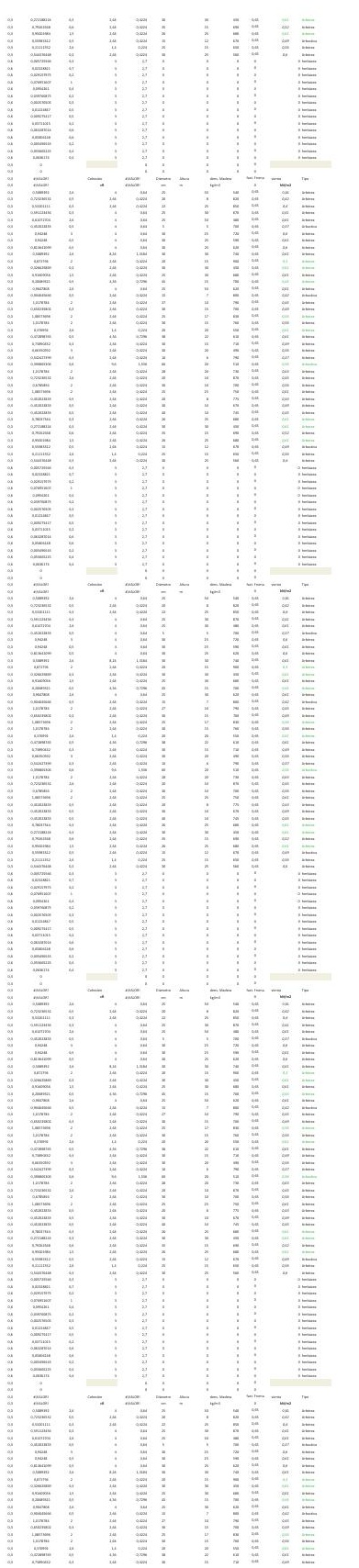

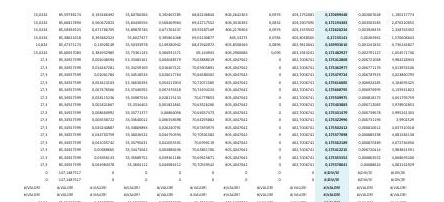
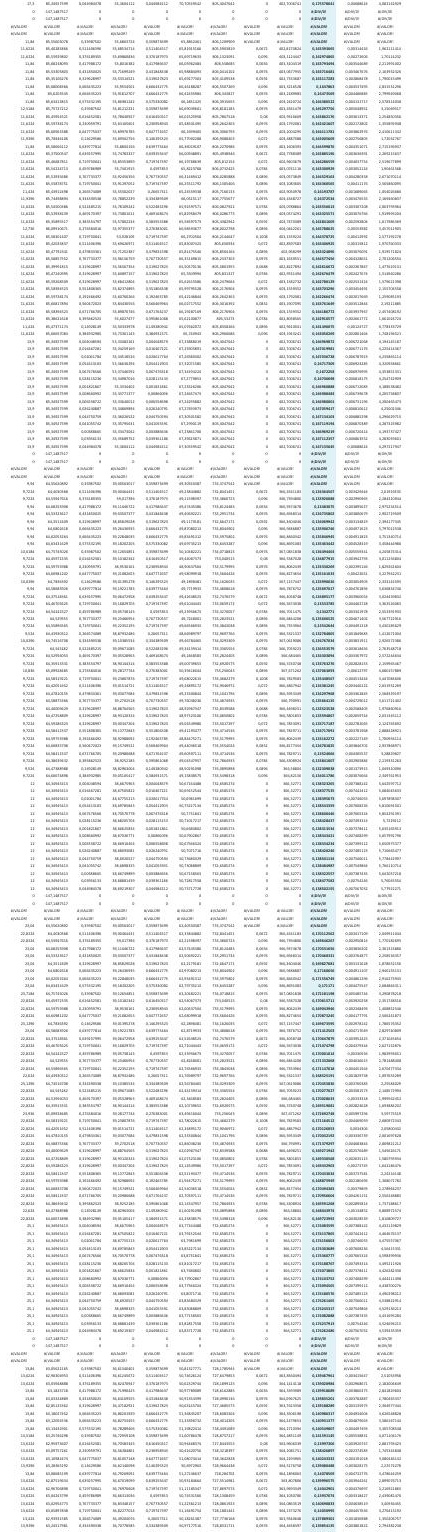

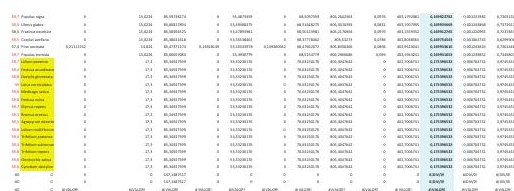

$=$

毫

毫

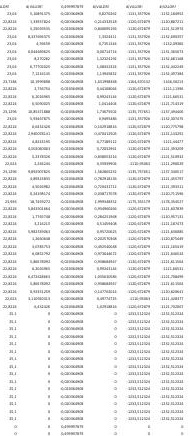

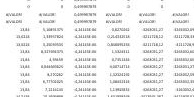

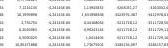

$\sqrt{\mathrm{c}}$

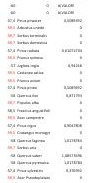
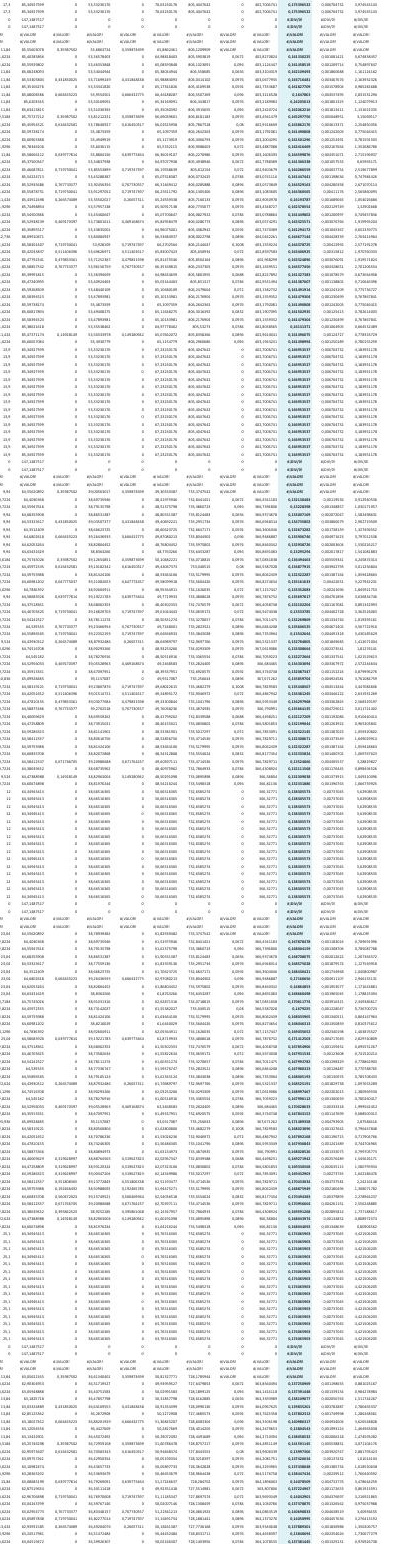


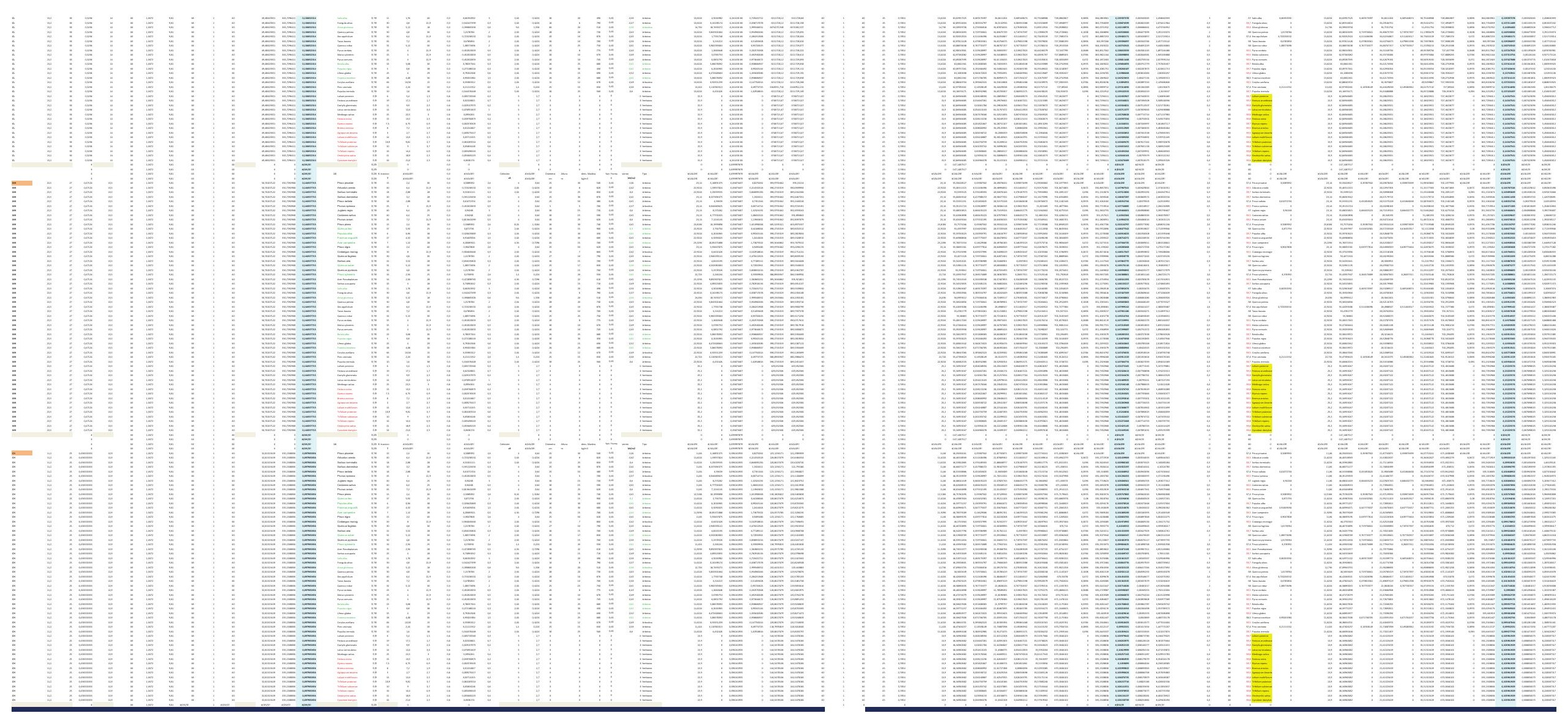



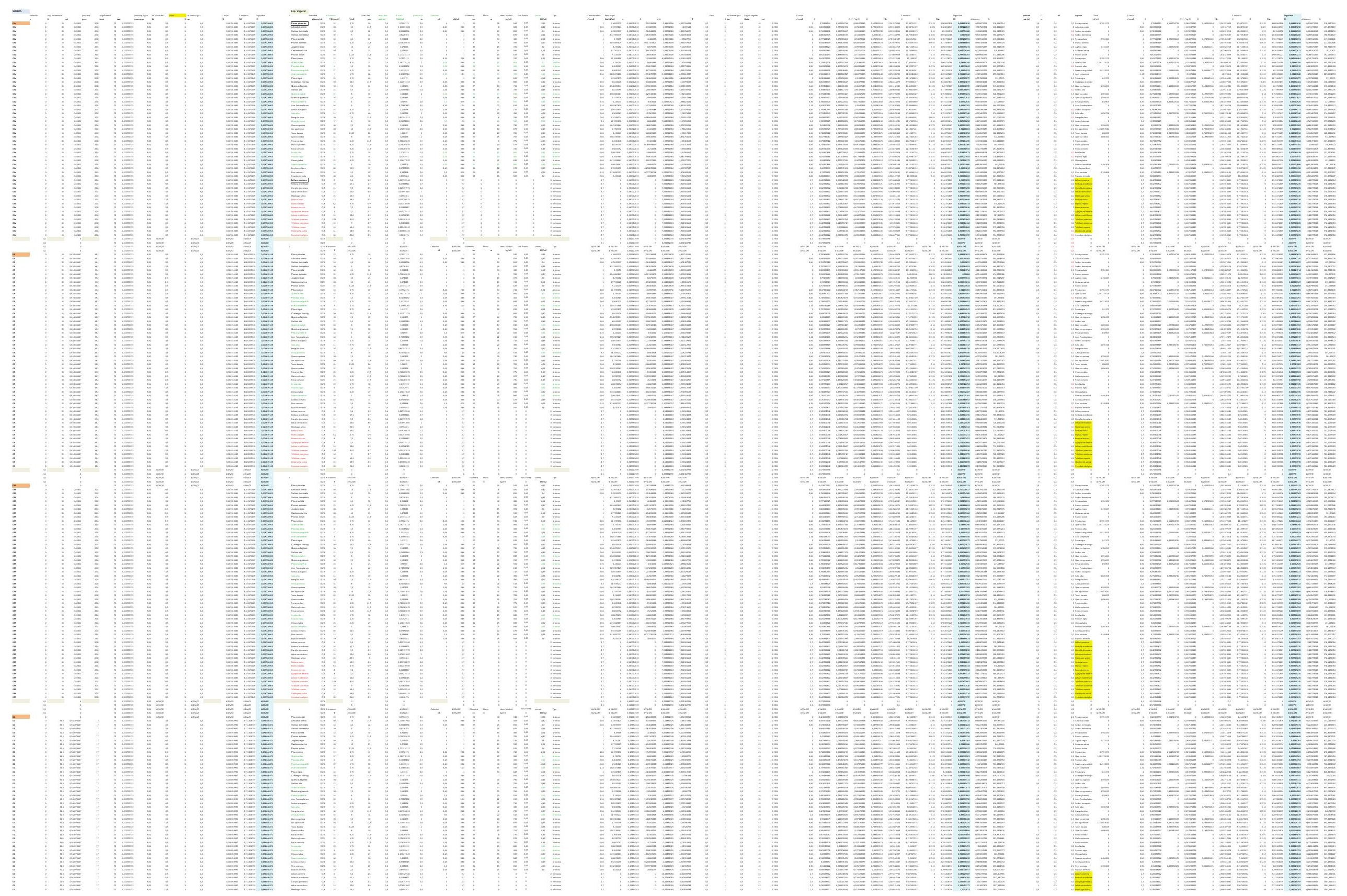

$\vdots$
$\vdots$
$\vdots$
$\vdots$
$\vdots$
$\vdots$
$\vdots$
$\vdots$
$\vdots$

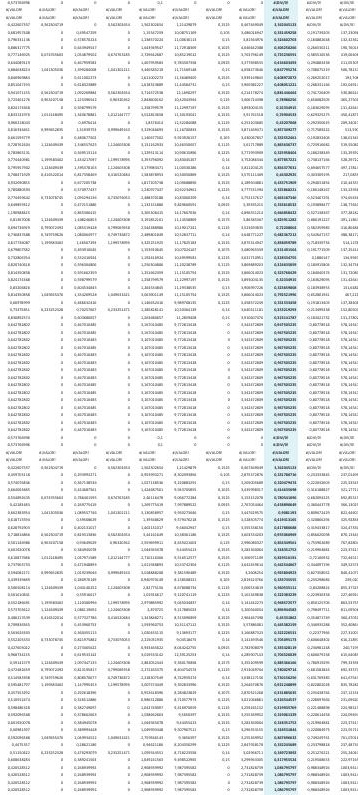




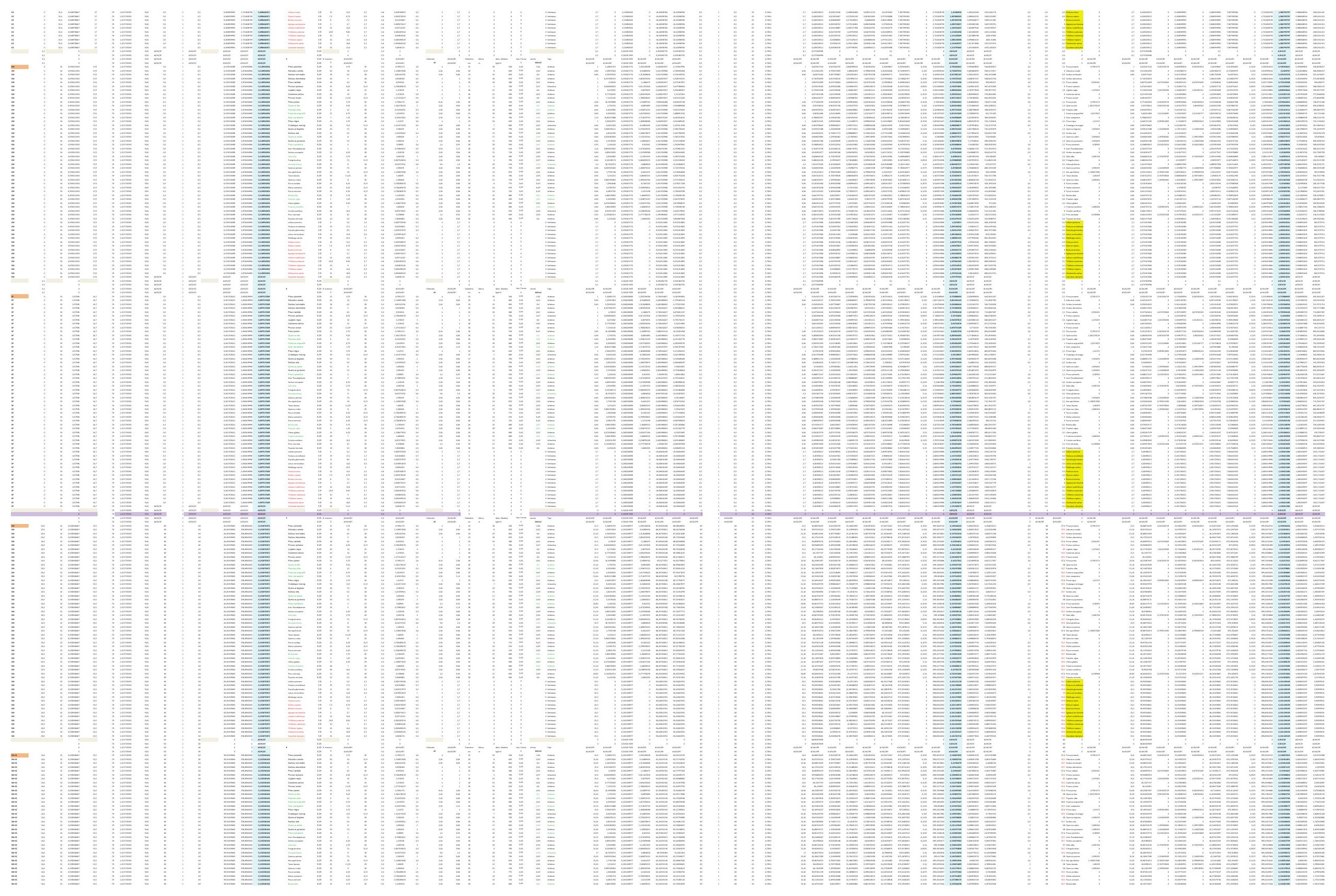



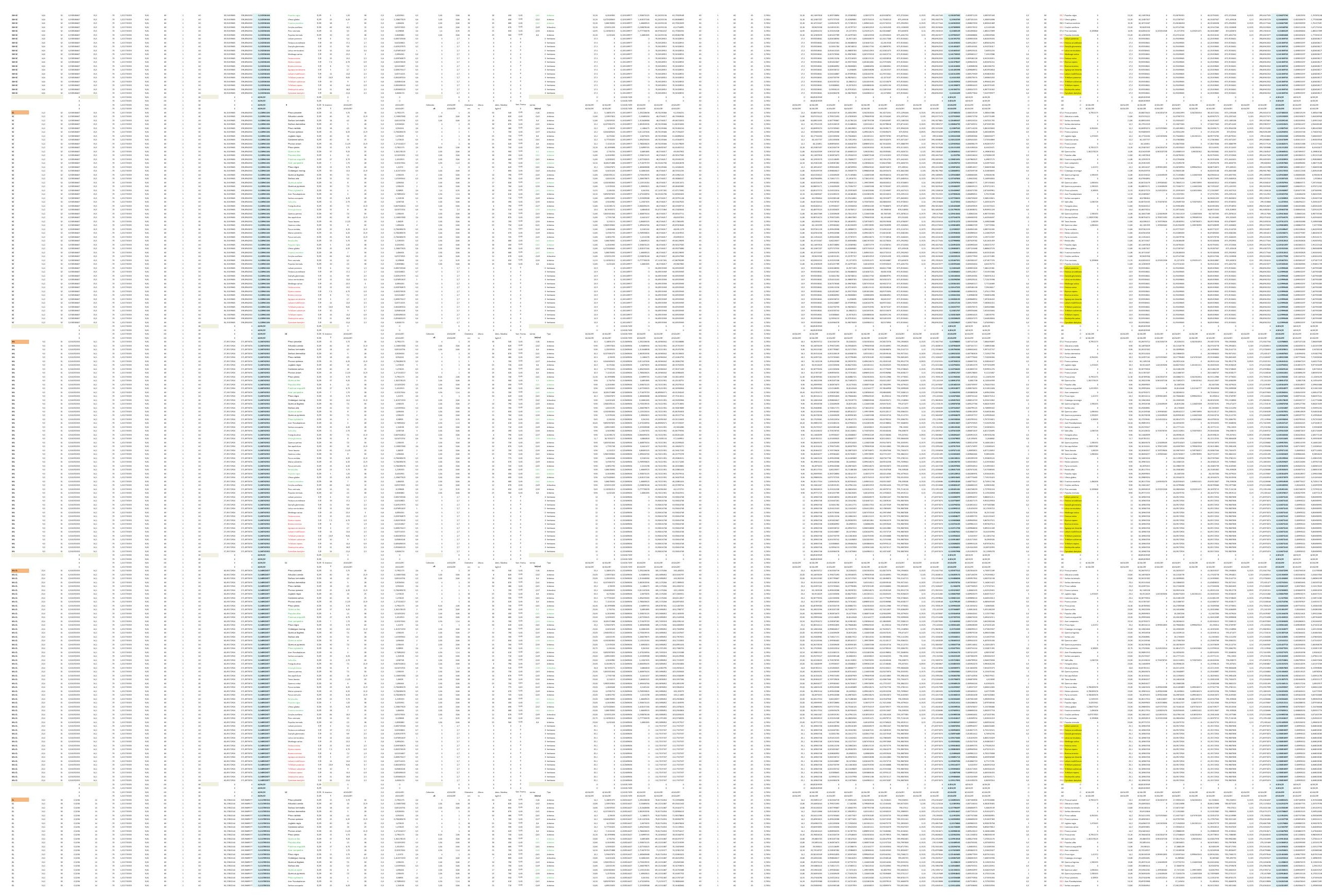

$\vdots$
$\vdots$
$\vdots$ $\equiv \equiv \equiv \equiv \equiv \equiv \equiv$

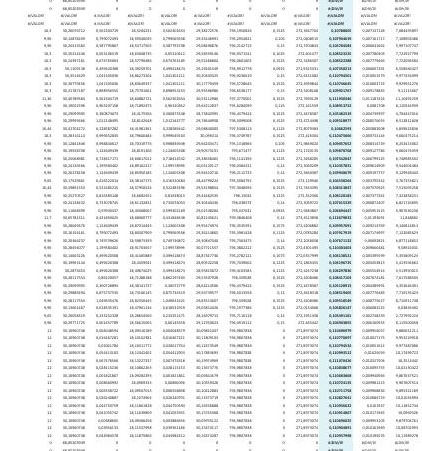

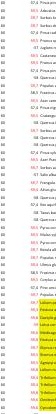

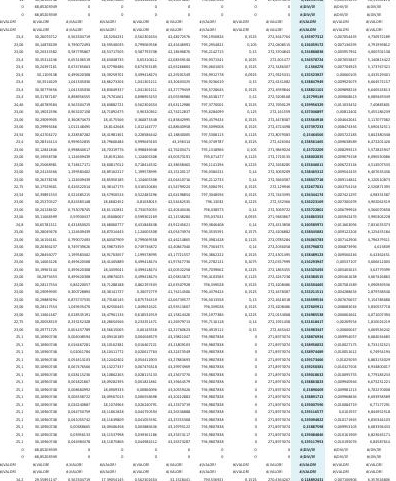

E

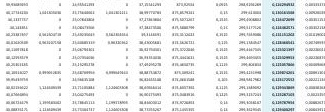

$\equiv \equiv \equiv \equiv \equiv \equiv \equiv \equiv$

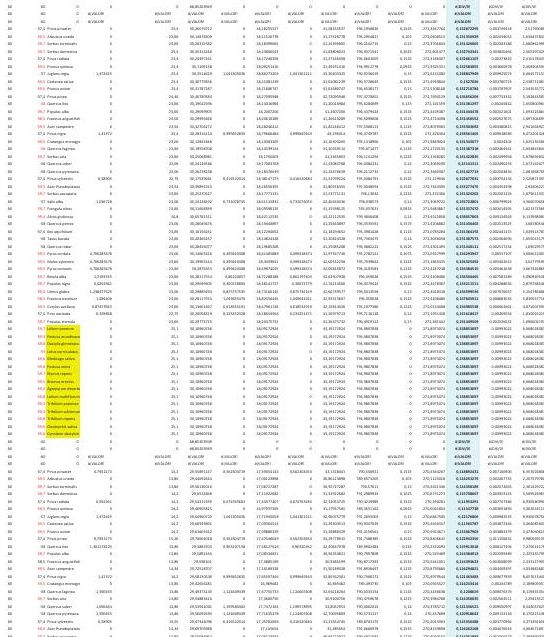




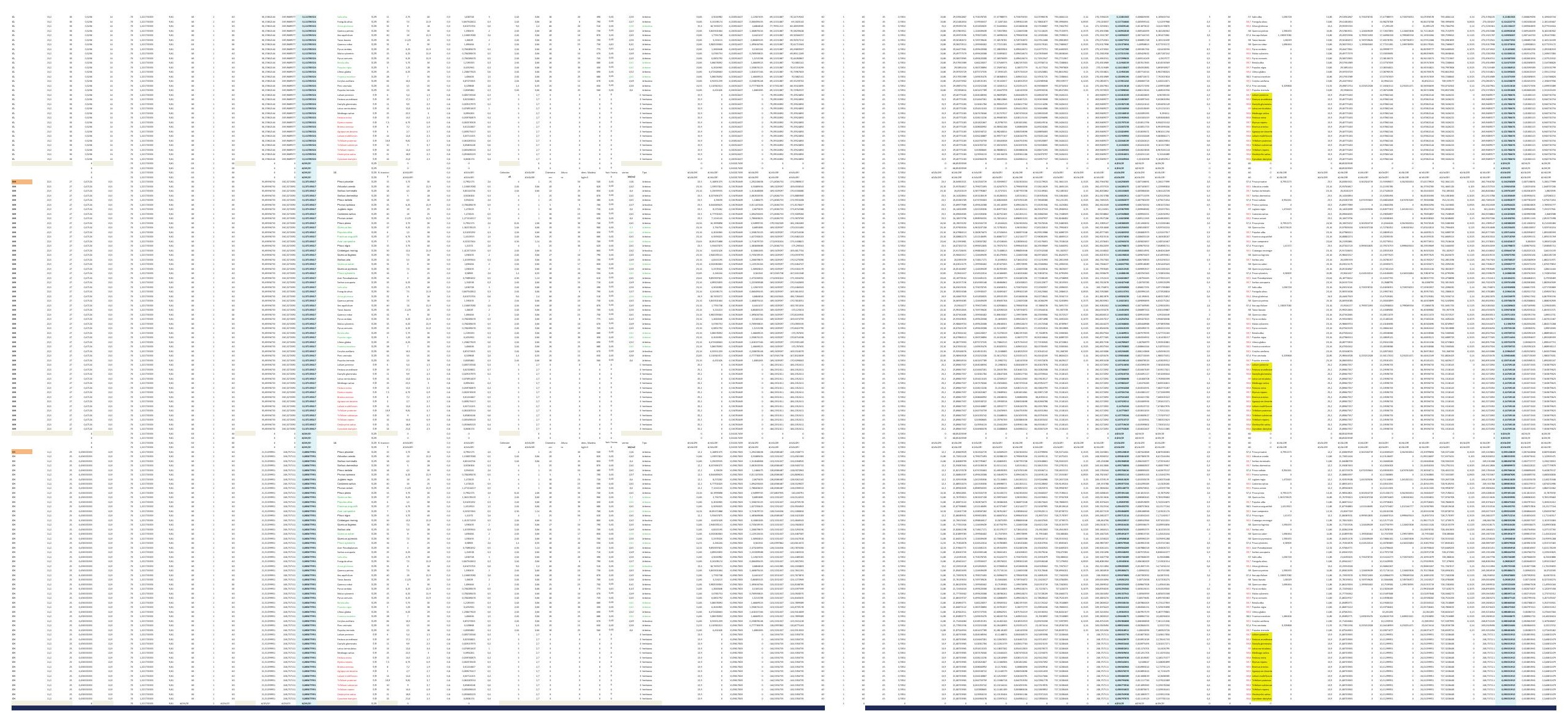



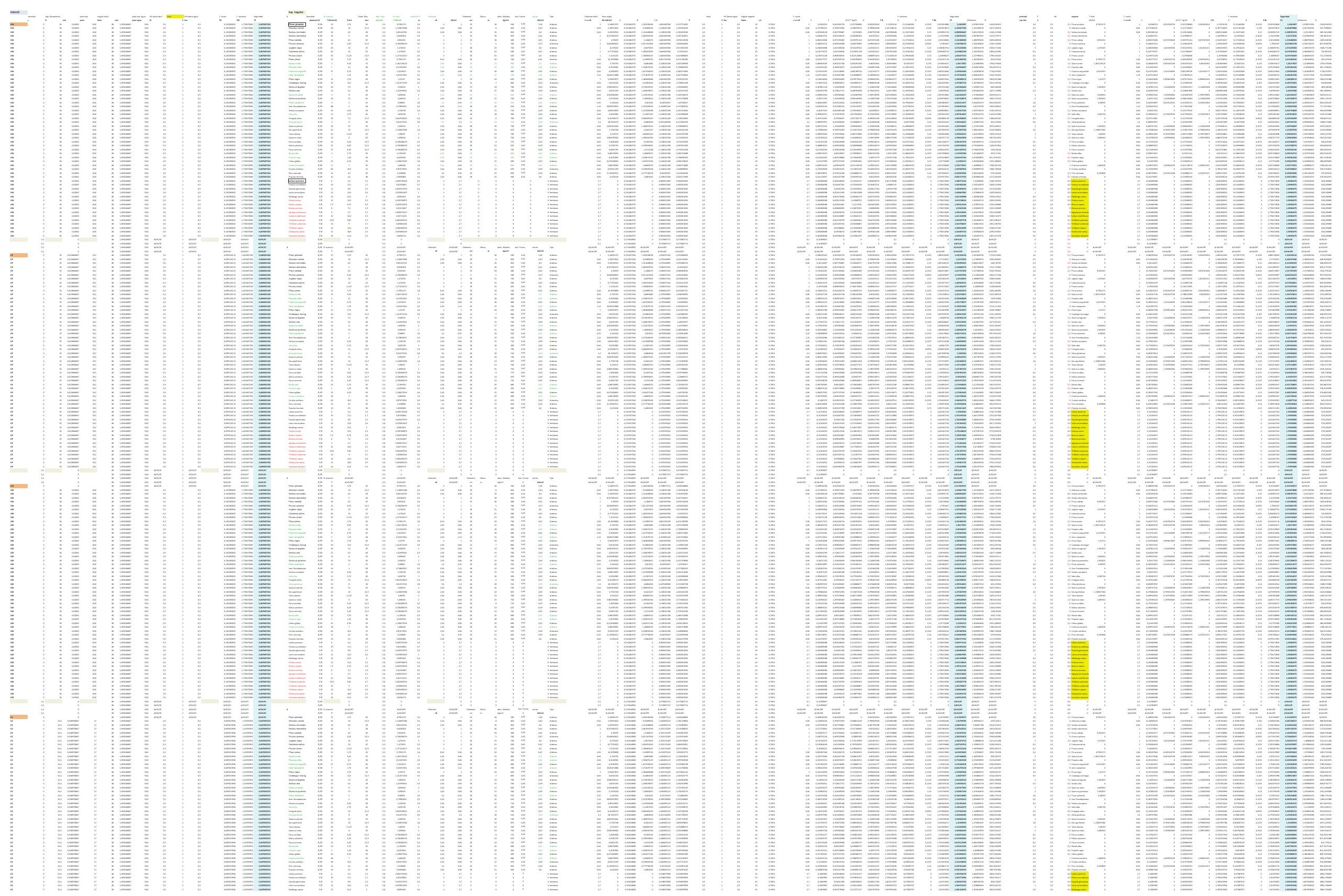

信 $\underline{\bar{E}} \equiv \bar{\equiv} \equiv \equiv \equiv$
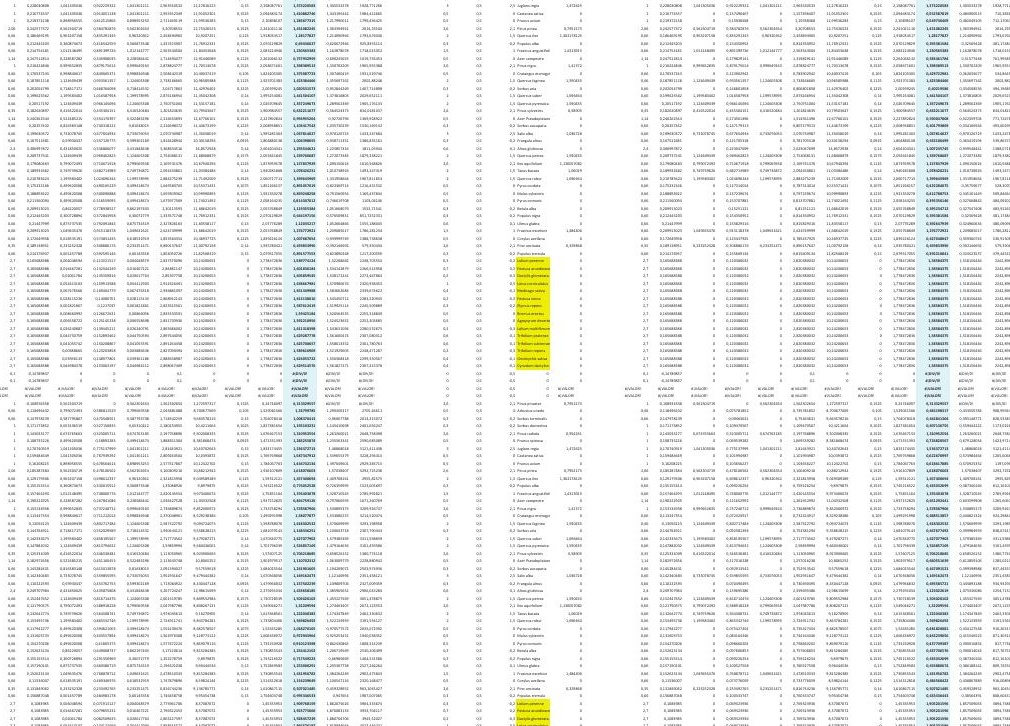

录

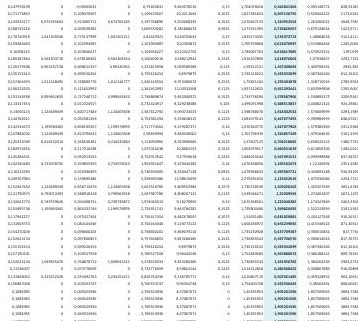




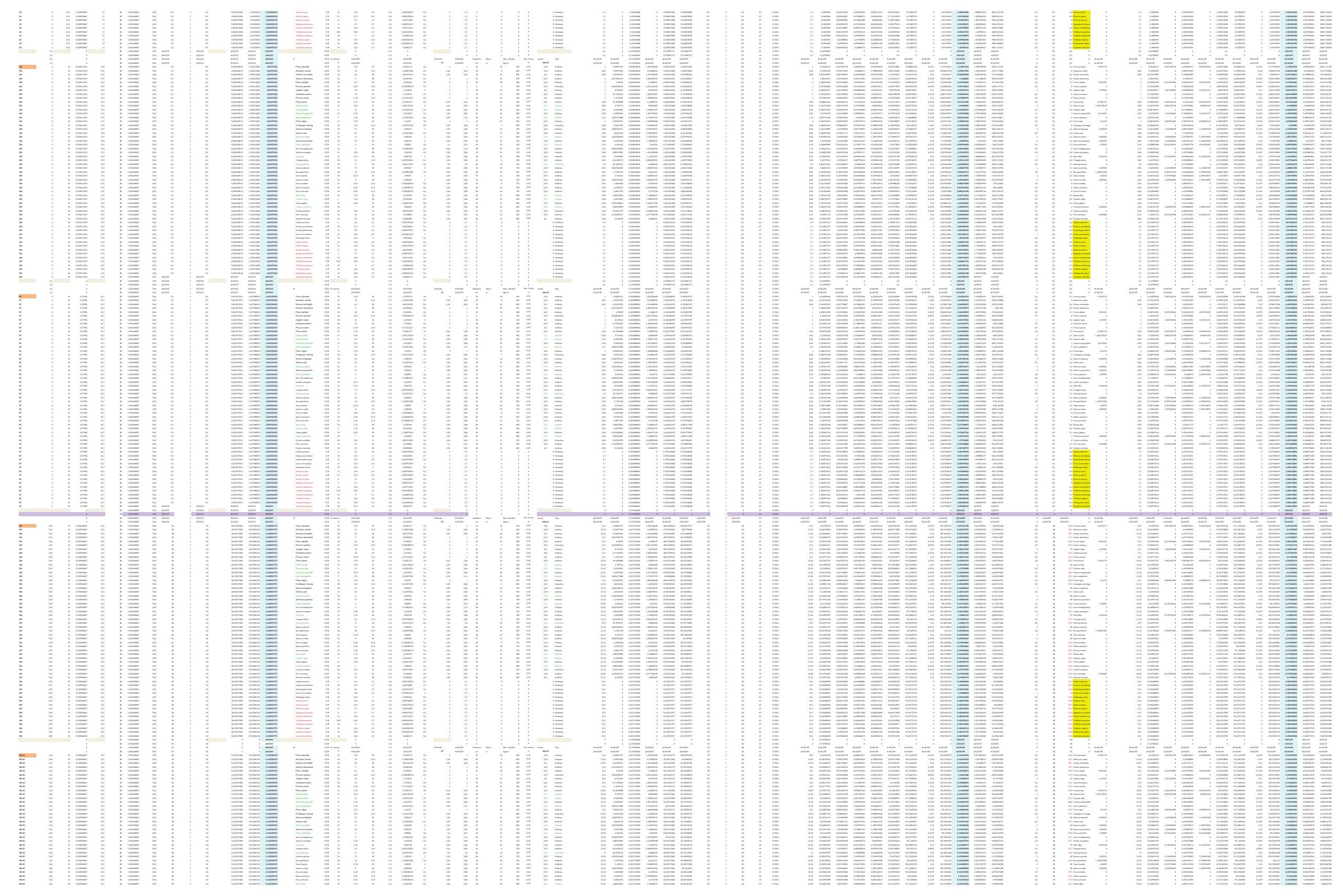



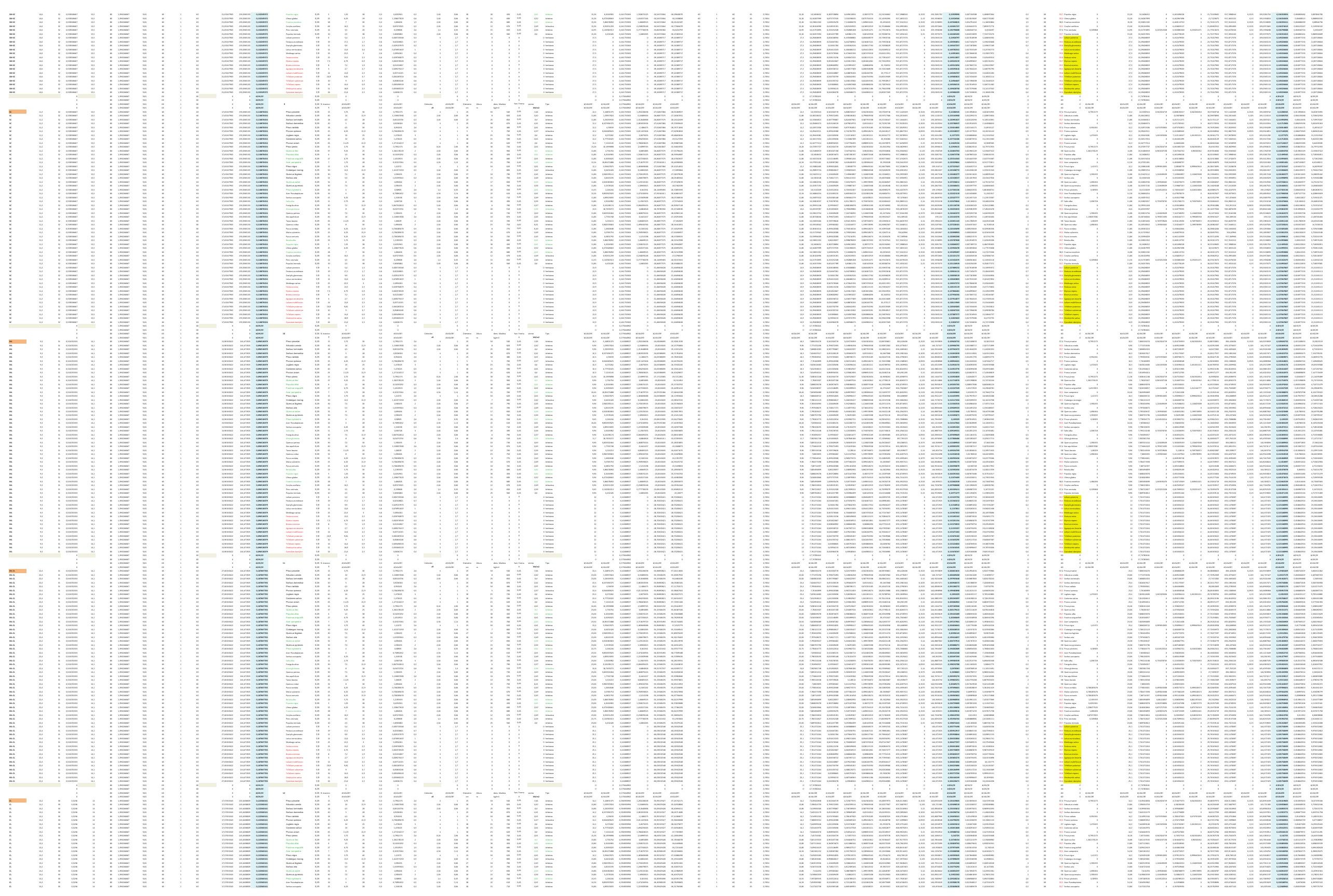


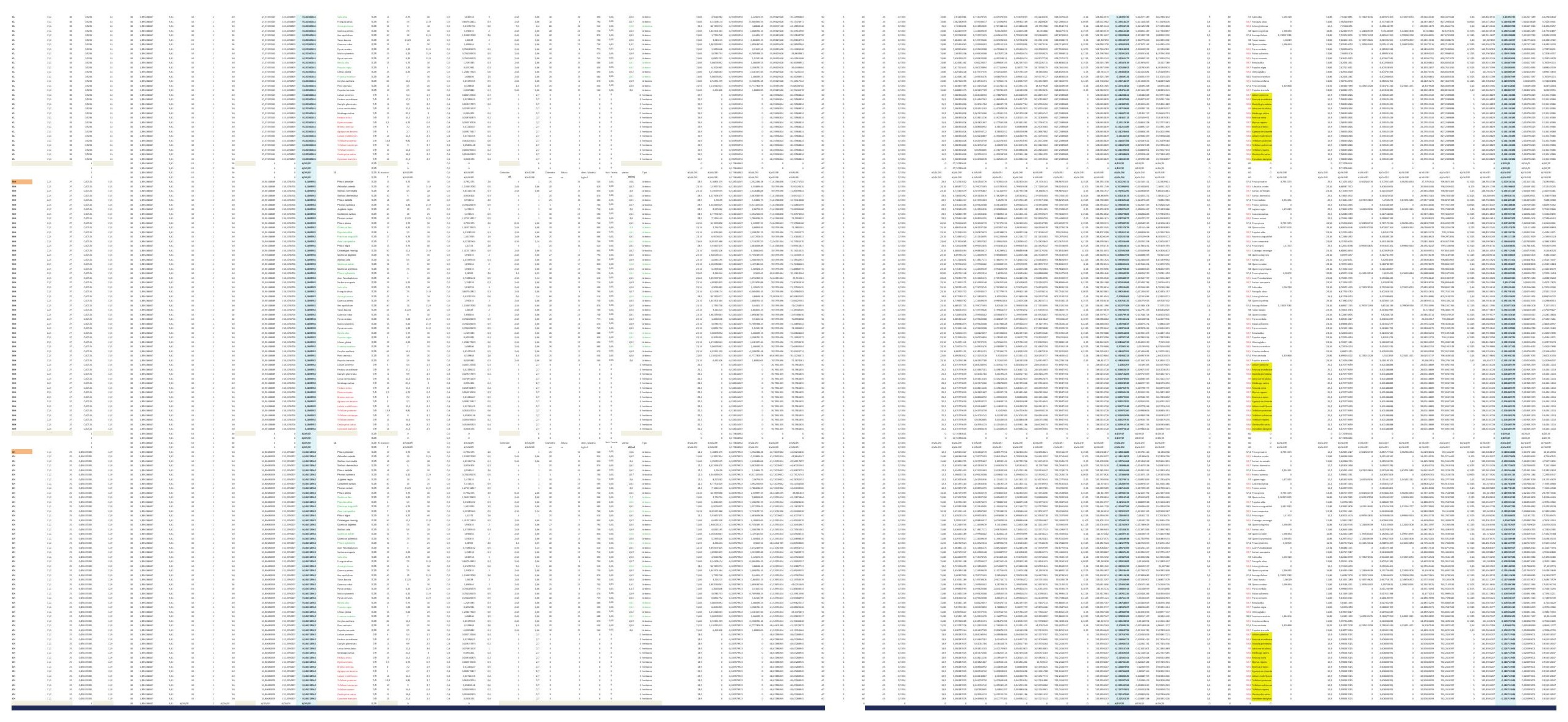


DESARROLLO DE UNA APLICACIÓN IMFORMÁTICA PARA EL CÁLCULO DE SOSTENIMIENTO DE TALUDES MEDIANTE VEGETACIÓN

A02. DENSIDAD DE PLANTACIÓN: 1.600 plantas/ha.

A02-1.POSICIÓN N.F. 1

A02-2.POSICIÓN N.F. 2

A02-3.POSICIÓN N.F. 3

A02-4.POSICIÓN N.F. 4

A02-5.POSICIÓN N.F. 5 
DESARROLLO DE UNA APLICACIÓN IMFORMÁTICA PARA EL CÁLCULO DE SOSTENIMIENTO DE TALUDES MEDIANTE VEGETACIÓN

A02. DENSIDAD DE PLANTACIÓN: 1.600 plantas/ha.

\section{A02-1.POSICIÓN N.F. 1}

INCLINACIÓN DE TALUD 6-100

INCLINACIÓN DE TALUD 10-200

INCLINACIÓN DE TALUD 20-30

INCLINACIÓN DE TALUD 30-40

INCLINACIÓN DE TALUD $35^{\circ}$

INCLINACIÓN DE TALUD 40-50

INCLINACIÓN DE TALUD 50-550

INCLINACIÓN DE TALUD 55-60

INCLINACIÓN DE TALUD 60-700

INCLINACIÓN DE TALUD 70-80 

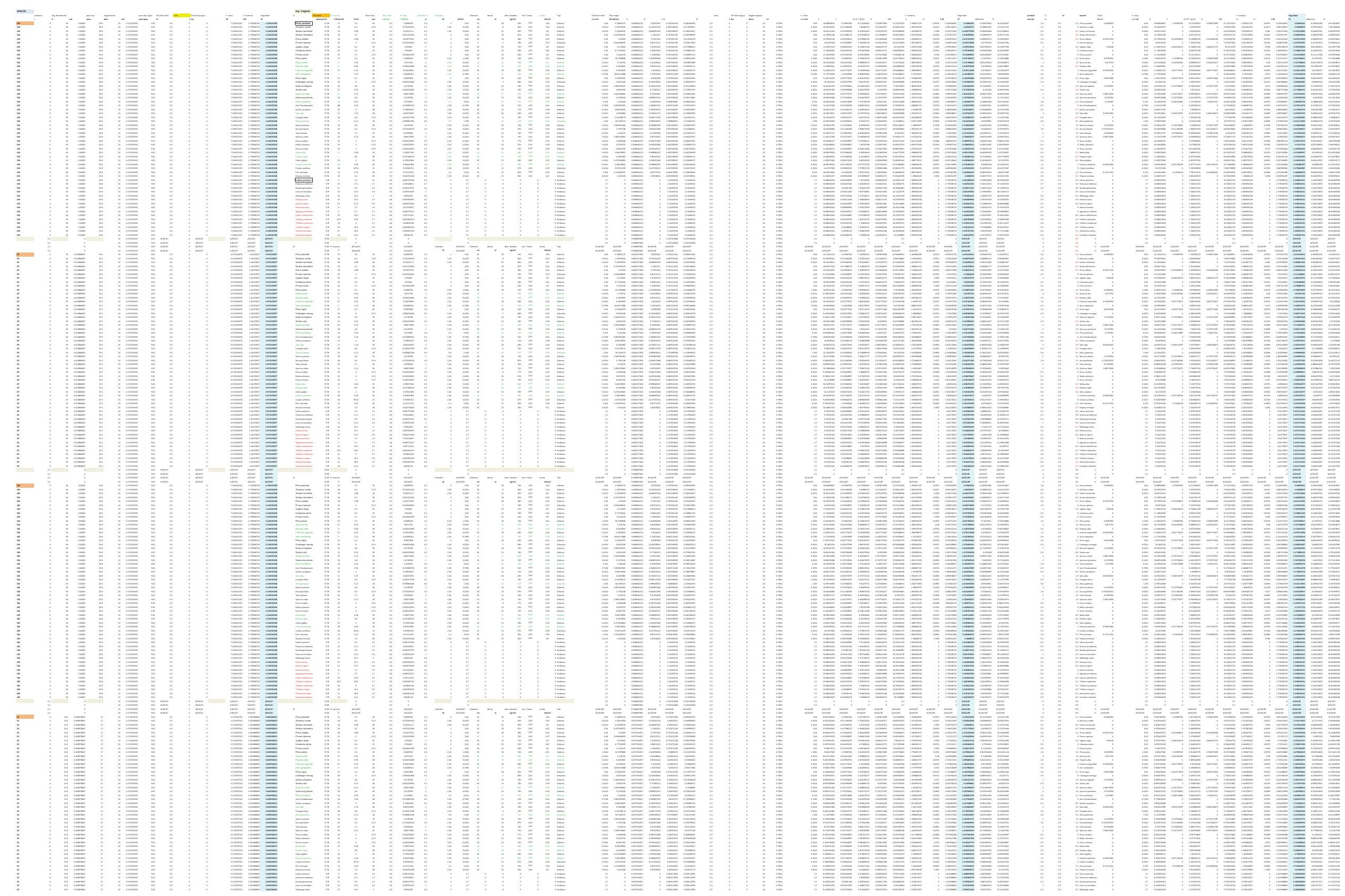


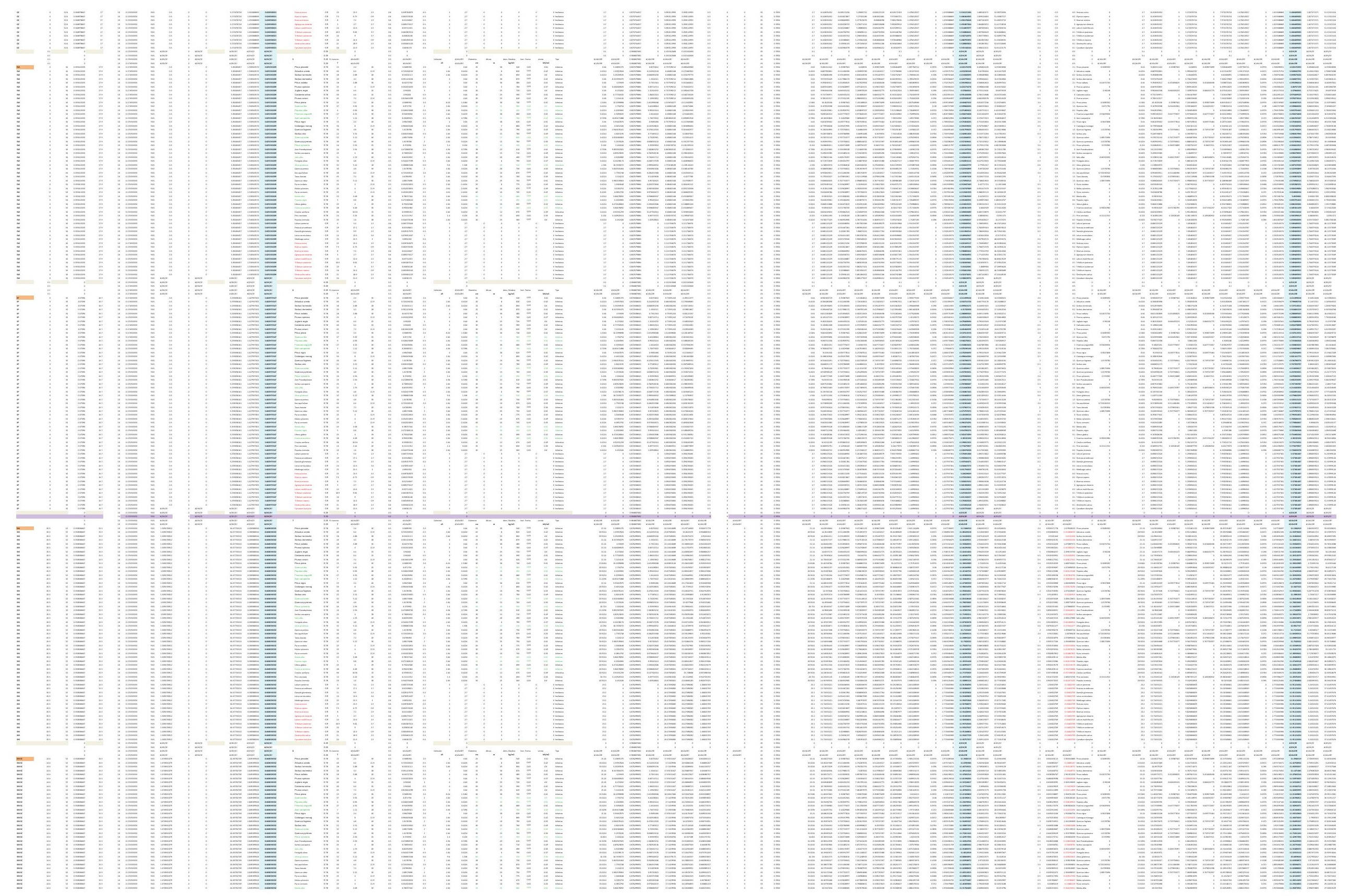



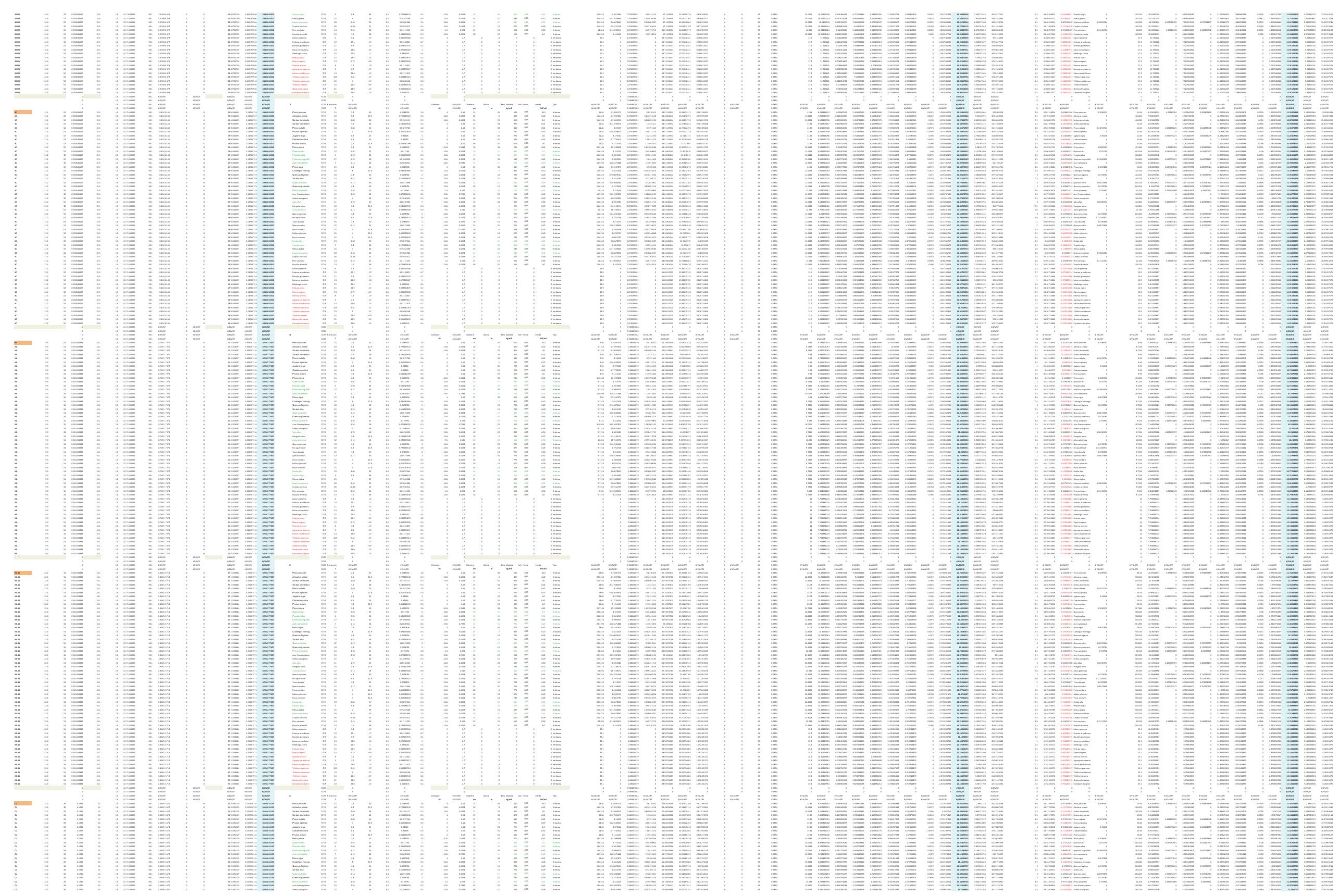

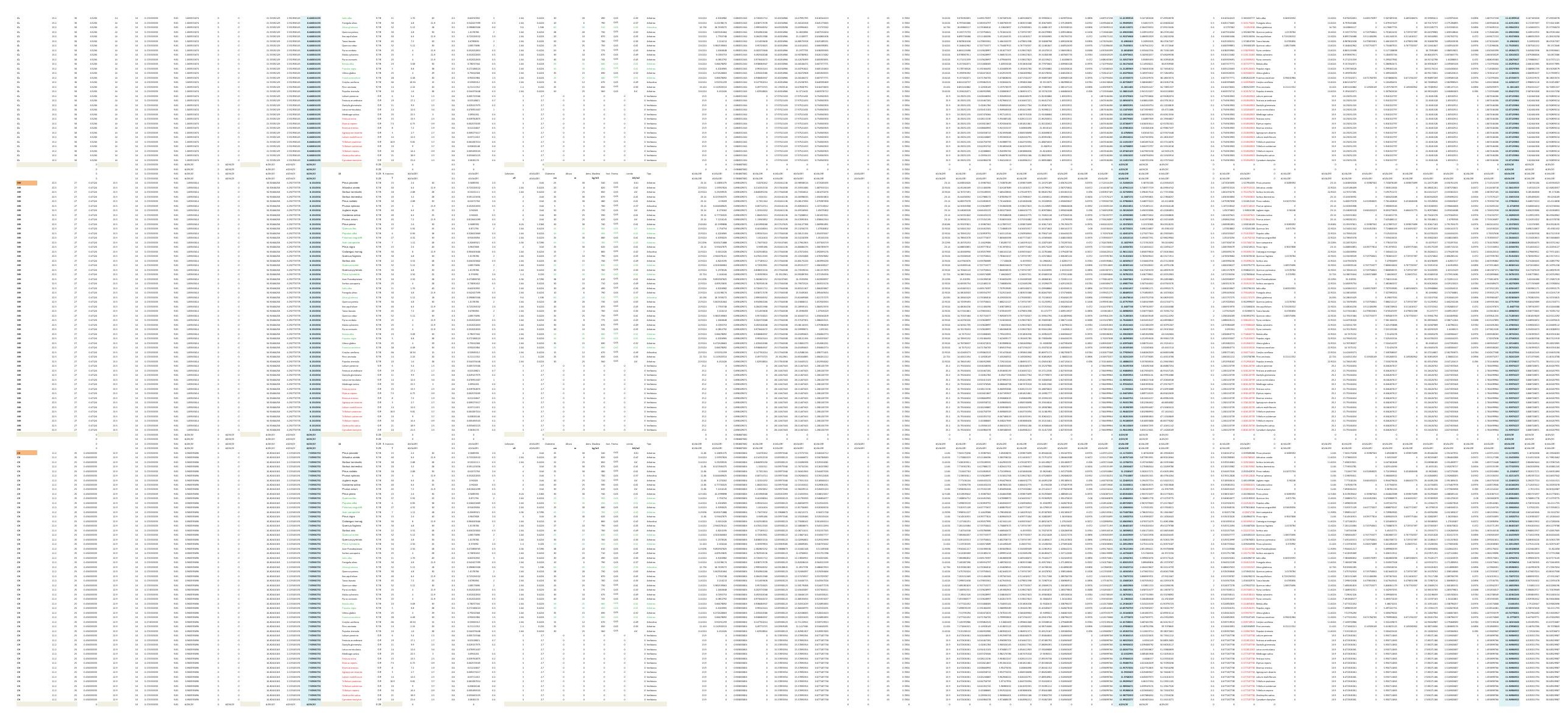

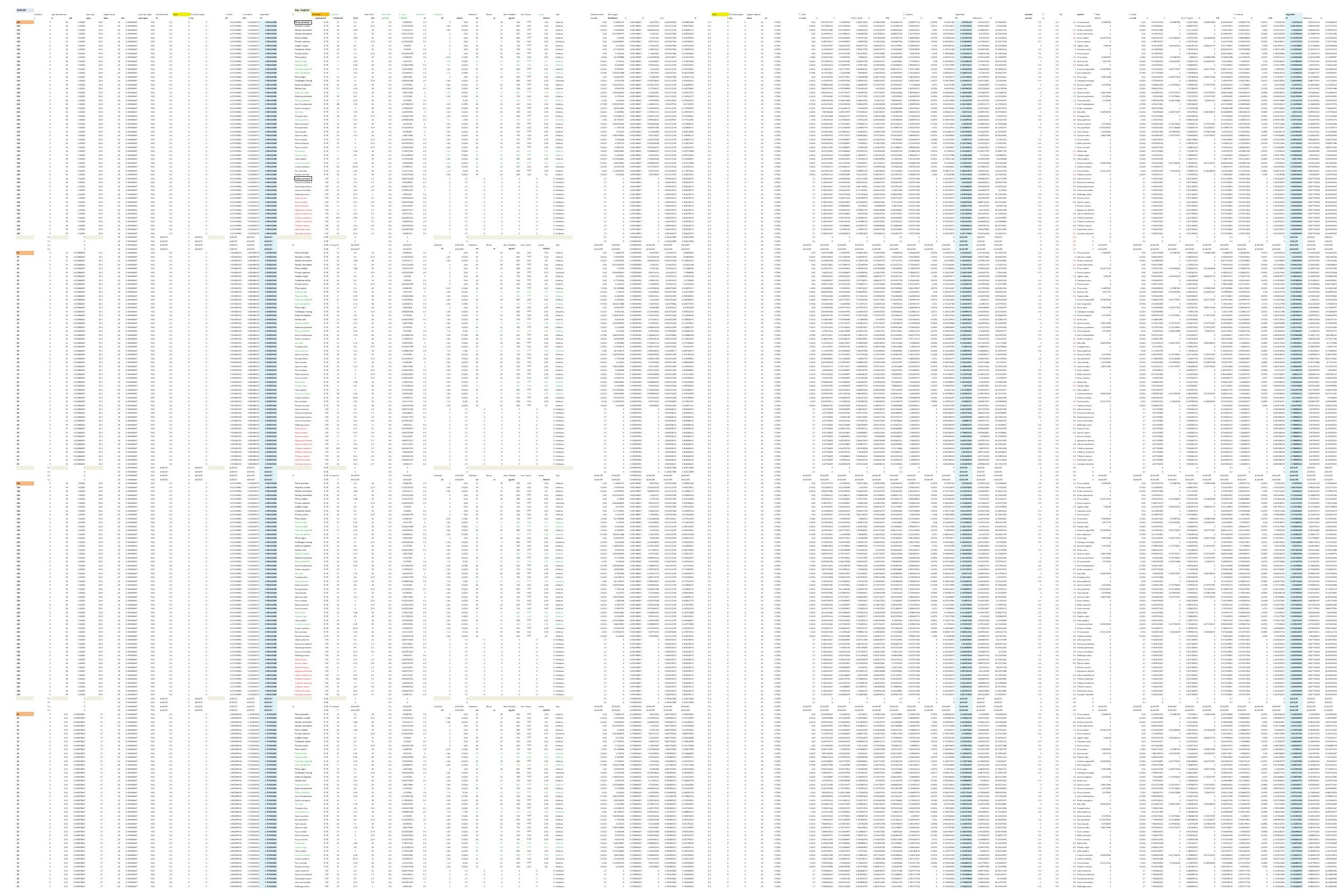


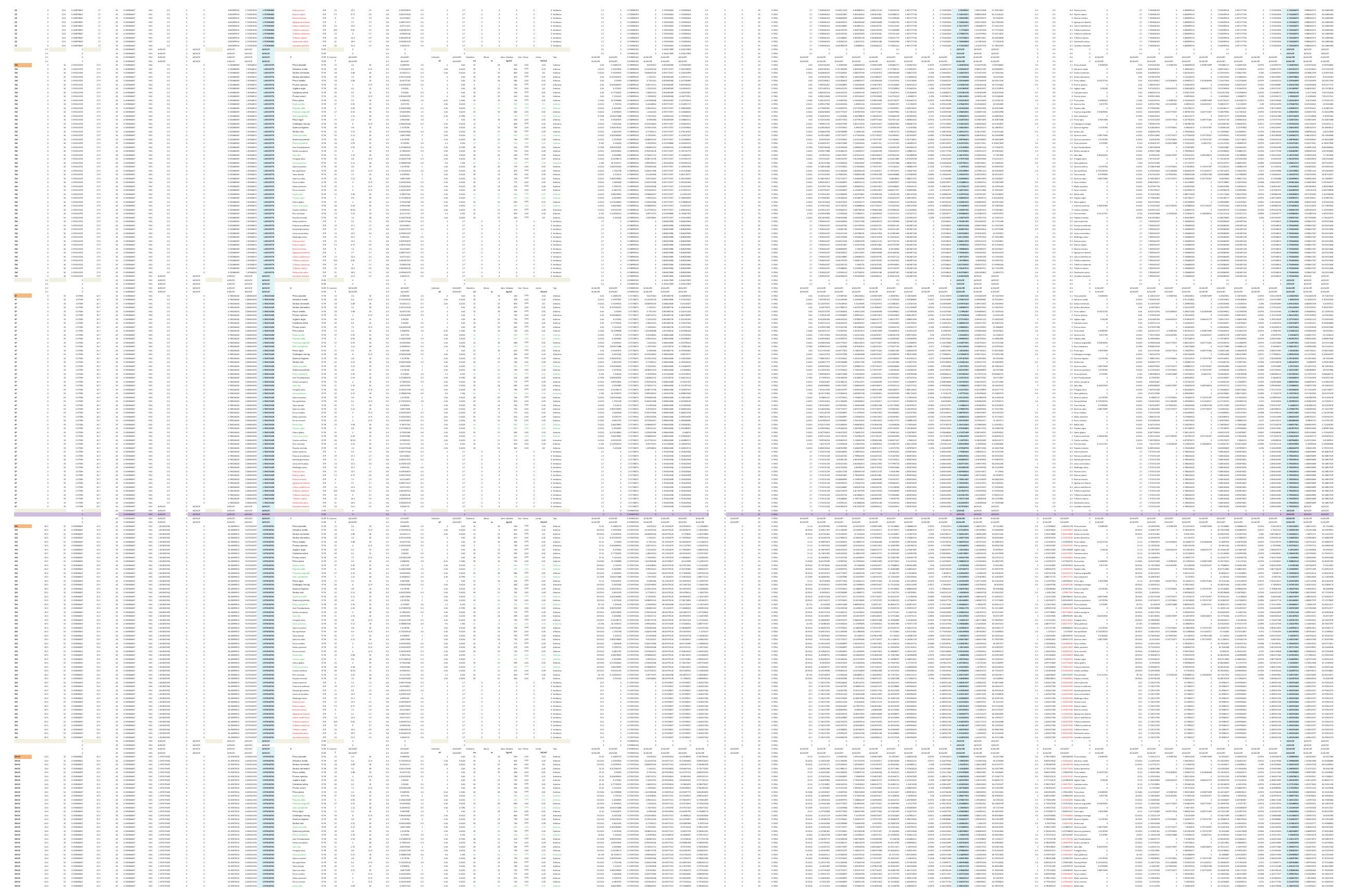



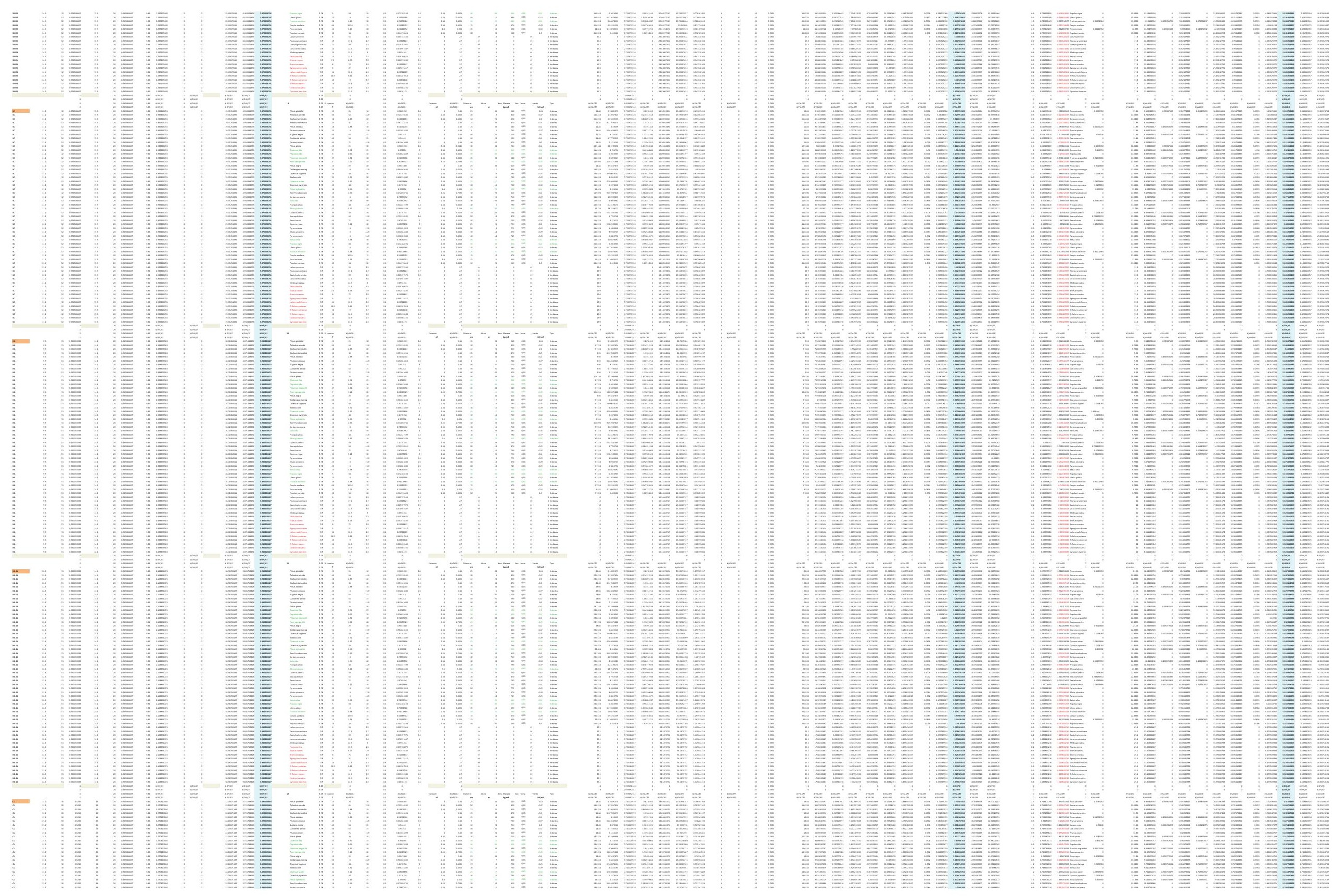


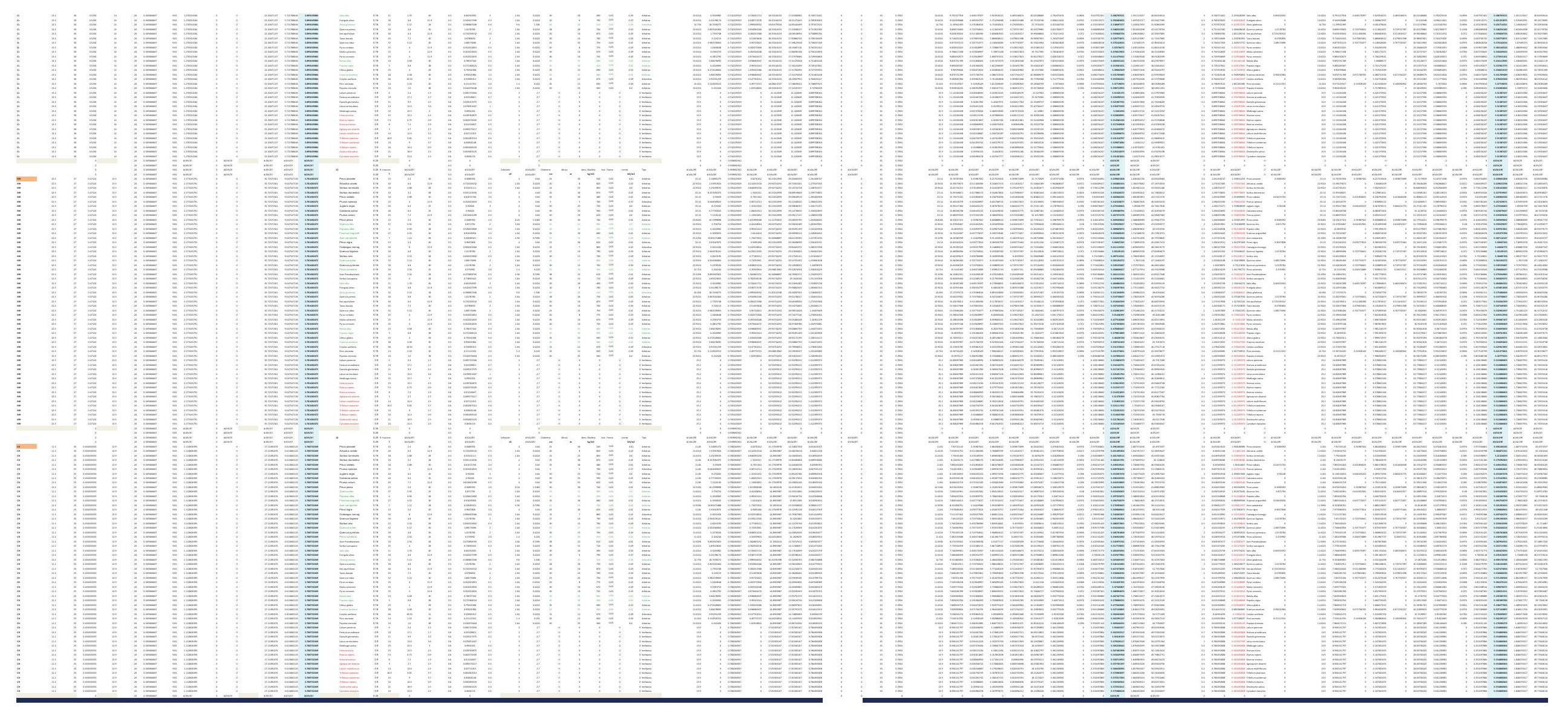



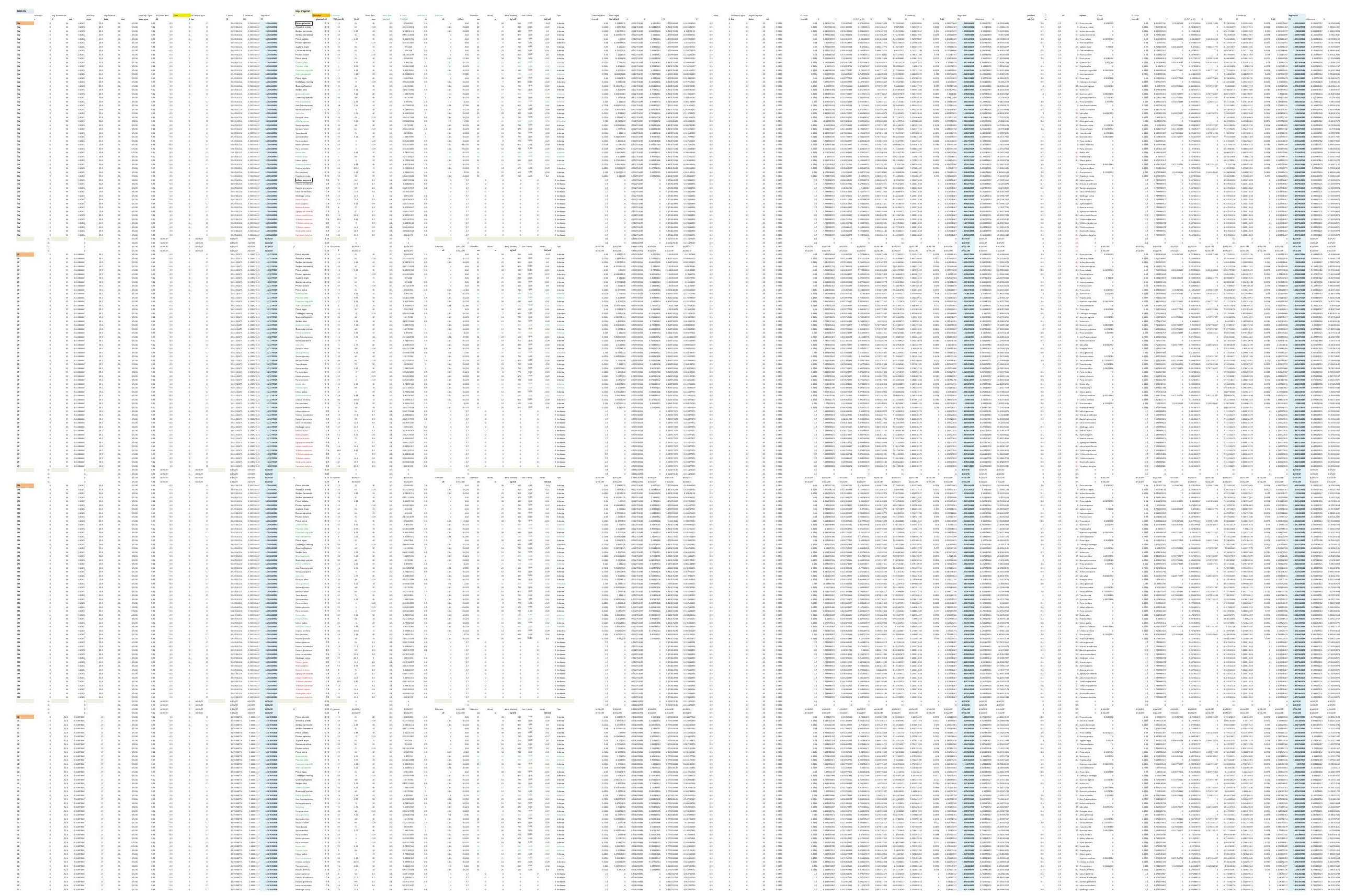


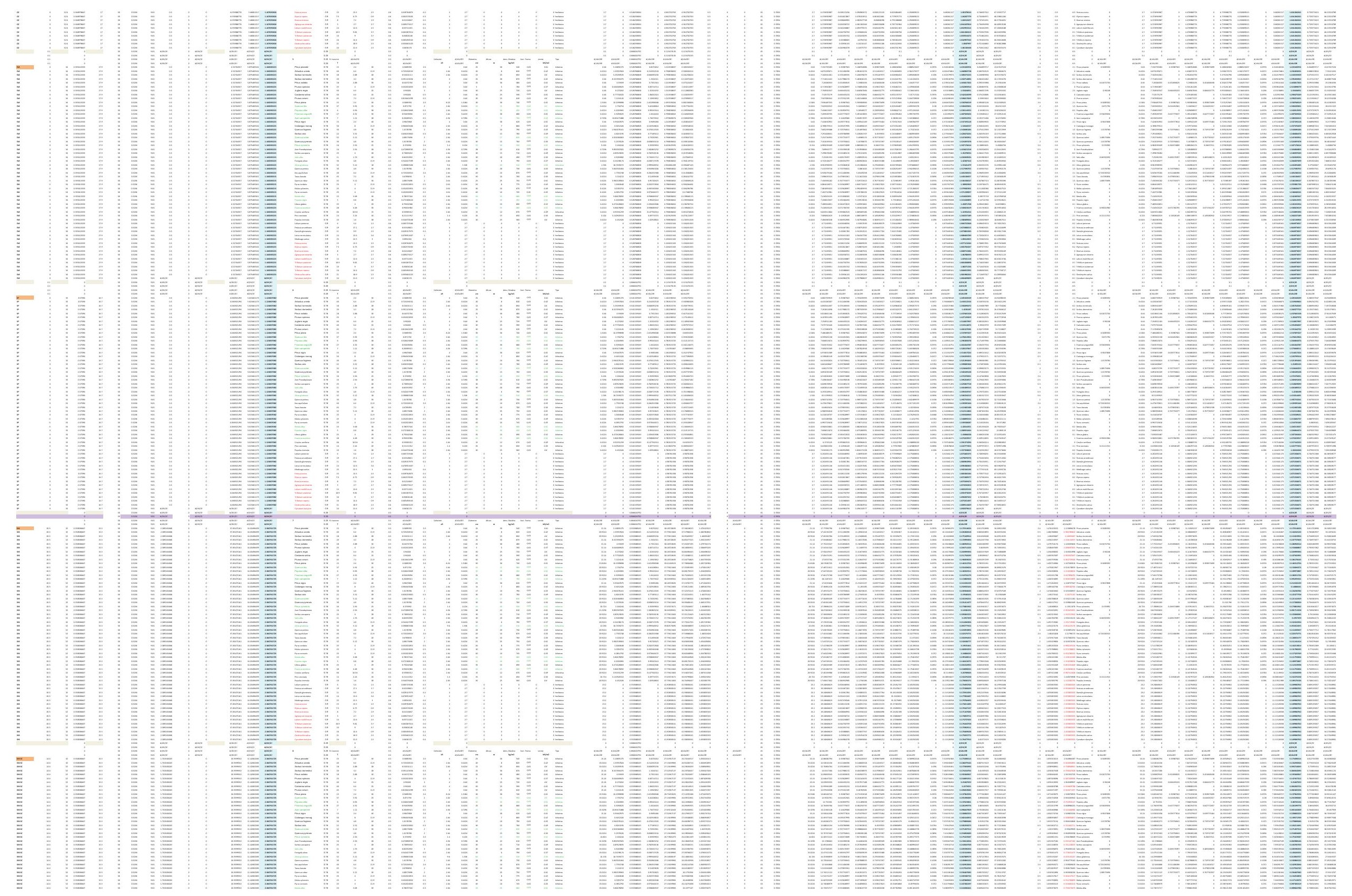



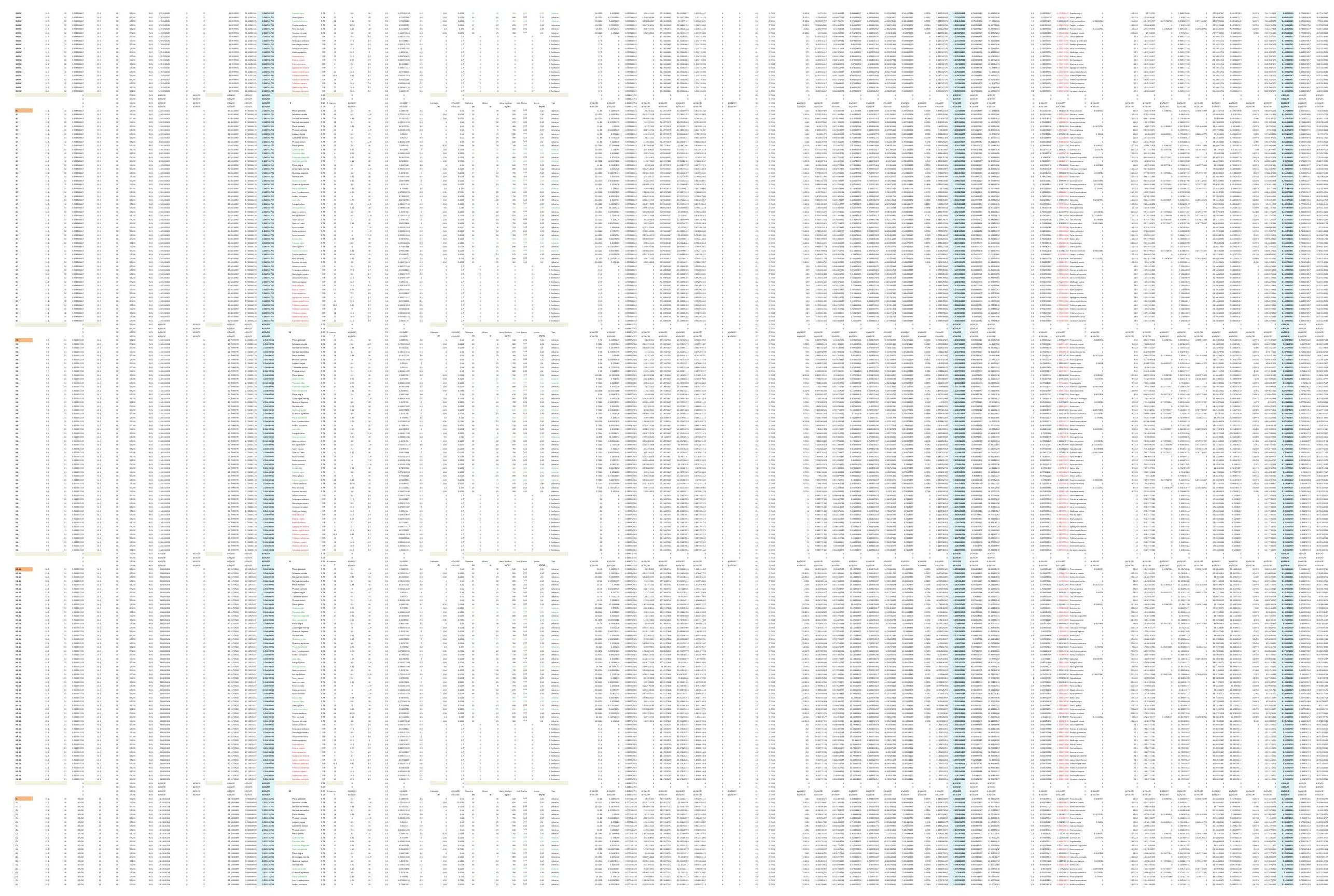


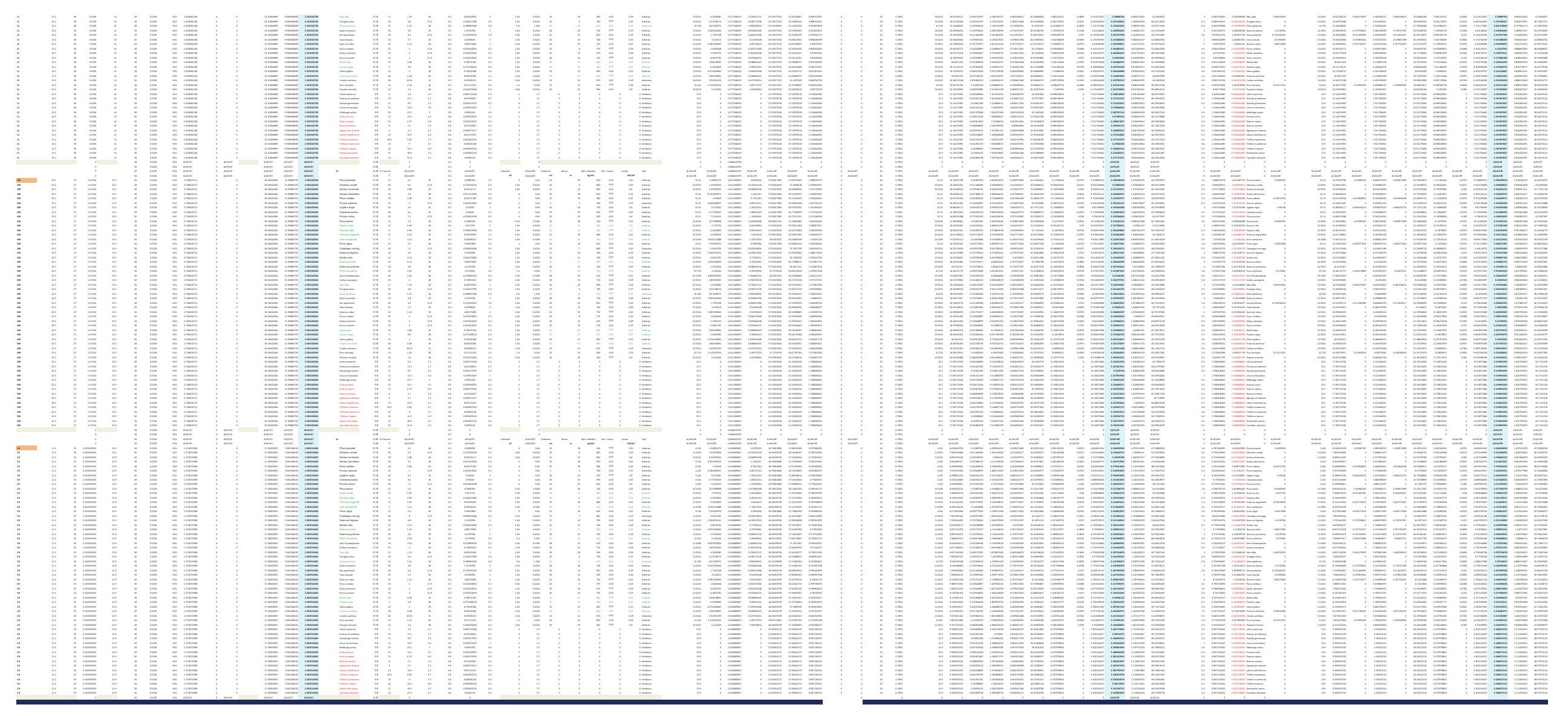



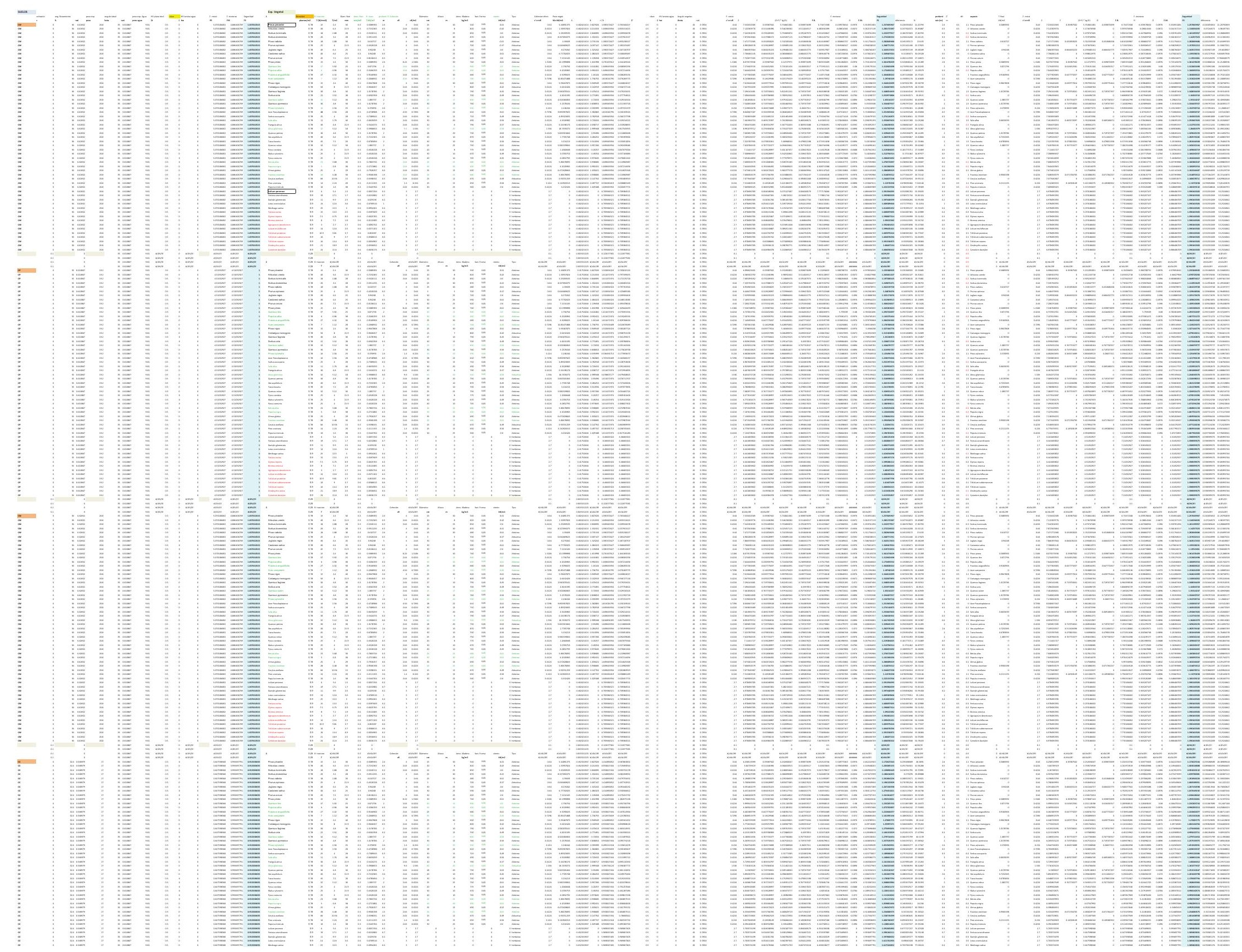


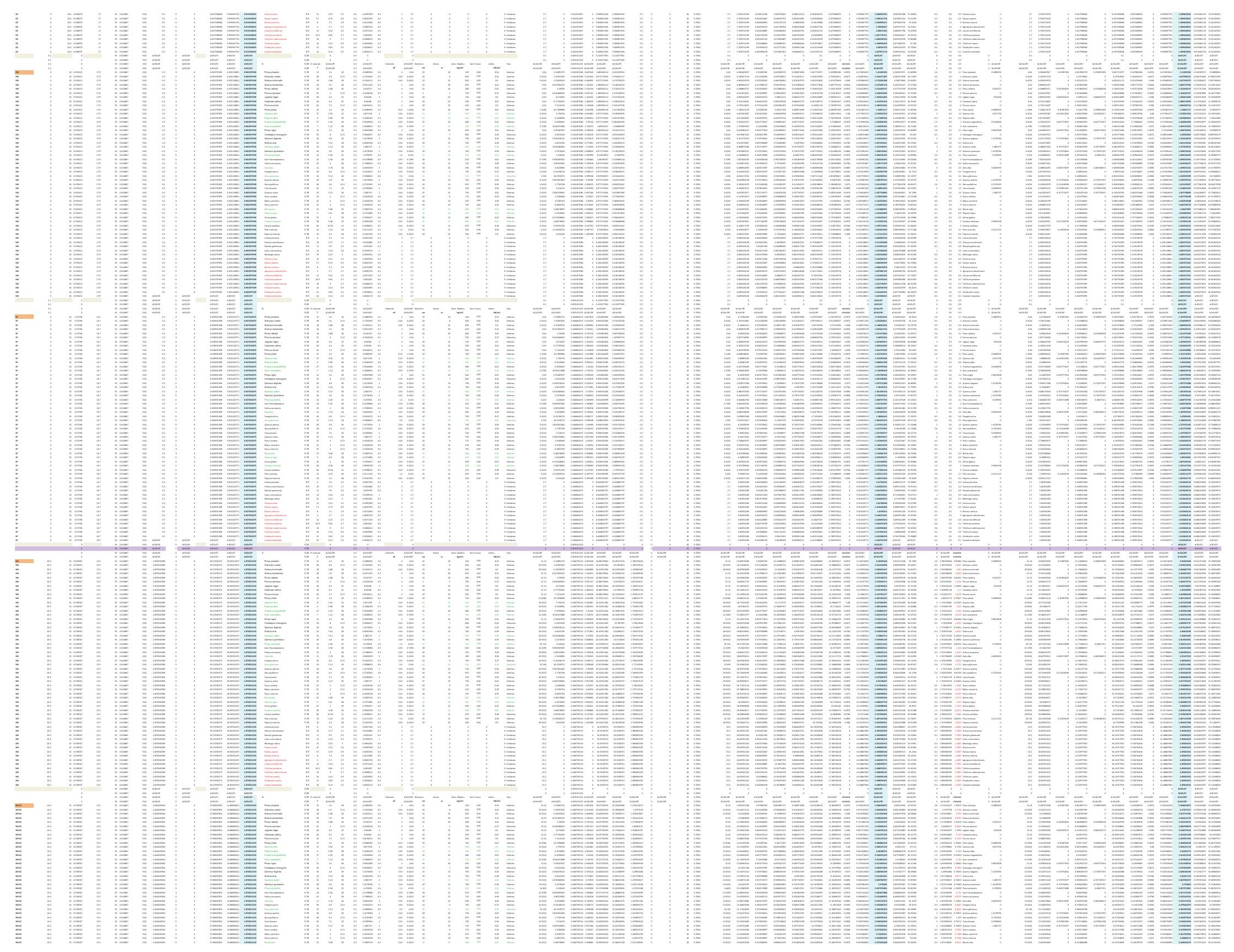



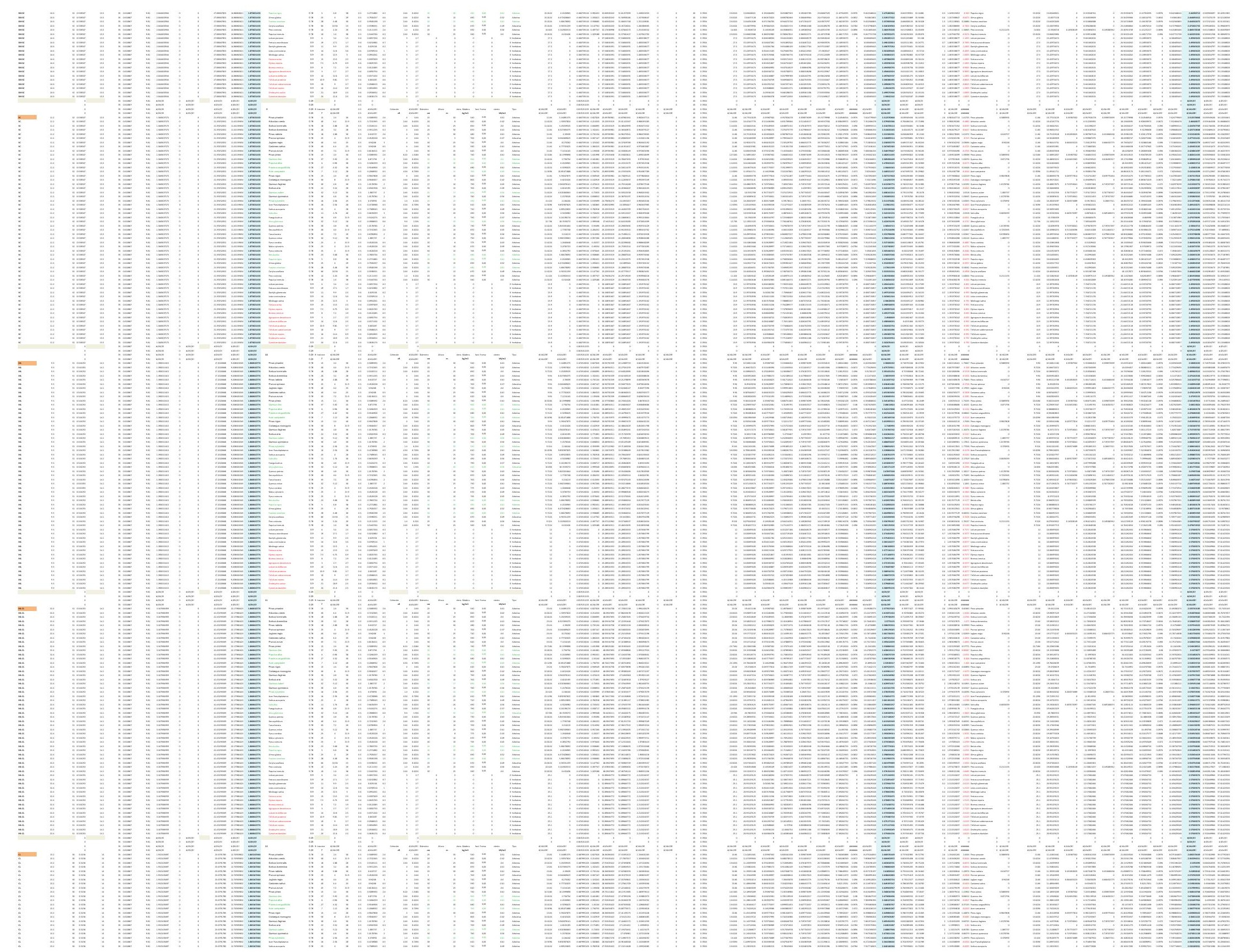


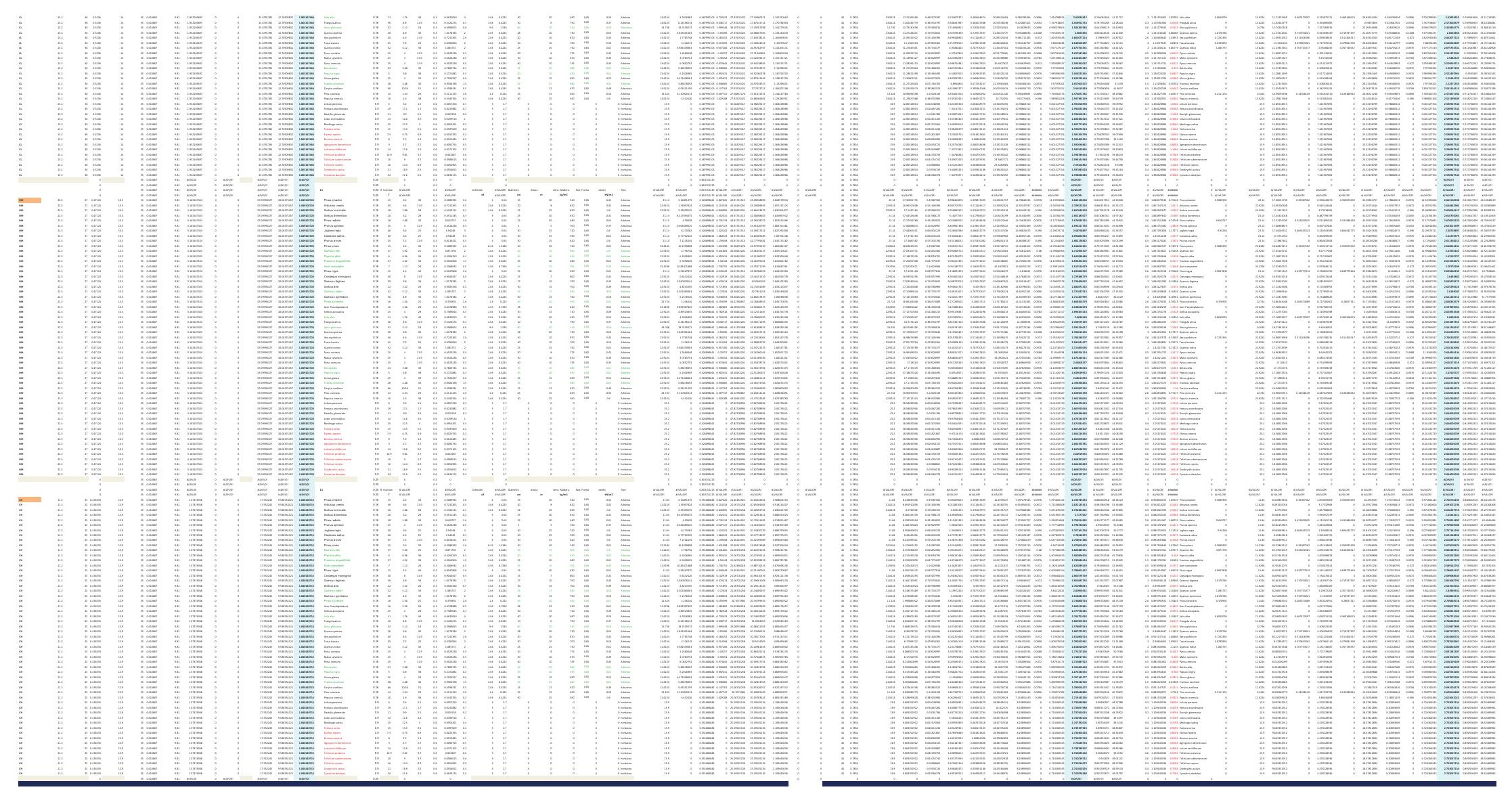



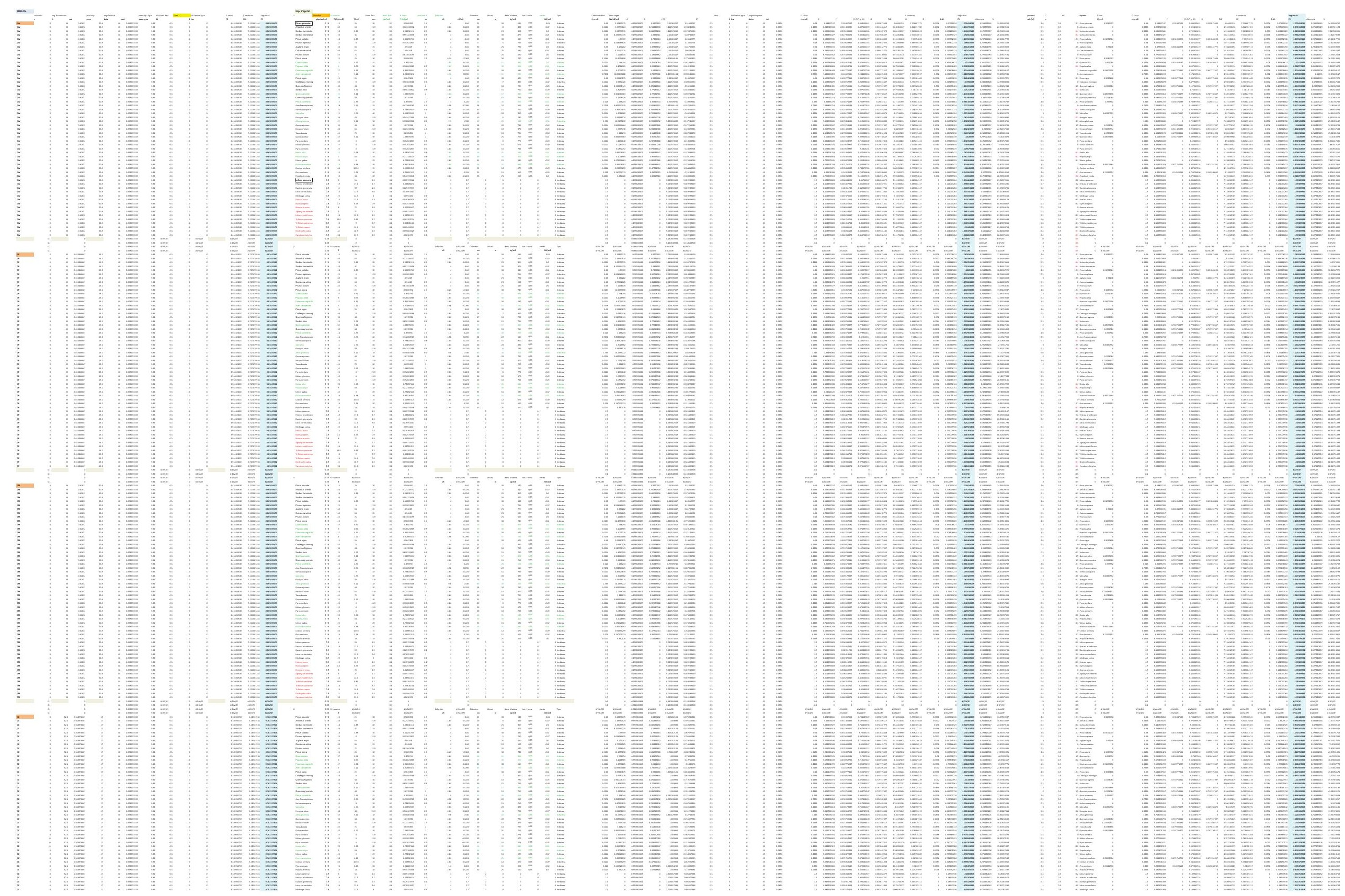


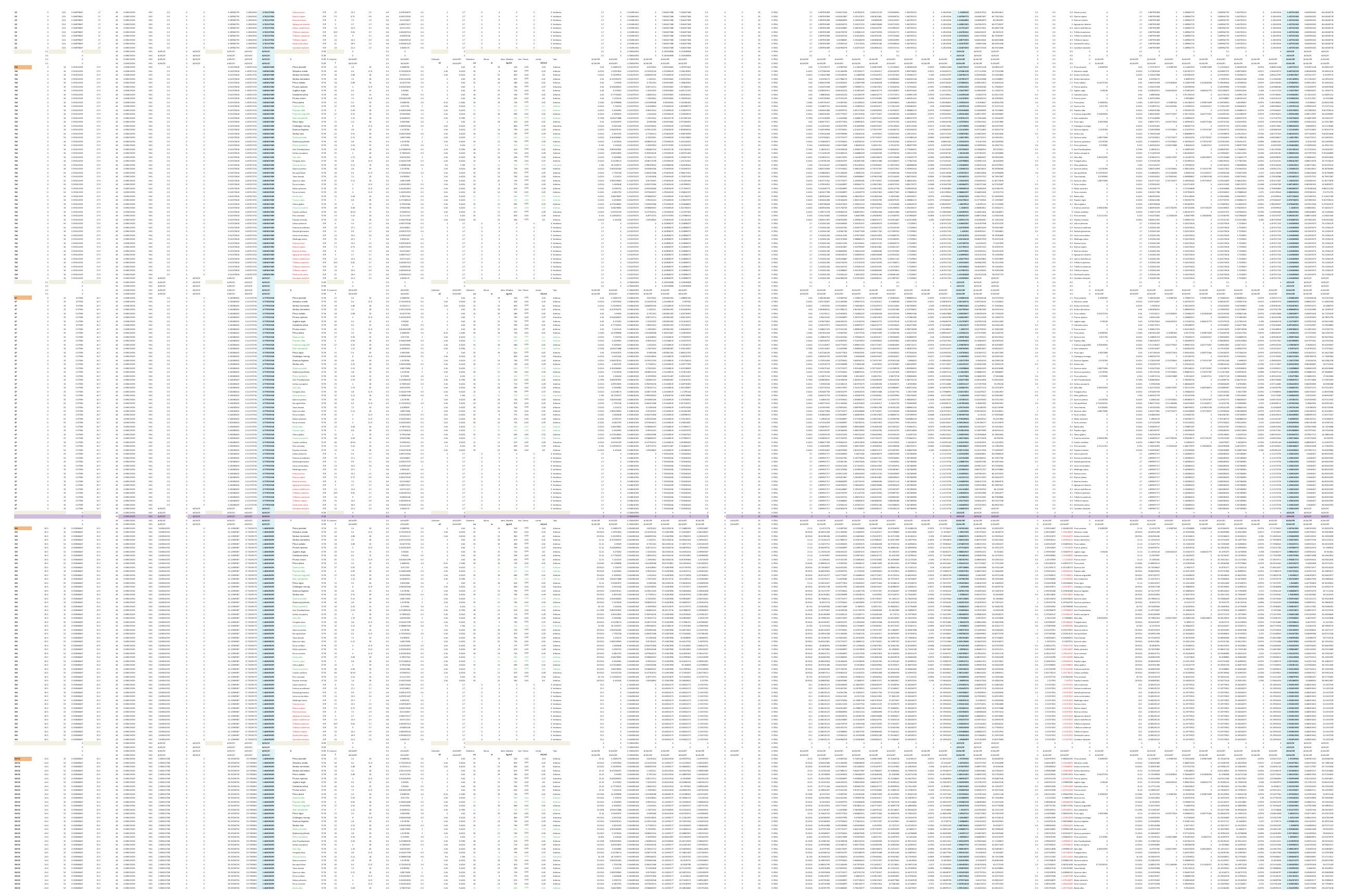



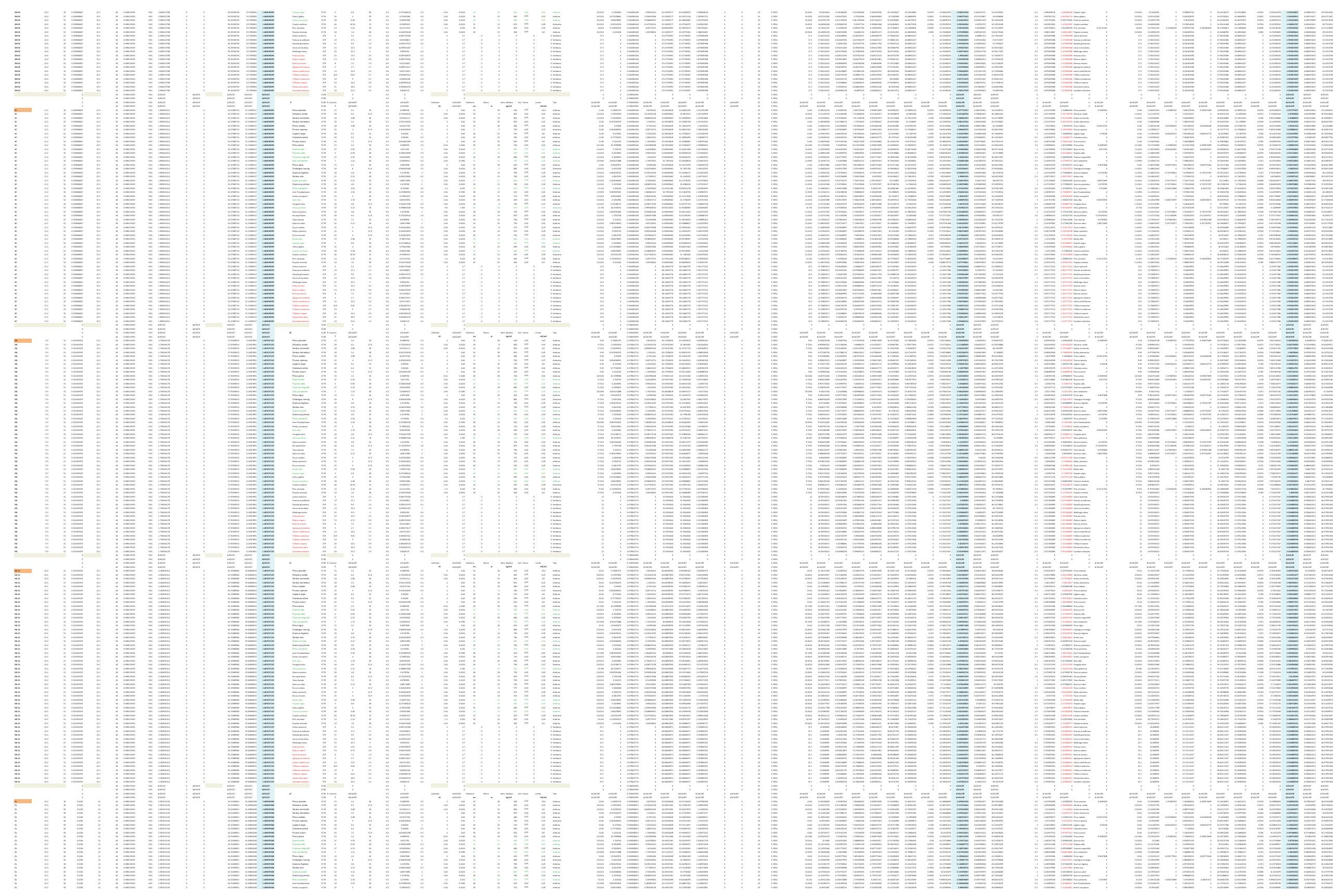


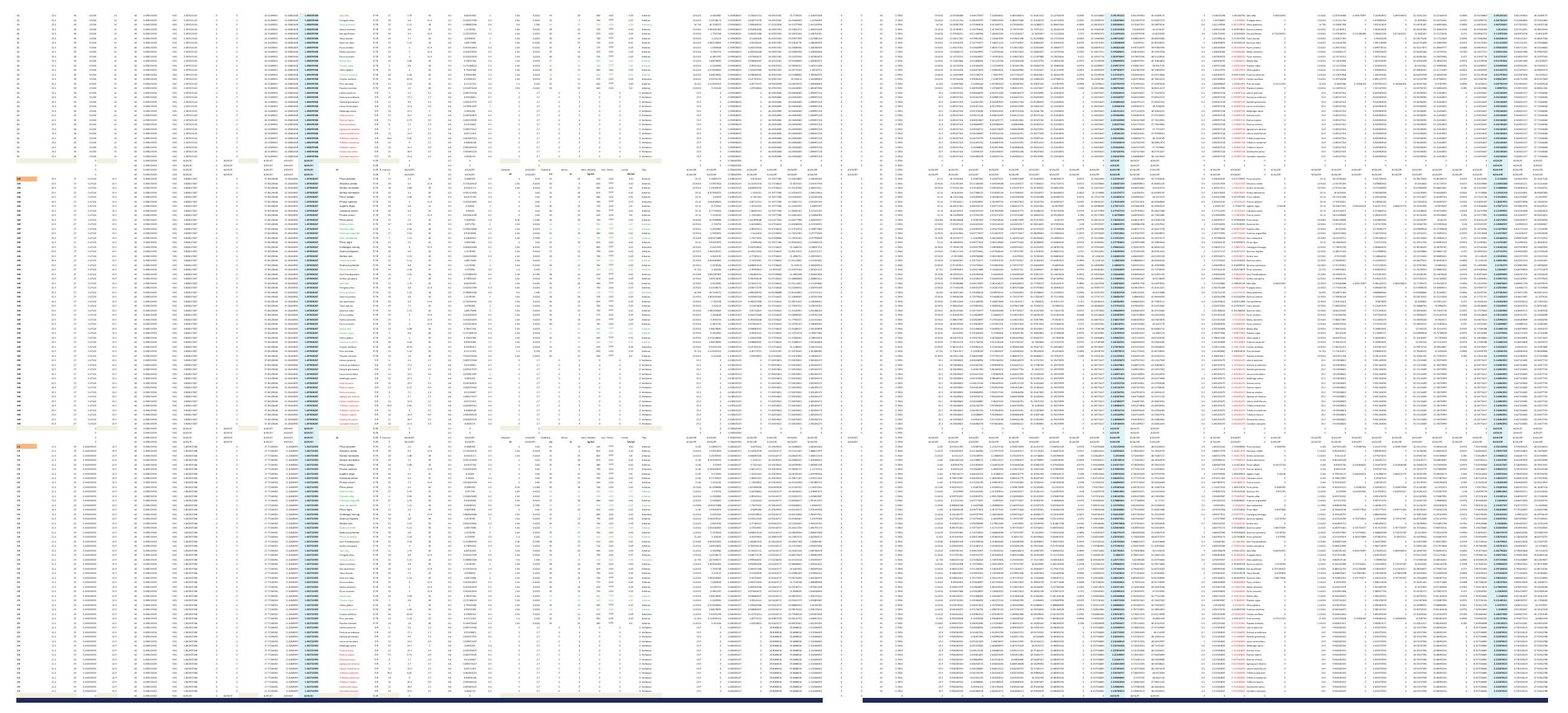



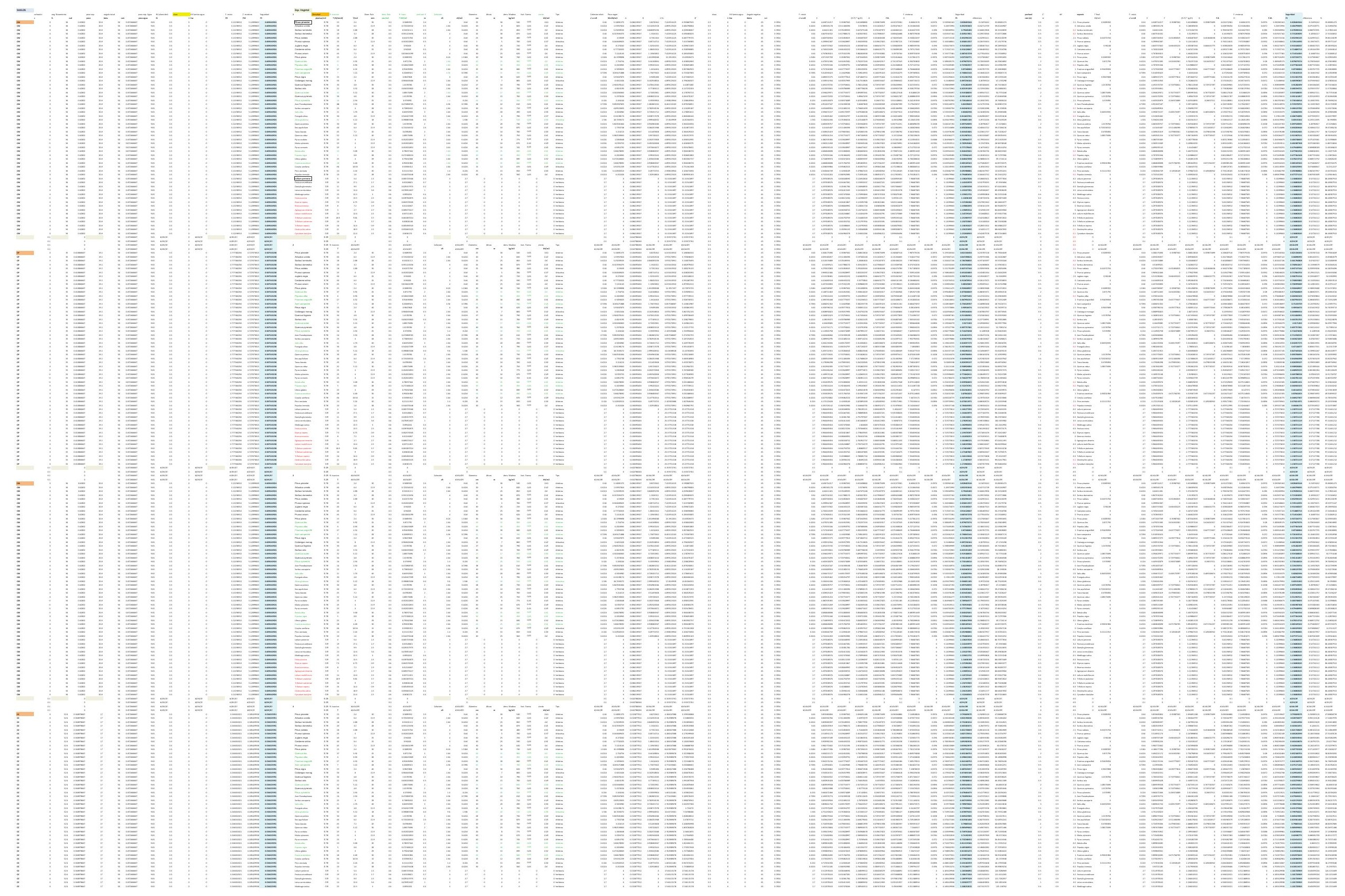


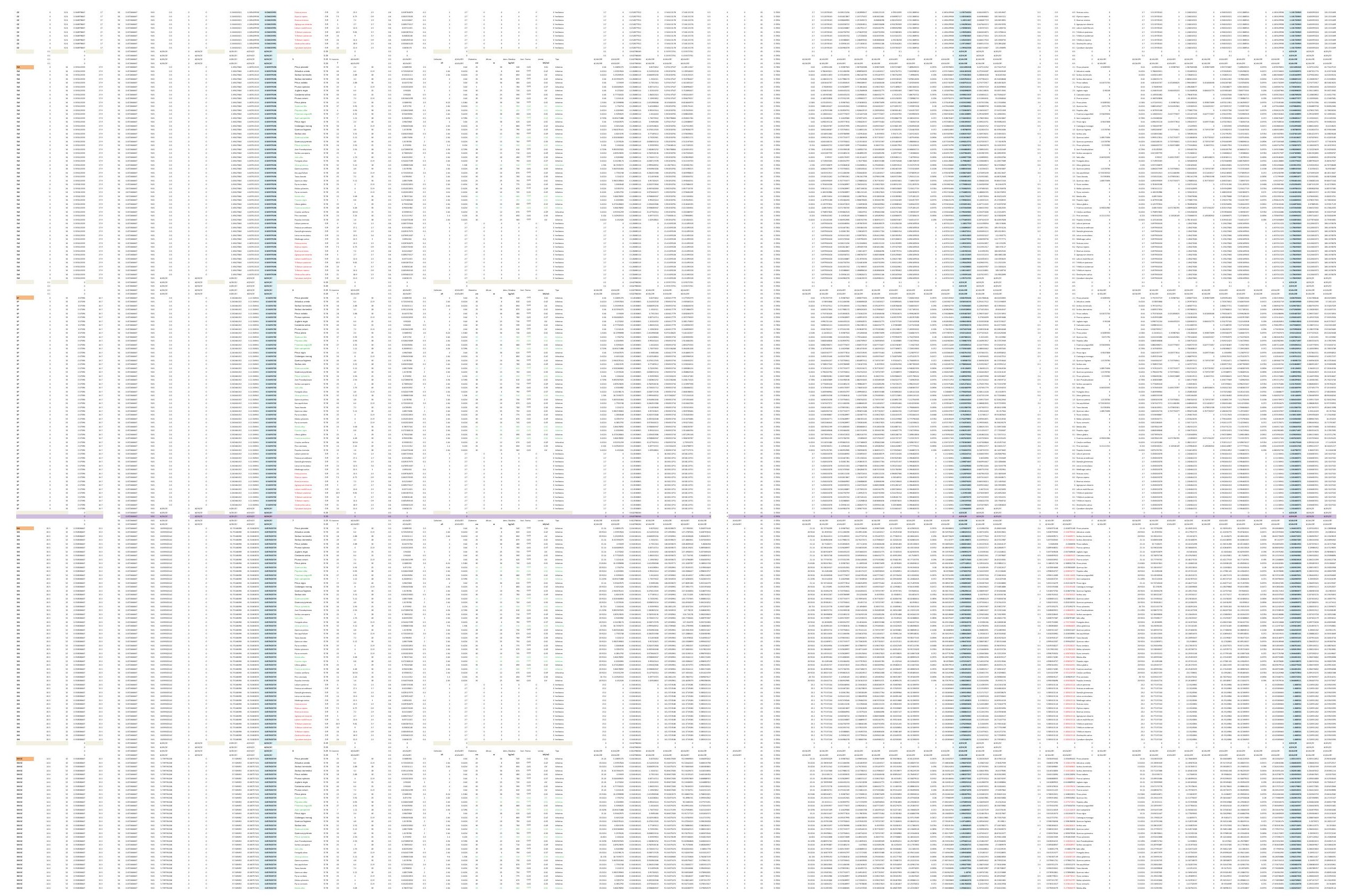



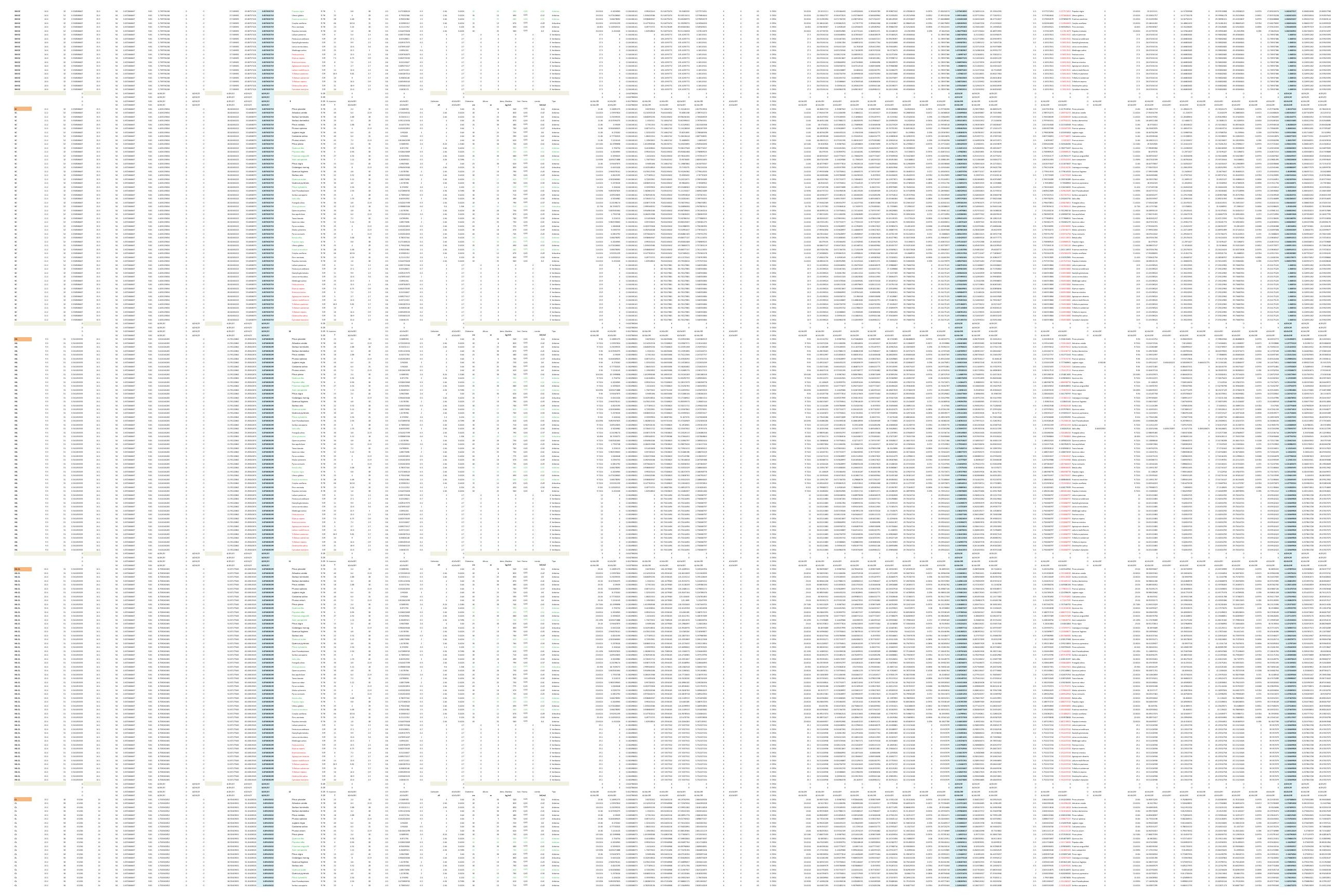


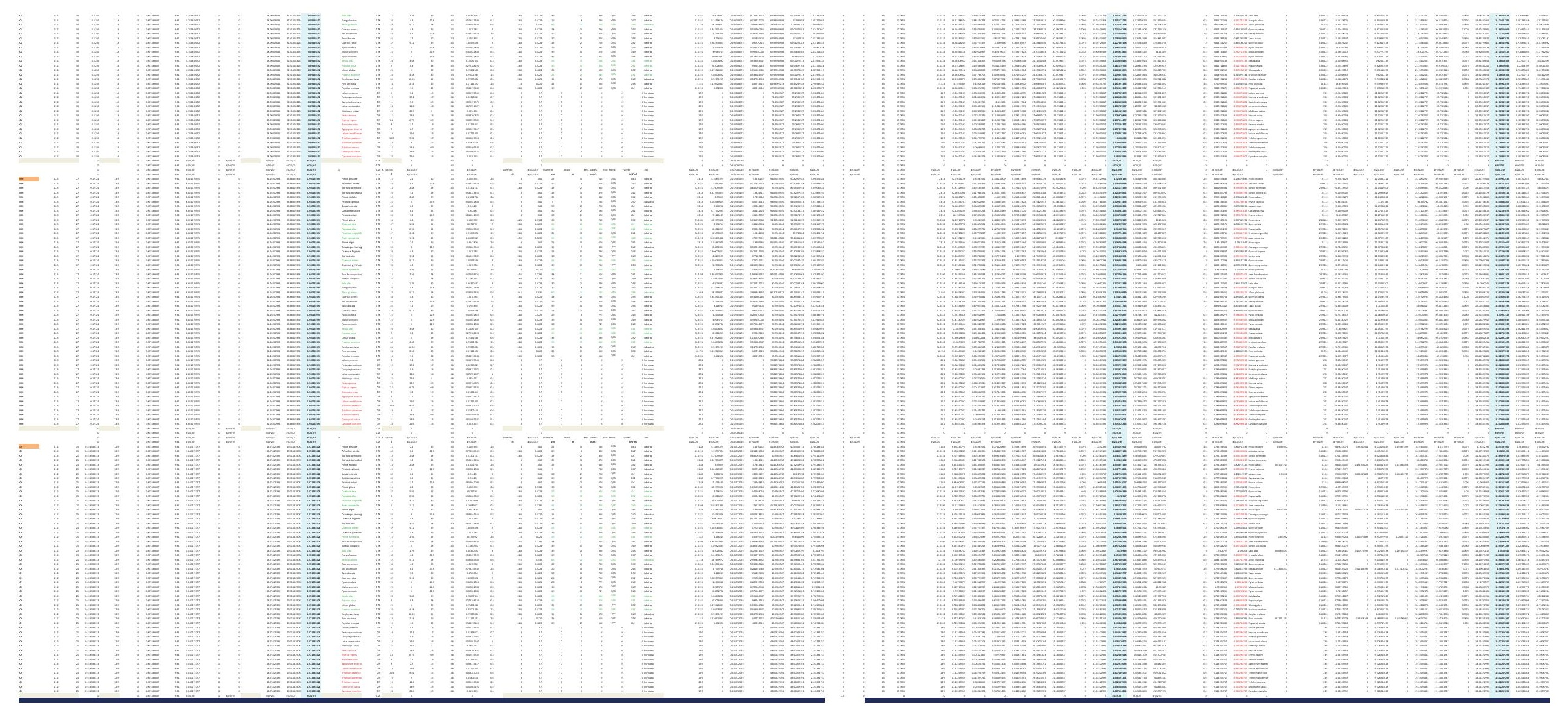



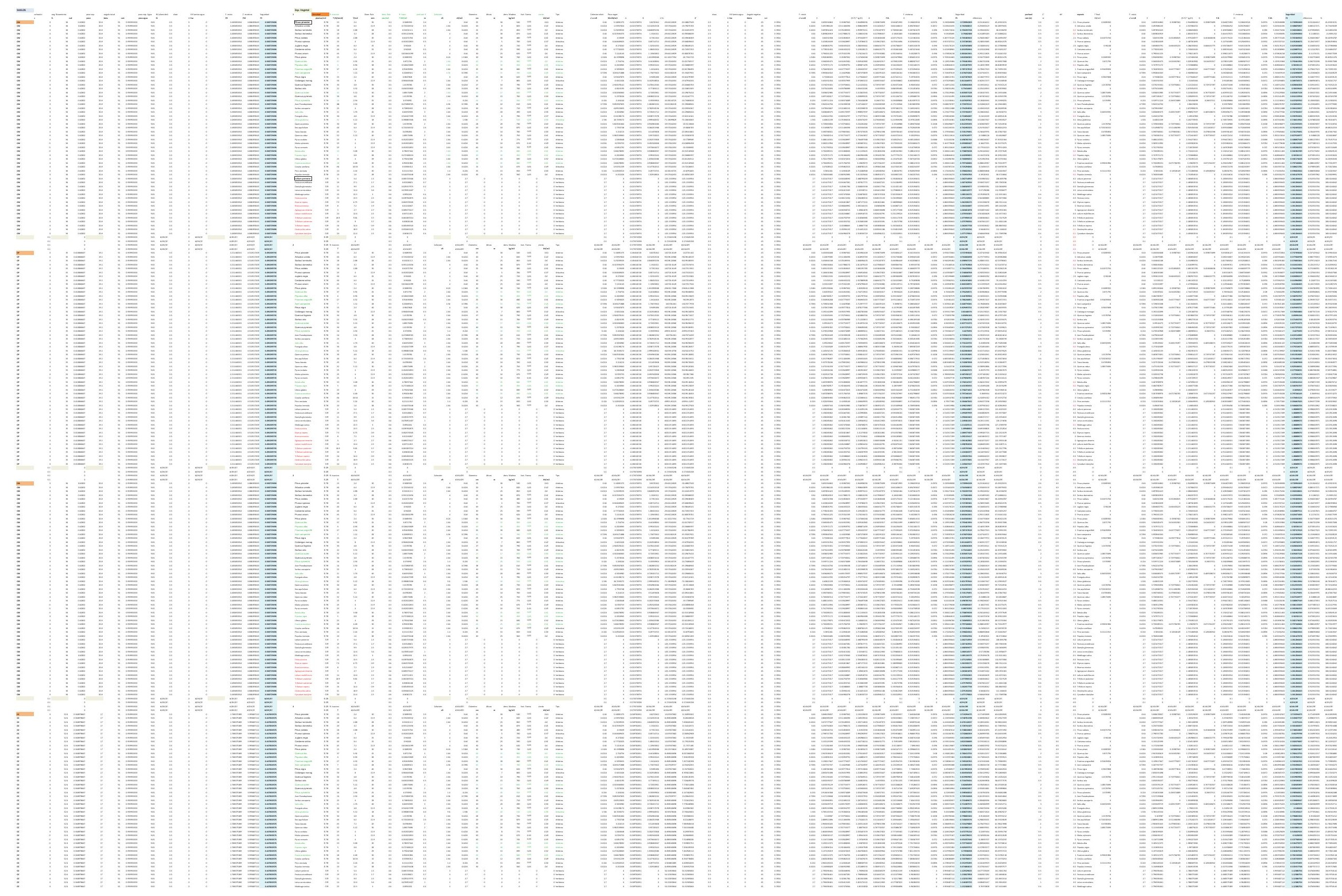


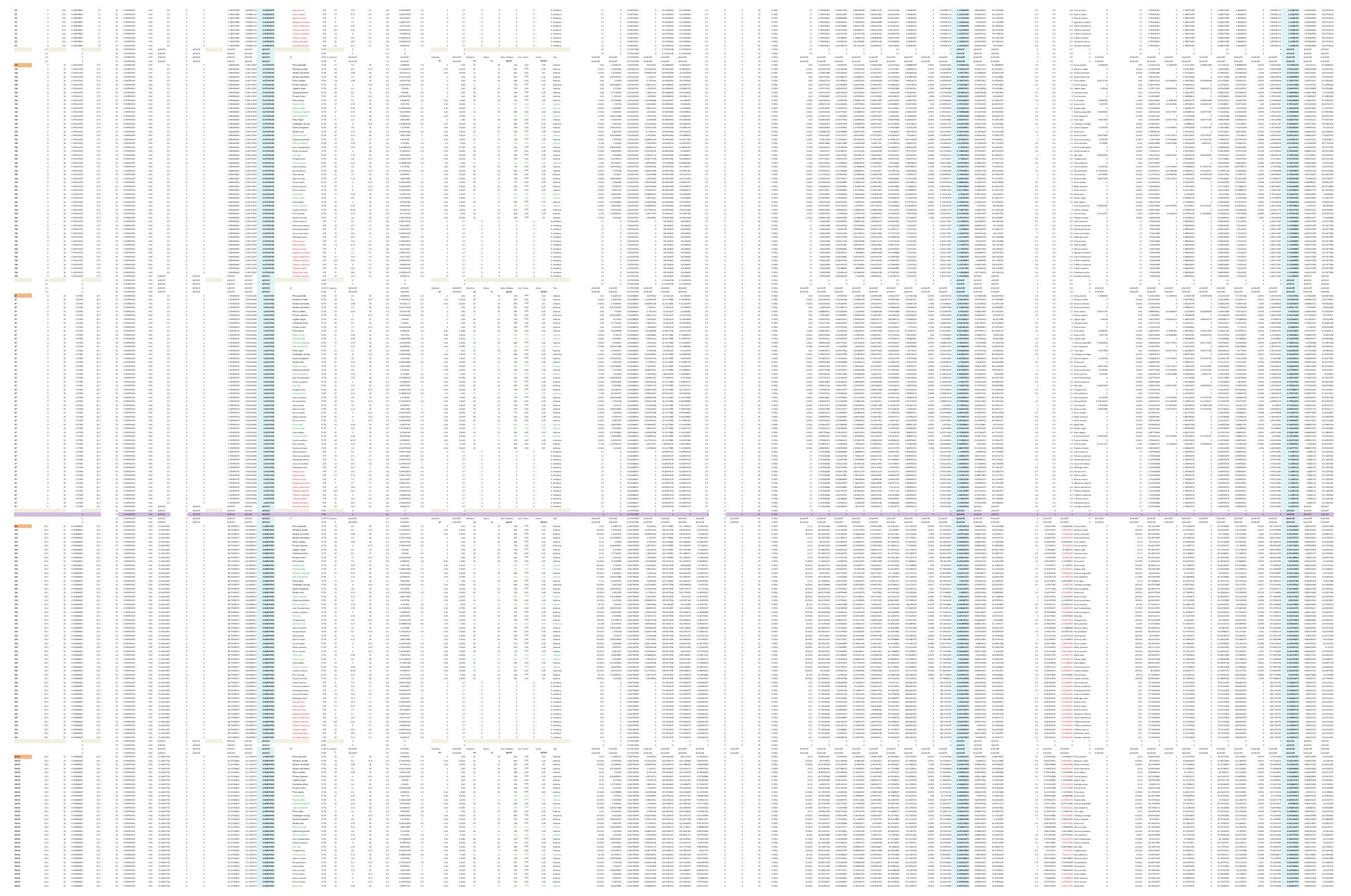



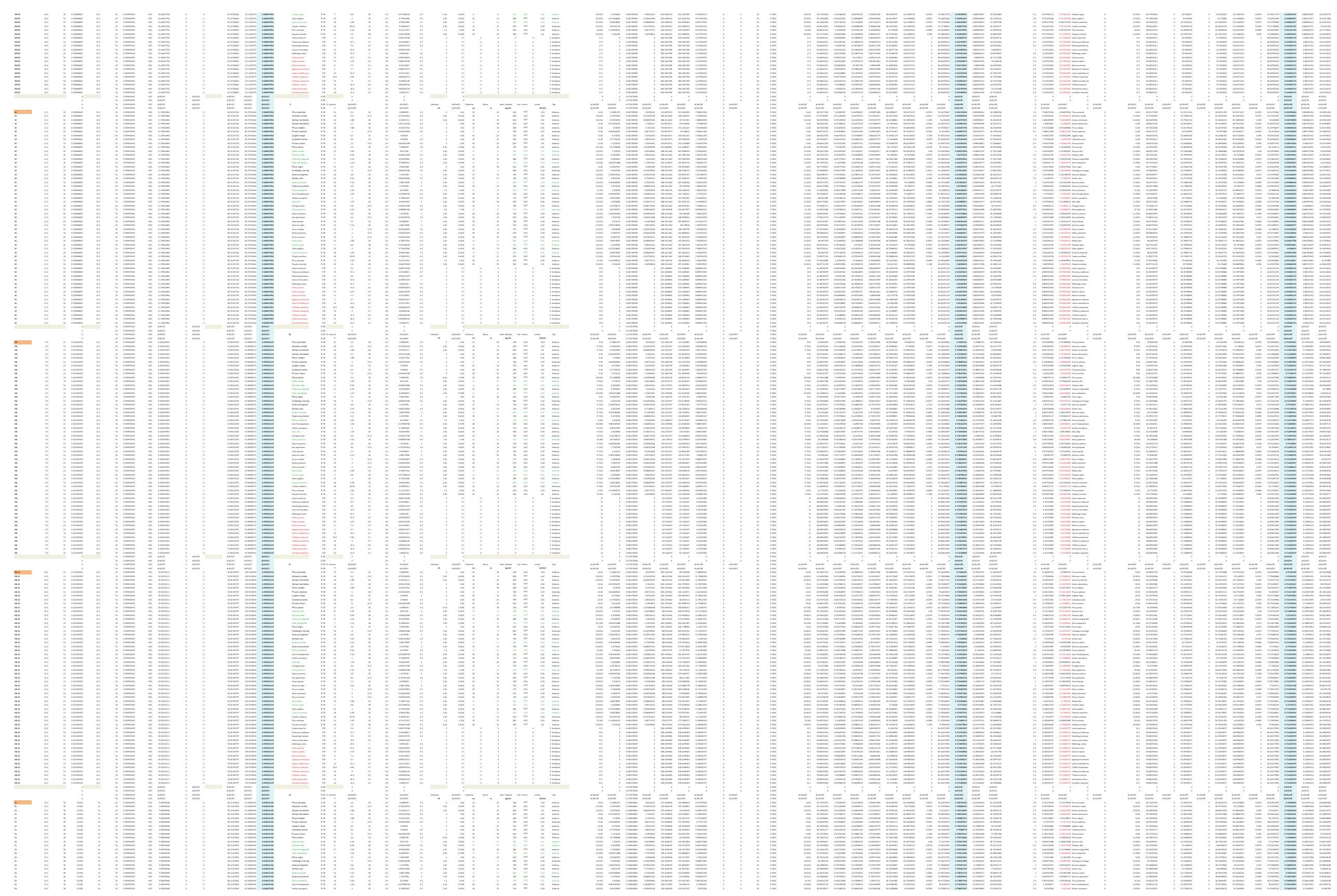


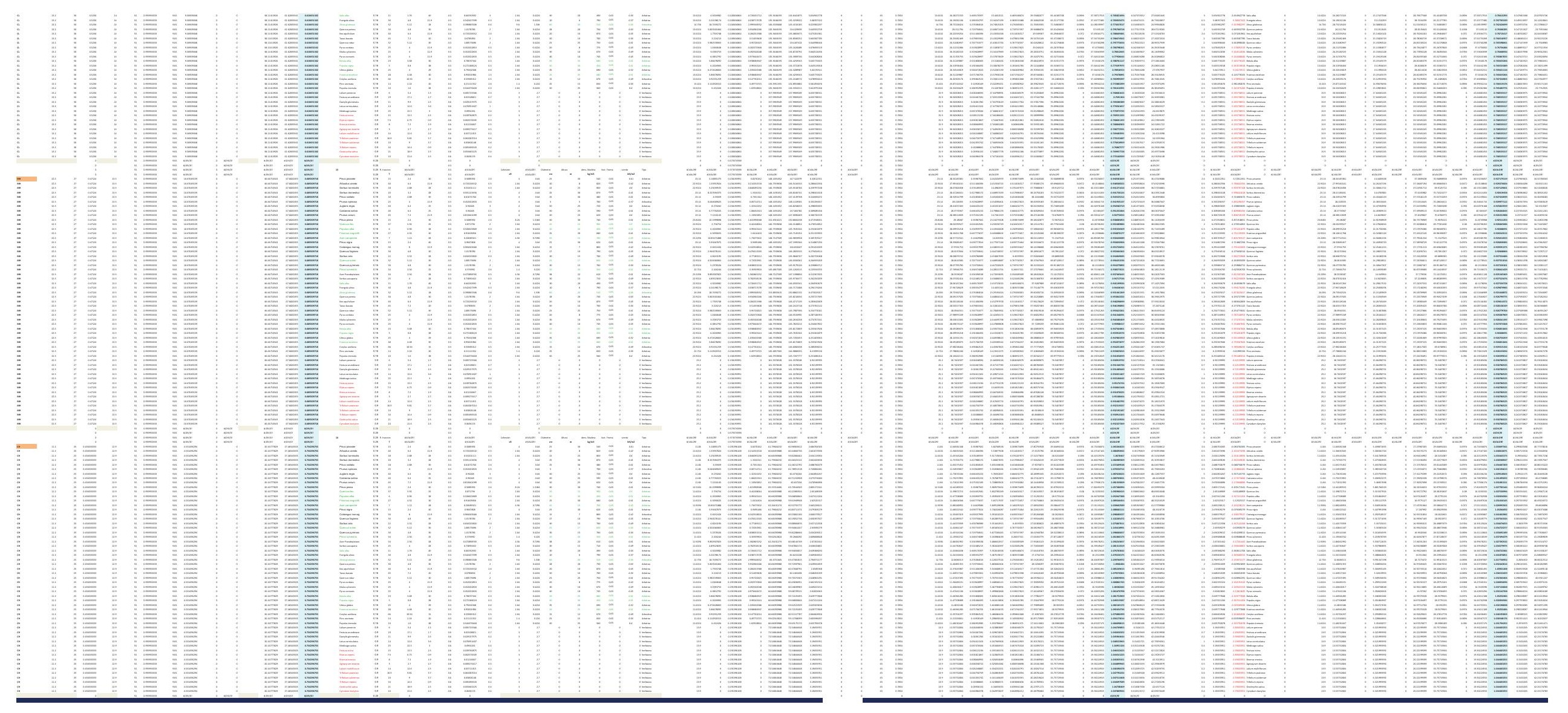



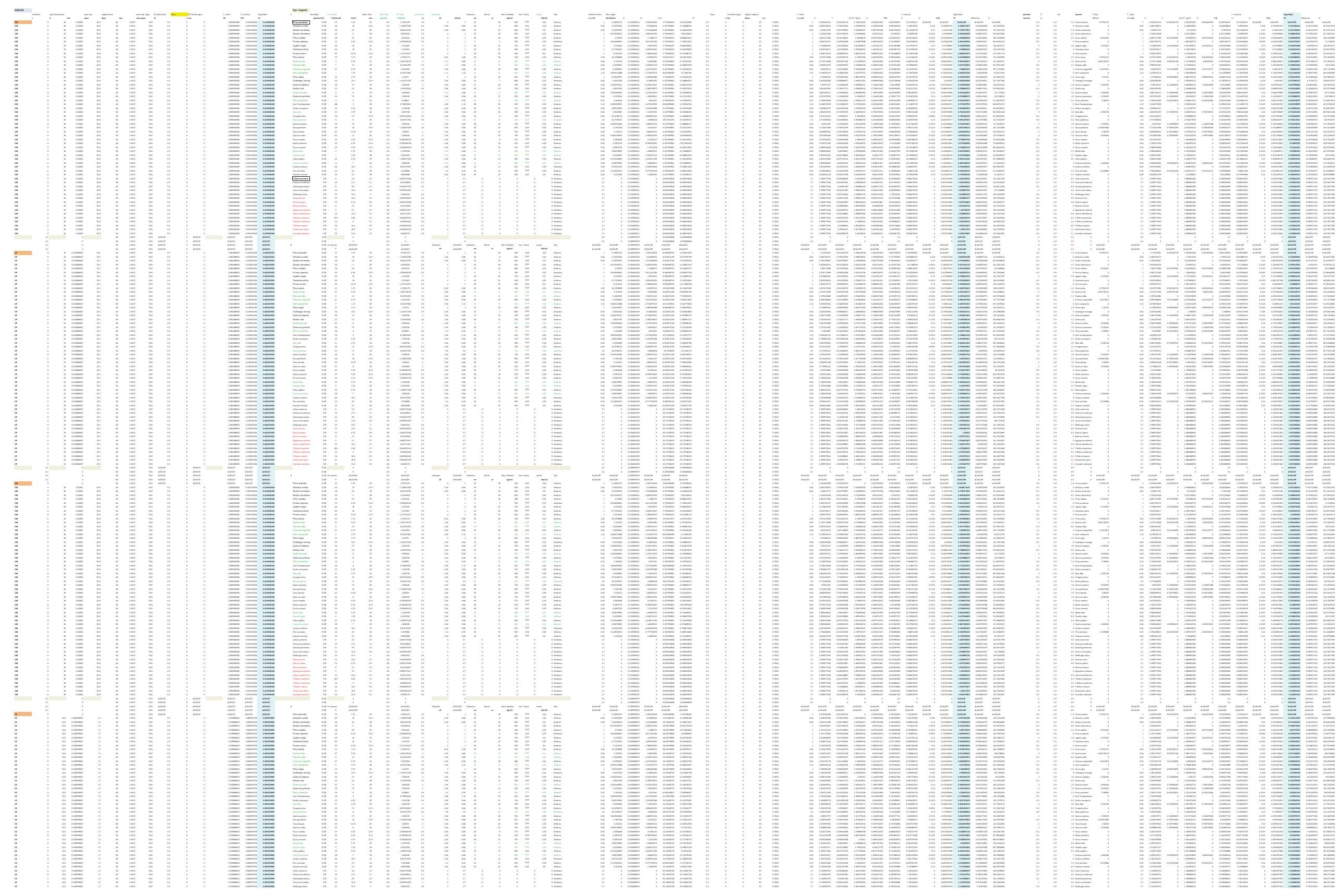


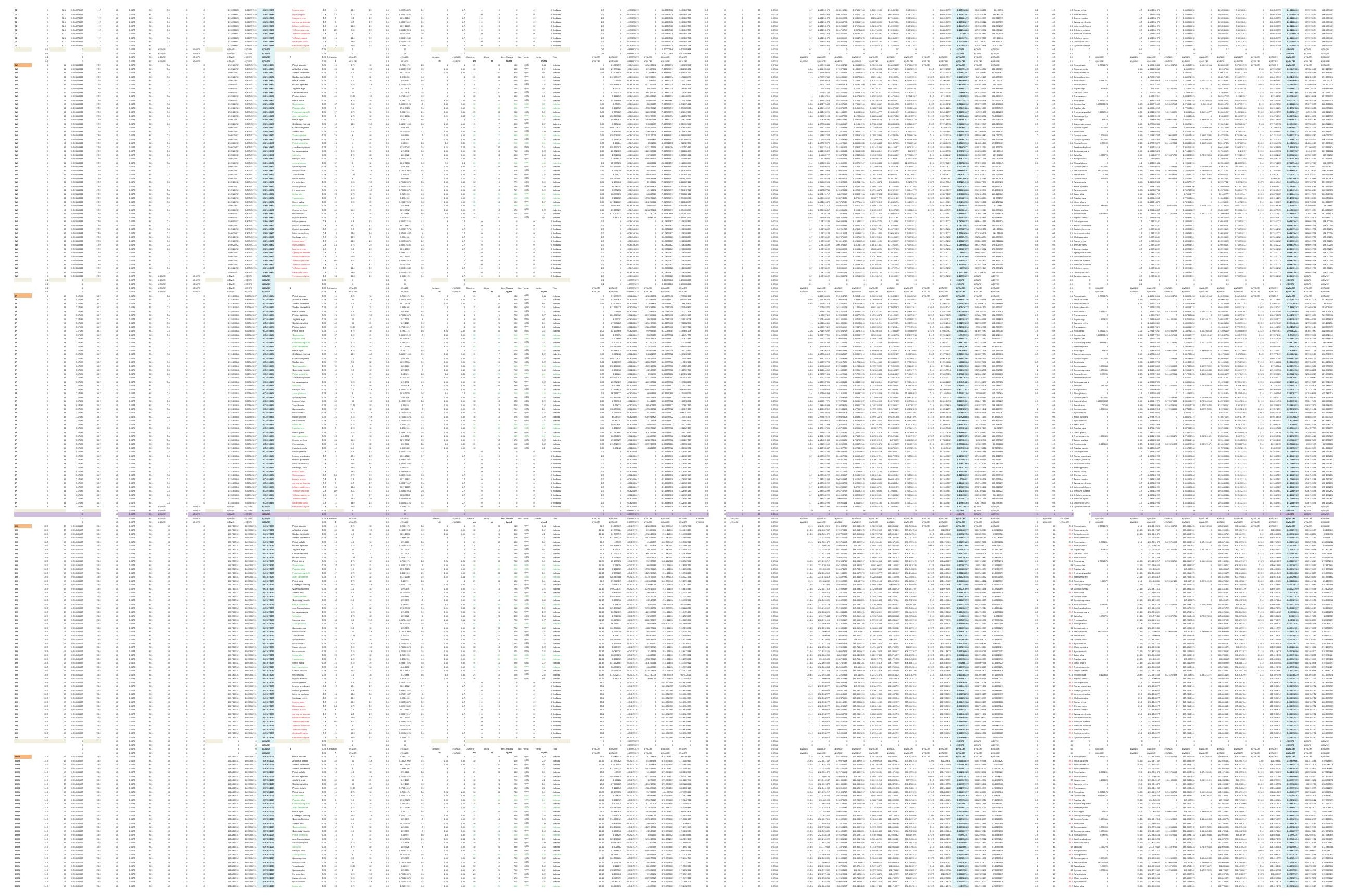



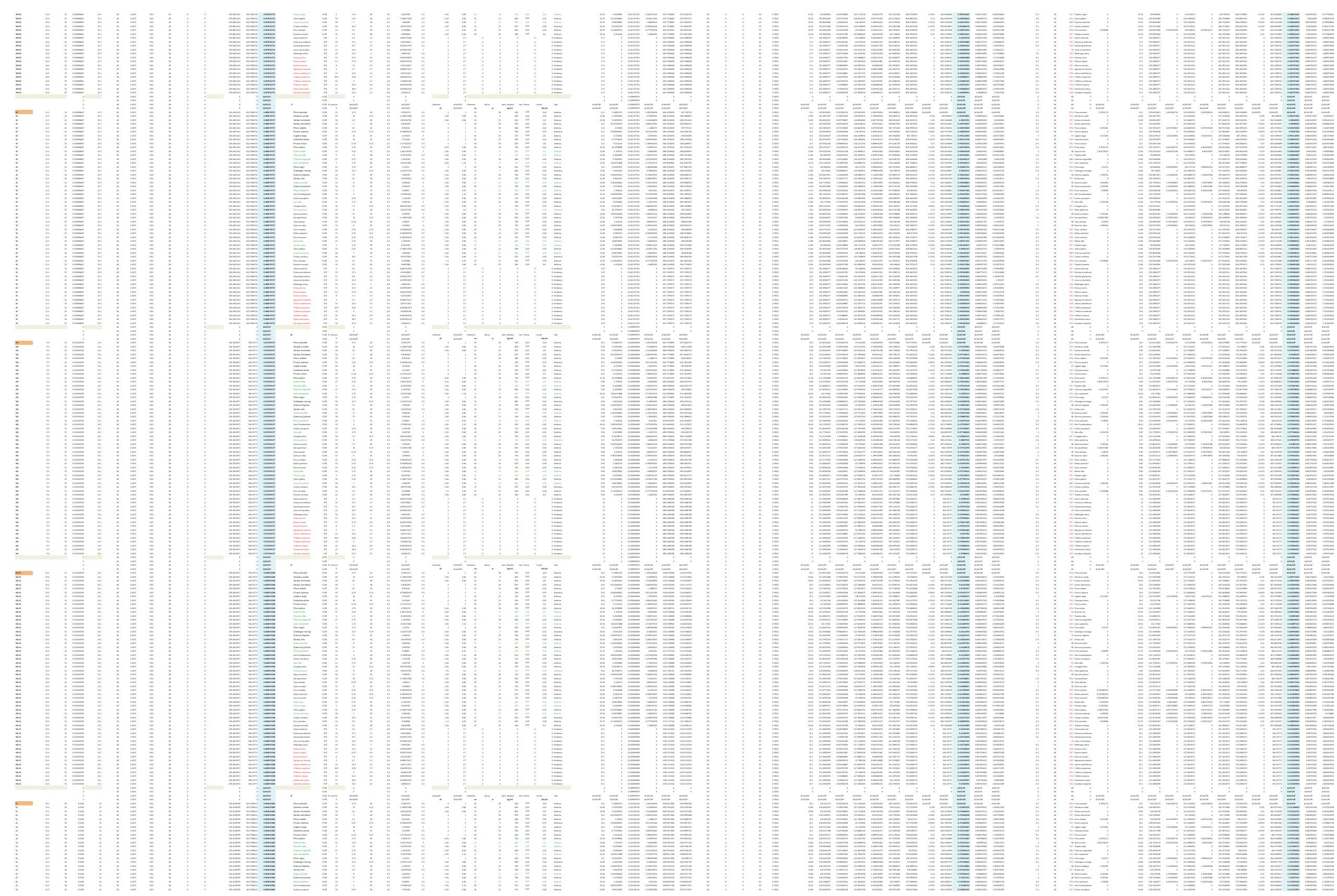


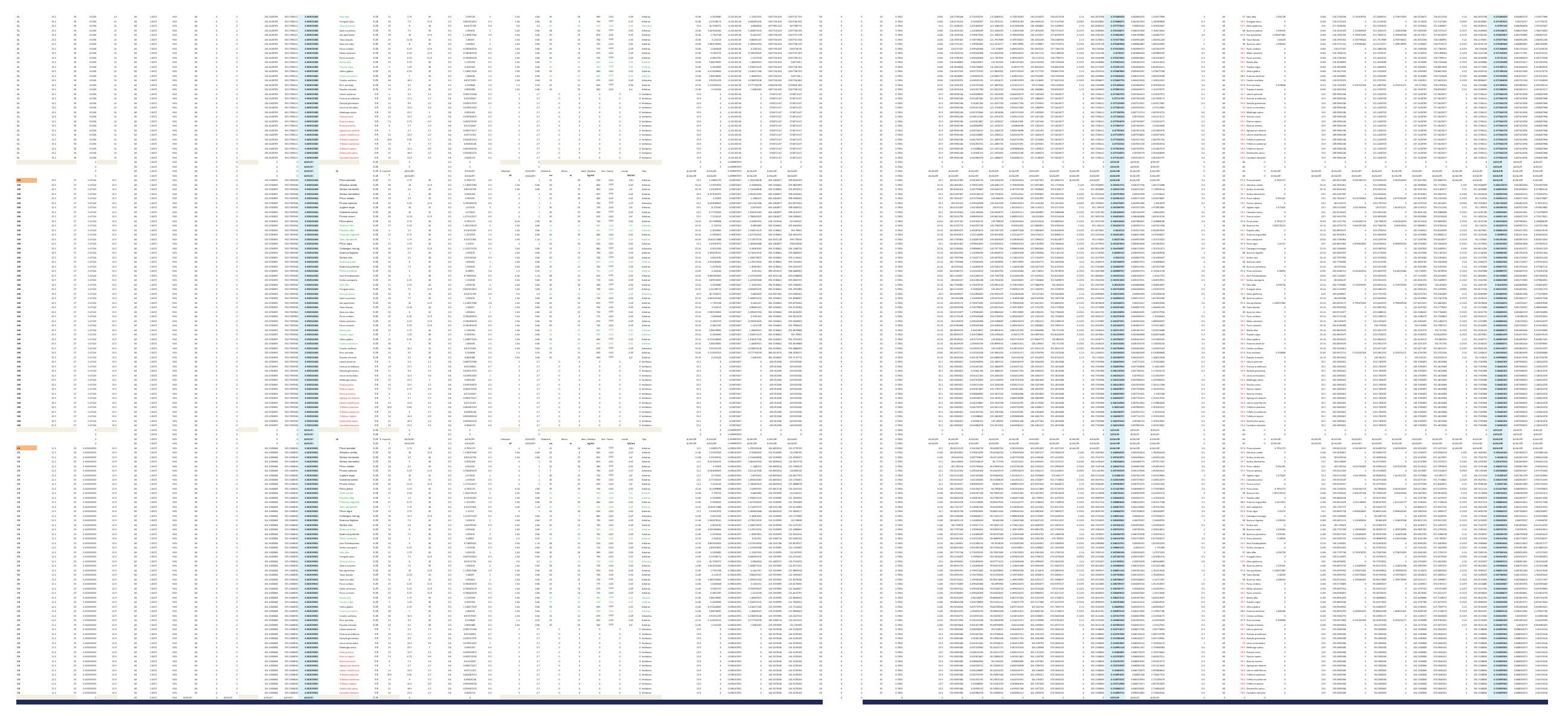



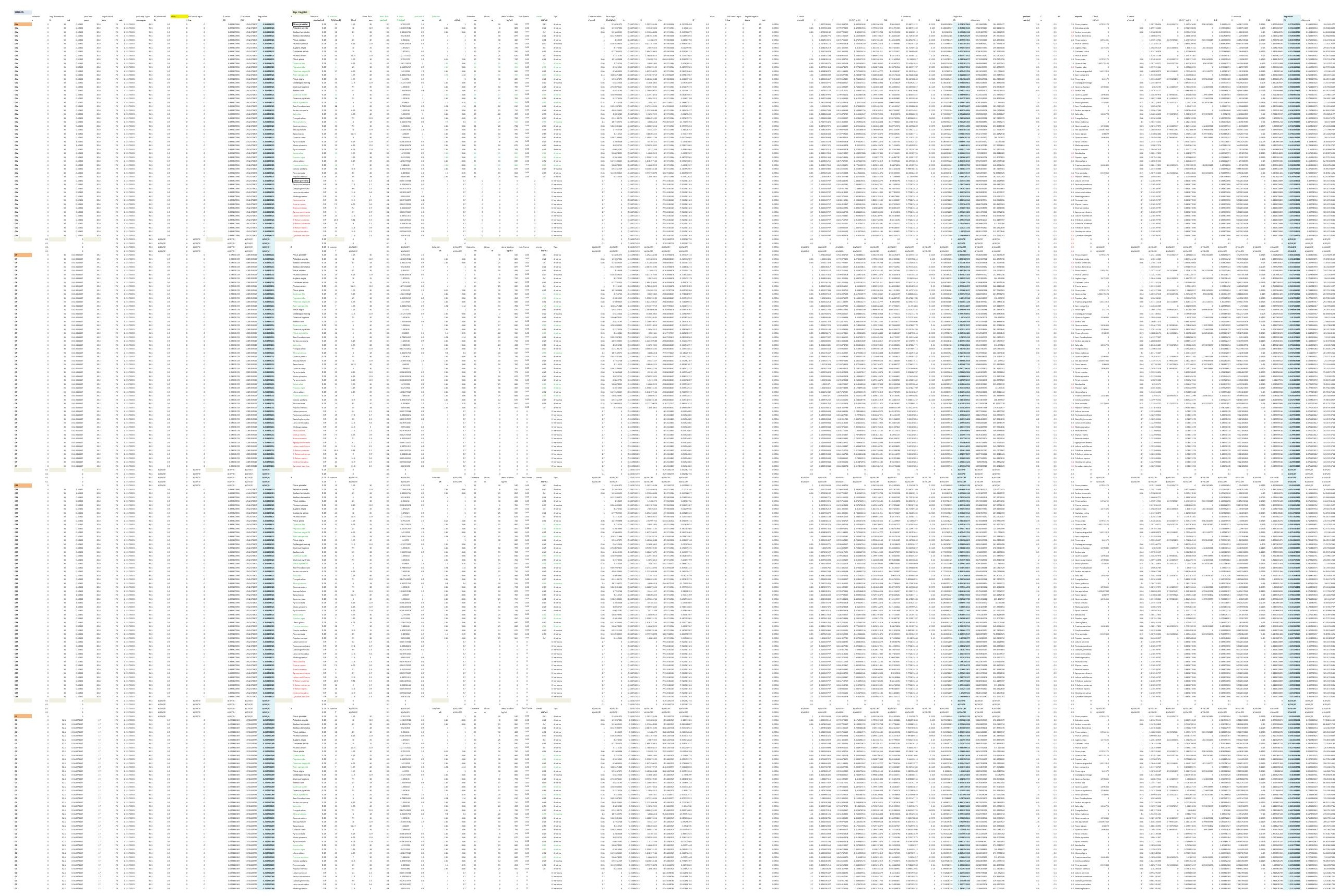


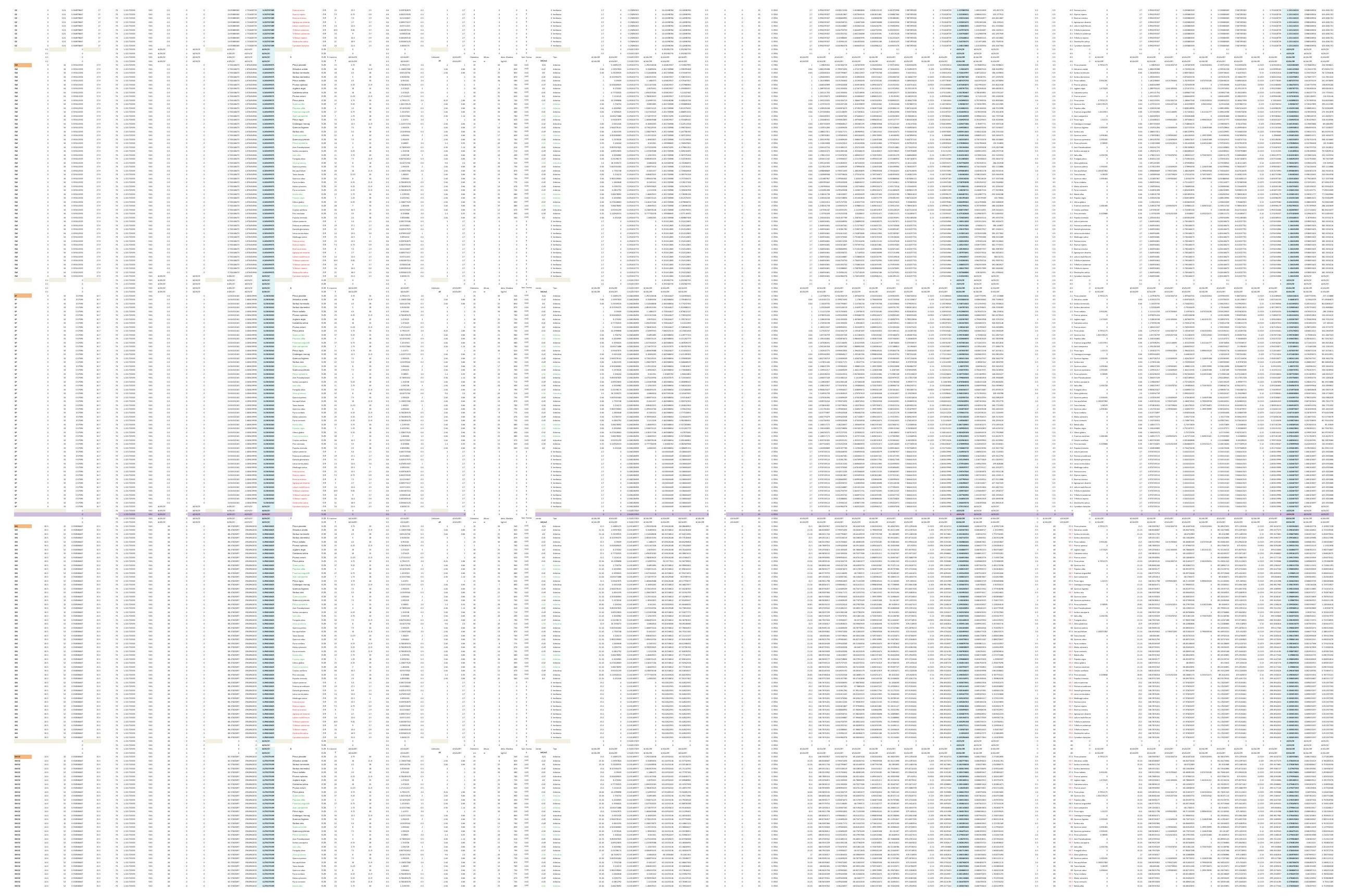



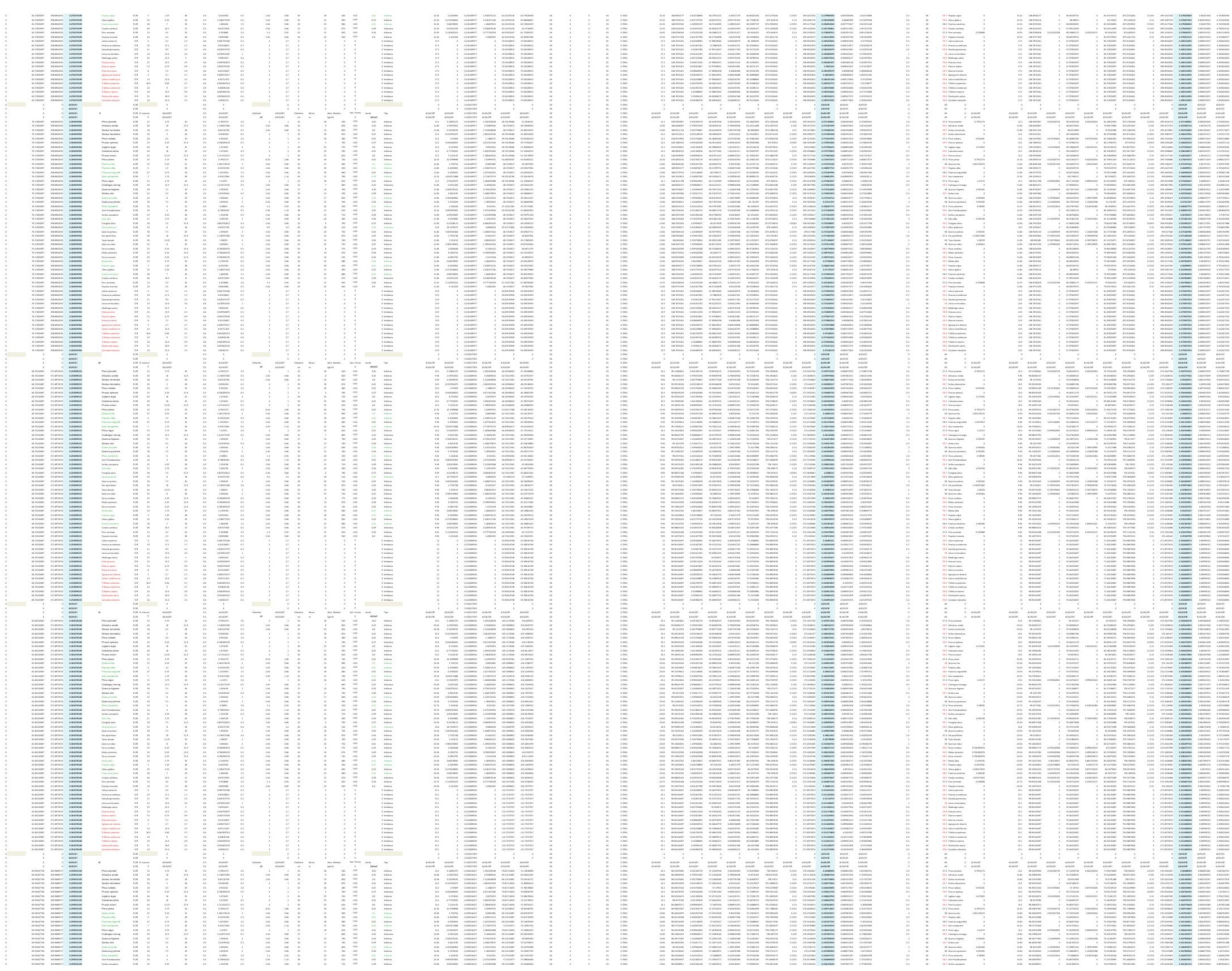


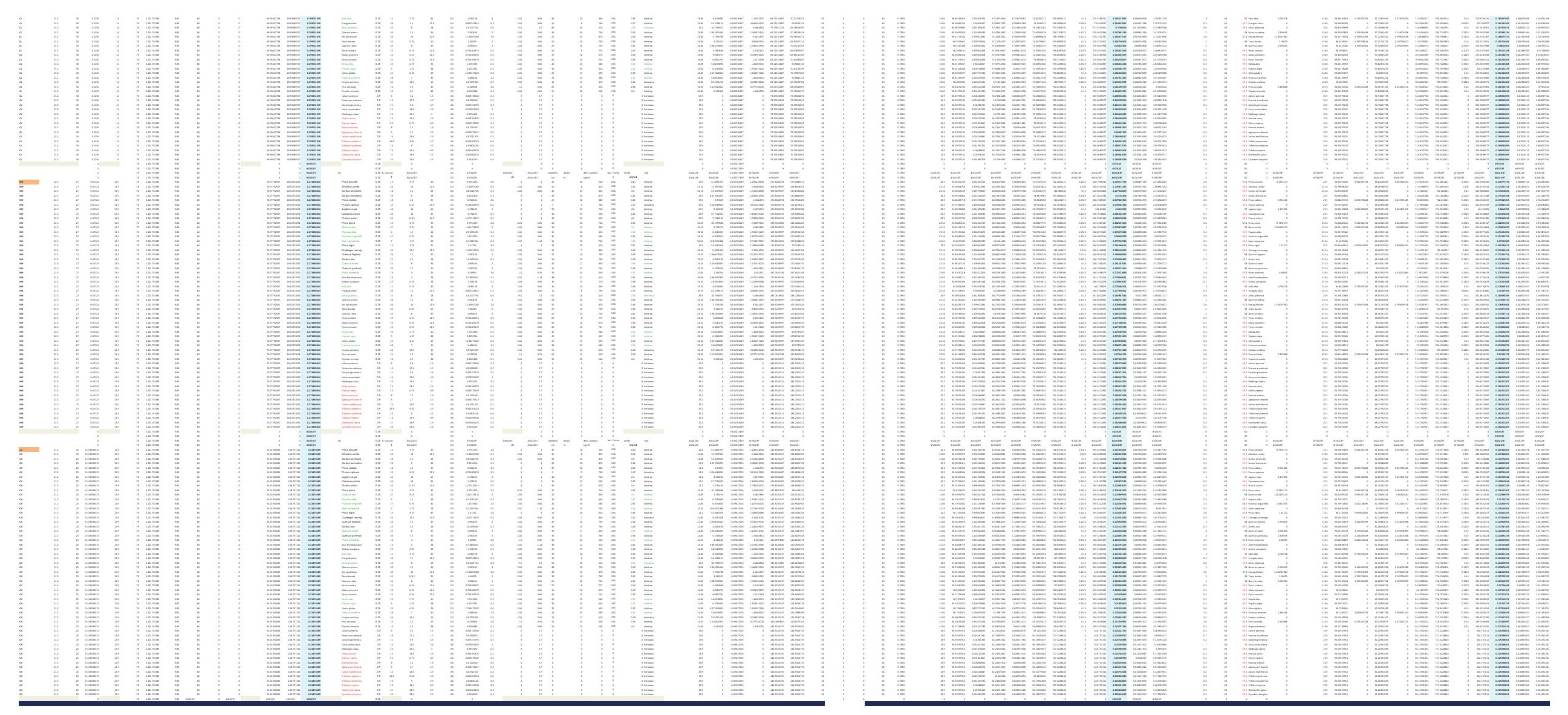



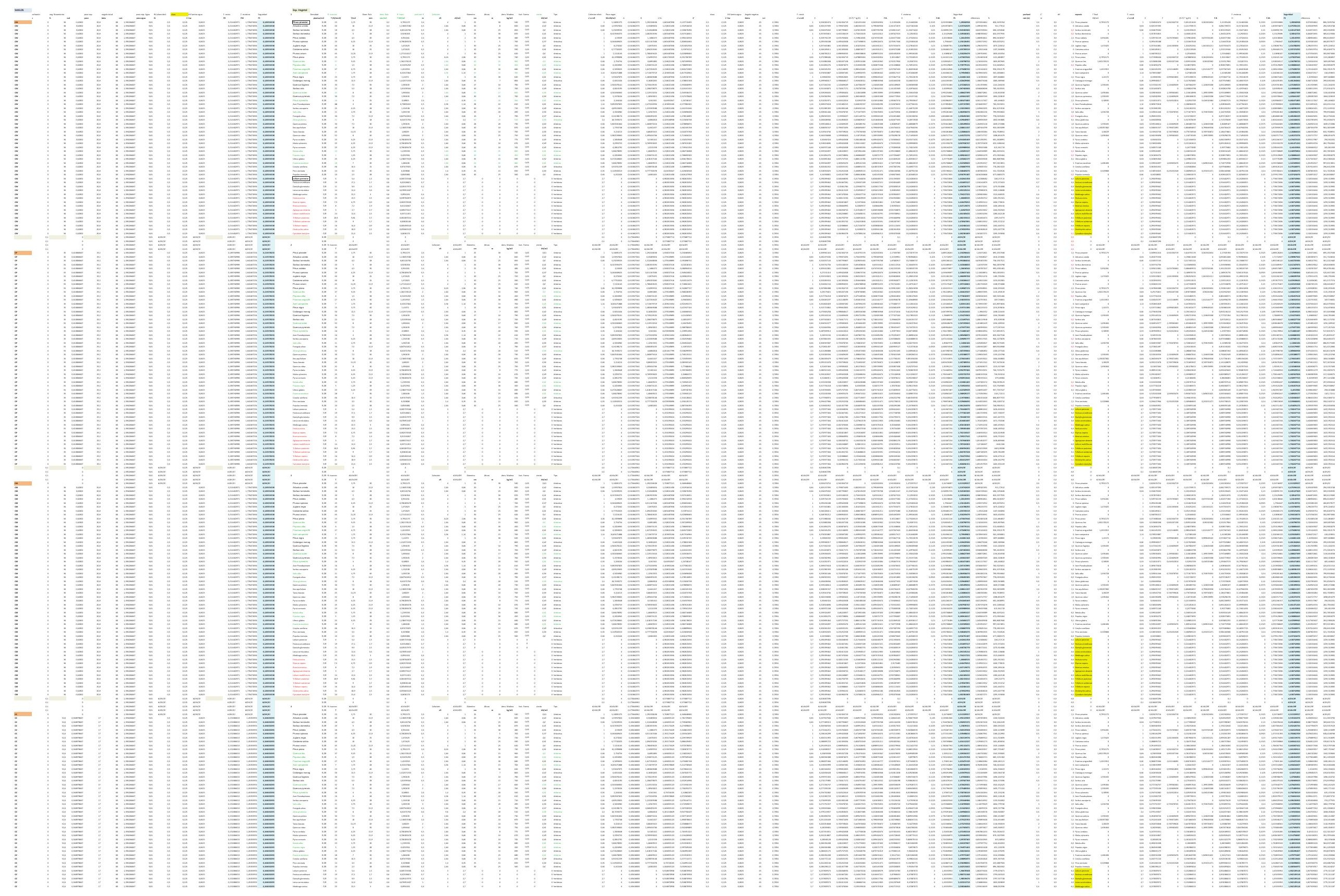


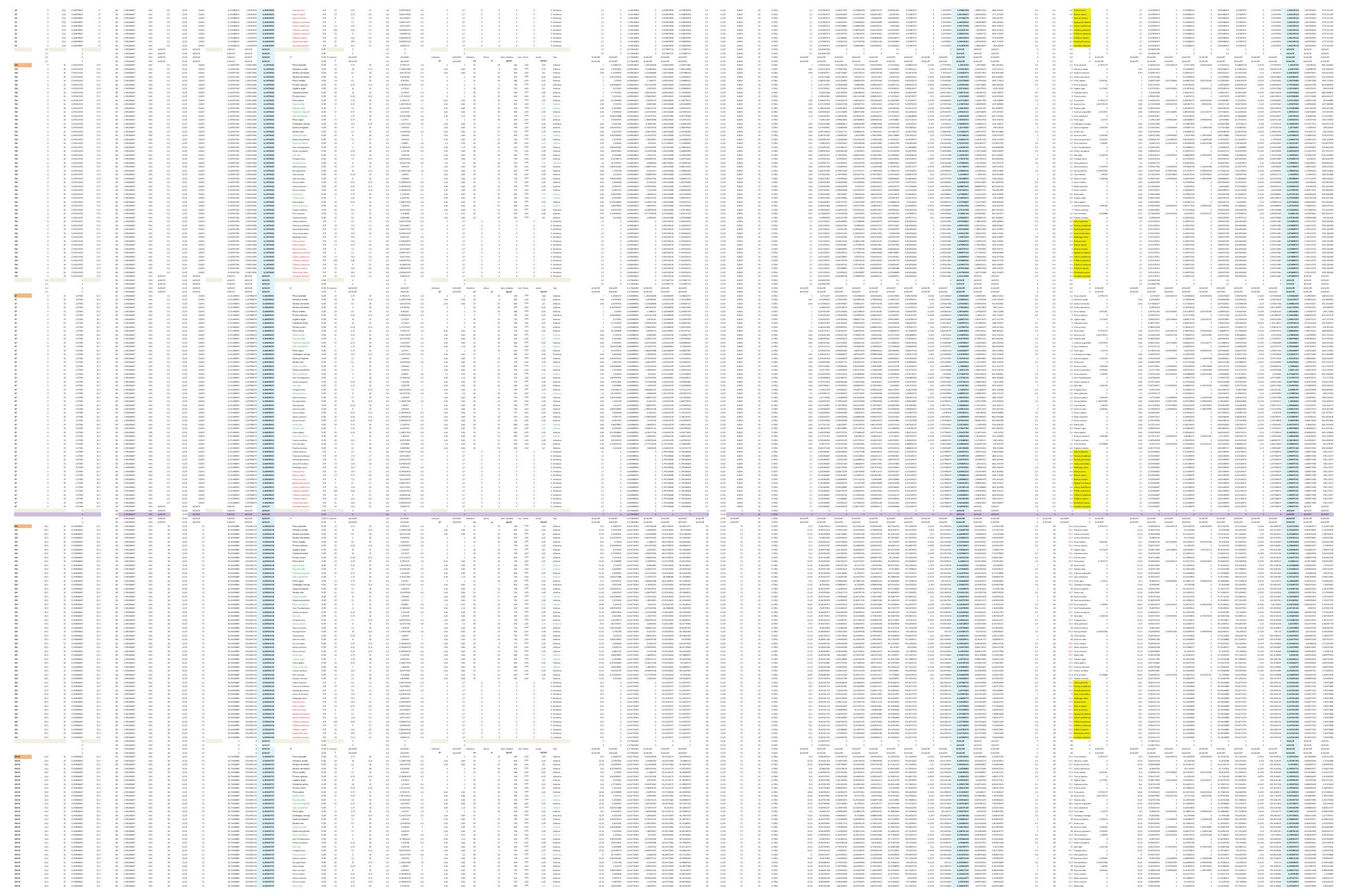




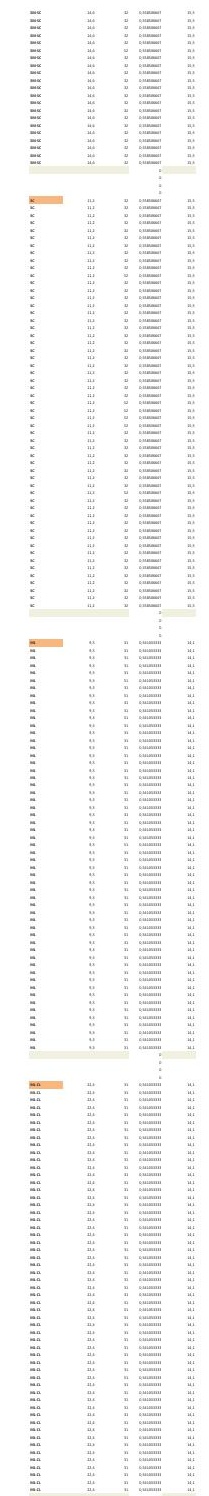

ำ
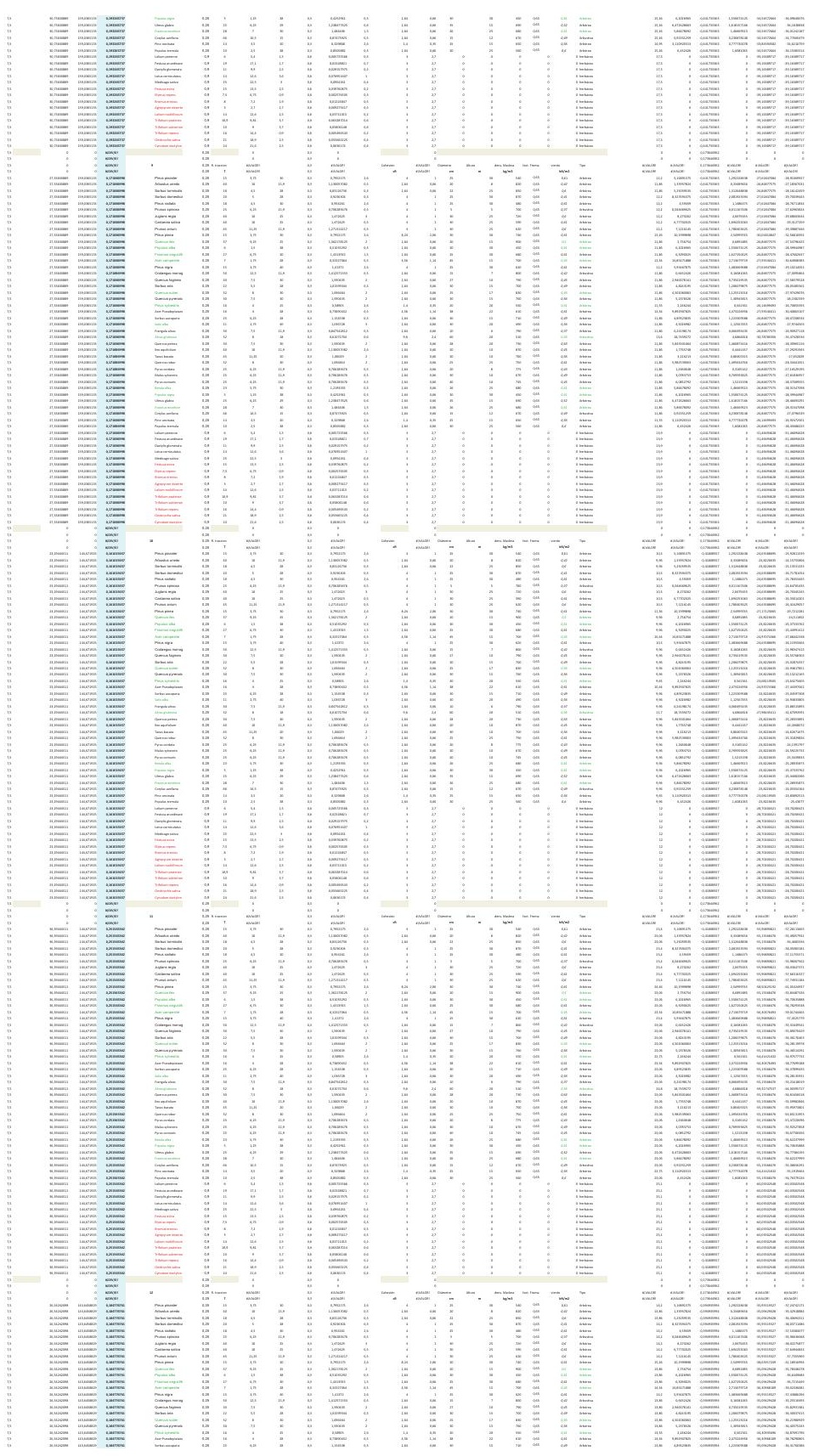
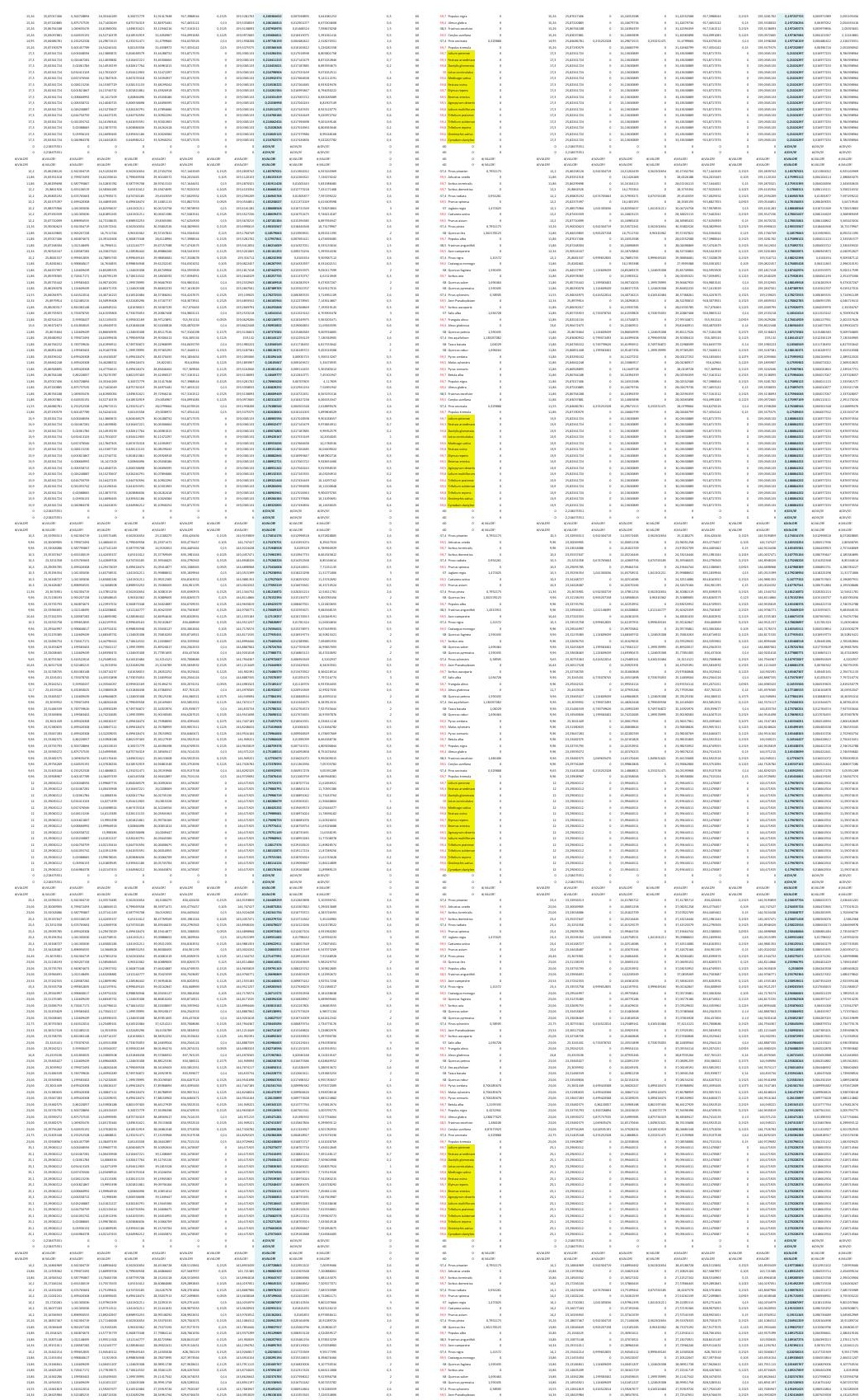

E
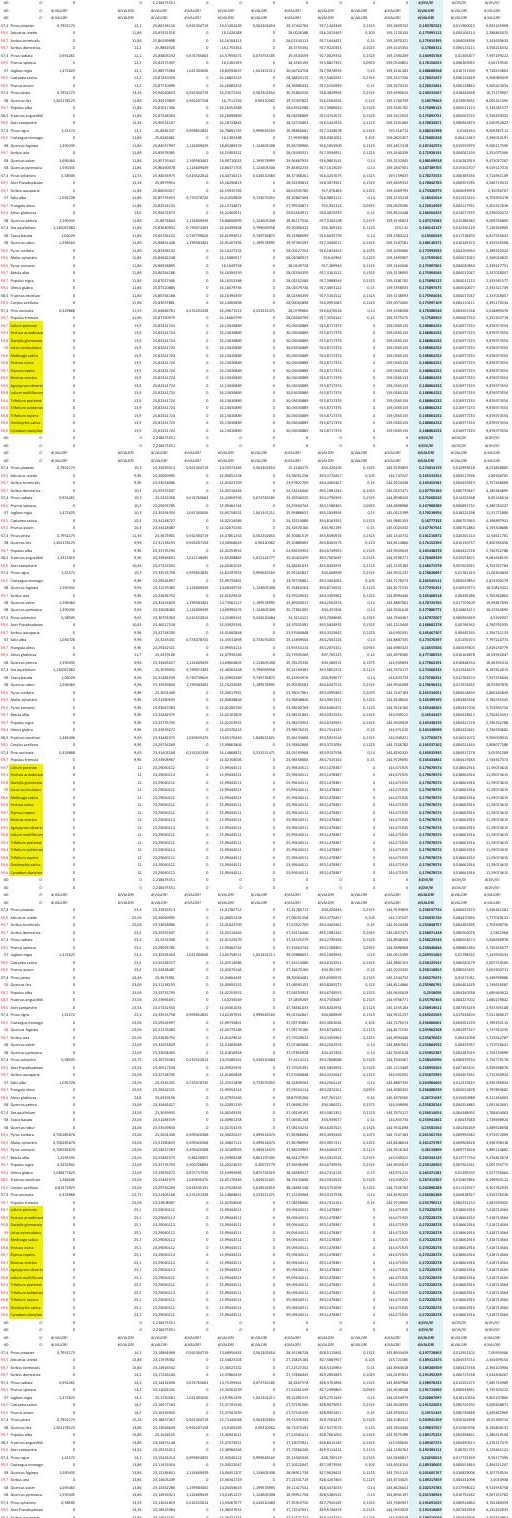


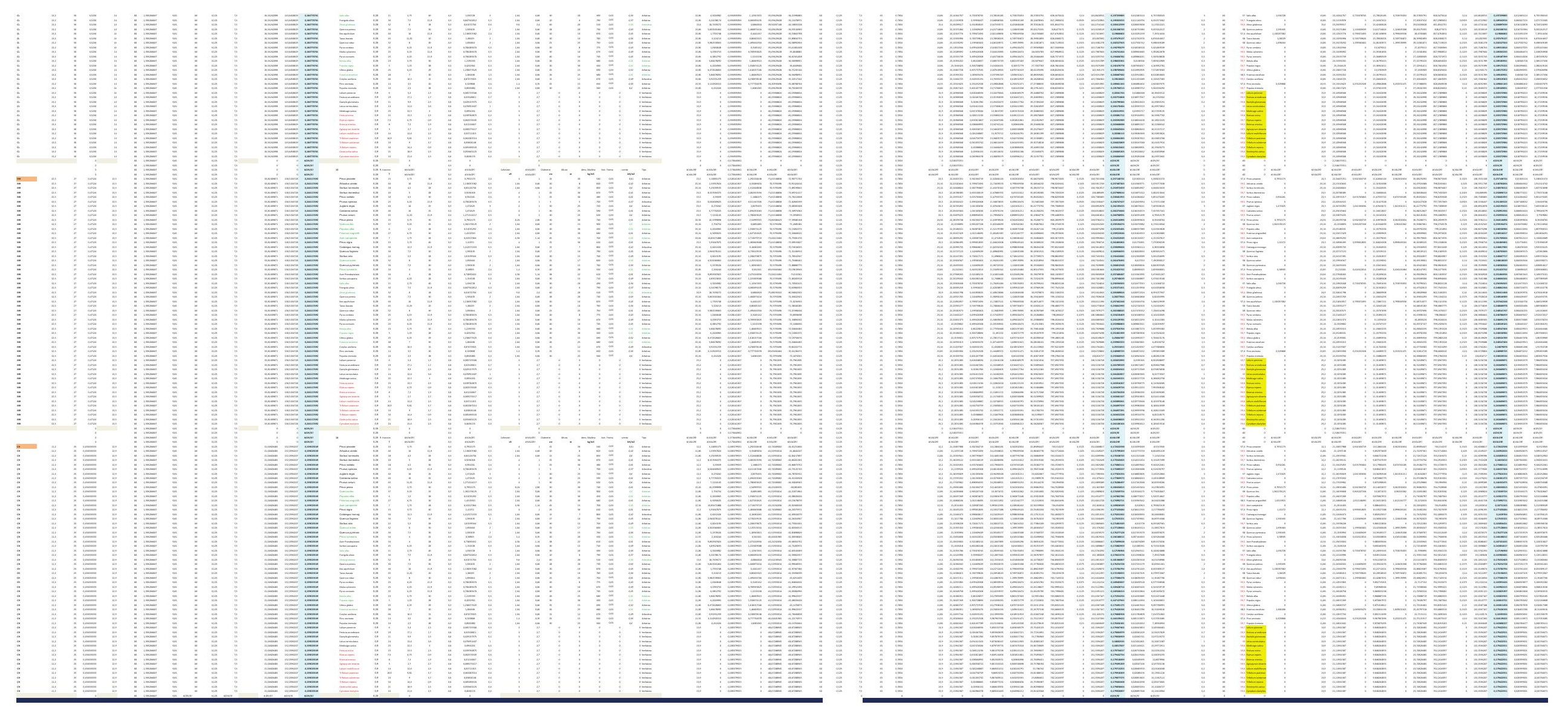


DESARROLLO DE UNA APLICACIÓN IMFORMÁTICA PARA EL CÁLCULO DE SOSTENIMIENTO DE TALUDES MEDIANTE VEGETACIÓN

A02. DENSIDAD DE PLANTACIÓN: 1.600 plantas/ha.

A02-2.POSICIÓN N.F. 2

INCLINACIÓN DE TALUD 6-100

INCLINACIÓN DE TALUD 10-200

INCLINACIÓN DE TALUD 20-30

INCLINACIÓN DE TALUD 30-40

INCLINACIÓN DE TALUD $35^{\circ}$

INCLINACIÓN DE TALUD 40-50

INCLINACIÓN DE TALUD 50-550

INCLINACIÓN DE TALUD 55-60

INCLINACIÓN DE TALUD 60-700

INCLINACIÓN DE TALUD 70-80 

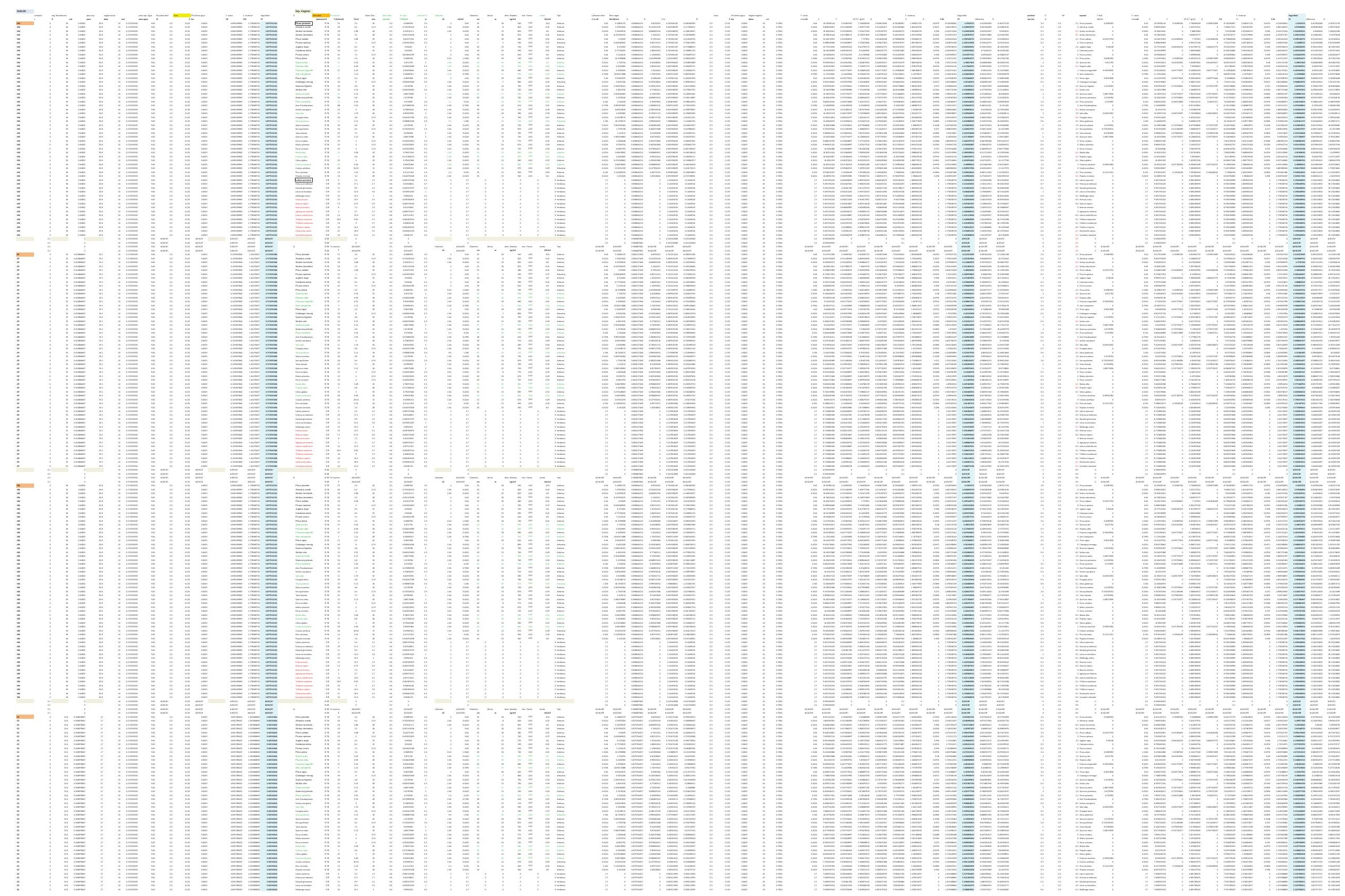


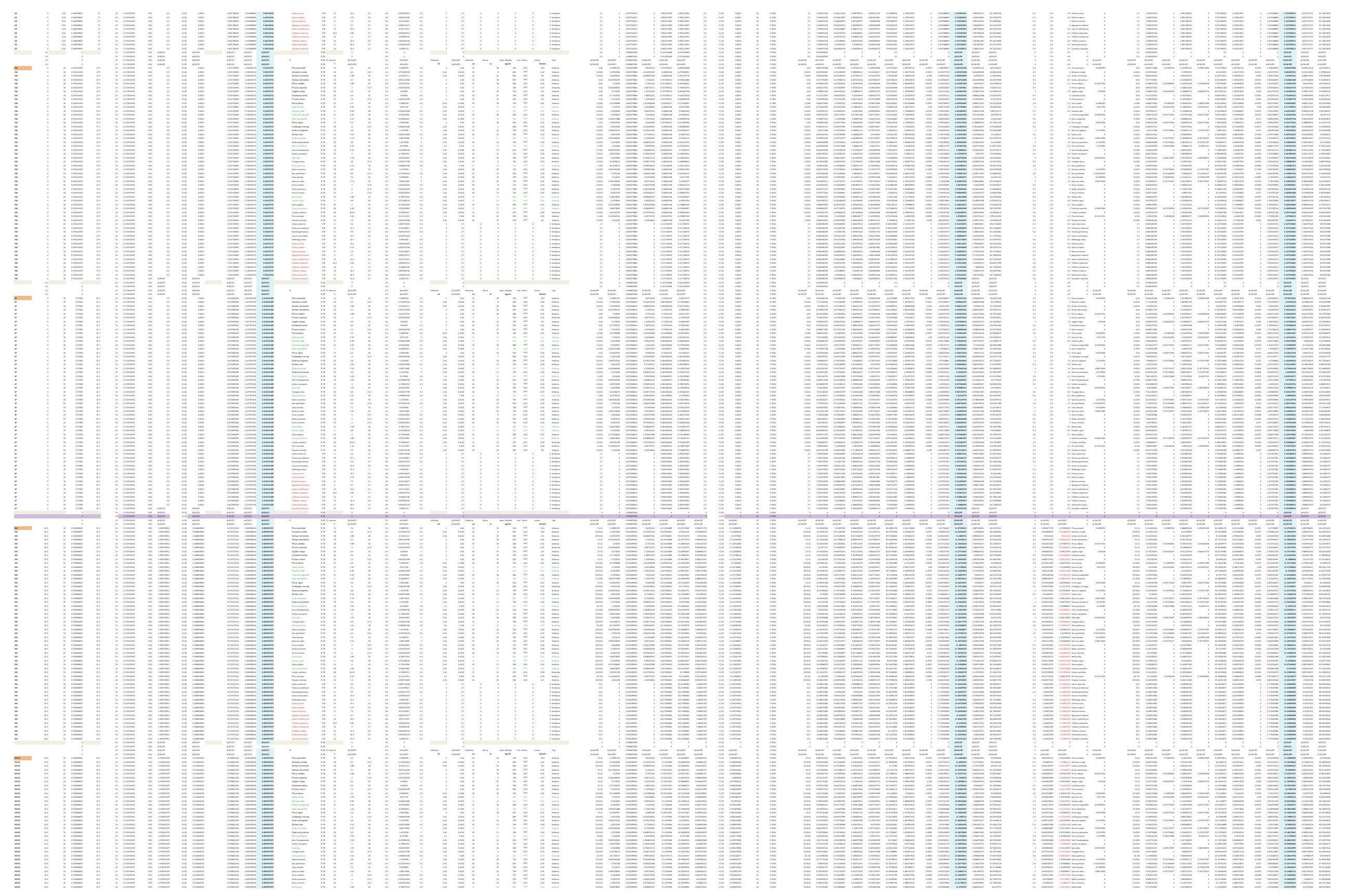



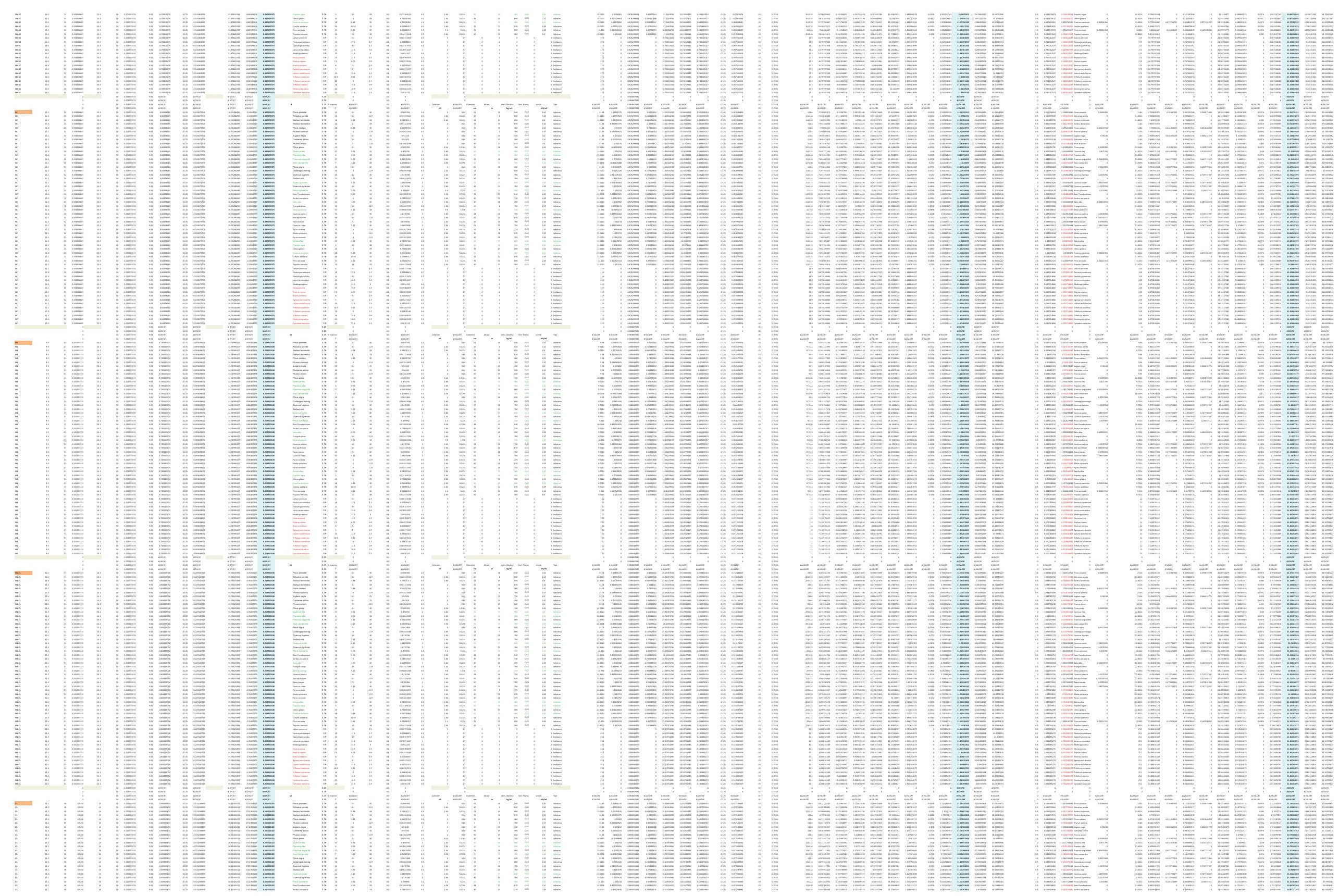


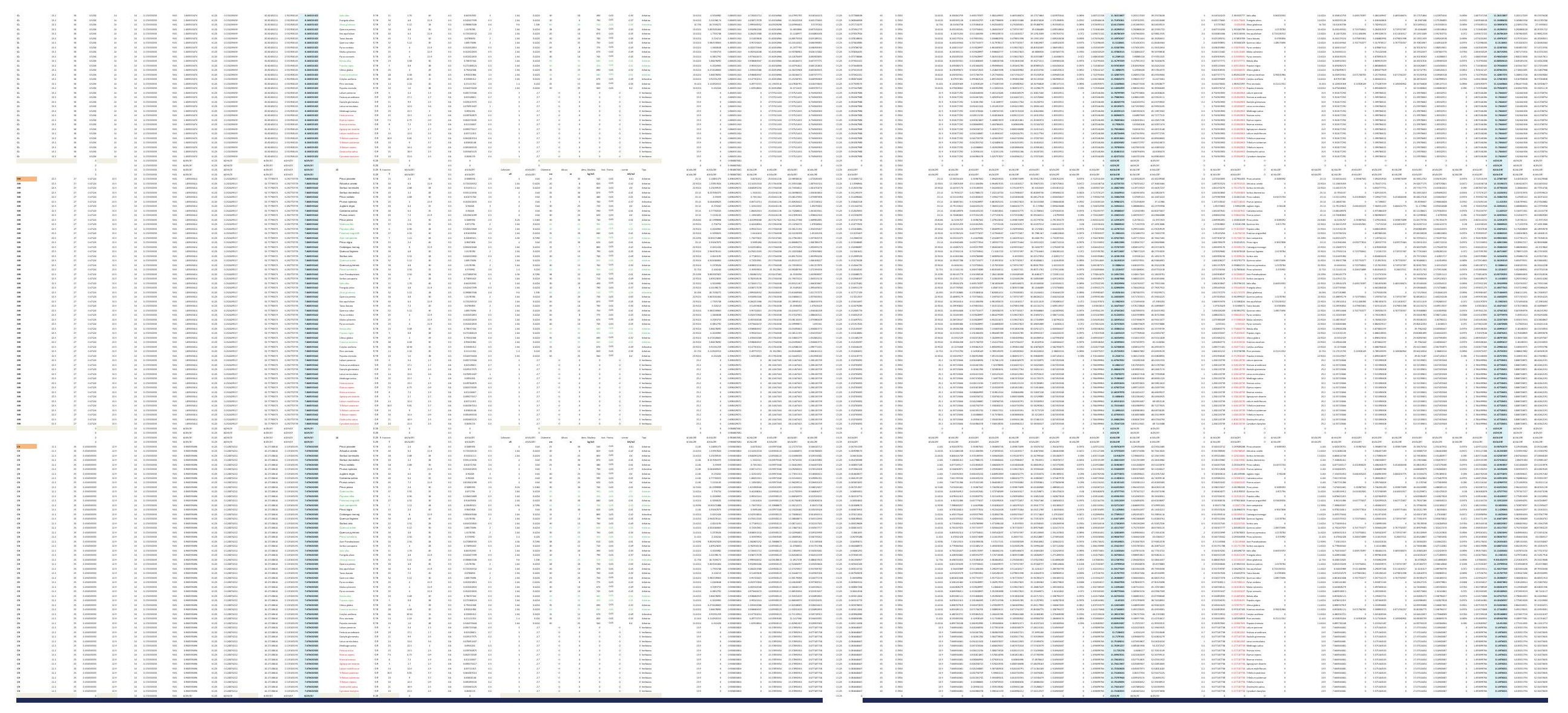



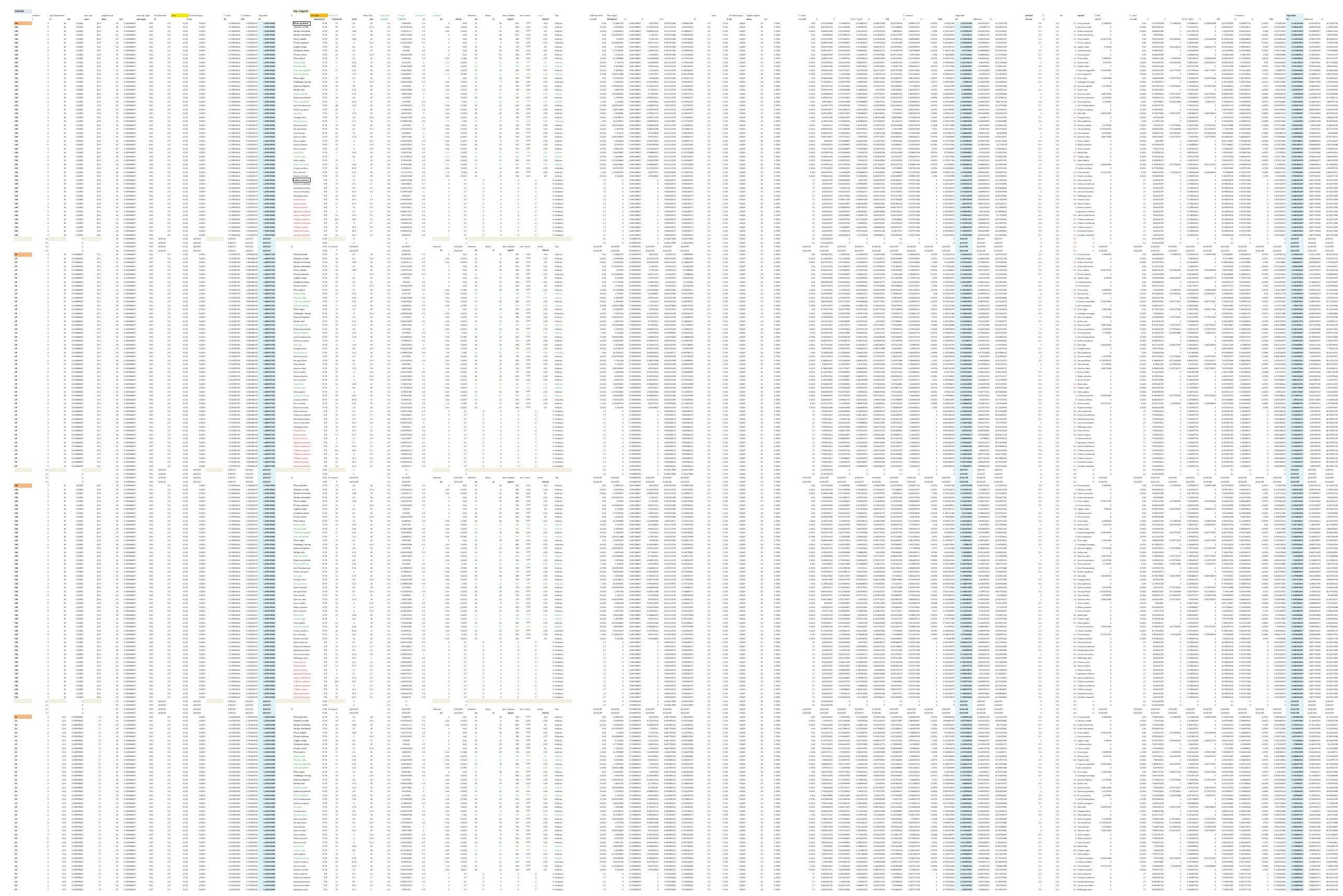


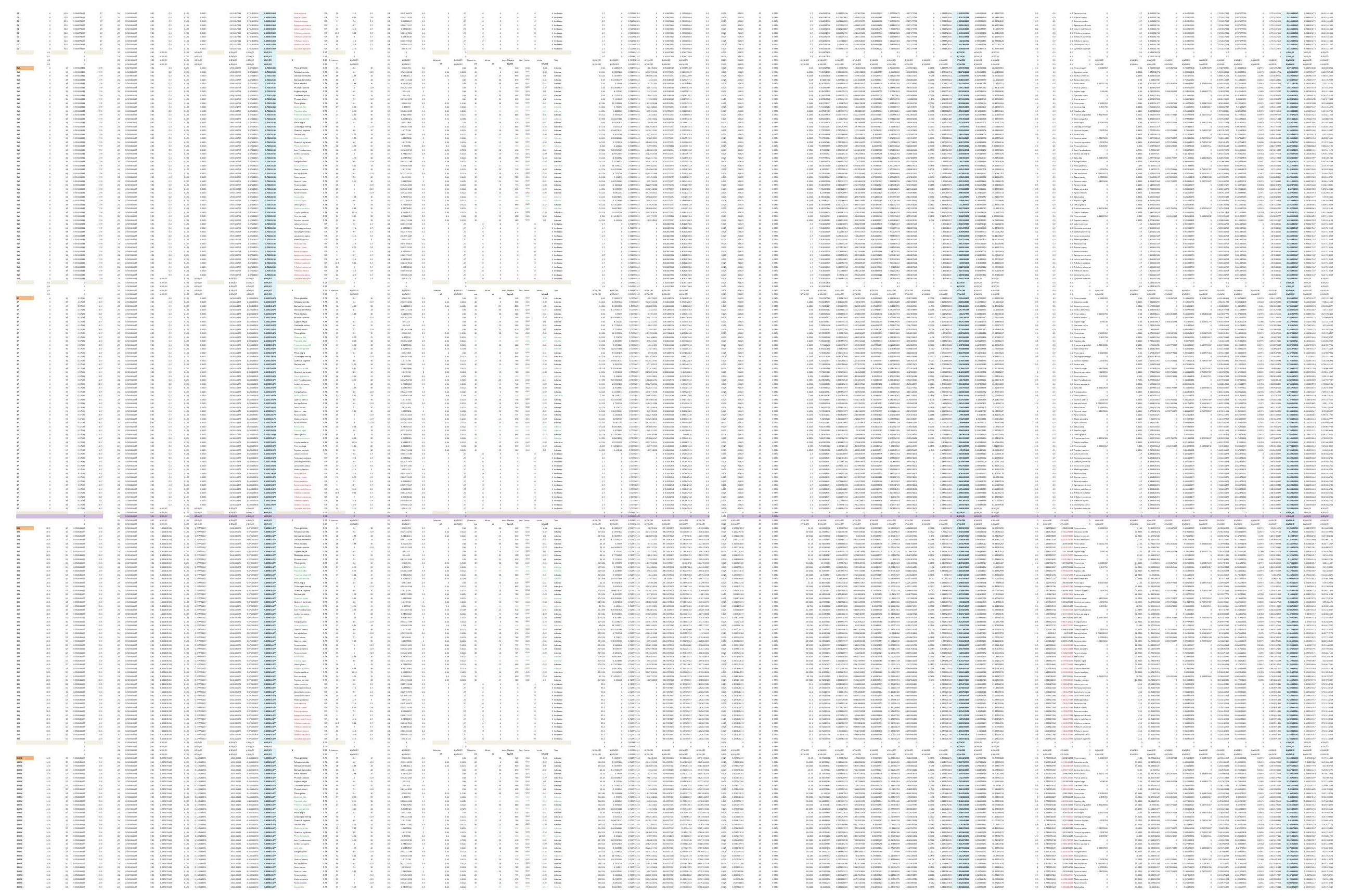



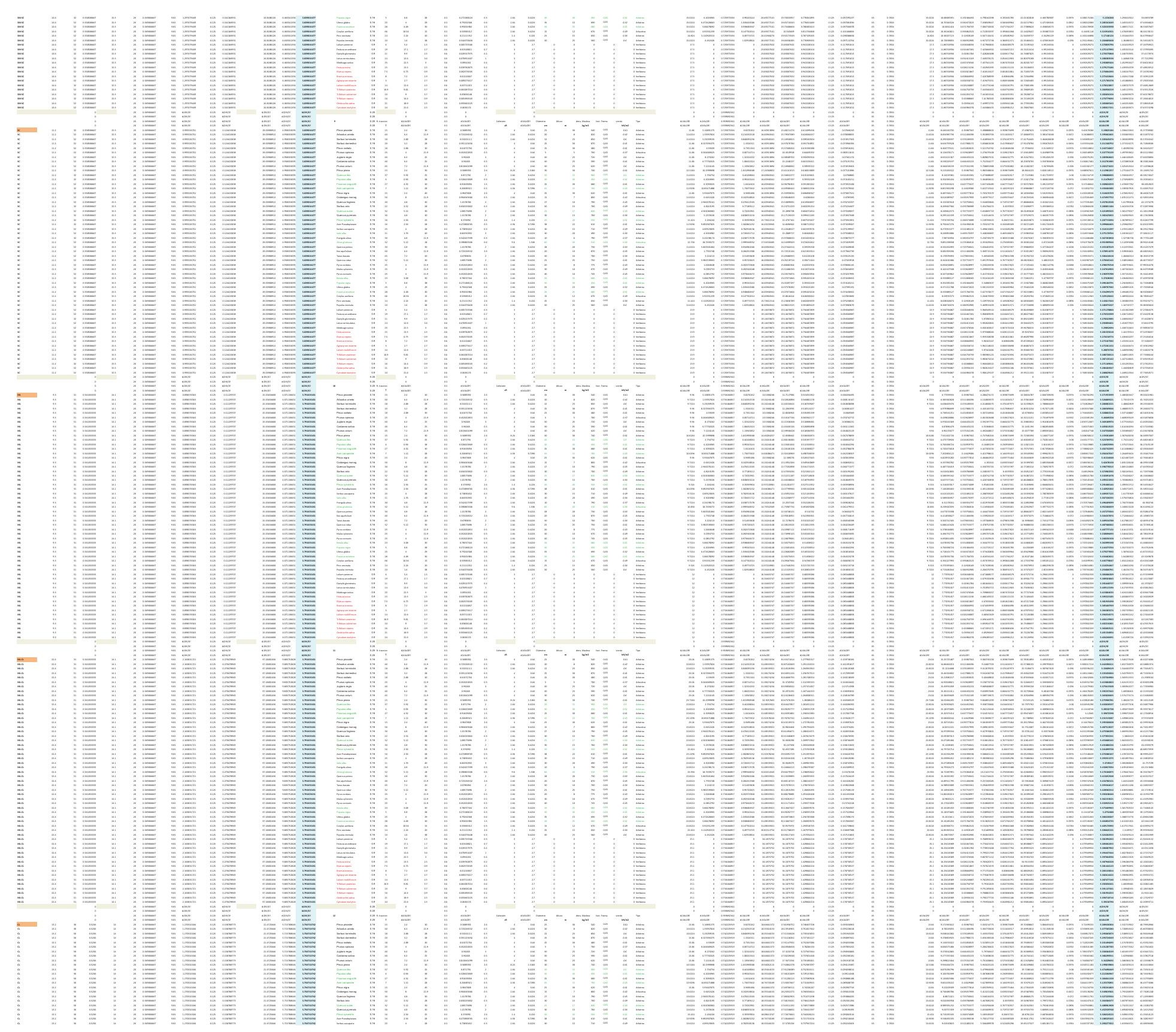

五主
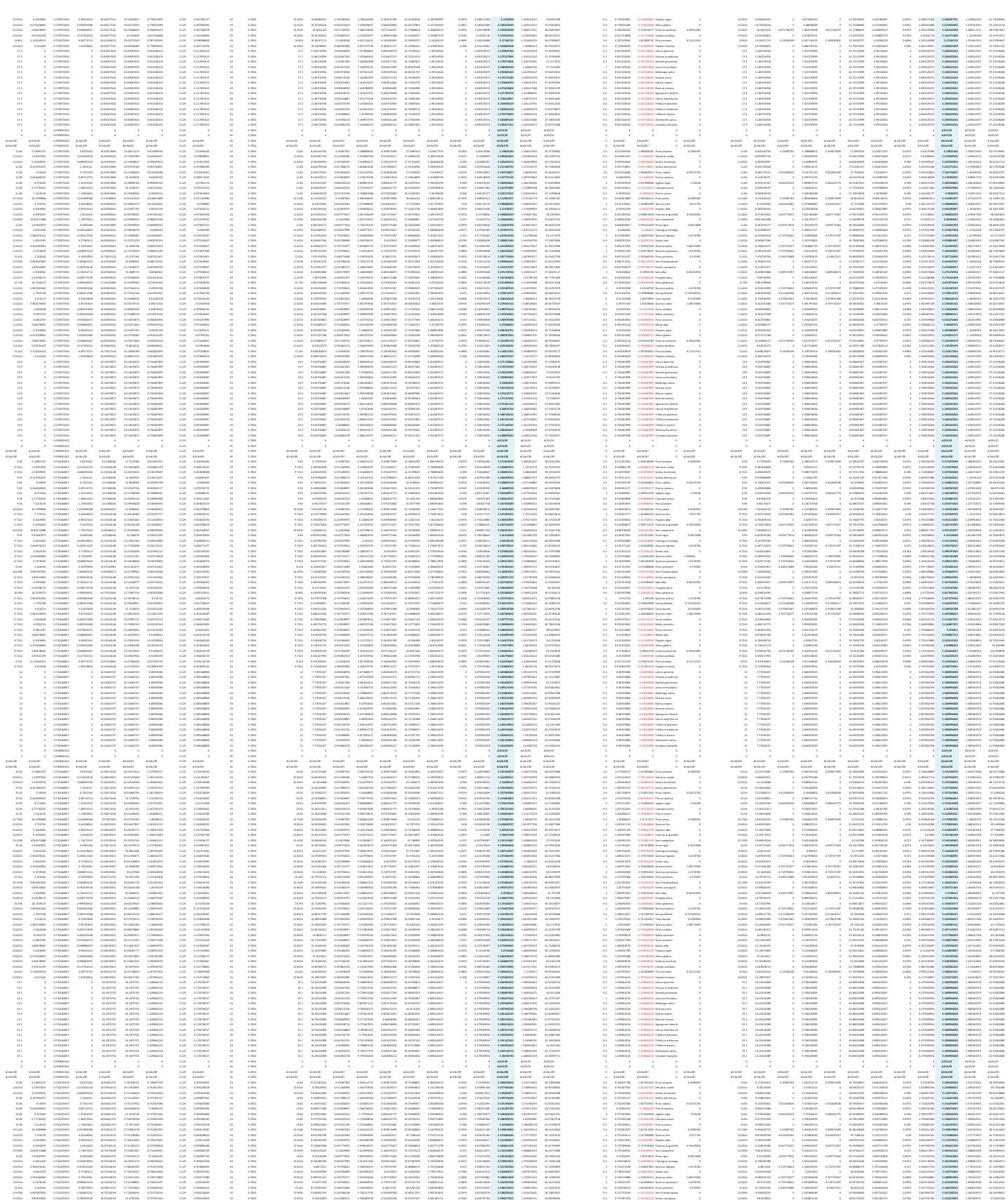


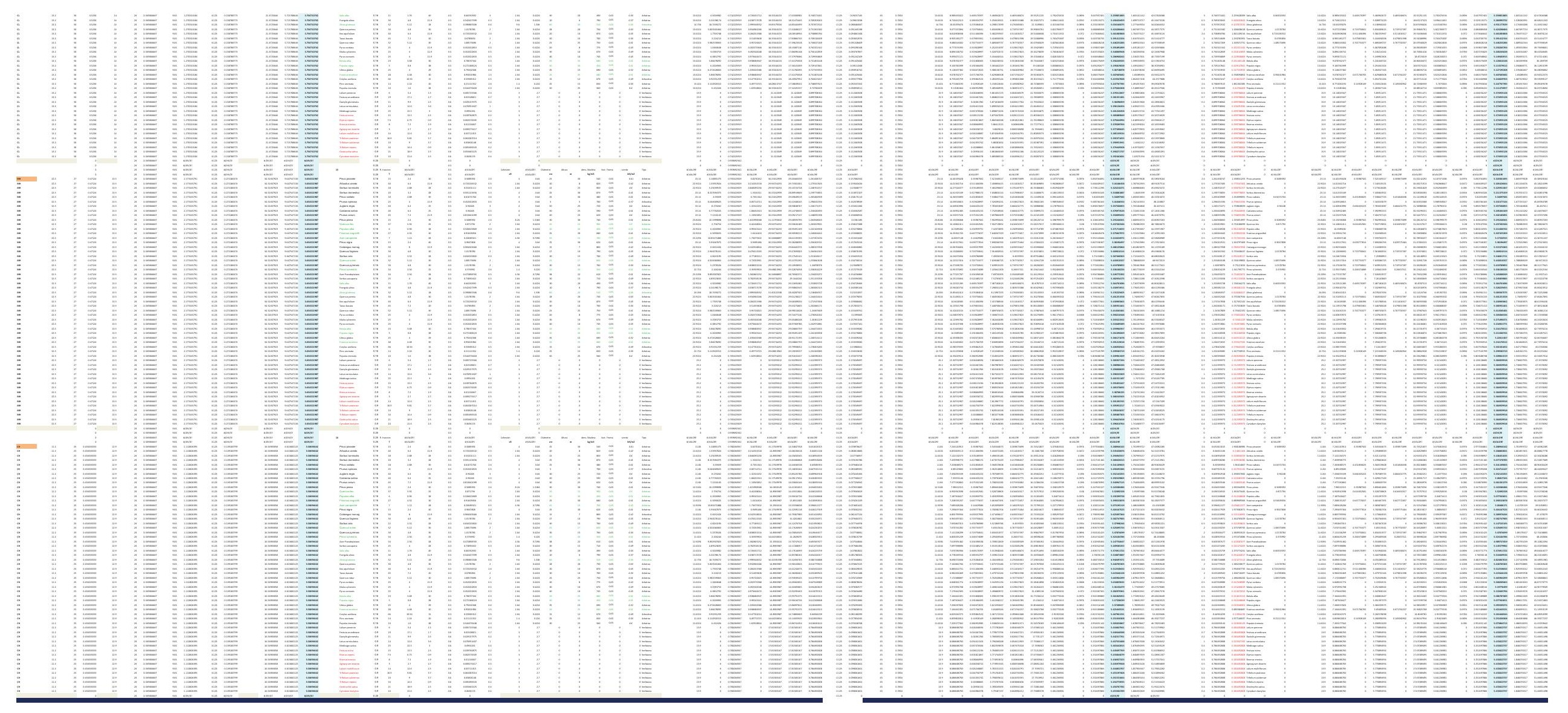



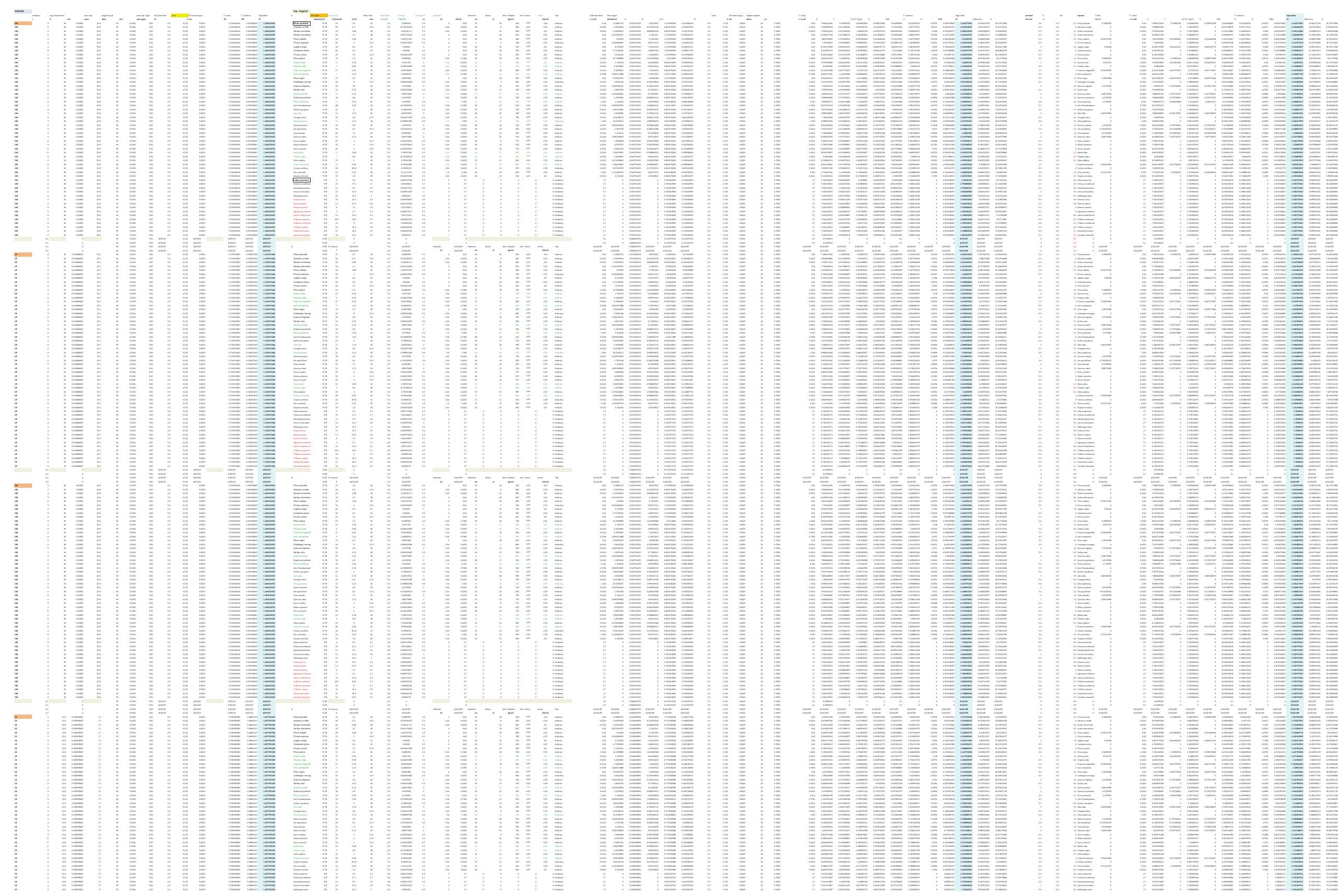


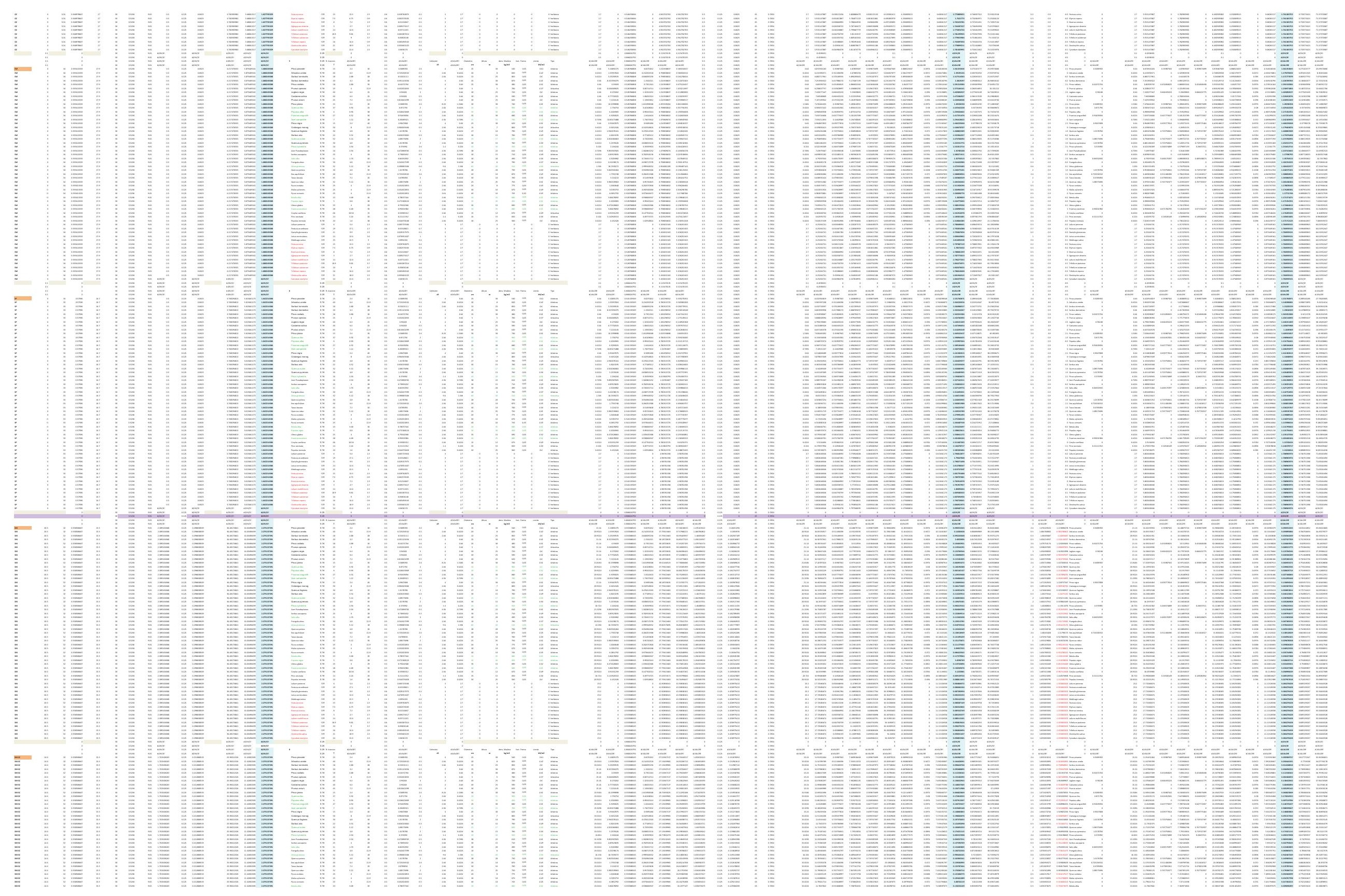



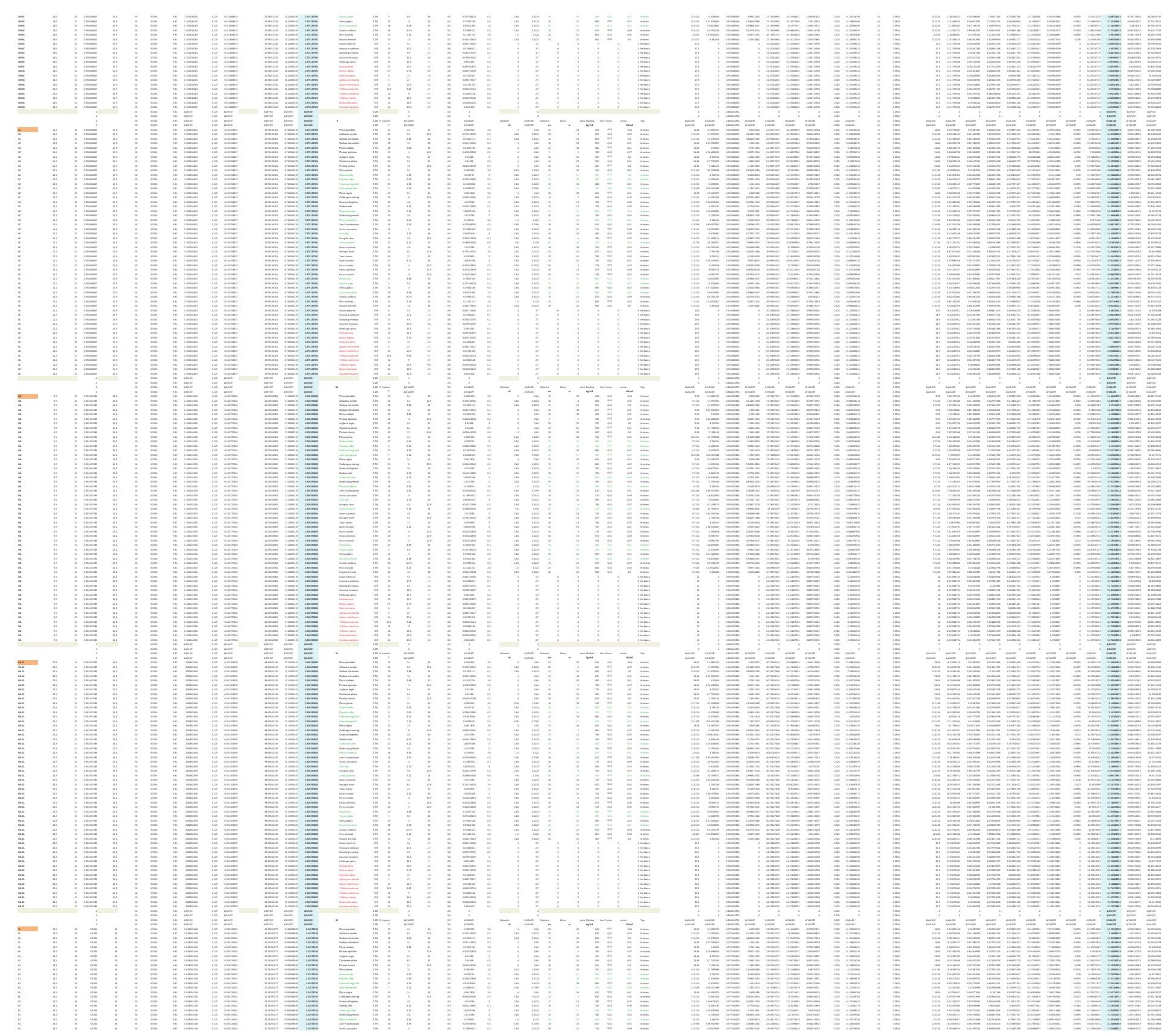

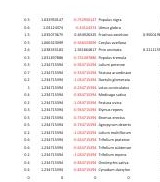
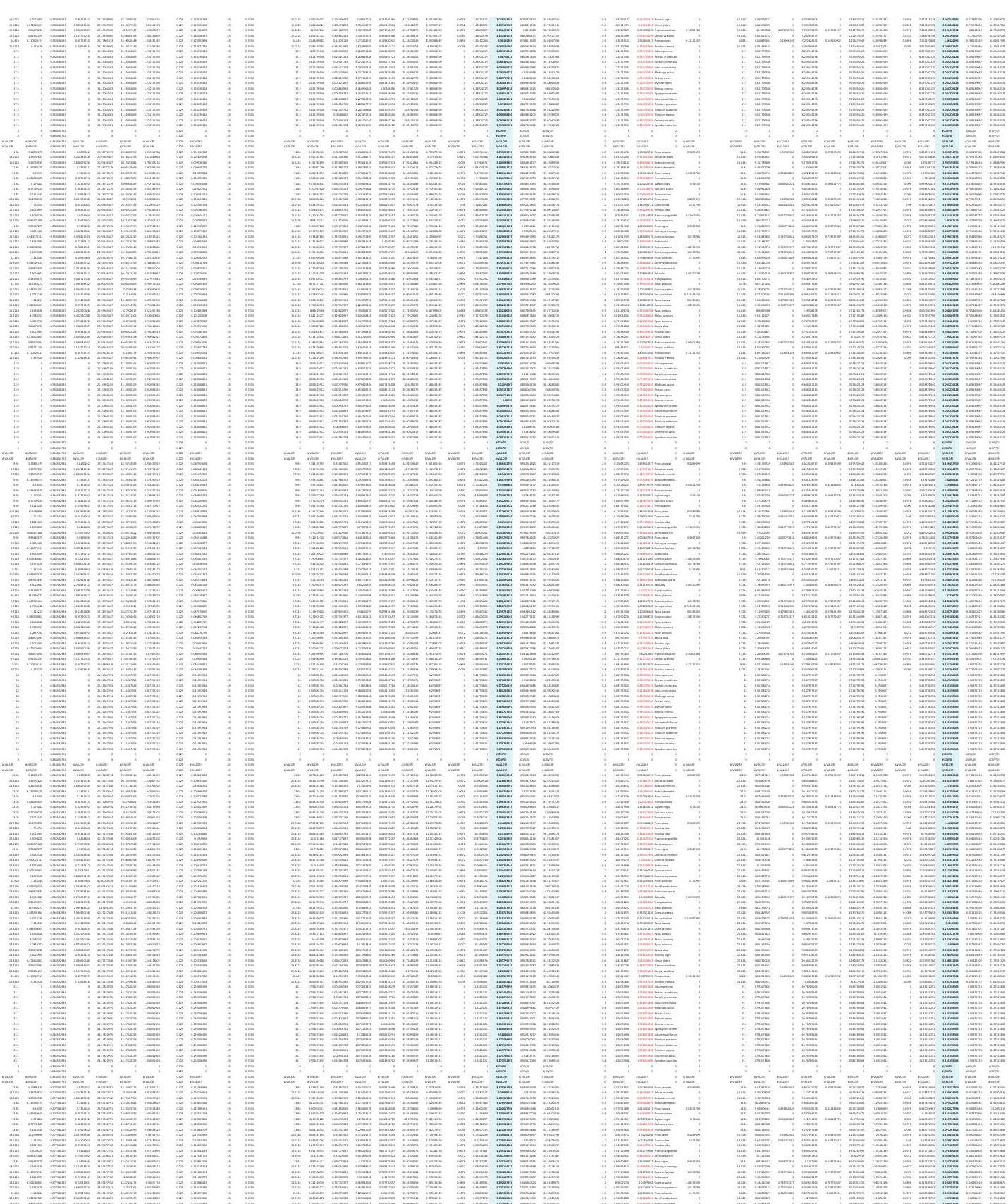


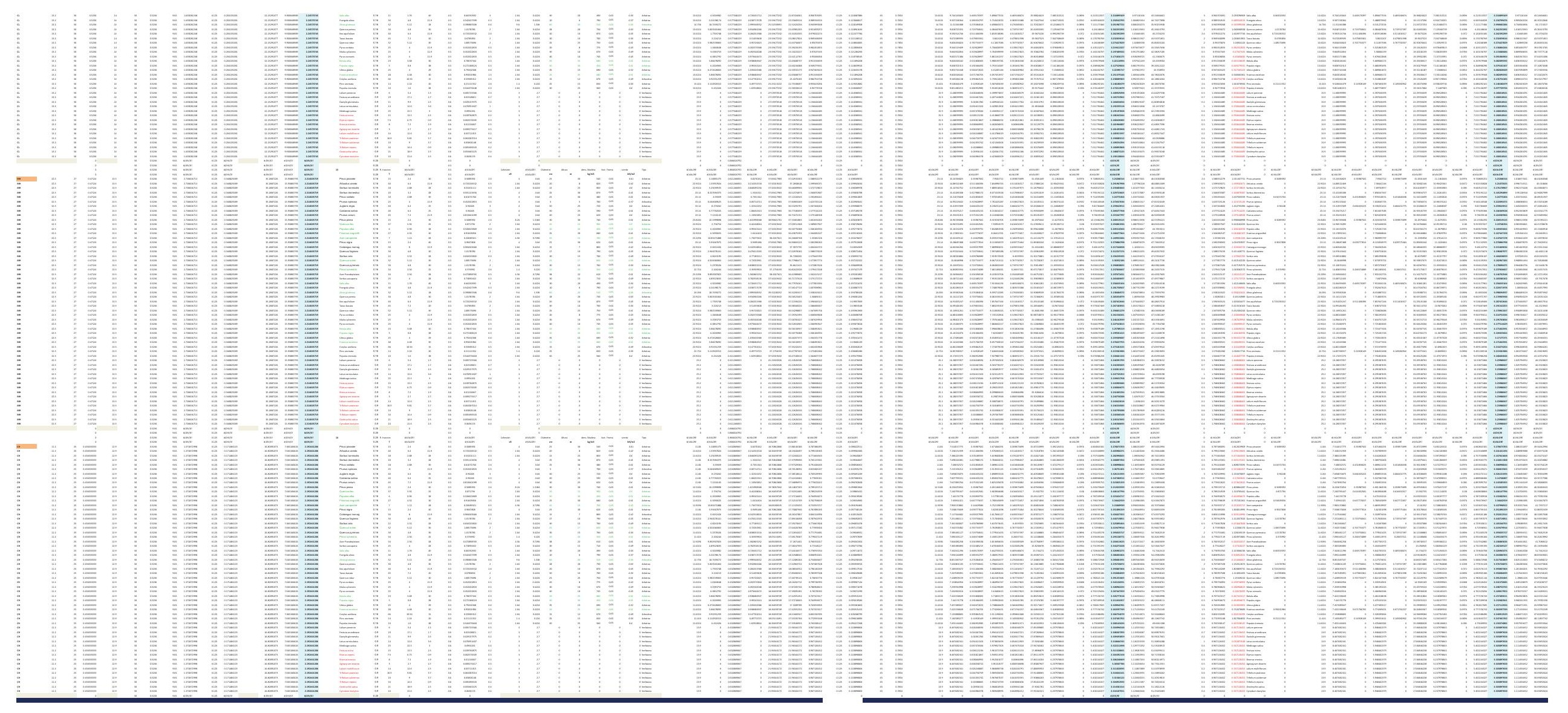



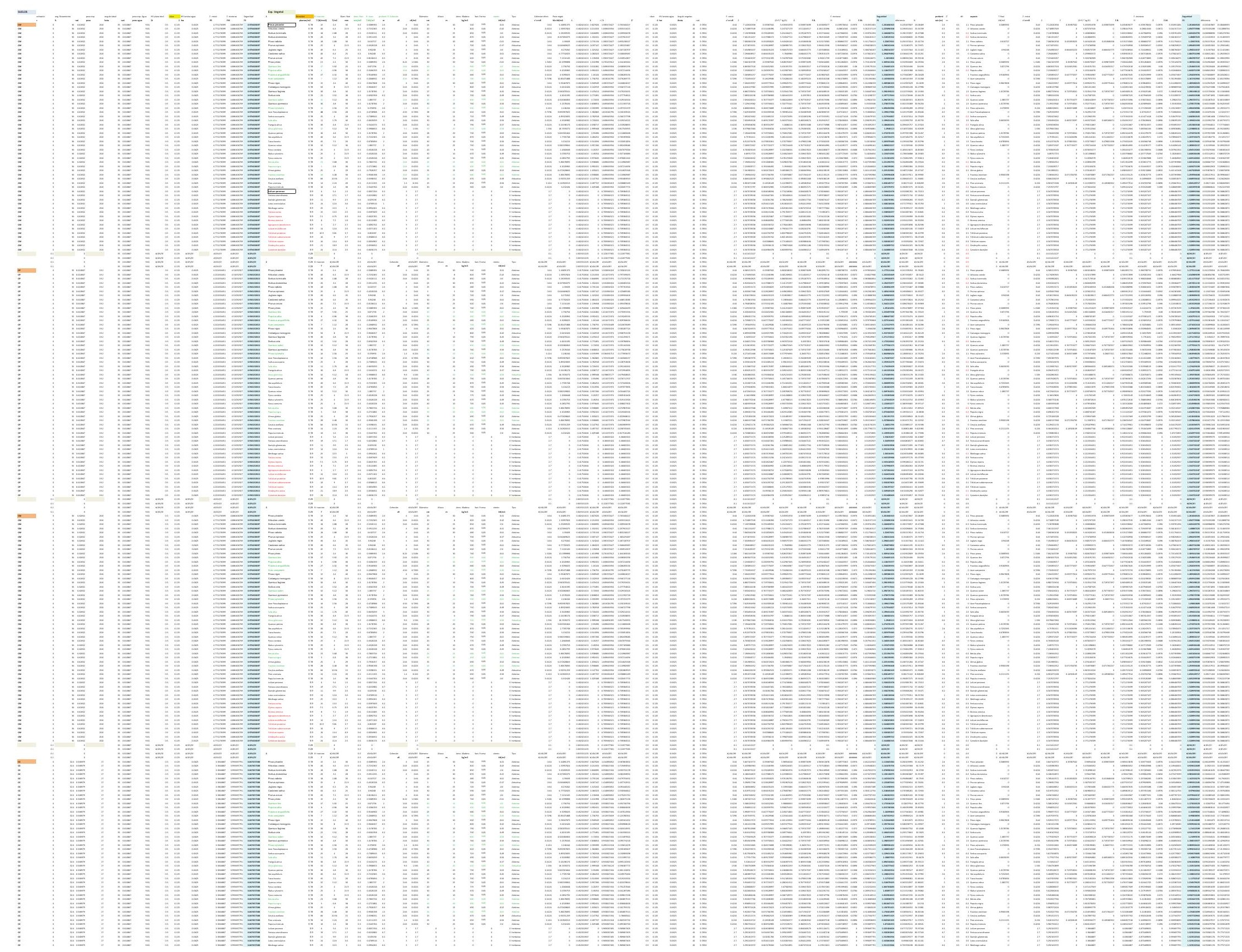

E $={ }^{\prime} \equiv \equiv \equiv \equiv \equiv$

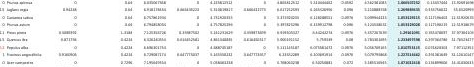

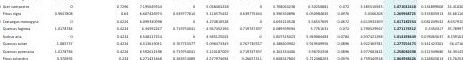

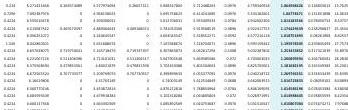

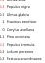

列

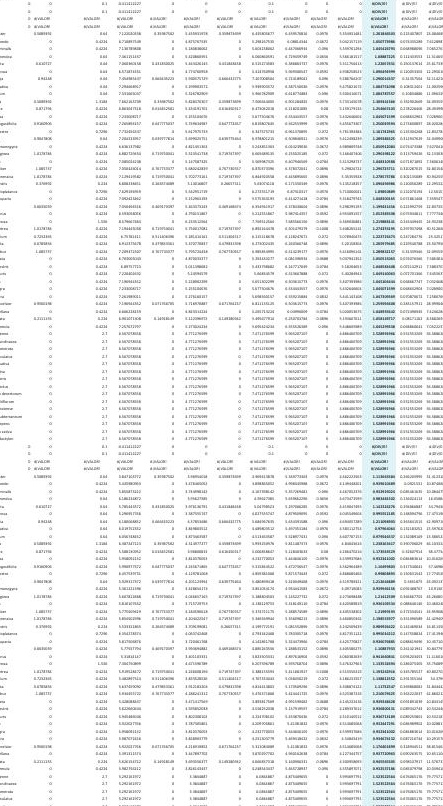




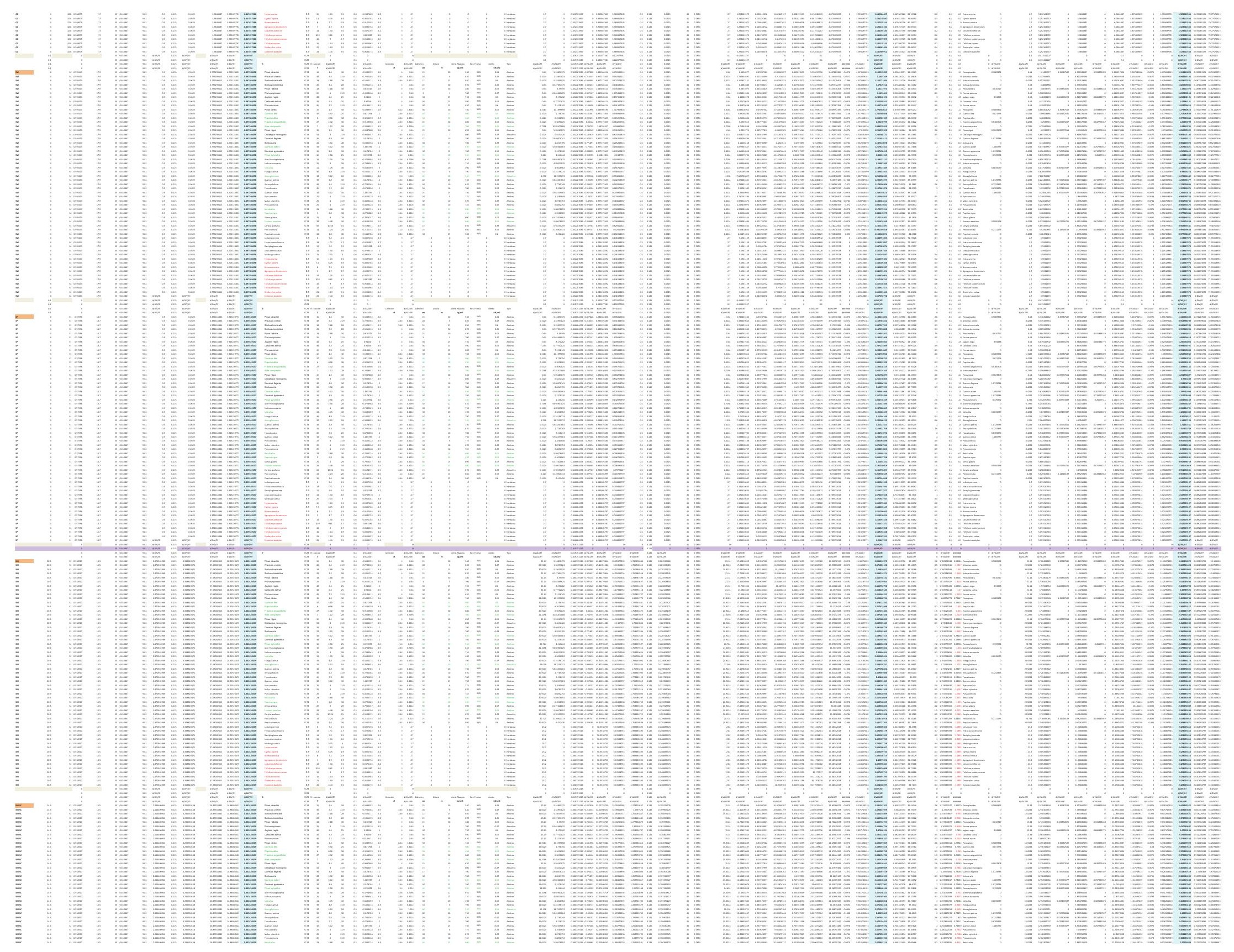



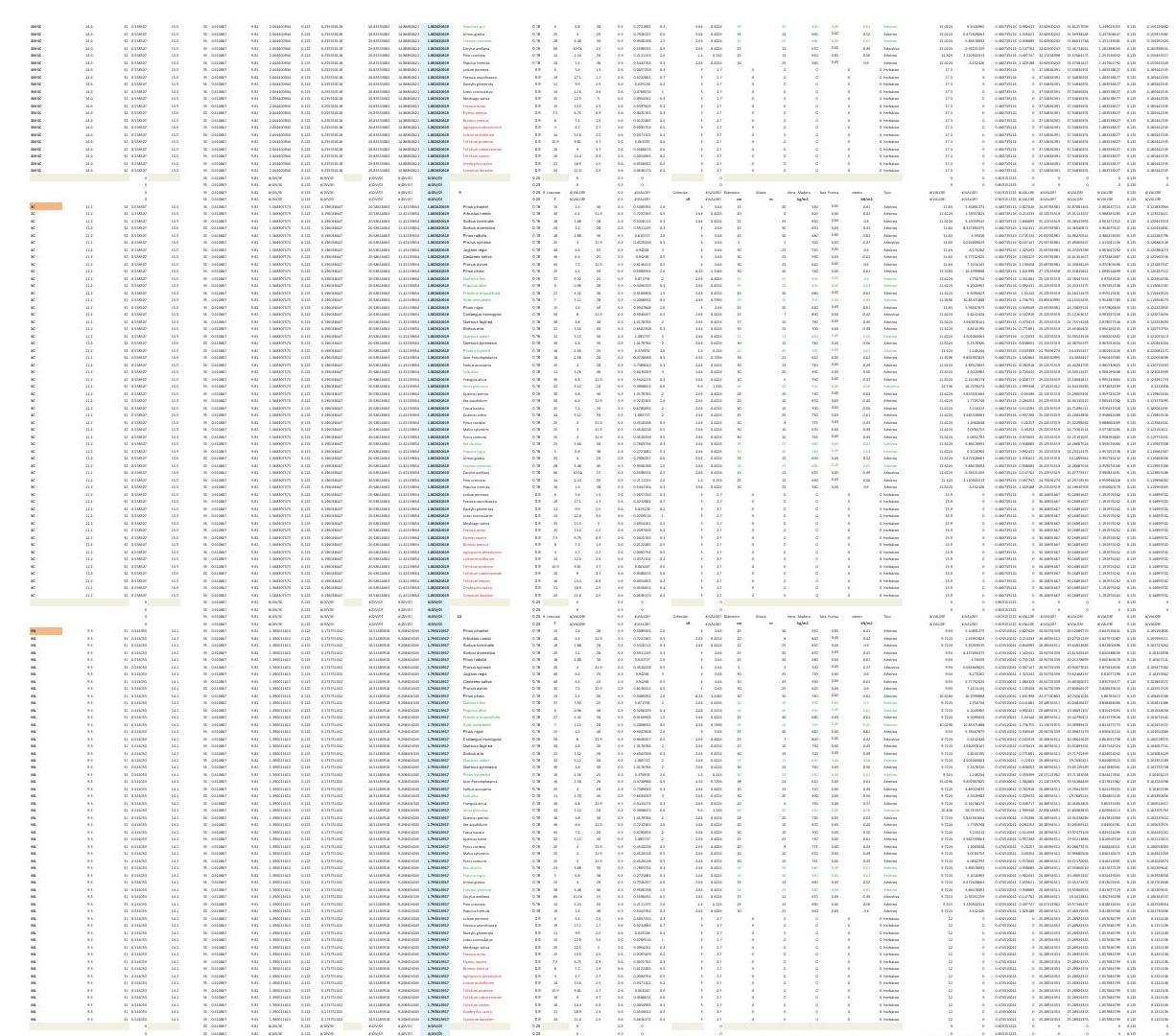

mIIII
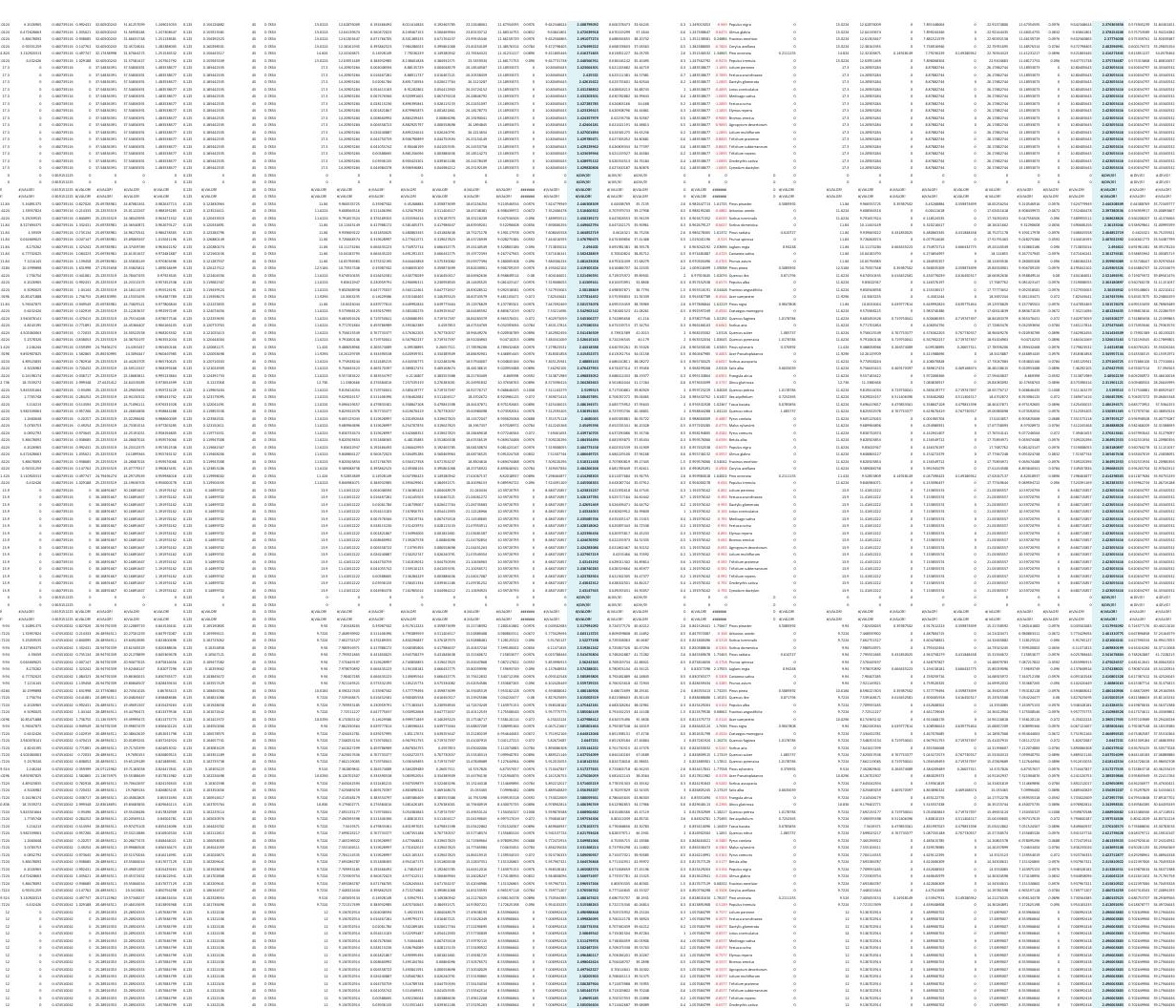

$=\equiv \equiv \equiv \equiv \equiv \equiv \equiv$

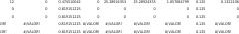
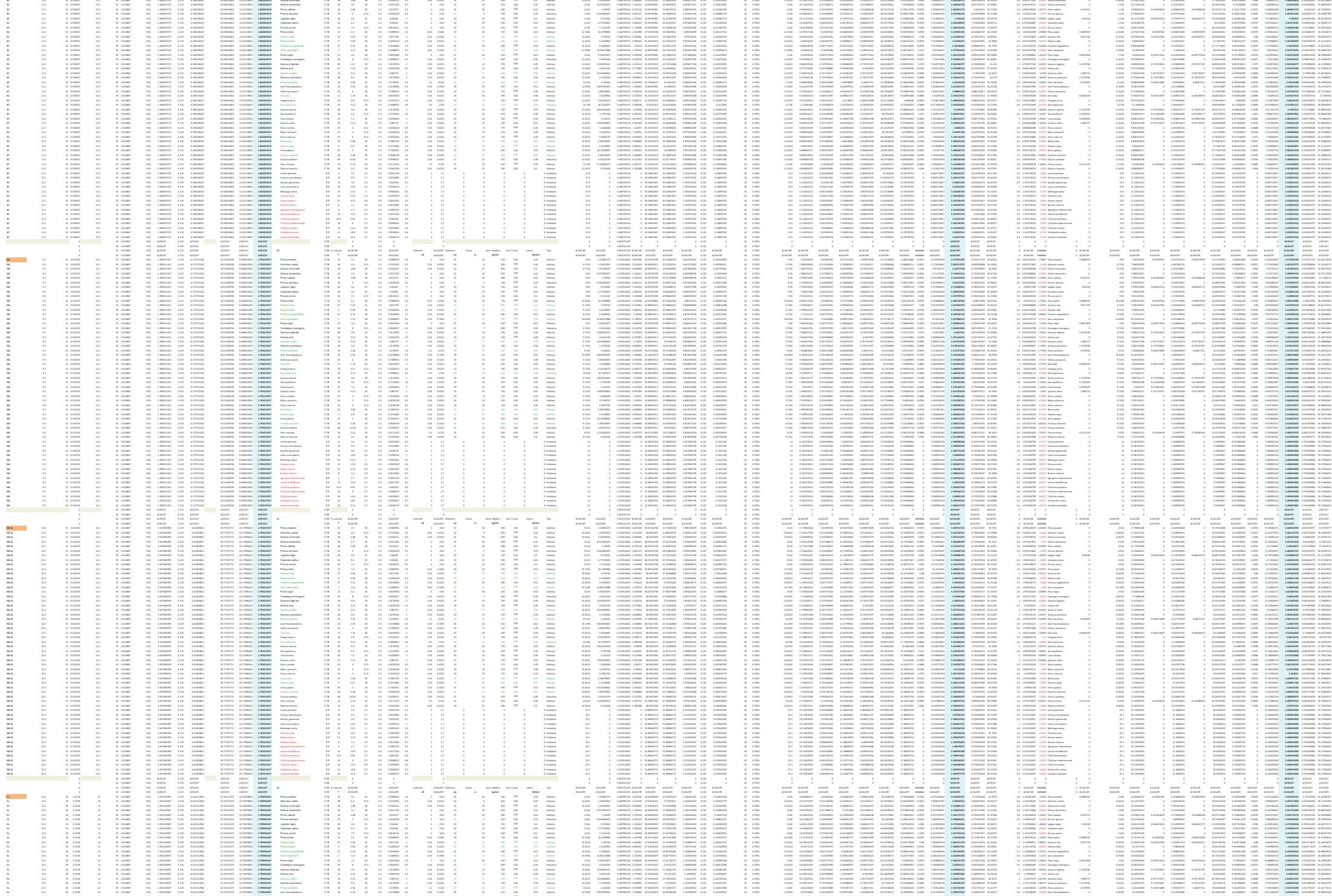


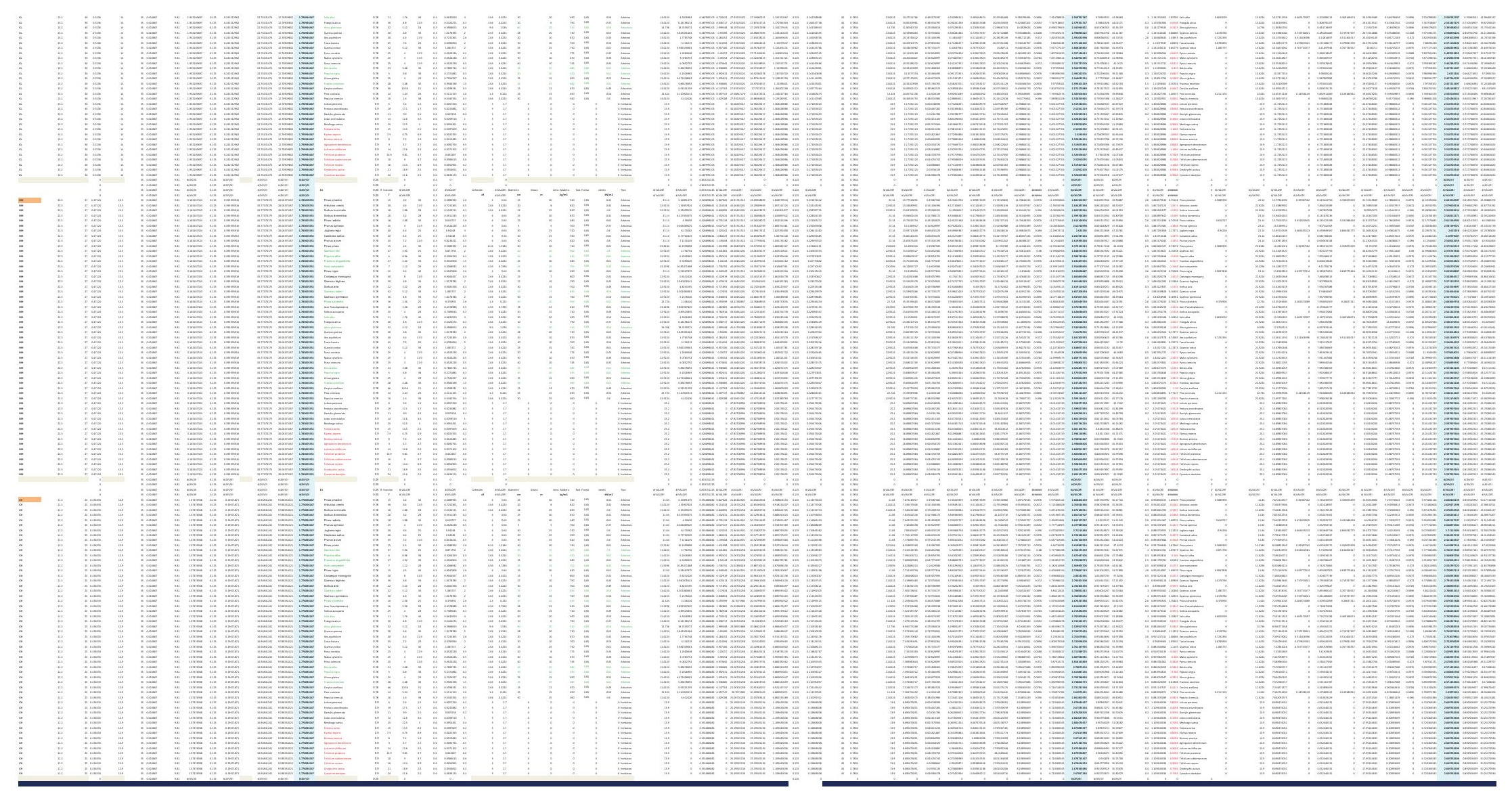



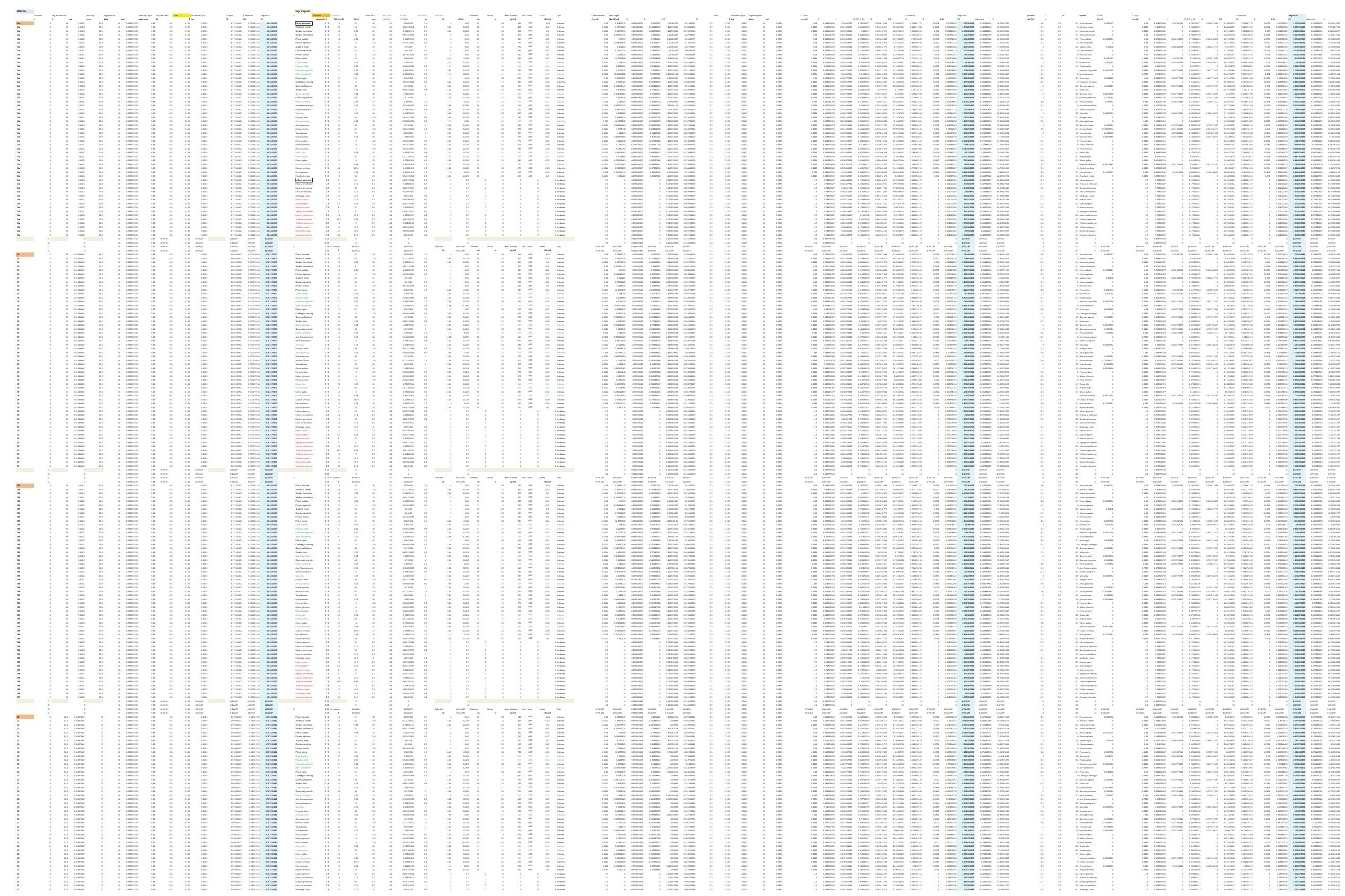


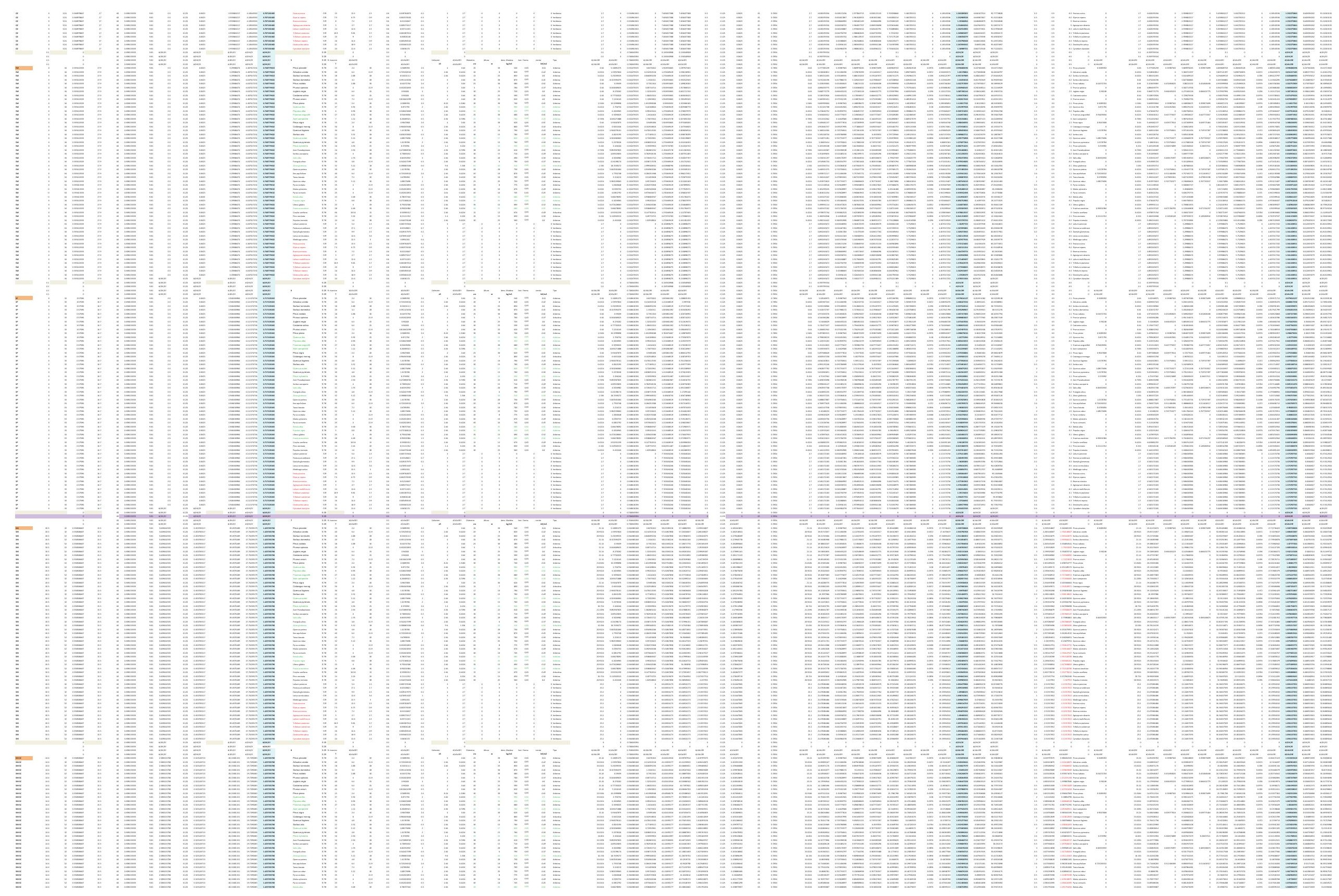



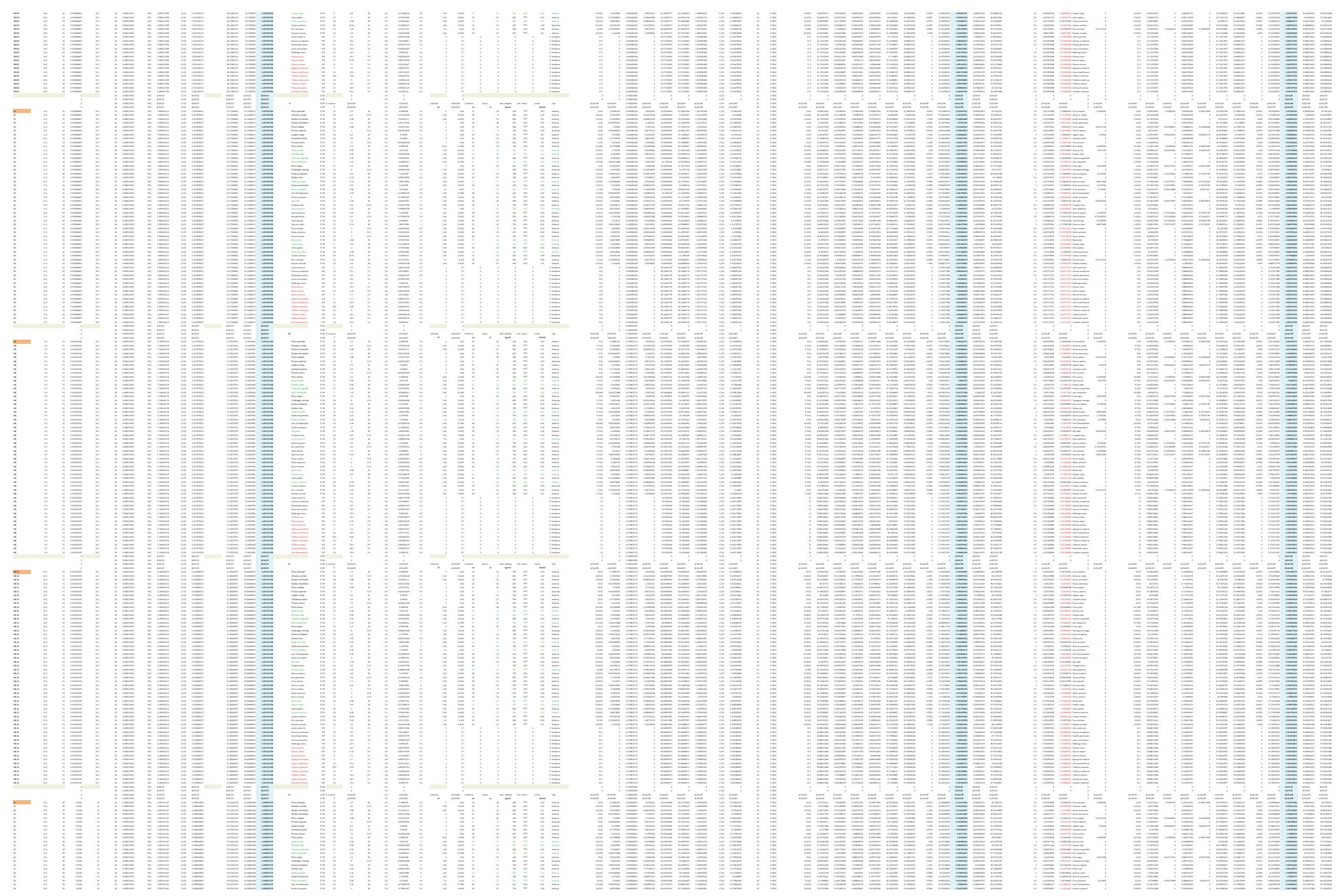


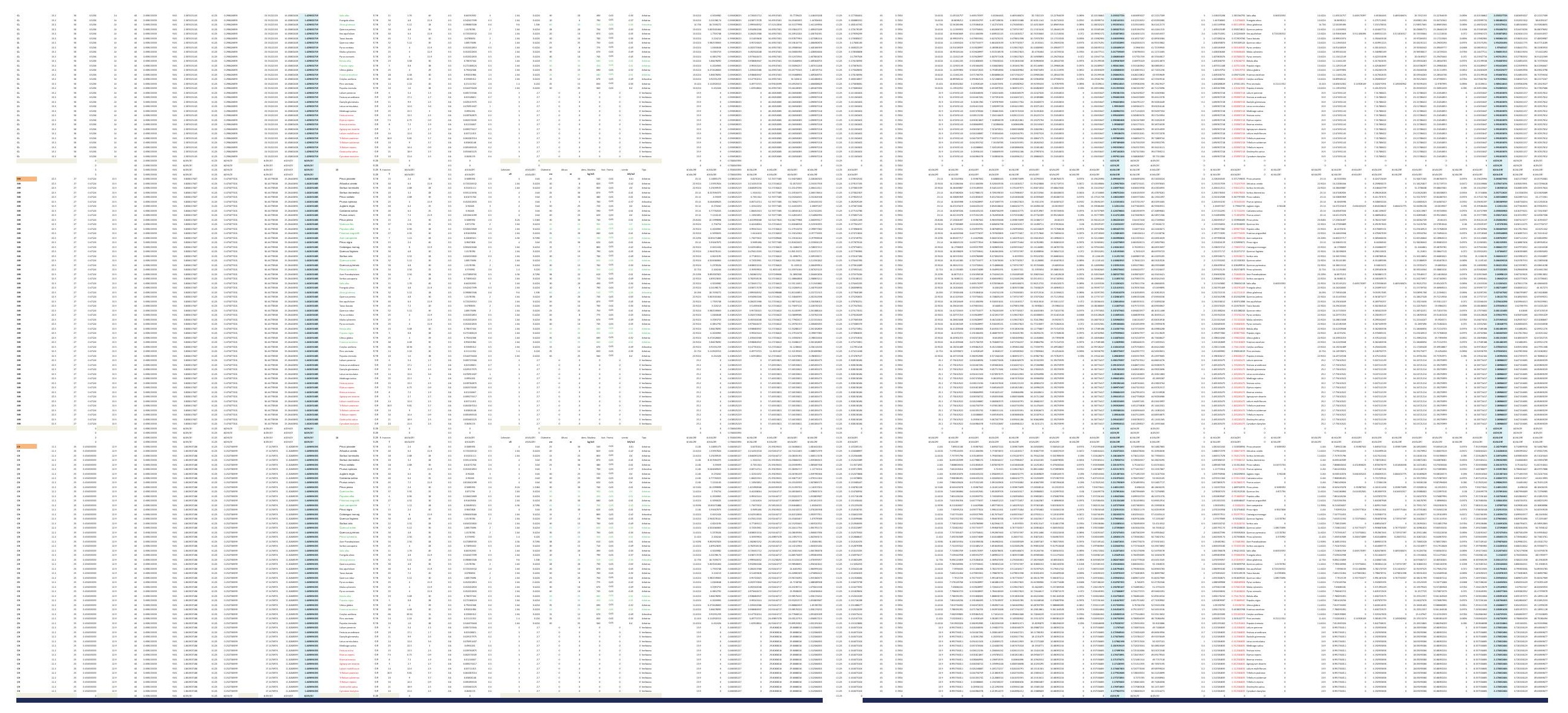



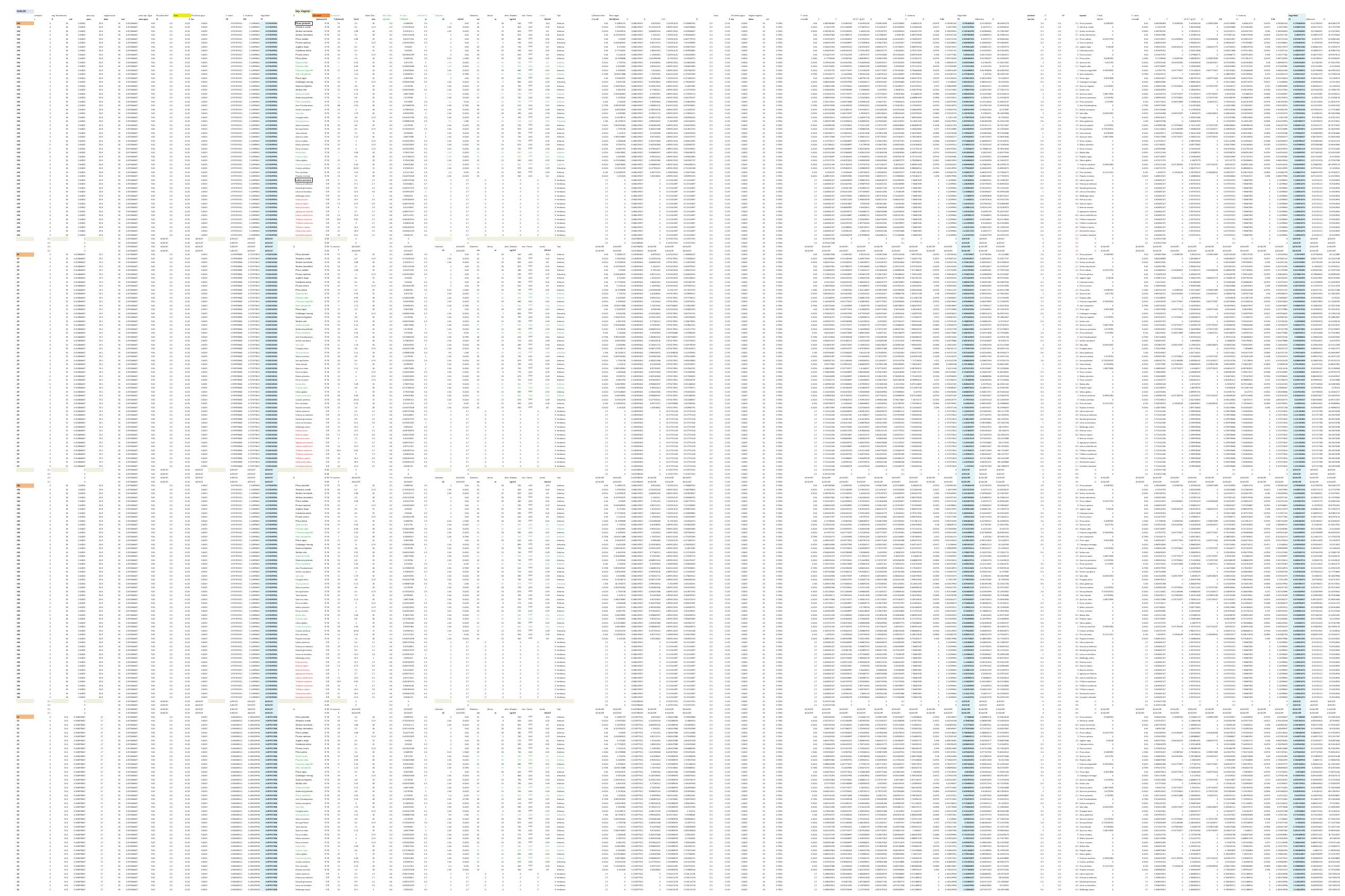


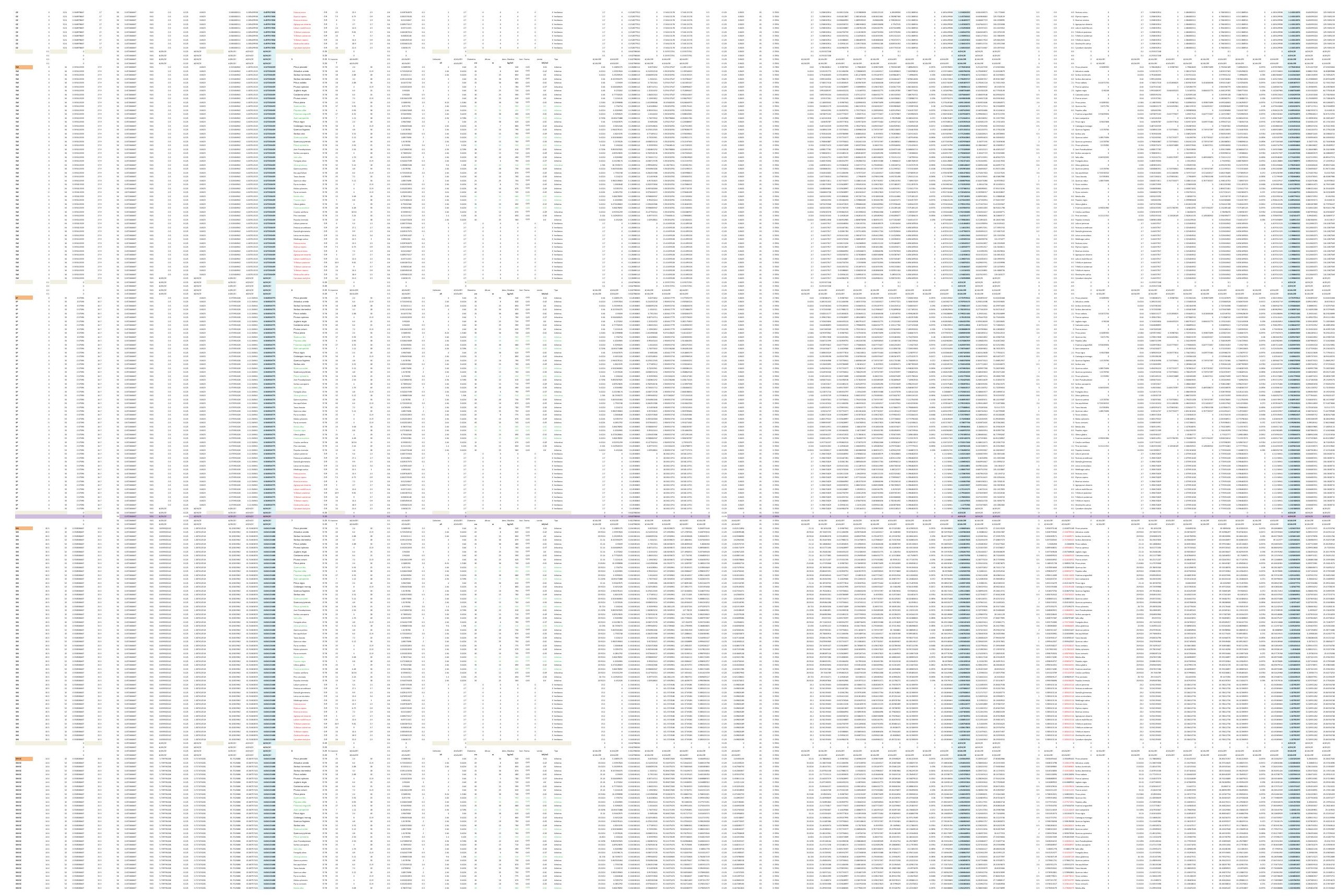




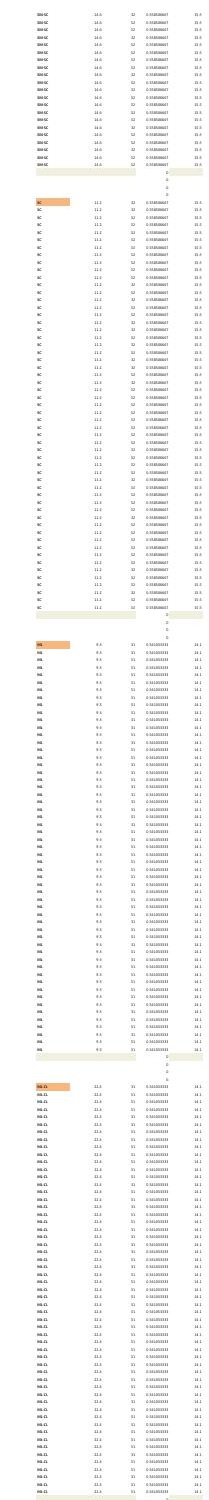

:

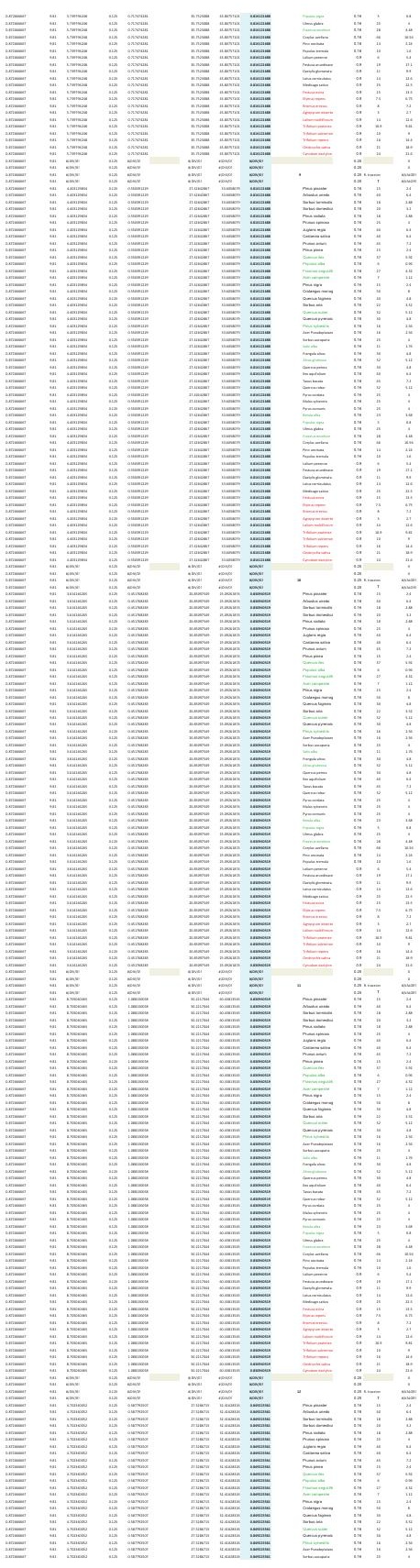

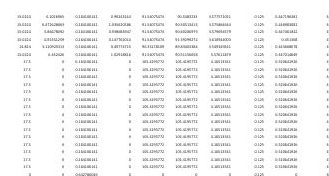
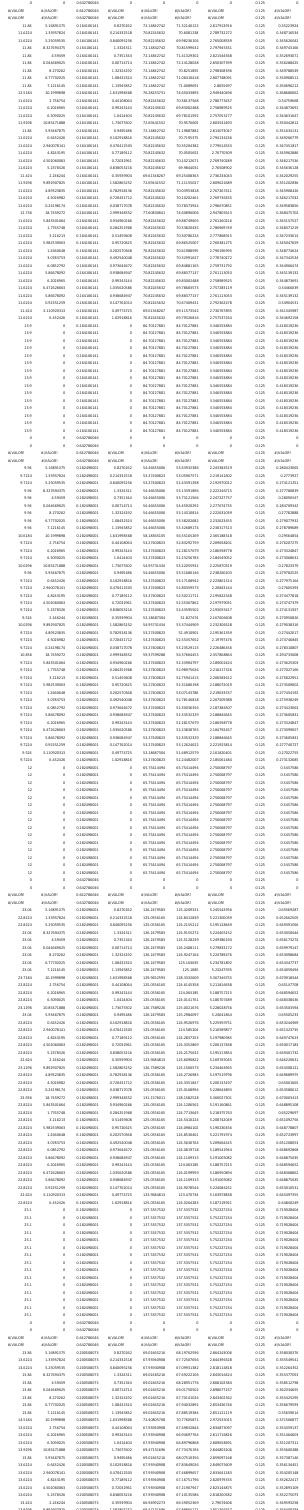

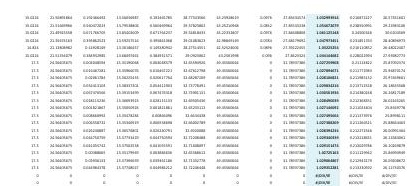

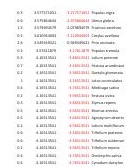

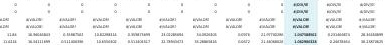

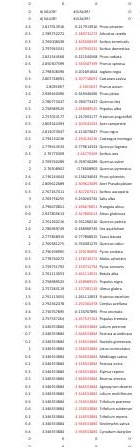
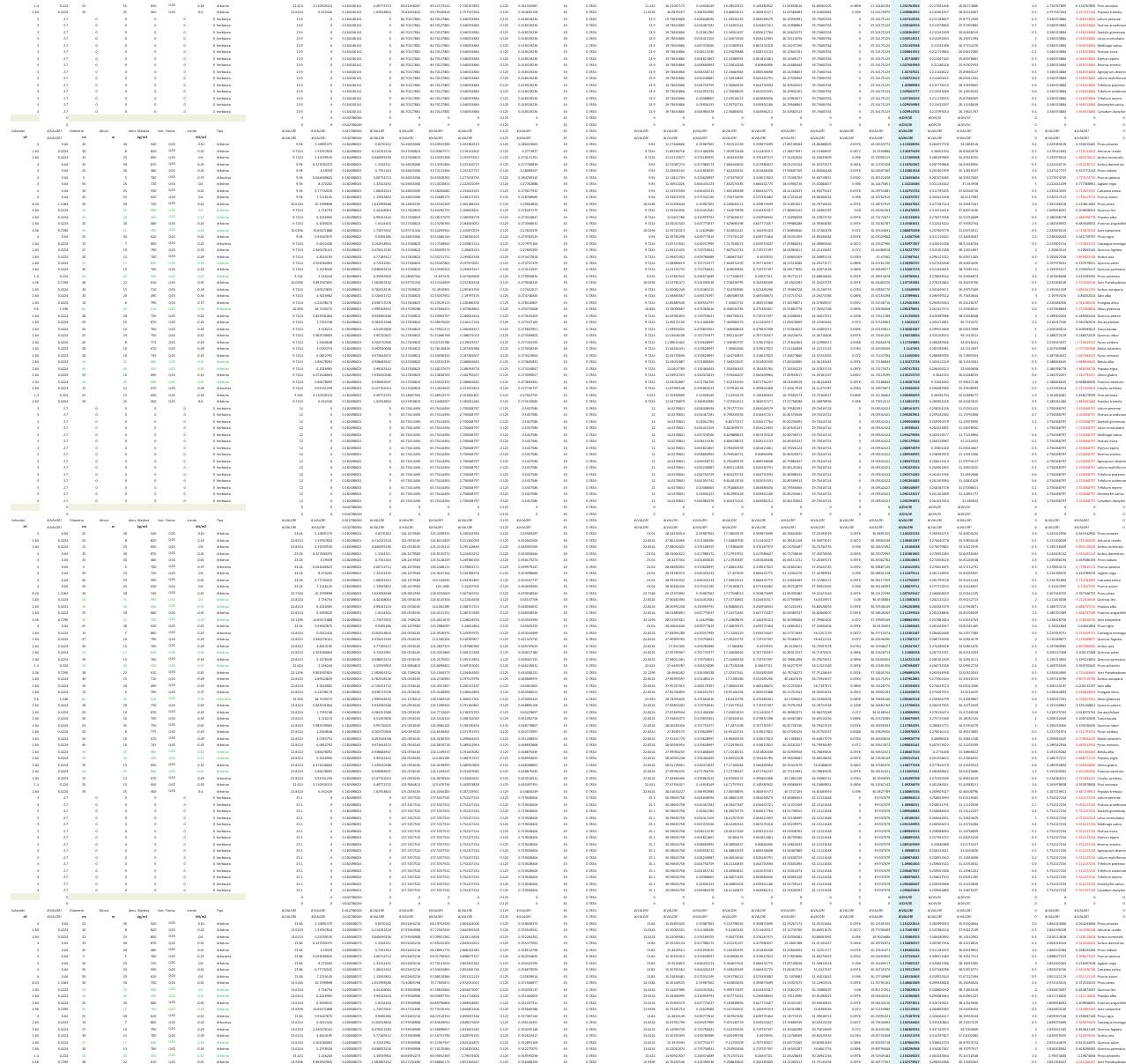
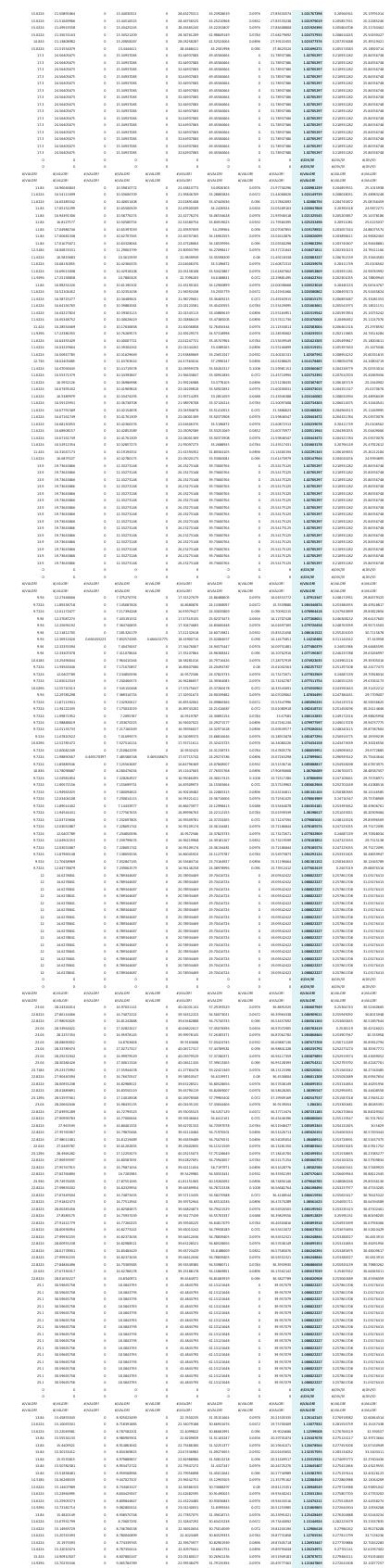


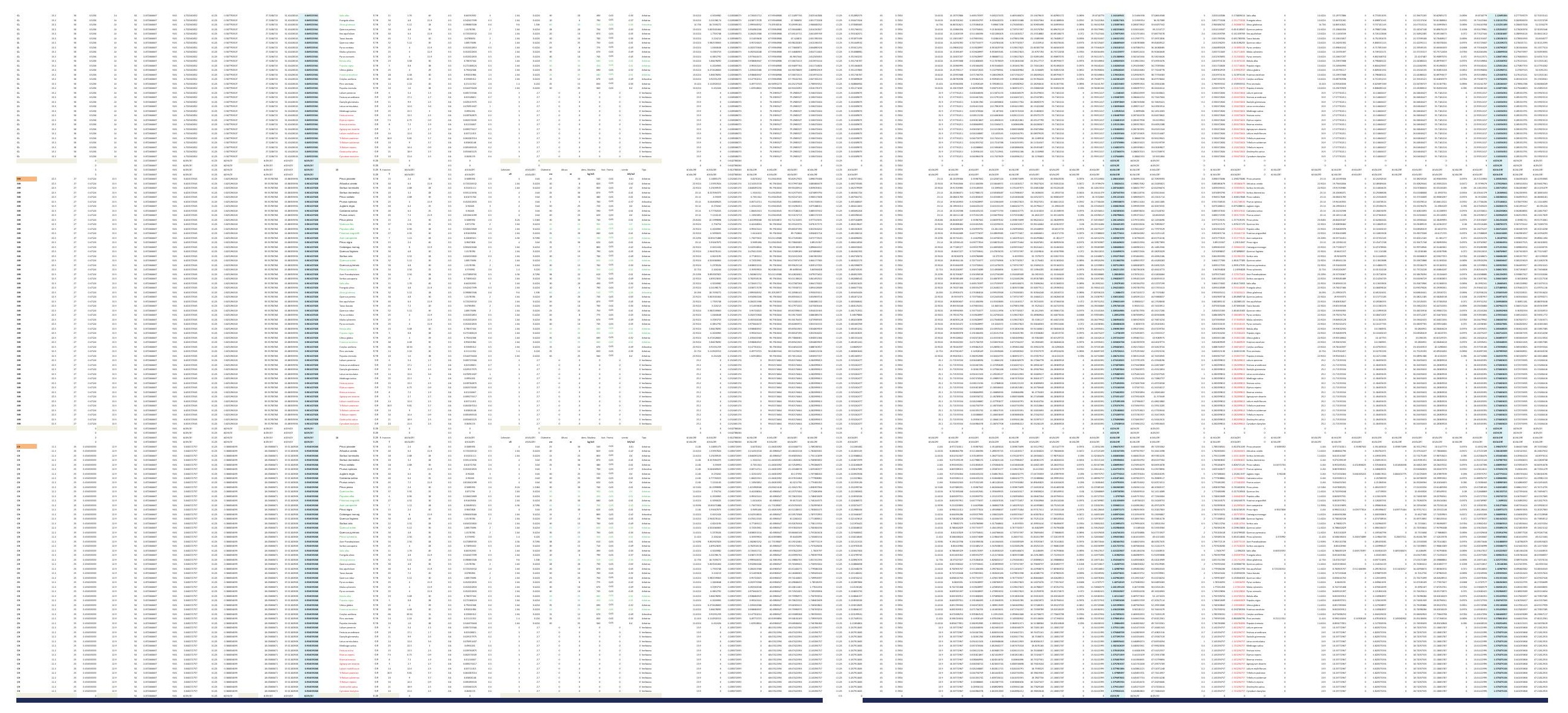



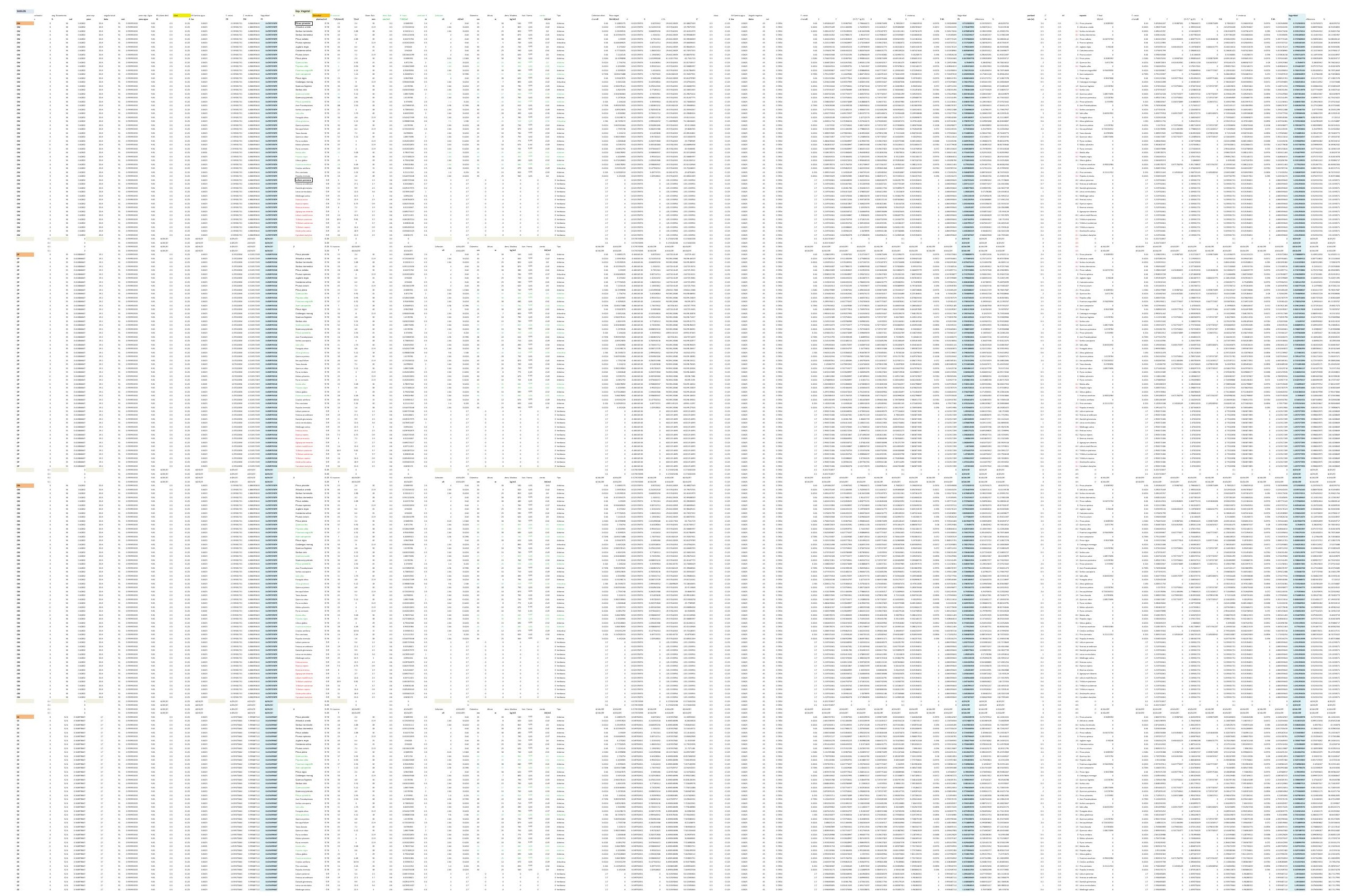


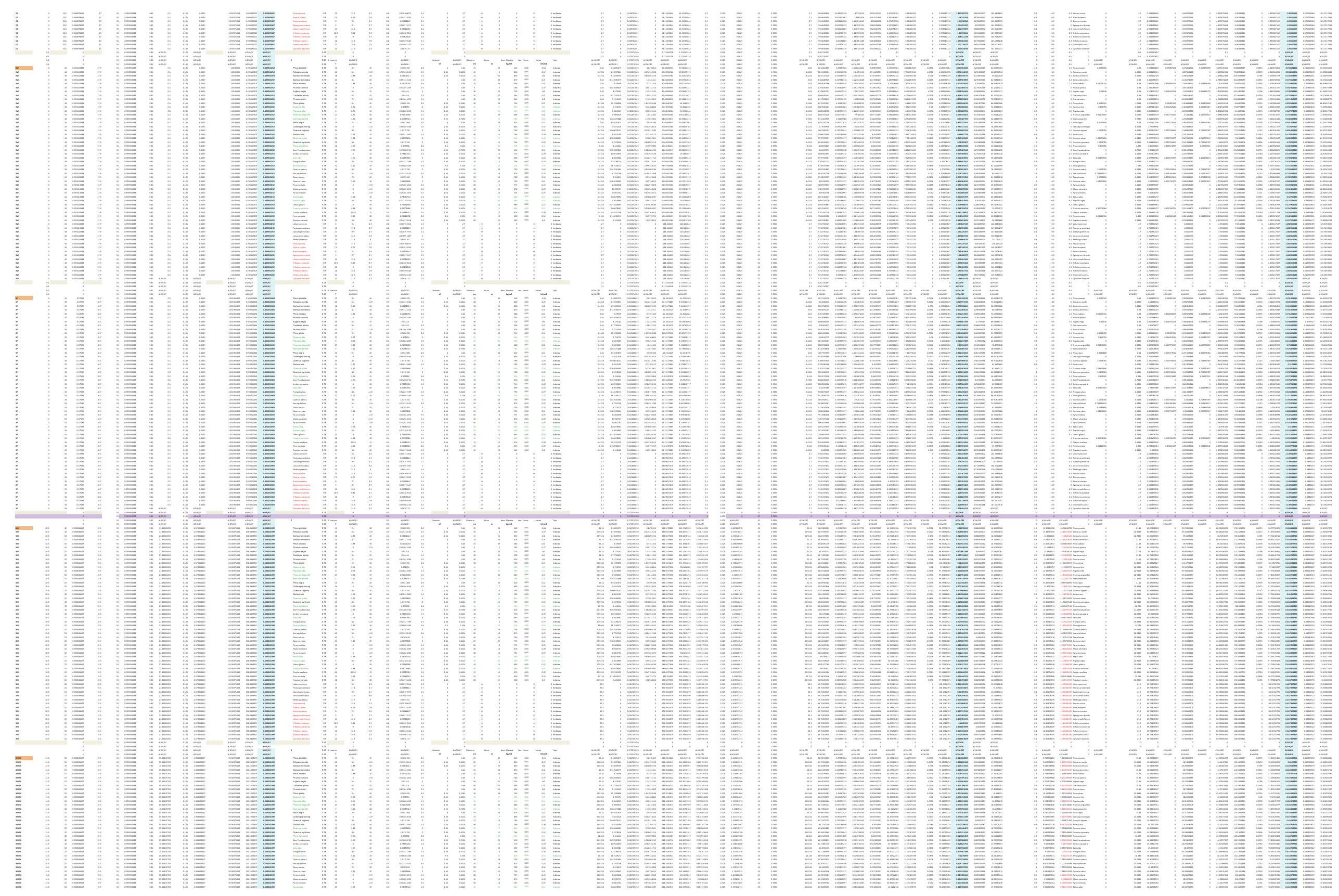



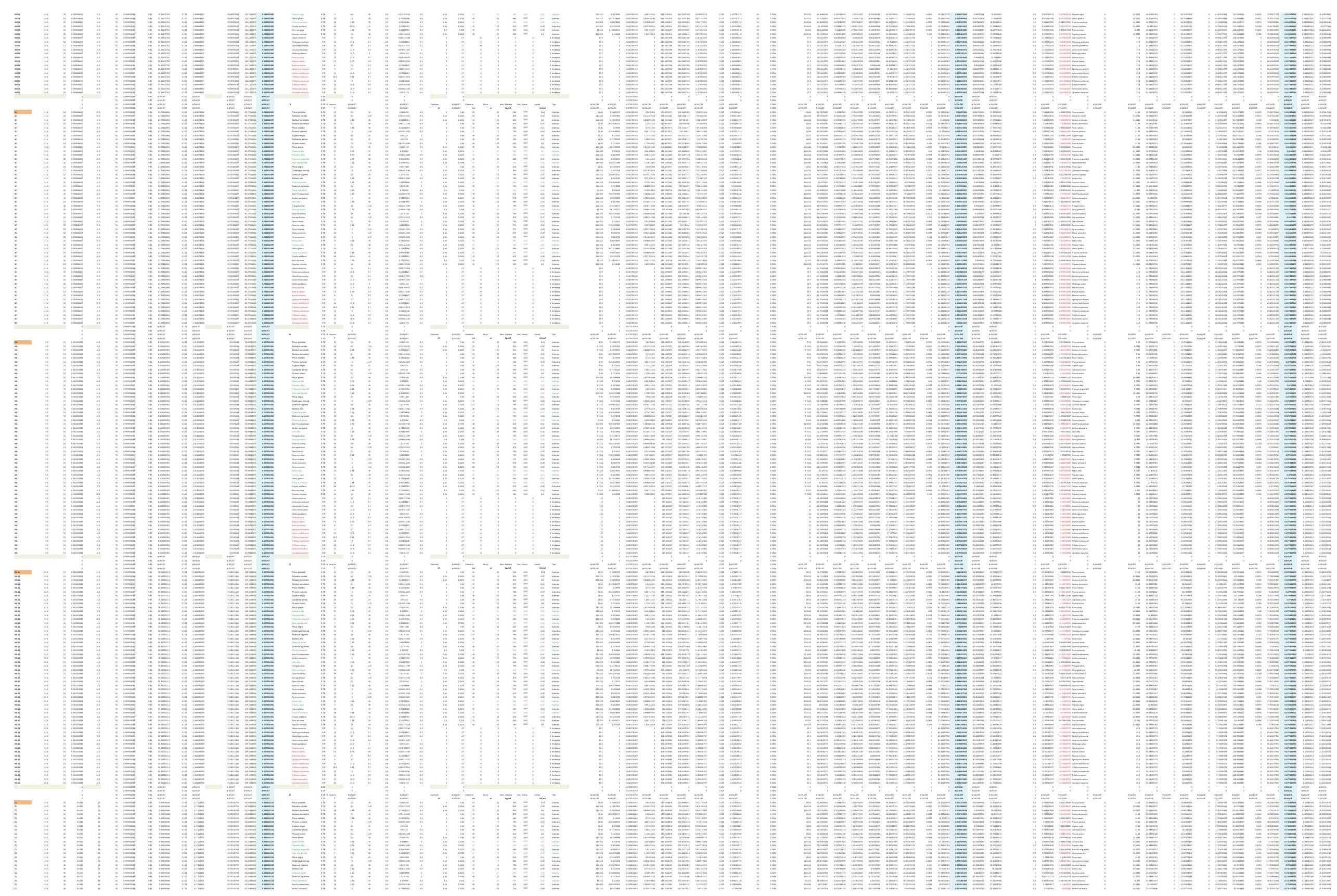


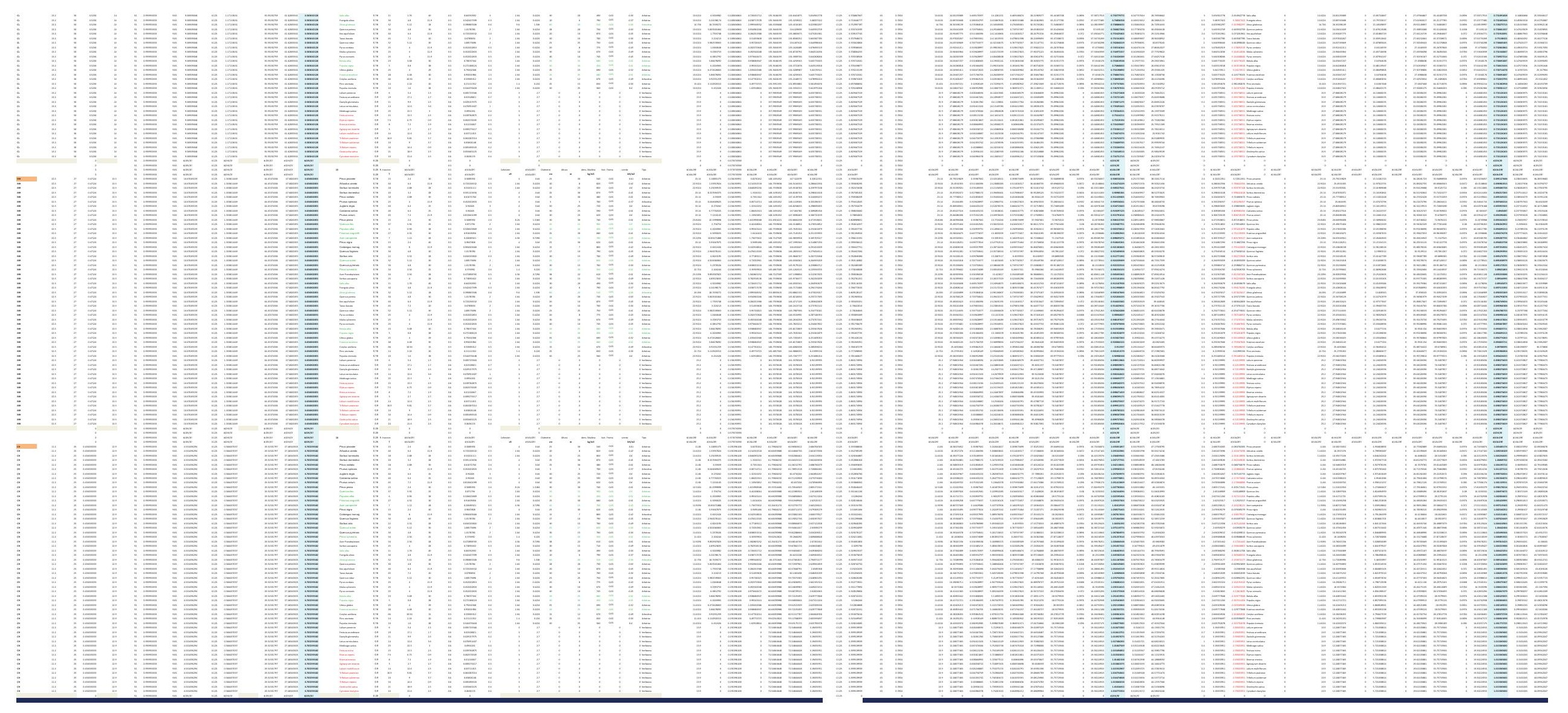



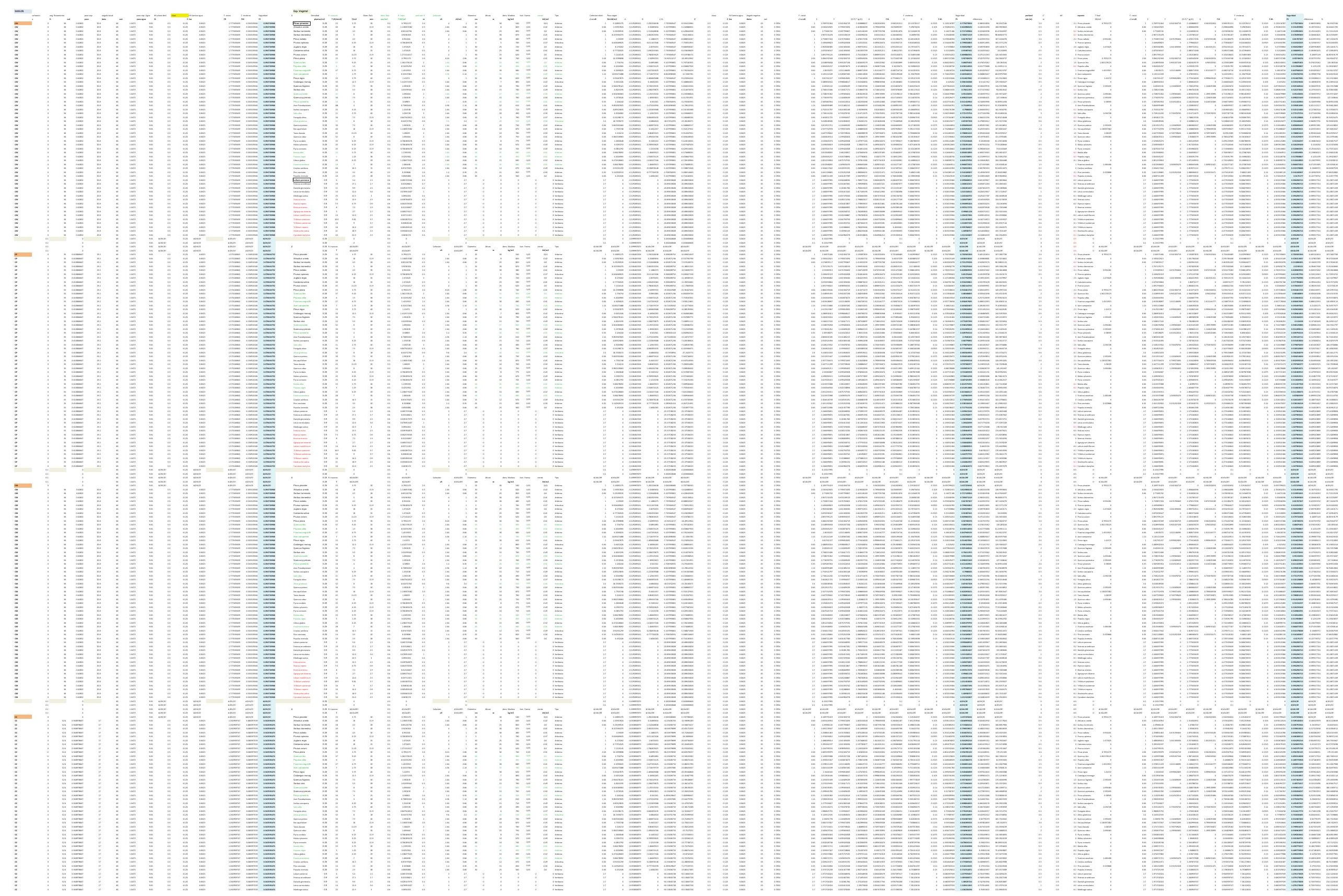


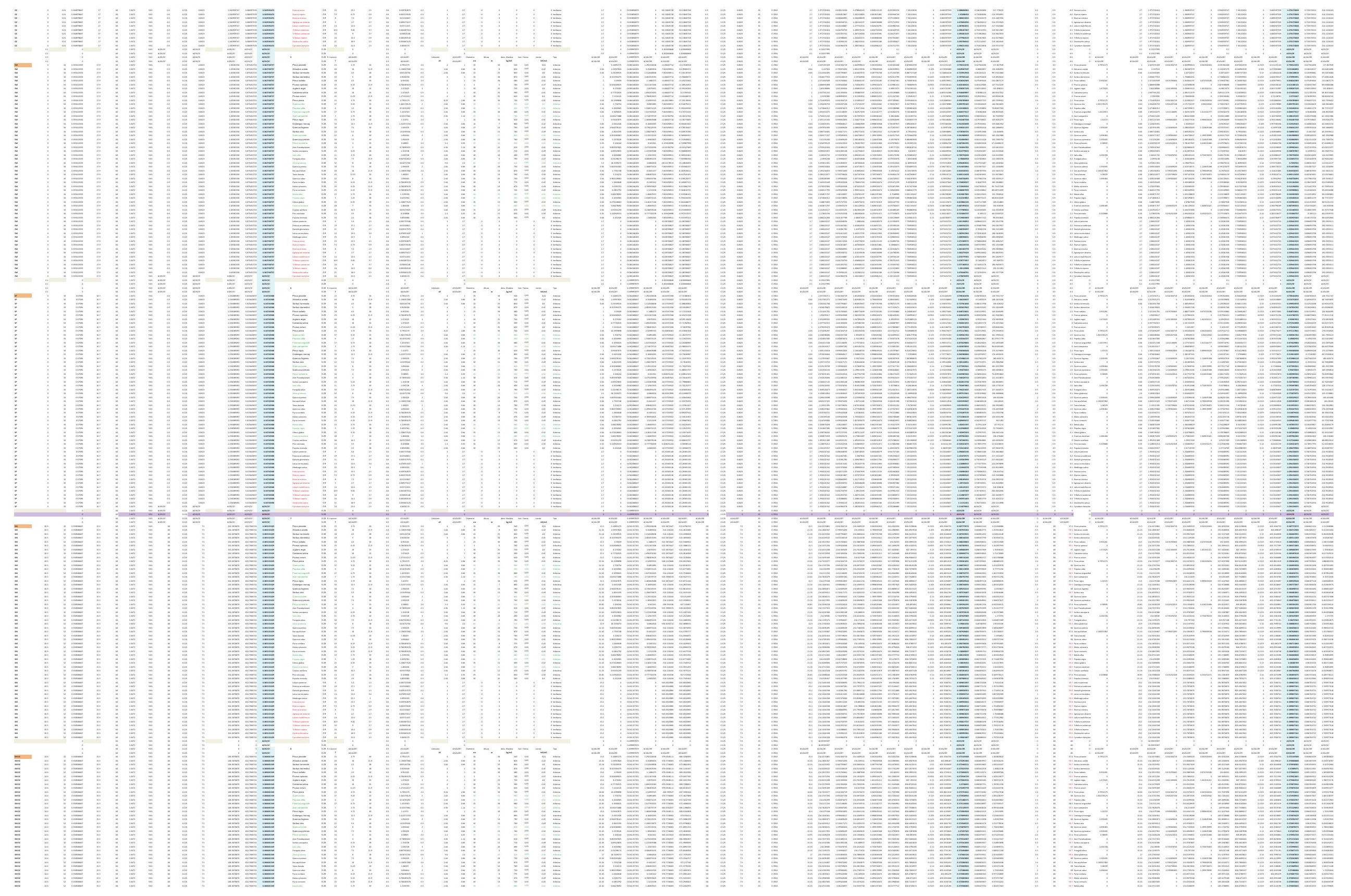



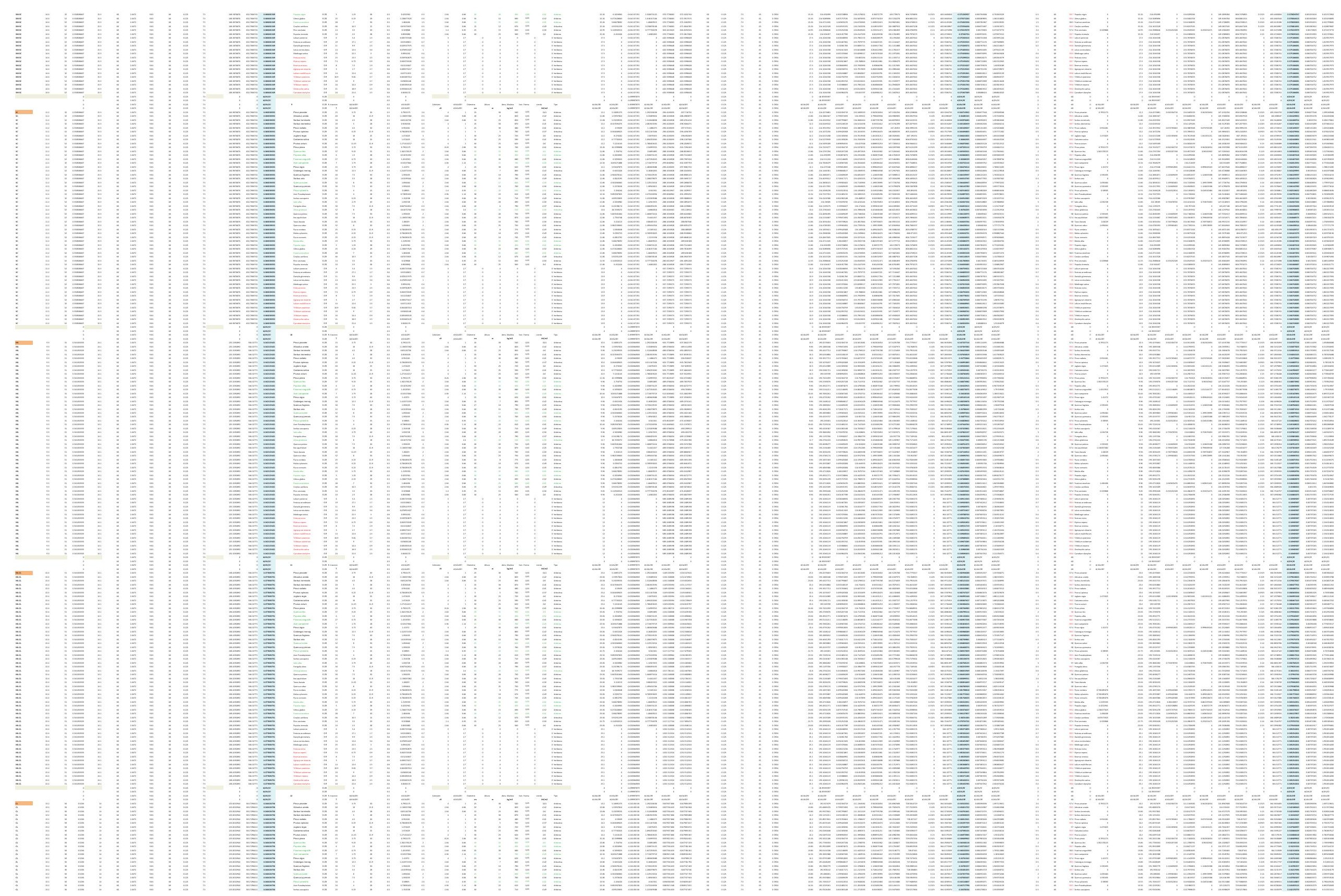


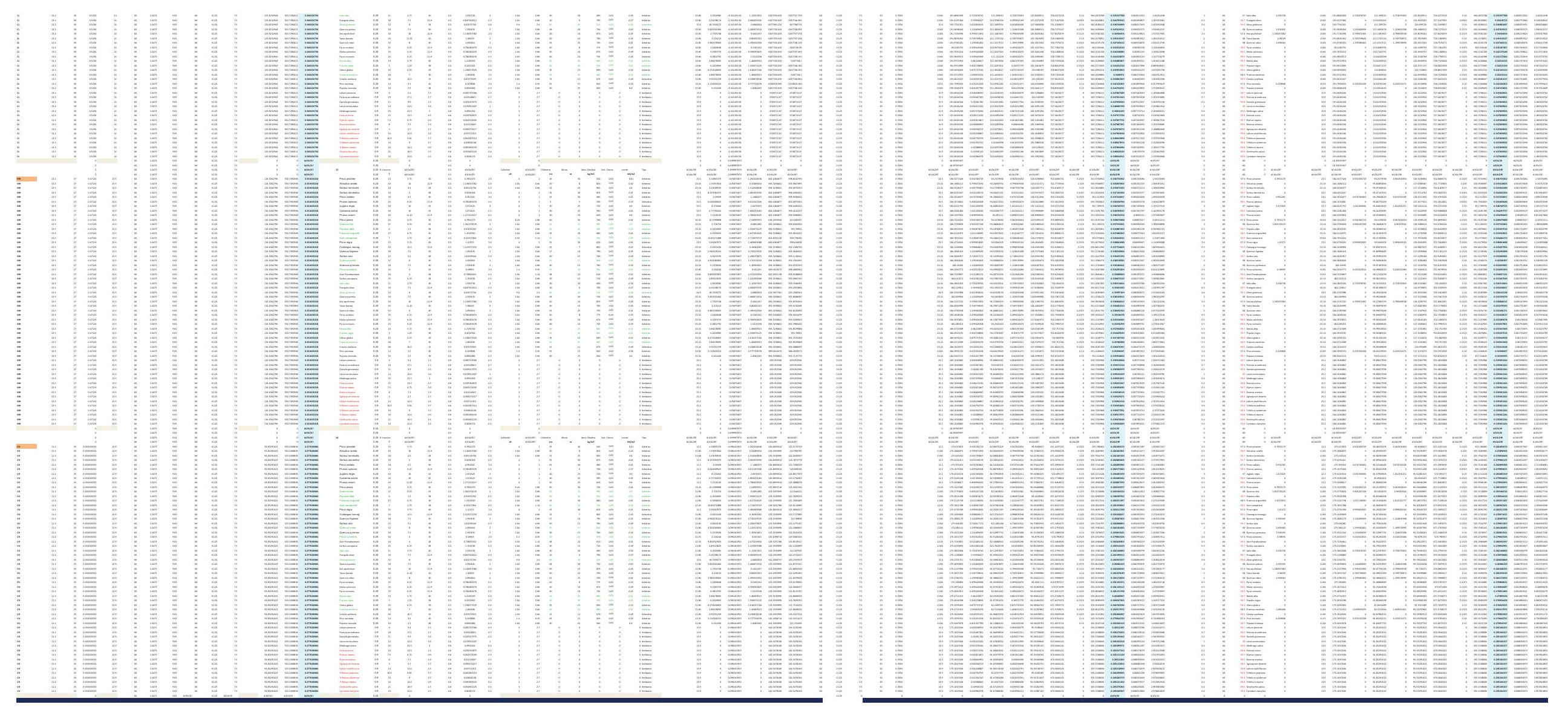



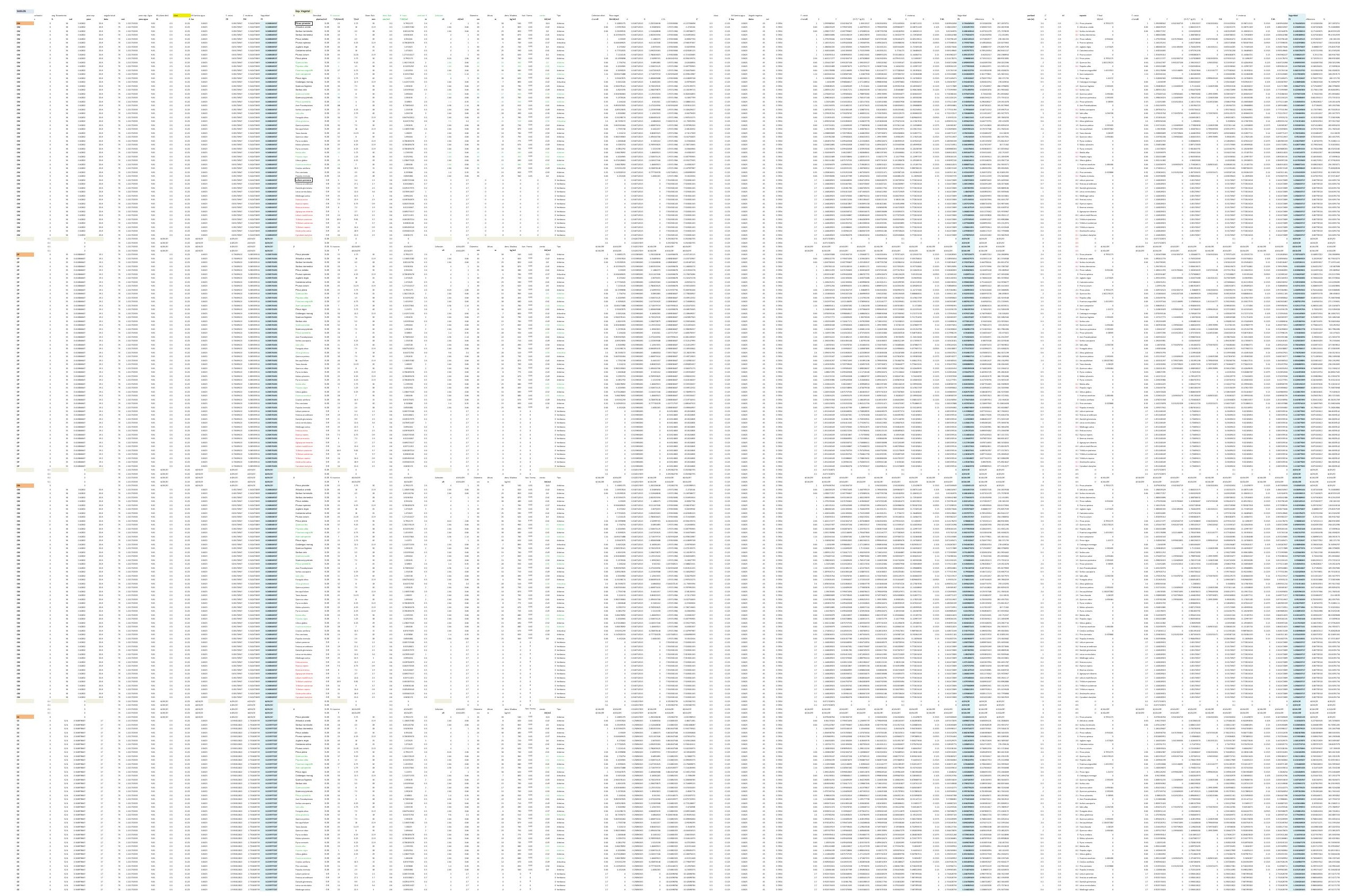


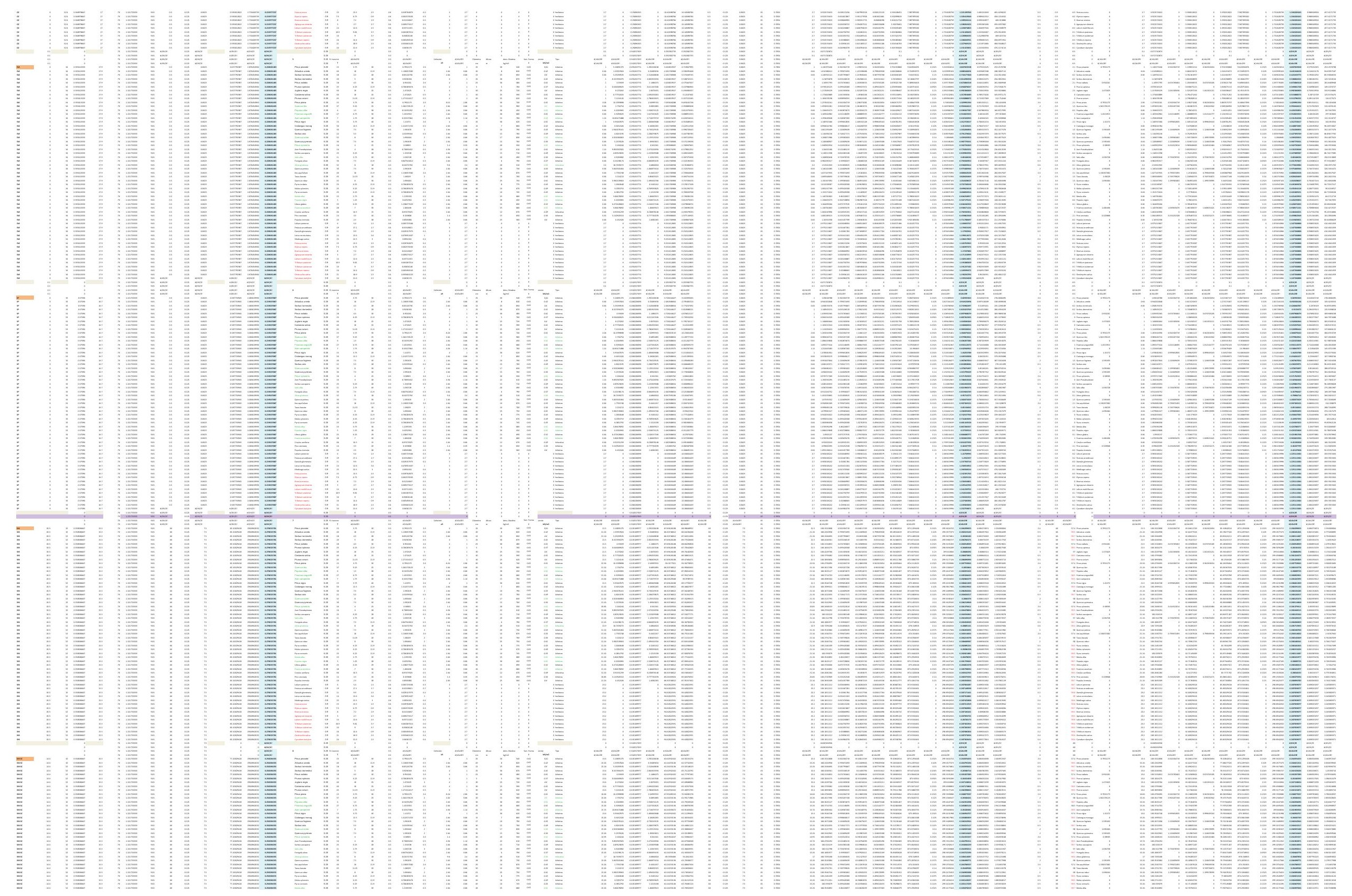




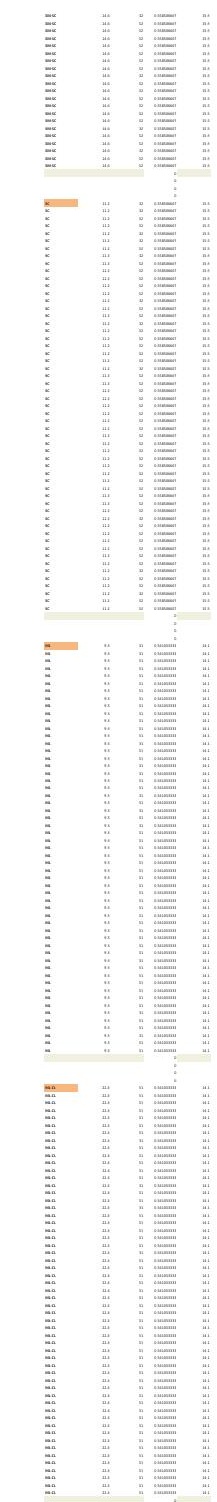

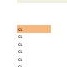

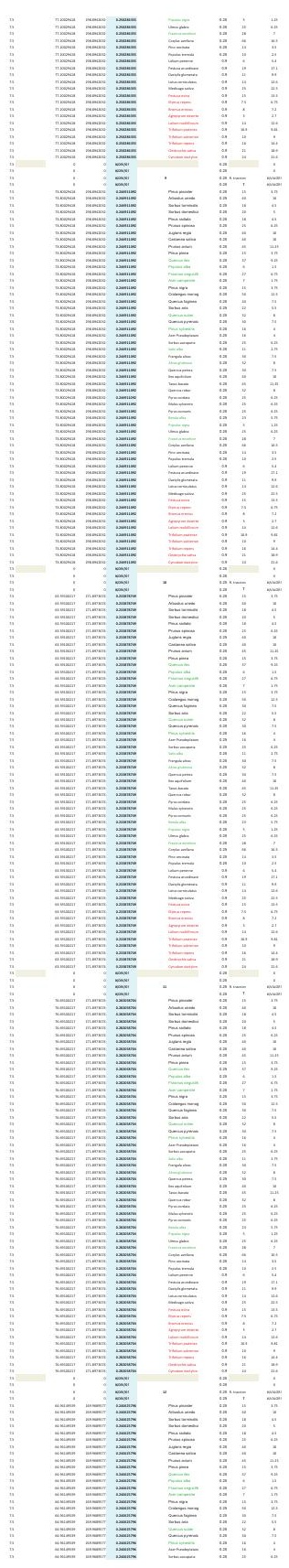

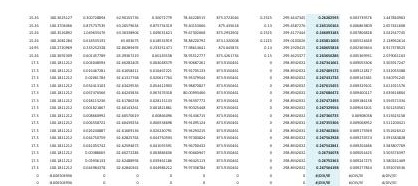
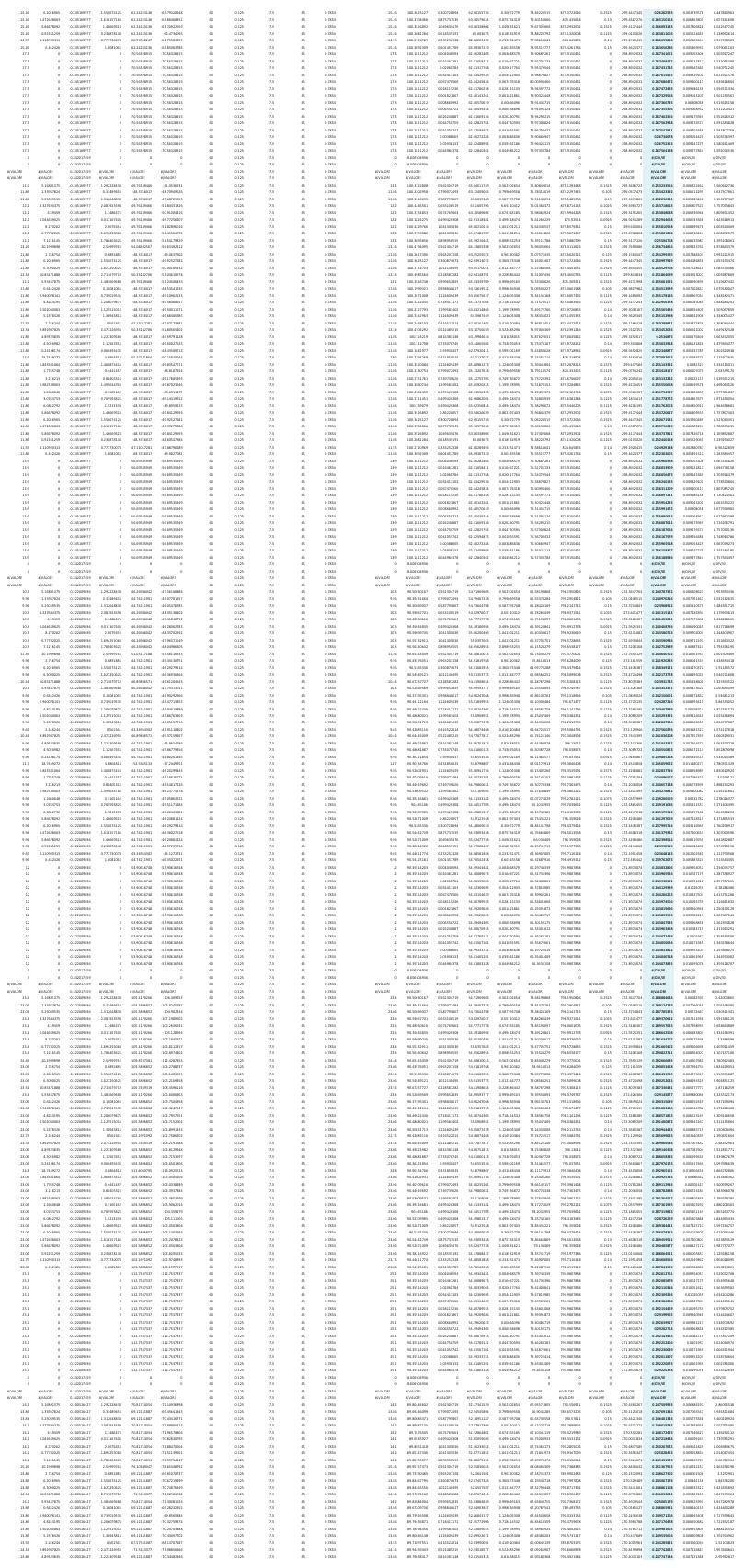

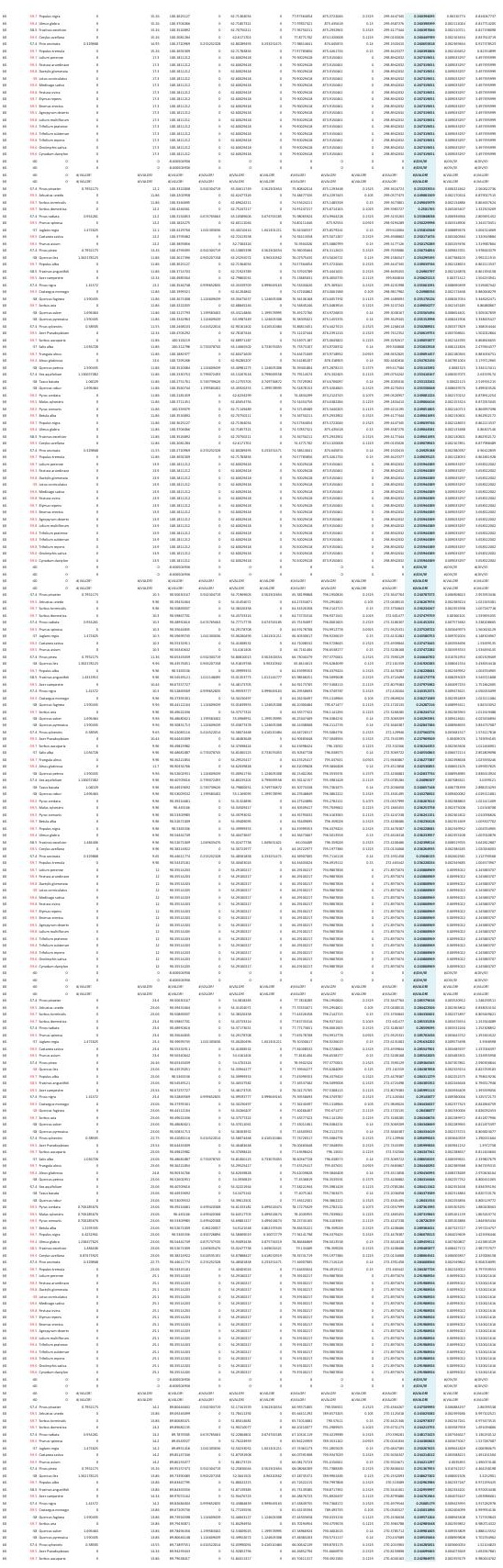




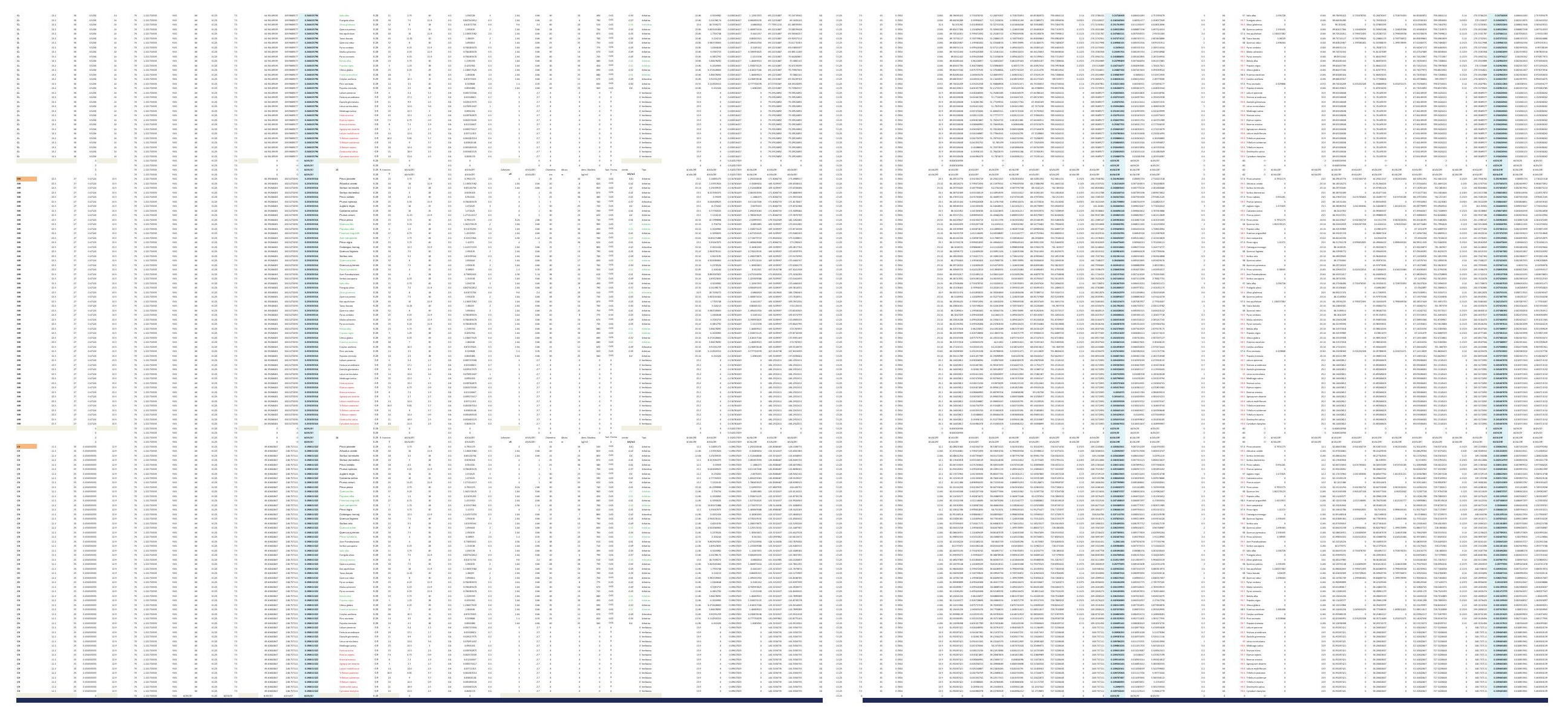



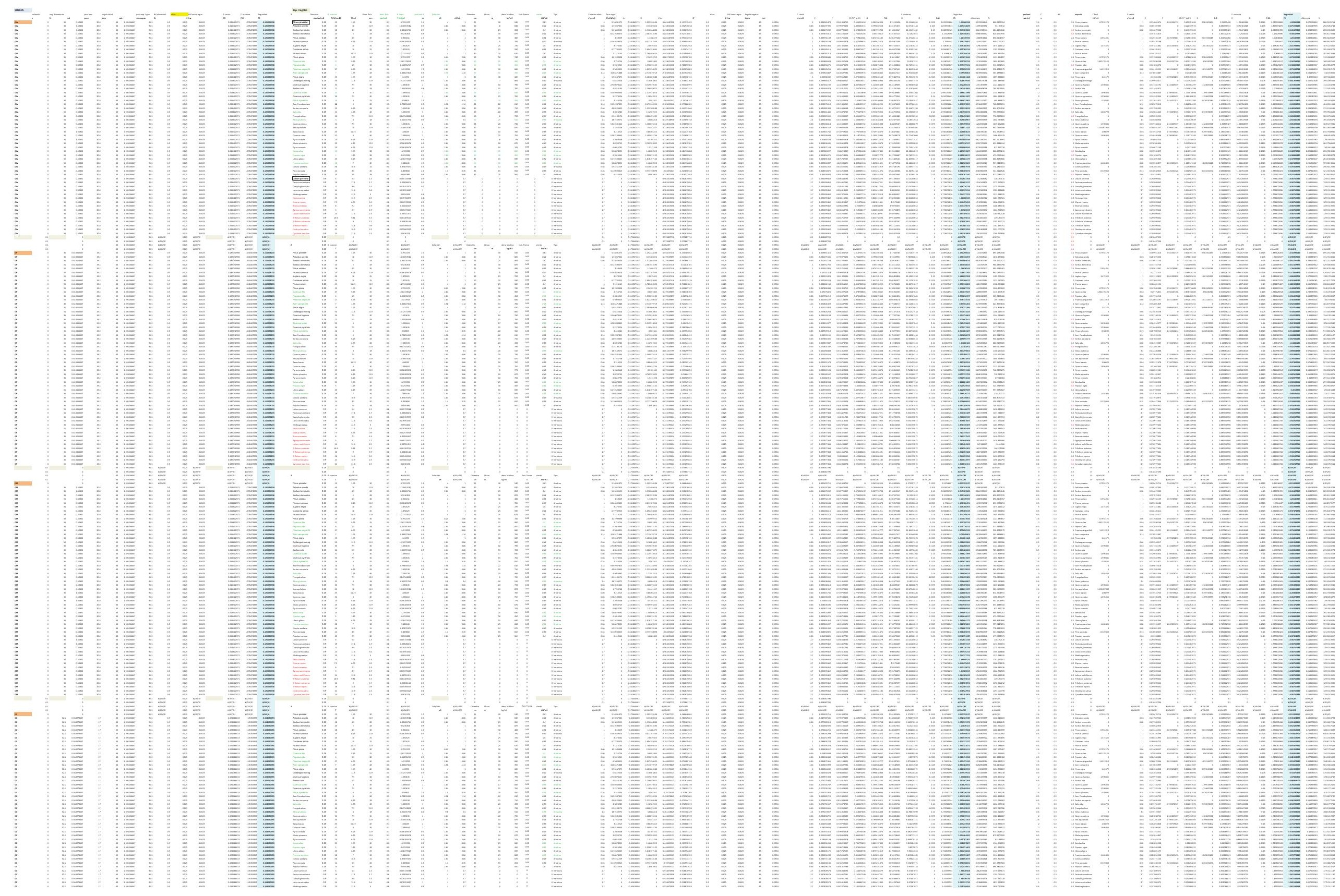


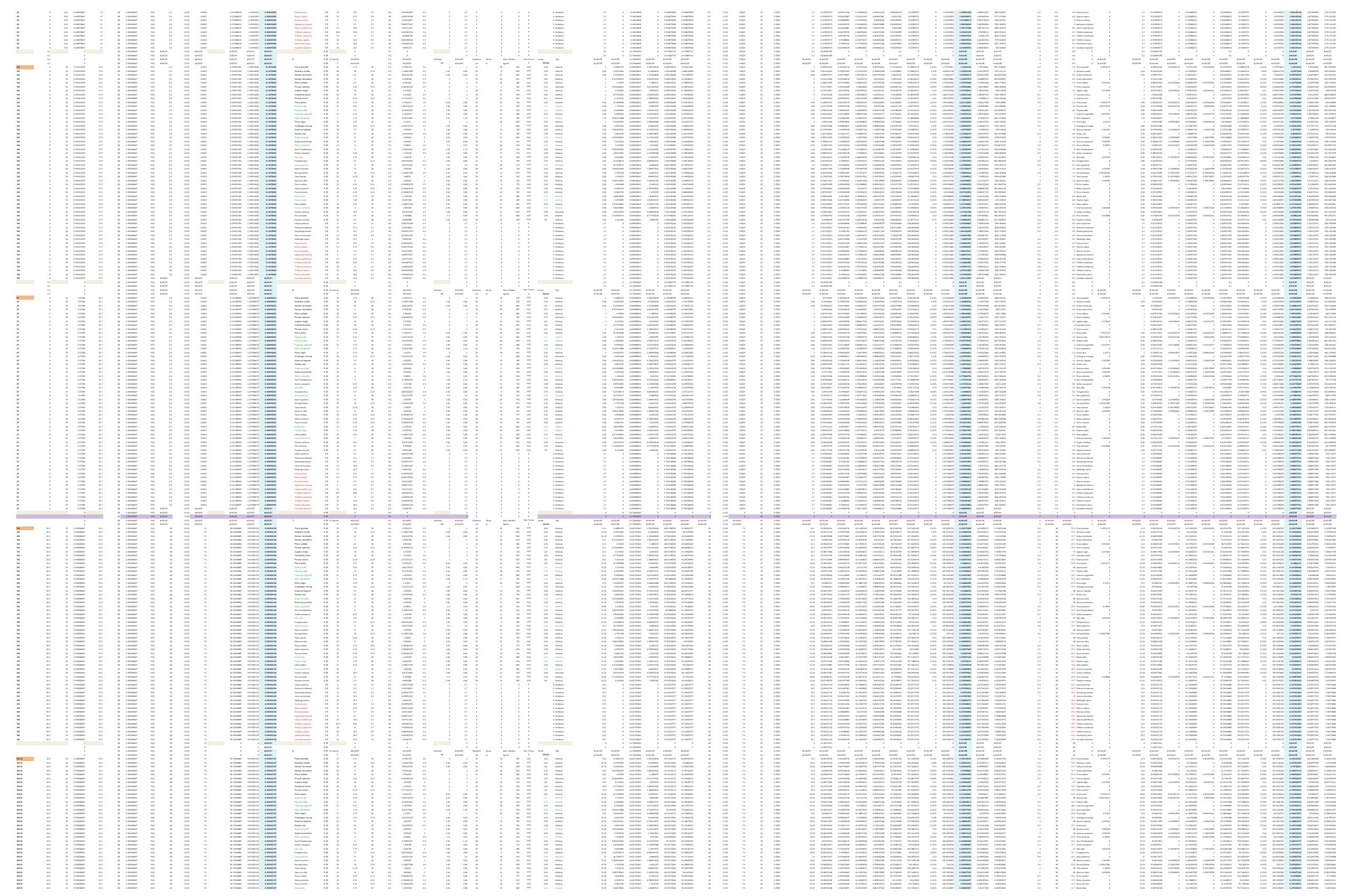




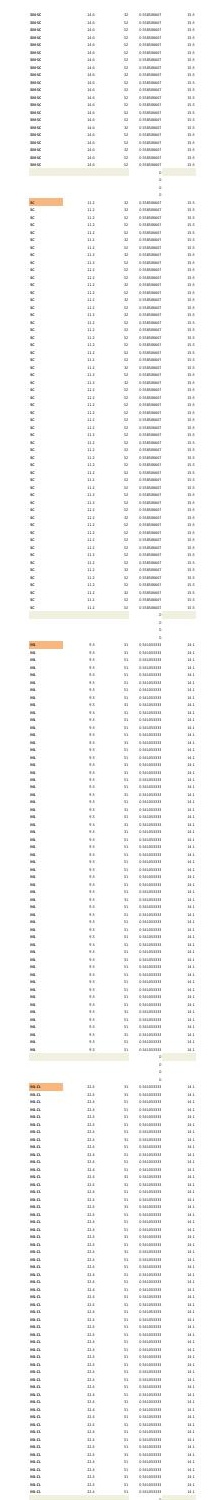

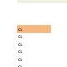
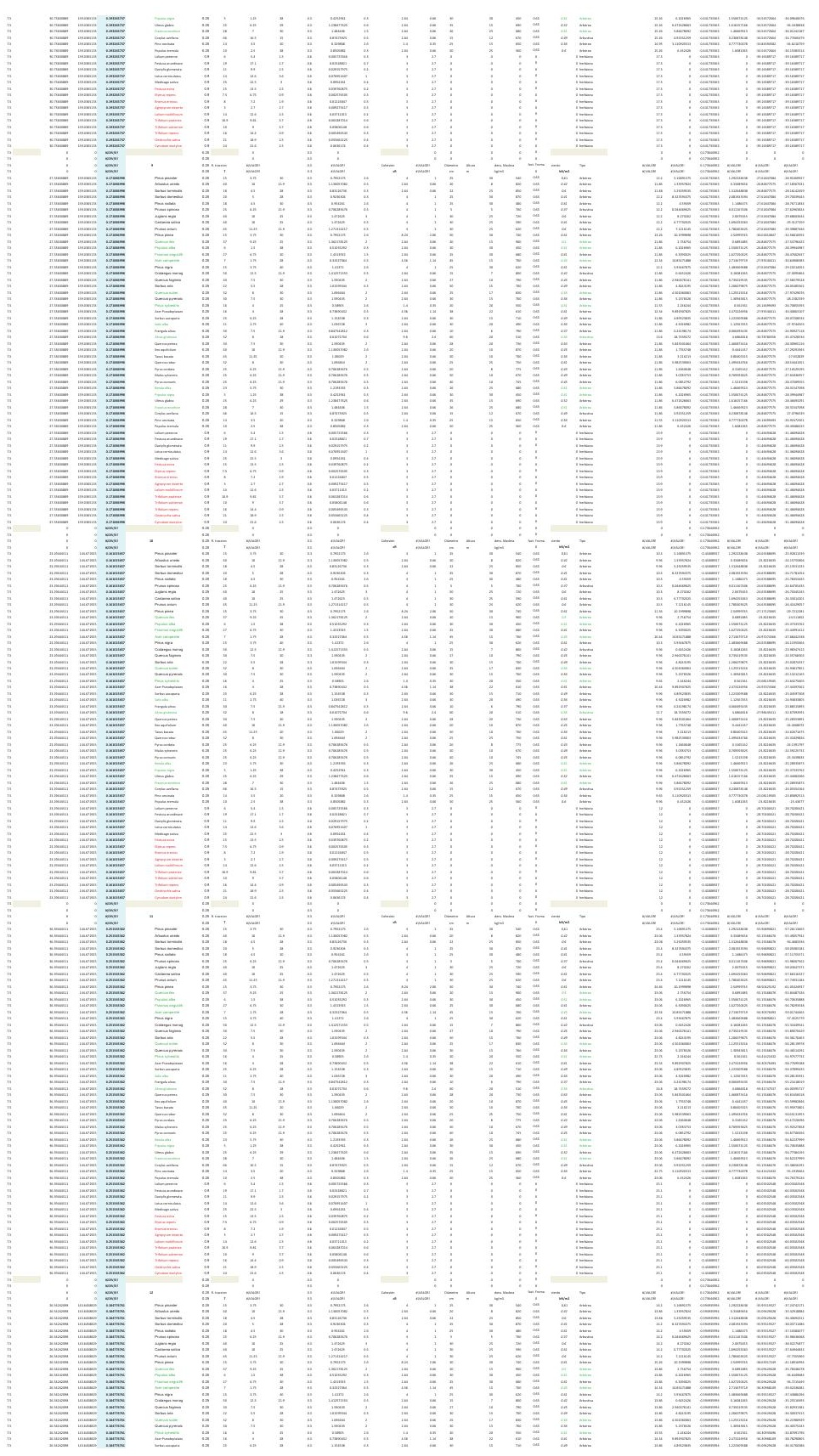
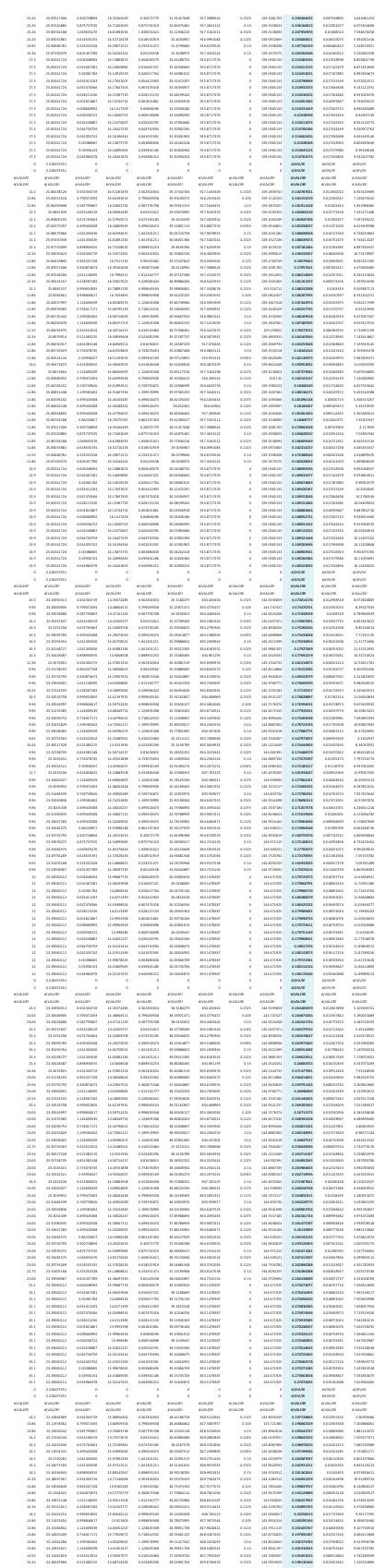

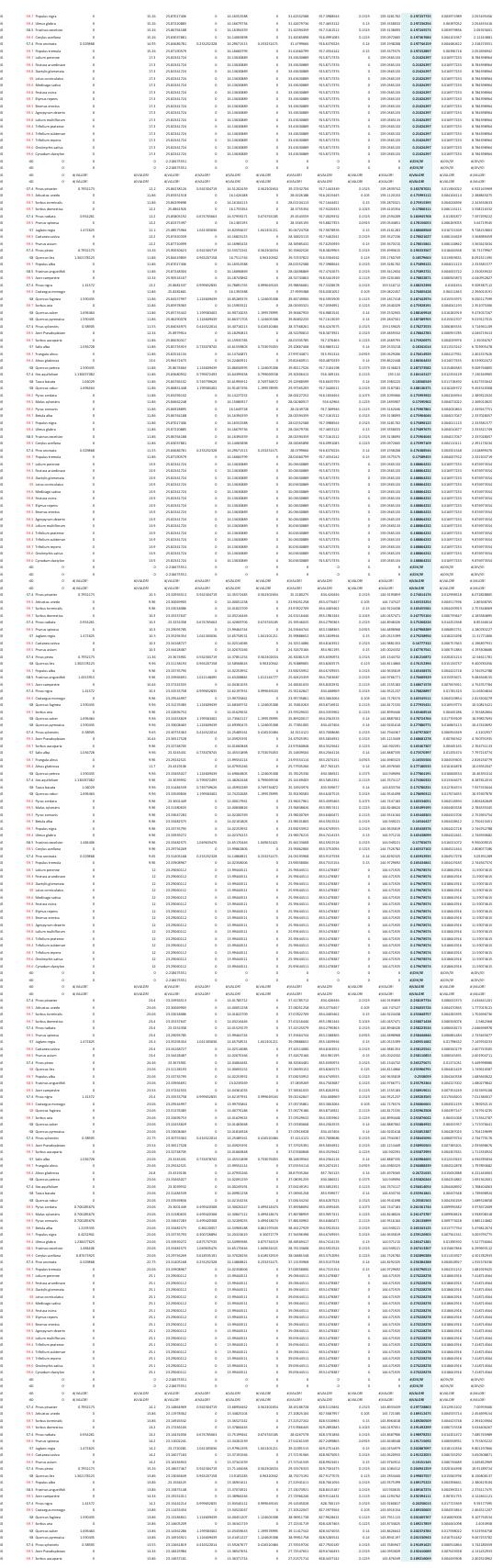




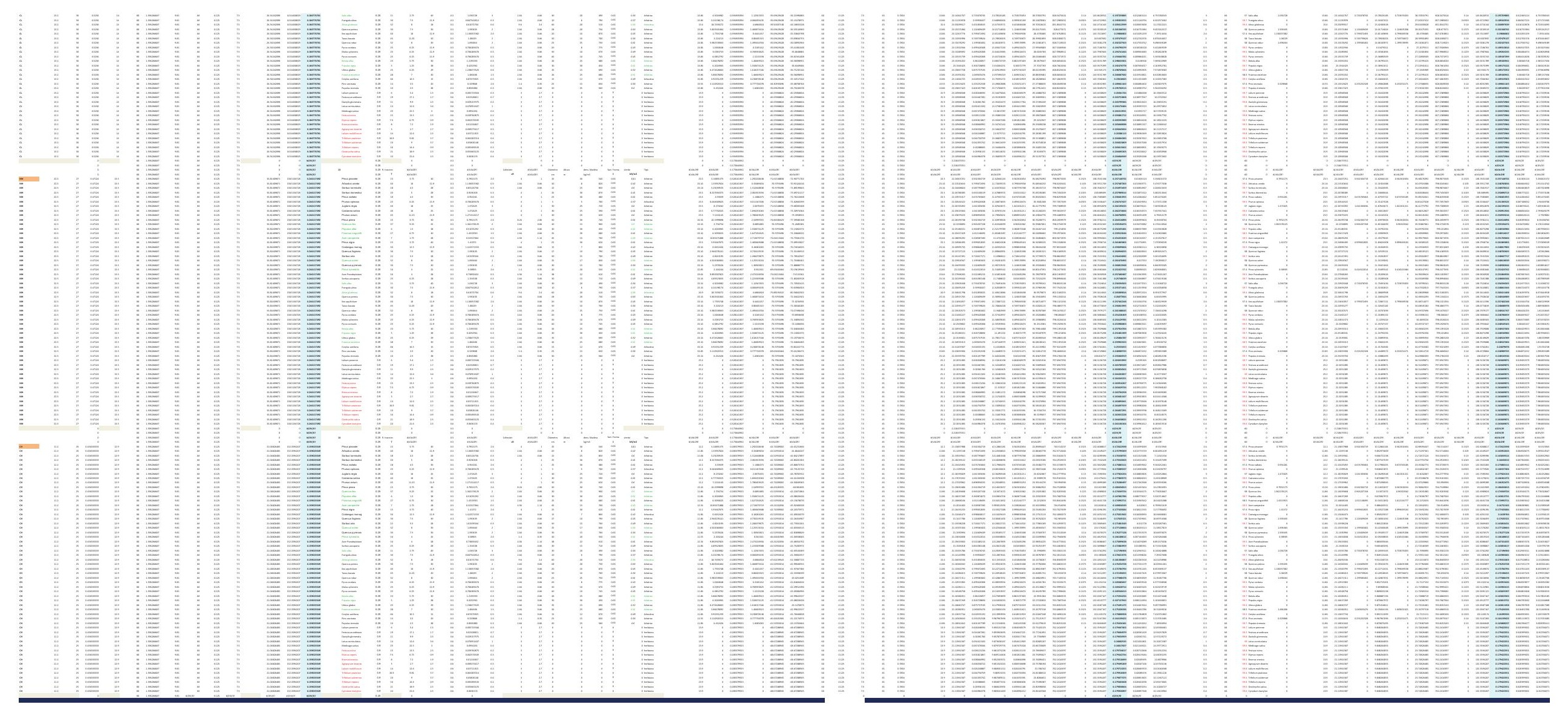


DESARROLLO DE UNA APLICACIÓN IMFORMÁTICA PARA EL CÁLCULO DE SOSTENIMIENTO DE TALUDES MEDIANTE VEGETACIÓN

A02. DENSIDAD DE PLANTACIÓN: 1.600 plantas/ha.

\section{A02-3.POSICIÓN N.F. 3}

INCLINACIÓN DE TALUD 6-100

INCLINACIÓN DE TALUD 10-200

INCLINACIÓN DE TALUD 20-30

INCLINACIÓN DE TALUD 30-40

INCLINACIÓN DE TALUD $35^{\circ}$

INCLINACIÓN DE TALUD 40-50

INCLINACIÓN DE TALUD 50-550

INCLINACIÓN DE TALUD 55-60

INCLINACIÓN DE TALUD 60-700

INCLINACIÓN DE TALUD 70-80 

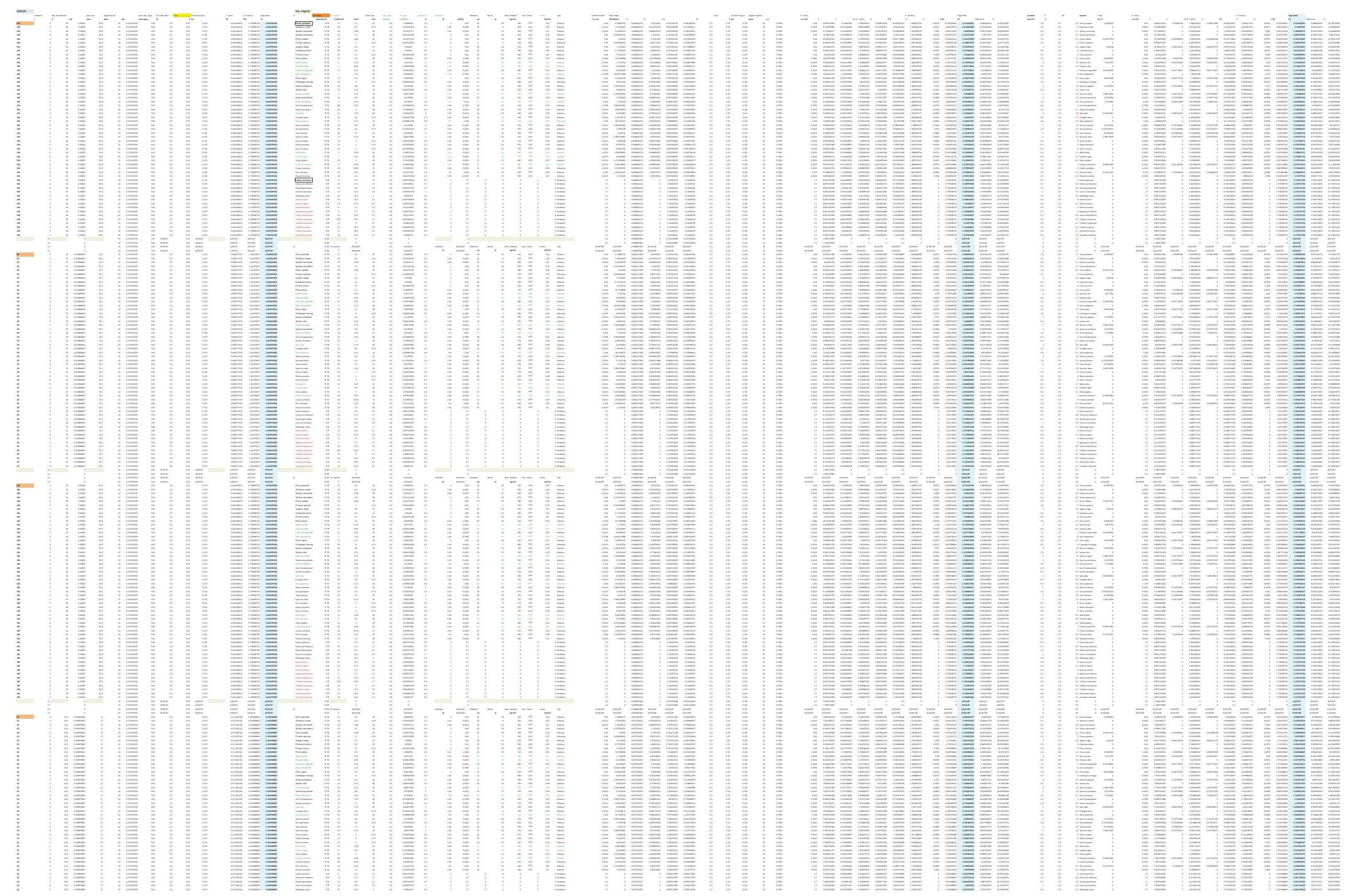


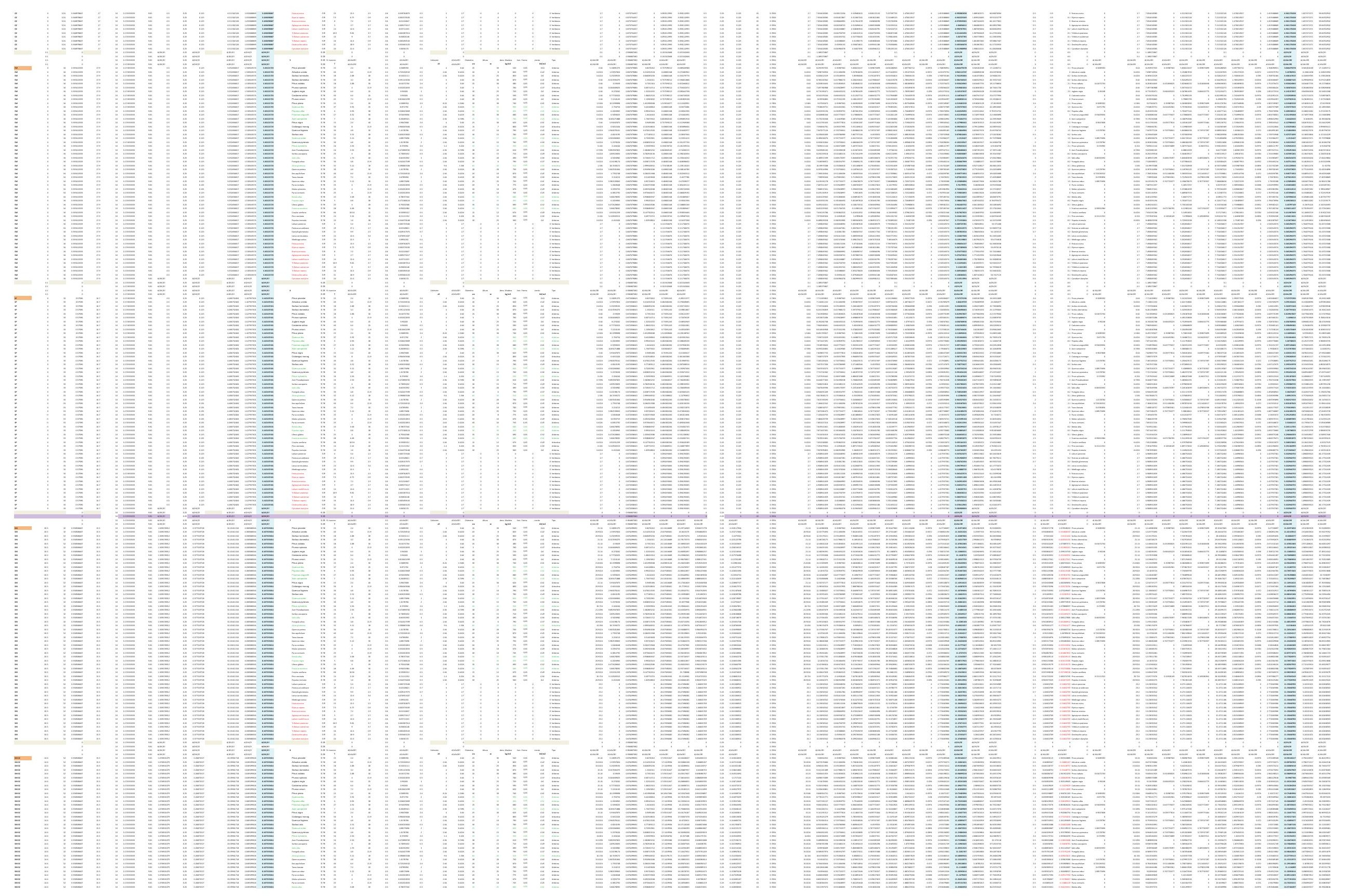



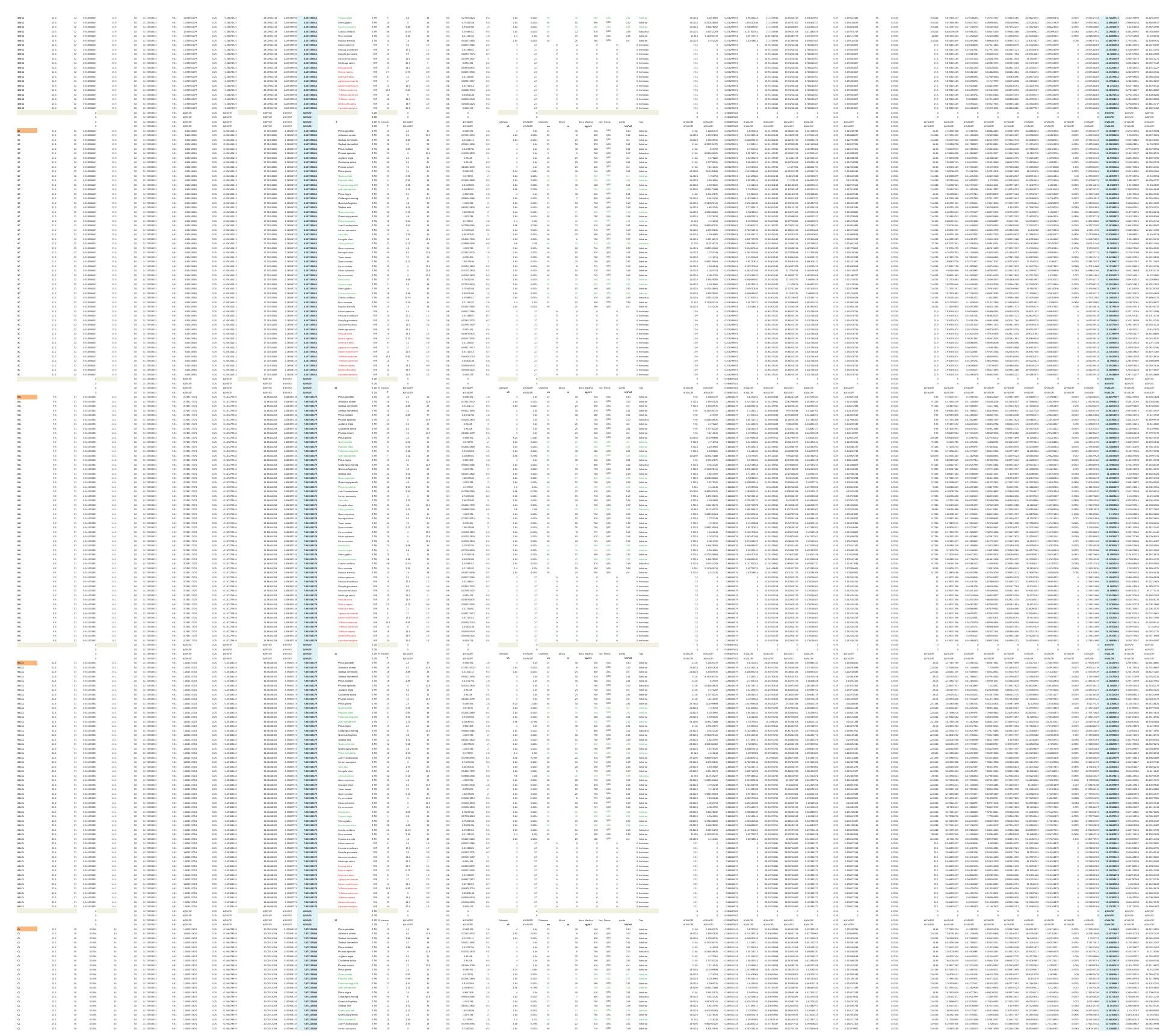

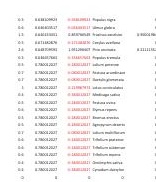
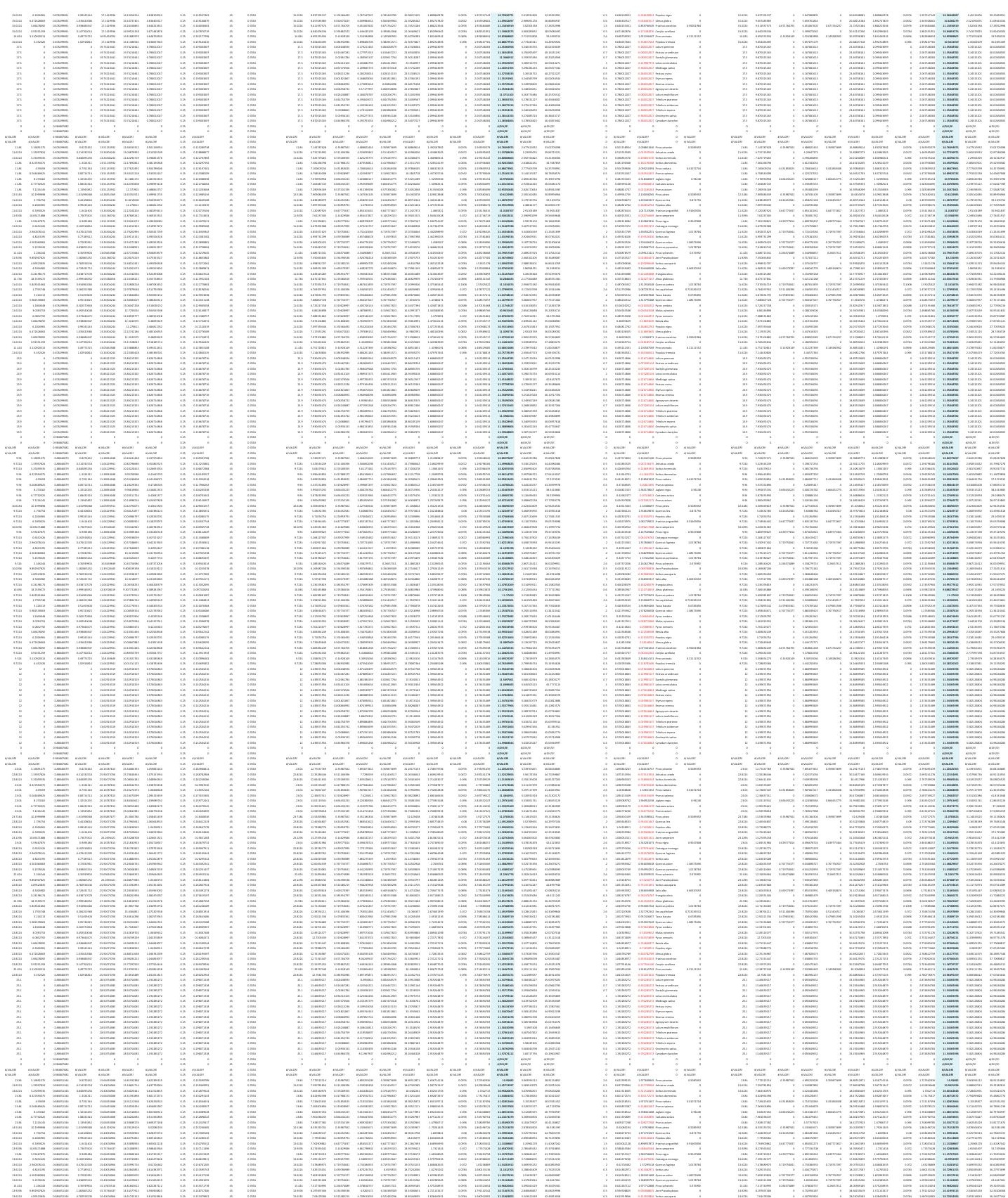


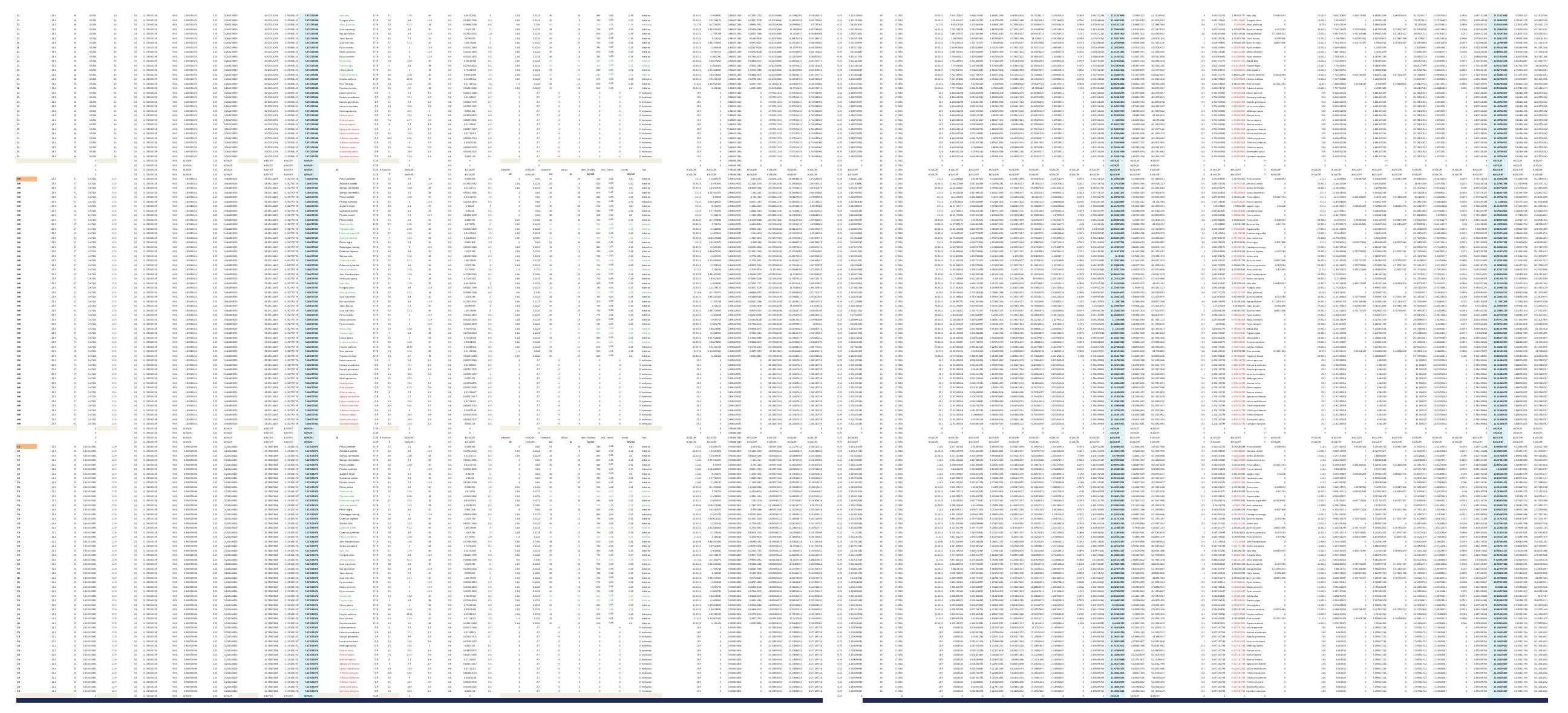



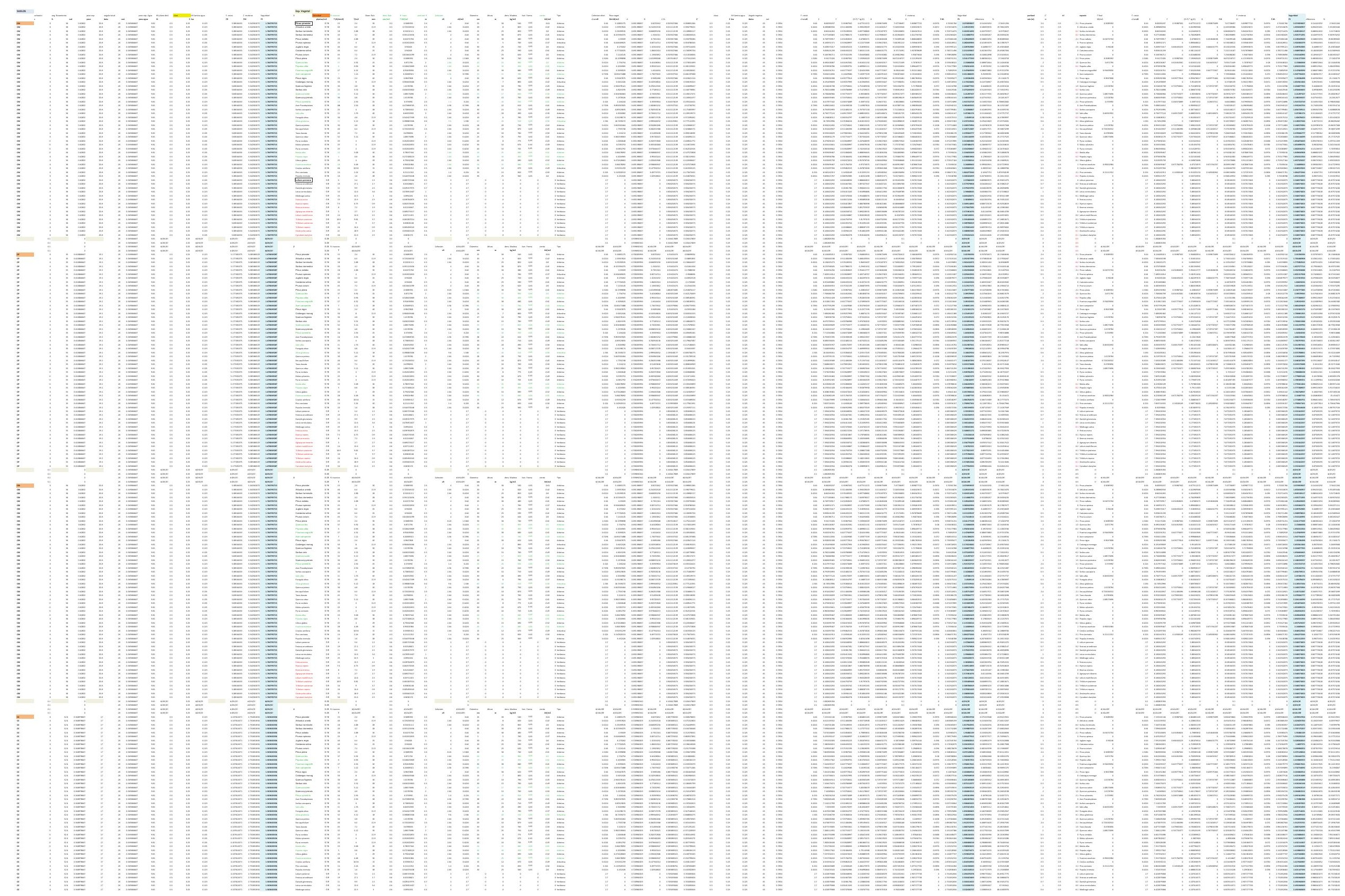


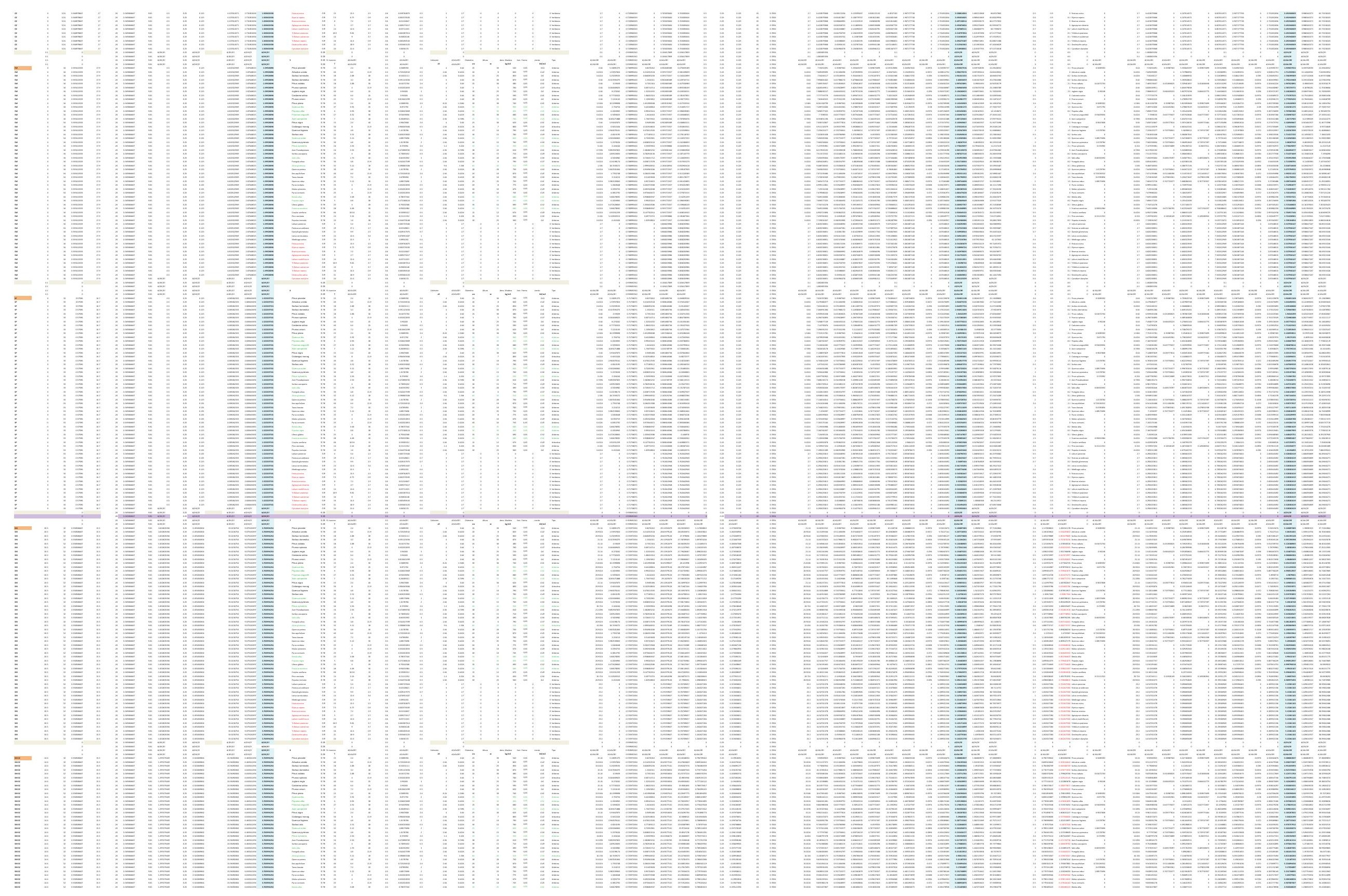



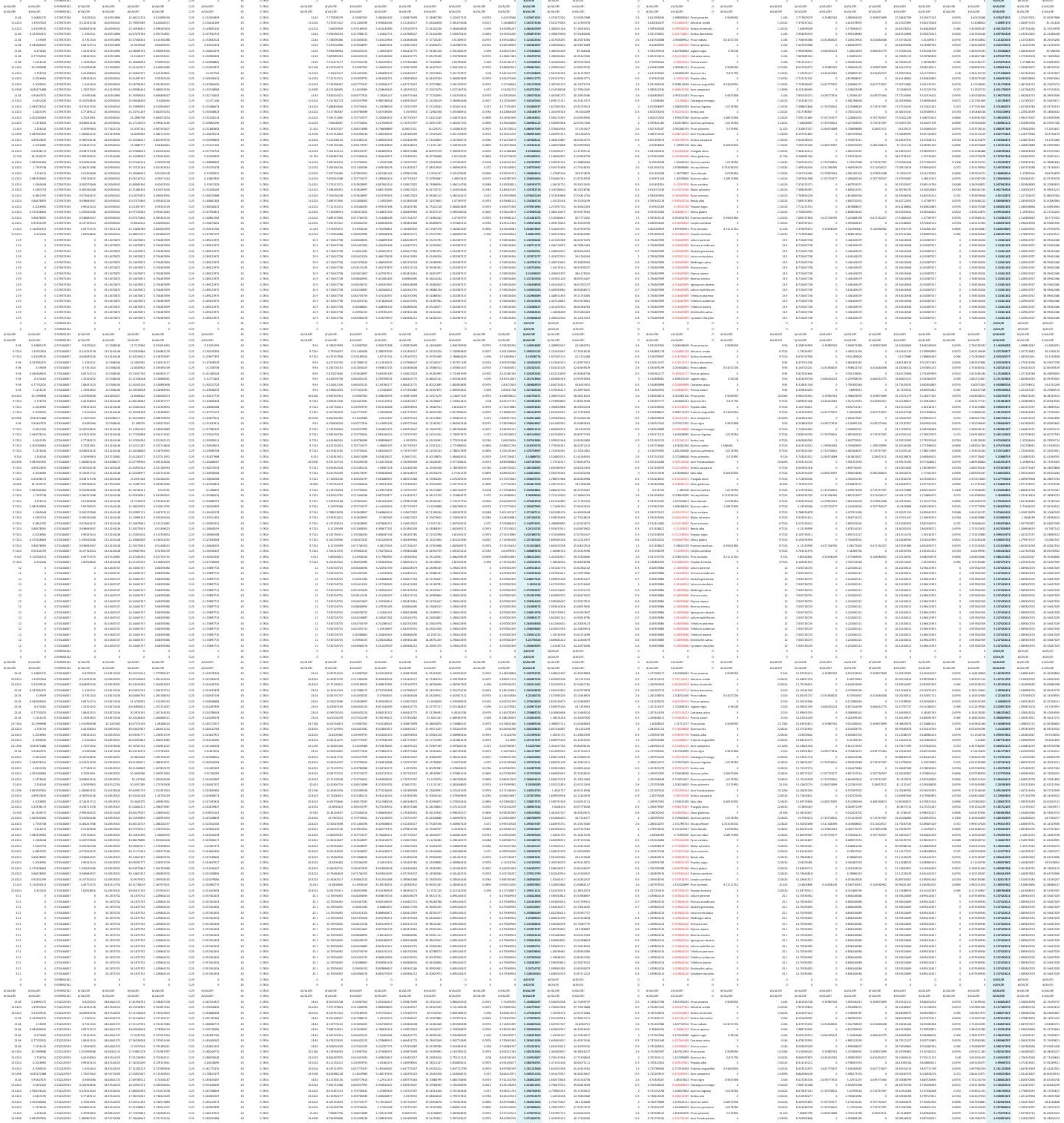


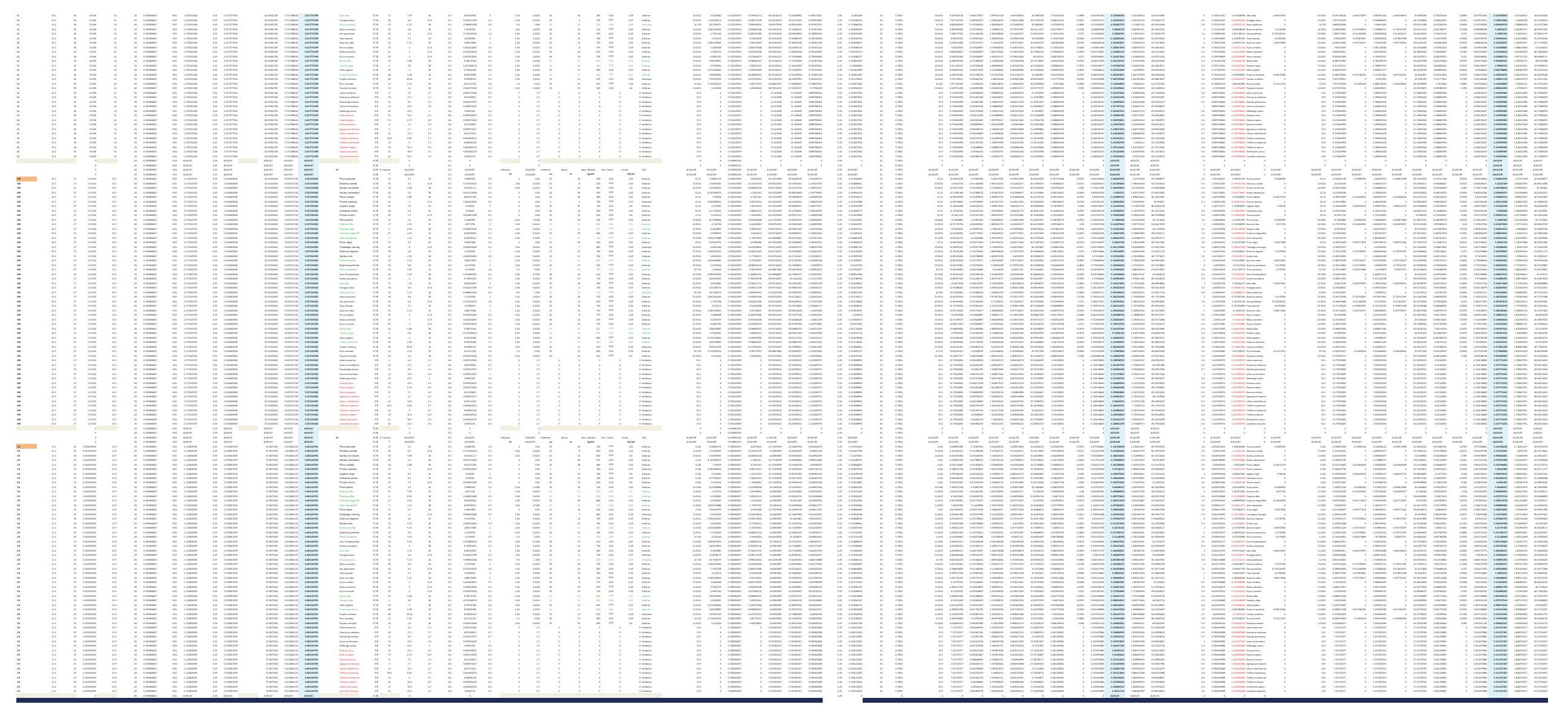



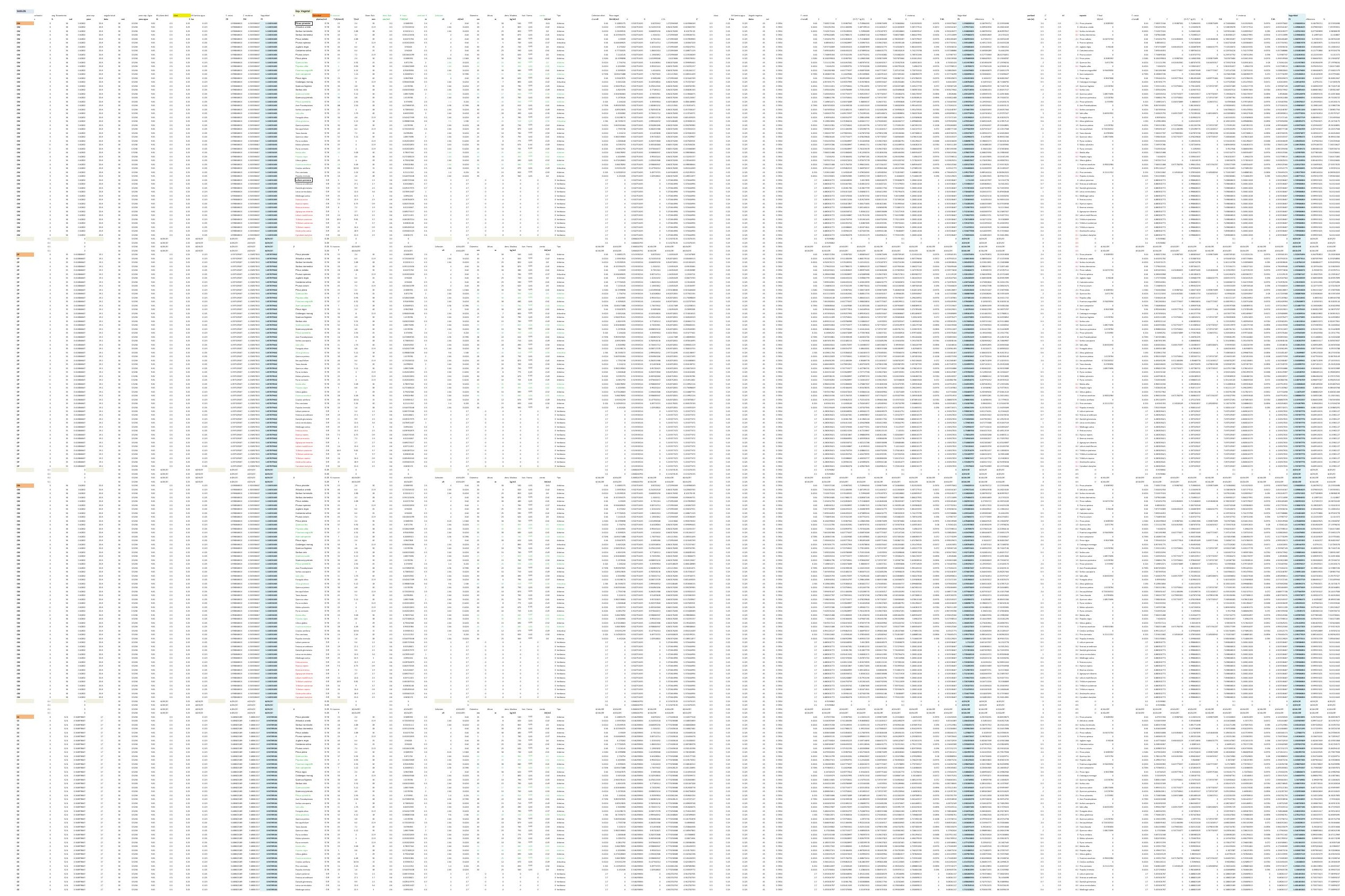


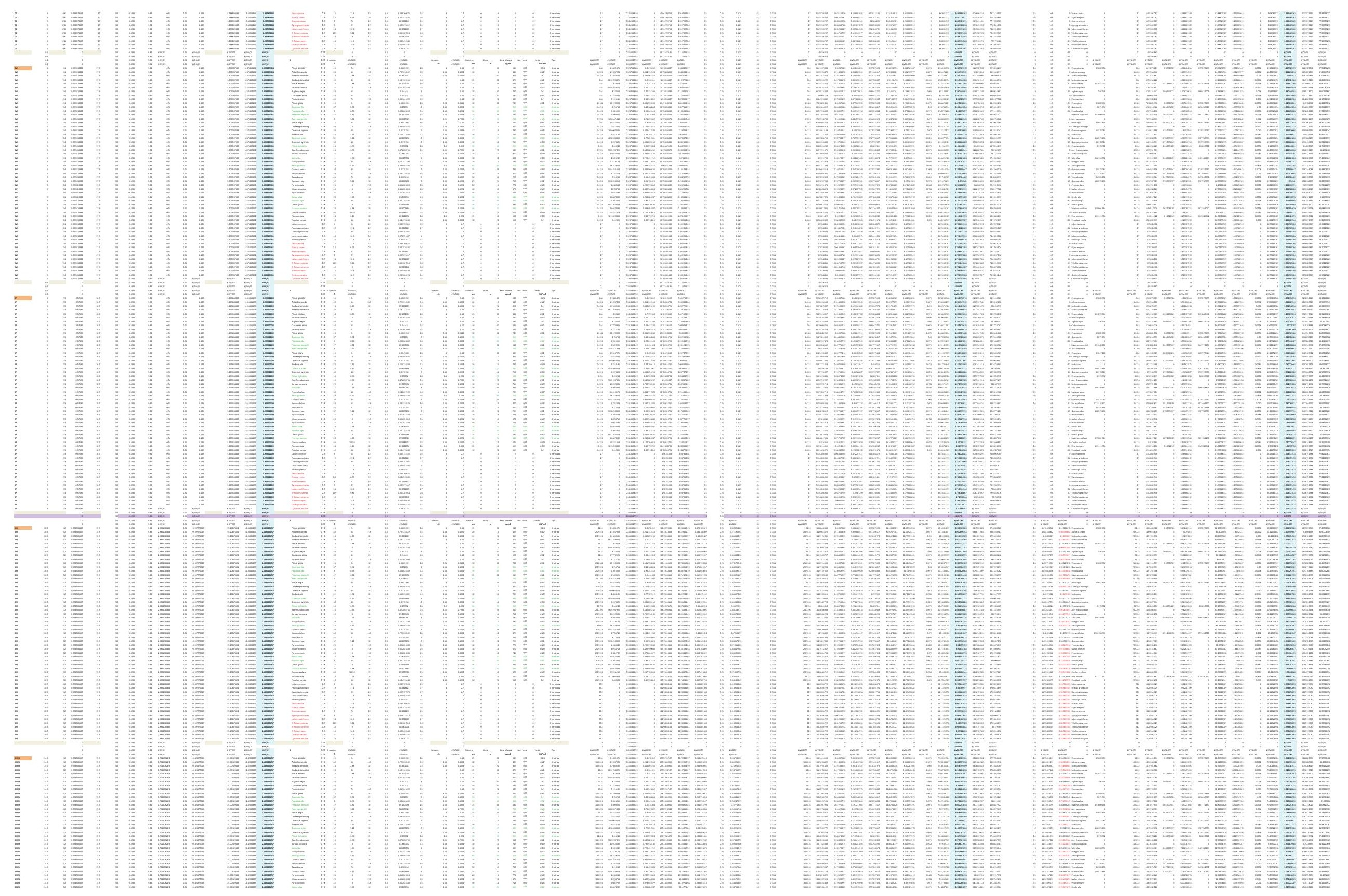



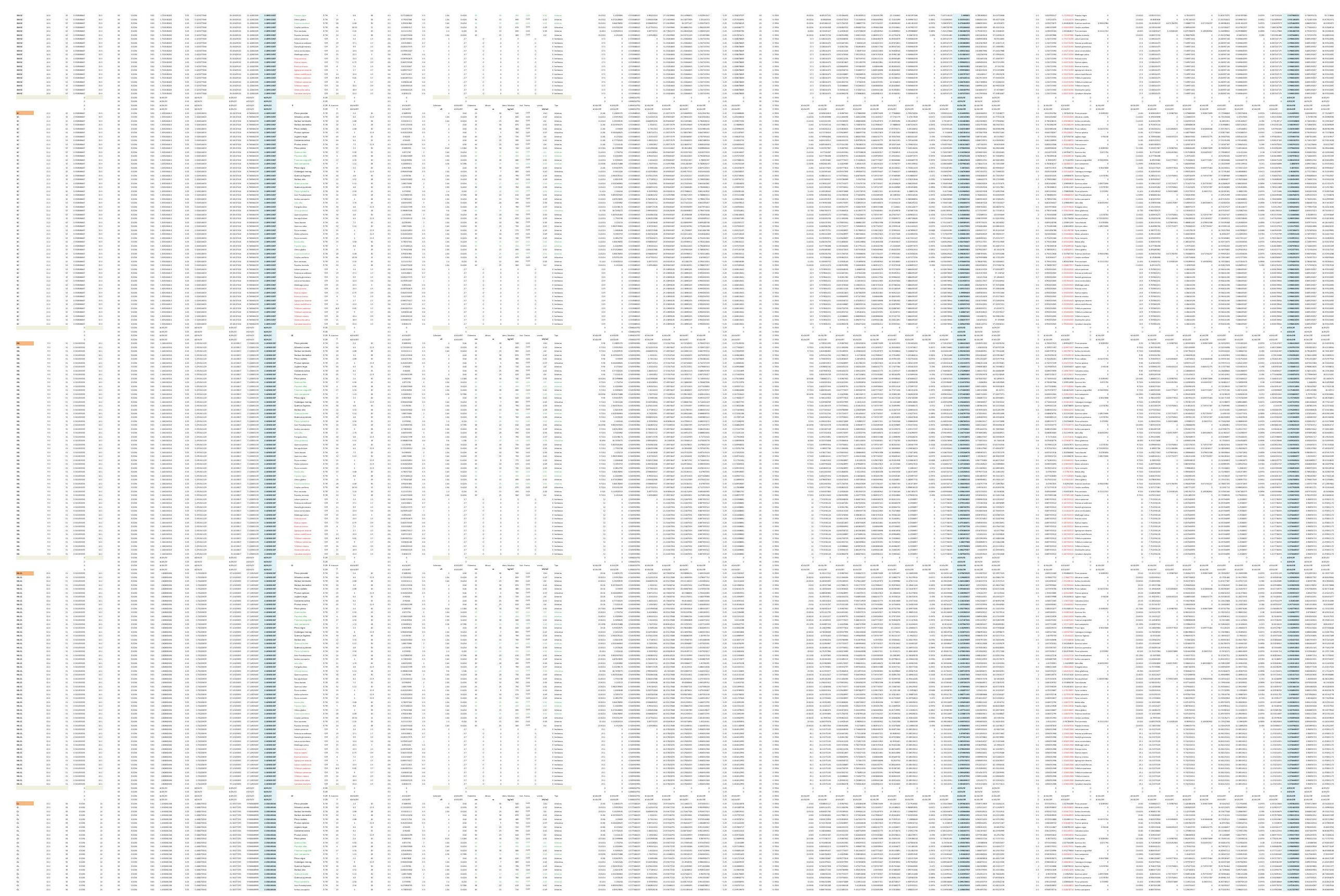


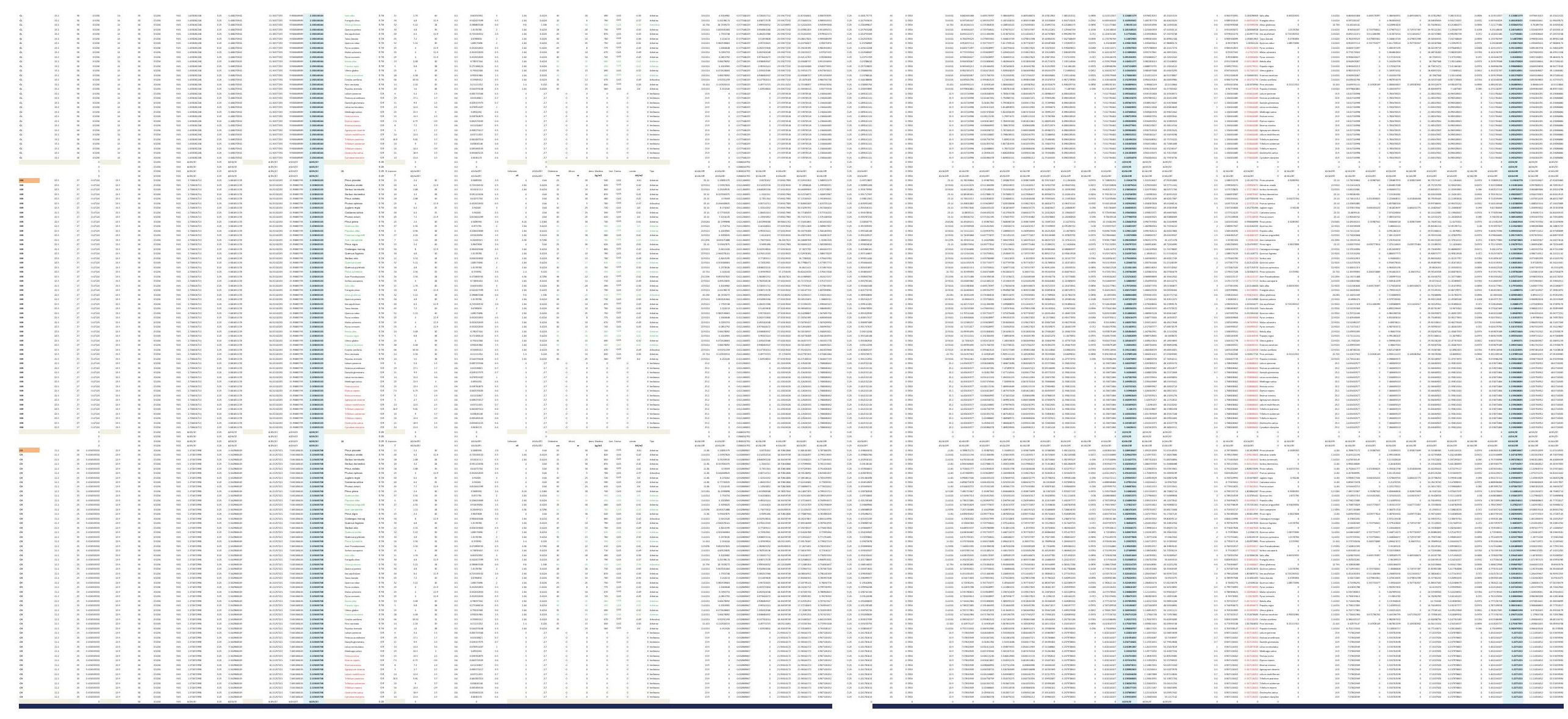



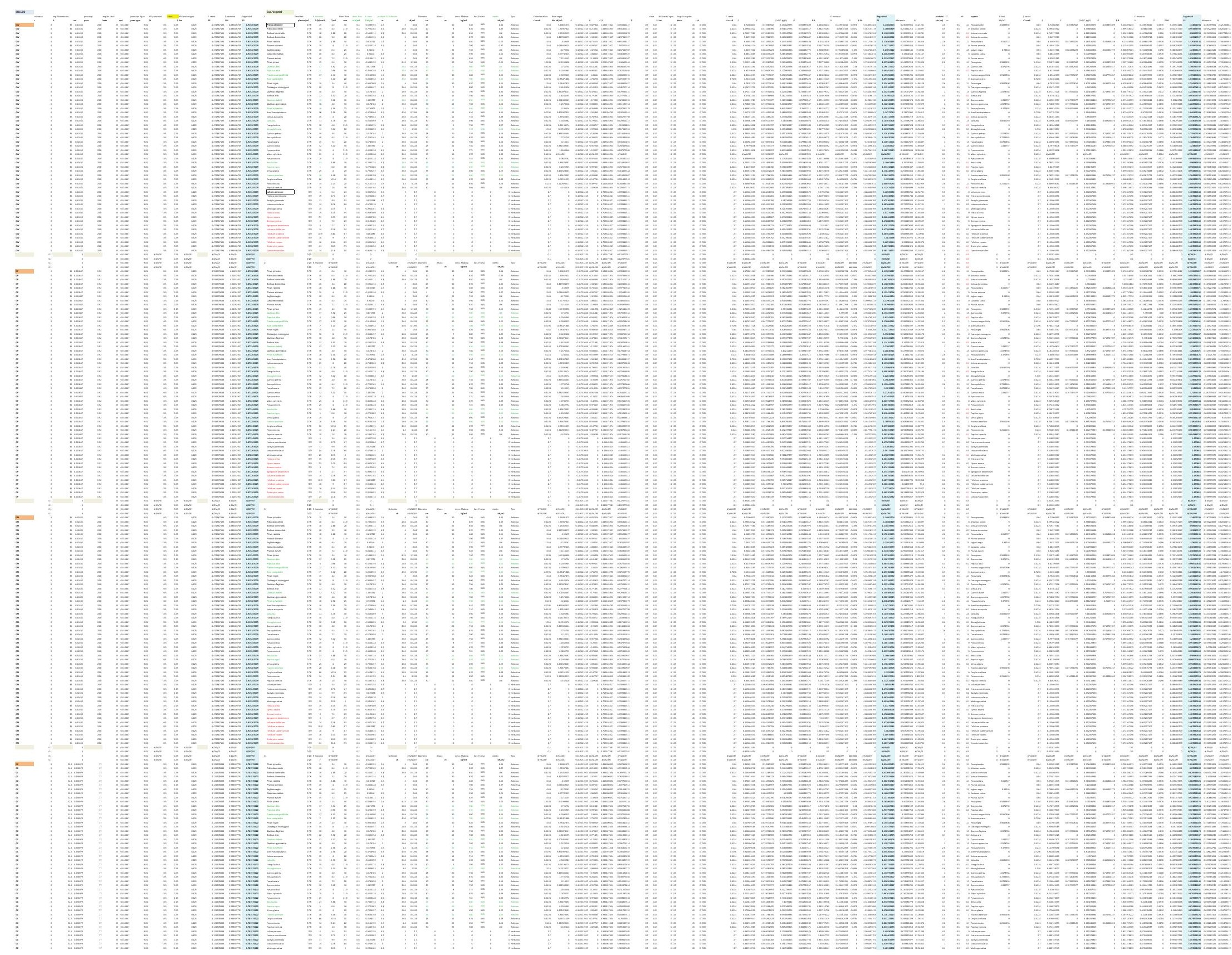


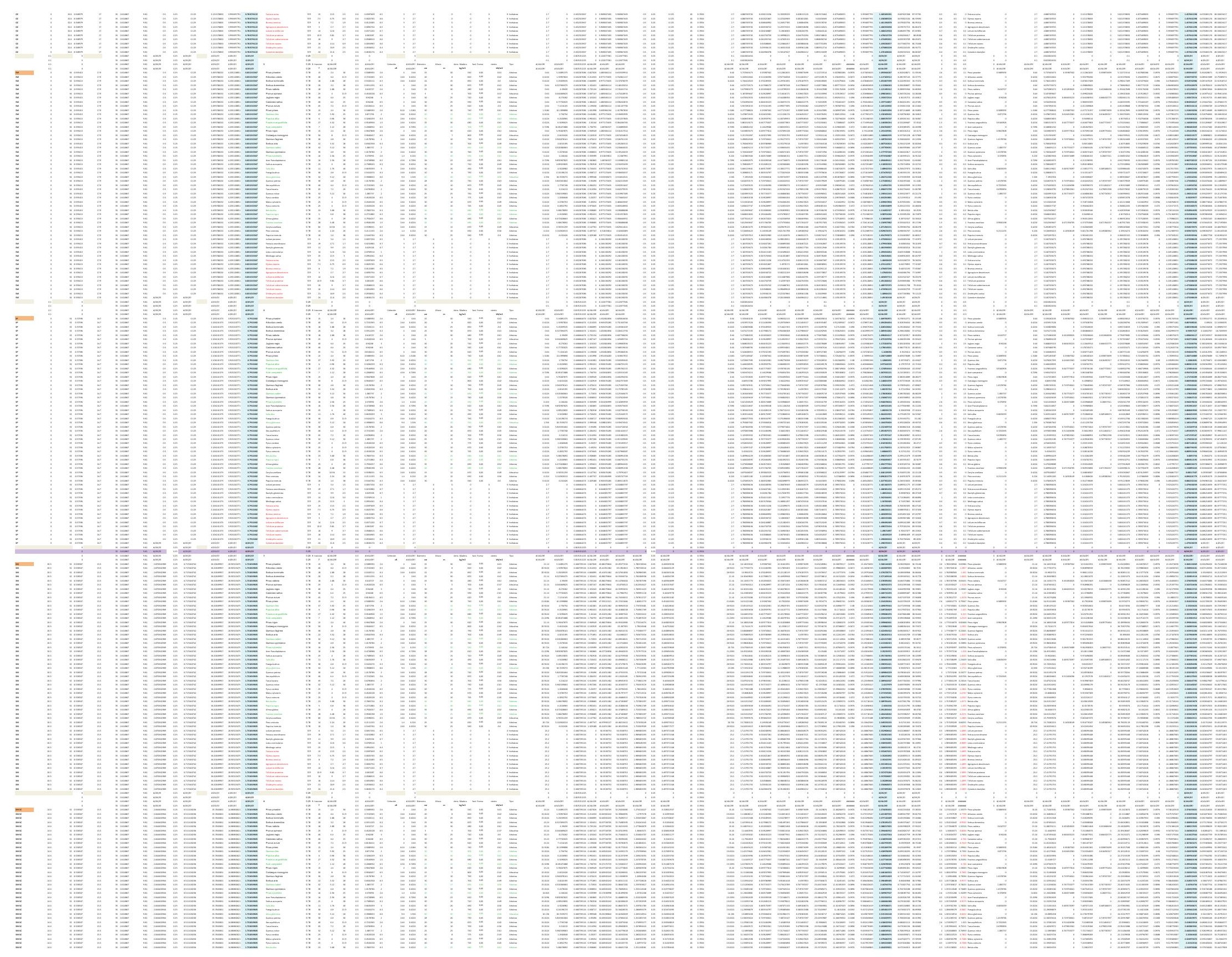



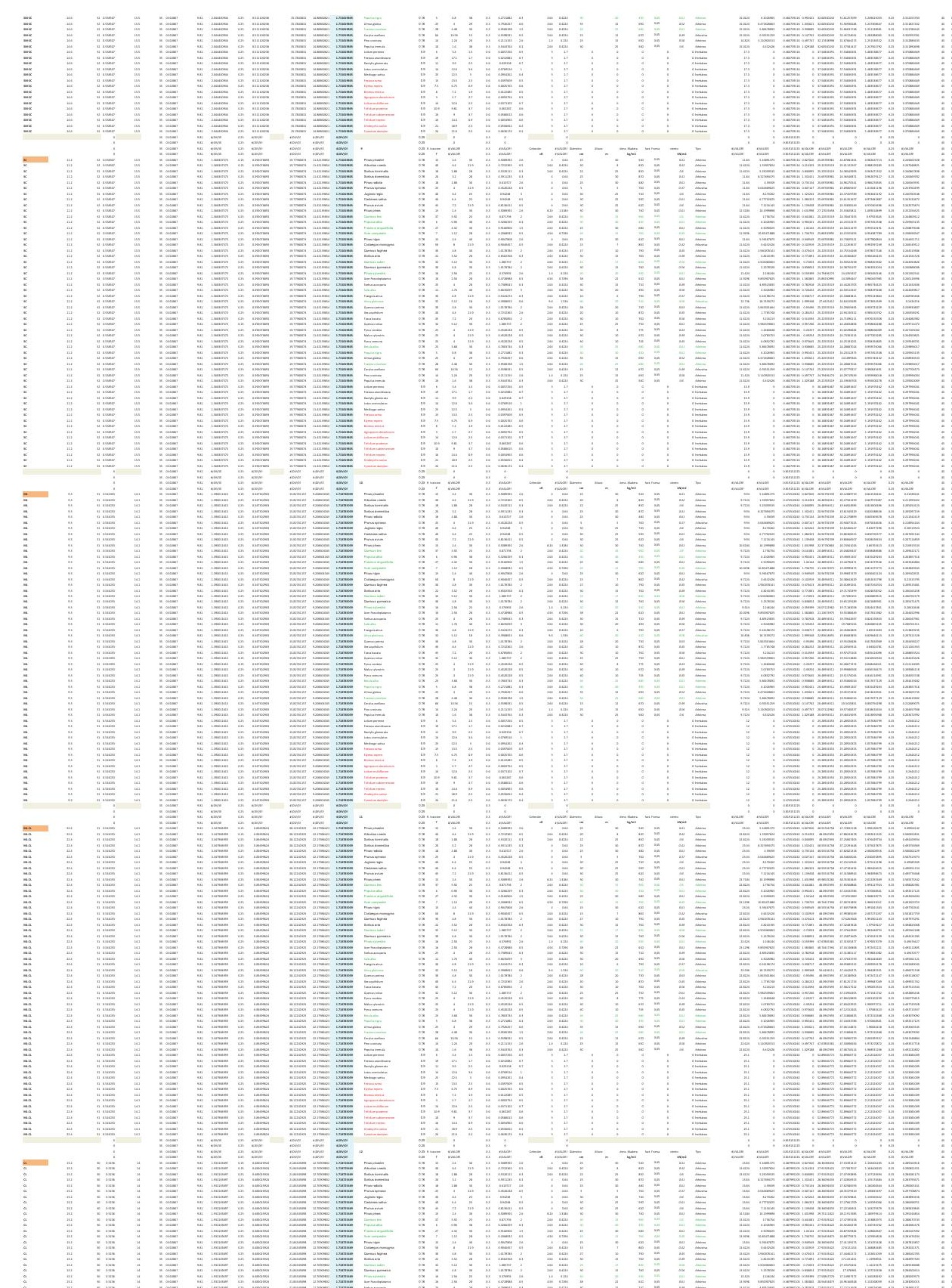

IIIIIIII
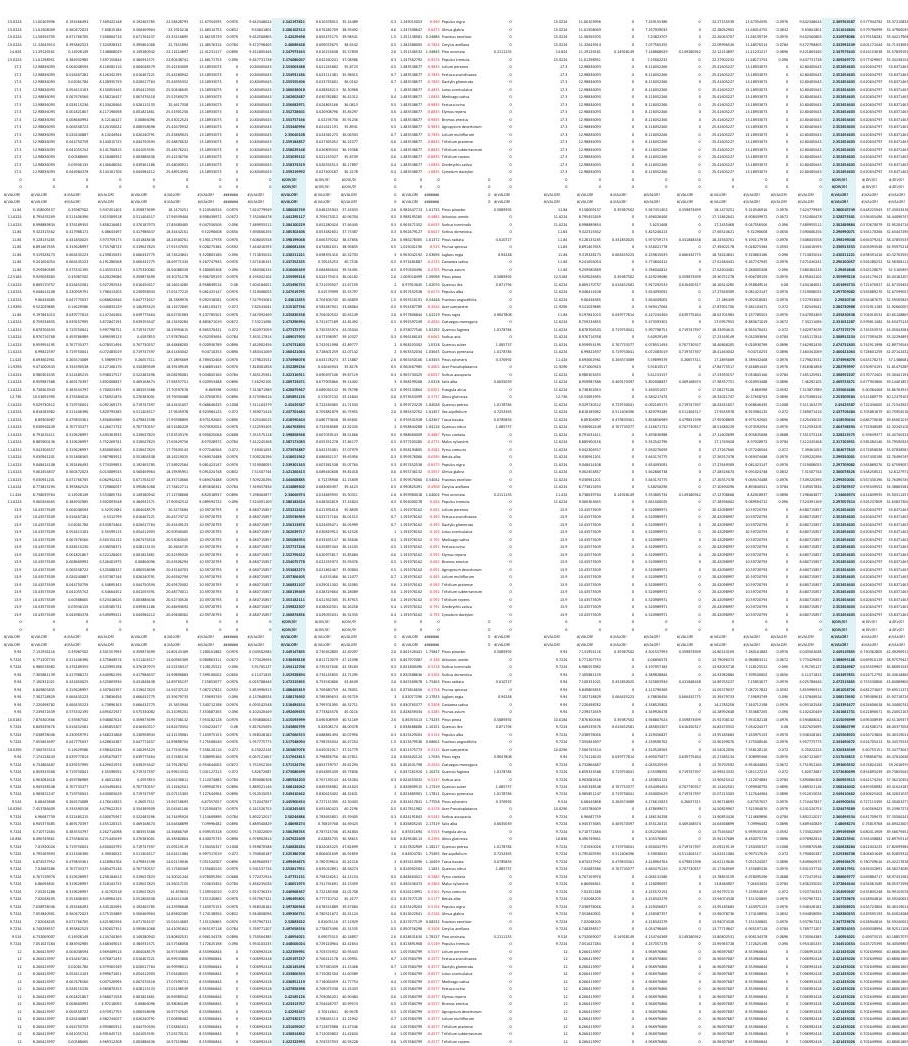

$=\equiv \equiv \equiv \equiv \equiv \equiv \equiv$
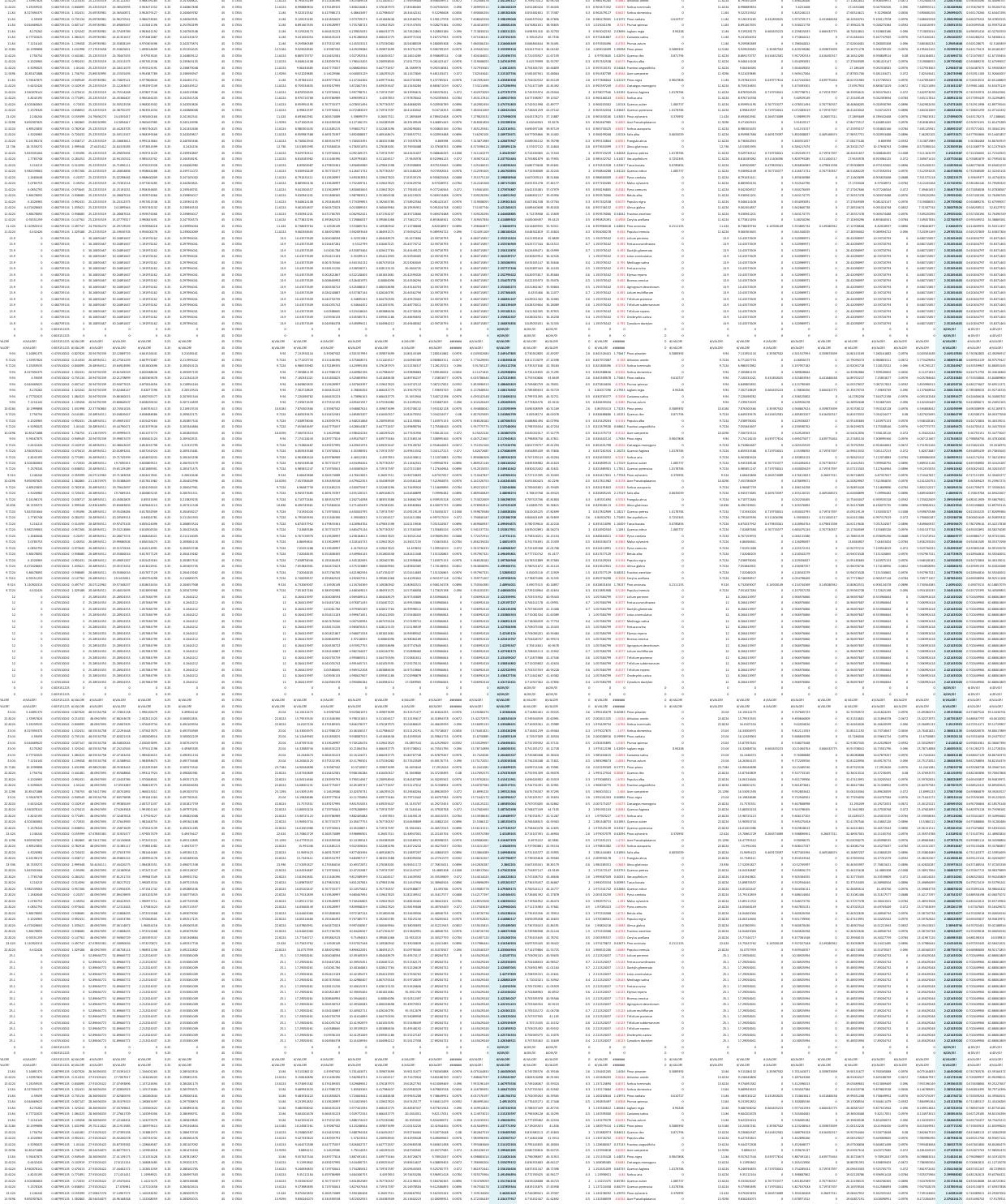


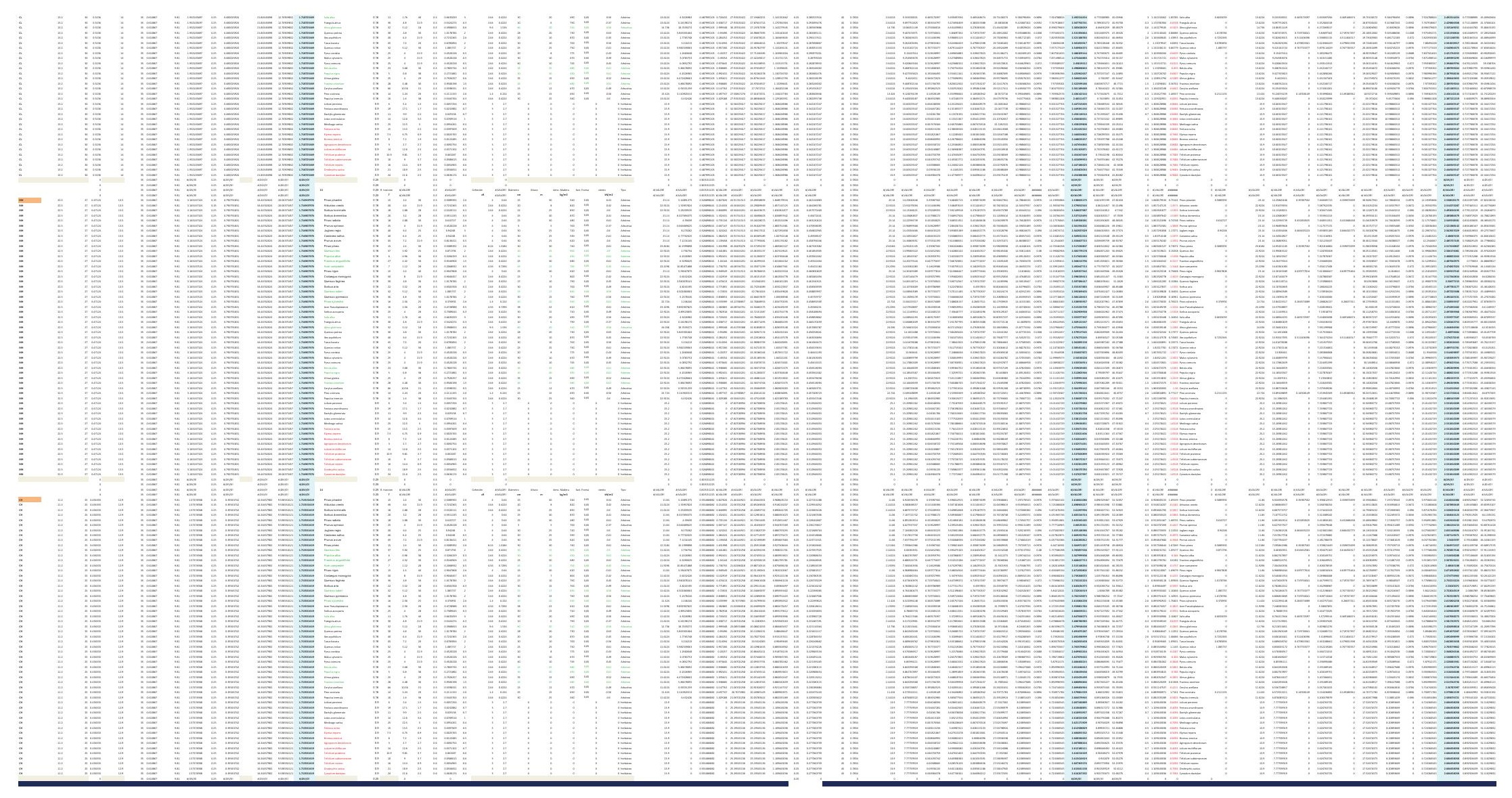



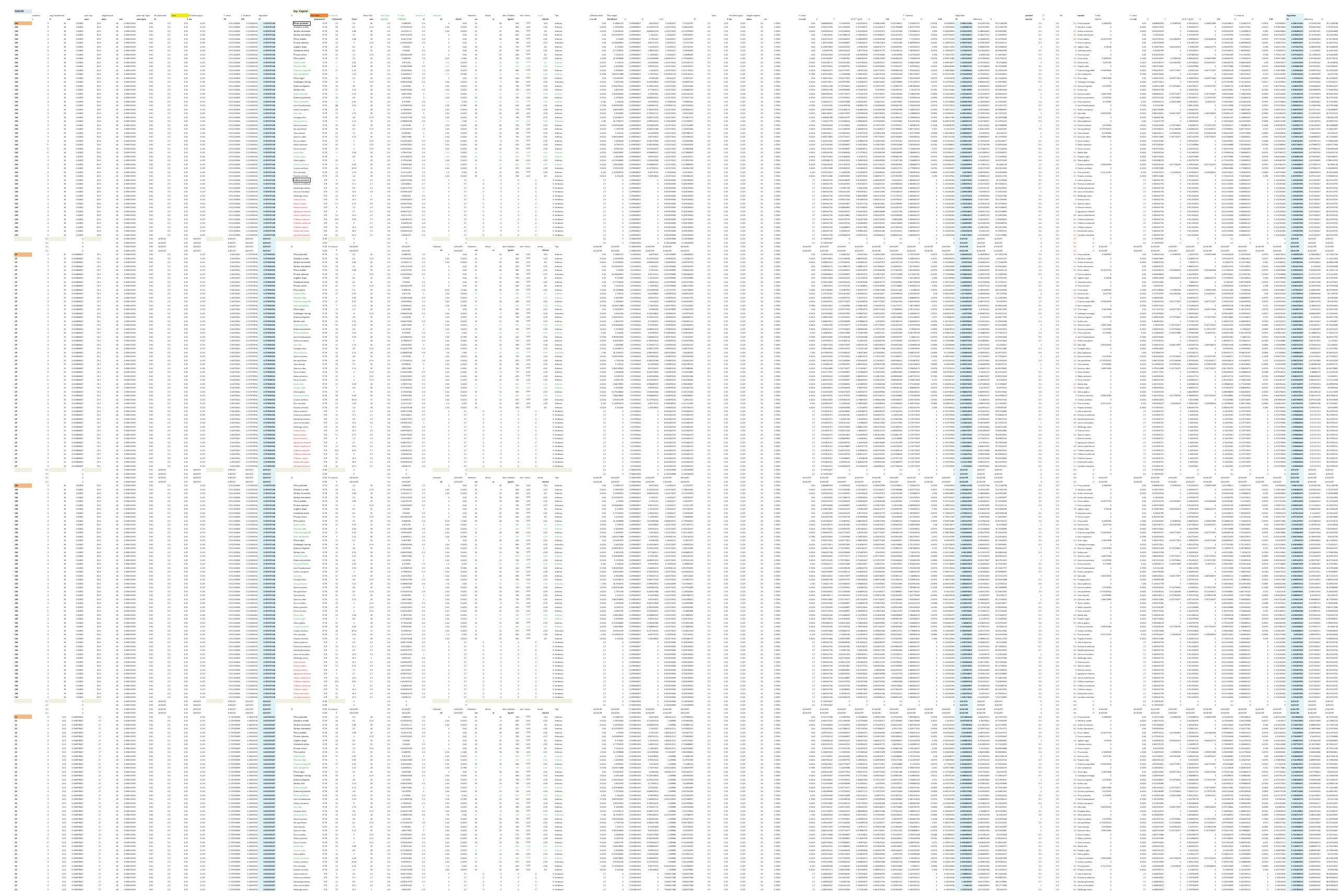


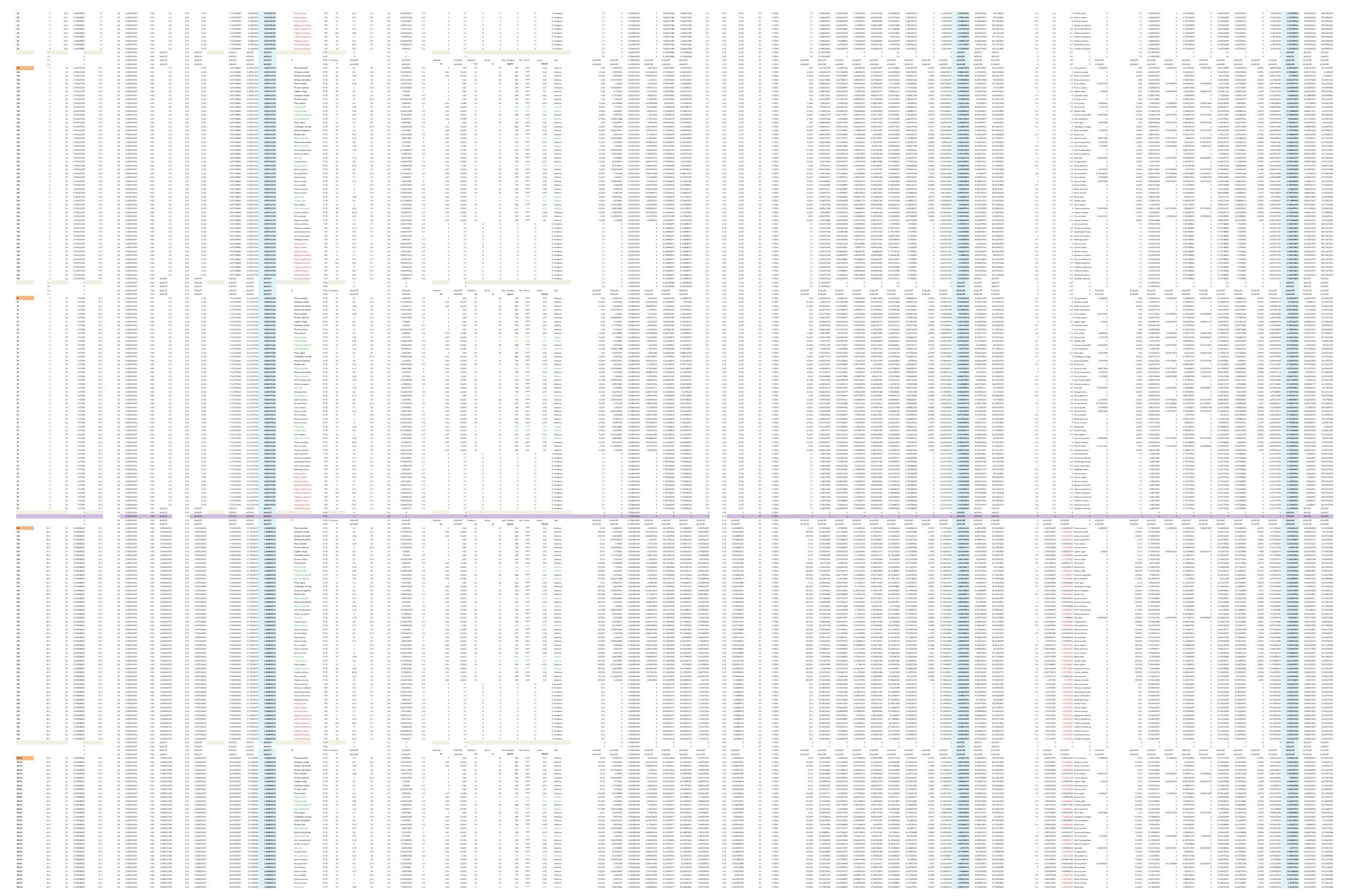



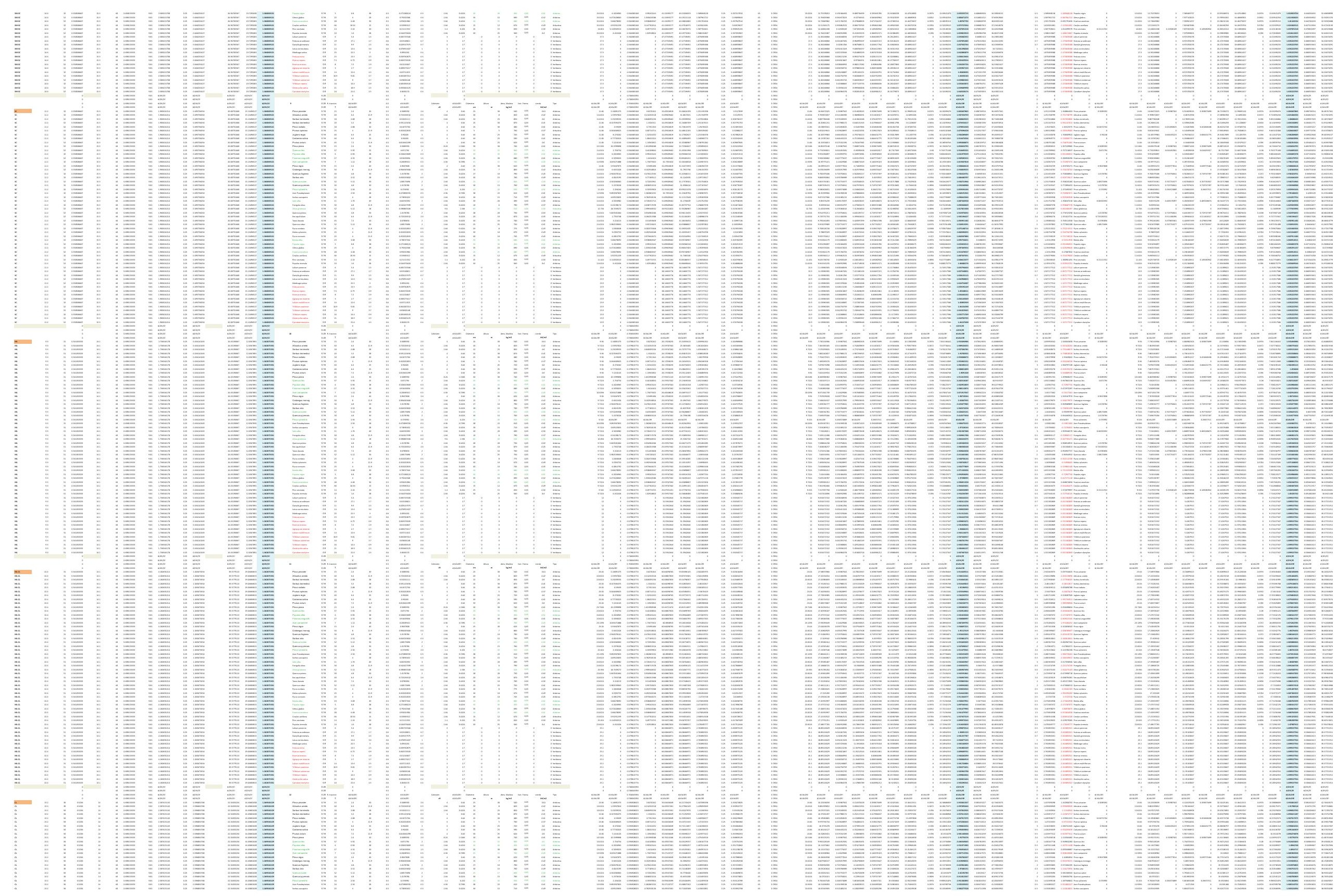


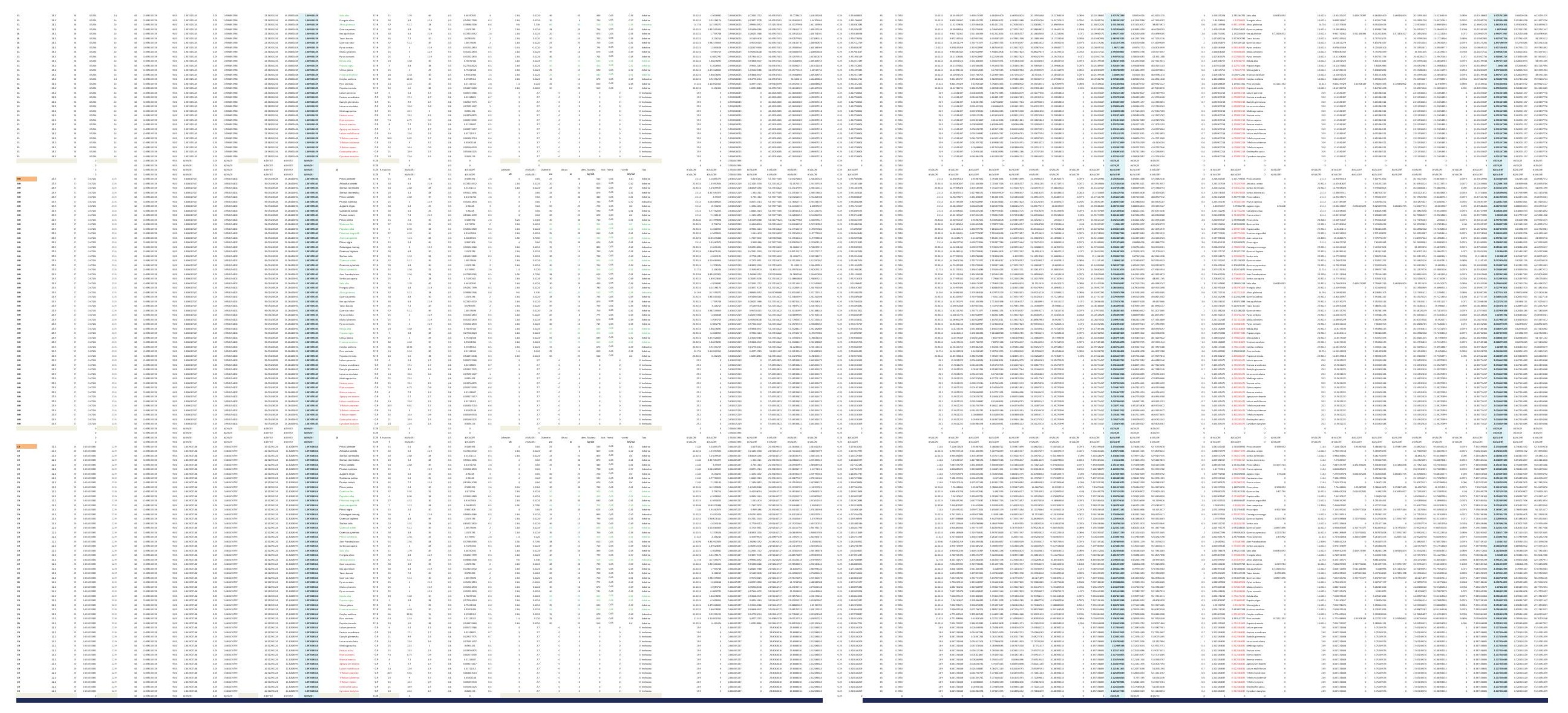



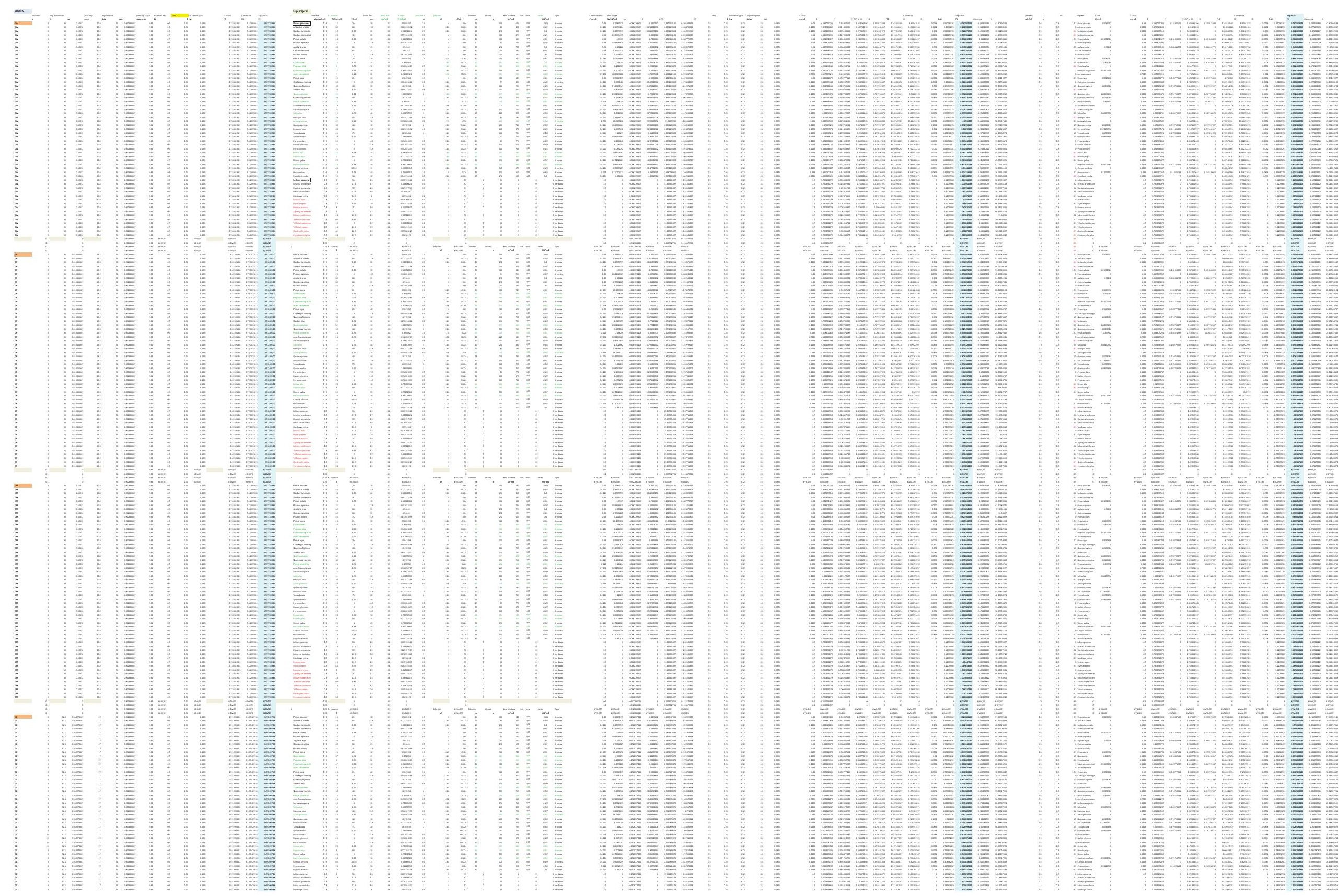


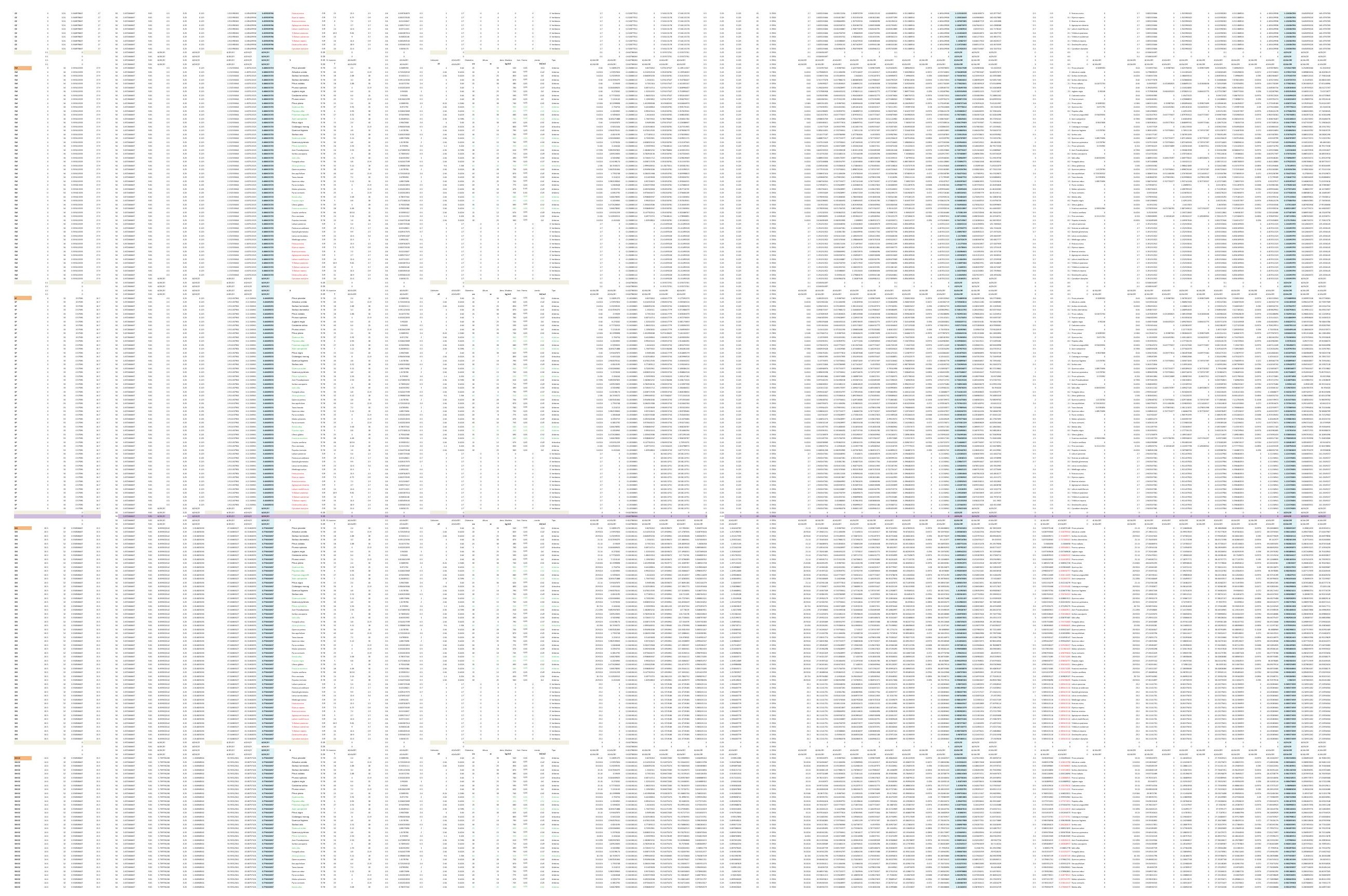



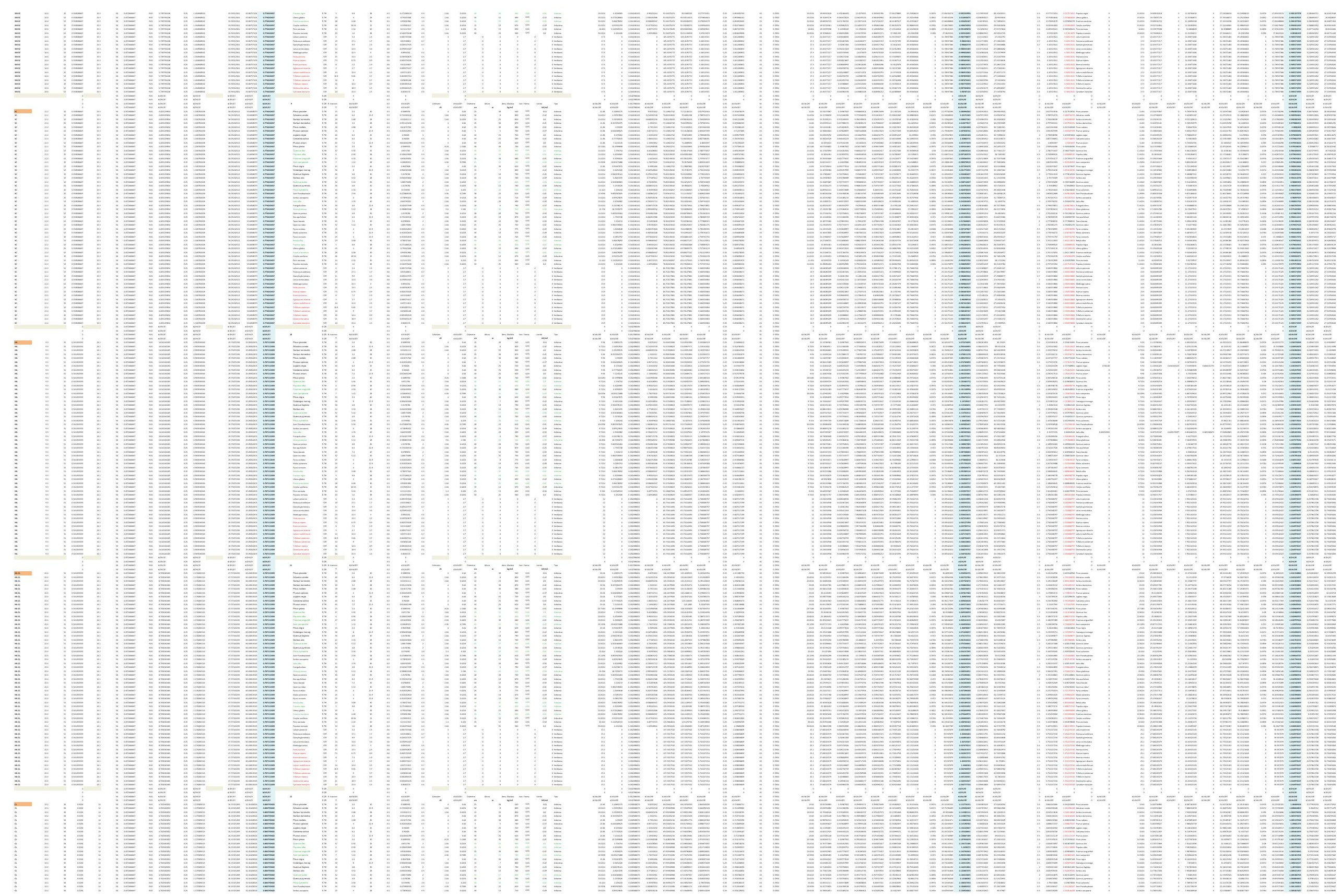


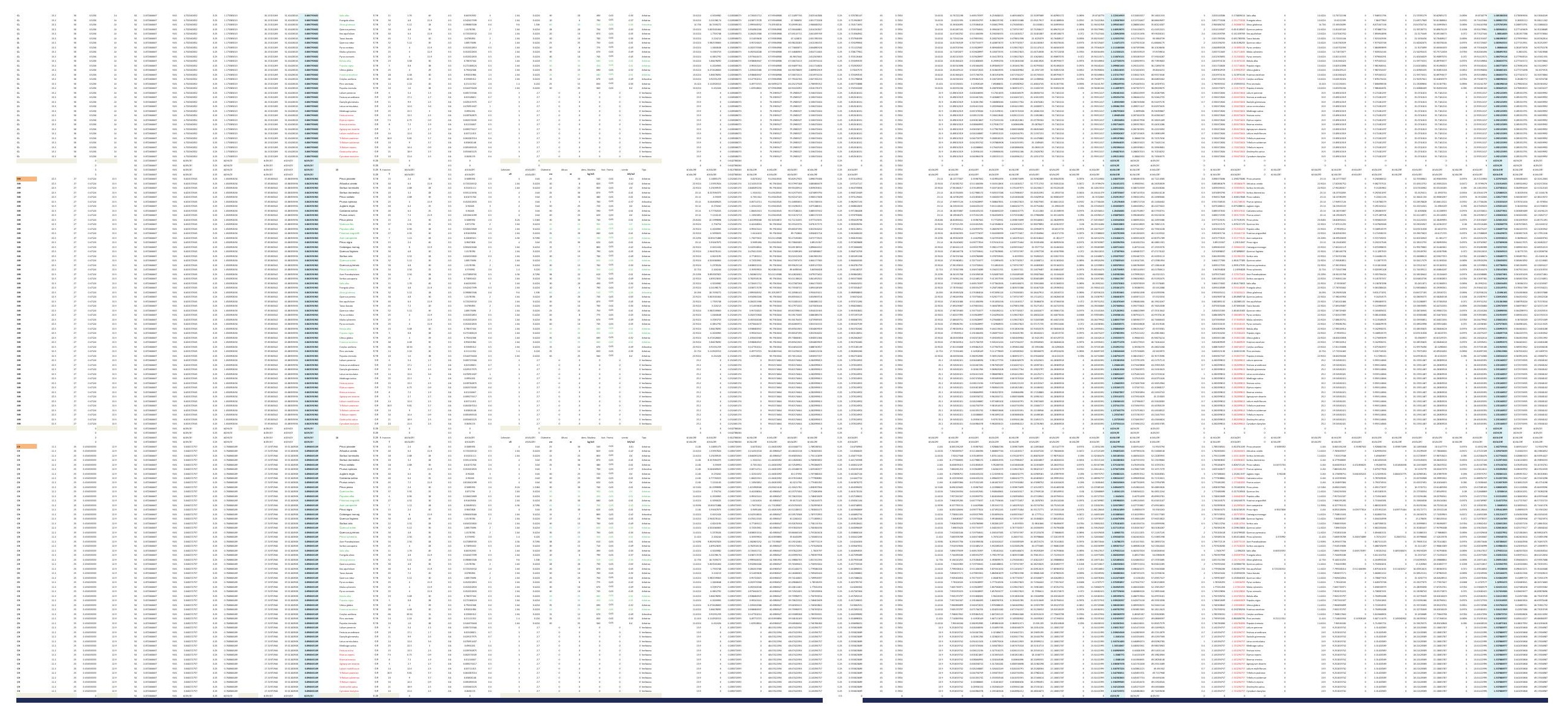



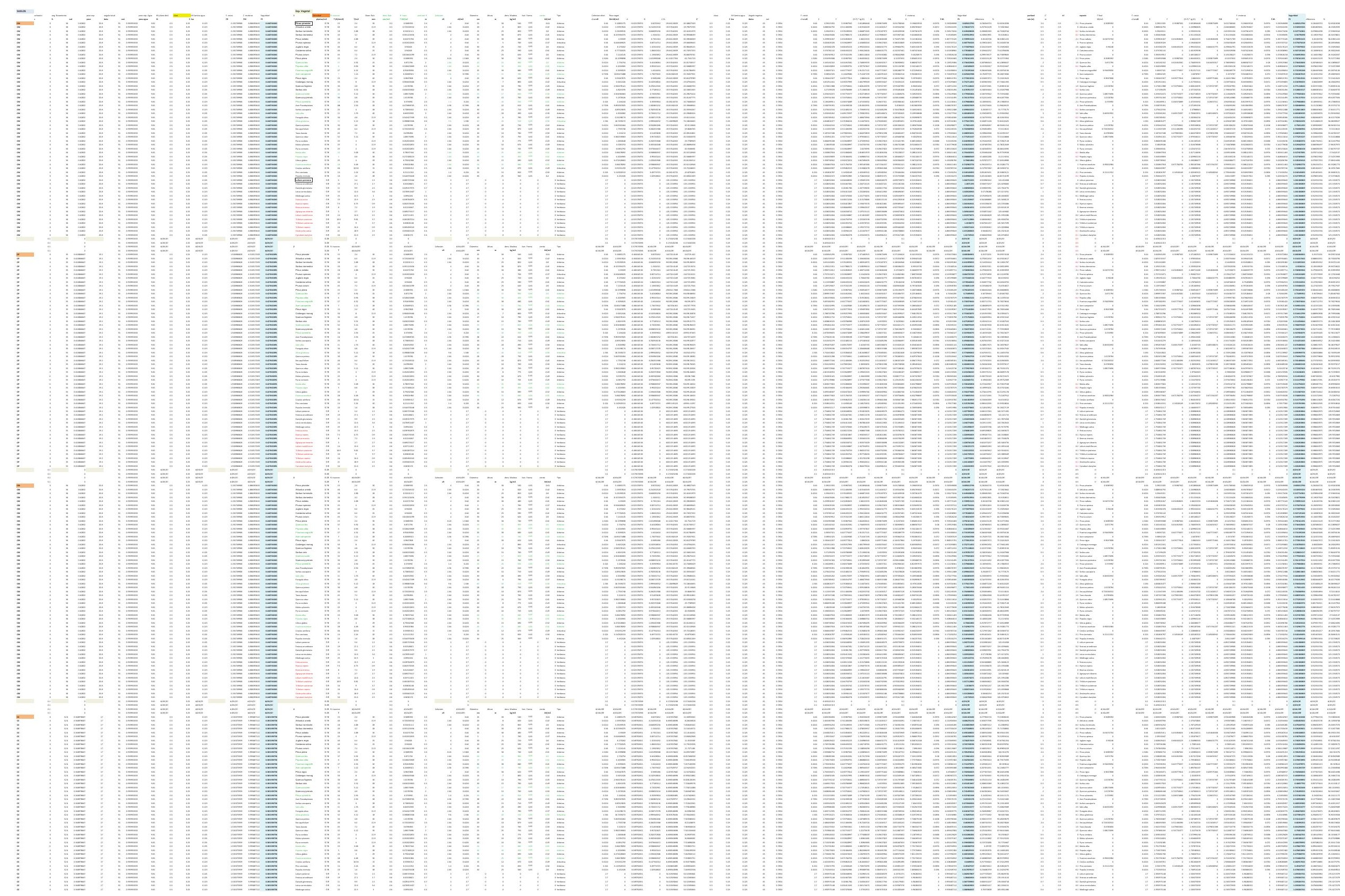


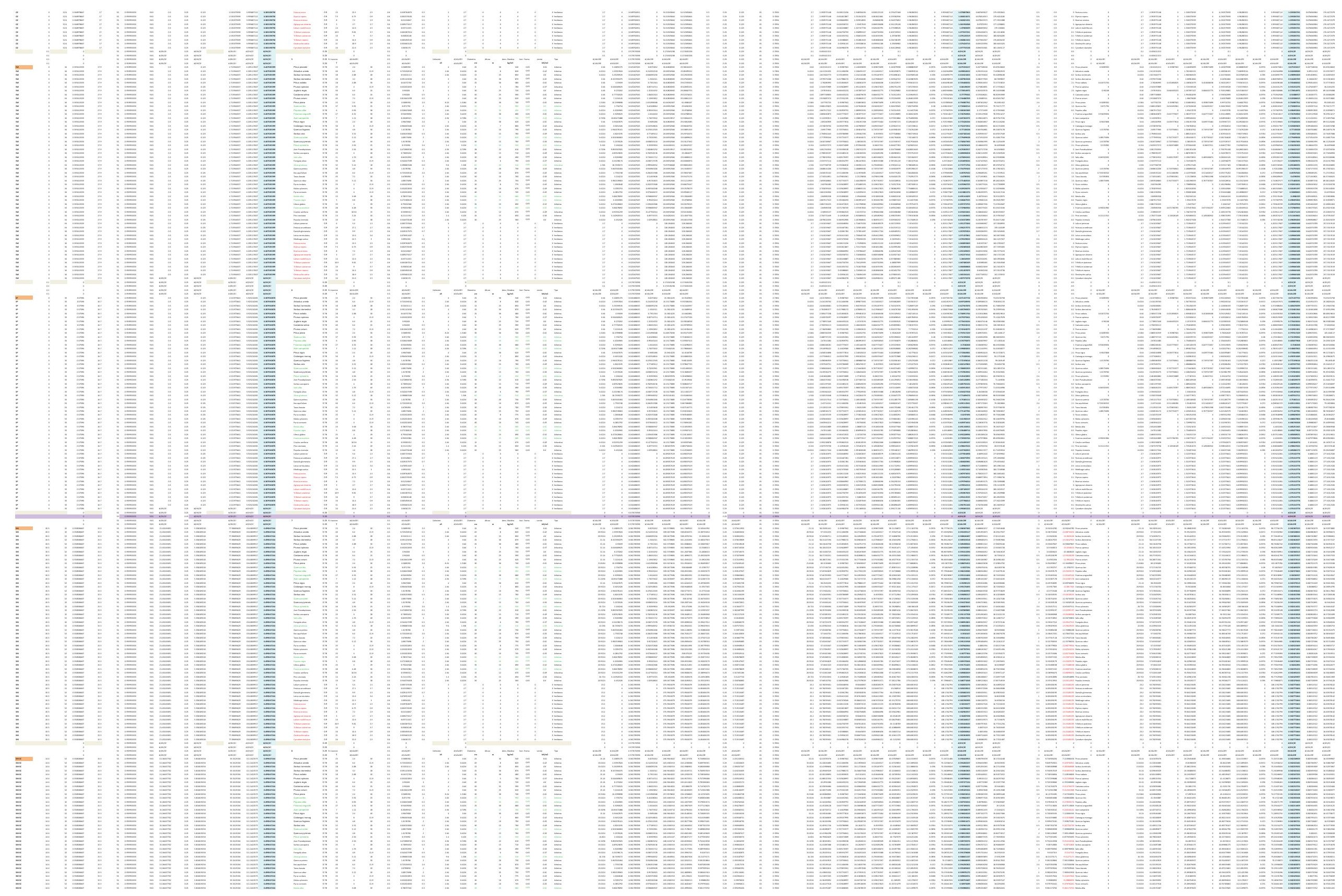



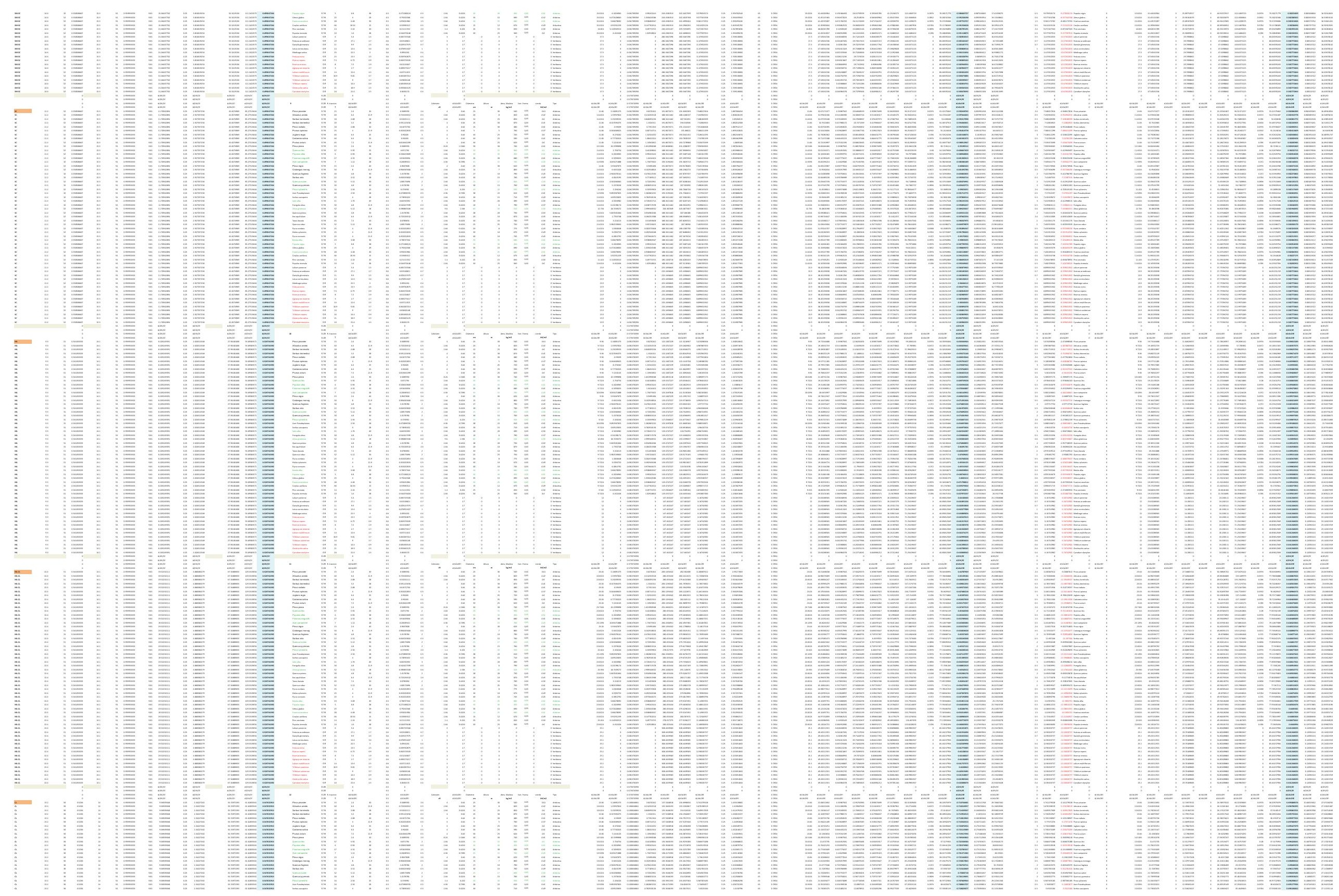


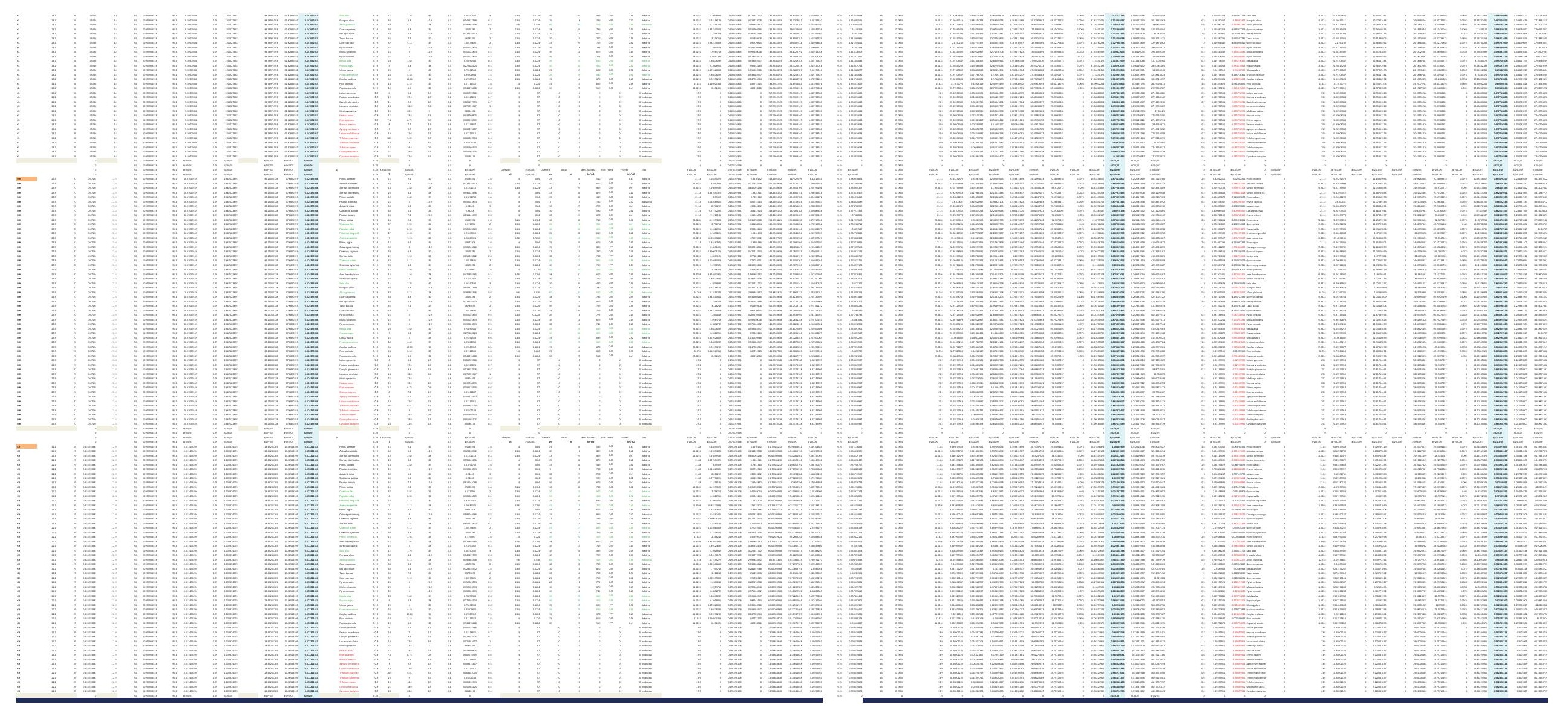



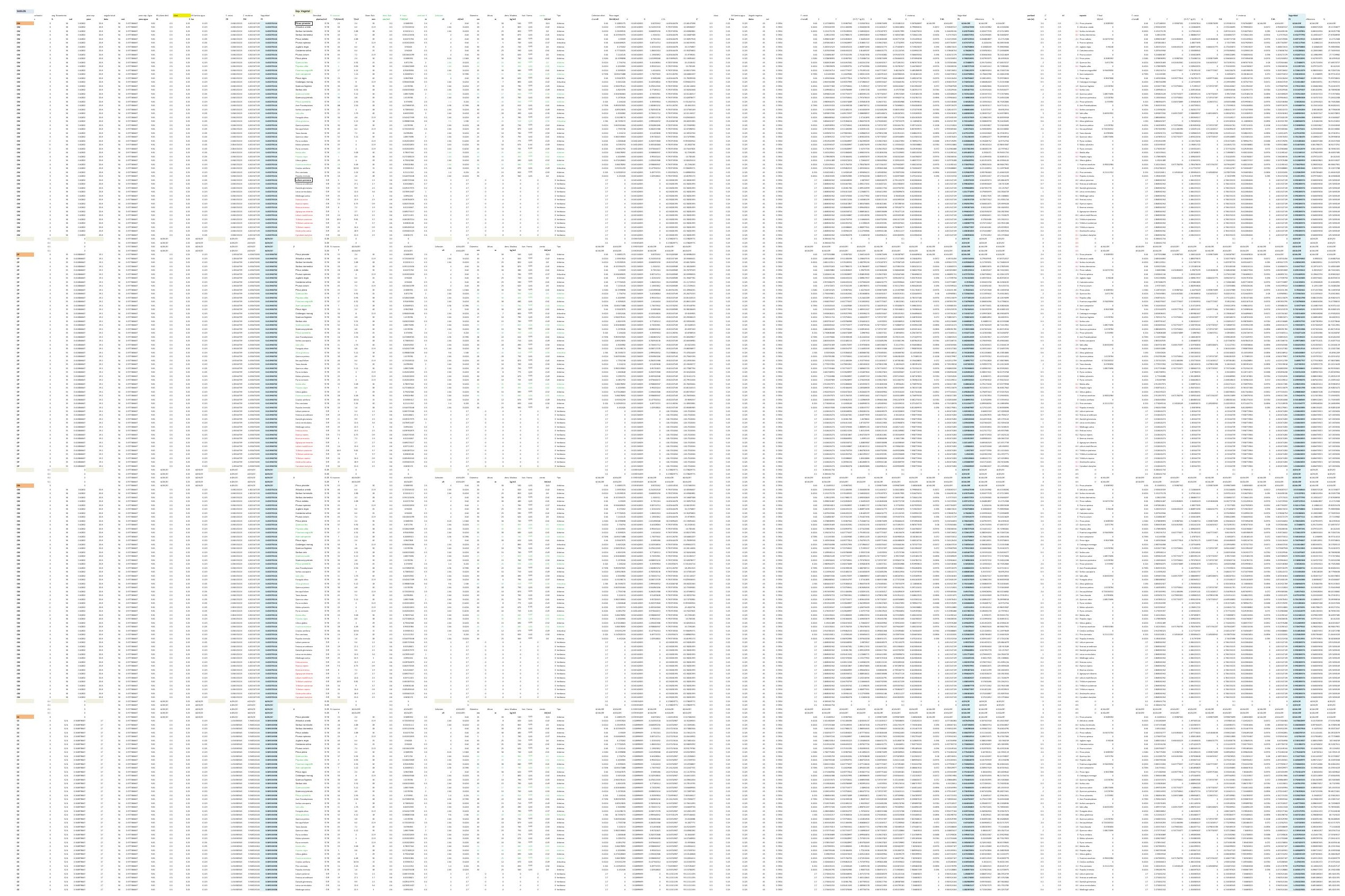


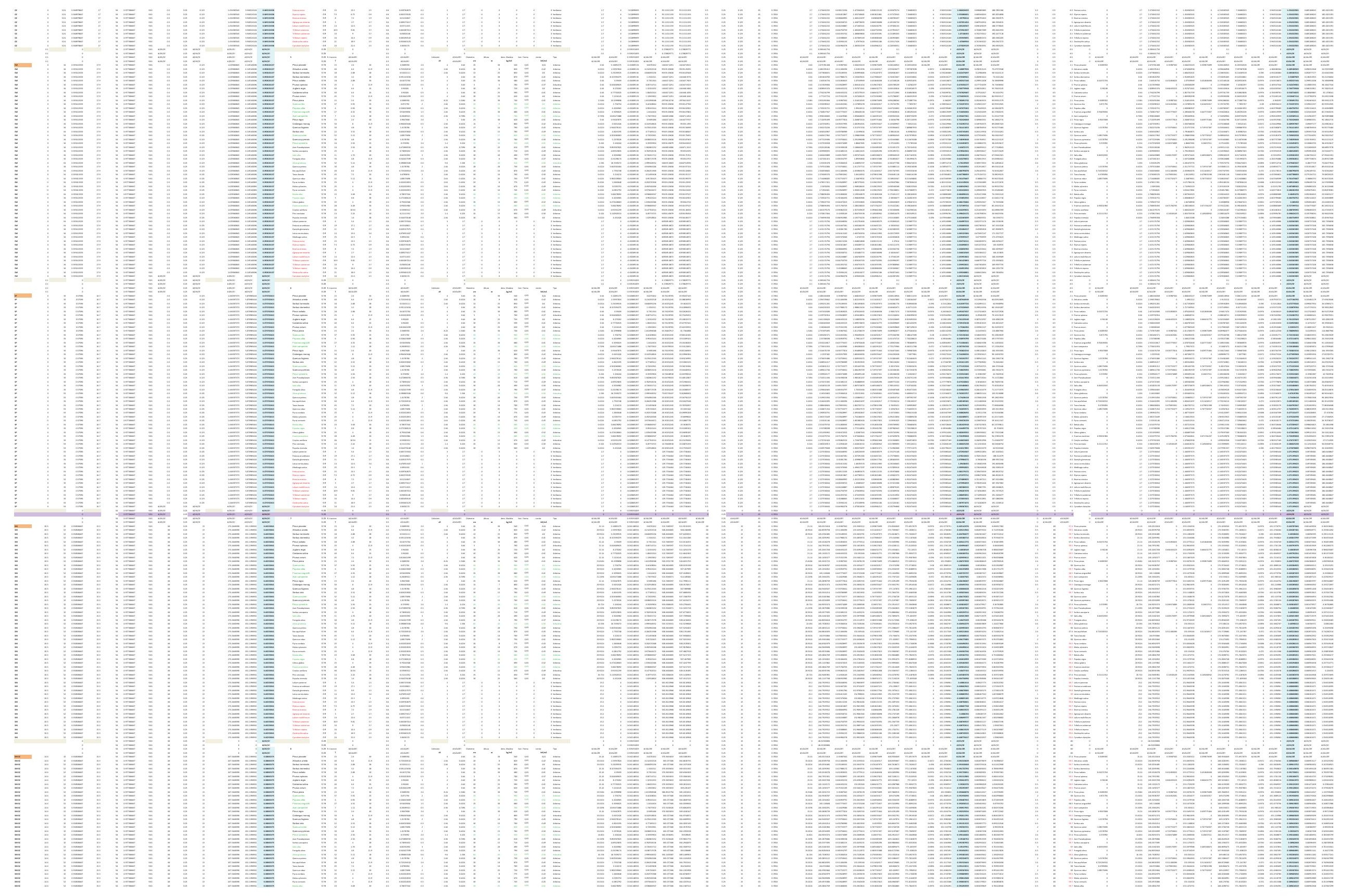



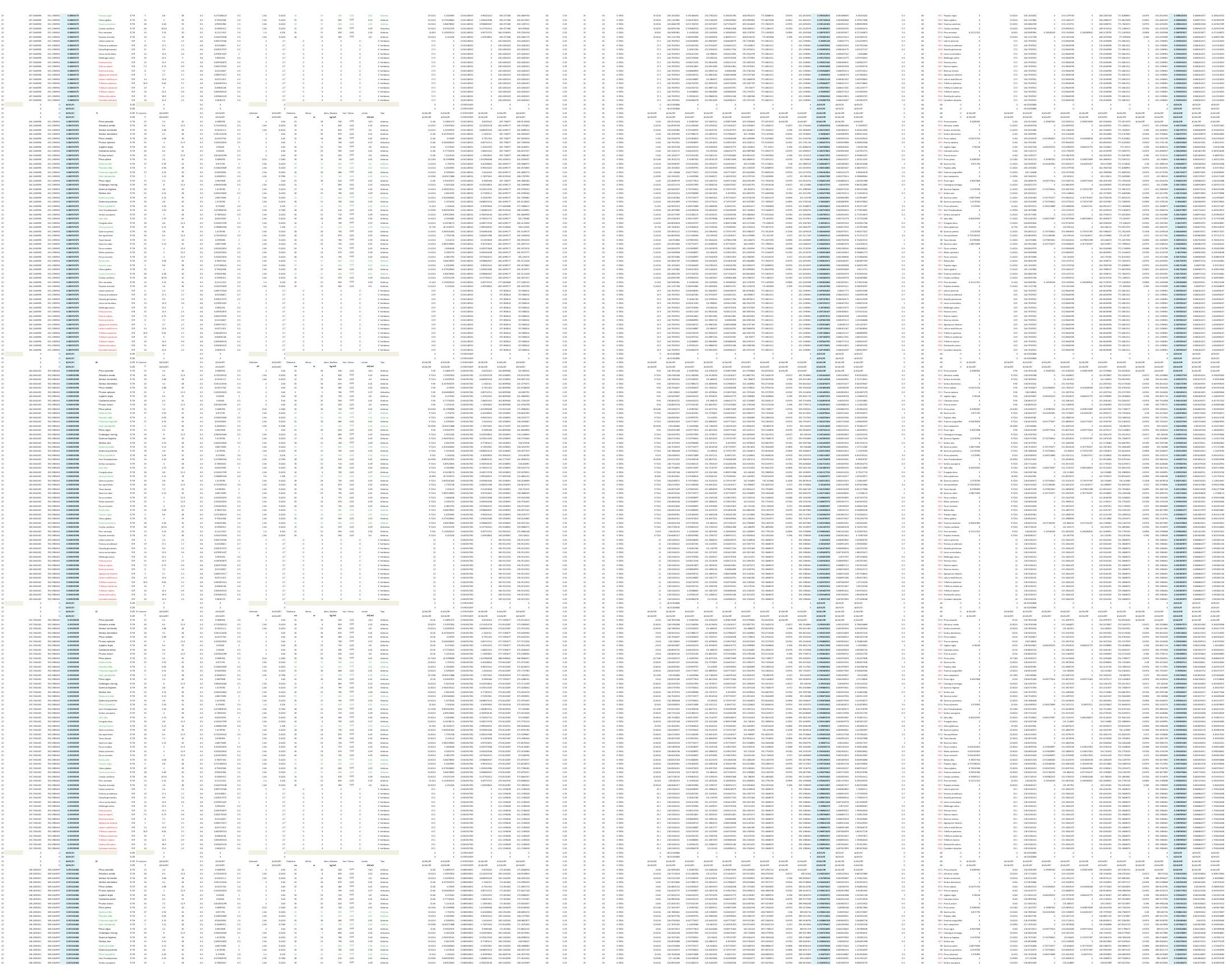


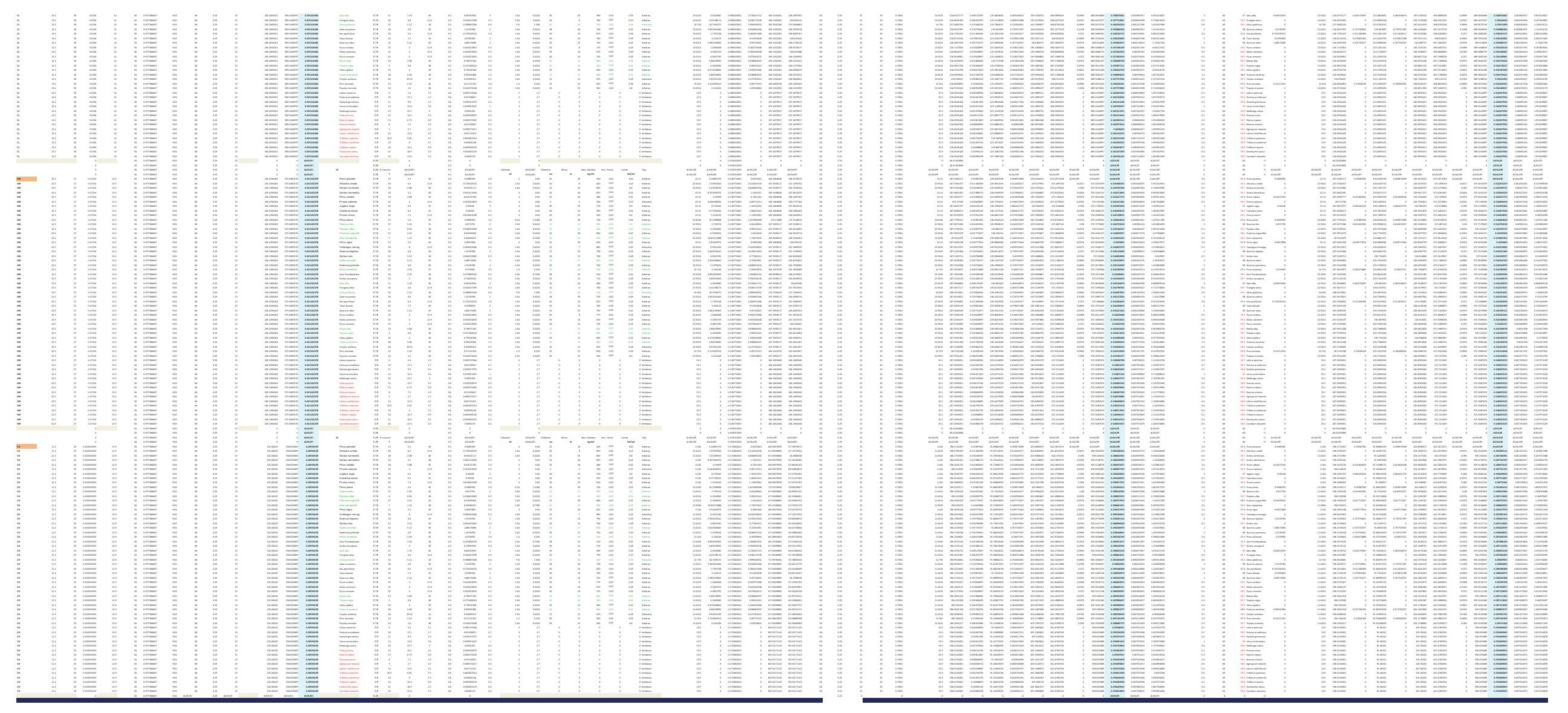



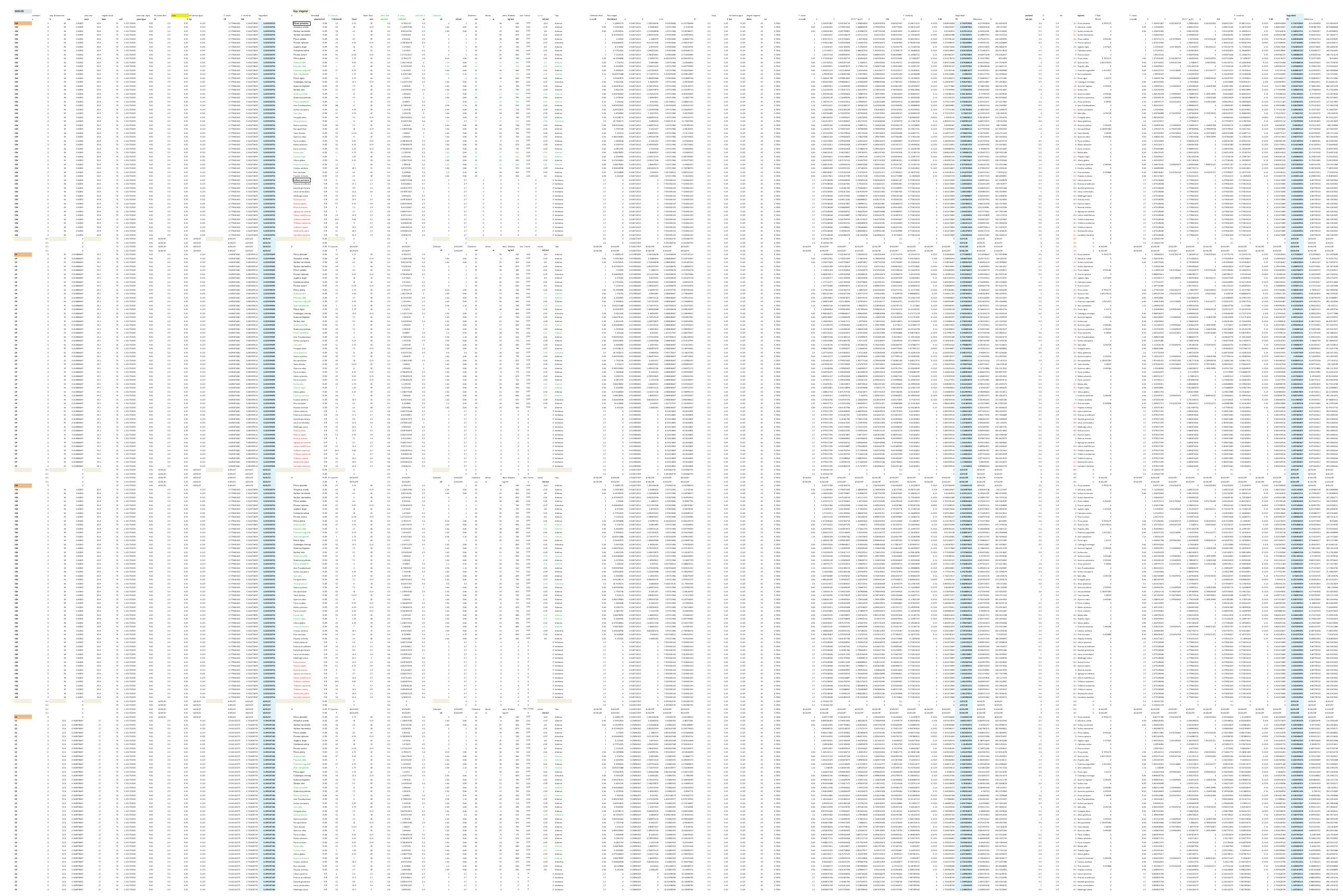


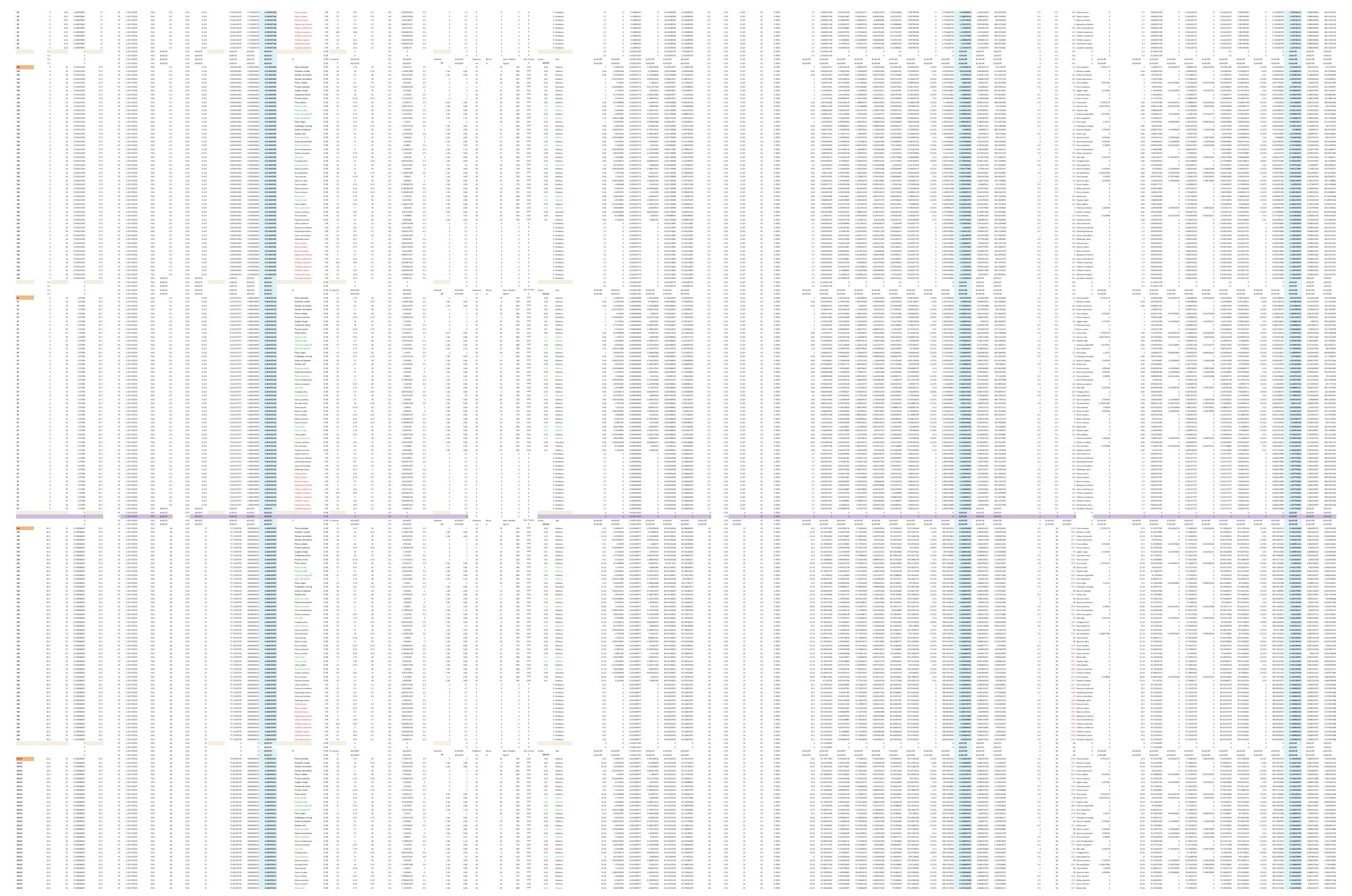



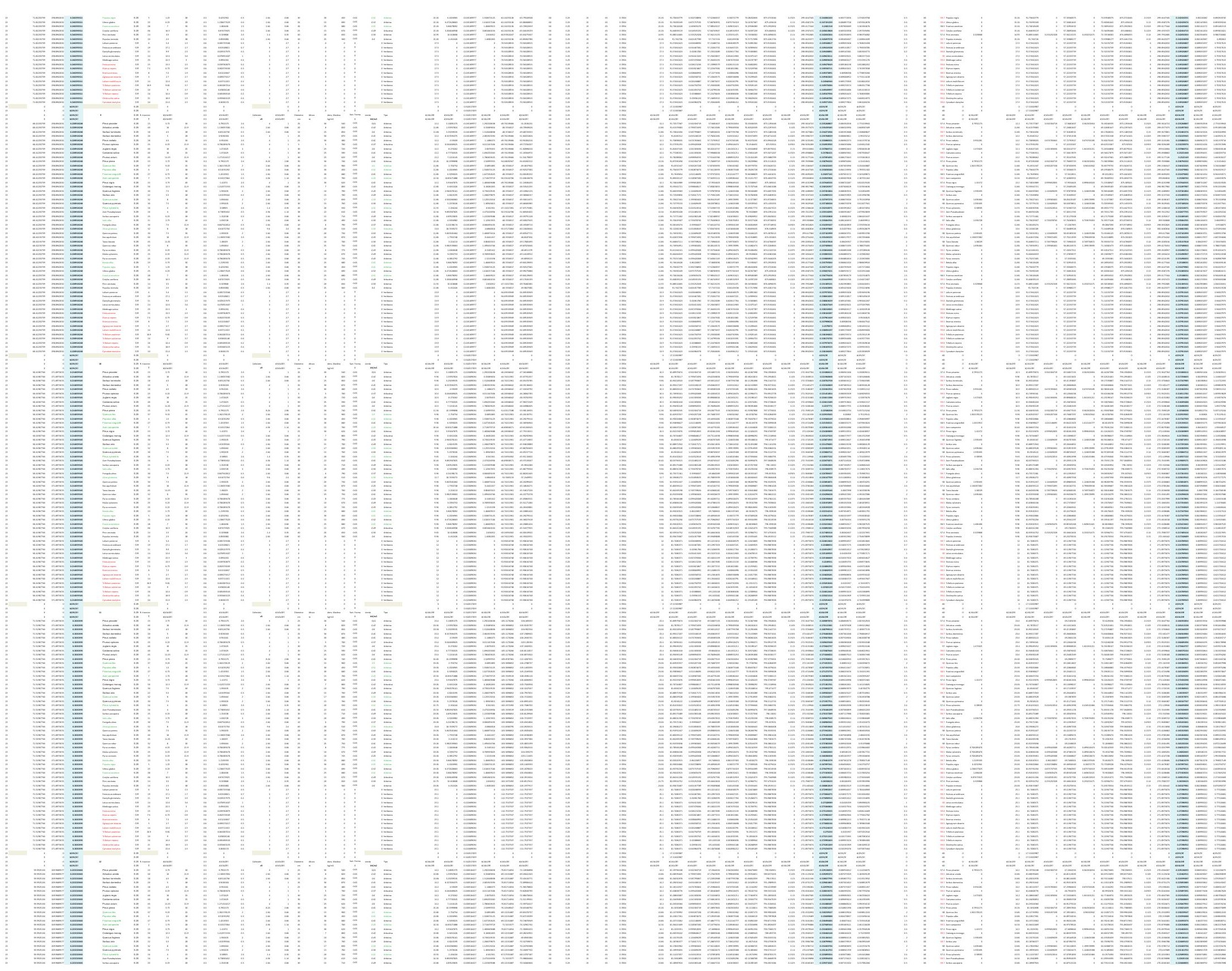


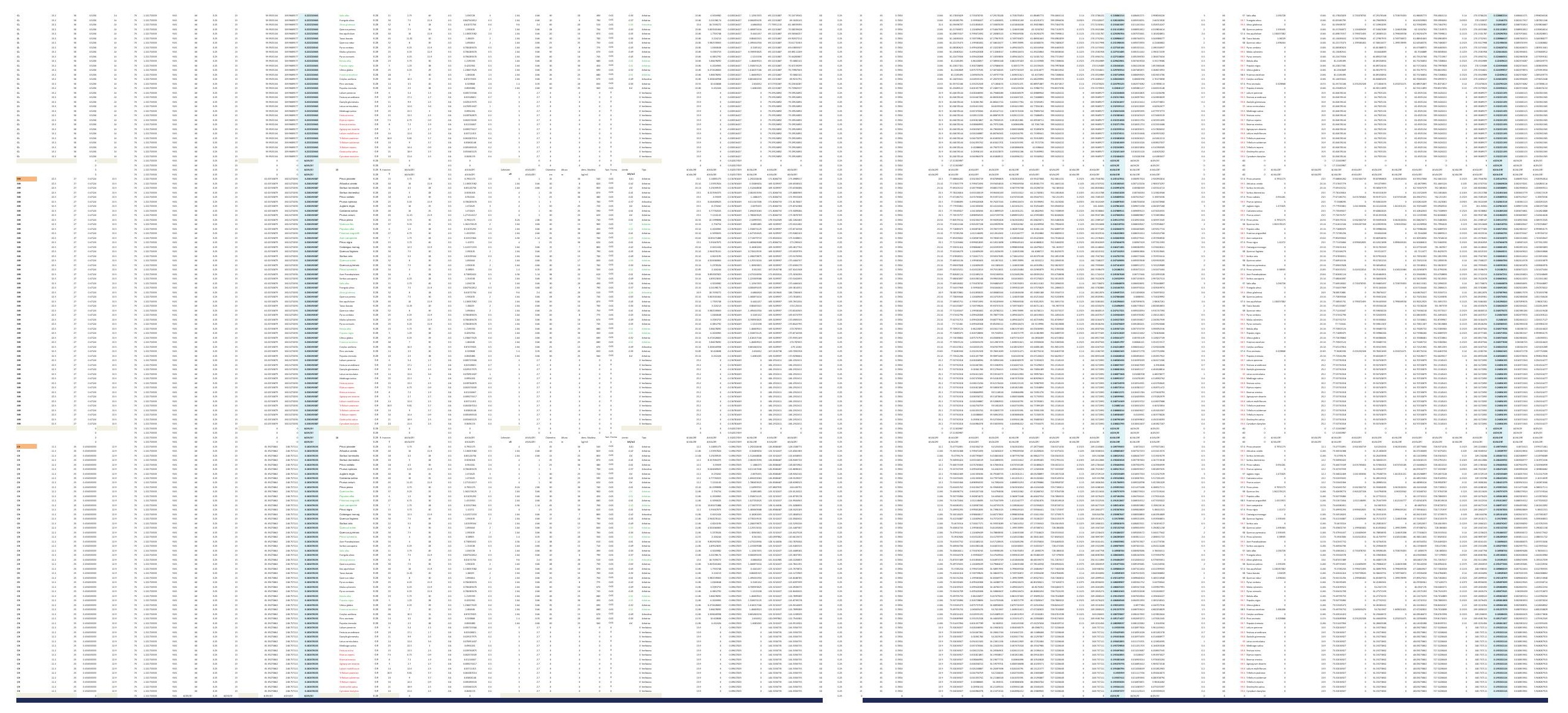



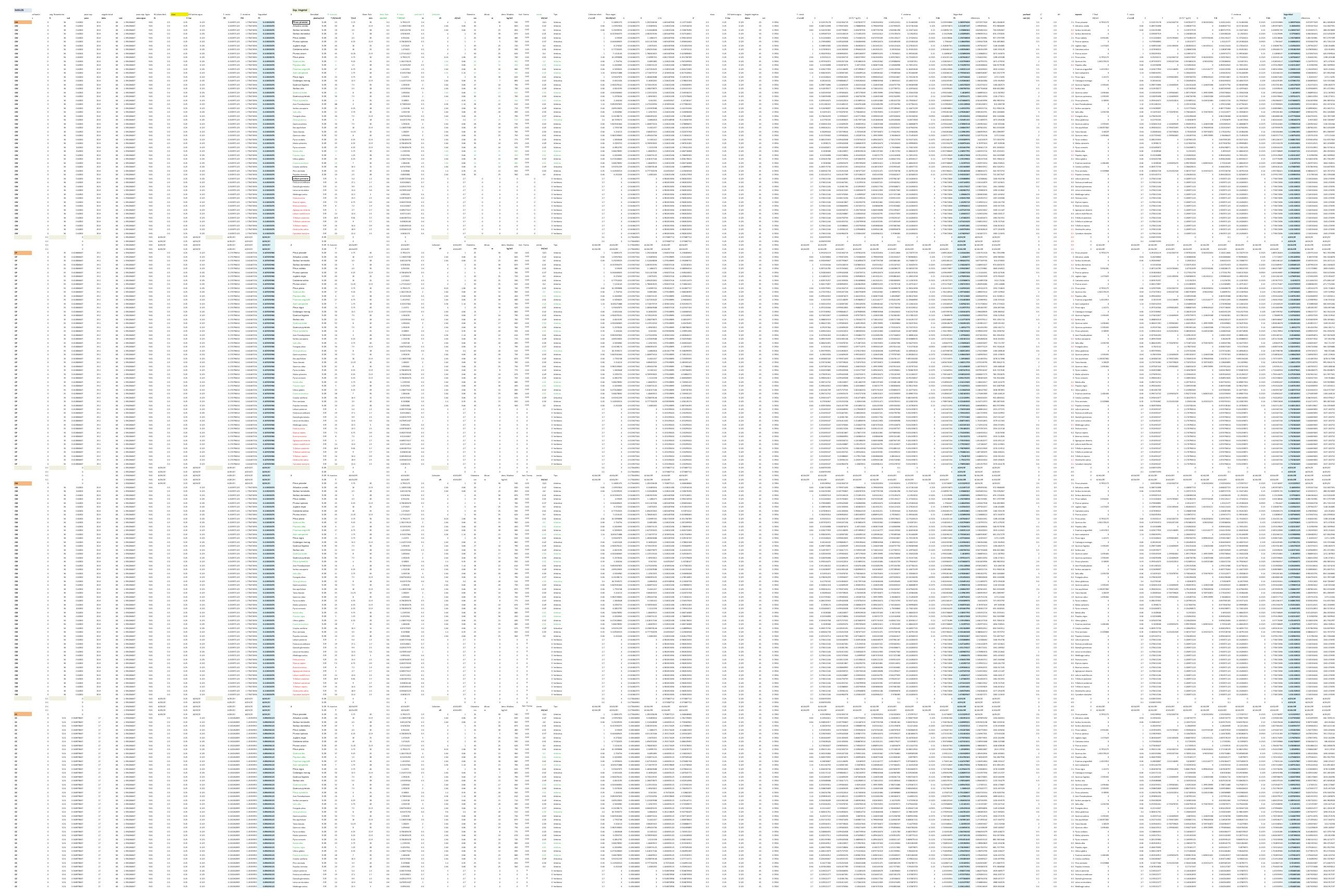


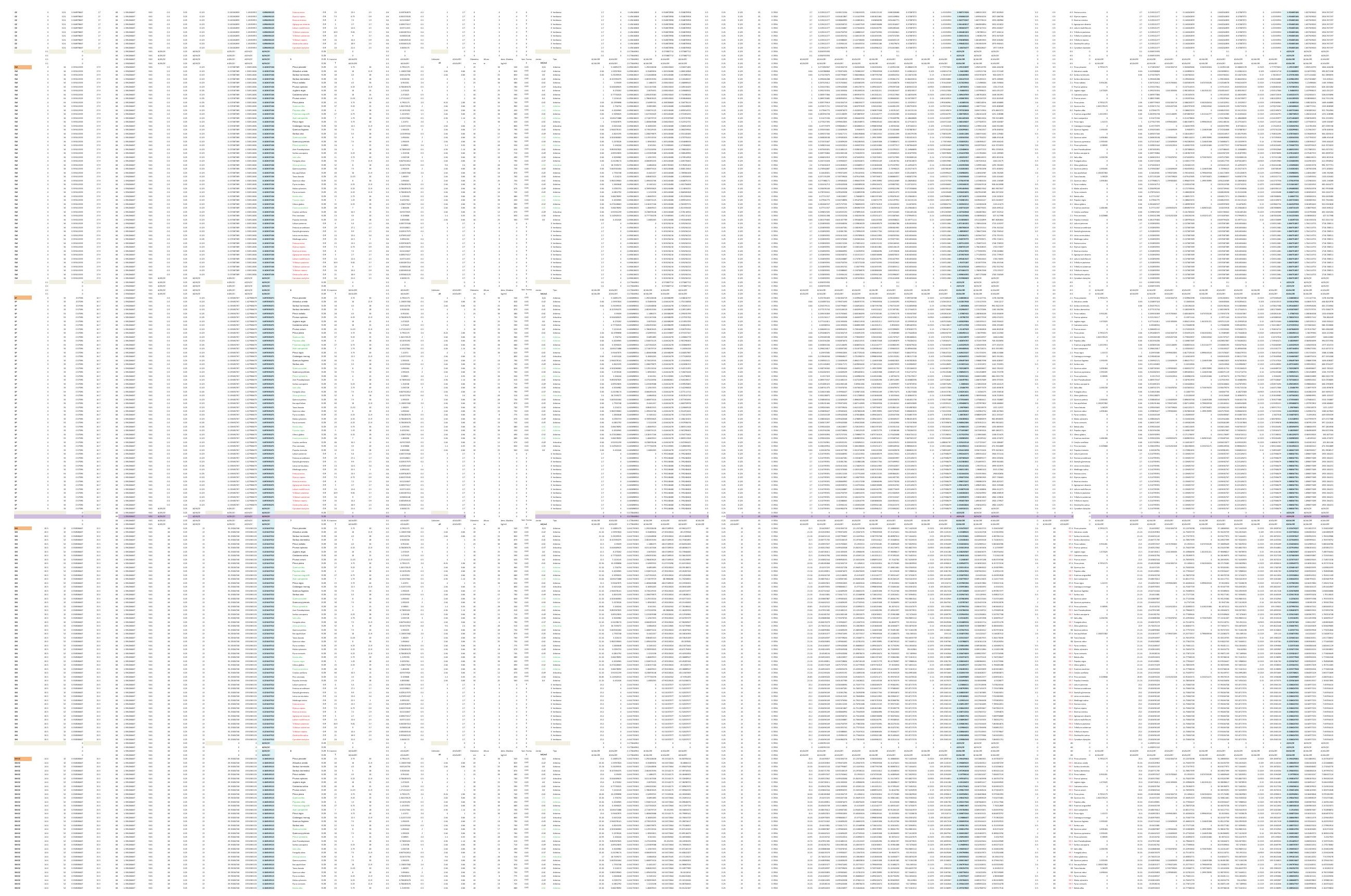



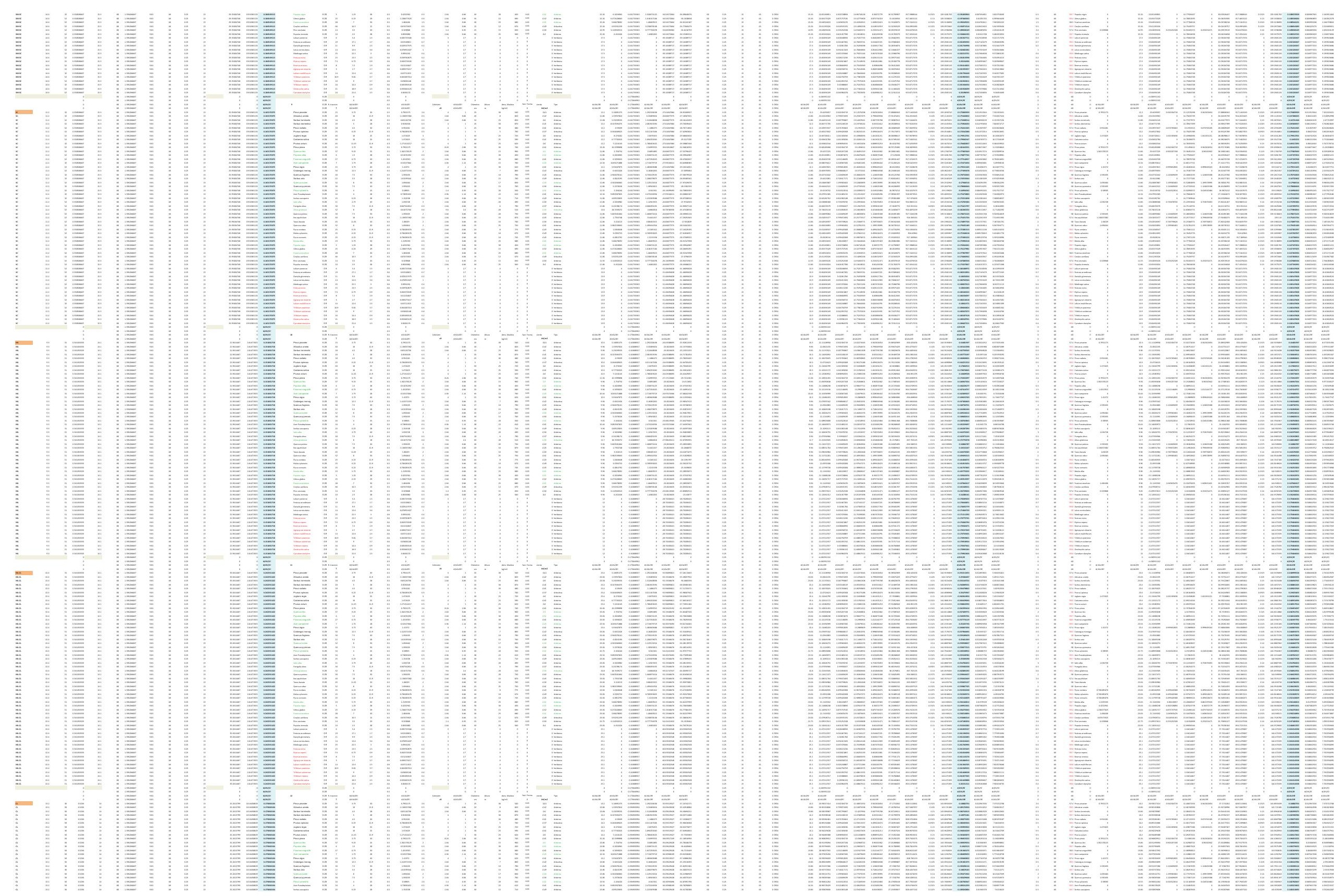


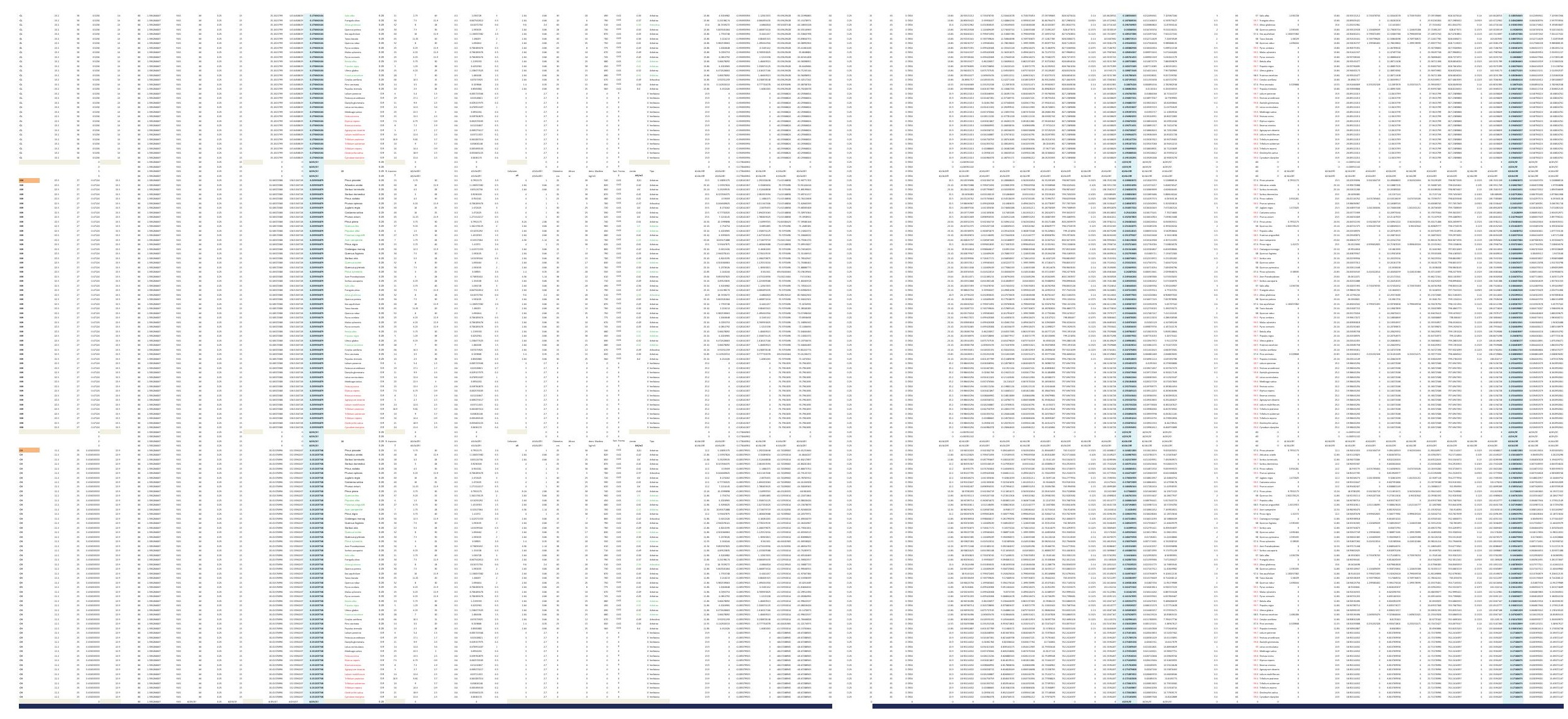


DESARROLLO DE UNA APLICACIÓN IMFORMÁTICA PARA EL CÁLCULO DE SOSTENIMIENTO DE TALUDES MEDIANTE VEGETACIÓN

A02. DENSIDAD DE PLANTACIÓN: 1.600 plantas/ha.

\section{A02-4.POSICIÓN N.F. 4}

INCLINACIÓN DE TALUD 6-100

INCLINACIÓN DE TALUD 10-200

INCLINACIÓN DE TALUD 20-30

INCLINACIÓN DE TALUD 30-40

INCLINACIÓN DE TALUD $35^{\circ}$

INCLINACIÓN DE TALUD 40-50

INCLINACIÓN DE TALUD 50-550

INCLINACIÓN DE TALUD 55-60

INCLINACIÓN DE TALUD 60-700

INCLINACIÓN DE TALUD 70-80 

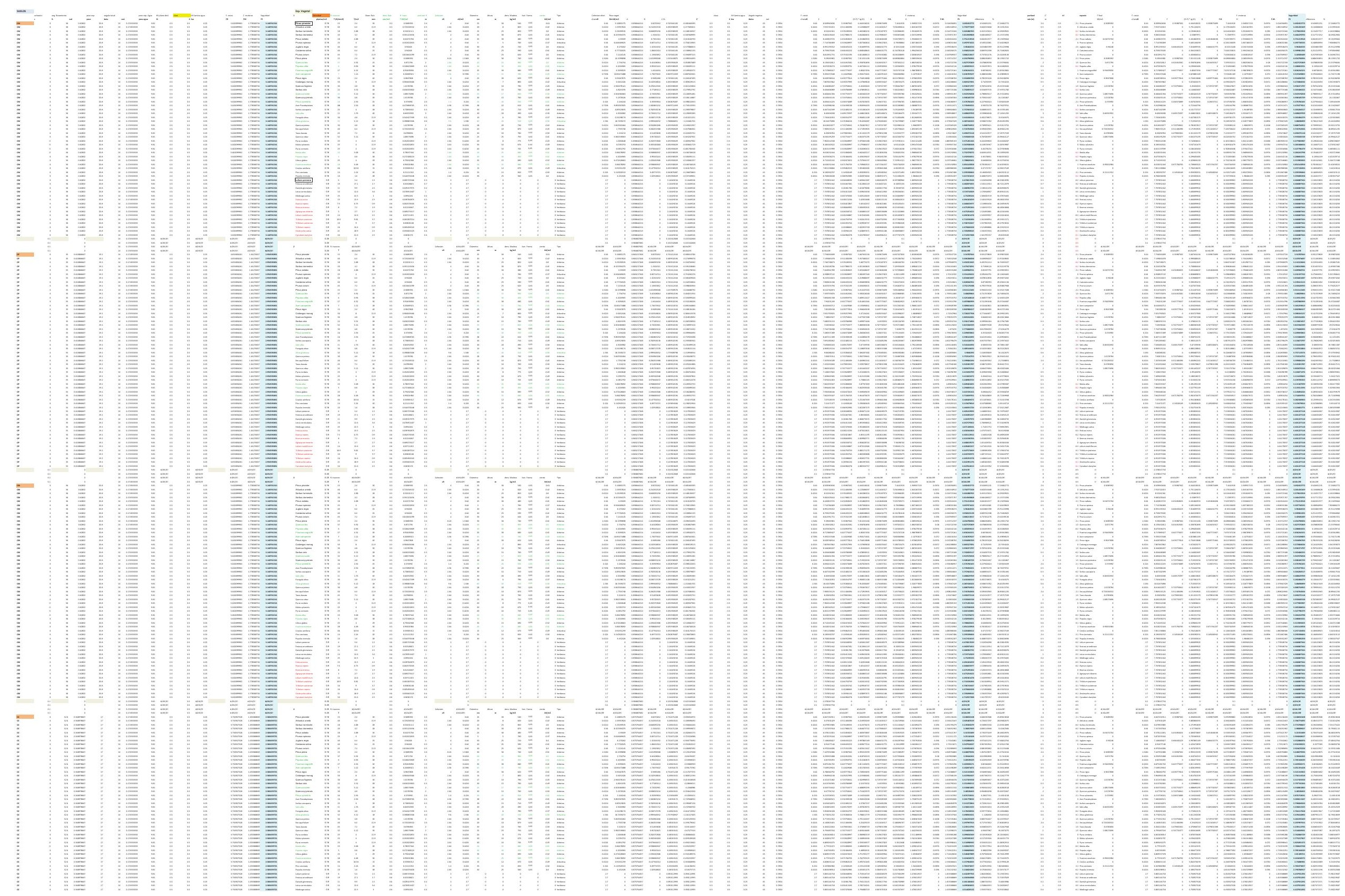


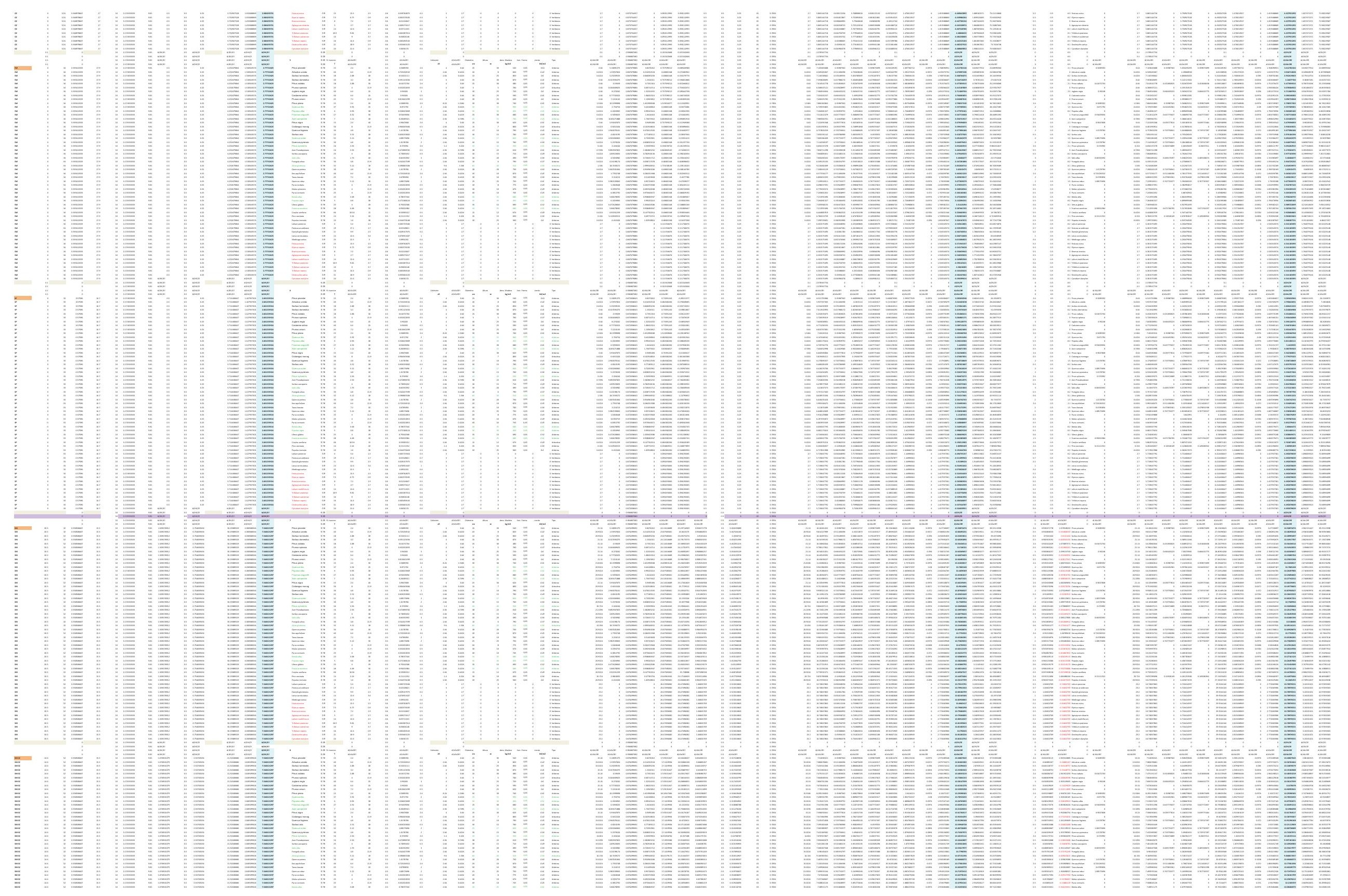



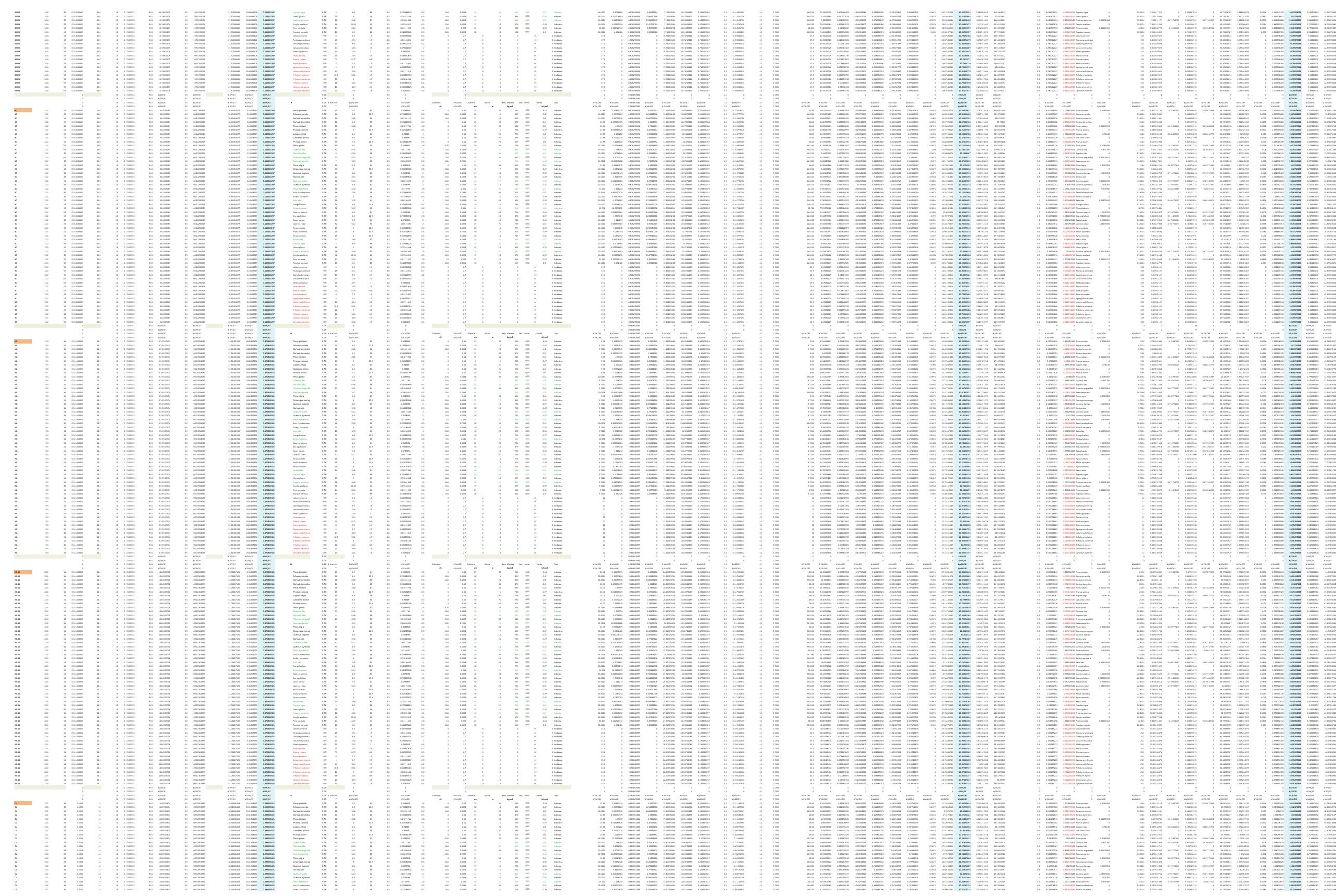


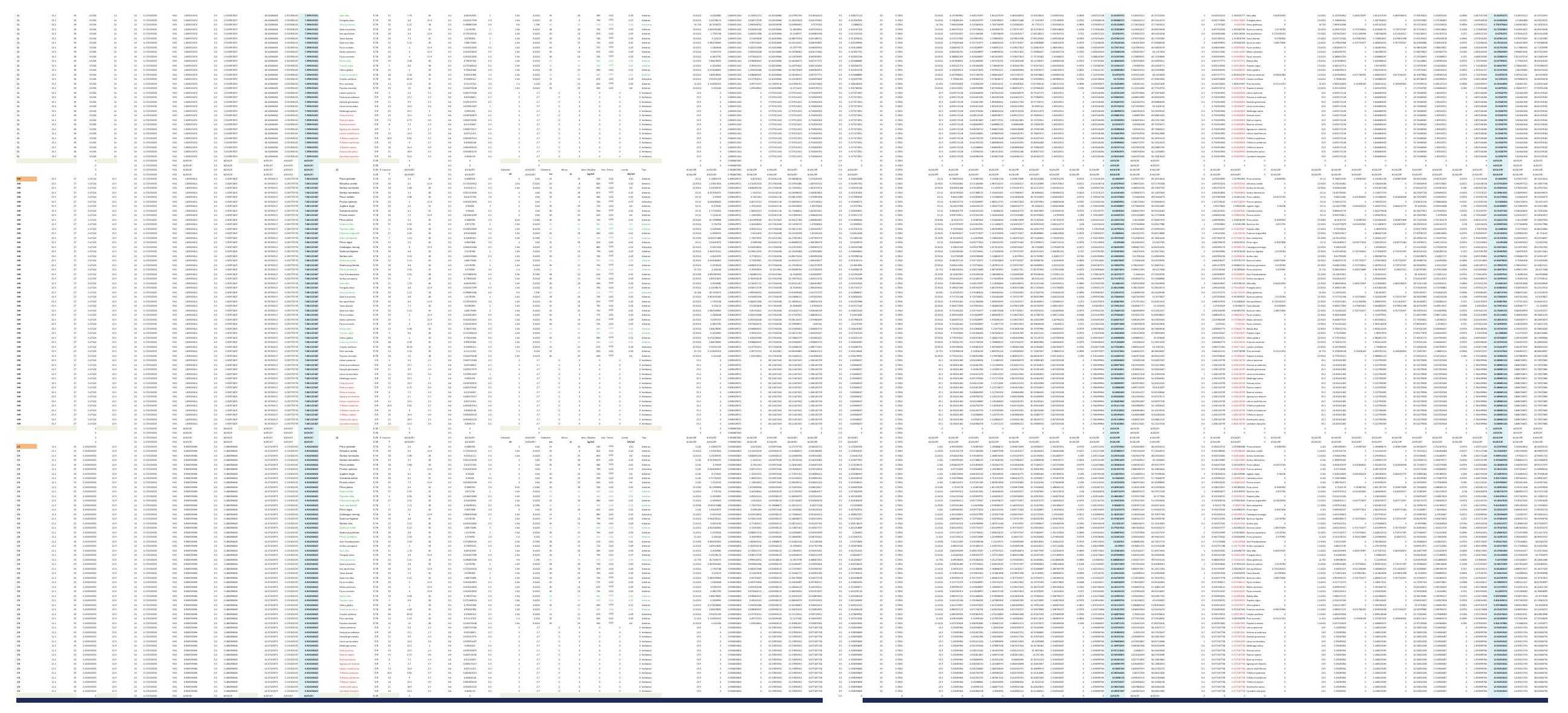



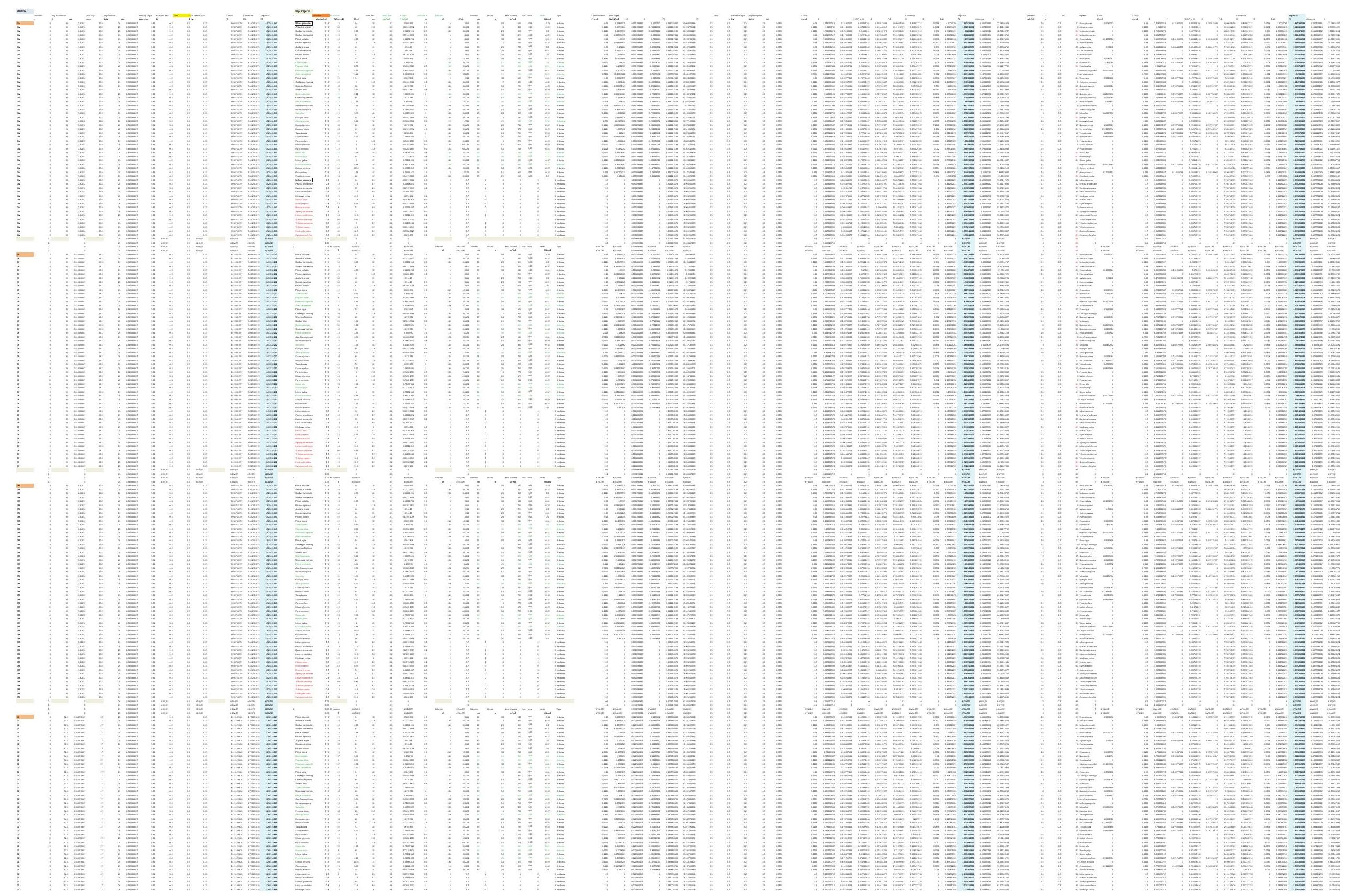


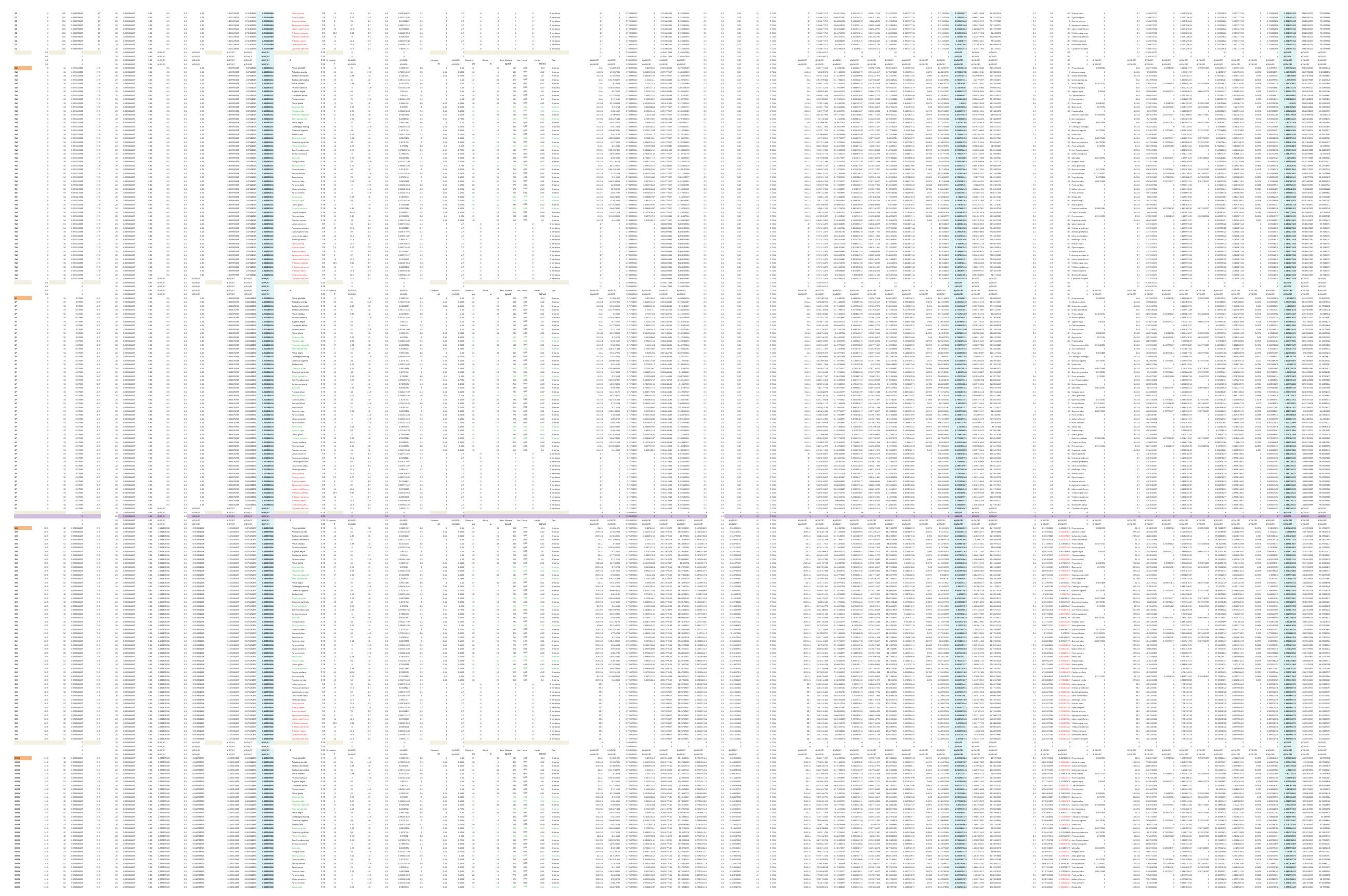



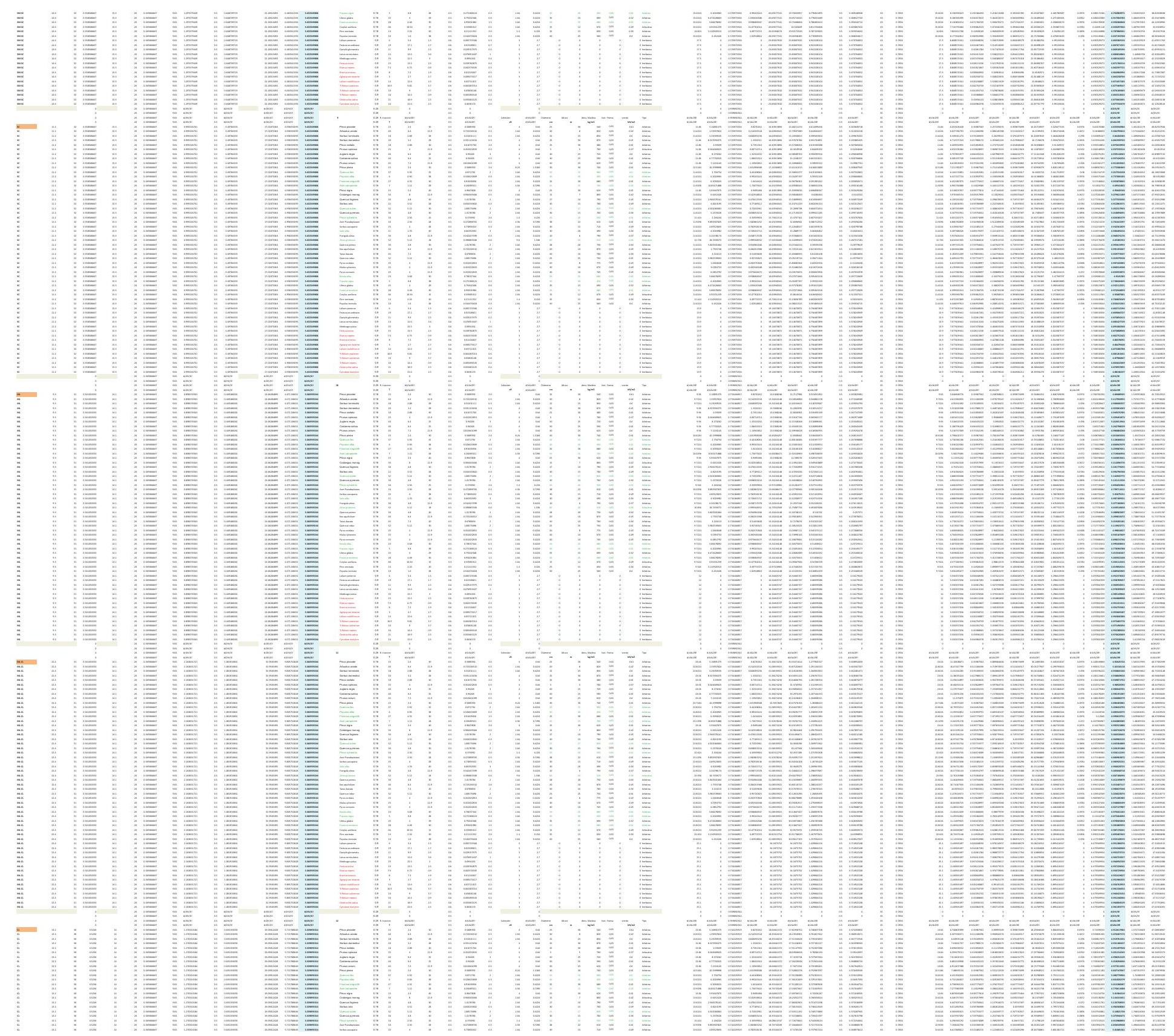

吕E三
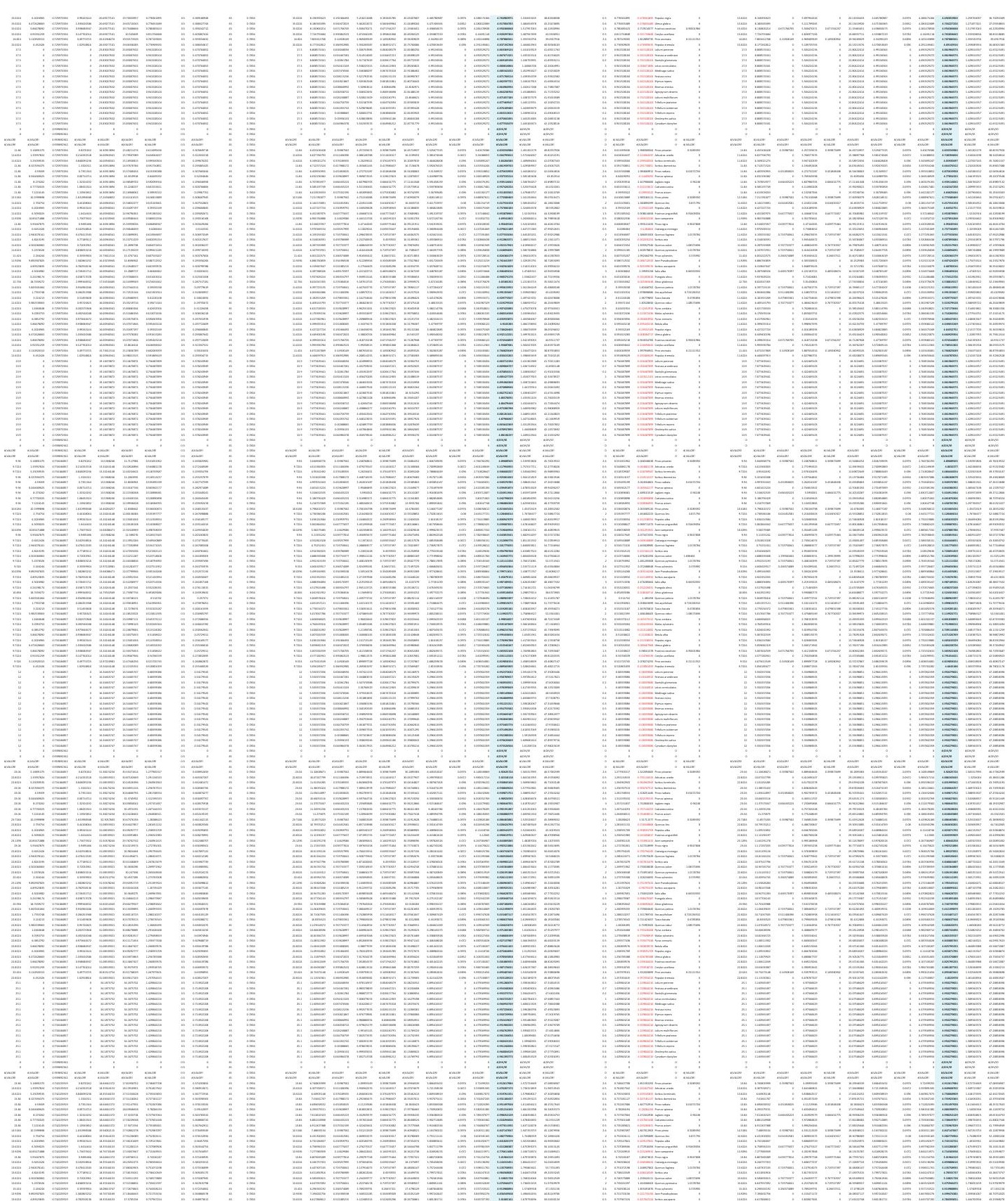


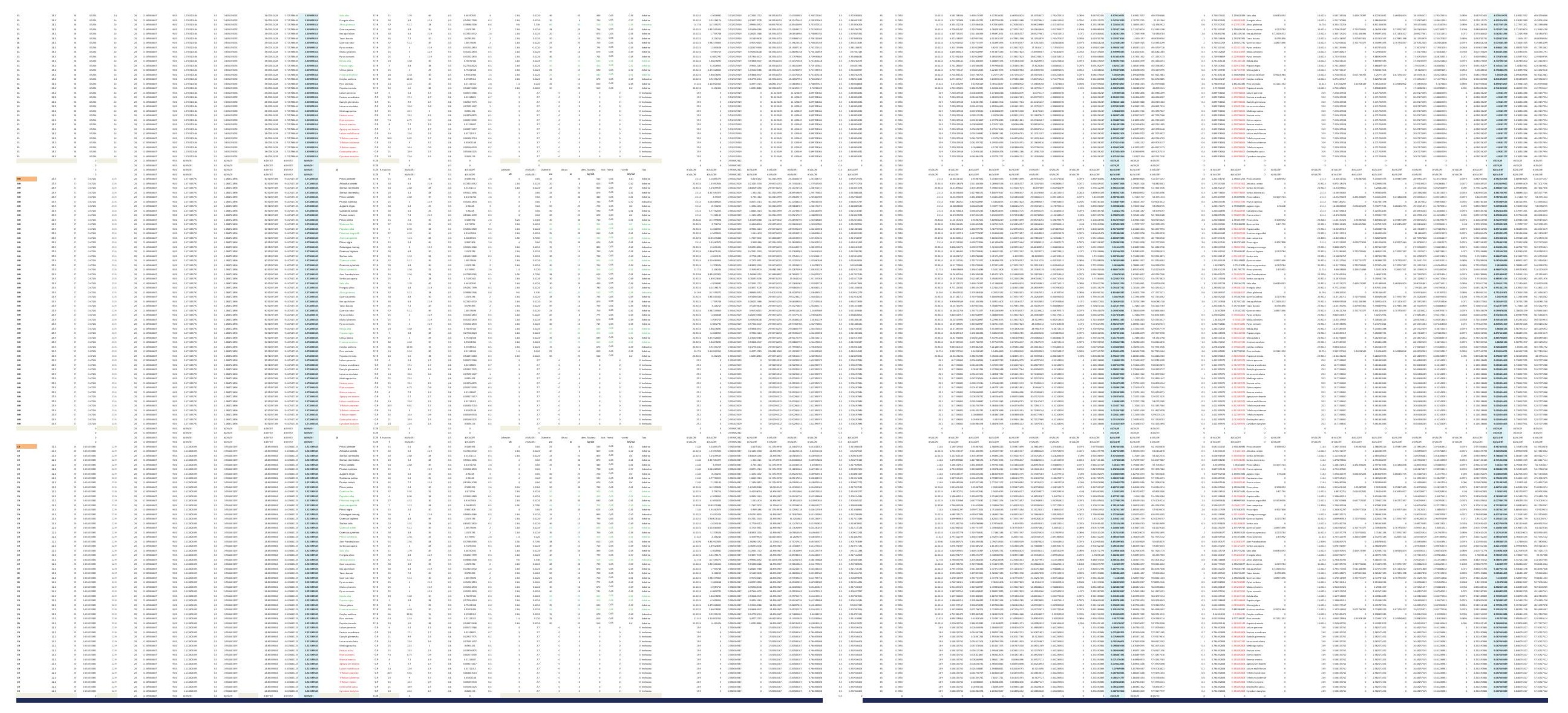



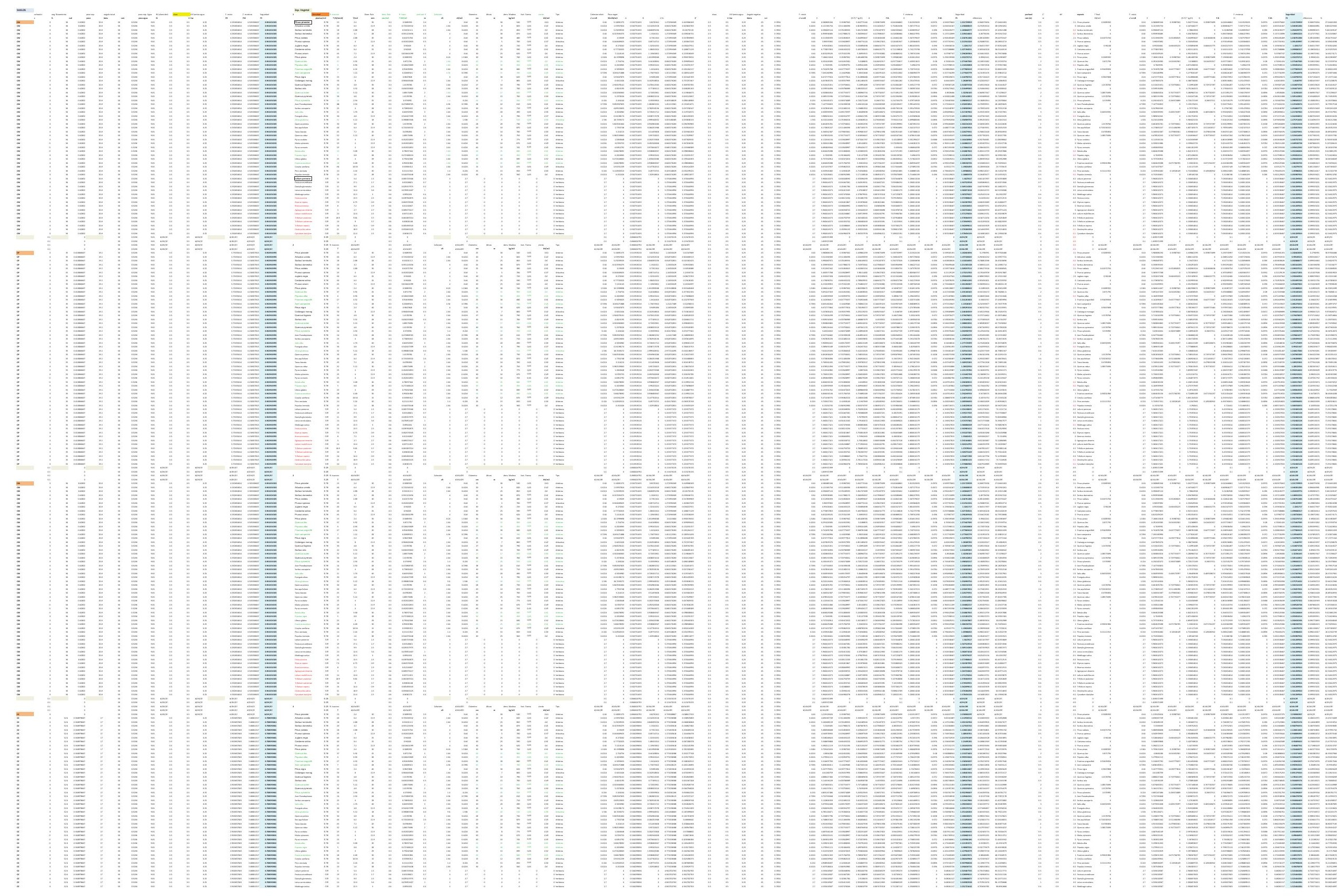


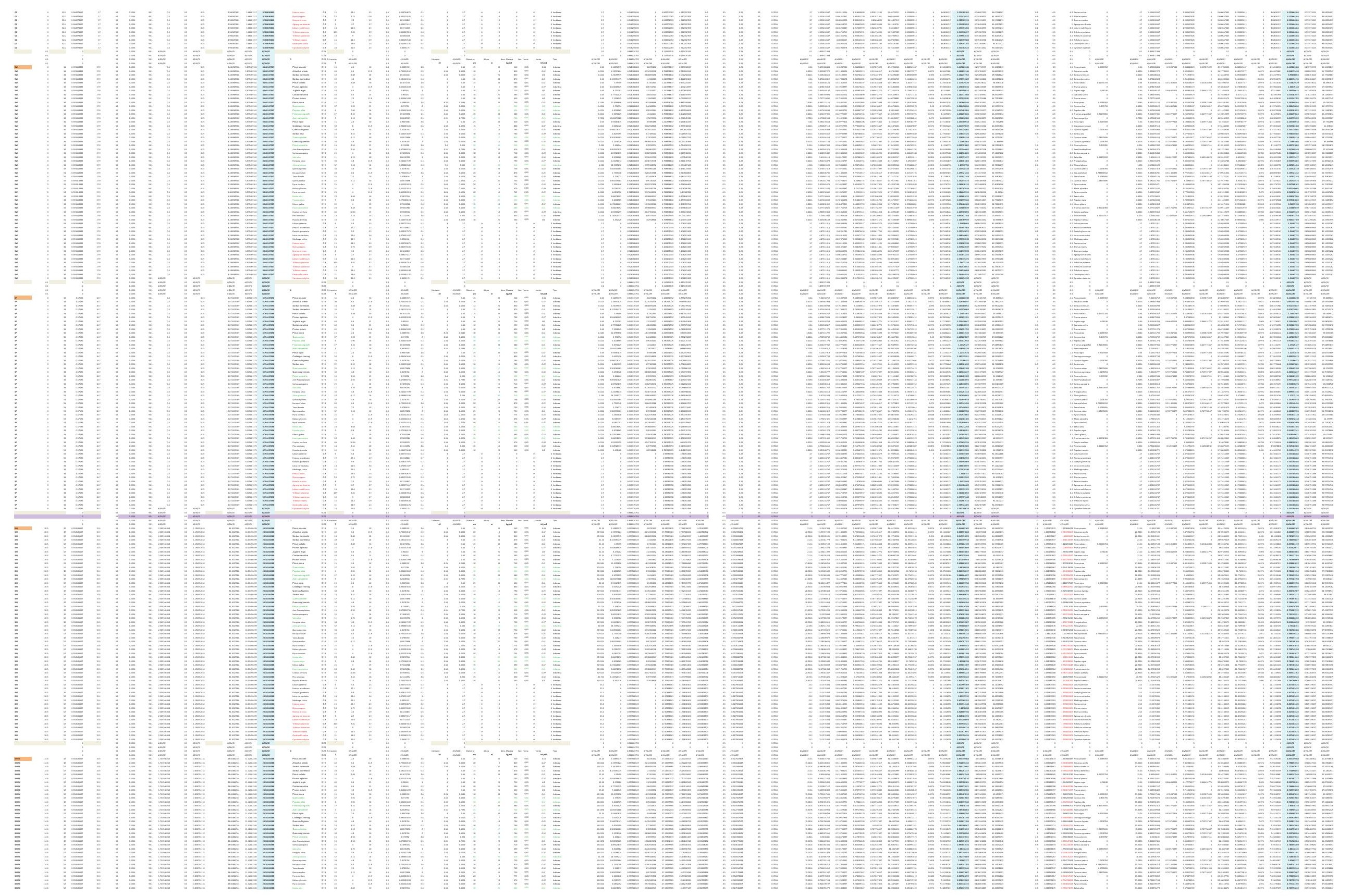



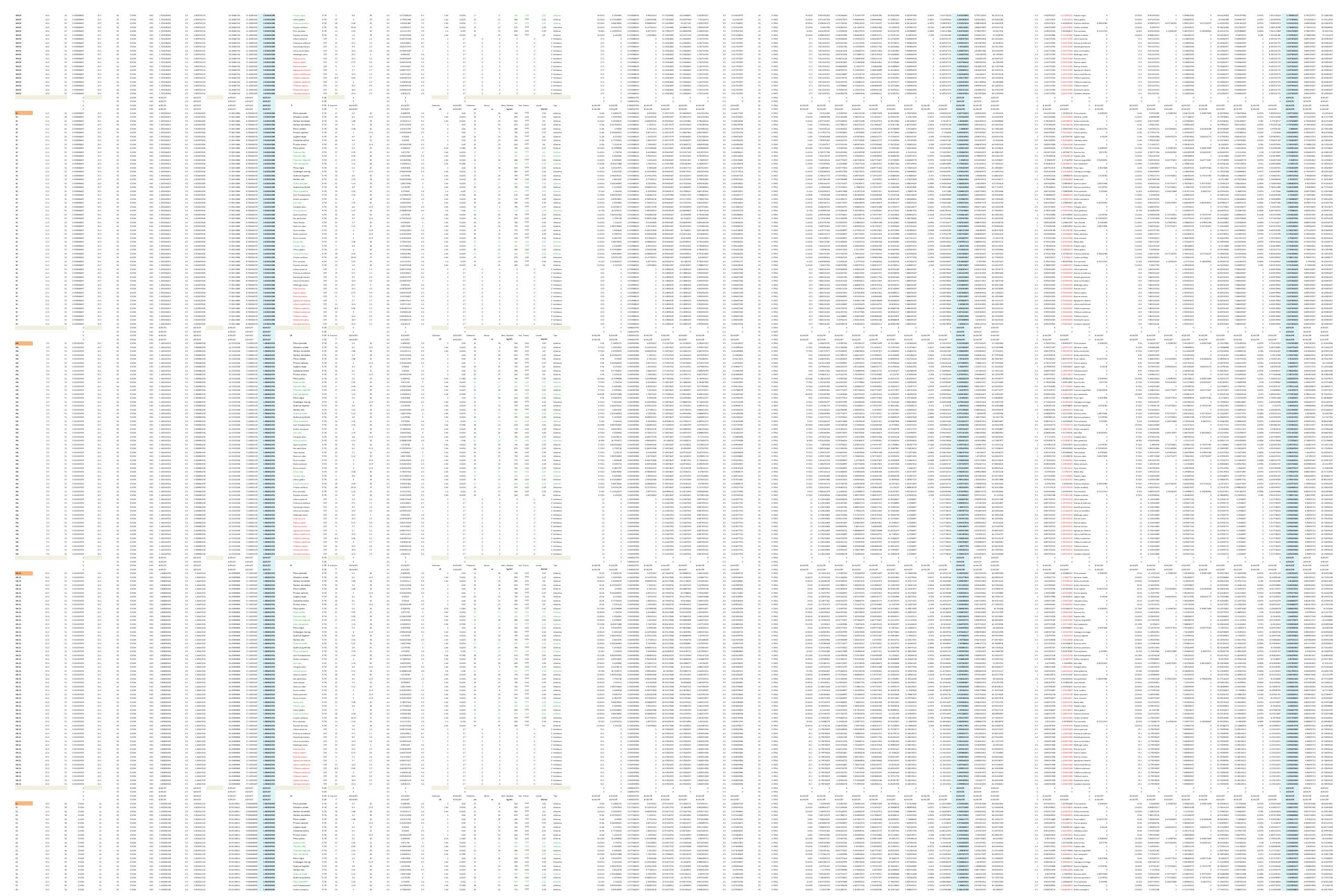


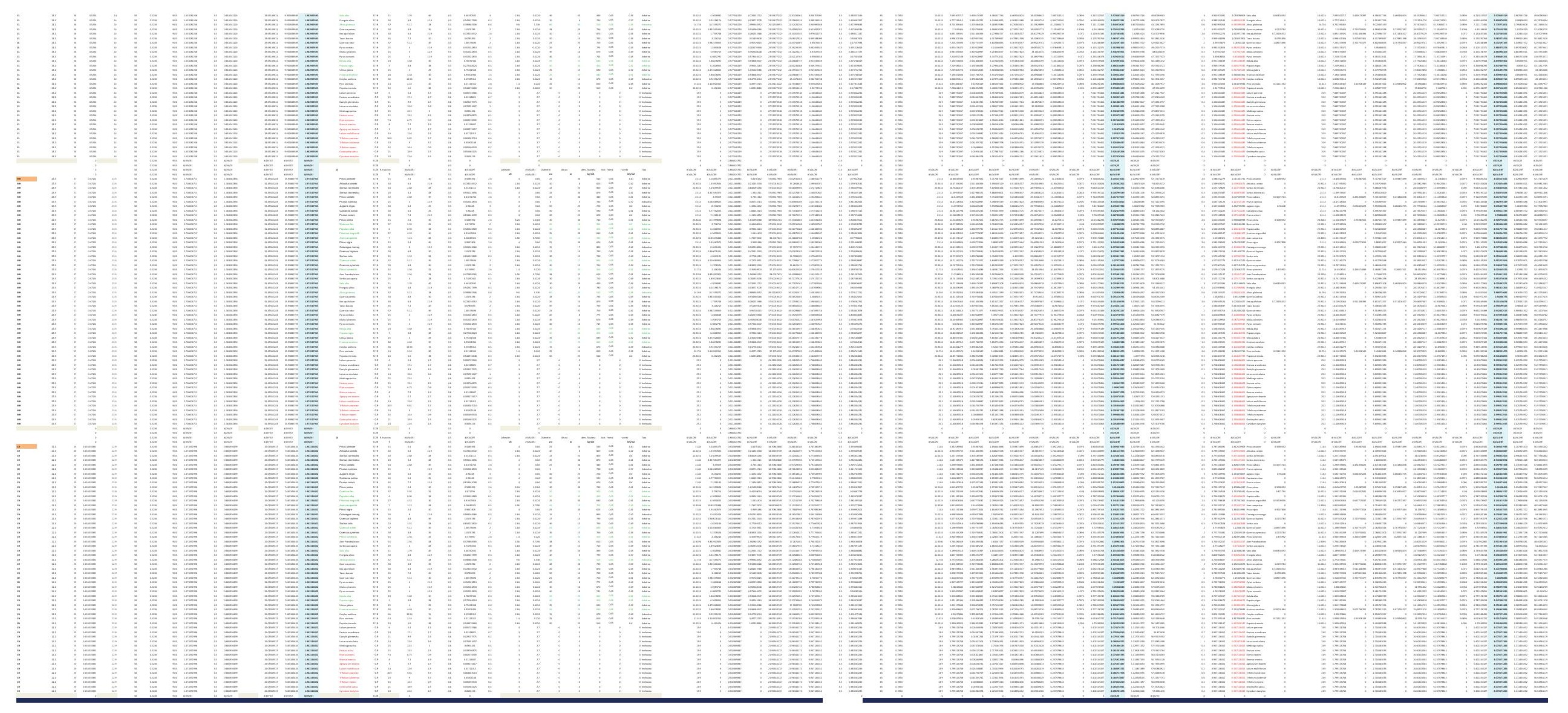



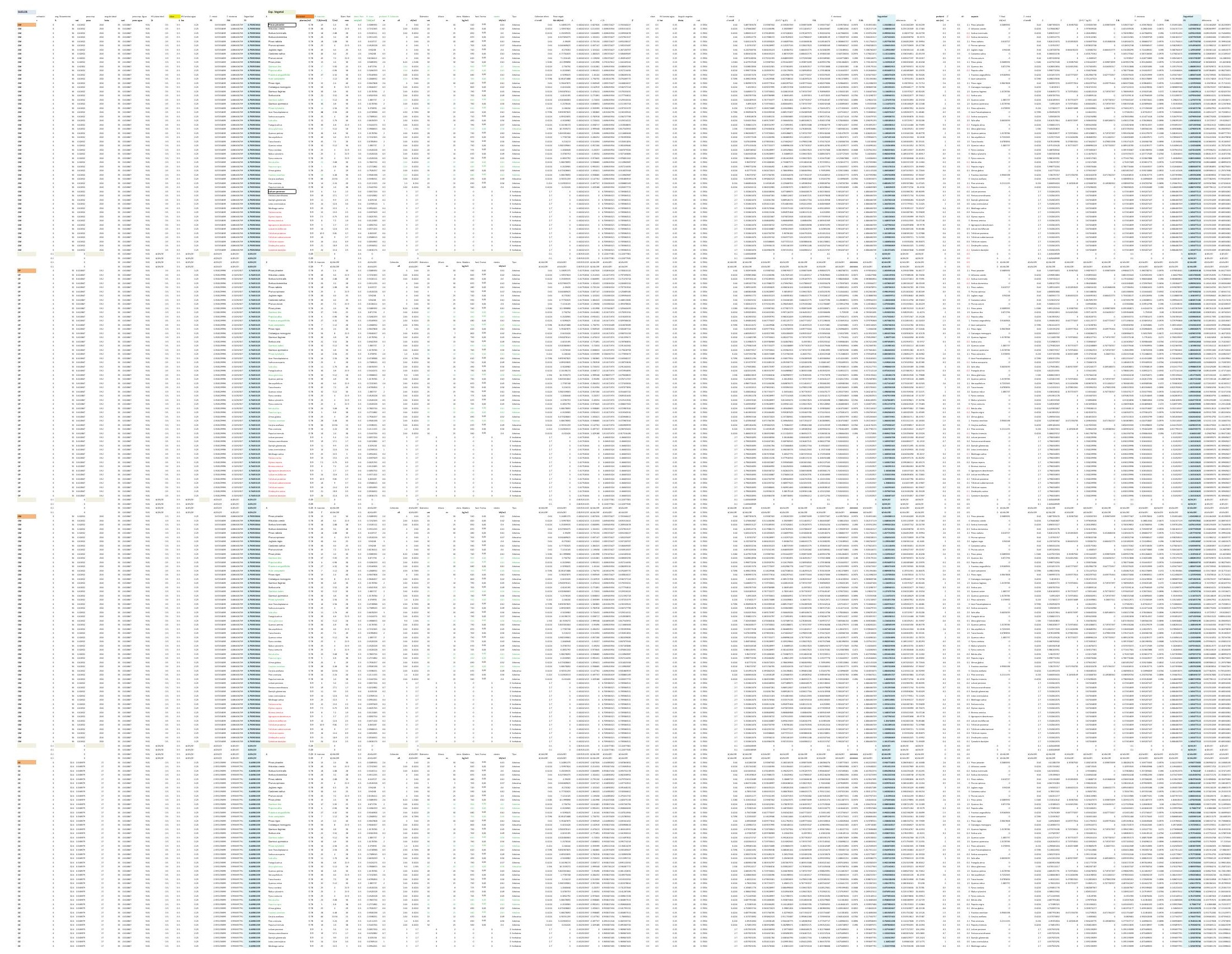


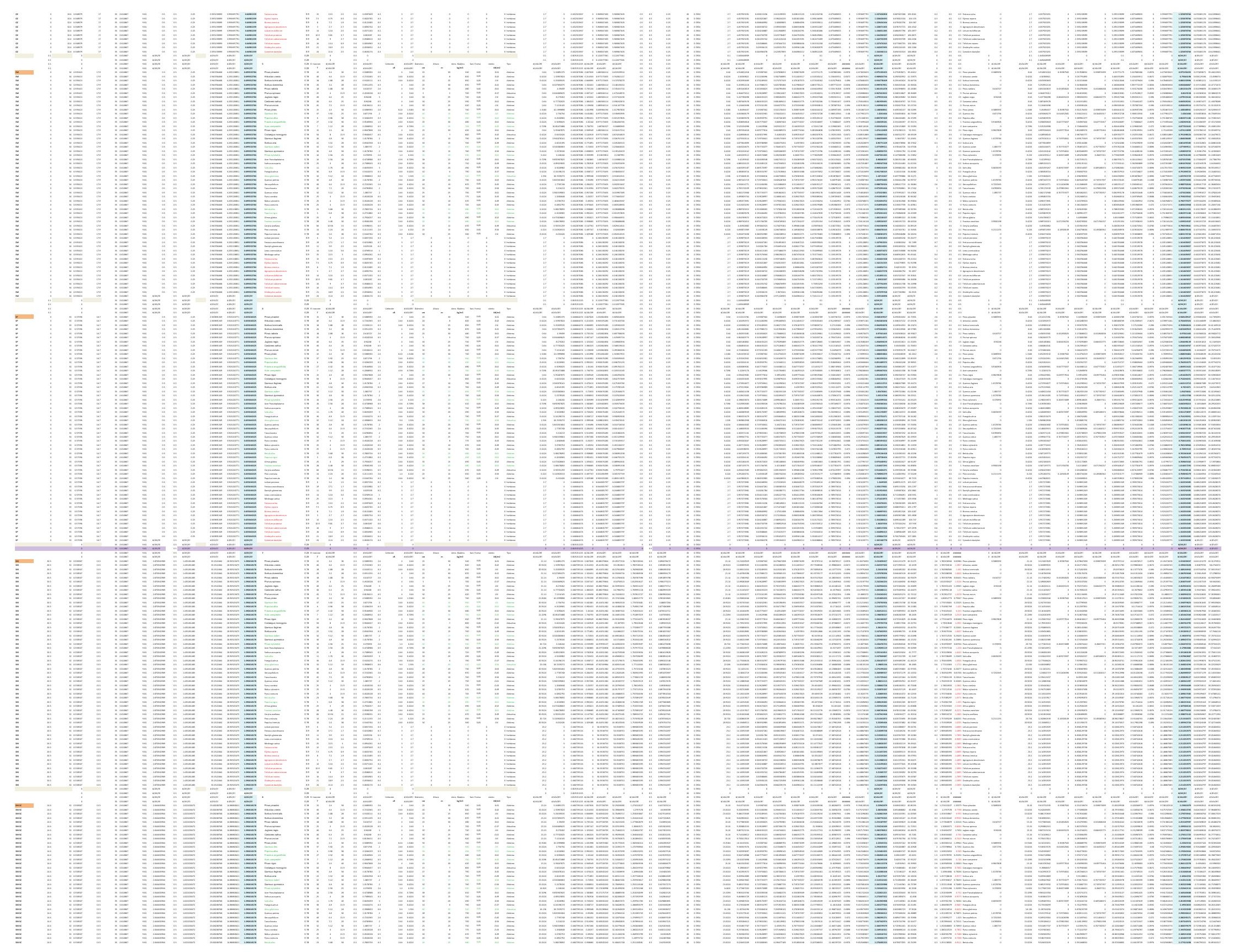



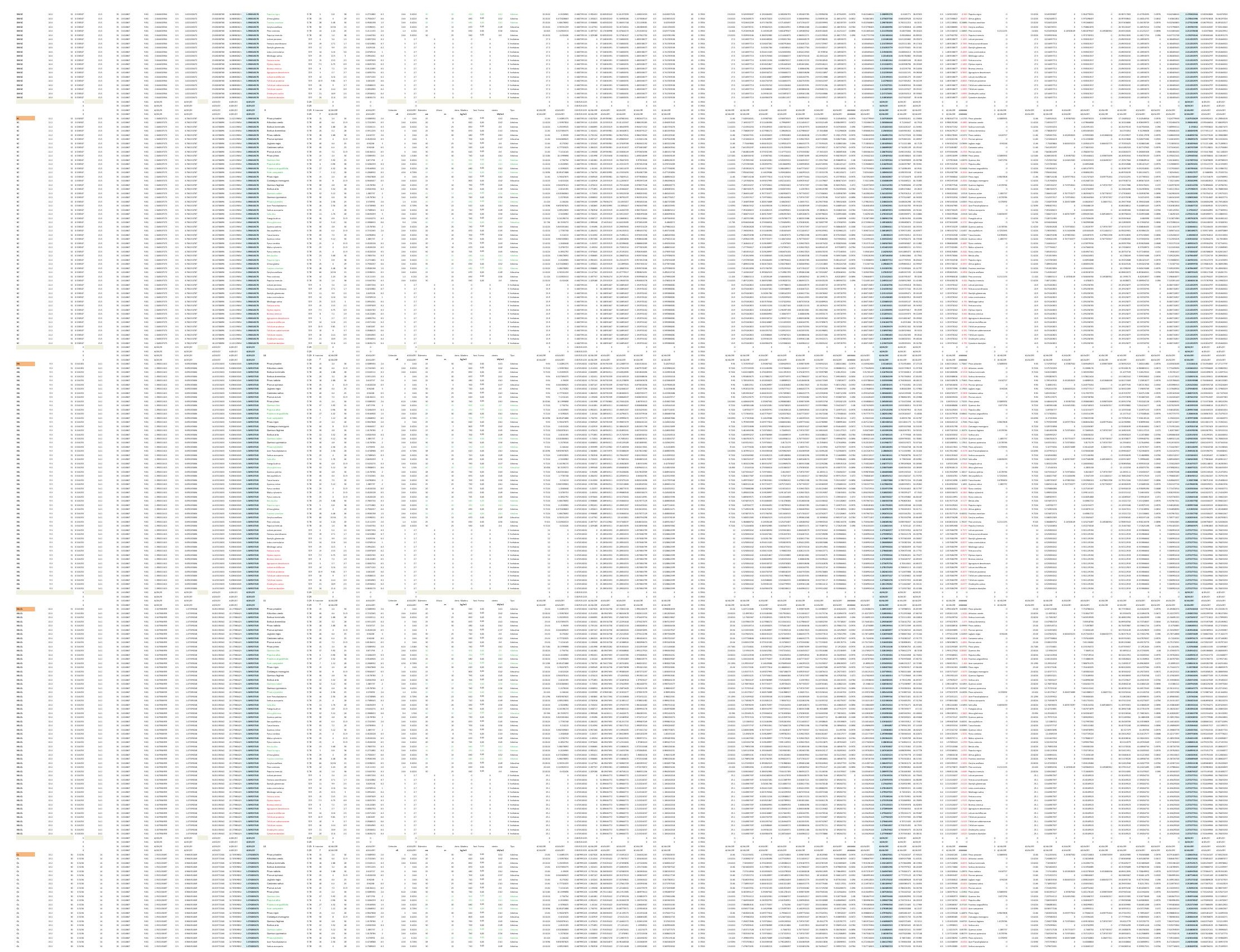


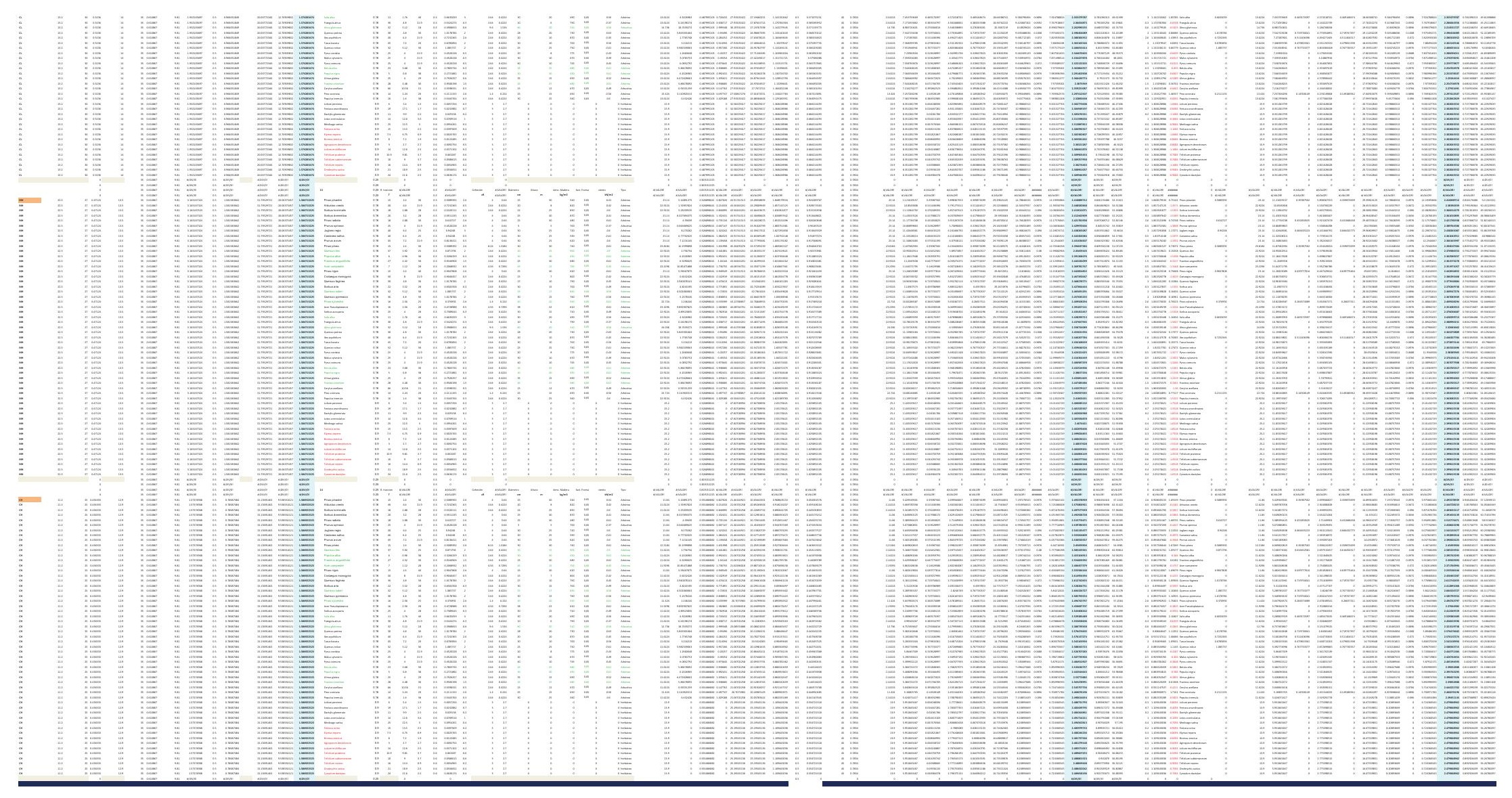



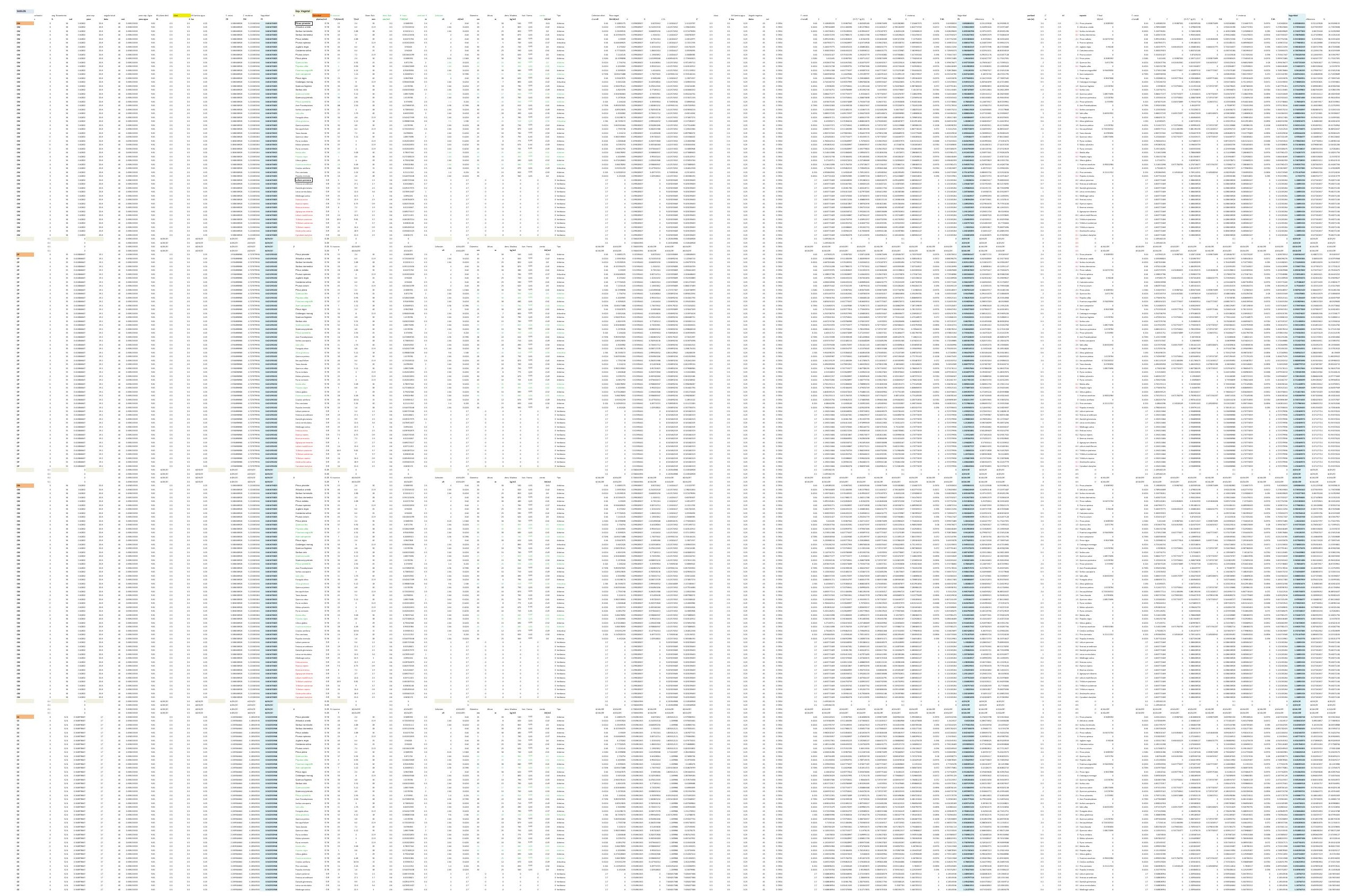


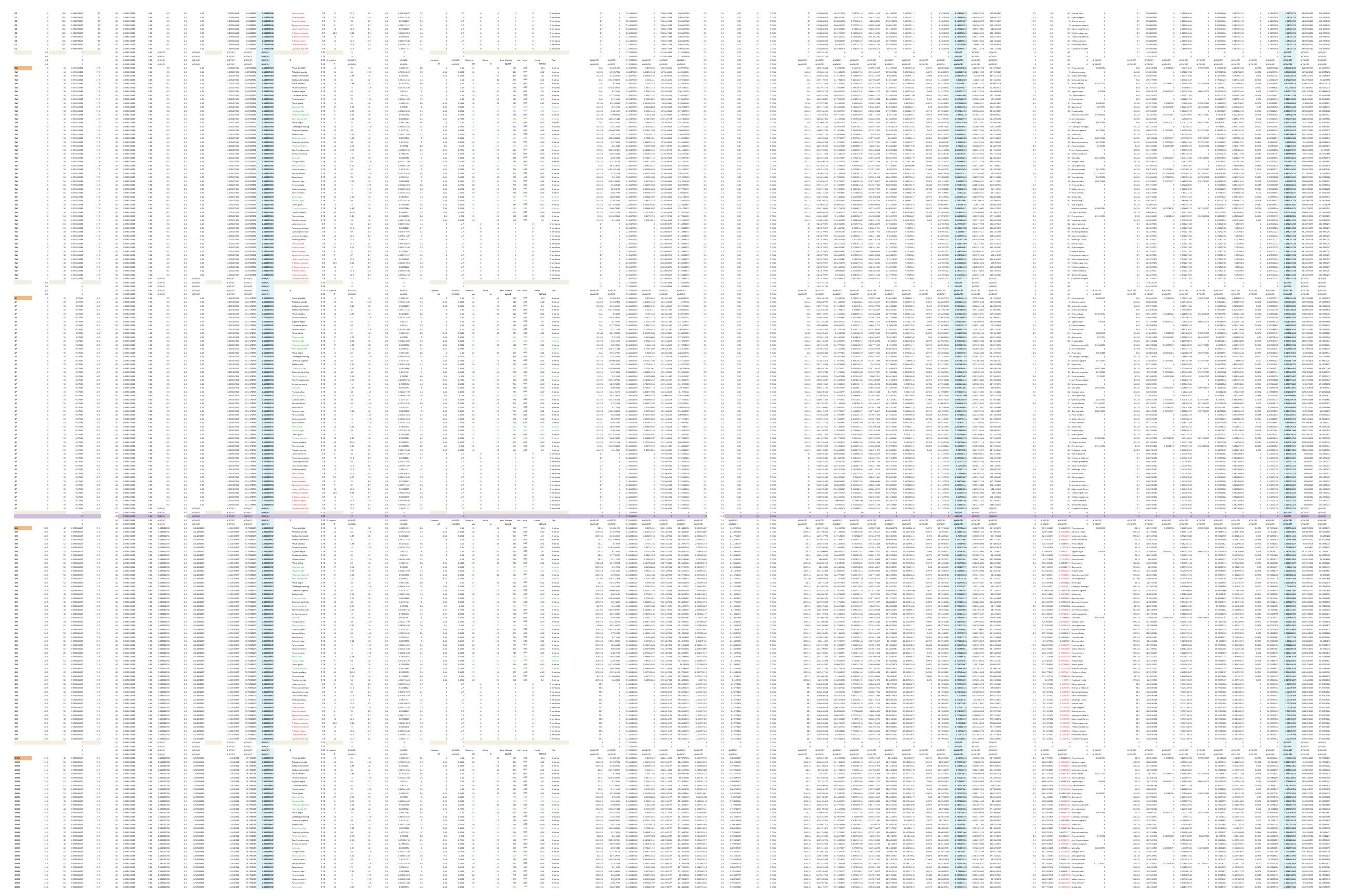



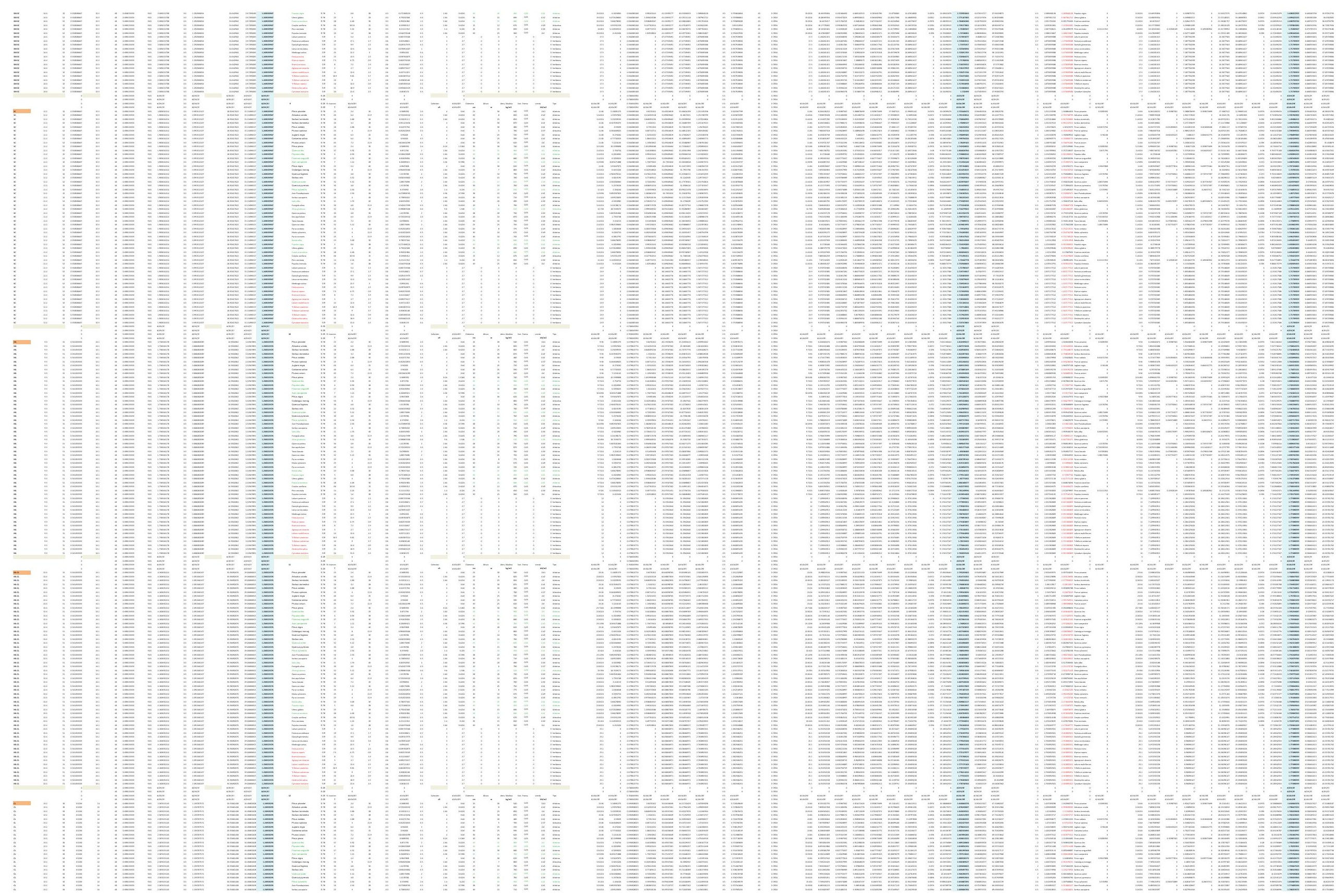


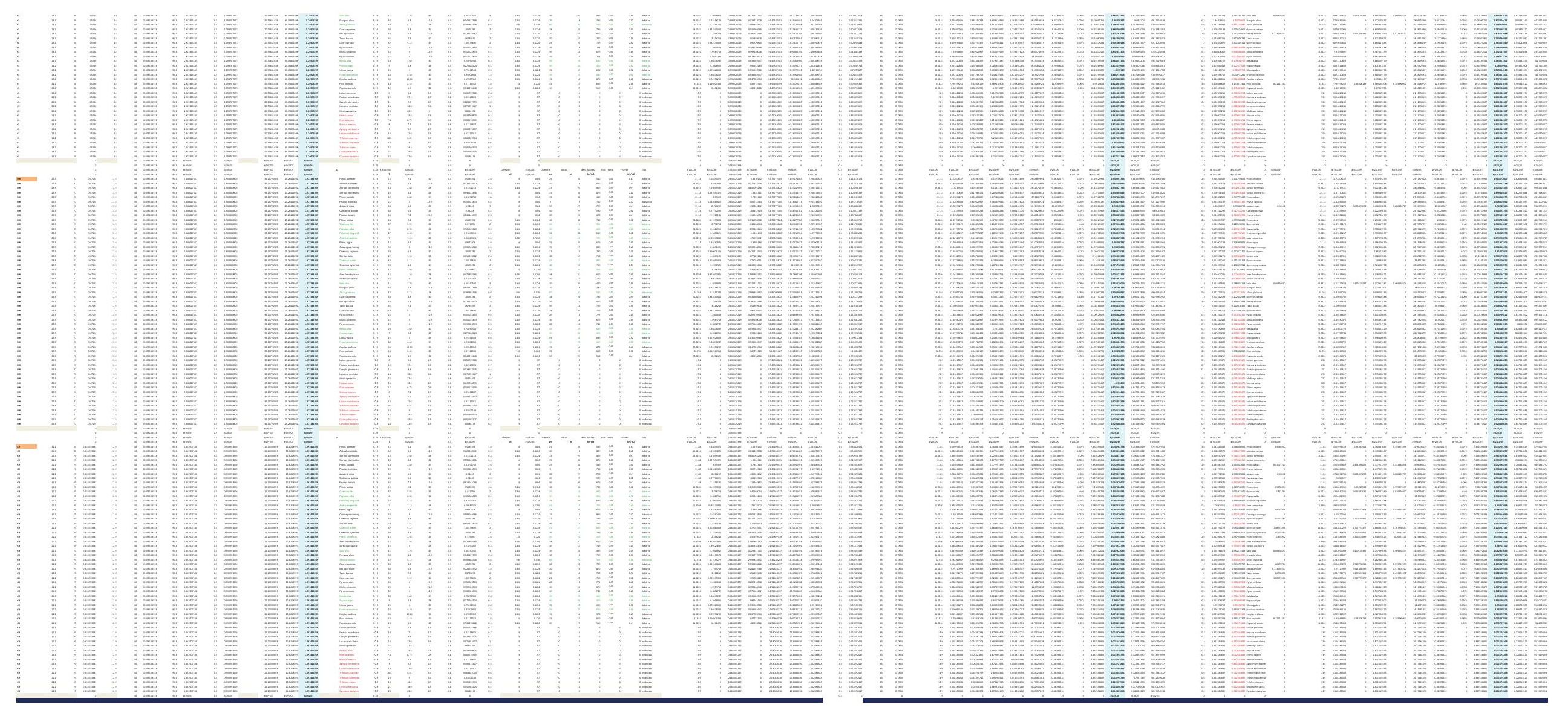



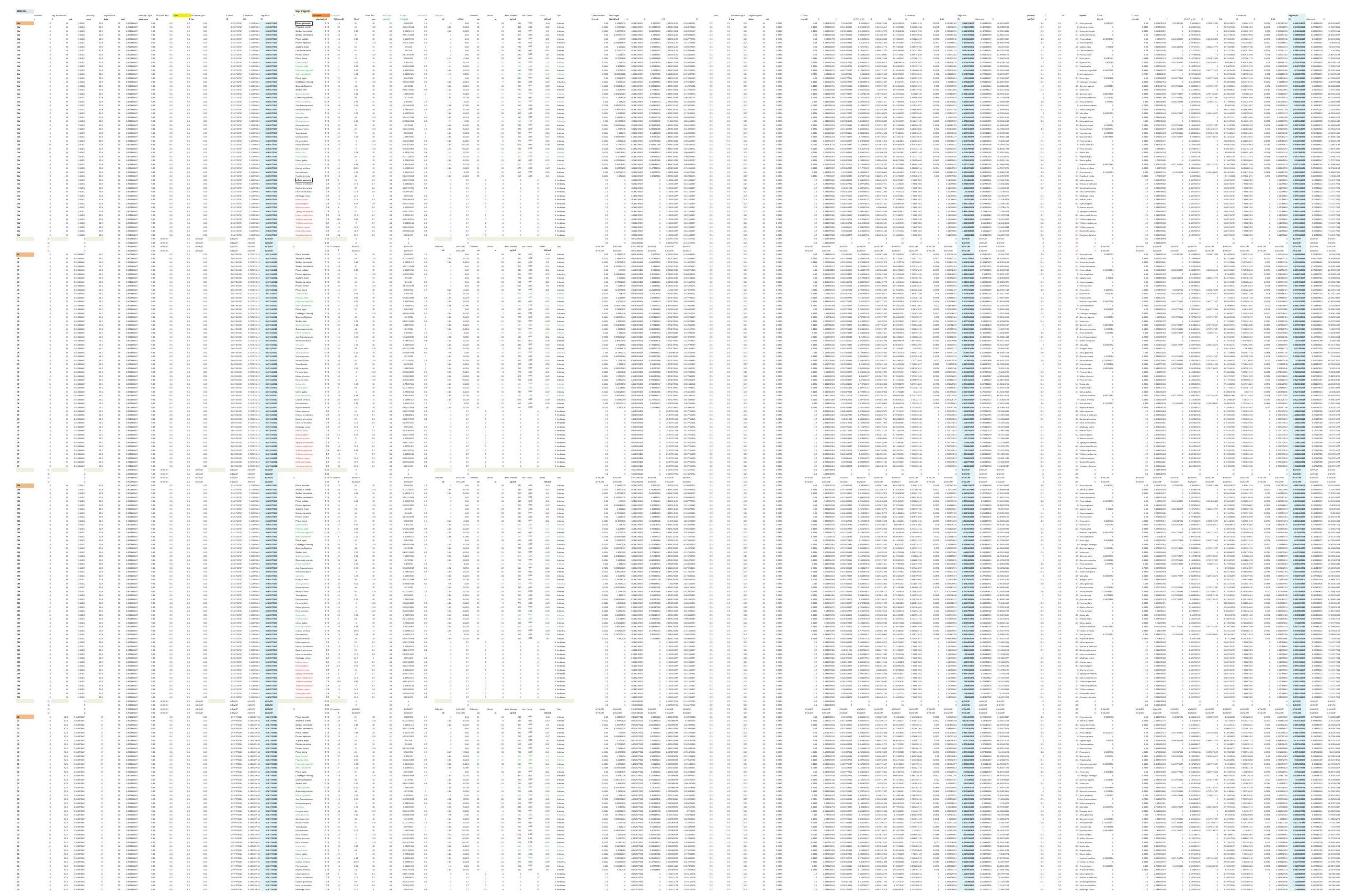


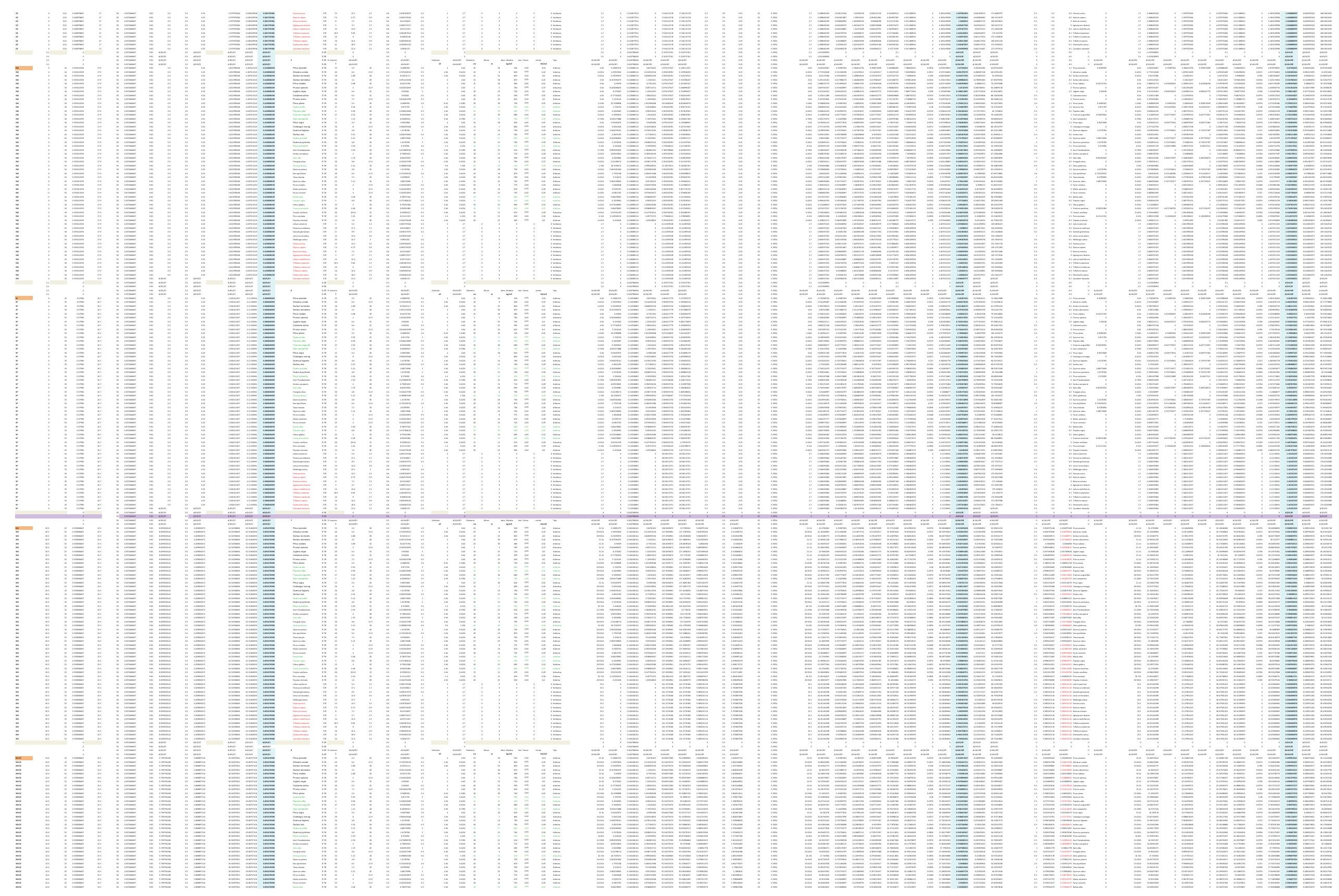



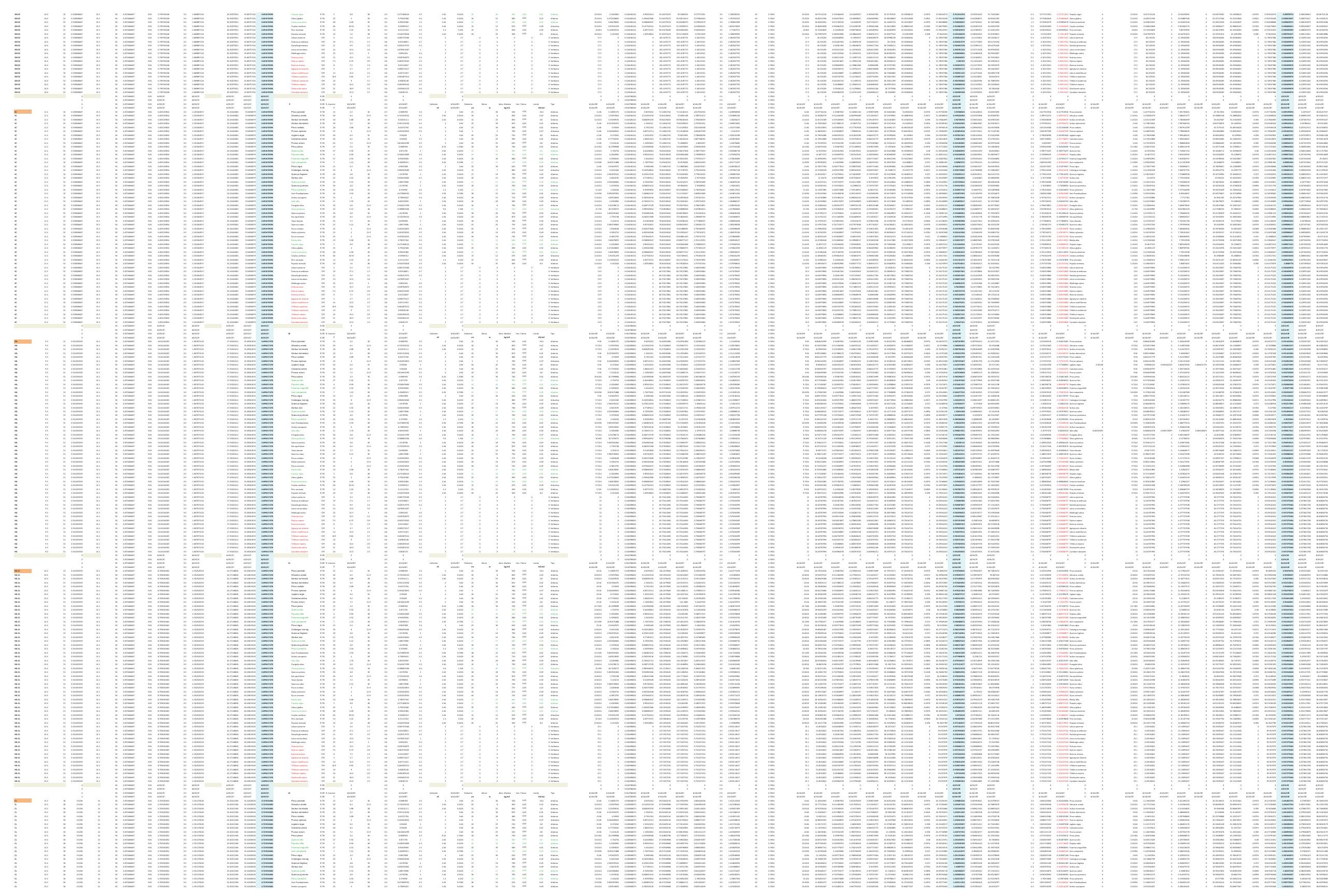


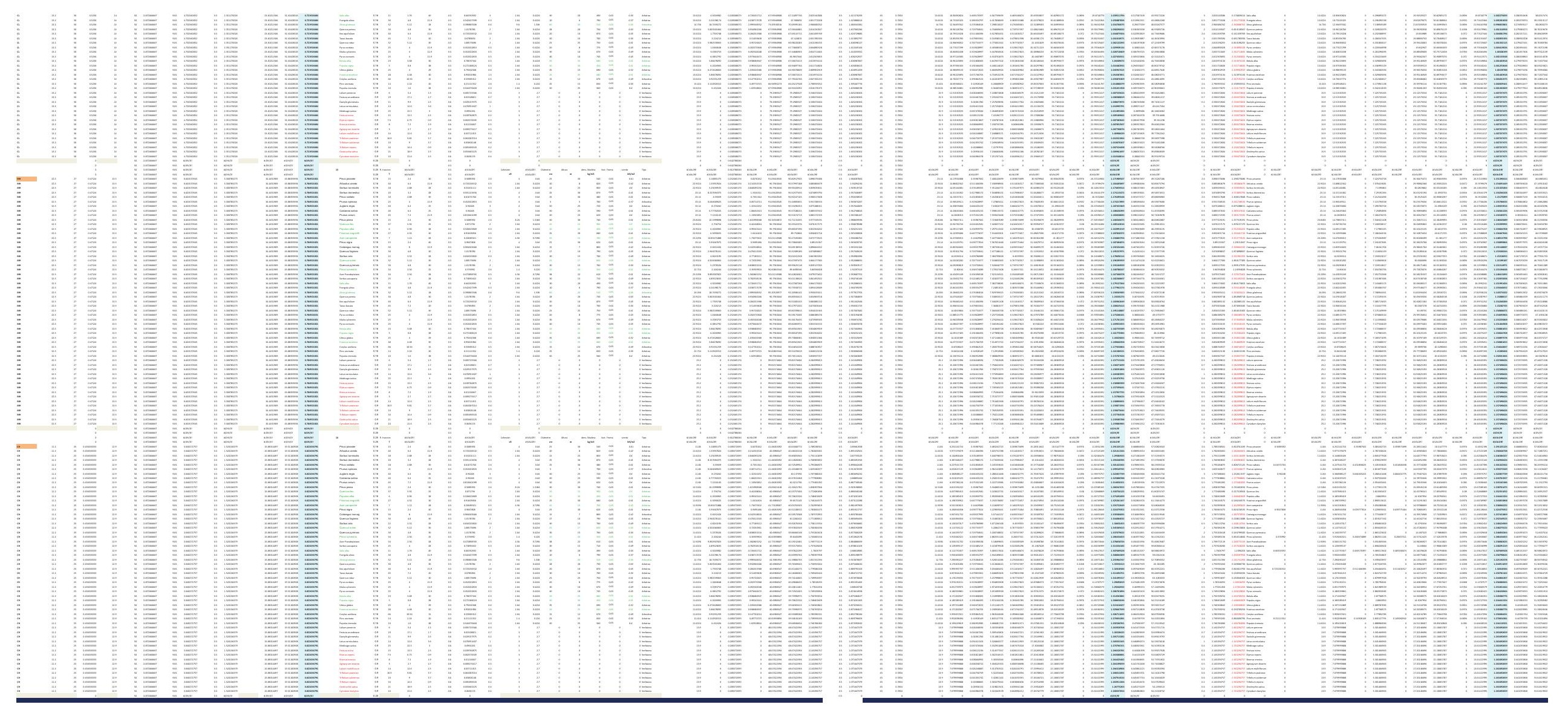



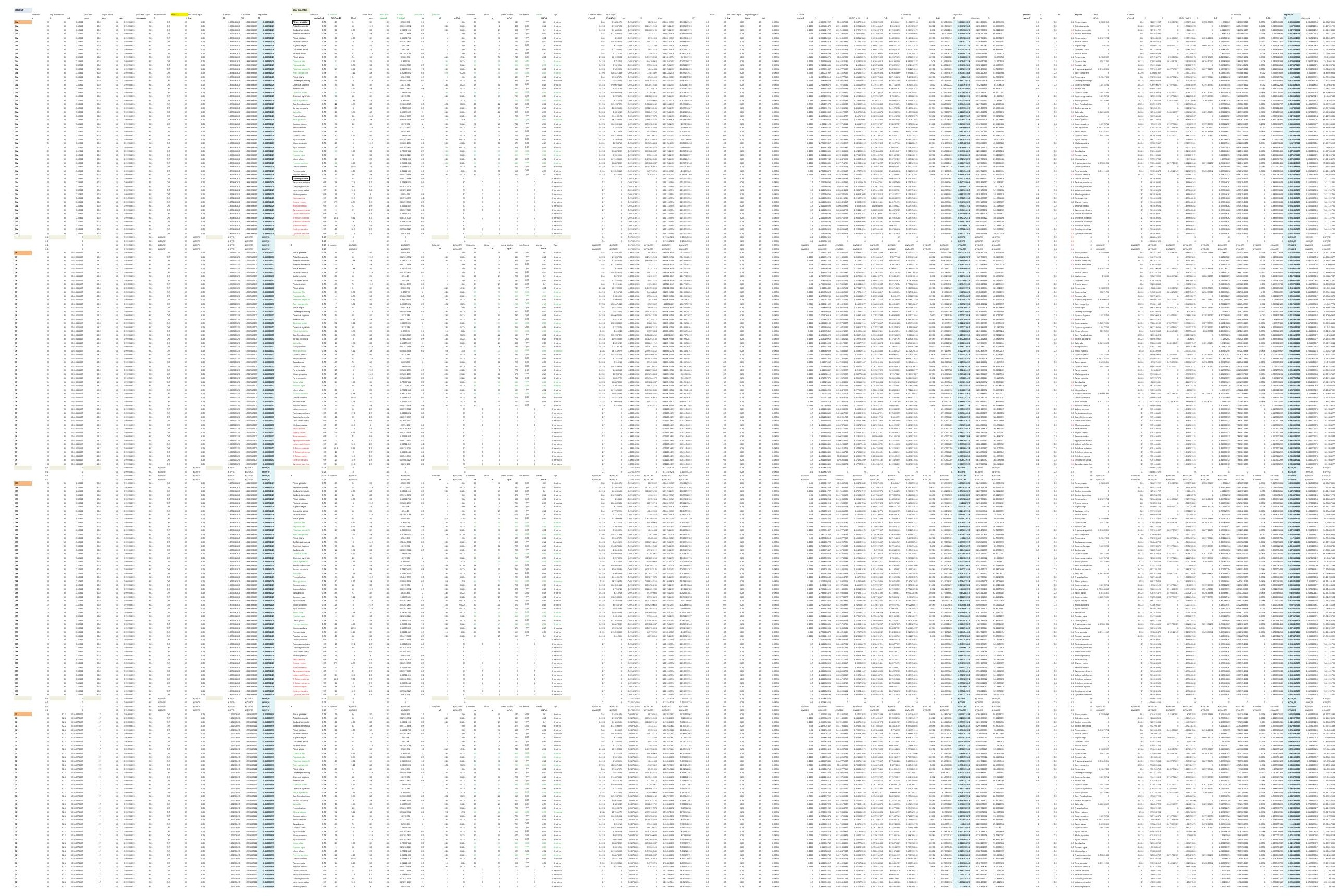


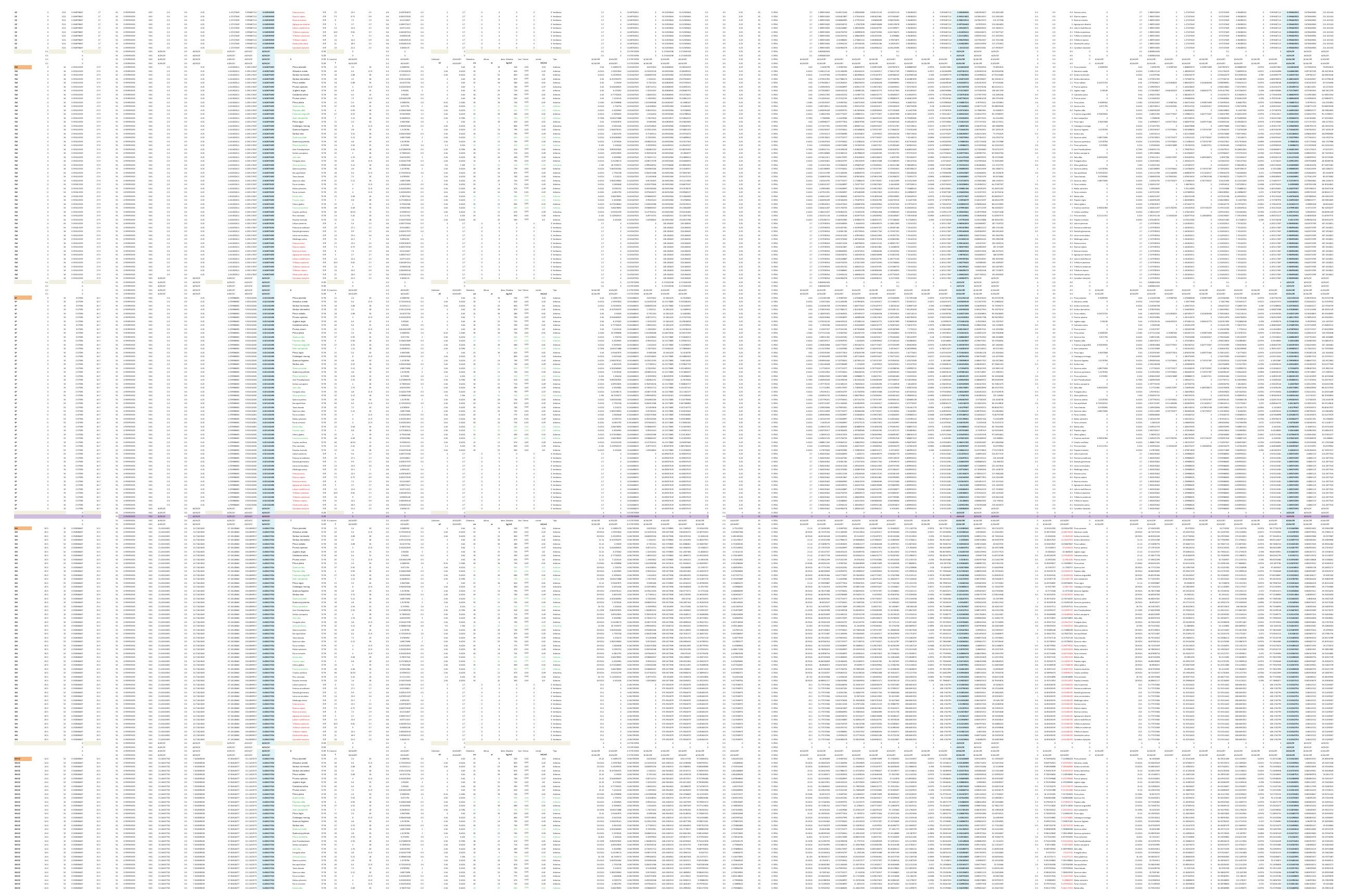



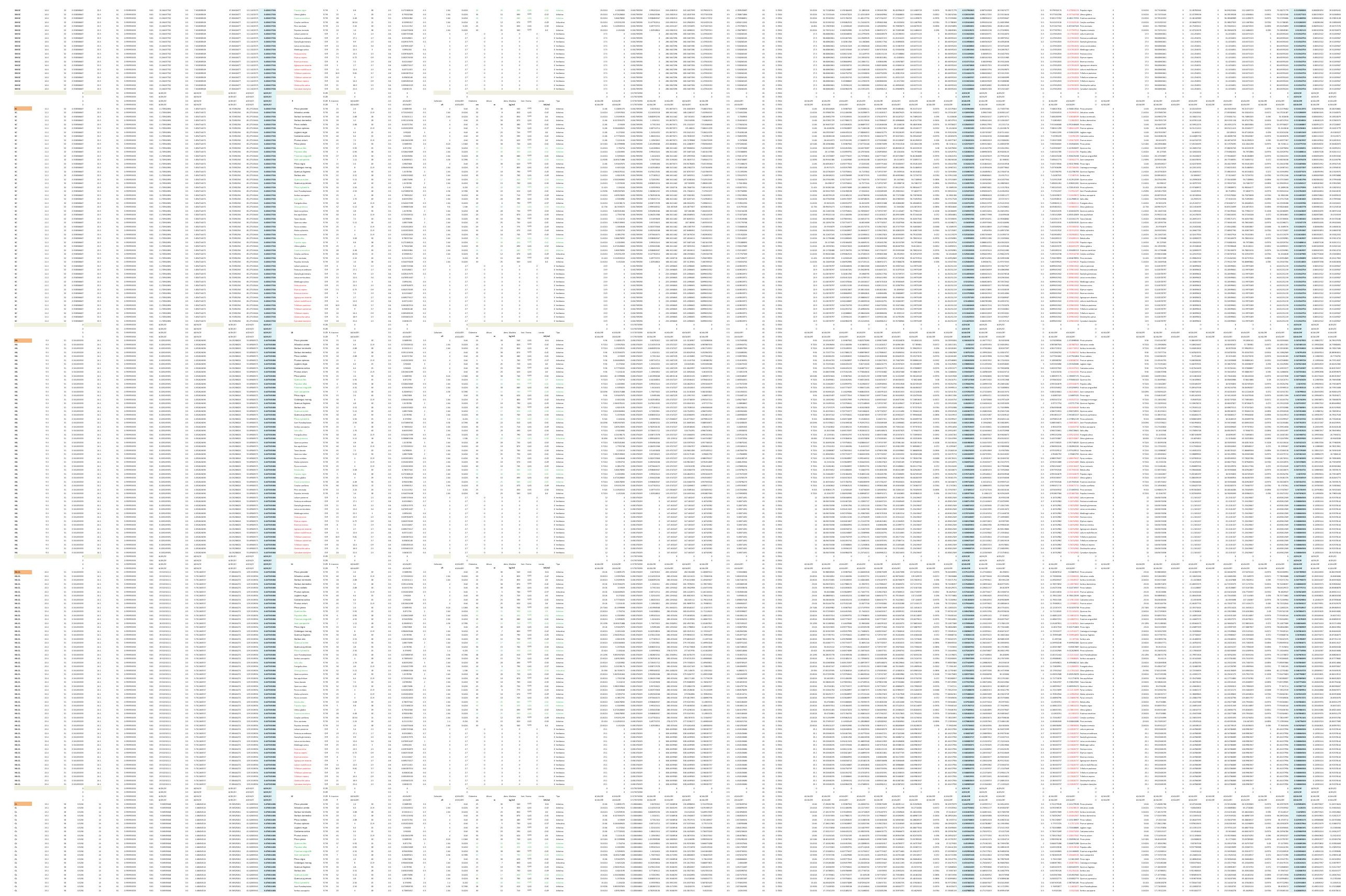


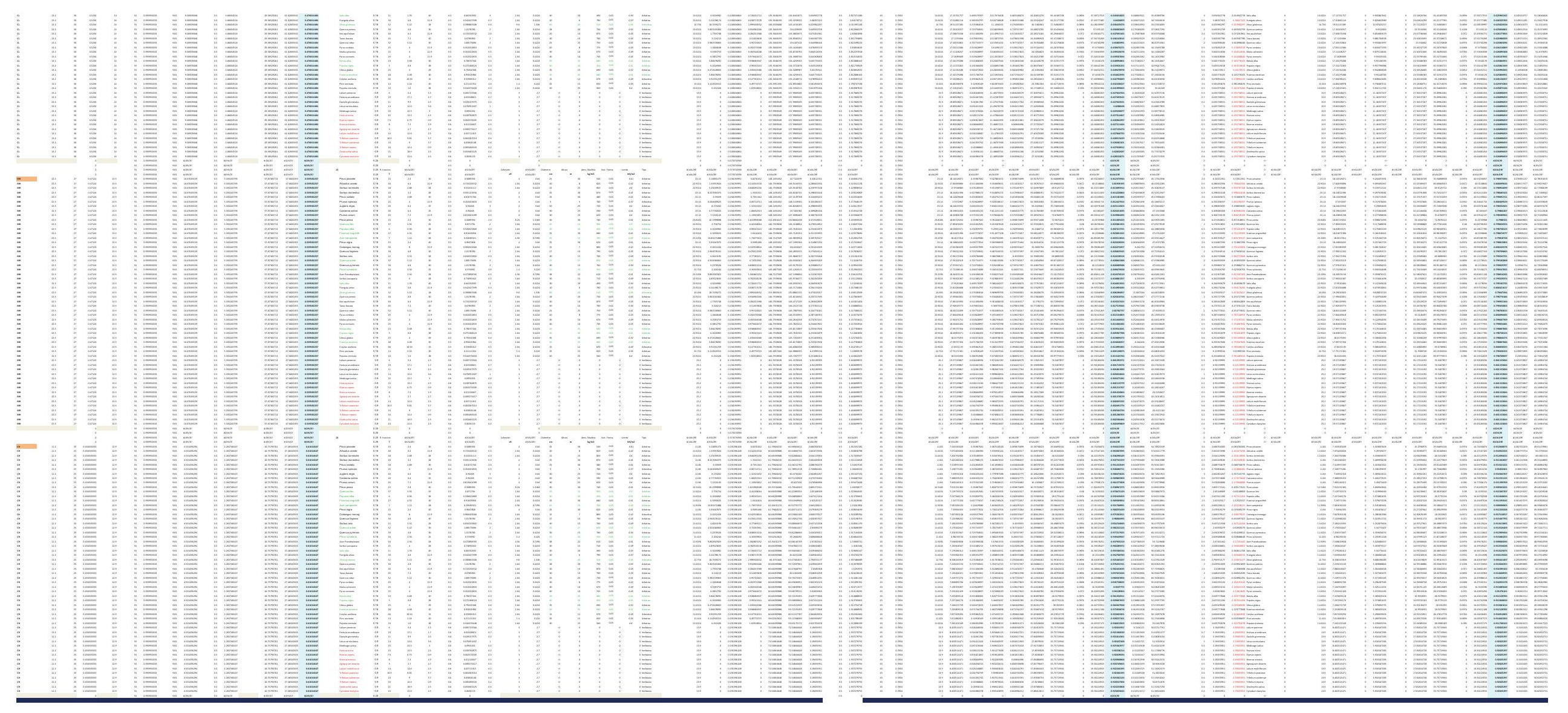



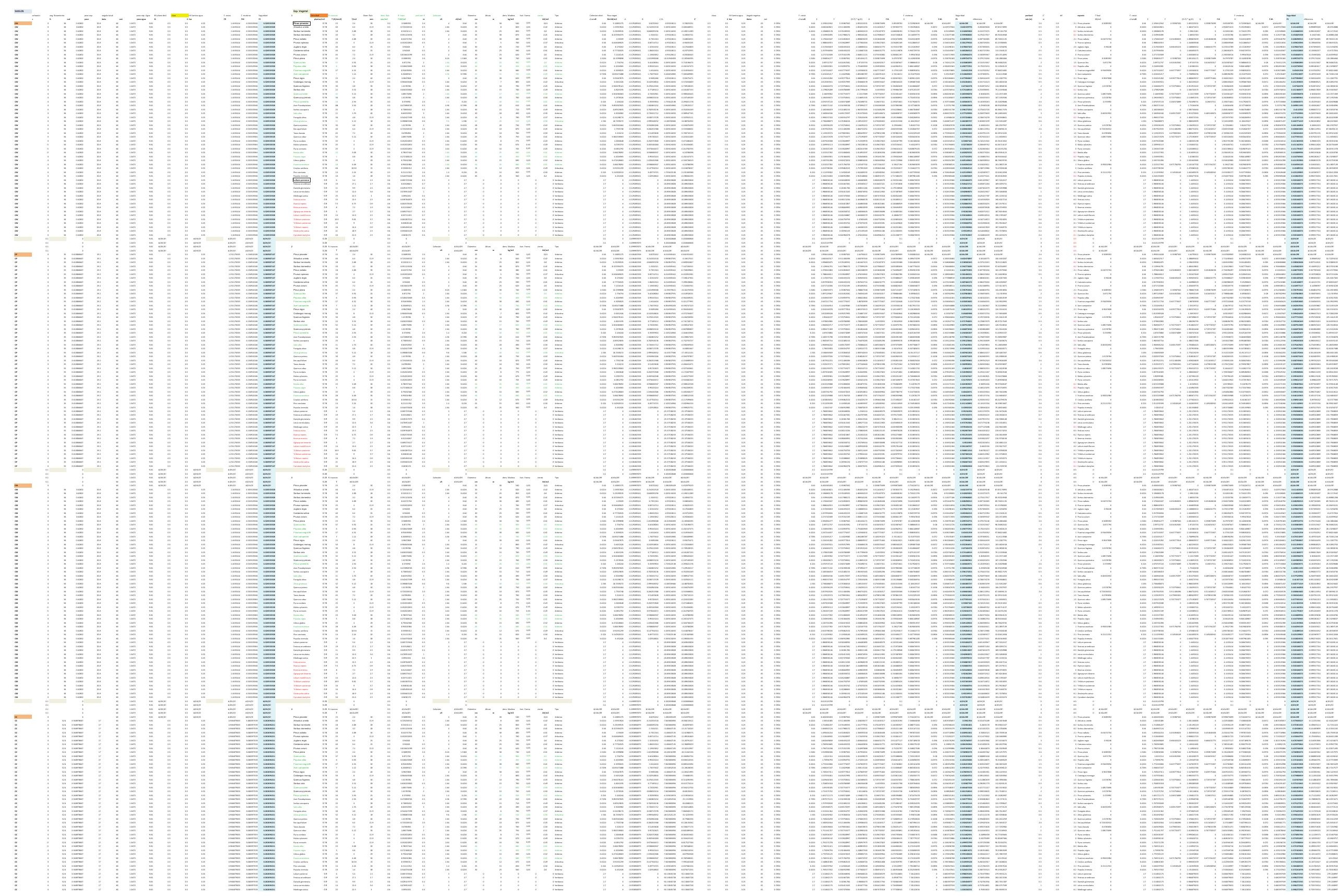


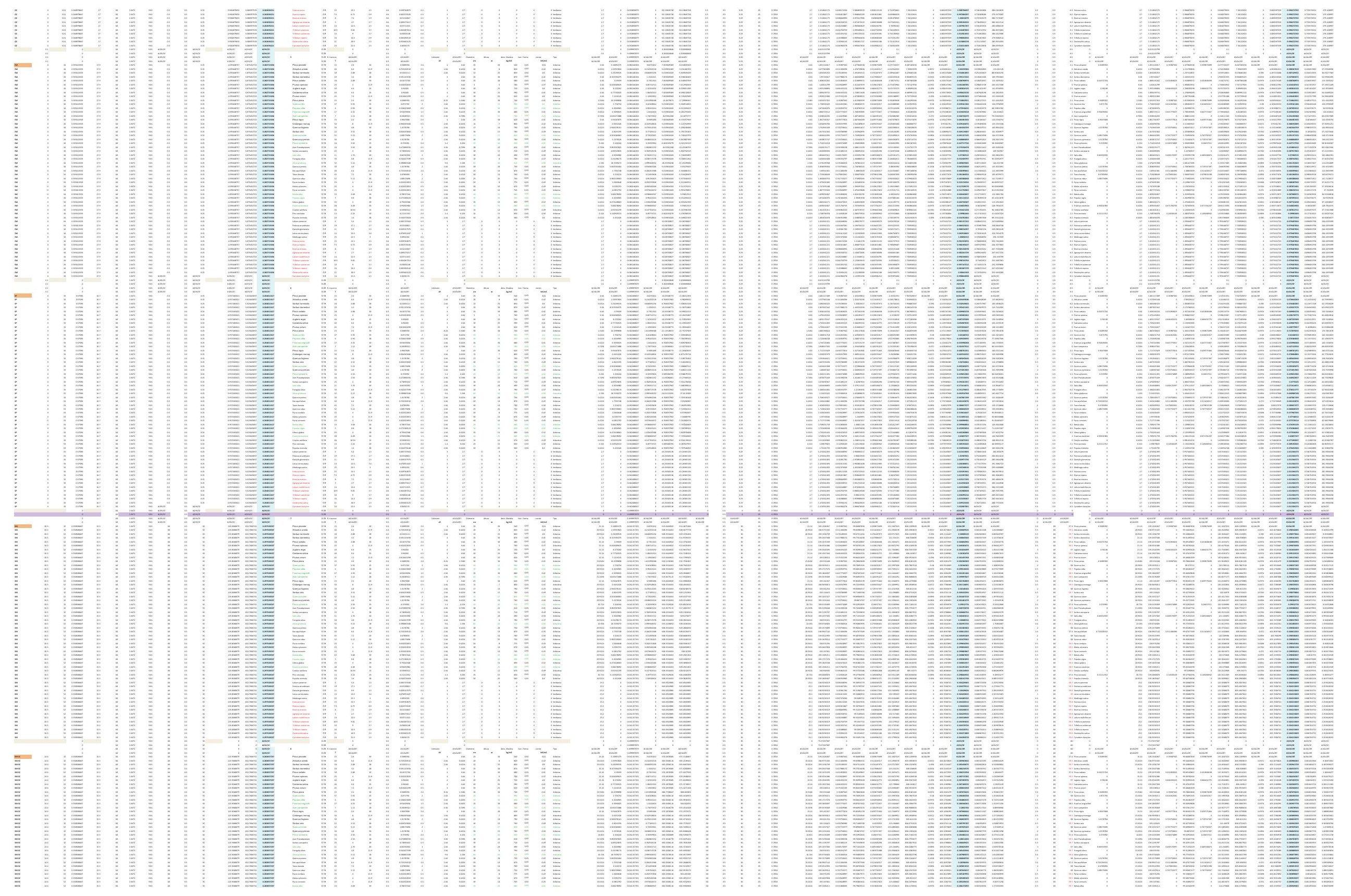



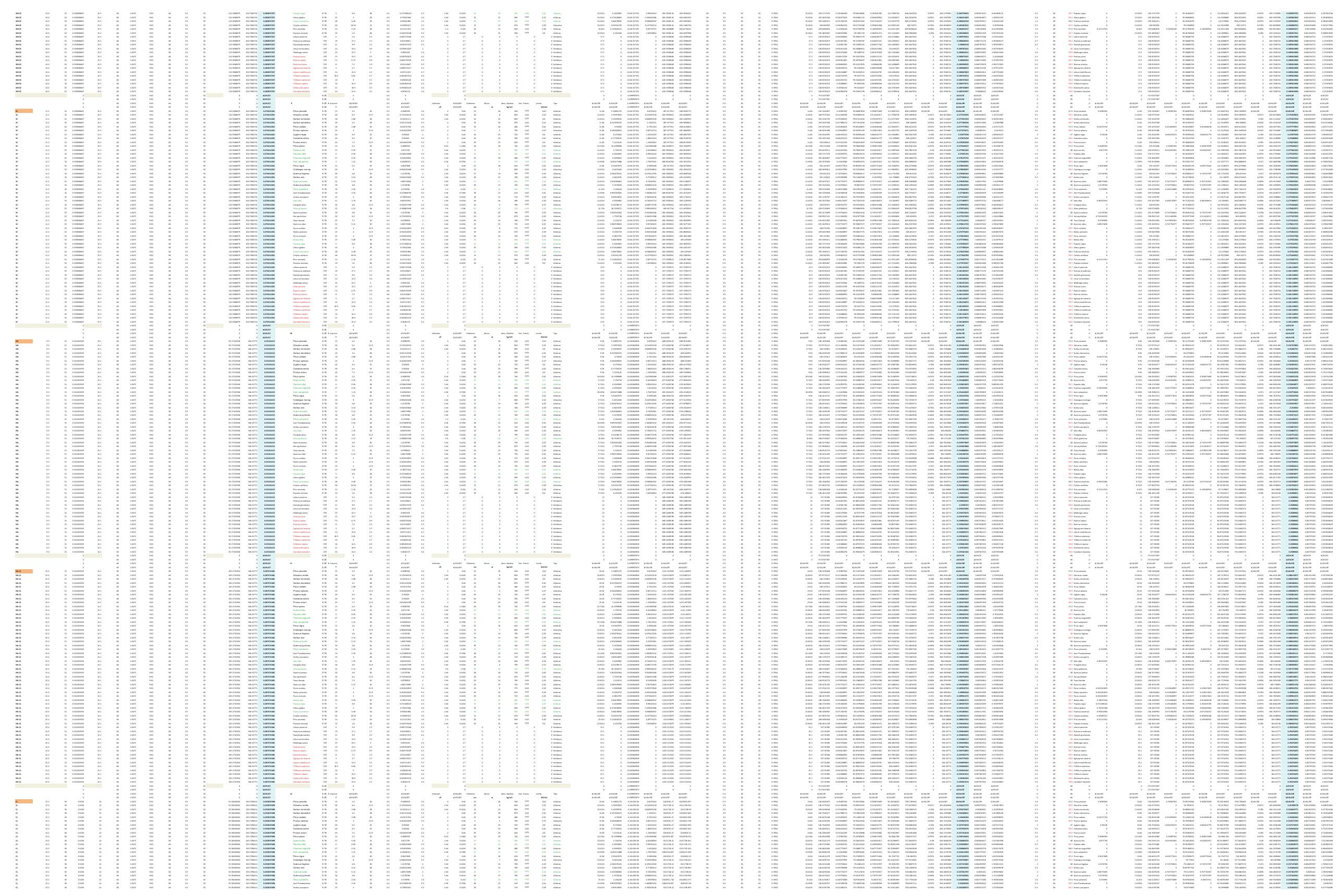


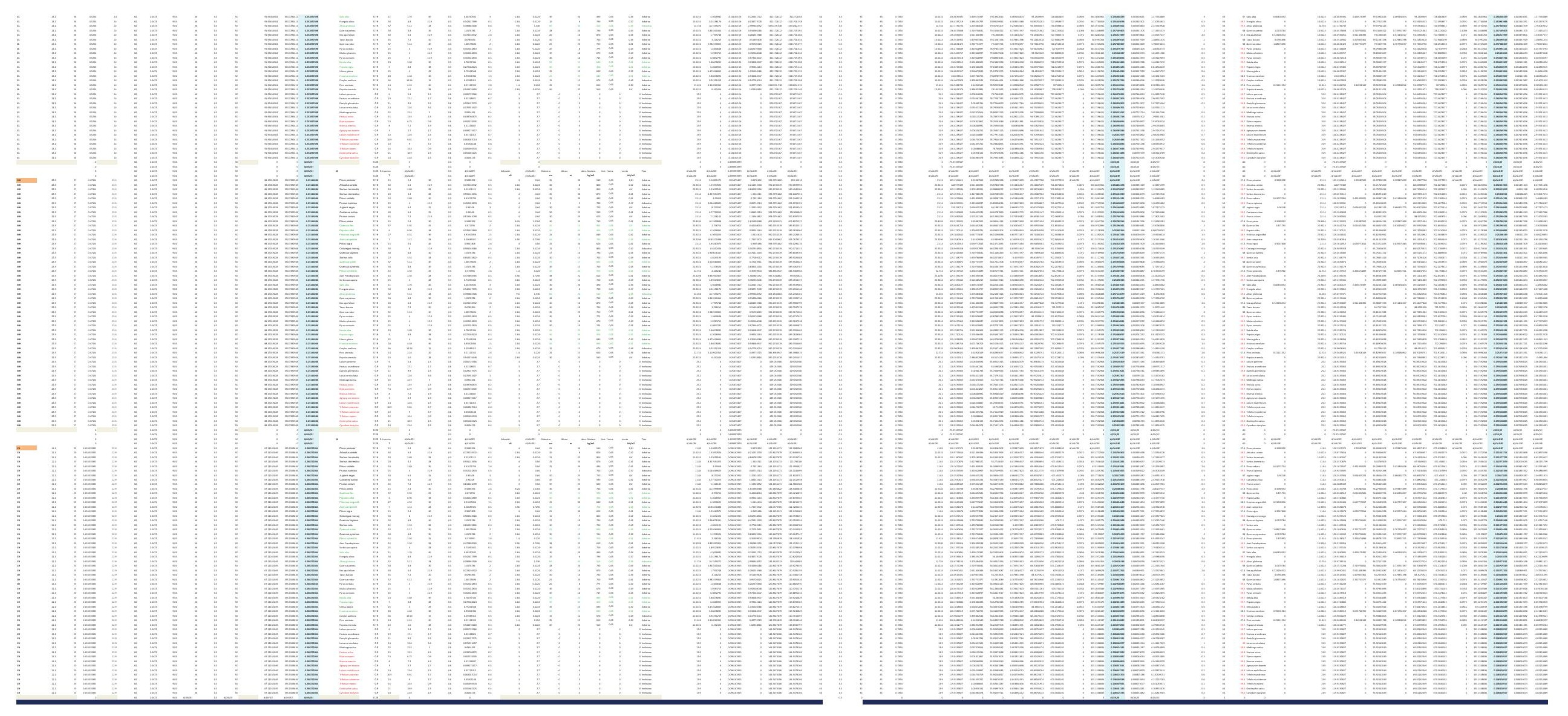



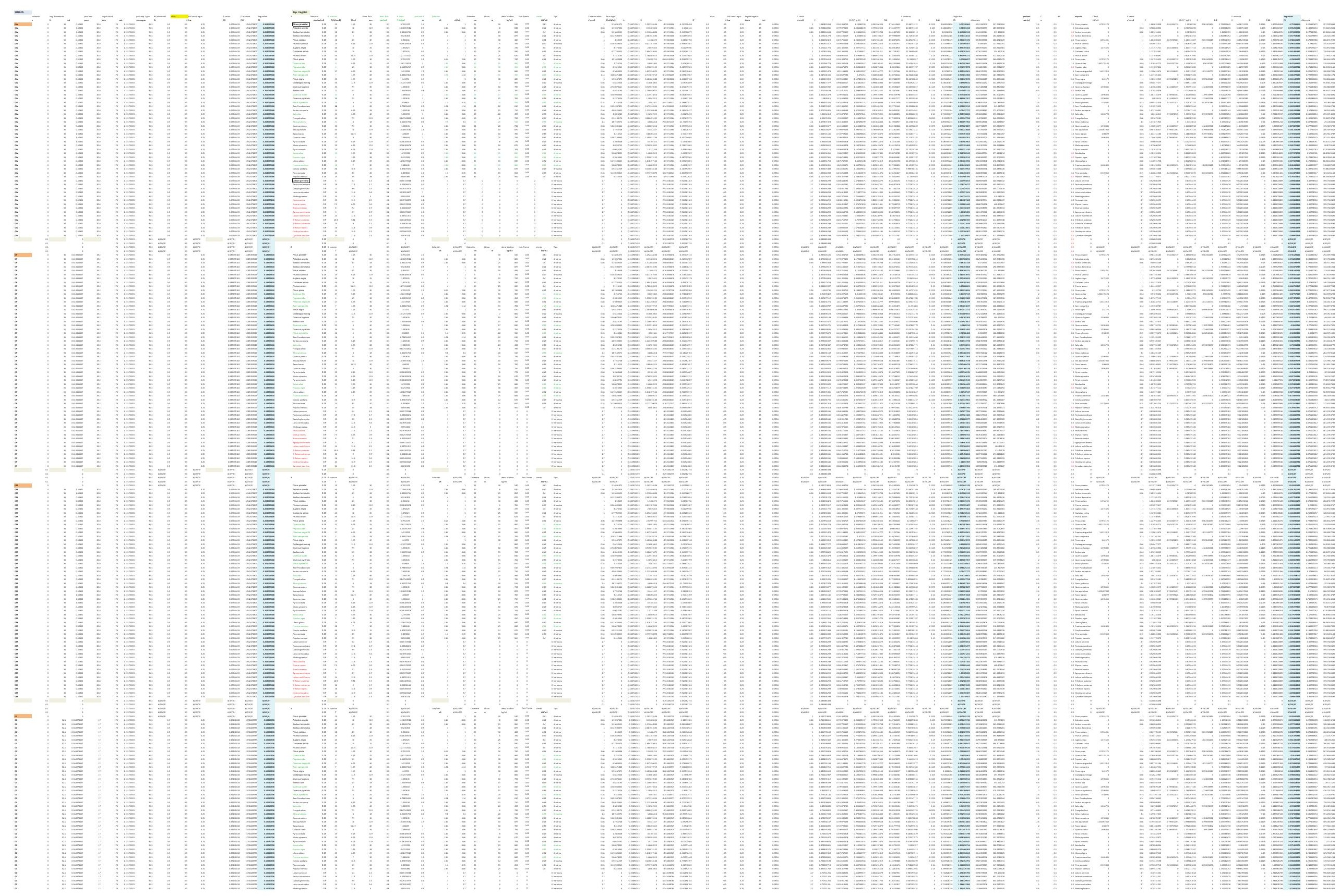


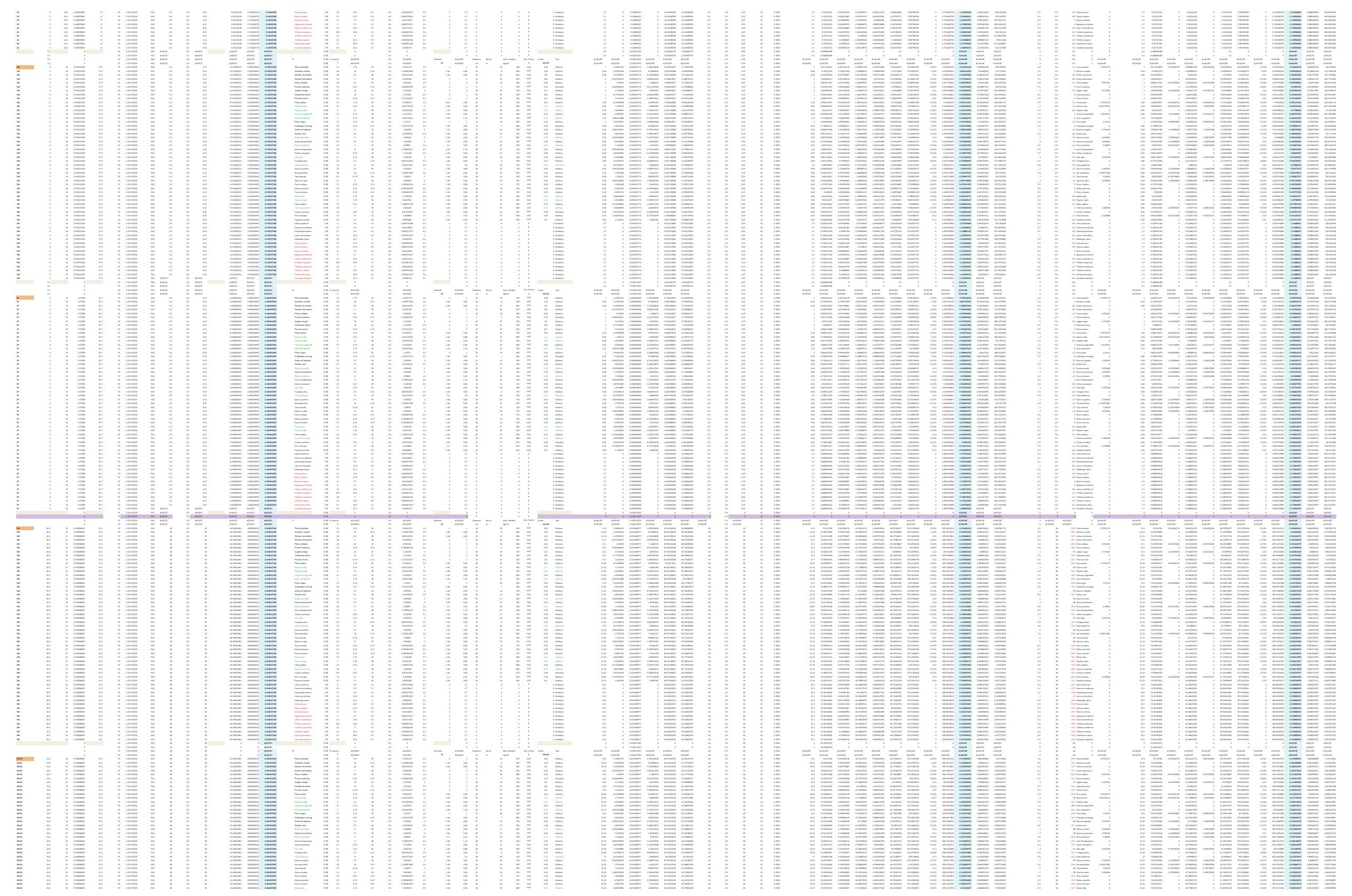




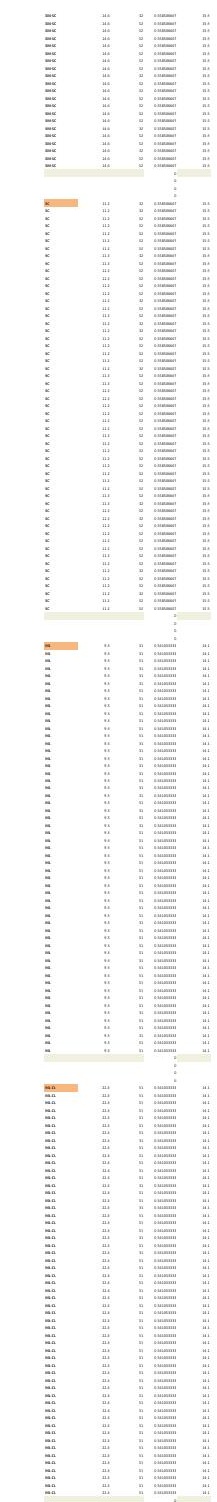

$-$
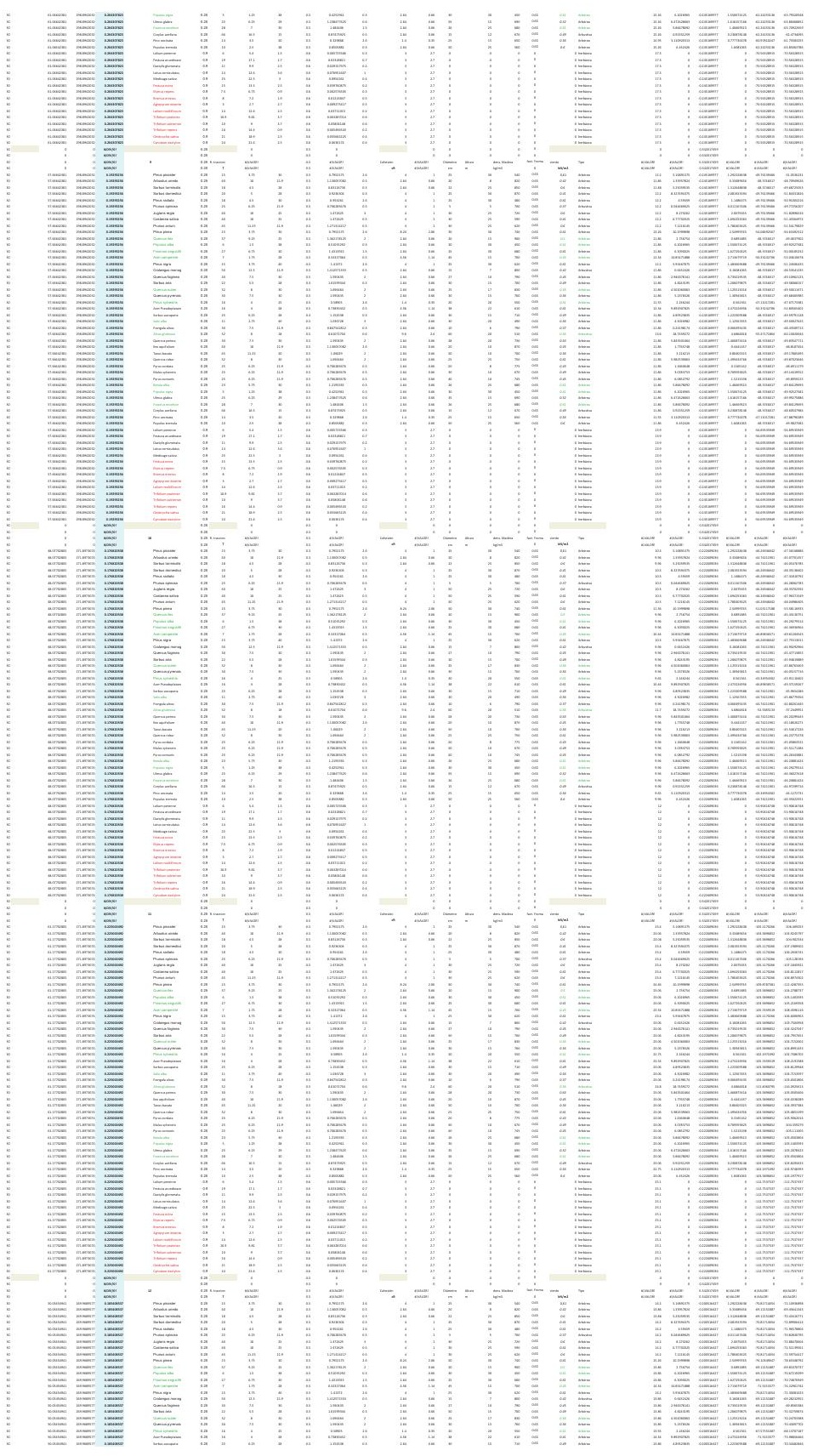
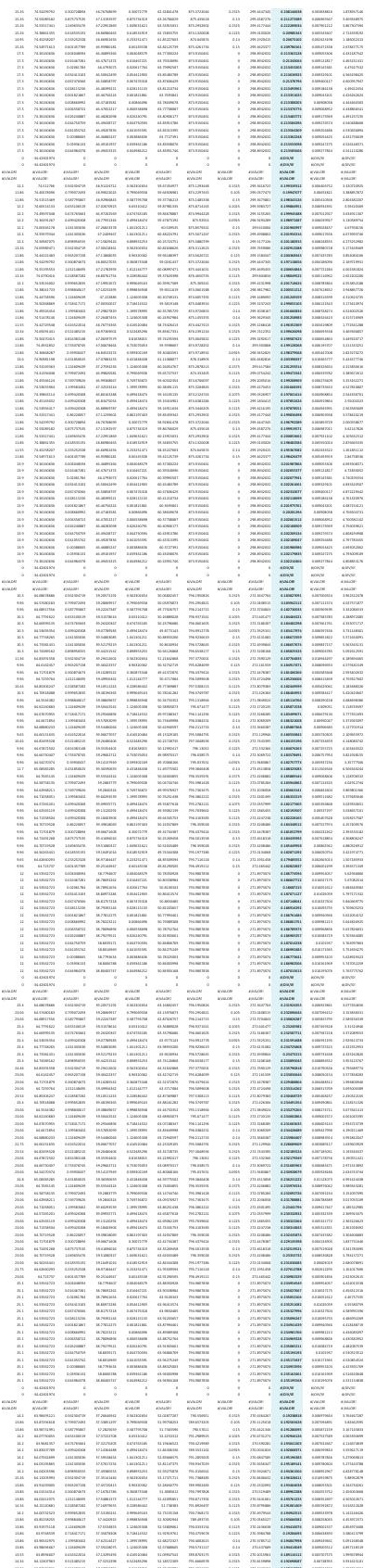

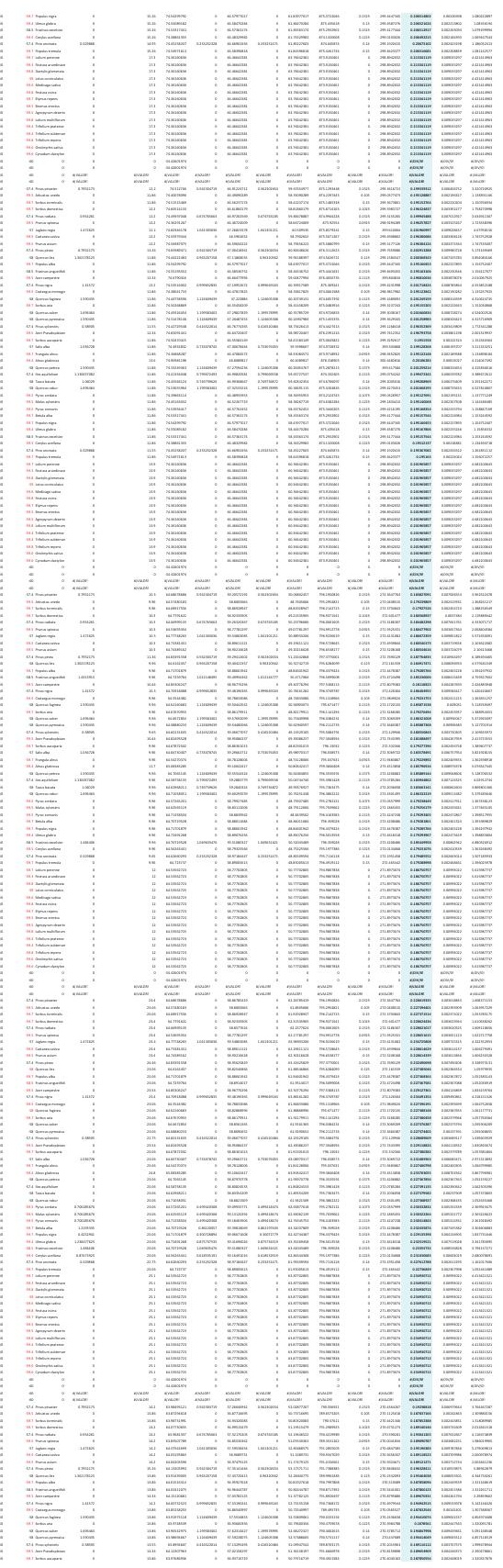




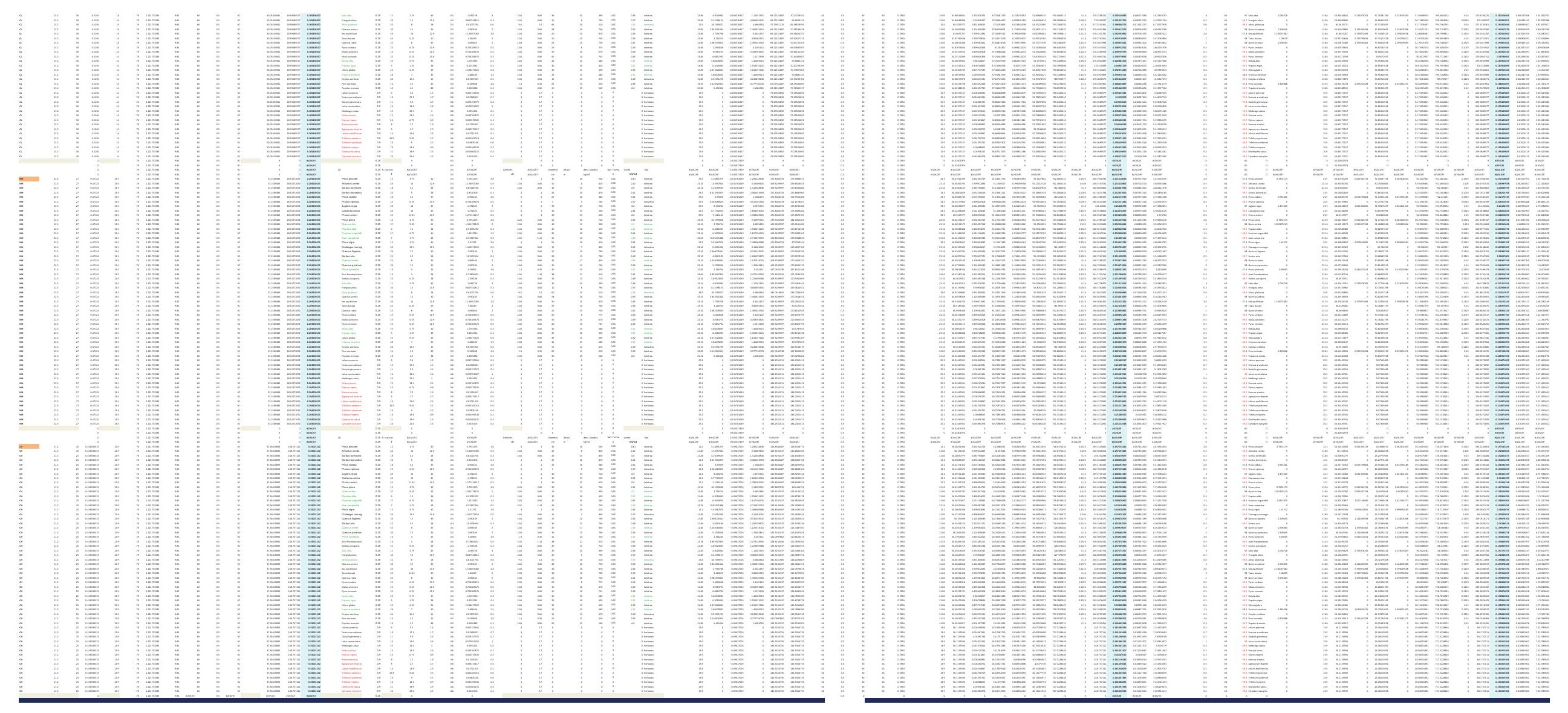



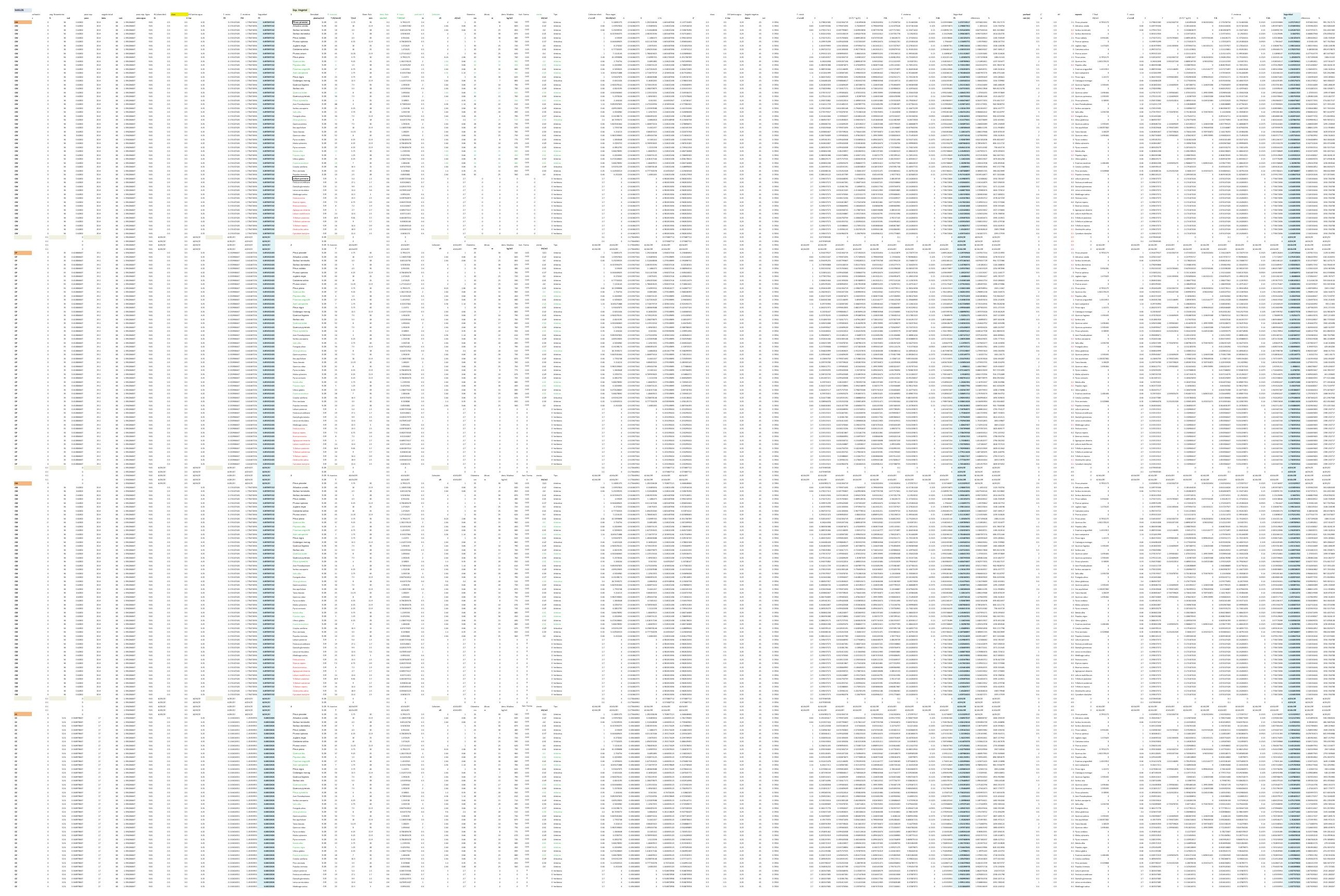


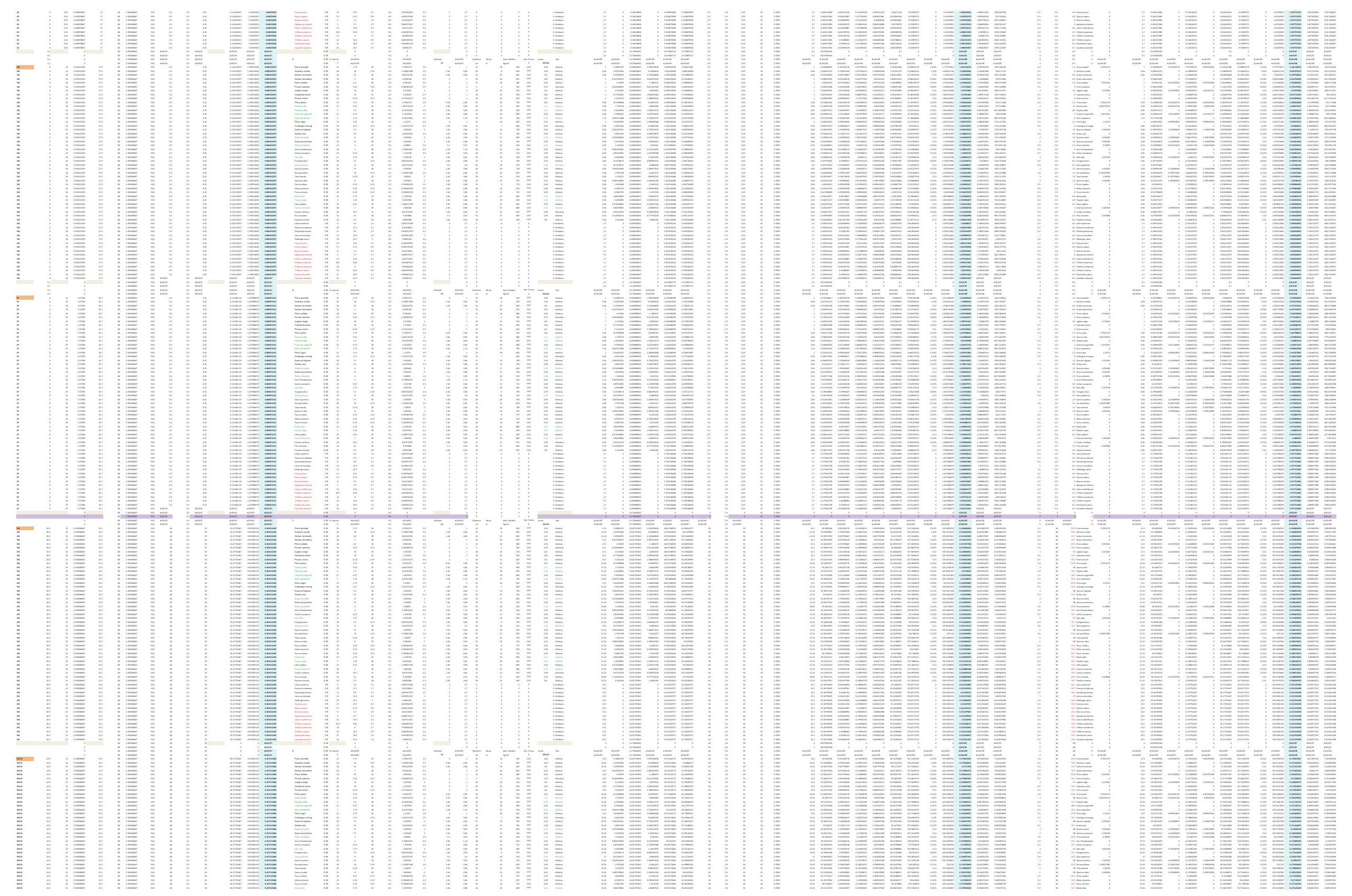



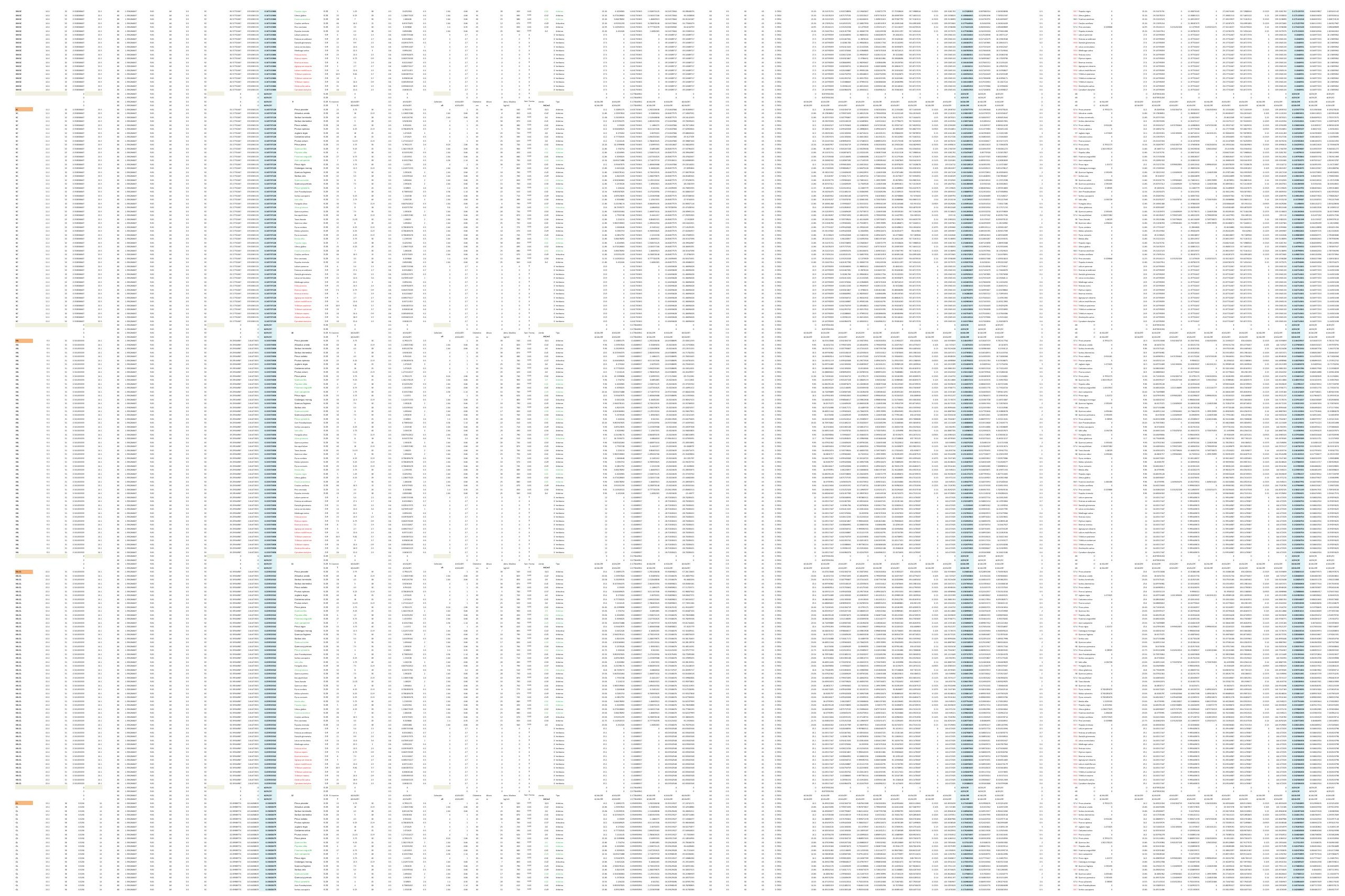


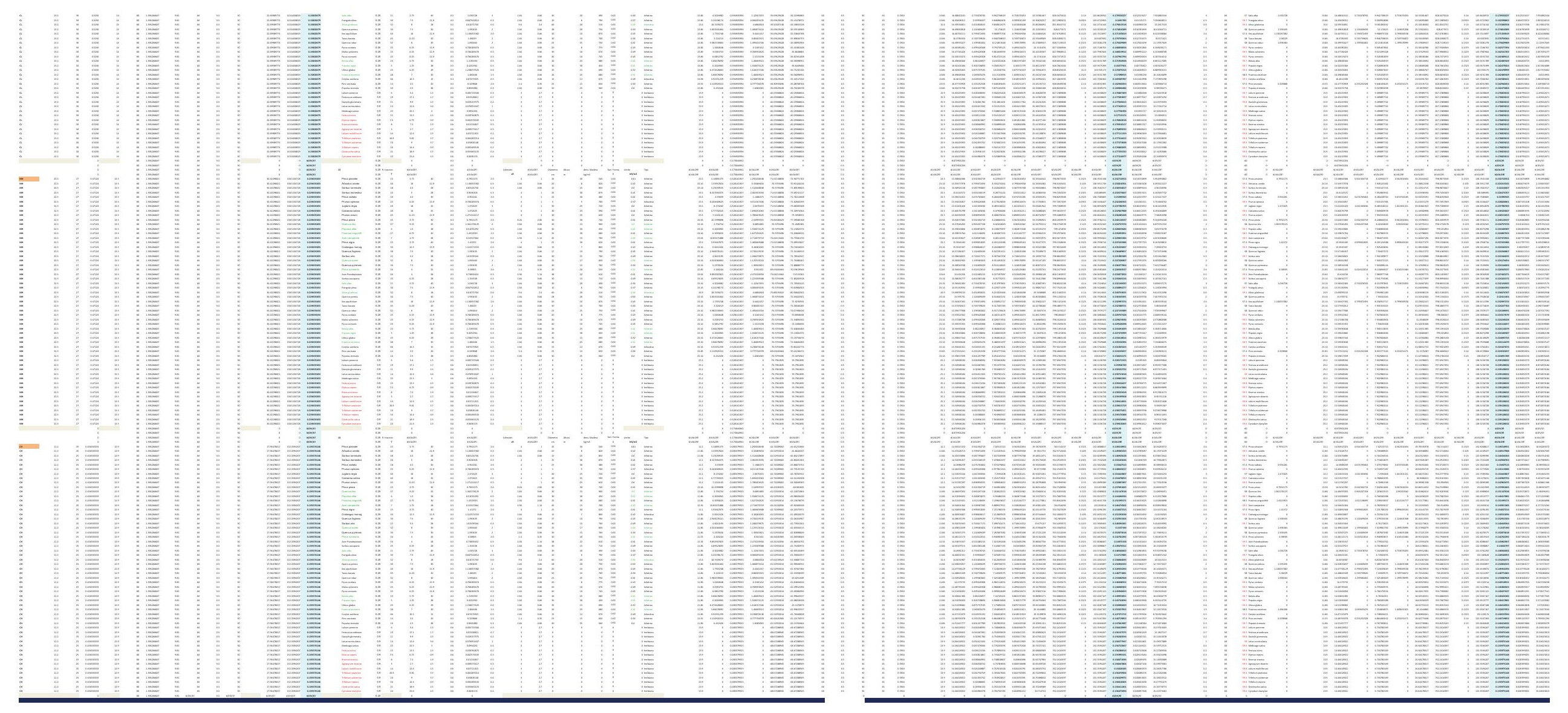


DESARROLLO DE UNA APLICACIÓN IMFORMÁTICA PARA EL CÁLCULO DE SOSTENIMIENTO DE TALUDES MEDIANTE VEGETACIÓN

A02. DENSIDAD DE PLANTACIÓN: 1.600 plantas/ha.

\section{A02-5.POSICIÓN N.F. 5}

INCLINACIÓN DE TALUD 6-100

INCLINACIÓN DE TALUD 10-200

INCLINACIÓN DE TALUD 20-30

INCLINACIÓN DE TALUD 30-40

INCLINACIÓN DE TALUD $35^{\circ}$

INCLINACIÓN DE TALUD 40-50

INCLINACIÓN DE TALUD 50-550

INCLINACIÓN DE TALUD 55-60

INCLINACIÓN DE TALUD 60-700

INCLINACIÓN DE TALUD 70-80 

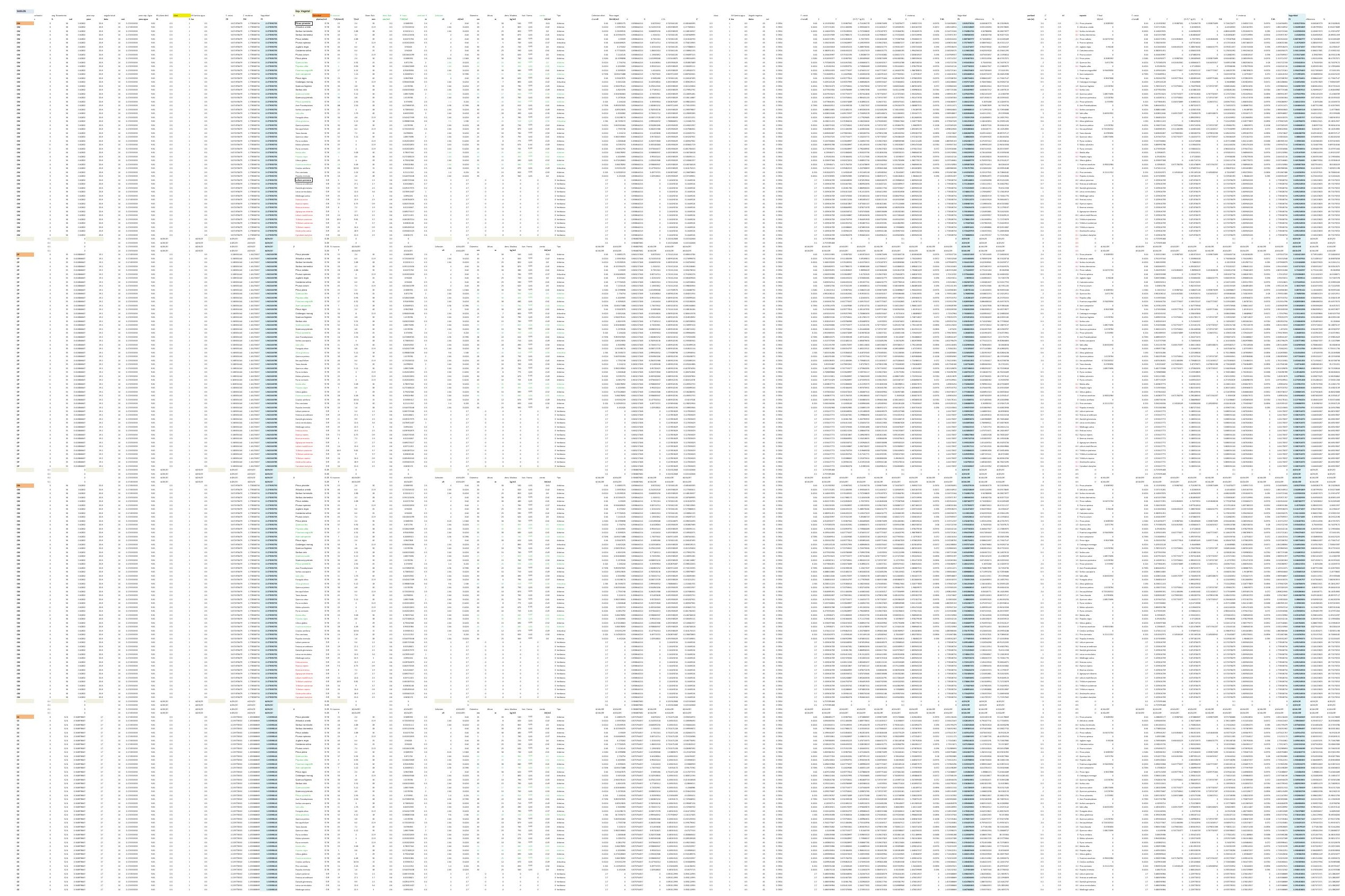


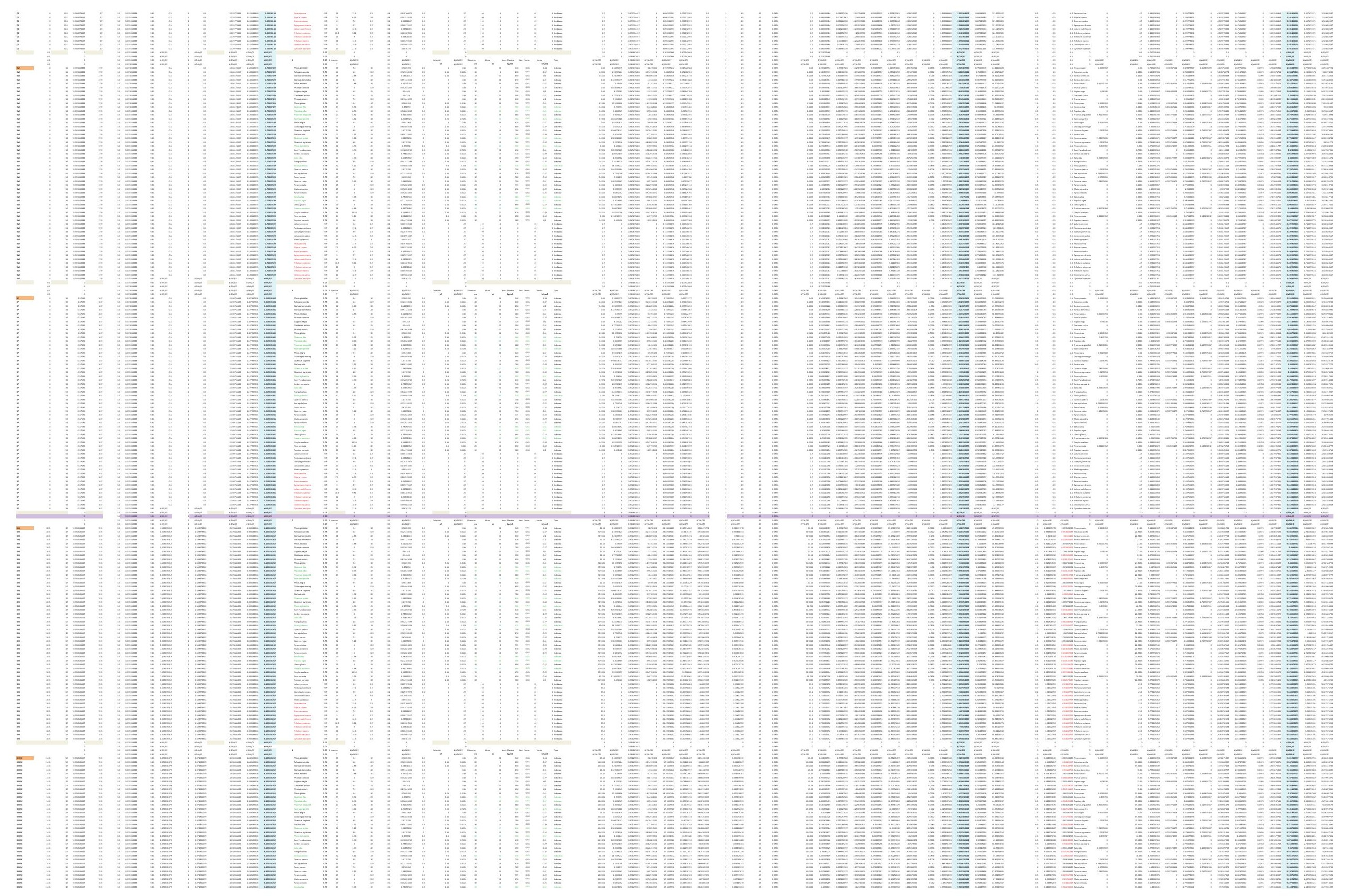



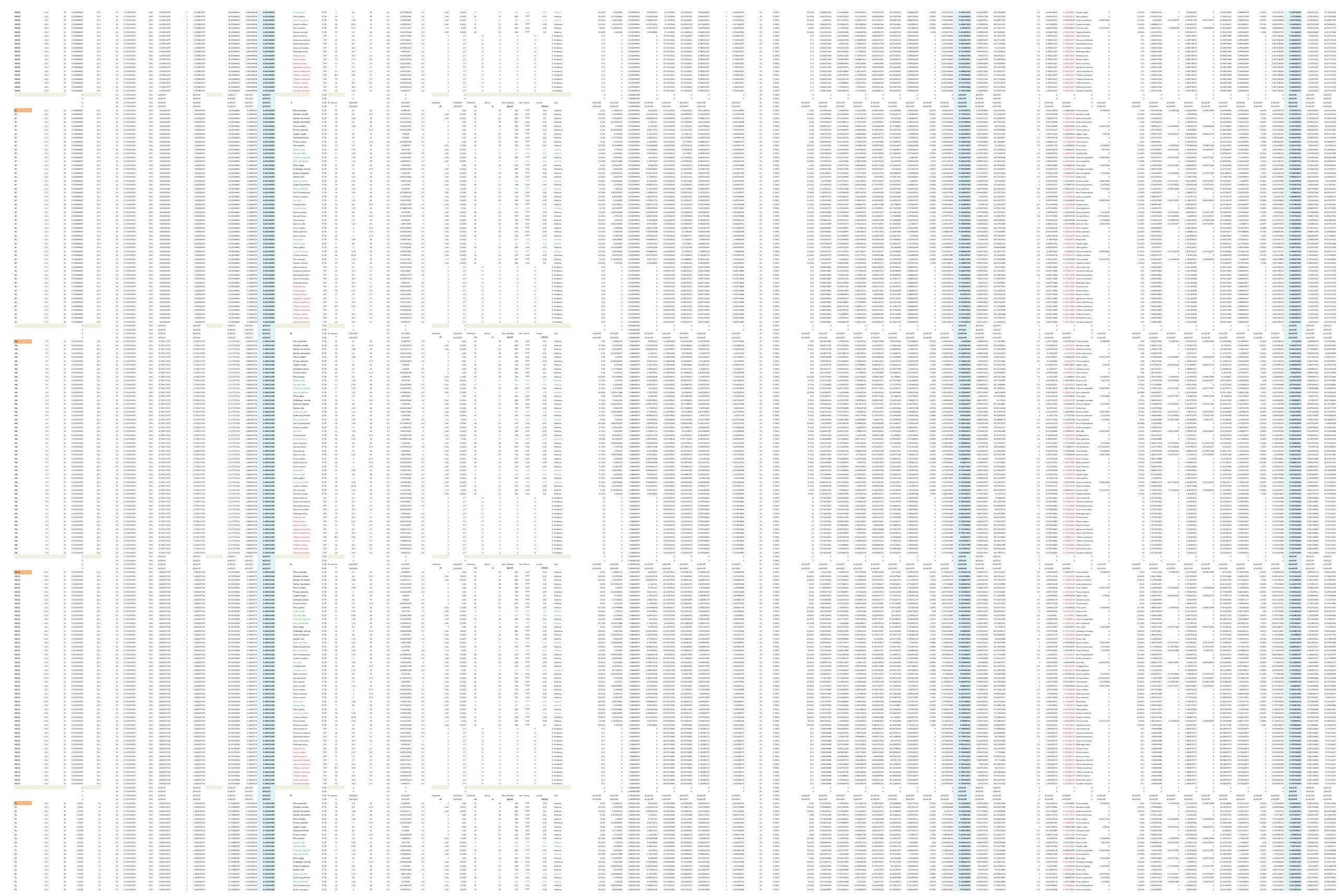


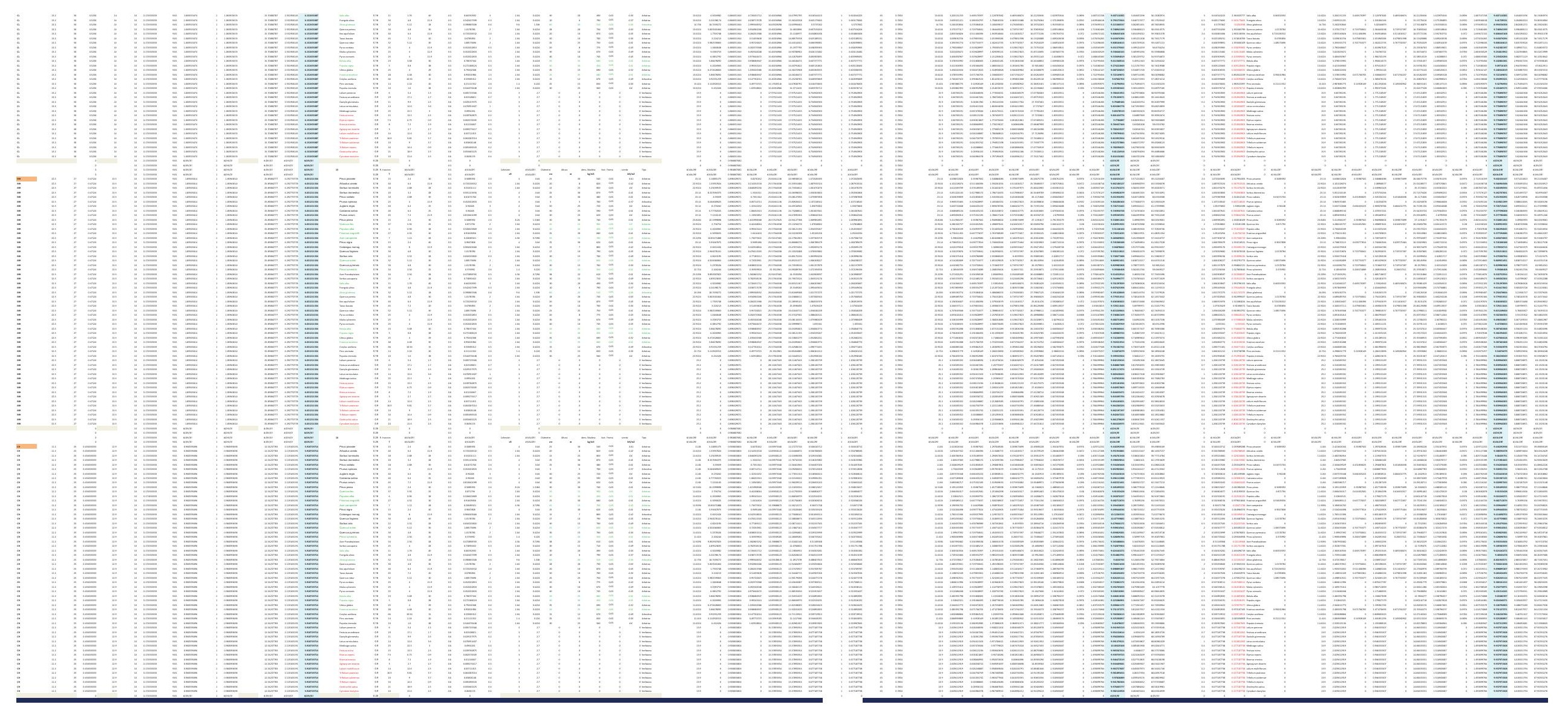



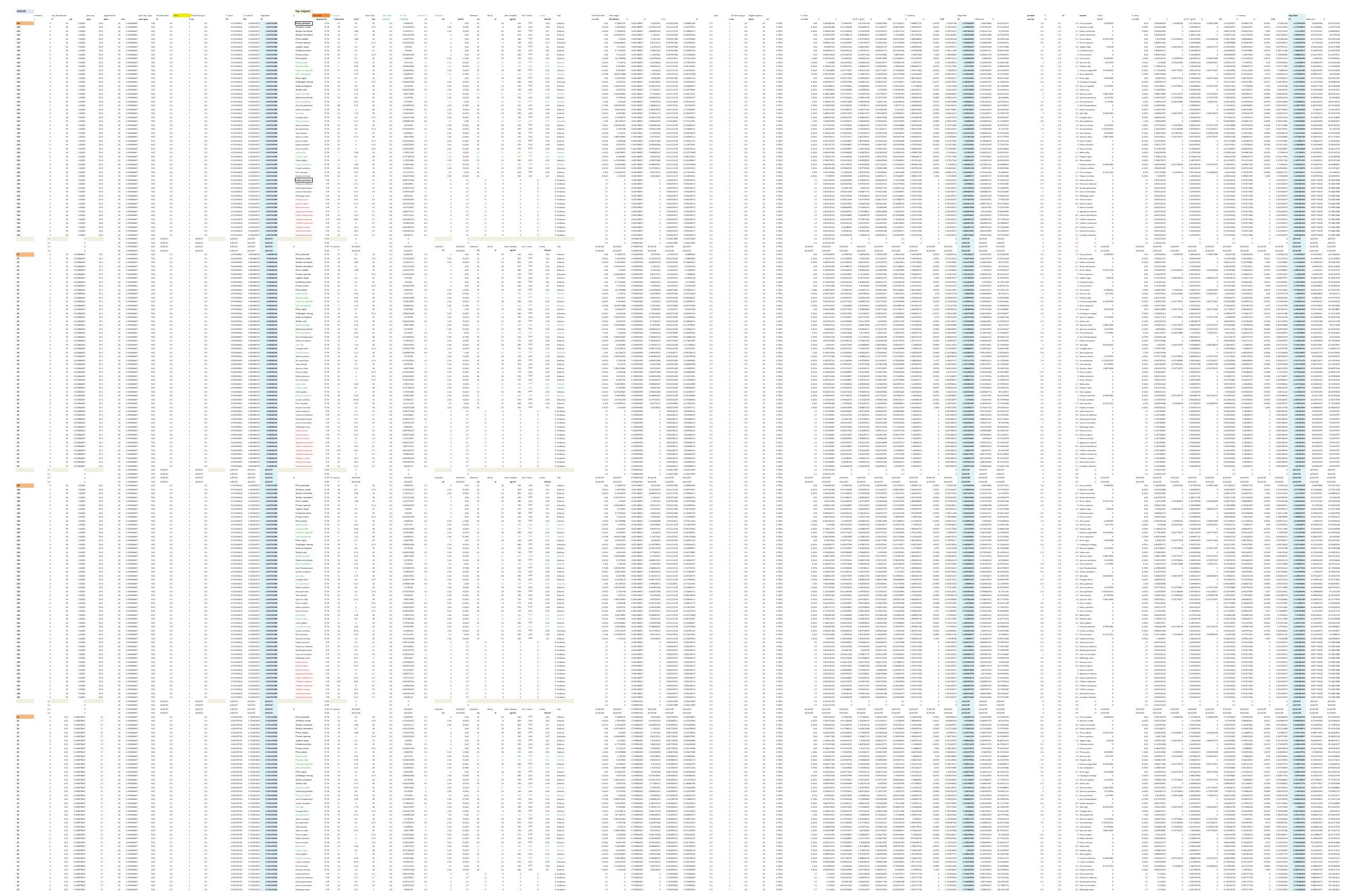


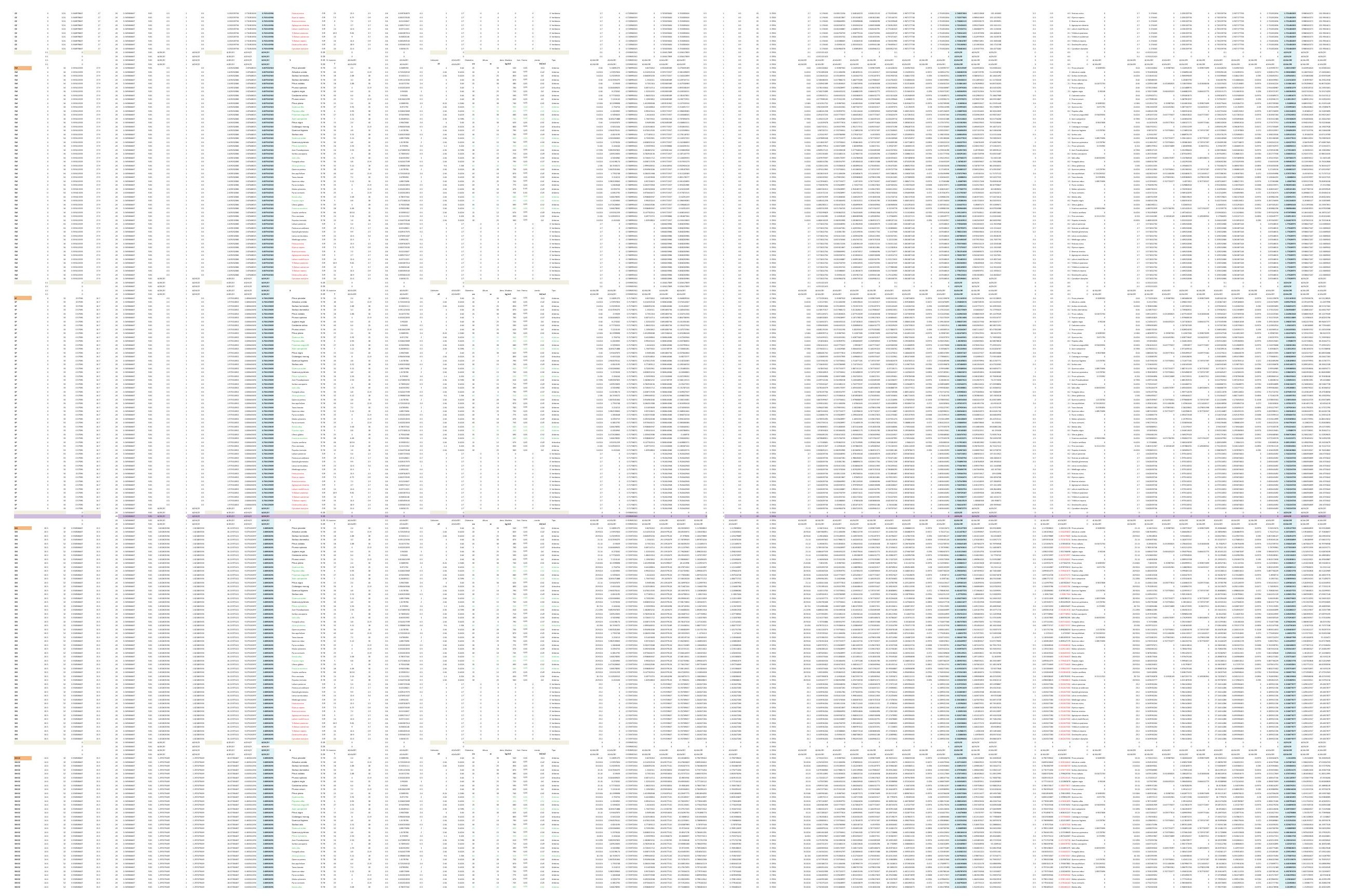



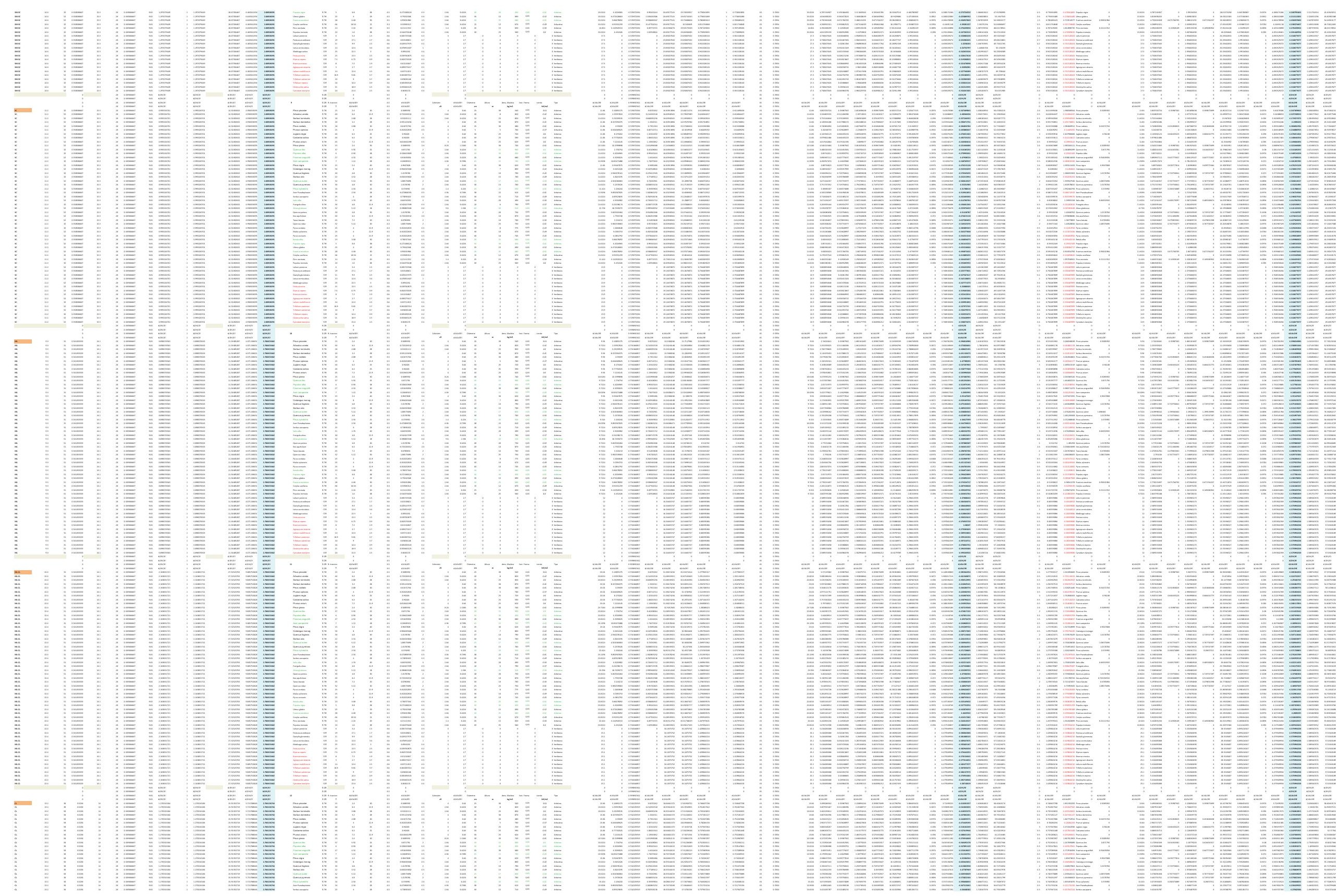


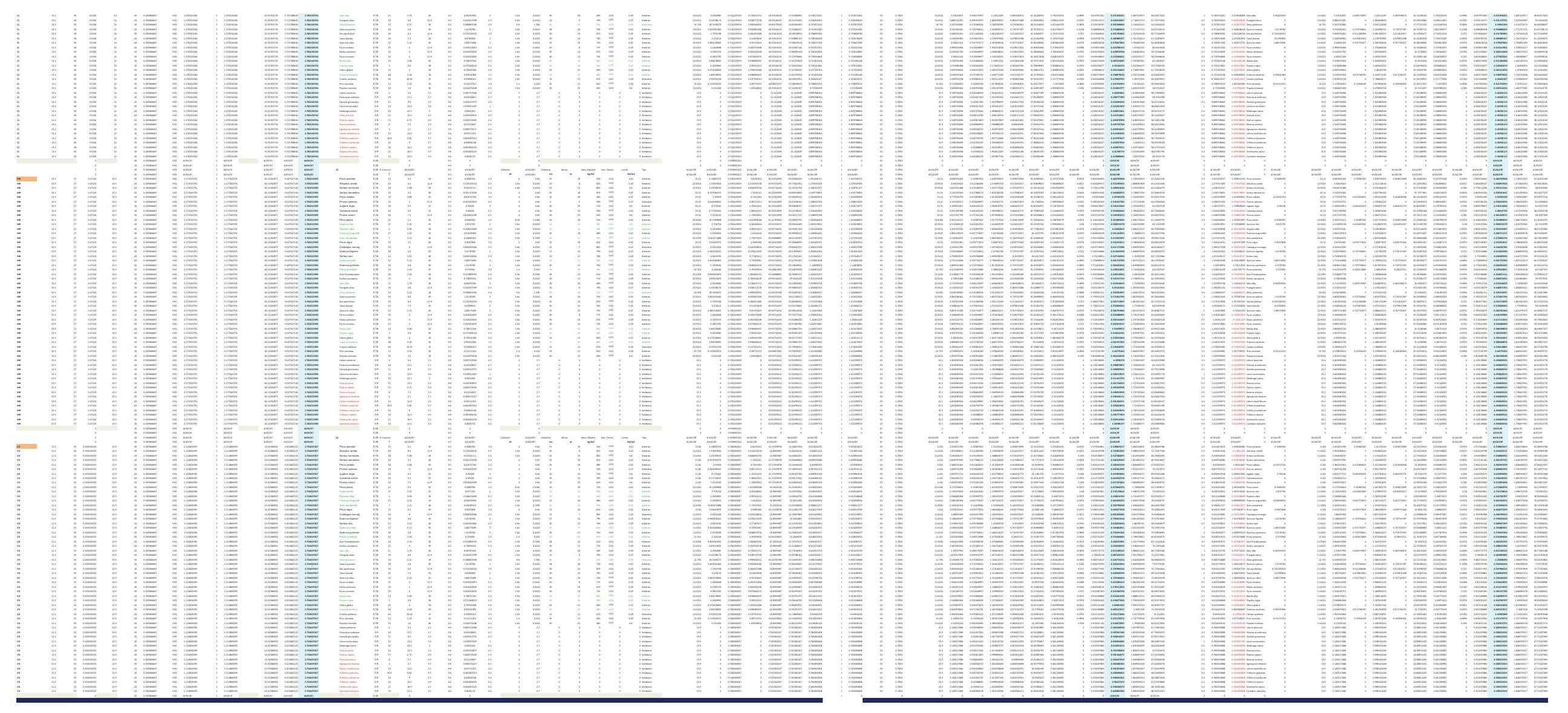



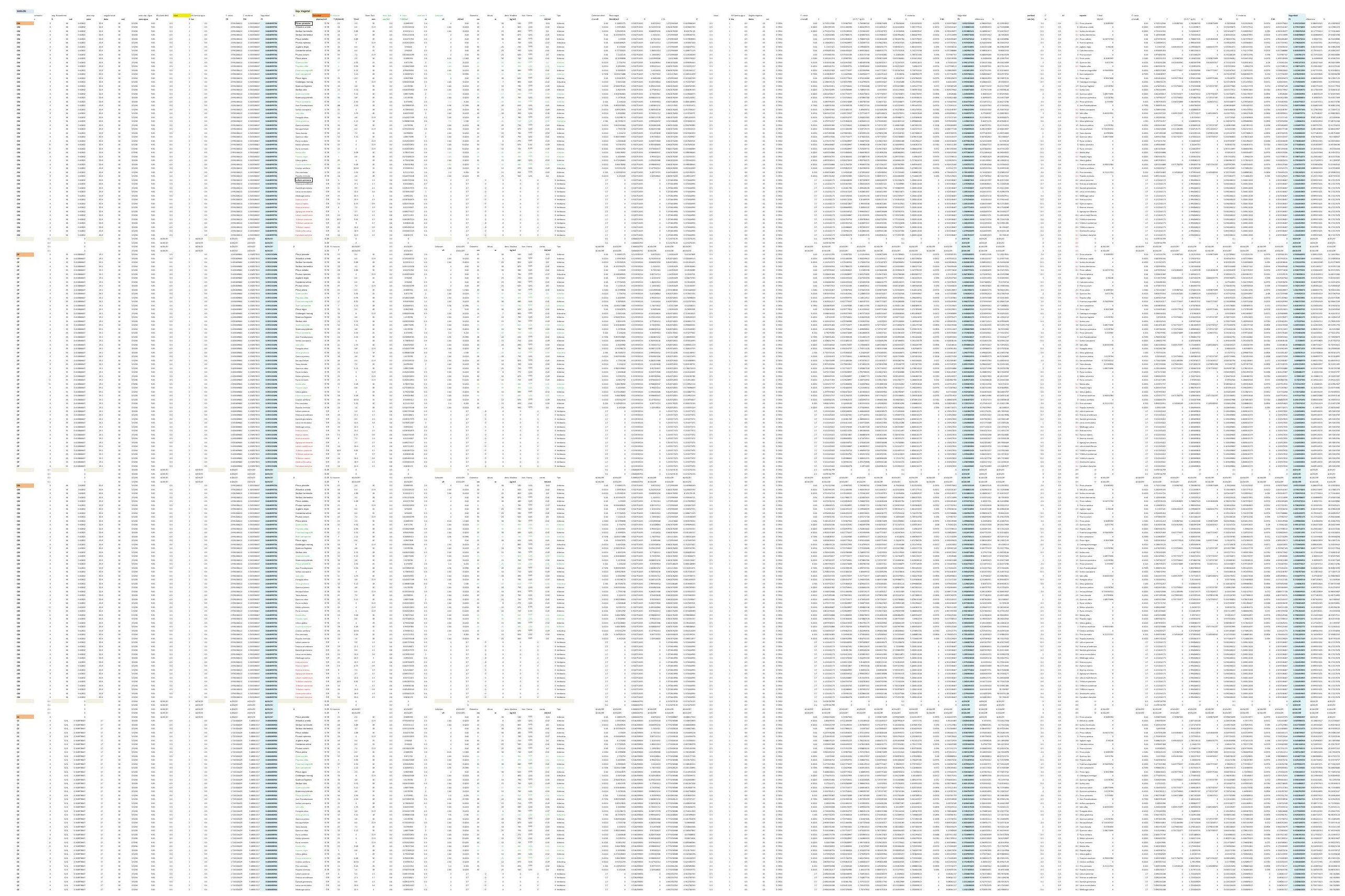


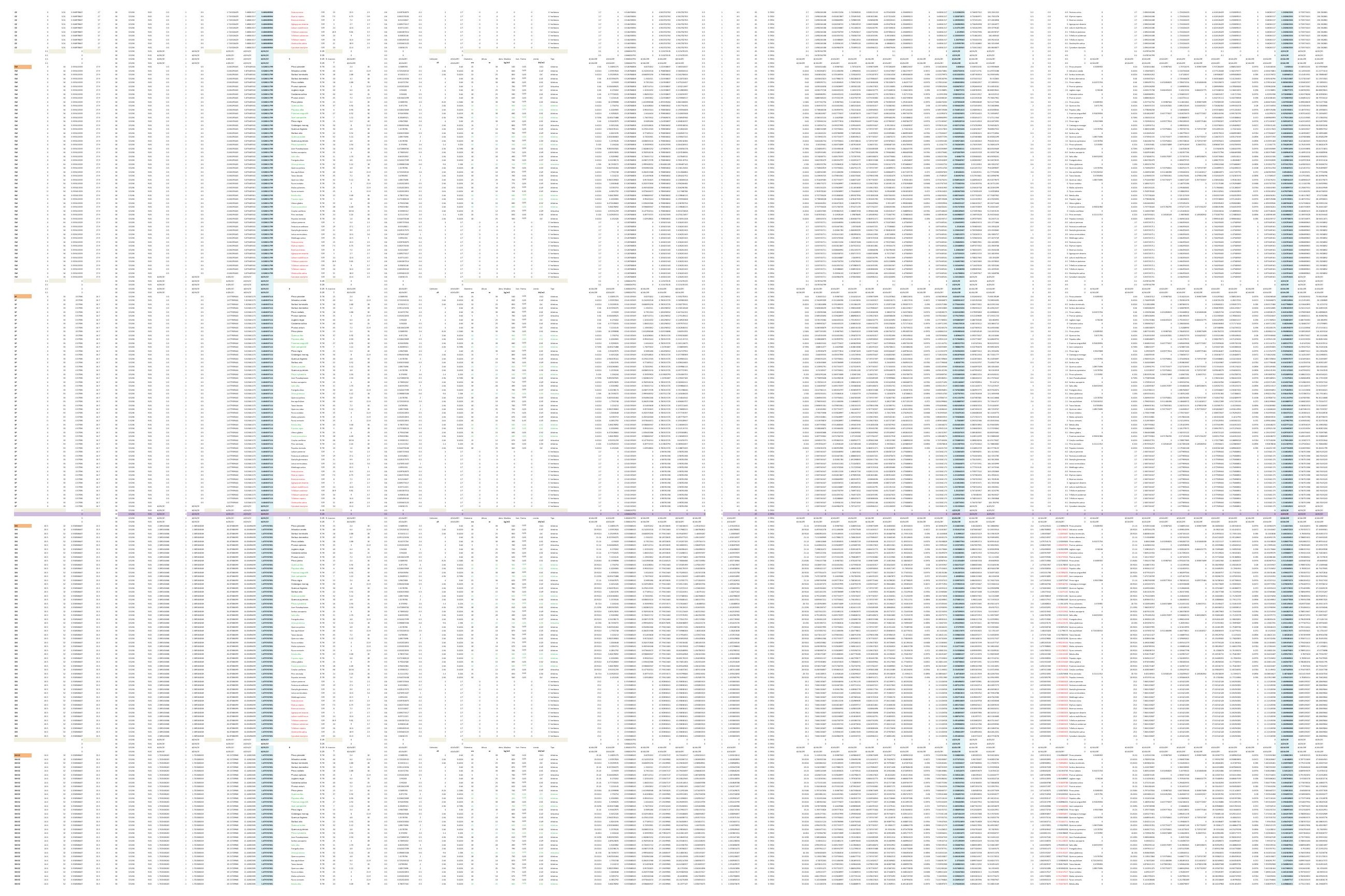



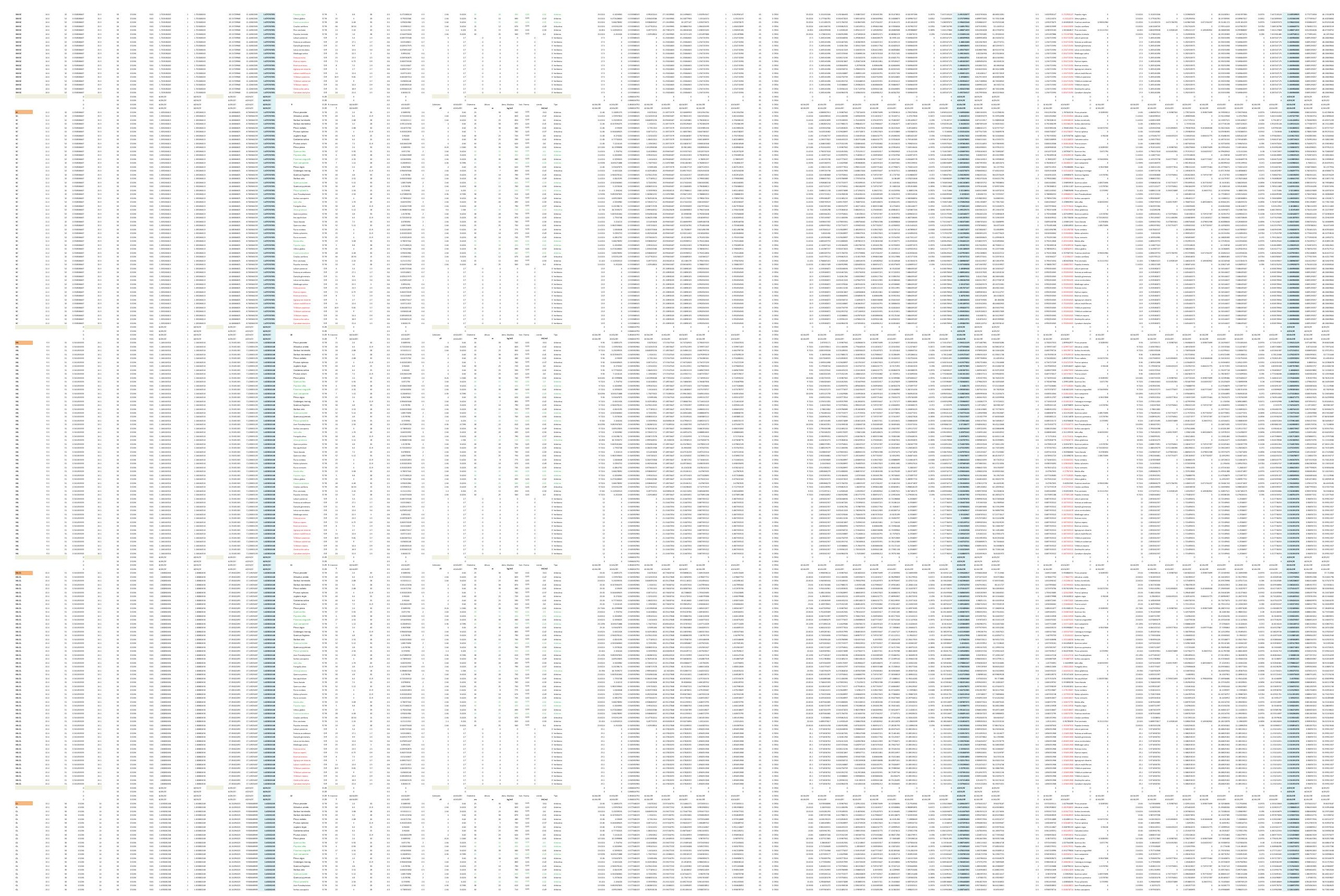


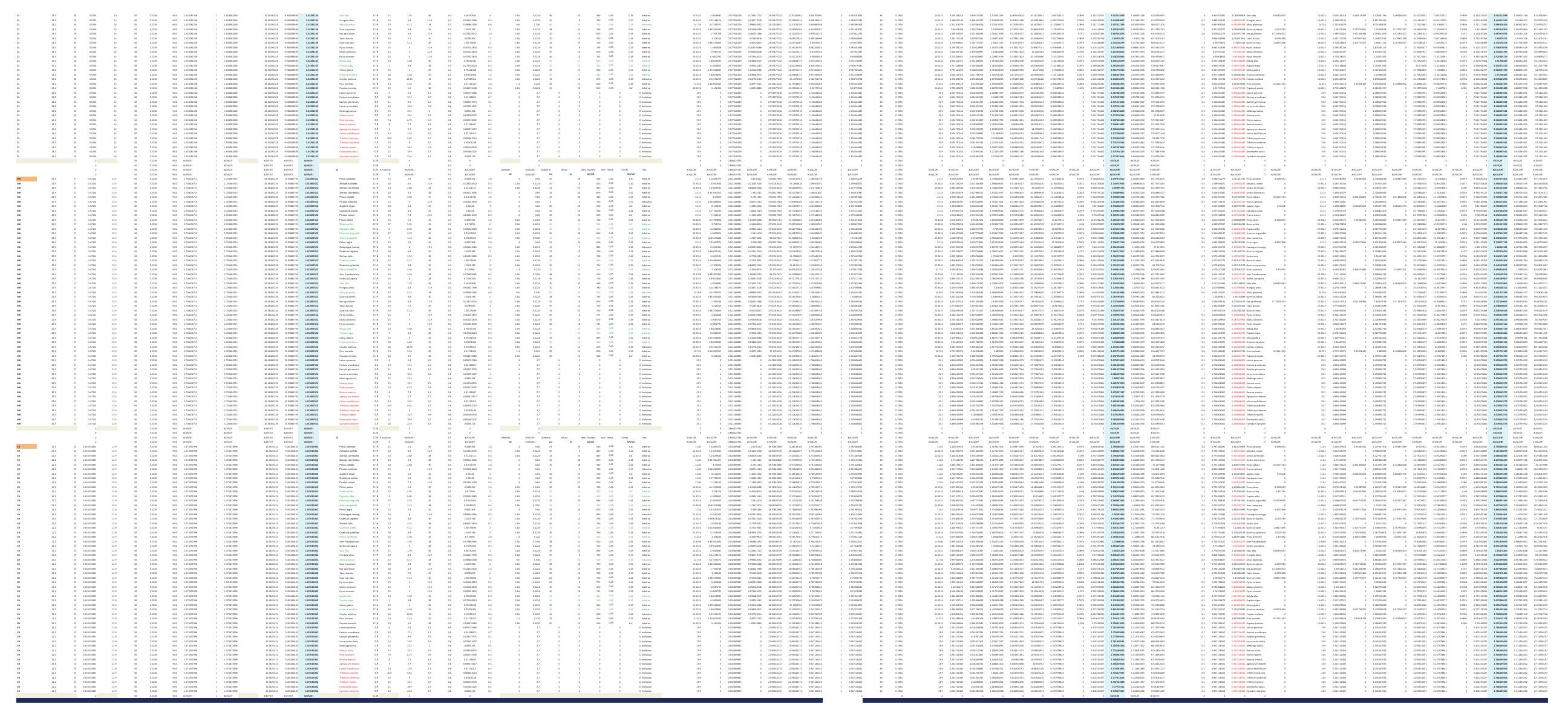



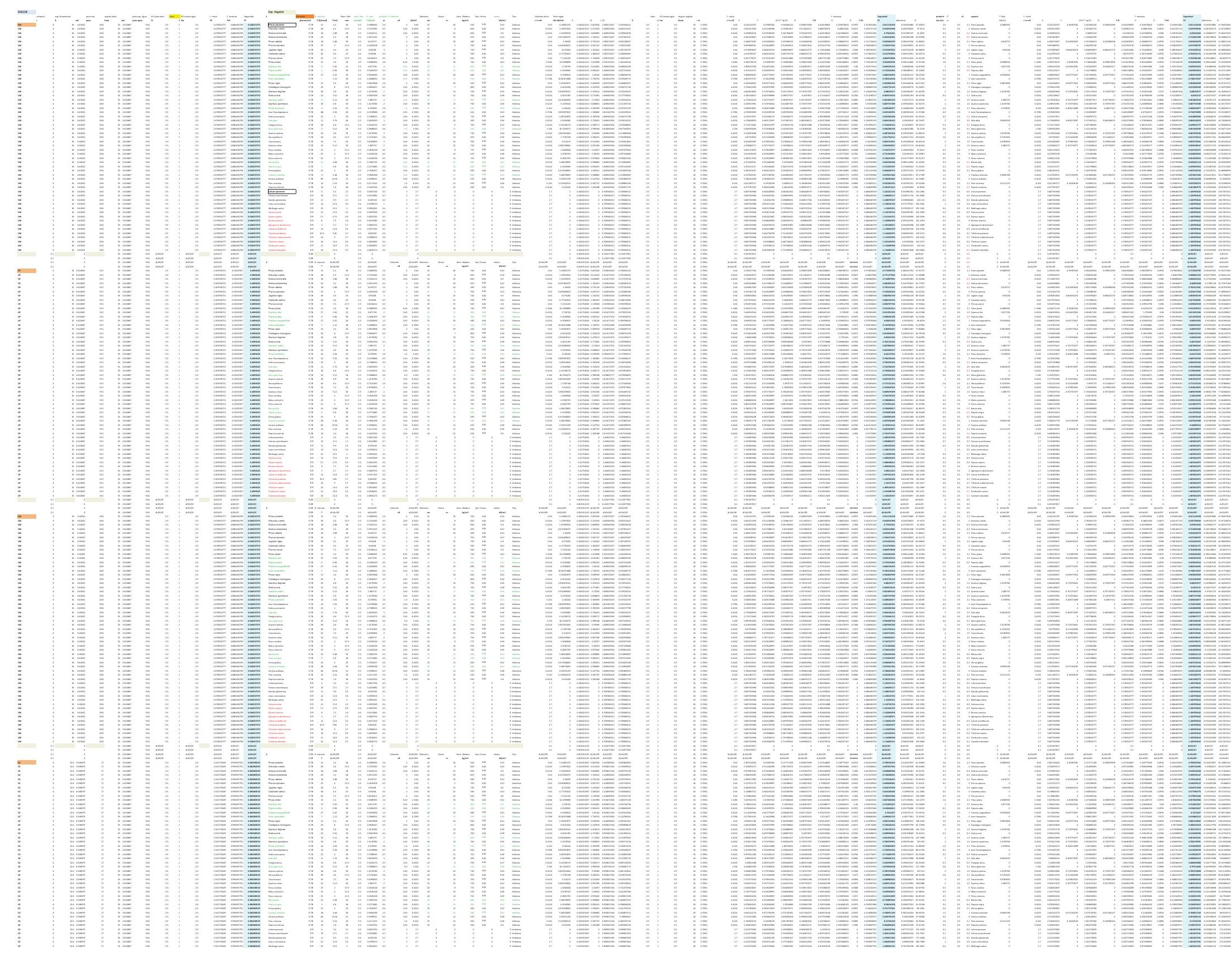


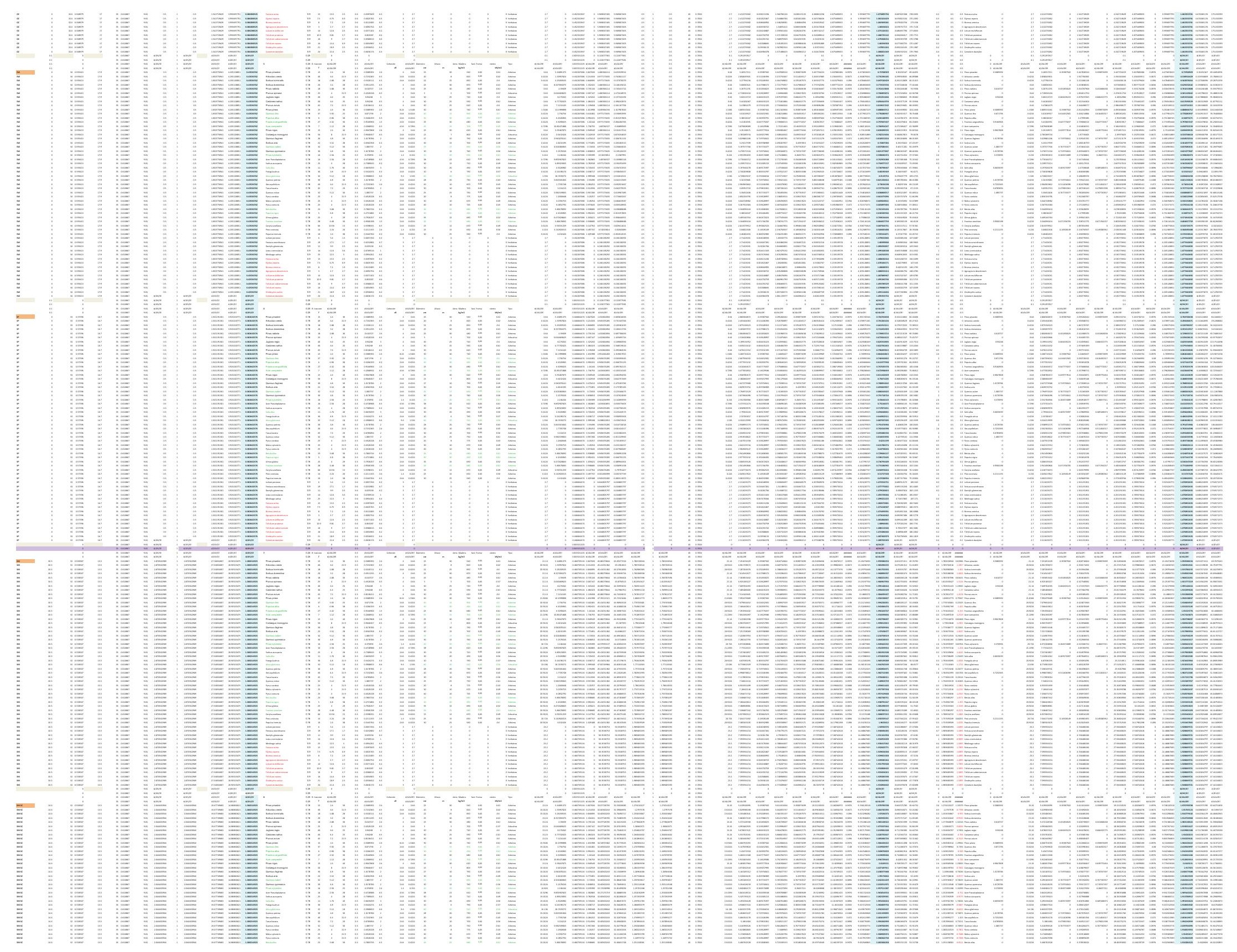



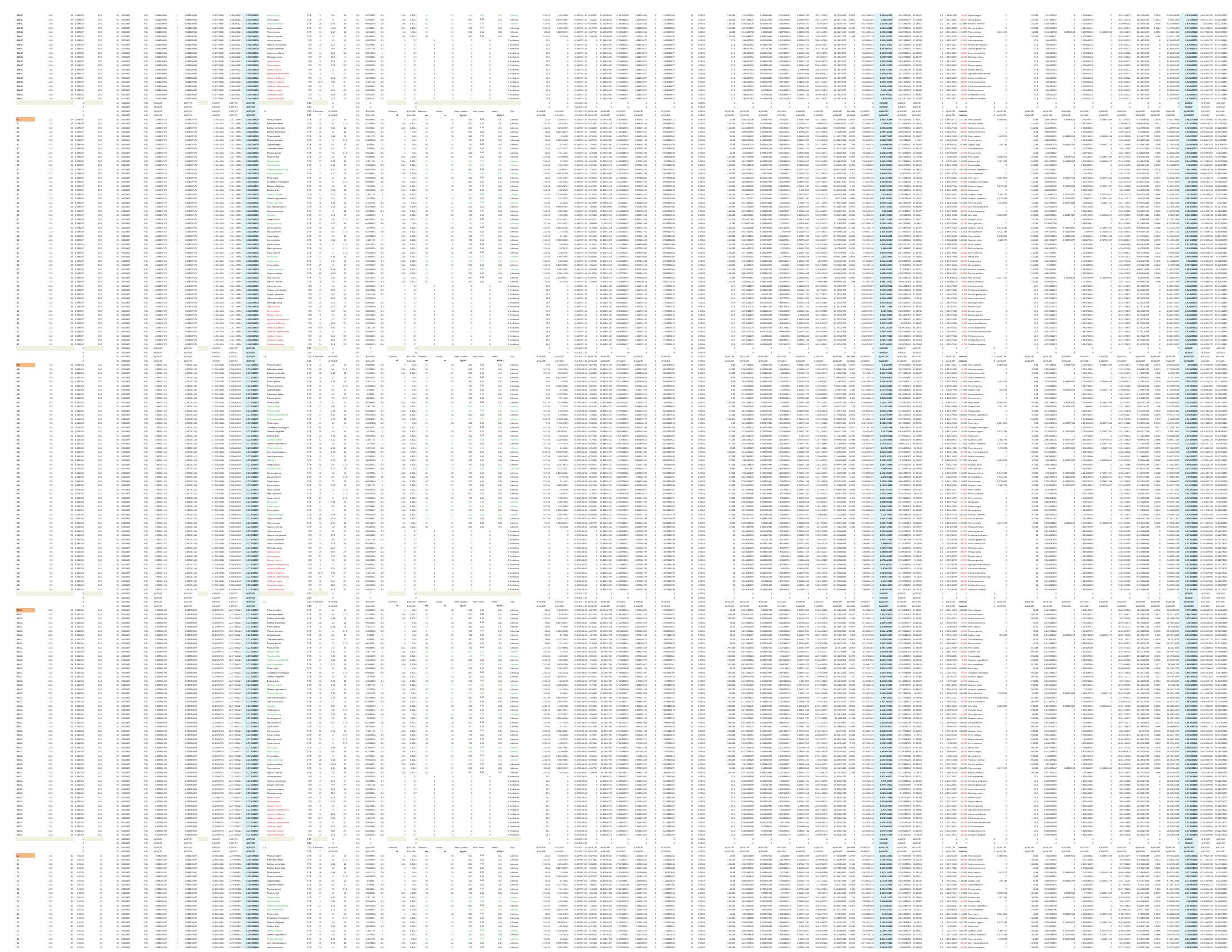


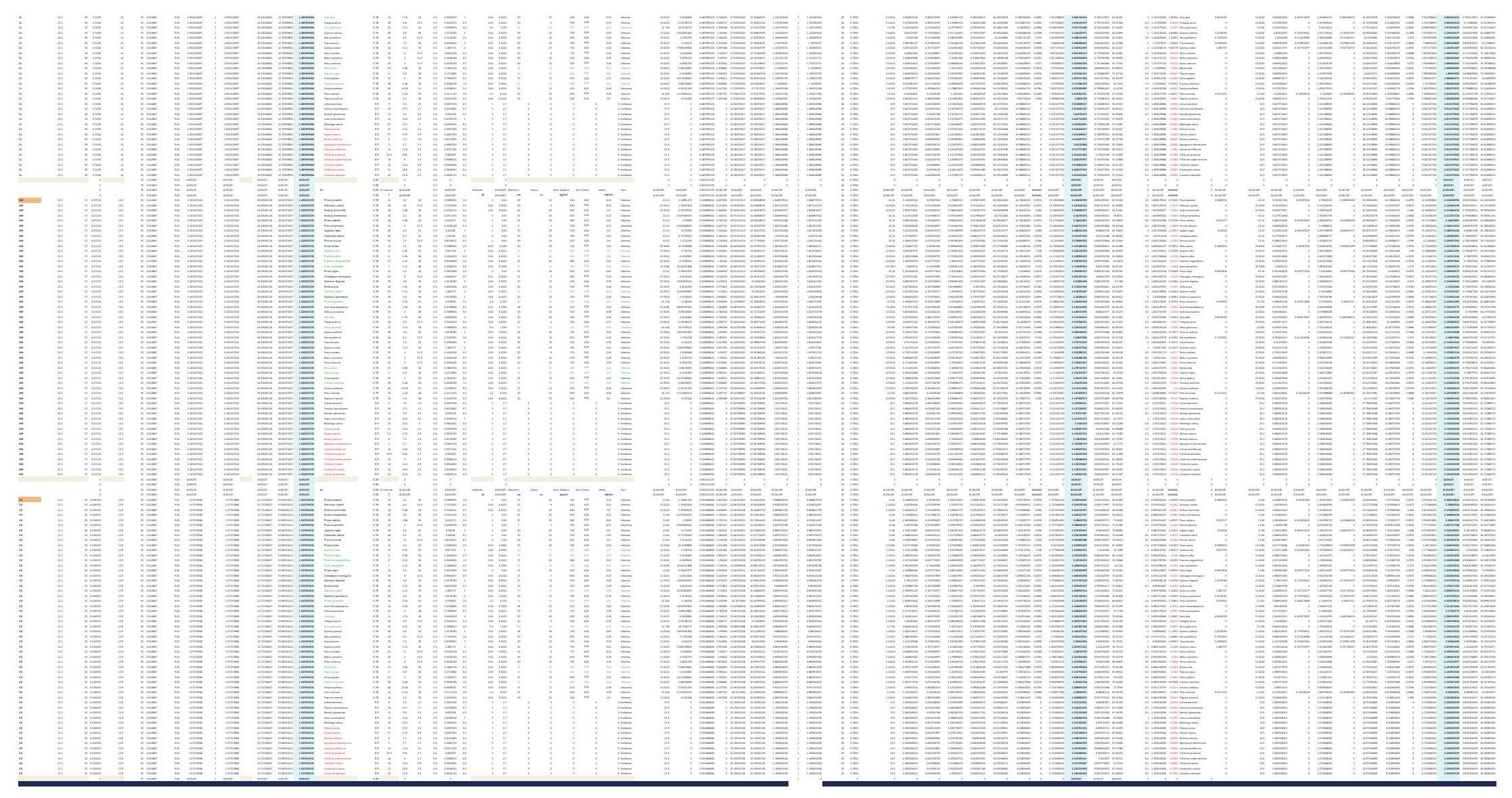



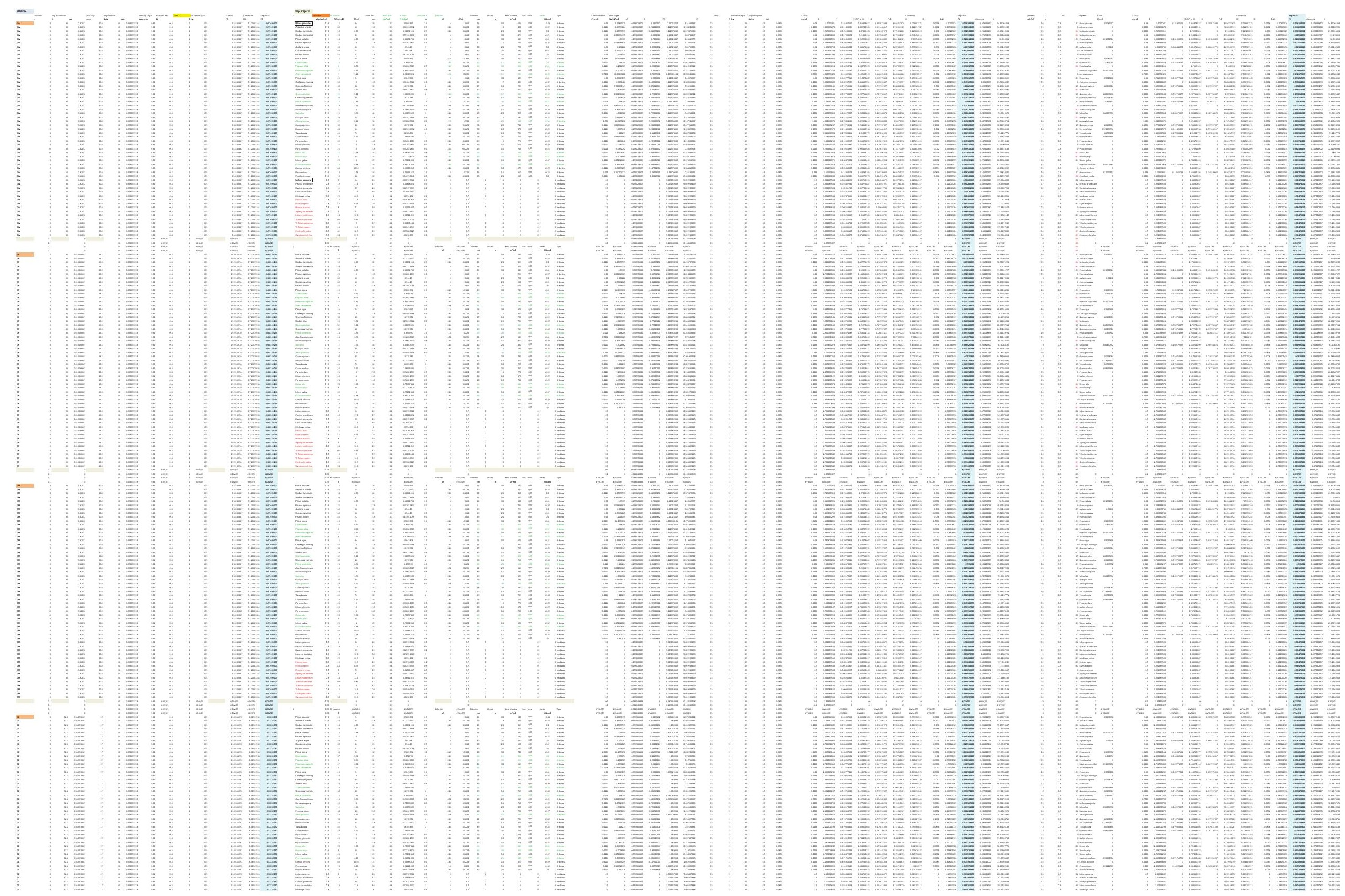


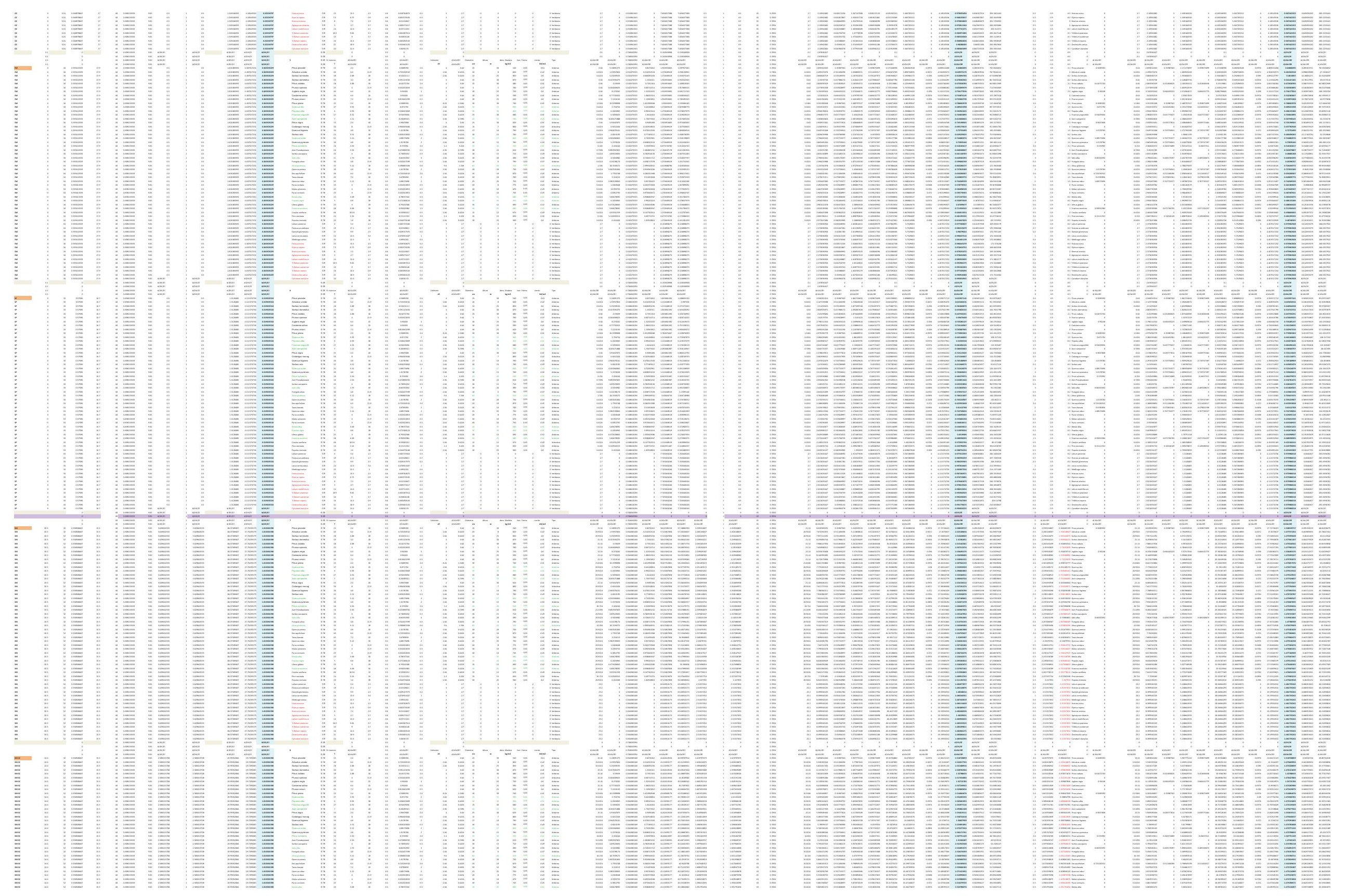



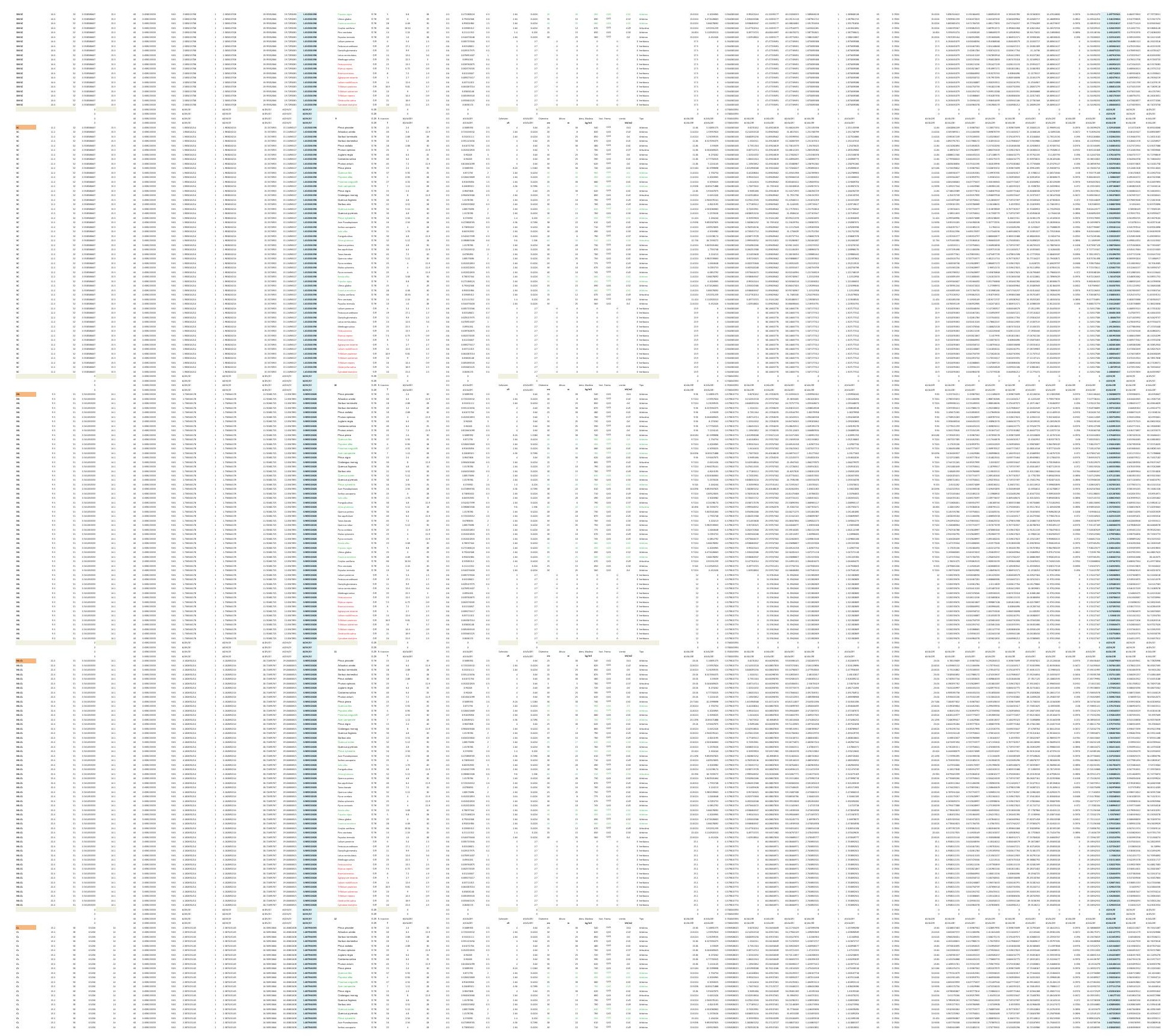

(1)
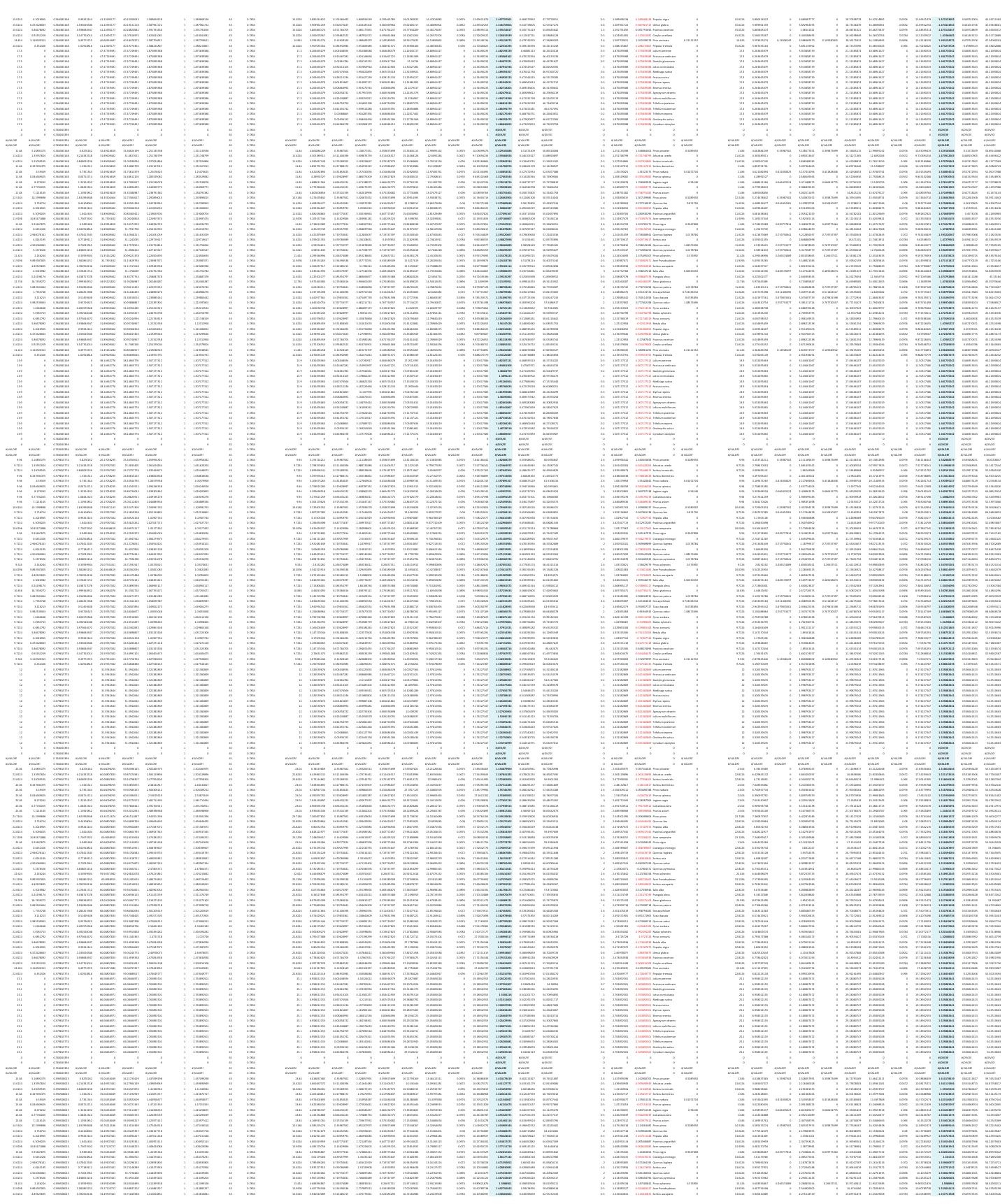


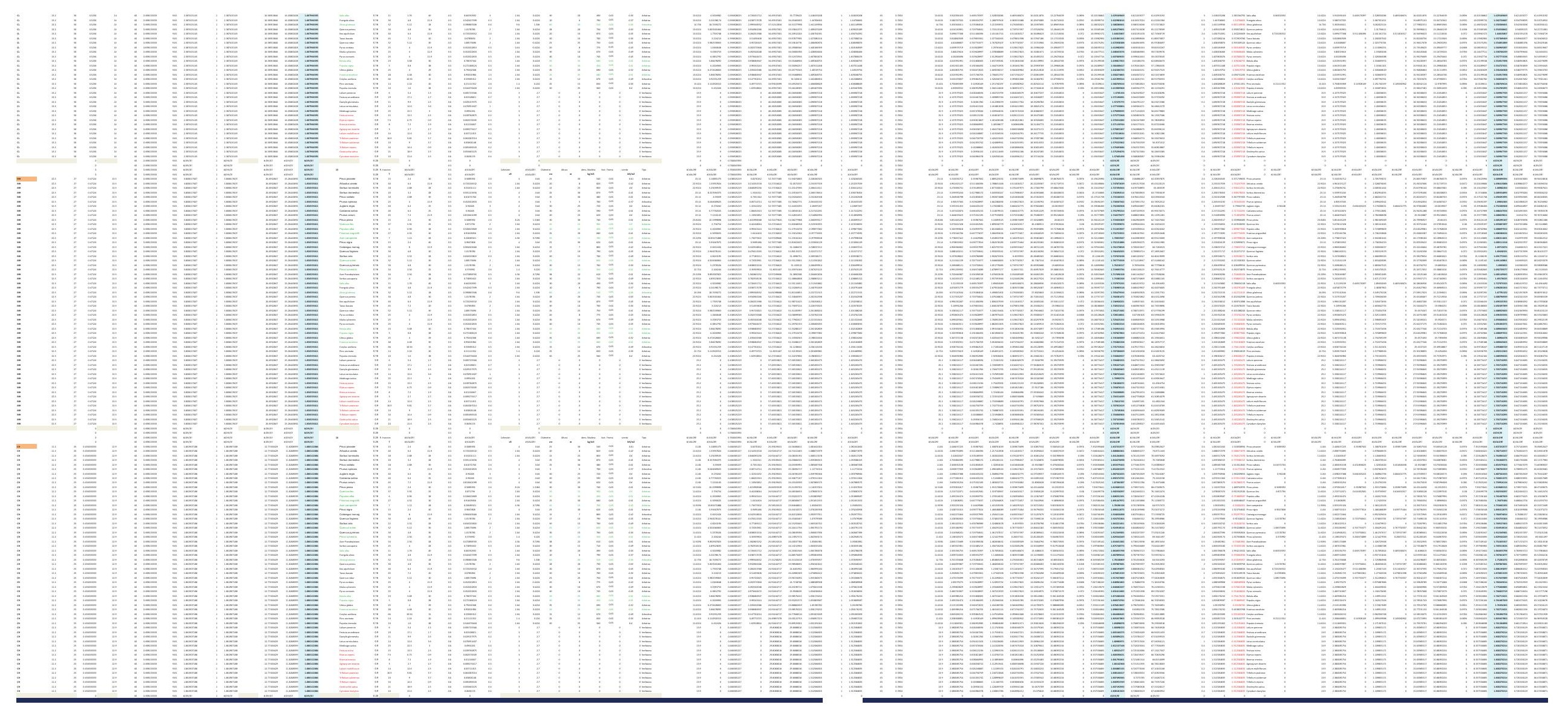



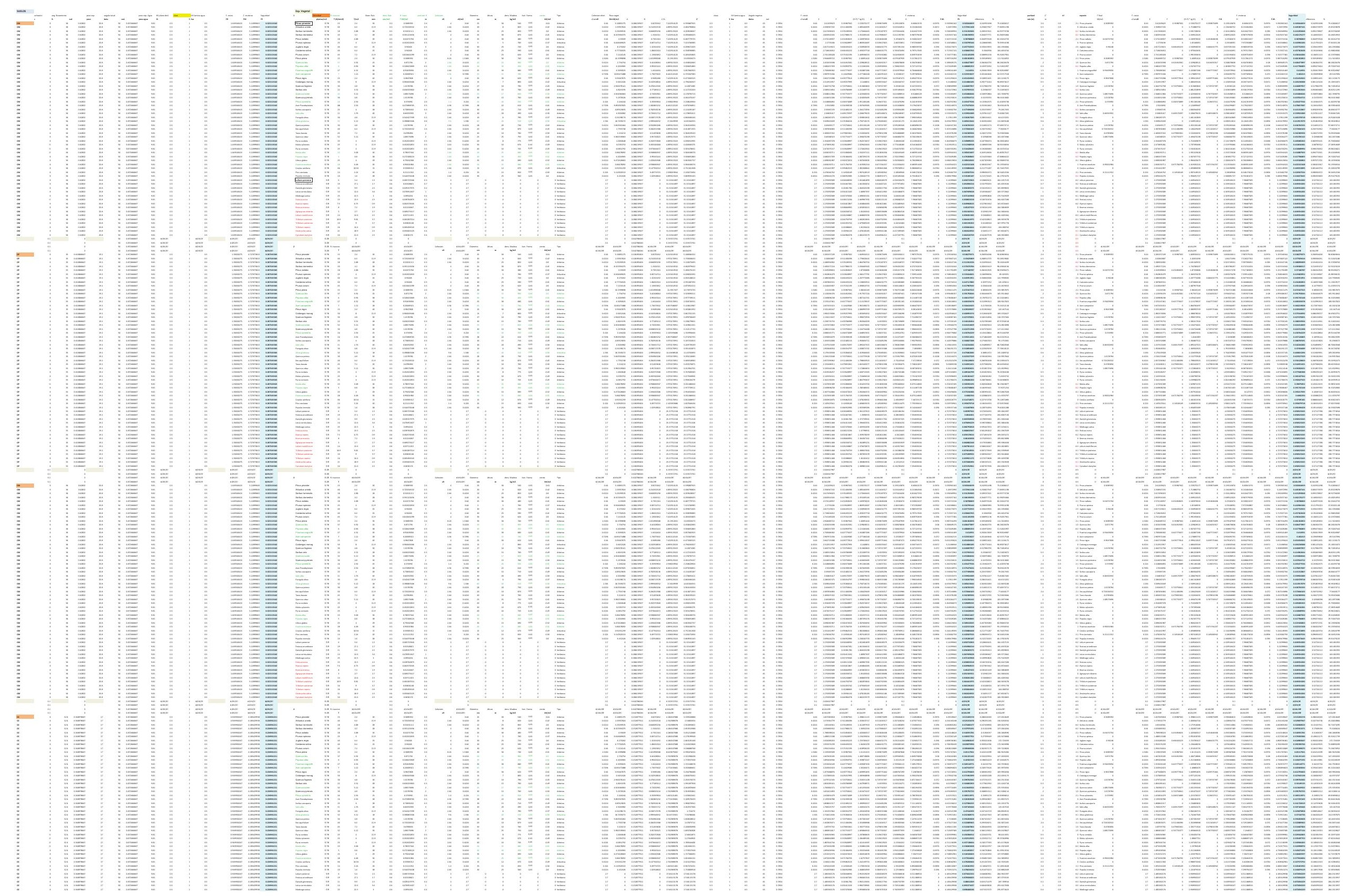


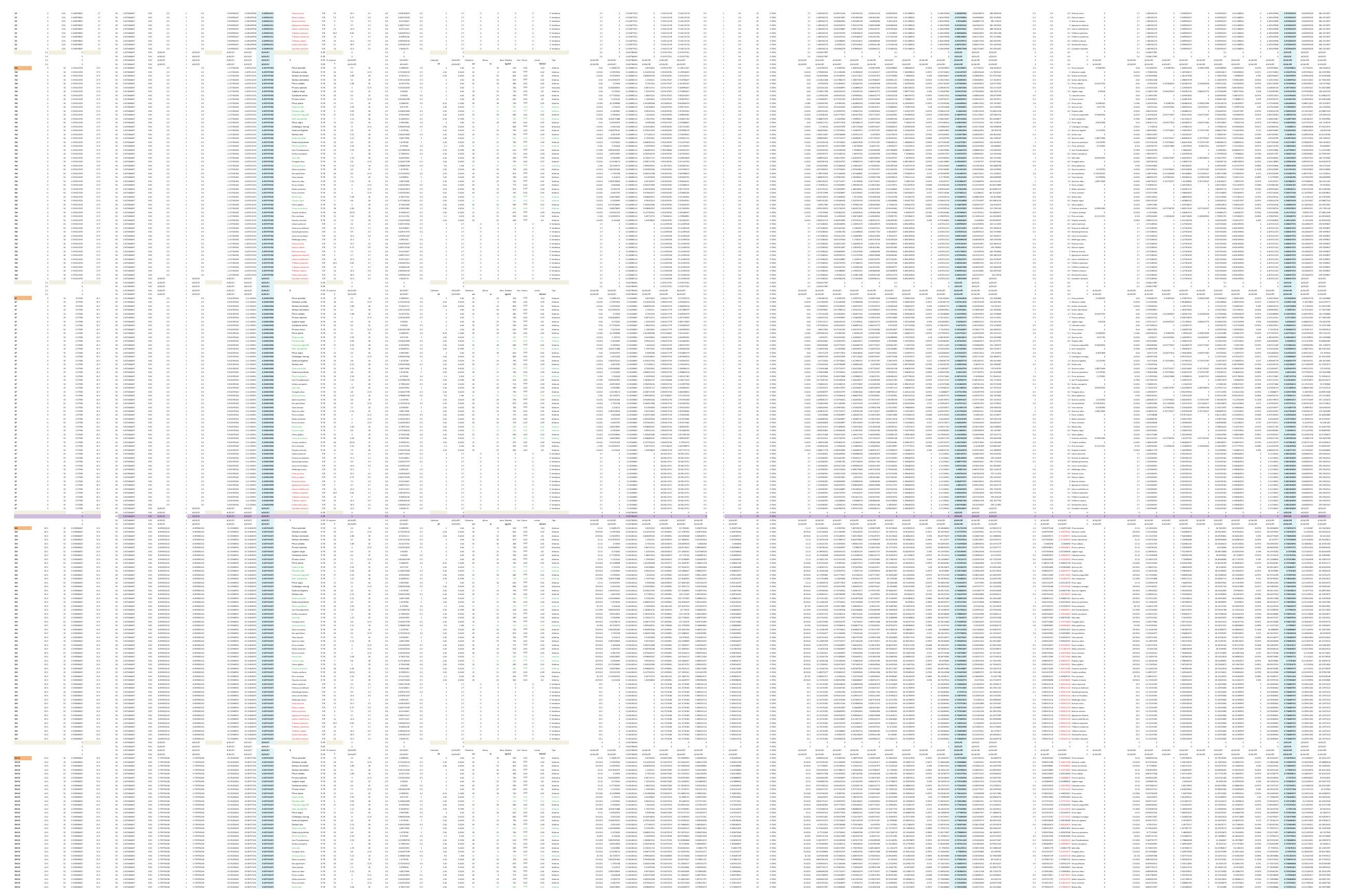




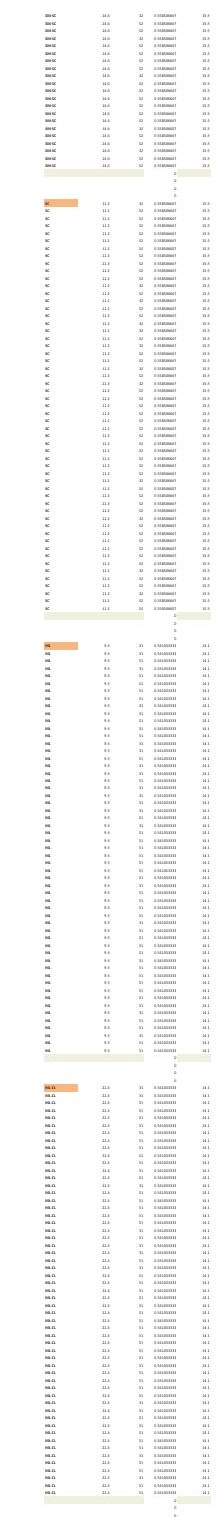

-

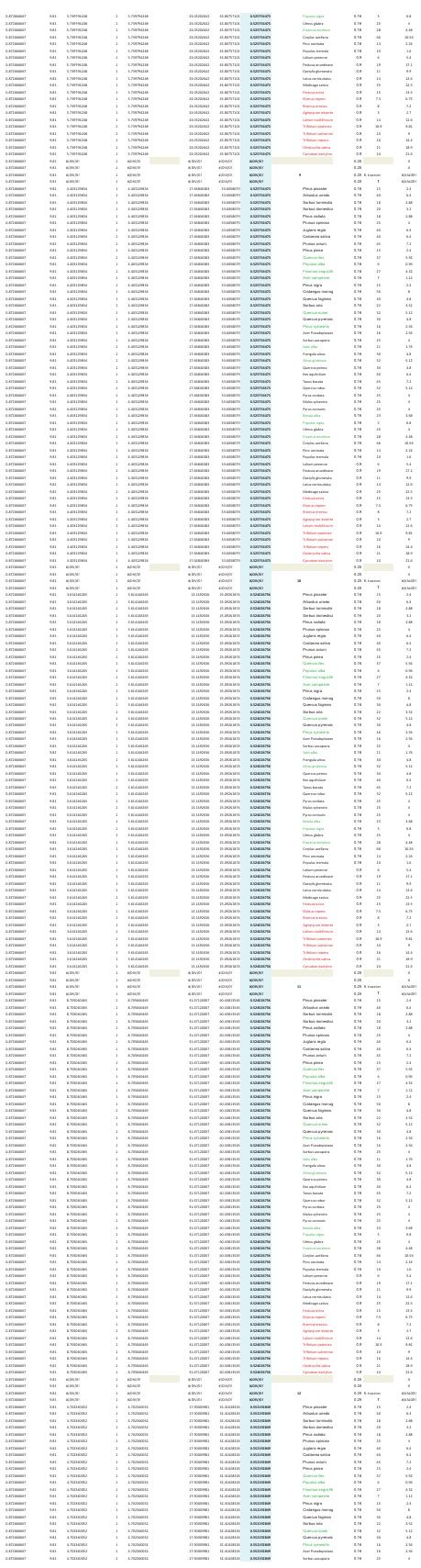

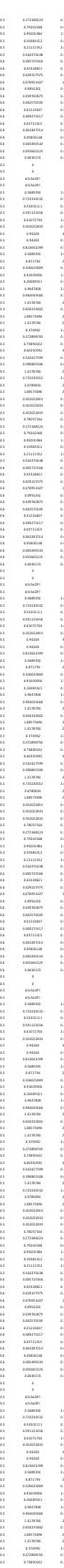

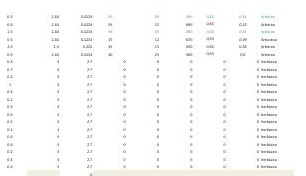

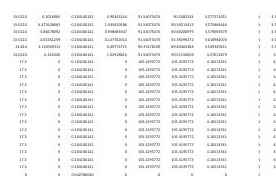
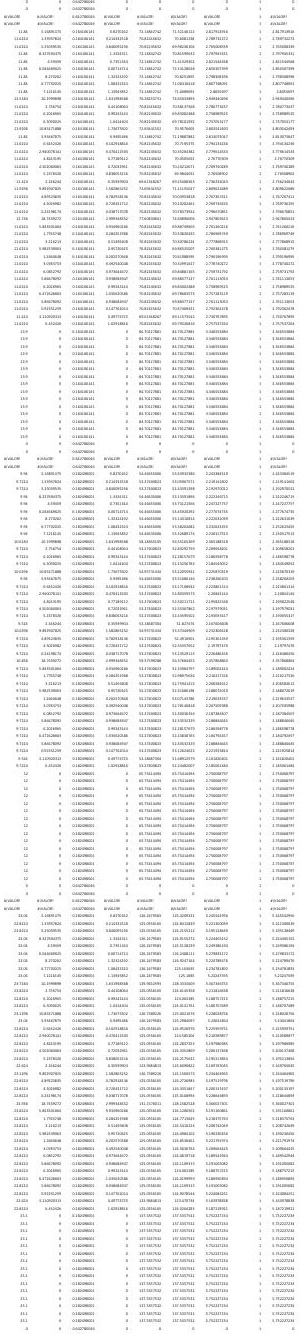

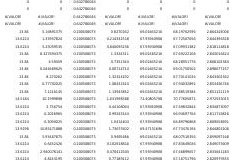

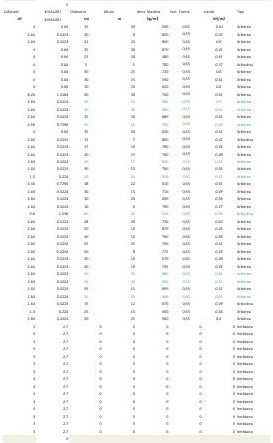

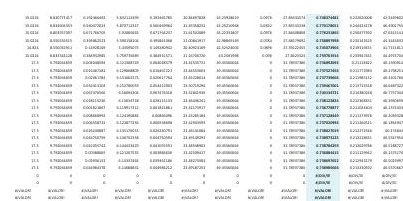

主引E

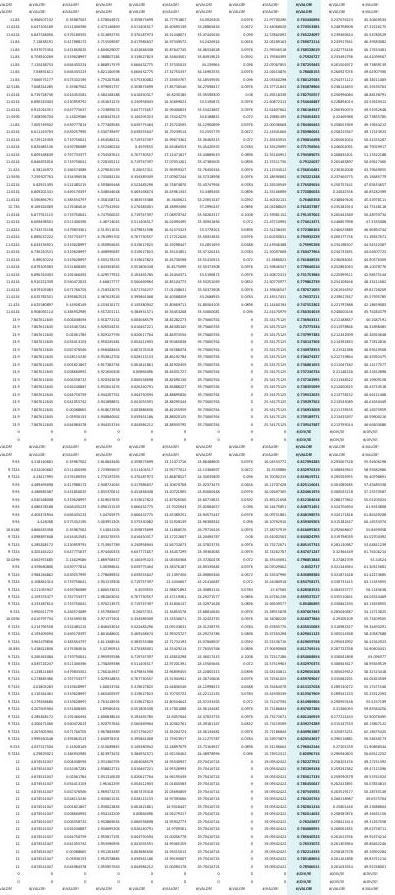

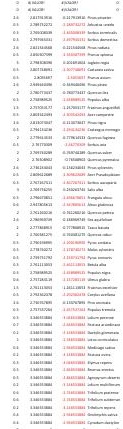
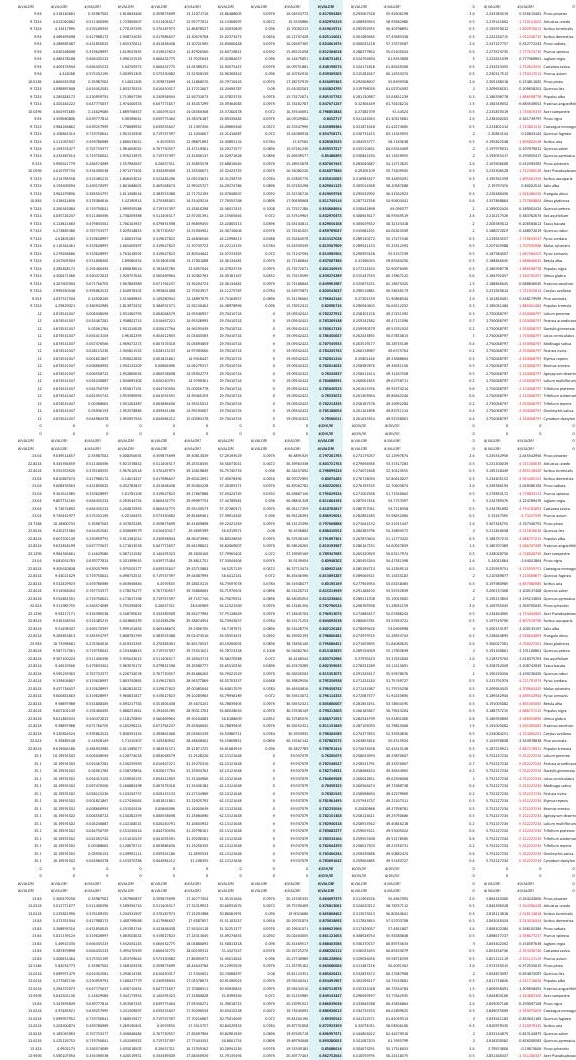
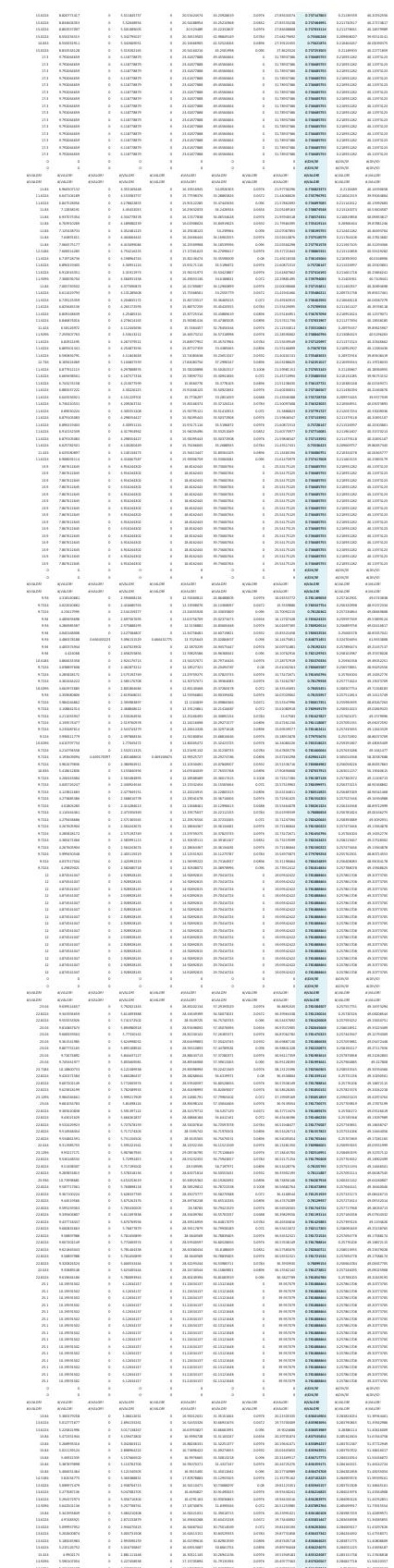


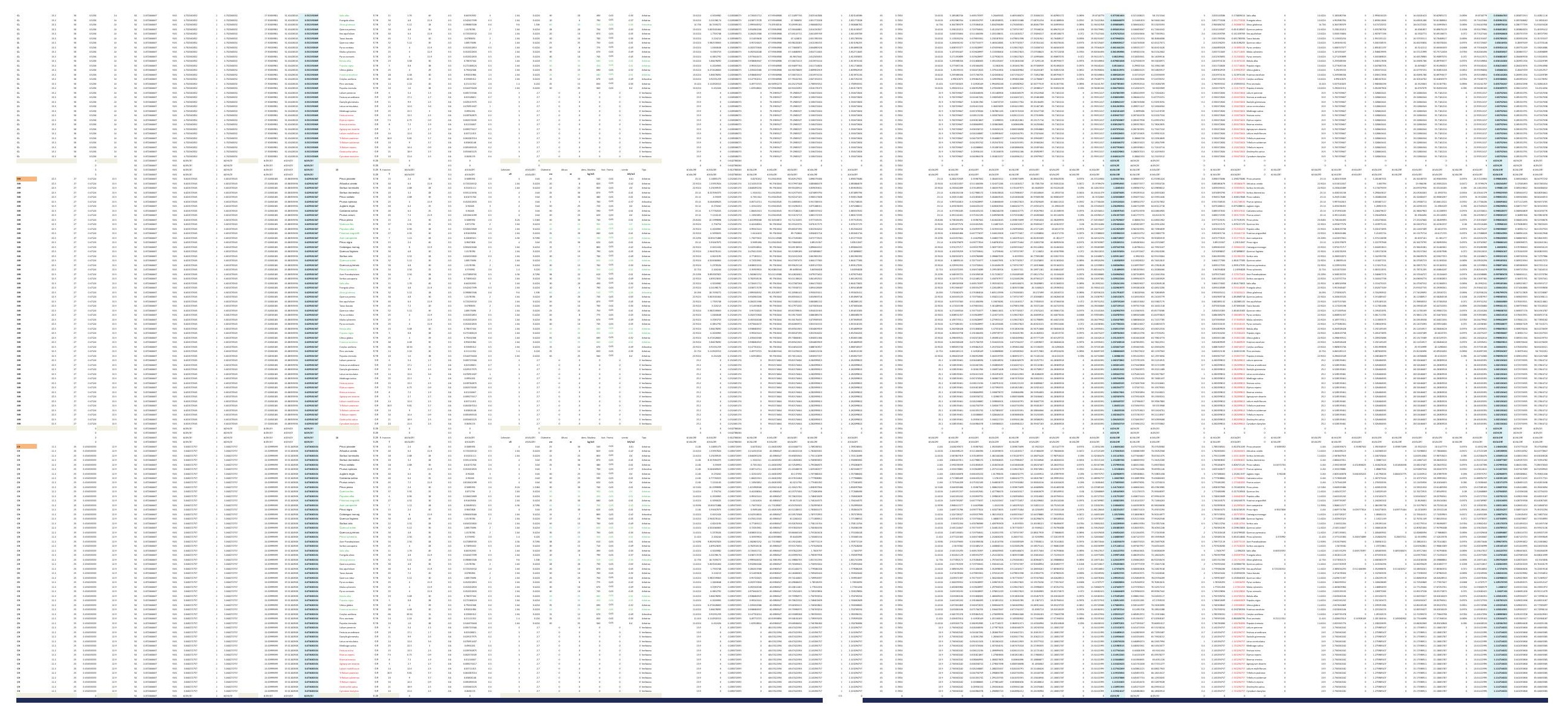



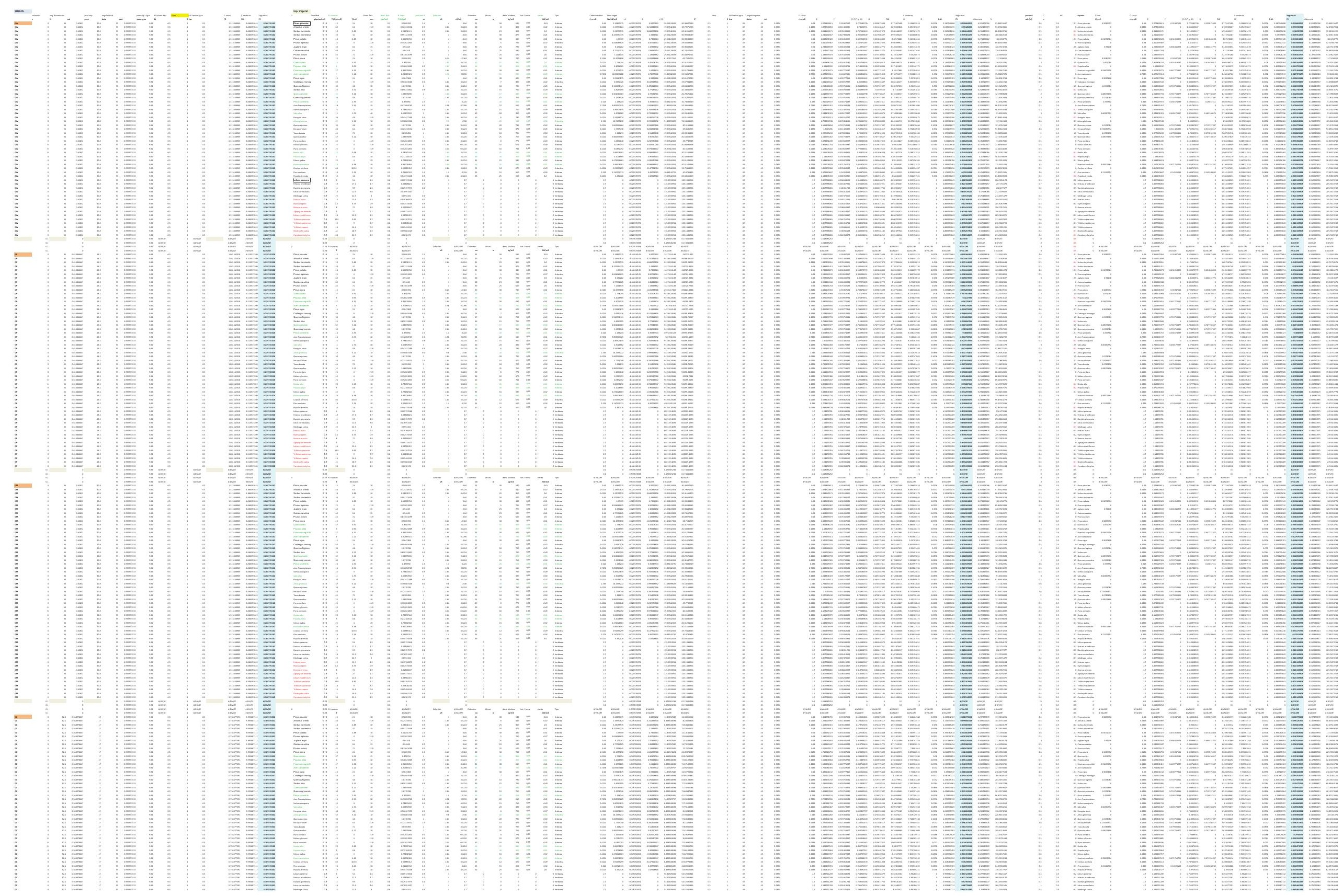


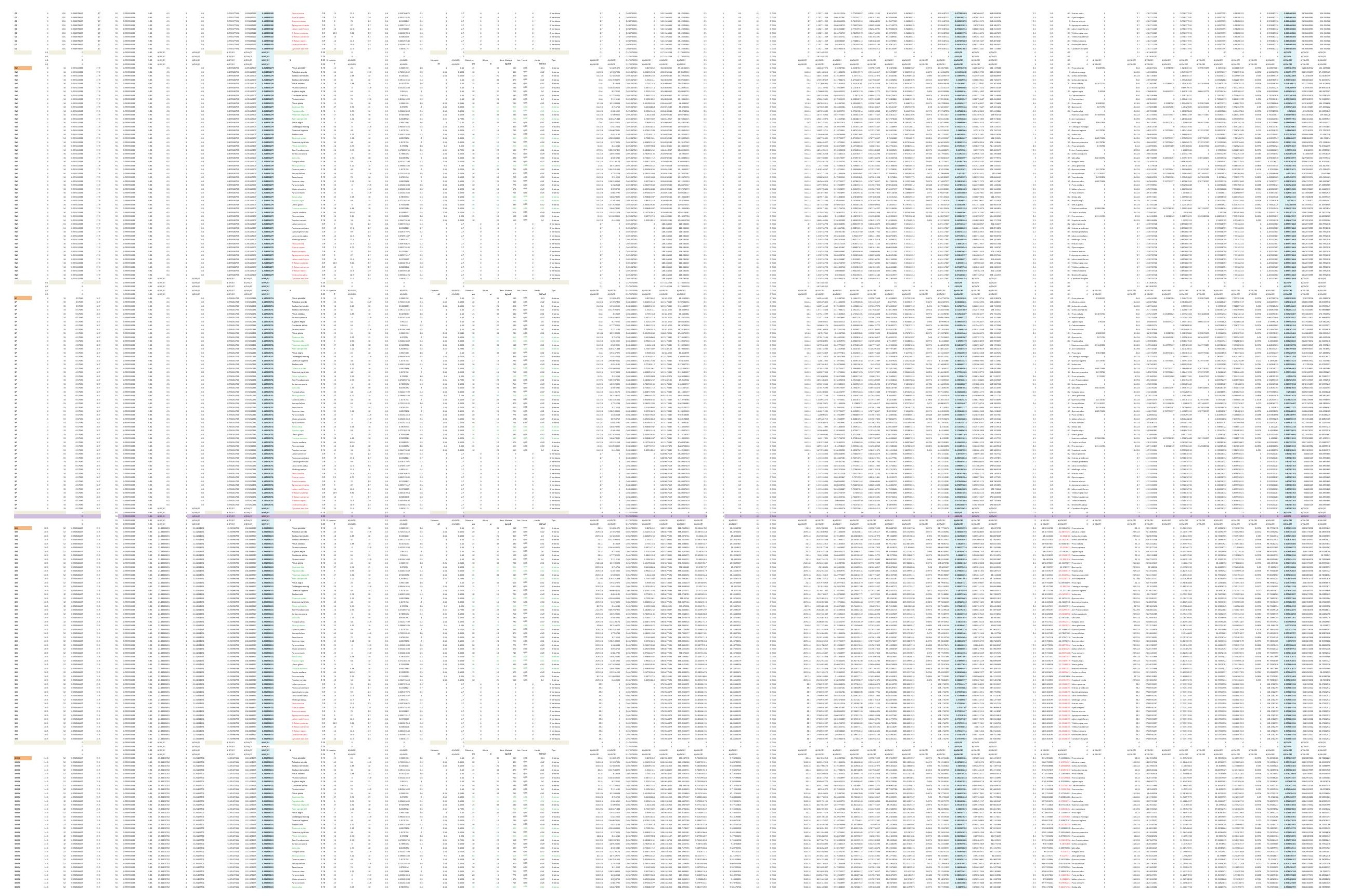



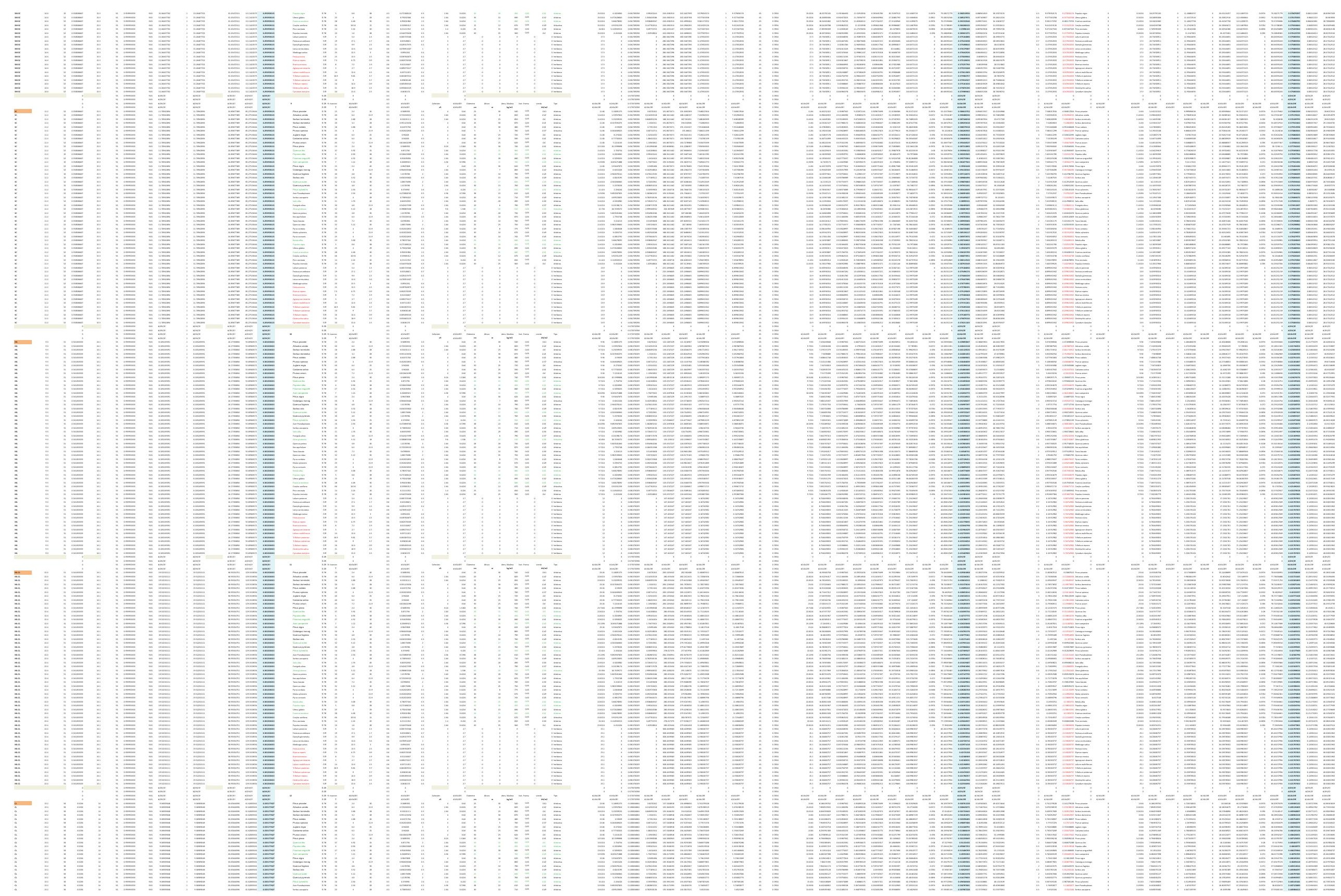


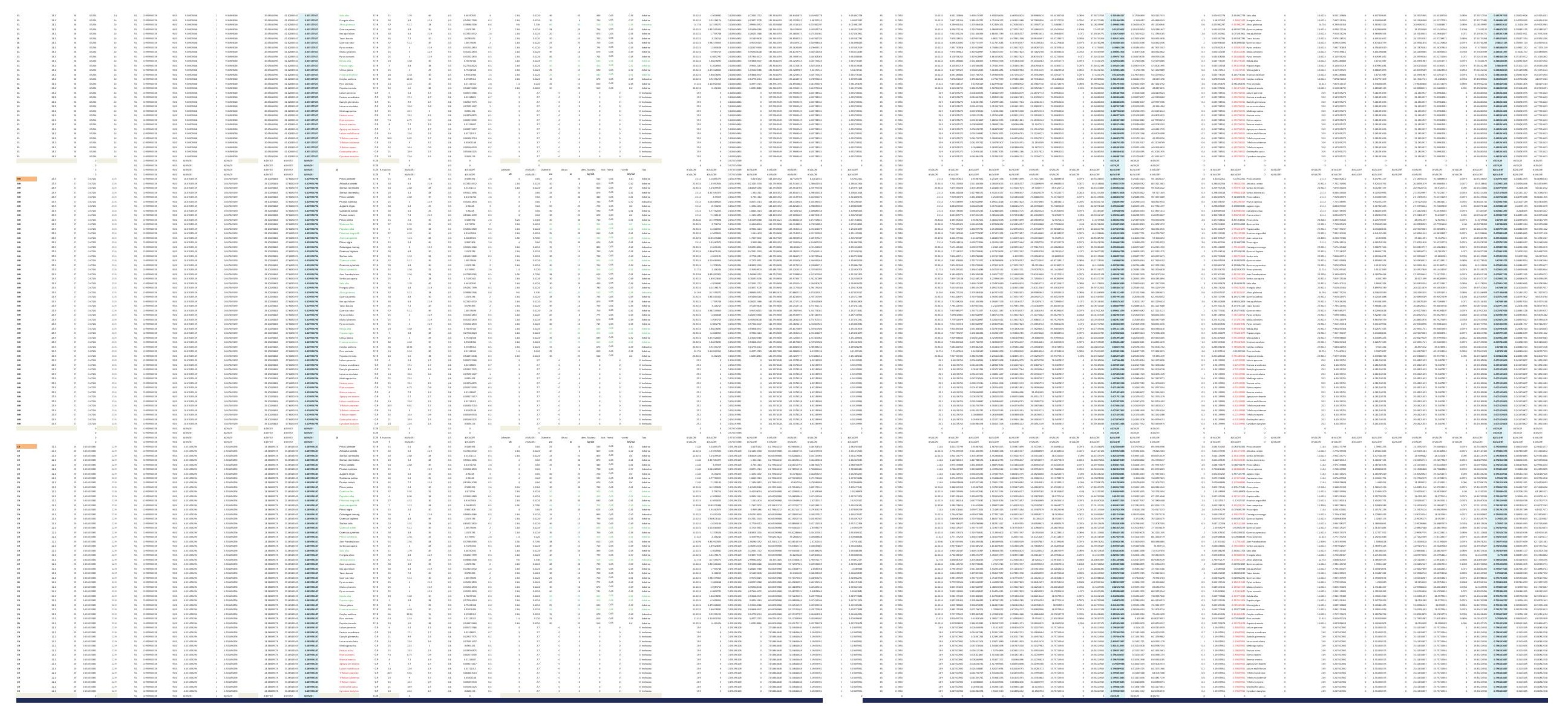



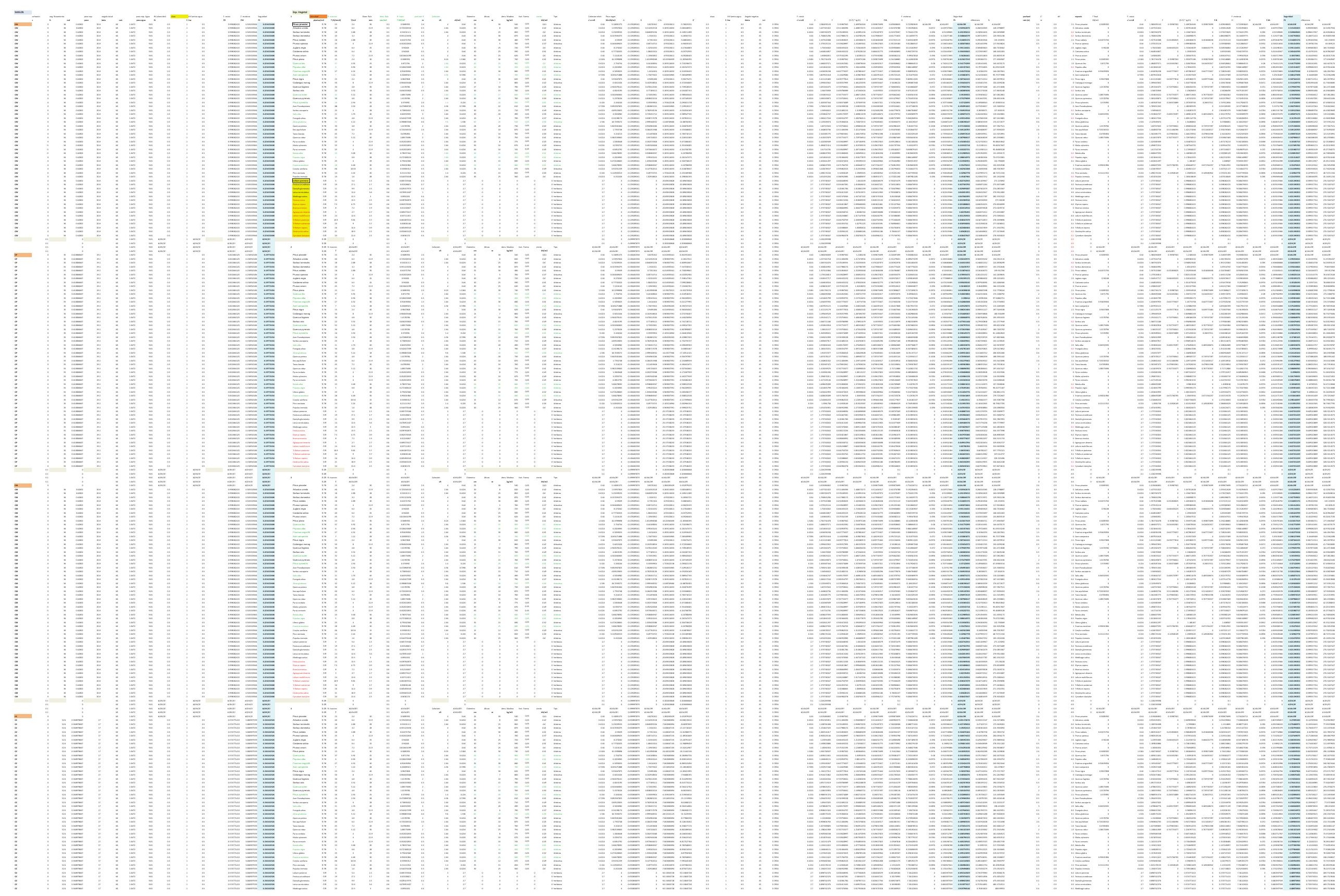


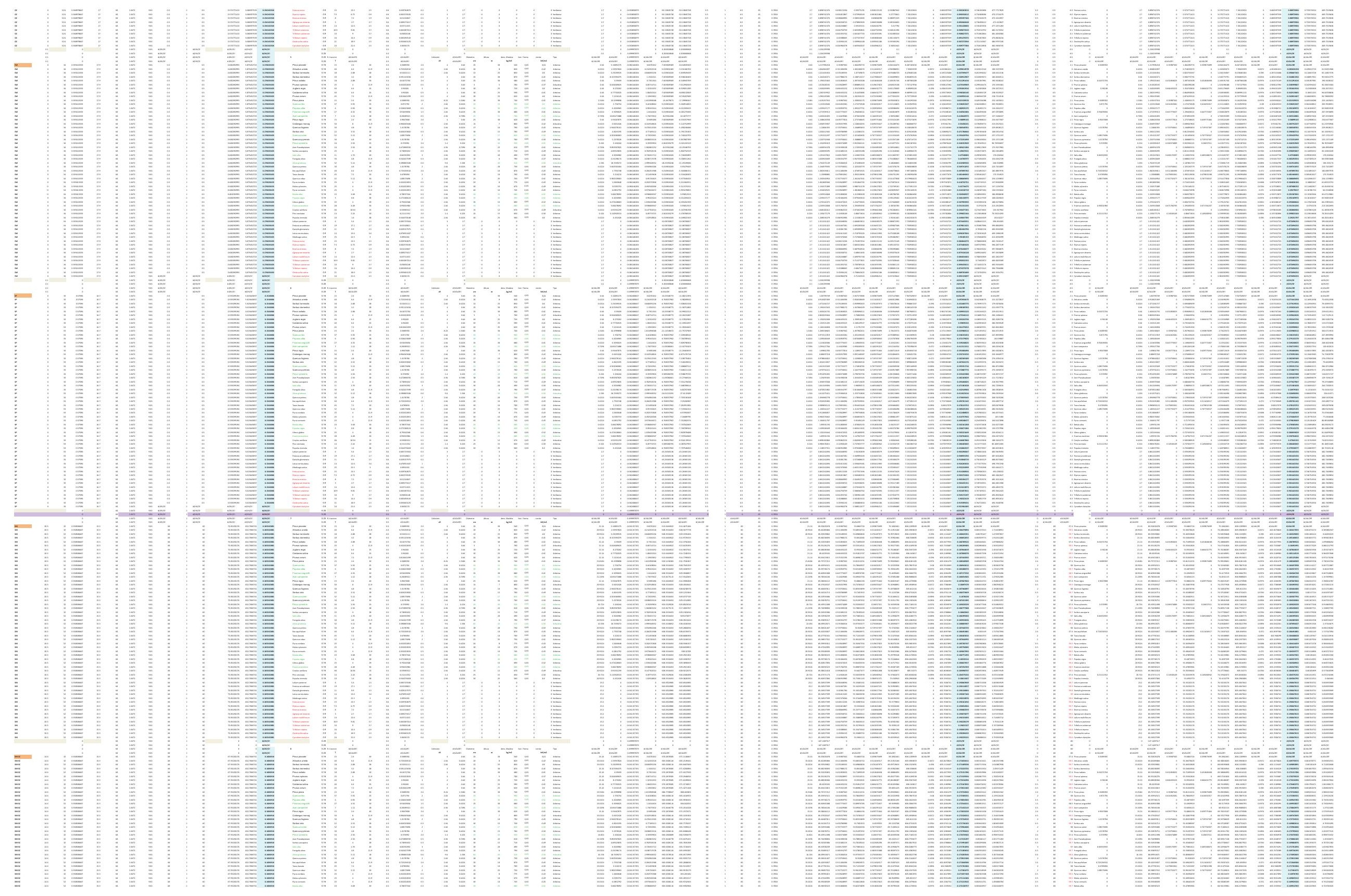



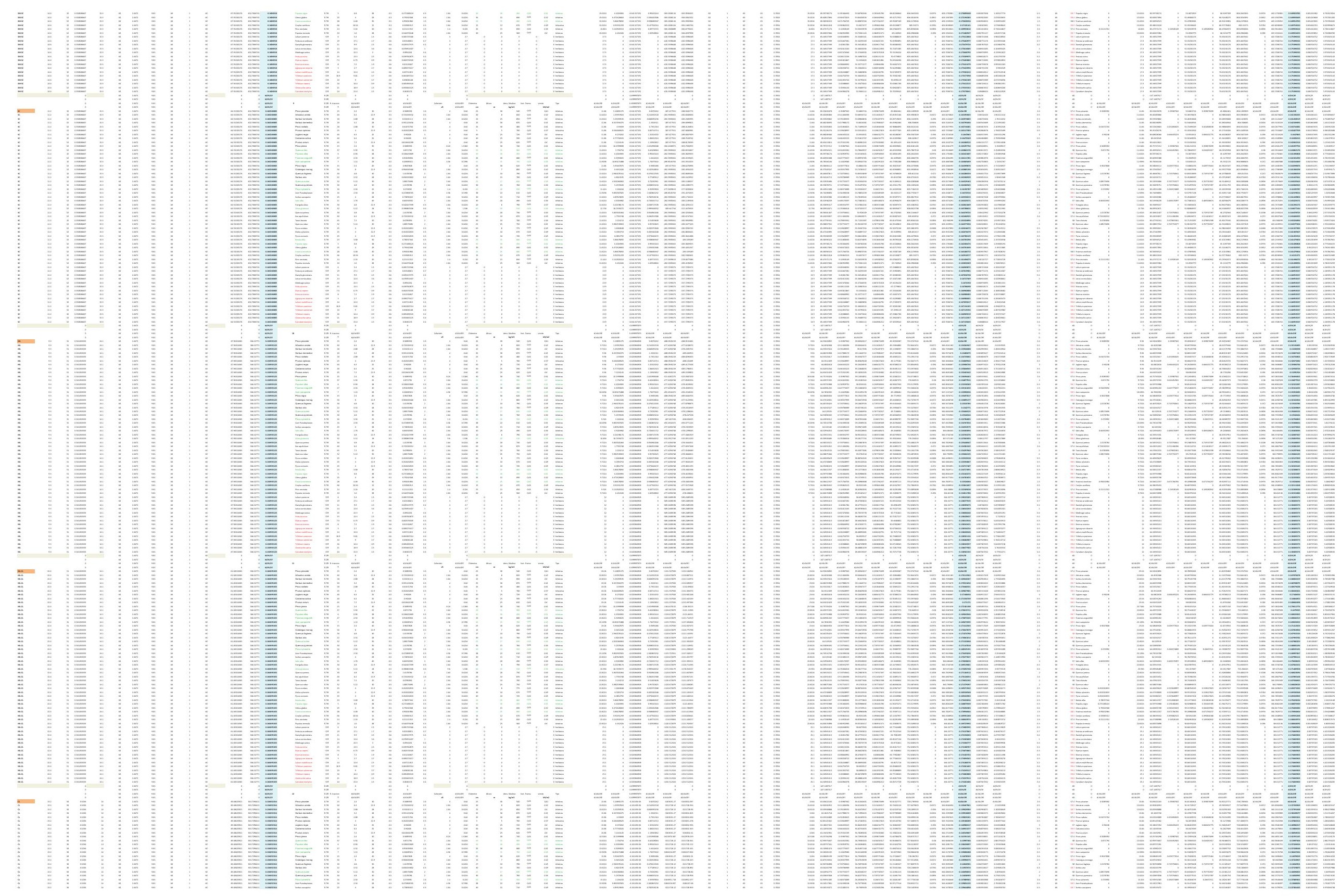

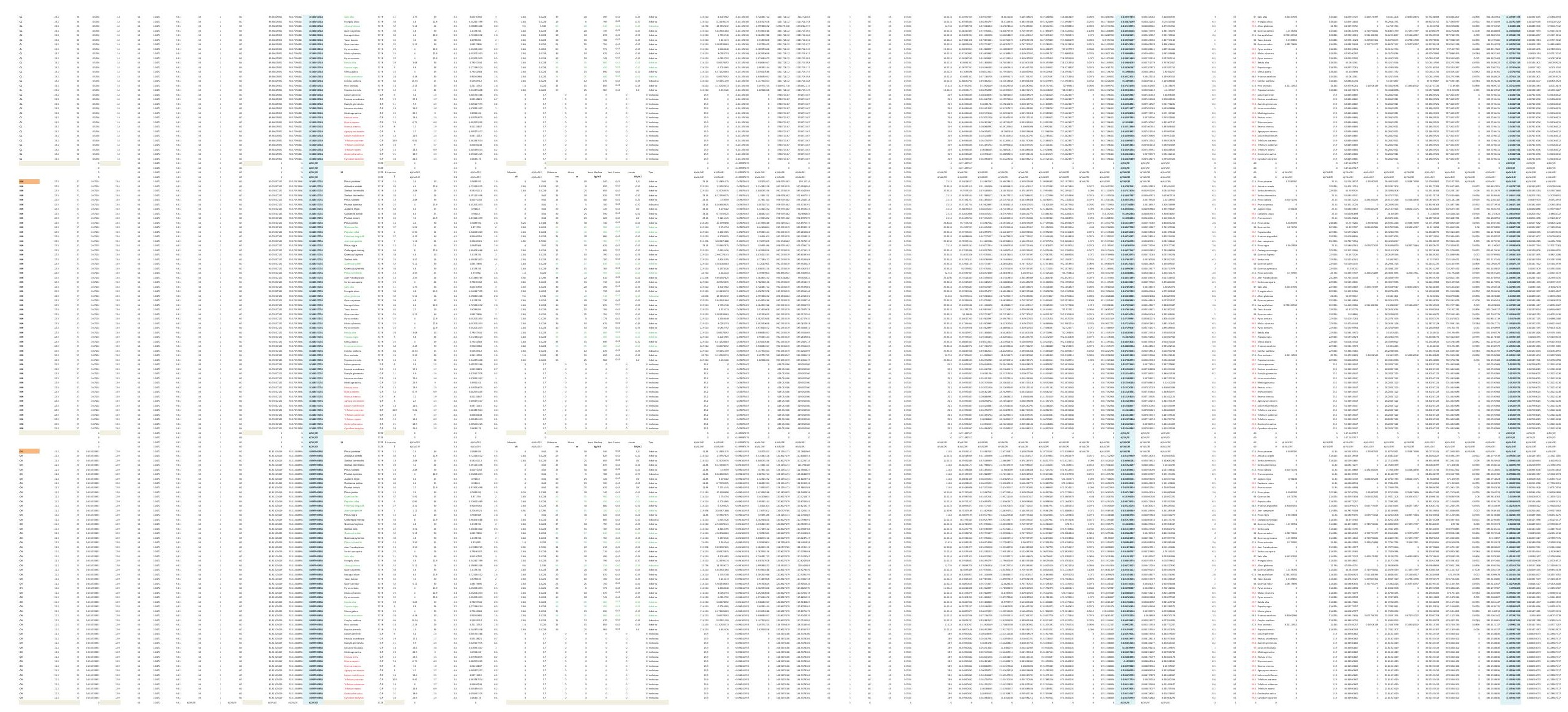

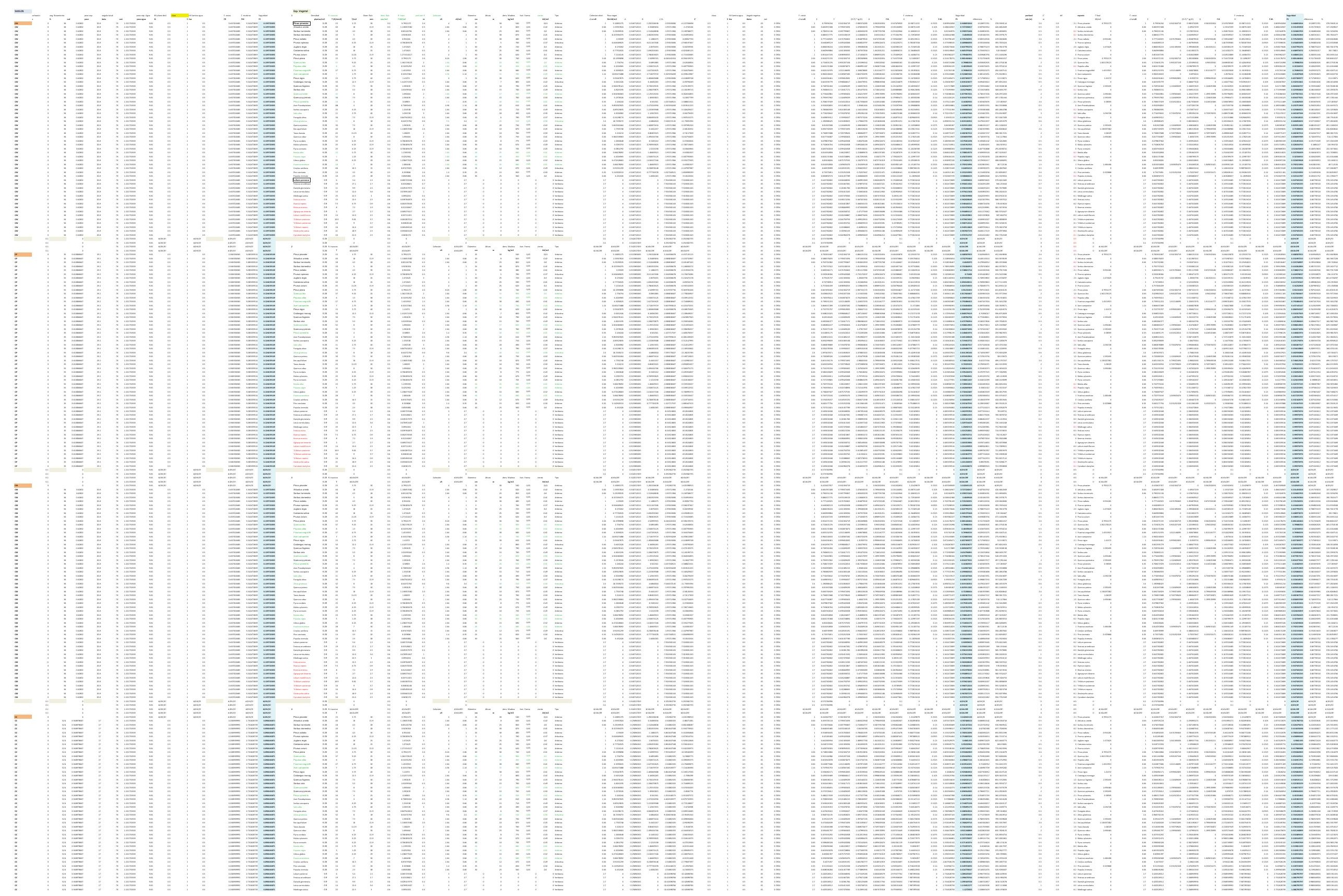


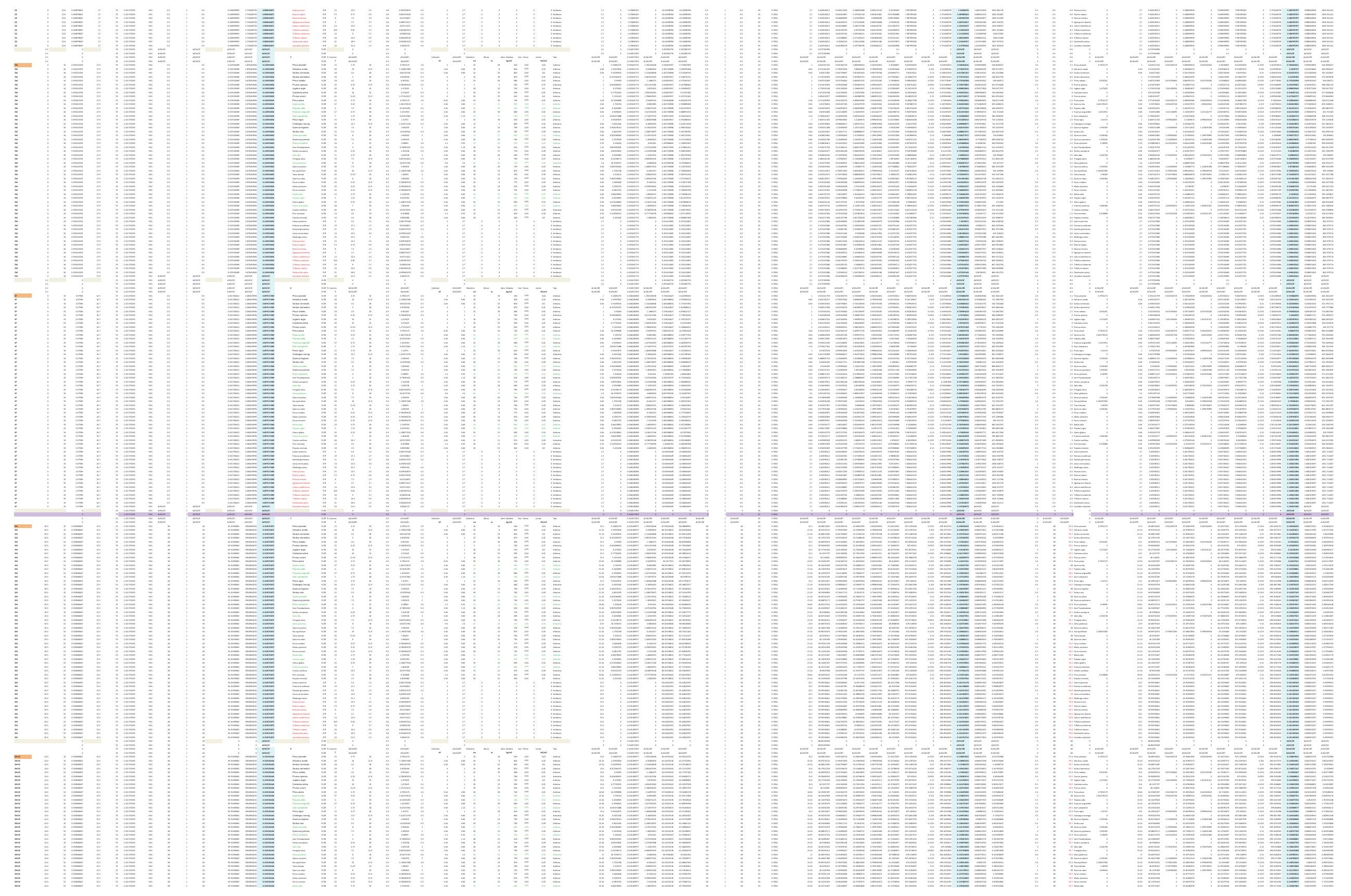




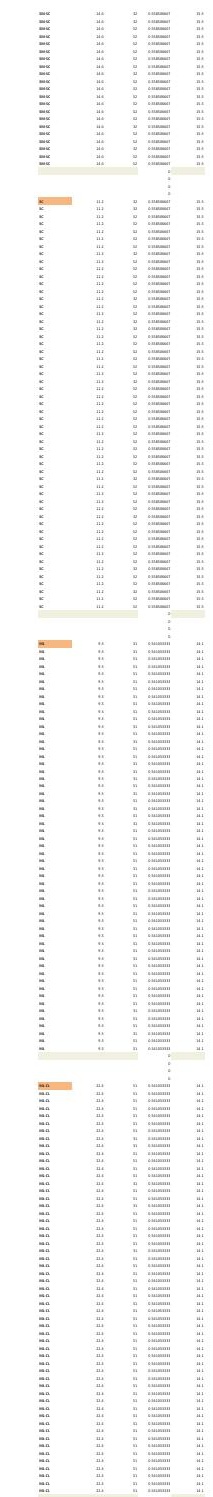

$-$

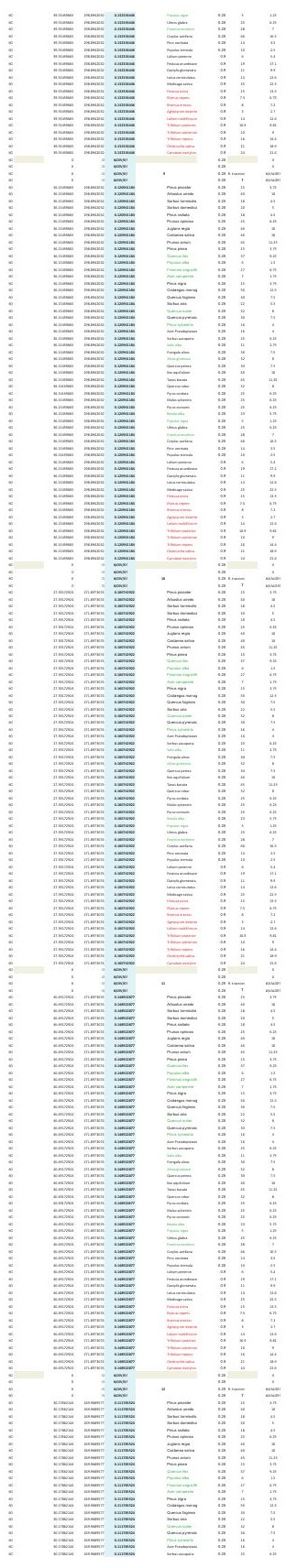

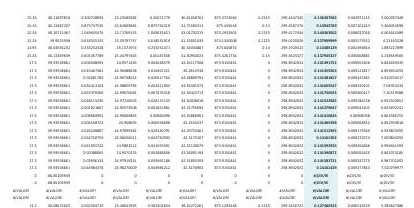

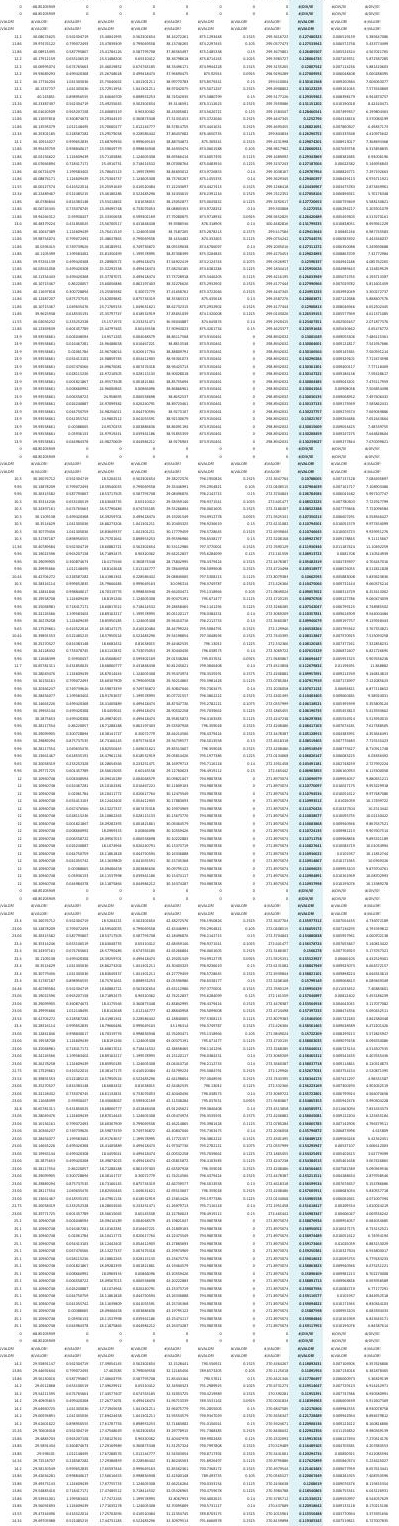

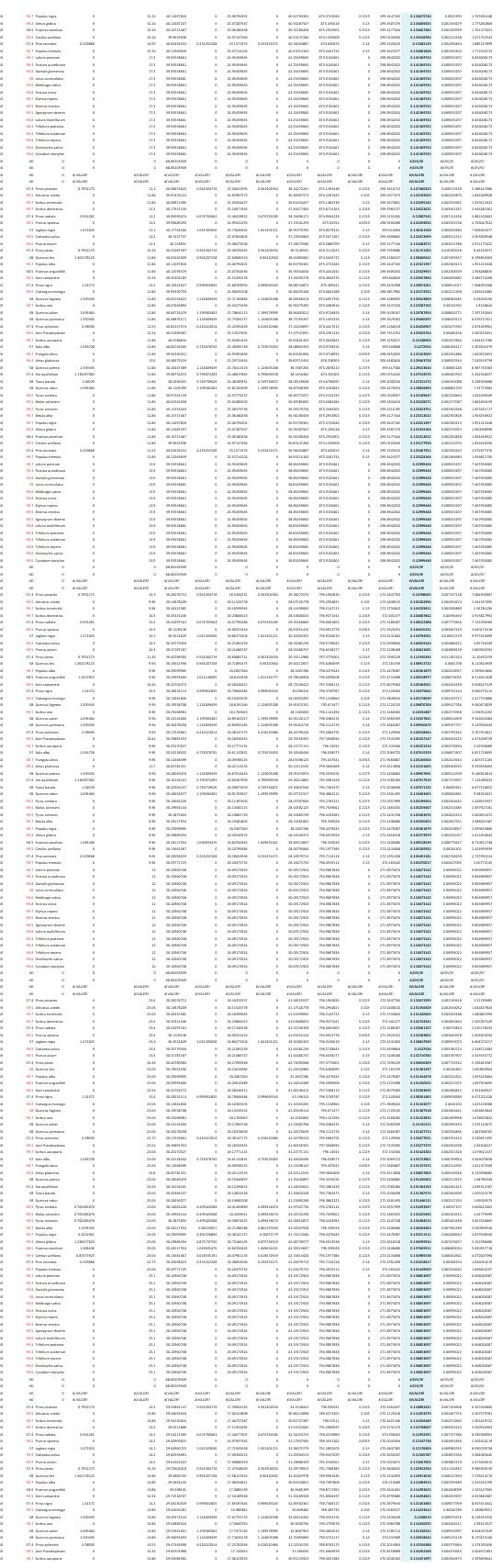




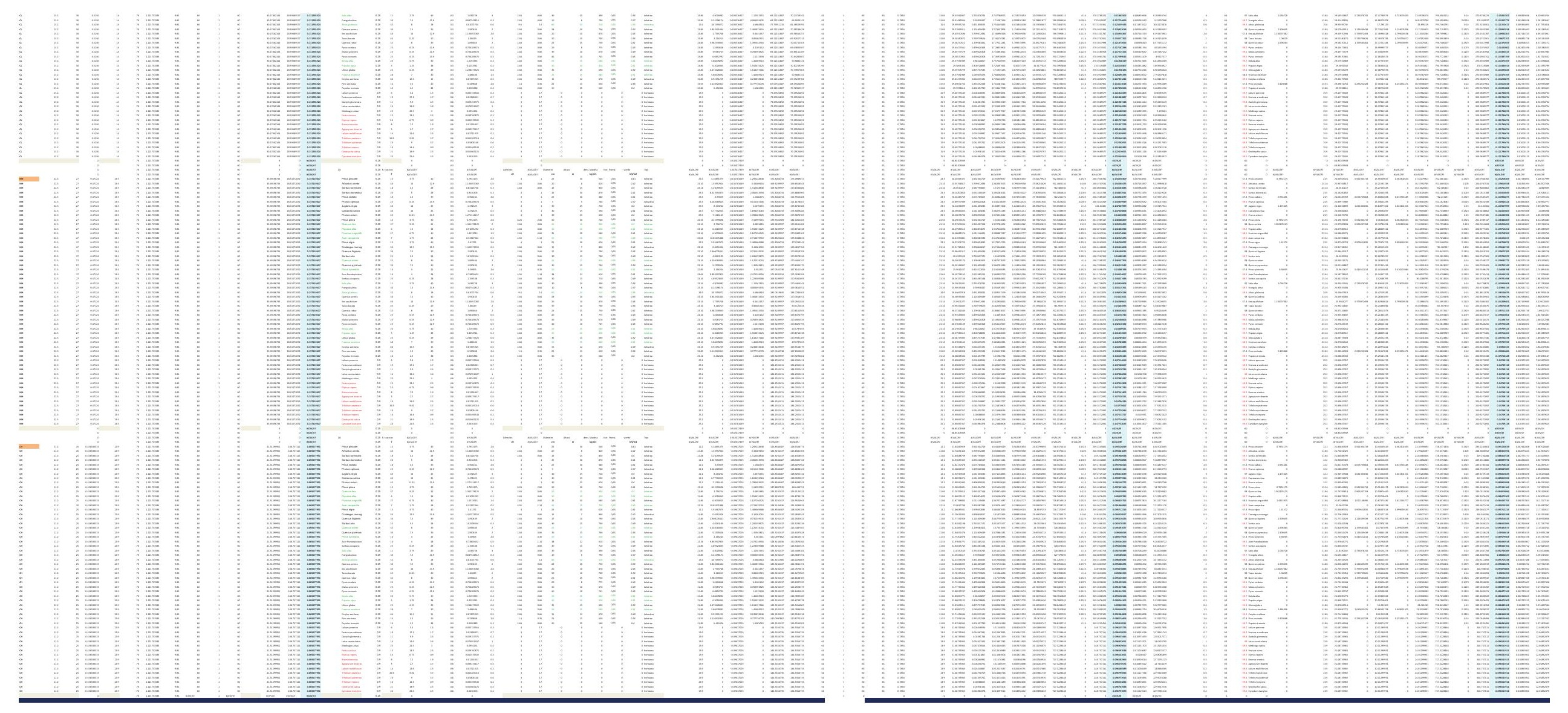



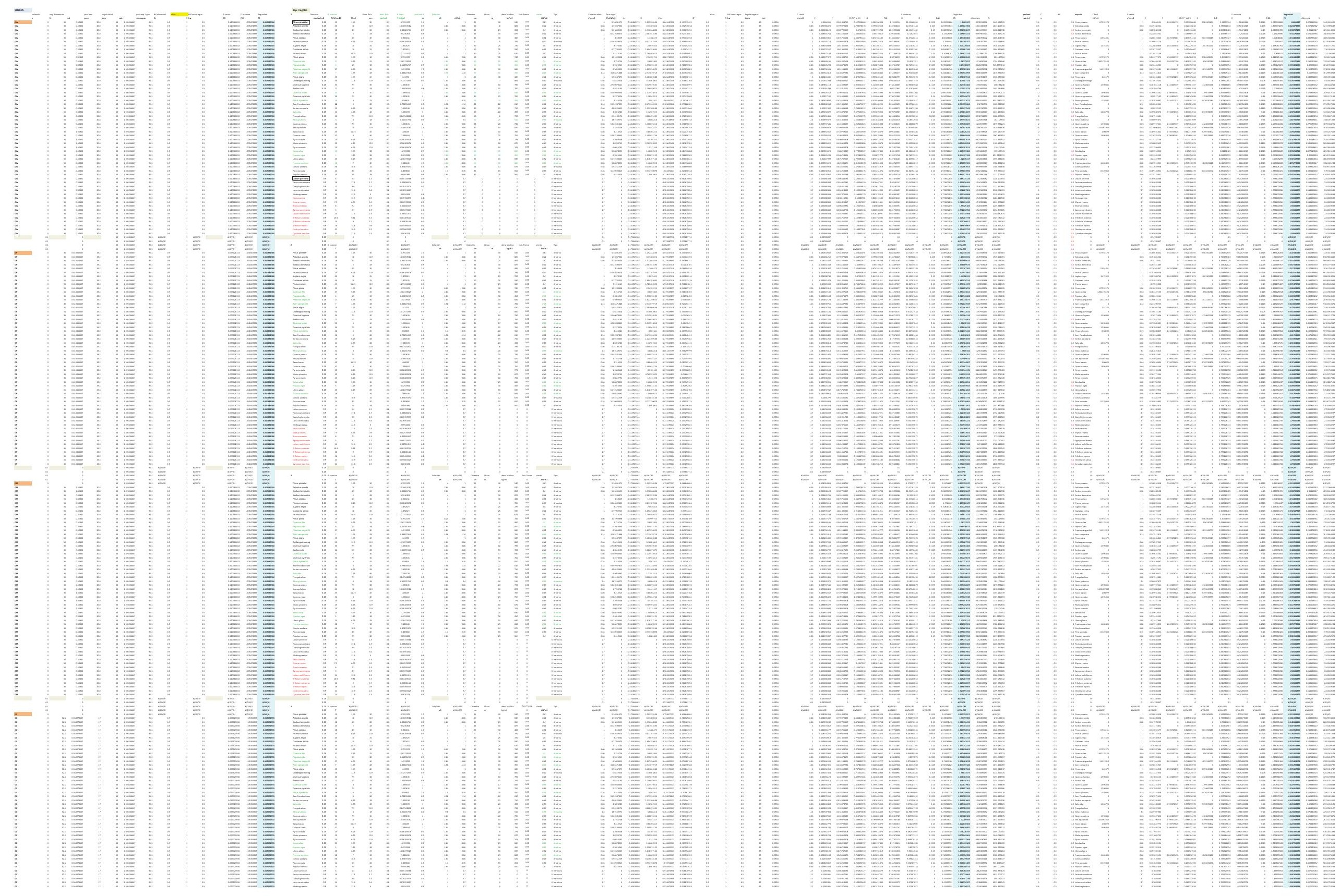


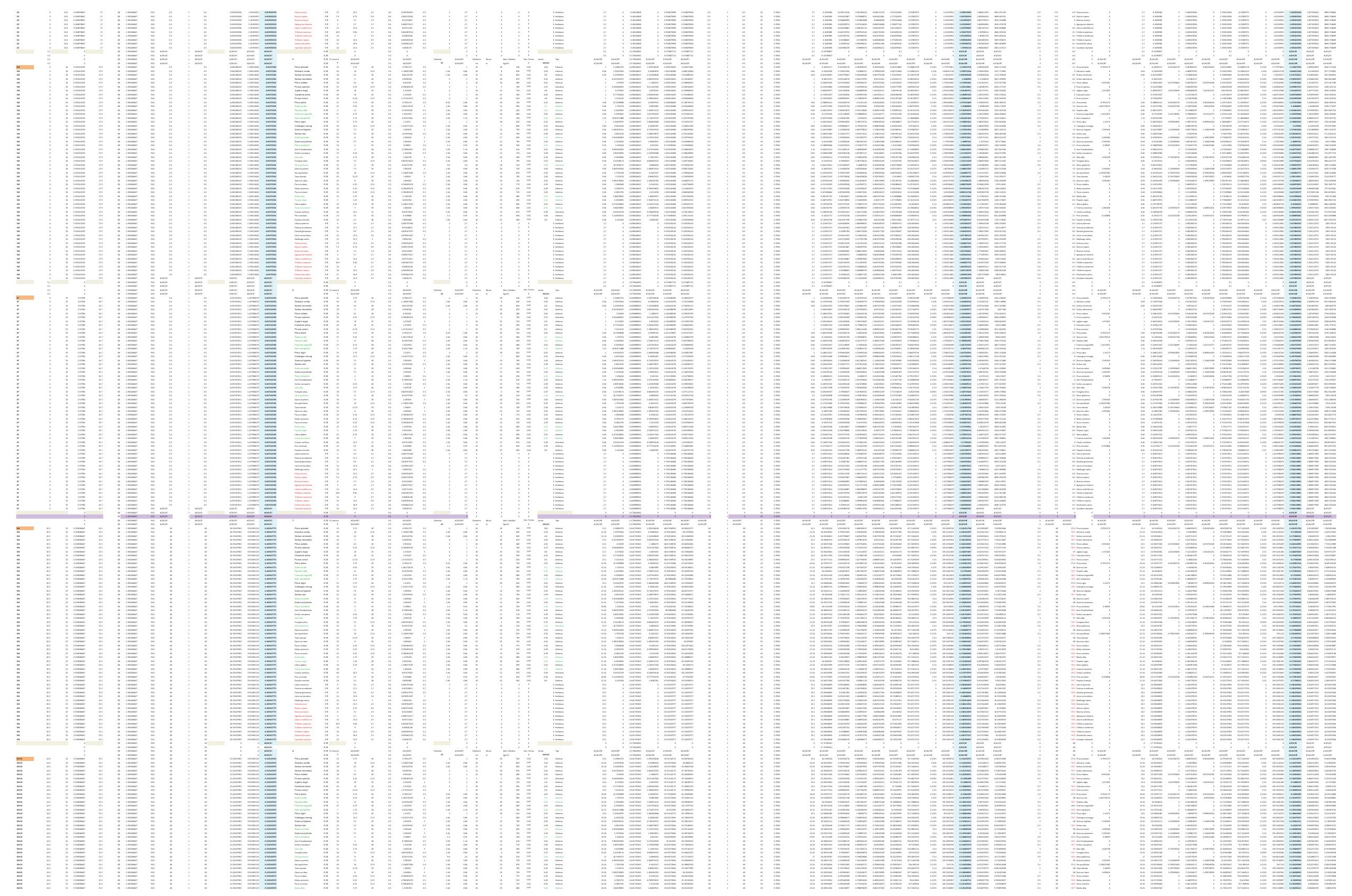




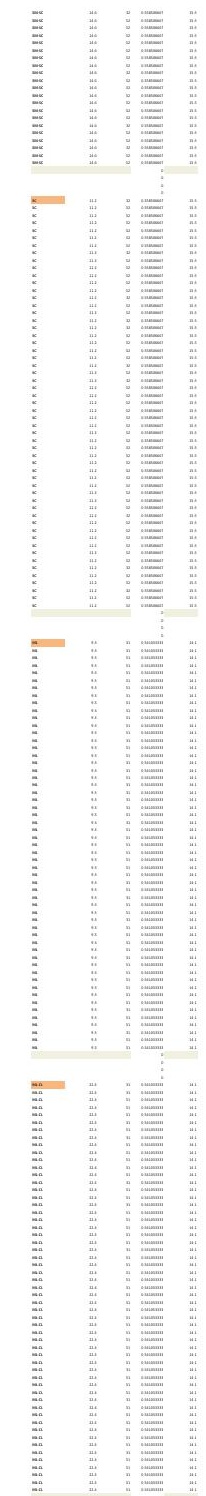

¿
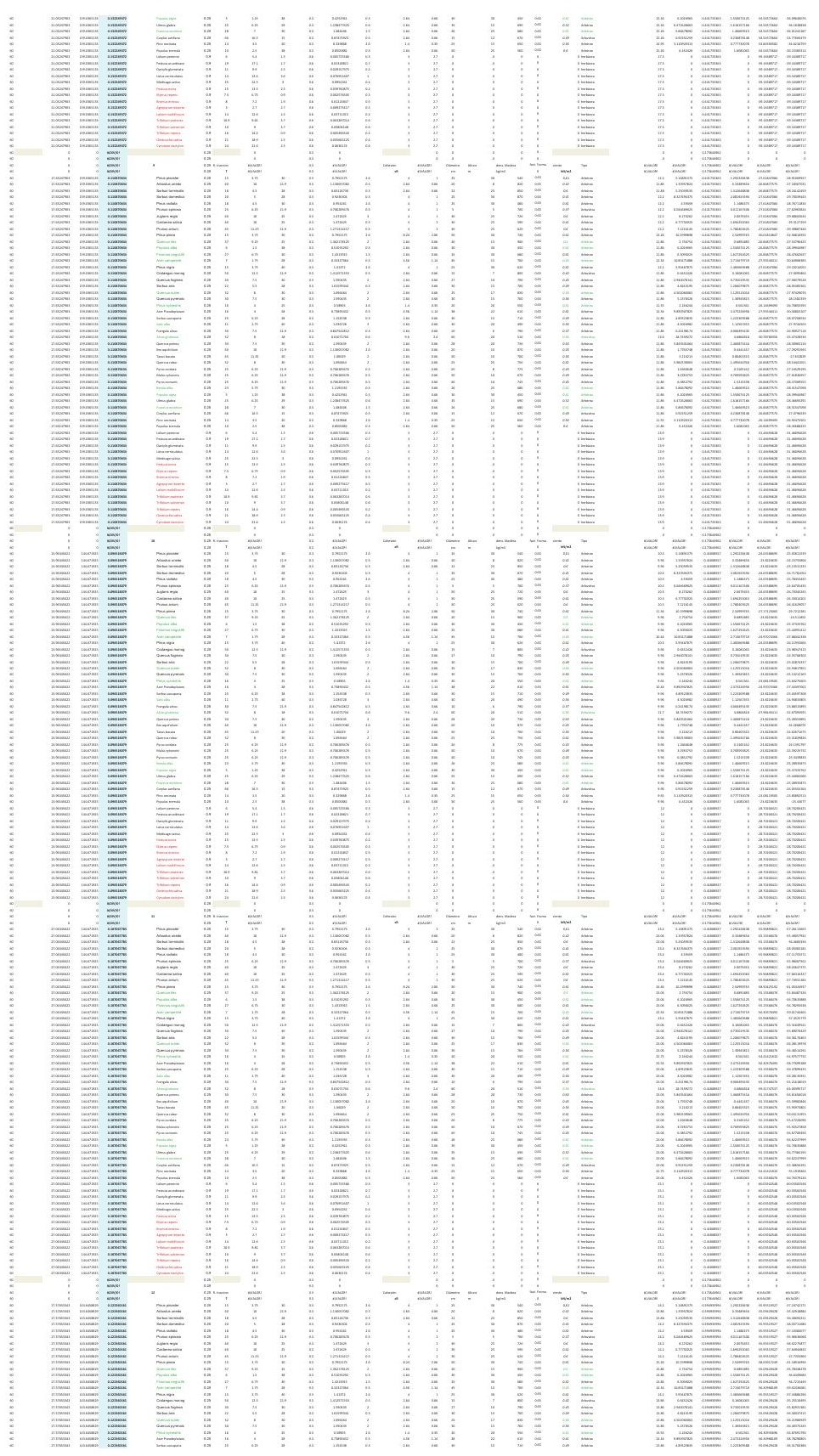
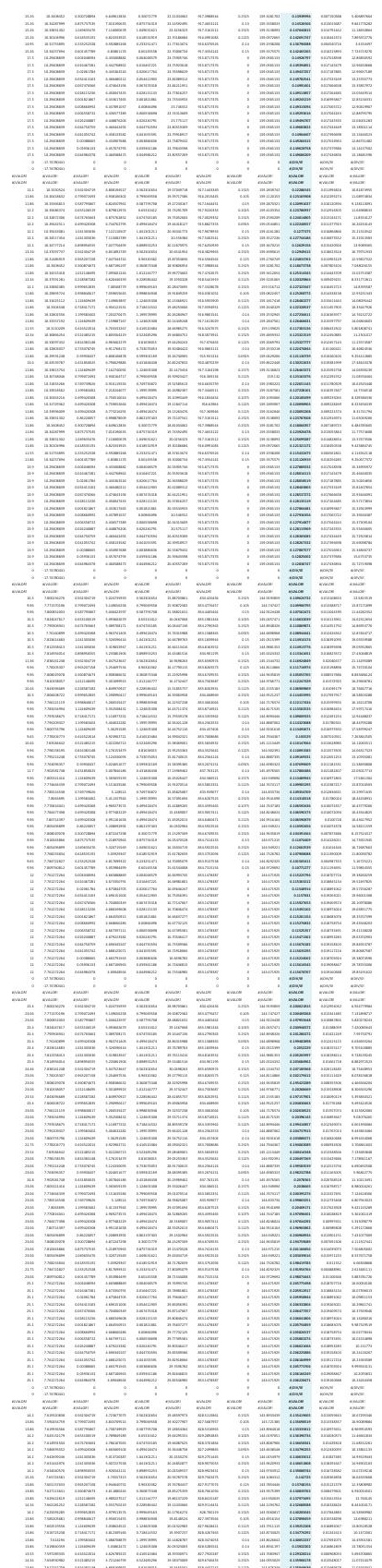

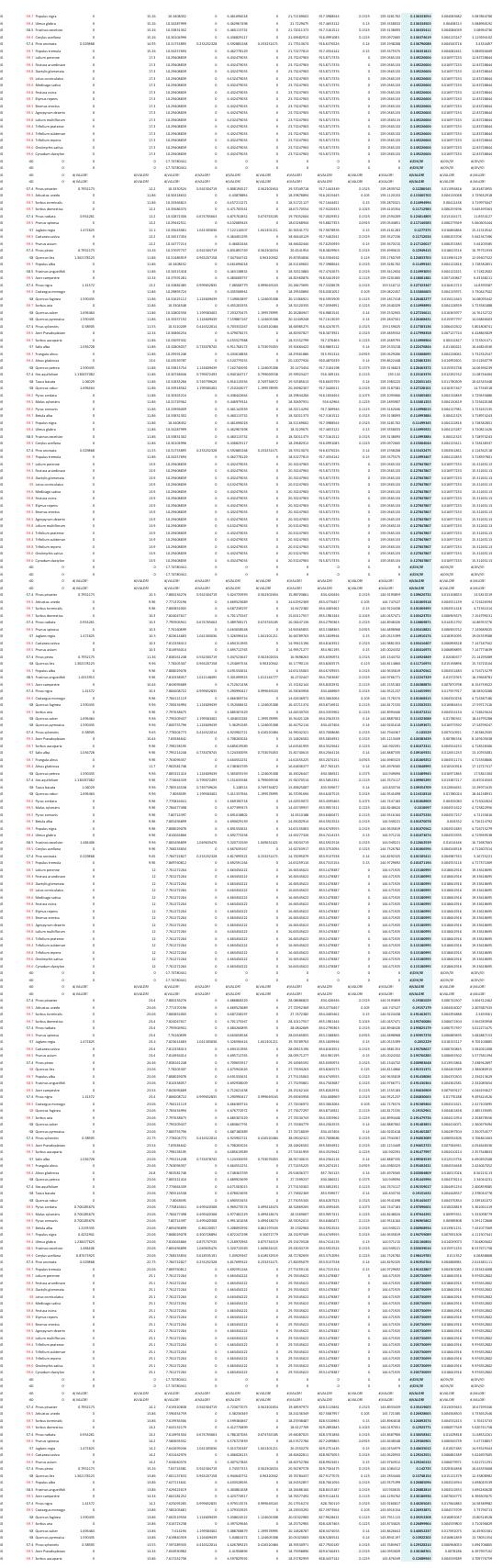




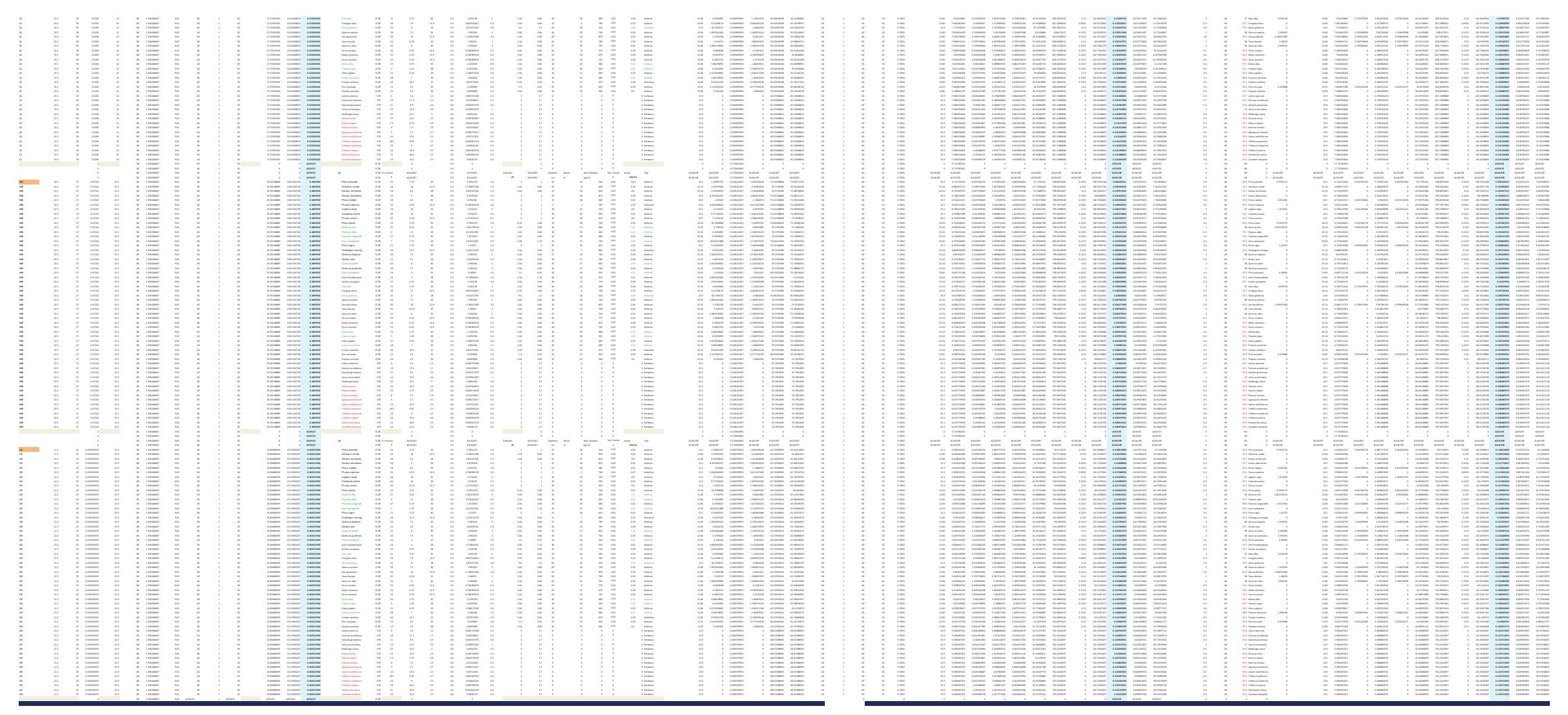


DESARROLLO DE UNA APLICACIÓN IMFORMÁTICA PARA EL CÁLCULO DE SOSTENIMIENTO DE TALUDES MEDIANTE VEGETACIÓN

PRUEBAS DEL MODELO MATEMÁTICO PARA EL CÁLCULO DE ESTABILIDAD DE TALUDES.

A03. DENSIDAD DE PLANTACIÓN: 2.500 plantas/ha.

A03-1.POSICIÓN N.F. 1

A03-2.POSICIÓN N.F. 2

A03-3.POSICIÓN N.F. 3

A03-4.POSICIÓN N.F. 4

A03-5.POSICIÓN N.F. 5 
DESARROLLO DE UNA APLICACIÓN IMFORMÁTICA PARA EL CÁLCULO DE SOSTENIMIENTO DE TALUDES MEDIANTE VEGETACIÓN

A03. DENSIDAD DE PLANTACIÓN: 2.500 plantas/ha.

\section{A03-1.POSICIÓN N.F. 1}

INCLINACIÓN DE TALUD 6-100

INCLINACIÓN DE TALUD 10-200

INCLINACIÓN DE TALUD 20-30

INCLINACIÓN DE TALUD 30-40

INCLINACIÓN DE TALUD $35^{\circ}$

INCLINACIÓN DE TALUD 40-50

INCLINACIÓN DE TALUD 50-550

INCLINACIÓN DE TALUD 55-60

INCLINACIÓN DE TALUD 60-700

INCLINACIÓN DE TALUD 70-80 

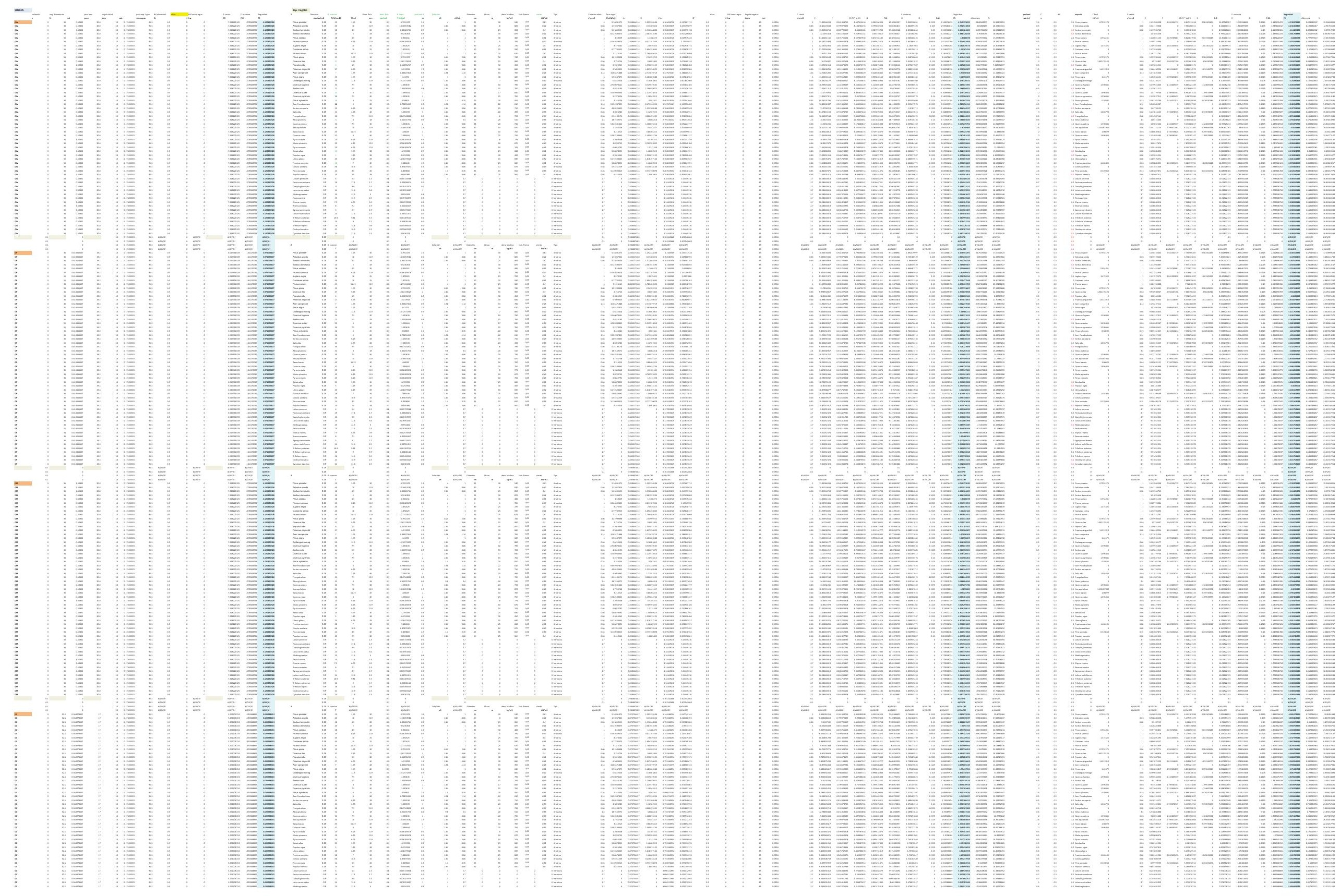


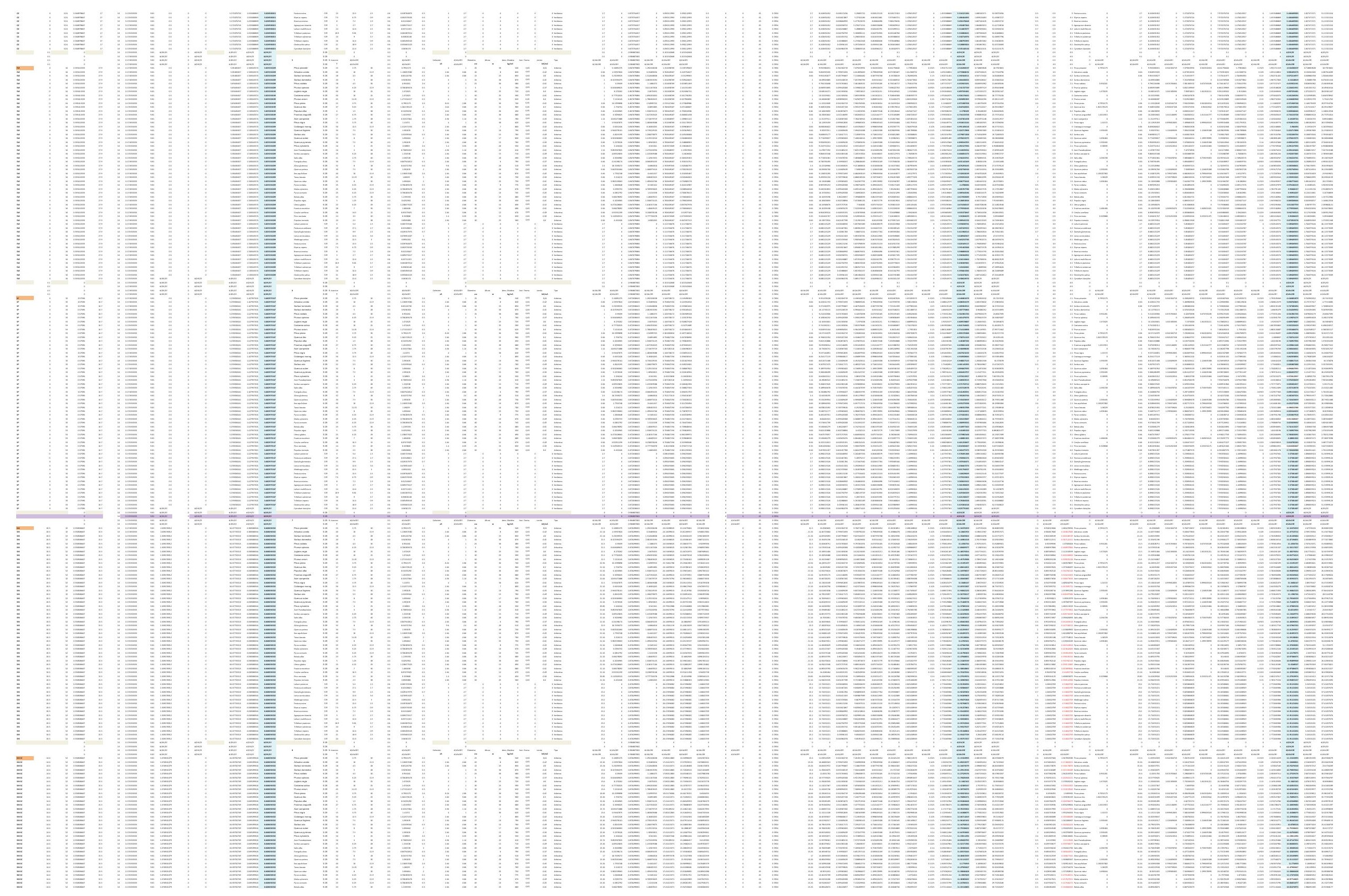



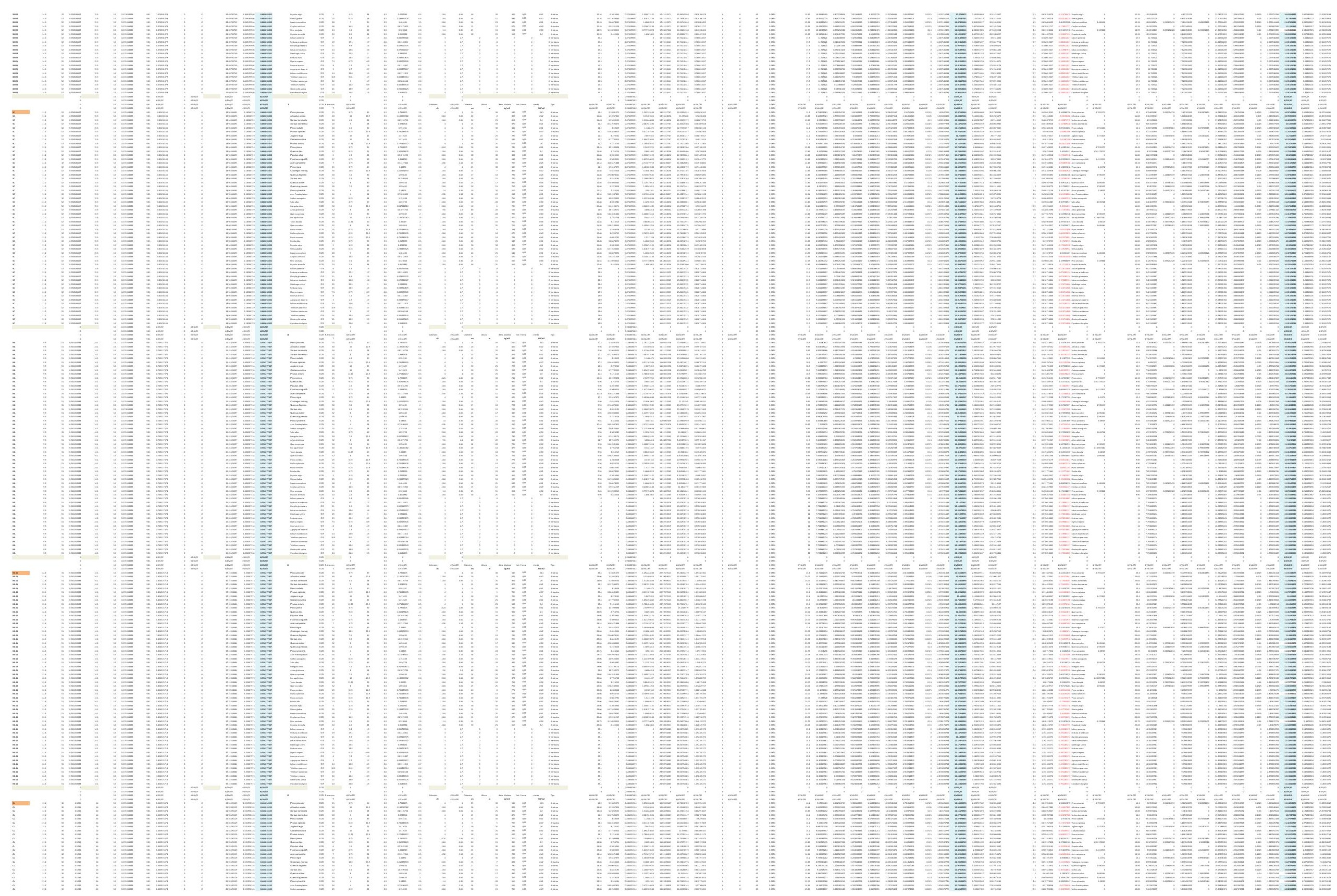


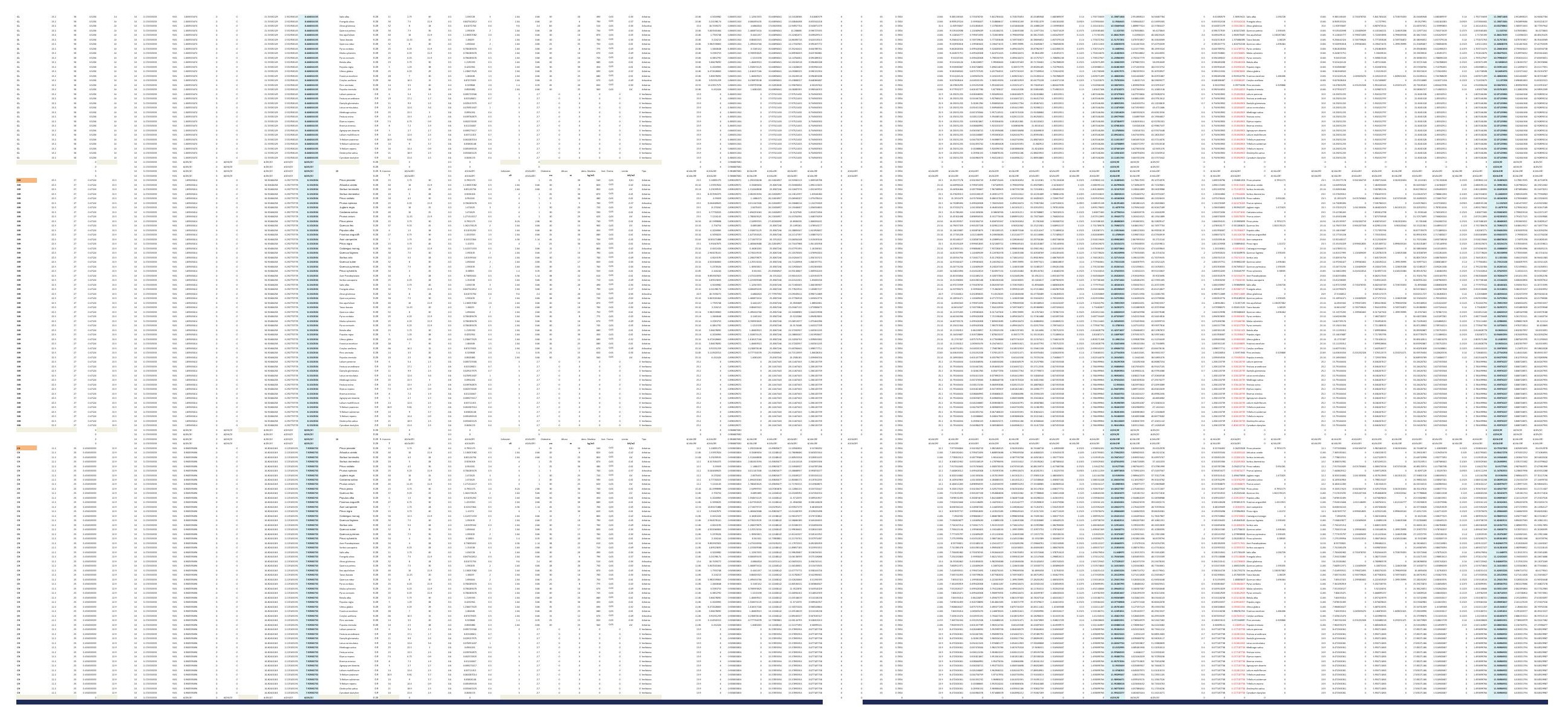



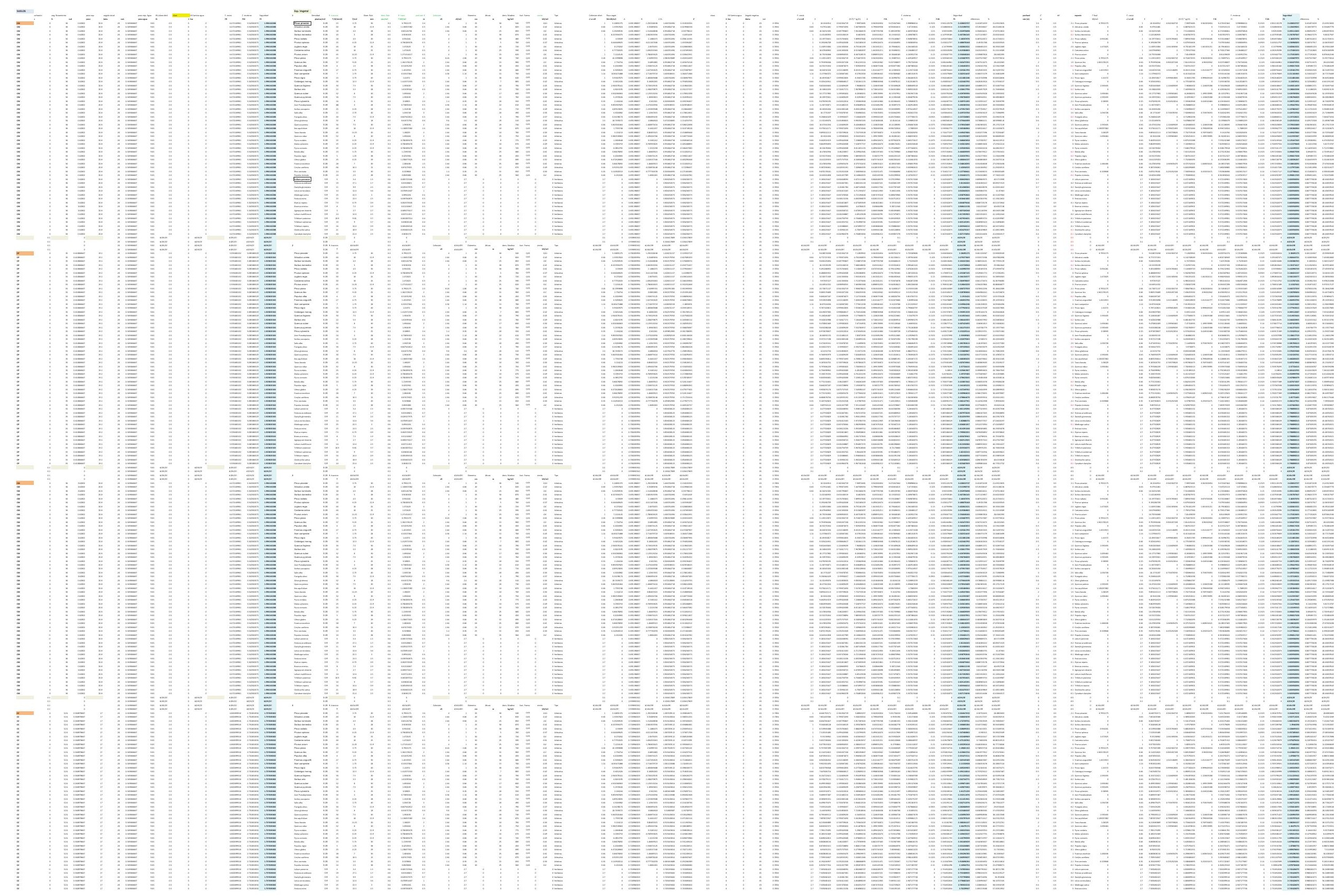


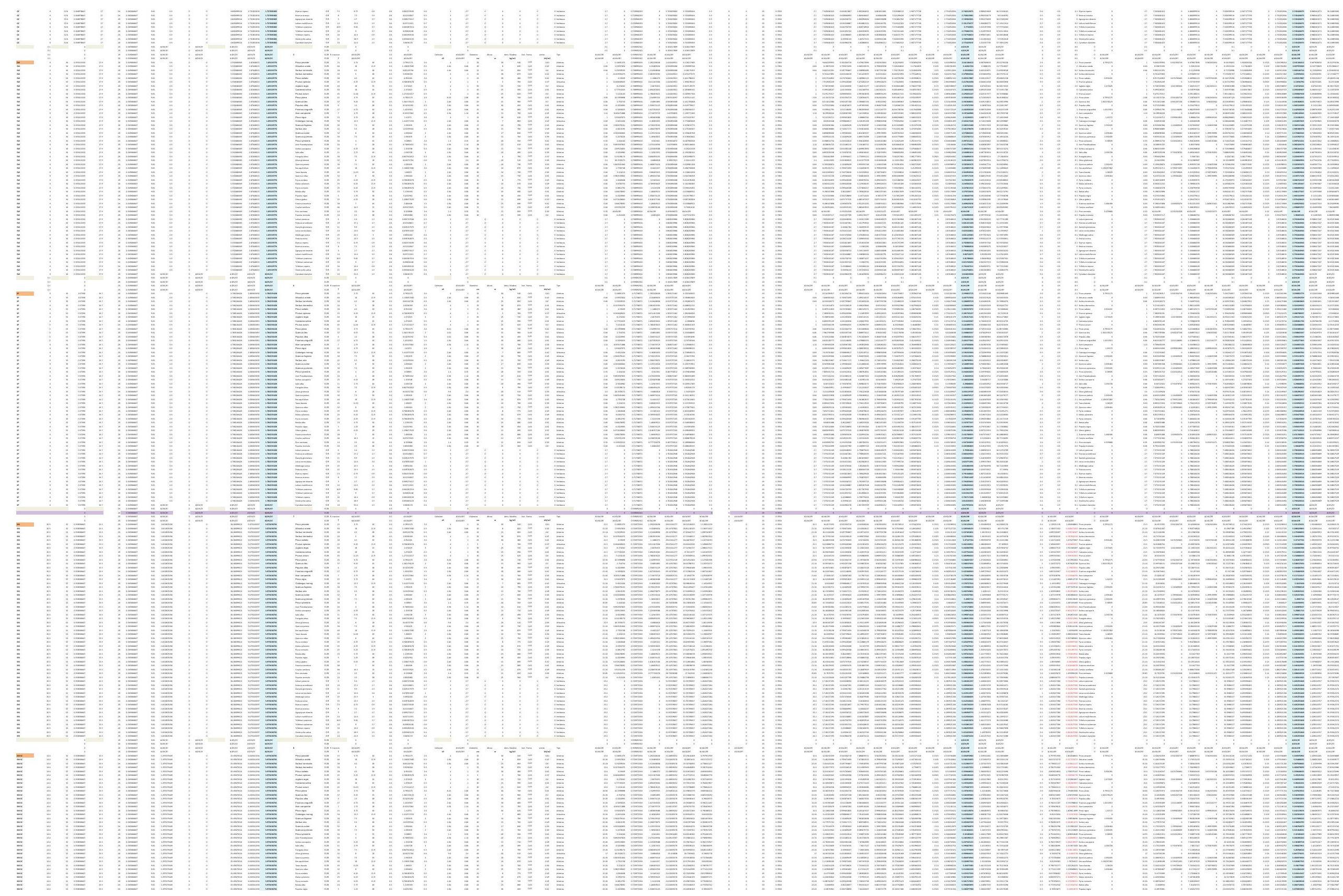



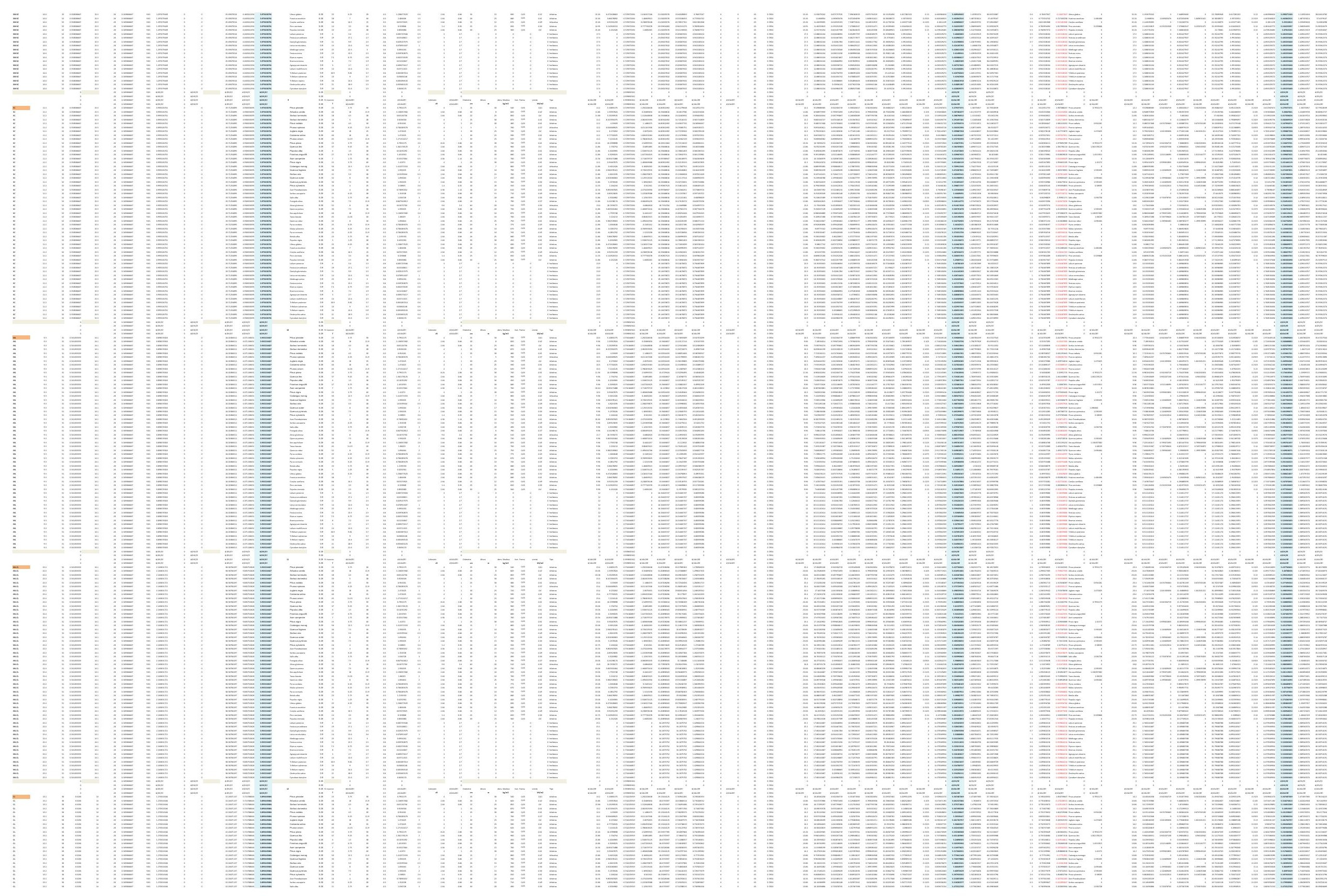


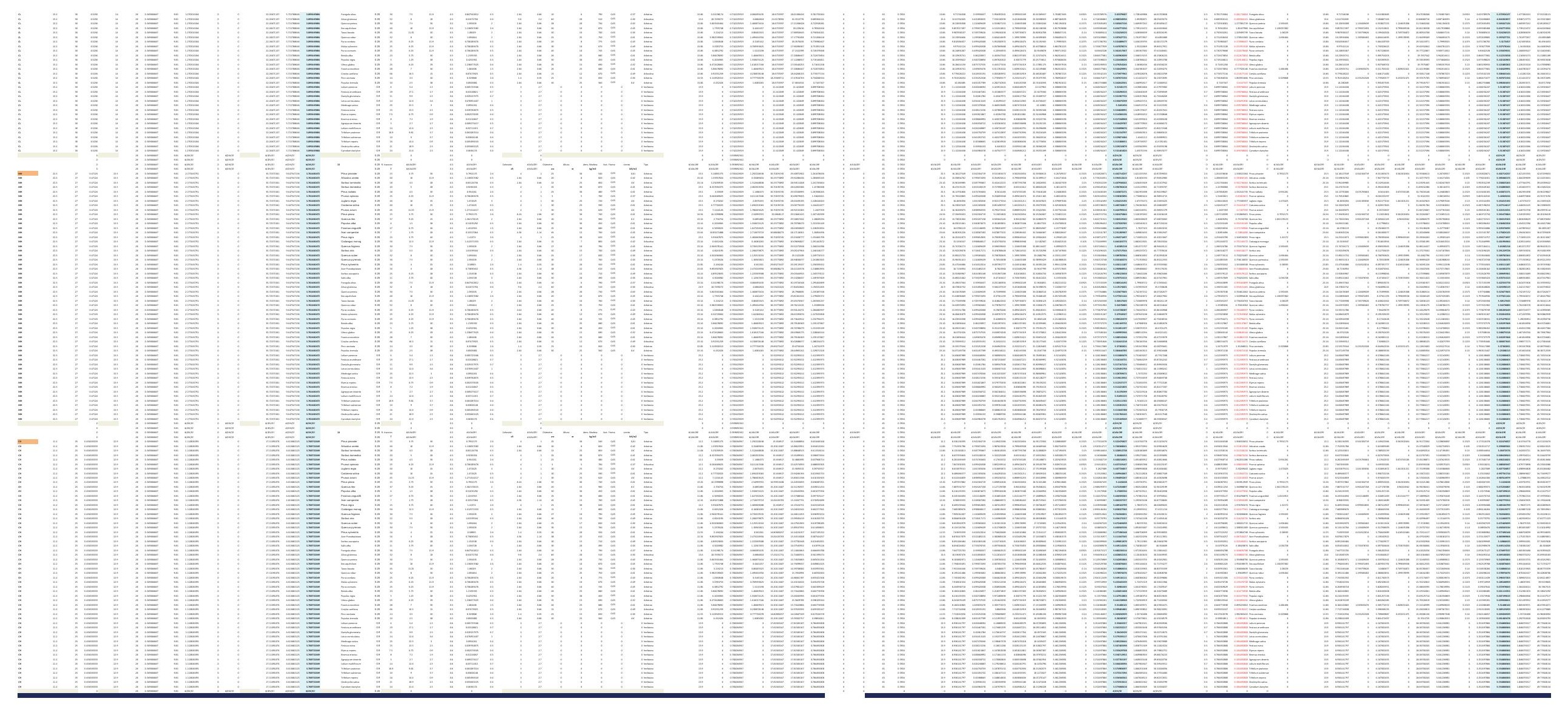



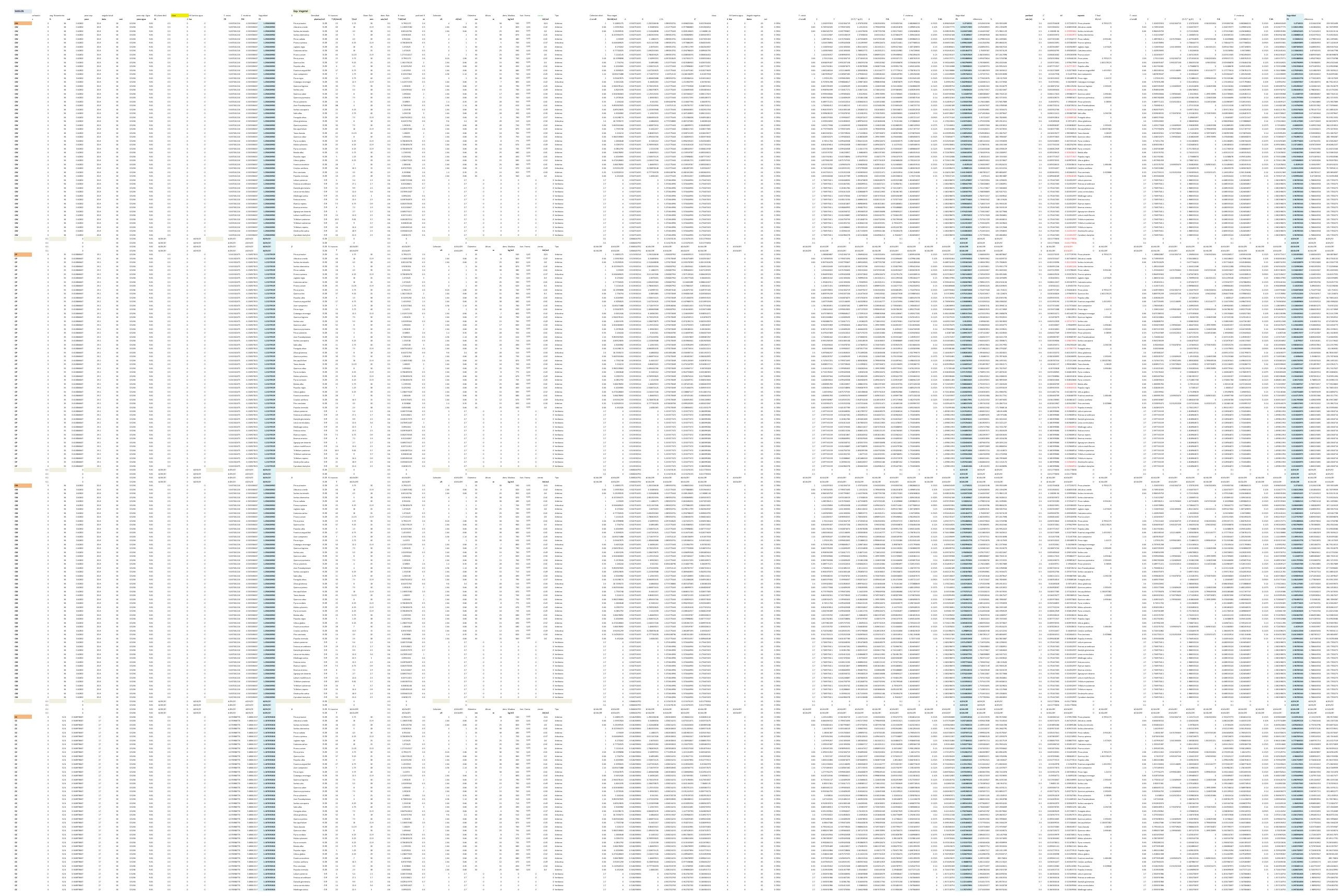


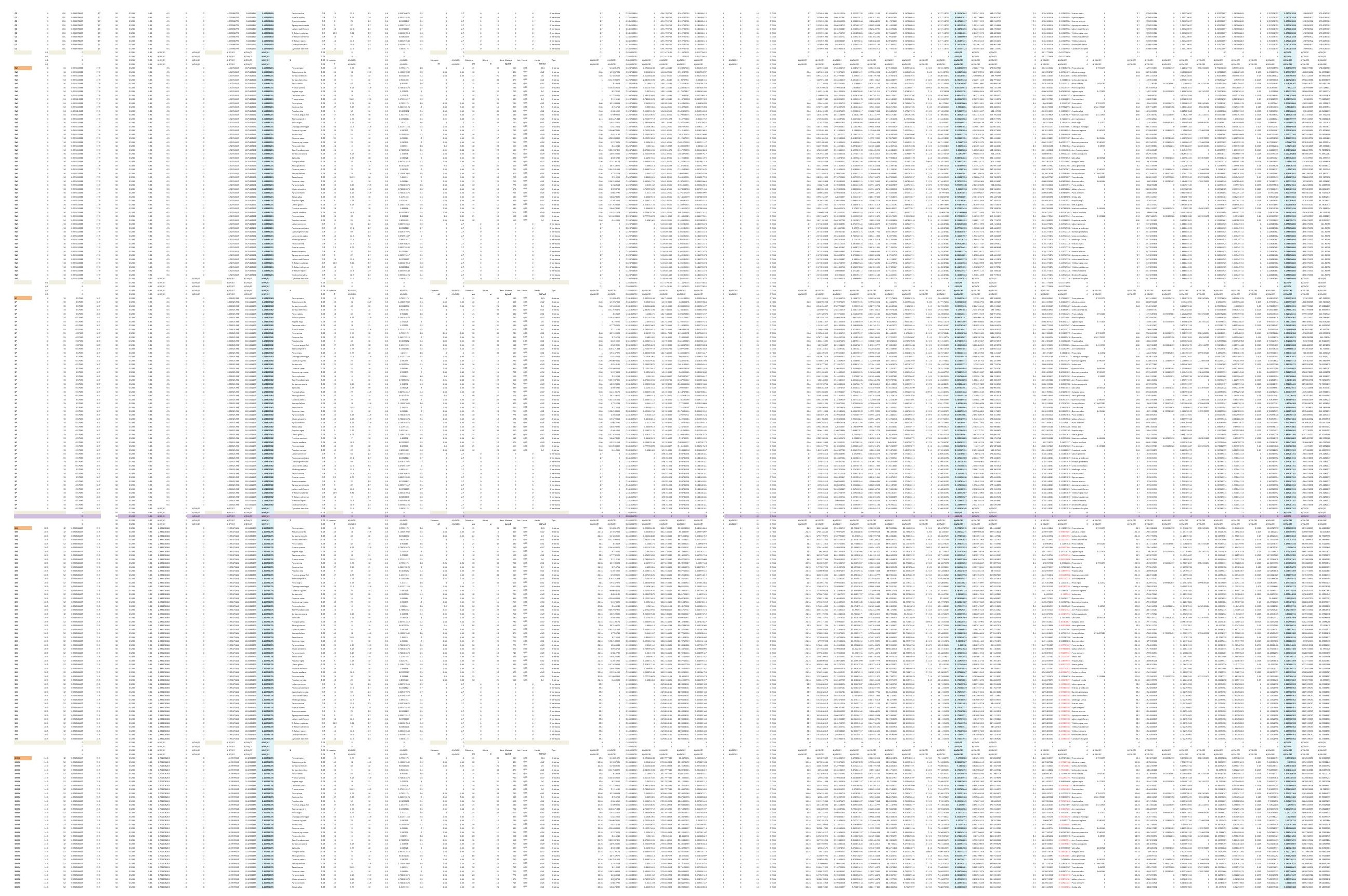



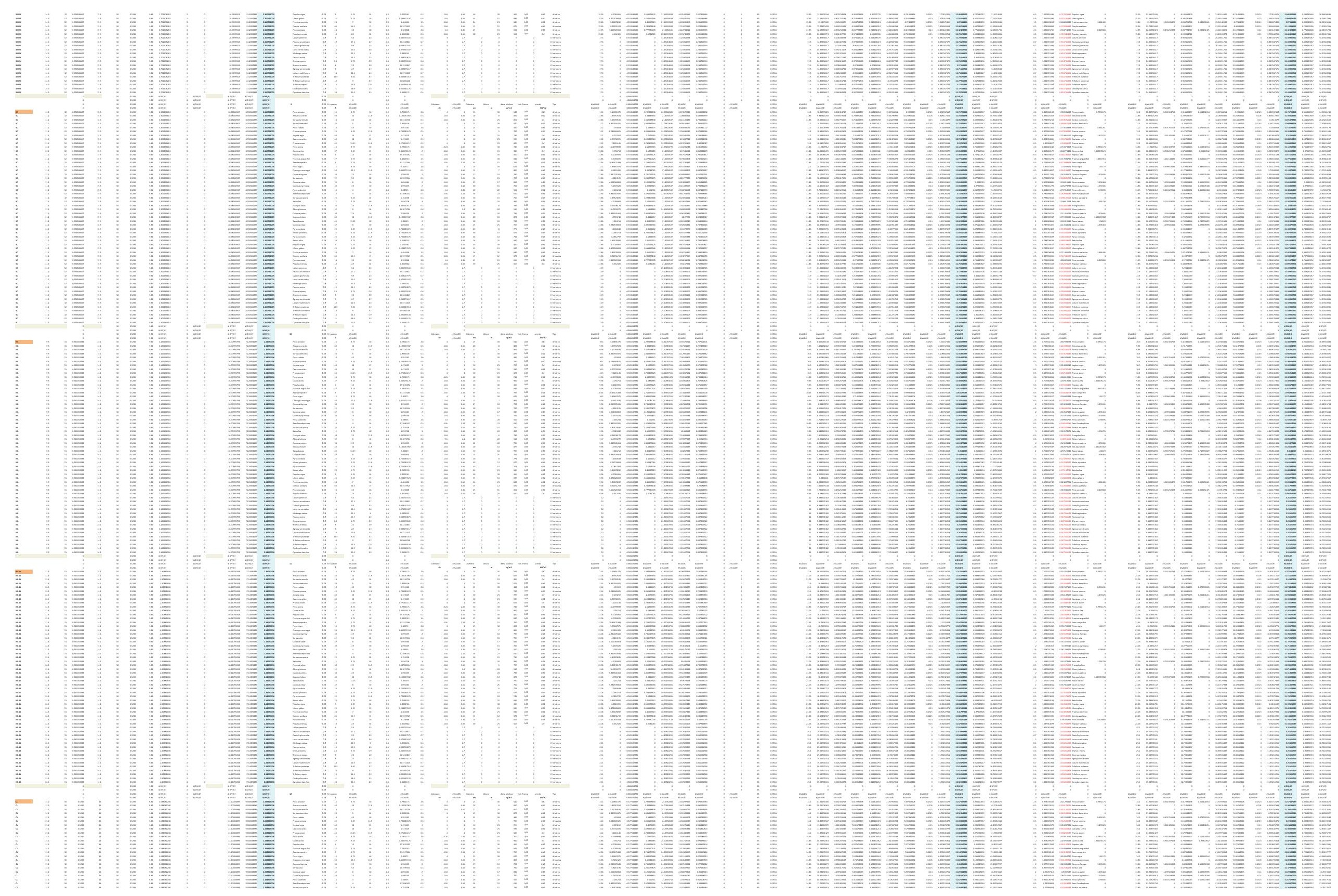


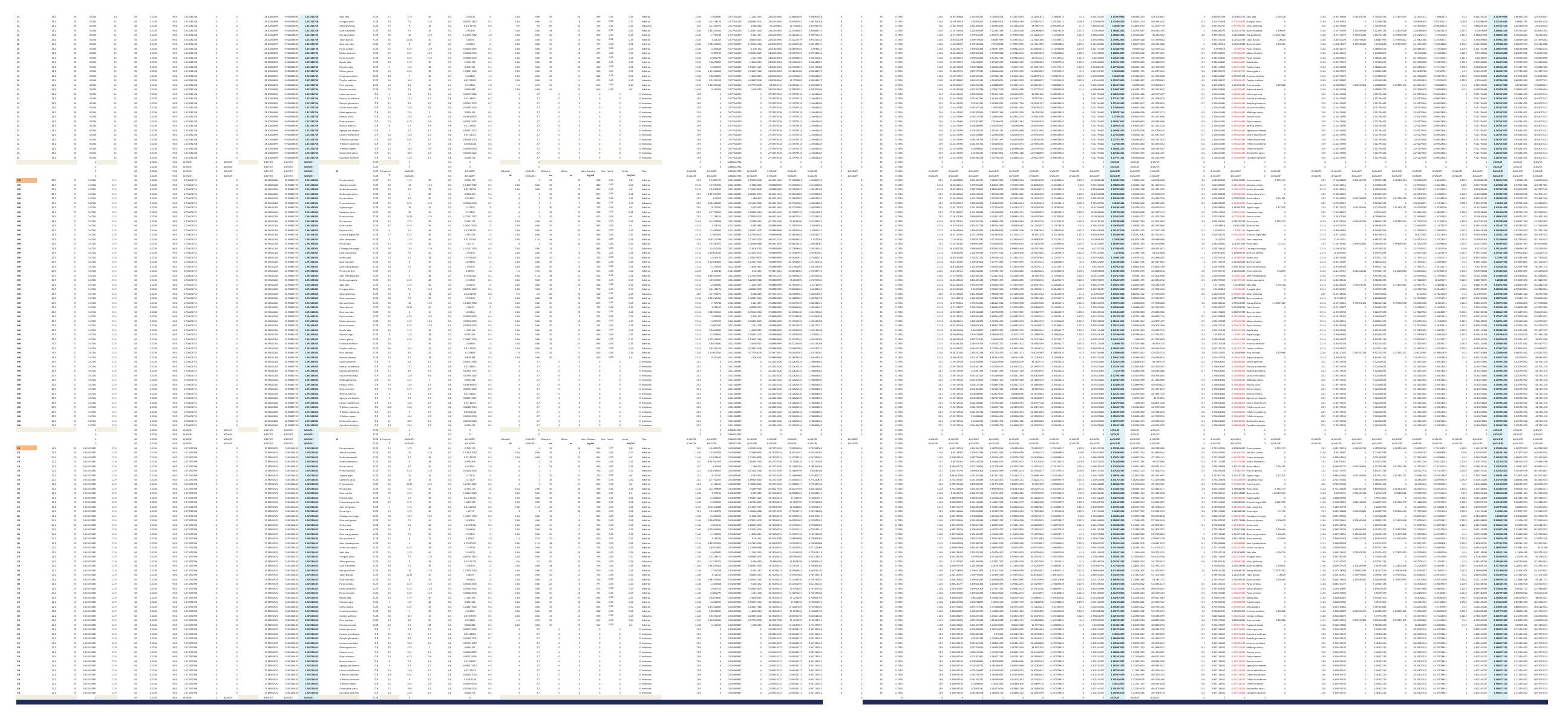



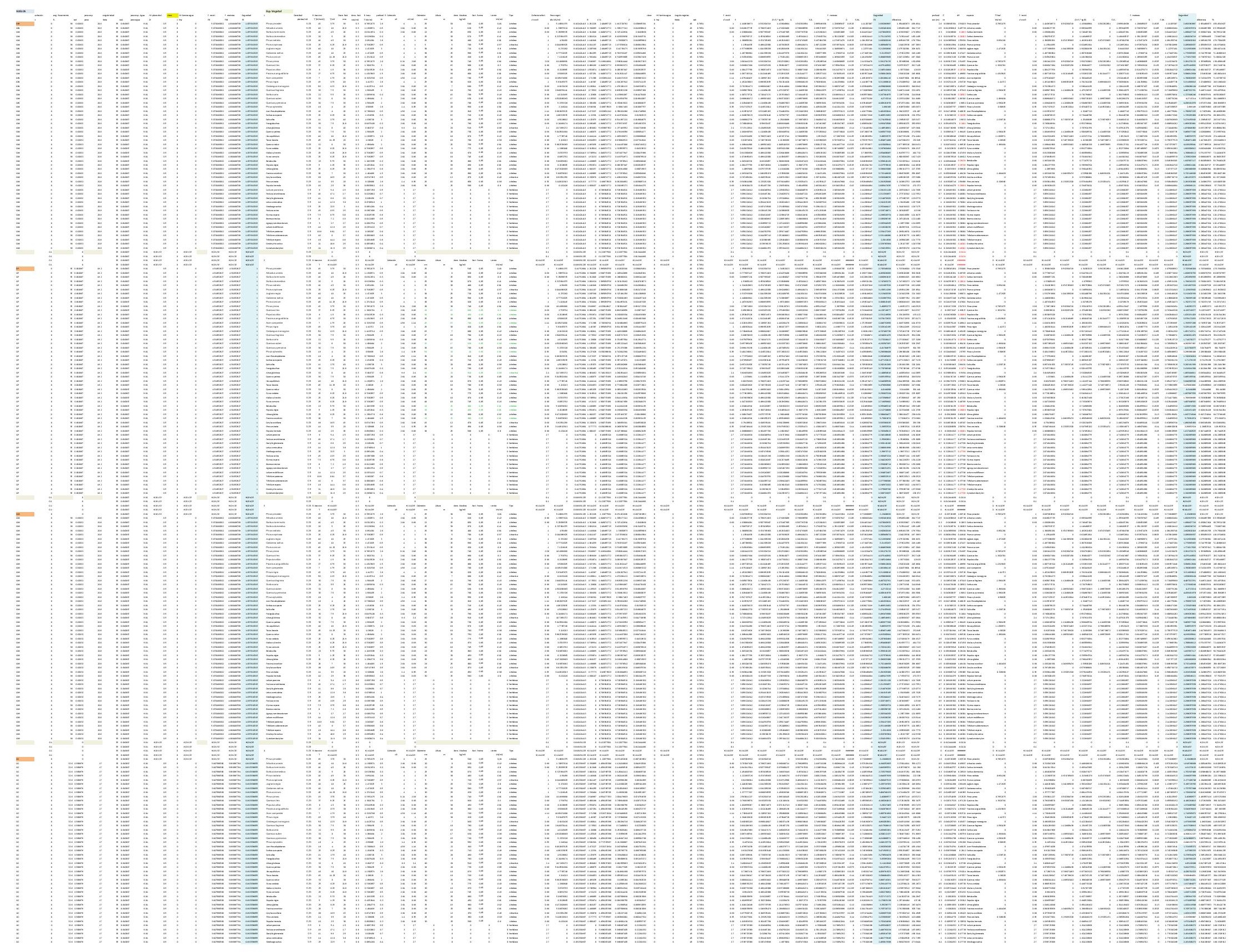


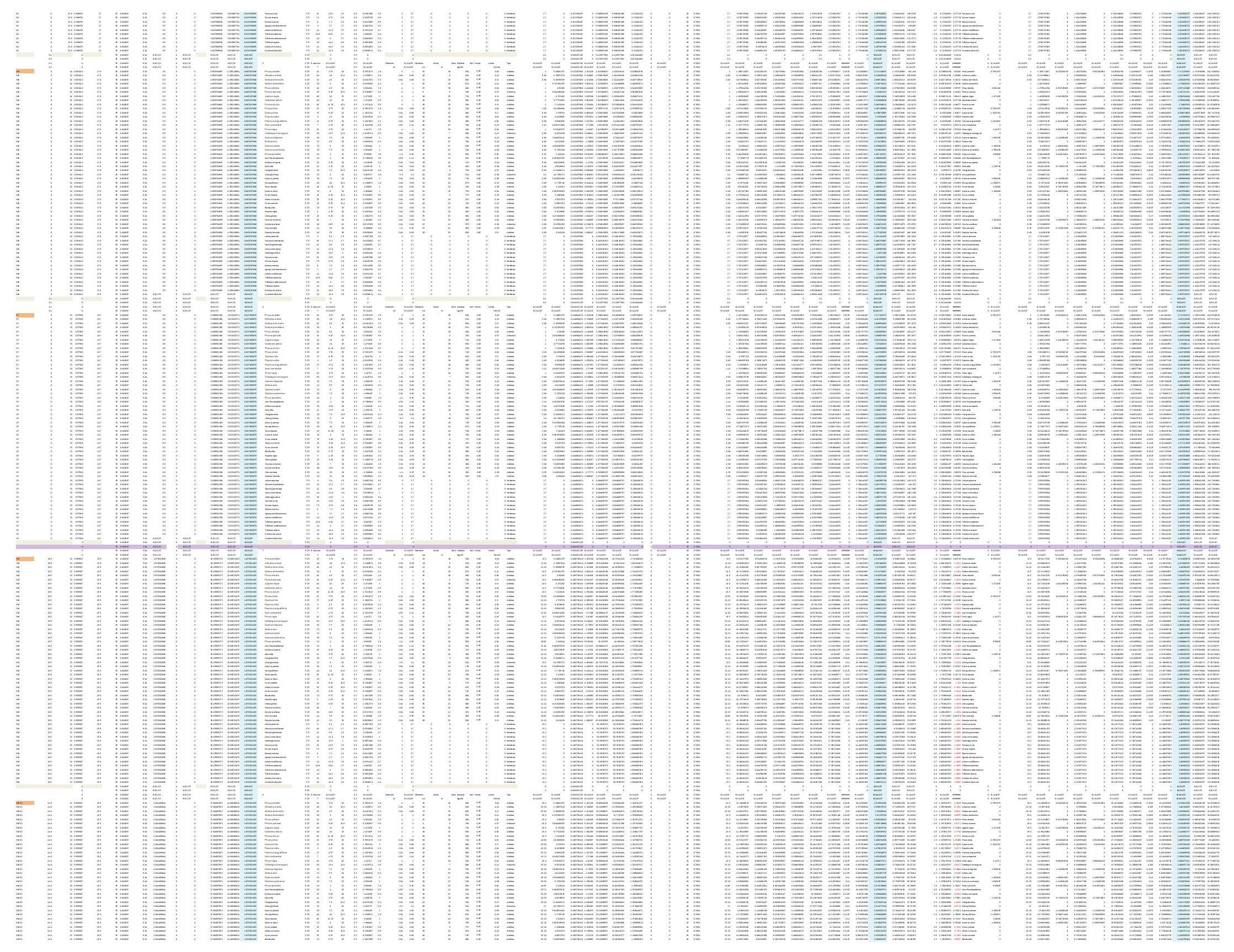



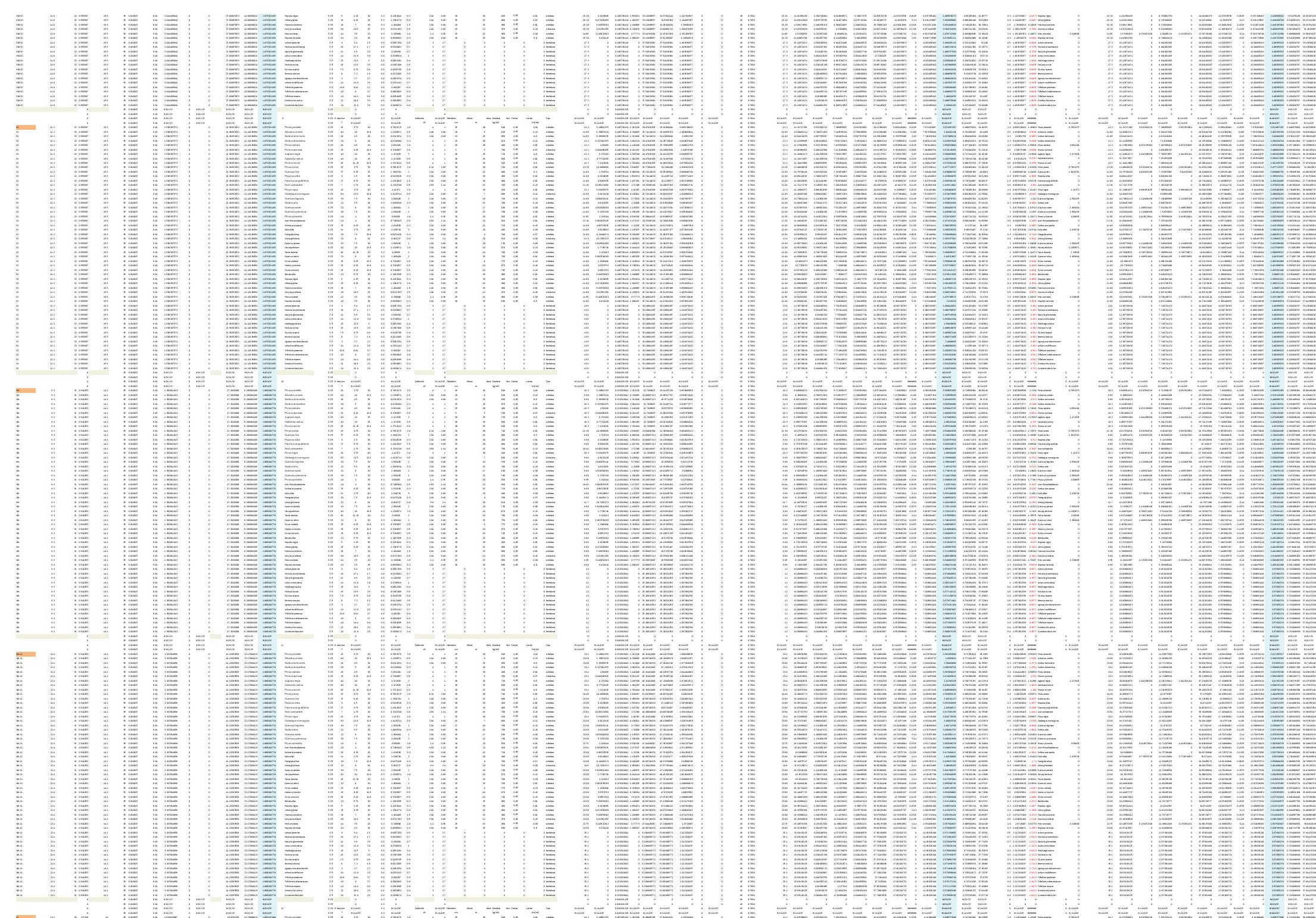

$\because \equiv \equiv \equiv \equiv \equiv \equiv \equiv$
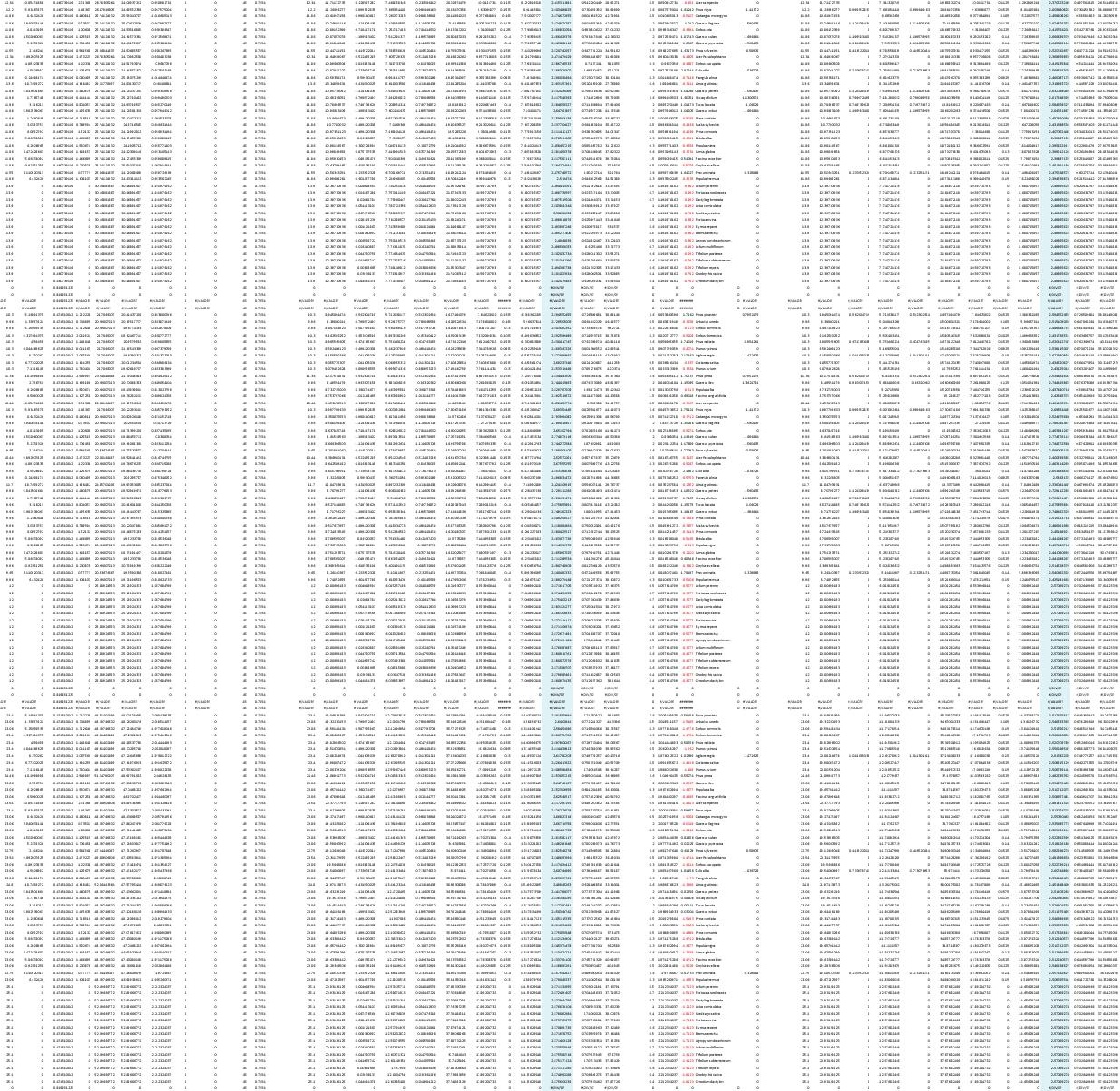

$-$ $=$

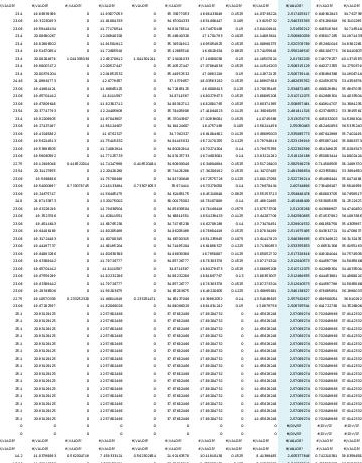

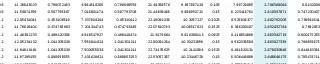

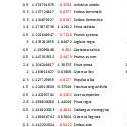

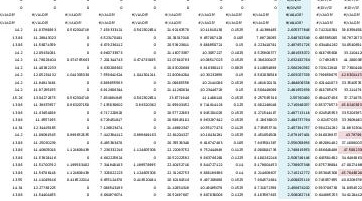




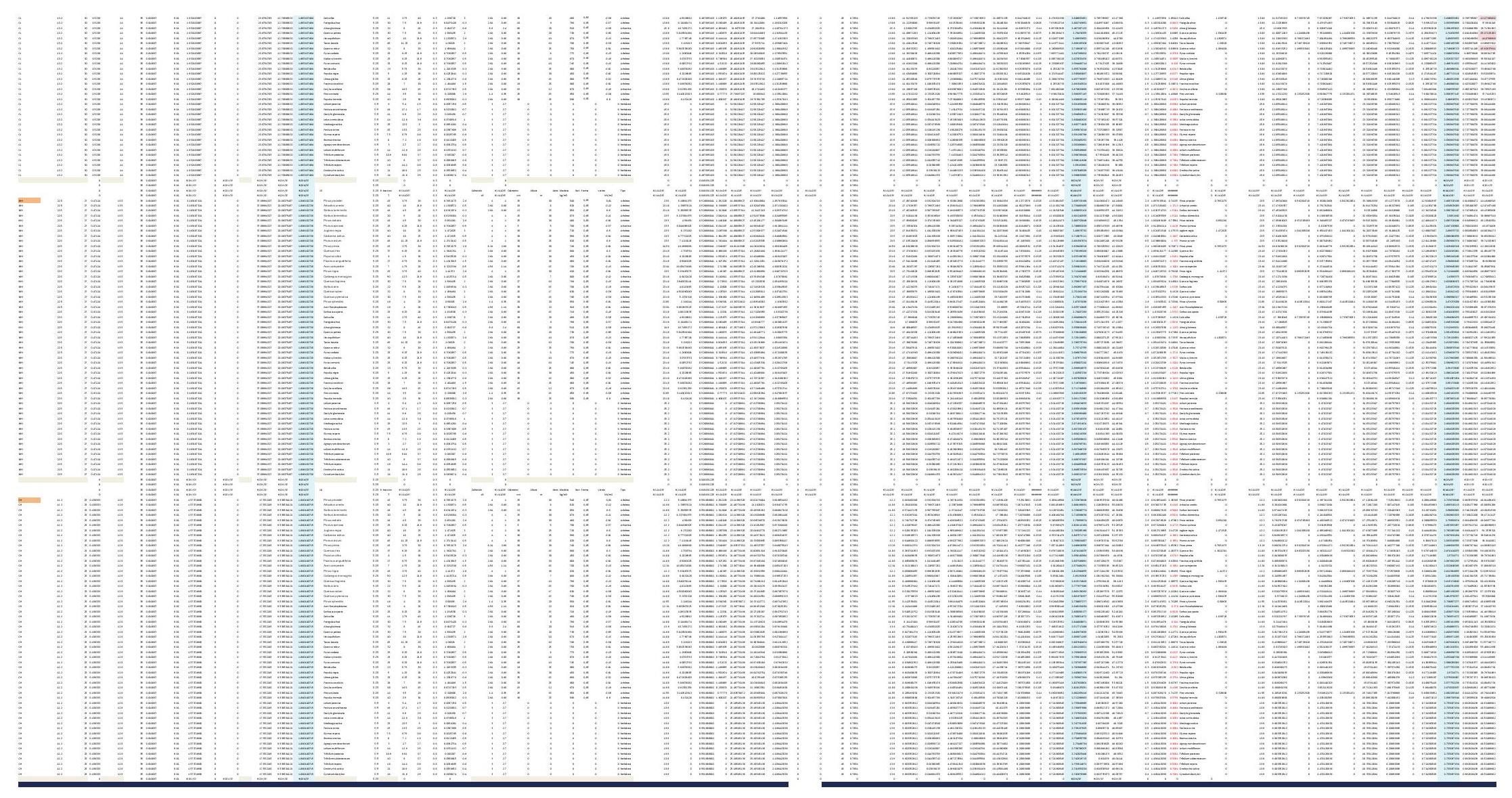



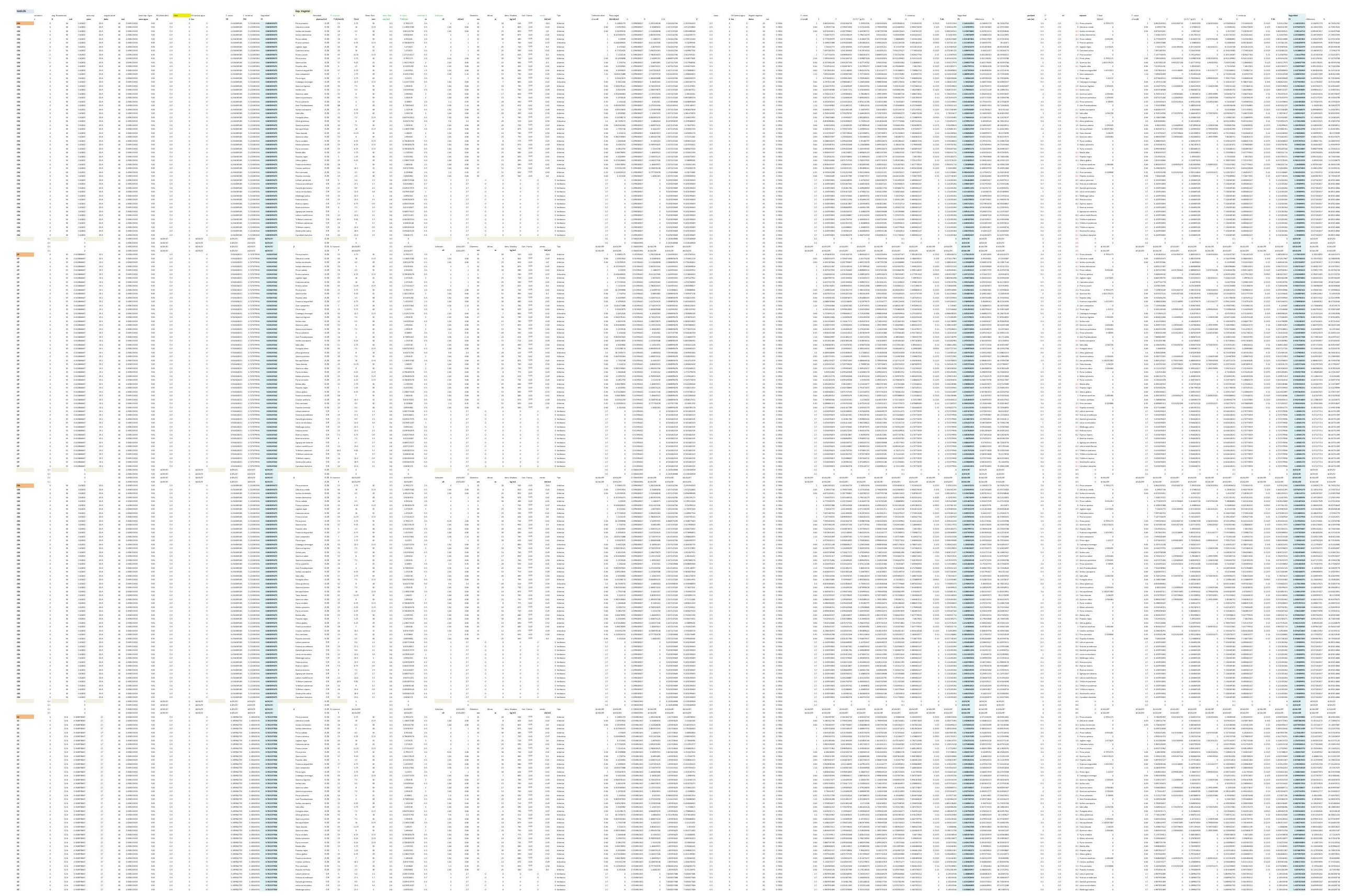


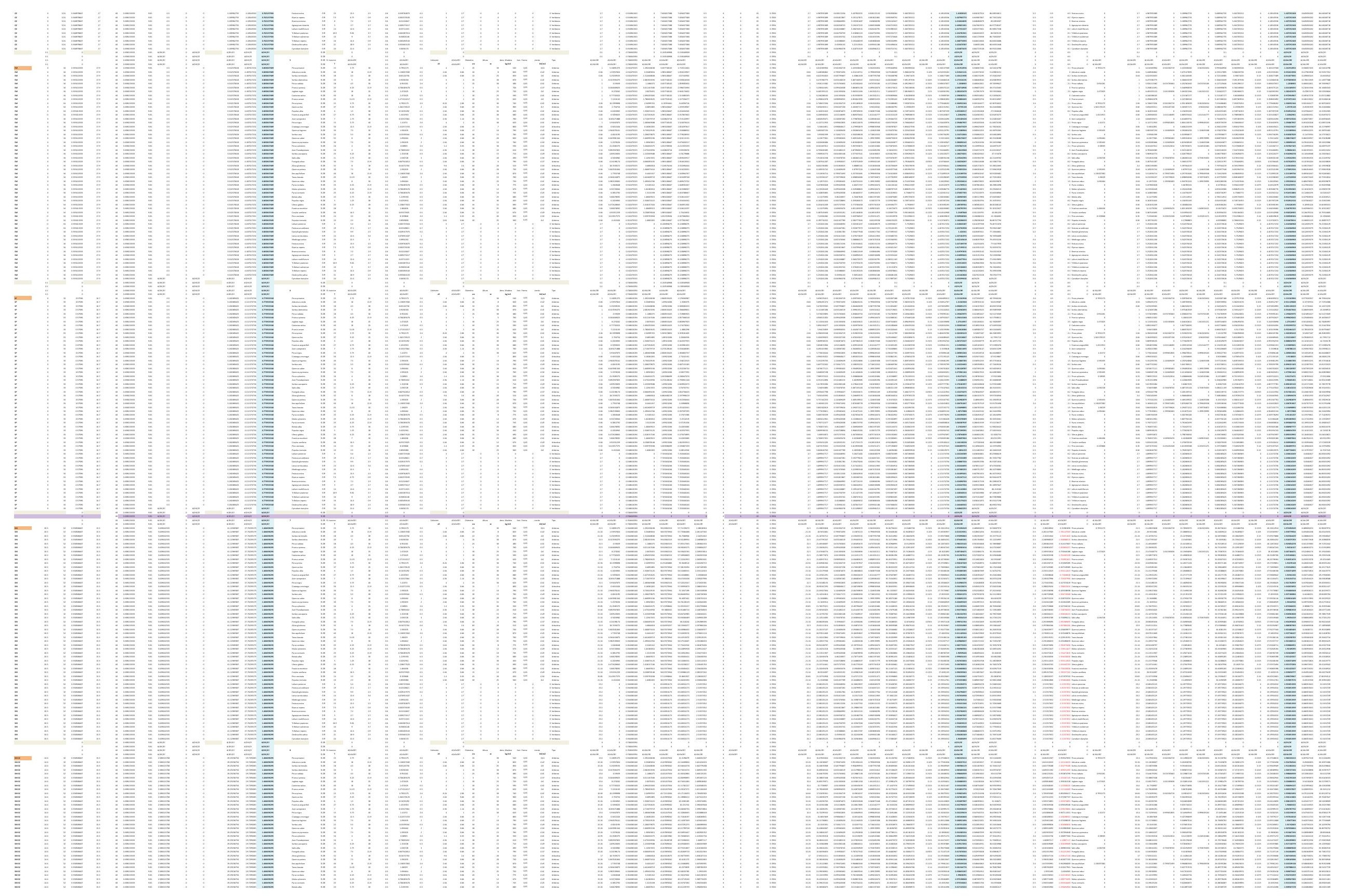



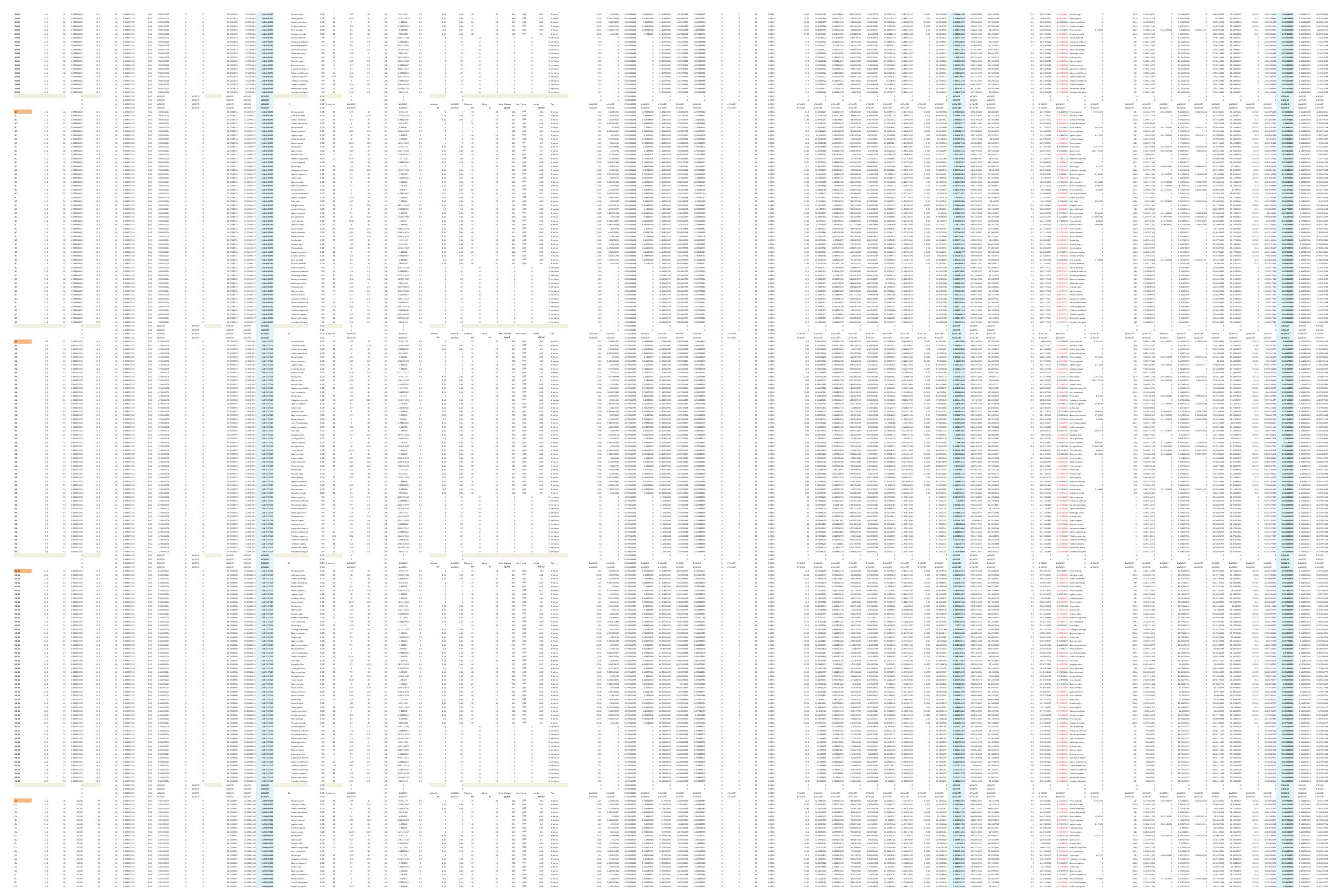


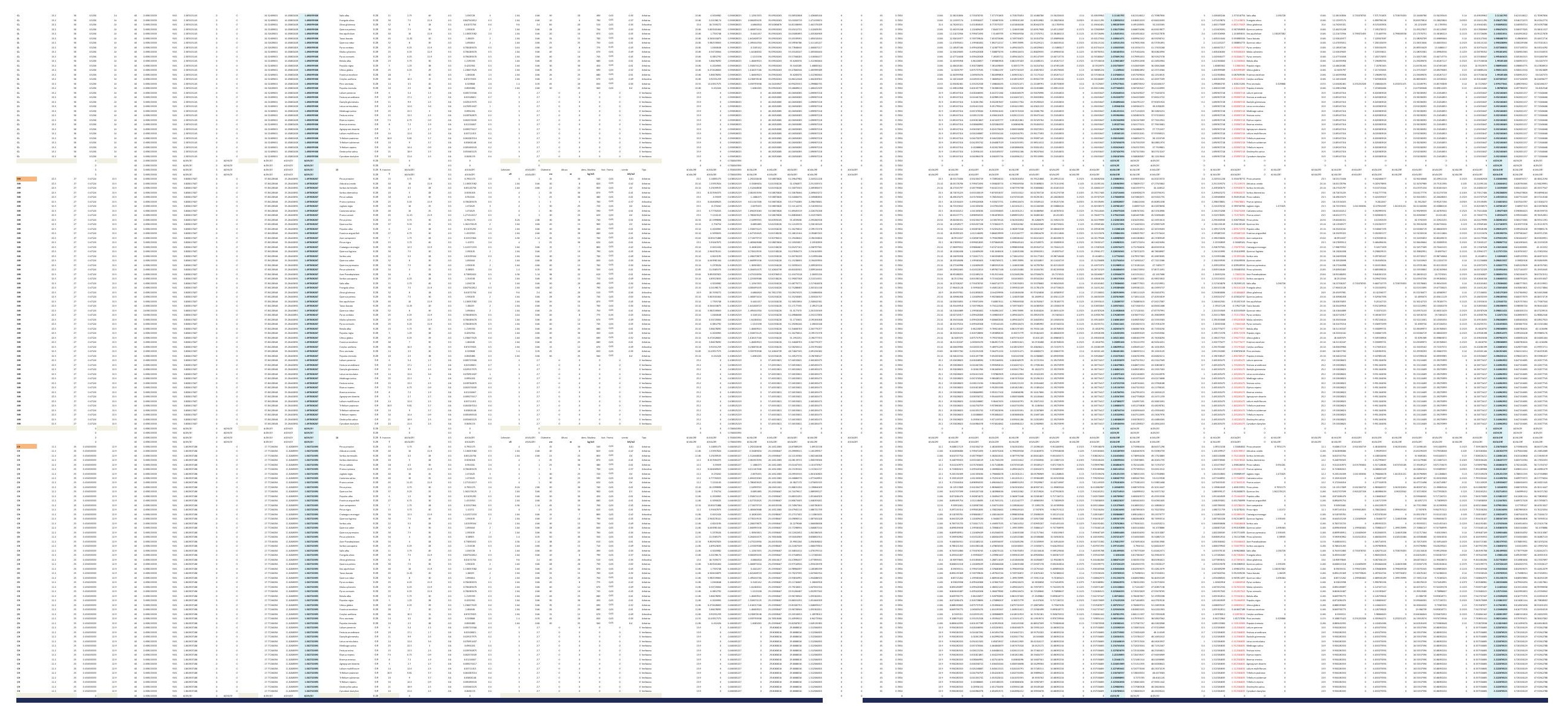



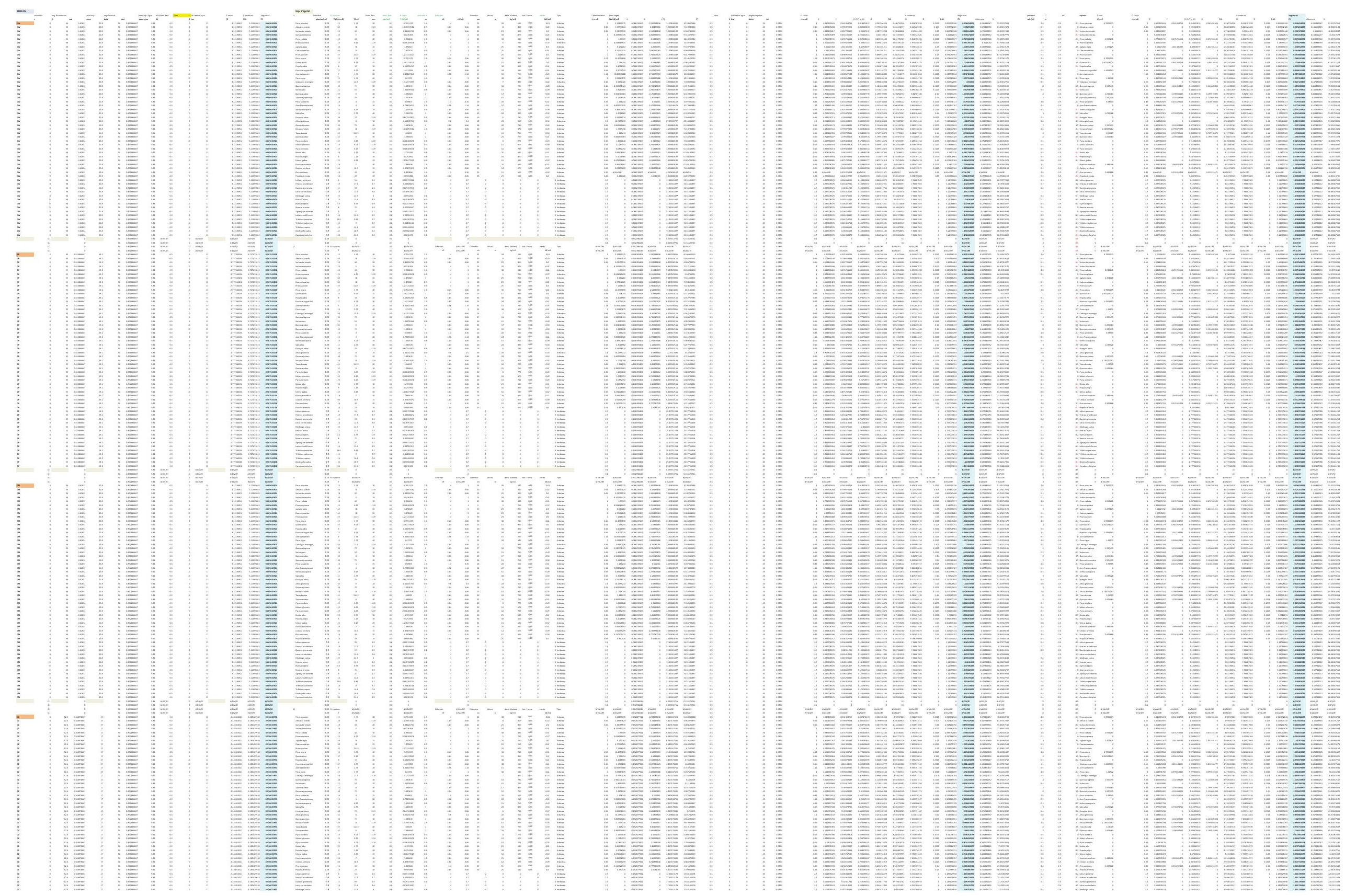


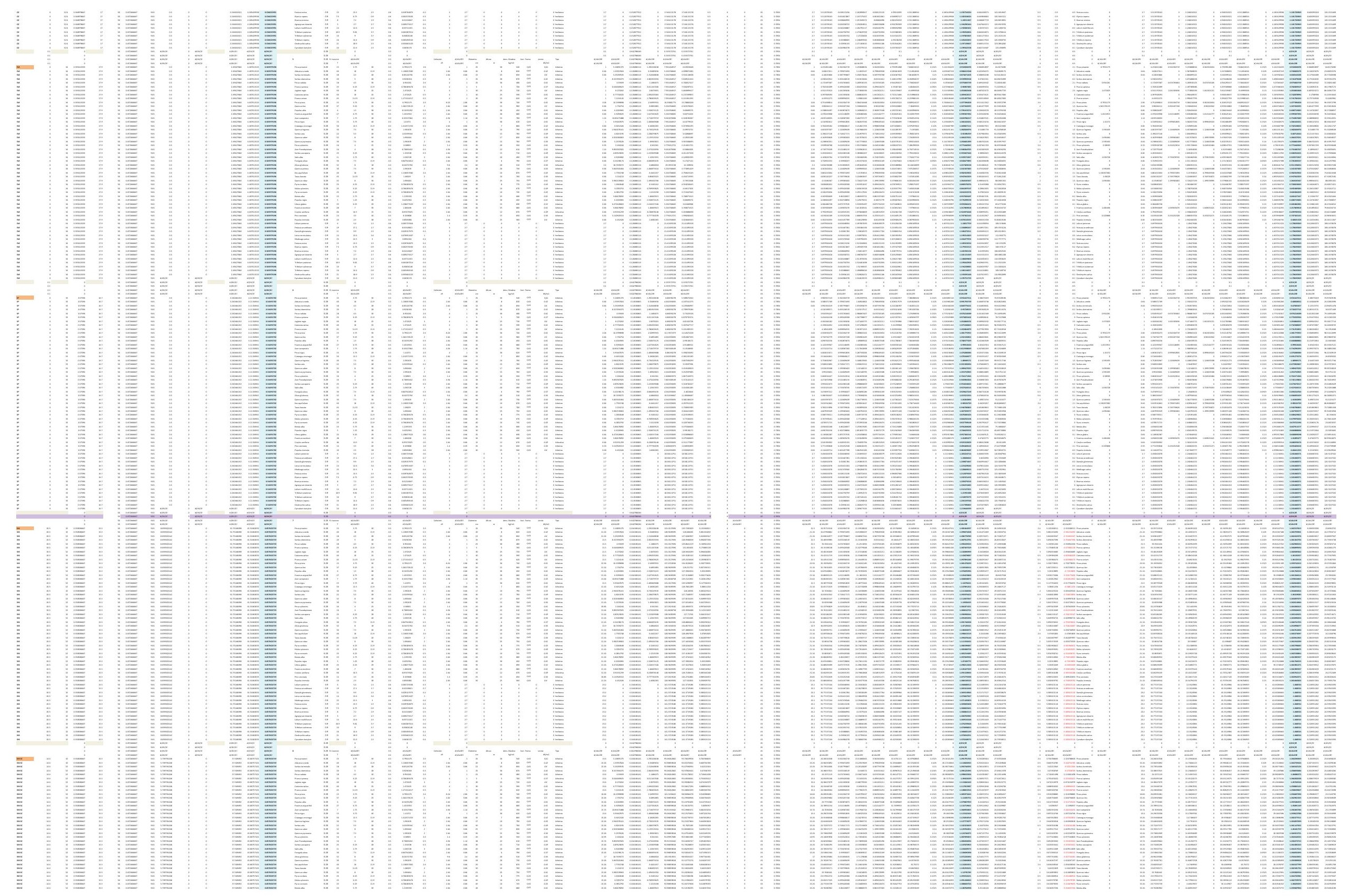



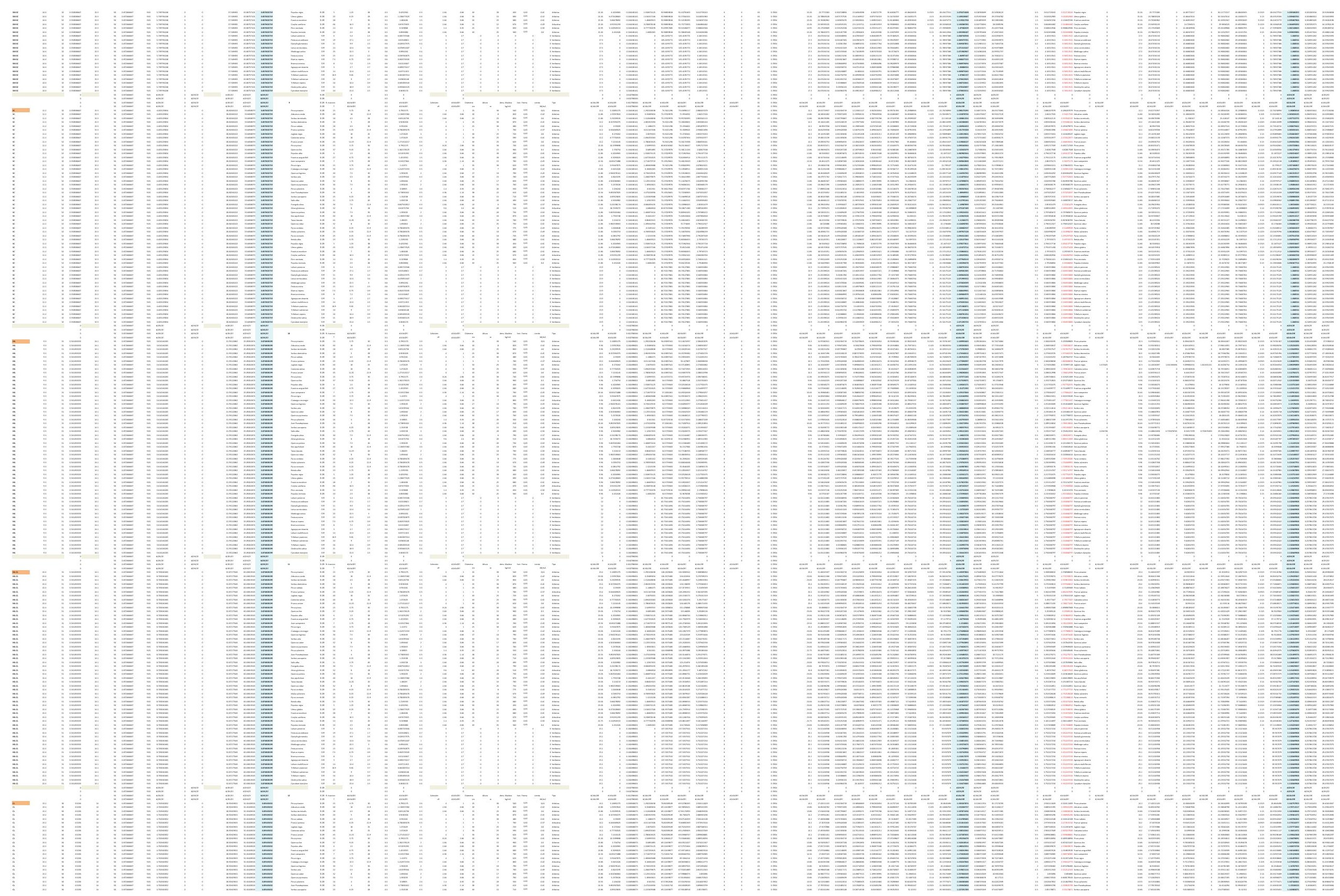


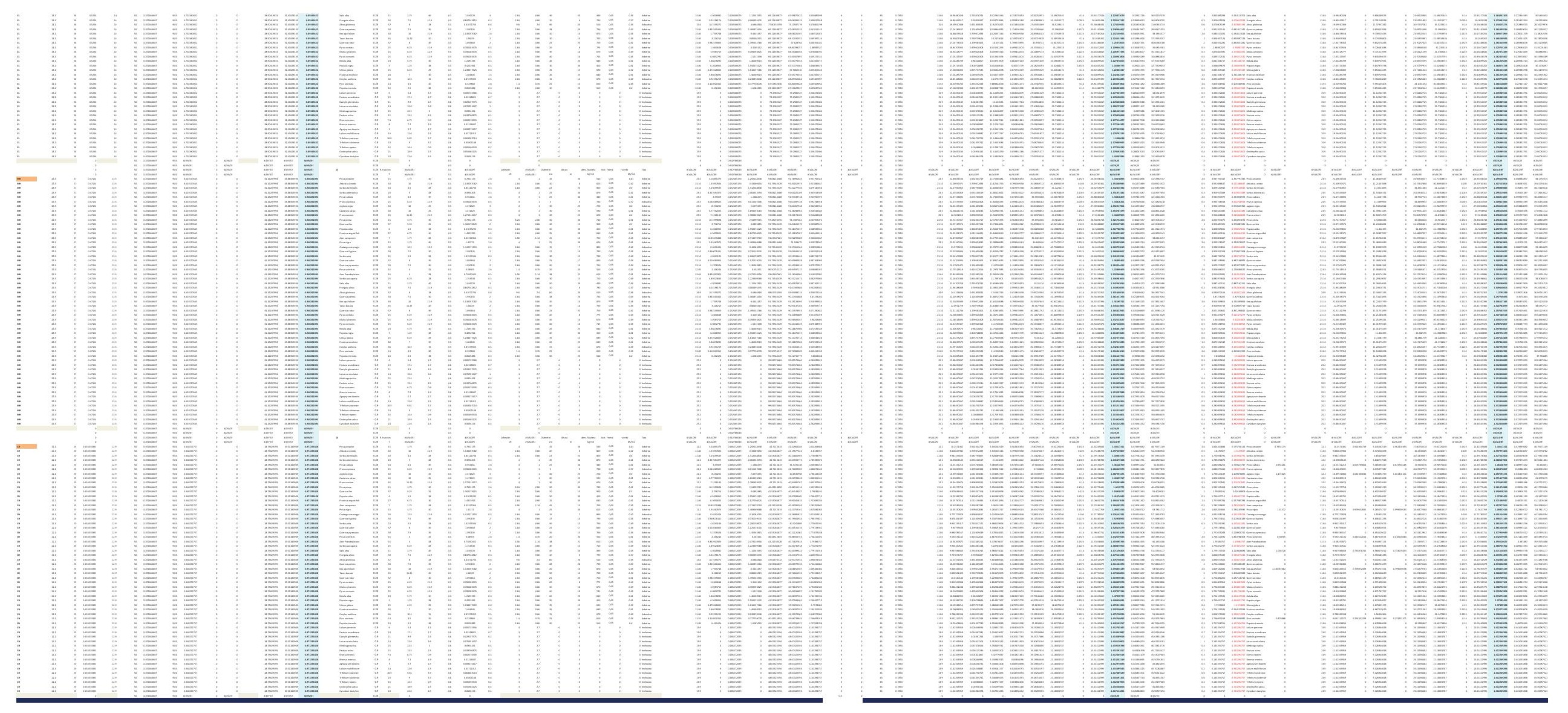



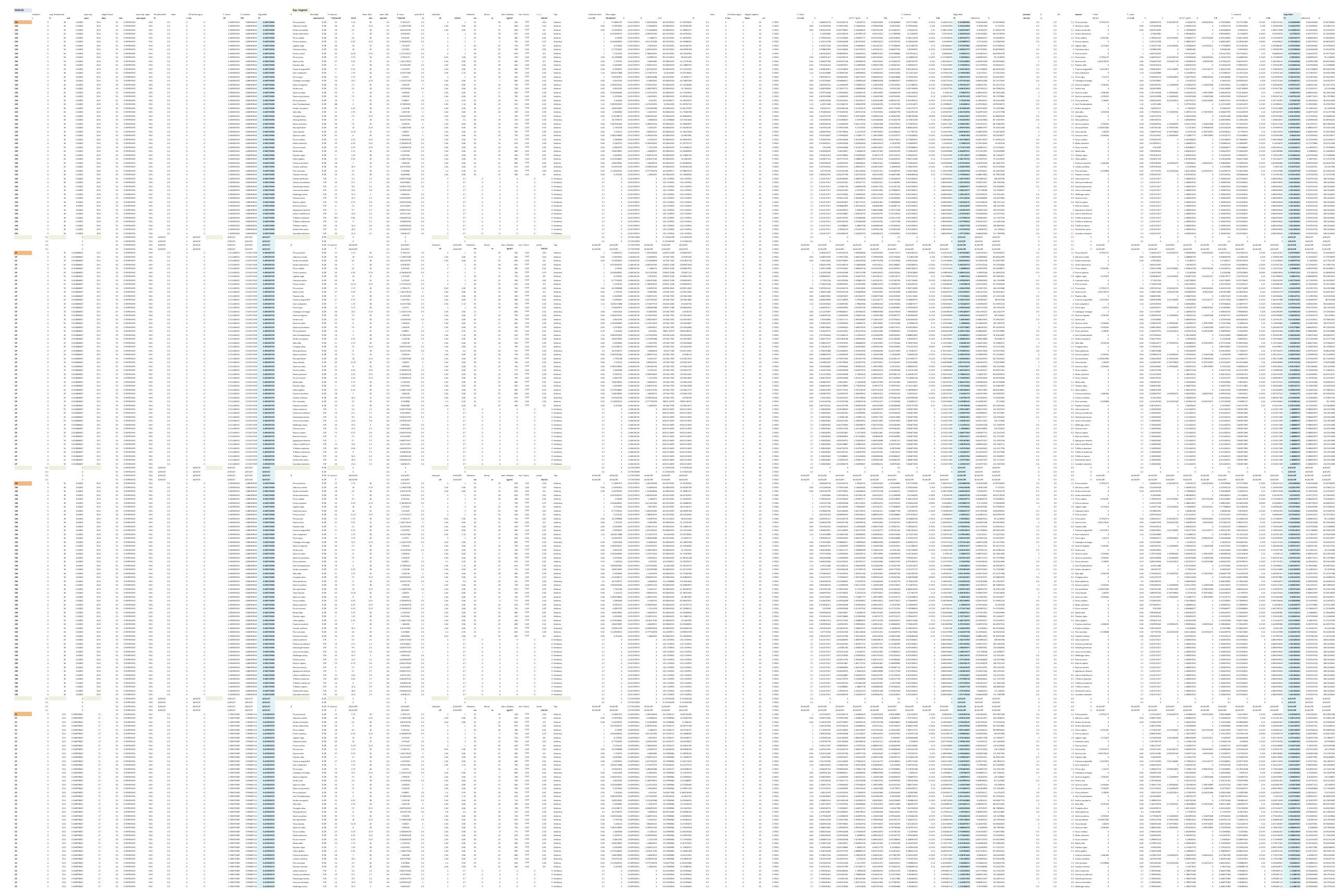


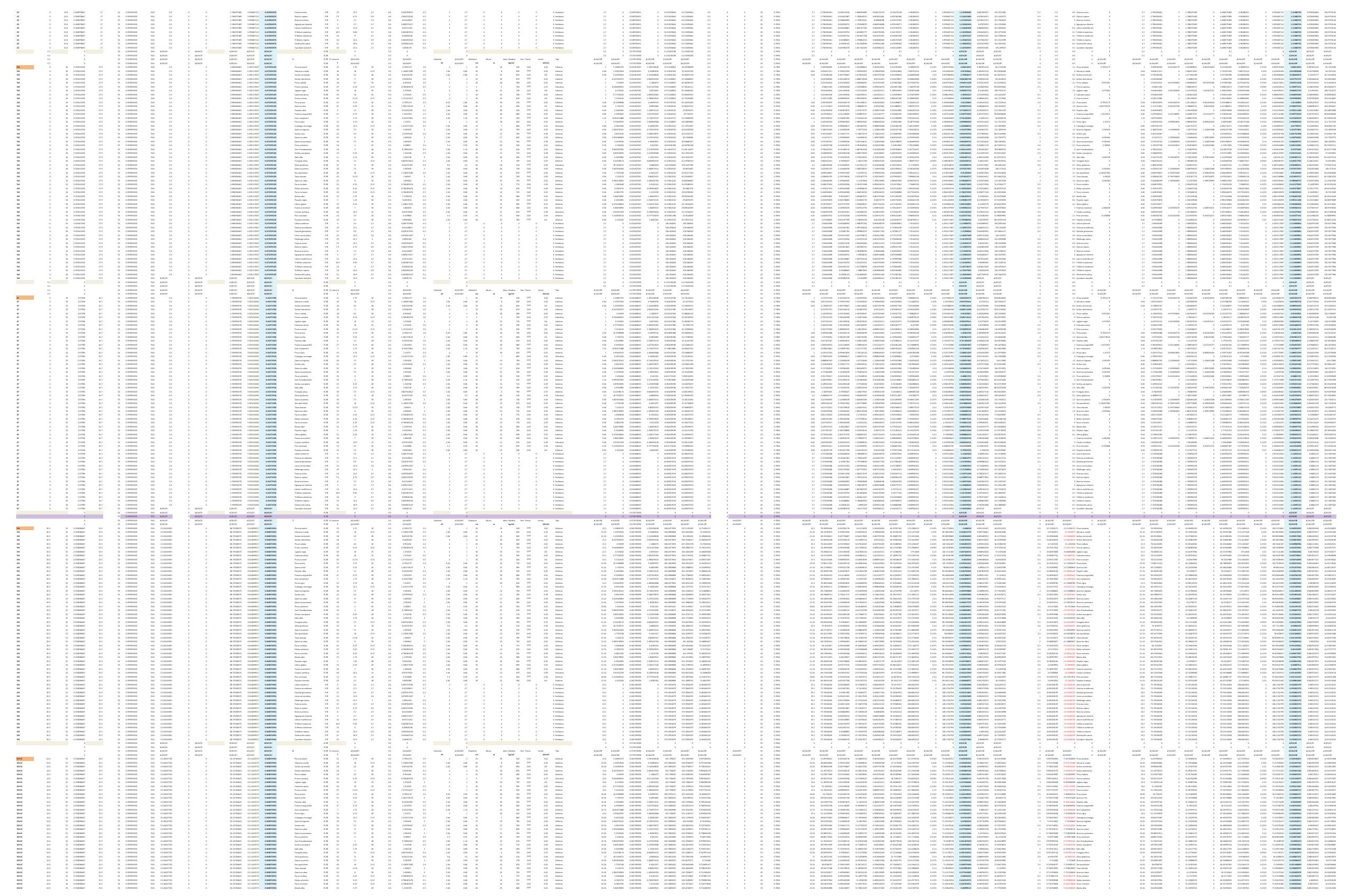



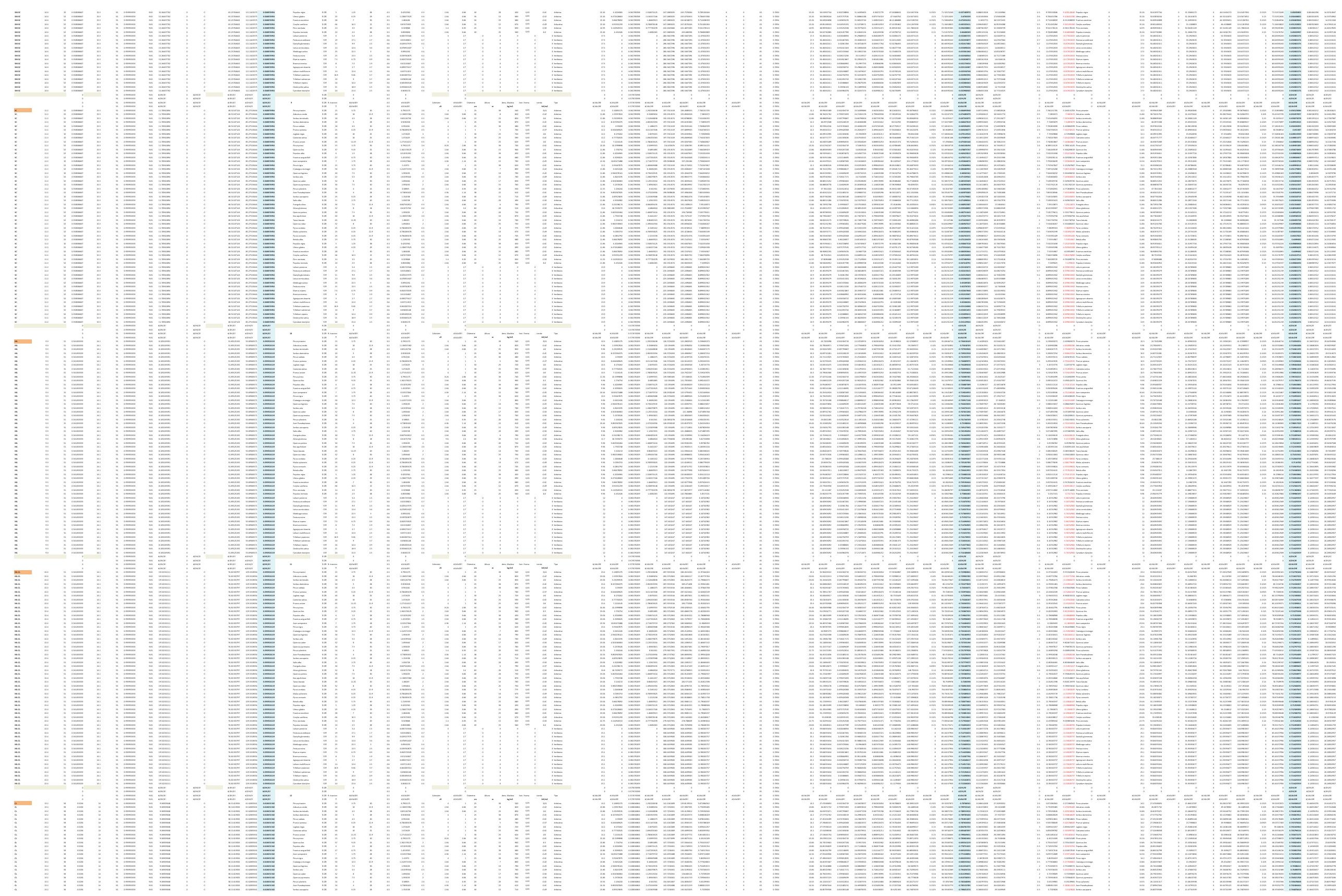


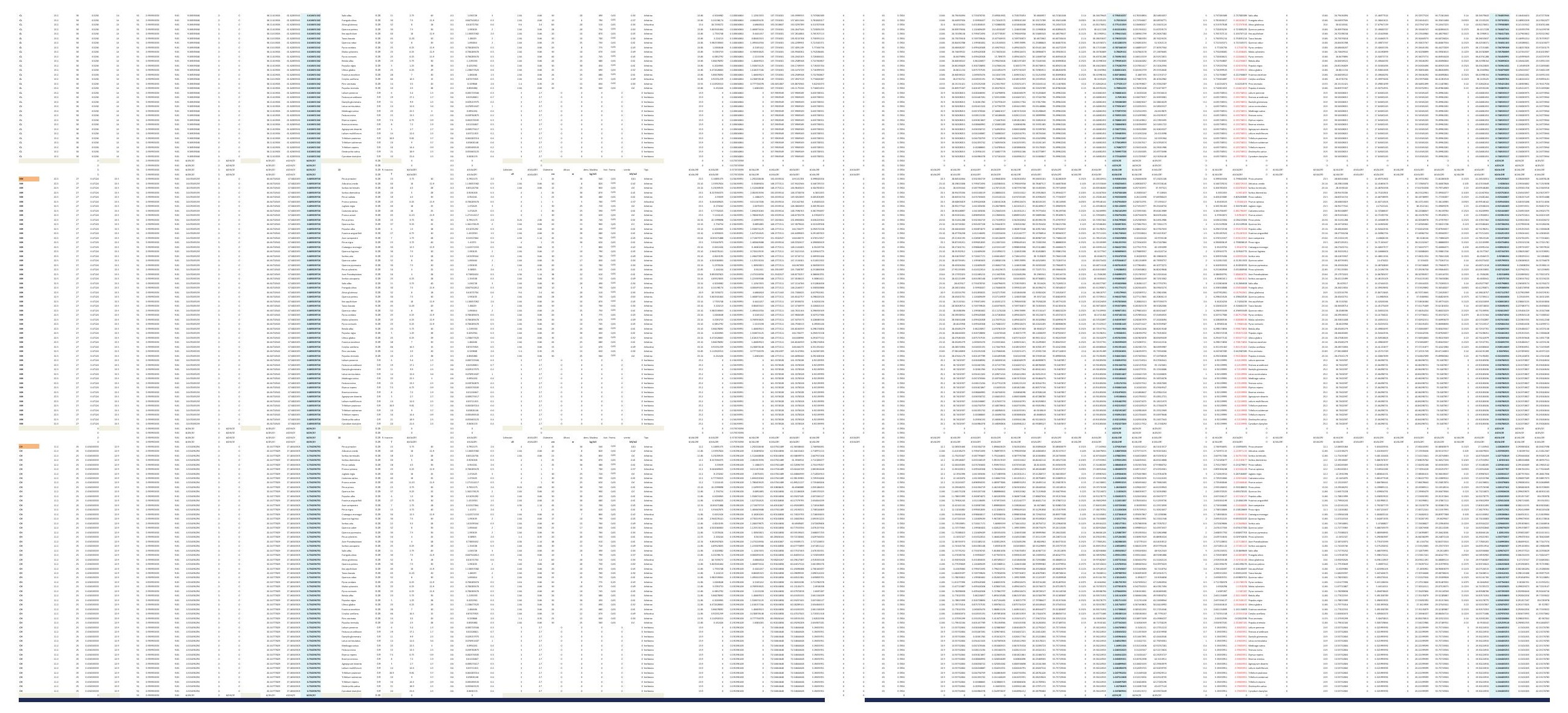



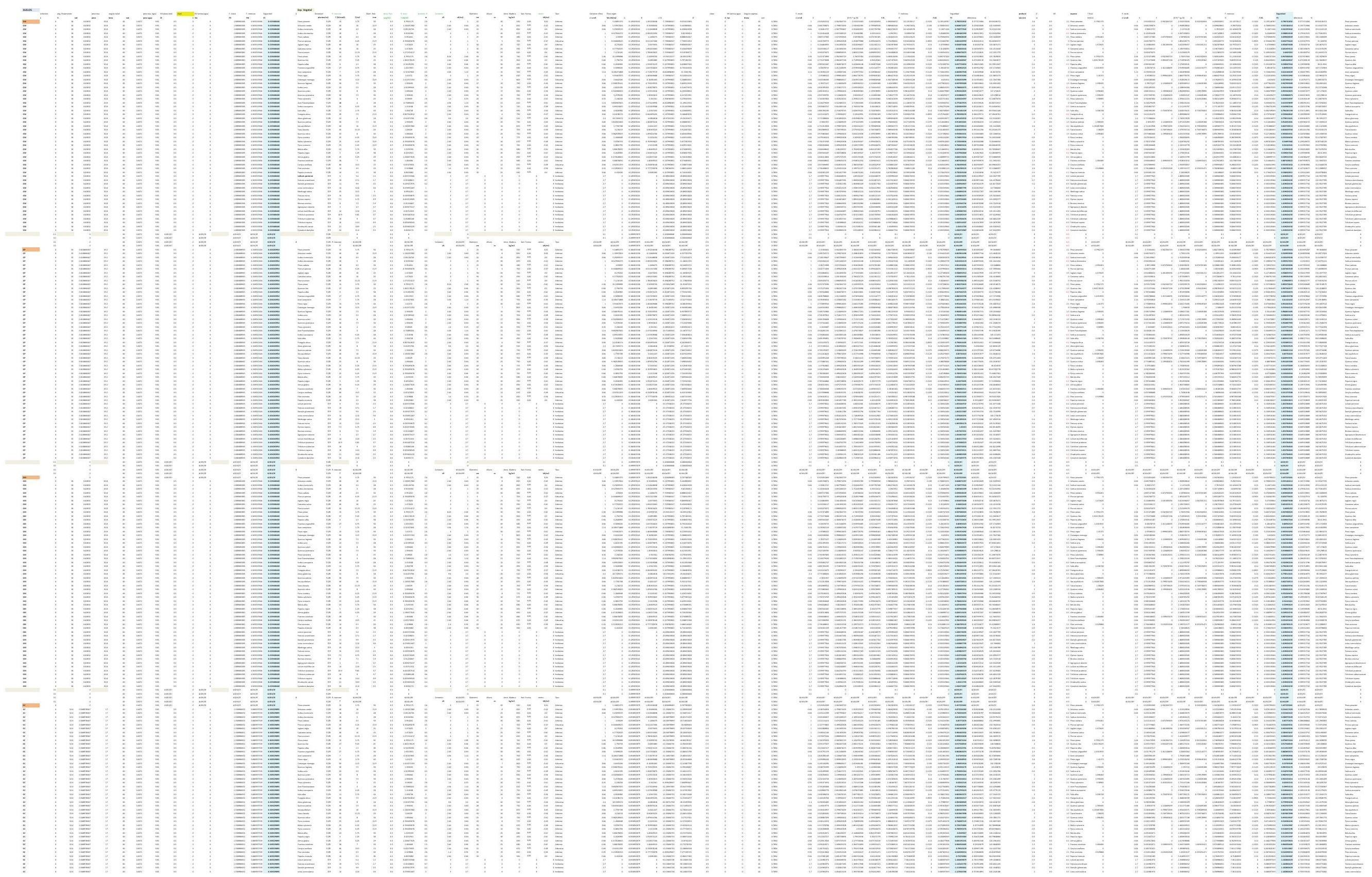


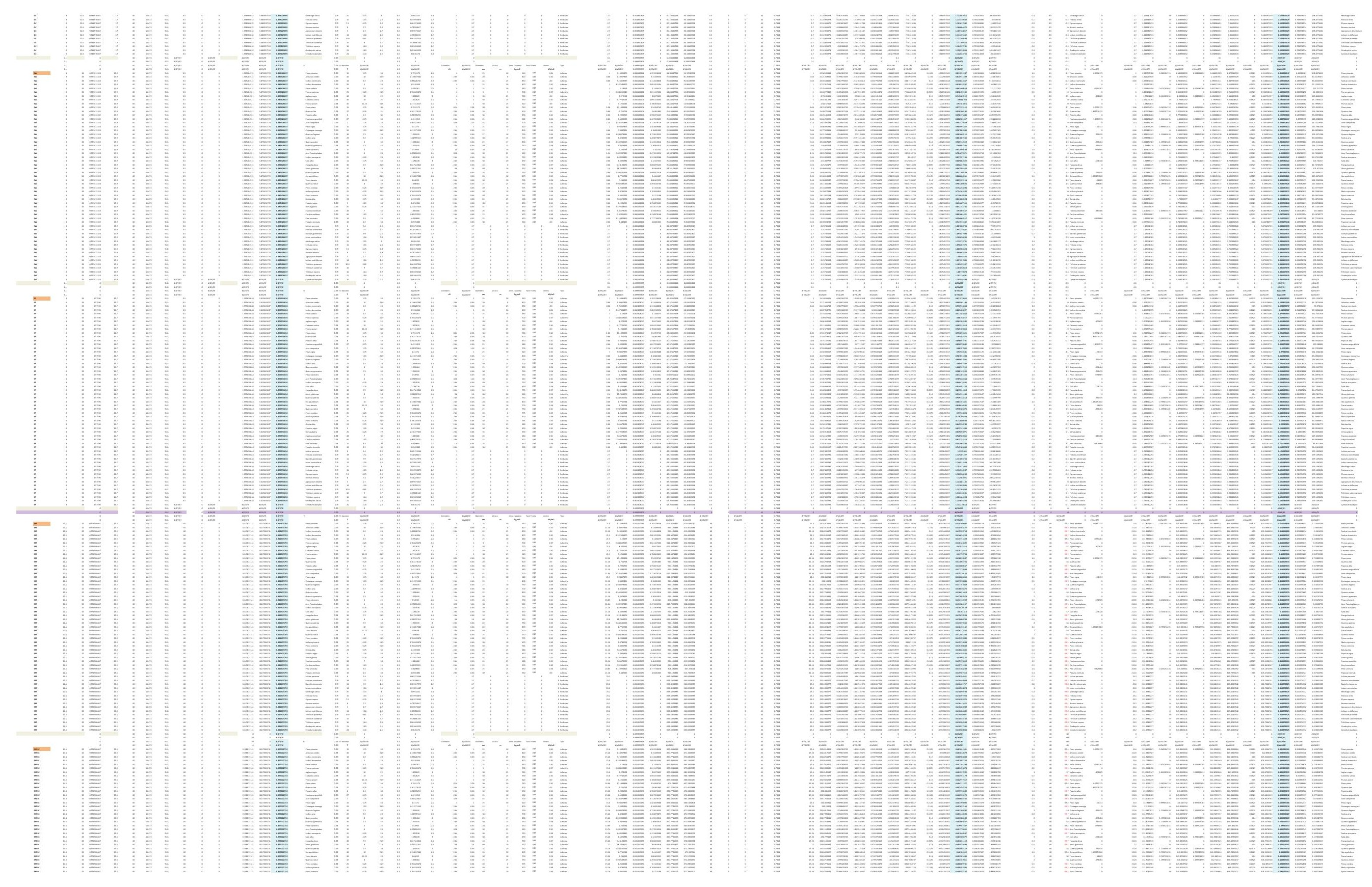



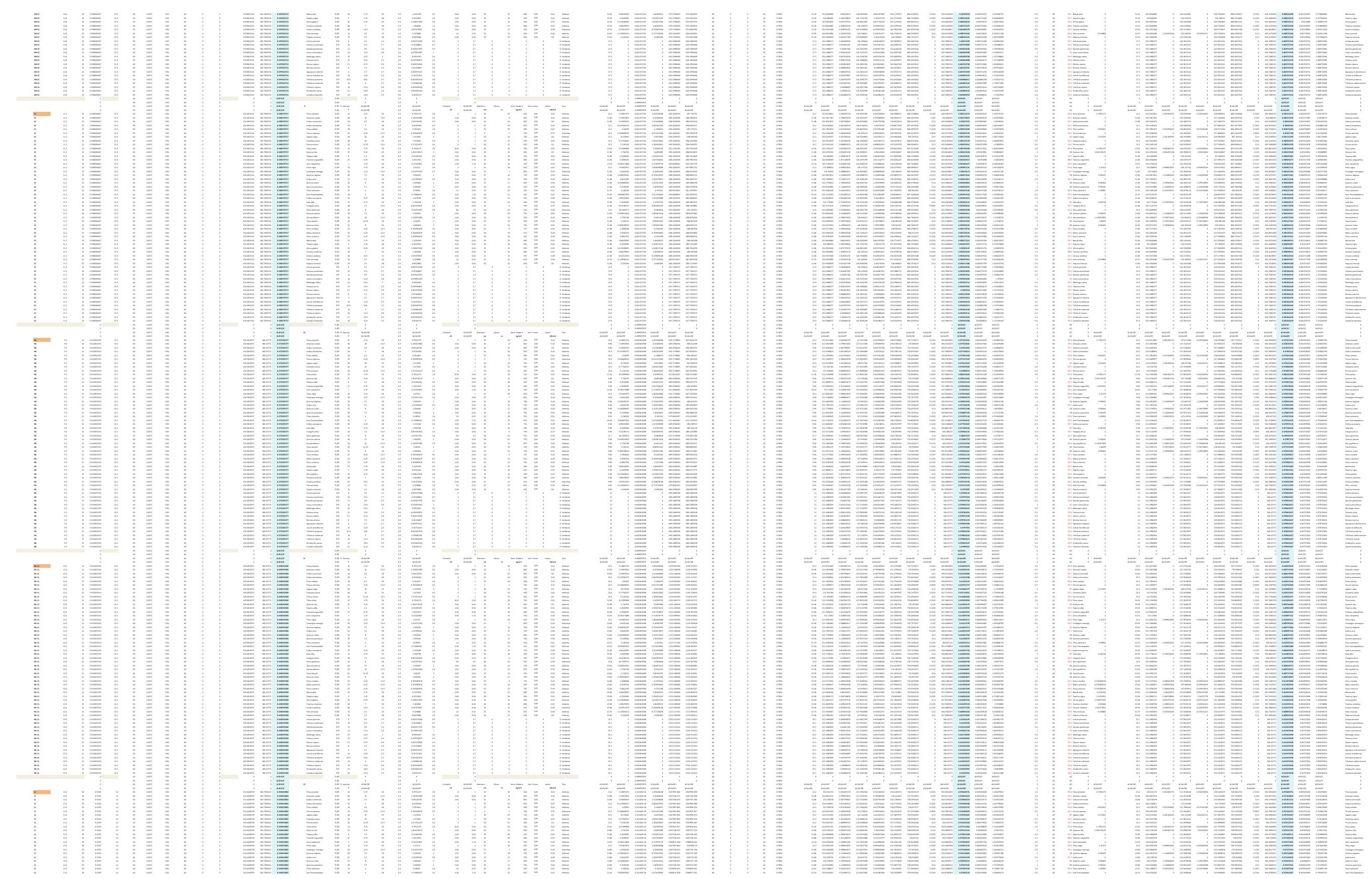

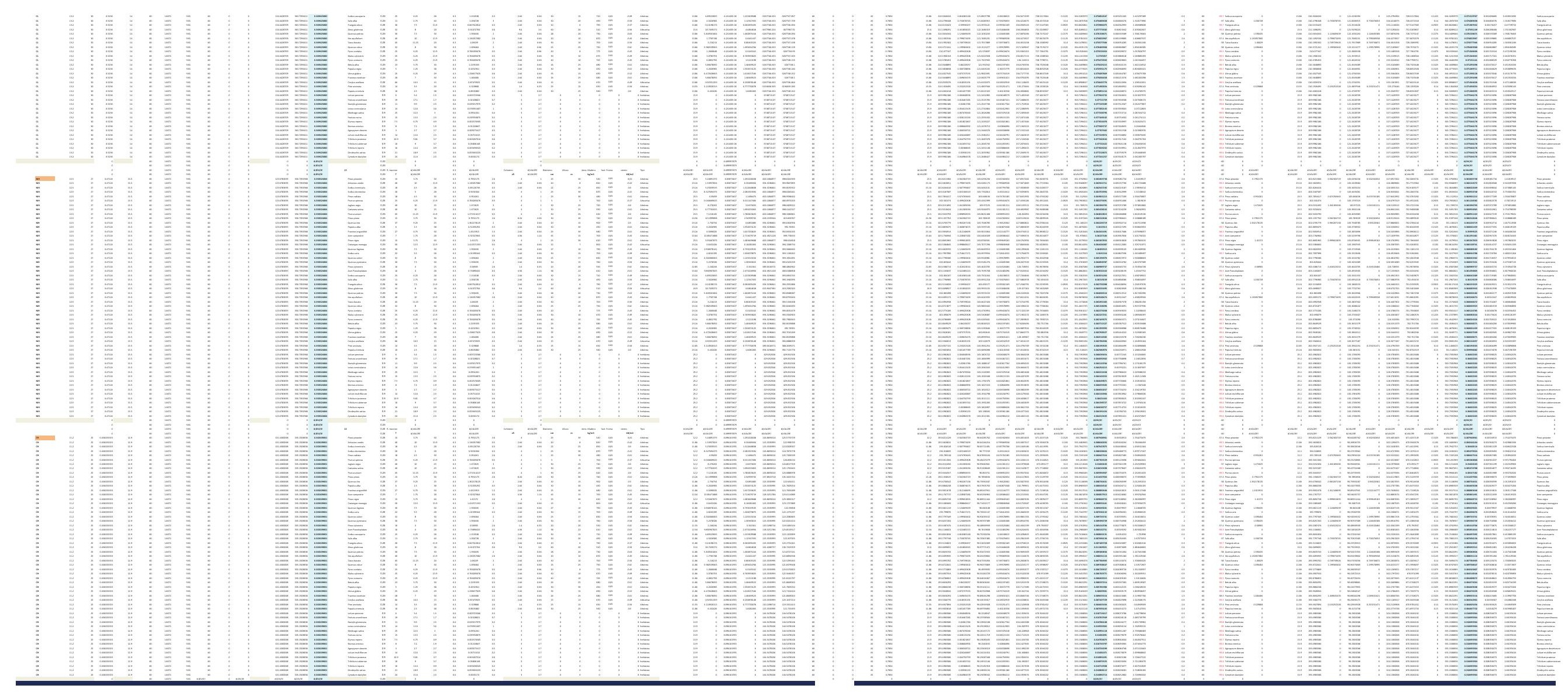

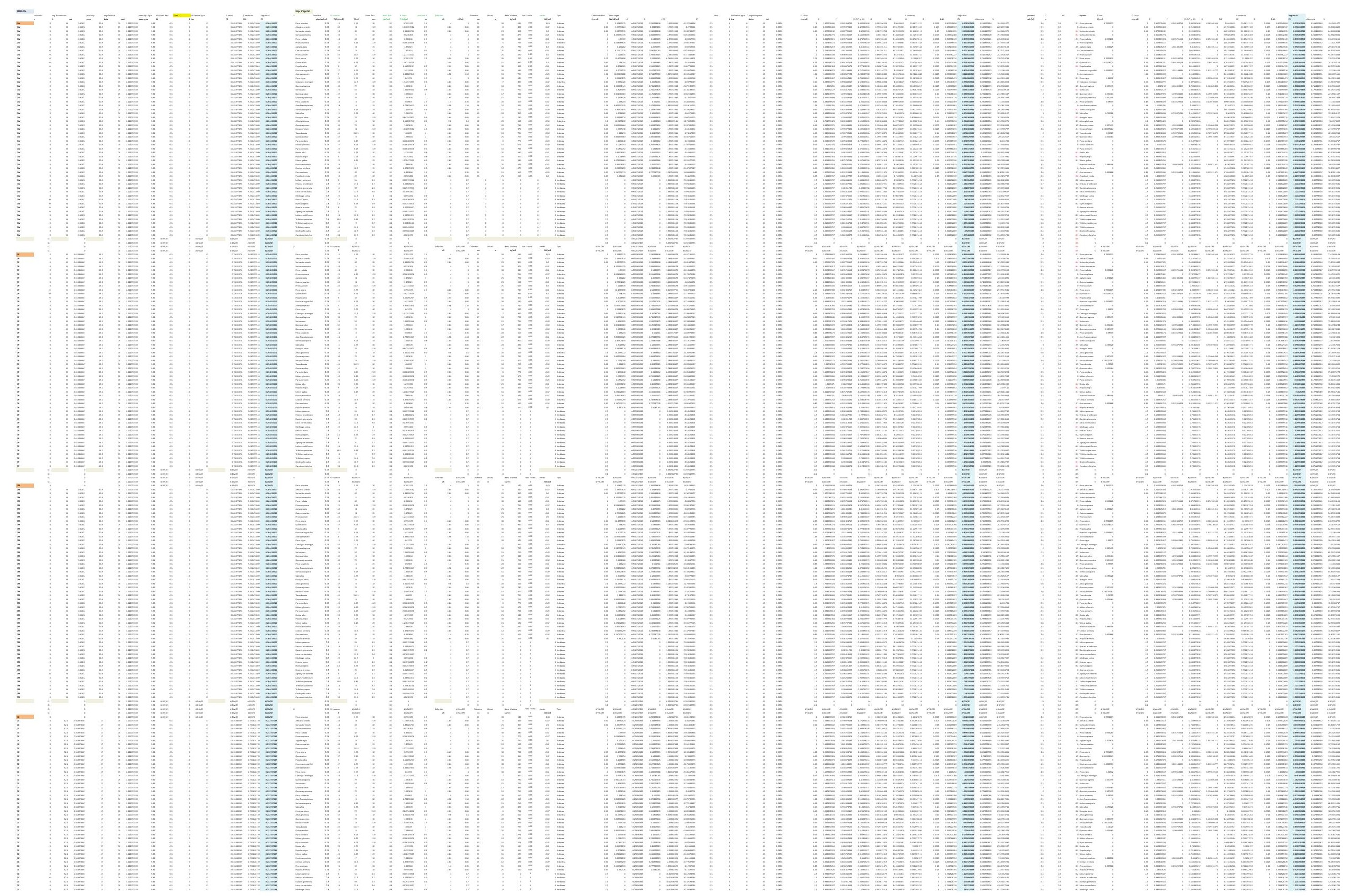


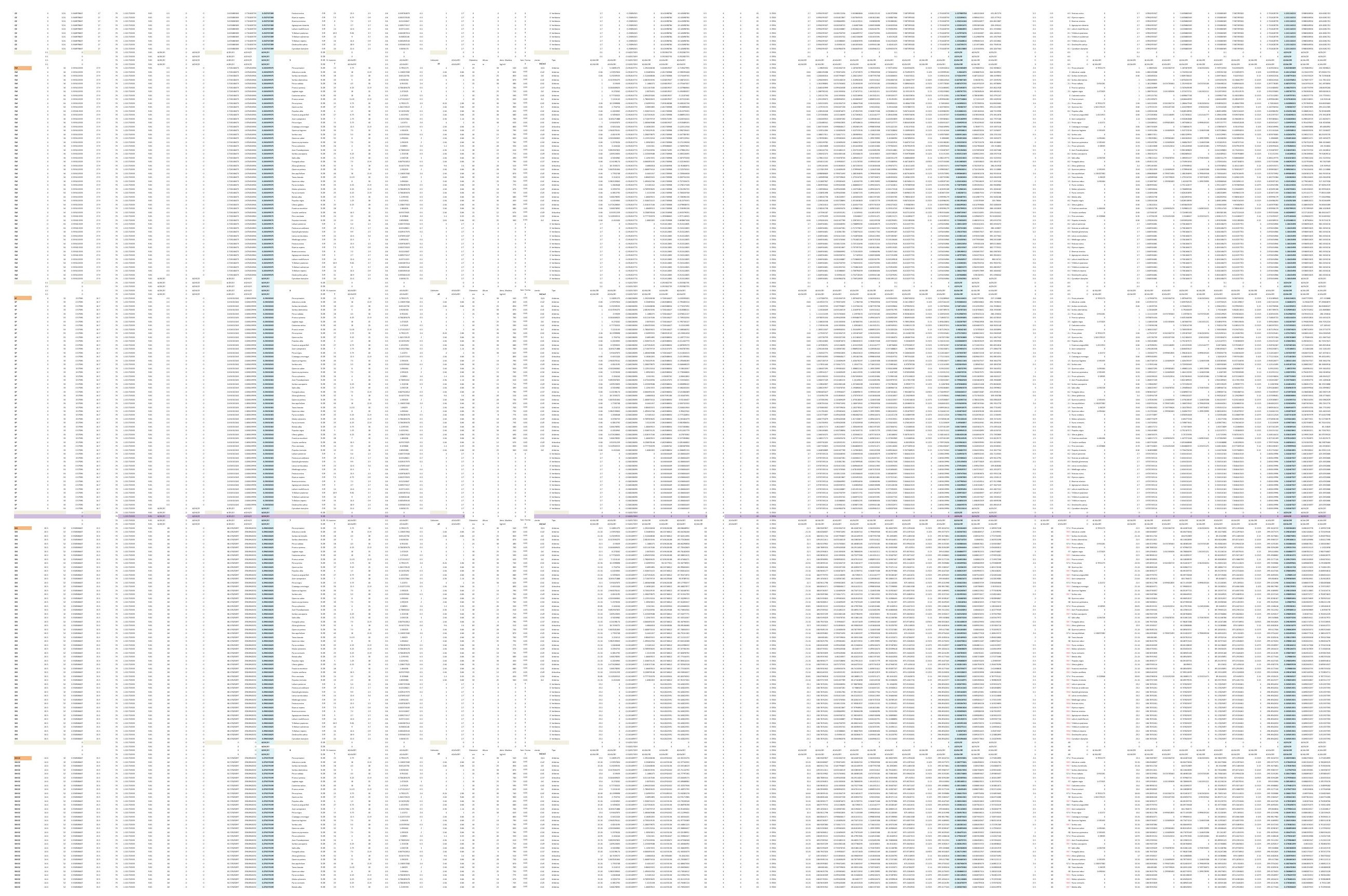



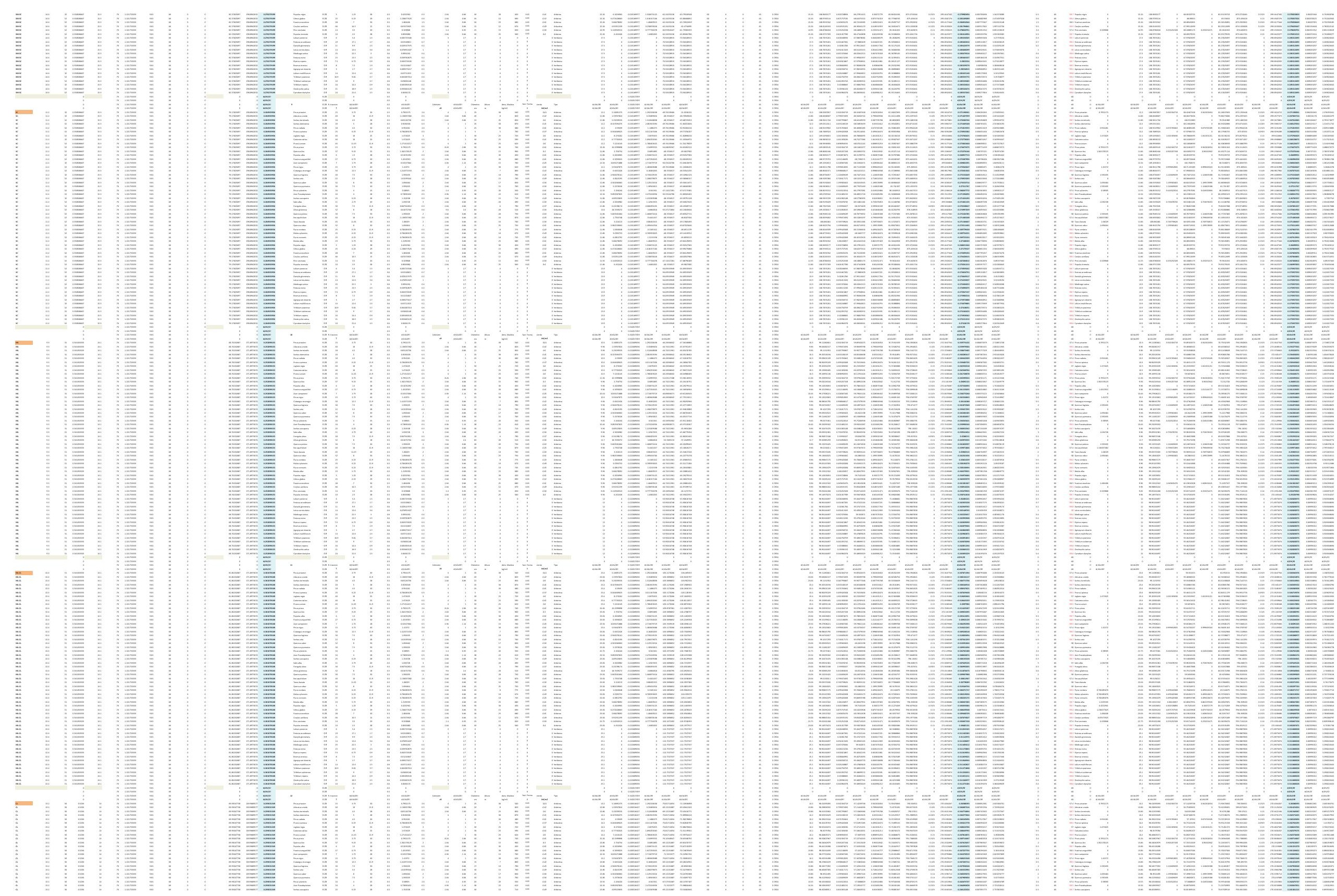


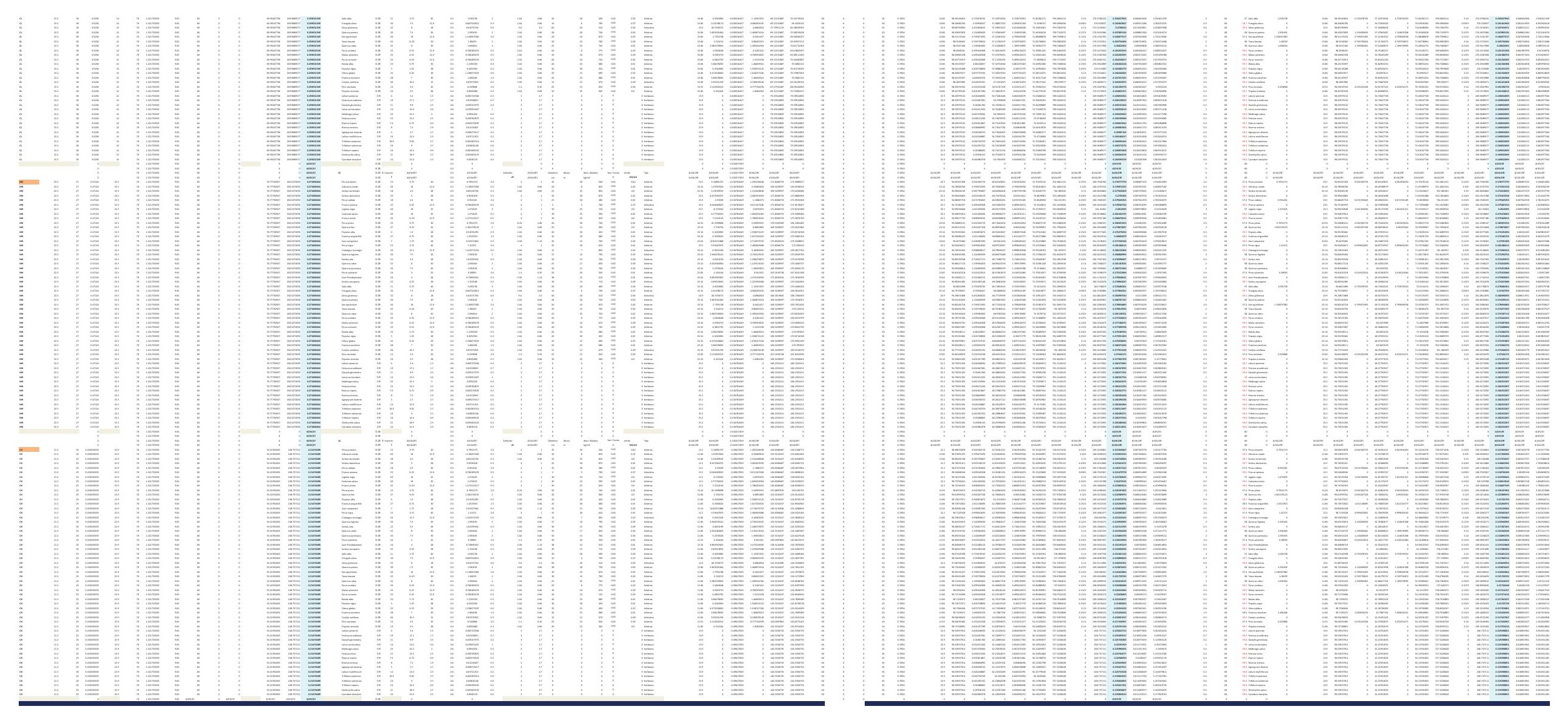



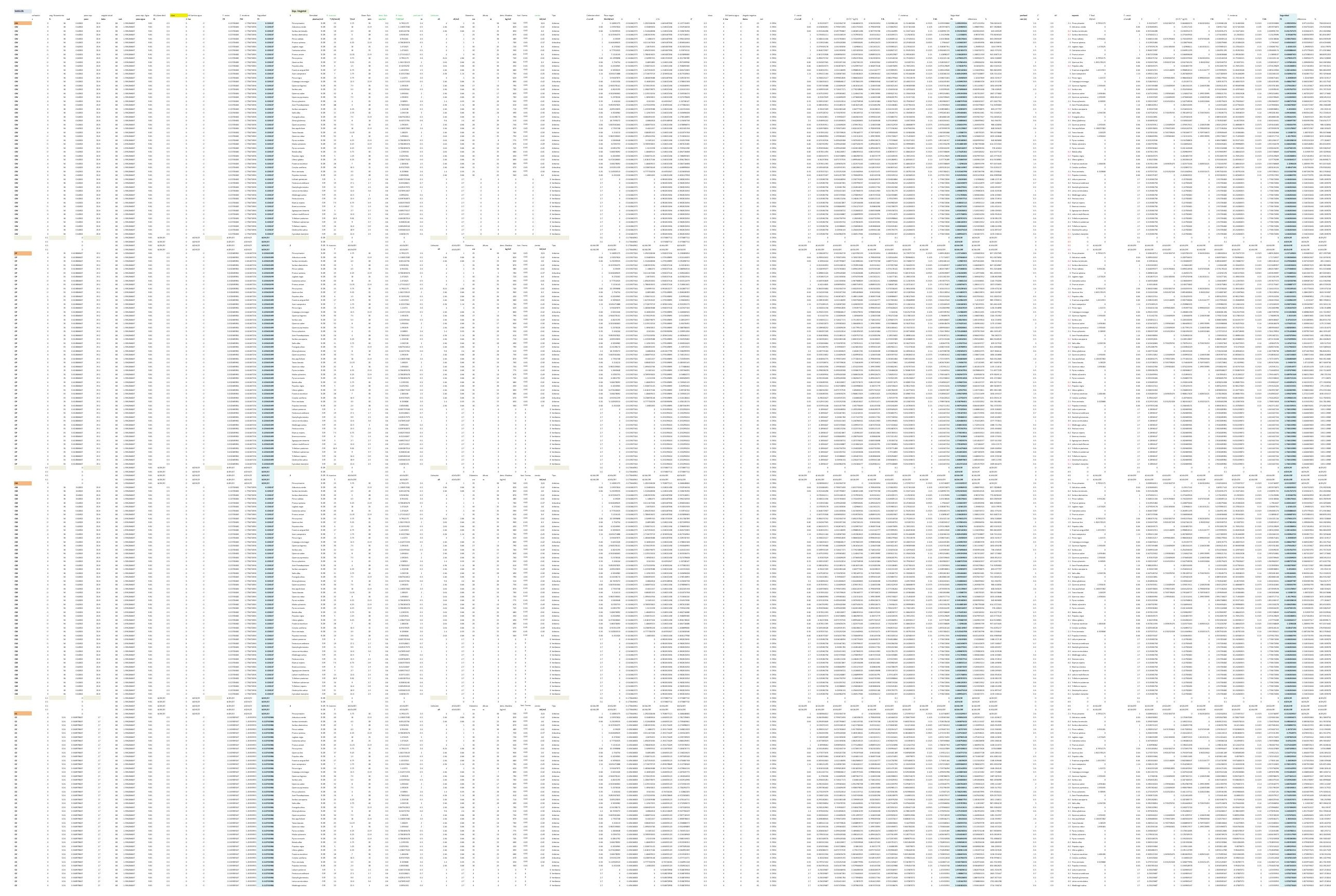


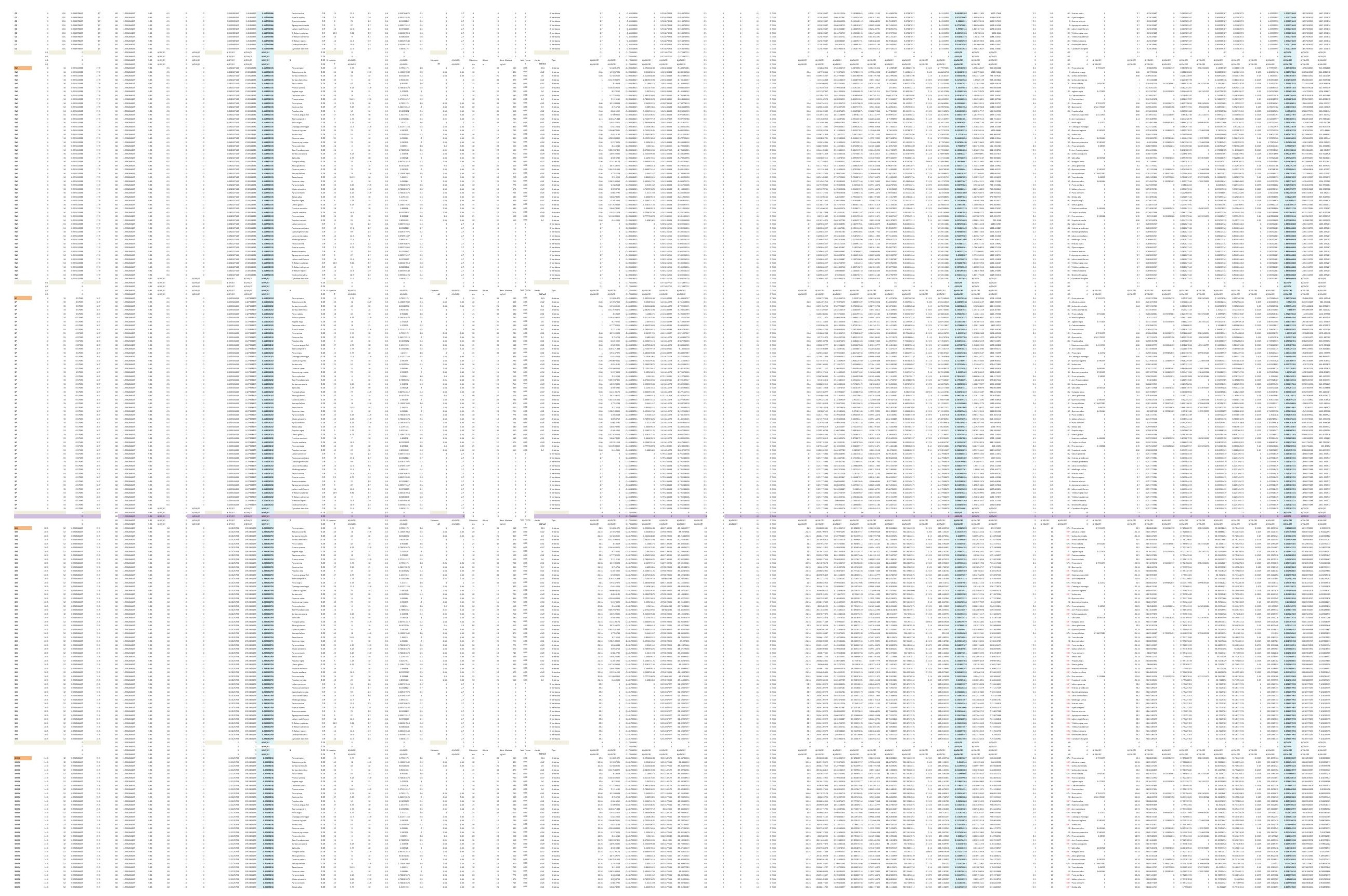




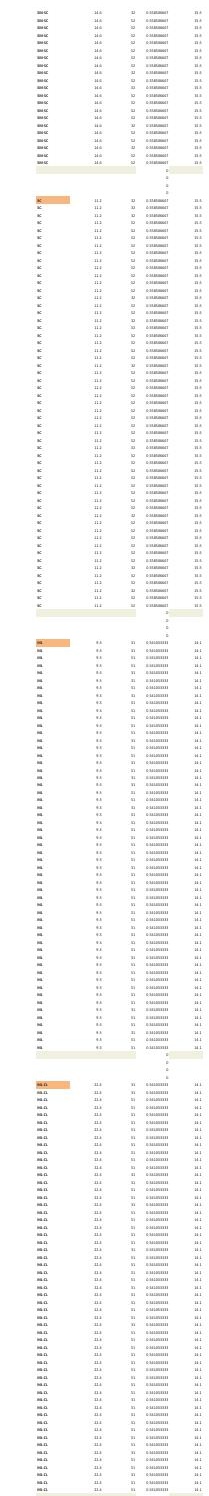

$-$

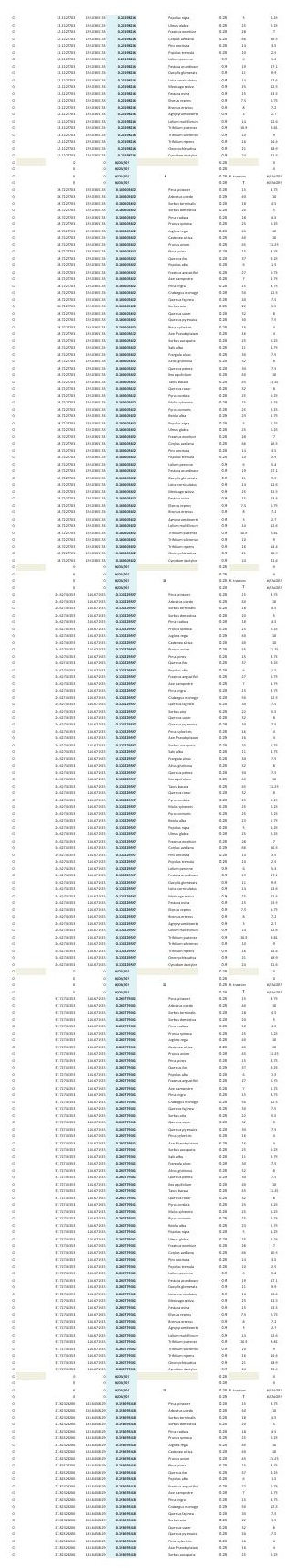

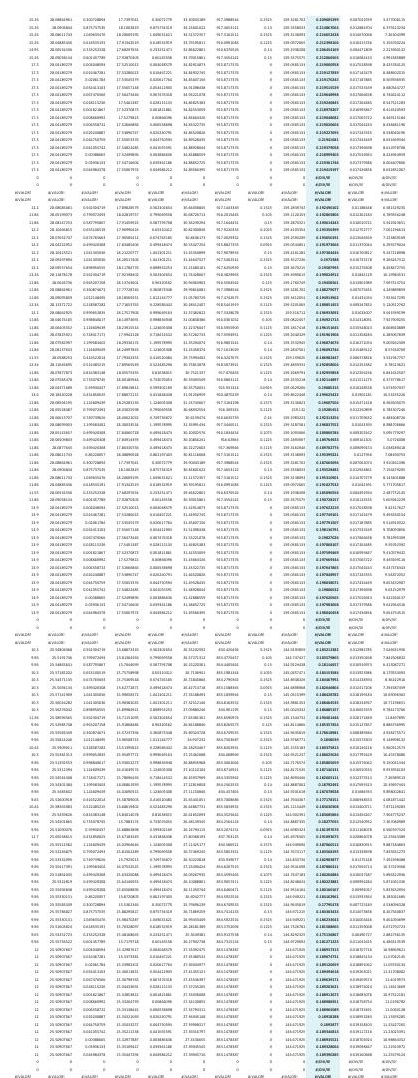

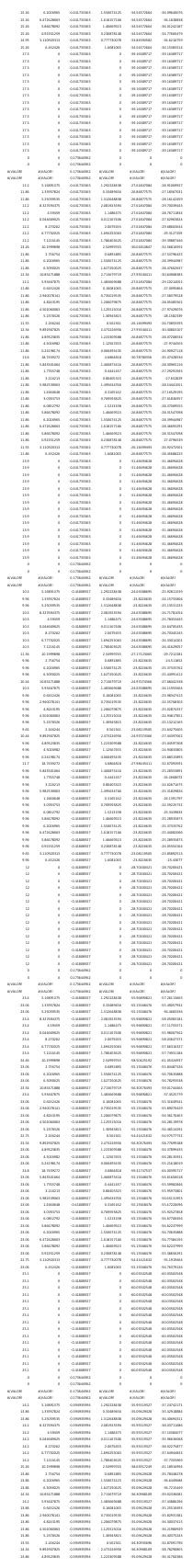

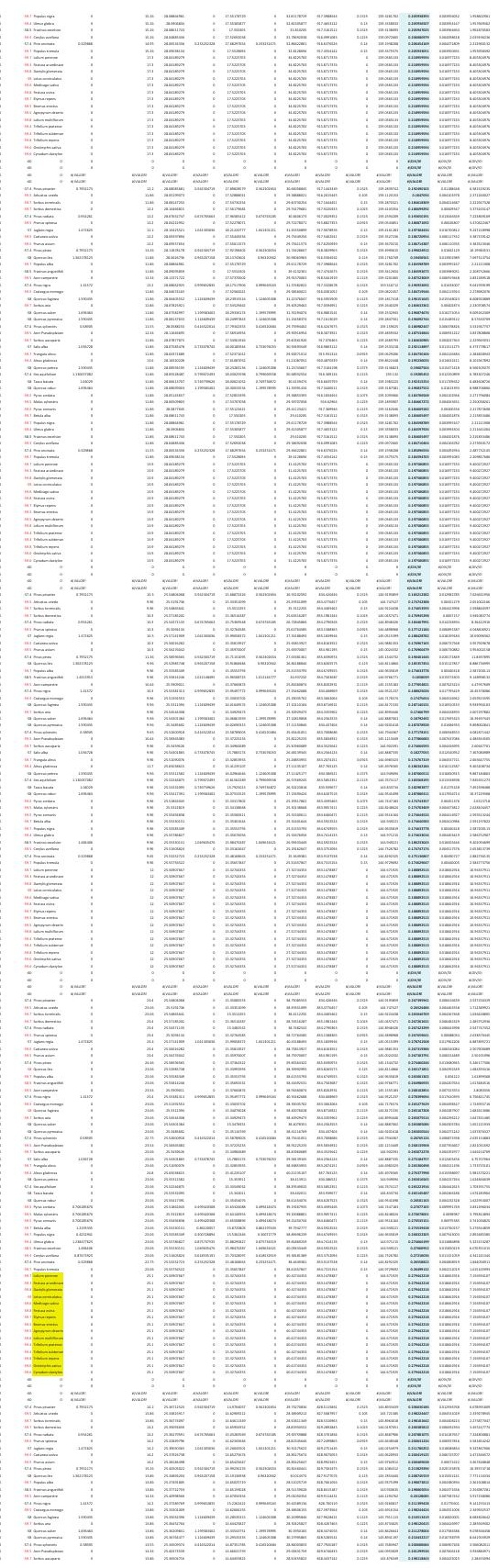




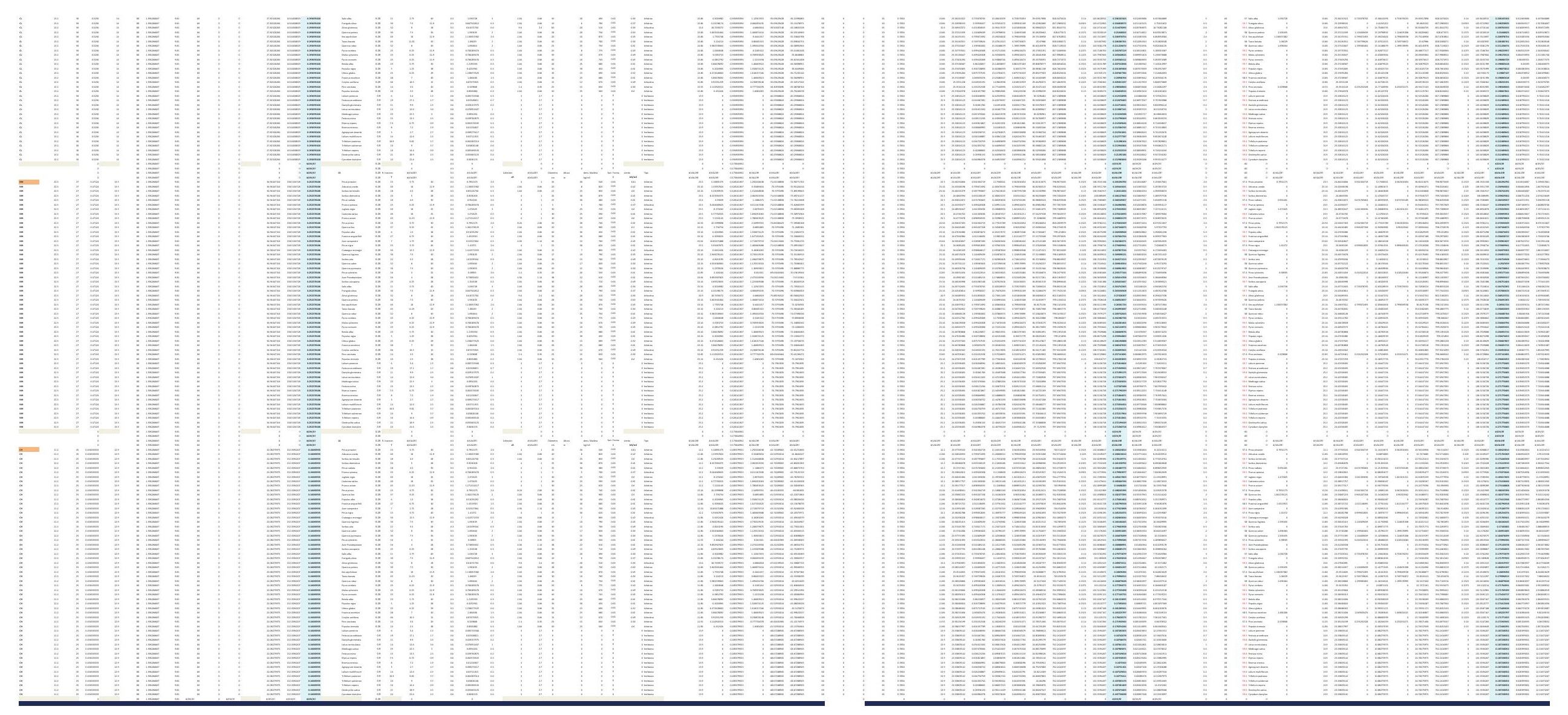


DESARROLLO DE UNA APLICACIÓN IMFORMÁTICA PARA EL CÁLCULO DE SOSTENIMIENTO DE TALUDES MEDIANTE VEGETACIÓN

A03. DENSIDAD DE PLANTACIÓN: 2.500 plantas/ha.

\section{A03-2.POSICIÓN N.F. 2}

INCLINACIÓN DE TALUD 6-100

INCLINACIÓN DE TALUD 10-200

INCLINACIÓN DE TALUD 20-30

INCLINACIÓN DE TALUD 30-40

INCLINACIÓN DE TALUD $35^{\circ}$

INCLINACIÓN DE TALUD 40-50

INCLINACIÓN DE TALUD 50-550

INCLINACIÓN DE TALUD 55-60

INCLINACIÓN DE TALUD 60-700

INCLINACIÓN DE TALUD 70-80 

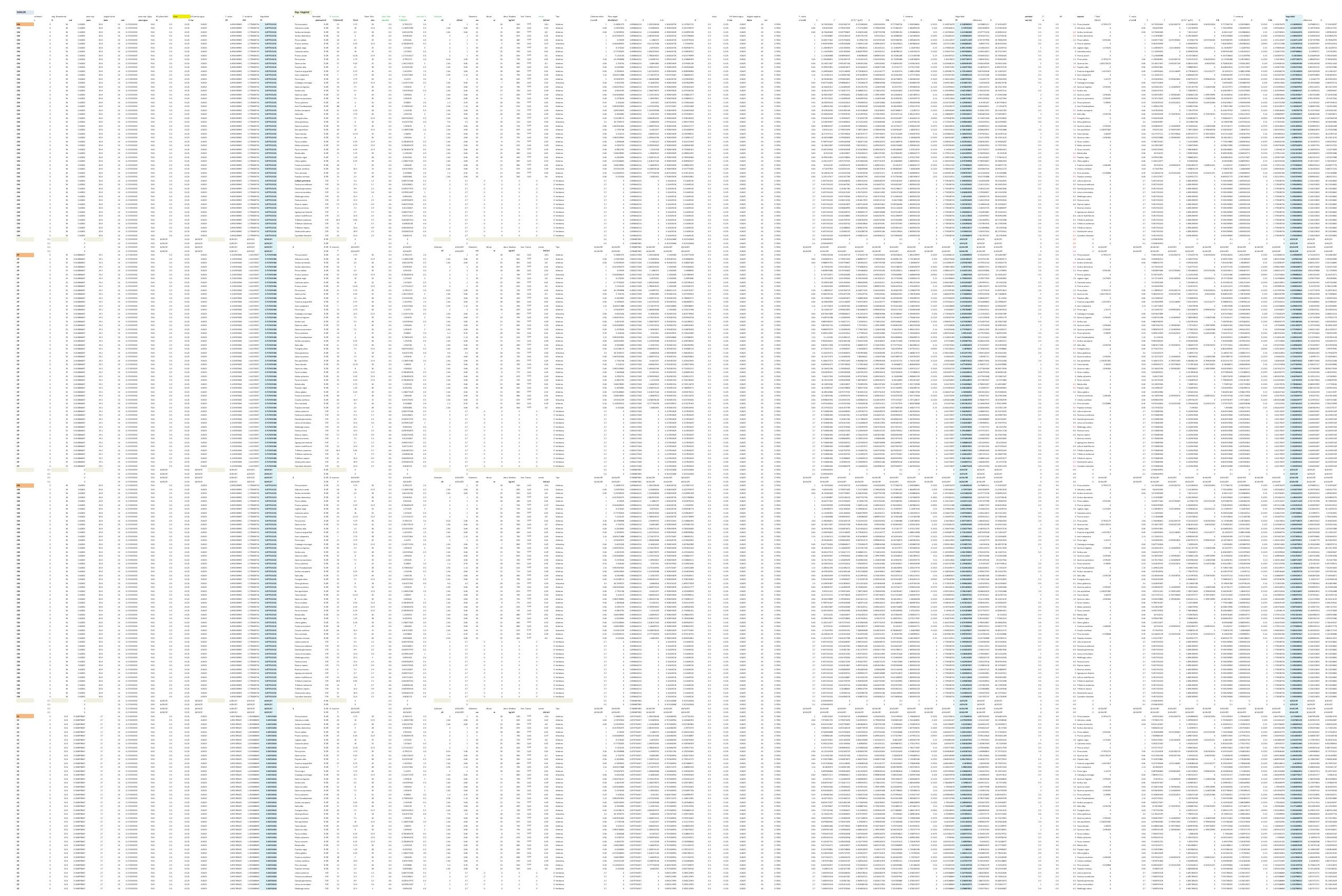


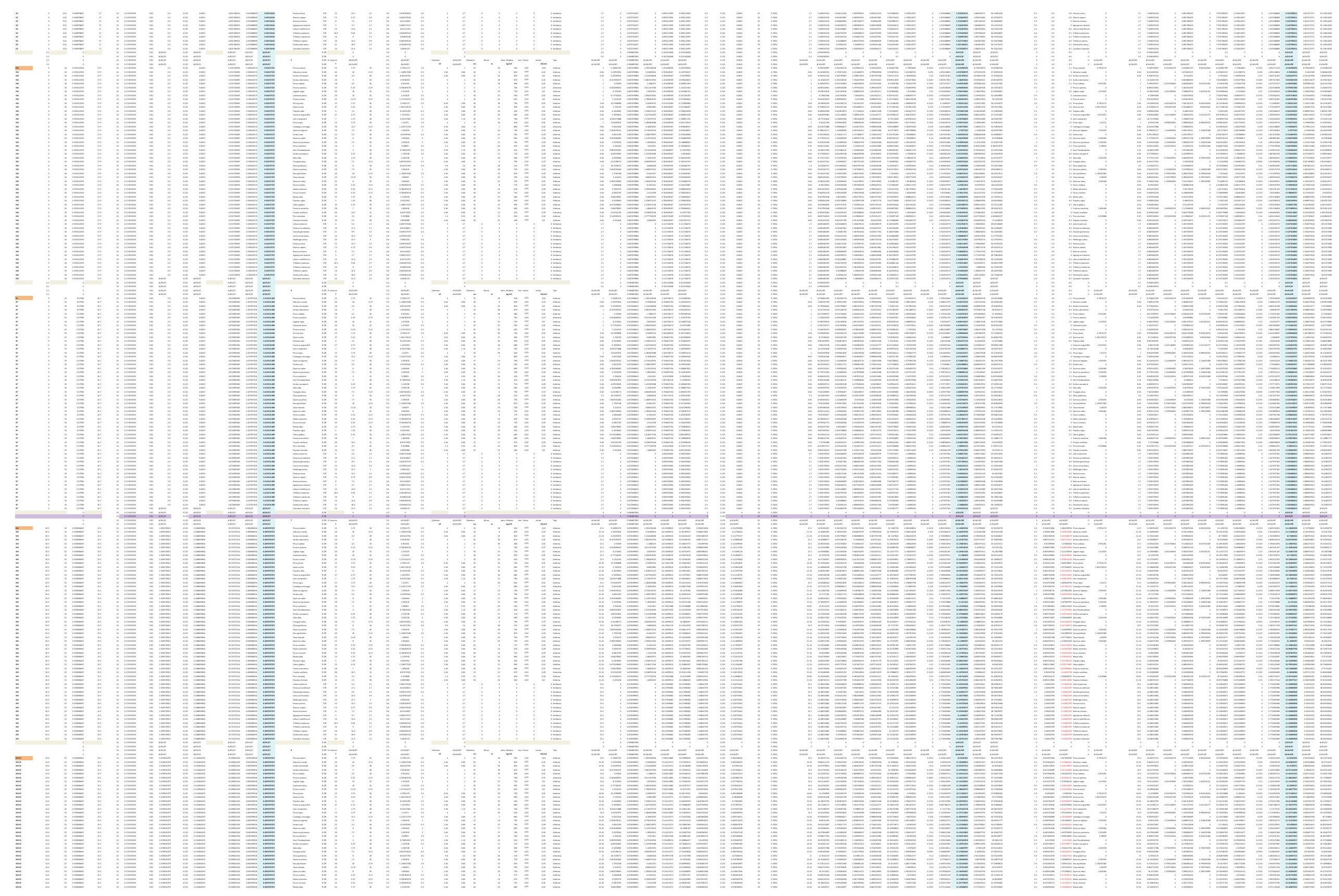



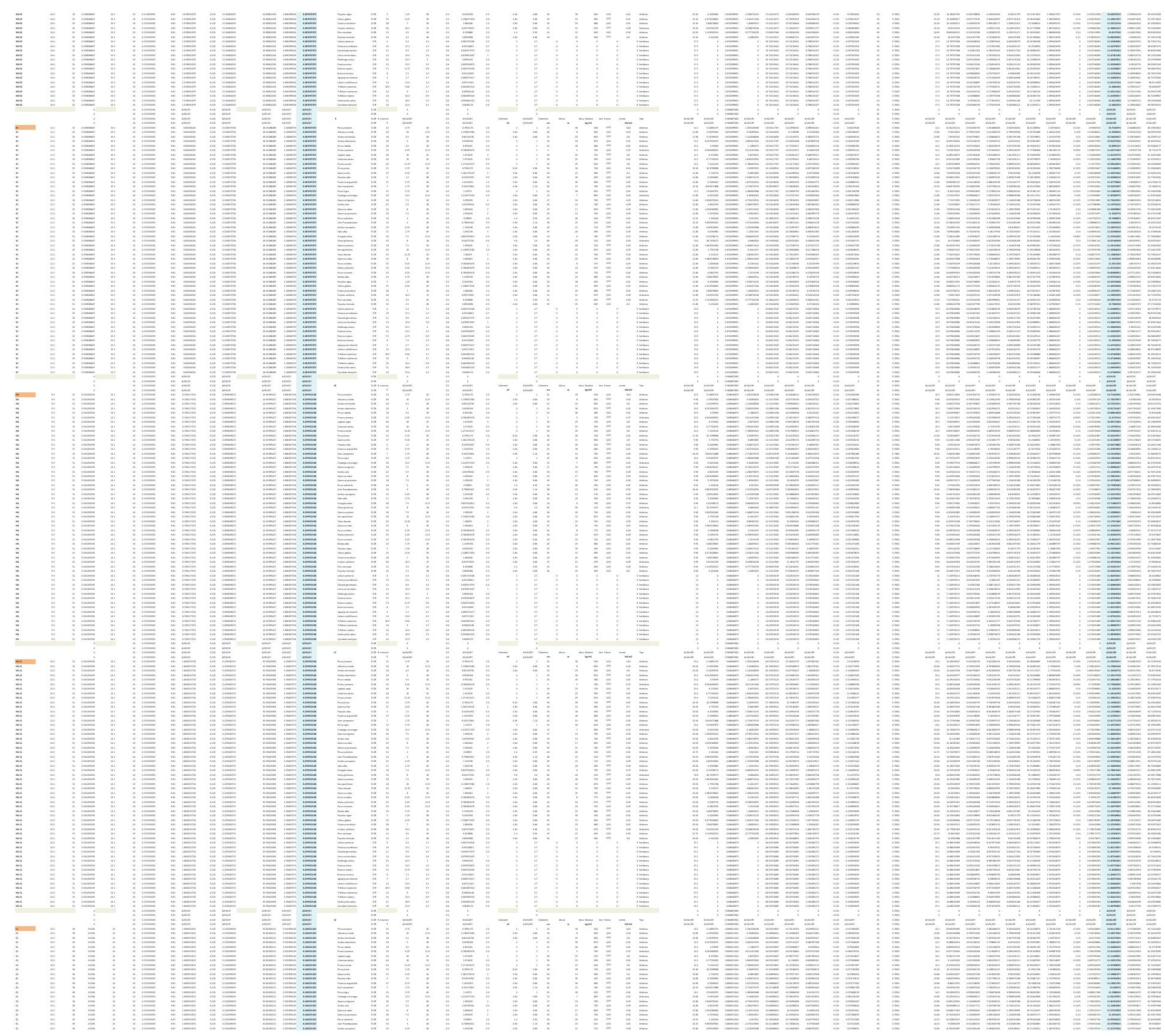

:
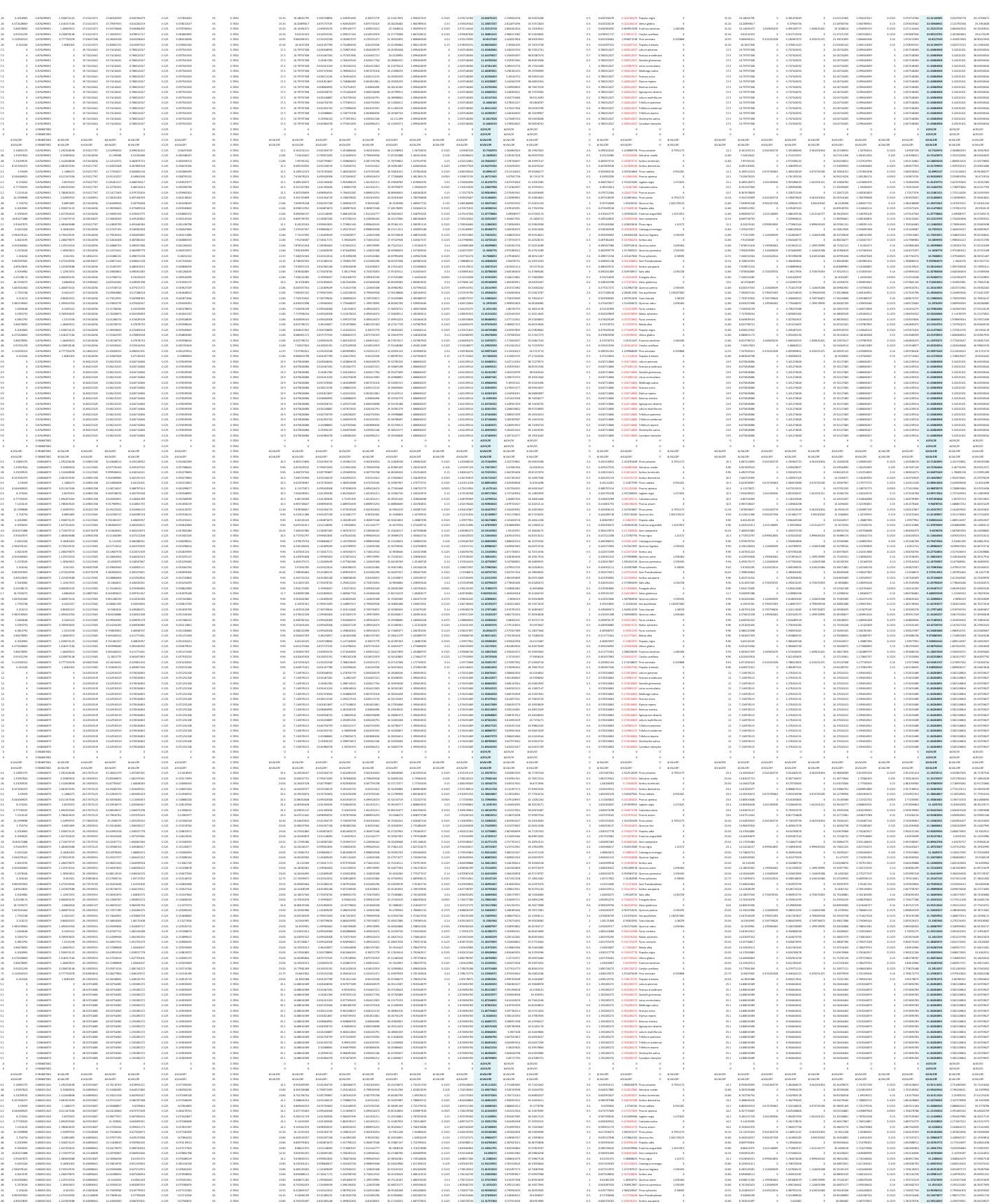


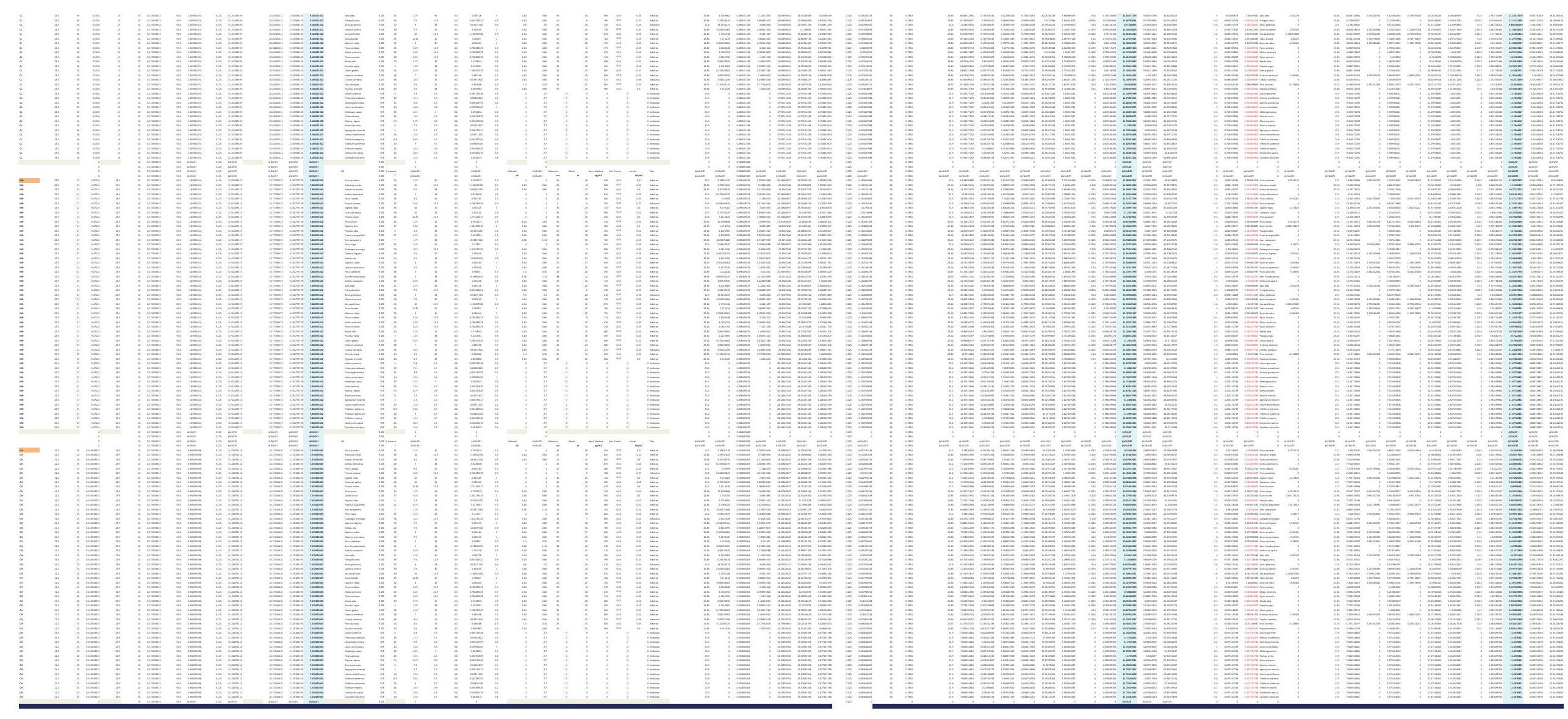



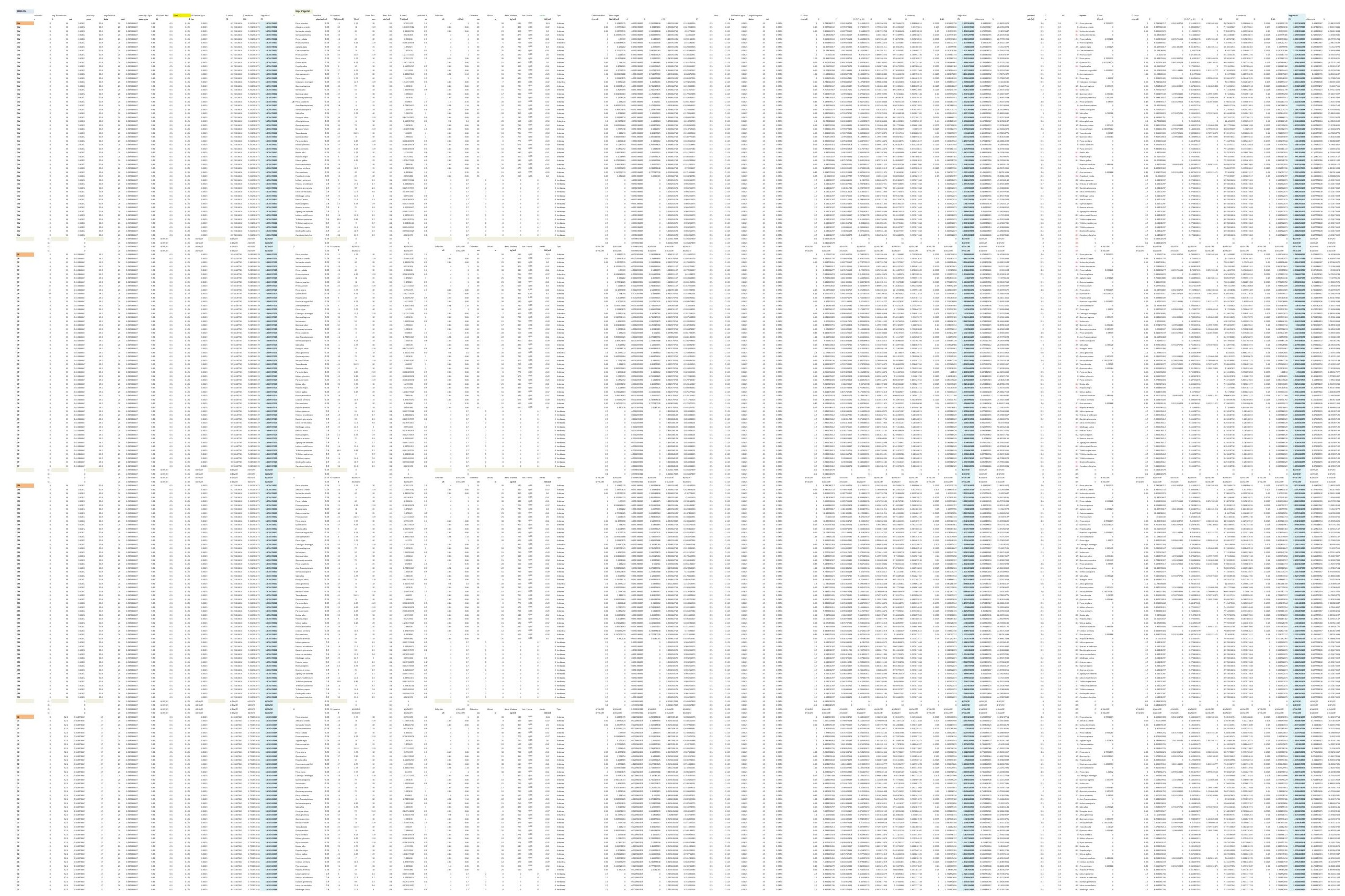


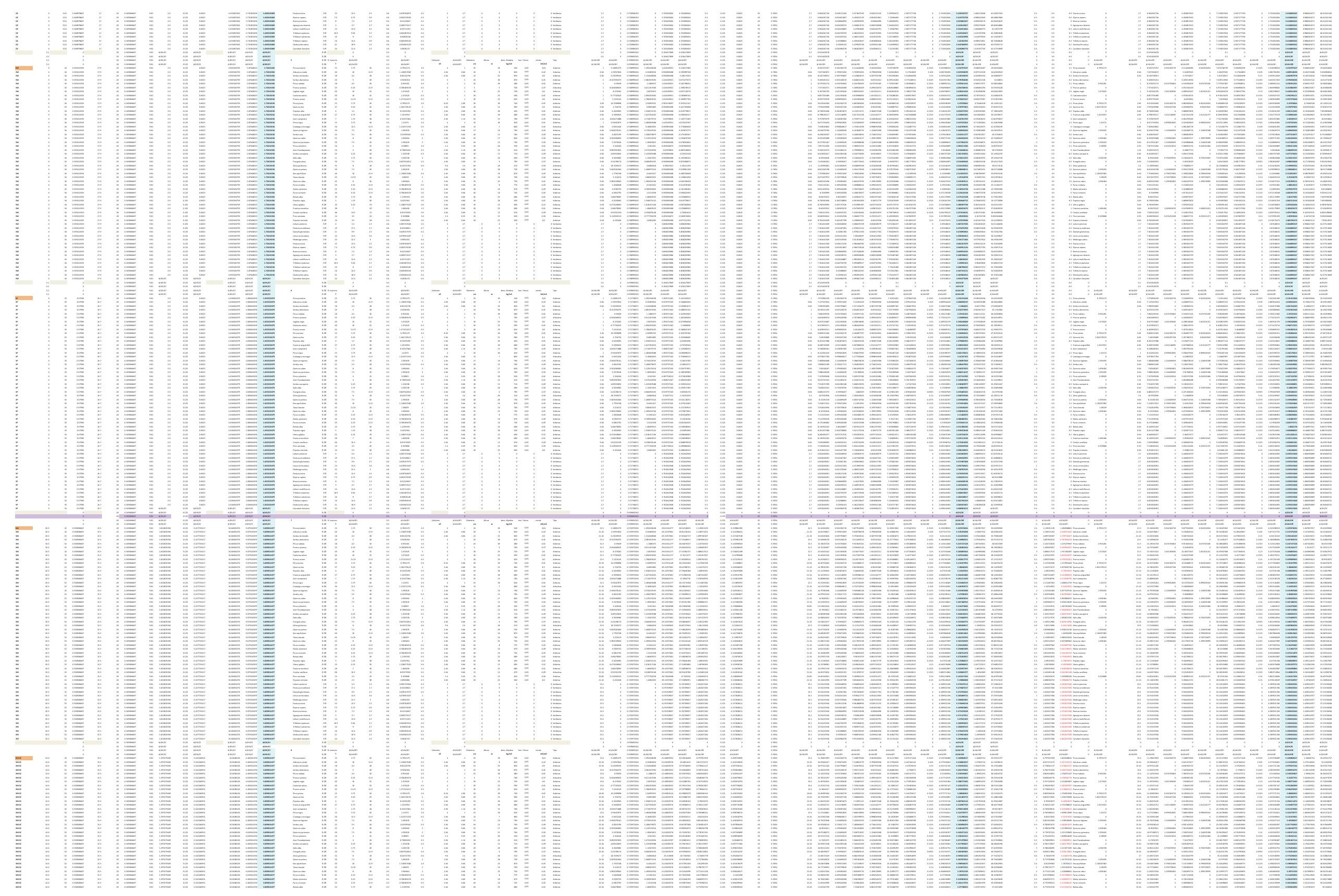



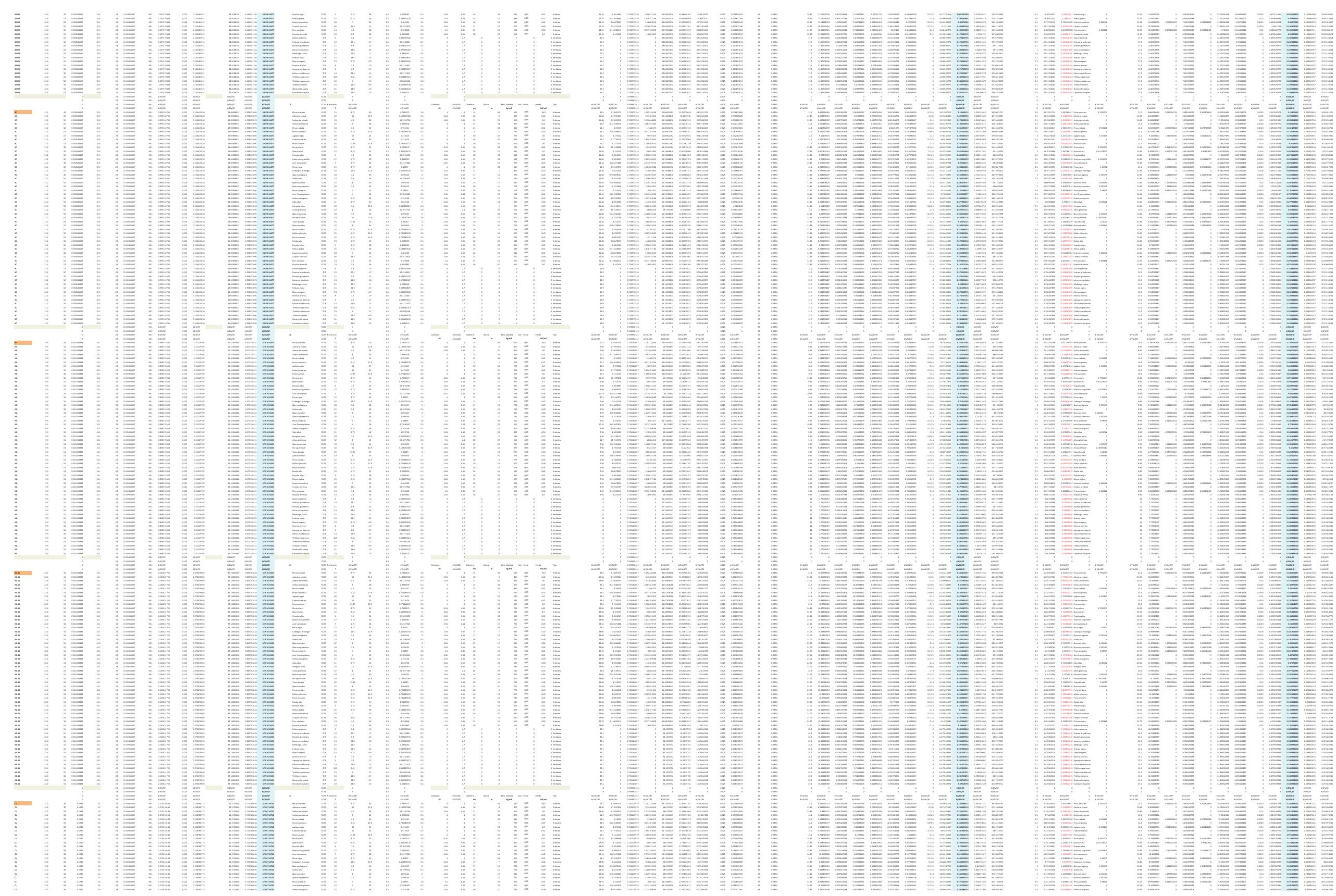


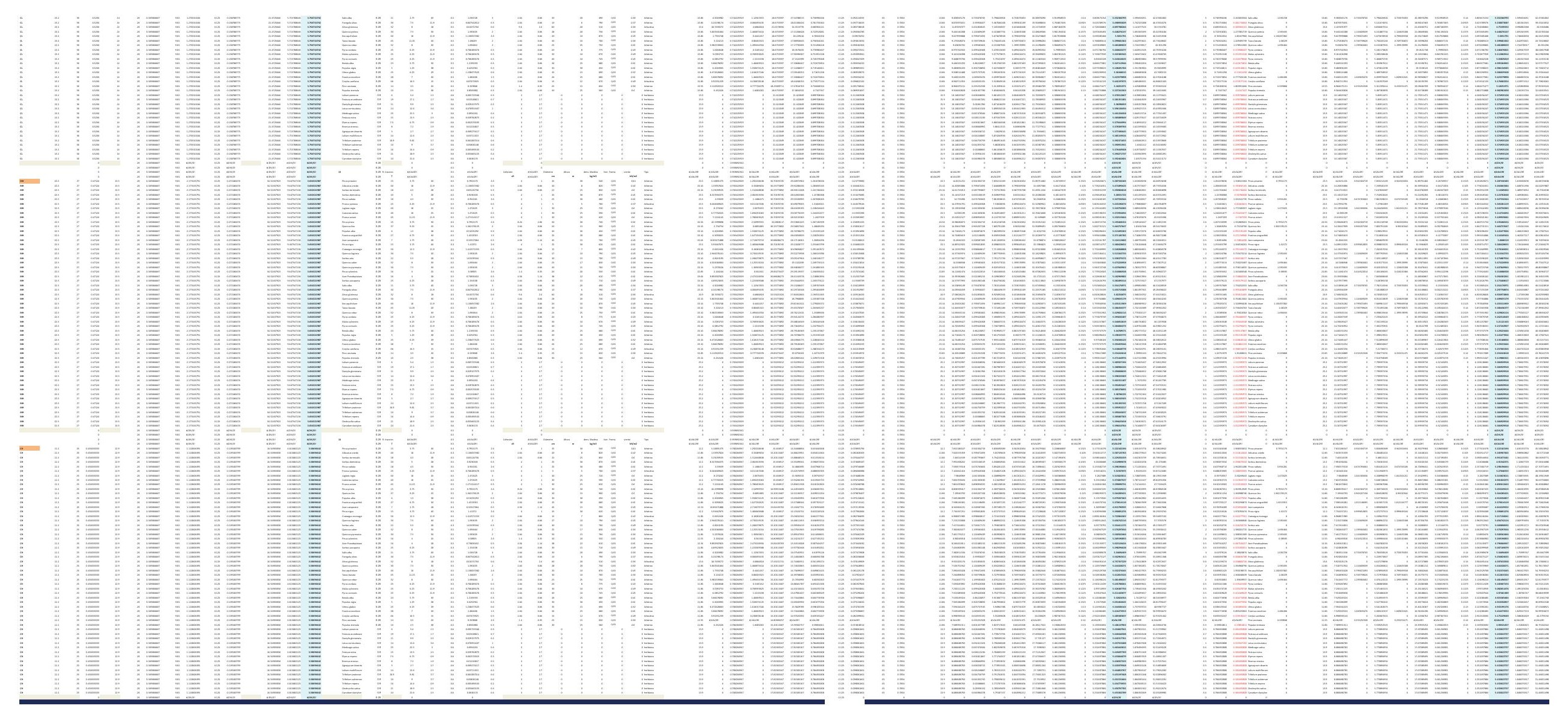



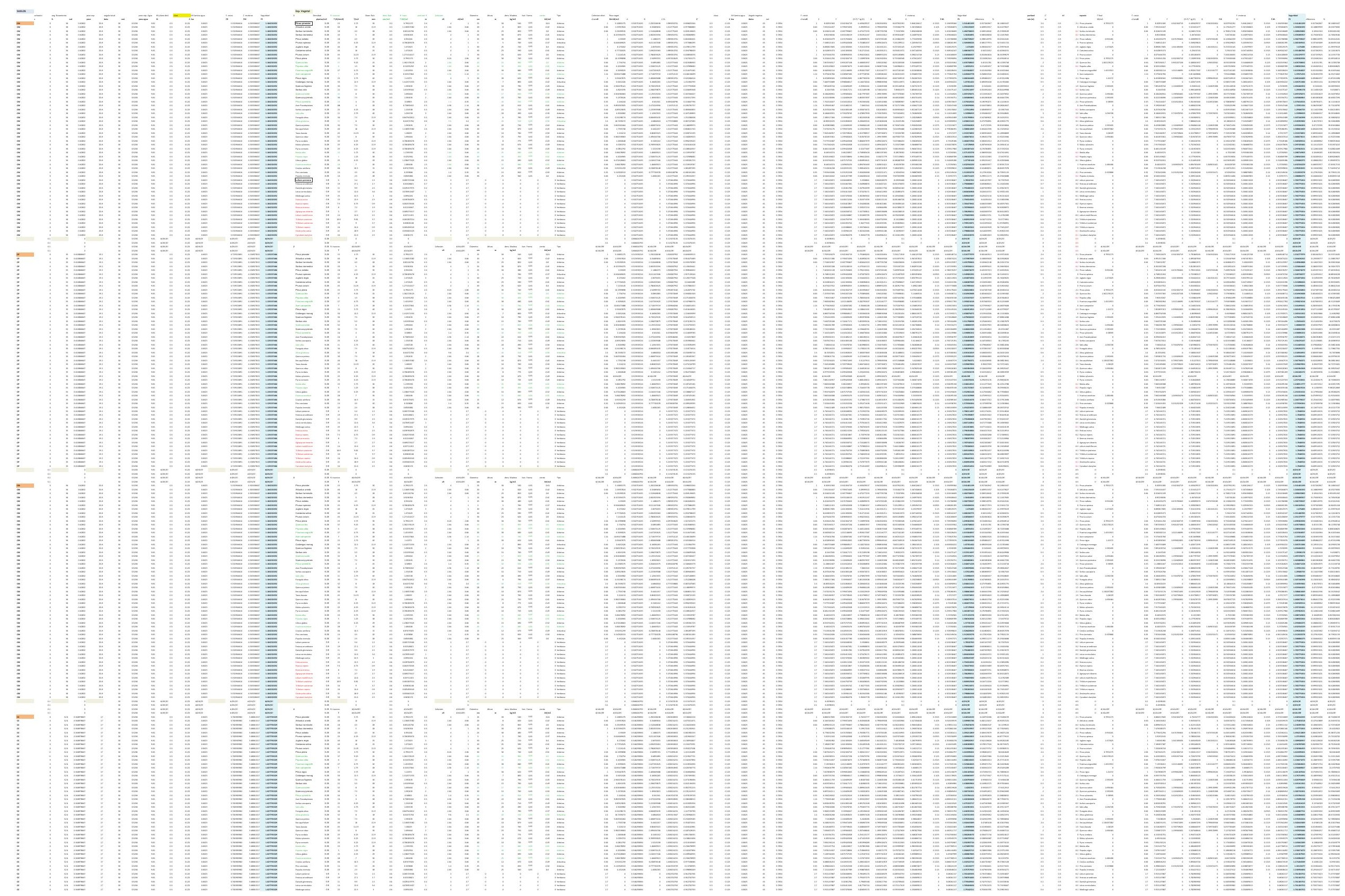


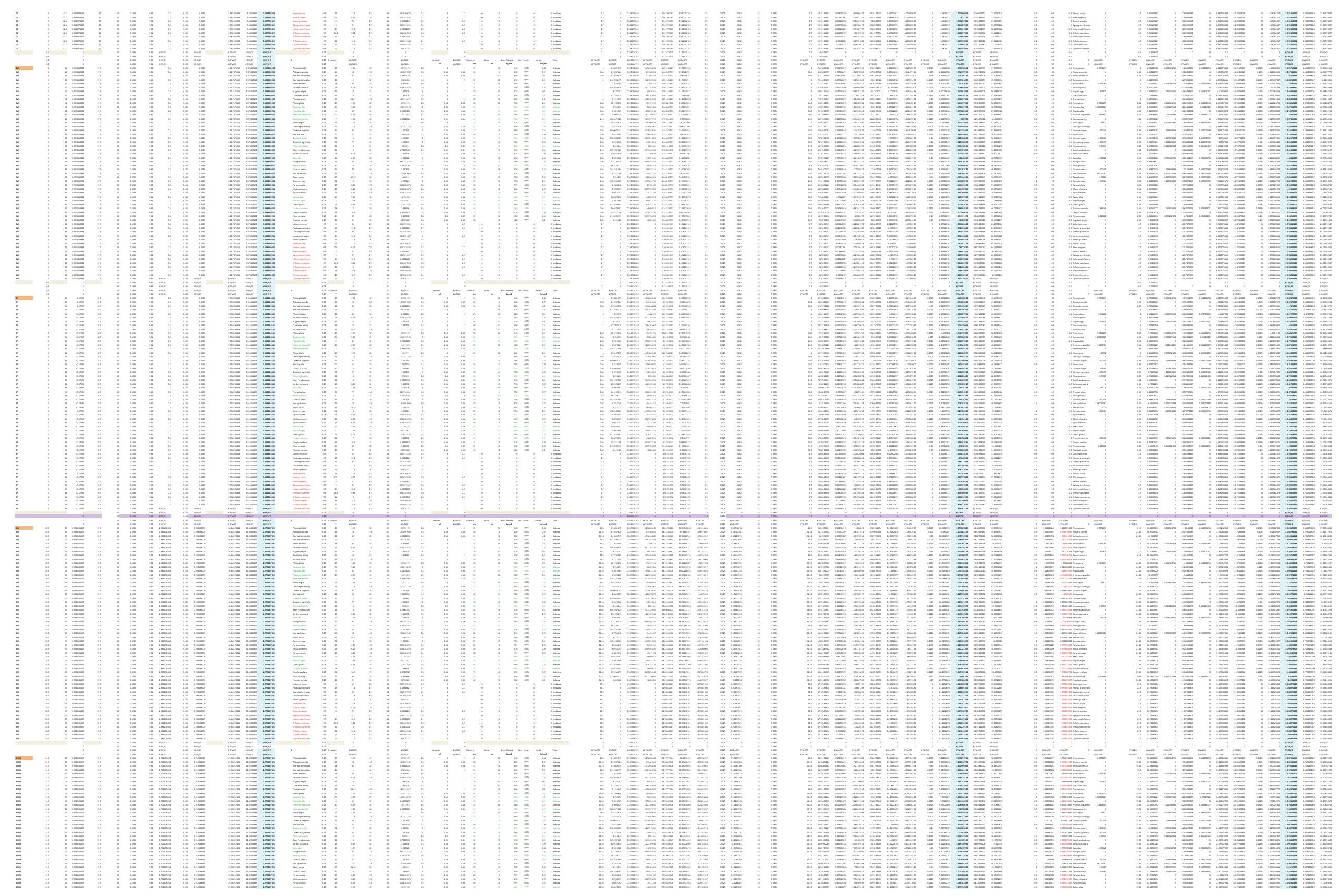



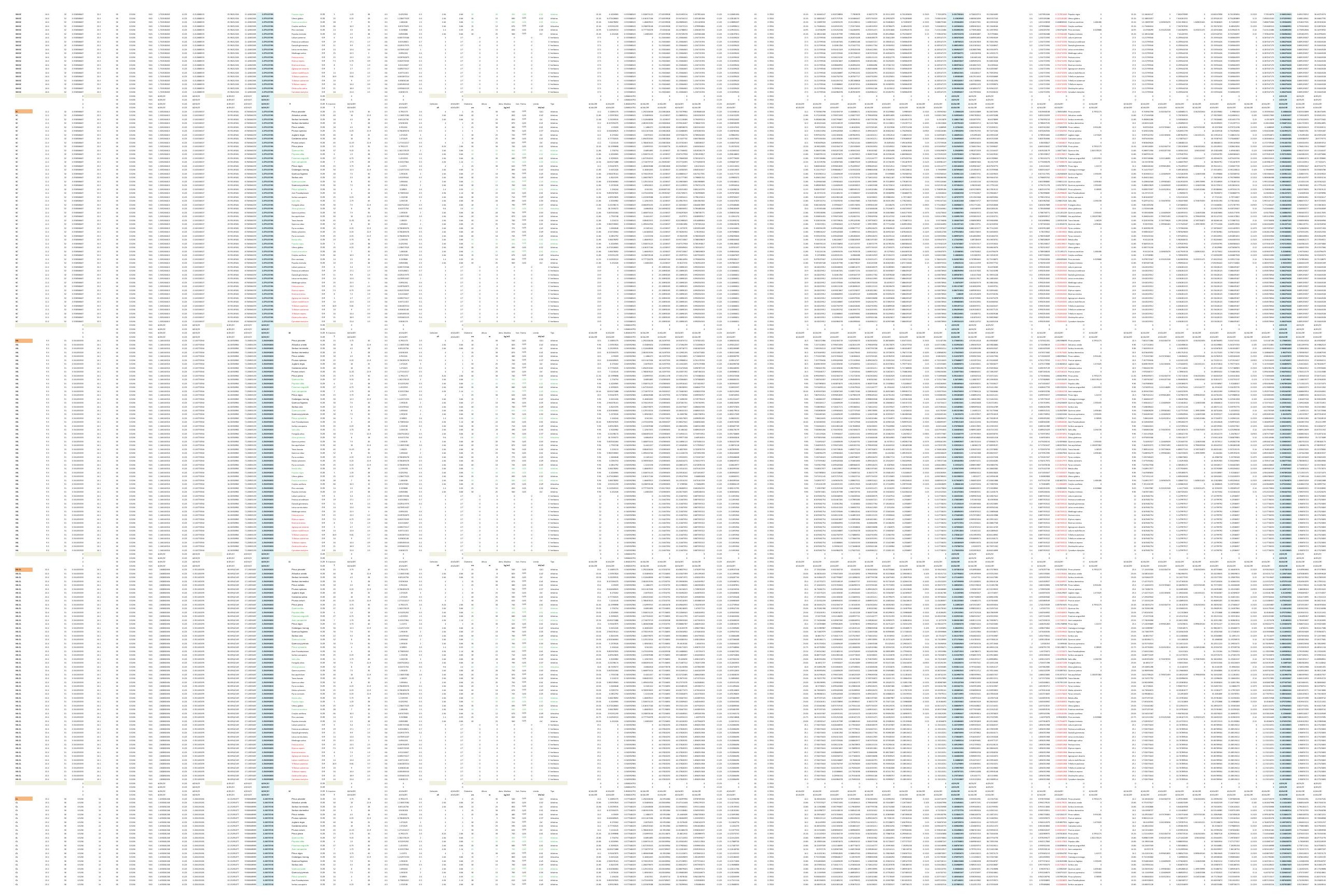


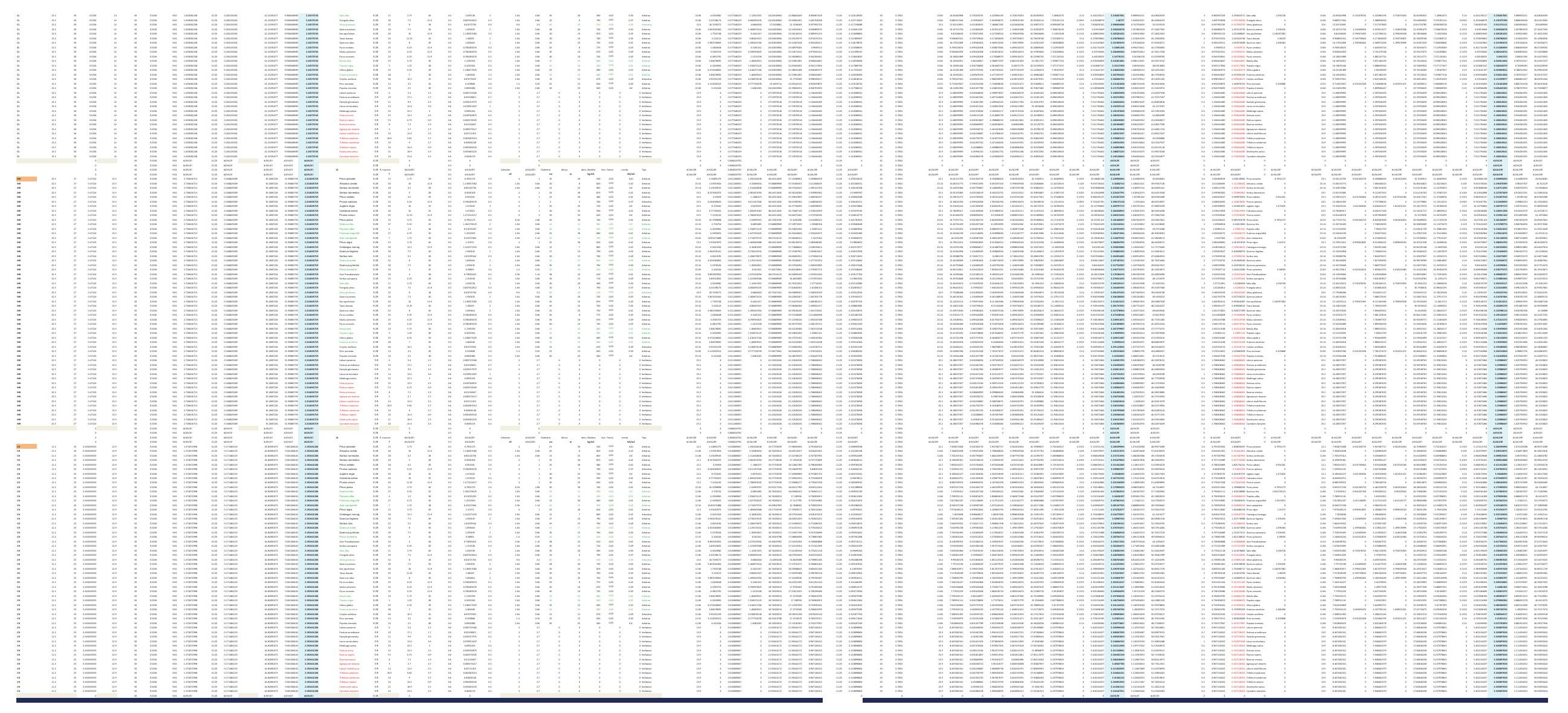



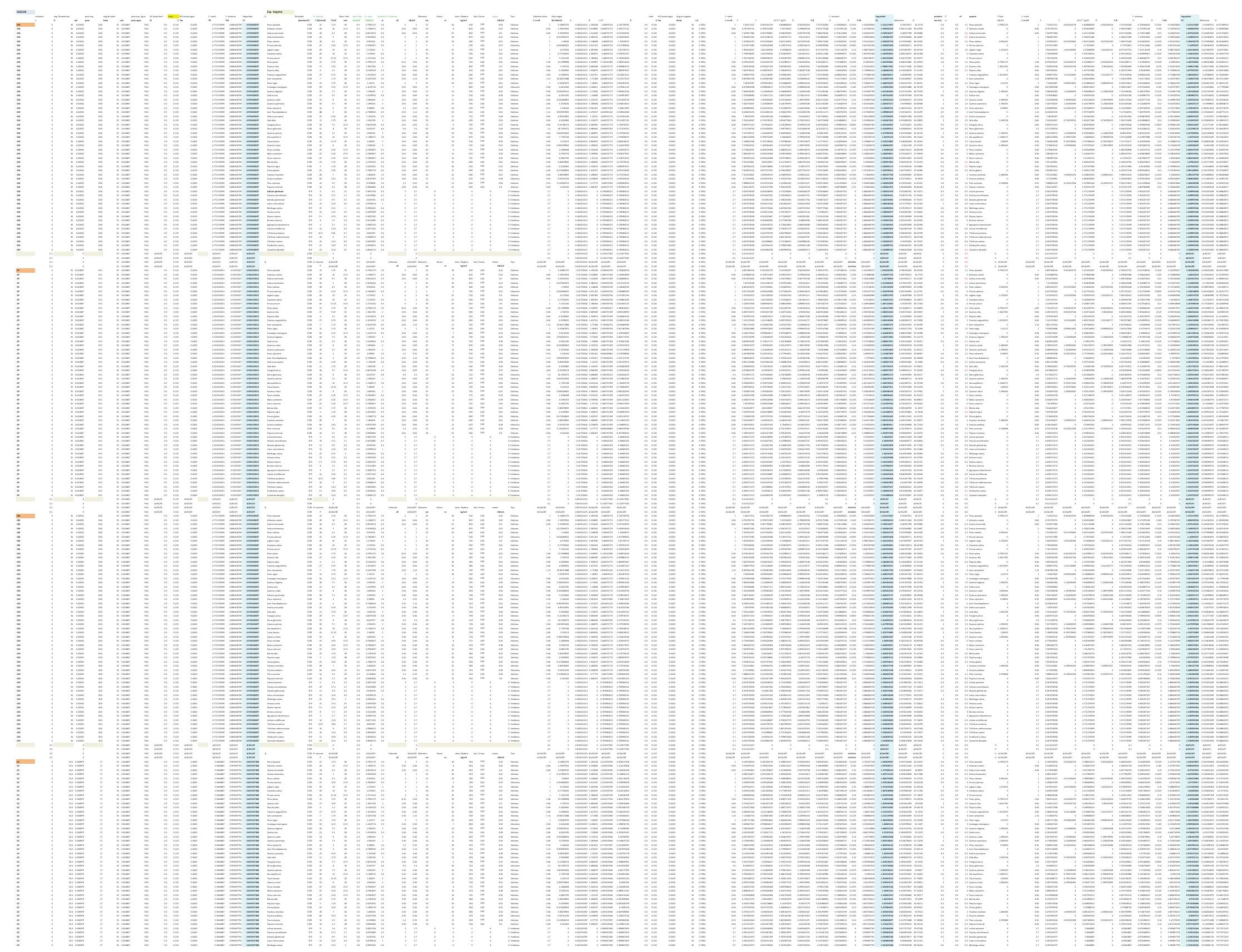


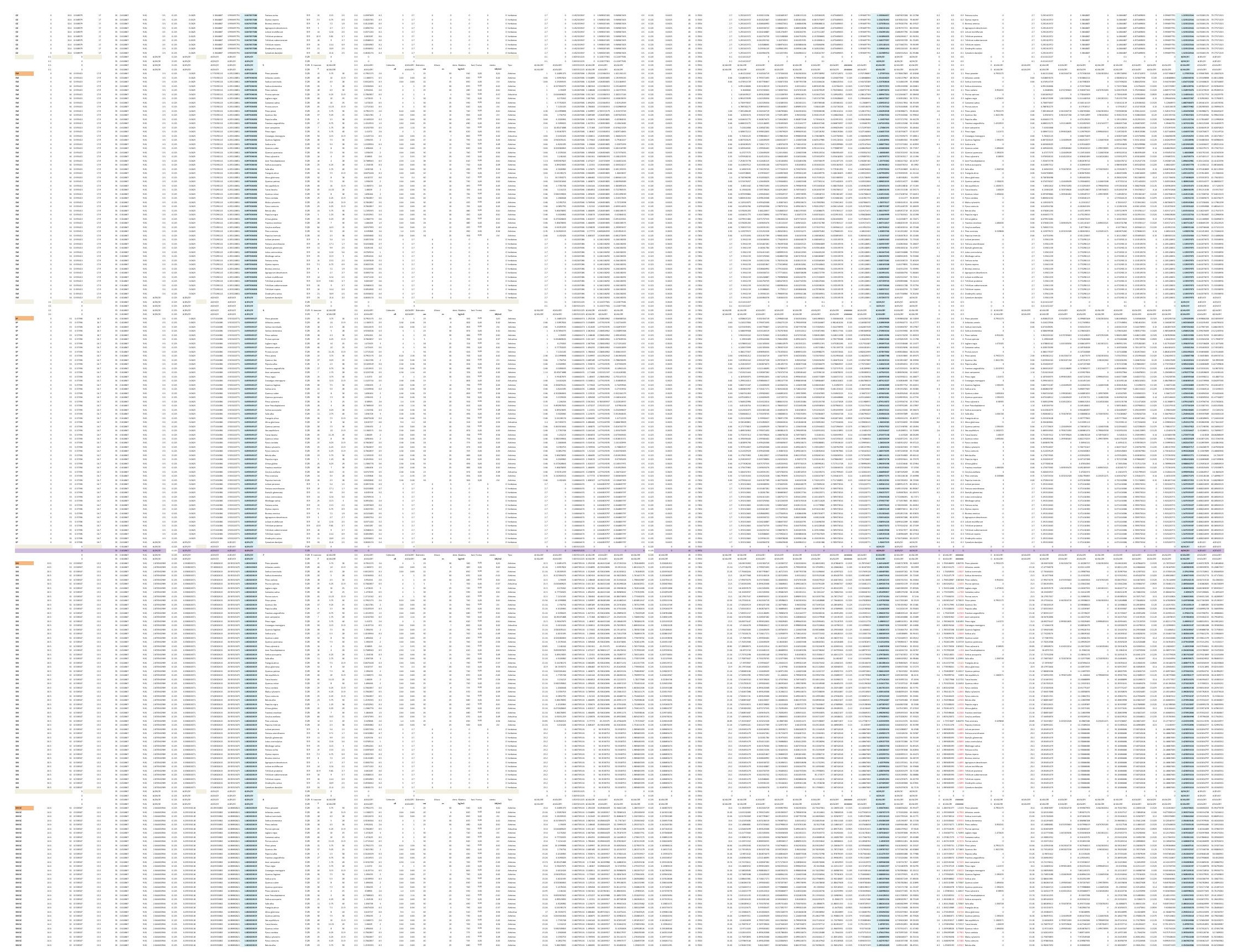



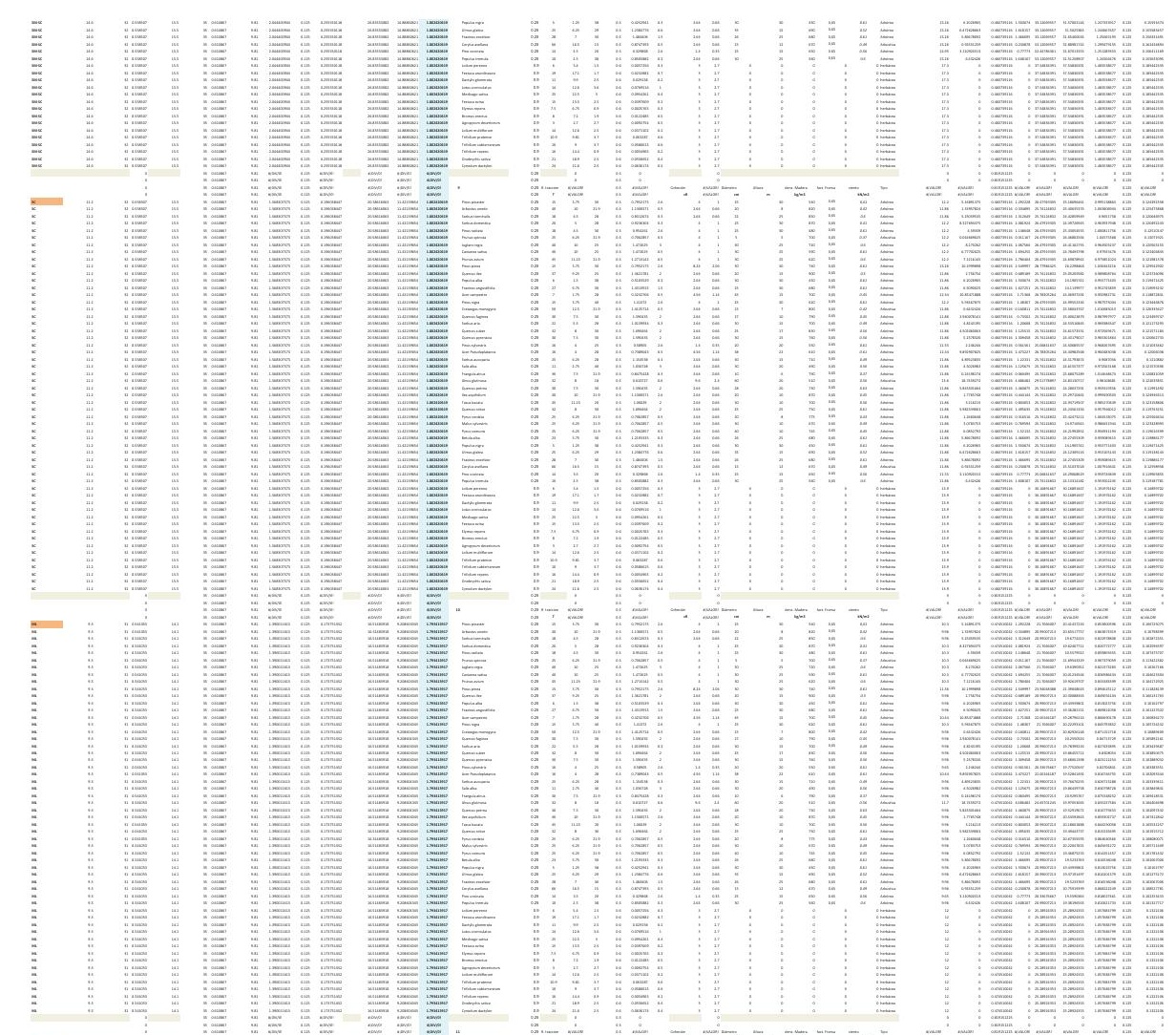

IIEIII
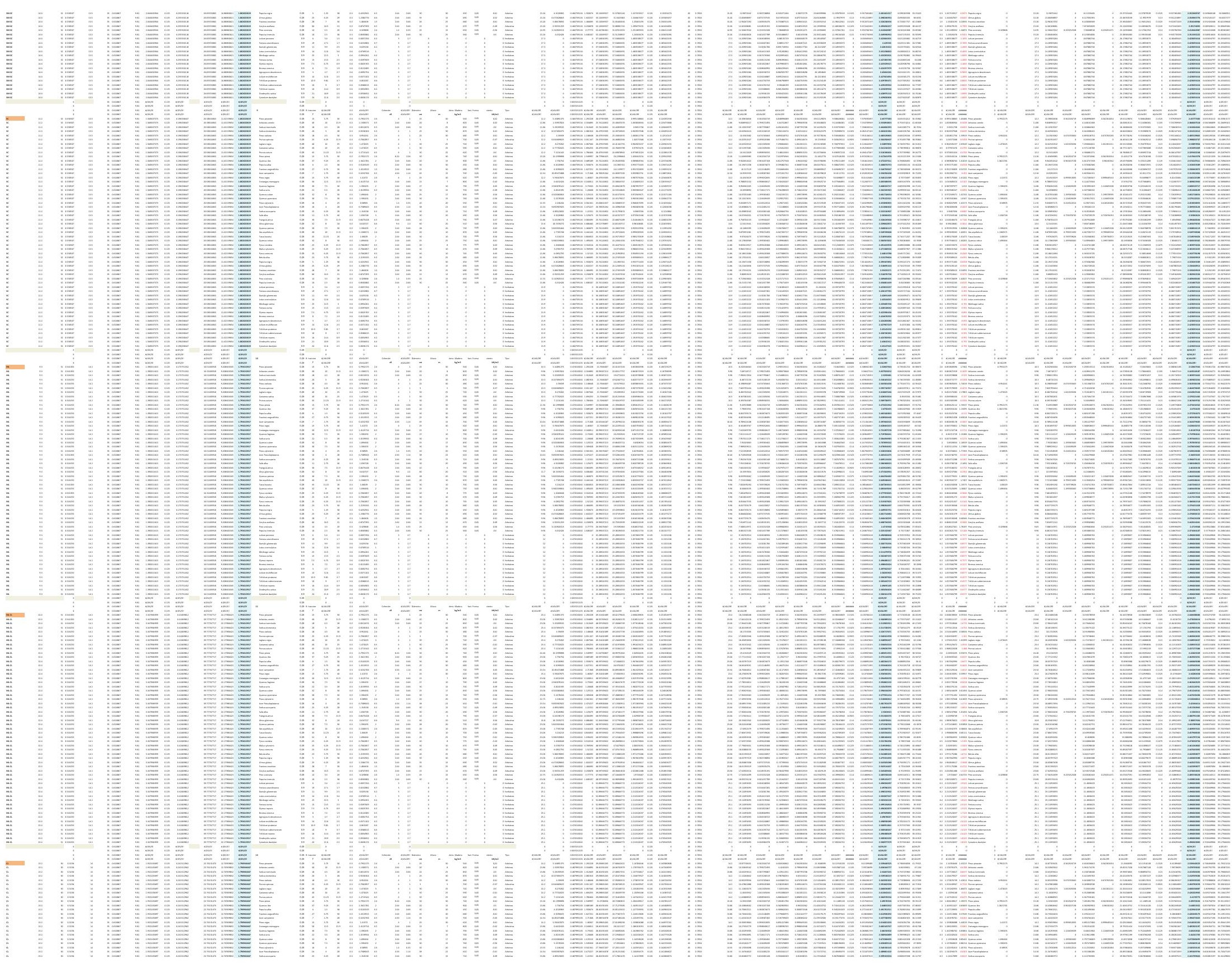


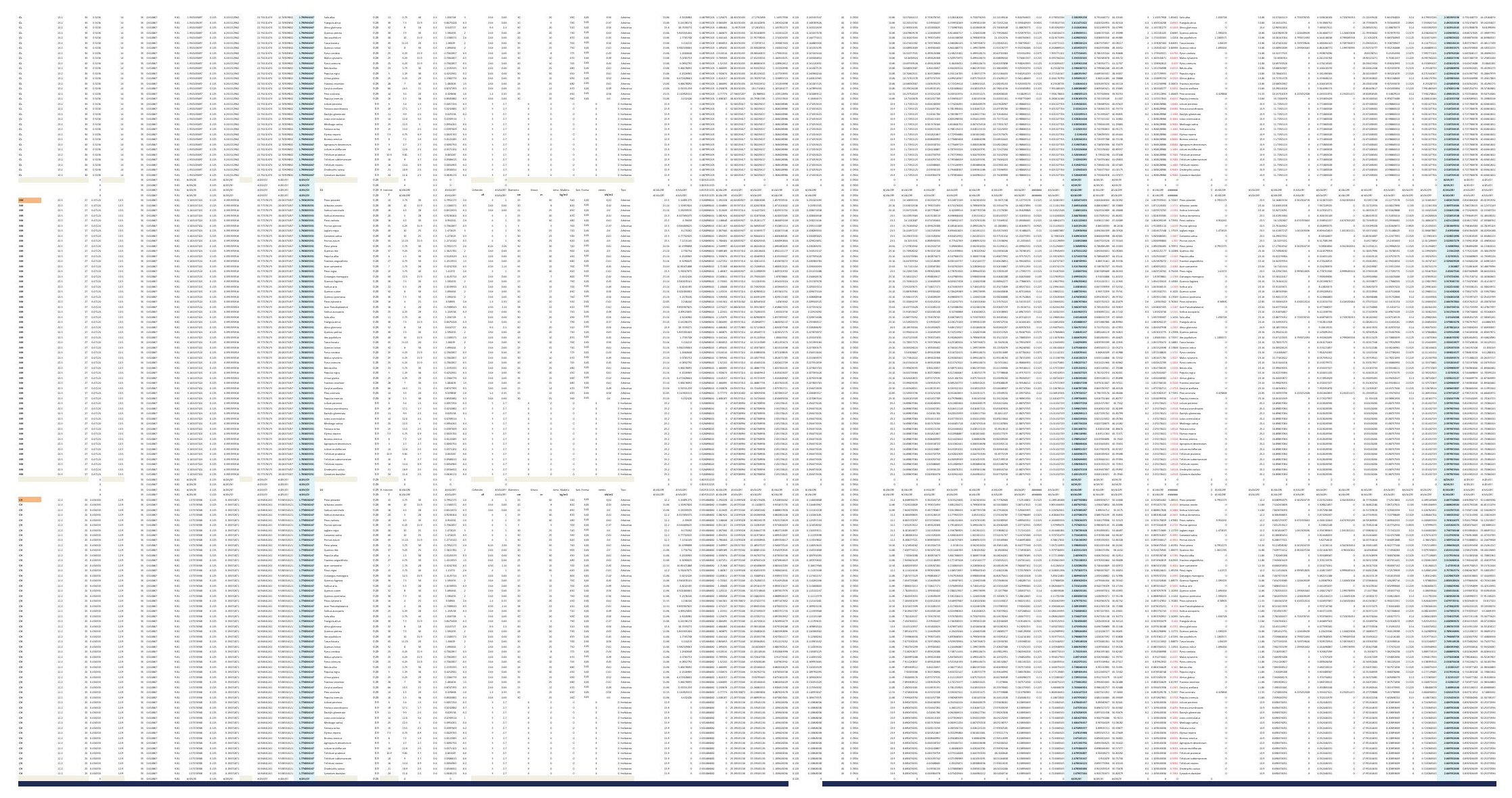



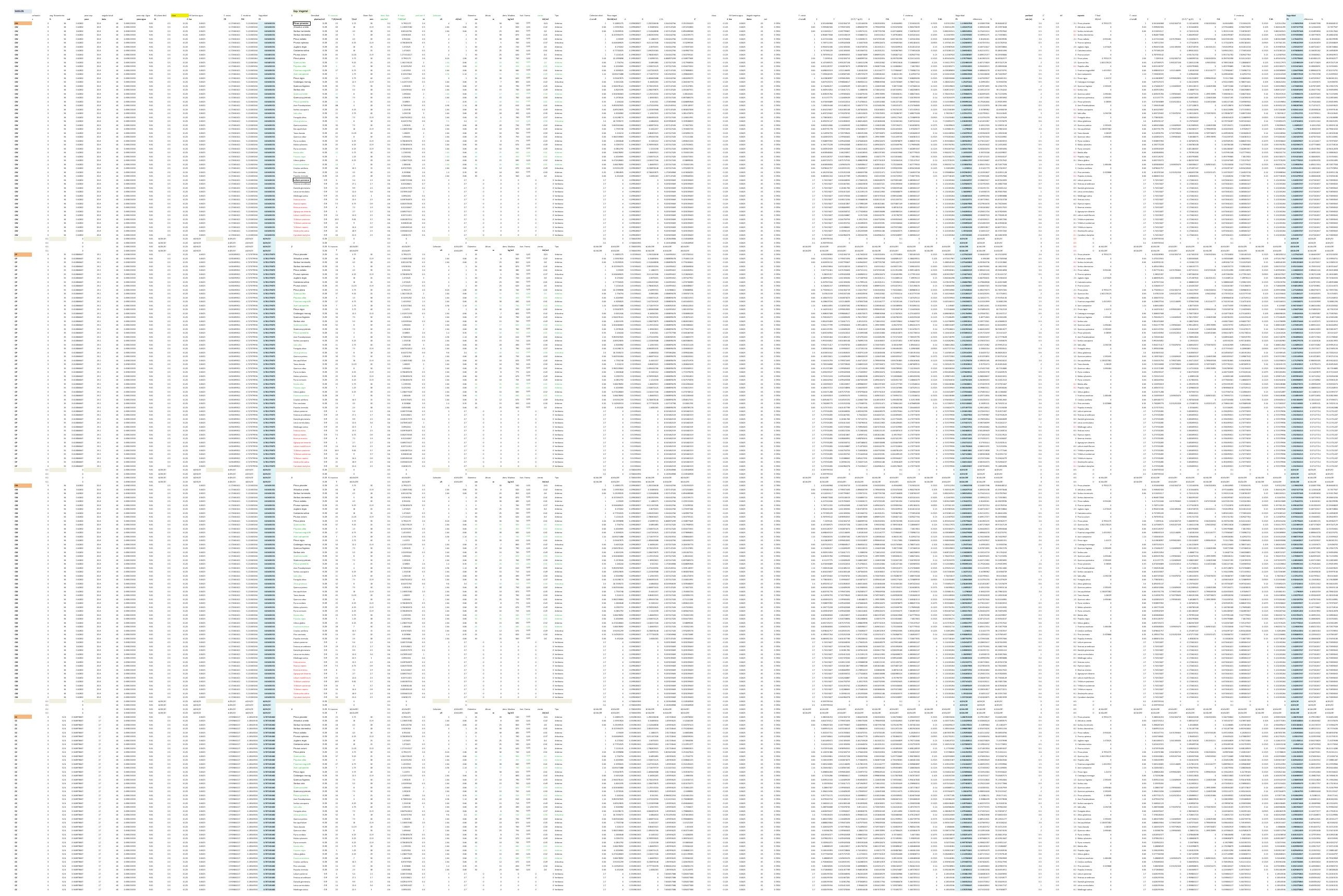


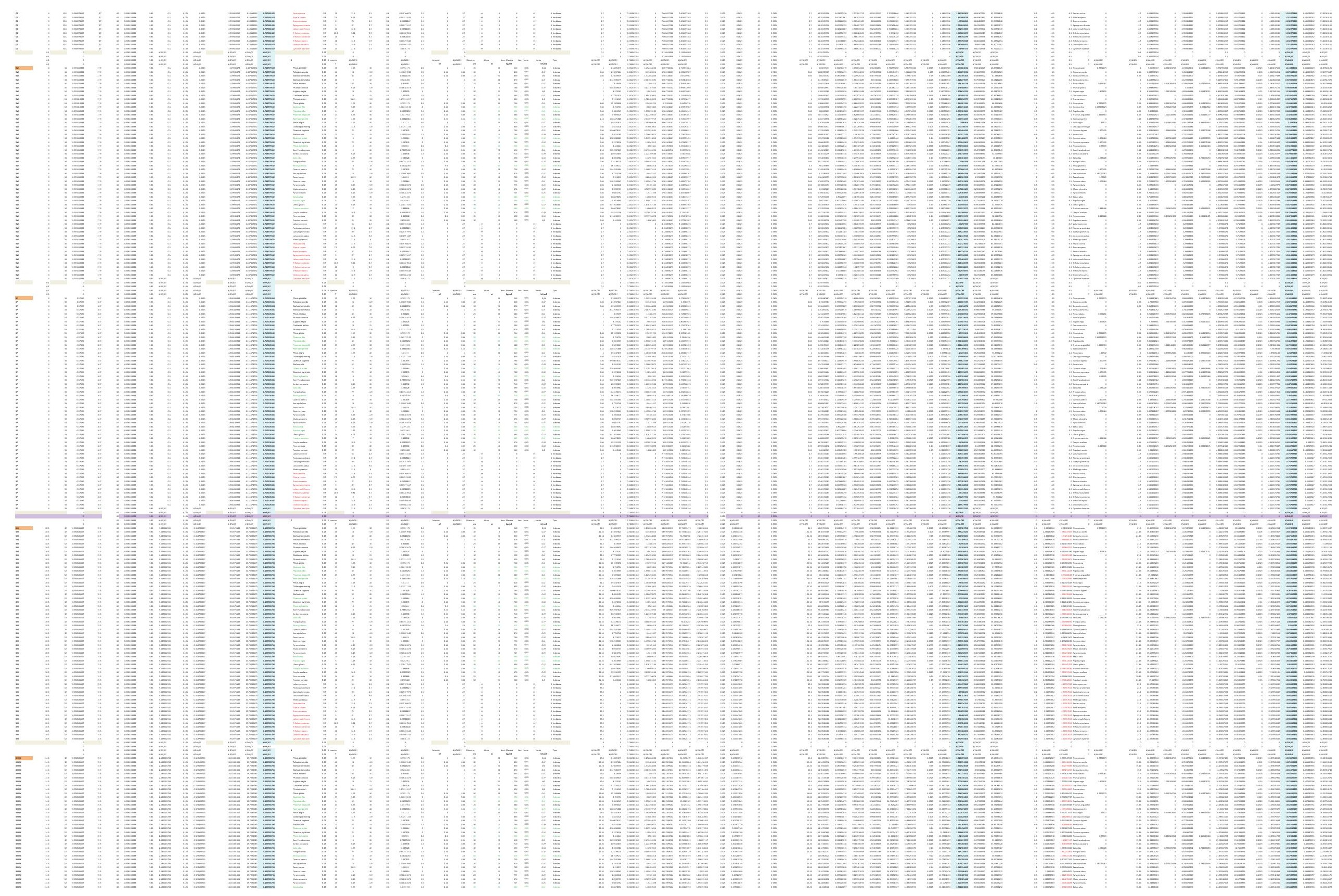



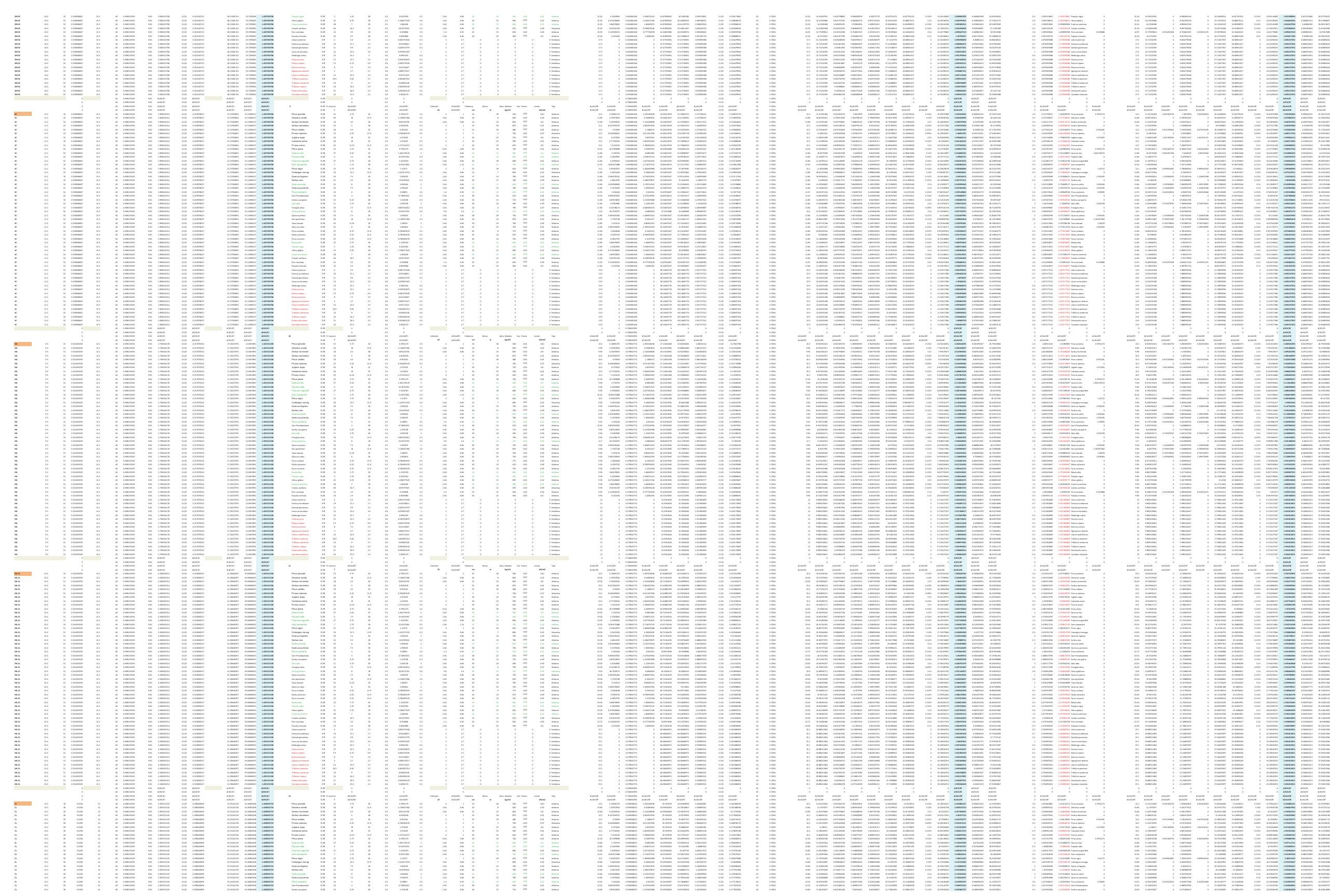


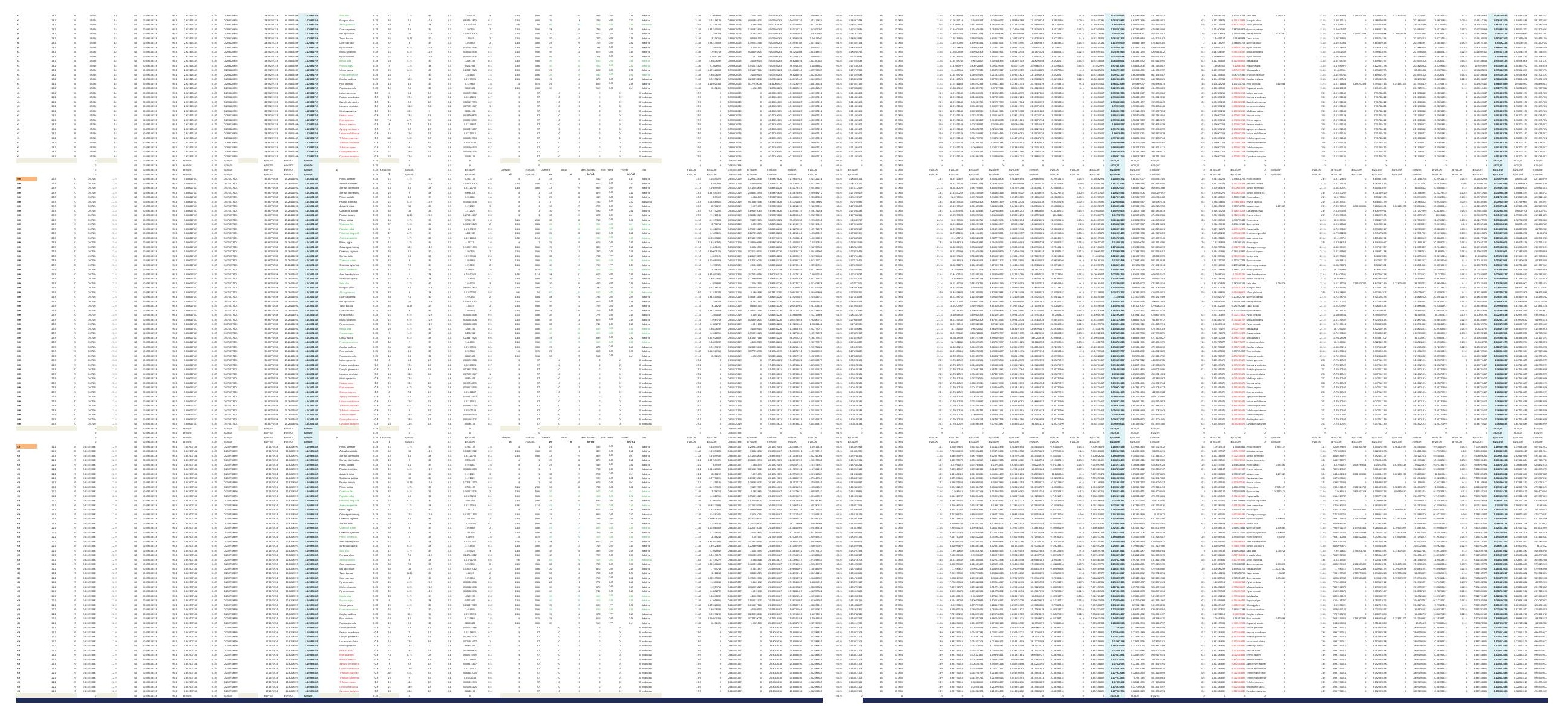



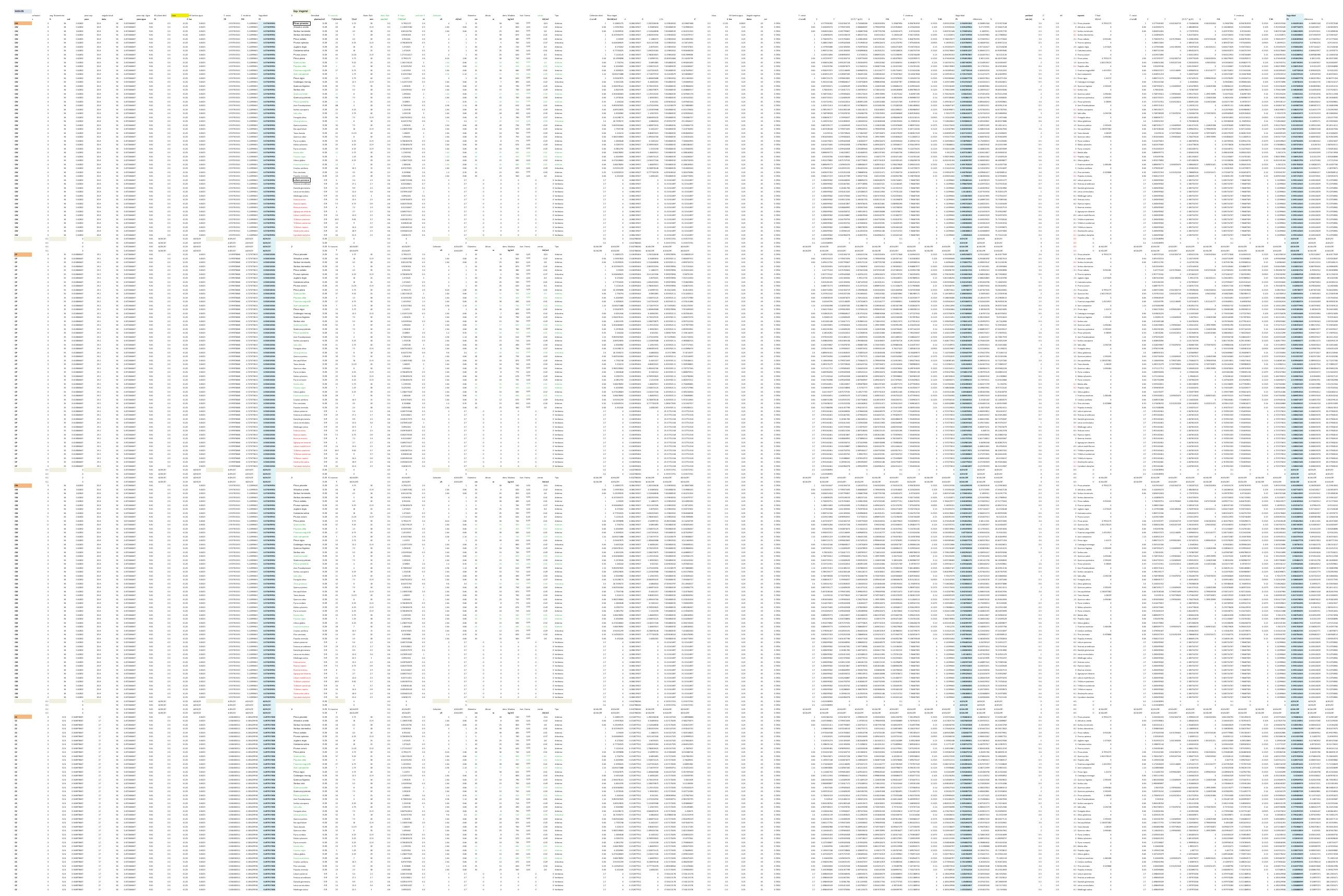


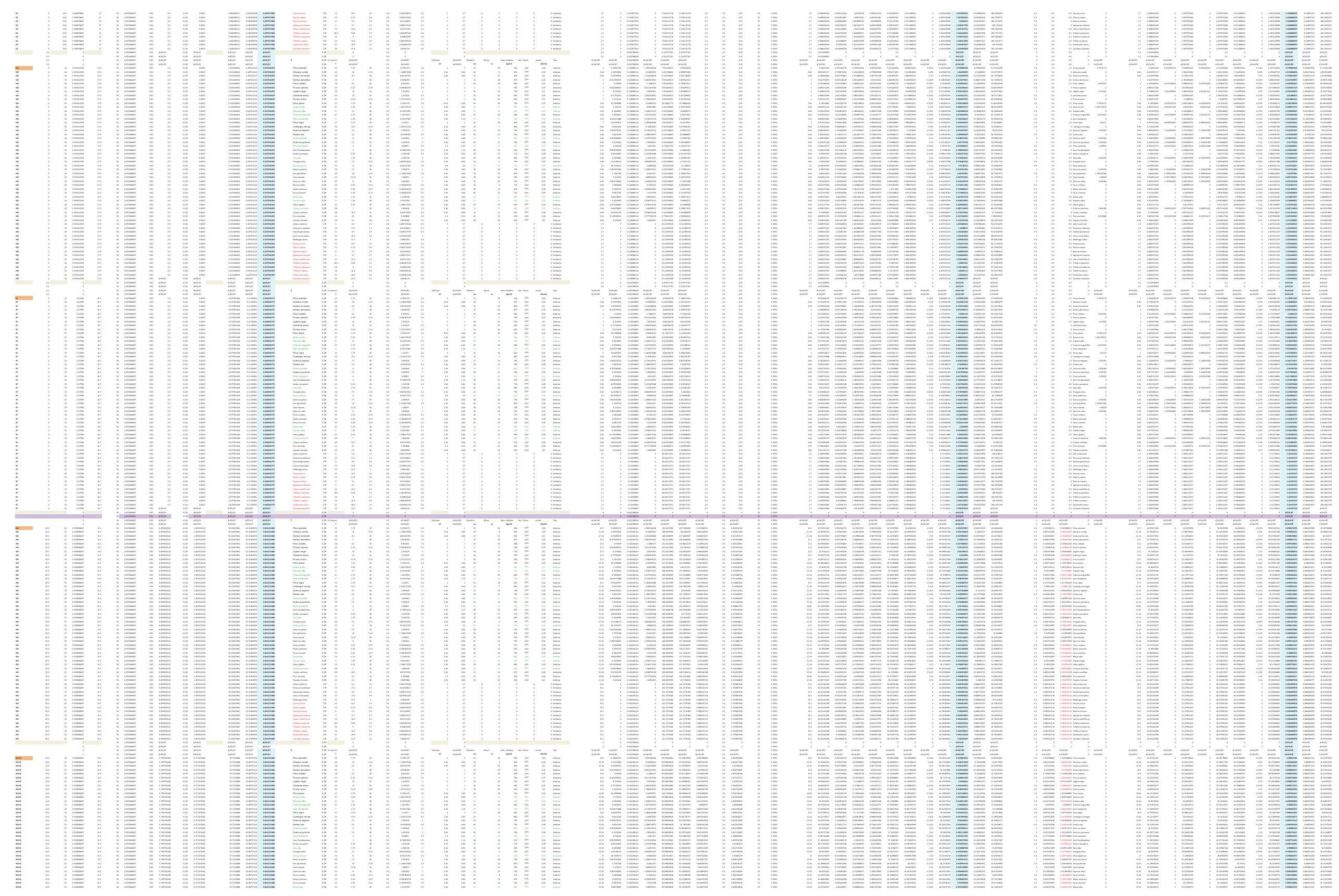



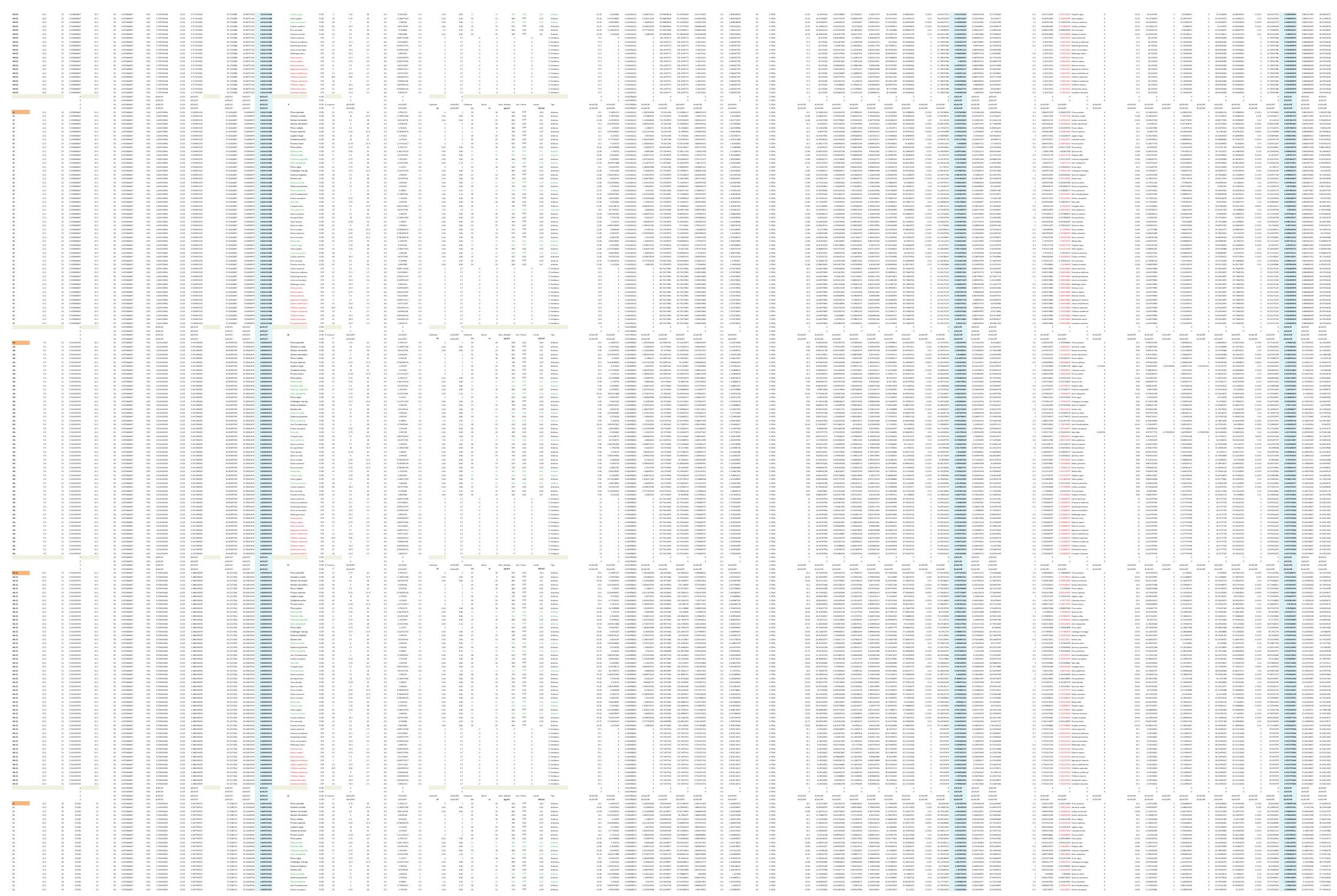


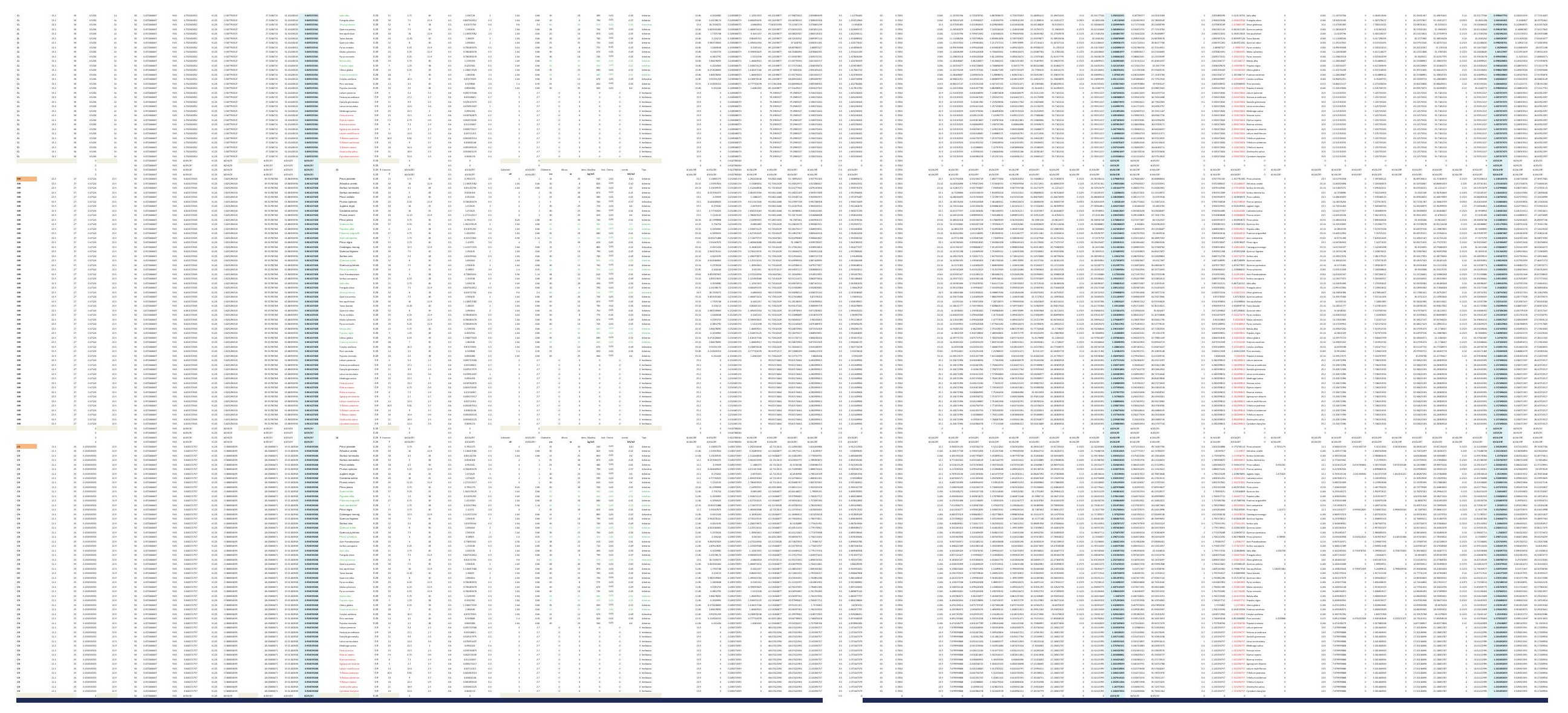



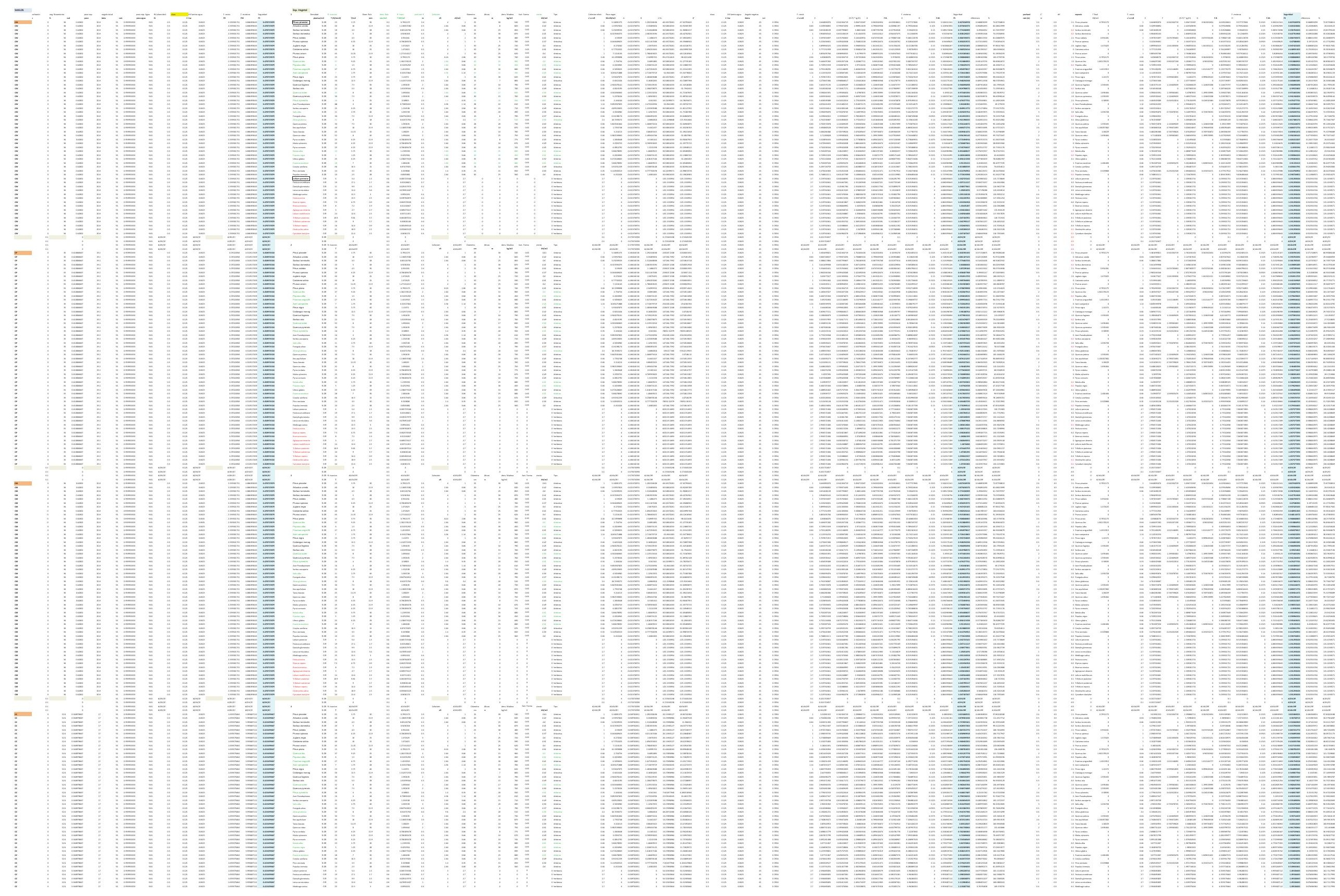


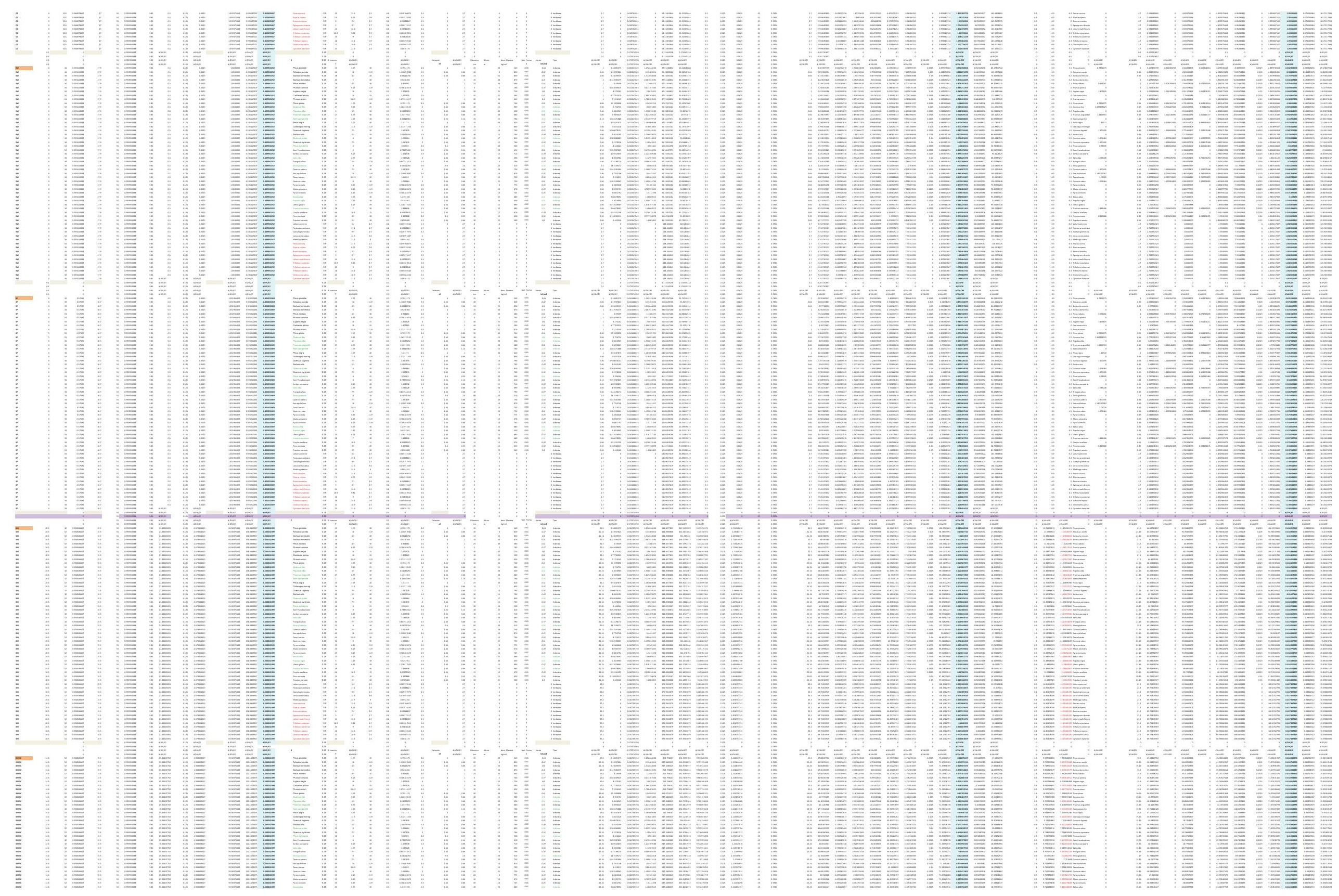



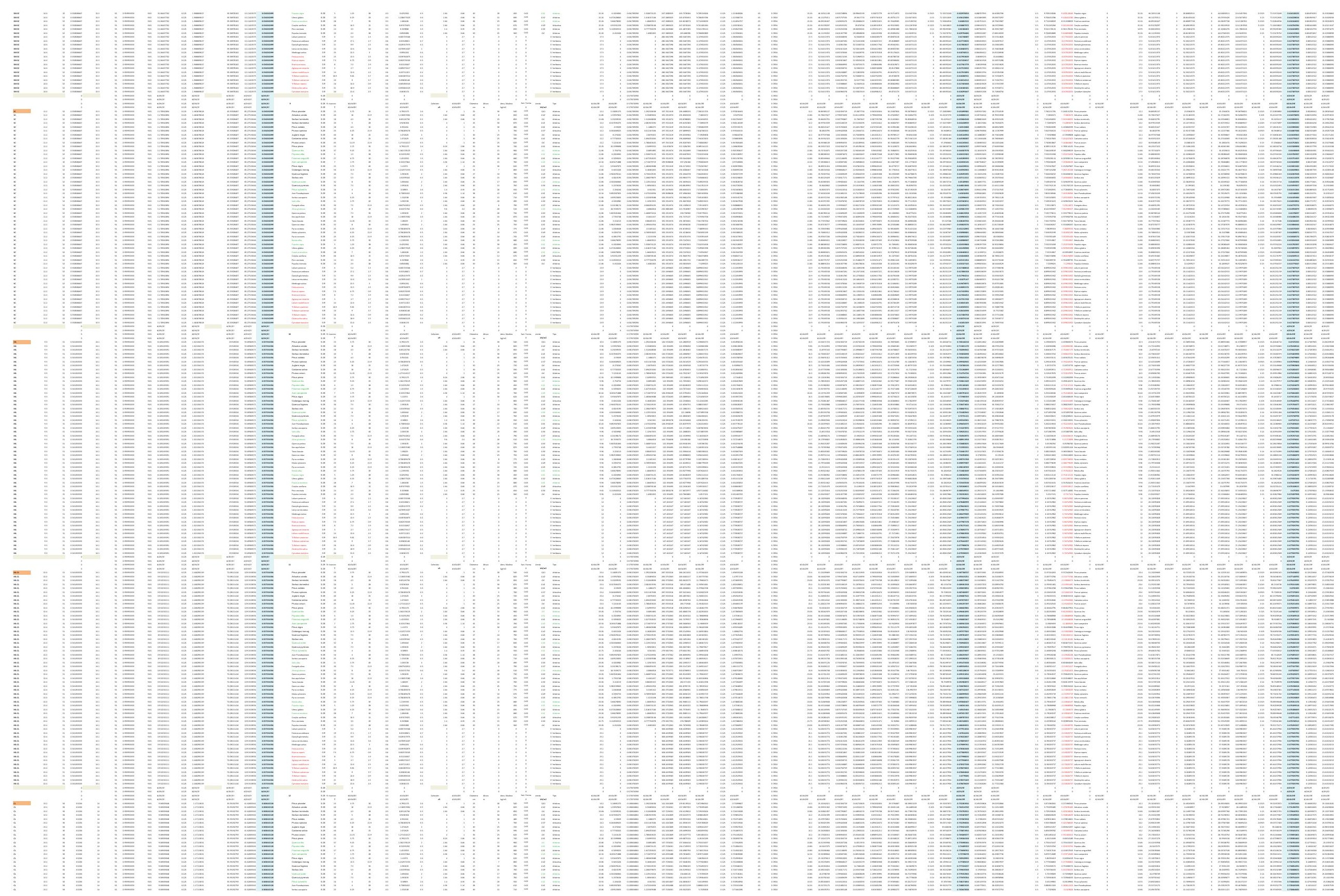


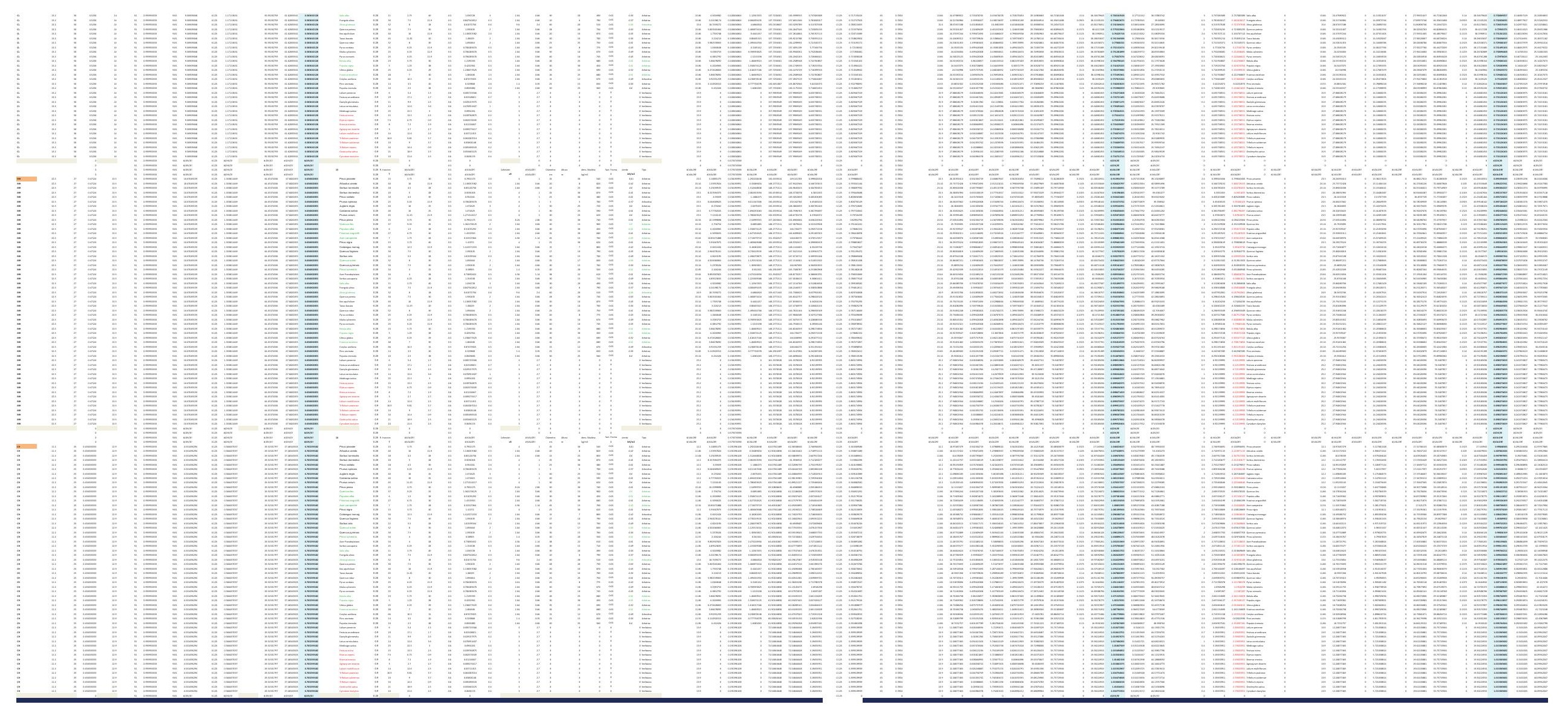



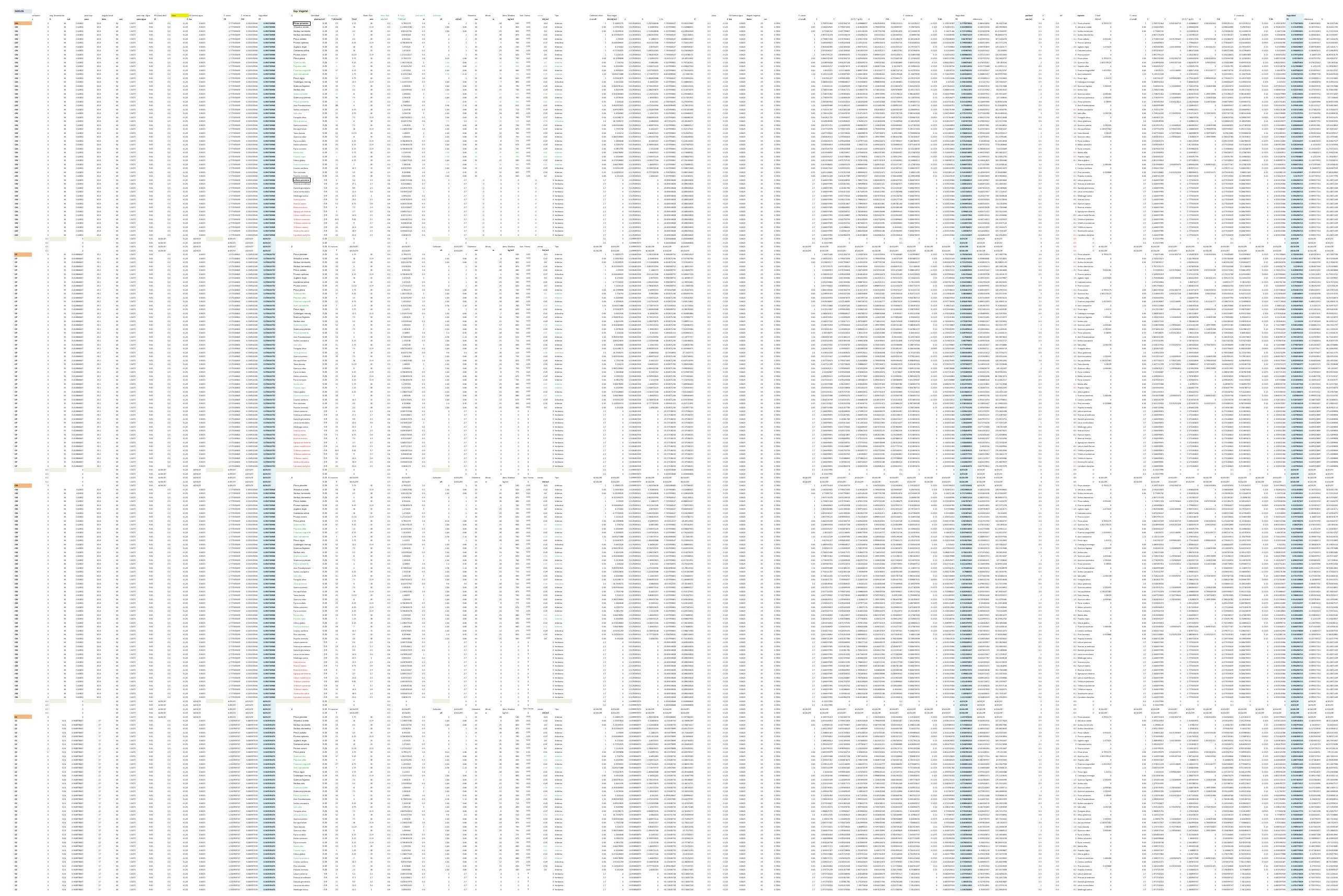


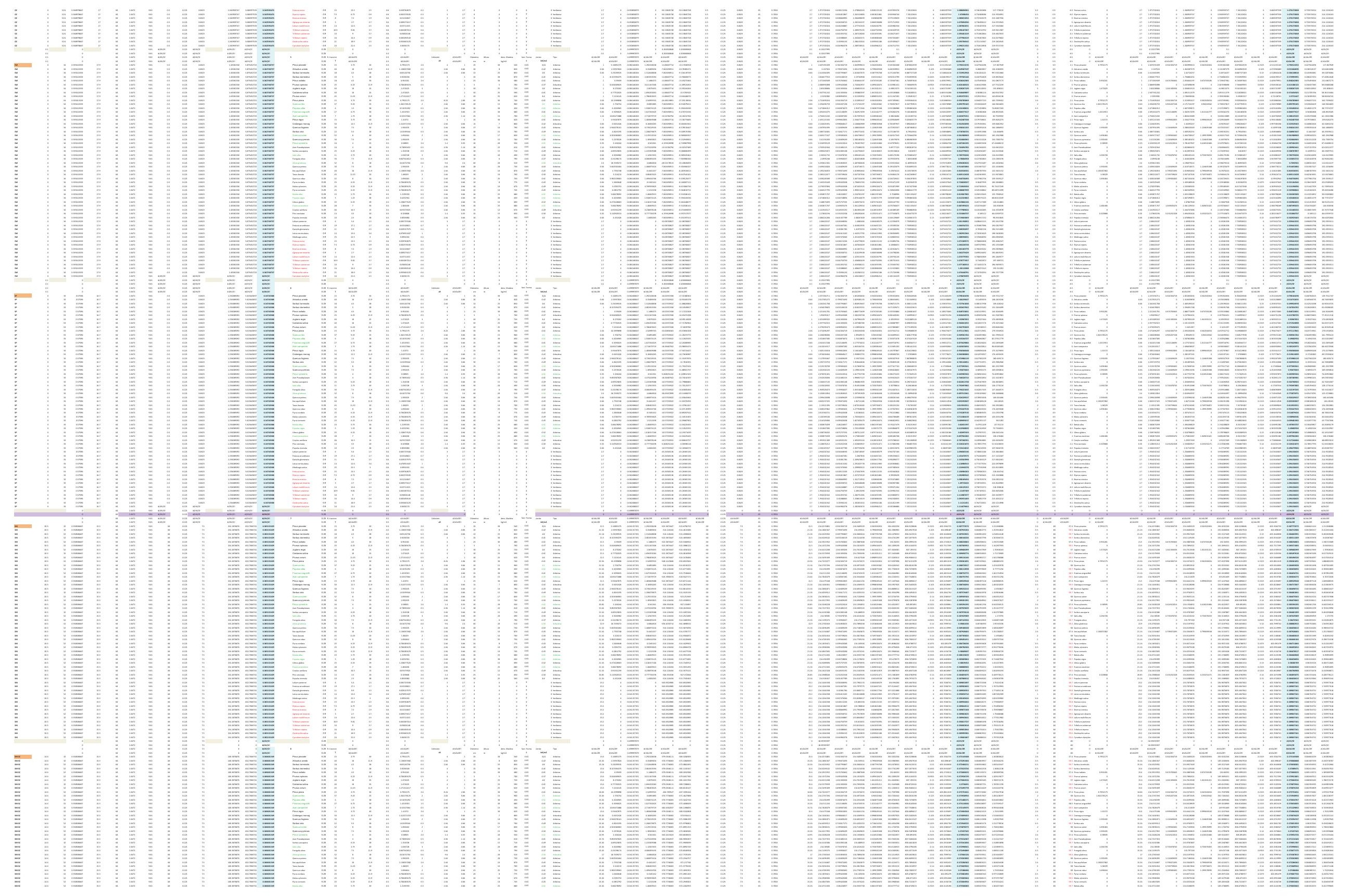



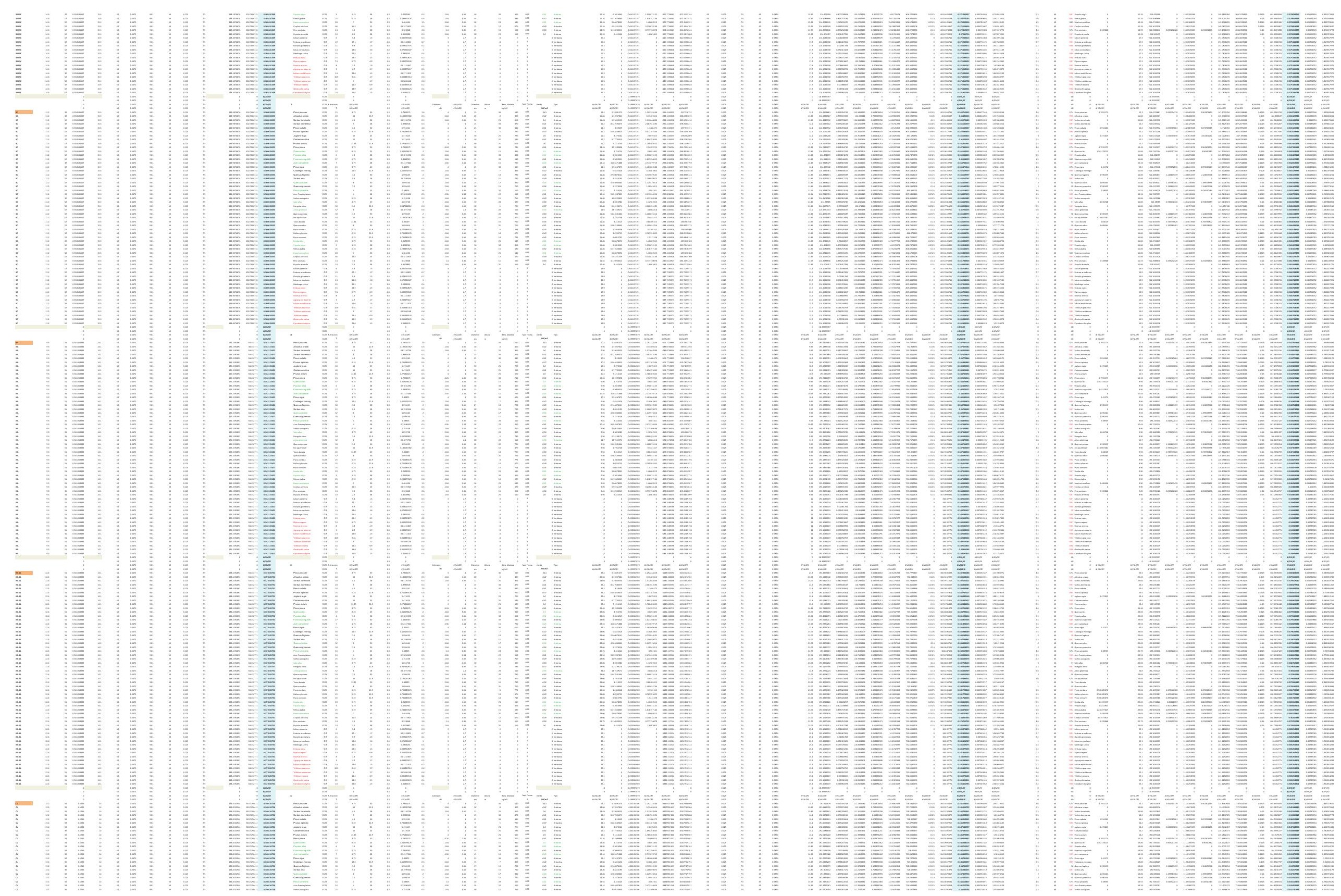


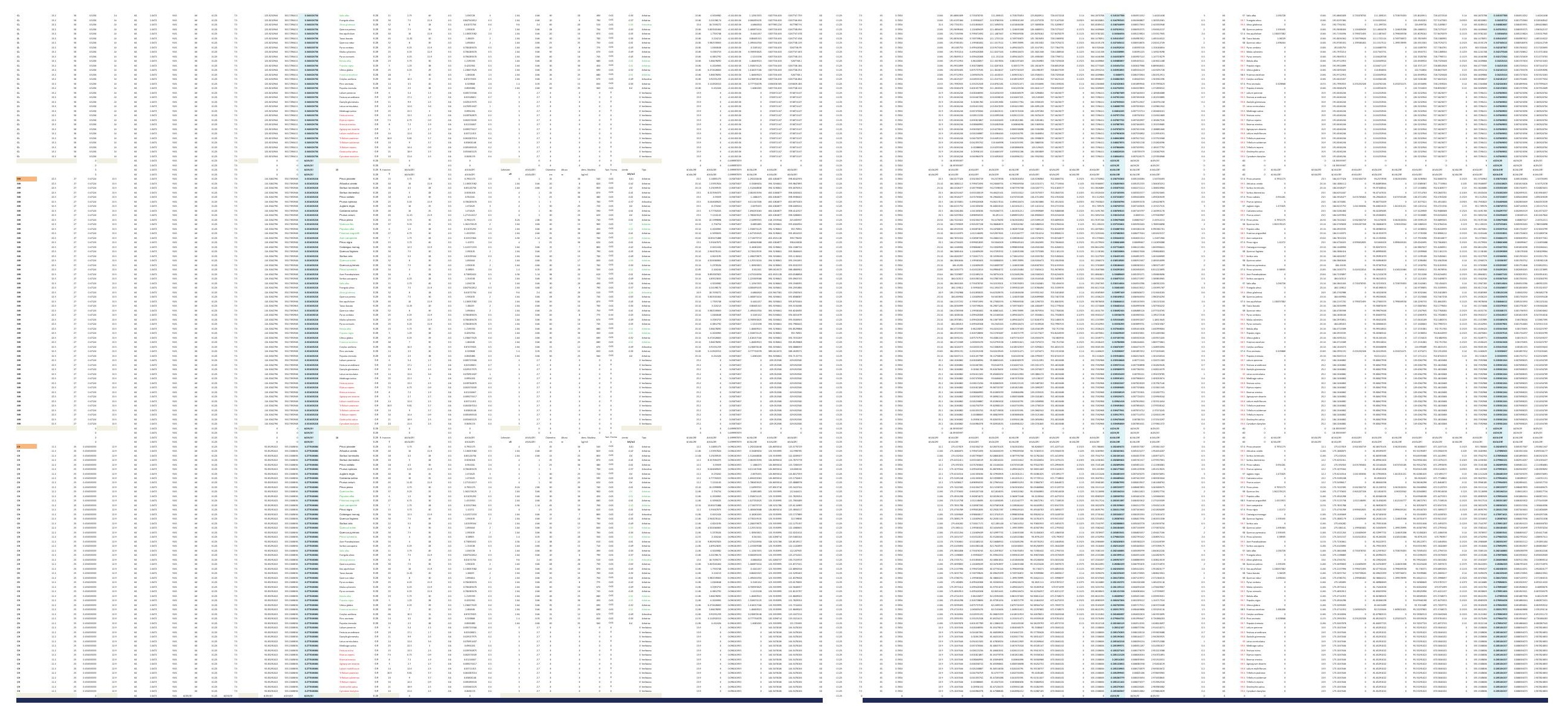



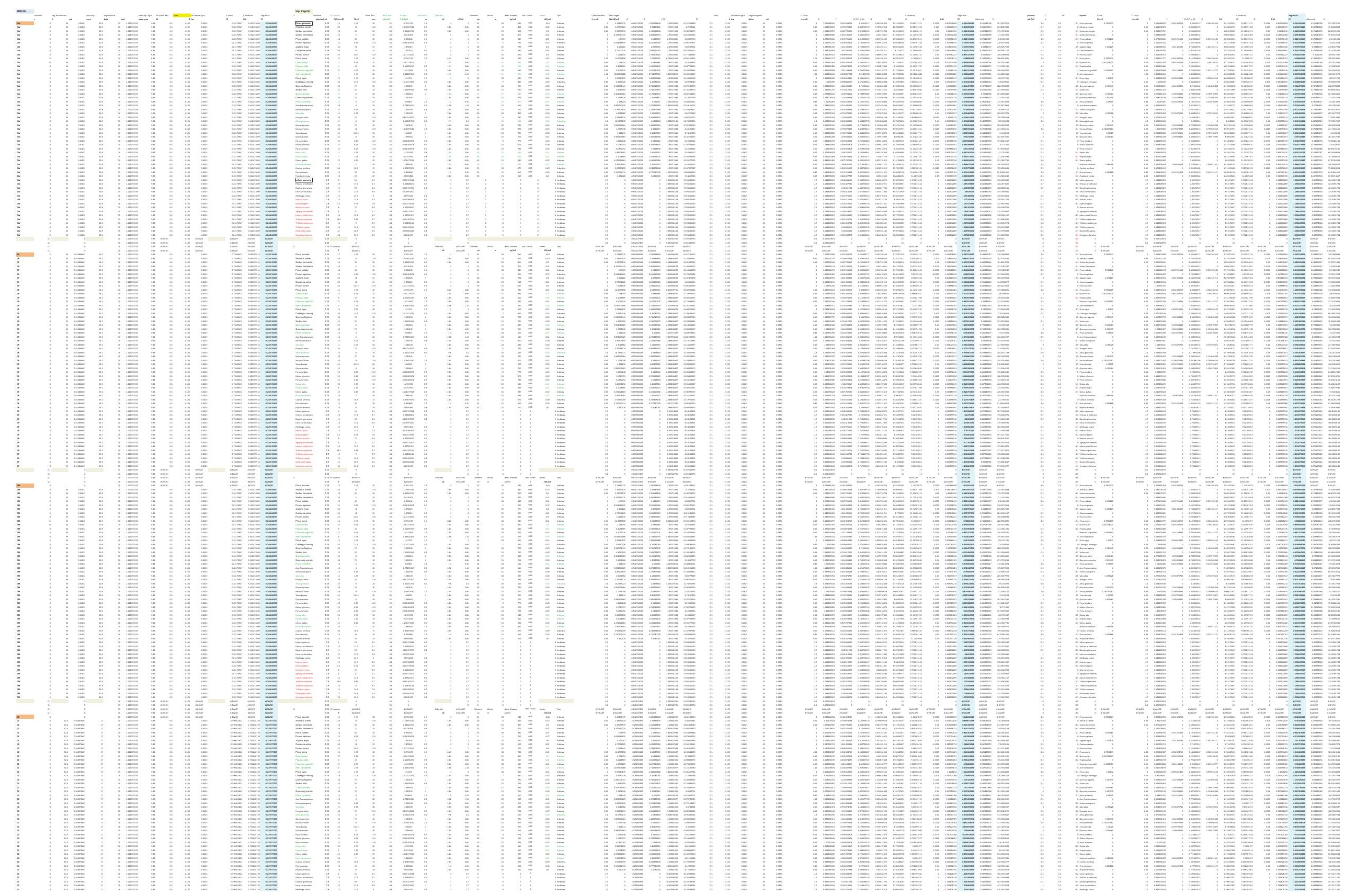


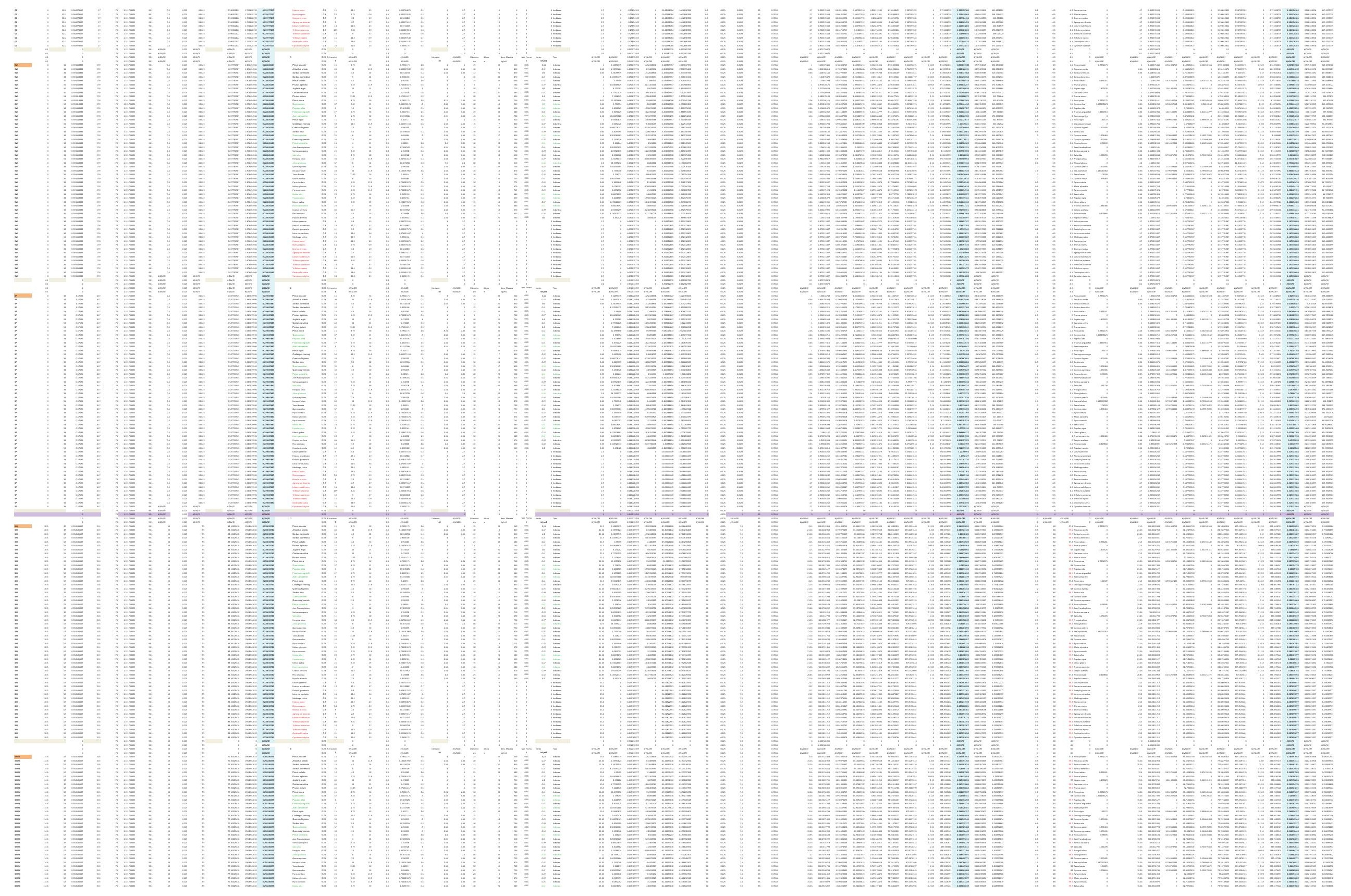




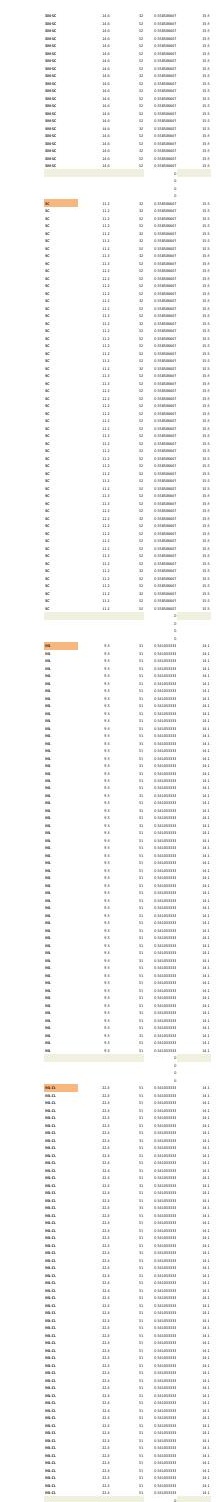

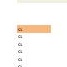

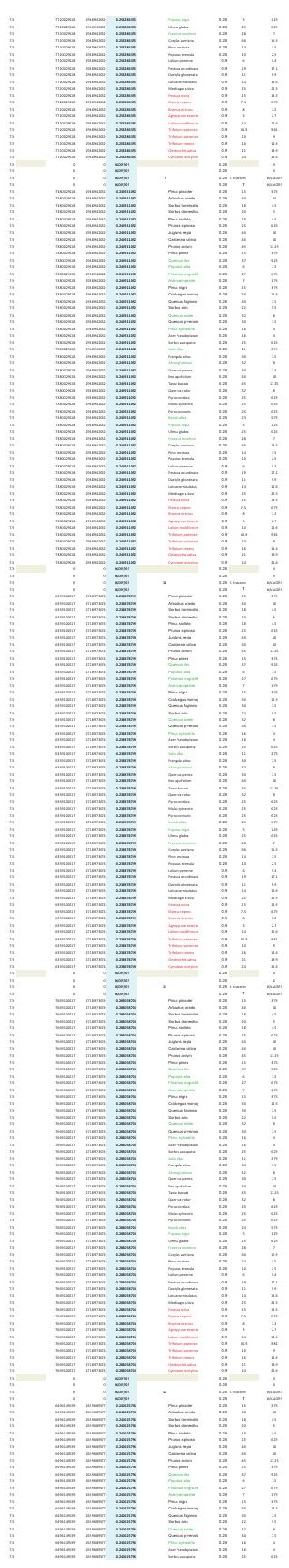

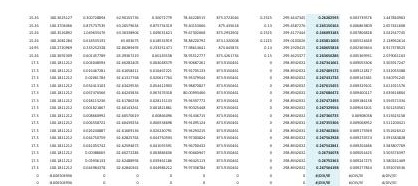
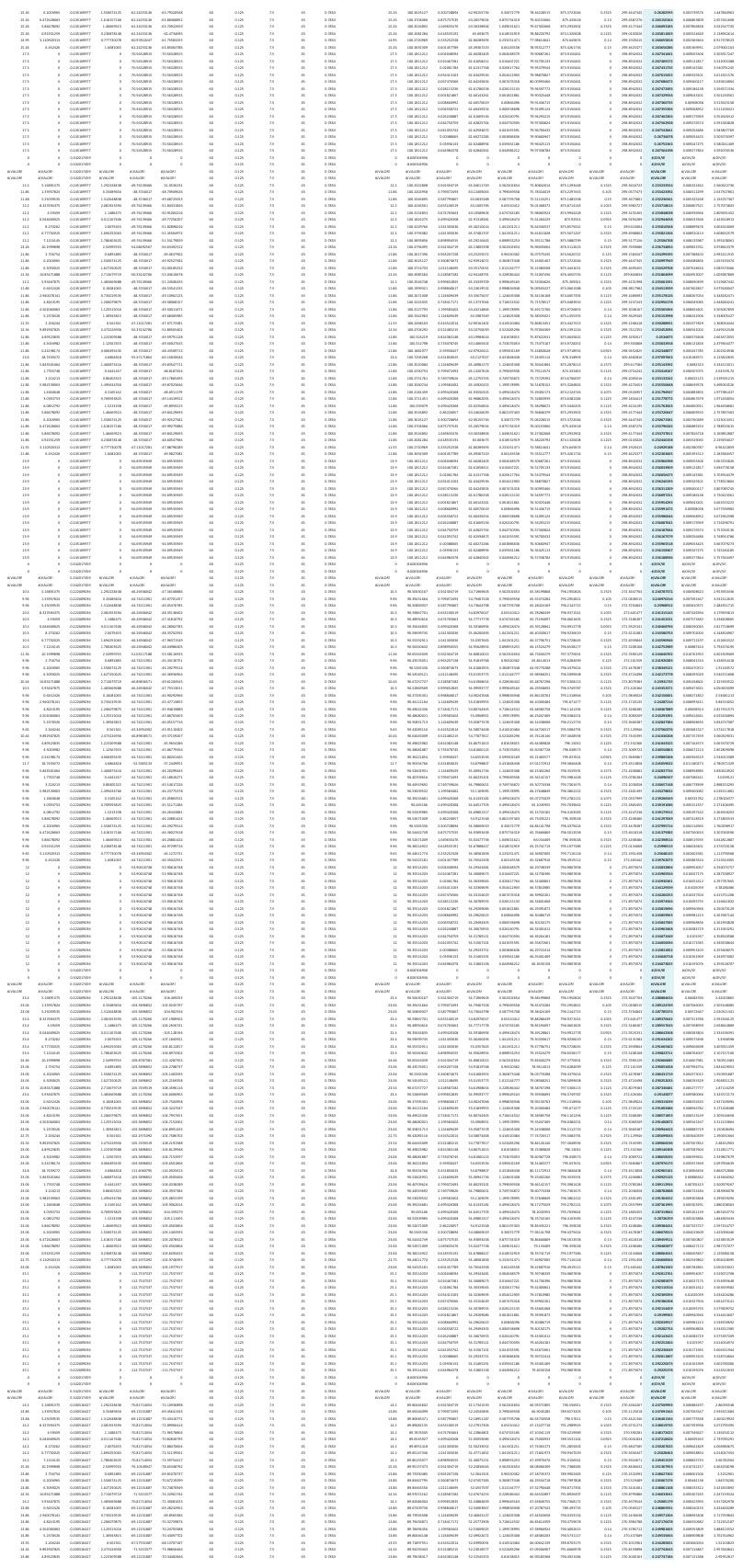

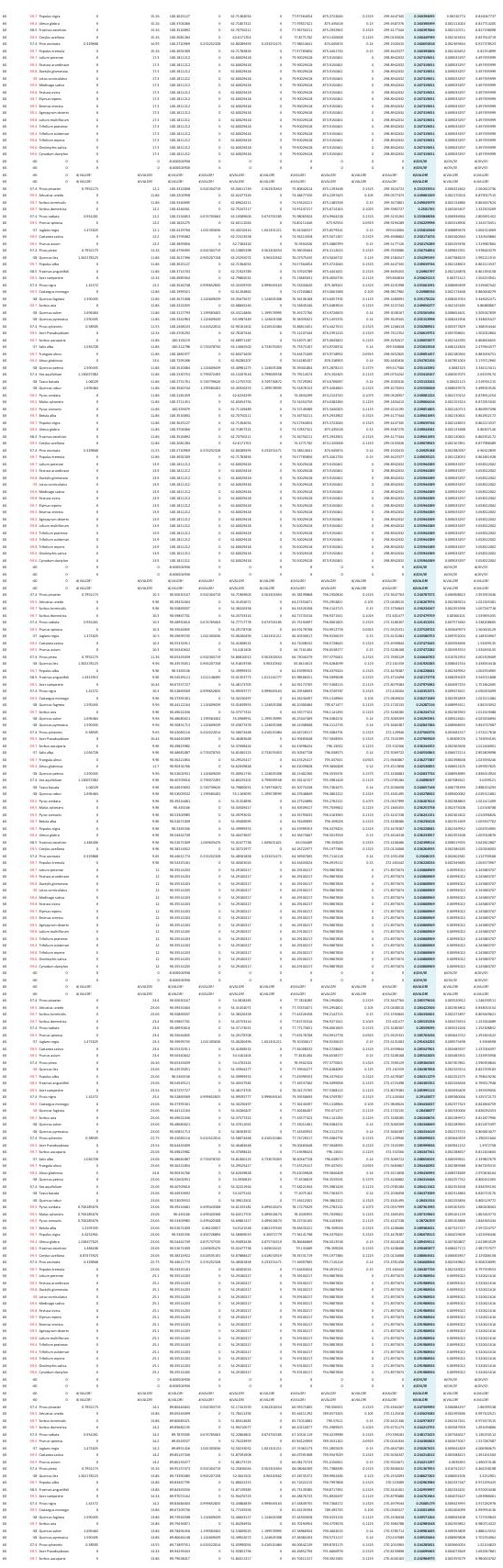




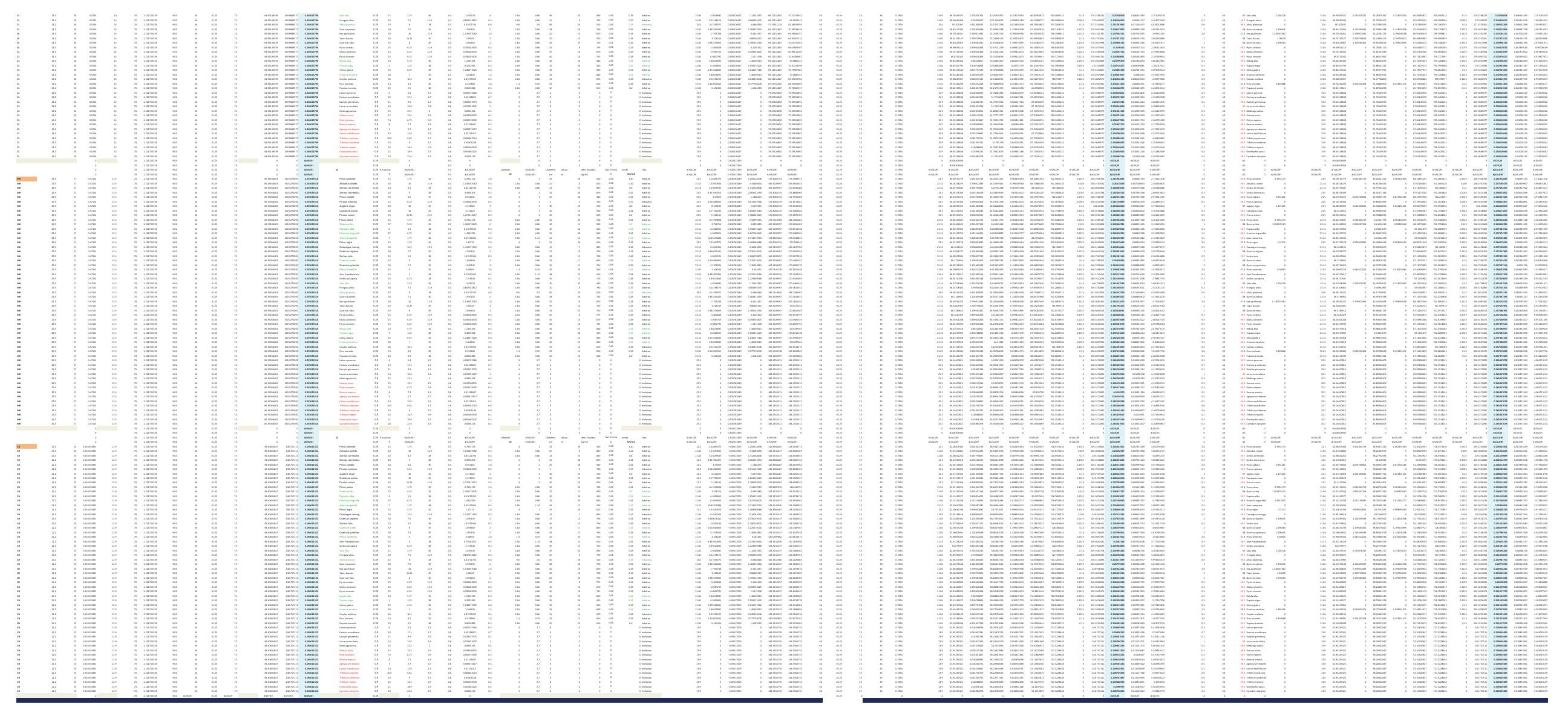



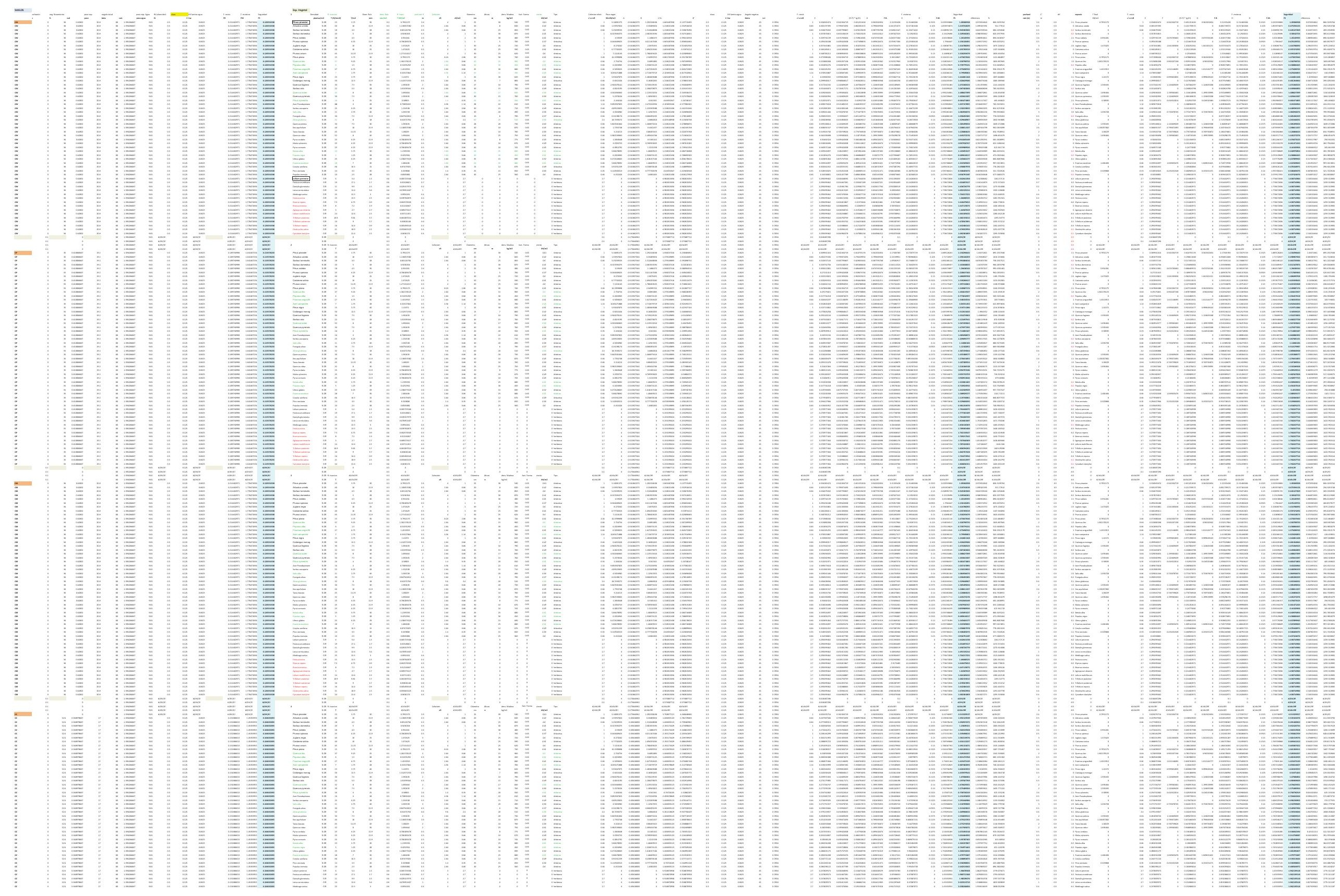


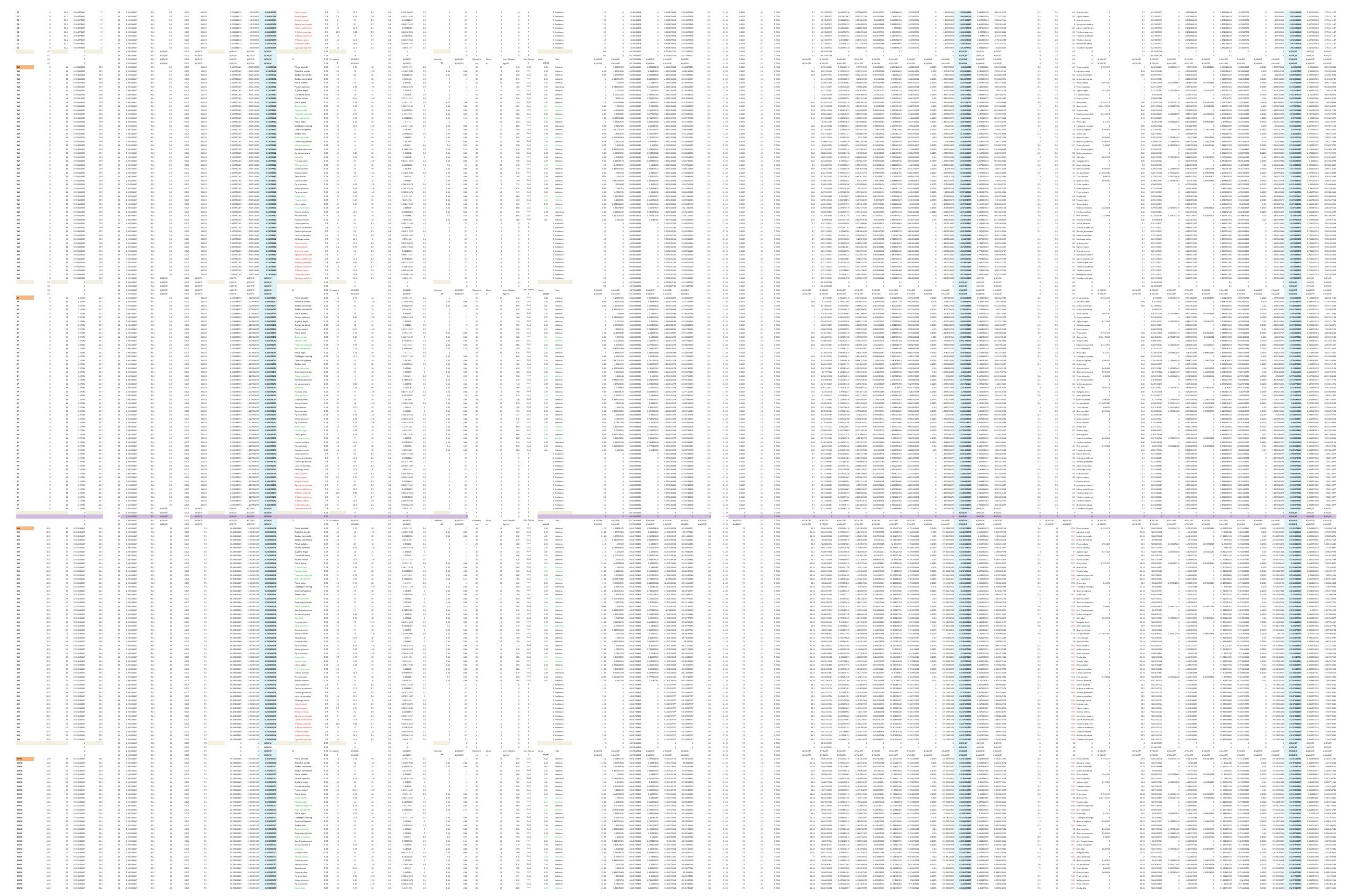




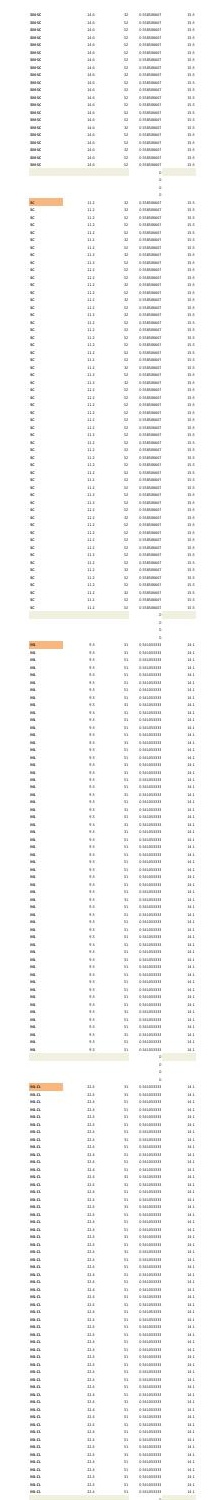

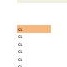
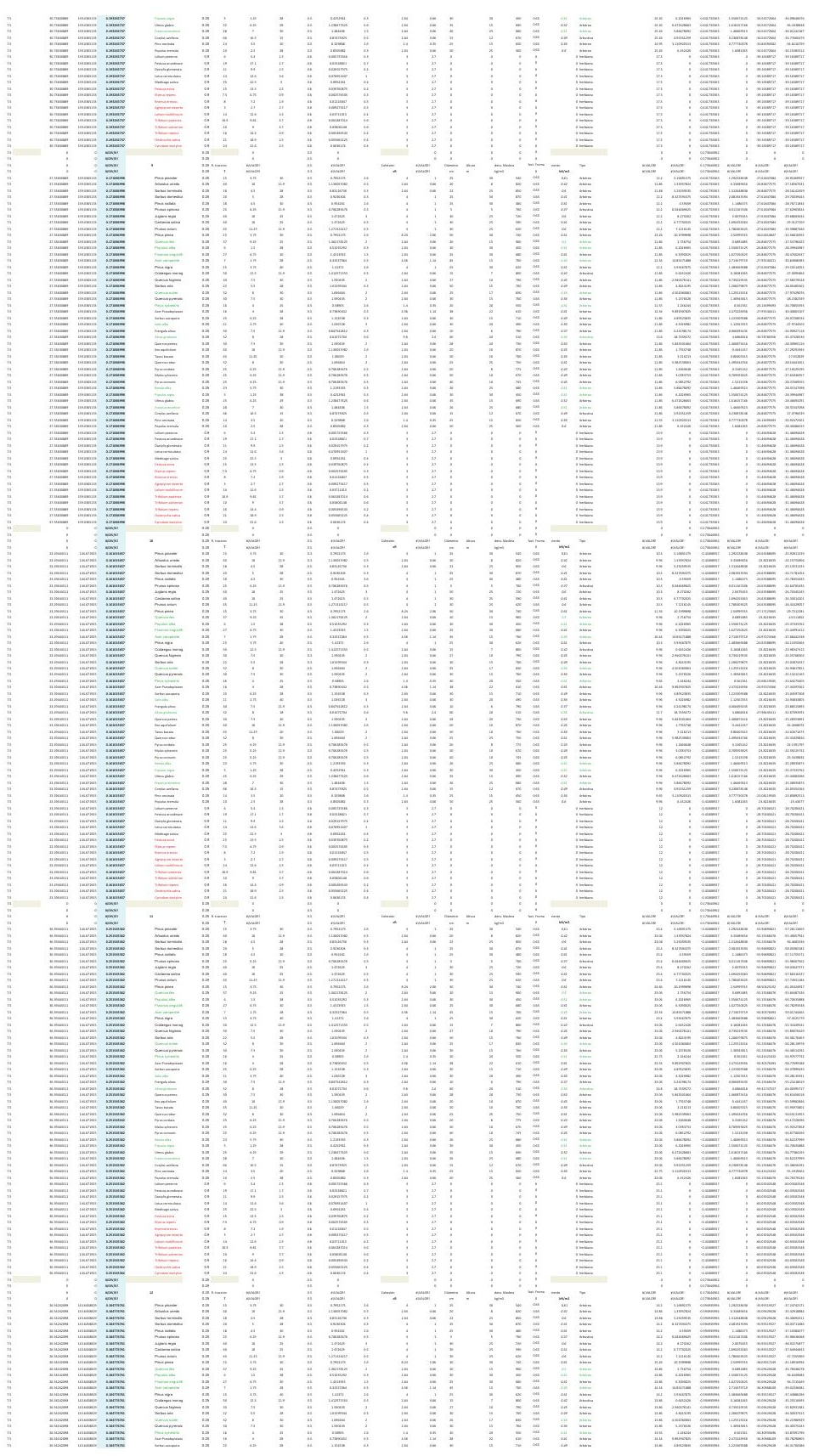
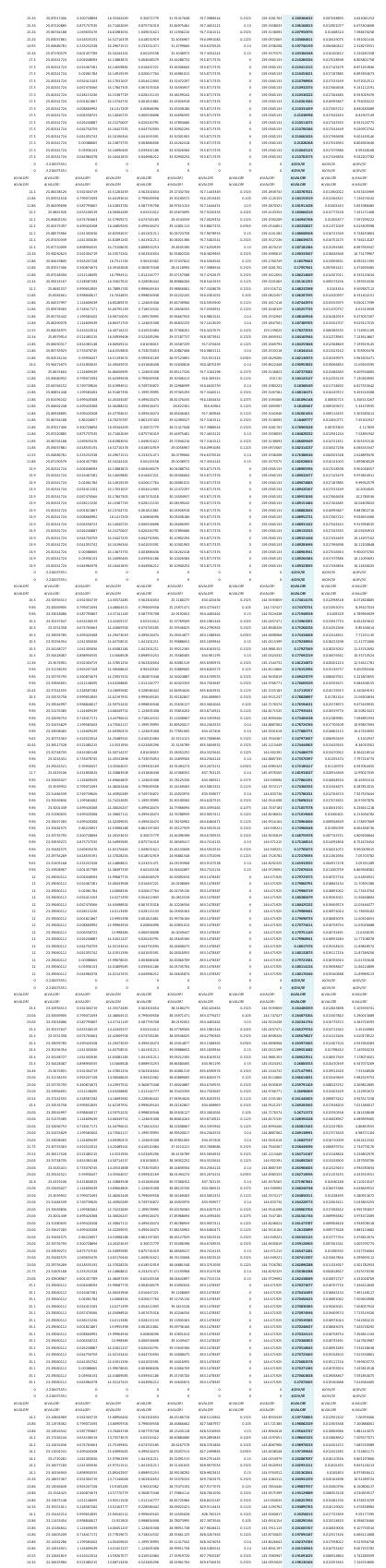

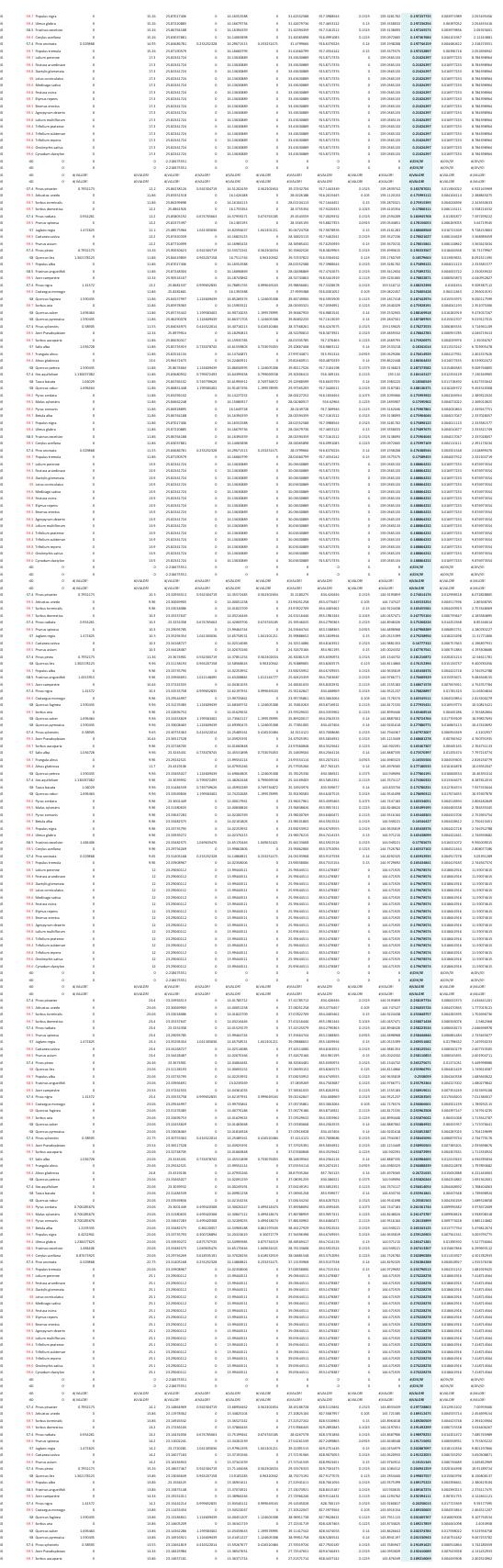




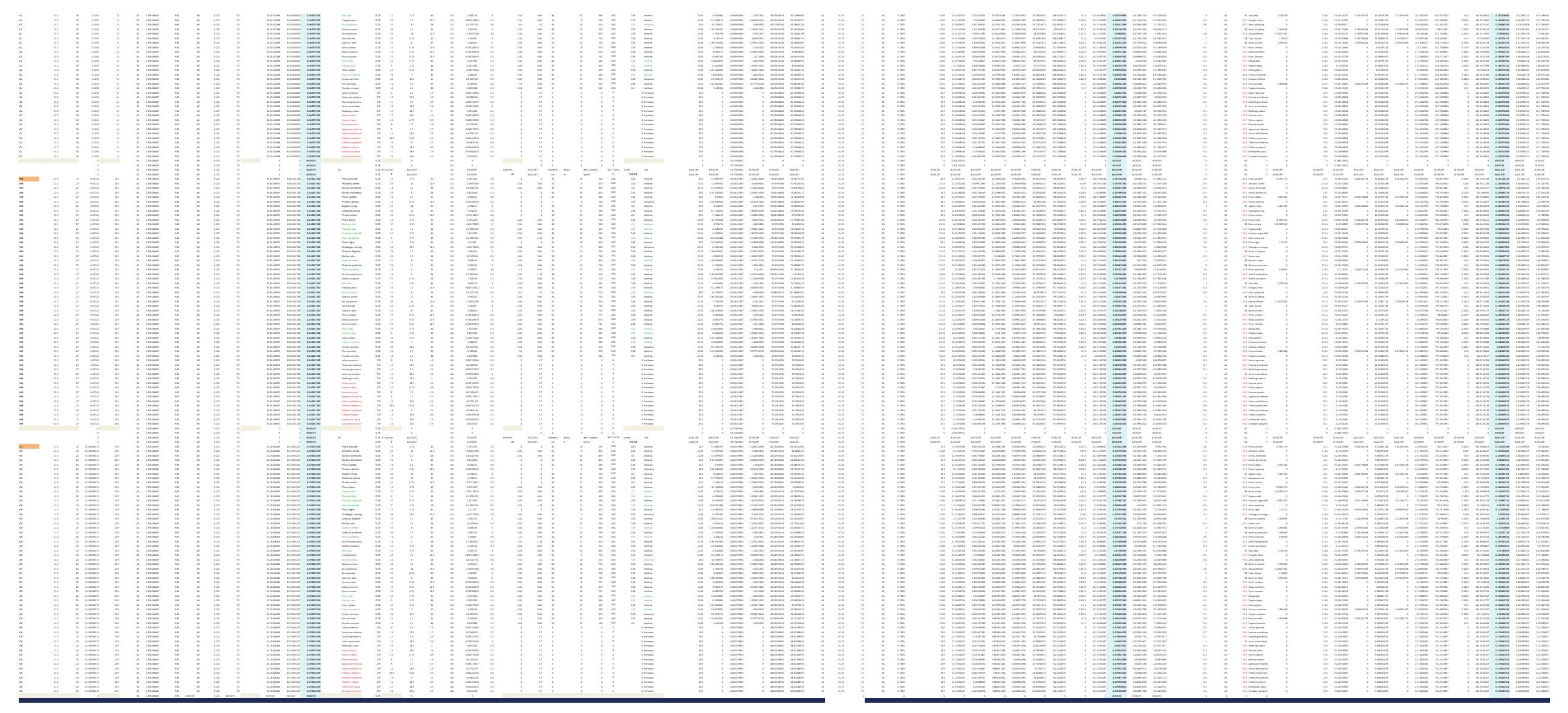


DESARROLLO DE UNA APLICACIÓN IMFORMÁTICA PARA EL CÁLCULO DE SOSTENIMIENTO DE TALUDES MEDIANTE VEGETACIÓN

A03. DENSIDAD DE PLANTACIÓN: 2.500 plantas/ha.

\section{A03-3.POSICIÓN N.F. 3}

INCLINACIÓN DE TALUD 6-100

INCLINACIÓN DE TALUD 10-200

INCLINACIÓN DE TALUD 20-30

INCLINACIÓN DE TALUD 30-40

INCLINACIÓN DE TALUD $35^{\circ}$

INCLINACIÓN DE TALUD 40-50

INCLINACIÓN DE TALUD 50-550

INCLINACIÓN DE TALUD 55-60

INCLINACIÓN DE TALUD 60-700

INCLINACIÓN DE TALUD 70-80 

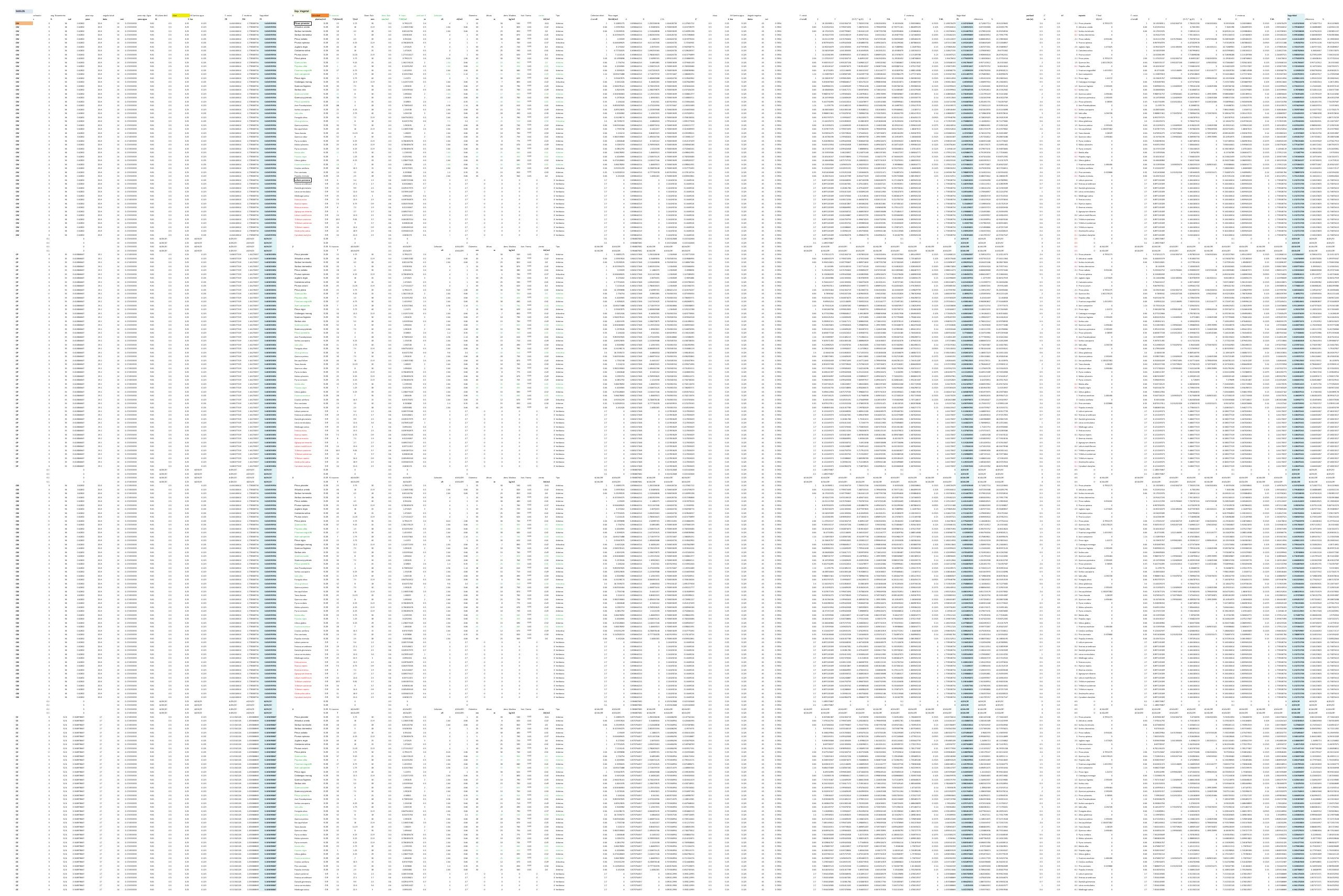

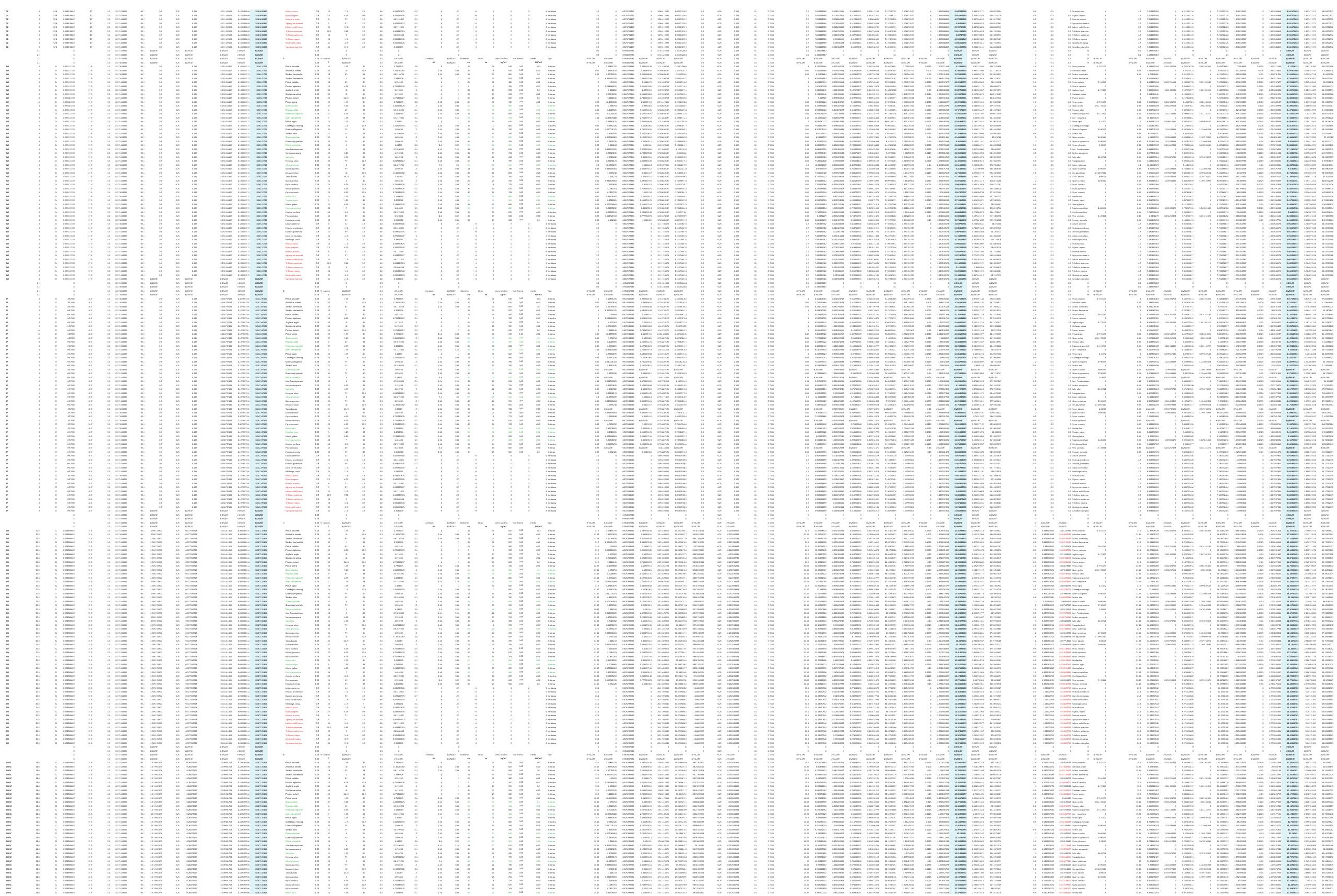


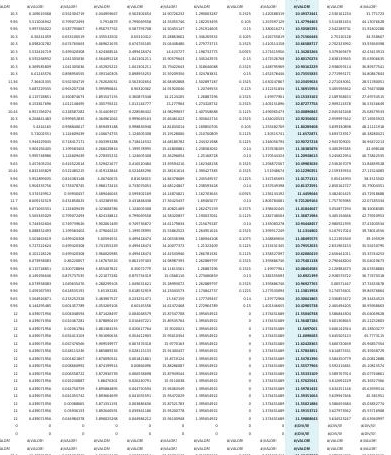

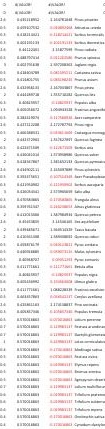
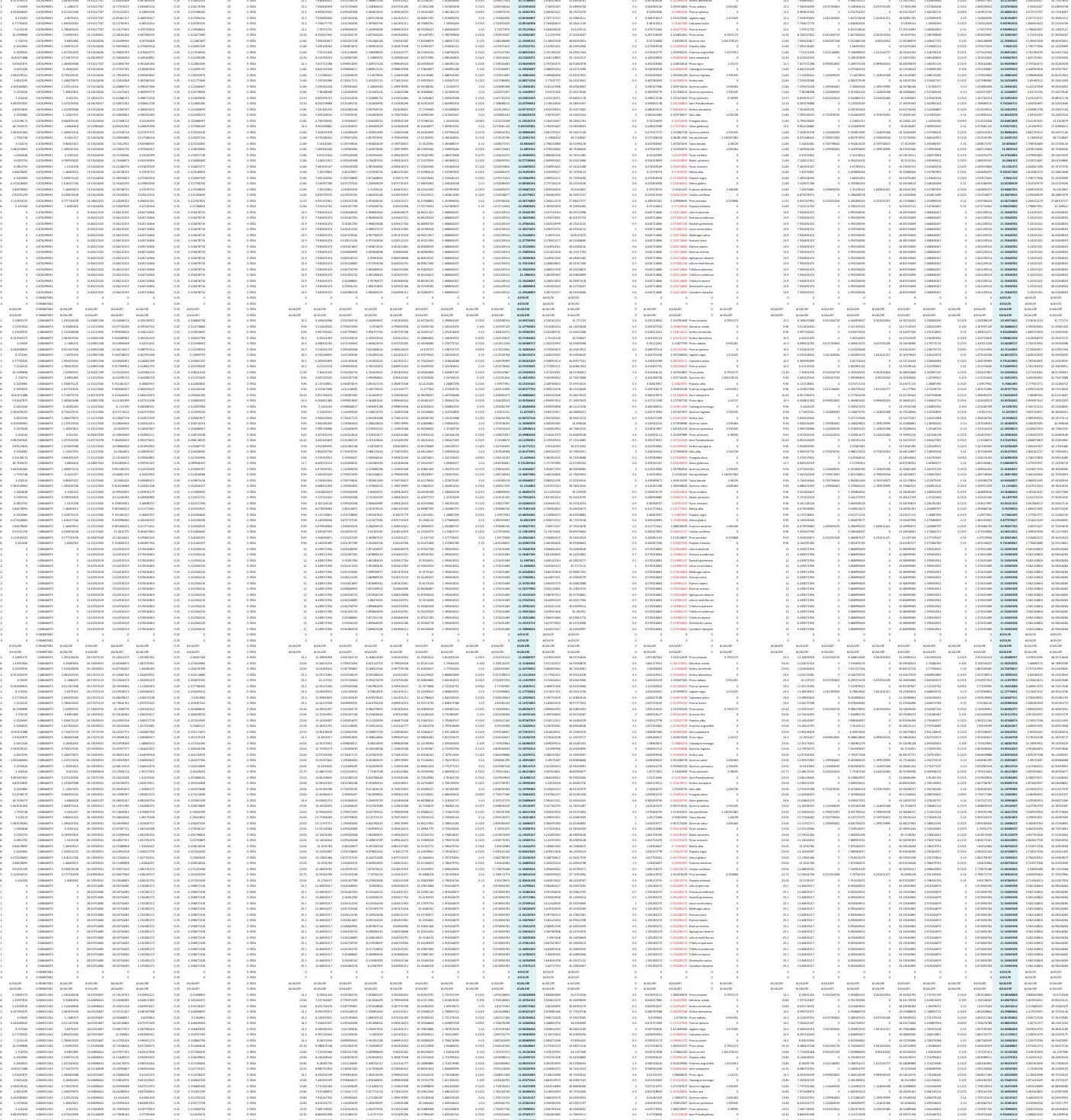


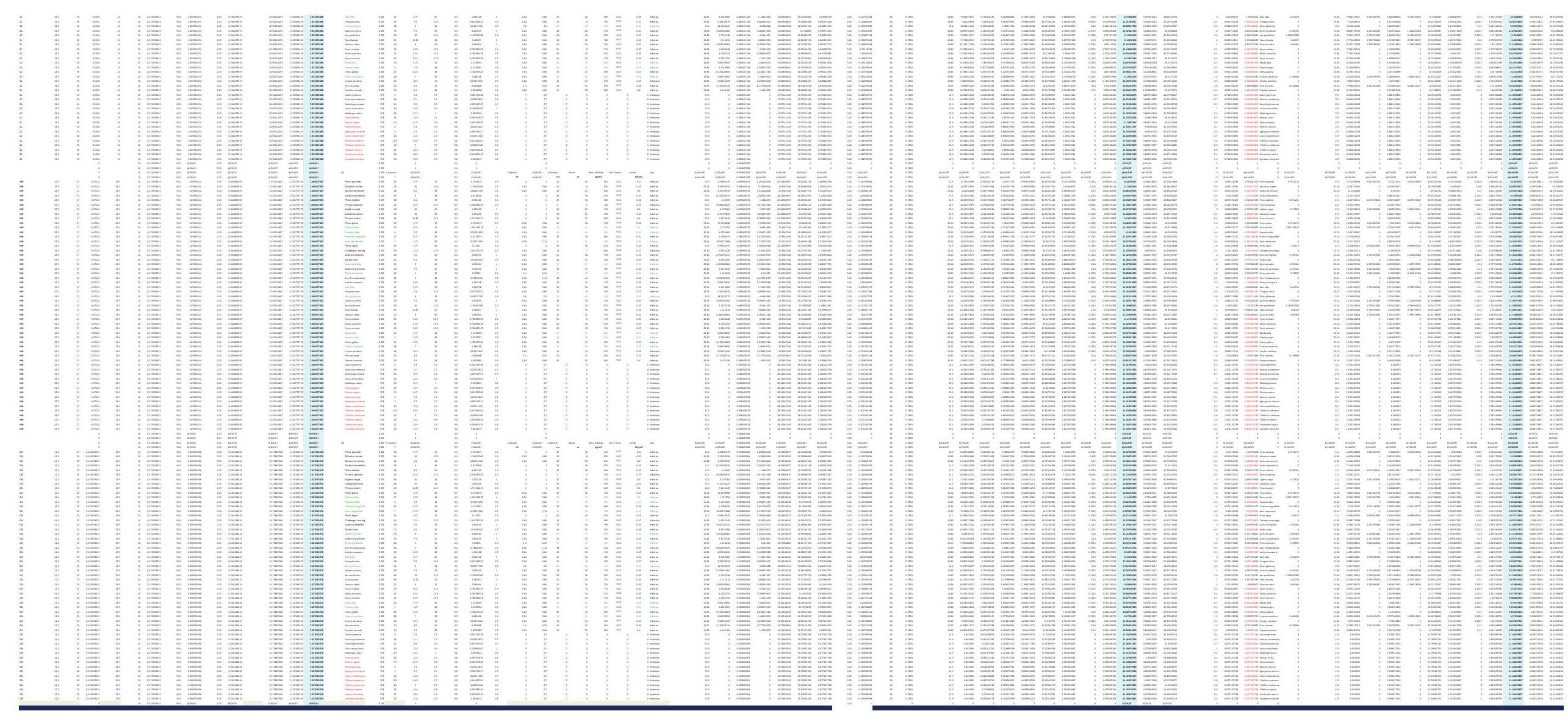



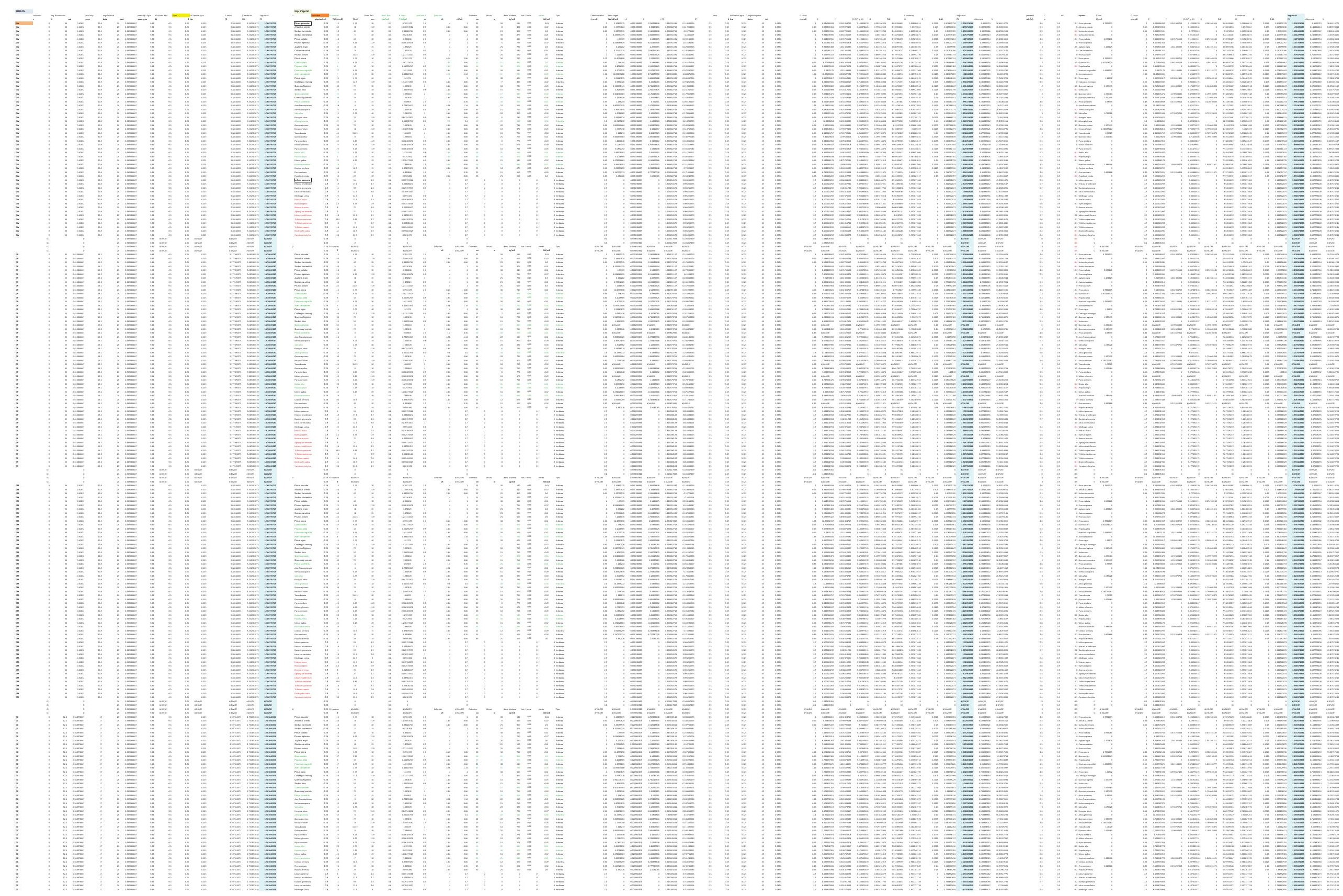

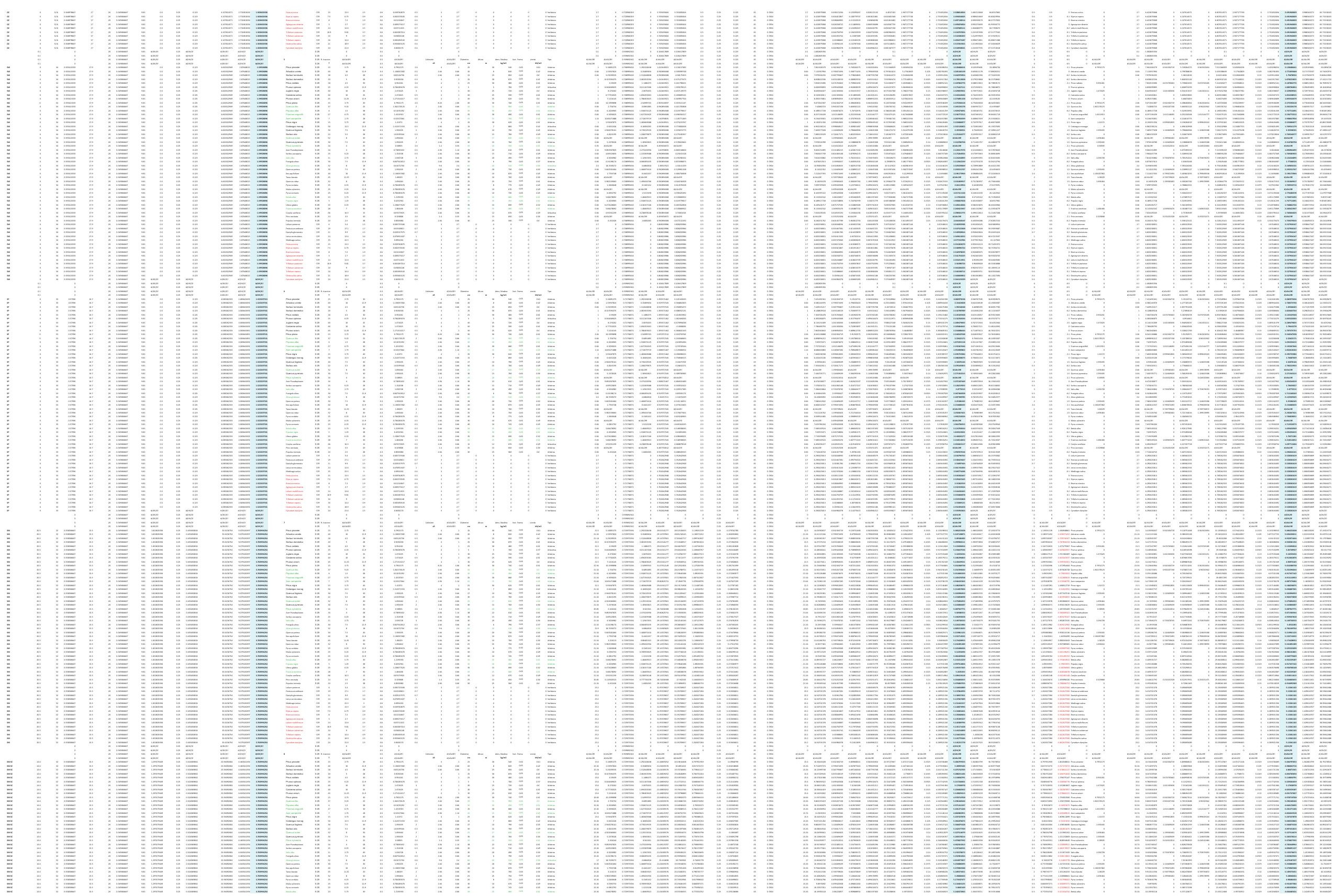

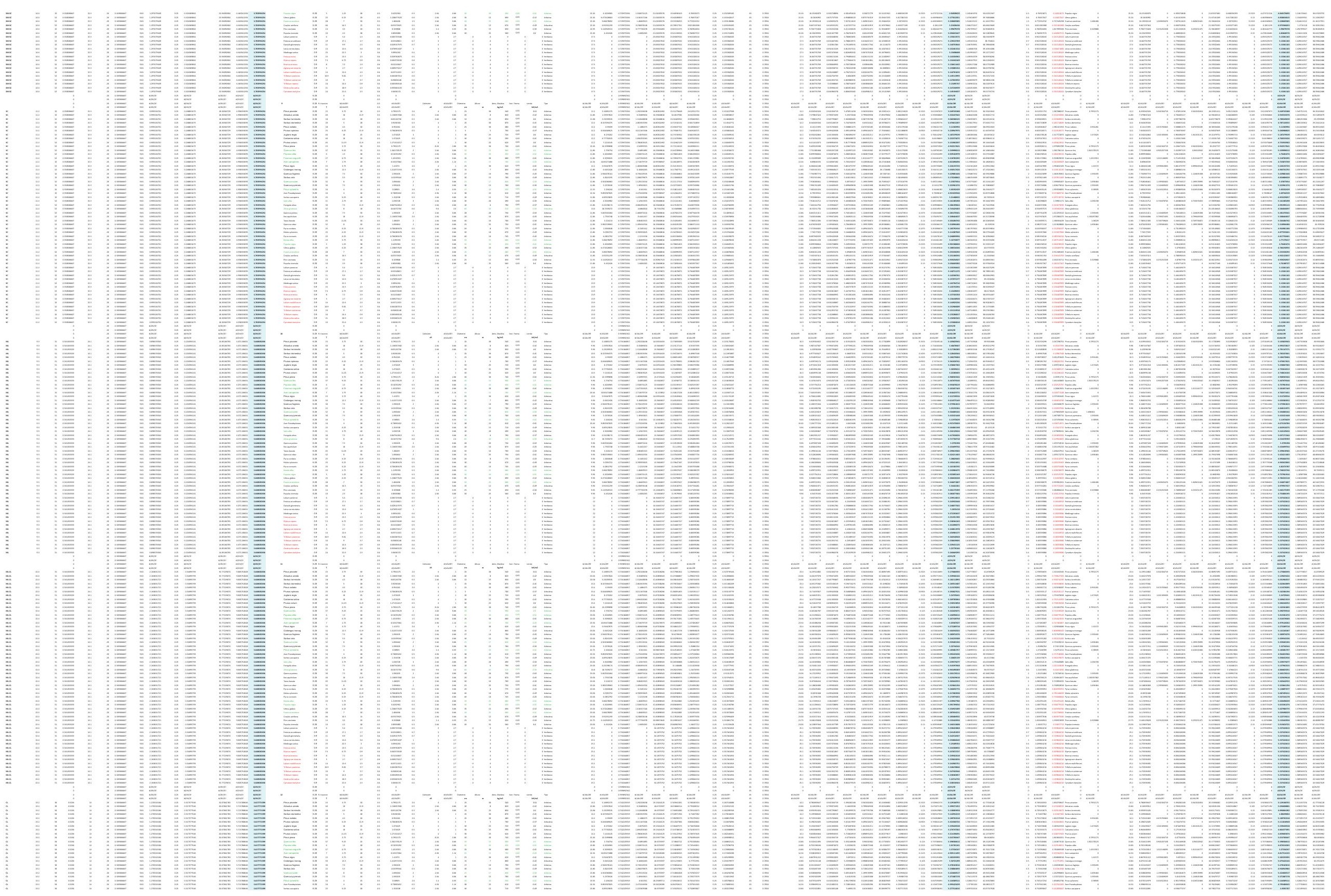


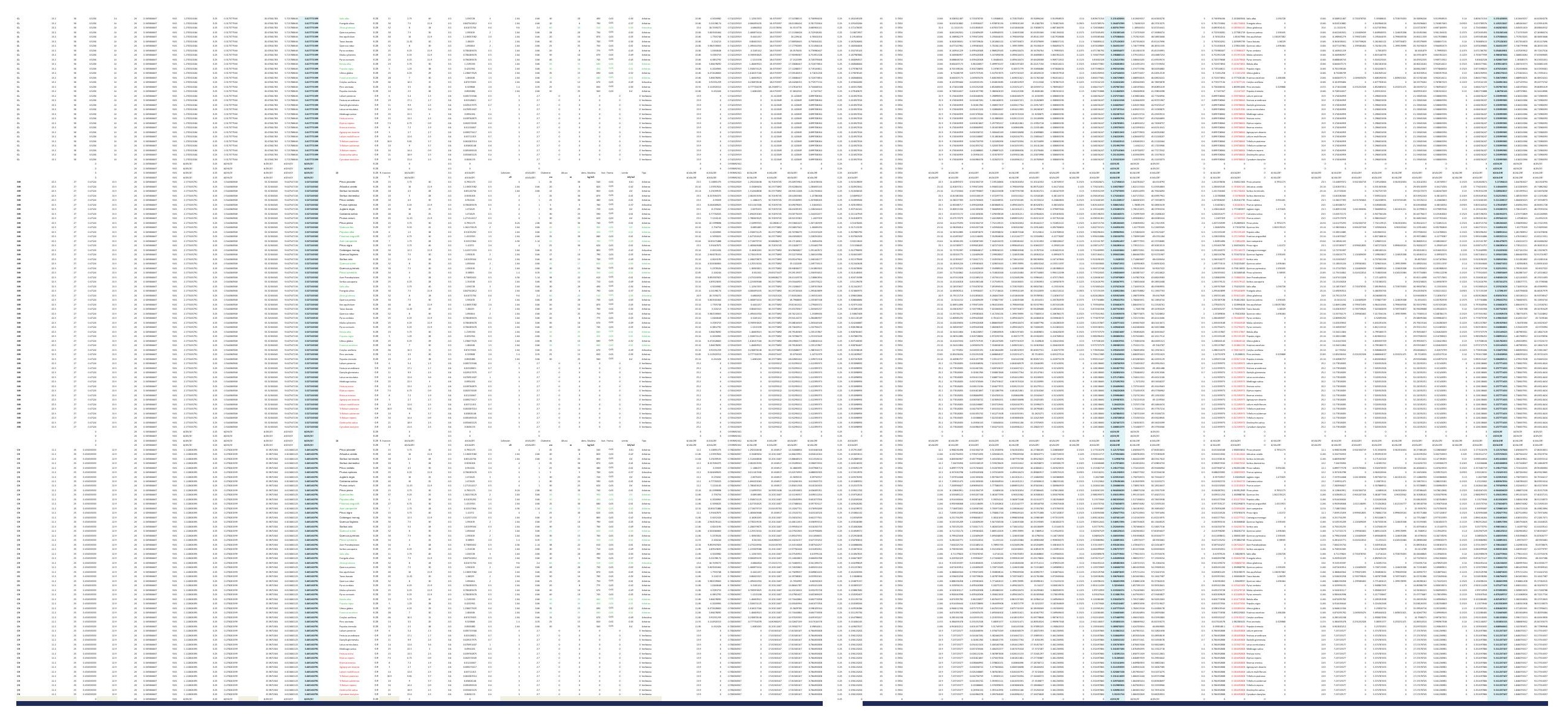



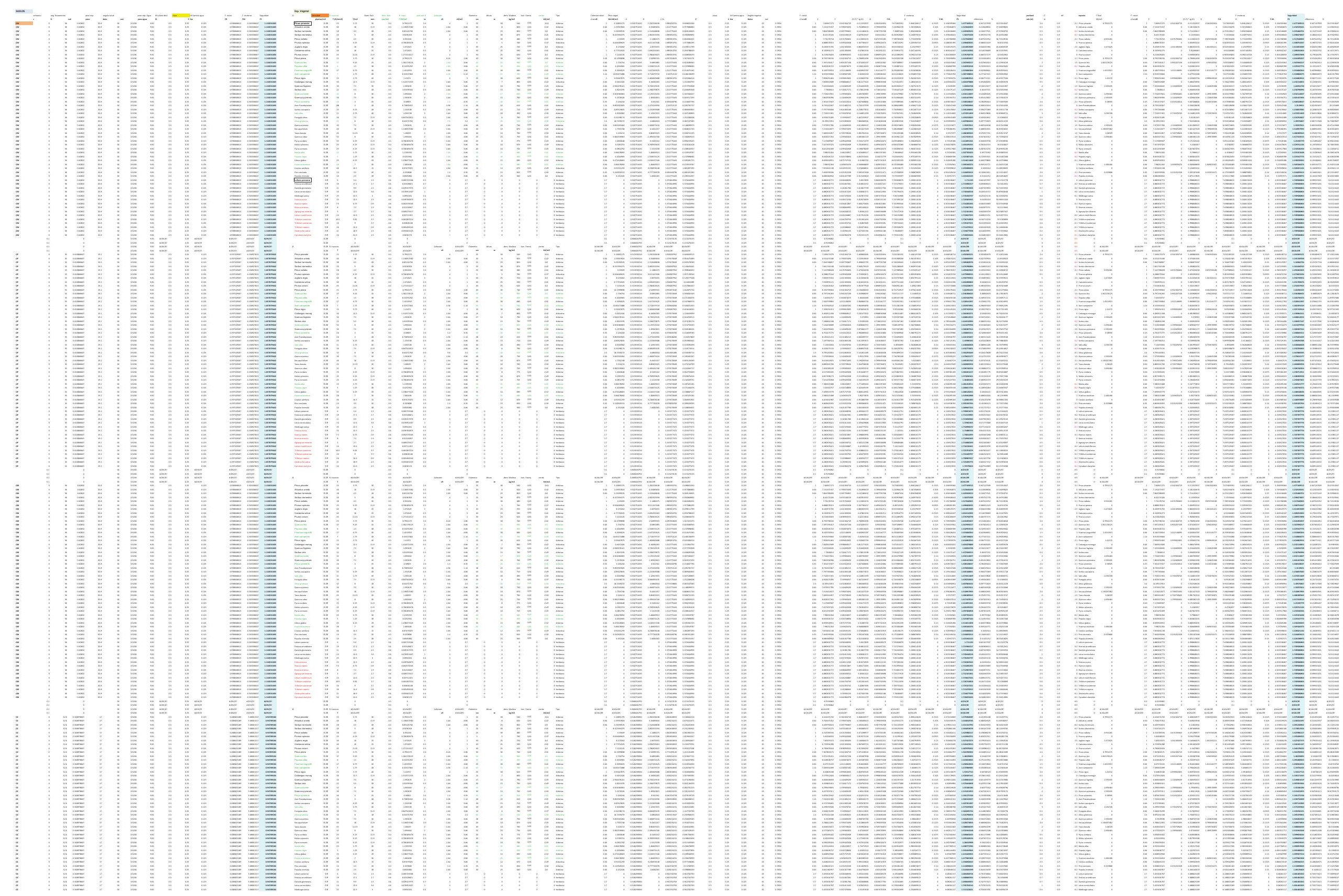

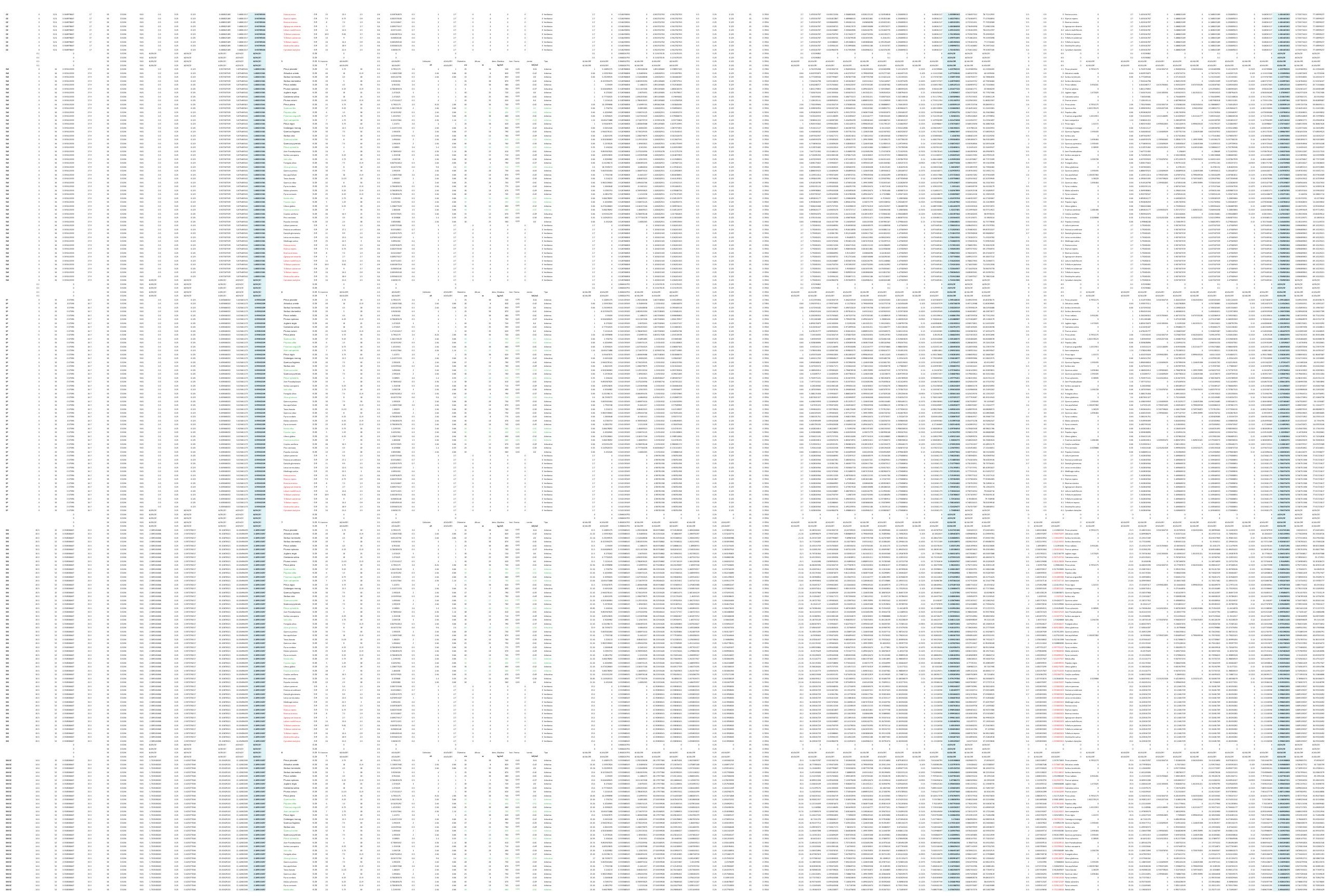

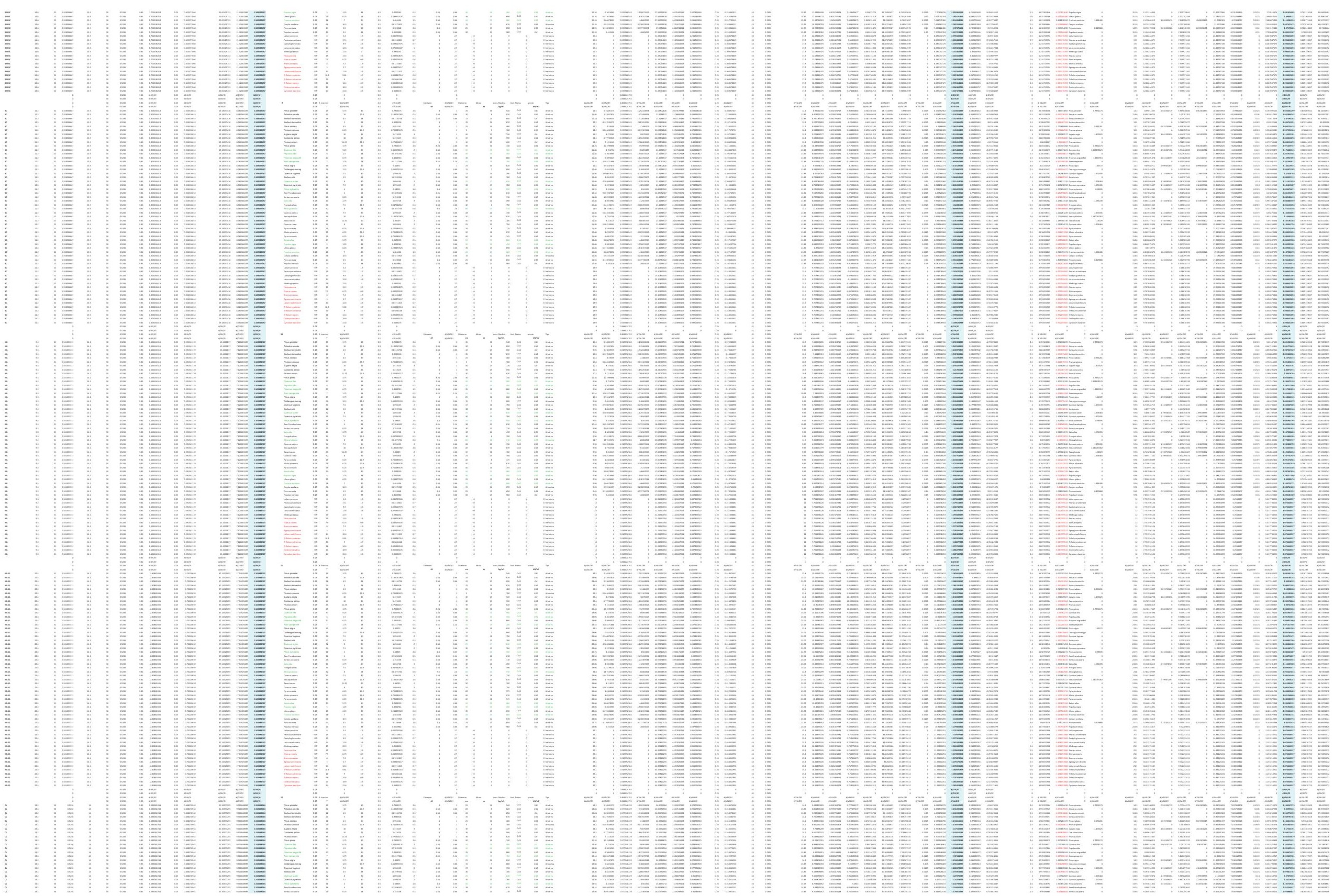


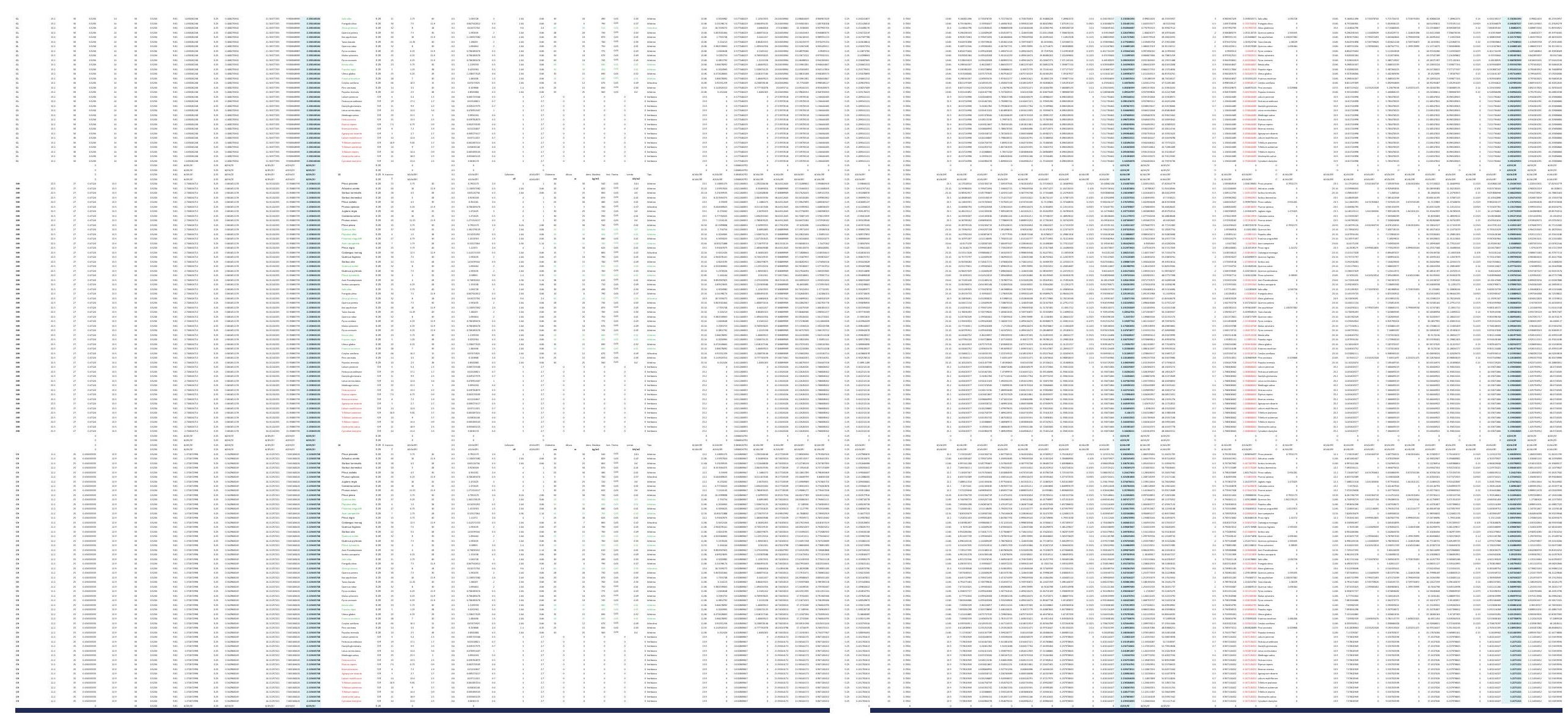



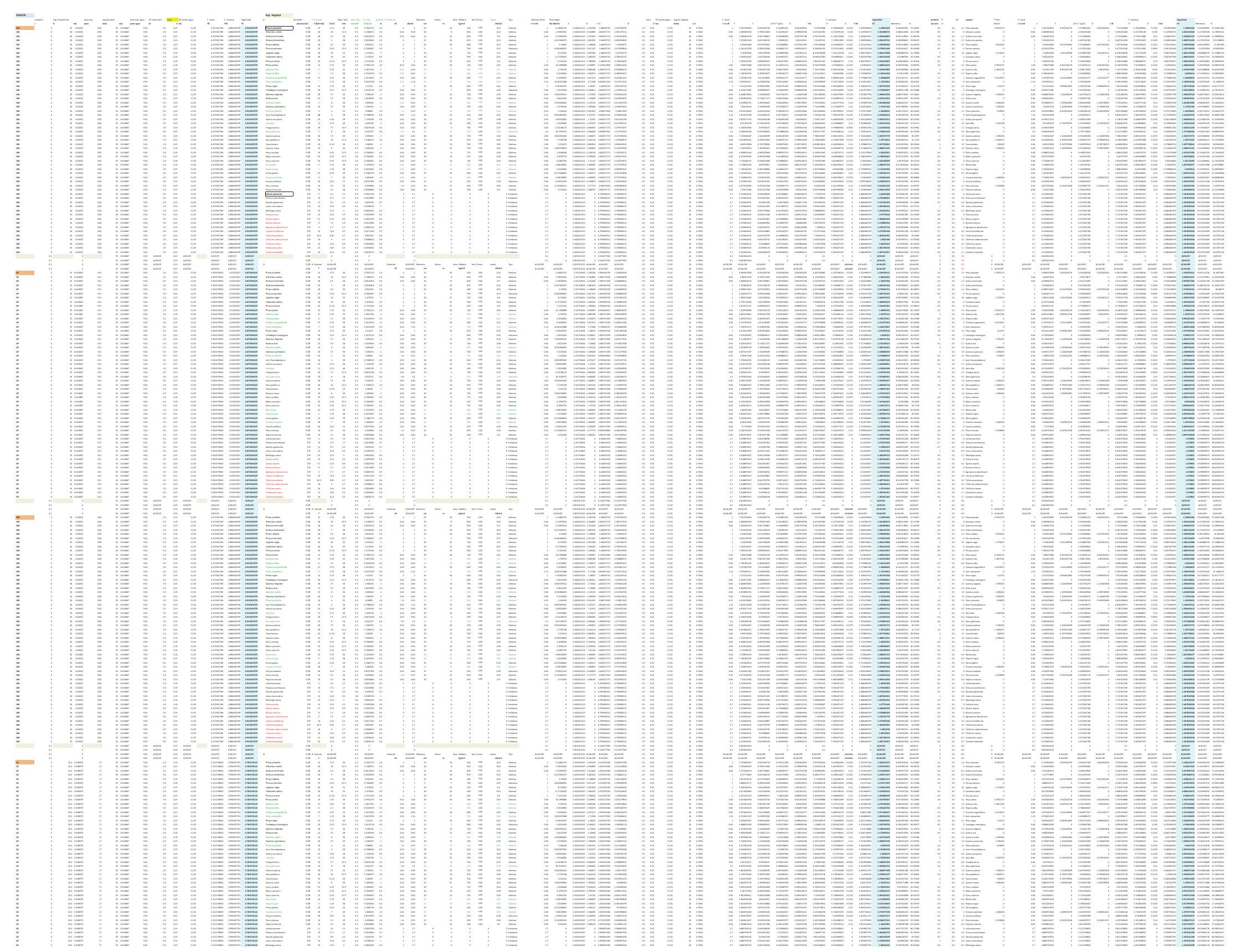


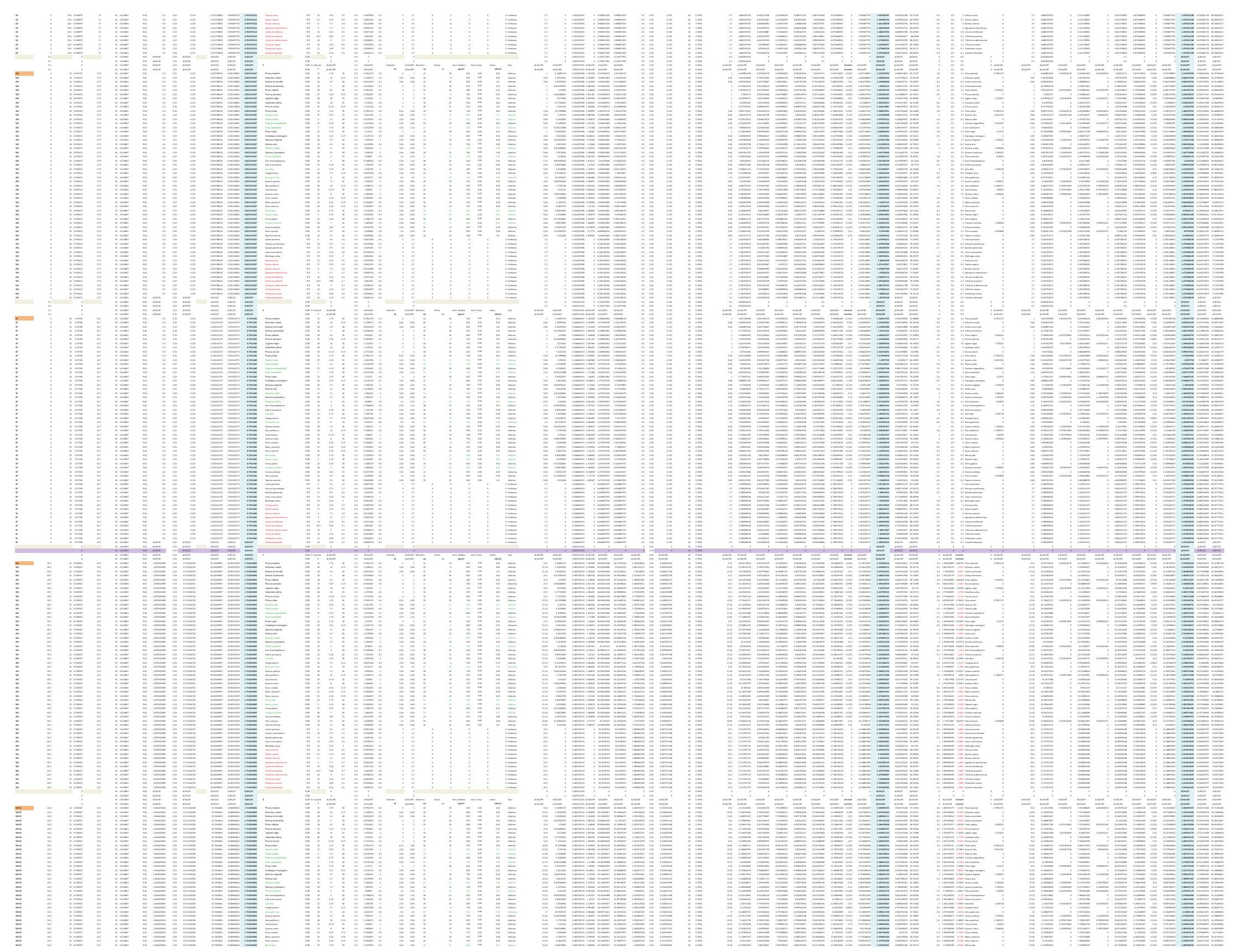



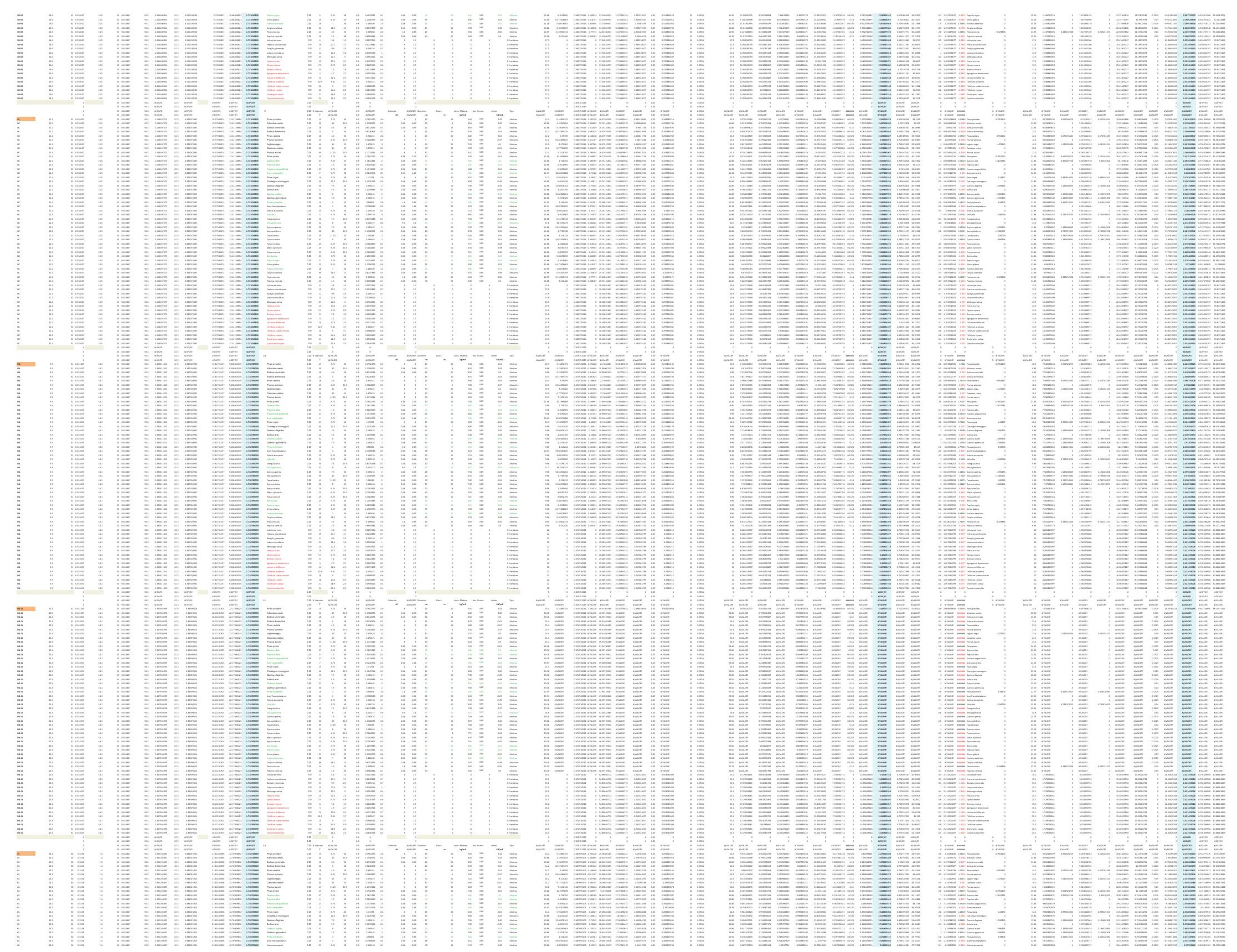


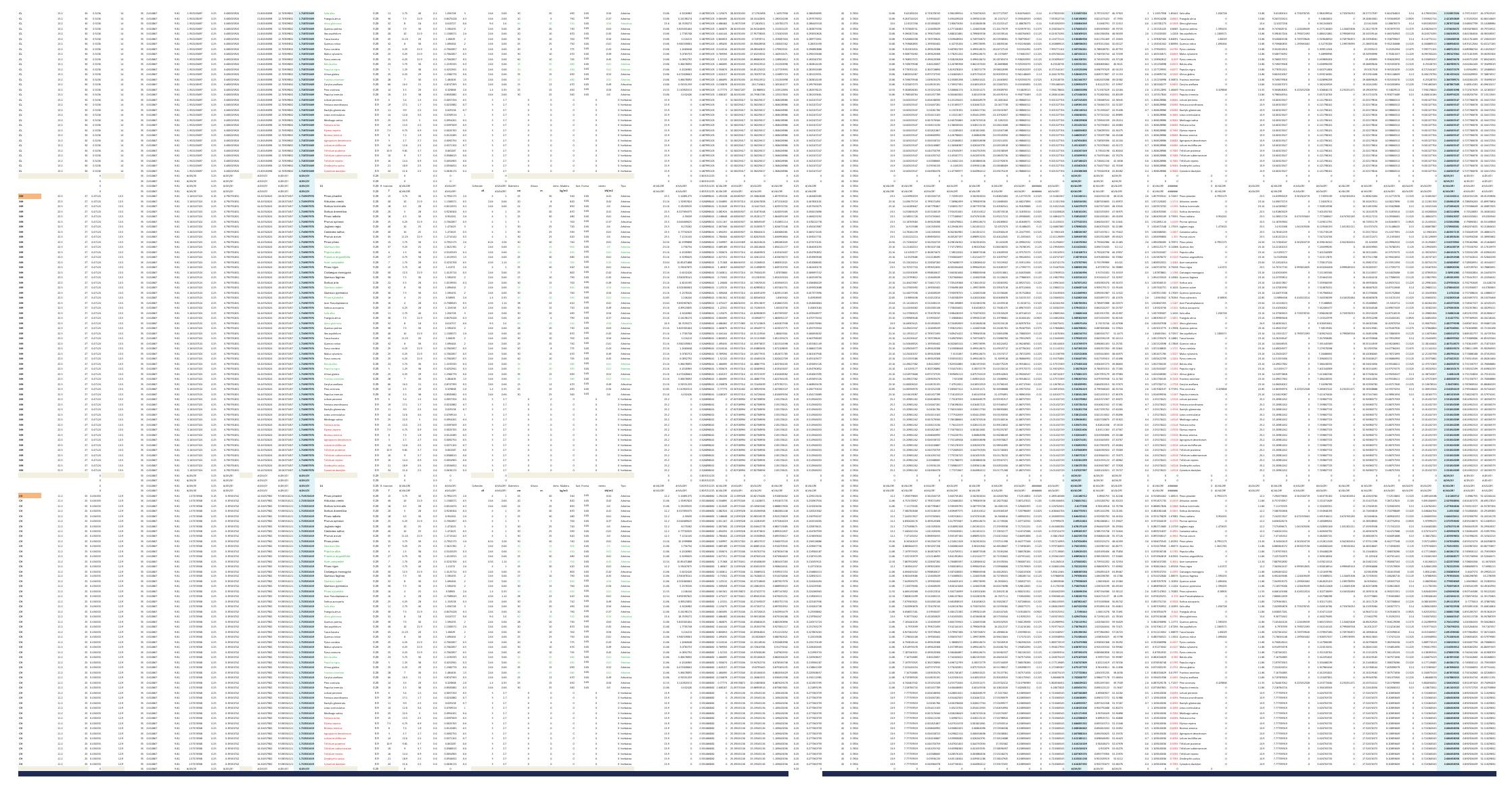



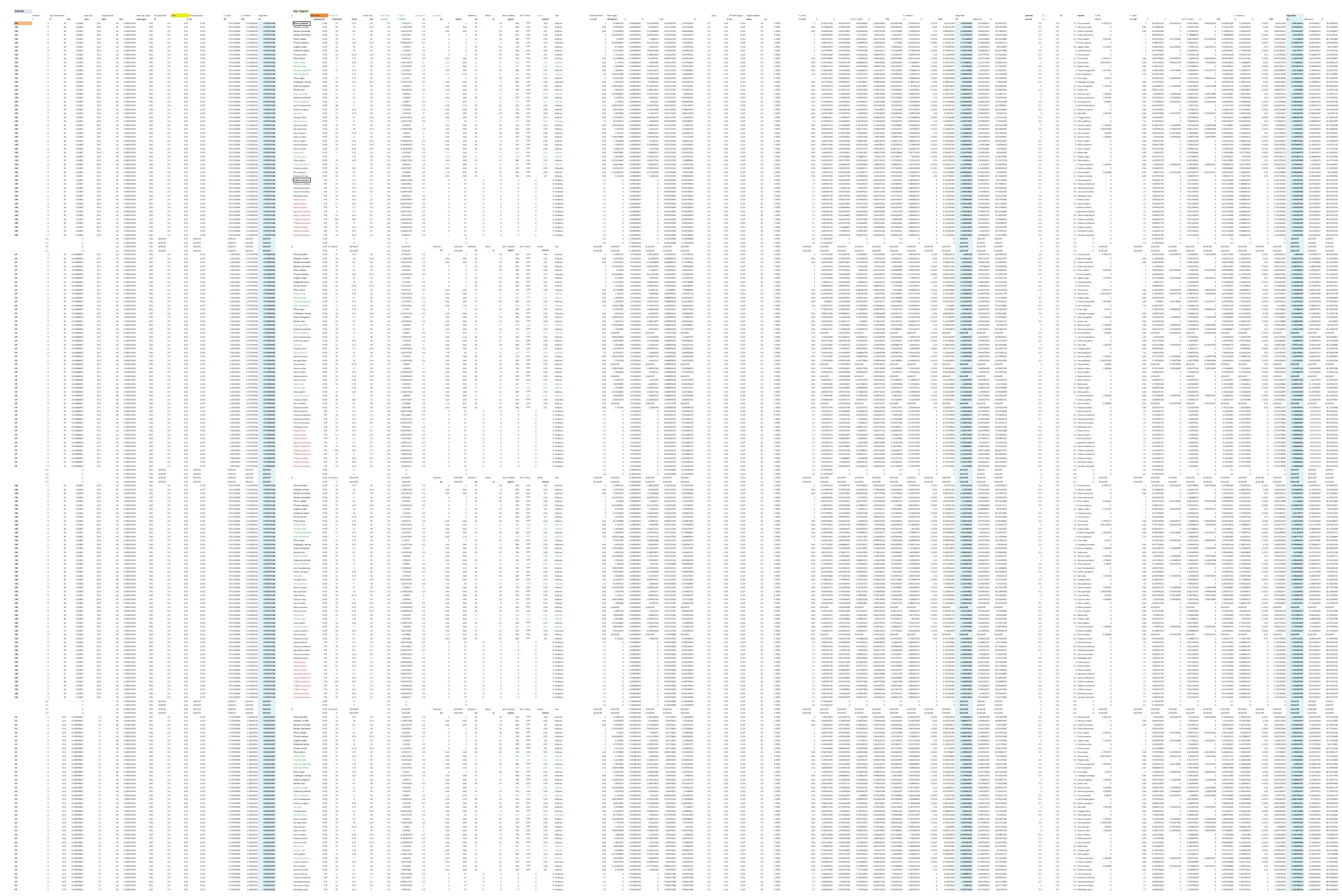

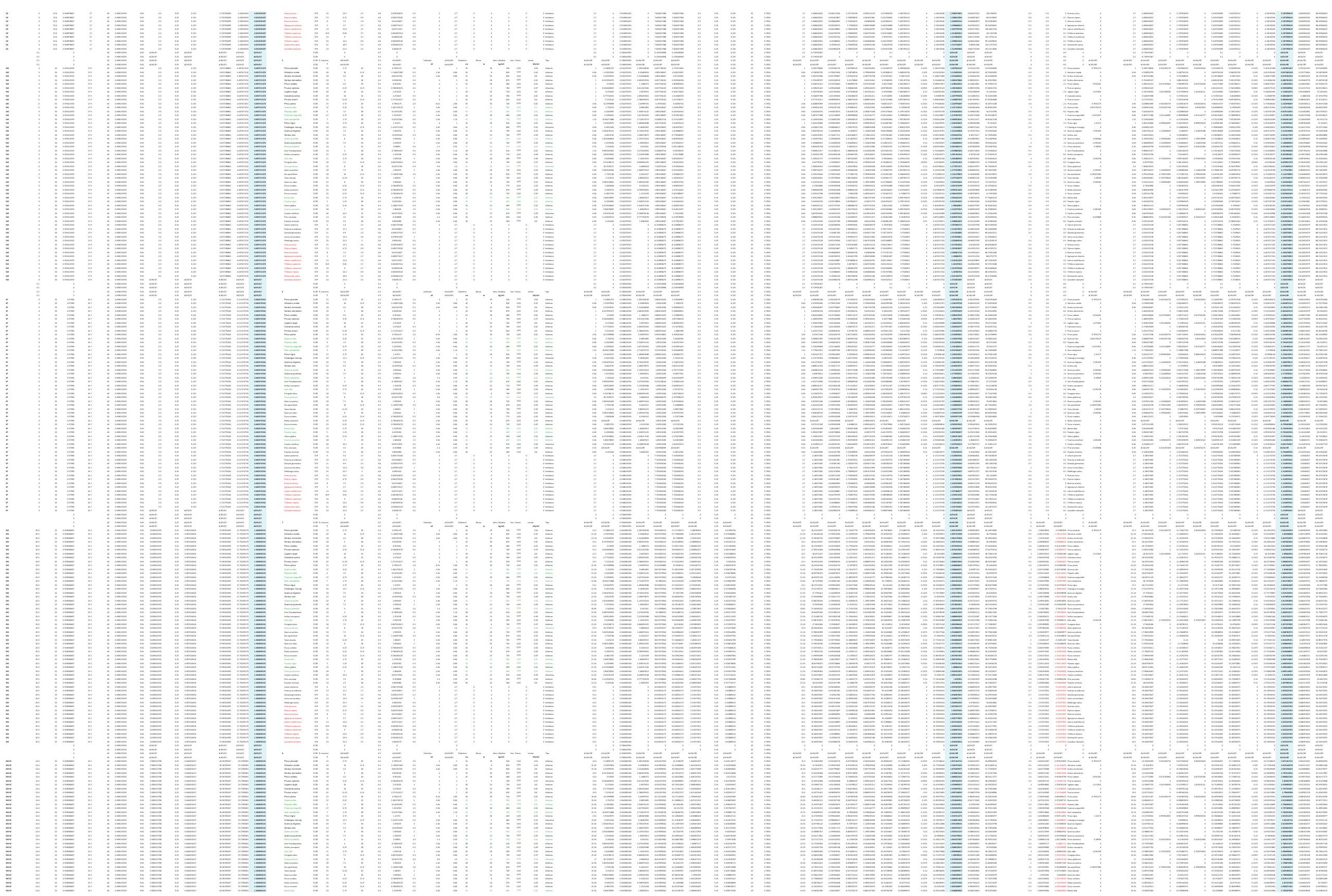

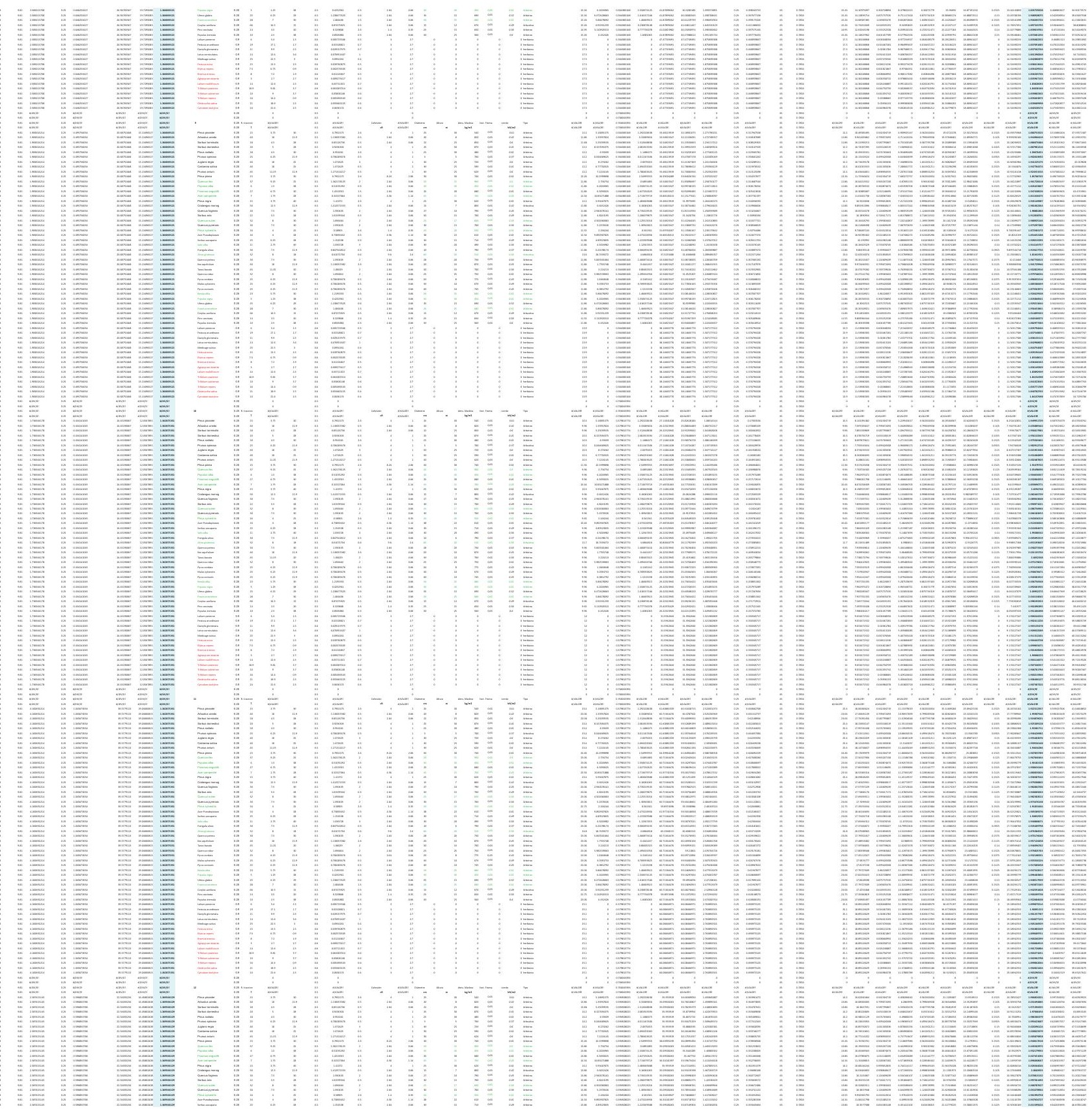

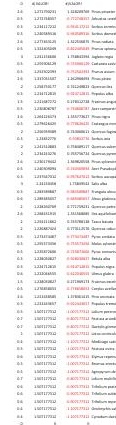
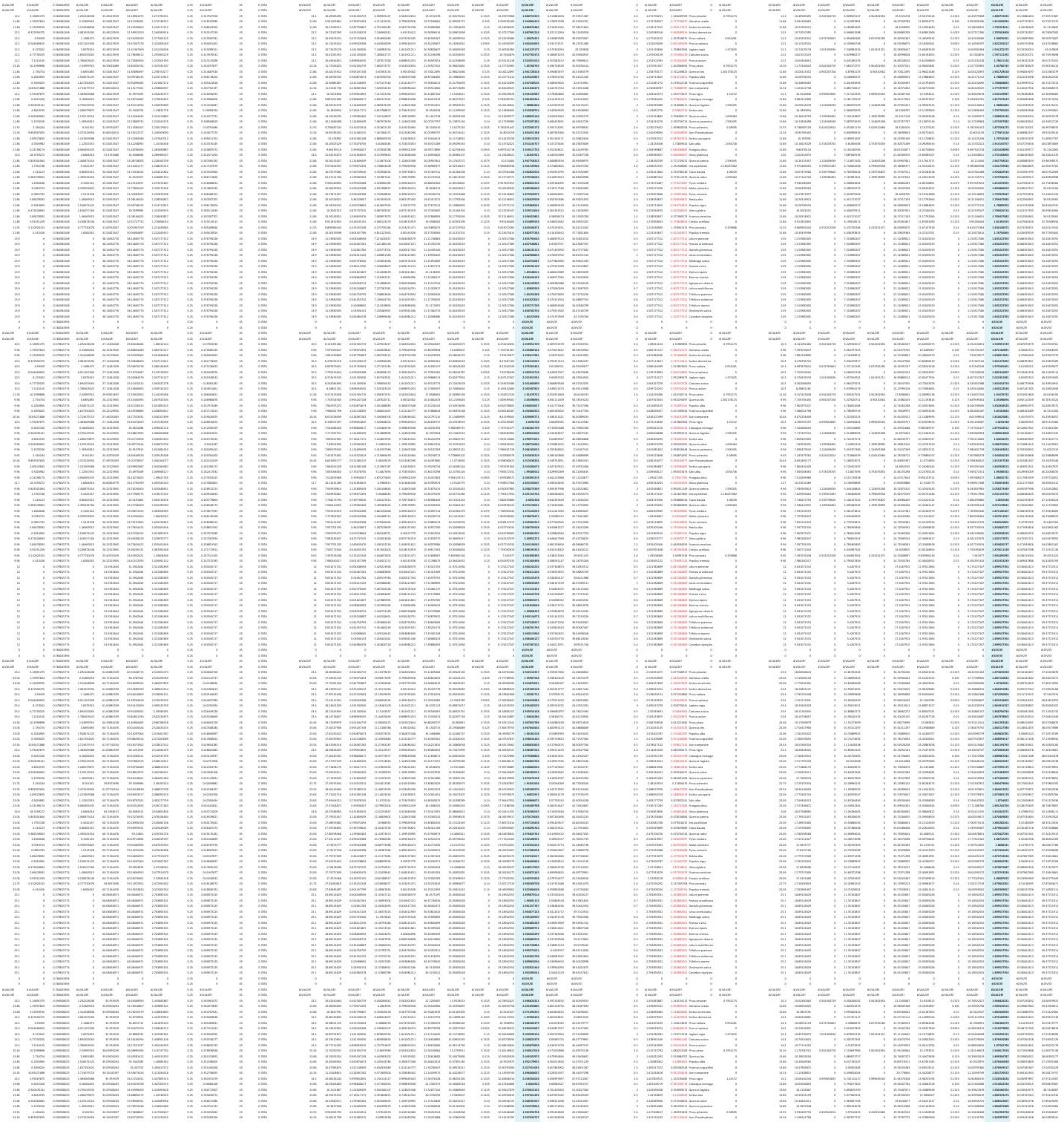


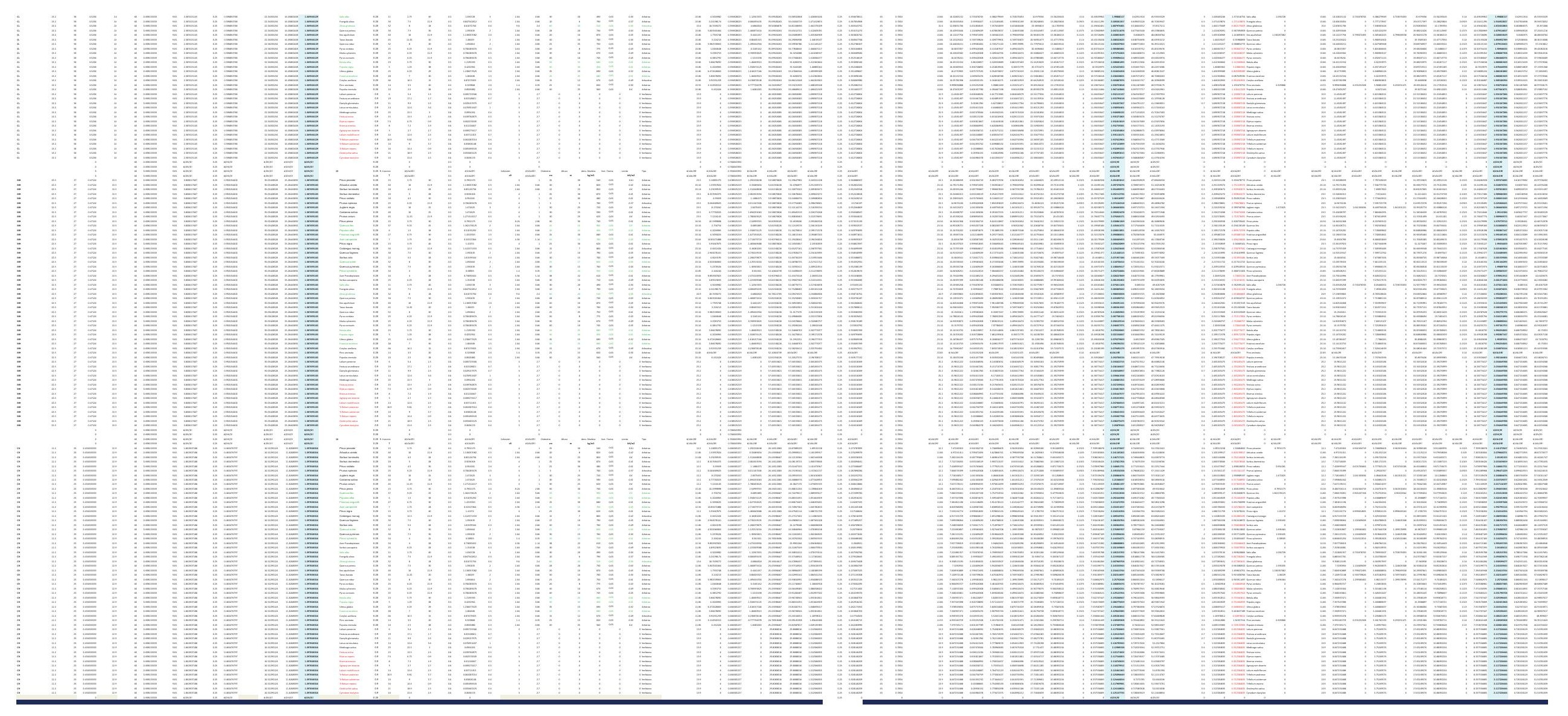



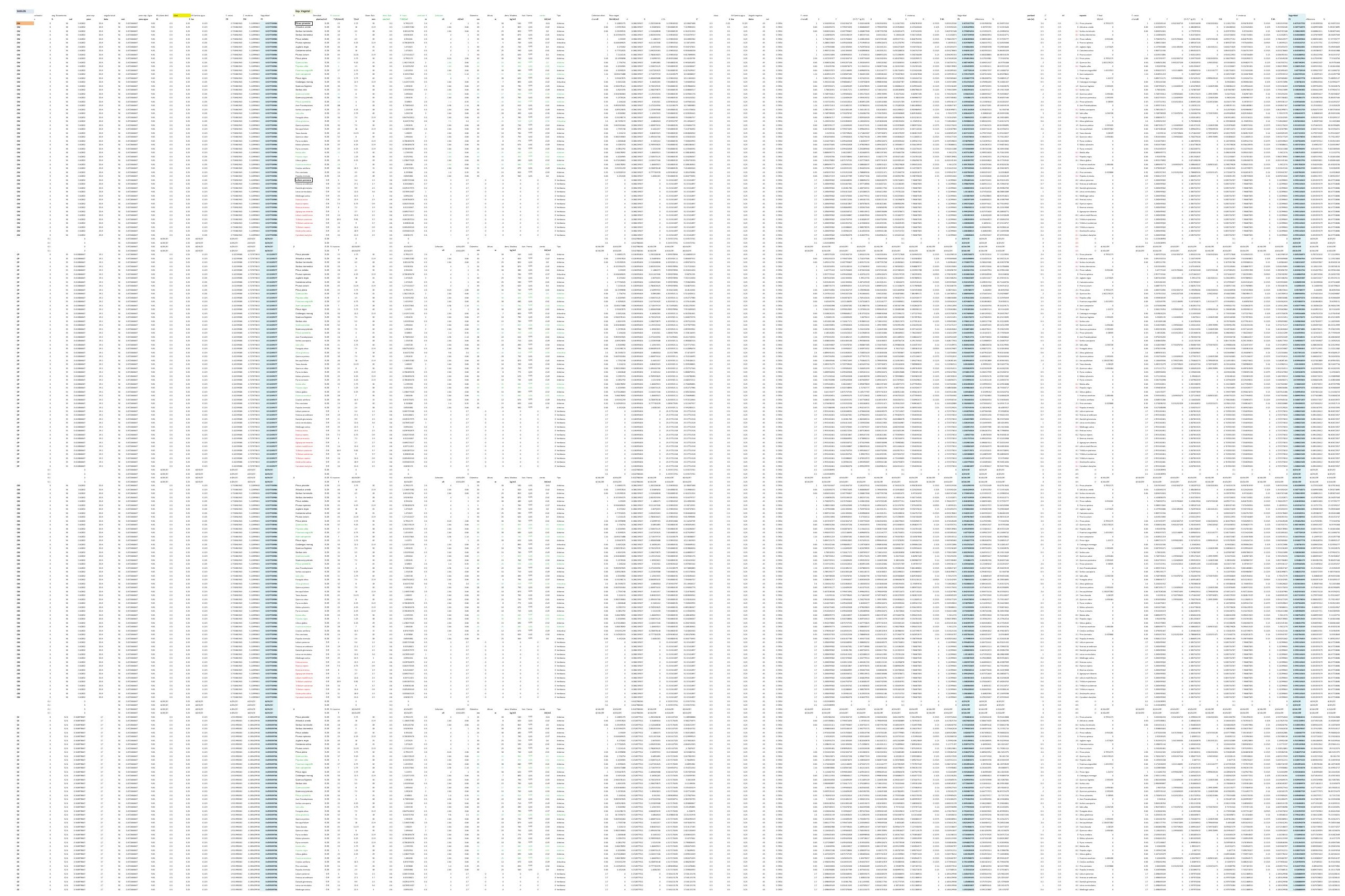

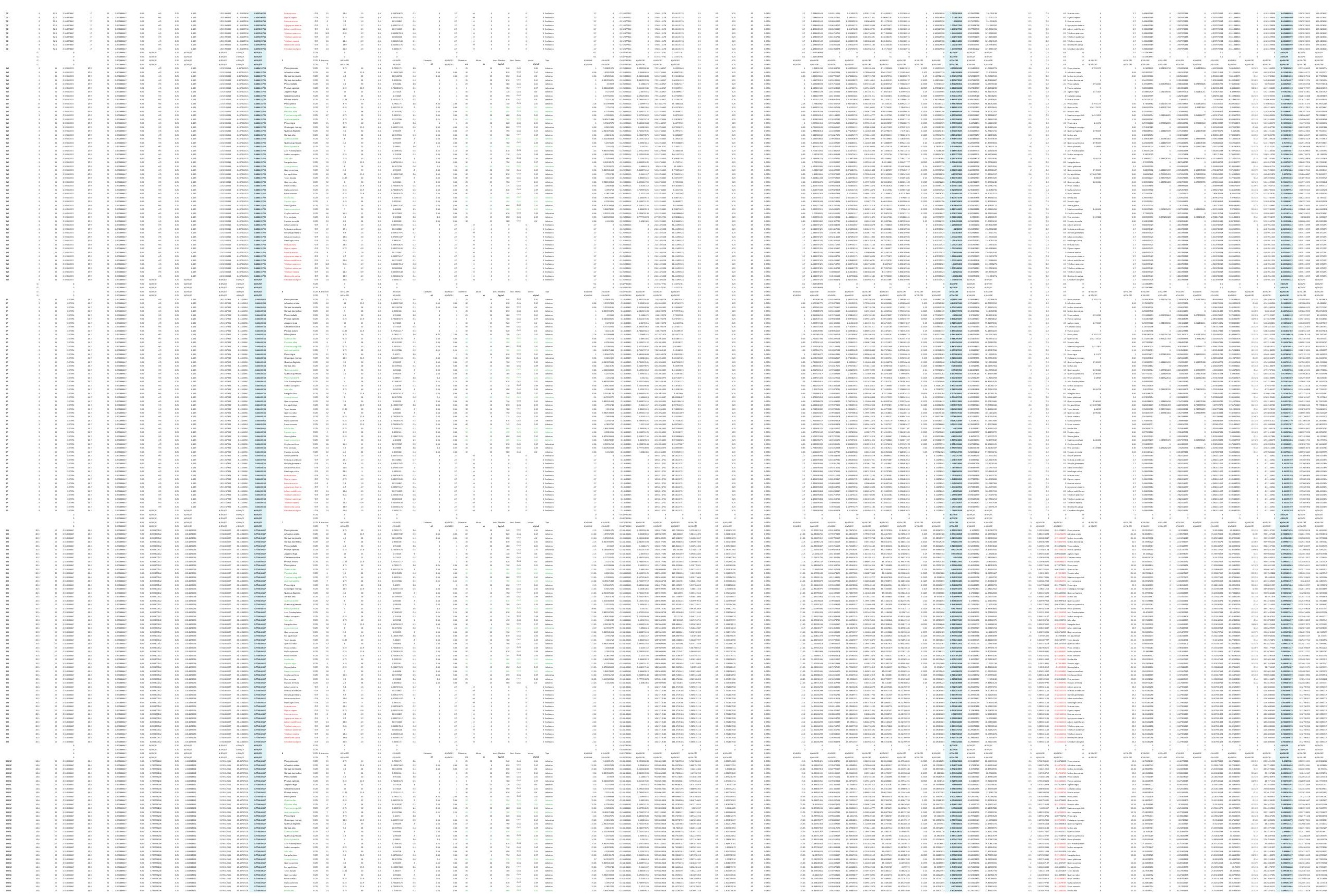

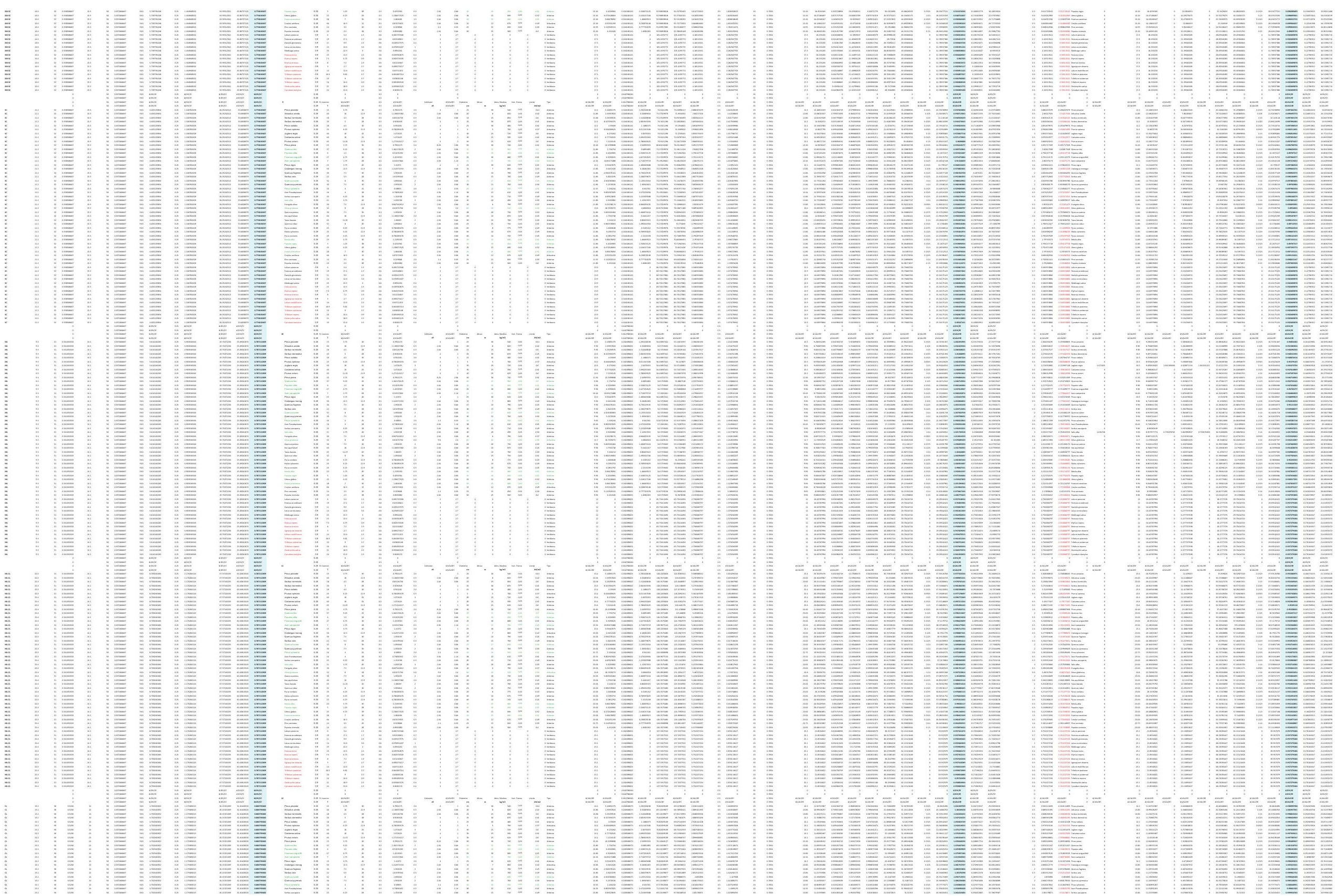


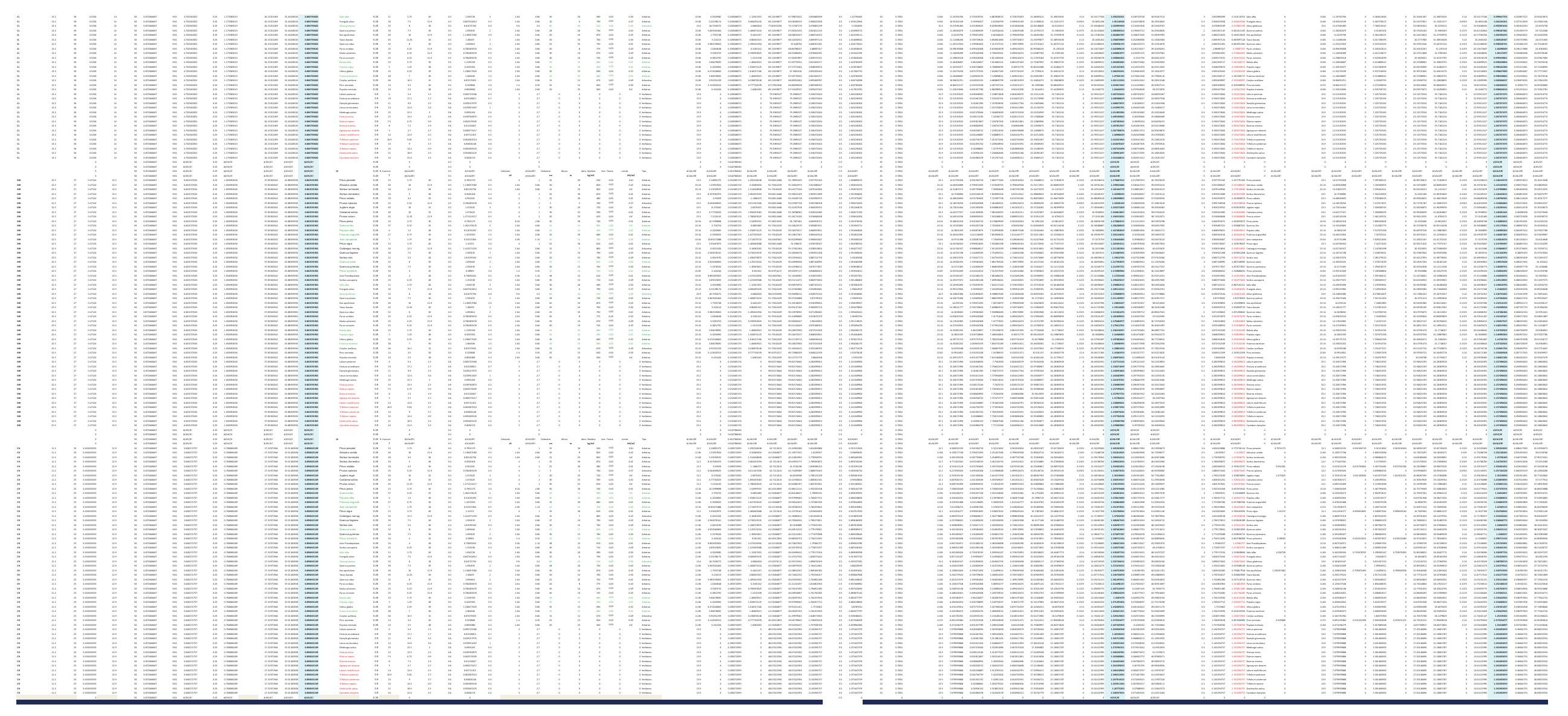



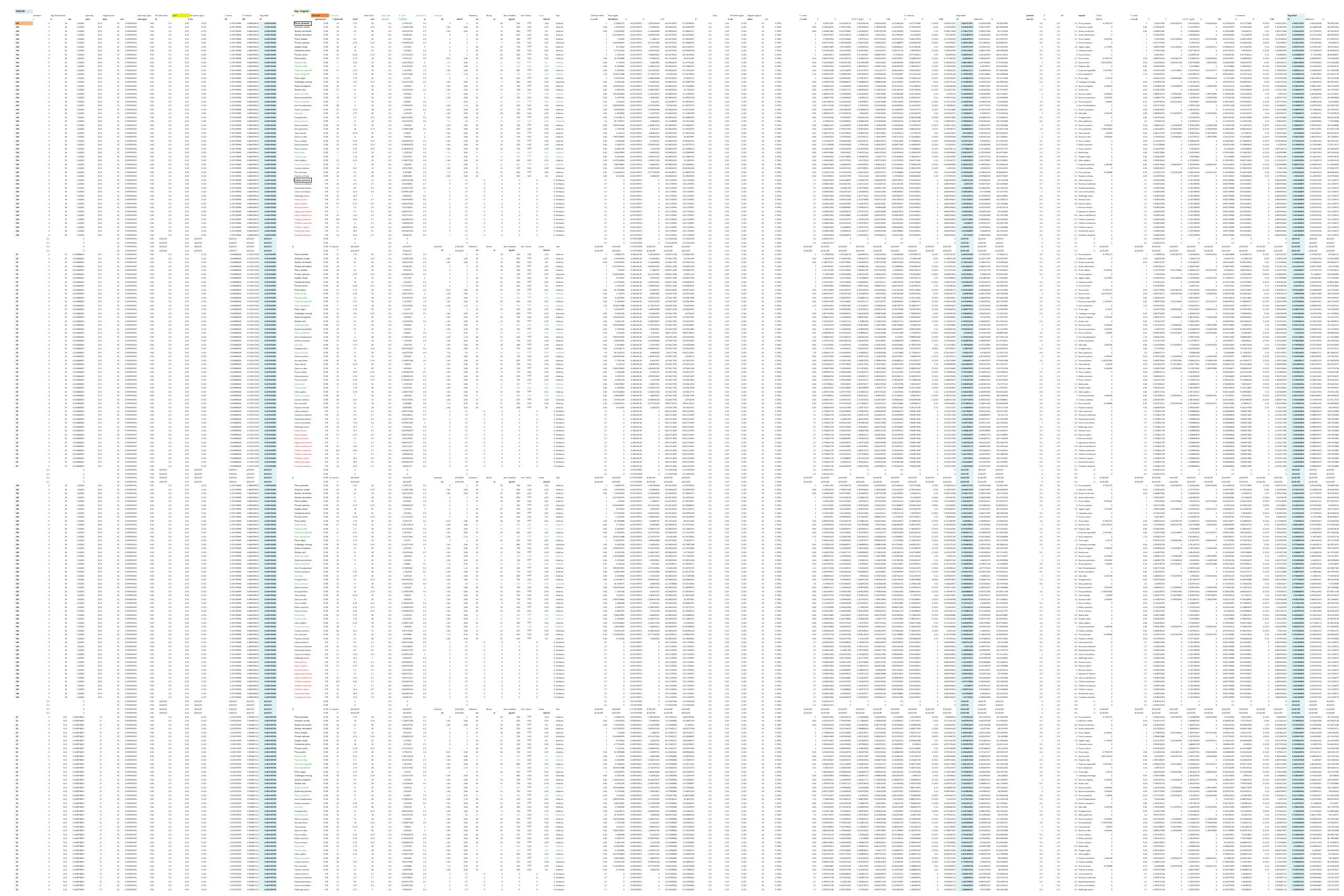


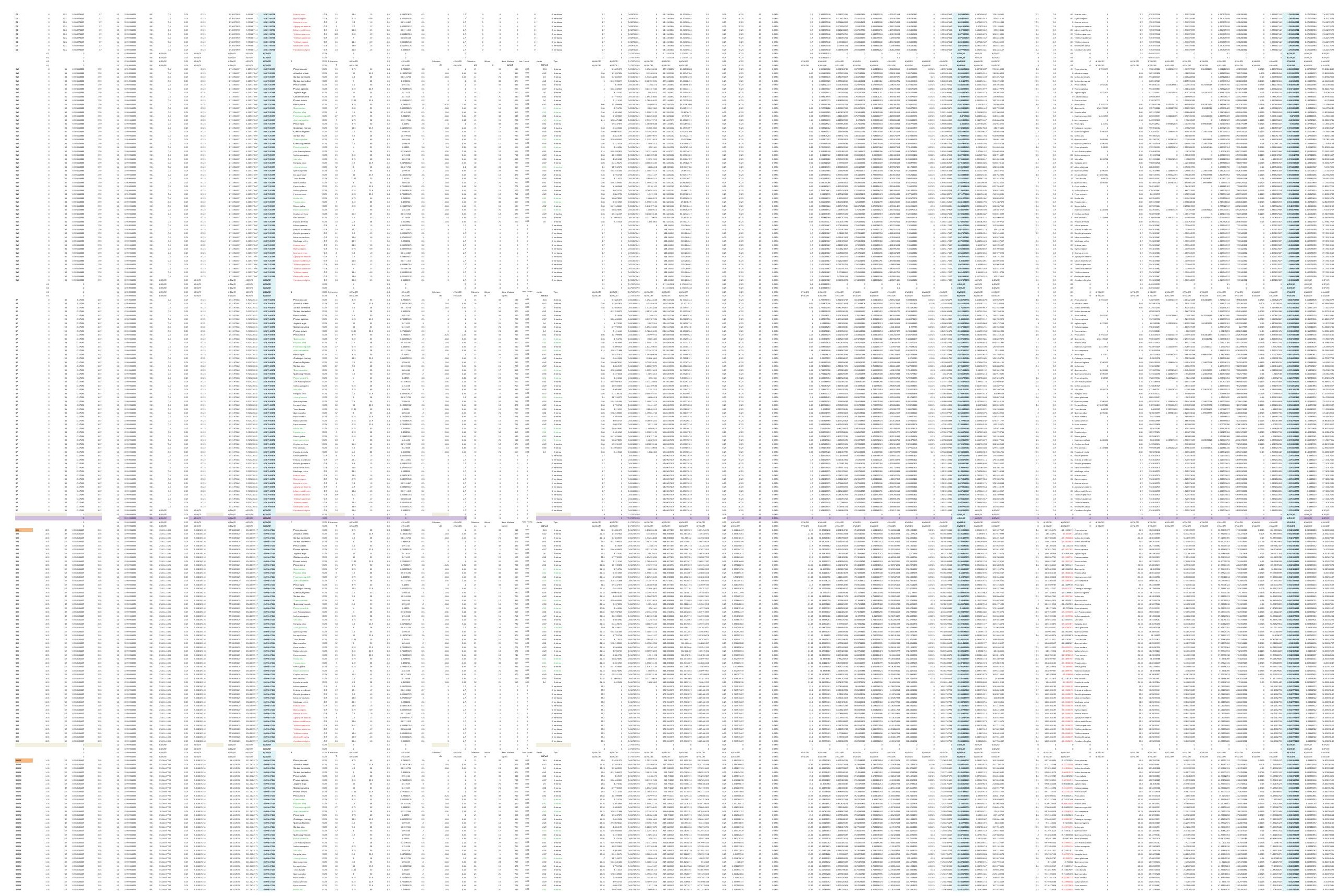



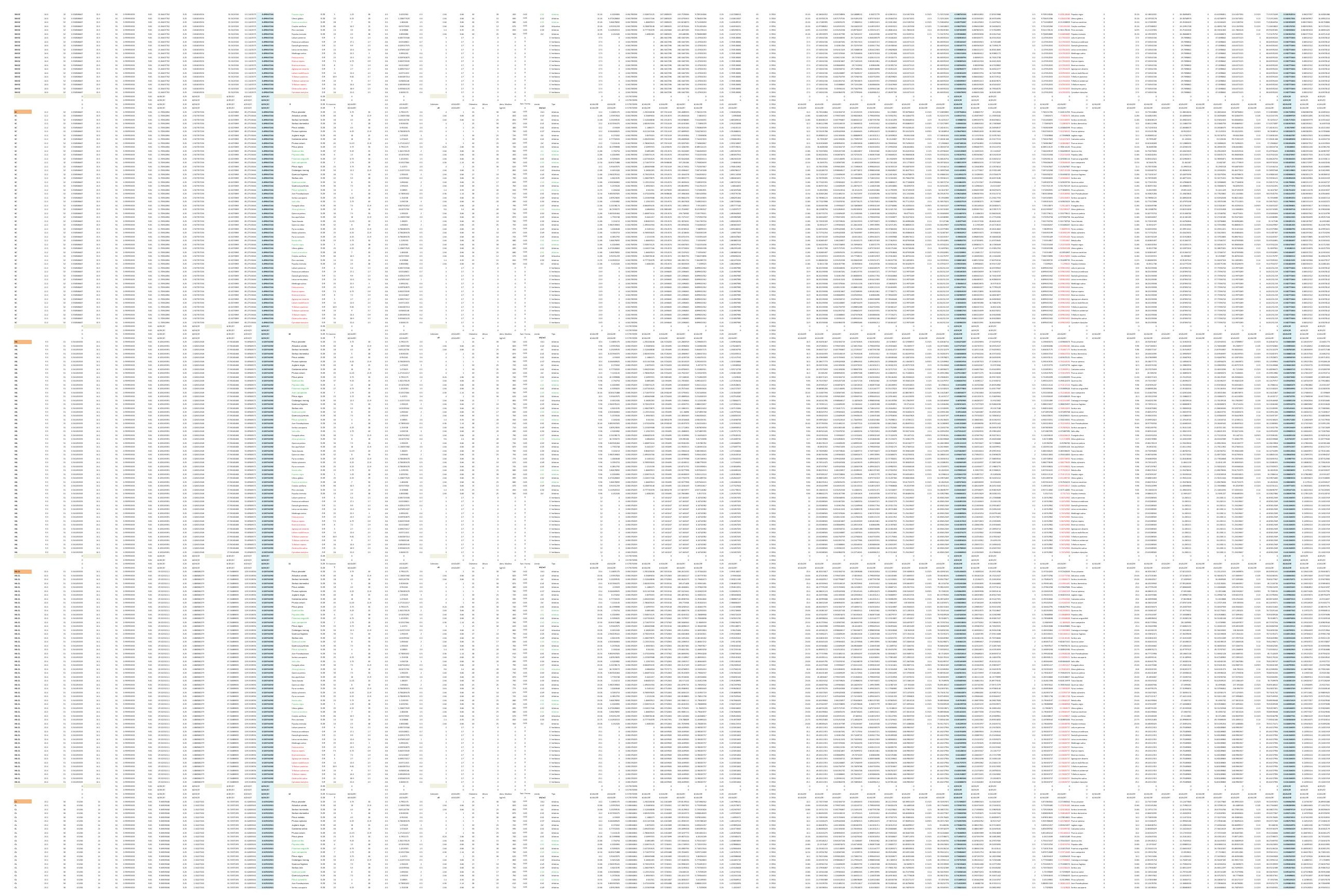


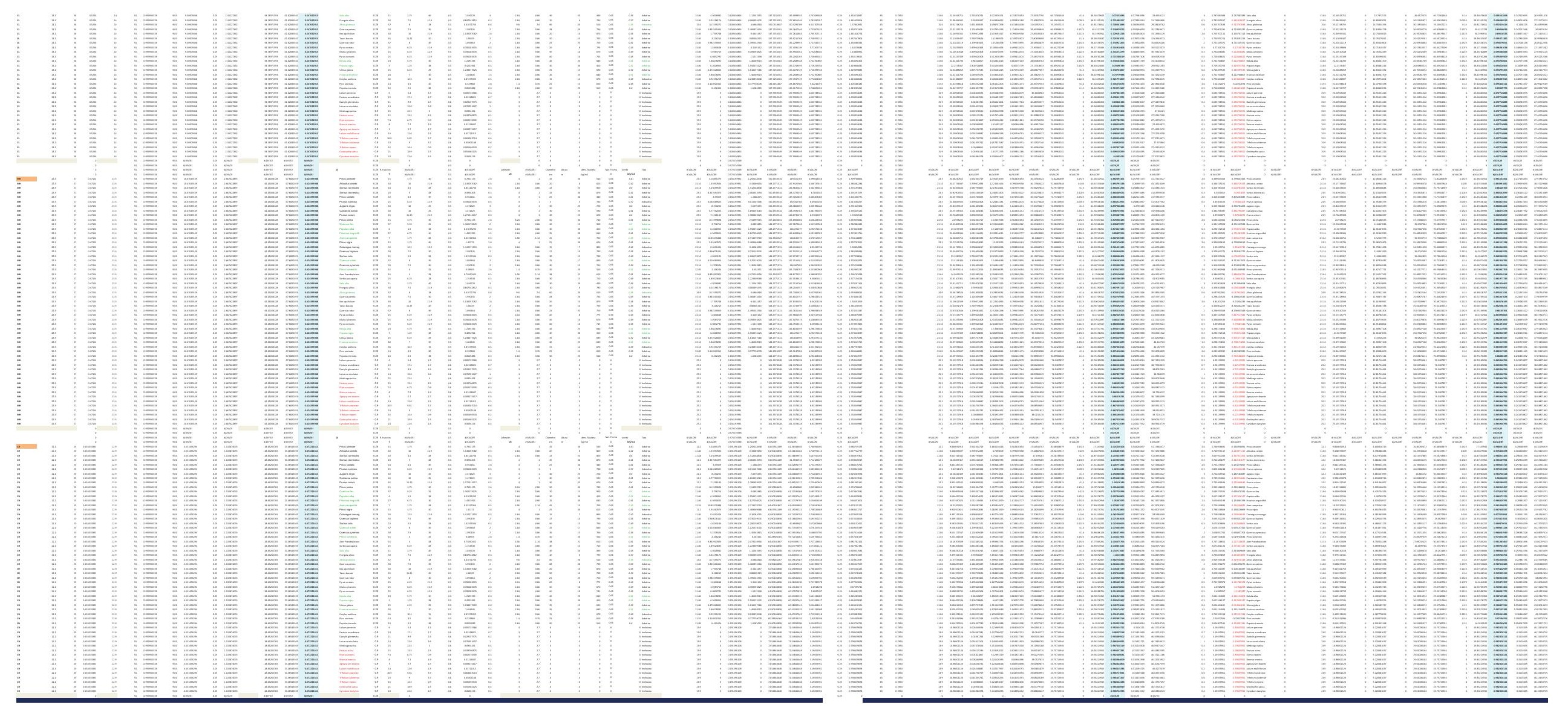



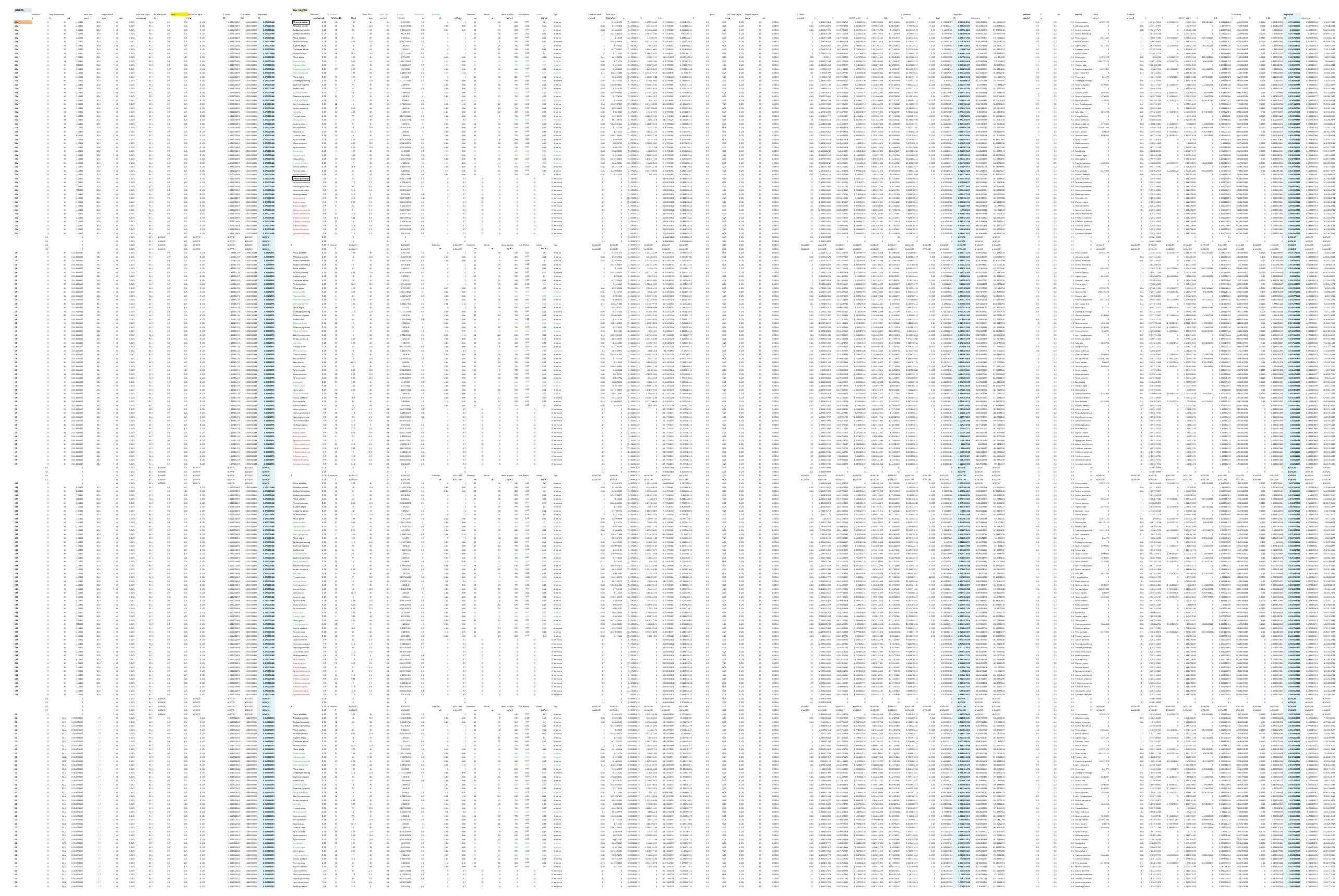

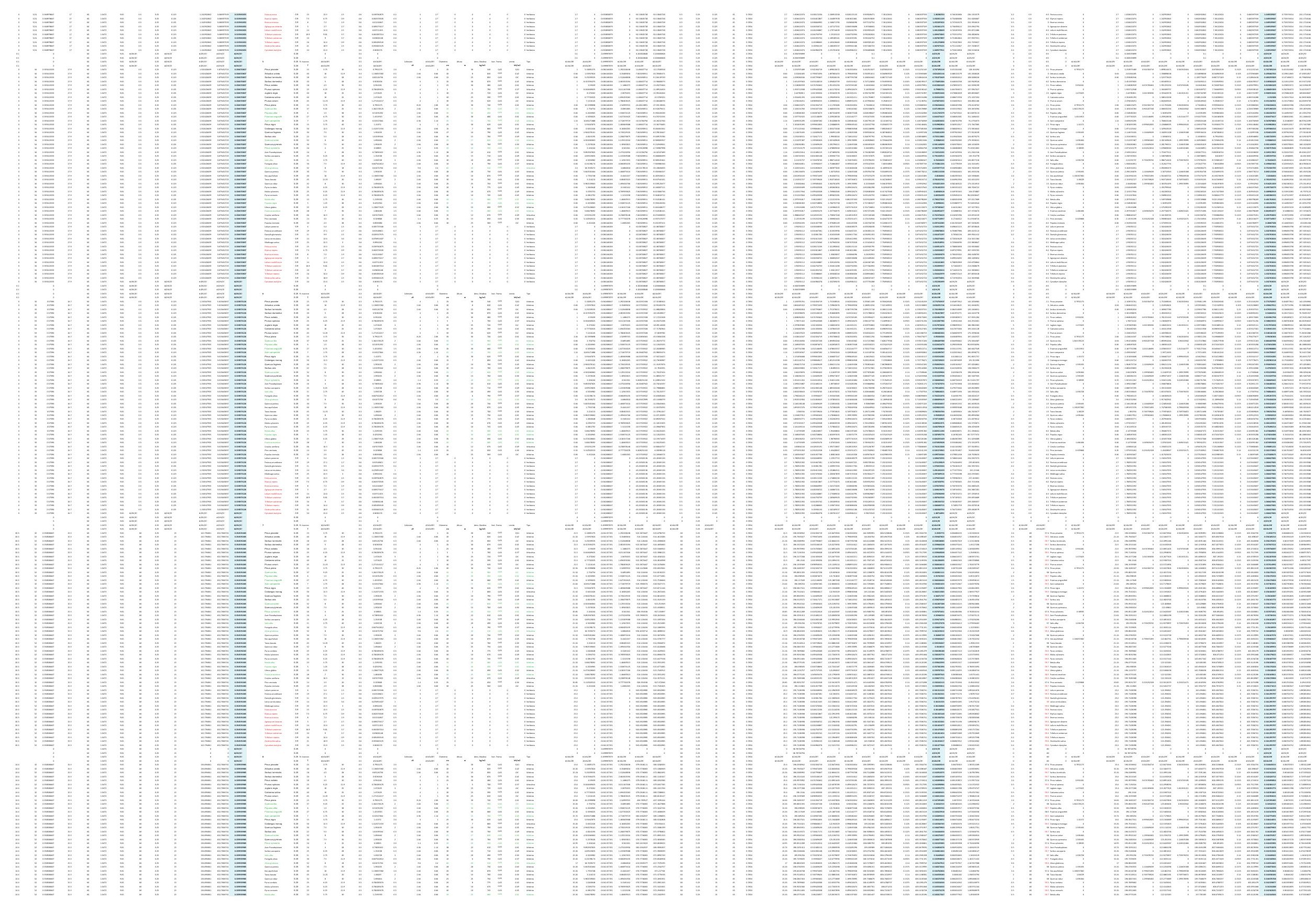

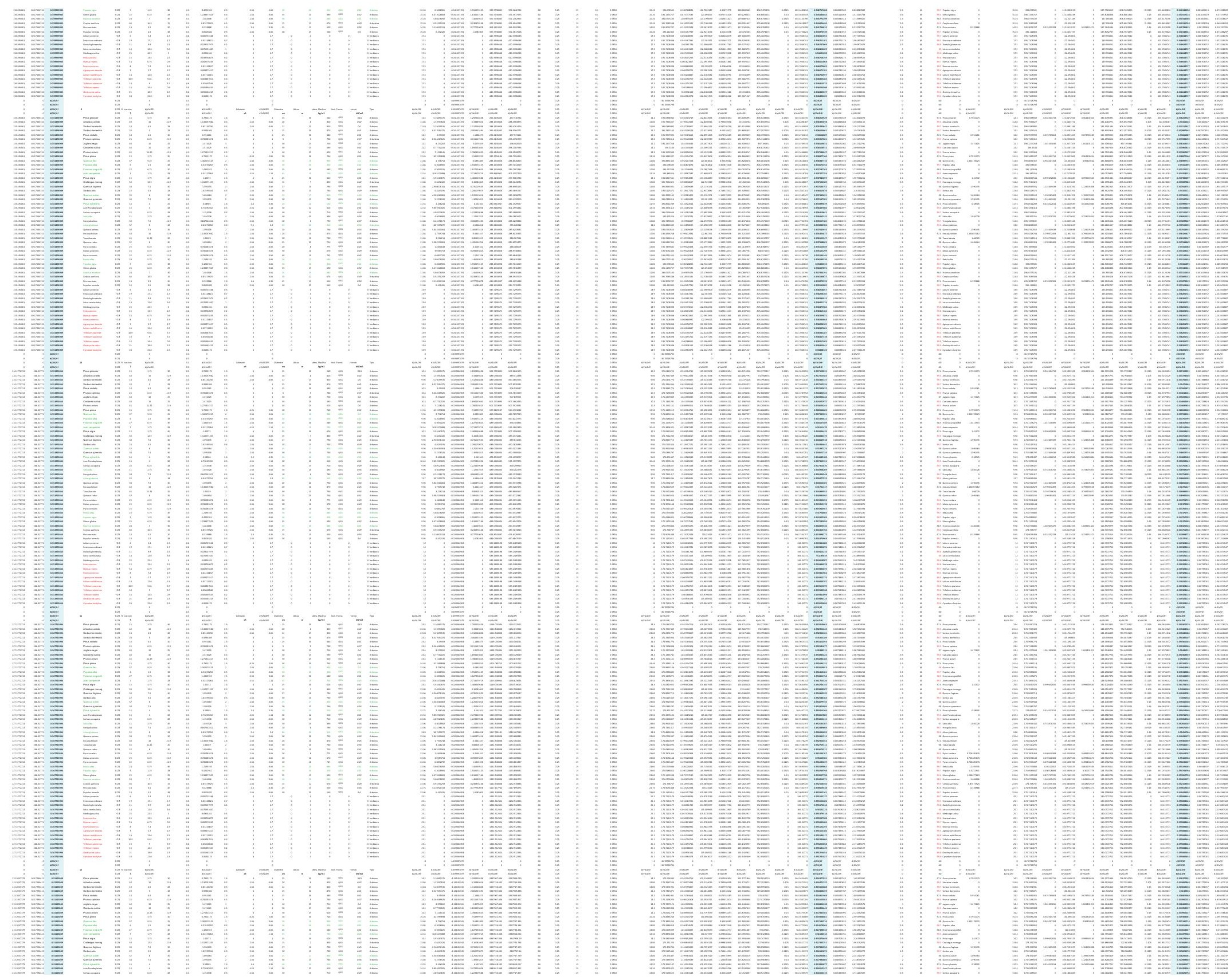


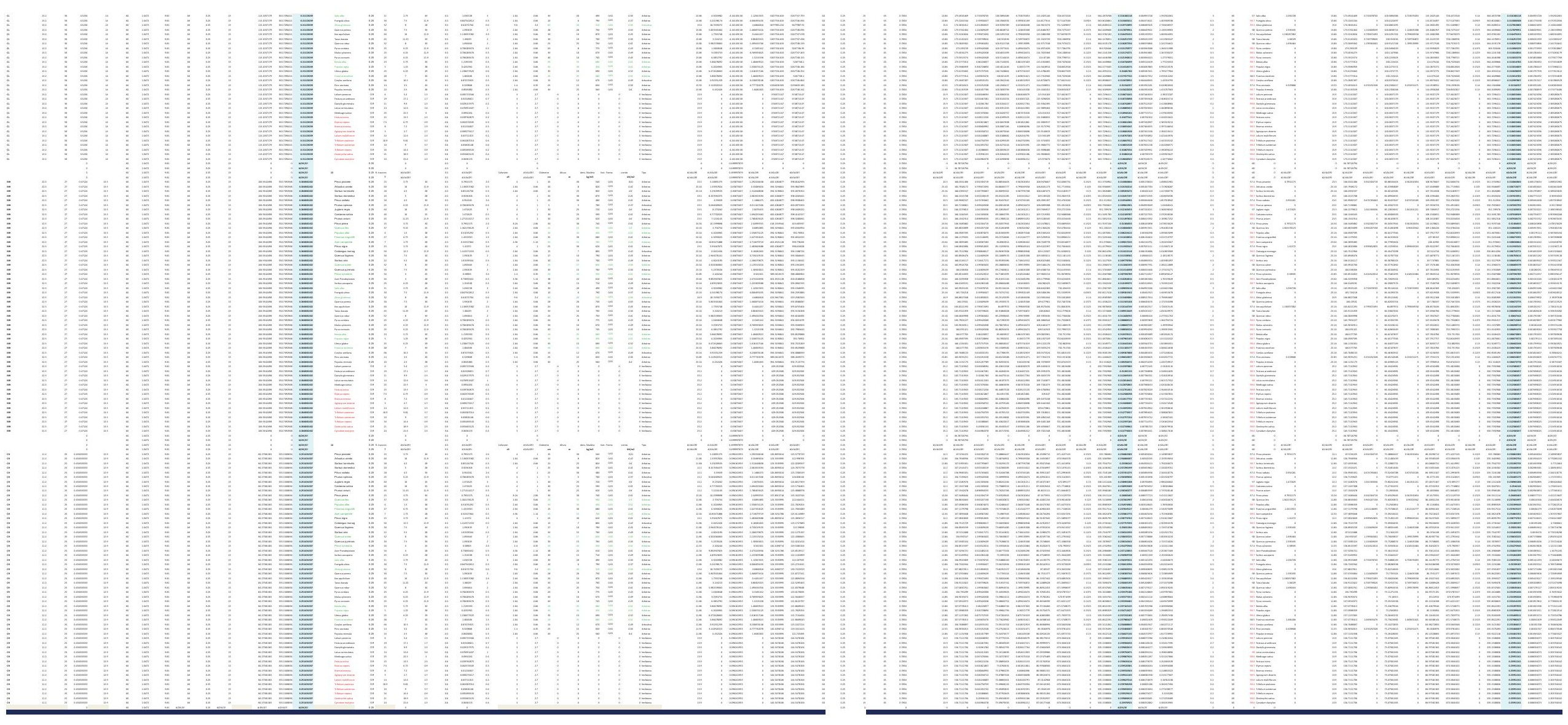



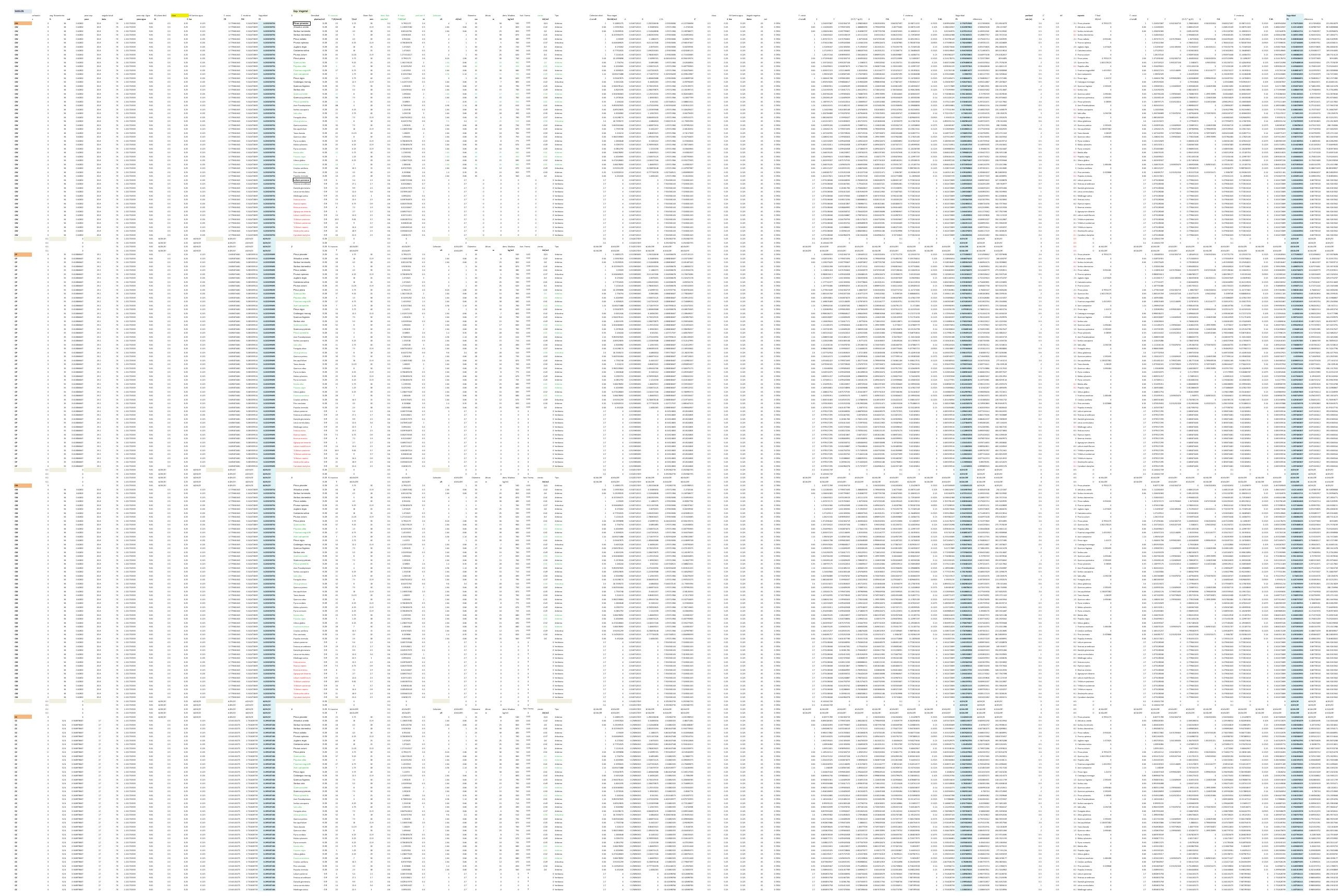


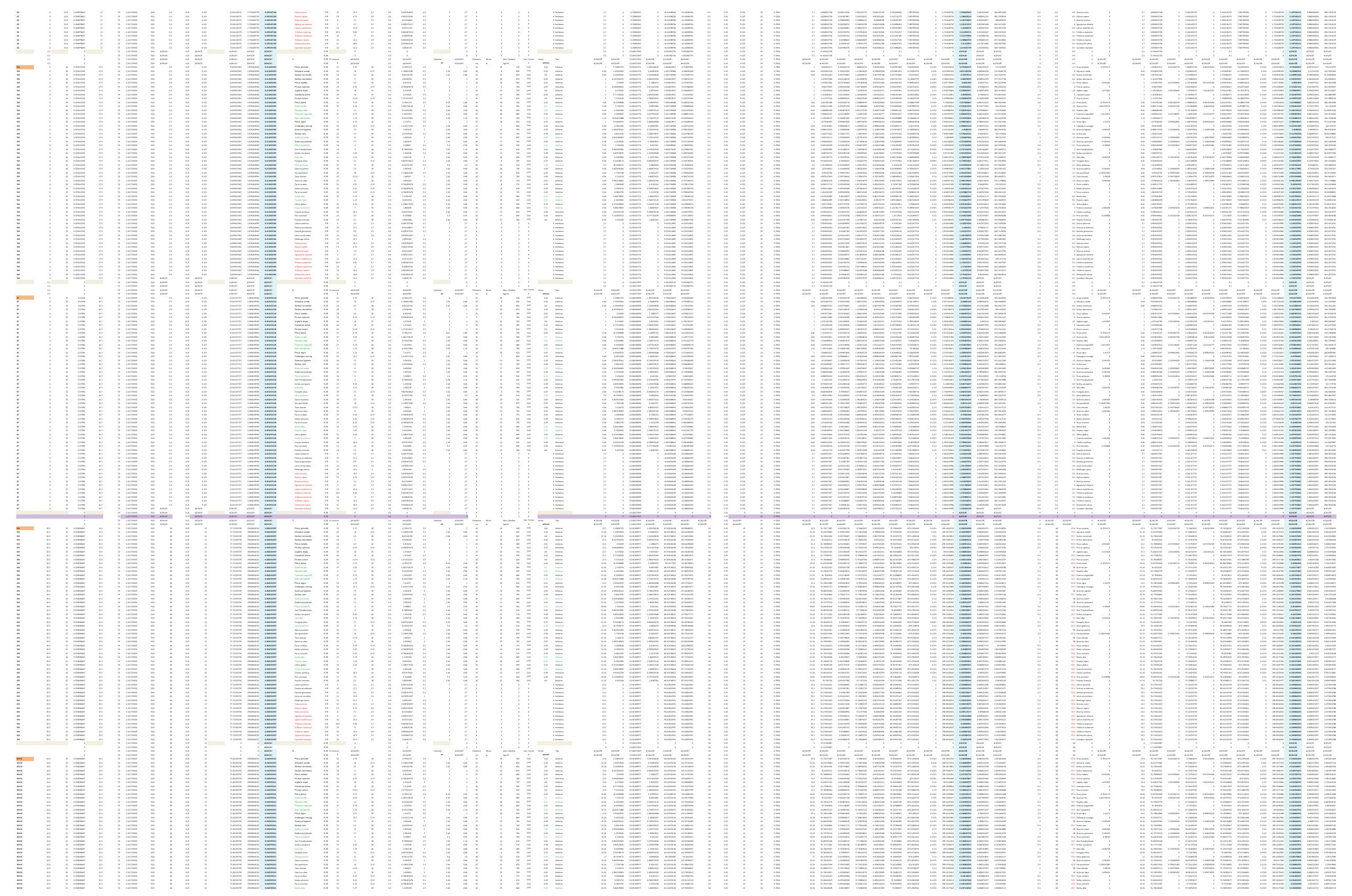



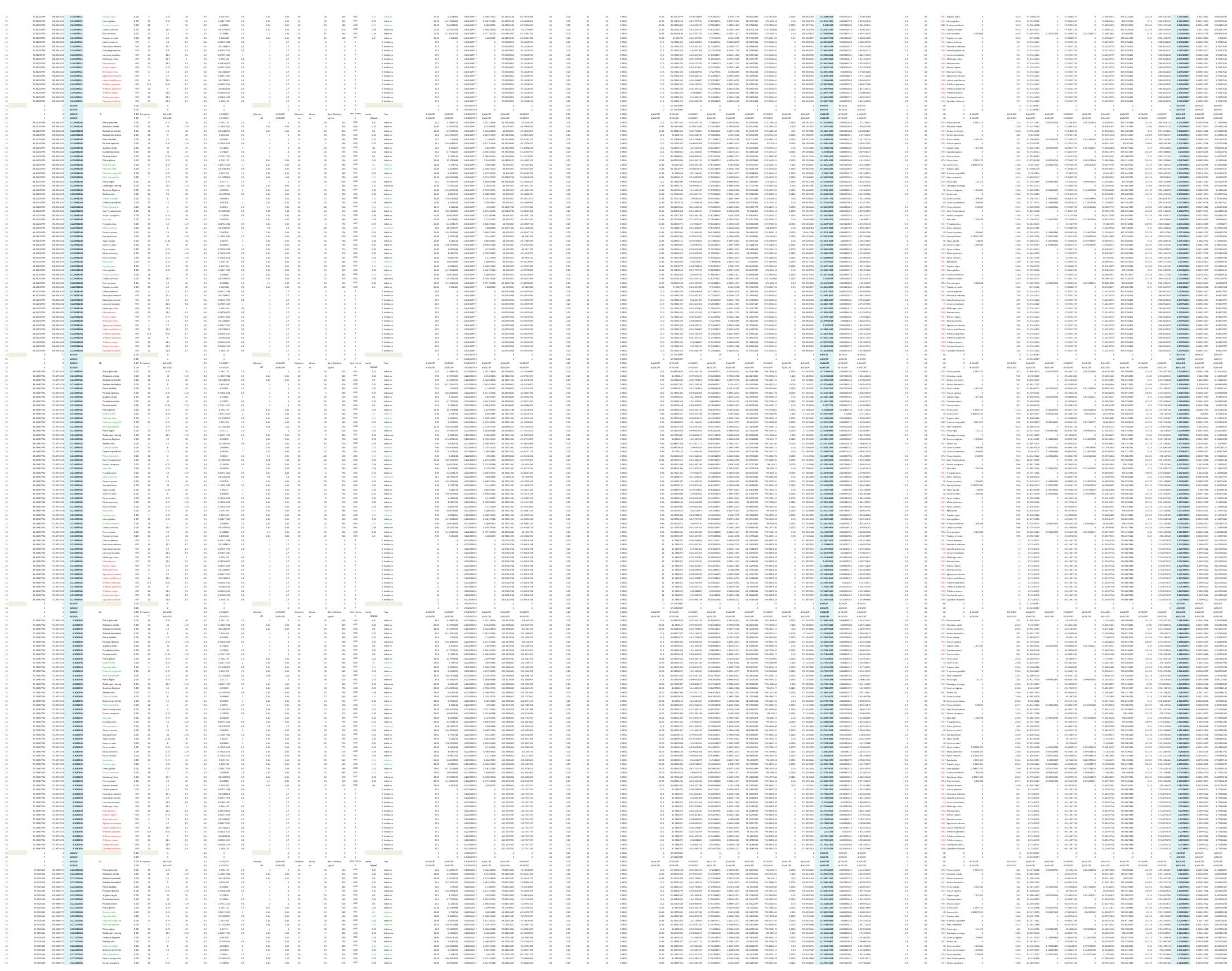


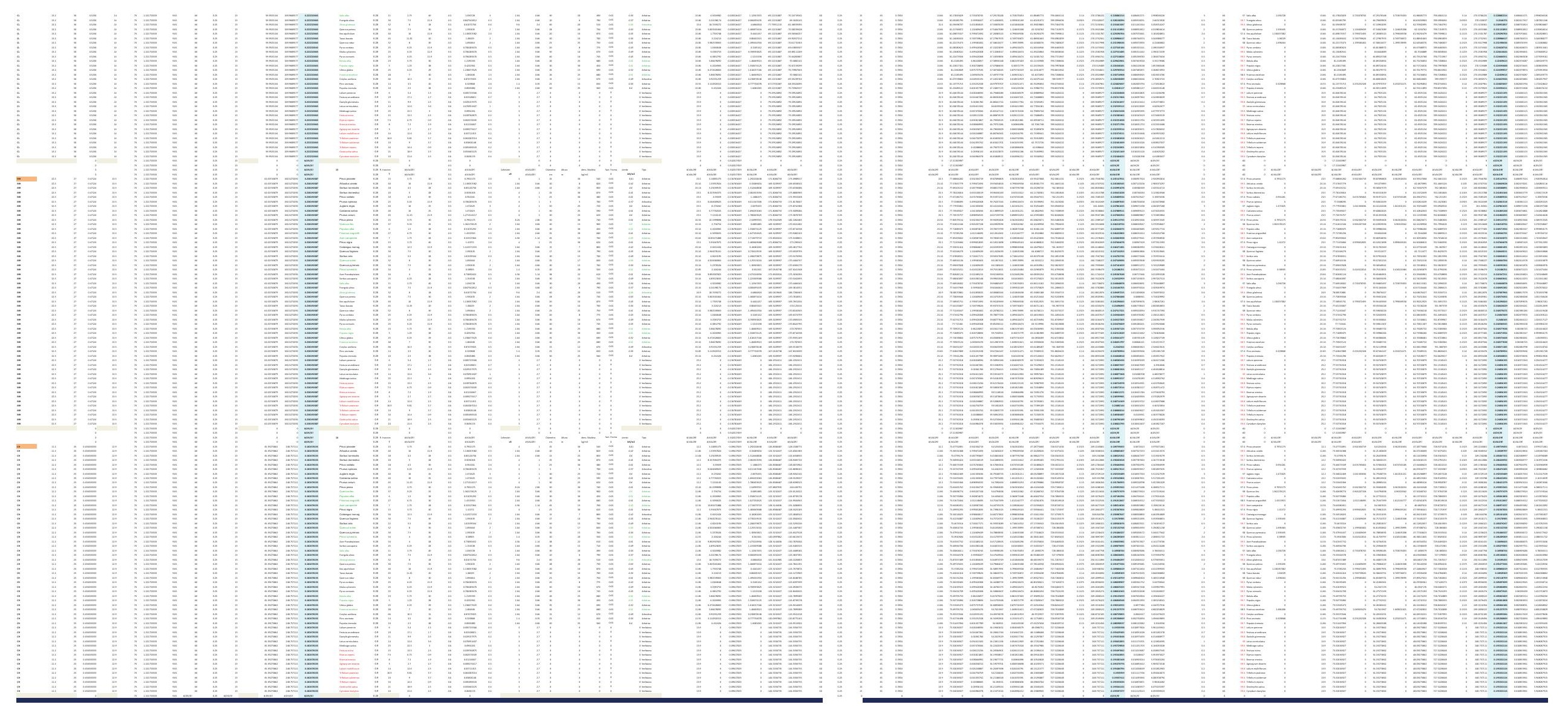



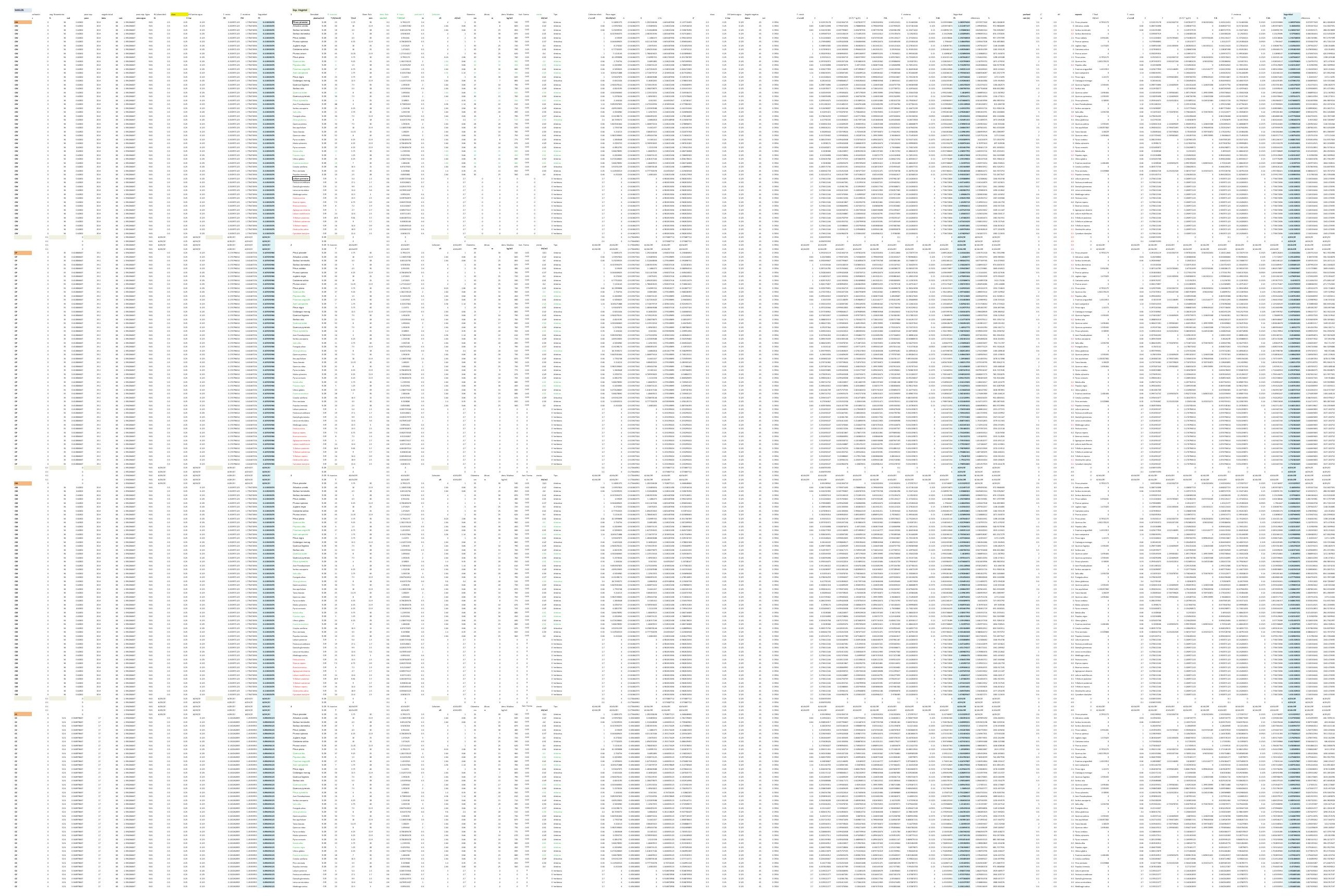


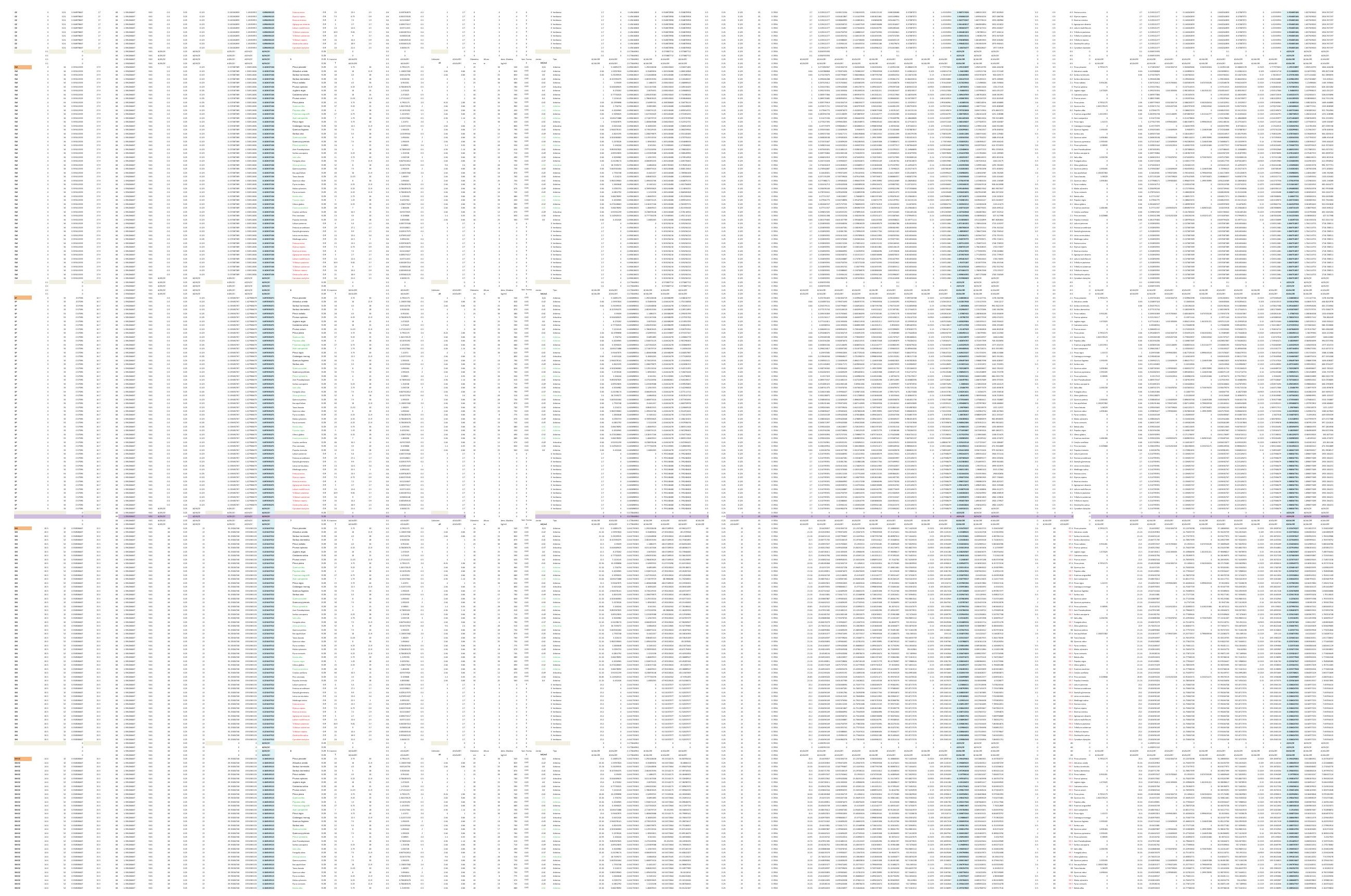



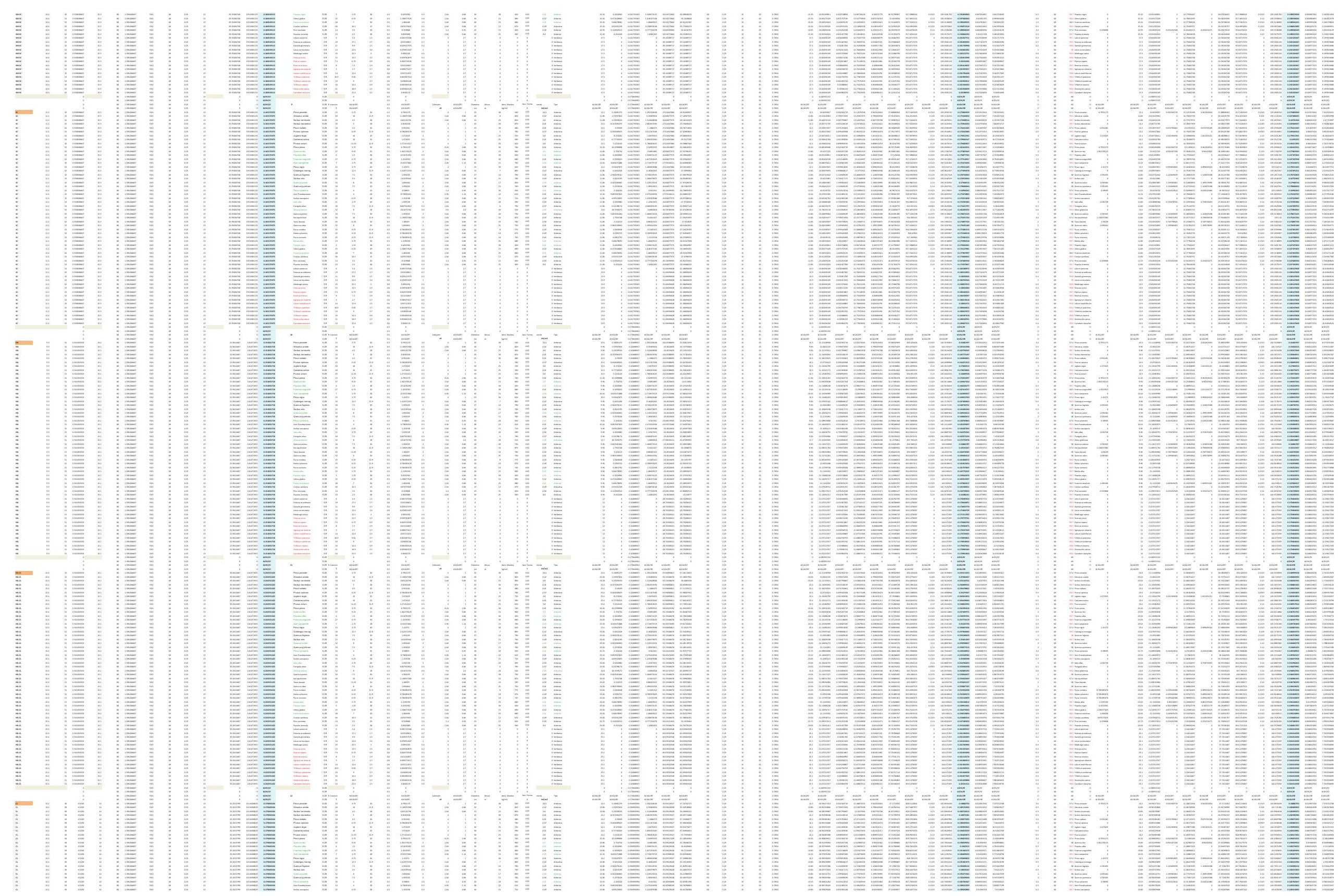


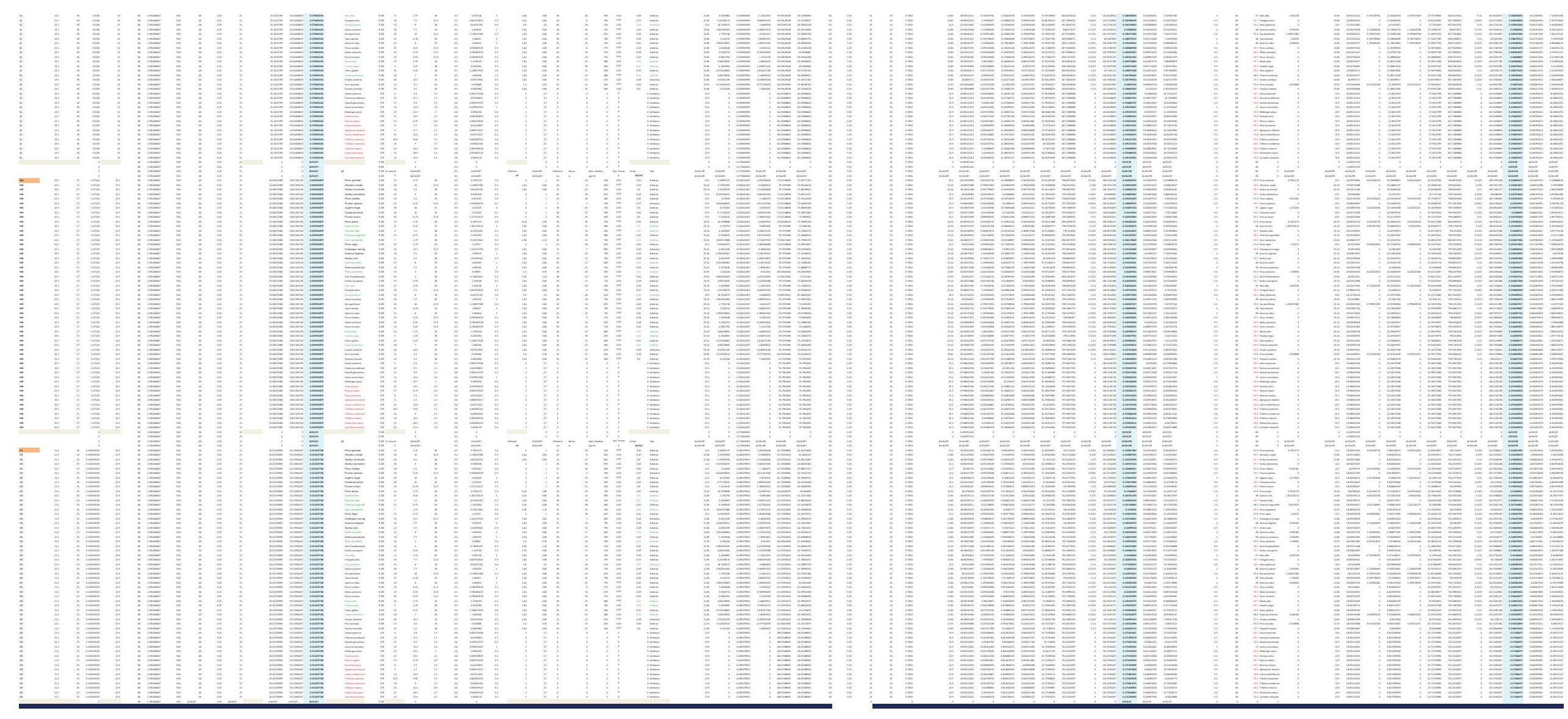


DESARROLLO DE UNA APLICACIÓN IMFORMÁTICA PARA EL CÁLCULO DE SOSTENIMIENTO DE TALUDES MEDIANTE VEGETACIÓN

A03. DENSIDAD DE PLANTACIÓN: 2.500 plantas/ha.

\section{A03-4.POSICIÓN N.F. 4}

INCLINACIÓN DE TALUD 6-100

INCLINACIÓN DE TALUD 10-200

INCLINACIÓN DE TALUD 20-30

INCLINACIÓN DE TALUD 30-40

INCLINACIÓN DE TALUD $35^{\circ}$

INCLINACIÓN DE TALUD 40-50

INCLINACIÓN DE TALUD 50-550

INCLINACIÓN DE TALUD 55-60

INCLINACIÓN DE TALUD 60-700

INCLINACIÓN DE TALUD 70-80 

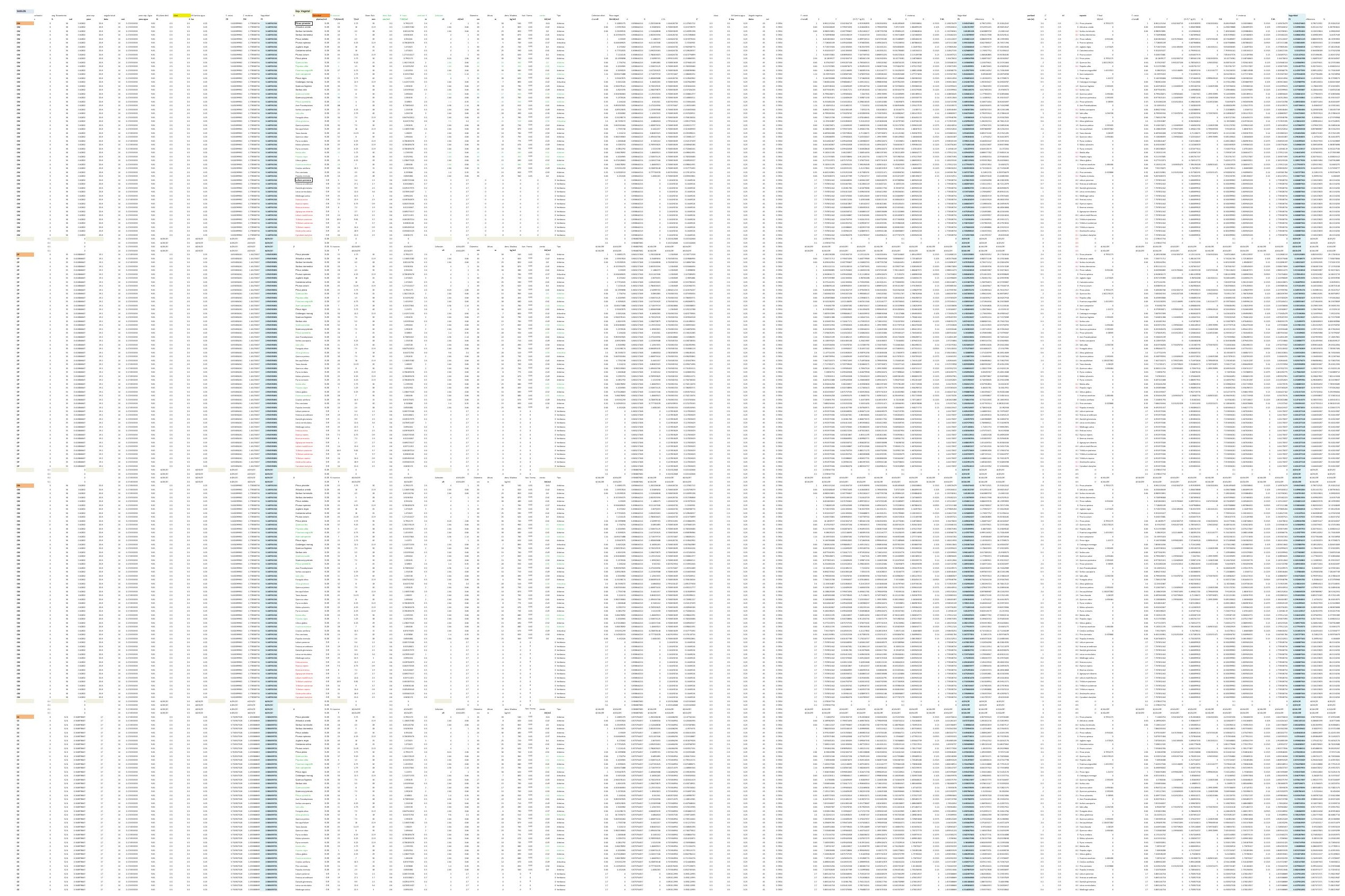


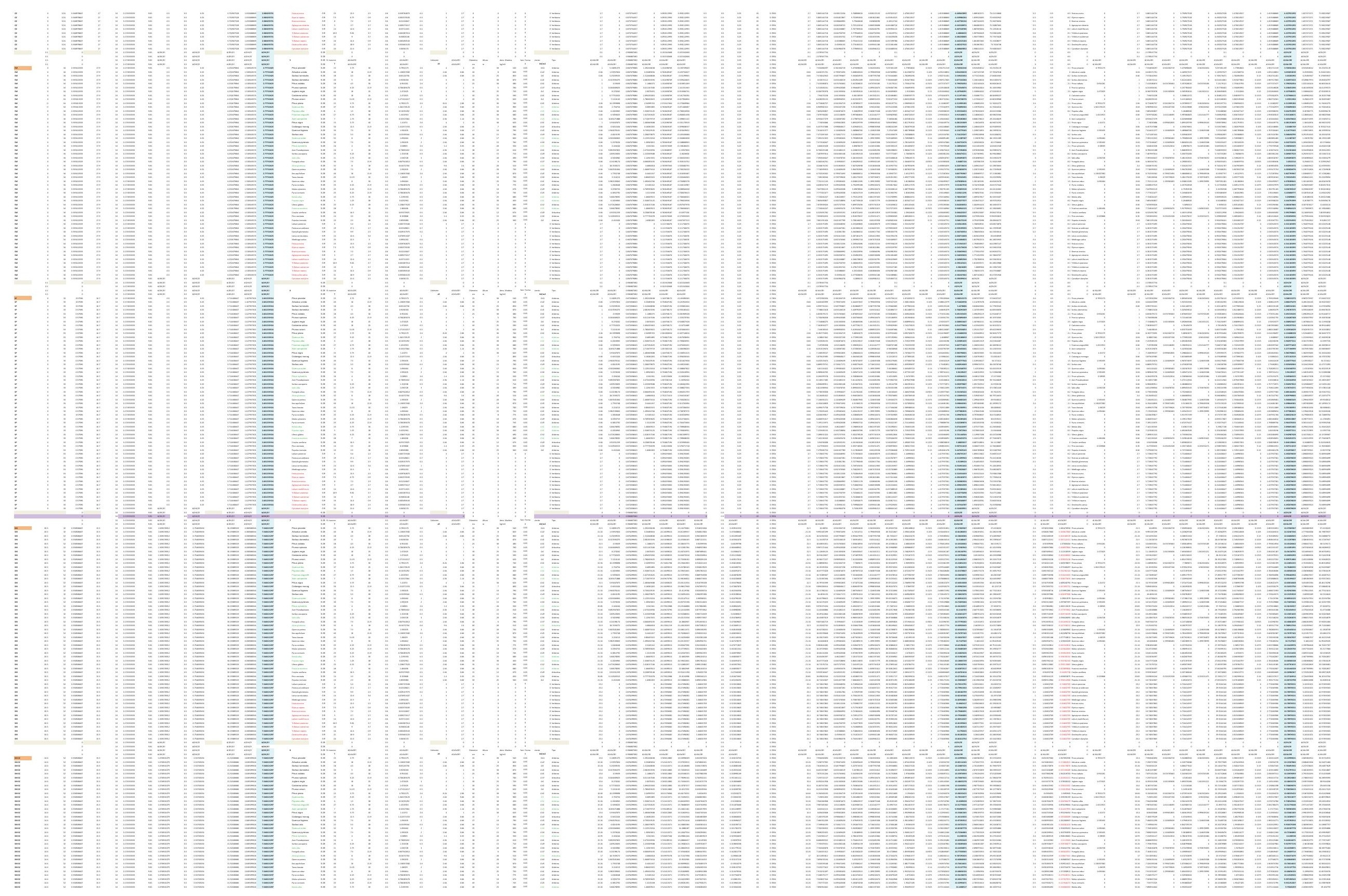



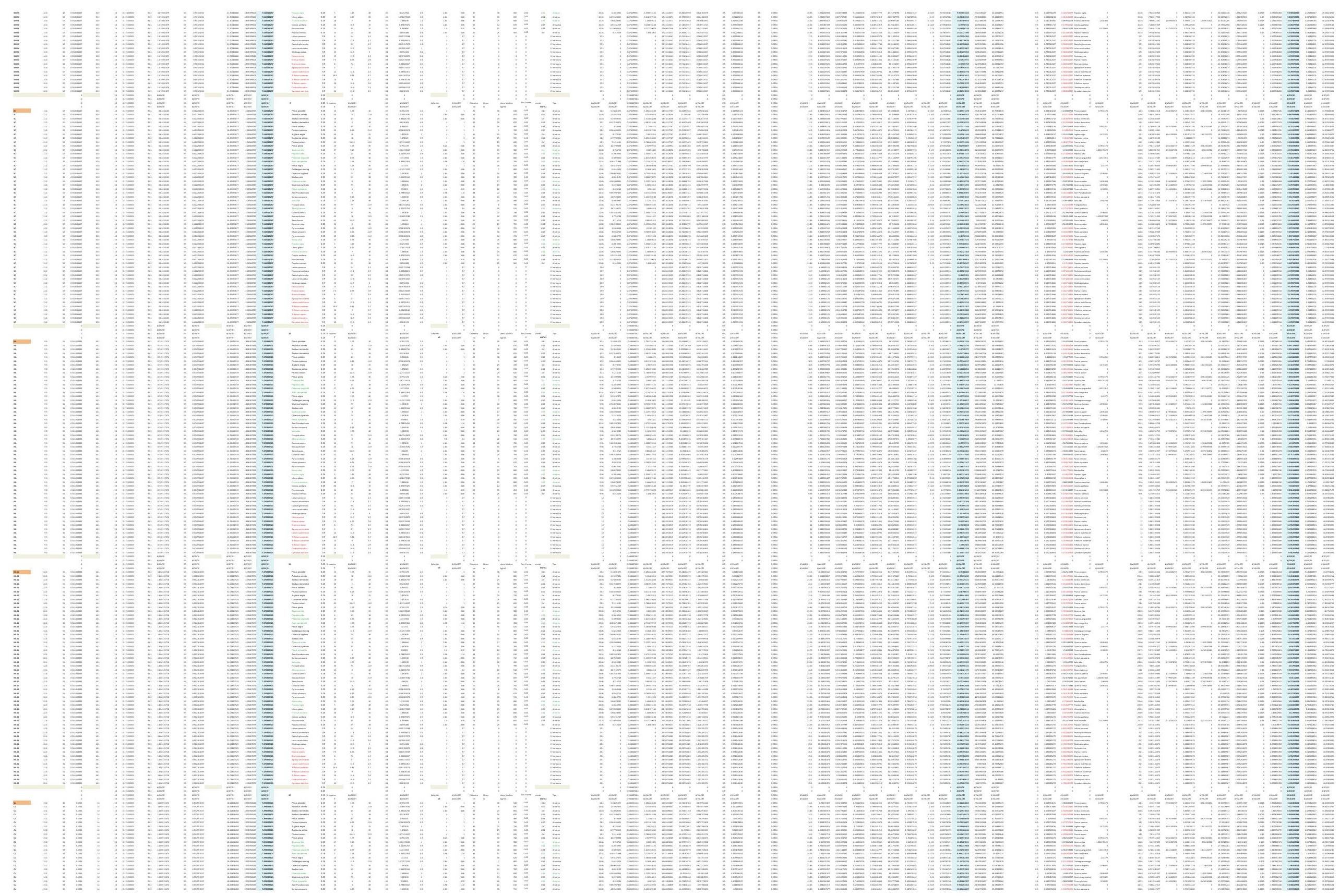


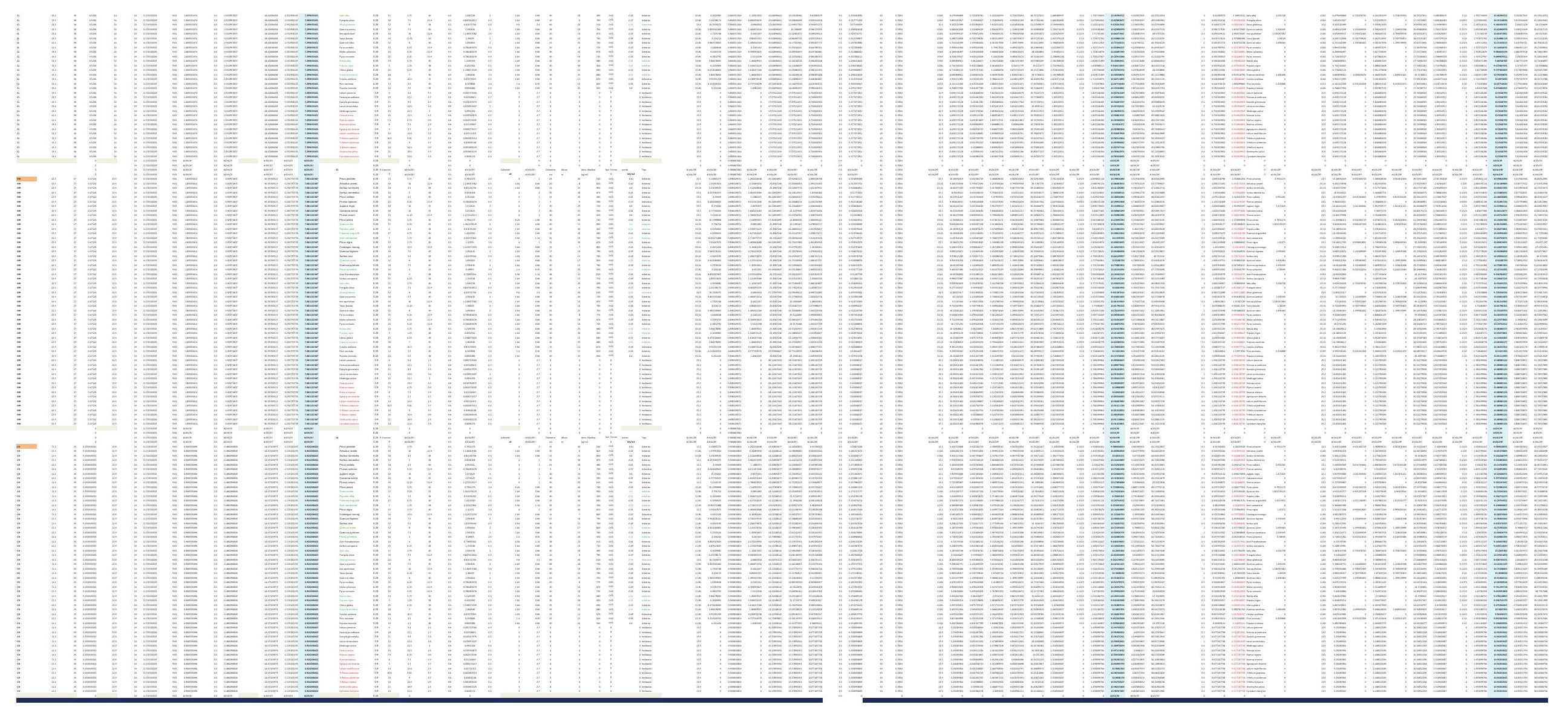



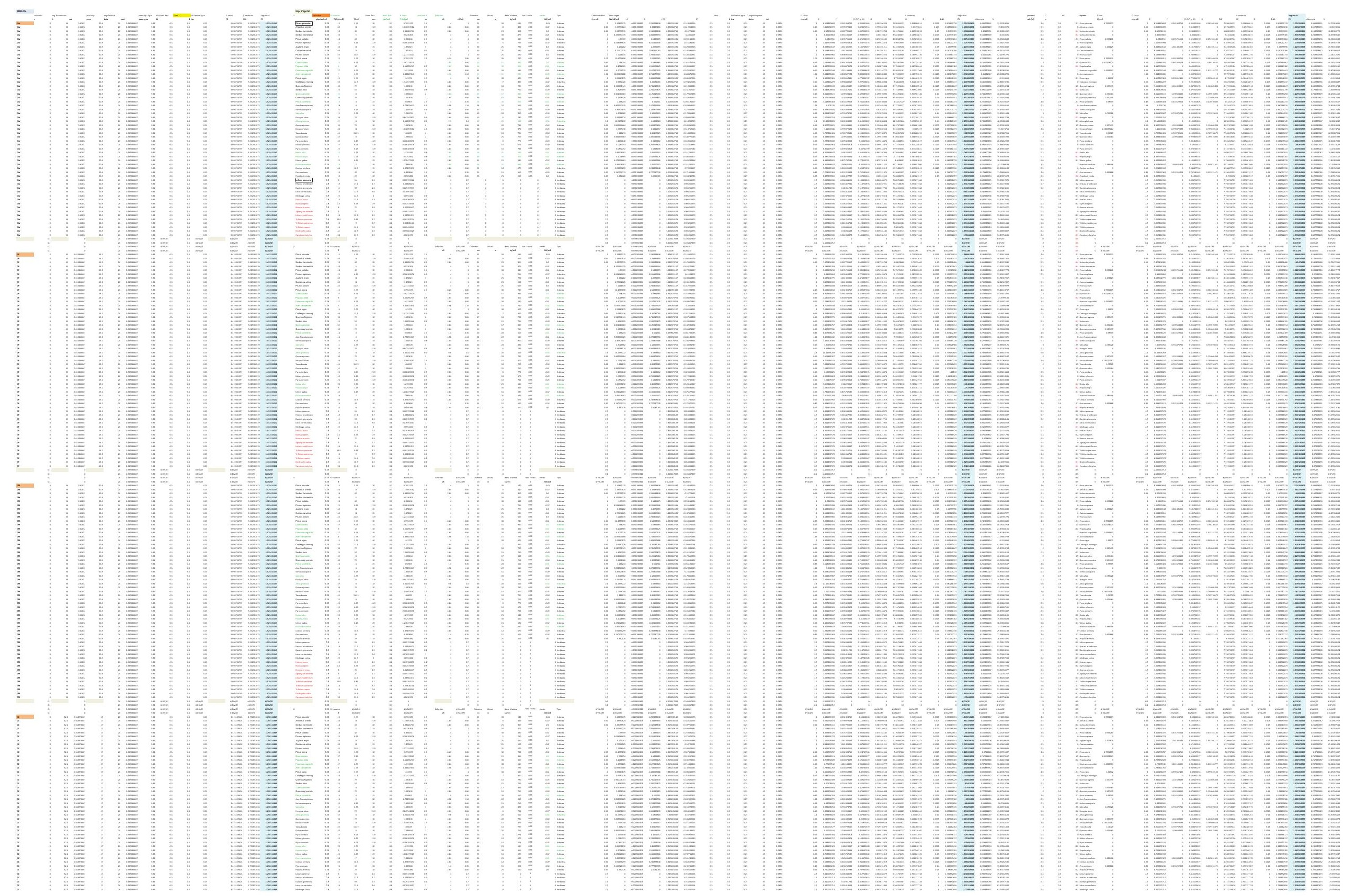


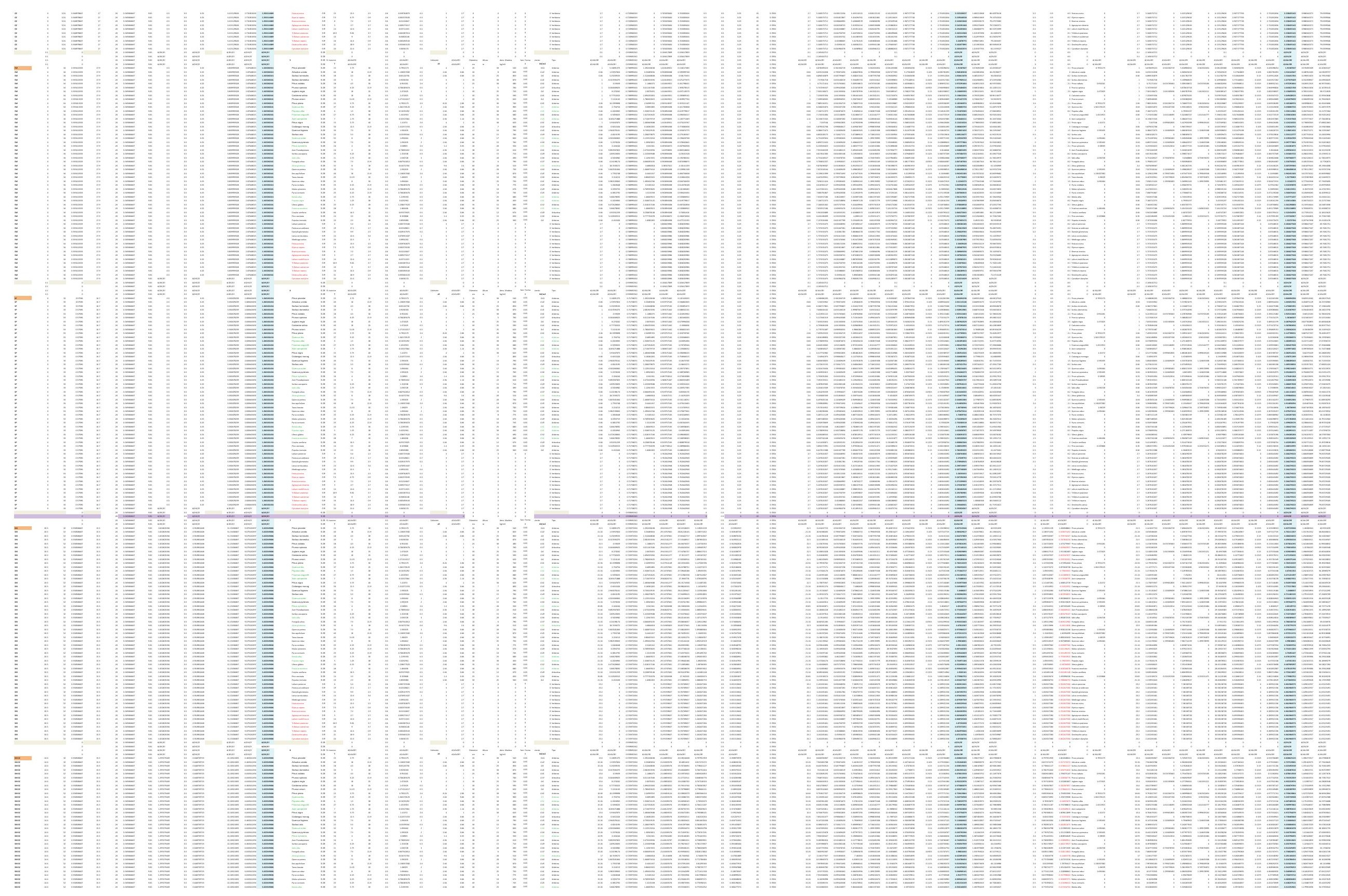



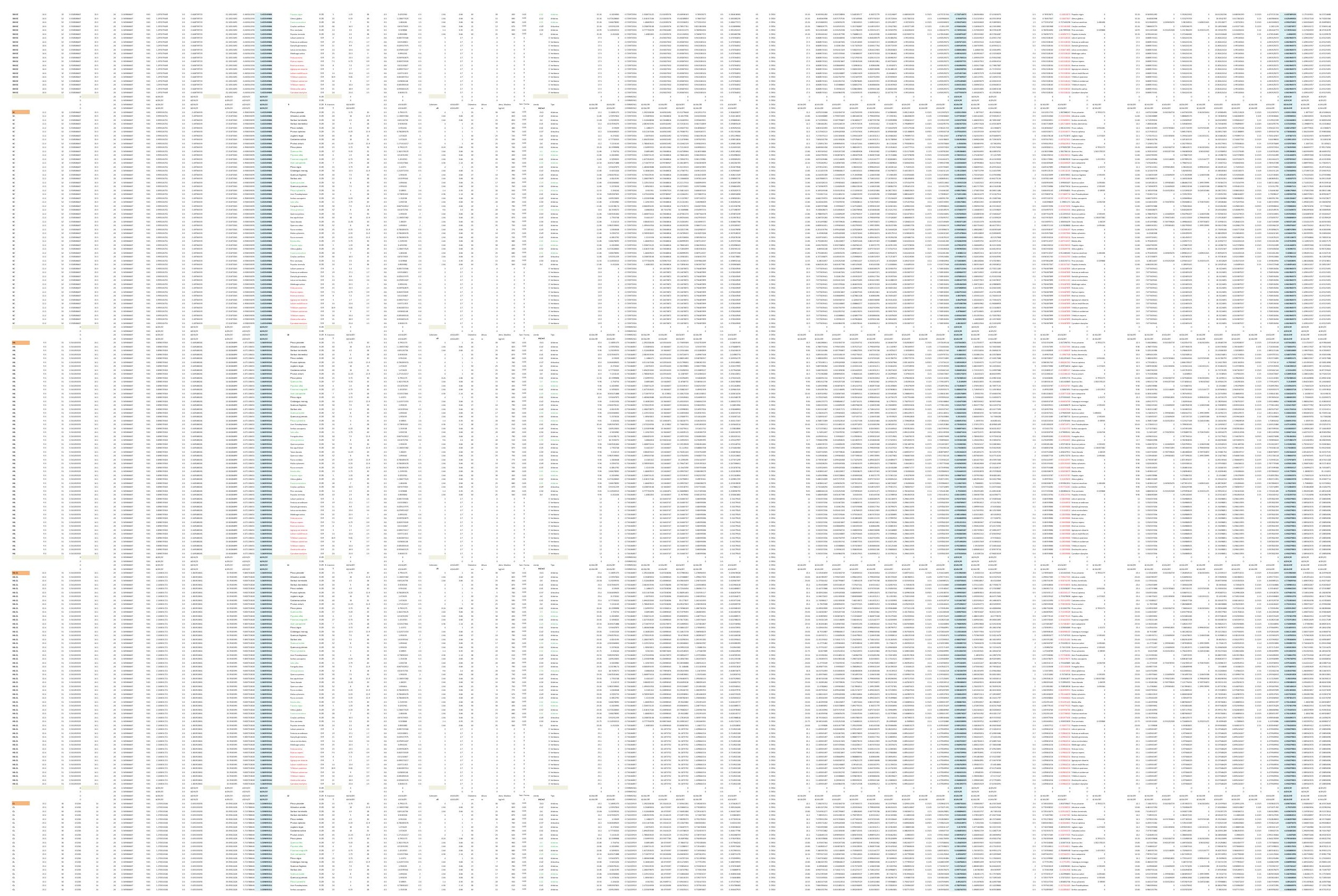


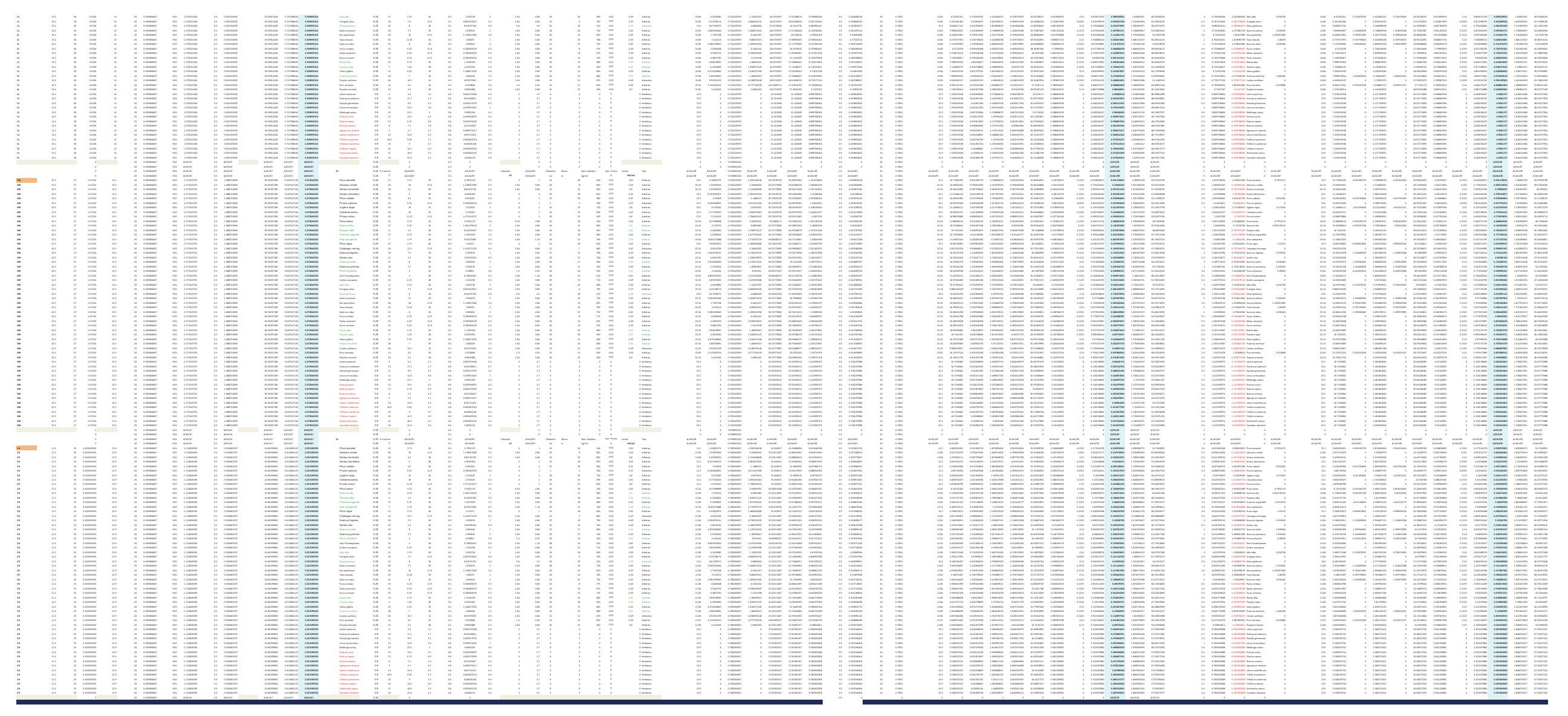



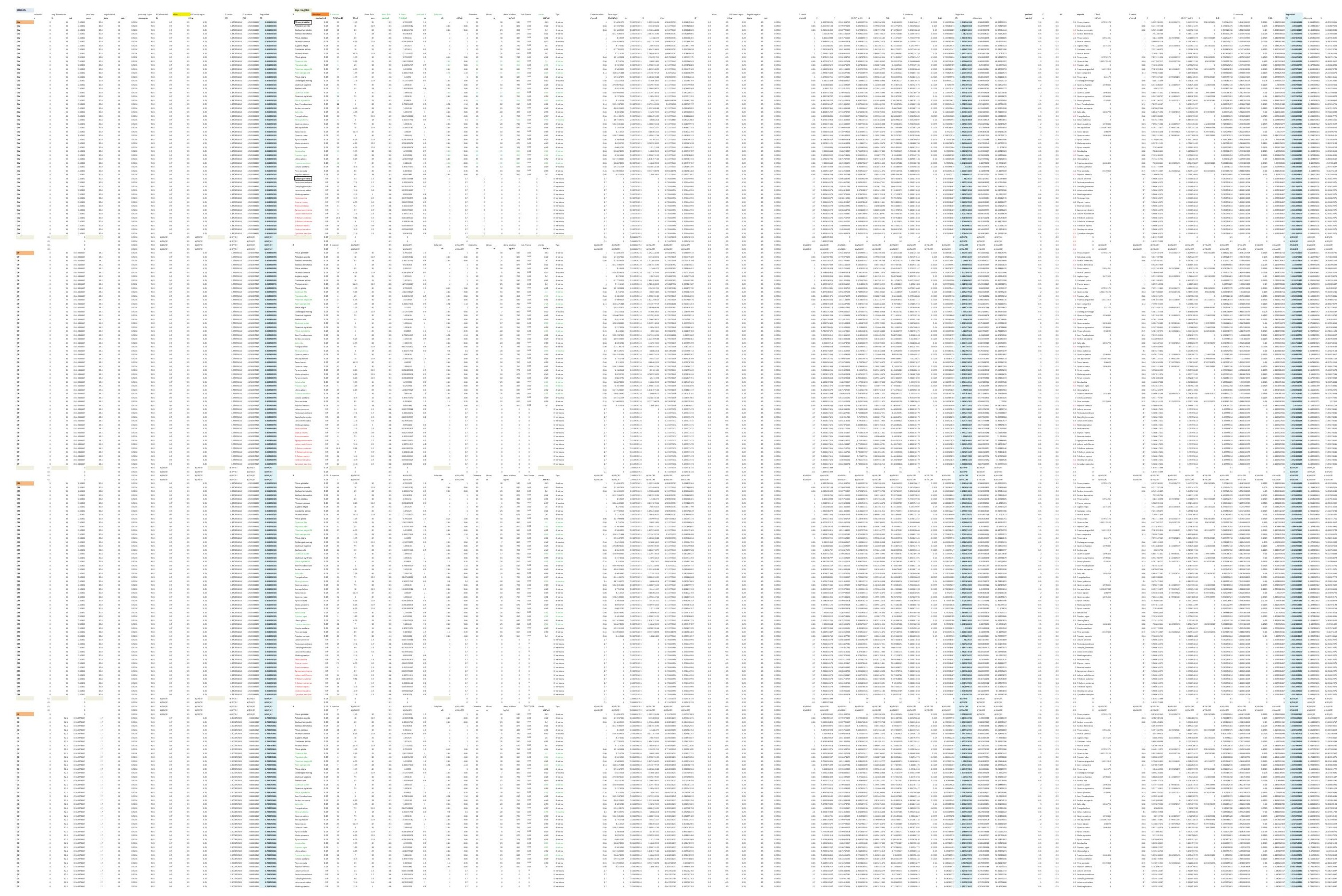


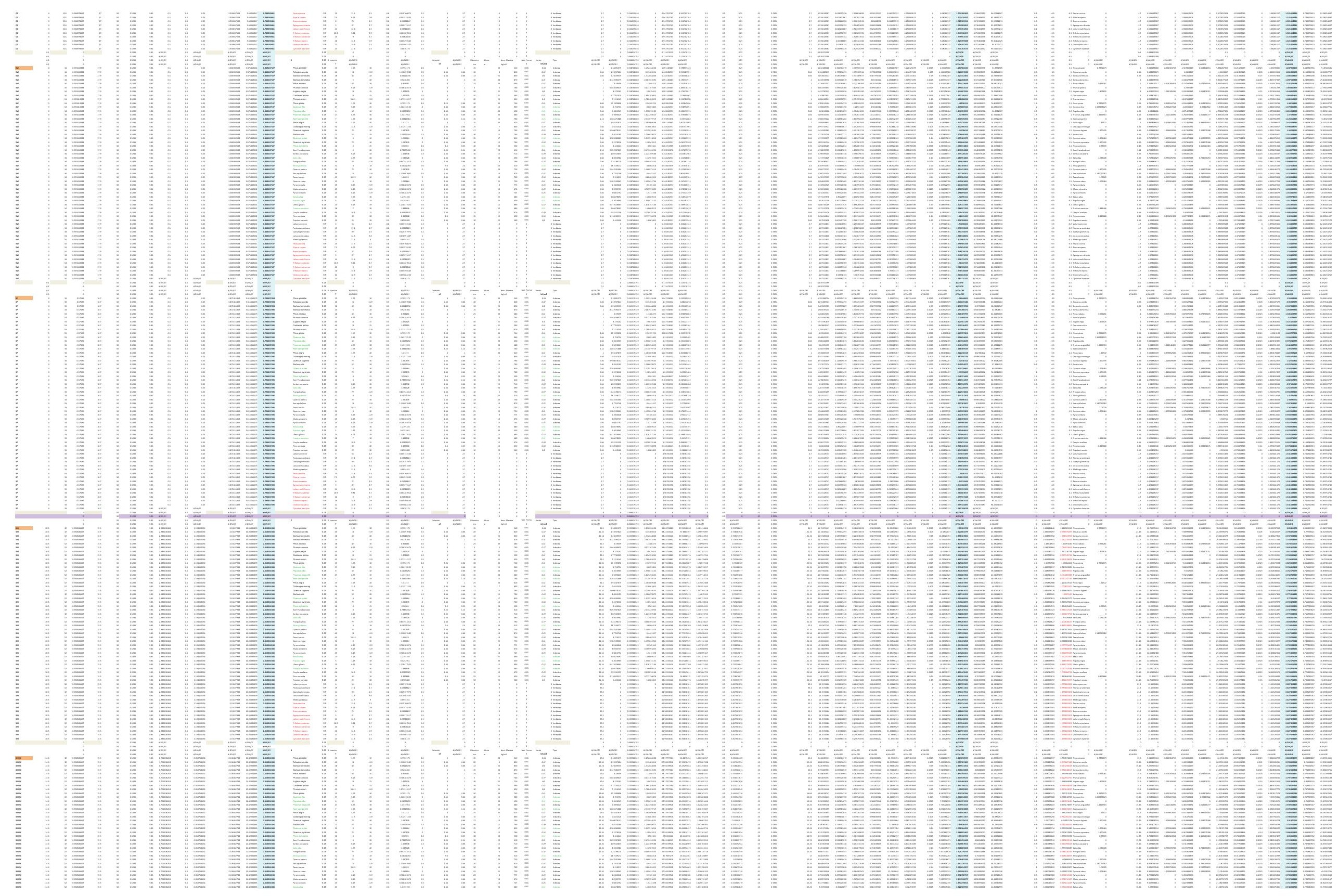



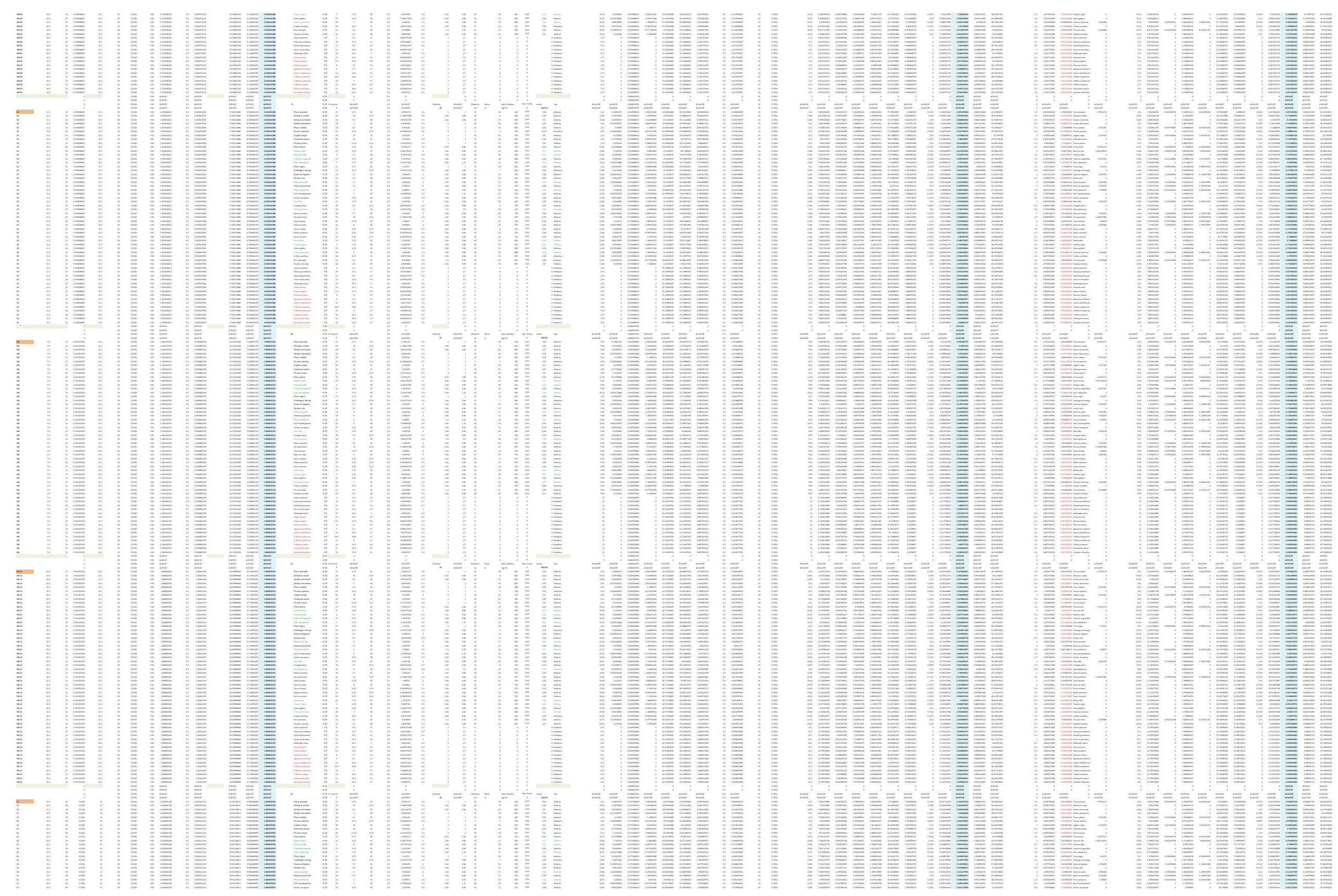


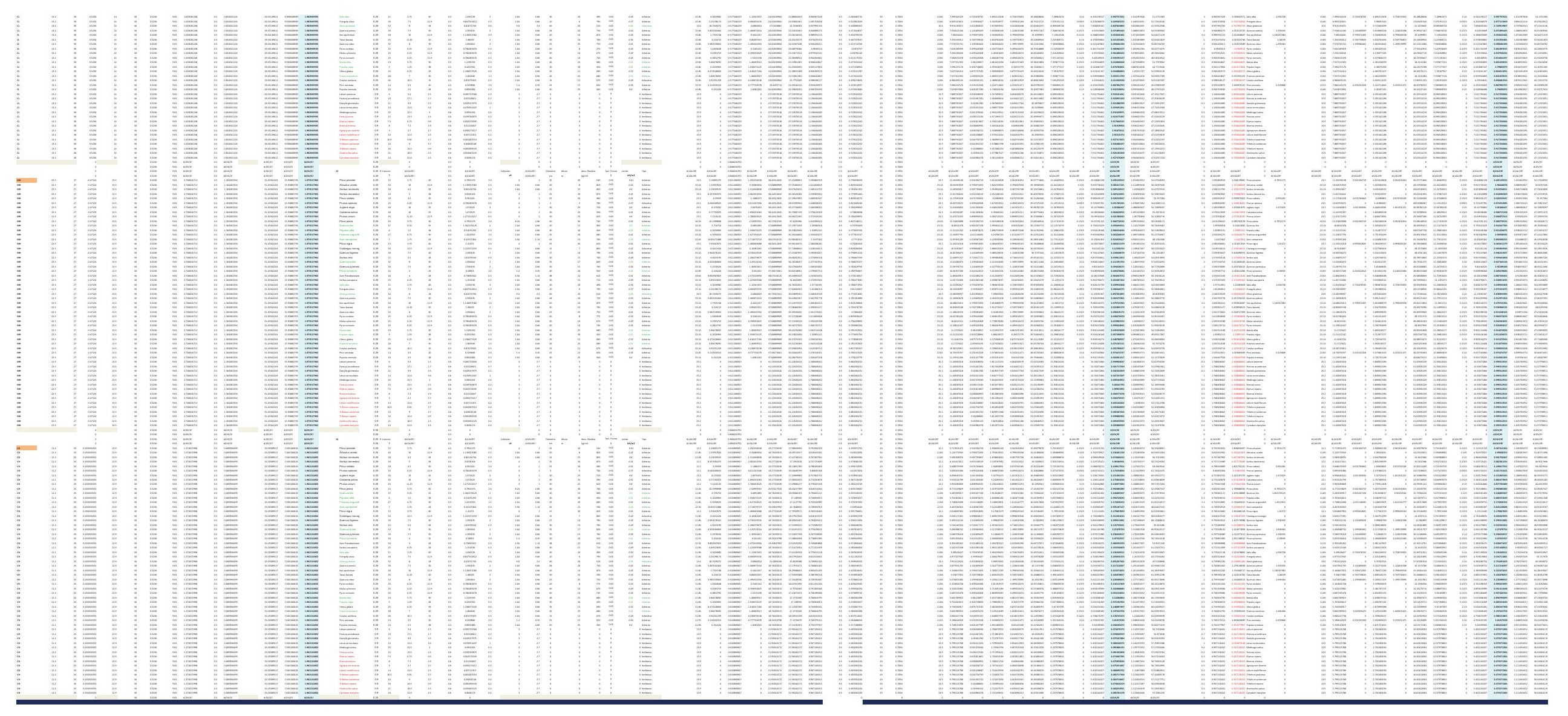



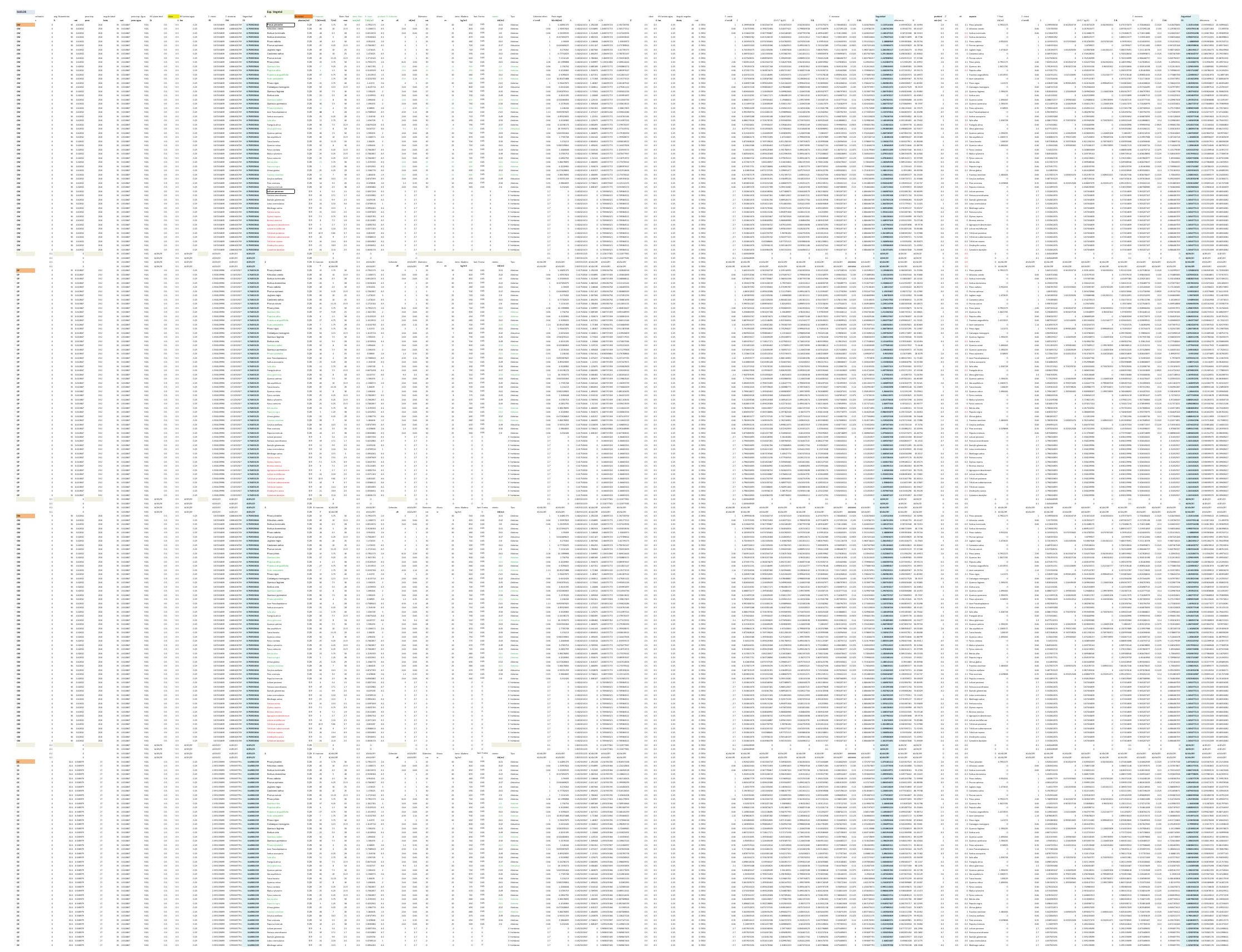


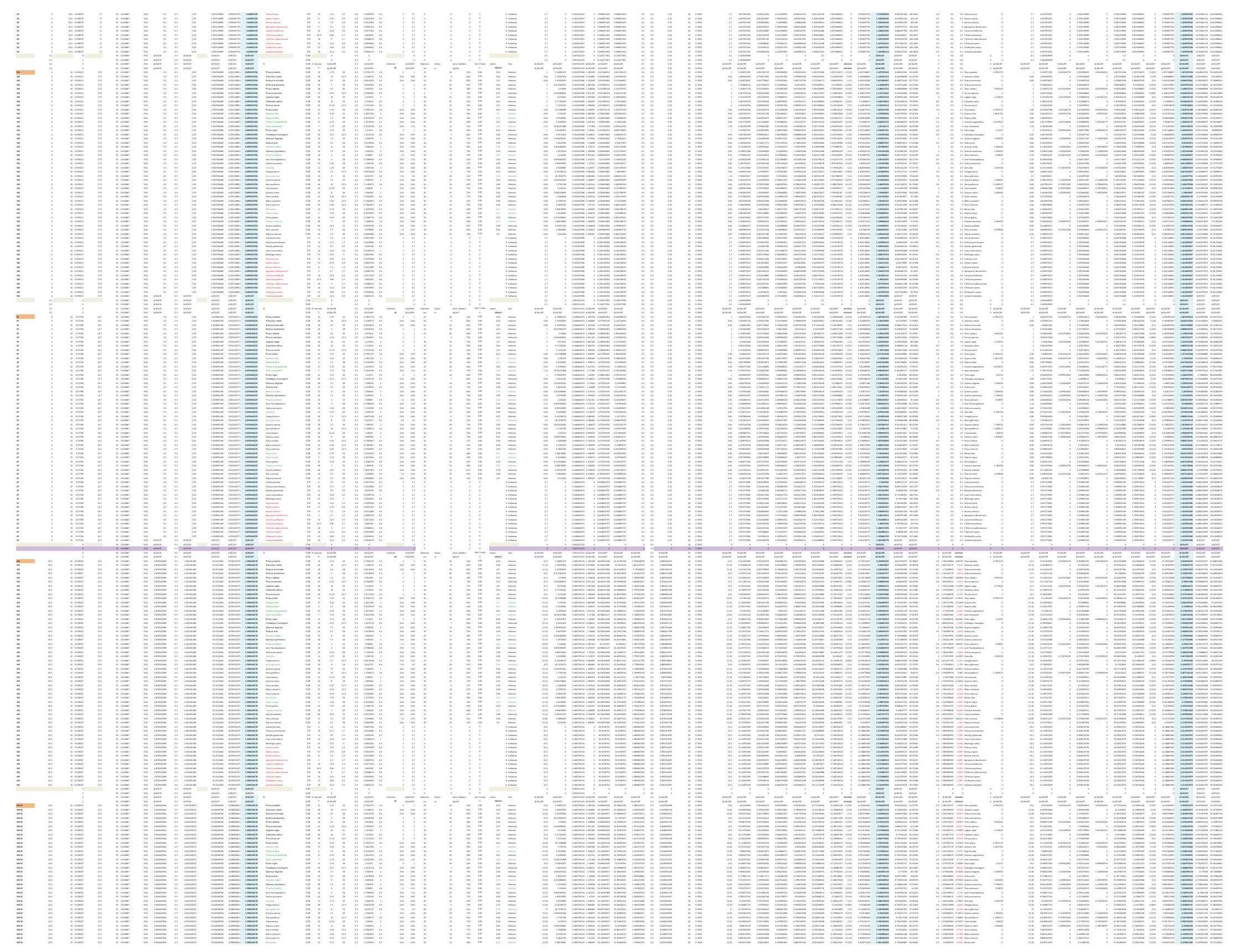



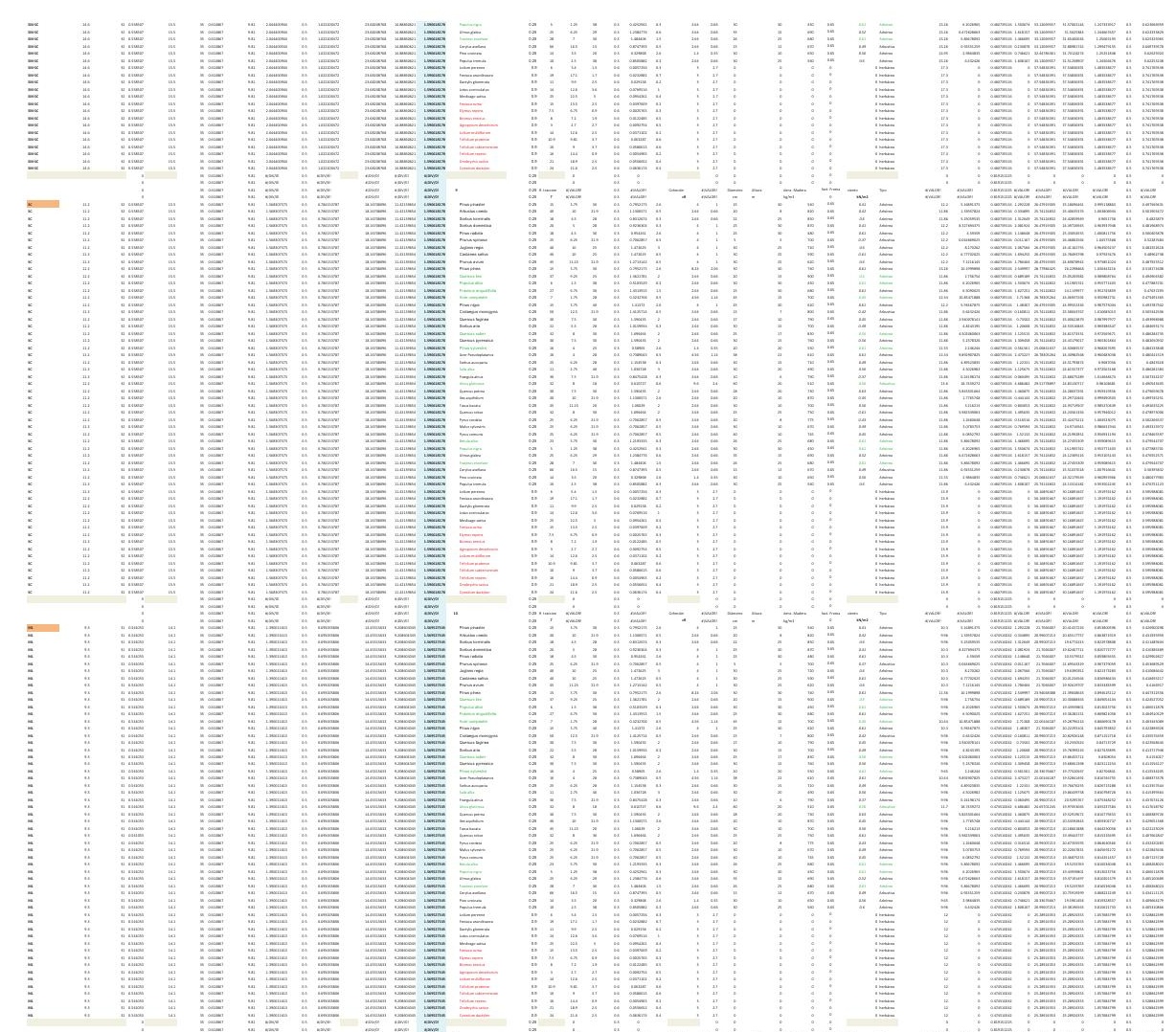

mIIIII
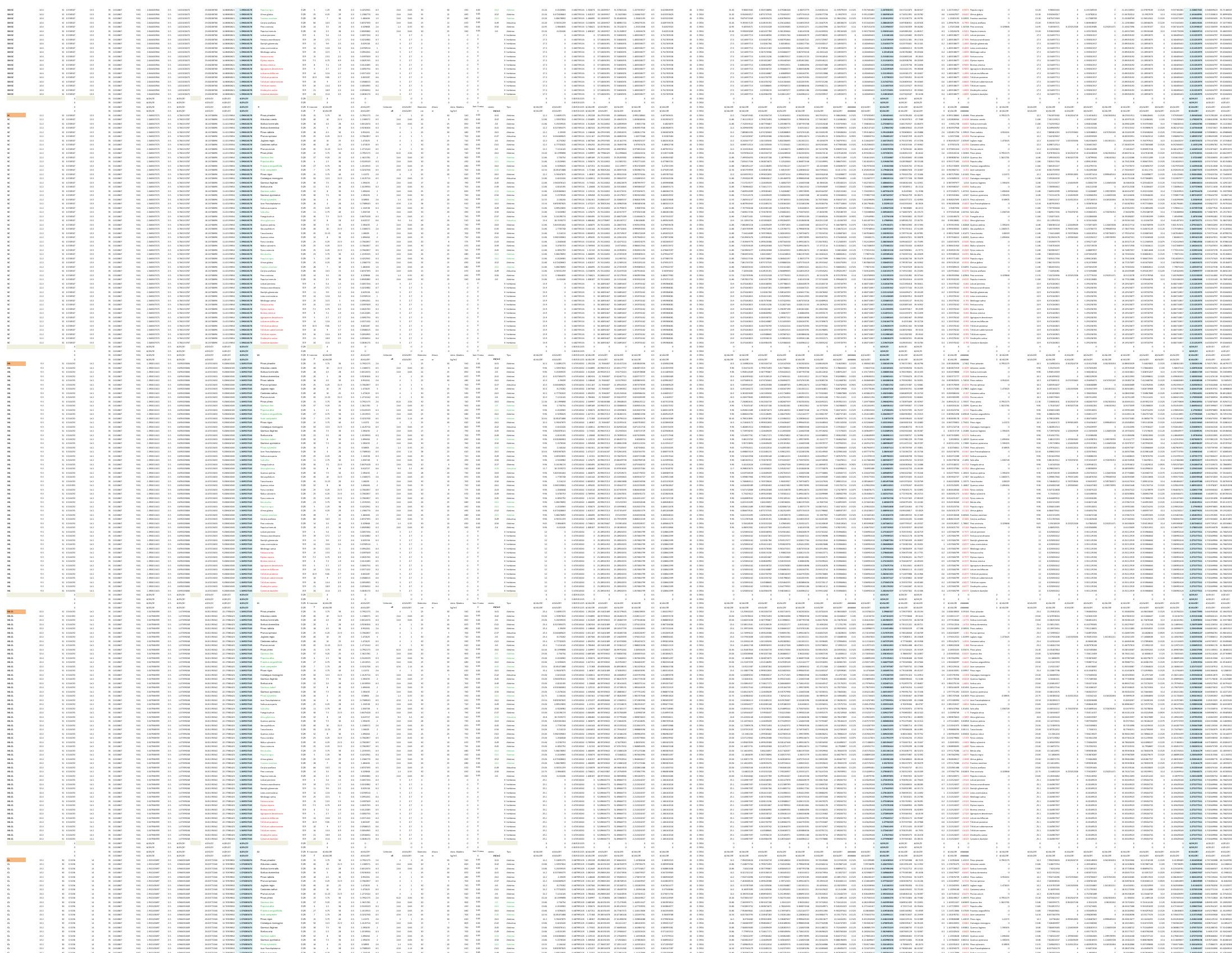


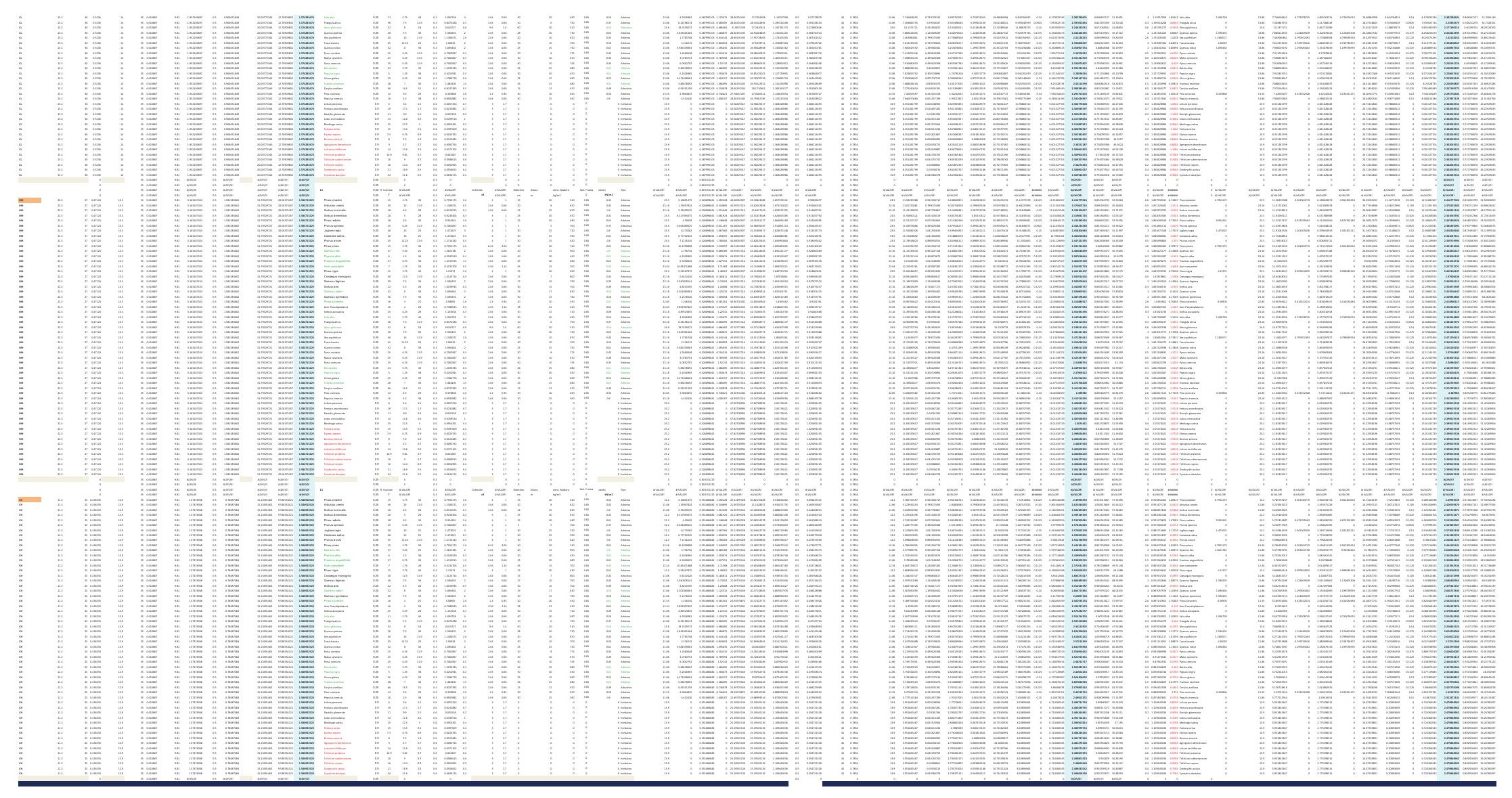



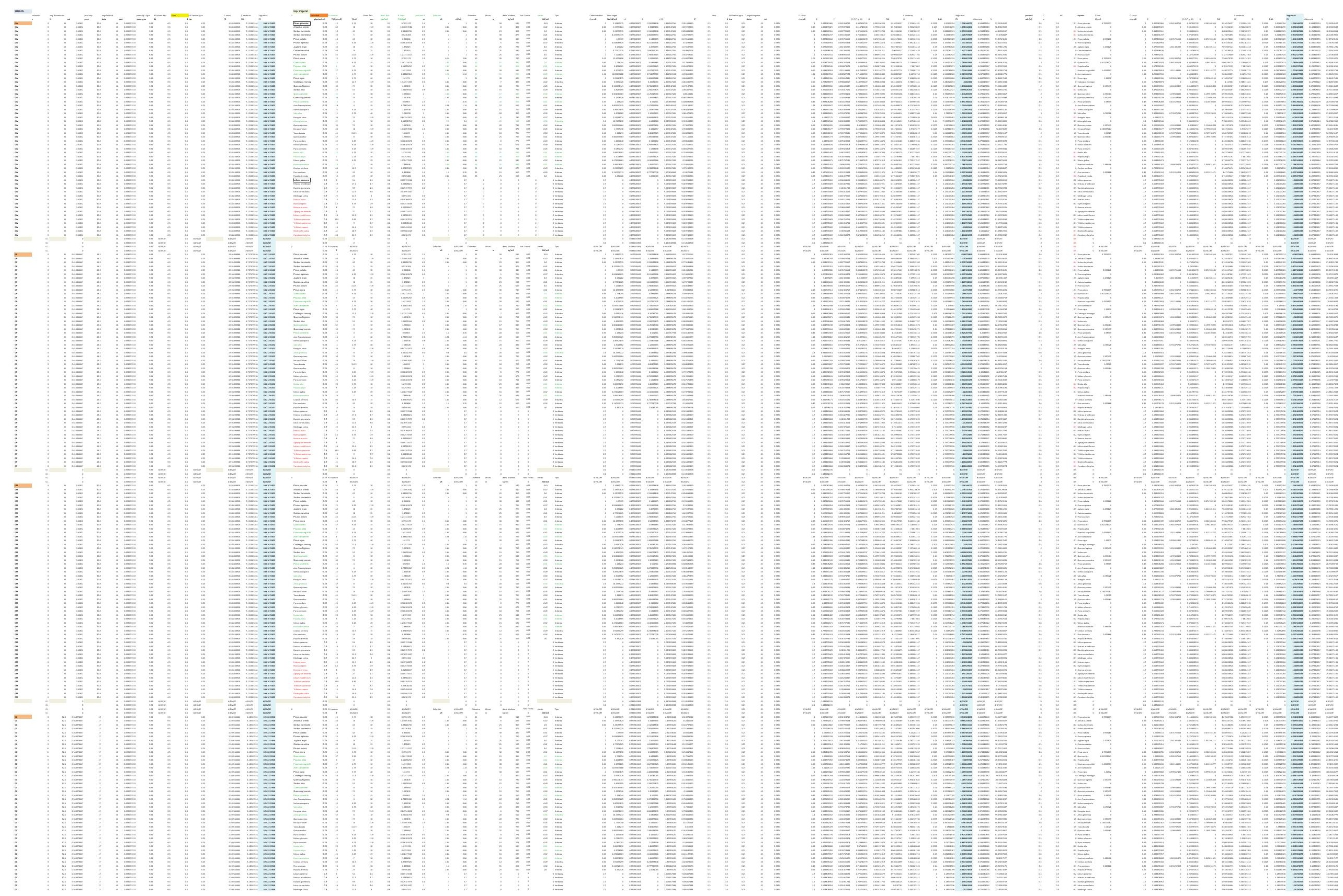


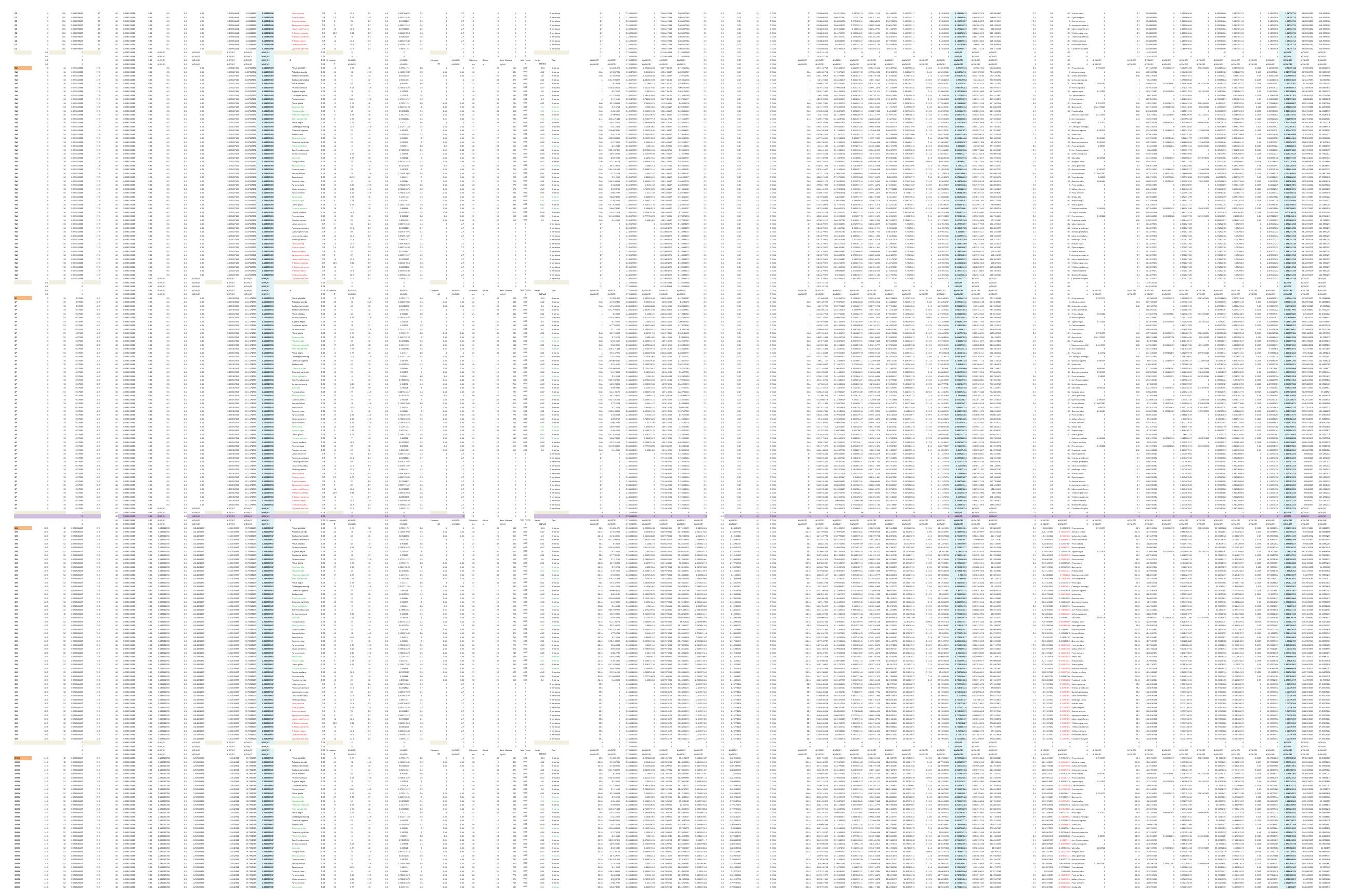



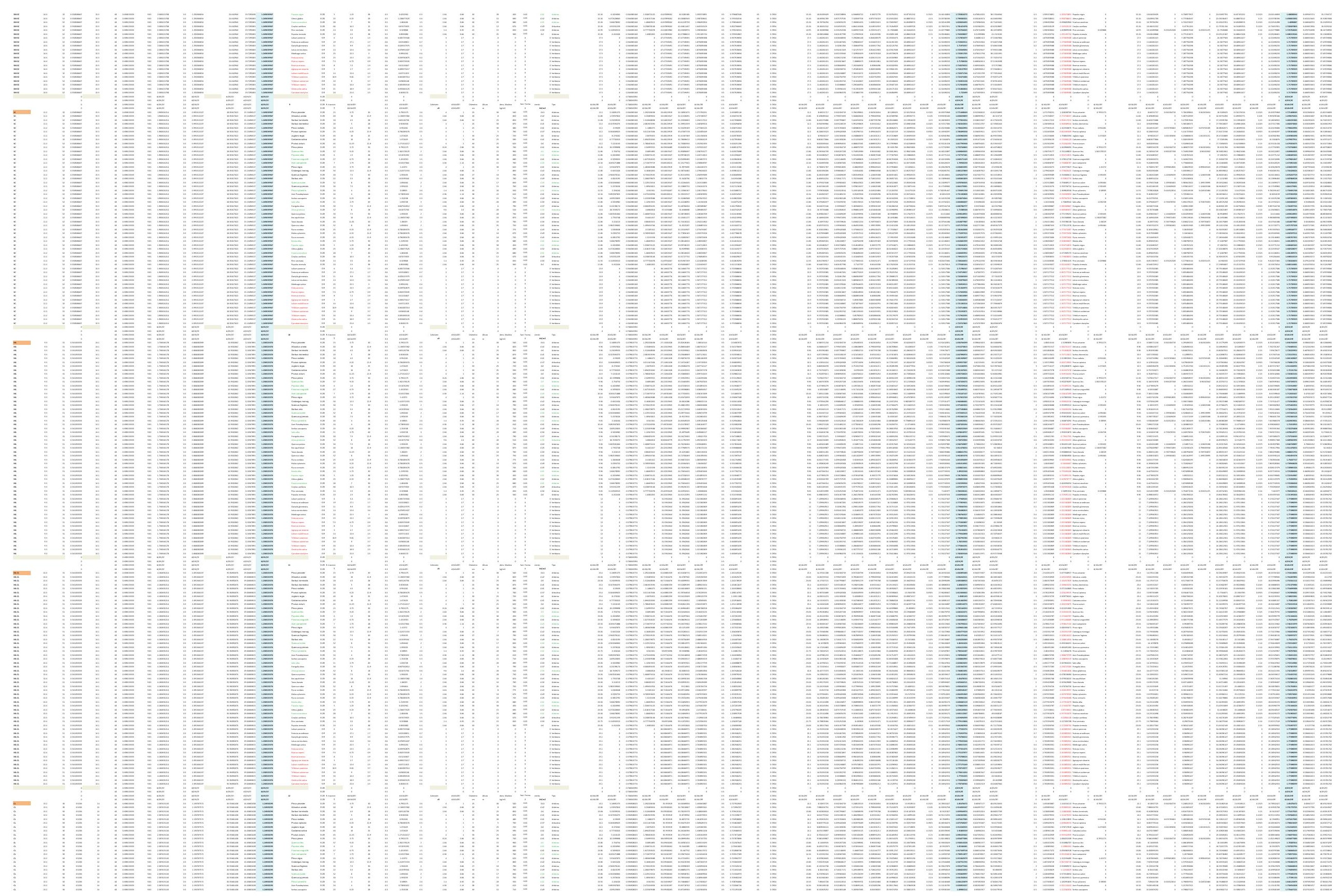


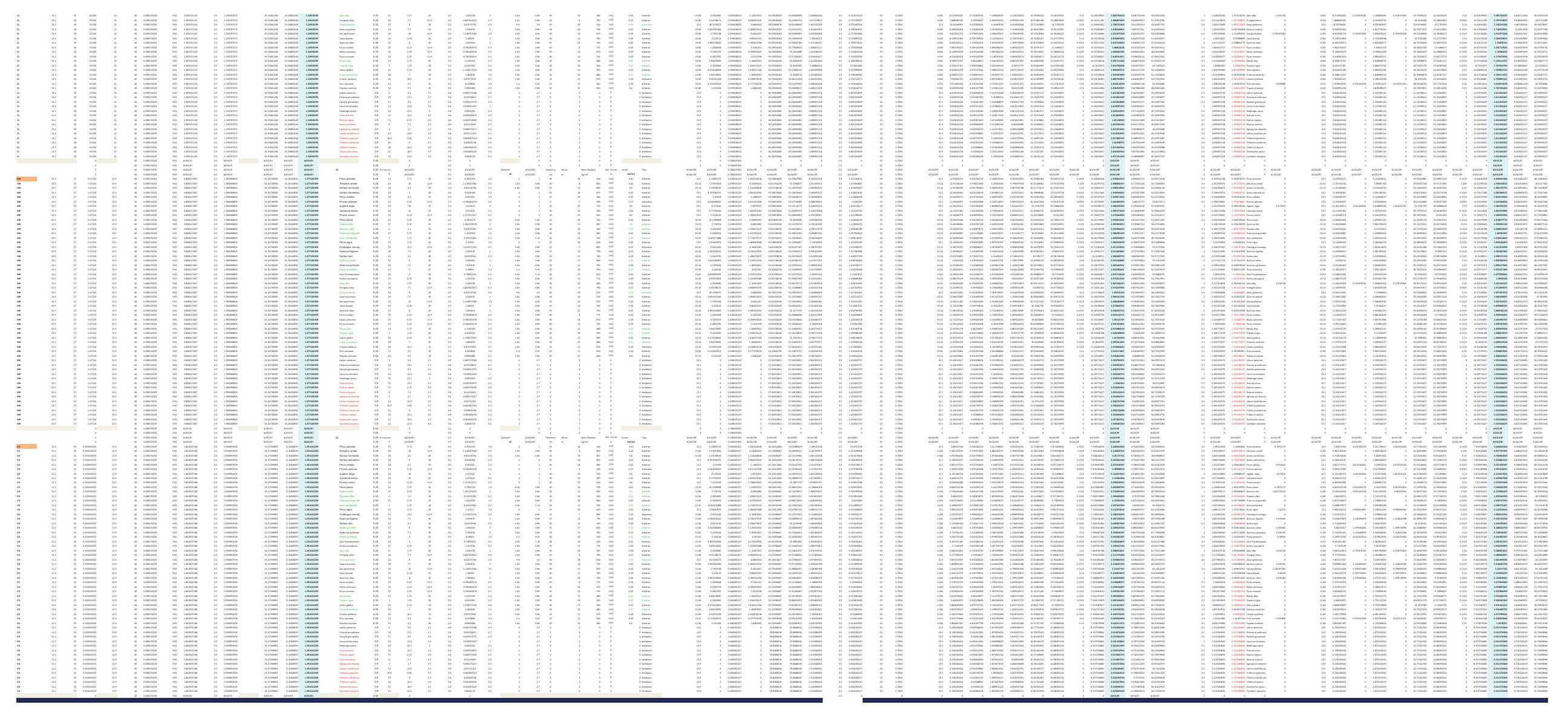



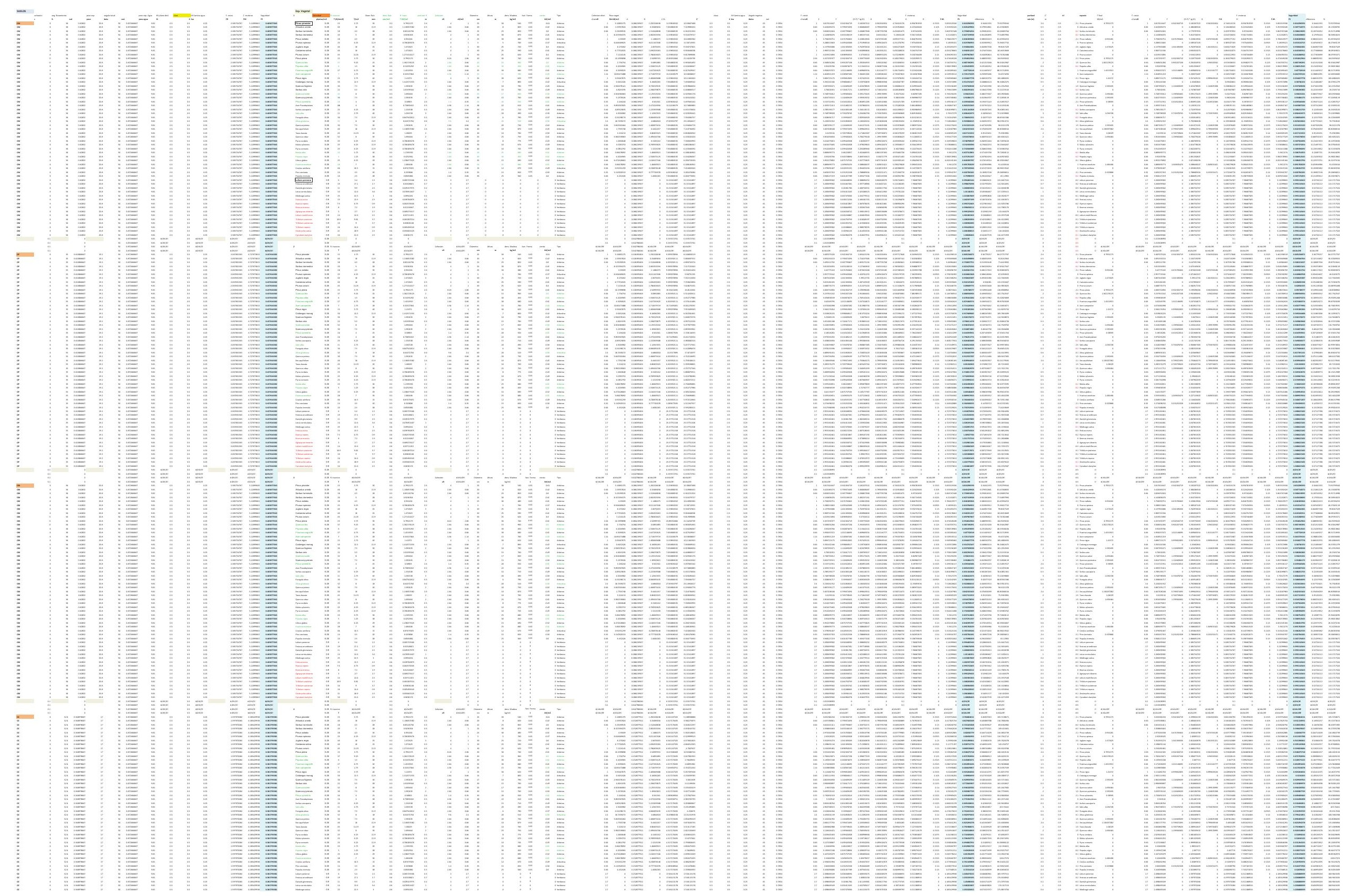


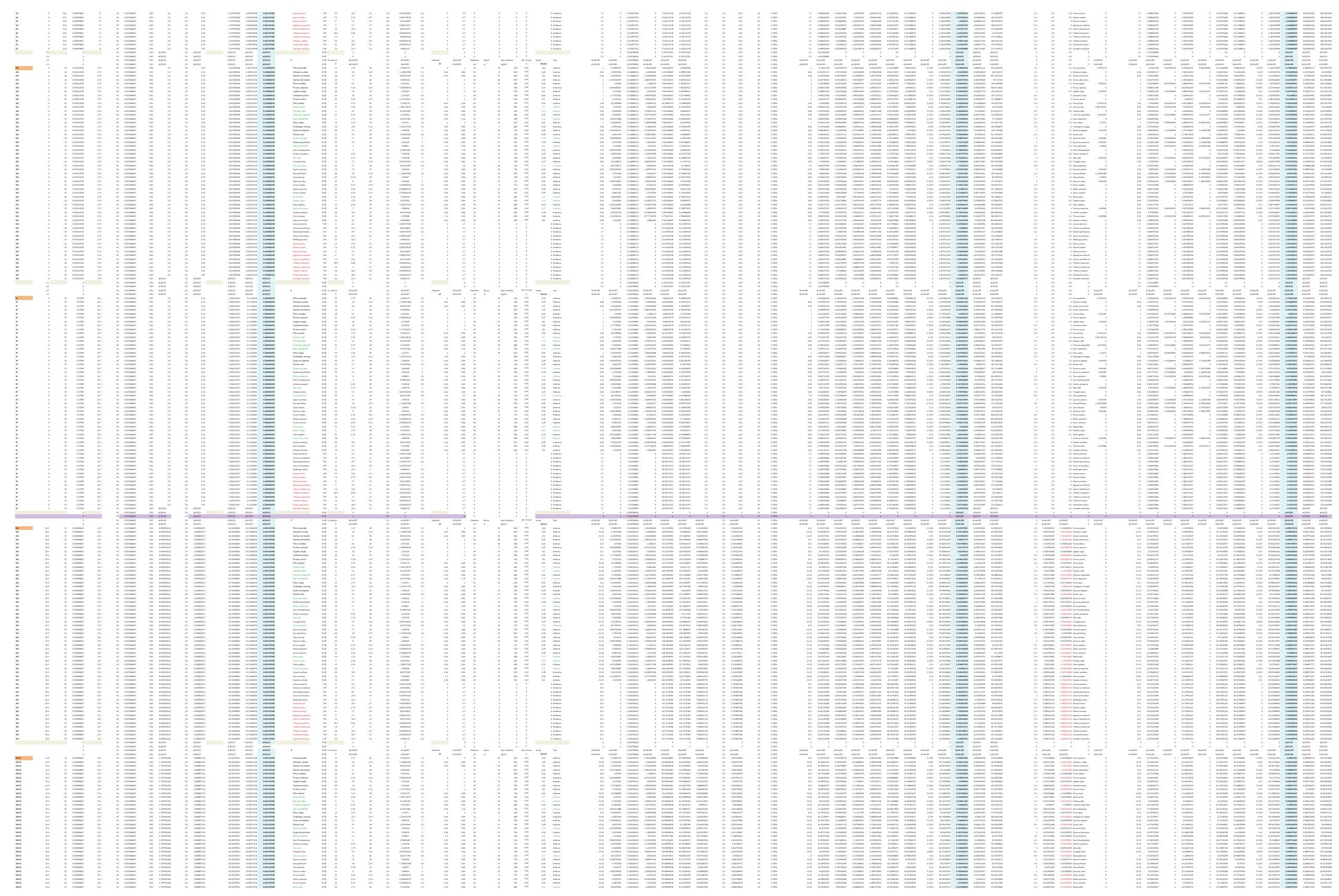



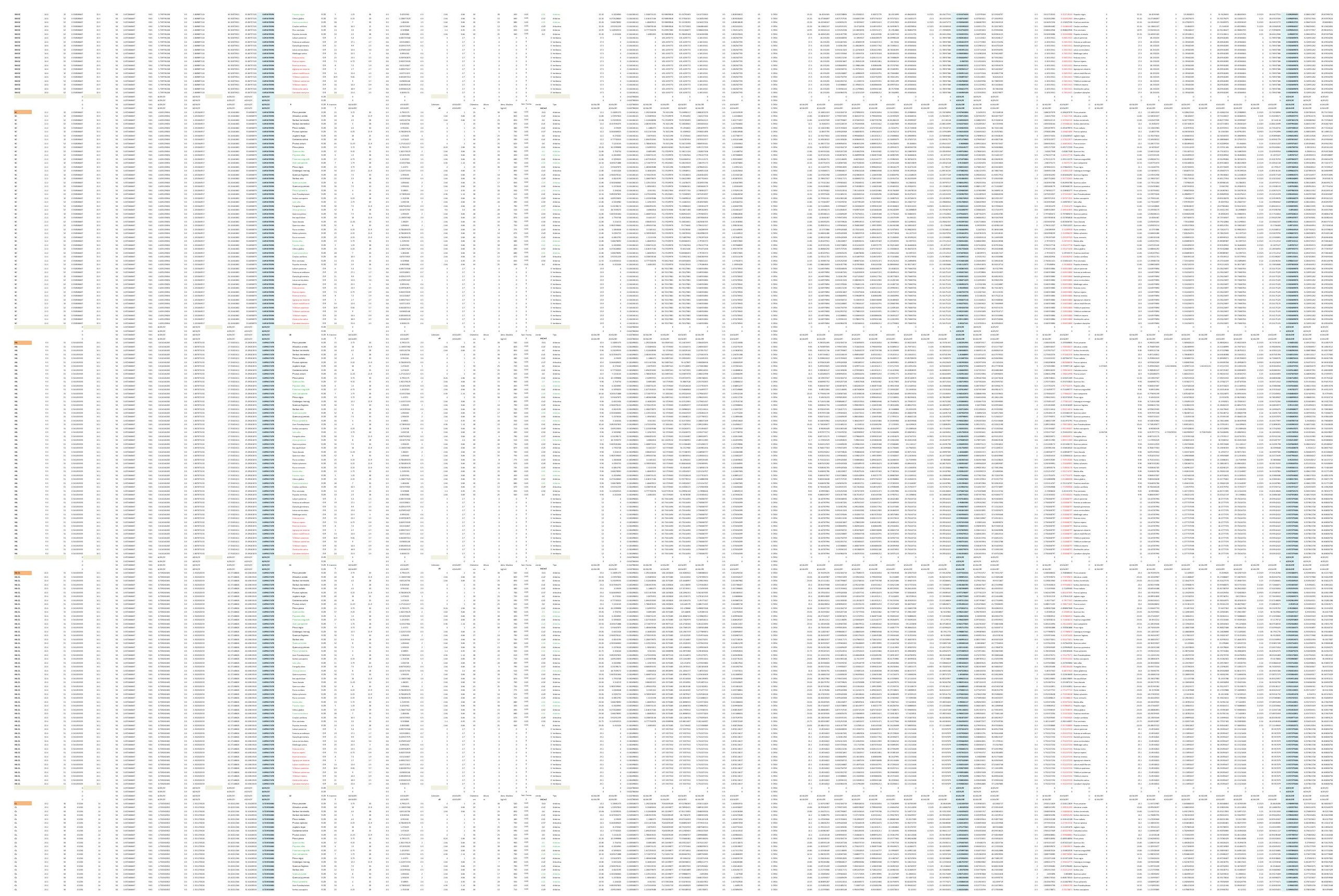


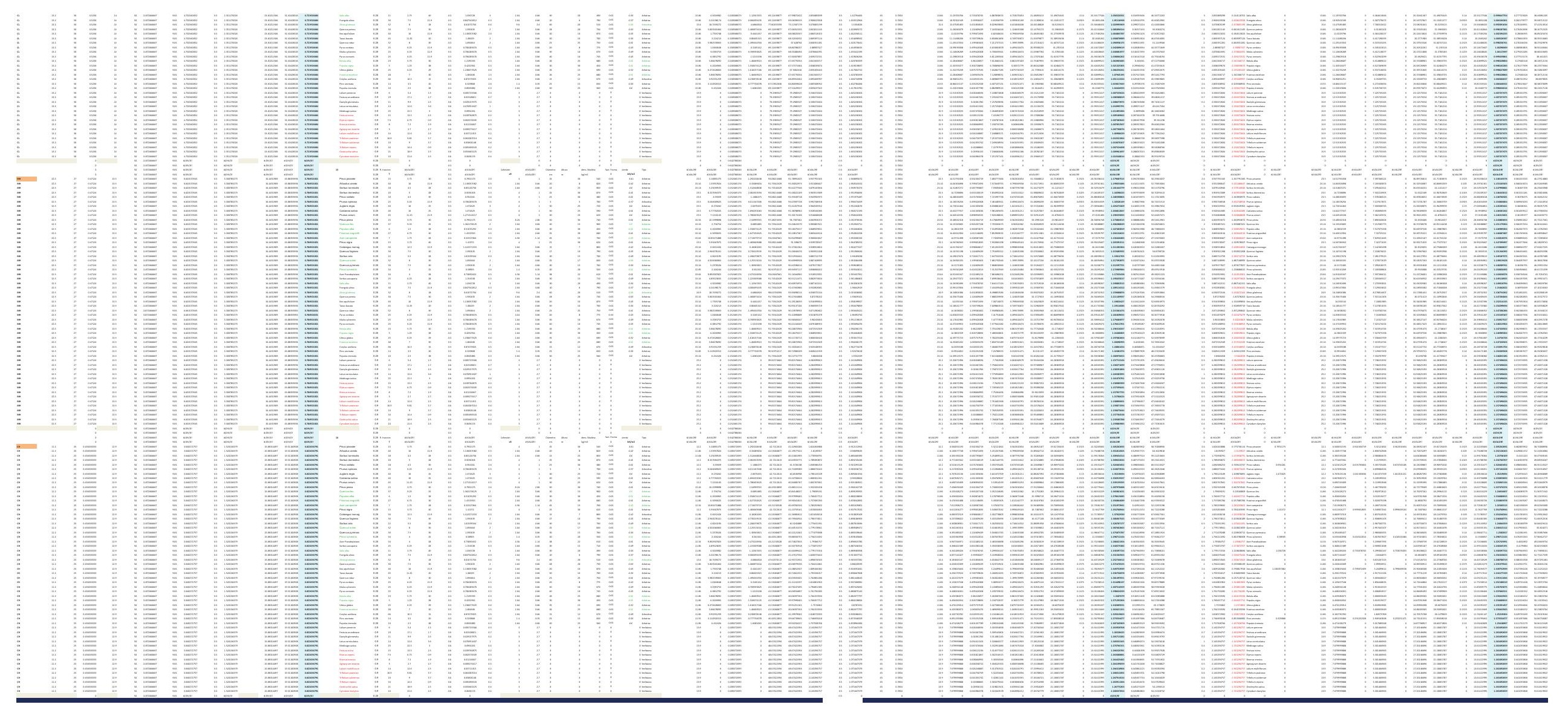



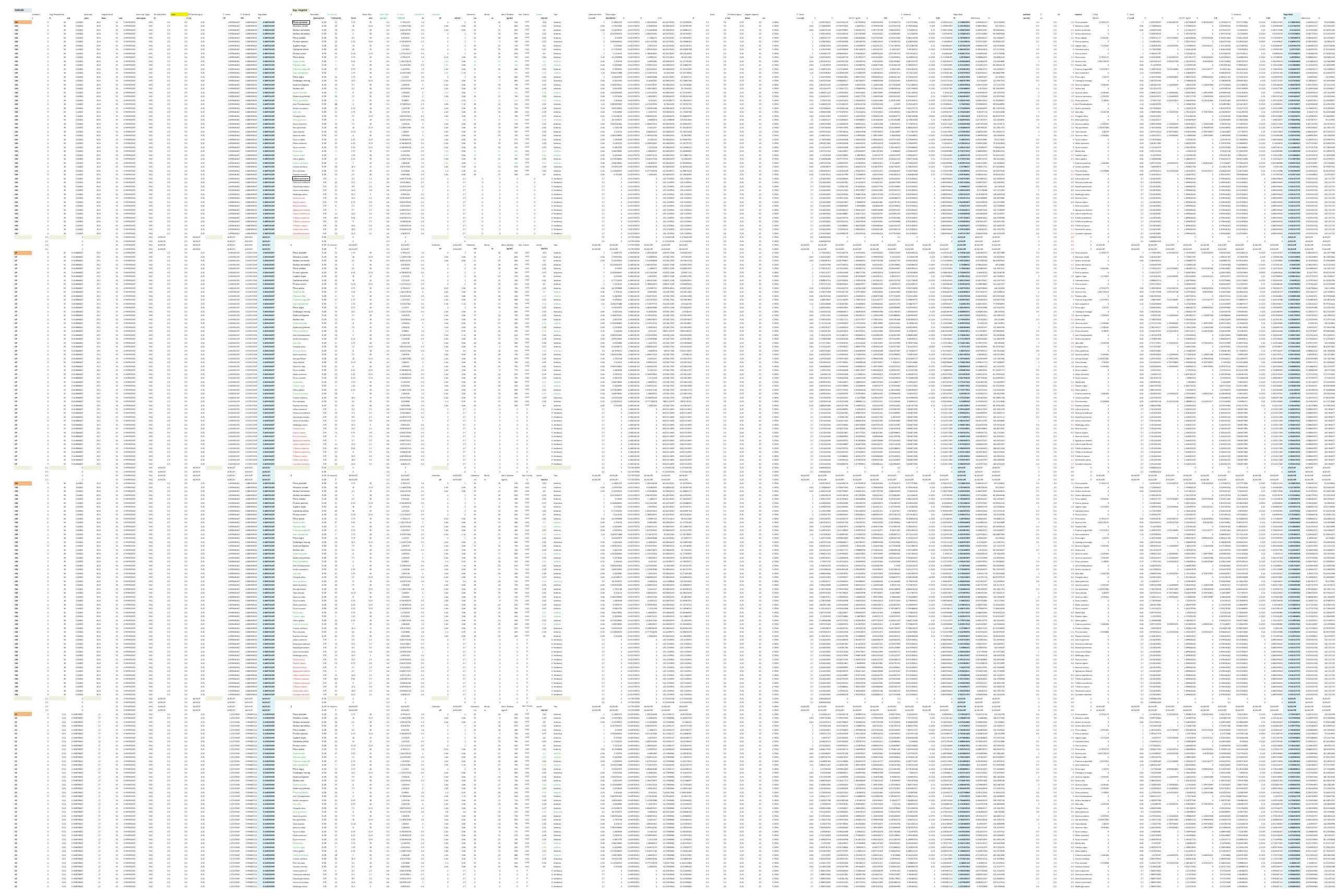


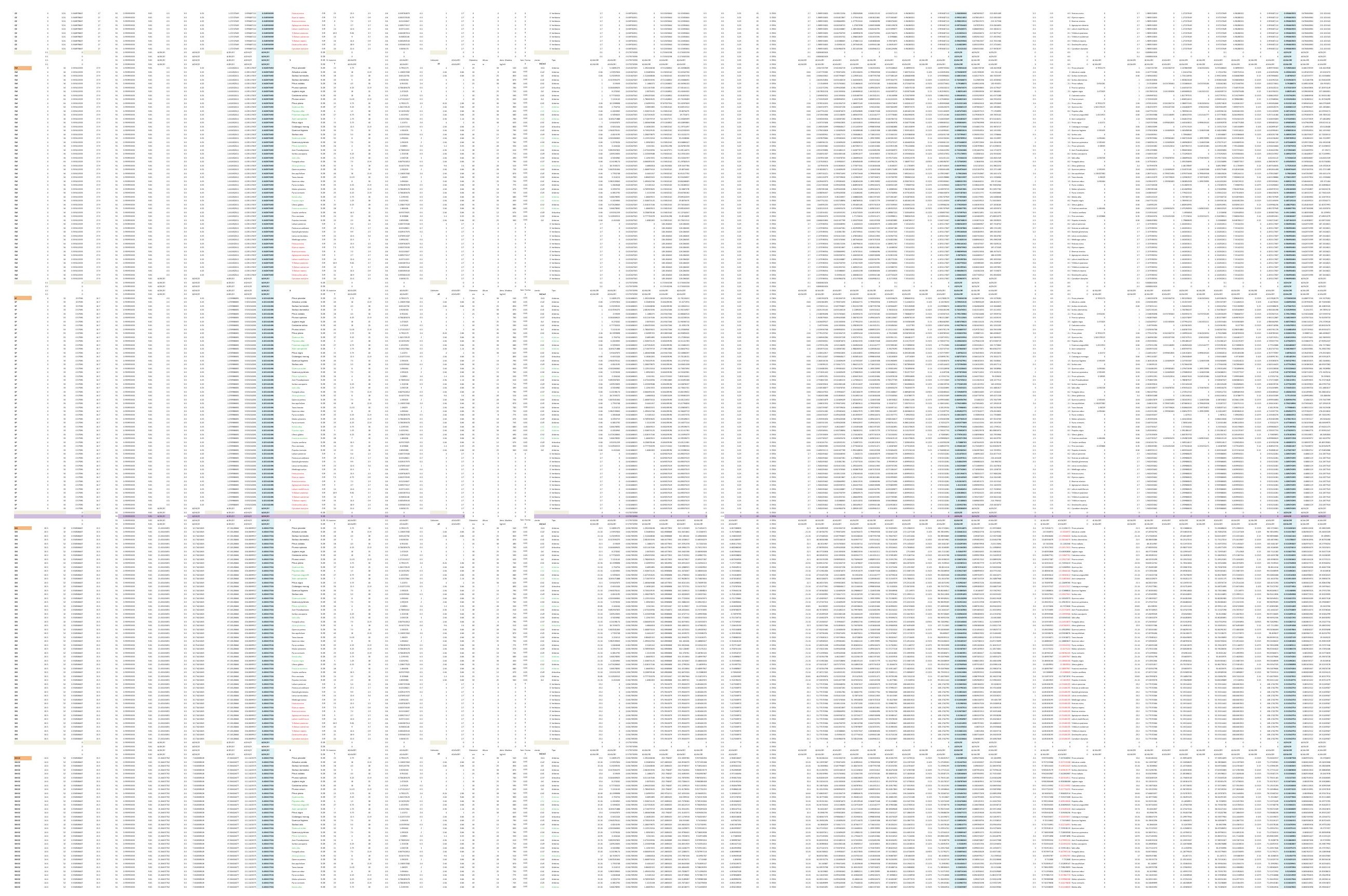



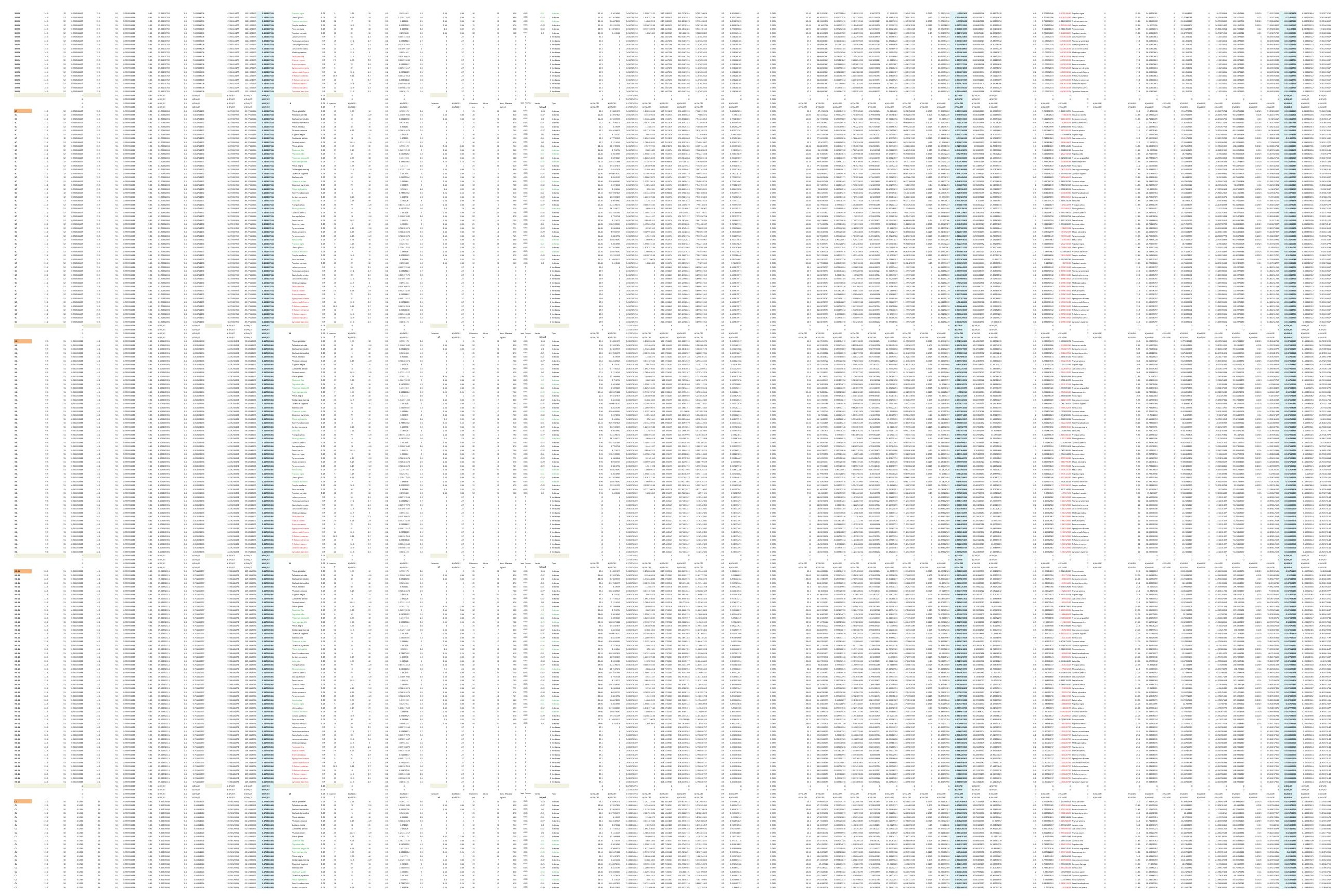


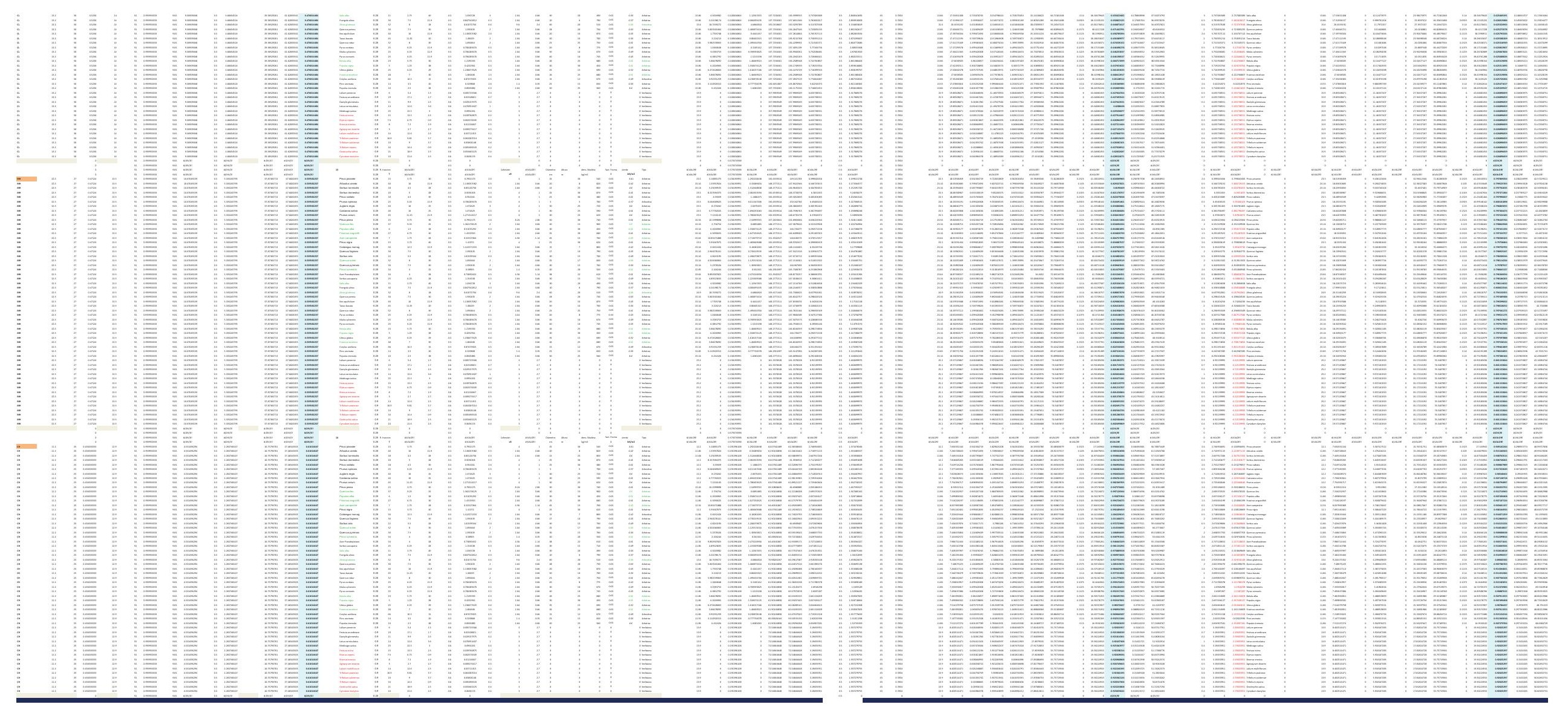



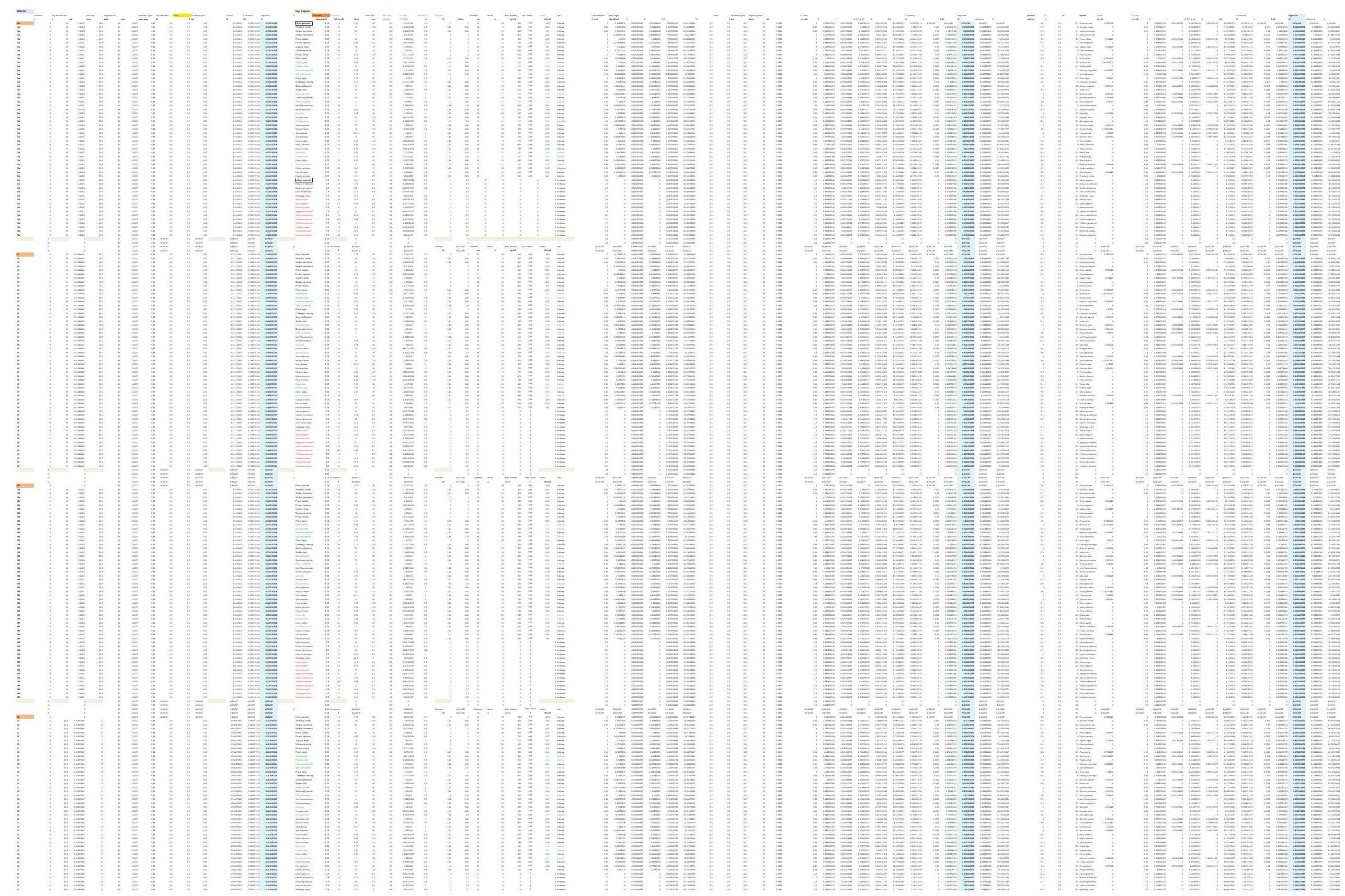


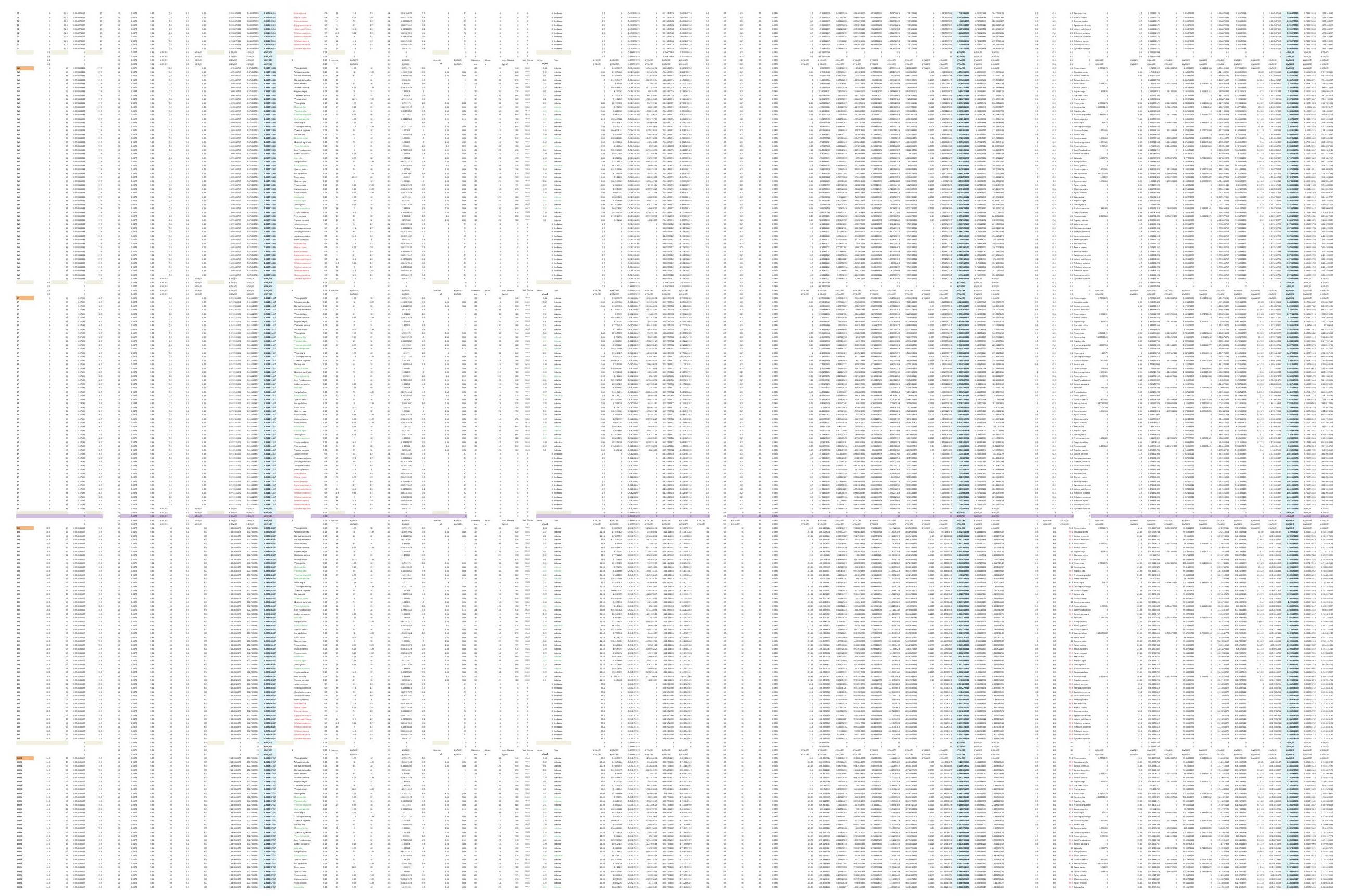



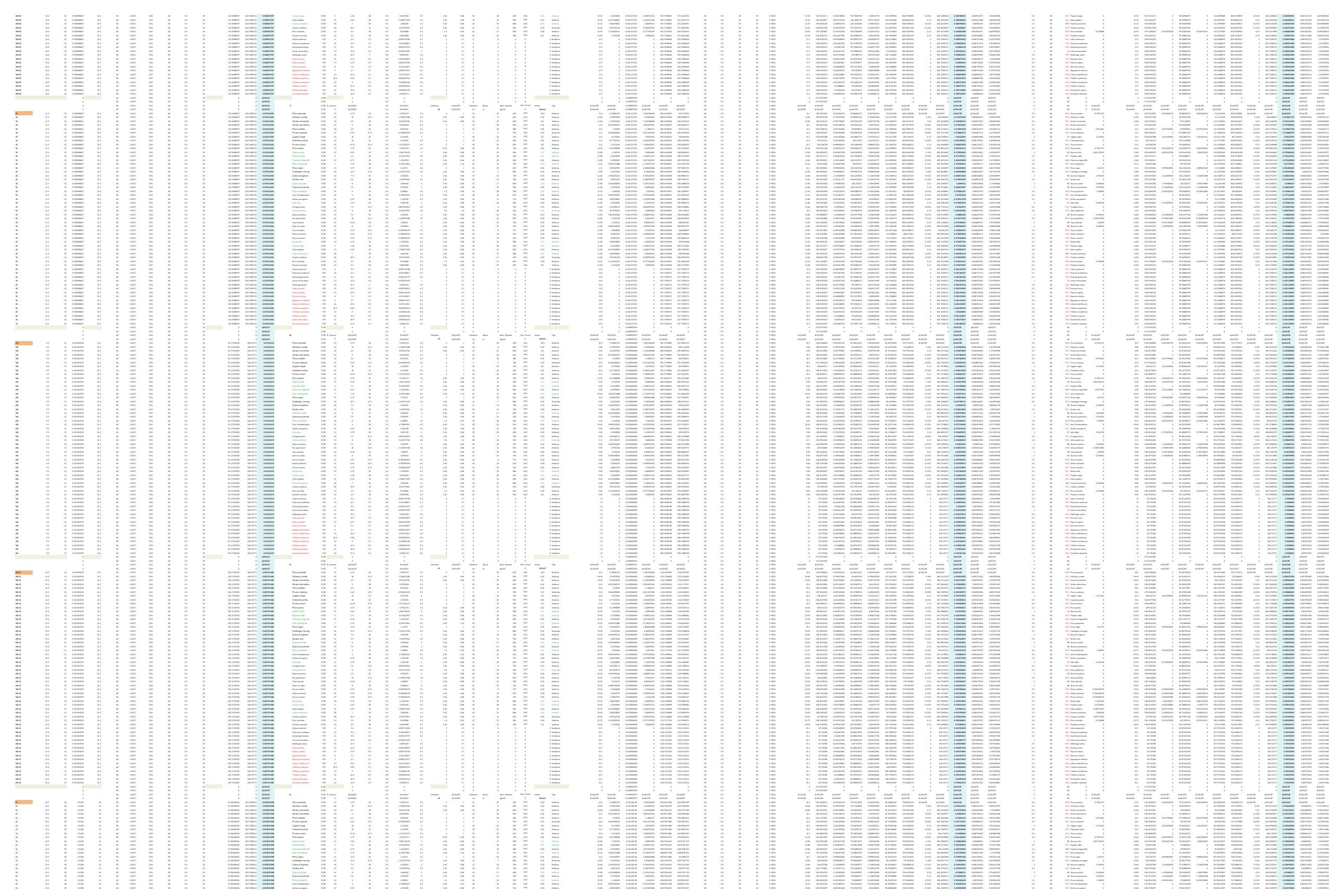


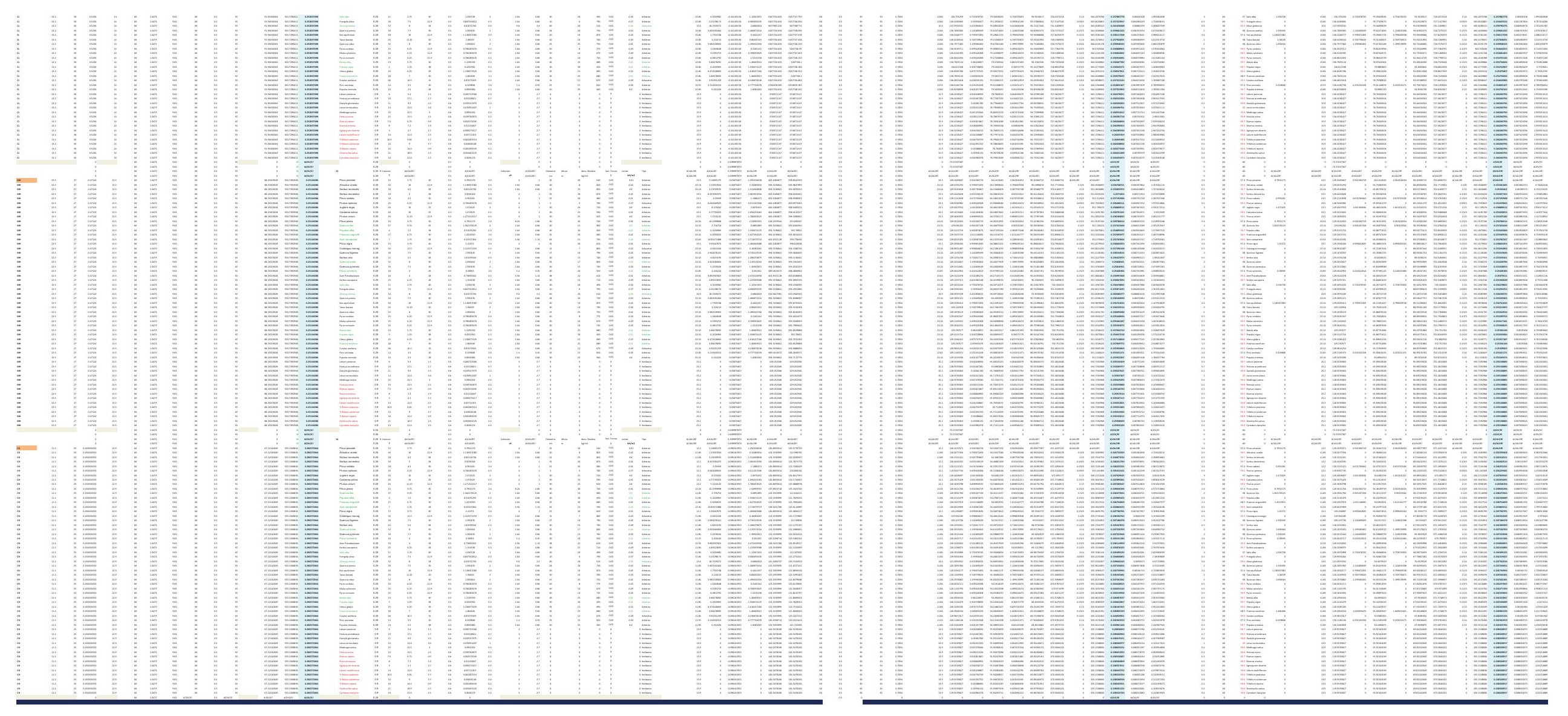



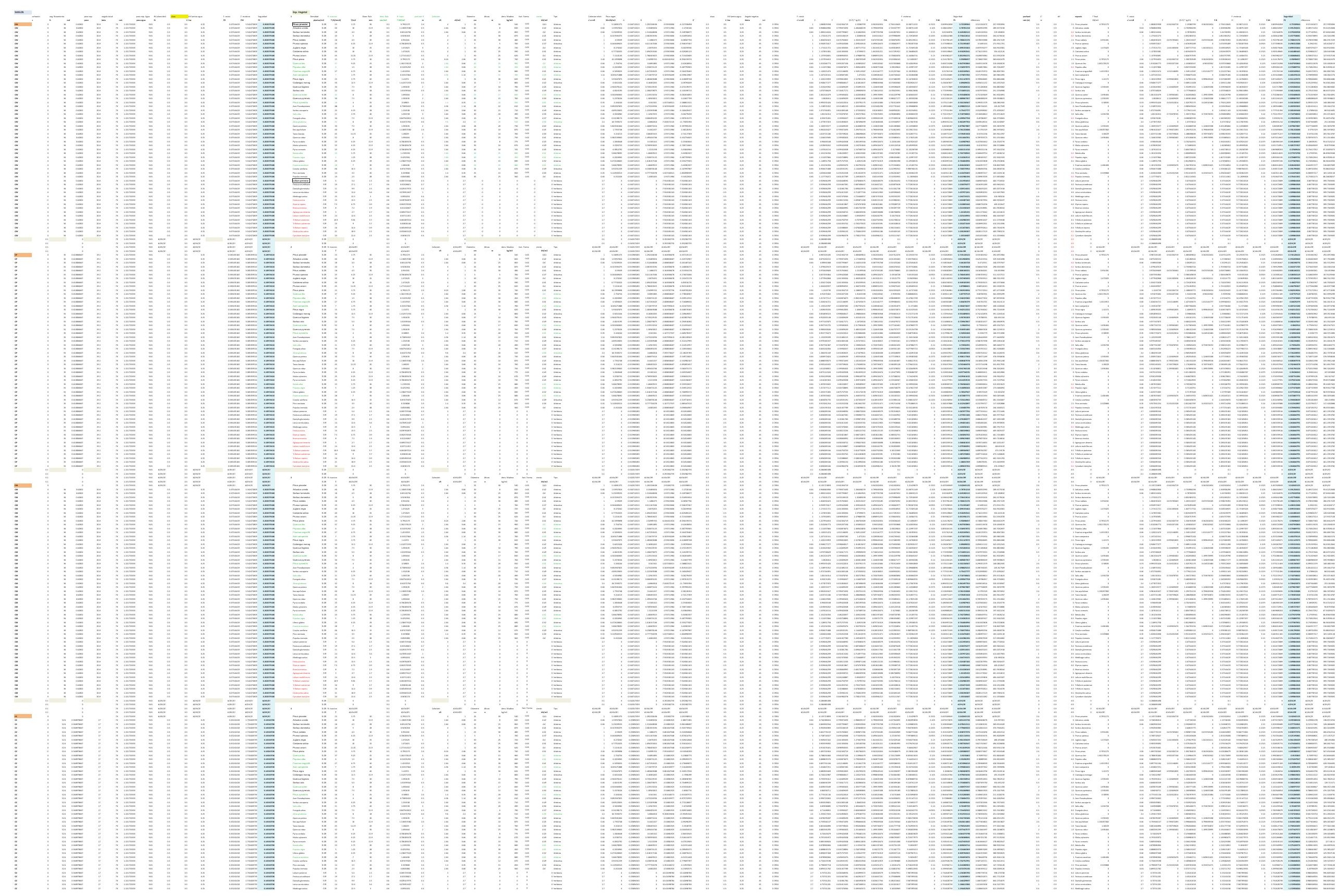


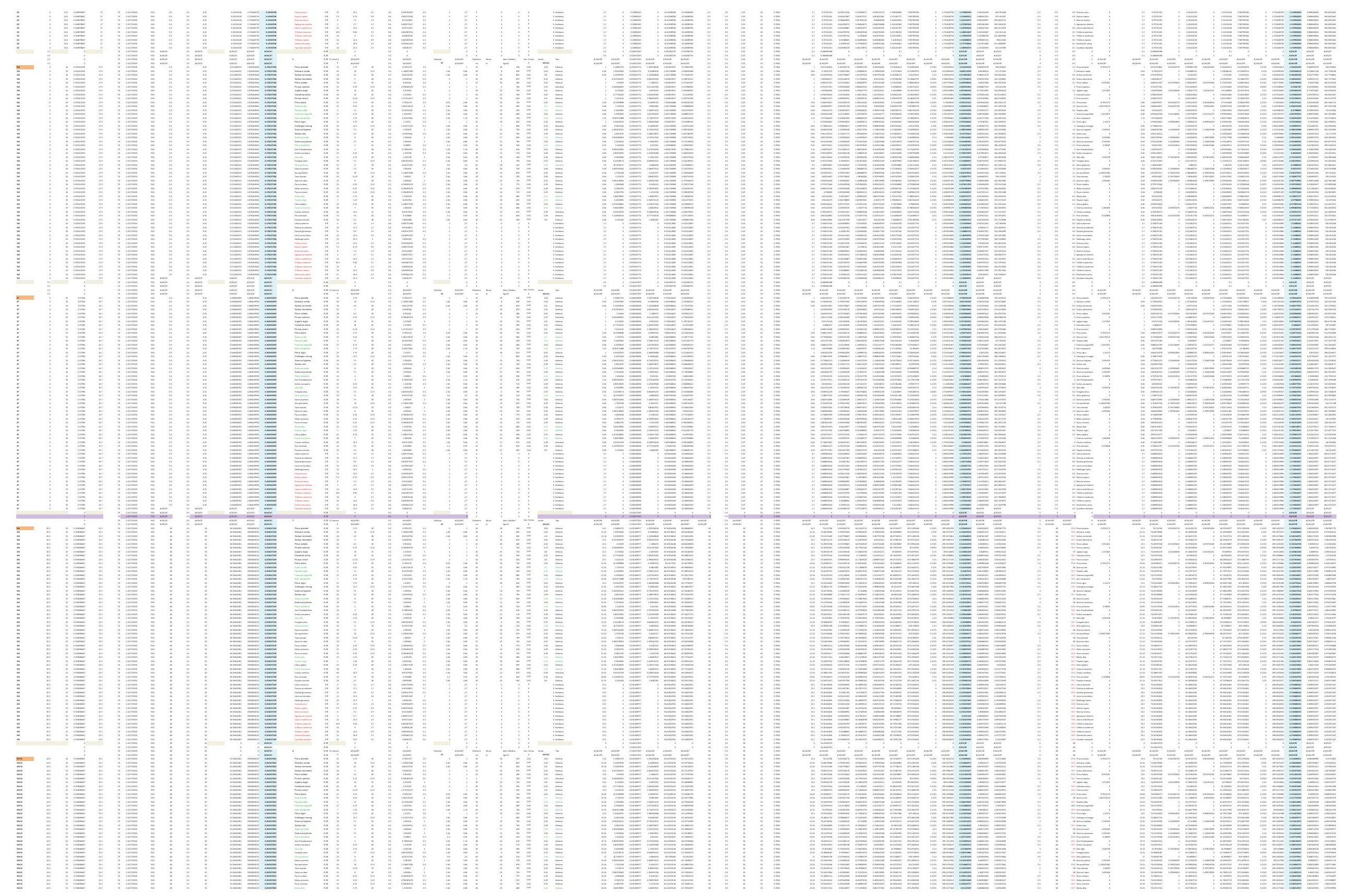




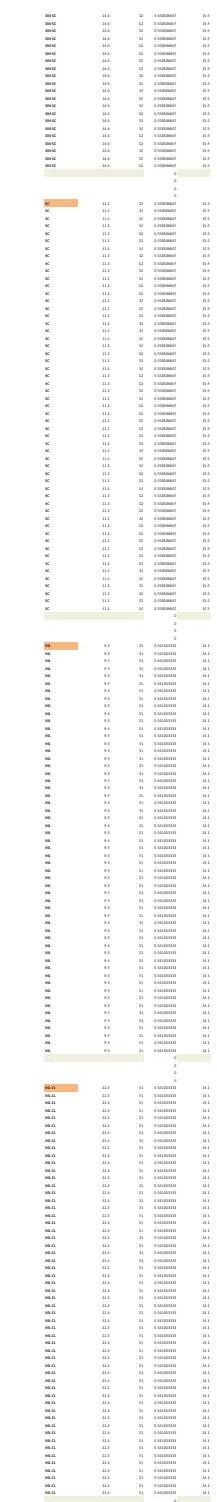

$-$
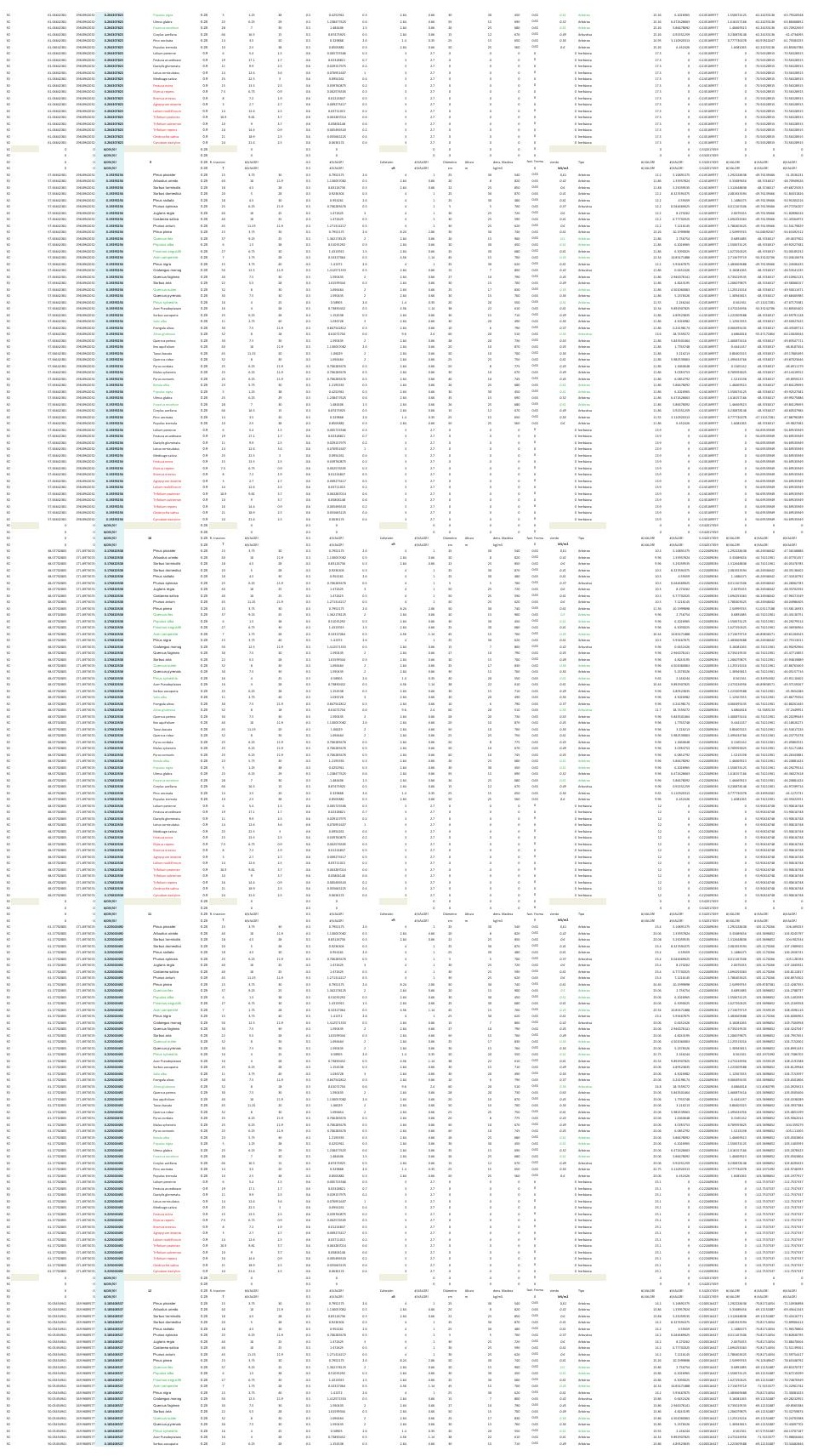
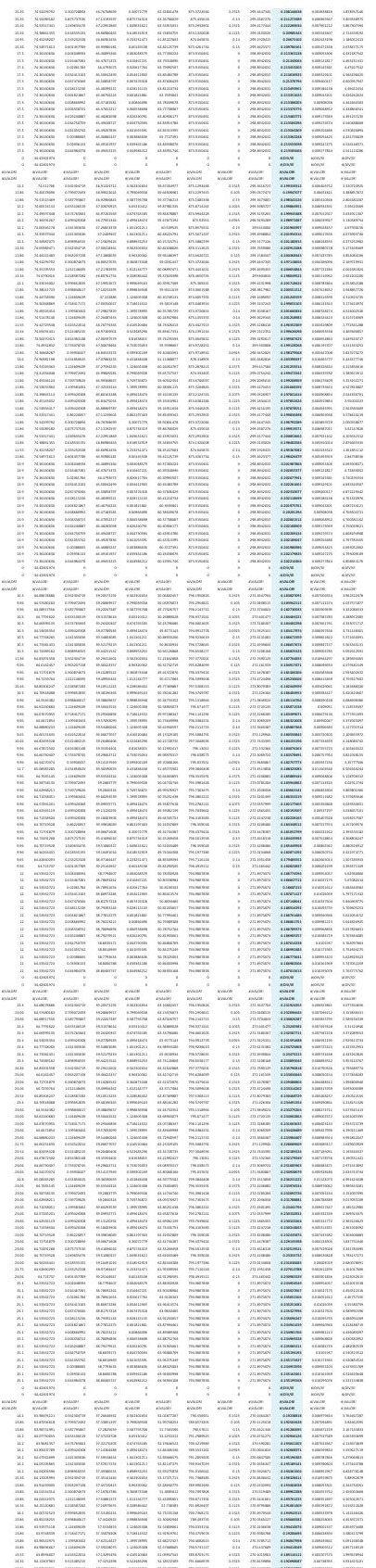

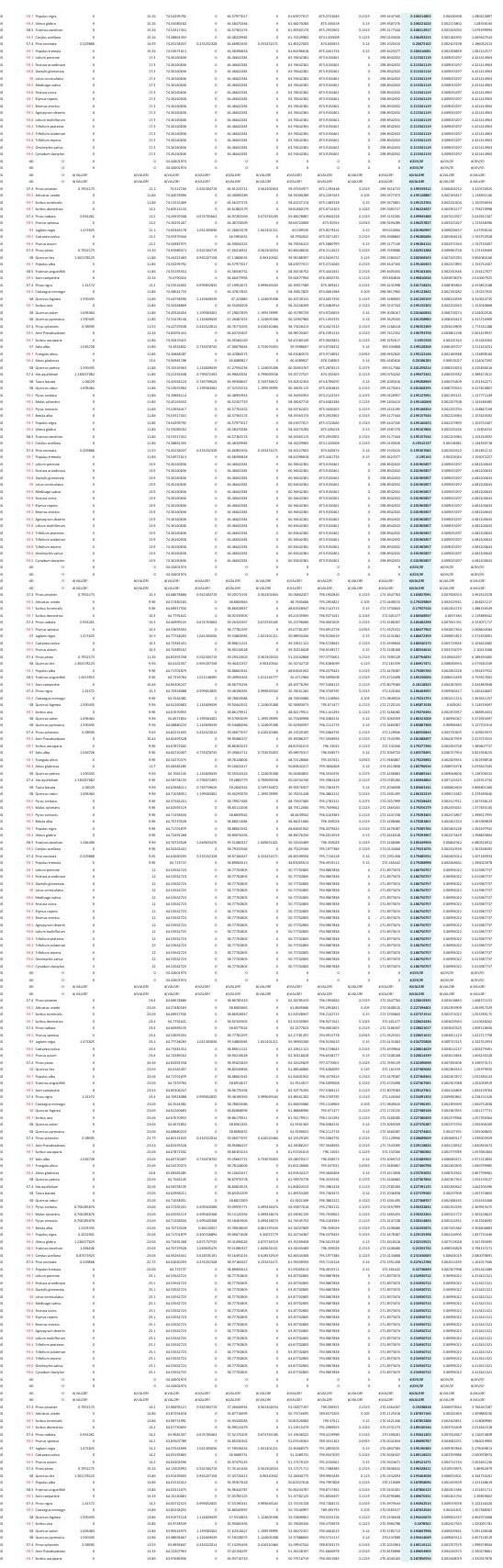




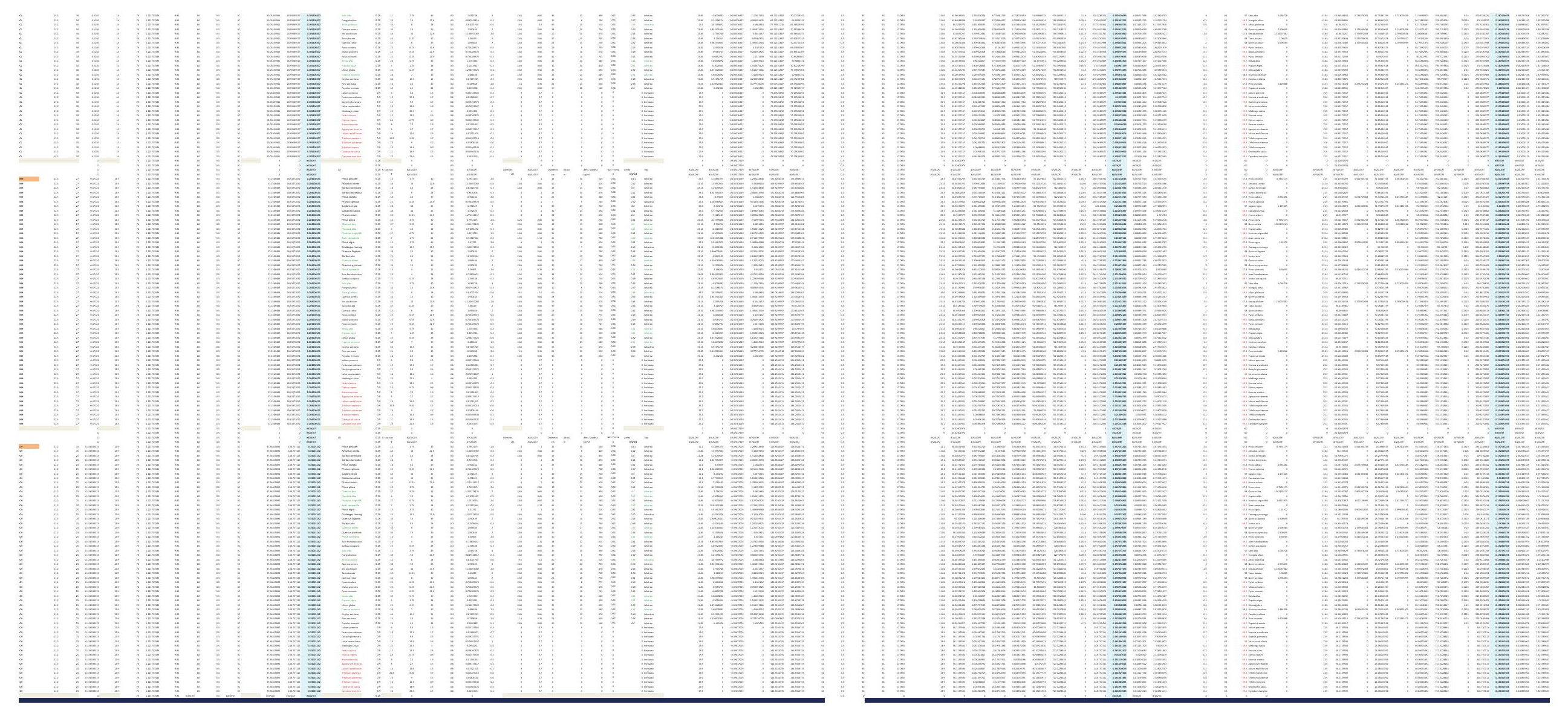



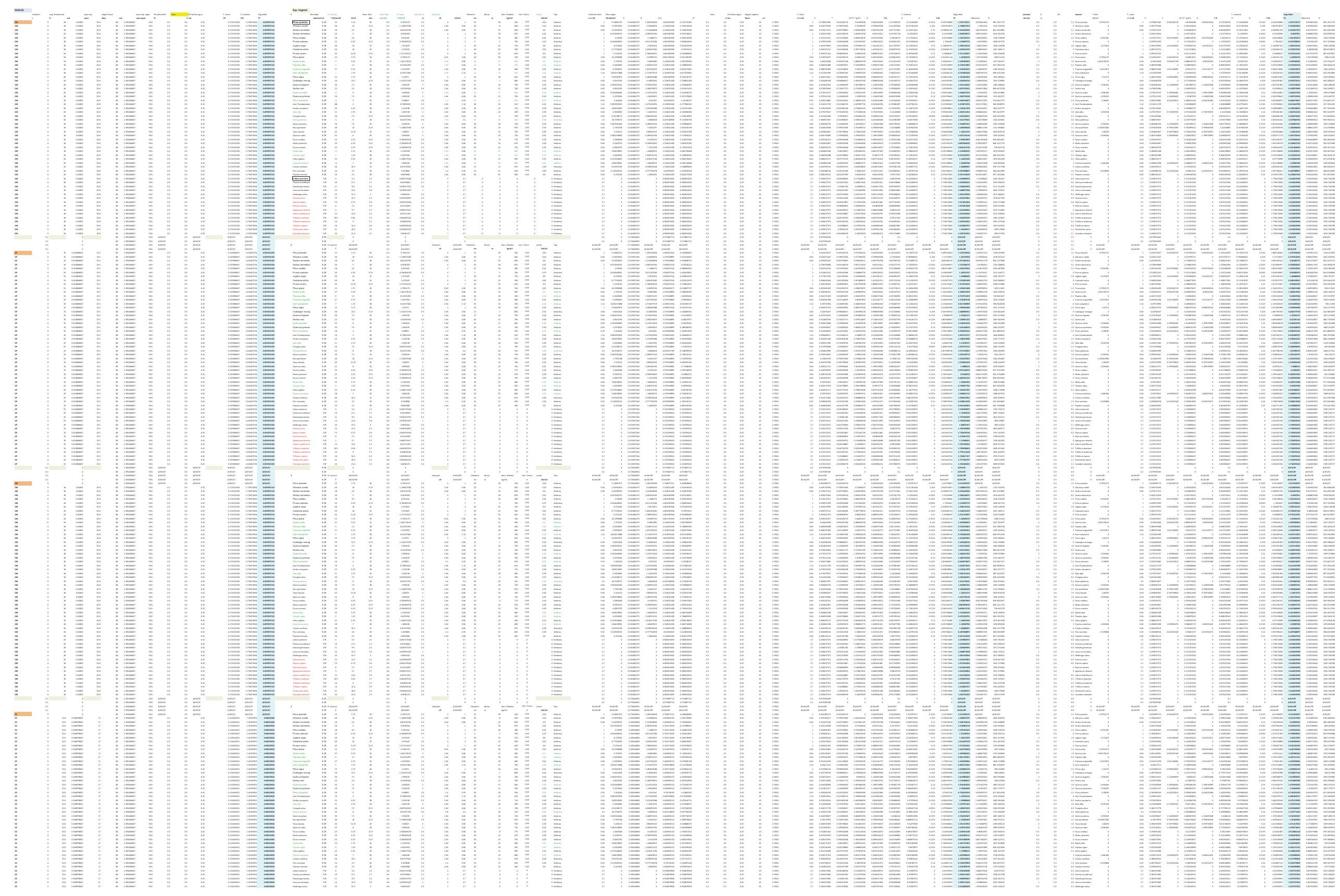


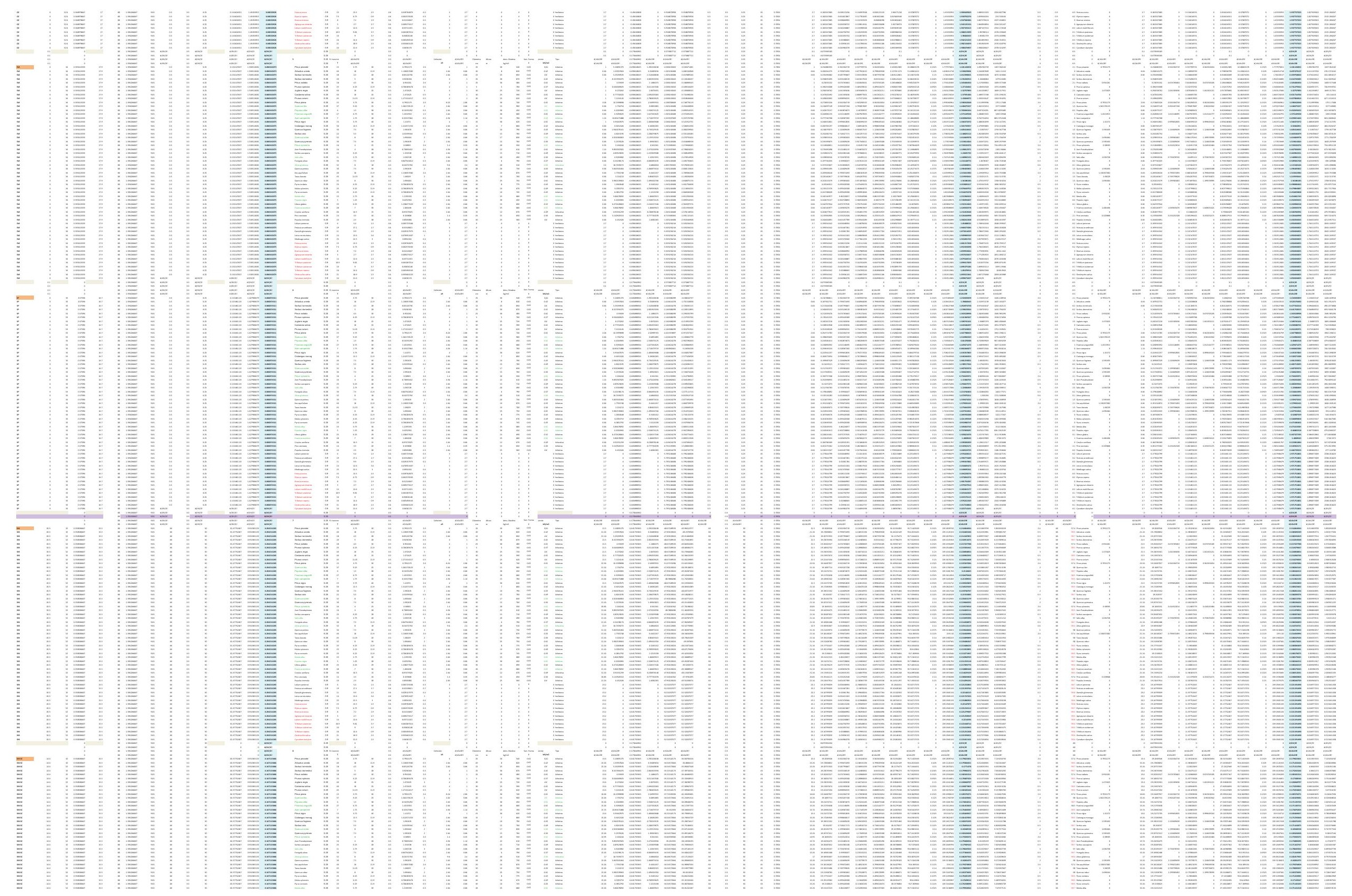



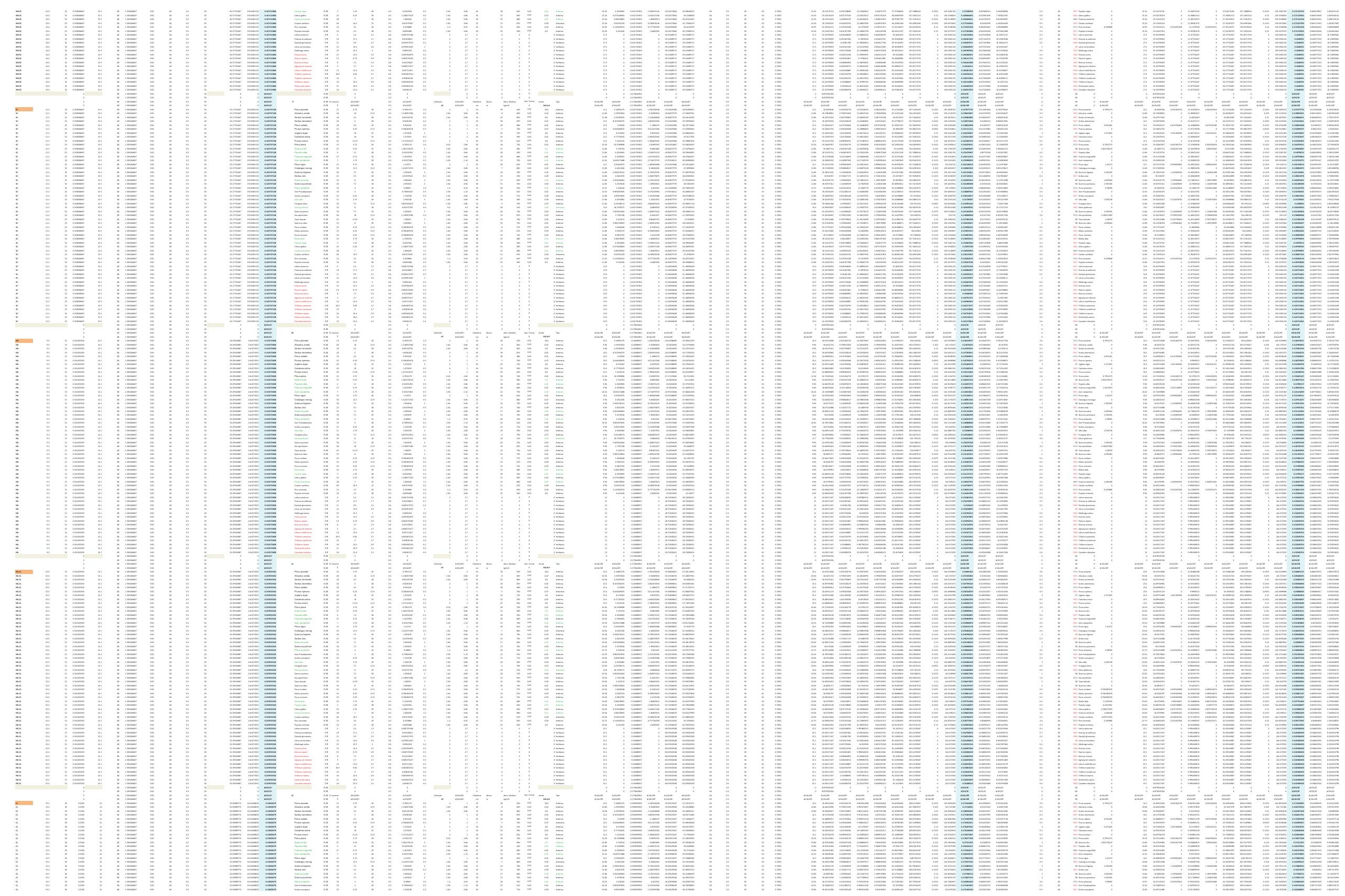


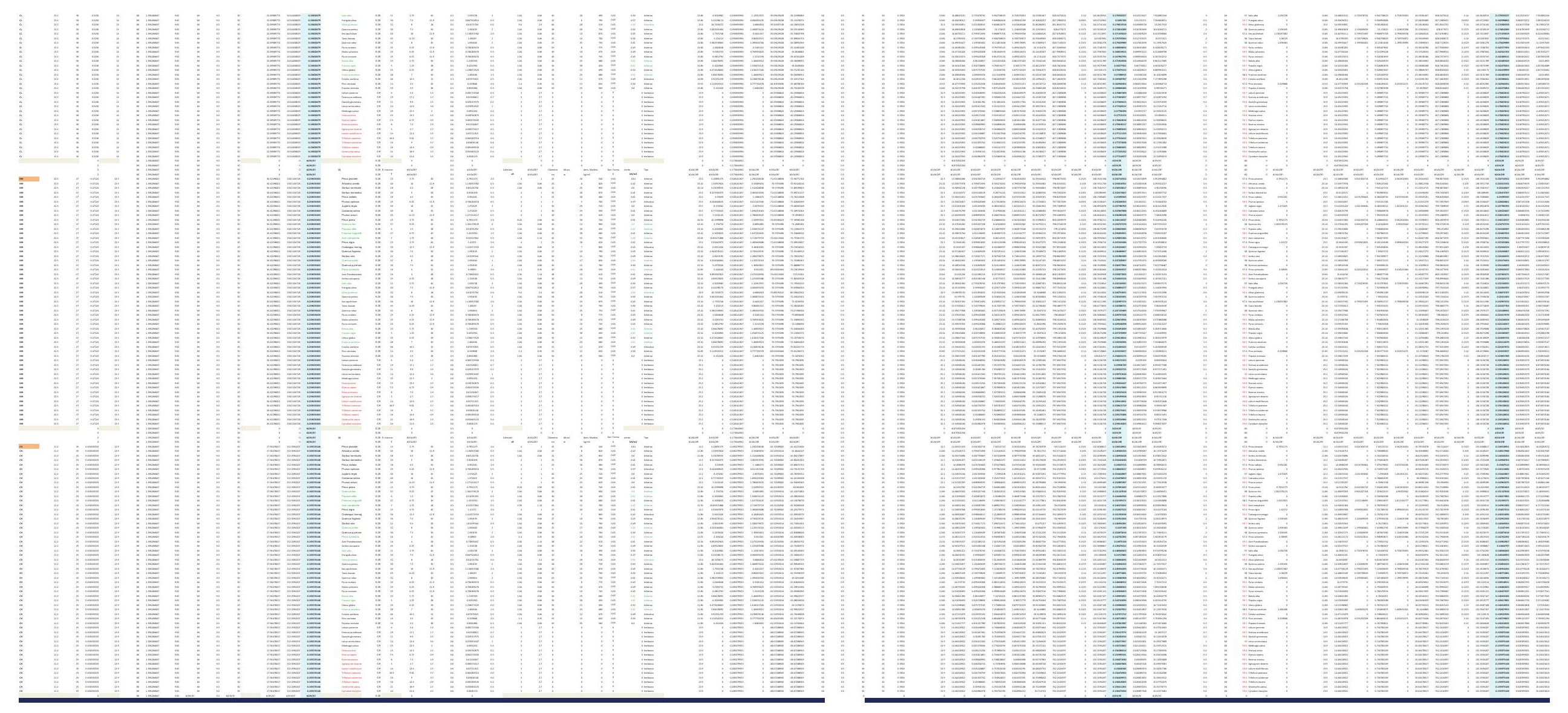


DESARROLLO DE UNA APLICACIÓN IMFORMÁTICA PARA EL CÁLCULO DE SOSTENIMIENTO DE TALUDES MEDIANTE VEGETACIÓN

A03. DENSIDAD DE PLANTACIÓN: 2.500 plantas/ha.

\section{A03-5.POSICIÓN N.F. 5}

INCLINACIÓN DE TALUD 6-100

INCLINACIÓN DE TALUD 10-200

INCLINACIÓN DE TALUD 20-30

INCLINACIÓN DE TALUD 30-40

INCLINACIÓN DE TALUD $35^{\circ}$

INCLINACIÓN DE TALUD 40-50

INCLINACIÓN DE TALUD 50-550

INCLINACIÓN DE TALUD 55-60

INCLINACIÓN DE TALUD 60-700

INCLINACIÓN DE TALUD 70-80 

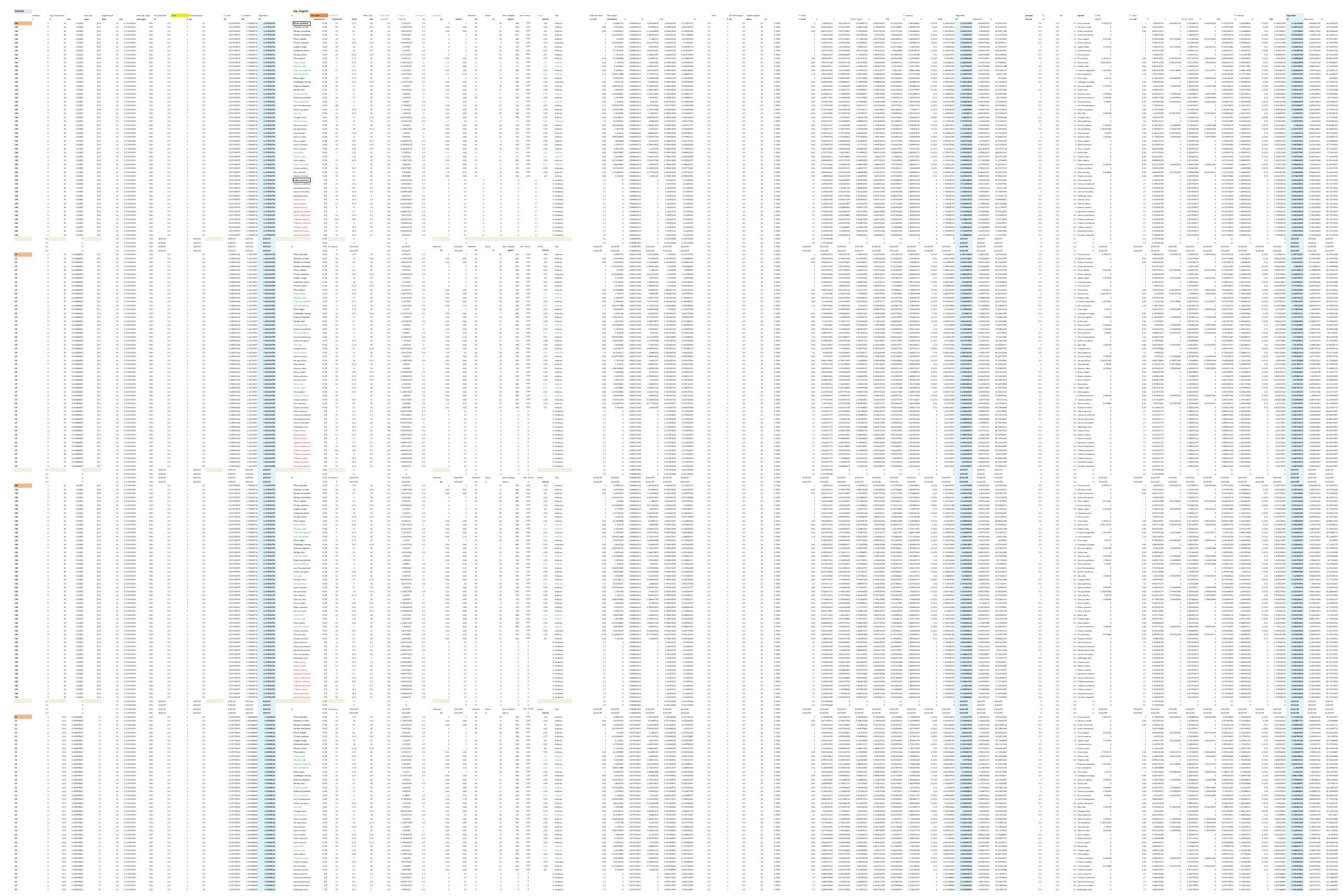


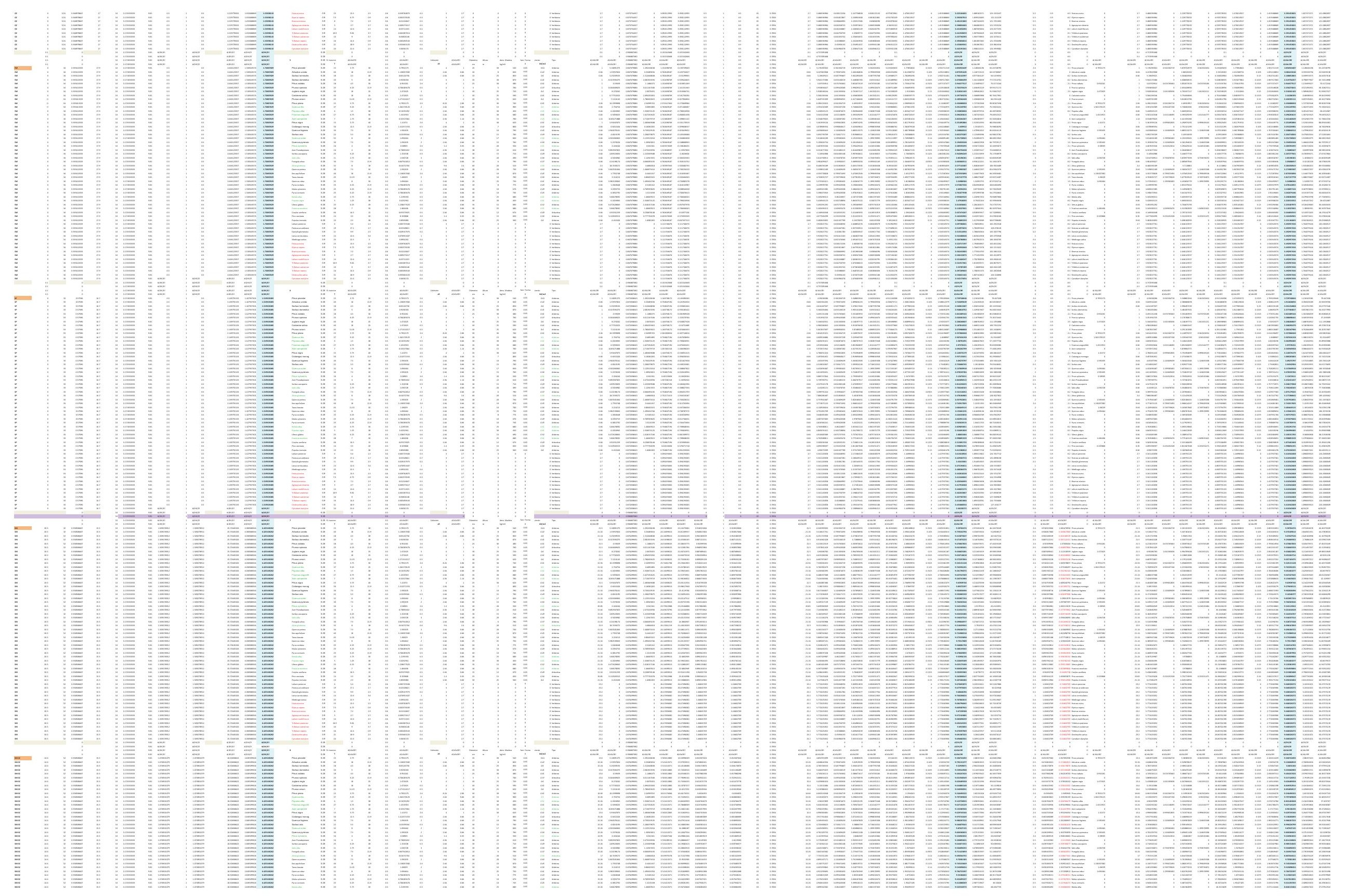



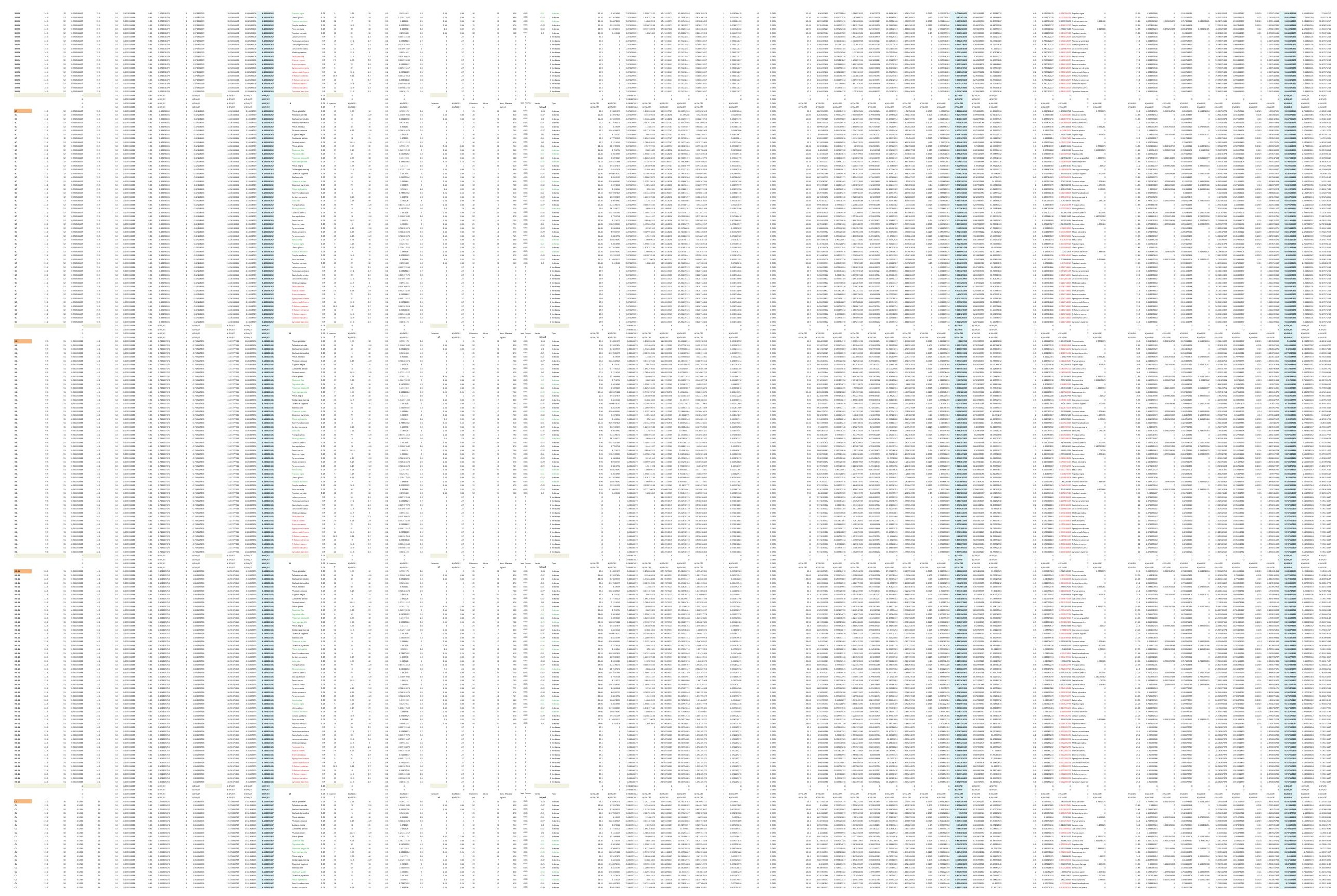


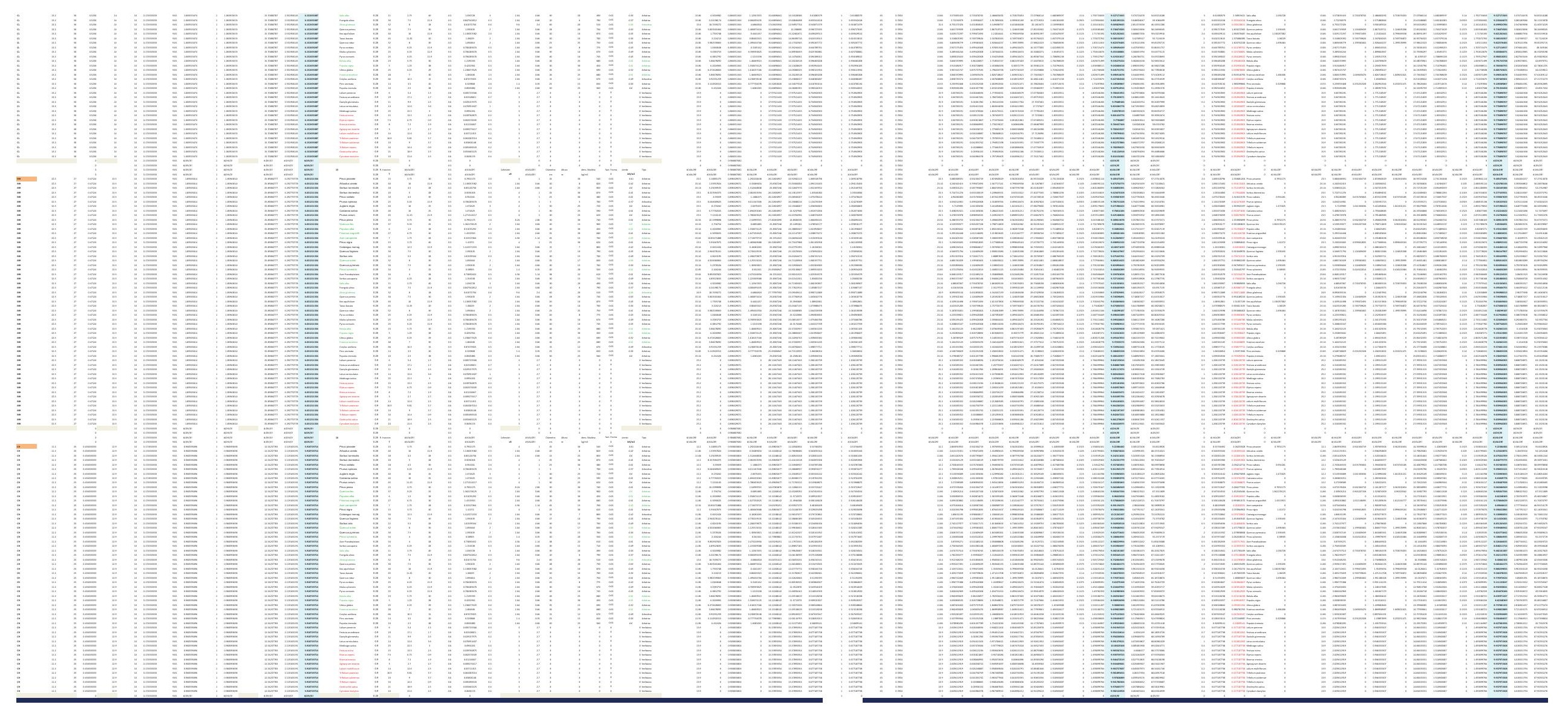



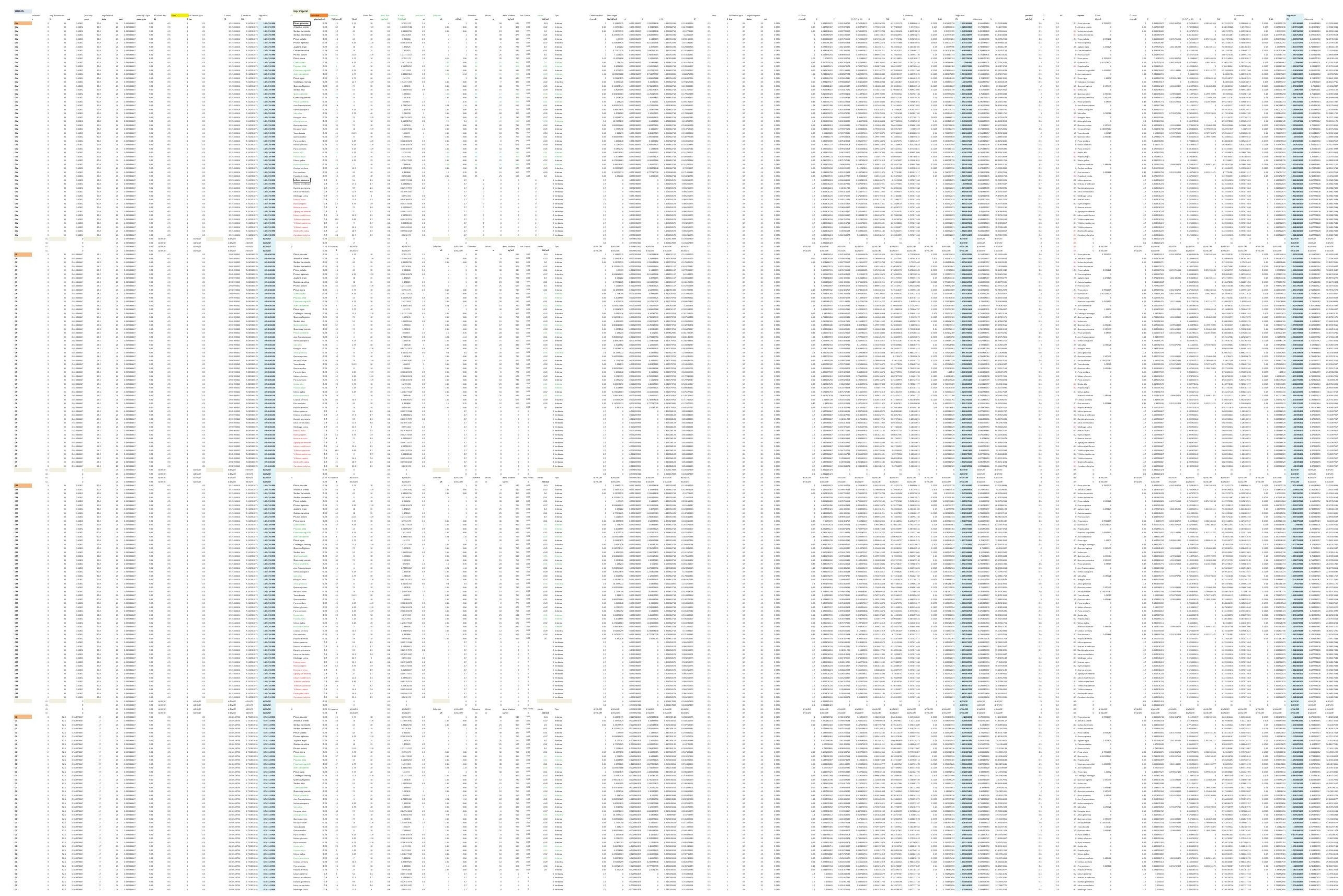


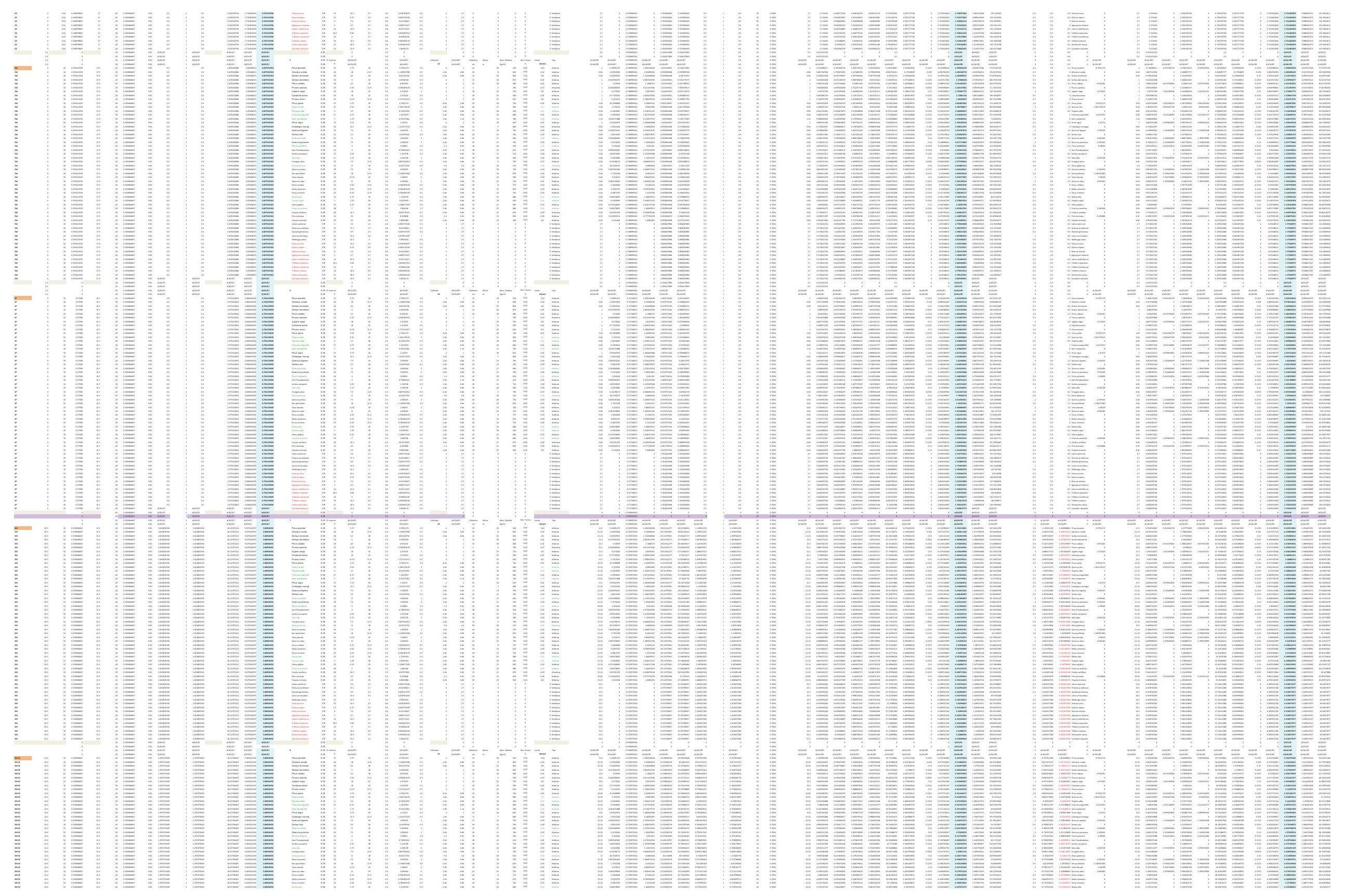



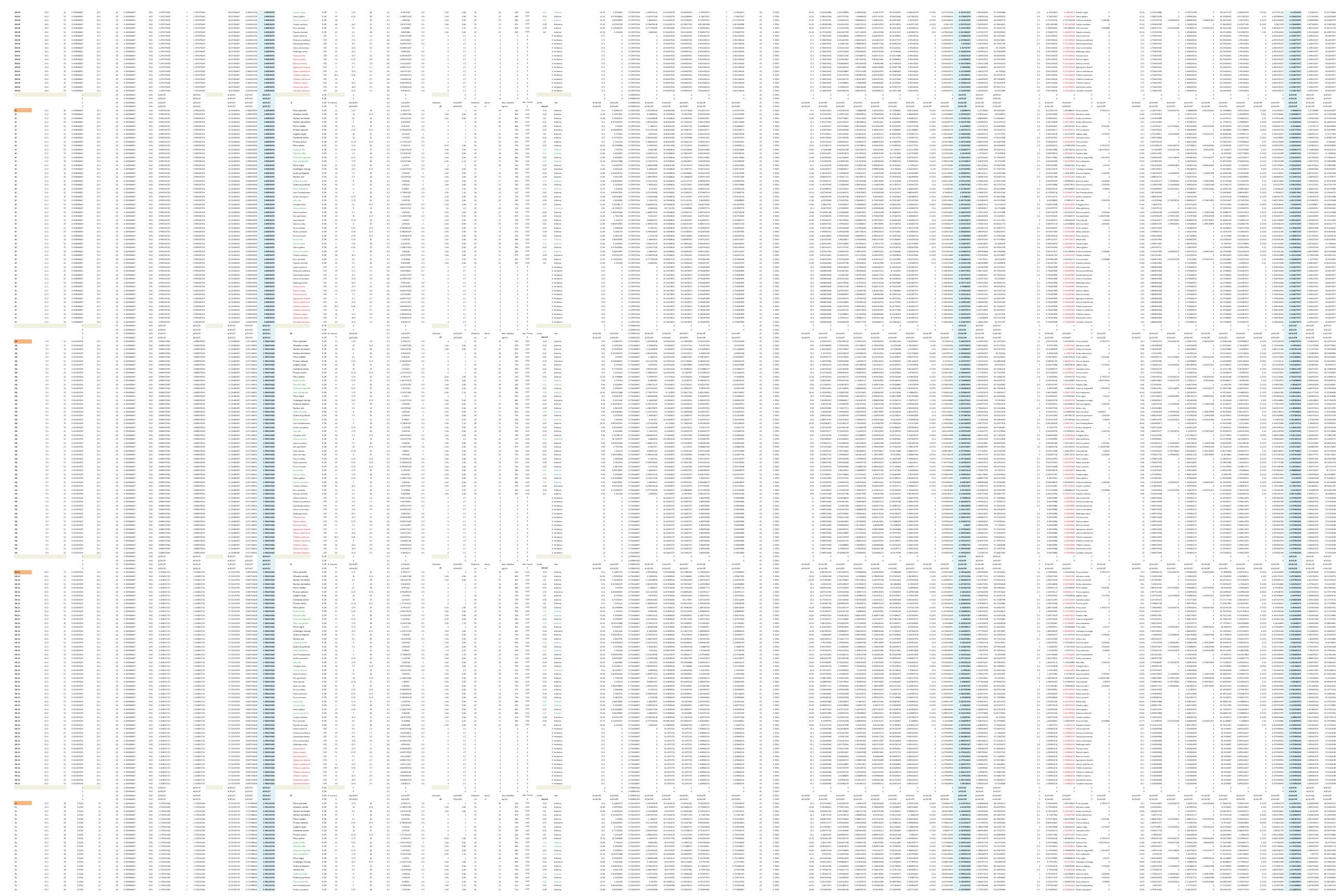


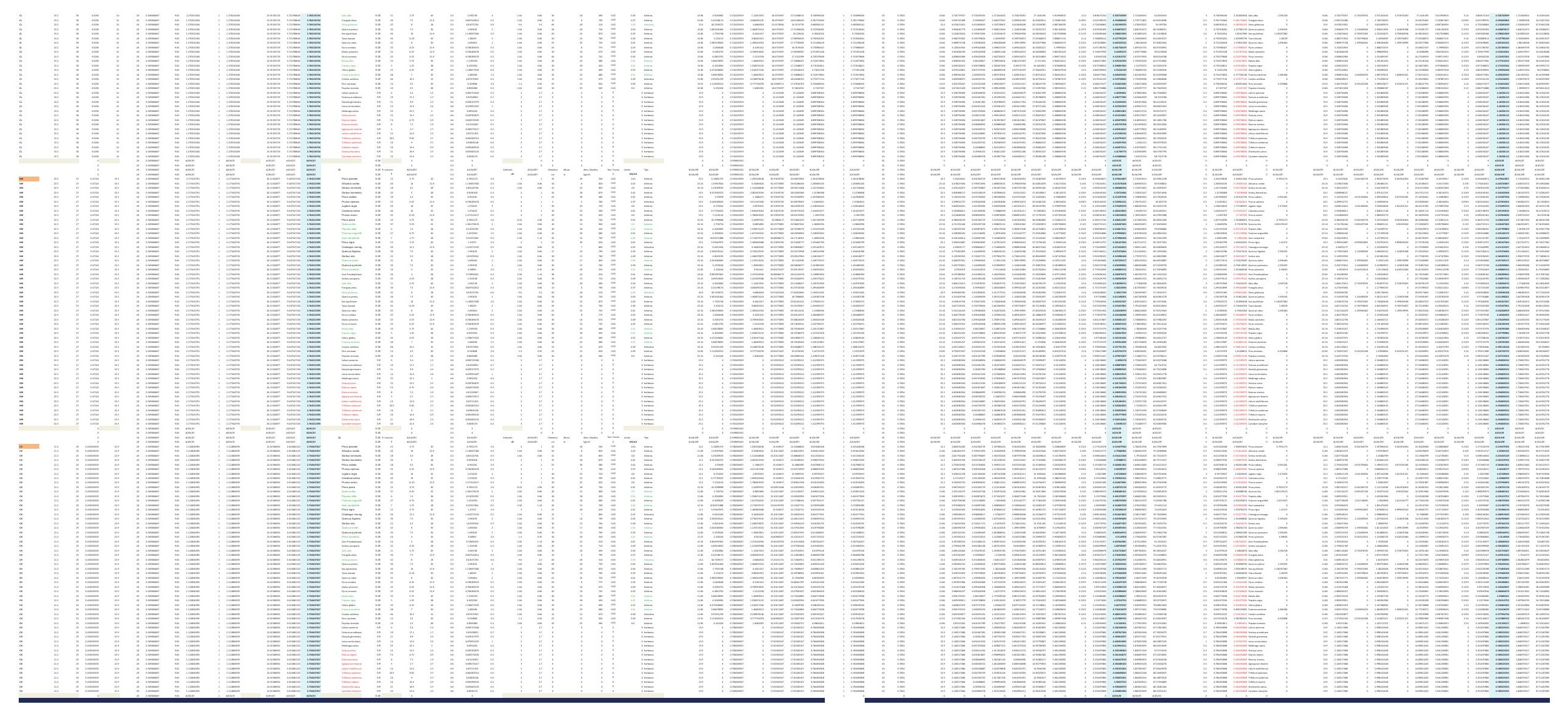



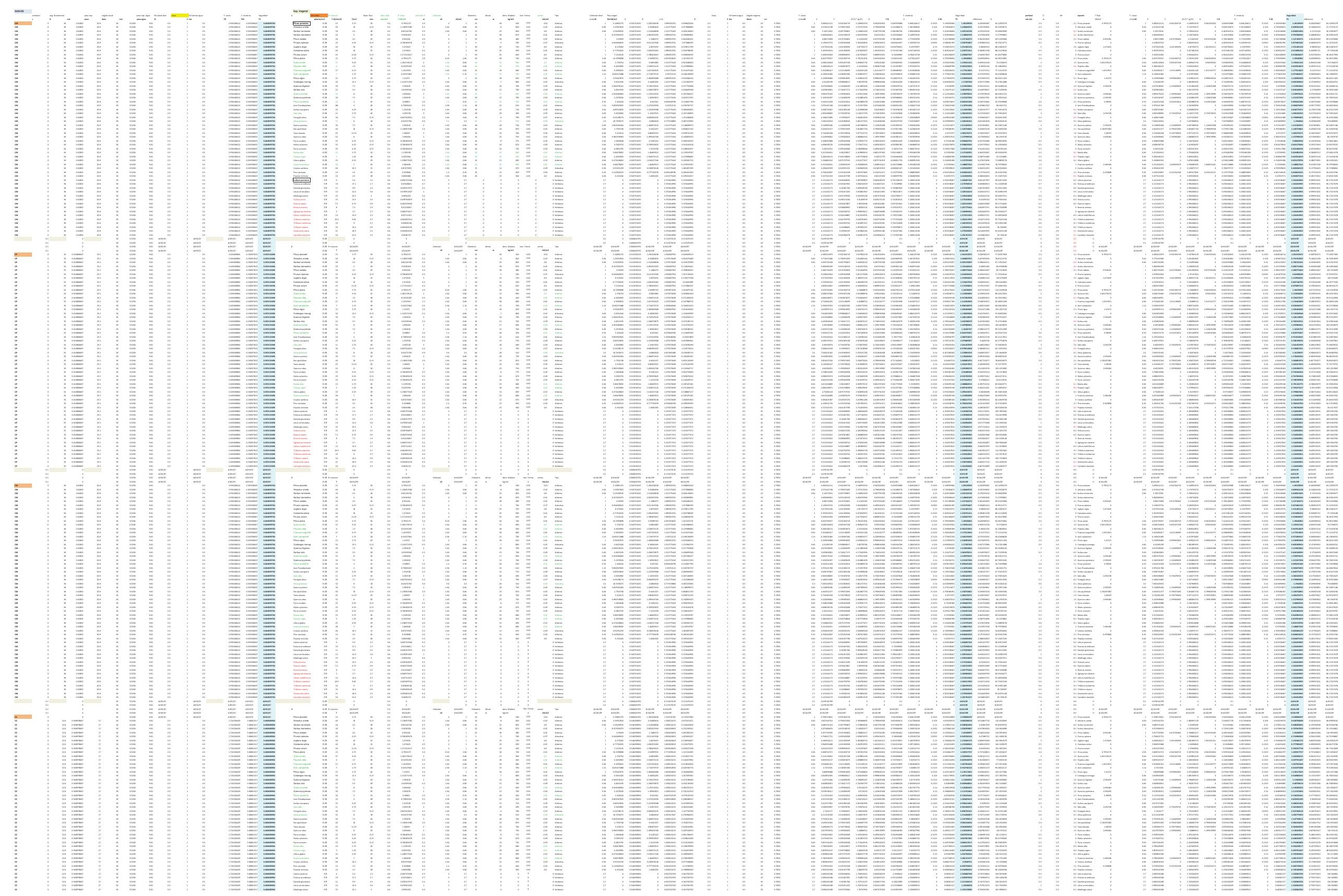


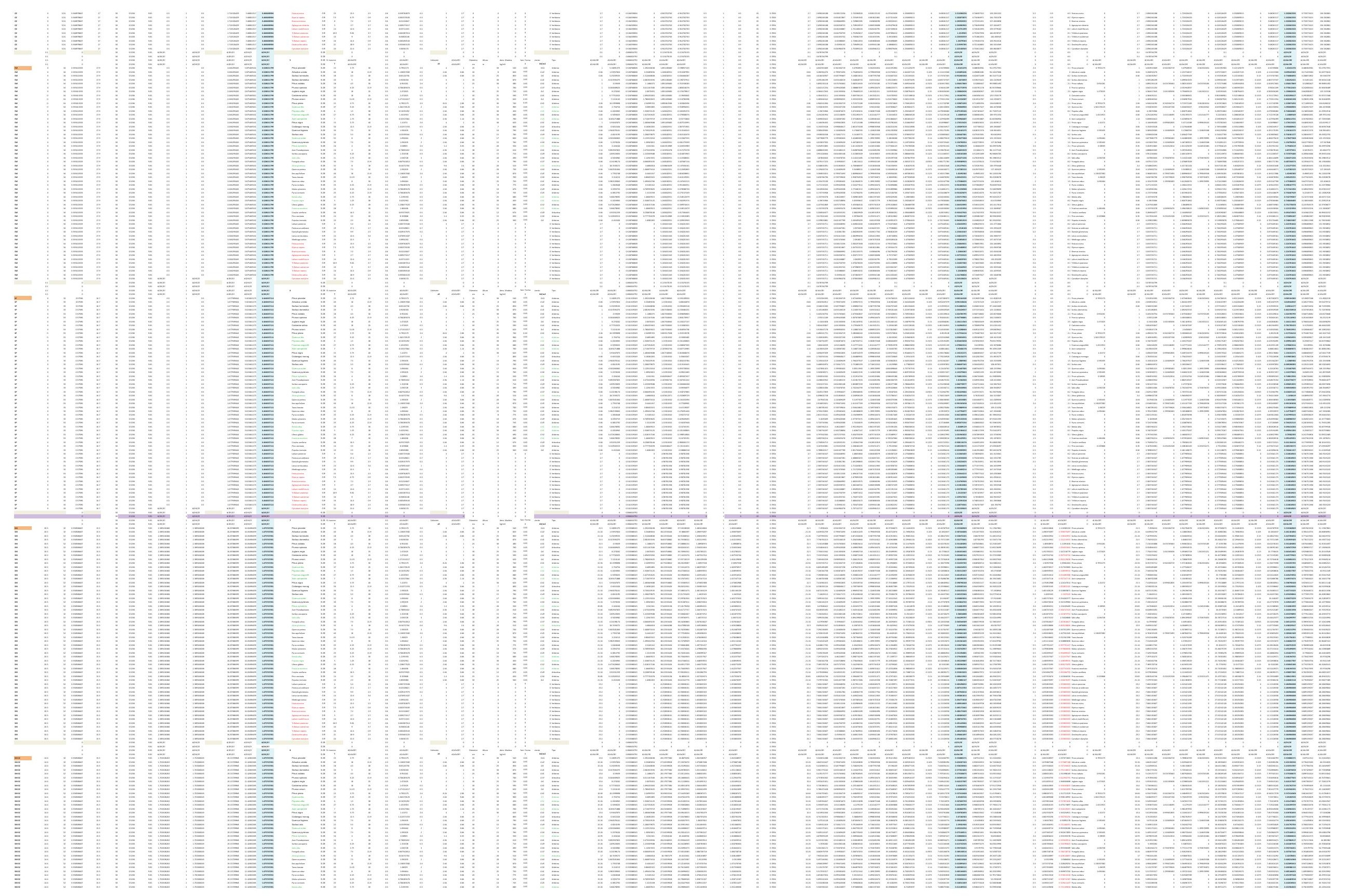



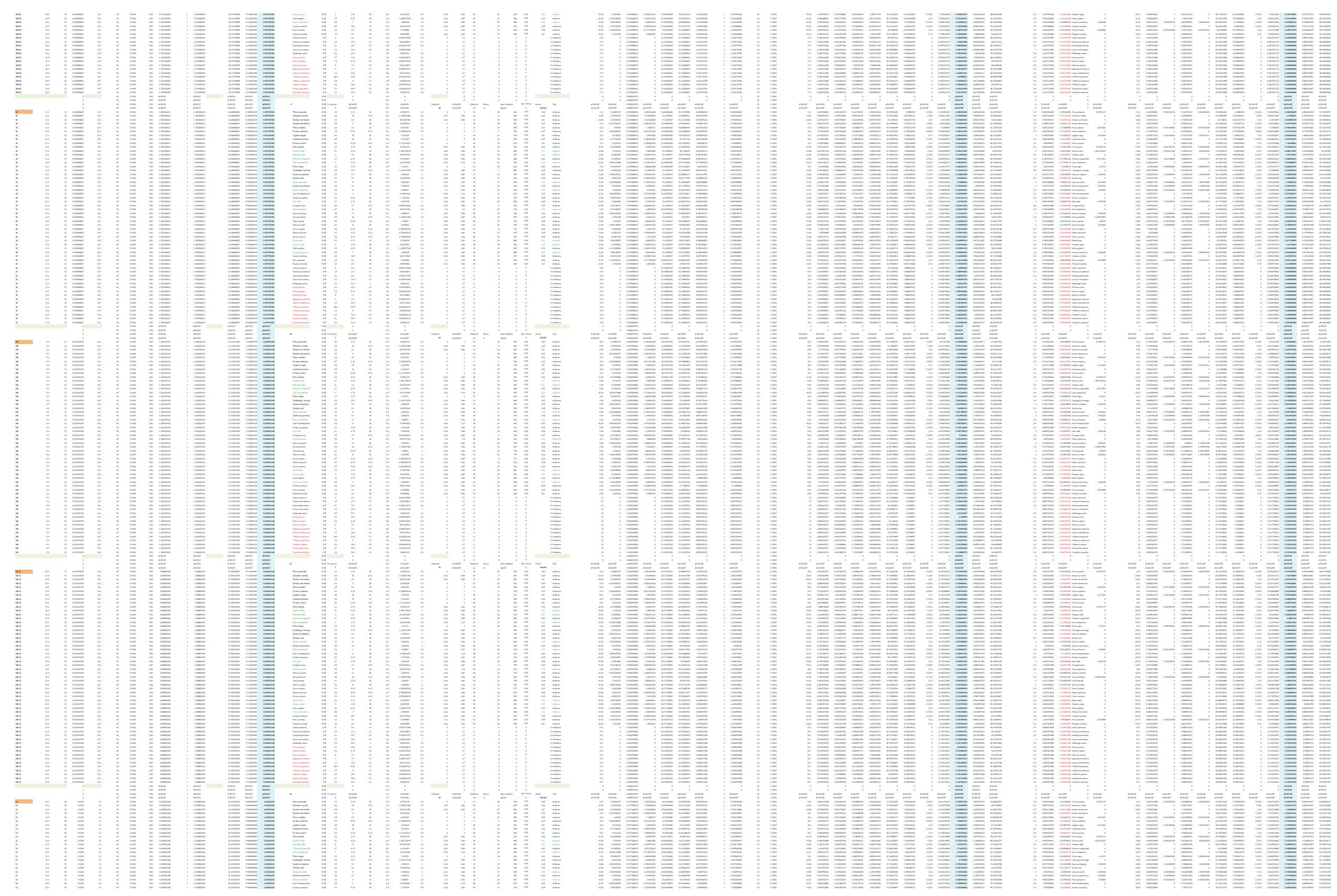


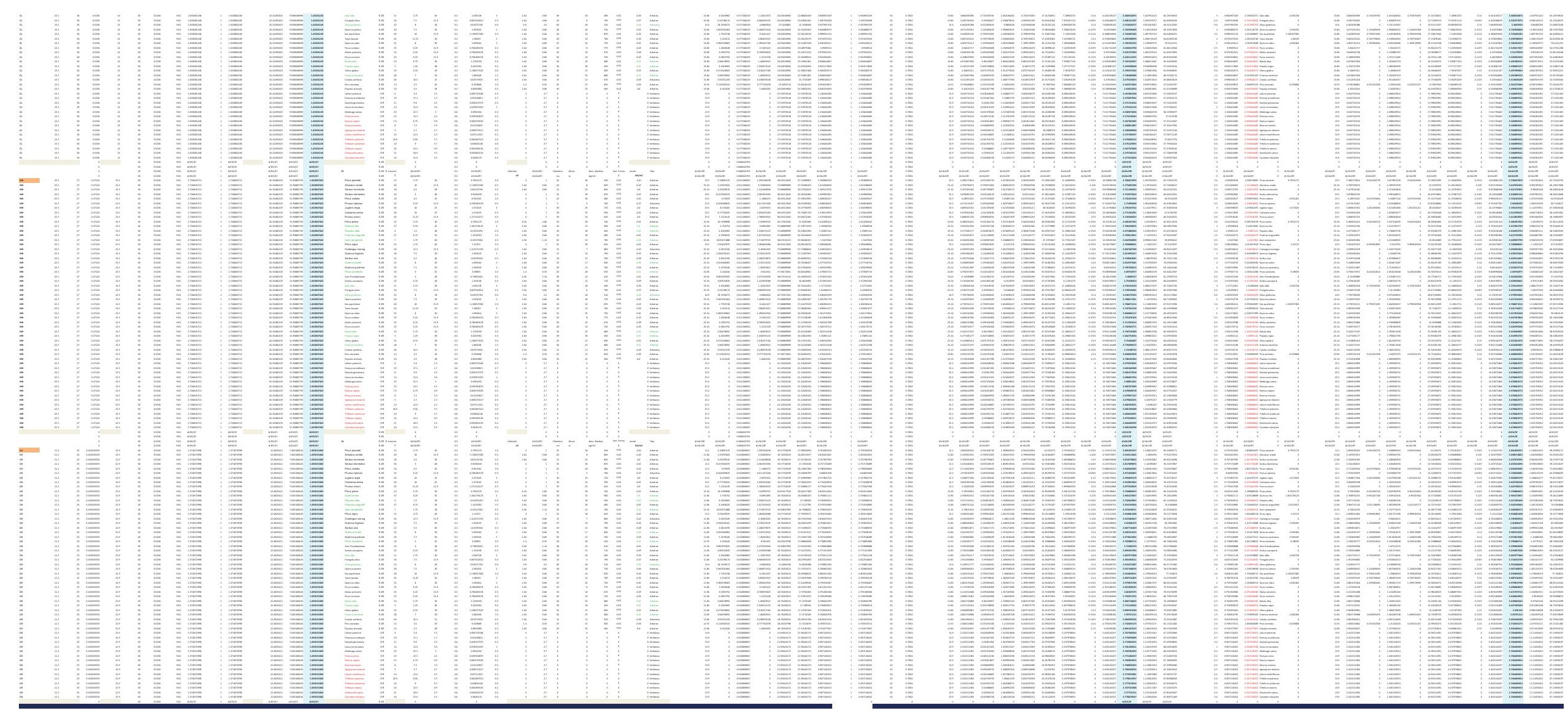



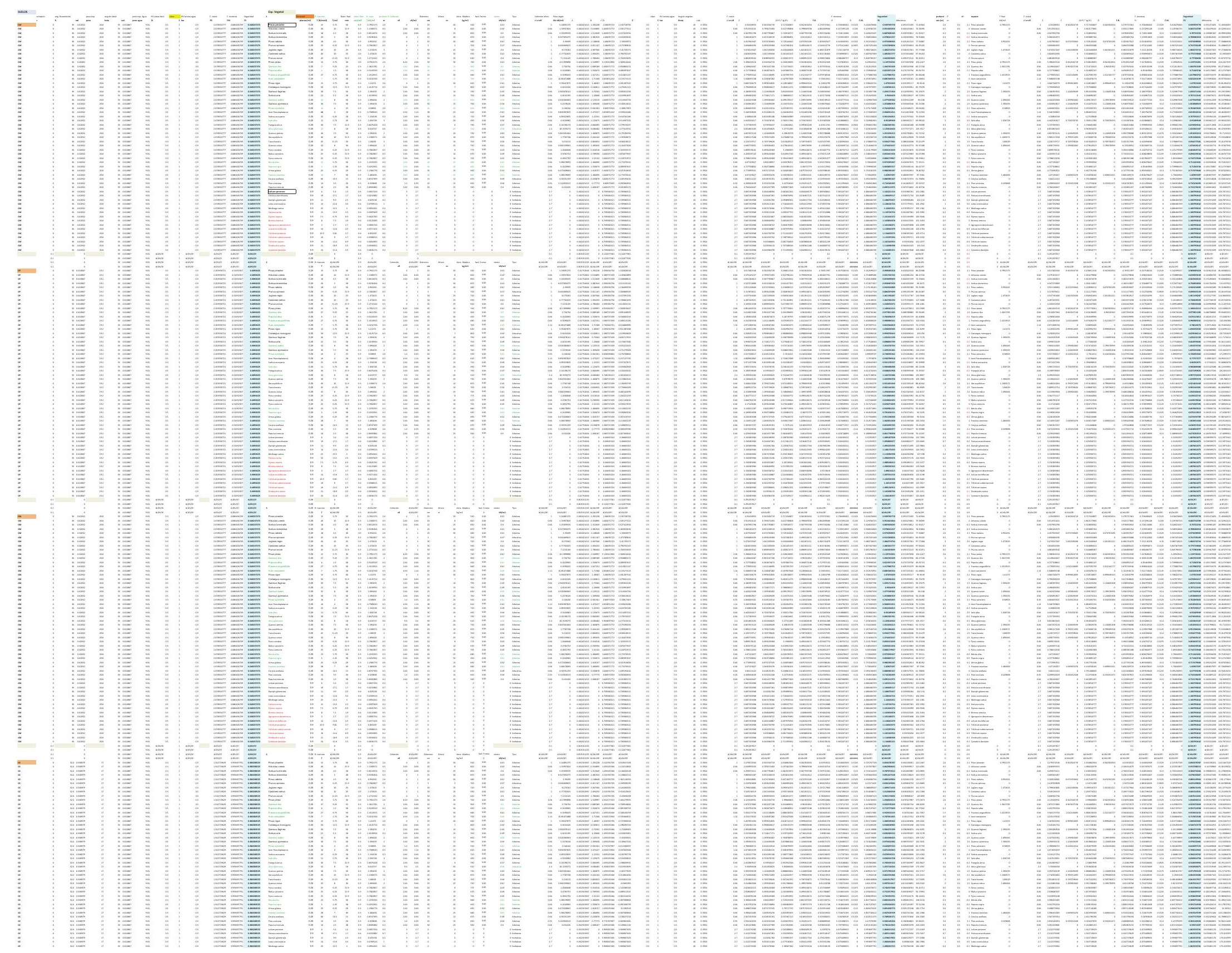


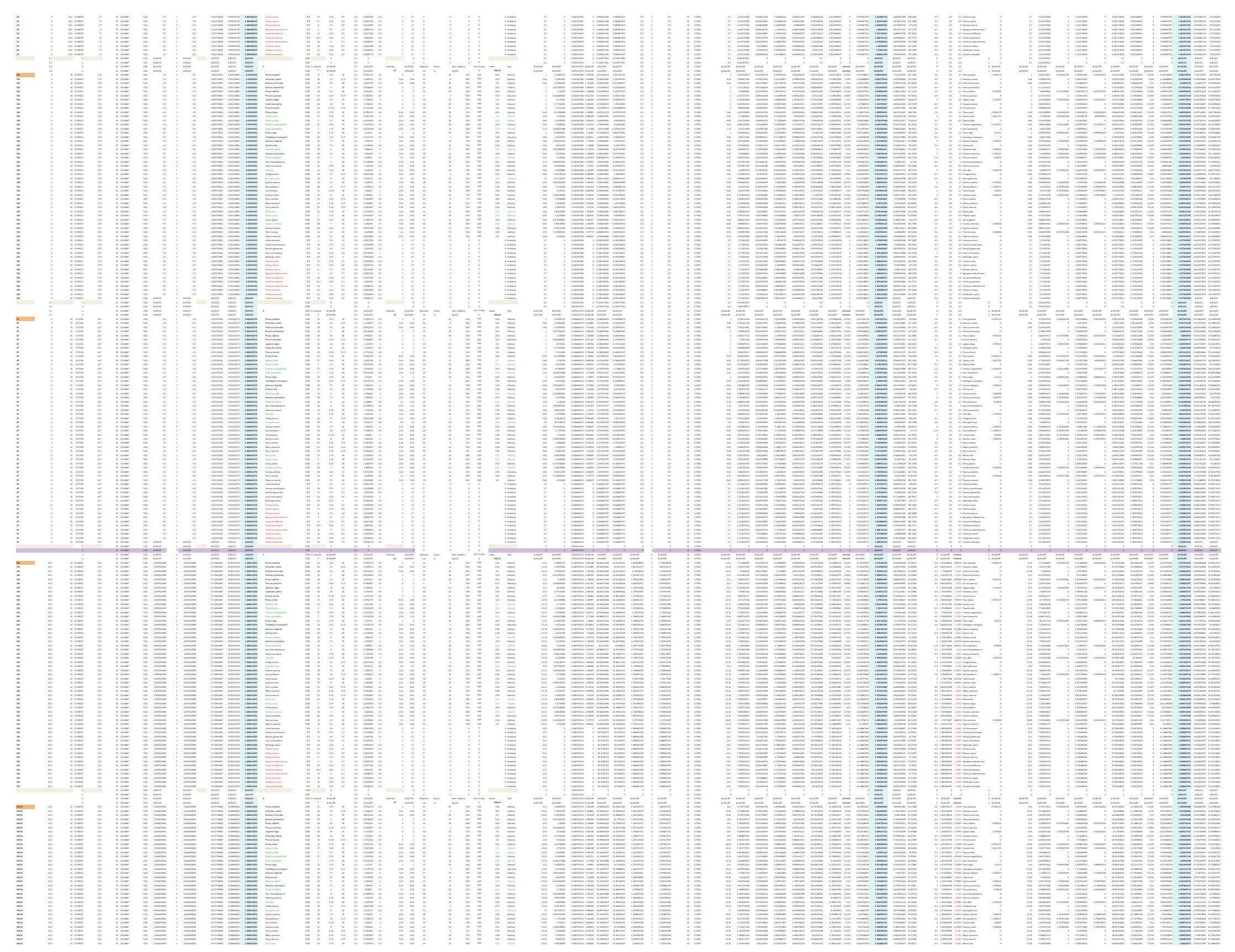



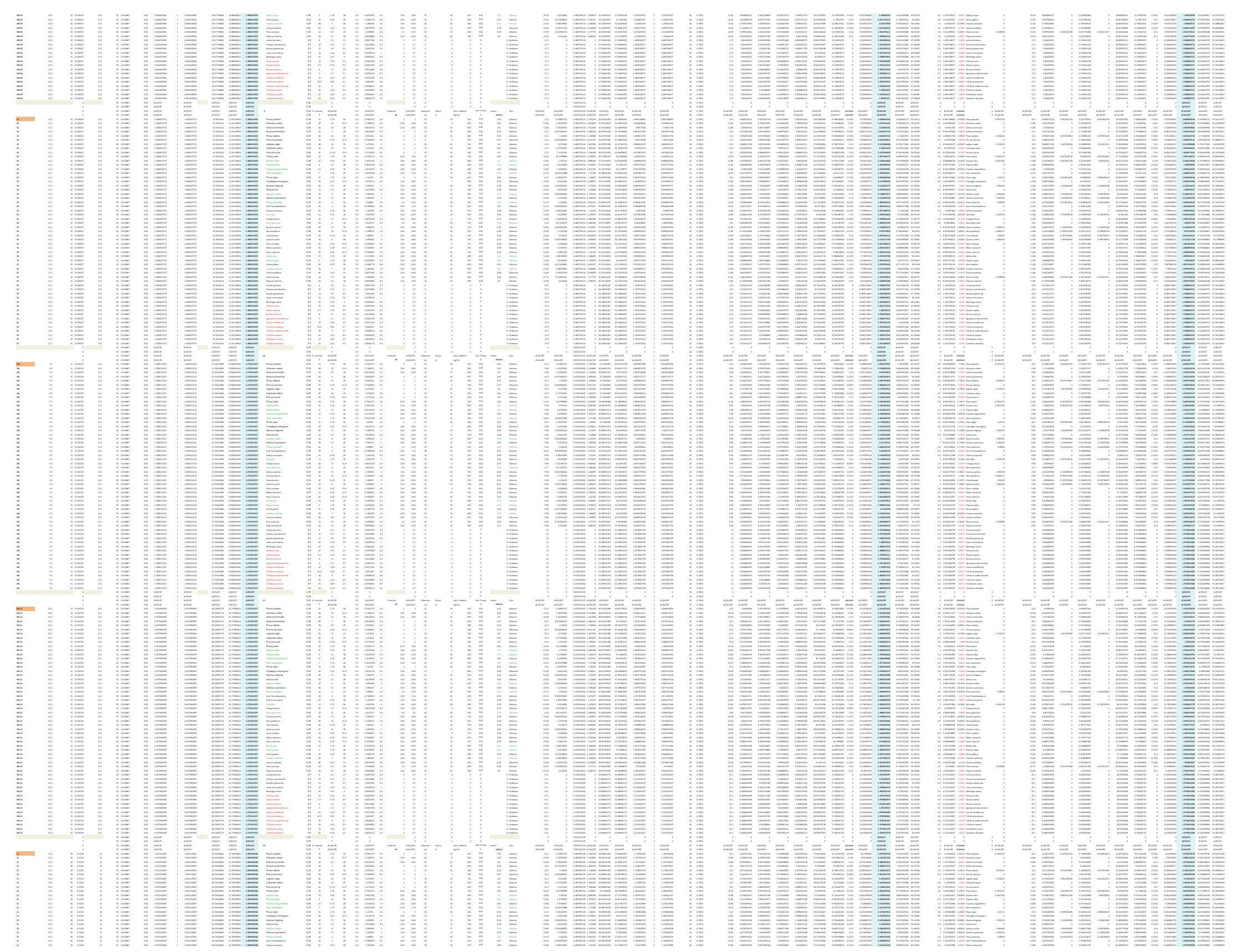


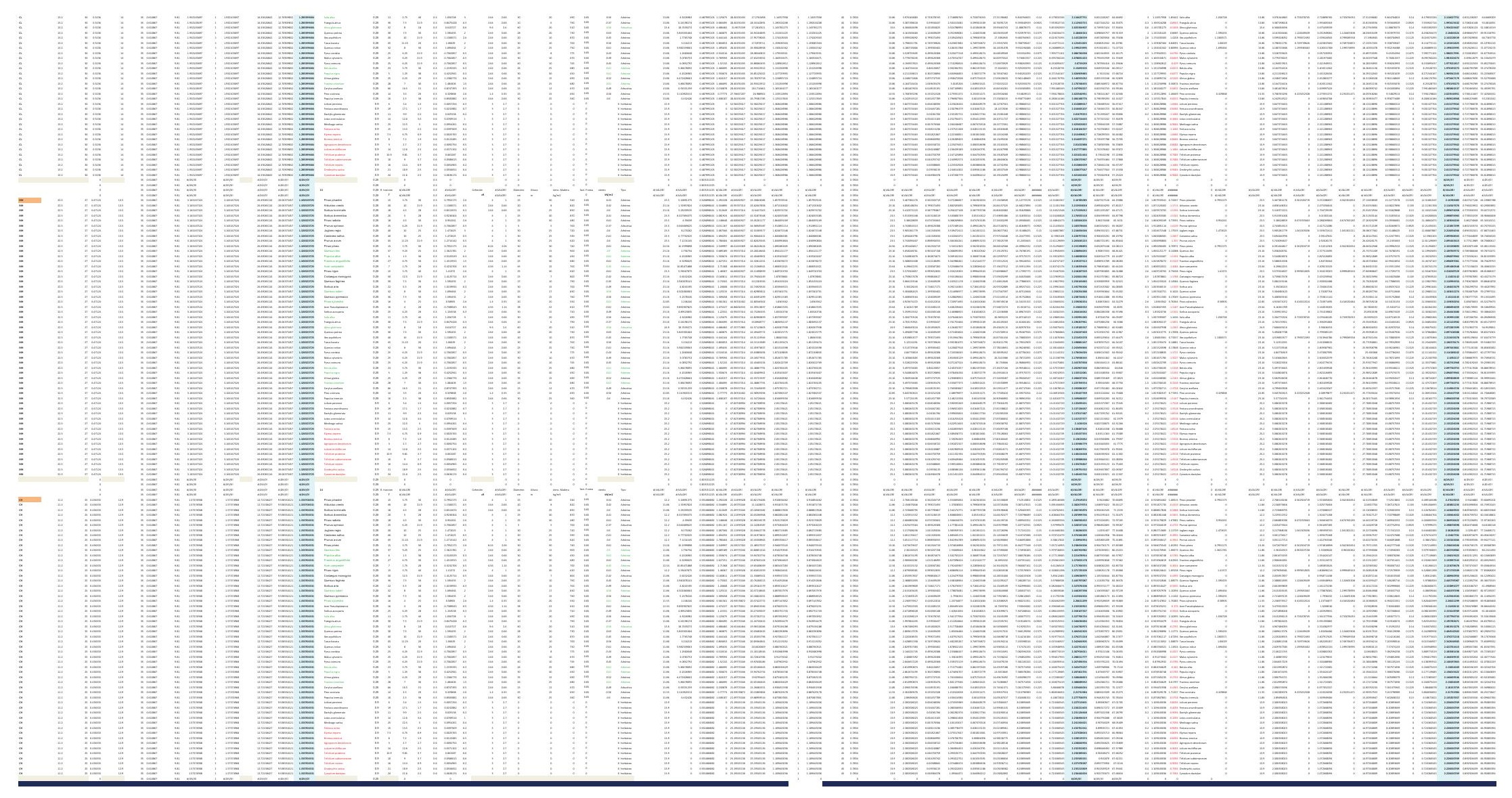



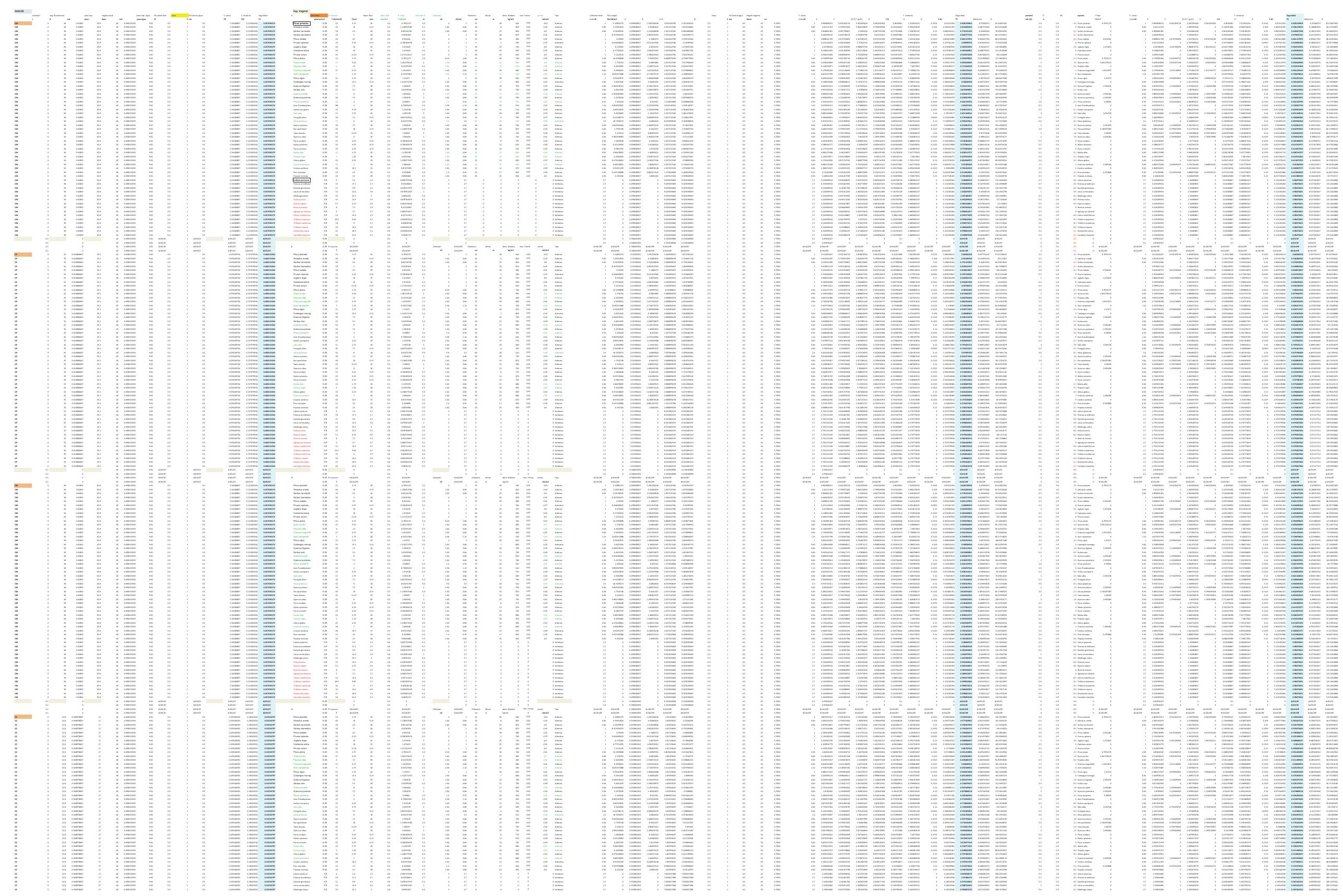


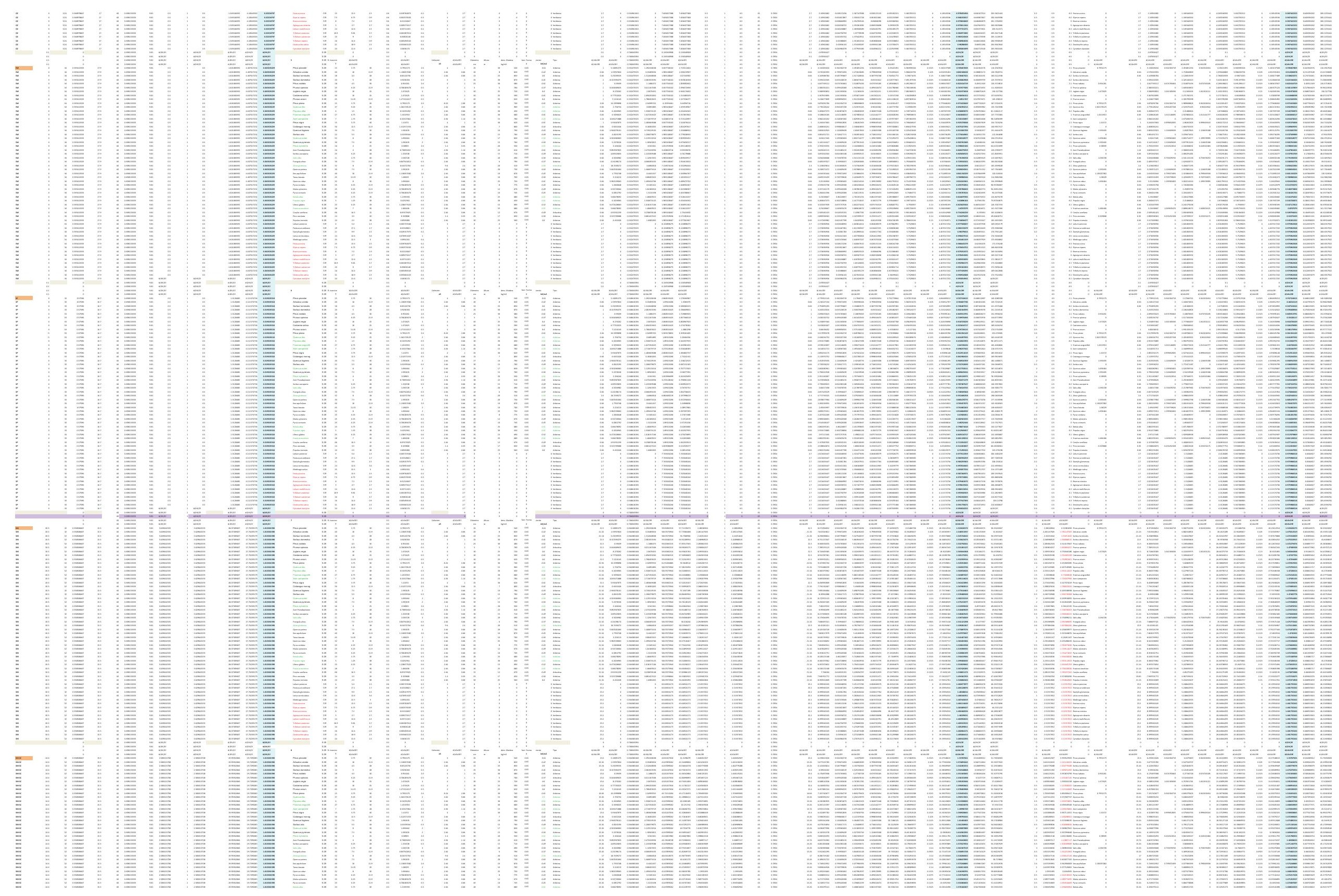



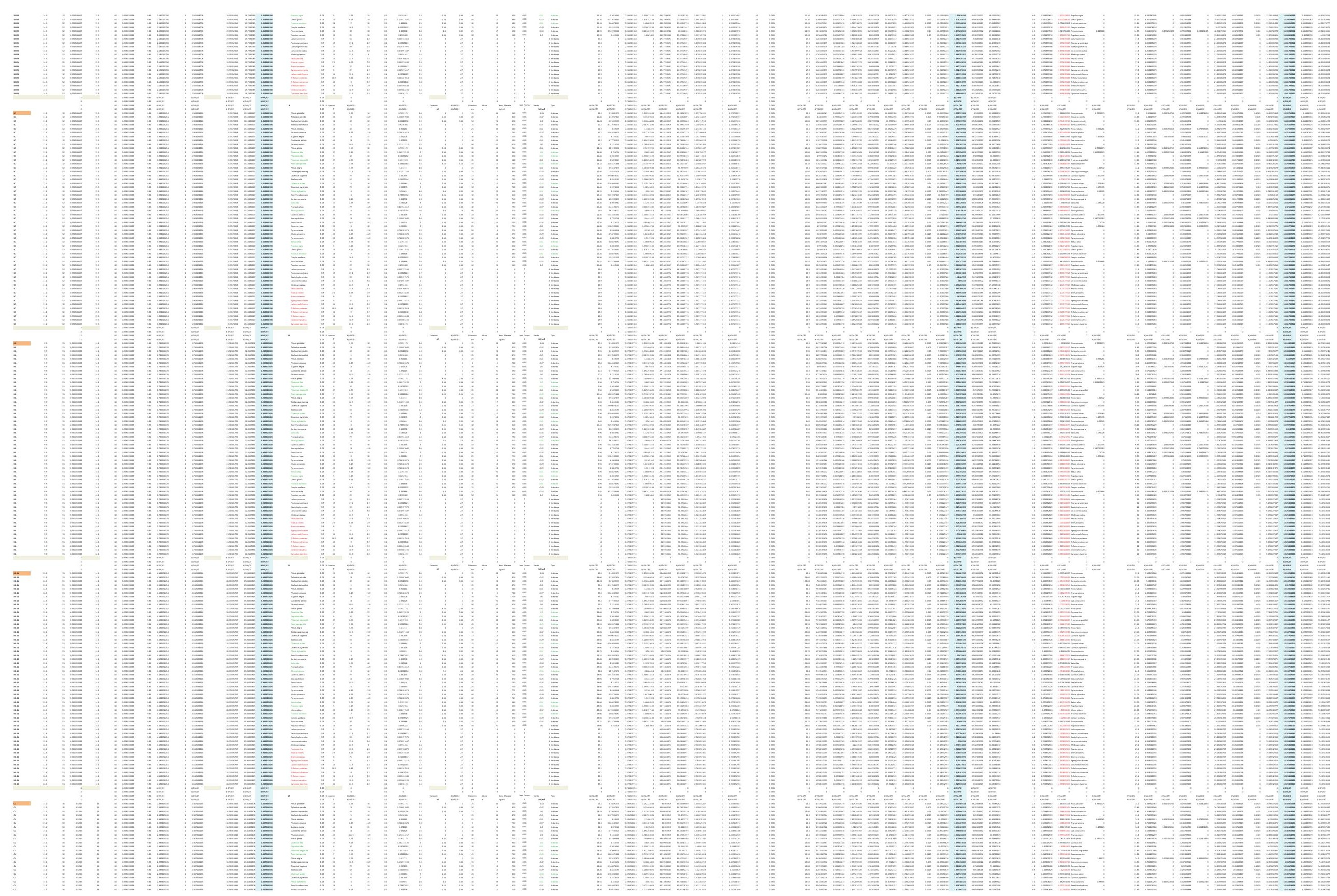


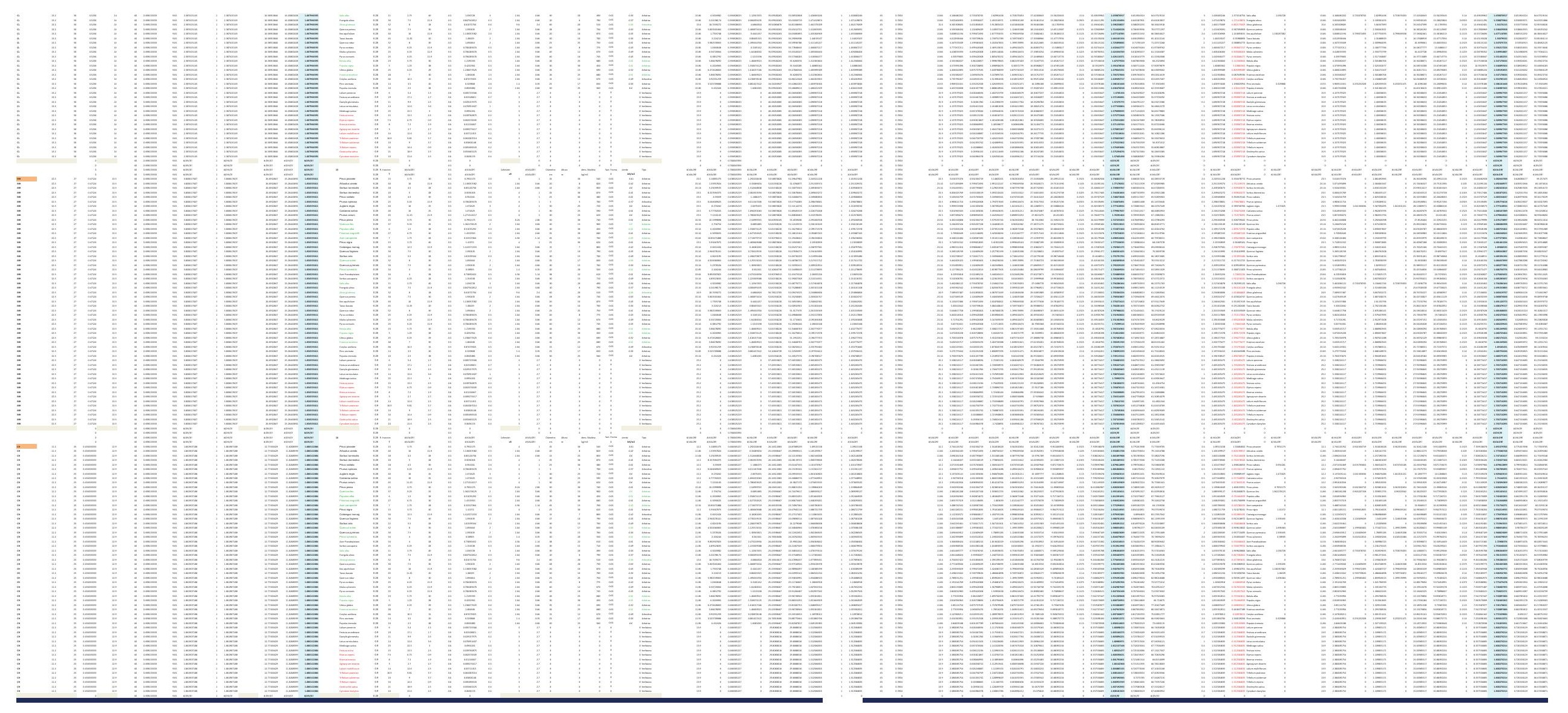



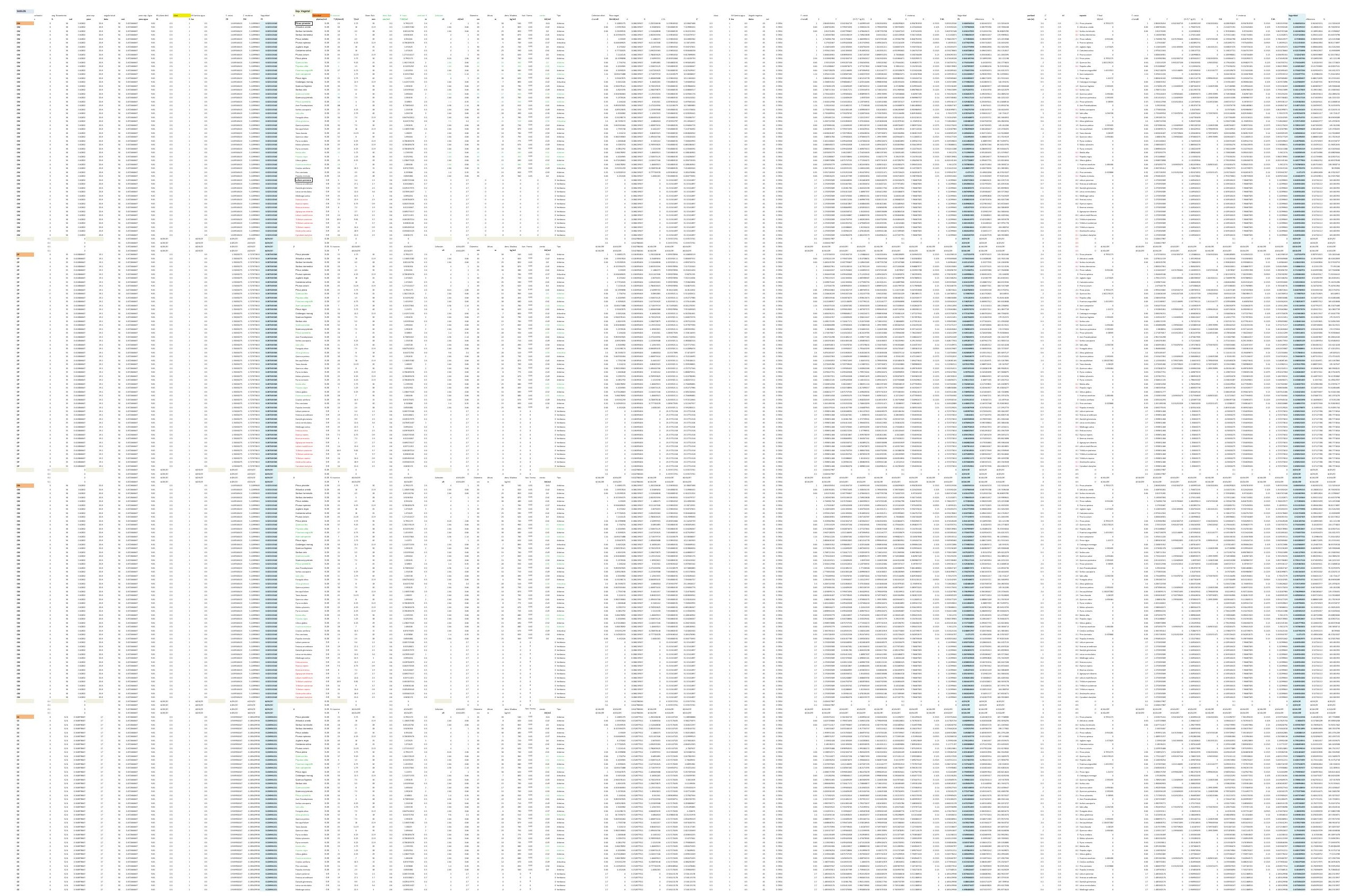


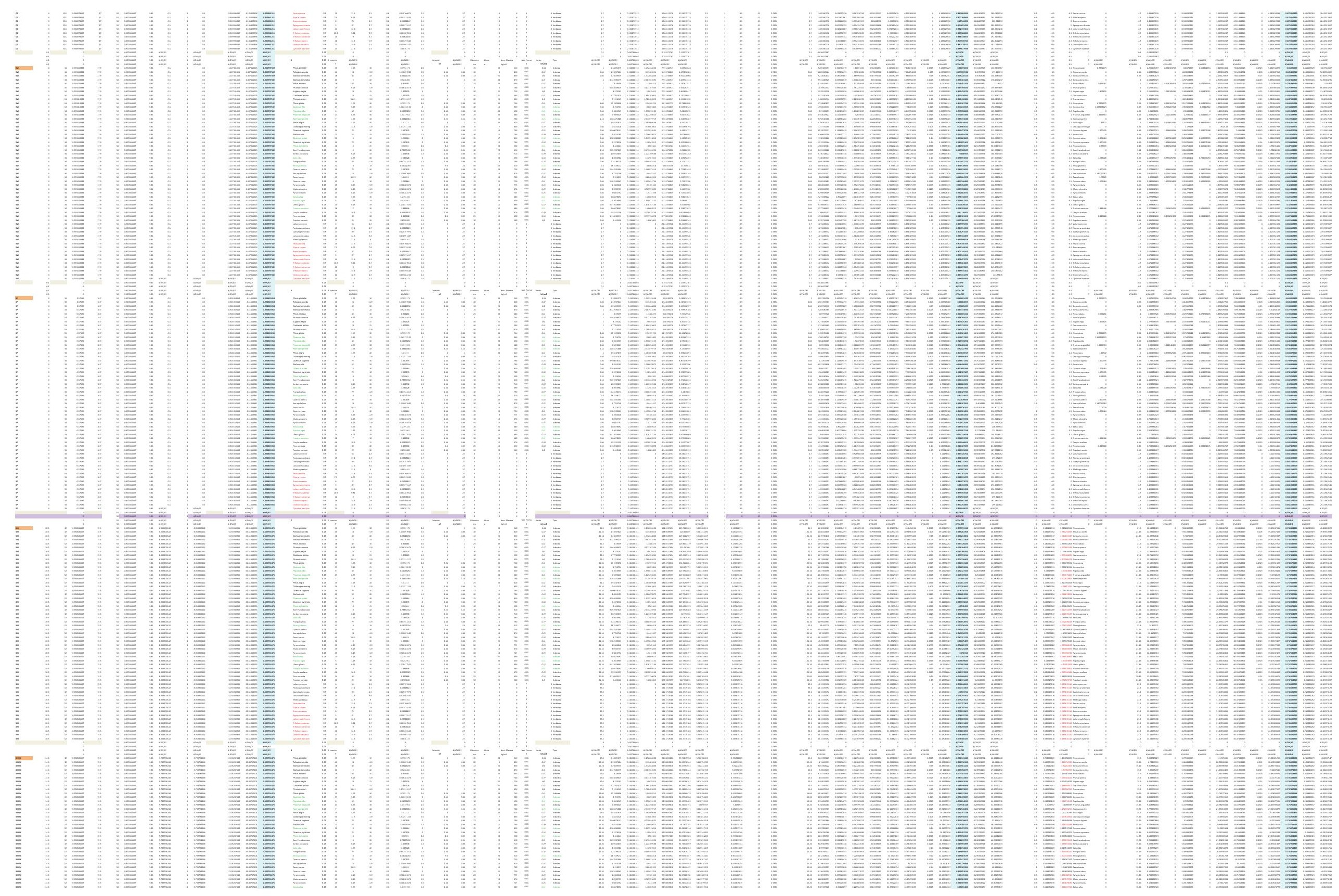



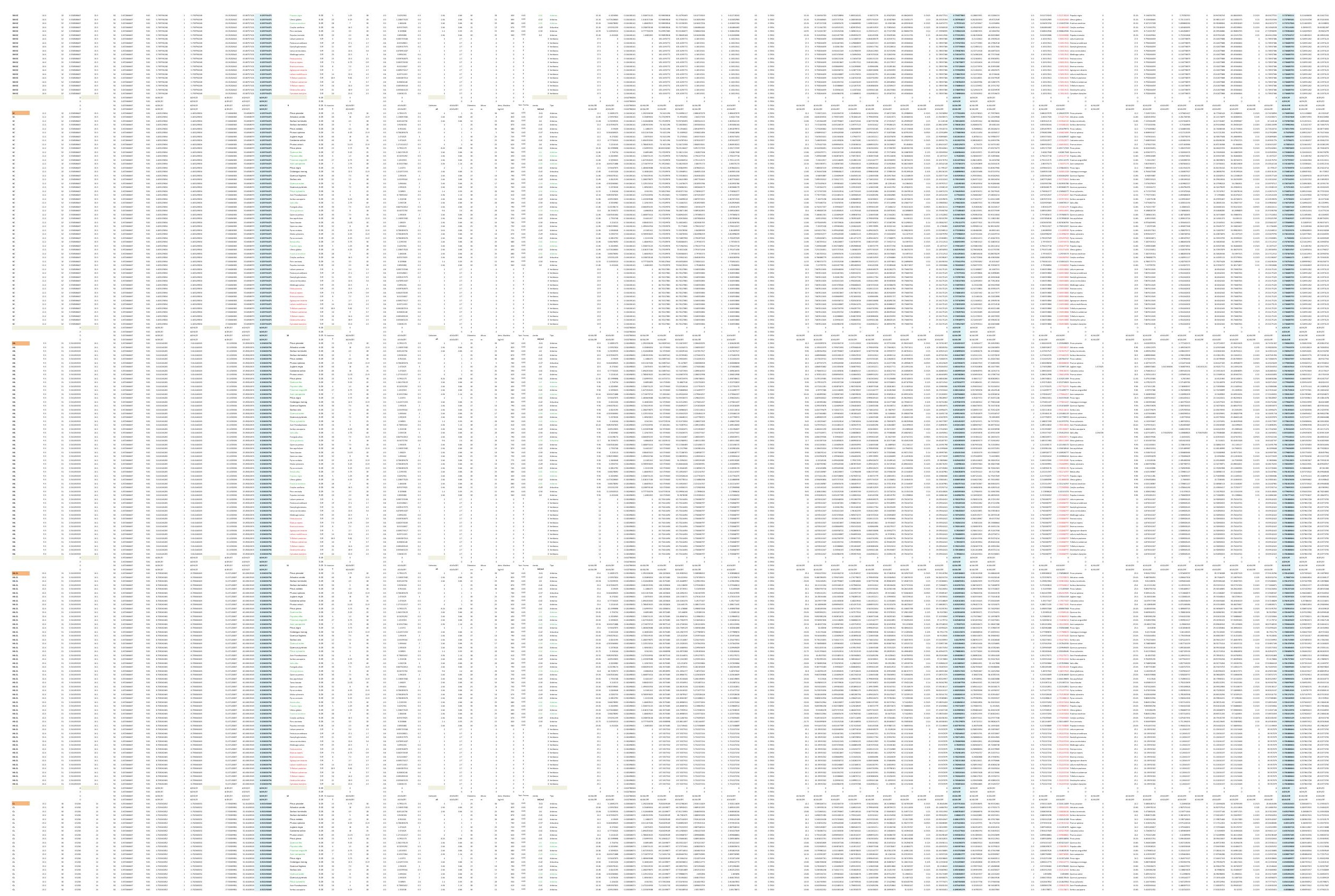


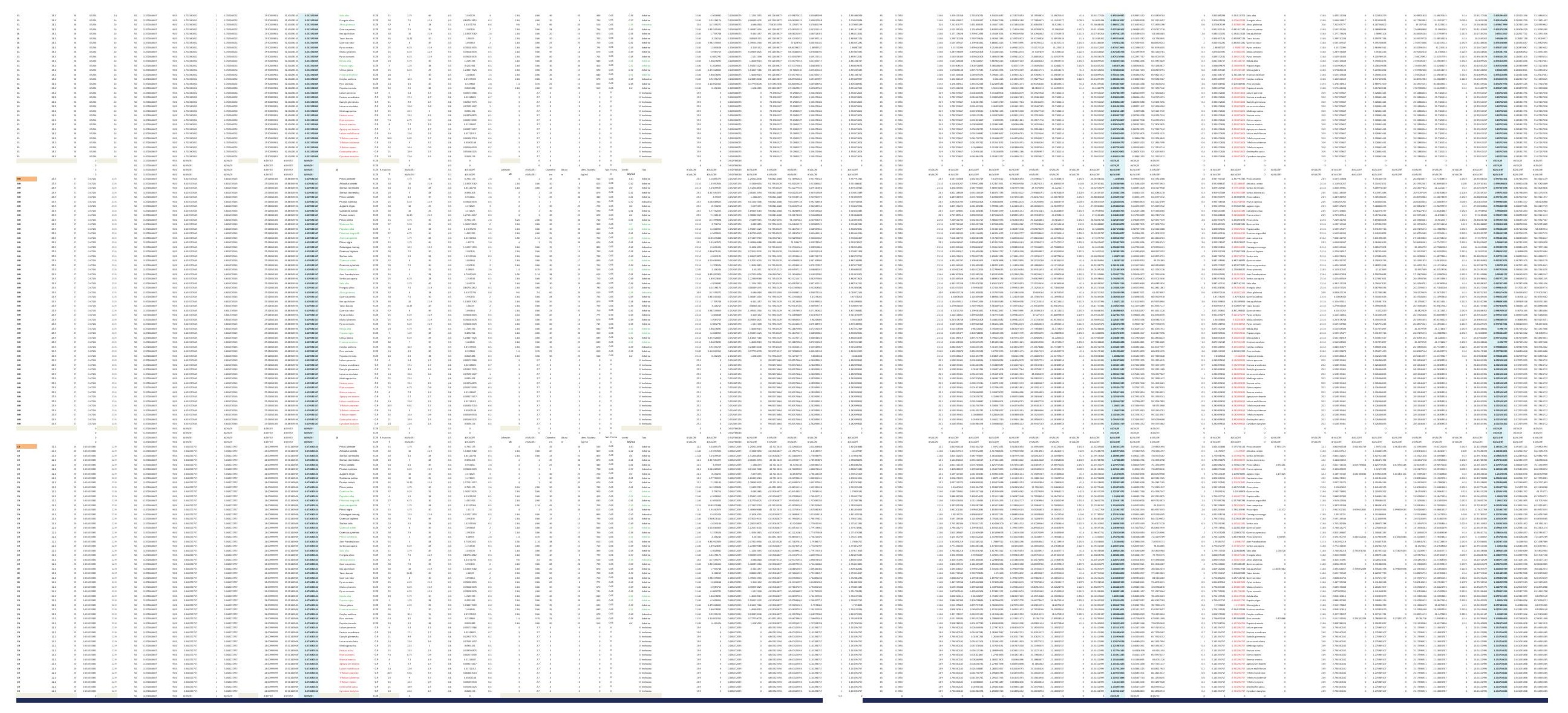



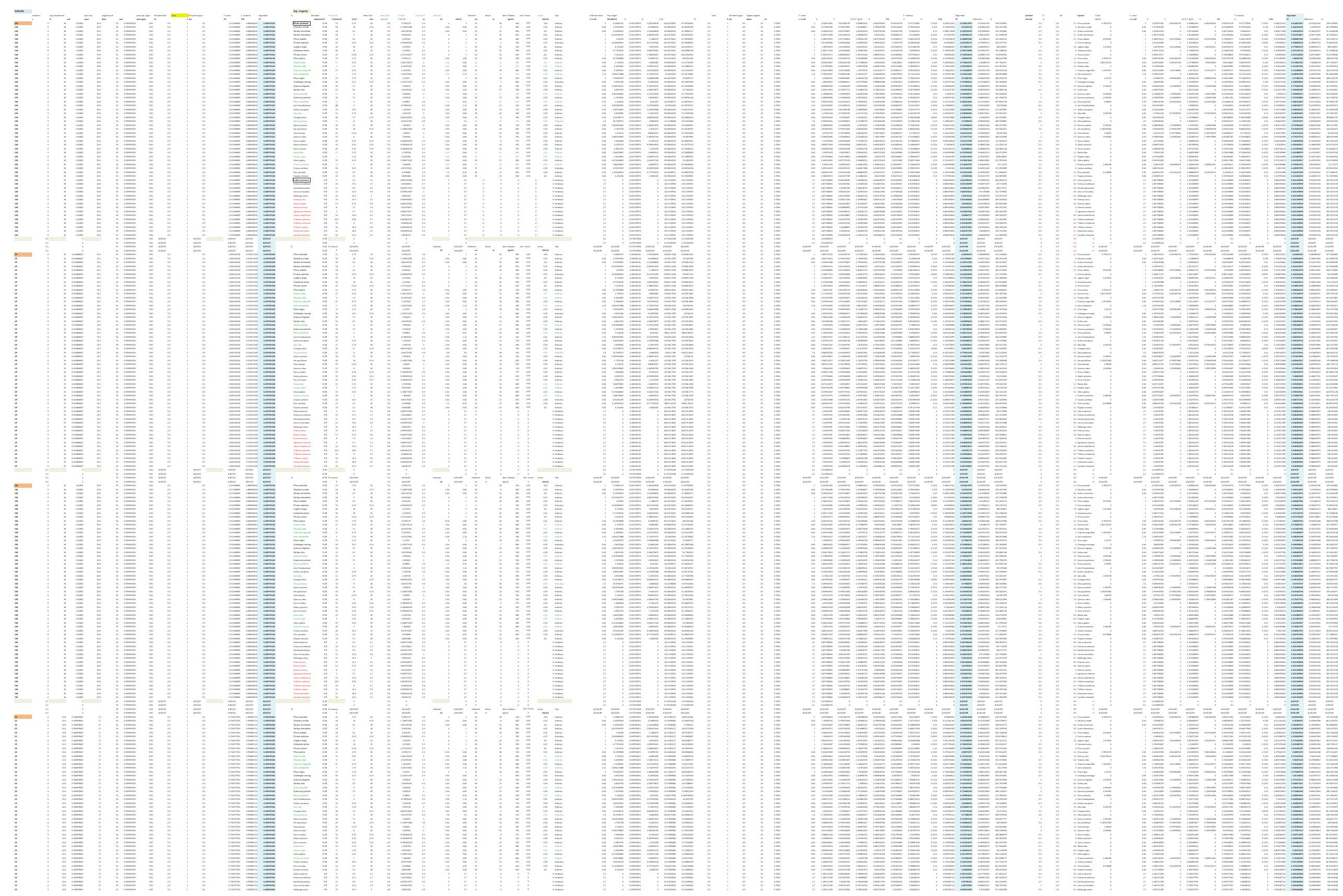


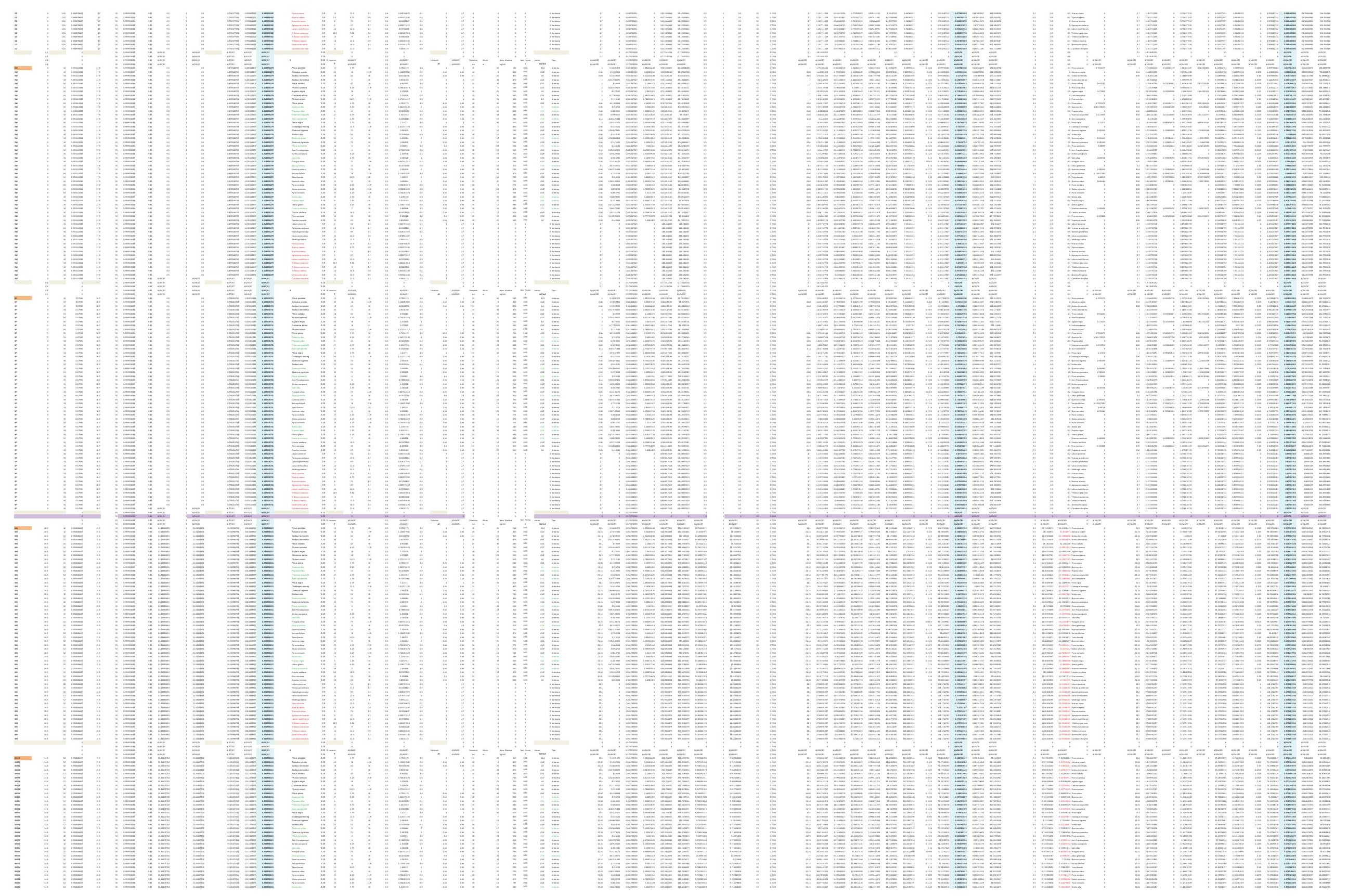



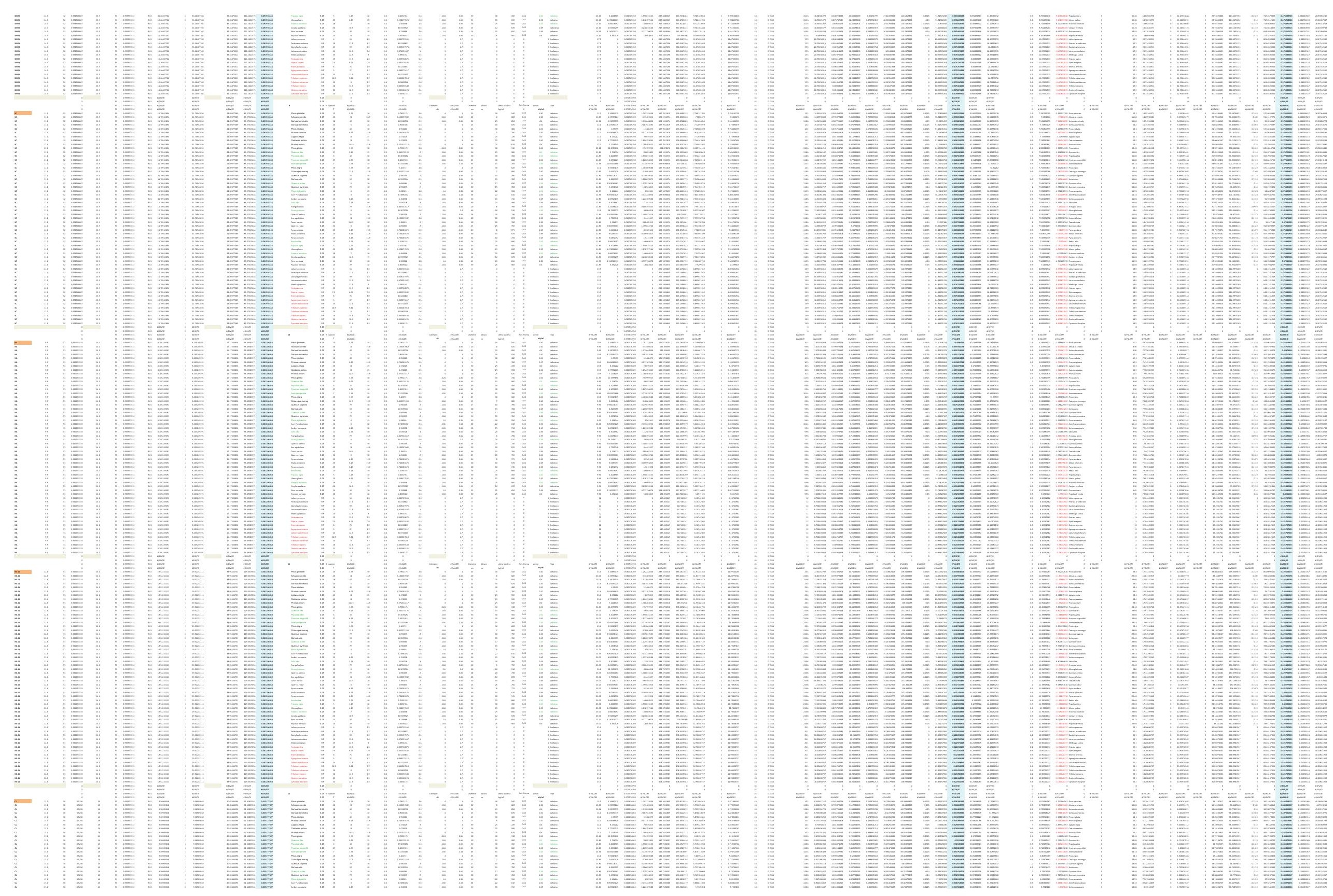


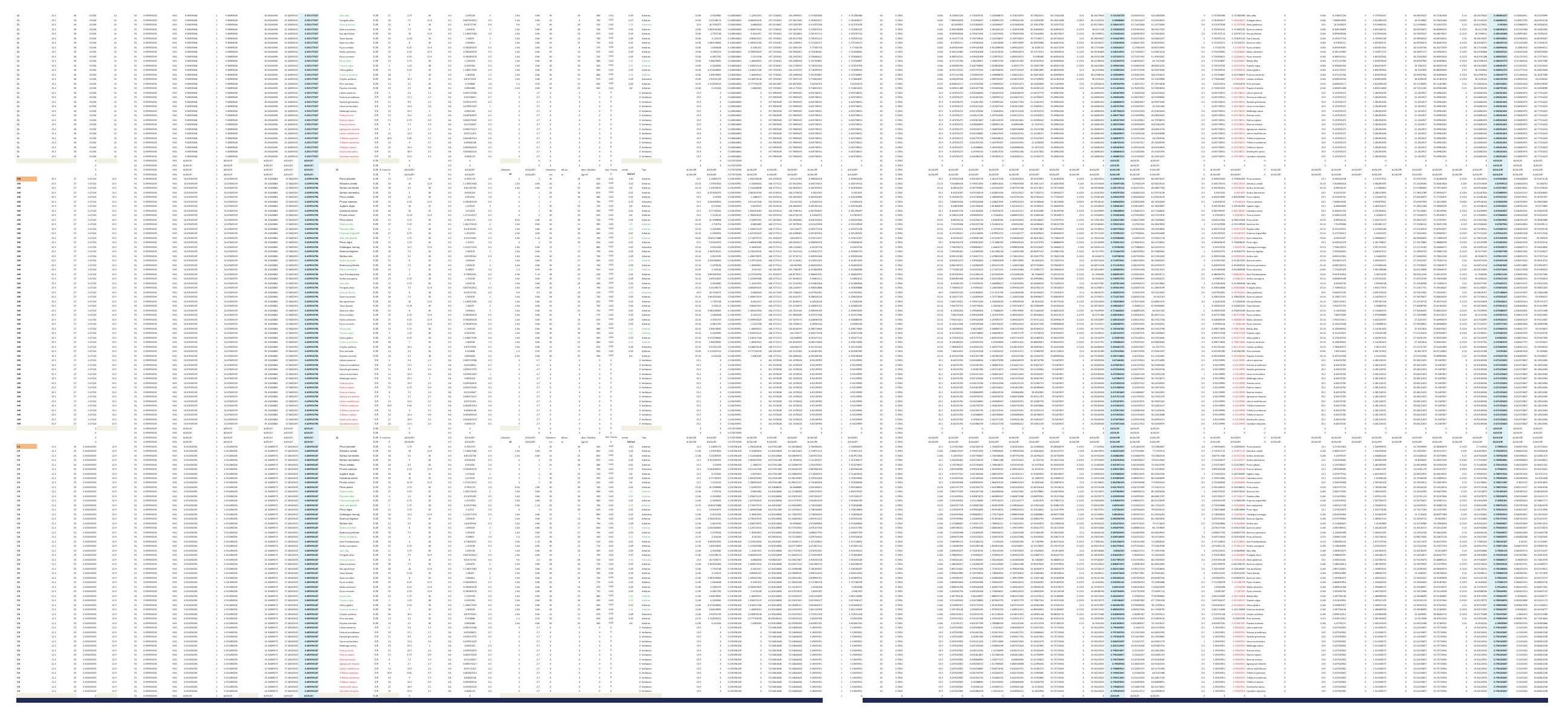



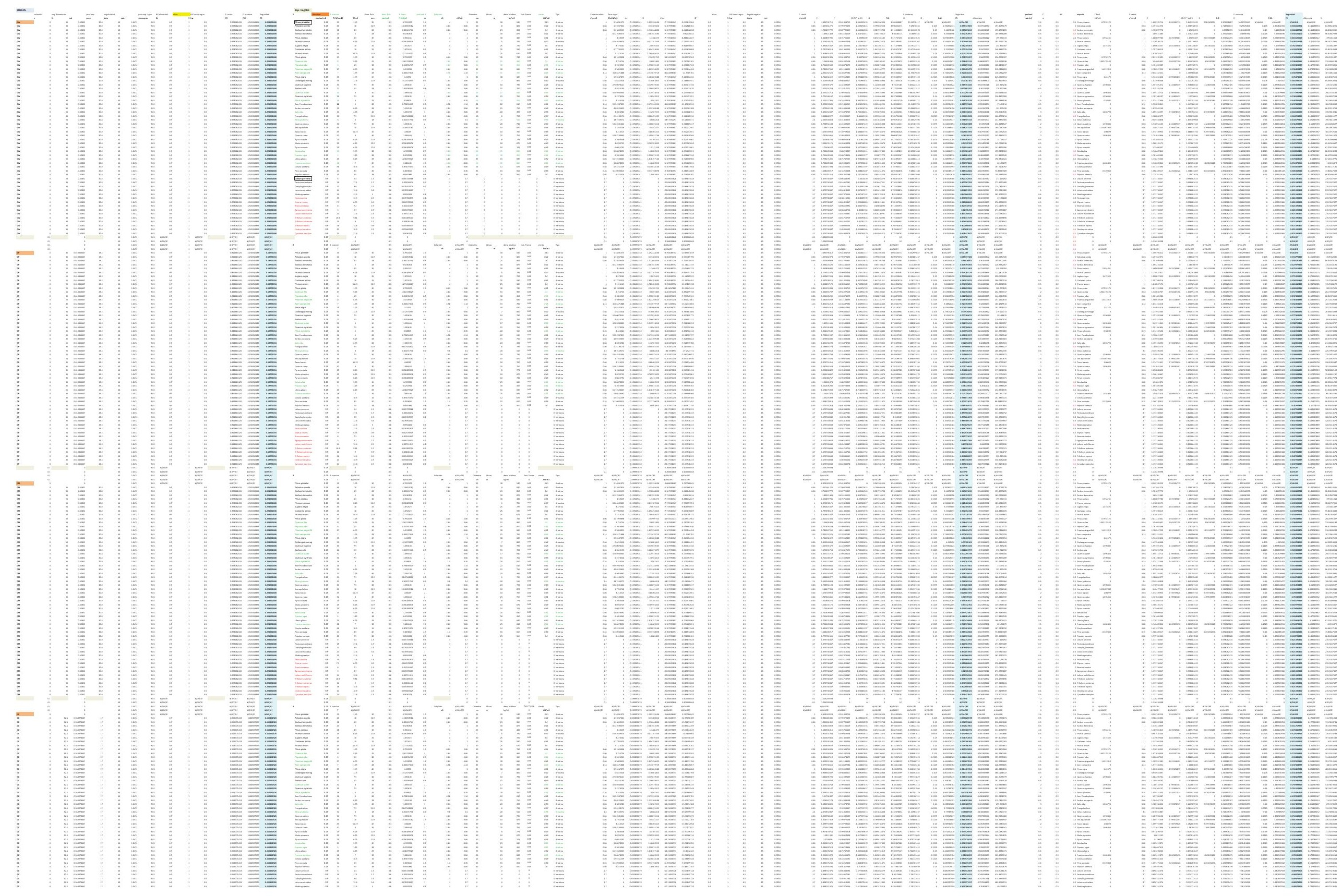


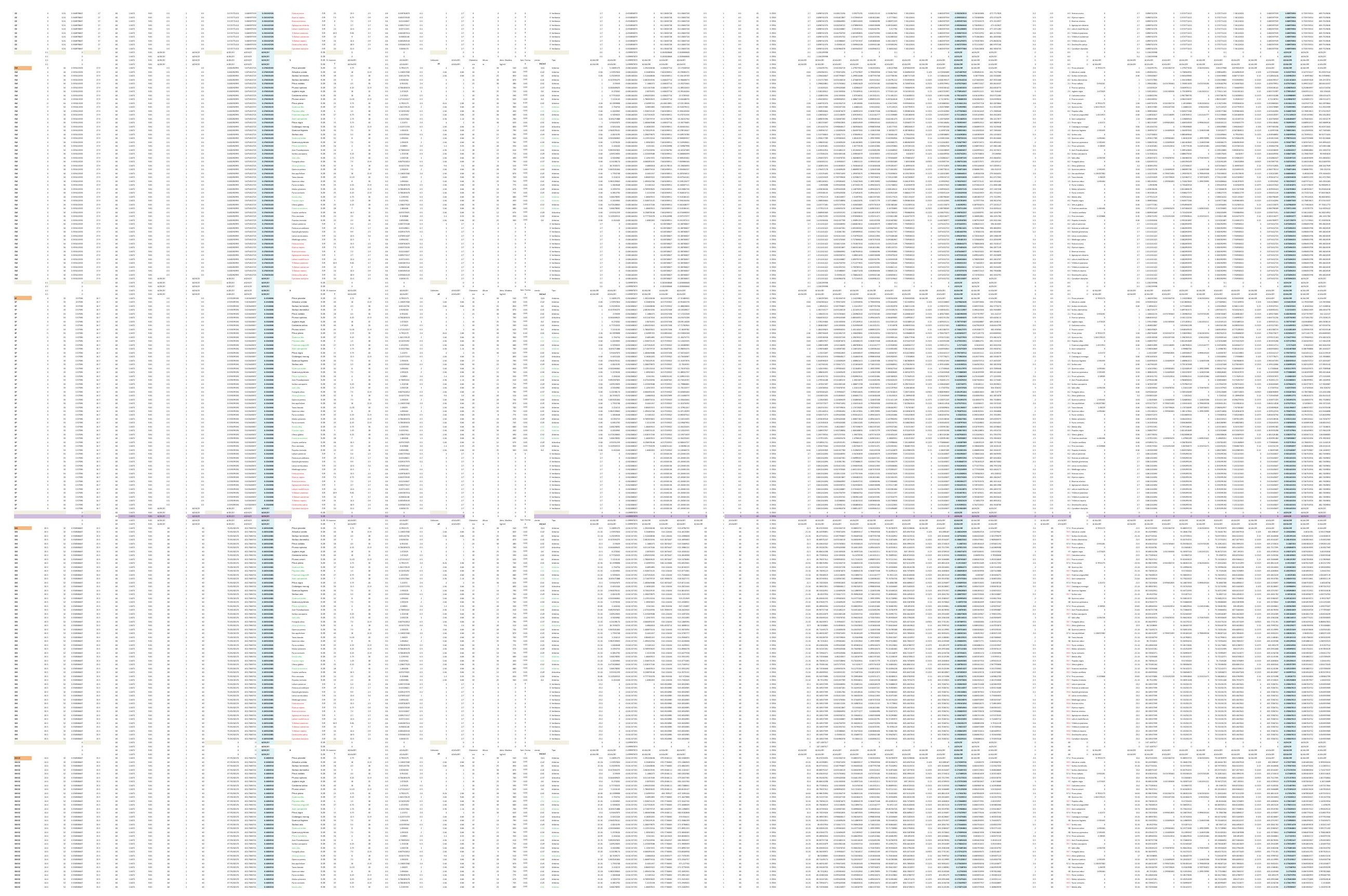



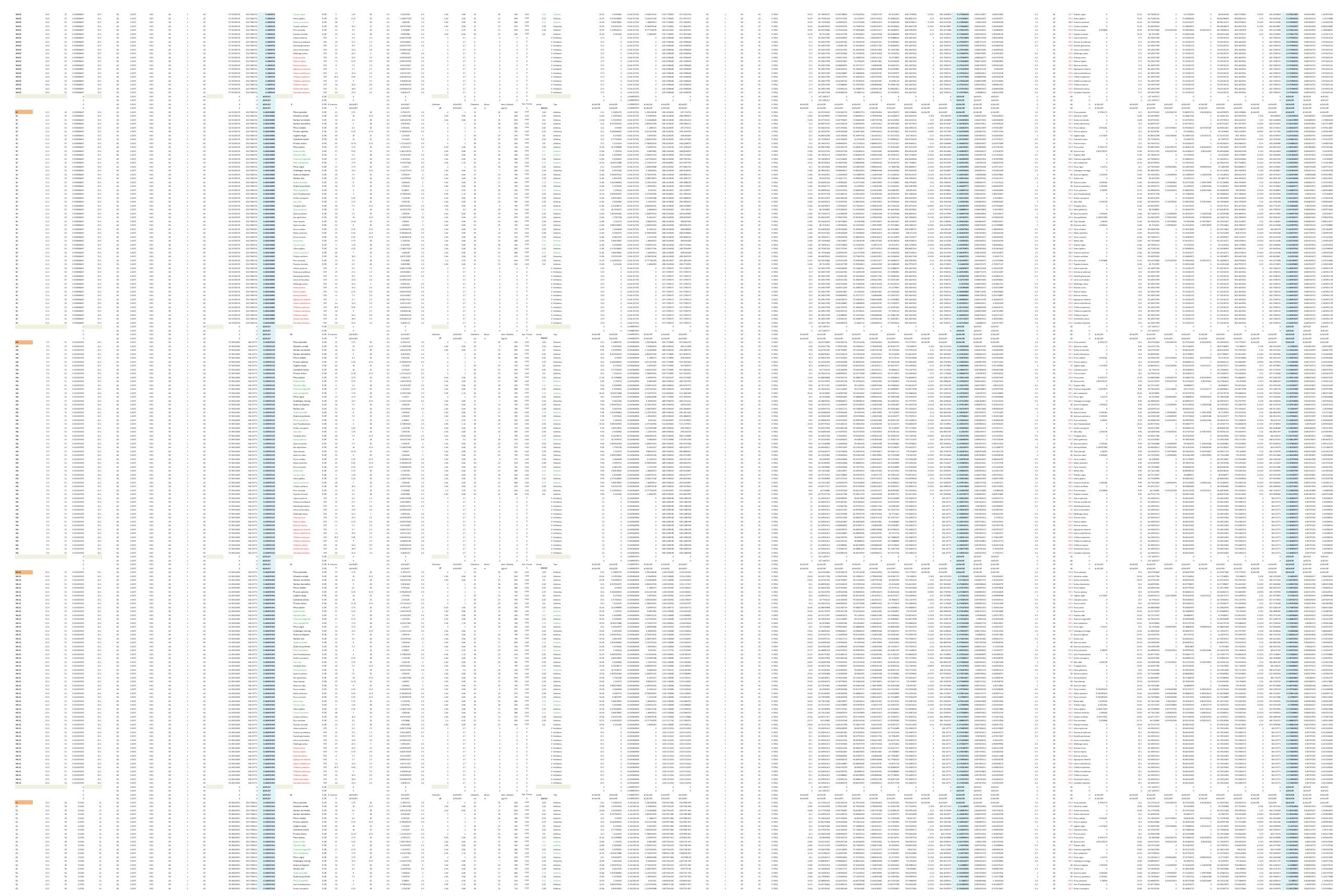


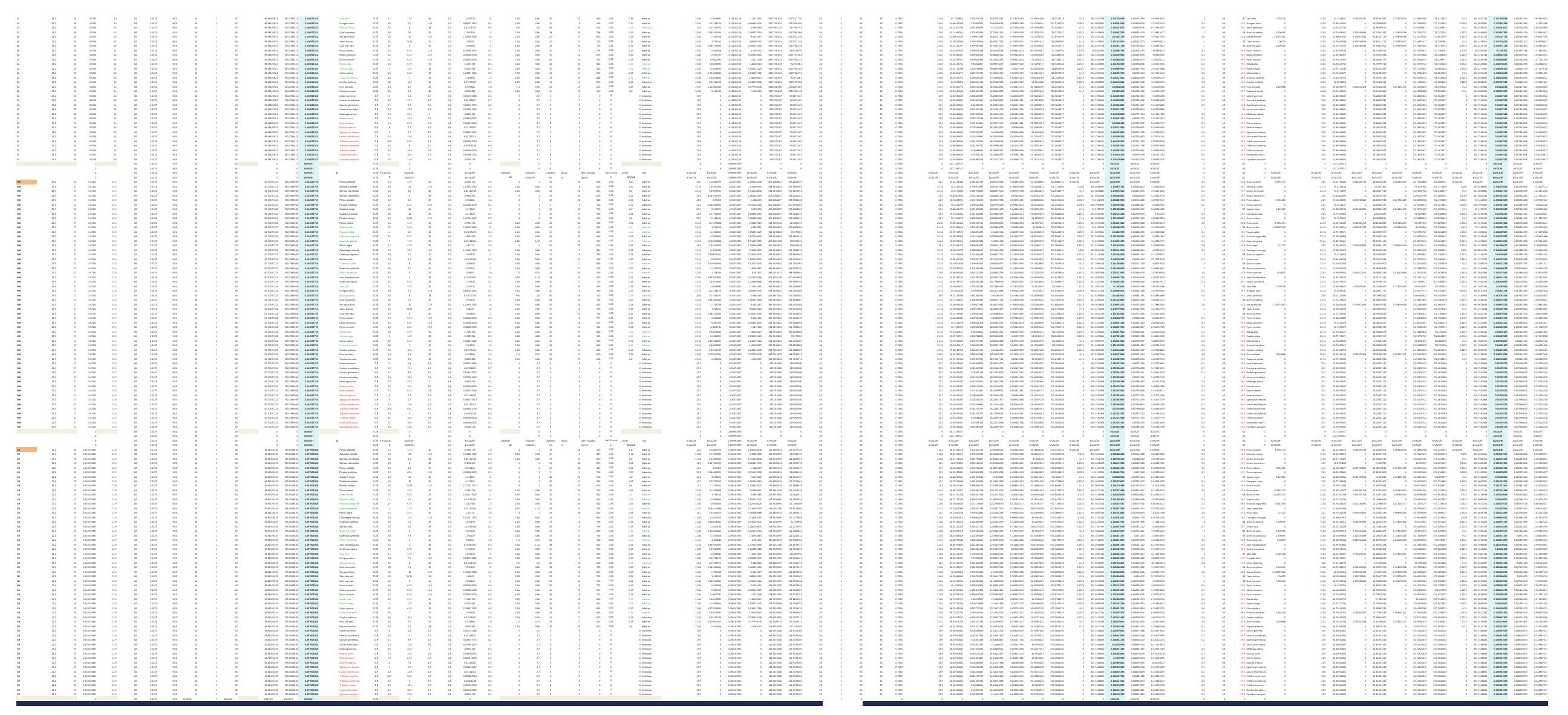



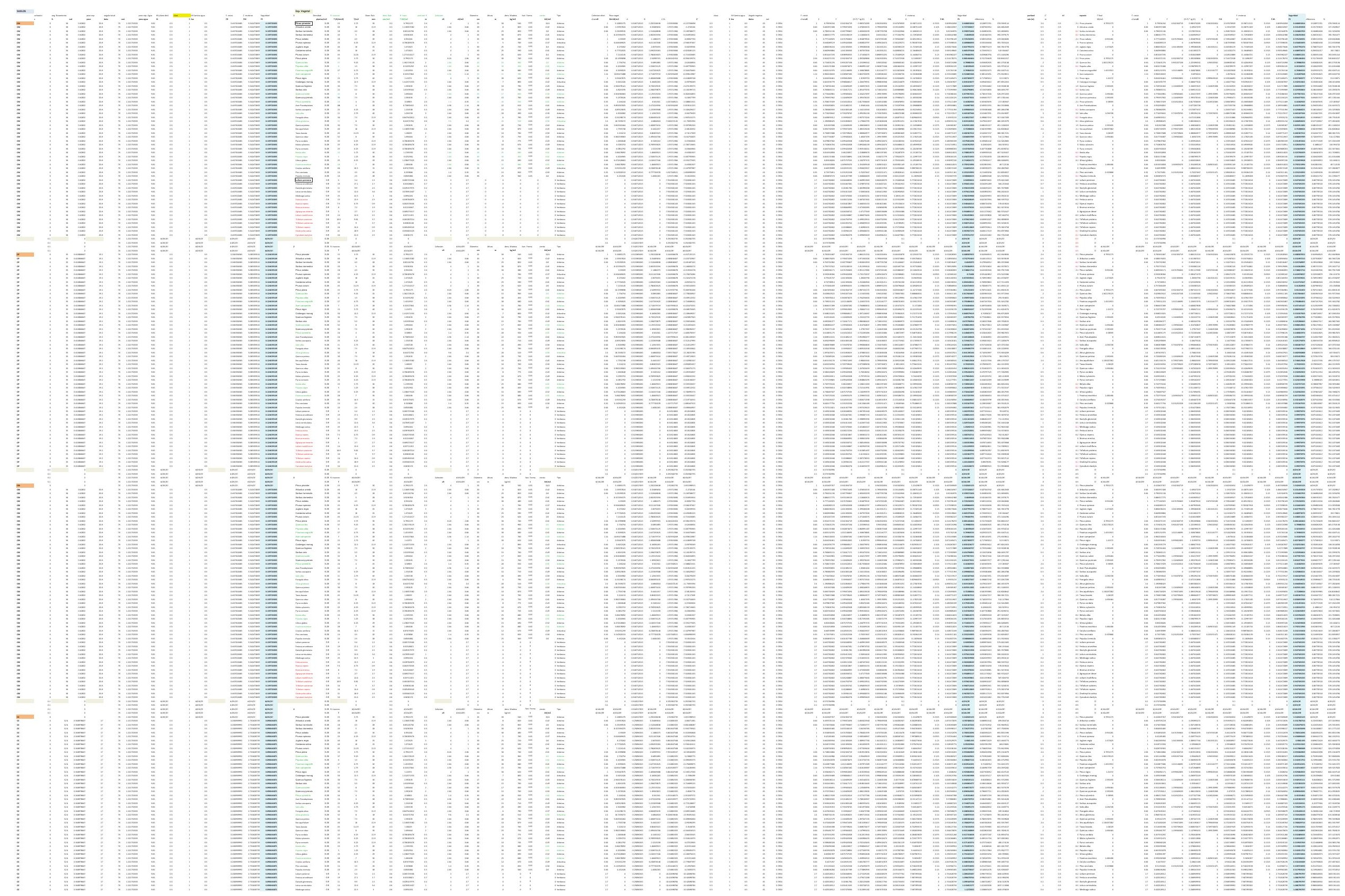


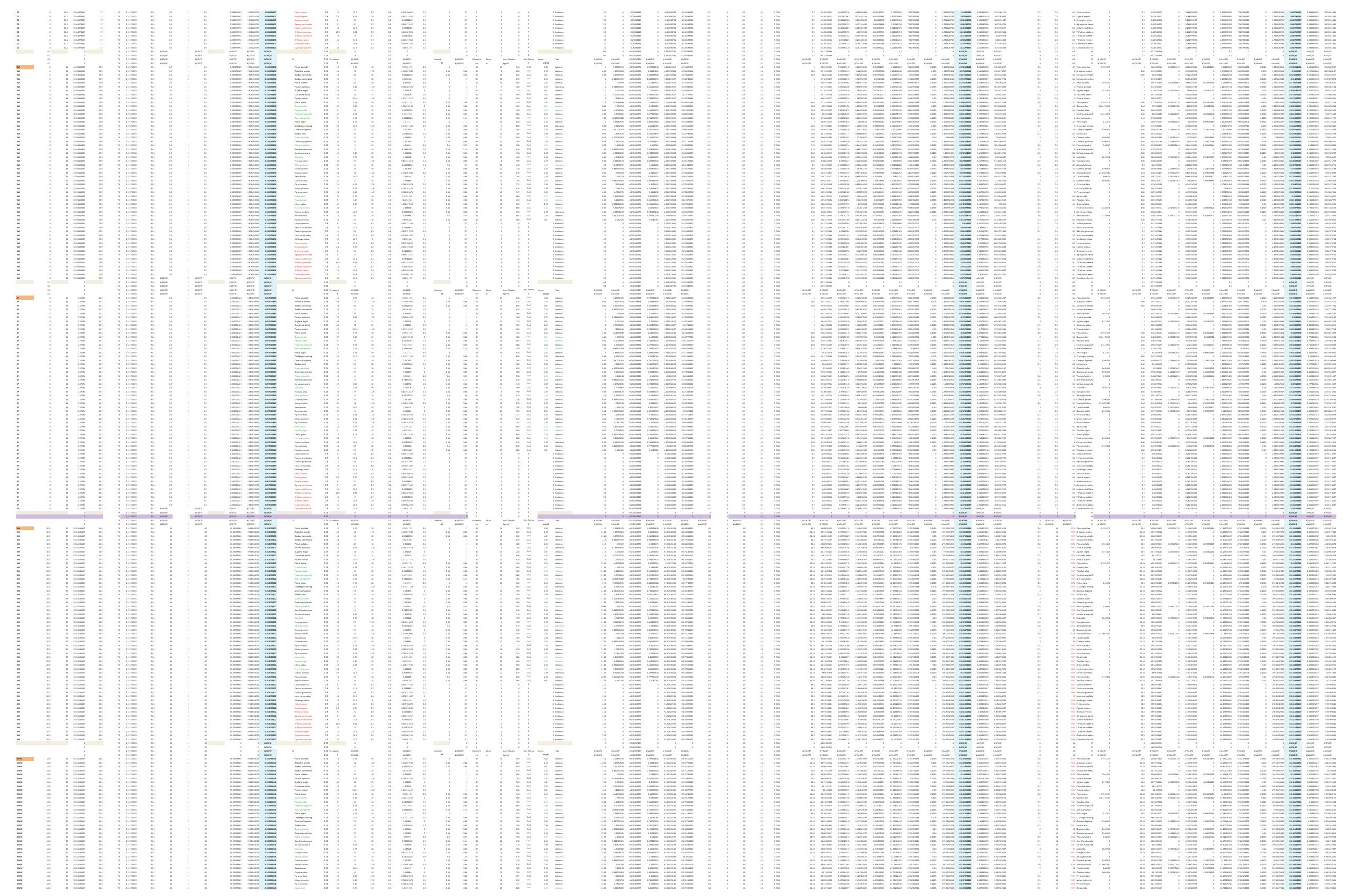



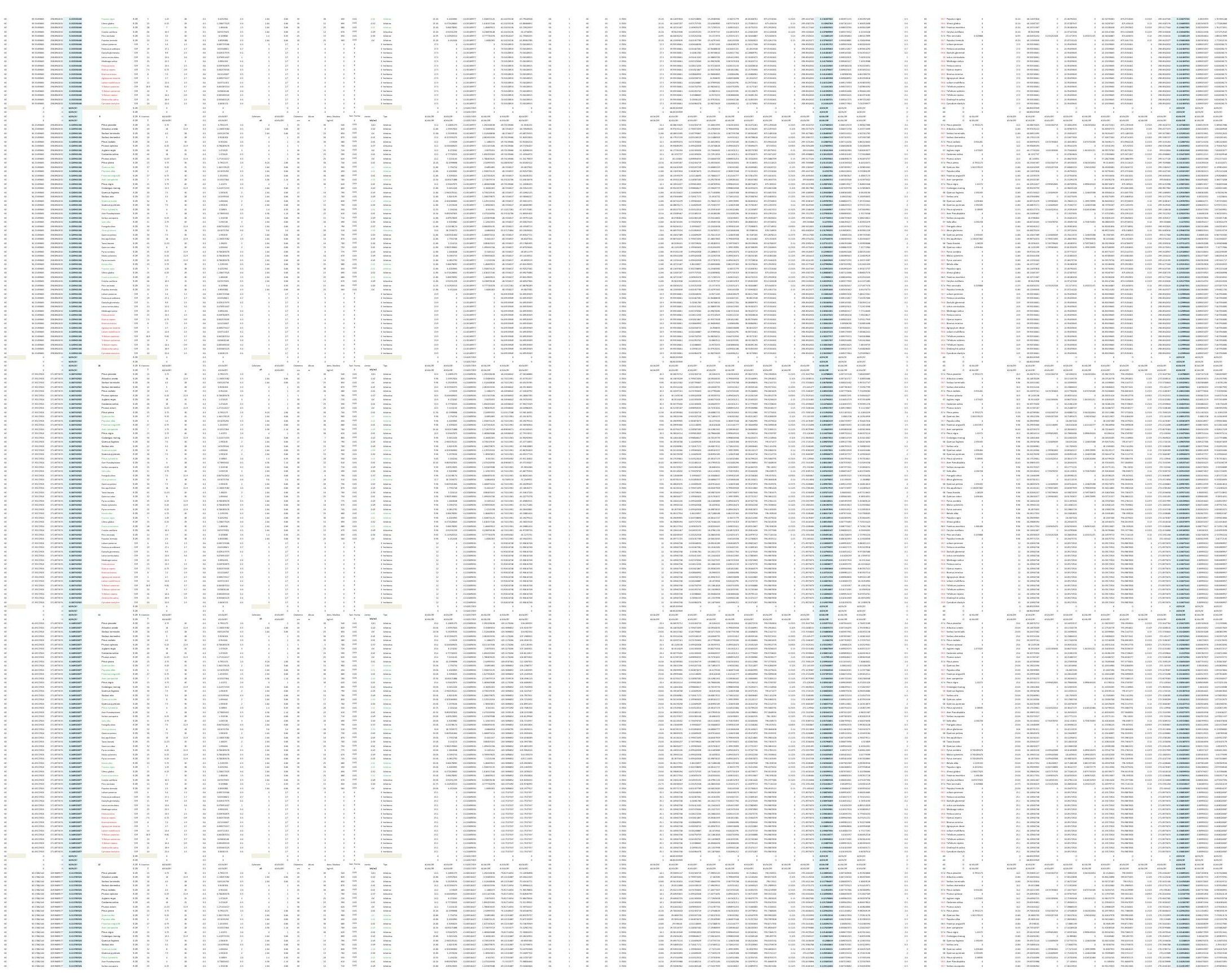


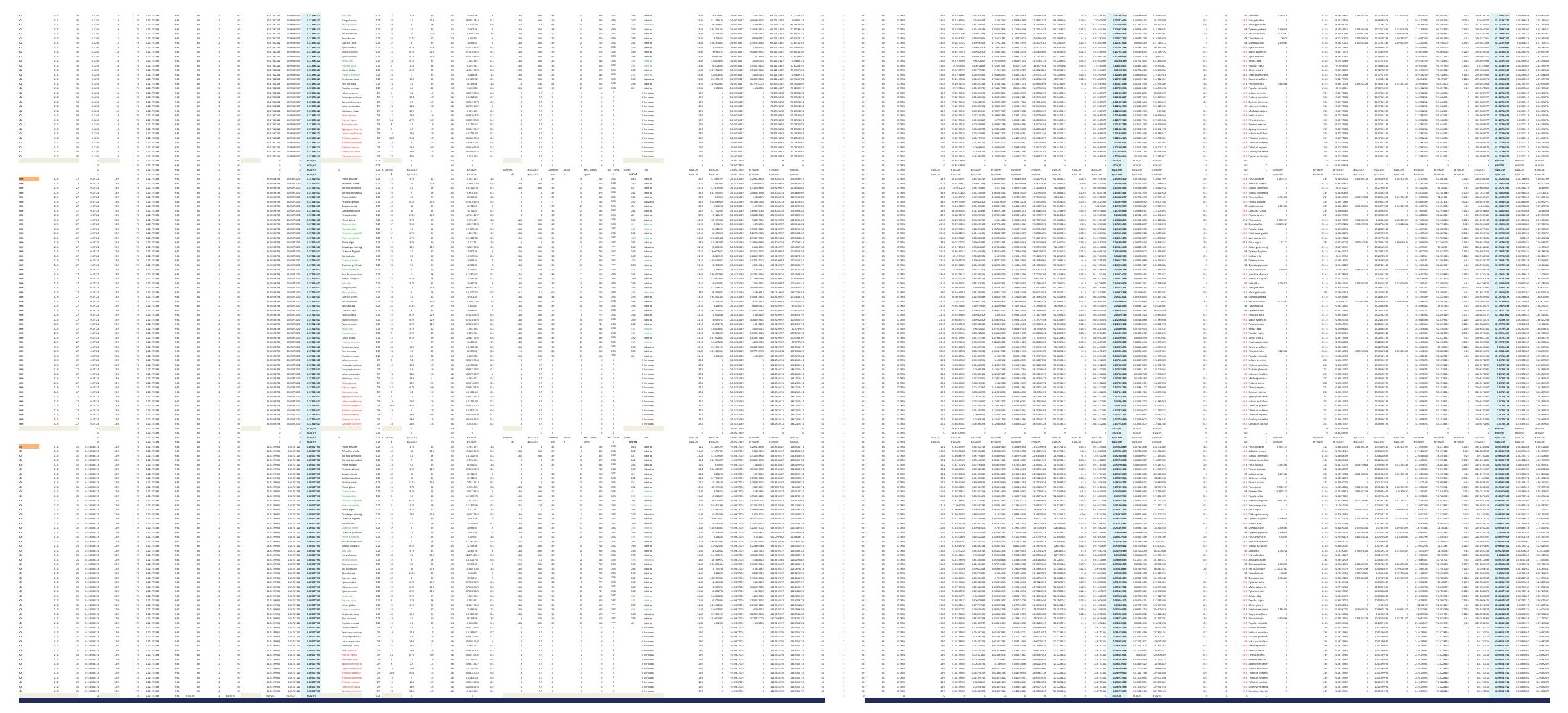



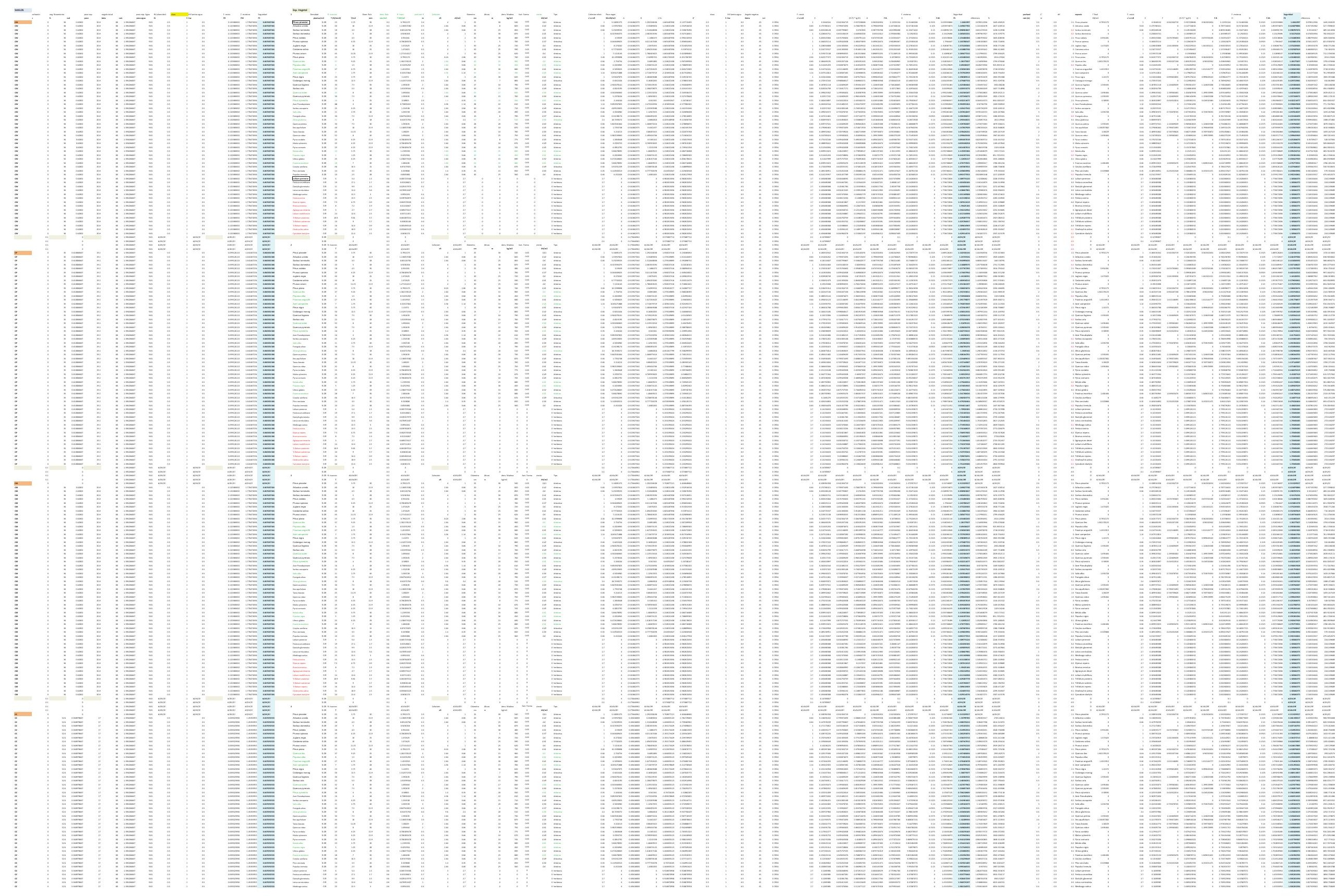


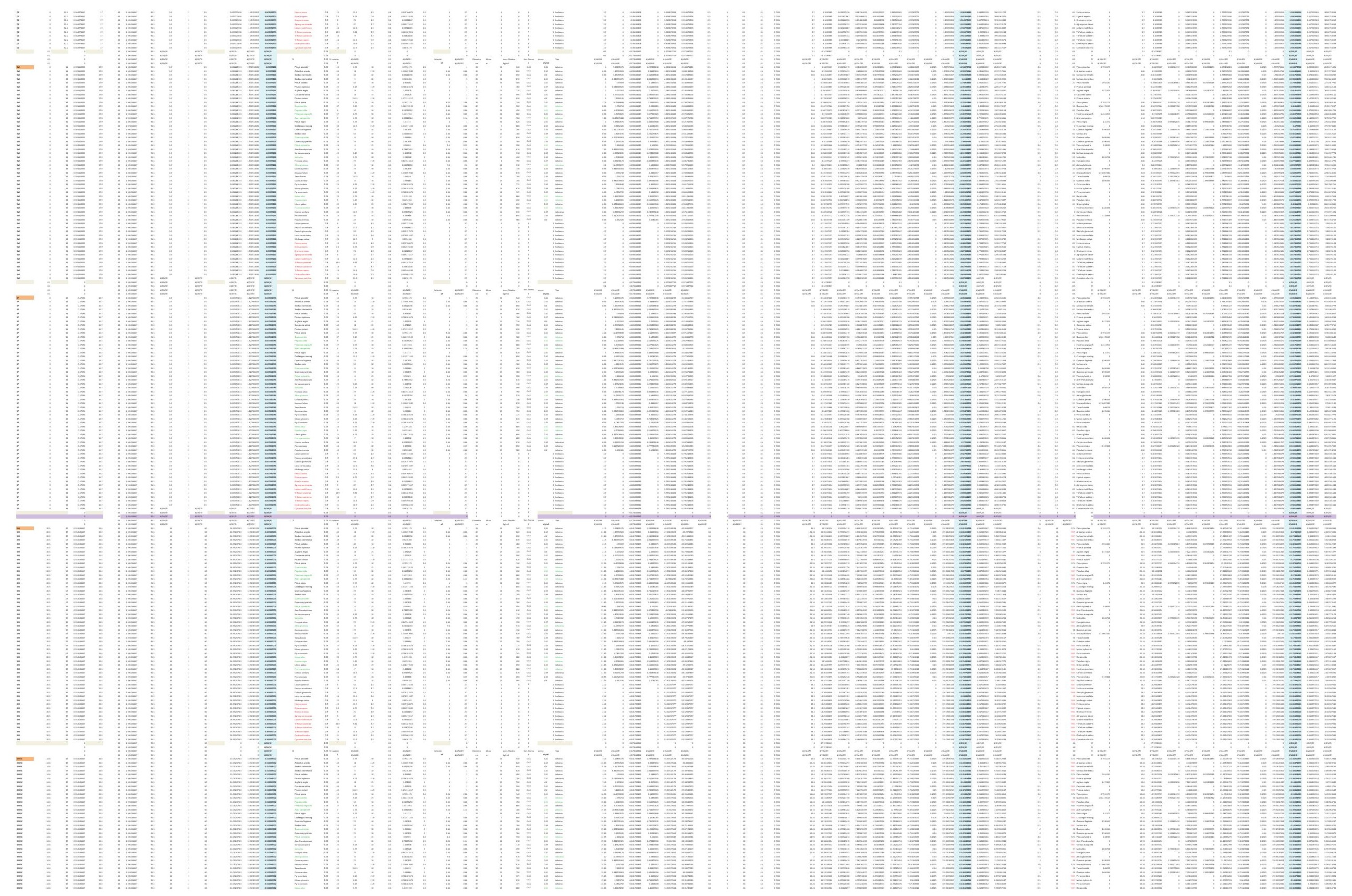




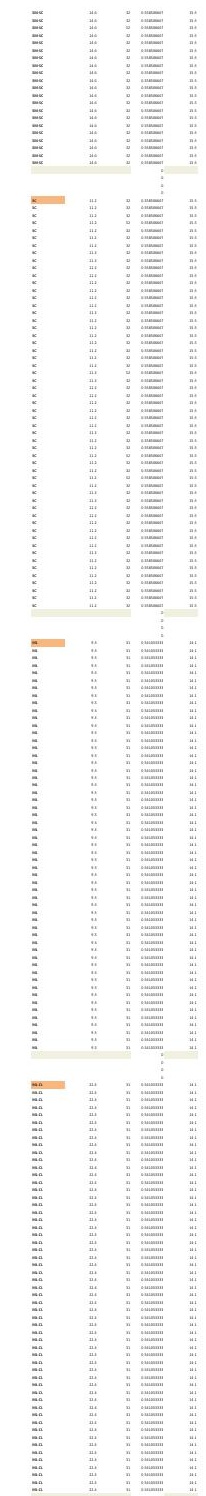

¿-
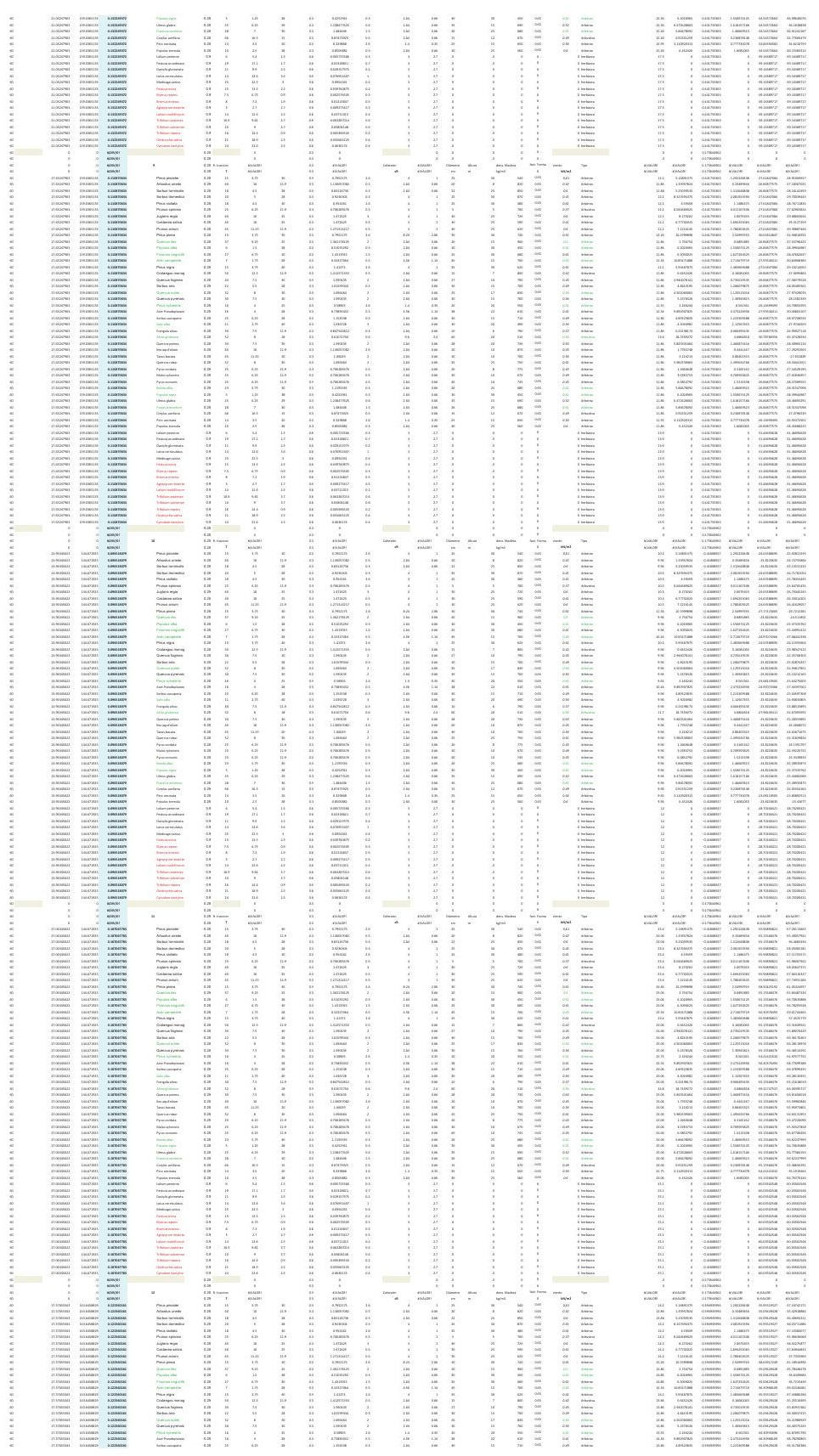
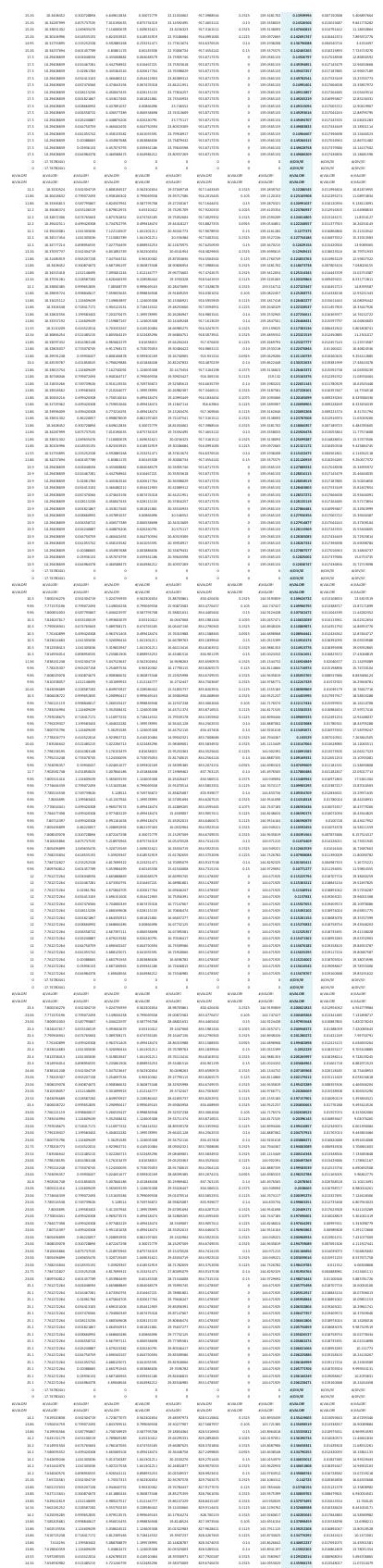

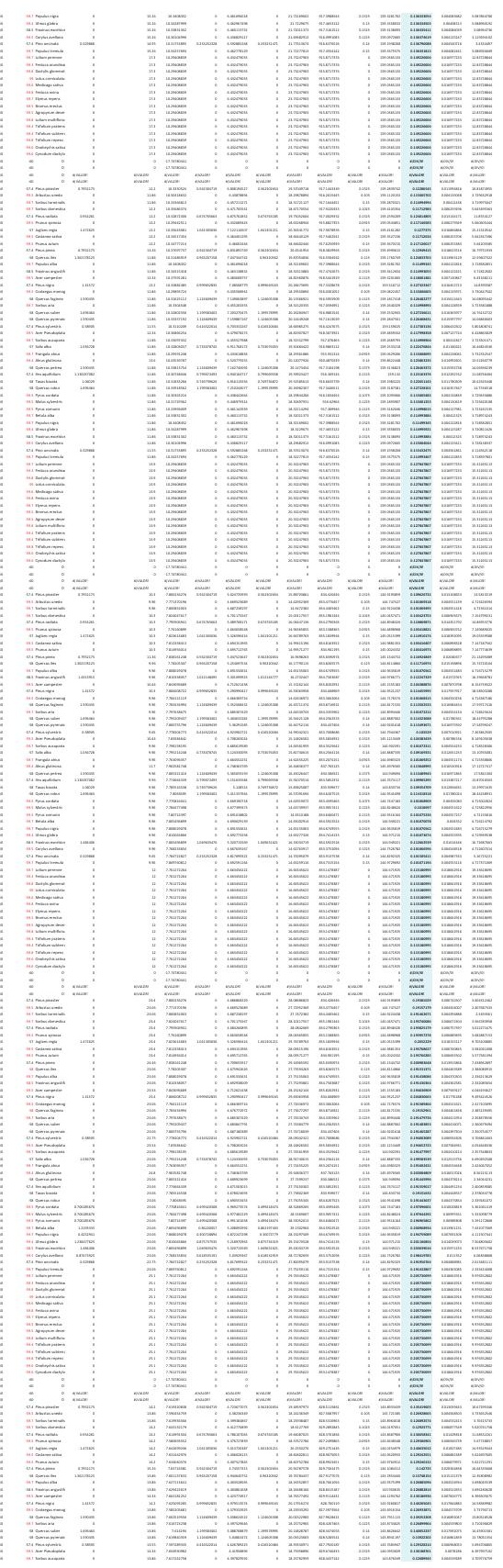




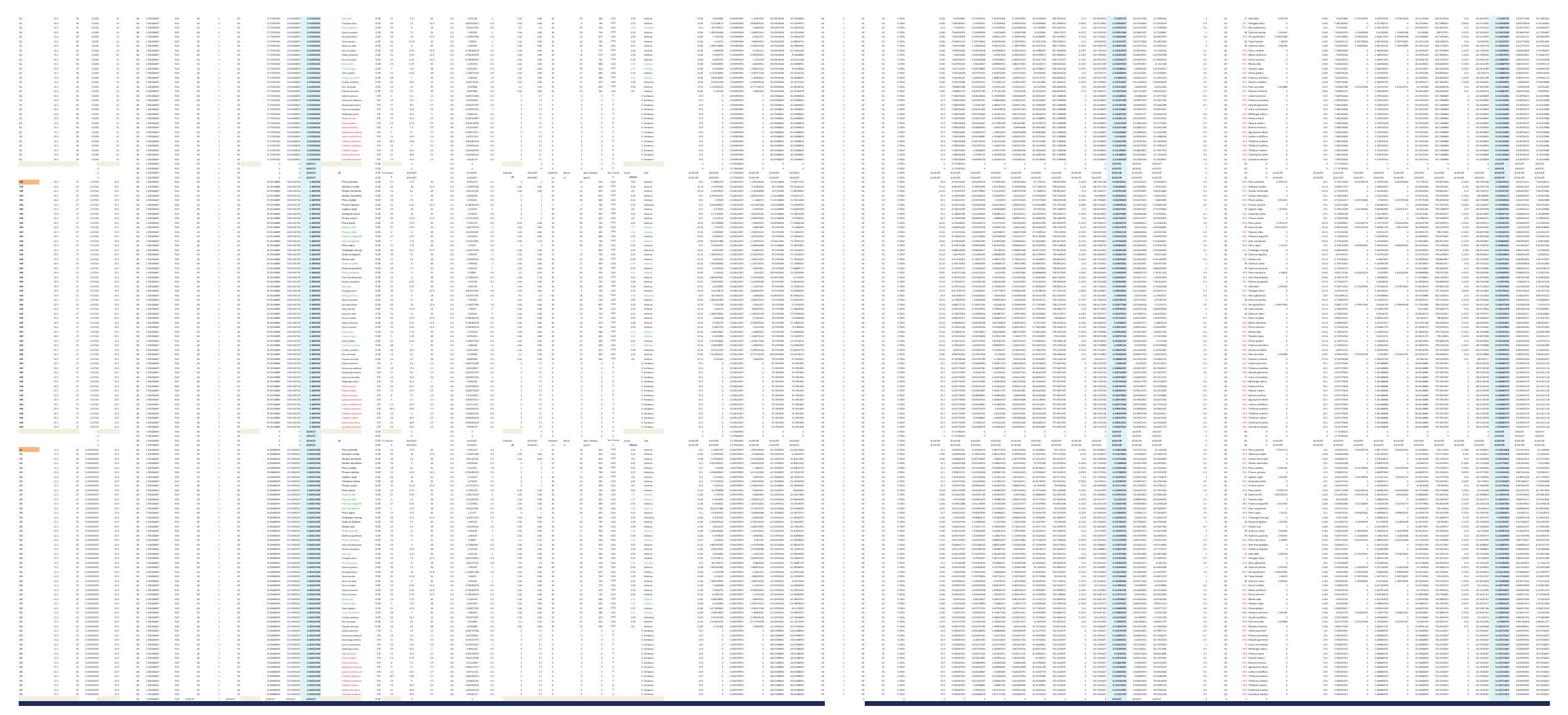


DESARROLLO DE UNA APLICACIÓN IMFORMÁTICA PARA EL CÁLCULO DE SOSTENIMIENTO DE TALUDES MEDIANTE VEGETACIÓN

PRUEBAS DEL MODELO MATEMÁTICO PARA EL CÁLCULO DE ESTABILIDAD DE TALUDES.

\section{PRUEBA B: COMBINACIONES DE ESPECIES}

B01. DENSIDAD DE PLANTACIÓN: 600 plantas/ha.

B01-1.POSICIÓN N.F. 1

B01-2.POSICIÓN N.F. 2

B01-3.POSICIÓN N.F. 3

B01-4.POSICIÓN N.F. 4

B01-5.POSICIÓN N.F. 5 
DESARROLLO DE UNA APLICACIÓN IMFORMÁTICA PARA EL CÁLCULO DE SOSTENIMIENTO DE TALUDES MEDIANTE VEGETACIÓN

B01. DENSIDAD DE PLANTACIÓN: 600 plantas/ha.

\section{B01-1.POSICIÓN N.F. 1}

INCLINACIÓN DE TALUD 6-100

INCLINACIÓN DE TALUD 10-200

INCLINACIÓN DE TALUD 20-30

INCLINACIÓN DE TALUD 30-40

INCLINACIÓN DE TALUD $35^{\circ}$

INCLINACIÓN DE TALUD 40-50

INCLINACIÓN DE TALUD 50-550

INCLINACIÓN DE TALUD 55-60

INCLINACIÓN DE TALUD 60-700

INCLINACIÓN DE TALUD 70-80 


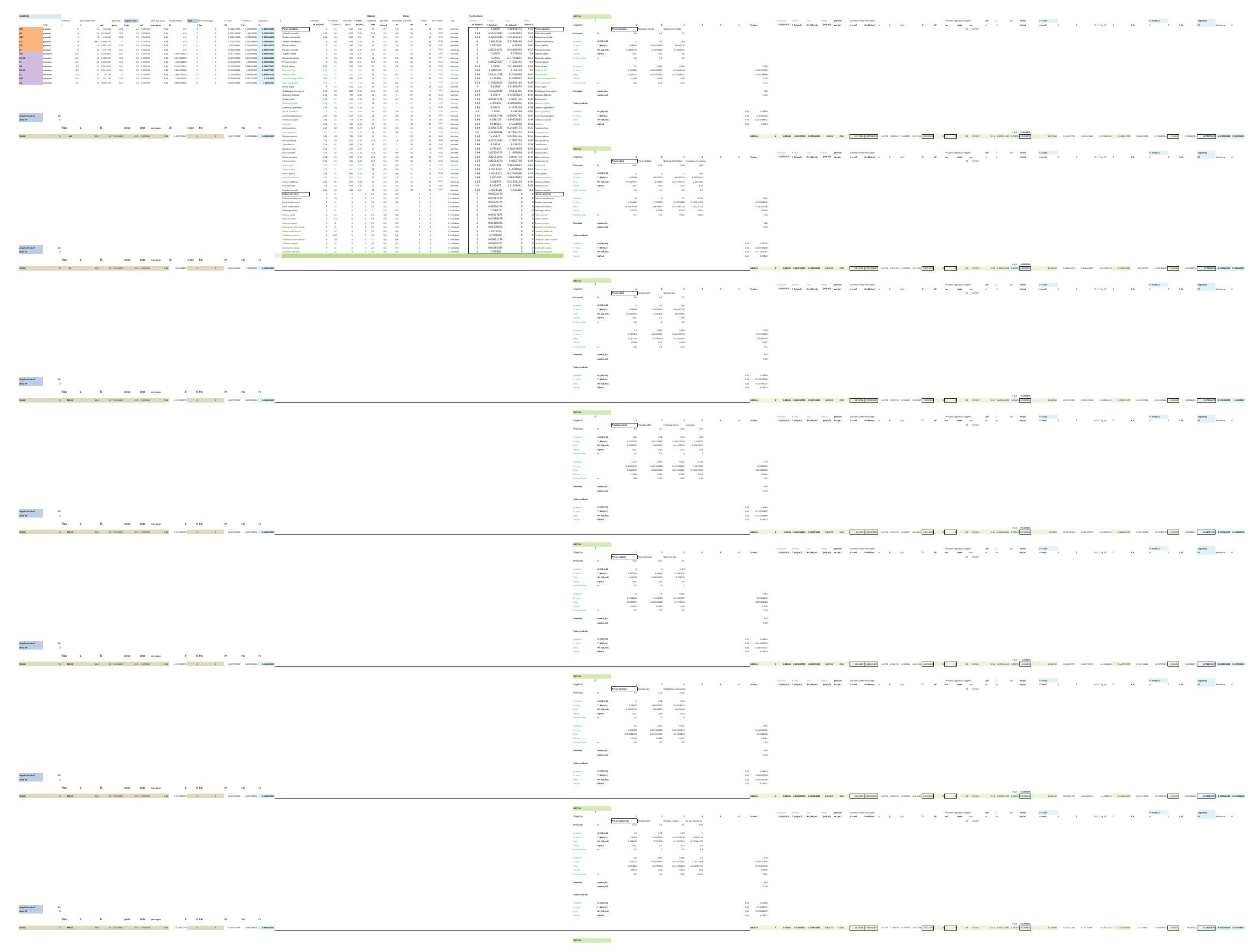




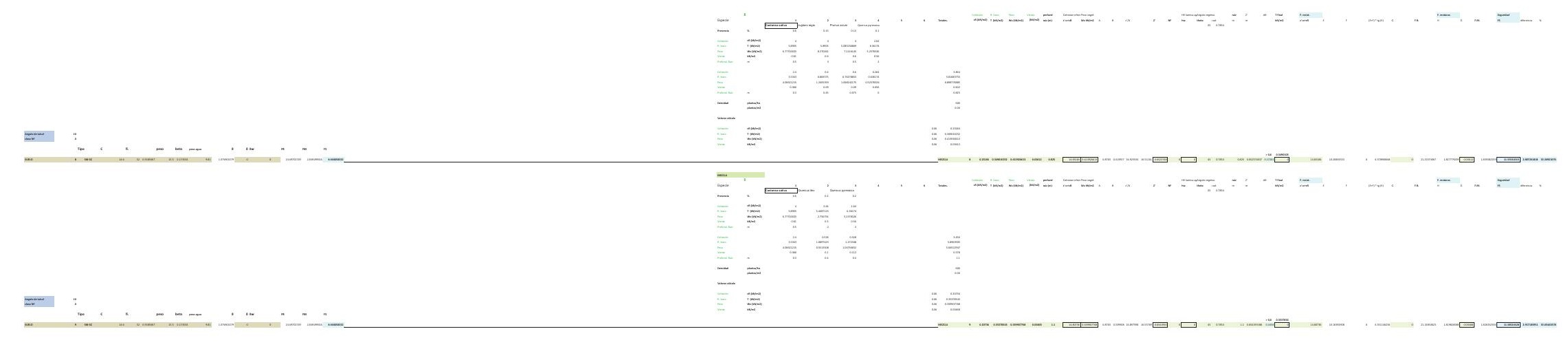




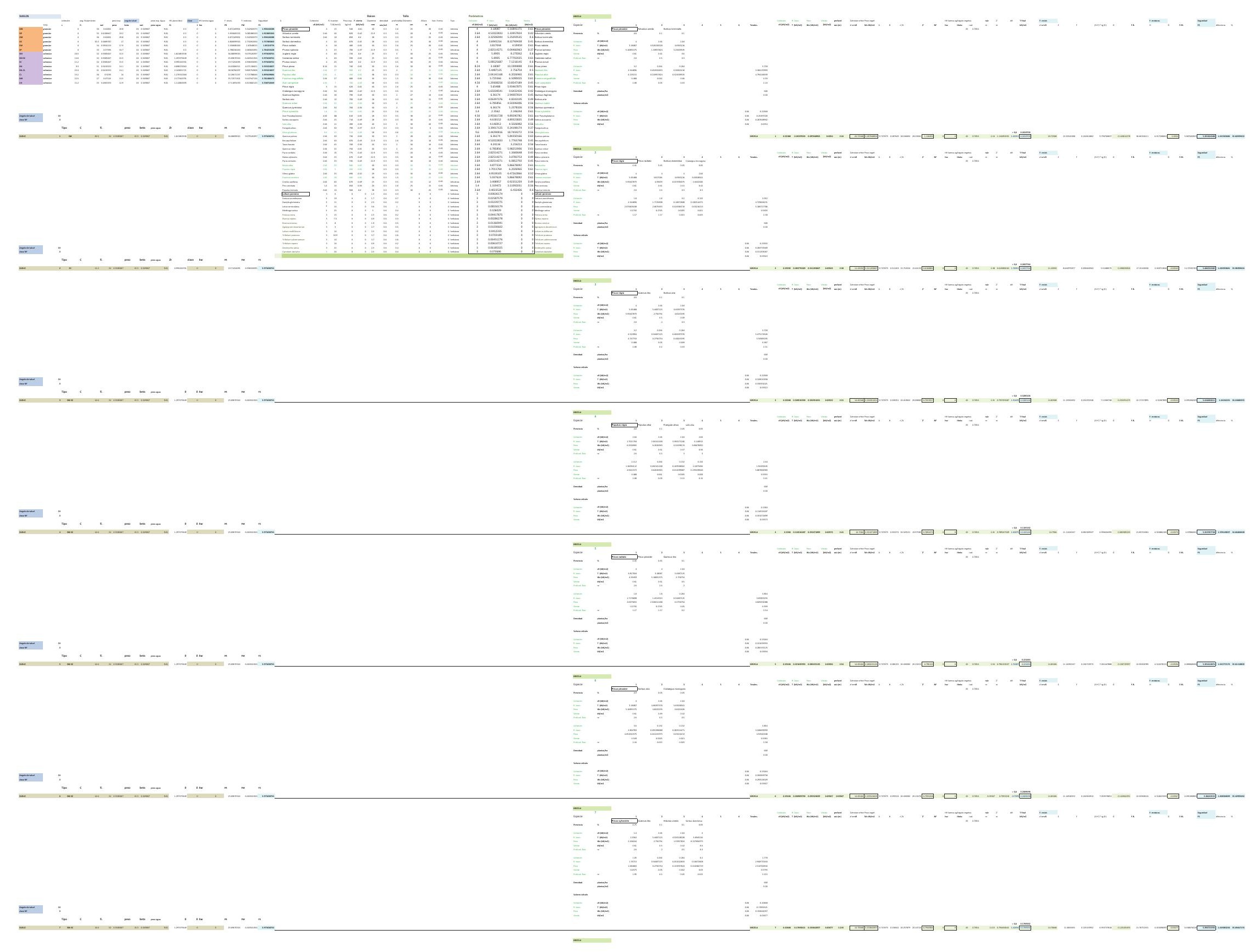




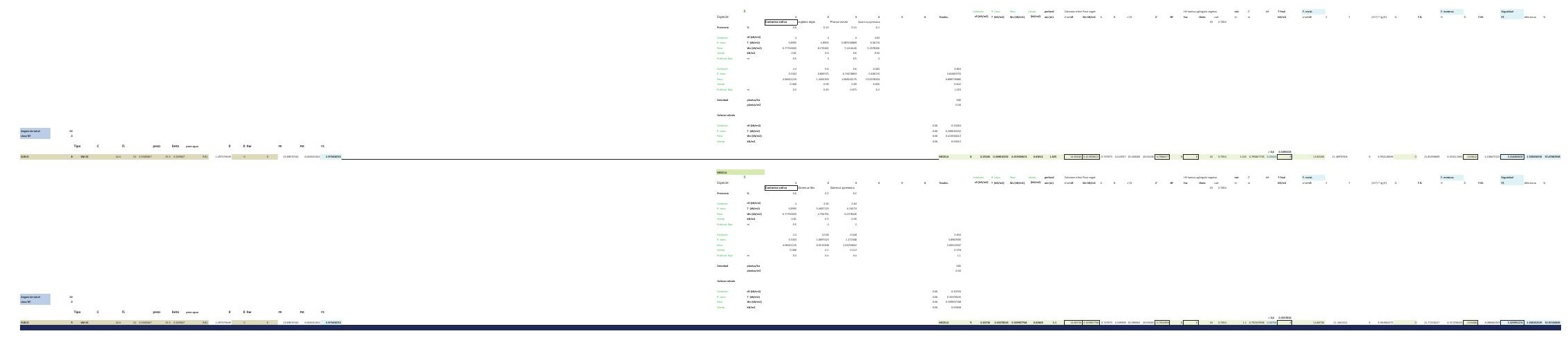




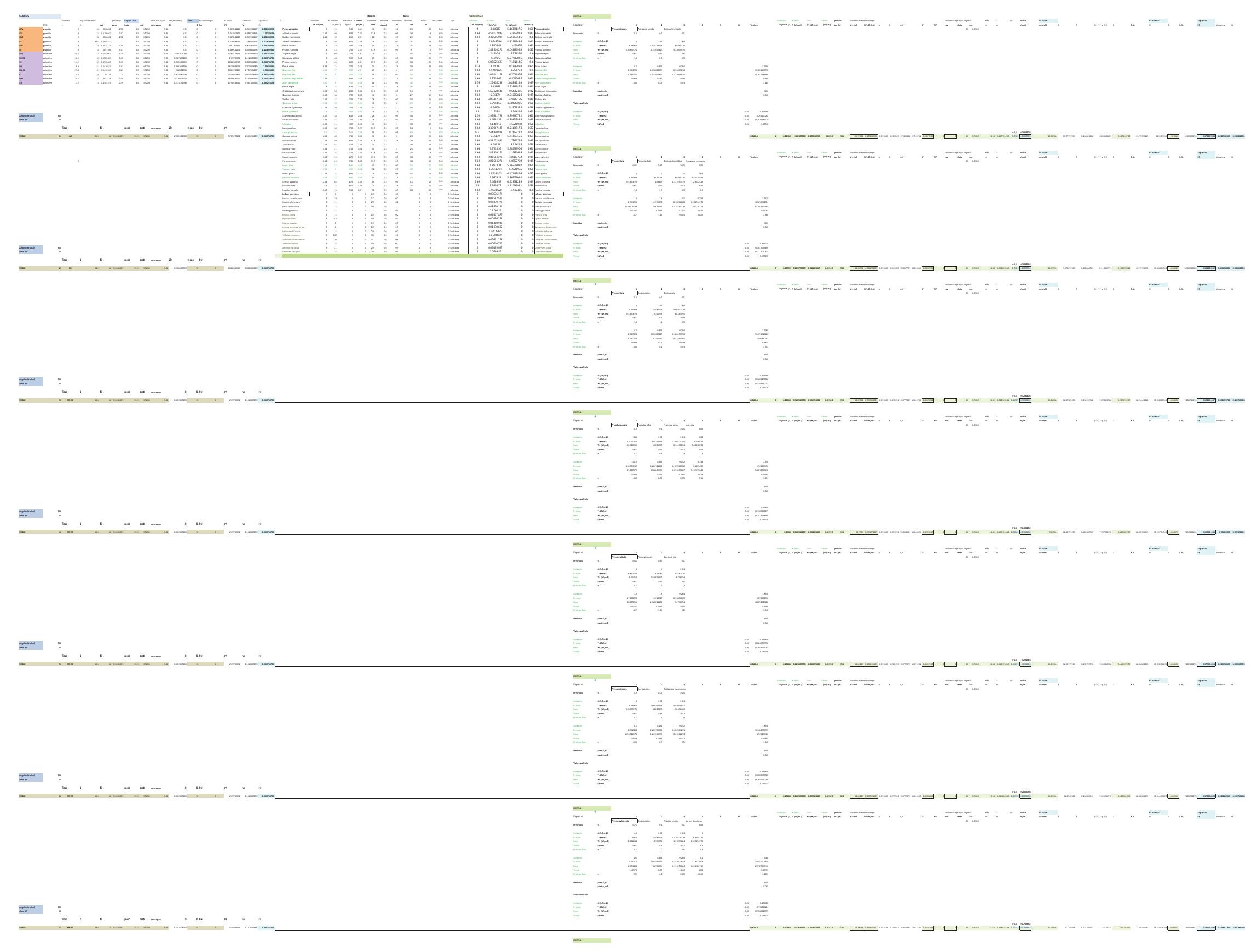




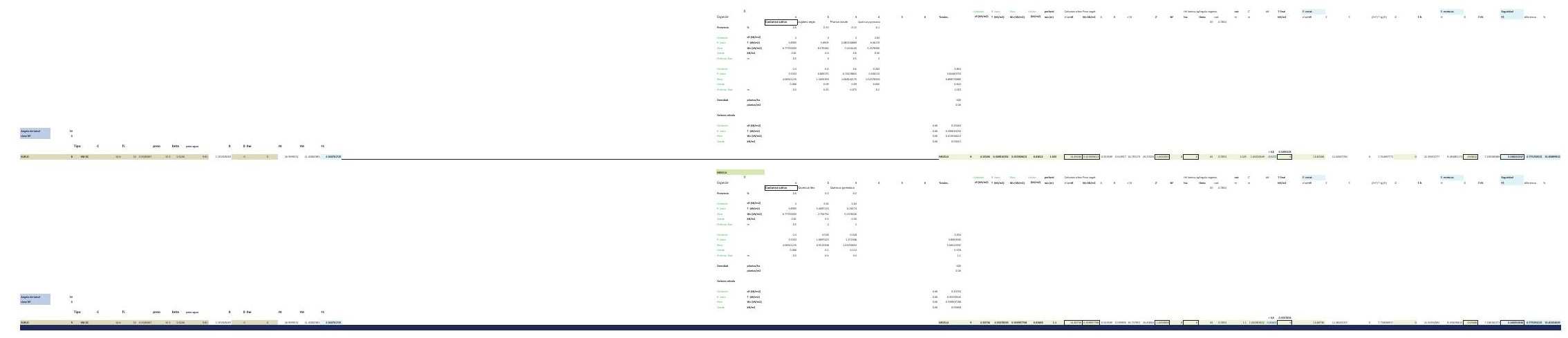




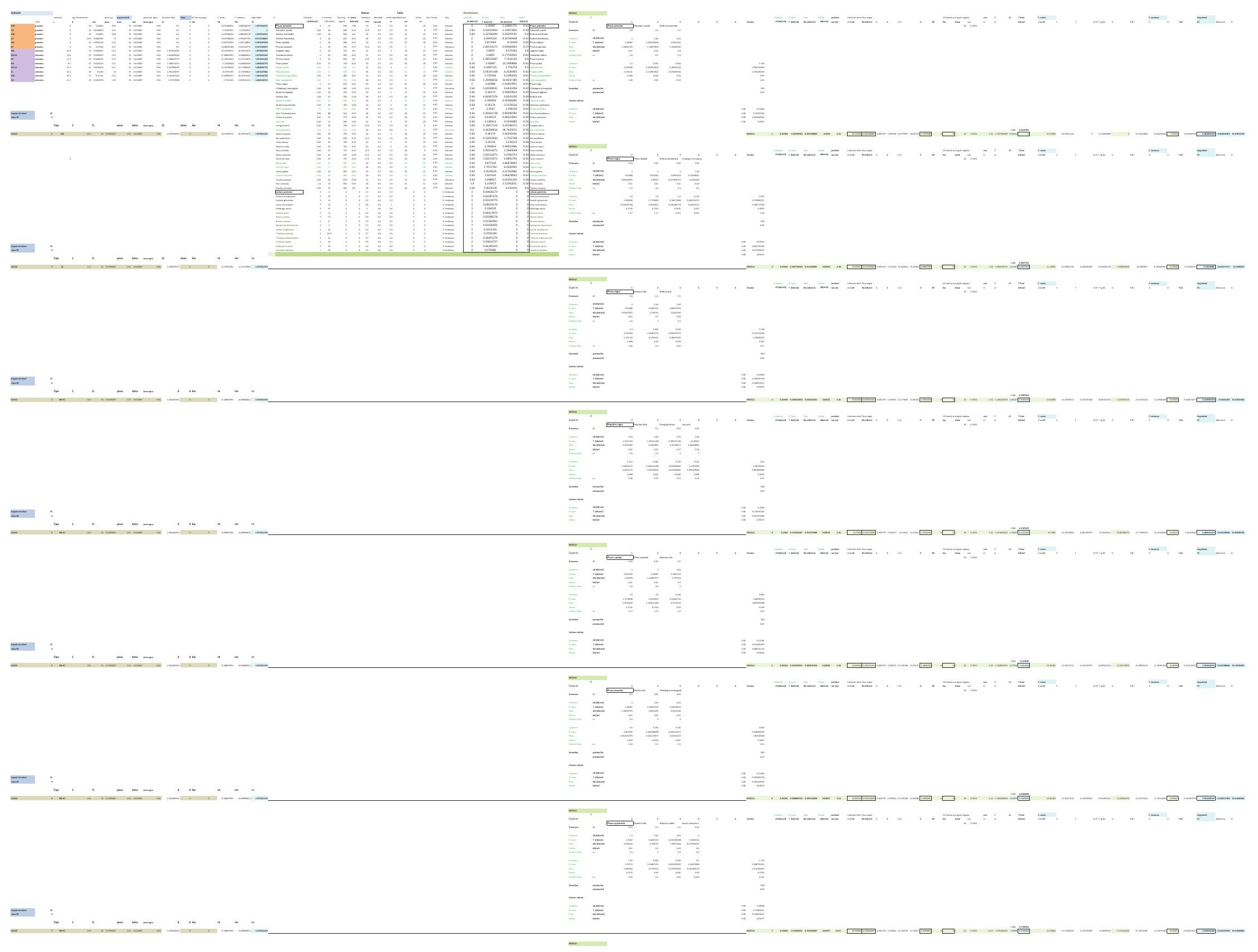




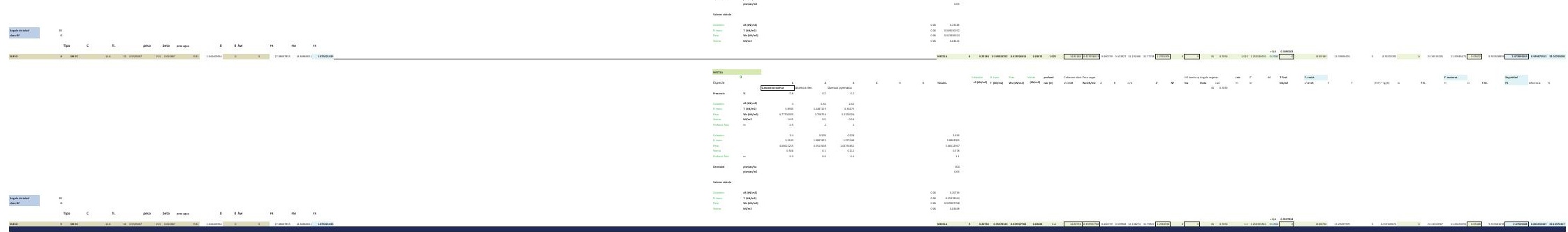




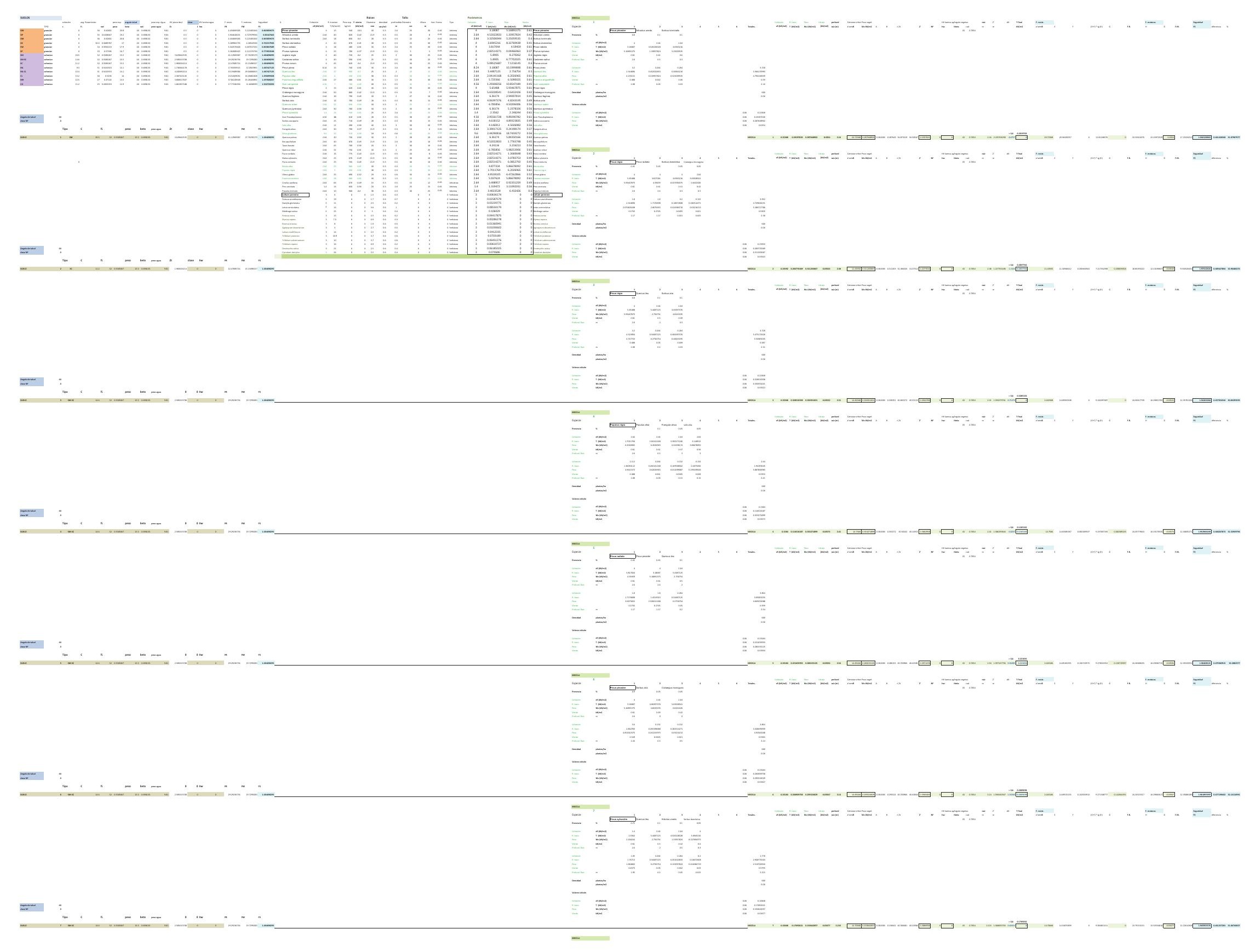




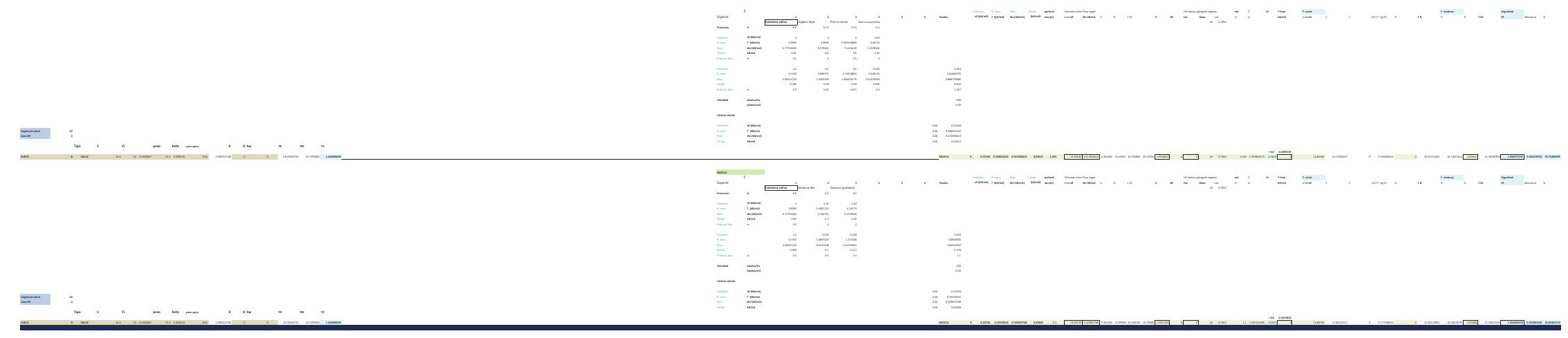




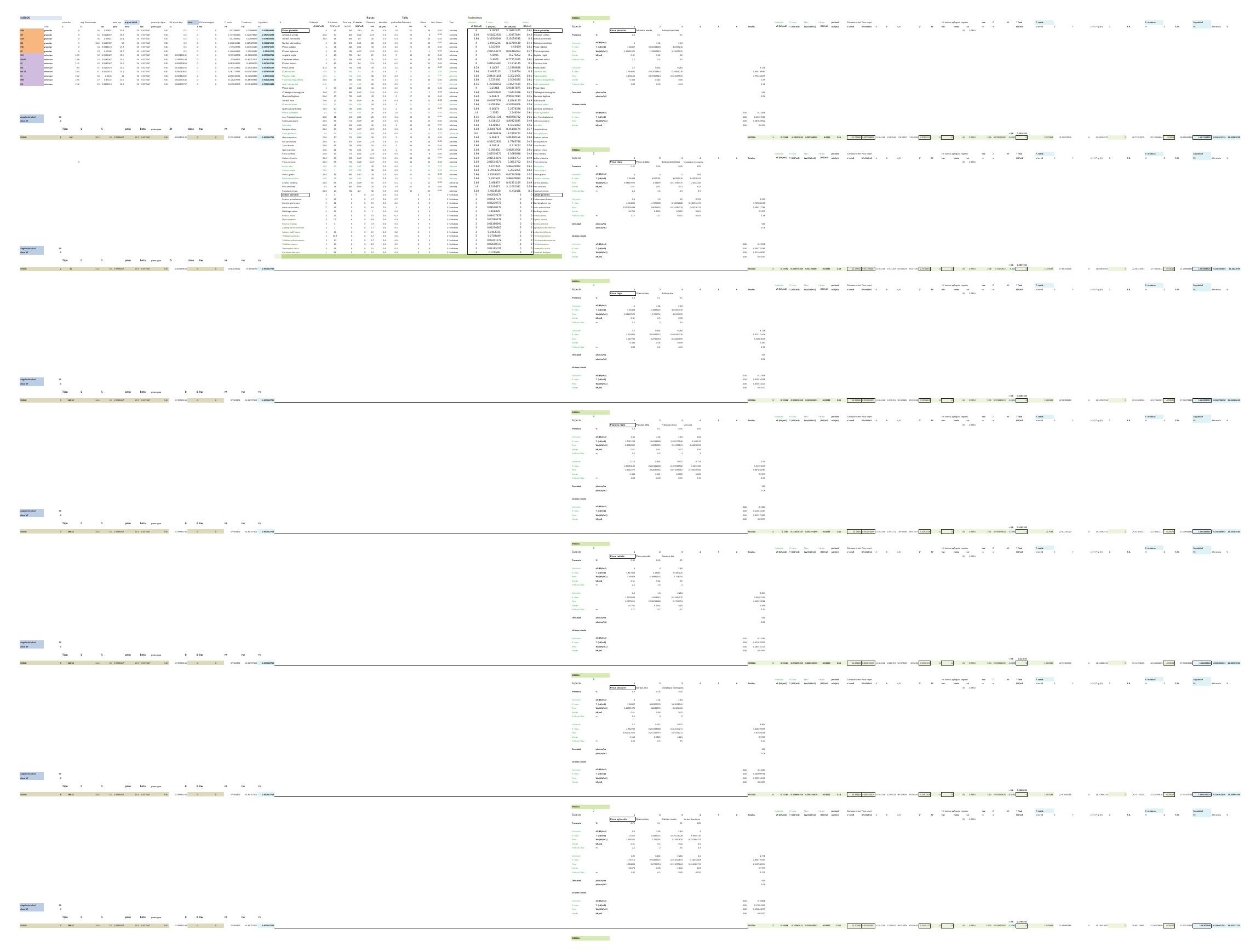




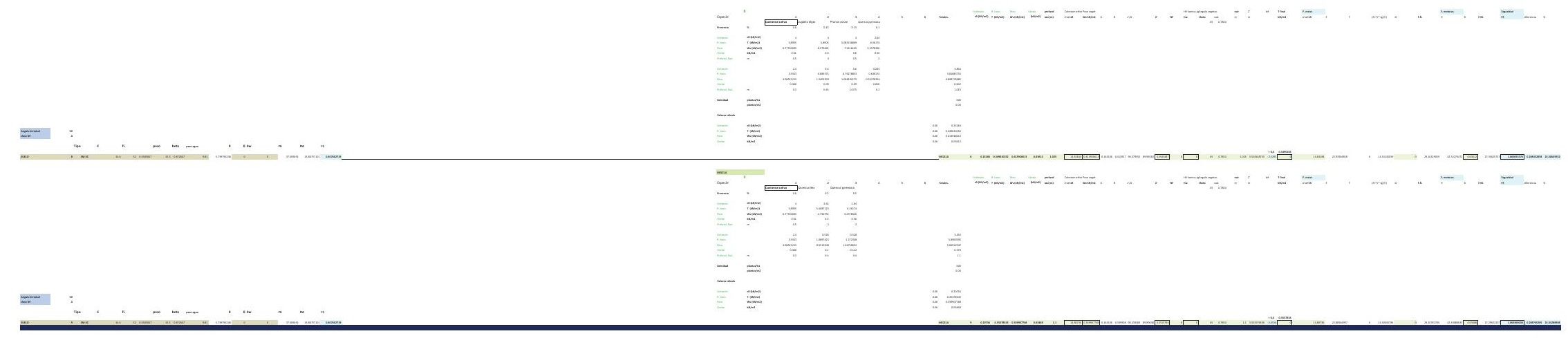




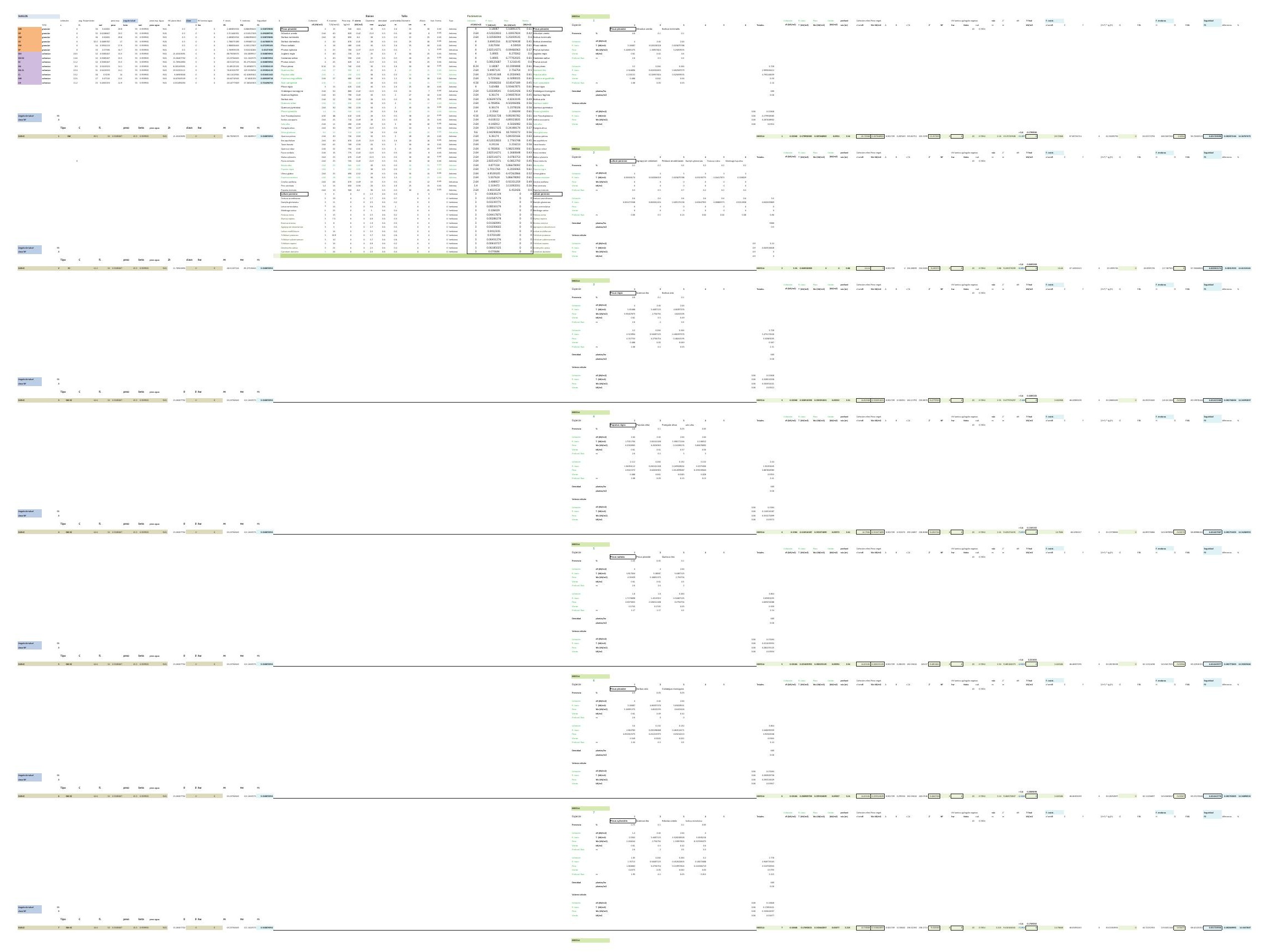




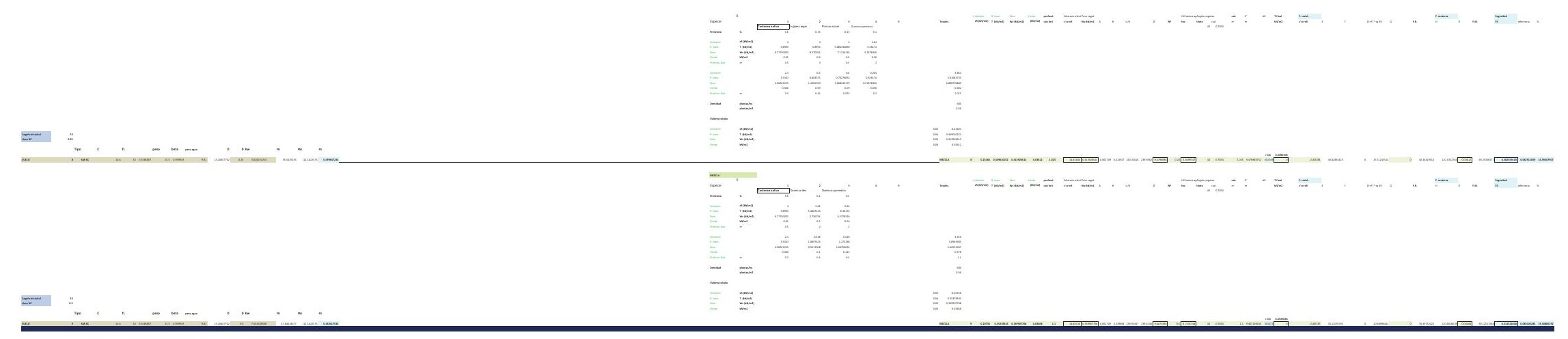




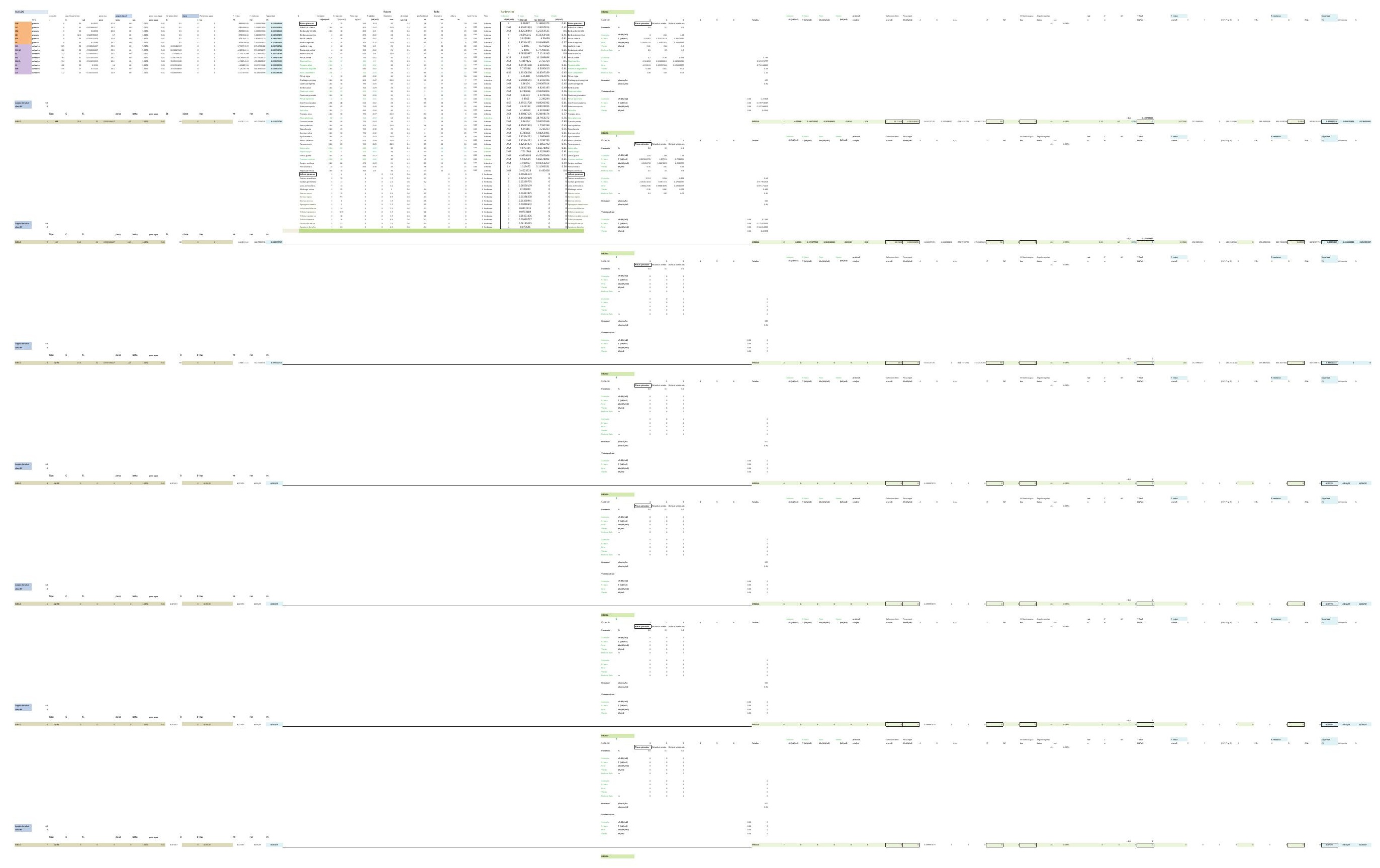




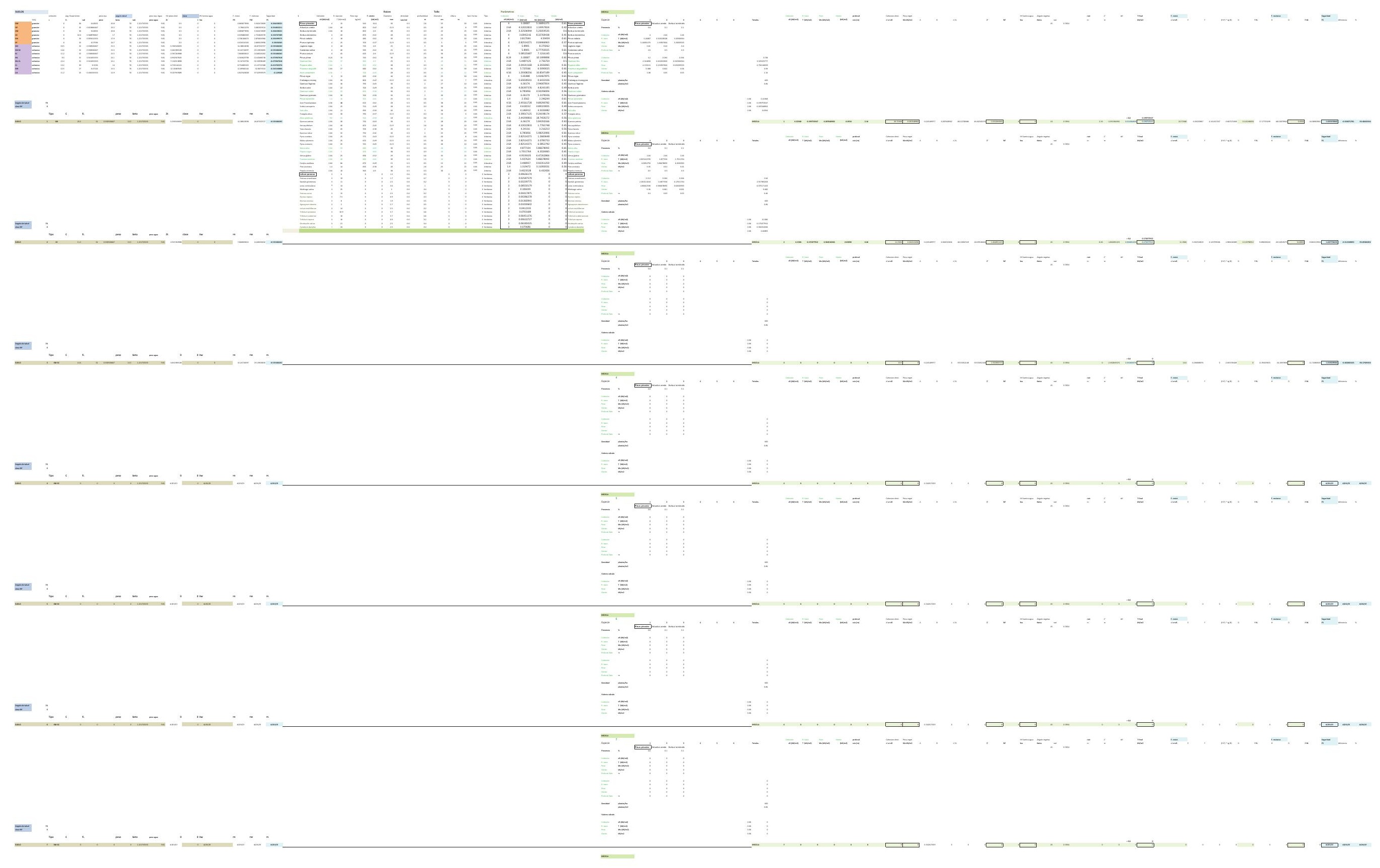




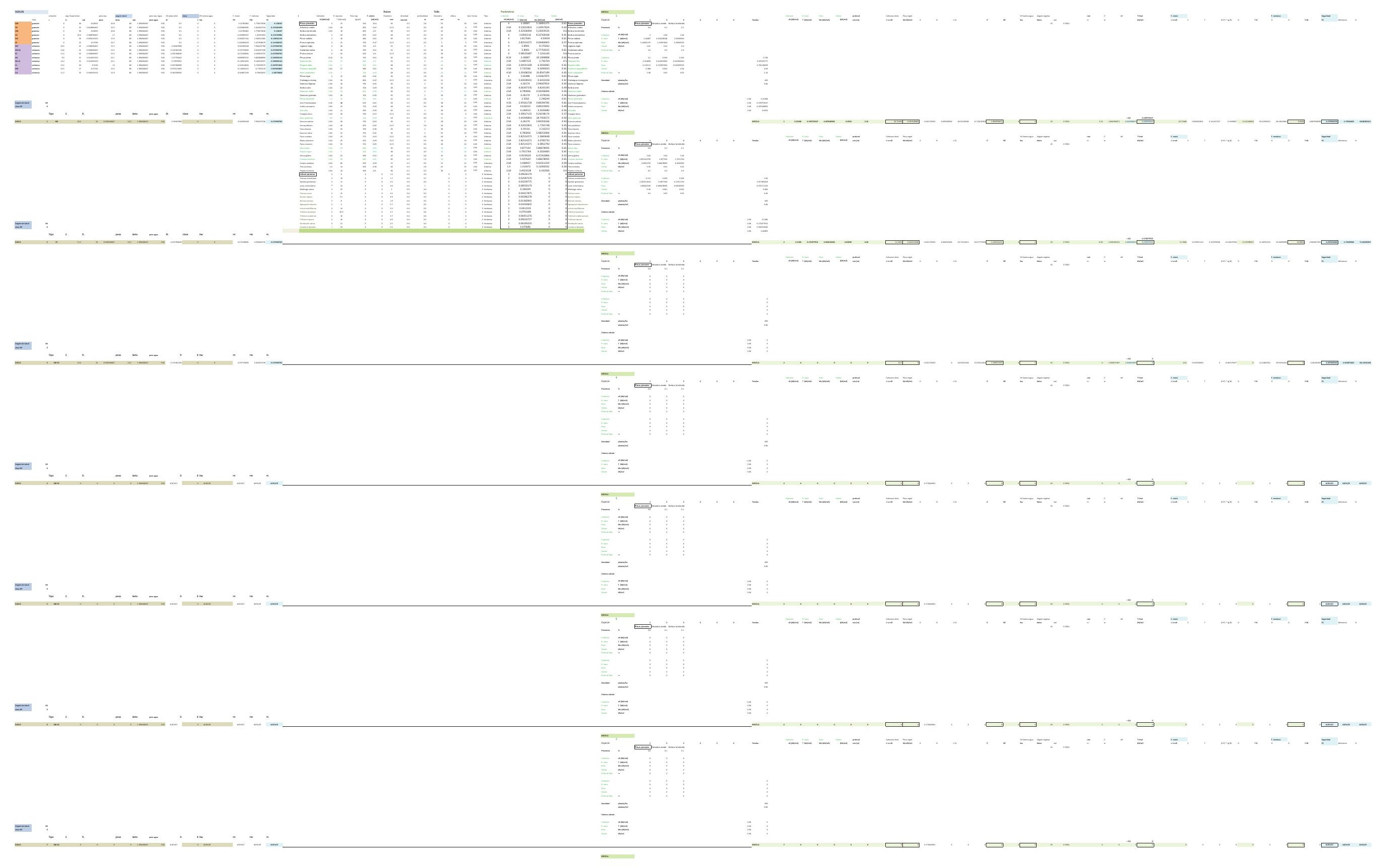


DESARROLLO DE UNA APLICACIÓN IMFORMÁTICA PARA EL CÁLCULO DE SOSTENIMIENTO DE TALUDES MEDIANTE VEGETACIÓN

B01. DENSIDAD DE PLANTACIÓN: 600 plantas/ha.

\section{B01-2.POSICIÓN N.F. 2}

INCLINACIÓN DE TALUD 6-100

INCLINACIÓN DE TALUD 10-200

INCLINACIÓN DE TALUD 20-30

INCLINACIÓN DE TALUD 30-40

INCLINACIÓN DE TALUD $35^{\circ}$

INCLINACIÓN DE TALUD 40-50

INCLINACIÓN DE TALUD 50-550

INCLINACIÓN DE TALUD 55-60

INCLINACIÓN DE TALUD 60-700

INCLINACIÓN DE TALUD 70-80 


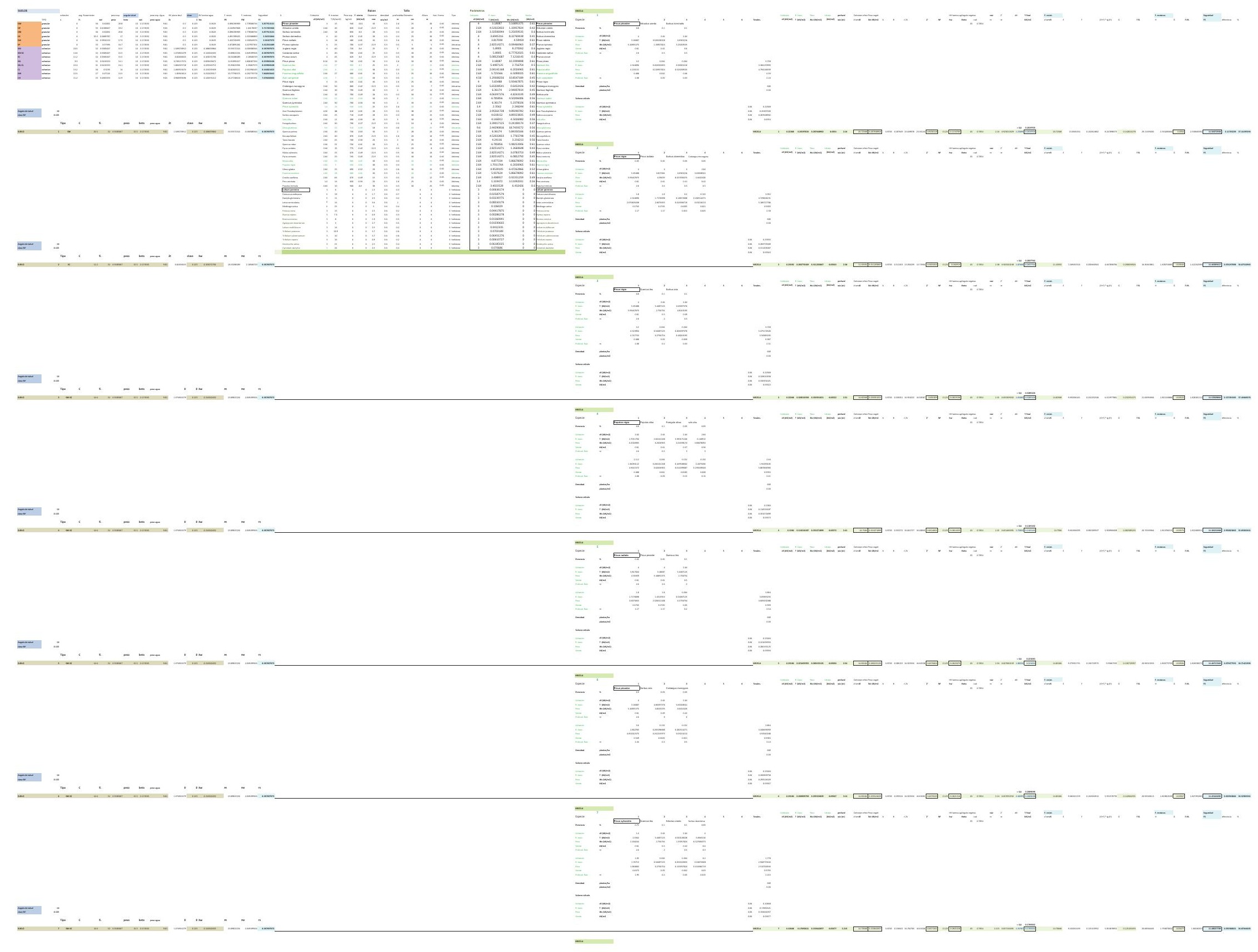




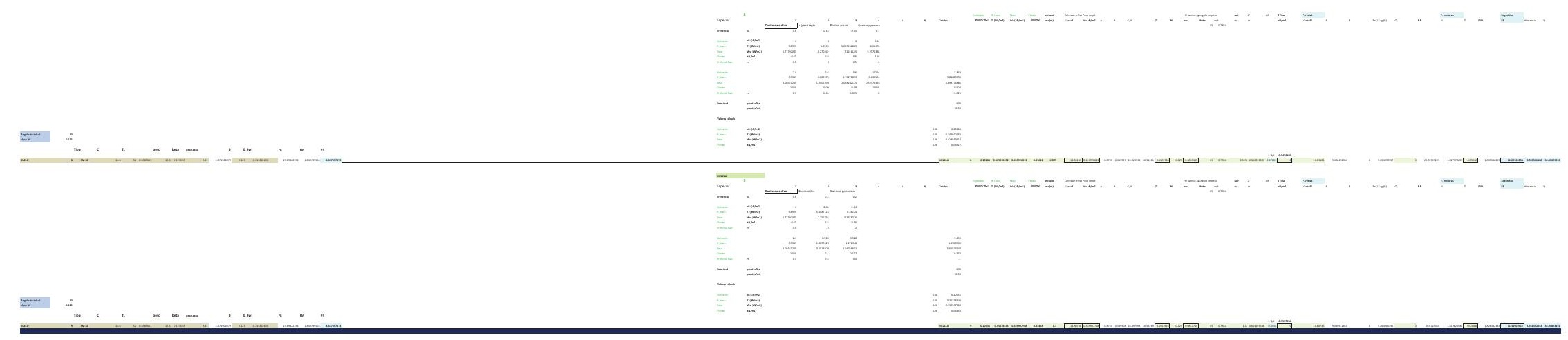




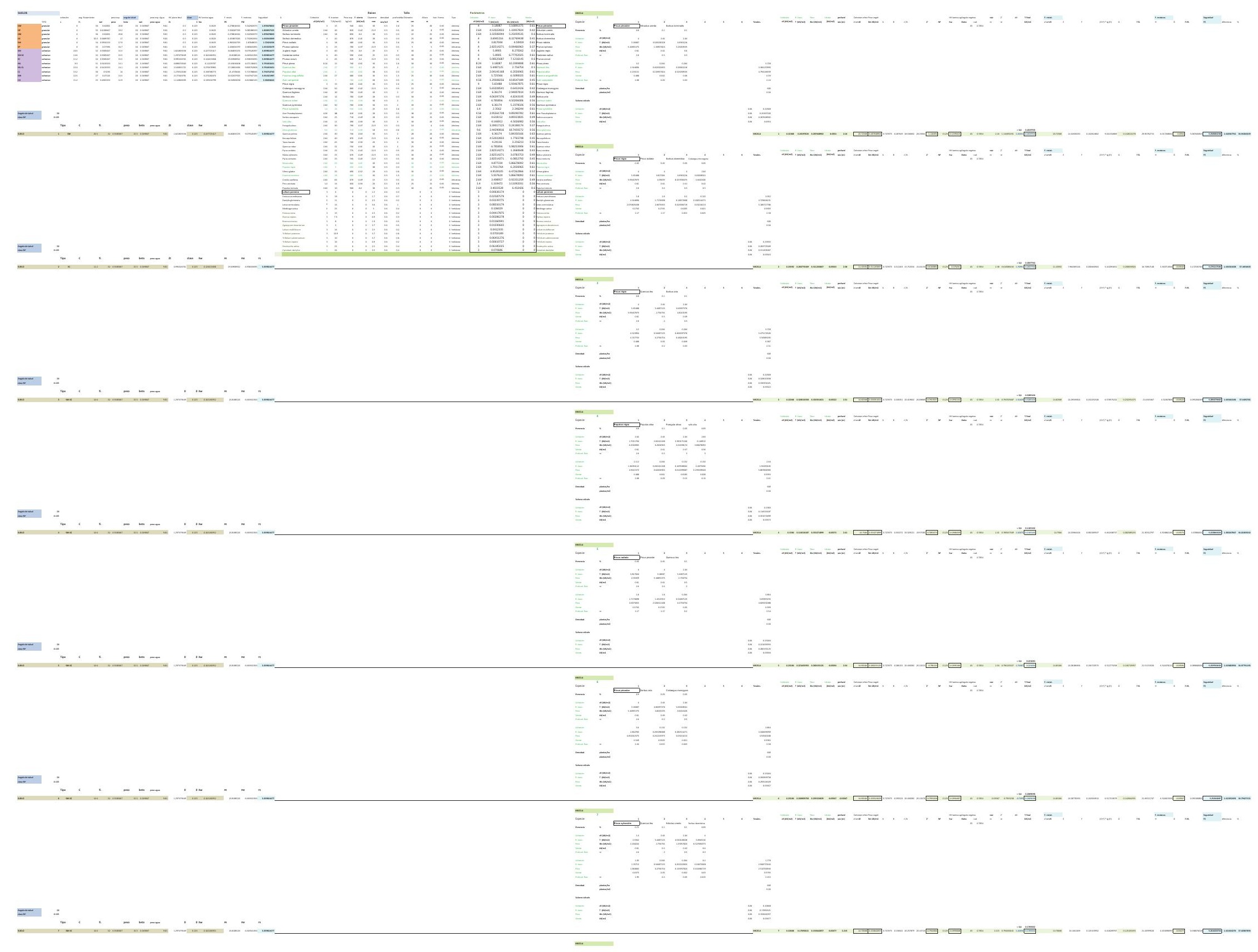




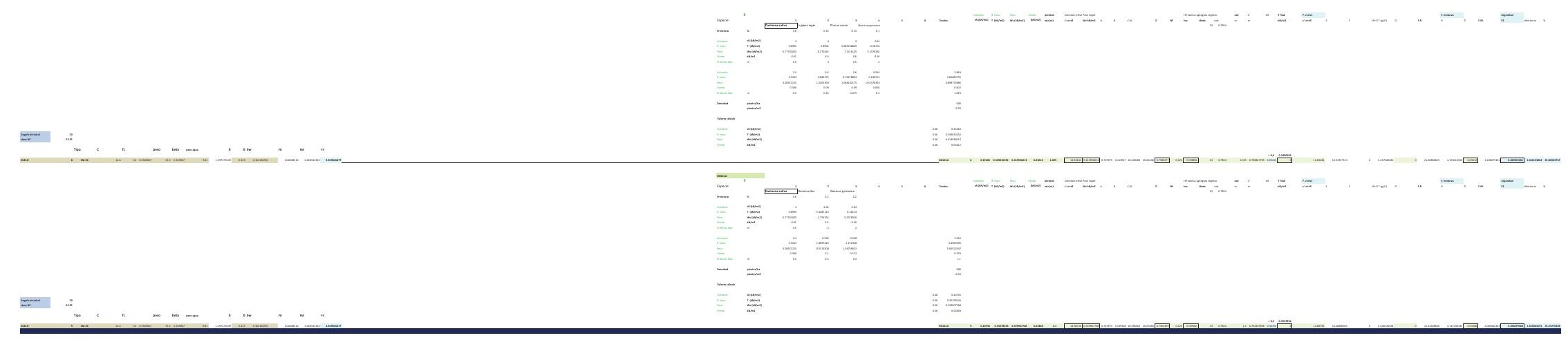




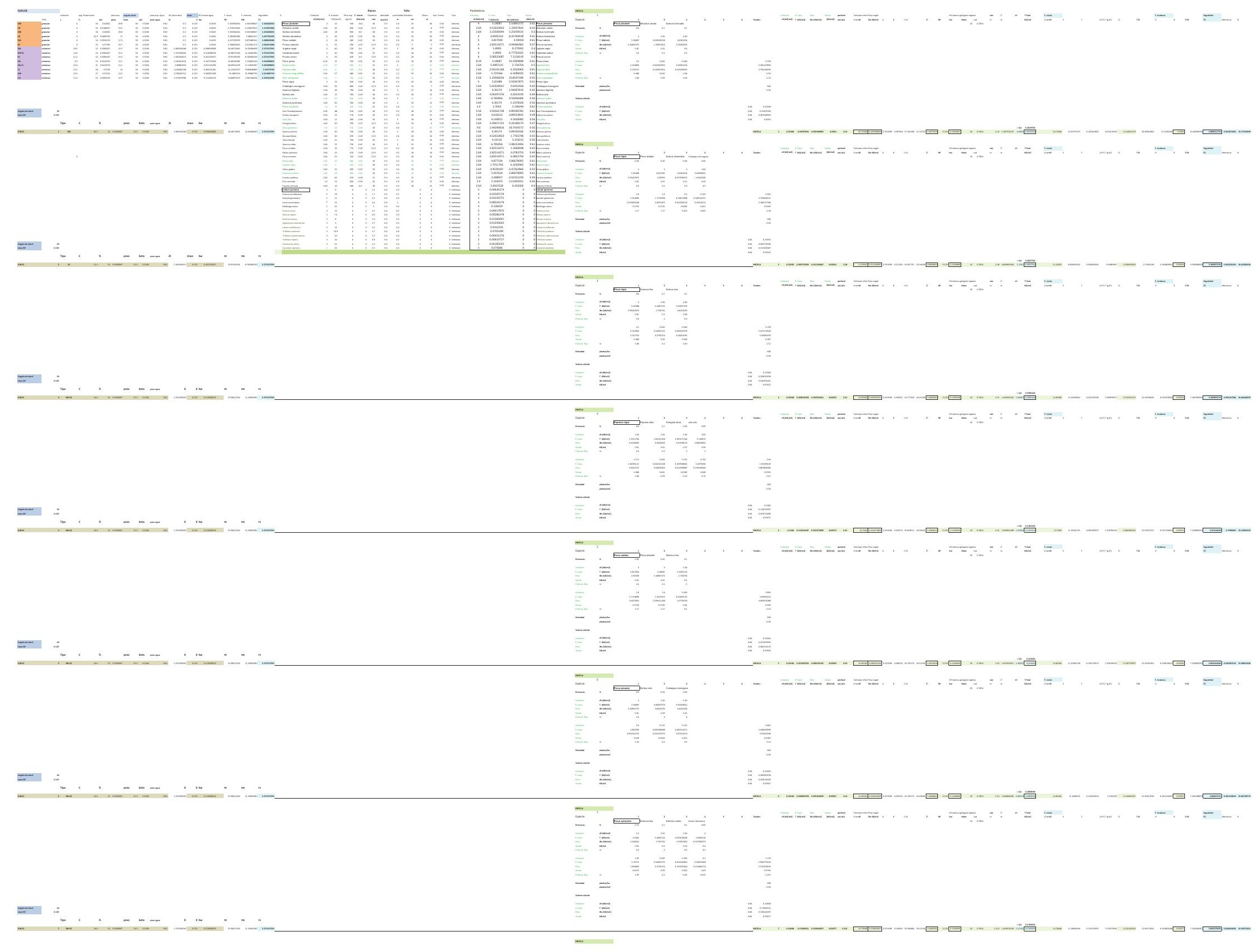




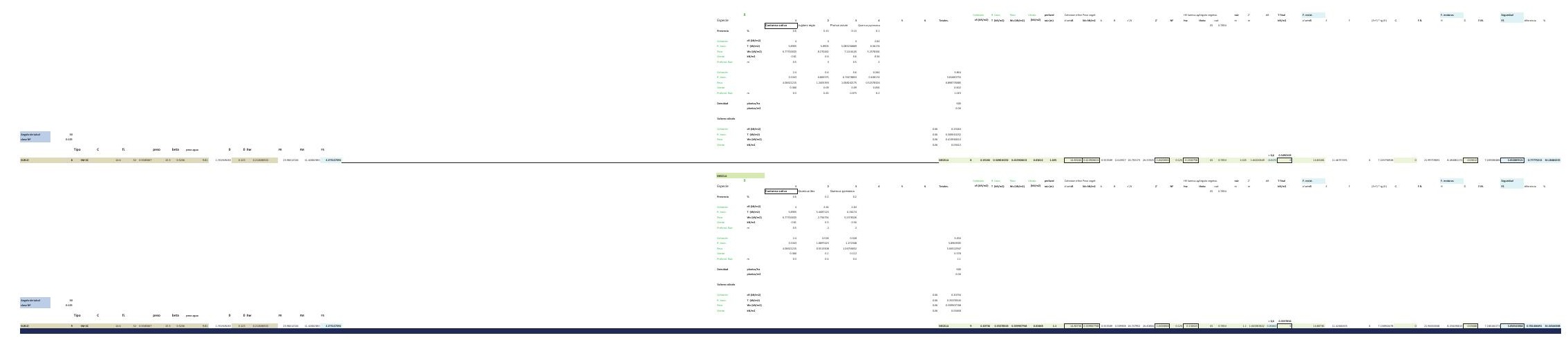




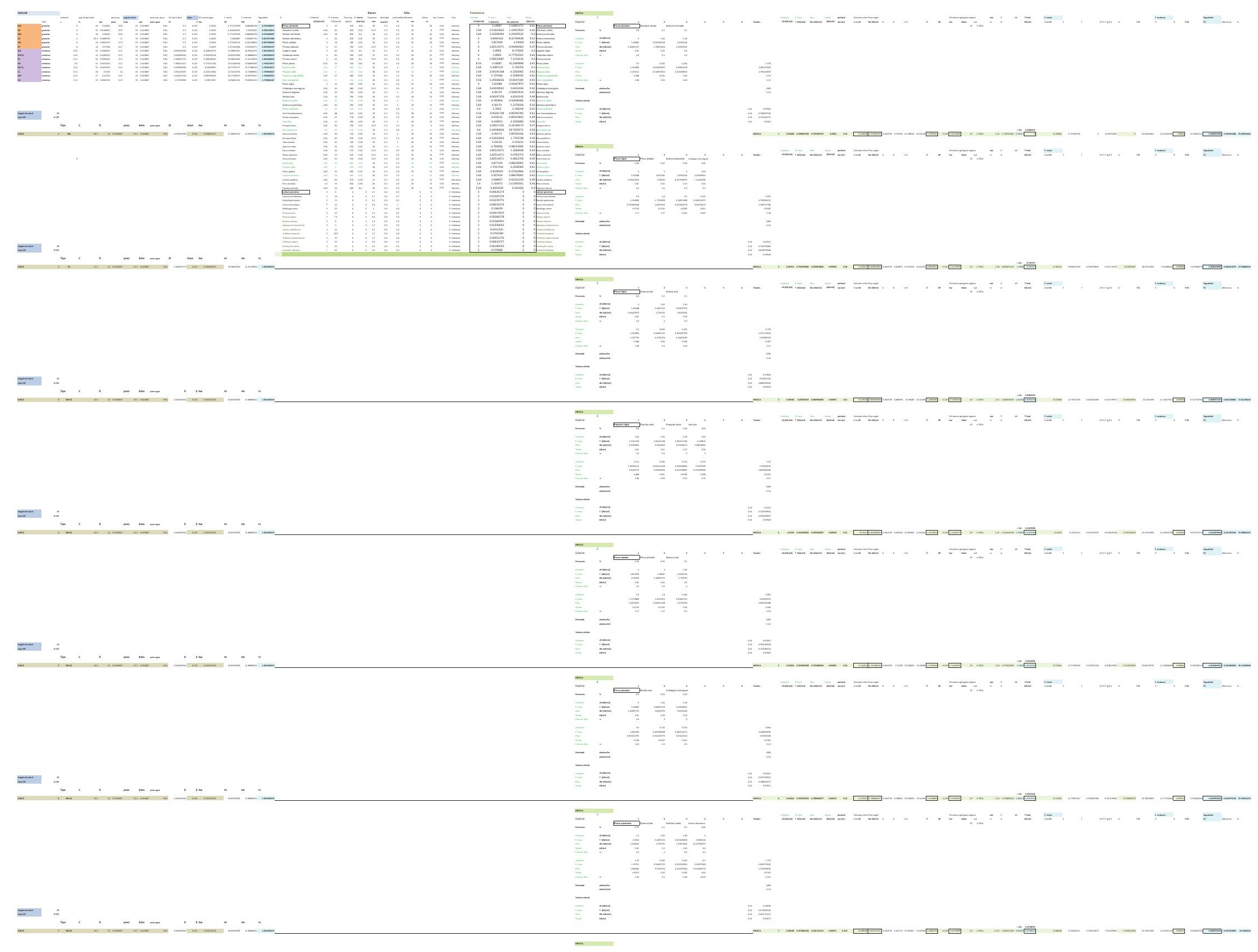




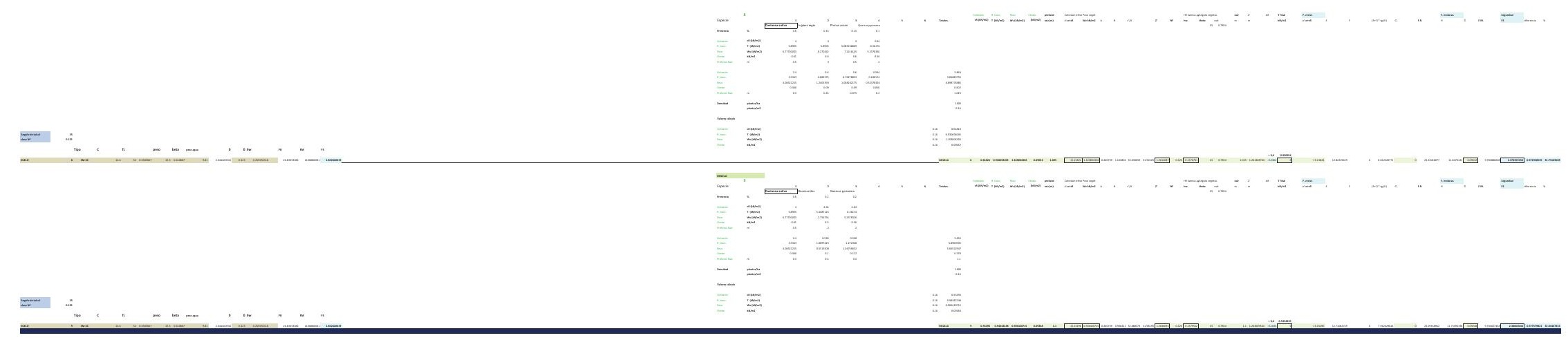




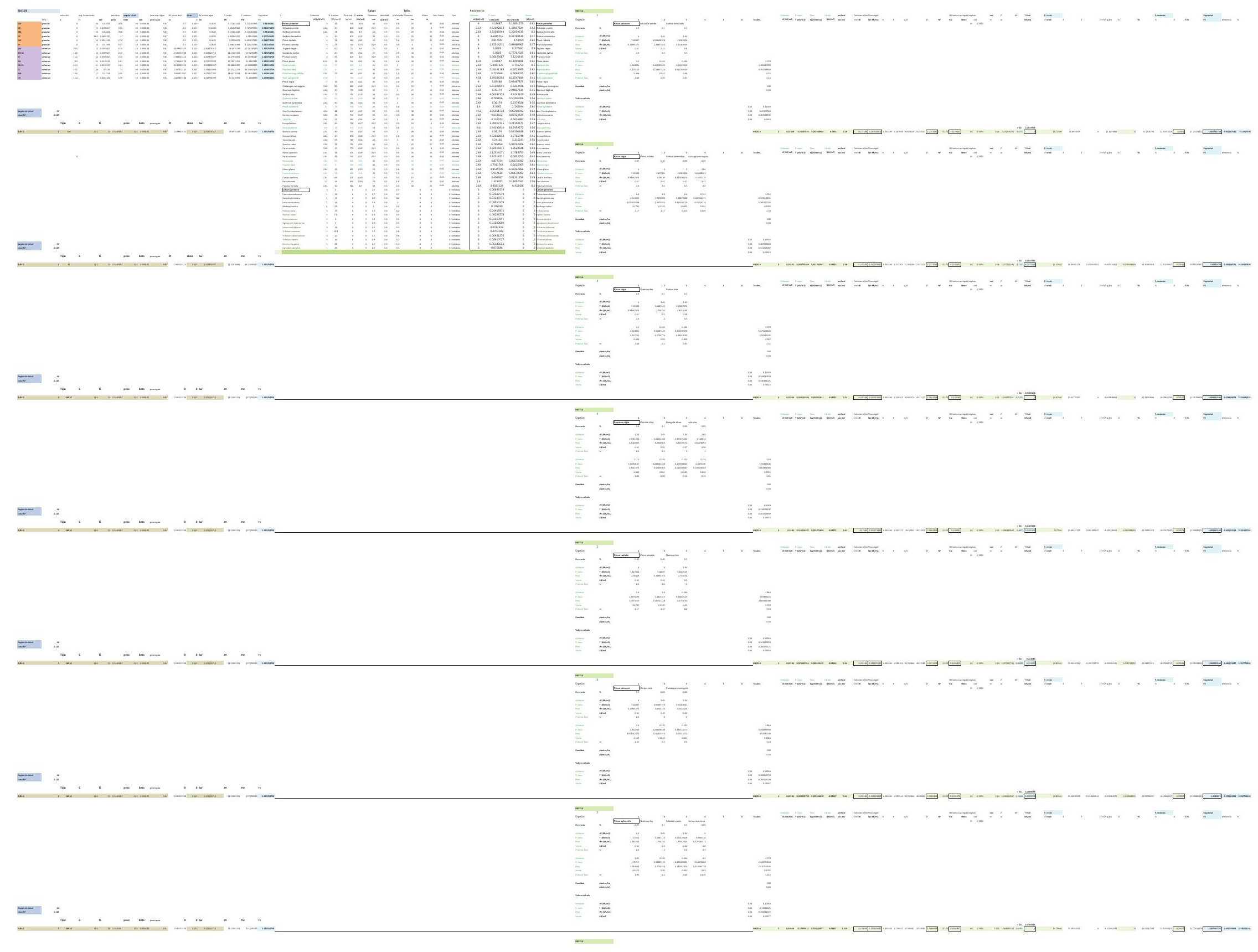




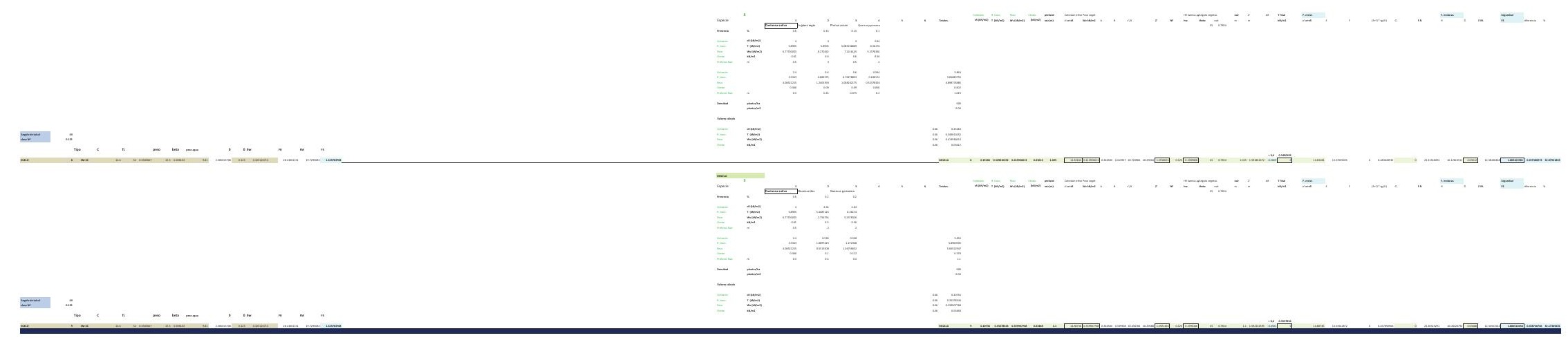




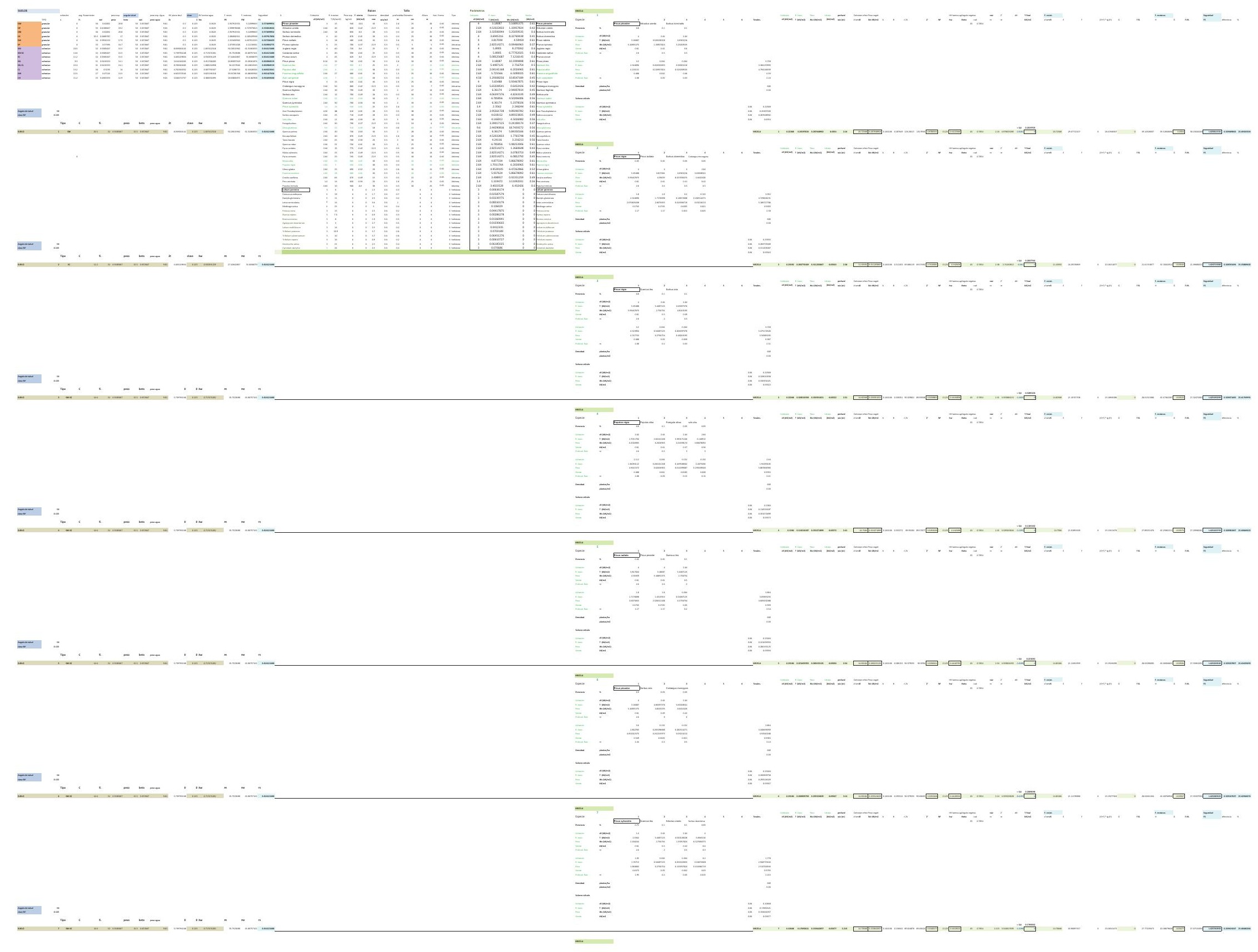




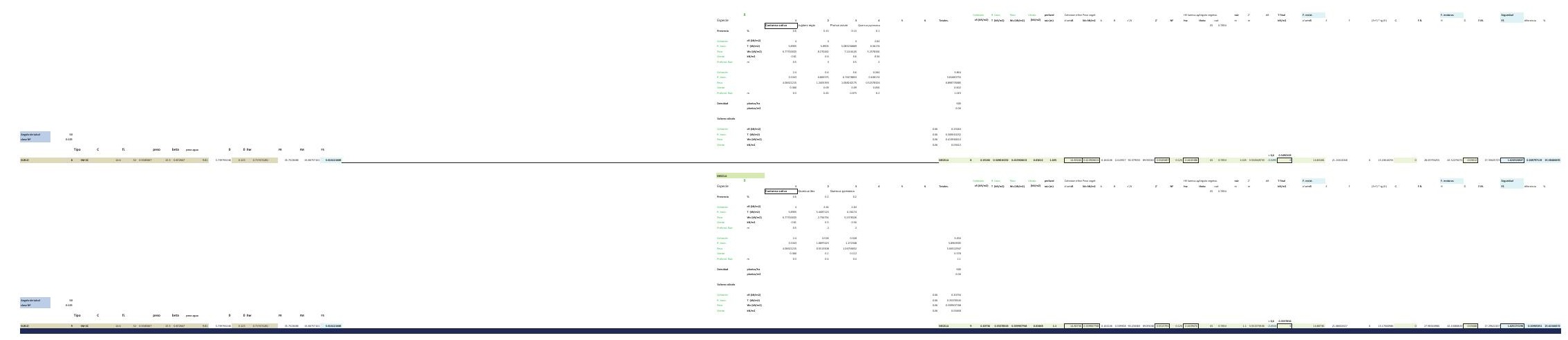




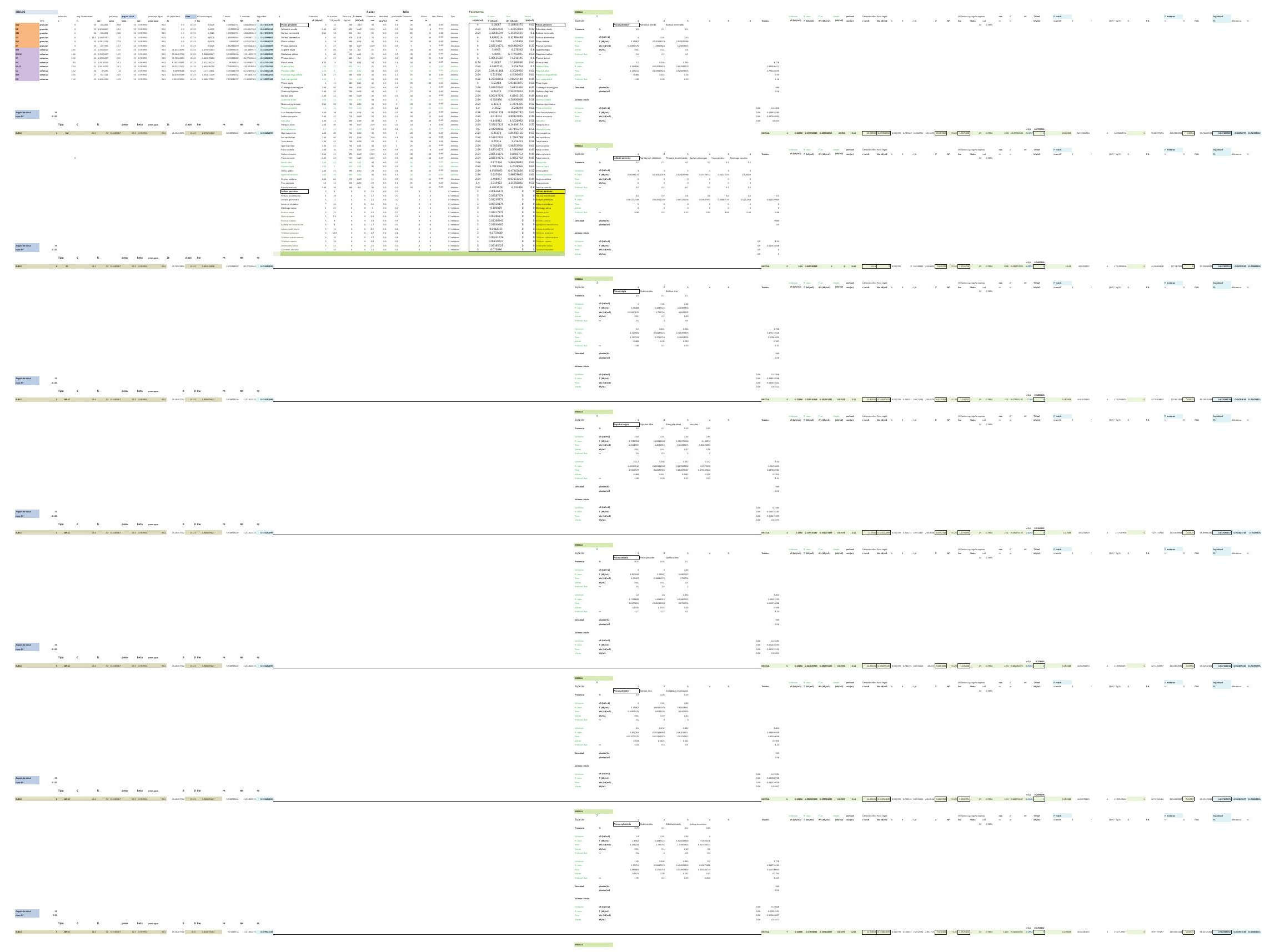




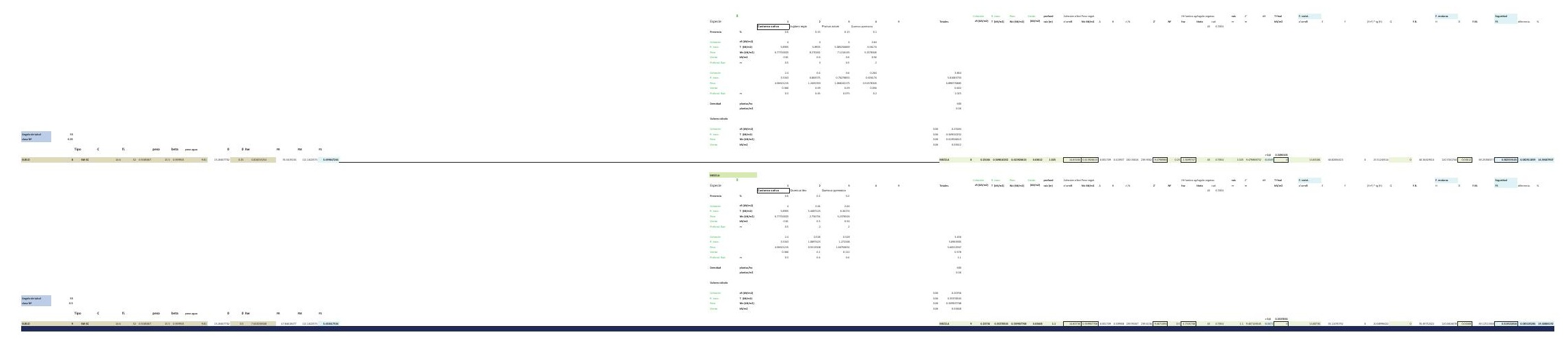




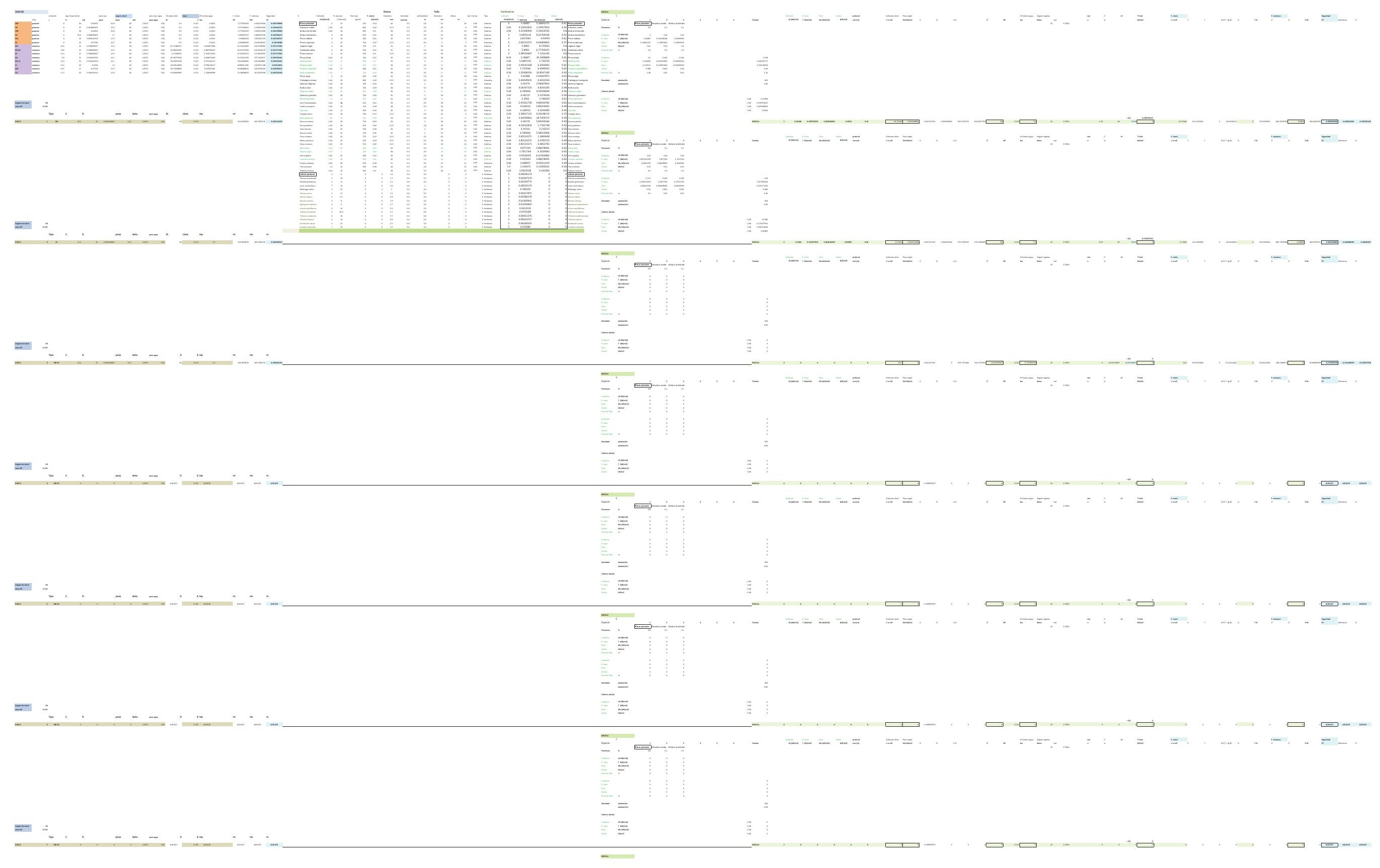


$=$

$\equiv \ldots \ldots \ldots \ldots$

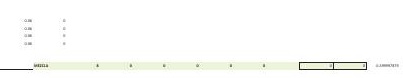

$\equiv \quad:$

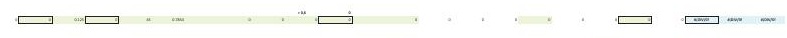

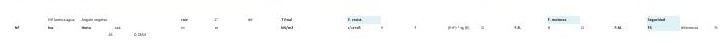




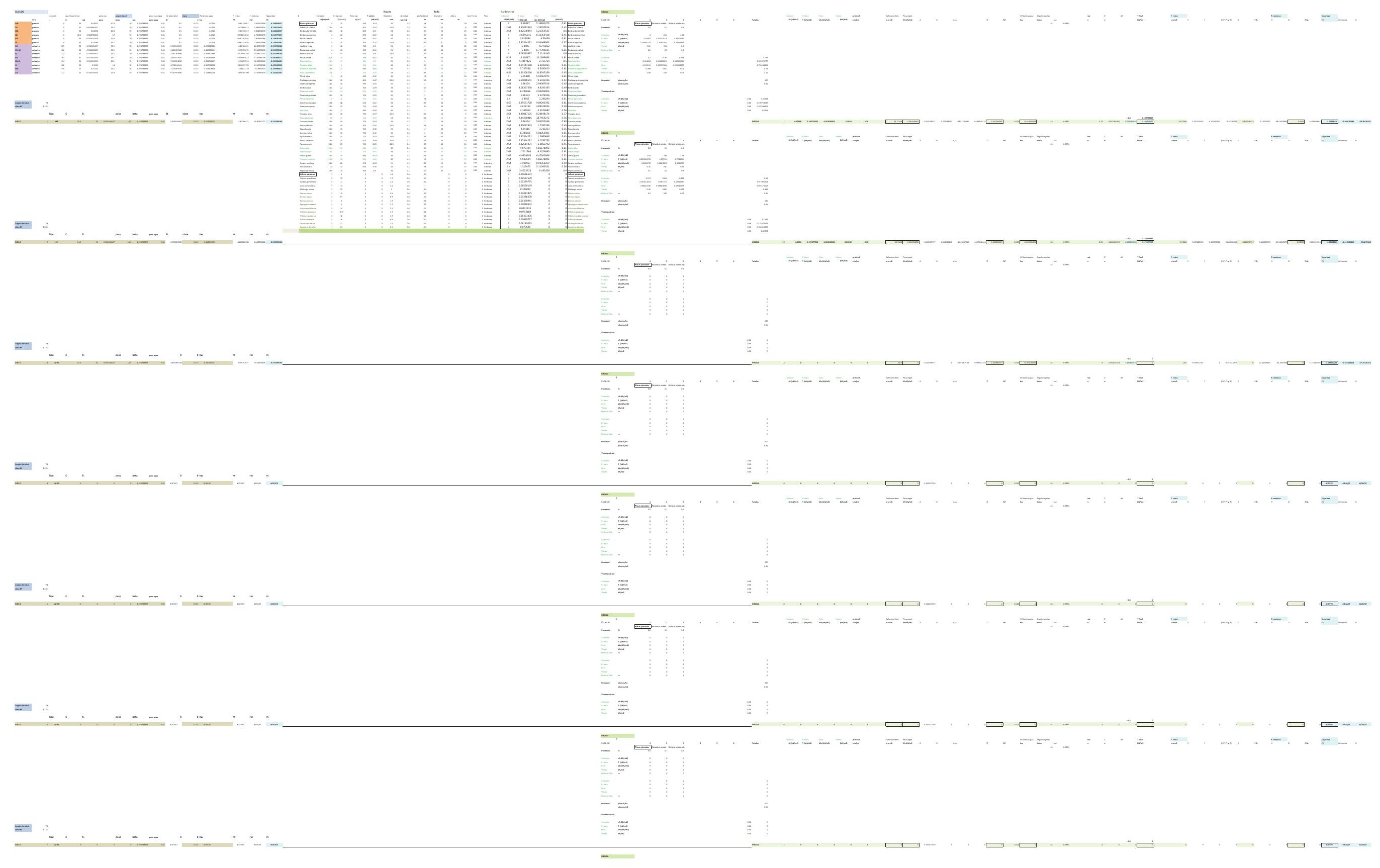




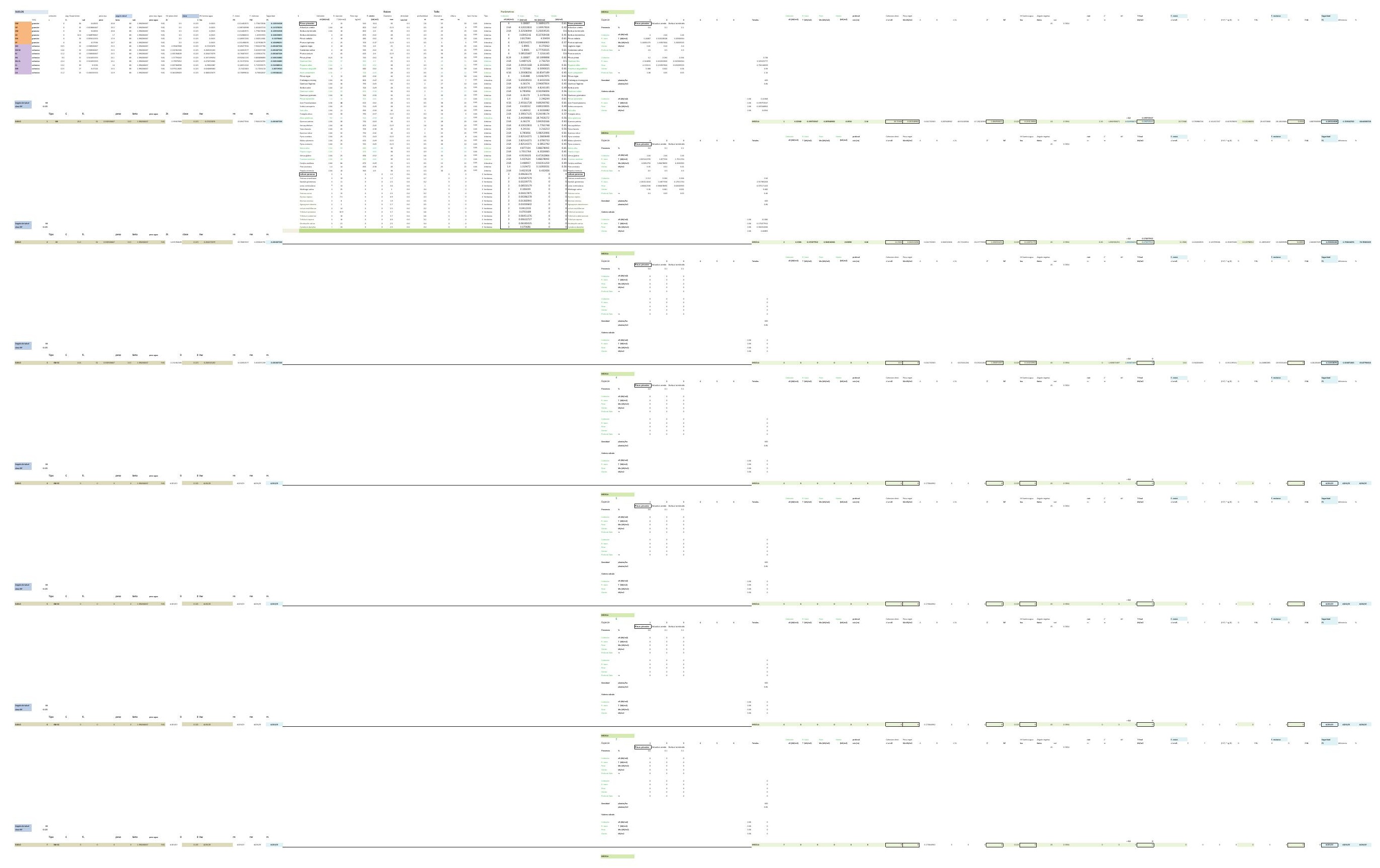


$=$

$\equiv \ldots \ldots \ldots \ldots$

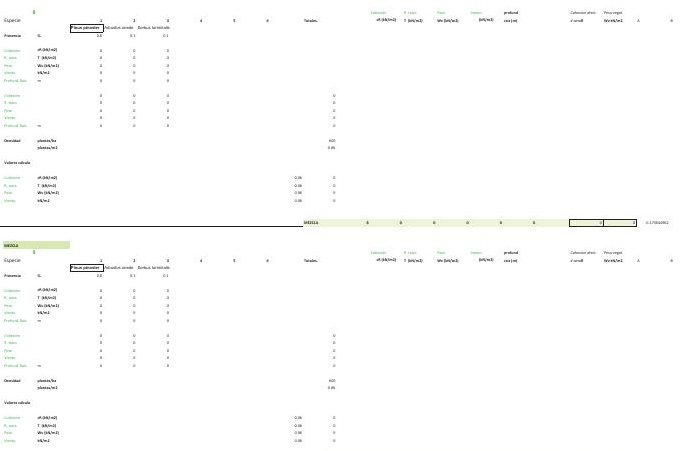

$\square-\square \cdots \cdots$

$\square--$

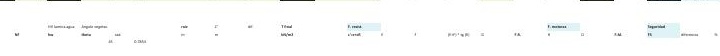


DESARROLLO DE UNA APLICACIÓN IMFORMÁTICA PARA EL CÁLCULO DE SOSTENIMIENTO DE TALUDES MEDIANTE VEGETACIÓN

B01. DENSIDAD DE PLANTACIÓN: 600 plantas/ha.

\section{B01-3.POSICIÓN N.F. 3}

INCLINACIÓN DE TALUD 6-100

INCLINACIÓN DE TALUD 10-200

INCLINACIÓN DE TALUD 20-30

INCLINACIÓN DE TALUD 30-40

INCLINACIÓN DE TALUD $35^{\circ}$

INCLINACIÓN DE TALUD 40-50

INCLINACIÓN DE TALUD 50-550

INCLINACIÓN DE TALUD 55-60

INCLINACIÓN DE TALUD 60-700

INCLINACIÓN DE TALUD 70-80 


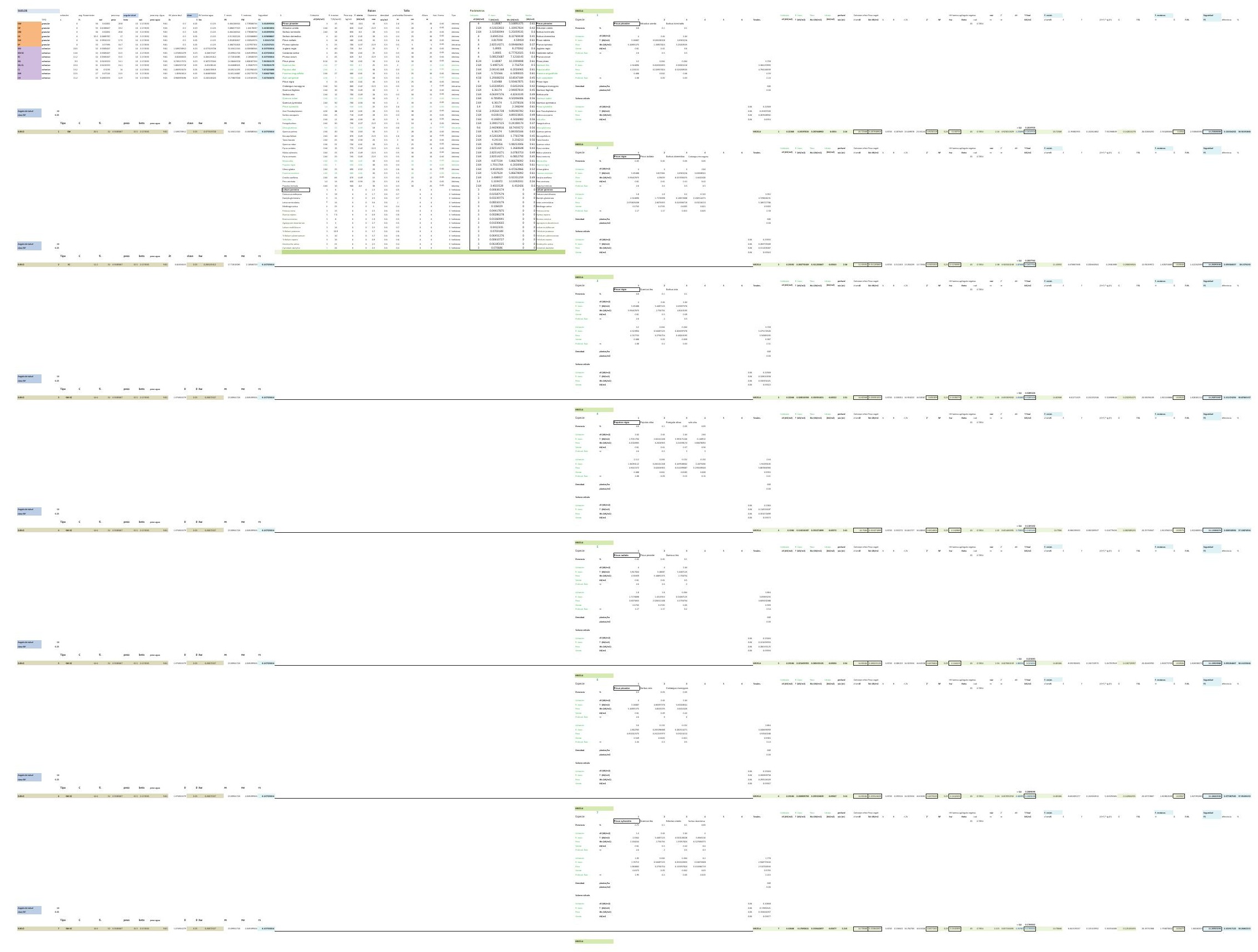




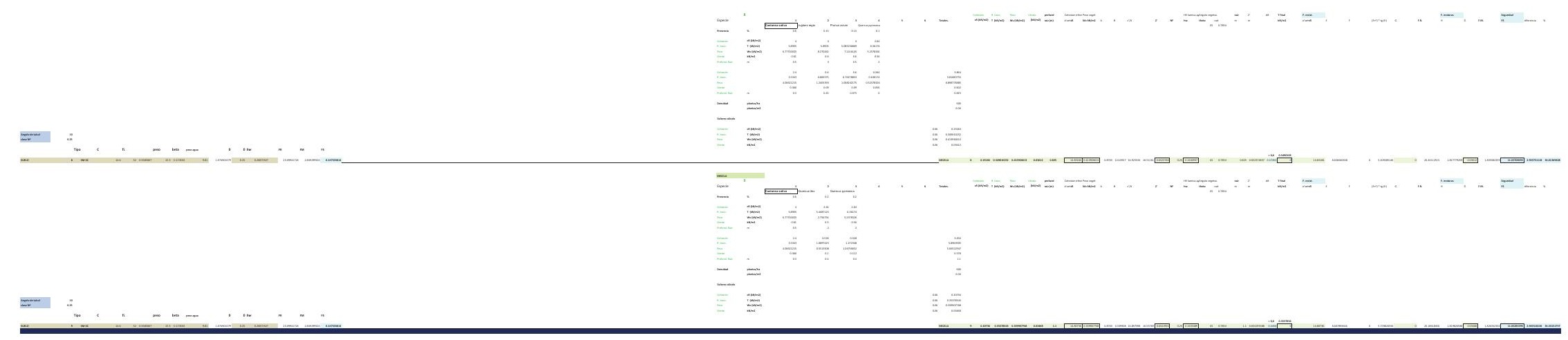




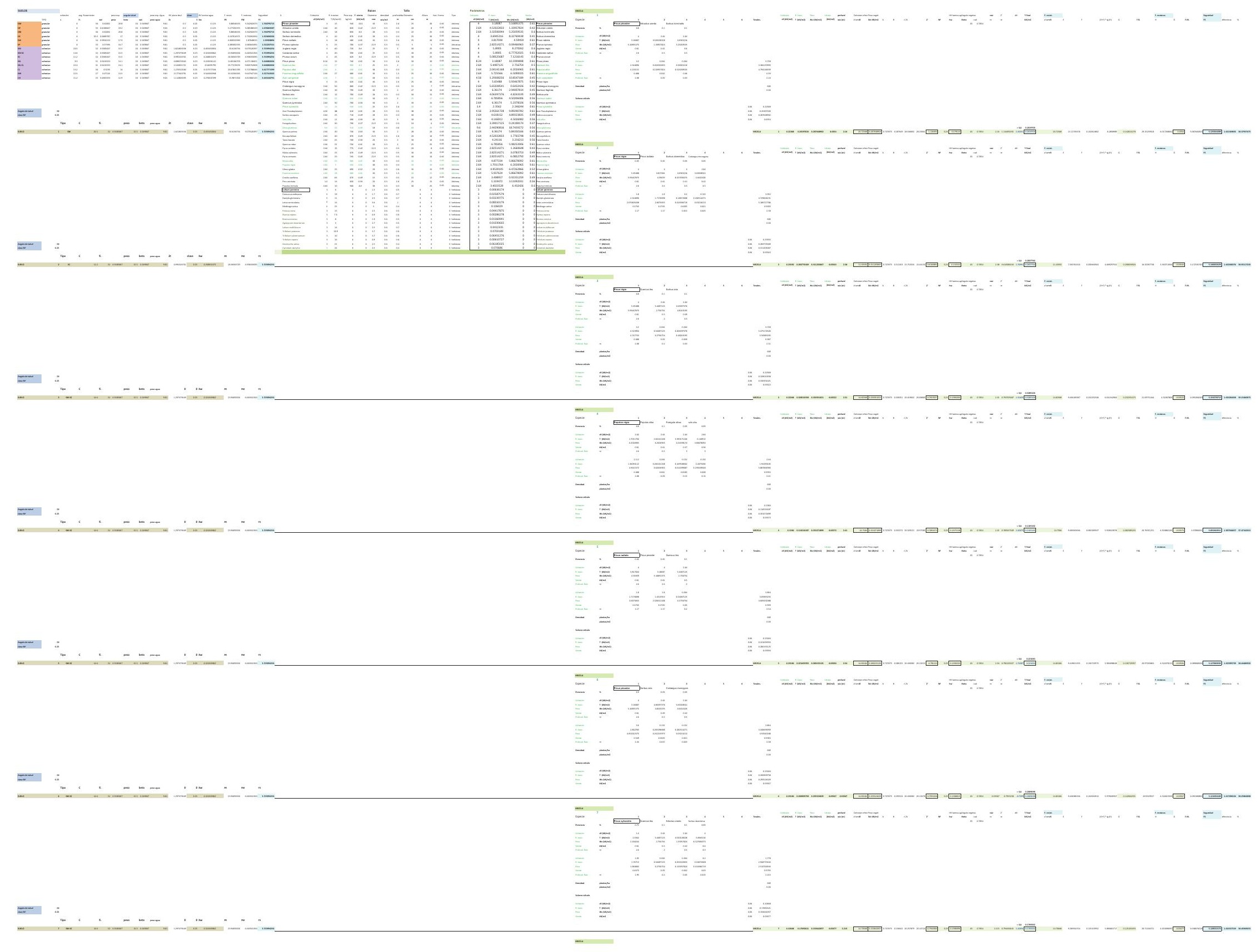




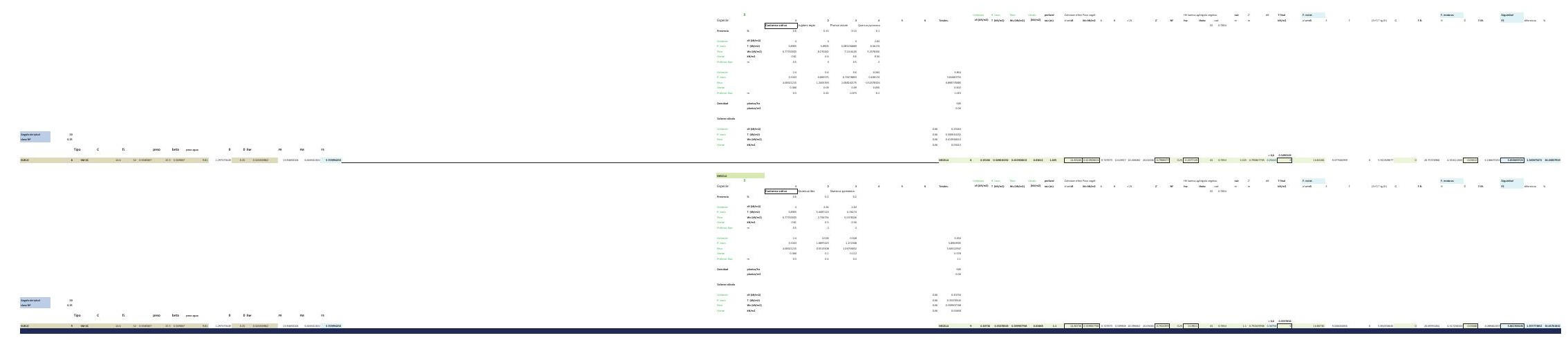




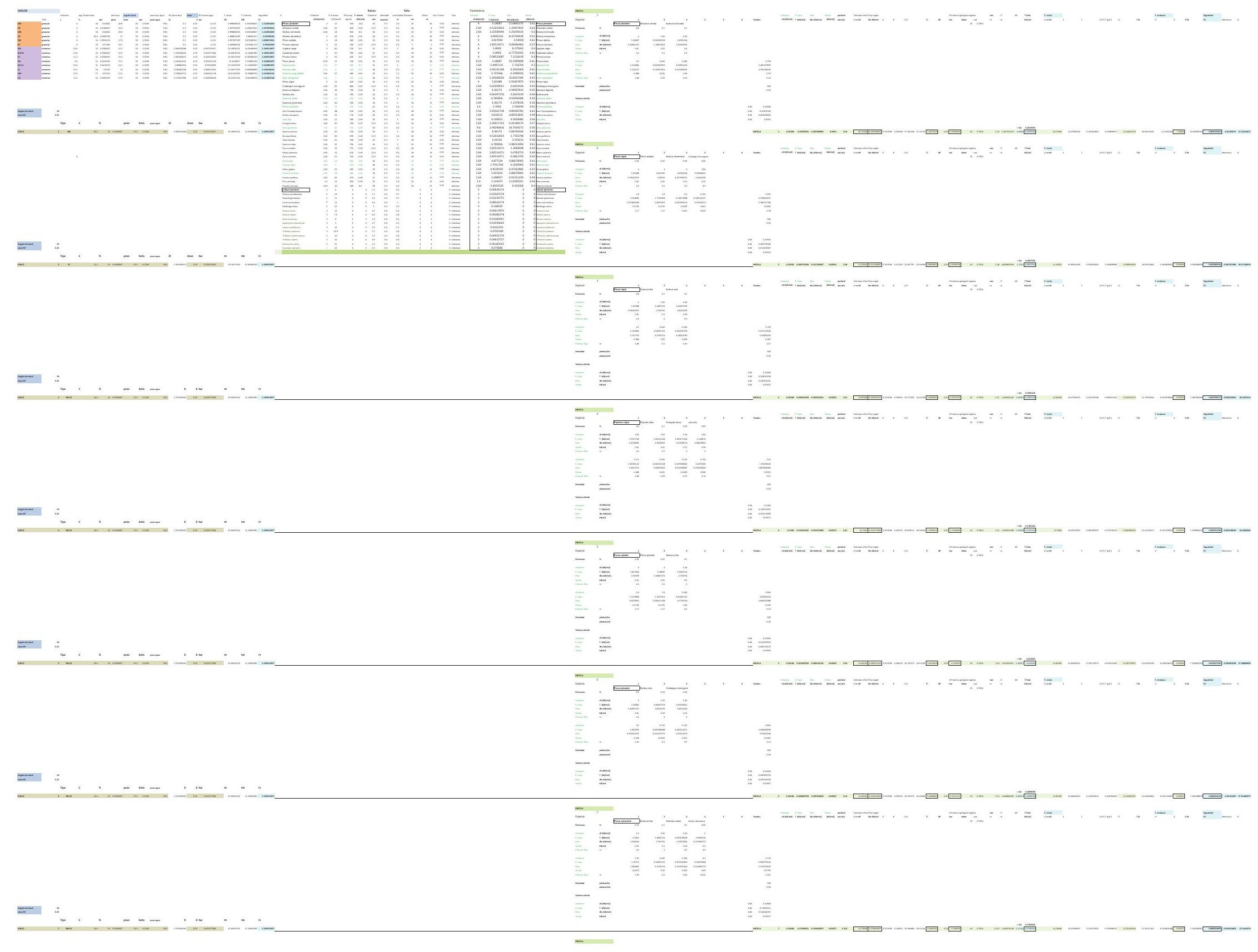




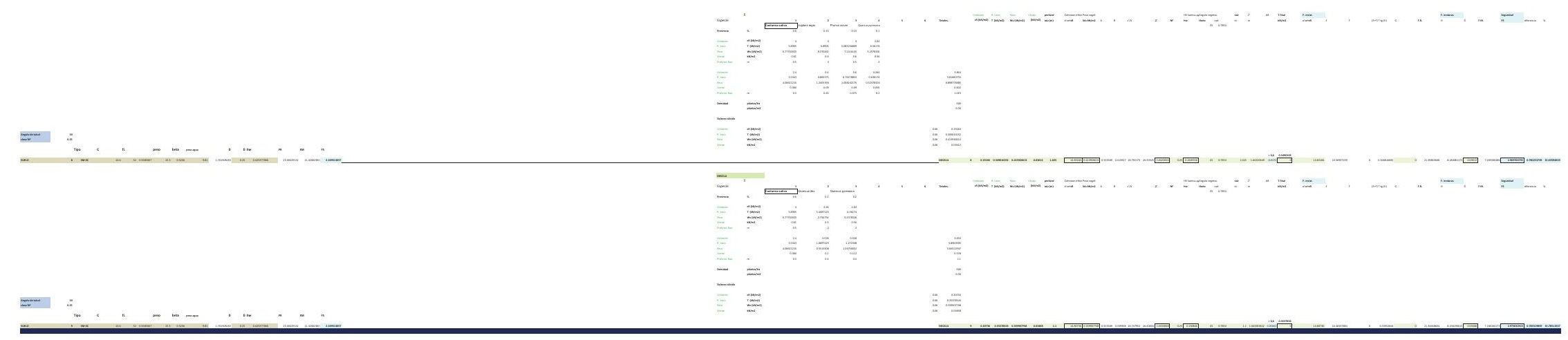




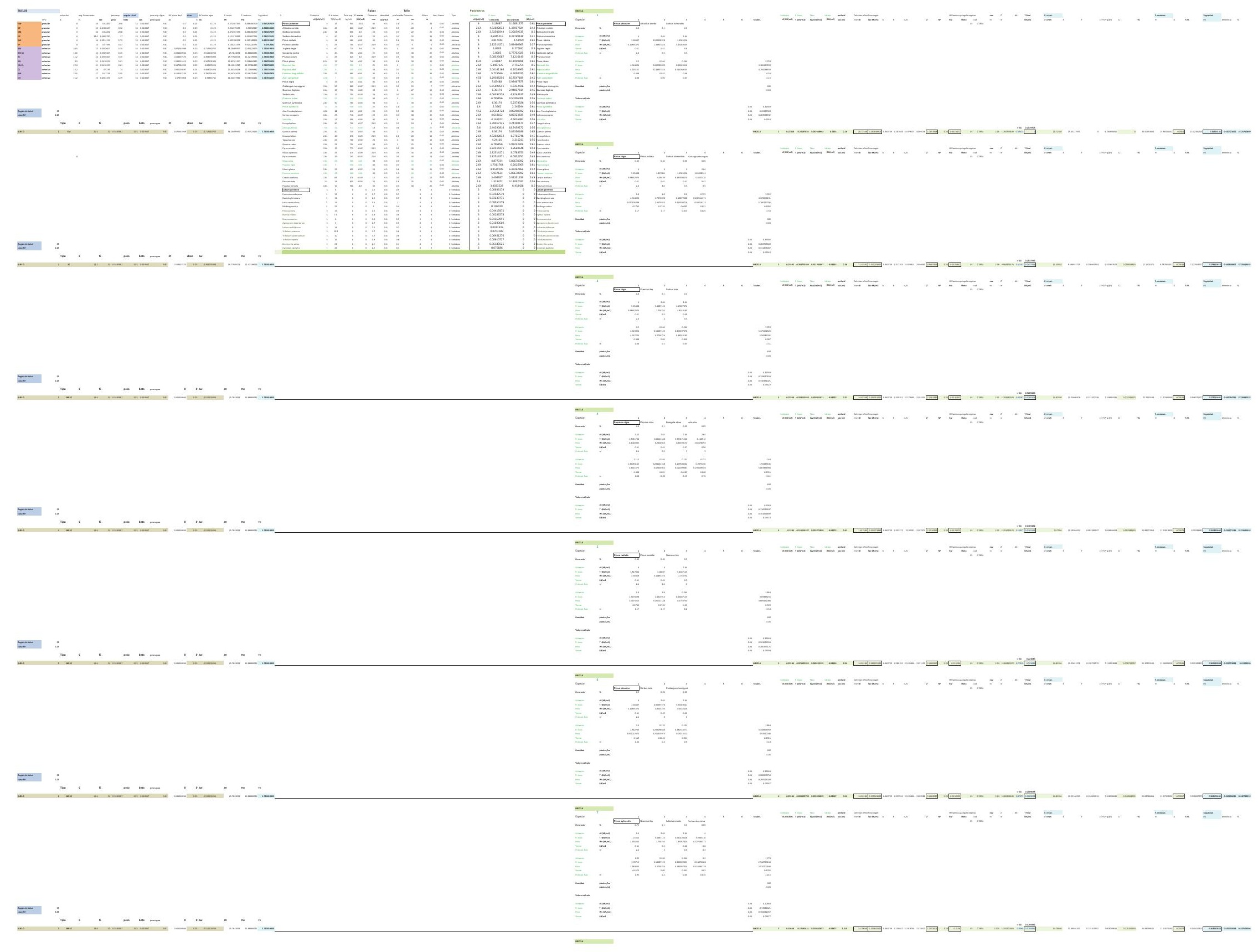




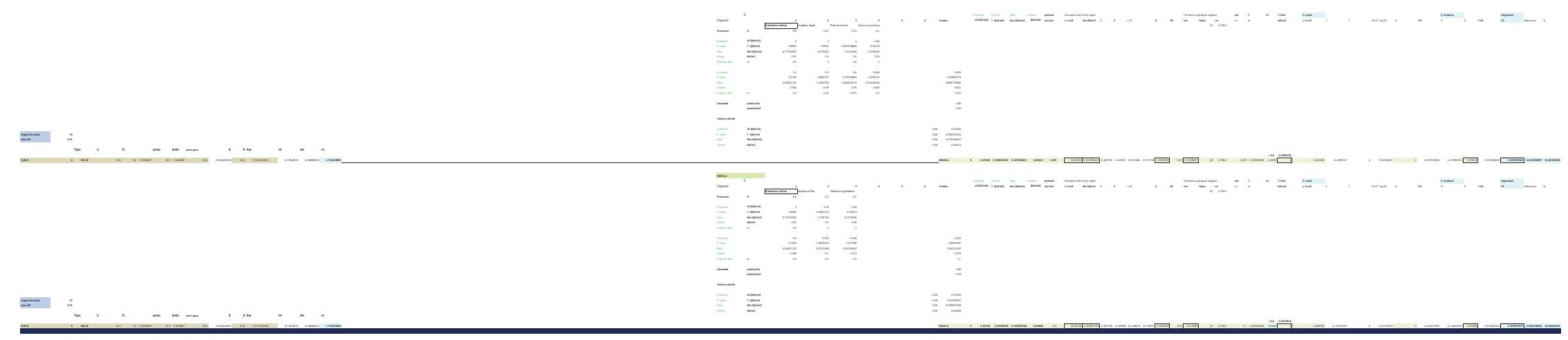




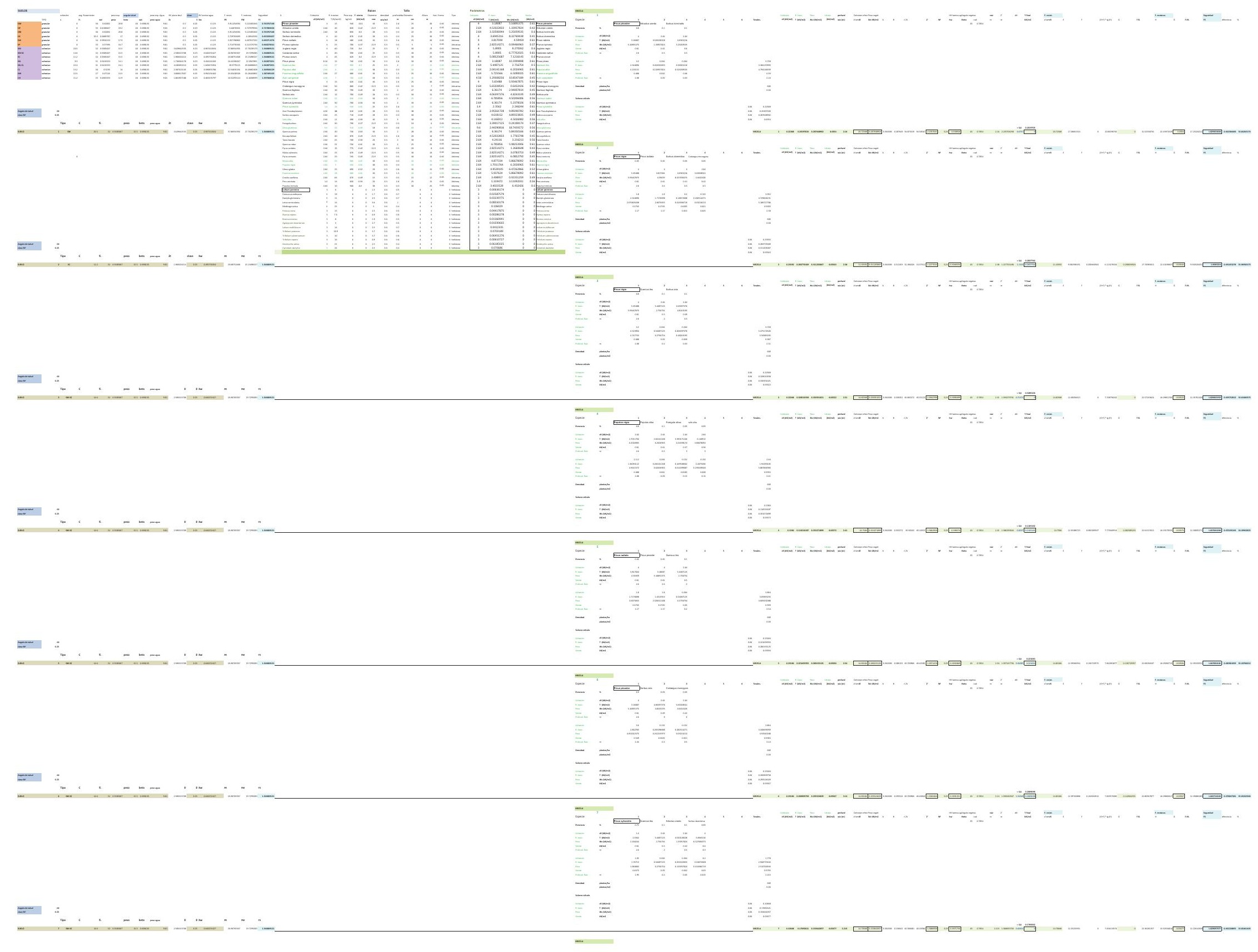




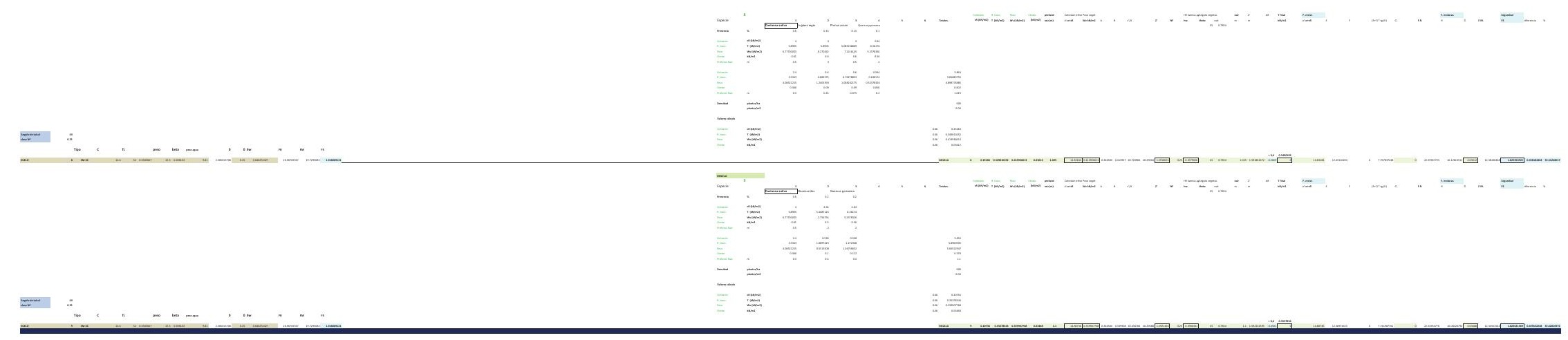




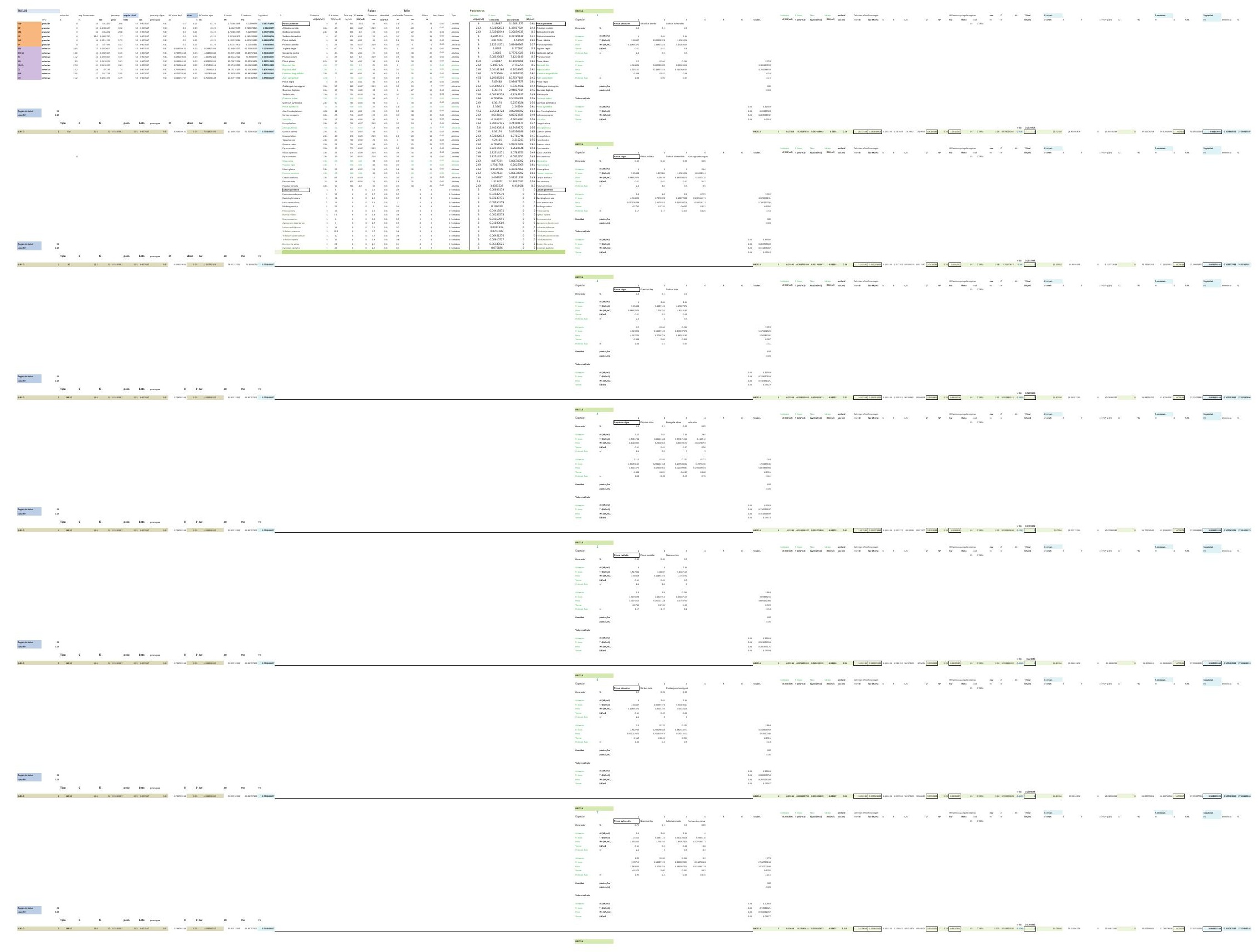




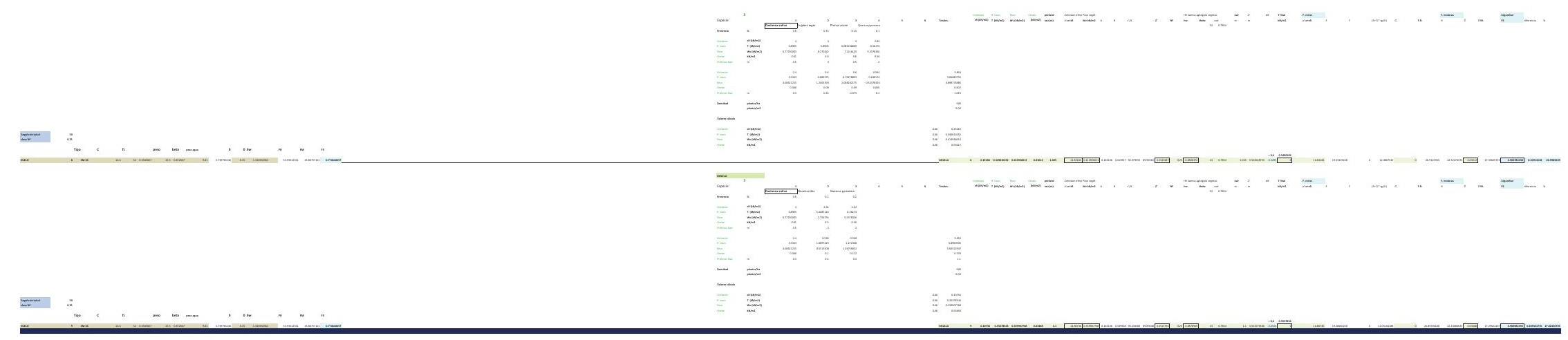




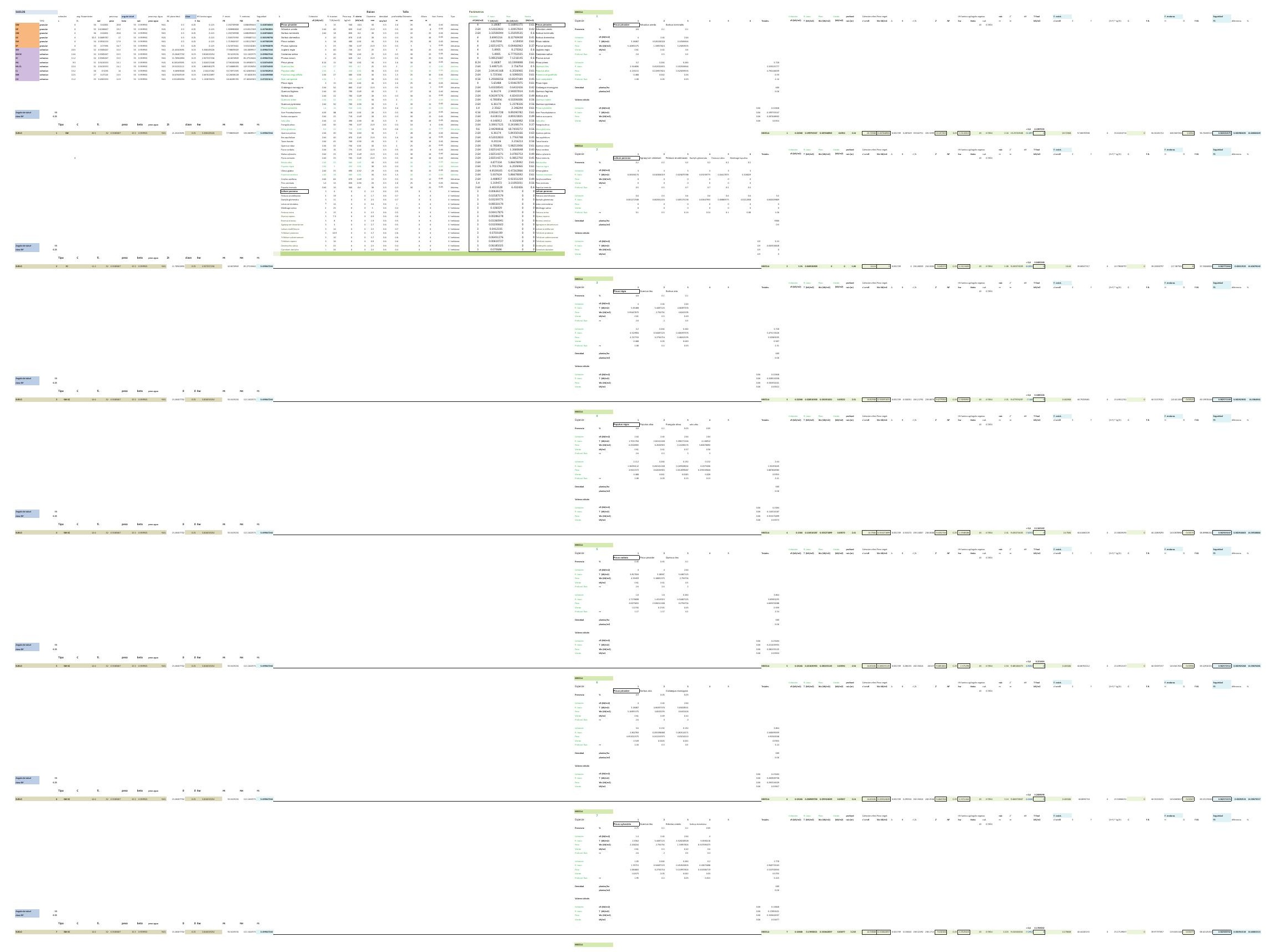




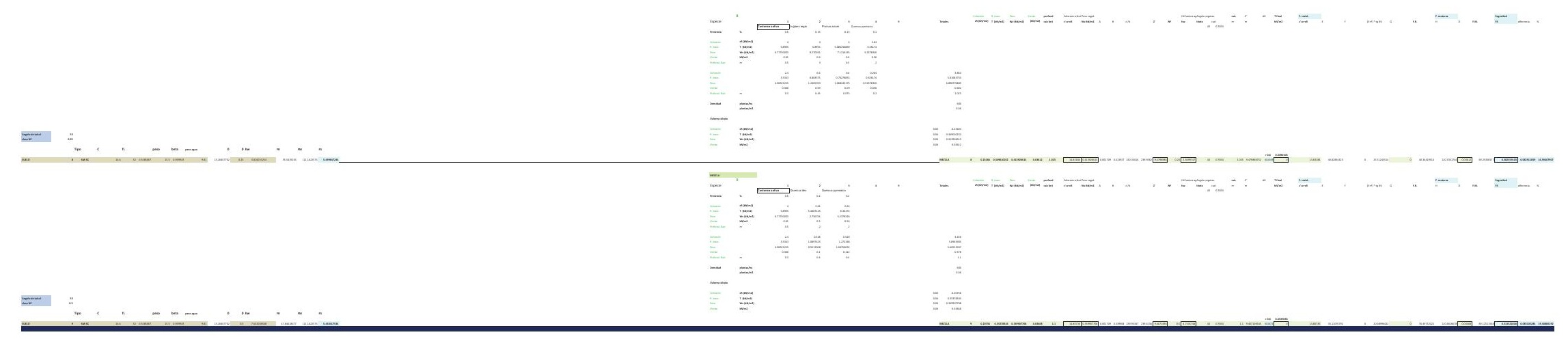




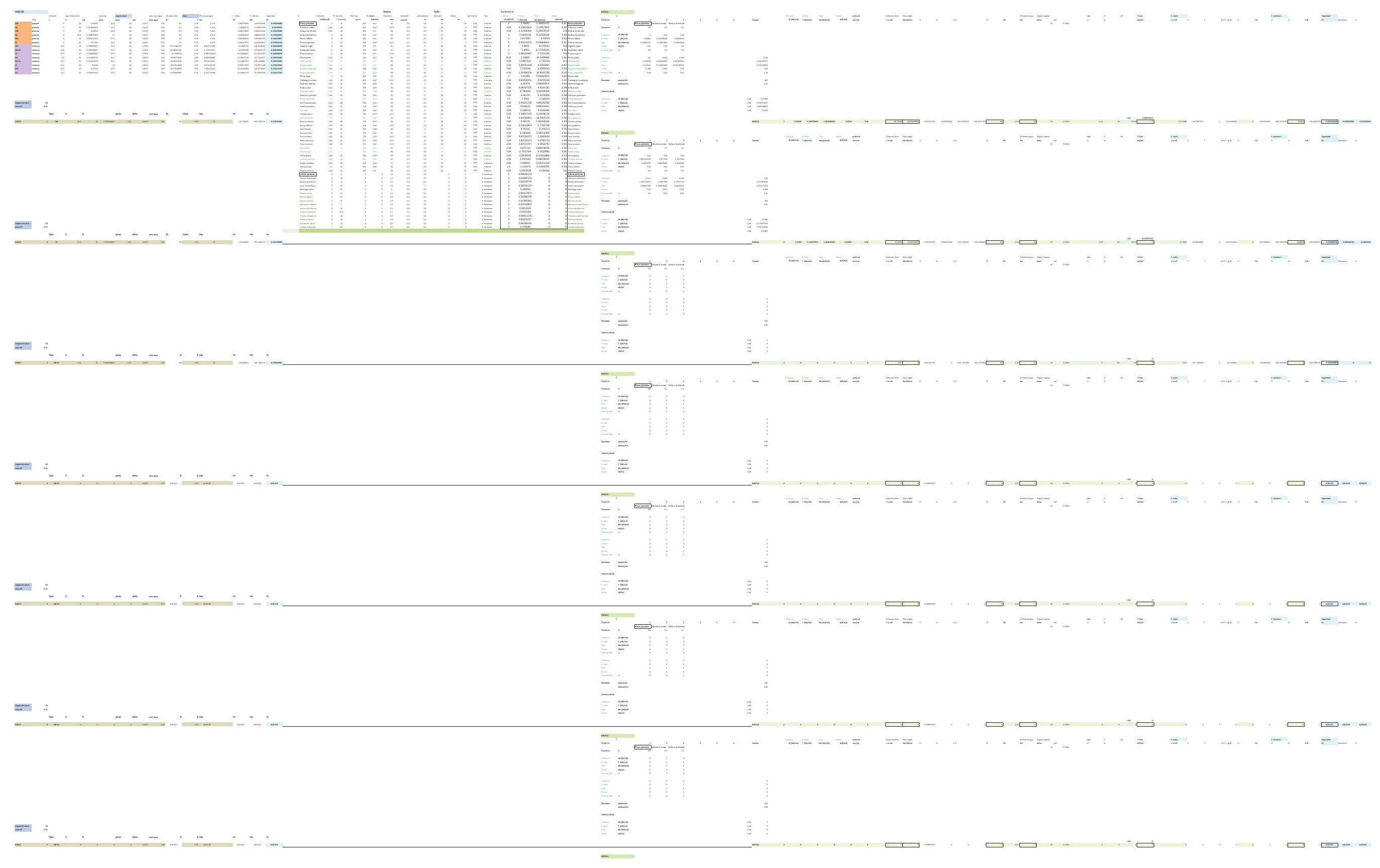




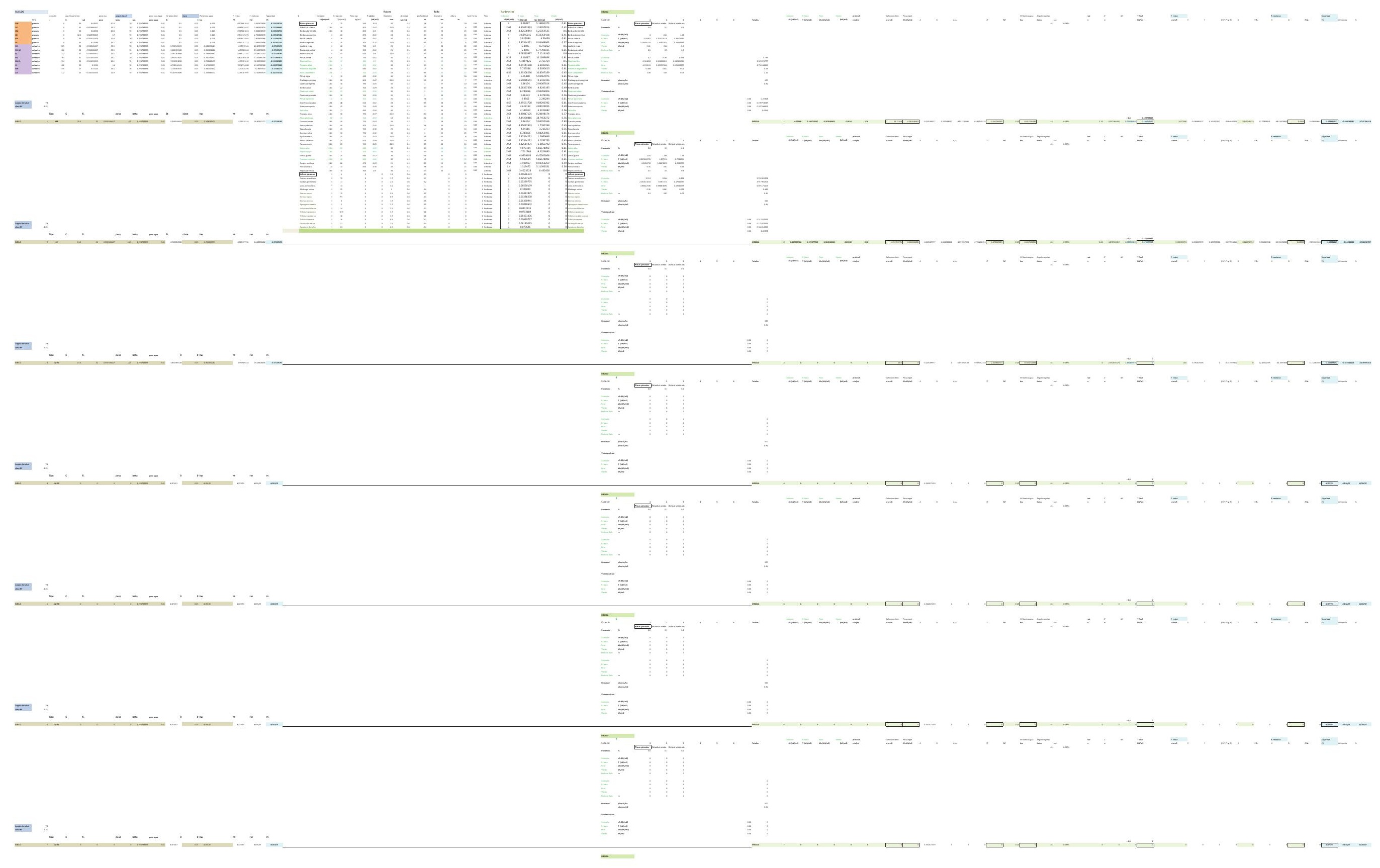




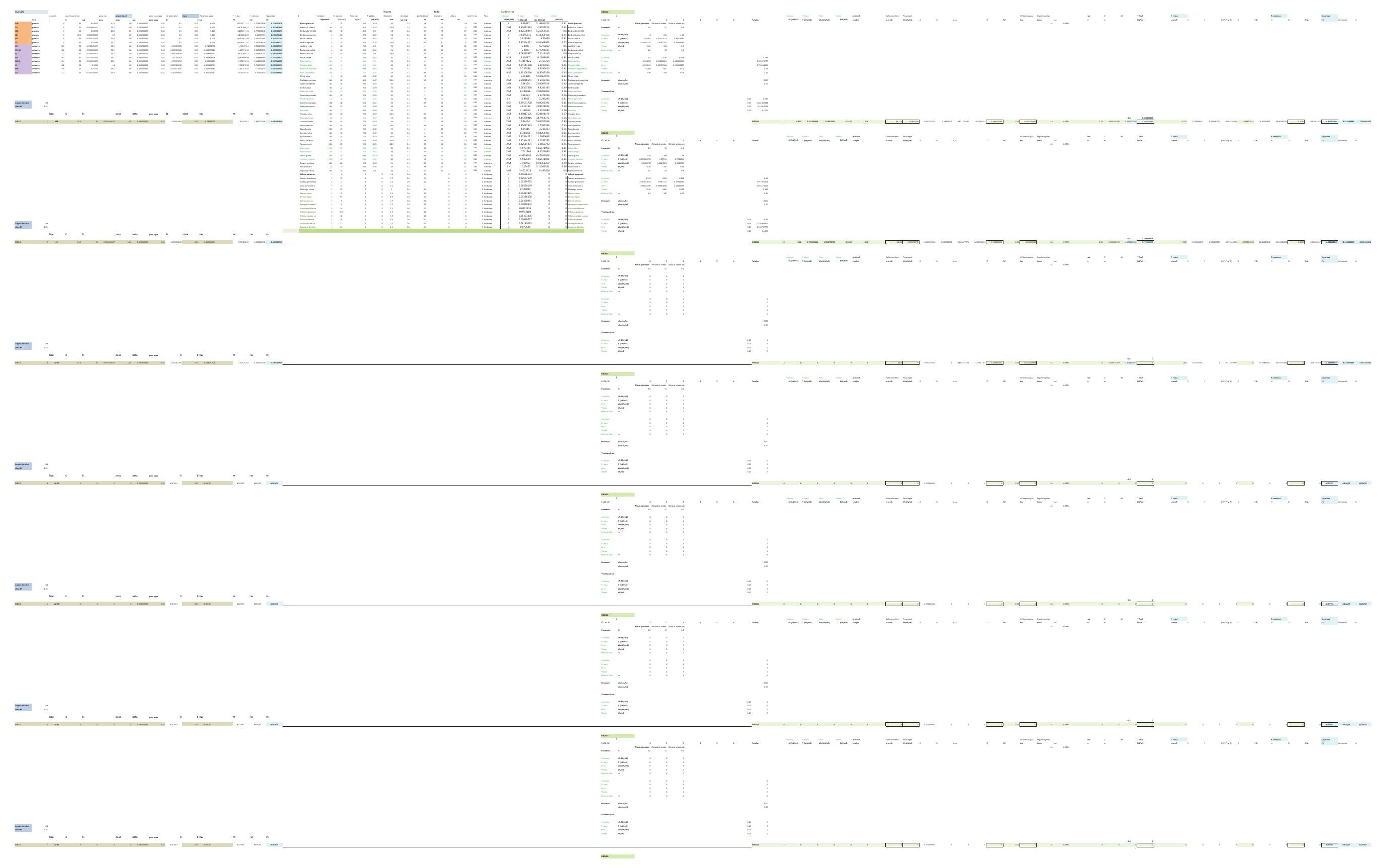


DESARROLLO DE UNA APLICACIÓN IMFORMÁTICA PARA EL CÁLCULO DE SOSTENIMIENTO DE TALUDES MEDIANTE VEGETACIÓN

B01. DENSIDAD DE PLANTACIÓN: 600 plantas/ha.

\section{B01-4.POSICIÓN N.F. 4}

INCLINACIÓN DE TALUD 6-100

INCLINACIÓN DE TALUD 10-200

INCLINACIÓN DE TALUD 20-30

INCLINACIÓN DE TALUD 30-40

INCLINACIÓN DE TALUD $35^{\circ}$

INCLINACIÓN DE TALUD 40-50

INCLINACIÓN DE TALUD 50-550

INCLINACIÓN DE TALUD 55-60

INCLINACIÓN DE TALUD 60-700

INCLINACIÓN DE TALUD 70-80 


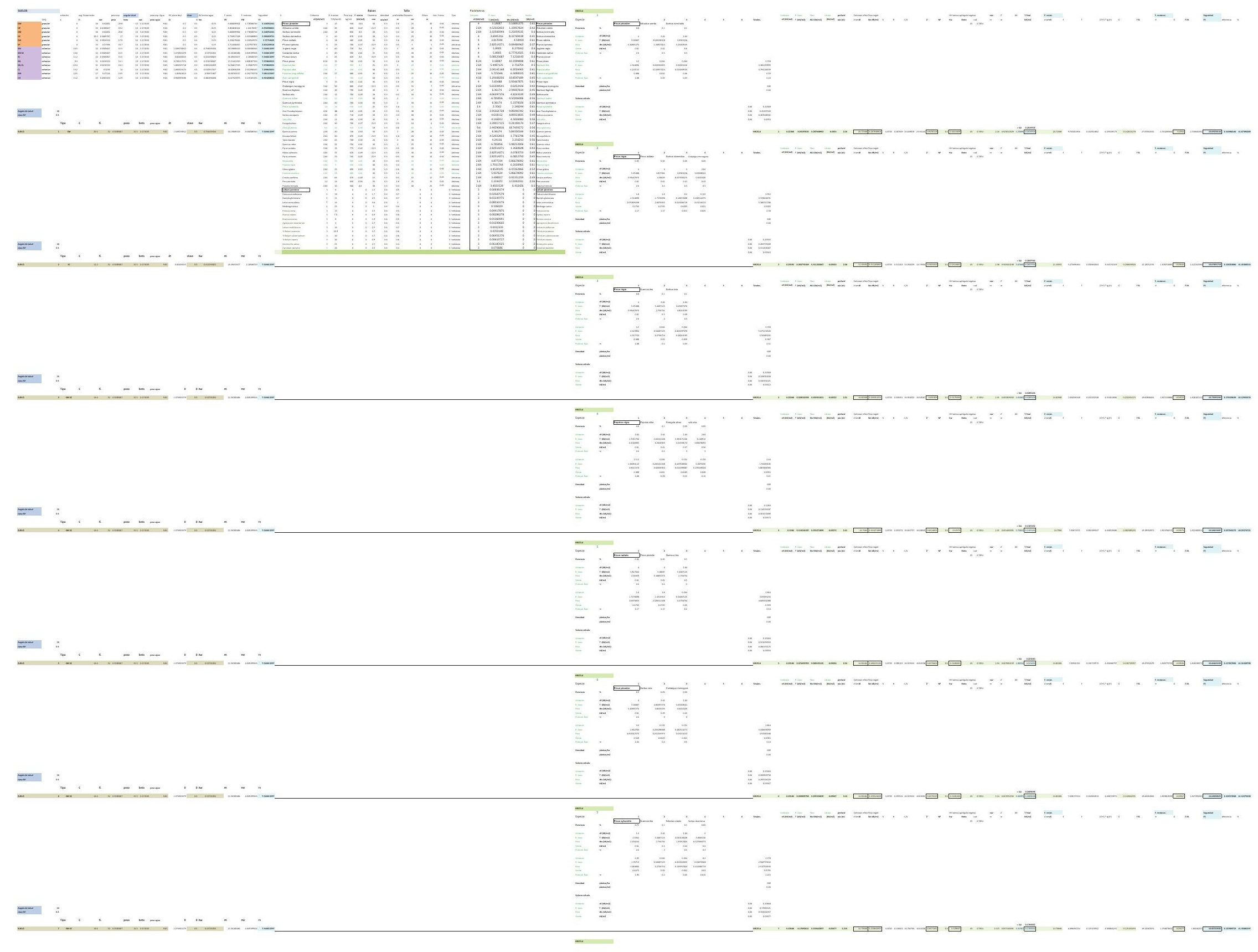




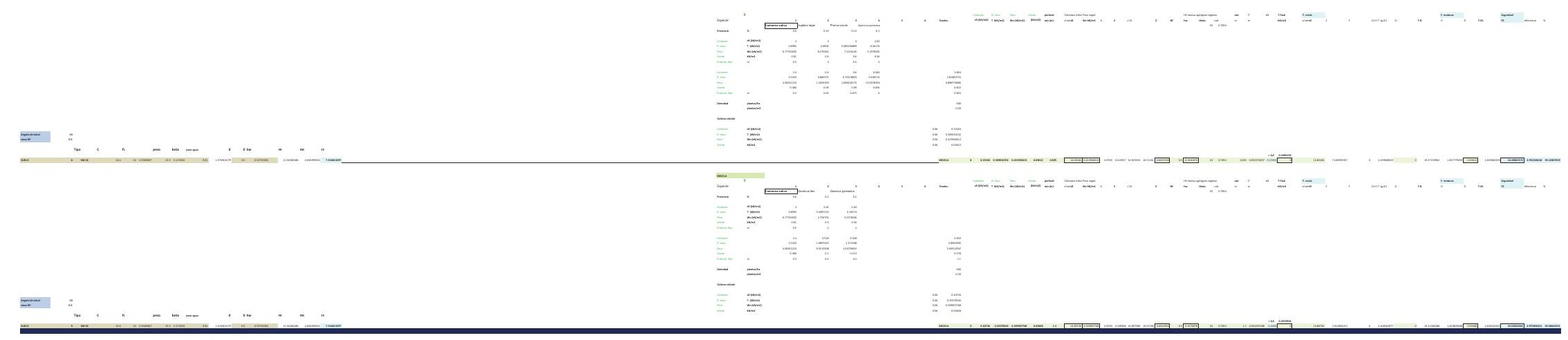




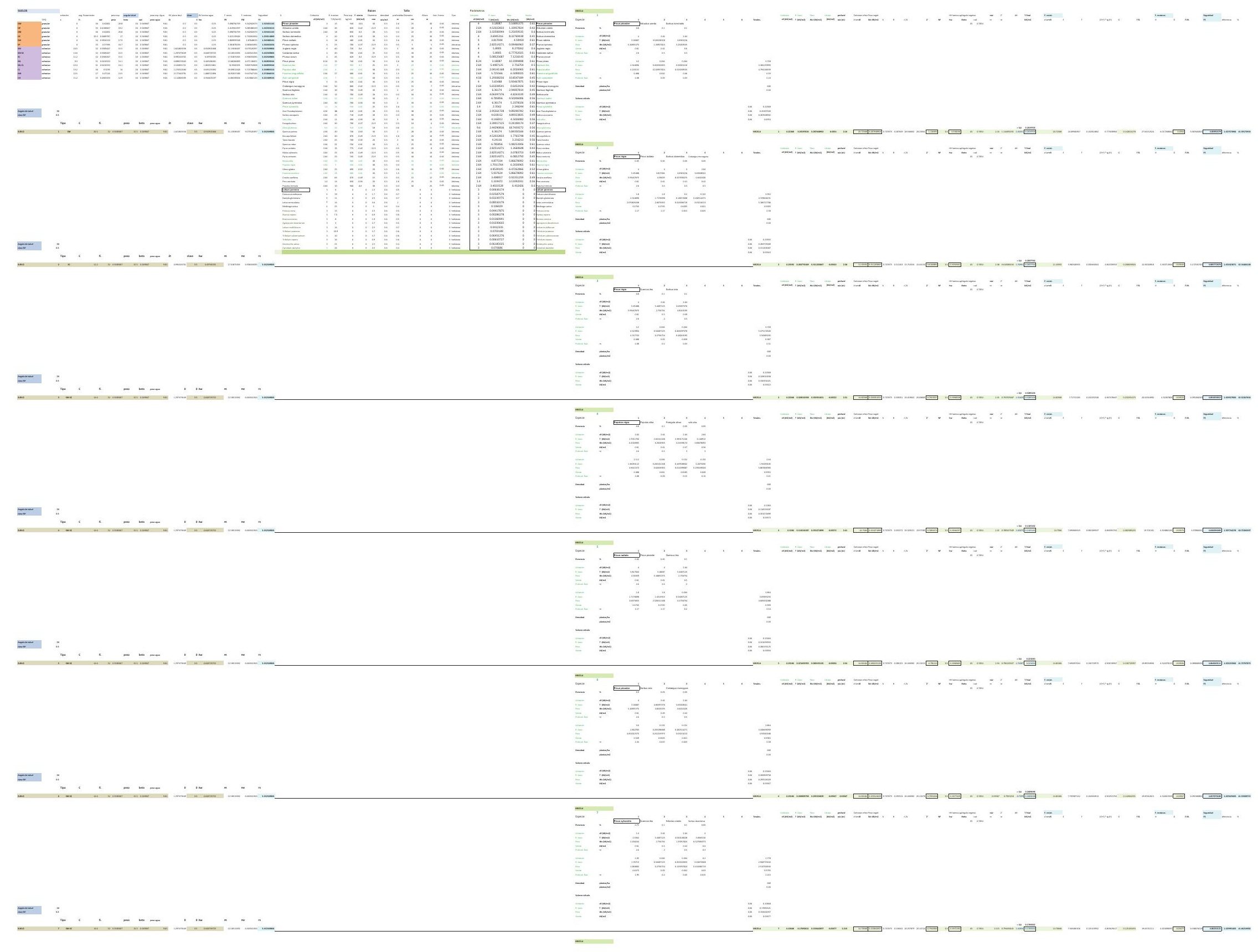




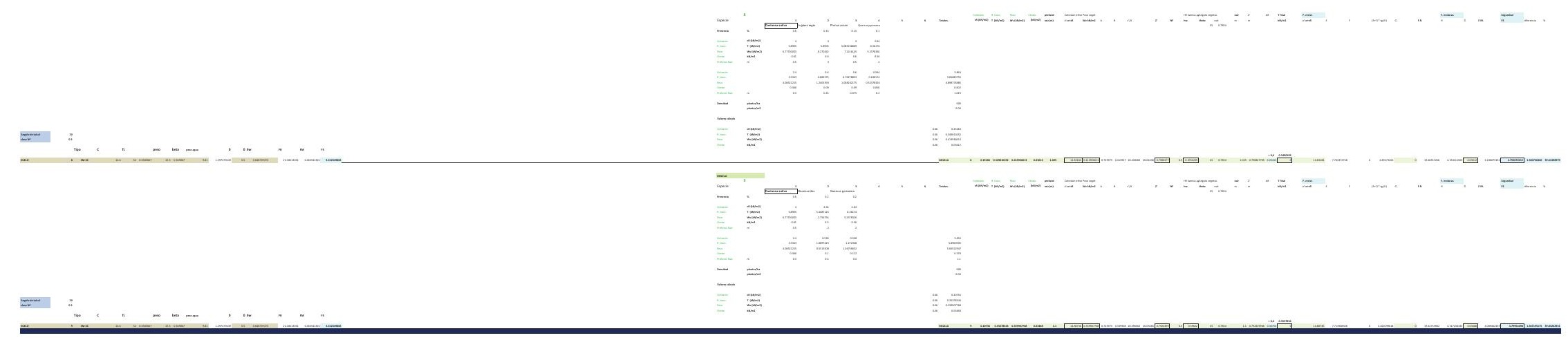




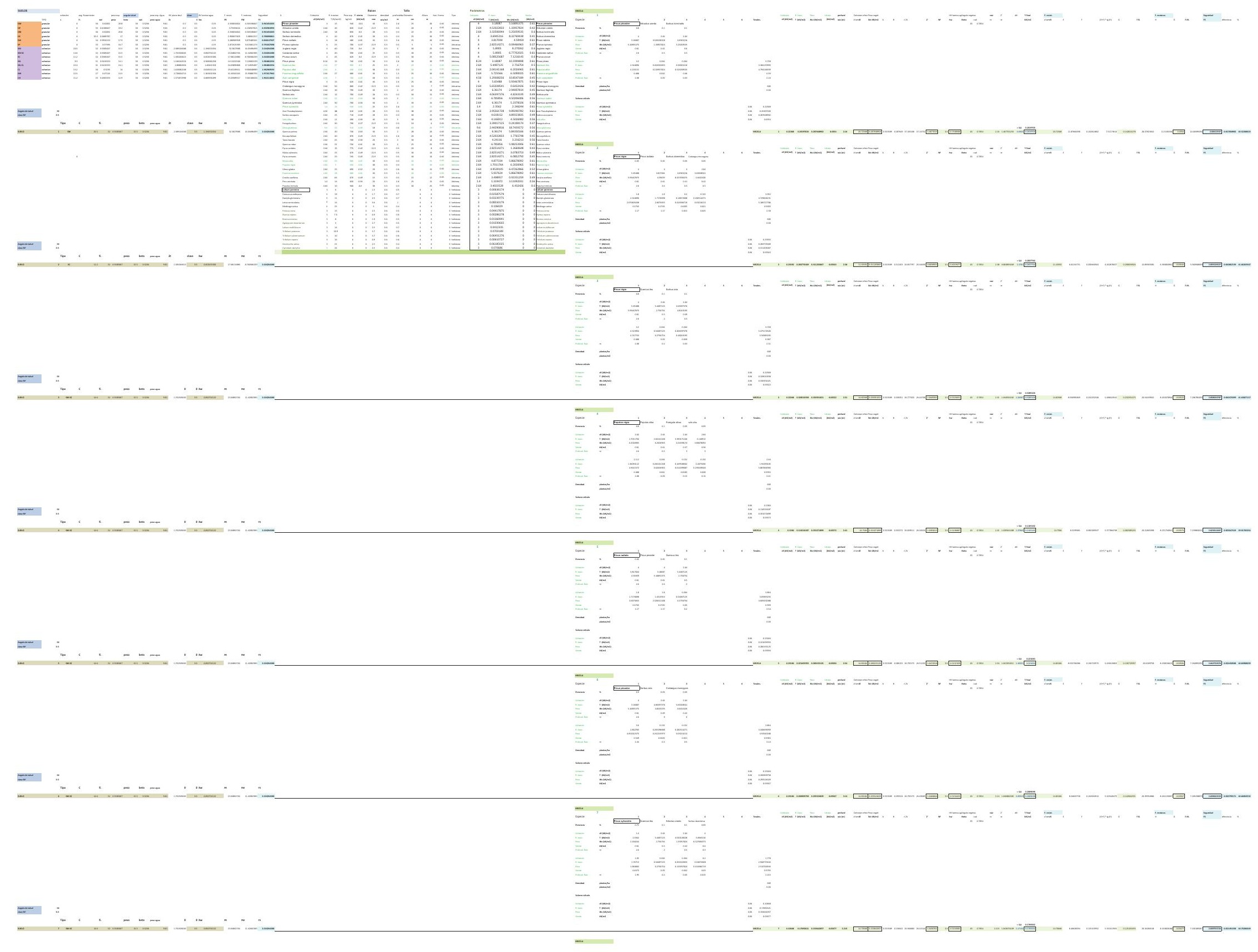




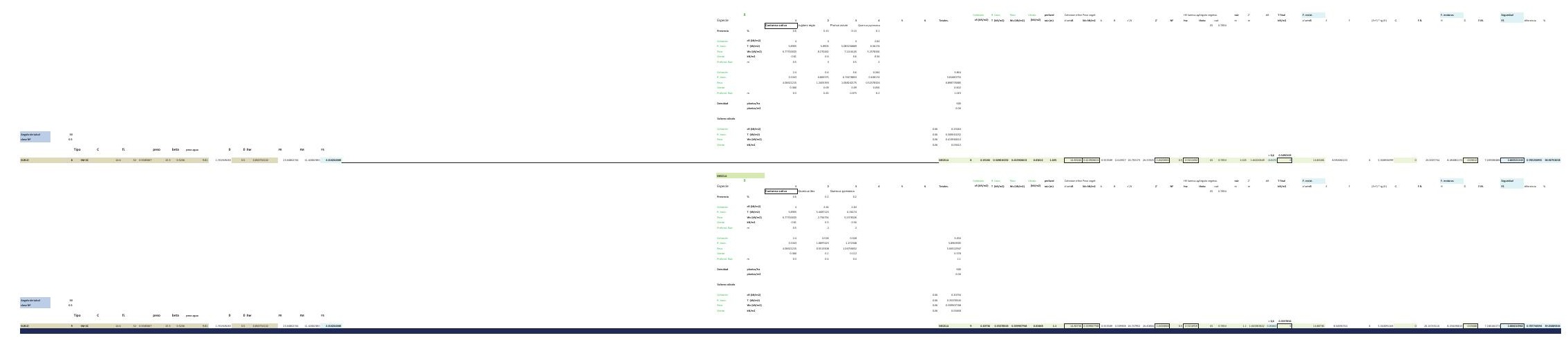




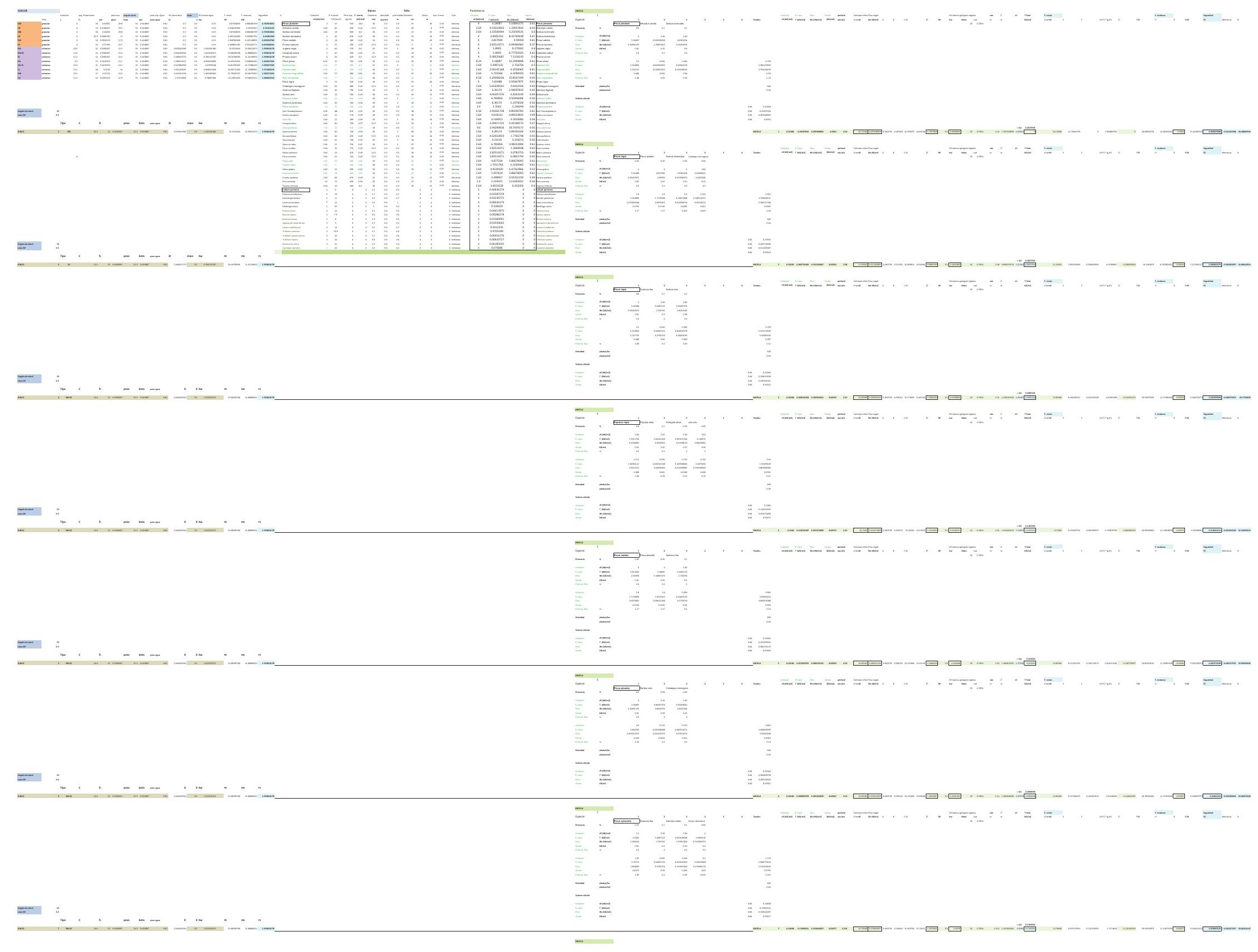




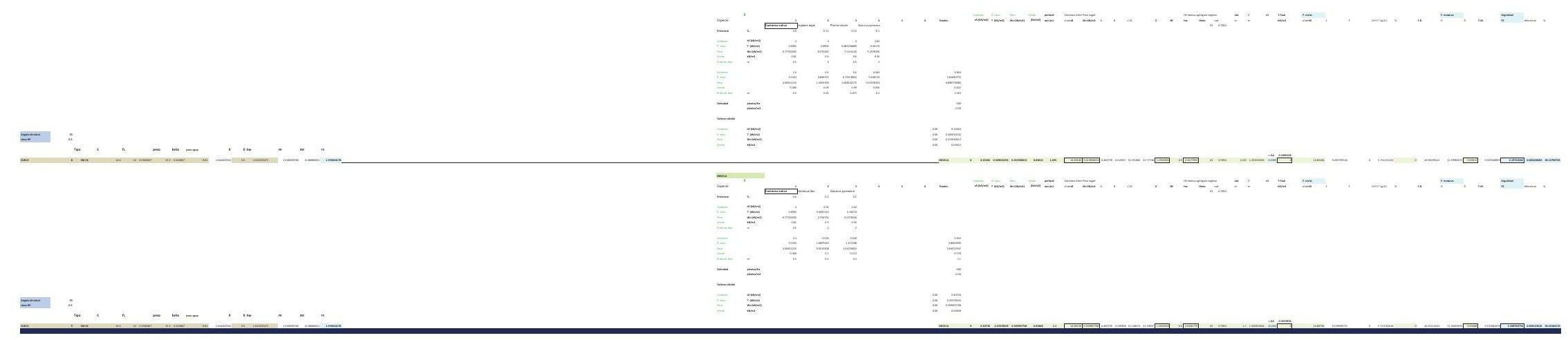




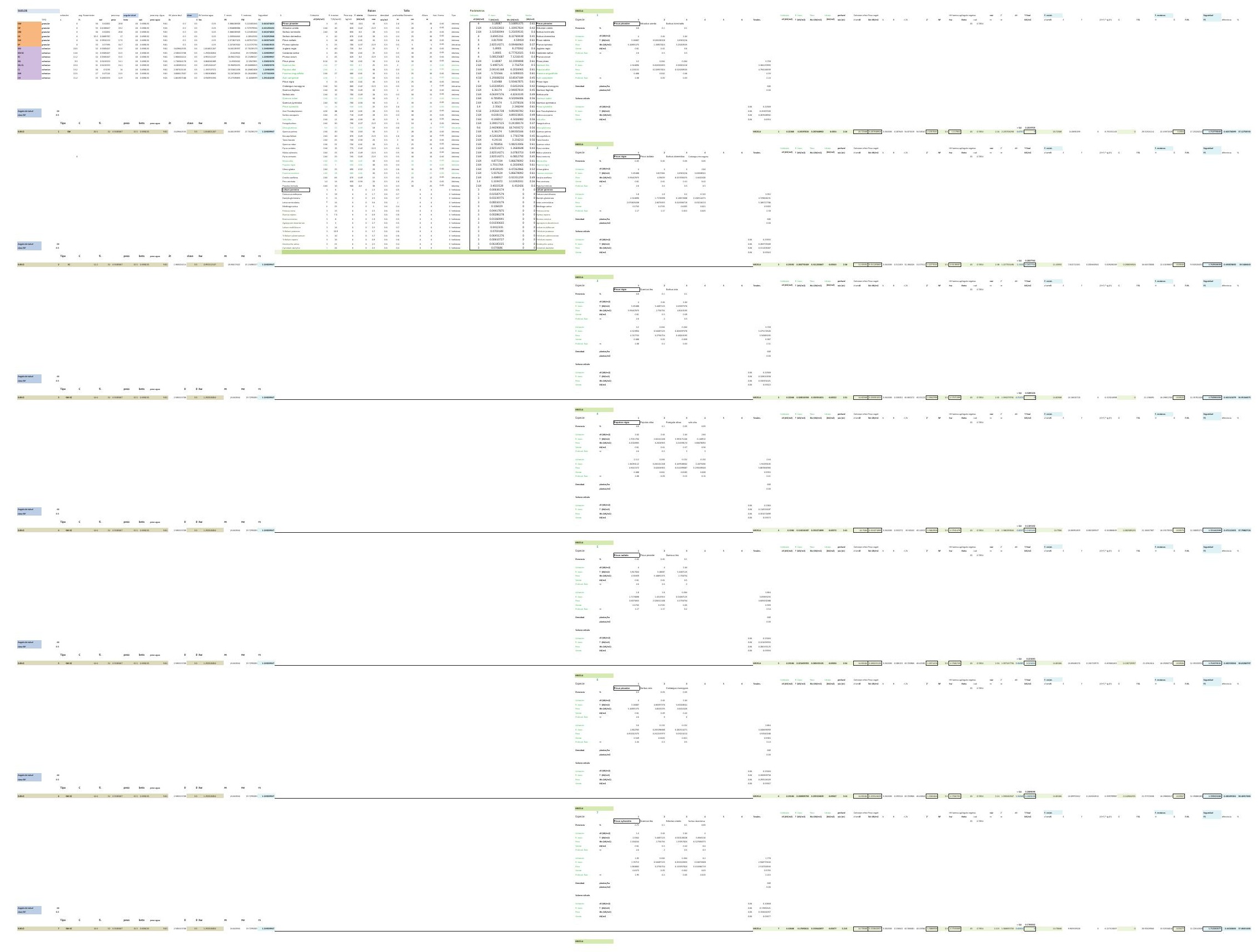




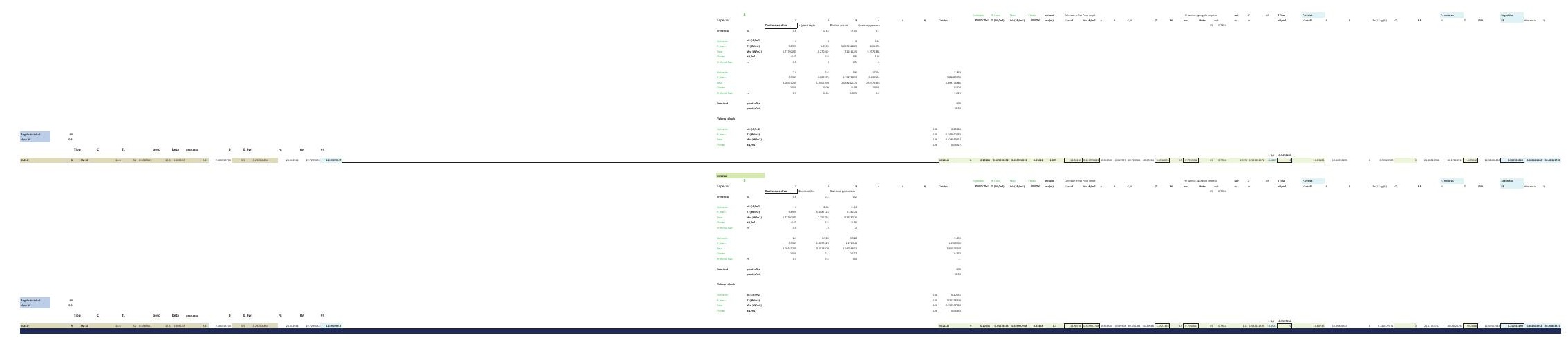




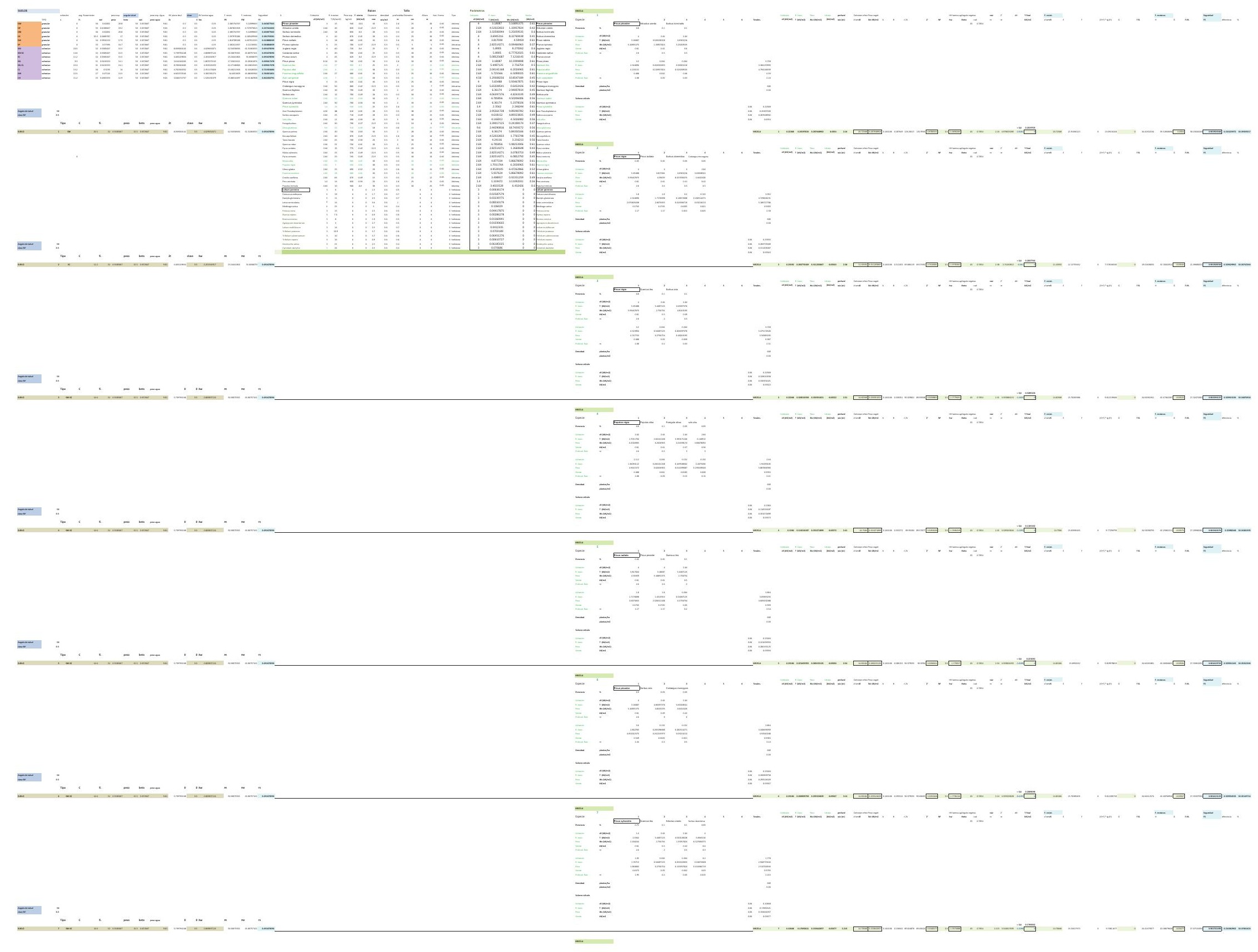




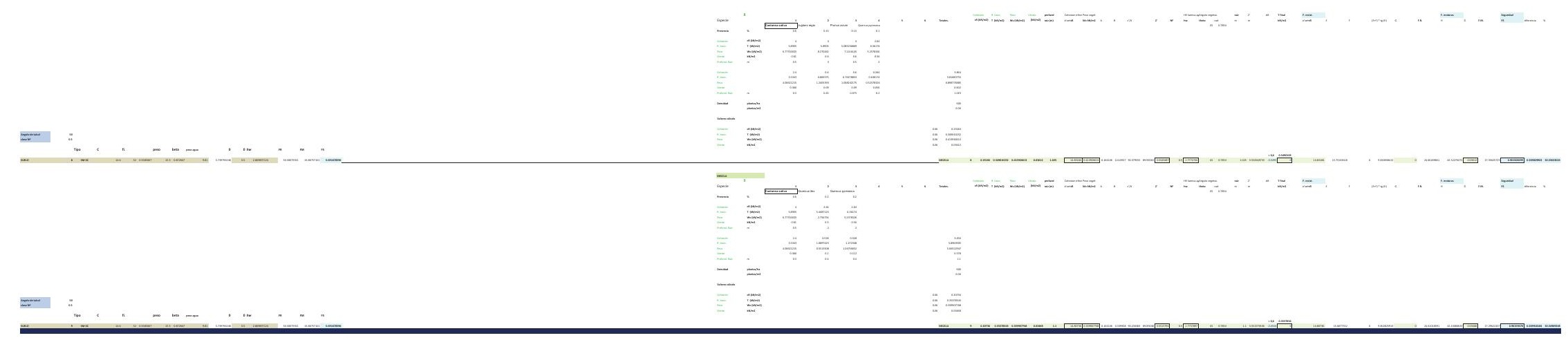




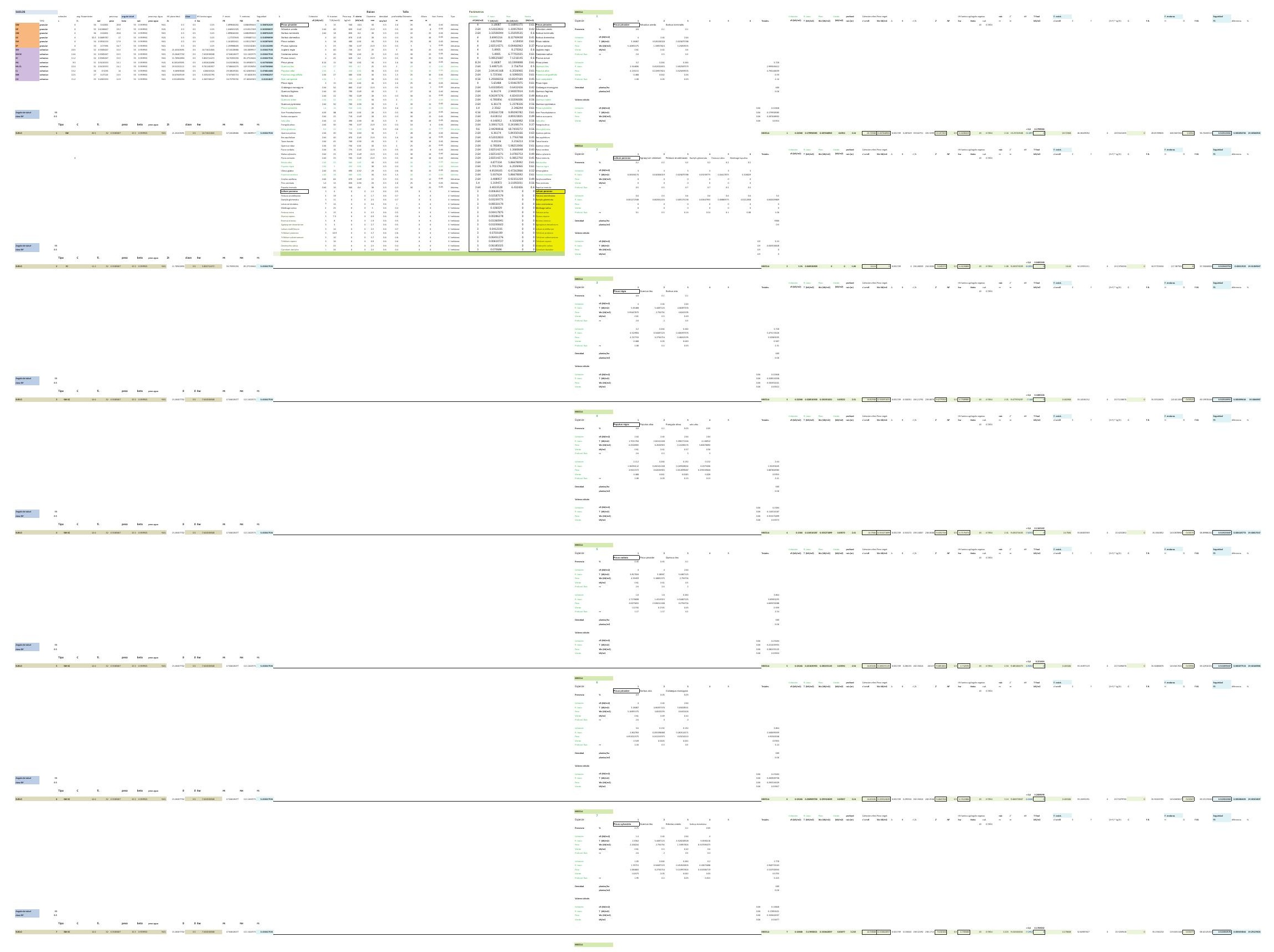




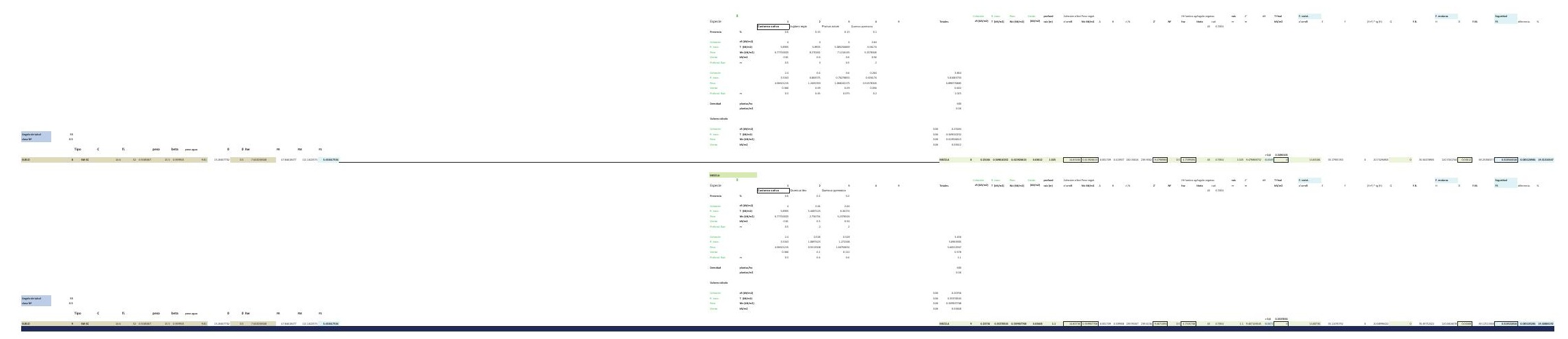




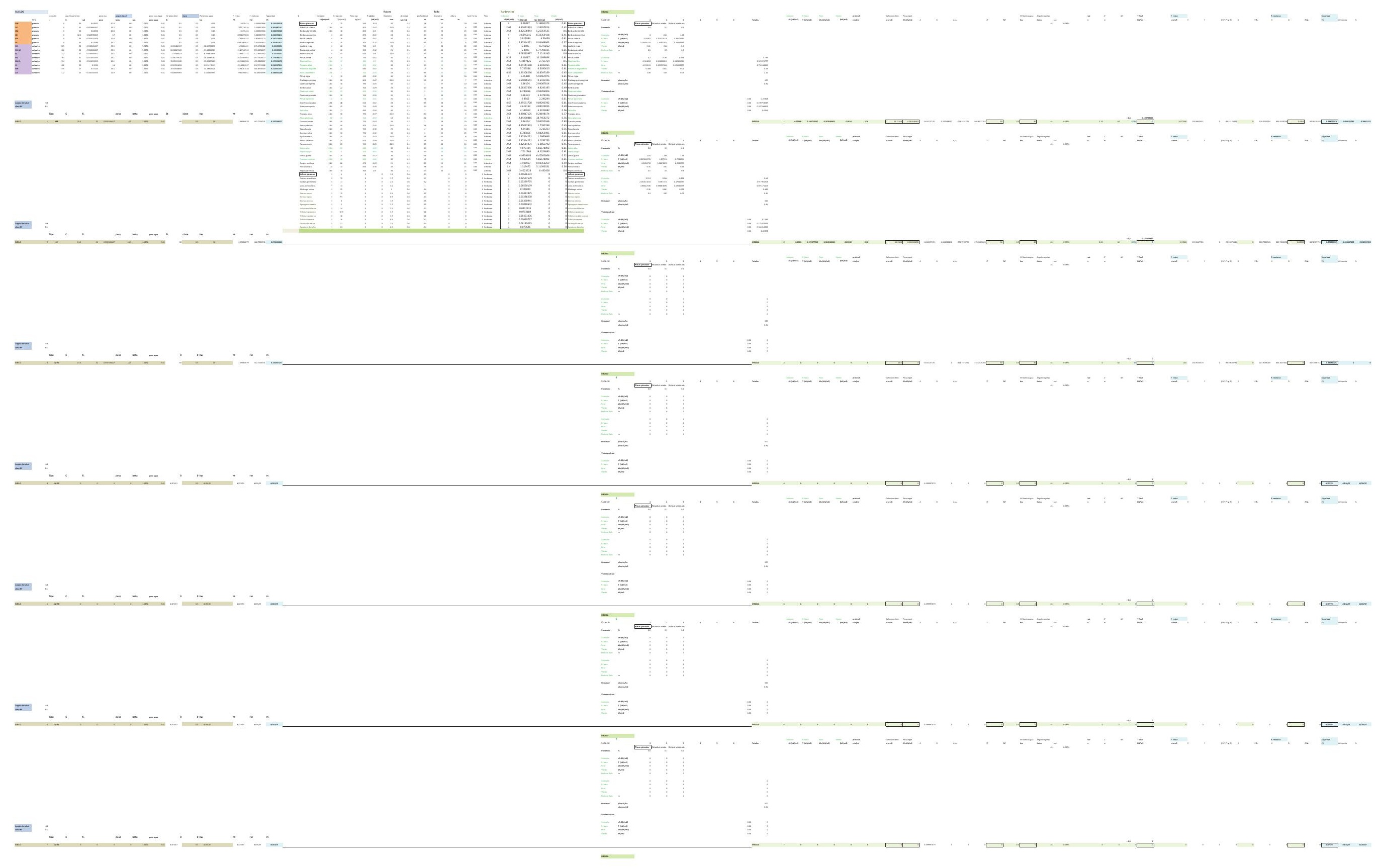




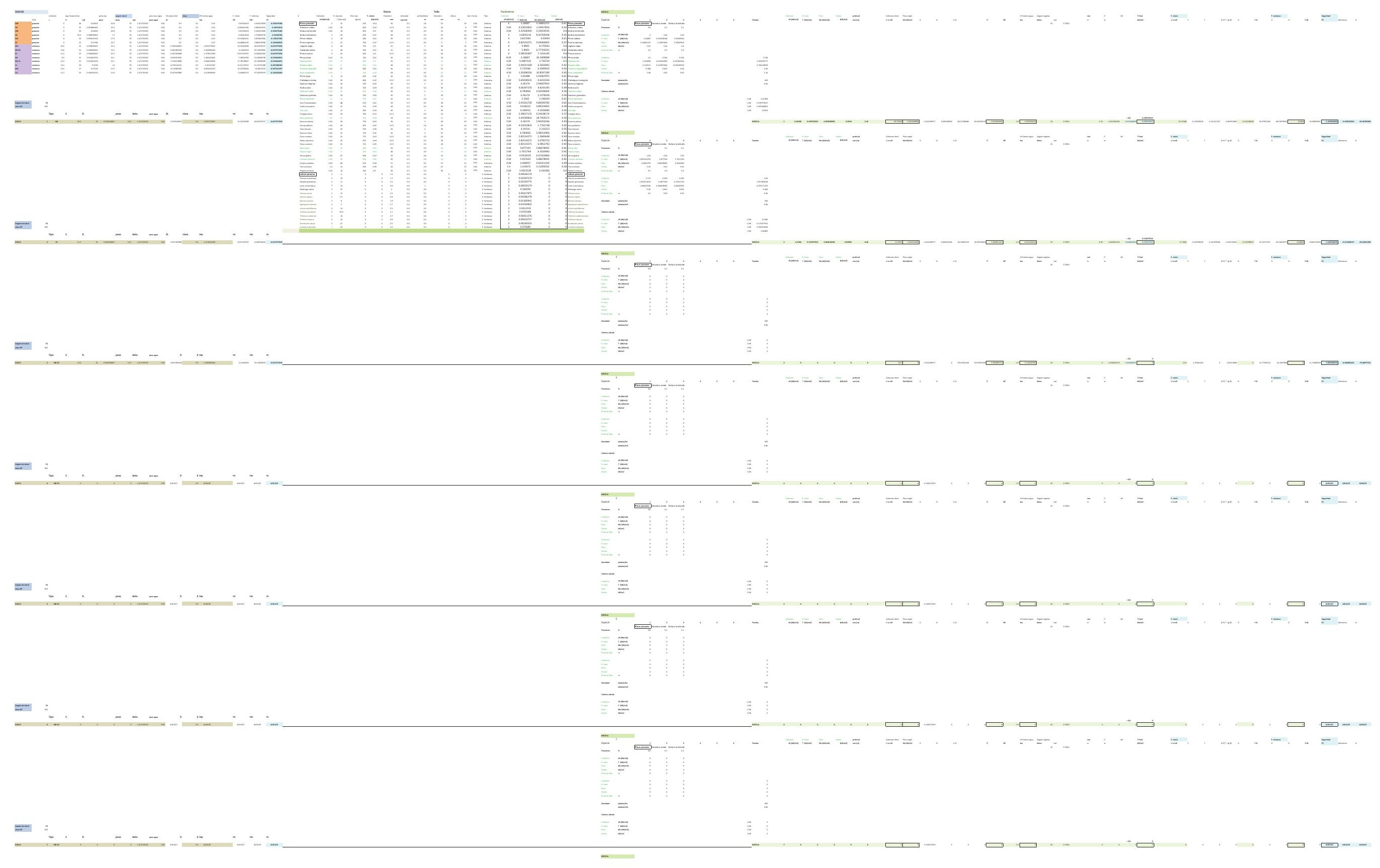




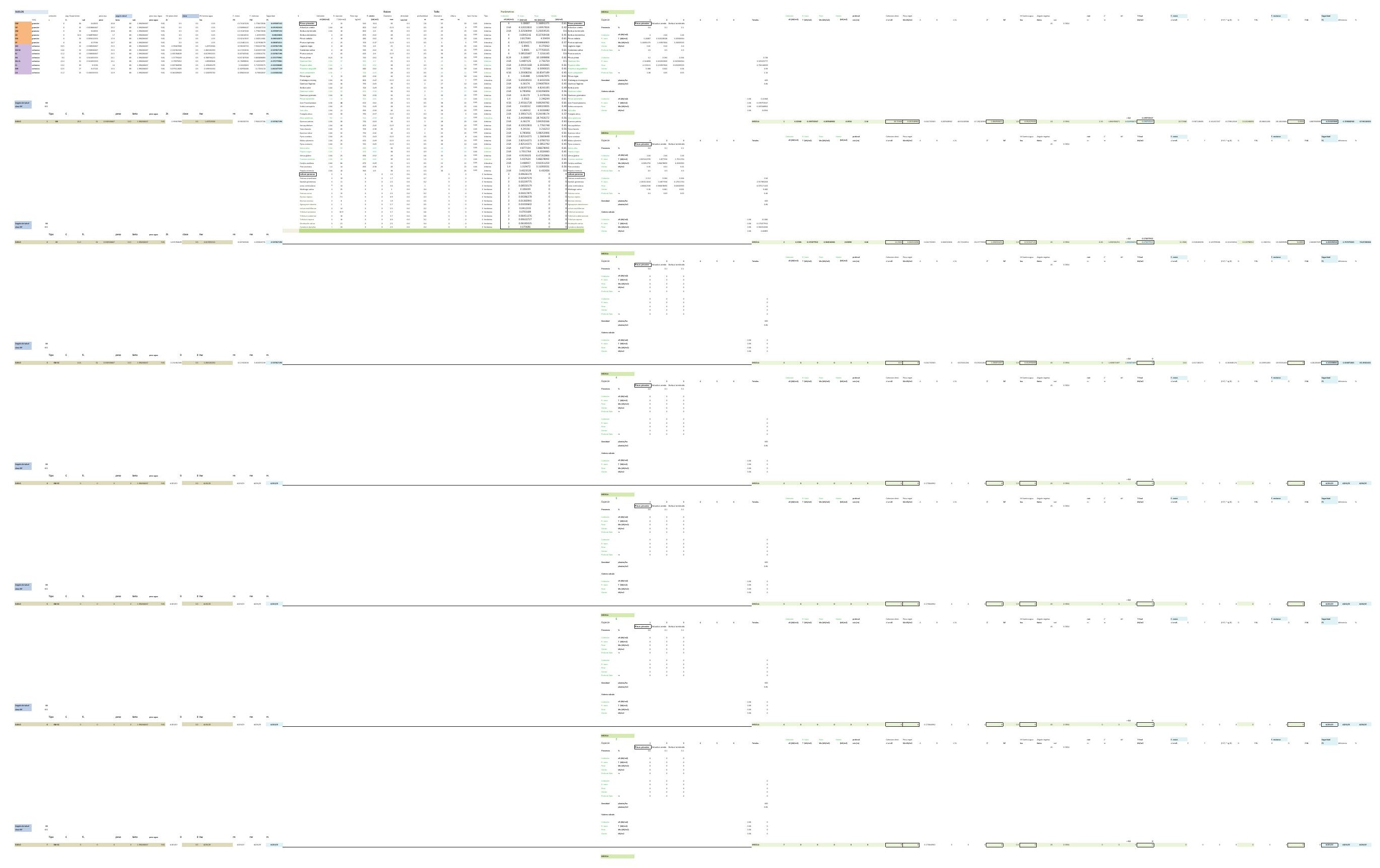


DESARROLLO DE UNA APLICACIÓN IMFORMÁTICA PARA EL CÁLCULO DE SOSTENIMIENTO DE TALUDES MEDIANTE VEGETACIÓN

B01. DENSIDAD DE PLANTACIÓN: 600 plantas/ha.

\section{B01-5.POSICIÓN N.F. 5}

INCLINACIÓN DE TALUD 6-100

INCLINACIÓN DE TALUD 10-200

INCLINACIÓN DE TALUD 20-30

INCLINACIÓN DE TALUD 30-40

INCLINACIÓN DE TALUD $35^{\circ}$

INCLINACIÓN DE TALUD 40-50

INCLINACIÓN DE TALUD 50-550

INCLINACIÓN DE TALUD 55-60

INCLINACIÓN DE TALUD 60-700

INCLINACIÓN DE TALUD 70-80 


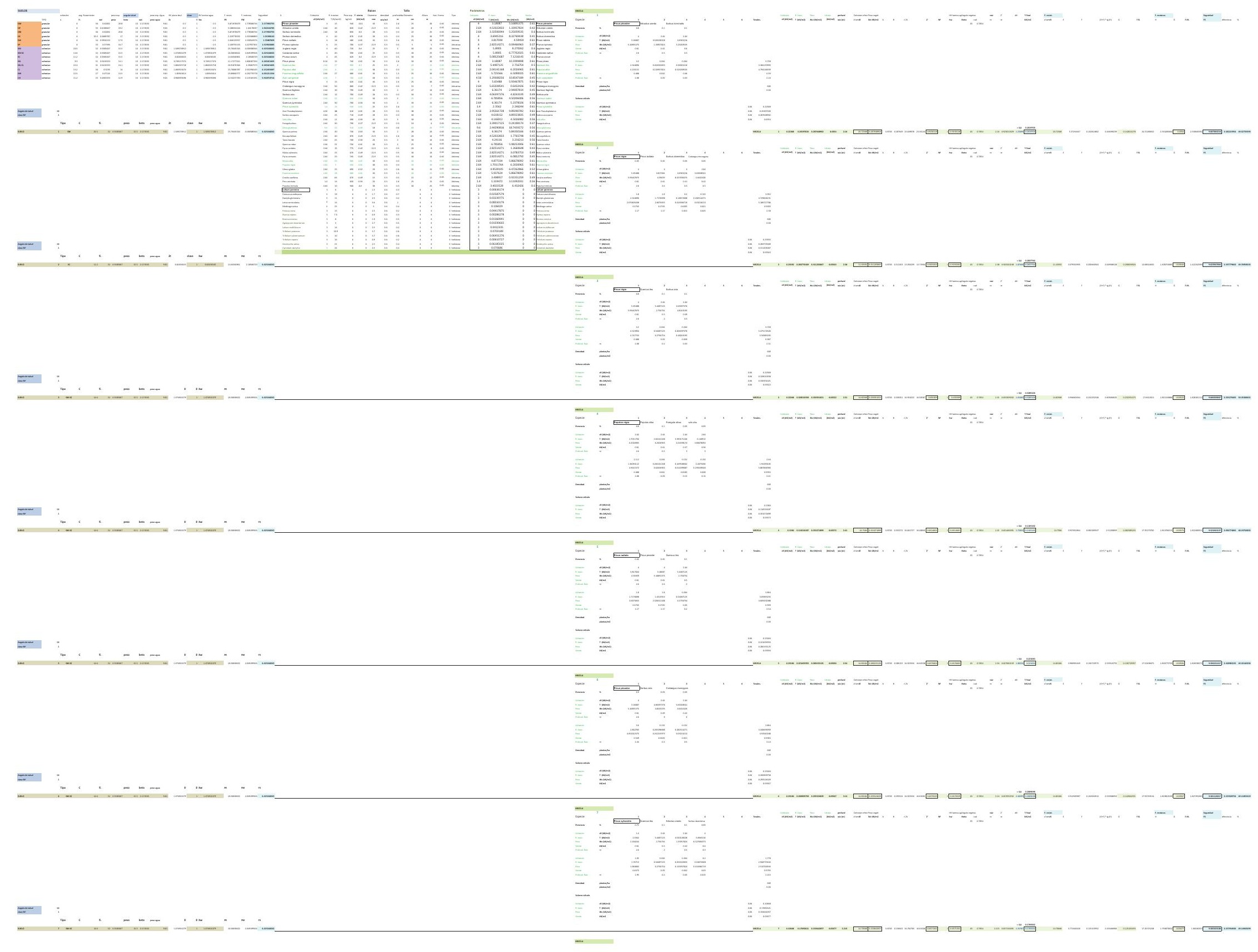




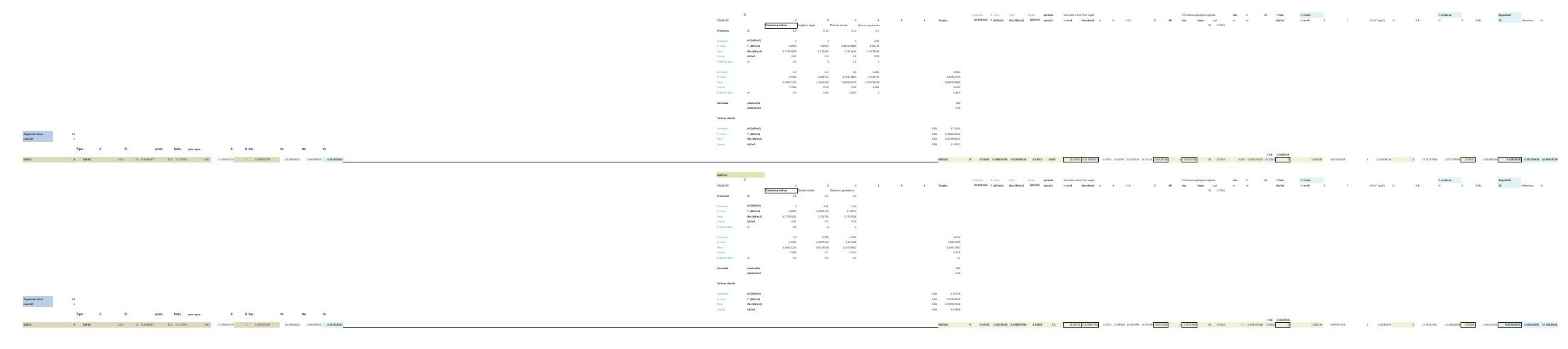




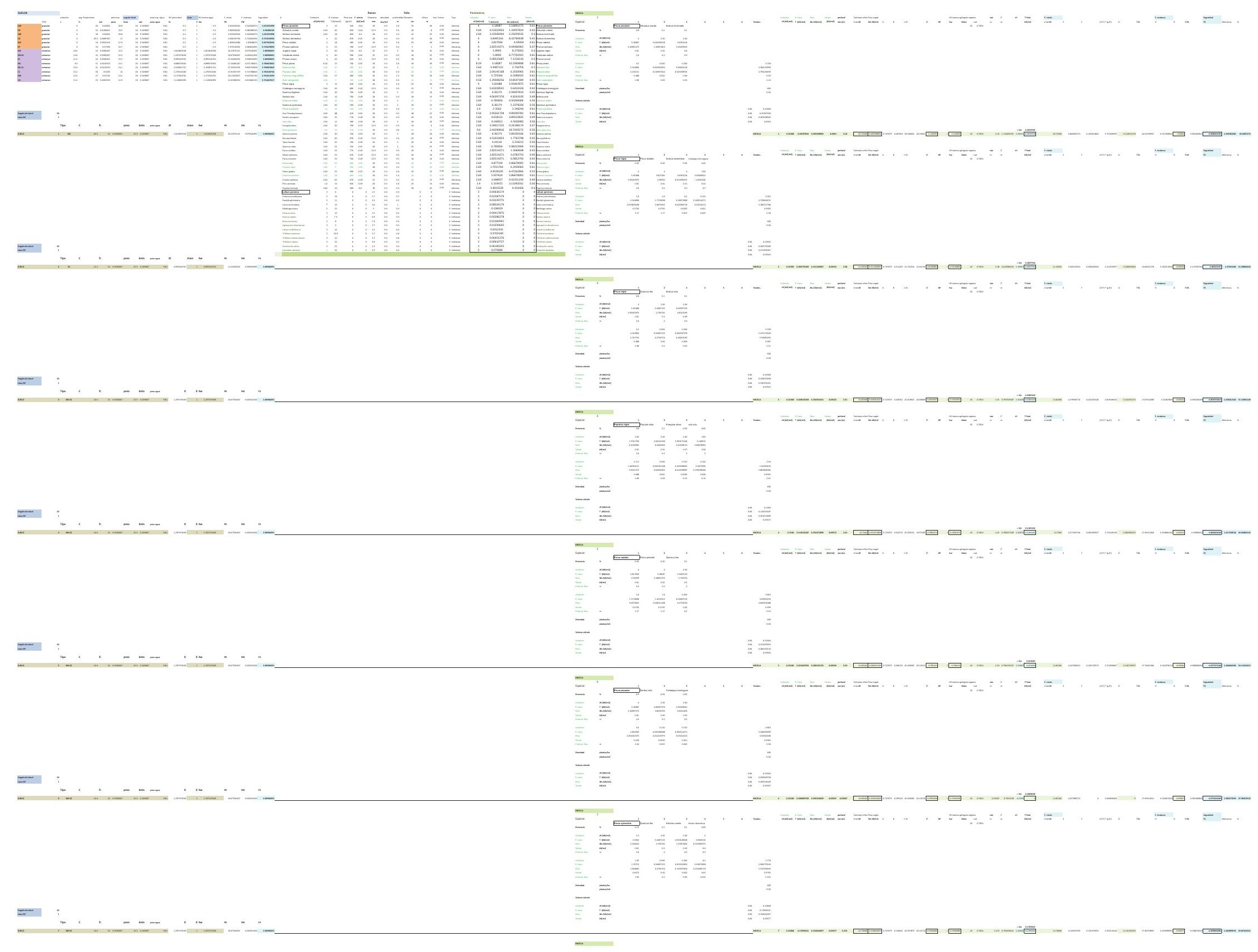




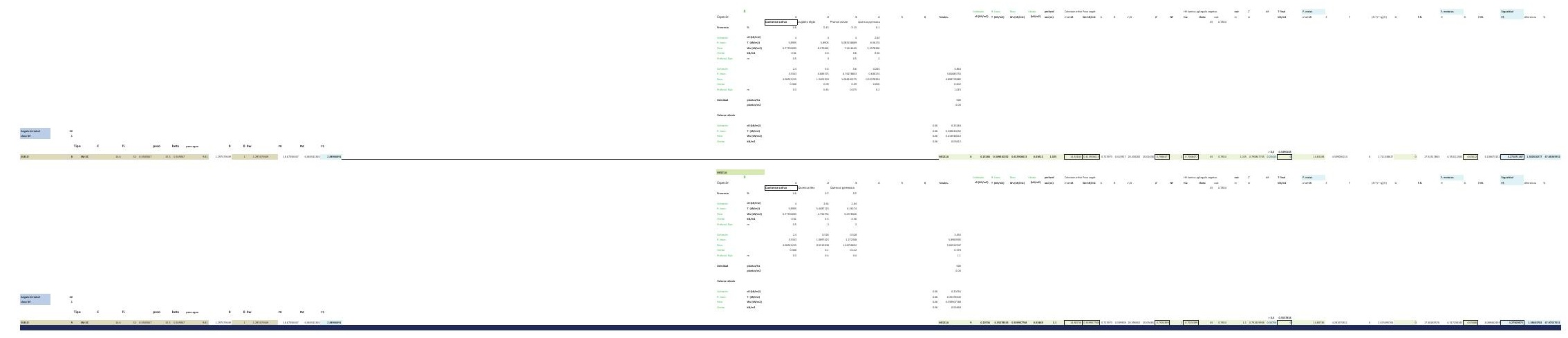




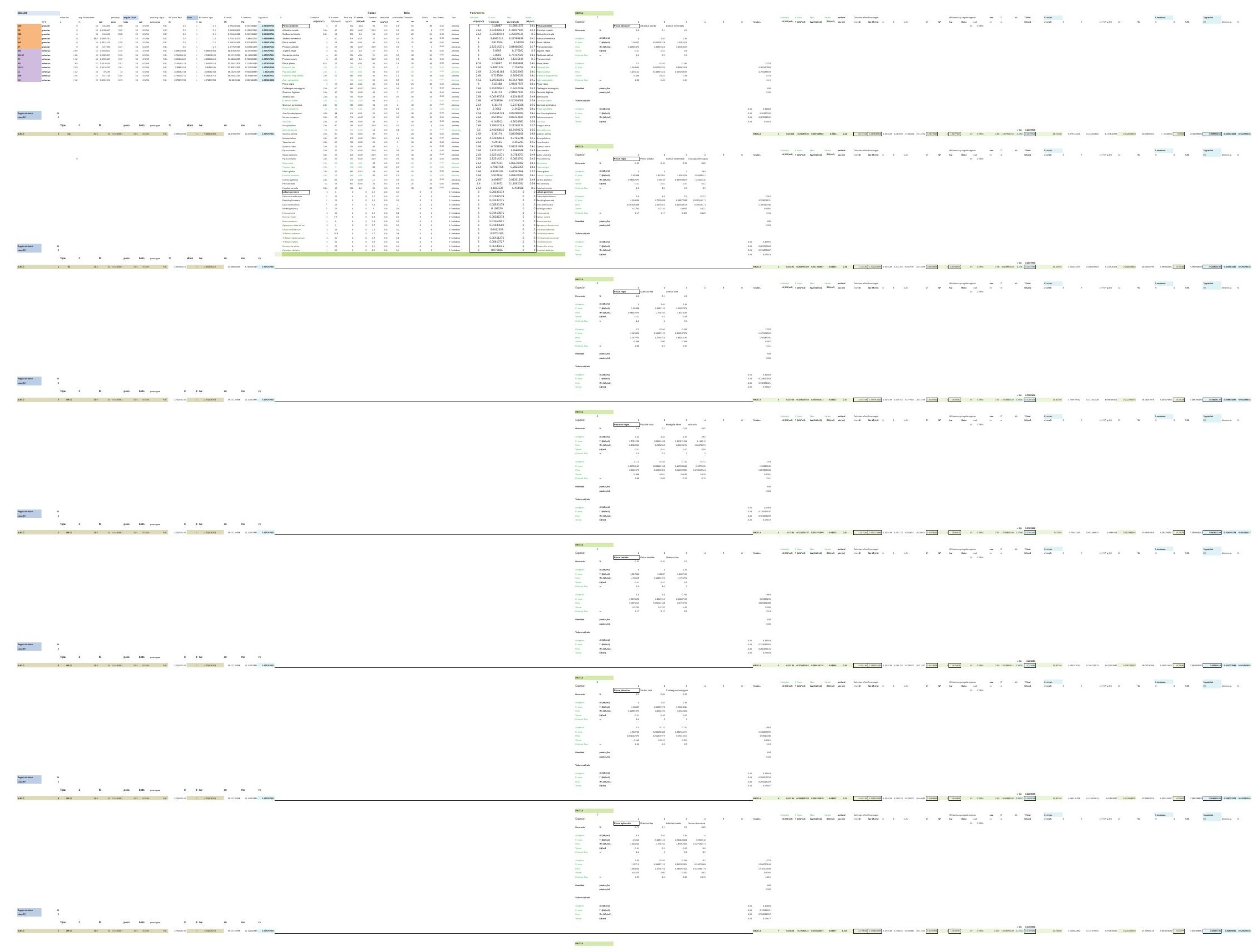




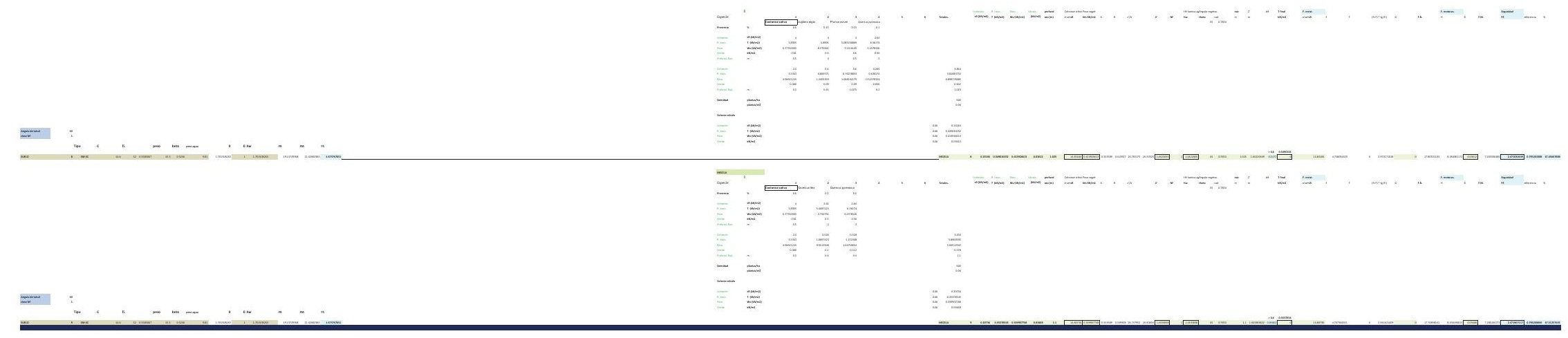




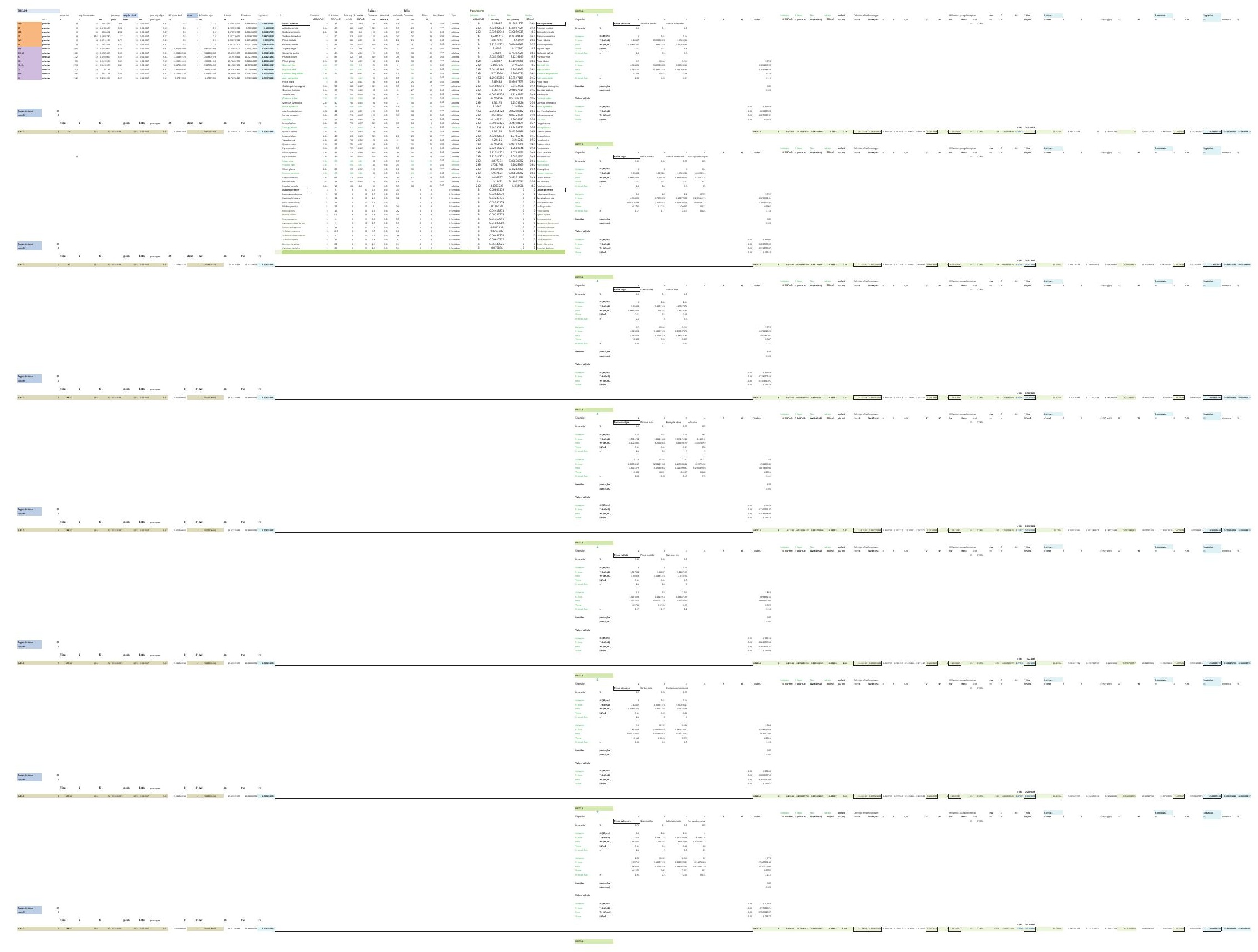




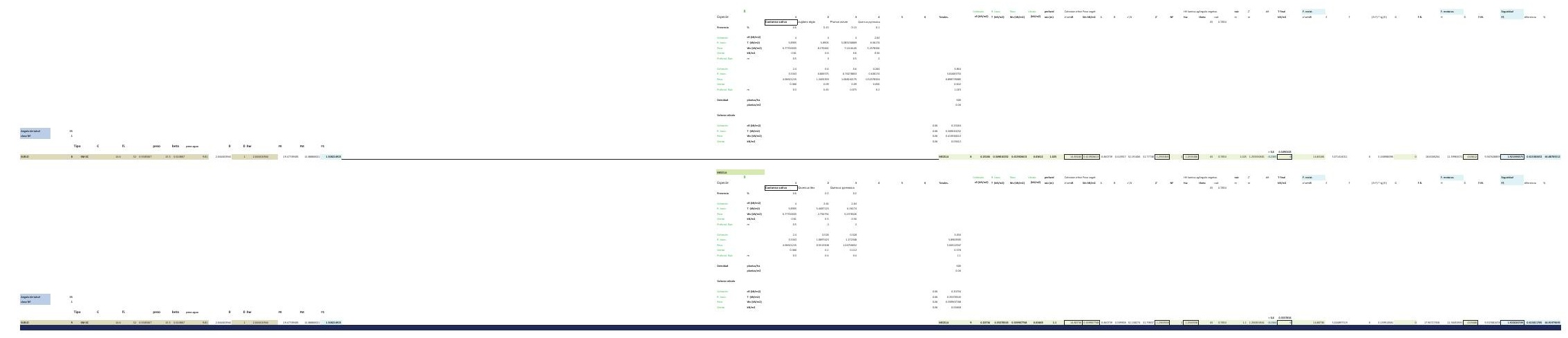




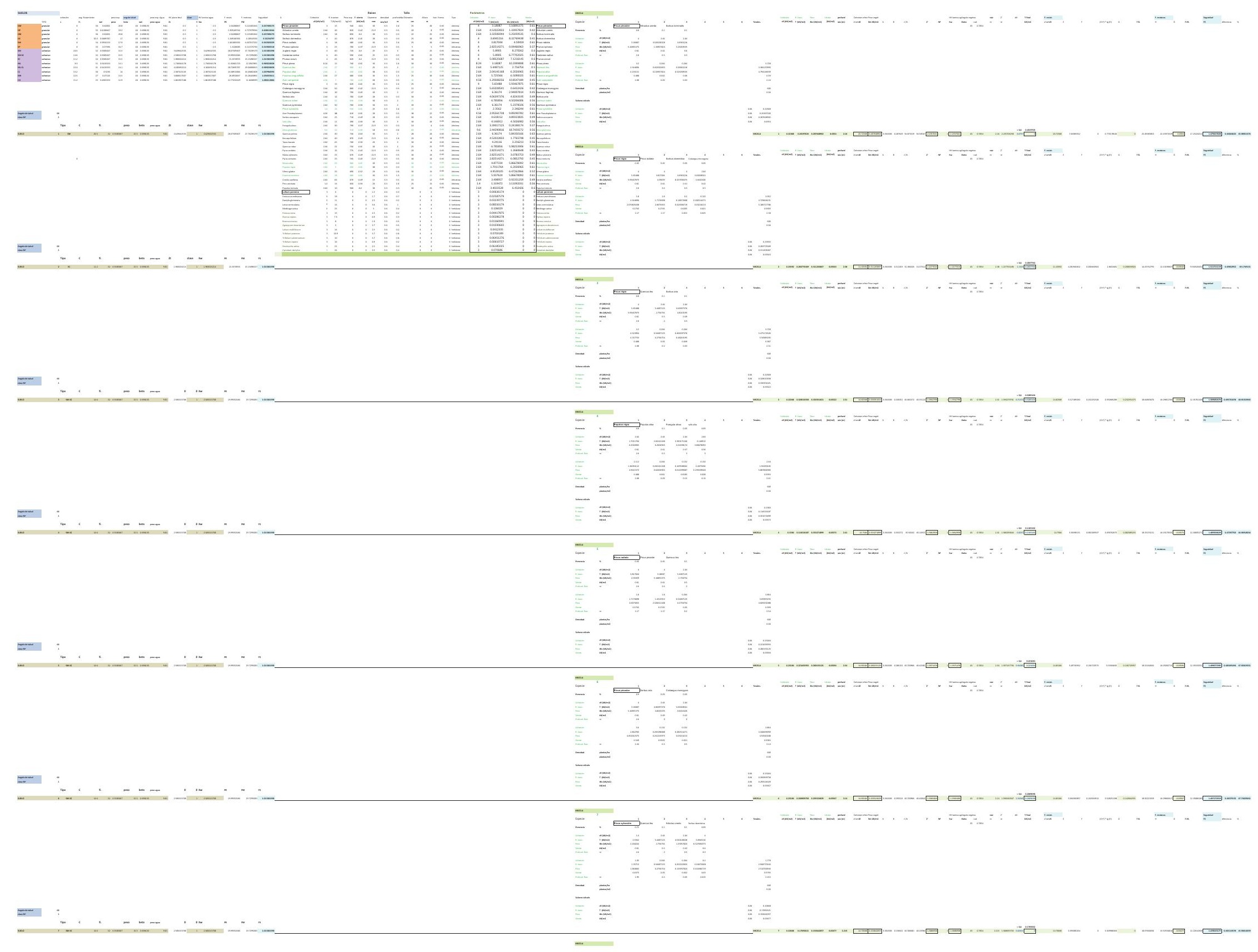




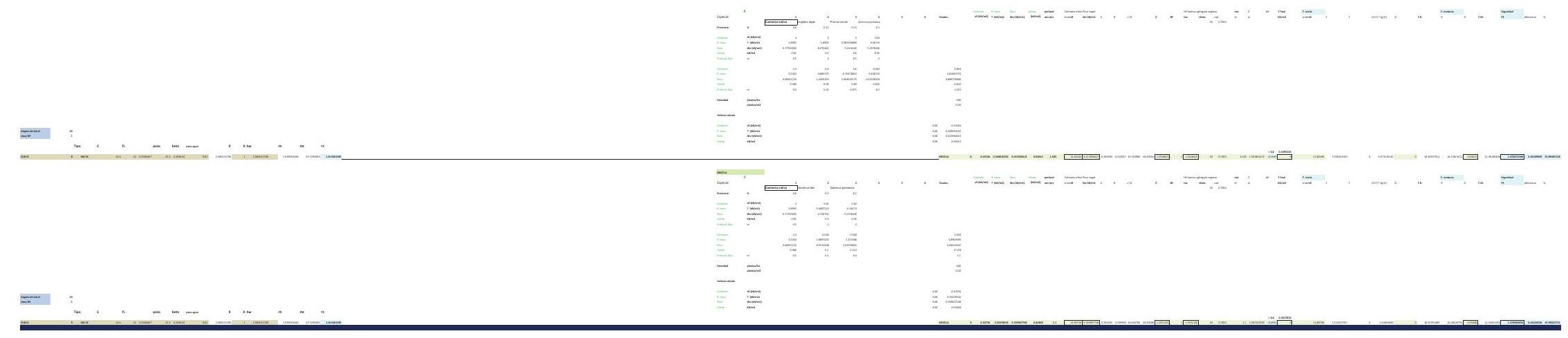




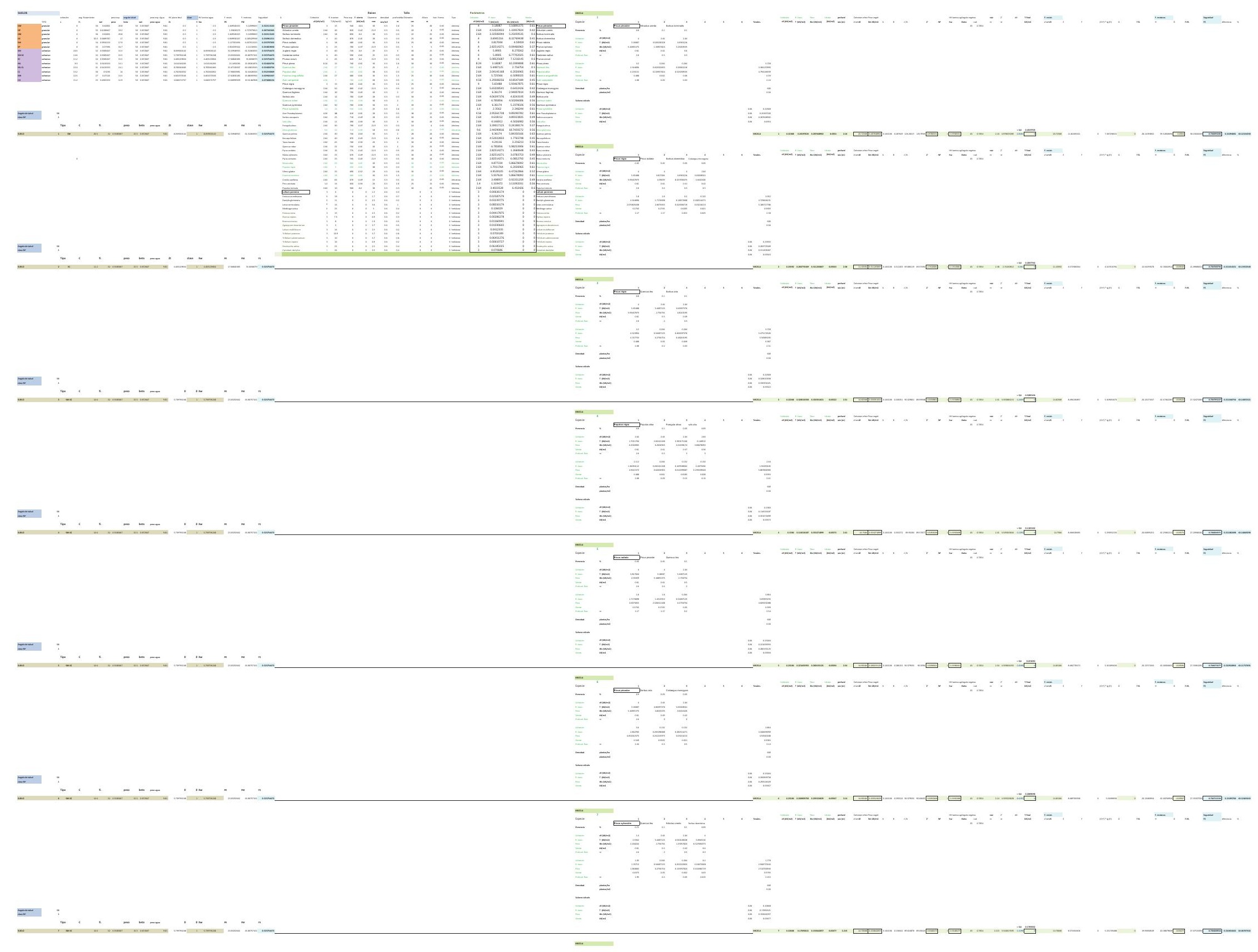




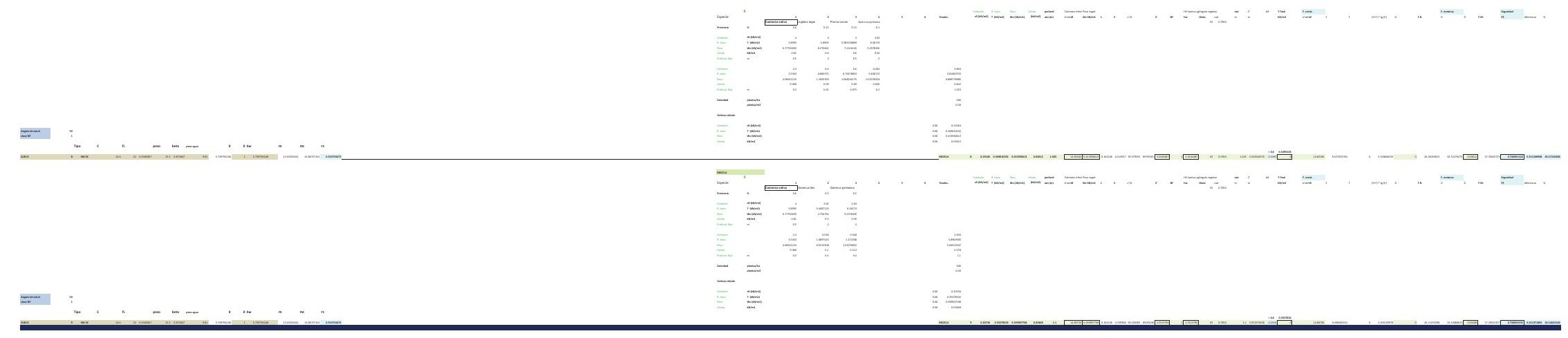




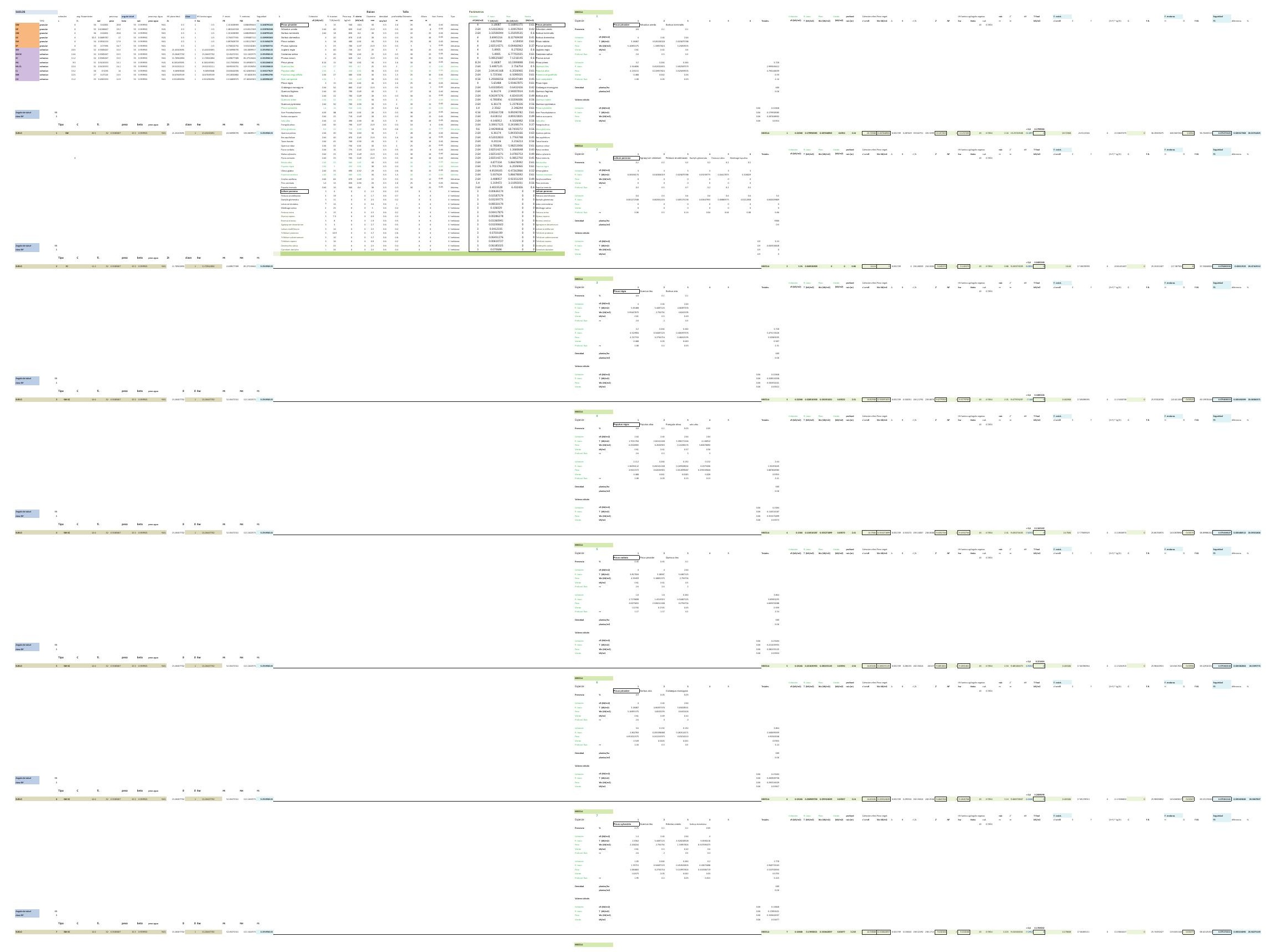


$=$

$=$

-

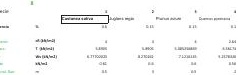

$=\stackrel{\#=}{=}=$

$-$

$\underline{E}$

$\equiv \pm=$

$\therefore=$

$=$
- 


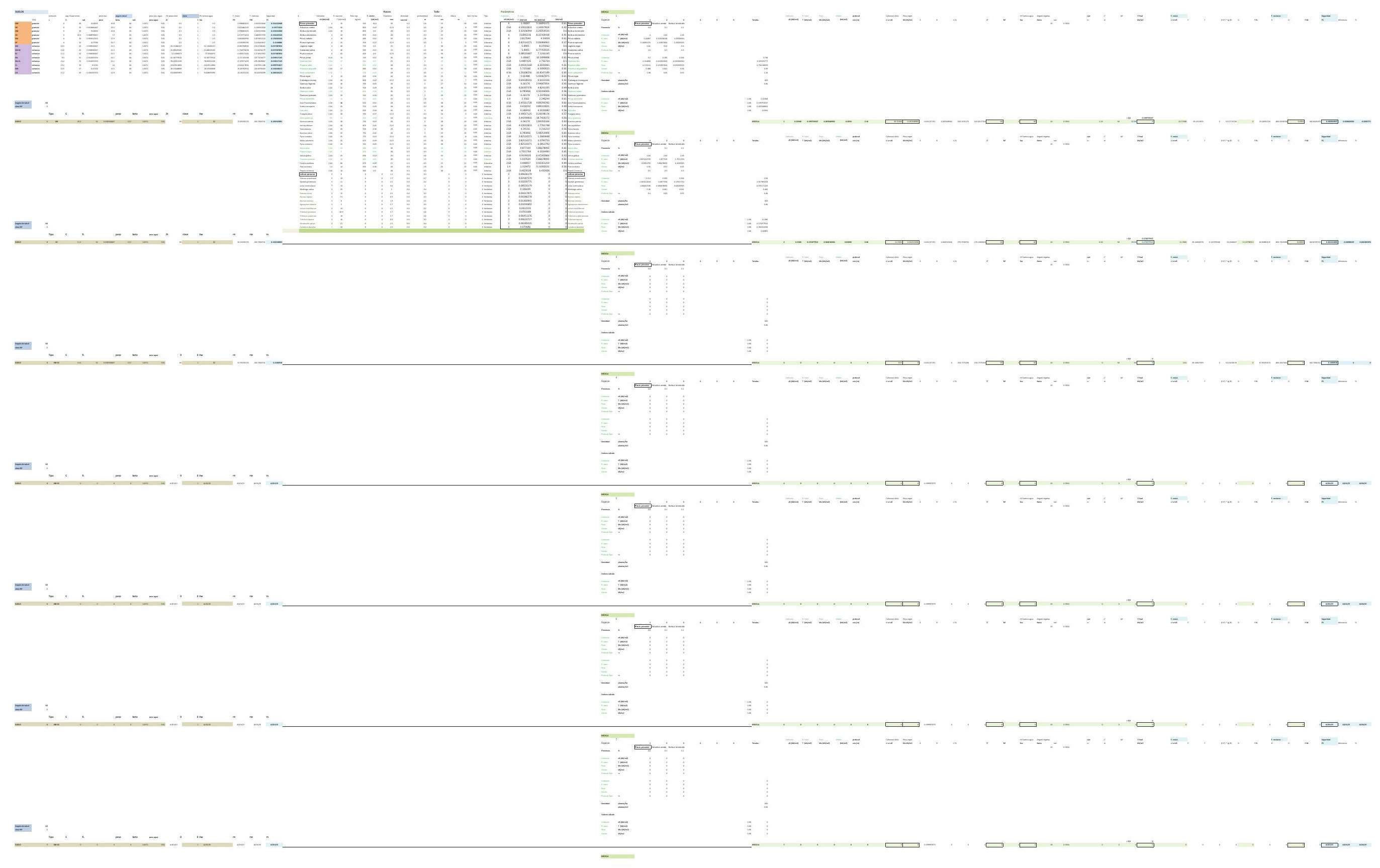




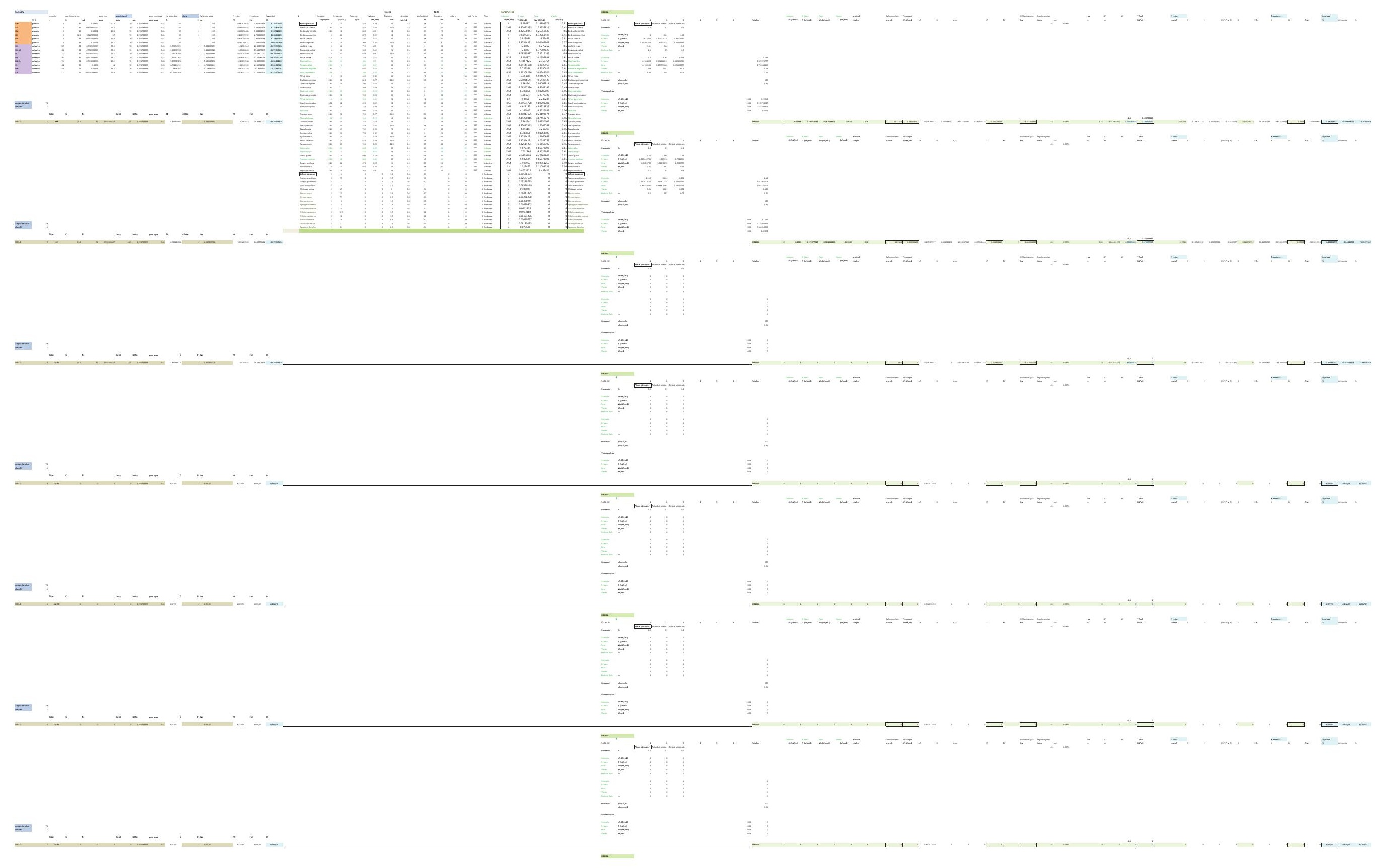


DESARROLLO DE UNA APLICACIÓN IMFORMÁTICA PARA EL CÁLCULO DE SOSTENIMIENTO DE TALUDES MEDIANTE VEGETACIÓN

PRUEBAS DEL MODELO MATEMÁTICO PARA EL CÁLCULO DE ESTABILIDAD DE TALUDES.

B02. DENSIDAD DE PLANTACIÓN: 1.600 plantas/ha.

B02-1.POSICIÓN N.F. 1

B02-2.POSICIÓN N.F. 2

B02-3.POSICIÓN N.F. 3

B02-4.POSICIÓN N.F. 4

B02-5.POSICIÓN N.F. 5 
DESARROLLO DE UNA APLICACIÓN IMFORMÁTICA PARA EL CÁLCULO DE SOSTENIMIENTO DE TALUDES MEDIANTE VEGETACIÓN

B02. DENSIDAD DE PLANTACIÓN: 1.600 plantas/ha.

\section{B02-1.POSICIÓN N.F. 1}

INCLINACIÓN DE TALUD 6-100

INCLINACIÓN DE TALUD 10-200

INCLINACIÓN DE TALUD 20-30

INCLINACIÓN DE TALUD 30-40

INCLINACIÓN DE TALUD $35^{\circ}$

INCLINACIÓN DE TALUD 40-50

INCLINACIÓN DE TALUD 50-550

INCLINACIÓN DE TALUD 55-60

INCLINACIÓN DE TALUD 60-700

INCLINACIÓN DE TALUD 70-80 


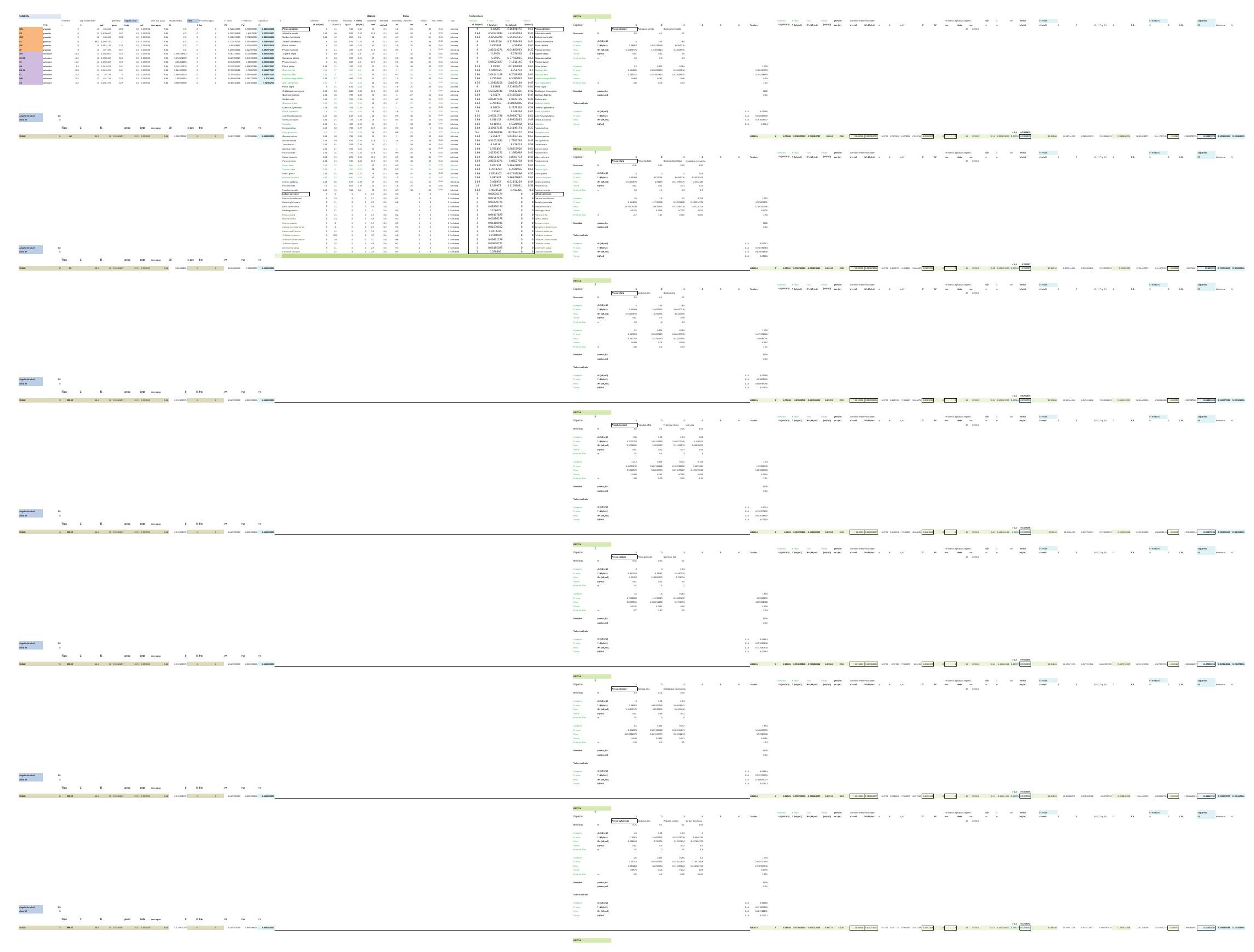




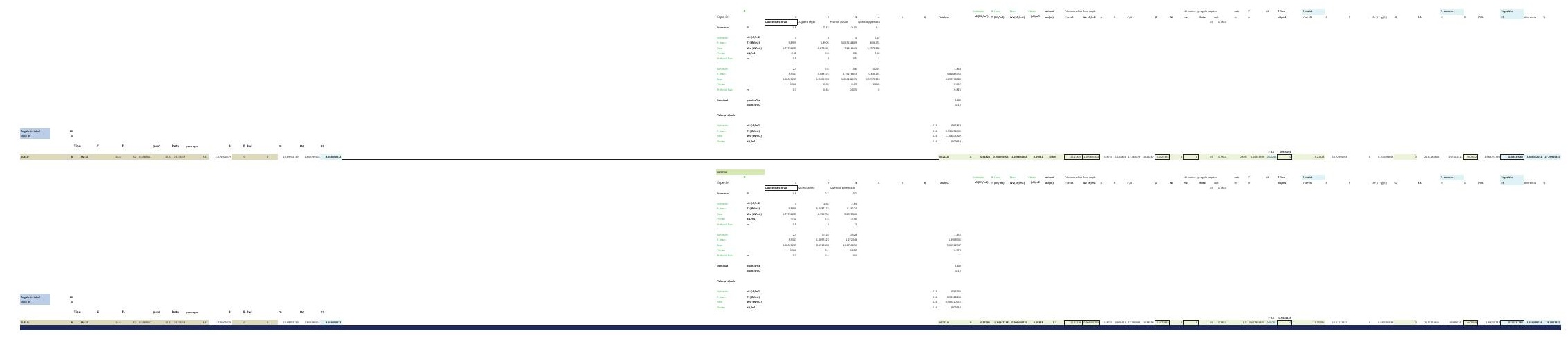




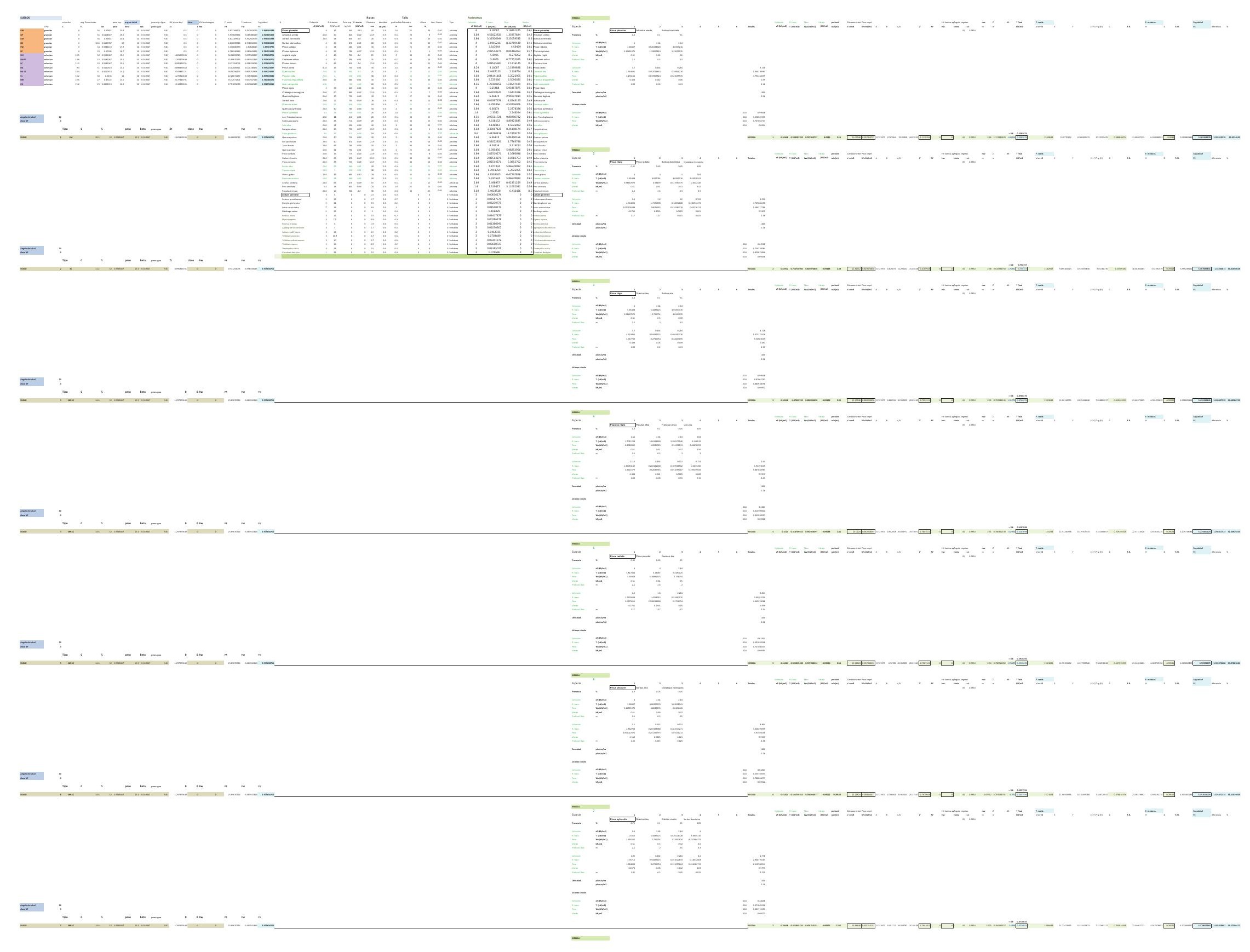




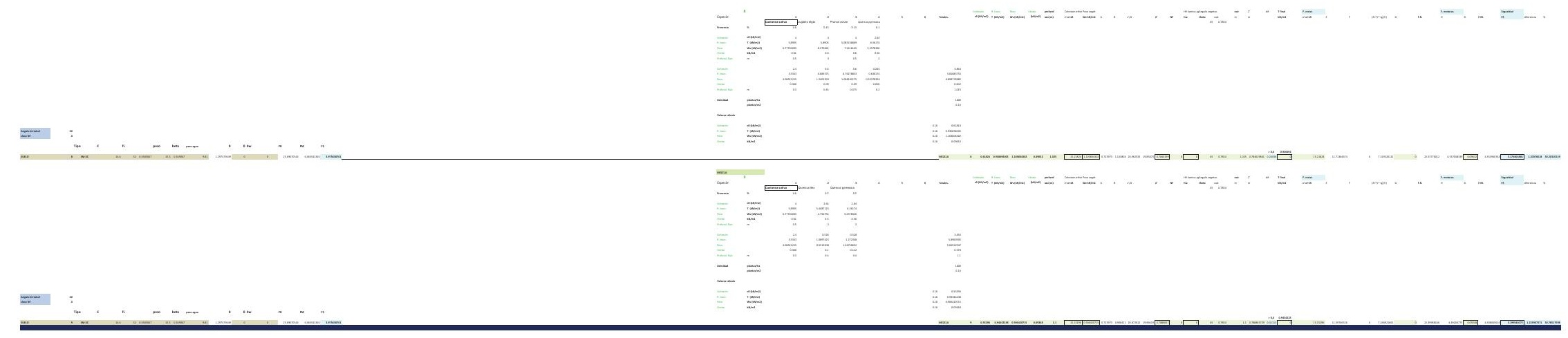




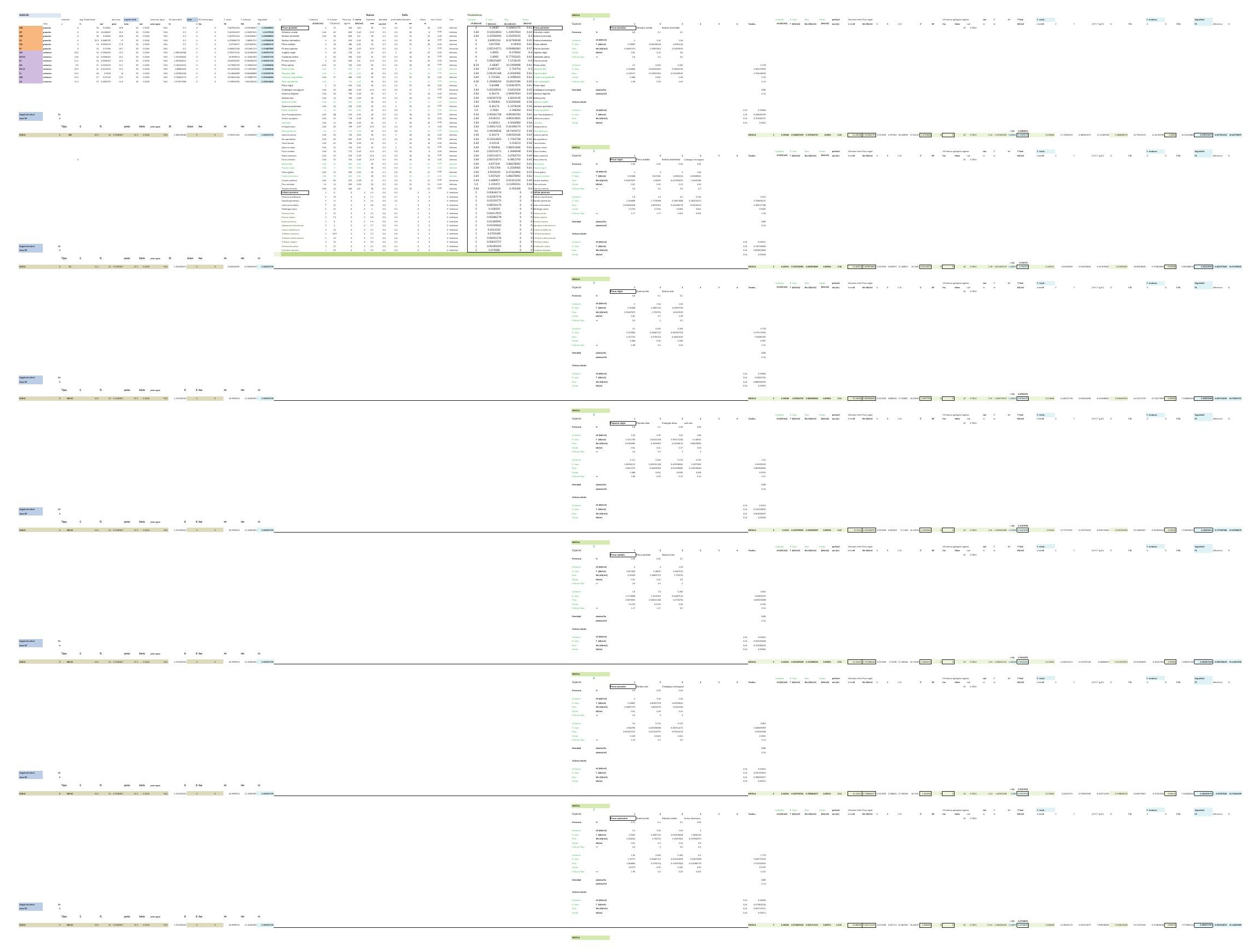




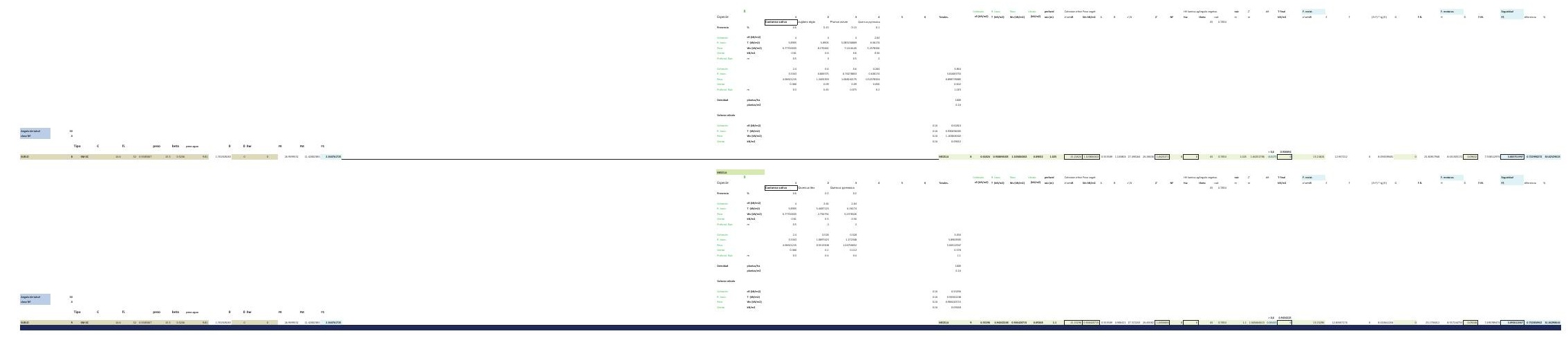




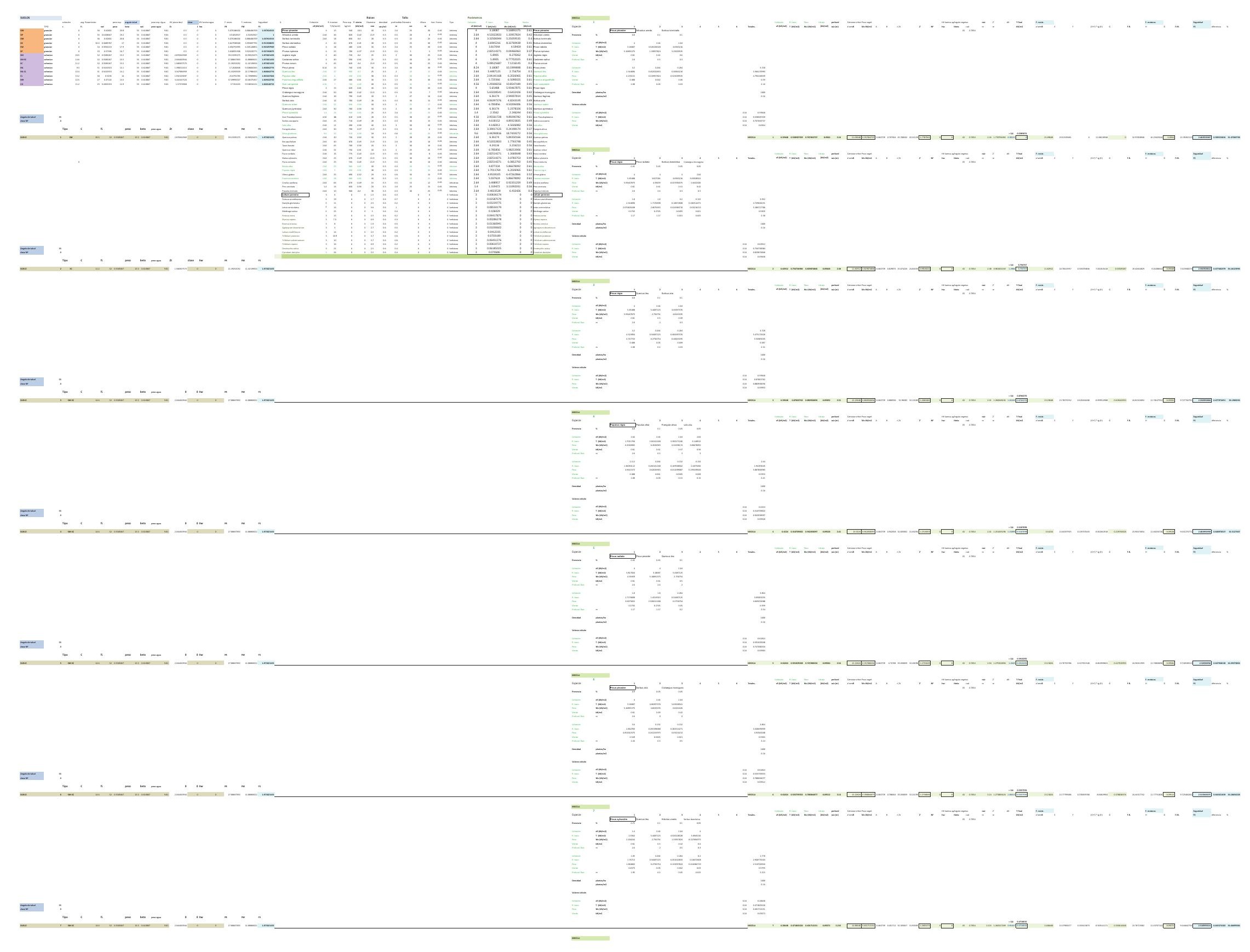




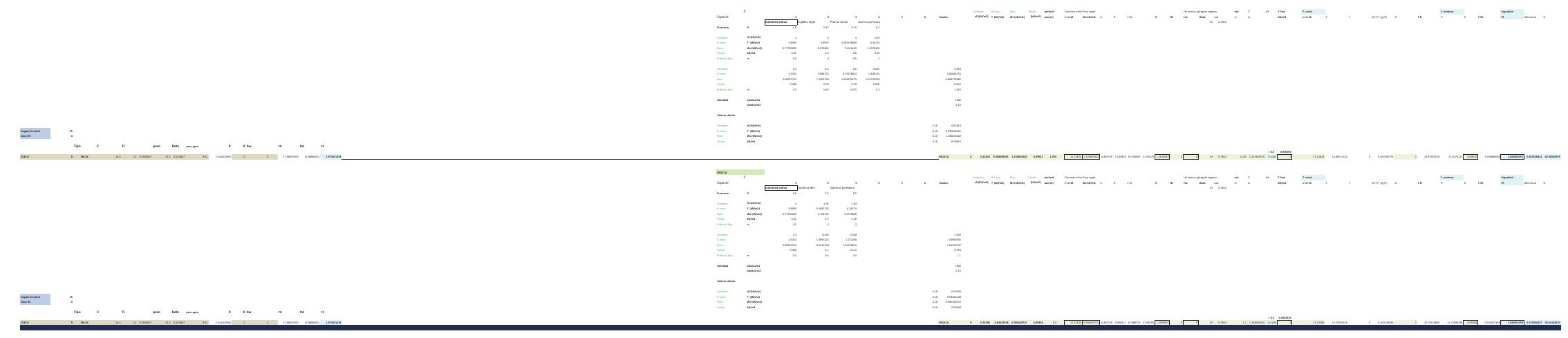




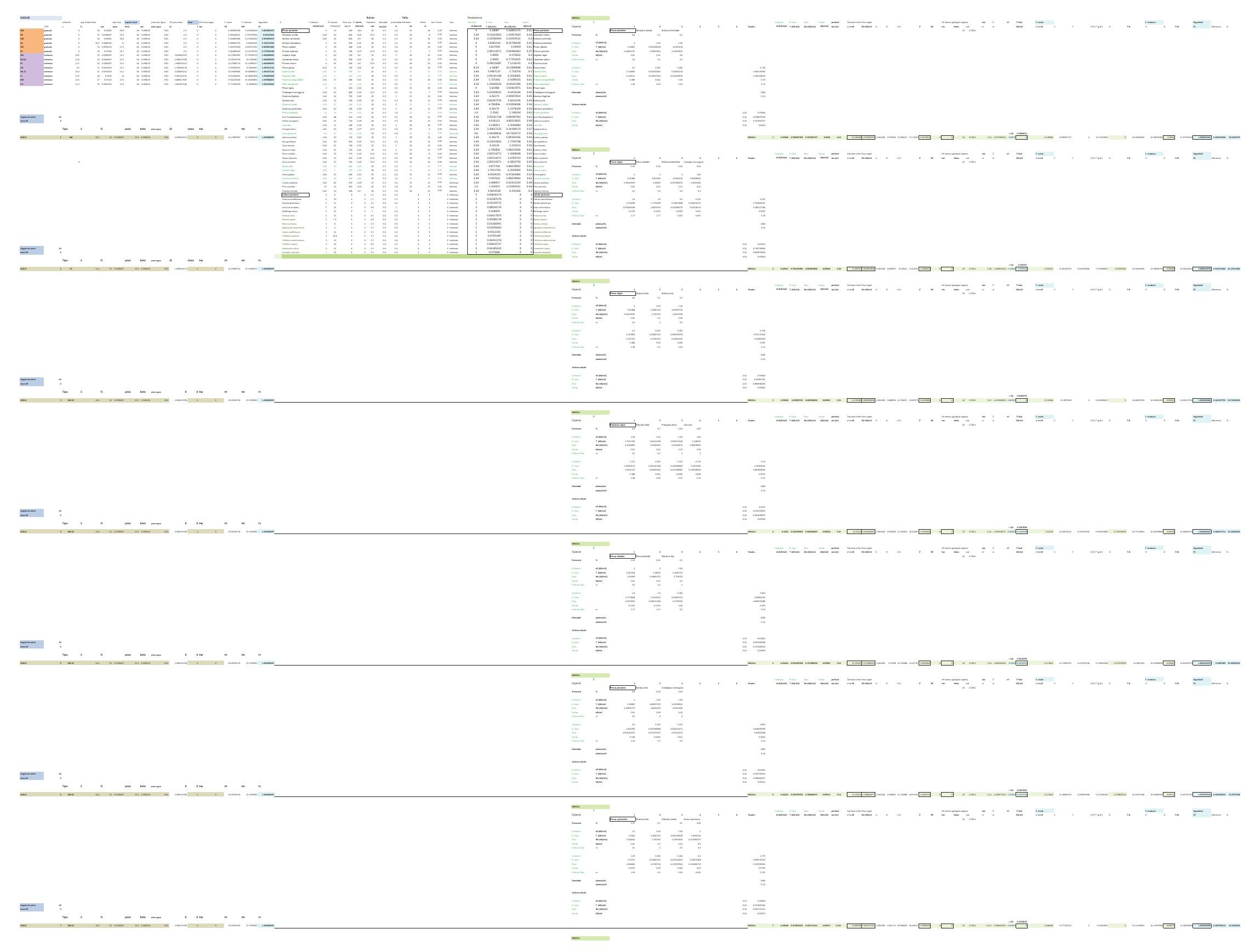




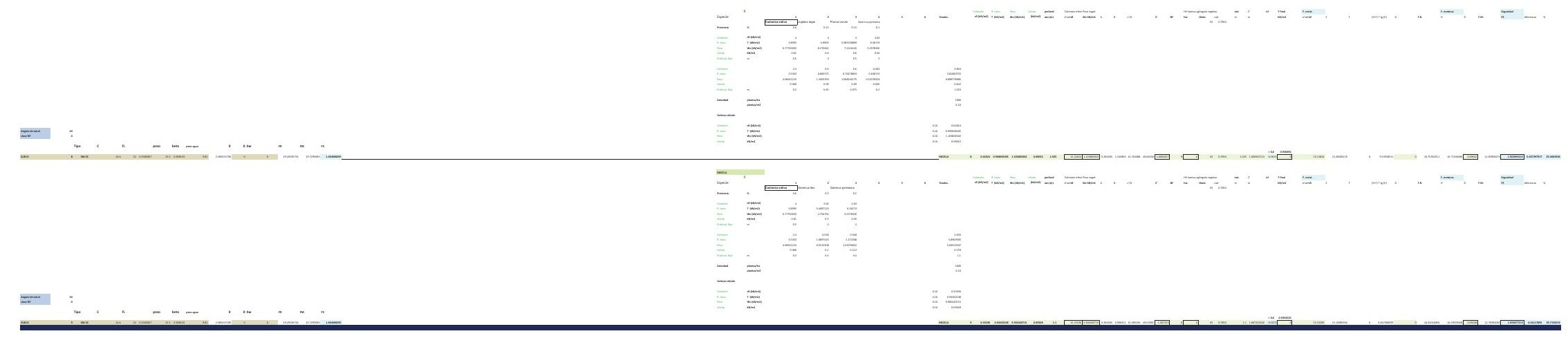




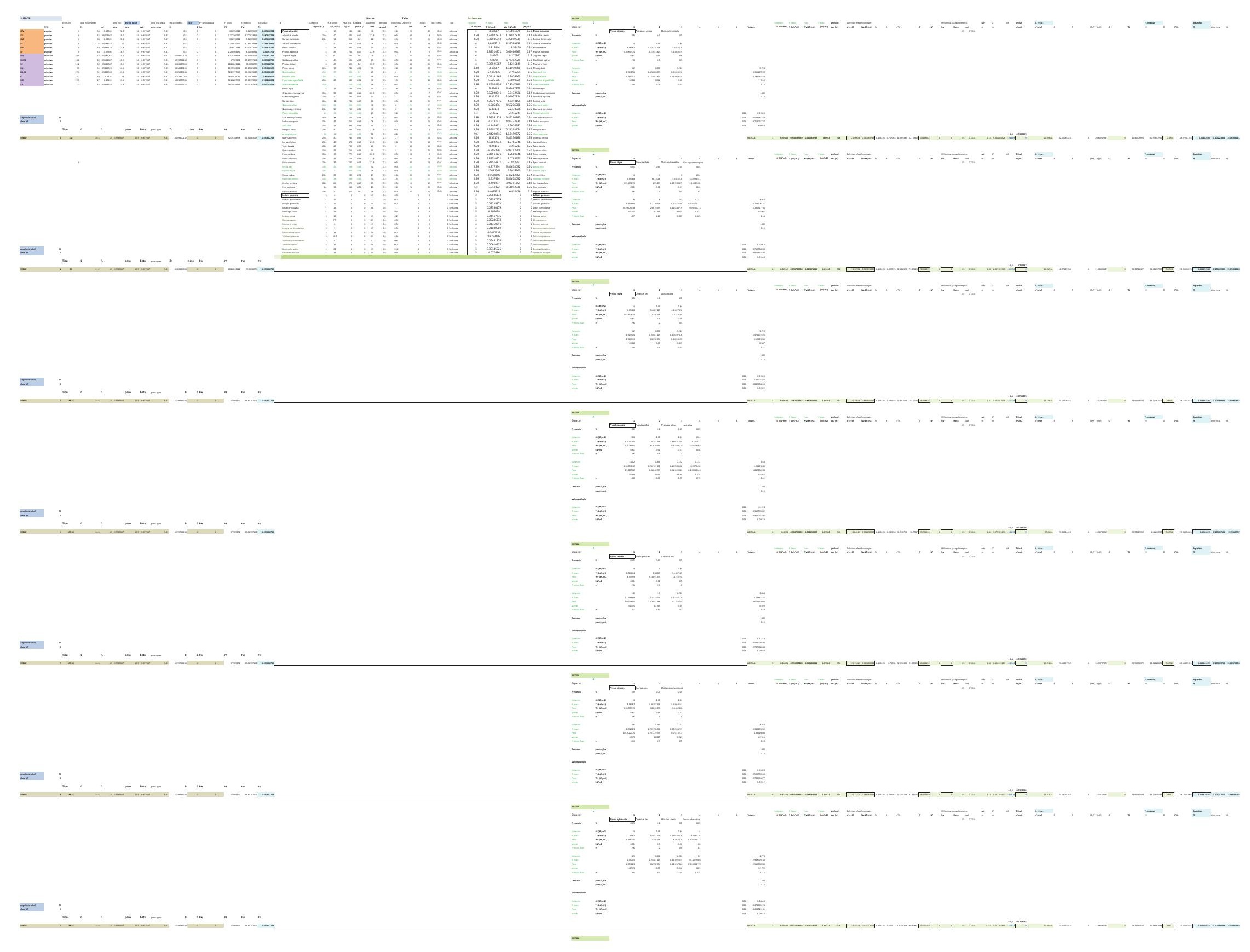




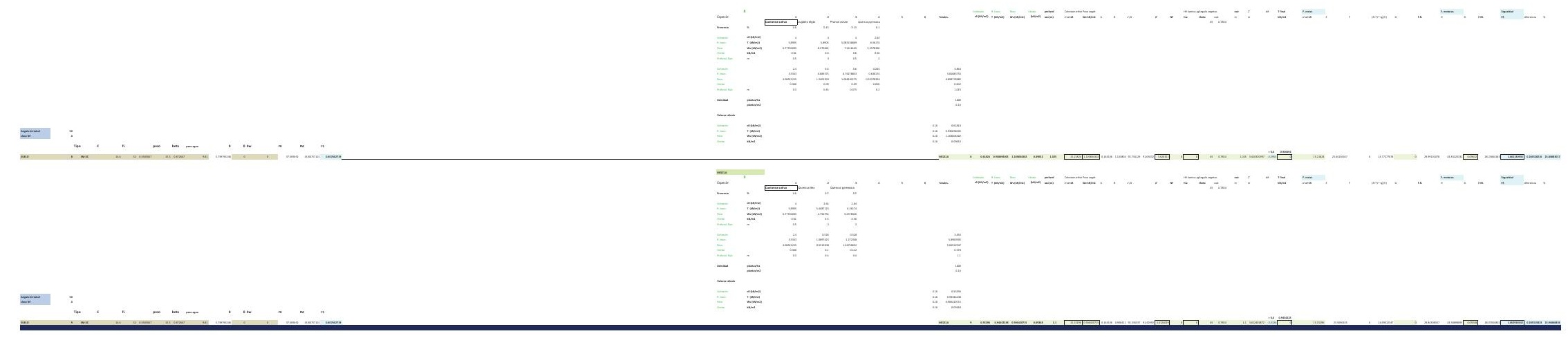




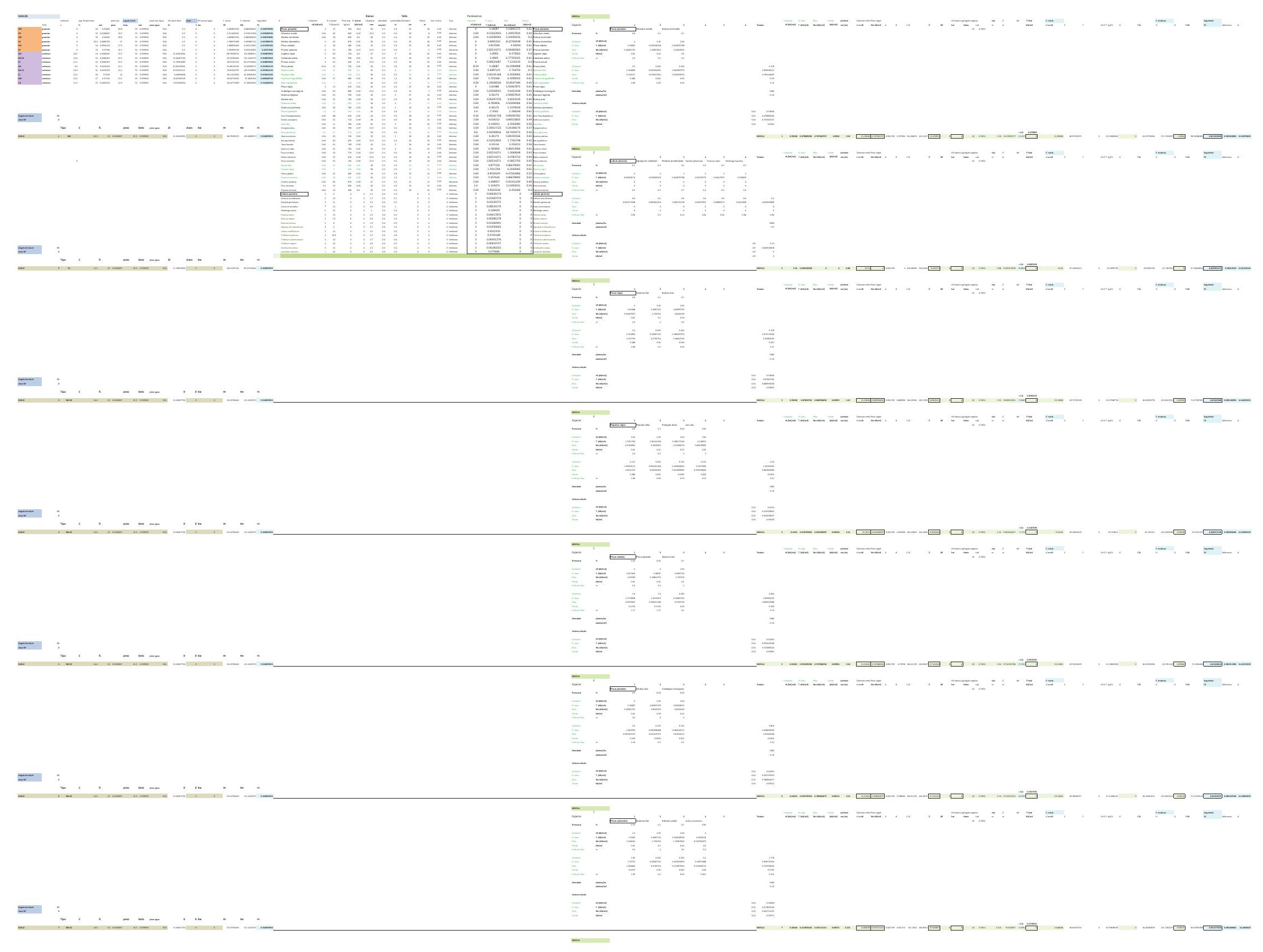




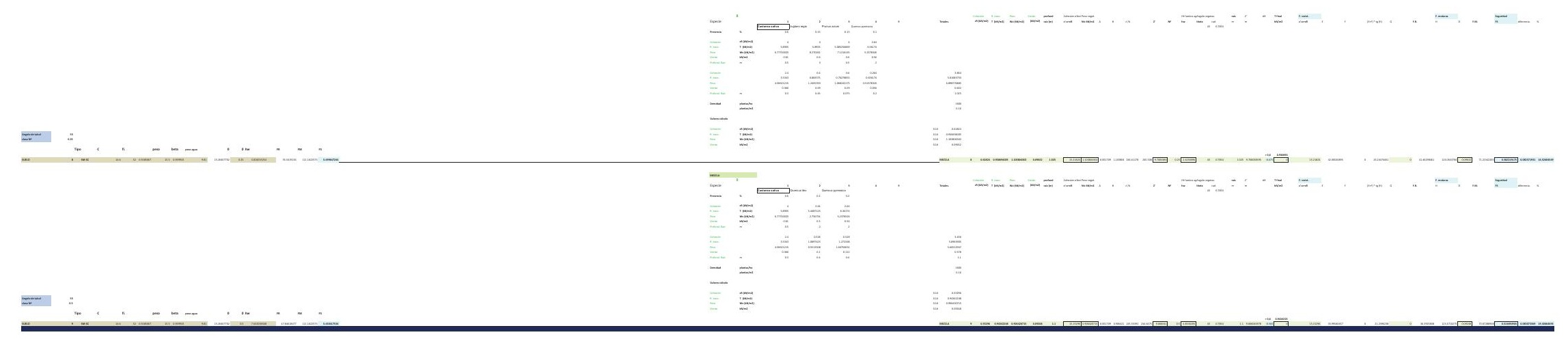




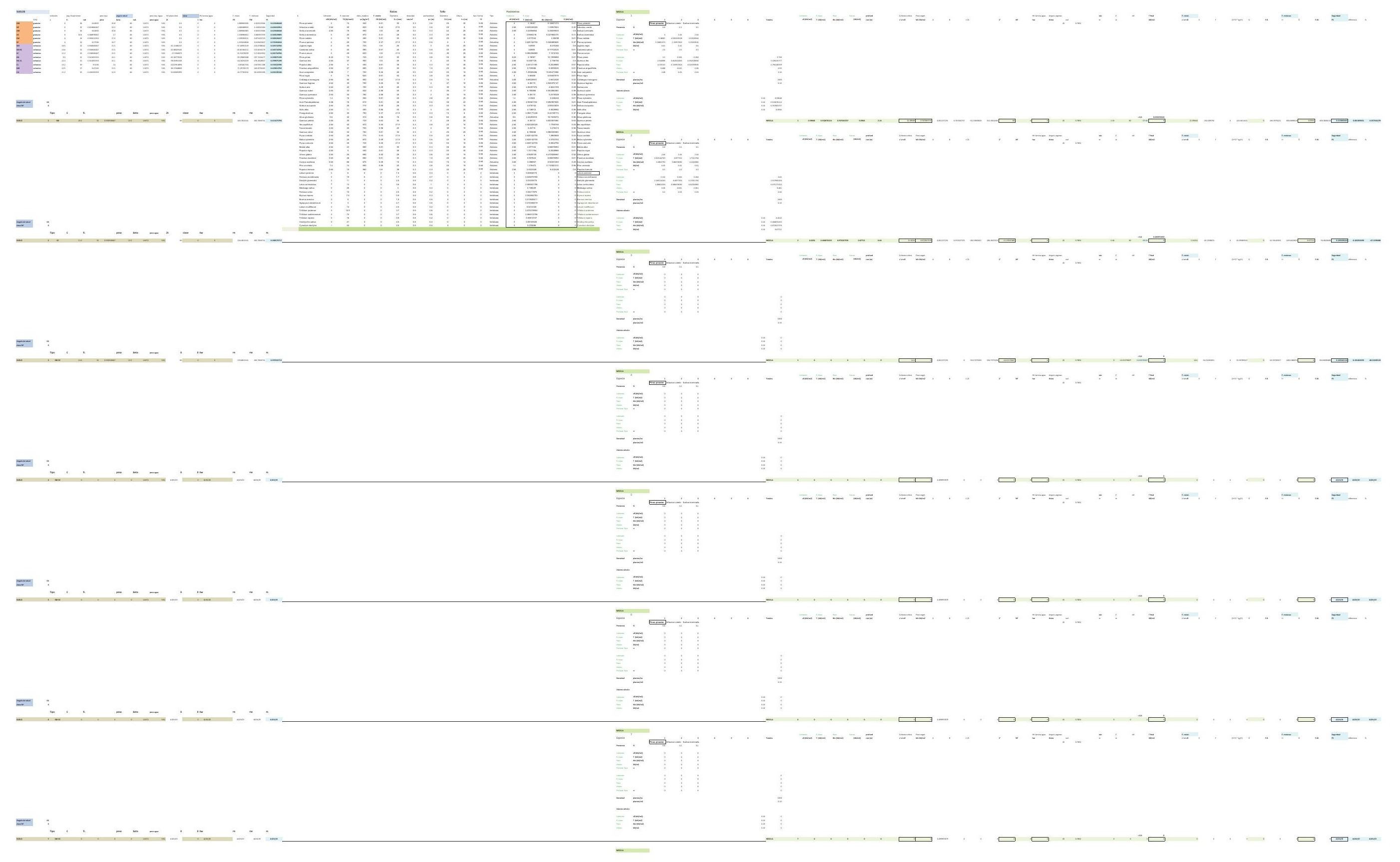




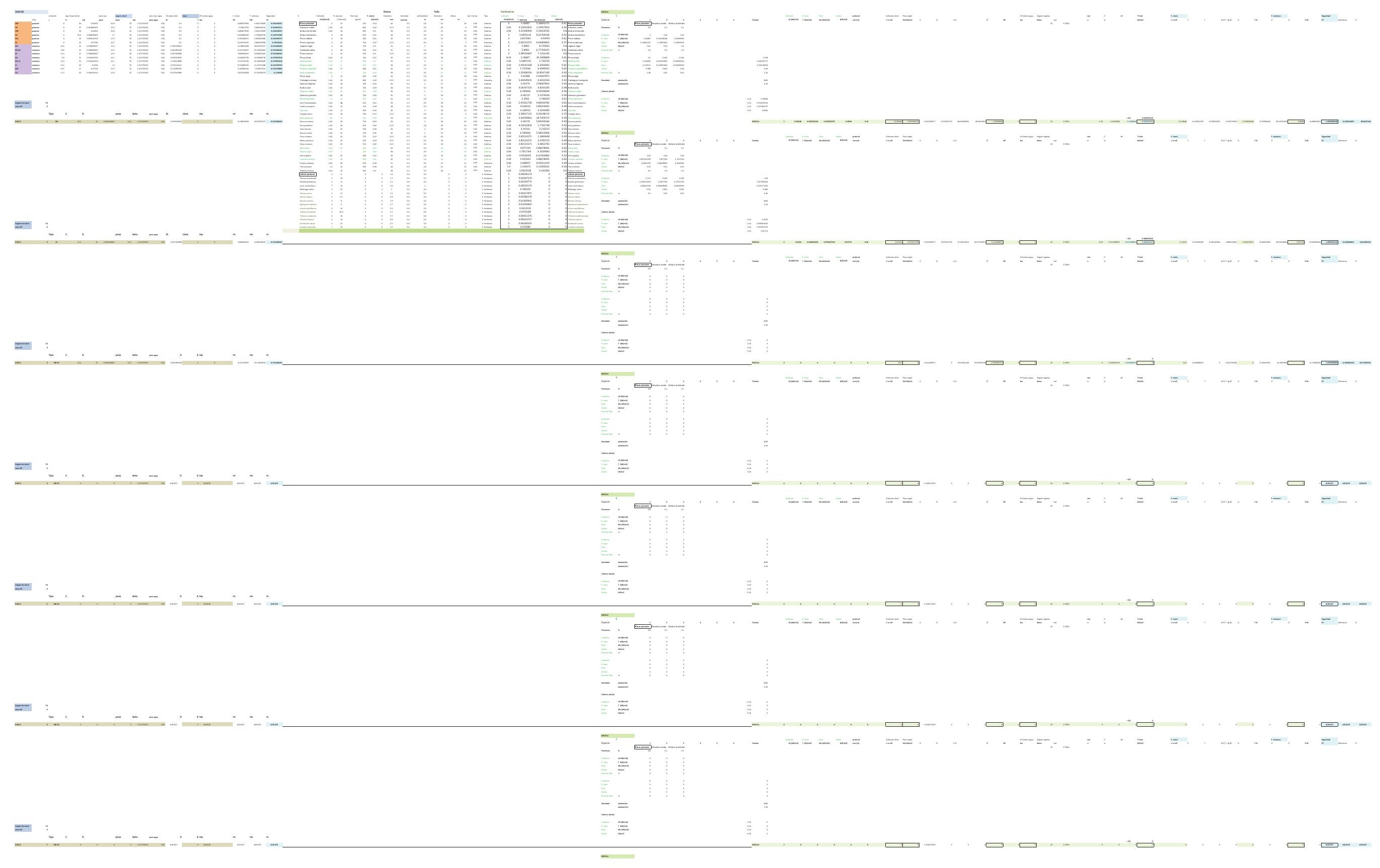




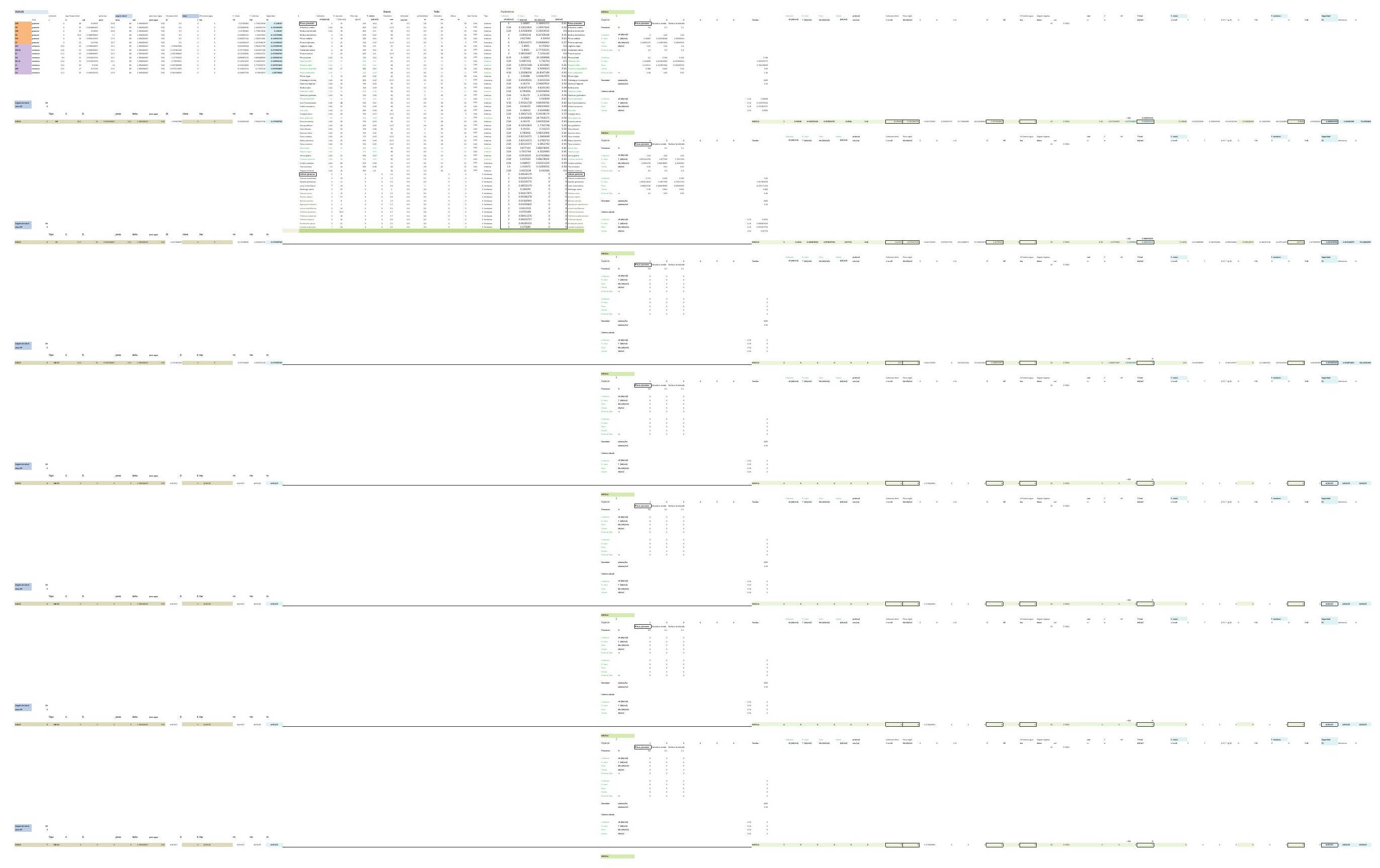


DESARROLLO DE UNA APLICACIÓN IMFORMÁTICA PARA EL CÁLCULO DE SOSTENIMIENTO DE TALUDES MEDIANTE VEGETACIÓN

B02. DENSIDAD DE PLANTACIÓN: 1.600 plantas/ha.

\section{B02-2.POSICIÓN N.F. 2}

INCLINACIÓN DE TALUD 6-100

INCLINACIÓN DE TALUD 10-200

INCLINACIÓN DE TALUD 20-30

INCLINACIÓN DE TALUD 30-40

INCLINACIÓN DE TALUD $35^{\circ}$

INCLINACIÓN DE TALUD 40-50

INCLINACIÓN DE TALUD 50-550

INCLINACIÓN DE TALUD 55-60

INCLINACIÓN DE TALUD 60-700

INCLINACIÓN DE TALUD 70-80 


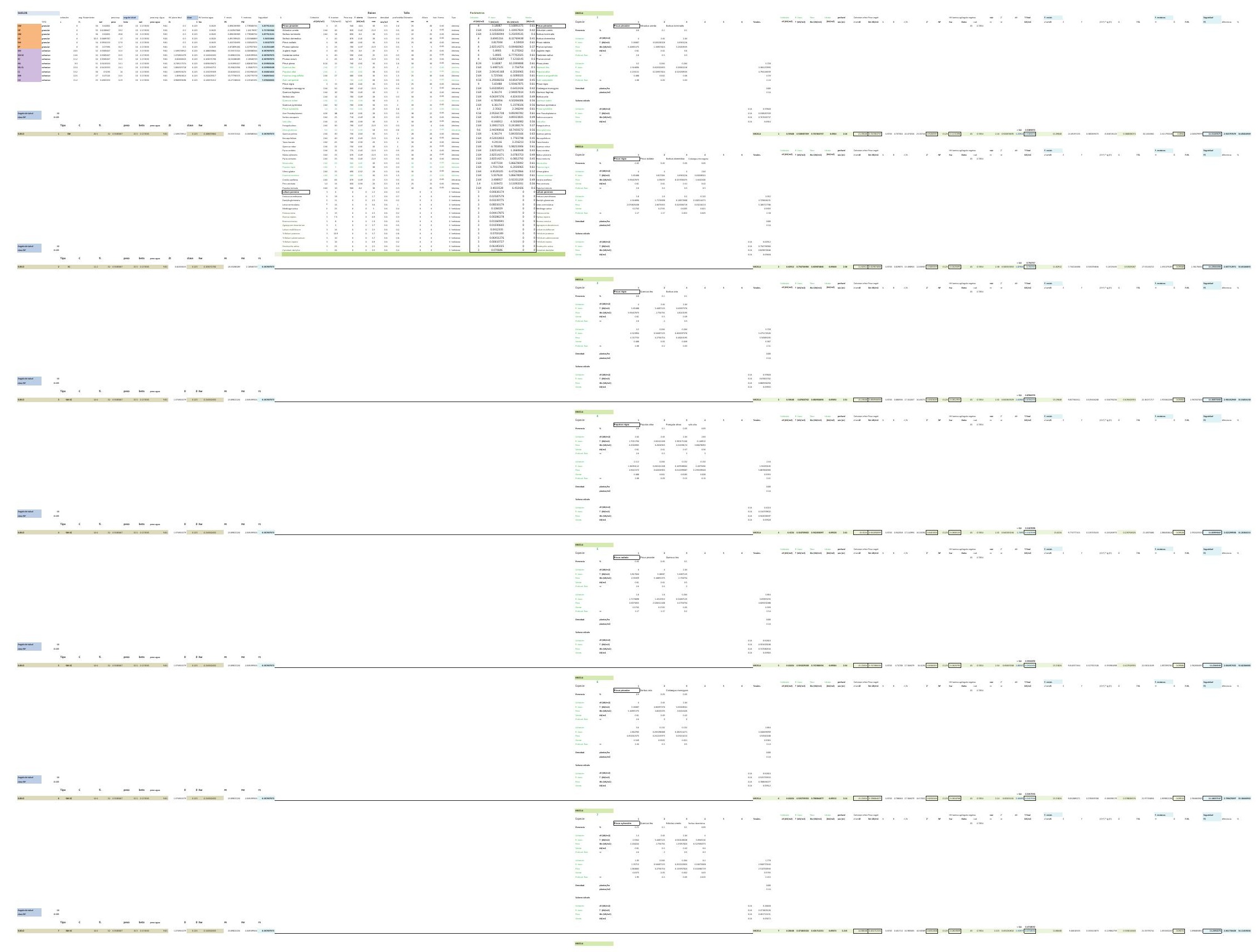




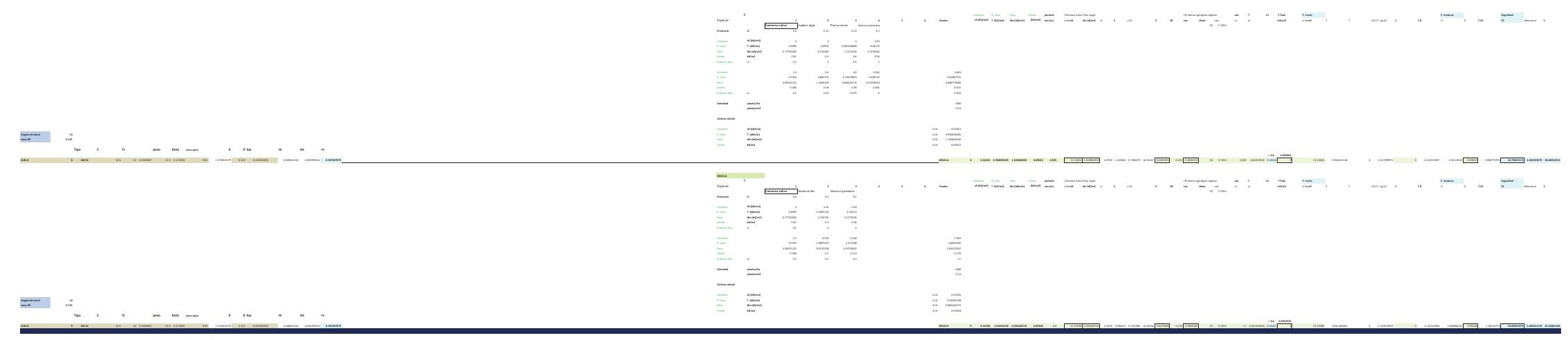




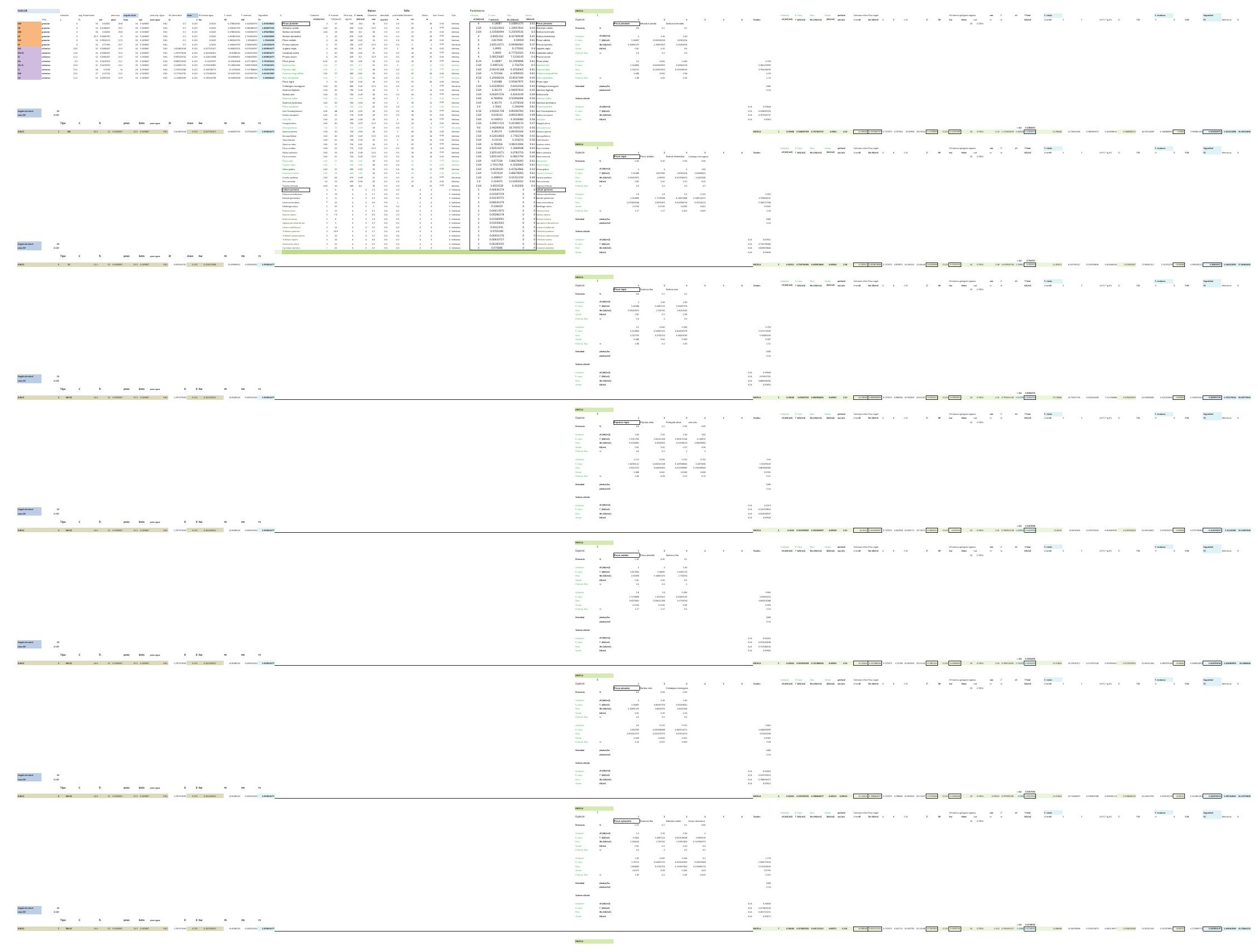




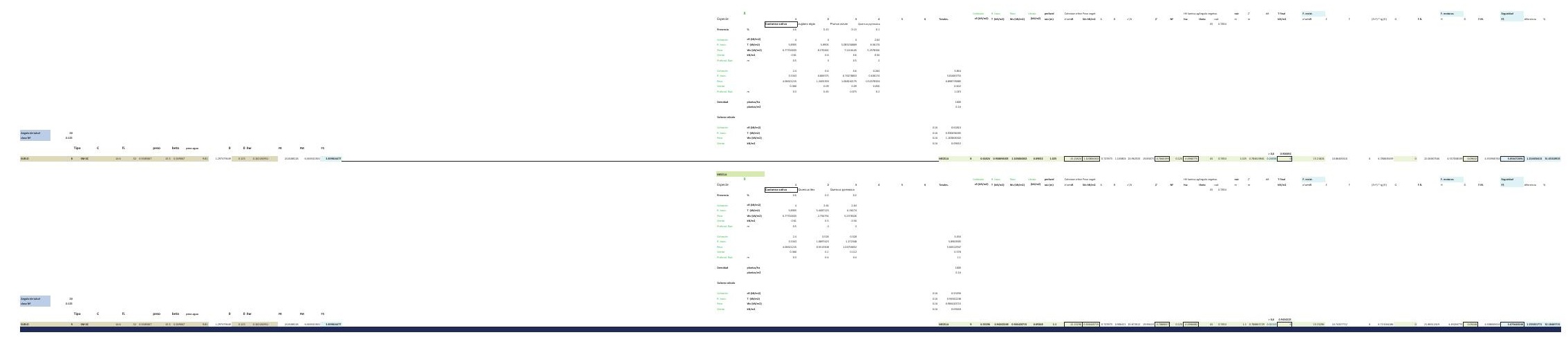




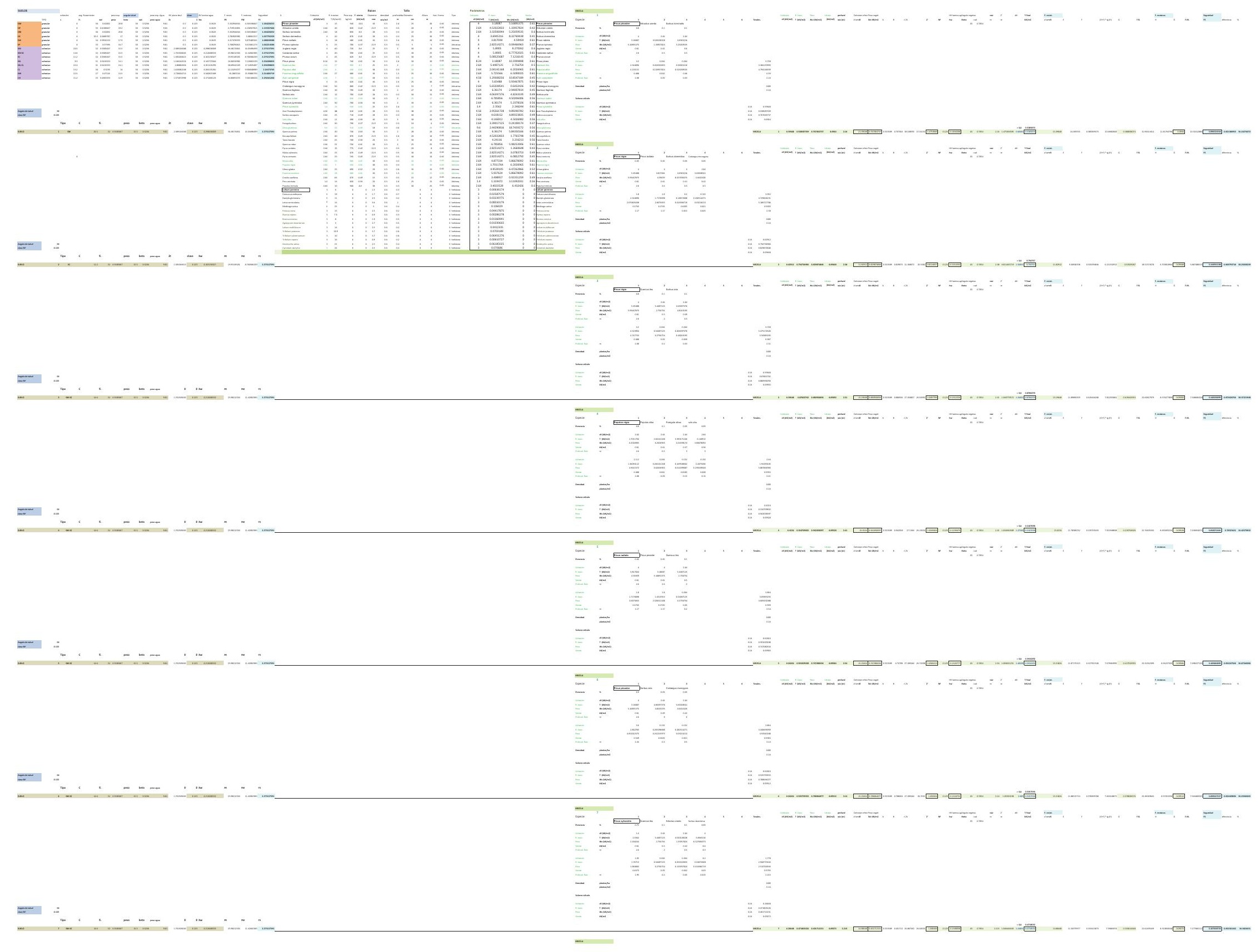




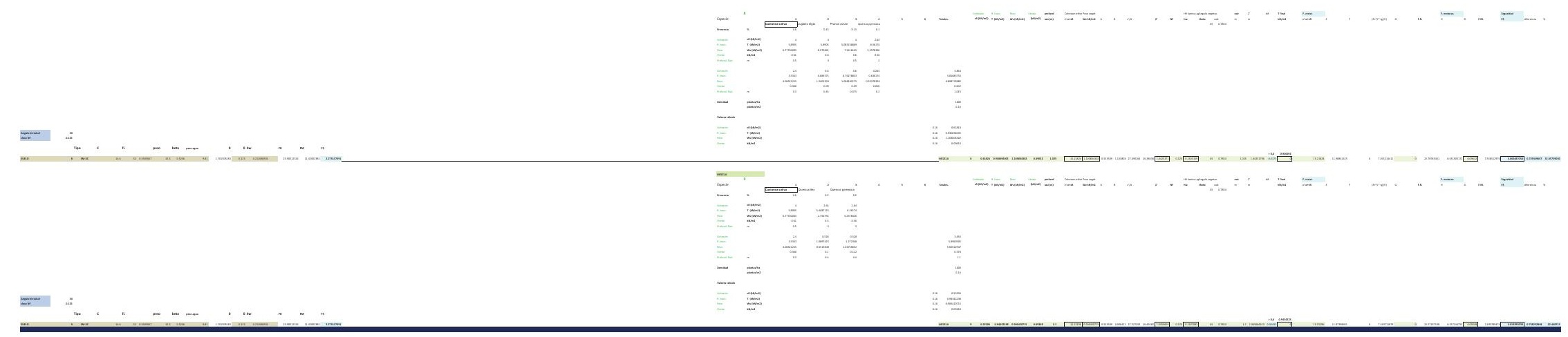




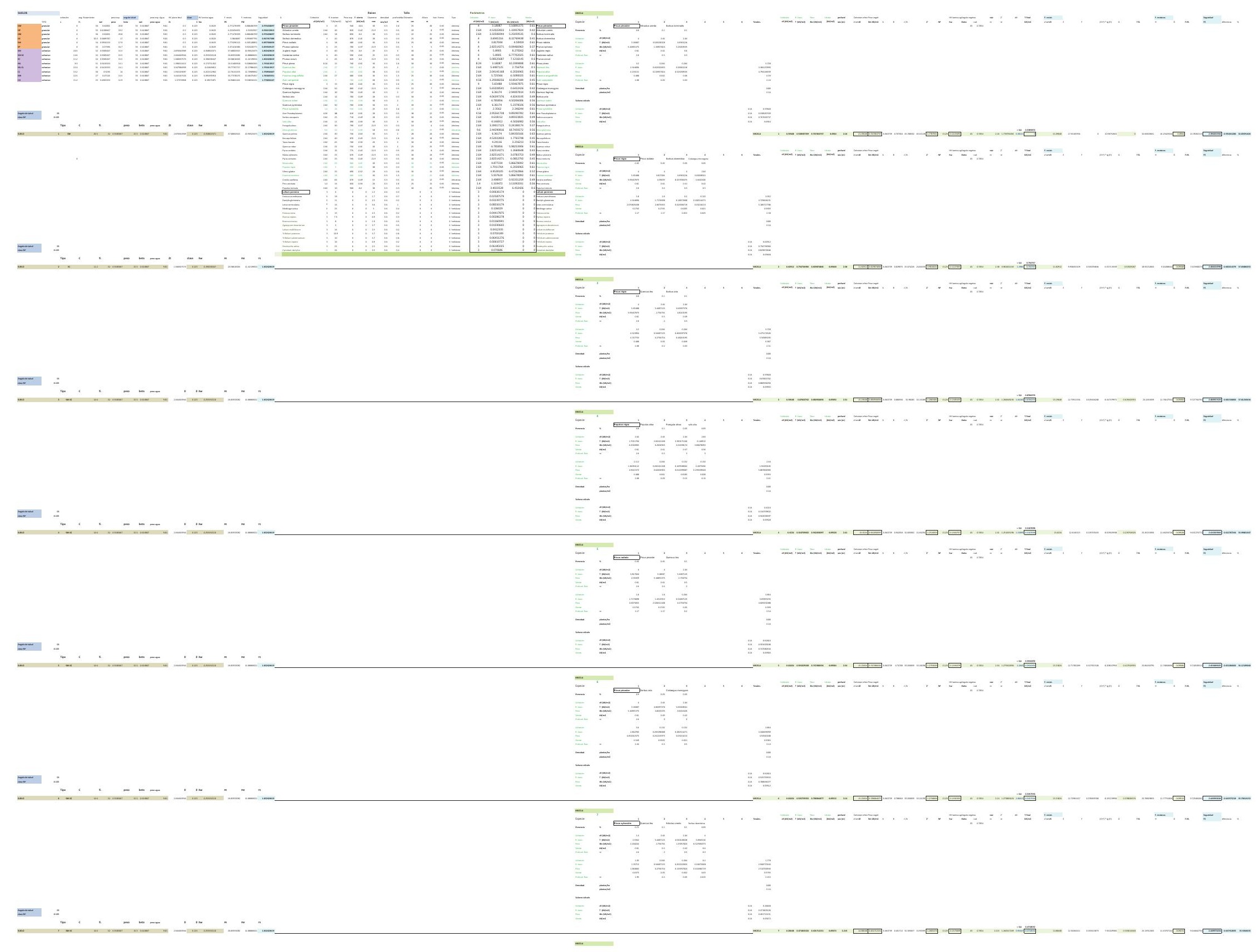




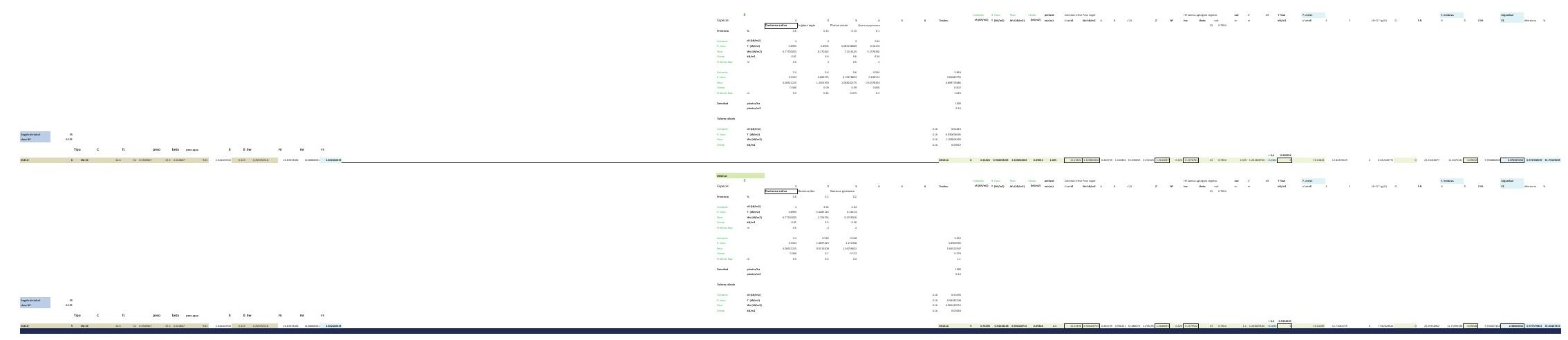




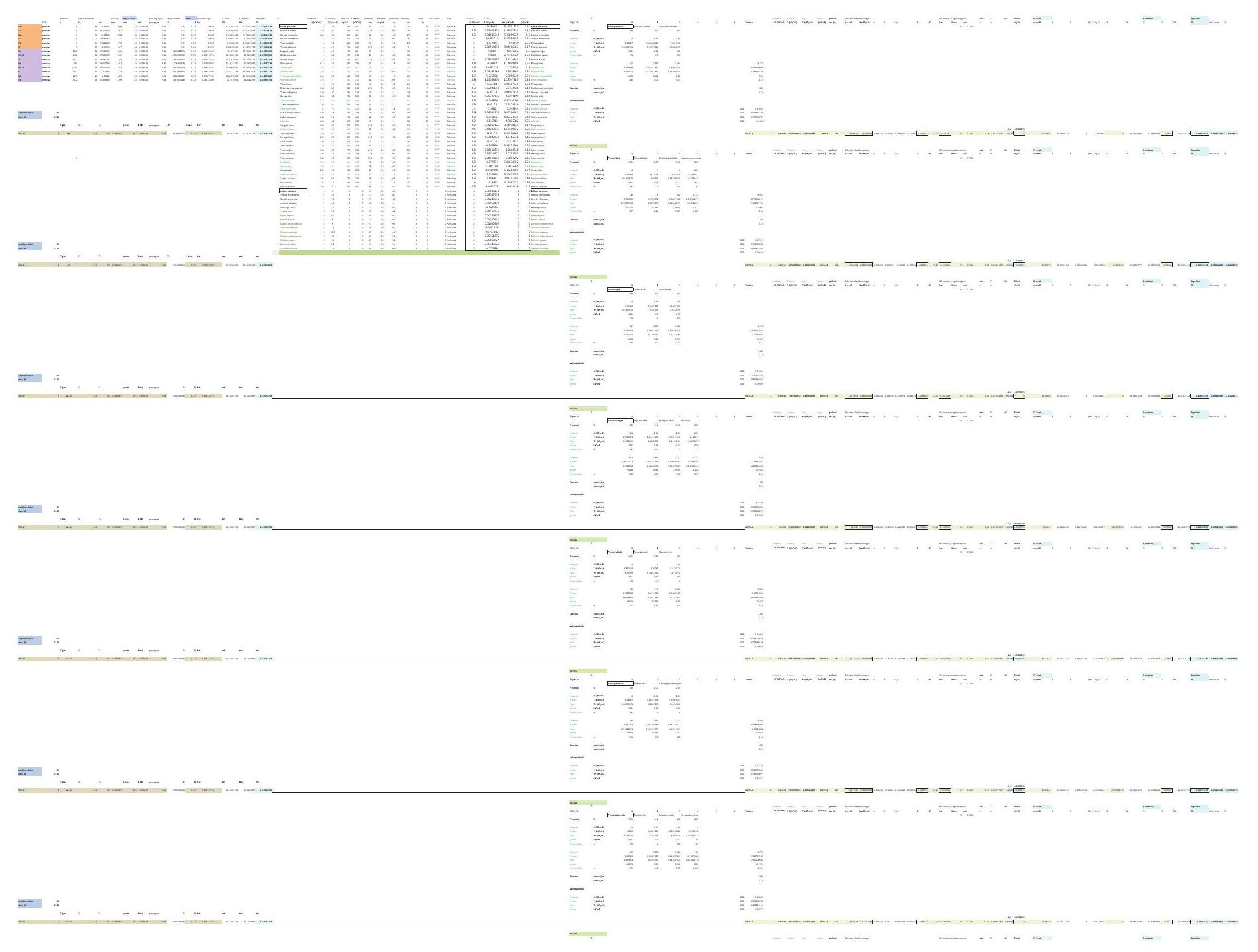




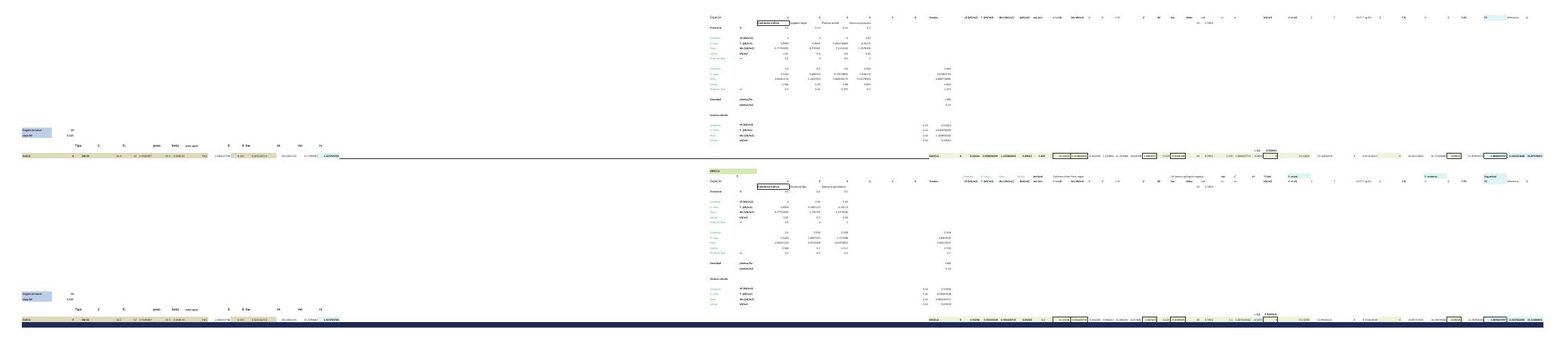




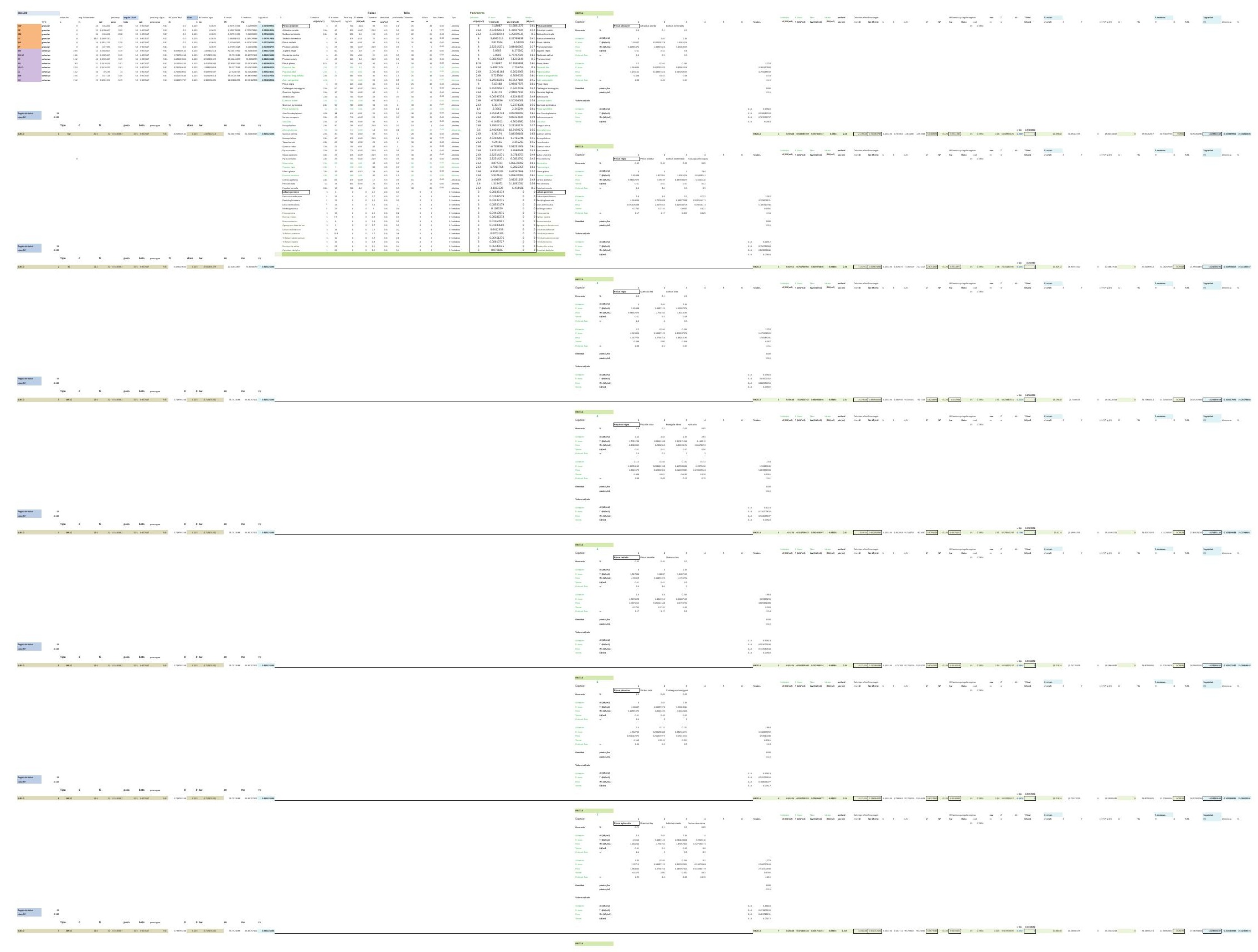




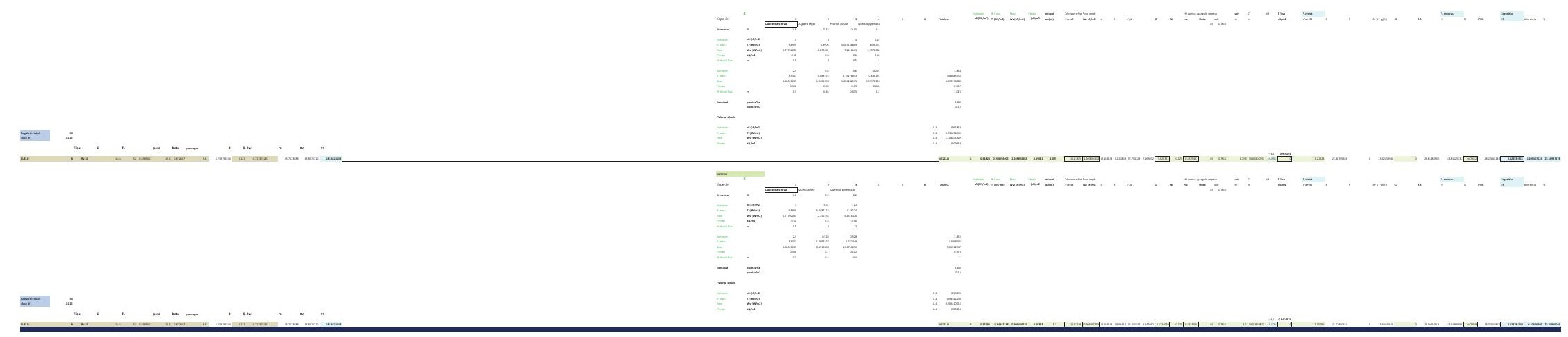




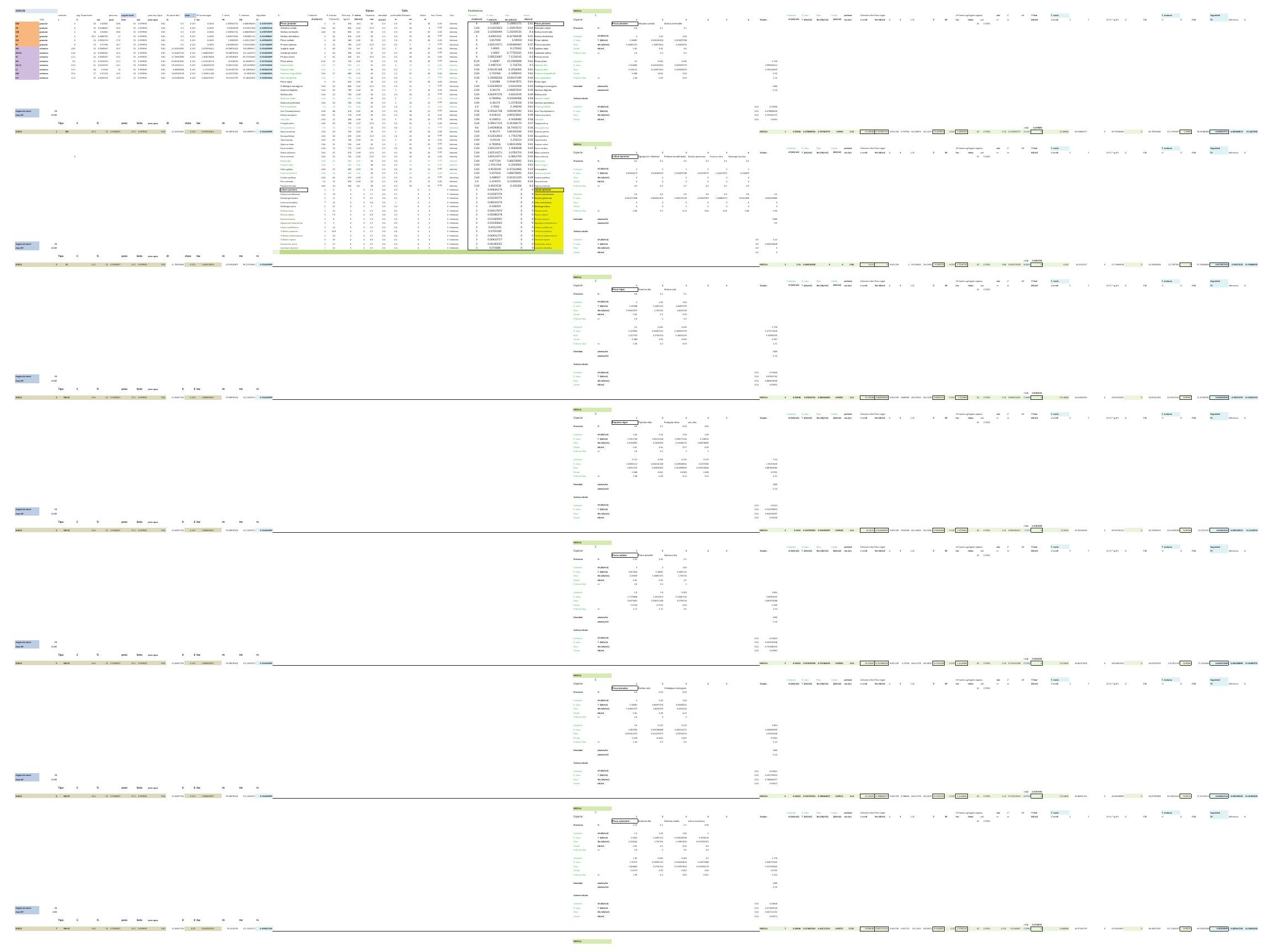




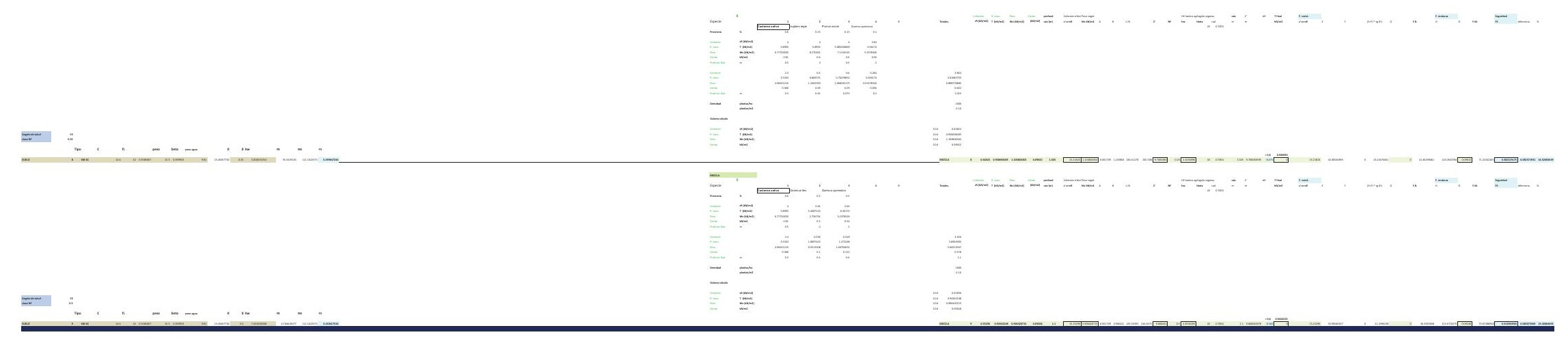




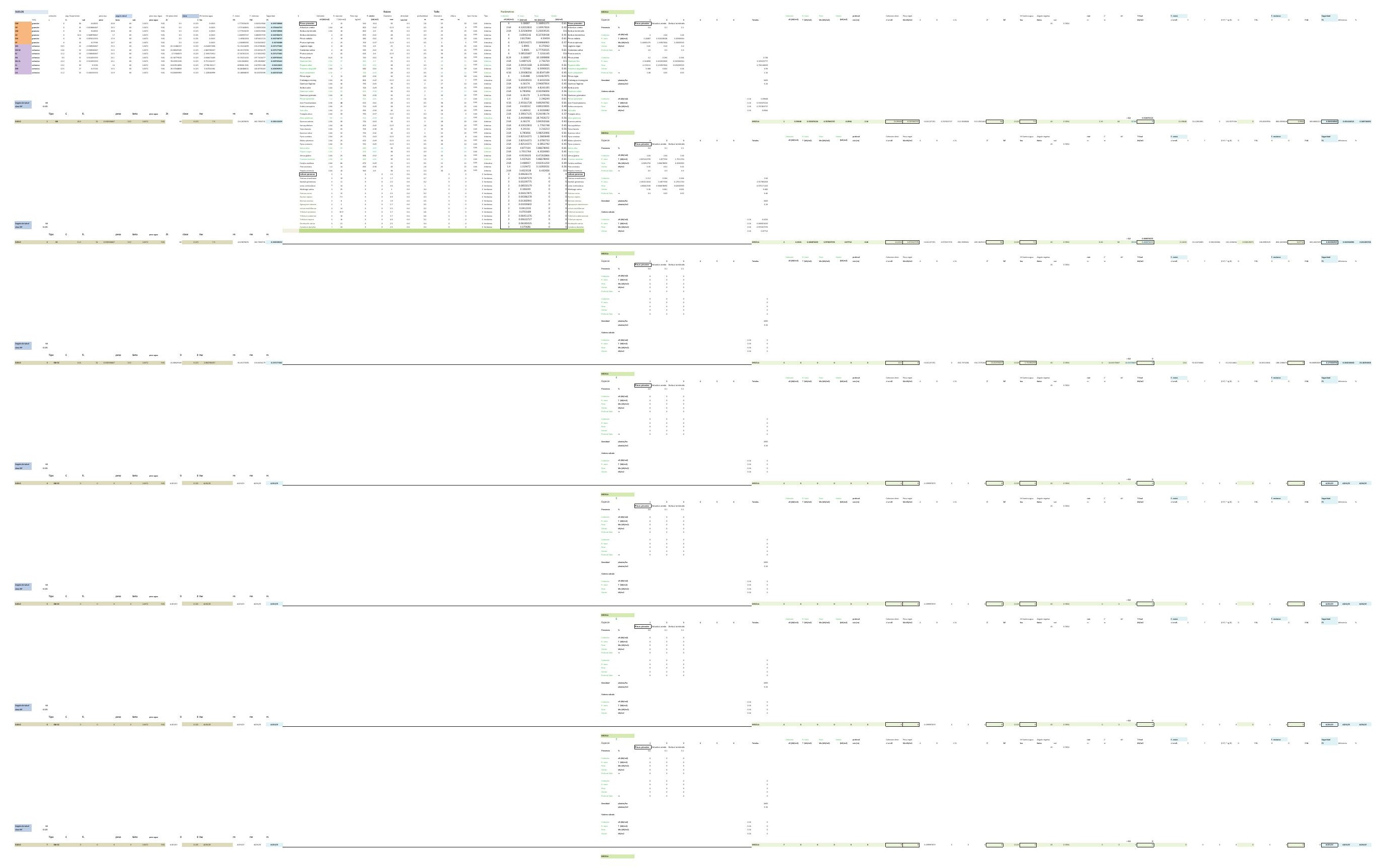


$=$

$$
=
$$

+........

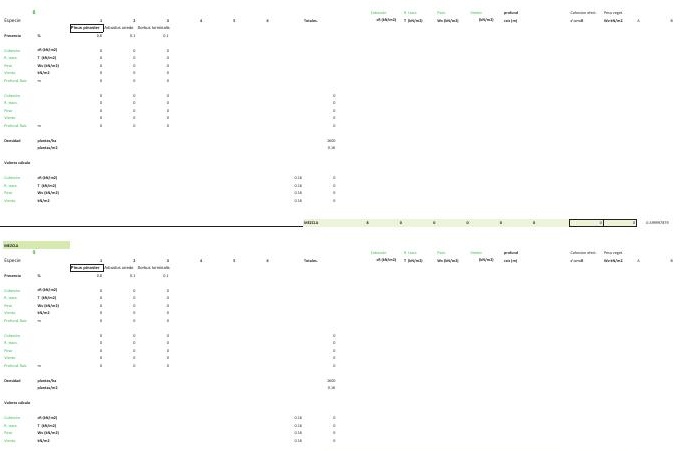

$\square-\square \cdots \cdots$

$\square-\cdots$

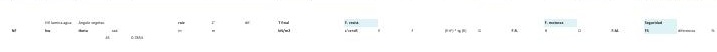




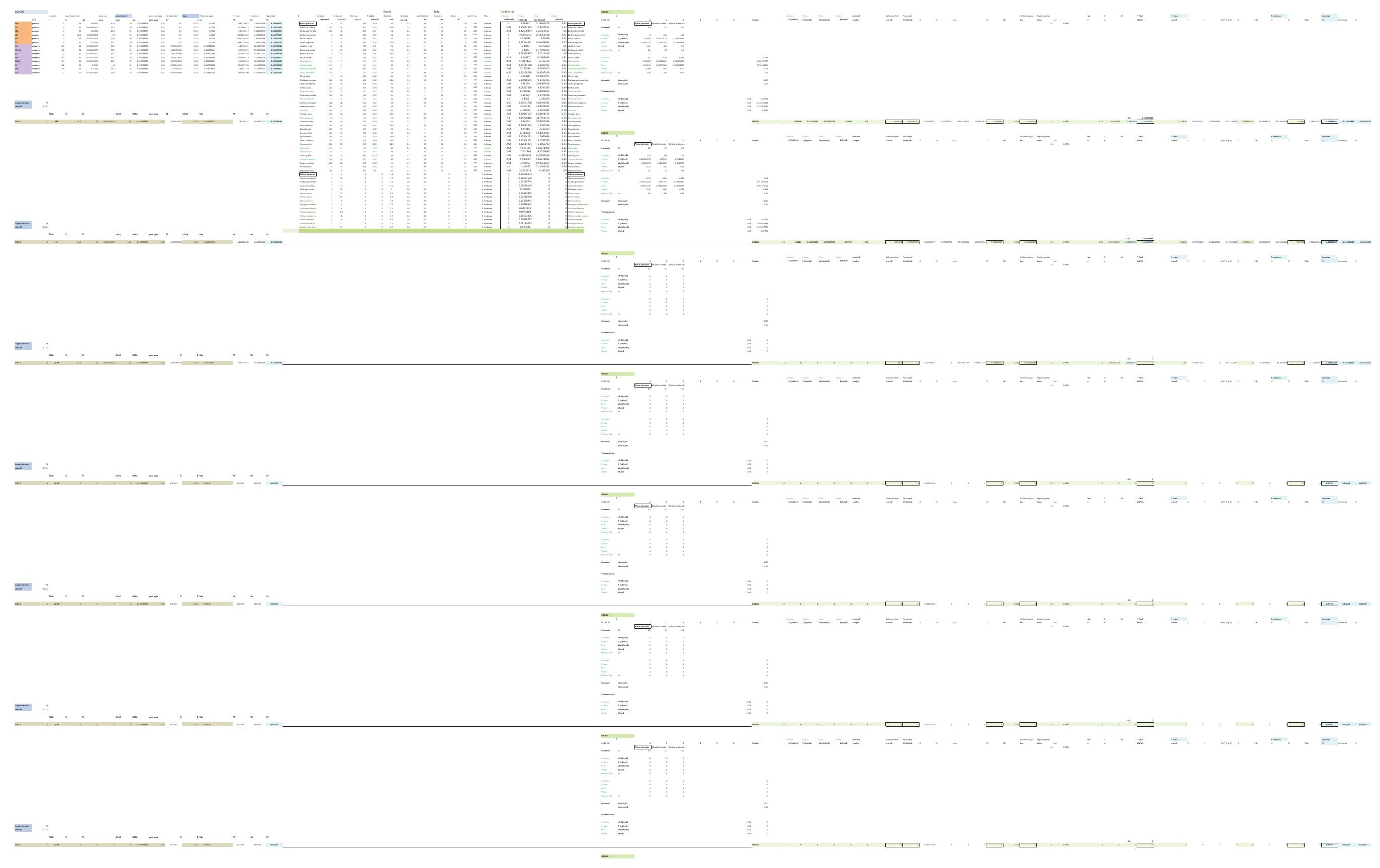




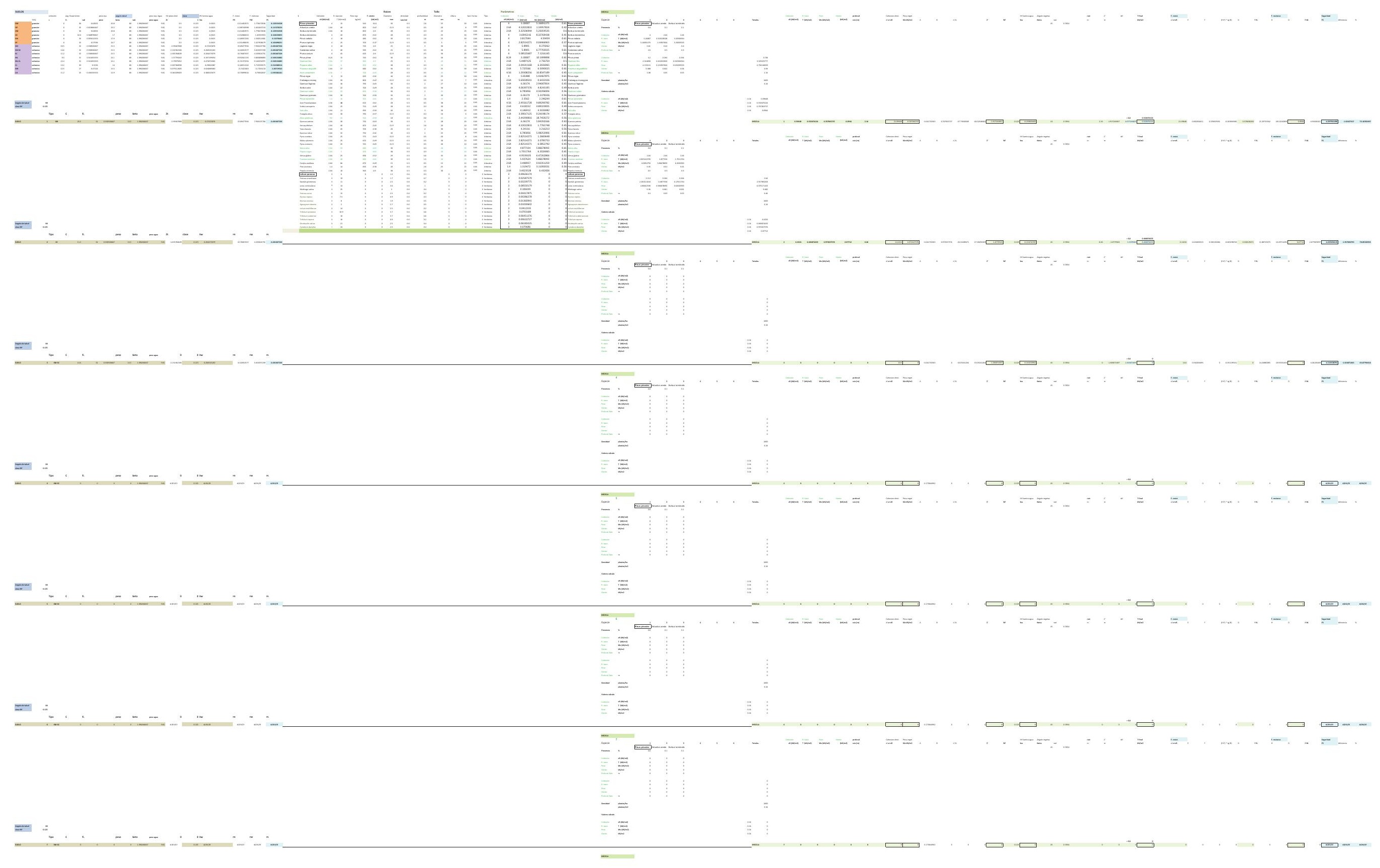


$=$

$\equiv \ldots \ldots \ldots \ldots$

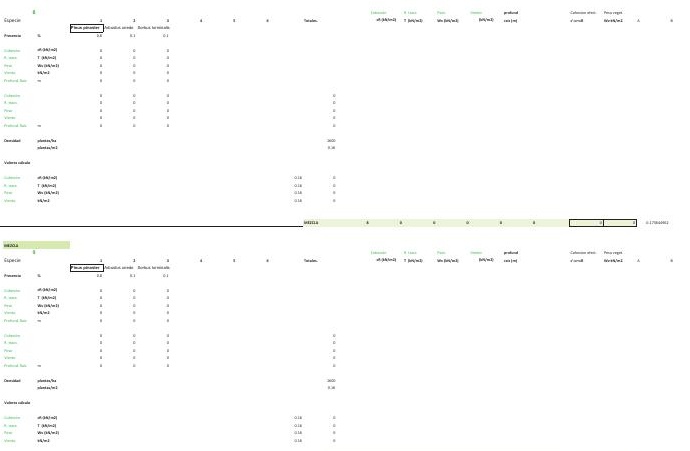

■ $\square-\cdots$

$\square-\cdots$

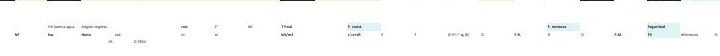


DESARROLLO DE UNA APLICACIÓN IMFORMÁTICA PARA EL CÁLCULO DE SOSTENIMIENTO DE TALUDES MEDIANTE VEGETACIÓN

B02. DENSIDAD DE PLANTACIÓN: 1.600 plantas/ha.

\section{B02-3.POSICIÓN N.F. 3}

INCLINACIÓN DE TALUD 6-100

INCLINACIÓN DE TALUD 10-200

INCLINACIÓN DE TALUD 20-30

INCLINACIÓN DE TALUD 30-40

INCLINACIÓN DE TALUD $35^{\circ}$

INCLINACIÓN DE TALUD 40-50

INCLINACIÓN DE TALUD 50-550

INCLINACIÓN DE TALUD 55-60

INCLINACIÓN DE TALUD 60-700

INCLINACIÓN DE TALUD 70-80 


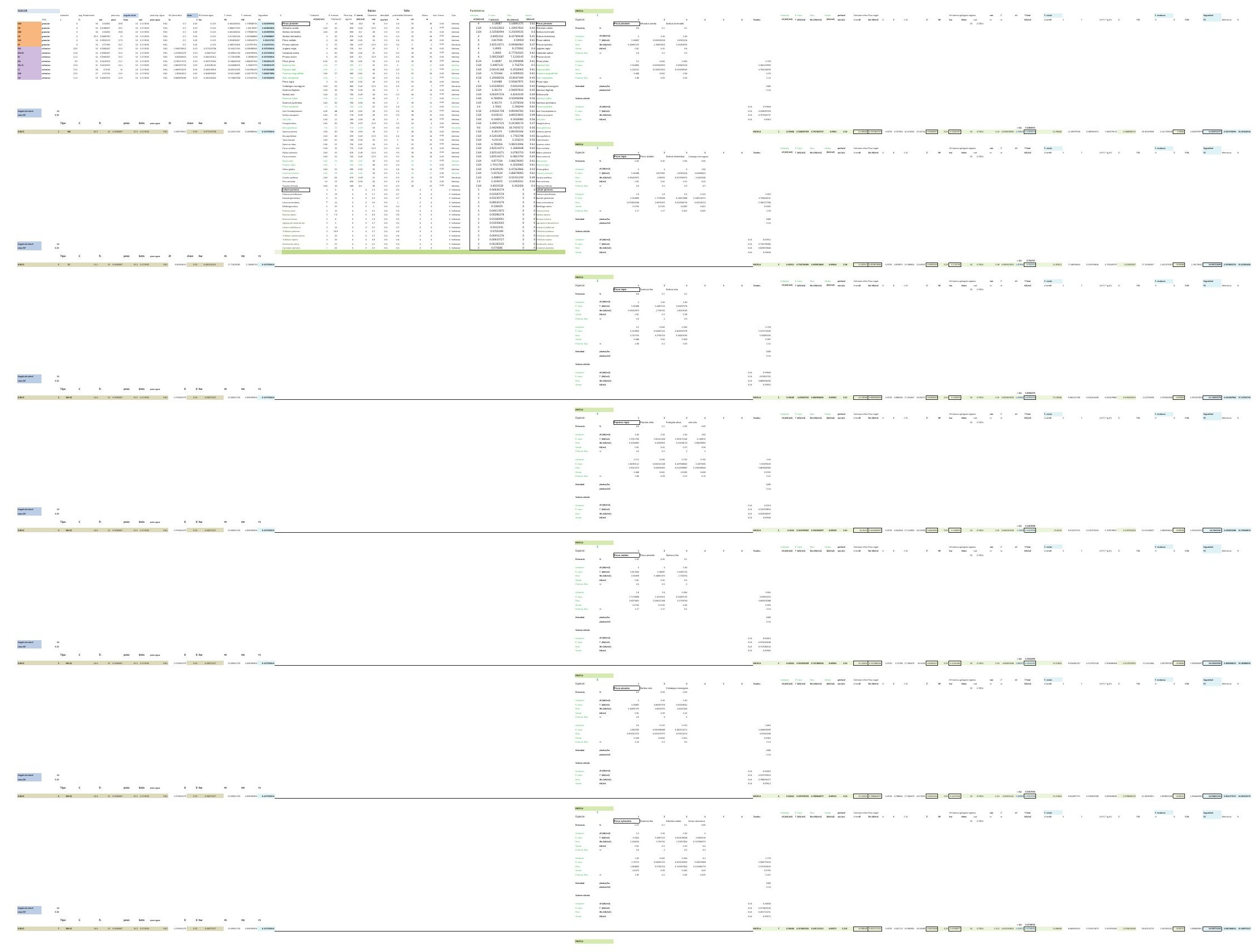




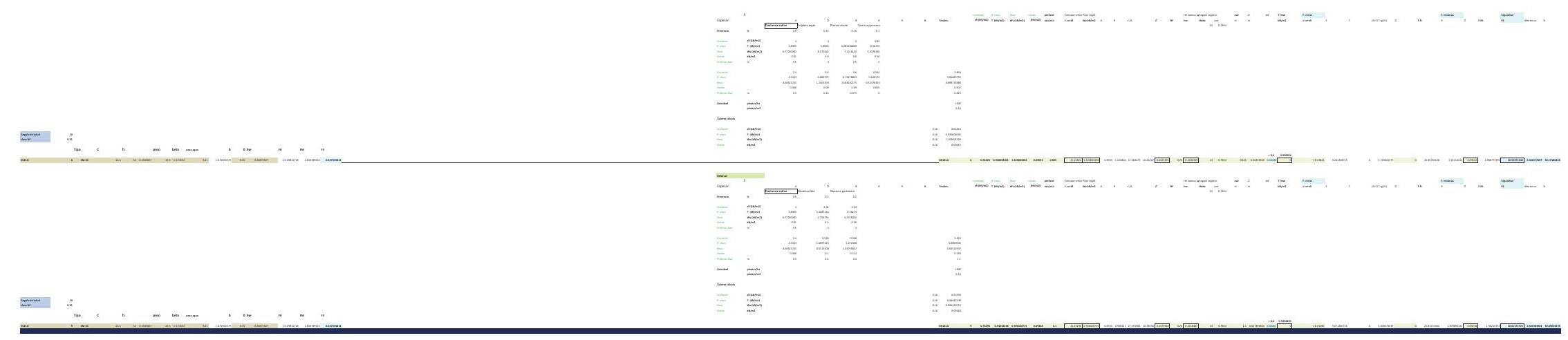




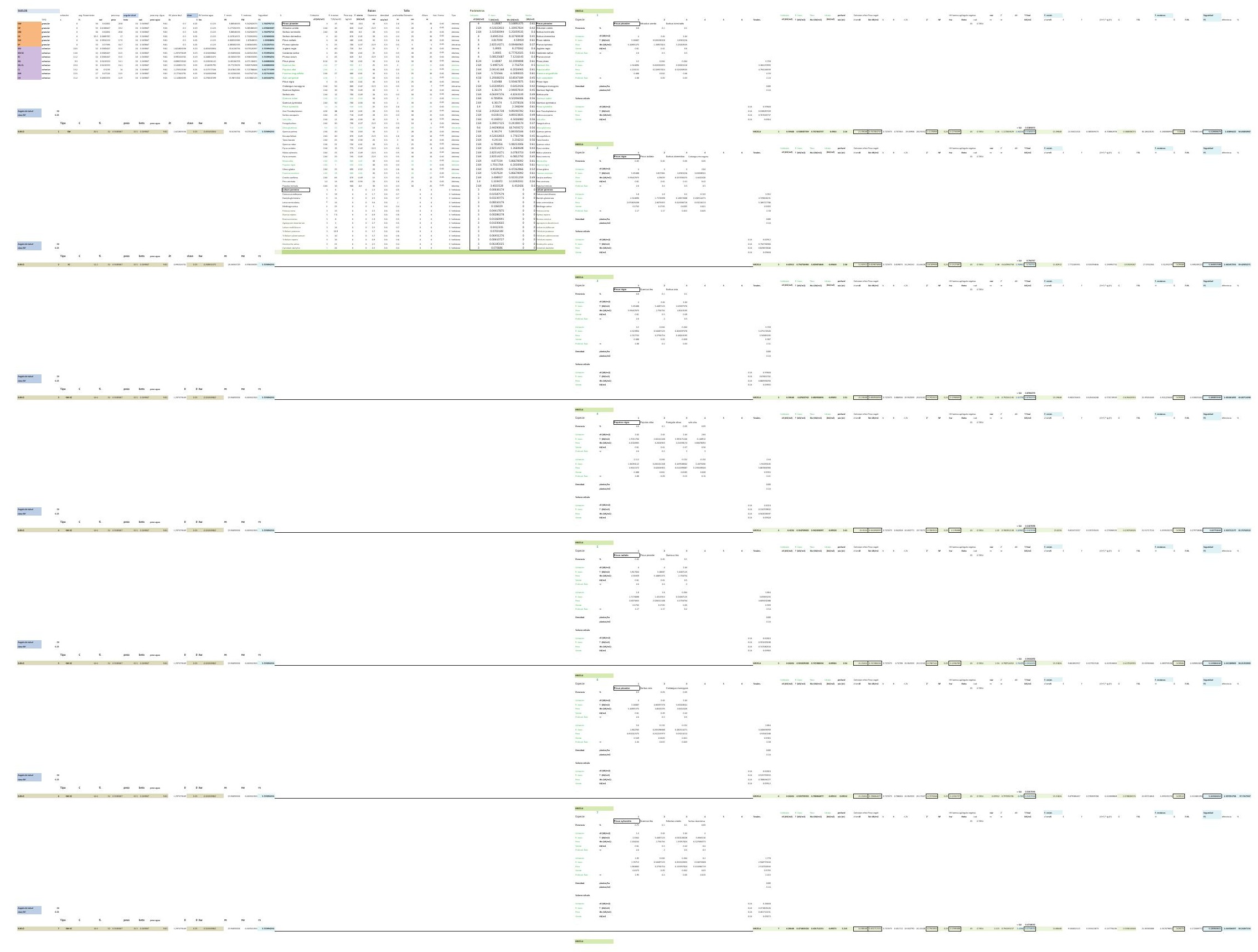




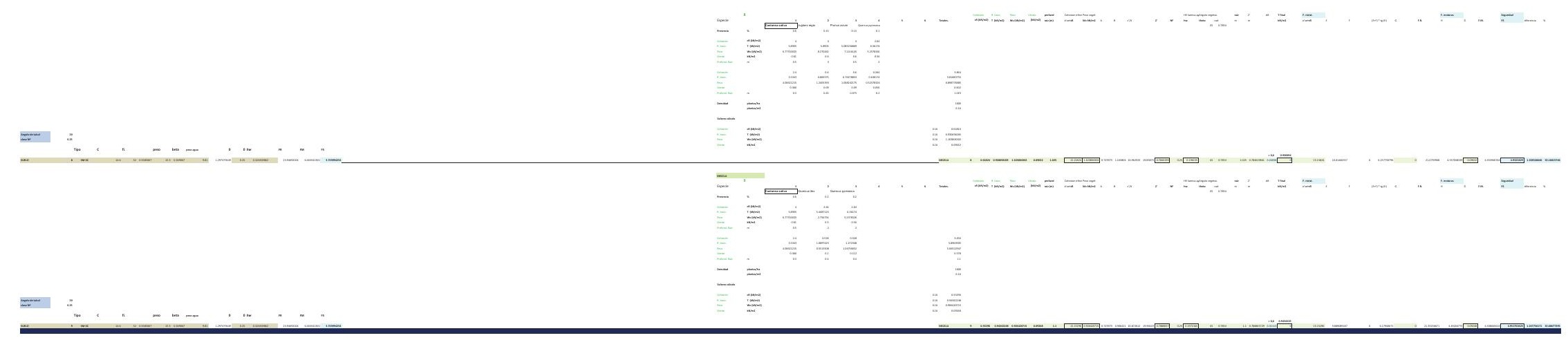




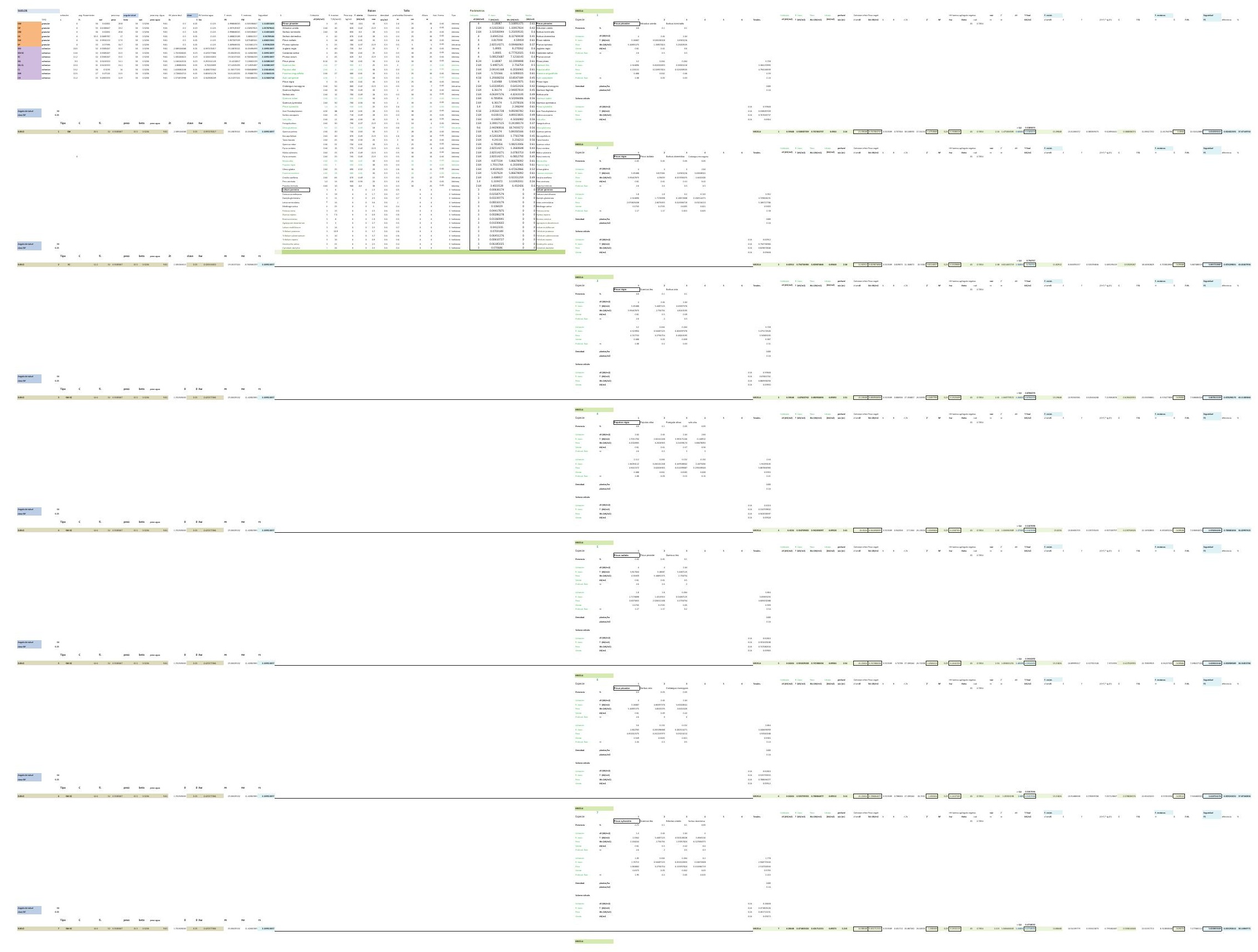




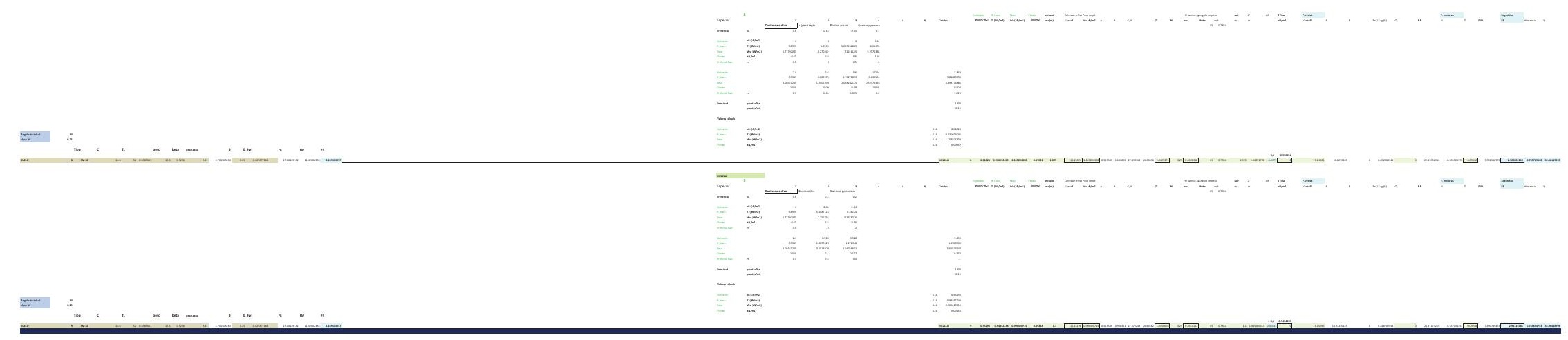




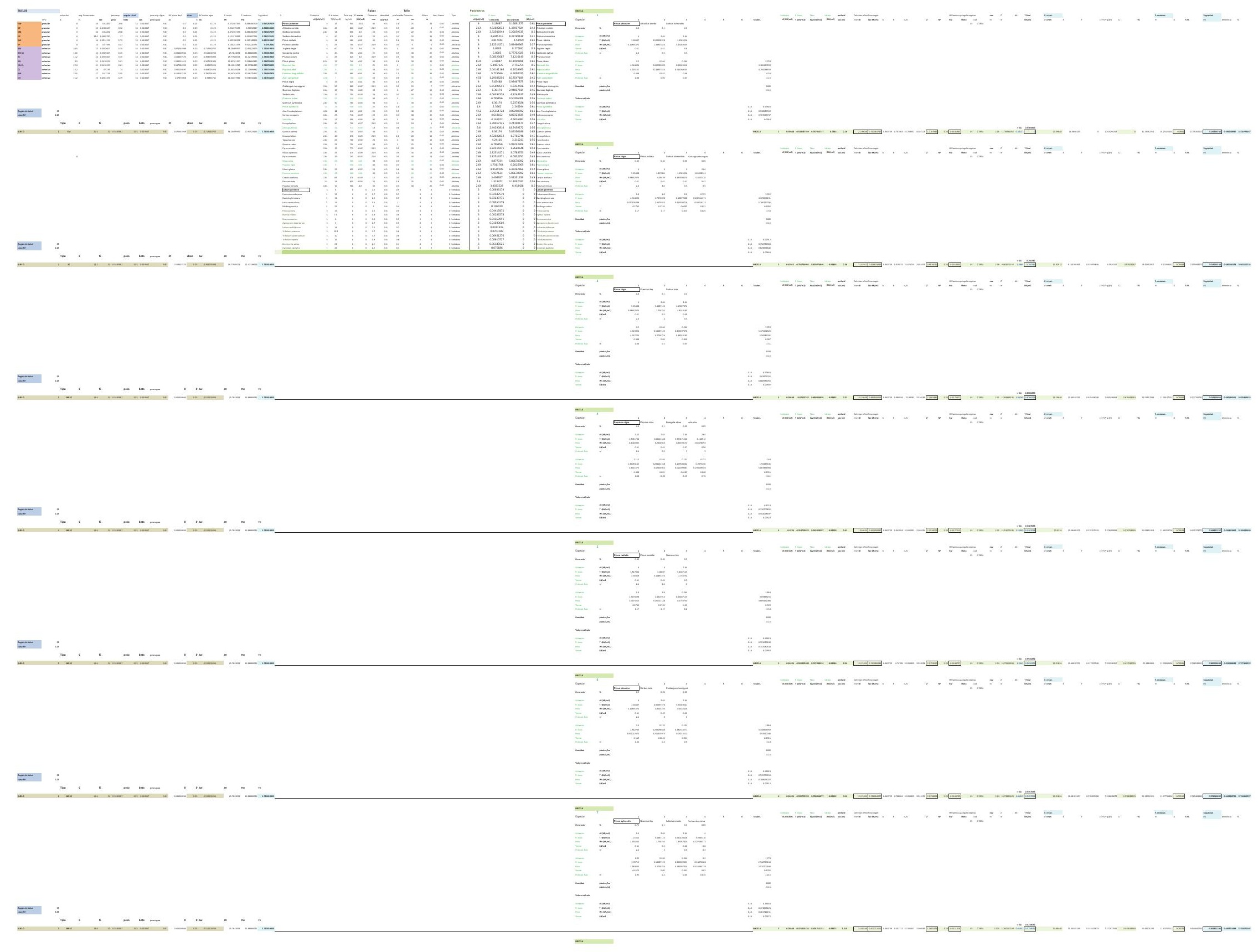




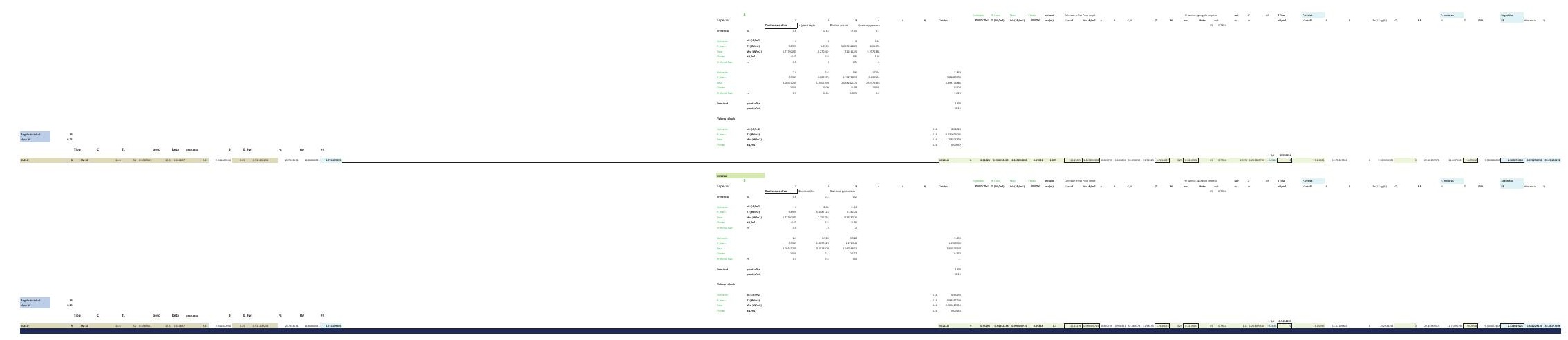




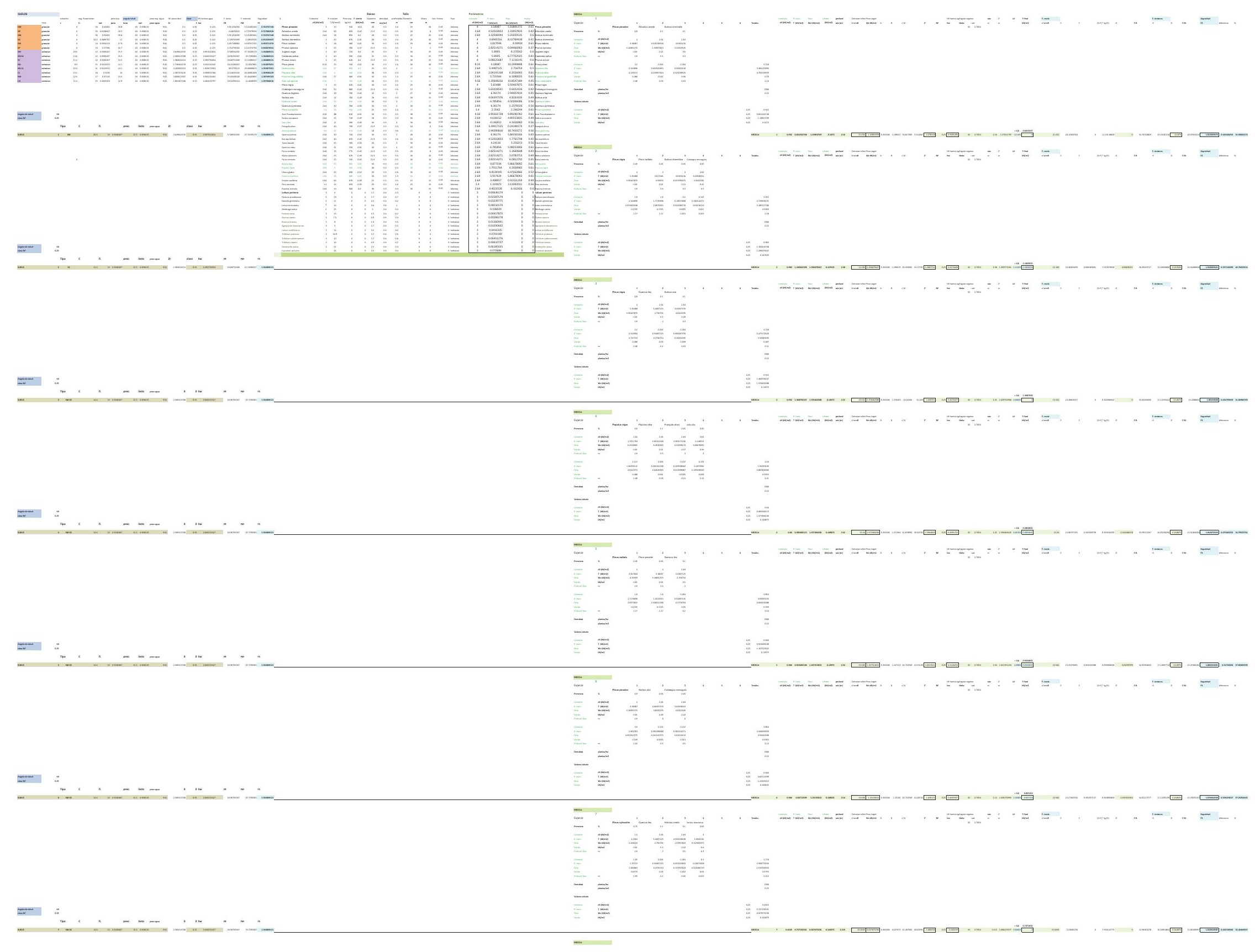


$=$

$=$

$n+\ldots+\cdots+\cdots$ $\pm$

(...

$\equiv=-$

E. $=$

$-$ 


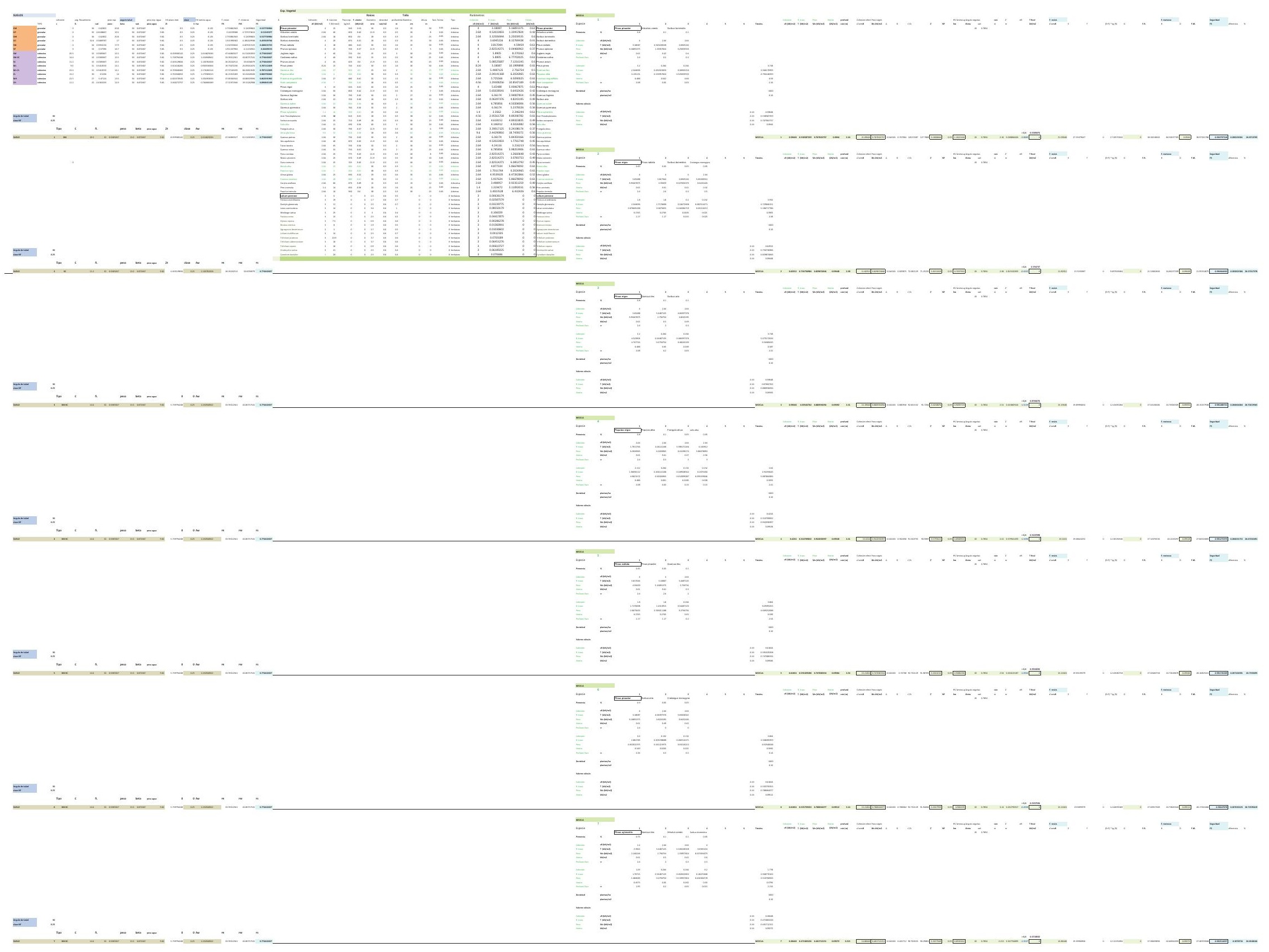




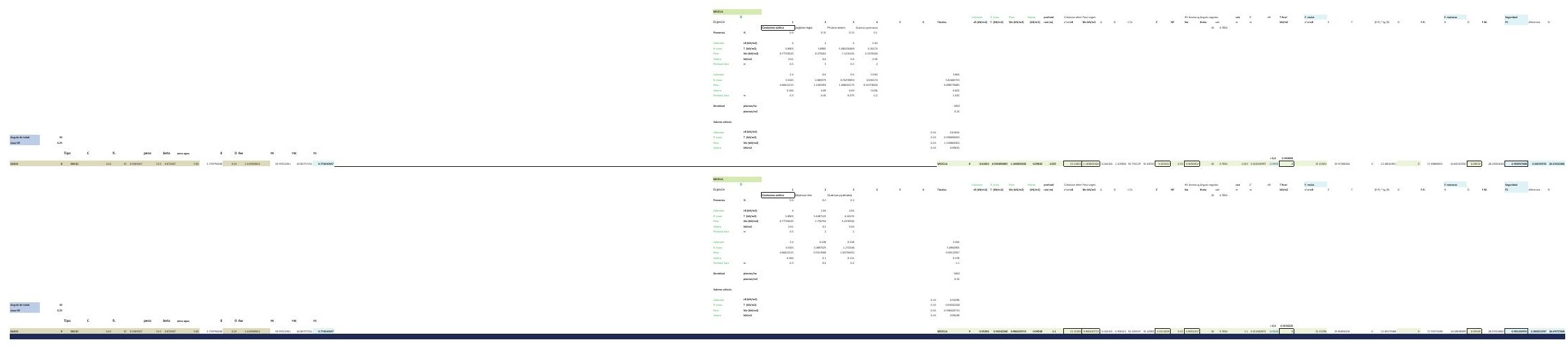




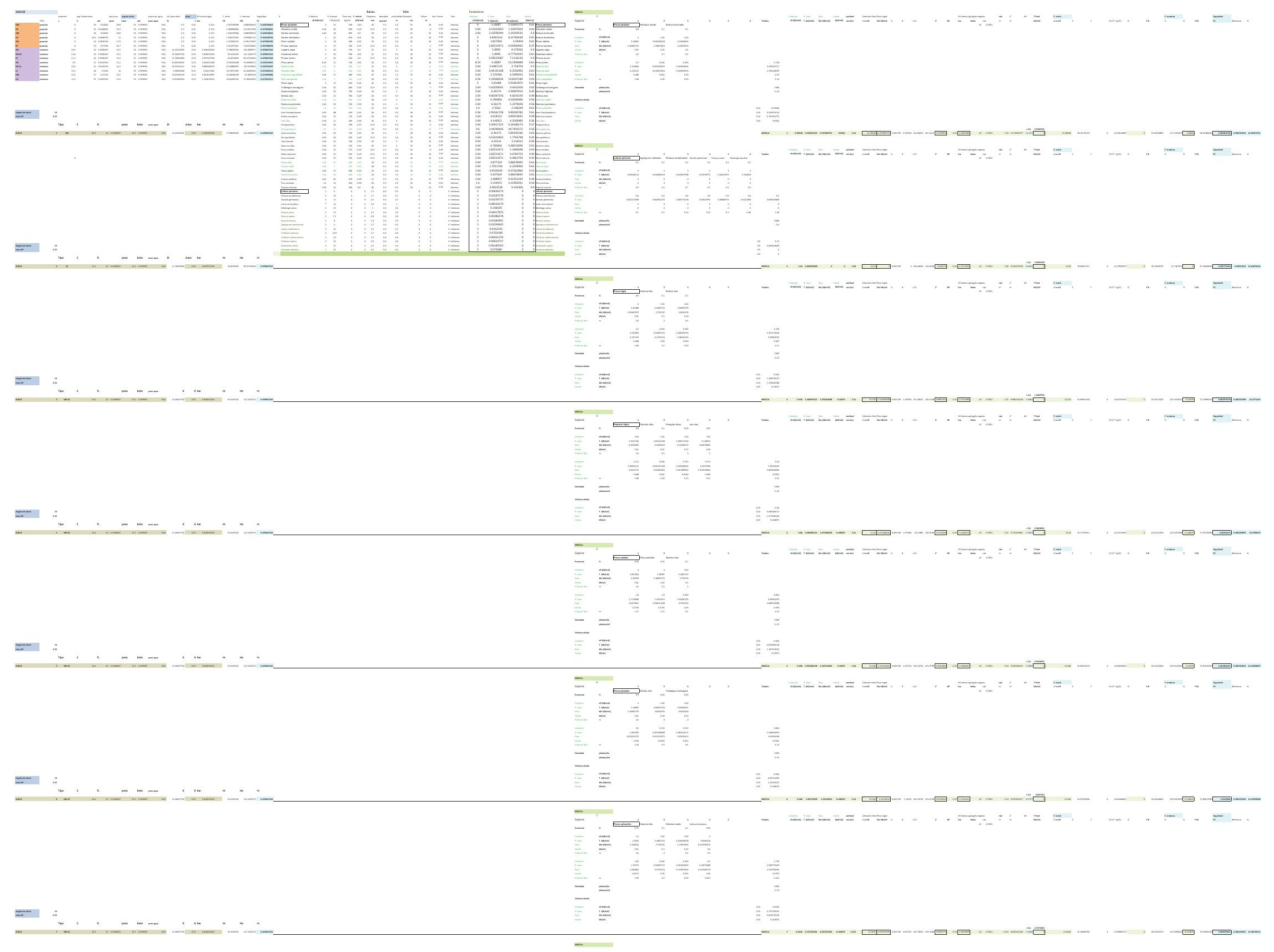




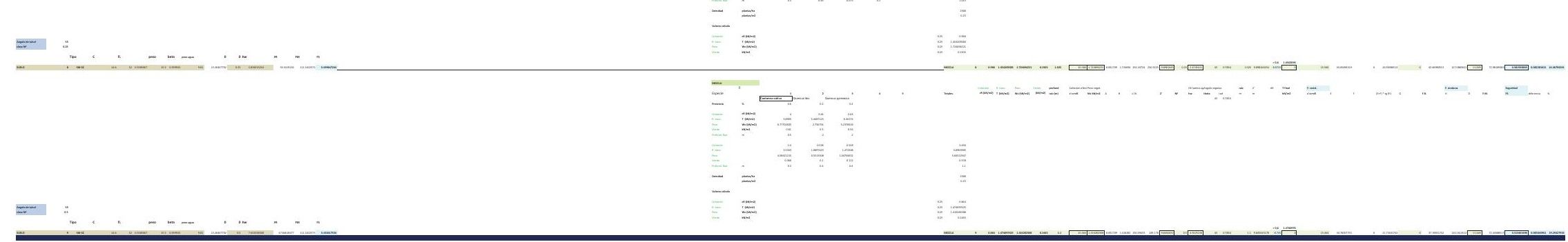




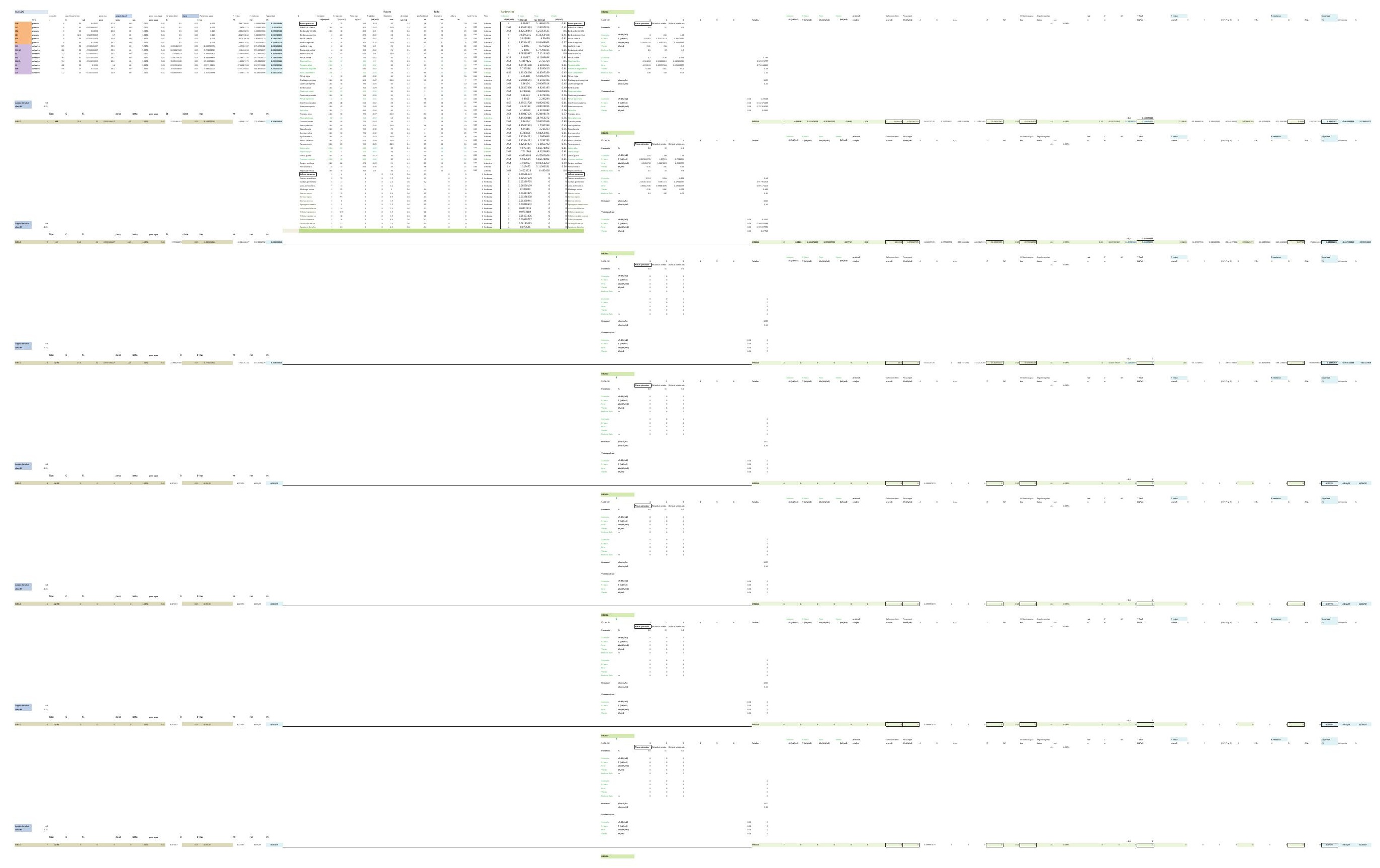




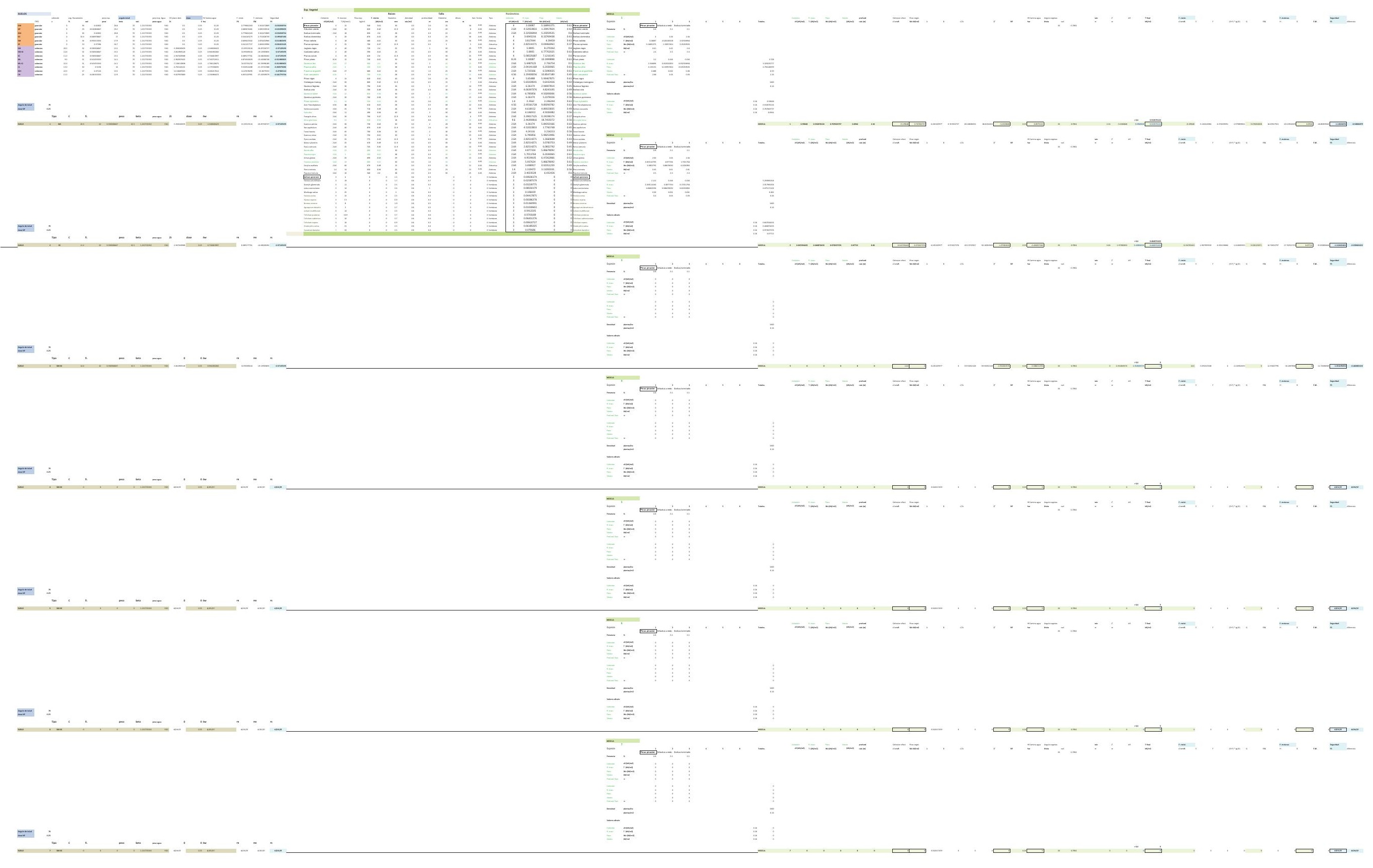




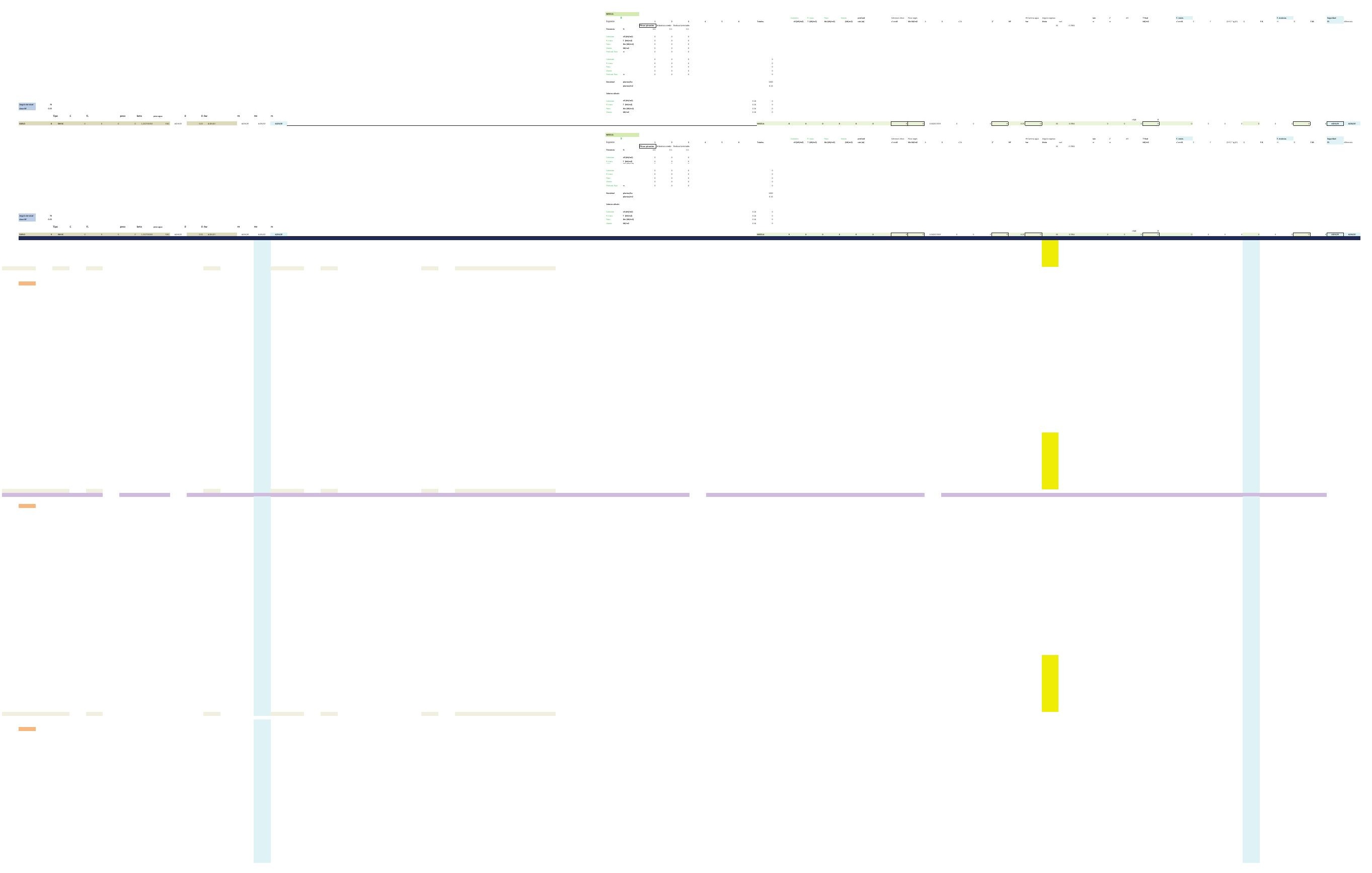




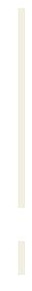




-




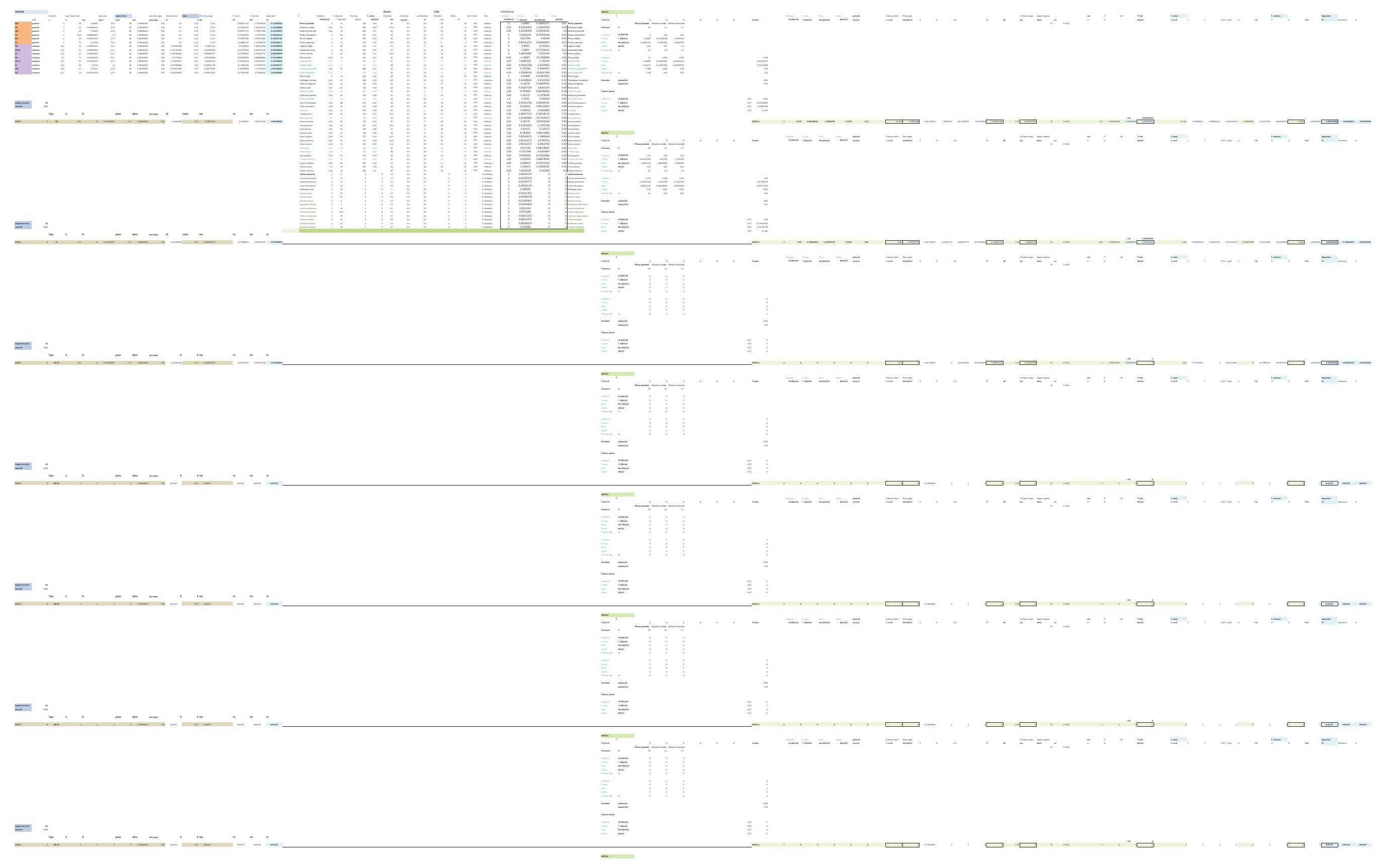


DESARROLLO DE UNA APLICACIÓN IMFORMÁTICA PARA EL CÁLCULO DE SOSTENIMIENTO DE TALUDES MEDIANTE VEGETACIÓN

B02. DENSIDAD DE PLANTACIÓN: 1.600 plantas/ha.

\section{B02-4.POSICIÓN N.F. 4}

INCLINACIÓN DE TALUD 6-100

INCLINACIÓN DE TALUD 10-200

INCLINACIÓN DE TALUD 20-30

INCLINACIÓN DE TALUD 30-40

INCLINACIÓN DE TALUD $35^{\circ}$

INCLINACIÓN DE TALUD 40-50

INCLINACIÓN DE TALUD 50-550

INCLINACIÓN DE TALUD 55-60

INCLINACIÓN DE TALUD 60-700

INCLINACIÓN DE TALUD 70-80 


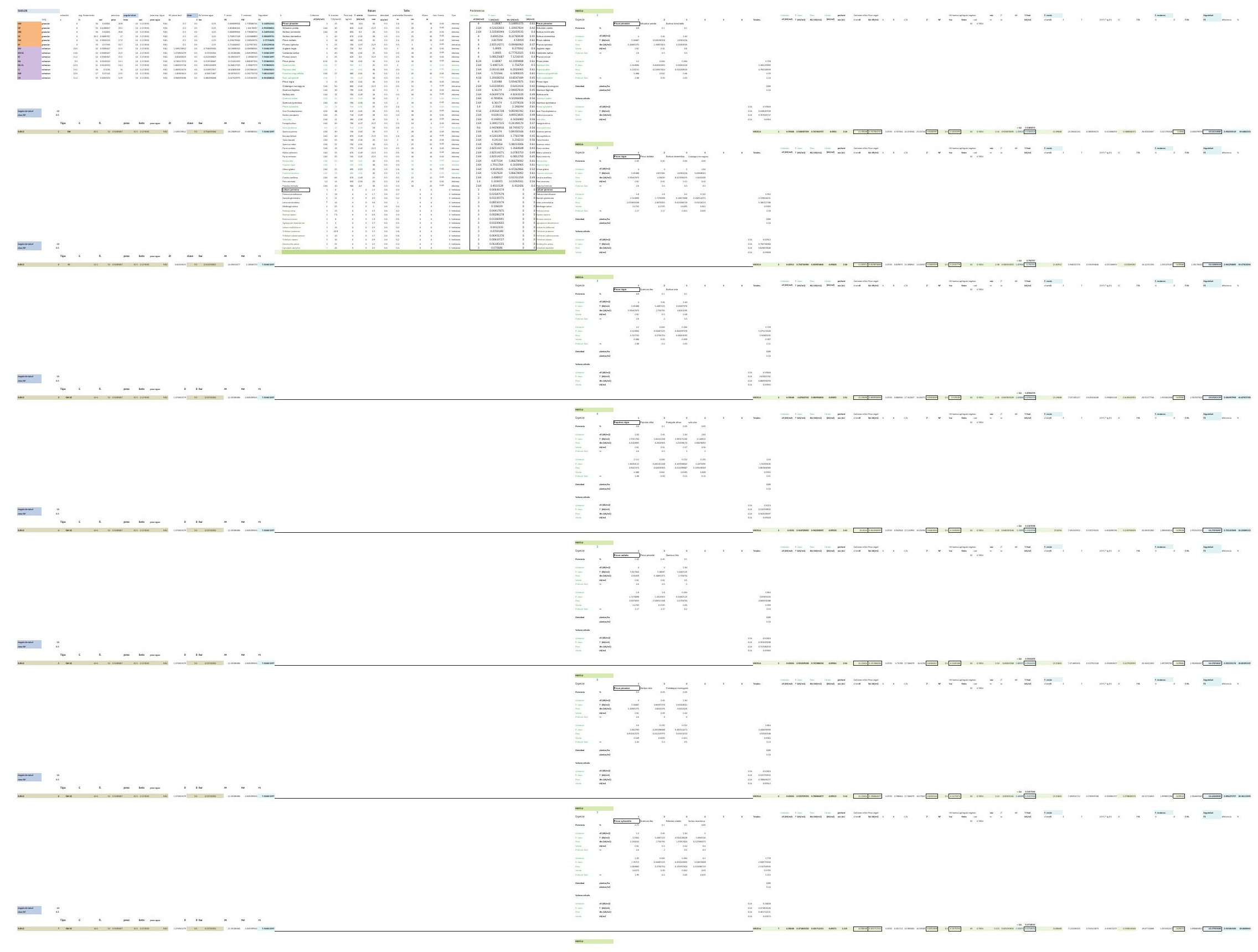




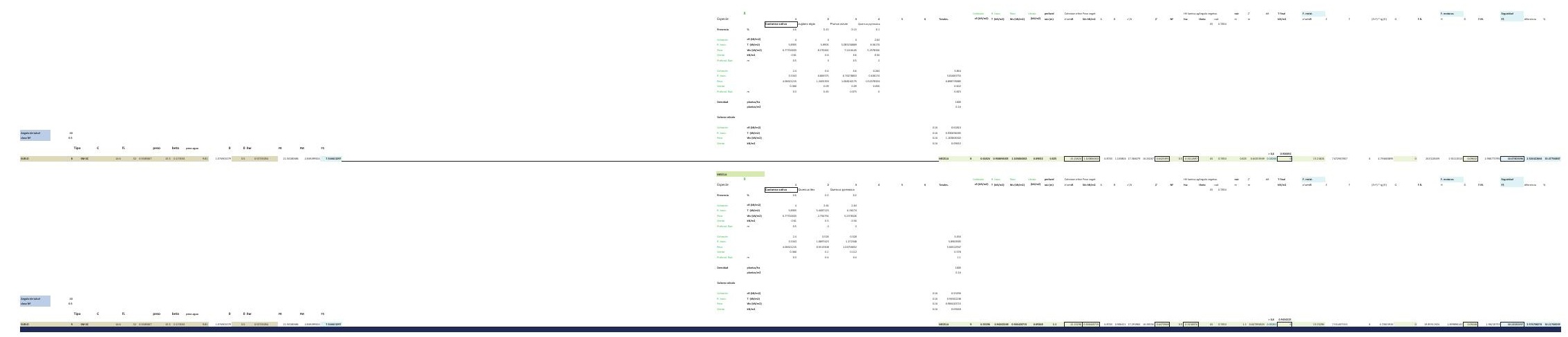




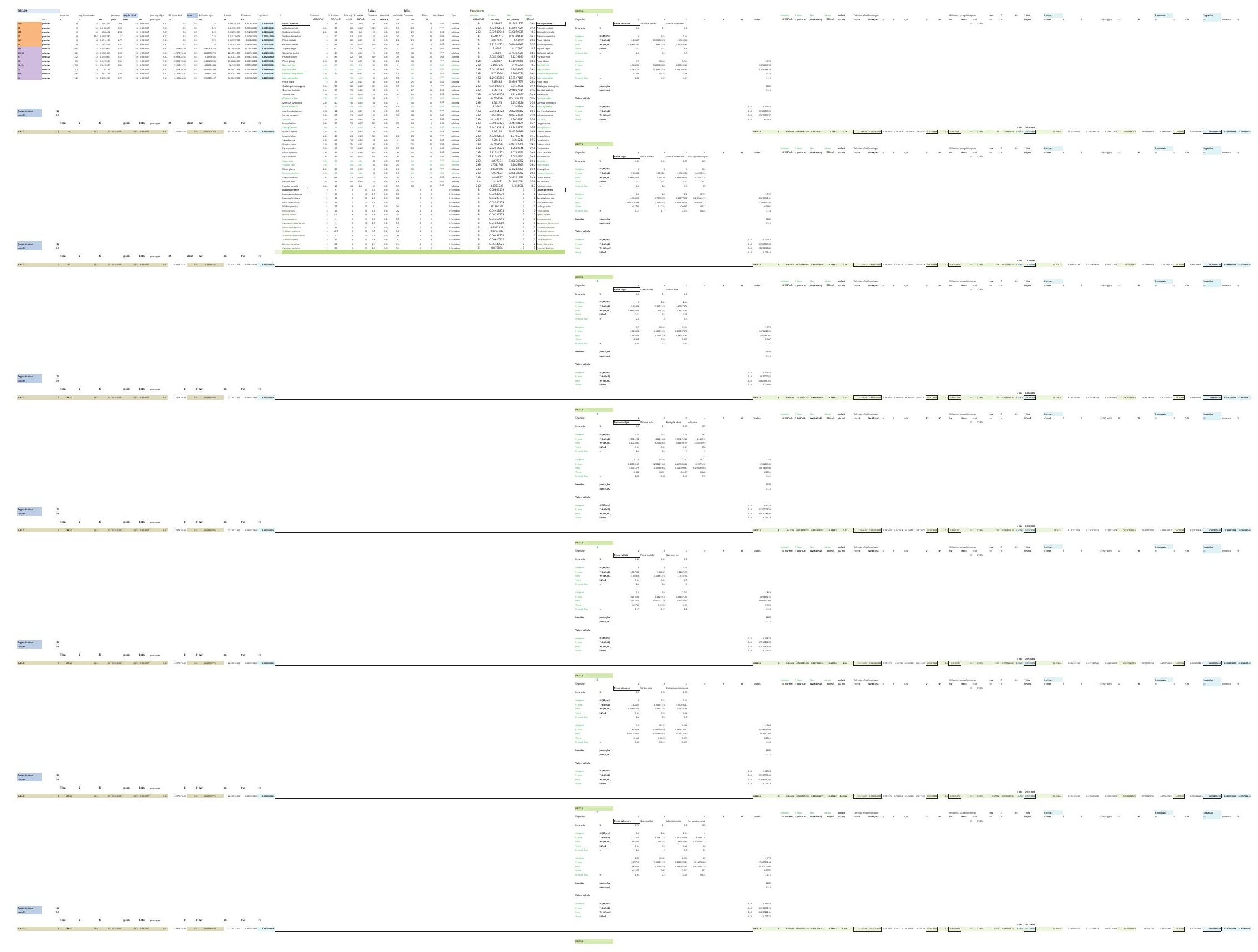




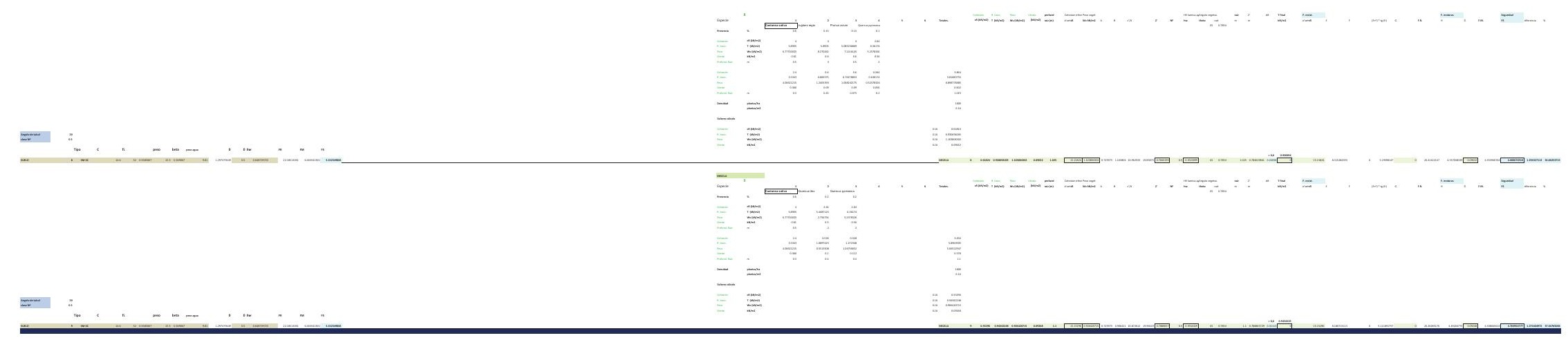




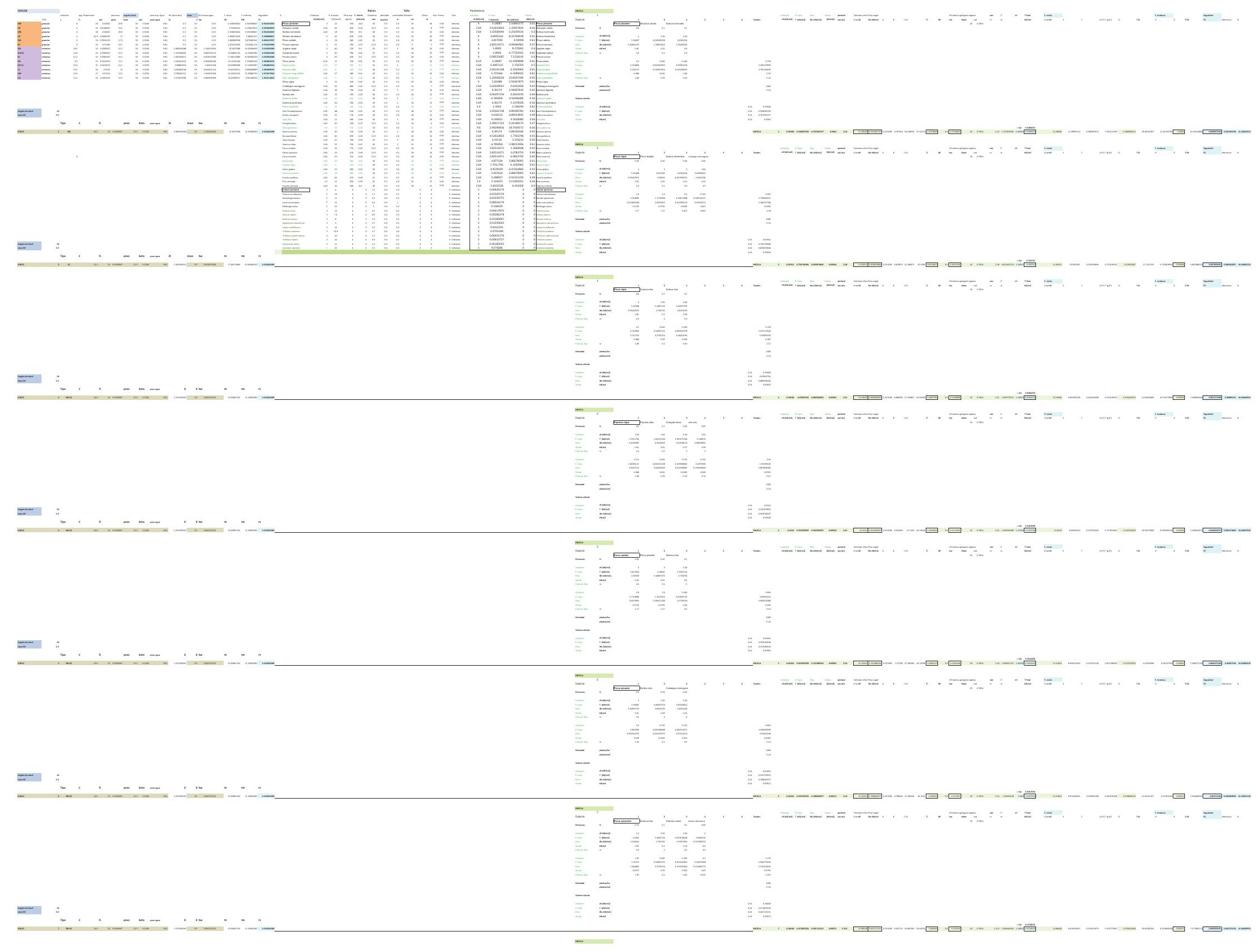




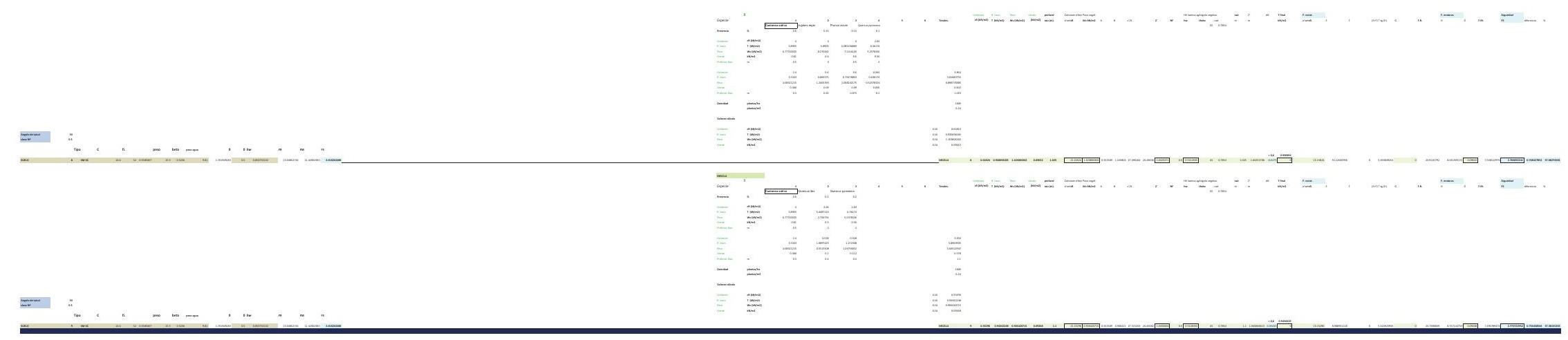




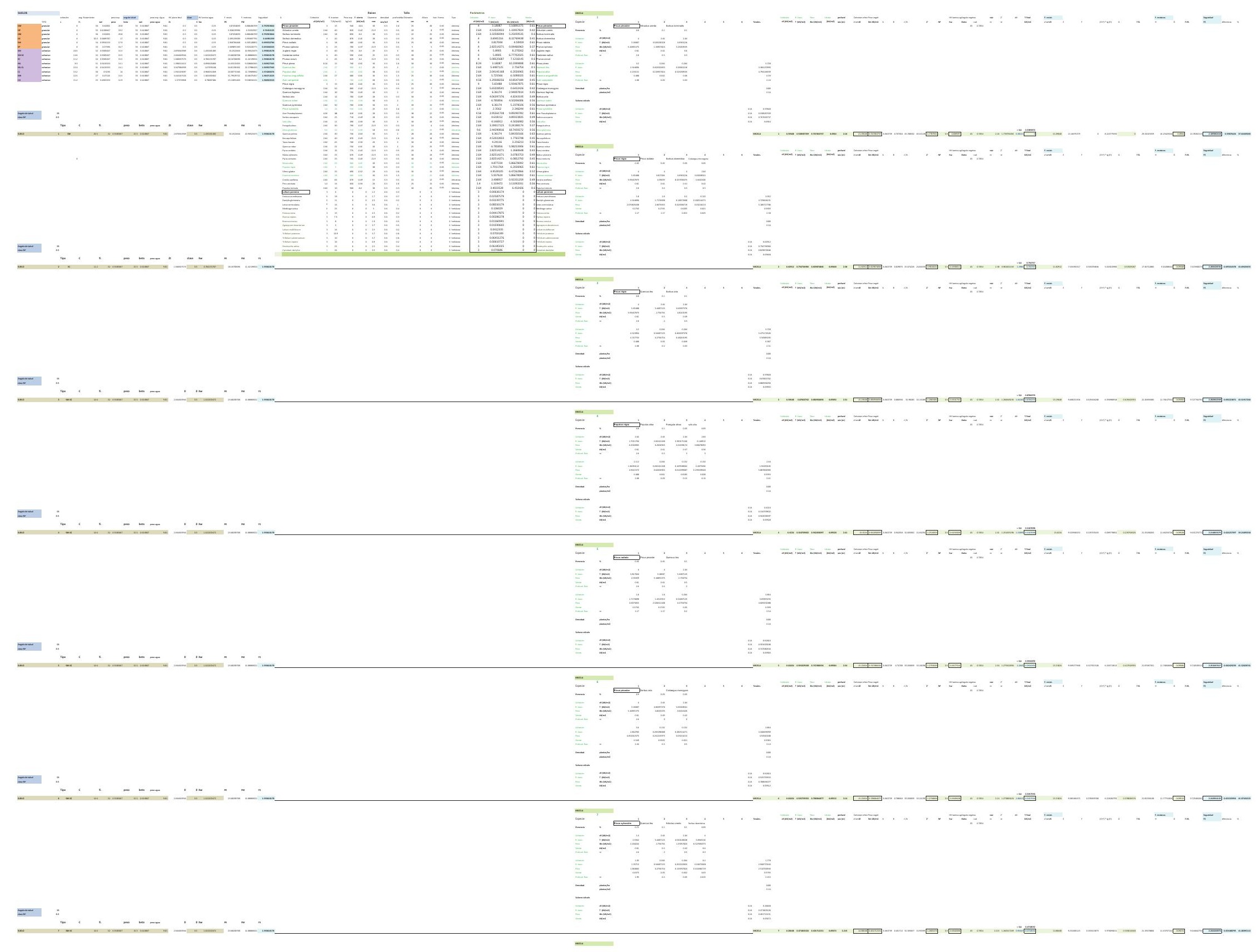




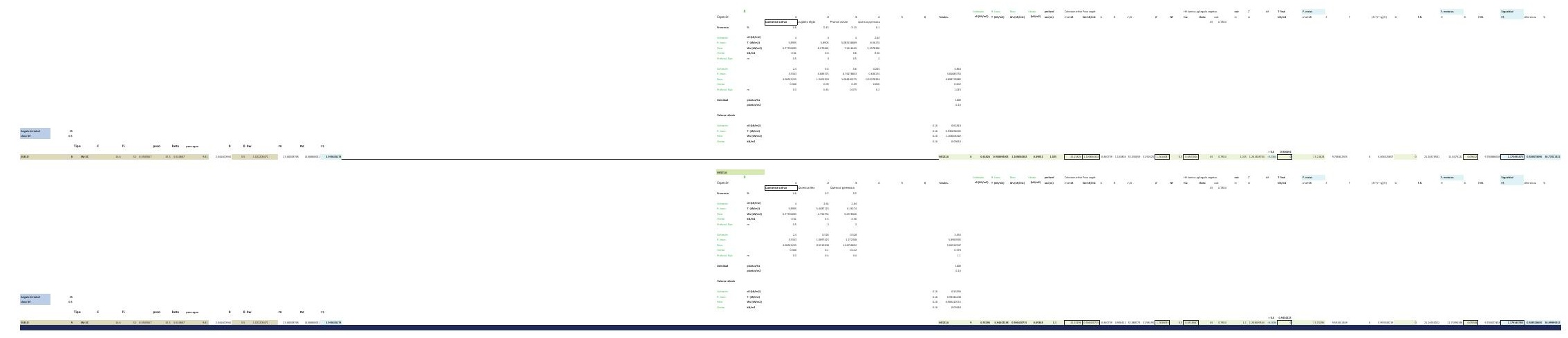




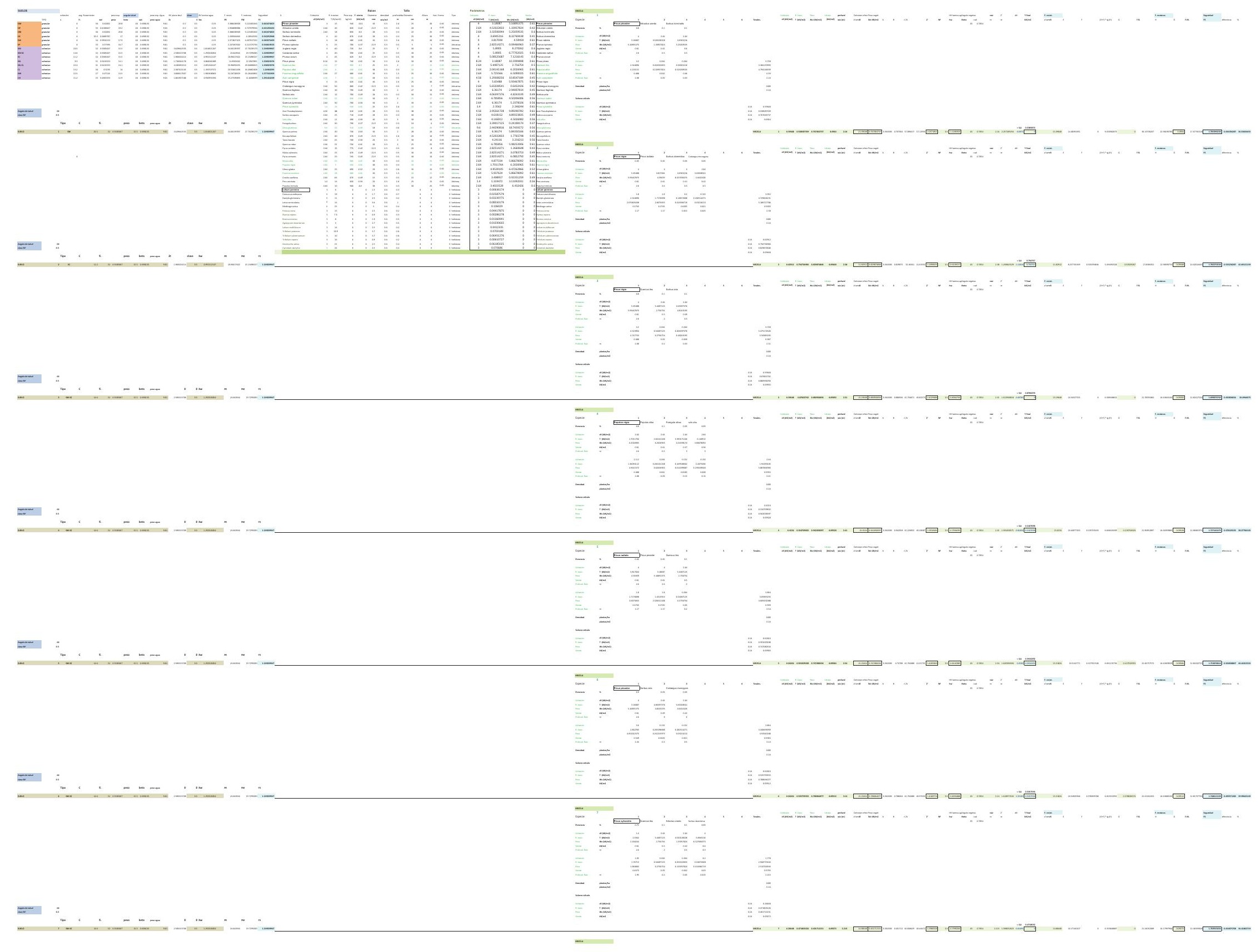




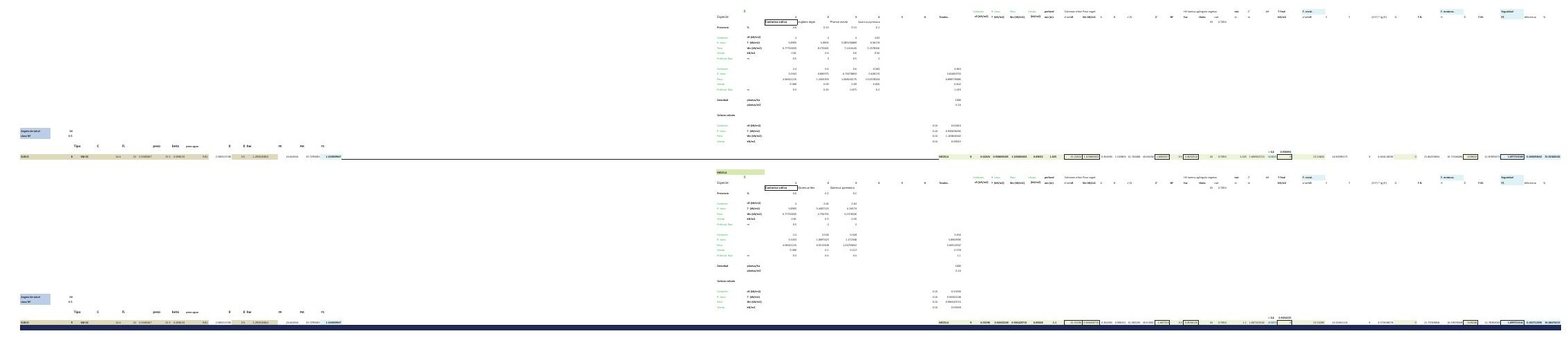




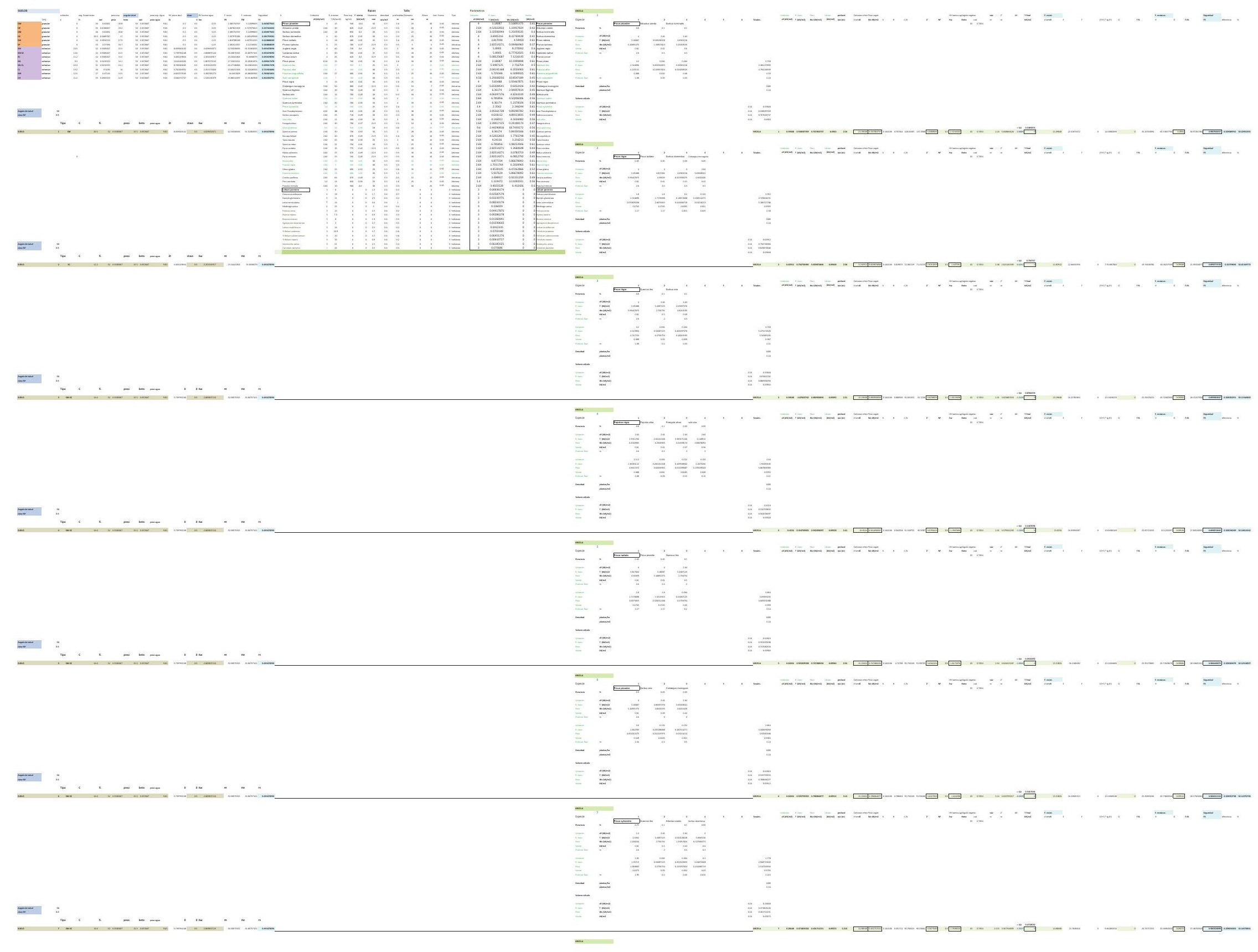




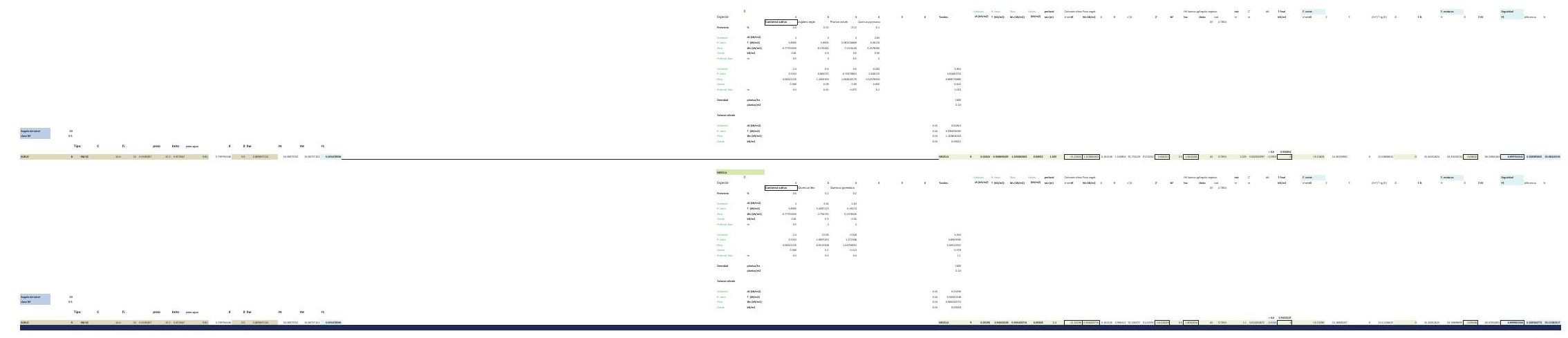




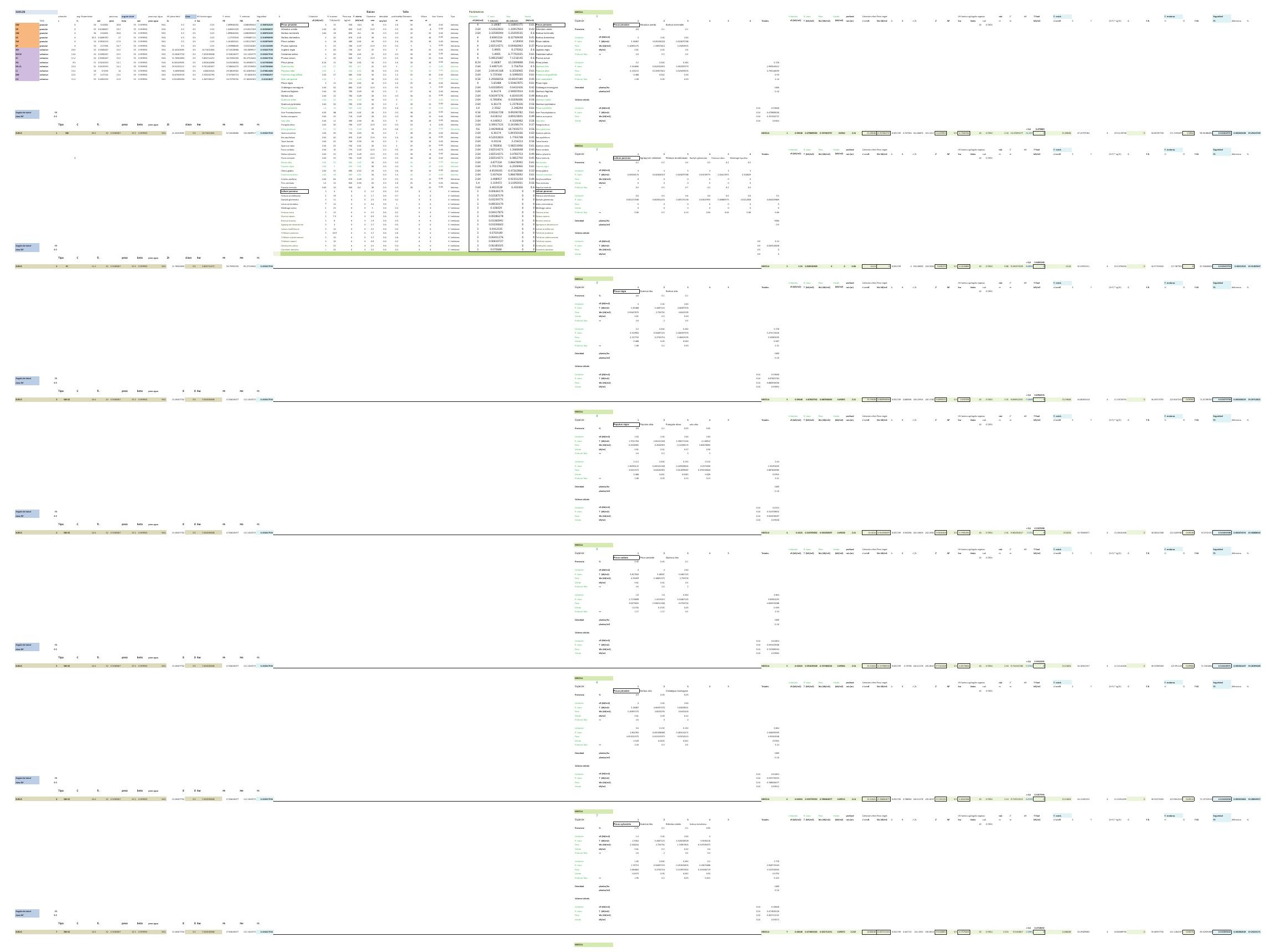




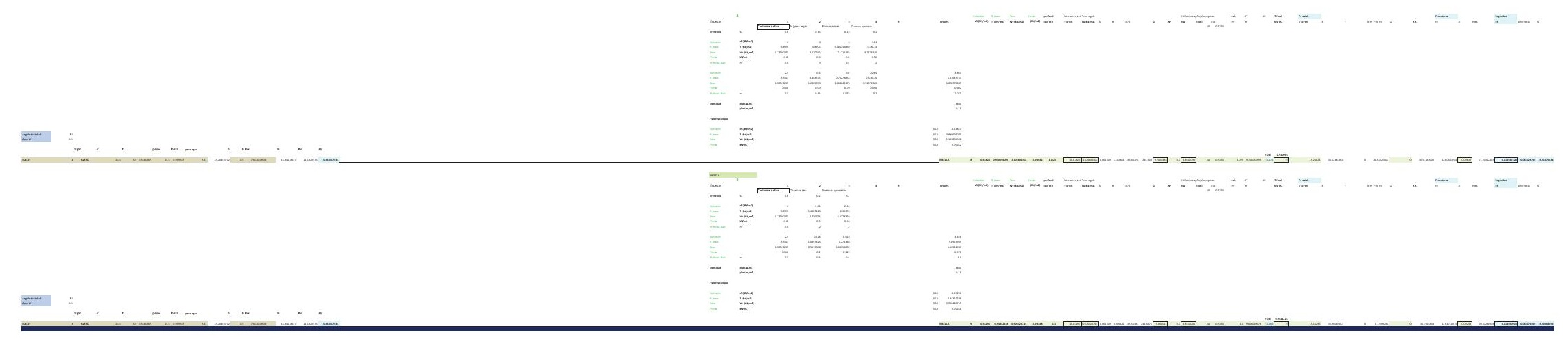




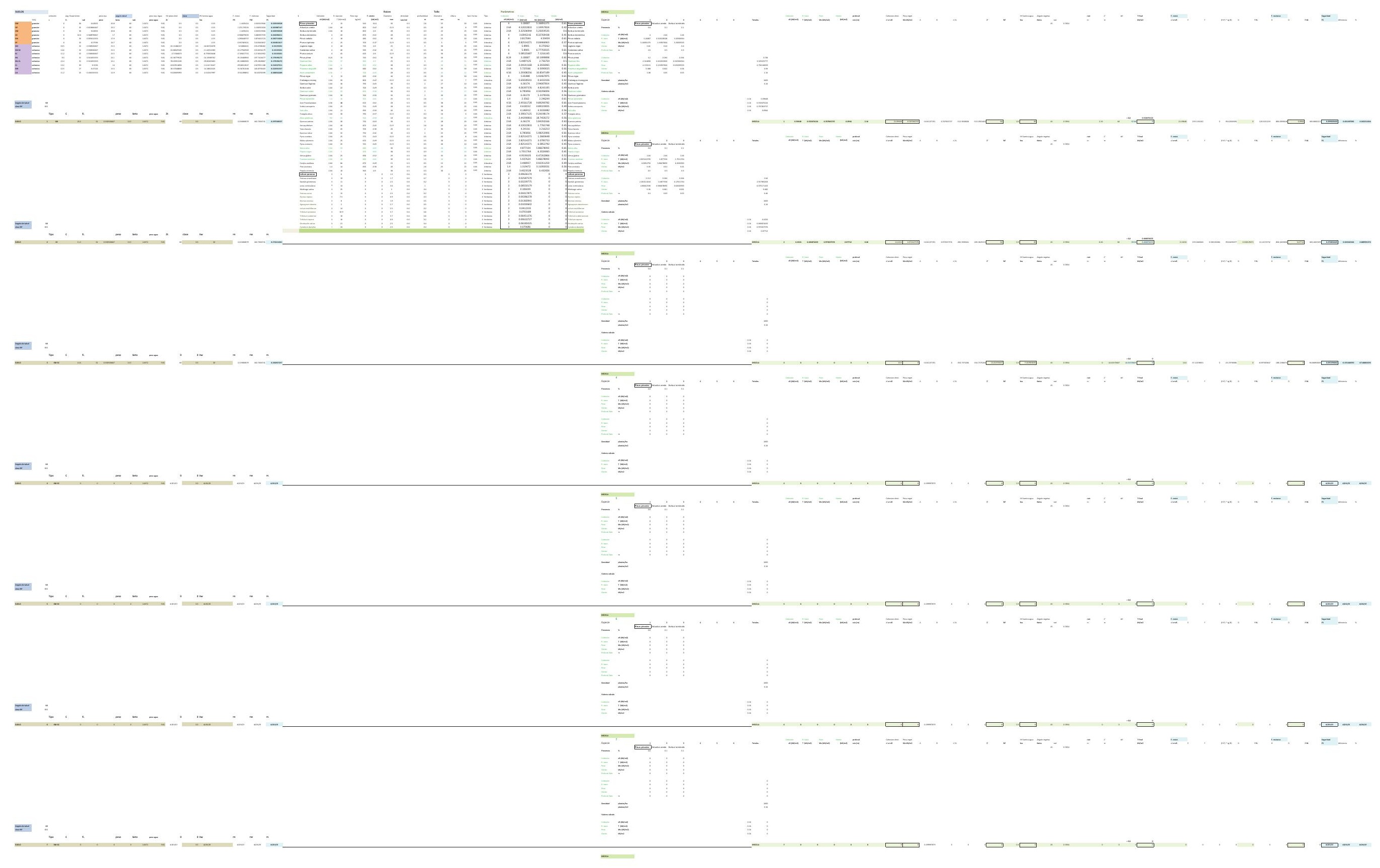


$-\div=\square=$

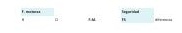




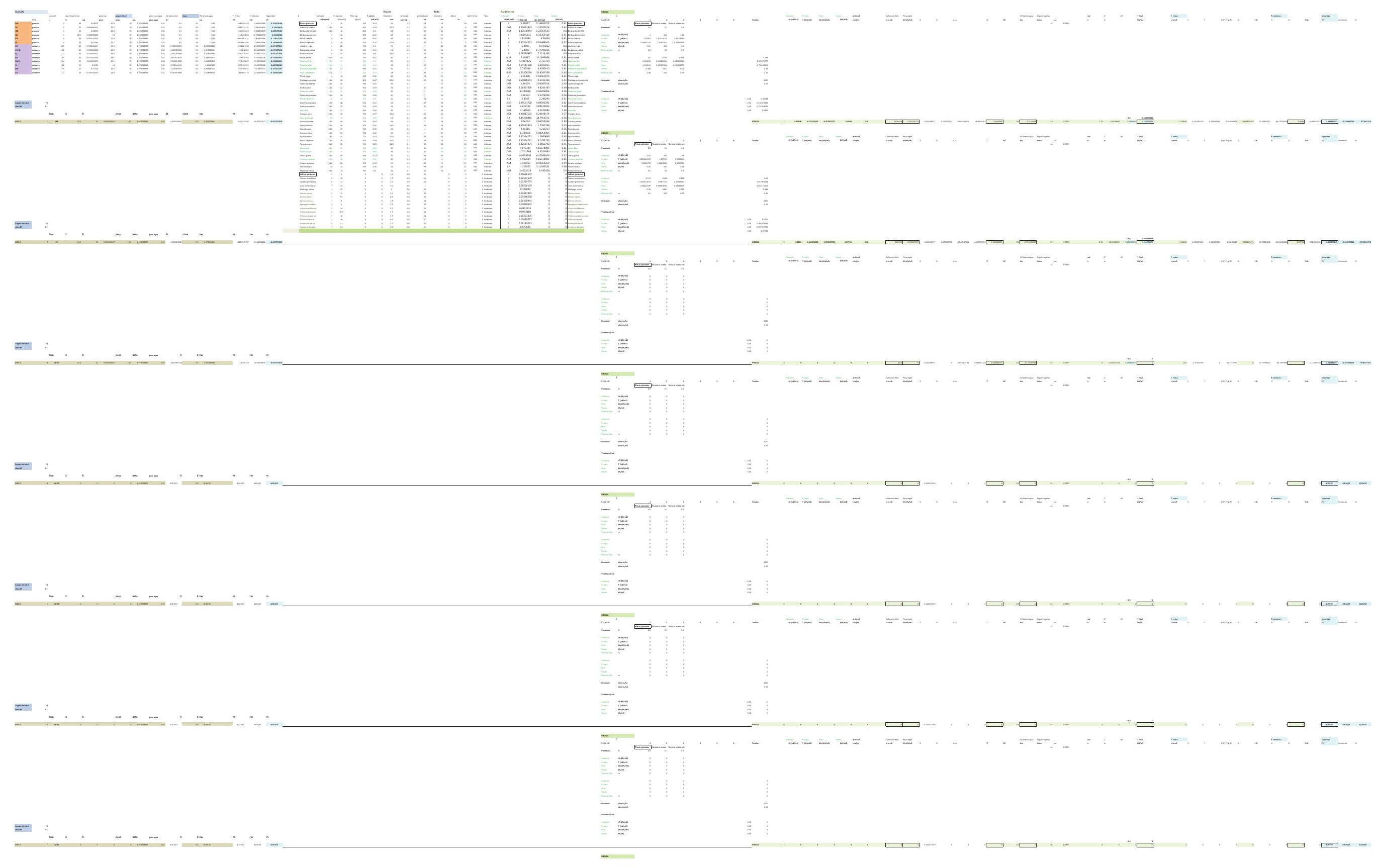


DESARROLLO DE UNA APLICACIÓN IMFORMÁTICA PARA EL CÁLCULO DE SOSTENIMIENTO DE TALUDES MEDIANTE VEGETACIÓN

B02. DENSIDAD DE PLANTACIÓN: 1.600 plantas/ha.

\section{B02-5.POSICIÓN N.F. 5}

INCLINACIÓN DE TALUD 6-100

INCLINACIÓN DE TALUD 10-200

INCLINACIÓN DE TALUD 20-30

INCLINACIÓN DE TALUD 30-40

INCLINACIÓN DE TALUD $35^{\circ}$

INCLINACIÓN DE TALUD 40-50

INCLINACIÓN DE TALUD 50-550

INCLINACIÓN DE TALUD 55-60

INCLINACIÓN DE TALUD 60-700

INCLINACIÓN DE TALUD 70-80 


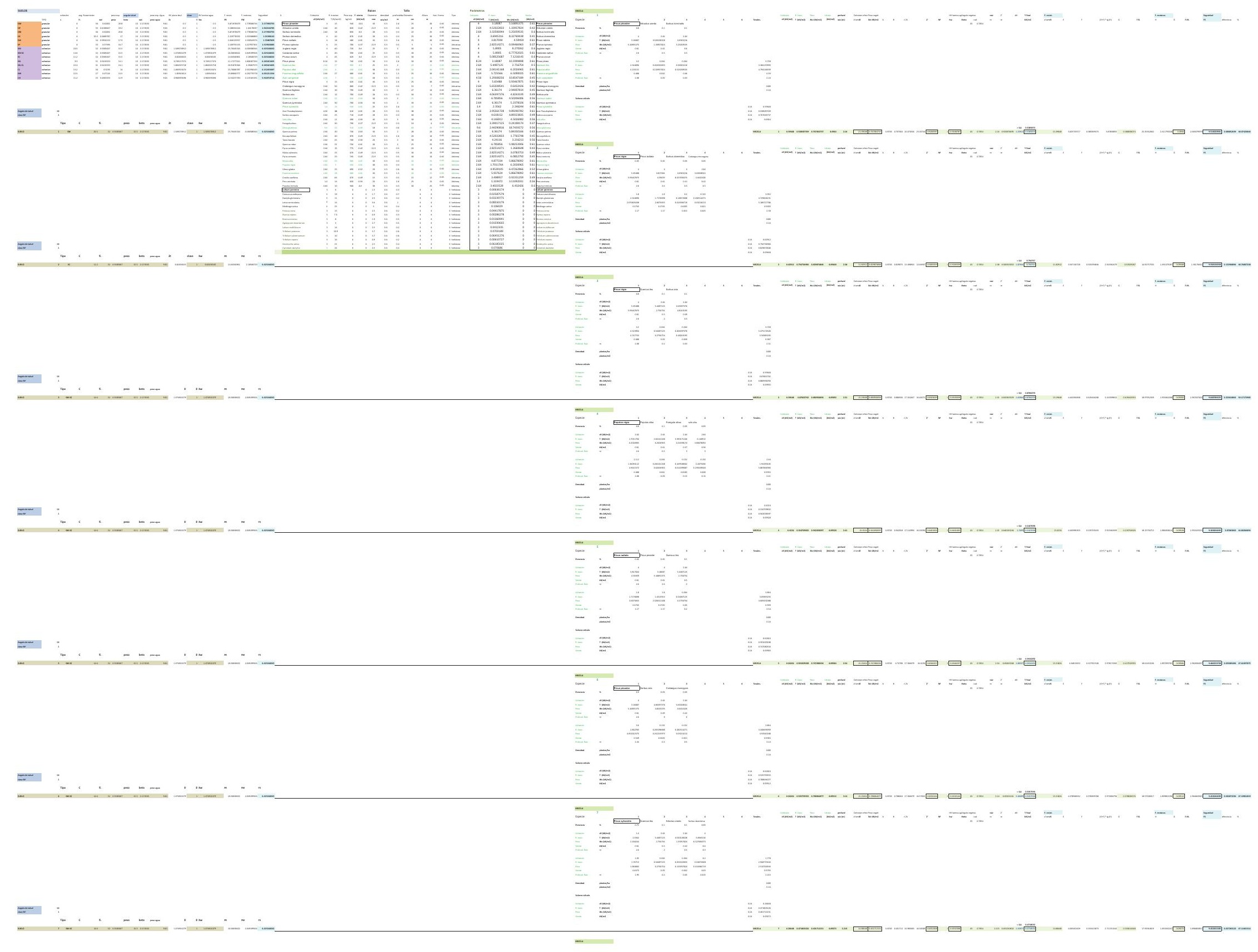




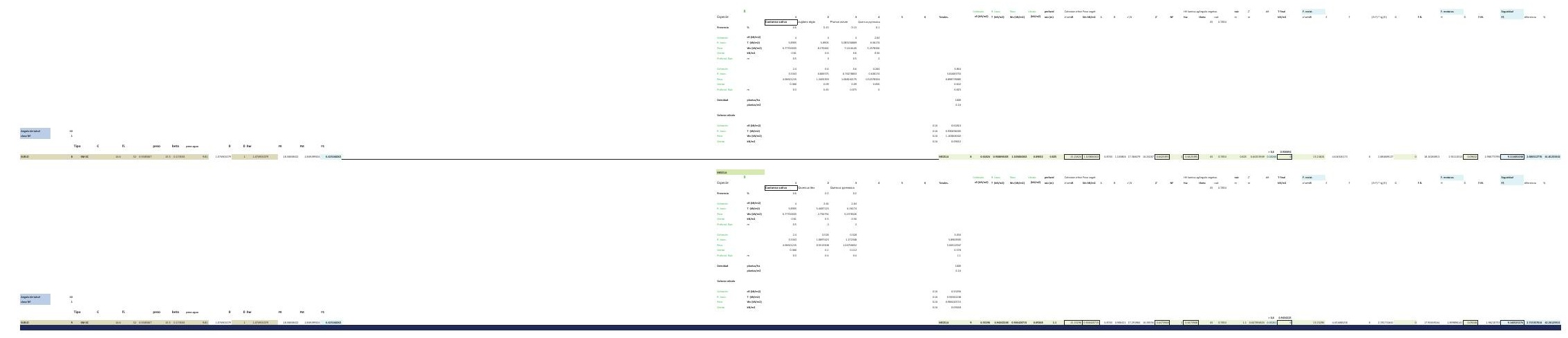




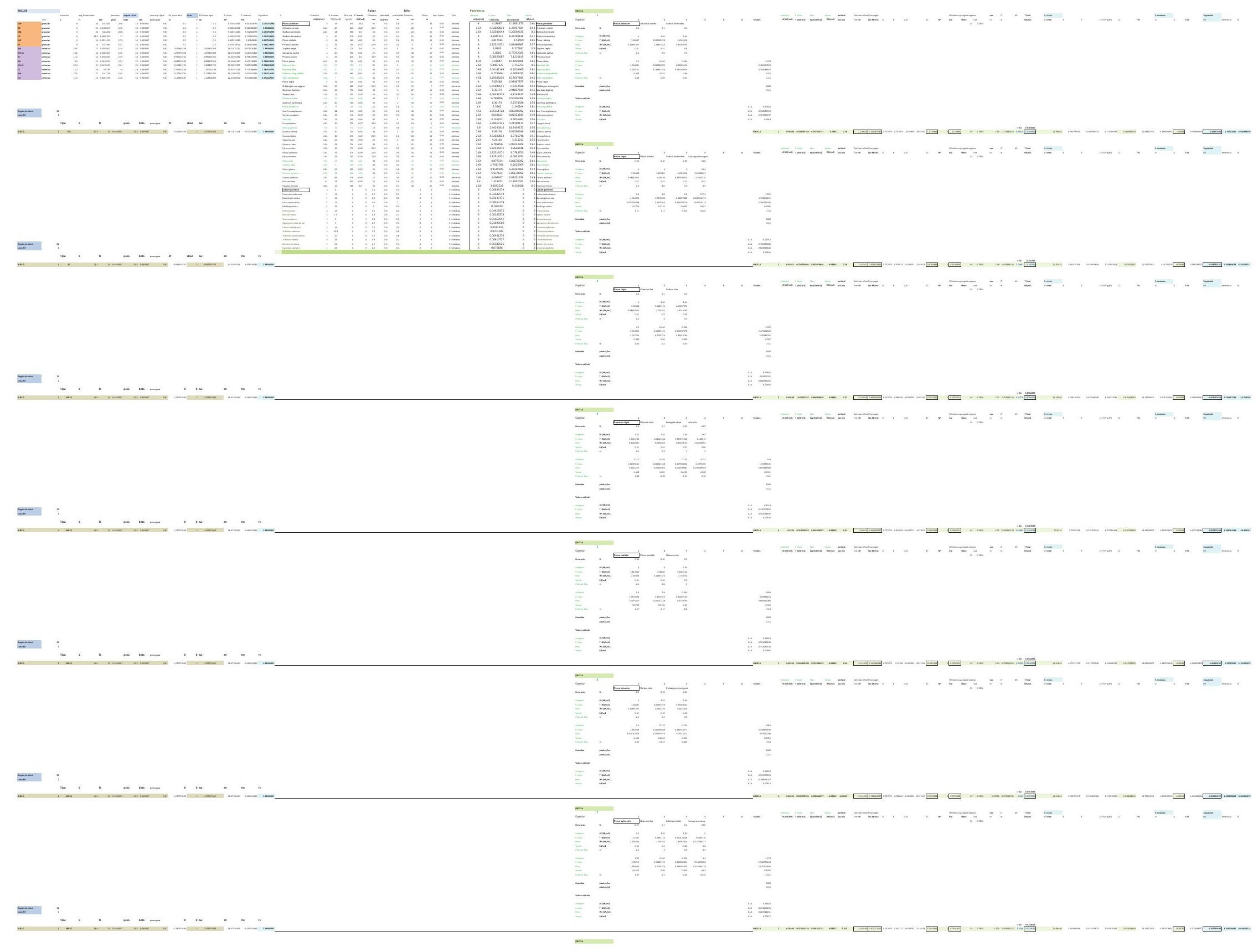




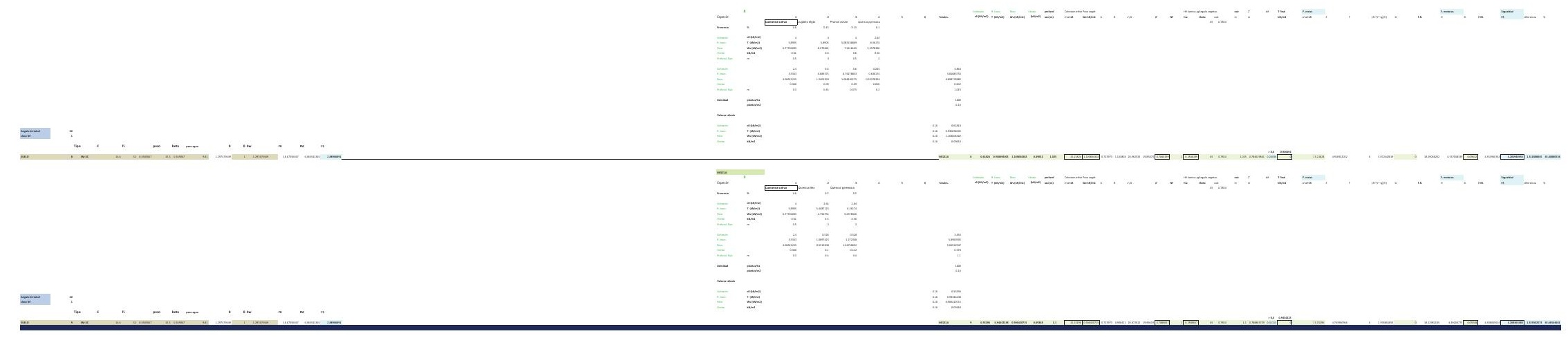




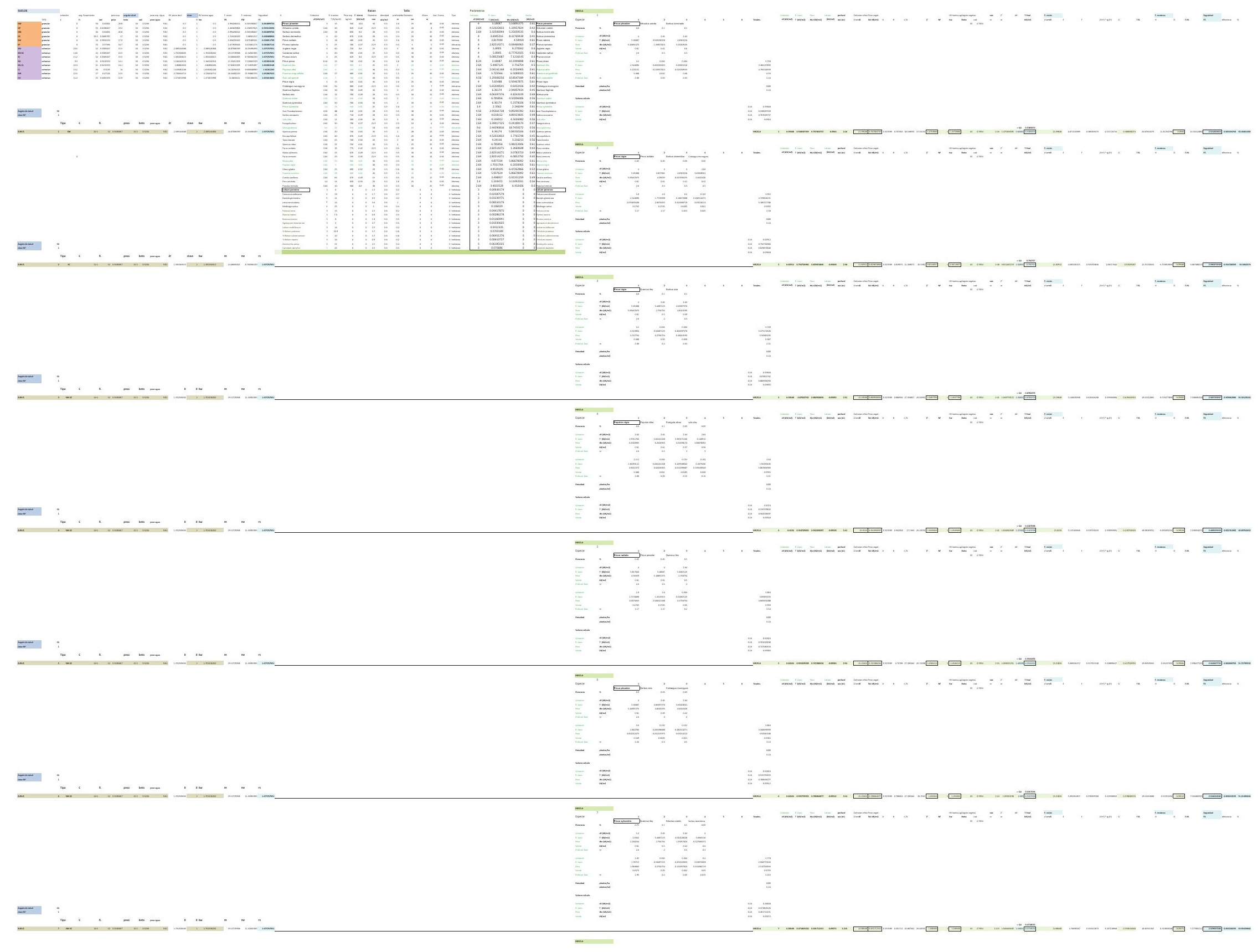




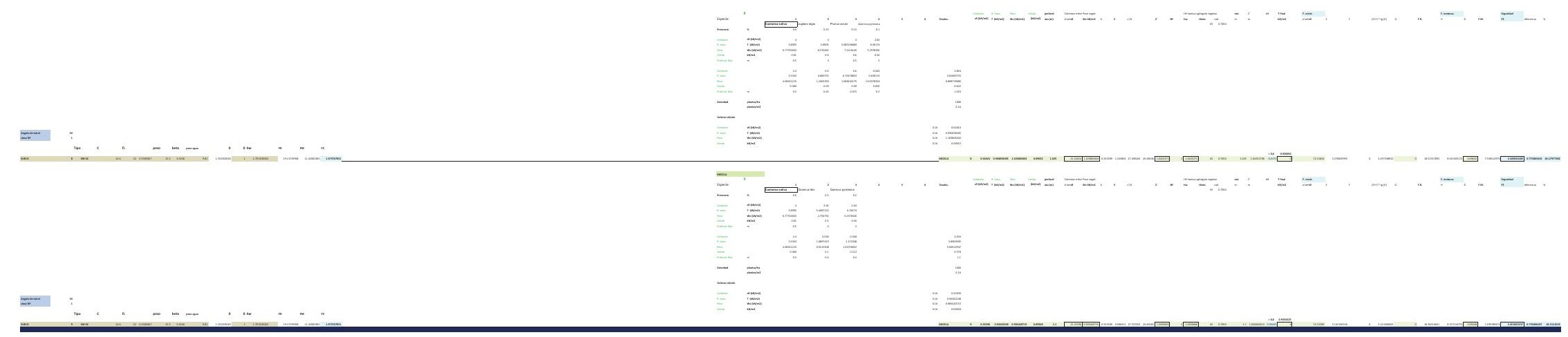




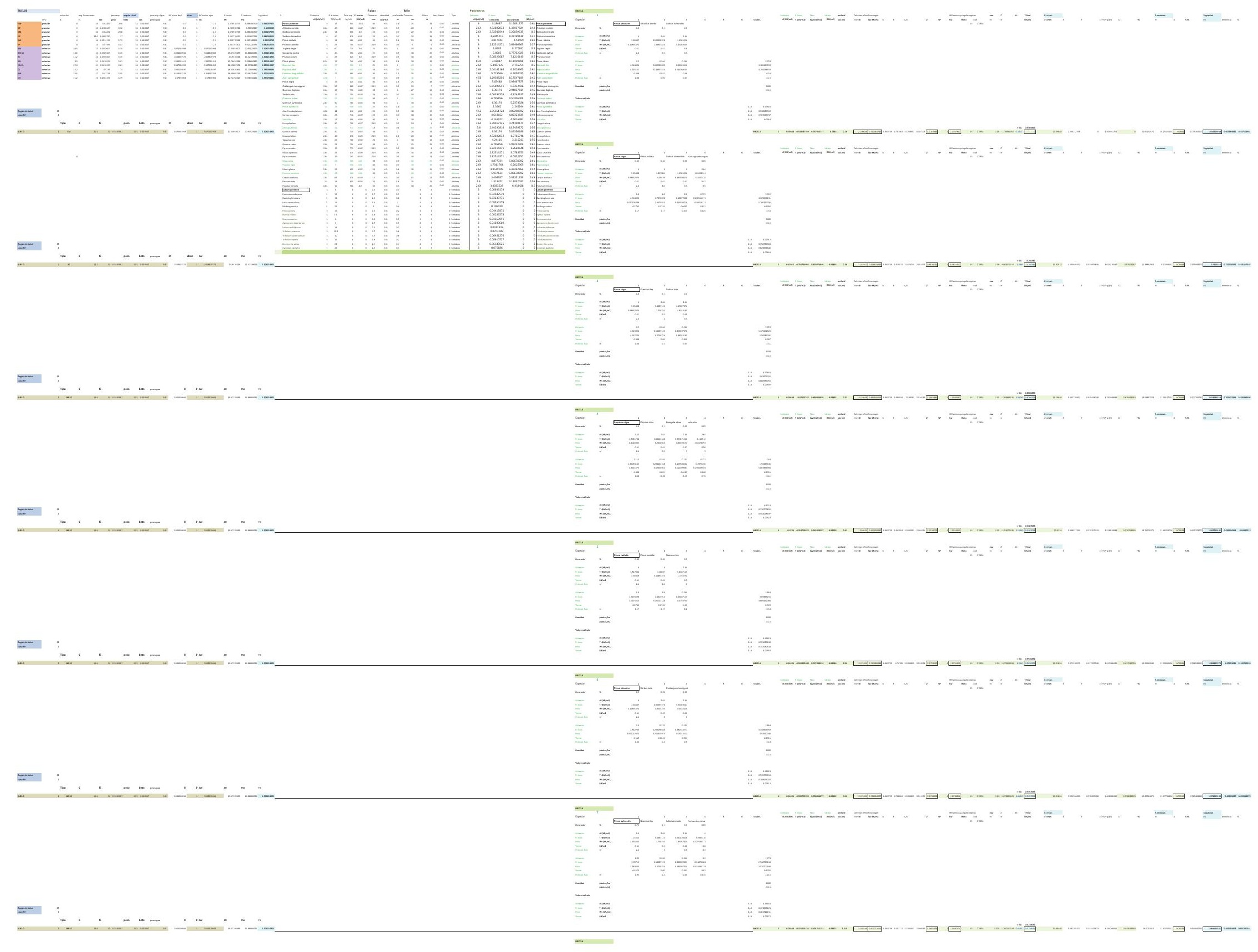




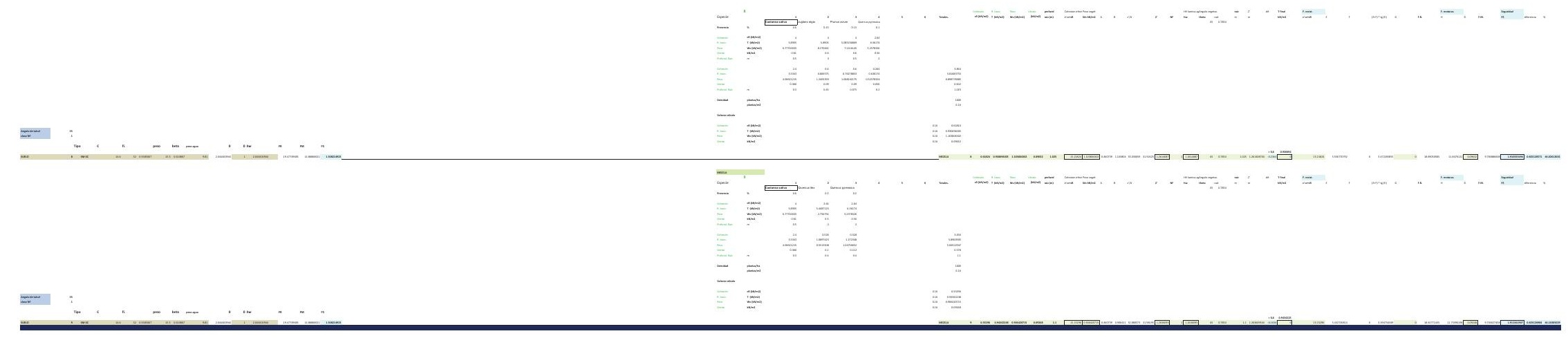




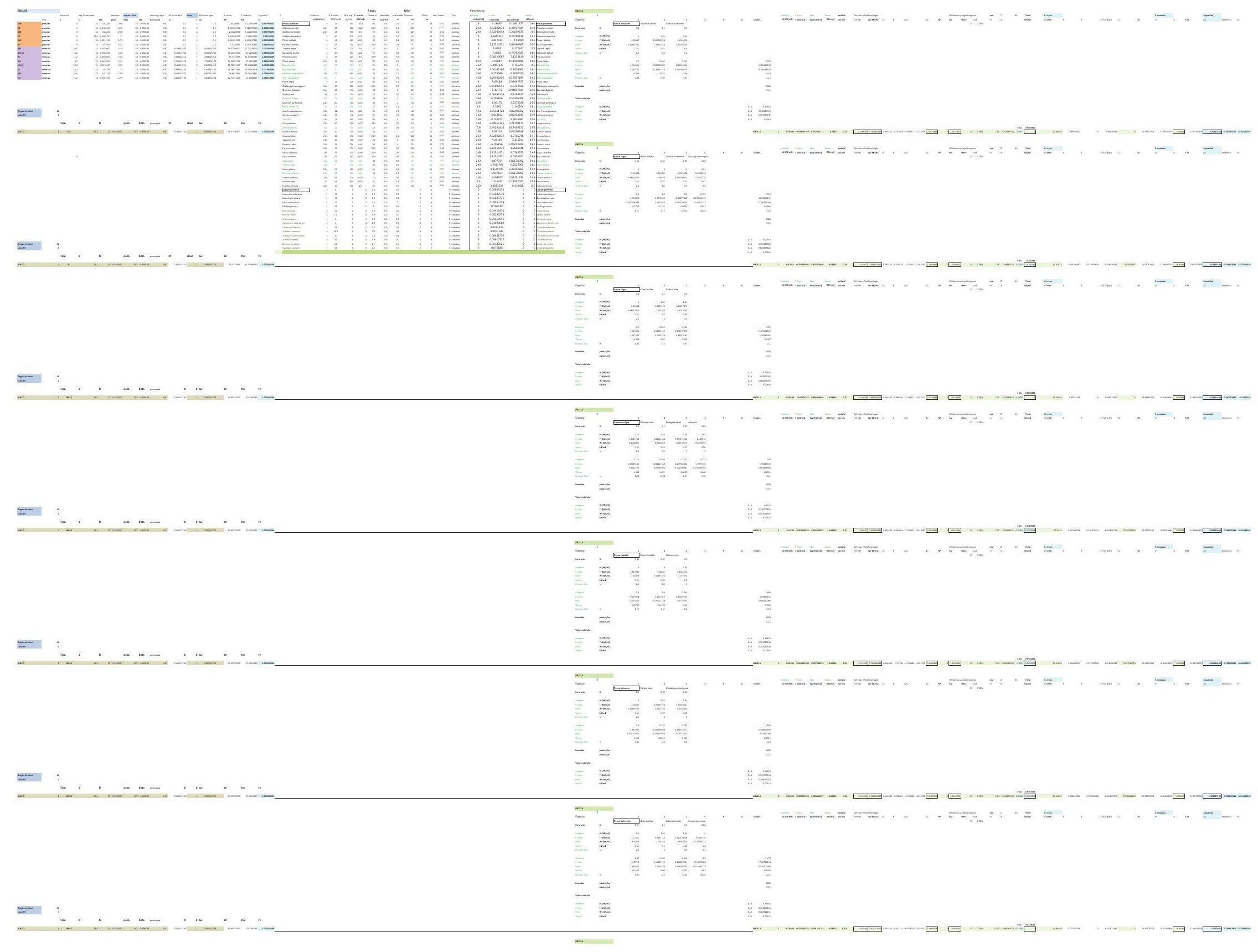




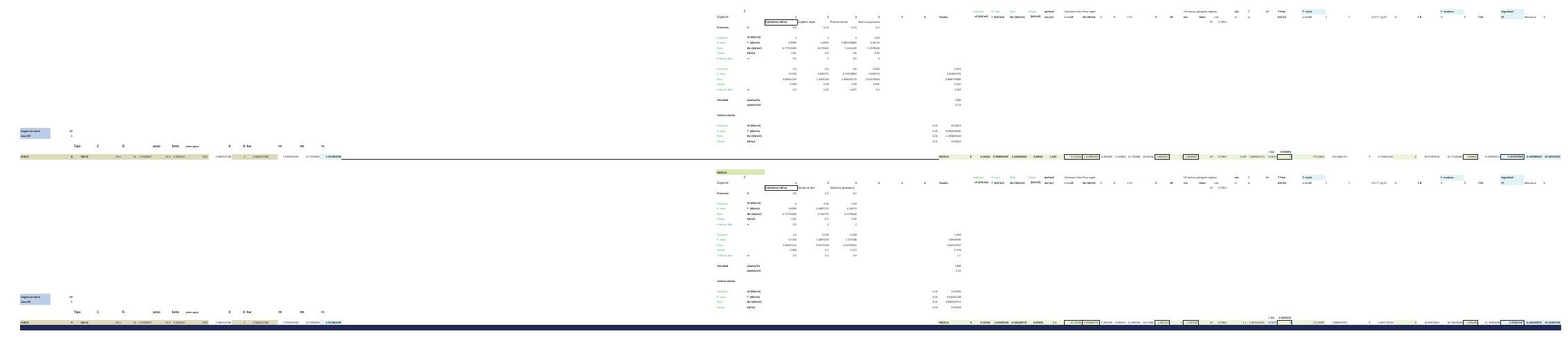




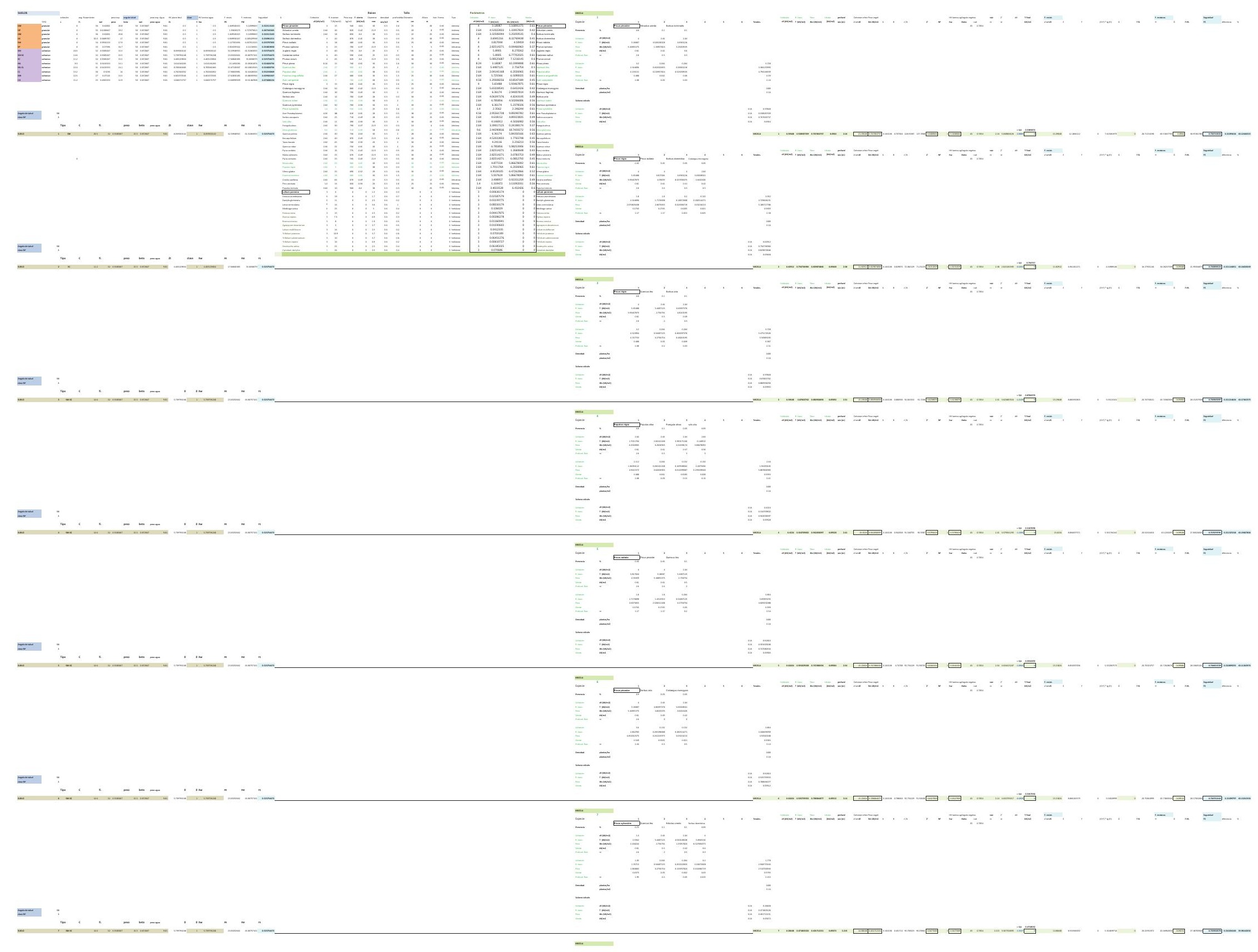




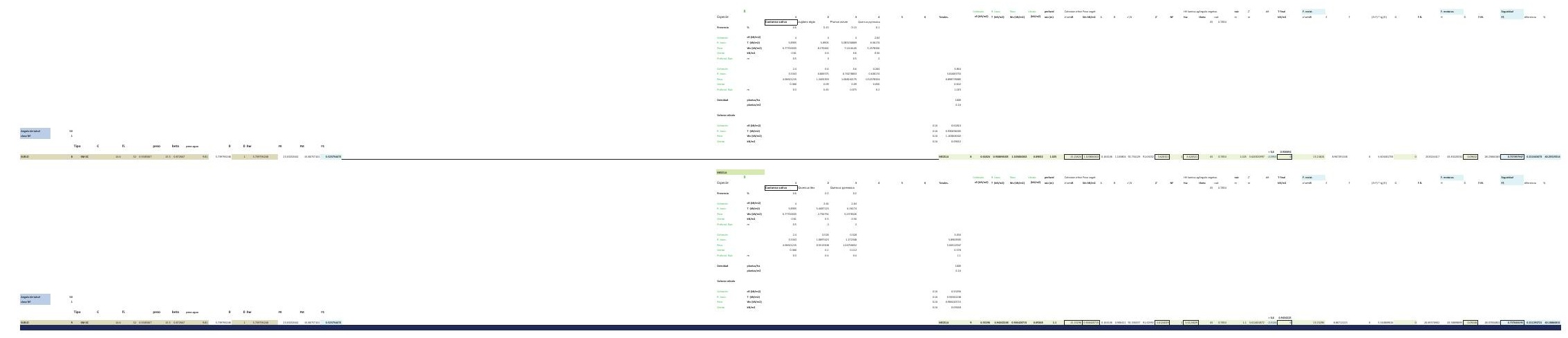




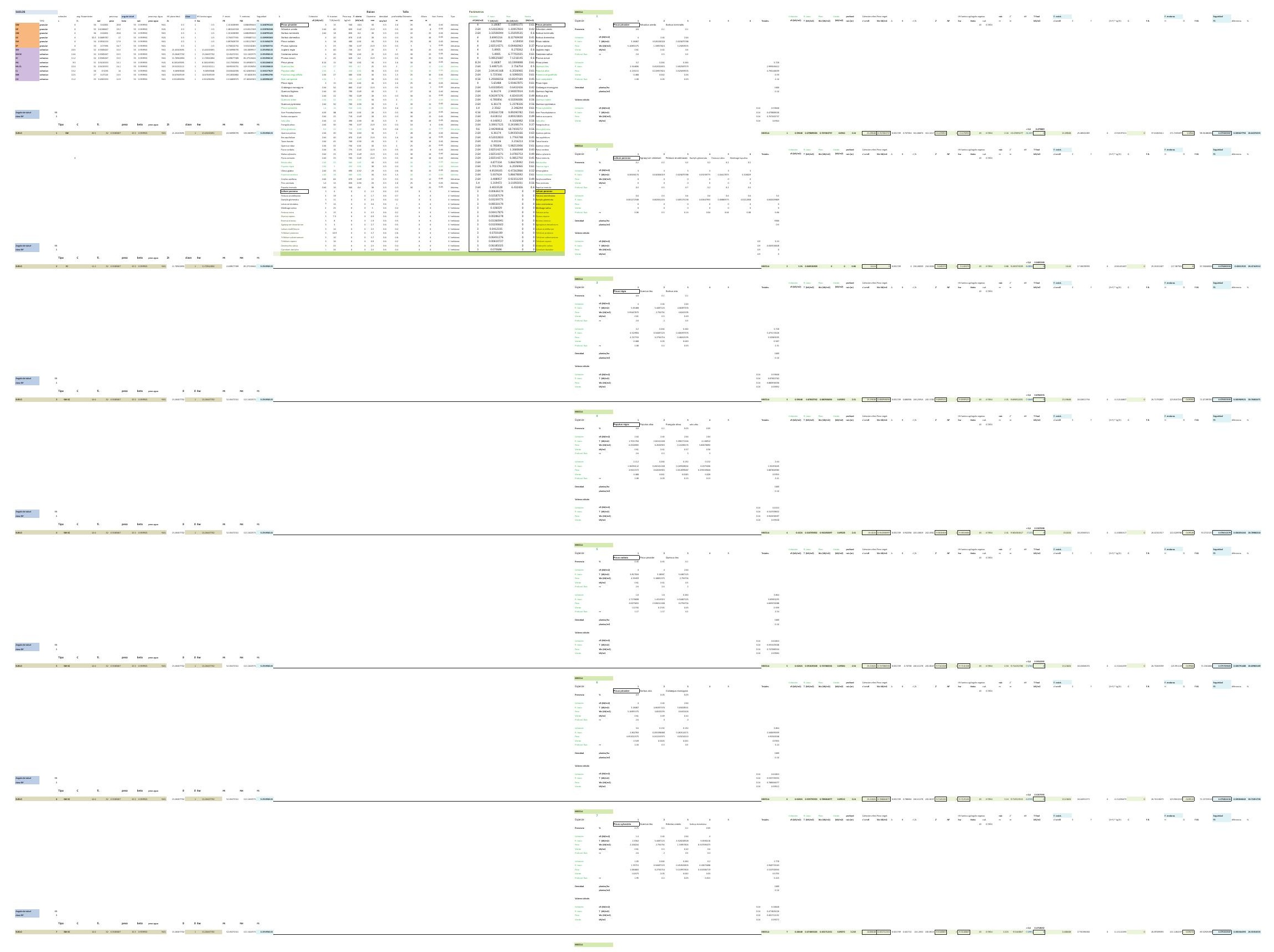


$=$

$=$

-

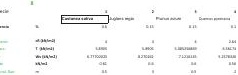

$\stackrel{*}{*}=$

$=$

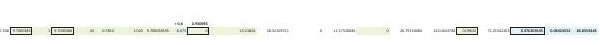

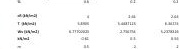

$\pm=$

$\bar{E}=$ 


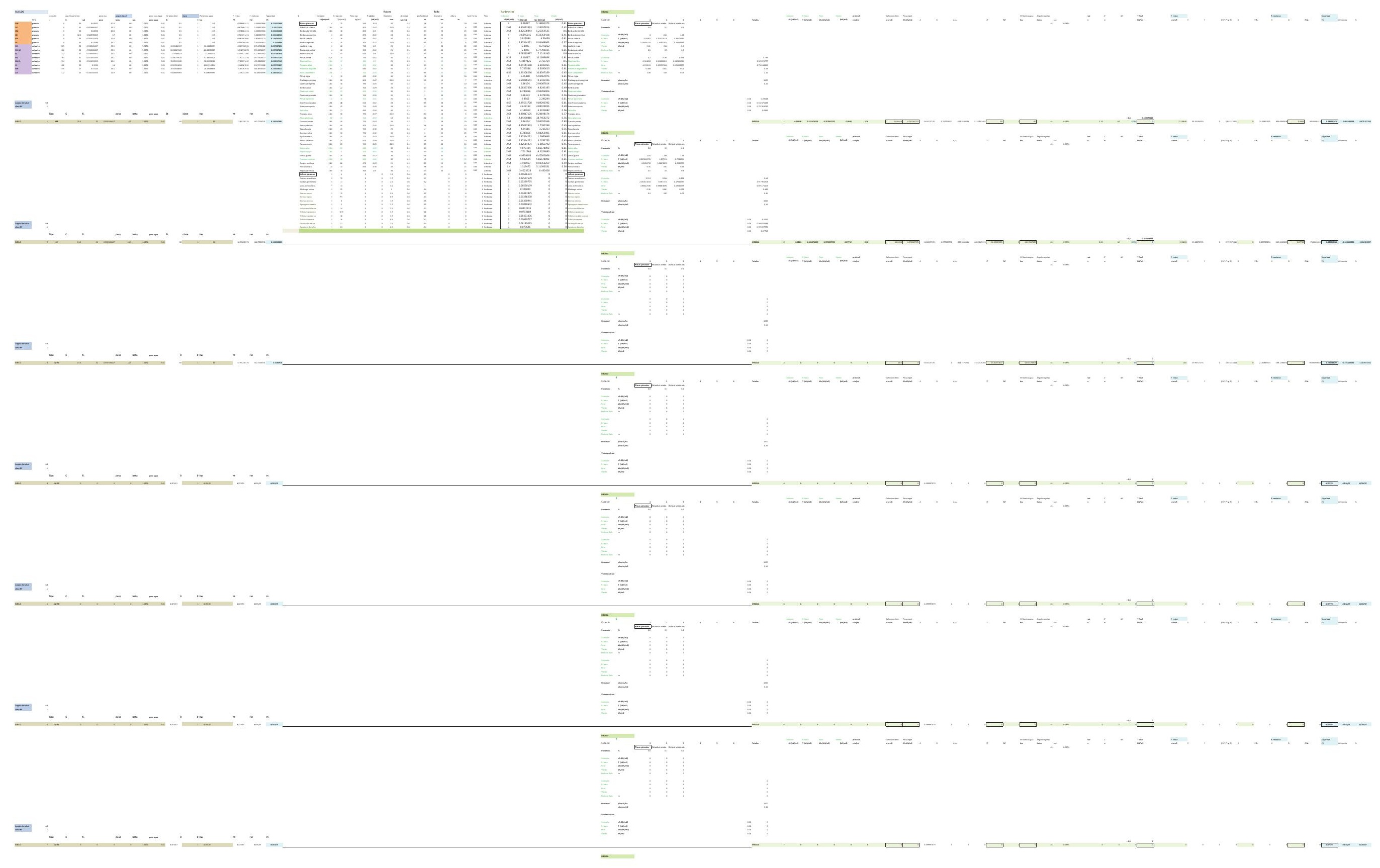




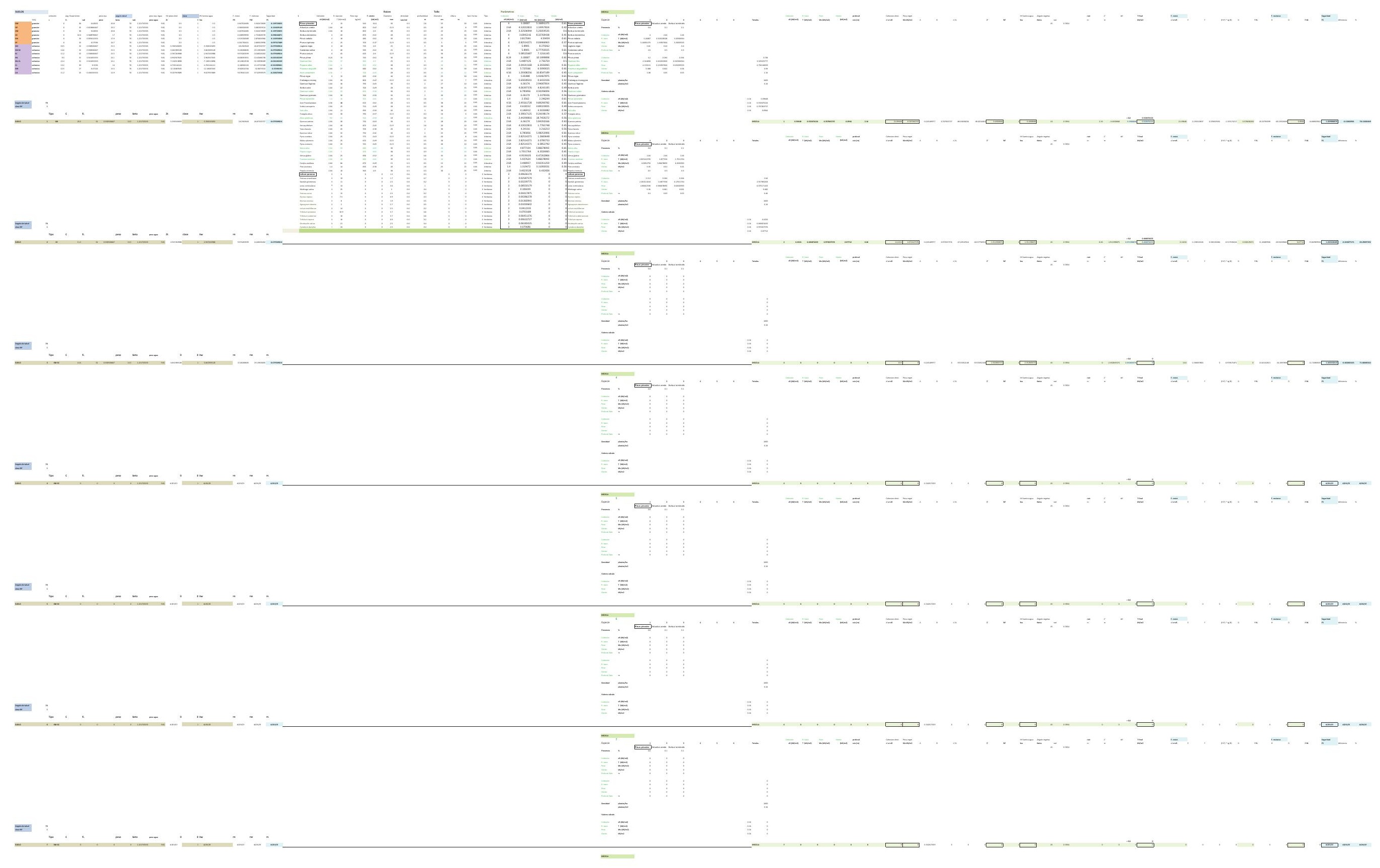




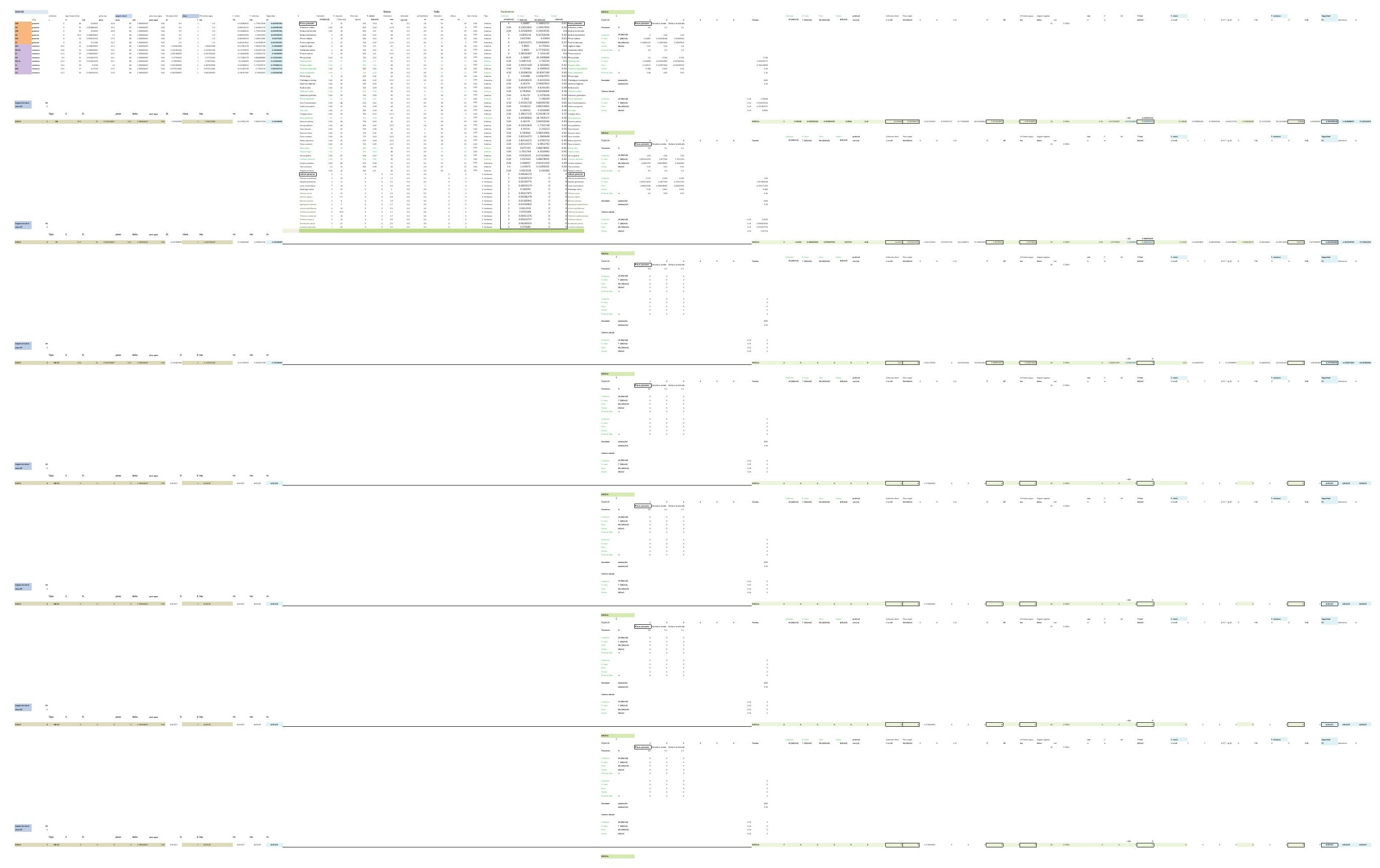


DESARROLLO DE UNA APLICACIÓN IMFORMÁTICA PARA EL CÁLCULO DE SOSTENIMIENTO DE TALUDES MEDIANTE VEGETACIÓN

PRUEBAS DEL MODELO MATEMÁTICO PARA EL CÁLCULO DE ESTABILIDAD DE TALUDES.

B03. DENSIDAD DE PLANTACIÓN: 2.500 plantas/ha.

B03-1.POSICIÓN N.F. 1

B03-2.POSICIÓN N.F. 2

B03-3.POSICIÓN N.F. 3

B03-4.POSICIÓN N.F. 4

B03-5.POSICIÓN N.F. 5 
DESARROLLO DE UNA APLICACIÓN IMFORMÁTICA PARA EL CÁLCULO DE SOSTENIMIENTO DE TALUDES MEDIANTE VEGETACIÓN

B03. DENSIDAD DE PLANTACIÓN: 2.500 plantas/ha.

\section{B03-1.POSICIÓN N.F. 1}

INCLINACIÓN DE TALUD 6-100

INCLINACIÓN DE TALUD 10-200

INCLINACIÓN DE TALUD 20-30

INCLINACIÓN DE TALUD 30-40

INCLINACIÓN DE TALUD $35^{\circ}$

INCLINACIÓN DE TALUD 40-50

INCLINACIÓN DE TALUD 50-550

INCLINACIÓN DE TALUD 55-60

INCLINACIÓN DE TALUD 60-700

INCLINACIÓN DE TALUD 70-80 


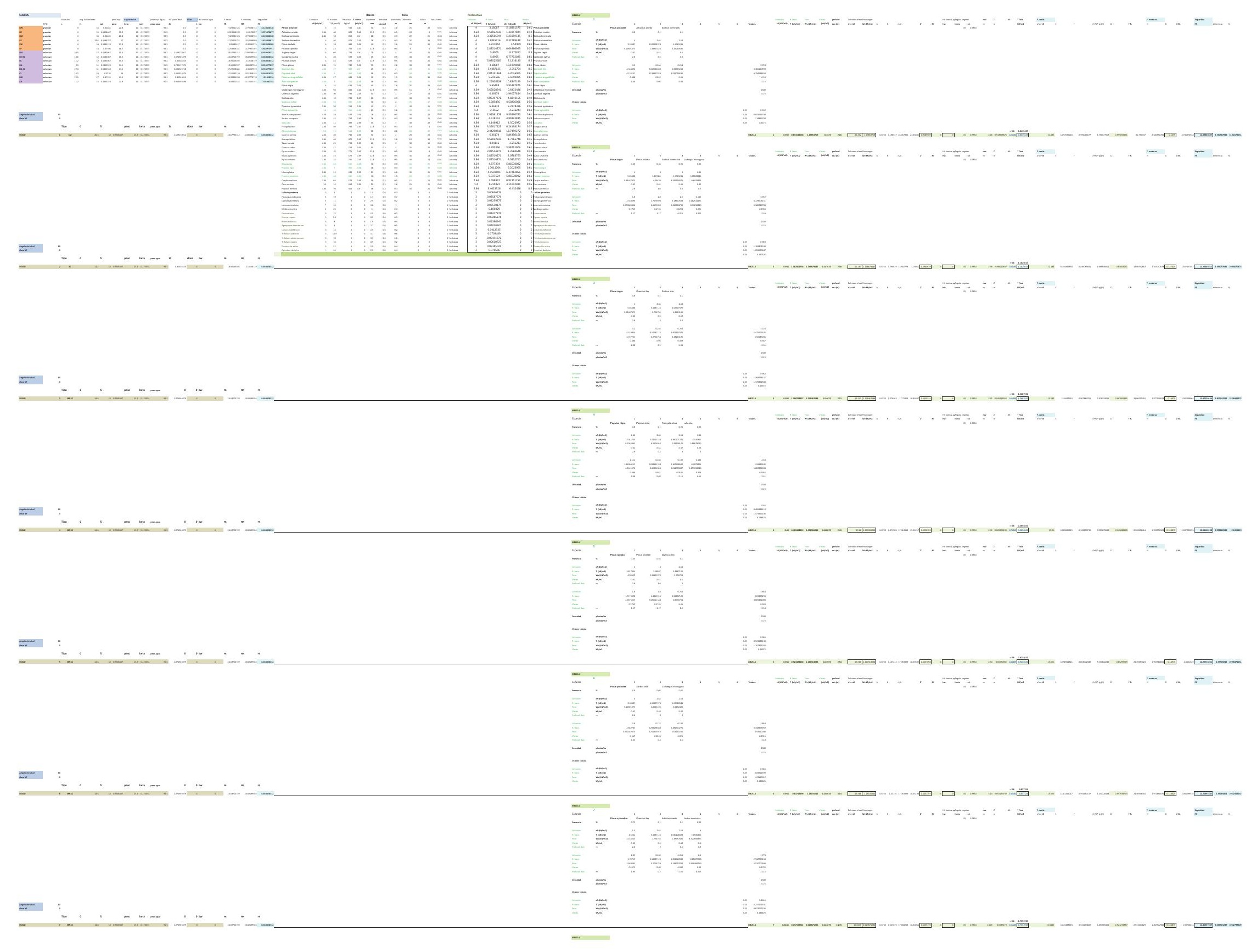


$=$

$=$

$+\cdots+\cdots$ $\pm$

$-\cdots+-\square-$

$\equiv= \pm$

$= \pm=$

$=$ 


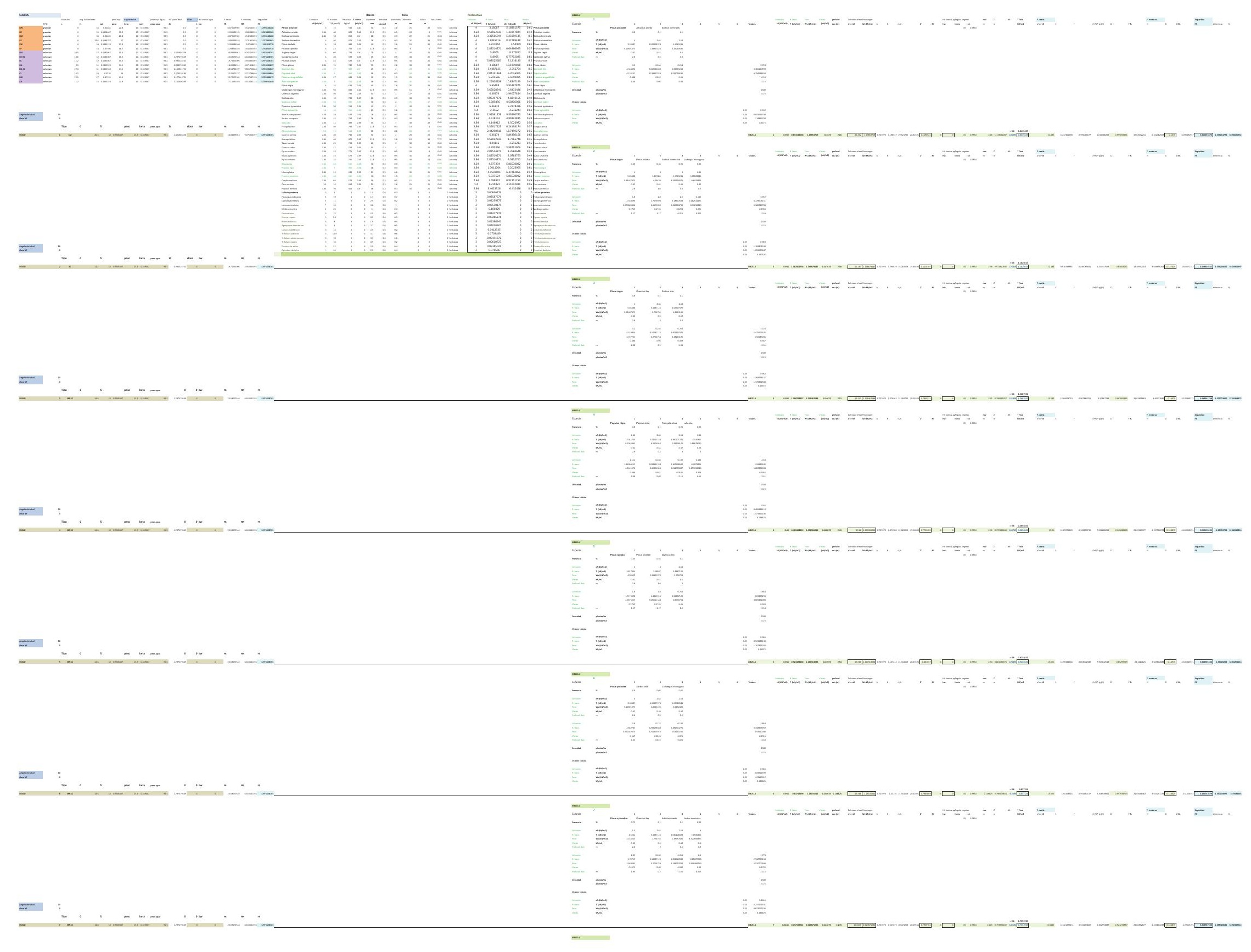


$=$

$=$

- $\pm$

1

$\equiv=-$

E. $=$

$-$

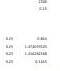




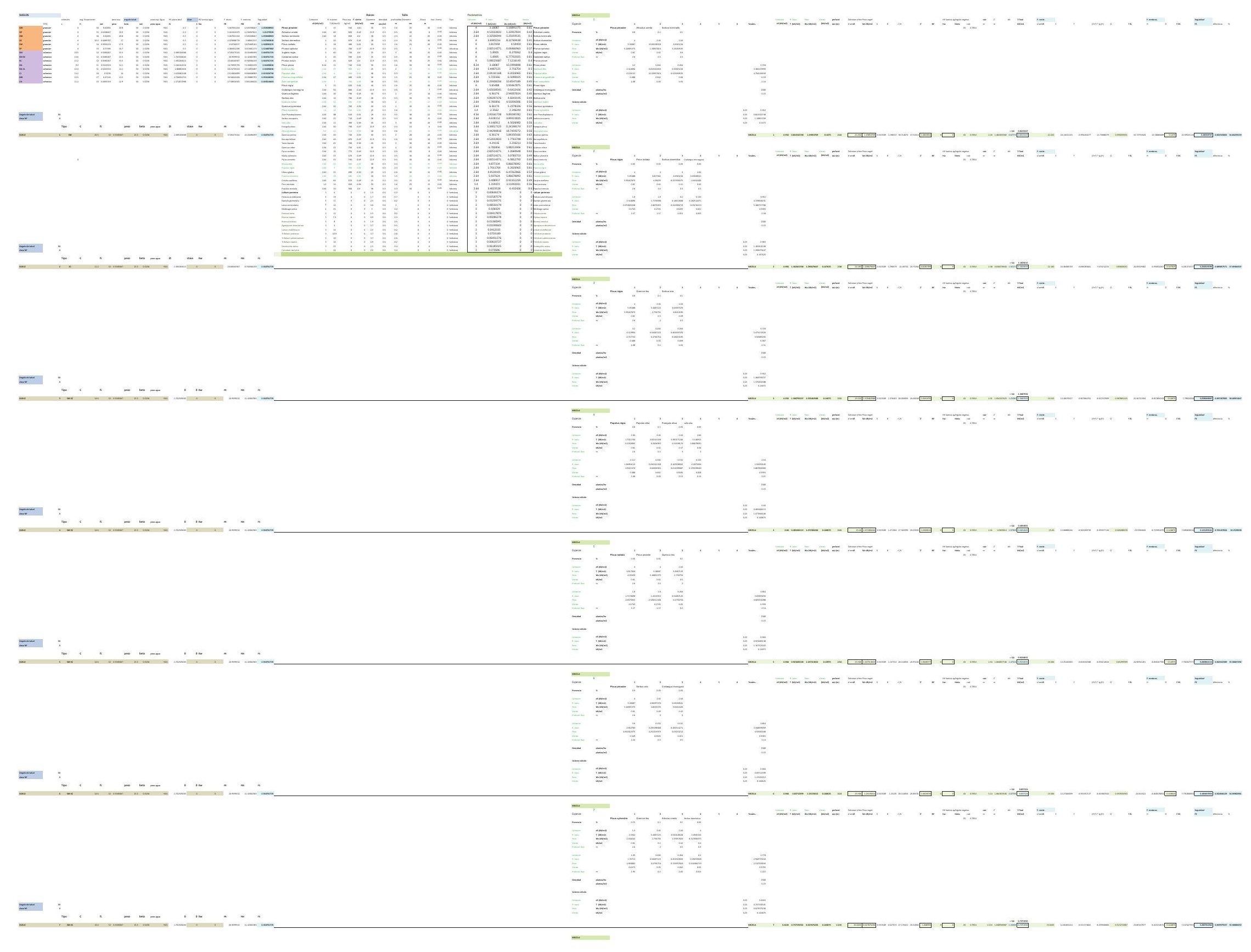


$=$

$=$

- $\pm$

(2.

$\equiv=-$

$= \pm$

$-$

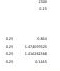




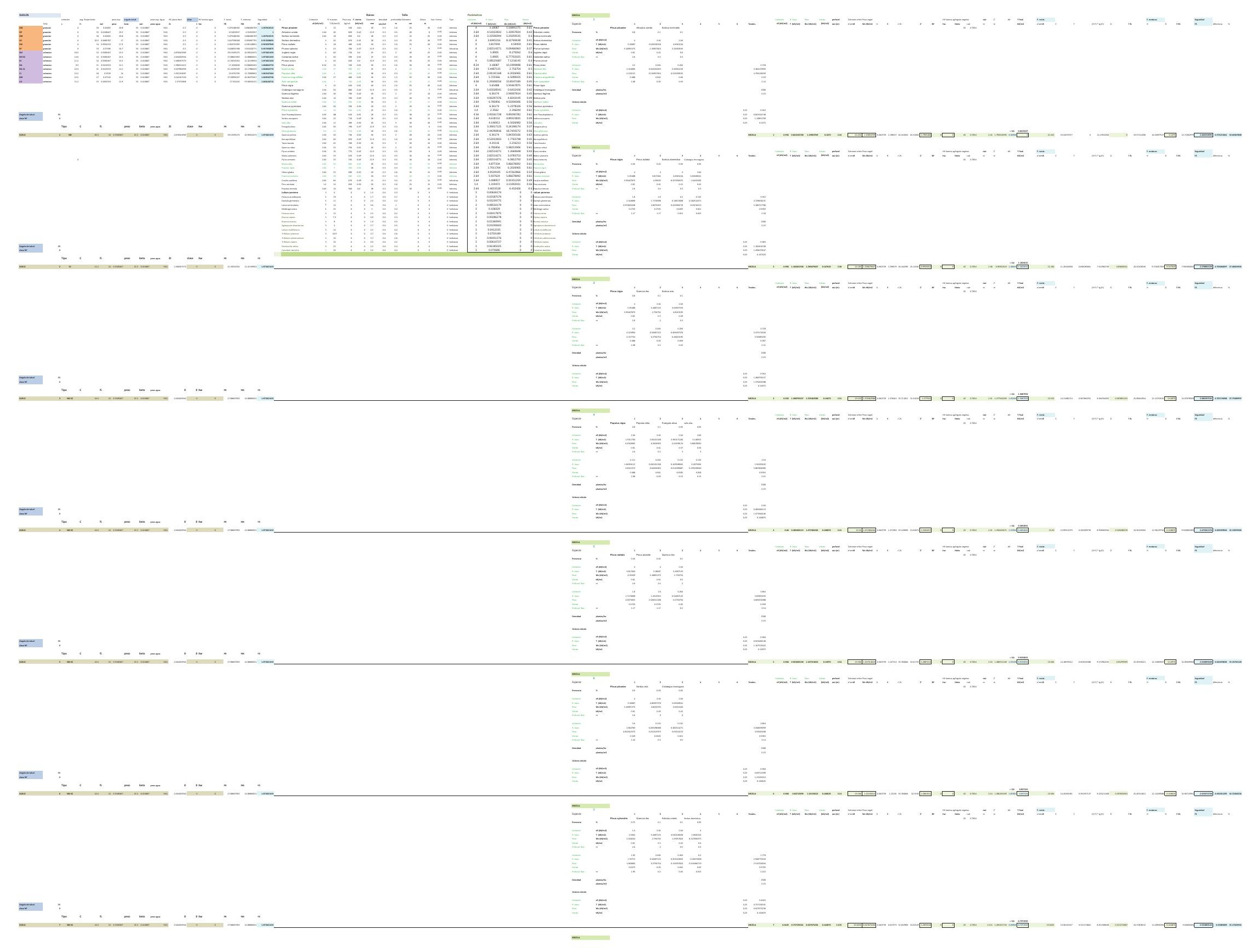


$=$

$=$

- $\pm$

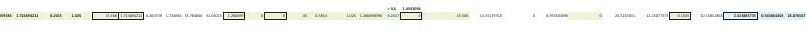

$\equiv=-$

$= \pm$

$-$

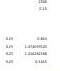




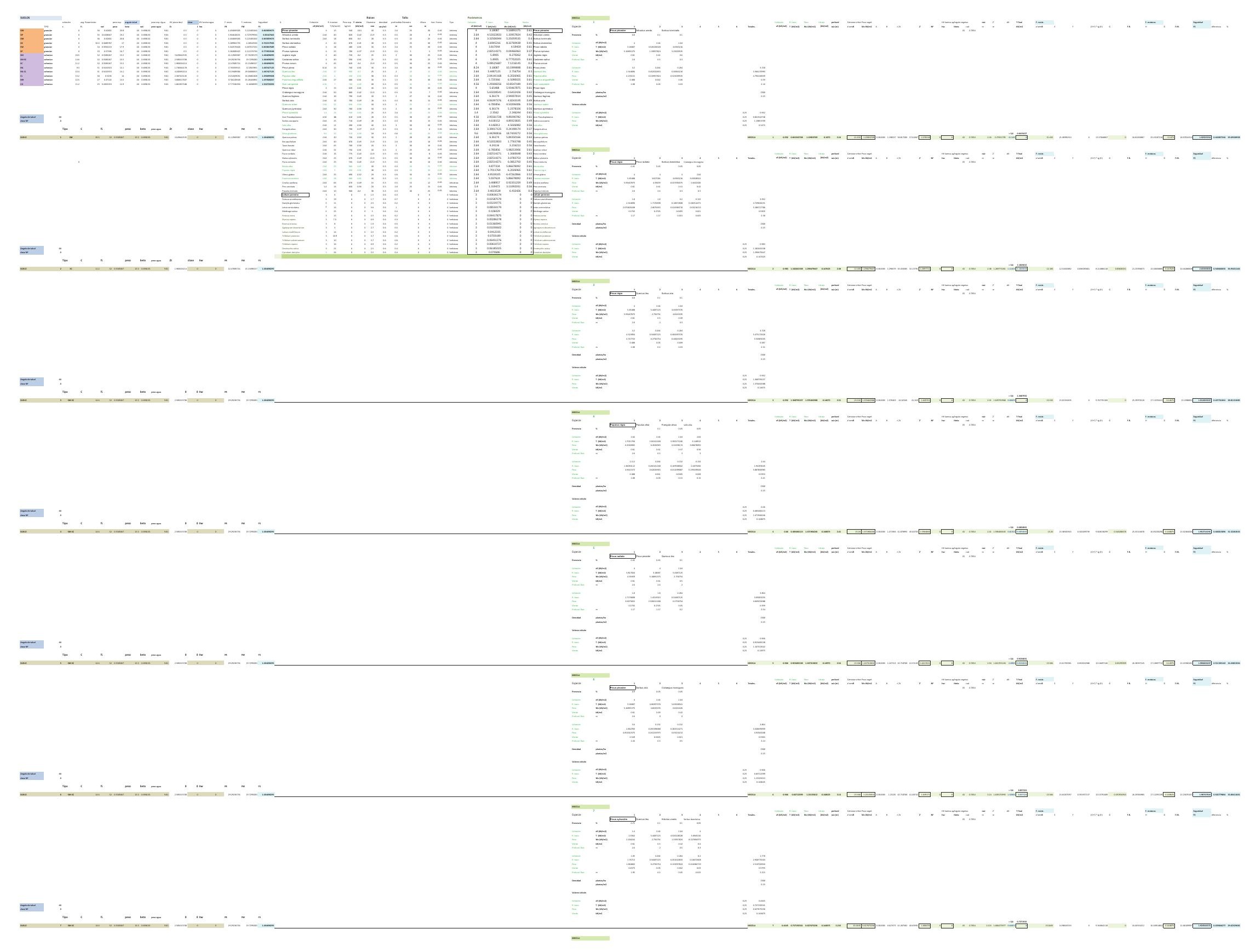




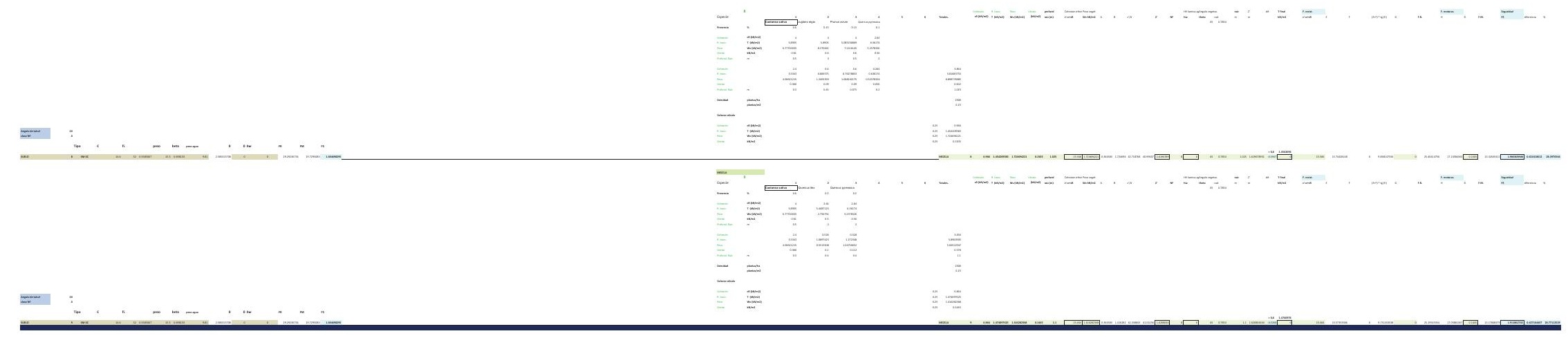




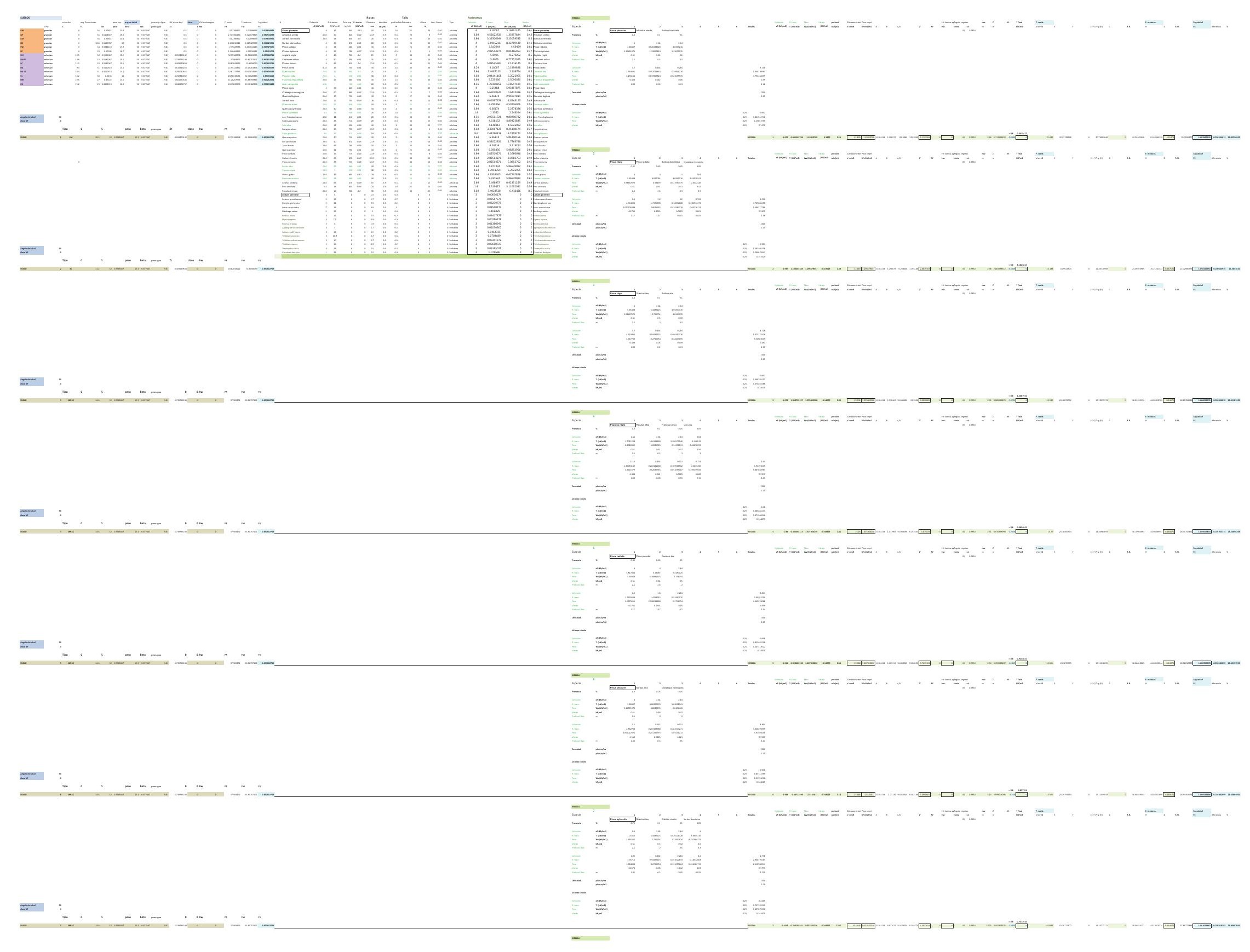




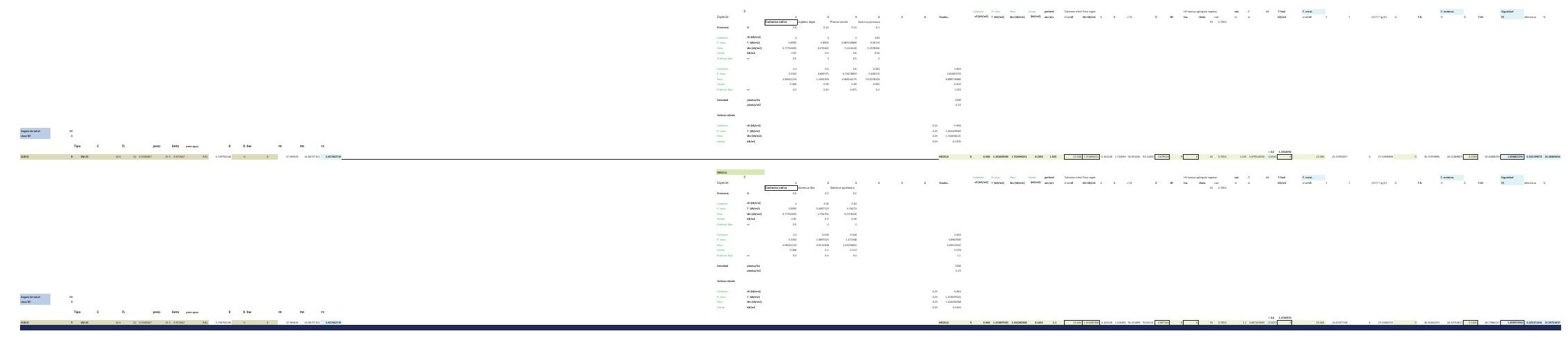




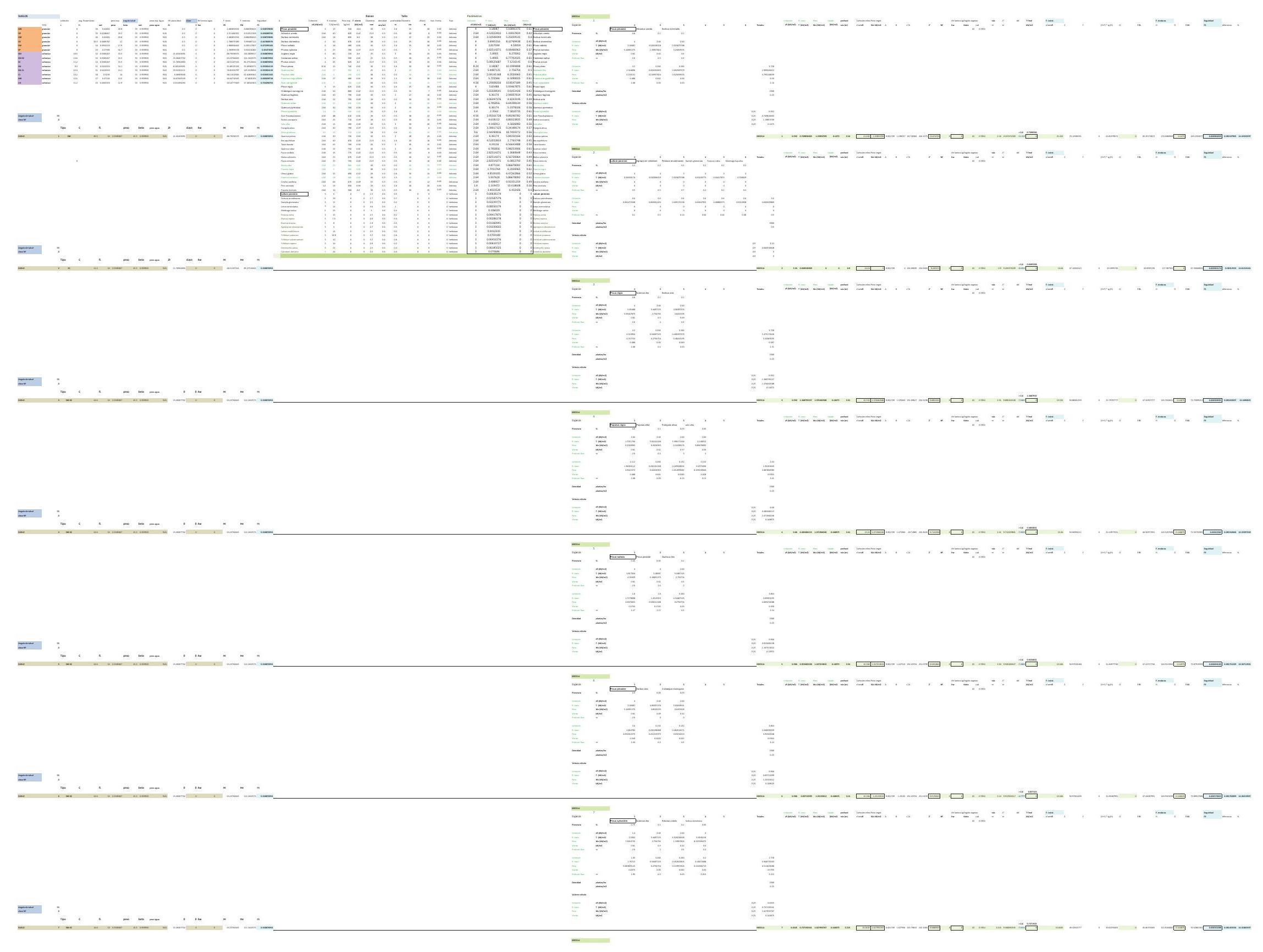




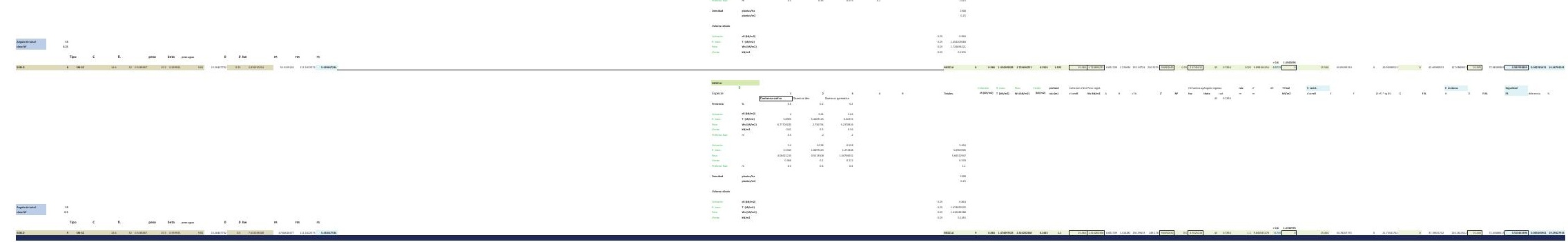




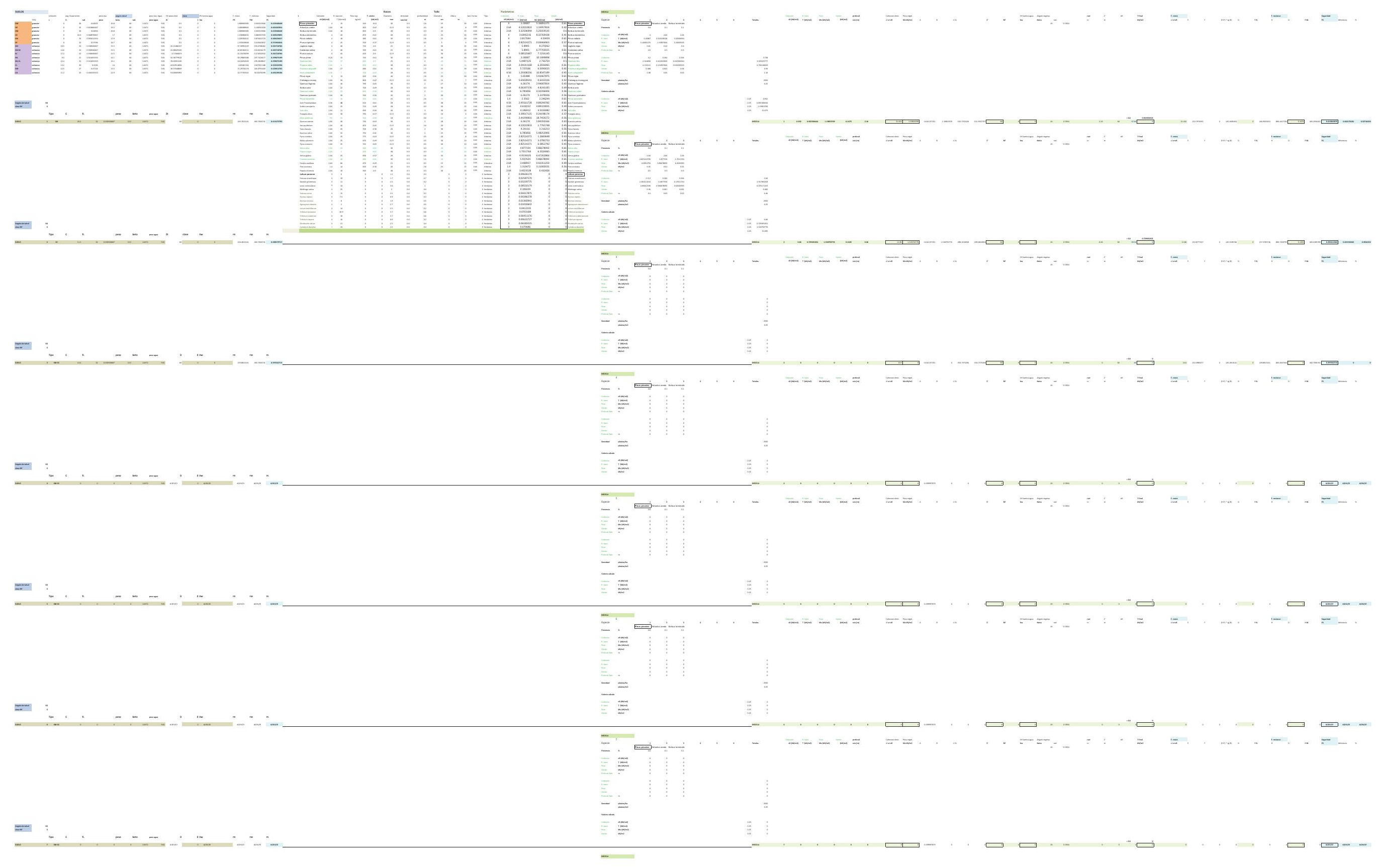




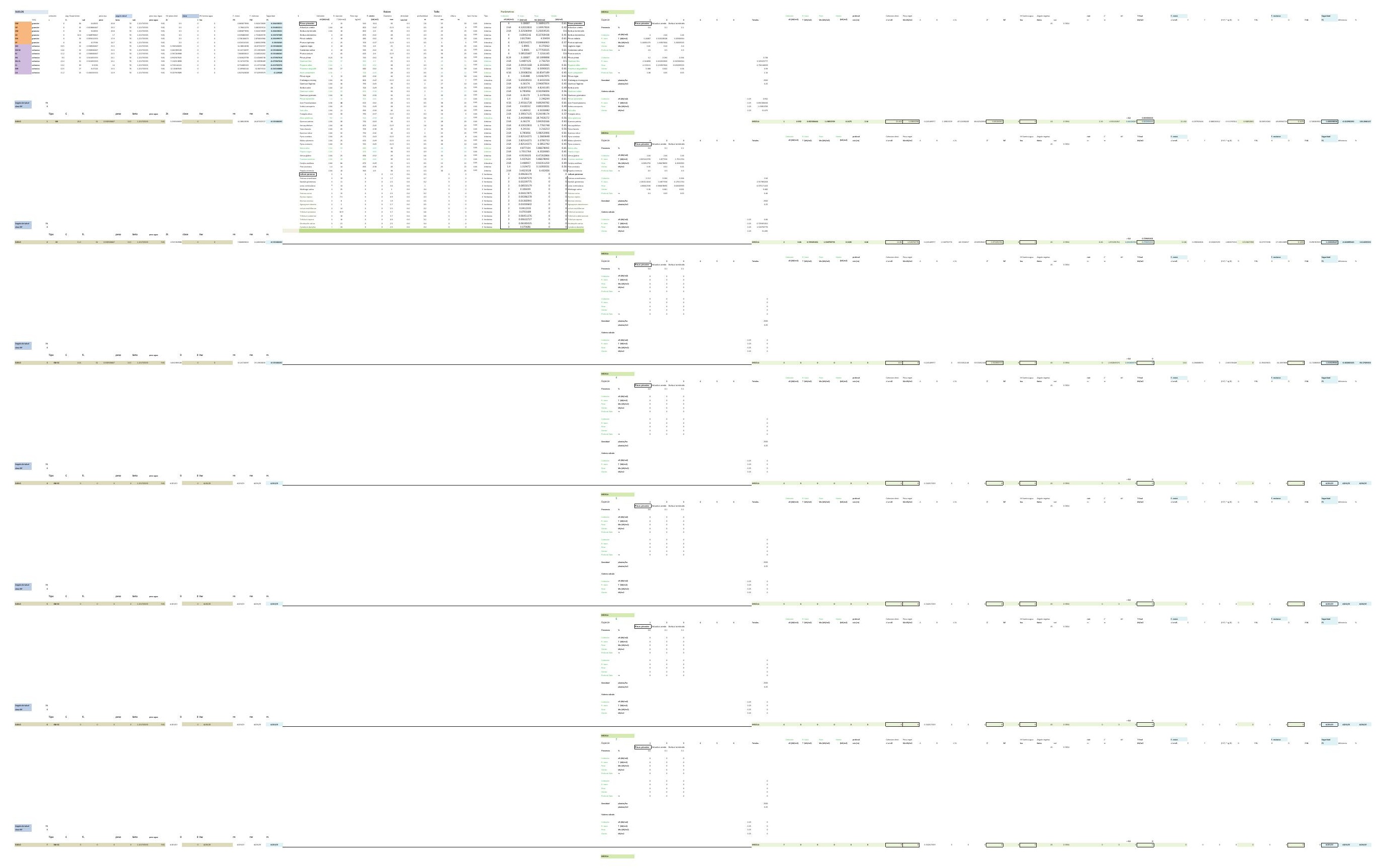




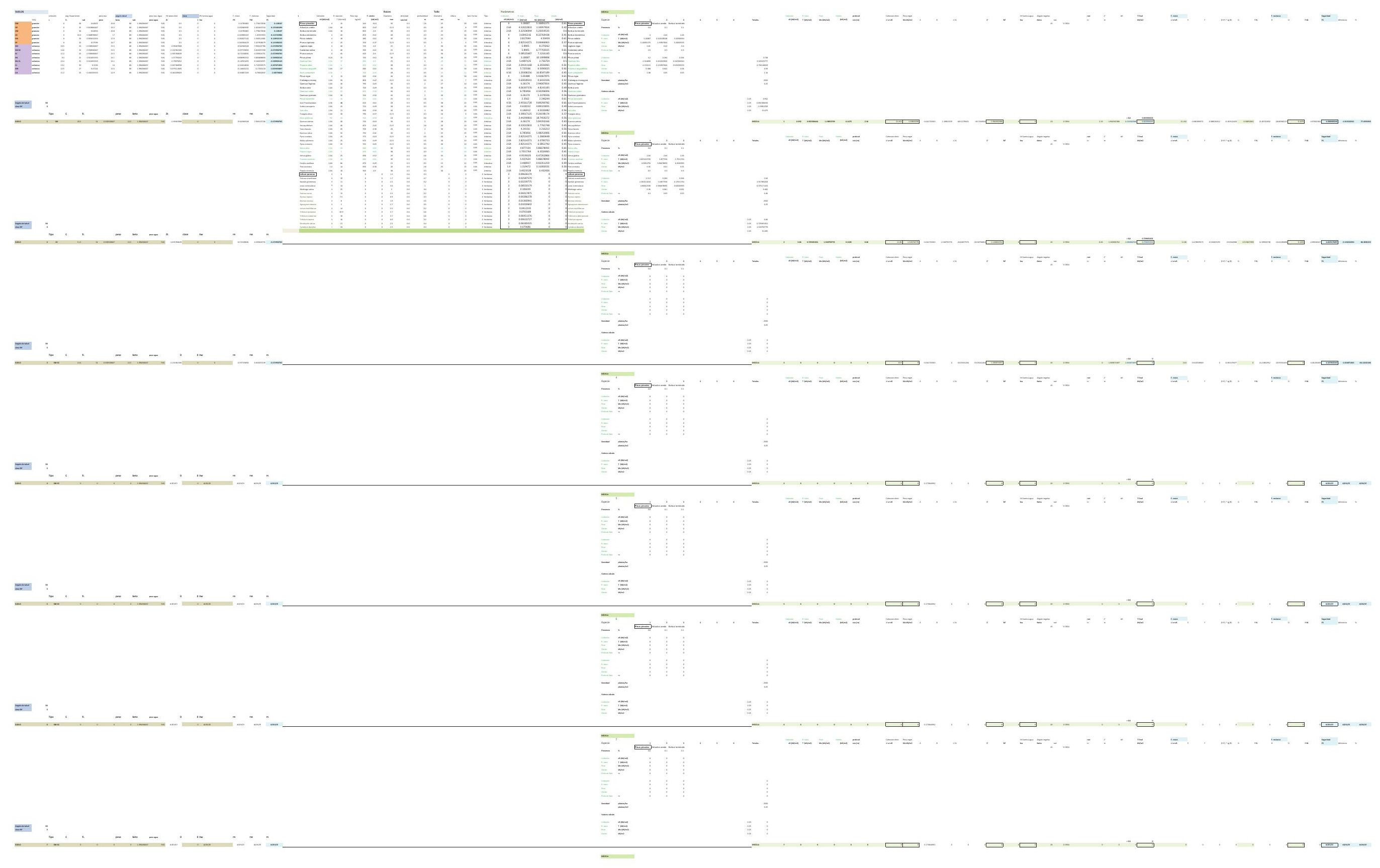


DESARROLLO DE UNA APLICACIÓN IMFORMÁTICA PARA EL CÁLCULO DE SOSTENIMIENTO DE TALUDES MEDIANTE VEGETACIÓN

PRUEBAS DEL MODELO MATEMÁTICO PARA EL CÁLCULO DE ESTABILIDAD DE TALUDES.

B03. DENSIDAD DE PLANTACIÓN: 2.500 plantas/ha.

B03-1.POSICIÓN N.F. 1

B03-2.POSICIÓN N.F. 2

B03-3.POSICIÓN N.F. 3

B03-4.POSICIÓN N.F. 4

B03-5.POSICIÓN N.F. 5 
DESARROLLO DE UNA APLICACIÓN IMFORMÁTICA PARA EL CÁLCULO DE SOSTENIMIENTO DE TALUDES MEDIANTE VEGETACIÓN

B03. DENSIDAD DE PLANTACIÓN: 2.500 plantas/ha.

\section{B03-1.POSICIÓN N.F. 1}

INCLINACIÓN DE TALUD 6-100

INCLINACIÓN DE TALUD 10-200

INCLINACIÓN DE TALUD 20-30

INCLINACIÓN DE TALUD 30-40

INCLINACIÓN DE TALUD $35^{\circ}$

INCLINACIÓN DE TALUD 40-50

INCLINACIÓN DE TALUD 50-550

INCLINACIÓN DE TALUD 55-60

INCLINACIÓN DE TALUD 60-700

INCLINACIÓN DE TALUD 70-80 


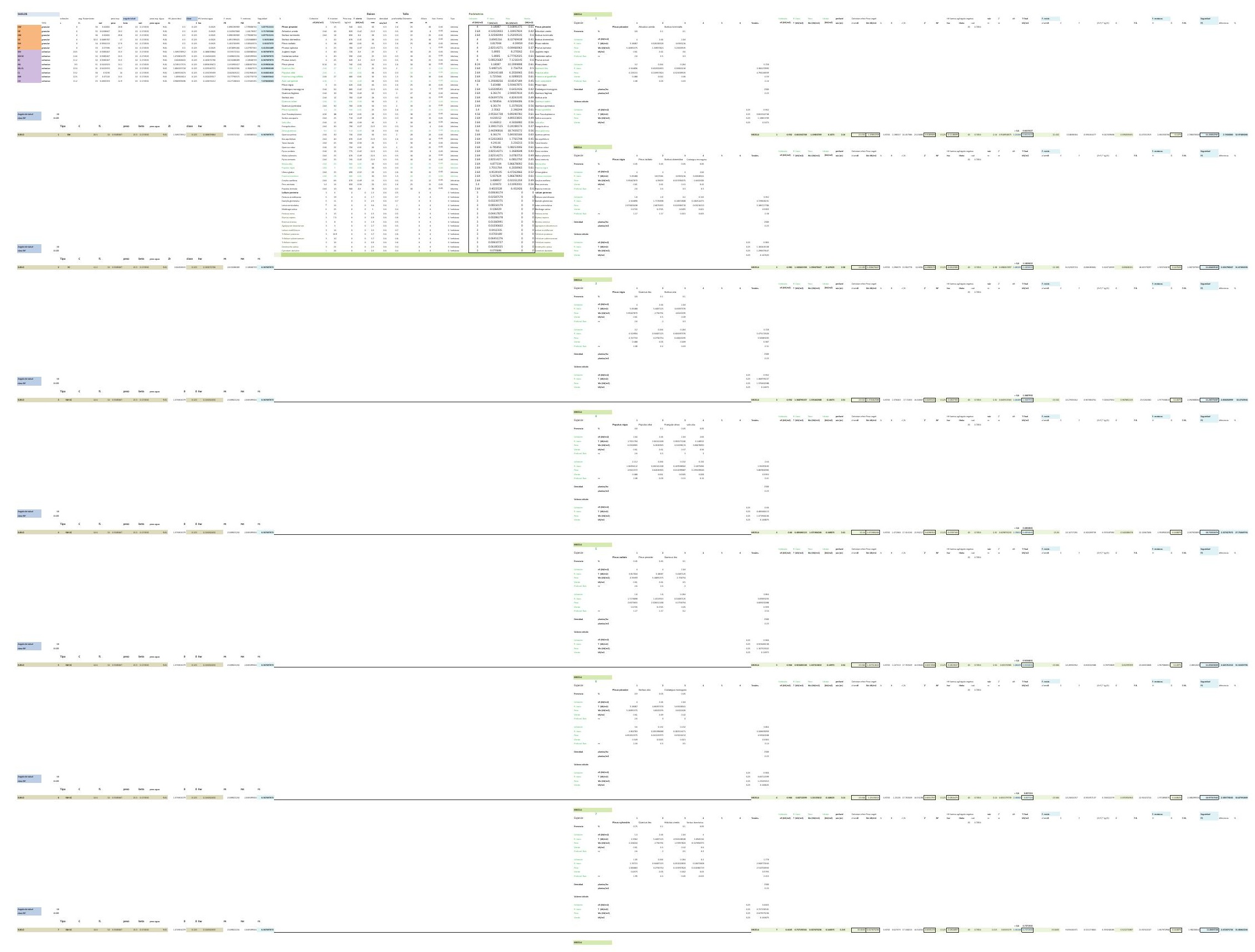


$=$

$=$

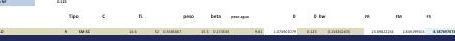

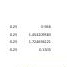

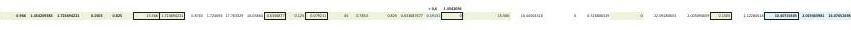

$\equiv=-$

$= \pm$

$-$

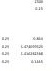




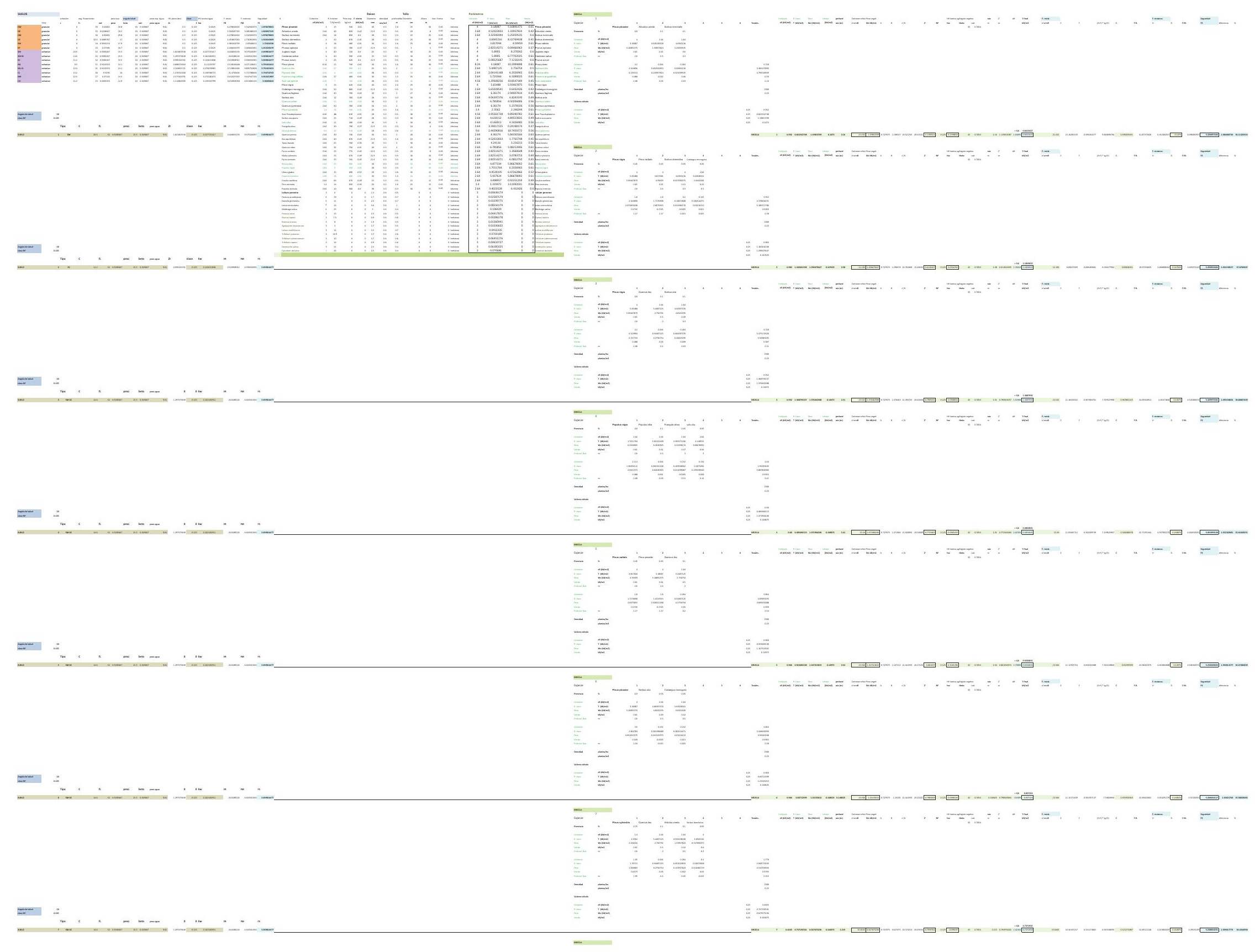


$=$

$=$

$n+\ldots+\cdots$

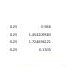

……

$\equiv=-$

$= \pm$

$-$

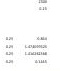




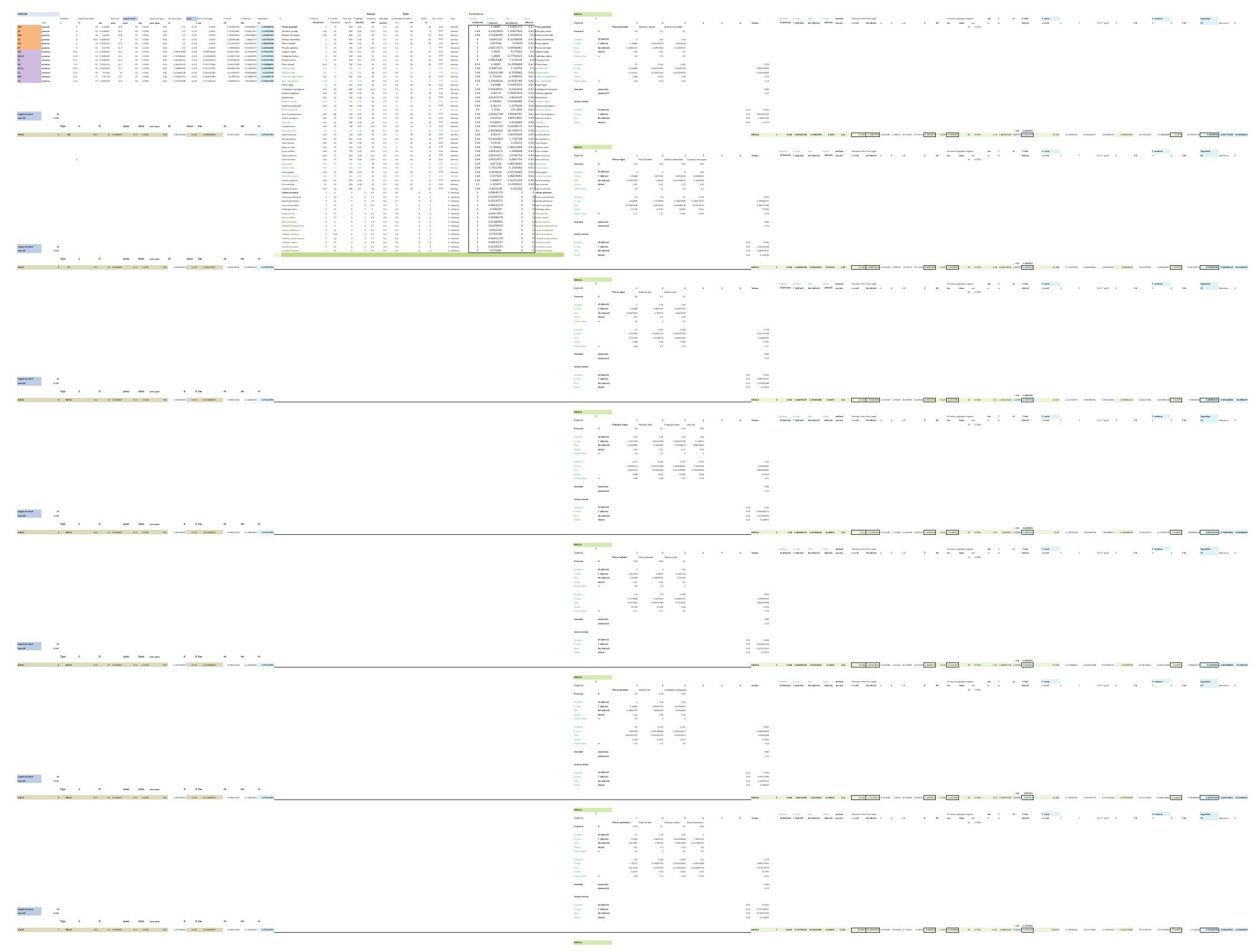


$=$

$=$

$-1+\cdots+\cdots$

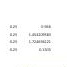

(...

$\equiv=-$

$= \pm$

$-$ 


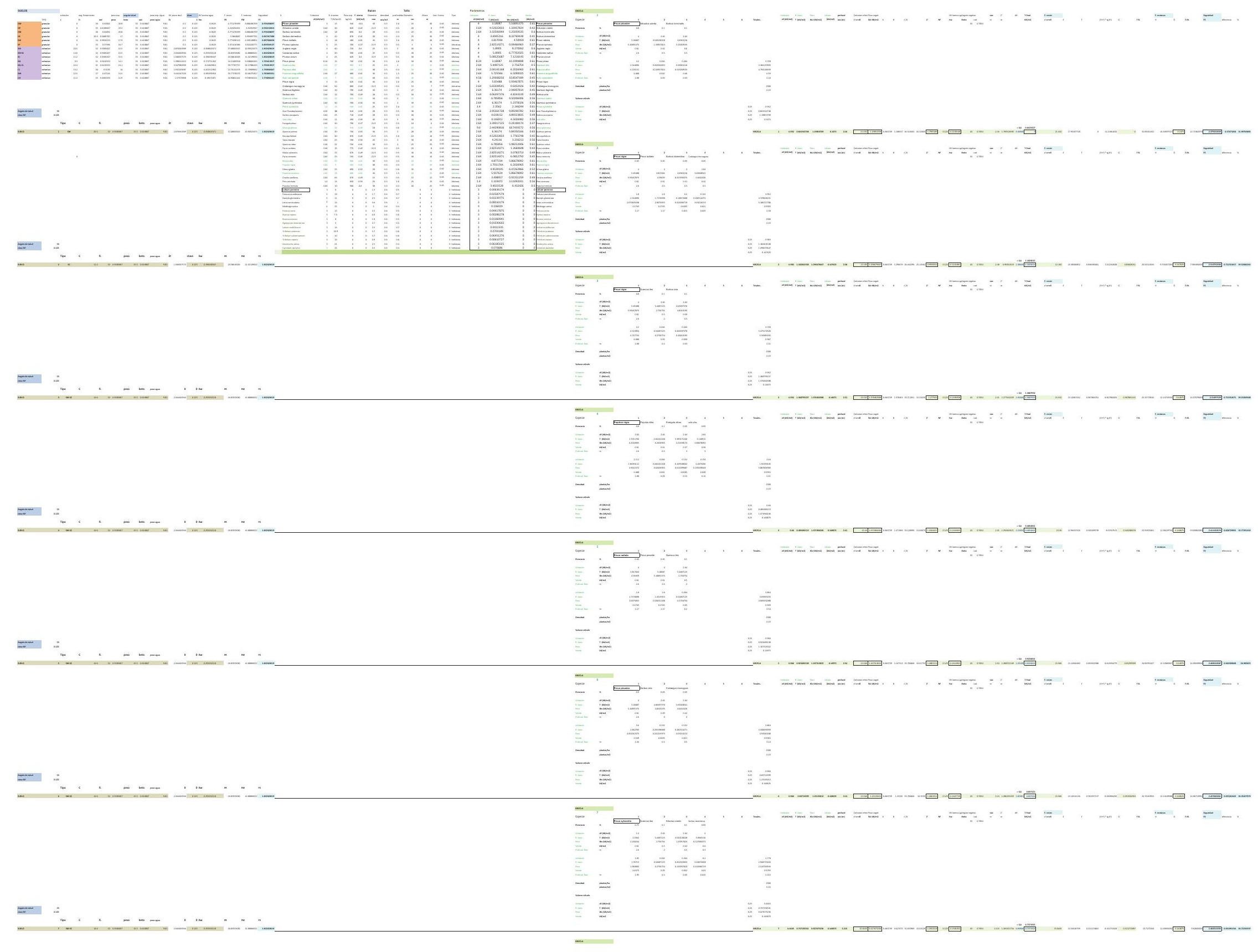




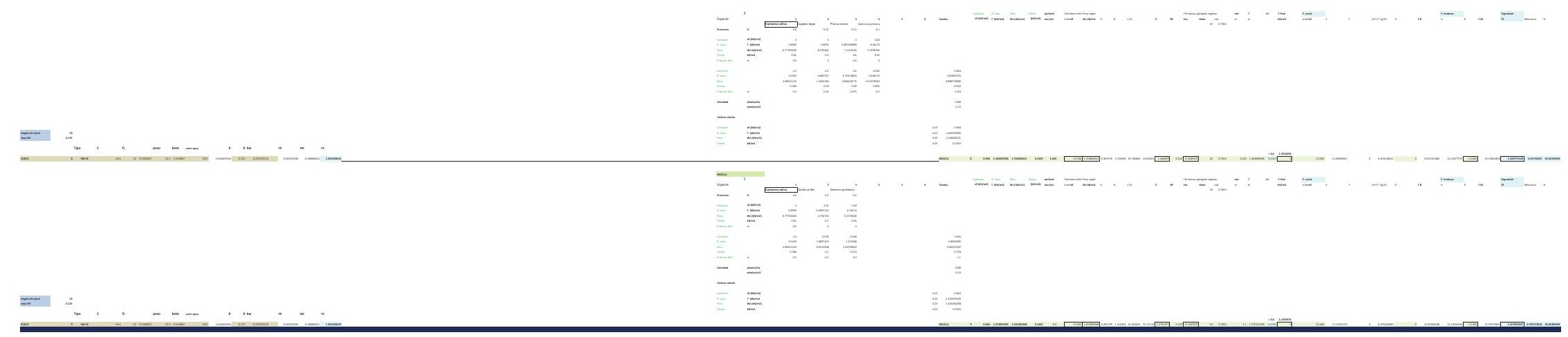




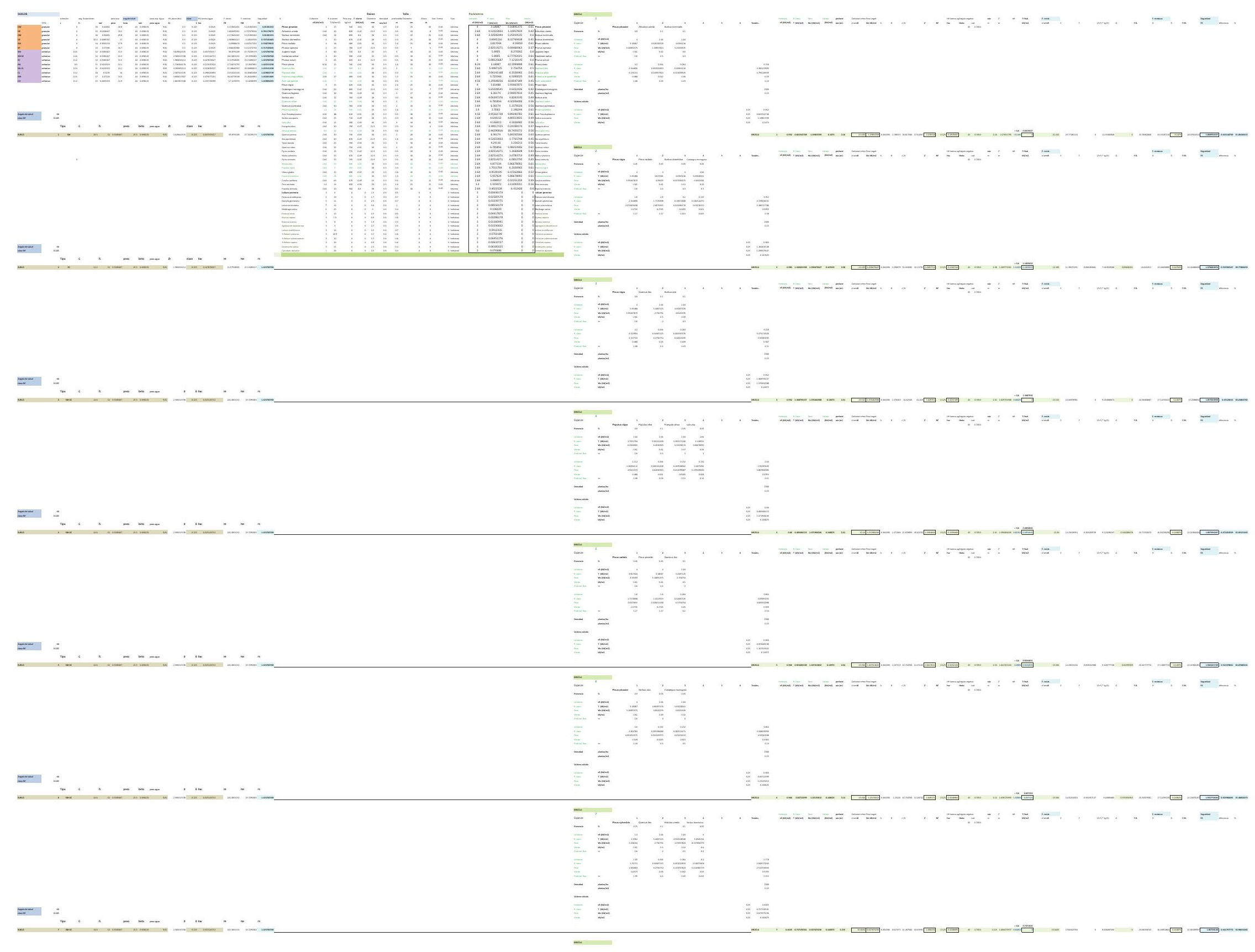


$=$

$=$

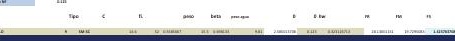

$\pm$

드.

$\equiv= \pm$

$= \pm$

$-$ 


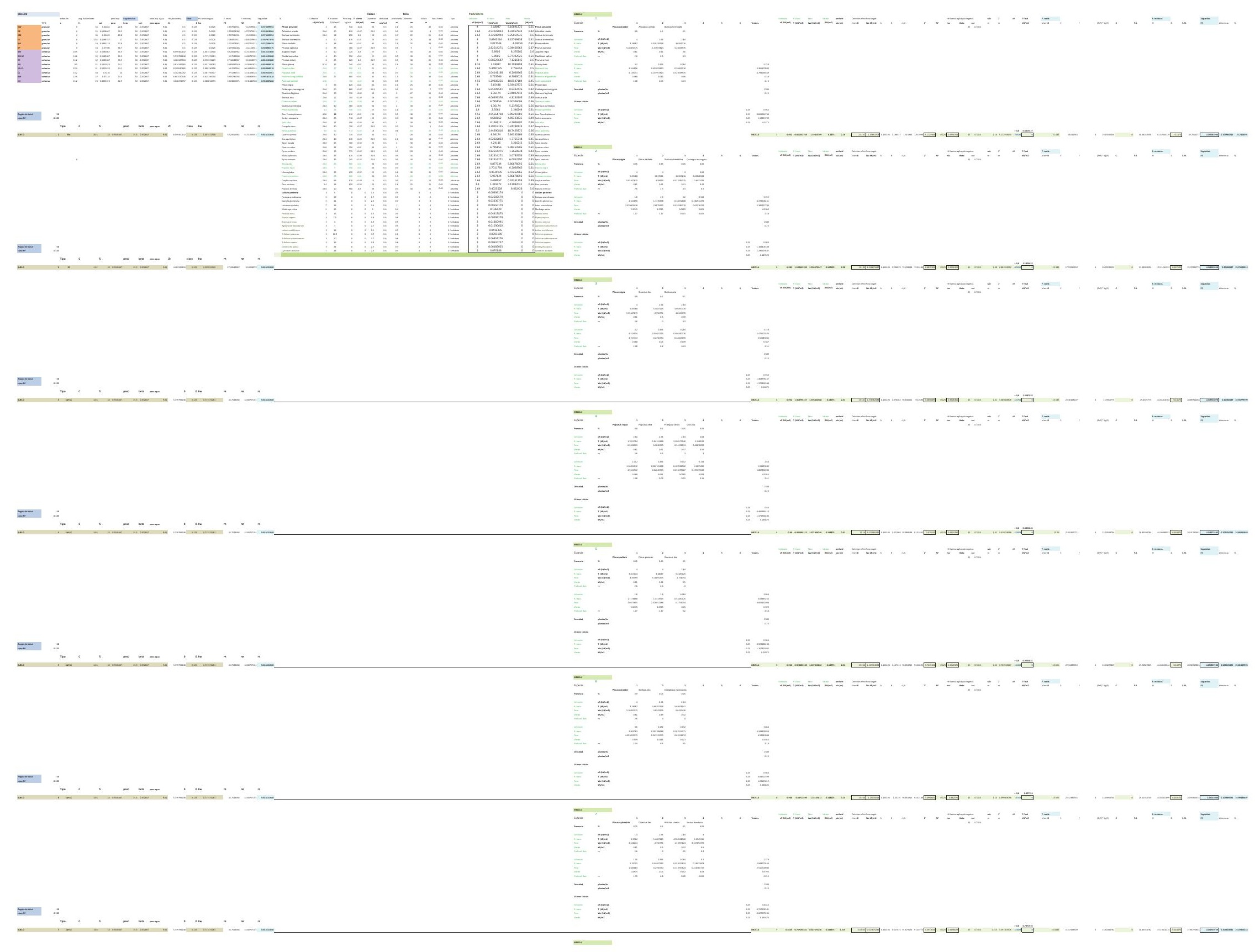


$=$

$=$

- $\pm$

……

$\equiv=-$

$\pm=$

$-$ 


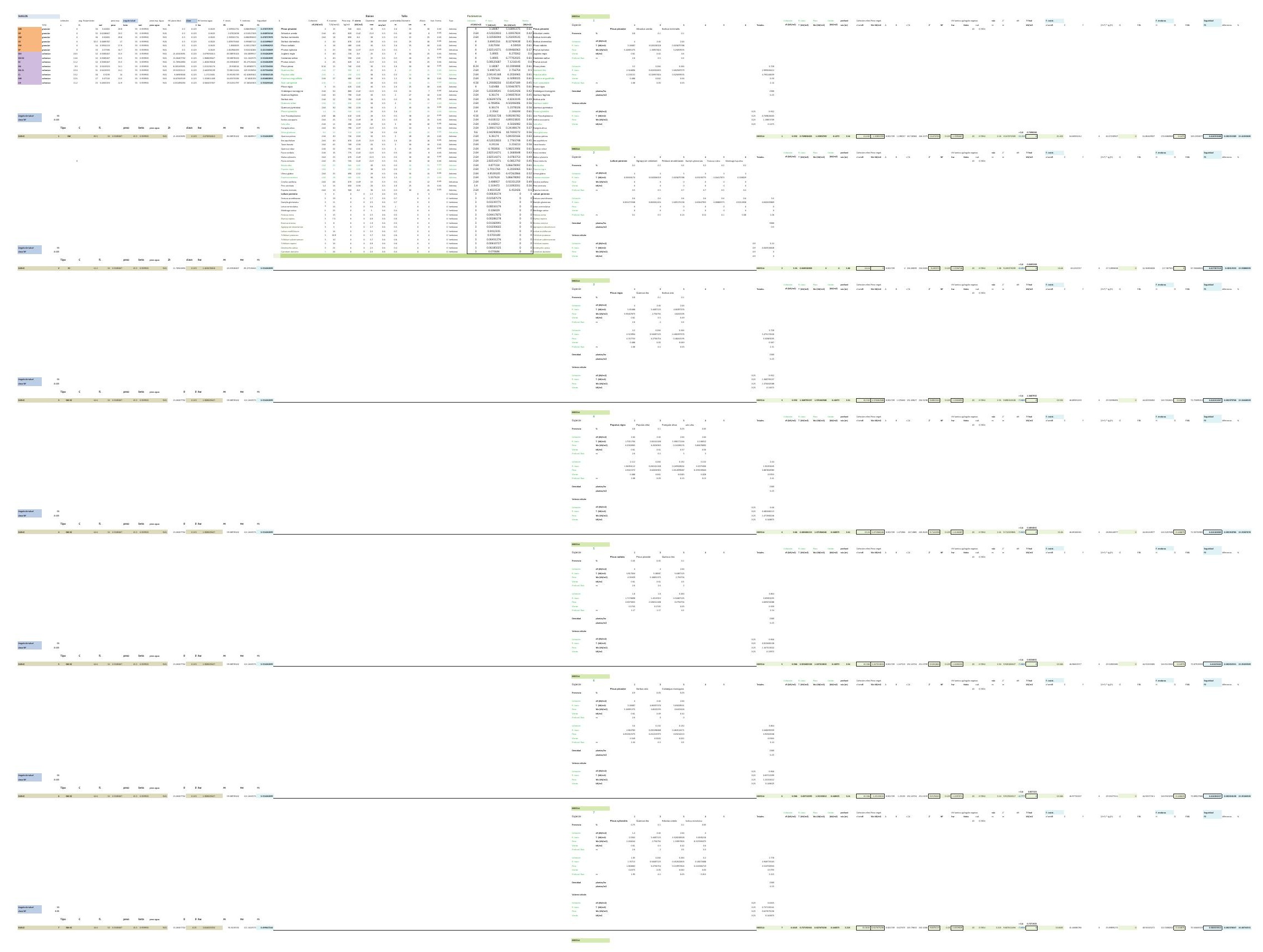


$=$

$=$

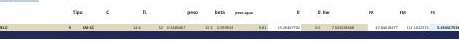

$=$

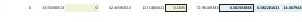

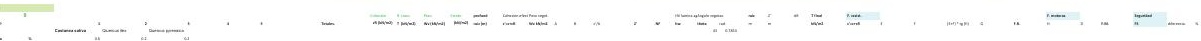

$\equiv= \pm$

$\pm= \pm$

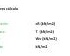




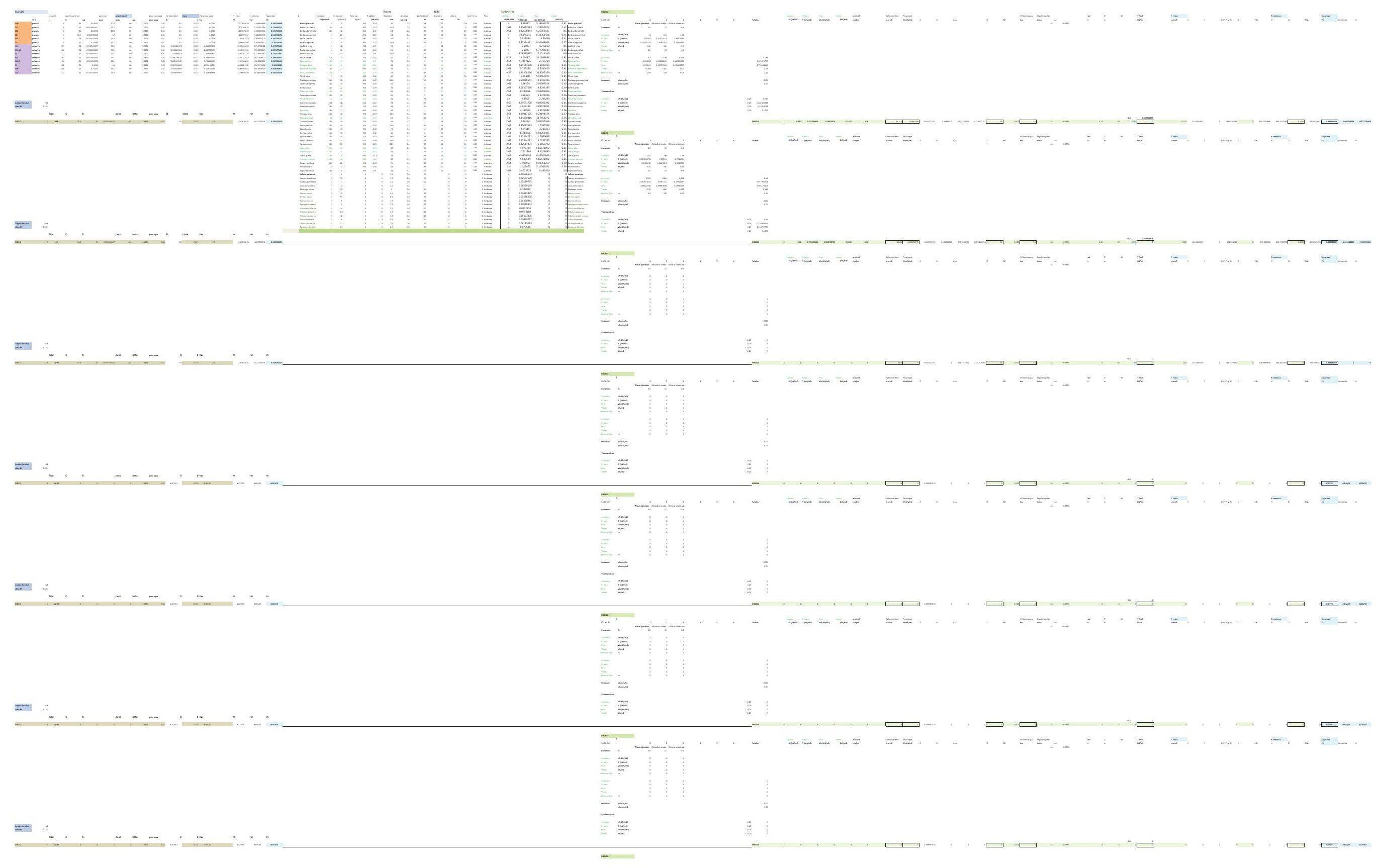




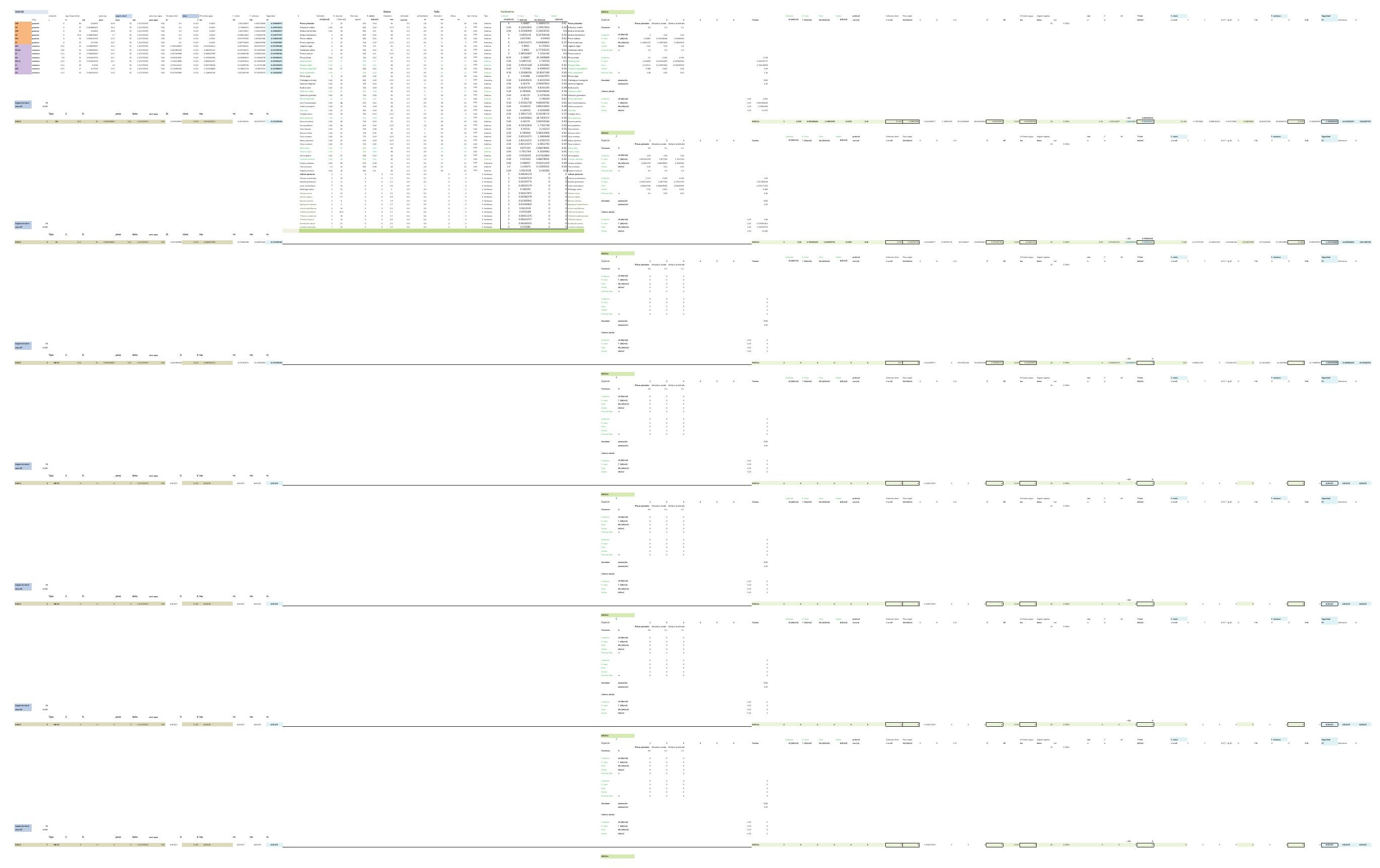




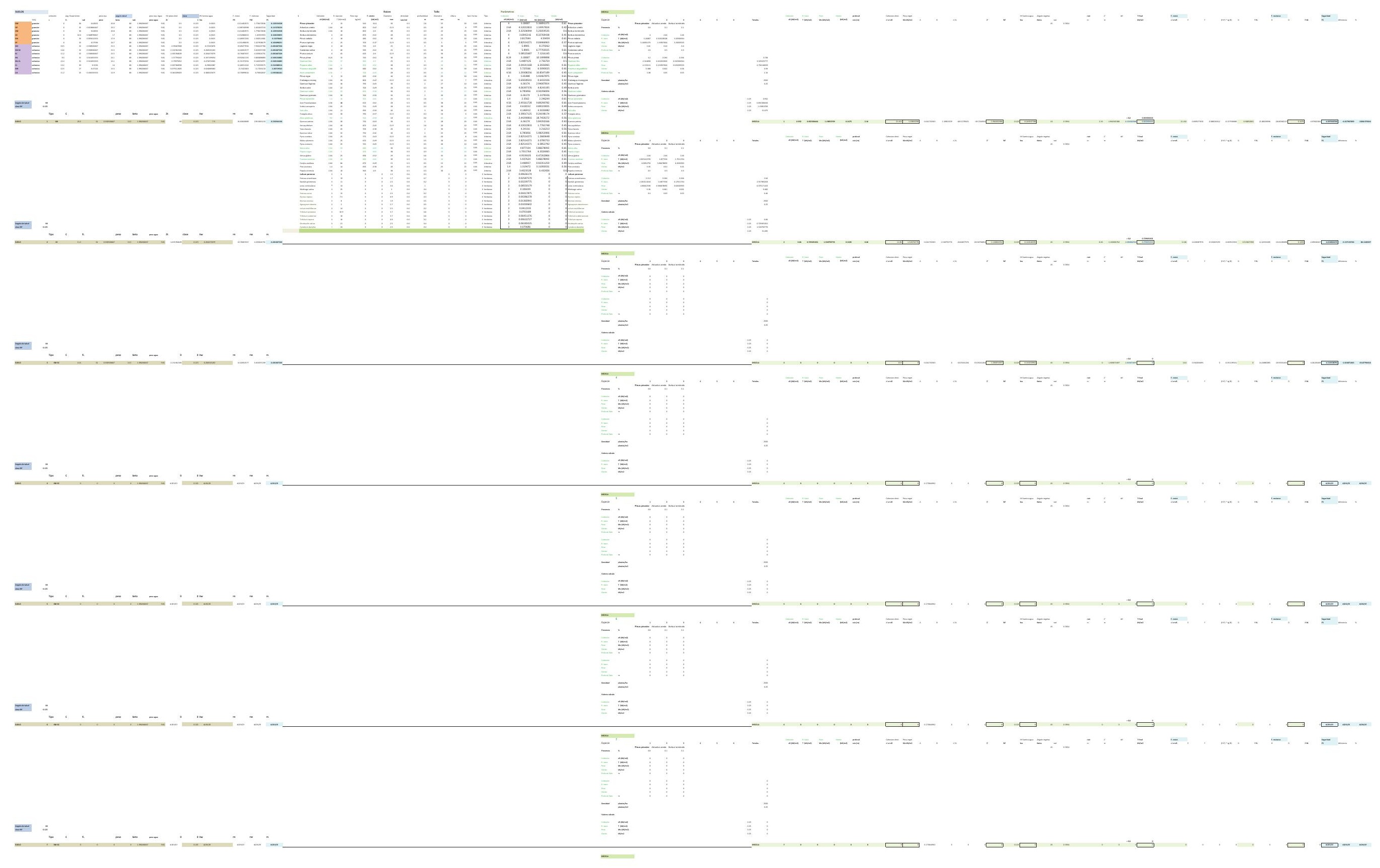


DESARROLLO DE UNA APLICACIÓN IMFORMÁTICA PARA EL CÁLCULO DE SOSTENIMIENTO DE TALUDES MEDIANTE VEGETACIÓN

B03. DENSIDAD DE PLANTACIÓN: 2.500 plantas/ha.

\section{B03-3.POSICIÓN N.F. 3}

INCLINACIÓN DE TALUD 6-100

INCLINACIÓN DE TALUD 10-200

INCLINACIÓN DE TALUD 20-30

INCLINACIÓN DE TALUD 30-40

INCLINACIÓN DE TALUD $35^{\circ}$

INCLINACIÓN DE TALUD 40-50

INCLINACIÓN DE TALUD 50-550

INCLINACIÓN DE TALUD 55-60

INCLINACIÓN DE TALUD 60-700

INCLINACIÓN DE TALUD 70-80 


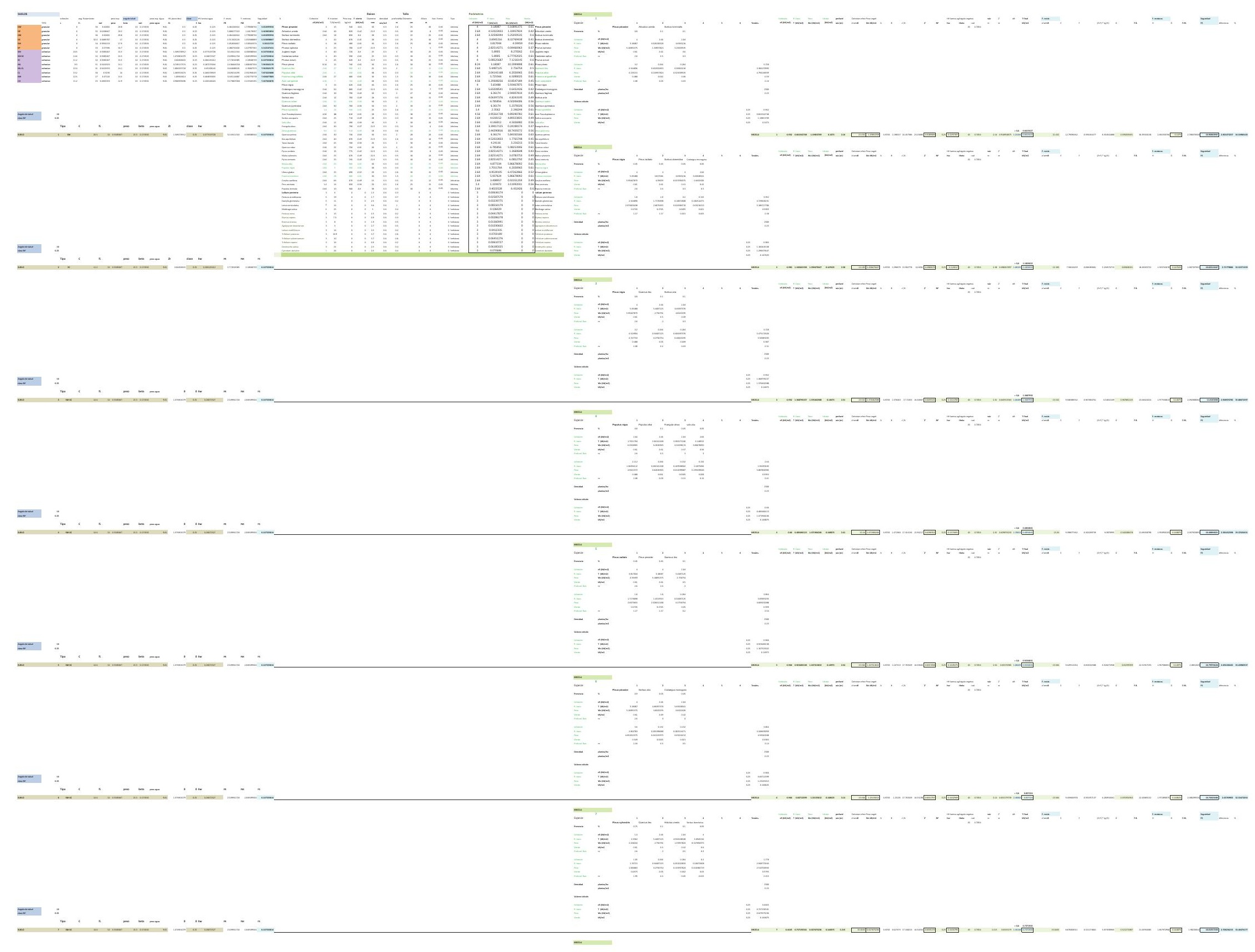


$=$

$=$

-

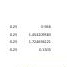

(....

$\equiv=-$

$= \pm \equiv$

$=$ 


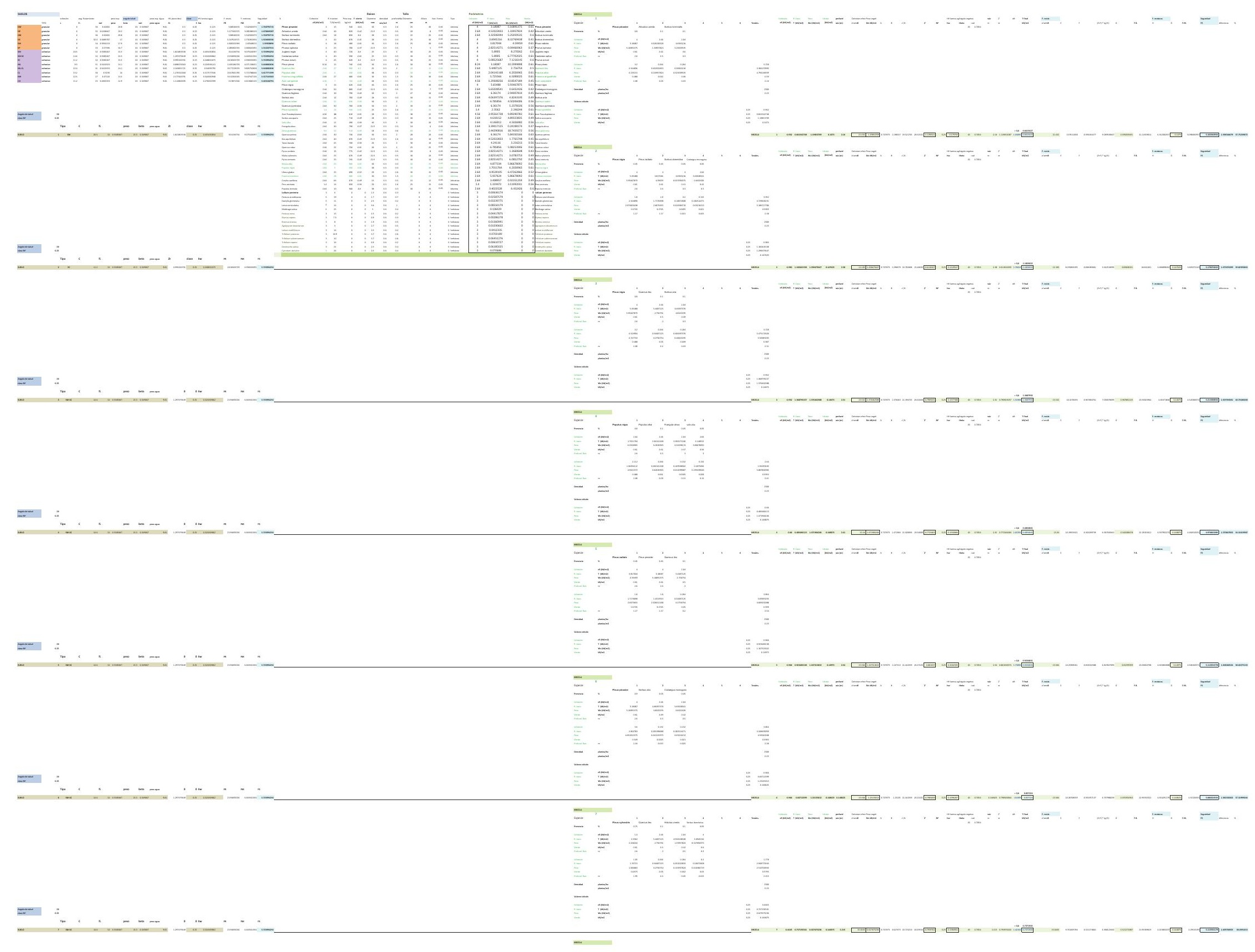


$=$

$=$

- $\pm$

(……

$\equiv= \pm$

E. $=$

$-$ 


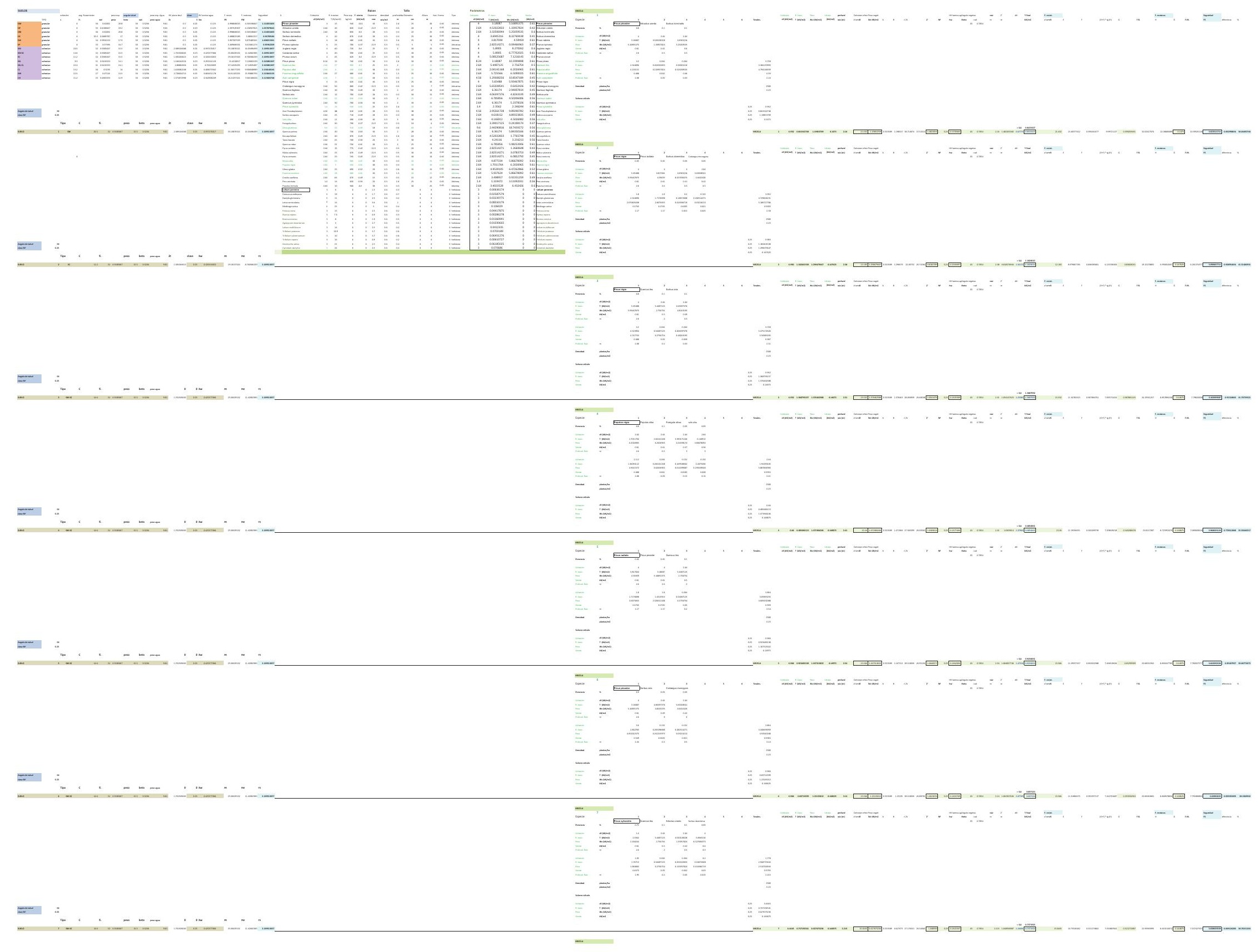




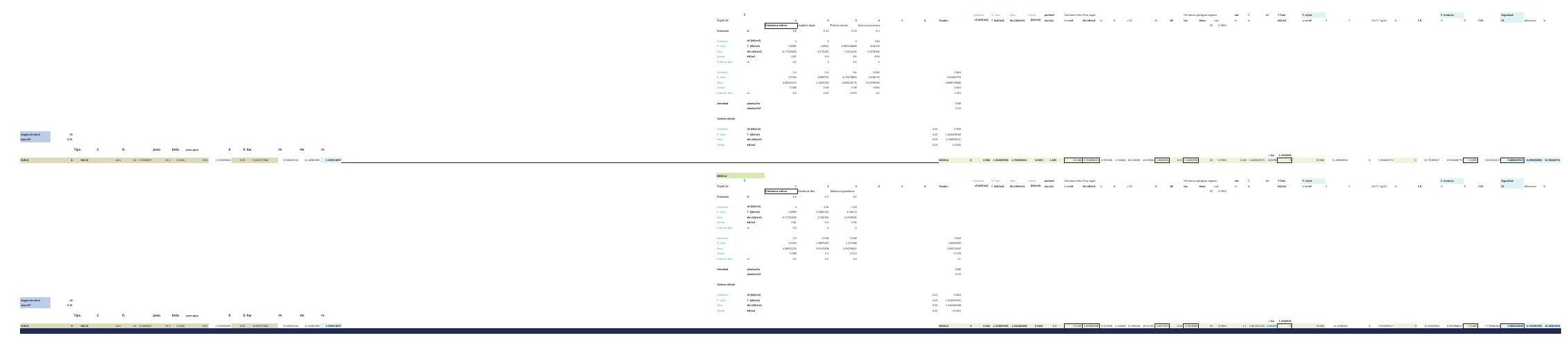




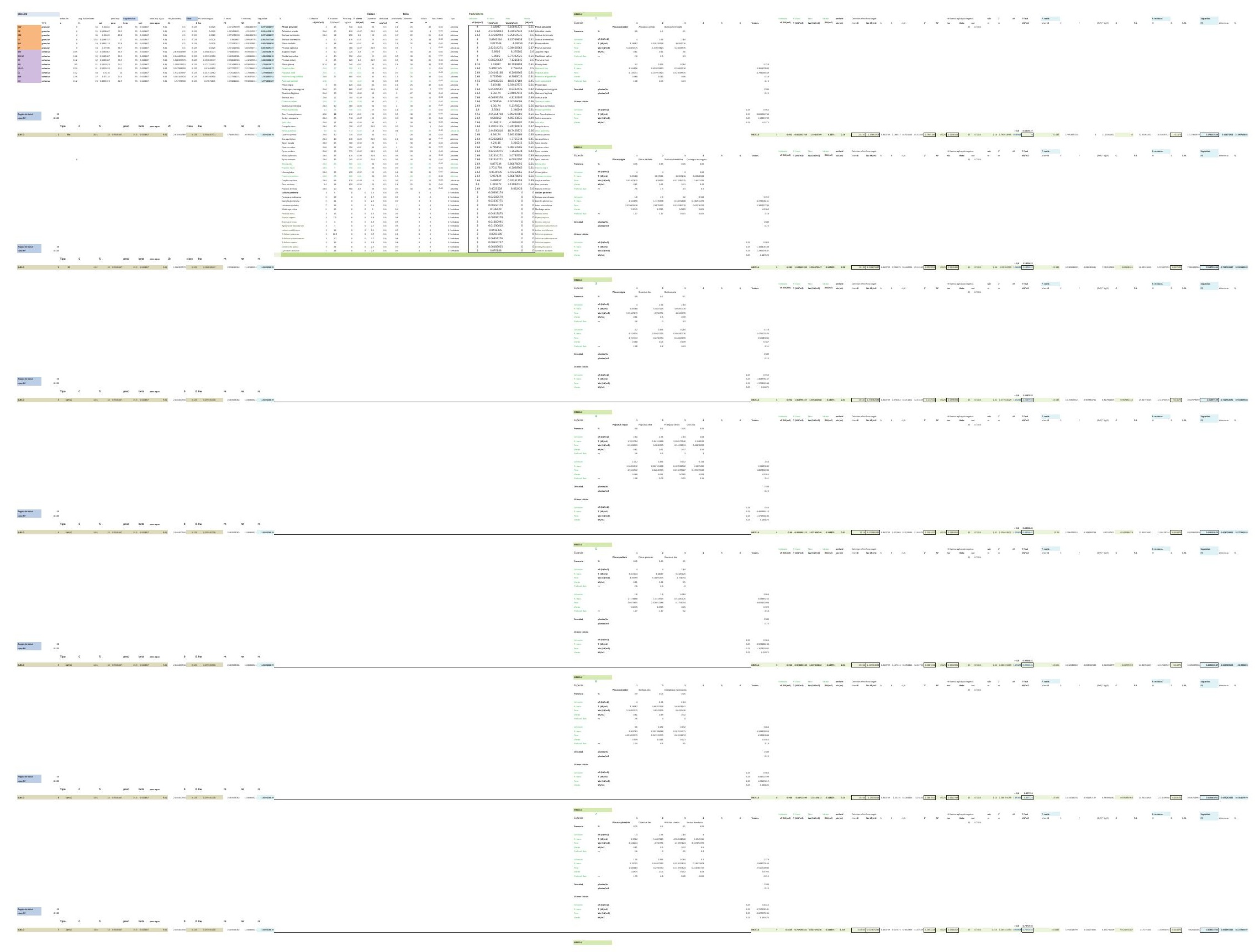


$=$

$=$

$-\ldots+\cdots+\cdots$

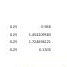

…드.

$\equiv=-$

$= \pm$

$-$ 


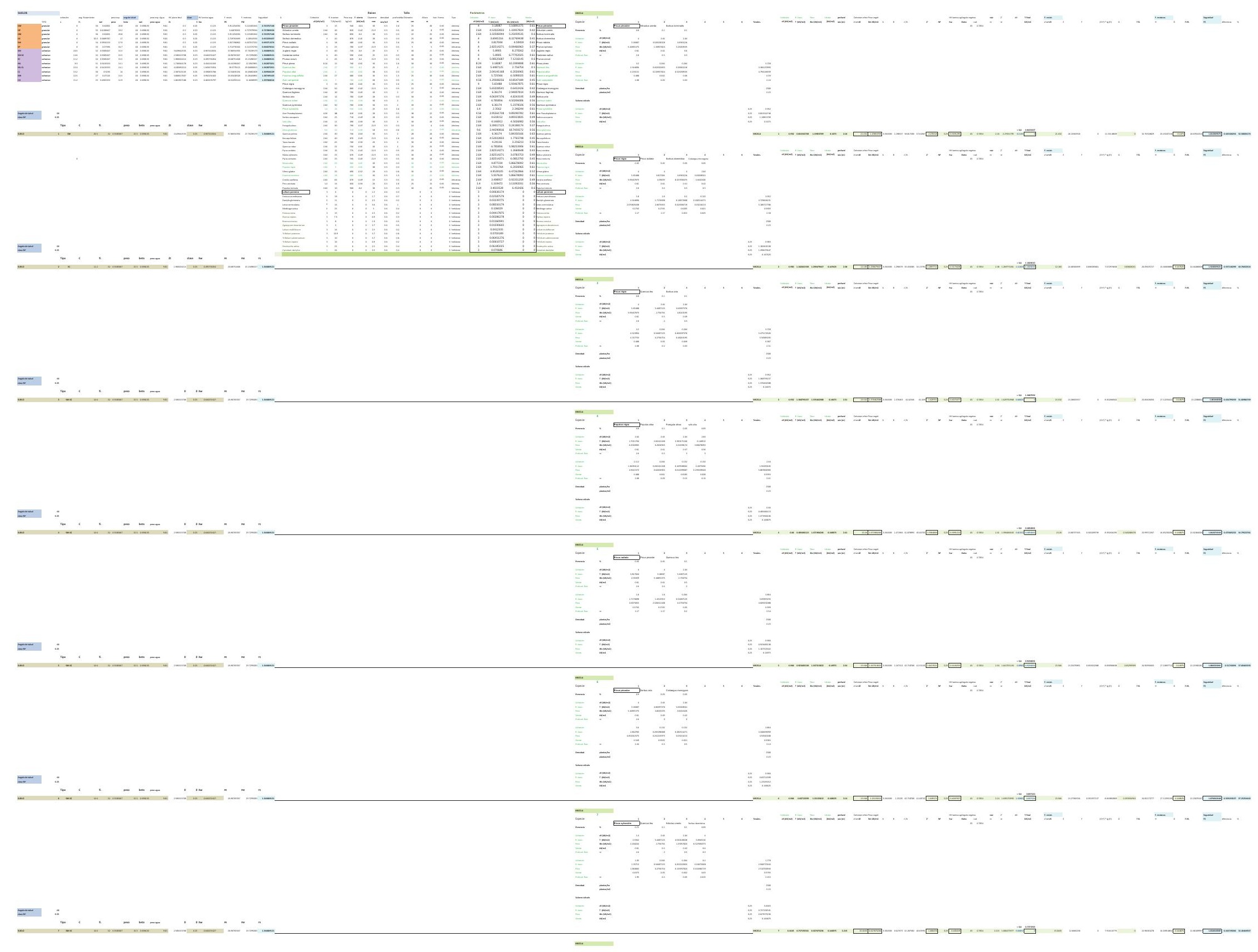




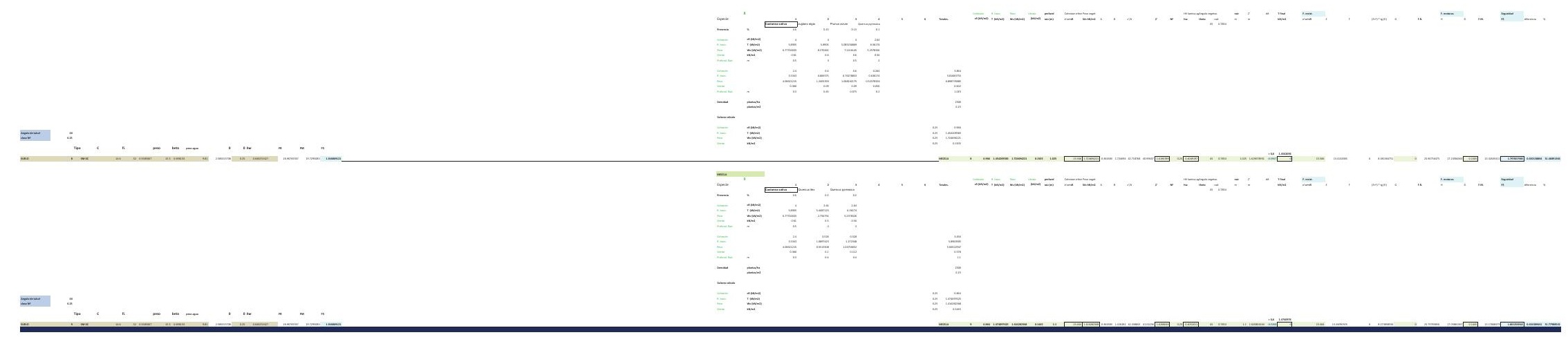




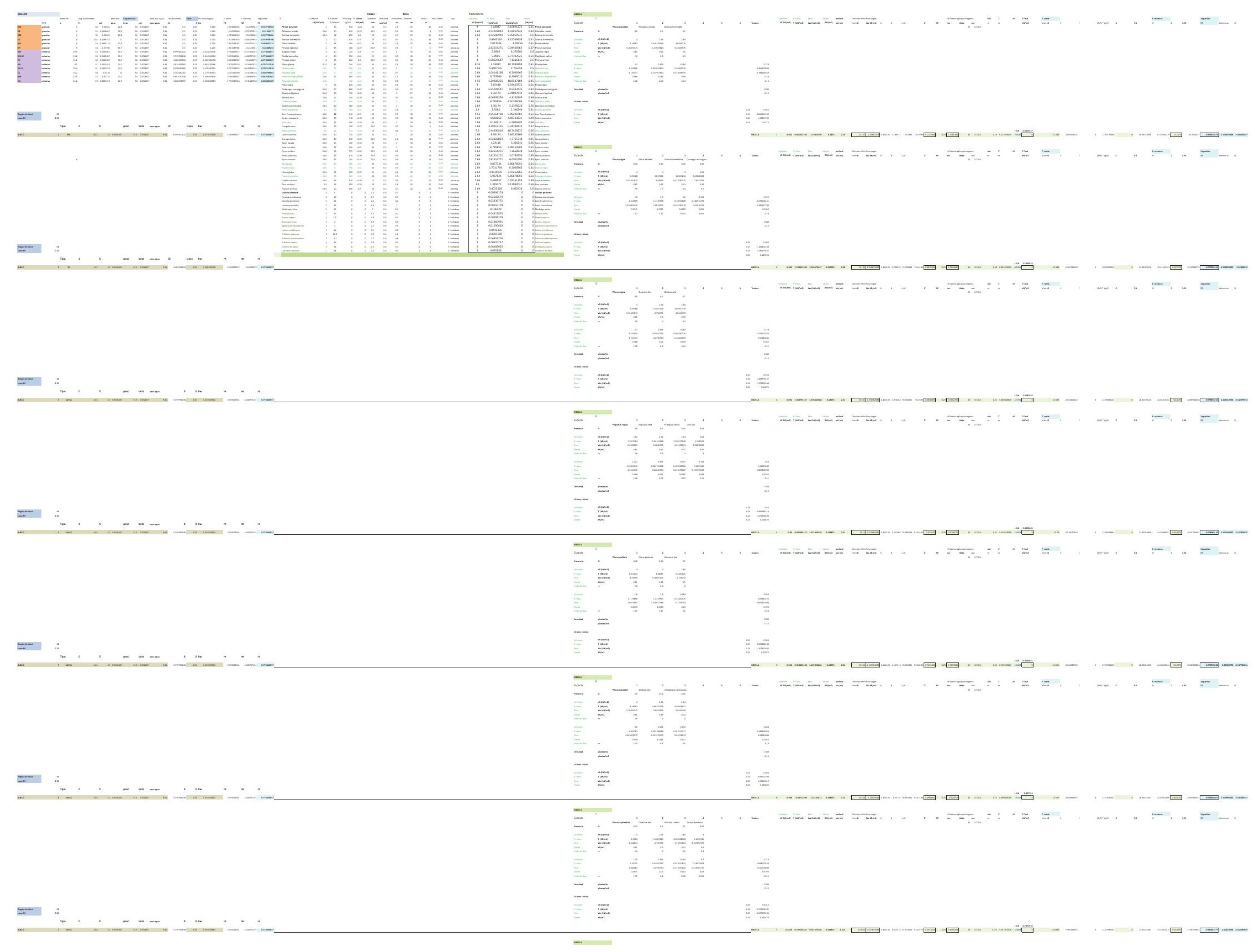


$=$

$=$

-

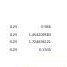

(....

$\equiv=-$

$= \pm$

$-$

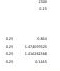




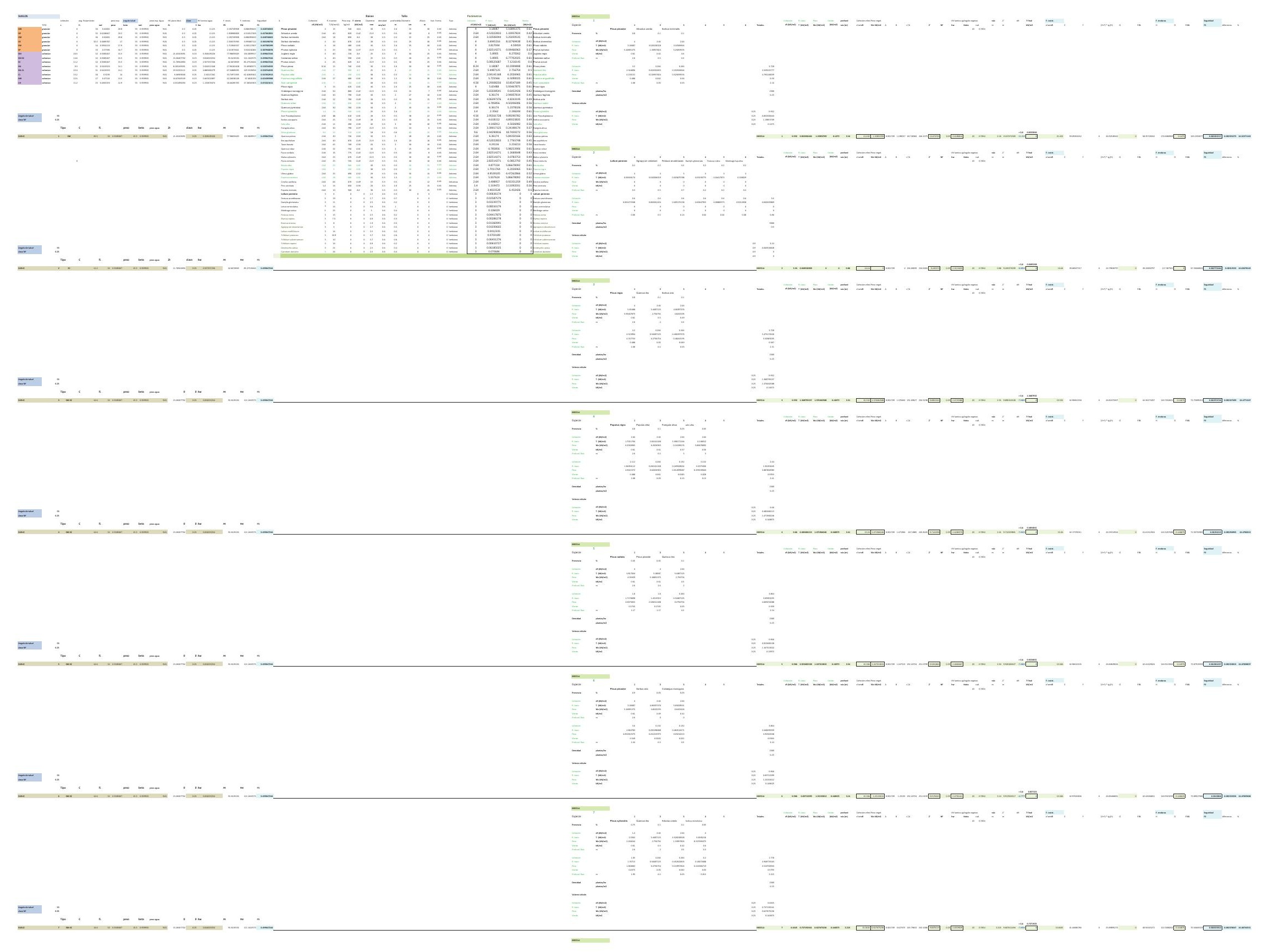


$=$

$=$

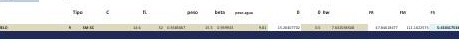

$=$

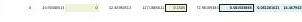

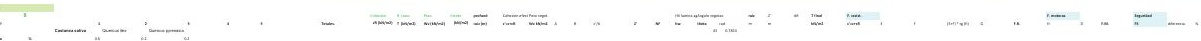

$\equiv= \pm$

$\pm= \pm$

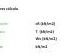




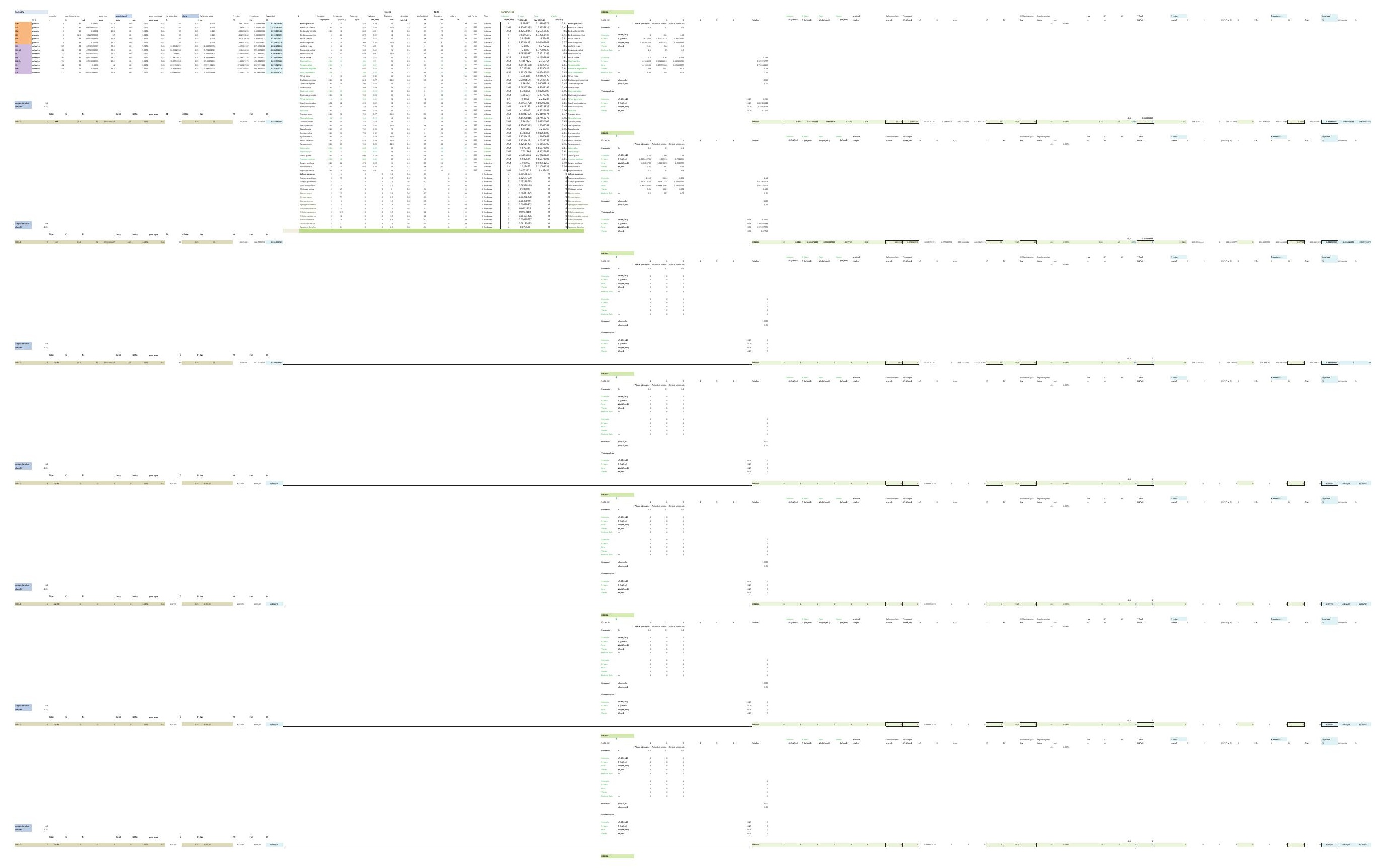




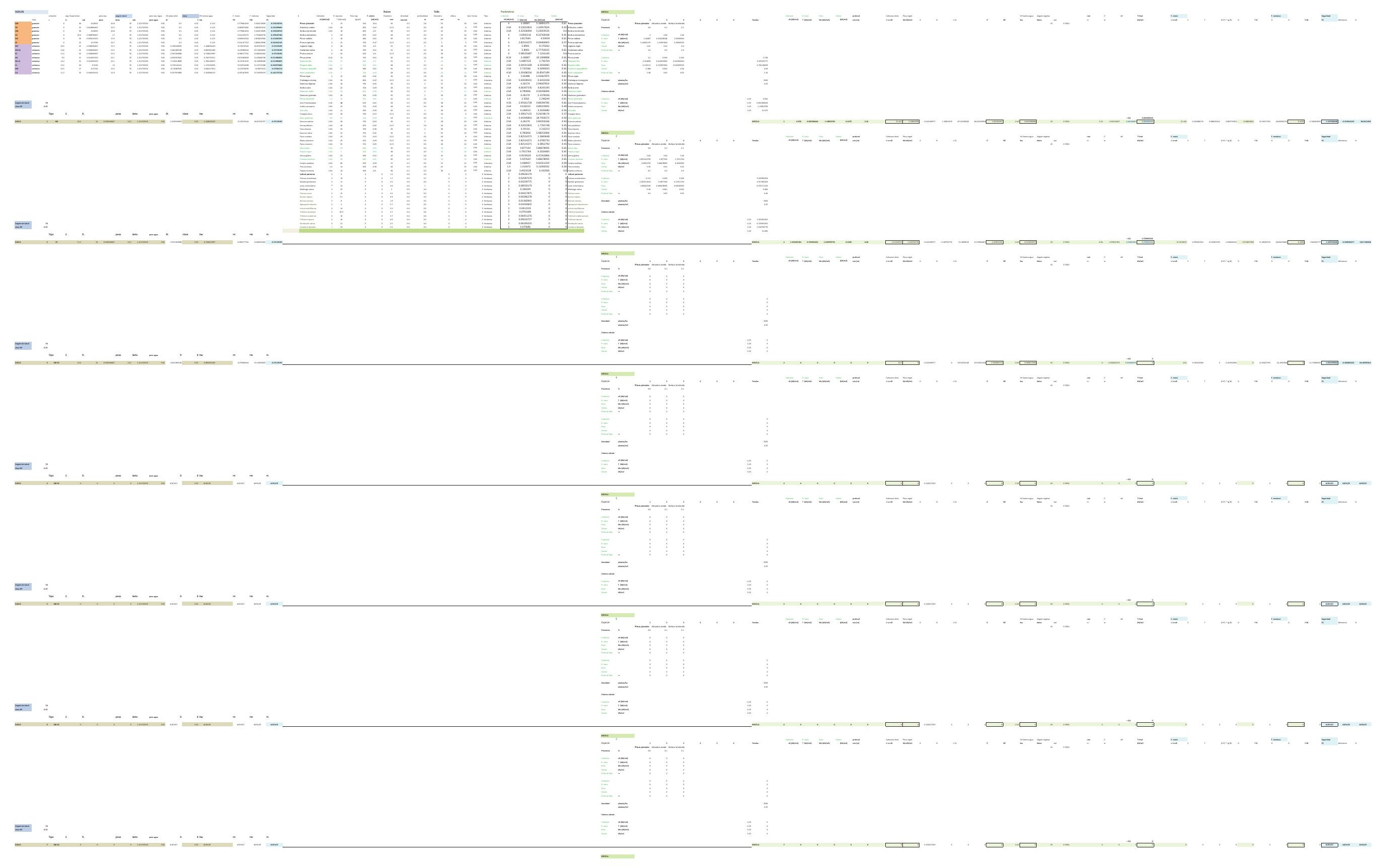




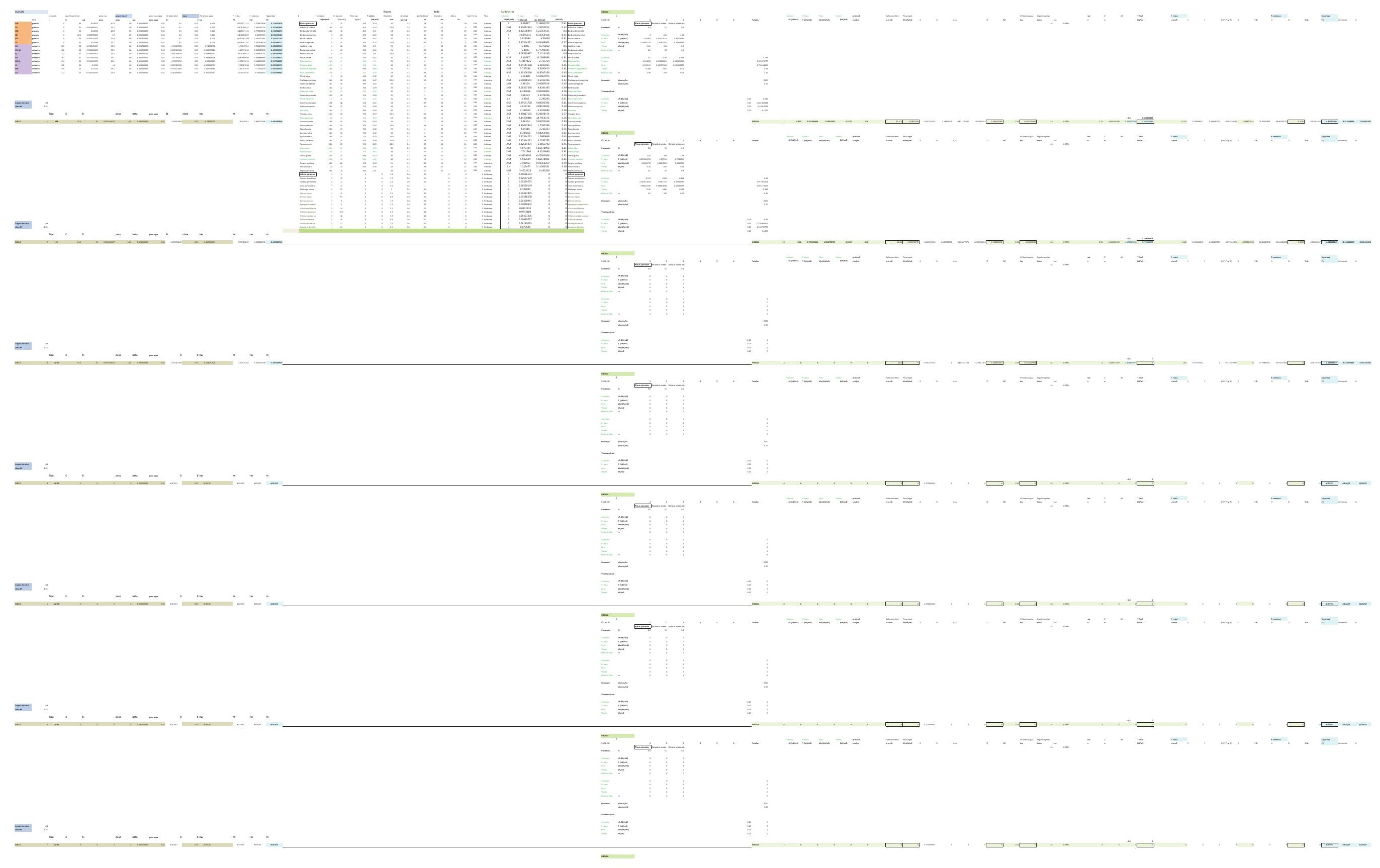


DESARROLLO DE UNA APLICACIÓN IMFORMÁTICA PARA EL CÁLCULO DE SOSTENIMIENTO DE TALUDES MEDIANTE VEGETACIÓN

B03. DENSIDAD DE PLANTACIÓN: 2.500 plantas/ha.

\section{BA03-4.POSICIÓN N.F. 4}

INCLINACIÓN DE TALUD 6-100

INCLINACIÓN DE TALUD 10-200

INCLINACIÓN DE TALUD 20-30

INCLINACIÓN DE TALUD 30-40

INCLINACIÓN DE TALUD $35^{\circ}$

INCLINACIÓN DE TALUD 40-50

INCLINACIÓN DE TALUD 50-550

INCLINACIÓN DE TALUD 55-60

INCLINACIÓN DE TALUD 60-700

INCLINACIÓN DE TALUD 70-80 


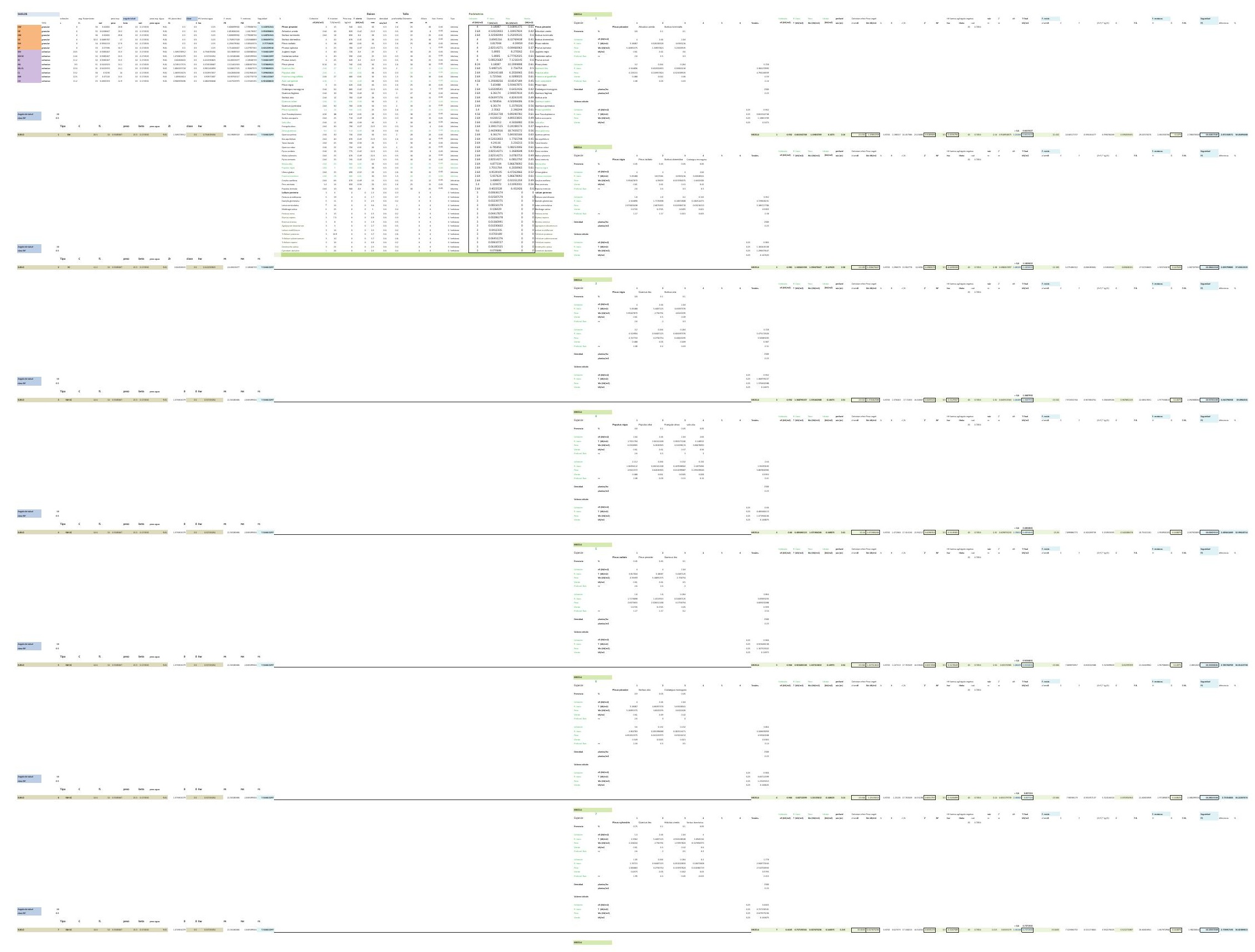


$=$

$=$

-

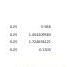

(....

$\equiv=-$

$= \pm=$

$=$ 


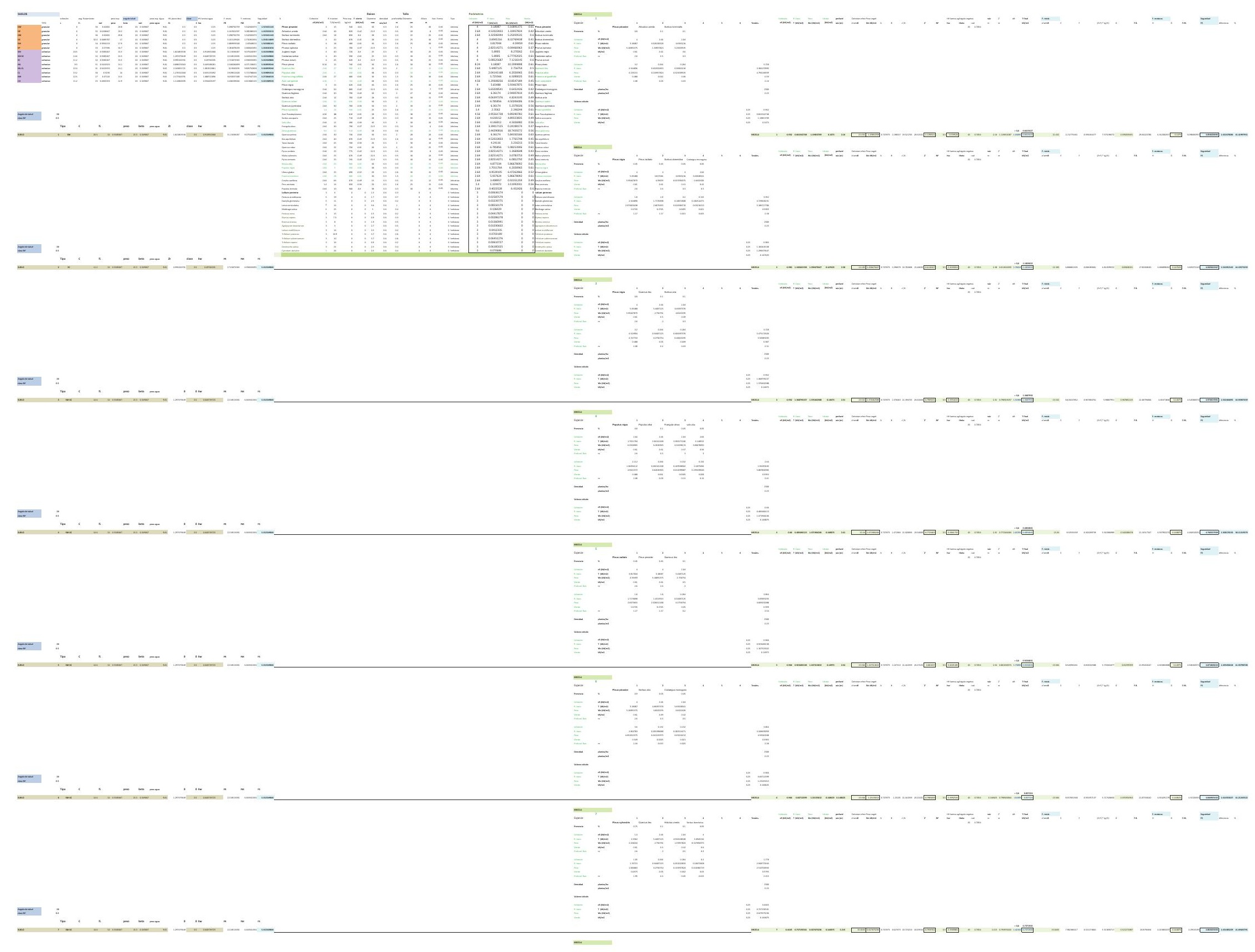


$=$

$=$

-

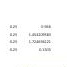

(…ㅁ․

$\equiv=-$

E. $=$

$-$

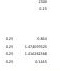




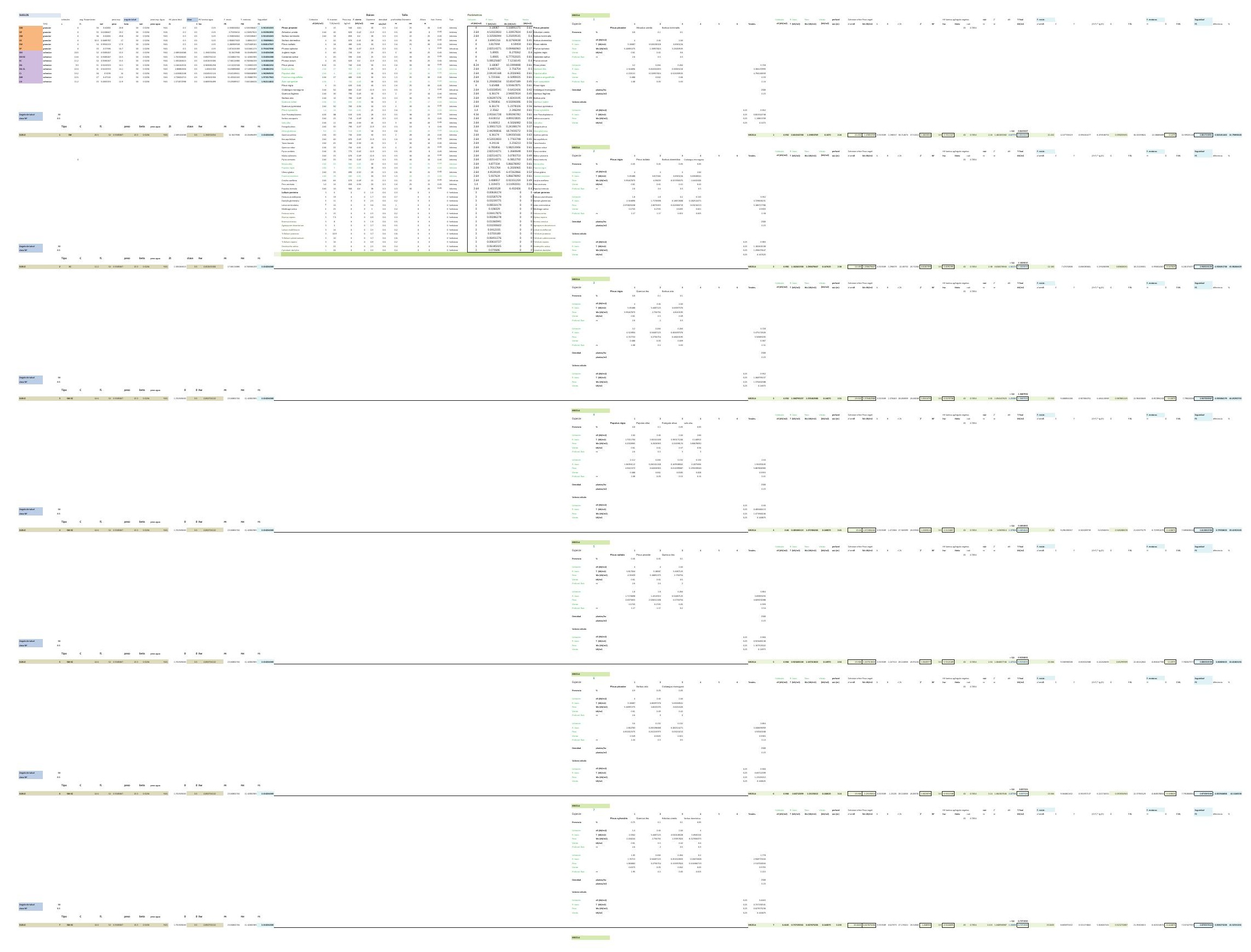


$=$

$=$

-

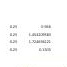

(...

$\equiv=-$

$= \pm$

$-$ 


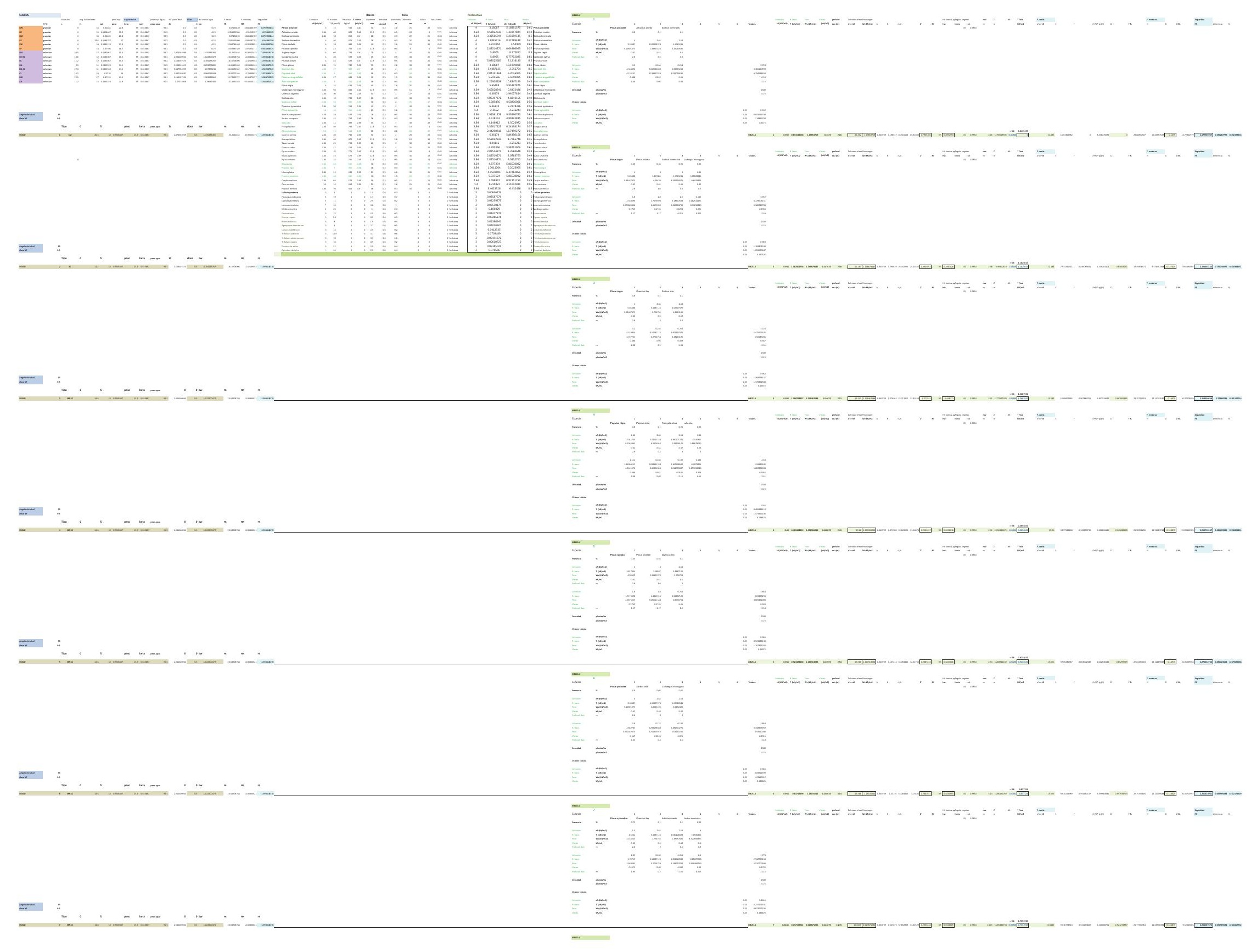


$=$

$=$

(n)

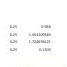

(...

$\equiv=-$

$= \pm$

$-$ 


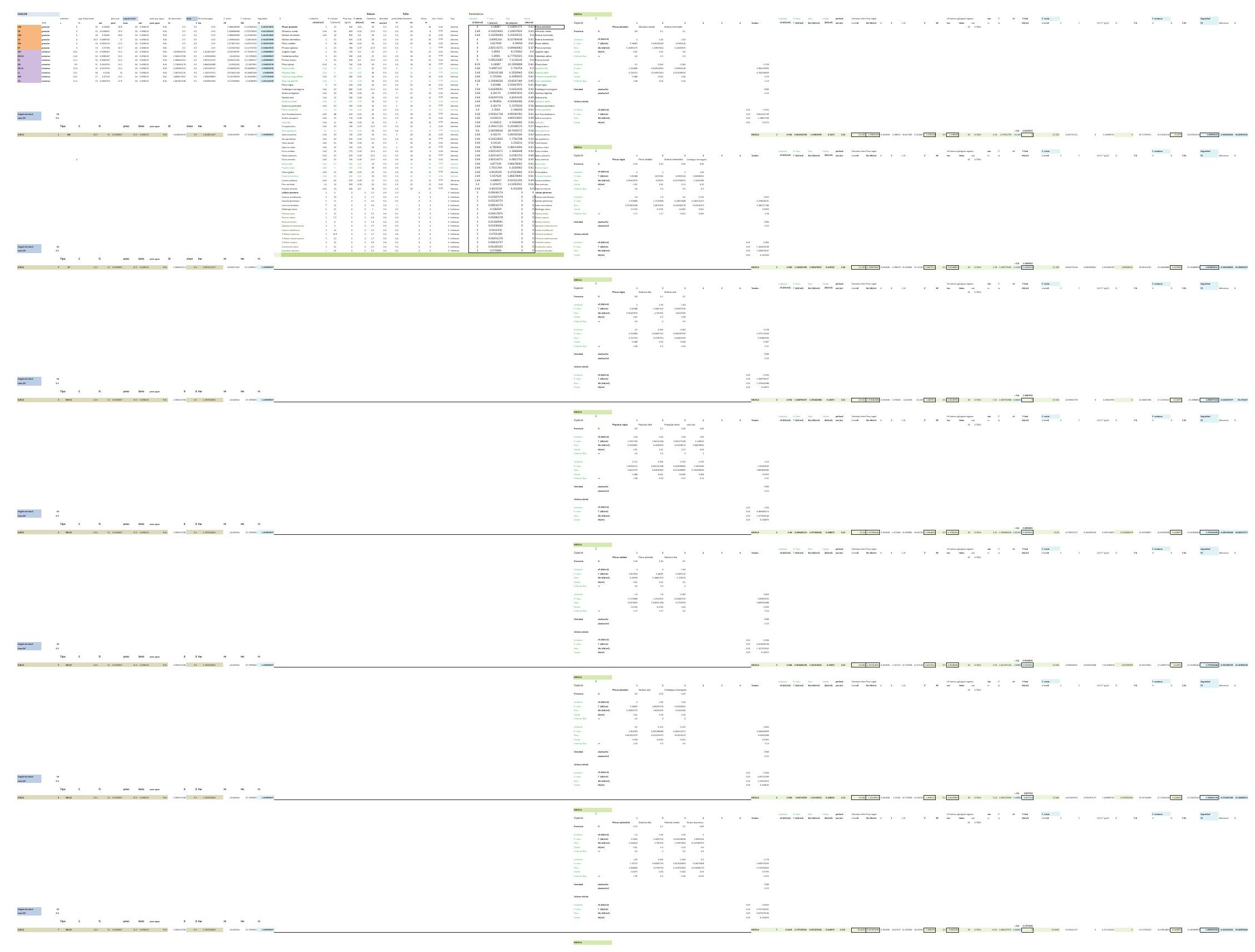


$=$

$=$

-

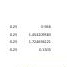

……

$\equiv=-$

$= \pm$

$-$ 


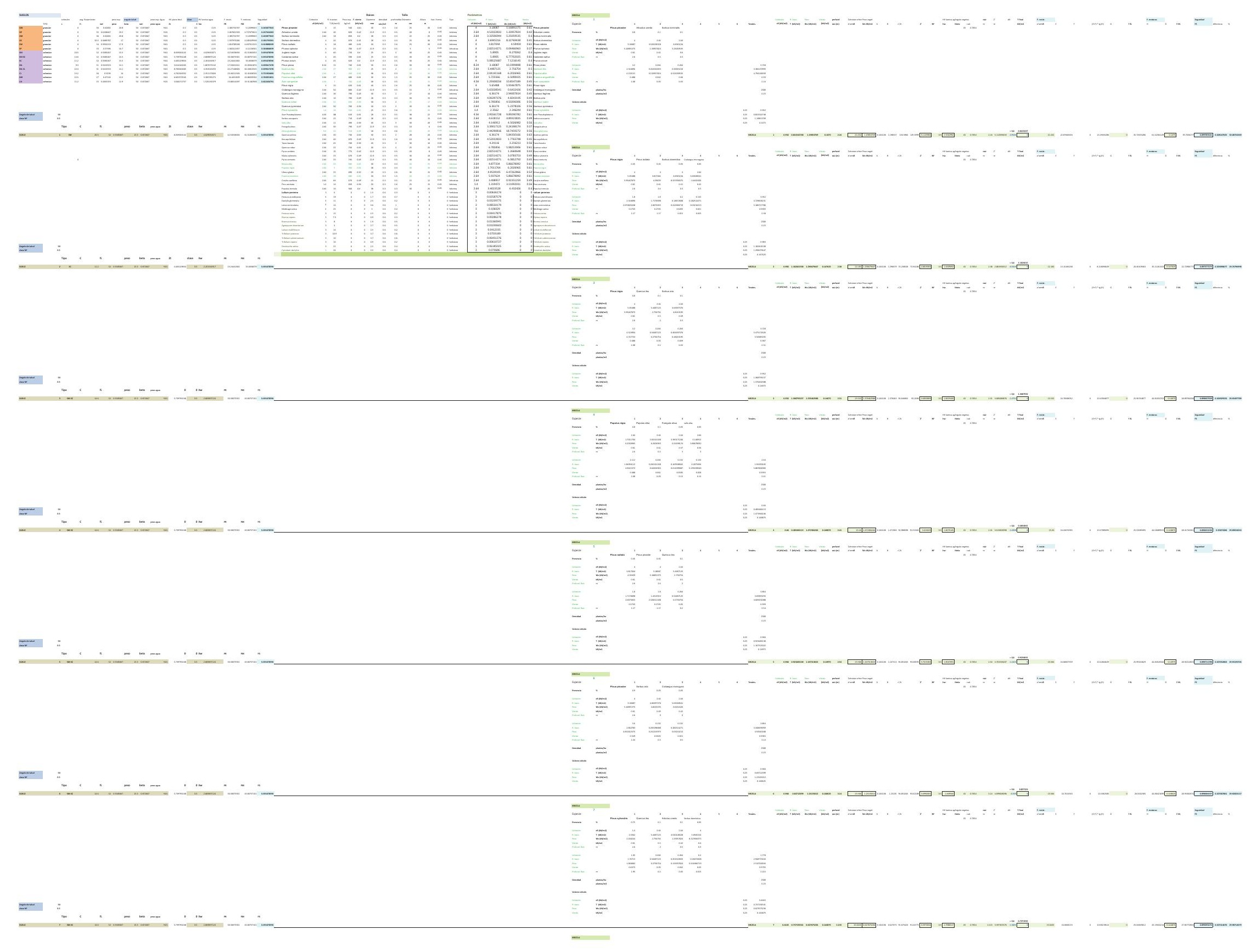


$=$

$=$

-

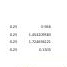

(....

$\equiv=-$

$= \pm$

$-$

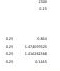




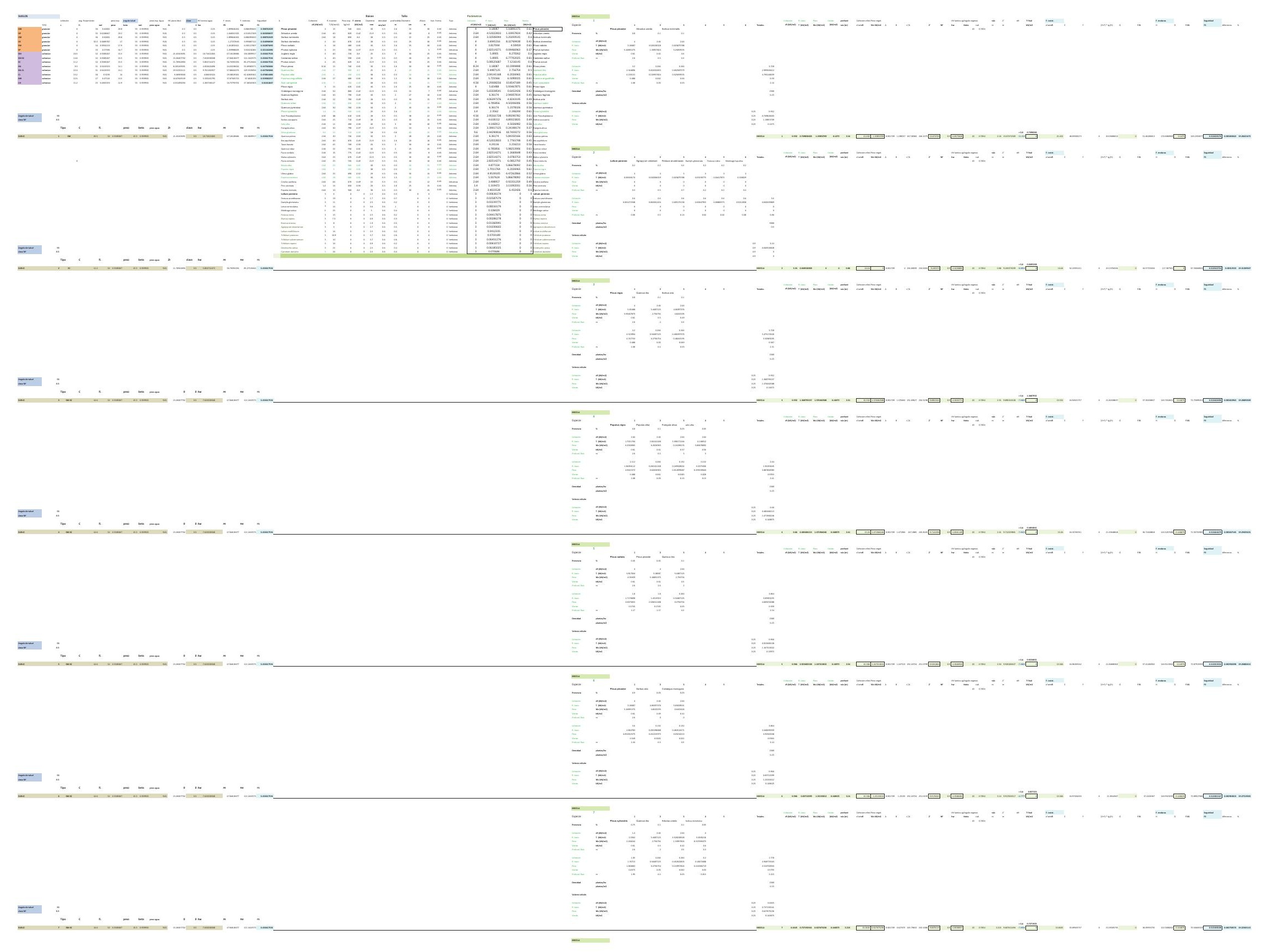


$=$

$=$

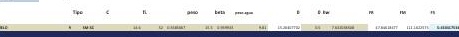

$=$

-

$\equiv= \pm$

$= \pm=$

$=$ 


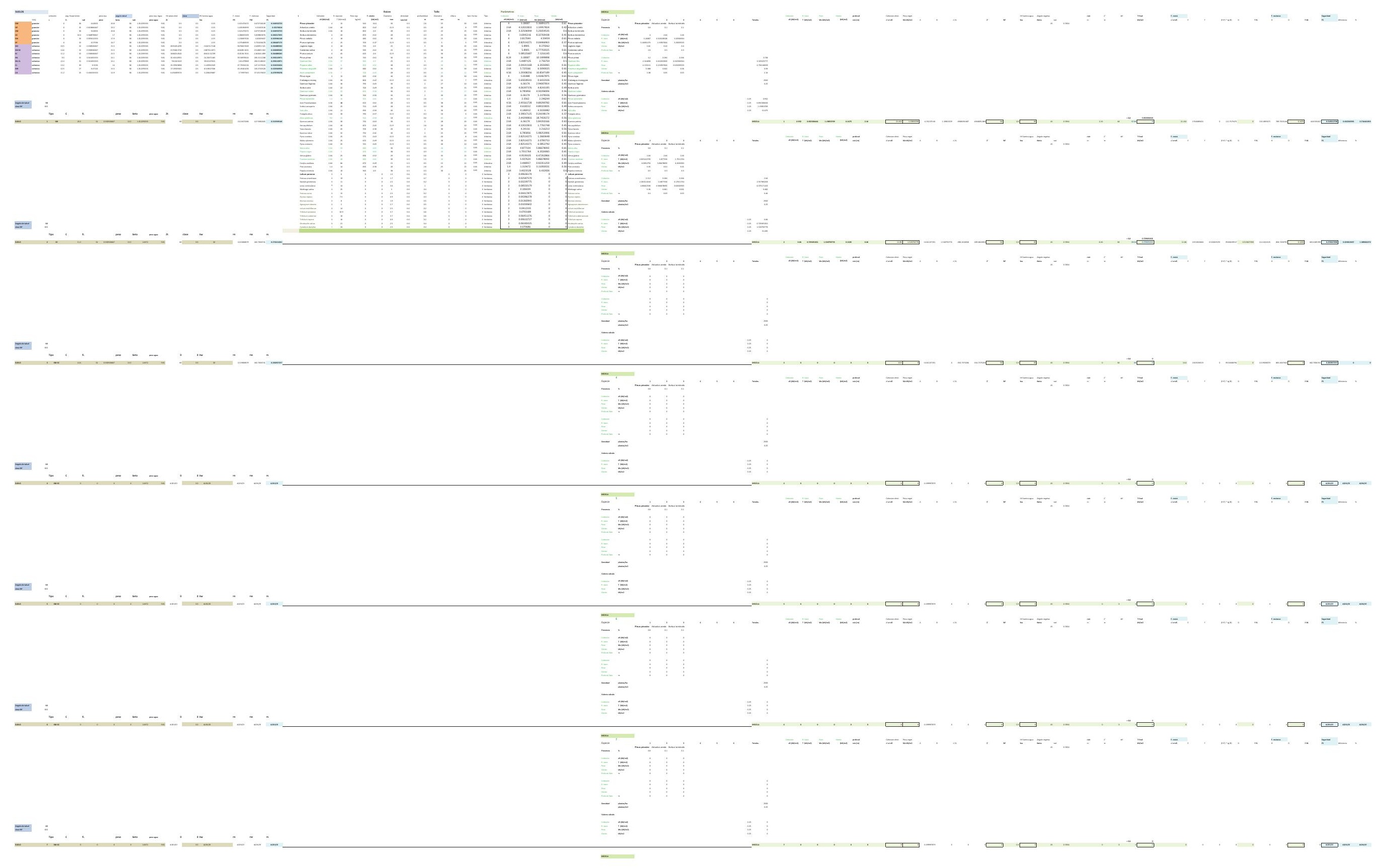




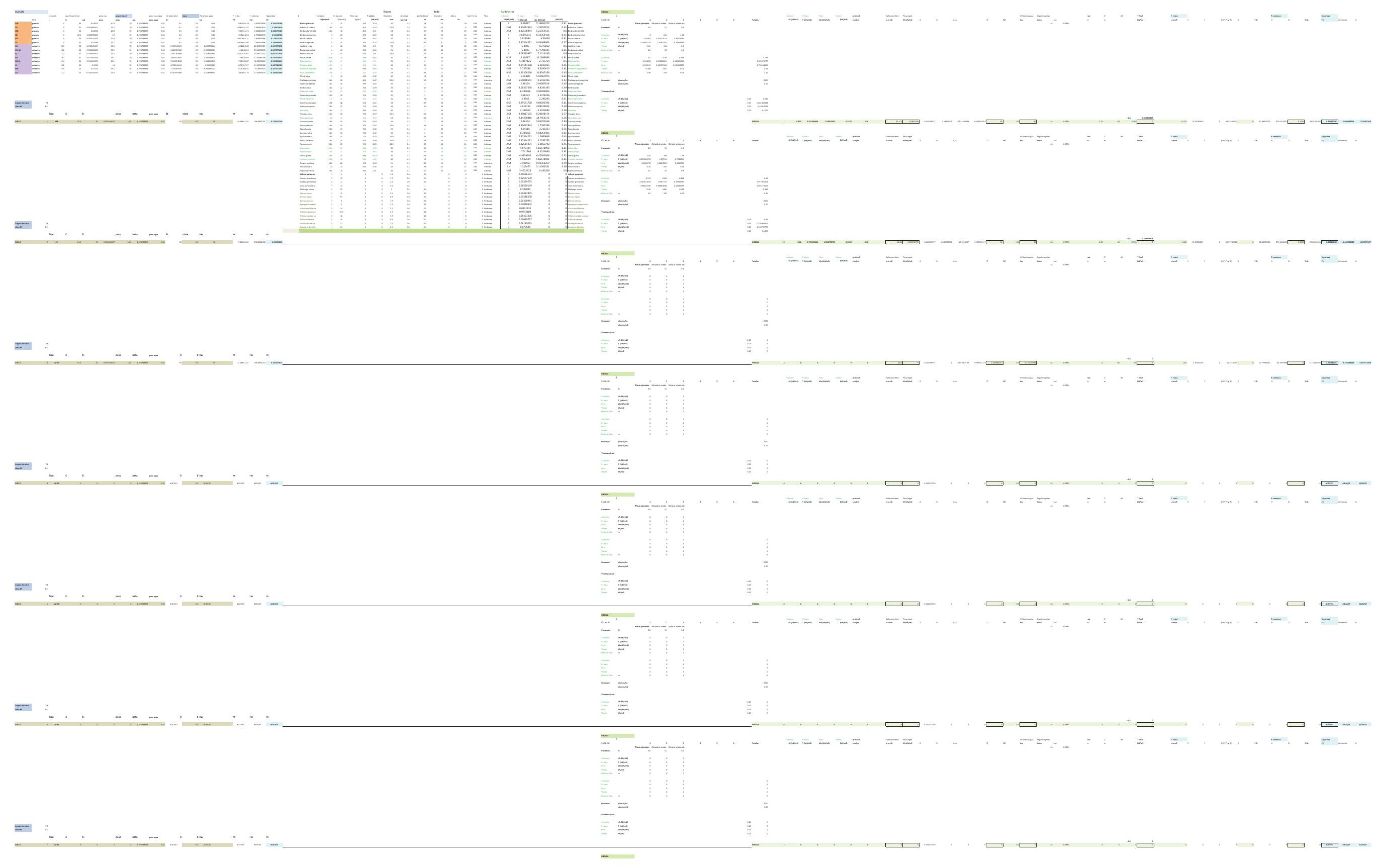




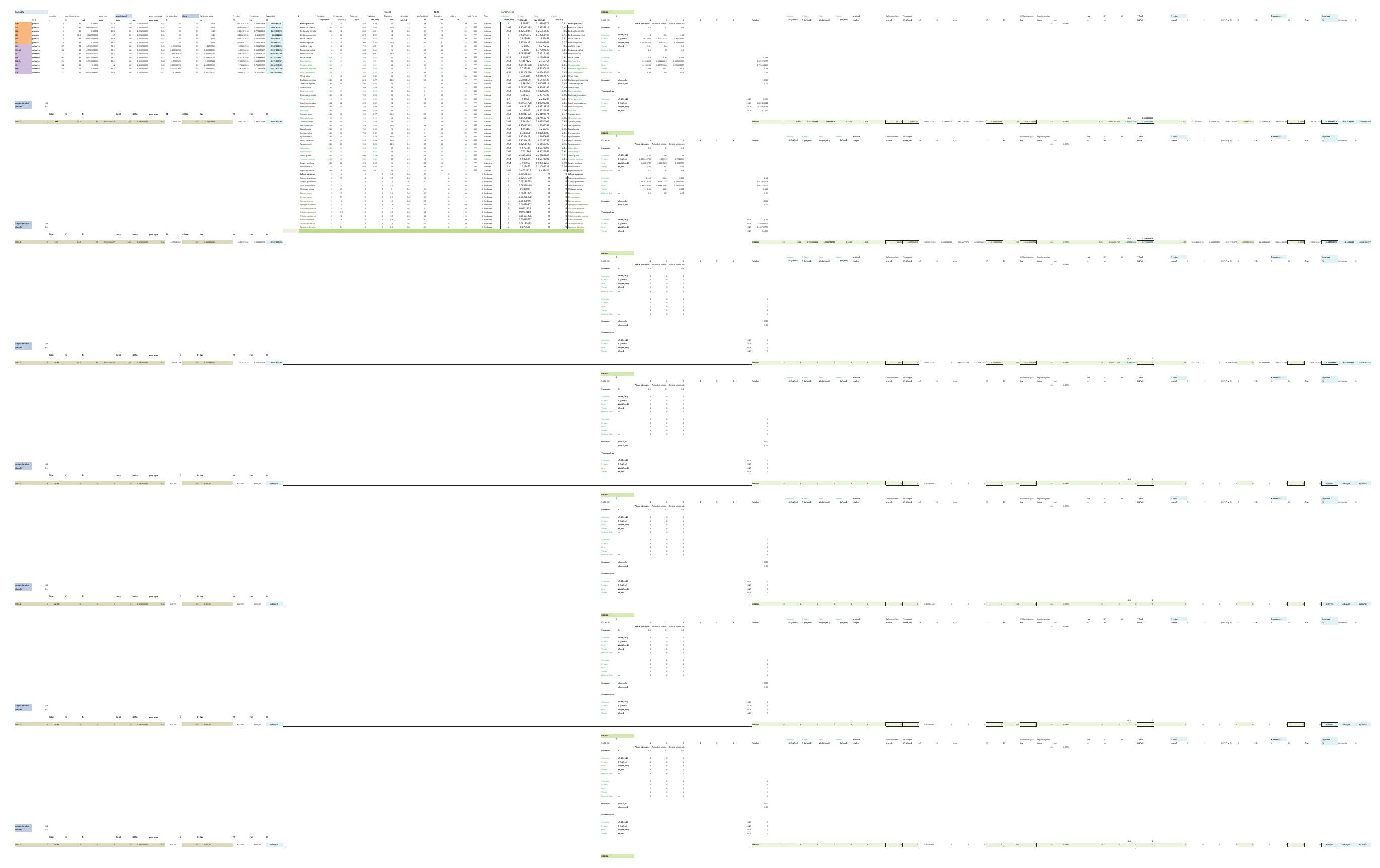


DESARROLLO DE UNA APLICACIÓN IMFORMÁTICA PARA EL CÁLCULO DE SOSTENIMIENTO DE TALUDES MEDIANTE VEGETACIÓN

B03. DENSIDAD DE PLANTACIÓN: 2.500 plantas/ha.

\section{B03-5.POSICIÓN N.F. 5}

INCLINACIÓN DE TALUD 6-100

INCLINACIÓN DE TALUD 10-200

INCLINACIÓN DE TALUD 20-30

INCLINACIÓN DE TALUD 30-40

INCLINACIÓN DE TALUD $35^{\circ}$

INCLINACIÓN DE TALUD 40-50

INCLINACIÓN DE TALUD 50-550

INCLINACIÓN DE TALUD 55-60

INCLINACIÓN DE TALUD 60-700

INCLINACIÓN DE TALUD 70-80 


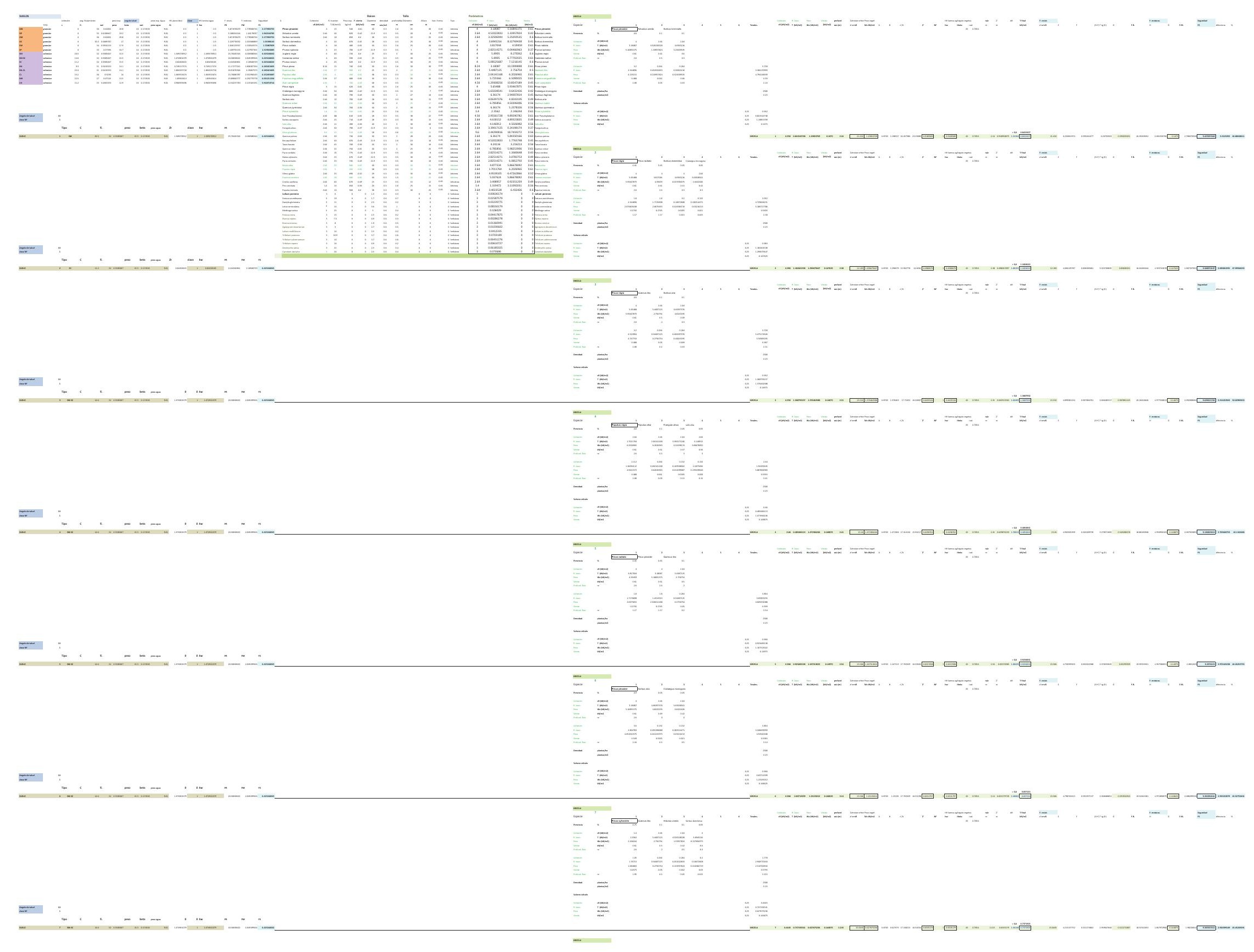




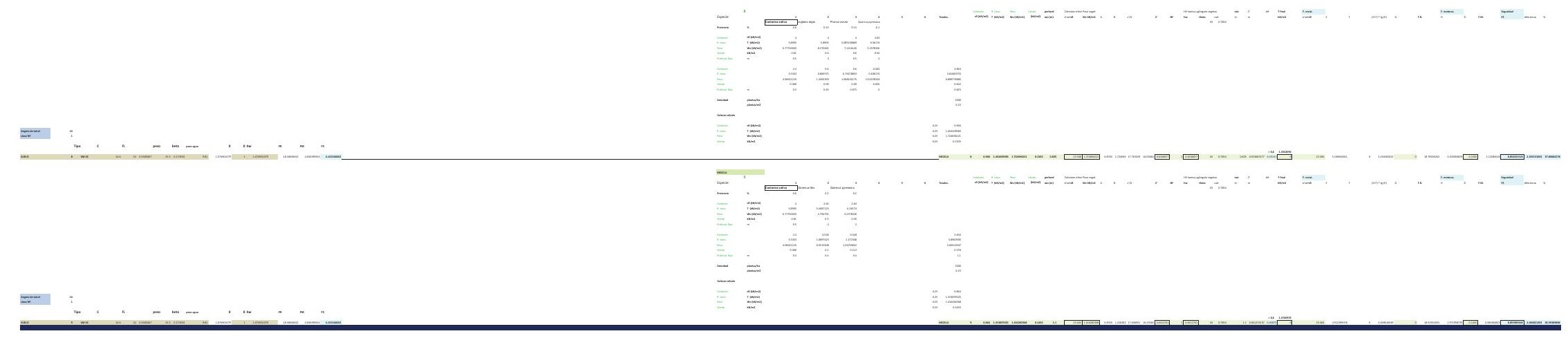




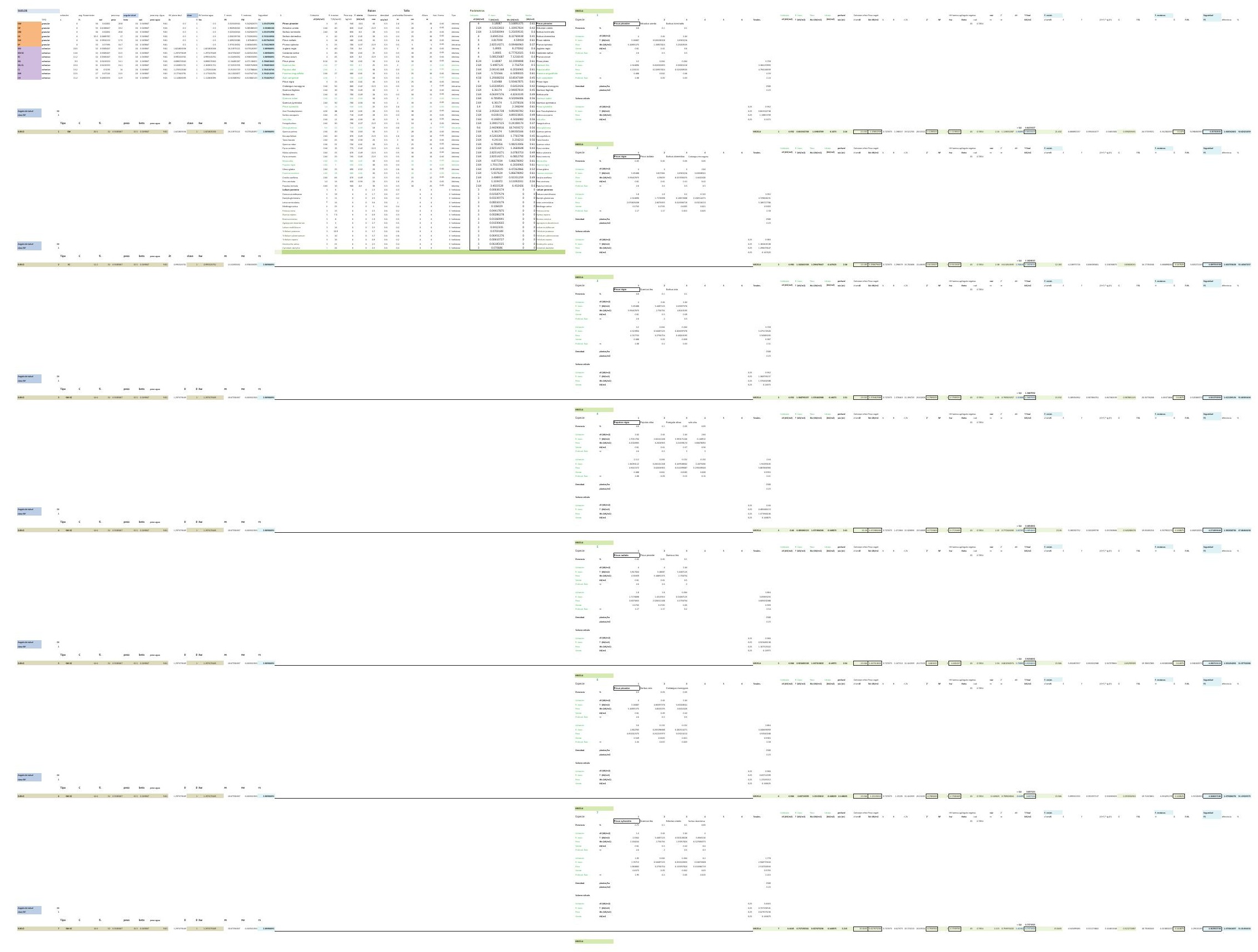




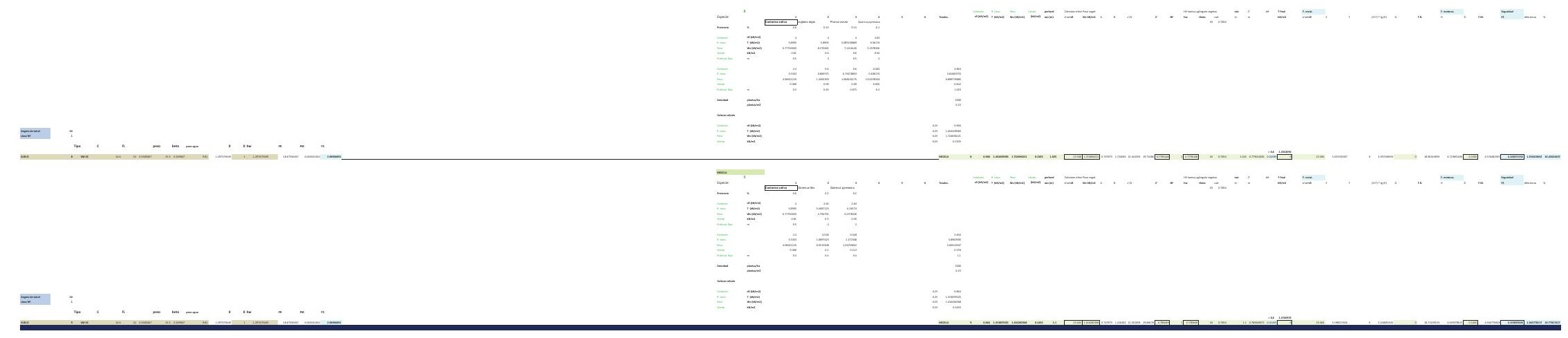




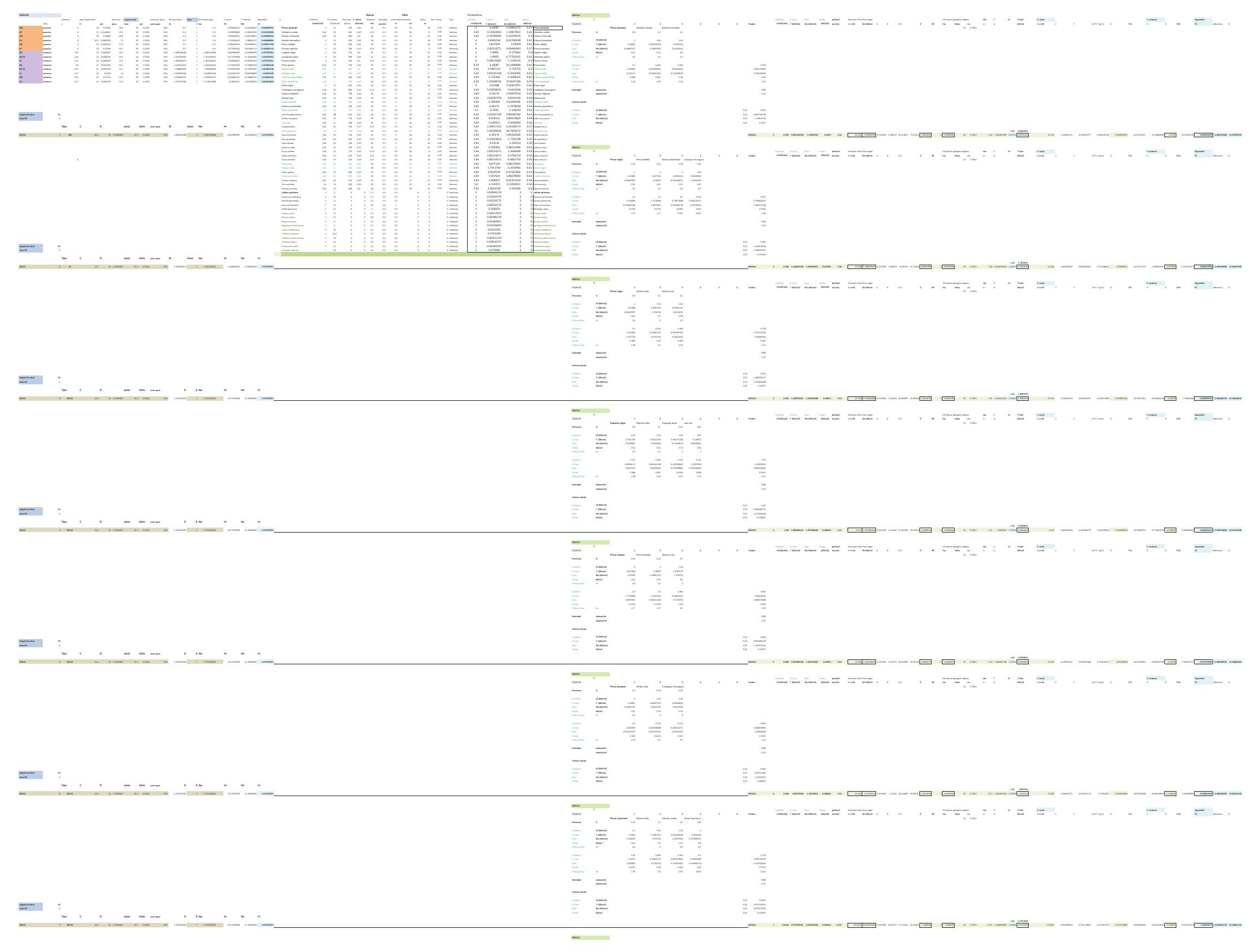


$=$

$=$

(n) $\pm$

(2.

$\equiv=-$

$= \pm$

$-$

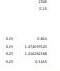




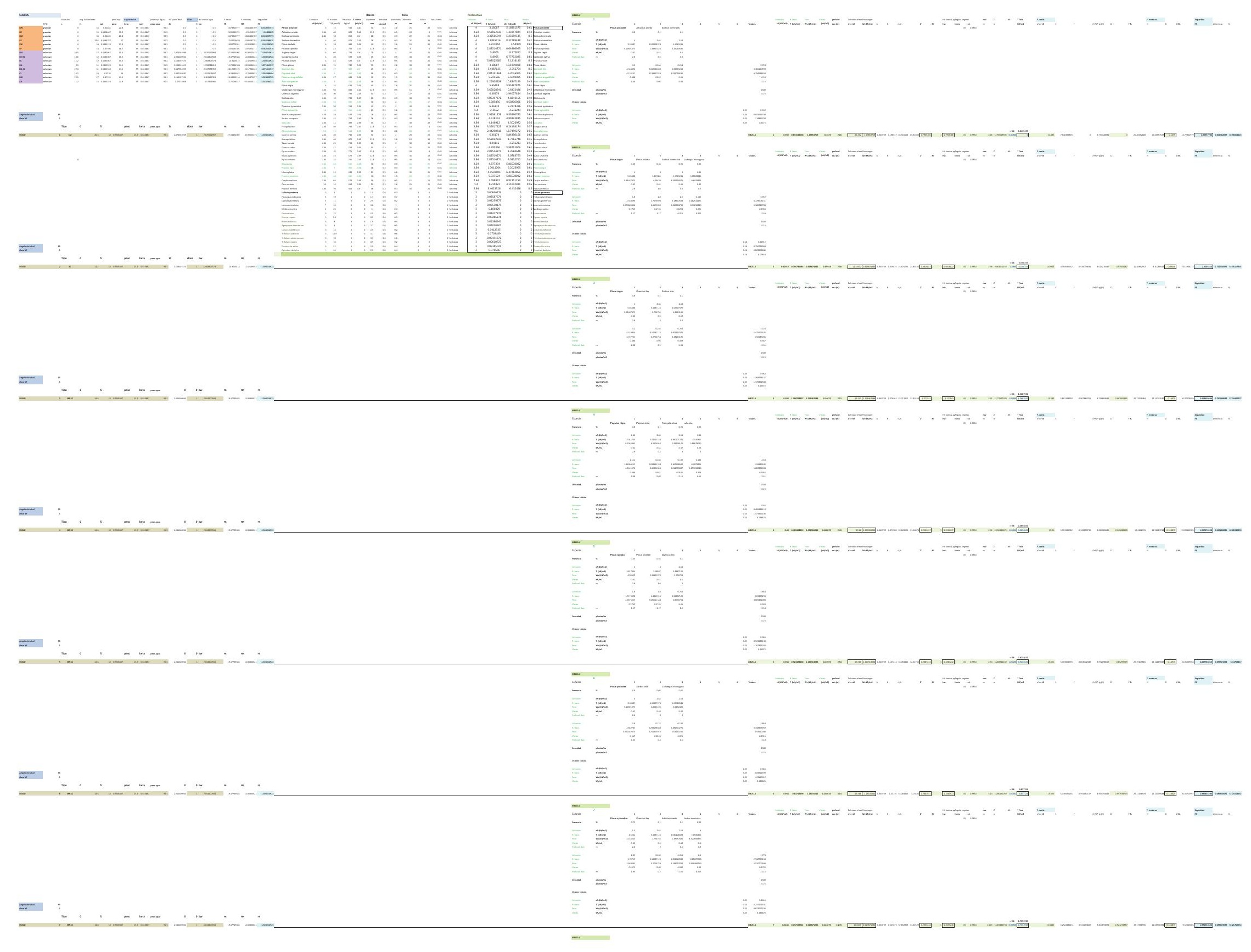


$=$

$=$

- $\pm$

(1)

$\equiv=-$

$= \pm=$

$=$

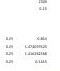




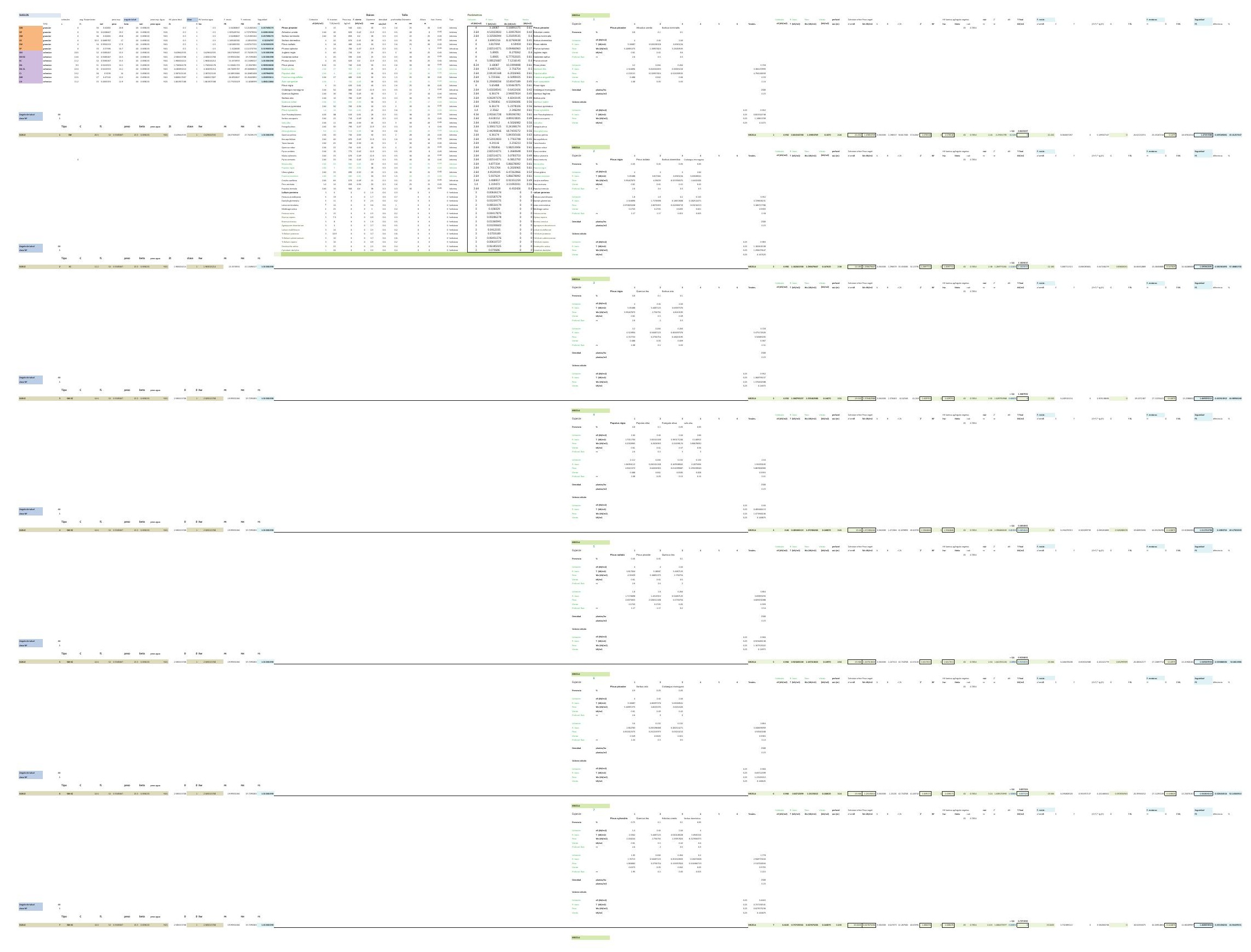


$=$

$=$

(n) $\pm$

1

$\equiv=-$

$= \pm$

$-$

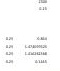




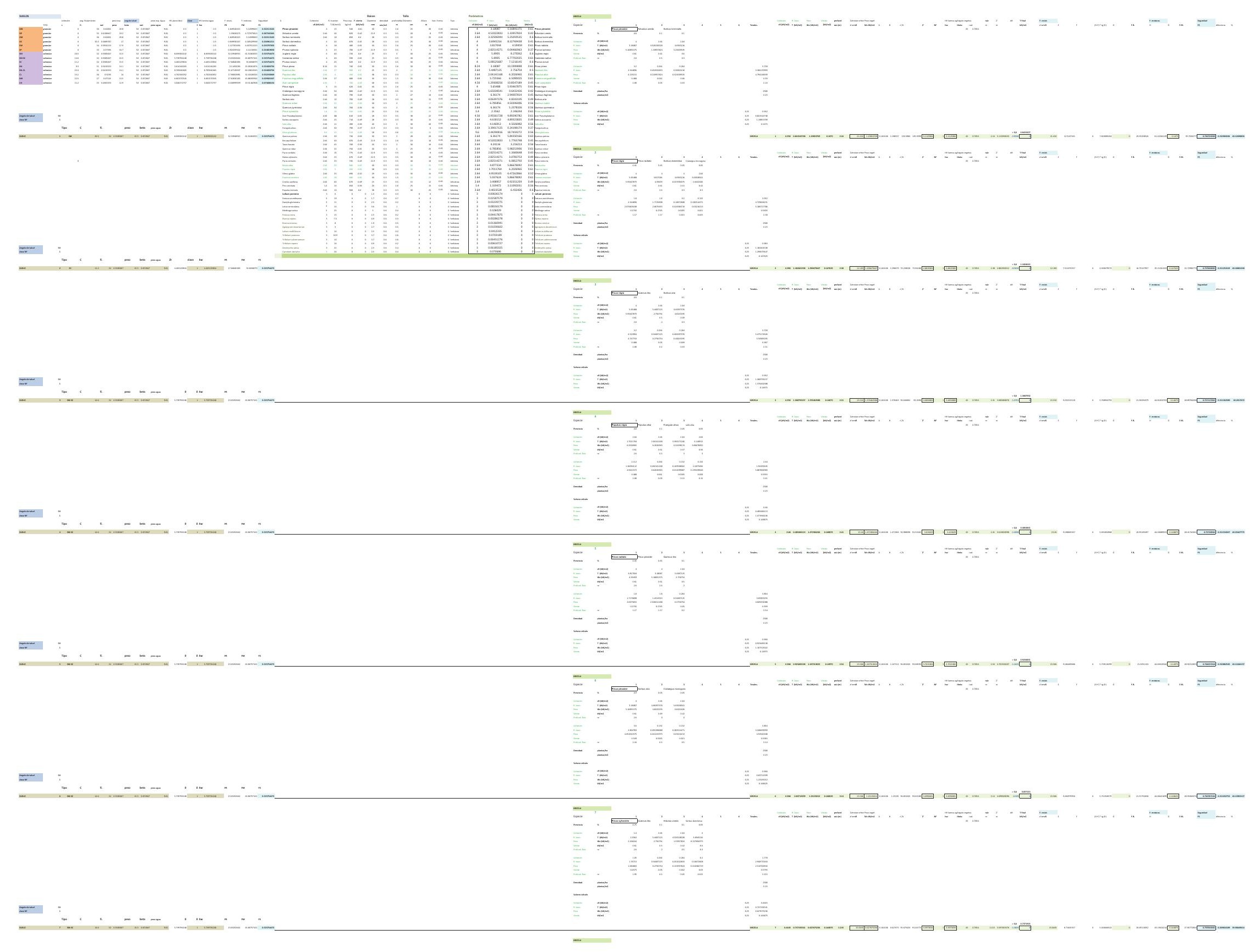




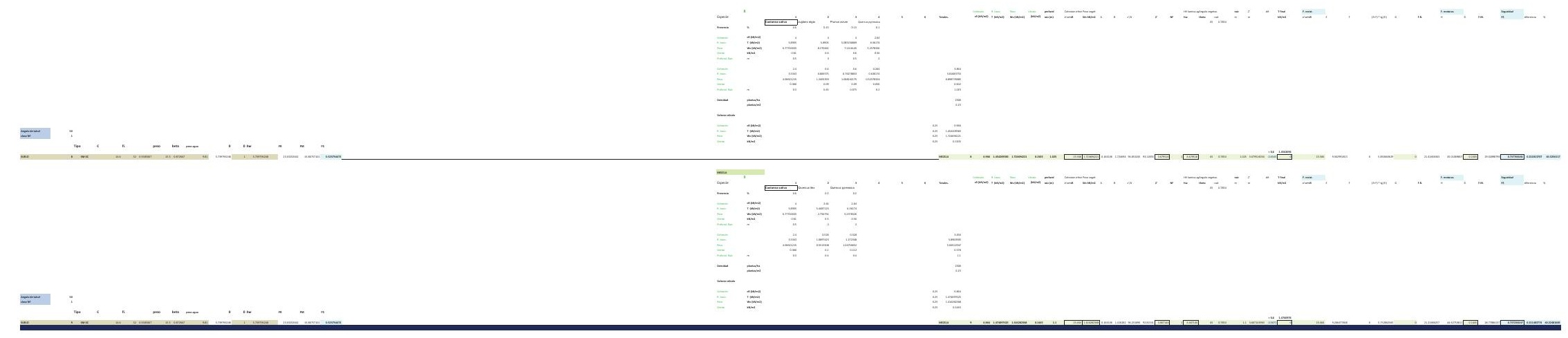




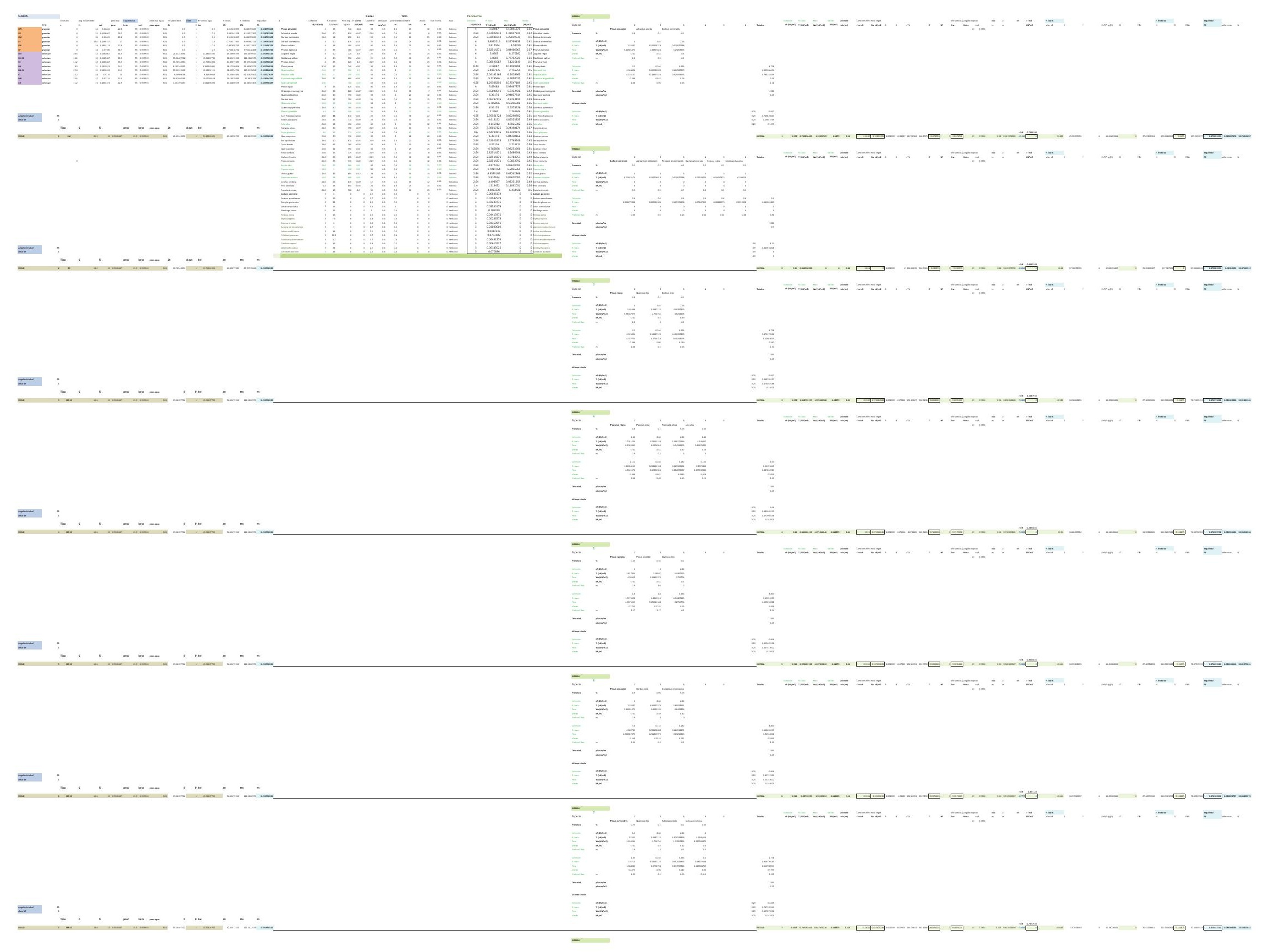


$=$

$=$

$-\ldots+\ldots \ldots$
$=$

-

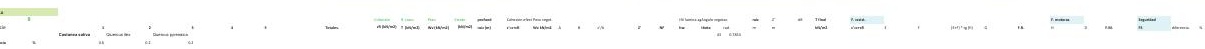

$\equiv=$

$= \pm=$

$=$ 


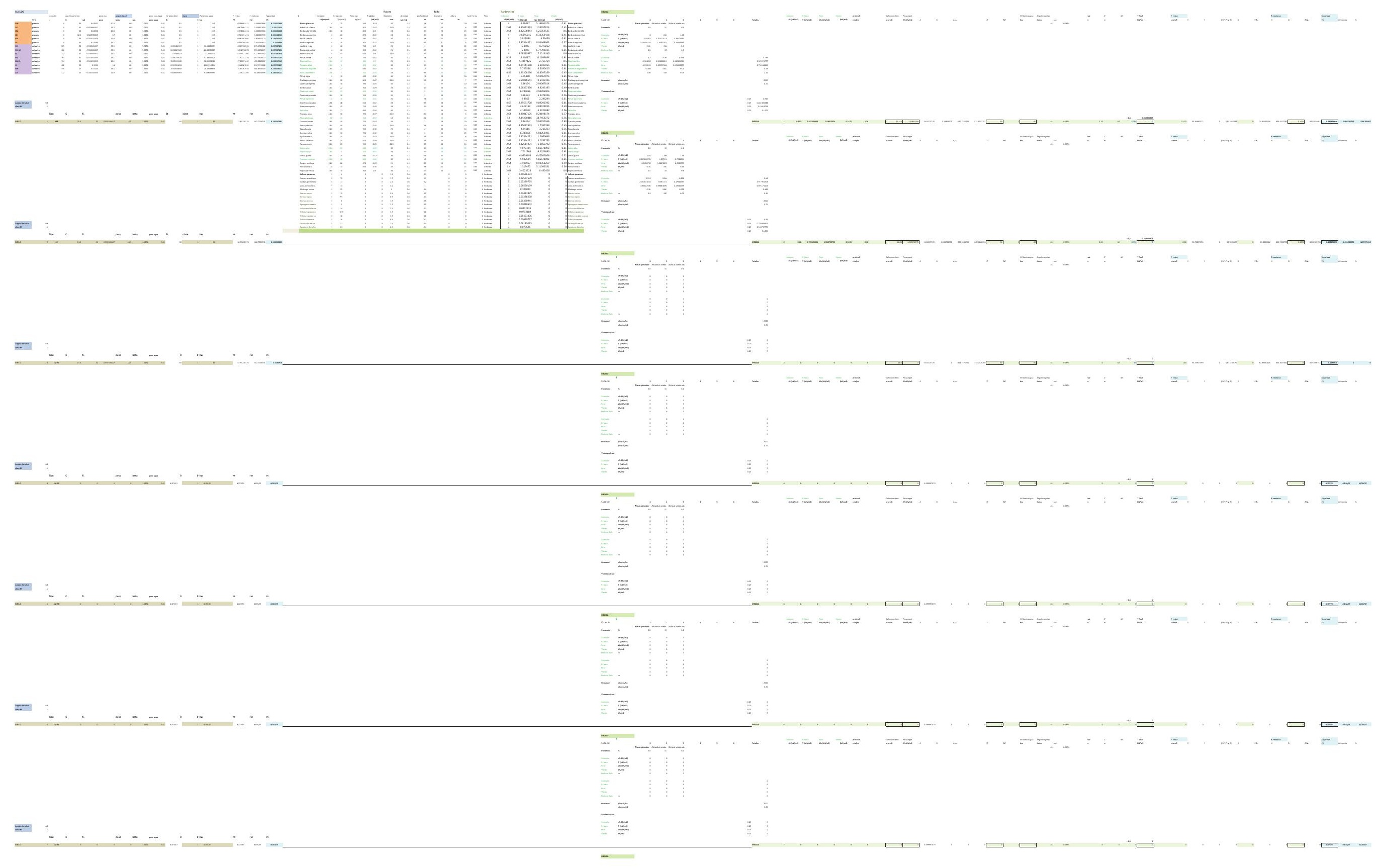




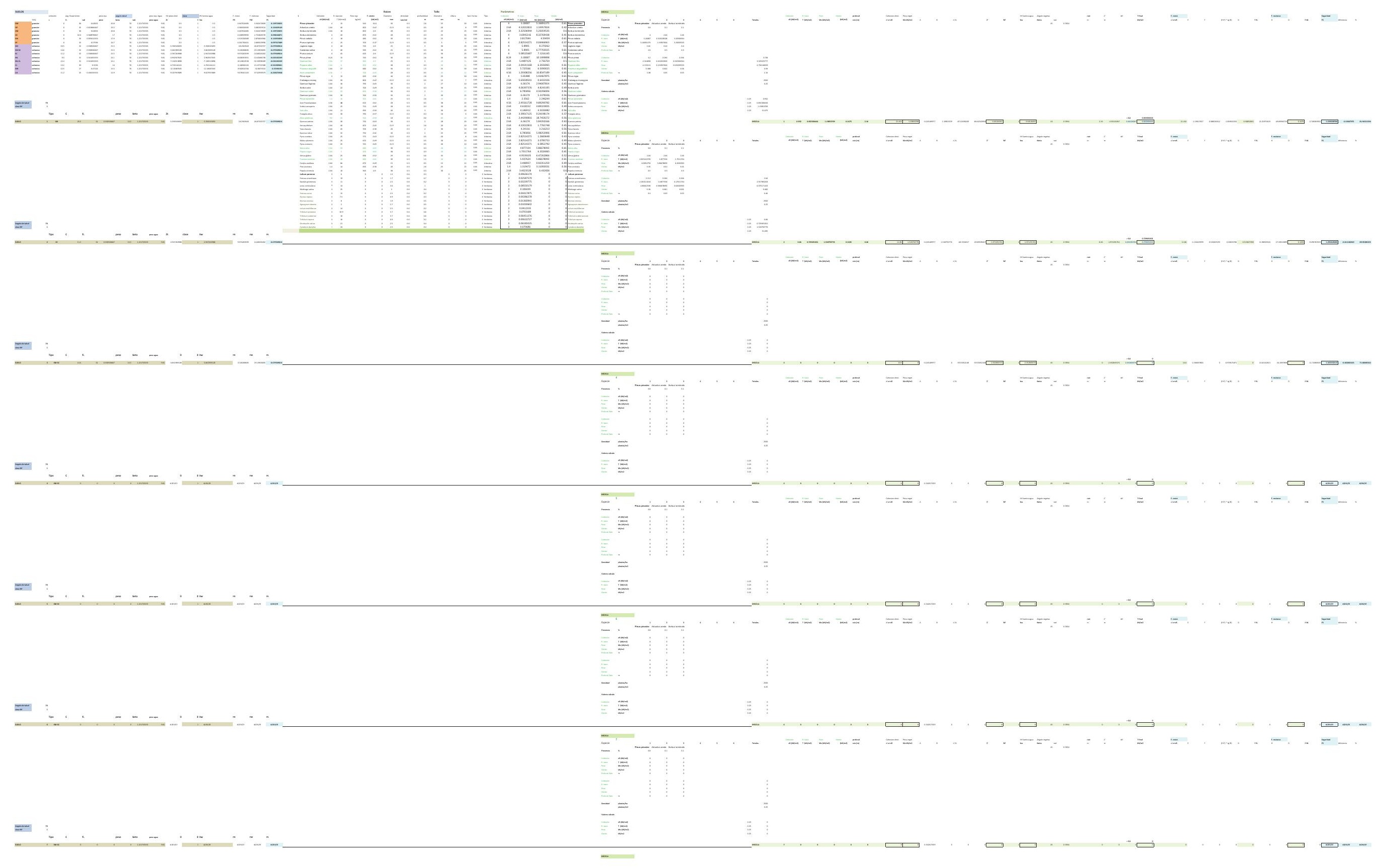




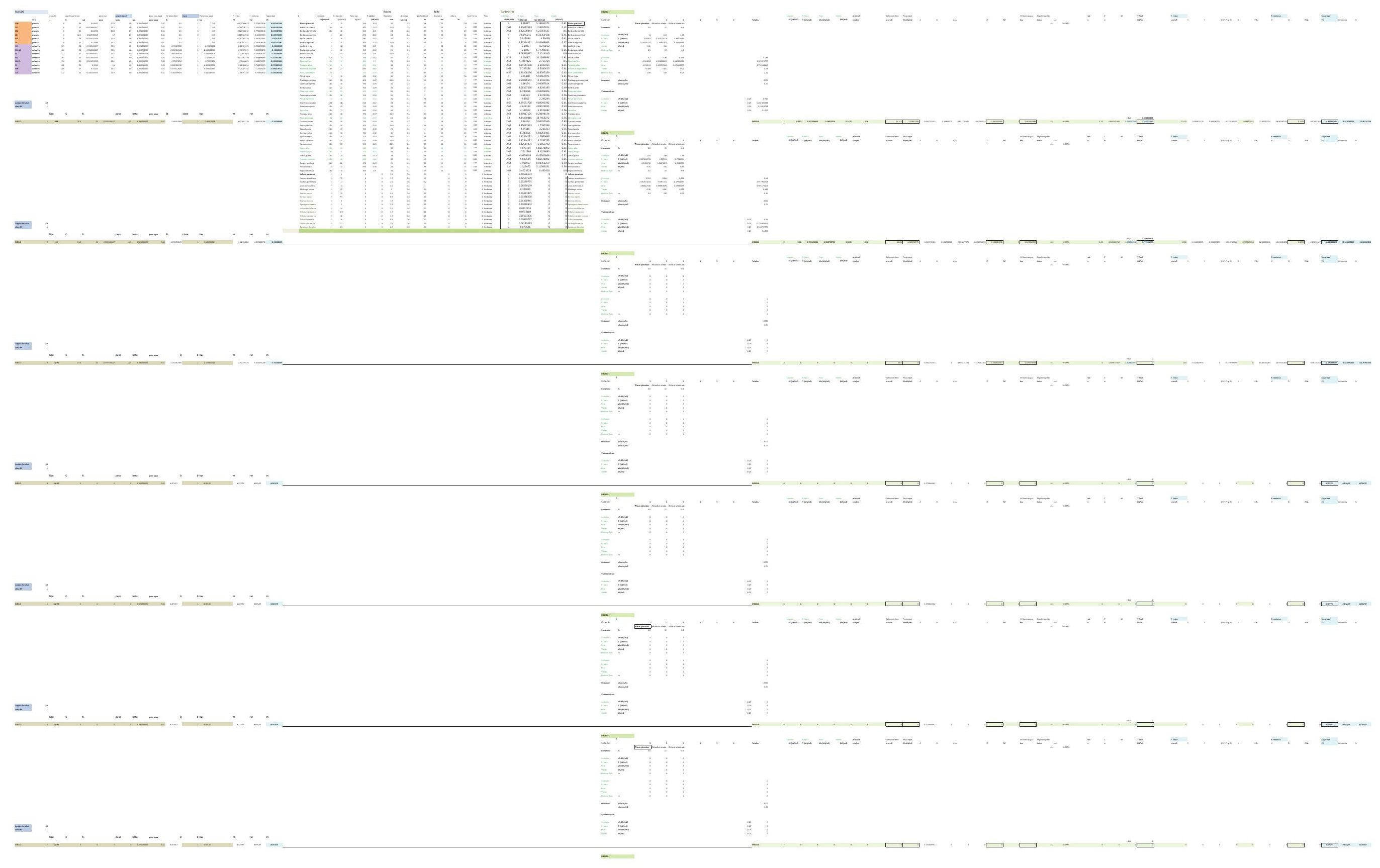




\section{Documento adjunto 1}

RESULTADOS DE ANÁLISIS DE LABORATORIO DE CARACTERIZACIÓN Y COMPOSICIÓN DE SUELOS.

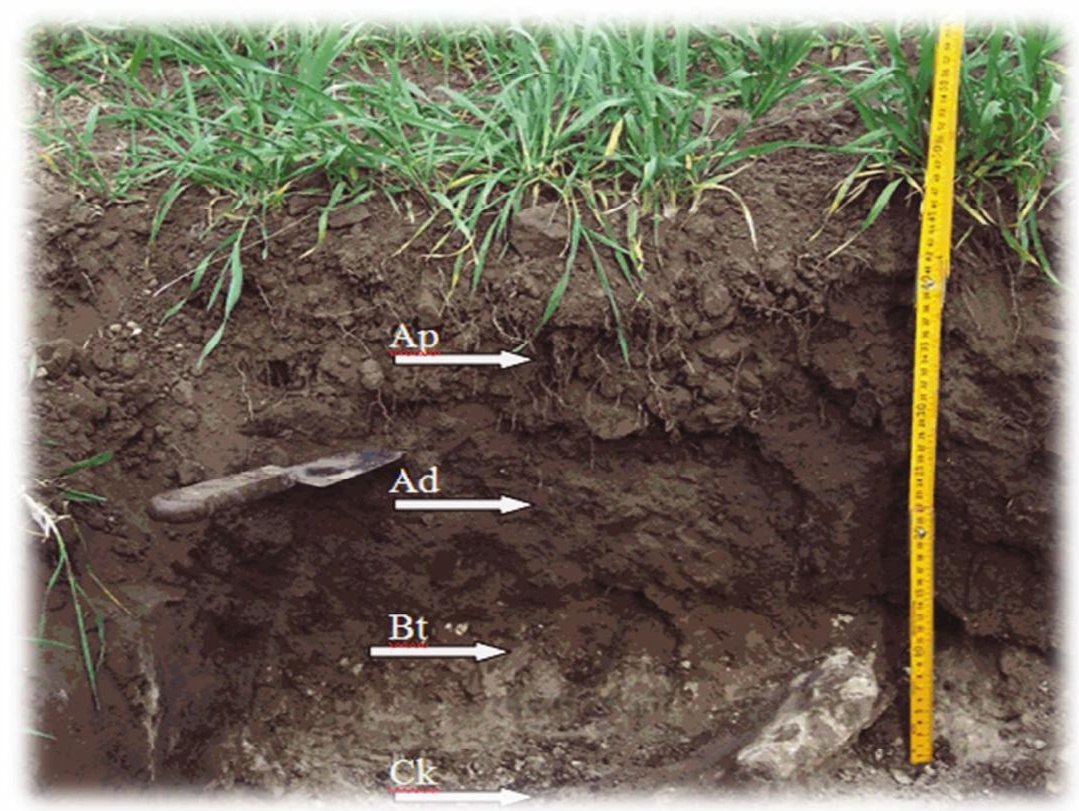


DESARROLLO DE UNA APLICACIÓN IMFORMÁTICA PARA EL CÁLCULO DE SOSTENIMIENTO DE TALUDES MEDIANTE VEGETACIÓN

RESULTADOS DE ANÁLISIS DE LABORATORIO DE CARACTERIZACIÓN Y COMPOSICIÓN DE SUELOS.

1.- RESULTADOS DE ANÁLISIS DE CARACTERIZACIÓN DE SUELOS. 


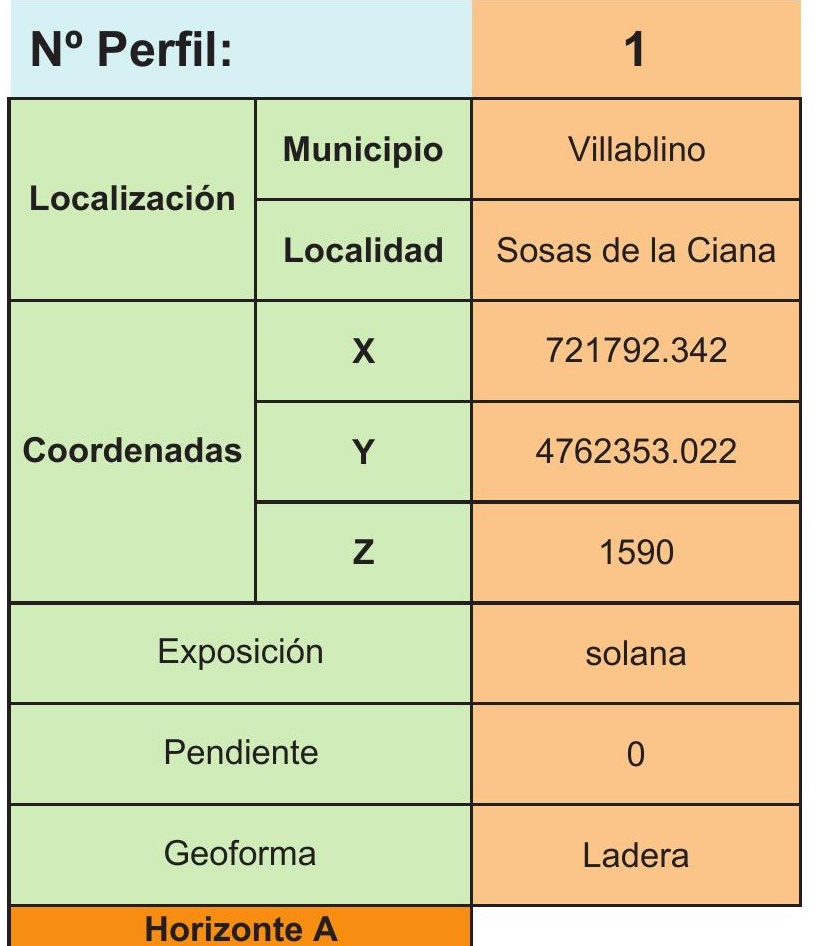

\begin{tabular}{|c|c|}
\hline Erosión & No hay manifestación \\
\hline Vegetación & Monte bajo robles y ericas \\
\hline Usos terreno & Grupo C, calse VII \\
\hline Roca Madre & Pizarras y areniscas \\
\hline Terren. Circu. & Igual características \\
\hline Aflor. Rocosos & Numerosos puntos \\
\hline Pedreg. Super. & Abundante \\
\hline Tiempo Atmosf. & Soleado y frío \\
\hline Profundidad & 0 - 10 cm \\
\hline
\end{tabular}

Abundante pedregosidad, constituida por piedras y cascajos. Consistencia blanda en seco y, color pardo en seco y en humedo pardo grisáceo oscuro, siendo la separación con el horizonte inferior difusa. Abundante raíces y actividad microbiana normal.

\section{Horizonte B}

\section{Profundidad}

$15-30 \mathrm{~cm}$

De características analogas al horizonte anterior en cuanto a las caracteristicas mineralogicas, con estruztura en bloques subangulares, moderada. Color en seco rojo debil y en huemdo rojo debil a pardo-rojizo. Baja ligeramente el contenido de elementos activos y de reserva. Raices frecuentes y poca actividad biologica.

\begin{tabular}{|c|l|l|}
\cline { 3 - 3 } Horizonte C & Profundidad & \multicolumn{1}{c|}{$>30 \mathrm{~cm}$} \\
\hline Roca madre de pizarras y cuarcitas. & \multicolumn{2}{l|}{} \\
\hline Horizonte & Profundidad & \\
\hline \multicolumn{3}{|l}{} \\
\hline
\end{tabular}


ANÁLISIS DE CARACTERIZACIÓN DE SUELOS

Desarrollo de una aplicación informática para el cálculo de sostenimiento de taludes mediante vegetación

$N^{\circ}$ Perfil:

\begin{tabular}{|c|c|c|}
\hline \multirow{2}{*}{ Localización } & Municipio & Villablino \\
\cline { 2 - 3 } & Localidad & Orallo \\
\hline \multirow{2}{*}{ Coordenadas } & $\mathbf{X}$ & 715692.8832 \\
\cline { 2 - 3 } & $\mathbf{Y}$ & 4760213.722 \\
\cline { 2 - 3 } & $\mathbf{Z}$ & 1452 \\
\hline Exposición & solana \\
\hline \multicolumn{2}{|c|}{ Pendiente \% } & 55 \\
\hline \multicolumn{2}{|c|}{ Geoforma } & Intermerdia \\
\hline \multicolumn{2}{|c|}{ Horizonte A } & \\
\hline
\end{tabular}

2

\begin{tabular}{|c|c|}
\hline Erosión & $\begin{array}{c}\text { Se manifiesta claramente } \\
\text { en gran parte de la zona. }\end{array}$ \\
\hline Vegetación & $\begin{array}{c}\text { Monte de robles y } \\
\text { carrascas. }\end{array}$ \\
\hline Usos terreno & Grupo C, calse VII \\
\hline Roca Madre & Pizarras y carbon \\
\hline Terren. Circu. & Igual caracteristicas \\
\hline Aflor. Rocosos & Numeros puntos \\
\hline Pedreg. Super. & Abundante \\
\hline Tiempo Atmosf. & Soleado y frio \\
\hline Profundidad & 0 - 20 cm \\
\hline
\end{tabular}

Horizonte constituido por gran cantidad de elementeos gruesos, piedras y cascajo anguloso. La separación con el horizonte inferior esta claramente definida. Color en seco pardo grisaceo y en humedo pardo oscuro. Consistencua blanda y estructura migajosa moderada, con raices abuandantes y activa vida biológica.

\begin{tabular}{|c|c|c|}
\hline Horizonte C & Profundidad & $>20 \mathrm{~cm}$ \\
\hline \multicolumn{3}{|l|}{ Pizarras } \\
\hline Horizonte & Profundidad & \\
\hline Horizonte & Profundidad & \\
\hline & & \\
\hline & & \\
\hline & & \\
\hline
\end{tabular}




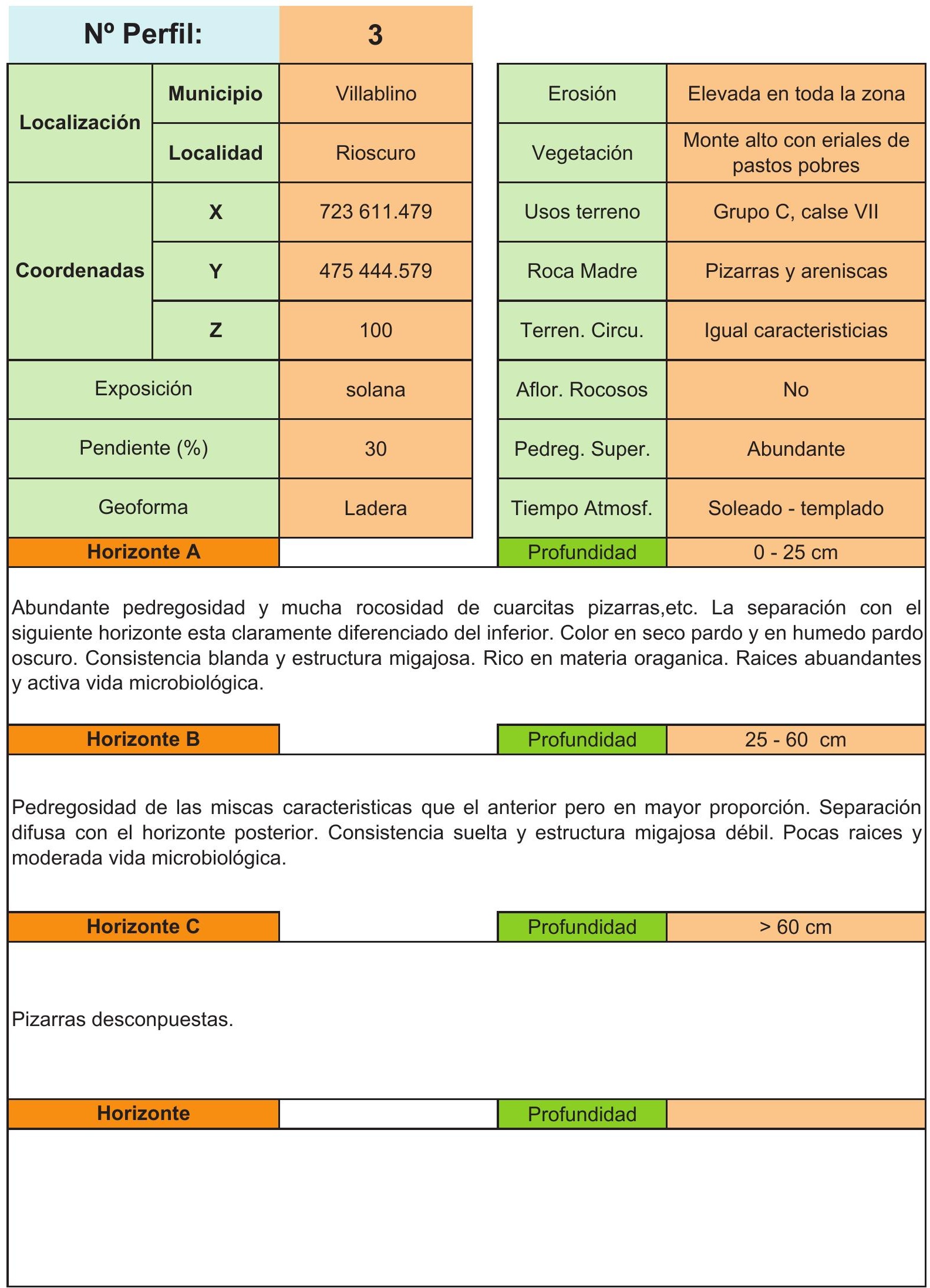




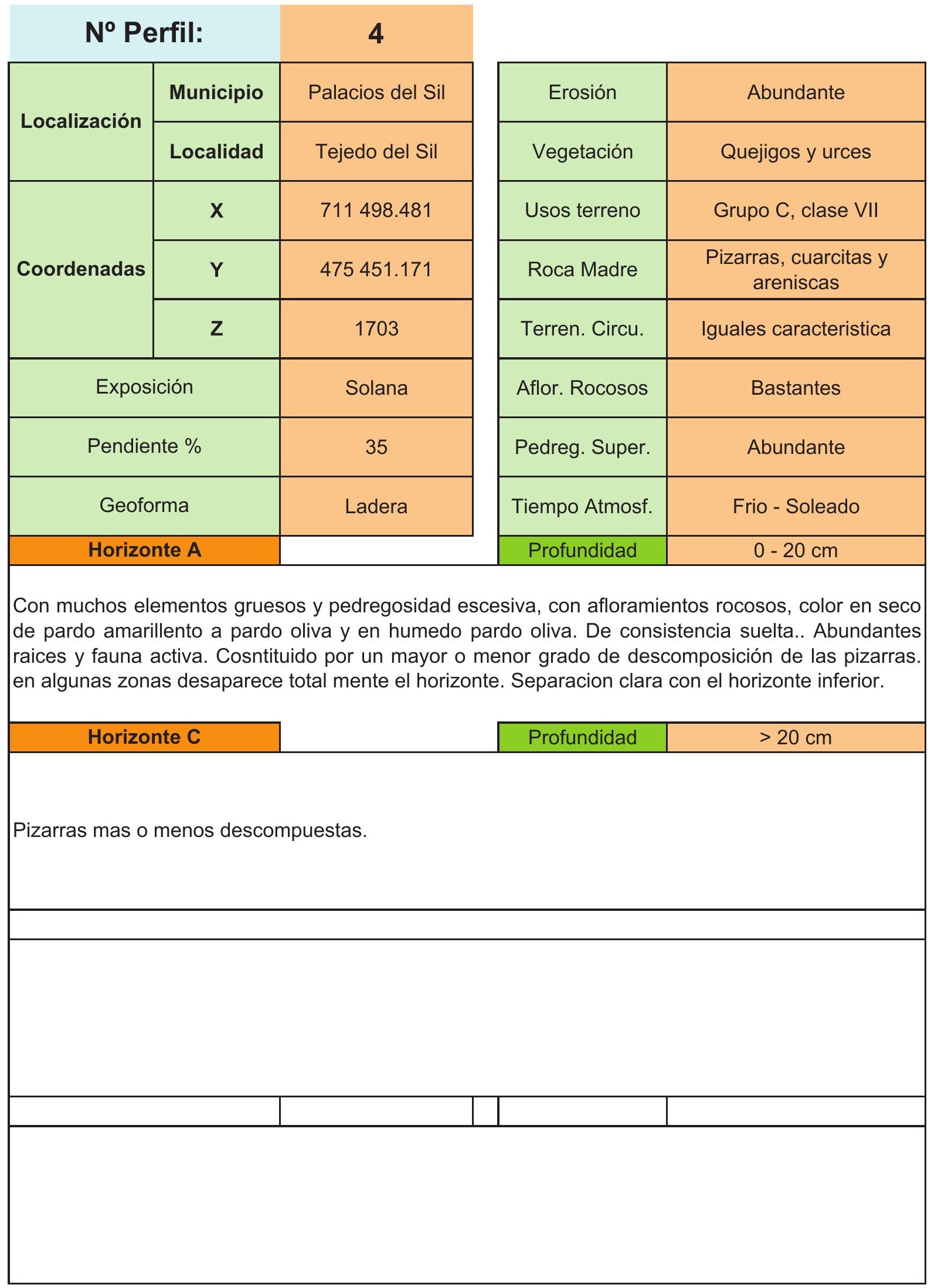


ANÁLISIS DE CARACTERIZACIÓN DE SUELOS

Desarrollo de una aplicación informática para el cálculo de sostenimiento de taludes mediante vegetación

No Perfil:

\begin{tabular}{|c|c|c|}
\hline \multirow{2}{*}{ Localización } & Municipio & Palacios del Sil \\
\cline { 2 - 3 } & Localidad & Valdeprado \\
\hline \multirow{2}{*}{ Coordenadas } & $\mathbf{X}$ & 708202.321 \\
\cline { 2 - 3 } & $\mathbf{Y}$ & 4750372.954 \\
\cline { 2 - 3 } & & 1301 \\
\hline Exposición & solana \\
\hline \multicolumn{2}{|c|}{ Pendiente \% } & 50 \\
\hline \multicolumn{2}{|c|}{ Geoforma } & Ladera \\
\hline \multicolumn{2}{|c|}{ Horizonte A } & \\
\hline
\end{tabular}

\section{5}

\begin{tabular}{|c|c|}
\hline Erosión & Poca \\
\hline Vegetación & Monte alto y bajo. \\
\hline Usos terreno & Grupo C, clase VII \\
\hline Roca Madre & $\begin{array}{c}\text { Pizarra, cuarcitas y } \\
\text { areniscas }\end{array}$ \\
\hline Terren. Circu. & Igual carracteristica \\
\hline Aflor. Rocosos & Abundante \\
\hline Pedreg. Super. & Poca \\
\hline Tiempo Atmosf. & Frio y humedo \\
\hline Profundidad & 0 - 20 cm \\
\hline
\end{tabular}

Horizonte con grandes afloramientos rocosos, pero sin gran pedregosidad, siendo estas del tipo planiforme. Terreno de consistencia blanda y estructura en bloques. Color pardo grisaceo. Abunadantes raices y activa vida microbiana.

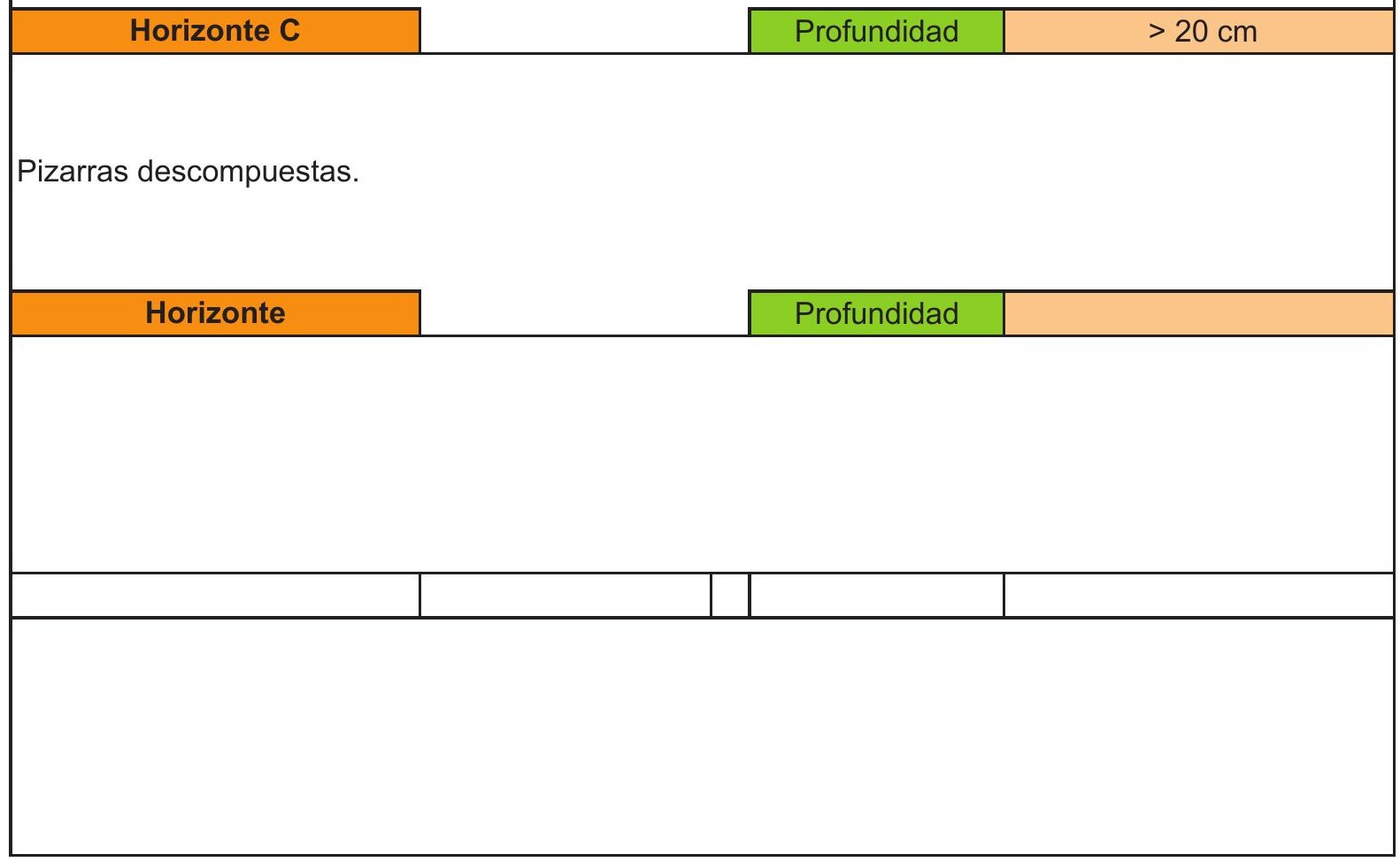




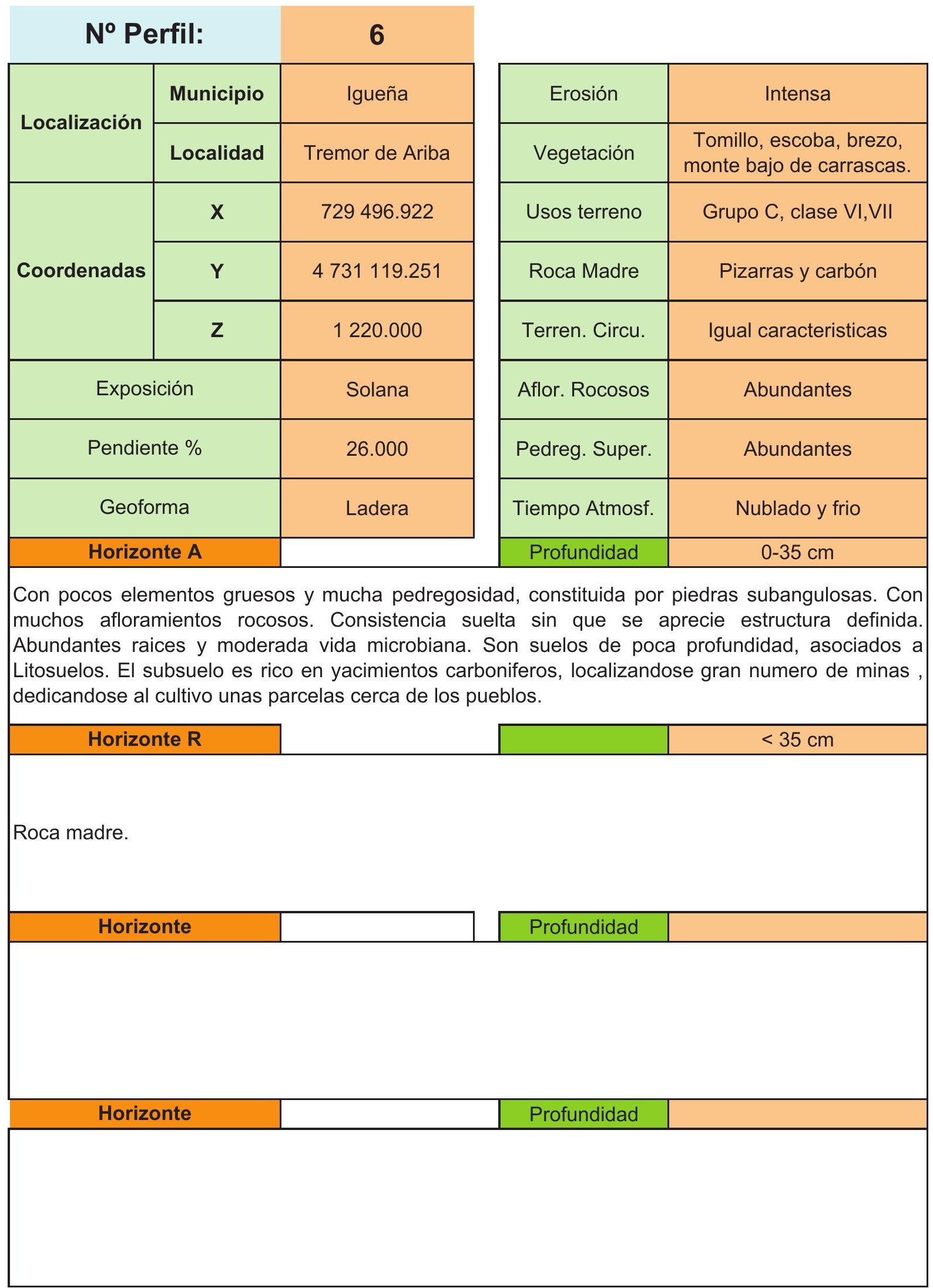




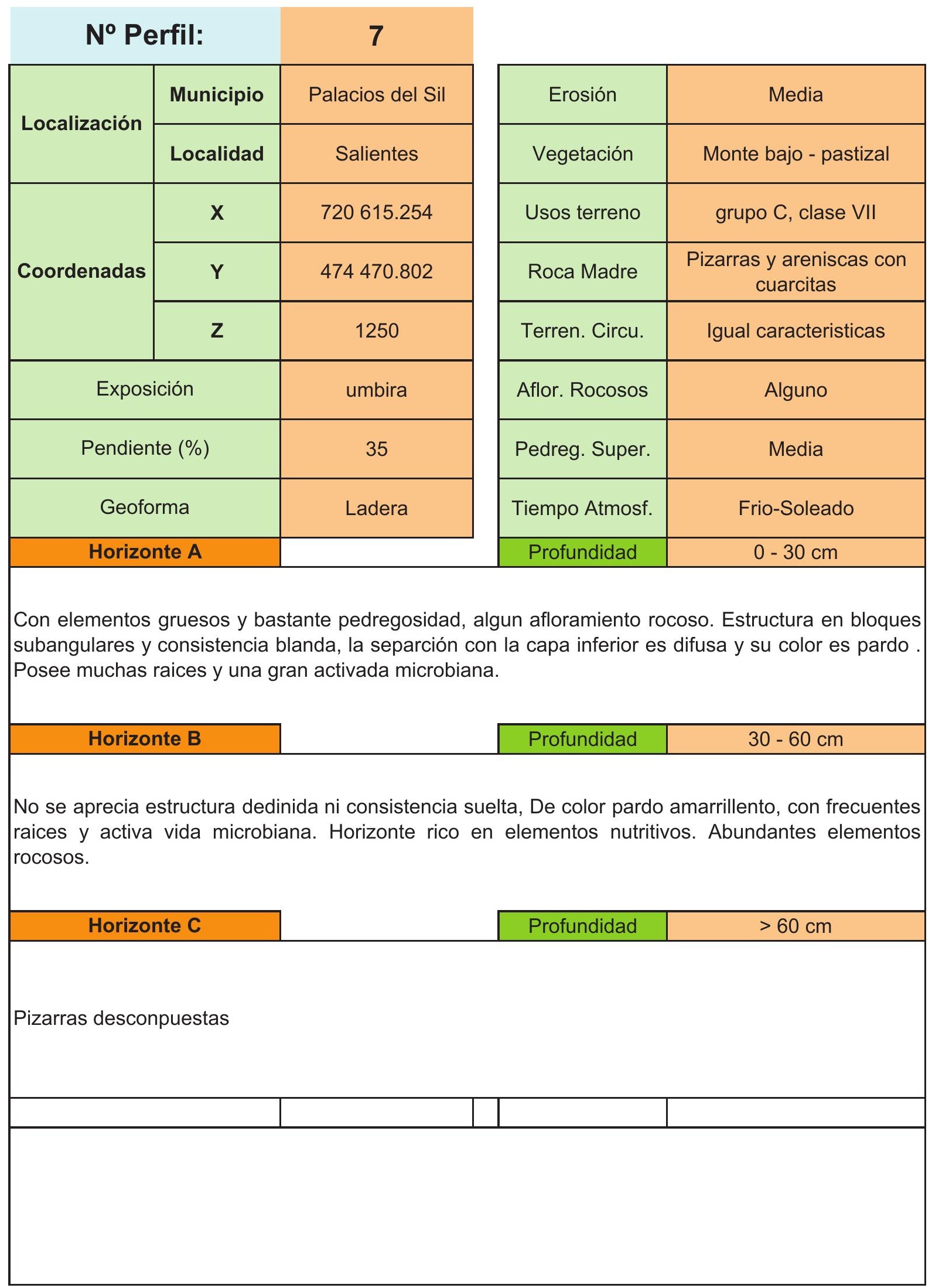


ANÁLISIS DE CARACTERIZACIÓN DE SUELOS

Desarrollo de una aplicación informática para el cálculo de sostenimiento de taludes mediante vegetación

No Perfil:

\begin{tabular}{|c|c|c|}
\hline \multirow{2}{*}{ Localización } & Municipio & Paramo del Sil \\
\cline { 2 - 3 } & Localidad & Anllares \\
\hline \multirow{2}{*}{ Coordenadas } & $\mathbf{X}$ & 702958.926 \\
\cline { 2 - 3 } & $\mathbf{Y}$ & 4747377.926 \\
\cline { 2 - 3 } & $\mathbf{Z}$ & 1310 \\
\hline Exposición & Solana \\
\hline Pendiente \% & 25 \\
\hline \multicolumn{2}{|c|}{ Geoforma } & Ladera \\
\hline \multicolumn{2}{|c|}{ Horizonte A } & \\
\hline
\end{tabular}

\section{8}

\begin{tabular}{|c|c|}
\hline Erosión & Fuerte \\
\hline Vegetación & Praderas y monte bajo \\
\hline Usos terreno & Grupo B, Clase IV \\
\hline Roca Madre & Pizarras \\
\hline Terren. Circu. & iguales caracteristicas \\
\hline Aflor. Rocosos & Bastantes \\
\hline Pedreg. Super. & Abunadantes \\
\hline Tiempo Atmosf. & Soleado y fresco \\
\hline Profundidad & 25 cm \\
\hline
\end{tabular}

Con elmentos grueso u bastante pedregosidad de piedras y cascajos angulosos y subangulosos. Mucha rocosidad. Color en seco pardo amarillento y en humedo pardo oscuro.Cosistencia blanda y estructura migajosa. Abunadantes raices y actividad microbiana normal.

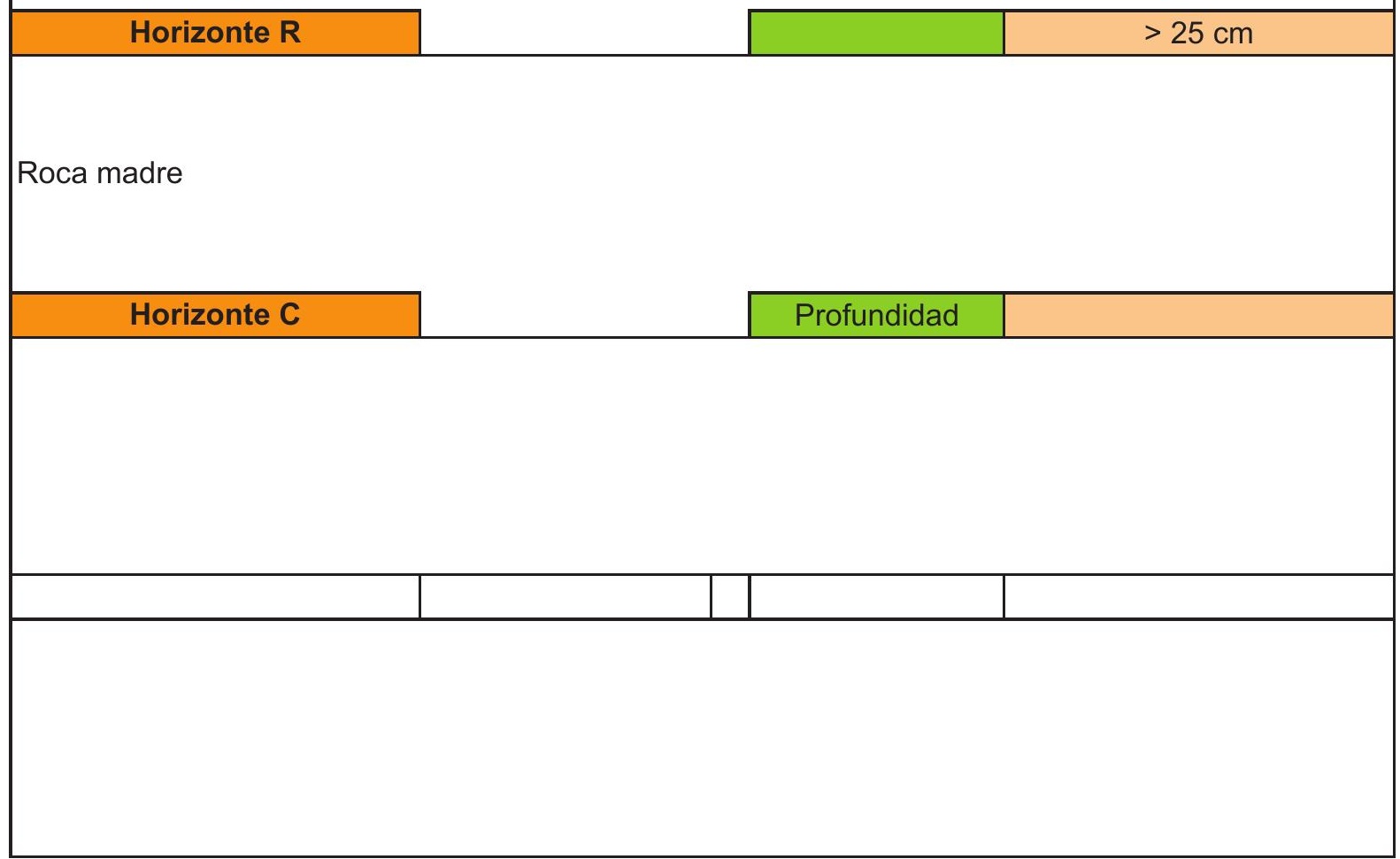


No Perfil:

\begin{tabular}{|c|c|c|}
\hline \multirow{2}{*}{ Localización } & Municipio & Parramo del Sil \\
\cline { 2 - 3 } & Localidad & Sorbeda \\
\hline \multirow{2}{*}{ Coordenadas } & $\mathbf{X}$ & 700178.716 \\
\cline { 2 - 3 } & $\mathbf{Y}$ & 474096.028 \\
\cline { 2 - 3 } & $\mathbf{Z}$ & 985 \\
\hline Exposición & Solana \\
\hline \multicolumn{2}{|c|}{ Pendiente } & 0.6 \\
\hline \multicolumn{2}{|c|}{ Geoforma } & Loma \\
\hline \multicolumn{2}{|c|}{ Horizonte A } & \\
\hline
\end{tabular}

\begin{tabular}{|c|c|}
\hline Erosión & Grande \\
\hline Vegetación & $\begin{array}{c}\text { Cereales y pasto, con algo } \\
\text { de monte bajo. }\end{array}$ \\
\hline Usos terreno & Grupo A, clase III \\
\hline Roca Madre & Arcillas y margas \\
\hline Terren. Circu. & Igual caracteristicas \\
\hline Aflor. Rocosos & Ninguno \\
\hline Pedreg. Super. & Poca \\
\hline Tiempo Atmosf. & Niebla \\
\hline Profundidad & 0 - $25 \mathrm{~cm}$ \\
\hline
\end{tabular}

Abundante pedregosidad formada por cascajo procedente de la descomposición de las pizarras y cuarcitas. Estructura en bloques subangulares de poca estabilidad y consistencia blanda. Corlor en huemdo pardo oscuro amarillento y en seco pardo amarillento. Separación definida con el horizonte inferior. con abundante raices y acitva vida microbiana.

Con pocos elementos gruesos y poca pedregosida constituida por piedras de cascajo redondeado. Color en humedo pardo rojizo y en seco pardo fuerte. Separción con el horizonte inferior es difusa, disminullendo la activiad biologica y pocas raices.

\section{Horizonte B2}

\section{$70-150 \mathrm{~cm}$}

Con pocos elementos gruesos y pedregosidad constituida por piedras de cascajo redondeado en mayor canticad que el horizonte anterior. Color en humedo pardo rojizo y en seco pardo fuerte. Separción con el horizonte inferior es difusa, sin activiad biologica y sin raices.

Horizonte C

$>150 \mathrm{~cm}$

Roca madre descompuesta. 
ANÁLISIS DE CARACTERIZACIÓN DE SUELOS

Desarrollo de una aplicación informática para el cálculo de sostenimiento de taludes mediante vegetación

No Perfil:

\begin{tabular}{|c|c|c|}
\hline \multirow{2}{*}{ Localización } & Municipio & Páramo del Sil \\
\cline { 2 - 3 } & Localidad & Santa Cruz del Sil \\
\hline \multirow{2}{*}{ Coordenadas } & $\mathbf{X}$ & 708568.008 \\
\cline { 2 - 3 } & $\mathbf{Y}$ & 4737250.975 \\
\cline { 2 - 3 } & $\mathbf{Z}$ & 1005 \\
\hline Exposición & Media luz \\
\hline \multicolumn{2}{|c|}{ Pendiente \% } & 15 \\
\hline \multicolumn{2}{|c|}{ Geoforma } & Ladera \\
\hline \multicolumn{2}{|c|}{ Horizonte A } & \\
\hline
\end{tabular}

10

\begin{tabular}{|c|c|}
\hline Erosión & Bastante \\
\hline Vegetación & Ericas y quejigos \\
\hline Usos terreno & Grupo C, clase IV \\
\hline Roca Madre & Pizarras \\
\hline Terren. Circu. & Iguales características \\
\hline Aflor. Rocosos & Abundantes \\
\hline Pedreg. Super. & Abundantes \\
\hline Tiempo Atmosf. & Nublado y frío \\
\hline Profundidad & $40 \mathrm{~cm}$ \\
\hline
\end{tabular}

Elementos grueso y abundante pedregosidad formada por piedras angulosas. Estructura en bloque débil y fina y de consistencia blanda, el color es amarillo rojizo. Con escasas raíces y poca vida microbiana.

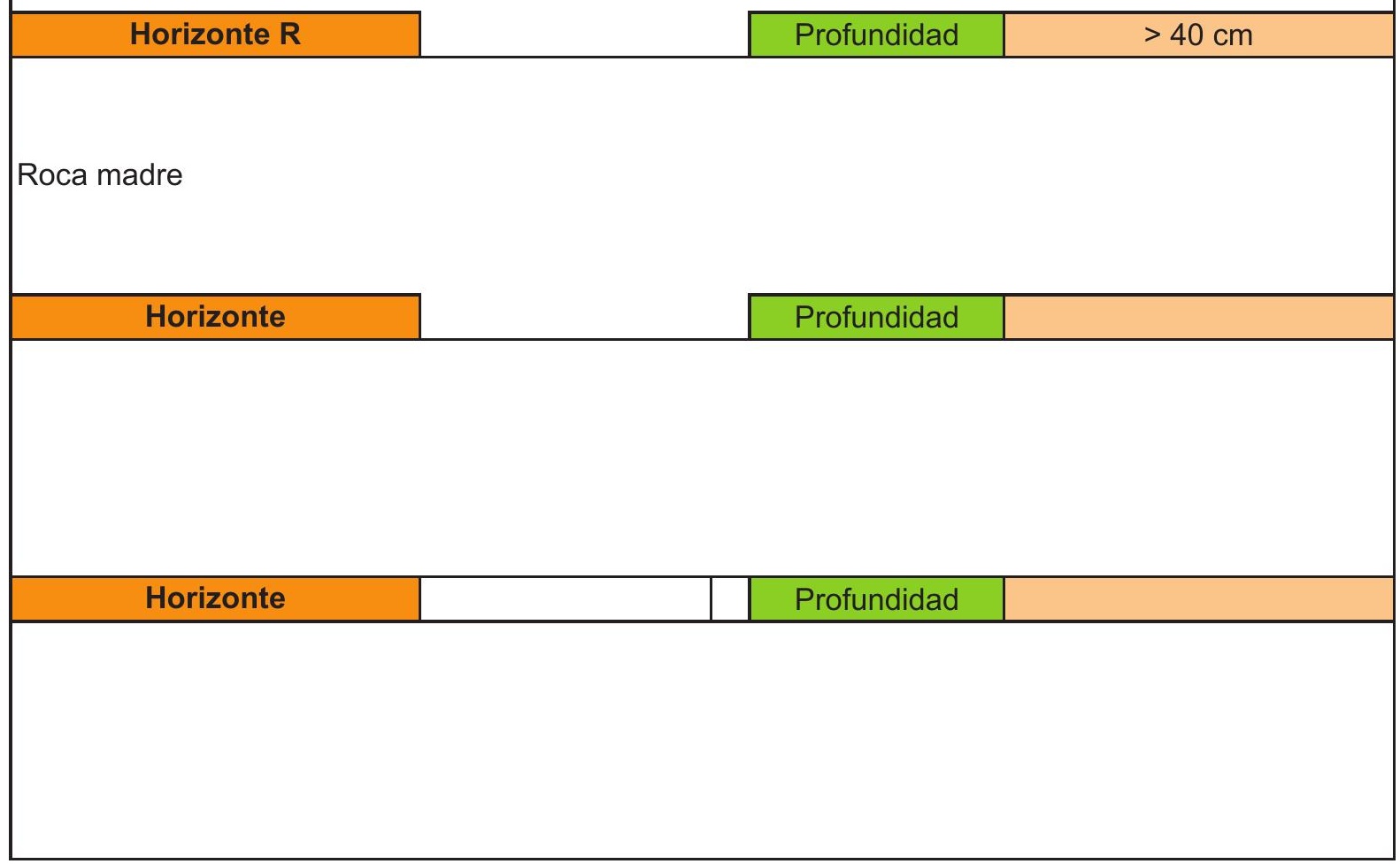


ANÁLISIS DE CARACTERIZACIÓN DE SUELOS

Desarrollo de una aplicación informática para el cálculo de sostenimiento de taludes mediante vegetación

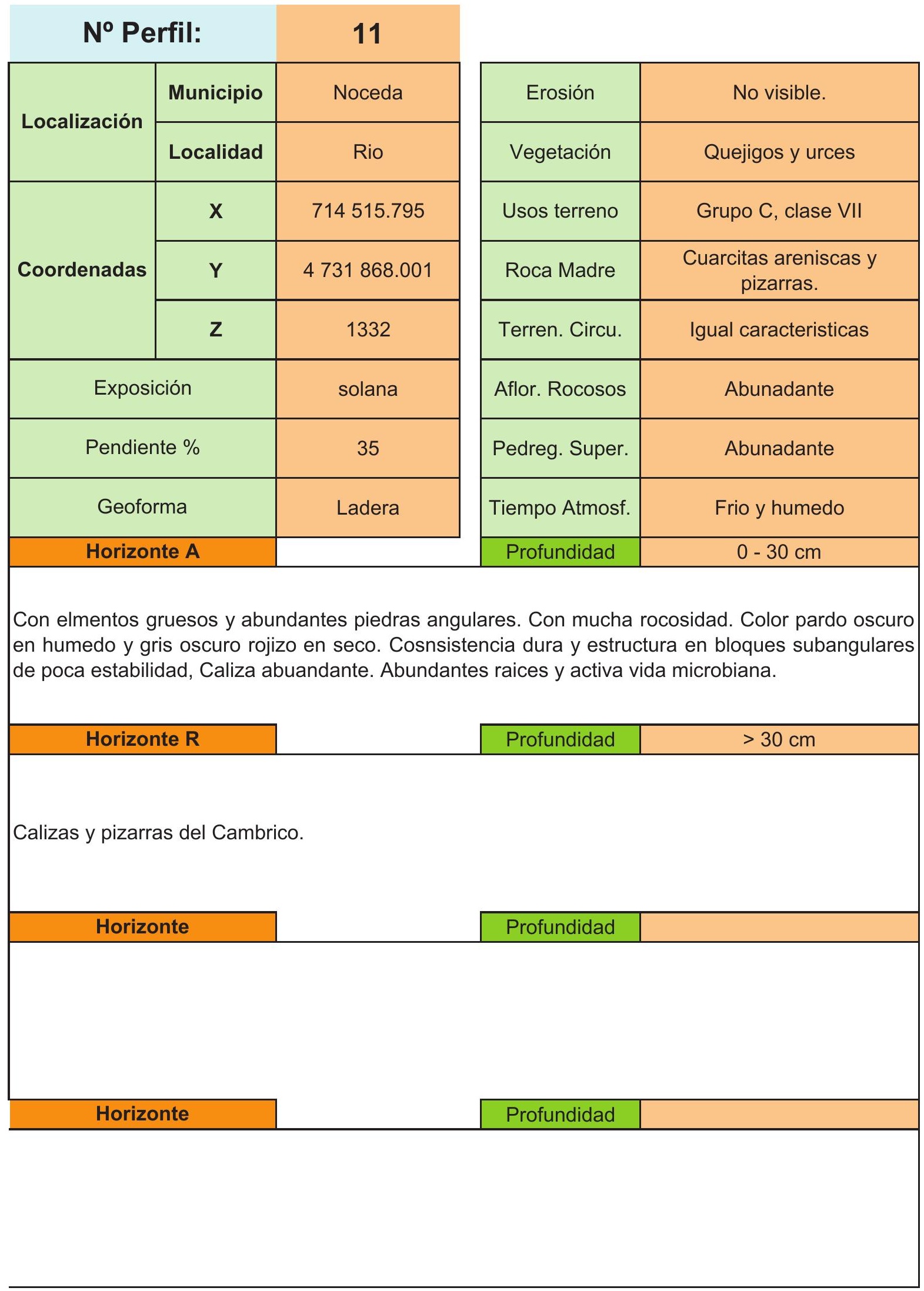




No Perfil:
\begin{tabular}{|c|c|c|}
\hline \multirow{2}{*}{ Localización } & Municipio & 12 \\
\cline { 2 - 3 } & Localidad & $\begin{array}{c}\text { Urdiales de la } \\
\text { Colina }\end{array}$ \\
\hline \multirow{2}{*}{ Coordenadas } & $\mathbf{X}$ & 718689.109 \\
\cline { 2 - 3 } & $\mathbf{Y}$ & 4735852.710 \\
\cline { 2 - 3 } & $\mathbf{Z}$ & 1325 \\
\hline Exposición & Solana \\
\hline Pendiente \% & 44 \\
\hline \multicolumn{2}{|c|}{ Geoforma } & Ladera \\
\hline \multicolumn{2}{|c|}{ Horizonte A } & \\
\hline
\end{tabular}

Con elementos gruesos y mucha pedregosidad formada por grava planiforme. Con mucha rocosidad. Estructura débil en bloques. Consistencia blanda. Escasas raices y moderada actividad microbiana. Con frecuencia el suelo desaparece, constituyendo verdaderos litosulos.

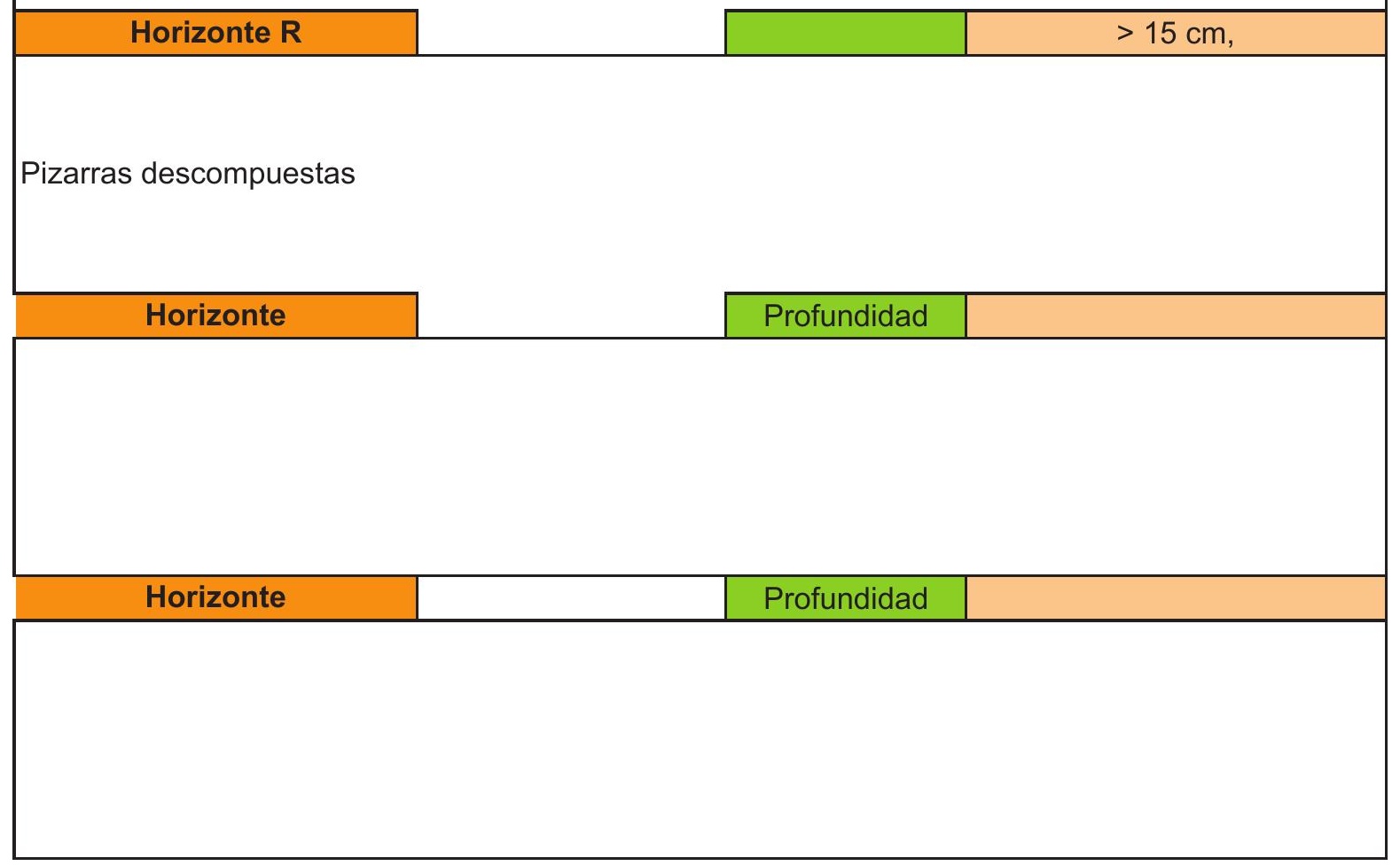




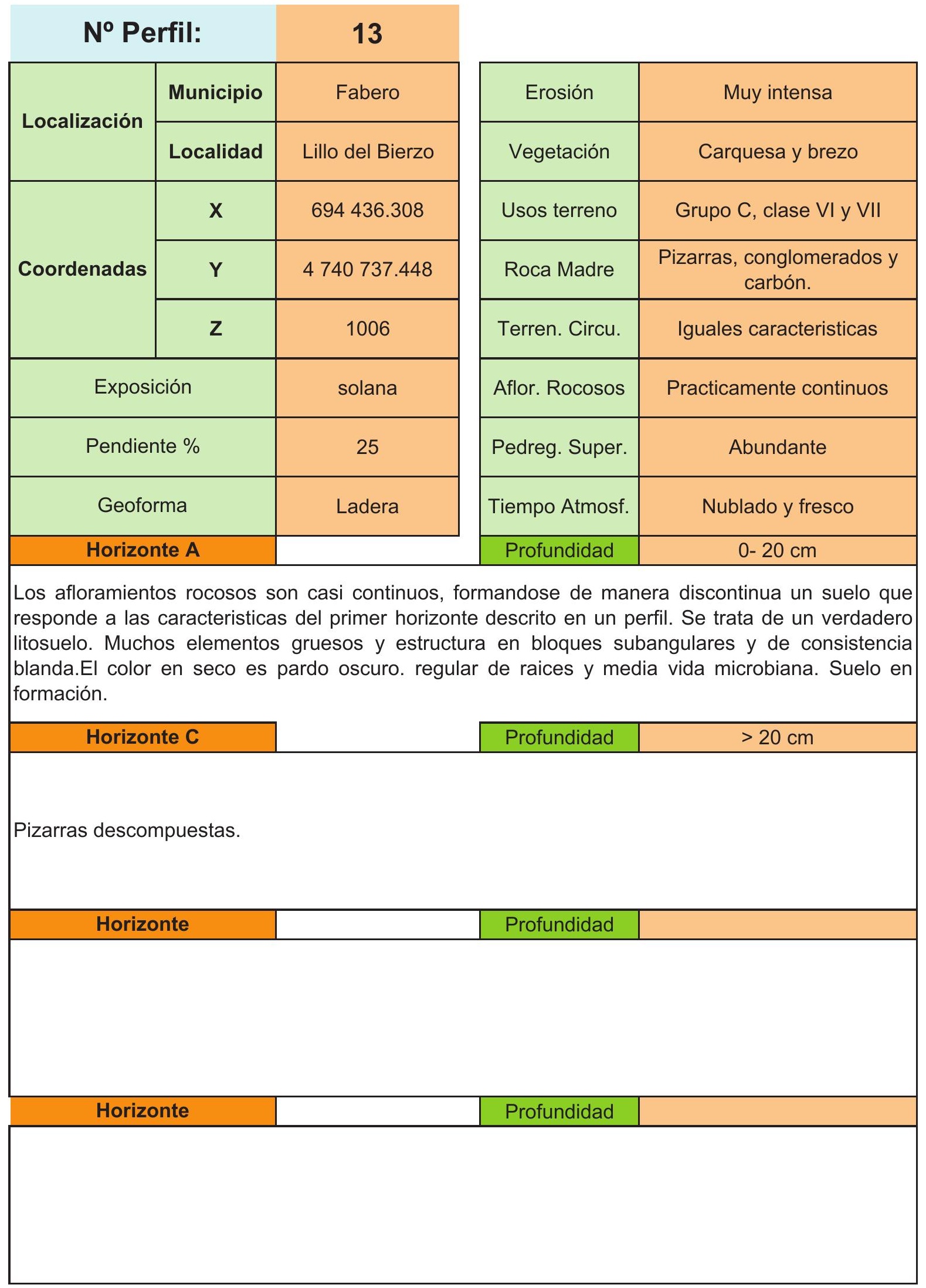


ANÁLISIS DE CARACTERIZACIÓN DE SUELOS

Desarrollo de una aplicación informática para el cálculo de sostenimiento de taludes mediante vegetación

\begin{tabular}{|c|c|c|c|c|}
\hline \multicolumn{2}{|c|}{ No Perfil: } & \multirow{2}{*}{14} & \multirow[b]{2}{*}{ Erosión } & \multirow[b]{2}{*}{ No hay manifestación } \\
\hline & Municipio & & & \\
\hline & Localidad & Villar de Trabiesas & Vegetación & Momte bajo robles y ericas \\
\hline \multirow{3}{*}{ Coordenadas } & $x$ & 707132.240 & Usos terreno & Forestal \\
\hline & $\mathbf{Y}$ & 4731119.251 & Roca Madre & Pizarras con conglomerados \\
\hline & $\mathbf{z}$ & 960 & Terren. Circu. & Igual carzteristicas \\
\hline \multicolumn{2}{|c|}{ Exposición } & solana & Aflor. Rocosos & Numeros puntos \\
\hline \multicolumn{2}{|c|}{ Pendiente } & 0 & Pedreg. Super. & Abundante \\
\hline \multicolumn{2}{|c|}{ Geoforma } & Ladera & Tiempo Atmosf. & Soleado y frio \\
\hline \multicolumn{2}{|c|}{ Horizonte A } & & Profundidad & $0-20 \mathrm{~cm}$ \\
\hline \multicolumn{5}{|c|}{$\begin{array}{l}\text { Elementos gruesos y mucha pedregosidad, estremadamente rocoso. Color en seco pardo oscuro y } \\
\text { en humedo pardo amarillento. Estando claramente definaida la separción con el horizonte inferior, } \\
\text { la consistencia en seco es blanda y la estructura migajosa débil. Abundante raices y moderada } \\
\text { acitividad microbiana. }\end{array}$} \\
\hline \multicolumn{2}{|c|}{ Horizonte $\mathbf{R}$} & & Profundidad & $>20 \mathrm{~cm}$ \\
\hline \multicolumn{5}{|l|}{ Roca Madre } \\
\hline \multicolumn{2}{|c|}{ Horizonte } & & Profundidad & \\
\hline \multicolumn{2}{|c|}{ Horizonte } & & Profundidad & \\
\hline
\end{tabular}


ANÁLISIS DE CARACTERIZACIÓN DE SUELOS

Desarrollo de una aplicación informática para el cálculo de sostenimiento de taludes mediante vegetación

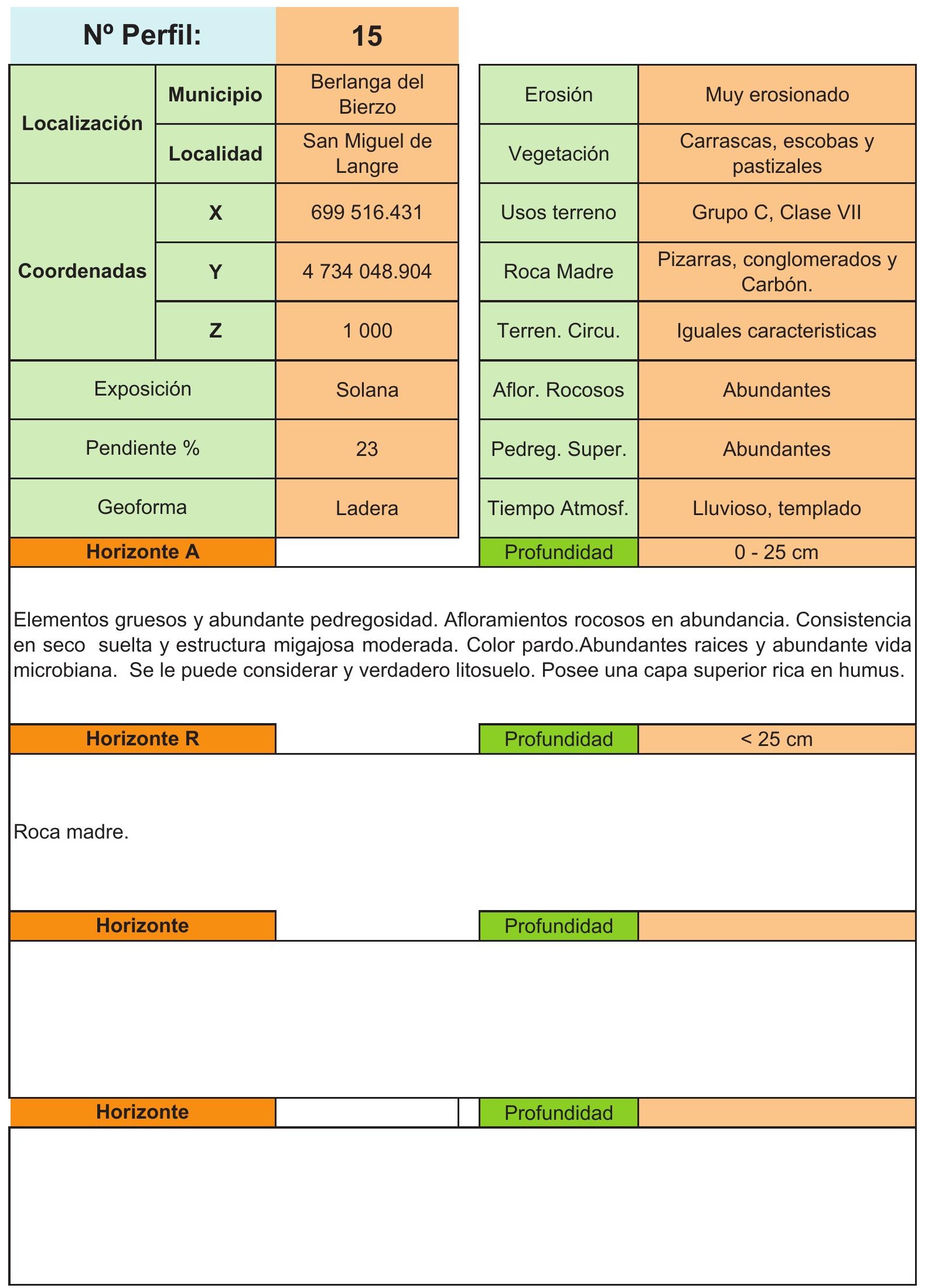




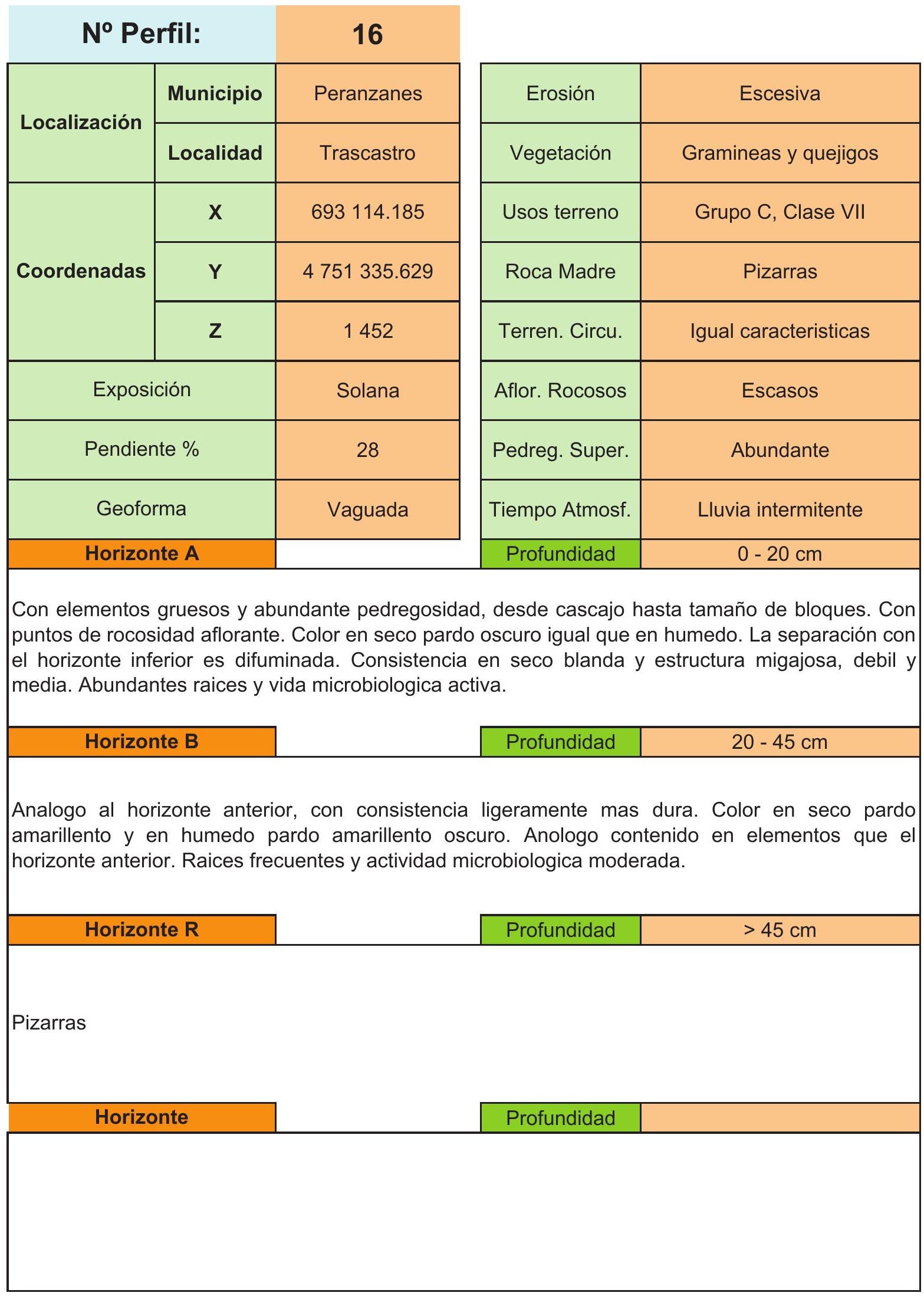




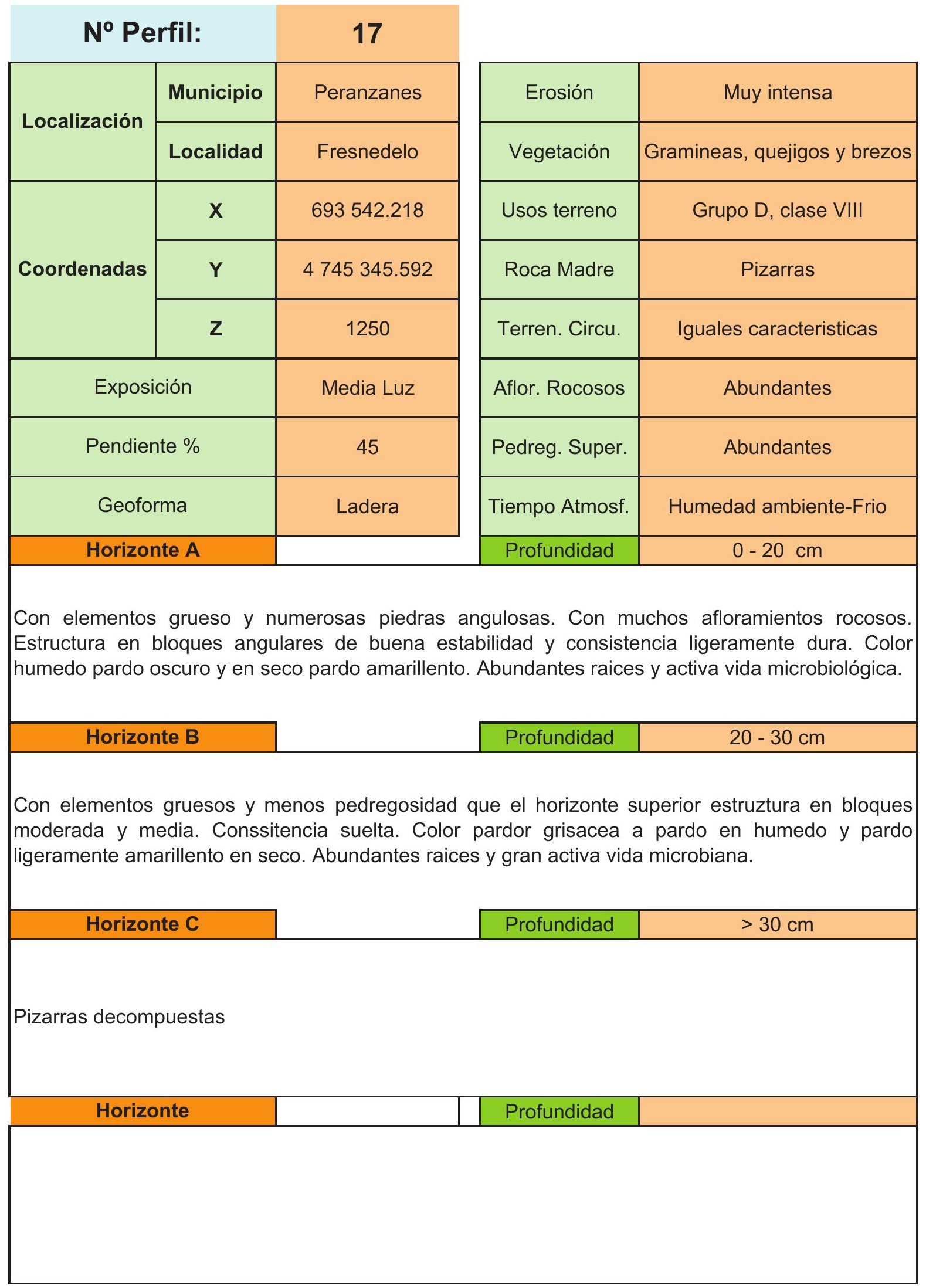


ANÁLISIS DE CARACTERIZACIÓN DE SUELOS

Desarrollo de una aplicación informática para el cálculo de sostenimiento de taludes mediante vegetación

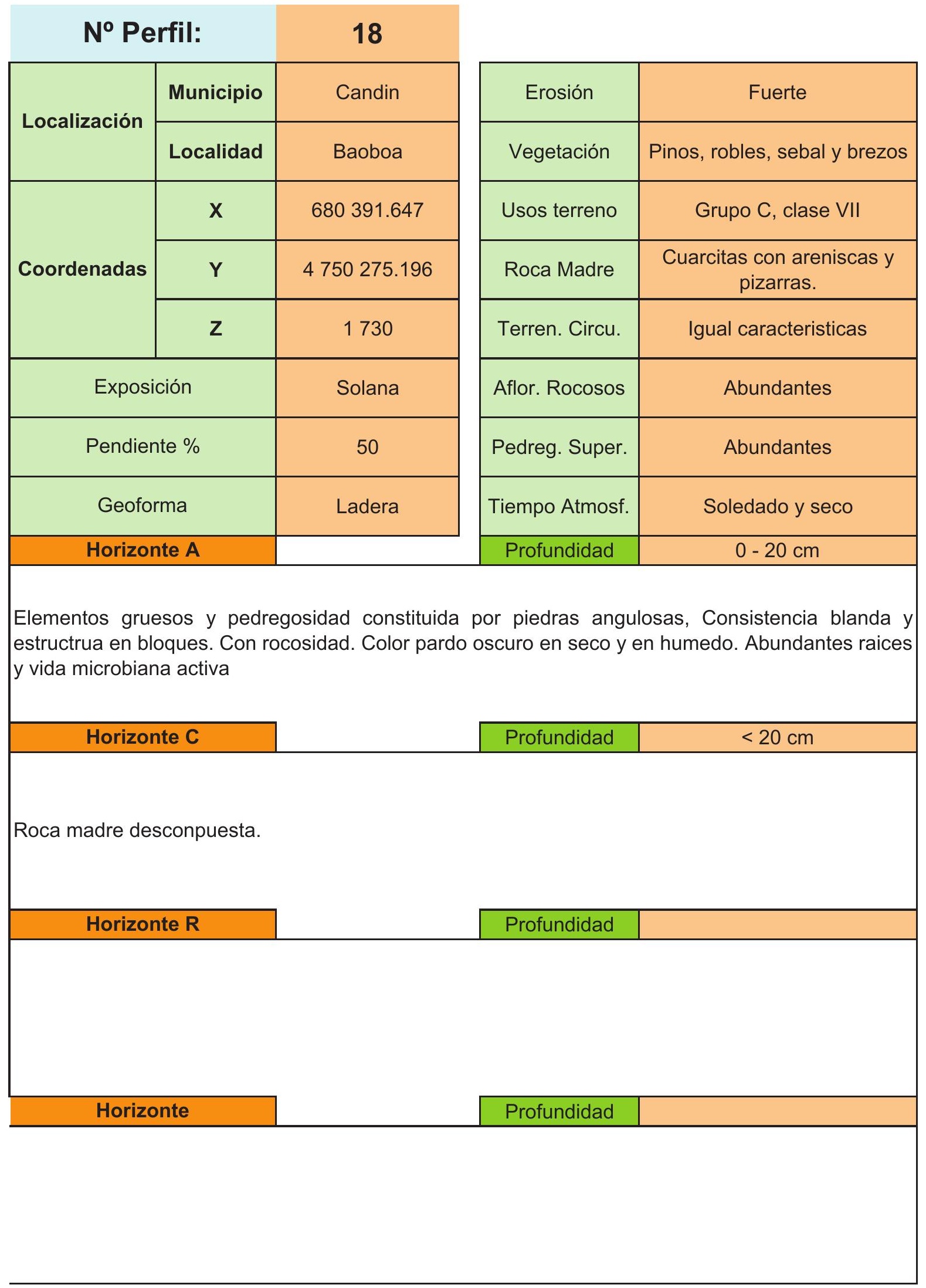


ANÁLISIS DE CARACTERIZACIÓN DE SUELOS

Desarrollo de una aplicación informática para el cálculo de sostenimiento de taludes mediante vegetación

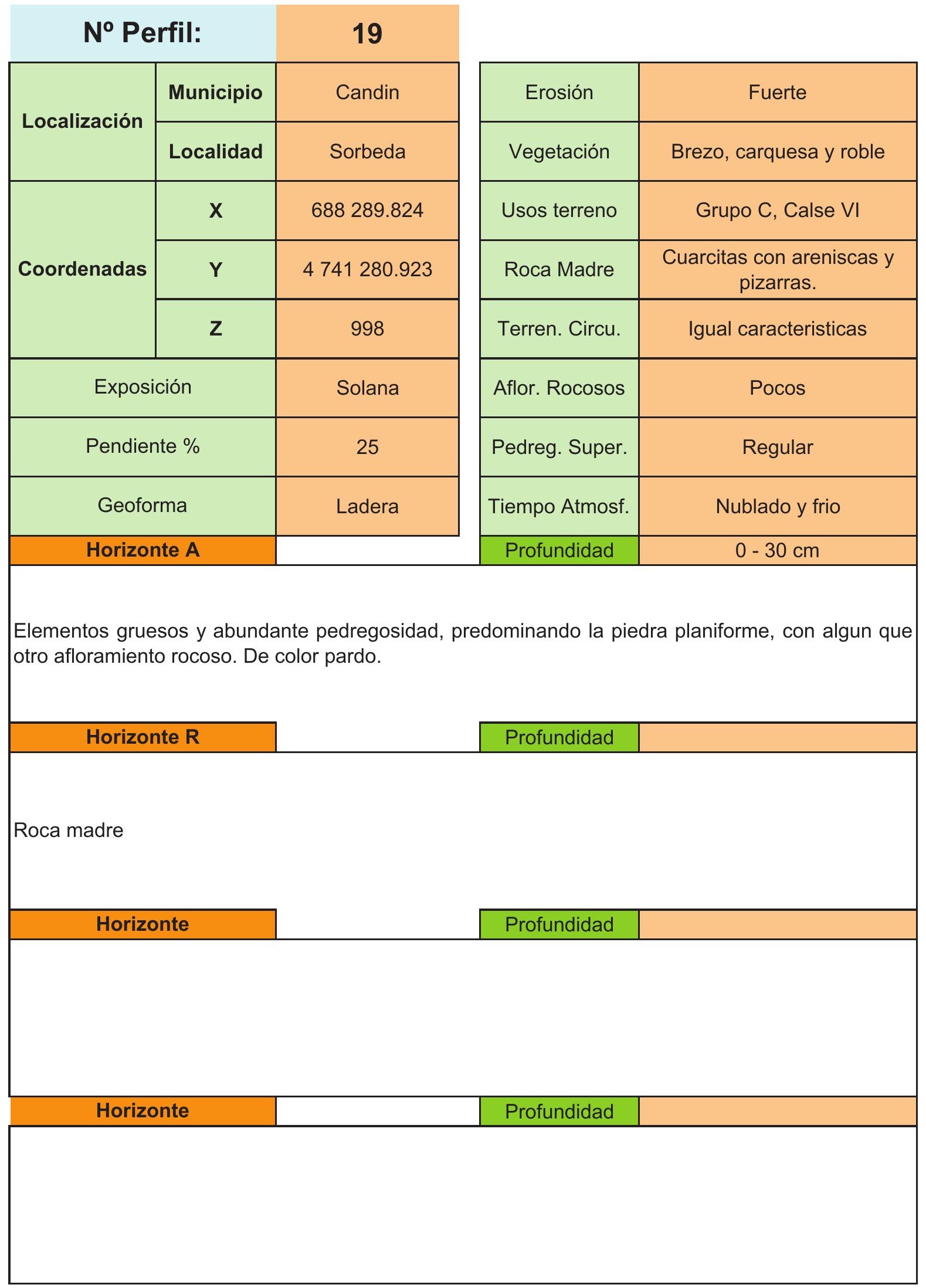


ANÁLISIS DE CARACTERIZACIÓN DE SUELOS

Desarrollo de una aplicación informática para el cálculo de sostenimiento de taludes mediante vegetación

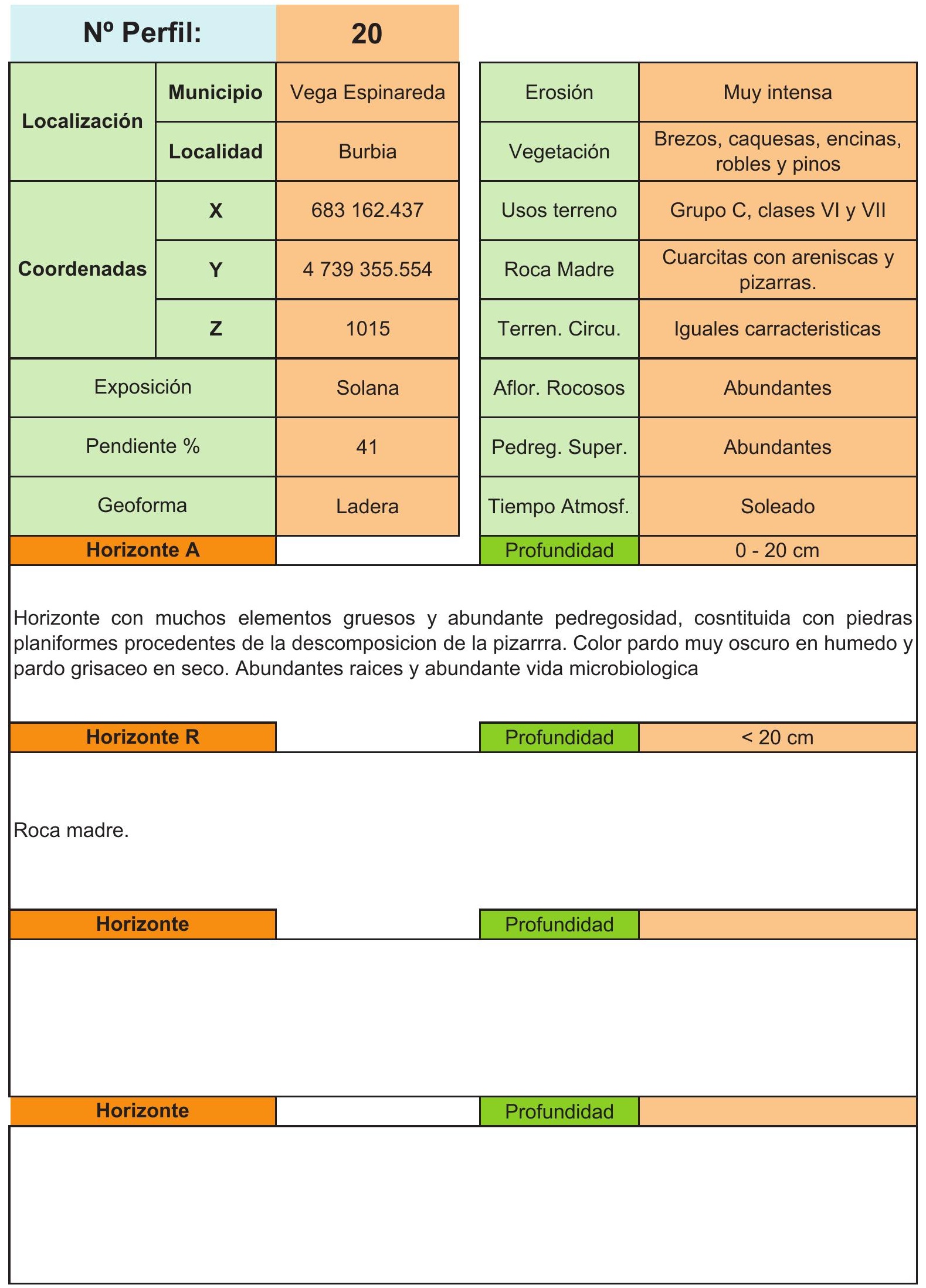




\begin{tabular}{|c|c|c|c|c|}
\hline \multicolumn{2}{|c|}{ No Perfil: } & \multirow{2}{*}{$\frac{21}{\text { Vega Espinareda }}$} & & \\
\hline \multirow{2}{*}{ Localización } & Municipio & & Erosión & Poco erosionado \\
\hline & Localidad & Moreda & Vegetación & Cereales, viña y monte bajo \\
\hline \multirow{3}{*}{ Coordenadas } & $x$ & 687228.743 & Usos terreno & $\begin{array}{c}\text { Grupo A, Clase II y Grupo B, } \\
\text { clase IV }\end{array}$ \\
\hline & $\mathbf{Y}$ & 4733258.550 & Roca Madre & Pizarras y cuarcitas \\
\hline & $\mathbf{z}$ & 720 & Terren. Circu. & Iguales características \\
\hline \multicolumn{2}{|c|}{ Exposición } & Media Luz & Aflor. Rocosos & Ninguno \\
\hline \multicolumn{2}{|c|}{ Pendiente \% } & 10 & Pedreg. Super. & Poca o nula \\
\hline \multicolumn{2}{|c|}{ Geoforma } & Vaguada & Tiempo Atmosf. & Soleado y seco \\
\hline \multicolumn{2}{|c|}{ Horizonte A } & & Profundidad & $0-40 \mathrm{~cm}$ \\
\hline \multicolumn{5}{|c|}{$\begin{array}{l}\text { Elementos gruesos y regular pedregosidad constituidos por piedra y cascajo, generalmente } \\
\text { cuarcitas. Estructura en bloque de débil estado de agregación y consistencia blanda. Color pardo en } \\
\text { húmedo y amarillo rojizo en seco. Sin rocosidad. Abundantes raices y buena actividad } \\
\text { microbiologica. La separación con el horizonte inferior esta bien definida. }\end{array}$} \\
\hline \multicolumn{2}{|c|}{ Horizonte B1 } & & & $40-110 \mathrm{~cm}$ \\
\hline \multicolumn{5}{|c|}{$\begin{array}{l}\text { Con pocos elementos gruesos y poca pedregosida constituida por piedras de cascajo redondeado } \\
\text { Color en humedo pardo rojizo y en seco pardo fuerte. Separción con el horizonte inferior es difusa, } \\
\text { disminullendo la activiad biologica y pocas raices. }\end{array}$} \\
\hline \multicolumn{2}{|c|}{ Horizonte B2 } & & & $110-200 \mathrm{~cm}$ \\
\hline \multicolumn{5}{|c|}{$\begin{array}{l}\text { Con pocos elementos gruesos y pedregosidad constituida por piedras de cascajo redondeado en } \\
\text { mayor canticad que el horizonte anterior. Color en humedo pardo rojizo y en seco pardo fuerte. } \\
\text { Separción con el horizonte inferior es difusa, sin activiad biologica y sin raices. }\end{array}$} \\
\hline \multicolumn{2}{|c|}{ Horizonte C } & & & $>200 \mathrm{~cm}$ \\
\hline \multicolumn{5}{|c|}{ Pizarras descompuestas y cuarcitas } \\
\hline
\end{tabular}


No Perfil:

\begin{tabular}{|c|c|c|}
\hline \multirow{2}{*}{ Localización } & Municipio & Vega Espinareda \\
\cline { 2 - 3 } & Localidad & Sésamo \\
\hline \multirow{2}{*}{ Coordenadas } & $\mathbf{X}$ & 692017.0025 \\
\cline { 2 - 3 } & $\mathbf{Z}$ & 4734163.981 \\
\hline Exposición & 652 \\
\hline \multicolumn{2}{|c|}{ Pendiente \% } & Solana \\
\hline \multicolumn{2}{|c|}{ Geoforma } & 6 \\
\hline Horizonte A & Vaguada \\
\hline
\end{tabular}

\section{2}

\begin{tabular}{|c|c|}
\hline Erosión & Intensa \\
\hline Vegetación & Vid, cerales y pinos \\
\hline Usos terreno & Grupo A, Clase II y III \\
\hline Roca Madre & Margas y comglomerado \\
\hline Terren. Circu. & Iguales caracteristicas \\
\hline Aflor. Rocosos & Ninguno \\
\hline Pedreg. Super. & Poca o nula \\
\hline Tiempo Atmosf. & Soledado y seco \\
\hline Profundidad & 0 - $40 \mathrm{~cm}$ \\
\hline
\end{tabular}

Elementos gruesos y regular pedregosidad. Sin rocosidad. Color en seco pardo y en humedo pardo rojizo. Consistencia en seco dura. Estructura en bloques débil y media. Abundantes raices y vida microbiana activa. La separación con el horizonte inferior esta bien definida.

\section{Horizonte B}

Profundidad

$40-86 \mathrm{~cm}$

Elementos gruesos y regular pedregosidad. Sin rocosidad. Color en seco pardo oscuro y en humedo pardo rojizo. Consistencia dura. Estructura en bloques subangulares, moderada y media. Abundantes raices y vida microbiana activa. La separación con el horizonte inferior esta definida.

\section{Horizonte B}

\section{Profundidad}

$86-152 \mathrm{~cm}$

Pocos elementos gruesos y abundantes piedres subangulares, Consistencia muy dura y estructura en bloque subangulares, fuerte y gruesa. Color en humedo de rojo a rojo oscuroy en seco rojo amarillento. Separado de la siguiente capa por una linea definida. Aumento del contenido en arcilla. Escasas raices y y regular actividad microbiana

\section{Horizonte C}

\section{Profundidad}

$>152 \mathrm{~cm}$

Horizonte de transición hacia la roca madre formadora. Sin raices ni vida microbiana. Consistencia dura y estructura fuerte. 


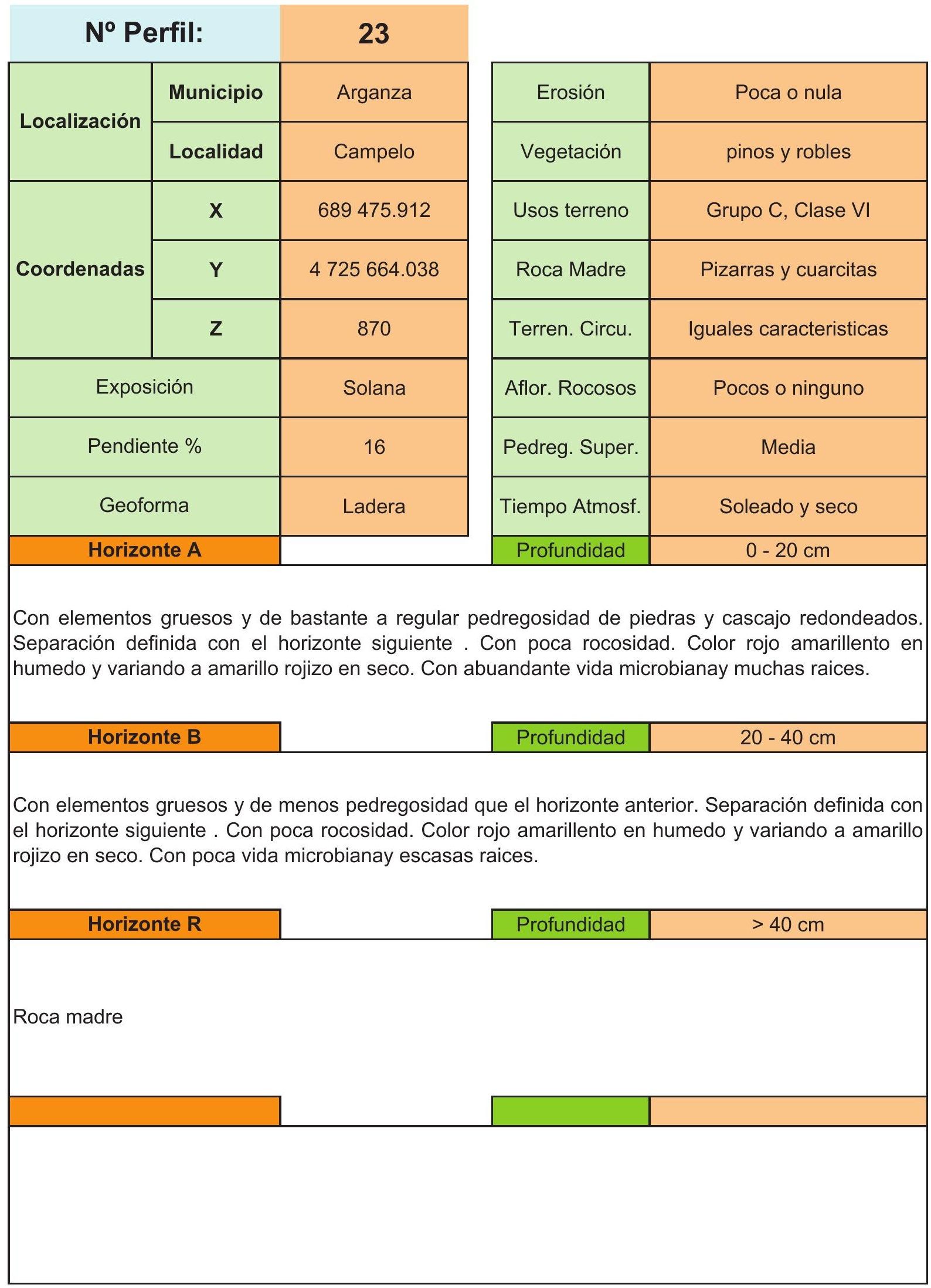




\begin{tabular}{|c|c|c|c|c|}
\hline \multicolumn{2}{|c|}{ No Perfil: } & \multirow{2}{*}{24} & & \\
\hline \multirow{2}{*}{ Localización } & Municipio & & Erosión & Fuerte \\
\hline & Localidad & Sancedo & Vegetación & $\begin{array}{c}\text { Encinares, viñas, cereales y } \\
\text { grupos de castaños }\end{array}$ \\
\hline \multirow{3}{*}{ Coordenadas } & $x$ & 6939335.025 & Usos terreno & Grupo C, clase VI \\
\hline & $\mathbf{Y}$ & 4725945.011 & Roca Madre & Margas y conglomerados \\
\hline & $\mathbf{z}$ & 670 & Terren. Circu. & Iguales caracteristicas \\
\hline \multicolumn{2}{|c|}{ Exposición } & Solana & Aflor. Rocosos & Ninguno \\
\hline \multicolumn{2}{|c|}{ Pendiente \% } & 12 & Pedreg. Super. & Poca o nula \\
\hline \multicolumn{2}{|c|}{ Geoforma } & Ladera & Tiempo Atmosf. & Soleado \\
\hline \multicolumn{2}{|c|}{ Horizonte A } & & Profundidad & $0-20 \mathrm{~cm}$ \\
\hline \multicolumn{5}{|c|}{$\begin{array}{l}\text { Horizonte con abundantes raices y actividad microbiana. Con elementos gruesos y abundante } \\
\text { pedregosidad del tamaño de piedra y forma redondeada. Separación difusa con la capa inferior. } \\
\text { Estructura en bloque angulares y consistencia en seco dura. Color amarillo rojizo. }\end{array}$} \\
\hline \multicolumn{3}{|c|}{ Horizonte B } & & $20-110 \mathrm{~cm}$ \\
\hline \multicolumn{5}{|c|}{$\begin{array}{l}\text { Con elementos gruesos y mucha pedregosidad constituidas por cuarcitas redondeadas. Estructura } \\
\text { en bloques subangulares de moderado grado de agregación y consistencia dura, la separación con } \\
\text { el siguiente horizonte sigue siendo difusa. El color es rojo amarrillento en humedo variando en seco. } \\
\text { Todavia posee abundantes raices y vida microbiana. }\end{array}$} \\
\hline \multicolumn{3}{|c|}{ Horizonte C } & & $110-145 \mathrm{~cm}$ \\
\hline \multicolumn{5}{|c|}{$\begin{array}{l}\text { Horizonte sin acitvidad microbiologica, ni raices, de color rojo a rojo oscuro en humedo y rojo } \\
\text { amarillento en seco. Con pocos elementos gruesos y menos pedregosidad que el horizonte superior } \\
\text { Con una estructura en bloques subangulares moderada. }\end{array}$} \\
\hline \multicolumn{2}{|c|}{ Horizonte $\mathbf{R}$} & & & $>145 \mathrm{~cm}$ \\
\hline \multicolumn{5}{|c|}{ Roca madre. } \\
\hline
\end{tabular}




\begin{tabular}{|c|c|c|c|c|}
\hline \multicolumn{2}{|c|}{ No Perfil: } & \multirow{2}{*}{25} & \multirow[b]{2}{*}{ Erosión } & \multirow[b]{2}{*}{ Baja } \\
\hline \multirow{2}{*}{ Localización } & Municipio & & & \\
\hline & Localidad & Villabuena & Vegetación & Cultivos de regadio \\
\hline \multirow{3}{*}{ Coordenadas } & $x$ & 684971.464 & Usos terreno & Grupo A, clase I \\
\hline & $\mathbf{Y}$ & 4723770.885 & Roca Madre & $\begin{array}{c}\text { Conglomerados, arcillas y } \\
\text { limos }\end{array}$ \\
\hline & $\mathbf{z}$ & 820 & Terren. Circu. & Iguales caracteristicas \\
\hline \multicolumn{2}{|c|}{ Exposición } & Solana & Aflor. Rocosos & Ninguno \\
\hline \multicolumn{2}{|c|}{ Pendiente \% } & 2 & Pedreg. Super. & Ninguno \\
\hline \multicolumn{2}{|c|}{ Geoforma } & Fondo de valle & Tiempo Atmosf. & Soleado \\
\hline \multicolumn{2}{|c|}{ Horizonte A } & & Profundidad & $0-30 \mathrm{~cm}$ \\
\hline \multicolumn{5}{|c|}{$\begin{array}{l}\text { Sin elementos gruesos y poca pedregosidad de forma redondeada y forma de piedra. Sin rocosidad } \\
\text { Estructura moderadamente fuerte, en bloque subangulares. Consistencia dura. Posee una } \\
\text { separación con el siguiente horizonte definida. Color pardo negruzco en humedo y pardo ligeramente } \\
\text { amarillo en seco. Abundantes racices y buena actividad microbiana. }\end{array}$} \\
\hline \multicolumn{2}{|c|}{ Horizonte B } & & & $30-60 \mathrm{~cm}$ \\
\hline \multicolumn{5}{|c|}{$\begin{array}{l}\text { Al igual que el anterior este tambien posee pocos elementos gruesos y poca pedregosidad. Colo } \\
\text { pardo negruzco en humedo y pardo amarillento en seco. Frecuentes raices y vida microbiologica } \\
\text { Estructura prismatica y consistencia dura. }\end{array}$} \\
\hline \multicolumn{2}{|c|}{ Horizonte B } & & & $60-110 \mathrm{~cm}$ \\
\hline \multicolumn{5}{|c|}{$\begin{array}{l}\text { Este horizonte presenta ya mas elementos gruesos y mucha pedregosidad sin que aparezca } \\
\text { estructura definida. Con una separación clara con el siguiente horizonte. Color pardo amarillento, y } \\
\text { ya con escasas raices y moderada vida microbiológica. }\end{array}$} \\
\hline \multicolumn{2}{|c|}{ Horizonte B } & & & $>110 \mathrm{~cm}$ \\
\hline \multicolumn{5}{|c|}{ Consistencia suelta, y sin estructura definida. Sin racices ni acitivida microbiológica. } \\
\hline
\end{tabular}




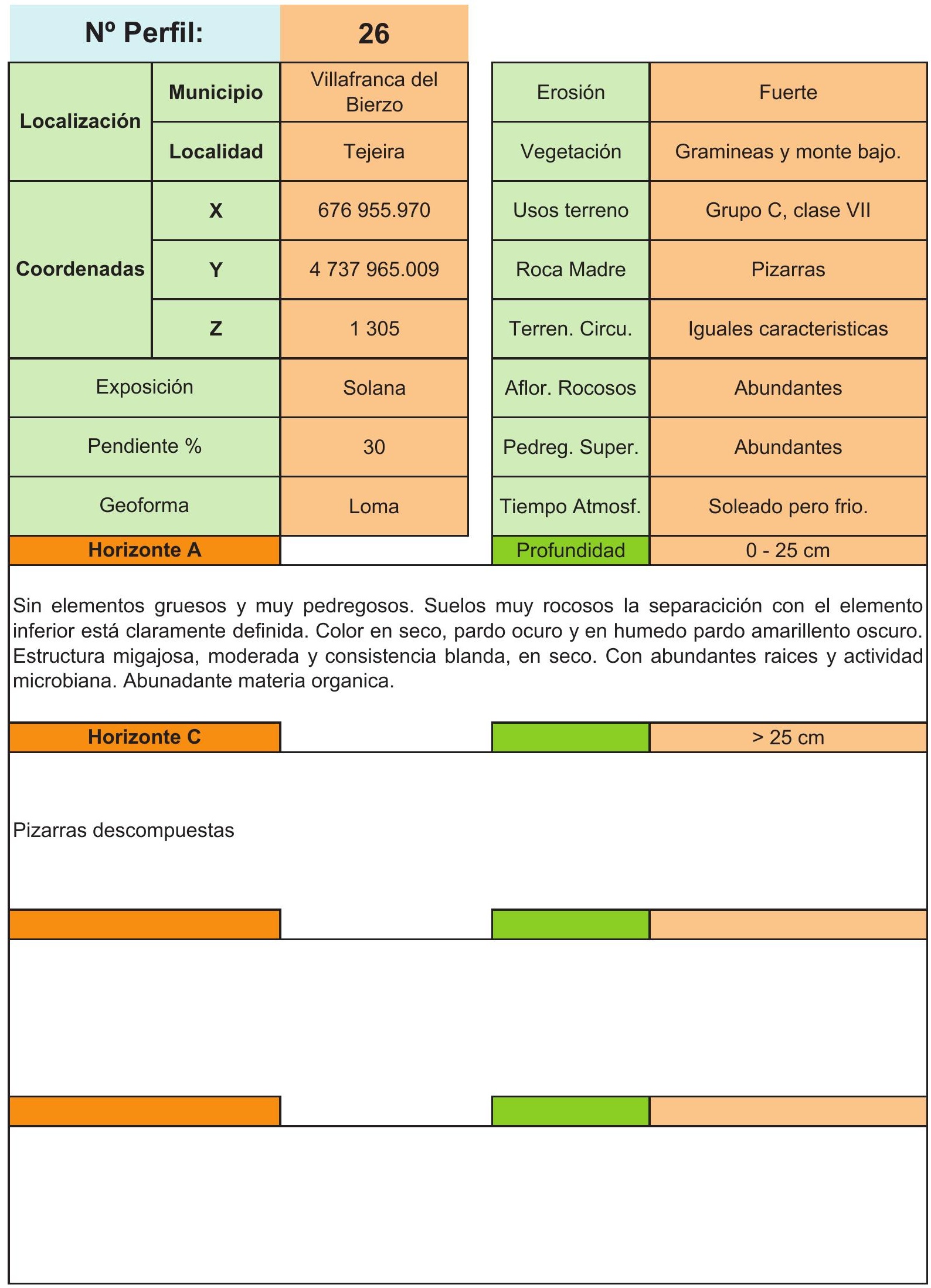




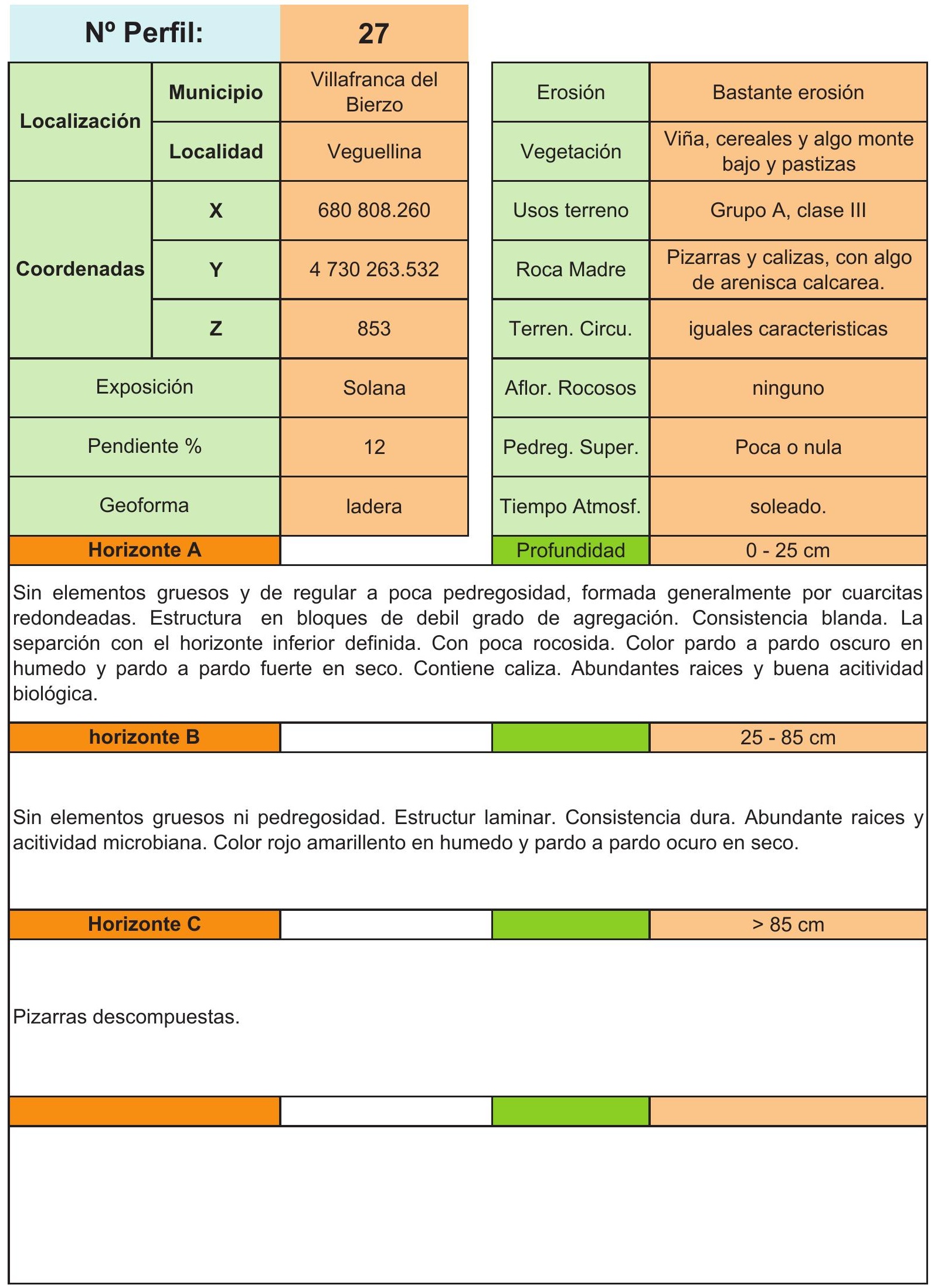


No Perfil:

\begin{tabular}{|c|c|c|}
\hline \multirow{2}{*}{ Localización } & Municipio & $\begin{array}{c}\text { Villafranca del } \\
\text { Biezo }\end{array}$ \\
\cline { 2 - 3 } & Localidad & $\begin{array}{c}\text { Villafranca del } \\
\text { Biezo }\end{array}$ \\
\hline \multirow{2}{*}{ Coordenadas } & $\mathbf{Y}$ & 679917.003 \\
\cline { 2 - 3 } & $\mathbf{Z}$ & 6479 \\
\hline Exposición & Solana \\
\hline Pendiente \% & 3 \\
\hline Geoforma & Fondo de valle \\
\hline Horizonte A & \\
\hline \multicolumn{2}{|c|}{} \\
\hline
\end{tabular}

\section{8}

\begin{tabular}{|c|c|}
\hline Erosión & Poca \\
\hline Vegetación & Viñedo y cultivos de huerta \\
\hline Usos terreno & Grupo A, clase II \\
\hline Roca Madre & $\begin{array}{c}\text { Arcilas con margas y } \\
\text { comglomerados }\end{array}$ \\
\hline Terren. Circu. & $\begin{array}{r}\text { Igual características } \\
\hline \text { Aflor. Rocosos }\end{array}$ \\
\hline Pedreg. Super. & No \\
\hline Tiempo Atmosf. & Humedo y frio \\
\hline Profundidad & $0-30 \mathrm{~cm}$ \\
\hline
\end{tabular}

Sin elementos gruesos y poca pedregosidad de forma redondeada y forma de piedra. Sin rocosidad. Estructura moderadamente fuerte, en bloque subangulares. Consistencia dura. Posee una separación con el siguiente horizonte definida. Color pardo negruzco en humedo y pardo ligeramente amarillo en seco. Abundantes racices y buena actividad microbiana.

\section{Horizonte B}

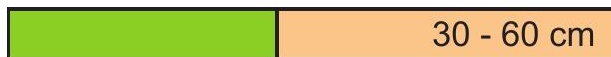

Al igual que el anterior este tambien posee pocos elementos gruesos y poca pedregosidad. Color pardo negruzco en humedo y pardo amarillento en seco. Frecuentes raices y vida microbiologica. Estructura prismatica y consistencia dura.

Horizonte B

\begin{tabular}{|r|r}
\hline & $60-110 \mathrm{~cm}$ \\
\hline
\end{tabular}

Este horizonte presenta ya mas elementos gruesos y mucha pedregosidad sin que aparezca estructura definida. Con una separación clara con el siguiente horizonte. Color pardo amarillento, y ya con escasas raices y moderada vida microbiológica.

Horizonte B

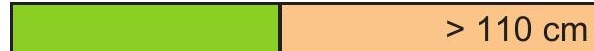

Cons+M193istencia suelta, y sin estructura definida. Sin racices ni acitivida microbiológica. 
ANÁLISIS DE CARACTERIZACIÓN DE SUELOS

Desarrollo de una aplicación informática para el cálculo de sostenimiento de taludes mediante vegetación

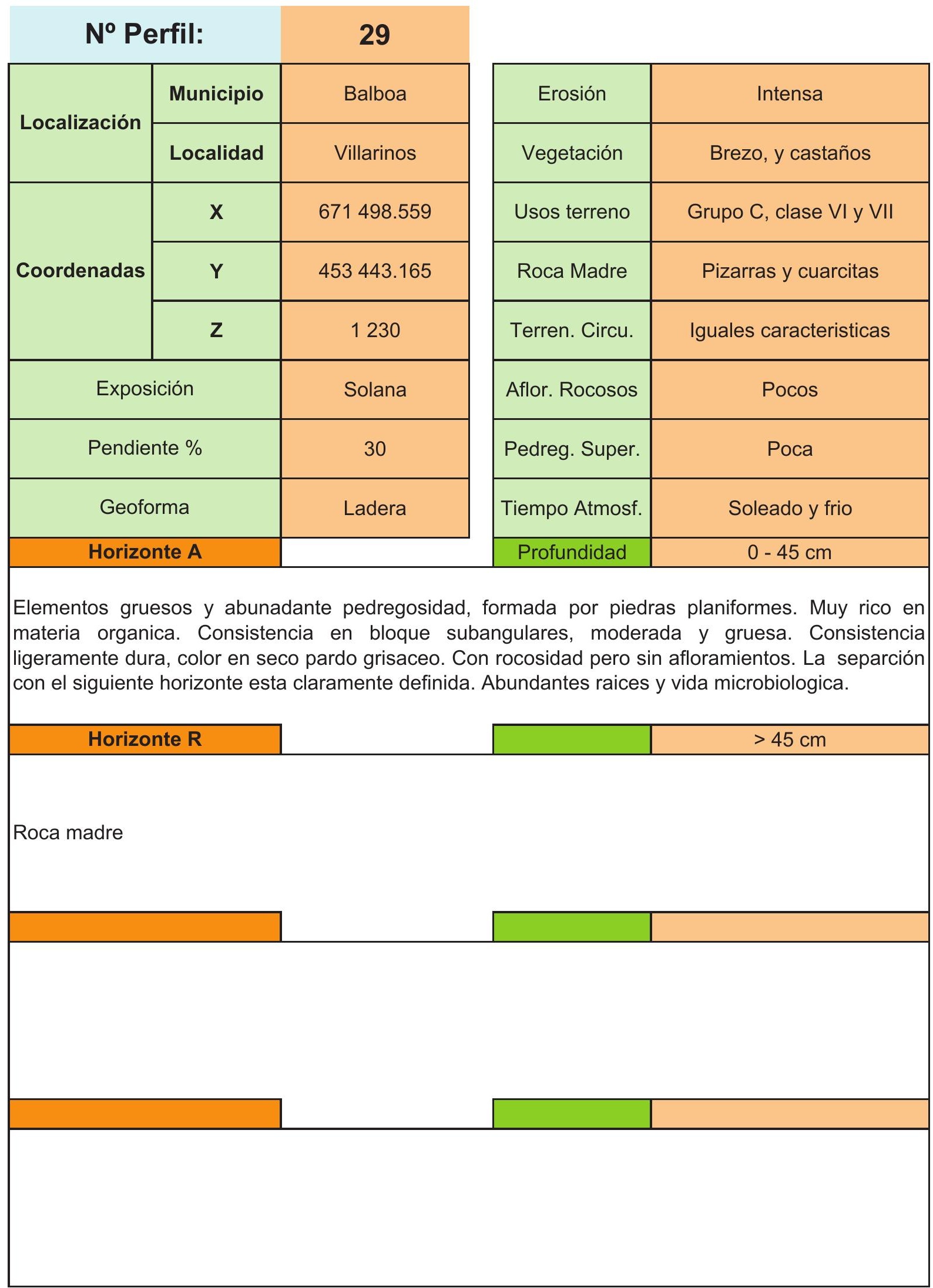


ANÁLISIS DE CARACTERIZACIÓN DE SUELOS

Desarrollo de una aplicación informática para el cálculo de sostenimiento de taludes mediante vegetación

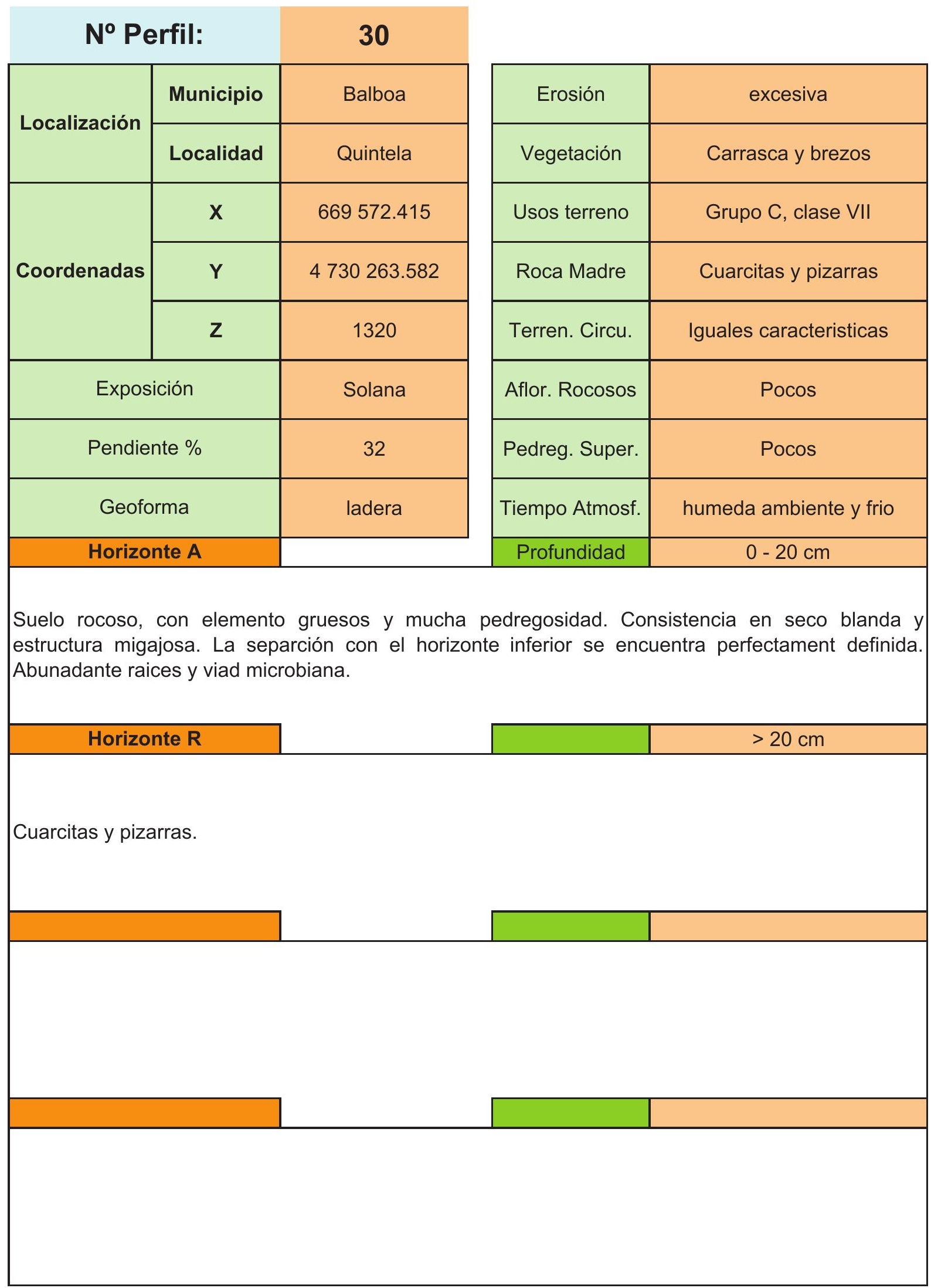


ANÁLISIS DE CARACTERIZACIÓN DE SUELOS

Desarrollo de una aplicación informática para el cálculo de sostenimiento de taludes mediante vegetación

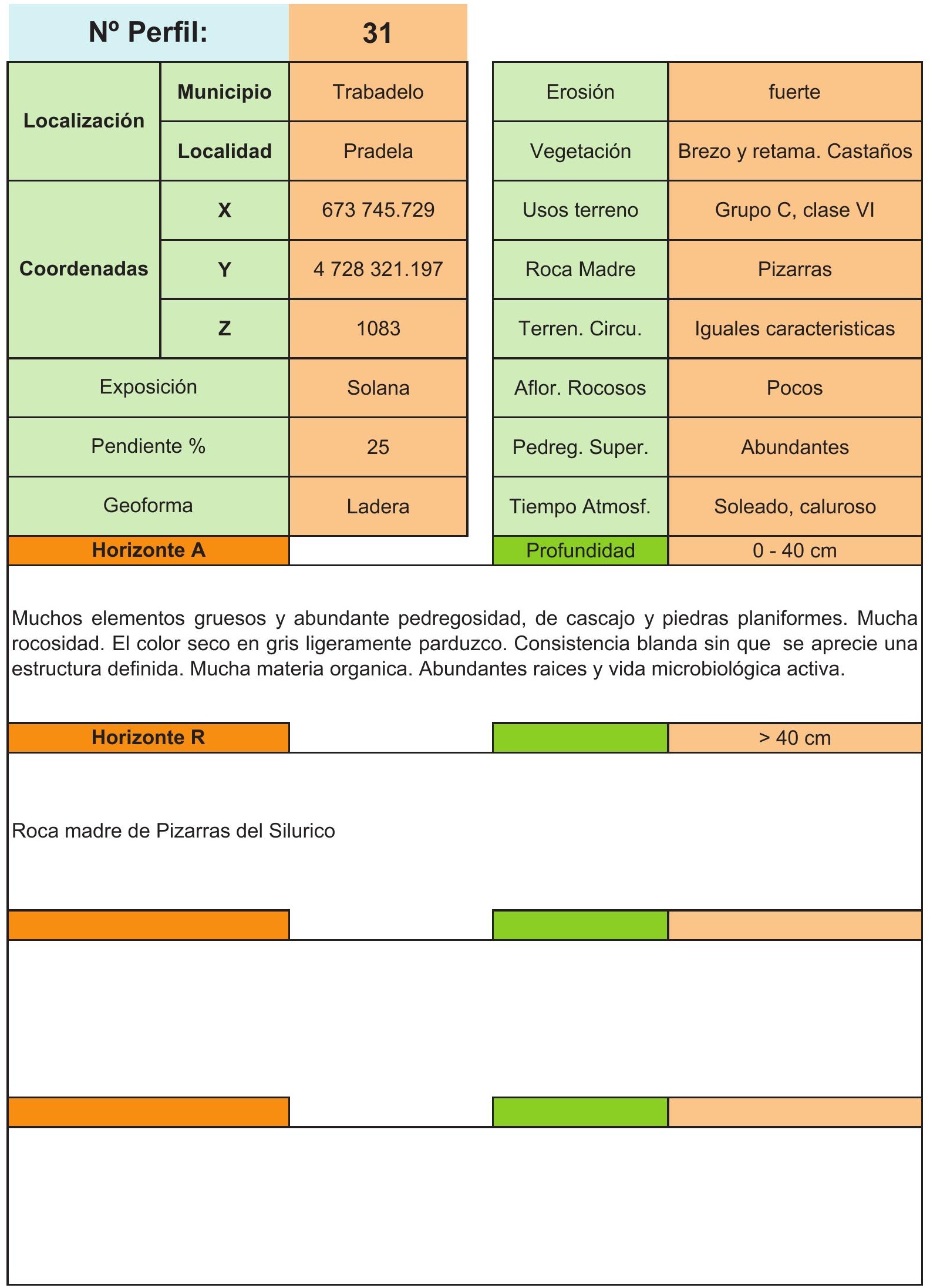


ANÁLISIS DE CARACTERIZACIÓN DE SUELOS

Desarrollo de una aplicación informática para el cálculo de sostenimiento de taludes mediante vegetación

No Perfil:
\begin{tabular}{|c|c|c|}
\hline \multirow{2}{*}{ Localización } & Municipio & Trabadelo \\
\cline { 2 - 3 } & Localidad & Sotoparada \\
\hline \multirow{2}{*}{ Coordenadas } & $\mathbf{X}$ & 671284.5436 \\
\cline { 2 - 3 } & $\mathbf{Y}$ & 4722348.124 \\
\cline { 2 - 3 } & $\mathbf{Z}$ & 891 \\
\hline Exposición & Solana \\
\hline Pendiente \% & 26 \\
\hline \multicolumn{2}{|c|}{ Geoforma } & Ladera \\
\hline \multicolumn{2}{|c|}{ Horizonte A } & \\
\hline
\end{tabular}

\begin{tabular}{|c|c|}
\hline Erosión & Intensa \\
\hline Vegetación & $\begin{array}{c}\text { Brezo y retama, con algo } \\
\text { de repoblación de pinos. }\end{array}$ \\
\hline Usos terreno & Grupo C, clase VII \\
\hline Roca Madre & Pizarras \\
\hline Terren. Circu. & Iguales caracteristicas \\
\hline Aflor. Rocosos & Abundantes \\
\hline Pedreg. Super. & Abundantes \\
\hline Tiempo Atmosf. & Soleado, caluroso \\
\hline Profundidad & $0-40 \mathrm{~cm}$ \\
\hline
\end{tabular}

Muchos elementos gruesos y abundante pedregosidad, de cascajo y piedras planiformes. Mucha rocosidad. El color seco en gris ligeramente parduzco. Consistencia blanda sin que se aprecie una estructura definida. Mucha materia organica. Abundantes raices y vida microbiológica activa.

Horizonte $\mathbf{R}$

$>40 \mathrm{~cm}$

Pizarras

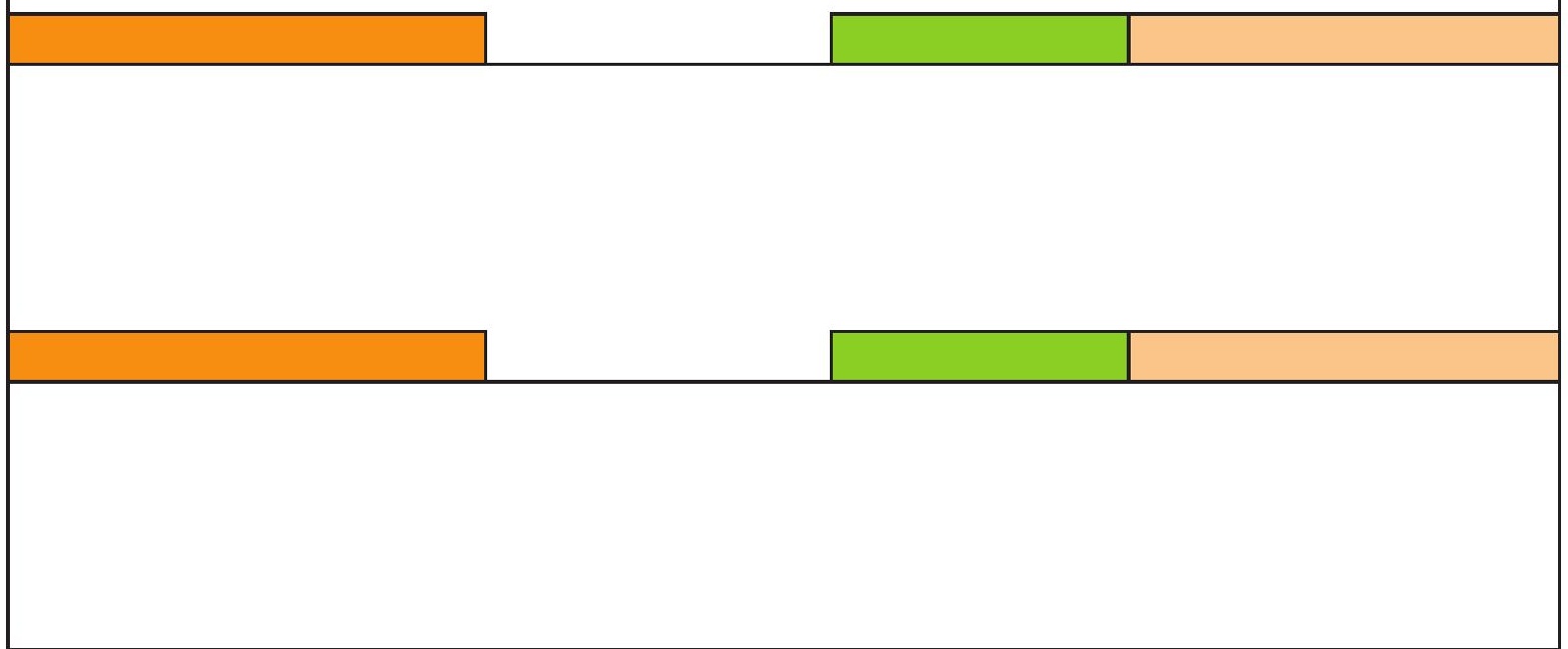


ANÁLISIS DE CARACTERIZACIÓN DE SUELOS

Desarrollo de una aplicación informática para el cálculo de sostenimiento de taludes mediante vegetación

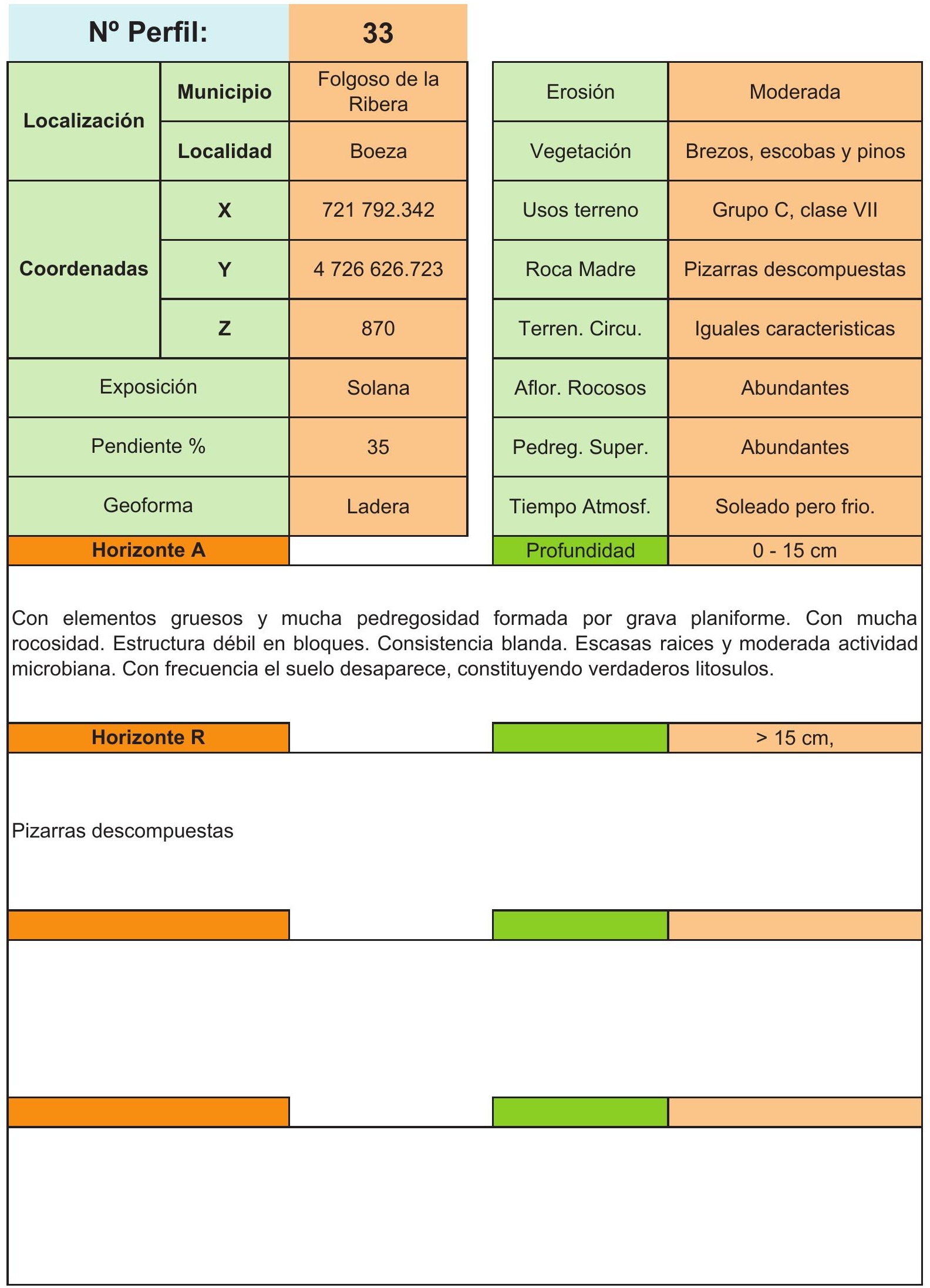


ANÁLISIS DE CARACTERIZACIÓN DE SUELOS

Desarrollo de una aplicación informática para el cálculo de sostenimiento de taludes mediante vegetación

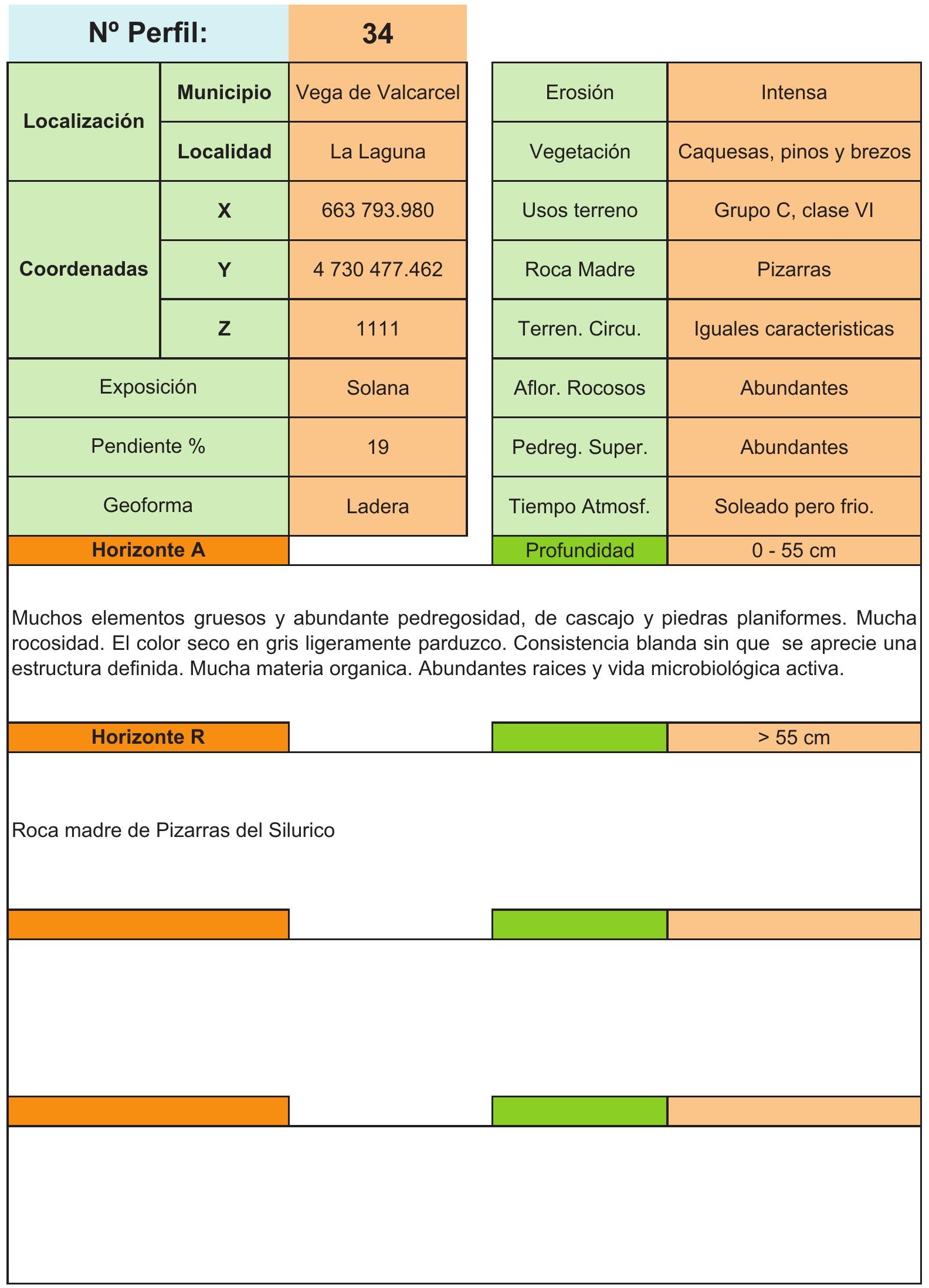




\begin{tabular}{|c|c|c|c|c|}
\hline \multicolumn{2}{|c|}{ No Perfil: } & \multirow{2}{*}{35} & \multirow[b]{2}{*}{ Erosión } & \multirow[b]{2}{*}{ Moderada } \\
\hline \multirow{2}{*}{ Localización } & Municipio & & & \\
\hline & Localidad & Corrales & Vegetación & Cultivos de huerta \\
\hline \multirow{3}{*}{ Coordenadas } & $\mathbf{x}$ & 667218.238 & Usos terreno & Grupo A, Clase I \\
\hline & $\mathbf{Y}$ & 4719994.895 & Roca Madre & $\begin{array}{c}\text { Sedimentos del } \\
\text { cuaternario }\end{array}$ \\
\hline & $\mathbf{z}$ & 530 & Terren. Circu. & Iguales caracteristicas \\
\hline \multicolumn{2}{|c|}{ Exposición } & Media luz & Aflor. Rocosos & Ninguno \\
\hline \multicolumn{2}{|c|}{ Pendiente \% } & 9 & Pedreg. Super. & Ninguna \\
\hline \multicolumn{2}{|c|}{ Geoforma } & Vaguada & Tiempo Atmosf. & Lluvioso \\
\hline \multicolumn{2}{|c|}{ Horizonte A } & & Profundidad & $0-30 \mathrm{~cm}$ \\
\hline \multicolumn{5}{|c|}{$\begin{array}{l}\text { Sin elementos gruesos y poca pedregosidad de forma redondeada y forma de piedra. Sin rocosidad } \\
\text { Estructura moderadamente fuerte, en bloque subangulares. Consistencia dura. Posee una } \\
\text { separación con el siguiente horizonte definida. Color pardo negruzco en humedo y pardd } \\
\text { ligeramente amarillo en seco. Abundantes racices y buena actividad microbiana. }\end{array}$} \\
\hline \multicolumn{2}{|c|}{ Horizonte B } & & & $30-60 \mathrm{~cm}$ \\
\hline \multicolumn{5}{|c|}{$\begin{array}{l}\text { Al igual que el anterior este tambien posee pocos elementos gruesos y poca pedregosidad. Colo } \\
\text { pardo negruzco en humedo y pardo amarillento en seco. Frecuentes raices y vida microbiologica } \\
\text { Estructura prismatica y consistencia dura. }\end{array}$} \\
\hline \multicolumn{3}{|c|}{ Horizonte B } & & $60-110 \mathrm{~cm}$ \\
\hline \multicolumn{5}{|c|}{$\begin{array}{l}\text { Este horizonte presenta ya mas elementos gruesos y mucha pedregosidad sin que aparezc } \\
\text { estructura definida. Con una separación clara con el siguiente horizonte. Color pardo amarillento, } \\
\text { ya con escasas raices y moderada vida microbiológica. }\end{array}$} \\
\hline \multicolumn{2}{|c|}{ Horizonte B } & & & $>110 \mathrm{~cm}$ \\
\hline \multicolumn{5}{|c|}{ Consistencia suelta, y sin estructura definida. Sin racices ni acitivida microbiológica. } \\
\hline
\end{tabular}


ANÁLISIS DE CARACTERIZACIÓN DE SUELOS

Desarrollo de una aplicación informática para el cálculo de sostenimiento de taludes mediante vegetación

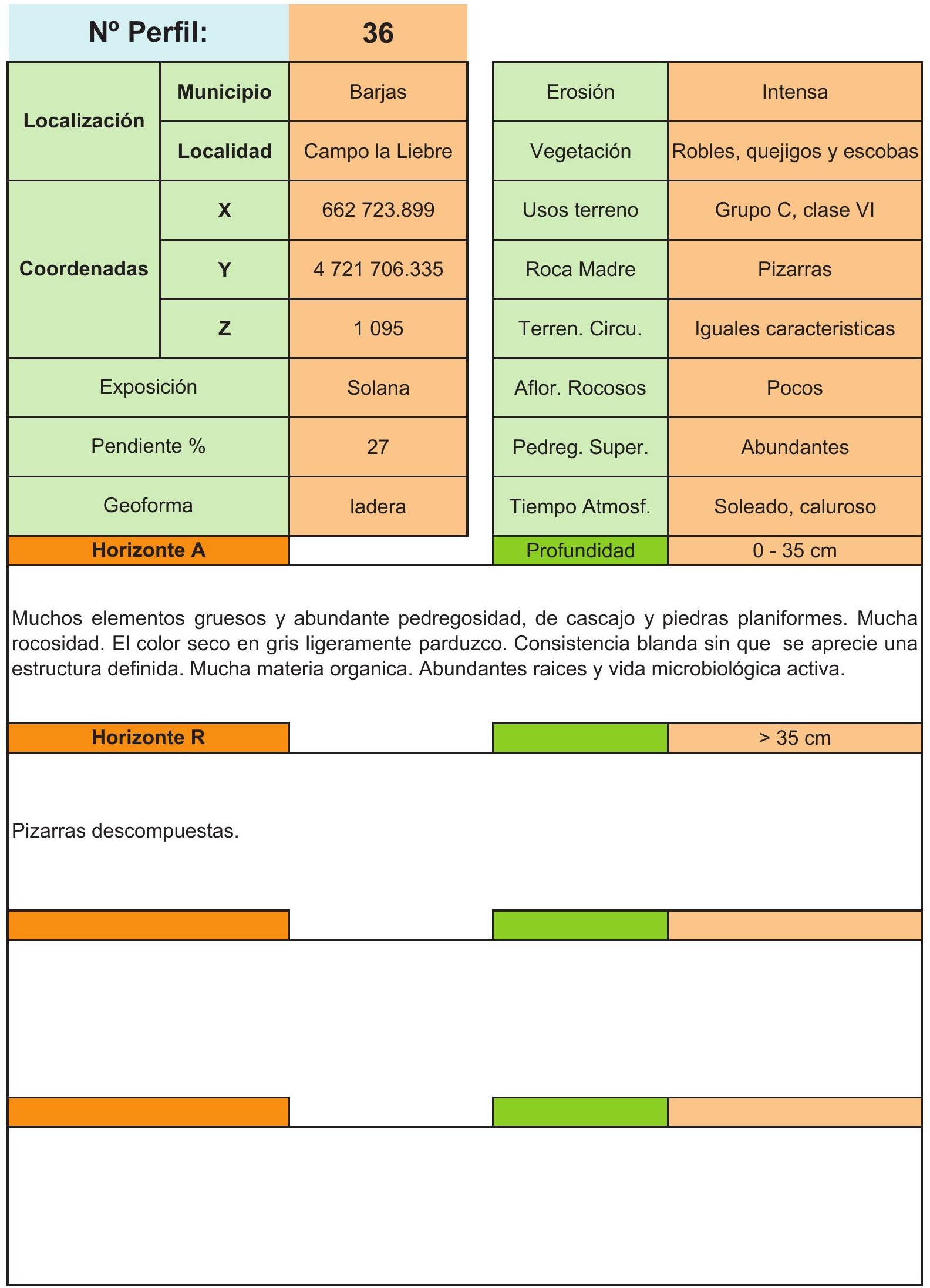


ANÁLISIS DE CARACTERIZACIÓN DE SUELOS

Desarrollo de una aplicación informática para el cálculo de sostenimiento de taludes mediante vegetación

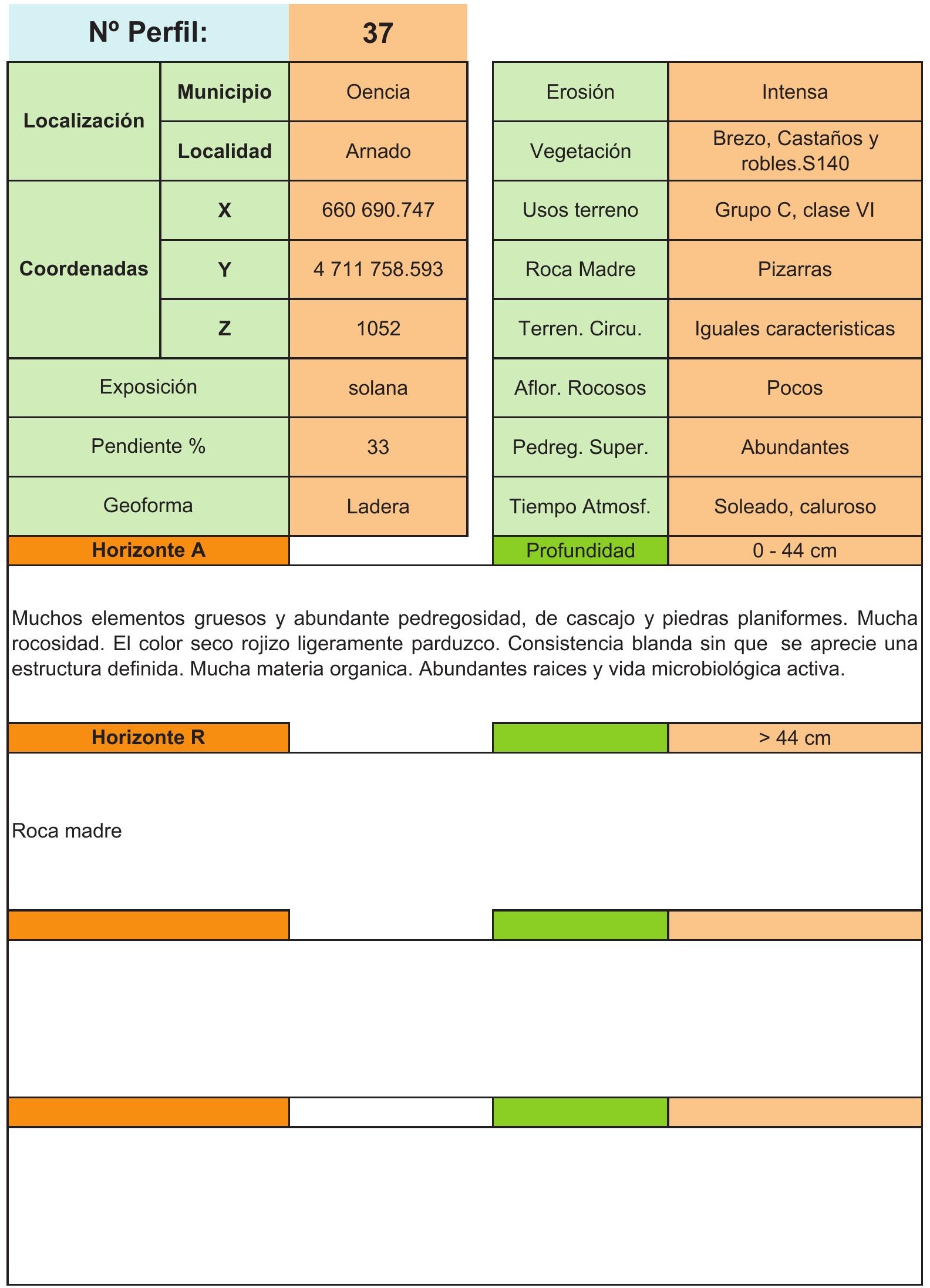


ANÁLISIS DE CARACTERIZACIÓN DE SUELOS

Desarrollo de una aplicación informática para el cálculo de sostenimiento de taludes mediante vegetación

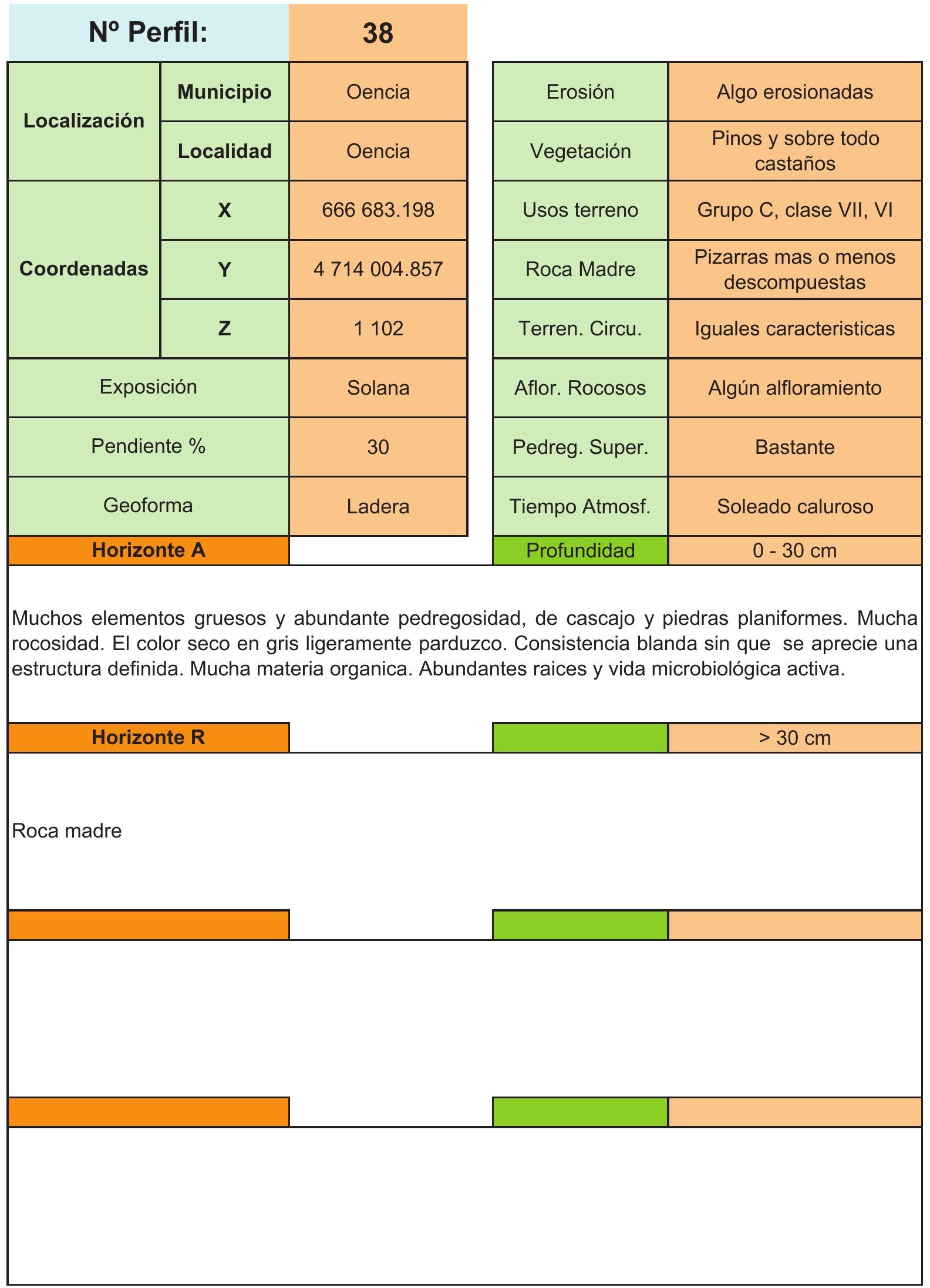


ANÁLISIS DE CARACTERIZACIÓN DE SUELOS

Desarrollo de una aplicación informática para el cálculo de sostenimiento de taludes mediante vegetación

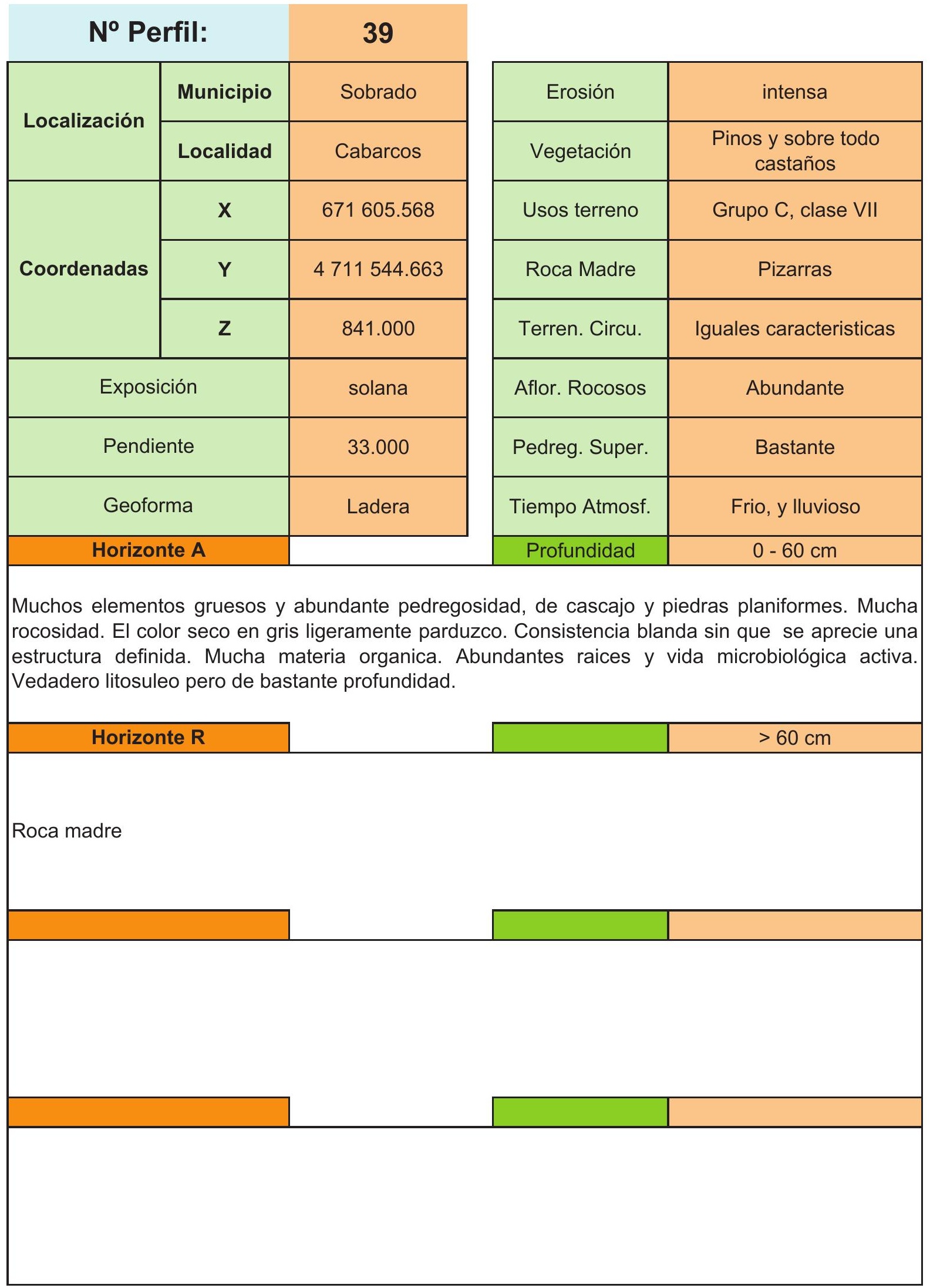




\begin{tabular}{|c|c|c|c|c|}
\hline \multicolumn{2}{|c|}{ No Perfil: } & \multirow{2}{*}{40} & \multirow[b]{2}{*}{ Erosión } & \multirow[b]{2}{*}{ Moderada } \\
\hline \multirow{2}{*}{ Localización } & Municipio & & & \\
\hline & Localidad & El Carril & Vegetación & Cultivos de huerta \\
\hline \multirow{3}{*}{ Coordenadas } & $\mathbf{x}$ & 675029.825 & Usos terreno & Grupo A, Clase I \\
\hline & $\mathbf{Y}$ & 4708763.574 & Roca Madre & $\begin{array}{c}\text { Sedimentos del } \\
\text { cuaternario }\end{array}$ \\
\hline & $\mathbf{z}$ & 370 & Terren. Circu. & Iguales caracteristicas \\
\hline \multicolumn{2}{|c|}{ Exposición } & Solana & Aflor. Rocosos & Ninguno \\
\hline \multicolumn{2}{|c|}{ Pendiente \% } & 5 & Pedreg. Super. & Ninguna \\
\hline \multicolumn{2}{|c|}{ Geoforma } & Vaguada & Tiempo Atmosf. & Lluvioso \\
\hline \multicolumn{2}{|c|}{ Horizonte A } & & Profundidad & $0-20 \mathrm{~cm}$ \\
\hline \multicolumn{5}{|c|}{$\begin{array}{l}\text { Sin elementos gruesos y poca pedregosidad de forma redondeada y forma de piedra. Sin rocosidad } \\
\text { Estructura moderadamente fuerte, en bloque subangulares. Consistencia dura. Posee una } \\
\text { separación con el siguiente horizonte definida. Color pardo negruzco en humedo y pardd } \\
\text { ligeramente amarillo en seco. Abundantes racices y buena actividad microbiana. }\end{array}$} \\
\hline \multicolumn{2}{|c|}{ Horizonte B } & & & $20-50 m$ \\
\hline \multicolumn{5}{|c|}{$\begin{array}{l}\text { Al igual que el anterior este tambien posee pocos elementos gruesos y poca pedregosidad. Colo } \\
\text { pardo negruzco en humedo y pardo amarillento en seco. Frecuentes raices y vida microbiologica } \\
\text { Estructura prismatica y consistencia dura. }\end{array}$} \\
\hline \multicolumn{3}{|c|}{ Horizonte B } & & $50-100 \mathrm{~cm}$ \\
\hline \multicolumn{5}{|c|}{$\begin{array}{l}\text { Este horizonte presenta ya mas elementos gruesos y mucha pedregosidad sin que aparezc } \\
\text { estructura definida. Con una separación clara con el siguiente horizonte. Color pardo amarillento, } \\
\text { ya con escasas raices y moderada vida microbiológica. }\end{array}$} \\
\hline \multicolumn{2}{|c|}{ Horizonte B } & & & $>100 \mathrm{~cm}$ \\
\hline \multicolumn{5}{|c|}{ Cosnistencia suelta, y sin estructura definida. Sin racices ni acitivida microbiológica. } \\
\hline
\end{tabular}




\begin{tabular}{|c|c|c|c|c|}
\hline $\mathrm{N}^{0} \mathrm{Pe}$ & rfil: & 41 & & \\
\hline & Municipio & Corullón & Erosión & Baja \\
\hline & Localidad & Melezna & Vegetación & Frutales \\
\hline & $\mathbf{x}$ & 672140.608 & Usos terreno & Grupo A, Clase II \\
\hline Coordenadas & $\mathbf{Y}$ & 4717213.806 & Roca Madre & Pizarras y cuarcitas \\
\hline & $\mathbf{Z}$ & 540 & Terren. Circu. & Iguales caracteristicas. \\
\hline Expos & ción & Solana & Aflor. Rocosos & Ninguno \\
\hline Pendie & te $\%$ & 6 & Pedreg. Super. & Escasa o nula \\
\hline Geofo & & Loma & Tiempo Atmosf. & Soleado pero fresco. \\
\hline Horizo & te $A$ & & Profundidad & $0-25 \mathrm{~cm}$ \\
\hline $\begin{array}{l}\text { Con elementos } \\
\text { moderada en bl } \\
\text { raices y moder } \\
\text { comienza a dist }\end{array}$ & $\begin{array}{l}\text { gruesos y pc } \\
\text { ques. Muy } r \\
\text { da actividac } \\
\text { gguirse difere }\end{array}$ & $\begin{array}{l}\text { o nula pedregc } \\
\text { en materia orga } \\
\text { icrobiana. Sepa } \\
\text { ias de color. }\end{array}$ & $\begin{array}{l}\text { d, esta es de ca } \\
\text { El color es pard } \\
\text { ón con el horizol }\end{array}$ & $\begin{array}{l}\text { ajo redondeado. Estructur } \\
\text { n seco. Posee abundante } \\
\text { inferior difusa, aunque }\end{array}$ \\
\hline Horizon & te B1 & & Profundidad & $25-50 \mathrm{~cm}$ \\
\hline $\begin{array}{l}\text { Mas elementos } \\
\text { redondeadas. } N \\
\text { horizonte inferic } \\
\text { amarillento a an }\end{array}$ & $\begin{array}{l}\text { gruesos y } \mathrm{m} \\
\text { o se aprecia } \\
\text { sigue sienc } \\
\text { arillo parduz }\end{array}$ & $\begin{array}{l}\text { pedregosidad } \\
\text { tructura definida } \\
\text { difusa. El color } \\
\text { en seco. Escasa }\end{array}$ & $\begin{array}{l}\text { el horizonte supe } \\
\text { a consistencia es } \\
\text { pardo oscuro am } \\
\text { ces y moderada a }\end{array}$ & $\begin{array}{l}\text { r, constituidas por piedra } \\
\text { anda.La separación con } \\
\text { lento en humedo y paro } \\
\text { jidad microbiana. }\end{array}$ \\
\hline Horizon & te $B 2$ & & Profundidad & $50-80 \mathrm{~cm}$ \\
\hline $\begin{array}{l}\text { Con abundantes } \\
\text { aveces se apros } \\
\text { Color como el h }\end{array}$ & $\begin{array}{l}\text { elementos } \mathrm{g} \\
\text { iman al tama } \\
\text { rizonte anter }\end{array}$ & $\begin{array}{l}\text { esos y mucha pe } \\
\text { de bloques. Sin } \\
\text { Sin raices y sin }\end{array}$ & $\begin{array}{l}\text { gosidad, formada } \\
\text { se aprecie estruc } \\
\text { jidad microbiana. }\end{array}$ & $\begin{array}{l}\text { piedras redondeadas qu } \\
\text { a y de consistencia suelt }\end{array}$ \\
\hline Horizo & te $\mathbf{R}$ & & Profundidad & $>80 \mathrm{~cm}$ \\
\hline Roca madre & & & & \\
\hline
\end{tabular}


ANÁLISIS DE CARACTERIZACIÓN DE SUELOS

Desarrollo de una aplicación informática para el cálculo de sostenimiento de taludes mediante vegetación

\begin{tabular}{|c|c|c|c|c|}
\hline \multicolumn{2}{|c|}{ No Perfil: } & 42 & & \\
\hline \multirow{2}{*}{ Localización } & Municipio & Corullón & Erosión & Intensa \\
\hline & Localidad & Corullón & Vegetación & Cereales, castaños, pastos.. \\
\hline \multirow{3}{*}{ Coordenadas } & $\mathbf{x}$ & 677491.011 & Usos terreno & Grupo C, Clases VI y VII \\
\hline & $\mathbf{Y}$ & 4714860.577 & Roca Madre & Pizarras, cuarcitas y calizas \\
\hline & $\mathbf{z}$ & 906 & Terren. Circu. & Iguales caracteristicas. \\
\hline \multicolumn{2}{|c|}{ Exposición } & Solana & Aflor. Rocosos & Abundantes \\
\hline \multicolumn{2}{|c|}{ Pendiente \% } & 24 & Pedreg. Super. & Abundantes \\
\hline \multicolumn{2}{|c|}{ Geoforma } & Ladera & Tiempo Atmosf. & Lluvioso \\
\hline \multicolumn{2}{|c|}{ Horizonte A } & & Profundidad & $0-25 \mathrm{~cm}$ \\
\hline \multicolumn{5}{|c|}{$\begin{array}{l}\text { Con elementos gruesos y mucha pedregosidad, esta es de cascajo, piedras y blques. Rocosidad } \\
\text { abunadante que da lugar a litosuelos. Muy rico en materia organica. El color es pardo en seco. } \\
\text { Posee abundantes raices y moderada actividad microbiana. Separación con el horizonte inferior } \\
\text { clara. }\end{array}$} \\
\hline \multicolumn{2}{|c|}{ Horizonte C } & & & $>25 \mathrm{~cm}$ \\
\hline \multicolumn{5}{|c|}{ Roca madre descompuesta } \\
\hline
\end{tabular}


No Perfil:

\begin{tabular}{|c|c|c|}
\hline \multirow{2}{*}{ Localización } & Municipio & Castropodame \\
\cline { 2 - 3 } & Localidad & Matanza \\
\hline \multirow{2}{*}{ Coordenadas } & $\mathbf{X}$ & 710128.465 \\
\cline { 2 - 3 } & $\mathbf{Y}$ & 4714004.857 \\
\cline { 2 - 3 } & $\mathbf{Z}$ & 1095 \\
\hline Exposición & Solana \\
\hline Pendiente \% & Ladera \\
\hline Geoforma & \\
\hline Honte A & \\
\hline
\end{tabular}

43

\begin{tabular}{|c|c|}
\hline Erosión & Media \\
\hline Vegetación & Vid, cerales y castaños \\
\hline Usos terreno & Grupo A, clase II \\
\hline Roca Madre & Pizarras. \\
\hline Terren. Circu. & Iguales caracteristicas \\
\hline Aflor. Rocosos & Ninguno \\
\hline Pedreg. Super. & Alguna \\
\hline Tiempo Atmosf. & Soleado \\
\hline Profundidad & $0-50 \mathrm{~cm}$ \\
\hline
\end{tabular}

Sin elementos gruesos y poca pedregosidad formadas por cuarcitas subangulosas y redondeadas. Color pardo muy oscuro grisaceo en humedo y en seco pardo. Con abundante materia organica pero sin llegar a se un horizonte $\mathrm{H}$. Limite difuso con el horizonte inferior. Abundantes raices y activa vida microviana.

\section{Horizonte B}

Profundidad

$50-120 \mathrm{~cm}$

Sin elementos gruesos ni pedregosidad escesiva. Estructura en bloques subangulares de regularar estabilidad. Consistencia ligeramente dura. Color pardo oscuro amarillento en humedo y pardo amarillento o amarillento parduzco en seco. Pocas raices y escasa actividad microbiana. Separación difuda con el horizonte inferior.

\section{Horizonte C}

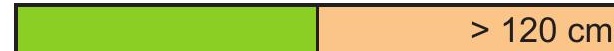

Roca madre descompuesta. 
ANÁLISIS DE CARACTERIZACIÓN DE SUELOS

Desarrollo de una aplicación informática para el cálculo de sostenimiento de taludes mediante vegetación

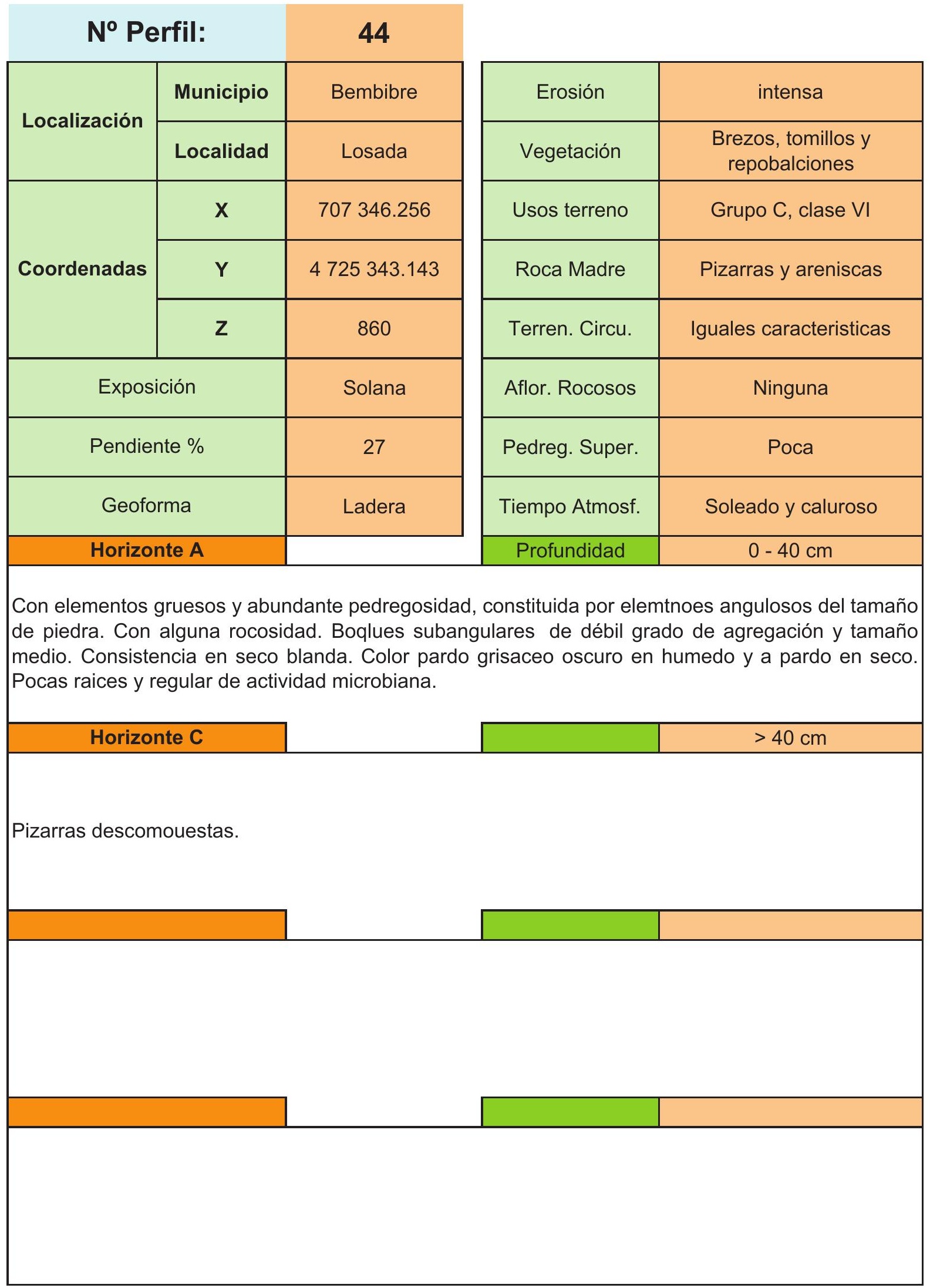


No Perfil:

\begin{tabular}{|c|c|c|}
\hline \multirow{2}{*}{ Localización } & Municipio & Carracedelo \\
\cline { 2 - 3 } & Localidad & Carracedelo \\
\hline \multirow{2}{*}{ Coordenadas } & $\mathbf{X}$ & 685302.598 \\
\cline { 2 - 3 } & $\mathbf{Y}$ & 4713790.928 \\
\hline Exposición & 423.000 \\
\hline \multicolumn{2}{|c|}{ Pendiente \% } & Solana \\
\hline \multicolumn{2}{|c|}{ Geoforma } & Fondo de valle \\
\hline Horizonte A & \\
\hline
\end{tabular}

\begin{tabular}{|c|c|}
\hline Erosión & Poca o ninguna \\
\hline Vegetación & $\begin{array}{c}\text { Castaños y monte bajo, con } \\
\text { alguna zona repoblada. }\end{array}$ \\
\hline Usos terreno & Grupo A, clase II \\
\hline Roca Madre & pizarras siluricas. \\
\hline Terren. Circu. & Iguales caracteristicas \\
\hline Aflor. Rocosos & Ninguno \\
\hline Pedreg. Super. & Ninguno \\
\hline Tiempo Atmosf. & Soleado y caluroso \\
\hline Profundidad & 0 - 40 \\
\hline
\end{tabular}

Pocos elementos gruesos y piedras redondeadas. Sin rocosidad. Estructura en bloque, moderada y media. Consistencia ligeramente dura. Color en humedo rojo amarillento y en seco amarillo rojizo. La separación con el siguiente horizonte esta claramente definida. De raices abundantes y activa vida microbiana.

\section{Horizonte B}

$40-100 \mathrm{~cm}$

Pocos elementos gruesos y piedras redondeadas. Sin rocosidad. Estructura en bloque, de buena estabilidad. Consistencia dura en seco. Color en humedo rojo amarillento y en seco amarillo rojizo. La separación con el siguiente horizonte esta claramente definida.Sin raices y escasa vida microbiana.

\section{Horizonte C}

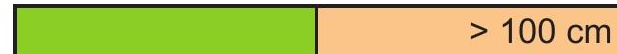

Estructura prismatica fuerte y media. Consistencia muy dura. Aumento de arcilla con respecto a las capas superiores. Con pocos elementos gruesos y poca pedregosidad, si afloramientos rocosos.

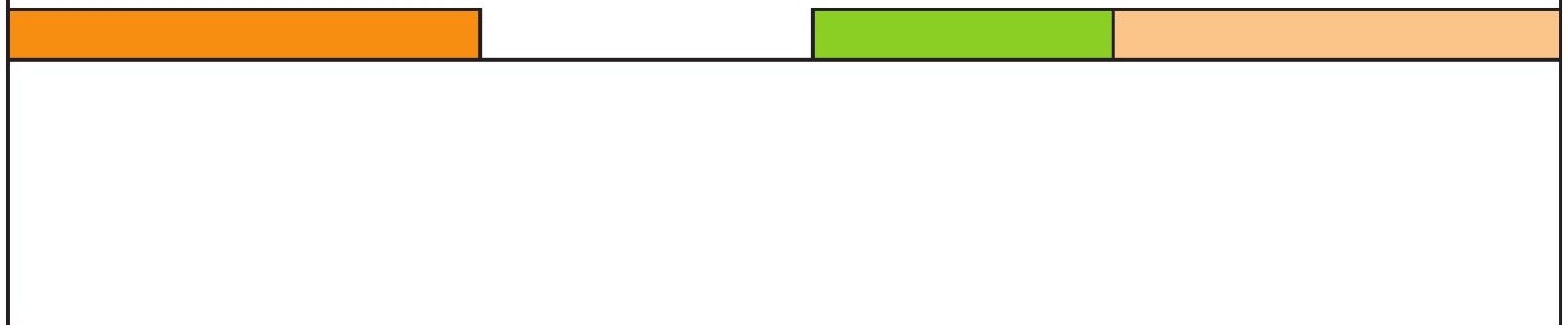


No Perfil:

\begin{tabular}{|c|c|c|}
\hline \multirow{2}{*}{ Localización } & Municipio & Molinaseca \\
\cline { 2 - 3 } & Localidad & Acebo \\
\hline \multirow{2}{*}{ Coordenadas } & $\mathbf{X}$ & 707873.809 \\
\cline { 2 - 3 } & $\mathbf{Y}$ & 4708100.483 \\
\cline { 2 - 3 } & $\mathbf{Z}$ & 322.000 \\
\hline Exposición & Solana \\
\hline Pendiente & 33.000 \\
\hline \multicolumn{2}{|c|}{ Geoforma } & Ladera \\
\hline Horizonte A & \\
\hline
\end{tabular}

46

\begin{tabular}{|c|c|}
\hline Erosión & Moderada \\
\hline Vegetación & Pastos, brezos, pinos \\
\hline Usos terreno & Grupo C, clase VI \\
\hline Roca Madre & cuarcitas y pizarras \\
\hline Terren. Circu. & Iguales caracteristicas \\
\hline Aflor. Rocosos & Escaos o ninguno \\
\hline Pedreg. Super. & Abundante \\
\hline Tiempo Atmosf. & Soleado y caluroso \\
\hline Profundidad & 0 - 40 \\
\hline
\end{tabular}

Pocos elementos gruesos y piedras redondeadas. Sin rocosidad. Estructura en bloque, moderada y media. Consistencia ligeramente dura. Color en humedo pardo amarillento y en seco pardo. La separación con el siguiente horizonte esta claramente definida. De raices abundantes y activa vida microbiana.

\section{Horizonte B}

$40-100 \mathrm{~cm}$

Pocos elementos gruesos y piedras redondeadas. Sin rocosidad. Estructura en bloque, de buena estabilidad. Consistencia blanda. Color en humedo rojo amarillento y en seco pardo rojizo. La separación con el siguiente horizonte esta claramente definida.Sin raices y escasa vida microbiana.

\section{Horizonte C}

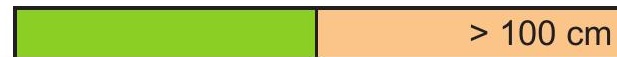

Roca madre descompuesta.

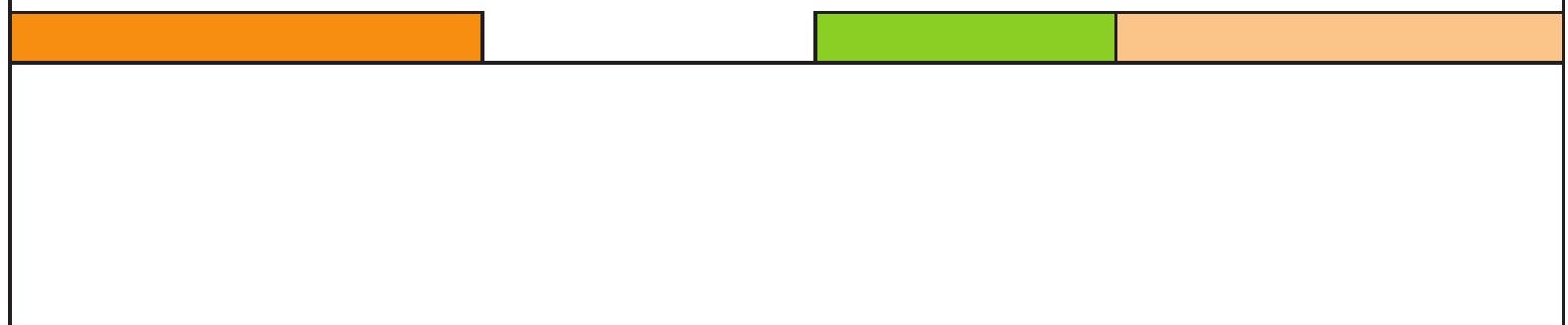




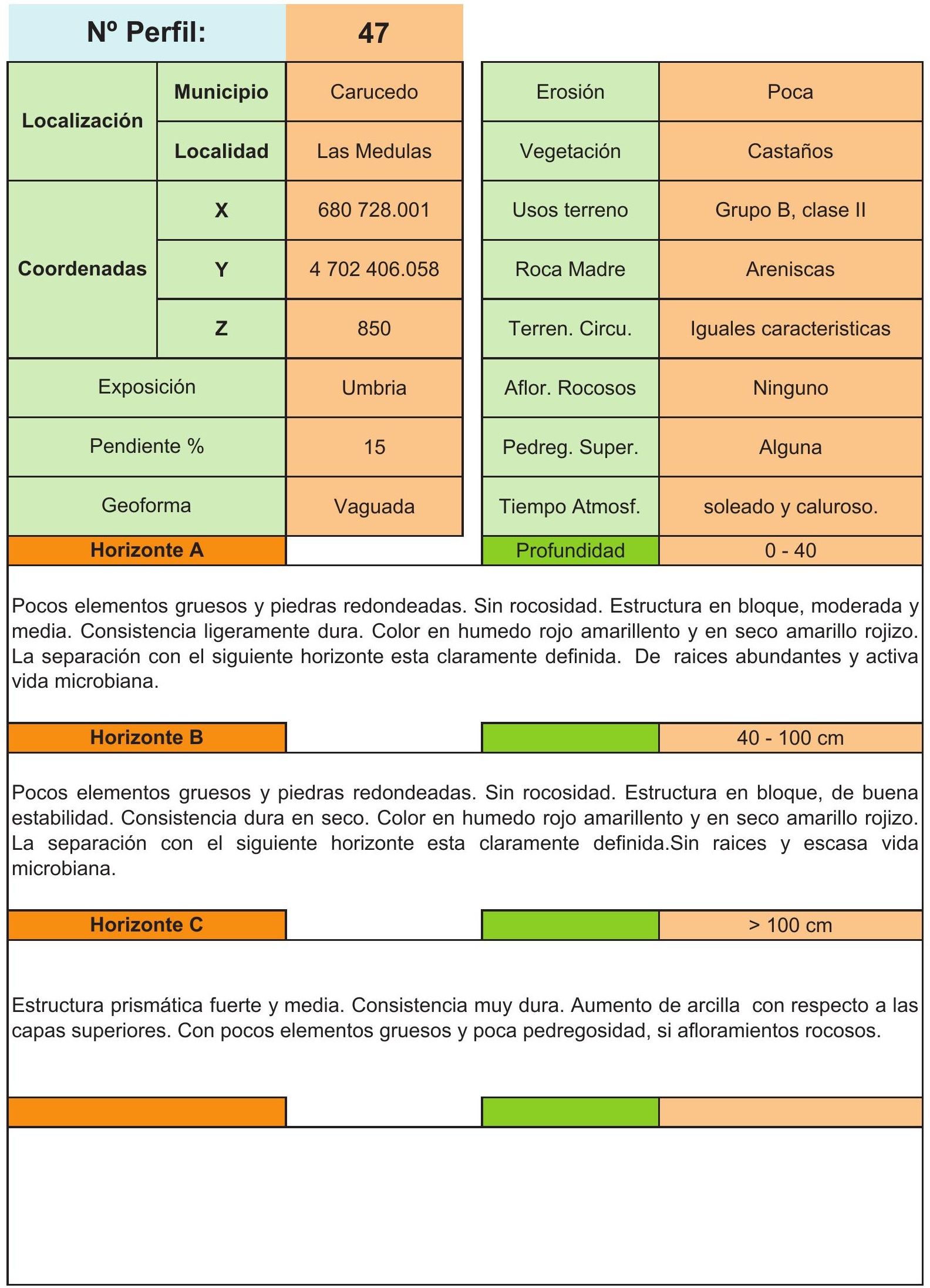


ANÁLISIS DE CARACTERIZACIÓN DE SUELOS

Desarrollo de una aplicación informática para el cálculo de sostenimiento de taludes mediante vegetación

No Perfil:

\begin{tabular}{|c|c|c|}
\hline \multirow{2}{*}{ Localización } & Municipio & Torre Bierzo \\
\cline { 2 - 3 } & Localidad & Polvobueno \\
\hline \multirow{2}{*}{ Coordenadas } & $\mathbf{X}$ & 716227.923 \\
\cline { 2 - 3 } & $\mathbf{Y}$ & 4710581.978 \\
\cline { 2 - 3 } & $\mathbf{Z}$ & 1115 \\
\hline Exposición & Solana \\
\hline \multicolumn{2}{|c|}{ Pendiente \% } & 41.000 \\
\hline \multicolumn{2}{|c|}{ Geoforma } & Ladera \\
\hline \multicolumn{2}{|c|}{ Horizonte A } & \\
\hline
\end{tabular}

48

\begin{tabular}{|c|c|}
\hline Erosión & Intensa \\
\hline Vegetación & Robles, pasto, escobas. \\
\hline Usos terreno & Grupo C, clase VII \\
\hline Roca Madre & Pizarras \\
\hline Terren. Circu. & Iguales caracteristicas \\
\hline Aflor. Rocosos & Abundantes \\
\hline Pedreg. Super. & Abundantes \\
\hline Tiempo Atmosf. & Niebla. \\
\hline Profundidad & 0 - 34 cm \\
\hline
\end{tabular}

Sin elementos gruesos pero con abundante pedregosidad del tamaño de piedra y cascajo y estremadamente rocoso. De estructura migajosa. Limite bien definido con la roca madre. Abundantes afloramientos rocosos

Horizonte R

$>34 \mathrm{~cm}$

Roca Madre 
No Perfil:

\begin{tabular}{|c|c|c|}
\hline \multirow{2}{*}{ Localización } & Municipio & Camponaraya \\
\hline & Localidad & La Valgona \\
\hline \multirow{3}{*}{ Coordenadas } & $x$ & 690224.968 \\
\hline & $\mathbf{Y}$ & 4717641.666 \\
\hline & $\mathbf{Z}$ & 465.000 \\
\hline \multicolumn{2}{|c|}{ Exposición } & Solana \\
\hline \multicolumn{2}{|c|}{ Pendiente \% } & 6.200 \\
\hline \multicolumn{2}{|c|}{ Geoforma } & Fondo de valle \\
\hline \multicolumn{2}{|c|}{ Horizonte A } & \\
\hline
\end{tabular}

49

\begin{tabular}{|c|c|}
\hline Erosión & Moderada \\
\hline Vegetación & $\begin{array}{c}\text { Castaños, cereales, Vid y } \\
\text { cultivos de huerta }\end{array}$ \\
\hline Usos terreno & Grupo A, clase II \\
\hline Roca Madre & $\begin{array}{c}\text { Arcillas con margas y } \\
\text { conglomerados }\end{array}$ \\
\hline Terren. Circu. & Iguales caracteristicas \\
\hline Aflor. Rocosos & Ninguno \\
\hline Pedreg. Super. & Ninguno \\
\hline Tiempo Atmosf. & Soleado y caluroso \\
\hline Profundidad & $0-30 \mathrm{~cm}$ \\
\hline
\end{tabular}

Pocos elementos gruesos y piedras redondeadas. Sin rocosidad. Estructura en bloque, moderada y media. Consistencia ligeramente dura. Color en humedo rojo amarillento y en seco amarillo rojizo. La separación con el siguiente horizonte esta claramente definida. De raices abundantes y activa vida microbiana.

\section{Horizonte B}

\section{$30-90 \mathrm{~cm}$}

Pocos elementos gruesos y piedras redondeadas. Sin rocosidad. Estructura en bloque, de buena estabilidad. Consistencia dura en seco. Color en humedo rojo amarillento y en seco amarillo rojizo. La separación con el siguiente horizonte esta claramente definida.Sin raices y escasa vida microbiana.

\section{Horizonte C}

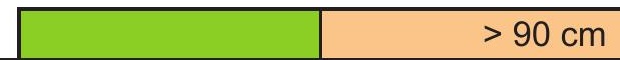

Estructura prismática fuerte y media. Consistencia muy dura. Aumento de arcilla con respecto a las capas superiores. Con pocos elementos gruesos y poca pedregosidad, si afloramientos rocosos.

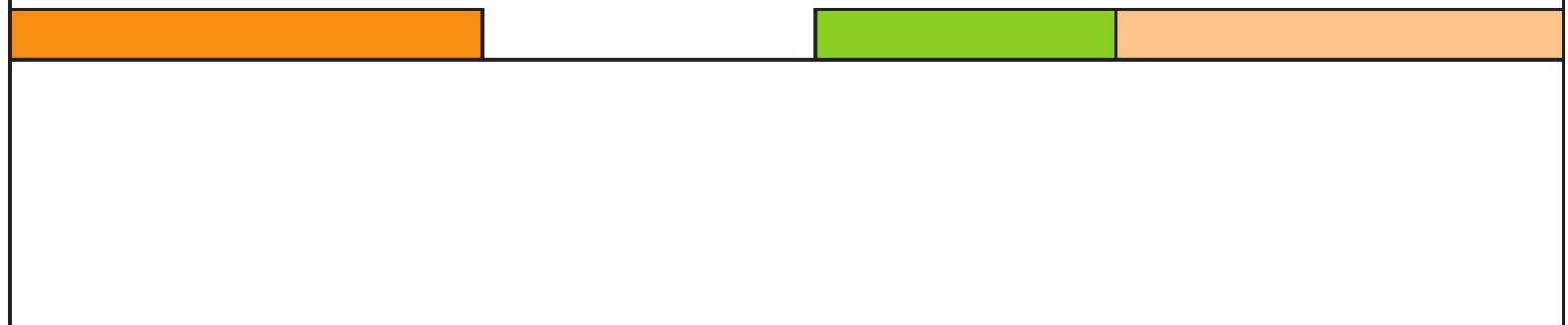


ANÁLISIS DE CARACTERIZACIÓN DE SUELOS

Desarrollo de una aplicación informática para el cálculo de sostenimiento de taludes mediante vegetación

No Perfil:

\begin{tabular}{|c|c|c|}
\hline \multirow{2}{*}{ Localización } & Municipio & $\begin{array}{c}\text { Priaranza del } \\
\text { Bierzo }\end{array}$ \\
\cline { 2 - 3 } & Localidad & Villavieja \\
\hline \multirow{2}{*}{ Coordenadas } & $\mathbf{X}$ & 689227.213 \\
\cline { 2 - 3 } & $\mathbf{Y}$ & 4706087.601 \\
\cline { 2 - 3 } & $\mathbf{Z}$ & 785 \\
\hline Exposición & Solana \\
\hline \multicolumn{2}{|c|}{ Pendiente } & 22 \\
\hline \multicolumn{2}{|c|}{ Geoforma } & Loma \\
\hline \multicolumn{2}{|c|}{ Horizonte A } & \\
\hline
\end{tabular}

\section{0}

\begin{tabular}{|c|c|}
\hline Erosión & Intensa \\
\hline Vegetación & Castaños, robles, escobas \\
\hline Usos terreno & Grupo C, clase VI \\
\hline Roca Madre & $\begin{array}{c}\text { Cuarcitas areniscas y } \\
\text { pizarras }\end{array}$ \\
\hline Terren. Circu. & Iguales caracteristicas \\
\hline Aflor. Rocosos & Abundantes \\
\hline Pedreg. Super. & Abundantes \\
\hline Tiempo Atmosf. & Soleado \\
\hline Profundidad & 0 - 45 cm \\
\hline
\end{tabular}

Con elementos gruesos y abundante pedregosidad, constituida por elementos angulosos del tamaño de piedra. Con alguna rocosidad. Boqlues subangulares de débil grado de agregación y tamaño medio. Consistencia en seco blanda. Color pardo grisaceo oscuro en humedo y a pardo en seco. Pocas raices y regular de actividad microbiana.

\section{Horizonte C}

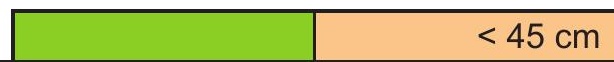

Roca madre descompuesta

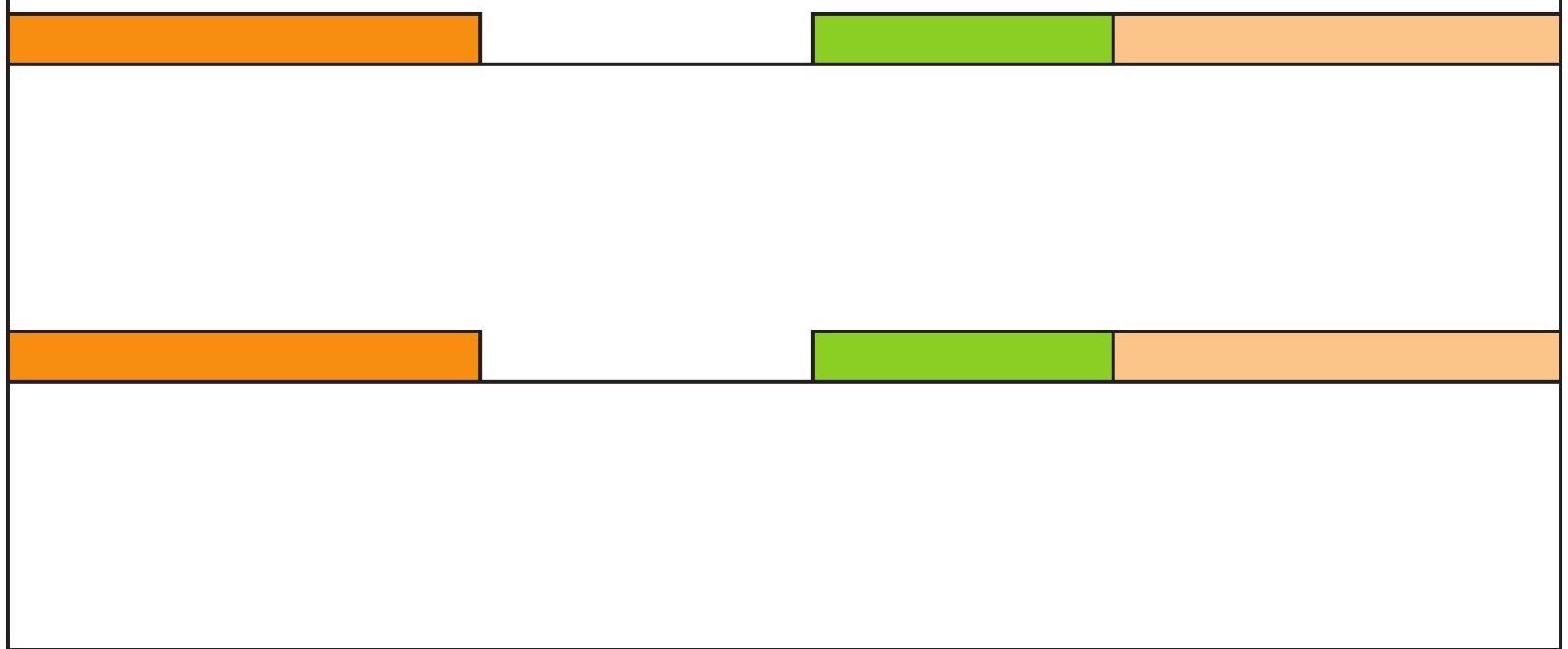


ANÁLISIS DE CARACTERIZACIÓN DE SUELOS

Desarrollo de una aplicación informática para el cálculo de sostenimiento de taludes mediante vegetación

No Perfil:

\begin{tabular}{|c|c|c|}
\hline \multirow{2}{*}{ Localización } & Municipio & $\begin{array}{c}\text { Pte. Domingo } \\
\text { Flórez }\end{array}$ \\
\cline { 2 - 3 } & Localidad & Vega de Yeres \\
\hline \multirow{2}{*}{ Coordenadas } & $\mathbf{X}$ & 680134.875 \\
\cline { 2 - 3 } & $\mathbf{Y}$ & 4697999.459 \\
\hline Exposición & 868 \\
\hline \multicolumn{2}{|c|}{ Pendiente } & Solana \\
\hline \multicolumn{2}{|c|}{ Geoforma } & 37 \\
\hline \multicolumn{2}{|c|}{ Horizonte A } & Ladera \\
\hline
\end{tabular}

\section{1}

\begin{tabular}{|c|c|}
\hline Erosión & Intensa \\
\hline Vegetación & Carracas, retamas, robles.... \\
\hline Usos terreno & Grupo C, clase VII \\
\hline Roca Madre & Pizarras con cuarcitas \\
\hline Terren. Circu. & Iguales caracteristicas \\
\hline Aflor. Rocosos & Abundantes \\
\hline Pedreg. Super. & Abundantes \\
\hline Tiempo Atmosf. & Soleado pero frio. \\
\hline Profundidad & 0 - 25 cm \\
\hline
\end{tabular}

Consistencia dura. Estructura en bloque subangulares moderada y media. Horizonte con pocos elementos gruesos y abundantes piedras angulares. Abundantes raices y vida microbiologica.

\section{Horizonte C}

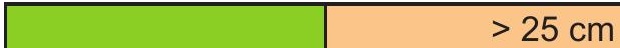

Roca madre en descomposición.

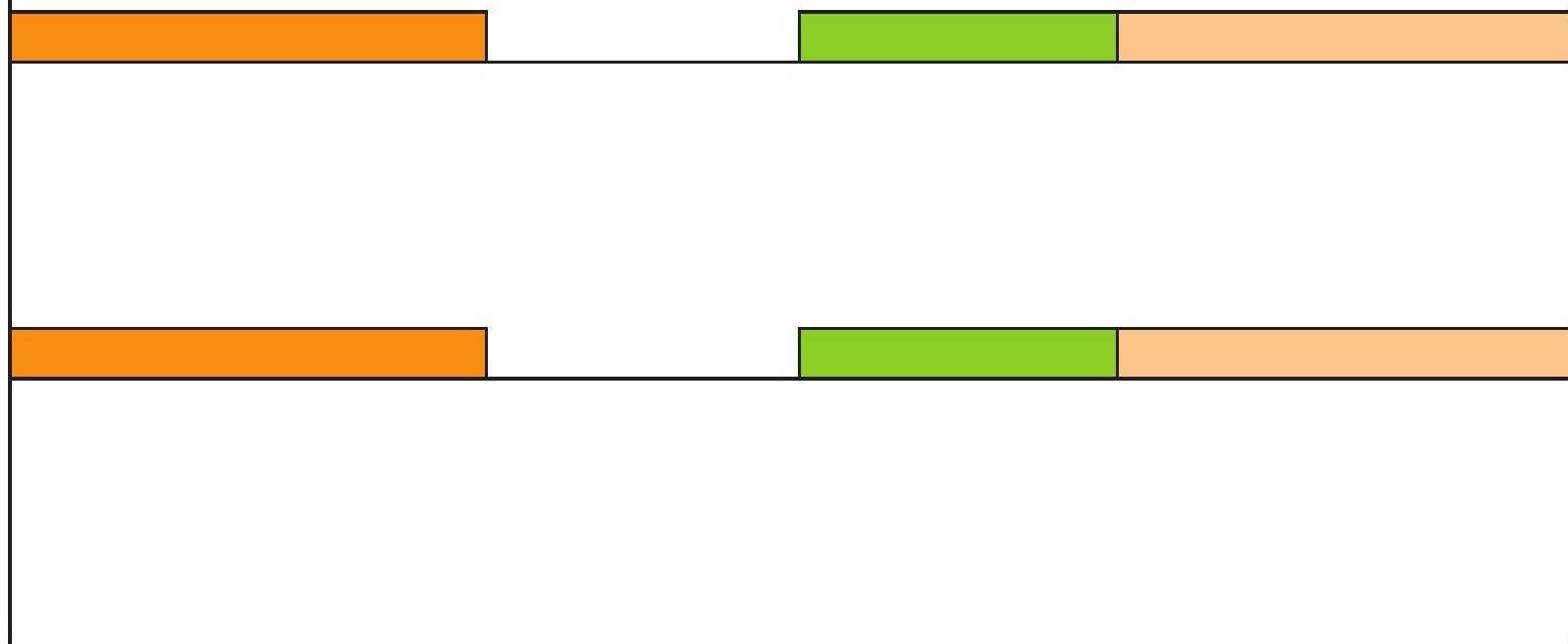


ANÁLISIS DE CARACTERIZACIÓN DE SUELOS

Desarrollo de una aplicación informática para el cálculo de sostenimiento de taludes mediante vegetación

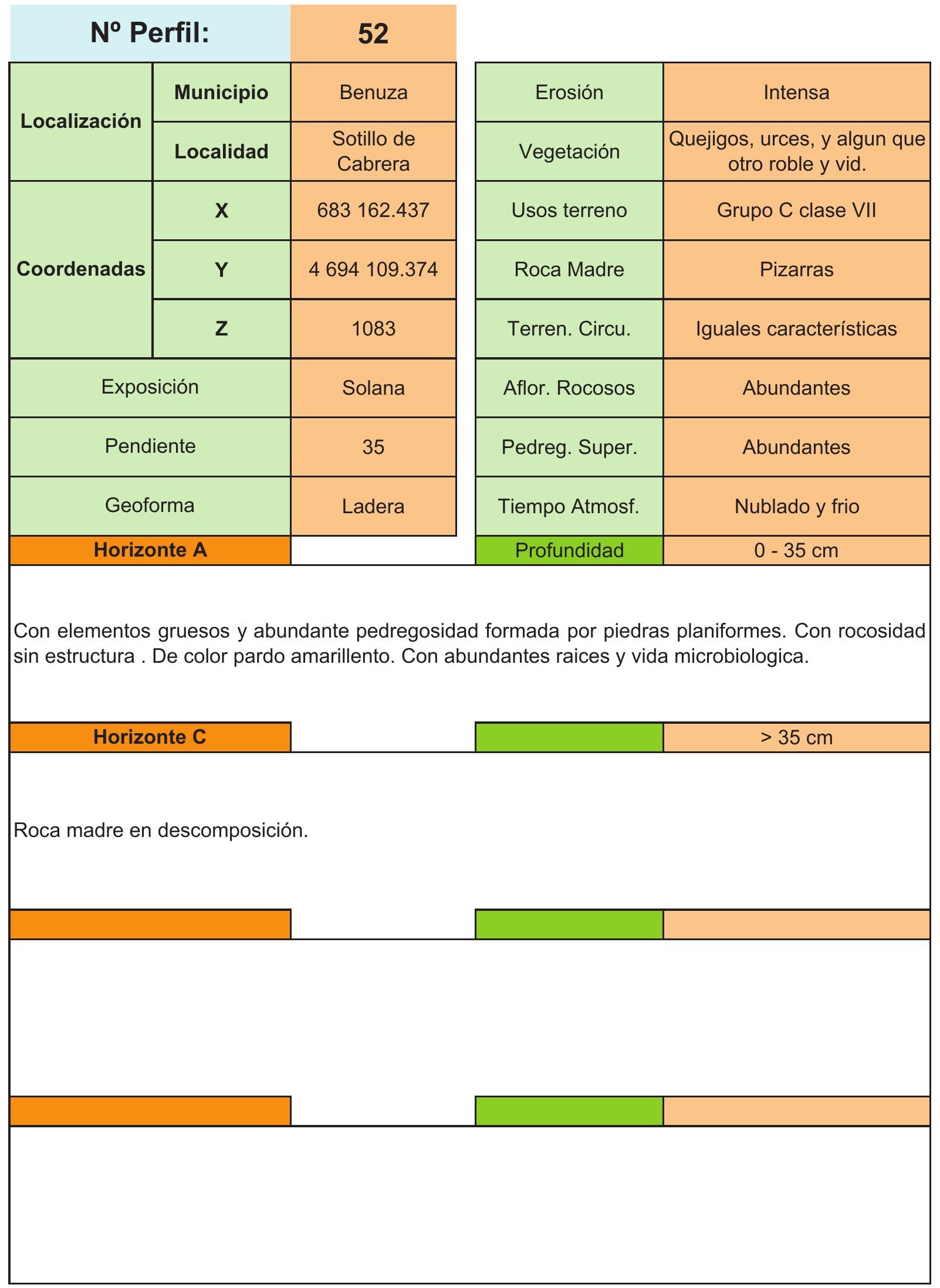


ANÁLISIS DE CARACTERIZACIÓN DE SUELOS

Desarrollo de una aplicación informática para el cálculo de sostenimiento de taludes mediante vegetación

No Perfil:

\begin{tabular}{|c|c|c|}
\hline \multirow{2}{*}{ Localización } & Municipio & Benuza \\
\cline { 2 - 3 } & Localidad & Lomba \\
\hline \multirow{2}{*}{ Coordenadas } & $\mathbf{X}$ & 690007.002 \\
\cline { 2 - 3 } & $\mathbf{Z}$ & 4691608.952 \\
\hline Exposición & 1023 \\
\hline Pendiente & Solana \\
\hline Geoforma & 33 \\
\hline Horizonte A & Ladera \\
\hline
\end{tabular}

\section{3}

\begin{tabular}{|c|c|}
\hline Erosión & Intensa \\
\hline Vegetación & $\begin{array}{c}\text { Quejigos, urces, y algun que } \\
\text { otro roble y vid. }\end{array}$ \\
\hline Usos terreno & Grupo C clase VII \\
\hline Roca Madre & Pizarras \\
\hline Terren. Circu. & Iguales características \\
\hline Aflor. Rocosos & Abundantes \\
\hline Pedreg. Super. & Abundantes \\
\hline Tiempo Atmosf. & Nublado y frio \\
\hline Profundidad & 0 - 38 cm \\
\hline
\end{tabular}

Con elementos gruesos y abundante pedregosidad formada por piedras planiformes. Con rocosidad sin estructura . De color pardo amarillento. Con abundantes raices y vida microbiologica.

Horizonte C

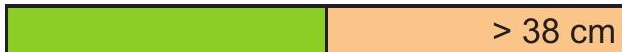

Roca madre en descomposición.

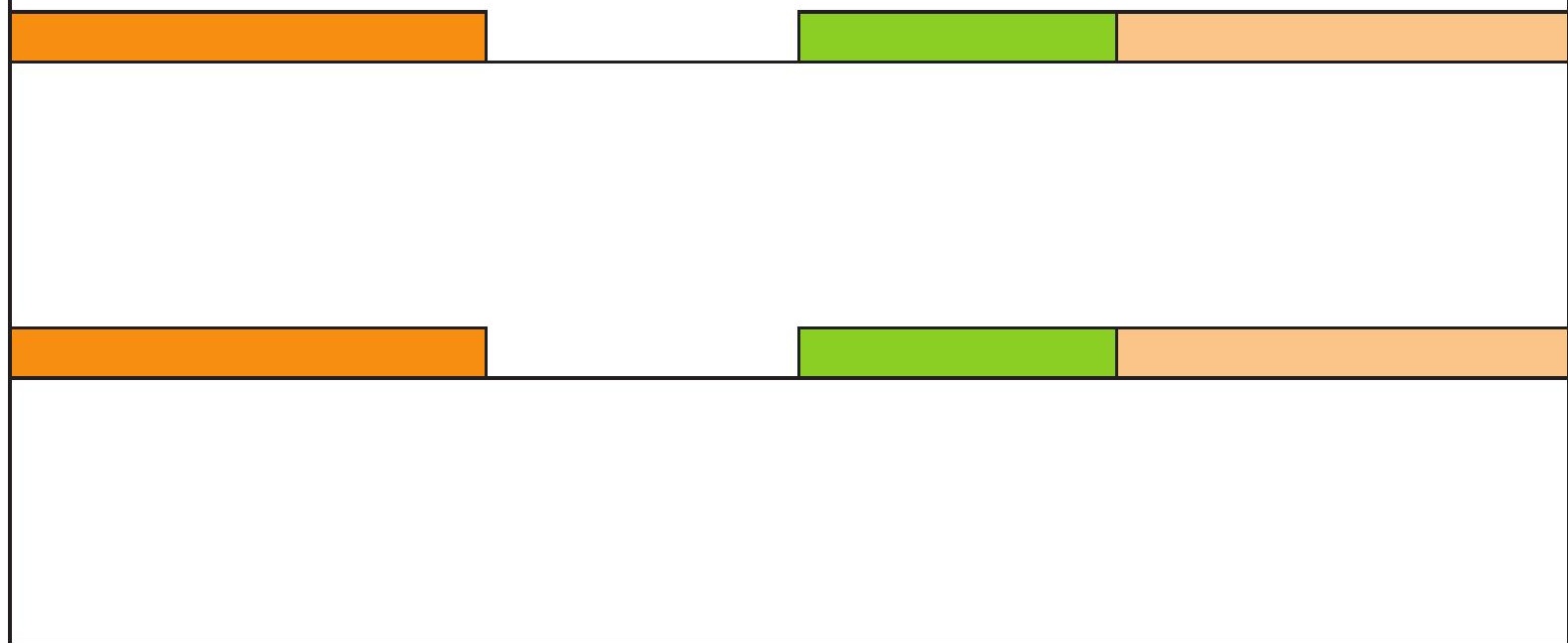


ANÁLISIS DE CARACTERIZACIÓN DE SUELOS

Desarrollo de una aplicación informática para el cálculo de sostenimiento de taludes mediante vegetación

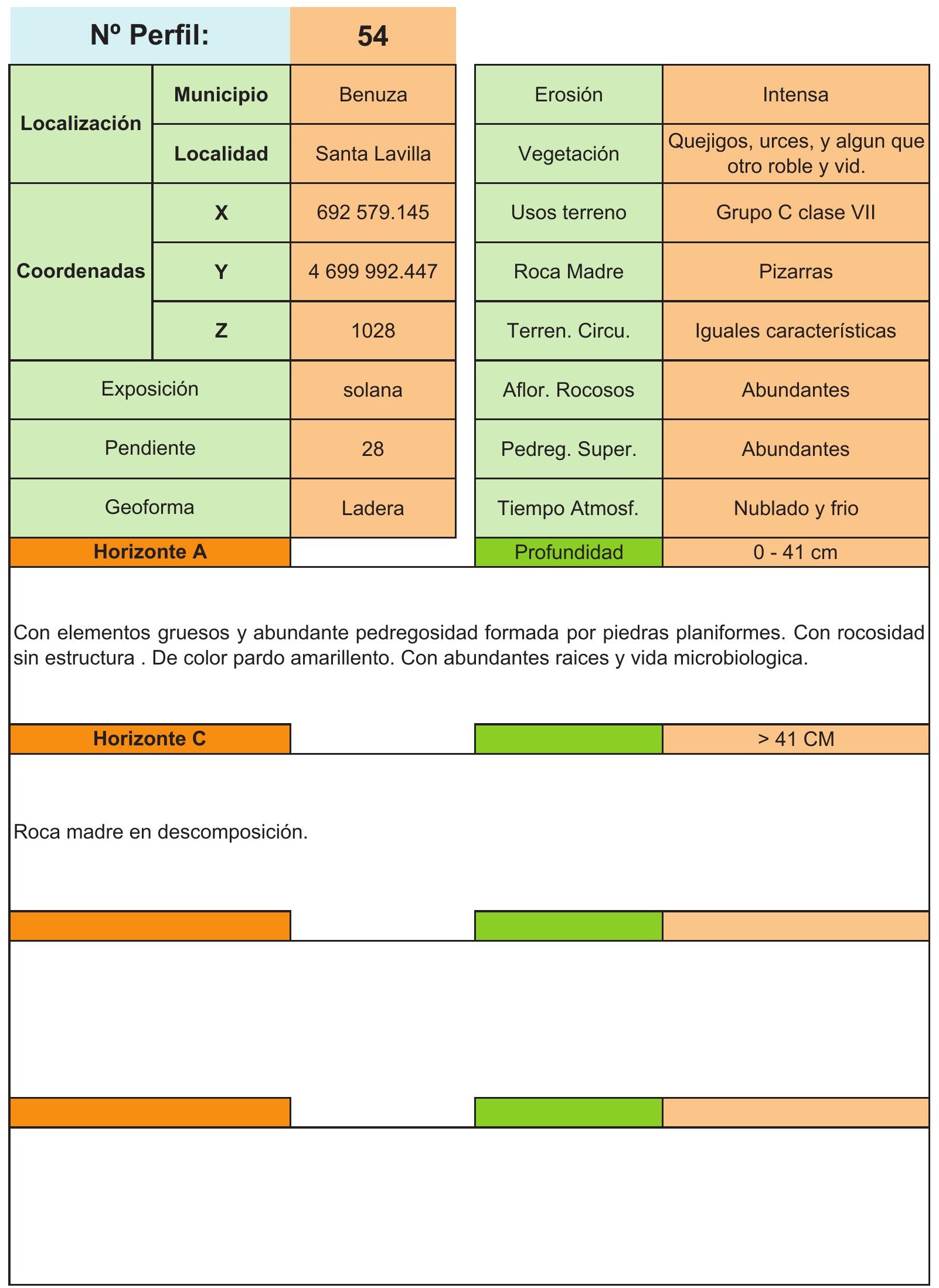




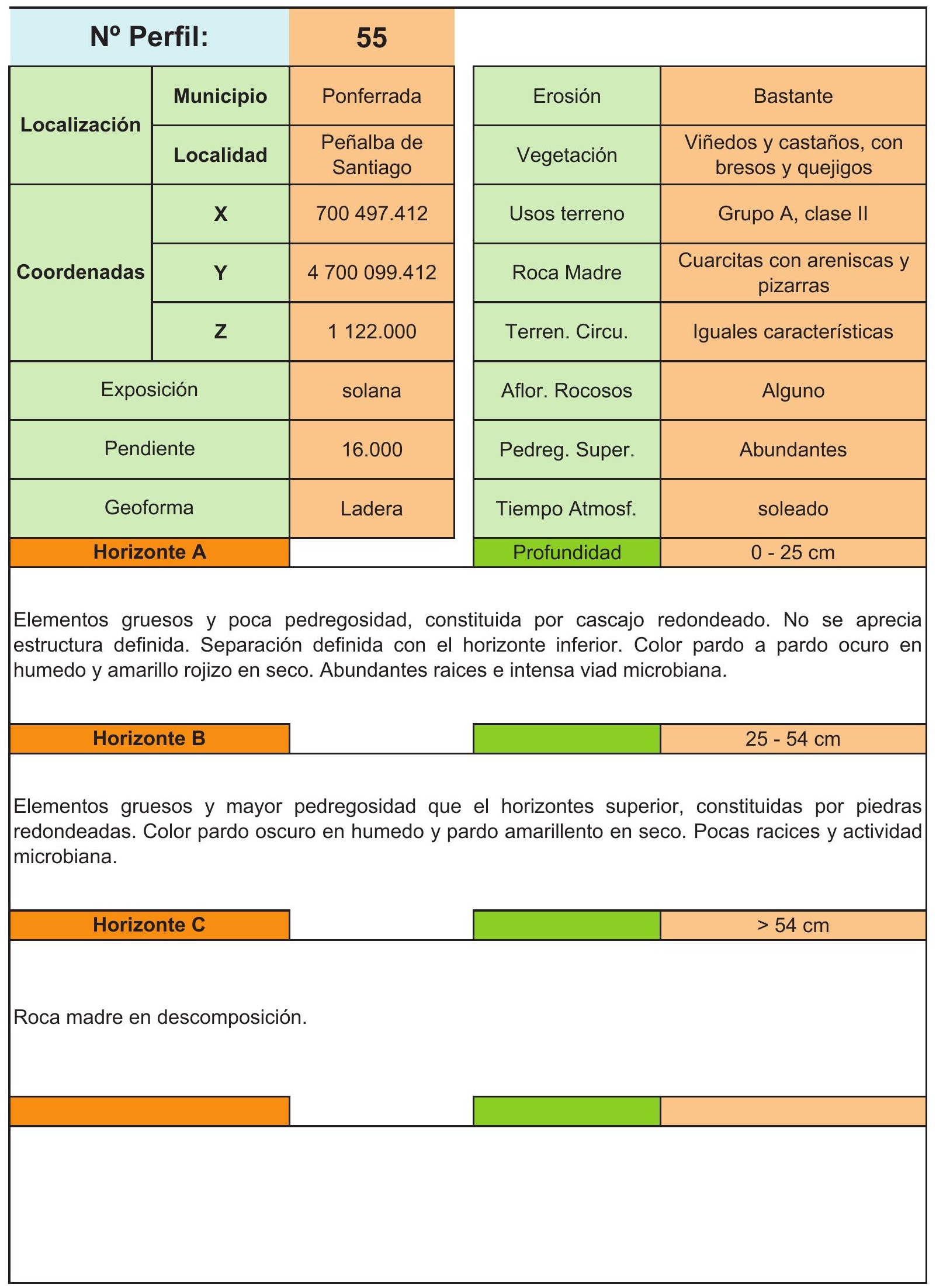


ANÁLISIS DE CARACTERIZACIÓN DE SUELOS

Desarrollo de una aplicación informática para el cálculo de sostenimiento de taludes mediante vegetación

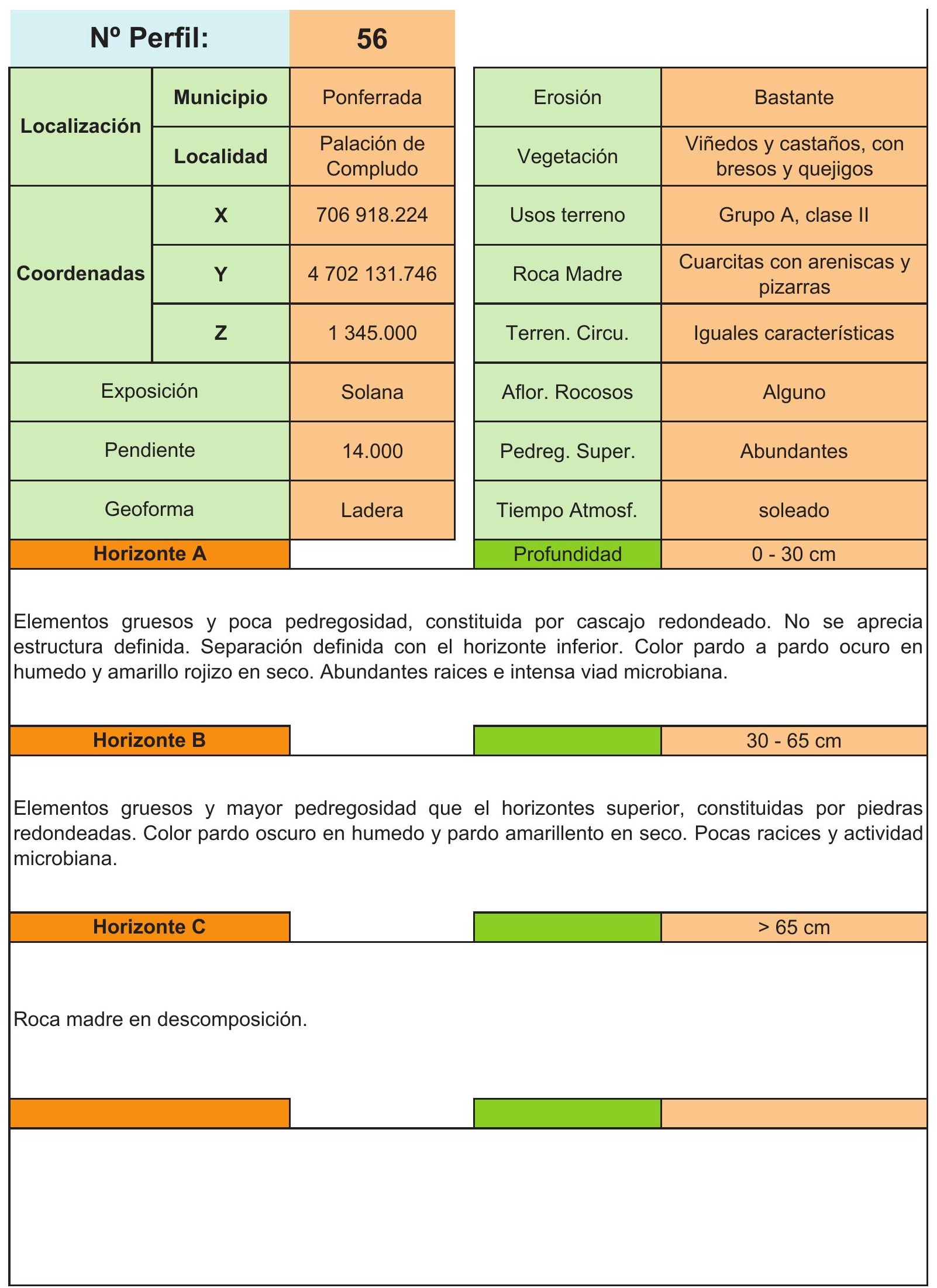




\begin{tabular}{|c|c|c|c|c|}
\hline \multicolumn{2}{|c|}{ No Perfil: } & \multirow{2}{*}{57} & & \\
\hline \multirow{2}{*}{ Localización } & Municipio & & Erosión & Baja \\
\hline & Localidad & Molinaseca & Vegetación & cultivos agricolas \\
\hline \multirow{3}{*}{ Coordenadas } & $x$ & 701754.976 & Usos terreno & Grupo A, clase I \\
\hline & $\mathbf{Y}$ & 4712584.755 & Roca Madre & $\begin{array}{l}\text { Arcillas con margas y } \\
\text { conglomerados }\end{array}$ \\
\hline & $\mathbf{z}$ & 488 & Terren. Circu. & iguales caracteristicas \\
\hline \multicolumn{2}{|c|}{ Exposición } & Solana & Aflor. Rocosos & Ninguno \\
\hline \multicolumn{2}{|c|}{ Pendiente \% } & 2 & Pedreg. Super. & Ninguno \\
\hline \multicolumn{2}{|c|}{ Geoforma } & Fondo de valle & Tiempo Atmosf. & Soleado \\
\hline \multicolumn{2}{|c|}{ Horizonte A } & & Profundidad & $0-25 \mathrm{~cm}$ \\
\hline \multicolumn{5}{|c|}{$\begin{array}{l}\text { Sin elementos gruesos y poca pedregosidad de forma redondeada y forma de piedra. Sin rocosidad } \\
\text { Estructura moderadamente fuerte, en bloque subangulares. Consistencia dura. Posee una } \\
\text { separación con el siguiente horizonte definida. Color pardo negruzco en humedo y pardo ligeramente } \\
\text { amarillo en seco. Abundantes racices y buena actividad microbiana. }\end{array}$} \\
\hline \multicolumn{2}{|c|}{ Horizonte B } & & & $25-55 \mathrm{~cm}$ \\
\hline \multicolumn{5}{|c|}{$\begin{array}{l}\text { Al igual que el anterior este tambien posee pocos elementos gruesos y poca pedregosidad. Colo } \\
\text { pardo negruzco en humedo y pardo amarillento en seco. Frecuentes raices y vida microbiologica } \\
\text { Estructura prismatica y consistencia dura. }\end{array}$} \\
\hline \multicolumn{2}{|c|}{ Horizonte B } & & & $55-120 \mathrm{~cm}$ \\
\hline \multicolumn{5}{|c|}{$\begin{array}{l}\text { Este horizonte presenta ya mas elementos gruesos y mucha pedregosidad sin que aparezc } \\
\text { estructura definida. Con una separación clara con el siguiente horizonte. Color pardo amarillento, y y } \\
\text { con escasas raices y moderada vida microbiológica. }\end{array}$} \\
\hline \multicolumn{2}{|c|}{ Horizonte B } & & & $>120 \mathrm{~cm}$ \\
\hline \multicolumn{5}{|c|}{ Cosnistencia suelta, y sin estructura definida. Sin racices ni acitivida microbiológica. } \\
\hline
\end{tabular}


ANÁLISIS DE CARACTERIZACIÓN DE SUELOS

Desarrollo de una aplicación informática para el cálculo de sostenimiento de taludes mediante vegetación

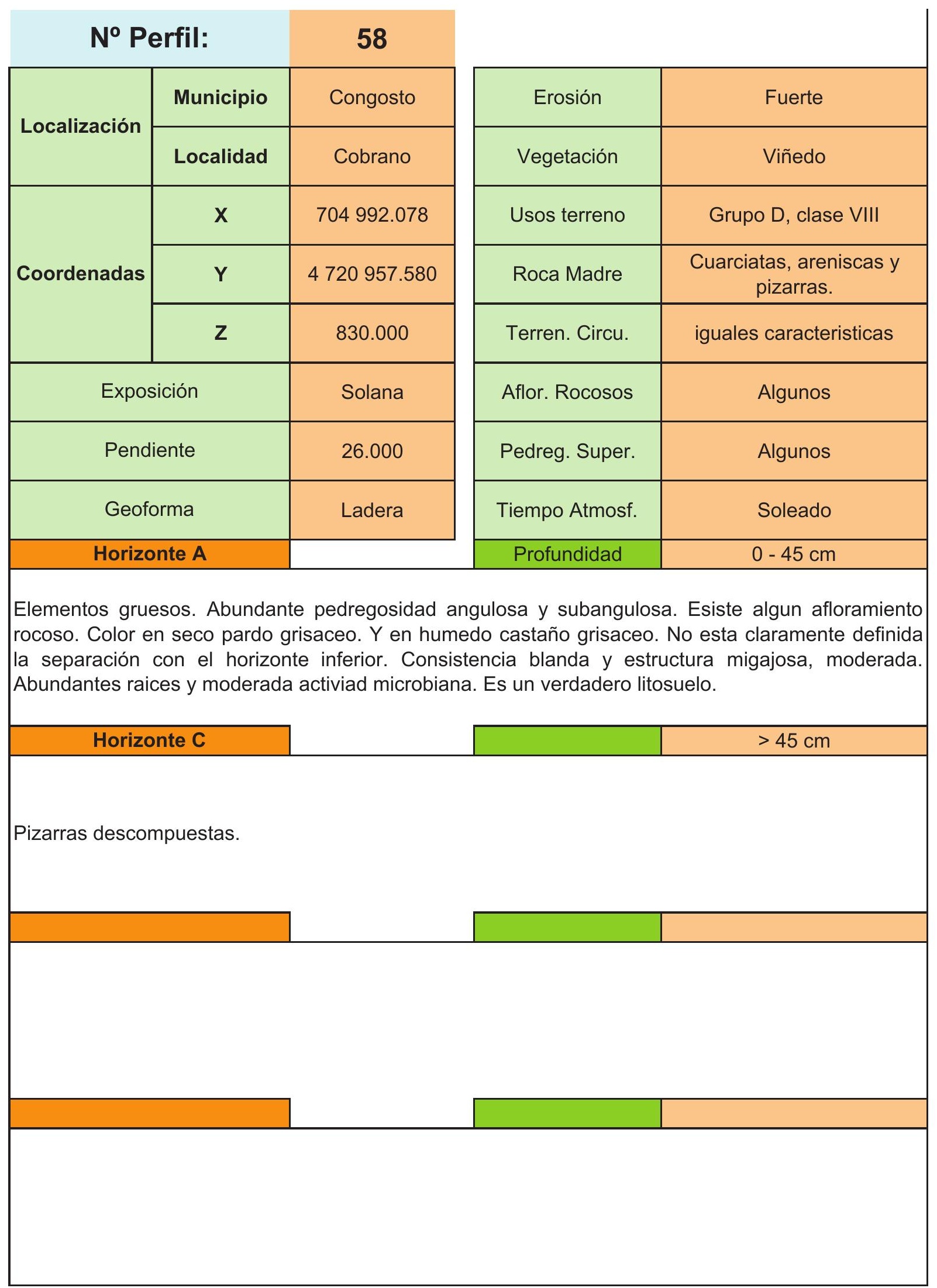




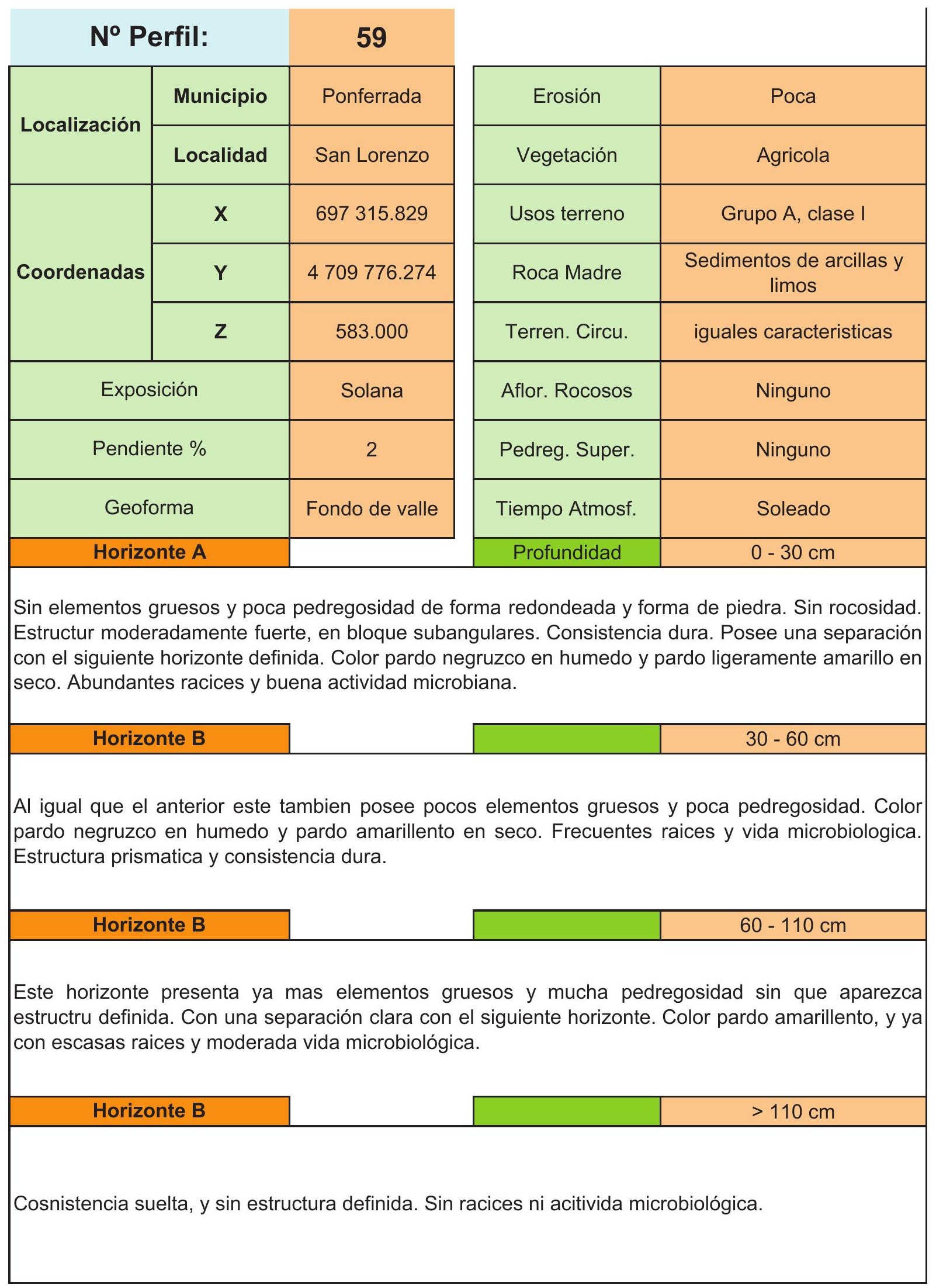




\begin{tabular}{|c|c|c|c|c|}
\hline \multicolumn{2}{|c|}{ No Perfil: } & \multirow{2}{*}{$\frac{60}{\text { Cabañas Raras }}$} & & \\
\hline \multirow{2}{*}{ Localización } & Municipio & & Erosión & Moderada \\
\hline & Localidad & Cabañas Raras & Vegetación & Agricola, sobre todo vid \\
\hline \multirow{3}{*}{ Coordenadas } & $x$ & 693863.242 & Usos terreno & Grupo A, clase I \\
\hline & $\mathbf{Y}$ & 4719567.035 & Roca Madre & $\begin{array}{l}\text { Arcillas con margas y } \\
\text { conglomerados }\end{array}$ \\
\hline & $\mathbf{z}$ & 511 & Terren. Circu. & iguales caracteristicas \\
\hline \multicolumn{2}{|c|}{ Exposición } & Solana & Aflor. Rocosos & Ninguno \\
\hline \multicolumn{2}{|c|}{ Pendiente \% } & 10 & Pedreg. Super. & Poca o nula \\
\hline \multicolumn{2}{|c|}{ Geoforma } & Ladera & Tiempo Atmosf. & Soleado \\
\hline \multicolumn{2}{|c|}{ Horizonte A } & & Profundidad & $0-20 \mathrm{~cm}$ \\
\hline \multicolumn{5}{|c|}{$\begin{array}{l}\text { Horizonte con abundantes raices y actividad microbiana. Con elementos gruesos y abundante } \\
\text { pedregosidad del tamaño de piedra y forma redondeada. Separación difusa con la capa inferior } \\
\text { Estructura en bloque angulares y consistencia en seco dura. Color amarillo rojizo. }\end{array}$} \\
\hline \multicolumn{3}{|c|}{ Horizonte B } & & $20-110 \mathrm{~cm}$ \\
\hline \multicolumn{5}{|c|}{$\begin{array}{l}\text { Con elementos gruesos y mucha pedregosidad constituidas por cuarcitas redondeadas. Estructura } \\
\text { en bloques subangulares de moderado grado de agregación y consistencia dura, la separación con e } \\
\text { siguiente horizonte sigue siendo difusa. El color es rojo amarrillento en humedo variando en seco. } \\
\text { Todavia posoe abundantes raices y vida microbiana. }\end{array}$} \\
\hline \multicolumn{3}{|c|}{ Horizonte C } & & $110-145 \mathrm{~cm}$ \\
\hline \multicolumn{5}{|c|}{$\begin{array}{l}\text { Horizonte sin acitvidad microbiologica, ni raices, de color rojo a rojo oscuro en humedo y rojc } \\
\text { amarillento en seco. Con pocos elementos gruesos y menos pedregosidad que el horizonte superior } \\
\text { Con una estructura en bloques subangulares moderada. }\end{array}$} \\
\hline \multicolumn{2}{|c|}{ Horizonte R } & & & $>145 \mathrm{~cm}$ \\
\hline \multicolumn{5}{|c|}{ Roca madre. } \\
\hline
\end{tabular}


$N^{\circ}$ Perfil:

\begin{tabular}{|c|c|c|}
\hline \multirow{2}{*}{ Localización } & Municipio & Cubillos del Sil \\
\cline { 2 - 3 } & Localidad & Finolledo \\
\hline \multirow{2}{*}{ Coordenadas } & $\mathbf{X}$ & 698357.580 \\
\cline { 2 - 3 } & $\mathbf{Z}$ & 4724915.283 \\
\cline { 2 - 3 } & & 783 \\
\hline Exposición & Solana \\
\hline Pendiente \% & 22 \\
\hline Geoforma & Ladera \\
\hline Horizonte A & \\
\hline
\end{tabular}

\section{1}

\begin{tabular}{|c|c|}
\hline Erosión & Media \\
\hline Vegetación & $\begin{array}{c}\text { Robles, encinas, pinos, } \\
\text { algo de cultivos agricolas. }\end{array}$ \\
\hline Usos terreno & Grupo B,C y clase VI \\
\hline Roca Madre & Pizarras y areniscas \\
\hline Terren. Circu. & Iguales caracteristicas \\
\hline Aflor. Rocosos & ninguno \\
\hline Pedreg. Super. & ninguna \\
\hline Tiempo Atmosf. & soledado y frio. \\
\hline Profundidad & 0 - 60 cm \\
\hline
\end{tabular}

Abundantes raices y activa vida microbiana, con pocos elementos gruesos y regular de pedregosidad, constituida por elementos subangulosos del tamaño de piedra . Sin rocosidad. De color pardo pálido en seco y ligeramente amarillo en humedo. Separación definida con el horizonte inferior.

Horizonte B

$>60 \mathrm{~cm}$

Estructura en bloques, Consistencia ligeramente dura. De color pardo. Sin raices ni vida microbiana activa. Abundante pedregosidad

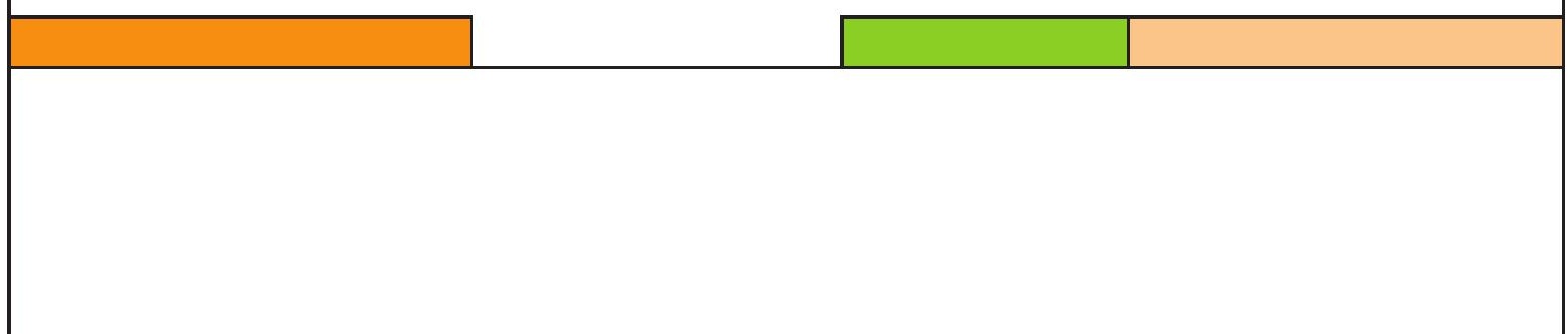


ANÁLISIS DE CARACTERIZACIÓN DE SUELOS

Desarrollo de una aplicación informática para el cálculo de sostenimiento de taludes mediante vegetación

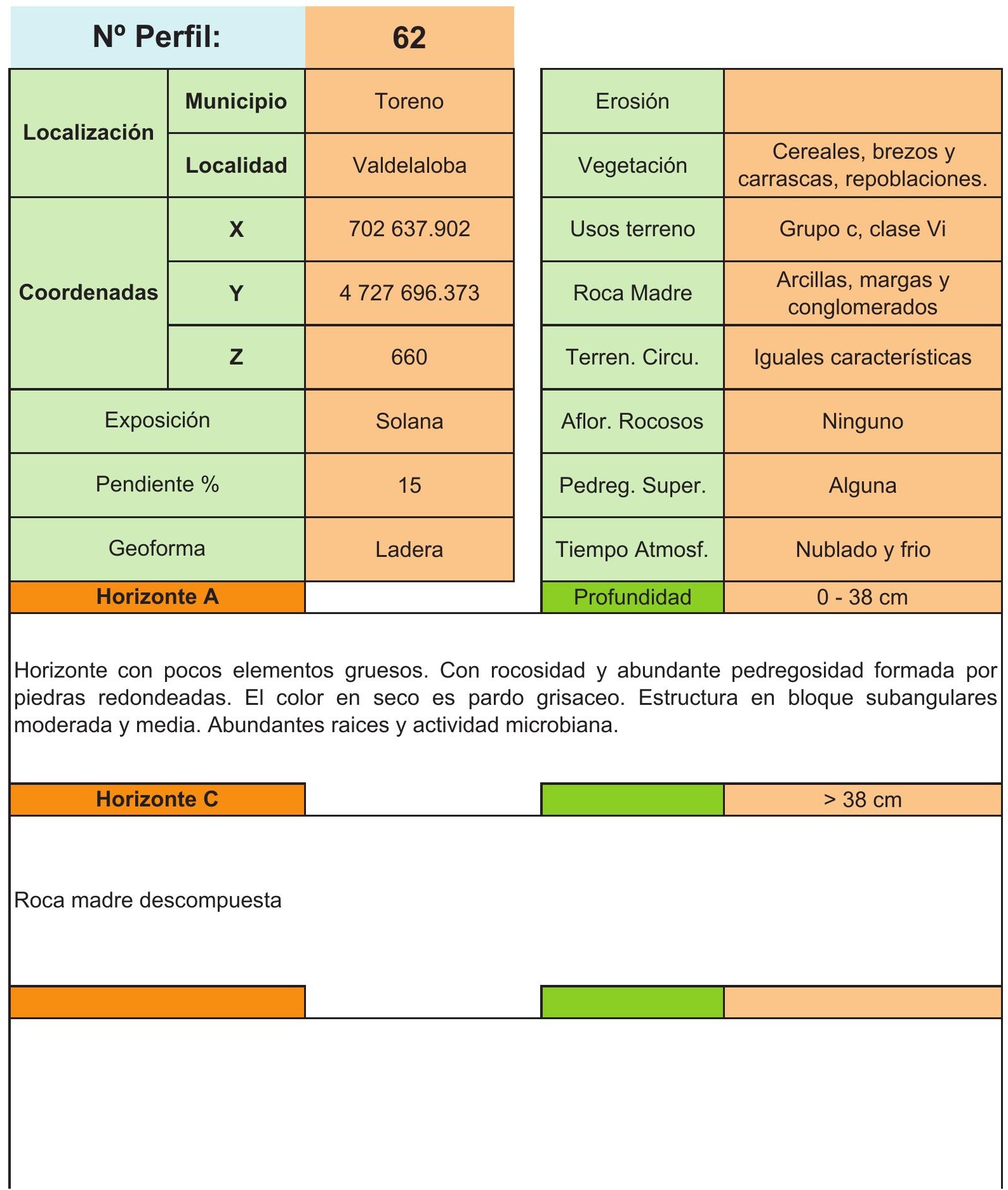


No Perfil:

\begin{tabular}{|c|c|c|}
\hline \multirow{2}{*}{ Localización } & Municipio & Torre Biezo \\
\cline { 2 - 3 } & Localidad & $\begin{array}{c}\text { San Andres de las } \\
\text { Fuentes }\end{array}$ \\
\hline \multirow{2}{*}{ Coordenadas } & $\mathbf{X}$ & 715906.891 \\
\cline { 2 - 3 } & $\mathbf{Z}$ & 4715716.297 \\
\hline Exposición & 963 \\
\hline Pendiente \% & Solana \\
\hline \multicolumn{2}{|c|}{ Geoforma } & 23 \\
\hline Horizonte A & Ladera \\
\hline
\end{tabular}

\section{3}

\begin{tabular}{|c|c|}
\hline Erosión & Intensa \\
\hline Vegetación & $\begin{array}{c}\text { Brezo y carrasas con } \\
\text { quejigos }\end{array}$ \\
\hline Usos terreno & Grupo C, clase VII \\
\hline Roca Madre & Pizarras con cuarcitas \\
\hline Terren. Circu. & Iguales características \\
\hline Aflor. Rocosos & Alguno \\
\hline Pedreg. Super. & Abundante \\
\hline Tiempo Atmosf. & humedad ambiente \\
\hline Profundidad & 0 - 36 cm \\
\hline
\end{tabular}

Con pocos elementos gruesos y abundante pedregosidad, de tamaño de piedra y cascajo subangulares. Con abuandante rocosidad. Consistencia ligermente dura en seco. Adherente y ligeramente plastico en humedo. Separación claramente diferenciada con la capa inferior. Color pardo en seco y pardo oscuro en humedo. Raices abundantes y normal actividad microbiana.

Horizonte C

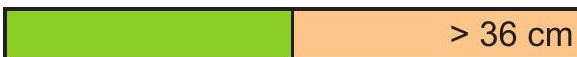

Roca madre descompuesta 
No Perfil:

\begin{tabular}{|c|c|c|}
\hline \multirow{2}{*}{ Localización } & Municipio & $\begin{array}{c}\text { Folgoso de la } \\
\text { Ribera }\end{array}$ \\
\cline { 2 - 3 } & Localidad & Villavicioso \\
\hline \multirow{2}{*}{ Coordenadas } & $\mathbf{X}$ & 717619.029 \\
\cline { 2 - 3 } & $\mathbf{Z}$ & 4721492.404 \\
\hline Exposición & 760 \\
\hline Pendiente \% & Solana \\
\hline \multicolumn{2}{|c|}{ Geoforma } & 19 \\
\hline Horizonte A & Ladera \\
\hline
\end{tabular}

\section{4}

\begin{tabular}{|c|c|}
\hline Erosión & Intensa \\
\hline Vegetación & $\begin{array}{c}\text { Brezo y carquesas, } \\
\text { repoblaciones de pinos }\end{array}$ \\
\hline Usos terreno & Grupo C clase VI \\
\hline Roca Madre & Pizarras \\
\hline Terren. Circu. & Iguales caracteristicas \\
\hline Aflor. Rocosos & Ninguno \\
\hline Pedreg. Super. & Alguna \\
\hline Tiempo Atmosf. & Frio \\
\hline Profundidad & 0 - 45 cm \\
\hline
\end{tabular}

Con elementos gruesos y abundante pedregosidad, constituida por piedras angulosas y planiformes. Sin que aprecie estructura definida y con consistencia blanda. En la parte inferior existe mucha rocosidad. Separado del horizonte inferior por una linea definida e irregular, Abundante raices y actividad microbiana. Se puede considerar un verdadero litosuelo..

Horizonte C

Roca madre descompuesta
$>45 \mathrm{~cm}$ 
DESARROLLO DE UNA APLICACIÓN IMFORMÁTICA PARA EL CÁLCULO DE SOSTENIMIENTO DE TALUDES MEDIANTE VEGETACIÓN

RESULTADOS DE ANÁLISIS DE LABORATORIO DE CARACTERIZACIÓN Y COMPOSICIÓN DE SUELOS.

2.- RESULTADOS DE ANÁLISIS DE COMPOSICIÓN DE SUELOS. 
ANÁLISIS DE COMPOSICIÓN DE SUELOS

Desarrollo de una aplicación informática para el cálculo de sostenimiento de taludes mediante vegetación

\begin{tabular}{|c|c|c|c|c|c|}
\hline \multirow[t]{2}{*}{ Perfil $n^{\circ}$} & \multirow[t]{2}{*}{1} & & & & \\
\hline & & Horizonte A & Horizonte B & Horizonte C & Horizonte \\
\hline \multirow{3}{*}{ Textura } & Arena (\%) & 64 & 59 & & \\
\hline & Limo (\%) & 27 & 30 & & \\
\hline & Arcilla (\%) & 9 & 11 & & \\
\hline \multicolumn{2}{|c|}{ Clase textural } & Fraco arenoso & Franca arenoso & & \\
\hline \multicolumn{2}{|l|}{ pH } & 5 & 5.1 & & \\
\hline \multicolumn{2}{|c|}{ Carbonatos (\% caliza) } & ip & ip & & \\
\hline \multicolumn{2}{|c|}{ Materia orgánica (\%) } & 4.2 & 0.5 & & \\
\hline \multicolumn{2}{|c|}{ Nitrogeno total (\%) } & 0.48 & 0.2 & & \\
\hline \multicolumn{2}{|c|}{ Relación C/N } & 4.375 & 1 & & \\
\hline \multicolumn{2}{|c|}{ Fosforo (olssen ppm) } & 8 & 11 & & \\
\hline \multicolumn{2}{|c|}{ Calcio (ppm) } & 68 & 79 & & \\
\hline \multicolumn{2}{|c|}{ Potasio (ppm) } & 50 & 60 & & \\
\hline \multicolumn{2}{|c|}{ Magnesio (ppm) } & 28 & 33 & & \\
\hline \multicolumn{2}{|l|}{$\mathrm{Ca} / \mathrm{Mg}$} & 2.429 & 2.394 & & \\
\hline \multicolumn{2}{|c|}{ Sodio (ppm) } & 0.6 & 1 & & \\
\hline \multicolumn{2}{|c|}{ C.I.C. Meq/100g } & 6.5 & 7.4 & & \\
\hline \multicolumn{2}{|c|}{ Manganeso (ppm) } & 45 & 50 & & \\
\hline \multicolumn{2}{|c|}{ Hierro (ppm) } & 3 & 1 & & \\
\hline \multicolumn{2}{|c|}{ Cobre (ppm) } & 0.2 & 2 & & \\
\hline \multicolumn{2}{|l|}{ Zinc (ppm) } & 2.5 & 2.5 & & \\
\hline \multicolumn{2}{|l|}{ Boro (ppm) } & 0.7 & 1 & & \\
\hline \multicolumn{2}{|c|}{ Conductividad (dS/m) } & 0.05 & 0.04 & & \\
\hline \multicolumn{2}{|c|}{ Observaciones } & & & & \\
\hline
\end{tabular}


ANÁLISIS DE COMPOSICIÓN DE SUELOS

Desarrollo de una aplicación informática para el cálculo de sostenimiento de taludes mediante vegetación

\begin{tabular}{|c|c|c|c|c|c|}
\hline \multirow[t]{2}{*}{ Perfil $n^{\circ}$} & \multirow[t]{2}{*}{2} & & & & \\
\hline & & Horizonte A & Horizonte C & Horizonte & Horizonte \\
\hline \multirow{3}{*}{ Textura } & Arena (\%) & 57 & & & \\
\hline & $\operatorname{Limo}(\%)$ & 32 & & & \\
\hline & Arcilla (\%) & 11 & & & \\
\hline \multicolumn{2}{|c|}{ Clase textural } & F. - Arenosa & & & \\
\hline \multicolumn{2}{|l|}{ pH } & 5.4 & & & \\
\hline \multicolumn{2}{|c|}{ Carbonatos (\% caliza) } & 2 & & & \\
\hline \multicolumn{2}{|c|}{ Materia orgánica (\%) } & 6 & & & \\
\hline \multicolumn{2}{|c|}{ Nitrogeno total (\%) } & 0.12 & & & \\
\hline \multicolumn{2}{|c|}{ Relación C/N } & 28.5 & & & \\
\hline \multicolumn{2}{|c|}{ Fosforo (olssen ppm) } & 0.8 & & & \\
\hline \multicolumn{2}{|c|}{ Calcio (ppm) } & 126 & & & \\
\hline \multicolumn{2}{|c|}{ Potasio (ppm) } & 2.5 & & & \\
\hline \multicolumn{2}{|c|}{ Magnesio (ppm) } & 37 & & & \\
\hline \multicolumn{2}{|l|}{$\mathrm{Ca} / \mathrm{Mg}$} & 3.405 & & & \\
\hline \multicolumn{2}{|c|}{ Sodio (ppm) } & 15 & & & \\
\hline \multicolumn{2}{|c|}{ C.I.C. Meq/100g } & 9.5 & & & \\
\hline \multicolumn{2}{|c|}{ Manganeso (ppm) } & 5 & & & \\
\hline \multicolumn{2}{|c|}{ Hierro (ppm) } & 1 & & & \\
\hline \multicolumn{2}{|c|}{ Cobre (ppm) } & 1.5 & & & \\
\hline \multicolumn{2}{|l|}{ Zinc (ppm) } & 1.5 & & & \\
\hline \multicolumn{2}{|l|}{ Boro (ppm) } & 0.7 & & & \\
\hline \multicolumn{2}{|c|}{ Conductividad (dS/m) } & 1.8 & & & \\
\hline \multicolumn{2}{|c|}{ Observaciones } & & & & \\
\hline & Suelo & pobre y poco $\mathrm{pt}$ & rofundo.Muy 1 & vado. & \\
\hline
\end{tabular}


ANÁLISIS DE COMPOSICIÓN DE SUELOS

Desarrollo de una aplicación informática para el cálculo de sostenimiento de taludes mediante vegetación

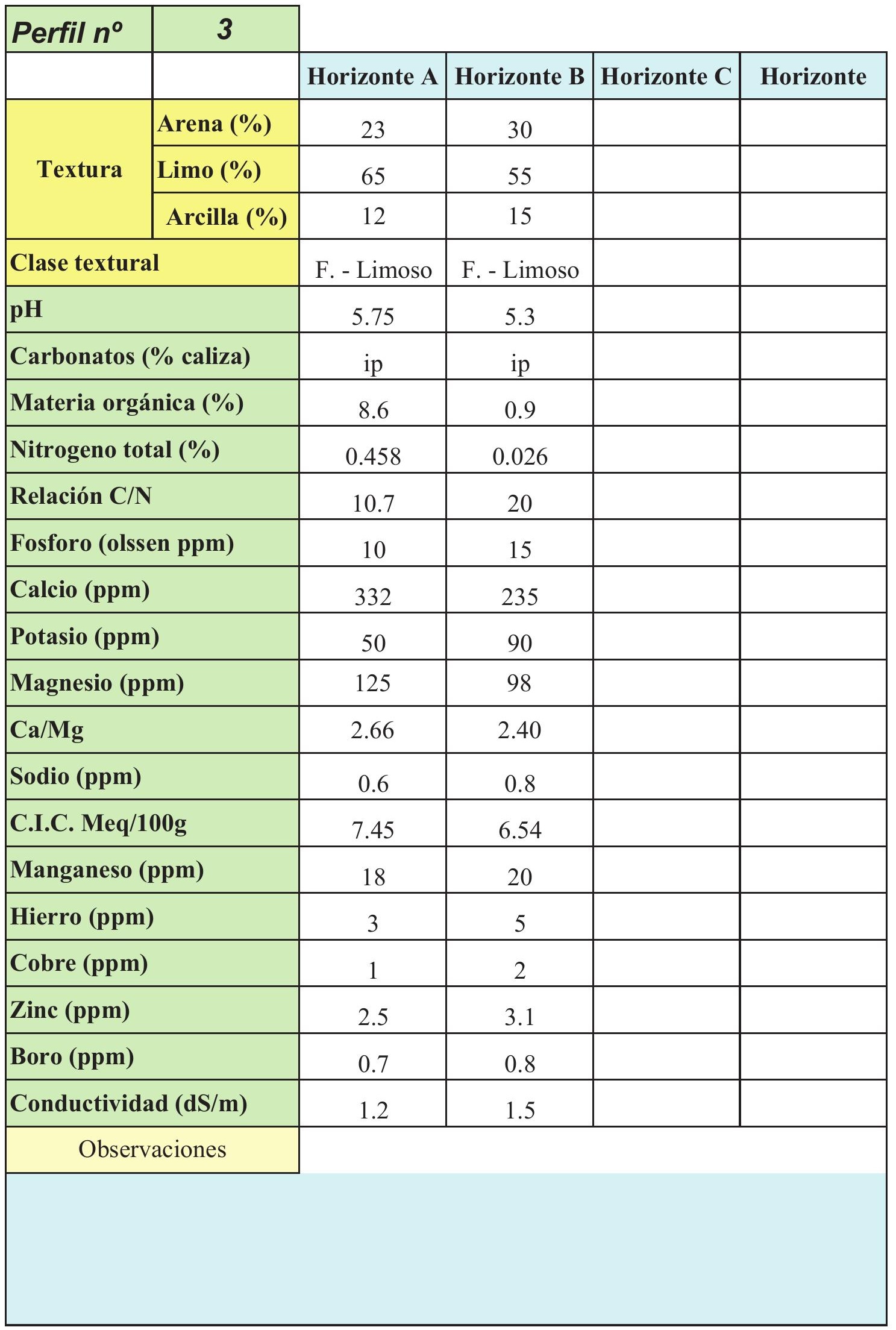


ANÁLISIS DE COMPOSICIÓN DE SUELOS

Desarrollo de una aplicación informática para el cálculo de sostenimiento de taludes mediante vegetación

\begin{tabular}{|c|c|c|c|c|c|}
\hline \multirow[t]{2}{*}{ Perfil $n^{\circ}$} & \multirow[t]{2}{*}{4} & \multirow[b]{2}{*}{ Horizonte A } & \multirow[b]{2}{*}{ Horizonte C } & \multirow[b]{2}{*}{ Horizonte } & \multirow[b]{2}{*}{ Horizonte } \\
\hline & & & & & \\
\hline \multirow{3}{*}{ Textura } & Arena (\%) & 68 & & & \\
\hline & $\operatorname{Limo}(\%)$ & 30 & & & \\
\hline & Arcilla (\%) & 2 & & & \\
\hline \multicolumn{2}{|c|}{ Clase texstural } & Franca-Areno & & & \\
\hline \multicolumn{2}{|l|}{ pH } & 5.5 & & & \\
\hline \multicolumn{2}{|c|}{ Carbonatos ( $\%$ caliza) } & ip & & & \\
\hline \multicolumn{2}{|c|}{ Materia orgánica (\%) } & 2.75 & & & \\
\hline \multicolumn{2}{|c|}{ Nitrogeno total (\%) } & 0.165 & & & \\
\hline \multicolumn{2}{|c|}{ Relación C/N } & 9.5 & & & \\
\hline \multicolumn{2}{|c|}{ Fosforo (olssen ppm) } & 4 & & & \\
\hline \multicolumn{2}{|c|}{ Calcio (ppm) } & 98 & & & \\
\hline \multicolumn{2}{|c|}{ Potasio (ppm) } & 60 & & & \\
\hline \multicolumn{2}{|c|}{ Magnesio (ppm) } & 25 & & & \\
\hline \multicolumn{2}{|l|}{$\mathrm{Ca} / \mathrm{Mg}$} & 3.92 & & & \\
\hline \multicolumn{2}{|c|}{ Sodio (ppm) } & 0.1 & & & \\
\hline \multicolumn{2}{|c|}{ C.I.C. Meq/100g } & 6 & & & \\
\hline \multicolumn{2}{|c|}{ Manganeso (ppm) } & 21 & & & \\
\hline \multicolumn{2}{|c|}{ Hierro (ppm) } & 1.5 & & & \\
\hline \multicolumn{2}{|c|}{ Cobre (ppm) } & 0.7 & & & \\
\hline \multicolumn{2}{|l|}{ Zinc (ppm) } & 2.3 & & & \\
\hline \multicolumn{2}{|l|}{ Boro (ppm) } & 0.2 & & & \\
\hline \multicolumn{2}{|c|}{ Conductividad (dS/m) } & 0.4 & & & \\
\hline \multicolumn{2}{|c|}{ Observaciones } & & & & \\
\hline
\end{tabular}


ANÁLISIS DE COMPOSICIÓN DE SUELOS

Desarrollo de una aplicación informática para el cálculo de sostenimiento de taludes mediante vegetación

\begin{tabular}{|c|c|c|c|c|c|}
\hline \multirow[t]{2}{*}{ Perfil $n^{\circ}$} & \multirow[t]{2}{*}{5} & \multirow[b]{2}{*}{ Horizonte A } & \multirow[b]{2}{*}{ Horizonte C } & \multirow[b]{2}{*}{ Horizonte } & \multirow[b]{2}{*}{ Horizonte } \\
\hline & & & & & \\
\hline \multirow{3}{*}{ Textura } & Arena (\%) & 25 & & & \\
\hline & Limo (\%) & 58 & & & \\
\hline & Arcilla (\%) & 17 & & & \\
\hline \multicolumn{2}{|c|}{ Clase textural } & Franca-limos & & & \\
\hline \multicolumn{2}{|l|}{ pH } & 5.5 & & & \\
\hline \multicolumn{2}{|c|}{ Carbonatos (\% caliza) } & ip & & & \\
\hline \multicolumn{2}{|c|}{ Materia orgánica (\%) } & 7.9 & & & \\
\hline \multicolumn{2}{|c|}{ Nitrogeno total (\%) } & 0.500 & & & \\
\hline \multicolumn{2}{|c|}{ Relación C/N } & 9 & & & \\
\hline \multicolumn{2}{|c|}{ Fosforo (olssen ppm) } & 2 & & & \\
\hline \multicolumn{2}{|c|}{ Calcio (ppm) } & 22 & & & \\
\hline \multicolumn{2}{|c|}{ Magnesio (ppm) } & 1.25 & & & \\
\hline \multicolumn{2}{|l|}{$\mathrm{Ca} / \mathrm{Mg}$} & 1.60 & & & \\
\hline \multicolumn{2}{|c|}{ Potasio (ppm) } & 10 & & & \\
\hline \multicolumn{2}{|c|}{ Sodio (ppm) } & 0.01 & & & \\
\hline \multicolumn{2}{|c|}{ C.I.C. Meq/100g } & 10 & & & \\
\hline \multicolumn{2}{|c|}{ Manganeso (ppm) } & 18 & & & \\
\hline \multicolumn{2}{|c|}{ Hierro (ppm) } & 1.4 & & & \\
\hline \multicolumn{2}{|c|}{ Cobre (ppm) } & 0.1 & & & \\
\hline \multicolumn{2}{|l|}{ Zinc (ppm) } & 1.3 & & & \\
\hline \multicolumn{2}{|l|}{ Boro (ppm) } & 0.26 & & & \\
\hline \multicolumn{2}{|c|}{ Conductividad (dS/m) } & 1.2 & & & \\
\hline \multicolumn{2}{|c|}{ Observaciones } & & & & \\
\hline
\end{tabular}


ANÁLISIS DE COMPOSICIÓN DE SUELOS

Desarrollo de una aplicación informática para el cálculo de sostenimiento de taludes mediante vegetación

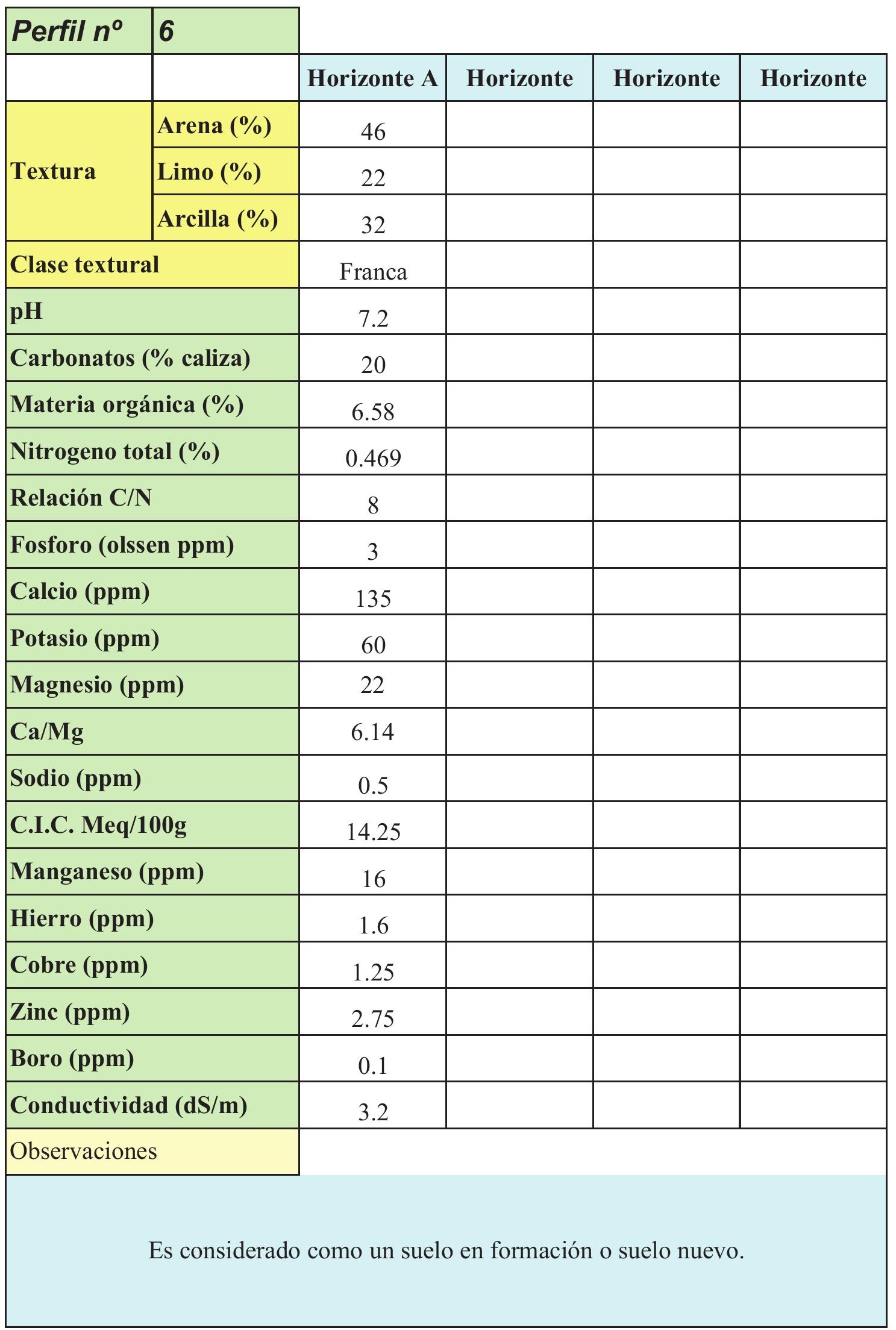


ANÁLISIS DE COMPOSICIÓN DE SUELOS

Desarrollo de una aplicación informática para el cálculo de sostenimiento de taludes mediante vegetación

\begin{tabular}{|c|c|c|c|c|c|}
\hline \multirow[t]{2}{*}{ Perfil $n^{\circ}$} & \multirow[t]{2}{*}{7} & \multirow[b]{2}{*}{ Horizonte A } & \multirow[b]{2}{*}{ Horizonte B } & \multirow[b]{2}{*}{ Horizonte C } & \multirow[b]{2}{*}{ Horizonte D } \\
\hline & & & & & \\
\hline \multirow{3}{*}{ Textura } & Arena (\%) & 33 & 28 & & \\
\hline & Limo (\%) & 54 & 61 & & \\
\hline & Arcilla (\%) & 13 & 11 & & \\
\hline \multicolumn{2}{|c|}{ Clase textural } & Fran - limo & Fran - limo & & \\
\hline \multicolumn{2}{|l|}{ pH } & 6.5 & 6.2 & & \\
\hline \multicolumn{2}{|c|}{ Carbonatos (\% caliza) } & ip & ip & & \\
\hline \multicolumn{2}{|c|}{ Materia orgánica (\%) } & 5.6 & 5.3 & & \\
\hline \multicolumn{2}{|c|}{ Nitrogeno total (\%) } & 0.355 & 0.325 & & \\
\hline \multicolumn{2}{|c|}{ Relación C/N } & 9 & 9.3 & & \\
\hline \multicolumn{2}{|c|}{ Fosforo (olssen ppm) } & 6 & 6 & & \\
\hline \multicolumn{2}{|c|}{ Calcio (ppm) } & 251 & 254 & & \\
\hline \multicolumn{2}{|c|}{ Potasio (ppm) } & 84 & 85 & & \\
\hline \multicolumn{2}{|c|}{ Magnesio (ppm) } & 90 & 88 & & \\
\hline \multicolumn{2}{|l|}{$\mathrm{Ca} / \mathrm{Mg}$} & 2.79 & 2.89 & & \\
\hline \multicolumn{2}{|c|}{ Sodio (ppm) } & 15 & 10 & & \\
\hline \multicolumn{2}{|c|}{ C.I.C. Meq/100g } & 12 & 11 & & \\
\hline \multicolumn{2}{|c|}{ Manganeso (ppm) } & 17 & 18 & & \\
\hline \multicolumn{2}{|c|}{ Hierro (ppm) } & 1.58 & 1.6 & & \\
\hline \multicolumn{2}{|c|}{ Cobre (ppm) } & 0.2 & 0.2 & & \\
\hline \multicolumn{2}{|l|}{ Zinc (ppm) } & 1.25 & 1.3 & & \\
\hline \multicolumn{2}{|l|}{ Boro (ppm) } & 0.35 & 0.24 & & \\
\hline \multicolumn{2}{|c|}{ Conductividad (dS/m) } & 1.5 & 1.6 & & \\
\hline \multicolumn{2}{|c|}{ Observaciones } & & & & \\
\hline
\end{tabular}


ANÁLISIS DE COMPOSICIÓN DE SUELOS

Desarrollo de una aplicación informática para el cálculo de sostenimiento de taludes mediante vegetación

\begin{tabular}{|c|c|c|c|c|c|}
\hline \multirow[t]{2}{*}{ Perfil $n^{\circ}$} & \multirow[t]{2}{*}{8} & \multirow[b]{2}{*}{ Horizonte A } & \multirow[b]{2}{*}{ Horizonte B } & \multirow[b]{2}{*}{ Horizonte C } & \multirow[b]{2}{*}{ Horizonte D } \\
\hline & & & & & \\
\hline \multirow{3}{*}{ Textura } & Arena (\%) & 70 & & & \\
\hline & Limo (\%) & 22 & & & \\
\hline & Arcilla (\%) & 8 & & & \\
\hline \multicolumn{2}{|c|}{ Clase textural } & Franca-Aren & & & \\
\hline \multicolumn{2}{|l|}{ pH } & 5.7 & & & \\
\hline \multicolumn{2}{|c|}{ Carbonatos ( $\%$ caliza) } & 0.1 & & & \\
\hline \multicolumn{2}{|c|}{ Materia orgánica (\%) } & 1.2 & & & \\
\hline \multicolumn{2}{|c|}{ Nitrogeno total (\%) } & 0.068 & & & \\
\hline \multicolumn{2}{|c|}{ Relación C/N } & 10 & & & \\
\hline \multicolumn{2}{|c|}{ Fosforo (olssen ppm) } & 4.2 & & & \\
\hline \multicolumn{2}{|c|}{ Calcio (ppm) } & 40 & & & \\
\hline \multicolumn{2}{|c|}{ Potasio (ppm) } & 30 & & & \\
\hline \multicolumn{2}{|c|}{ Magnesio (ppm) } & 75 & & & \\
\hline \multicolumn{2}{|l|}{$\mathrm{Ca} / \mathrm{Mg}$} & 0.53 & & & \\
\hline \multicolumn{2}{|c|}{ Sodio (ppm) } & 23 & & & \\
\hline \multicolumn{2}{|c|}{ C.I.C. Meq/100g } & 4 & & & \\
\hline \multicolumn{2}{|c|}{ Manganeso (ppm) } & 12 & & & \\
\hline \multicolumn{2}{|c|}{ Hierro (ppm) } & 1.53 & & & \\
\hline \multicolumn{2}{|c|}{ Cobre (ppm) } & 0.02 & & & \\
\hline \multicolumn{2}{|l|}{ Zinc (ppm) } & ip & & & \\
\hline \multicolumn{2}{|l|}{ Boro (ppm) } & 0.03 & & & \\
\hline \multicolumn{2}{|c|}{ Conductividad (dS/m) } & 0.03 & & & \\
\hline \multicolumn{2}{|c|}{ Observaciones } & & & & \\
\hline
\end{tabular}


ANÁLISIS DE COMPOSICIÓN DE SUELOS

Desarrollo de una aplicación informática para el cálculo de sostenimiento de taludes mediante vegetación

\begin{tabular}{|c|c|c|c|c|c|}
\hline \multirow[t]{2}{*}{ Perfil $n^{\circ}$} & \multirow[t]{2}{*}{9} & \multirow[b]{2}{*}{ Horizonte A } & \multirow[b]{2}{*}{ Horizonte B } & \multirow[b]{2}{*}{ Horizonte C } & \multirow[b]{2}{*}{ Horizonte D } \\
\hline & & & & & \\
\hline \multirow{3}{*}{ Textura } & Arena (\%) & 38 & 30 & 10 & \\
\hline & Limo (\%) & 42 & 35 & 55 & \\
\hline & Arcilla (\%) & 20 & 35 & 35 & \\
\hline \multicolumn{2}{|c|}{ Clase textural } & Franca & Franca-Arcil & Fran-Arc-Lim & \\
\hline \multicolumn{2}{|l|}{ pH } & 5.4 & 5.5 & 5.6 & \\
\hline \multicolumn{2}{|c|}{ Carbonatos ( $\%$ caliza) } & 5.2 & 4 & --- & \\
\hline \multicolumn{2}{|c|}{ Materia orgánica (\%) } & 2.8 & 0.5 & --- & \\
\hline \multicolumn{2}{|c|}{ Nitrogeno total $(\%)$} & 0.177 & 0.057 & --- & \\
\hline \multicolumn{2}{|c|}{ Relación C/N } & 9 & 5 & --- & \\
\hline \multicolumn{2}{|c|}{ Fosforo (olssen ppm) } & 10 & 20 & 8 & \\
\hline \multicolumn{2}{|c|}{ Calcio (ppm) } & 823 & 942 & 1121 & \\
\hline \multicolumn{2}{|c|}{ Potasio (ppm) } & 144 & 210 & 153 & \\
\hline \multicolumn{2}{|c|}{ Magnesio (ppm) } & 38 & 44 & 53 & \\
\hline \multicolumn{2}{|l|}{$\mathrm{Ca} / \mathrm{Mg}$} & 21.66 & 21.41 & 21.15 & \\
\hline \multicolumn{2}{|c|}{ Sodio (ppm) } & 30 & 35 & 43 & \\
\hline \multicolumn{2}{|c|}{ C.I.C. Meq/100g } & 18 & 19 & 20 & \\
\hline \multicolumn{2}{|c|}{ Manganeso (ppm) } & 30 & 35 & 10 & \\
\hline \multicolumn{2}{|c|}{ Hierro (ppm) } & 3 & 3.5 & 4 & \\
\hline \multicolumn{2}{|c|}{ Cobre (ppm) } & ip & ip & ip & \\
\hline \multicolumn{2}{|l|}{ Zinc (ppm) } & ip & ip & ip & \\
\hline \multicolumn{2}{|l|}{ Boro (ppm) } & 0.2 & 0.3 & 0.1 & \\
\hline \multicolumn{2}{|c|}{ Conductividad (dS/m) } & 1 & 1.1 & 1.4 & \\
\hline \multicolumn{2}{|c|}{ Observaciones } & & & & \\
\hline
\end{tabular}


ANÁLISIS DE COMPOSICIÓN DE SUELOS

Desarrollo de una aplicación informática para el cálculo de sostenimiento de taludes mediante vegetación

\begin{tabular}{|c|c|c|c|c|c|}
\hline \multirow[t]{2}{*}{ Perfil $n^{\circ}$} & \multirow[t]{2}{*}{10} & \multirow[b]{2}{*}{ Horizonte A } & \multirow[b]{2}{*}{ Horizonte B } & \multirow[b]{2}{*}{ Horizonte C } & \multirow[b]{2}{*}{ Horizonte D } \\
\hline & & & & & \\
\hline \multirow{3}{*}{ Textura } & Arena (\%) & 28 & & & \\
\hline & Limo (\%) & 9 & & & \\
\hline & Arcilla (\%) & 15 & & & \\
\hline \multicolumn{2}{|c|}{ Clase textural } & Franc-Lim & & & \\
\hline \multicolumn{2}{|l|}{ pH } & 6.6 & & & \\
\hline \multicolumn{2}{|c|}{ Carbonatos (\% caliza) } & 6.01 & & & \\
\hline \multicolumn{2}{|c|}{ Materia orgánica (\%) } & 3.1 & & & \\
\hline \multicolumn{2}{|c|}{ Nitrogeno total (\%) } & 0.177 & & & \\
\hline \multicolumn{2}{|c|}{ Relación C/N } & 10 & & & \\
\hline \multicolumn{2}{|c|}{ Fosforo (olssen ppm) } & 14.5 & & & \\
\hline \multicolumn{2}{|c|}{ Calcio (ppm) } & 811 & & & \\
\hline \multicolumn{2}{|c|}{ Potasio (ppm) } & 183 & & & \\
\hline \multicolumn{2}{|c|}{ Magnesio (ppm) } & 133 & & & \\
\hline \multicolumn{2}{|l|}{$\mathrm{Ca} / \mathrm{Mg}$} & 6.10 & & & \\
\hline \multicolumn{2}{|c|}{ Sodio (ppm) } & 40 & & & \\
\hline \multicolumn{2}{|c|}{ C.I.C. Meq/100g } & 10 & & & \\
\hline \multicolumn{2}{|c|}{ Manganeso (ppm) } & 15 & & & \\
\hline \multicolumn{2}{|c|}{ Hierro (ppm) } & 0.2 & & & \\
\hline \multicolumn{2}{|c|}{ Cobre (ppm) } & 0.3 & & & \\
\hline \multicolumn{2}{|l|}{ Zinc (ppm) } & 0.22 & & & \\
\hline \multicolumn{2}{|l|}{ Boro (ppm) } & 0.8 & & & \\
\hline \multicolumn{2}{|c|}{ Conductividad (dS/m) } & 1.1 & & & \\
\hline \multicolumn{2}{|c|}{ Observaciones } & & & & \\
\hline
\end{tabular}


ANÁLISIS DE COMPOSICIÓN DE SUELOS

Desarrollo de una aplicación informática para el cálculo de sostenimiento de taludes mediante vegetación

\begin{tabular}{|c|c|c|c|c|c|}
\hline \multirow[t]{2}{*}{ Perfil $n^{\circ}$} & \multirow[t]{2}{*}{11} & & & & \\
\hline & & Horizonte A & Horizonte $\mathrm{C}$ & Horizonte & Horizonte \\
\hline \multirow{3}{*}{ Textura } & Arena (\%) & 26 & & & \\
\hline & $\operatorname{Limo}(\%)$ & 58 & & & \\
\hline & Arcilla (\%) & 16 & & & \\
\hline \multicolumn{2}{|c|}{ Clase textural } & Franc-Limo & & & \\
\hline \multicolumn{2}{|l|}{ pH } & 6.2 & & & \\
\hline \multicolumn{2}{|c|}{ Carbonatos ( $\%$ caliza) } & 2.25 & & & \\
\hline \multicolumn{2}{|c|}{ Materia orgánica (\%) } & 1.3 & & & \\
\hline \multicolumn{2}{|c|}{ Nitrogeno total (\%) } & 0.05 & & & \\
\hline \multicolumn{2}{|c|}{ Relación C/N } & 14.82 & & & \\
\hline \multicolumn{2}{|c|}{ Fosforo (olssen ppm) } & 3.01 & & & \\
\hline \multicolumn{2}{|c|}{ Calcio (ppm) } & 685 & & & \\
\hline \multicolumn{2}{|c|}{ Potasio (ppm) } & 35 & & & \\
\hline \multicolumn{2}{|c|}{ Magnesio (ppm) } & 251 & & & \\
\hline \multicolumn{2}{|l|}{$\mathrm{Ca} / \mathrm{Mg}$} & 2.729 & & & \\
\hline \multicolumn{2}{|c|}{ Sodio (ppm) } & 10 & & & \\
\hline \multicolumn{2}{|c|}{ C.I.C. Meq/100g } & 3 & & & \\
\hline \multicolumn{2}{|c|}{ Manganeso (ppm) } & 9.75 & & & \\
\hline \multicolumn{2}{|c|}{ Hierro (ppm) } & 0.5 & & & \\
\hline \multicolumn{2}{|c|}{ Cobre (ppm) } & ip & & & \\
\hline \multicolumn{2}{|l|}{ Zinc (ppm) } & ip & & & \\
\hline \multicolumn{2}{|l|}{ Boro (ppm) } & ip & & & \\
\hline \multicolumn{2}{|c|}{ Conductividad (dS/m) } & 1.1 & & & \\
\hline \multicolumn{2}{|c|}{ Observaciones } & & & & \\
\hline \multicolumn{6}{|c|}{ Pobre en microelementos y macroelementos estudiados } \\
\hline
\end{tabular}


ANÁLISIS DE COMPOSICIÓN DE SUELOS

Desarrollo de una aplicación informática para el cálculo de sostenimiento de taludes mediante vegetación

\begin{tabular}{|c|c|c|c|c|c|}
\hline \multirow[t]{2}{*}{ Perfil $n^{\circ}$} & \multirow[t]{2}{*}{12} & & & & \\
\hline & & Horizonte A & $\begin{array}{l}\text { Horizonte } \\
\text { Cures }\end{array}$ & Horizonte & Horizonte \\
\hline \multirow{3}{*}{ Textura } & Arena (\%) & 63 & & & \\
\hline & Limo (\%) & 24 & & & \\
\hline & Arcilla (\%) & 13 & & & \\
\hline \multicolumn{2}{|c|}{ Clase textural } & Fran-Aren & & & \\
\hline \multicolumn{2}{|l|}{ pH } & 5.5 & & & \\
\hline \multicolumn{2}{|c|}{ Carbonatos (\% caliza) } & 3.5 & & & \\
\hline \multicolumn{2}{|c|}{ Materia orgánica (\%) } & 3.26 & & & \\
\hline \multicolumn{2}{|c|}{ Nitrogeno total (\%) } & 0.09 & & & \\
\hline \multicolumn{2}{|c|}{ Relación C/N } & 11 & & & \\
\hline \multicolumn{2}{|c|}{ Fosforo (olssen ppm) } & 2.5 & & & \\
\hline \multicolumn{2}{|c|}{ Calcio (ppm) } & 234 & & & \\
\hline \multicolumn{2}{|c|}{ Potasio (ppm) } & 35 & & & \\
\hline \multicolumn{2}{|c|}{ Magnesio (ppm) } & 101 & & & \\
\hline \multicolumn{2}{|l|}{$\mathrm{Ca} / \mathrm{Mg}$} & 2.317 & & & \\
\hline \multicolumn{2}{|l|}{ Sodio (ppm) } & 16 & & & \\
\hline \multicolumn{2}{|c|}{ C.I.C. Meq/100g } & 18 & & & \\
\hline \multicolumn{2}{|c|}{ Manganeso (ppm) } & 105 & & & \\
\hline \multicolumn{2}{|c|}{ Hierro (ppm) } & ip & & & \\
\hline \multicolumn{2}{|c|}{ Cobre (ppm) } & ip & & & \\
\hline \multicolumn{2}{|l|}{ Zinc (ppm) } & ip & & & \\
\hline \multicolumn{2}{|l|}{ Boro (ppm) } & ip & & & \\
\hline \multicolumn{2}{|c|}{ Conductividad (dS/m) } & 0.25 & & & \\
\hline \multicolumn{2}{|c|}{ Observaciones } & & & & \\
\hline
\end{tabular}


ANÁLISIS DE COMPOSICIÓN DE SUELOS

Desarrollo de una aplicación informática para el cálculo de sostenimiento de taludes mediante vegetación

\begin{tabular}{|c|c|c|c|c|c|}
\hline \multirow[t]{2}{*}{ Perfil $n^{\circ}$} & \multirow[t]{2}{*}{13} & & & & \\
\hline & & Horizonte A & Horizonte C & Horizonte & Horizonte \\
\hline \multirow{3}{*}{ Textura } & Arena (\%) & 62 & & & \\
\hline & Limo (\%) & 27 & & & \\
\hline & Arcilla (\%) & 11 & & & \\
\hline \multicolumn{2}{|c|}{ Clase textural } & Aren-Limo & & & \\
\hline \multicolumn{2}{|l|}{$\mathrm{pH}$} & 5.5 & & & \\
\hline \multicolumn{2}{|c|}{ Carbonatos (\% caliza) } & 1.1 & & & \\
\hline \multicolumn{2}{|c|}{ Materia orgánica (\%) } & 4.6 & & & \\
\hline \multicolumn{2}{|c|}{ Nitrogeno total (\%) } & 0.291 & & & \\
\hline \multicolumn{2}{|c|}{ Relación C/N } & 9 & & & \\
\hline \multicolumn{2}{|c|}{ Fosforo (olssen ppm) } & 12 & & & \\
\hline \multicolumn{2}{|c|}{ Calcio (ppm) } & 250 & & & \\
\hline \multicolumn{2}{|c|}{ Potasio (ppm) } & 60 & & & \\
\hline \multicolumn{2}{|c|}{ Magnesio (ppm) } & 100 & & & \\
\hline \multicolumn{2}{|l|}{$\mathrm{Ca} / \mathrm{Mg}$} & 2.50 & & & \\
\hline \multicolumn{2}{|c|}{ Sodio (ppm) } & 20 & & & \\
\hline \multicolumn{2}{|c|}{ C.I.C. Meq/100g } & 6 & & & \\
\hline \multicolumn{2}{|c|}{ Manganeso (ppm) } & 13 & & & \\
\hline \multicolumn{2}{|c|}{ Hierro (ppm) } & ip & & & \\
\hline \multicolumn{2}{|c|}{ Cobre (ppm) } & ip & & & \\
\hline \multicolumn{2}{|l|}{ Zinc (ppm) } & ip & & & \\
\hline \multicolumn{2}{|l|}{ Boro (ppm) } & ip & & & \\
\hline \multicolumn{2}{|c|}{ Conductividad (dS/m) } & 0.8 & & & \\
\hline \multicolumn{2}{|c|}{ Observaciones } & & & & \\
\hline
\end{tabular}


ANÁLISIS DE COMPOSICIÓN DE SUELOS

Desarrollo de una aplicación informática para el cálculo de sostenimiento de taludes mediante vegetación

\begin{tabular}{|c|c|c|c|c|c|}
\hline \multirow[t]{2}{*}{ Perfil $n^{\circ}$} & \multirow[t]{2}{*}{14} & \multirow[b]{2}{*}{ Horizonte A } & \multirow[b]{2}{*}{ Horizonte C } & \multirow[b]{2}{*}{ Horizonte } & \multirow[b]{2}{*}{ Horizonte } \\
\hline & & & & & \\
\hline \multirow{3}{*}{ Textura } & Arena (\%) & 35 & & & \\
\hline & Limo (\%) & 40 & & & \\
\hline & Arcilla (\%) & 25 & & & \\
\hline \multicolumn{2}{|c|}{ Clase texstural } & Franca & & & \\
\hline \multicolumn{2}{|l|}{ pH } & 5.5 & & & \\
\hline \multicolumn{2}{|c|}{ Carbonatos (\% caliza) } & 20 & & & \\
\hline \multicolumn{2}{|c|}{ Materia orgánica (\%) } & 3 & & & \\
\hline \multicolumn{2}{|c|}{ Nitrogeno total (\%) } & 0.155 & & & \\
\hline \multicolumn{2}{|c|}{ Relación C/N } & 11 & & & \\
\hline \multicolumn{2}{|c|}{ Fosforo (olssen ppm) } & 25 & & & \\
\hline \multicolumn{2}{|c|}{ Calcio (ppm) } & 275 & & & \\
\hline \multicolumn{2}{|c|}{ Potasio (ppm) } & 35 & & & \\
\hline \multicolumn{2}{|c|}{ Magnesio (ppm) } & 36 & & & \\
\hline \multicolumn{2}{|l|}{$\mathrm{Ca} / \mathrm{Mg}$} & 7.64 & & & \\
\hline \multicolumn{2}{|c|}{ Sodio (ppm) } & 65 & & & \\
\hline \multicolumn{2}{|c|}{ C.I.C. Meq/100g } & 12 & & & \\
\hline \multicolumn{2}{|c|}{ Manganeso (ppm) } & 25 & & & \\
\hline \multicolumn{2}{|c|}{ Hierro (ppm) } & 0.5 & & & \\
\hline \multicolumn{2}{|c|}{ Cobre (ppm) } & 0.02 & & & \\
\hline \multicolumn{2}{|l|}{ Zinc (ppm) } & 0.2 & & & \\
\hline \multicolumn{2}{|l|}{ Boro (ppm) } & 0.9 & & & \\
\hline \multicolumn{2}{|c|}{ Conductividad (dS/m) } & 1.1 & & & \\
\hline \multicolumn{2}{|c|}{ Observaciones } & & & & \\
\hline
\end{tabular}


ANÁLISIS DE COMPOSICIÓN DE SUELOS

Desarrollo de una aplicación informática para el cálculo de sostenimiento de taludes mediante vegetación

\begin{tabular}{|c|c|c|c|c|c|}
\hline \multirow[t]{2}{*}{ Perfil $n^{\circ}$} & \multirow[t]{2}{*}{15} & & & & \\
\hline & & Horizonte A & Horizonte B & Horizonte C & Horizonte D \\
\hline \multirow{3}{*}{ Textura } & Arena (\%) & 55 & & & \\
\hline & Limo (\%) & 29 & & & \\
\hline & Arcilla (\%) & 16 & & & \\
\hline \multicolumn{2}{|c|}{ Clase textural } & Fran-Aren & & & \\
\hline \multicolumn{2}{|l|}{ pH } & 5.2 & & & \\
\hline \multicolumn{2}{|c|}{ Carbonatos ( $\%$ caliza) } & 0.9 & & & \\
\hline \multicolumn{2}{|c|}{ Materia orgánica (\%) } & 2.55 & & & \\
\hline \multicolumn{2}{|c|}{ Nitrogeno total (\%) } & 0.162 & & & \\
\hline \multicolumn{2}{|c|}{ Relación C/N } & 9 & & & \\
\hline \multicolumn{2}{|c|}{ Fosforo (olssen ppm) } & 3 & & & \\
\hline \multicolumn{2}{|c|}{ Calcio (ppm) } & 321 & & & \\
\hline \multicolumn{2}{|c|}{ Magnesio (ppm) } & 95 & & & \\
\hline \multicolumn{2}{|l|}{$\mathrm{Ca} / \mathrm{Mg}$} & 3.38 & & & \\
\hline \multicolumn{2}{|c|}{ Potasio (ppm) } & 30 & & & \\
\hline \multicolumn{2}{|l|}{ Sodio (ppm) } & 10 & & & \\
\hline \multicolumn{2}{|c|}{ C.I.C. Meq/100g } & ip & & & \\
\hline \multicolumn{2}{|c|}{ Manganeso (ppm) } & ip & & & \\
\hline \multicolumn{2}{|c|}{ Hierro (ppm) } & ip & & & \\
\hline \multicolumn{2}{|c|}{ Cobre (ppm) } & ip & & & \\
\hline \multicolumn{2}{|l|}{ Zinc (ppm) } & ip & & & \\
\hline \multicolumn{2}{|l|}{ Boro (ppm) } & ip & & & \\
\hline \multicolumn{2}{|c|}{ Conductividad (dS/m) } & 0.9 & & & \\
\hline \multicolumn{2}{|c|}{ Observaciones } & & & & \\
\hline \multicolumn{6}{|c|}{ Pobre en elementos y oligoelementos esenciales. } \\
\hline
\end{tabular}


ANÁLISIS DE COMPOSICIÓN DE SUELOS

Desarrollo de una aplicación informática para el cálculo de sostenimiento de taludes mediante vegetación

\begin{tabular}{|c|c|c|c|c|c|}
\hline \multirow[t]{2}{*}{ Perfil $n^{\circ}$} & \multirow[t]{2}{*}{16} & \multirow[b]{2}{*}{ Horizonte A } & \multirow[b]{2}{*}{ Horizonte B } & \multirow[b]{2}{*}{ Horizonte C } & \multirow[b]{2}{*}{ Horizonte D } \\
\hline & & & & & \\
\hline \multirow{3}{*}{ Textura } & Arena (\%) & 41 & 35 & & \\
\hline & Limo (\%) & 34 & 28 & & \\
\hline & Arcilla (\%) & 25 & 37 & & \\
\hline \multicolumn{2}{|c|}{ Clase textural } & Franca & Fran-Arci & & \\
\hline \multicolumn{2}{|l|}{ pH } & 6 & 5 & & \\
\hline \multicolumn{2}{|c|}{ Carbonatos (\% caliza) } & 0.03 & 0.01 & & \\
\hline \multicolumn{2}{|c|}{ Materia orgánica (\%) } & 3 & 0.9 & & \\
\hline \multicolumn{2}{|c|}{ Nitrogeno total (\%) } & 0.171 & 0.064 & & \\
\hline \multicolumn{2}{|c|}{ Relación C/N } & 10 & 8 & & \\
\hline \multicolumn{2}{|c|}{ Fosforo (olssen ppm) } & 5.4 & 6.3 & & \\
\hline \multicolumn{2}{|c|}{ Calcio (ppm) } & 92 & 89 & & \\
\hline \multicolumn{2}{|c|}{ Potasio (ppm) } & 80 & 101 & & \\
\hline \multicolumn{2}{|c|}{ Magnesio (ppm) } & 23 & 34 & & \\
\hline \multicolumn{2}{|l|}{$\mathrm{Ca} / \mathrm{Mg}$} & 4.00 & 2.62 & & \\
\hline \multicolumn{2}{|c|}{ Sodio (ppm) } & 13 & 11 & & \\
\hline \multicolumn{2}{|c|}{ C.I.C. Meq/100g } & 6 & 6 & & \\
\hline \multicolumn{2}{|c|}{ Manganeso (ppm) } & 10 & 9 & & \\
\hline \multicolumn{2}{|c|}{ Hierro (ppm) } & 0.5 & 0.52 & & \\
\hline \multicolumn{2}{|c|}{ Cobre (ppm) } & 0.02 & 0.06 & & \\
\hline \multicolumn{2}{|l|}{ Zinc (ppm) } & 1.05 & 1.1 & & \\
\hline \multicolumn{2}{|l|}{ Boro (ppm) } & 0.01 & 0.02 & & \\
\hline \multicolumn{2}{|c|}{ Conductividad (dS/m) } & 0.9 & 0.9 & & \\
\hline \multicolumn{2}{|c|}{ Observaciones } & & & & \\
\hline
\end{tabular}


ANÁLISIS DE COMPOSICIÓN DE SUELOS

Desarrollo de una aplicación informática para el cálculo de sostenimiento de taludes mediante vegetación

\begin{tabular}{|c|c|c|c|c|c|}
\hline \multirow[t]{2}{*}{ Perfil $n^{\circ}$} & \multirow[t]{2}{*}{17} & \multirow[b]{2}{*}{ Horizonte A } & \multirow[b]{2}{*}{ Horizonte B } & \multirow[b]{2}{*}{ Horizonte C } & \multirow[b]{2}{*}{ Horizonte D } \\
\hline & & & & & \\
\hline \multirow{3}{*}{ Textura } & Arena (\%) & 56 & 38 & & \\
\hline & Limo (\%) & 26 & 39 & & \\
\hline & Arcilla (\%) & 18 & 23 & & \\
\hline \multicolumn{2}{|c|}{ Clase textural } & Fran-Aren & Fran-Arci & & \\
\hline \multicolumn{2}{|l|}{ pH } & 5.5 & 6 & & \\
\hline \multicolumn{2}{|c|}{ Carbonatos (\% caliza) } & 1.2 & 1.4 & & \\
\hline \multicolumn{2}{|c|}{ Materia orgánica (\%) } & 7.25 & 1.3 & & \\
\hline \multicolumn{2}{|c|}{ Nitrogeno total $(\%)$} & 0.376 & 0.057 & & \\
\hline \multicolumn{2}{|c|}{ Relación C/N } & 11 & 13 & & \\
\hline \multicolumn{2}{|c|}{ Fosforo (olssen ppm) } & 18 & 22 & & \\
\hline \multicolumn{2}{|c|}{ Calcio (ppm) } & 350 & 425 & & \\
\hline \multicolumn{2}{|c|}{ Potasio (ppm) } & 156 & 185 & & \\
\hline \multicolumn{2}{|c|}{ Magnesio (ppm) } & 75 & 86 & & \\
\hline \multicolumn{2}{|l|}{$\mathrm{Ca} / \mathrm{Mg}$} & 4.67 & 4.94 & & \\
\hline \multicolumn{2}{|c|}{ Sodio (ppm) } & 25 & 20 & & \\
\hline \multicolumn{2}{|c|}{ C.I.C. Meq/100g } & 9 & 5 & & \\
\hline \multicolumn{2}{|c|}{ Manganeso (ppm) } & 18 & 23 & & \\
\hline \multicolumn{2}{|c|}{ Hierro (ppm) } & 0.2 & 0.8 & & \\
\hline \multicolumn{2}{|c|}{ Cobre (ppm) } & 0.05 & 0.1 & & \\
\hline \multicolumn{2}{|l|}{ Zinc (ppm) } & 0.9 & 0.6 & & \\
\hline \multicolumn{2}{|l|}{ Boro (ppm) } & 0.6 & 0.8 & & \\
\hline \multicolumn{2}{|c|}{ Conductividad (dS/m) } & 0.5 & 0.6 & & \\
\hline \multicolumn{2}{|c|}{ Observaciones } & & & & \\
\hline
\end{tabular}


ANÁLISIS DE COMPOSICIÓN DE SUELOS

Desarrollo de una aplicación informática para el cálculo de sostenimiento de taludes mediante vegetación

\begin{tabular}{|c|c|c|c|c|c|}
\hline \multirow[t]{2}{*}{ Perfil $n^{\circ}$} & \multirow[t]{2}{*}{18} & \multirow[b]{2}{*}{ Horizonte A } & \multirow[b]{2}{*}{ Horizonte B } & \multirow[b]{2}{*}{ Horizonte C } & \multirow[b]{2}{*}{ Horizonte D } \\
\hline & & & & & \\
\hline \multirow{3}{*}{ Textura } & Arena (\%) & 43 & & & \\
\hline & Limo (\%) & 46 & & & \\
\hline & Arcilla (\%) & 11 & & & \\
\hline \multicolumn{2}{|c|}{ Clase textural } & Franca & & & \\
\hline \multicolumn{2}{|l|}{ pH } & 5.7 & & & \\
\hline \multicolumn{2}{|c|}{ Carbonatos ( $\%$ caliza) } & 2.3 & & & \\
\hline \multicolumn{2}{|c|}{ Materia orgánica (\%) } & 1.9 & & & \\
\hline \multicolumn{2}{|c|}{ Nitrogeno total (\%) } & 0.07 & & & \\
\hline \multicolumn{2}{|c|}{ Relación C/N } & 6 & & & \\
\hline \multicolumn{2}{|c|}{ Fosforo (olssen ppm) } & 18 & & & \\
\hline \multicolumn{2}{|c|}{ Calcio (ppm) } & 122 & & & \\
\hline \multicolumn{2}{|c|}{ Potasio (ppm) } & 101 & & & \\
\hline \multicolumn{2}{|c|}{ Magnesio (ppm) } & 35 & & & \\
\hline \multicolumn{2}{|l|}{$\mathrm{Ca} / \mathrm{Mg}$} & 3.49 & & & \\
\hline \multicolumn{2}{|c|}{ Sodio (ppm) } & 23 & & & \\
\hline \multicolumn{2}{|c|}{ C.I.C. Meq/100g } & 6 & & & \\
\hline \multicolumn{2}{|c|}{ Manganeso (ppm) } & 22 & & & \\
\hline \multicolumn{2}{|c|}{ Hierro (ppm) } & 0.8 & & & \\
\hline \multicolumn{2}{|c|}{ Cobre (ppm) } & 0.09 & & & \\
\hline \multicolumn{2}{|l|}{ Zinc (ppm) } & 1.3 & & & \\
\hline \multicolumn{2}{|l|}{ Boro (ppm) } & 0.6 & & & \\
\hline \multicolumn{2}{|c|}{ Conductividad (dS/m) } & 1.2 & & & \\
\hline \multicolumn{2}{|c|}{ Observaciones } & & & & \\
\hline
\end{tabular}


ANÁLISIS DE COMPOSICIÓN DE SUELOS

Desarrollo de una aplicación informática para el cálculo de sostenimiento de taludes mediante vegetación

\begin{tabular}{|c|c|c|c|c|c|}
\hline \multirow[t]{2}{*}{ Perfil $n^{0}$} & \multirow[t]{2}{*}{19} & \multirow[b]{2}{*}{ Horizonte A } & \multirow[b]{2}{*}{ Horizonte B } & \multirow[b]{2}{*}{ Horizonte C } & \multirow[b]{2}{*}{ Horizonte D } \\
\hline & & & & & \\
\hline \multirow{3}{*}{ Textura } & Arena (\%) & 55 & & & \\
\hline & Limo (\%) & 23 & & & \\
\hline & Arcilla (\%) & 22 & & & \\
\hline \multicolumn{2}{|c|}{ Clase textural } & Fran-Aren & & & \\
\hline \multicolumn{2}{|l|}{ pH } & 5.2 & & & \\
\hline \multicolumn{2}{|c|}{ Carbonatos ( $\%$ caliza) } & 2.3 & & & \\
\hline \multicolumn{2}{|c|}{ Materia orgánica (\%) } & 1.2 & & & \\
\hline \multicolumn{2}{|c|}{ Nitrogeno total (\%) } & 0.08 & & & \\
\hline \multicolumn{2}{|c|}{ Relación C/N } & 8 & & & \\
\hline \multicolumn{2}{|c|}{ Fosforo (olssen ppm) } & 11 & & & \\
\hline \multicolumn{2}{|c|}{ Calcio (ppm) } & 123 & & & \\
\hline \multicolumn{2}{|c|}{ Potasio (ppm) } & 83 & & & \\
\hline \multicolumn{2}{|c|}{ Magnesio (ppm) } & 54 & & & \\
\hline \multicolumn{2}{|l|}{$\mathrm{Ca} / \mathrm{Mg}$} & 2.28 & & & \\
\hline \multicolumn{2}{|c|}{ Sodio (ppm) } & 33 & & & \\
\hline \multicolumn{2}{|c|}{ C.I.C. Meq/100g } & 9 & & & \\
\hline \multicolumn{2}{|c|}{ Manganeso (ppm) } & 15 & & & \\
\hline \multicolumn{2}{|c|}{ Hierro (ppm) } & 1.2 & & & \\
\hline \multicolumn{2}{|c|}{ Cobre (ppm) } & 0.7 & & & \\
\hline \multicolumn{2}{|l|}{ Zinc (ppm) } & 0.4 & & & \\
\hline \multicolumn{2}{|l|}{ Boro (ppm) } & 0.03 & & & \\
\hline \multicolumn{2}{|c|}{ Conductividad (dS/m) } & 0.9 & & & \\
\hline \multicolumn{2}{|c|}{ Observaciones } & & & & \\
\hline
\end{tabular}


ANÁLISIS DE COMPOSICIÓN DE SUELOS

Desarrollo de una aplicación informática para el cálculo de sostenimiento de taludes mediante vegetación

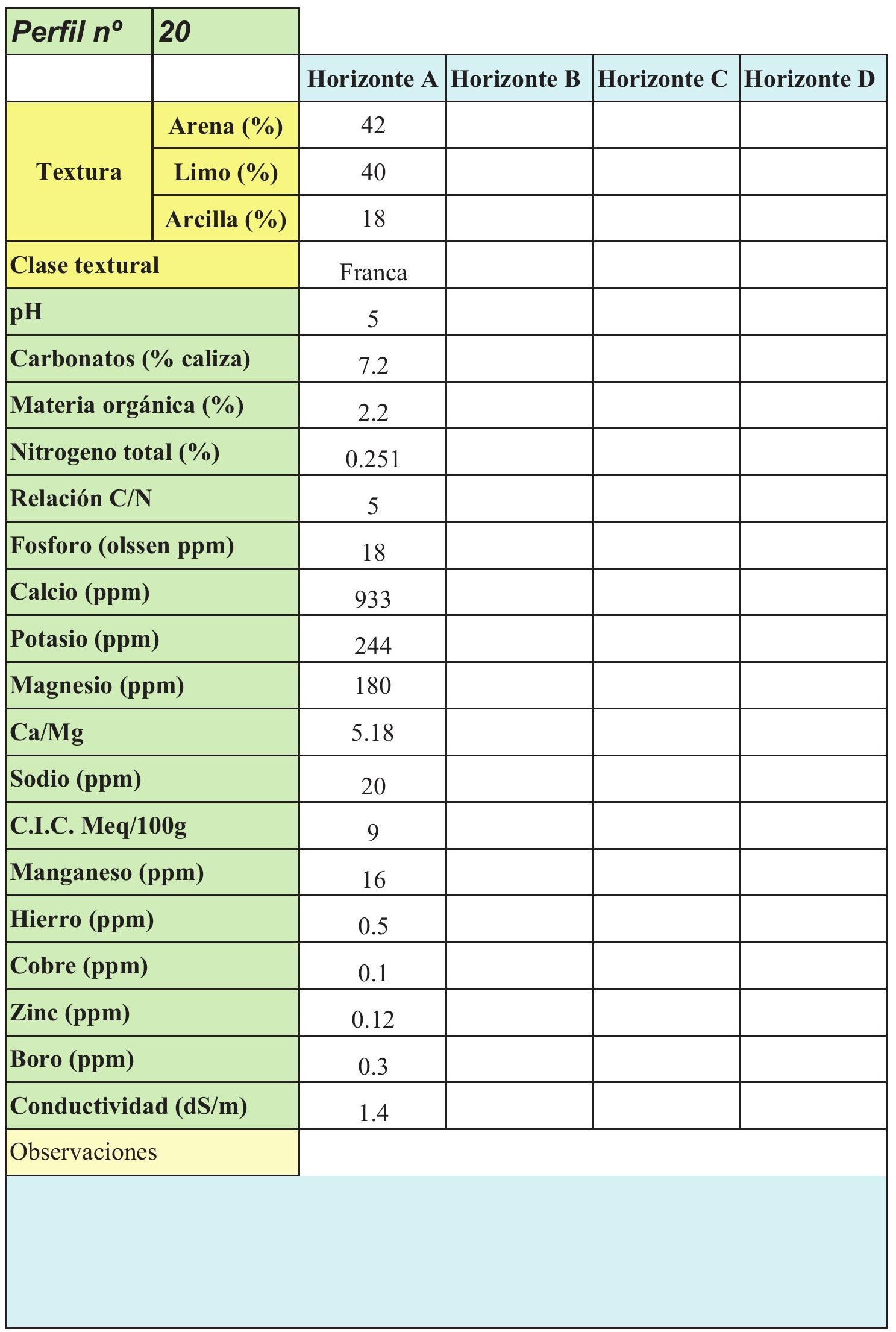


ANÁLISIS DE COMPOSICIÓN DE SUELOS

Desarrollo de una aplicación informática para el cálculo de sostenimiento de taludes mediante vegetación

\begin{tabular}{|c|c|c|c|c|c|}
\hline \multirow[t]{2}{*}{ Perfil $n^{\circ}$} & \multirow[t]{2}{*}{21} & & & & \\
\hline & & Horizonte A & Horizonte B & Horizonte C & Horizonte D \\
\hline \multirow{3}{*}{ Textura } & Arena (\%) & 39 & 42 & 63 & \\
\hline & Limo (\%) & 37 & 40 & 19 & \\
\hline & Arcilla (\%) & 24 & 18 & 18 & \\
\hline \multicolumn{2}{|c|}{ Clase textural } & Franca & Franca & Fran-Are-Arc & \\
\hline \multicolumn{2}{|l|}{ pH } & 5.1 & 5 & 4.09 & \\
\hline \multicolumn{2}{|c|}{ Carbonatos (\% caliza) } & 19 & 7.2 & ---- & \\
\hline \multicolumn{2}{|c|}{ Materia orgánica (\%) } & 3.2 & 2.2 & ---- & \\
\hline \multicolumn{2}{|c|}{ Nitrogeno total (\%) } & 1.5 & 0.251 & ---- & \\
\hline \multicolumn{2}{|c|}{ Relación C/N } & 15 & 5 & ---- & \\
\hline \multicolumn{2}{|c|}{ Fosforo (olssen ppm) } & 27 & 18 & 9 & \\
\hline \multicolumn{2}{|c|}{ Calcio (ppm) } & 281 & 933 & 1111 & \\
\hline \multicolumn{2}{|c|}{ Potasio (ppm) } & 354 & 244 & 135 & \\
\hline \multicolumn{2}{|c|}{ Magnesio (ppm) } & 80 & 180 & 92 & \\
\hline \multicolumn{2}{|l|}{$\mathrm{Ca} / \mathrm{Mg}$} & 3.513 & 5.18 & 12.08 & \\
\hline \multicolumn{2}{|c|}{ Sodio (ppm) } & 32 & 20 & 30 & \\
\hline \multicolumn{2}{|c|}{ C.I.C. Meq/100g } & 10.5 & 9 & 8 & \\
\hline \multicolumn{2}{|c|}{ Manganeso (ppm) } & 26 & 16 & 21 & \\
\hline \multicolumn{2}{|c|}{ Hierro (ppm) } & 0.6 & 0.5 & 0.8 & \\
\hline \multicolumn{2}{|c|}{ Cobre (ppm) } & 0.03 & 0.1 & 0.02 & \\
\hline \multicolumn{2}{|l|}{ Zinc (ppm) } & 0.3 & 0.12 & 0.09 & \\
\hline \multicolumn{2}{|l|}{ Boro (ppm) } & 1.1 & 0.3 & 0.2 & \\
\hline \multicolumn{2}{|c|}{ Conductividad (dS/m) } & 1.1 & 1.4 & 2.1 & \\
\hline \multicolumn{2}{|c|}{ Observaciones } & & & & \\
\hline
\end{tabular}


ANÁLISIS DE COMPOSICIÓN DE SUELOS

Desarrollo de una aplicación informática para el cálculo de sostenimiento de taludes mediante vegetación

\begin{tabular}{|c|c|c|c|c|c|}
\hline \multirow[t]{2}{*}{ Perfil $n^{\circ}$} & \multirow[t]{2}{*}{22} & & & & \\
\hline & & Horizonte A & Horizonte B & Horizonte C & Horizonte D \\
\hline \multirow{3}{*}{ Textura } & Arena (\%) & 25 & 41 & 23 & \\
\hline & Limo (\%) & 66 & 37 & 37 & \\
\hline & Arcilla (\%) & 9 & 22 & 40 & \\
\hline \multicolumn{2}{|c|}{ Clase textural } & Franc-Lim & Franca & Fran-Are-Arc & \\
\hline \multicolumn{2}{|l|}{ pH } & 6.2 & 5.3 & 4.09 & \\
\hline \multicolumn{2}{|c|}{ Carbonatos ( $\%$ caliza) } & 5.8 & 6.5 & ---- & \\
\hline \multicolumn{2}{|c|}{ Materia orgánica (\%) } & 2.8 & 0.84 & ---- & \\
\hline \multicolumn{2}{|c|}{ Nitrogeno total (\%) } & 0.25 & 0.2 & ---- & \\
\hline \multicolumn{2}{|c|}{ Relación C/N } & 13 & 6 & ---- & \\
\hline \multicolumn{2}{|c|}{ Fosforo (olssen ppm) } & 19 & 15 & 5 & \\
\hline \multicolumn{2}{|c|}{ Calcio (ppm) } & 958 & 758 & 598 & \\
\hline \multicolumn{2}{|c|}{ Potasio (ppm) } & 182 & 154 & 135 & \\
\hline \multicolumn{2}{|c|}{ Magnesio (ppm) } & 98 & 58 & 92 & \\
\hline \multicolumn{2}{|l|}{$\mathrm{Ca} / \mathrm{Mg}$} & 1.857 & 2.655 & 6.50 & \\
\hline \multicolumn{2}{|c|}{ Sodio (ppm) } & 36 & 21 & 19 & \\
\hline \multicolumn{2}{|c|}{ C.I.C. Meq/100g } & 15 & 17 & 8 & \\
\hline \multicolumn{2}{|c|}{ Manganeso (ppm) } & 17 & 18 & 21 & \\
\hline \multicolumn{2}{|c|}{ Hierro (ppm) } & 0.5 & 0.6 & 0.8 & \\
\hline \multicolumn{2}{|c|}{ Cobre (ppm) } & 0.25 & 0.4 & 0.02 & \\
\hline \multicolumn{2}{|l|}{ Zinc (ppm) } & 0.15 & 0.14 & 0.09 & \\
\hline \multicolumn{2}{|l|}{ Boro (ppm) } & 0.7 & 0.5 & 0.2 & \\
\hline \multicolumn{2}{|c|}{ Conductividad (dS/m) } & 1.1 & 1.4 & 2.1 & \\
\hline \multicolumn{2}{|c|}{ Observaciones } & & & & \\
\hline
\end{tabular}


ANÁLISIS DE COMPOSICIÓN DE SUELOS

Desarrollo de una aplicación informática para el cálculo de sostenimiento de taludes mediante vegetación

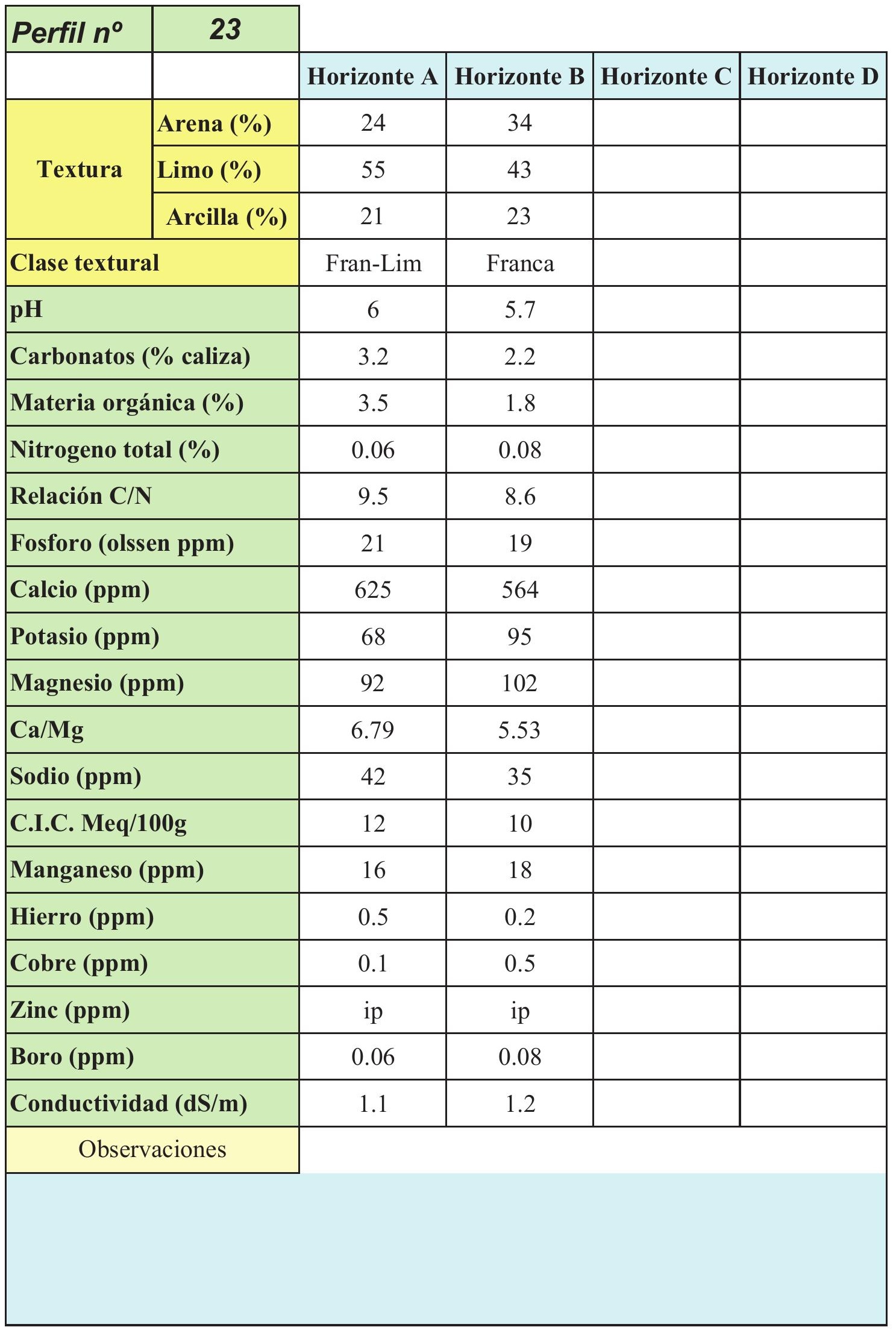


ANÁLISIS DE COMPOSICIÓN DE SUELOS

Desarrollo de una aplicación informática para el cálculo de sostenimiento de taludes mediante vegetación

\begin{tabular}{|c|c|c|c|c|c|}
\hline \multirow[t]{2}{*}{ Perfil $n^{\circ}$} & \multirow[t]{2}{*}{24} & & & & \\
\hline & & Horizonte A & Horizonte B & Horizonte C & Horizonte D \\
\hline \multirow{3}{*}{ Textura } & Arena (\%) & 46 & 38 & 41 & \\
\hline & Limo (\%) & 33 & 42 & 44 & \\
\hline & Arcilla (\%) & 21 & 20 & 15 & \\
\hline \multicolumn{2}{|c|}{ Clase textural } & Franca & Franca & Franca & \\
\hline \multicolumn{2}{|l|}{ pH } & 6.5 & 5 & 5 & \\
\hline \multicolumn{2}{|c|}{ Carbonatos (\% caliza) } & 7.3 & 15 & --- & \\
\hline \multicolumn{2}{|c|}{ Materia orgánica (\%) } & 2.8 & 1.5 & --- & \\
\hline \multicolumn{2}{|c|}{ Nitrogeno total (\%) } & 0.9 & 0.076 & --- & \\
\hline \multicolumn{2}{|c|}{ Relación C/N } & 10 & 11.2 & --- & \\
\hline \multicolumn{2}{|c|}{ Fosforo (olssen ppm) } & 9 & 29 & 22 & \\
\hline \multicolumn{2}{|c|}{ Calcio (ppm) } & 795 & 222 & 255 & \\
\hline \multicolumn{2}{|c|}{ Potasio (ppm) } & 135 & 29.3 & 32 & \\
\hline \multicolumn{2}{|c|}{ Magnesio (ppm) } & 98 & 49 & 125 & \\
\hline \multicolumn{2}{|l|}{$\mathrm{Ca} / \mathrm{Mg}$} & 8.11 & 4.53 & 2.04 & \\
\hline \multicolumn{2}{|c|}{ Sodio (ppm) } & 26 & 30 & 20 & \\
\hline \multicolumn{2}{|c|}{ C.I.C. Meq/100g } & 10 & 10 & 7 & \\
\hline \multicolumn{2}{|c|}{ Manganeso (ppm) } & 0.5 & 10 & 8 & \\
\hline \multicolumn{2}{|c|}{ Hierro (ppm) } & 1.2 & 0.9 & 1 & \\
\hline \multicolumn{2}{|c|}{ Cobre (ppm) } & 0.9 & 0.04 & 0.3 & \\
\hline \multicolumn{2}{|l|}{ Zinc (ppm) } & 0.8 & 0.1 & 0.3 & \\
\hline \multicolumn{2}{|l|}{ Boro (ppm) } & 0.35 & 0.7 & 0.2 & \\
\hline \multicolumn{2}{|c|}{ Conductividad (dS/m) } & 0.03 & 0.7 & 0.3 & \\
\hline \multicolumn{2}{|c|}{ Observaciones } & & & & \\
\hline
\end{tabular}


ANÁLISIS DE COMPOSICIÓN DE SUELOS

Desarrollo de una aplicación informática para el cálculo de sostenimiento de taludes mediante vegetación

\begin{tabular}{|c|c|c|c|c|c|}
\hline \multirow[t]{2}{*}{ Perfil $n^{\circ}$} & \multirow[t]{2}{*}{25} & & & & \\
\hline & & Horizonte A & Horizonte B & Horizonte $\mathrm{C}$ & Horizonte D \\
\hline \multirow{3}{*}{ Textura } & Arena (\%) & 25 & 33 & 54 & \\
\hline & Limo (\%) & 66 & 44 & 33 & \\
\hline & Arcilla (\%) & 9 & 23 & 13 & \\
\hline \multicolumn{2}{|c|}{ Clase textural } & Fran-Lim & Franca & Fran-Aren & \\
\hline \multicolumn{2}{|l|}{ pH } & 5.6 & 5.9 & 6 & \\
\hline \multicolumn{2}{|c|}{ Carbonatos (\% caliza) } & 12 & 10 & 0.6 & \\
\hline \multicolumn{2}{|c|}{ Materia orgánica (\%) } & 3.2 & 2.5 & 0.6 & \\
\hline \multicolumn{2}{|c|}{ Nitrogeno total $(\%)$} & 0.39 & 0.5 & 0.02 & \\
\hline \multicolumn{2}{|c|}{ Relación C/N } & 3 & 10 & 9 & \\
\hline \multicolumn{2}{|c|}{ Fosforo (olssen ppm) } & 15 & 13 & 14 & \\
\hline \multicolumn{2}{|c|}{ Calcio (ppm) } & 930 & 852 & 705 & \\
\hline \multicolumn{2}{|c|}{ Magnesio (ppm) } & 235 & 203 & 88 & \\
\hline \multicolumn{2}{|l|}{$\mathrm{Ca} / \mathrm{Mg}$} & 3.96 & 4.20 & 8.01 & \\
\hline \multicolumn{2}{|c|}{ Potasio (ppm) } & 220 & 175 & 136 & \\
\hline \multicolumn{2}{|c|}{ Sodio (ppm) } & 23 & 33 & 44 & \\
\hline \multicolumn{2}{|c|}{ C.I.C. Meq/100g } & 13 & 11 & 9 & \\
\hline \multicolumn{2}{|c|}{ Manganeso (ppm) } & 15 & 16 & 22 & \\
\hline \multicolumn{2}{|c|}{ Hierro (ppm) } & 0.2 & 0.9 & 2.3 & \\
\hline \multicolumn{2}{|c|}{ Cobre (ppm) } & 0.1 & 0.3 & 0.2 & \\
\hline \multicolumn{2}{|l|}{ Zinc (ppm) } & 1.5 & 1.3 & 1.2 & \\
\hline \multicolumn{2}{|l|}{ Boro (ppm) } & ip & ip & ip & \\
\hline \multicolumn{2}{|c|}{ Conductividad (dS/m) } & 1.1 & 0.9 & 0.78 & \\
\hline \multicolumn{2}{|c|}{ Observaciones } & & & & \\
\hline
\end{tabular}


ANÁLISIS DE COMPOSICIÓN DE SUELOS

Desarrollo de una aplicación informática para el cálculo de sostenimiento de taludes mediante vegetación

\begin{tabular}{|c|c|c|c|c|c|}
\hline \multirow[t]{2}{*}{ Perfil $n^{\circ}$} & \multirow[t]{2}{*}{26} & & & & \\
\hline & & Horizonte A & Horizonte B & Horizonte $\mathrm{C}$ & Horizonte D \\
\hline \multirow{3}{*}{ Textura } & Arena (\%) & 55 & & & \\
\hline & Limo (\%) & 25 & & & \\
\hline & Arcilla (\%) & 20 & & & \\
\hline \multicolumn{2}{|c|}{ Clase textural } & Fran-Aren & & & \\
\hline \multicolumn{2}{|l|}{ pH } & 5.4 & & & \\
\hline \multicolumn{2}{|c|}{ Carbonatos ( $\%$ caliza) } & 0.9 & & & \\
\hline \multicolumn{2}{|c|}{ Materia orgánica (\%) } & 3.2 & & & \\
\hline \multicolumn{2}{|c|}{ Nitrogeno total (\%) } & 0.02 & & & \\
\hline \multicolumn{2}{|c|}{ Relación C/N } & 3 & & & \\
\hline \multicolumn{2}{|c|}{ Fosforo (olssen ppm) } & 7 & & & \\
\hline \multicolumn{2}{|c|}{ Calcio (ppm) } & 88 & & & \\
\hline \multicolumn{2}{|c|}{ Potasio (ppm) } & 83 & & & \\
\hline \multicolumn{2}{|c|}{ Magnesio (ppm) } & 73 & & & \\
\hline \multicolumn{2}{|l|}{$\mathrm{Ca} / \mathrm{Mg}$} & 1.21 & & & \\
\hline \multicolumn{2}{|c|}{ Sodio (ppm) } & 11 & & & \\
\hline \multicolumn{2}{|c|}{ C.I.C. Meq/100g } & 6 & & & \\
\hline \multicolumn{2}{|c|}{ Manganeso (ppm) } & ip & & & \\
\hline \multicolumn{2}{|c|}{ Hierro (ppm) } & ip & & & \\
\hline \multicolumn{2}{|c|}{ Cobre (ppm) } & ip & & & \\
\hline \multicolumn{2}{|l|}{ Zinc (ppm) } & ip & & & \\
\hline \multicolumn{2}{|l|}{ Boro (ppm) } & ip & & & \\
\hline \multicolumn{2}{|c|}{ Conductividad (dS/m) } & 1.05 & & & \\
\hline \multicolumn{2}{|c|}{ Observaciones } & & & & \\
\hline
\end{tabular}


ANÁLISIS DE COMPOSICIÓN DE SUELOS

Desarrollo de una aplicación informática para el cálculo de sostenimiento de taludes mediante vegetación

\begin{tabular}{|c|c|c|c|c|c|}
\hline \multirow[t]{2}{*}{ Perfil $n^{\circ}$} & \multirow[t]{2}{*}{27} & \multirow[b]{2}{*}{ Horizonte A } & \multirow[b]{2}{*}{ Horizonte B } & \multirow[b]{2}{*}{ Horizonte C } & \multirow[b]{2}{*}{ Horizonte D } \\
\hline & & & & & \\
\hline \multirow{3}{*}{ Textura } & Arena (\%) & 44 & 61 & & \\
\hline & Limo (\%) & 33 & 27 & & \\
\hline & Arcilla (\%) & 23 & 12 & & \\
\hline \multicolumn{2}{|c|}{ Clase textural } & Franca & fran-Aren & & \\
\hline \multicolumn{2}{|l|}{ pH } & 6.2 & 5.9 & & \\
\hline \multicolumn{2}{|c|}{ Carbonatos ( $\%$ caliza) } & 1.1 & 1.3 & & \\
\hline \multicolumn{2}{|c|}{ Materia orgánica (\%) } & 4.3 & 2.1 & & \\
\hline \multicolumn{2}{|c|}{ Nitrogeno total (\%) } & 0.35 & 0.44 & & \\
\hline \multicolumn{2}{|c|}{ Relación C/N } & 4 & 3 & & \\
\hline \multicolumn{2}{|c|}{ Fosforo (olssen ppm) } & 8 & 9 & & \\
\hline \multicolumn{2}{|c|}{ Calcio (ppm) } & 90 & 102 & & \\
\hline \multicolumn{2}{|c|}{ Potasio (ppm) } & 30 & 44 & & \\
\hline \multicolumn{2}{|c|}{ Magnesio (ppm) } & 27 & 33 & & \\
\hline \multicolumn{2}{|l|}{$\mathrm{Ca} / \mathrm{Mg}$} & 3.33 & 3.09 & & \\
\hline \multicolumn{2}{|c|}{ Sodio (ppm) } & 5 & 6 & & \\
\hline \multicolumn{2}{|c|}{ C.I.C. Meq/100g } & 3 & 4 & & \\
\hline \multicolumn{2}{|c|}{ Manganeso (ppm) } & ip & ip & & \\
\hline \multicolumn{2}{|c|}{ Hierro (ppm) } & ip & ip & & \\
\hline \multicolumn{2}{|c|}{ Cobre (ppm) } & ip & ip & & \\
\hline \multicolumn{2}{|l|}{ Zinc (ppm) } & ip & ip & & \\
\hline \multicolumn{2}{|l|}{ Boro (ppm) } & ip & ip & & \\
\hline \multicolumn{2}{|c|}{ Conductividad (dS/m) } & 0.9 & 0.7 & & \\
\hline \multicolumn{2}{|c|}{ Observaciones } & & & & \\
\hline
\end{tabular}


ANÁLISIS DE COMPOSICIÓN DE SUELOS

Desarrollo de una aplicación informática para el cálculo de sostenimiento de taludes mediante vegetación

\begin{tabular}{|c|c|c|c|c|c|}
\hline \multirow[t]{2}{*}{ Perfil $n^{\circ}$} & \multirow[t]{2}{*}{28} & & & & \\
\hline & & Horizonte A & Horizonte B & Horizonte C & Horizonte D \\
\hline \multirow{3}{*}{ Textura } & Arena (\%) & 25 & 27 & 38 & \\
\hline & Limo (\%) & 66 & 57 & 41 & \\
\hline & Arcilla (\%) & 7 & 5 & 59 & \\
\hline \multicolumn{2}{|c|}{ Clase textural } & Fran-Lim & Fran-Lim & Franca & \\
\hline \multicolumn{2}{|l|}{ pH } & 6.1 & 5.8 & 5.2 & \\
\hline \multicolumn{2}{|c|}{ Carbonatos (\% caliza) } & 10 & 8 & 1 & \\
\hline \multicolumn{2}{|c|}{ Materia orgánica (\%) } & 3.2 & 1.1 & ---- & \\
\hline \multicolumn{2}{|c|}{ Nitrogeno total (\%) } & 0.29 & 0.15 & 0.7 & \\
\hline \multicolumn{2}{|c|}{ Relación C/N } & 20 & 10 & ----- & \\
\hline \multicolumn{2}{|c|}{ Fosforo (olssen ppm) } & 32 & 25 & 12 & \\
\hline \multicolumn{2}{|c|}{ Calcio (ppm) } & 1025 & 821 & 935 & \\
\hline \multicolumn{2}{|c|}{ Potasio (ppm) } & 265 & 168 & 154 & \\
\hline \multicolumn{2}{|c|}{ Magnesio (ppm) } & 220 & 156 & 89 & \\
\hline \multicolumn{2}{|l|}{$\mathrm{Ca} / \mathrm{Mg}$} & 4.66 & 5.26 & 10.51 & \\
\hline \multicolumn{2}{|c|}{ Sodio (ppm) } & 24 & 12 & 16 & \\
\hline \multicolumn{2}{|c|}{ C.I.C. Meq/100g } & 26 & 14 & 2 & \\
\hline \multicolumn{2}{|c|}{ Manganeso (ppm) } & 31 & 28 & 26 & \\
\hline \multicolumn{2}{|c|}{ Hierro (ppm) } & 0.8 & 0.6 & 0.9 & \\
\hline \multicolumn{2}{|c|}{ Cobre (ppm) } & 0.2 & 0.6 & 0.4 & \\
\hline \multicolumn{2}{|l|}{ Zinc (ppm) } & ip & ip & ip & \\
\hline \multicolumn{2}{|l|}{ Boro (ppm) } & 0.9 & 0.5 & 0.7 & \\
\hline \multicolumn{2}{|c|}{ Conductividad (dS/m) } & 1.1 & 0.9 & 1.3 & \\
\hline \multicolumn{2}{|c|}{ Observaciones } & & & & \\
\hline
\end{tabular}


ANÁLISIS DE COMPOSICIÓN DE SUELOS

Desarrollo de una aplicación informática para el cálculo de sostenimiento de taludes mediante vegetación

\begin{tabular}{|c|c|c|c|c|c|}
\hline \multirow[t]{2}{*}{ Perfil $n^{\circ}$} & \multirow[t]{2}{*}{29} & & & & \\
\hline & & Horizonte A & Horizonte B & Horizonte $\mathrm{C}$ & Horizonte D \\
\hline \multirow{3}{*}{ Textura } & Arena (\%) & 49 & & & \\
\hline & Limo (\%) & 31 & & & \\
\hline & Arcilla (\%) & 20 & & & \\
\hline \multicolumn{2}{|c|}{ Clase textural } & Franca & & & \\
\hline \multicolumn{2}{|l|}{ pH } & 5.6 & & & \\
\hline \multicolumn{2}{|c|}{ Carbonatos ( $\%$ caliza) } & 3 & & & \\
\hline \multicolumn{2}{|c|}{ Materia orgánica (\%) } & 1.9 & & & \\
\hline \multicolumn{2}{|c|}{ Nitrogeno total (\%) } & 0.05 & & & \\
\hline \multicolumn{2}{|c|}{ Relación C/N } & 6 & & & \\
\hline \multicolumn{2}{|c|}{ Fosforo (olssen ppm) } & 29 & & & \\
\hline \multicolumn{2}{|c|}{ Calcio (ppm) } & 258 & & & \\
\hline \multicolumn{2}{|c|}{ Potasio (ppm) } & 69 & & & \\
\hline \multicolumn{2}{|c|}{ Magnesio (ppm) } & 42 & & & \\
\hline \multicolumn{2}{|l|}{$\mathrm{Ca} / \mathrm{Mg}$} & 6.14 & & & \\
\hline \multicolumn{2}{|c|}{ Sodio (ppm) } & 13 & & & \\
\hline \multicolumn{2}{|c|}{ C.I.C. Meq/100g } & 3 & & & \\
\hline \multicolumn{2}{|c|}{ Manganeso (ppm) } & ip & & & \\
\hline \multicolumn{2}{|c|}{ Hierro (ppm) } & ip & & & \\
\hline \multicolumn{2}{|c|}{ Cobre (ppm) } & ip & & & \\
\hline \multicolumn{2}{|l|}{ Zinc (ppm) } & ip & & & \\
\hline \multicolumn{2}{|l|}{ Boro (ppm) } & ip & & & \\
\hline \multicolumn{2}{|c|}{ Conductividad (dS/m) } & 0.6 & & & \\
\hline \multicolumn{2}{|c|}{ Observaciones } & & & & \\
\hline
\end{tabular}


ANÁLISIS DE COMPOSICIÓN DE SUELOS

Desarrollo de una aplicación informática para el cálculo de sostenimiento de taludes mediante vegetación

\begin{tabular}{|c|c|c|c|c|c|}
\hline \multirow[t]{2}{*}{ Perfil $n^{\circ}$} & \multirow[t]{2}{*}{30} & & & & \\
\hline & & Horizonte A & Horizonte B & Horizonte $\mathrm{C}$ & Horizonte D \\
\hline \multirow{3}{*}{ Textura } & Arena (\%) & 56 & & & \\
\hline & Limo (\%) & 24 & & & \\
\hline & Arcilla (\%) & 20 & & & \\
\hline \multicolumn{2}{|c|}{ Clase textural } & Fran-Aren & & & \\
\hline \multicolumn{2}{|l|}{ pH } & 4.9 & & & \\
\hline \multicolumn{2}{|c|}{ Carbonatos ( $\%$ caliza) } & 1.2 & & & \\
\hline \multicolumn{2}{|c|}{ Materia orgánica (\%) } & 8.1 & & & \\
\hline \multicolumn{2}{|c|}{ Nitrogeno total (\%) } & 0.06 & & & \\
\hline \multicolumn{2}{|c|}{ Relación C/N } & 18 & & & \\
\hline \multicolumn{2}{|c|}{ Fosforo (olssen ppm) } & 6 & & & \\
\hline \multicolumn{2}{|c|}{ Calcio (ppm) } & 125 & & & \\
\hline \multicolumn{2}{|c|}{ Potasio (ppm) } & 69 & & & \\
\hline \multicolumn{2}{|c|}{ Magnesio (ppm) } & 20 & & & \\
\hline \multicolumn{2}{|l|}{$\mathrm{Ca} / \mathrm{Mg}$} & 6.25 & & & \\
\hline \multicolumn{2}{|c|}{ Sodio (ppm) } & 11 & & & \\
\hline \multicolumn{2}{|c|}{ C.I.C. Meq/100g } & 7 & & & \\
\hline \multicolumn{2}{|c|}{ Manganeso (ppm) } & ip & & & \\
\hline \multicolumn{2}{|c|}{ Hierro (ppm) } & ip & & & \\
\hline \multicolumn{2}{|c|}{ Cobre (ppm) } & ip & & & \\
\hline \multicolumn{2}{|l|}{ Zinc (ppm) } & ip & & & \\
\hline \multicolumn{2}{|l|}{ Boro (ppm) } & ip & & & \\
\hline \multicolumn{2}{|c|}{ Conductividad (dS/m) } & 0.67 & & & \\
\hline \multicolumn{2}{|c|}{ Observaciones } & & & & \\
\hline
\end{tabular}


ANÁLISIS DE COMPOSICIÓN DE SUELOS

Desarrollo de una aplicación informática para el cálculo de sostenimiento de taludes mediante vegetación

\begin{tabular}{|c|c|c|c|c|c|}
\hline \multirow[t]{2}{*}{ Perfil $n^{\circ}$} & \multirow[t]{2}{*}{31} & & & & \\
\hline & & Horizonte A & Horizonte B & Horizonte C & Horizonte D \\
\hline \multirow{3}{*}{ Textura } & Arena (\%) & 38 & & & \\
\hline & Limo (\%) & 38 & & & \\
\hline & Arcilla (\%) & 24 & & & \\
\hline \multicolumn{2}{|c|}{ Clase textural } & Franca & & & \\
\hline \multicolumn{2}{|l|}{ pH } & 5.5 & & & \\
\hline \multicolumn{2}{|c|}{ Carbonatos ( $\%$ caliza) } & 3.2 & & & \\
\hline \multicolumn{2}{|c|}{ Materia orgánica (\%) } & 3.7 & & & \\
\hline \multicolumn{2}{|c|}{ Nitrogeno total (\%) } & 0.12 & & & \\
\hline \multicolumn{2}{|c|}{ Relación C/N } & 8 & & & \\
\hline \multicolumn{2}{|c|}{ Fosforo (olssen ppm) } & 19 & & & \\
\hline \multicolumn{2}{|c|}{ Calcio (ppm) } & 365 & & & \\
\hline \multicolumn{2}{|c|}{ Potasio (ppm) } & 69 & & & \\
\hline \multicolumn{2}{|c|}{ Magnesio (ppm) } & 59 & & & \\
\hline \multicolumn{2}{|l|}{$\mathrm{Ca} / \mathrm{Mg}$} & 6.186 & & & \\
\hline \multicolumn{2}{|c|}{ Sodio (ppm) } & 15 & & & \\
\hline \multicolumn{2}{|c|}{ C.I.C. Meq/100g } & 4 & & & \\
\hline \multicolumn{2}{|c|}{ Manganeso (ppm) } & ip & & & \\
\hline \multicolumn{2}{|c|}{ Hierro (ppm) } & ip & & & \\
\hline \multicolumn{2}{|c|}{ Cobre (ppm) } & ip & & & \\
\hline \multicolumn{2}{|l|}{ Zinc (ppm) } & ip & & & \\
\hline \multicolumn{2}{|l|}{ Boro (ppm) } & ip & & & \\
\hline \multicolumn{2}{|c|}{ Conductividad (dS/m) } & 0.09 & & & \\
\hline \multicolumn{2}{|c|}{ Observaciones } & & & & \\
\hline
\end{tabular}


ANÁLISIS DE COMPOSICIÓN DE SUELOS

Desarrollo de una aplicación informática para el cálculo de sostenimiento de taludes mediante vegetación

\begin{tabular}{|c|c|c|c|c|c|}
\hline \multirow[t]{2}{*}{ Perfil $n^{\circ}$} & \multirow[t]{2}{*}{32} & & & & \\
\hline & & Horizonte A & Horizonte B & Horizonte C & Horizonte D \\
\hline \multirow{3}{*}{ Textura } & Arena (\%) & 32 & & & \\
\hline & Limo (\%) & 44 & & & \\
\hline & Arcilla (\%) & 24 & & & \\
\hline \multicolumn{2}{|c|}{ Clase textural } & Franca & & & \\
\hline \multicolumn{2}{|l|}{ pH } & 5.3 & & & \\
\hline \multicolumn{2}{|c|}{ Carbonatos (\% caliza) } & ip & & & \\
\hline \multicolumn{2}{|c|}{ Materia orgánica (\%) } & 0.9 & & & \\
\hline \multicolumn{2}{|c|}{ Nitrogeno total $(\%)$} & 0.026 & & & \\
\hline \multicolumn{2}{|c|}{ Relación C/N } & 20 & & & \\
\hline \multicolumn{2}{|c|}{ Fosforo (olssen ppm) } & 15 & & & \\
\hline \multicolumn{2}{|c|}{ Calcio (ppm) } & 235 & & & \\
\hline \multicolumn{2}{|c|}{ Potasio (ppm) } & 90 & & & \\
\hline \multicolumn{2}{|c|}{ Magnesio (ppm) } & 98 & & & \\
\hline \multicolumn{2}{|l|}{$\mathrm{Ca} / \mathrm{Mg}$} & 2.40 & & & \\
\hline \multicolumn{2}{|c|}{ Sodio (ppm) } & 0.8 & & & \\
\hline \multicolumn{2}{|c|}{ C.I.C. Meq/100g } & 6.54 & & & \\
\hline \multicolumn{2}{|c|}{ Manganeso (ppm) } & 20 & & & \\
\hline \multicolumn{2}{|c|}{ Hierro (ppm) } & 5 & & & \\
\hline \multicolumn{2}{|c|}{ Cobre (ppm) } & 2 & & & \\
\hline \multicolumn{2}{|l|}{ Zinc (ppm) } & 3.1 & & & \\
\hline \multicolumn{2}{|l|}{ Boro (ppm) } & 0.8 & & & \\
\hline \multicolumn{2}{|c|}{ Conductividad (dS/m) } & 1.5 & & & \\
\hline \multicolumn{2}{|c|}{ Observaciones } & & & & \\
\hline
\end{tabular}


ANÁLISIS DE COMPOSICIÓN DE SUELOS

Desarrollo de una aplicación informática para el cálculo de sostenimiento de taludes mediante vegetación

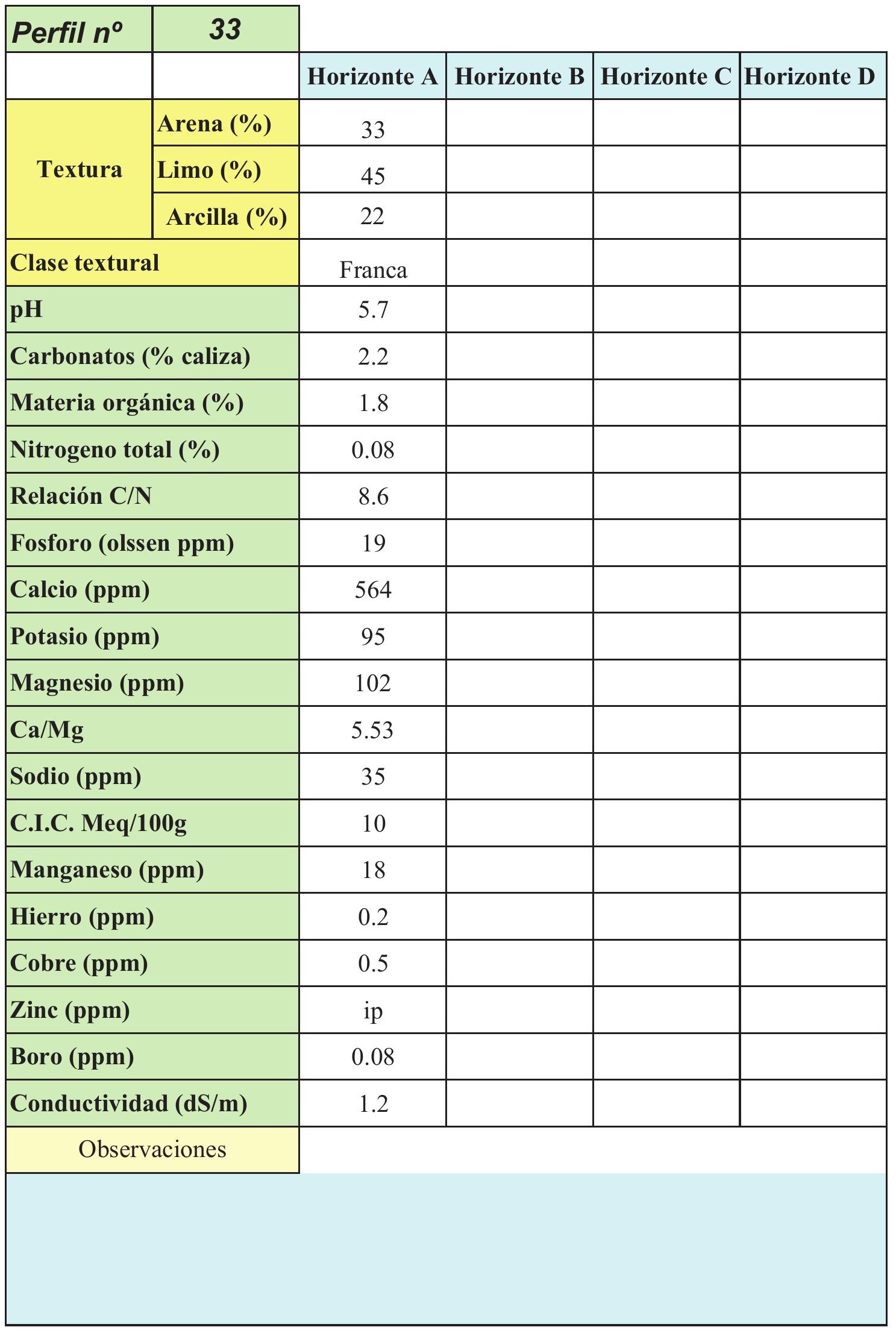


ANÁLISIS DE COMPOSICIÓN DE SUELOS

Desarrollo de una aplicación informática para el cálculo de sostenimiento de taludes mediante vegetación

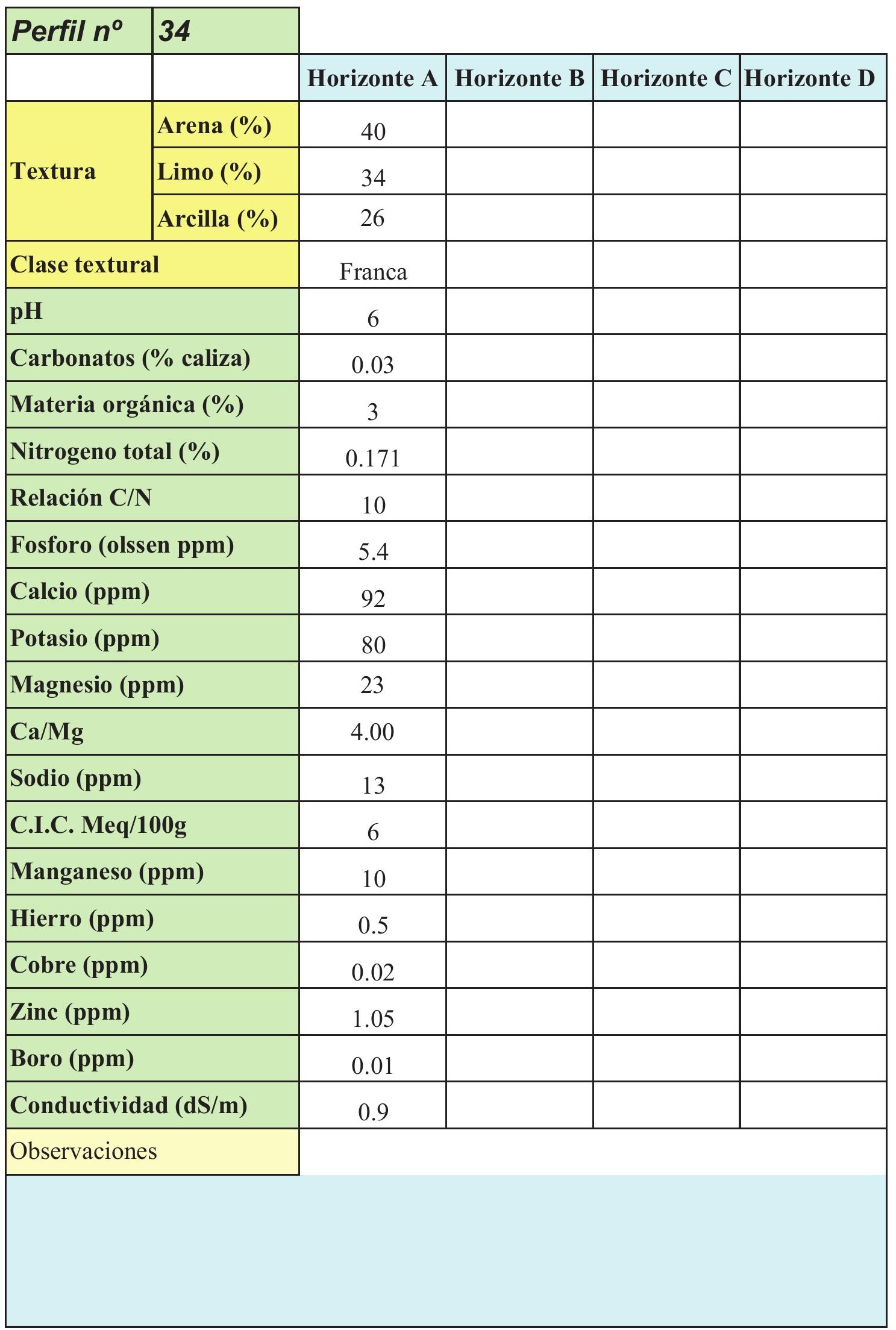




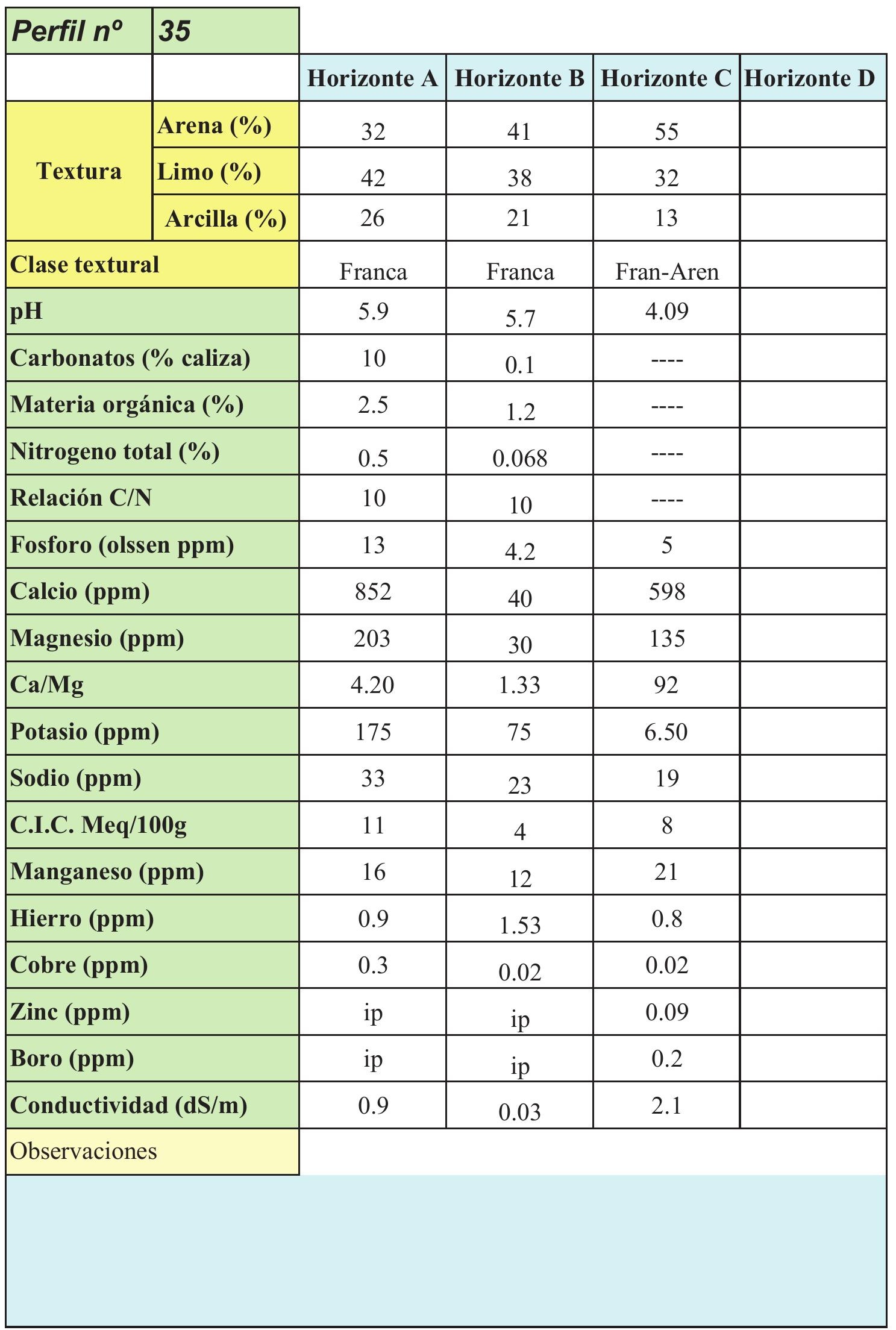


ANÁLISIS DE COMPOSICIÓN DE SUELOS

Desarrollo de una aplicación informática para el cálculo de sostenimiento de taludes mediante vegetación

\begin{tabular}{|c|c|c|c|c|c|}
\hline \multirow[t]{2}{*}{ Perfil $n^{\circ}$} & \multirow[t]{2}{*}{36} & \multirow[b]{2}{*}{ Horizonte A } & \multirow[b]{2}{*}{ Horizonte B } & \multirow[b]{2}{*}{ Horizonte C } & \multirow[b]{2}{*}{ Horizonte D } \\
\hline & & & & & \\
\hline \multirow{3}{*}{ Textura } & Arena (\%) & 39 & & & \\
\hline & Limo (\%) & 35 & & & \\
\hline & Arcilla (\%) & 26 & & & \\
\hline \multicolumn{2}{|c|}{ Clase textural } & Franca & & & \\
\hline \multicolumn{2}{|l|}{ pH } & 5.9 & & & \\
\hline \multicolumn{2}{|c|}{ Carbonatos ( $\%$ caliza) } & 10 & & & \\
\hline \multicolumn{2}{|c|}{ Materia orgánica (\%) } & 2.5 & & & \\
\hline \multicolumn{2}{|c|}{ Nitrogeno total (\%) } & 0.5 & & & \\
\hline \multicolumn{2}{|c|}{ Relación C/N } & 10 & & & \\
\hline \multicolumn{2}{|c|}{ Fosforo (olssen ppm) } & 13 & & & \\
\hline \multicolumn{2}{|c|}{ Calcio (ppm) } & 852 & & & \\
\hline \multicolumn{2}{|c|}{ Potasio (ppm) } & 203 & & & \\
\hline \multicolumn{2}{|c|}{ Magnesio (ppm) } & 4.20 & & & \\
\hline \multicolumn{2}{|l|}{$\mathrm{Ca} / \mathrm{Mg}$} & 175 & & & \\
\hline \multicolumn{2}{|c|}{ Sodio (ppm) } & 33 & & & \\
\hline \multicolumn{2}{|c|}{ C.I.C. Meq/100g } & 11 & & & \\
\hline \multicolumn{2}{|c|}{ Manganeso (ppm) } & 16 & & & \\
\hline \multicolumn{2}{|c|}{ Hierro (ppm) } & 0.9 & & & \\
\hline \multicolumn{2}{|c|}{ Cobre (ppm) } & 0.3 & & & \\
\hline \multicolumn{2}{|l|}{ Zinc (ppm) } & 1.3 & & & \\
\hline \multicolumn{2}{|l|}{ Boro (ppm) } & ip & & & \\
\hline \multicolumn{2}{|c|}{ Conductividad (dS/m) } & 0.9 & & & \\
\hline \multicolumn{2}{|c|}{ Observaciones } & & & & \\
\hline
\end{tabular}


ANÁLISIS DE COMPOSICIÓN DE SUELOS

Desarrollo de una aplicación informática para el cálculo de sostenimiento de taludes mediante vegetación

\begin{tabular}{|c|c|c|c|c|c|}
\hline \multirow[t]{2}{*}{ Perfil $n^{\circ}$} & \multirow[t]{2}{*}{37} & \multirow[b]{2}{*}{ Horizonte A } & \multirow[b]{2}{*}{ Horizonte B } & \multirow[b]{2}{*}{ Horizonte C } & \multirow[b]{2}{*}{ Horizonte D } \\
\hline & & & & & \\
\hline \multirow{3}{*}{ Textura } & Arena (\%) & 55 & & & \\
\hline & Limo (\%) & 36 & & & \\
\hline & Arcilla (\%) & 9 & & & \\
\hline \multicolumn{2}{|c|}{ Clase textural } & Fran-Aren & & & \\
\hline \multicolumn{2}{|l|}{ pH } & 5.3 & & & \\
\hline \multicolumn{2}{|c|}{ Carbonatos ( $\%$ caliza) } & 2.5 & & & \\
\hline \multicolumn{2}{|c|}{ Materia orgánica (\%) } & 2.6 & & & \\
\hline \multicolumn{2}{|c|}{ Nitrogeno total (\%) } & 0.06 & & & \\
\hline \multicolumn{2}{|c|}{ Relación C/N } & 6 & & & \\
\hline \multicolumn{2}{|c|}{ Fosforo (olssen ppm) } & 10 & & & \\
\hline \multicolumn{2}{|c|}{ Calcio (ppm) } & 152 & & & \\
\hline \multicolumn{2}{|c|}{ Potasio (ppm) } & 50 & & & \\
\hline \multicolumn{2}{|c|}{ Magnesio (ppm) } & 35 & & & \\
\hline \multicolumn{2}{|l|}{$\mathrm{Ca} / \mathrm{Mg}$} & 4.34 & & & \\
\hline \multicolumn{2}{|c|}{ Sodio (ppm) } & 11 & & & \\
\hline \multicolumn{2}{|c|}{ C.I.C. Meq/100g } & 5.2 & & & \\
\hline \multicolumn{2}{|c|}{ Manganeso (ppm) } & ip & & & \\
\hline \multicolumn{2}{|c|}{ Hierro (ppm) } & ip & & & \\
\hline \multicolumn{2}{|c|}{ Cobre (ppm) } & ip & & & \\
\hline \multicolumn{2}{|l|}{ Zinc (ppm) } & ip & & & \\
\hline \multicolumn{2}{|l|}{ Boro (ppm) } & ip & & & \\
\hline \multicolumn{2}{|c|}{ Conductividad (dS/m) } & 0.68 & & & \\
\hline \multicolumn{2}{|c|}{ Observaciones } & & & & \\
\hline
\end{tabular}


ANÁLISIS DE COMPOSICIÓN DE SUELOS

Desarrollo de una aplicación informática para el cálculo de sostenimiento de taludes mediante vegetación

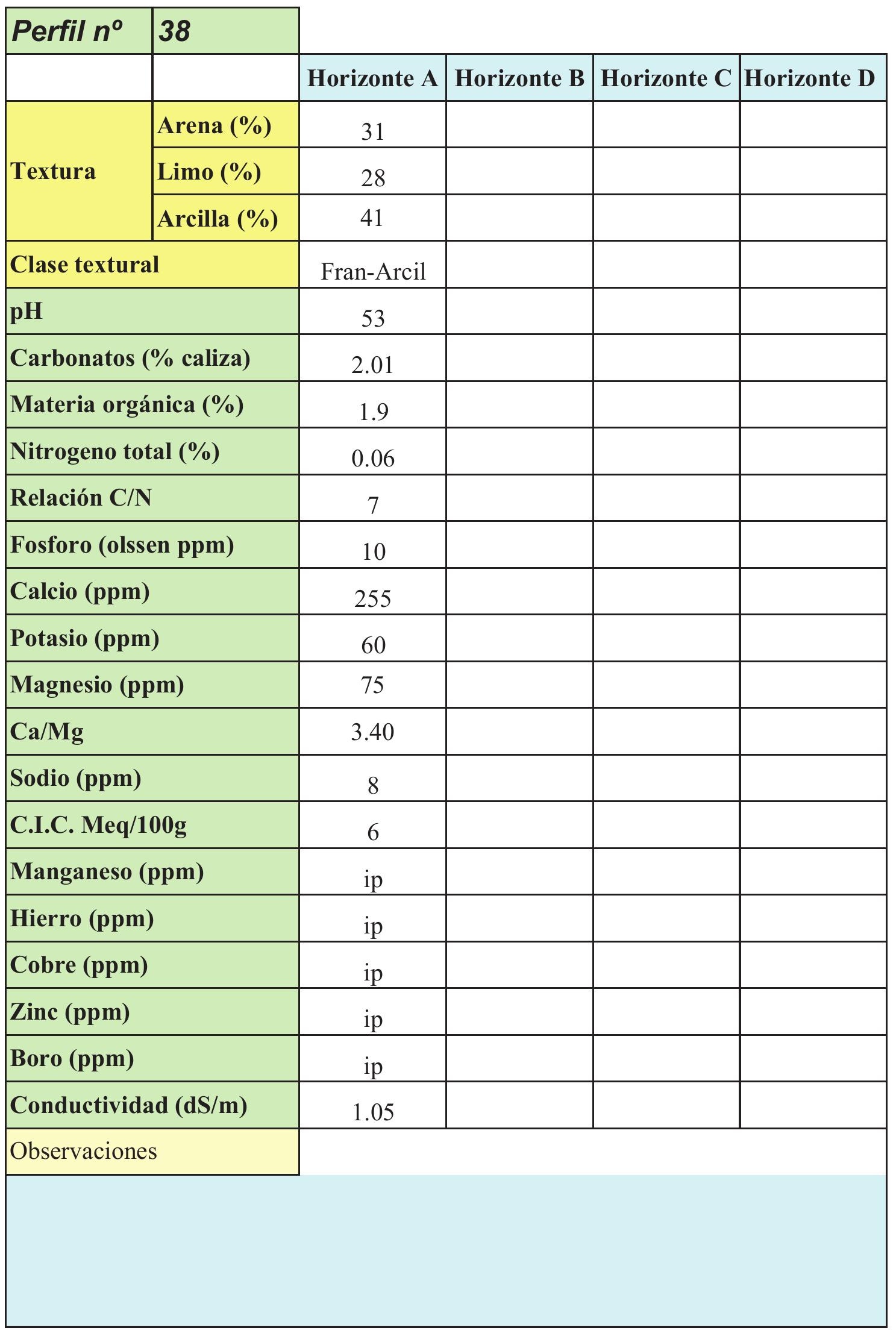


ANÁLISIS DE COMPOSICIÓN DE SUELOS

Desarrollo de una aplicación informática para el cálculo de sostenimiento de taludes mediante vegetación

\begin{tabular}{|c|c|c|c|c|c|}
\hline \multirow[t]{2}{*}{ Perfil $n^{\circ}$} & \multirow[t]{2}{*}{39} & \multirow[b]{2}{*}{ Horizonte A } & \multirow[b]{2}{*}{ Horizonte B } & \multirow[b]{2}{*}{ Horizonte C } & \multirow[b]{2}{*}{ Horizonte D } \\
\hline & & & & & \\
\hline \multirow{3}{*}{ Textura } & Arena (\%) & 38 & & & \\
\hline & Limo (\%) & 42 & & & \\
\hline & Arcilla (\%) & 20 & & & \\
\hline \multicolumn{2}{|c|}{ Clase textural } & Franca & & & \\
\hline \multicolumn{2}{|l|}{ pH } & 6.1 & & & \\
\hline \multicolumn{2}{|c|}{ Carbonatos ( $\%$ caliza) } & 1.3 & & & \\
\hline \multicolumn{2}{|c|}{ Materia orgánica (\%) } & 2.2 & & & \\
\hline \multicolumn{2}{|c|}{ Nitrogeno total (\%) } & 0.08 & & & \\
\hline \multicolumn{2}{|c|}{ Relación C/N } & 6 & & & \\
\hline \multicolumn{2}{|c|}{ Fosforo (olssen ppm) } & 15 & & & \\
\hline \multicolumn{2}{|c|}{ Calcio (ppm) } & 332 & & & \\
\hline \multicolumn{2}{|c|}{ Potasio (ppm) } & 75 & & & \\
\hline \multicolumn{2}{|c|}{ Magnesio (ppm) } & 83 & & & \\
\hline \multicolumn{2}{|l|}{$\mathrm{Ca} / \mathrm{Mg}$} & 4.00 & & & \\
\hline \multicolumn{2}{|c|}{ Sodio (ppm) } & 9 & & & \\
\hline \multicolumn{2}{|c|}{ C.I.C. Meq/100g } & 5 & & & \\
\hline \multicolumn{2}{|c|}{ Manganeso (ppm) } & ip & & & \\
\hline \multicolumn{2}{|c|}{ Hierro (ppm) } & ip & & & \\
\hline \multicolumn{2}{|c|}{ Cobre (ppm) } & ip & & & \\
\hline \multicolumn{2}{|l|}{ Zinc (ppm) } & ip & & & \\
\hline \multicolumn{2}{|l|}{ Boro (ppm) } & ip & & & \\
\hline \multicolumn{2}{|c|}{ Conductividad (dS/m) } & 0.9 & & & \\
\hline \multicolumn{2}{|c|}{ Observaciones } & & & & \\
\hline
\end{tabular}


ANÁLISIS DE COMPOSICIÓN DE SUELOS

Desarrollo de una aplicación informática para el cálculo de sostenimiento de taludes mediante vegetación

\begin{tabular}{|c|c|c|c|c|c|}
\hline \multirow[t]{2}{*}{ Perfil $n^{\circ}$} & \multirow[t]{2}{*}{40} & \multirow[b]{2}{*}{ Horizonte A } & \multirow[b]{2}{*}{ Horizonte B } & \multirow[b]{2}{*}{ Horizonte C } & \multirow[b]{2}{*}{ Horizonte D } \\
\hline & & & & & \\
\hline \multirow{3}{*}{ Textura } & Arena (\%) & 41 & 48 & 54 & \\
\hline & Limo (\%) & 37 & 32 & 22 & \\
\hline & Arcilla (\%) & 22 & 20 & 24 & \\
\hline \multicolumn{2}{|c|}{ Clase textural } & Franca & Franca & Fran-Are & \\
\hline \multicolumn{2}{|l|}{ pH } & 6.1 & 5.9 & 5.2 & \\
\hline \multicolumn{2}{|c|}{ Carbonatos (\% caliza) } & 1.12 & 0.68 & ---- & \\
\hline \multicolumn{2}{|c|}{ Materia orgánica (\%) } & 3.25 & 2.58 & ---- & \\
\hline \multicolumn{2}{|c|}{ Nitrogeno total (\%) } & 1.05 & 0.86 & ---- & \\
\hline \multicolumn{2}{|c|}{ Relación C/N } & 13 & 9 & ---- & \\
\hline \multicolumn{2}{|c|}{ Fosforo (olssen ppm) } & 25 & 19 & 24 & \\
\hline \multicolumn{2}{|c|}{ Calcio (ppm) } & 958 & 856 & 789 & \\
\hline \multicolumn{2}{|c|}{ Potasio (ppm) } & 169 & 158 & 45 & \\
\hline \multicolumn{2}{|c|}{ Magnesio (ppm) } & 125 & 145 & 98 & \\
\hline \multicolumn{2}{|l|}{$\mathrm{Ca} / \mathrm{Mg}$} & 7.66 & 5.90 & 8.05 & \\
\hline \multicolumn{2}{|c|}{ Sodio (ppm) } & 15 & 13 & 12 & \\
\hline \multicolumn{2}{|c|}{ C.I.C. Meq/100g } & 6 & 5 & 4 & \\
\hline \multicolumn{2}{|c|}{ Manganeso (ppm) } & 12 & 14 & 10 & \\
\hline \multicolumn{2}{|c|}{ Hierro (ppm) } & ip & ip & ip & \\
\hline \multicolumn{2}{|c|}{ Cobre (ppm) } & ip & ip & ip & \\
\hline \multicolumn{2}{|l|}{ Zinc (ppm) } & ip & ip & ip & \\
\hline \multicolumn{2}{|l|}{ Boro (ppm) } & ip & ip & ip & \\
\hline \multicolumn{2}{|c|}{ Conductividad (dS/m) } & 1.2 & 0.9 & 0.85 & \\
\hline \multicolumn{2}{|c|}{ Observaciones } & & & & \\
\hline
\end{tabular}


ANÁLISIS DE COMPOSICIÓN DE SUELOS

Desarrollo de una aplicación informática para el cálculo de sostenimiento de taludes mediante vegetación

\begin{tabular}{|c|c|c|c|c|c|}
\hline \multirow[t]{2}{*}{ Perfil $n^{\circ}$} & \multirow[t]{2}{*}{41} & & & & \\
\hline & & Horizonte A & Horizonte B & Horizonte C & Horizonte D \\
\hline \multirow{3}{*}{ Textura } & Arena (\%) & 38 & 43 & 63 & \\
\hline & Limo (\%) & 35 & 39 & 21 & \\
\hline & Arcilla (\%) & 27 & 18 & 16 & \\
\hline \multicolumn{2}{|c|}{ Clase textural } & Franca & Franca & Fran-Are-Arc & \\
\hline \multicolumn{2}{|l|}{ pH } & 6.2 & 5.8 & 5.1 & \\
\hline \multicolumn{2}{|c|}{ Carbonatos (\% caliza) } & 2.25 & 1.56 & ---- & \\
\hline \multicolumn{2}{|c|}{ Materia orgánica (\%) } & 3.1 & 2.2 & ---- & \\
\hline \multicolumn{2}{|c|}{ Nitrogeno total (\%) } & 0.9 & 0.800 & ---- & \\
\hline \multicolumn{2}{|c|}{ Relación C/N } & 2.0 & 1.6 & ---- & \\
\hline \multicolumn{2}{|c|}{ Fosforo (olssen ppm) } & 22 & 18 & 25 & \\
\hline \multicolumn{2}{|c|}{ Calcio (ppm) } & 685 & 933 & 315 & \\
\hline \multicolumn{2}{|c|}{ Potasio (ppm) } & 154 & 144 & 98 & \\
\hline \multicolumn{2}{|c|}{ Magnesio (ppm) } & 251 & 180 & 48 & \\
\hline \multicolumn{2}{|l|}{$\mathrm{Ca} / \mathrm{Mg}$} & 2.729 & 5.18 & 6.563 & \\
\hline \multicolumn{2}{|c|}{ Sodio (ppm) } & 10 & 20 & 16 & \\
\hline \multicolumn{2}{|c|}{ C.I.C. Meq/100g } & 8 & 6 & 5 & \\
\hline \multicolumn{2}{|c|}{ Manganeso (ppm) } & 9.75 & 6.5 & 8.9 & \\
\hline \multicolumn{2}{|c|}{ Hierro (ppm) } & 0.5 & 0.3 & 0.2 & \\
\hline \multicolumn{2}{|c|}{ Cobre (ppm) } & ip & ip & ip & \\
\hline \multicolumn{2}{|l|}{ Zinc (ppm) } & ip & ip & ip & \\
\hline \multicolumn{2}{|l|}{ Boro (ppm) } & ip & ip & ip & \\
\hline \multicolumn{2}{|c|}{ Conductividad (dS/m) } & 1.1 & 1.4 & 1.3 & \\
\hline \multicolumn{2}{|c|}{ Observaciones } & & & & \\
\hline
\end{tabular}


ANÁLISIS DE COMPOSICIÓN DE SUELOS

Desarrollo de una aplicación informática para el cálculo de sostenimiento de taludes mediante vegetación

\begin{tabular}{|c|c|c|c|c|c|}
\hline \multirow[t]{2}{*}{ Perfil $n^{\circ}$} & \multirow[t]{2}{*}{42} & \multirow[b]{2}{*}{ Horizonte A } & \multirow[b]{2}{*}{ Horizonte B } & \multirow[b]{2}{*}{ Horizonte C } & \multirow[b]{2}{*}{ Horizonte D } \\
\hline & & & & & \\
\hline \multirow{3}{*}{ Textura } & Arena (\%) & 31 & & & \\
\hline & Limo (\%) & 48 & & & \\
\hline & Arcilla (\%) & 21 & & & \\
\hline \multicolumn{2}{|c|}{ Clase textural } & Franca & & & \\
\hline \multicolumn{2}{|l|}{ pH } & 5.4 & & & \\
\hline \multicolumn{2}{|c|}{ Carbonatos (\% caliza) } & 1.4 & & & \\
\hline \multicolumn{2}{|c|}{ Materia orgánica (\%) } & 2.9 & & & \\
\hline \multicolumn{2}{|c|}{ Nitrogeno total (\%) } & 0.25 & & & \\
\hline \multicolumn{2}{|c|}{ Relación C/N } & 11 & & & \\
\hline \multicolumn{2}{|c|}{ Fosforo (olssen ppm) } & 15 & & & \\
\hline \multicolumn{2}{|c|}{ Calcio (ppm) } & 422 & & & \\
\hline \multicolumn{2}{|c|}{ Potasio (ppm) } & 80 & & & \\
\hline \multicolumn{2}{|c|}{ Magnesio (ppm) } & 92 & & & \\
\hline \multicolumn{2}{|l|}{$\mathrm{Ca} / \mathrm{Mg}$} & 4.587 & & & \\
\hline \multicolumn{2}{|l|}{ Sodio (ppm) } & 11 & & & \\
\hline \multicolumn{2}{|c|}{ C.I.C. Meq/100g } & 10 & & & \\
\hline \multicolumn{2}{|c|}{ Manganeso (ppm) } & ip & & & \\
\hline \multicolumn{2}{|c|}{ Hierro (ppm) } & ip & & & \\
\hline \multicolumn{2}{|c|}{ Cobre (ppm) } & ip & & & \\
\hline \multicolumn{2}{|l|}{ Zinc (ppm) } & ip & & & \\
\hline \multicolumn{2}{|l|}{ Boro (ppm) } & ip & & & \\
\hline \multicolumn{2}{|c|}{ Conductividad (dS/m) } & 1.1 & & & \\
\hline \multicolumn{2}{|c|}{ Observaciones } & & & & \\
\hline
\end{tabular}


ANÁLISIS DE COMPOSICIÓN DE SUELOS

Desarrollo de una aplicación informática para el cálculo de sostenimiento de taludes mediante vegetación

\begin{tabular}{|c|c|c|c|c|c|}
\hline \multirow[t]{2}{*}{ Perfil $n^{\circ}$} & \multirow[t]{2}{*}{43} & & & & \\
\hline & & Horizonte A & Horizonte B & Horizonte C & Horizonte D \\
\hline \multirow{3}{*}{ Textura } & Arena (\%) & 50 & 62 & & \\
\hline & Limo (\%) & 33 & 27 & & \\
\hline & Arcilla (\%) & 17 & 11 & & \\
\hline \multicolumn{2}{|c|}{ Clase textural } & Franca & Fran-Aren & & \\
\hline \multicolumn{2}{|l|}{ pH } & 5.8 & 5.5 & & \\
\hline \multicolumn{2}{|c|}{ Carbonatos (\% caliza) } & 1.6 & 1.1 & & \\
\hline \multicolumn{2}{|c|}{ Materia orgánica (\%) } & 2.8 & 4.6 & & \\
\hline \multicolumn{2}{|c|}{ Nitrogeno total $(\%)$} & 0.04 & 0.291 & & \\
\hline \multicolumn{2}{|c|}{ Relación C/N } & 6 & 9 & & \\
\hline \multicolumn{2}{|c|}{ Fosforo (olssen ppm) } & 14 & 12 & & \\
\hline \multicolumn{2}{|c|}{ Calcio (ppm) } & 735 & 250 & & \\
\hline \multicolumn{2}{|c|}{ Potasio (ppm) } & 70 & 60 & & \\
\hline \multicolumn{2}{|c|}{ Magnesio (ppm) } & 88 & 100 & & \\
\hline \multicolumn{2}{|l|}{$\mathrm{Ca} / \mathrm{Mg}$} & 8.35 & 2.50 & & \\
\hline \multicolumn{2}{|c|}{ Sodio (ppm) } & 27 & 20 & & \\
\hline \multicolumn{2}{|c|}{ C.I.C. Meq/100g } & 7 & 6 & & \\
\hline \multicolumn{2}{|c|}{ Manganeso (ppm) } & ip & 13 & & \\
\hline \multicolumn{2}{|c|}{ Hierro (ppm) } & ip & ip & & \\
\hline \multicolumn{2}{|c|}{ Cobre (ppm) } & ip & ip & & \\
\hline \multicolumn{2}{|l|}{ Zinc (ppm) } & ip & ip & & \\
\hline \multicolumn{2}{|l|}{ Boro (ppm) } & ip & ip & & \\
\hline \multicolumn{2}{|c|}{ Conductividad (dS/m) } & 0.95 & 0.8 & & \\
\hline \multicolumn{2}{|c|}{ Observaciones } & & & & \\
\hline
\end{tabular}


ANÁLISIS DE COMPOSICIÓN DE SUELOS

Desarrollo de una aplicación informática para el cálculo de sostenimiento de taludes mediante vegetación

\begin{tabular}{|c|c|c|c|c|c|}
\hline \multirow[t]{2}{*}{ Perfil $n^{\circ}$} & \multirow[t]{2}{*}{44} & \multirow[b]{2}{*}{ Horizonte A } & \multirow[b]{2}{*}{ Horizonte B } & \multirow[b]{2}{*}{ Horizonte C } & \multirow[b]{2}{*}{ Horizonte D } \\
\hline & & & & & \\
\hline \multirow{3}{*}{ Textura } & Arena (\%) & 28 & & & \\
\hline & Limo (\%) & 52 & & & \\
\hline & Arcilla (\%) & 20 & & & \\
\hline \multicolumn{2}{|c|}{ Clase textural } & Fran-lim & & & \\
\hline \multicolumn{2}{|l|}{ pH } & 5.85 & & & \\
\hline \multicolumn{2}{|c|}{ Carbonatos ( $\%$ caliza) } & 0.8 & & & \\
\hline \multicolumn{2}{|c|}{ Materia orgánica (\%) } & 1.8 & & & \\
\hline \multicolumn{2}{|c|}{ Nitrogeno total (\%) } & 0.08 & & & \\
\hline \multicolumn{2}{|c|}{ Relación C/N } & 6 & & & \\
\hline \multicolumn{2}{|c|}{ Fosforo (olssen ppm) } & 10 & & & \\
\hline \multicolumn{2}{|c|}{ Calcio (ppm) } & 525 & & & \\
\hline \multicolumn{2}{|c|}{ Potasio (ppm) } & 72 & & & \\
\hline \multicolumn{2}{|c|}{ Magnesio (ppm) } & 85 & & & \\
\hline \multicolumn{2}{|l|}{$\mathrm{Ca} / \mathrm{Mg}$} & 6.18 & & & \\
\hline \multicolumn{2}{|c|}{ Sodio (ppm) } & 22 & & & \\
\hline \multicolumn{2}{|c|}{ C.I.C. Meq/100g } & 7 & & & \\
\hline \multicolumn{2}{|c|}{ Manganeso (ppm) } & 9 & & & \\
\hline \multicolumn{2}{|c|}{ Hierro (ppm) } & ip & & & \\
\hline \multicolumn{2}{|c|}{ Cobre (ppm) } & ip & & & \\
\hline \multicolumn{2}{|l|}{ Zinc (ppm) } & ip & & & \\
\hline \multicolumn{2}{|l|}{ Boro (ppm) } & ip & & & \\
\hline \multicolumn{2}{|c|}{ Conductividad (dS/m) } & 2.05 & & & \\
\hline \multicolumn{2}{|c|}{ Observaciones } & & & & \\
\hline
\end{tabular}


ANÁLISIS DE COMPOSICIÓN DE SUELOS

Desarrollo de una aplicación informática para el cálculo de sostenimiento de taludes mediante vegetación

\begin{tabular}{|c|c|c|c|c|c|}
\hline \multirow[t]{2}{*}{ Perfil $n^{\circ}$} & \multirow[t]{2}{*}{45} & \multirow[b]{2}{*}{ Horizonte A } & \multirow[b]{2}{*}{ Horizonte B } & \multirow[b]{2}{*}{ Horizonte C } & \multirow[b]{2}{*}{ Horizonte D } \\
\hline & & & & & \\
\hline \multirow{3}{*}{ Textura } & Arena (\%) & 33 & 41 & 55 & \\
\hline & Limo (\%) & 45 & 38 & 32 & \\
\hline & Arcilla (\%) & 22 & 21 & 13 & 100 \\
\hline \multicolumn{2}{|c|}{ Clase textural } & Franca & Franca & Fran-Aren & \\
\hline \multicolumn{2}{|l|}{ pH } & 5.8 & 5.7 & 4.09 & \\
\hline \multicolumn{2}{|c|}{ Carbonatos ( $\%$ caliza) } & 4.2 & 0.1 & ---- & \\
\hline \multicolumn{2}{|c|}{ Materia orgánica (\%) } & 1.2 & 1.2 & --- & \\
\hline \multicolumn{2}{|c|}{ Nitrogeno total (\%) } & 0.03 & 0.068 & ---- & \\
\hline \multicolumn{2}{|c|}{ Relación C/N } & 5 & 10 & --- & \\
\hline \multicolumn{2}{|c|}{ Fosforo (olssen ppm) } & 10 & 4.2 & 5 & \\
\hline \multicolumn{2}{|c|}{ Calcio (ppm) } & 322 & 40 & 598 & \\
\hline \multicolumn{2}{|c|}{ Magnesio (ppm) } & 128 & 30 & 135 & \\
\hline \multicolumn{2}{|l|}{$\mathrm{Ca} / \mathrm{Mg}$} & 75 & 1.33 & 92 & \\
\hline \multicolumn{2}{|c|}{ Potasio (ppm) } & 4.29 & 75 & 6.50 & \\
\hline \multicolumn{2}{|c|}{ Sodio (ppm) } & 22 & 23 & 19 & \\
\hline \multicolumn{2}{|c|}{ C.I.C. Meq/100g } & 11 & 4 & 8 & \\
\hline \multicolumn{2}{|c|}{ Manganeso (ppm) } & 19 & 12 & 21 & \\
\hline \multicolumn{2}{|c|}{ Hierro (ppm) } & 1.1 & 1.53 & 0.8 & \\
\hline \multicolumn{2}{|c|}{ Cobre (ppm) } & 0.5 & 0.02 & 0.02 & \\
\hline \multicolumn{2}{|l|}{ Zinc (ppm) } & 1.1 & ip & 0.09 & \\
\hline \multicolumn{2}{|l|}{ Boro (ppm) } & 0.07 & ip & 0.2 & \\
\hline \multicolumn{2}{|c|}{ Conductividad (dS/m) } & 0.9 & 0.03 & 2.1 & \\
\hline \multicolumn{2}{|c|}{ Observaciones } & & & & \\
\hline
\end{tabular}


ANÁLISIS DE COMPOSICIÓN DE SUELOS

Desarrollo de una aplicación informática para el cálculo de sostenimiento de taludes mediante vegetación

\begin{tabular}{|c|c|c|c|c|c|}
\hline \multirow[t]{2}{*}{ Perfil $n^{\circ}$} & \multirow[t]{2}{*}{46} & \multirow[b]{2}{*}{ Horizonte A } & \multirow[b]{2}{*}{ Horizonte B } & \multirow[b]{2}{*}{ Horizonte C } & \multirow[b]{2}{*}{ Horizonte D } \\
\hline & & & & & \\
\hline \multirow{3}{*}{ Textura } & Arena (\%) & 46 & 48 & & \\
\hline & Limo (\%) & 22 & 18 & & \\
\hline & Arcilla (\%) & 32 & 34 & & \\
\hline \multicolumn{2}{|c|}{ Clase textural } & Franca & Fra-Aren-Lim & & \\
\hline \multicolumn{2}{|l|}{ pH } & 7.2 & 6.2 & & \\
\hline \multicolumn{2}{|c|}{ Carbonatos (\% caliza) } & 20 & 12 & & \\
\hline \multicolumn{2}{|c|}{ Materia orgánica (\%) } & 6.58 & 1.3 & & \\
\hline \multicolumn{2}{|c|}{ Nitrogeno total (\%) } & 0.469 & 0.05 & & \\
\hline \multicolumn{2}{|c|}{ Relación C/N } & 8 & 6 & & \\
\hline \multicolumn{2}{|c|}{ Fosforo (olssen ppm) } & 15 & 3 & & \\
\hline \multicolumn{2}{|c|}{ Calcio (ppm) } & 135 & 99 & & \\
\hline \multicolumn{2}{|c|}{ Potasio (ppm) } & 60 & 65 & & \\
\hline \multicolumn{2}{|c|}{ Magnesio (ppm) } & 22 & 25 & & \\
\hline \multicolumn{2}{|l|}{$\mathrm{Ca} / \mathrm{Mg}$} & 6.14 & 3.96 & & \\
\hline \multicolumn{2}{|c|}{ Sodio (ppm) } & 0.5 & 0.06 & & \\
\hline \multicolumn{2}{|c|}{ C.I.C. Meq/100g } & 14.25 & 11 & & \\
\hline \multicolumn{2}{|c|}{ Manganeso (ppm) } & 16 & 11 & & \\
\hline \multicolumn{2}{|c|}{ Hierro (ppm) } & 1.6 & ip & & \\
\hline \multicolumn{2}{|c|}{ Cobre (ppm) } & 1.25 & ip & & \\
\hline \multicolumn{2}{|l|}{ Zinc (ppm) } & 2.75 & ip & & \\
\hline \multicolumn{2}{|l|}{ Boro (ppm) } & 0.1 & ip & & \\
\hline \multicolumn{2}{|c|}{ Conductividad (dS/m) } & 3.2 & 2.1 & & \\
\hline \multicolumn{2}{|c|}{ Observaciones } & & & & \\
\hline
\end{tabular}


ANÁLISIS DE COMPOSICIÓN DE SUELOS

Desarrollo de una aplicación informática para el cálculo de sostenimiento de taludes mediante vegetación

\begin{tabular}{|c|c|c|c|c|c|}
\hline \multirow[t]{2}{*}{ Perfil $n^{\circ}$} & \multirow[t]{2}{*}{47} & \multirow[b]{2}{*}{ Horizonte A } & \multirow[b]{2}{*}{ Horizonte B } & \multirow[b]{2}{*}{ Horizonte C } & \multirow[b]{2}{*}{ Horizonte D } \\
\hline & & & & & \\
\hline \multirow{3}{*}{ Textura } & Arena (\%) & 27 & 41 & 38 & \\
\hline & Limo (\%) & 66 & 41 & 45 & \\
\hline & Arcilla (\%) & 7 & 18 & 17 & \\
\hline \multicolumn{2}{|c|}{ Clase textural } & Fran-Lim & Franca & Franca & \\
\hline \multicolumn{2}{|l|}{ pH } & 5.8 & 5.2 & 5 & \\
\hline \multicolumn{2}{|c|}{ Carbonatos ( $\%$ caliza) } & 6.01 & 5 & 4.9 & \\
\hline \multicolumn{2}{|c|}{ Materia orgánica (\%) } & 3.2 & 2.1 & ---- & \\
\hline \multicolumn{2}{|c|}{ Nitrogeno total $(\%)$} & 0.18 & 0.25 & ---- & \\
\hline \multicolumn{2}{|c|}{ Relación C/N } & 10 & 5 & & \\
\hline \multicolumn{2}{|c|}{ Fosforo (olssen ppm) } & 15 & 19 & 6 & \\
\hline \multicolumn{2}{|c|}{ Calcio (ppm) } & 825 & 921 & 125 & \\
\hline \multicolumn{2}{|c|}{ Potasio (ppm) } & 22 & 25 & 13 & \\
\hline \multicolumn{2}{|c|}{ Magnesio (ppm) } & 135 & 159 & 56 & \\
\hline \multicolumn{2}{|l|}{$\mathrm{Ca} / \mathrm{Mg}$} & 6.11 & 5.79 & 2.23 & \\
\hline \multicolumn{2}{|c|}{ Sodio (ppm) } & 38 & 22 & 25 & \\
\hline \multicolumn{2}{|c|}{ C.I.C. Meq/100g } & 14 & 16 & 20 & \\
\hline \multicolumn{2}{|c|}{ Manganeso (ppm) } & ip & ip & ip & \\
\hline \multicolumn{2}{|c|}{ Hierro (ppm) } & ip & ip & ip & \\
\hline \multicolumn{2}{|c|}{ Cobre (ppm) } & ip & ip & ip & \\
\hline \multicolumn{2}{|l|}{ Zinc (ppm) } & ip & ip & ip & \\
\hline \multicolumn{2}{|l|}{ Boro (ppm) } & ip & ip & ip & \\
\hline \multicolumn{2}{|c|}{ Conductividad (dS/m) } & 1.1 & 1.5 & 1.6 & \\
\hline \multicolumn{2}{|c|}{ Observaciones } & & & & \\
\hline
\end{tabular}


ANÁLISIS DE COMPOSICIÓN DE SUELOS

Desarrollo de una aplicación informática para el cálculo de sostenimiento de taludes mediante vegetación

\begin{tabular}{|c|c|c|c|c|c|}
\hline \multirow[t]{2}{*}{ Perfil $n^{\circ}$} & \multirow[t]{2}{*}{48} & \multirow[b]{2}{*}{ Horizonte A } & \multirow[b]{2}{*}{ Horizonte B } & \multirow[b]{2}{*}{ Horizonte C } & \multirow[b]{2}{*}{ Horizonte D } \\
\hline & & & & & \\
\hline \multirow{3}{*}{ Textura } & Arena (\%) & 41 & & & \\
\hline & Limo (\%) & 42 & & & \\
\hline & Arcilla (\%) & 17 & & & \\
\hline \multicolumn{2}{|c|}{ Clase textural } & Franca & & & \\
\hline \multicolumn{2}{|l|}{ pH } & 5.6 & & & \\
\hline \multicolumn{2}{|c|}{ Carbonatos ( $\%$ caliza) } & 1.3 & & & \\
\hline \multicolumn{2}{|c|}{ Materia orgánica (\%) } & 2.35 & & & \\
\hline \multicolumn{2}{|c|}{ Nitrogeno total (\%) } & 0.12 & & & \\
\hline \multicolumn{2}{|c|}{ Relación C/N } & 7 & & & \\
\hline \multicolumn{2}{|c|}{ Fosforo (olssen ppm) } & 12 & & & \\
\hline \multicolumn{2}{|c|}{ Calcio (ppm) } & 475 & & & \\
\hline \multicolumn{2}{|c|}{ Potasio (ppm) } & 83 & & & \\
\hline \multicolumn{2}{|c|}{ Magnesio (ppm) } & 69 & & & \\
\hline \multicolumn{2}{|l|}{$\mathrm{Ca} / \mathrm{Mg}$} & 6.88 & & & \\
\hline \multicolumn{2}{|c|}{ Sodio (ppm) } & 15 & & & \\
\hline \multicolumn{2}{|c|}{ C.I.C. Meq/100g } & 6 & & & \\
\hline \multicolumn{2}{|c|}{ Manganeso (ppm) } & 8 & & & \\
\hline \multicolumn{2}{|c|}{ Hierro (ppm) } & ip & & & \\
\hline \multicolumn{2}{|c|}{ Cobre (ppm) } & ip & & & \\
\hline \multicolumn{2}{|l|}{ Zinc (ppm) } & ip & & & \\
\hline \multicolumn{2}{|l|}{ Boro (ppm) } & 0.2 & & & \\
\hline \multicolumn{2}{|c|}{ Conductividad (dS/m) } & 1.83 & & & \\
\hline \multicolumn{2}{|c|}{ Observaciones } & & & & \\
\hline
\end{tabular}


ANÁLISIS DE COMPOSICIÓN DE SUELOS

Desarrollo de una aplicación informática para el cálculo de sostenimiento de taludes mediante vegetación

\begin{tabular}{|c|c|c|c|c|c|}
\hline \multirow[t]{2}{*}{ Perfil $n^{\circ}$} & \multirow[t]{2}{*}{49} & & & & \\
\hline & & Horizonte A & Horizonte B & Horizonte C & Horizonte D \\
\hline \multirow{3}{*}{ Textura } & Arena (\%) & 55 & 39 & 10 & \\
\hline & Limo (\%) & 23 & 35 & 55 & \\
\hline & Arcilla (\%) & 22 & 26 & 35 & \\
\hline \multicolumn{2}{|c|}{ Clase textural } & Fran-Aren & Franca & Fran-Arc-Lim & \\
\hline \multicolumn{2}{|l|}{ pH } & 5.2 & 5.9 & 5.6 & \\
\hline \multicolumn{2}{|c|}{ Carbonatos ( $\%$ caliza) } & 2.3 & 10 & --- & \\
\hline \multicolumn{2}{|c|}{ Materia orgánica (\%) } & 1.2 & 2.5 & --- & \\
\hline \multicolumn{2}{|c|}{ Nitrogeno total $(\%)$} & 0.08 & 0.5 & --- & \\
\hline \multicolumn{2}{|c|}{ Relación C/N } & 8 & 10 & --- & \\
\hline \multicolumn{2}{|c|}{ Fosforo (olssen ppm) } & 11 & 13 & 8 & \\
\hline \multicolumn{2}{|c|}{ Calcio (ppm) } & 858 & 852 & 369 & \\
\hline \multicolumn{2}{|c|}{ Potasio (ppm) } & 83 & 203 & 153 & \\
\hline \multicolumn{2}{|c|}{ Magnesio (ppm) } & 105 & 89.00 & 53 & \\
\hline \multicolumn{2}{|l|}{$\mathrm{Ca} / \mathrm{Mg}$} & 8.17 & 9.57 & 6.96 & \\
\hline \multicolumn{2}{|c|}{ Sodio (ppm) } & 33 & 33 & 43 & \\
\hline \multicolumn{2}{|c|}{ C.I.C. Meq/100g } & 9 & 11 & 20 & \\
\hline \multicolumn{2}{|c|}{ Manganeso (ppm) } & 15 & 16 & 10 & \\
\hline \multicolumn{2}{|c|}{ Hierro (ppm) } & 1.2 & 0.9 & 4 & \\
\hline \multicolumn{2}{|c|}{ Cobre (ppm) } & 0.7 & 0.3 & ip & \\
\hline \multicolumn{2}{|l|}{ Zinc (ppm) } & 0.4 & 1.3 & ip & \\
\hline \multicolumn{2}{|l|}{ Boro (ppm) } & 0.03 & ip & 0.1 & \\
\hline \multicolumn{2}{|c|}{ Conductividad (dS/m) } & 0.9 & 0.9 & 1.4 & \\
\hline \multicolumn{2}{|c|}{ Observaciones } & & & & \\
\hline
\end{tabular}


ANÁLISIS DE COMPOSICIÓN DE SUELOS

Desarrollo de una aplicación informática para el cálculo de sostenimiento de taludes mediante vegetación

\begin{tabular}{|c|c|c|c|c|c|}
\hline \multirow[t]{2}{*}{ Perfil $n^{\circ}$} & \multirow[t]{2}{*}{50} & \multirow[b]{2}{*}{ Horizonte A } & \multirow[b]{2}{*}{ Horizonte B } & \multirow[b]{2}{*}{ Horizonte C } & \multirow[b]{2}{*}{ Horizonte D } \\
\hline & & & & & \\
\hline \multirow{3}{*}{ Textura } & Arena (\%) & 44 & & & \\
\hline & Limo (\%) & 38 & & & \\
\hline & Arcilla (\%) & 18 & & & \\
\hline \multicolumn{2}{|c|}{ Clase textural } & Franca & & & \\
\hline \multicolumn{2}{|l|}{ pH } & 5.1 & & & \\
\hline \multicolumn{2}{|c|}{ Carbonatos (\% caliza) } & 0.95 & & & \\
\hline \multicolumn{2}{|c|}{ Materia orgánica (\%) } & 2.93 & & & \\
\hline \multicolumn{2}{|c|}{ Nitrogeno total (\%) } & 0.09 & & & \\
\hline \multicolumn{2}{|c|}{ Relación C/N } & 5.8 & & & \\
\hline \multicolumn{2}{|c|}{ Fosforo (olssen ppm) } & 9 & & & \\
\hline \multicolumn{2}{|c|}{ Calcio (ppm) } & 495 & & & \\
\hline \multicolumn{2}{|c|}{ Potasio (ppm) } & 88 & & & \\
\hline \multicolumn{2}{|c|}{ Magnesio (ppm) } & 79 & & & \\
\hline \multicolumn{2}{|l|}{$\mathrm{Ca} / \mathrm{Mg}$} & 6.27 & & & \\
\hline \multicolumn{2}{|c|}{ Sodio (ppm) } & 35 & & & \\
\hline \multicolumn{2}{|c|}{ C.I.C. Meq/100g } & 8 & & & \\
\hline \multicolumn{2}{|c|}{ Manganeso (ppm) } & 11 & & & \\
\hline \multicolumn{2}{|c|}{ Hierro (ppm) } & ip & & & \\
\hline \multicolumn{2}{|c|}{ Cobre (ppm) } & ip & & & \\
\hline \multicolumn{2}{|l|}{ Zinc (ppm) } & ip & & & \\
\hline \multicolumn{2}{|l|}{ Boro (ppm) } & 0.3 & & & \\
\hline \multicolumn{2}{|c|}{ Conductividad (dS/m) } & 1.35 & & & \\
\hline \multicolumn{2}{|c|}{ Observaciones } & & & & \\
\hline
\end{tabular}


ANÁLISIS DE COMPOSICIÓN DE SUELOS

Desarrollo de una aplicación informática para el cálculo de sostenimiento de taludes mediante vegetación

\begin{tabular}{|c|c|c|c|c|c|}
\hline \multirow[t]{2}{*}{ Perfil $n^{\circ}$} & \multirow[t]{2}{*}{51} & & & & \\
\hline & & Horizonte A & Horizonte B & Horizonte $\mathrm{C}$ & Horizonte D \\
\hline \multirow{3}{*}{ Textura } & Arena (\%) & 43 & & & \\
\hline & Limo (\%) & 33 & & & \\
\hline & Arcilla (\%) & 24 & & & \\
\hline \multicolumn{2}{|c|}{ Clase textural } & Franca & & & \\
\hline \multicolumn{2}{|l|}{ pH } & 5.7 & & & \\
\hline \multicolumn{2}{|c|}{ Carbonatos ( $\%$ caliza) } & 1.3 & & & \\
\hline \multicolumn{2}{|c|}{ Materia orgánica (\%) } & 2.6 & & & \\
\hline \multicolumn{2}{|c|}{ Nitrogeno total (\%) } & 0.05 & & & \\
\hline \multicolumn{2}{|c|}{ Relación C/N } & 6 & & & \\
\hline \multicolumn{2}{|c|}{ Fosforo (olssen ppm) } & 10 & & & \\
\hline \multicolumn{2}{|c|}{ Calcio (ppm) } & 623 & & & \\
\hline \multicolumn{2}{|c|}{ Potasio (ppm) } & 69 & & & \\
\hline \multicolumn{2}{|c|}{ Magnesio (ppm) } & 102 & & & \\
\hline \multicolumn{2}{|l|}{$\mathrm{Ca} / \mathrm{Mg}$} & 6.108 & & & \\
\hline \multicolumn{2}{|c|}{ Sodio (ppm) } & 23 & & & \\
\hline \multicolumn{2}{|c|}{ C.I.C. Meq/100g } & 12 & & & \\
\hline \multicolumn{2}{|c|}{ Manganeso (ppm) } & ip & & & \\
\hline \multicolumn{2}{|c|}{ Hierro (ppm) } & ip & & & \\
\hline \multicolumn{2}{|c|}{ Cobre (ppm) } & ip & & & \\
\hline \multicolumn{2}{|l|}{ Zinc (ppm) } & ip & & & \\
\hline \multicolumn{2}{|l|}{ Boro (ppm) } & ip & & & \\
\hline \multicolumn{2}{|c|}{ Conductividad (dS/m) } & 1 & & & \\
\hline \multicolumn{2}{|c|}{ Observaciones } & & & & \\
\hline
\end{tabular}


ANÁLISIS DE COMPOSICIÓN DE SUELOS

Desarrollo de una aplicación informática para el cálculo de sostenimiento de taludes mediante vegetación

\begin{tabular}{|c|c|c|c|c|c|}
\hline \multirow[t]{2}{*}{ Perfil $n^{\circ}$} & \multirow[t]{2}{*}{52} & & & & \\
\hline & & Horizonte A & Horizonte B & Horizonte C & Horizonte D \\
\hline \multirow{3}{*}{ Textura } & Arena (\%) & 43 & & & \\
\hline & Limo (\%) & 31 & & & \\
\hline & Arcilla (\%) & 26 & & & \\
\hline \multicolumn{2}{|c|}{ Clase textural } & Franca & & & \\
\hline \multicolumn{2}{|l|}{ pH } & 5.2 & & & \\
\hline \multicolumn{2}{|c|}{ Carbonatos (\% caliza) } & 1.5 & & & \\
\hline \multicolumn{2}{|c|}{ Materia orgánica (\%) } & 309 & & & \\
\hline \multicolumn{2}{|c|}{ Nitrogeno total (\%) } & 0.06 & & & \\
\hline \multicolumn{2}{|c|}{ Relación C/N } & 7 & & & \\
\hline \multicolumn{2}{|c|}{ Fosforo (olssen ppm) } & 12 & & & \\
\hline \multicolumn{2}{|c|}{ Calcio (ppm) } & 584 & & & \\
\hline \multicolumn{2}{|c|}{ Potasio (ppm) } & 73 & & & \\
\hline \multicolumn{2}{|c|}{ Magnesio (ppm) } & 98 & & & \\
\hline \multicolumn{2}{|l|}{$\mathrm{Ca} / \mathrm{Mg}$} & 0.745 & & & \\
\hline \multicolumn{2}{|l|}{ Sodio (ppm) } & 29 & & & \\
\hline \multicolumn{2}{|c|}{ C.I.C. Meq/100g } & 15 & & & \\
\hline \multicolumn{2}{|c|}{ Manganeso (ppm) } & 12 & & & \\
\hline \multicolumn{2}{|c|}{ Hierro (ppm) } & ip & & & \\
\hline \multicolumn{2}{|c|}{ Cobre (ppm) } & ip & & & \\
\hline \multicolumn{2}{|l|}{ Zinc (ppm) } & ip & & & \\
\hline \multicolumn{2}{|l|}{ Boro (ppm) } & ip & & & \\
\hline \multicolumn{2}{|c|}{ Conductividad (dS/m) } & 1.05 & & & \\
\hline \multicolumn{2}{|c|}{ Observaciones } & & & & \\
\hline
\end{tabular}


ANÁLISIS DE COMPOSICIÓN DE SUELOS

Desarrollo de una aplicación informática para el cálculo de sostenimiento de taludes mediante vegetación

\begin{tabular}{|c|c|c|c|c|c|}
\hline \multirow[t]{2}{*}{ Perfil $n^{\circ}$} & \multirow[t]{2}{*}{53} & \multirow[b]{2}{*}{ Horizonte A } & \multirow[b]{2}{*}{ Horizonte B } & \multirow[b]{2}{*}{ Horizonte C } & \multirow[b]{2}{*}{ Horizonte D } \\
\hline & & & & & \\
\hline \multirow{3}{*}{ Textura } & Arena (\%) & 50 & & & \\
\hline & Limo (\%) & 33 & & & \\
\hline & Arcilla (\%) & 17 & & & \\
\hline \multicolumn{2}{|c|}{ Clase textural } & Franca & & & \\
\hline \multicolumn{2}{|l|}{ pH } & 5.8 & & & \\
\hline \multicolumn{2}{|c|}{ Carbonatos (\% caliza) } & 1.6 & & & \\
\hline \multicolumn{2}{|c|}{ Materia orgánica (\%) } & 2.8 & & & \\
\hline \multicolumn{2}{|c|}{ Nitrogeno total (\%) } & 0.04 & & & \\
\hline \multicolumn{2}{|c|}{ Relación C/N } & 6 & & & \\
\hline \multicolumn{2}{|c|}{ Fosforo (olssen ppm) } & 14 & & & \\
\hline \multicolumn{2}{|c|}{ Calcio (ppm) } & 735 & & & \\
\hline \multicolumn{2}{|c|}{ Potasio (ppm) } & 70 & & & \\
\hline \multicolumn{2}{|c|}{ Magnesio (ppm) } & 88 & & & \\
\hline \multicolumn{2}{|l|}{$\mathrm{Ca} / \mathrm{Mg}$} & 8.35 & & & \\
\hline \multicolumn{2}{|c|}{ Sodio (ppm) } & 27 & & & \\
\hline \multicolumn{2}{|c|}{ C.I.C. Meq/100g } & 7 & & & \\
\hline \multicolumn{2}{|c|}{ Manganeso (ppm) } & ip & & & \\
\hline \multicolumn{2}{|c|}{ Hierro (ppm) } & ip & & & \\
\hline \multicolumn{2}{|c|}{ Cobre (ppm) } & ip & & & \\
\hline \multicolumn{2}{|l|}{ Zinc (ppm) } & ip & & & \\
\hline \multicolumn{2}{|l|}{ Boro (ppm) } & ip & & & \\
\hline \multicolumn{2}{|c|}{ Conductividad (dS/m) } & 0.95 & & & \\
\hline \multicolumn{2}{|c|}{ Observaciones } & & & & \\
\hline
\end{tabular}


ANÁLISIS DE COMPOSICIÓN DE SUELOS

Desarrollo de una aplicación informática para el cálculo de sostenimiento de taludes mediante vegetación

\begin{tabular}{|c|c|c|c|c|c|}
\hline \multirow[t]{2}{*}{ Perfil $n^{\circ}$} & \multirow[t]{2}{*}{54} & & & & \\
\hline & & Horizonte A & Horizonte B & Horizonte C & Horizonte D \\
\hline \multirow{3}{*}{ Textura } & Arena (\%) & 44 & & & \\
\hline & Limo (\%) & 33 & & & \\
\hline & Arcilla (\%) & 23 & & & \\
\hline \multicolumn{2}{|c|}{ Clase textural } & Franca & & & \\
\hline \multicolumn{2}{|l|}{ pH } & 5.3 & & & \\
\hline \multicolumn{2}{|c|}{ Carbonatos (\% caliza) } & 0.9 & & & \\
\hline \multicolumn{2}{|c|}{ Materia orgánica (\%) } & 1.7 & & & \\
\hline \multicolumn{2}{|c|}{ Nitrogeno total (\%) } & 0.08 & & & \\
\hline \multicolumn{2}{|c|}{ Relación C/N } & 7 & & & \\
\hline \multicolumn{2}{|c|}{ Fosforo (olssen ppm) } & 12 & & & \\
\hline \multicolumn{2}{|c|}{ Calcio (ppm) } & 823 & & & \\
\hline \multicolumn{2}{|c|}{ Potasio (ppm) } & 81 & & & \\
\hline \multicolumn{2}{|c|}{ Magnesio (ppm) } & 105 & & & \\
\hline \multicolumn{2}{|l|}{$\mathrm{Ca} / \mathrm{Mg}$} & 7.84 & & & \\
\hline \multicolumn{2}{|c|}{ Sodio (ppm) } & 25 & & & \\
\hline \multicolumn{2}{|c|}{ C.I.C. Meq/100g } & 8 & & & \\
\hline \multicolumn{2}{|c|}{ Manganeso (ppm) } & ip & & & \\
\hline \multicolumn{2}{|c|}{ Hierro (ppm) } & ip & & & \\
\hline \multicolumn{2}{|c|}{ Cobre (ppm) } & ip & & & \\
\hline \multicolumn{2}{|l|}{ Zinc (ppm) } & ip & & & \\
\hline \multicolumn{2}{|l|}{ Boro (ppm) } & ip & & & \\
\hline \multicolumn{2}{|c|}{ Conductividad (dS/m) } & 0.88 & & & \\
\hline \multicolumn{2}{|c|}{ Observaciones } & & & & \\
\hline
\end{tabular}


ANÁLISIS DE COMPOSICIÓN DE SUELOS

Desarrollo de una aplicación informática para el cálculo de sostenimiento de taludes mediante vegetación

\begin{tabular}{|c|c|c|c|c|c|}
\hline \multirow[t]{2}{*}{ Perfil $n^{\circ}$} & \multirow[t]{2}{*}{55} & \multirow[b]{2}{*}{ Horizonte A } & \multirow[b]{2}{*}{ Horizonte B } & \multirow[b]{2}{*}{ Horizonte C } & \multirow[b]{2}{*}{ Horizonte D } \\
\hline & & & & & \\
\hline \multirow{3}{*}{ Textura } & Arena (\%) & 55 & & & \\
\hline & Limo (\%) & 29 & & & \\
\hline & Arcilla (\%) & 16 & 100 & 100 & 100 \\
\hline \multicolumn{2}{|c|}{ Clase textural } & Fran-Aren & & & \\
\hline \multicolumn{2}{|l|}{ pH } & 5.8 & 5.7 & 4.5 & \\
\hline \multicolumn{2}{|c|}{ Carbonatos ( $\%$ caliza) } & 0.9 & 0.1 & --- & \\
\hline \multicolumn{2}{|c|}{ Materia orgánica (\%) } & 2.55 & 1.2 & ---- & \\
\hline \multicolumn{2}{|c|}{ Nitrogeno total $(\%)$} & 0.162 & 0.068 & --- & \\
\hline \multicolumn{2}{|c|}{ Relación C/N } & 9 & 10 & ---- & \\
\hline \multicolumn{2}{|c|}{ Fosforo (olssen ppm) } & 12 & 4.2 & 2.3 & \\
\hline \multicolumn{2}{|c|}{ Calcio (ppm) } & 321 & 322 & 152 & \\
\hline \multicolumn{2}{|c|}{ Magnesio (ppm) } & 95 & 128 & 69 & \\
\hline \multicolumn{2}{|l|}{$\mathrm{Ca} / \mathrm{Mg}$} & 3.38 & 2.52 & 2.20 & \\
\hline \multicolumn{2}{|c|}{ Potasio (ppm) } & 30 & 75 & 21 & \\
\hline \multicolumn{2}{|c|}{ Sodio (ppm) } & 10 & 22 & 11 & \\
\hline \multicolumn{2}{|c|}{ C.I.C. Meq/100g } & ip & ip & ip & \\
\hline \multicolumn{2}{|c|}{ Manganeso (ppm) } & ip & ip & ip & \\
\hline \multicolumn{2}{|c|}{ Hierro (ppm) } & ip & ip & ip & \\
\hline \multicolumn{2}{|c|}{ Cobre (ppm) } & ip & ip & ip & \\
\hline \multicolumn{2}{|l|}{ Zinc (ppm) } & ip & ip & ip & \\
\hline \multicolumn{2}{|l|}{ Boro (ppm) } & ip & ip & ip & \\
\hline \multicolumn{2}{|c|}{ Conductividad (dS/m) } & 0.8 & 1.5 & 1.2 & \\
\hline \multicolumn{2}{|c|}{ Observaciones } & & & & \\
\hline
\end{tabular}


ANÁLISIS DE COMPOSICIÓN DE SUELOS

Desarrollo de una aplicación informática para el cálculo de sostenimiento de taludes mediante vegetación

\begin{tabular}{|c|c|c|c|c|c|}
\hline \multirow[t]{2}{*}{ Perfil $n^{\circ}$} & \multirow[t]{2}{*}{56} & & & & \\
\hline & & Horizonte A & Horizonte B & Horizonte $\mathrm{C}$ & Horizonte D \\
\hline \multirow{3}{*}{ Textura } & Arena (\%) & 44 & 54 & & \\
\hline & Limo (\%) & 42 & 33 & & \\
\hline & Arcilla (\%) & 14 & 13 & & \\
\hline \multicolumn{2}{|c|}{ Clase textural } & Franca & Fran-Aren & & \\
\hline \multicolumn{2}{|l|}{ pH } & 6.1 & 6 & & \\
\hline \multicolumn{2}{|c|}{ Carbonatos ( $\%$ caliza) } & 1.2 & 0.6 & & \\
\hline \multicolumn{2}{|c|}{ Materia orgánica (\%) } & 2.9 & 0.6 & & \\
\hline \multicolumn{2}{|c|}{ Nitrogeno total $(\%)$} & 0.3 & 0.02 & & \\
\hline \multicolumn{2}{|c|}{ Relación C/N } & 11 & 9 & & \\
\hline \multicolumn{2}{|c|}{ Fosforo (olssen ppm) } & 20 & 14 & & \\
\hline \multicolumn{2}{|c|}{ Calcio (ppm) } & 954 & 705 & & \\
\hline \multicolumn{2}{|c|}{ Potasio (ppm) } & 58 & 88 & & \\
\hline \multicolumn{2}{|c|}{ Magnesio (ppm) } & 125 & 80.10 & & \\
\hline \multicolumn{2}{|l|}{$\mathrm{Ca} / \mathrm{Mg}$} & 7.63 & 8.80 & & \\
\hline \multicolumn{2}{|c|}{ Sodio (ppm) } & 14 & 44 & & \\
\hline \multicolumn{2}{|c|}{ C.I.C. Meq/100g } & 10 & 9 & & \\
\hline \multicolumn{2}{|c|}{ Manganeso (ppm) } & 22 & 12 & & \\
\hline \multicolumn{2}{|c|}{ Hierro (ppm) } & 2.3 & 0.5 & & \\
\hline \multicolumn{2}{|c|}{ Cobre (ppm) } & 0.2 & ip & & \\
\hline \multicolumn{2}{|l|}{ Zinc (ppm) } & 1.2 & ip & & \\
\hline \multicolumn{2}{|l|}{ Boro (ppm) } & ip & ip & & \\
\hline \multicolumn{2}{|c|}{ Conductividad (dS/m) } & 1.8 & 0.78 & & \\
\hline \multicolumn{2}{|c|}{ Observaciones } & & & & \\
\hline
\end{tabular}


ANÁLISIS DE COMPOSICIÓN DE SUELOS

Desarrollo de una aplicación informática para el cálculo de sostenimiento de taludes mediante vegetación

\begin{tabular}{|c|c|c|c|c|c|}
\hline \multirow[t]{2}{*}{ Perfil $n^{\circ}$} & \multirow[t]{2}{*}{57} & & & & \\
\hline & & Horizonte A & Horizonte B & Horizonte C & Horizonte D \\
\hline \multirow{3}{*}{ Textura } & Arena (\%) & 36 & & & \\
\hline & Limo (\%) & 41 & & & \\
\hline & Arcilla (\%) & 23 & 100 & 100 & \\
\hline \multicolumn{2}{|c|}{ Clase textural } & Franca & Franca & Franca & \\
\hline \multicolumn{2}{|l|}{ pH } & 5.5 & 5.1 & 5.8 & \\
\hline \multicolumn{2}{|c|}{ Carbonatos (\% caliza) } & ip & ip & ip & \\
\hline \multicolumn{2}{|c|}{ Materia orgánica (\%) } & 1.5 & 0.5 & ----- & \\
\hline \multicolumn{2}{|c|}{ Nitrogeno total (\%) } & 0.5 & 0.2 & ---- & \\
\hline \multicolumn{2}{|c|}{ Relación C/N } & 6 & 1 & ----- & \\
\hline \multicolumn{2}{|c|}{ Fosforo (olssen ppm) } & 25 & 11 & 15 & \\
\hline \multicolumn{2}{|c|}{ Calcio (ppm) } & 89 & 79 & 56 & \\
\hline \multicolumn{2}{|c|}{ Potasio (ppm) } & 71 & 60 & 22 & \\
\hline \multicolumn{2}{|c|}{ Magnesio (ppm) } & 41 & 33 & 25 & \\
\hline \multicolumn{2}{|l|}{$\mathrm{Ca} / \mathrm{Mg}$} & 2.17 & 2.394 & 2.24 & \\
\hline \multicolumn{2}{|c|}{ Sodio (ppm) } & 15 & 25 & 38 & \\
\hline \multicolumn{2}{|c|}{ C.I.C. Meq/100g } & 10 & 7.4 & 9 & \\
\hline \multicolumn{2}{|c|}{ Manganeso (ppm) } & 45 & 50 & ip & \\
\hline \multicolumn{2}{|c|}{ Hierro (ppm) } & 0.5 & 1 & ip & \\
\hline \multicolumn{2}{|c|}{ Cobre (ppm) } & 0.66 & 0.5 & ip & \\
\hline \multicolumn{2}{|l|}{ Zinc (ppm) } & ip & ip & ip & \\
\hline \multicolumn{2}{|l|}{ Boro (ppm) } & ip & ip & ip & \\
\hline \multicolumn{2}{|c|}{ Conductividad (dS/m) } & 1.5 & 1.2 & 1.1 & \\
\hline \multicolumn{2}{|c|}{ Observaciones } & & & & \\
\hline
\end{tabular}


ANÁLISIS DE COMPOSICIÓN DE SUELOS

Desarrollo de una aplicación informática para el cálculo de sostenimiento de taludes mediante vegetación

\begin{tabular}{|c|c|c|c|c|c|}
\hline \multirow[t]{2}{*}{ Perfil $n^{\circ}$} & \multirow[t]{2}{*}{58} & \multirow[b]{2}{*}{ Horizonte A } & \multirow[b]{2}{*}{ Horizonte B } & \multirow[b]{2}{*}{ Horizonte C } & \multirow[b]{2}{*}{ Horizonte D } \\
\hline & & & & & \\
\hline \multirow{3}{*}{ Textura } & Arena (\%) & 39 & & & \\
\hline & Limo (\%) & 43 & & & \\
\hline & Arcilla (\%) & 18 & & & \\
\hline \multicolumn{2}{|c|}{ Clase textural } & Franca & & & \\
\hline \multicolumn{2}{|l|}{ pH } & 5.5 & & & \\
\hline \multicolumn{2}{|c|}{ Carbonatos ( $\%$ caliza) } & 1.5 & & & \\
\hline \multicolumn{2}{|c|}{ Materia orgánica (\%) } & 2.5 & & & \\
\hline \multicolumn{2}{|c|}{ Nitrogeno total (\%) } & 0.07 & & & \\
\hline \multicolumn{2}{|c|}{ Relación C/N } & 5 & & & \\
\hline \multicolumn{2}{|c|}{ Fosforo (olssen ppm) } & 10 & & & \\
\hline \multicolumn{2}{|c|}{ Calcio (ppm) } & 699 & & & \\
\hline \multicolumn{2}{|c|}{ Potasio (ppm) } & 92 & & & \\
\hline \multicolumn{2}{|c|}{ Magnesio (ppm) } & 201 & & & \\
\hline \multicolumn{2}{|l|}{$\mathrm{Ca} / \mathrm{Mg}$} & 3.48 & & & \\
\hline \multicolumn{2}{|c|}{ Sodio (ppm) } & 23 & & & \\
\hline \multicolumn{2}{|c|}{ C.I.C. Meq/100g } & 6 & & & \\
\hline \multicolumn{2}{|c|}{ Manganeso (ppm) } & 14 & & & \\
\hline \multicolumn{2}{|c|}{ Hierro (ppm) } & 0.25 & & & \\
\hline \multicolumn{2}{|c|}{ Cobre (ppm) } & ip & & & \\
\hline \multicolumn{2}{|l|}{ Zinc (ppm) } & ip & & & \\
\hline \multicolumn{2}{|l|}{ Boro (ppm) } & 0.15 & & & \\
\hline \multicolumn{2}{|c|}{ Conductividad (dS/m) } & 1.22 & & & \\
\hline \multicolumn{2}{|c|}{ Observaciones } & & & & \\
\hline
\end{tabular}




\begin{tabular}{|c|c|c|c|c|c|}
\hline \multirow[t]{2}{*}{ Perfil $n^{\circ}$} & \multirow[t]{2}{*}{59} & \multirow[b]{2}{*}{ Horizonte A } & \multirow[b]{2}{*}{ Horizonte B } & \multirow[b]{2}{*}{ Horizonte C } & \multirow[b]{2}{*}{ Horizonte D } \\
\hline & & & & & \\
\hline \multirow{3}{*}{ Textura } & Arena (\%) & 38 & 30 & 10 & \\
\hline & Limo (\%) & 42 & 35 & 55 & \\
\hline & Arcilla (\%) & 20 & 35 & 35 & \\
\hline \multicolumn{2}{|c|}{ Clase textural } & Franca & Fran-Arci & Fra-Arc-Limo & \\
\hline \multicolumn{2}{|l|}{ pH } & 5.6 & 5.4 & 5.7 & \\
\hline \multicolumn{2}{|c|}{ Carbonatos (\% caliza) } & 5.1 & 4.2 & ---- & \\
\hline \multicolumn{2}{|c|}{ Materia orgánica (\%) } & 2.7 & 0.5 & ---- & \\
\hline \multicolumn{2}{|c|}{ Nitrogeno total (\%) } & 0.16 & ----- & ---- & \\
\hline \multicolumn{2}{|c|}{ Relación C/N } & 9.5 & ---- & ---- & \\
\hline \multicolumn{2}{|c|}{ Fosforo (olssen ppm) } & 10 & 19 & 8 & \\
\hline \multicolumn{2}{|c|}{ Calcio (ppm) } & 832 & 965 & 269 & \\
\hline \multicolumn{2}{|c|}{ Potasio (ppm) } & 154 & 215 & 96 & \\
\hline \multicolumn{2}{|c|}{ Magnesio (ppm) } & 265 & 158 & 64 & \\
\hline \multicolumn{2}{|l|}{$\mathrm{Ca} / \mathrm{Mg}$} & 3.14 & 6.11 & 4.20 & \\
\hline \multicolumn{2}{|c|}{ Sodio (ppm) } & 28 & 27 & 42 & \\
\hline \multicolumn{2}{|c|}{ C.I.C. Meq/100g } & 15 & 14 & 10 & \\
\hline \multicolumn{2}{|c|}{ Manganeso (ppm) } & 2 & 2.5 & ip & \\
\hline \multicolumn{2}{|c|}{ Hierro (ppm) } & ip & ip & ip & \\
\hline \multicolumn{2}{|c|}{ Cobre (ppm) } & ip & ip & ip & \\
\hline \multicolumn{2}{|l|}{ Zinc (ppm) } & 0.2 & ip & ip & \\
\hline \multicolumn{2}{|l|}{ Boro (ppm) } & 1.1 & 0.3 & ip & \\
\hline \multicolumn{2}{|c|}{ Conductividad (dS/m) } & 1.1 & 1.2 & 2.6 & \\
\hline \multicolumn{2}{|c|}{ Observaciones } & & & & \\
\hline
\end{tabular}


ANÁLISIS DE COMPOSICIÓN DE SUELOS

Desarrollo de una aplicación informática para el cálculo de sostenimiento de taludes mediante vegetación

\begin{tabular}{|c|c|c|c|c|c|}
\hline \multirow[t]{2}{*}{ Perfil no } & \multirow[t]{2}{*}{60} & & & & \\
\hline & & Horizonte A & Horizonte B & Horizonte C & Horizonte D \\
\hline \multirow{3}{*}{ Textura } & Arena (\%) & 27 & 44 & 58 & \\
\hline & Limo (\%) & 62 & 38 & 10 & \\
\hline & Arcilla (\%) & 11 & 18 & 32 & \\
\hline \multicolumn{2}{|c|}{ Clase textural } & Franc-Lim & Franca & Fra-Are-Arc & \\
\hline \multicolumn{2}{|l|}{ pH } & 5.8 & 5.7 & 5.6 & \\
\hline \multicolumn{2}{|c|}{ Carbonatos (\% caliza) } & 5.6 & 5.2 & 4.1 & \\
\hline \multicolumn{2}{|c|}{ Materia orgánica (\%) } & 3.4 & 1.1 & ----- & \\
\hline \multicolumn{2}{|c|}{ Nitrogeno total (\%) } & 0.18 & 0.256 & ----- & \\
\hline \multicolumn{2}{|c|}{ Relación C/N } & 10 & 5 & ----- & \\
\hline \multicolumn{2}{|c|}{ Fosforo (olssen ppm) } & 14.5 & 18 & 6 & \\
\hline \multicolumn{2}{|c|}{ Calcio (ppm) } & 825 & 921 & 573 & \\
\hline \multicolumn{2}{|c|}{ Potasio (ppm) } & 133 & 244 & 132 & \\
\hline \multicolumn{2}{|c|}{ Magnesio (ppm) } & 201 & 123 & 94 & \\
\hline \multicolumn{2}{|l|}{$\mathrm{Ca} / \mathrm{Mg}$} & 4.10 & 7.49 & 6.10 & \\
\hline \multicolumn{2}{|c|}{ Sodio (ppm) } & 21 & 26 & 31 & \\
\hline \multicolumn{2}{|c|}{ C.I.C. Meq/100g } & 13 & 10 & 9 & \\
\hline \multicolumn{2}{|c|}{ Manganeso (ppm) } & 19 & 17 & 22 & \\
\hline \multicolumn{2}{|c|}{ Hierro (ppm) } & 0.1 & 0.4 & 0.7 & \\
\hline \multicolumn{2}{|c|}{ Cobre (ppm) } & 0.2 & 0.15 & 0.05 & \\
\hline \multicolumn{2}{|l|}{ Zinc (ppm) } & 0.18 & 0.2 & 0.04 & \\
\hline \multicolumn{2}{|l|}{ Boro (ppm) } & 0.9 & 0.4 & 0.15 & \\
\hline \multicolumn{2}{|c|}{ Conductividad (dS/m) } & 1.1 & 1.4 & 2.1 & \\
\hline \multicolumn{2}{|c|}{ Observaciones } & & & & \\
\hline
\end{tabular}


ANÁLISIS DE COMPOSICIÓN DE SUELOS

Desarrollo de una aplicación informática para el cálculo de sostenimiento de taludes mediante vegetación

\begin{tabular}{|c|c|c|c|c|c|}
\hline \multirow[t]{2}{*}{ Perfil no } & \multirow[t]{2}{*}{61} & & & & \\
\hline & & Horizonte A & Horizonte B & Horizonte C & Horizonte D \\
\hline \multirow{3}{*}{ Textura } & Arena (\%) & 62 & 38 & & \\
\hline & Limo (\%) & 21 & 38 & & \\
\hline & Arcilla (\%) & 17 & 24 & & \\
\hline \multicolumn{2}{|c|}{ Clase textural } & Franc-Aren & Franca & & \\
\hline \multicolumn{2}{|l|}{ pH } & 6.7 & 5.5 & & \\
\hline \multicolumn{2}{|c|}{ Carbonatos (\% caliza) } & 4.5 & 3.2 & & \\
\hline \multicolumn{2}{|c|}{ Materia orgánica (\%) } & 1.05 & 3.7 & & \\
\hline \multicolumn{2}{|c|}{ Nitrogeno total (\%) } & 0.08 & 0.12 & & \\
\hline \multicolumn{2}{|c|}{ Relación C/N } & 7 & 8 & & \\
\hline \multicolumn{2}{|c|}{ Fosforo (olssen ppm) } & 22 & 19 & & \\
\hline \multicolumn{2}{|c|}{ Calcio (ppm) } & 305 & 365 & & \\
\hline \multicolumn{2}{|c|}{ Potasio (ppm) } & 186 & 69 & & \\
\hline \multicolumn{2}{|c|}{ Magnesio (ppm) } & 165 & 59 & & \\
\hline \multicolumn{2}{|l|}{$\mathrm{Ca} / \mathrm{Mg}$} & 1.848 & 6.186 & & \\
\hline \multicolumn{2}{|c|}{ Sodio (ppm) } & 15 & 15 & & \\
\hline \multicolumn{2}{|c|}{ C.I.C. Meq/100g } & 14 & 4 & & \\
\hline \multicolumn{2}{|c|}{ Manganeso (ppm) } & 0.2 & ip & & \\
\hline \multicolumn{2}{|c|}{ Hierro (ppm) } & 0.05 & ip & & \\
\hline \multicolumn{2}{|c|}{ Cobre (ppm) } & 1.5 & ip & & \\
\hline \multicolumn{2}{|c|}{ Zinc (ppm) } & 0.03 & ip & & \\
\hline \multicolumn{2}{|c|}{ Boro (ppm) } & 0.07 & ip & & \\
\hline \multicolumn{2}{|c|}{ Conductividad (dS/m) } & 1.02 & 0.09 & & \\
\hline \multicolumn{2}{|c|}{ Observaciones } & & & & \\
\hline
\end{tabular}


ANÁLISIS DE COMPOSICIÓN DE SUELOS

Desarrollo de una aplicación informática para el cálculo de sostenimiento de taludes mediante vegetación

\begin{tabular}{|c|c|c|c|c|c|}
\hline Perfil $n^{o}$ & 62 & & & & \\
\hline & & Horizonte A & Horizonte B & Horizonte C & Horizonte D \\
\hline & Arena (\%) & 43 & & & \\
\hline Textura & Limo (\%) & 38 & & & \\
\hline & Arcilla (\%) & 19 & & & \\
\hline Clase textu & & Franc & & & \\
\hline pH & & 5.3 & & & \\
\hline Carbonatos & (\% caliza) & 6.5 & & & \\
\hline Materia or & ́́nica (\%) & 2.2 & & & \\
\hline Nitrogeno $t$ & tal (\%) & 0.11 & & & \\
\hline Relación C/ & & 11 & & & \\
\hline Fosforo (ols & en ppm) & 19 & & & \\
\hline Calcio (ppn & & 455 & & & \\
\hline Potasio (pp & & 174 & & & \\
\hline Magnesio ( & pm) & 86 & & & \\
\hline $\mathrm{Ca} / \mathrm{Mg}$ & & 2.023 & & & \\
\hline Sodio (ppm & & 12 & & & \\
\hline C.I.C. Meq & $00 \mathrm{~g}$ & 10 & & & \\
\hline Manganeso & ppm) & 22 & & & \\
\hline Hierro (ppr & & 3 & & & \\
\hline Cobre (ppn & & 0.2 & & & \\
\hline Zinc (ppm) & & 0.01 & & & \\
\hline Boro (ppm) & & 1.1 & & & \\
\hline Conductivi & ad $(\mathrm{dS} / \mathrm{m})$ & 0.09 & & & \\
\hline Observacion & & & & & \\
\hline
\end{tabular}


ANÁLISIS DE COMPOSICIÓN DE SUELOS

Desarrollo de una aplicación informática para el cálculo de sostenimiento de taludes mediante vegetación

\begin{tabular}{|c|c|c|c|c|c|}
\hline Perfil $n^{o}$ & 63 & & & & \\
\hline & & Horizonte A & Horizonte B & Horizonte C & Horizonte D \\
\hline & Arena $(\%)$ & 31 & & & \\
\hline Textura & Limo (\%) & 52 & & & \\
\hline & Arcilla (\%) & 17 & & & \\
\hline Clase textu & & Franc-Limo & & & \\
\hline pH & & 6 & & & \\
\hline Carbonatos & \% caliza) & 6.2 & & & \\
\hline Materia or & inica (\%) & 0.98 & & & \\
\hline Nitrogeno t & tal (\%) & 0.08 & & & \\
\hline Relación C/ & & 10 & & & \\
\hline Fosforo (ols & en ppm) & 11 & & & \\
\hline Calcio (ppn & & 435 & & & \\
\hline Potasio (pp & & 101 & & & \\
\hline Magnesio (I & m) & 103 & & & \\
\hline $\mathrm{Ca} / \mathrm{Mg}$ & & 4.22 & & & \\
\hline \begin{tabular}{|l|} 
Sodio (ppm \\
\end{tabular} & & 36 & & & \\
\hline C.I.C. Meq & $00 \mathrm{~g}$ & 9 & & & \\
\hline Manganeso & ppm) & 13 & & & \\
\hline Hierro (ppr & & 0.5 & & & \\
\hline Cobre (ppn & & 0.02 & & & \\
\hline Zinc (ppm) & & 0.05 & & & \\
\hline Boro (ppm) & & 0.03 & & & \\
\hline Conductivi & $\mathrm{d}(\mathrm{dS} / \mathrm{m})$ & 1.1 & & & \\
\hline Observacion & & & & & \\
\hline
\end{tabular}


ANÁLISIS DE COMPOSICIÓN DE SUELOS

Desarrollo de una aplicación informática para el cálculo de sostenimiento de taludes mediante vegetación

\begin{tabular}{|c|c|c|c|c|c|}
\hline Perfil no & 64 & & & & \\
\hline & & Horizonte A & Horizonte B & Horizonte C & Horizonte D \\
\hline & Arena (\%) & 33 & & & \\
\hline Textura & Limo (\%) & 56 & & & \\
\hline & Arcilla (\%) & 11 & & & \\
\hline Clase text & & Franc-Limo & & & \\
\hline pH & & 5.8 & & & \\
\hline Carbonato & (\% caliza) & 4.2 & & & \\
\hline Materia or & ́́nica (\%) & 1.2 & & & \\
\hline Nitrogeno & tal (\%) & 0.03 & & & \\
\hline Relación C & & 5 & & & \\
\hline Fosforo (o & en ppm) & 10 & & & \\
\hline Calcio (pp & & 322 & & & \\
\hline Potasio (pI & & 128 & & & \\
\hline Magnesio & pm) & 75 & & & \\
\hline $\mathrm{Ca} / \mathrm{Mg}$ & & 4.29 & & & \\
\hline Sodio (ppn & & 22 & & & \\
\hline C.I.C. Mec & $00 \mathrm{~g}$ & 11 & & & \\
\hline Manganes & ppm) & 19 & & & \\
\hline Hierro (pp & & 1.1 & & & \\
\hline Cobre (pp & & 0.5 & & & \\
\hline Zinc (ppm & & 1.1 & & & \\
\hline Boro (ppm & & 0.07 & & & \\
\hline Conductiv & $\operatorname{ad}(\mathrm{dS} / \mathrm{m})$ & 0.9 & & & \\
\hline Observacio & & & & & \\
\hline
\end{tabular}




\section{Documento adjunto 2}

\section{PRUEBAS DEL MODELO MATEMÁTICO PARA EL CÁLCULO DE}

ESTABILIDAD DE TALUDES.

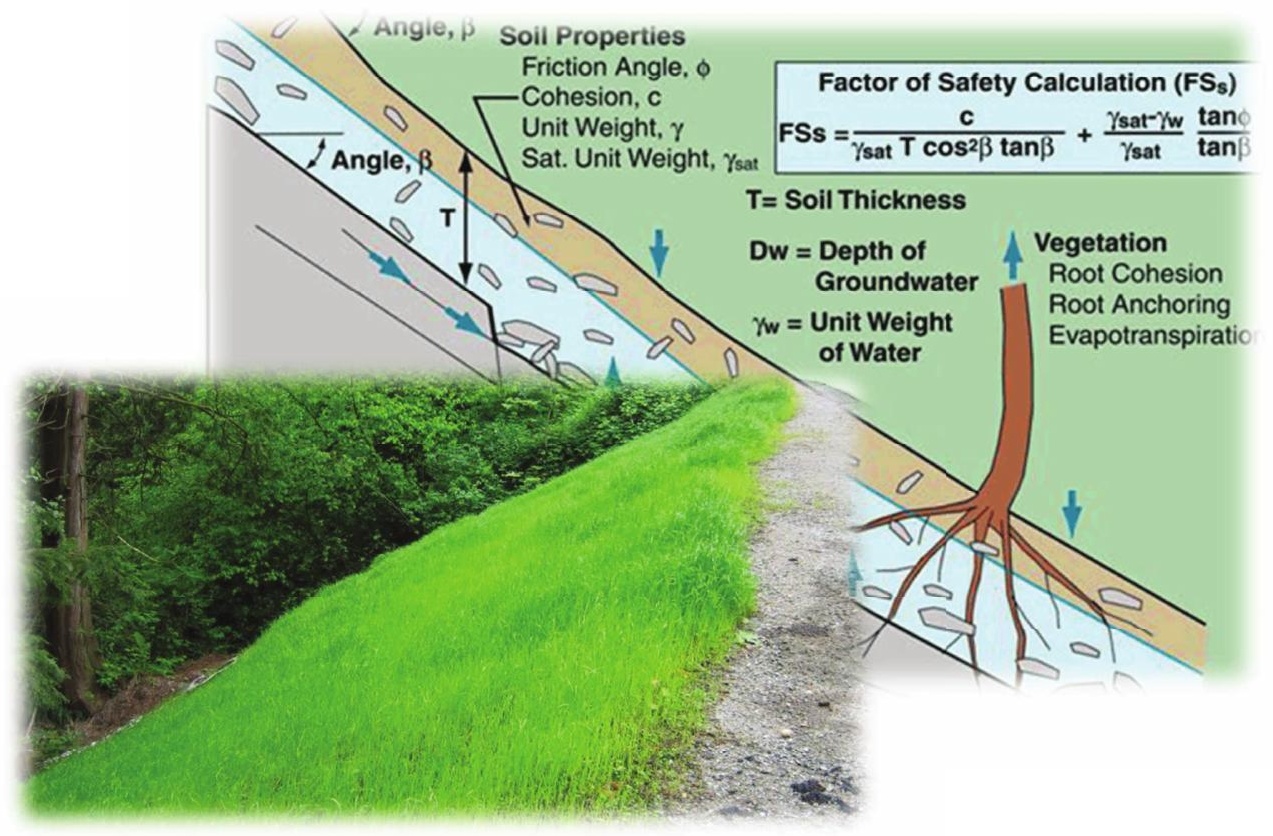


DESARROLLO DE UNA APLICACIÓN IMFORMÁTICA PARA EL CÁLCULO DE SOSTENIMIENTO DE TALUDES MEDIANTE VEGETACIÓN

\section{PRUEBA A: ESPECIES INDIVIDUALES}

A01. DENSIDAD DE PLANTACIÓN: 600 plantas/ha. A02. DENSIDAD DE PLANTACIÓN: 1600 plantas/ha. A03. DENSIDAD DE PLANTACIÓN: 2500 plantas/ha.

\section{PRUEBA B: COMBINACIONES DE ESPECIES}

B01. DENSIDAD DE PLANTACIÓN: 600 plantas/ha.

B02. DENSIDAD DE PLANTACIÓN: 1600 plantas/ha.

B03. DENSIDAD DE PLANTACIÓN: 2500 plantas/ha. 
DESARROLLO DE UNA APLICACIÓN IMFORMÁTICA PARA EL CÁLCULO DE SOSTENIMIENTO DE TALUDES MEDIANTE VEGETACIÓN

PRUEBAS DEL MODELO MATEMÁTICO PARA EL CÁLCULO DE ESTABILIDAD DE TALUDES.

\section{PRUEBA A: ESPECIES INDIVIDUALES}

A01. DENSIDAD DE PLANTACIÓN: 600 plantas/ha.

A01-1.POSICIÓN N.F. 1

A01-2.POSICIÓN N.F. 2

A01-3.POSICIÓN N.F. 3

A01-4.POSICIÓN N.F. 4

A01-5.POSICIÓN N.F. 5 
DESARROLLO DE UNA APLICACIÓN IMFORMÁTICA PARA EL CÁLCULO DE SOSTENIMIENTO DE TALUDES MEDIANTE VEGETACIÓN

A01. DENSIDAD DE PLANTACIÓN: 600 plantas/ha.

\section{A01-1.POSICIÓN N.F. 1}

INCLINACIÓN DE TALUD 6-100

INCLINACIÓN DE TALUD 10-200

INCLINACIÓN DE TALUD 20-30

INCLINACIÓN DE TALUD 30-40

INCLINACIÓN DE TALUD $35^{\circ}$

INCLINACIÓN DE TALUD 40-50

INCLINACIÓN DE TALUD 50-550

INCLINACIÓN DE TALUD 55-60

INCLINACIÓN DE TALUD 60-700

INCLINACIÓN DE TALUD 70-80 

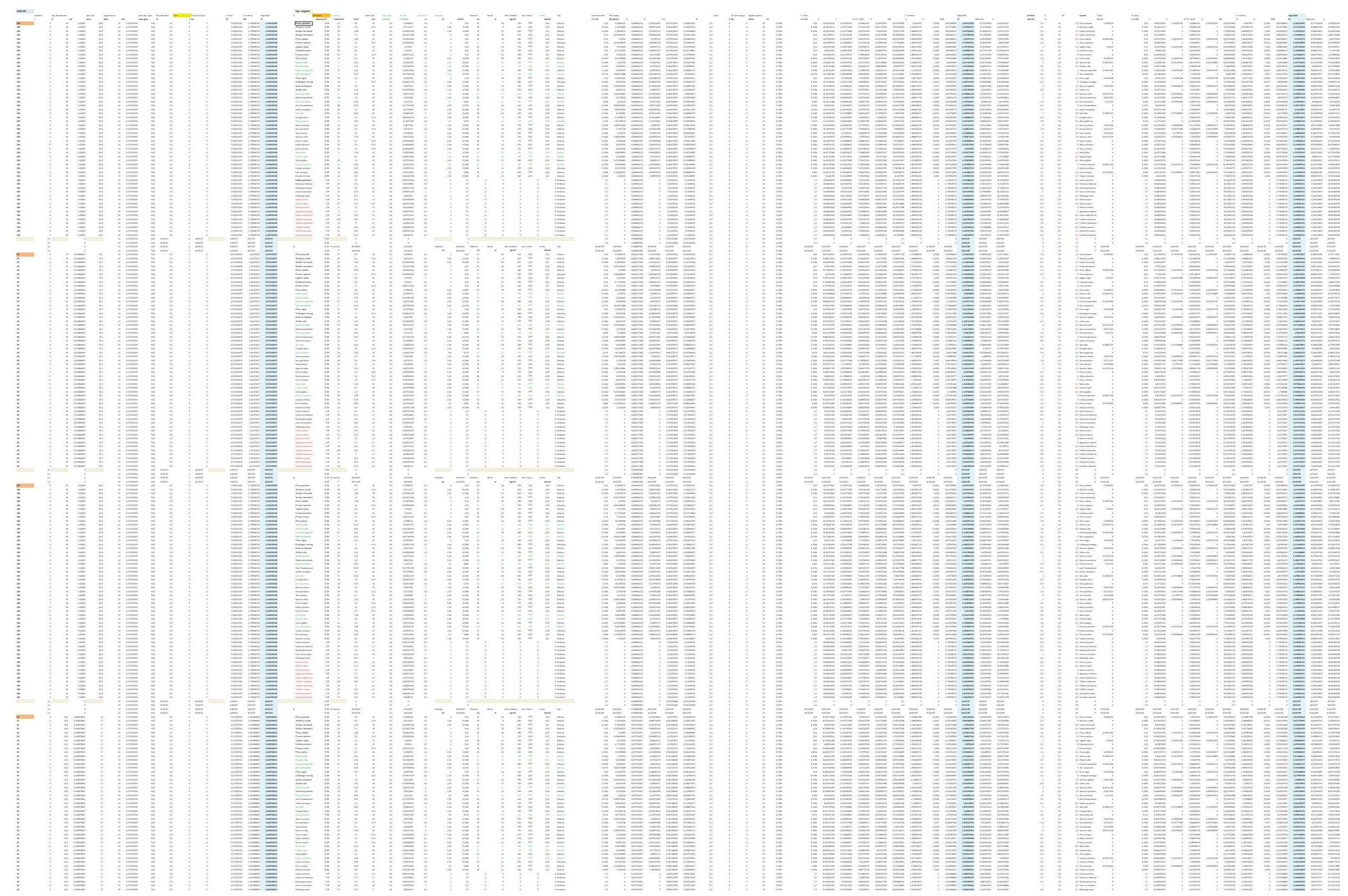


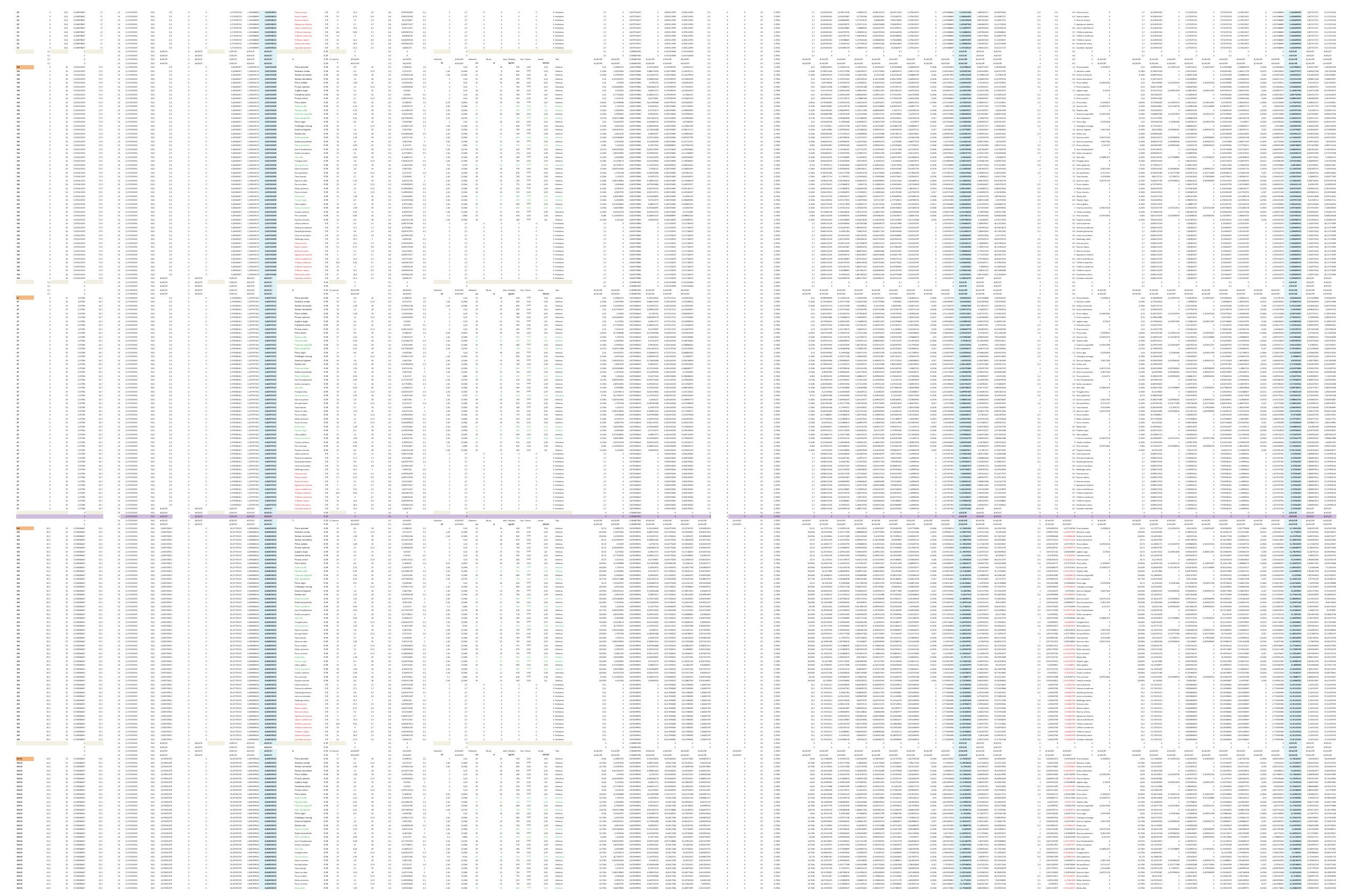



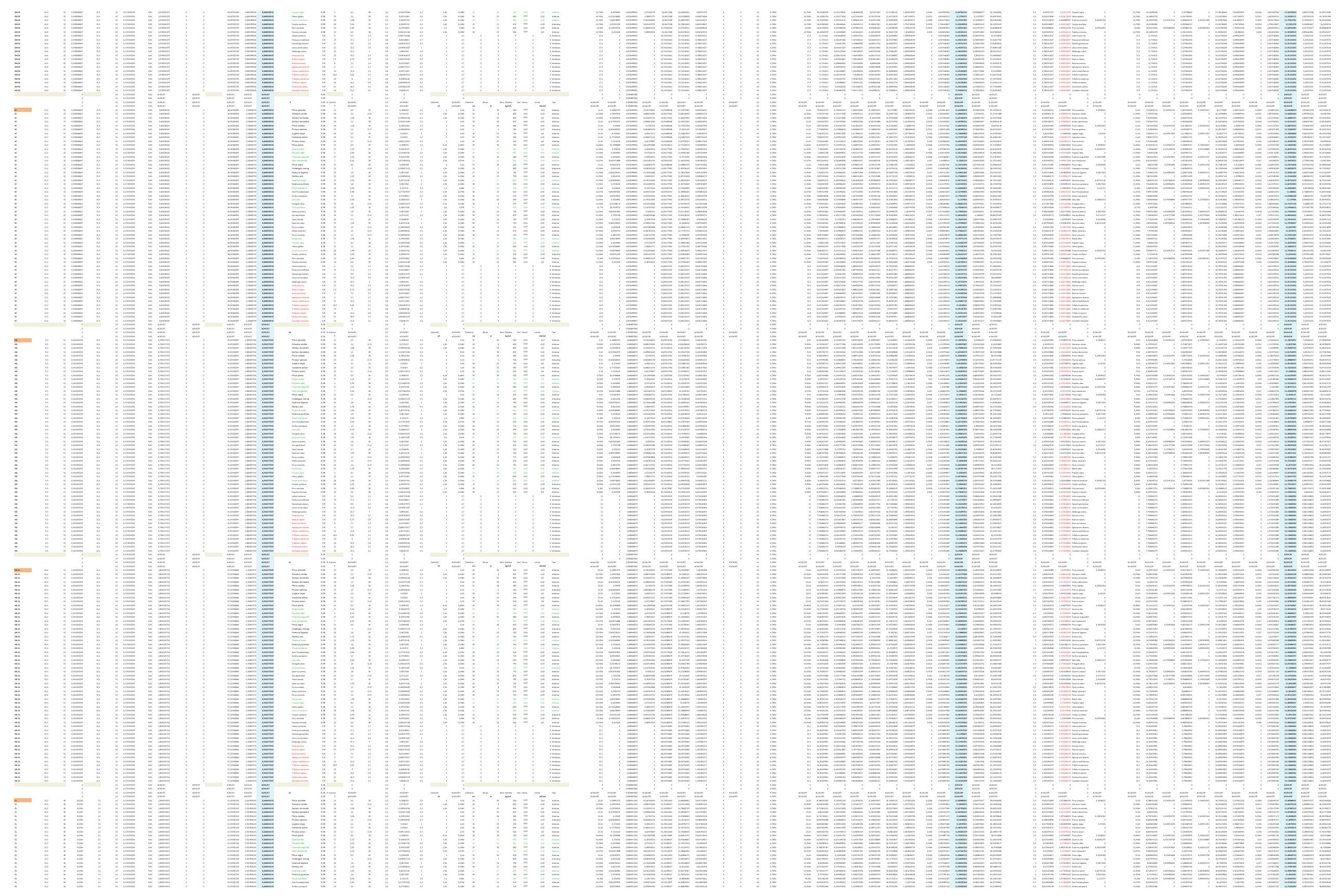


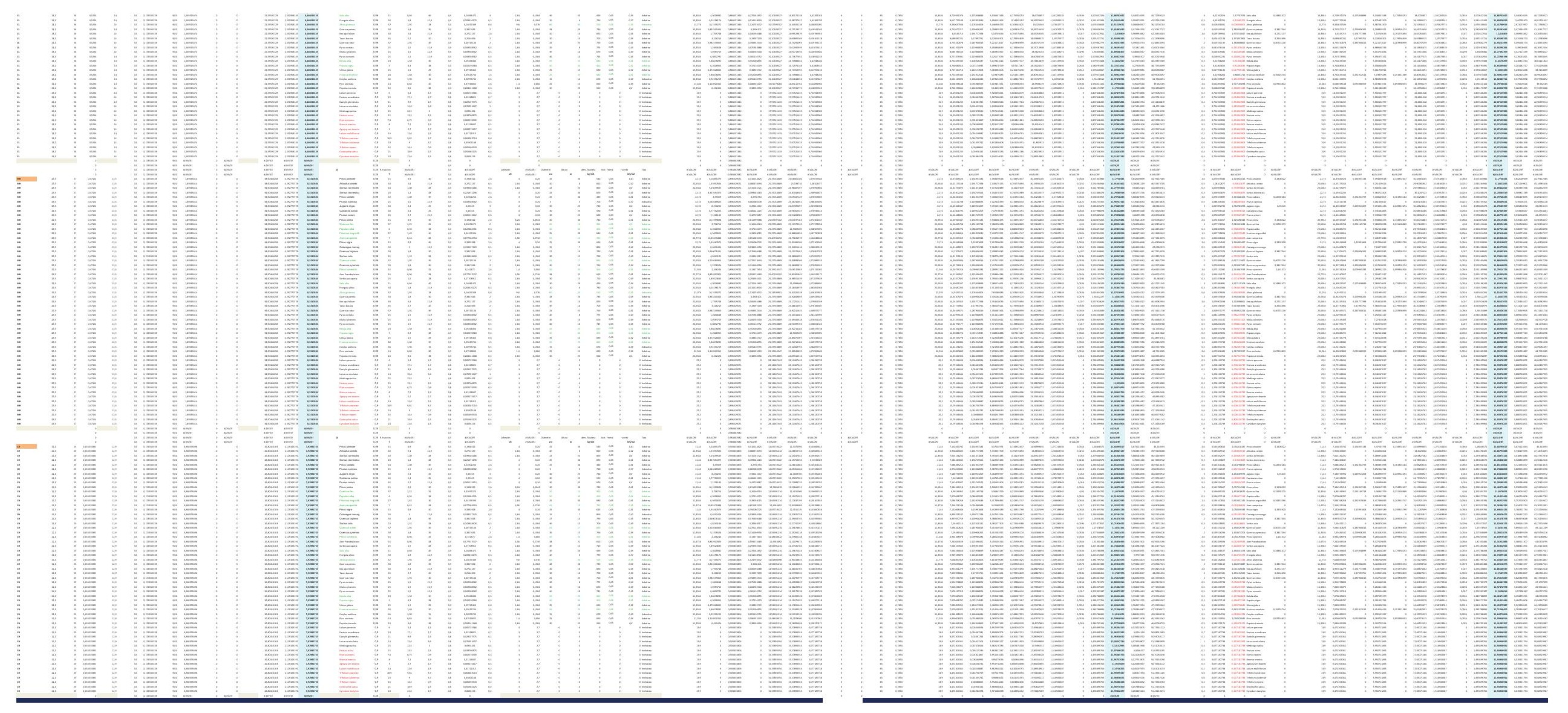



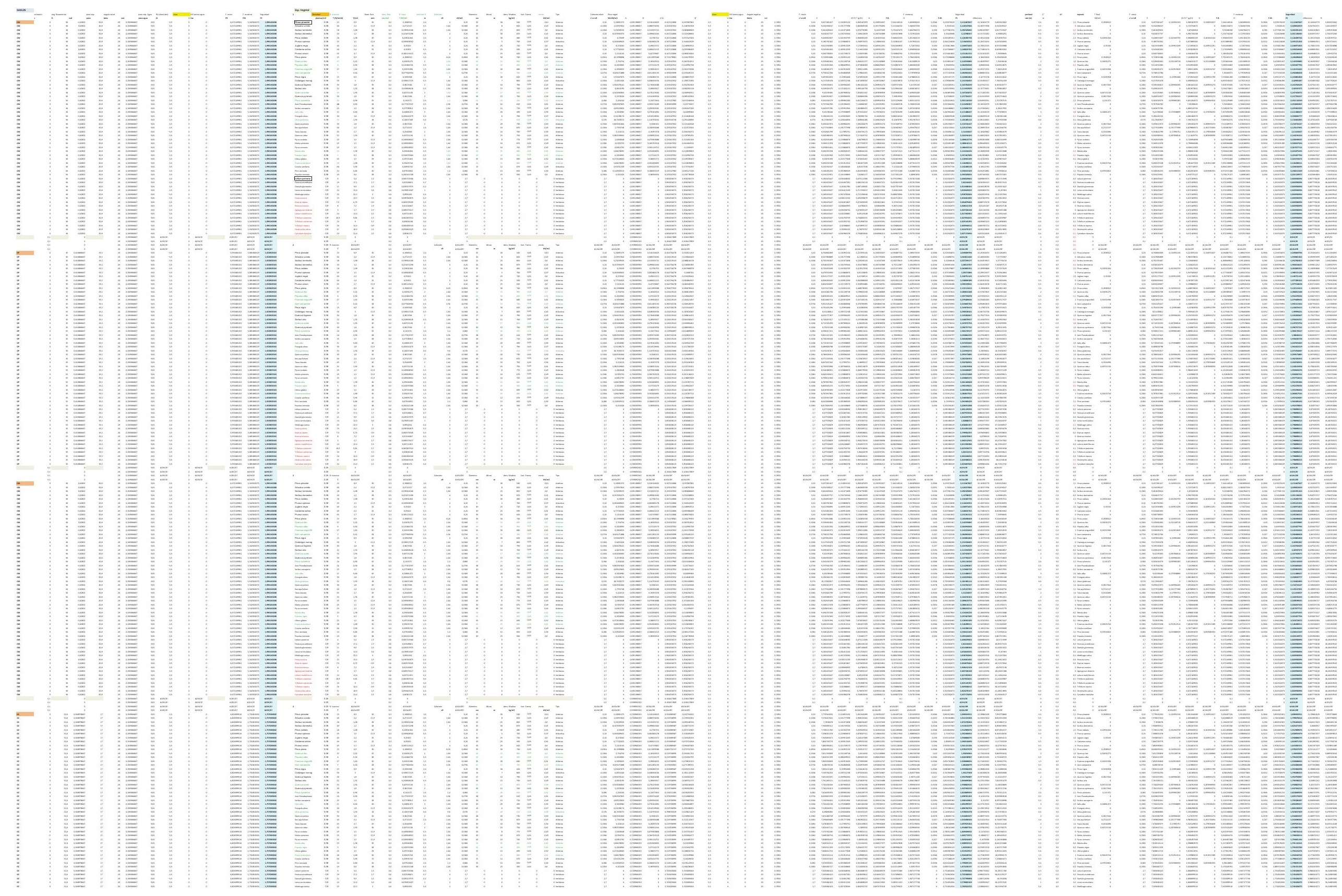


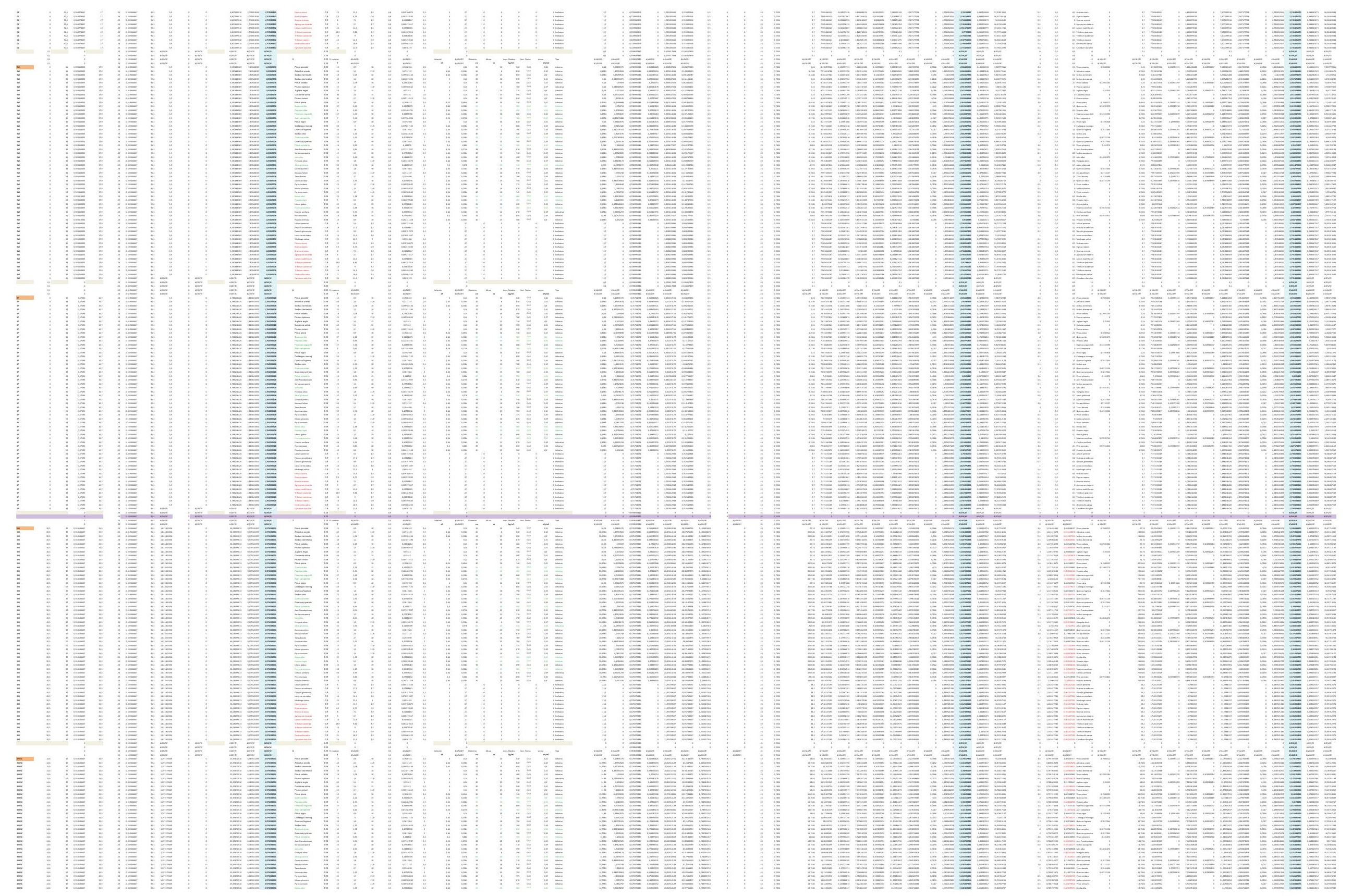



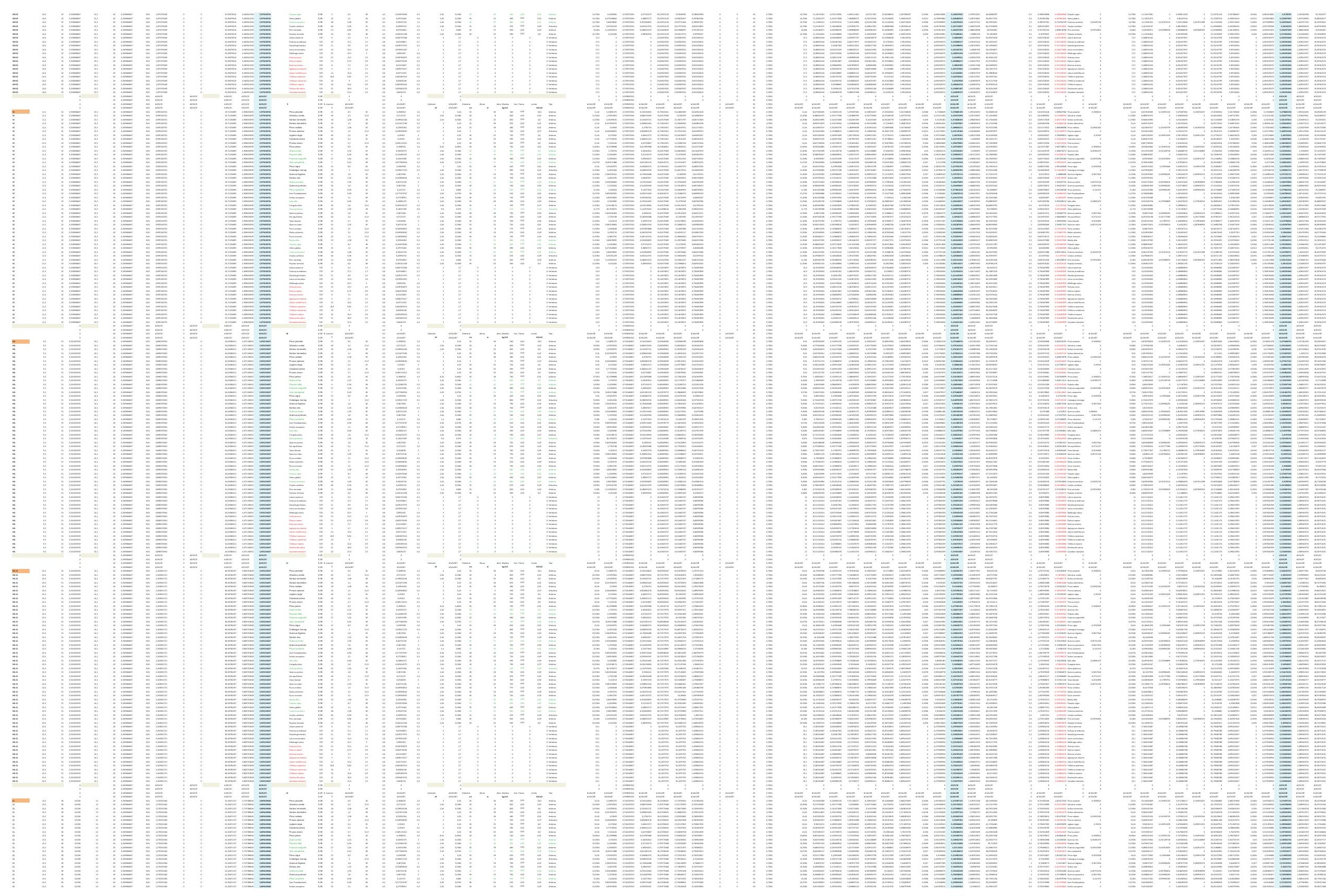


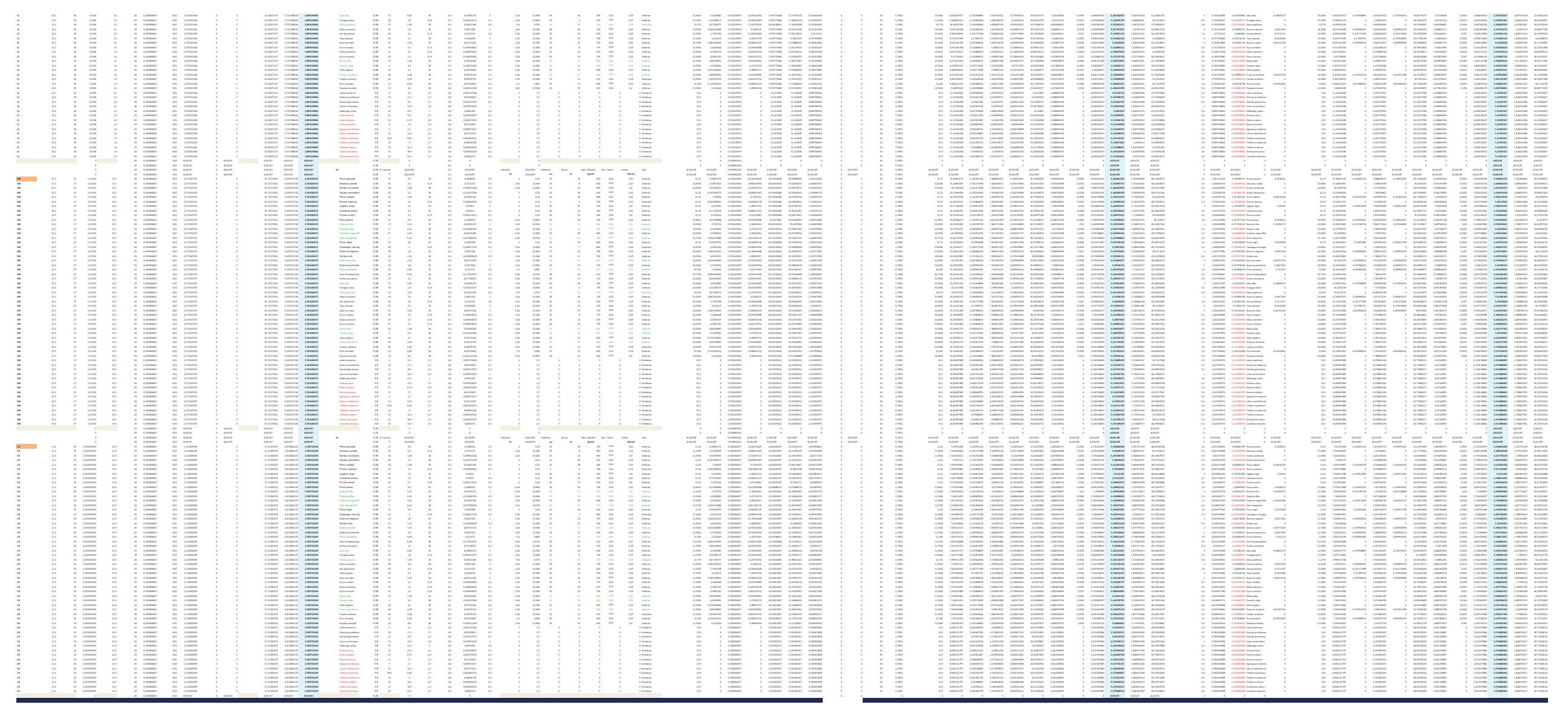



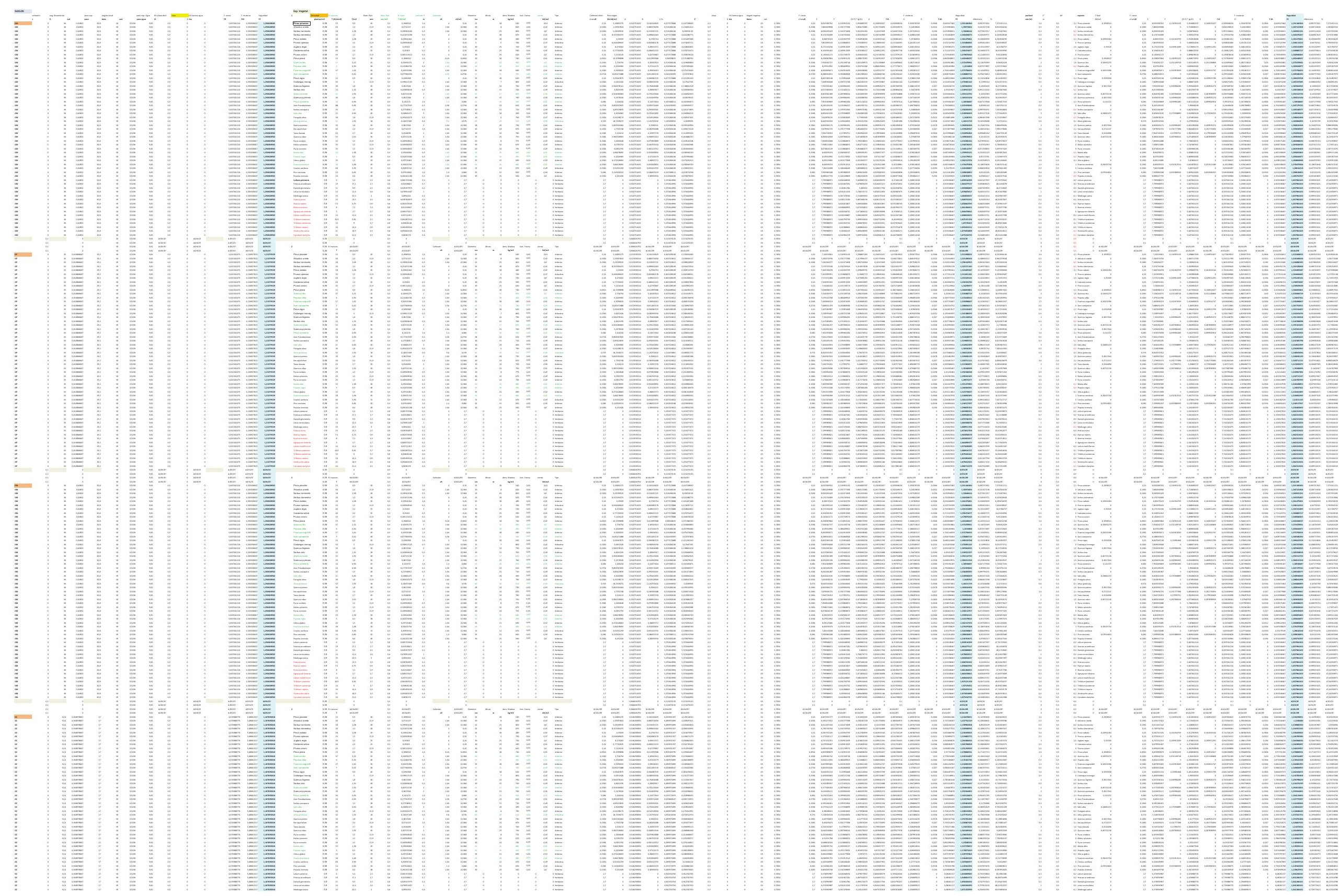


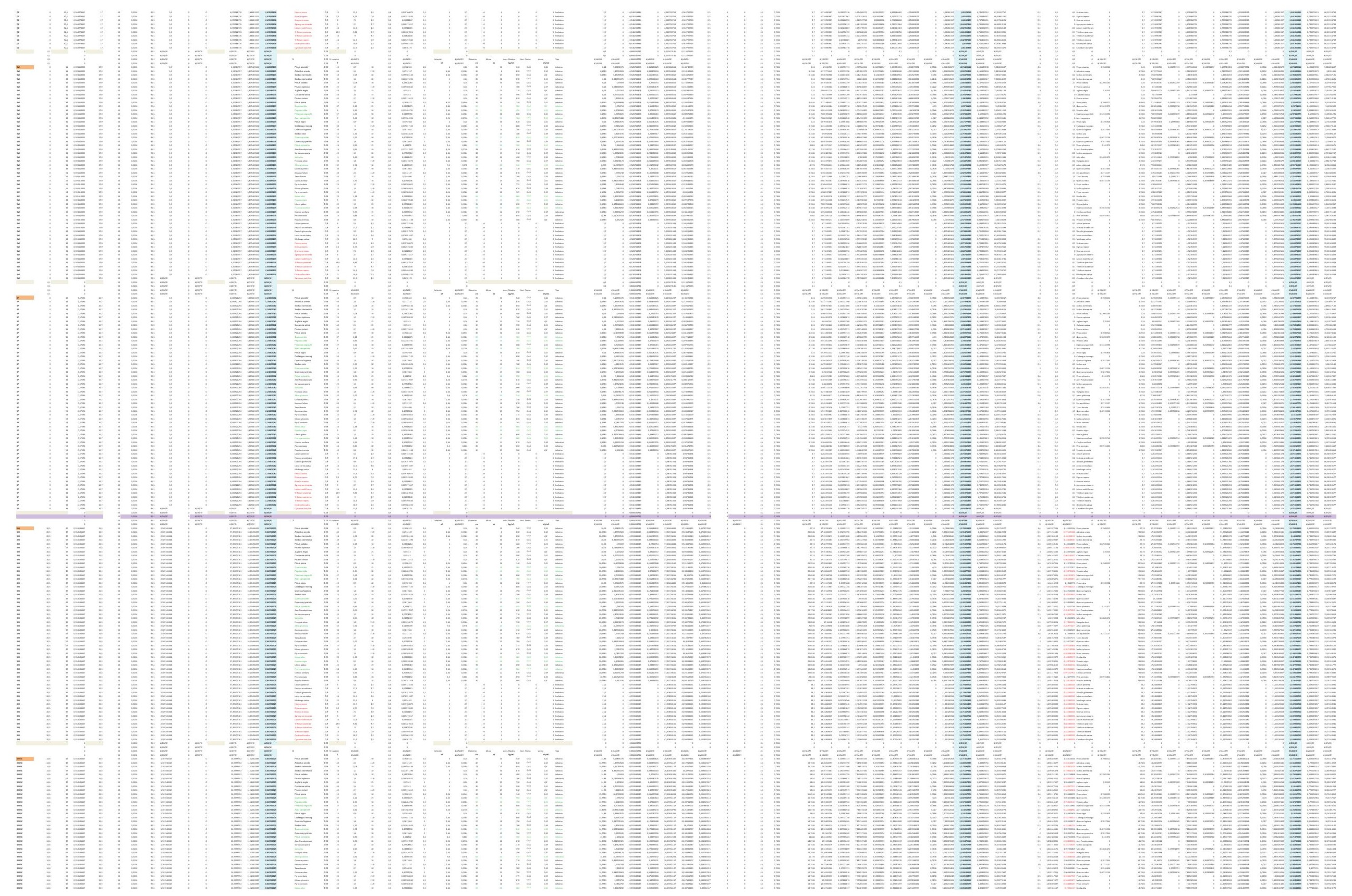



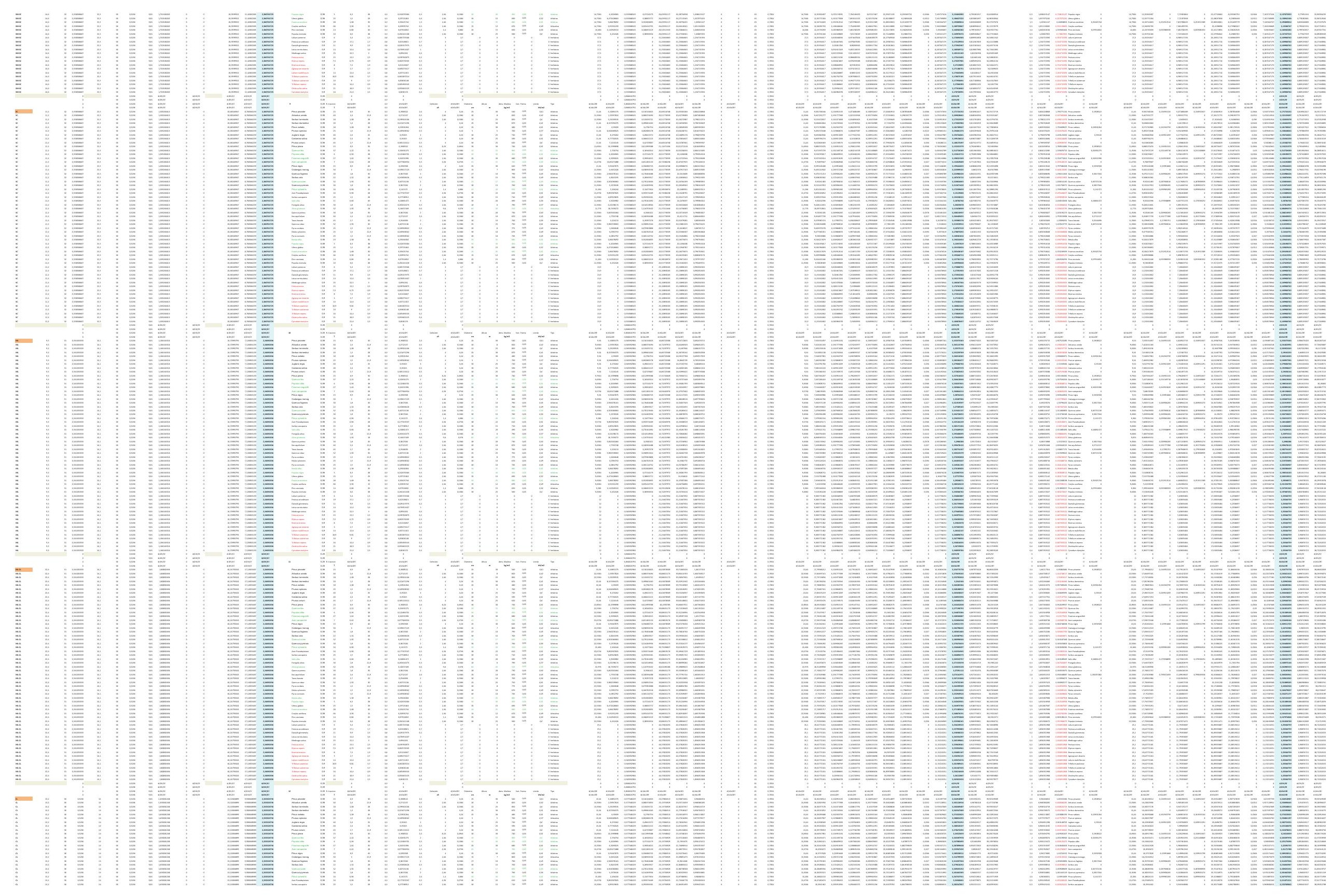


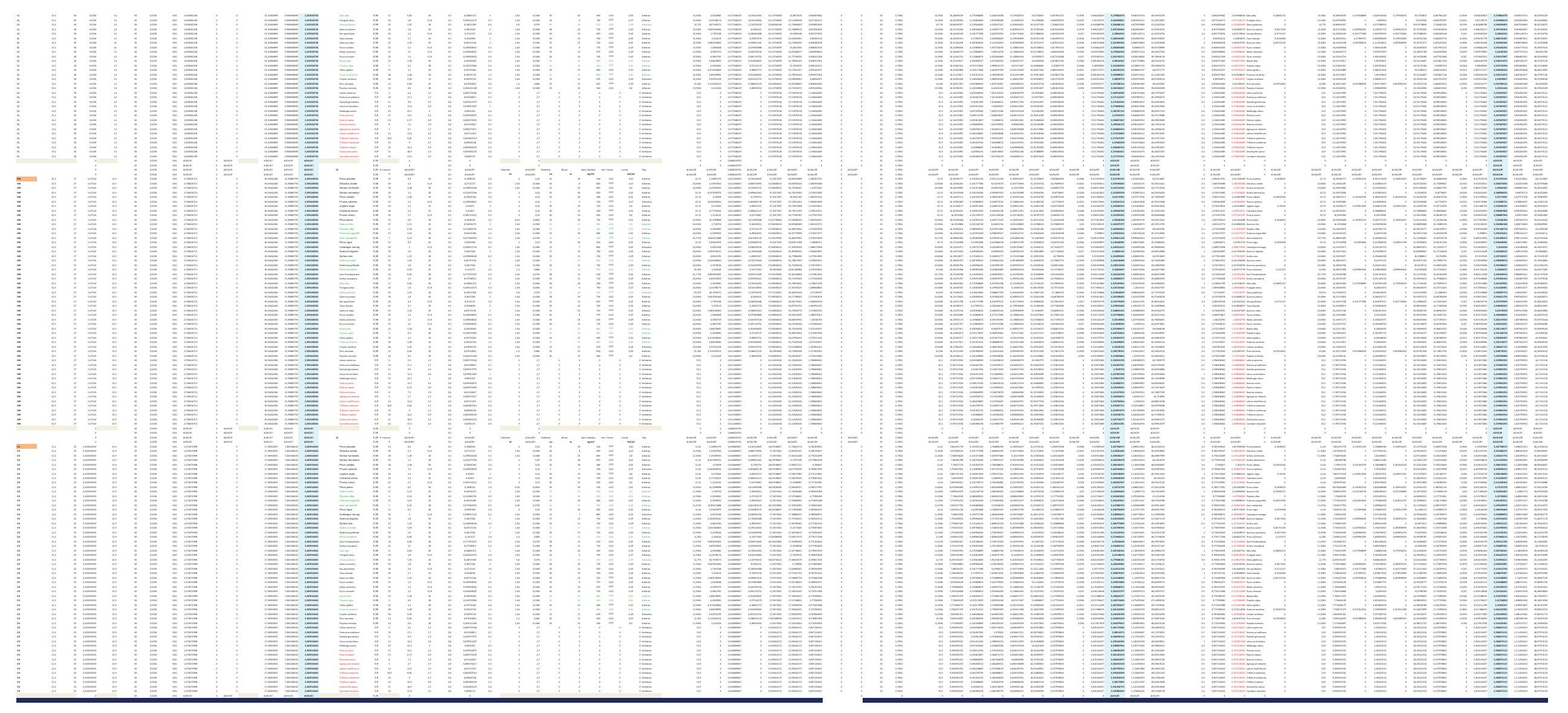



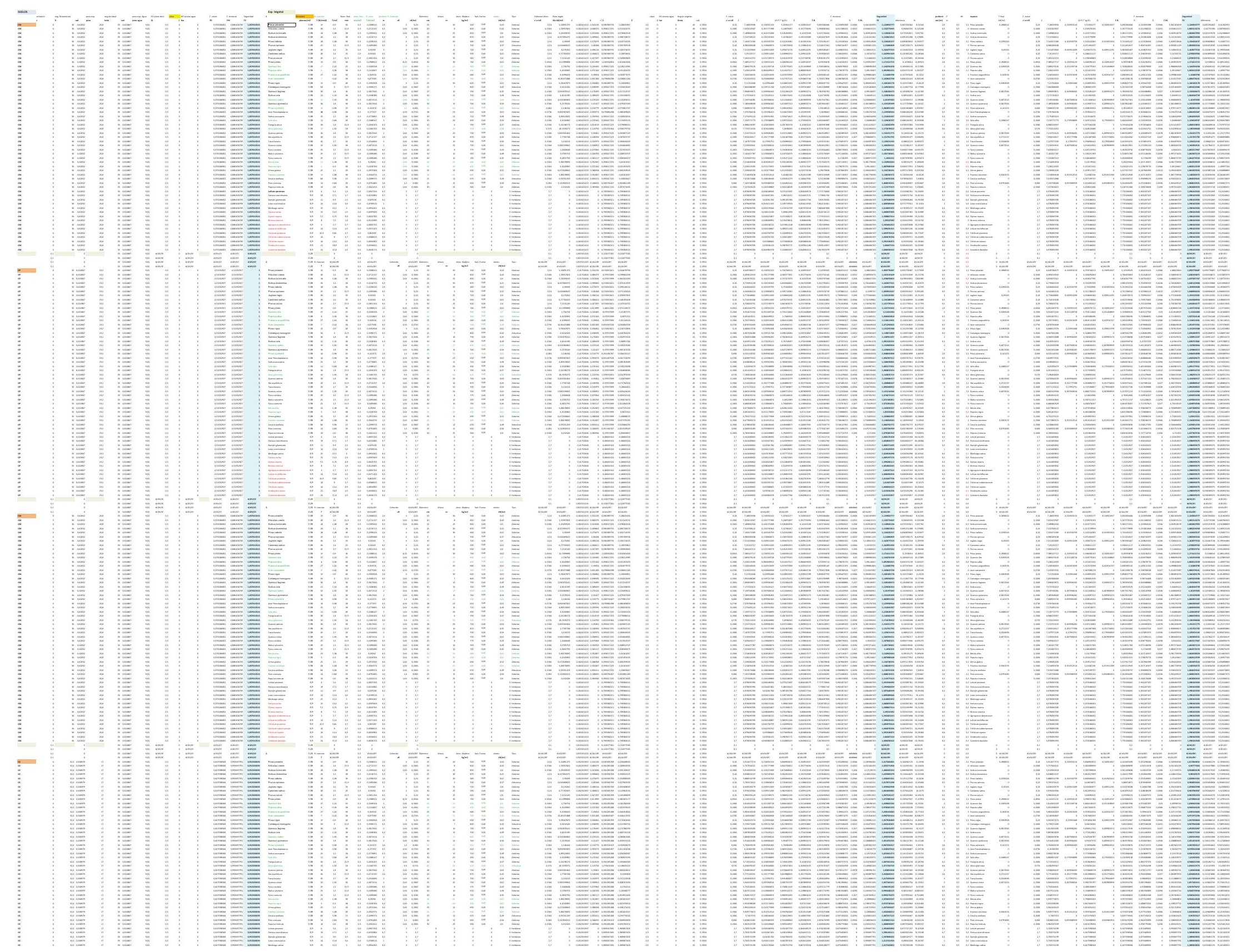


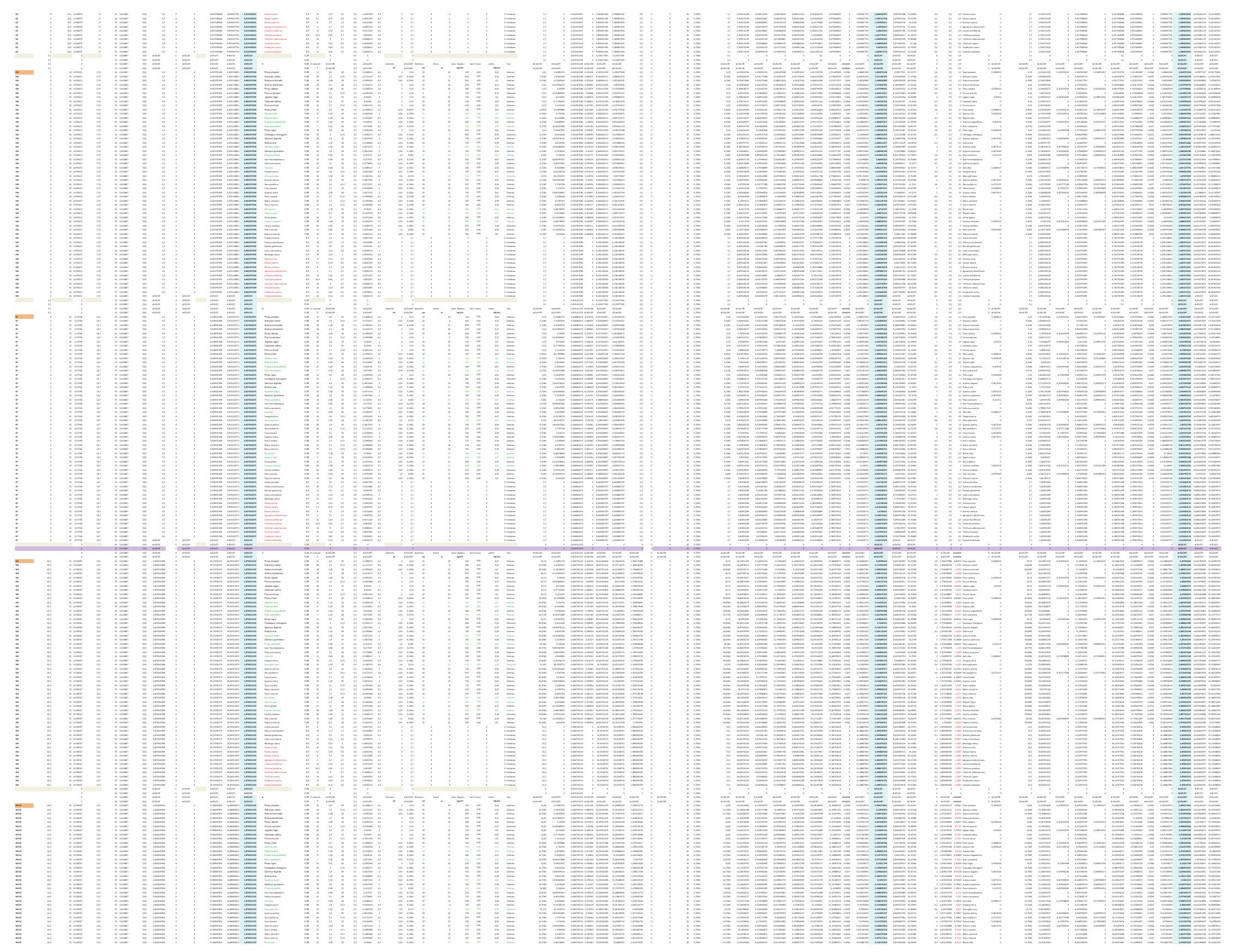



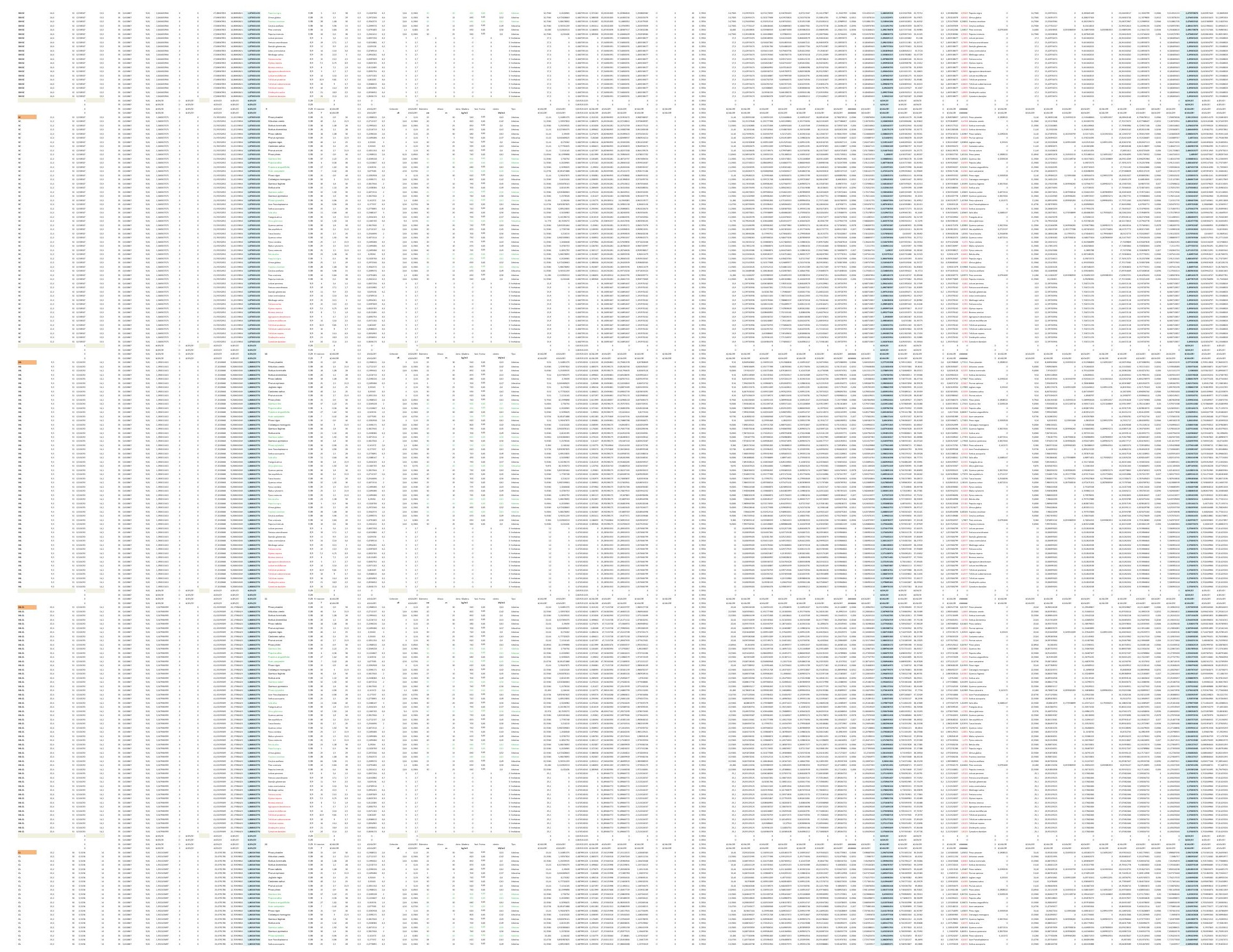


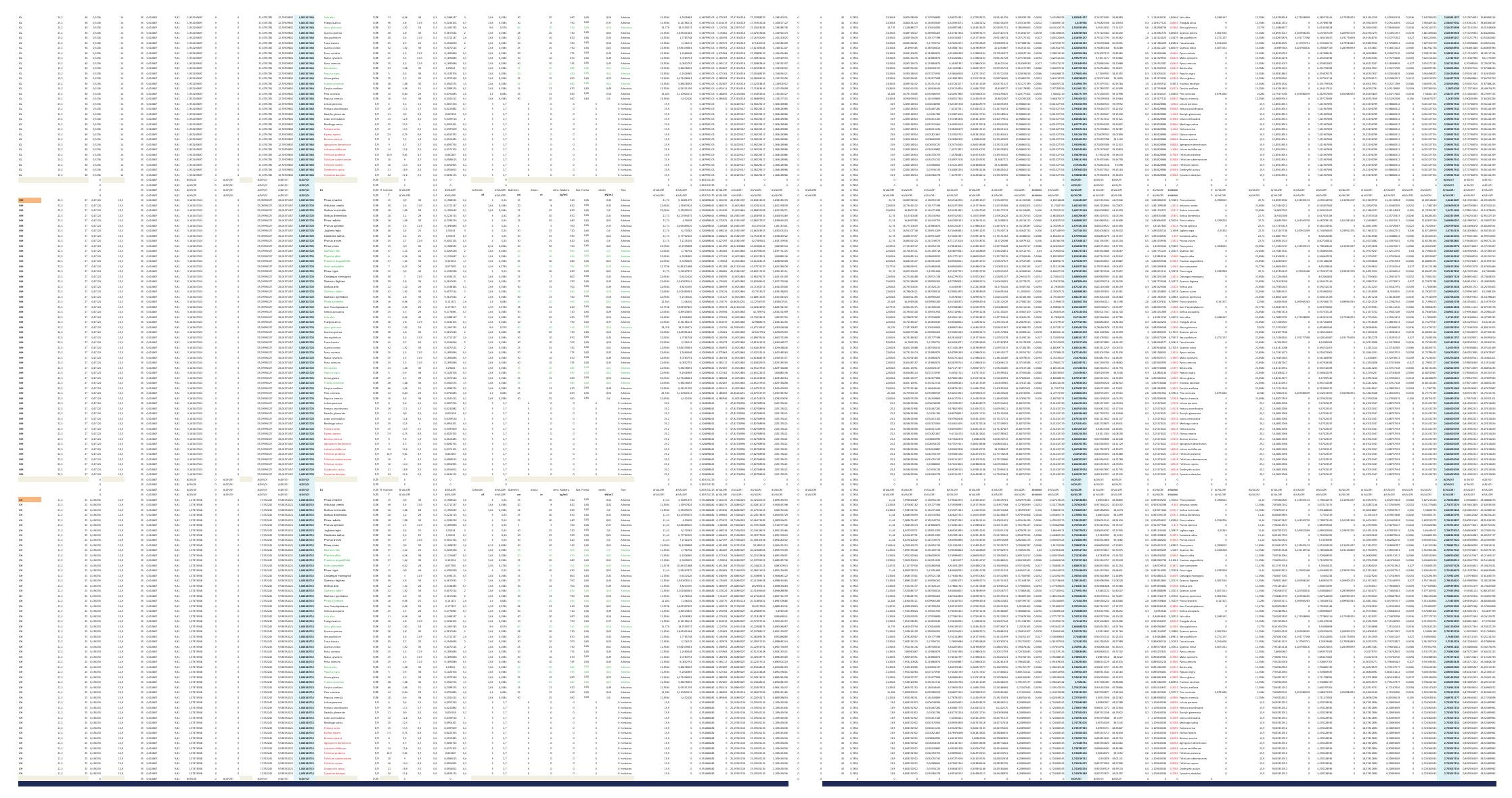



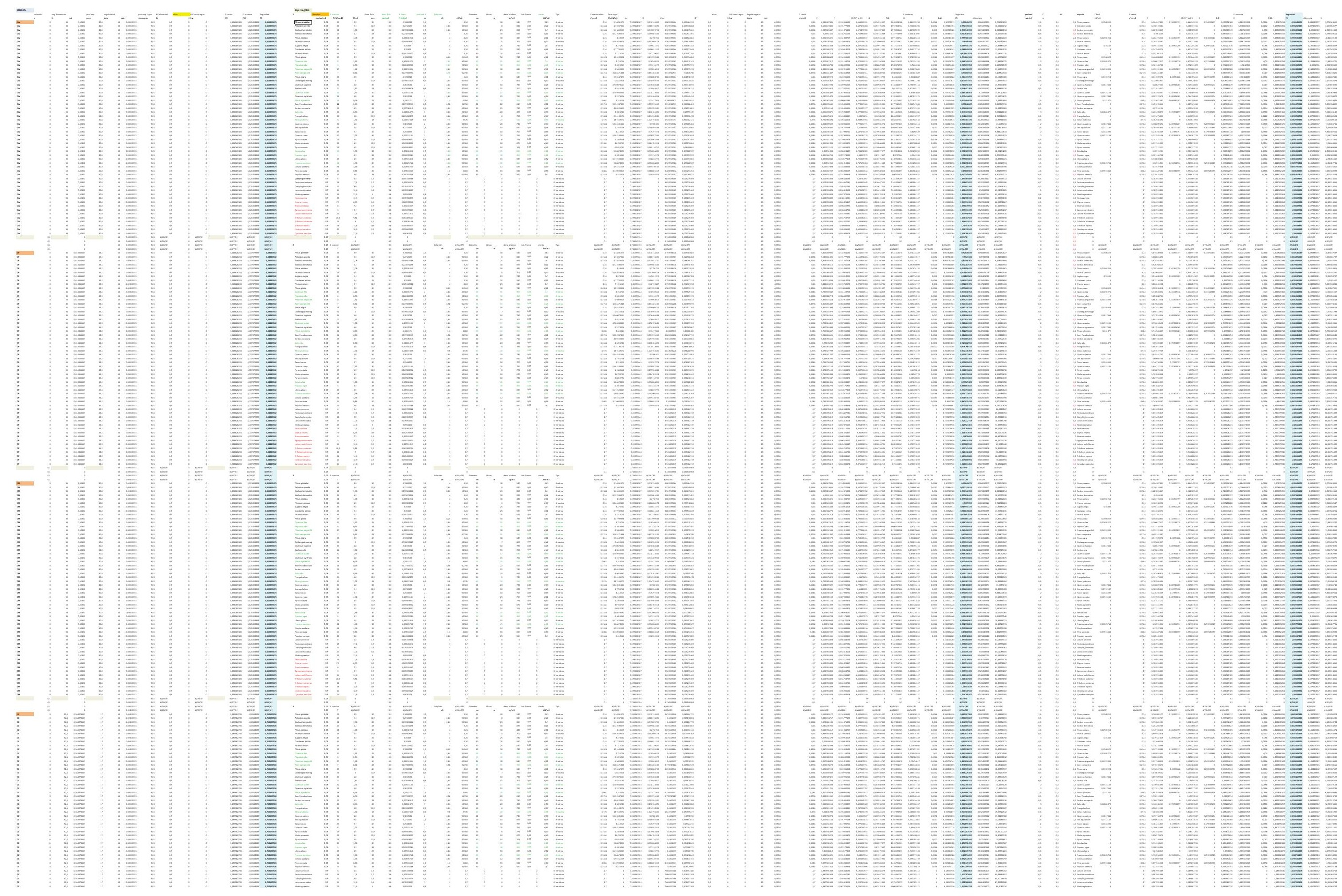


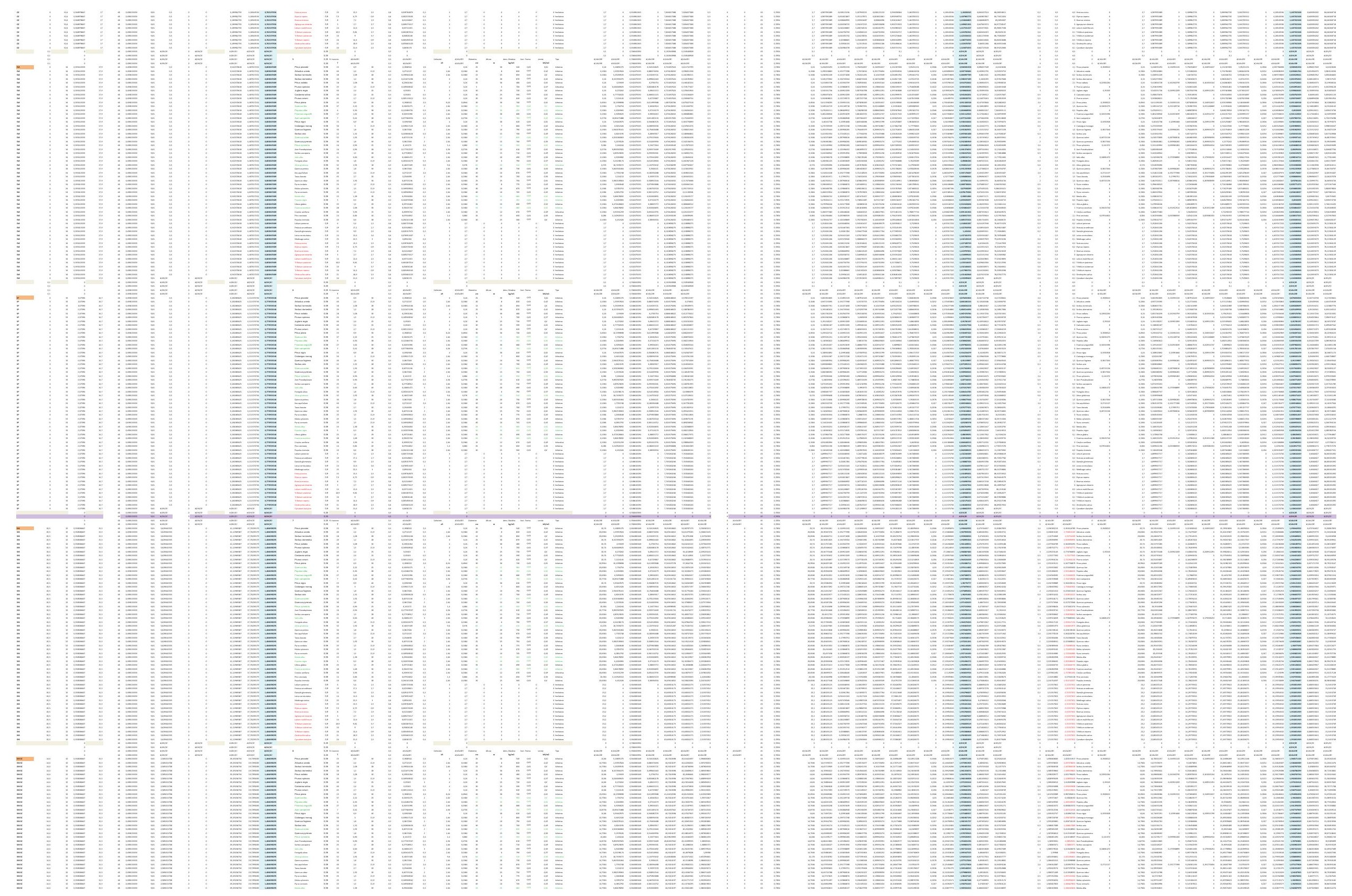



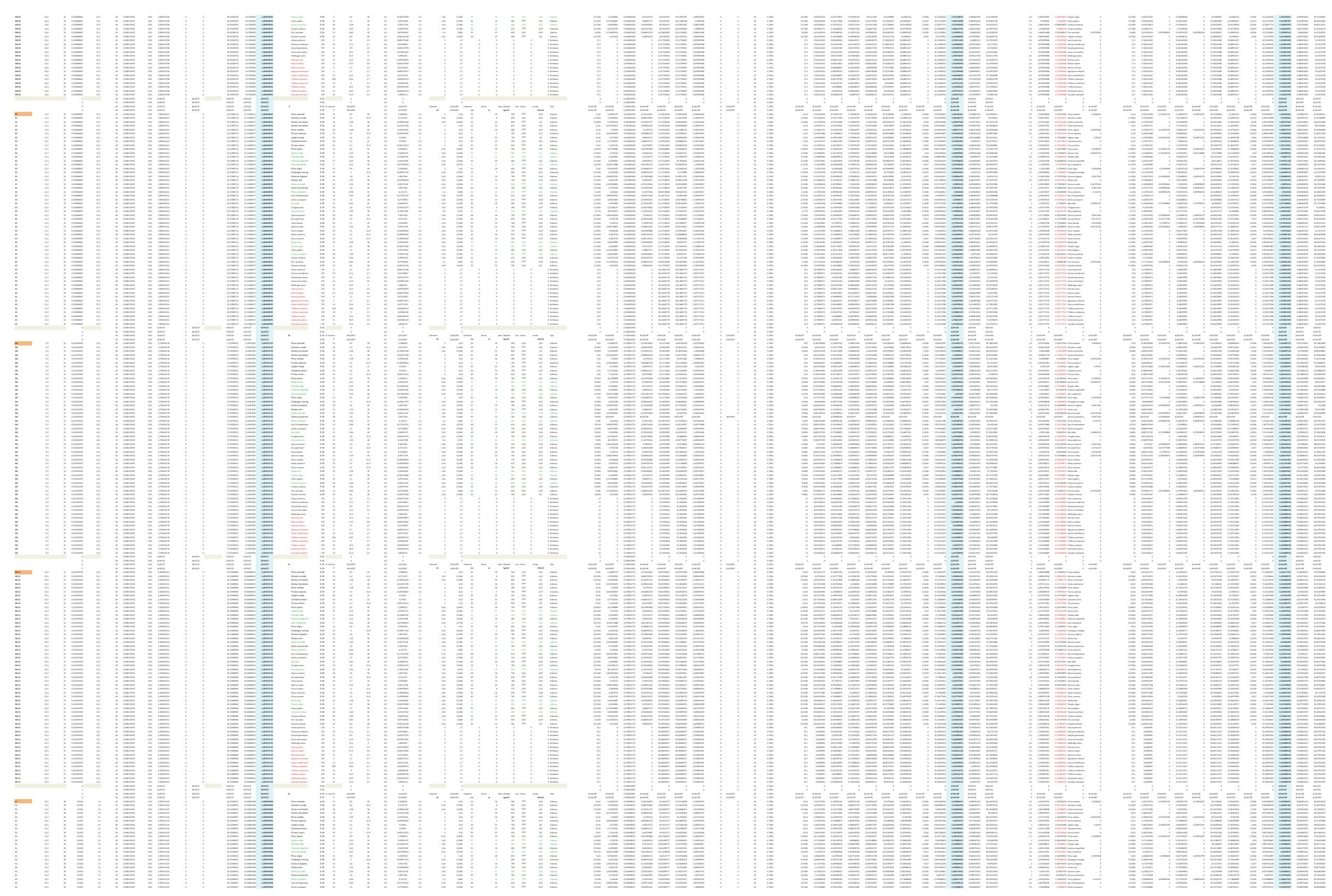


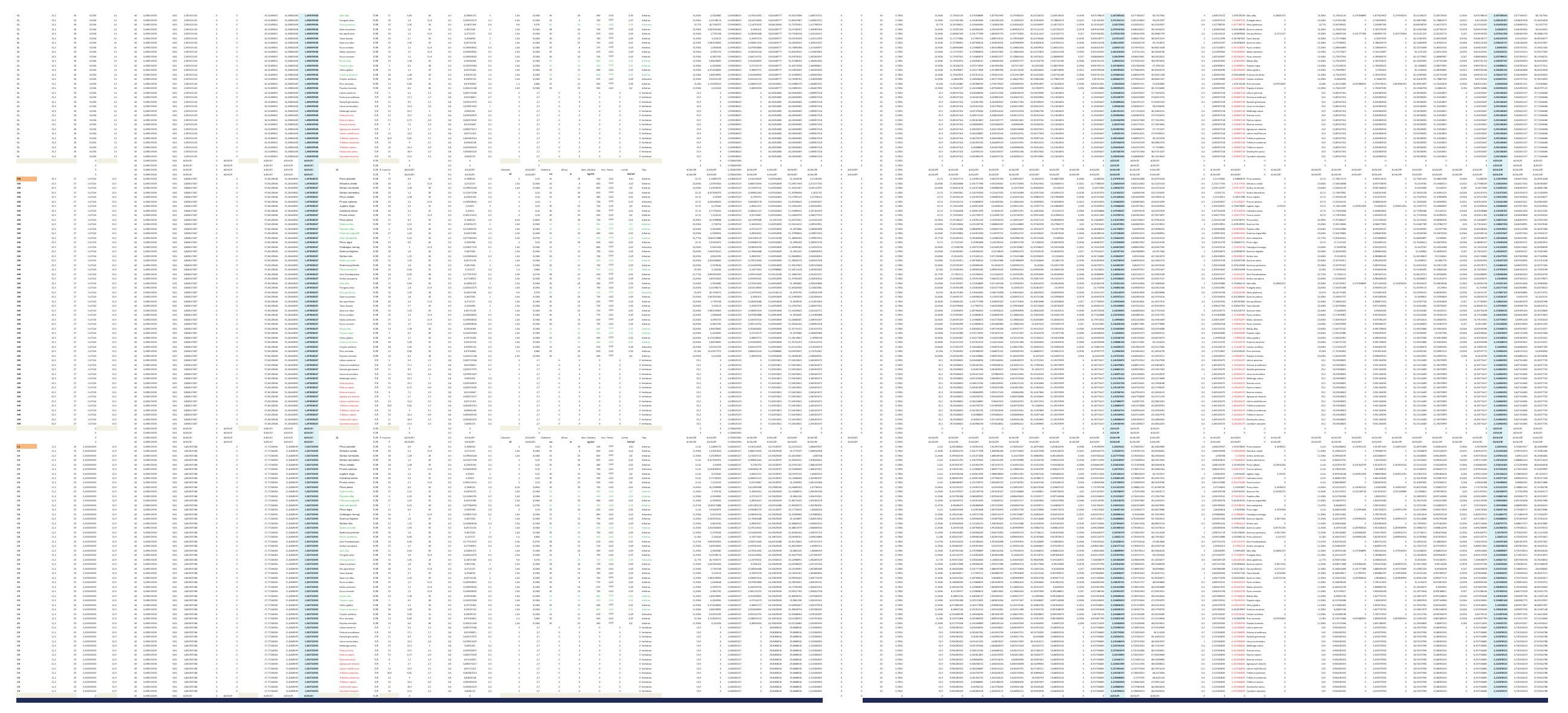



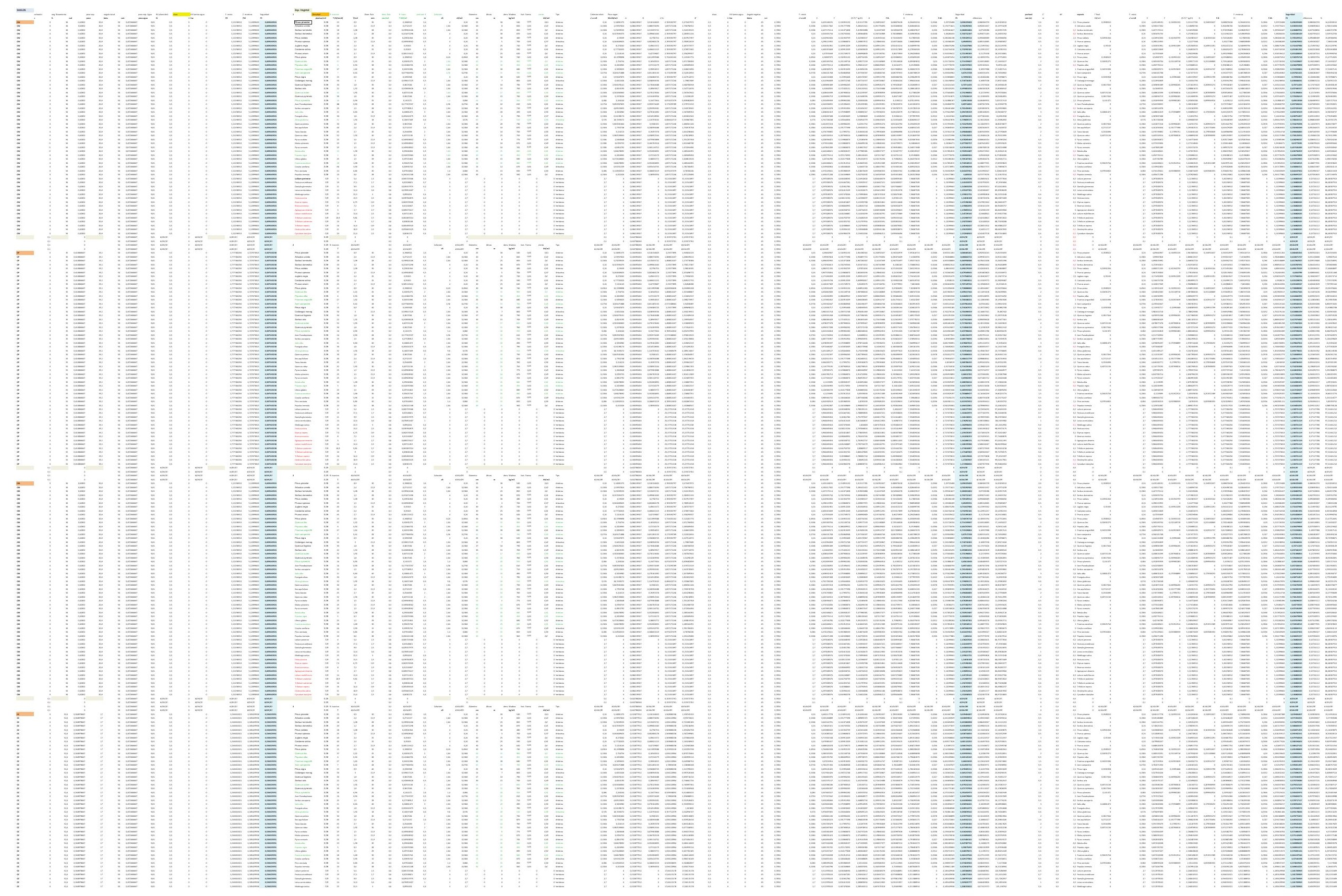


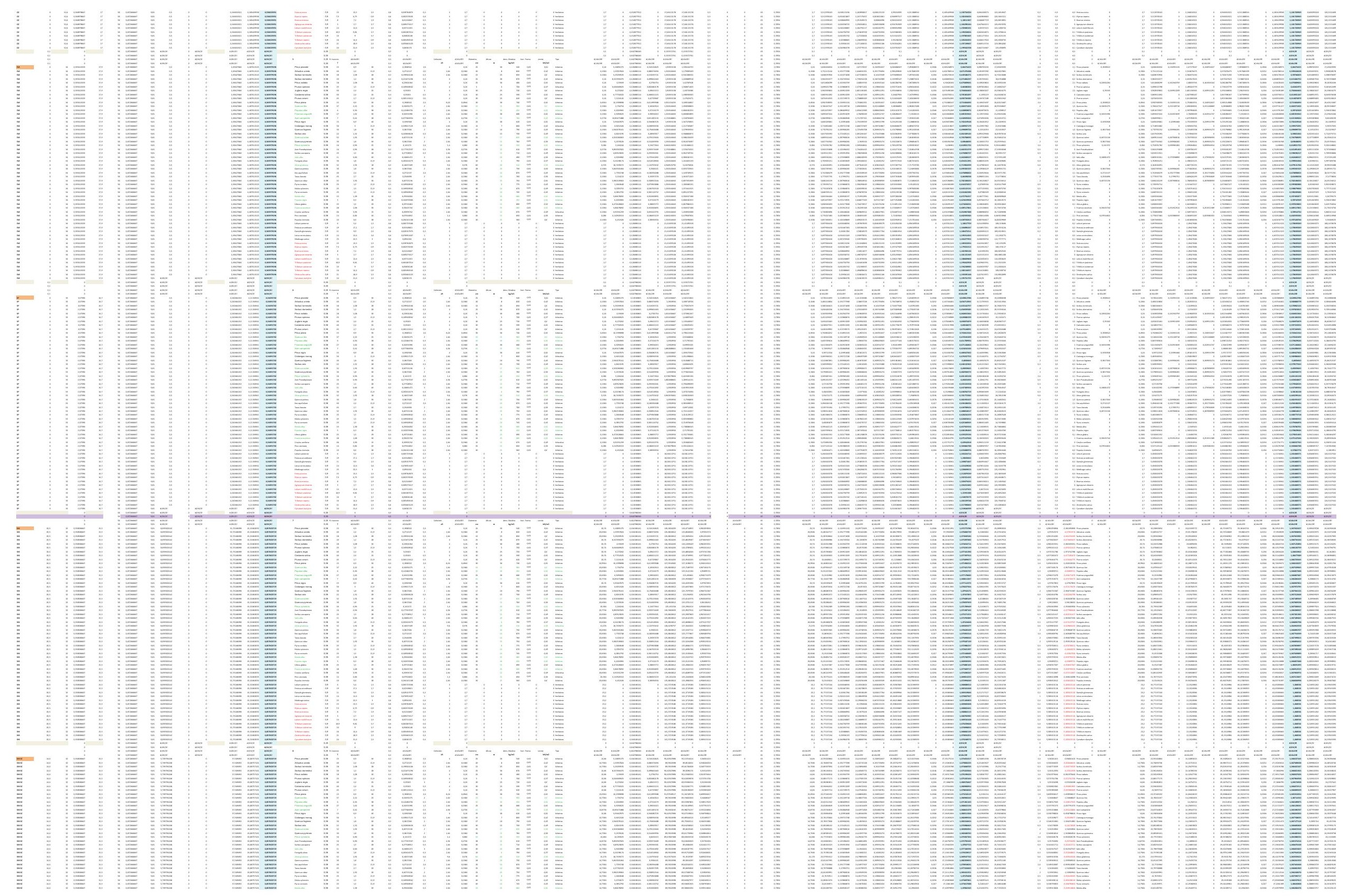



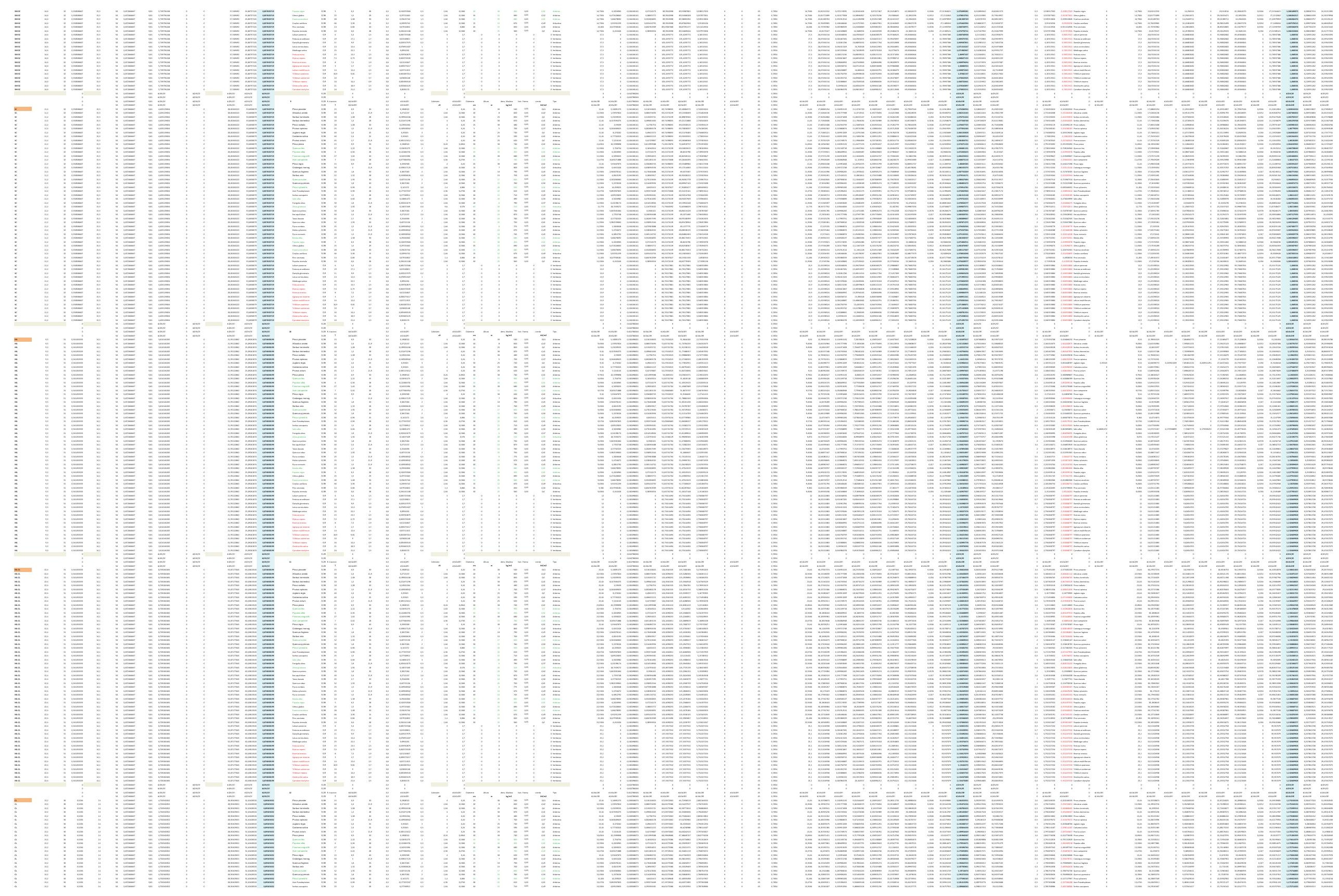


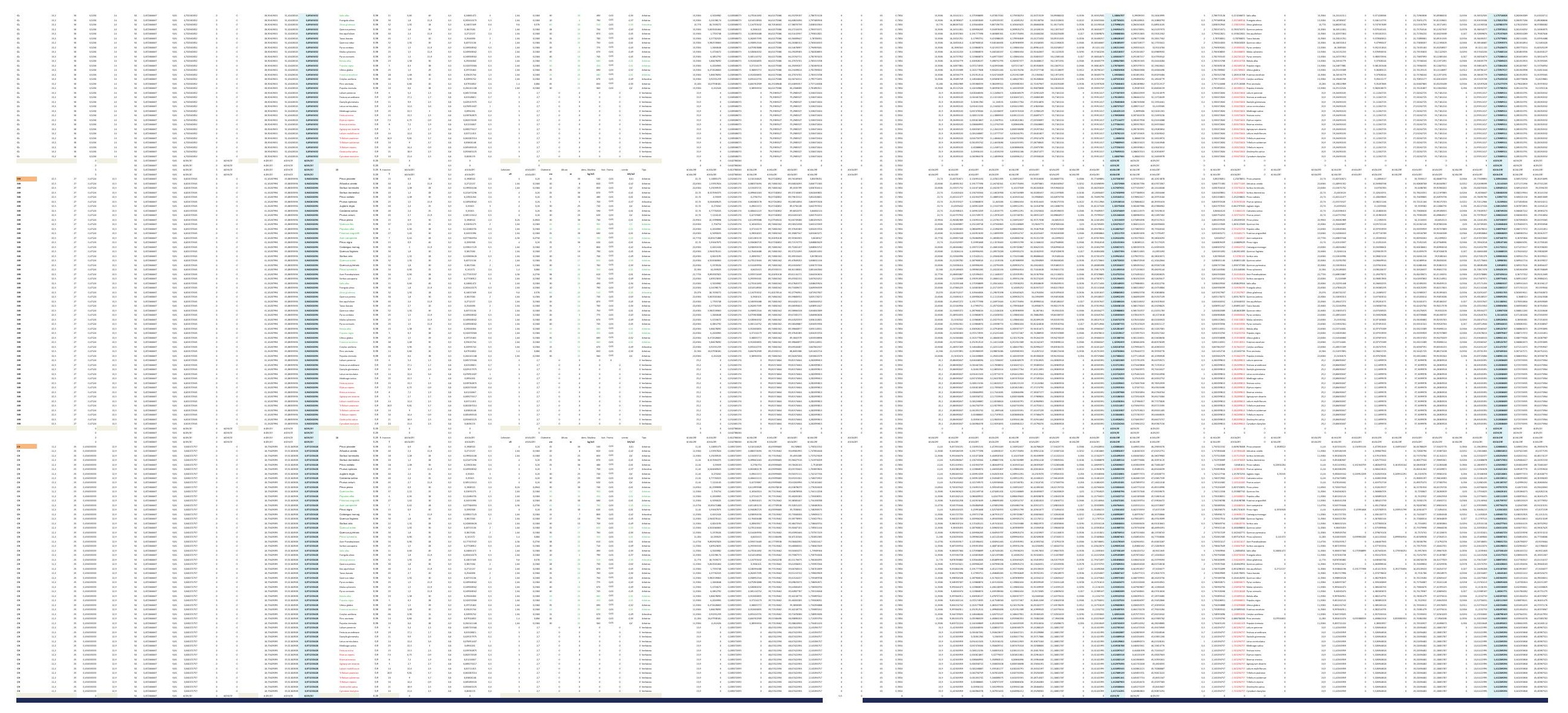



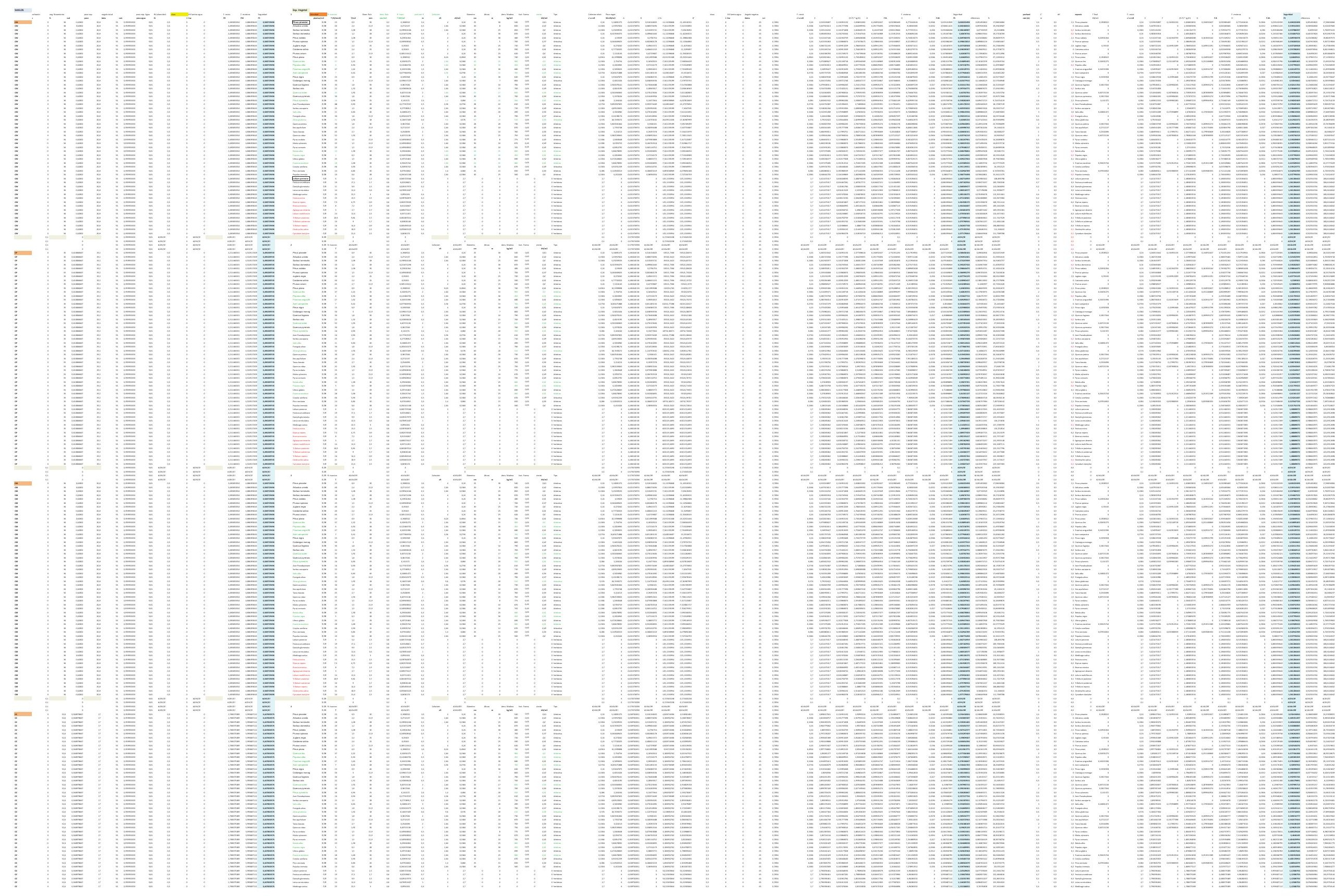


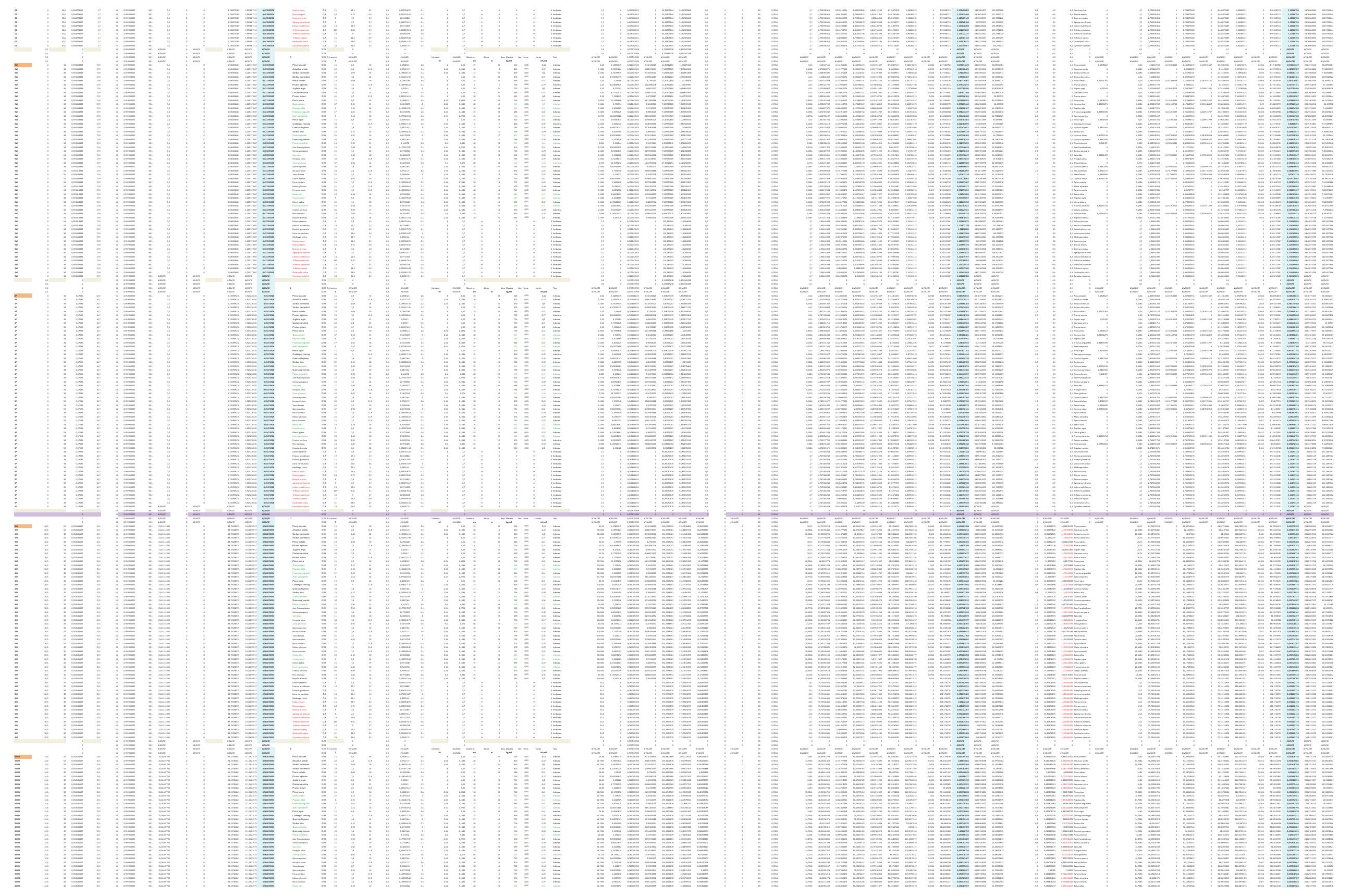



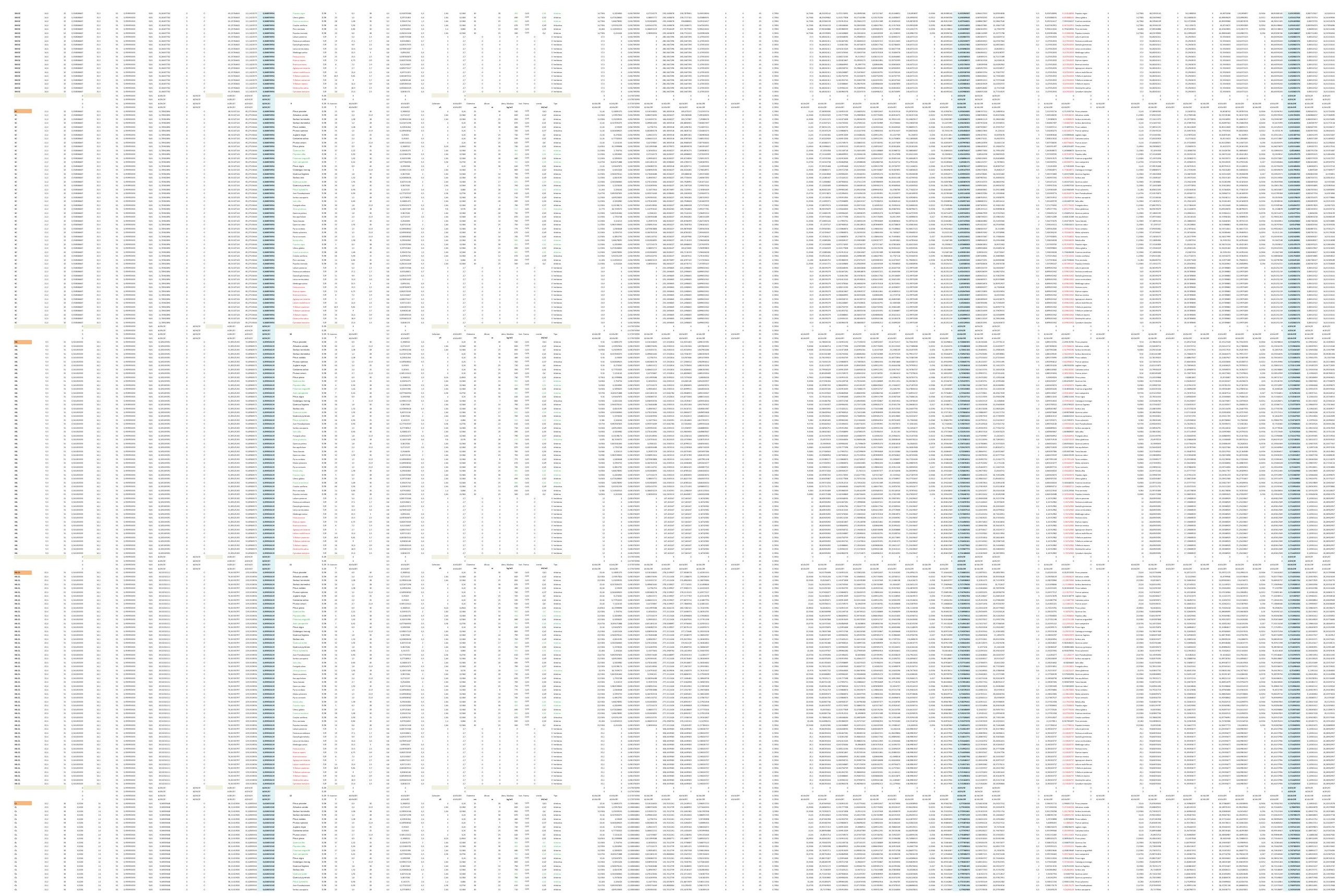


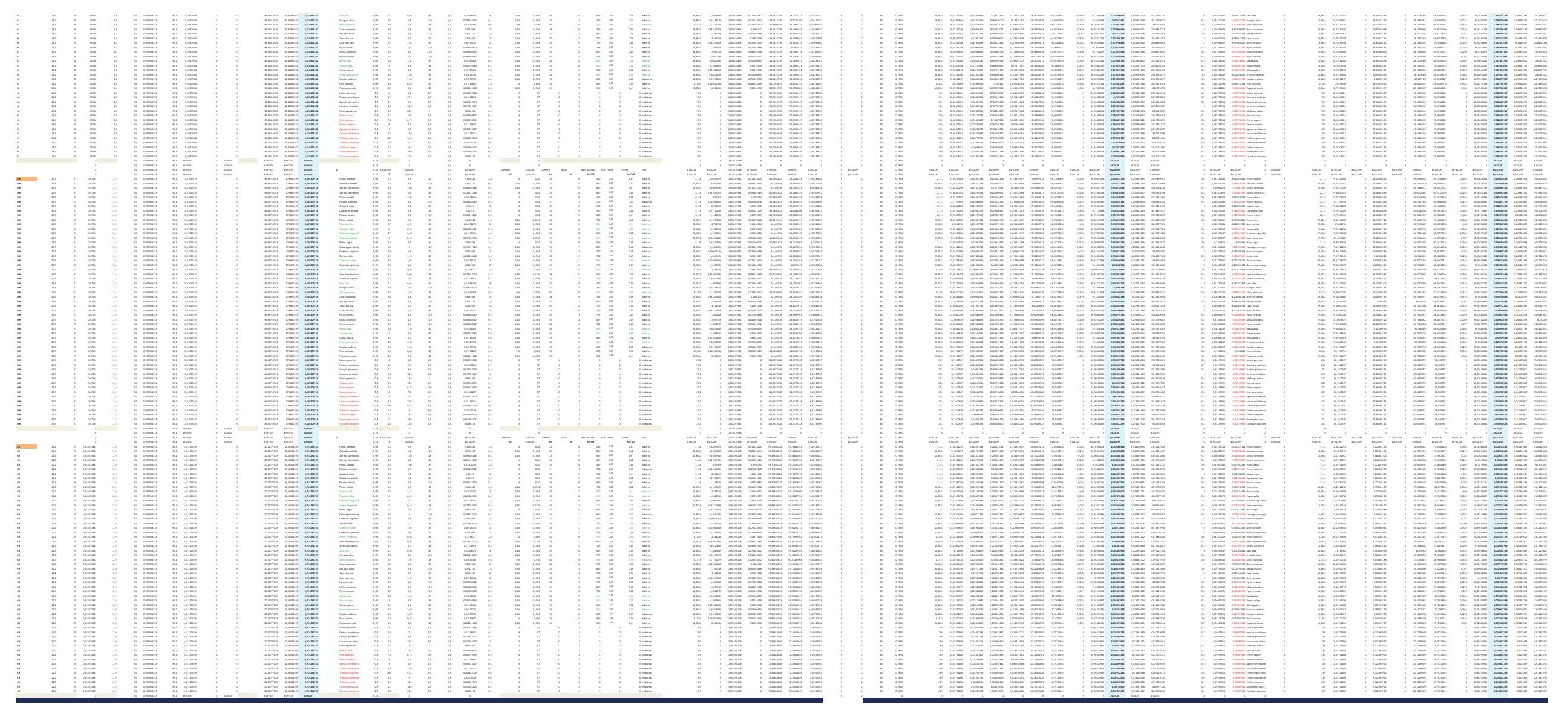



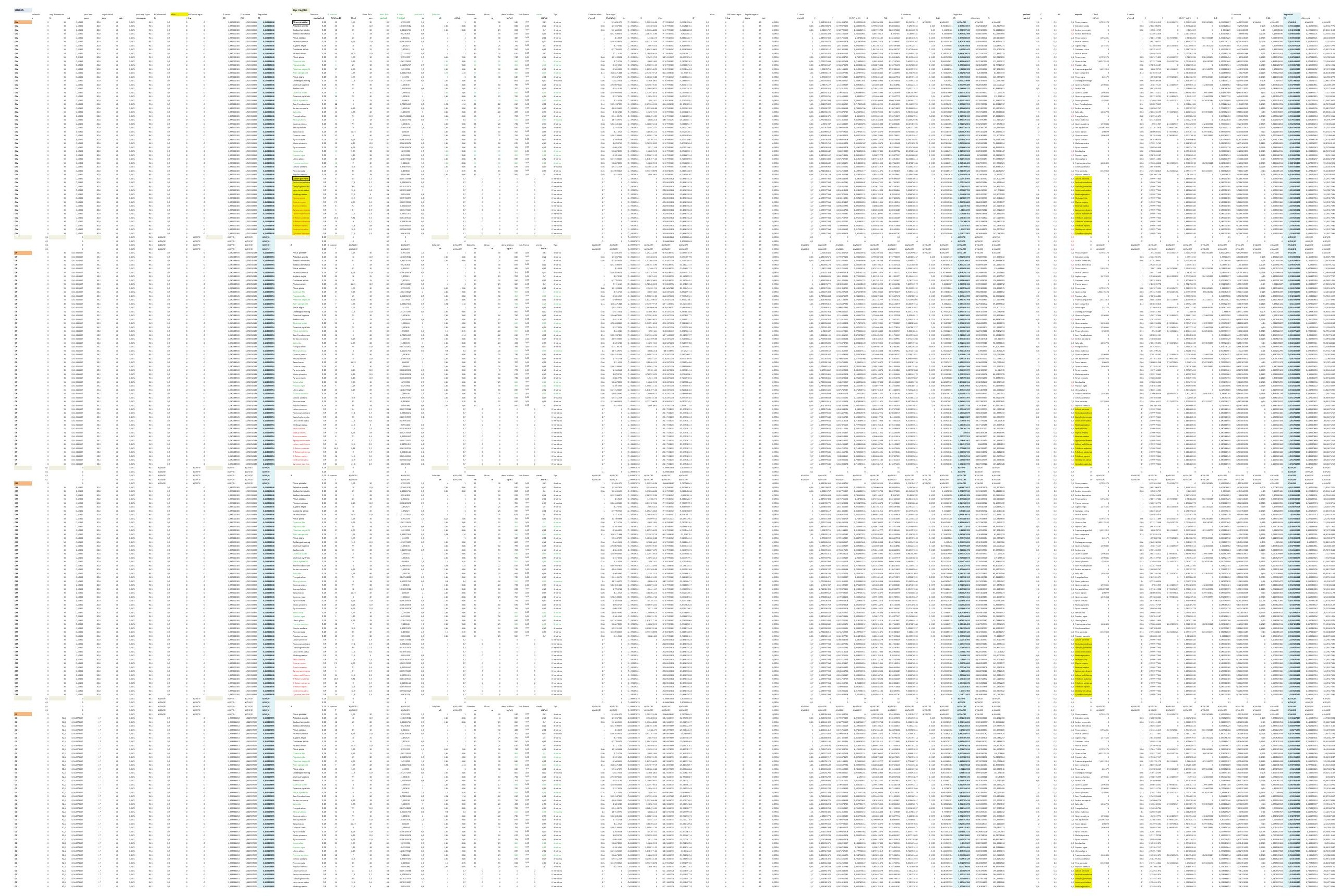


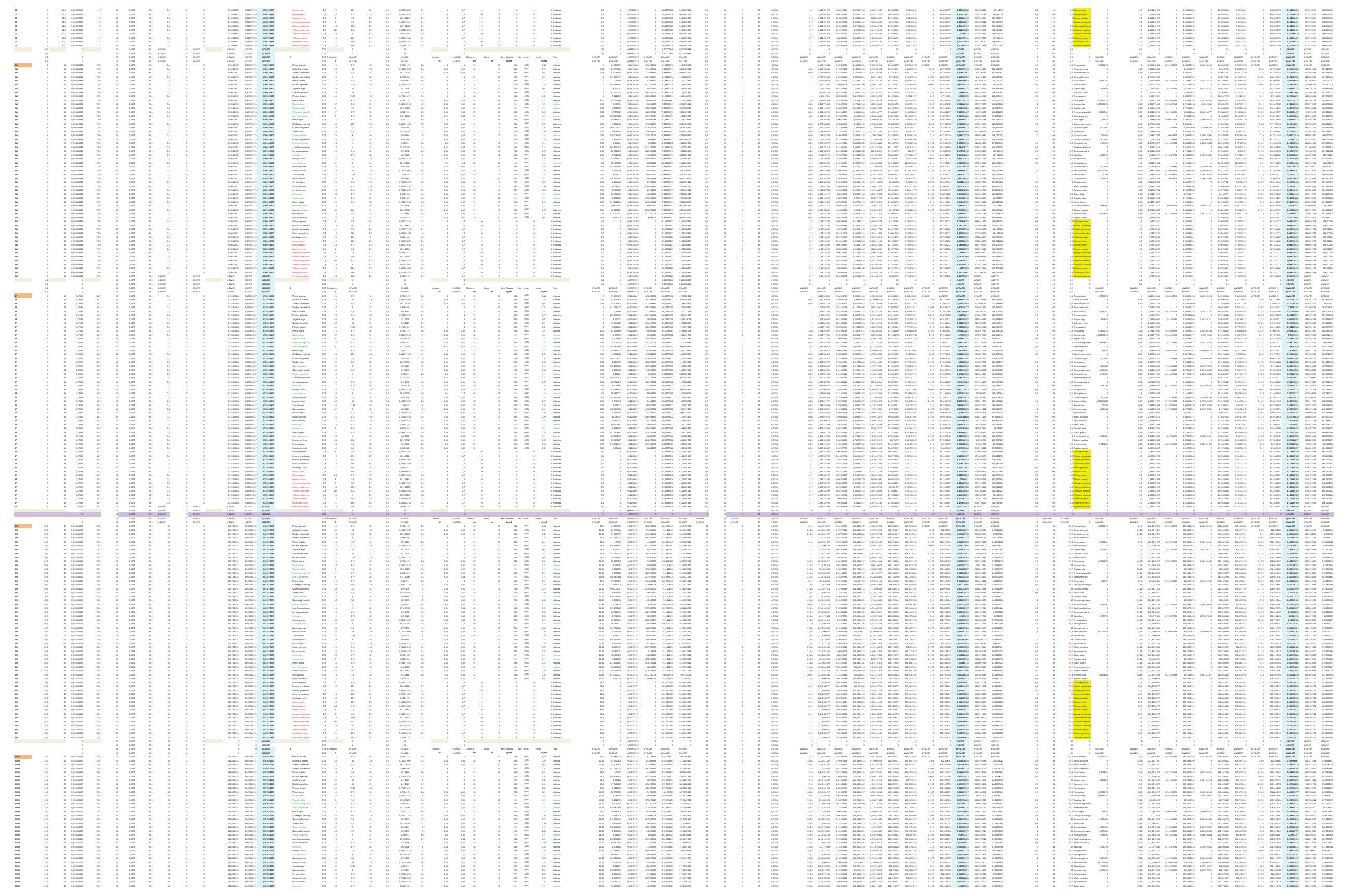



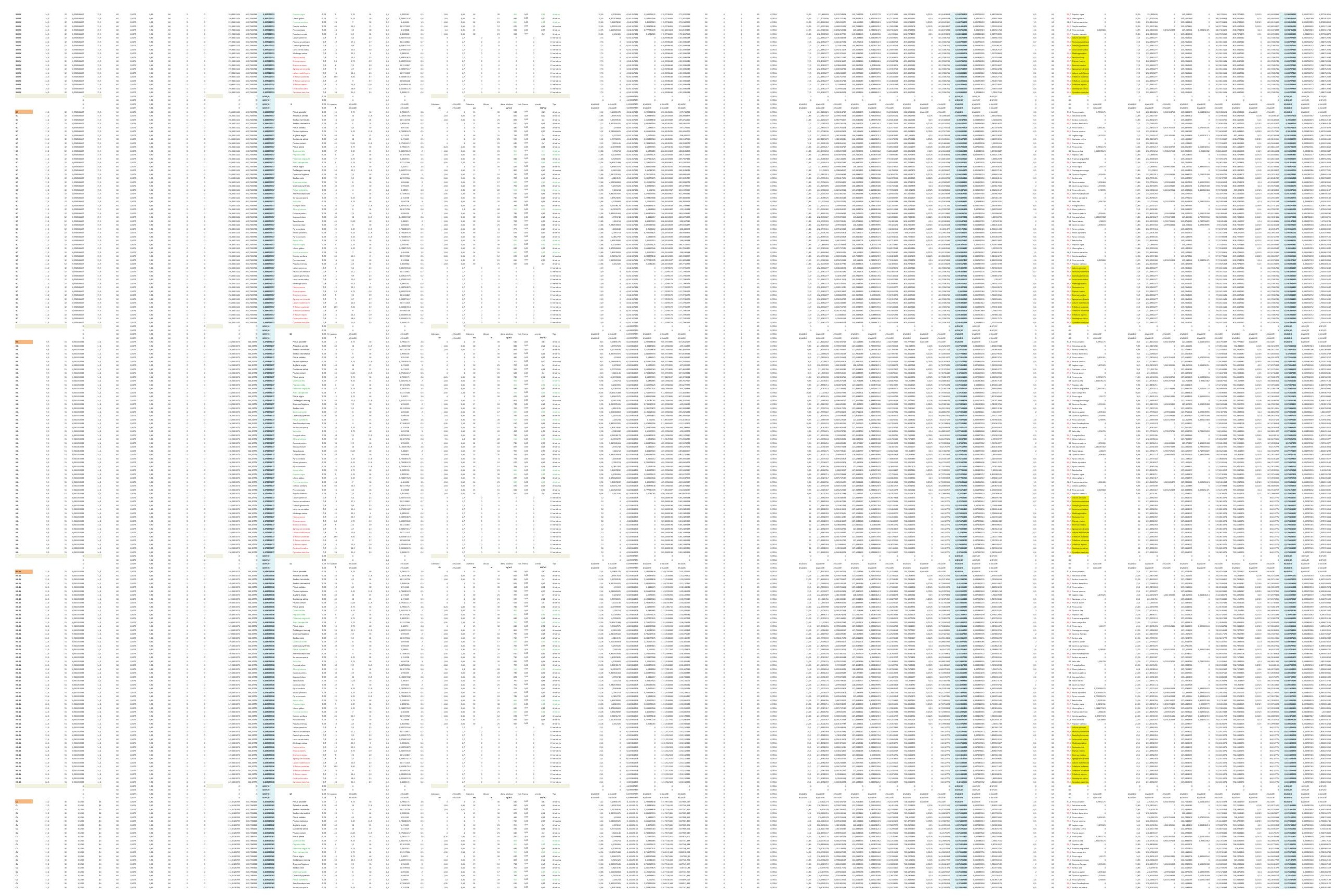


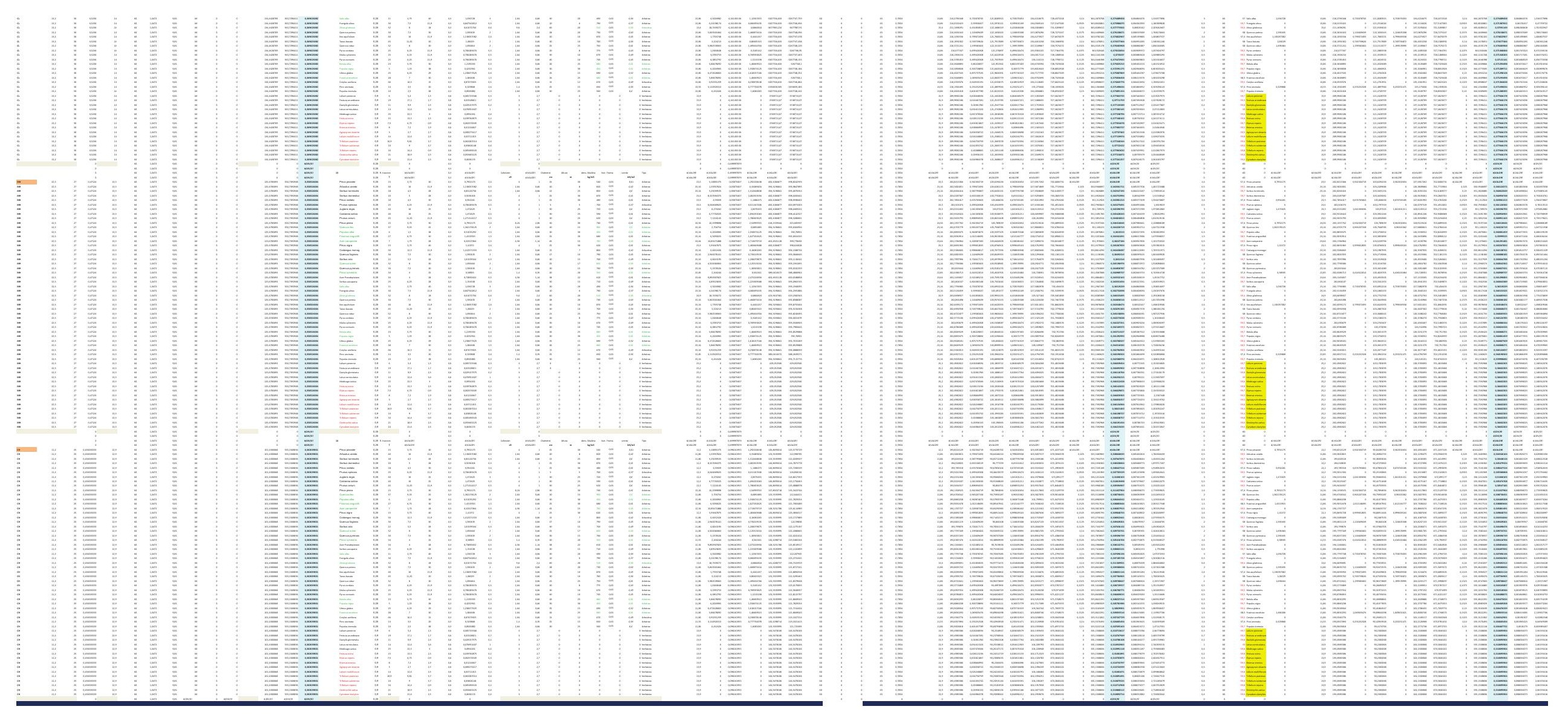



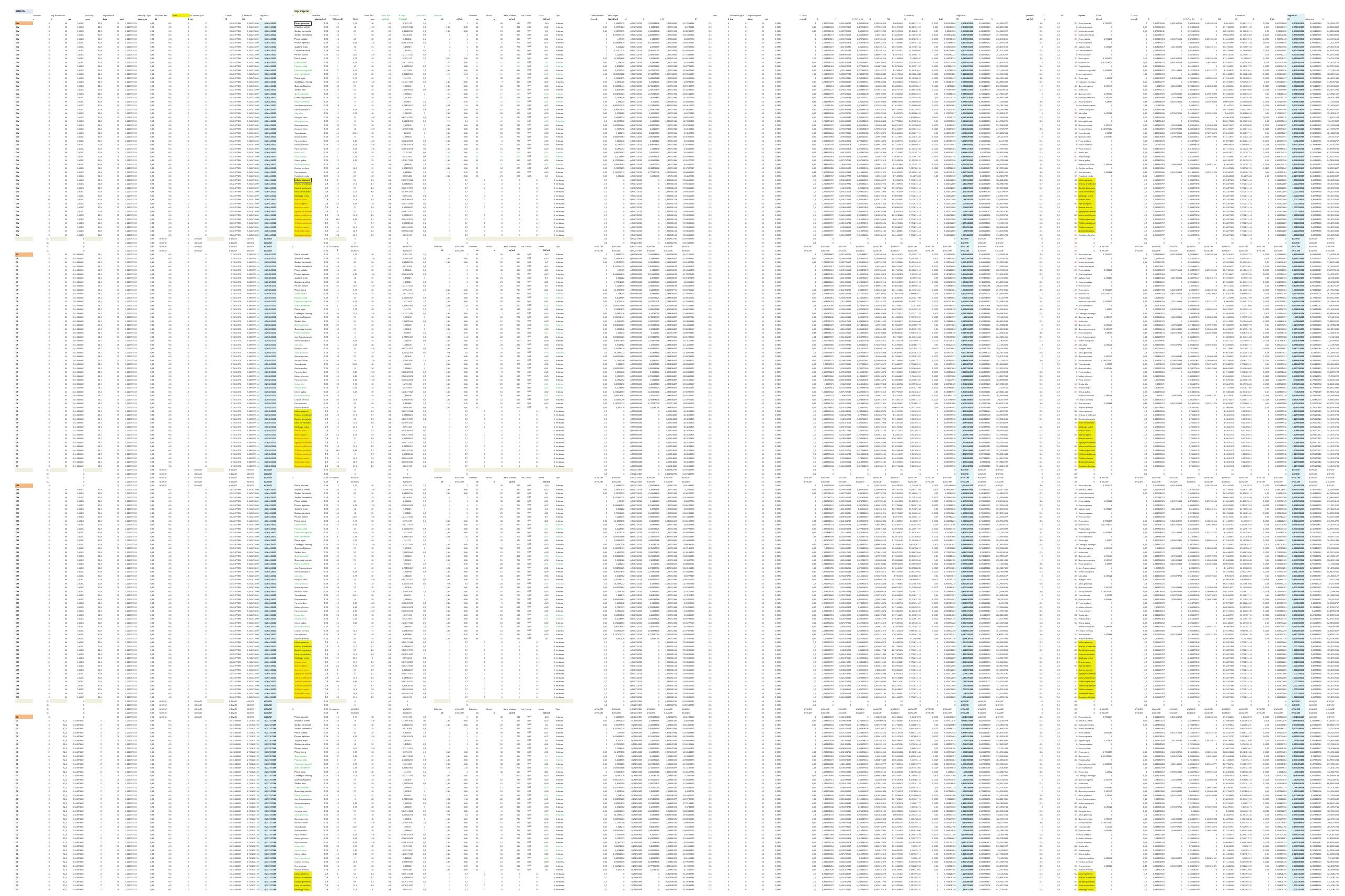


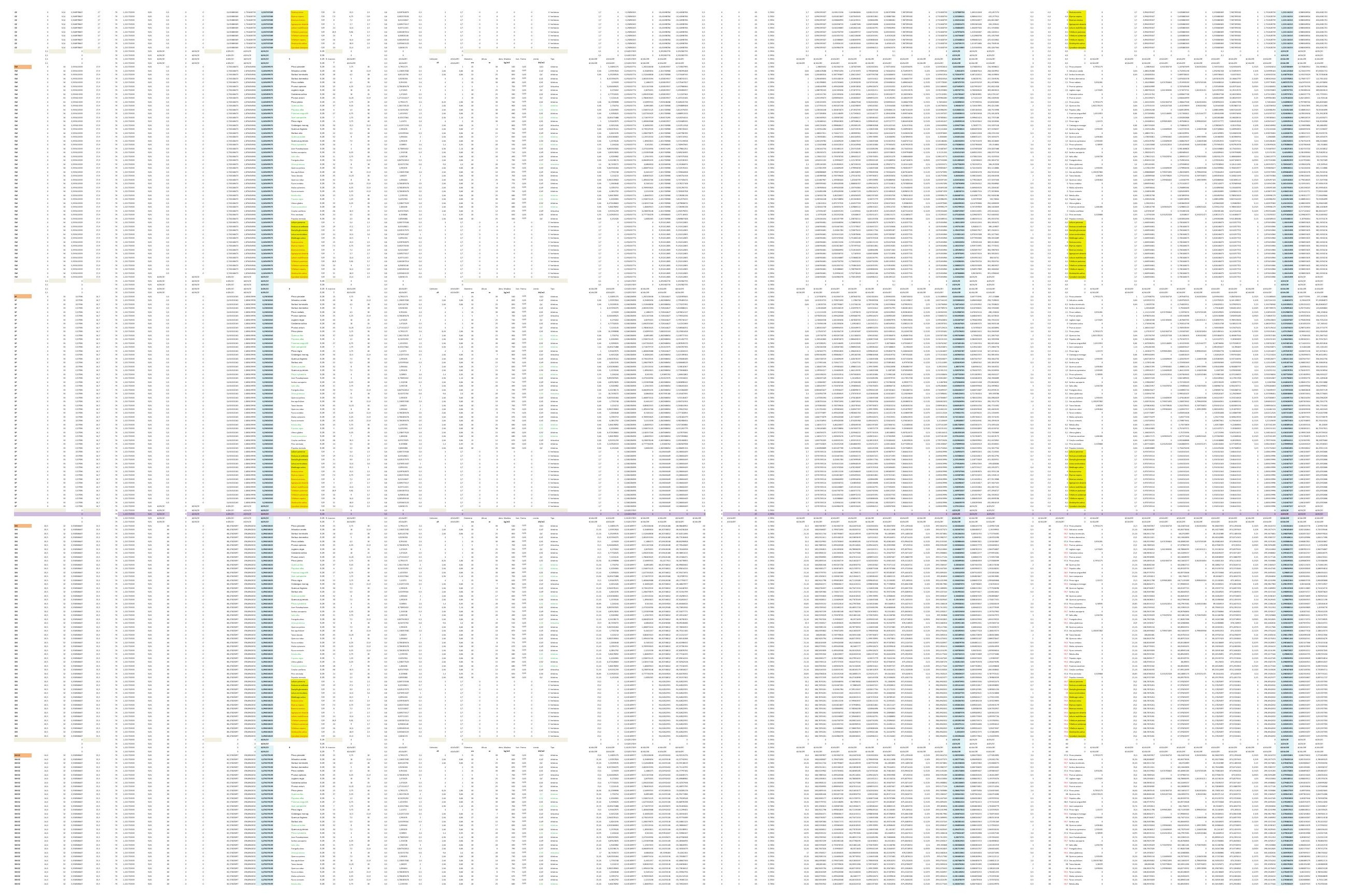



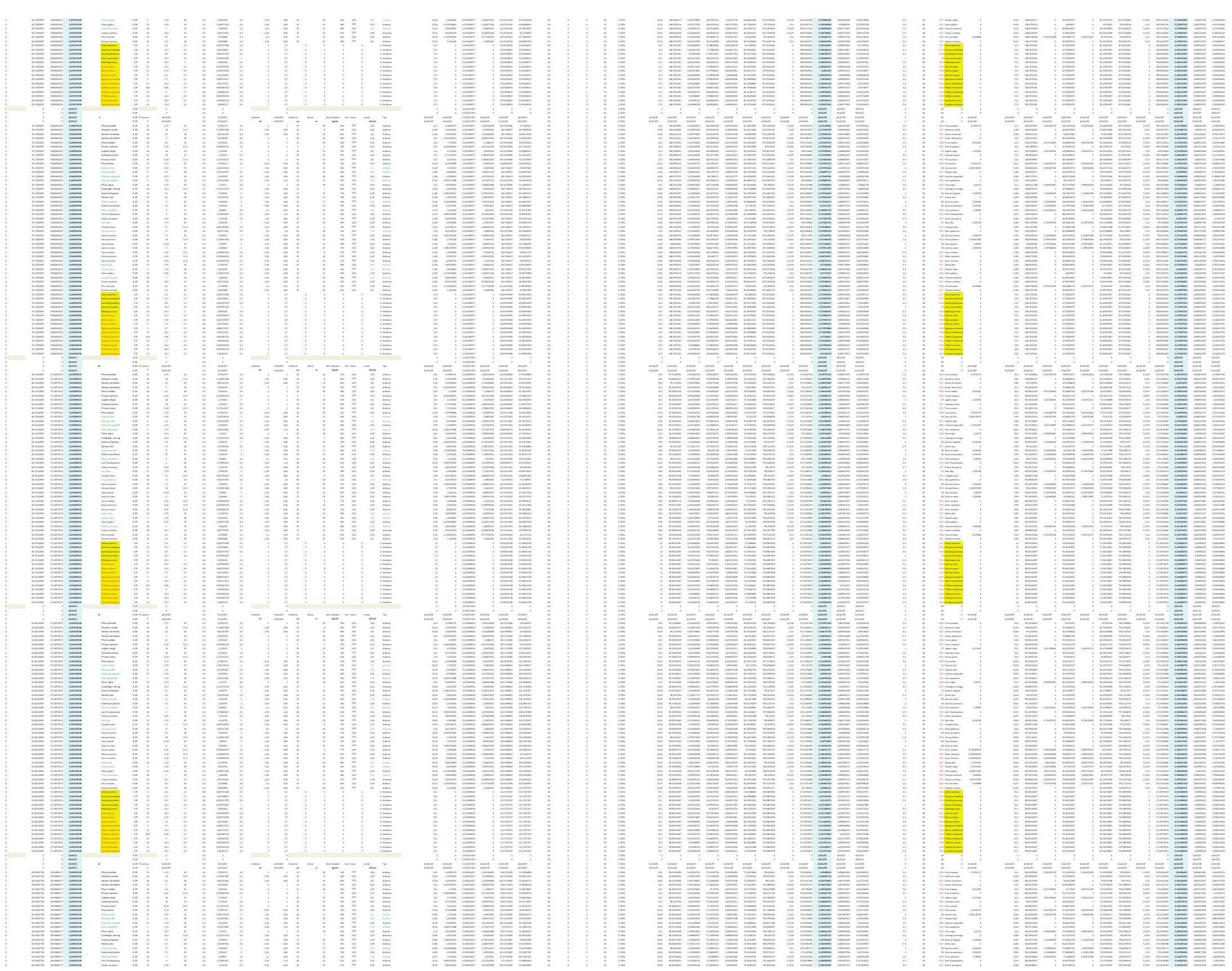


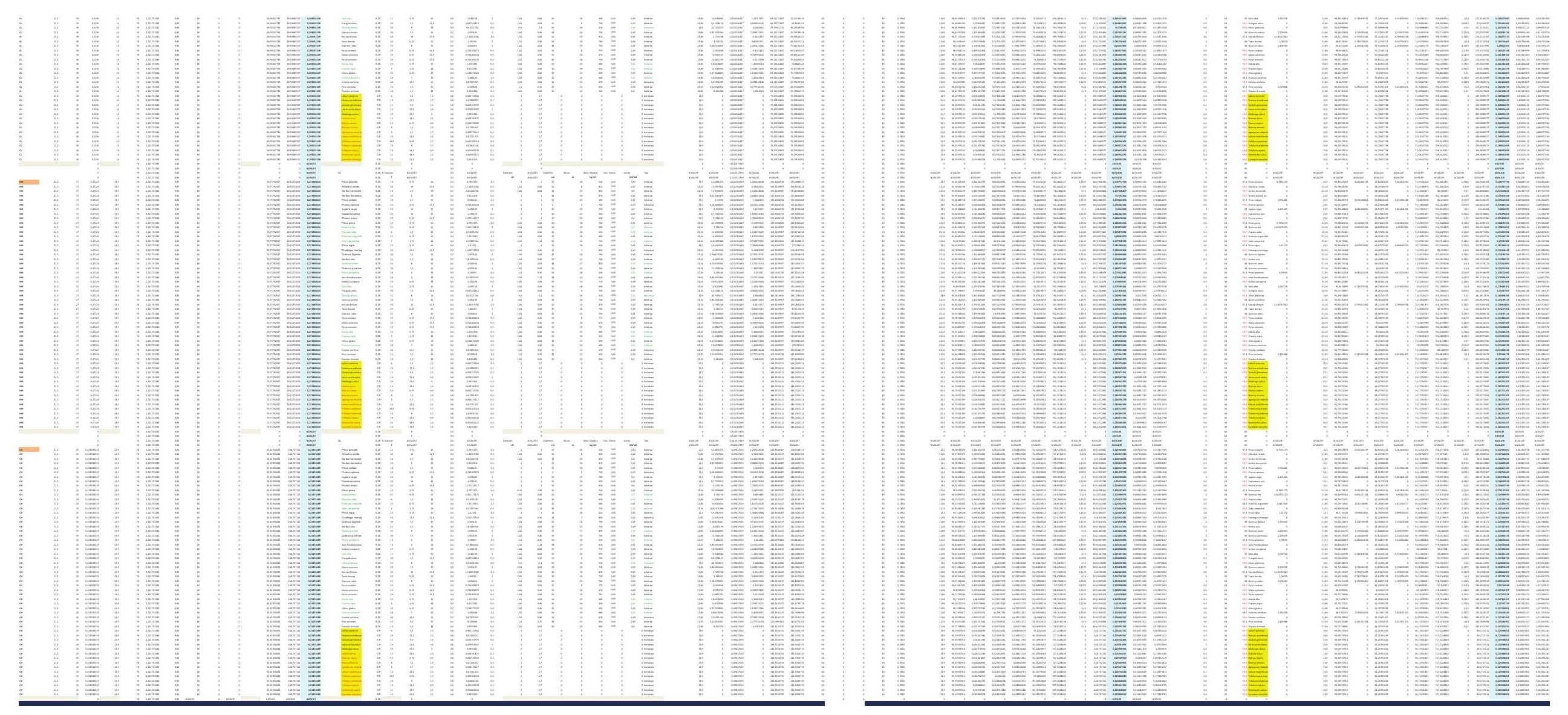



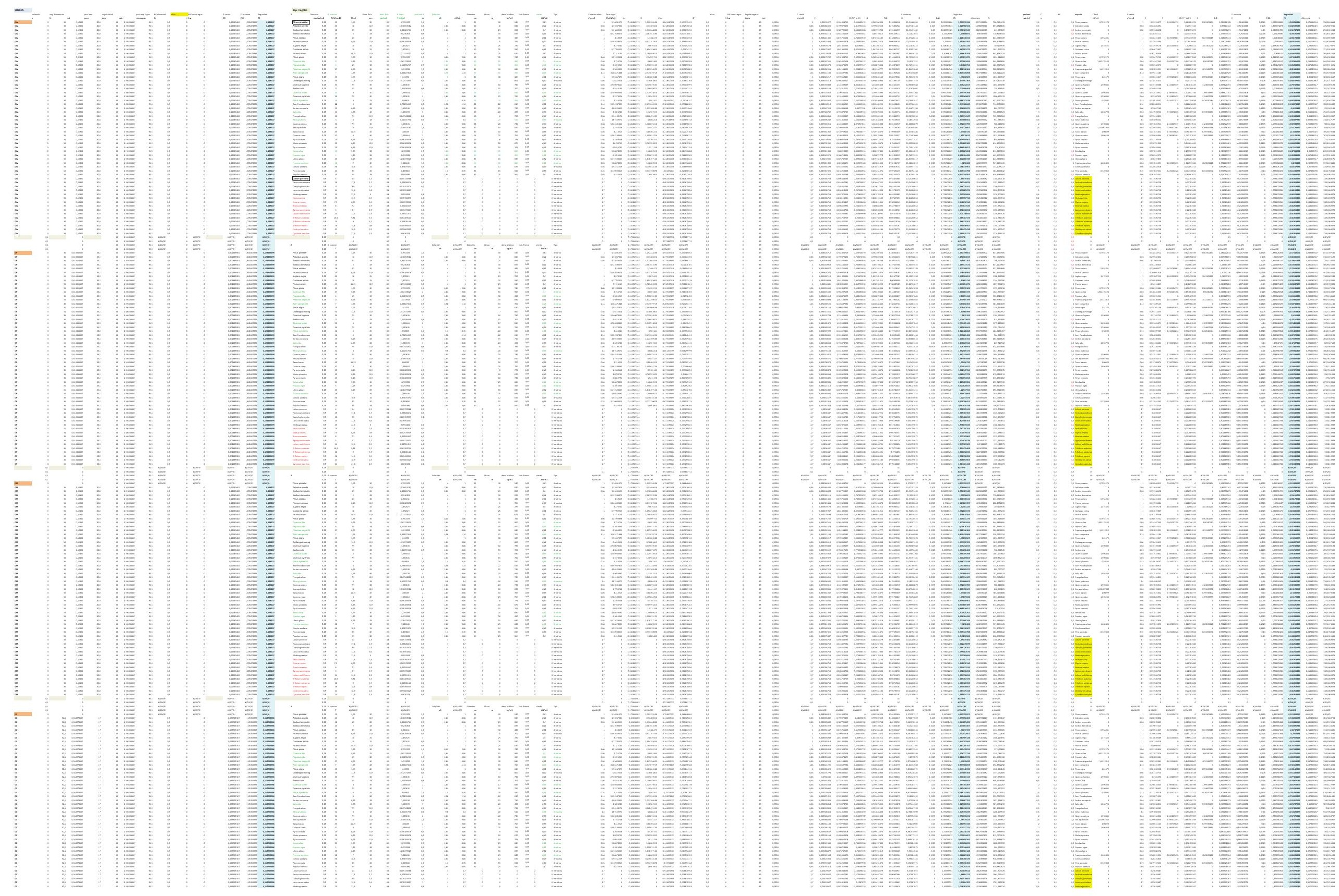


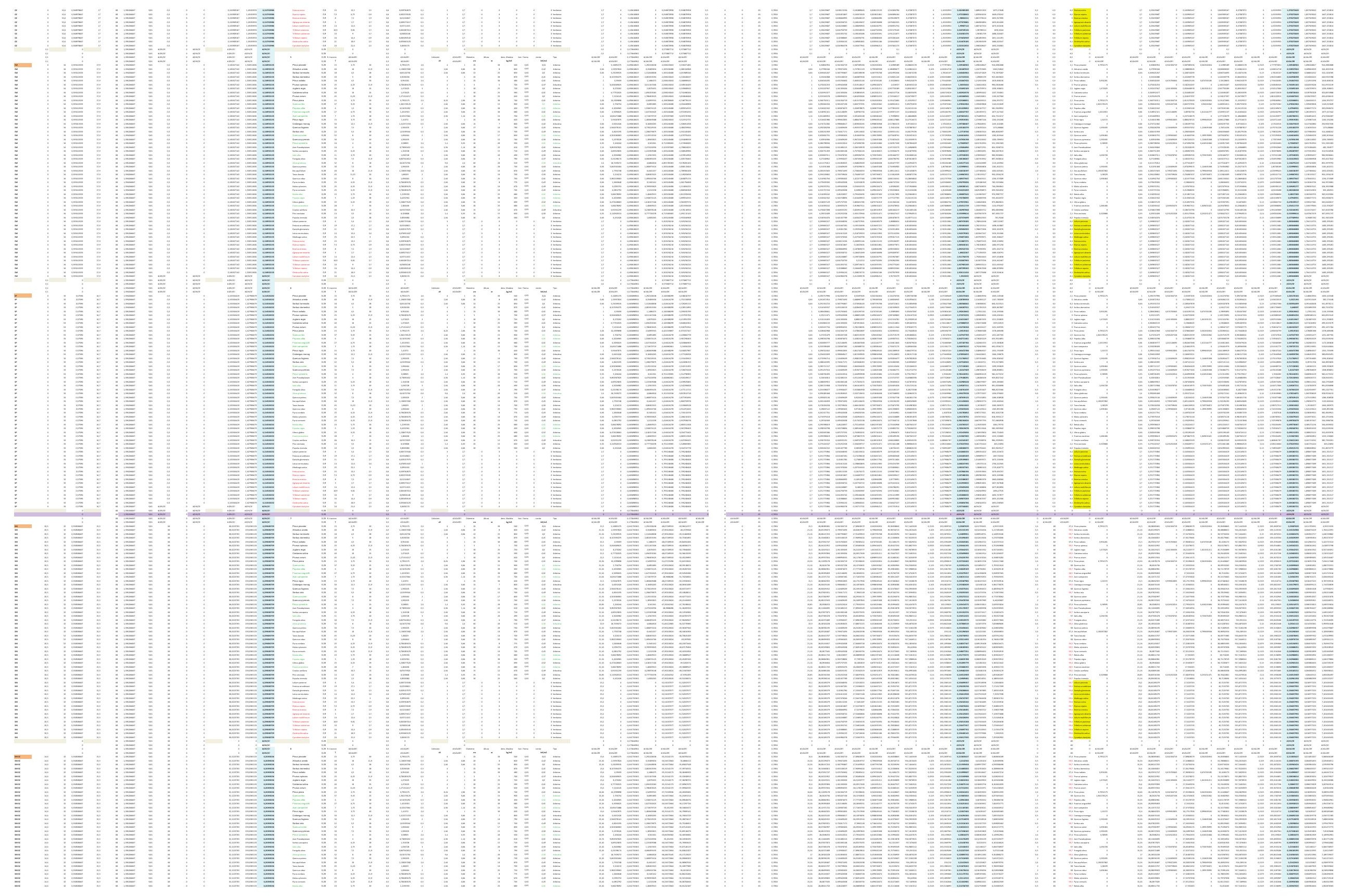



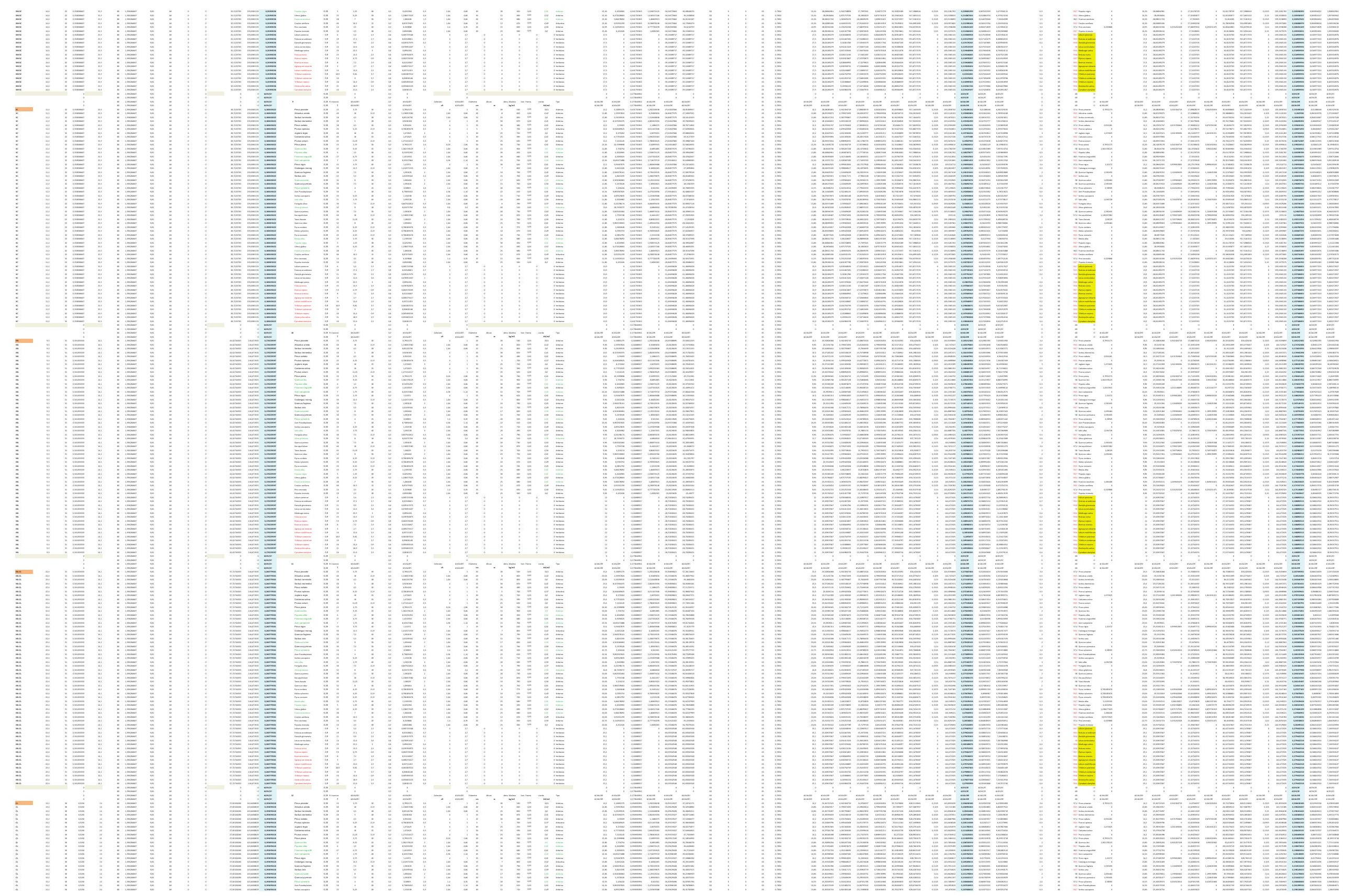


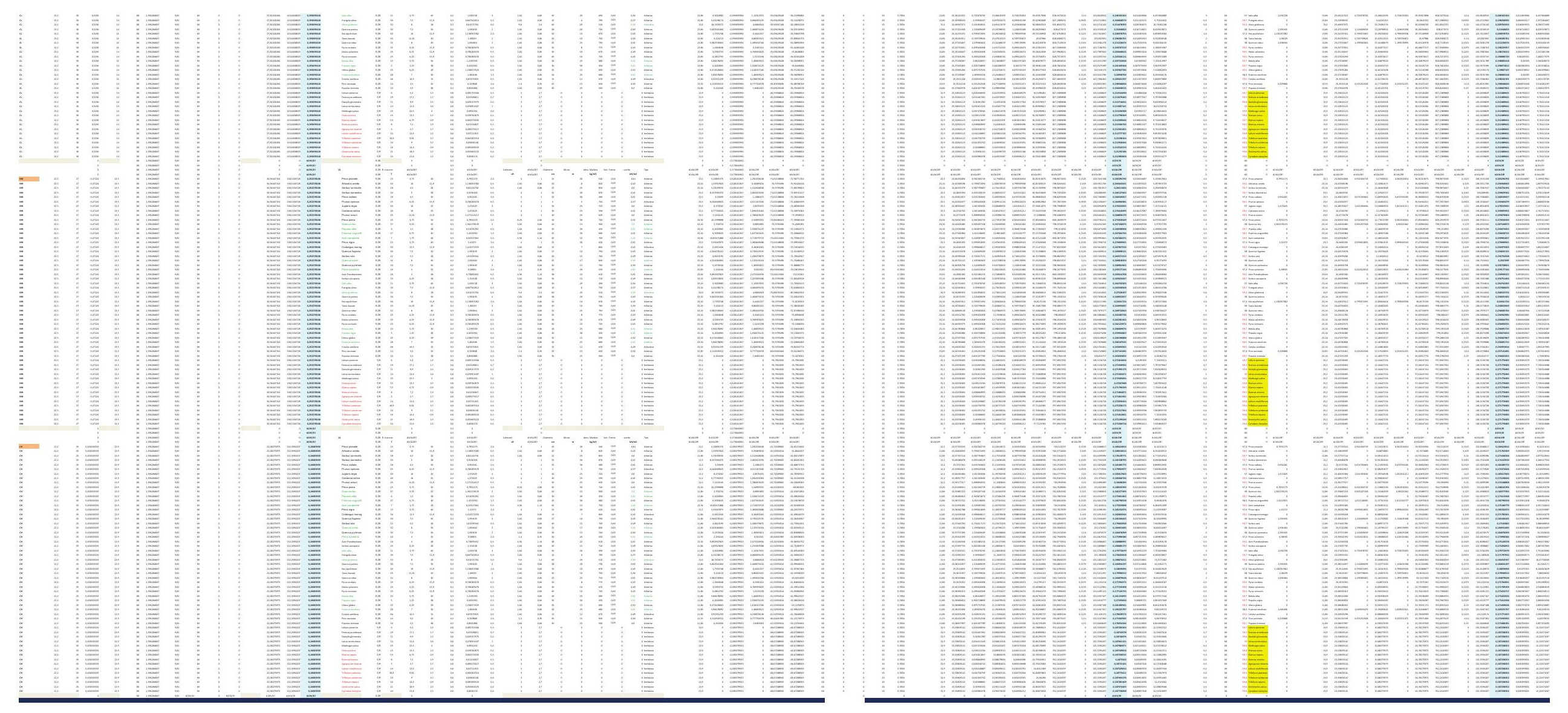


DESARROLLO DE UNA APLICACIÓN IMFORMÁTICA PARA EL CÁLCULO DE SOSTENIMIENTO DE TALUDES MEDIANTE VEGETACIÓN

A01. DENSIDAD DE PLANTACIÓN: 600 plantas/ha.

\section{A01-2.POSICIÓN N.F. 2}

INCLINACIÓN DE TALUD 6-100

INCLINACIÓN DE TALUD 10-200

INCLINACIÓN DE TALUD 20-30

INCLINACIÓN DE TALUD 30-40

INCLINACIÓN DE TALUD $35^{\circ}$

INCLINACIÓN DE TALUD 40-50

INCLINACIÓN DE TALUD 50-550

INCLINACIÓN DE TALUD 55-60

INCLINACIÓN DE TALUD 60-700

INCLINACIÓN DE TALUD 70-80 

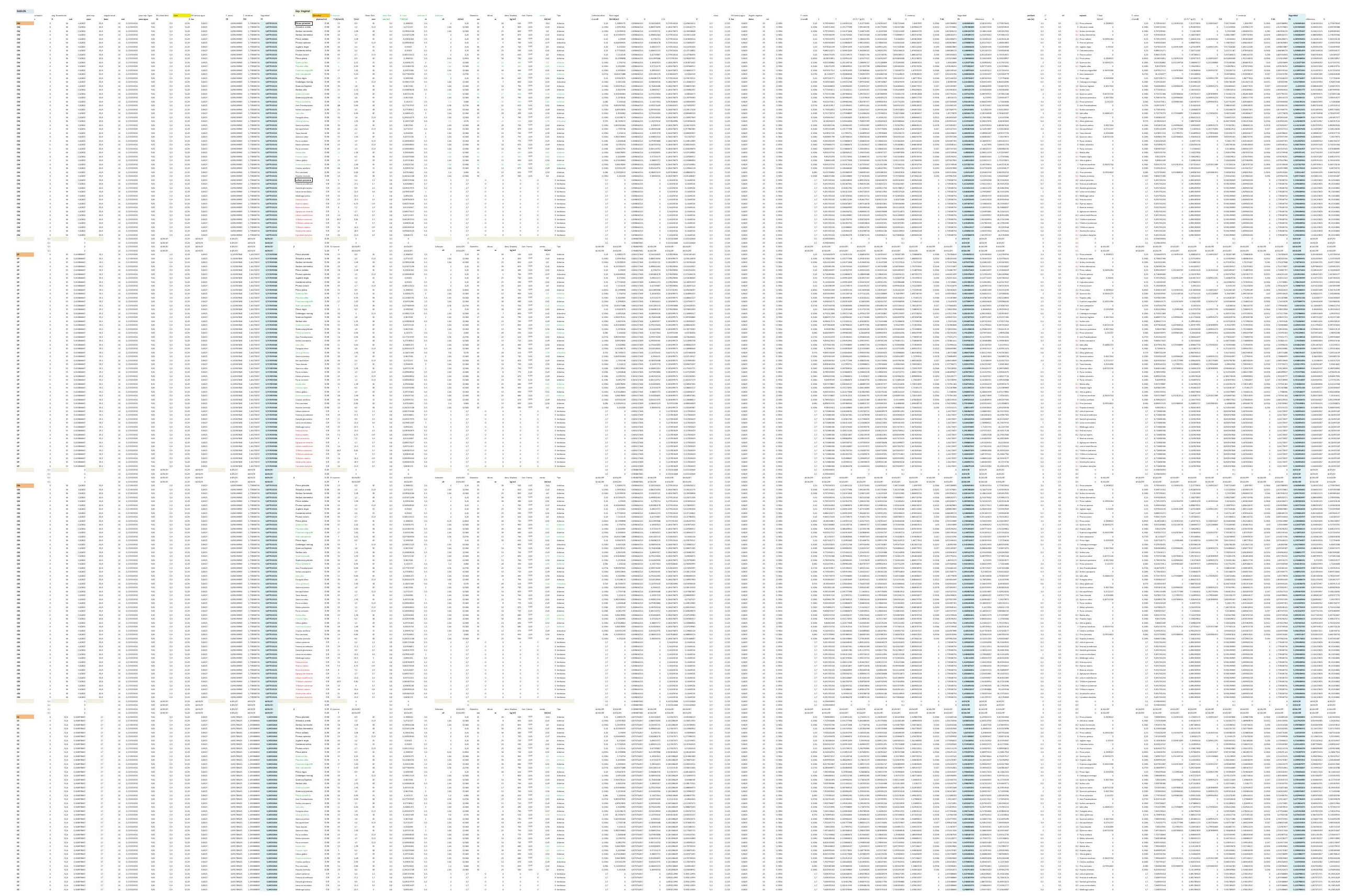


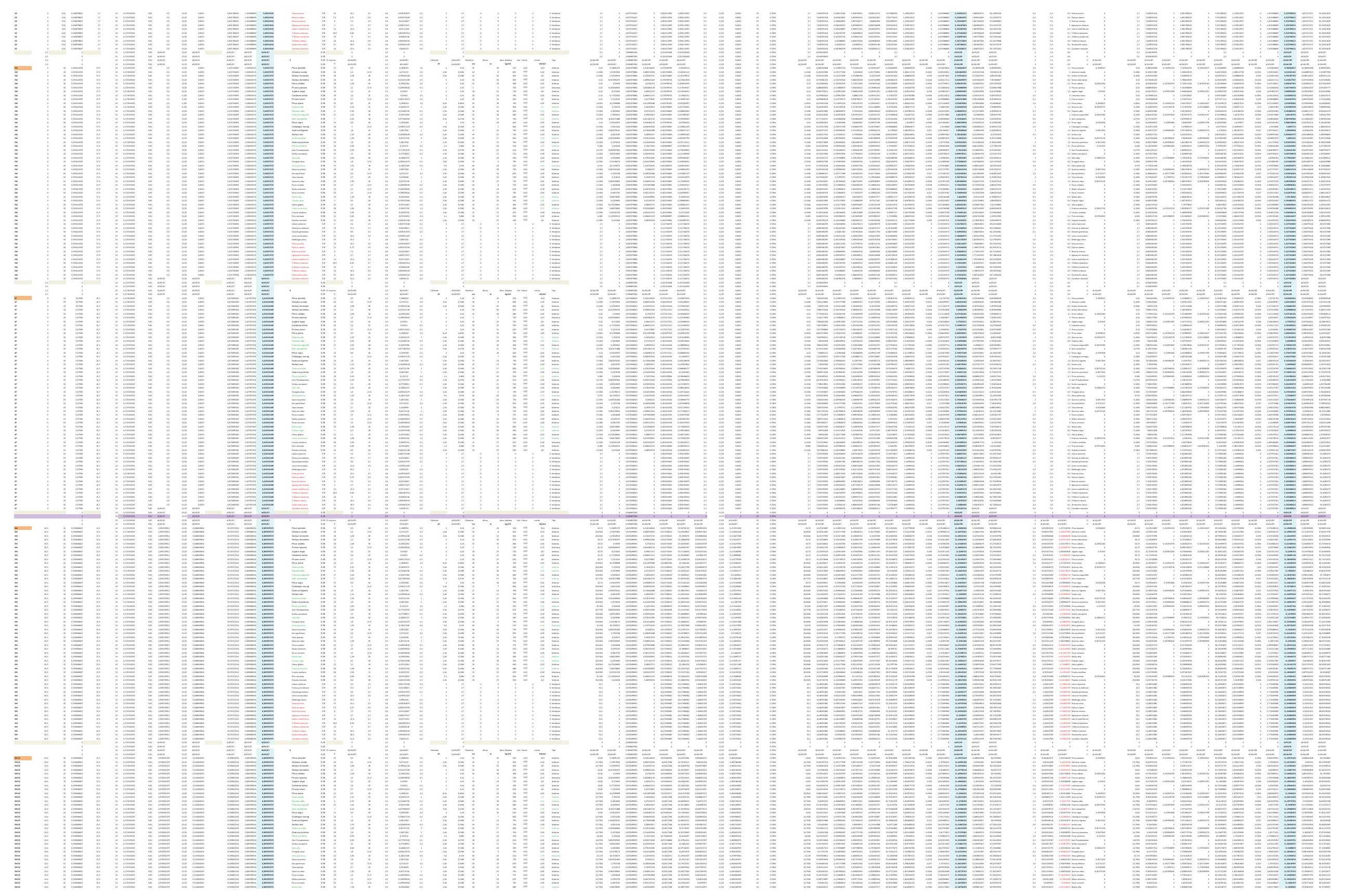



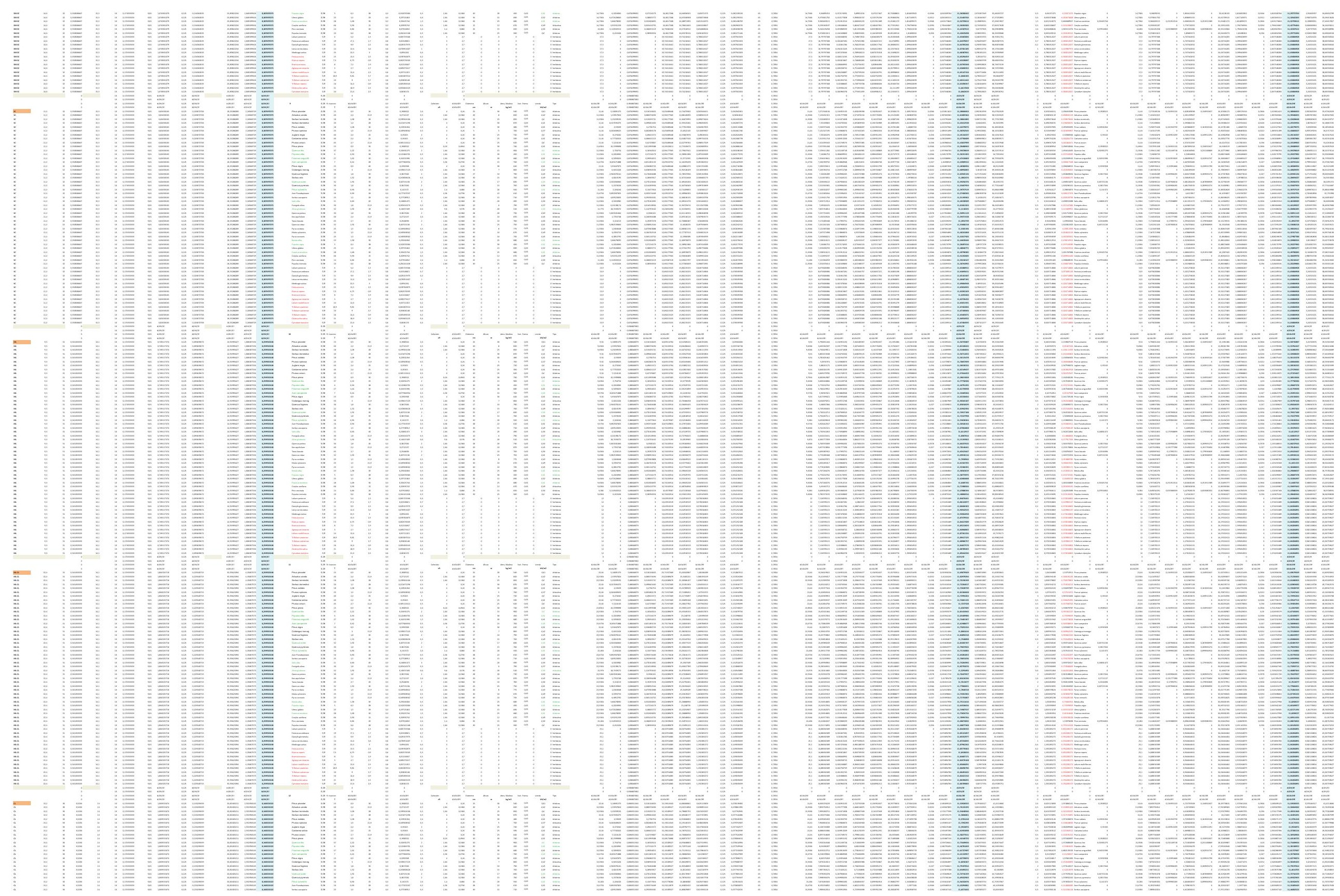


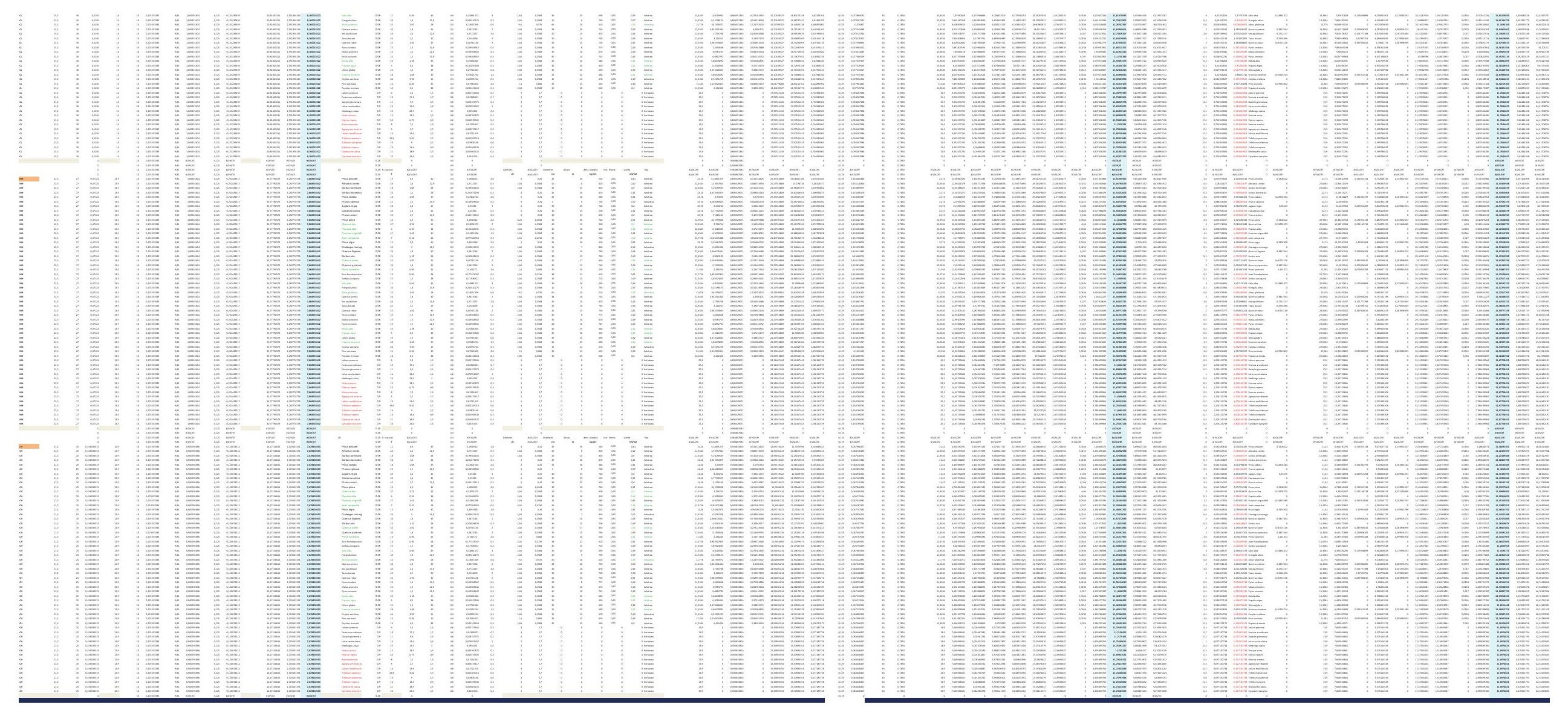



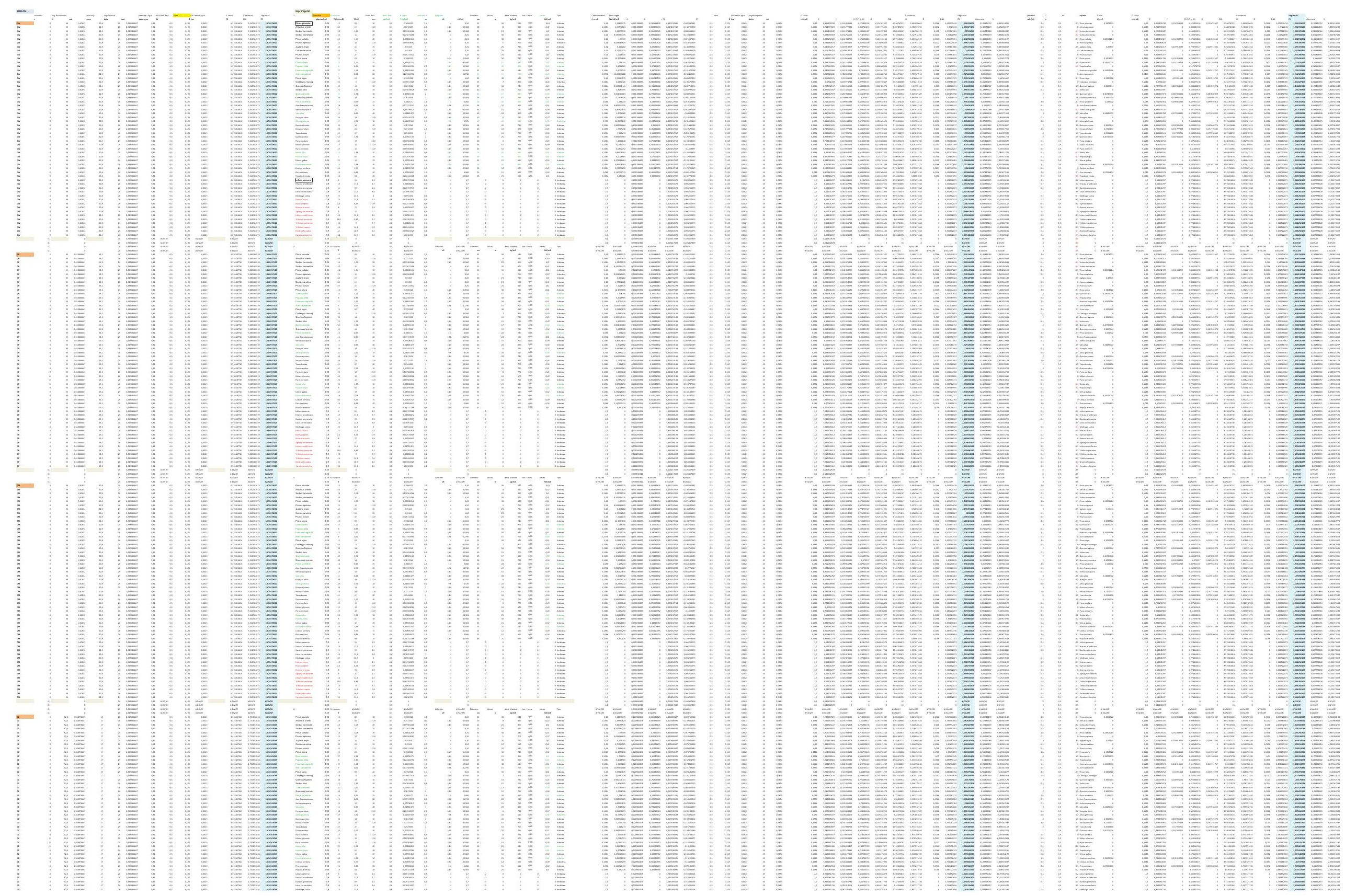


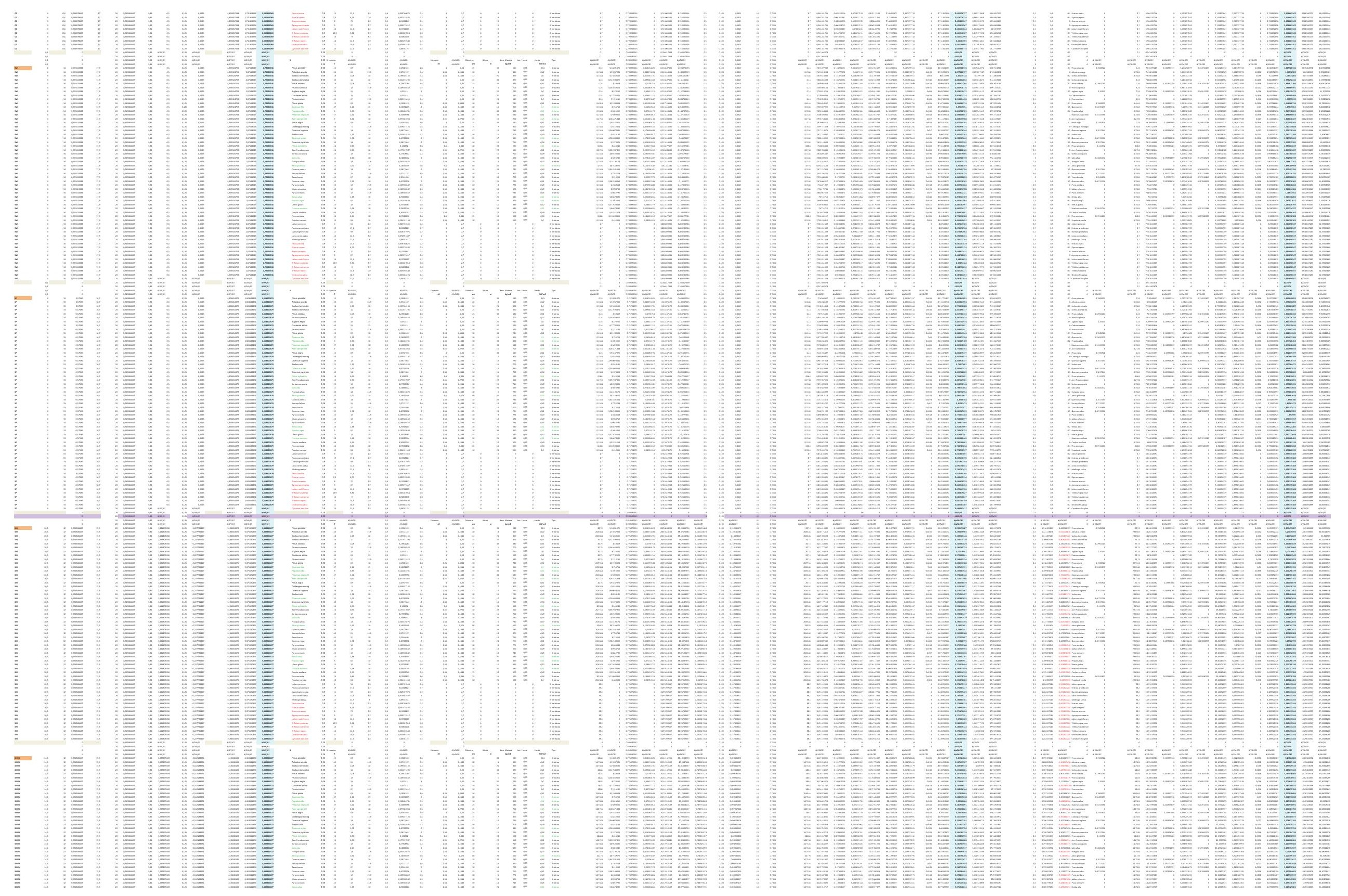



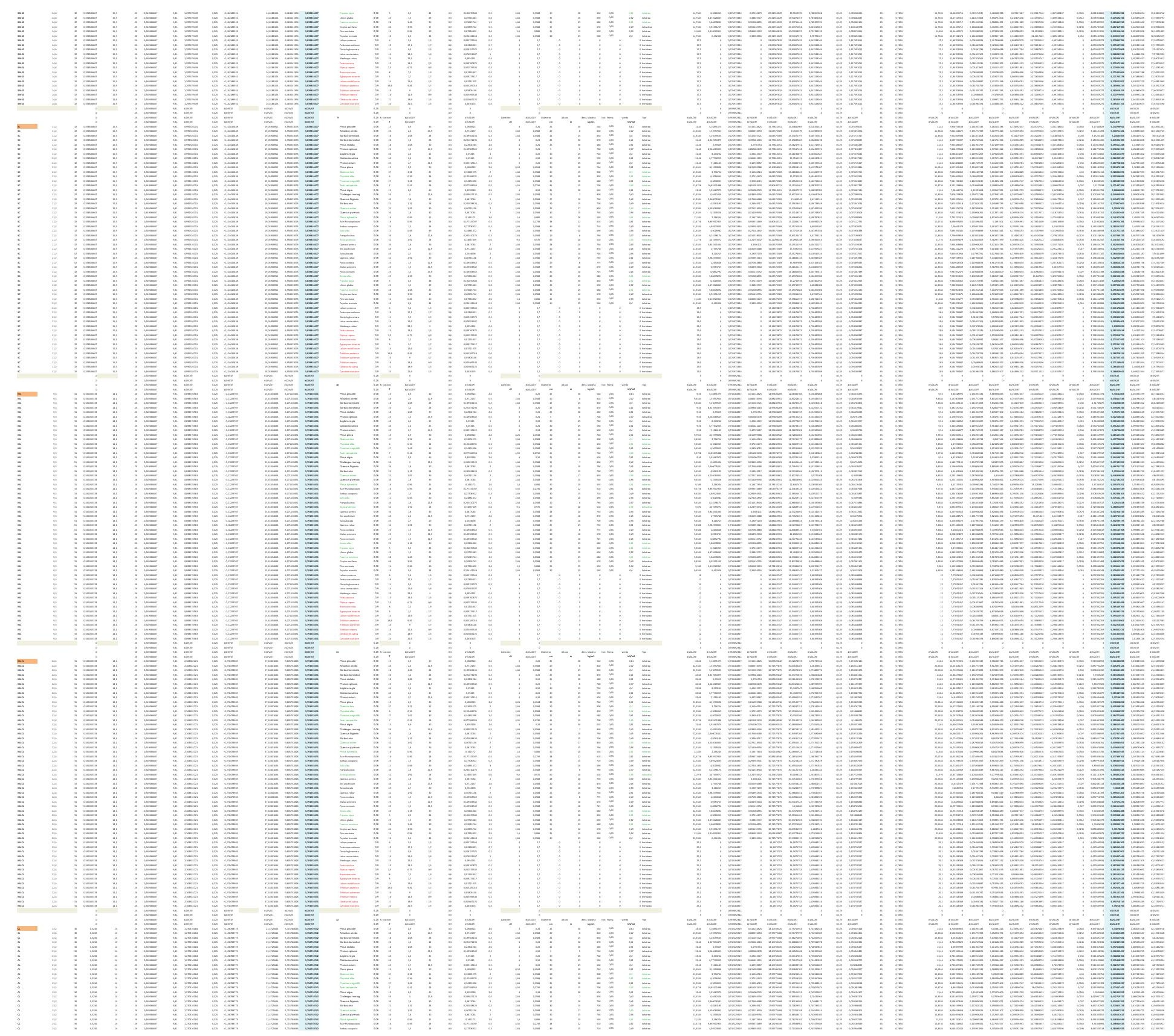

:
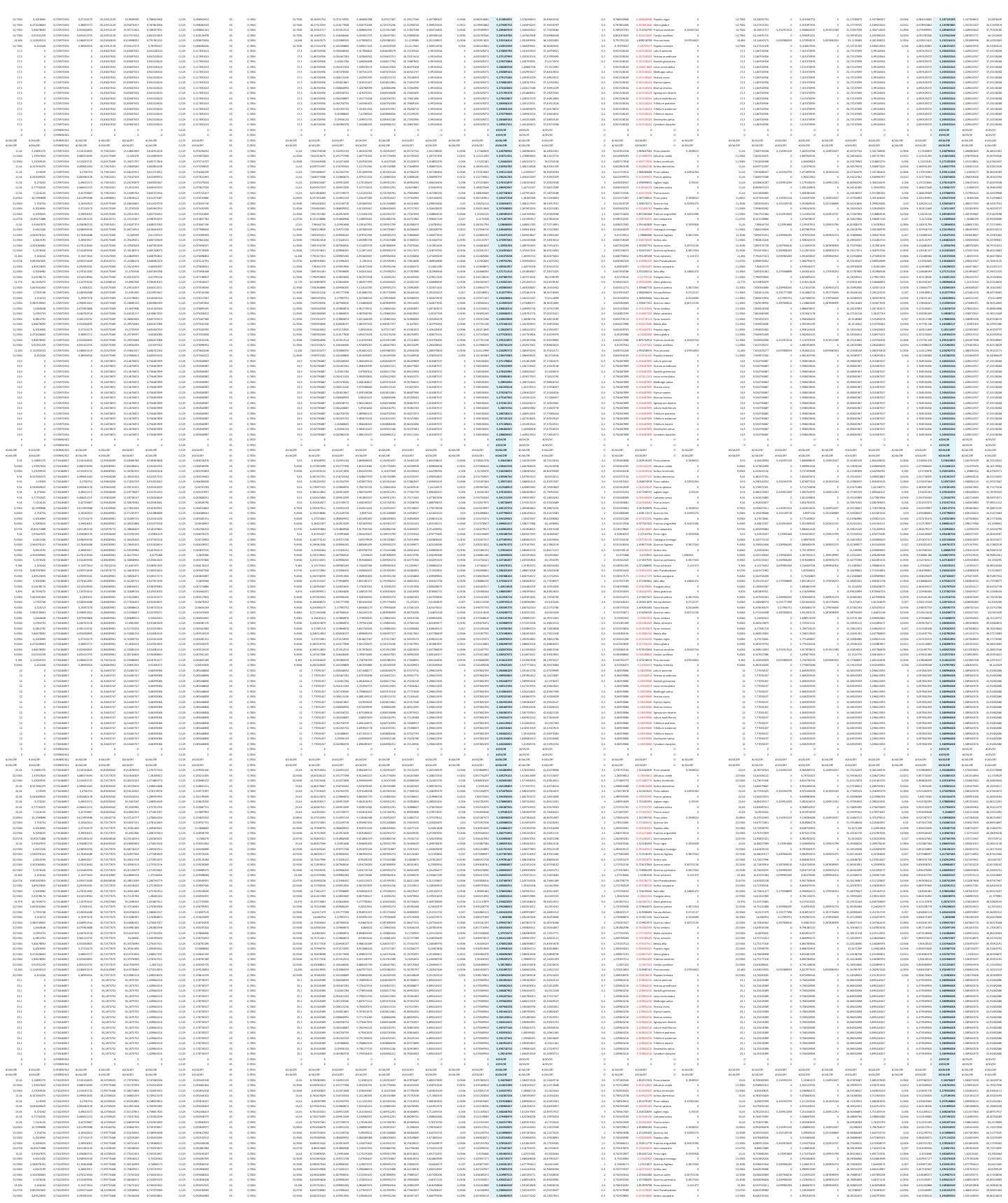


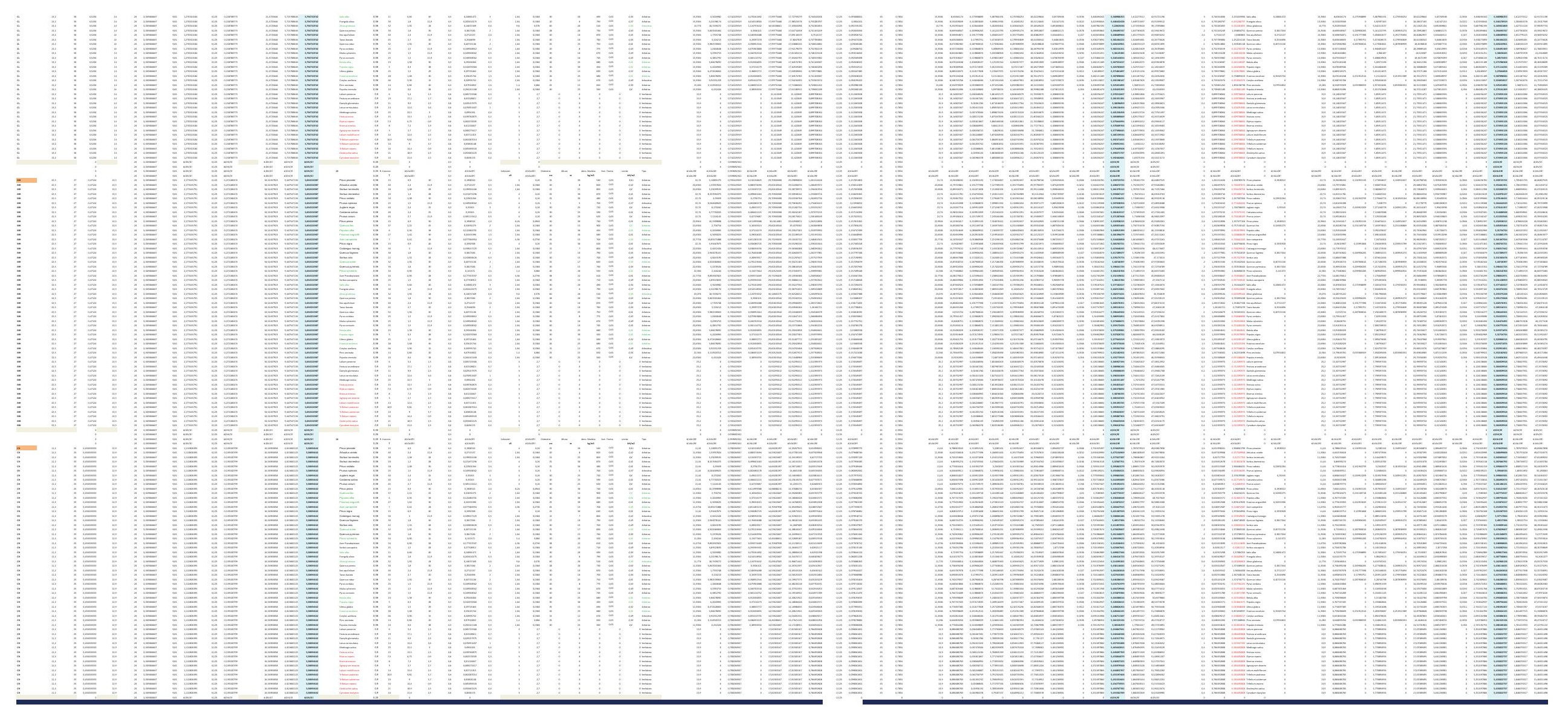



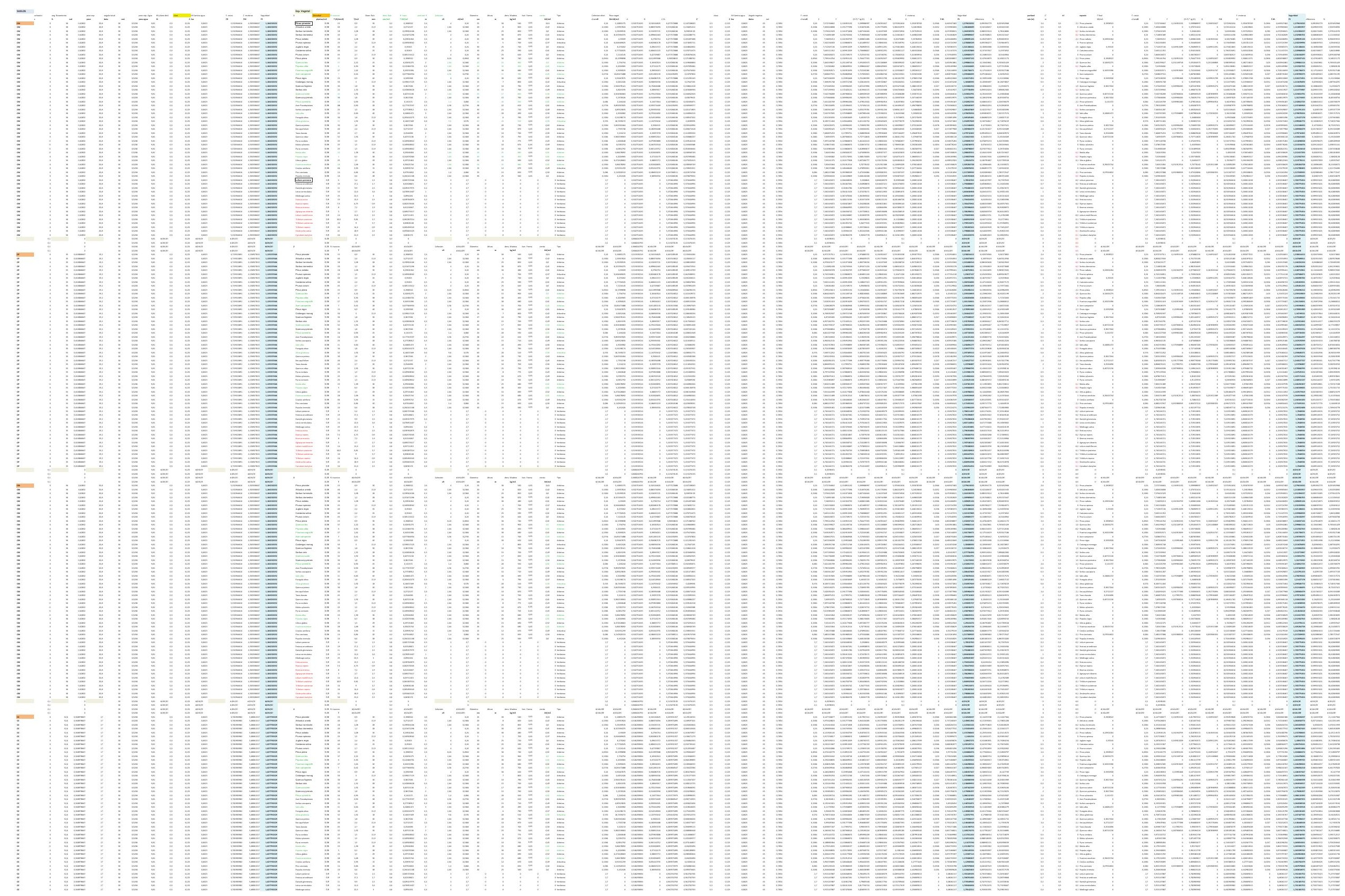


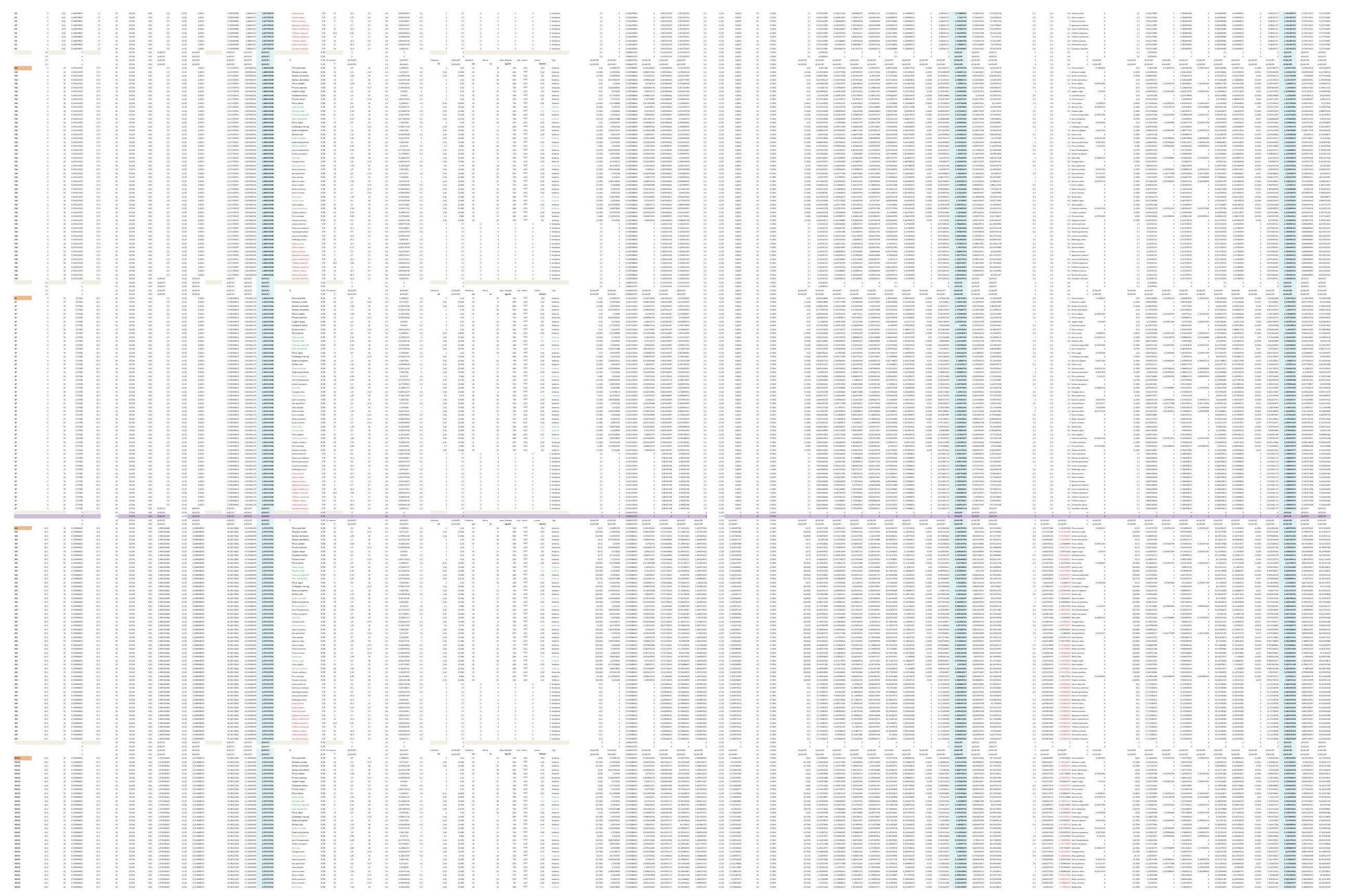



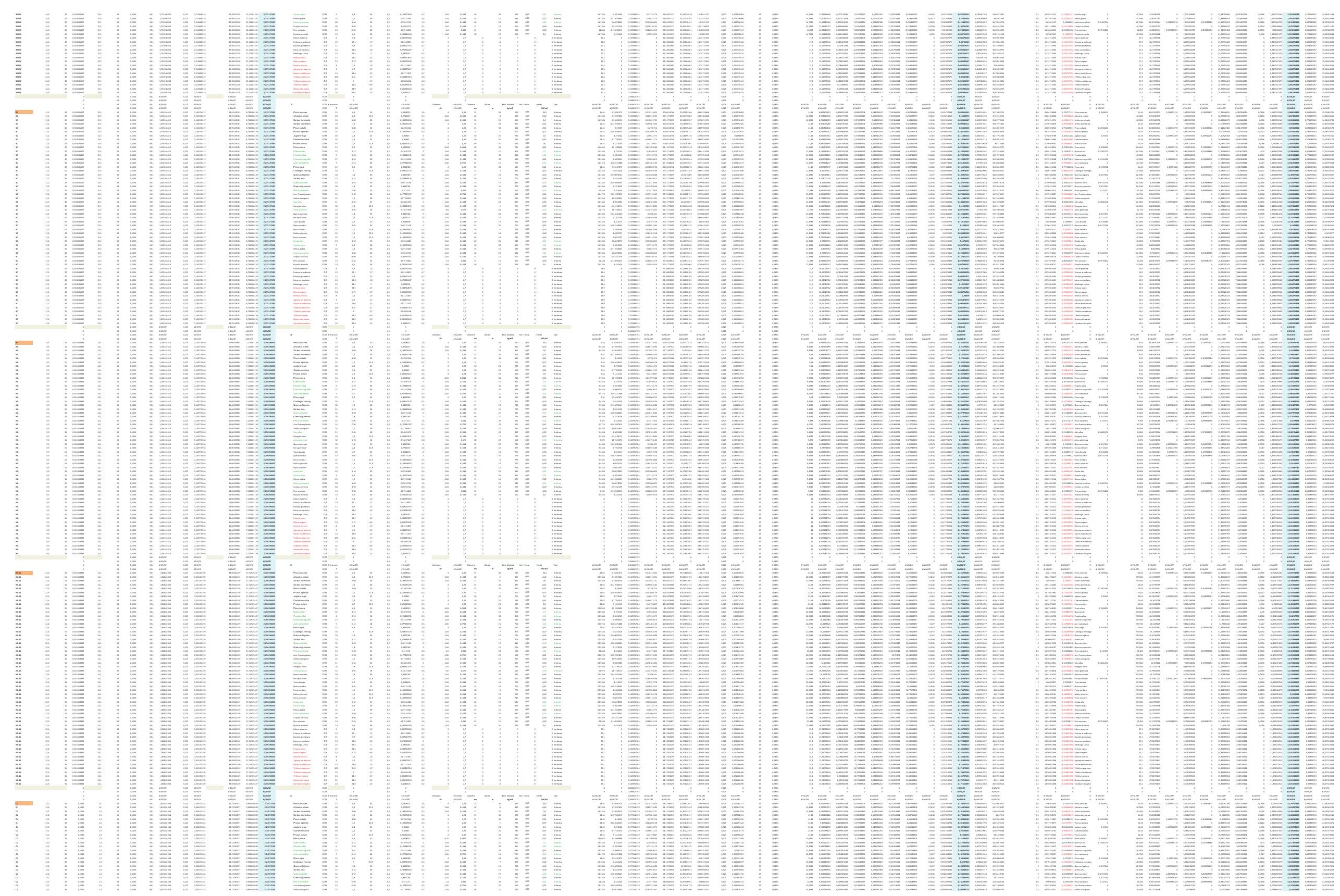


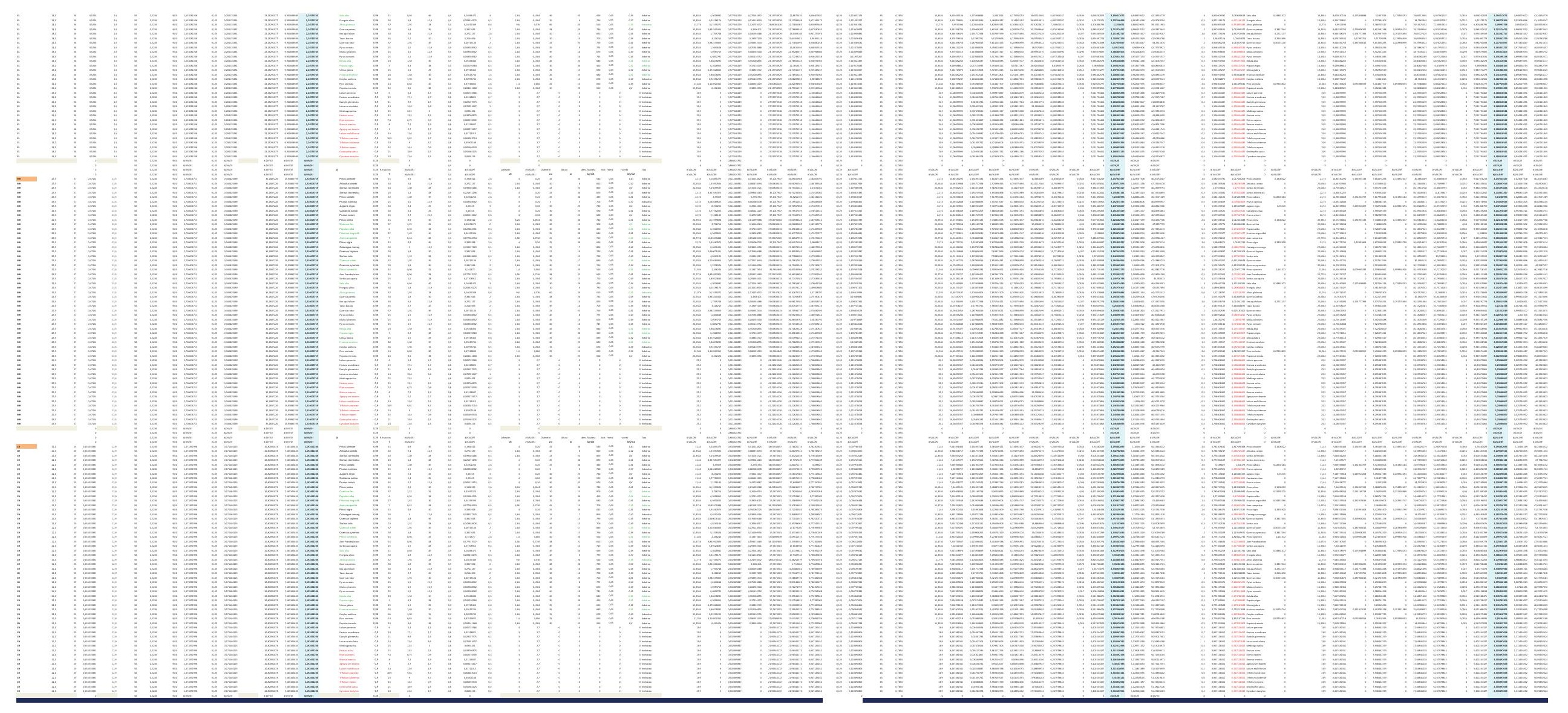



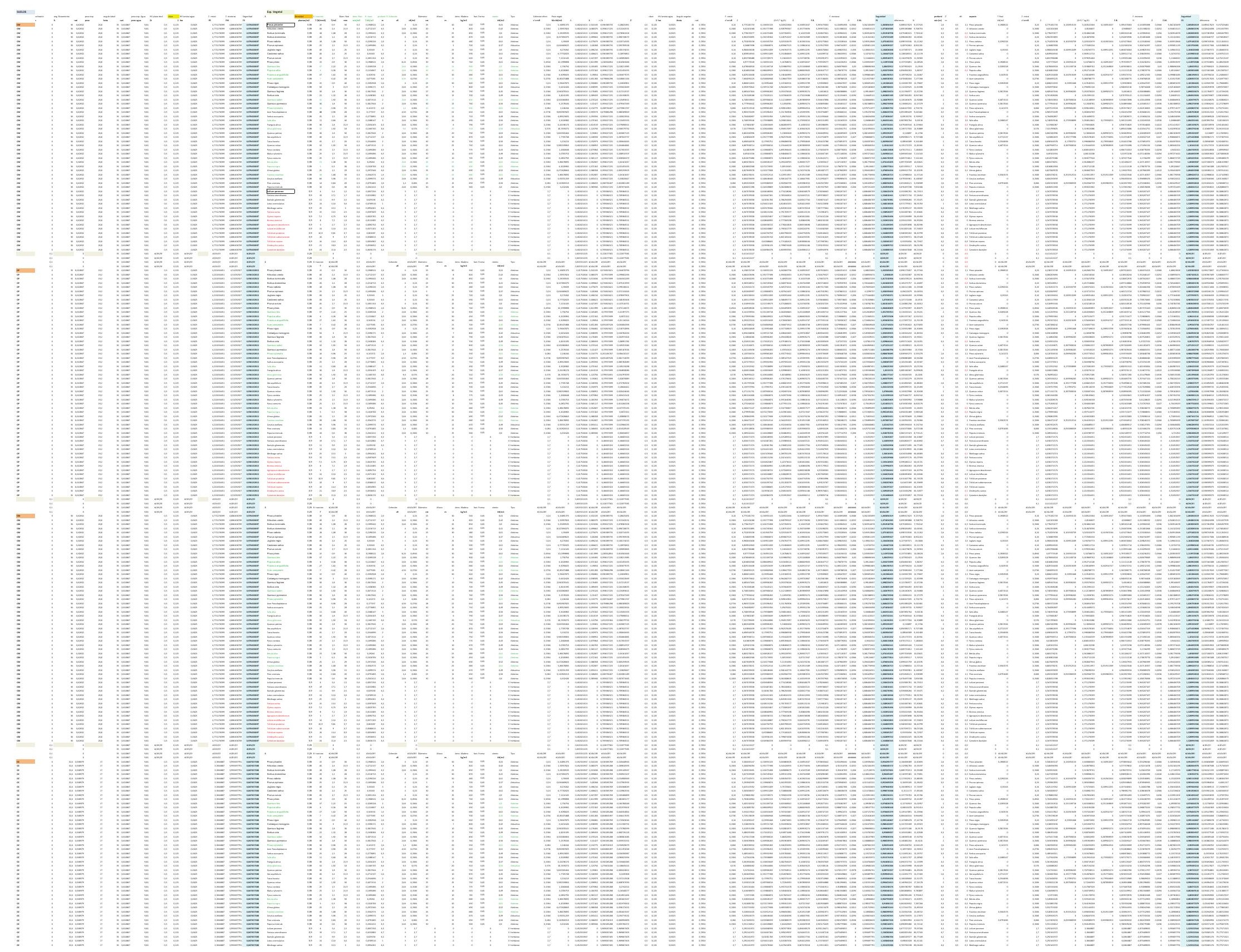


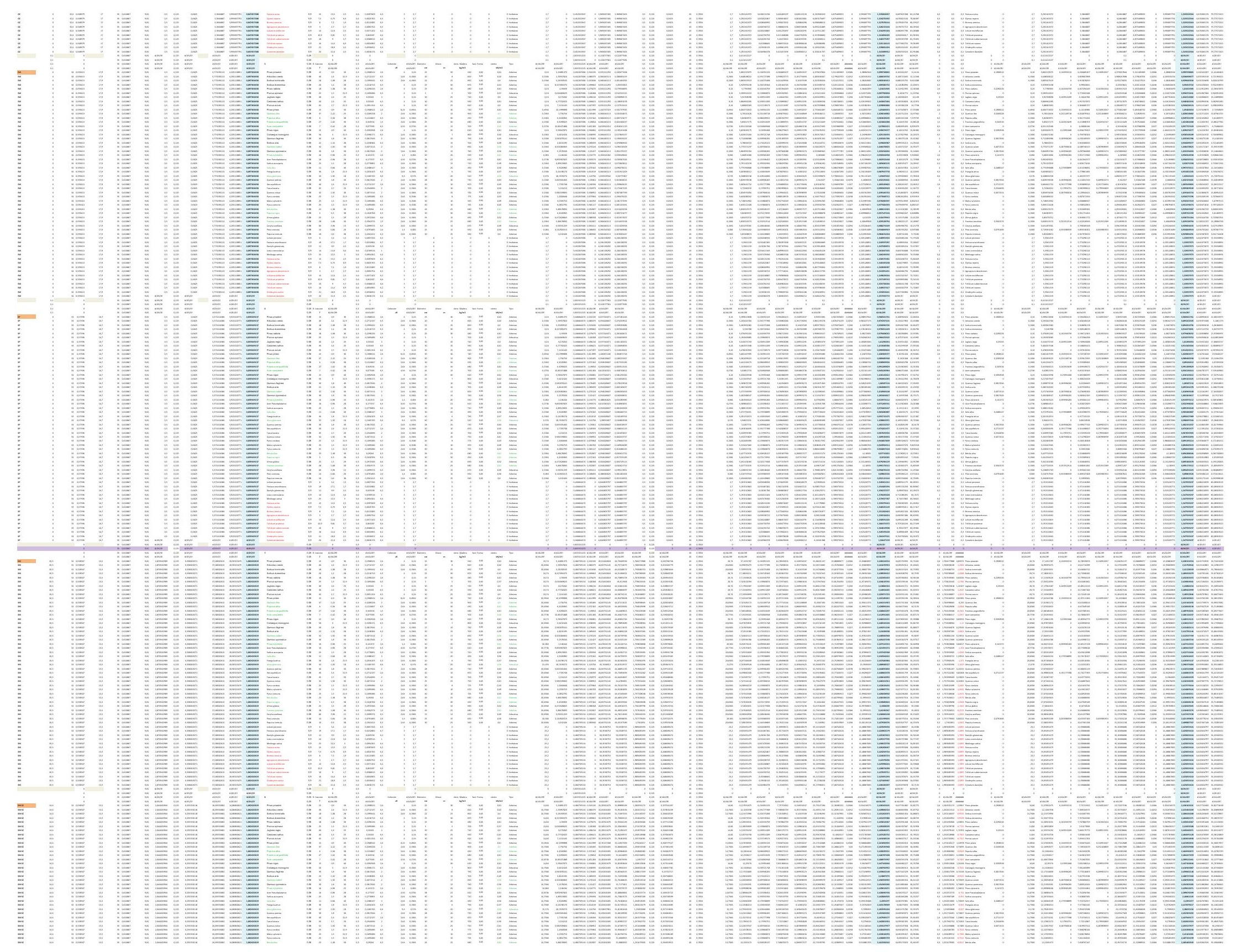



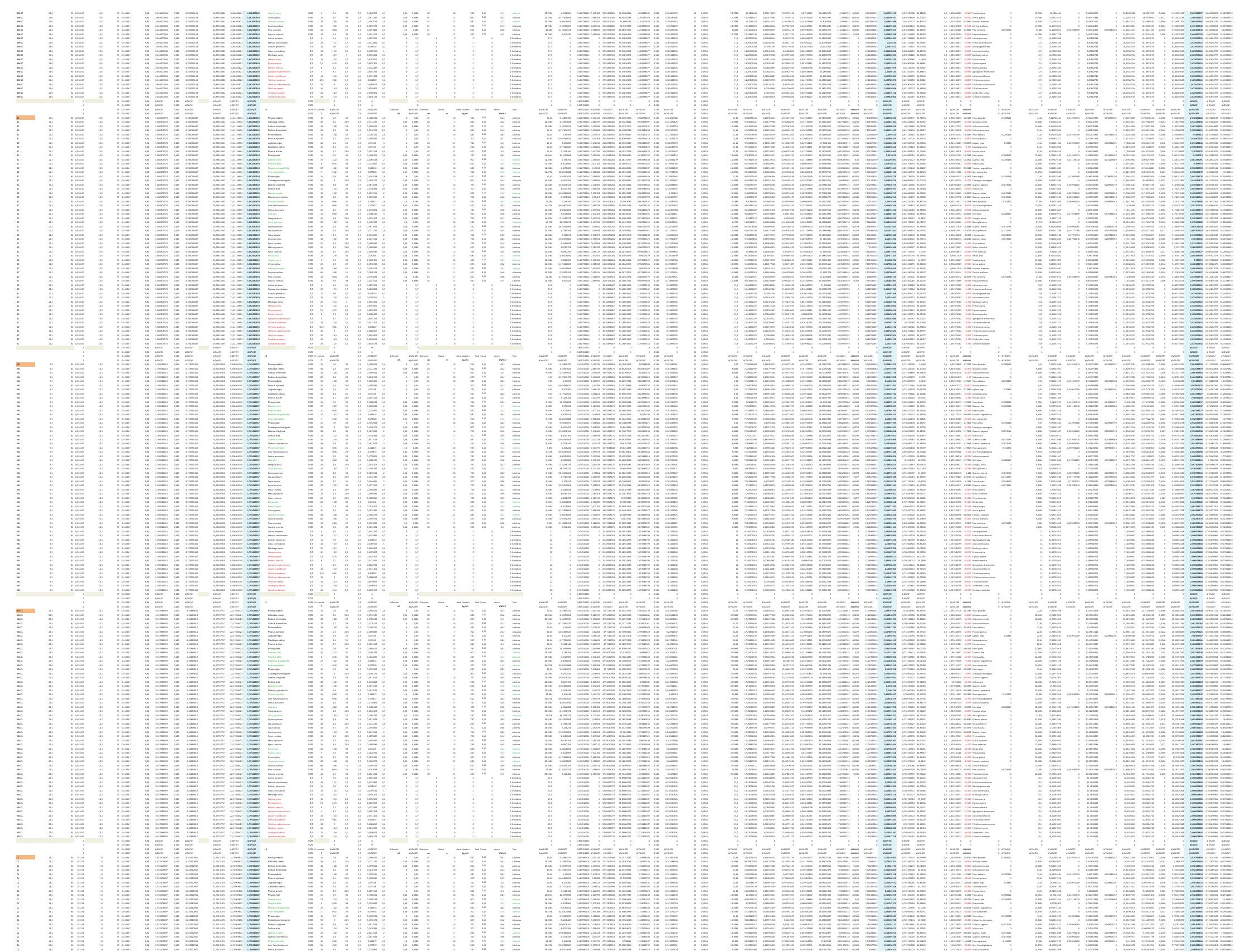


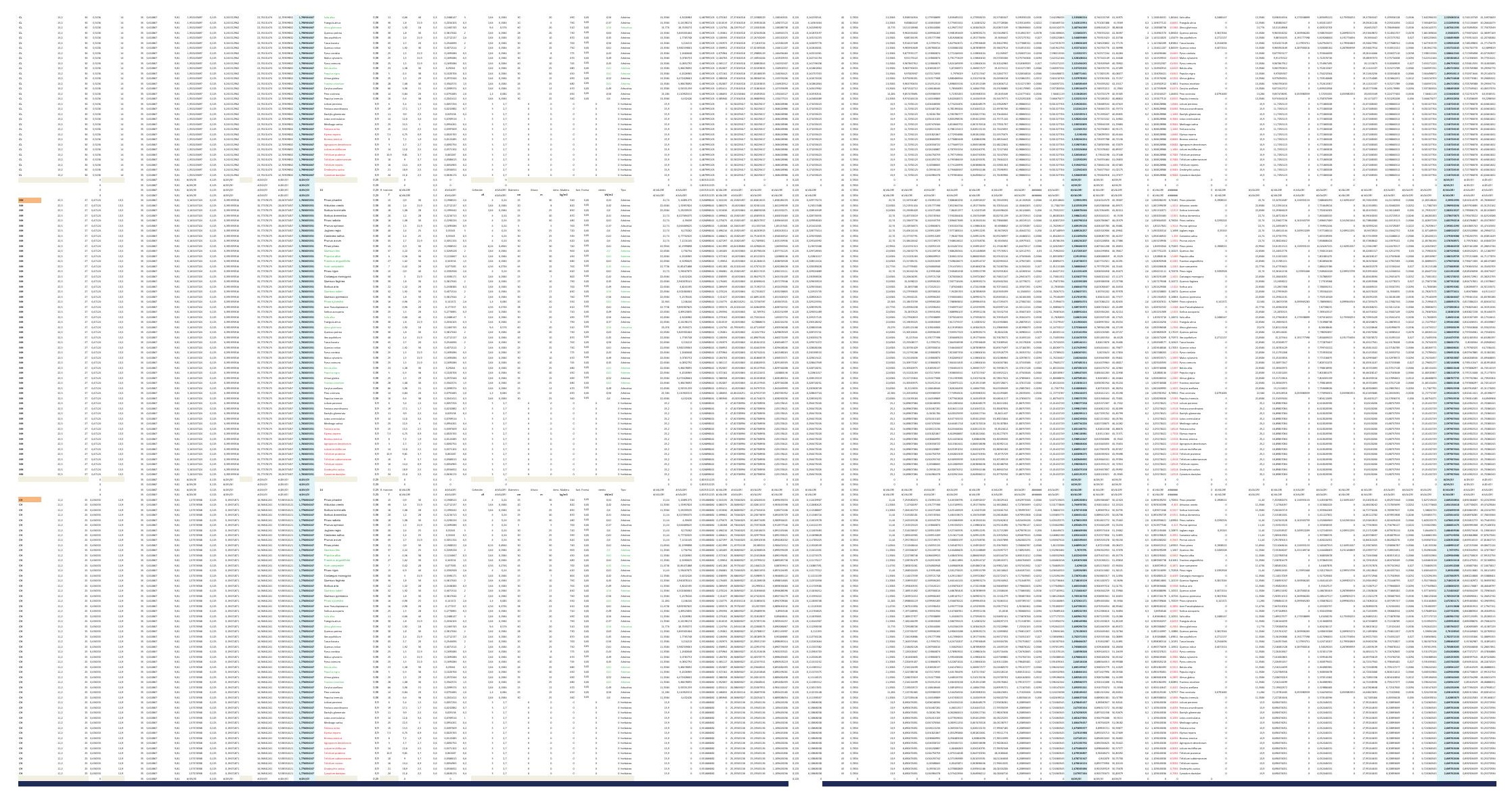



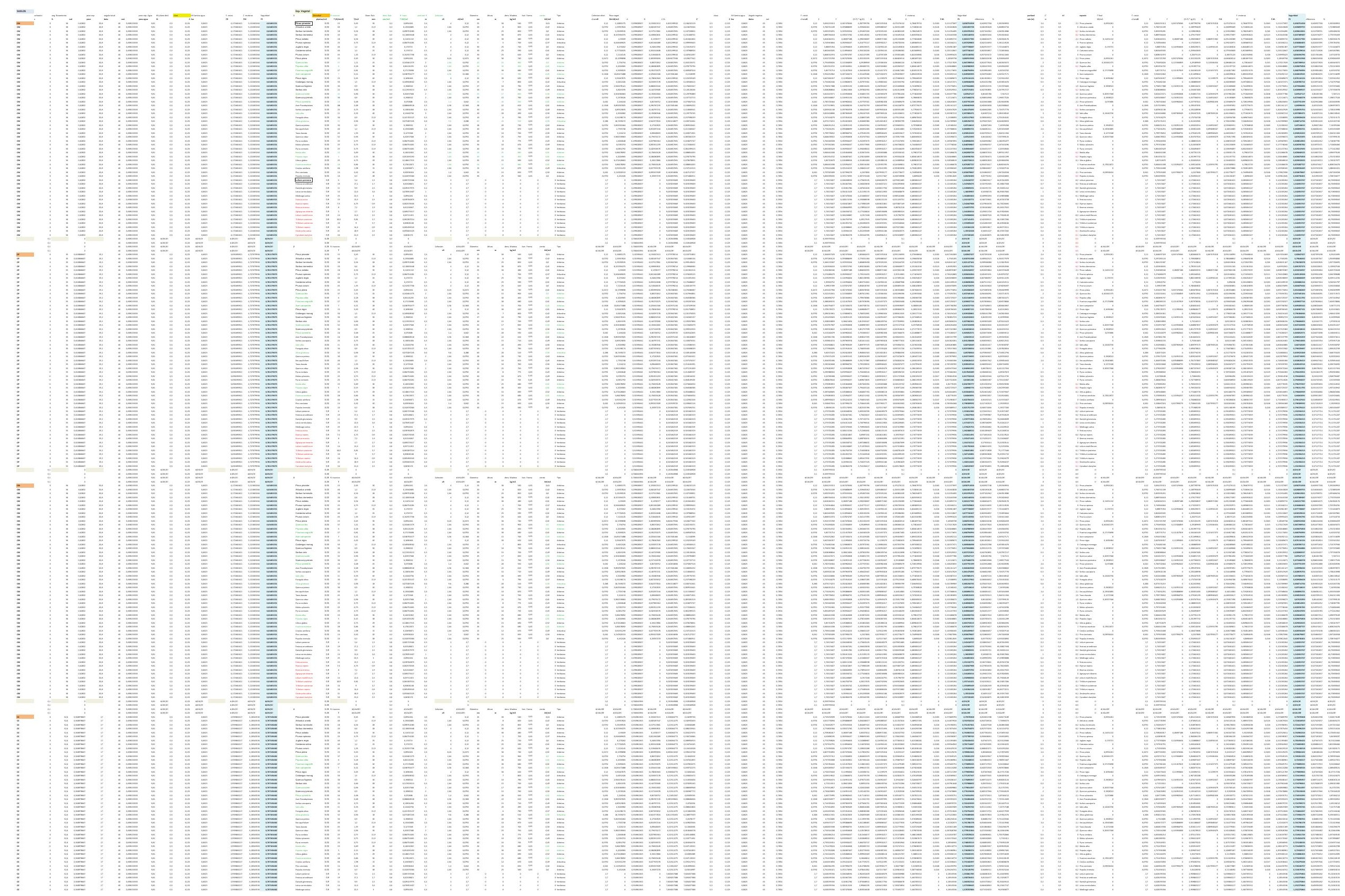


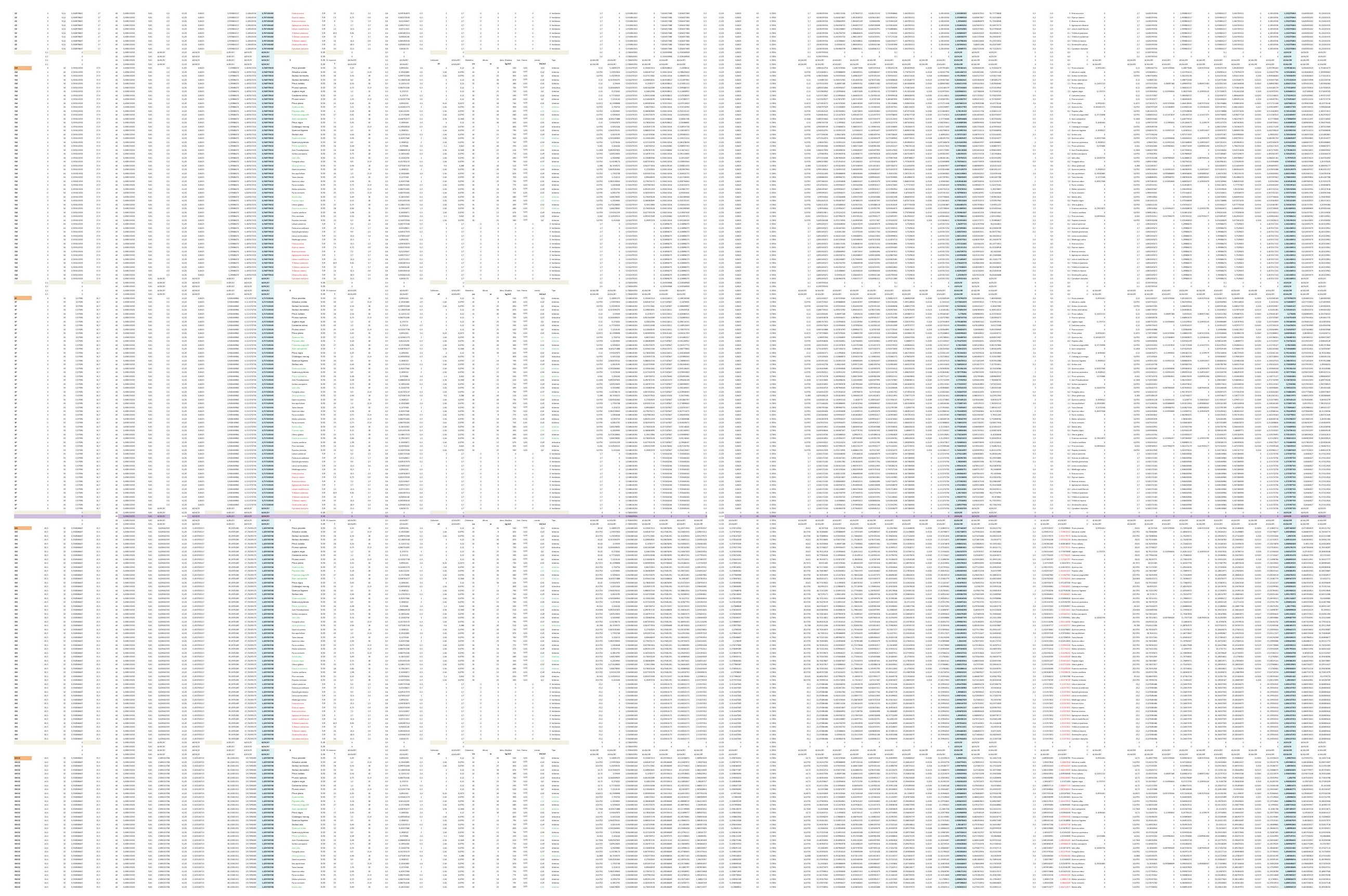



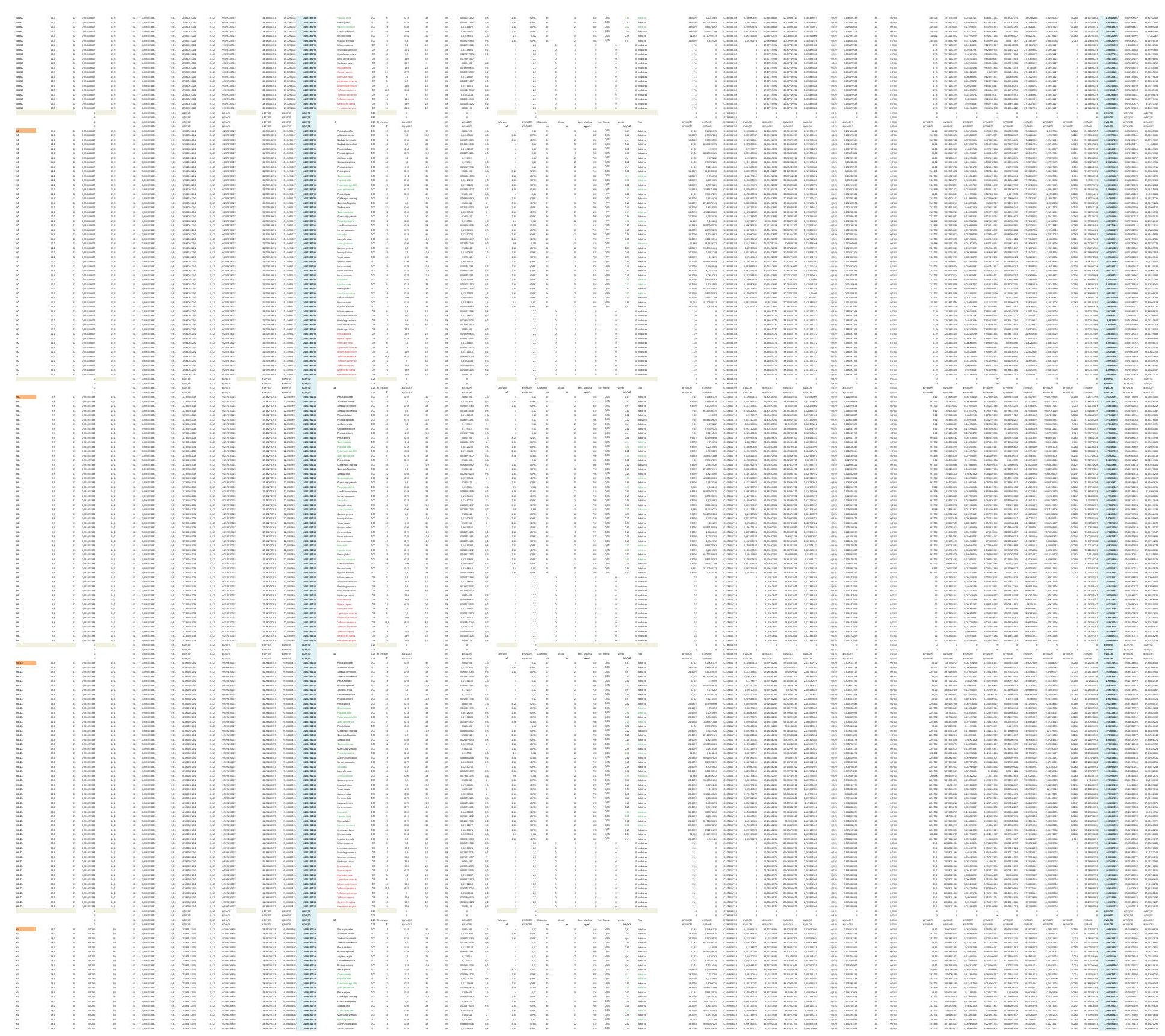

II
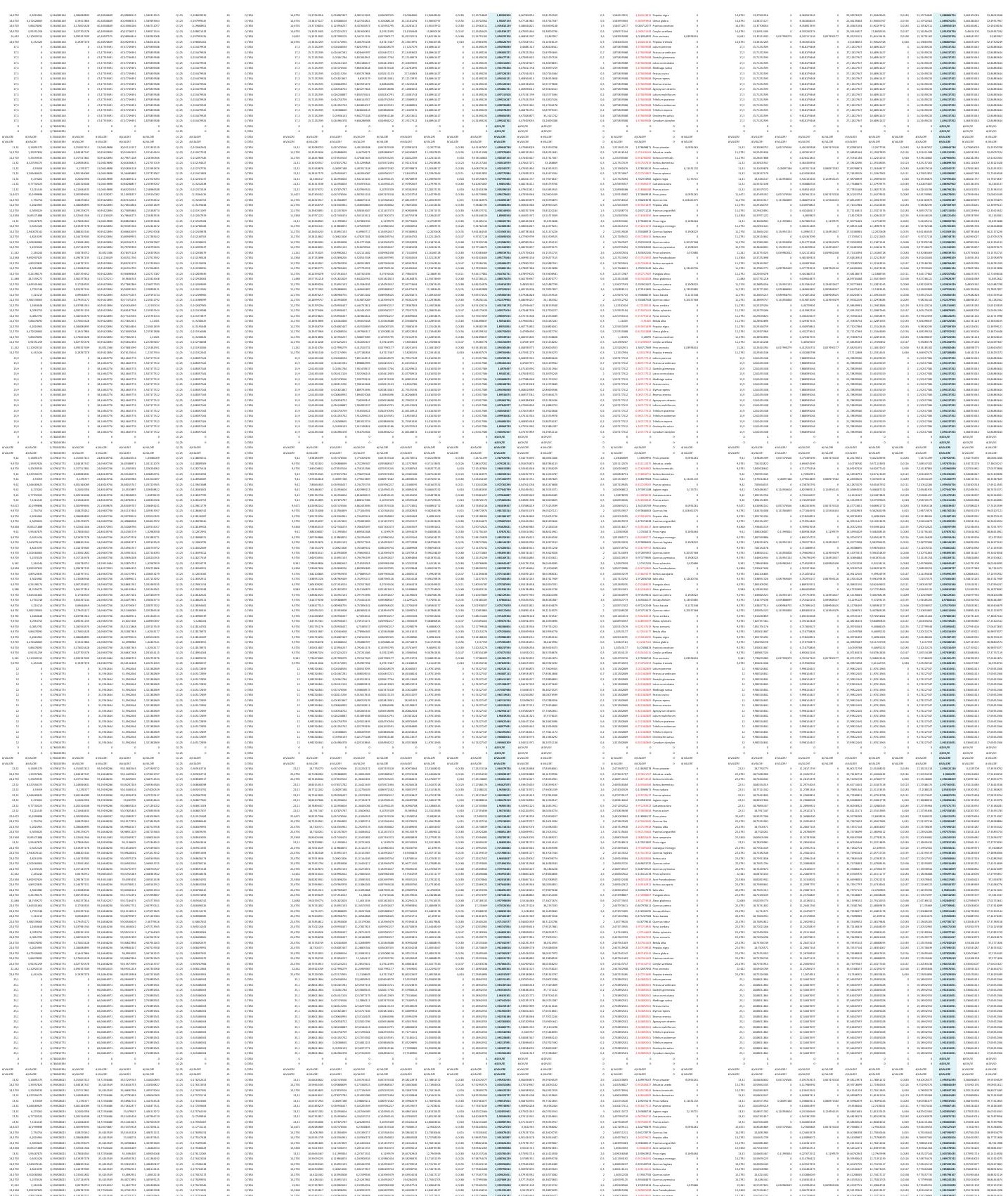


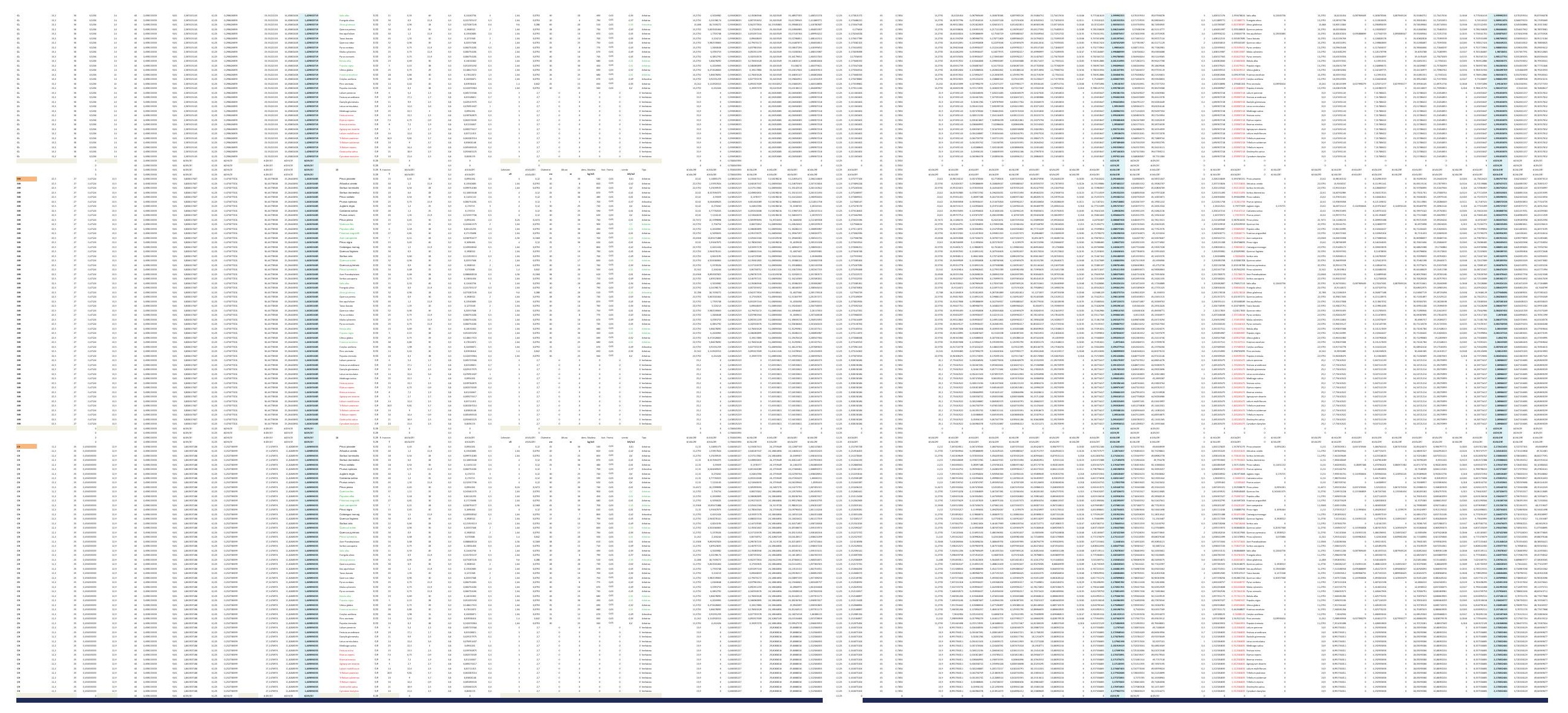



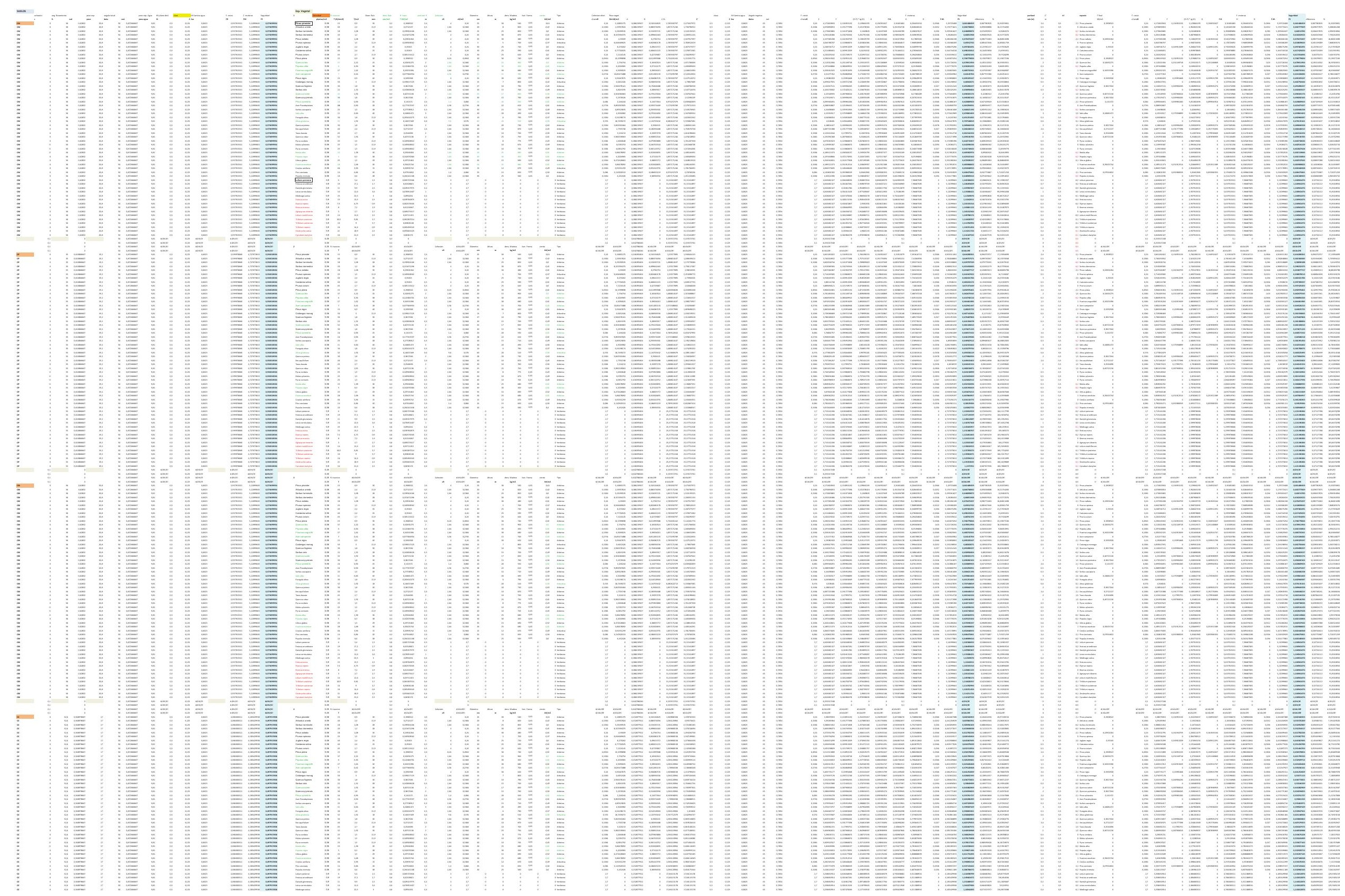


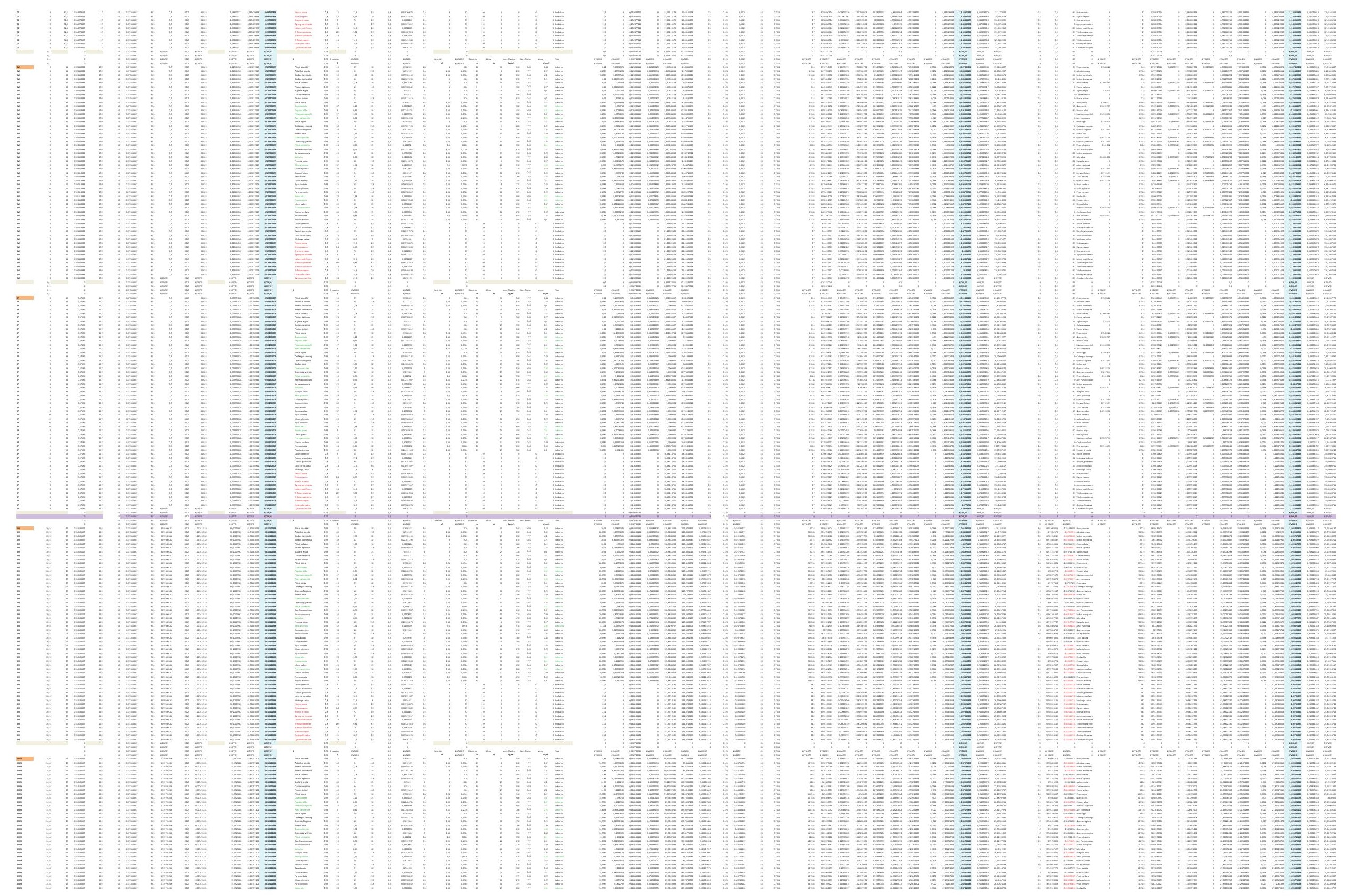




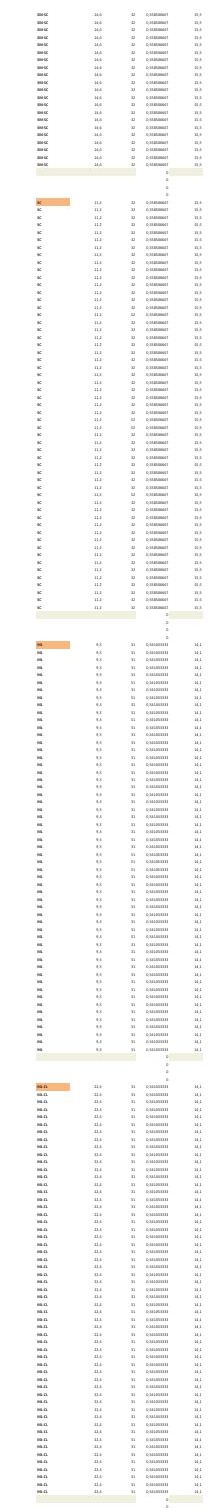

؛

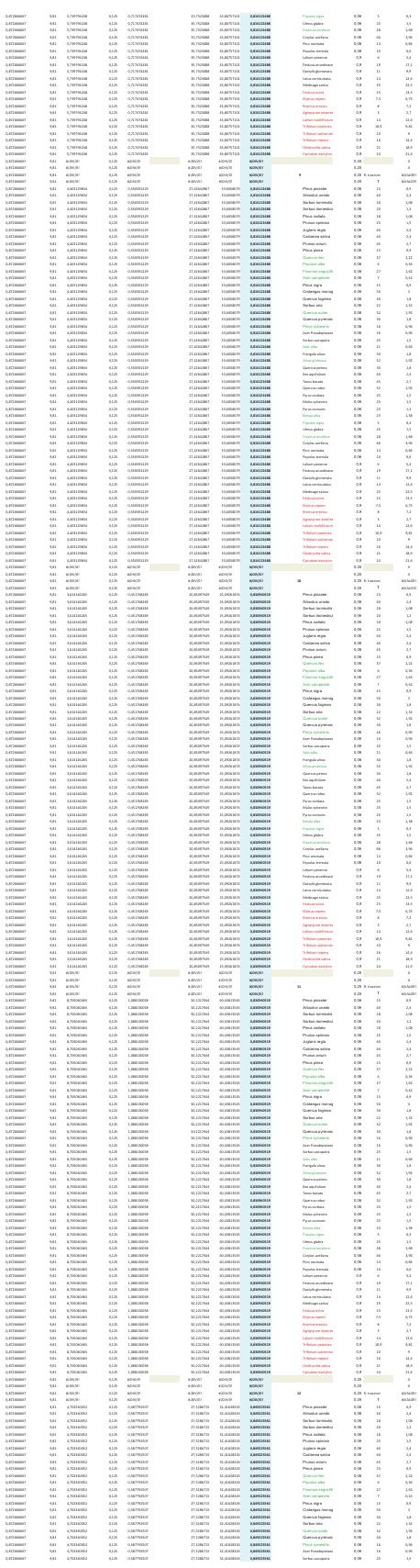

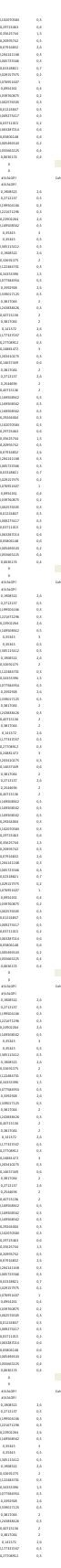
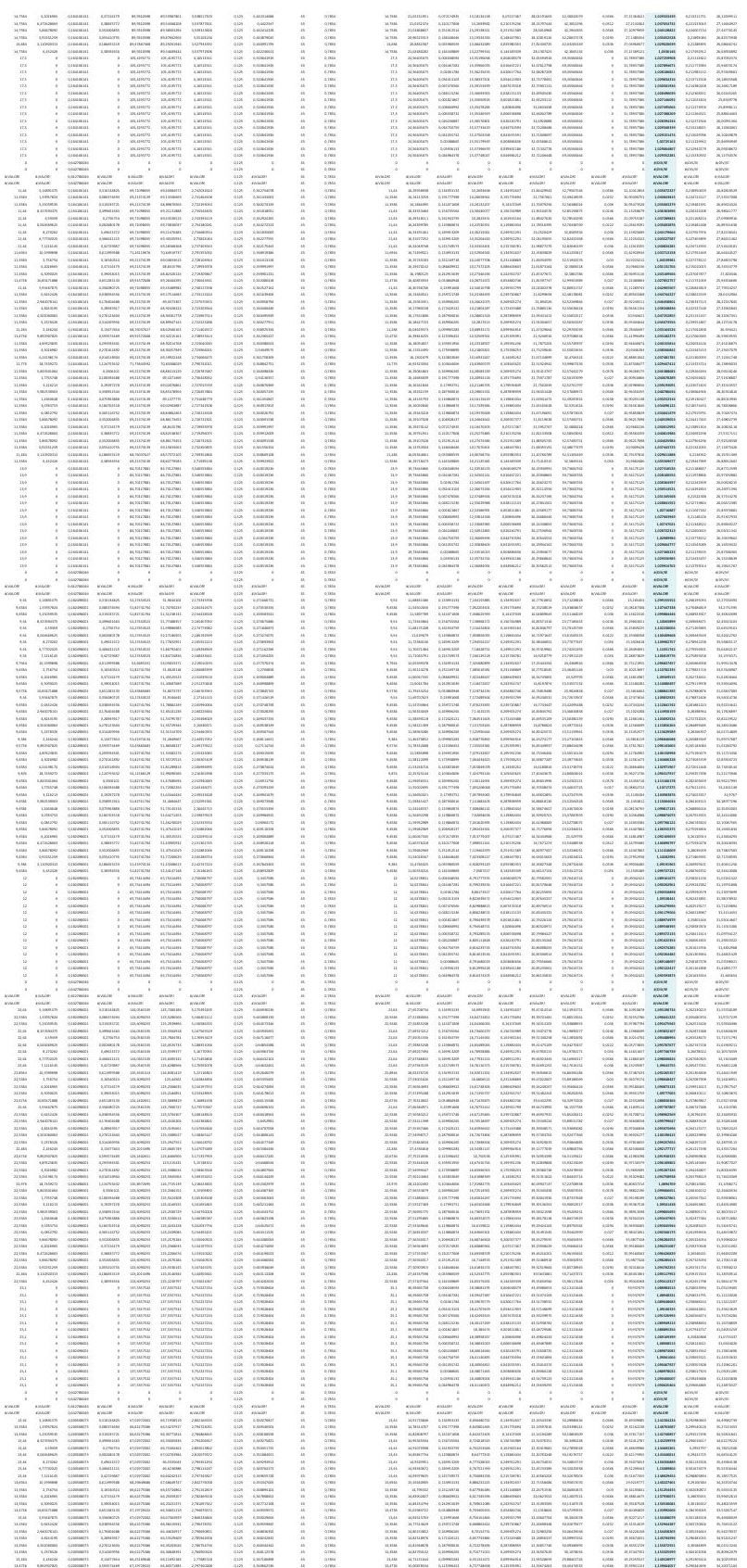
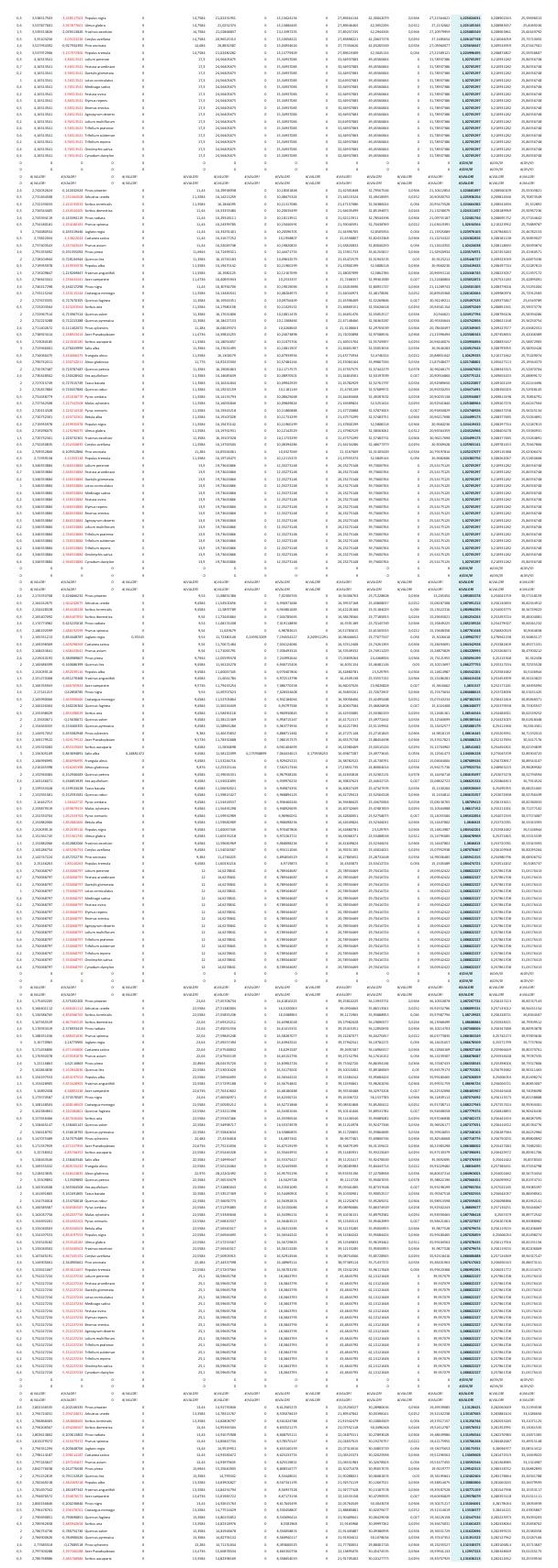


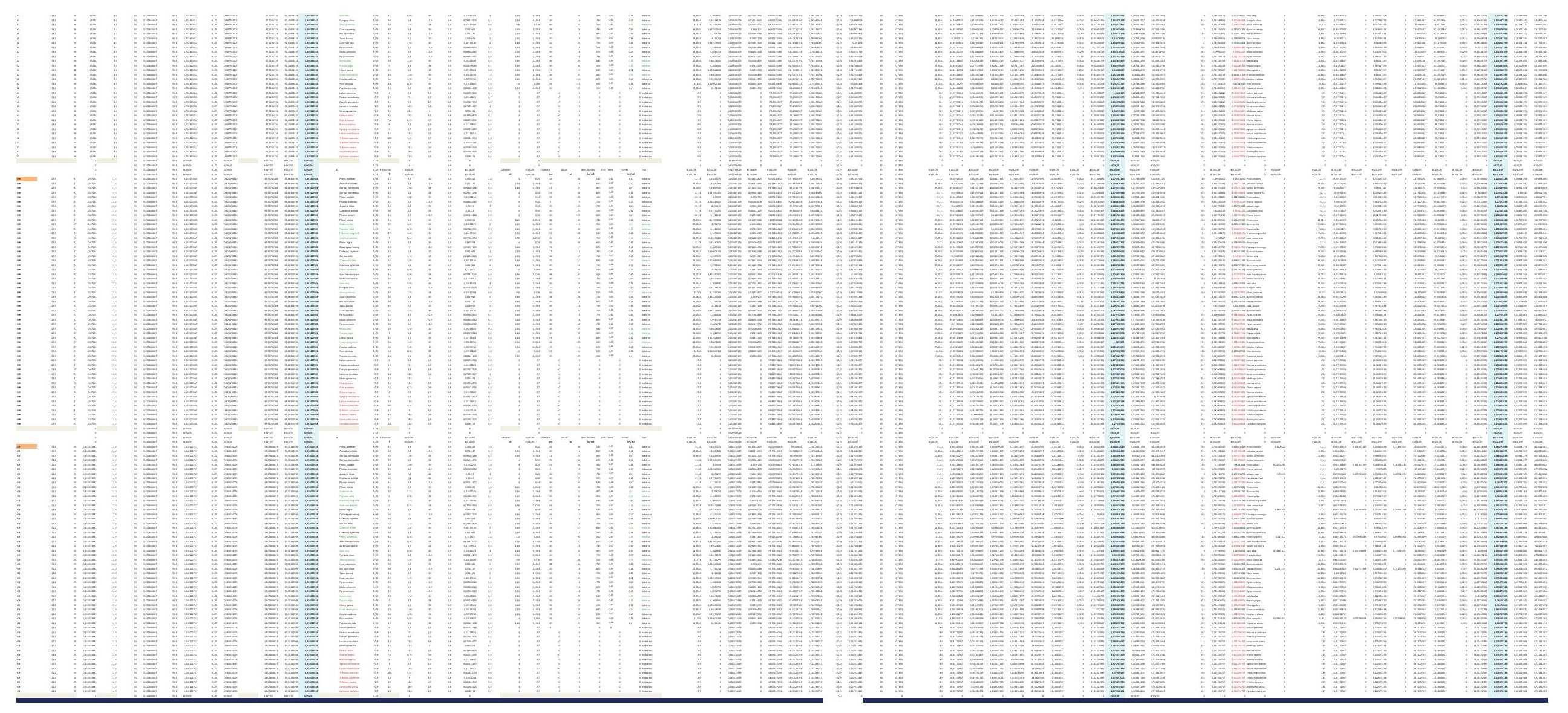



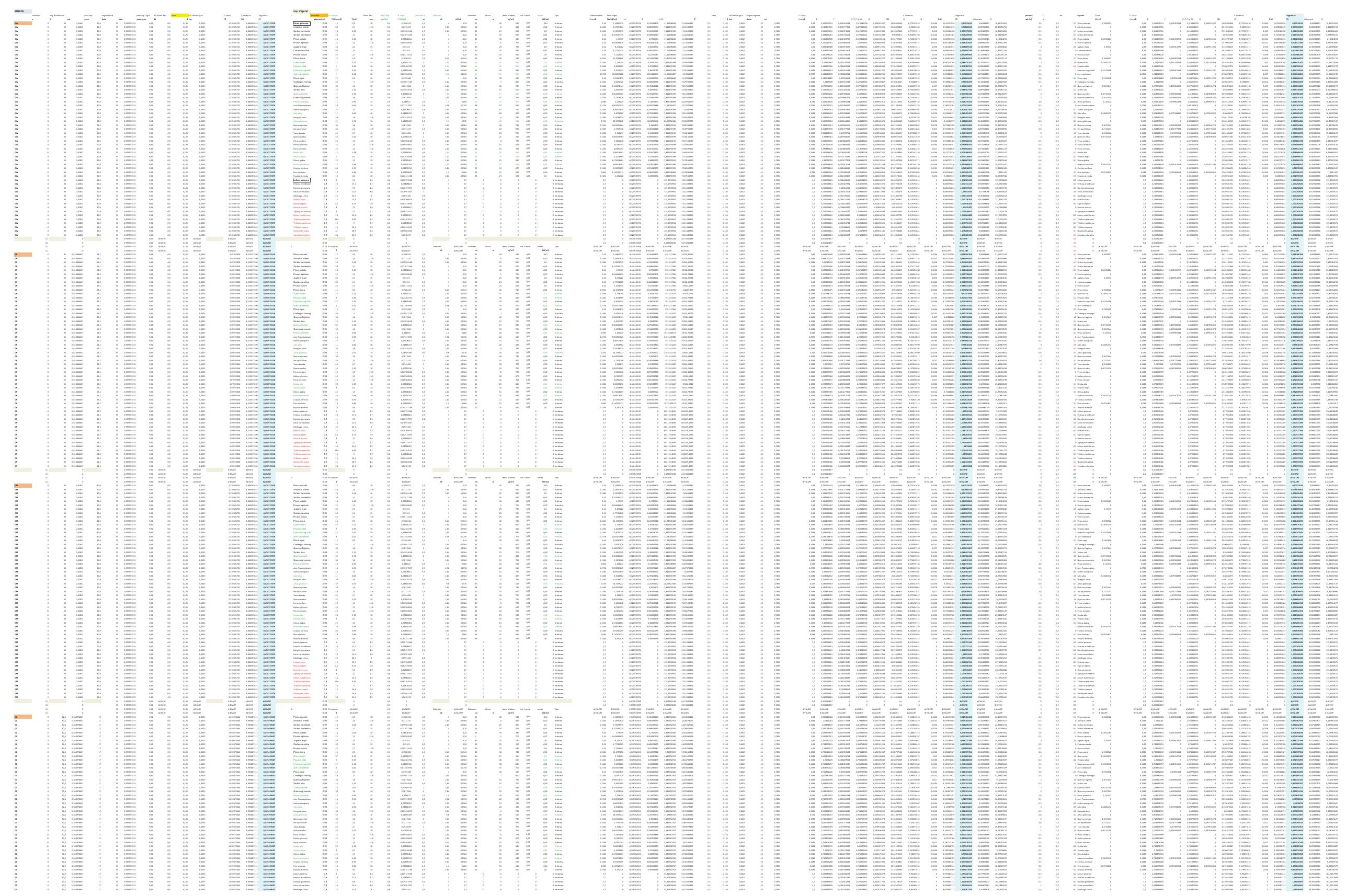


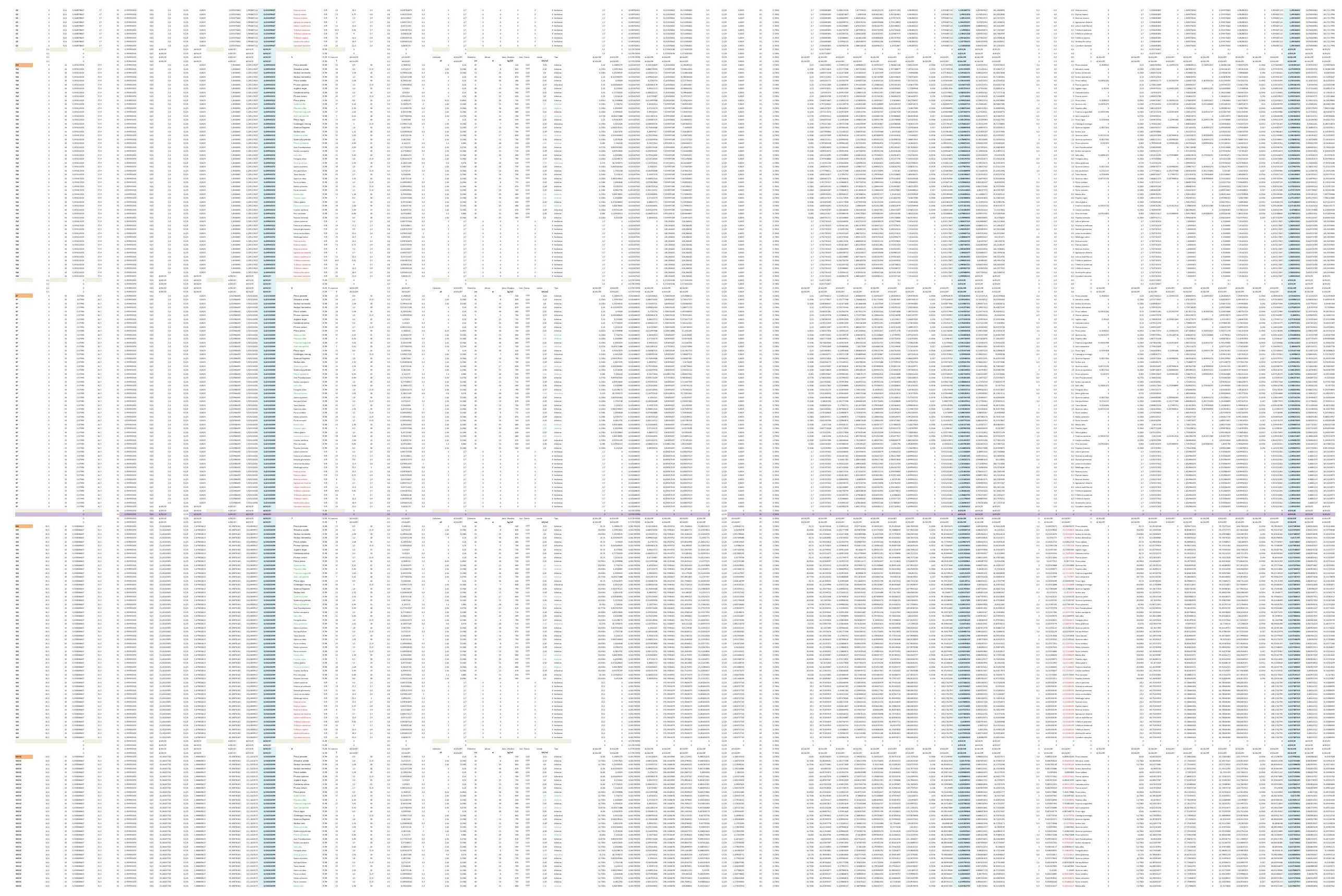



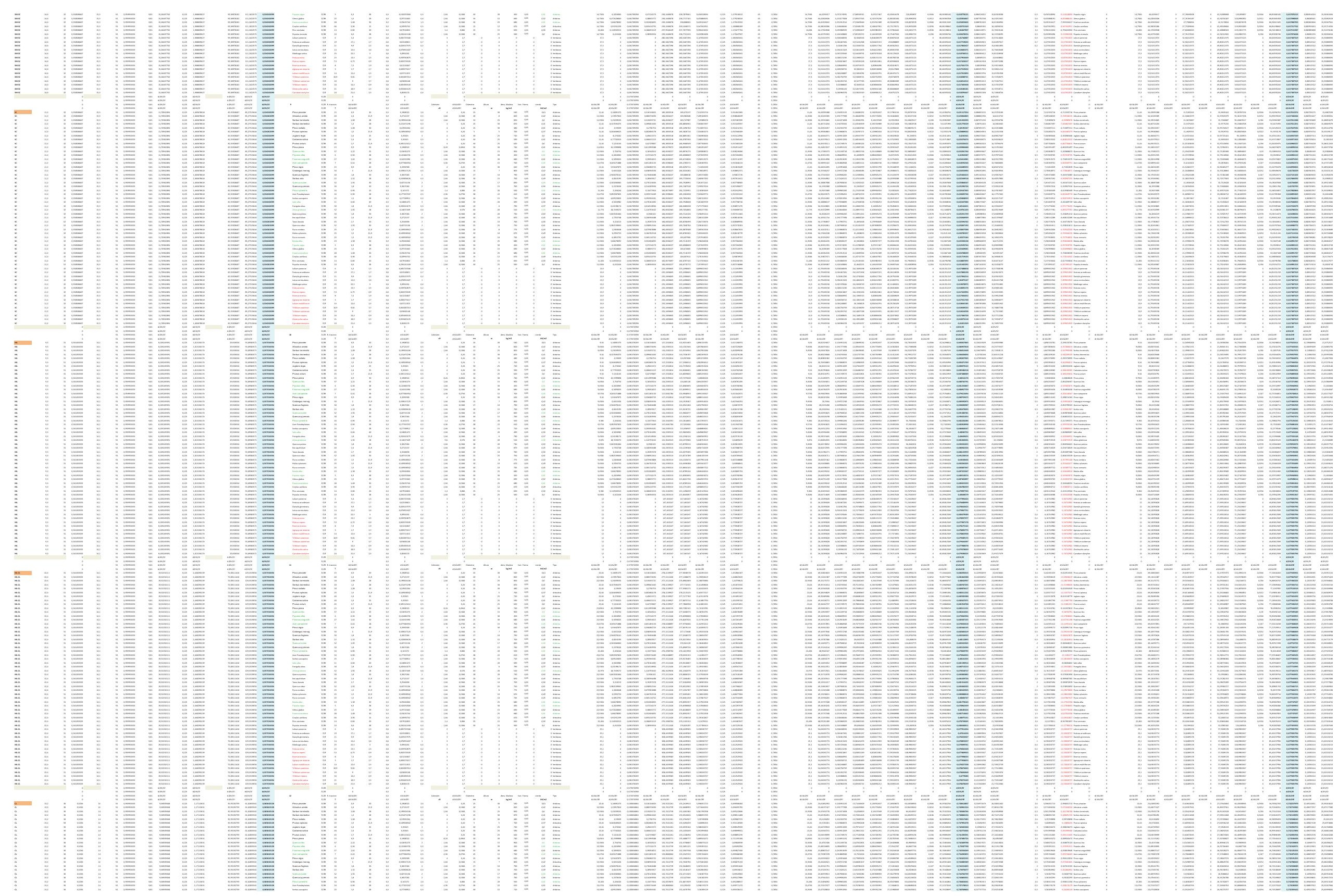


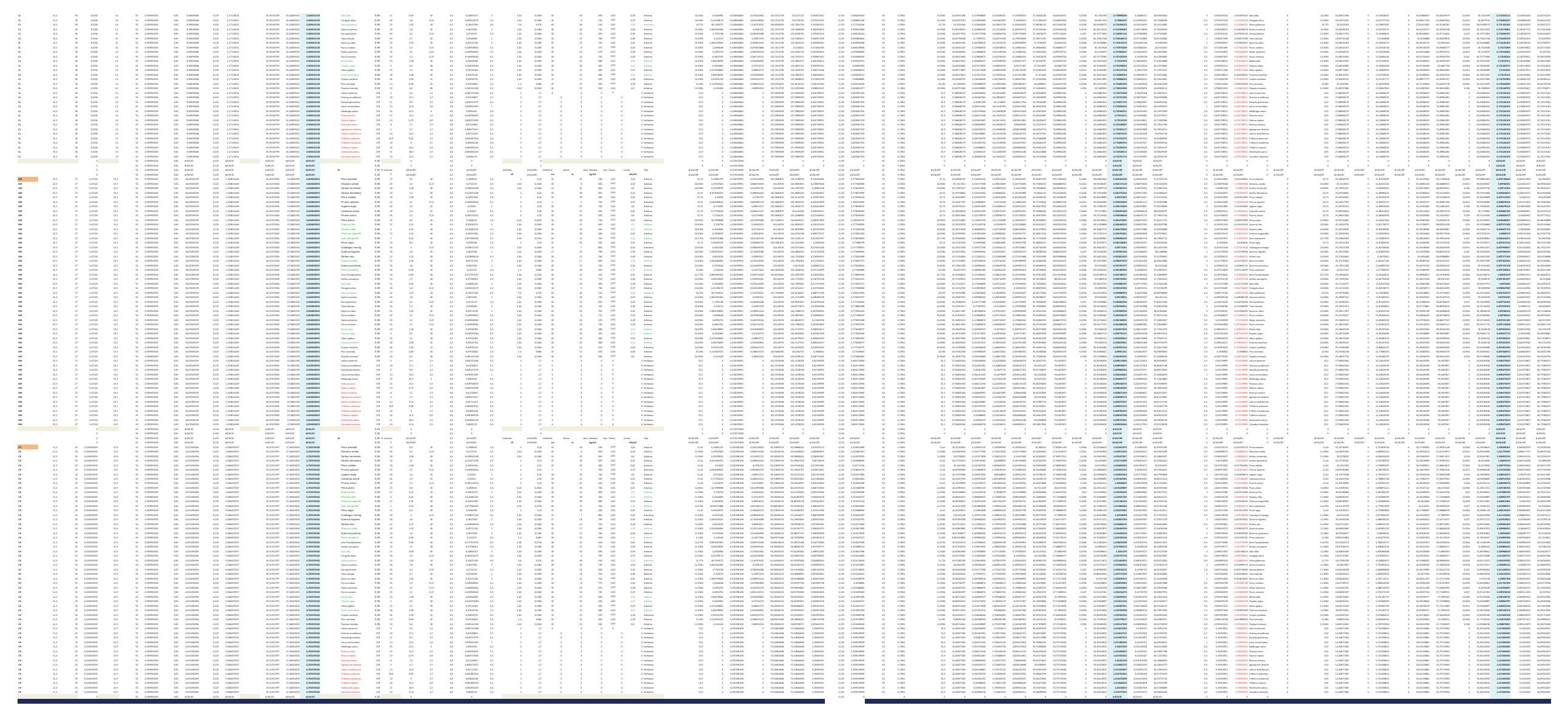



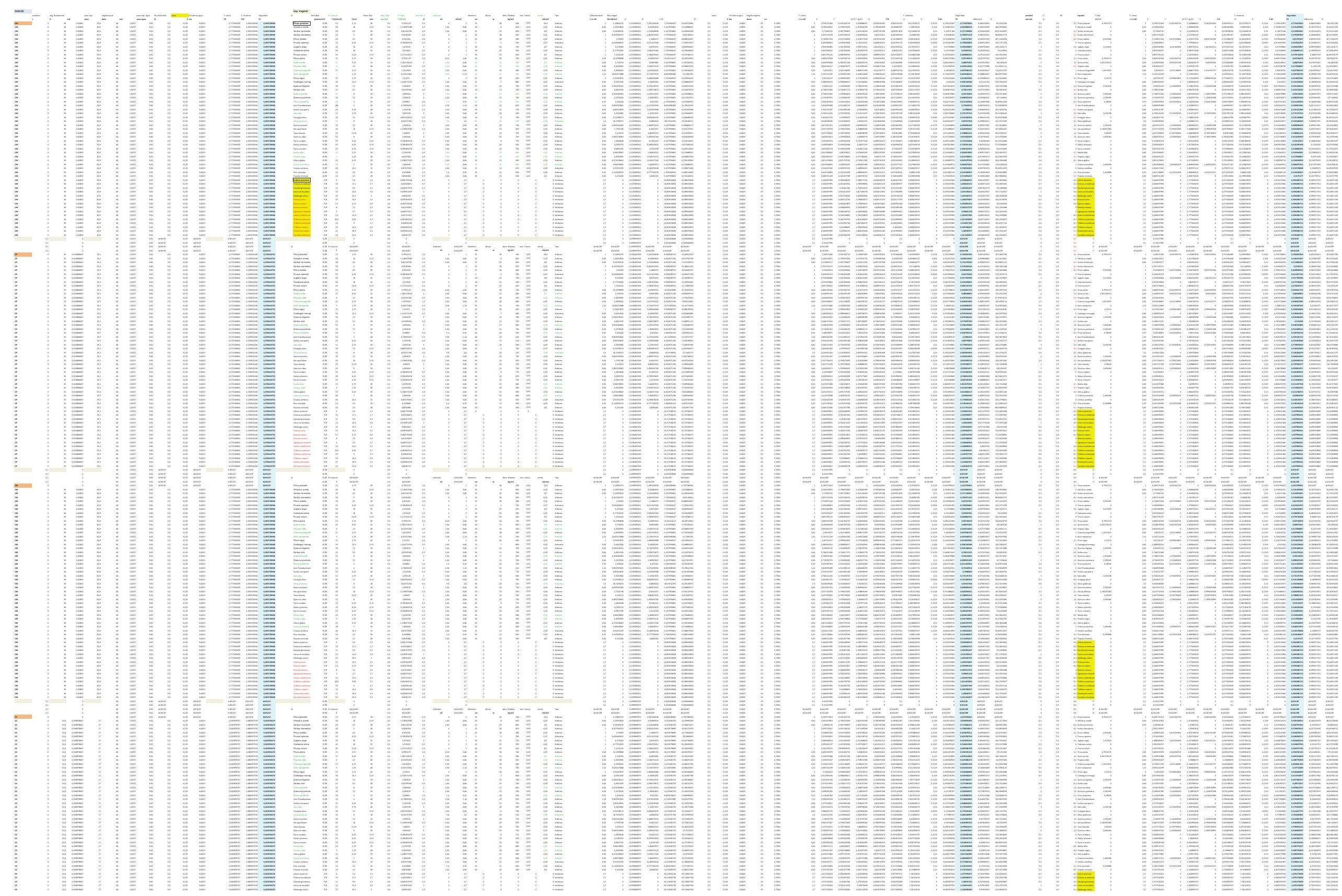


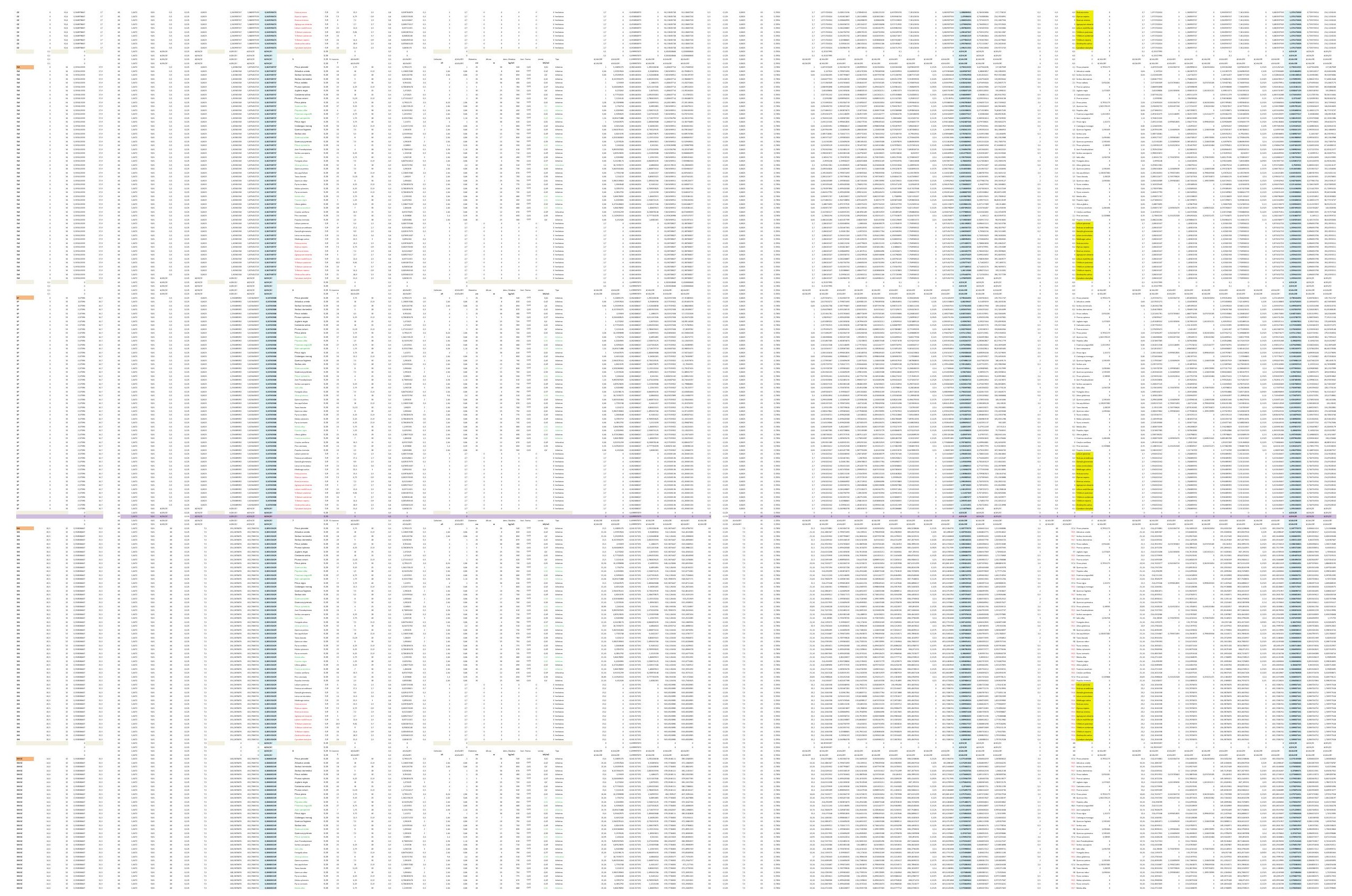



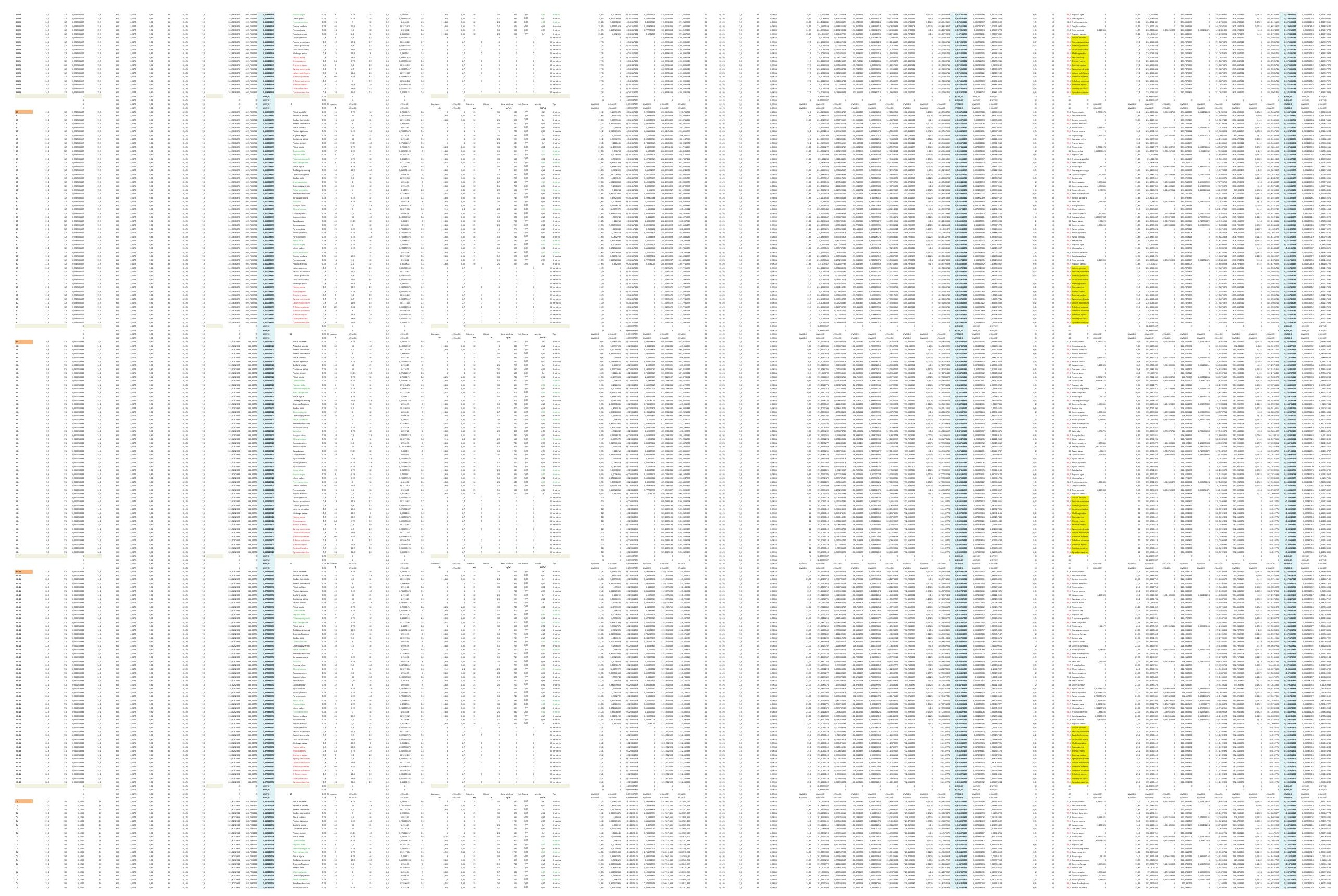


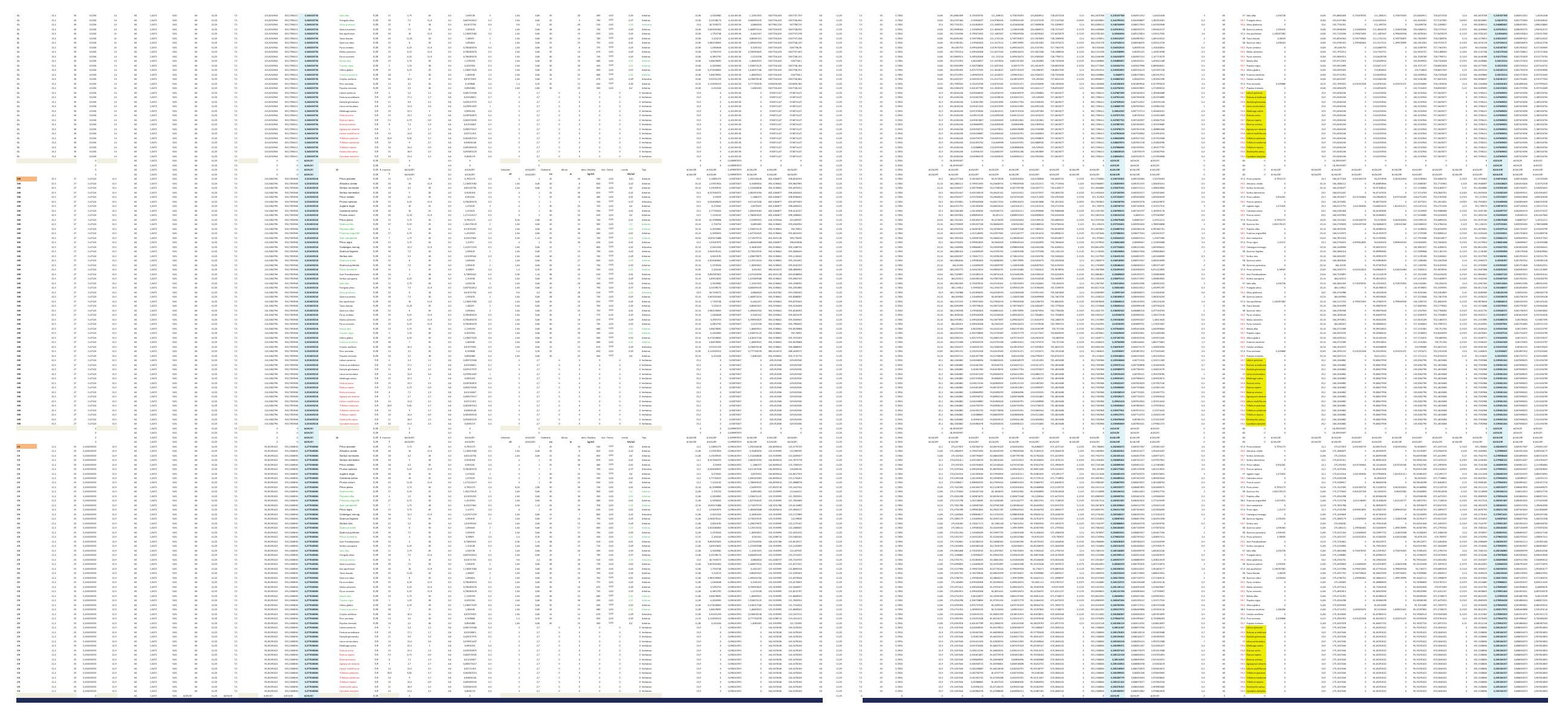



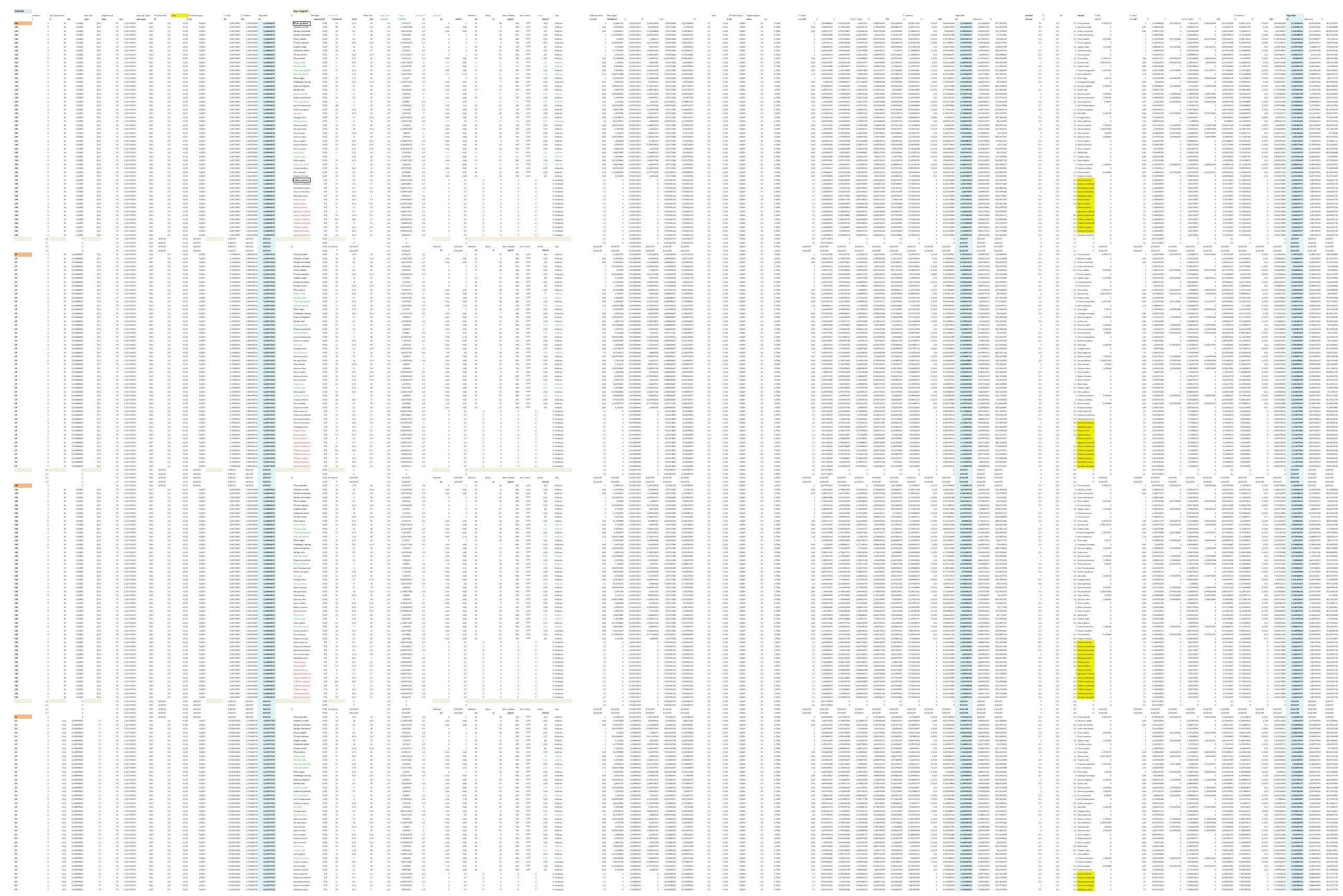


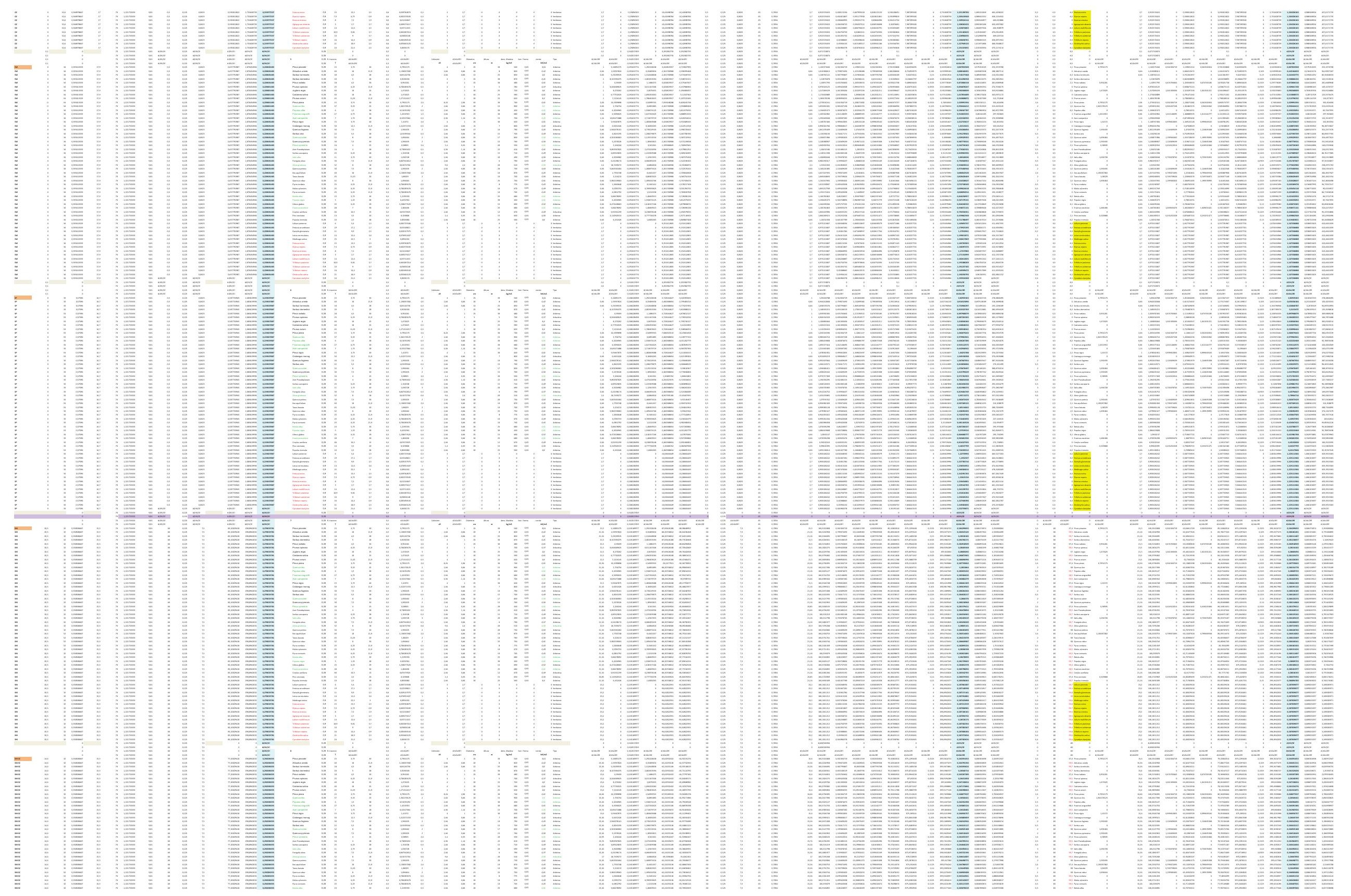




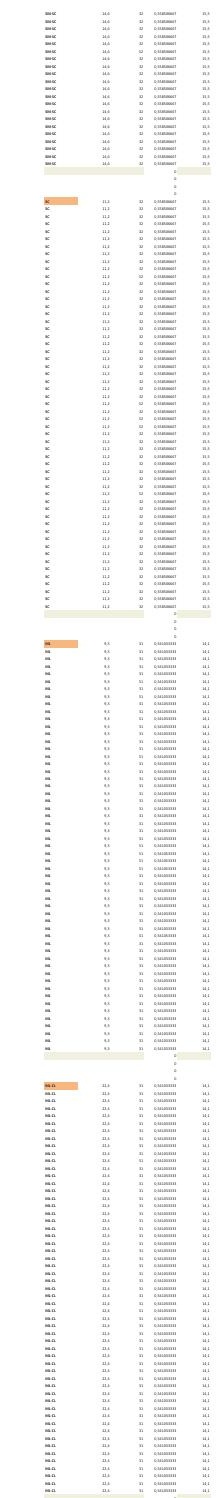

$-$

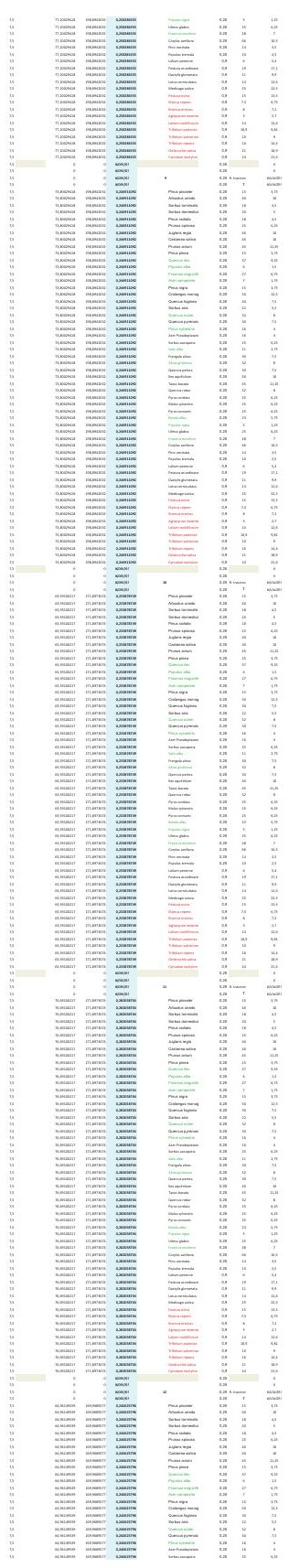

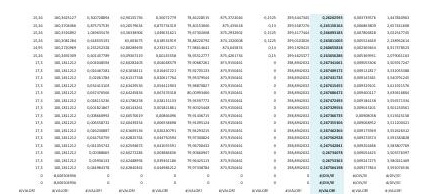
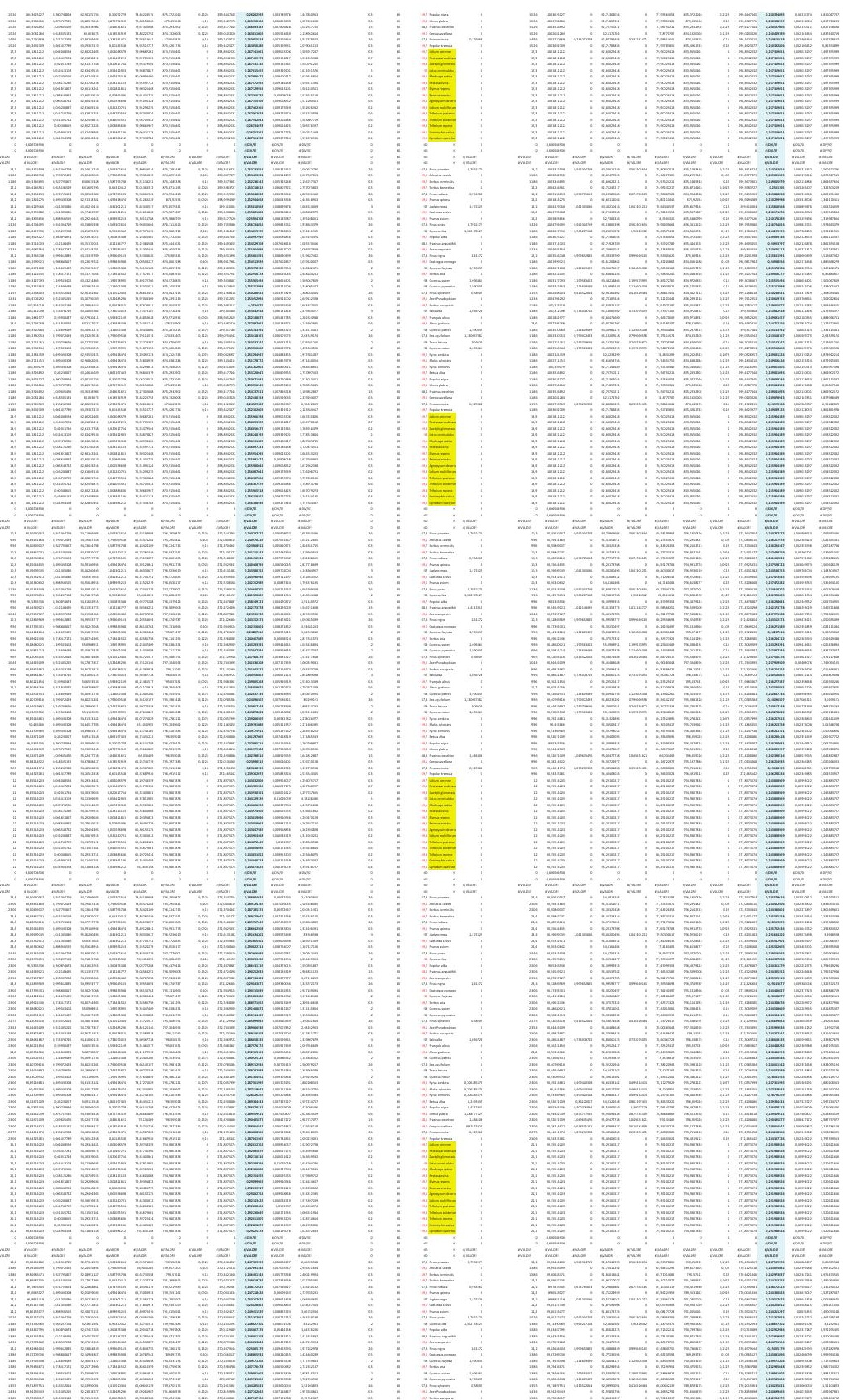


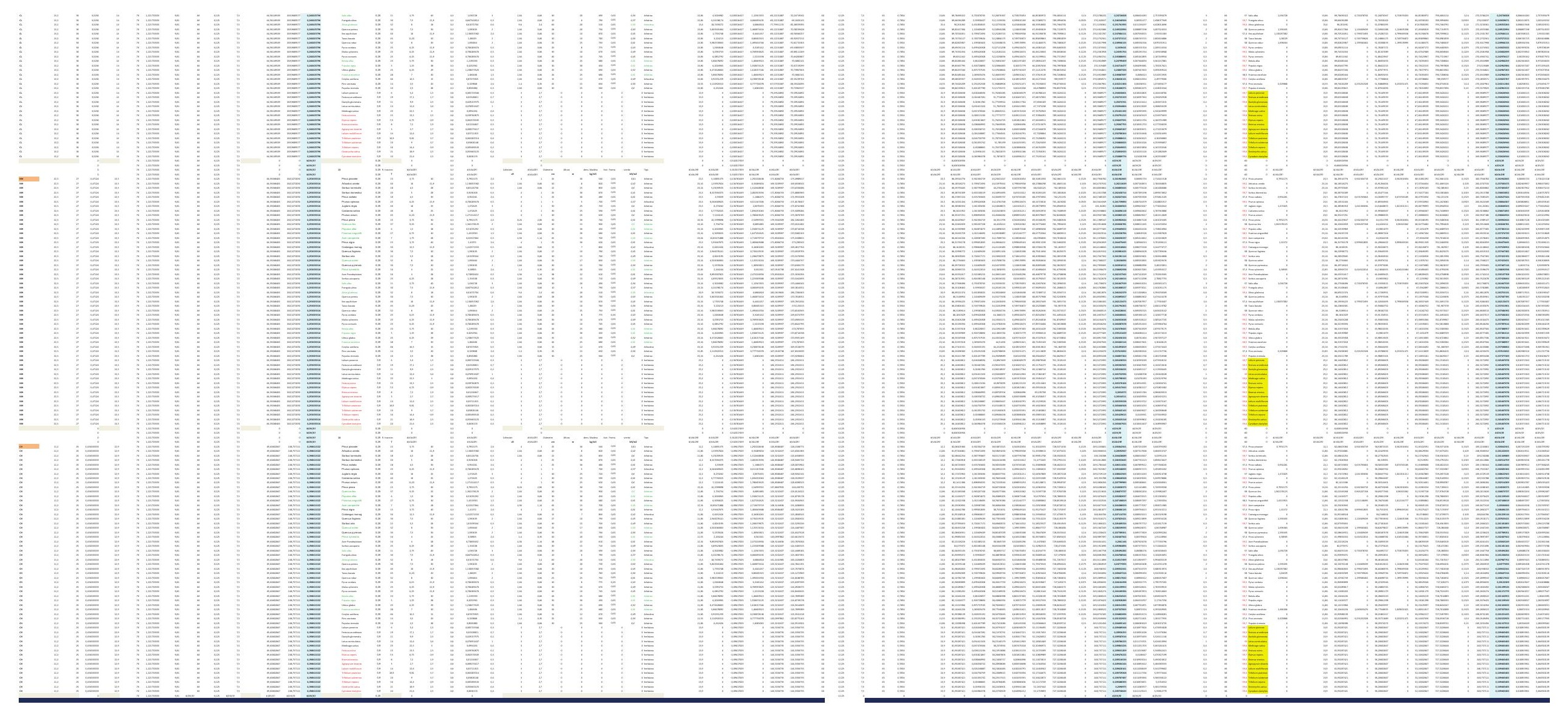



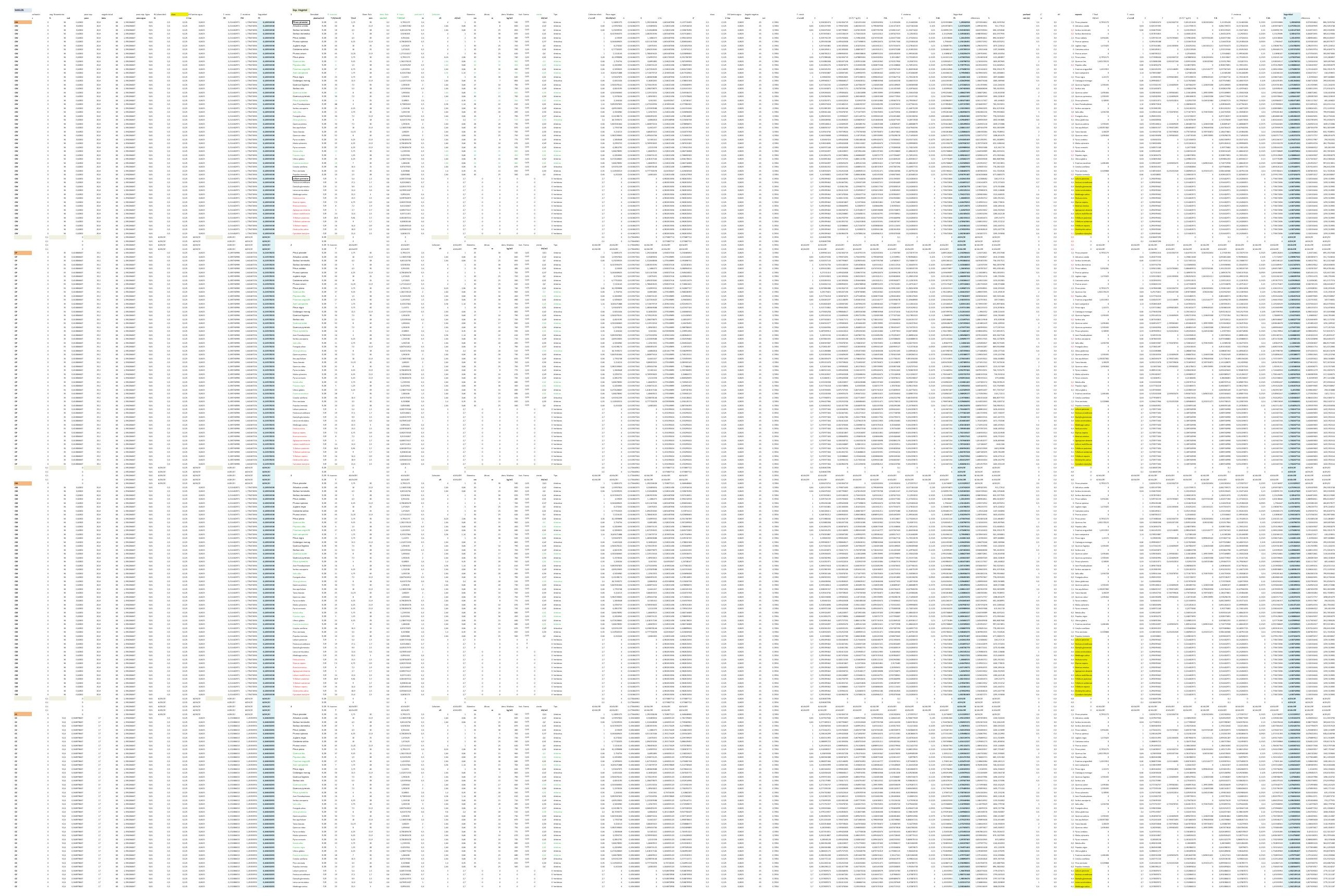


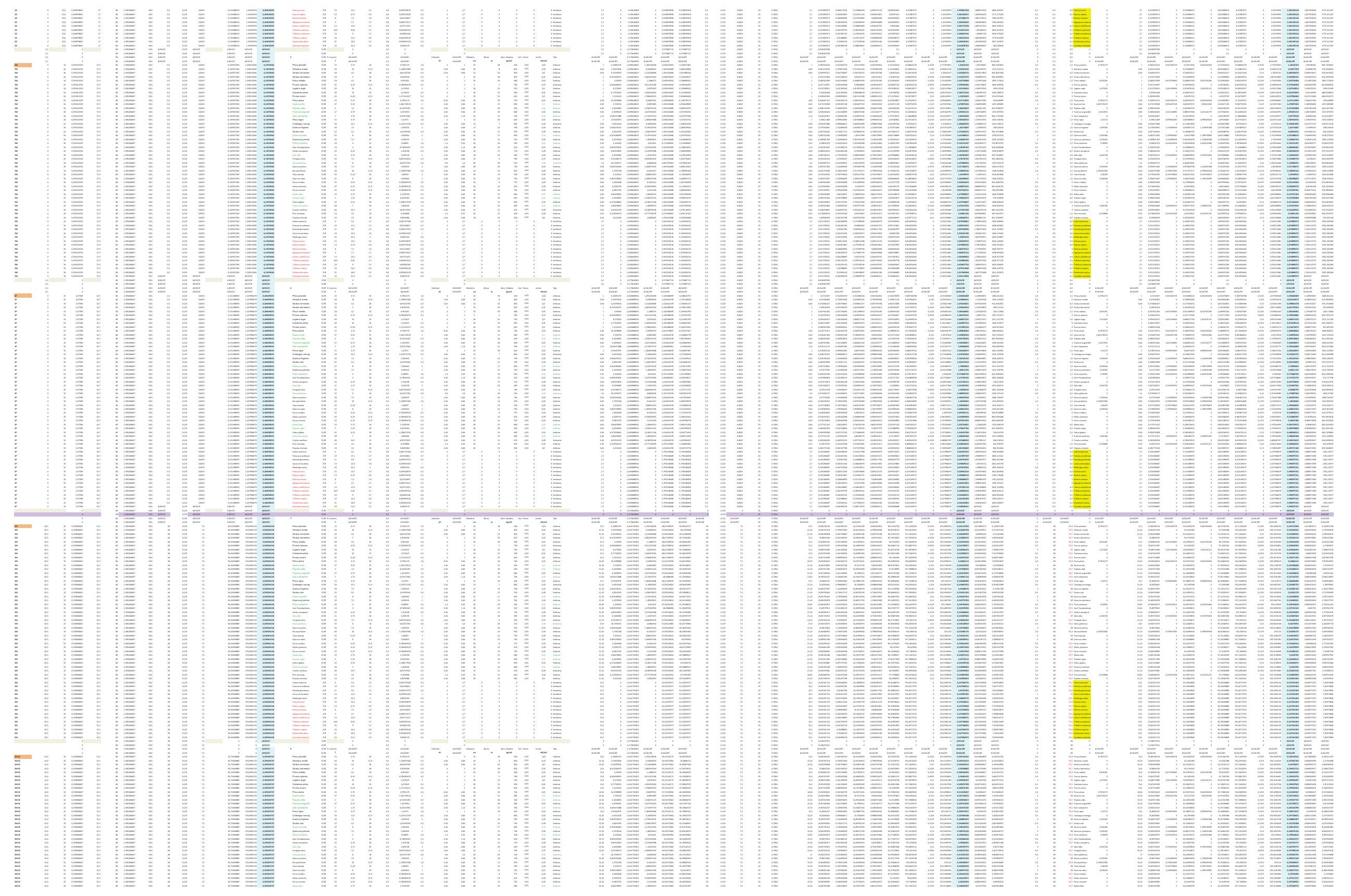




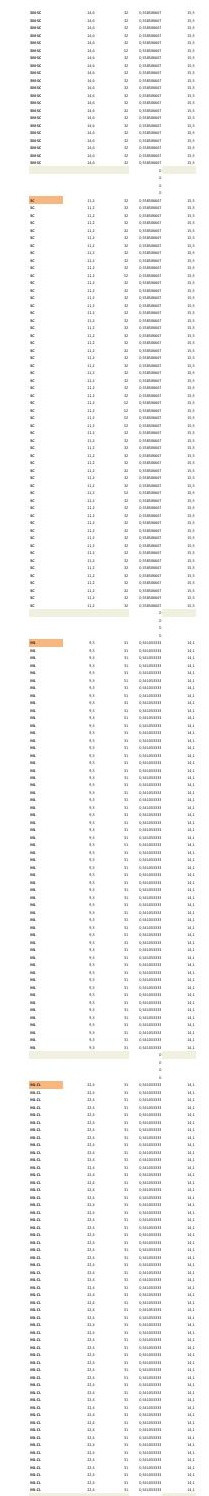

ำ
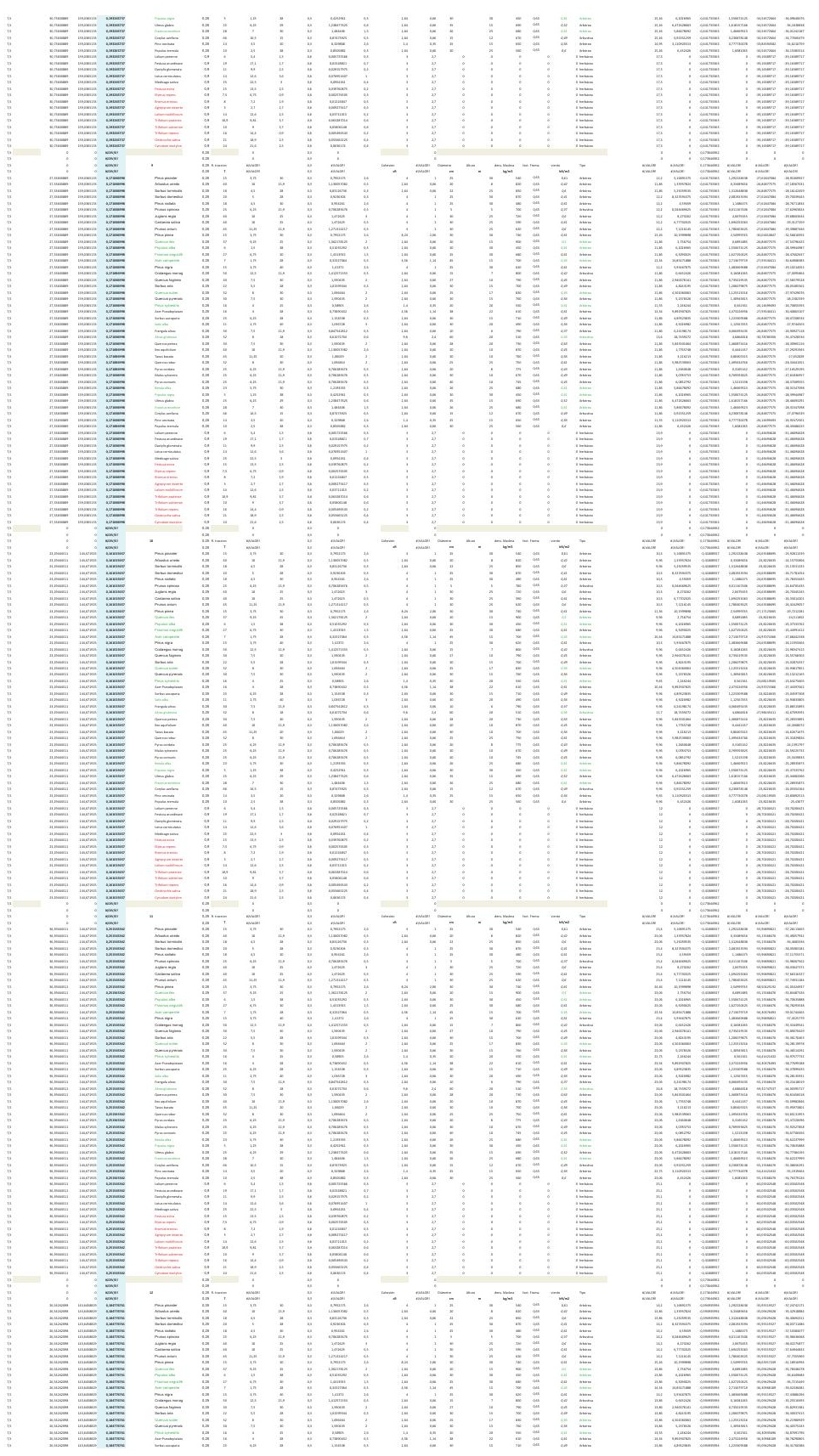
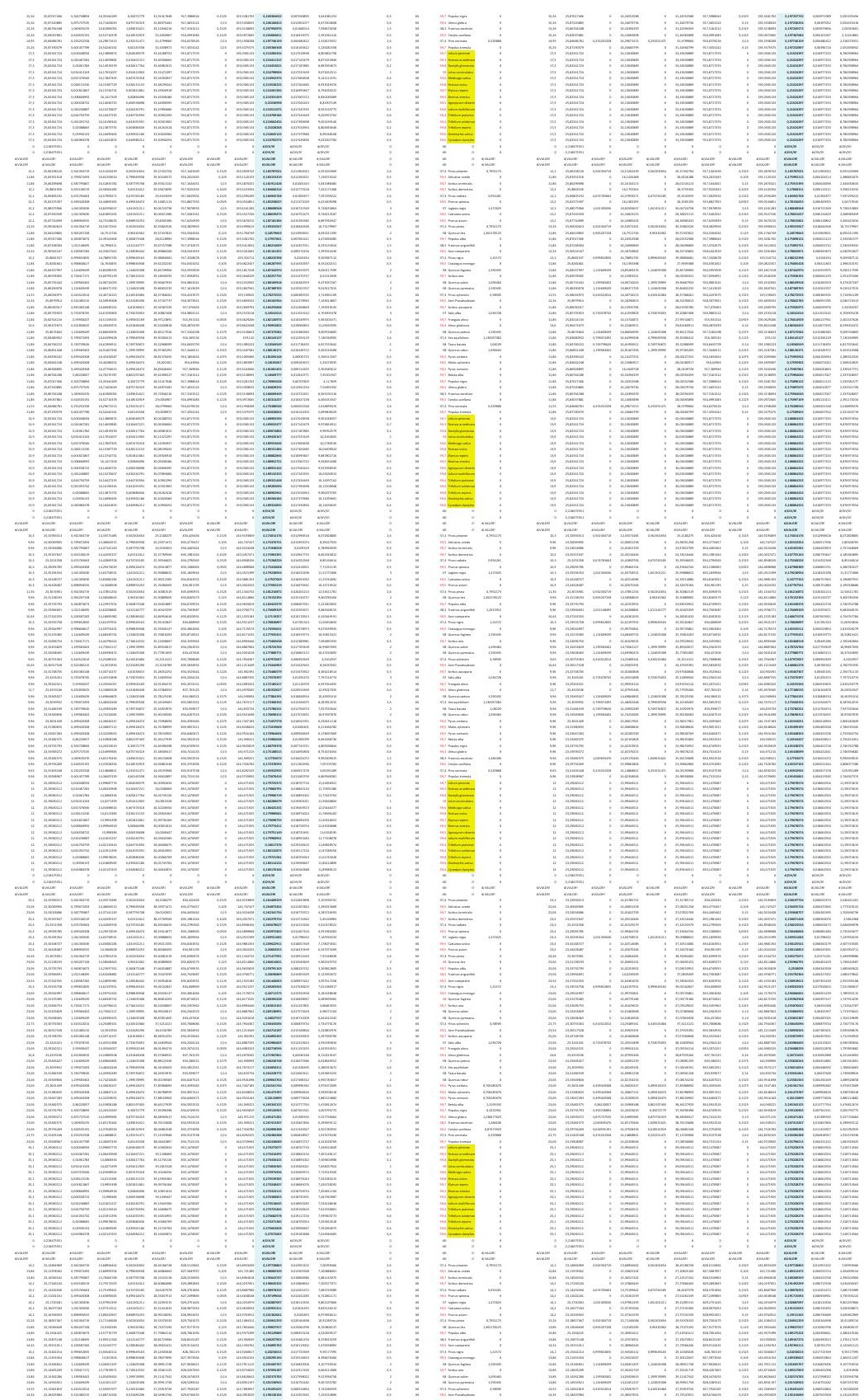

E
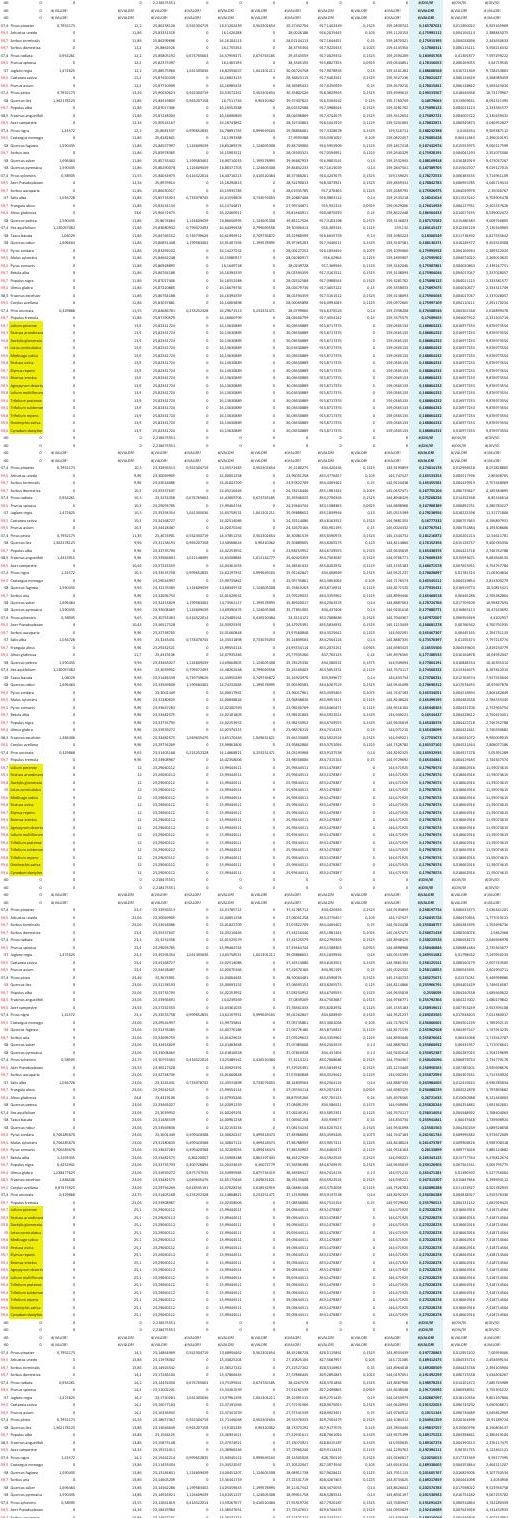


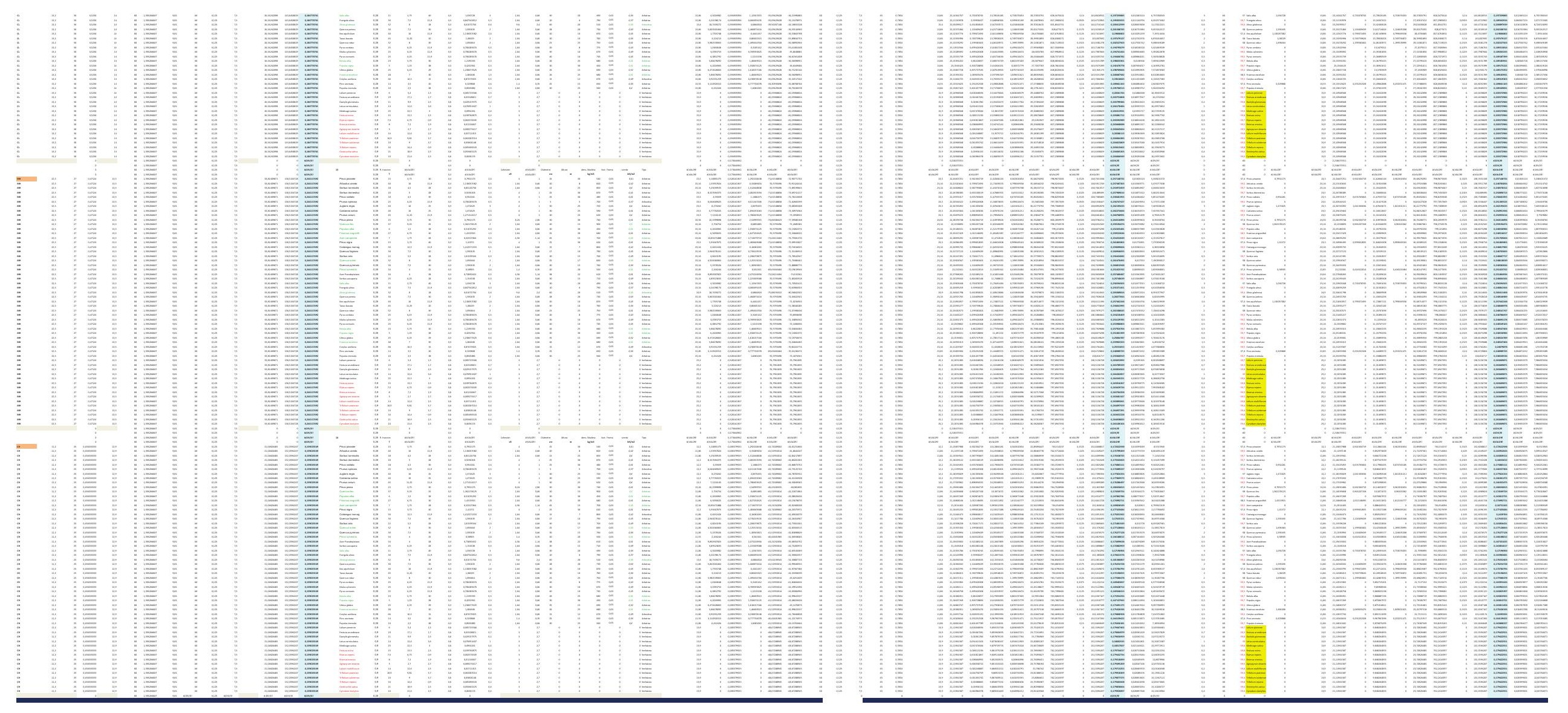


DESARROLLO DE UNA APLICACIÓN IMFORMÁTICA PARA EL CÁLCULO DE SOSTENIMIENTO DE TALUDES MEDIANTE VEGETACIÓN

A01. DENSIDAD DE PLANTACIÓN: 600 plantas/ha.

\section{A01-3.POSICIÓN N.F. 3}

INCLINACIÓN DE TALUD 6-100

INCLINACIÓN DE TALUD 10-200

INCLINACIÓN DE TALUD 20-30

INCLINACIÓN DE TALUD 30-40

INCLINACIÓN DE TALUD $35^{\circ}$

INCLINACIÓN DE TALUD 40-50

INCLINACIÓN DE TALUD 50-550

INCLINACIÓN DE TALUD 55-60

INCLINACIÓN DE TALUD 60-700

INCLINACIÓN DE TALUD 70-80 

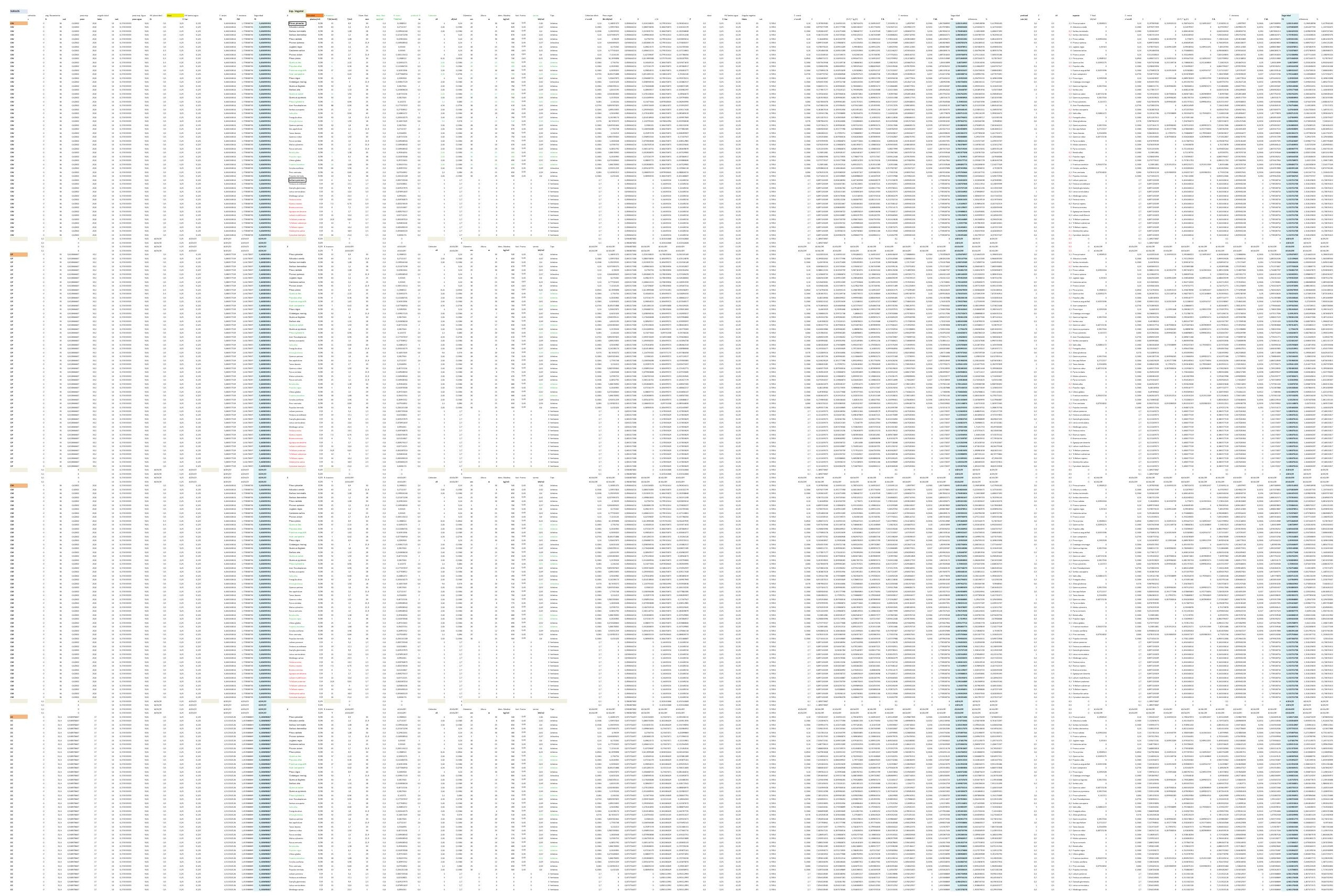


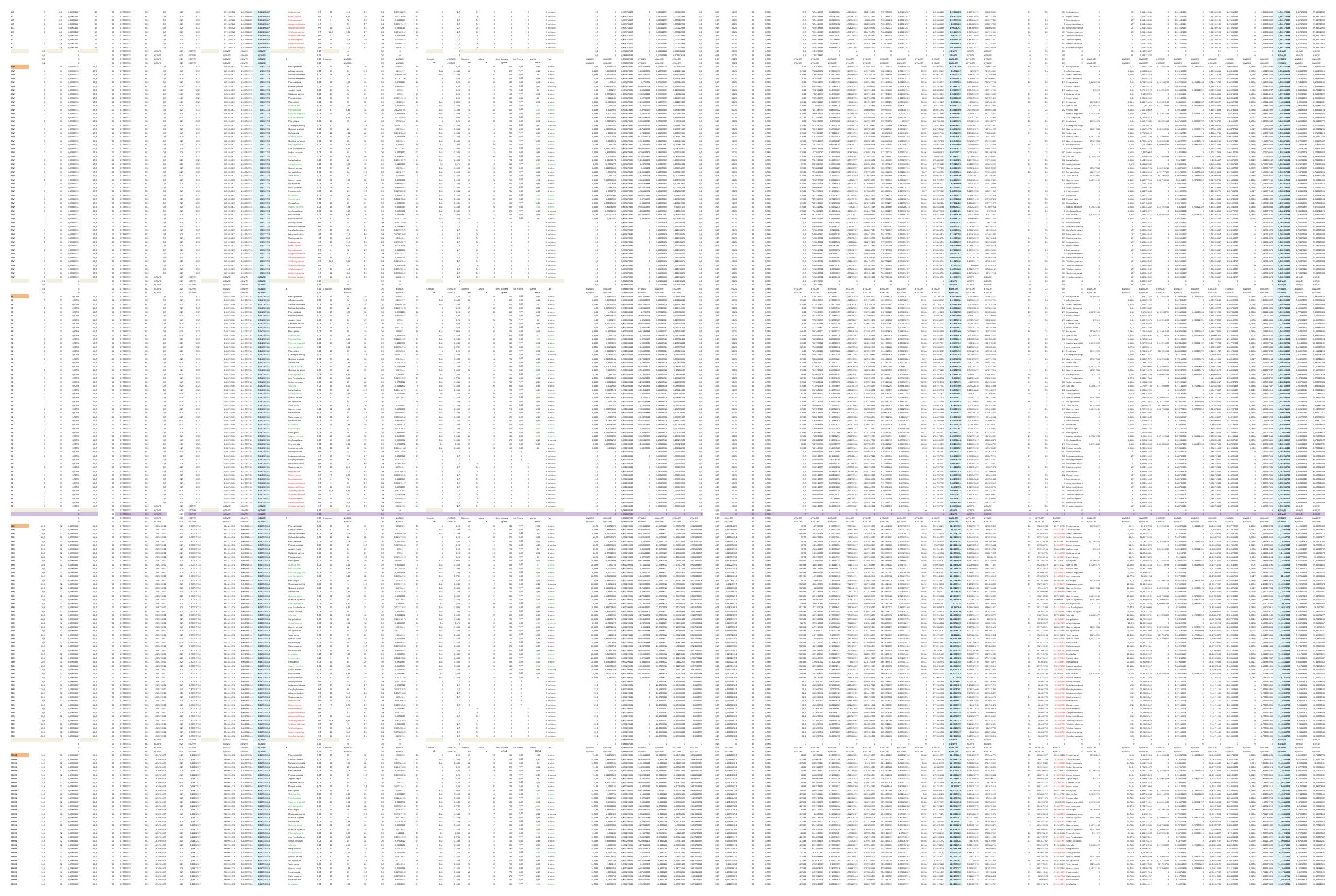



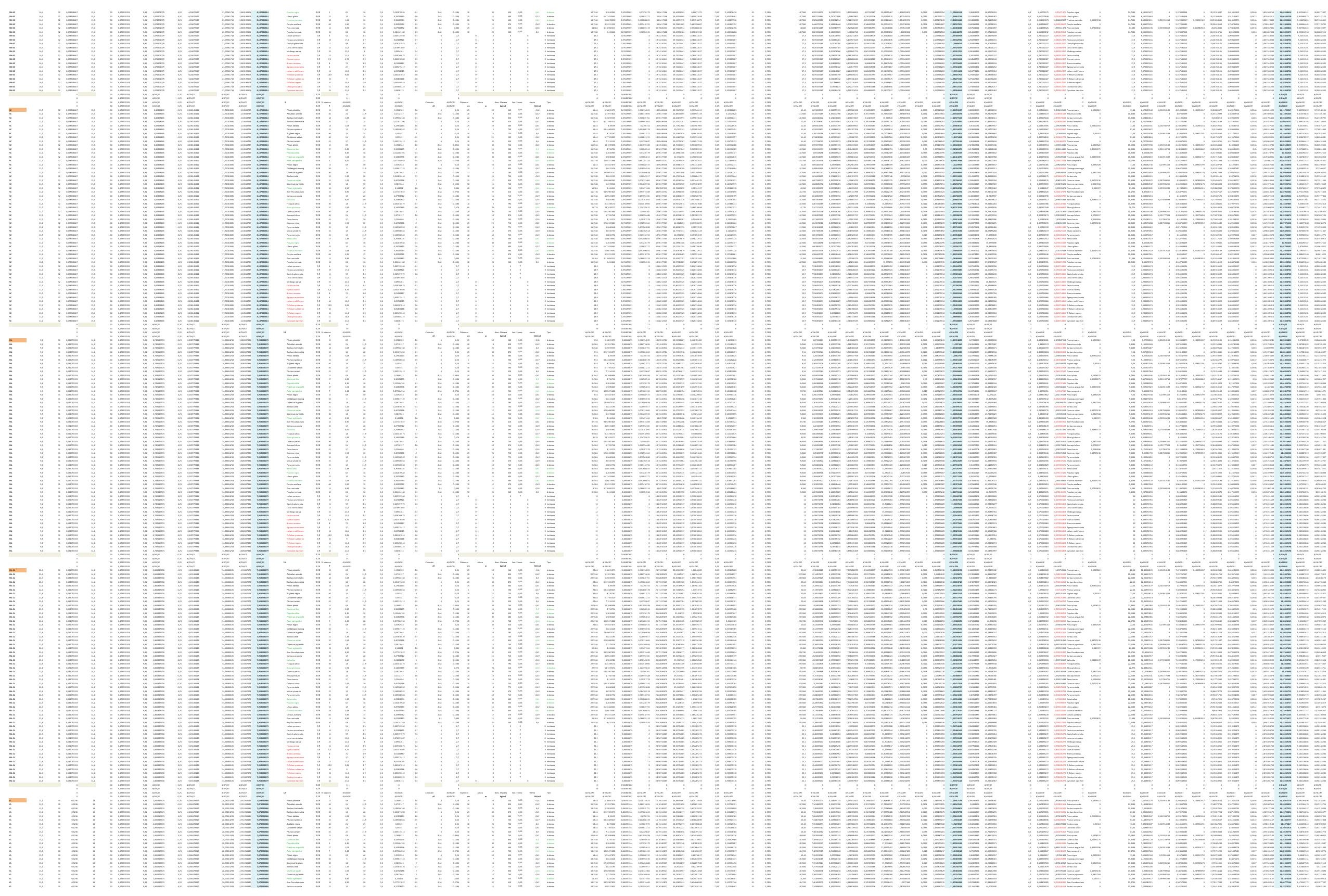

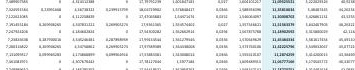




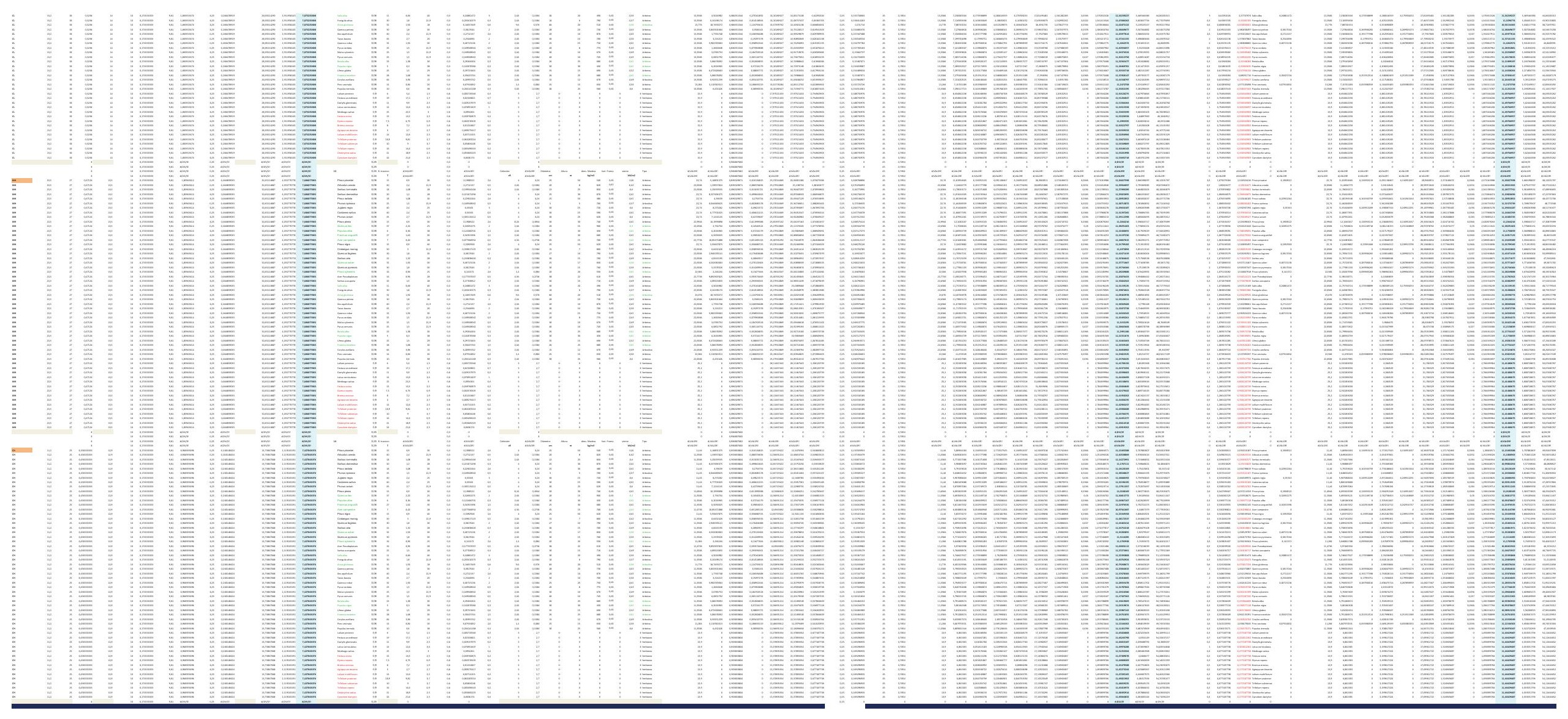



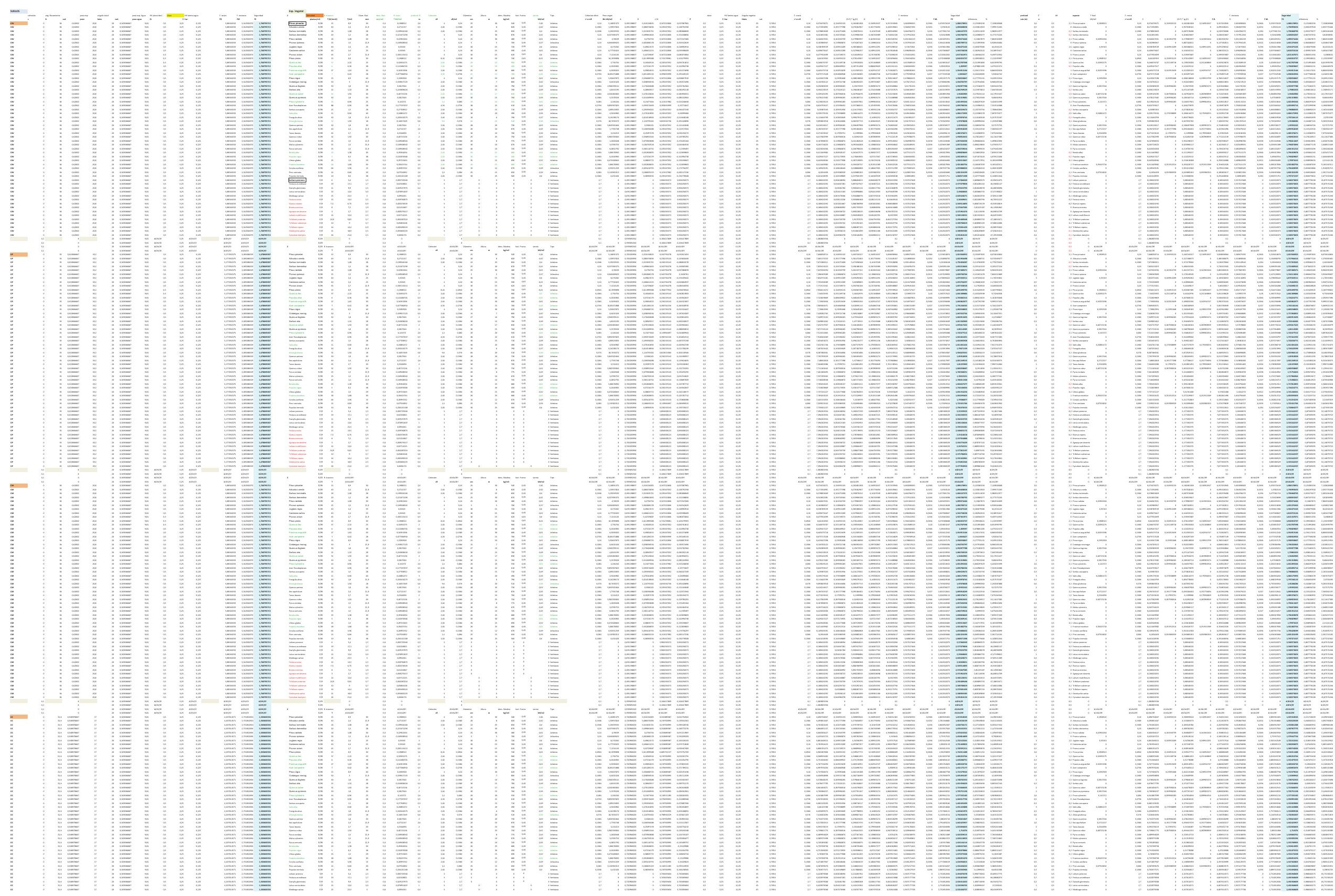

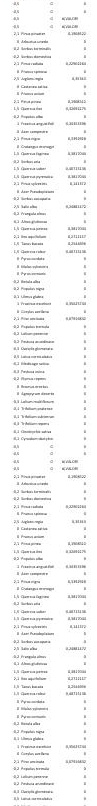

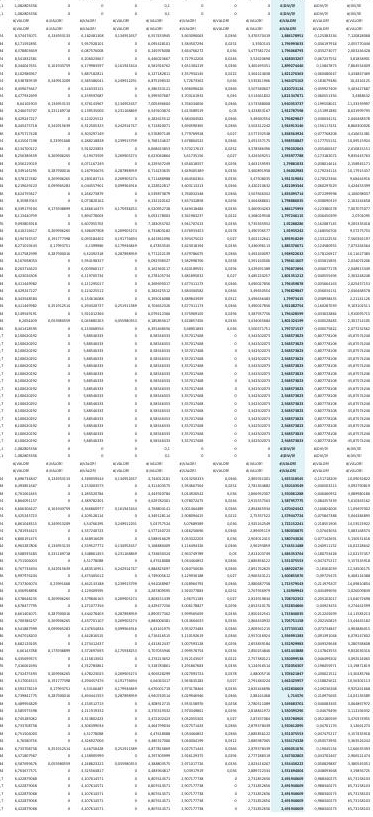




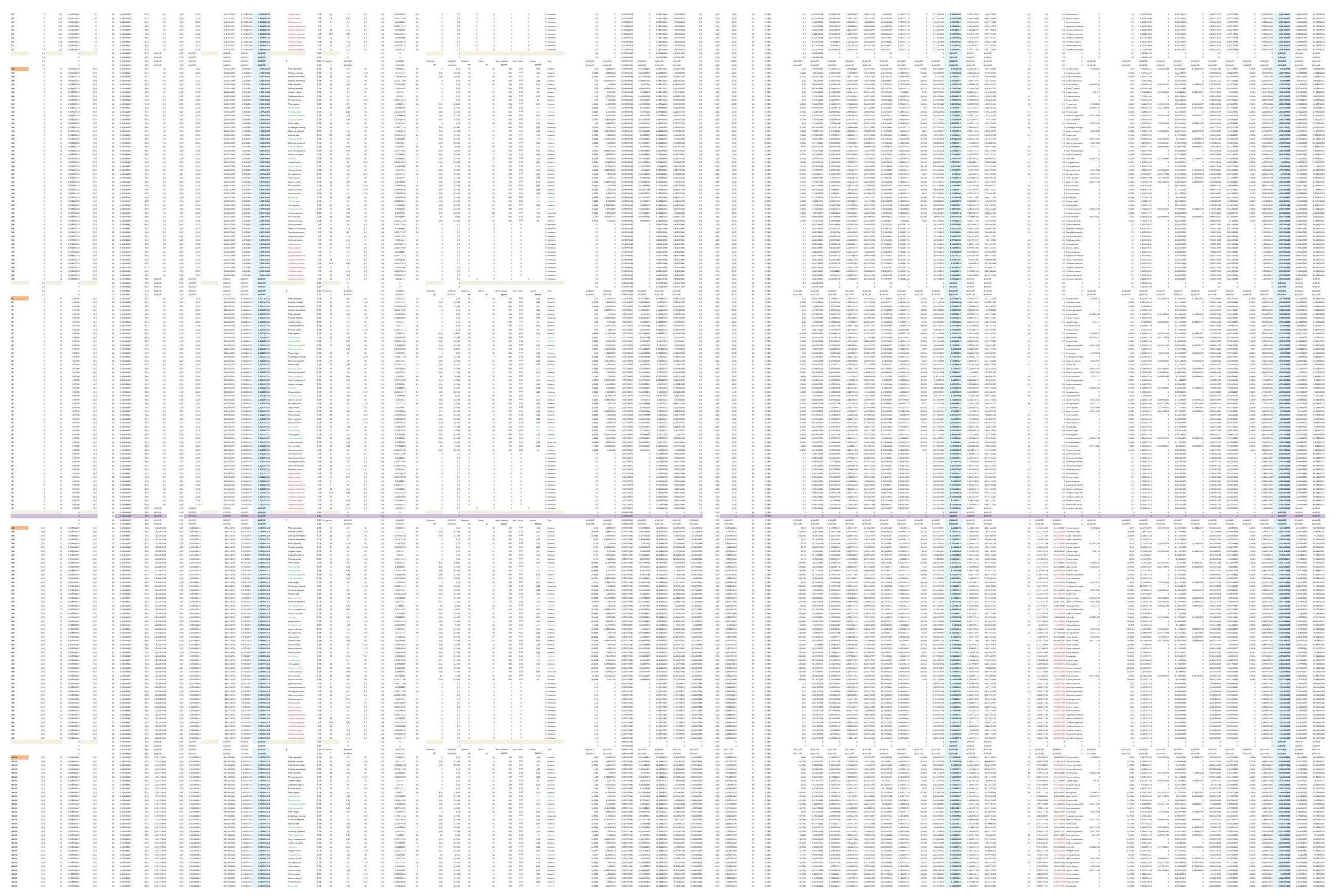



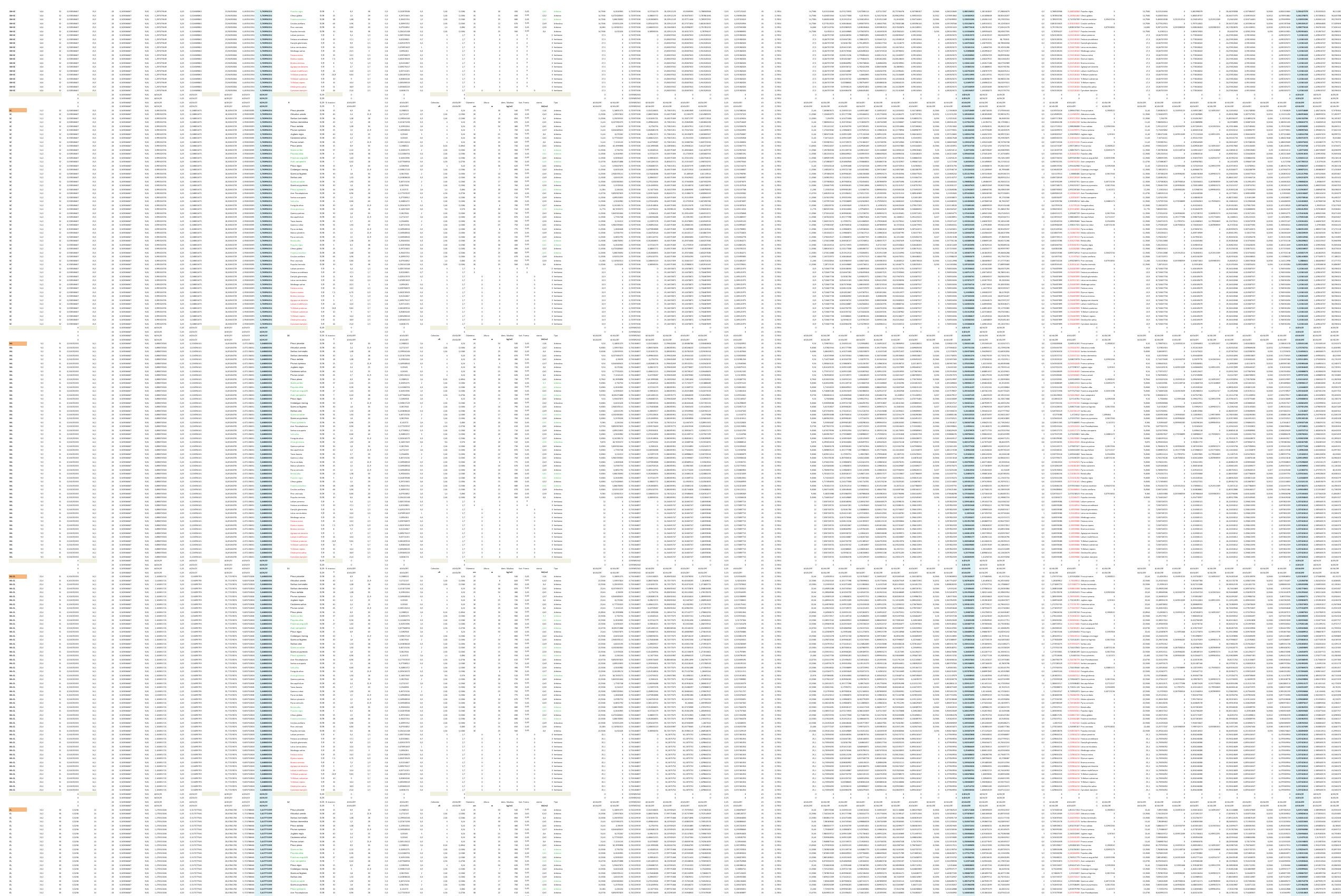

=
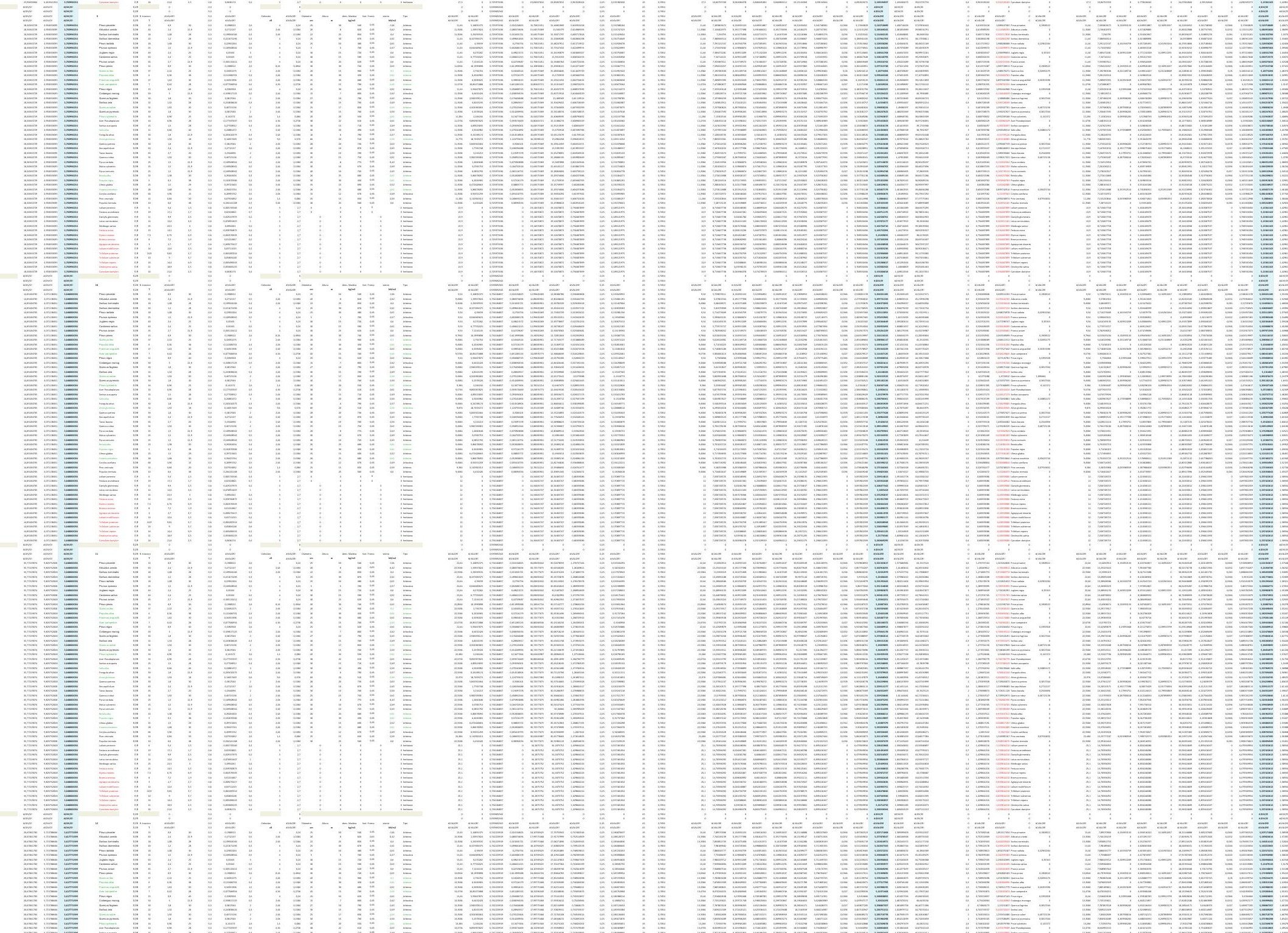

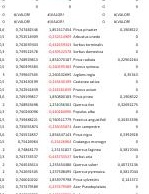

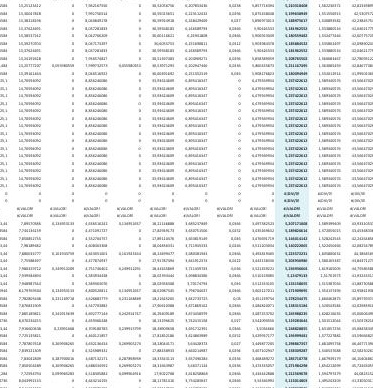




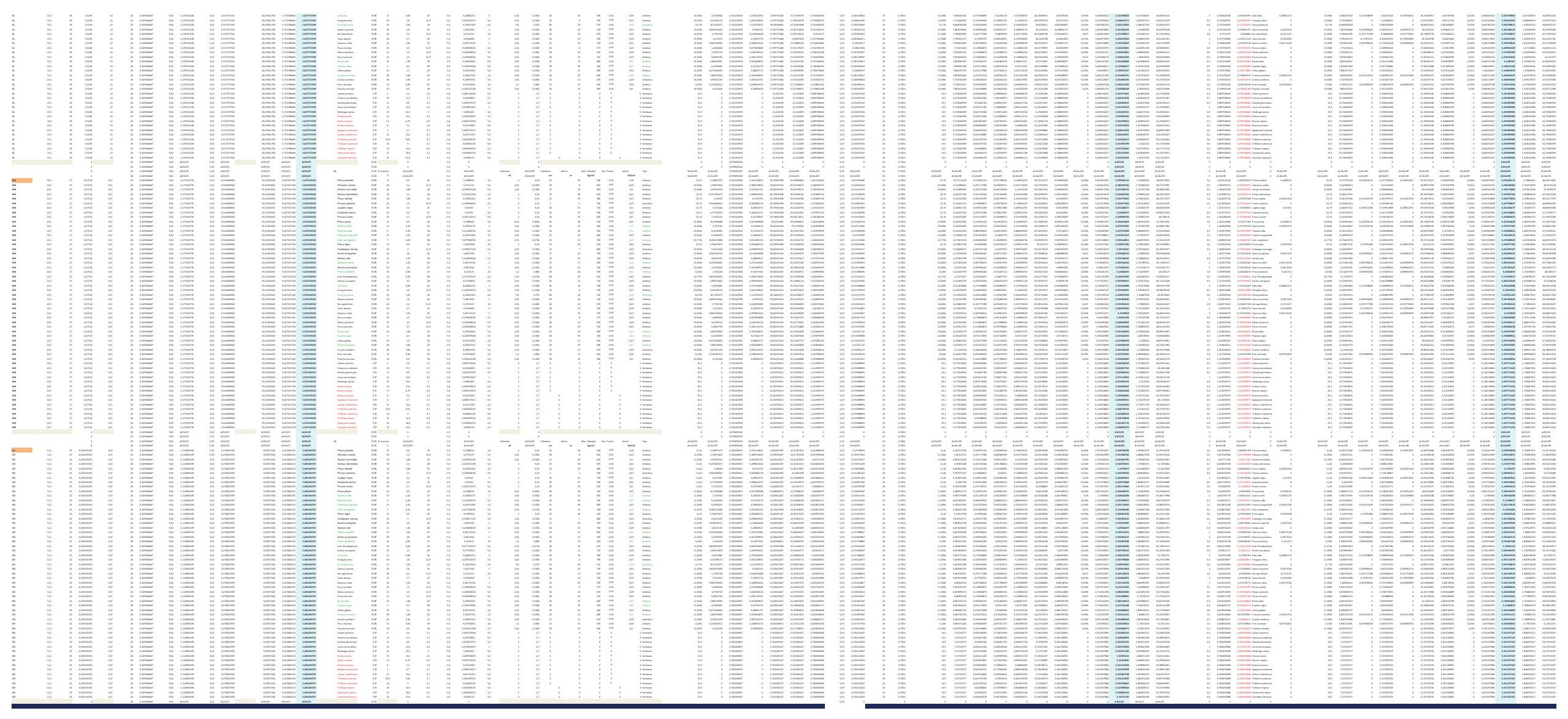



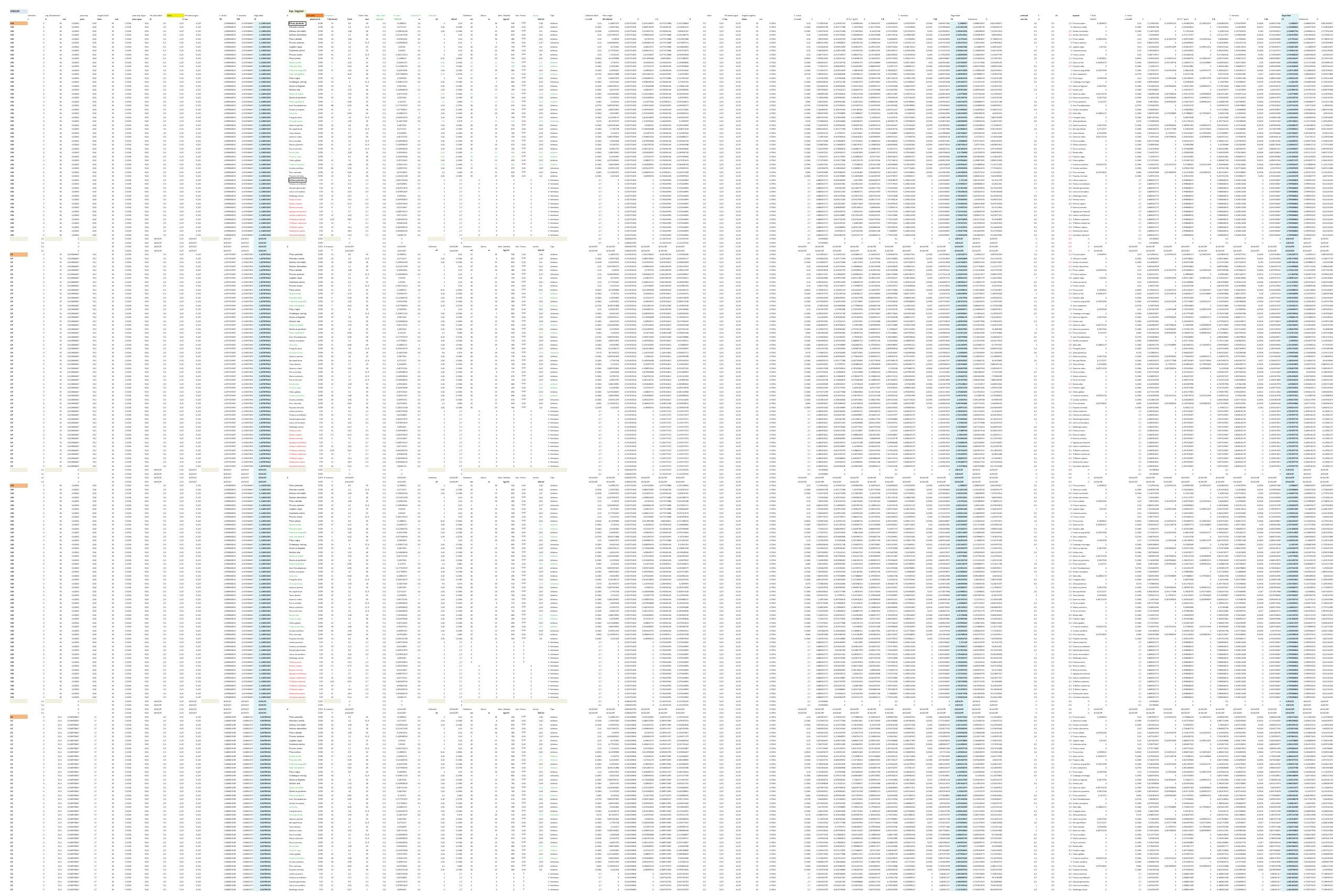

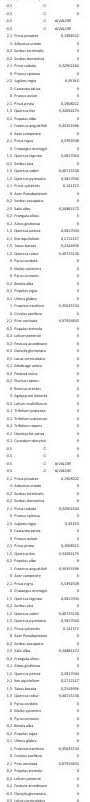

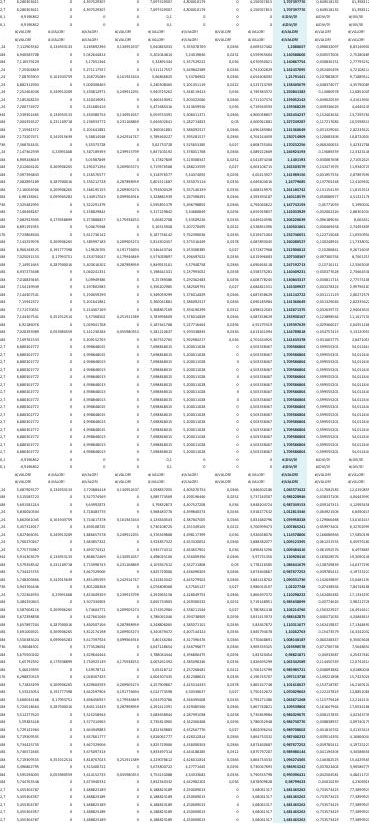




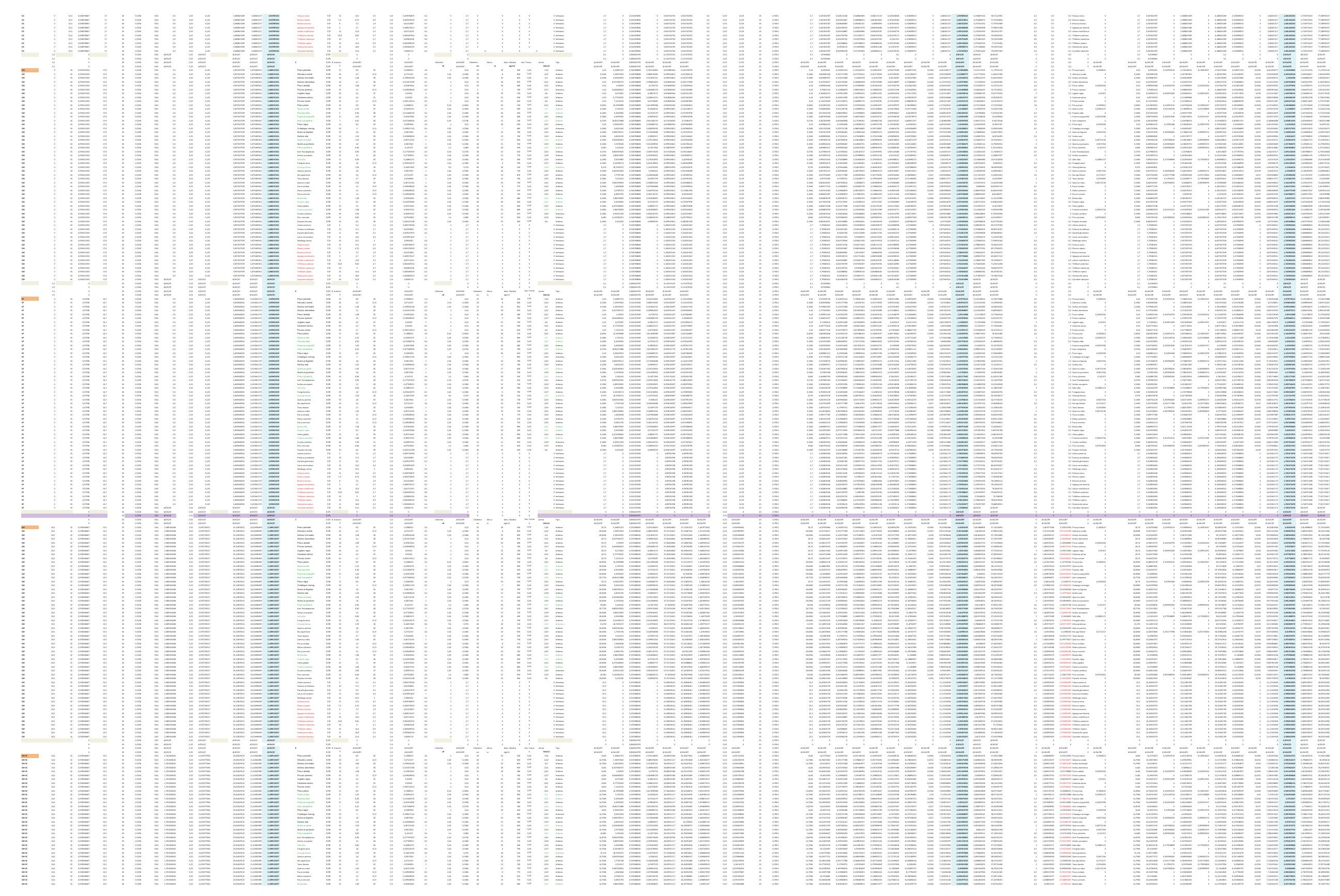



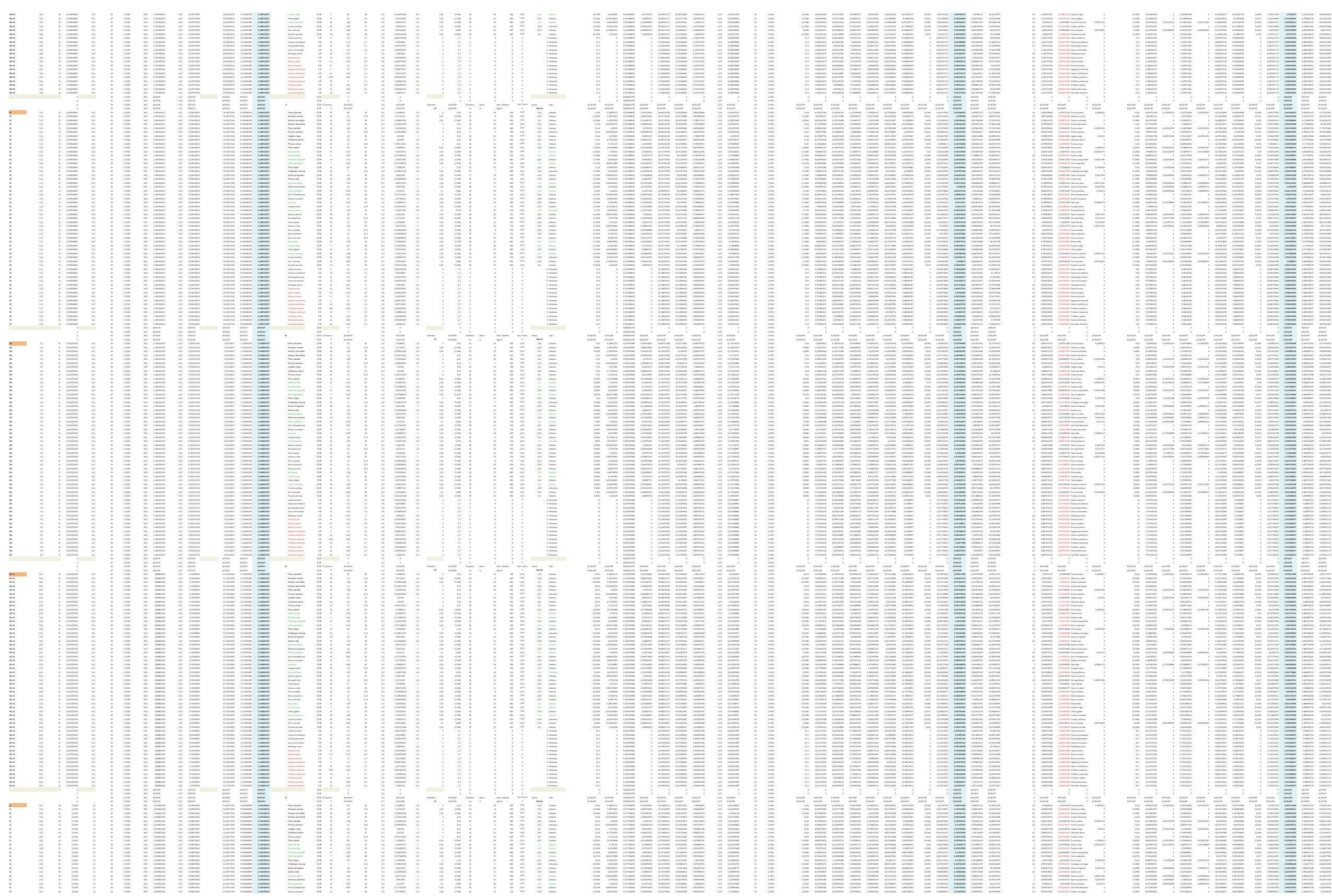

$=$
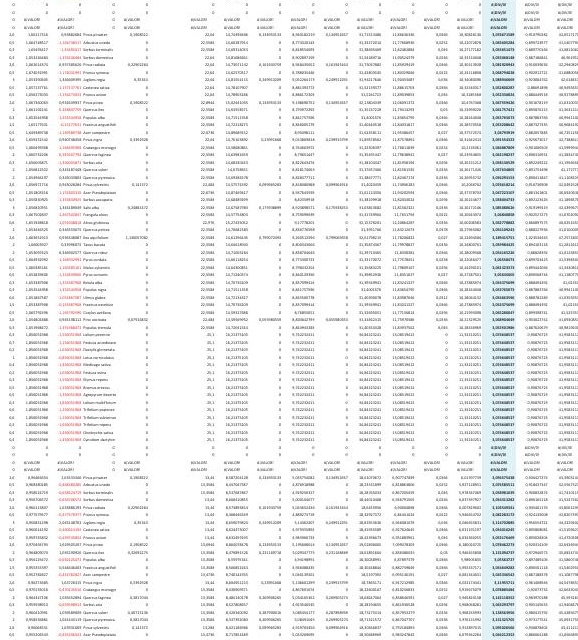


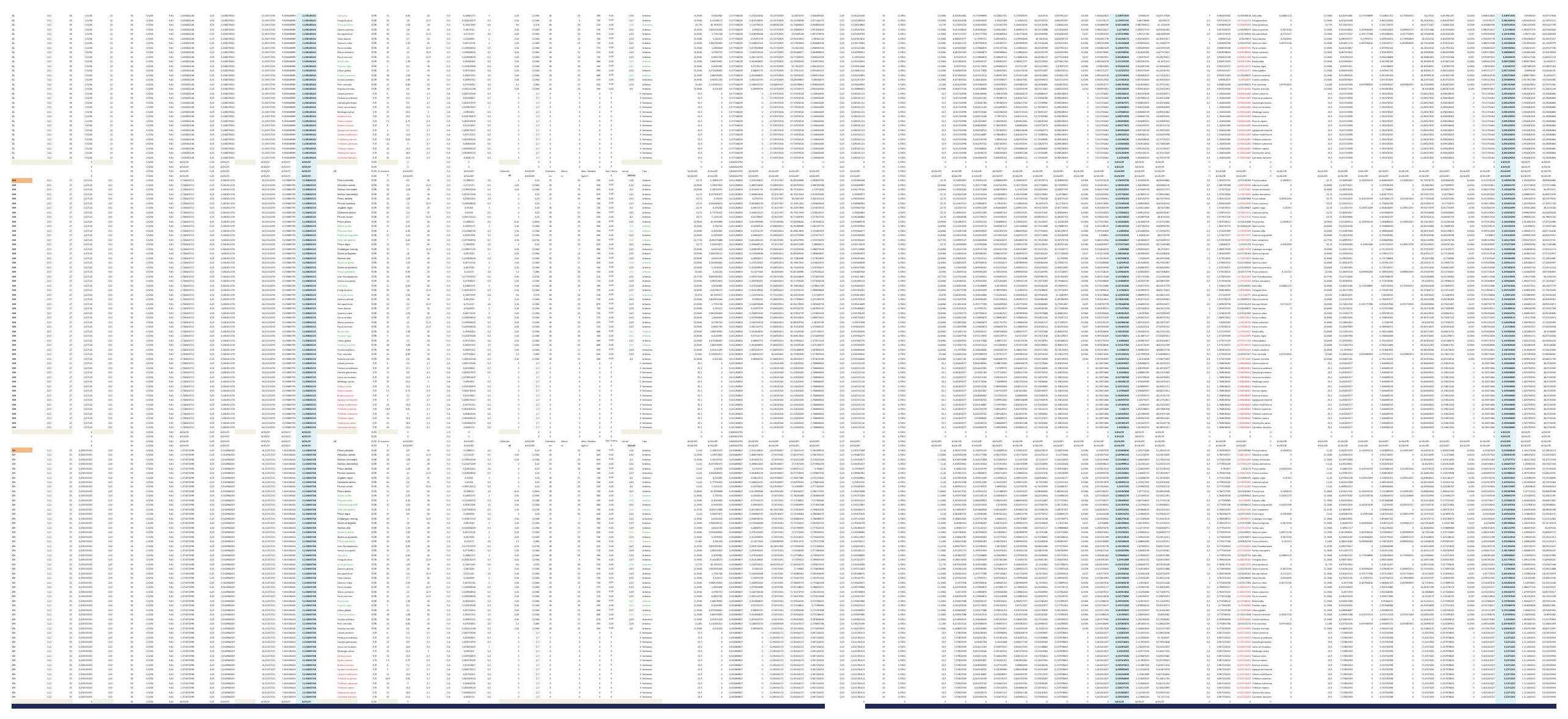



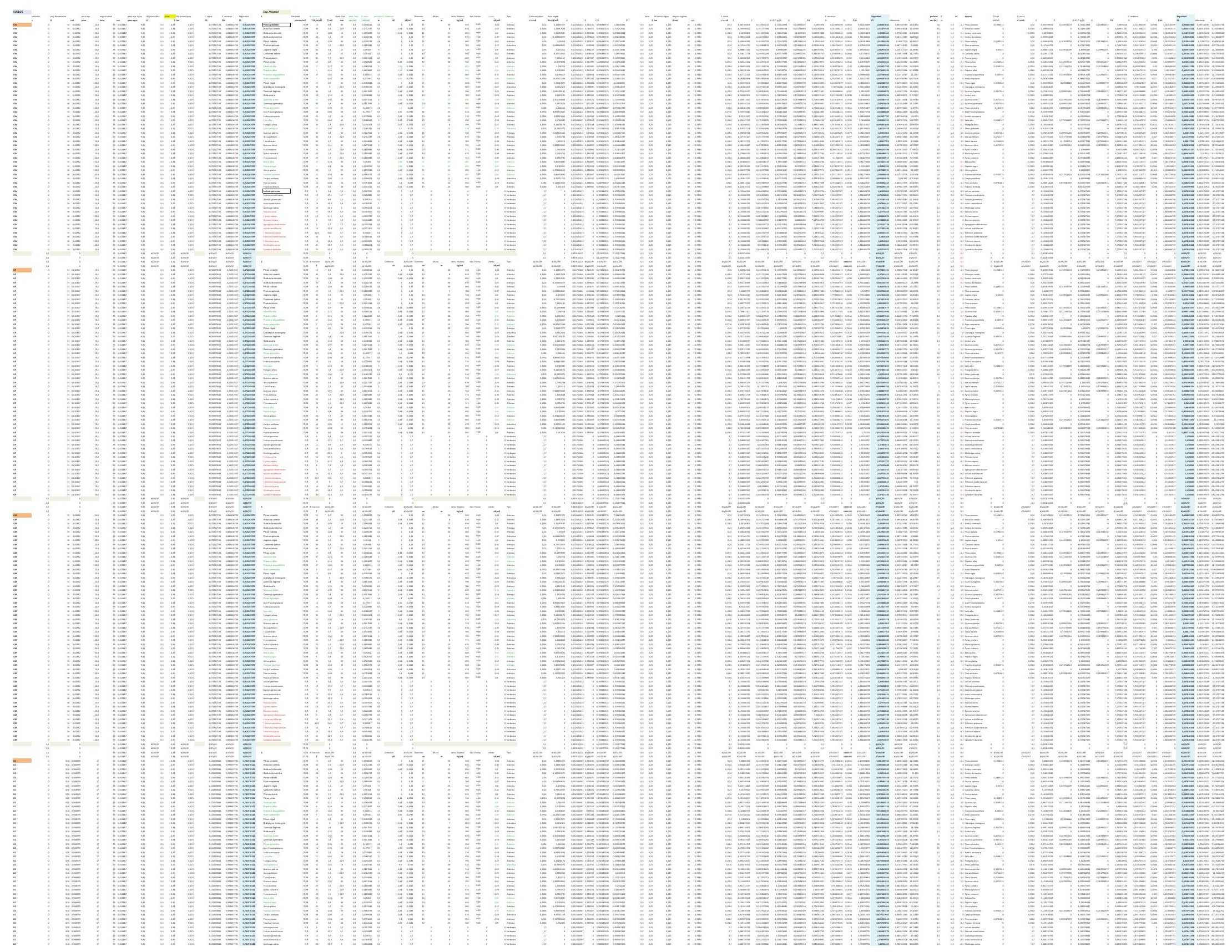


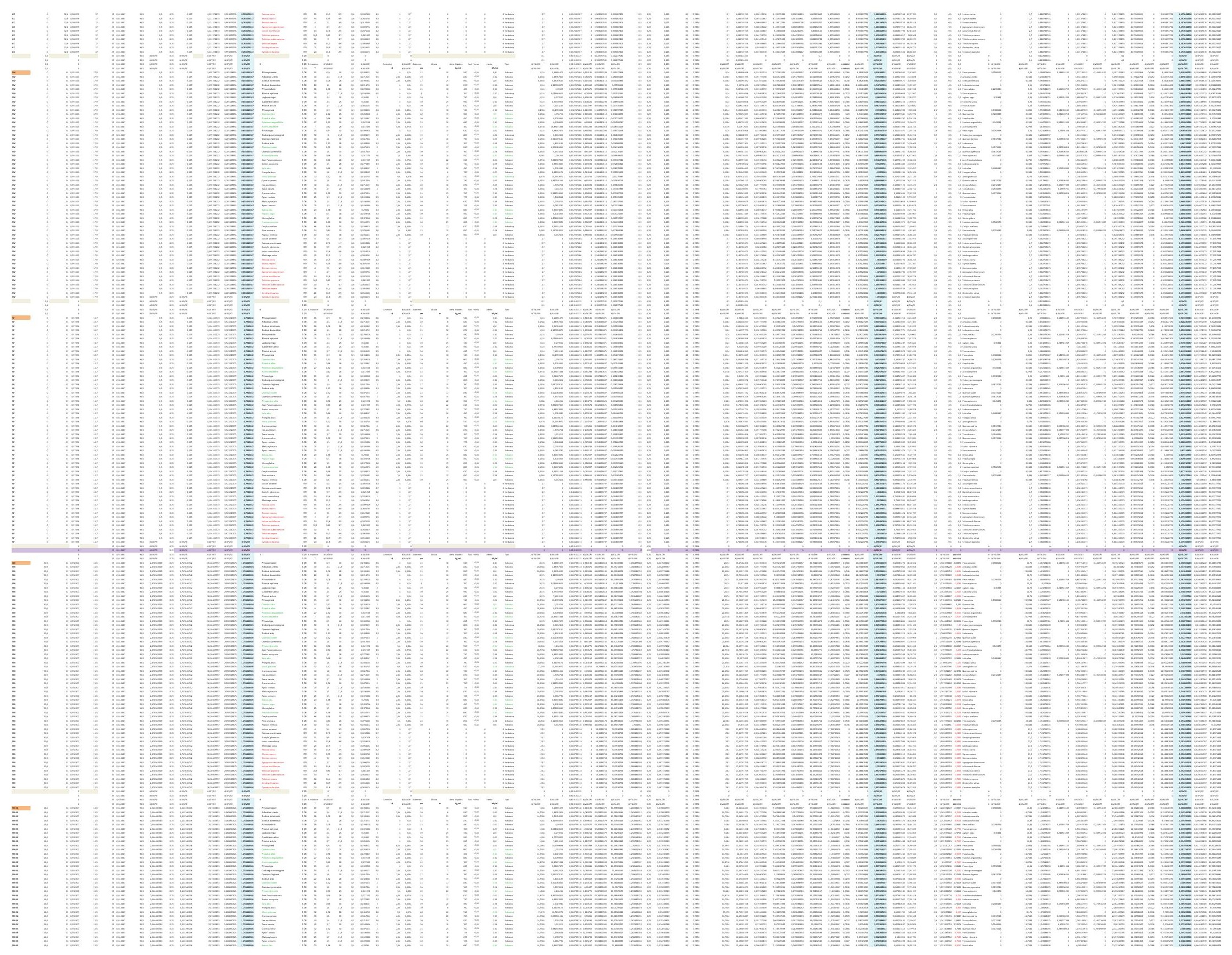



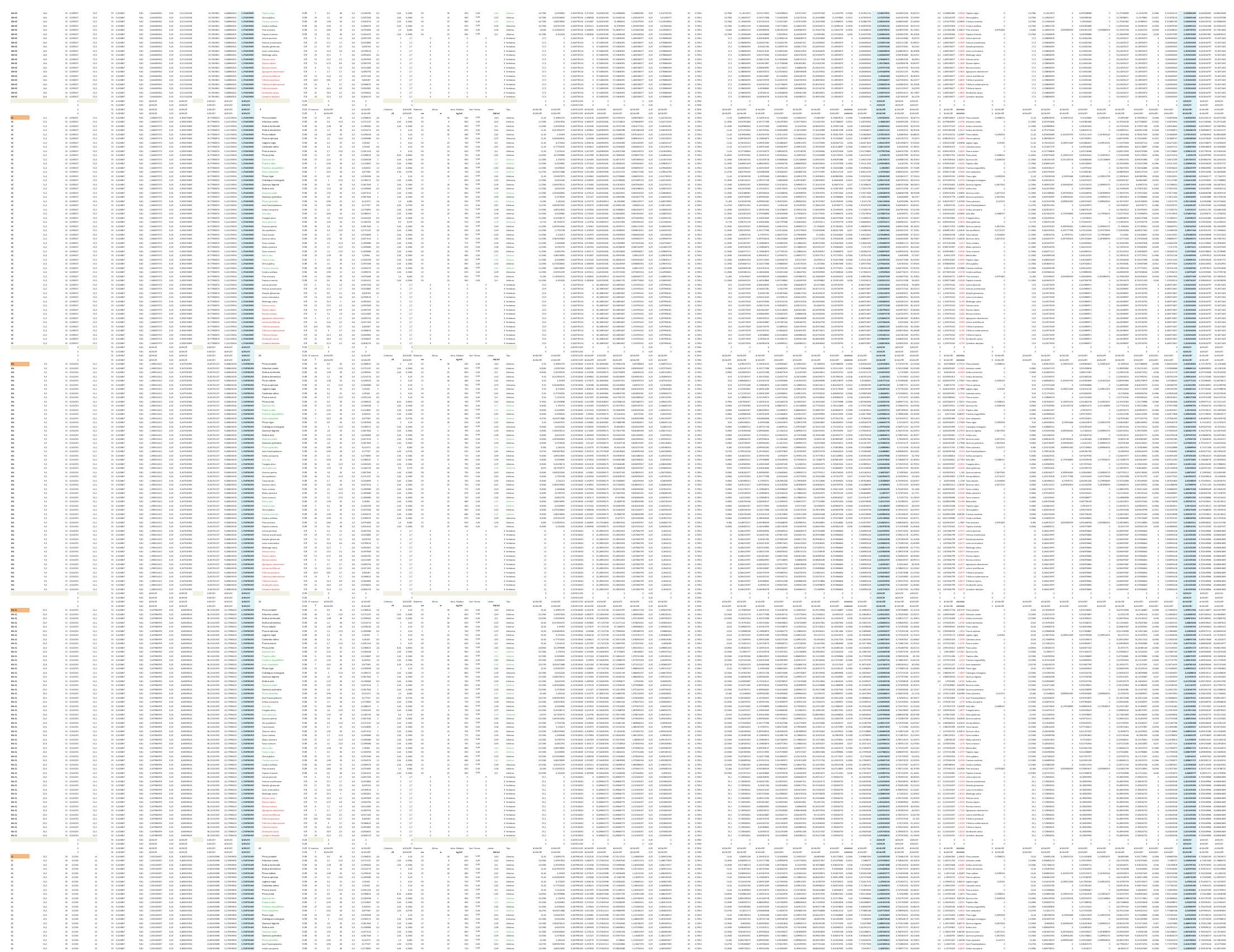

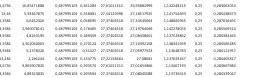

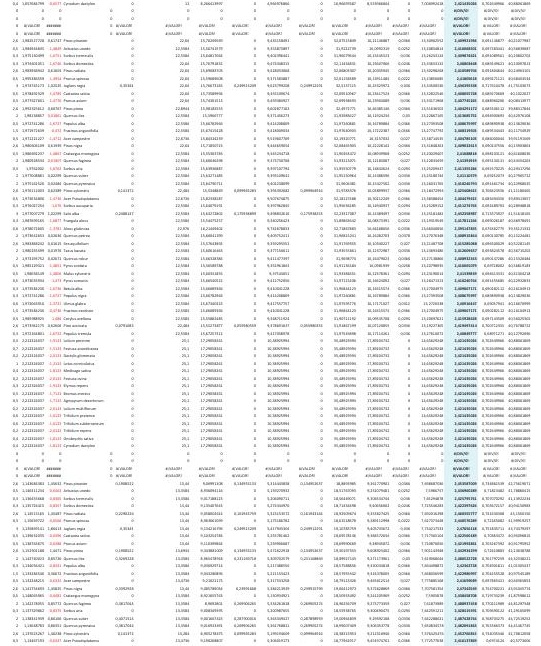




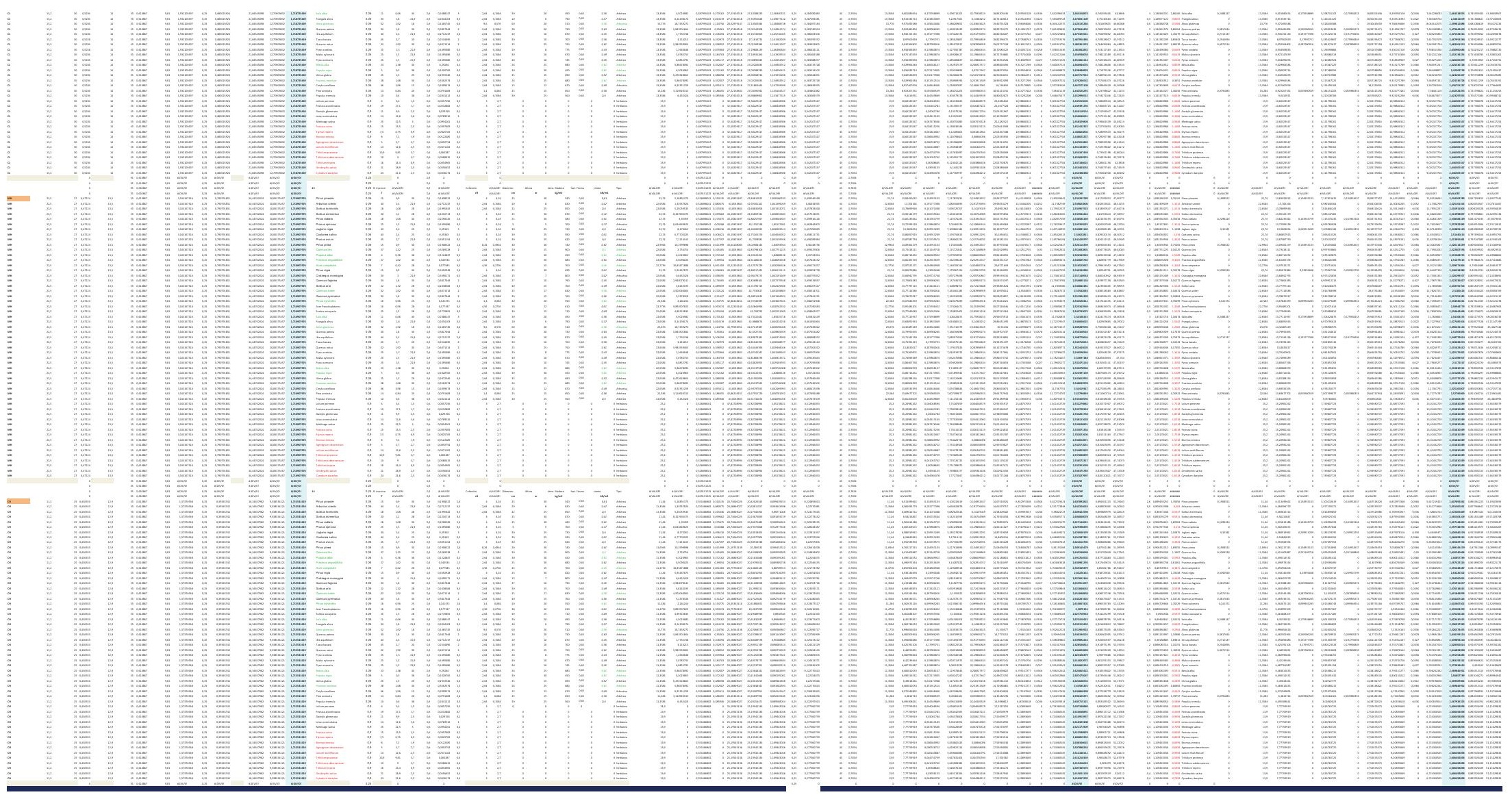



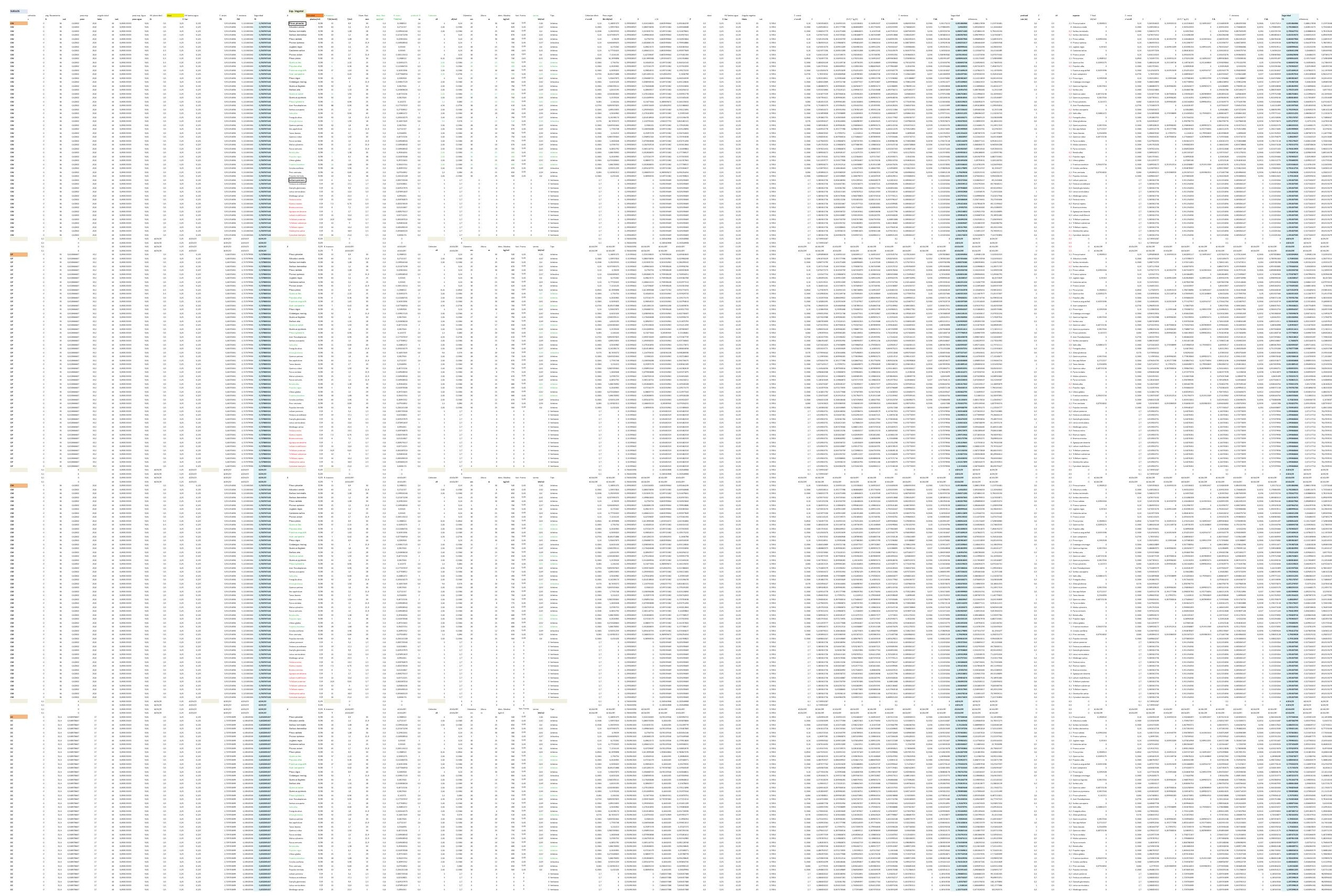


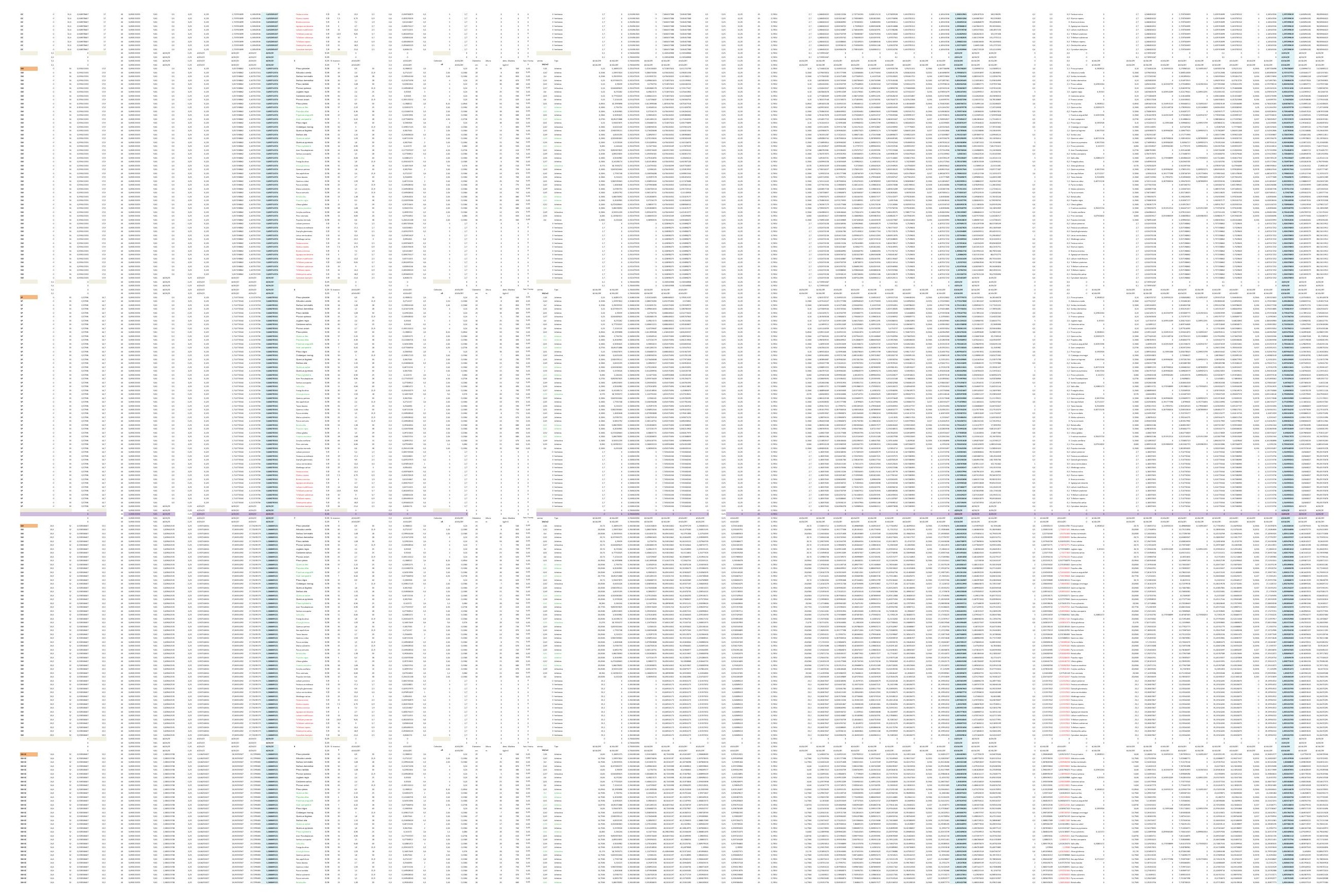



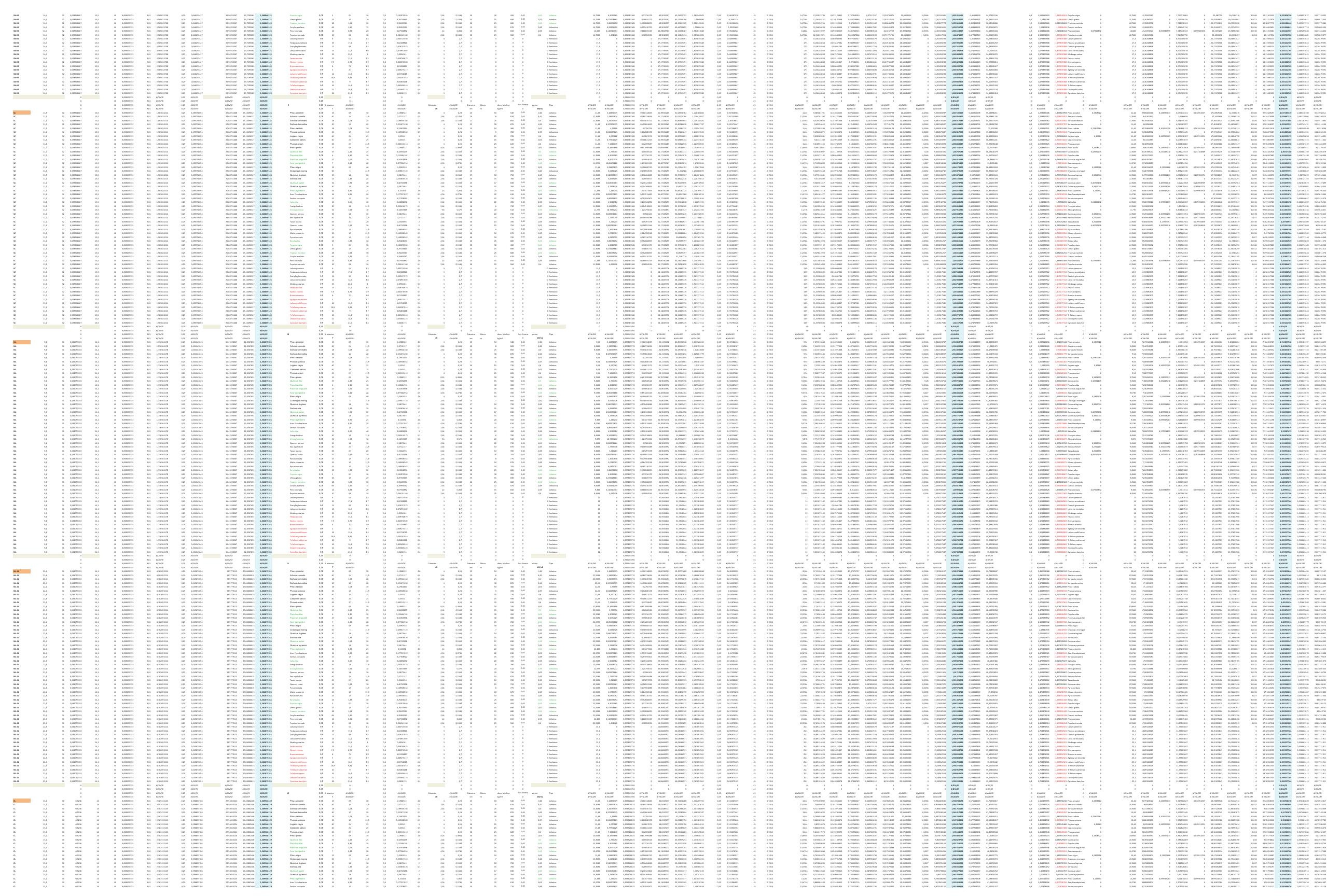


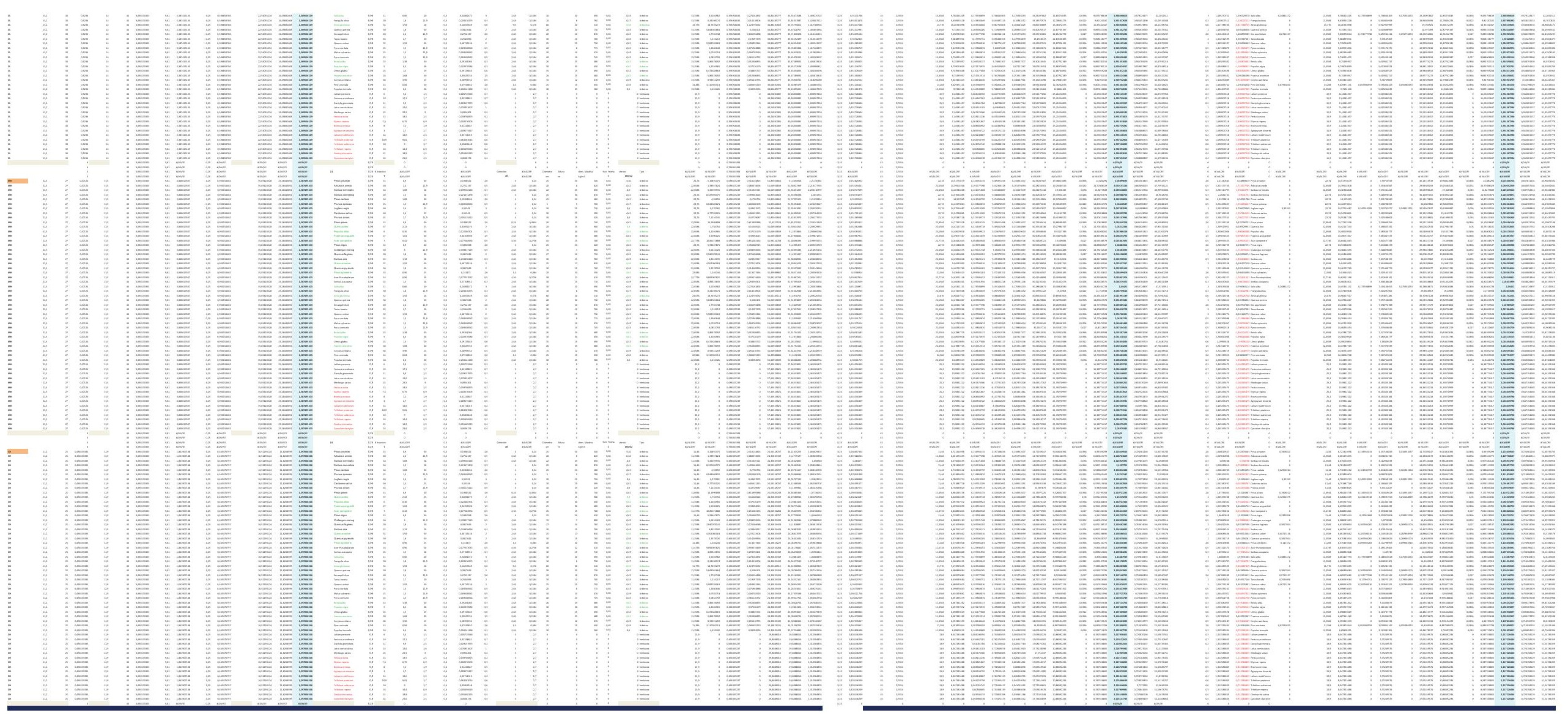



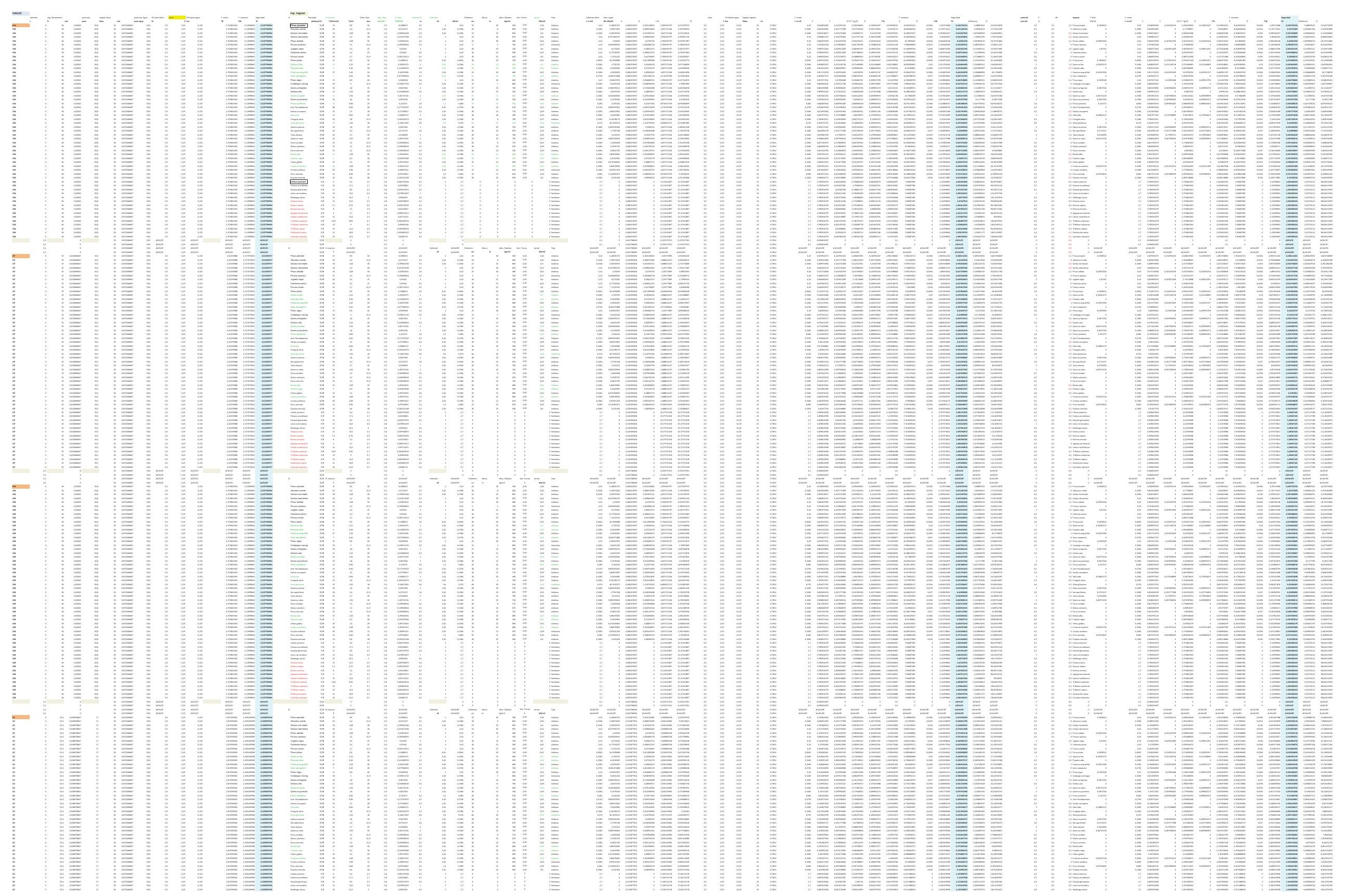


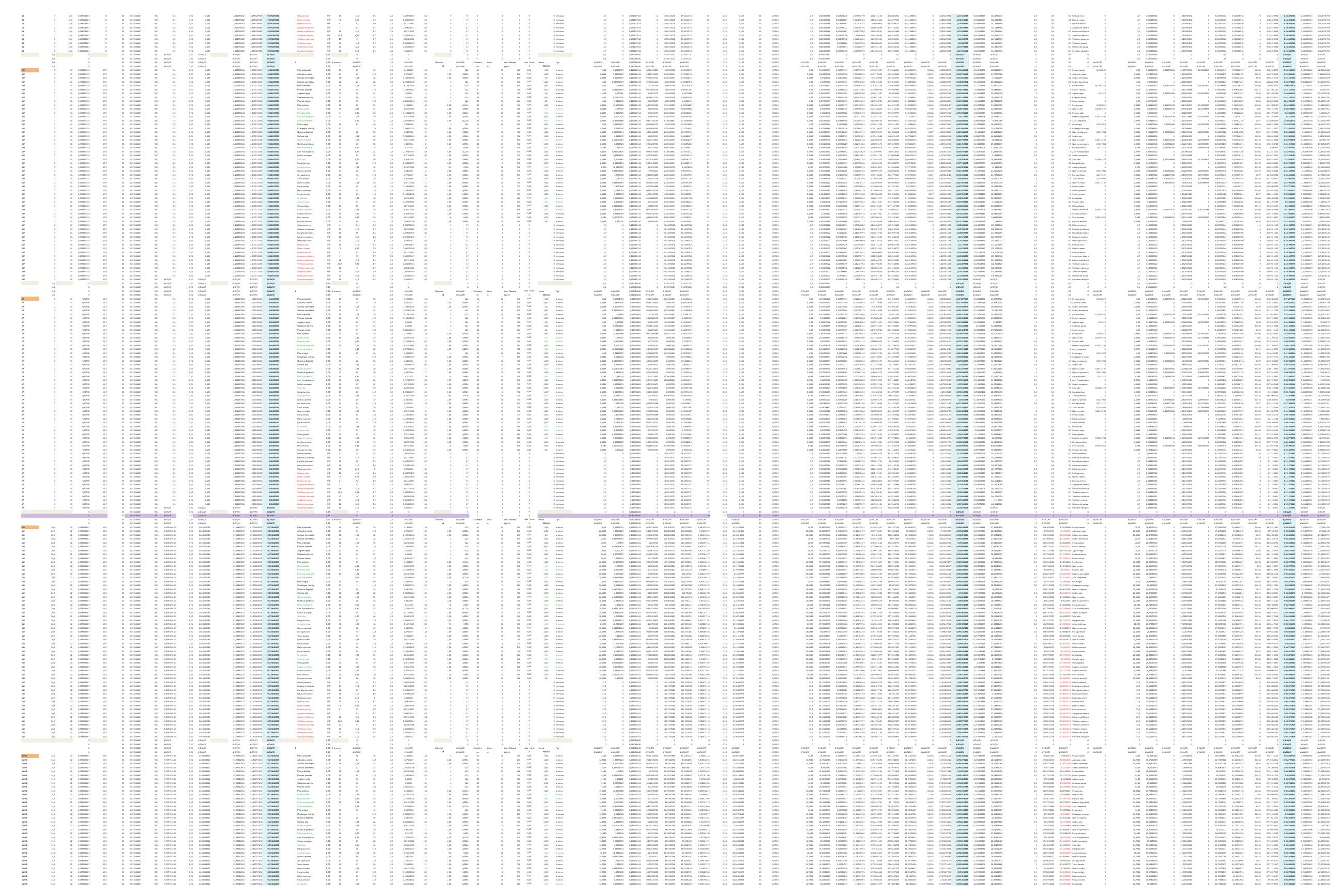



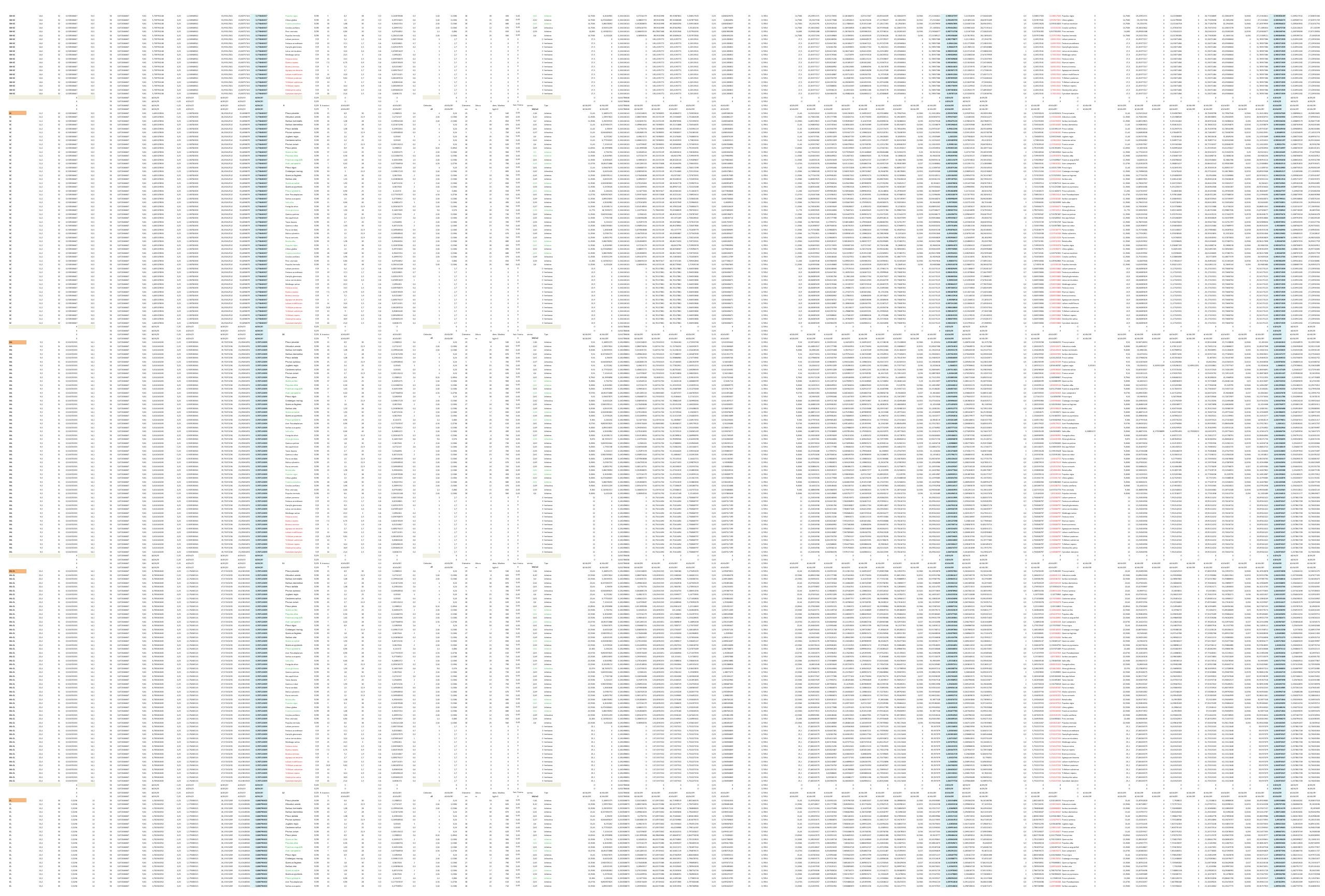


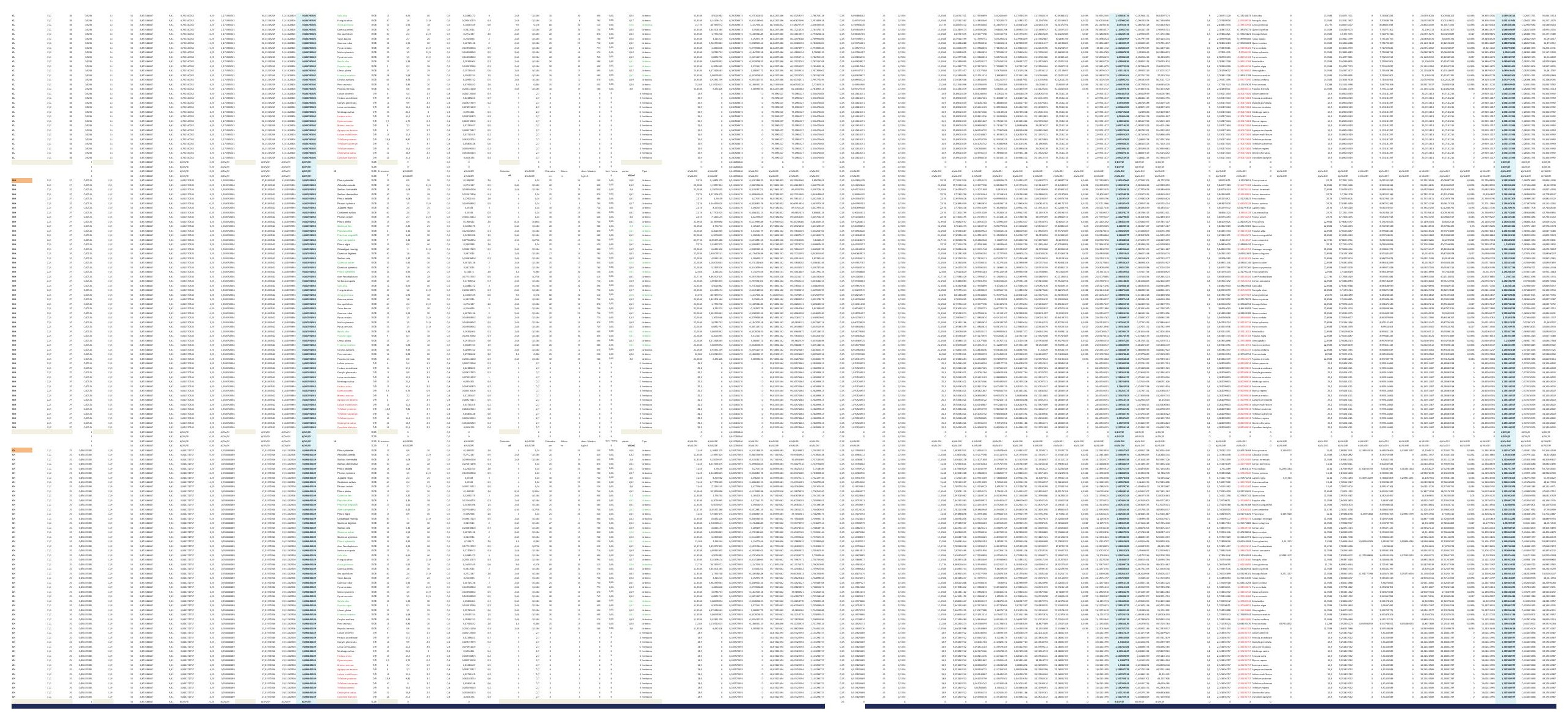



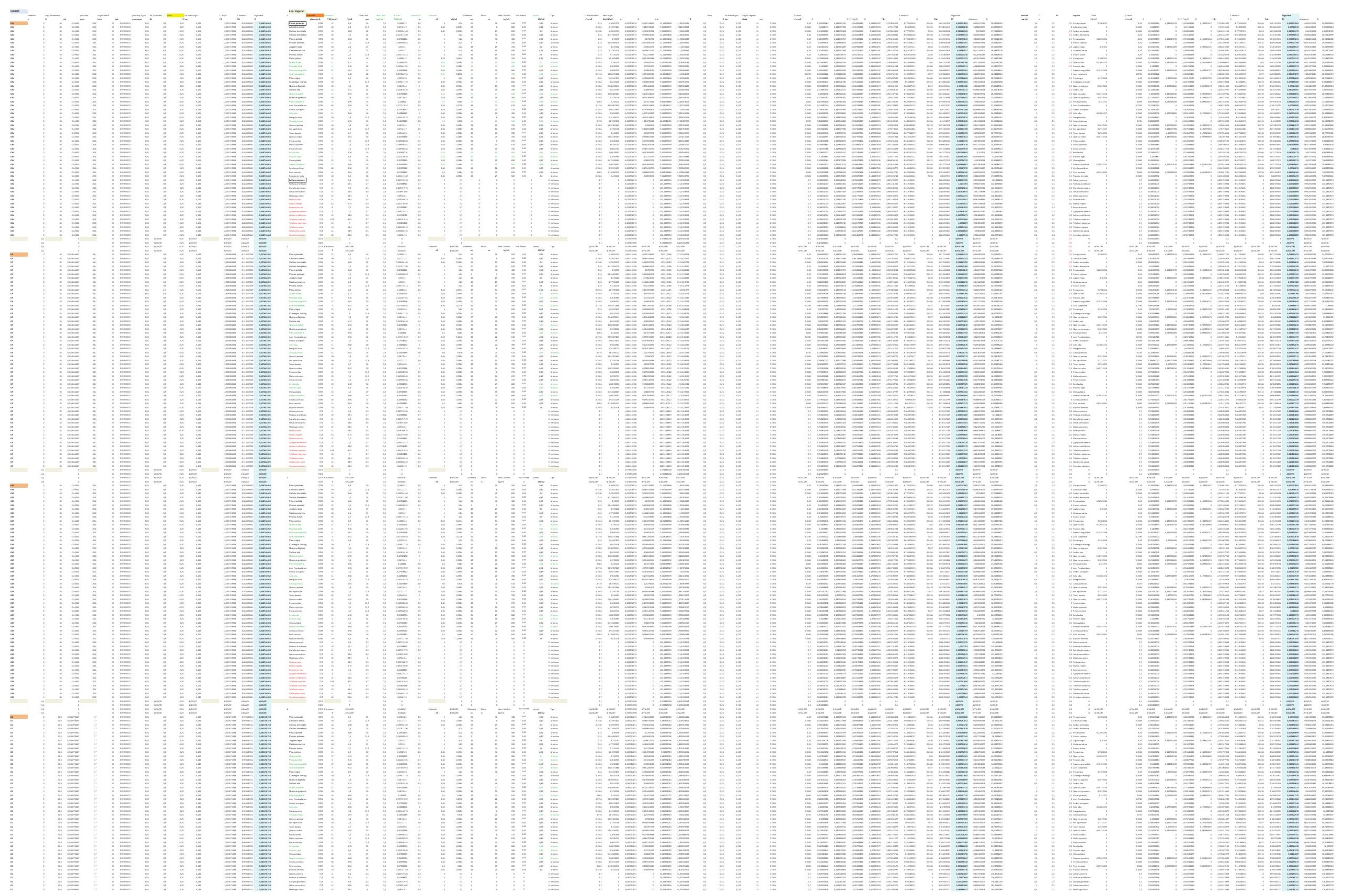

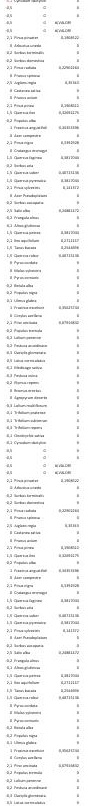

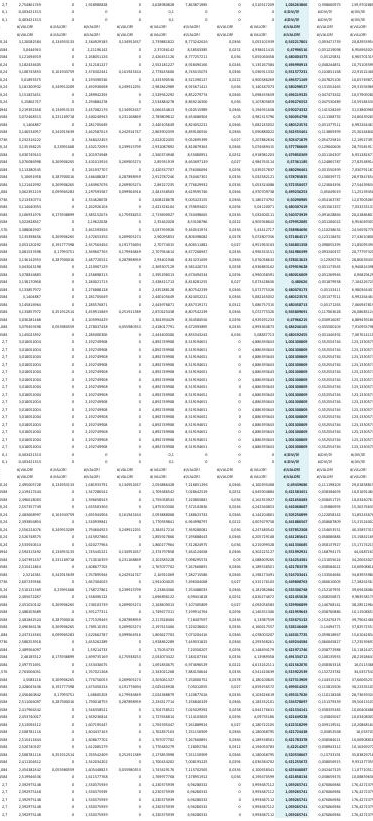




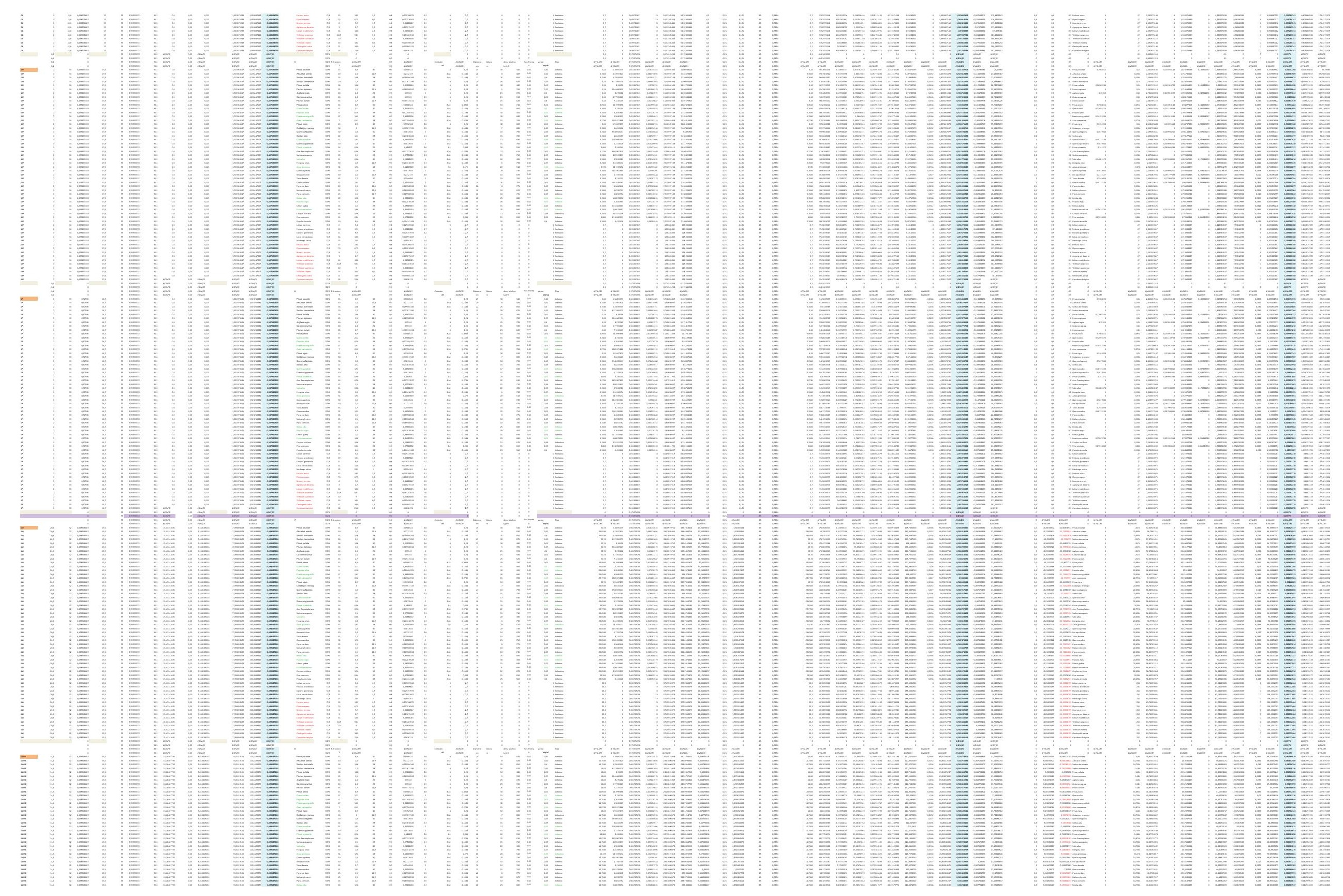



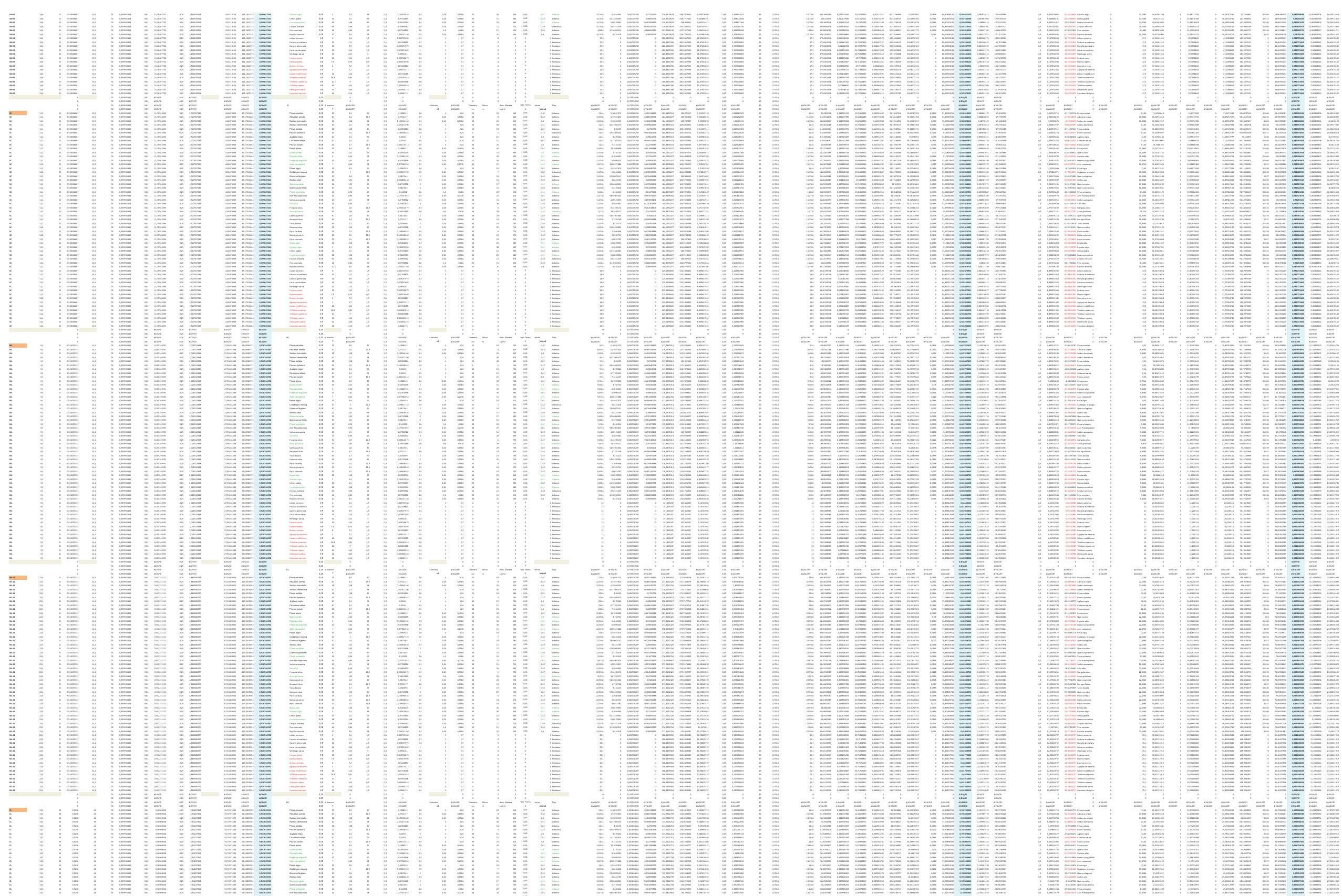

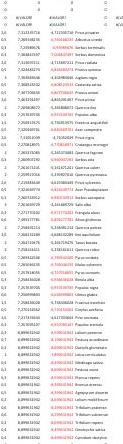
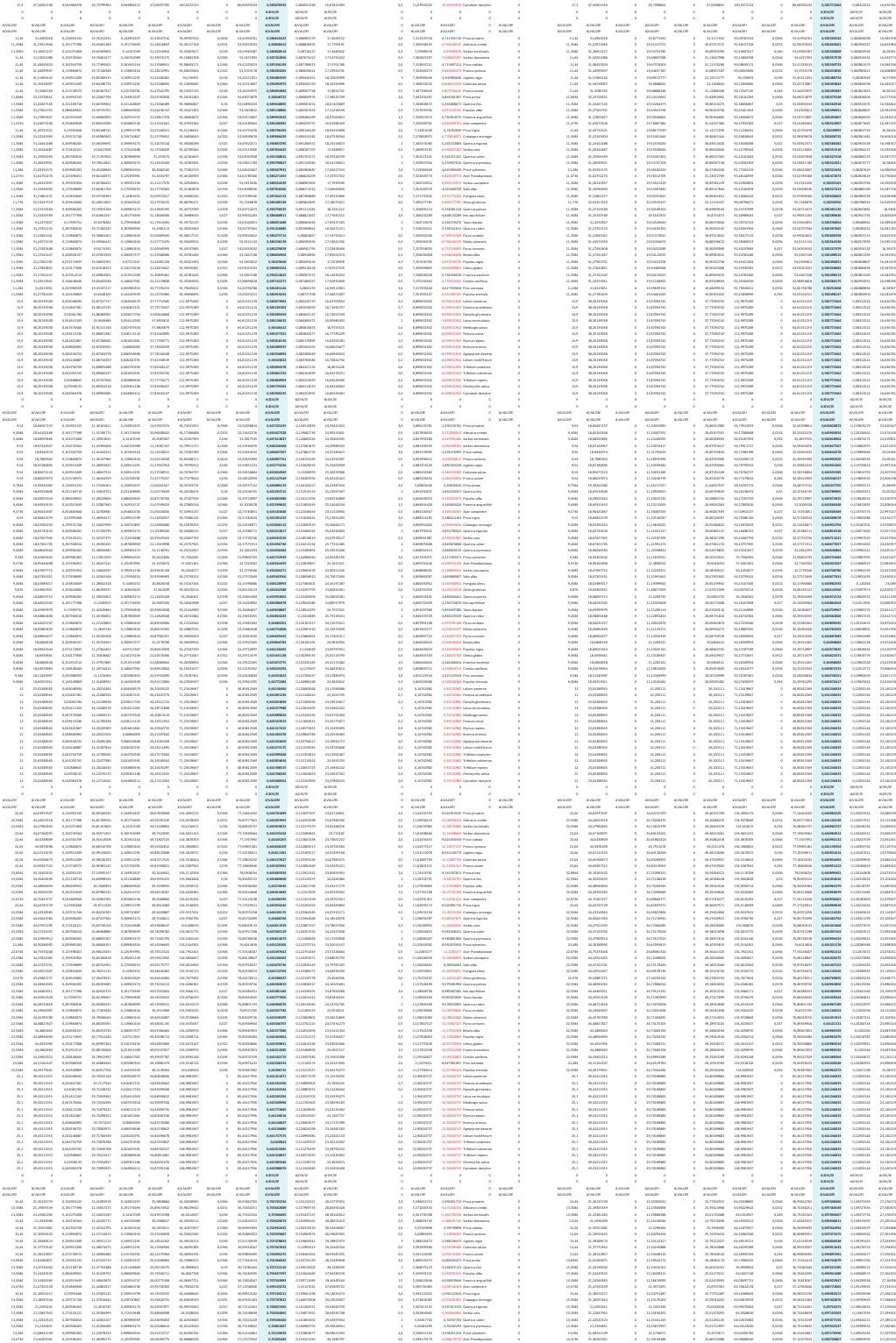

II 


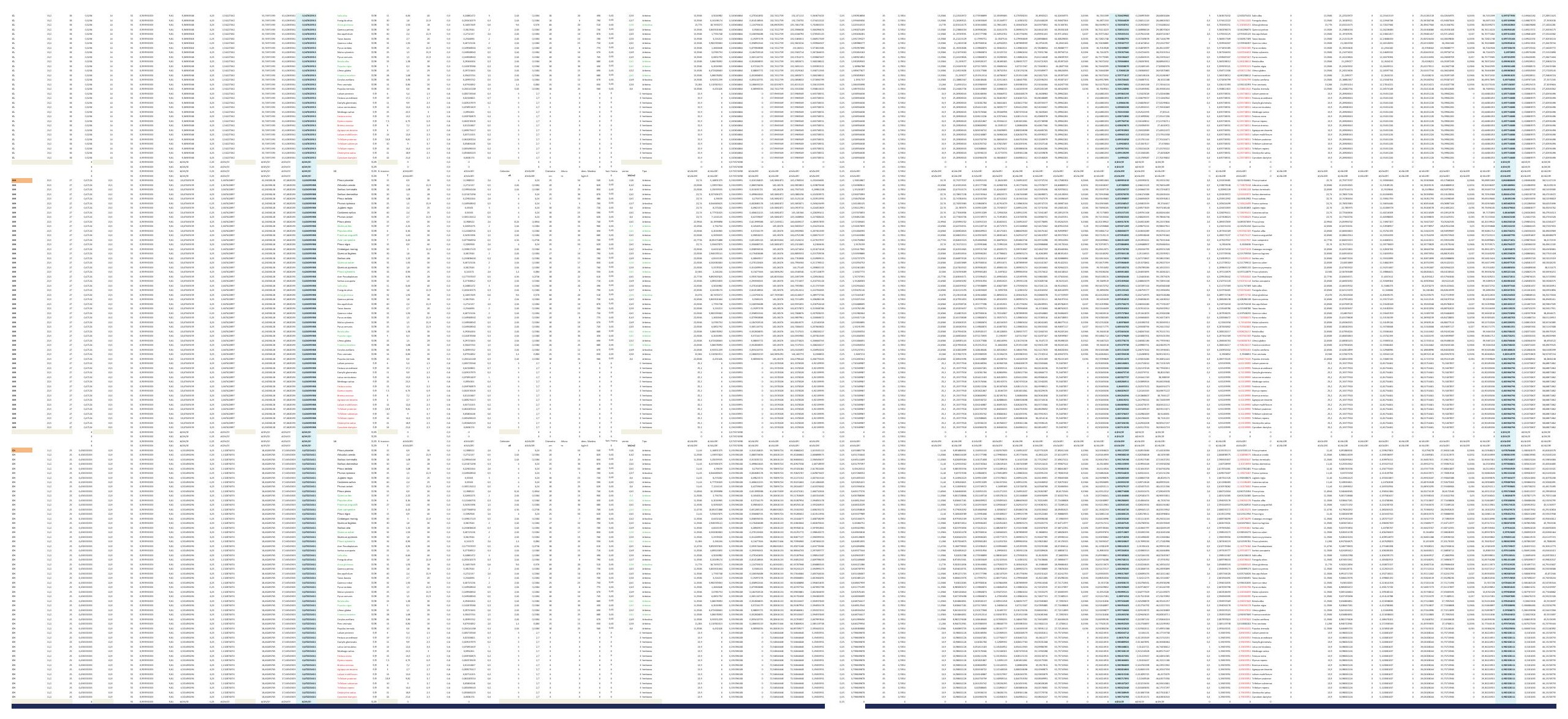



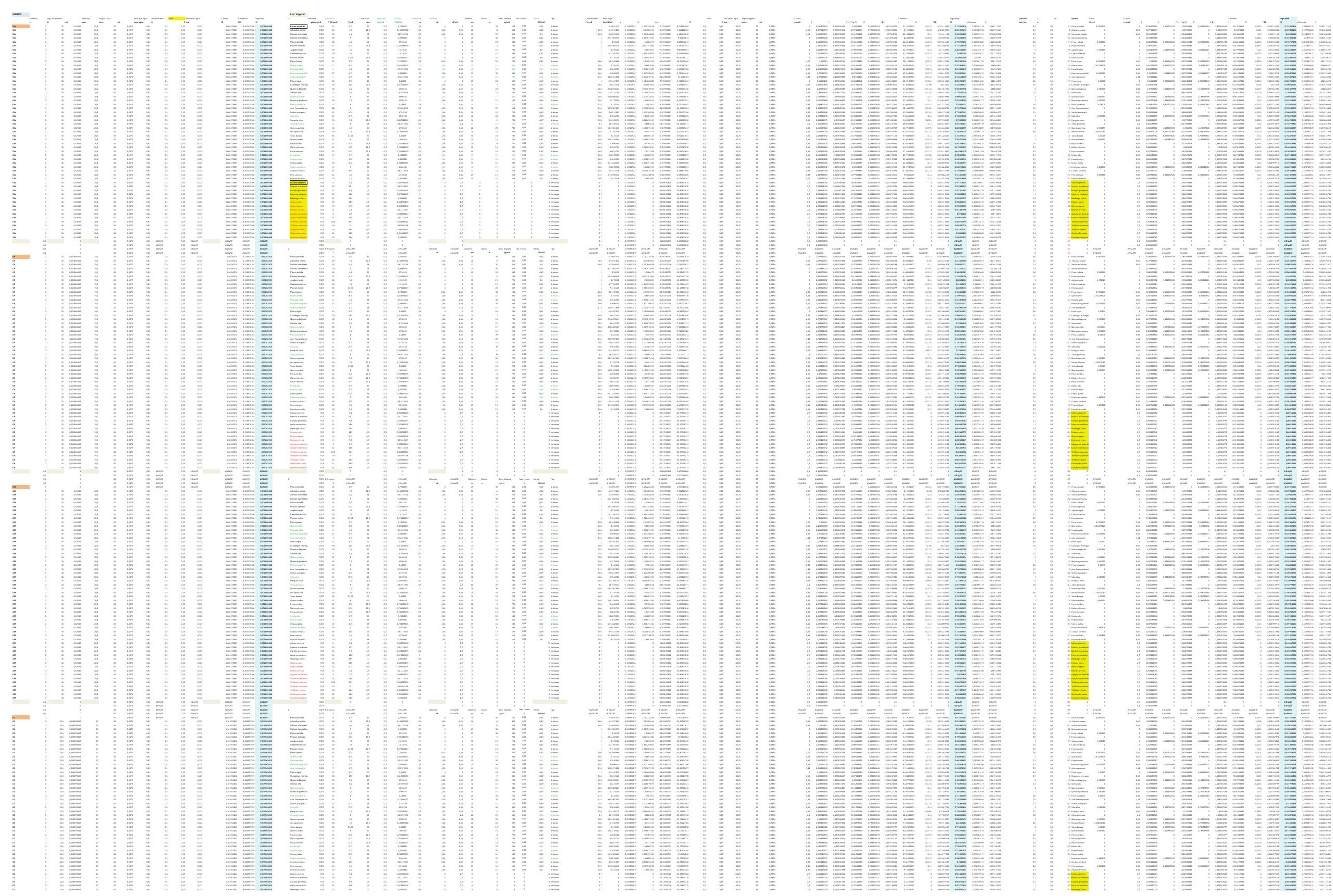


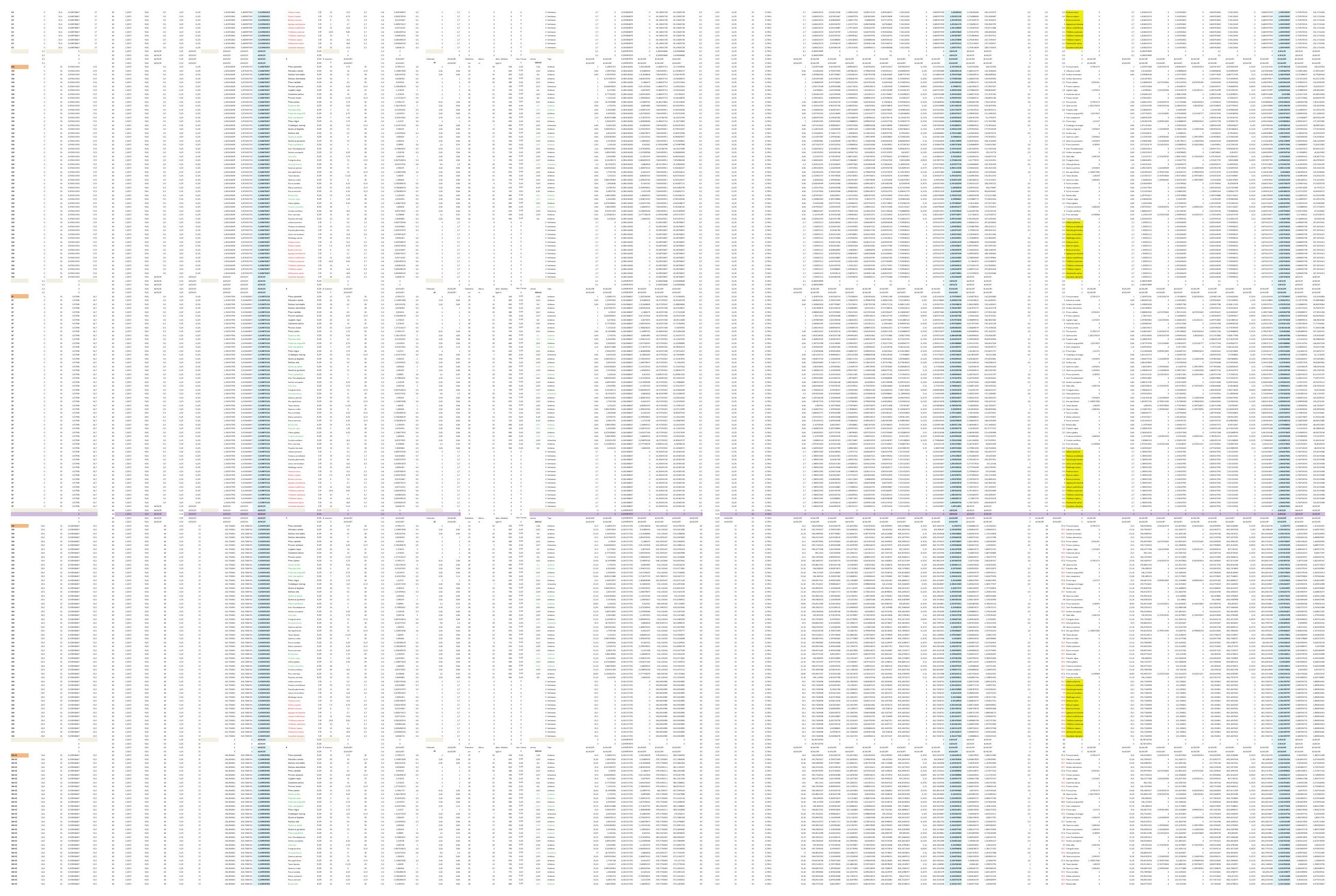



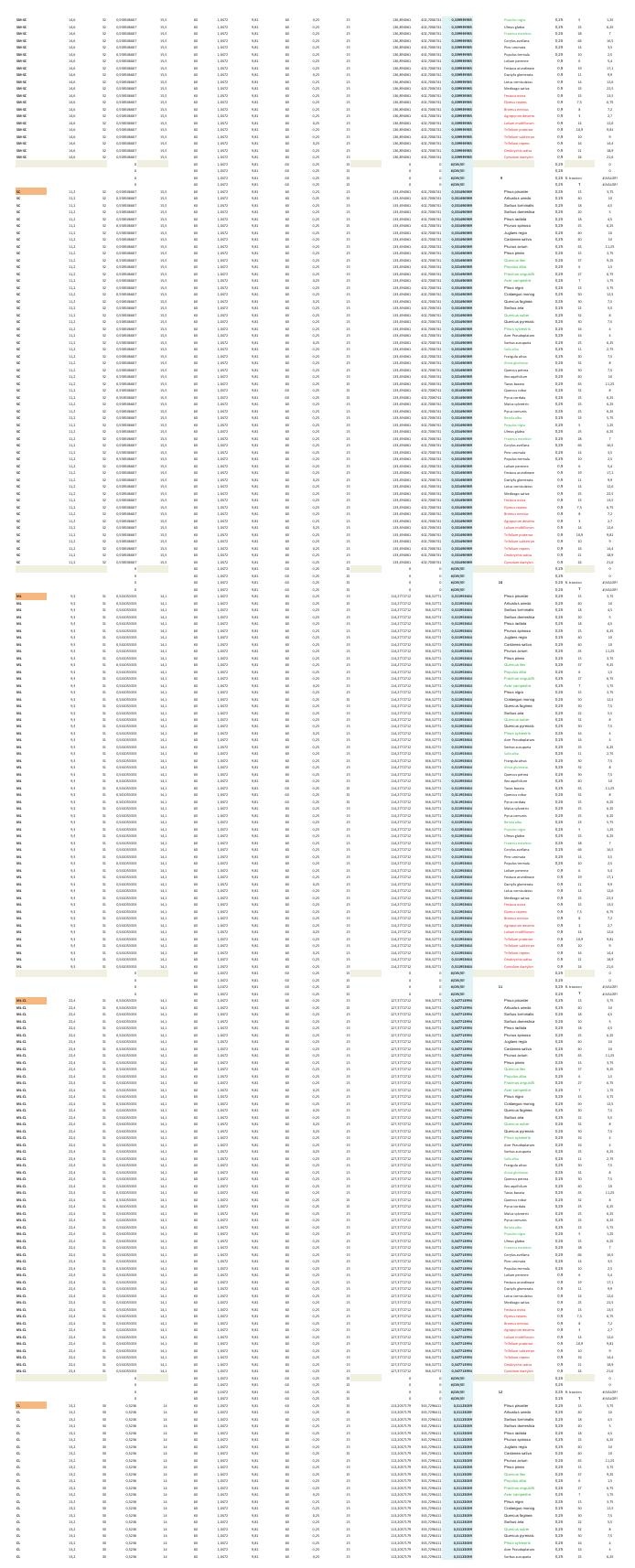

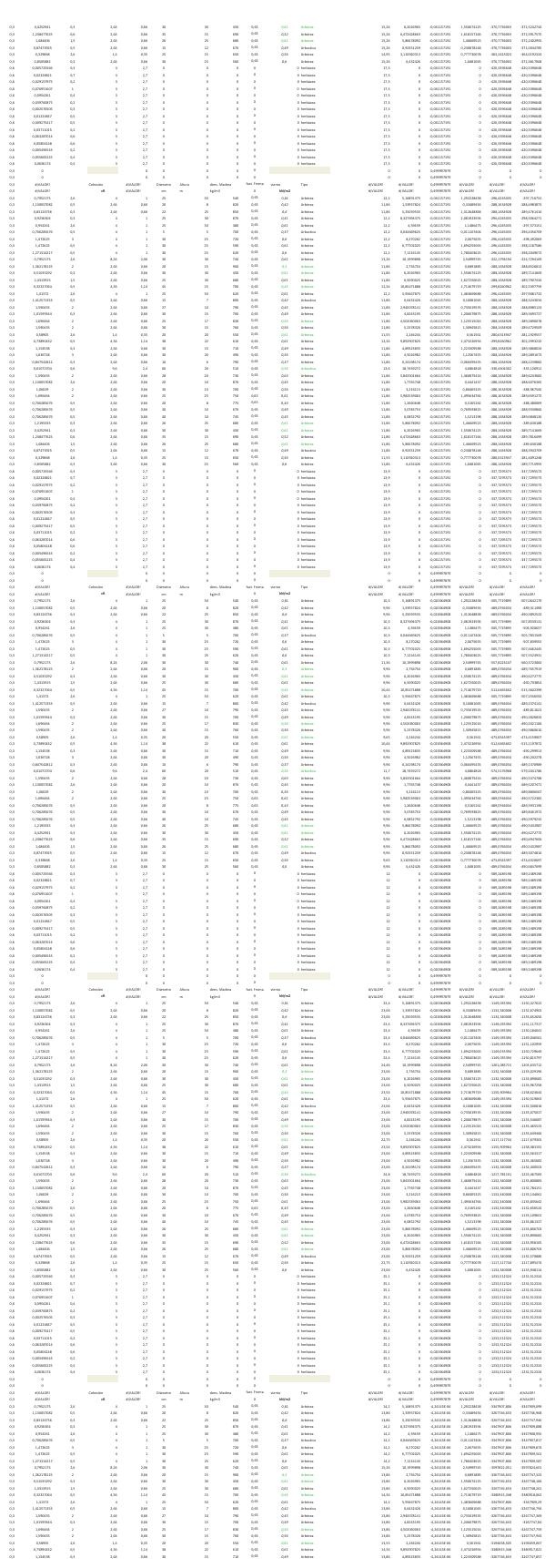

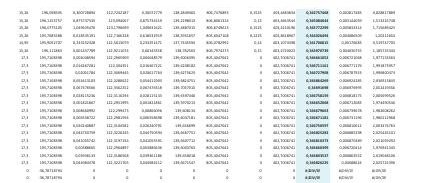
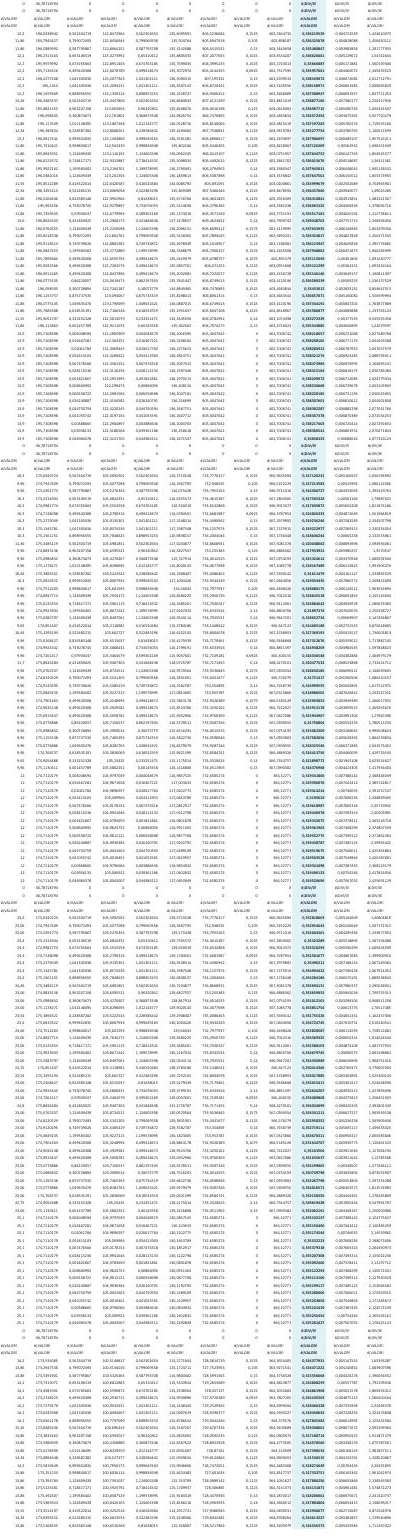

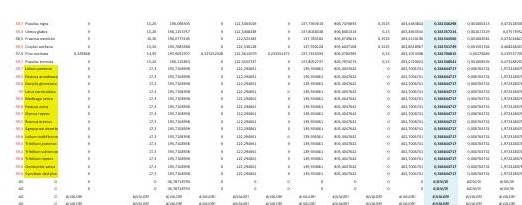

毫

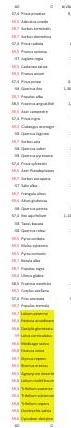

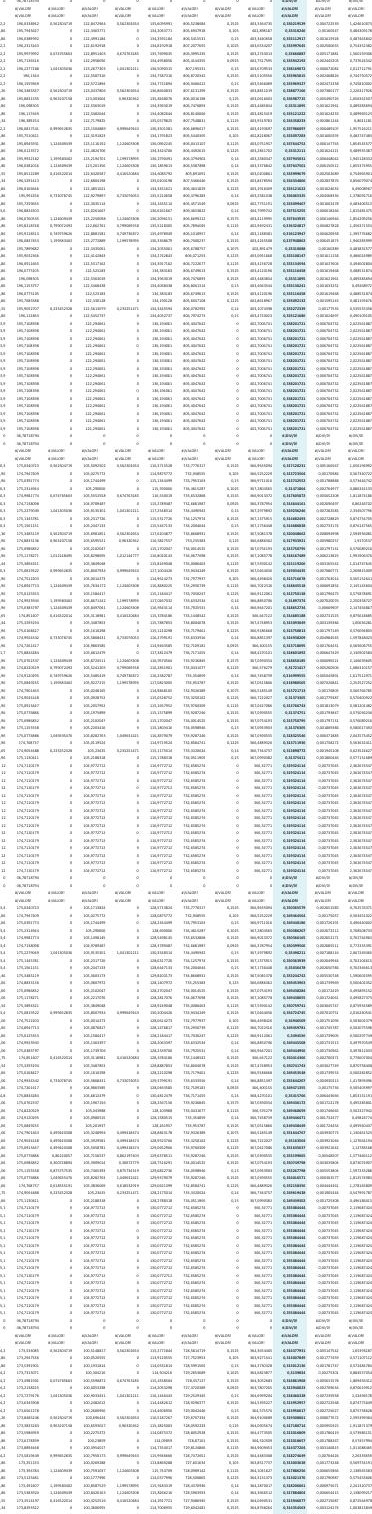

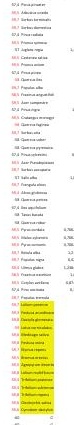

咅 


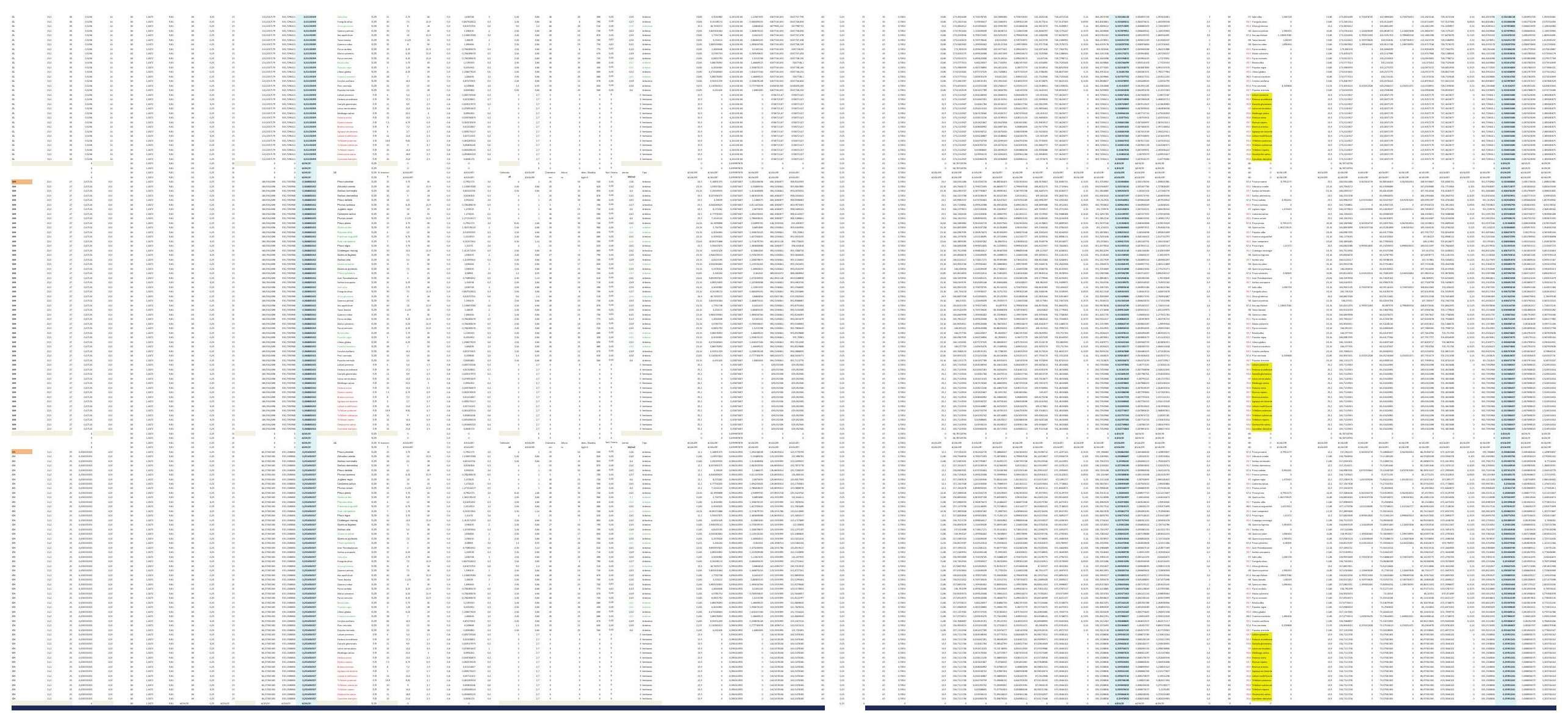



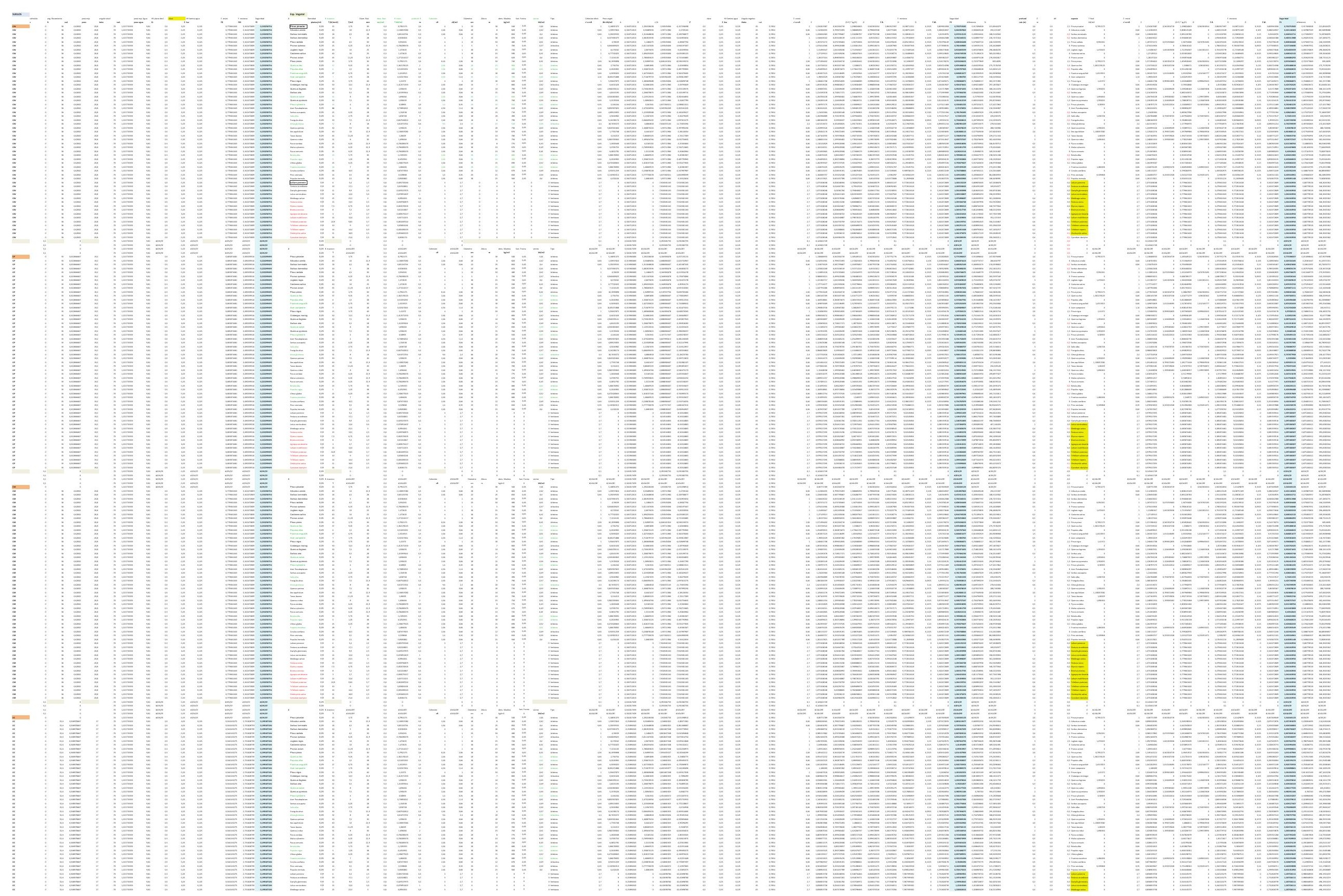

翌

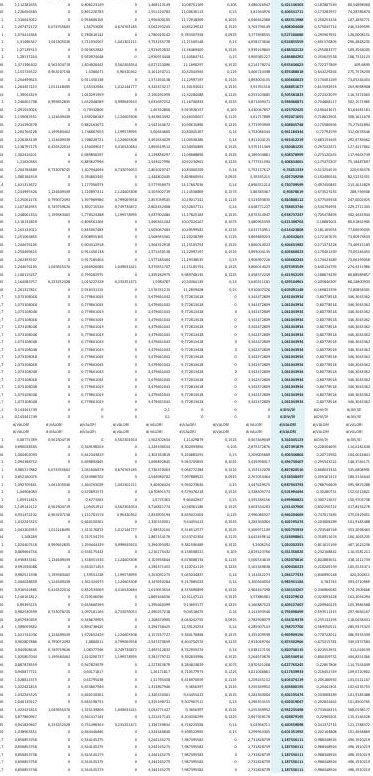




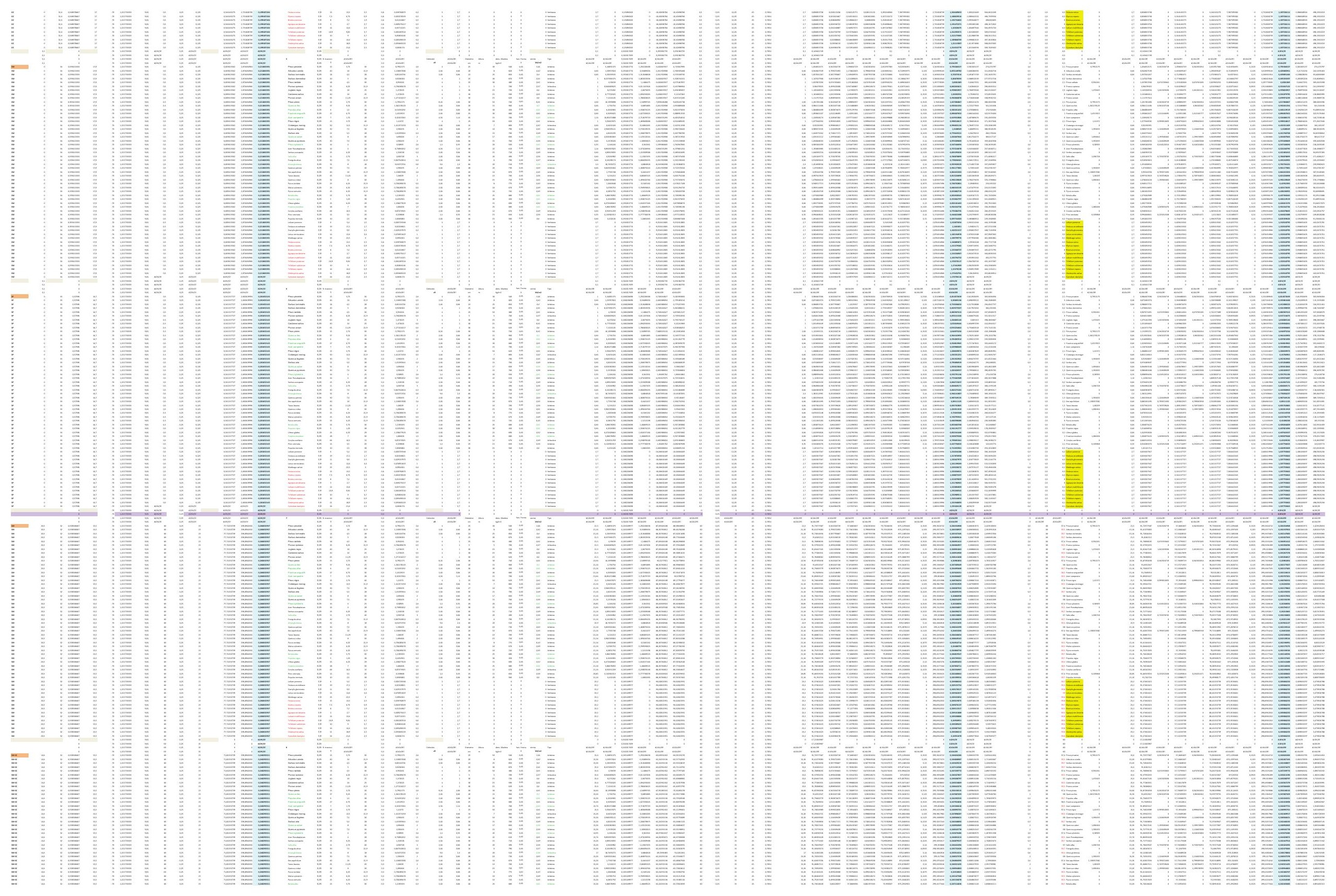




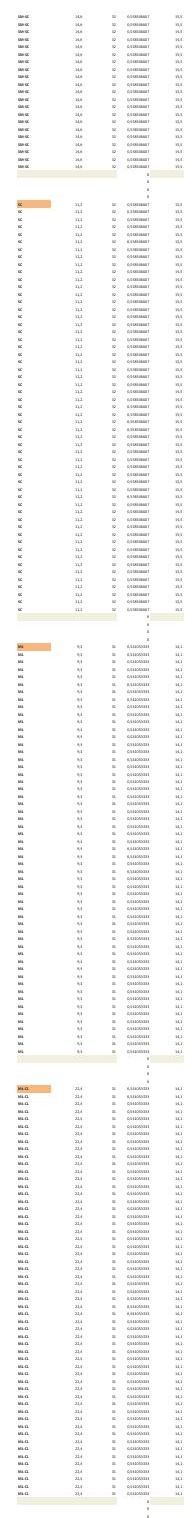

$-$

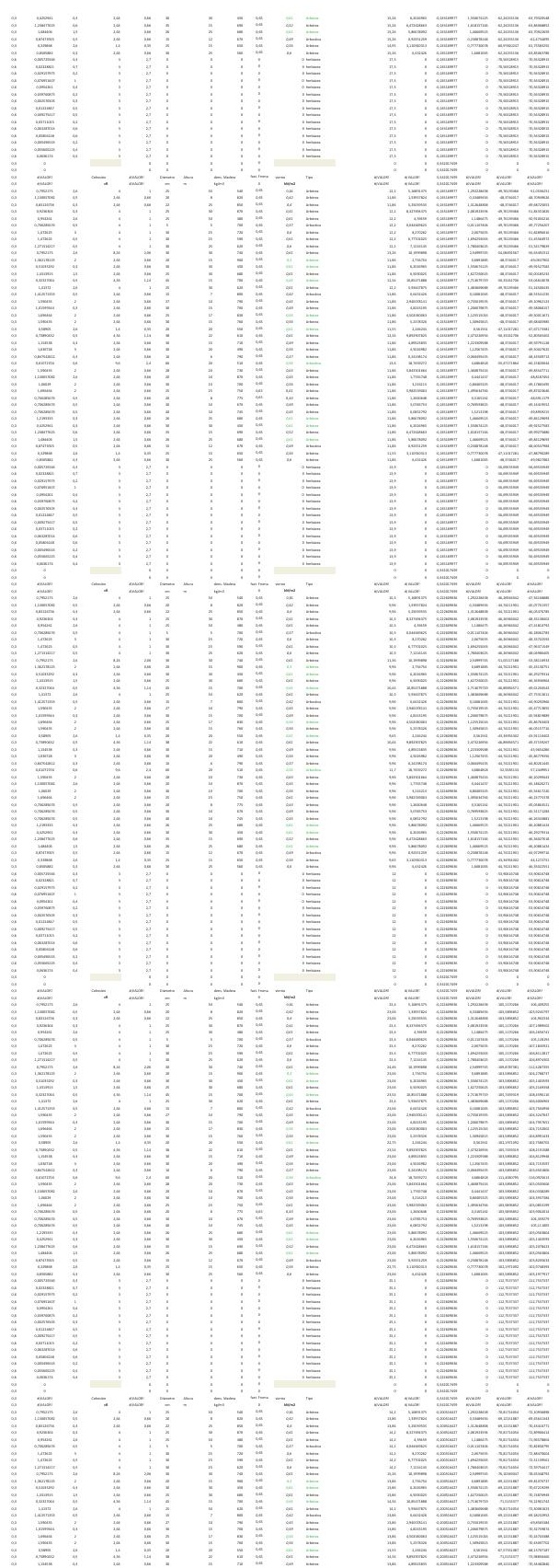

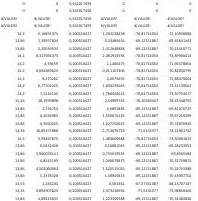
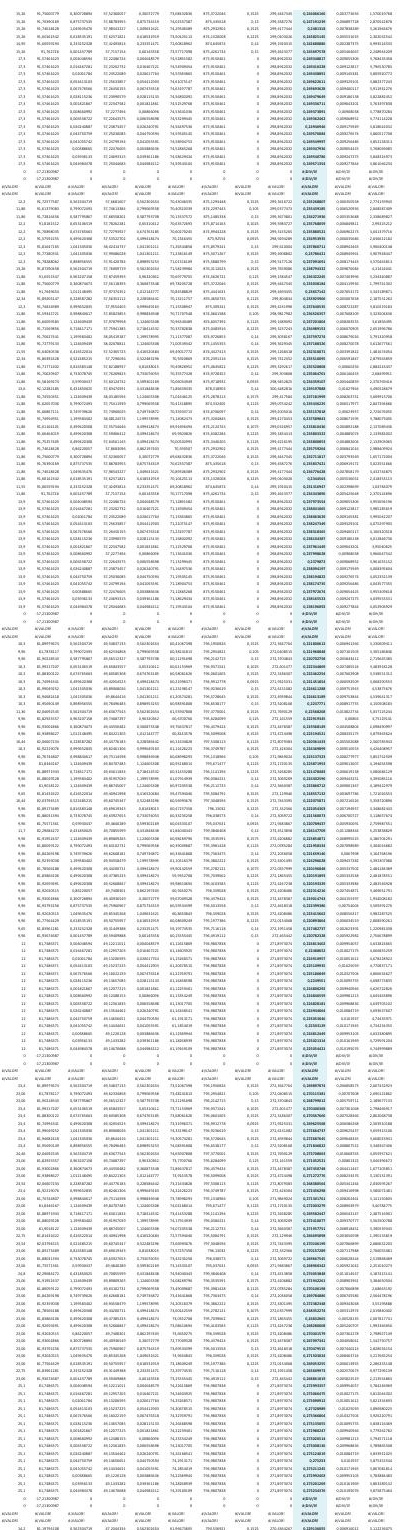

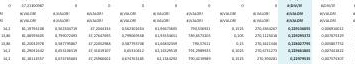

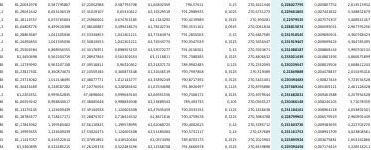

झ

=

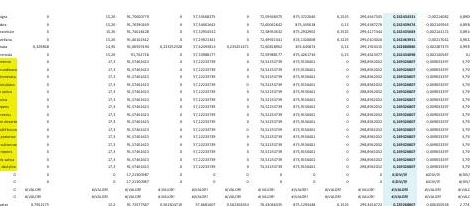

离

$\mid$
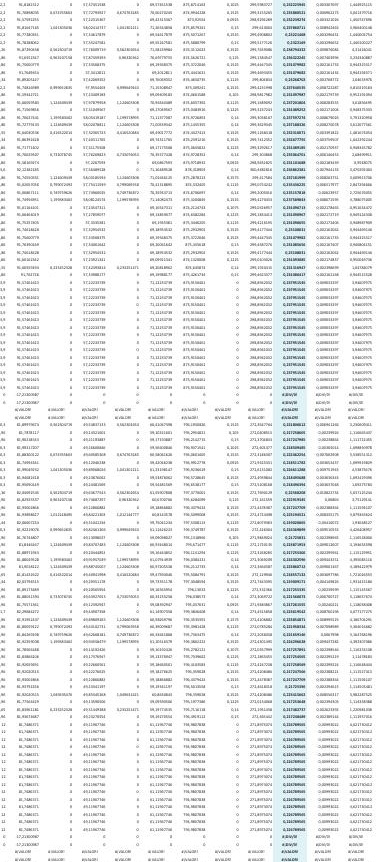

$\equiv$
$\equiv$
$\equiv$
$\equiv$
$\equiv$
$\equiv$
$\equiv$
$\equiv$
$\equiv$

$\vdots$
$\equiv$
$\equiv$
$\equiv$
$\equiv$

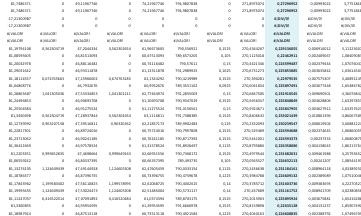




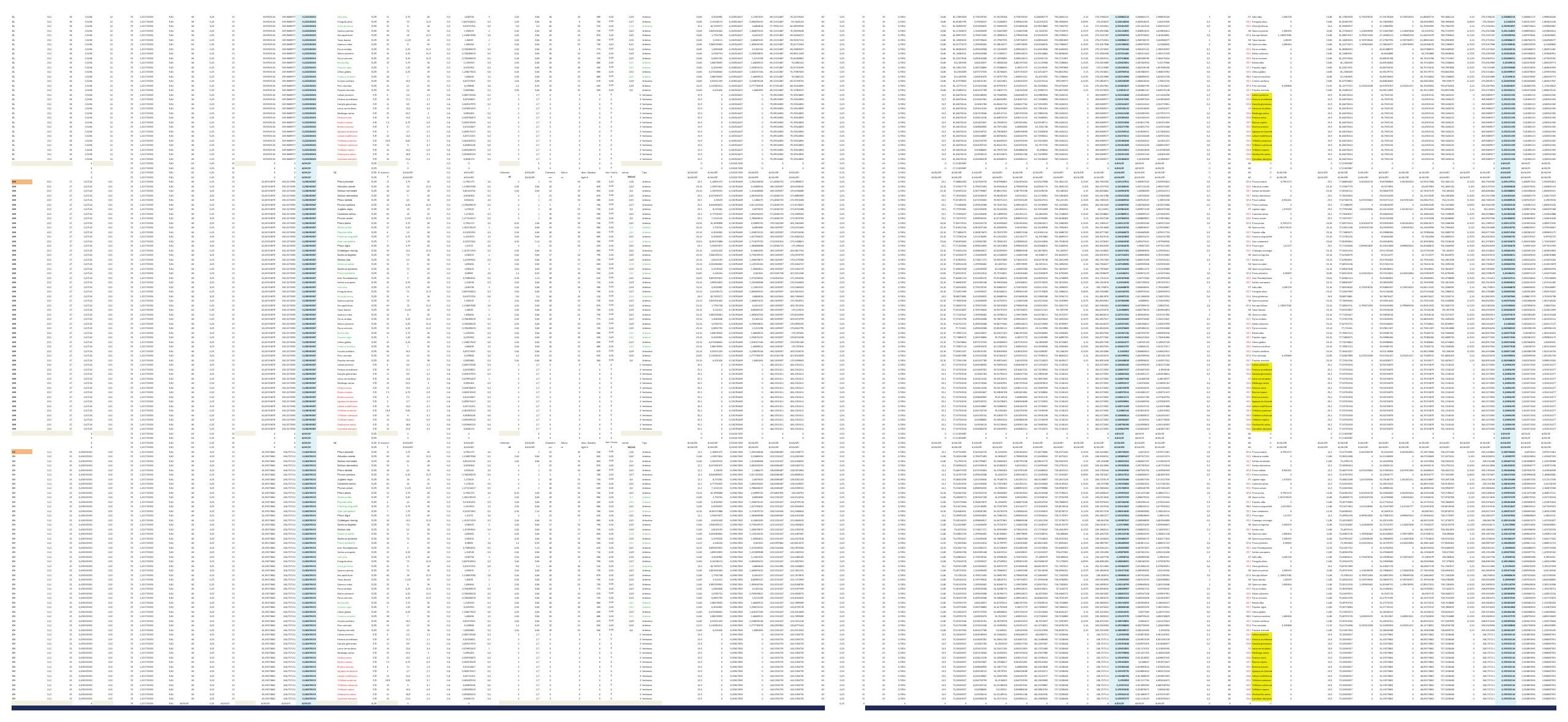



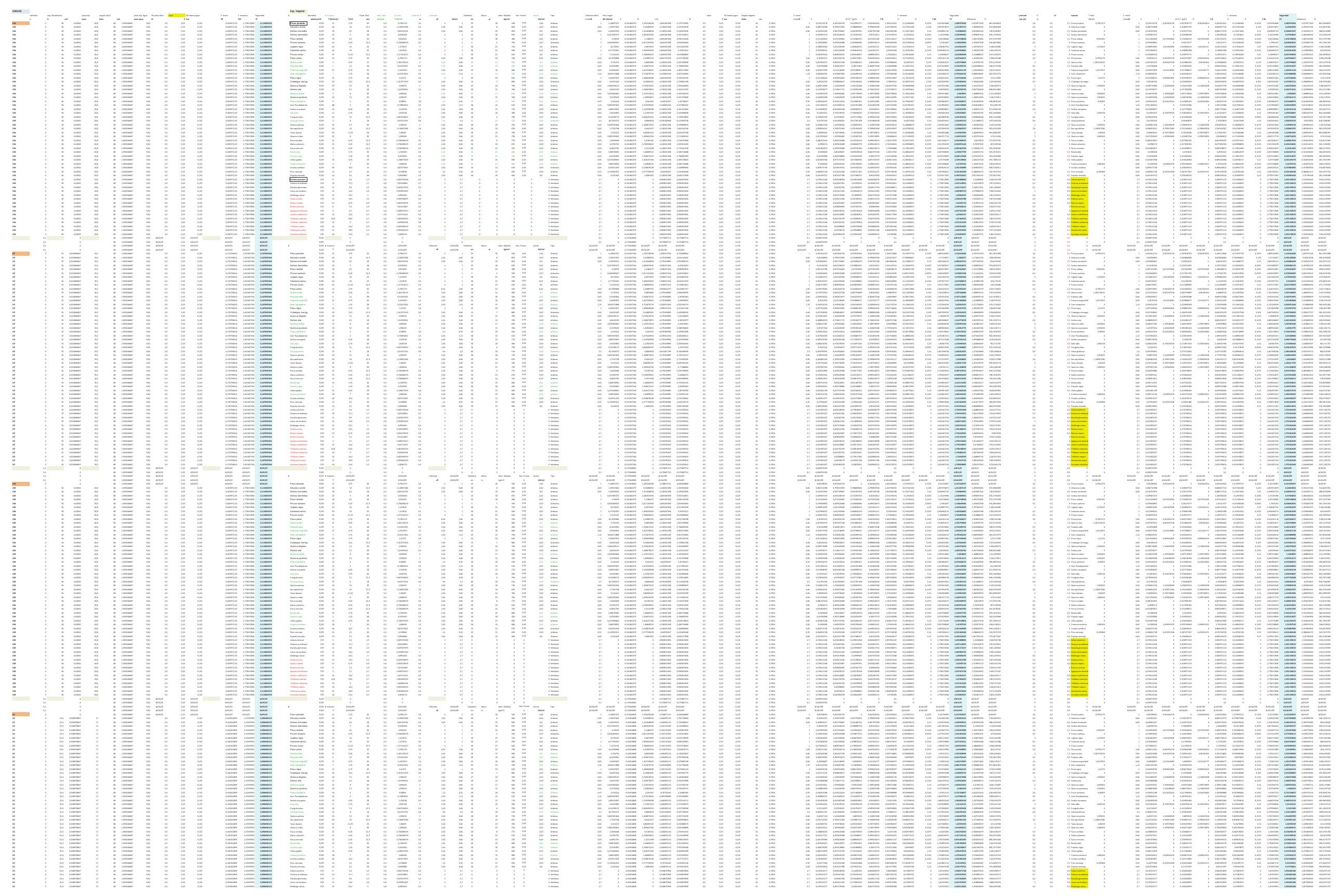


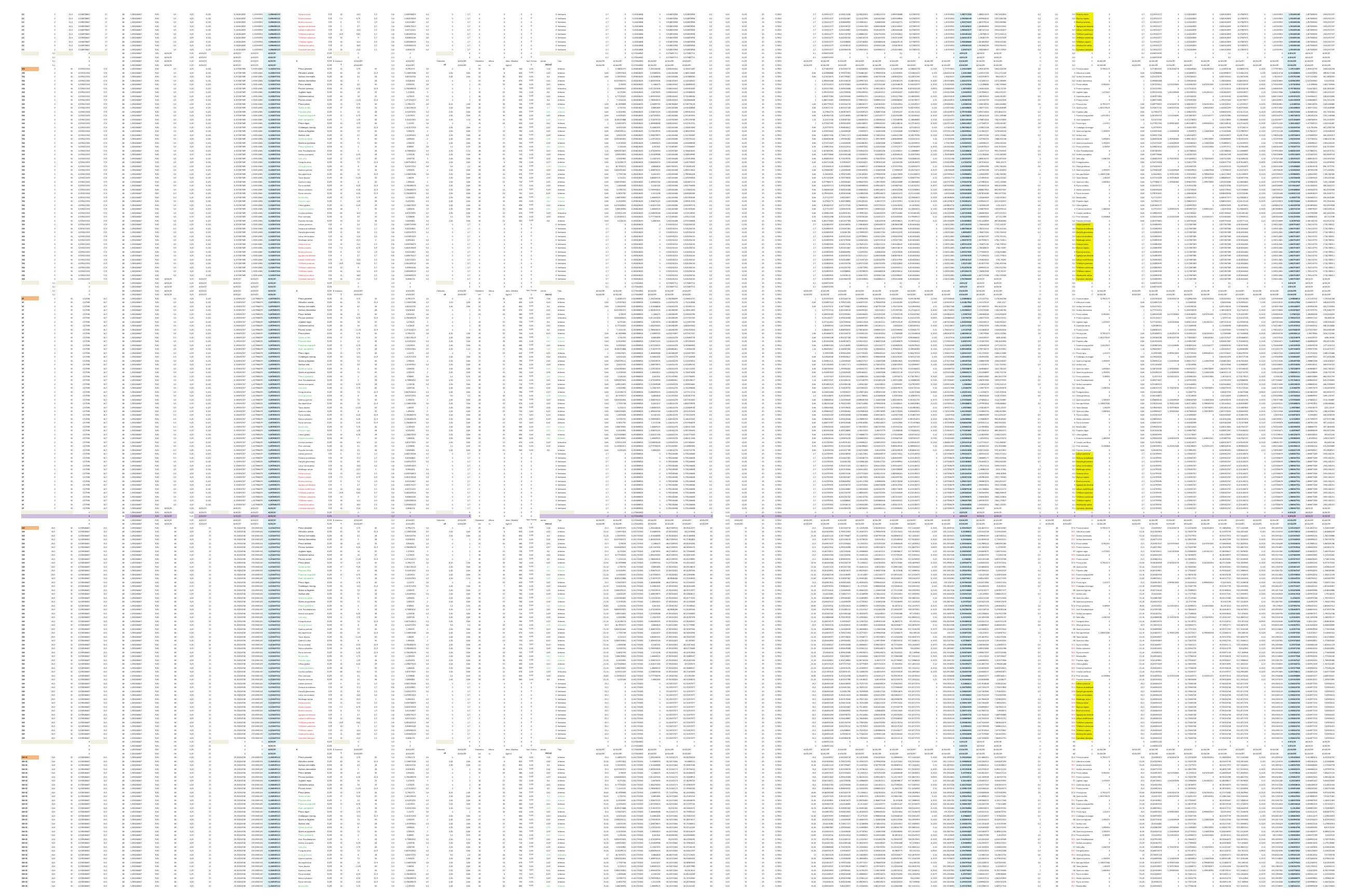



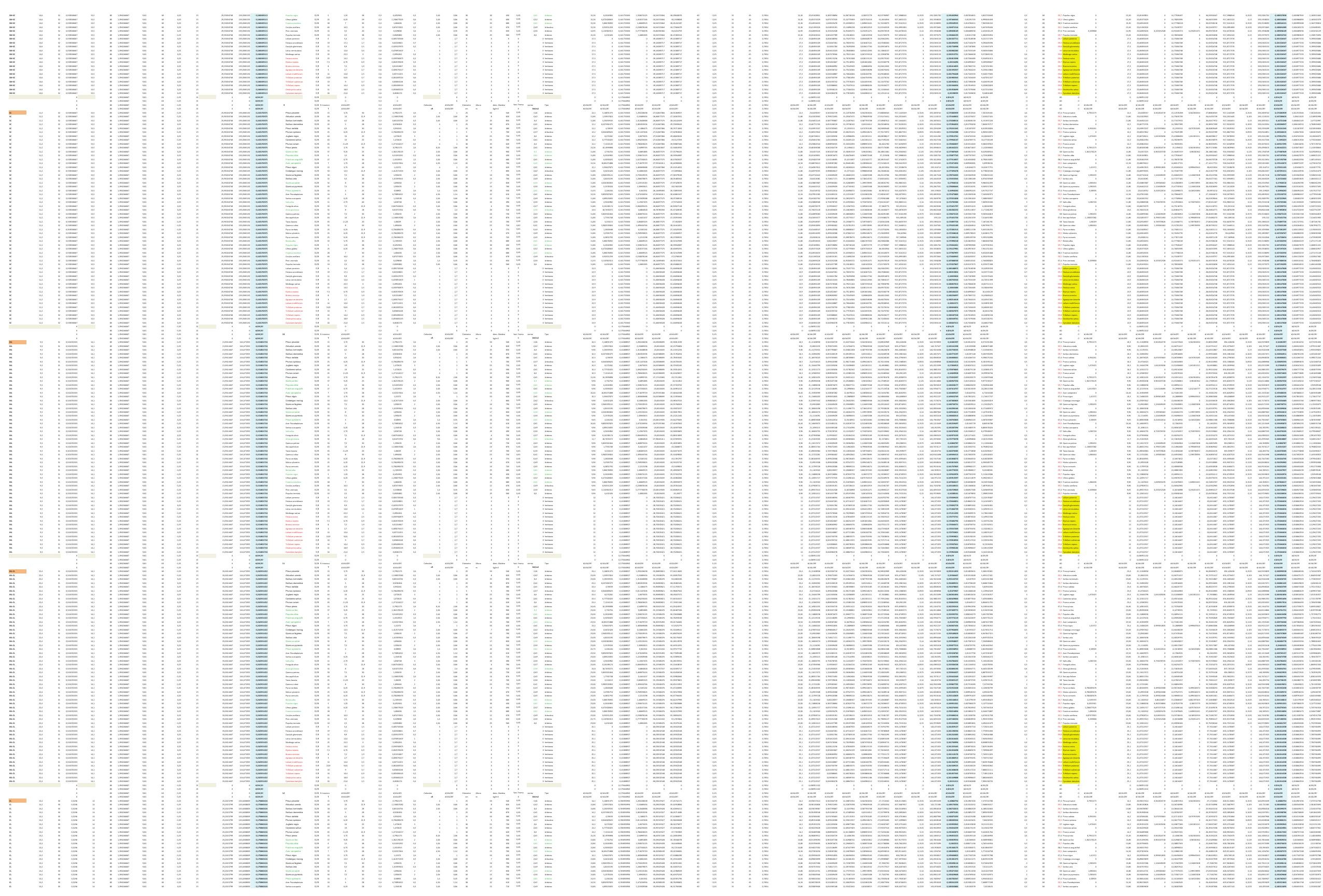

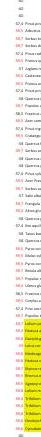
$\equiv \equiv \equiv \equiv \equiv \equiv \equiv$

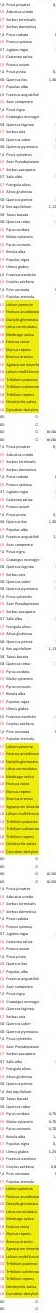
$\equiv \equiv \equiv \equiv \equiv \equiv$

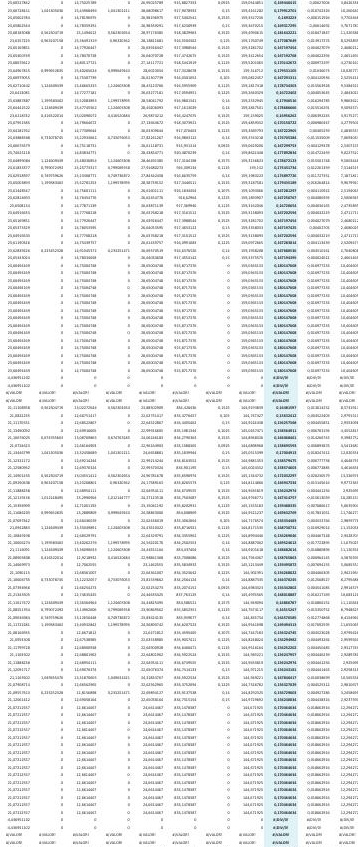

$=\equiv$
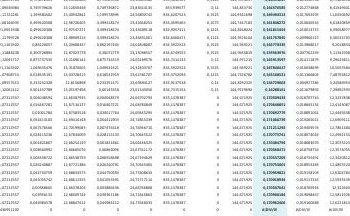

E
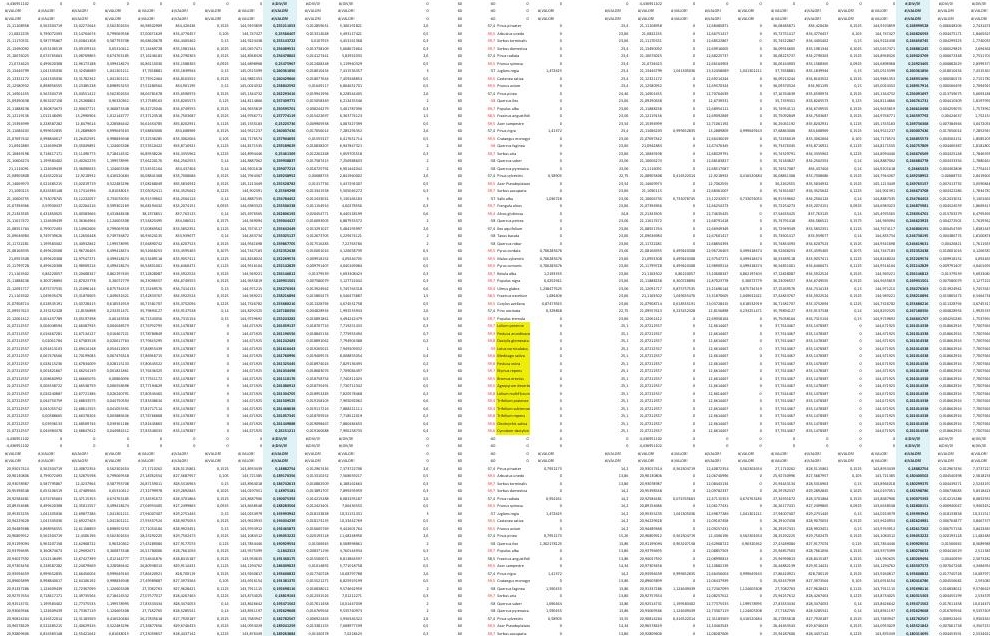


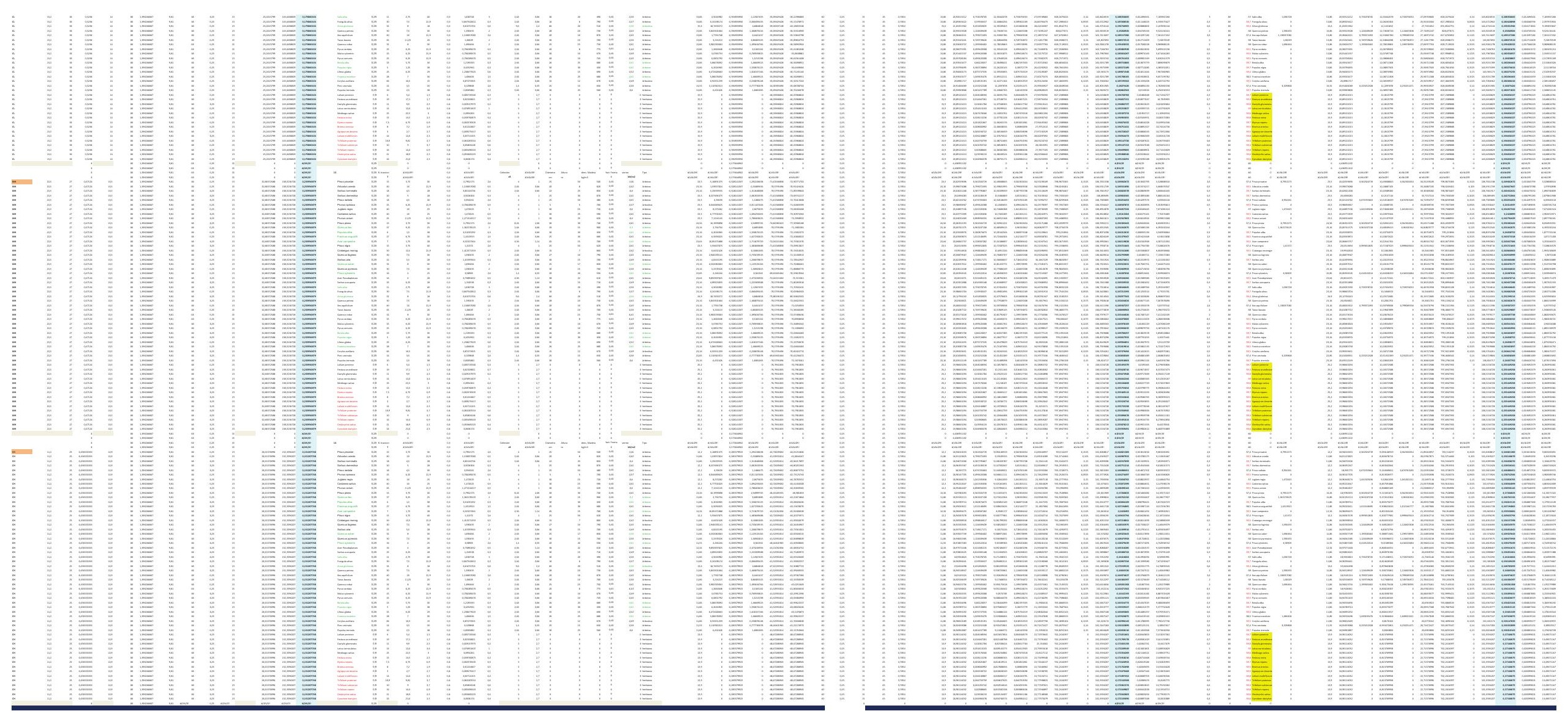


DESARROLLO DE UNA APLICACIÓN IMFORMÁTICA PARA EL CÁLCULO DE SOSTENIMIENTO DE TALUDES MEDIANTE VEGETACIÓN

A01. DENSIDAD DE PLANTACIÓN: 600 plantas/ha.

\section{A01-4.POSICIÓN N.F. 4}

INCLINACIÓN DE TALUD 6-100

INCLINACIÓN DE TALUD 10-200

INCLINACIÓN DE TALUD 20-30

INCLINACIÓN DE TALUD 30-40

INCLINACIÓN DE TALUD $35^{\circ}$

INCLINACIÓN DE TALUD 40-50

INCLINACIÓN DE TALUD 50-550

INCLINACIÓN DE TALUD 55-60

INCLINACIÓN DE TALUD 60-700

INCLINACIÓN DE TALUD 70-80 

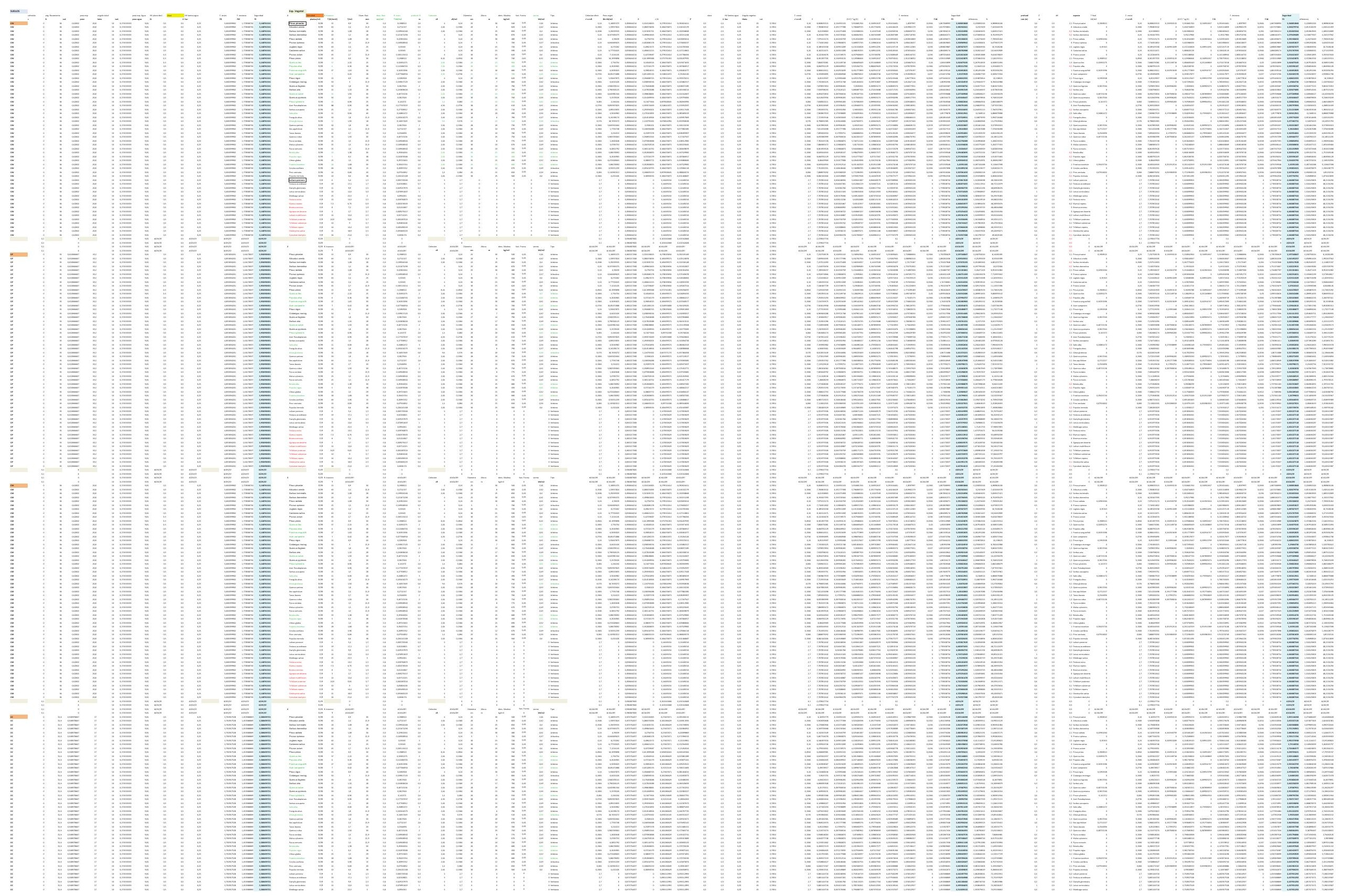


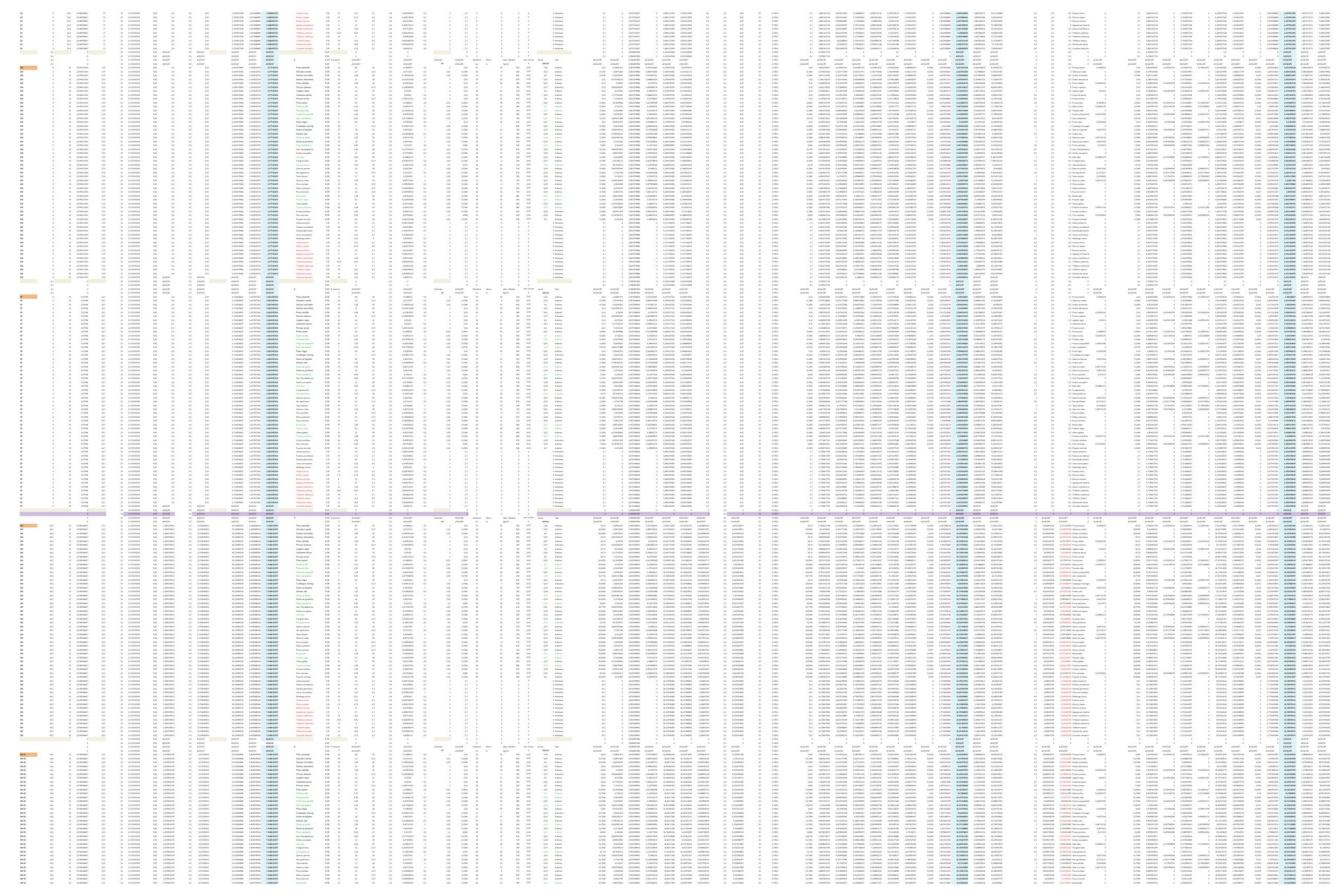



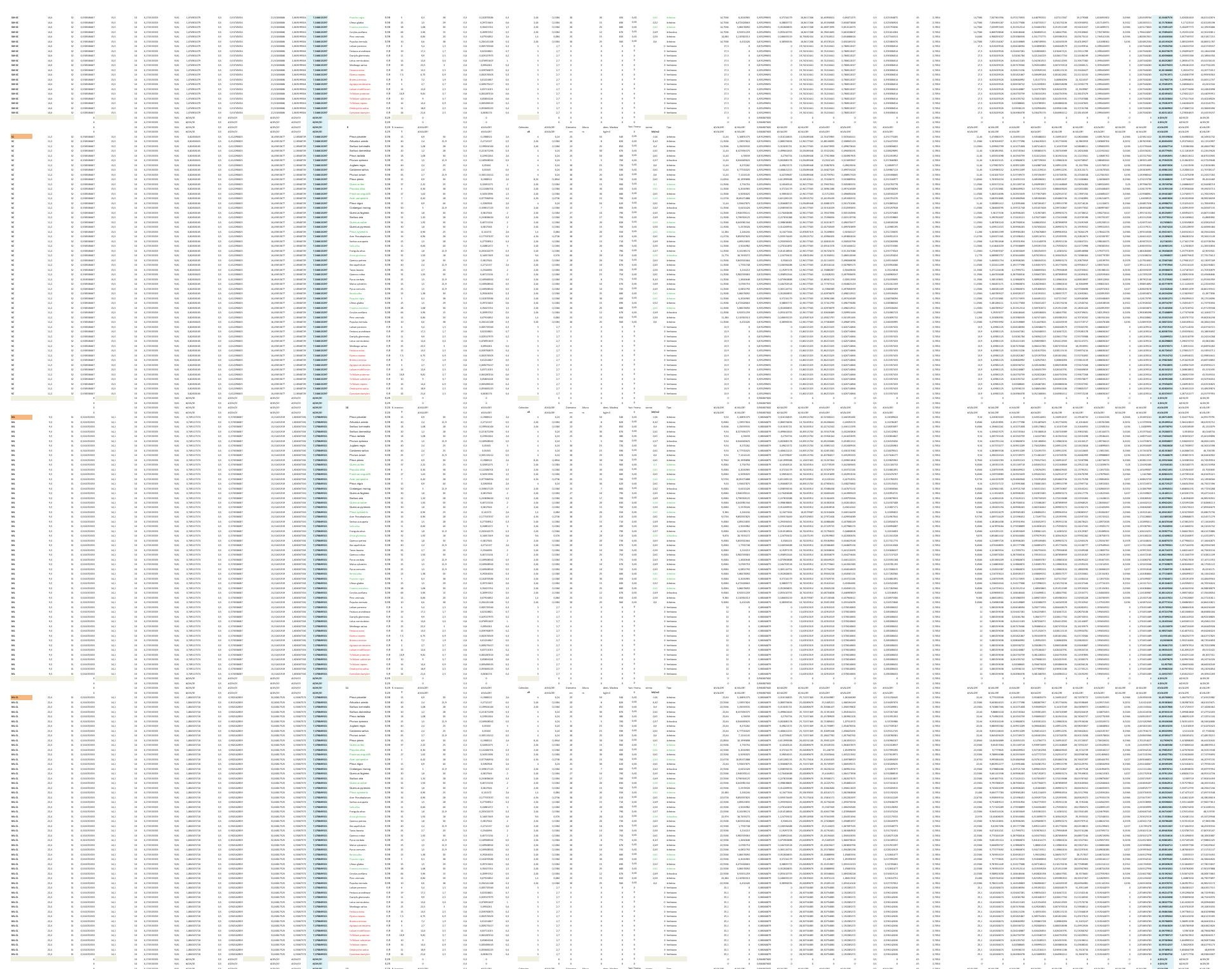

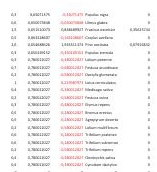
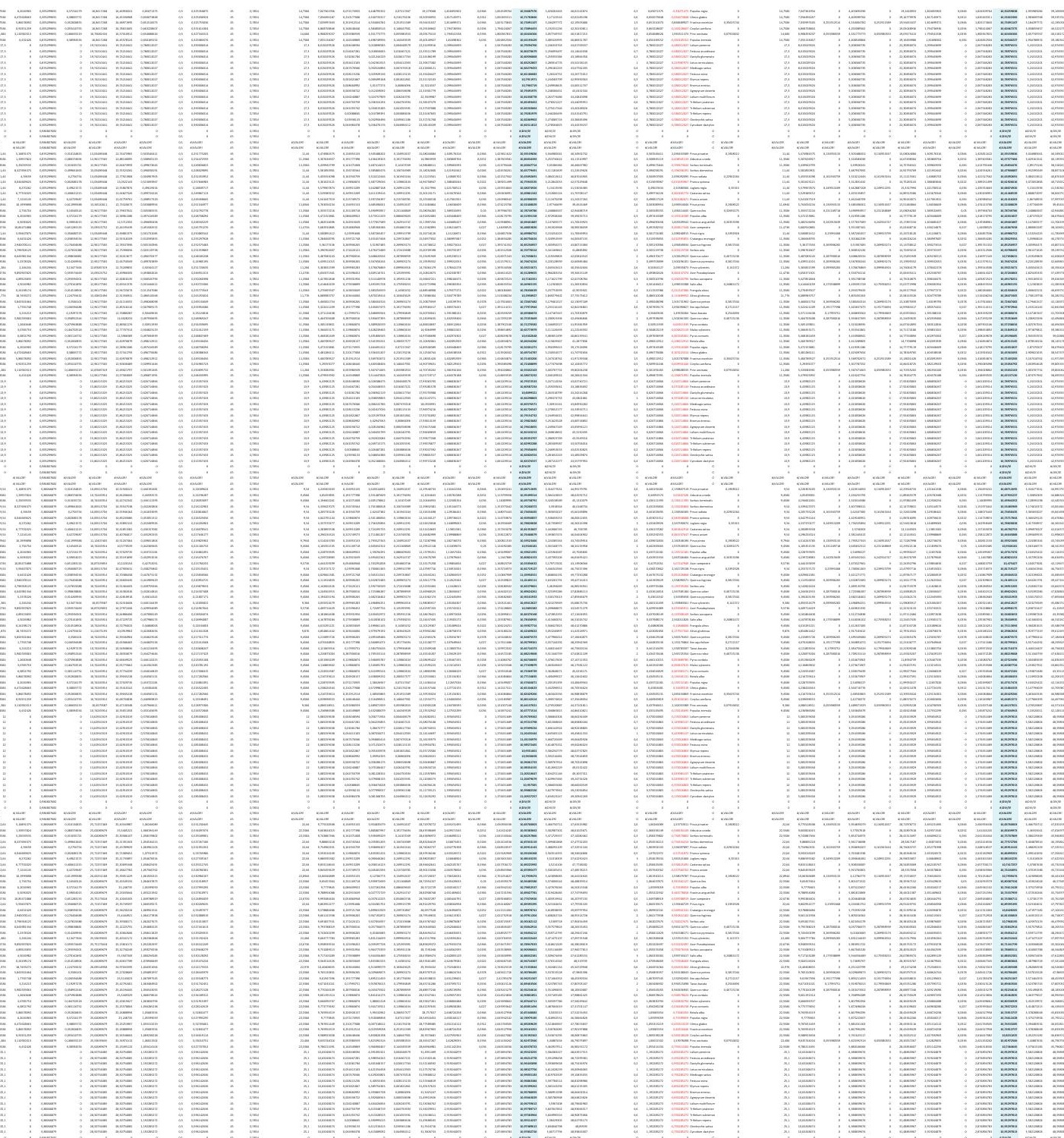

$\equiv \equiv$
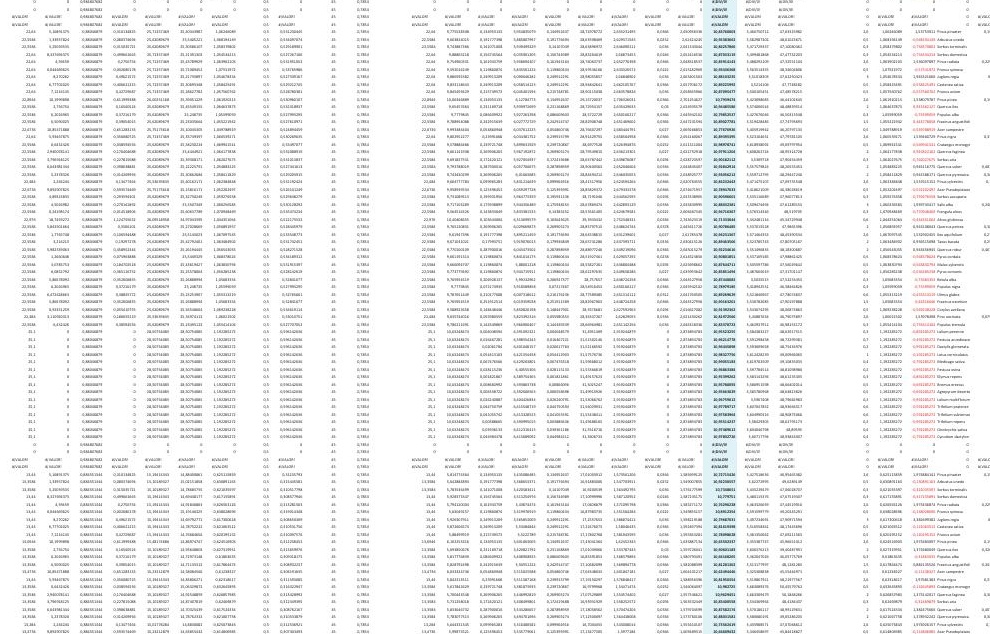

$\sqrt{E^{E}}=$

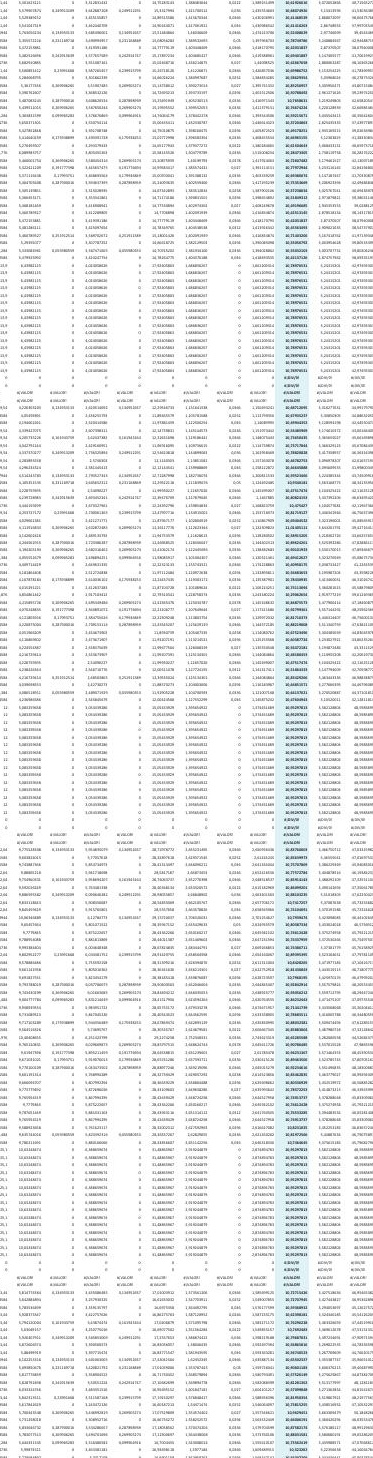




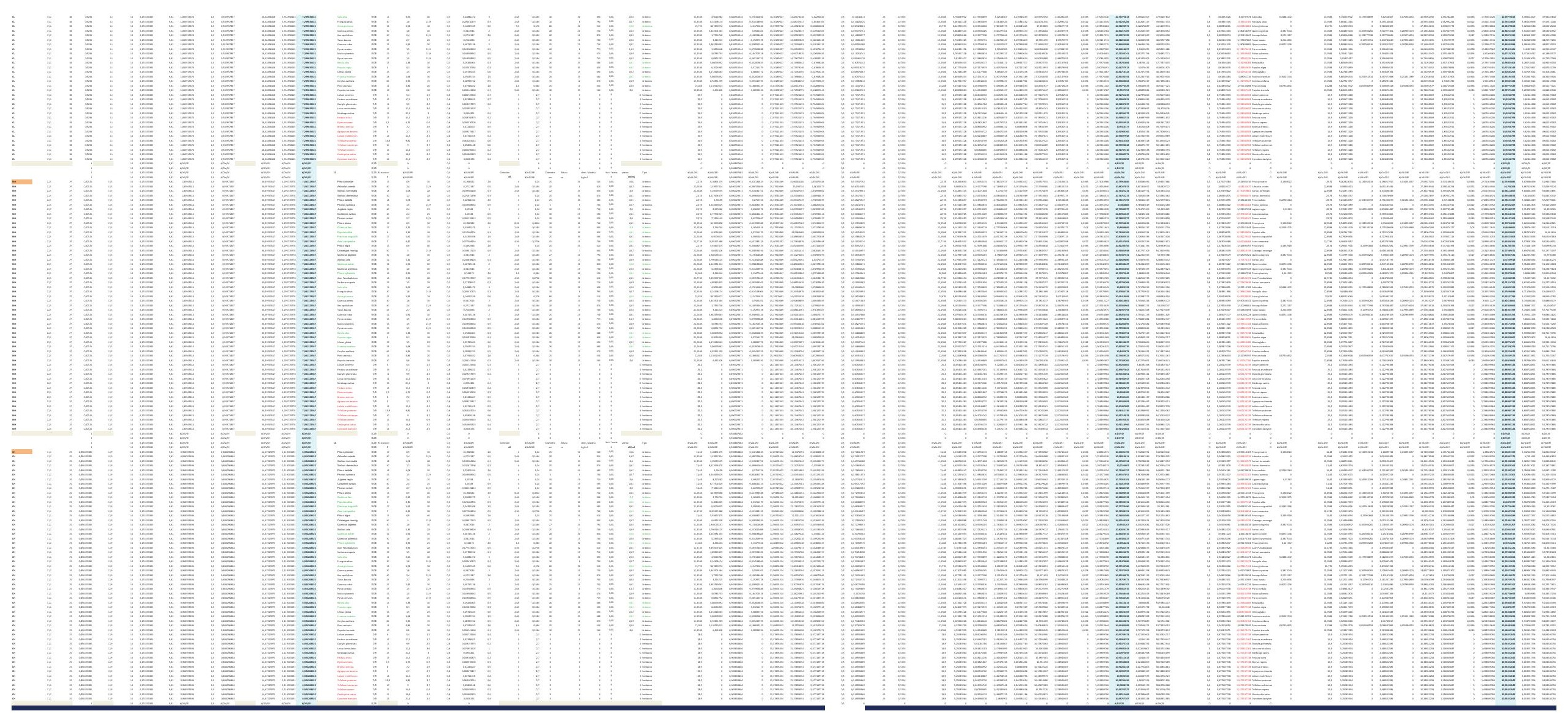



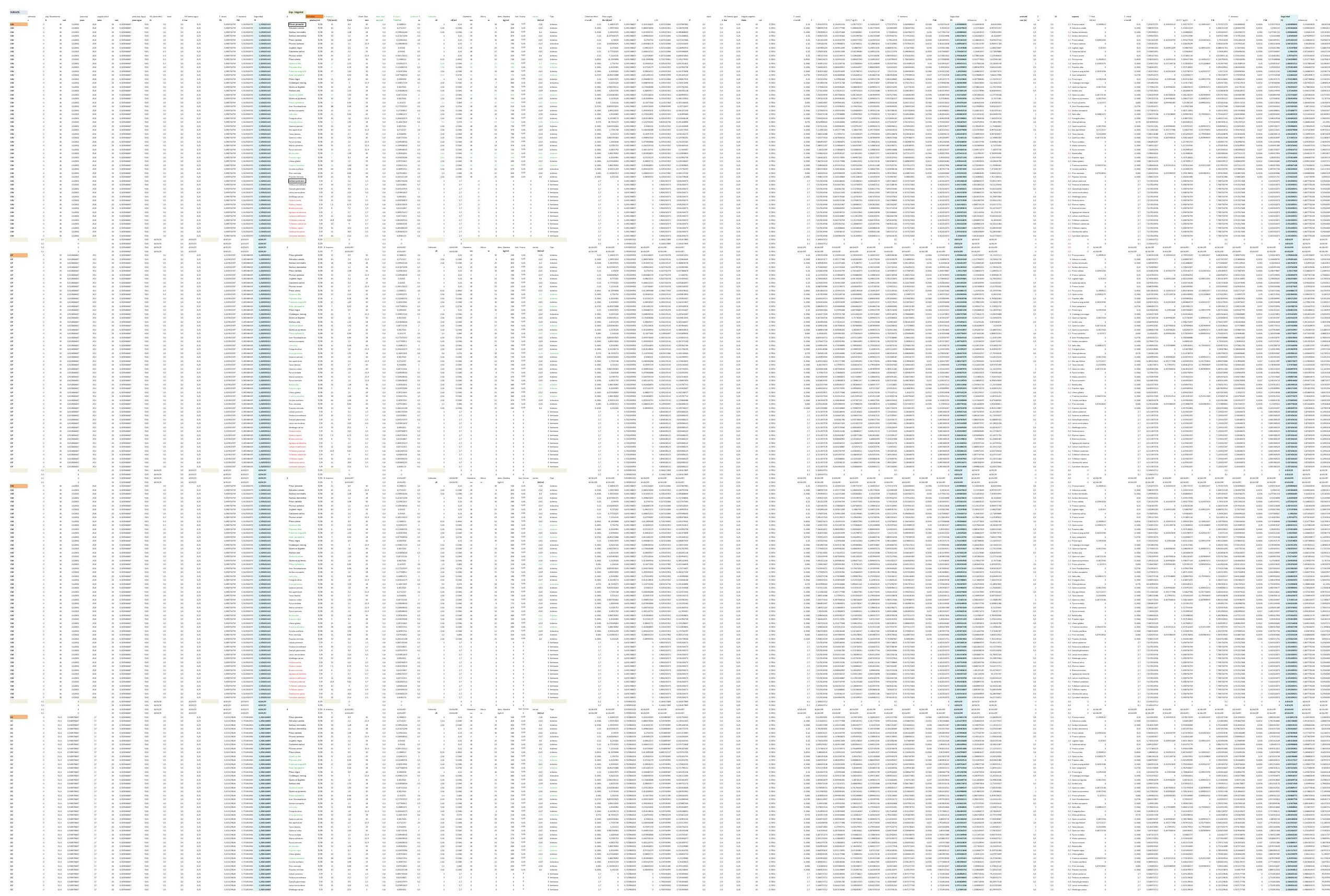

准

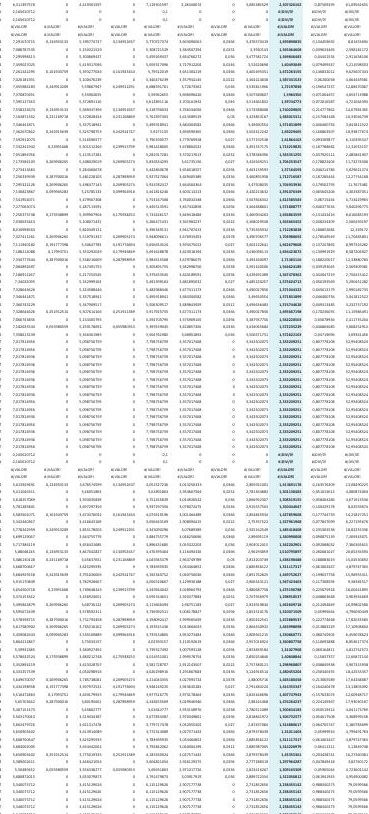




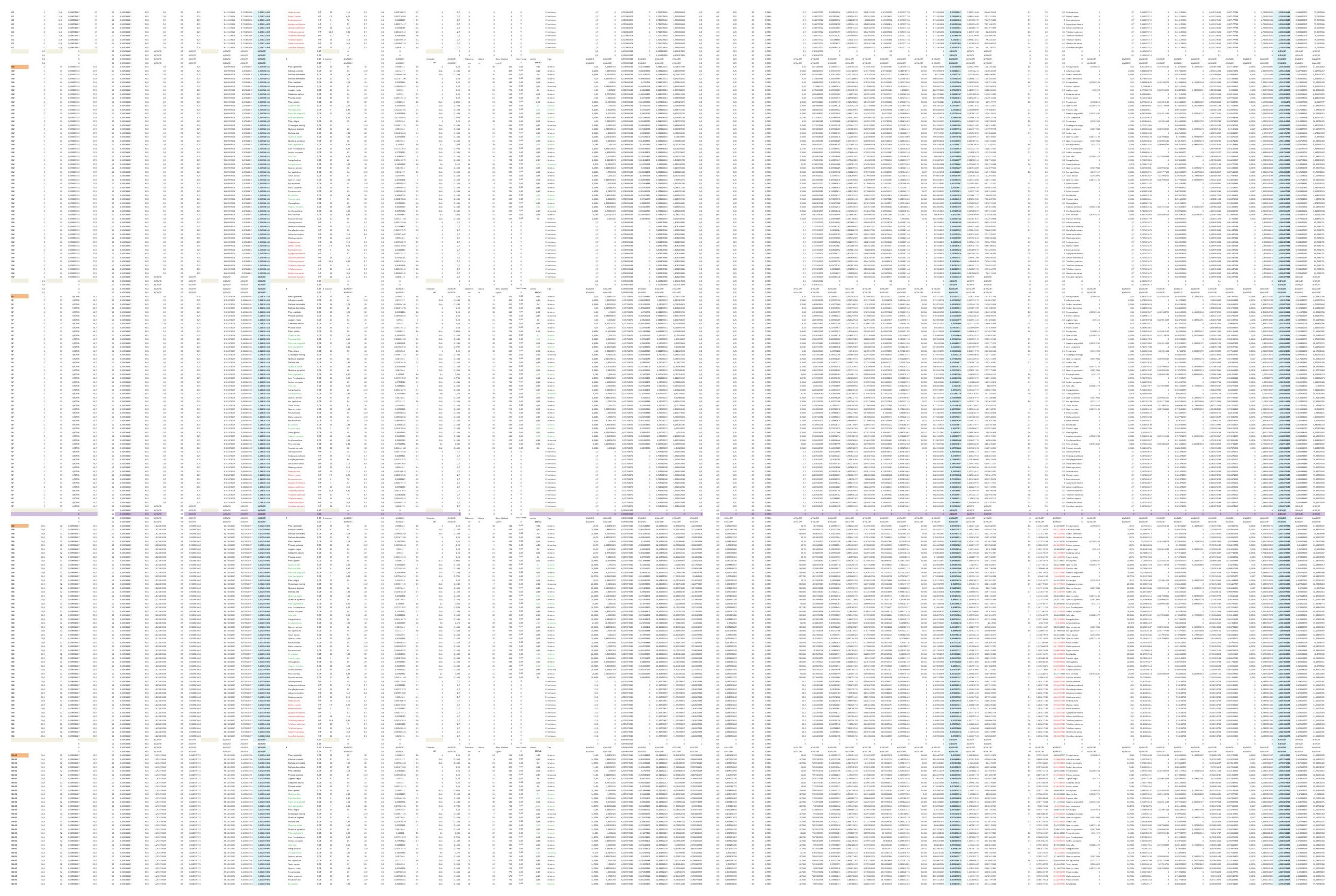



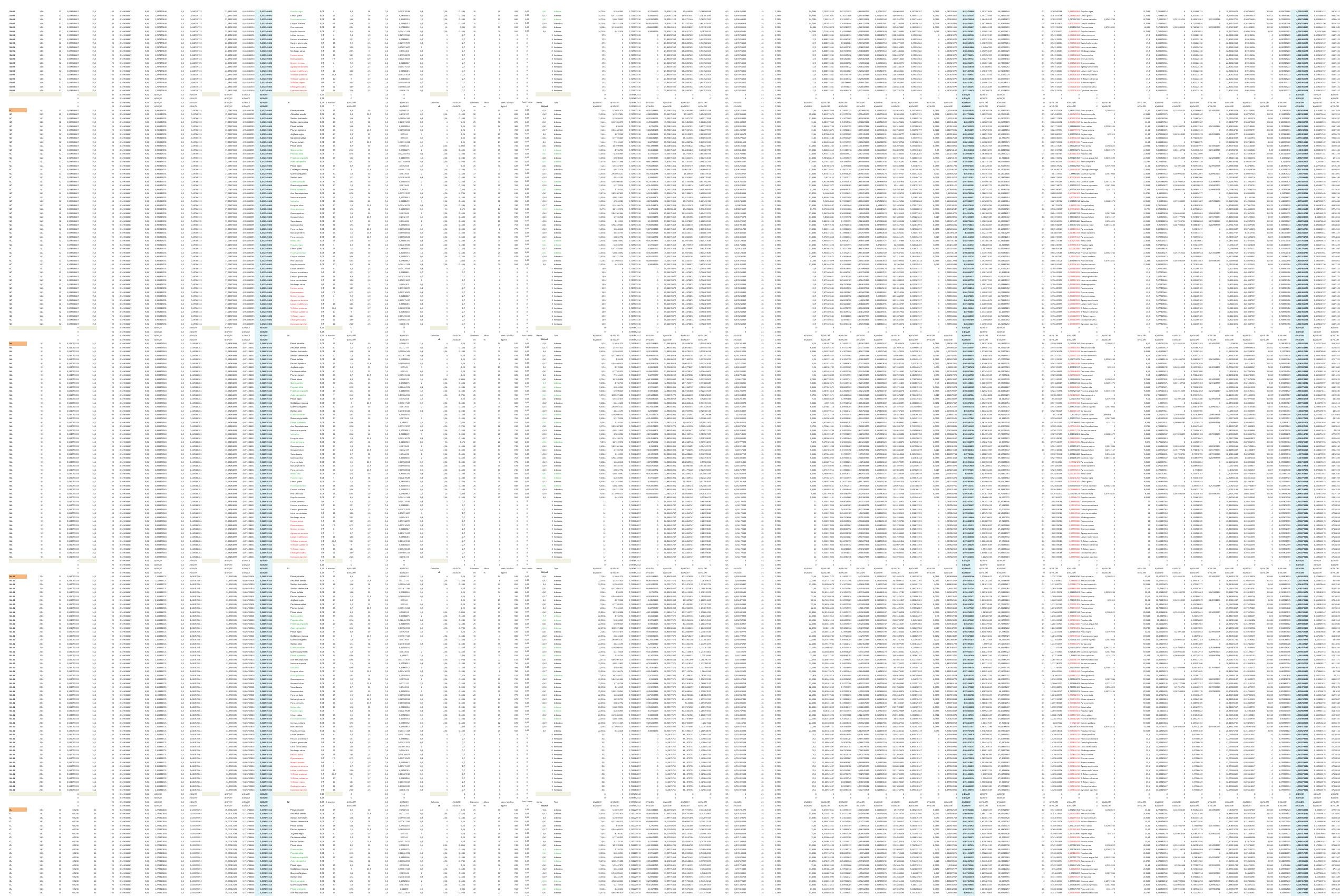

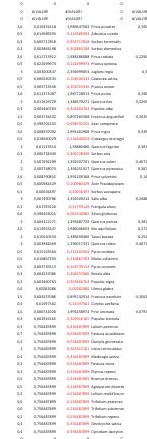
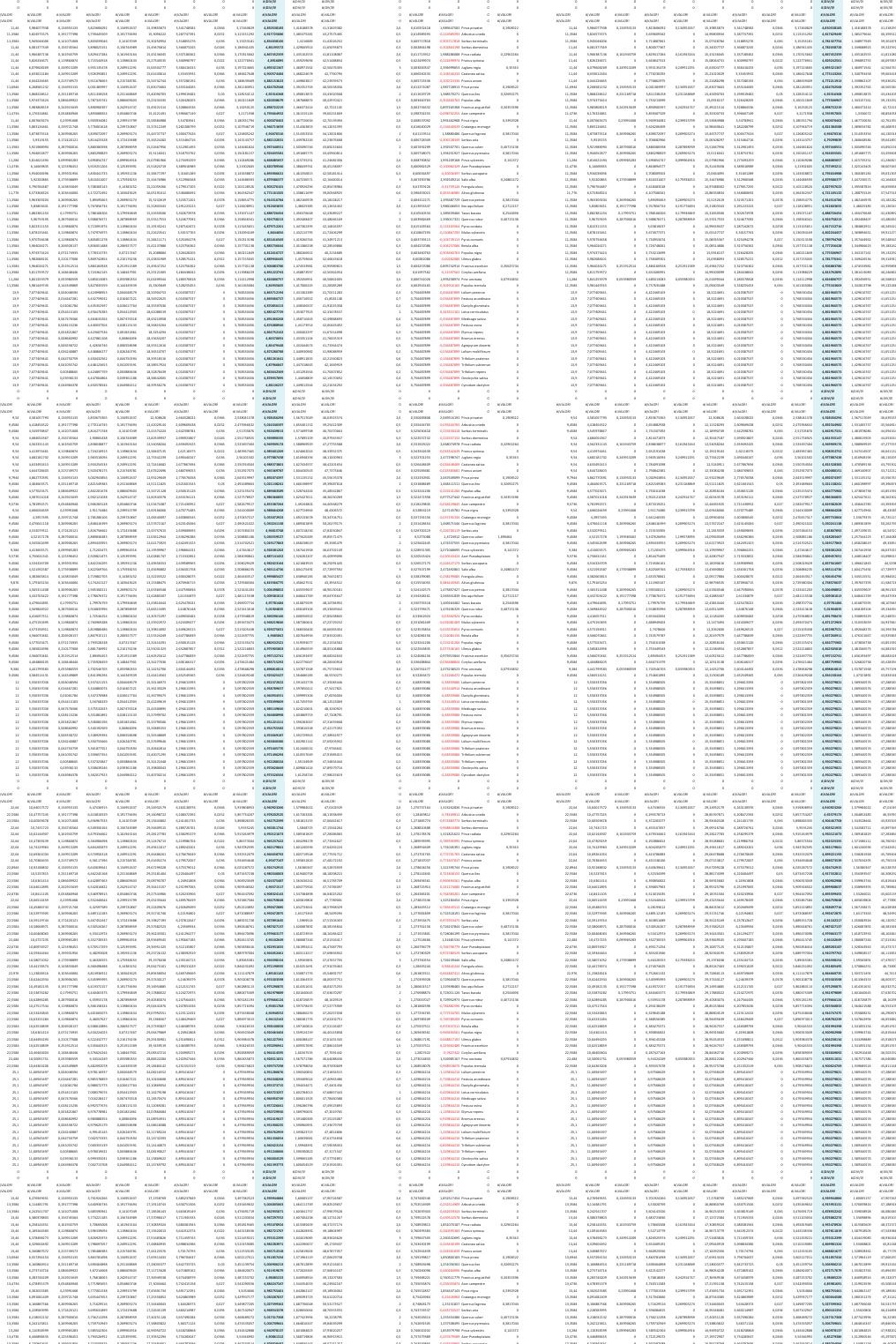

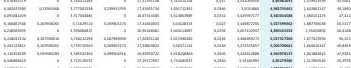




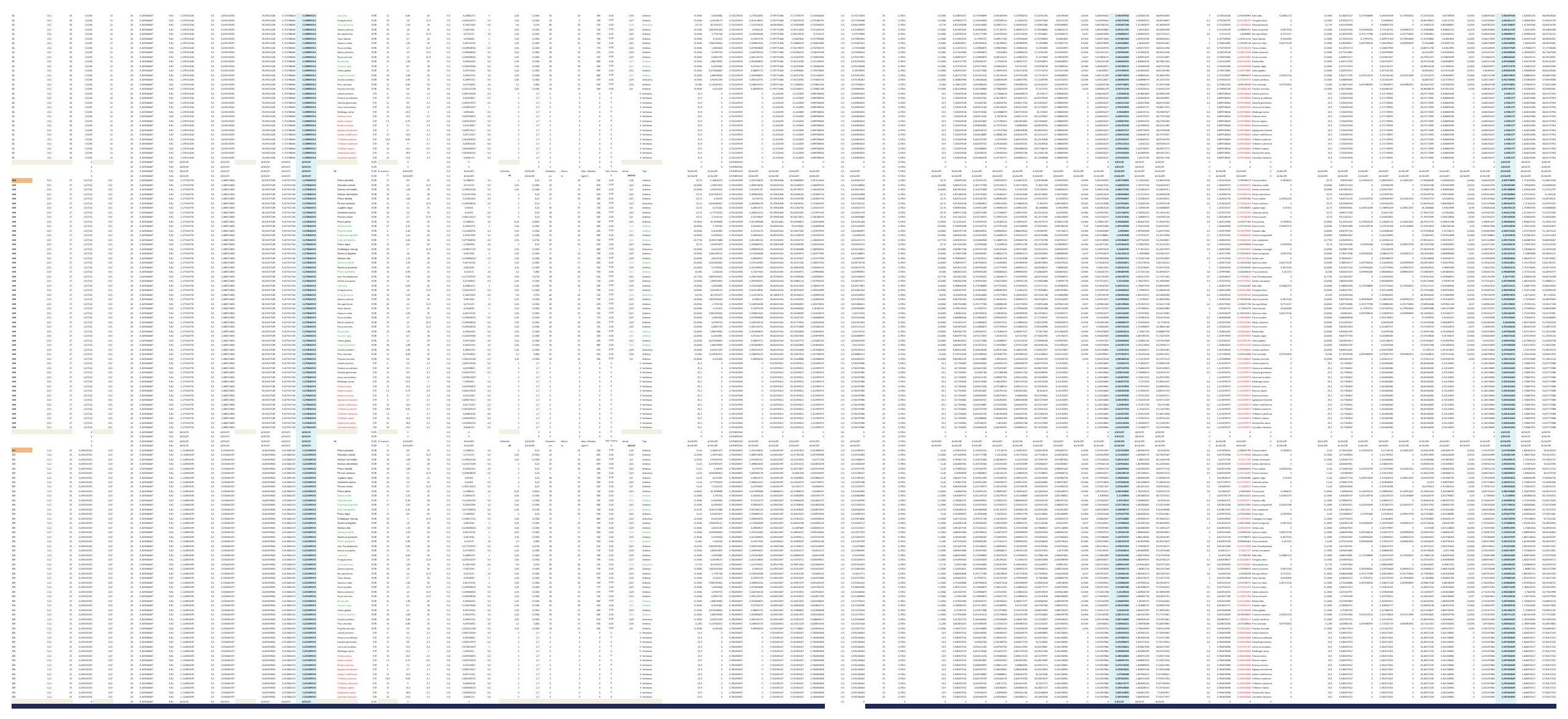



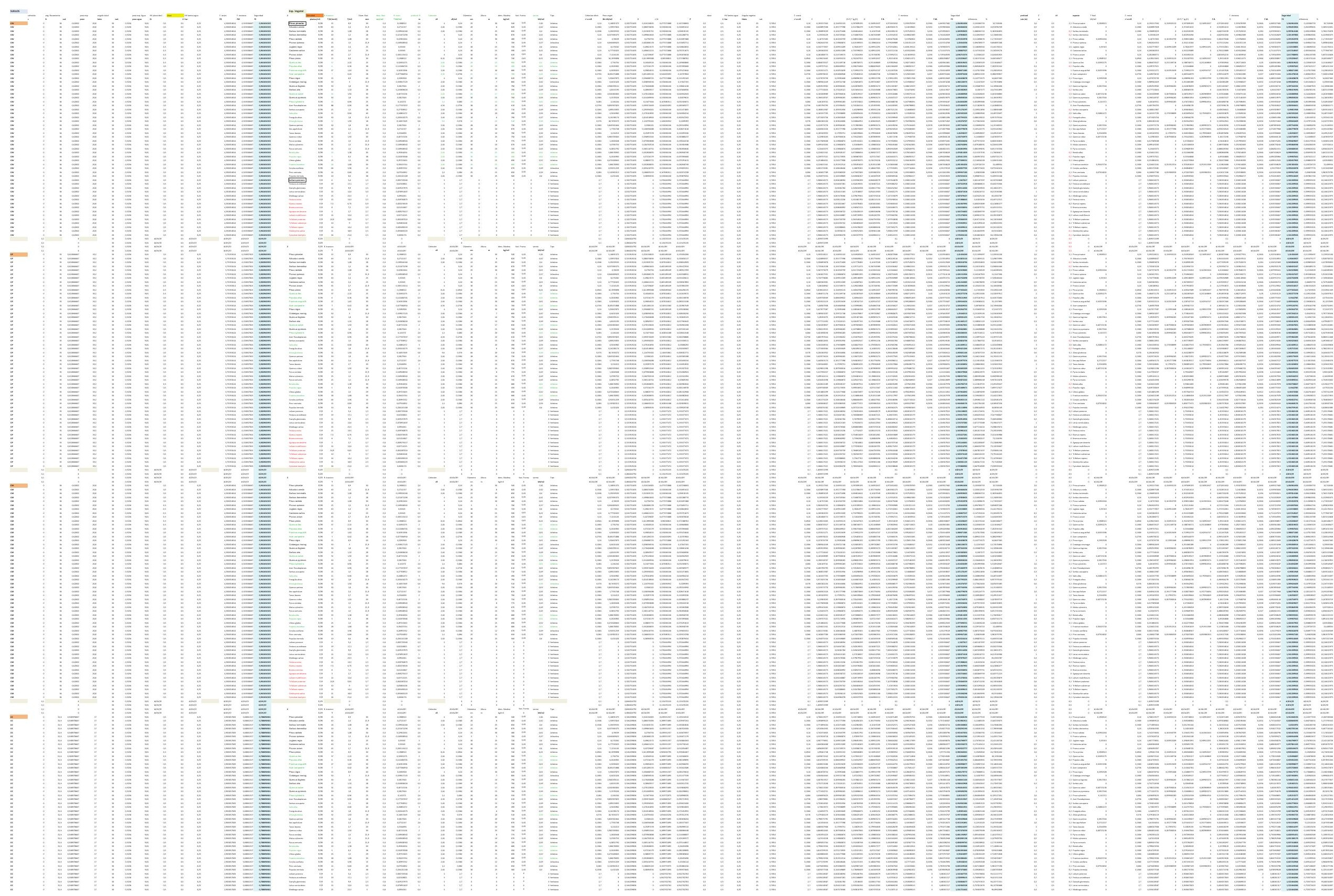


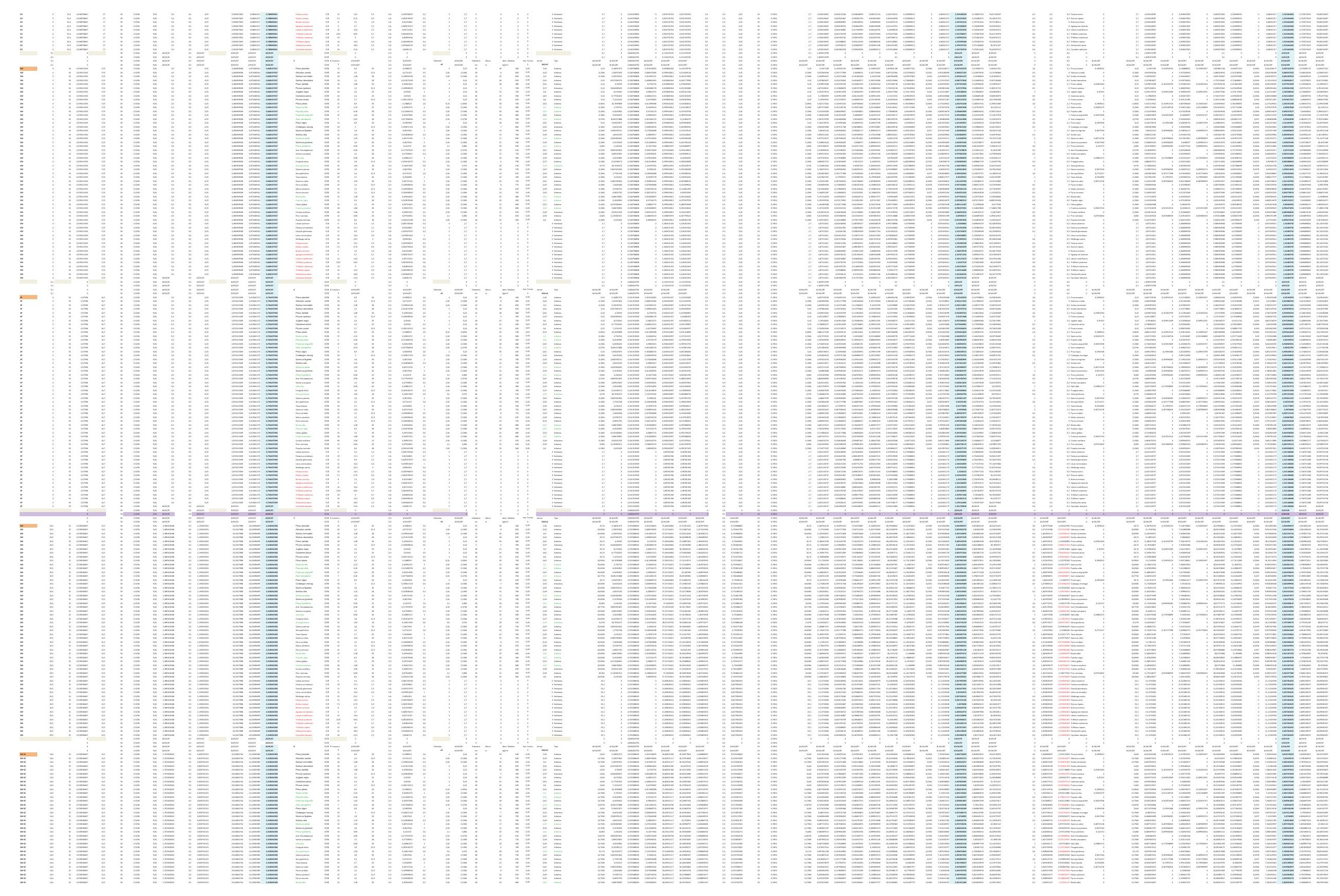



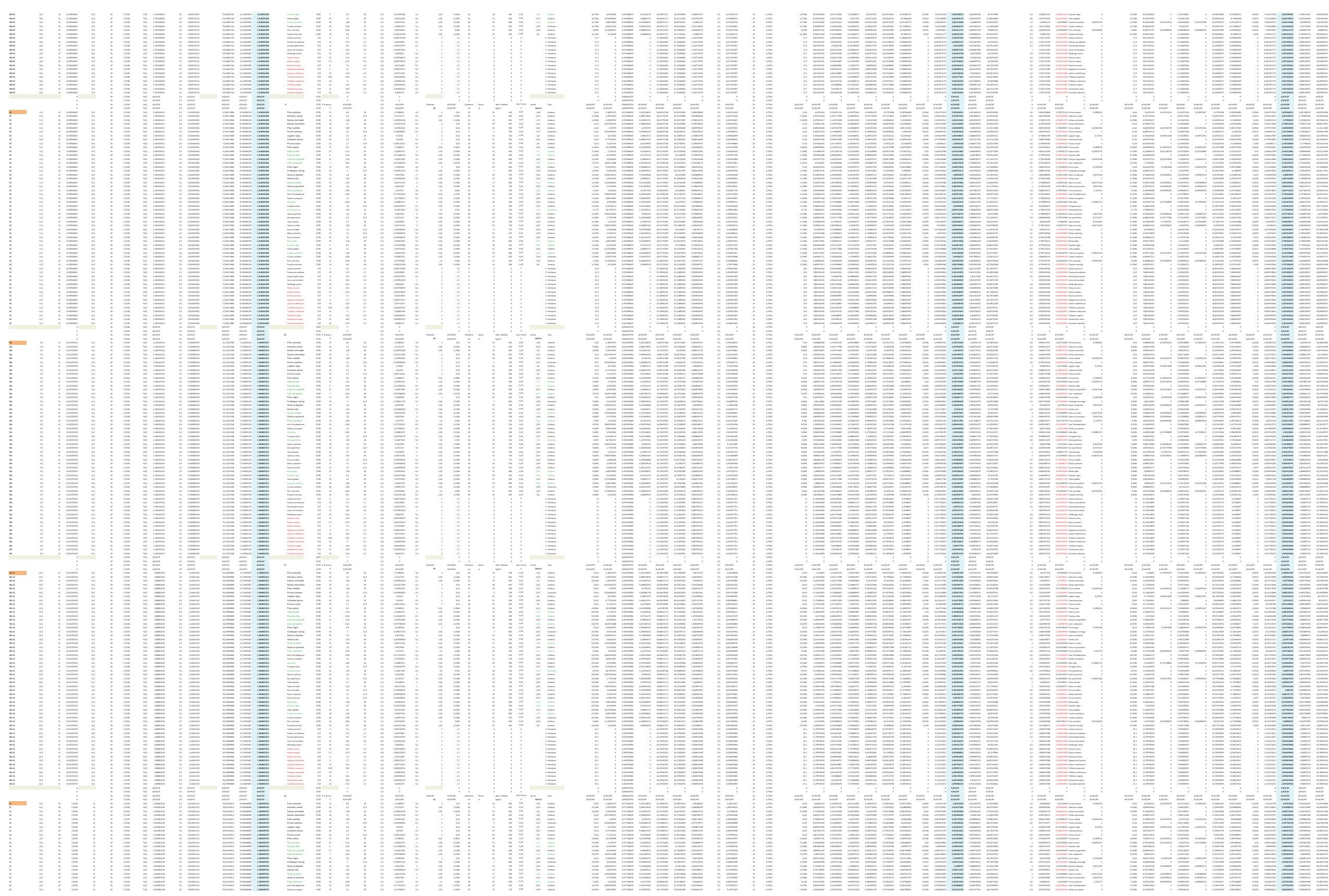

,
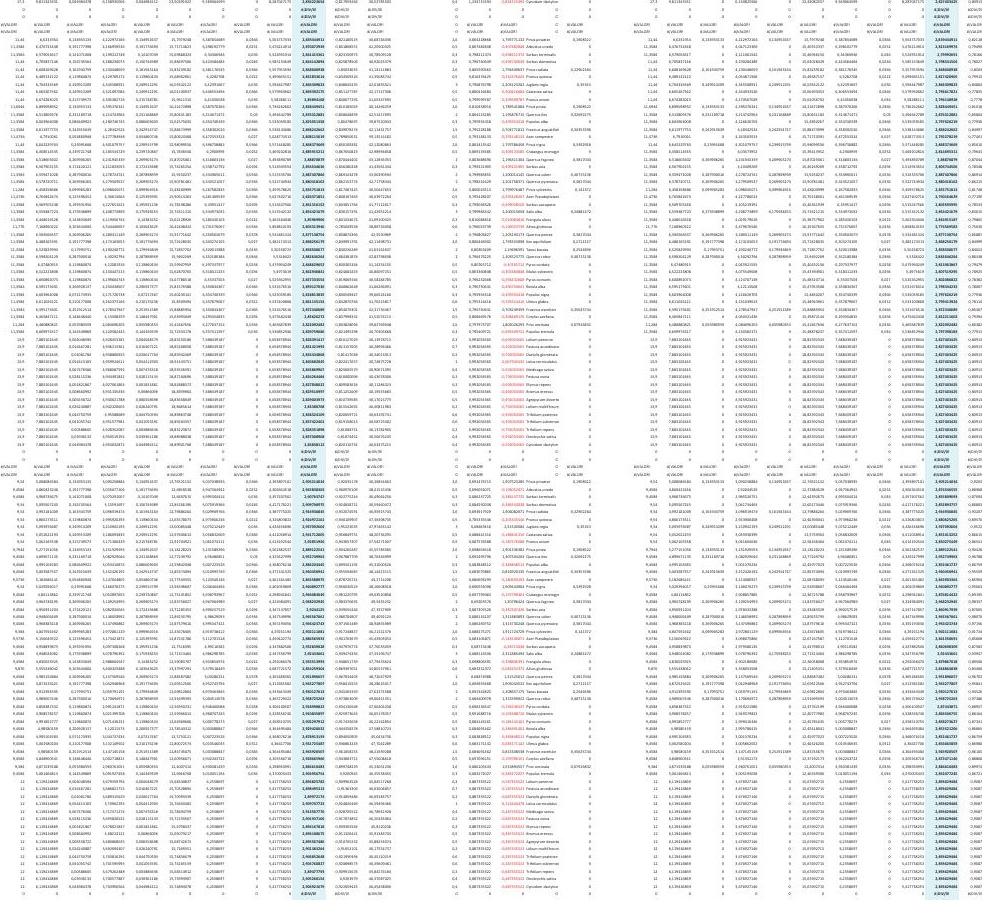

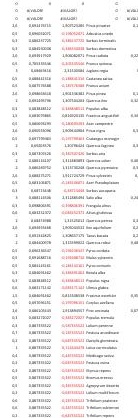
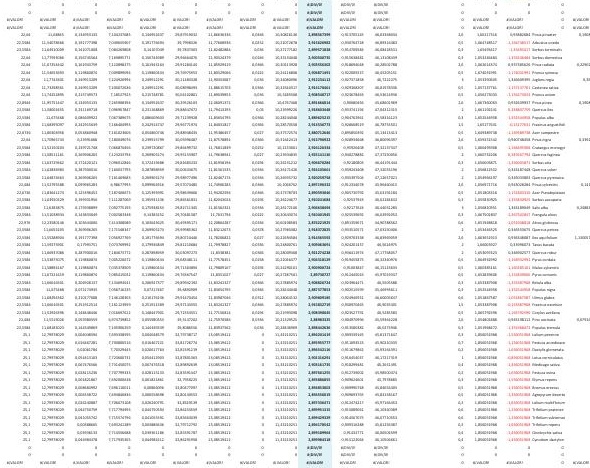

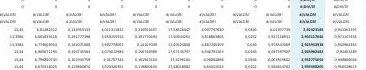

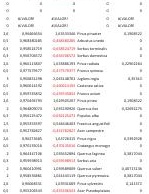

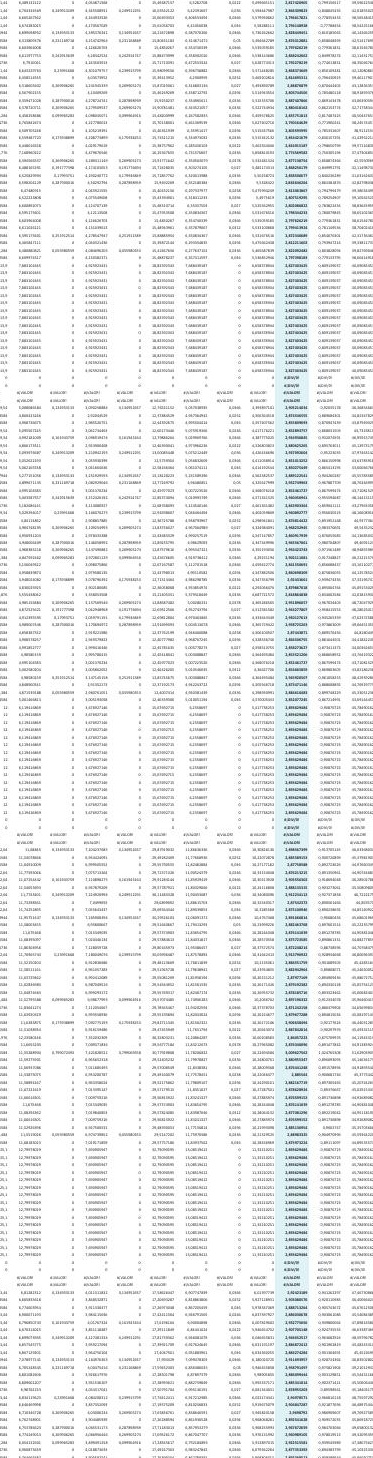




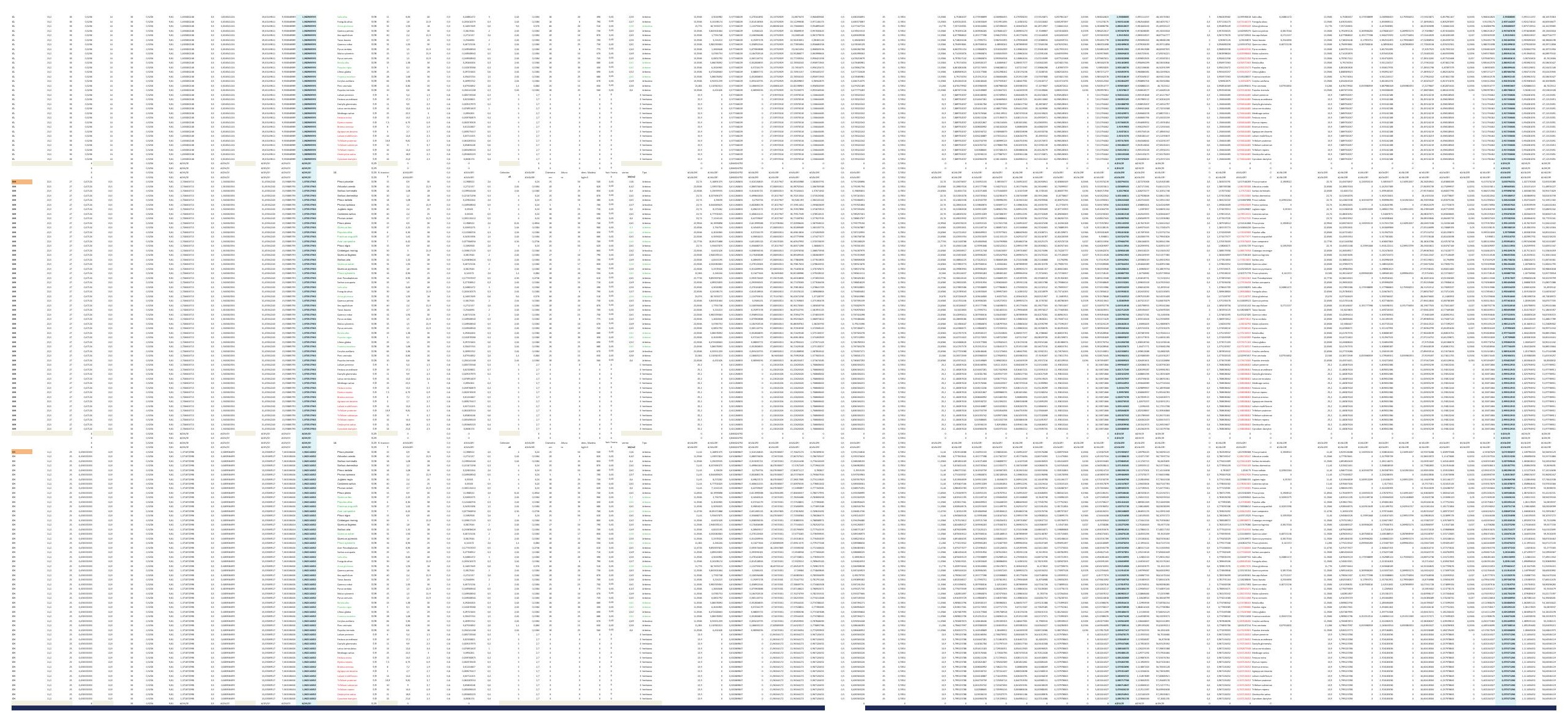



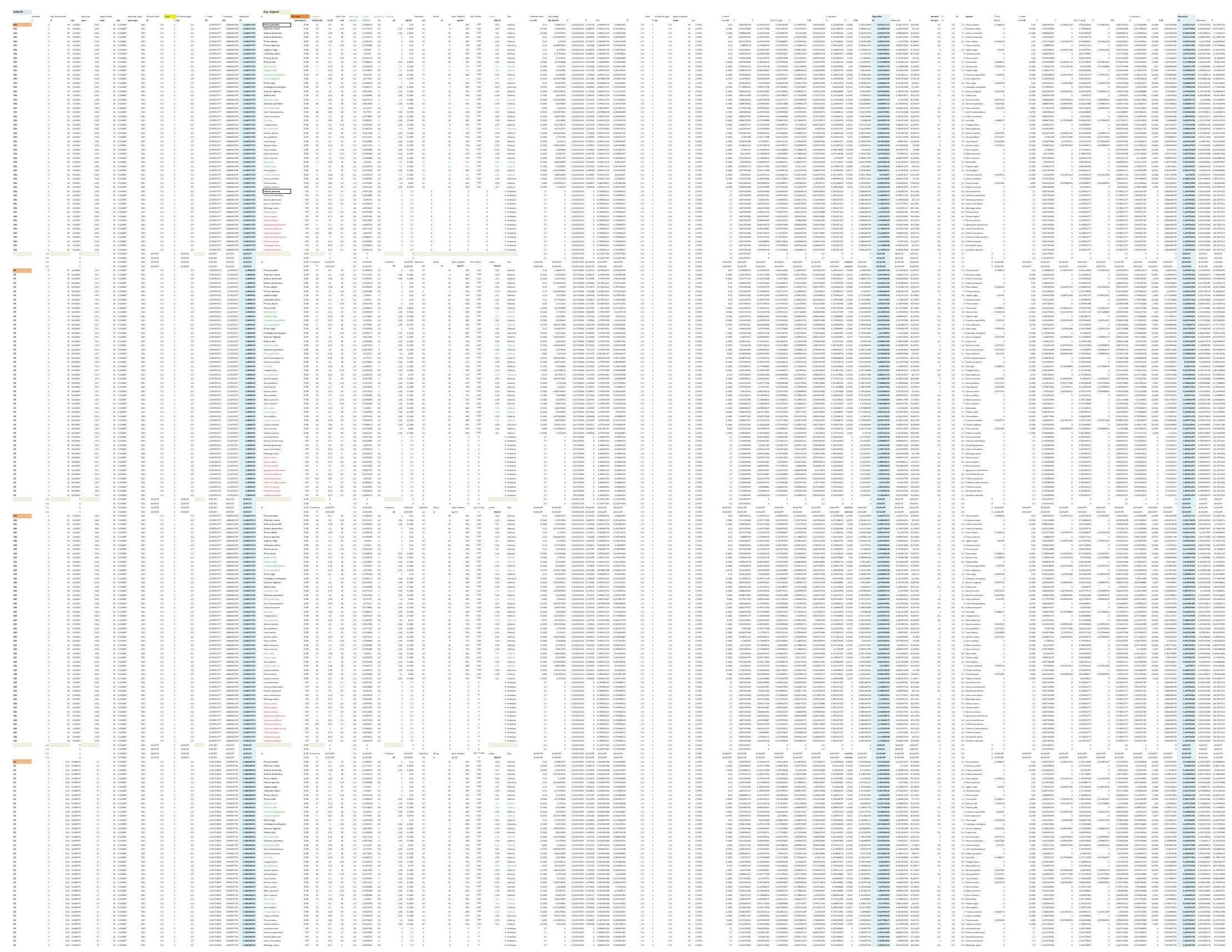


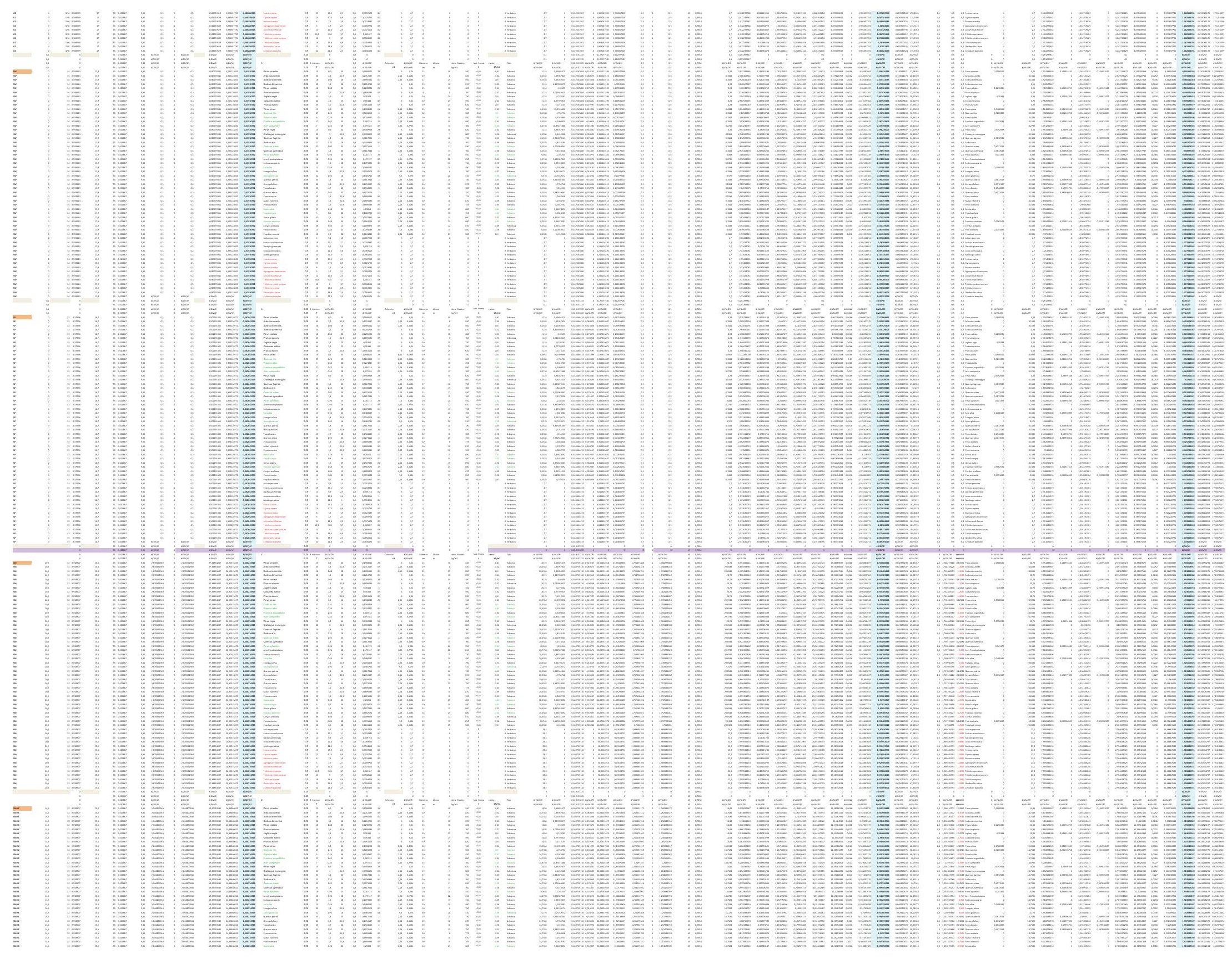



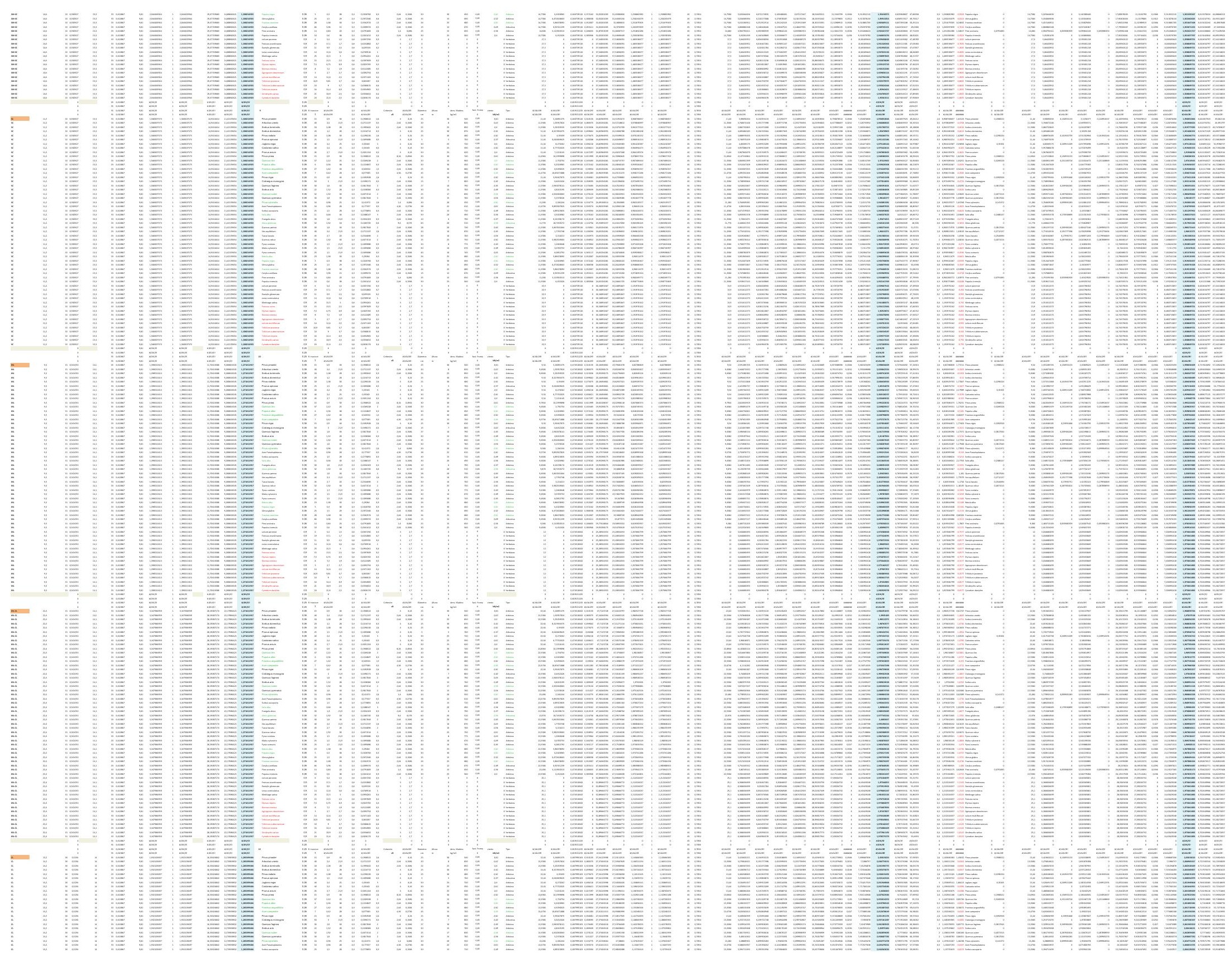

$-$
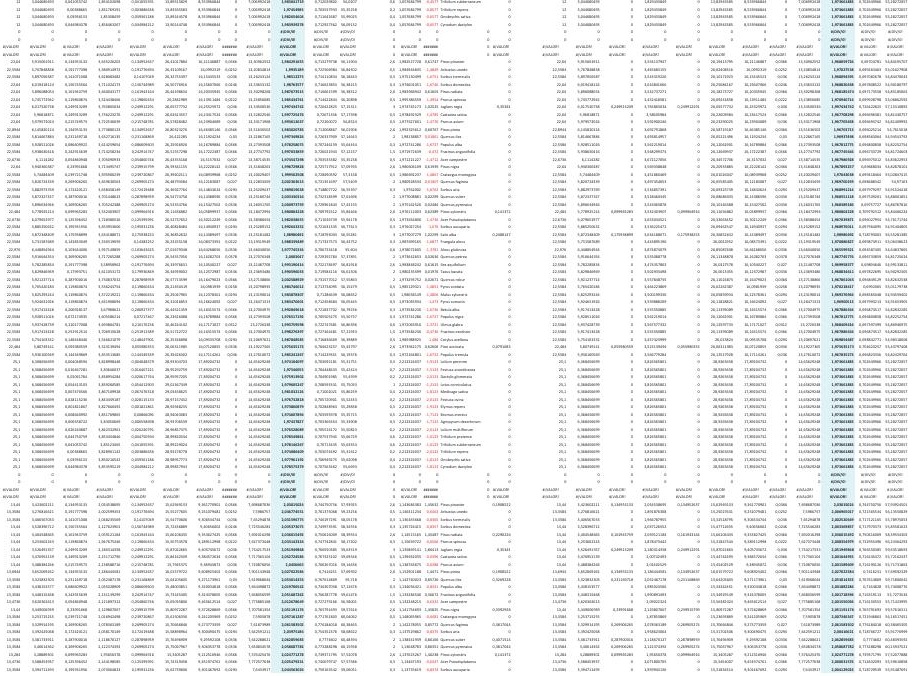


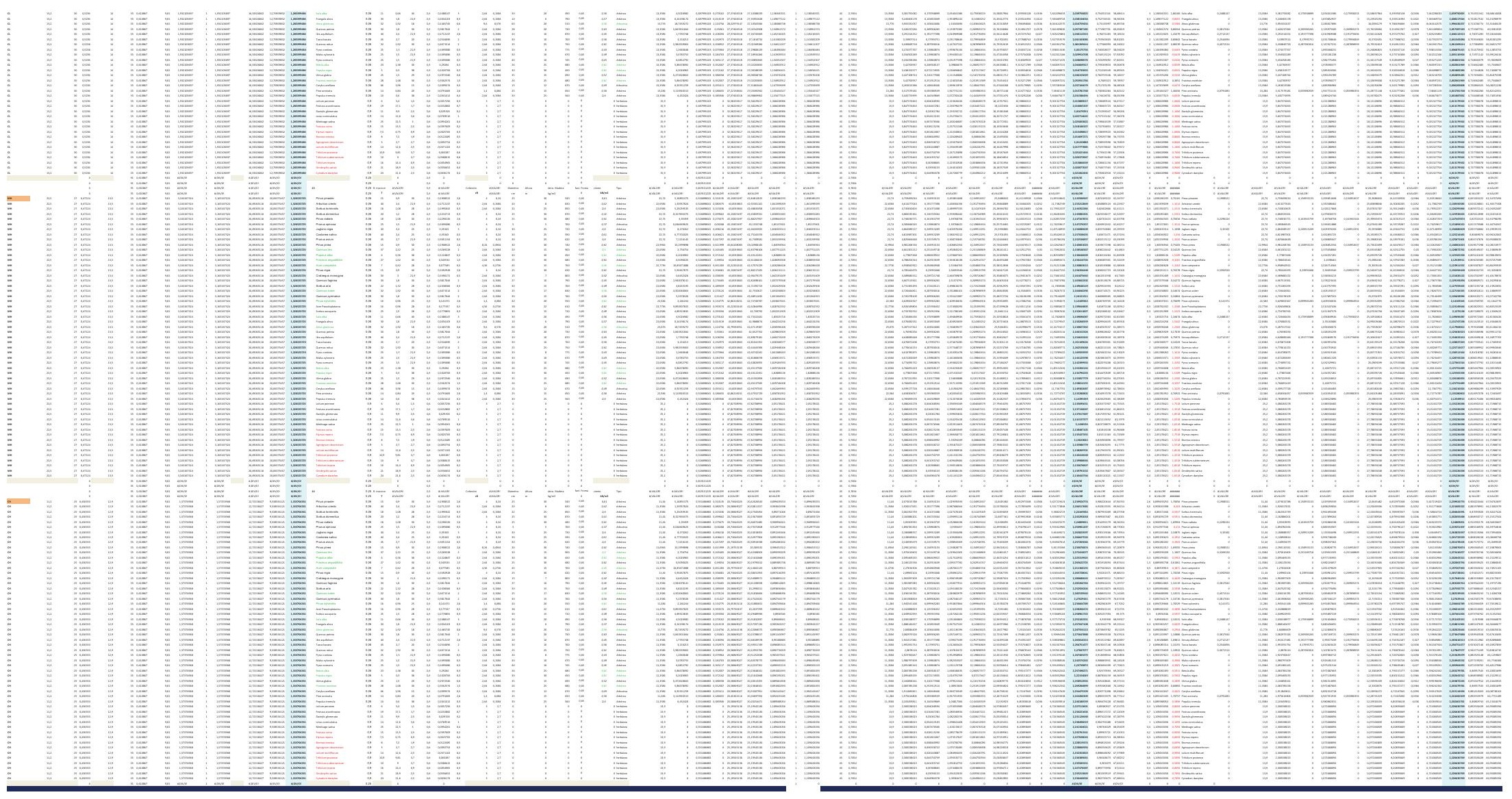



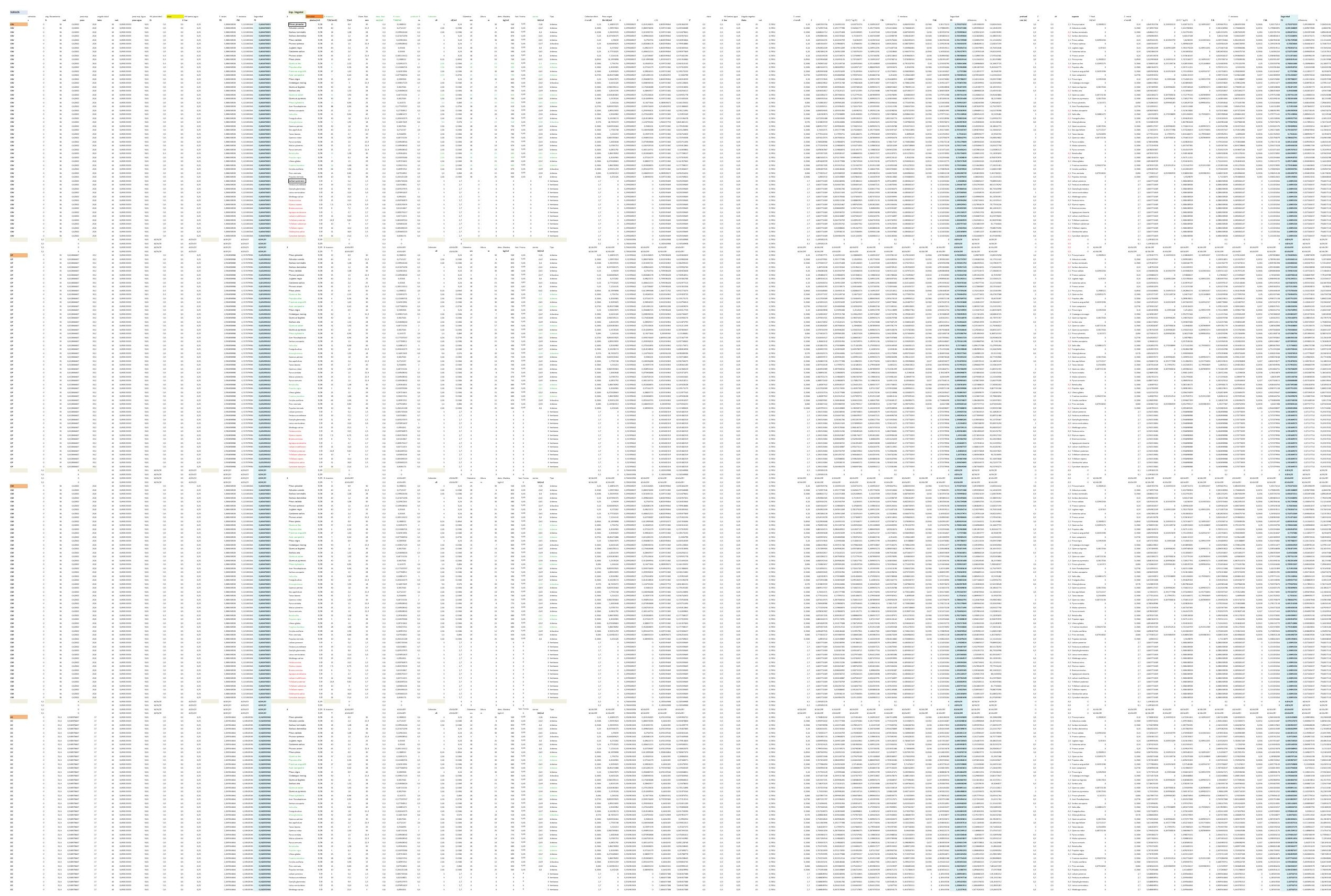


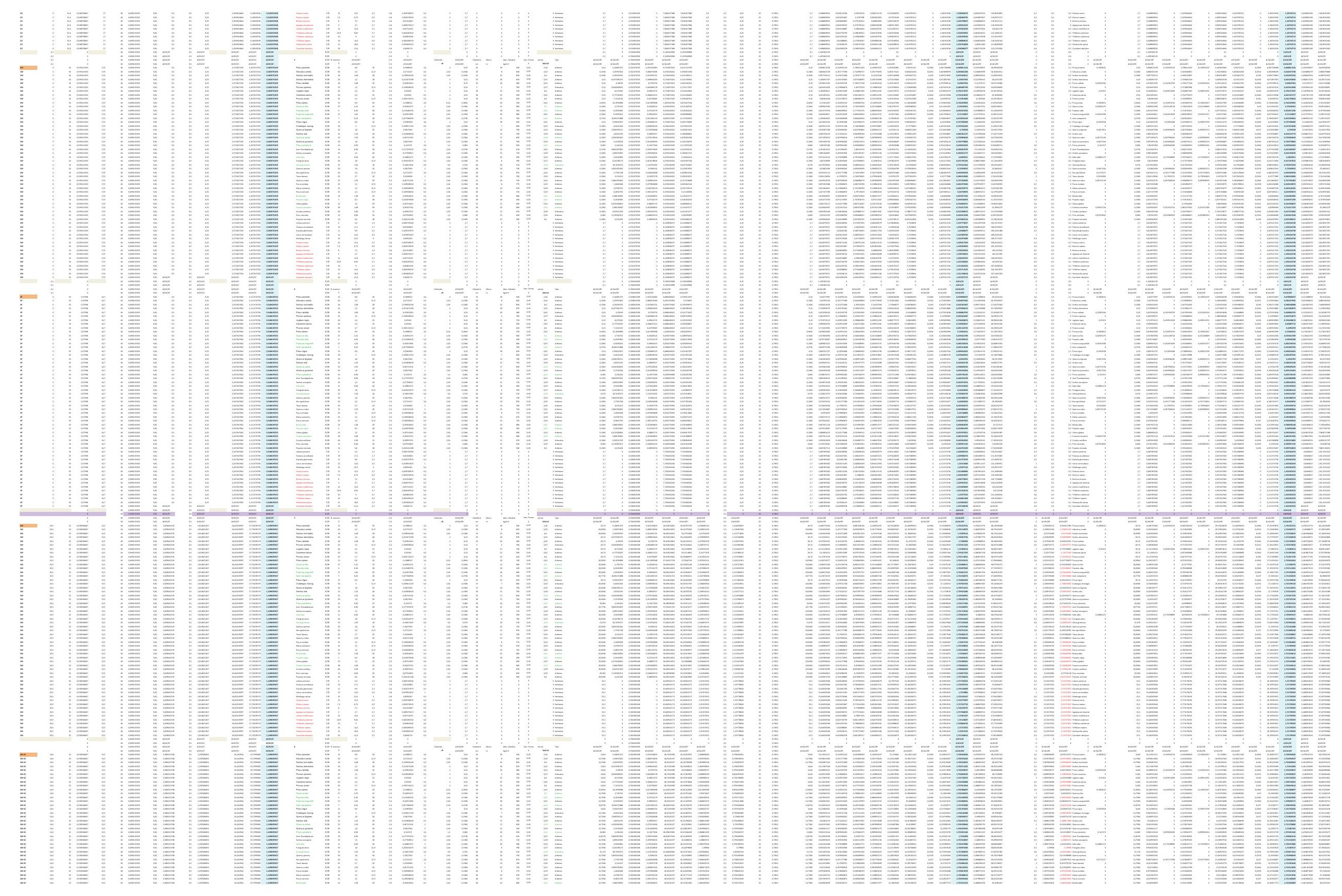



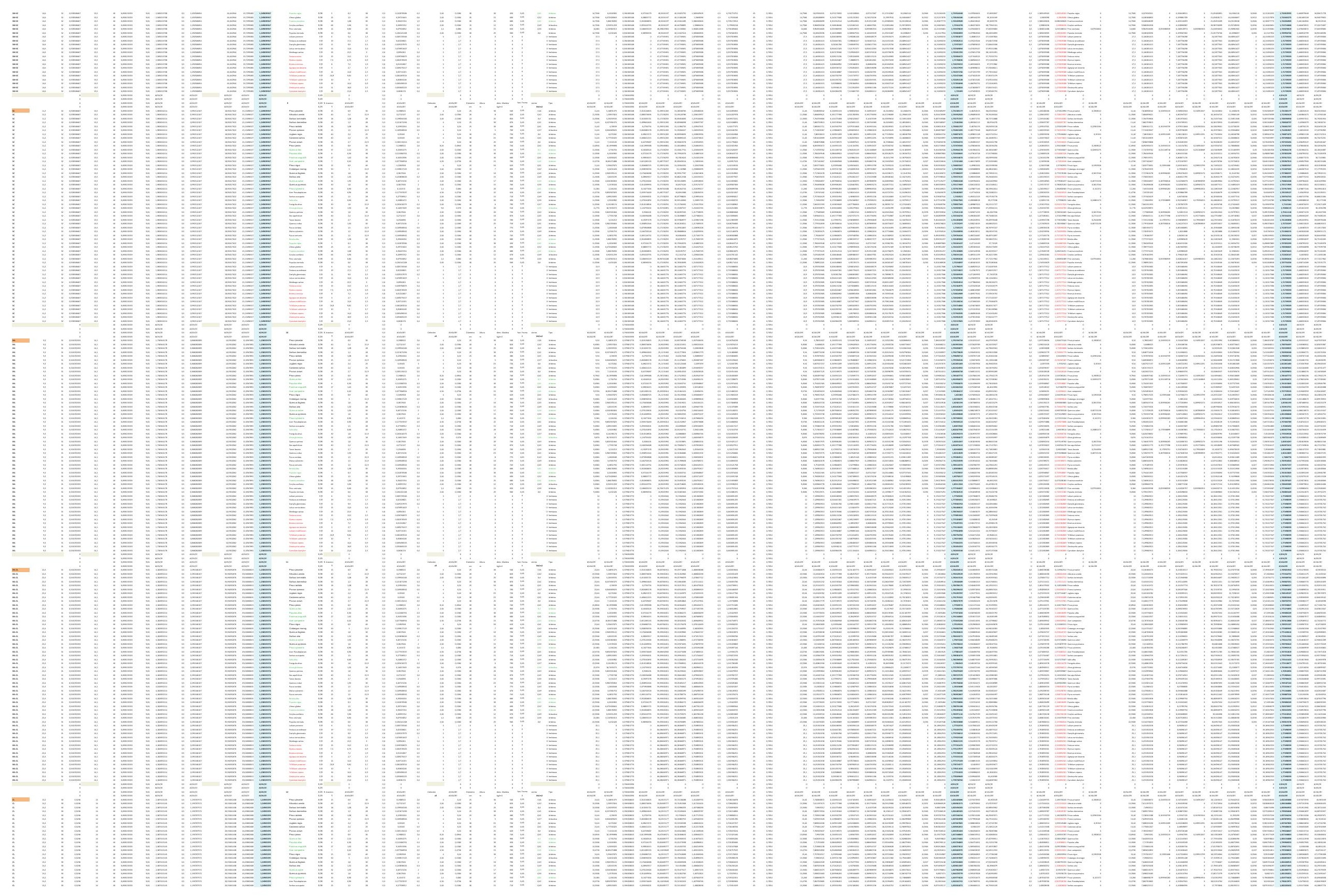


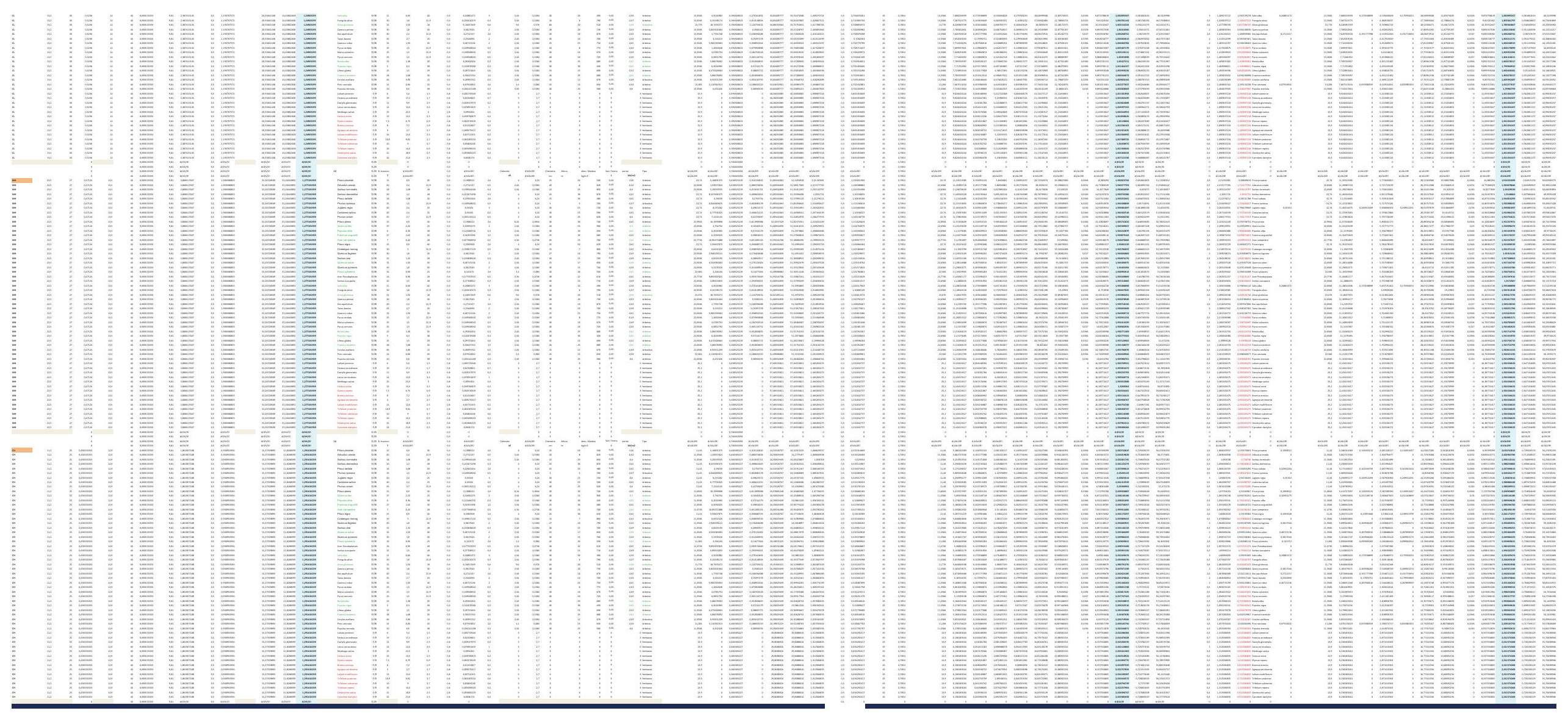



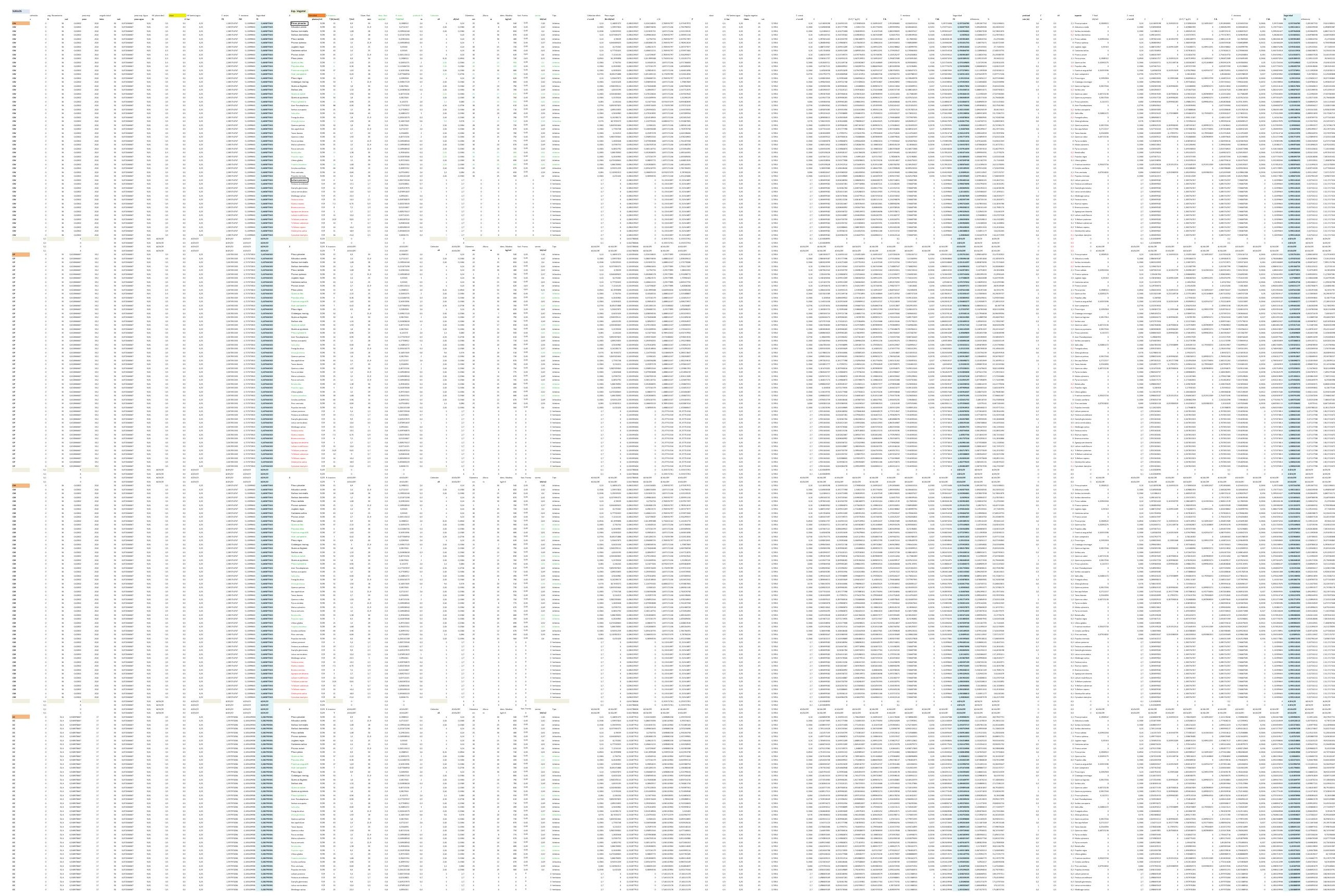


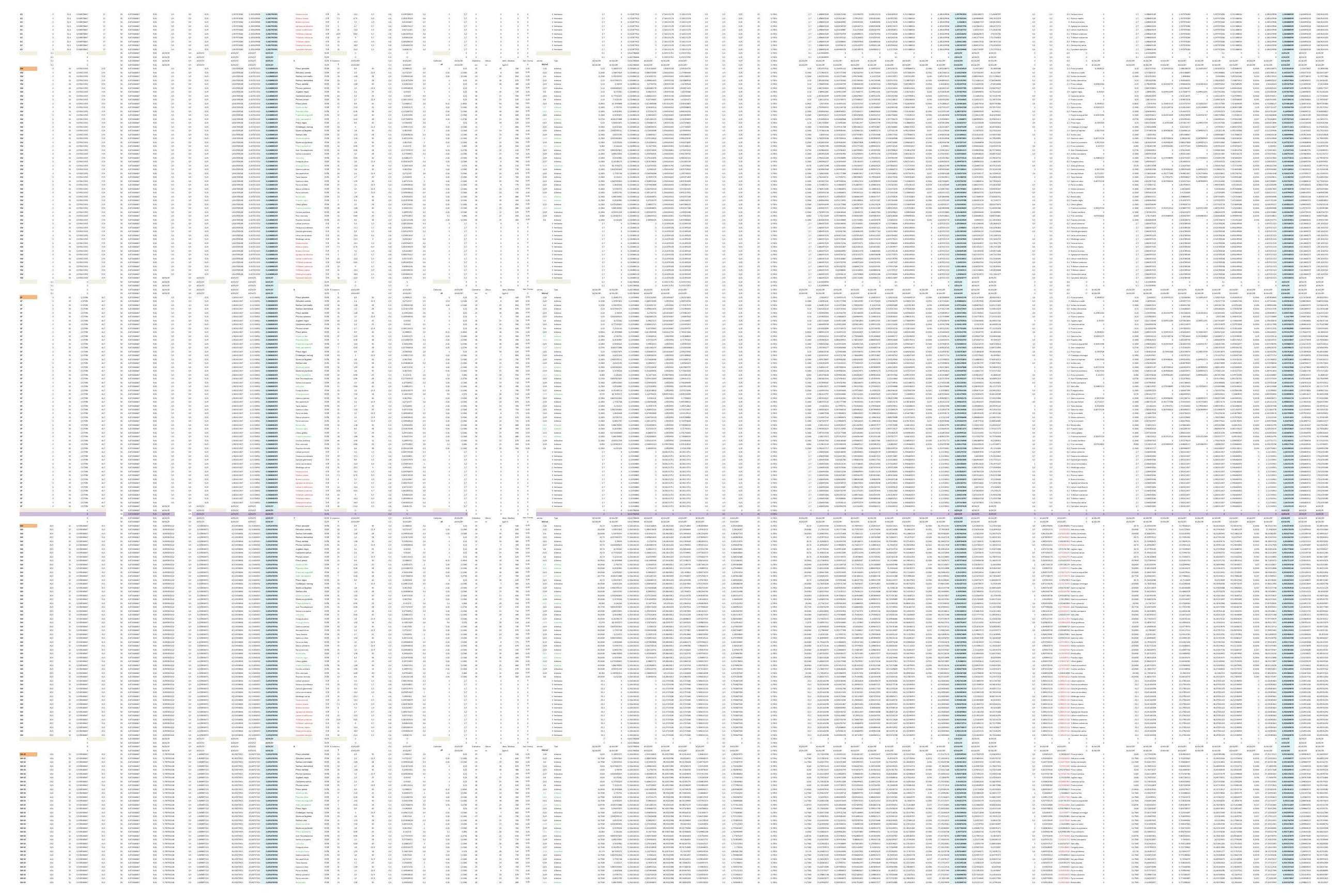



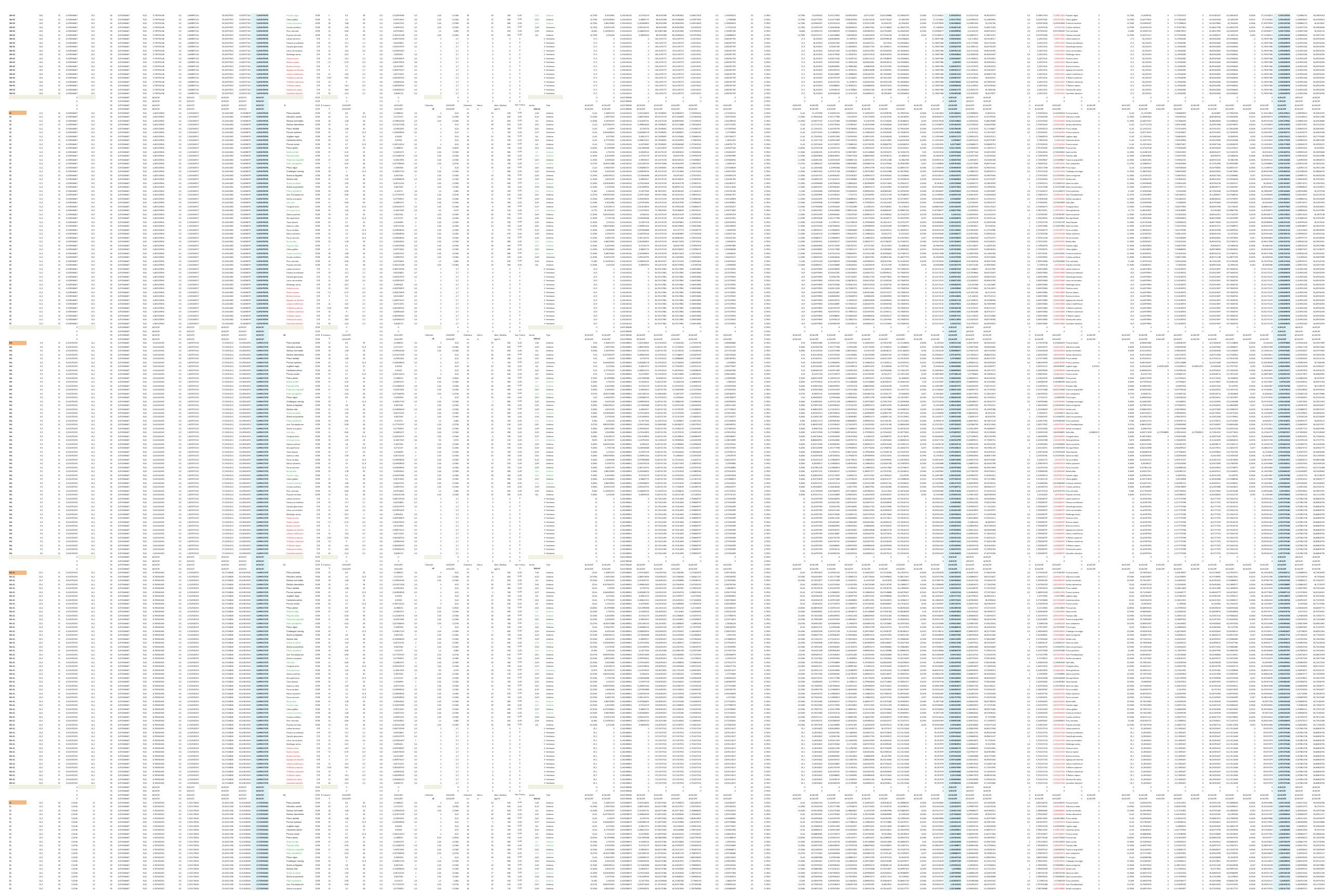


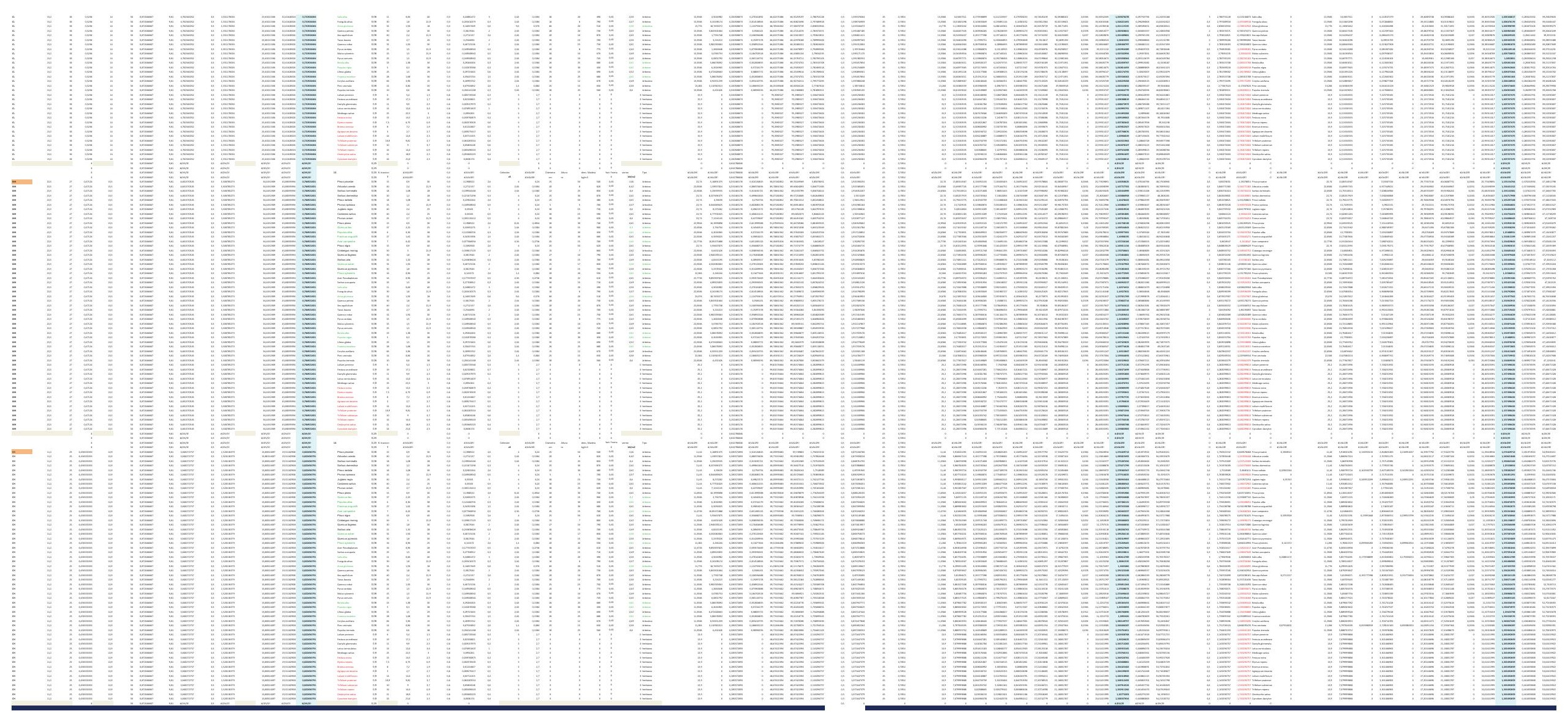



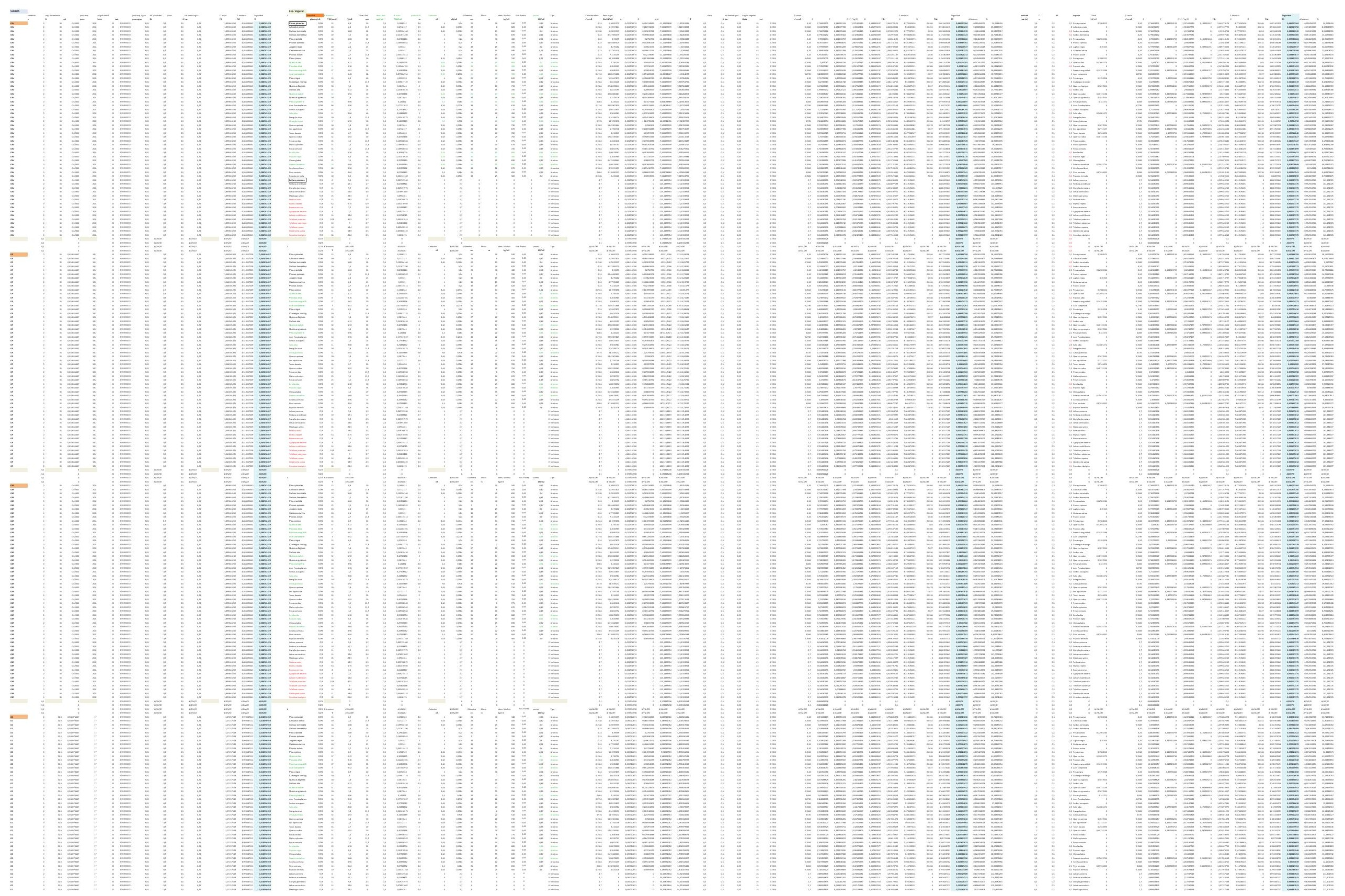


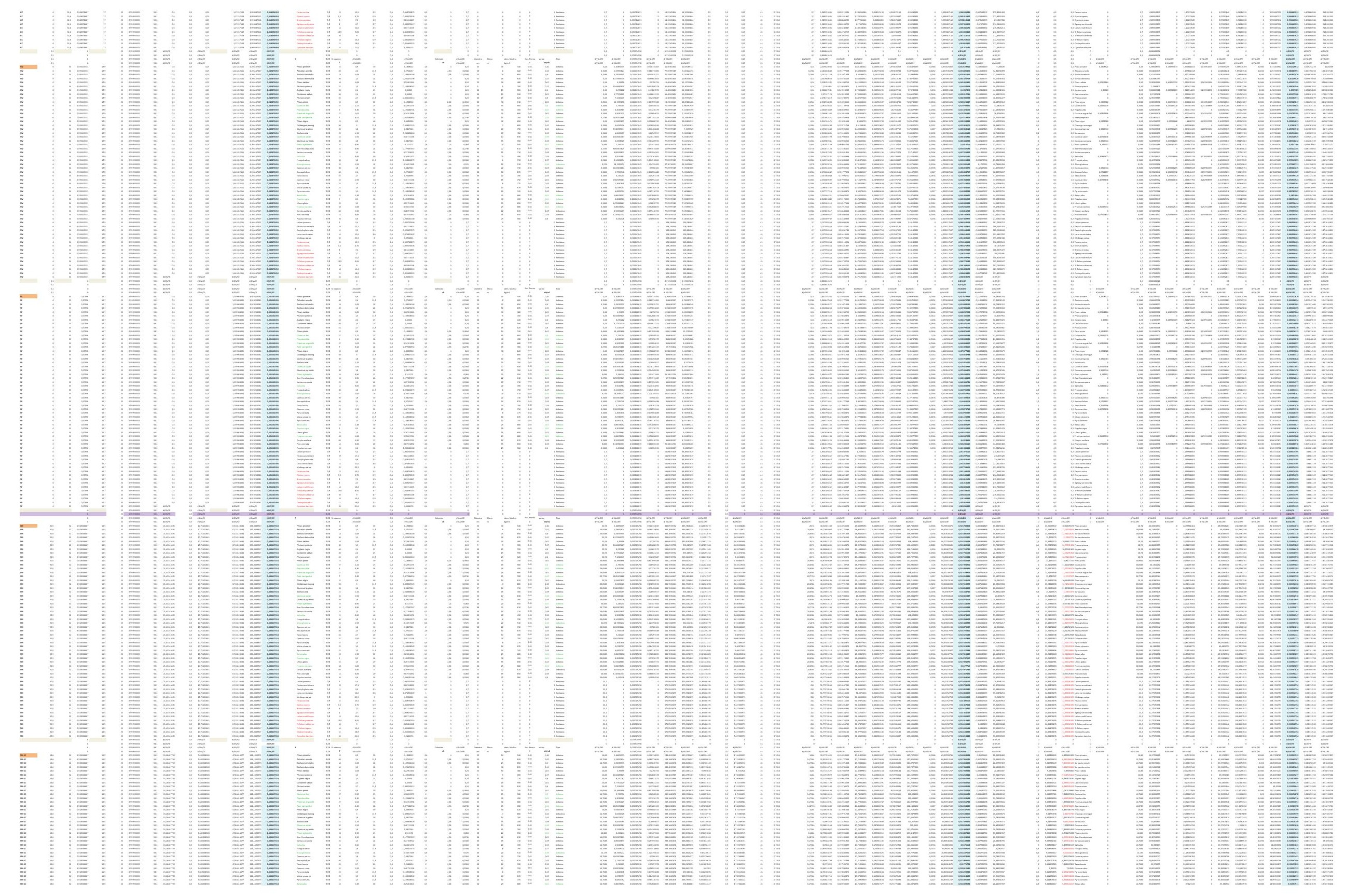



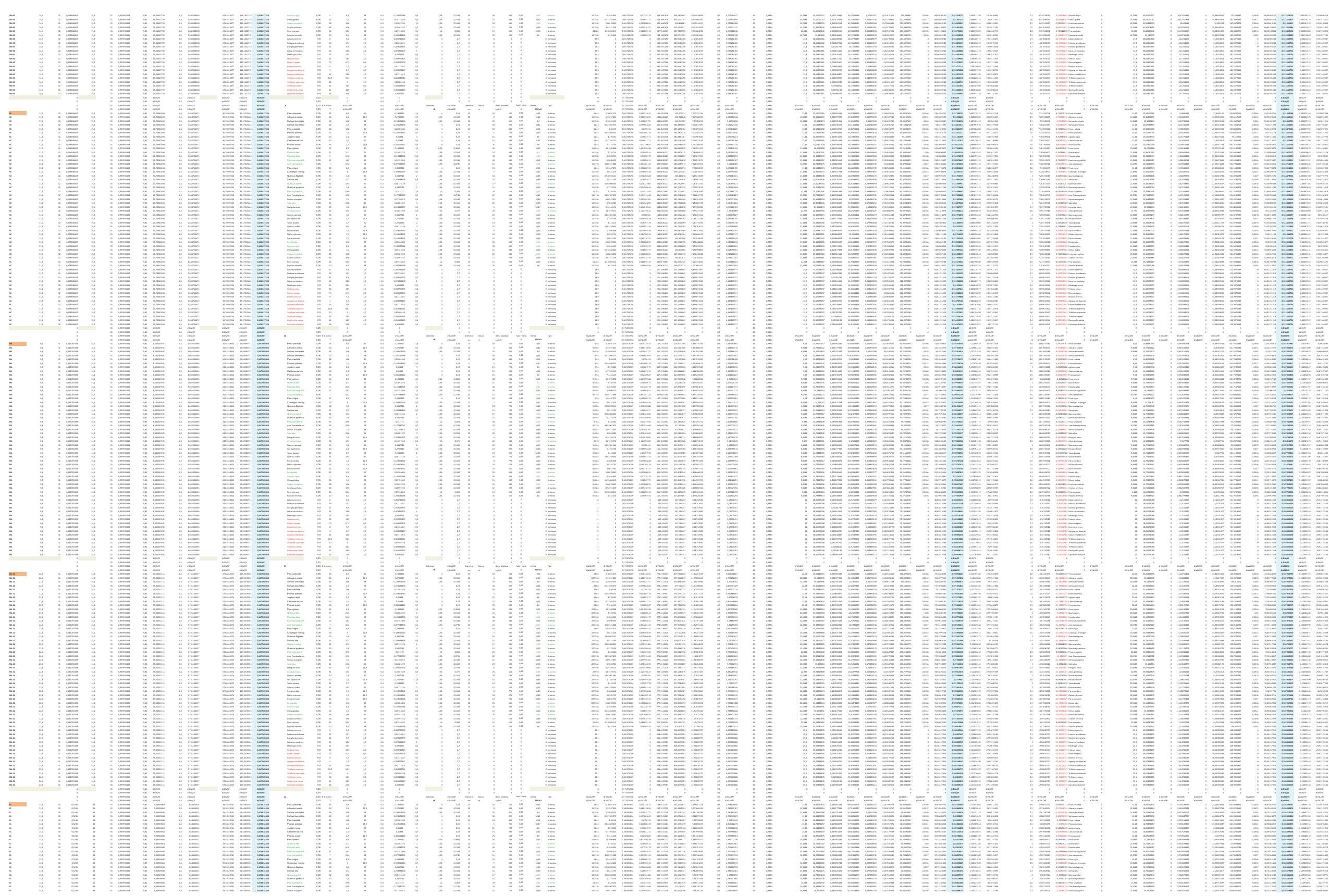


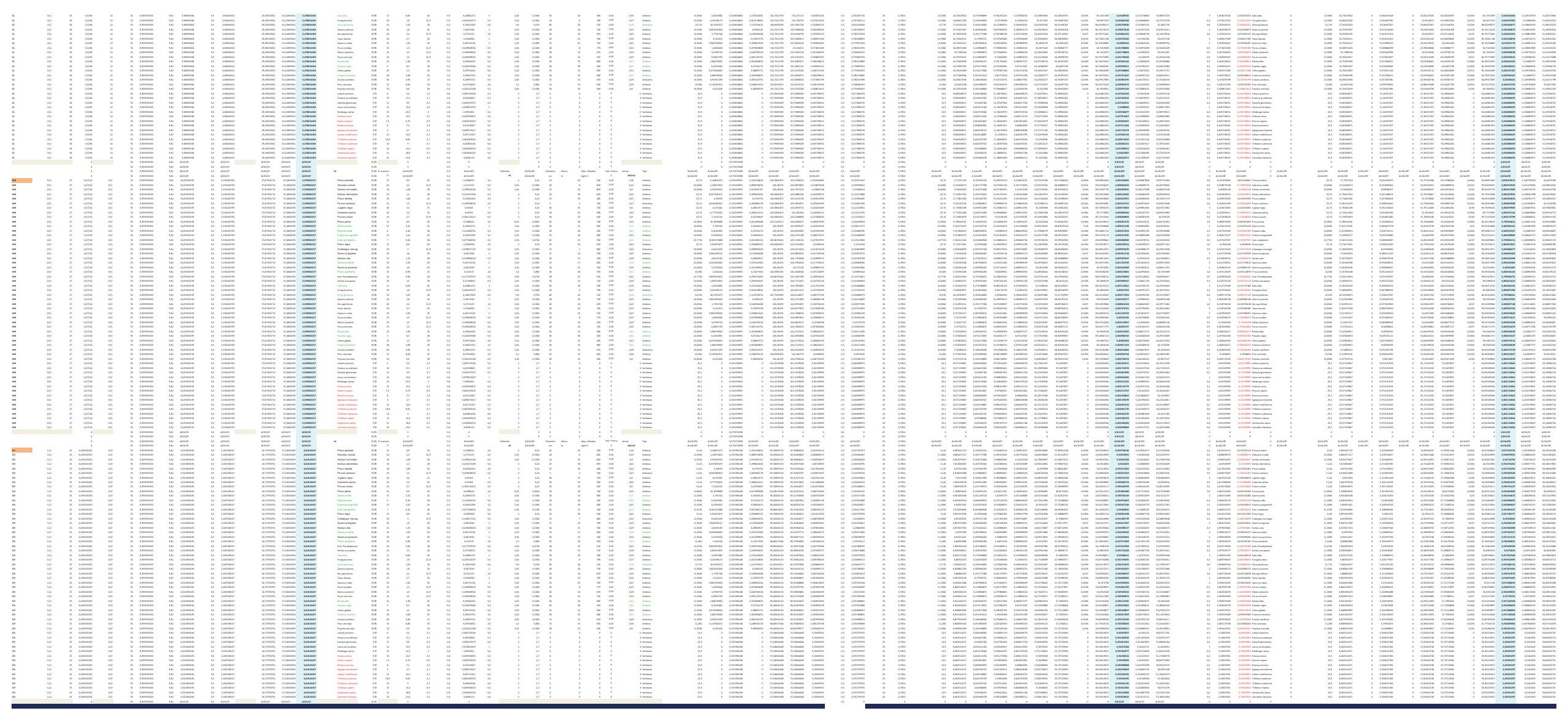



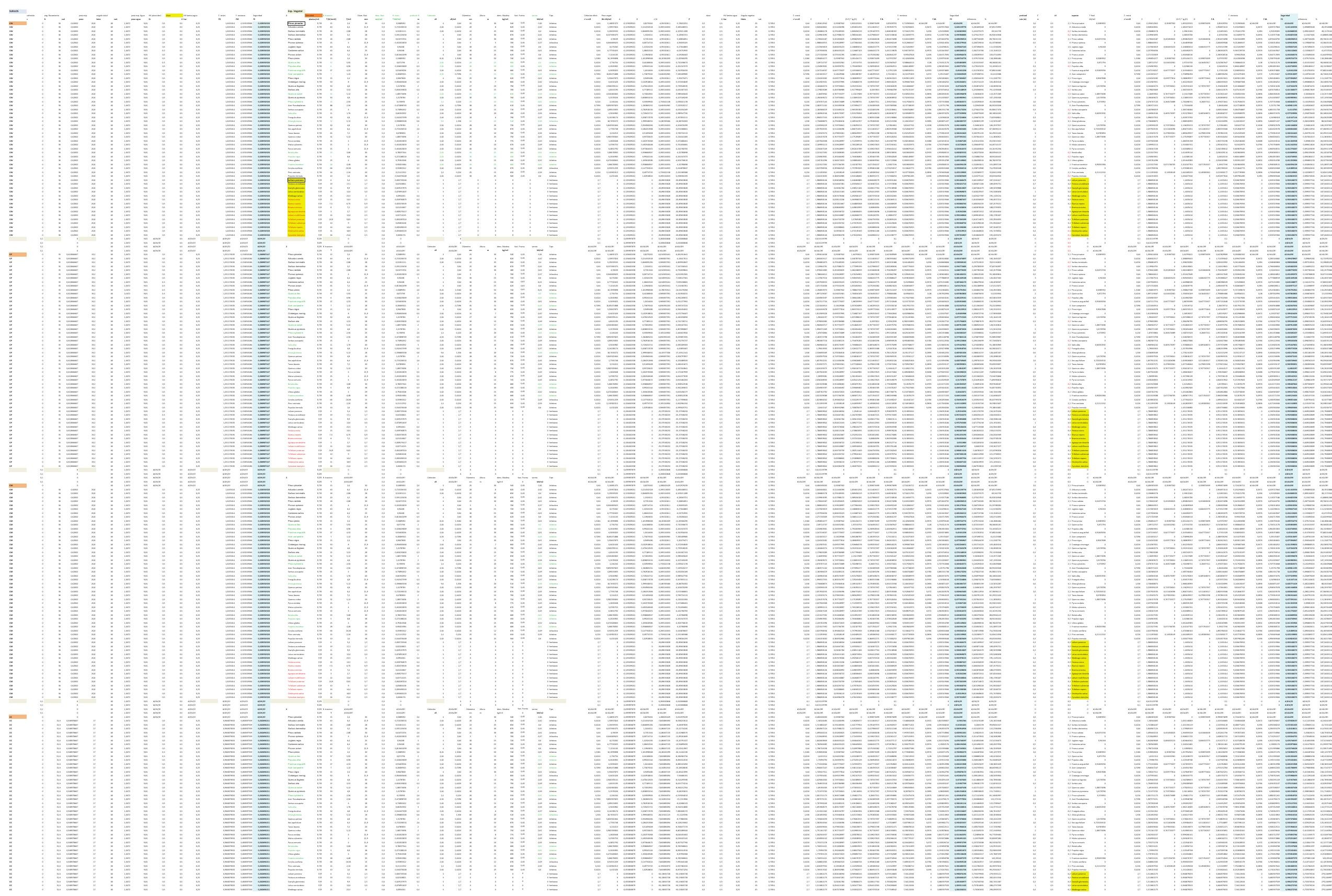

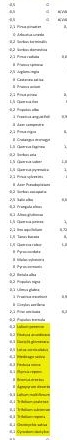

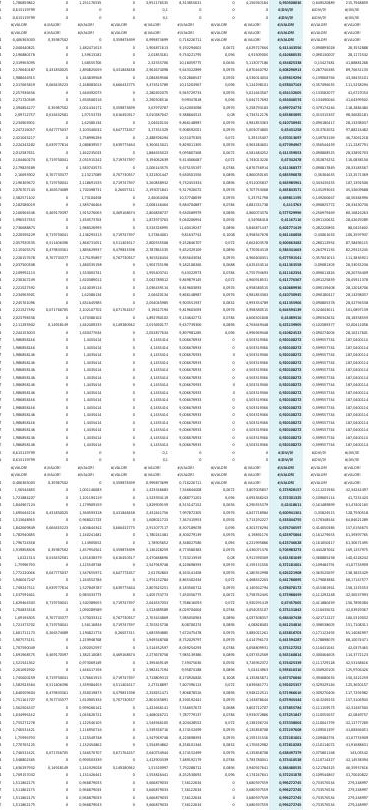




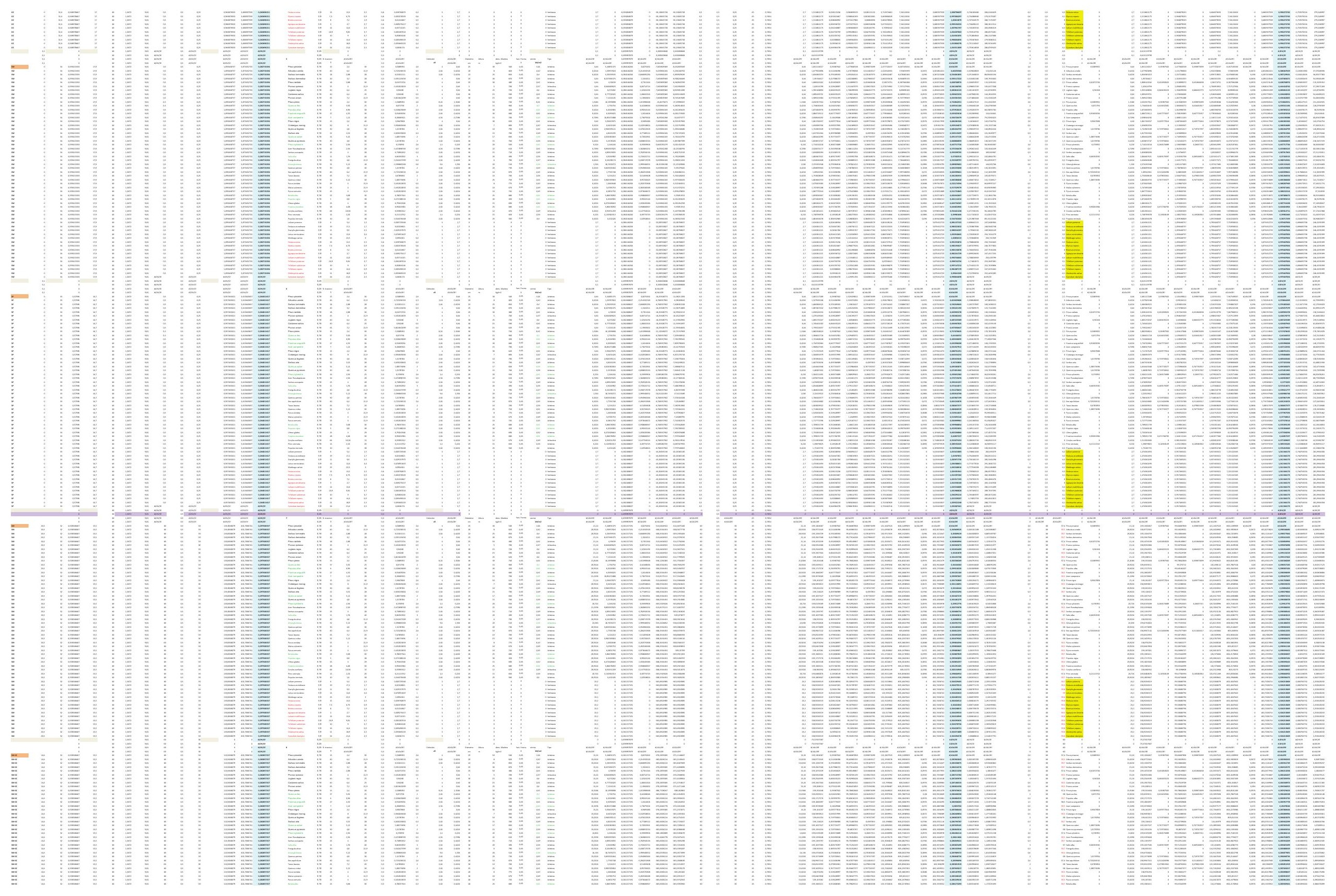



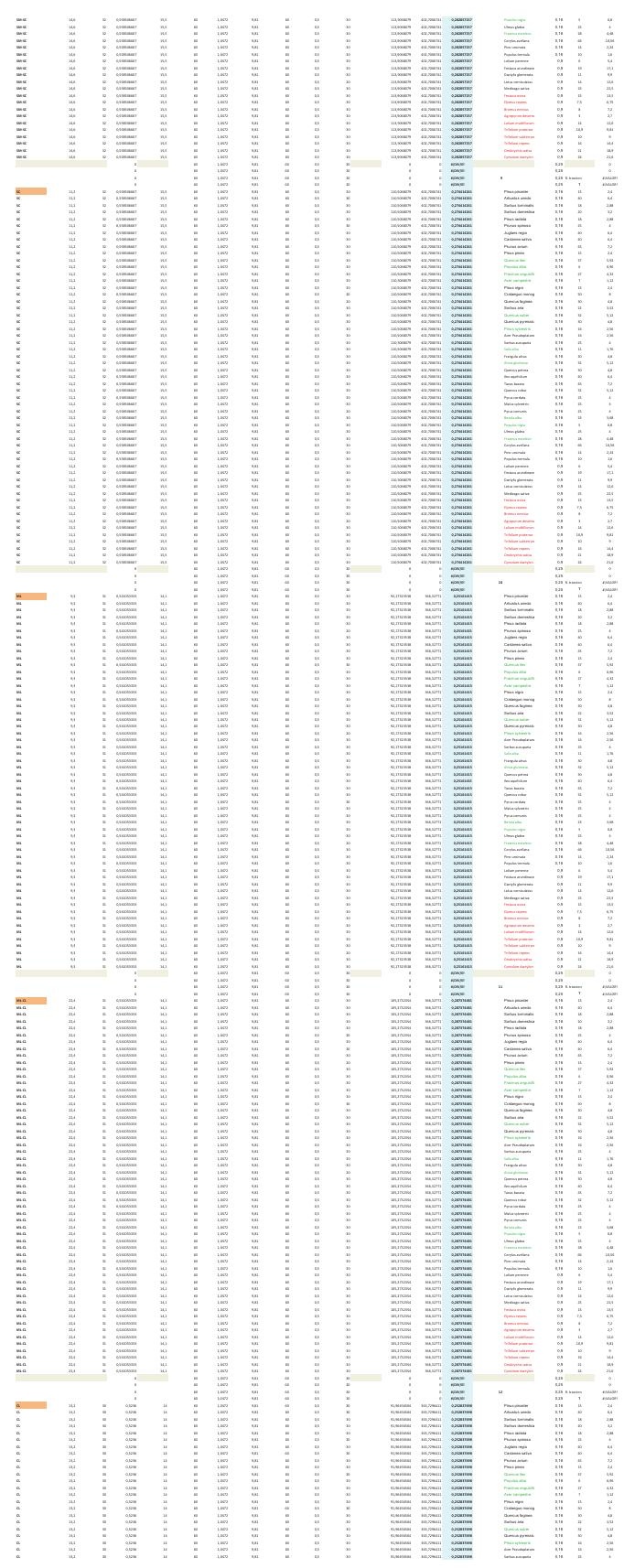

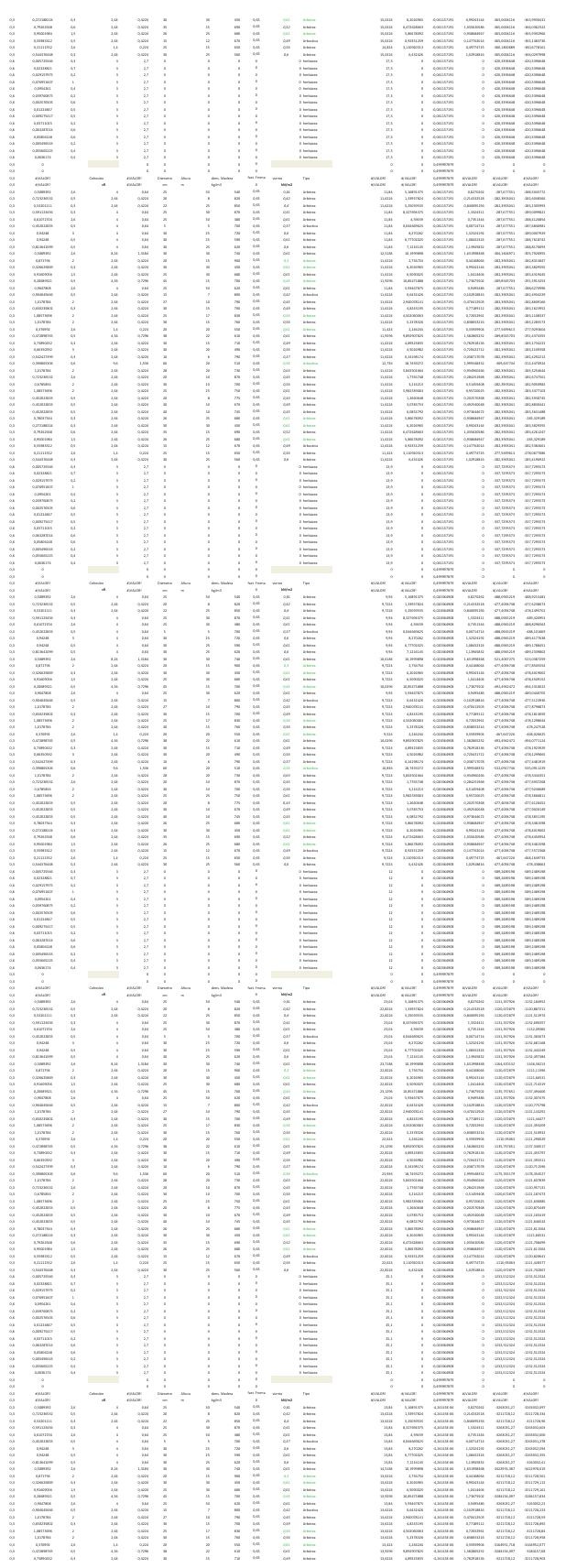

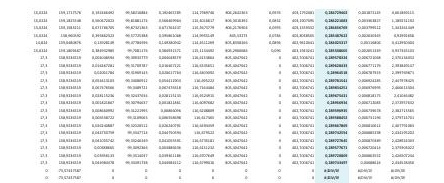
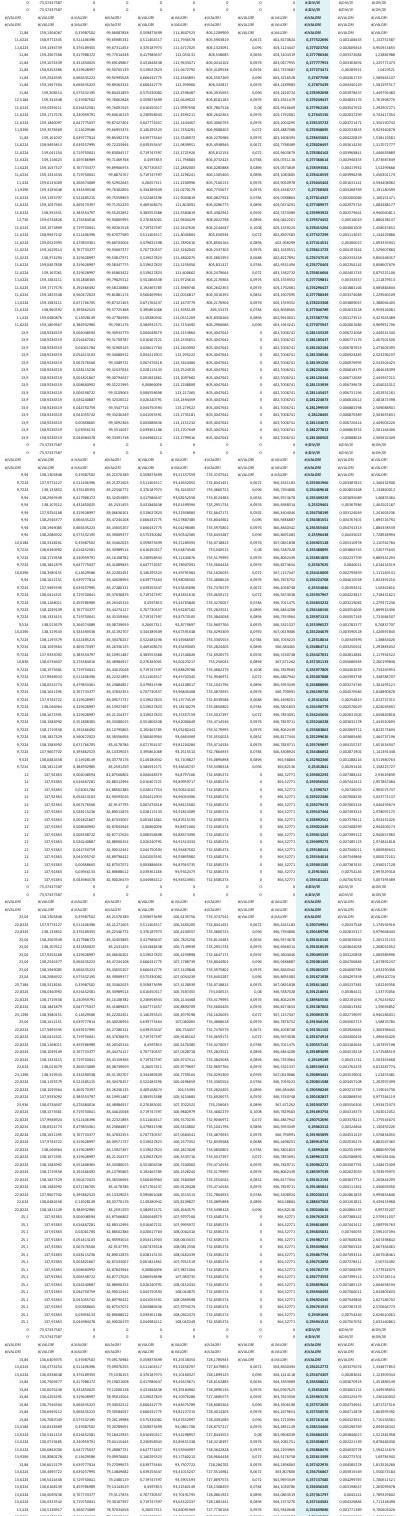

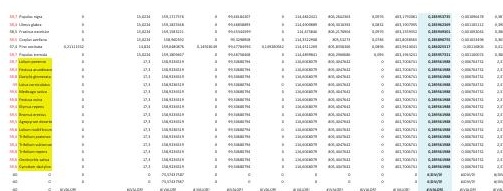

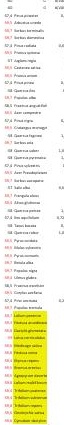

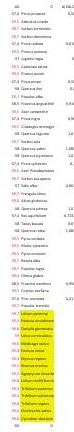

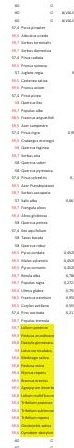

雍

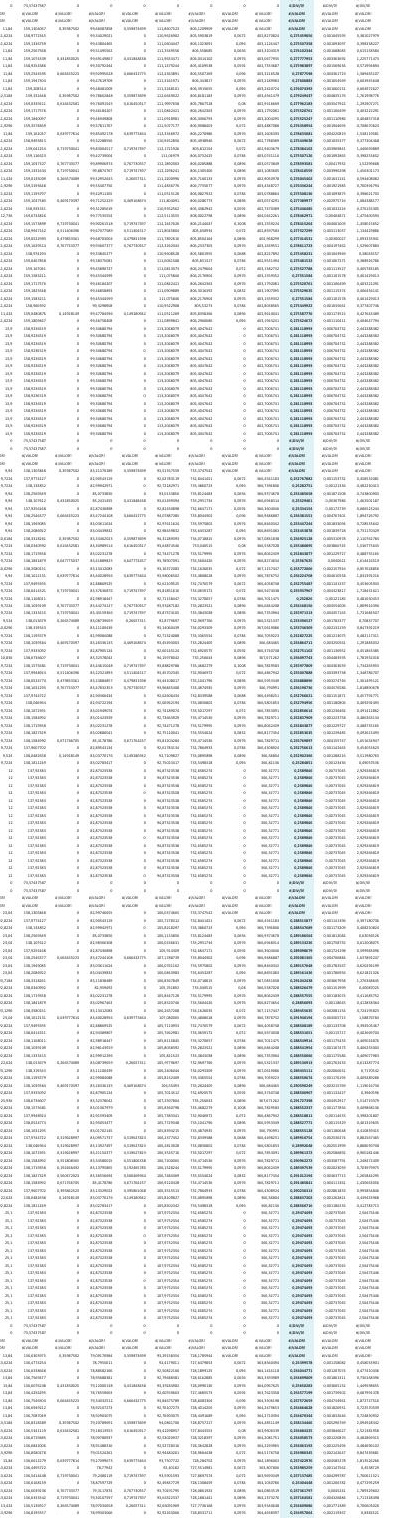




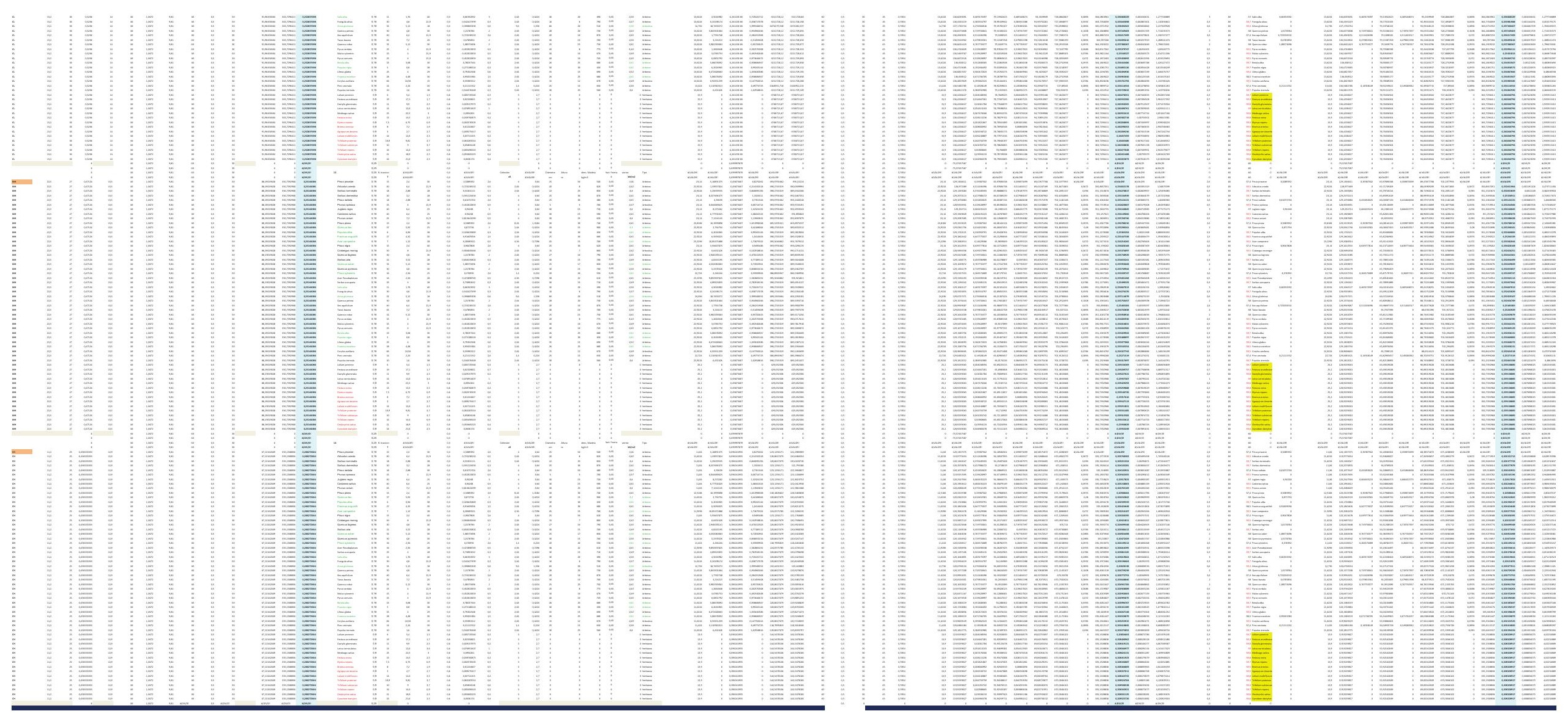



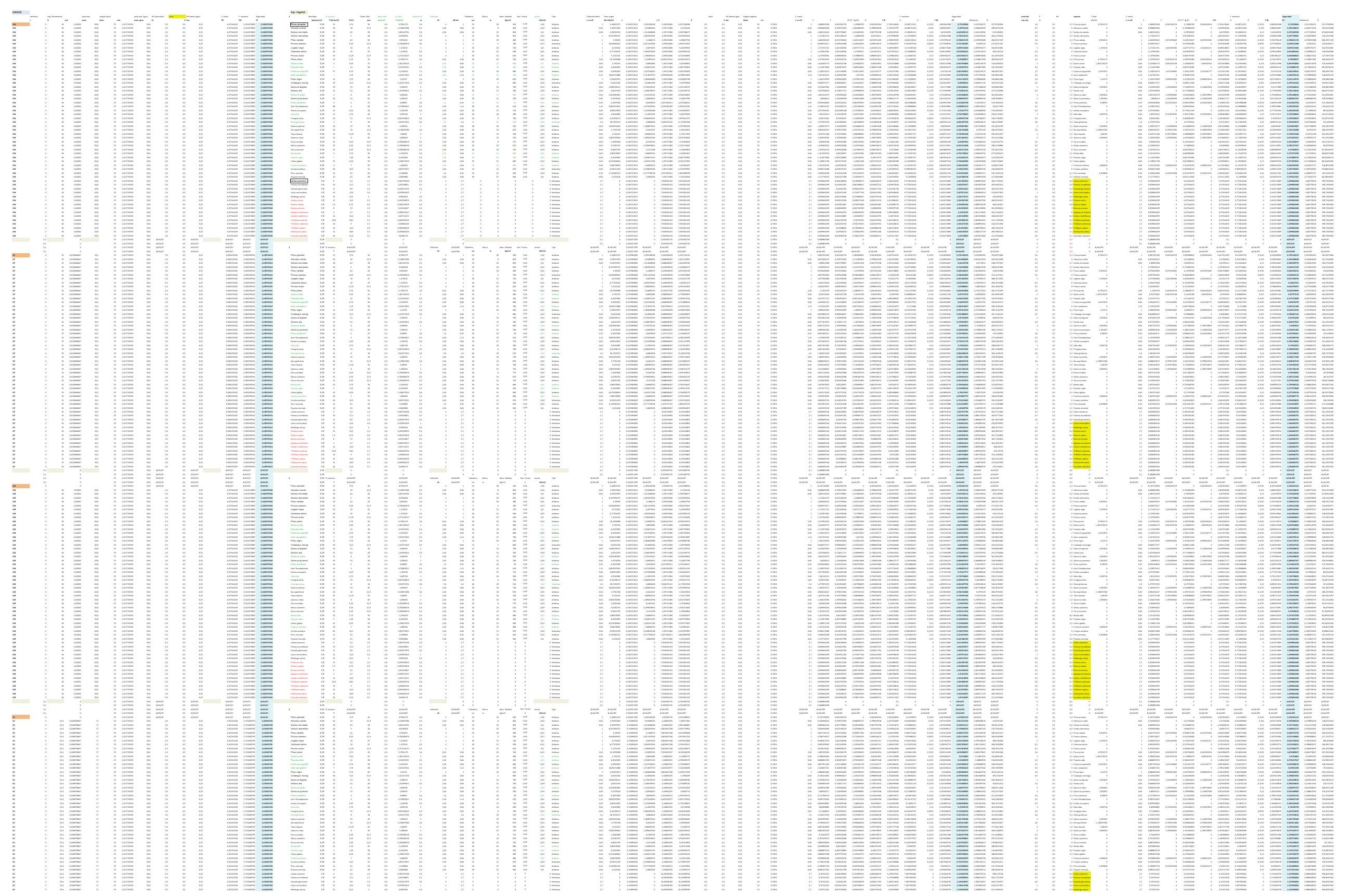

佰

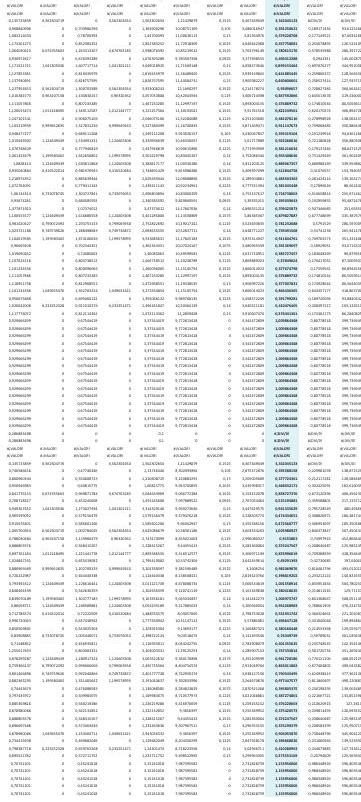




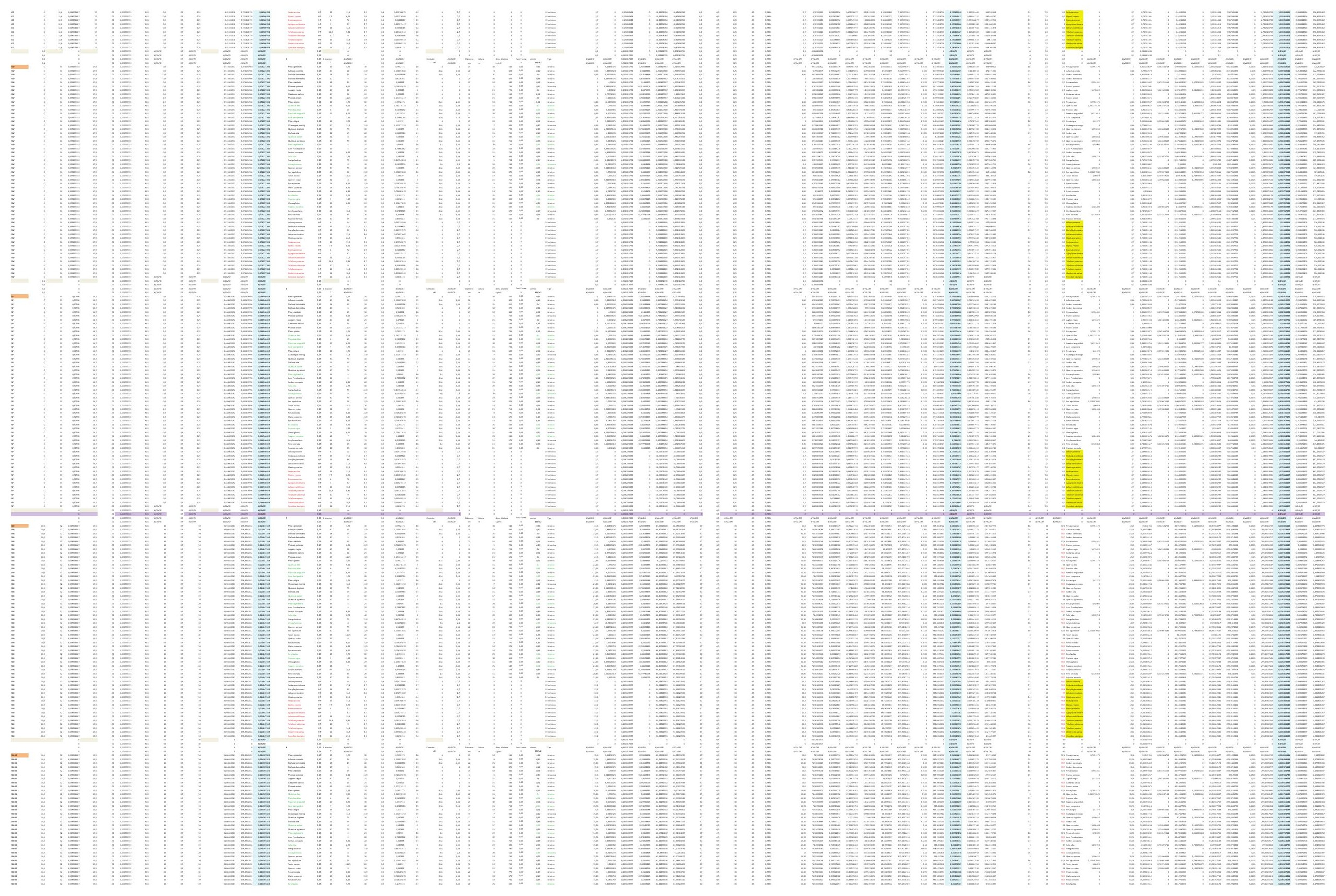




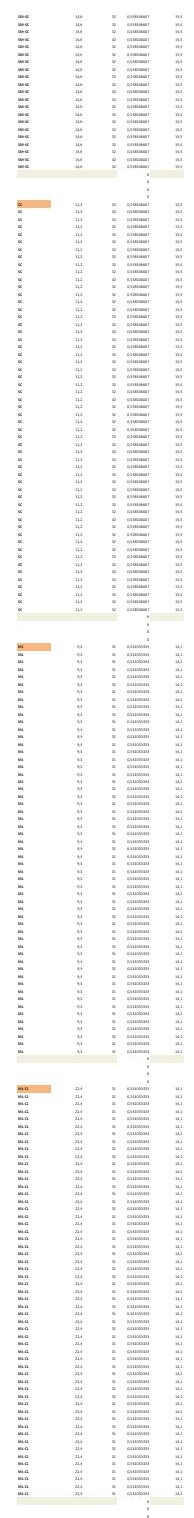

$-$
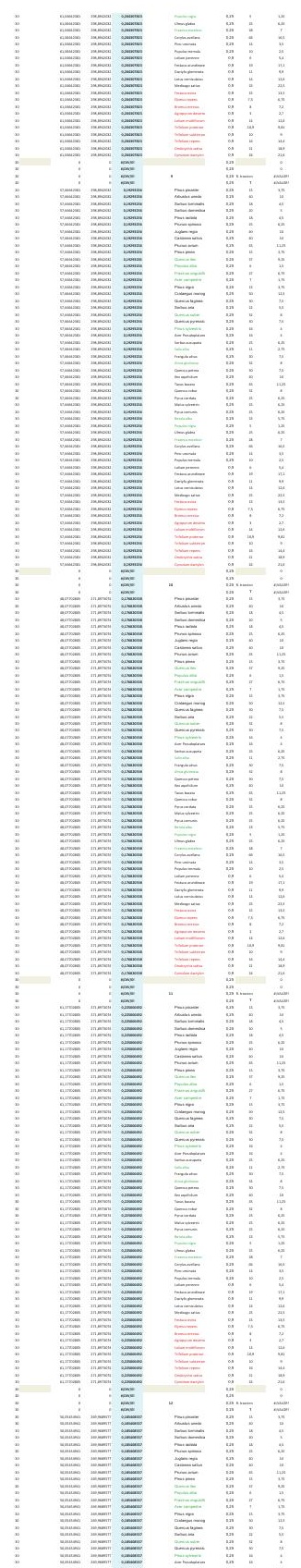

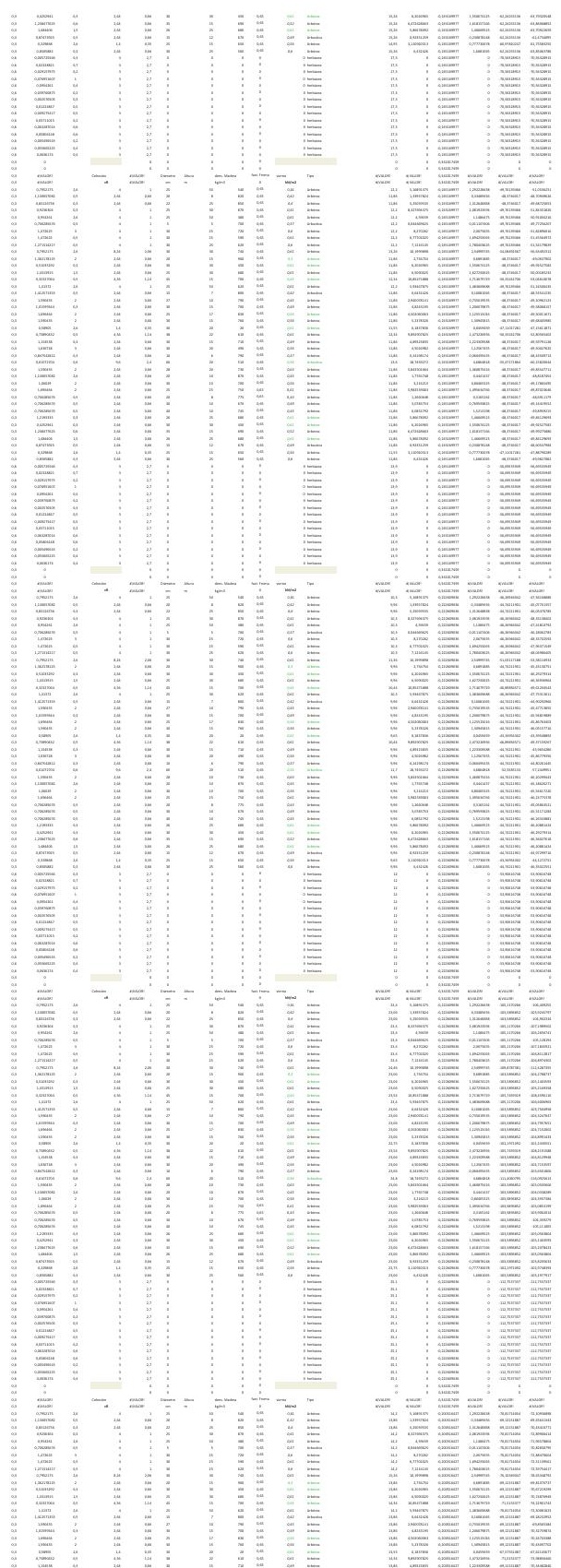

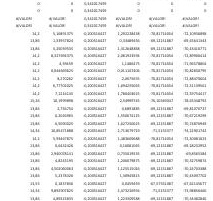

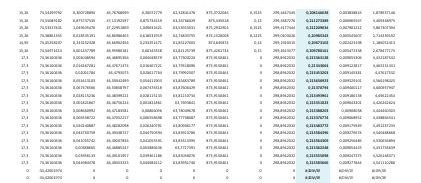

$\equiv$
$\equiv$
$\equiv$
$\equiv$

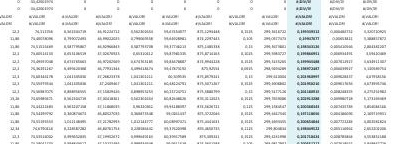

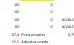

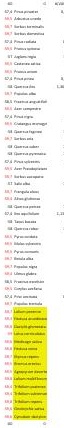
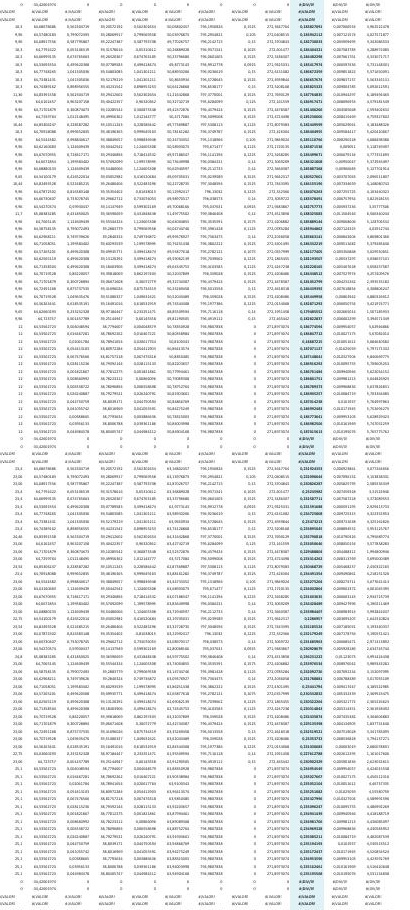

$-\equiv \equiv \equiv \equiv \equiv \equiv \equiv$

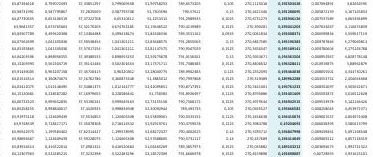

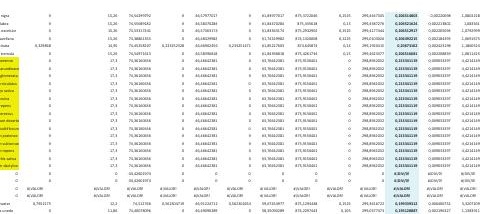
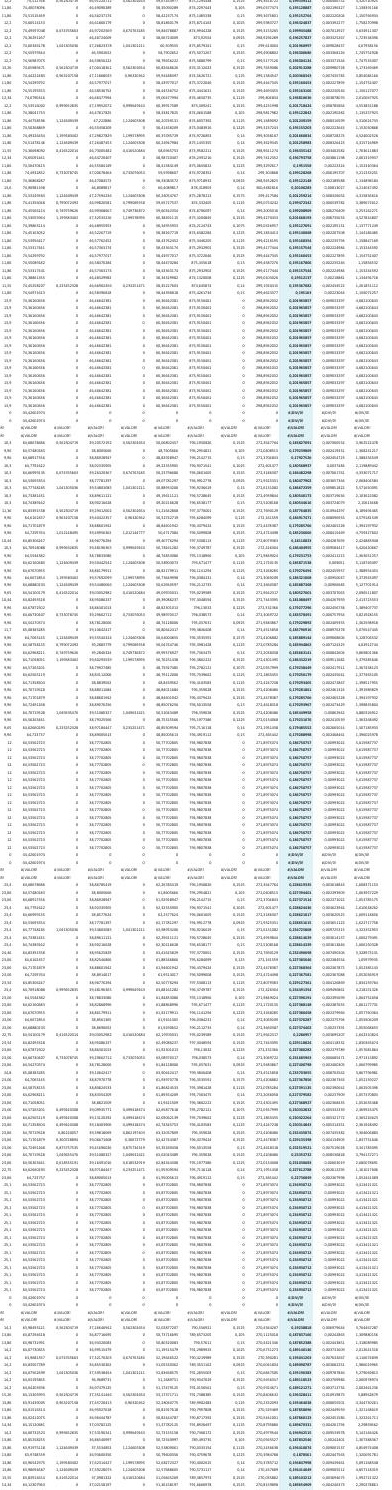


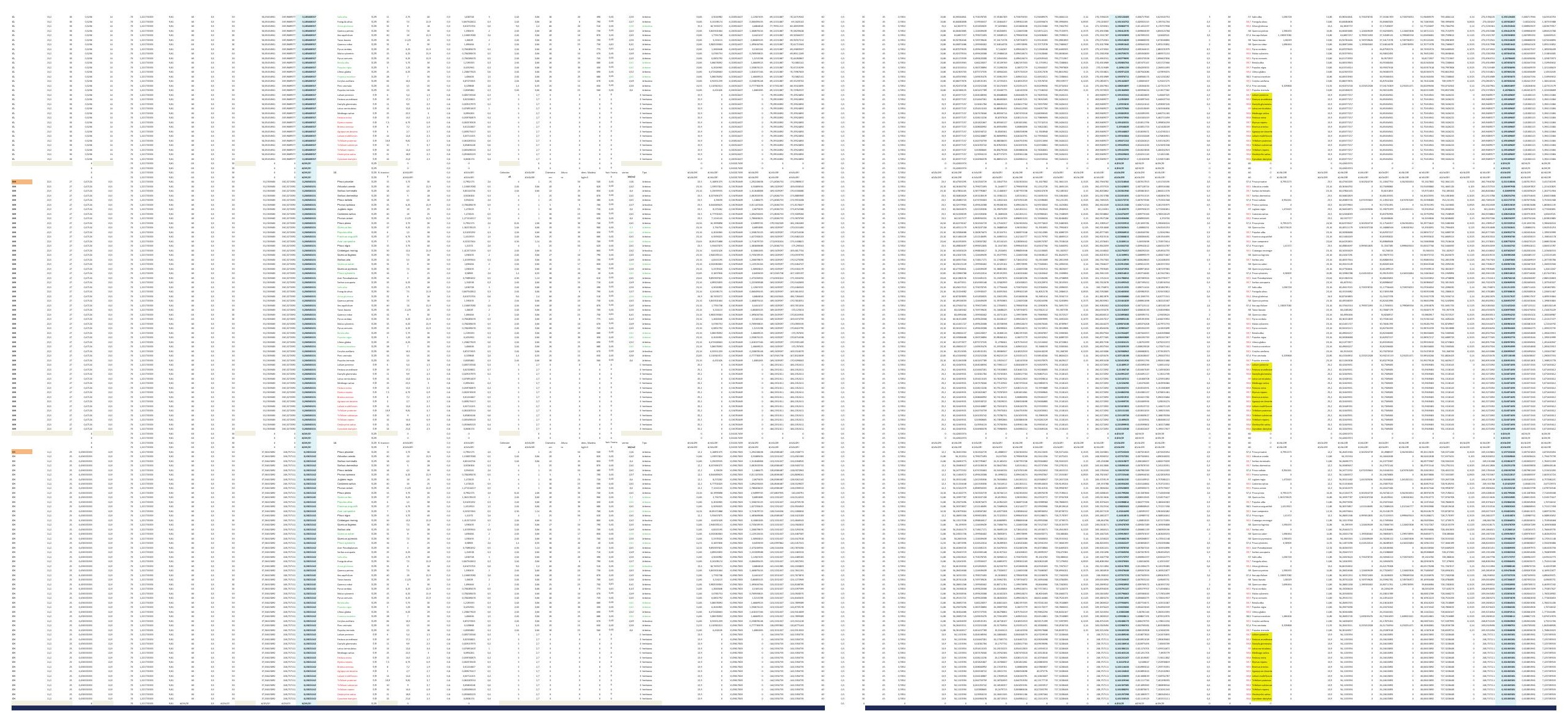



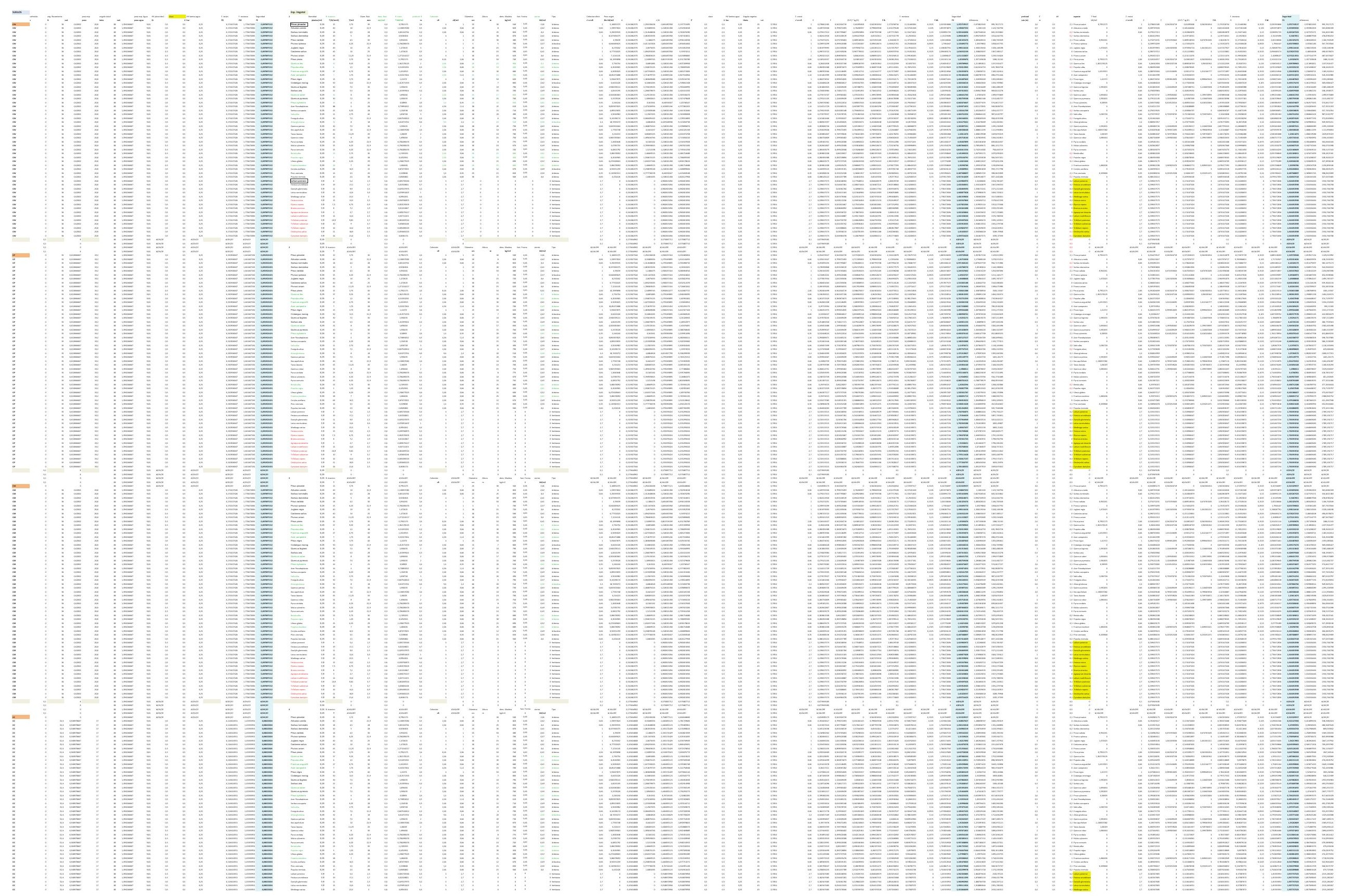

䎑

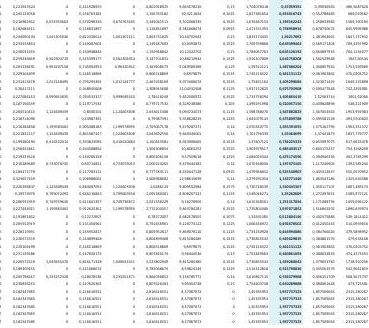




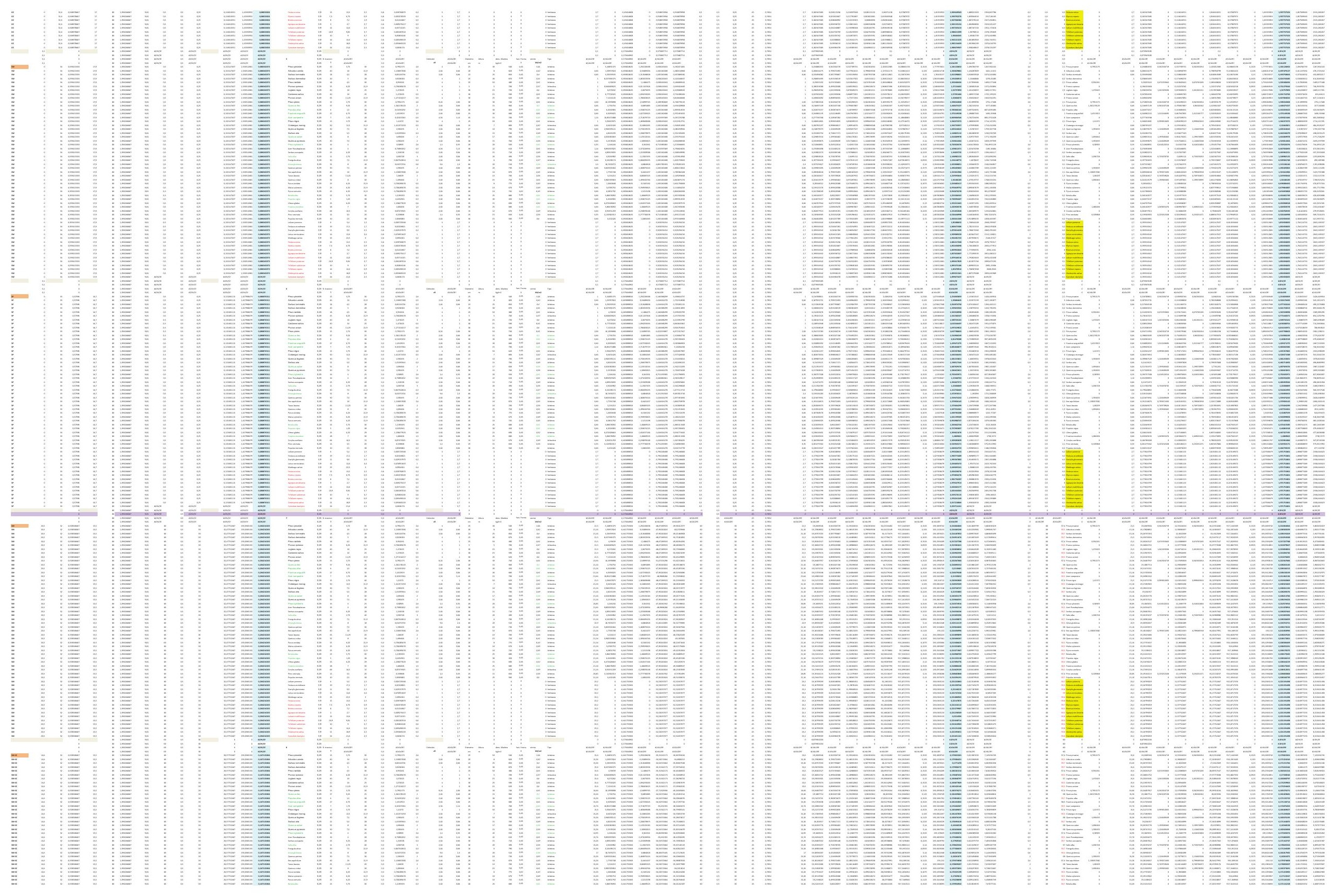



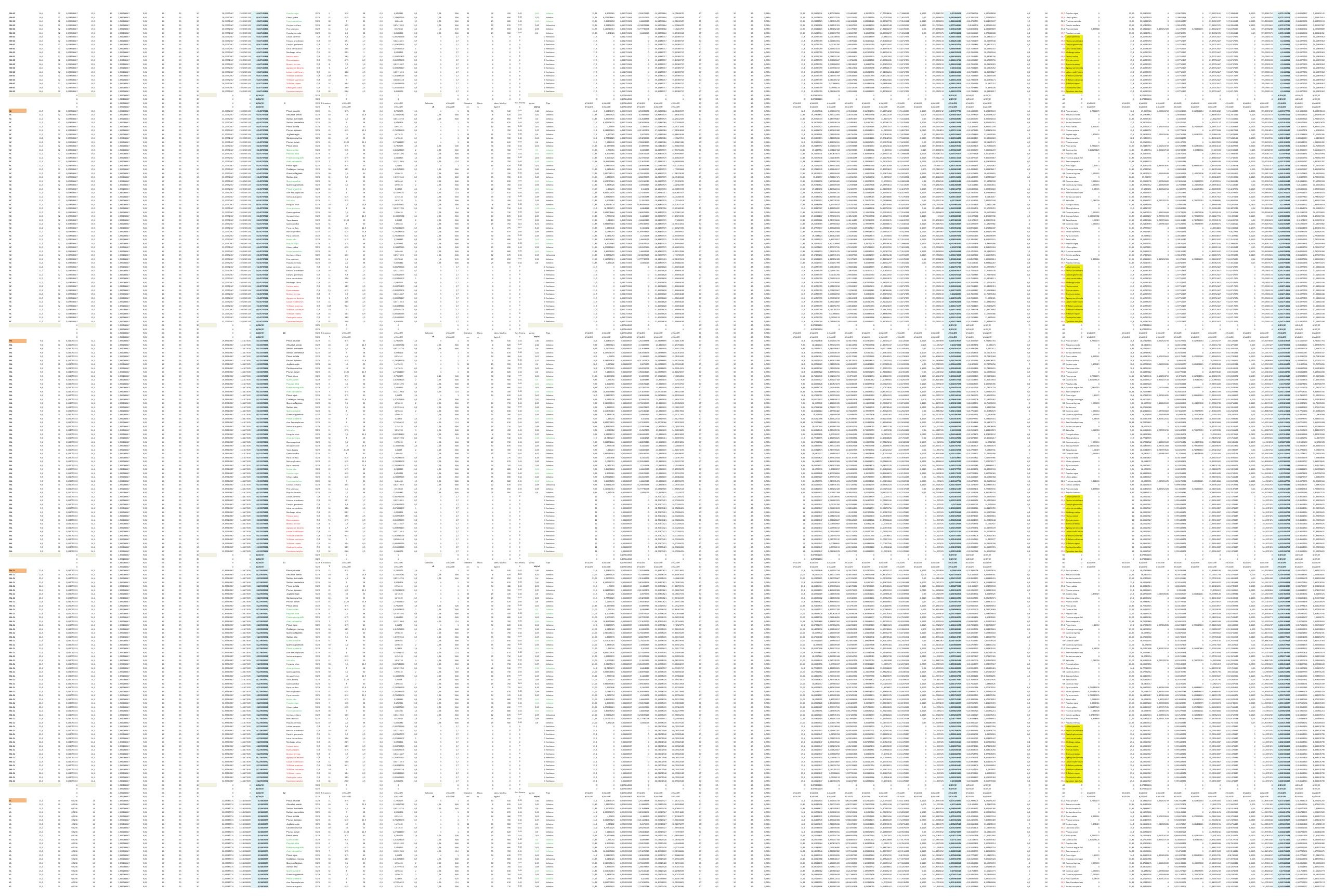


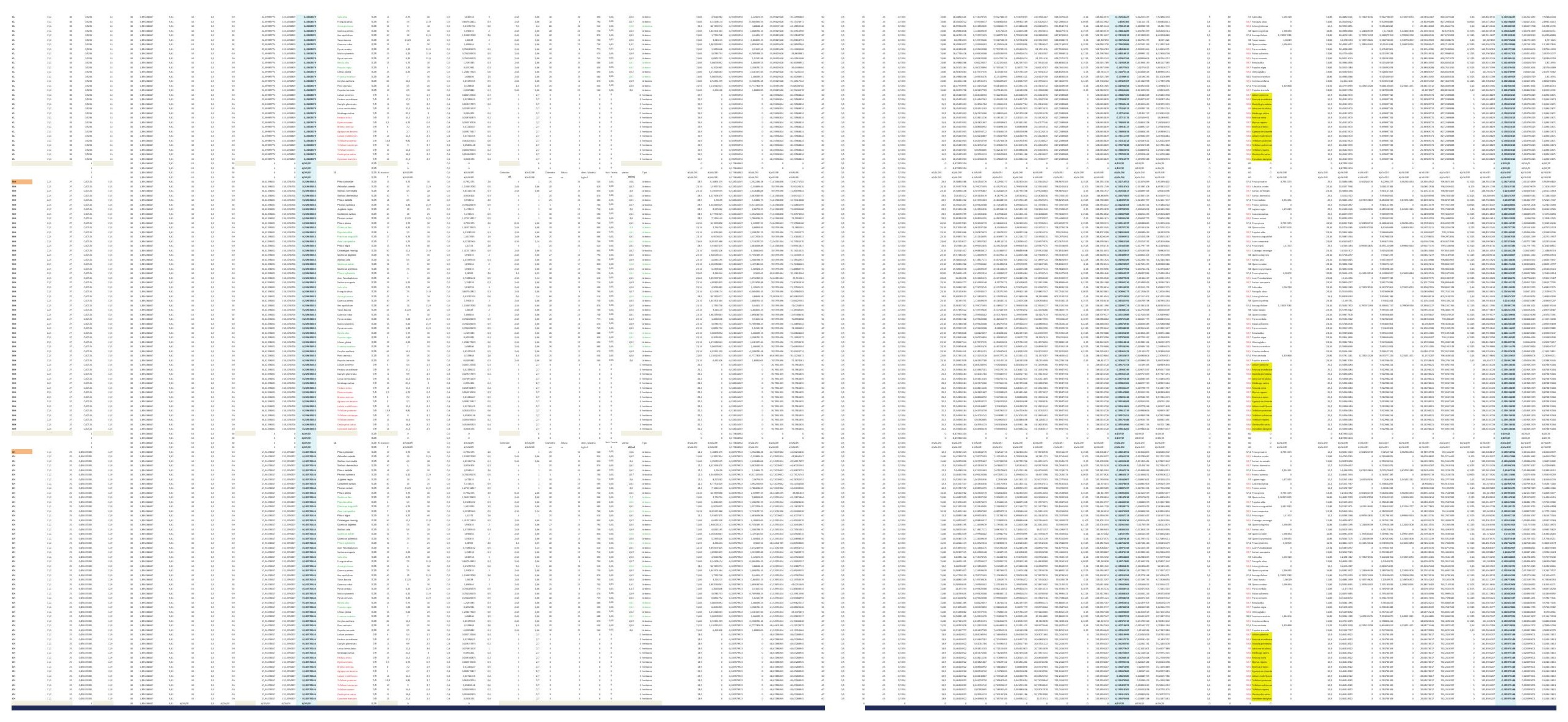


DESARROLLO DE UNA APLICACIÓN IMFORMÁTICA PARA EL CÁLCULO DE SOSTENIMIENTO DE TALUDES MEDIANTE VEGETACIÓN

A01. DENSIDAD DE PLANTACIÓN: 600 plantas/ha.

\section{A01-5.POSICIÓN N.F. 5}

INCLINACIÓN DE TALUD 6-100

INCLINACIÓN DE TALUD 10-200

INCLINACIÓN DE TALUD 20-30

INCLINACIÓN DE TALUD 30-40

INCLINACIÓN DE TALUD $35^{\circ}$

INCLINACIÓN DE TALUD 40-50

INCLINACIÓN DE TALUD 50-550

INCLINACIÓN DE TALUD 55-60

INCLINACIÓN DE TALUD 60-700

INCLINACIÓN DE TALUD 70-80 

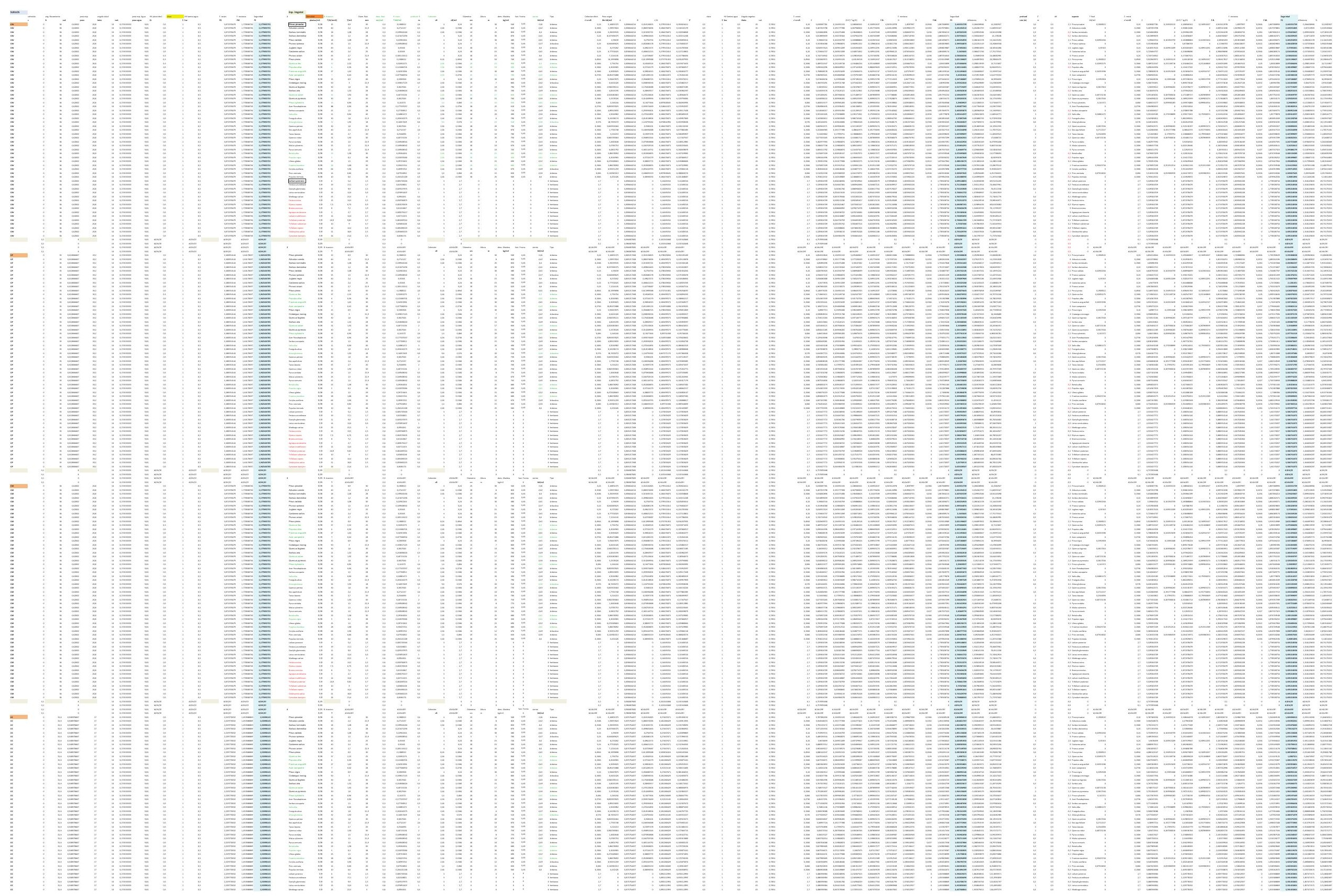

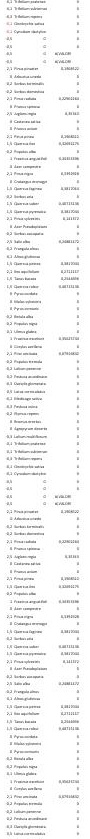

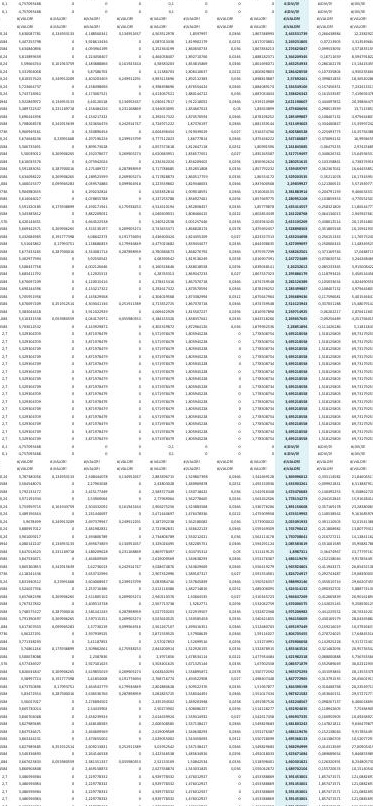




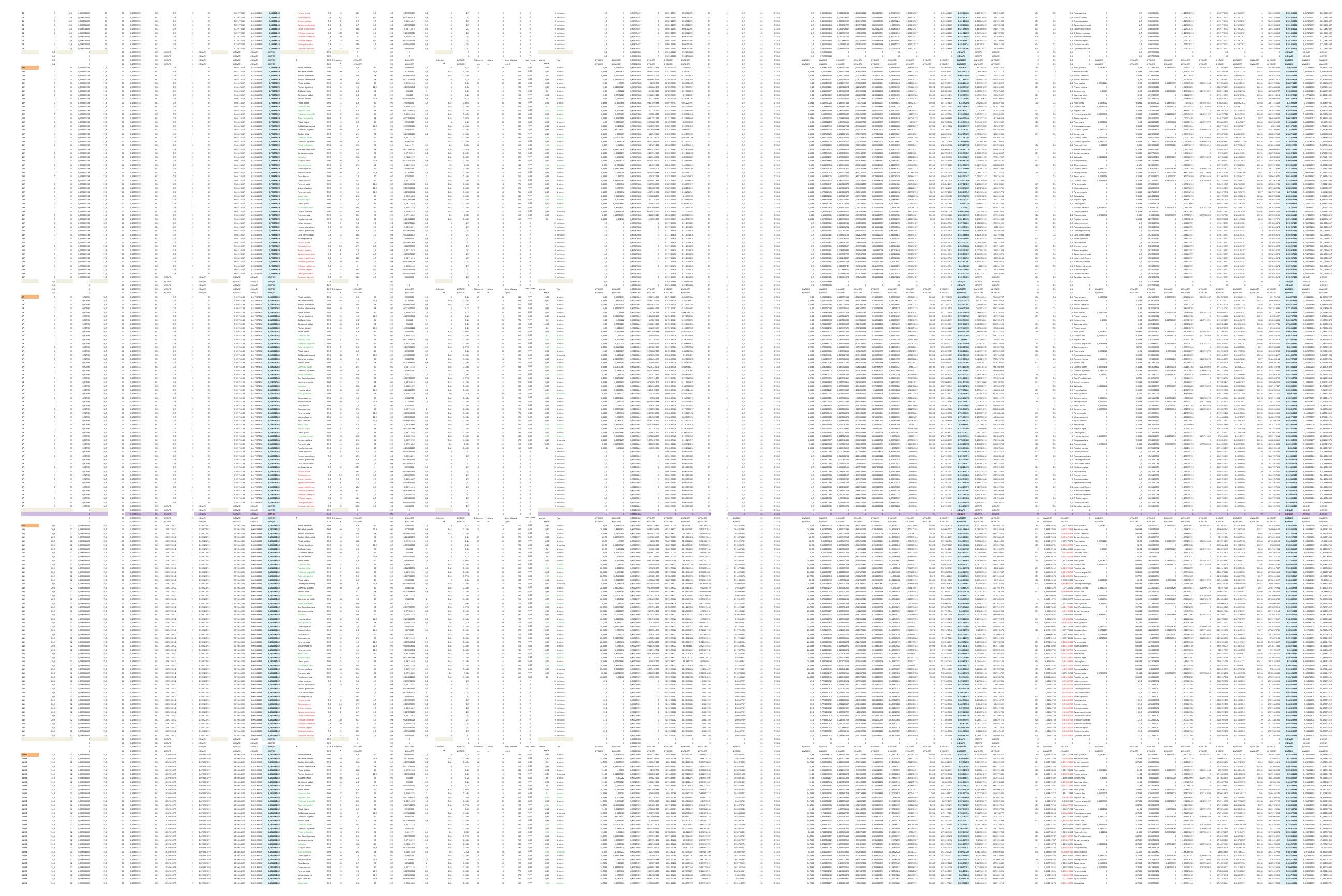



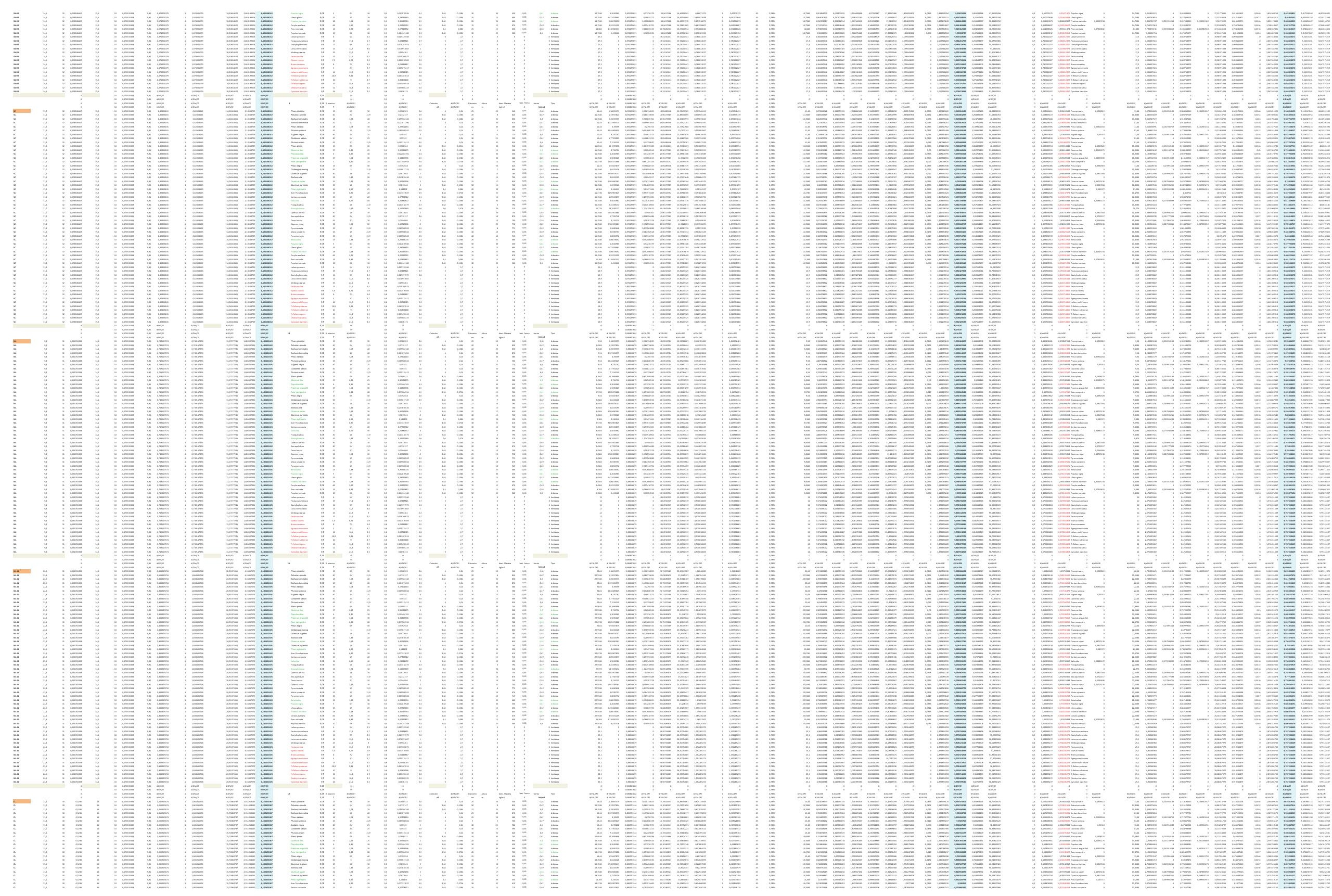

敃=
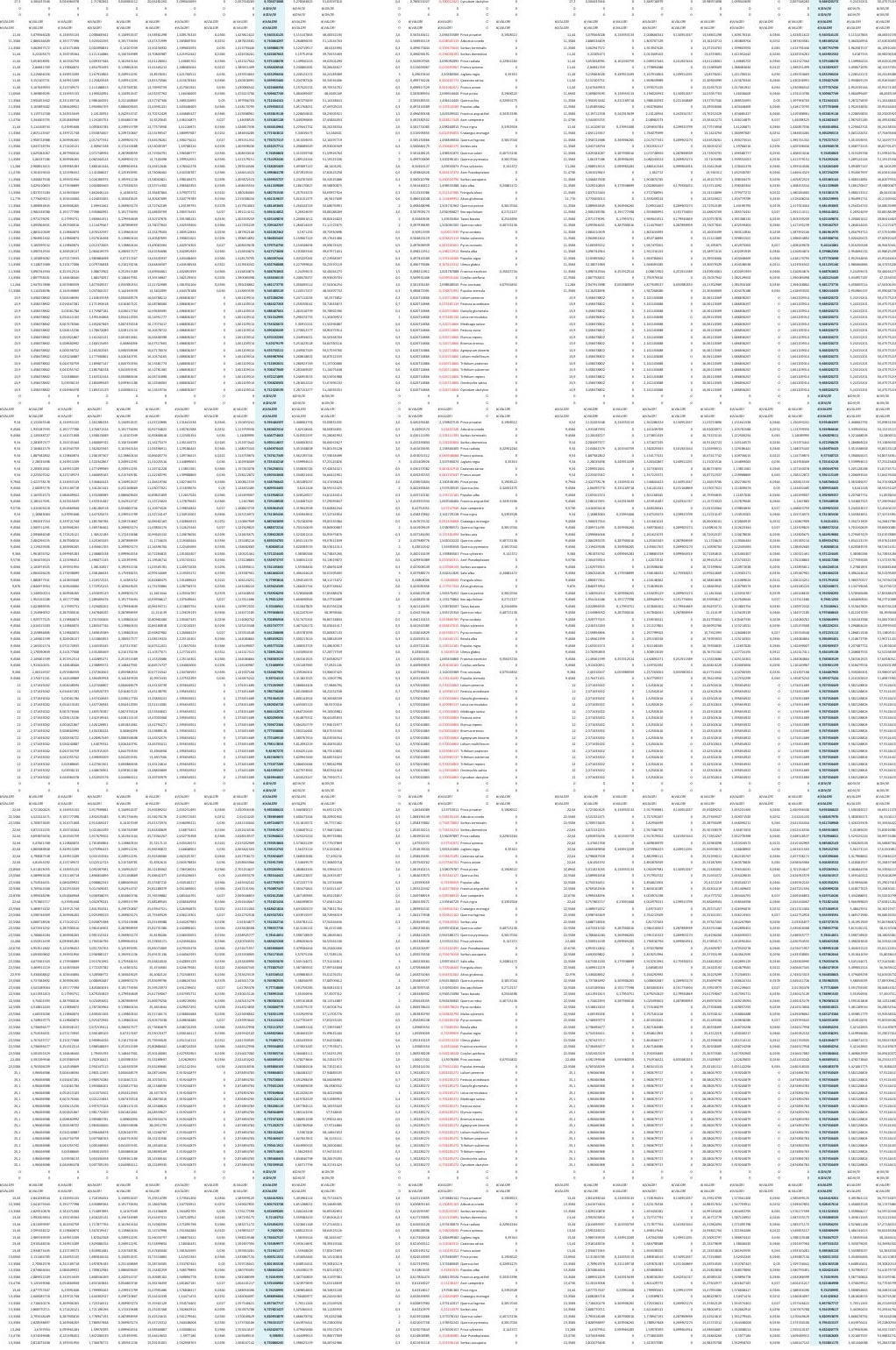

$=\equiv \equiv \equiv \equiv \equiv \equiv$

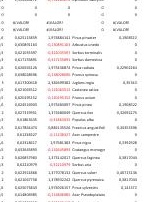




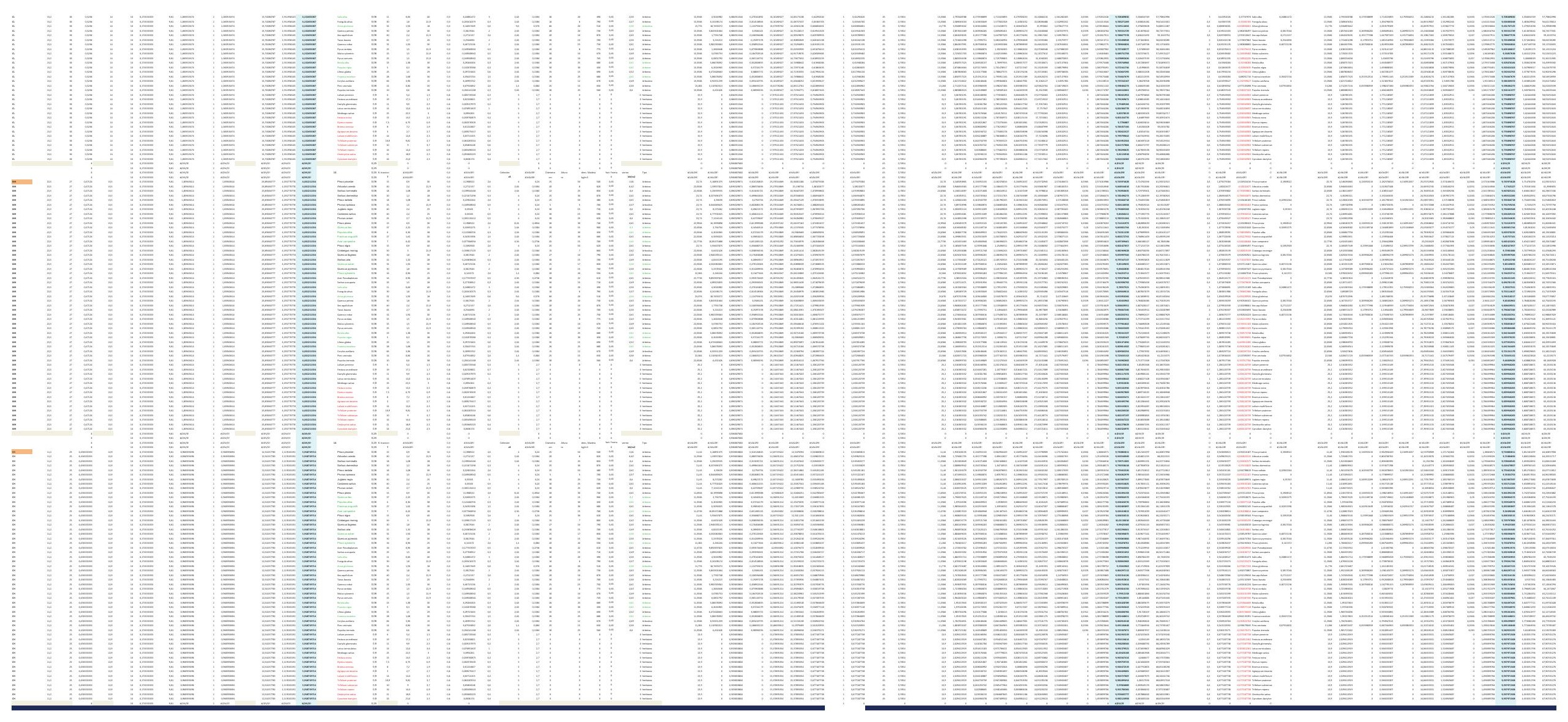



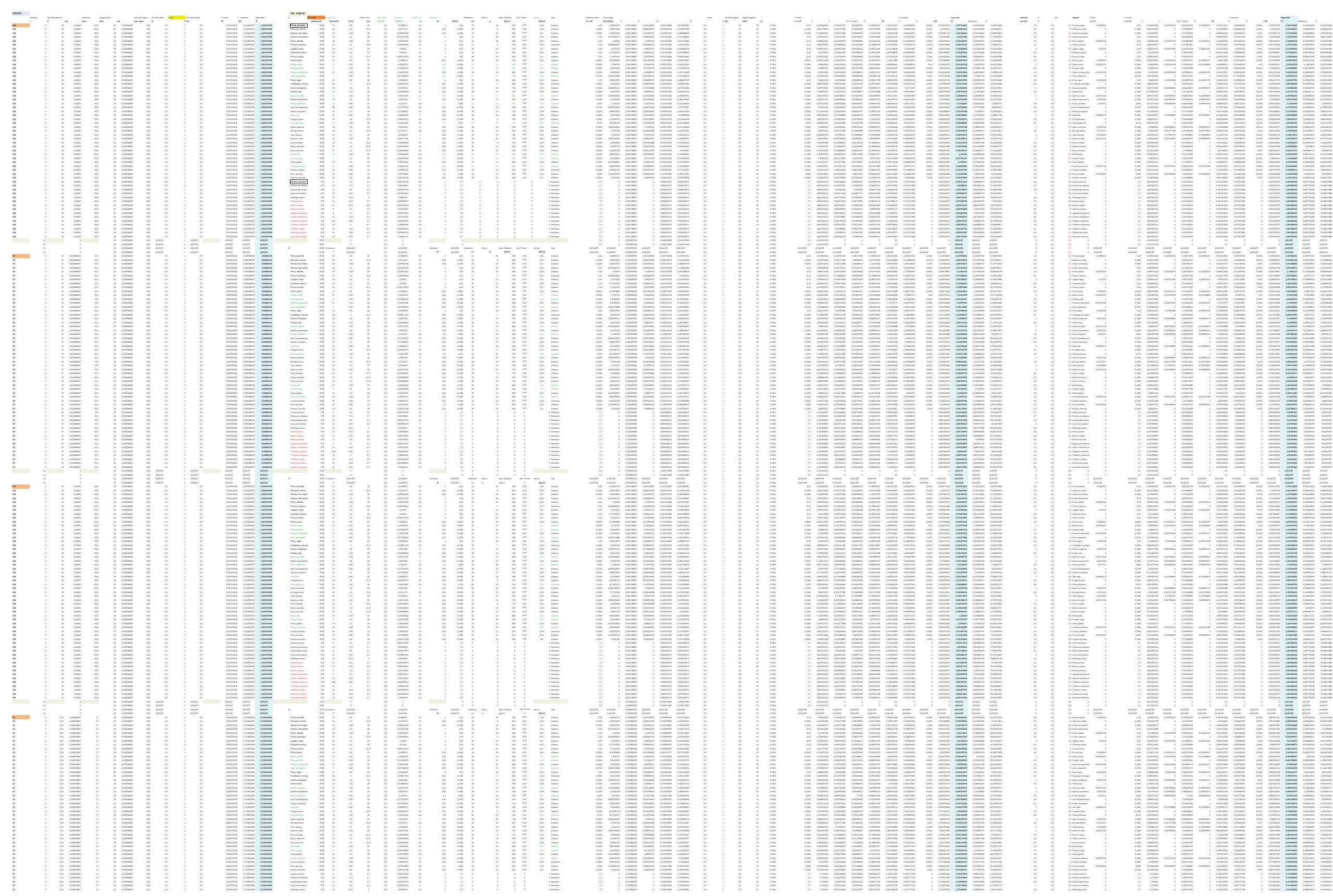


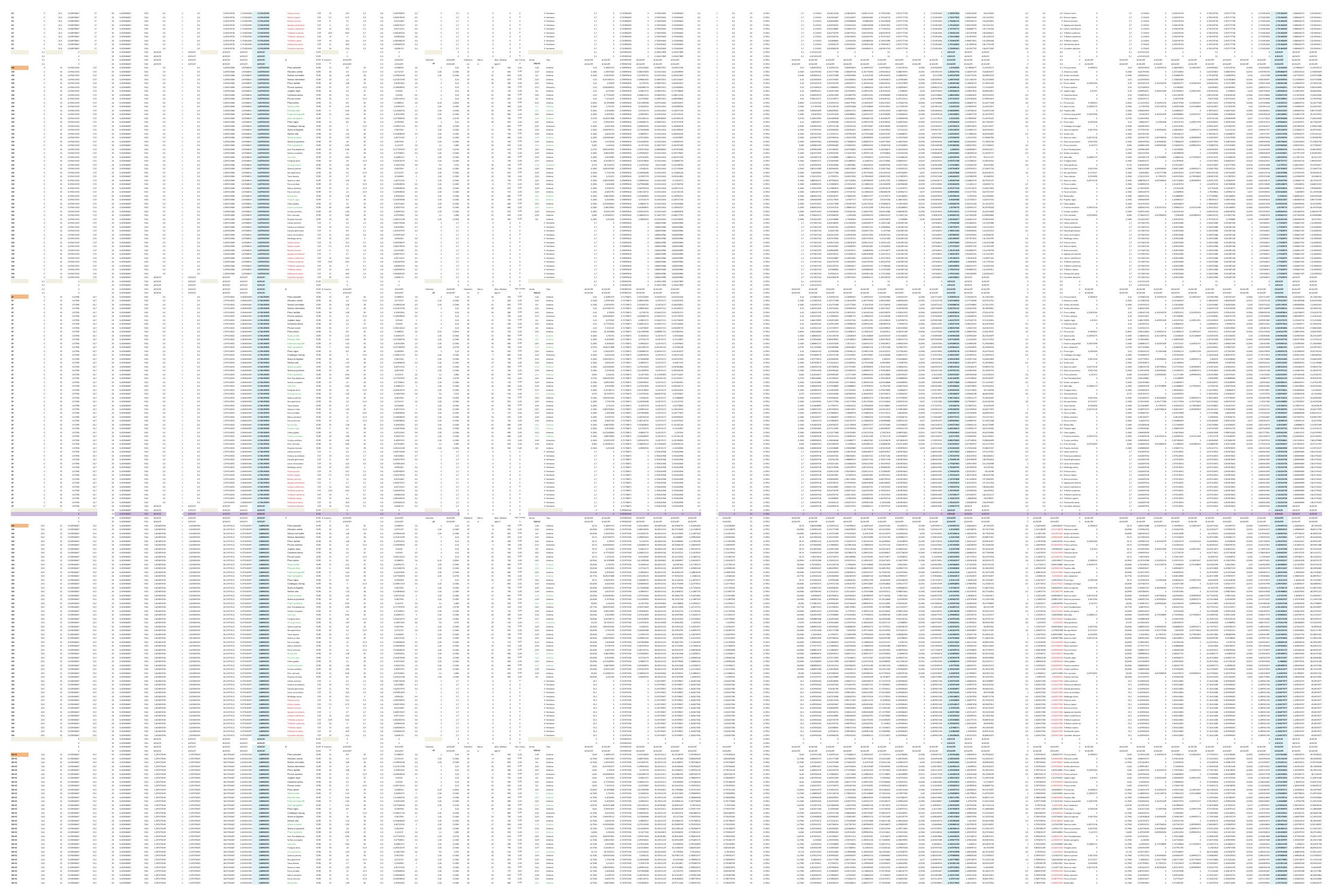



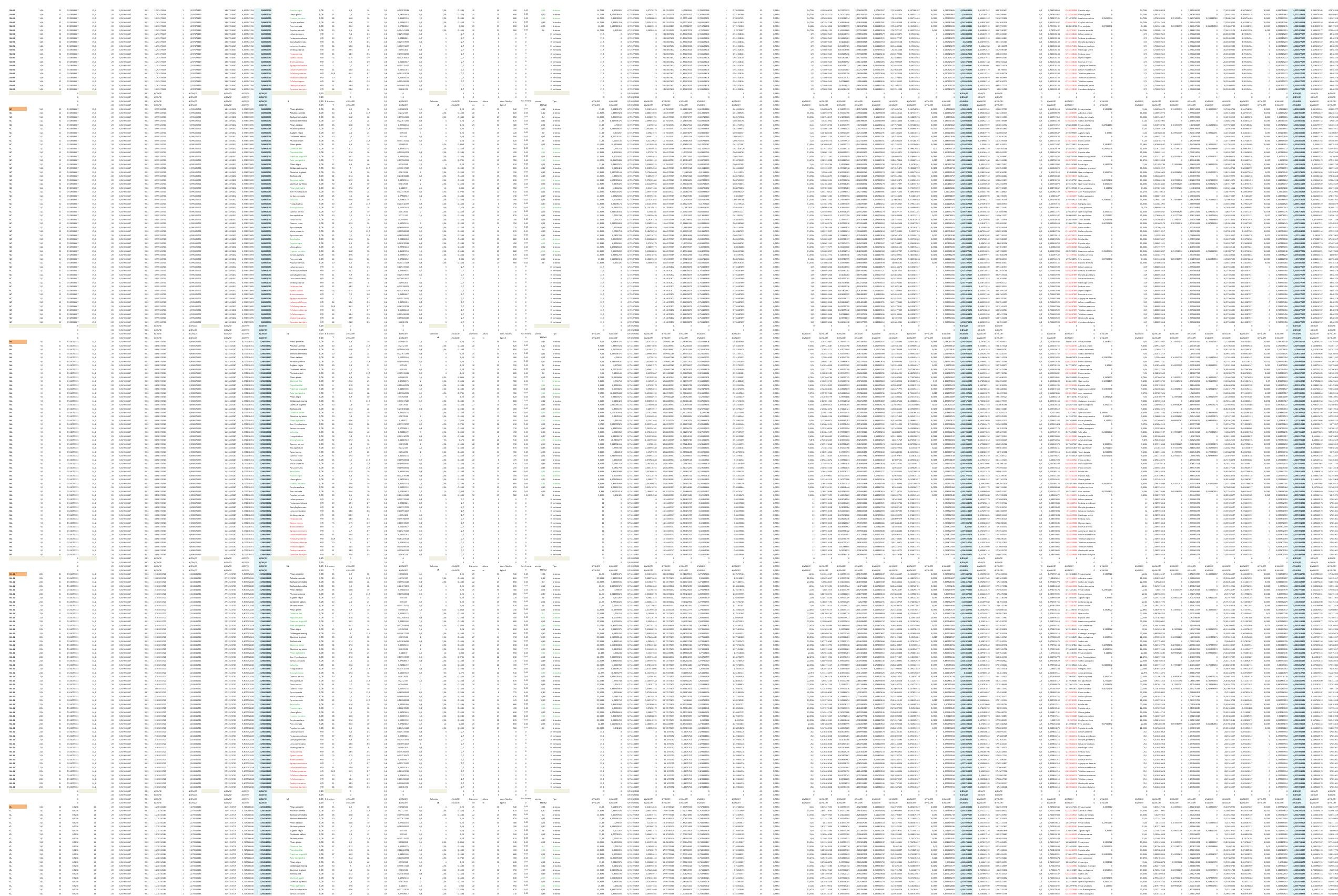

$\equiv \equiv$
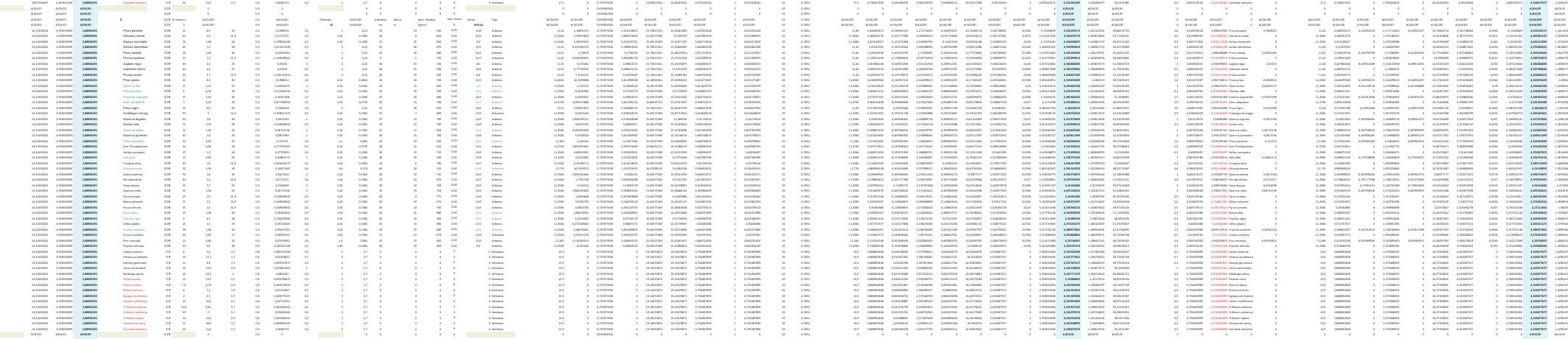

$=$

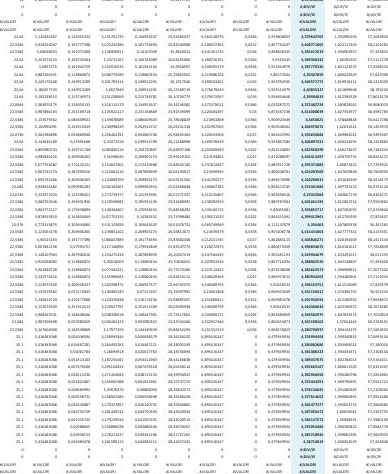

$=$

$=\equiv \equiv \equiv \equiv \equiv \equiv \equiv \equiv$

$\equiv \equiv$
$\equiv \equiv$
$\equiv \equiv$

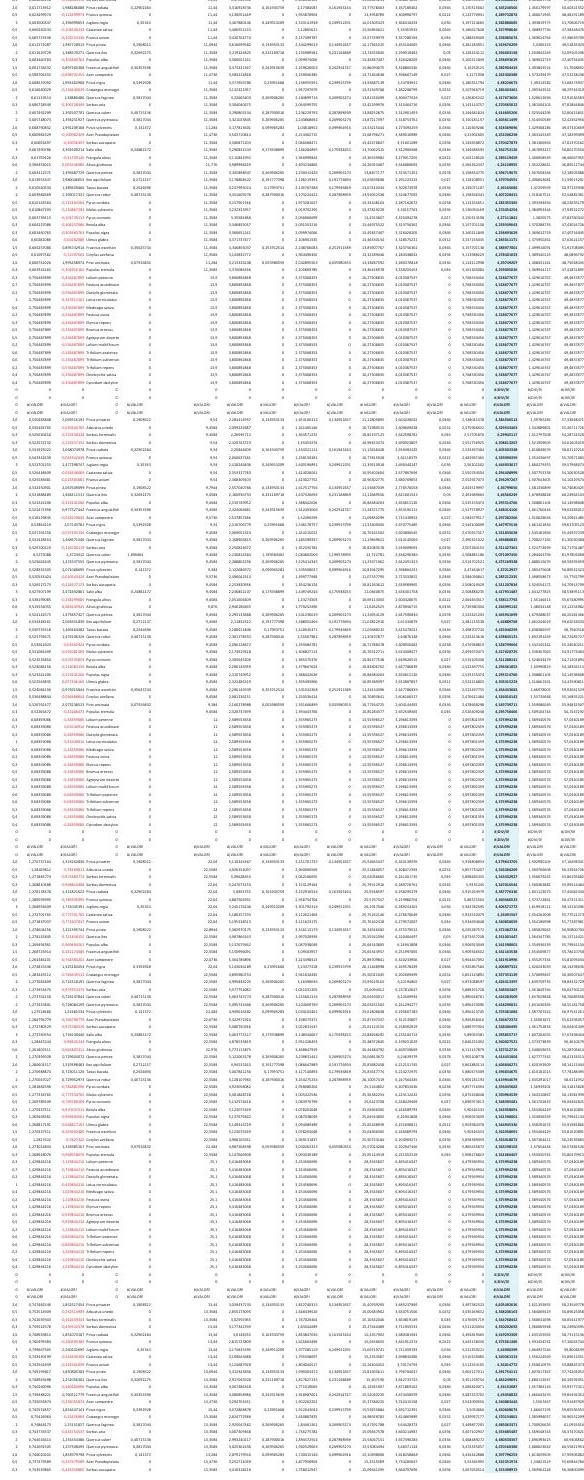

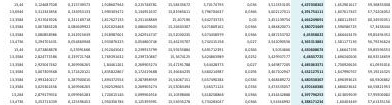




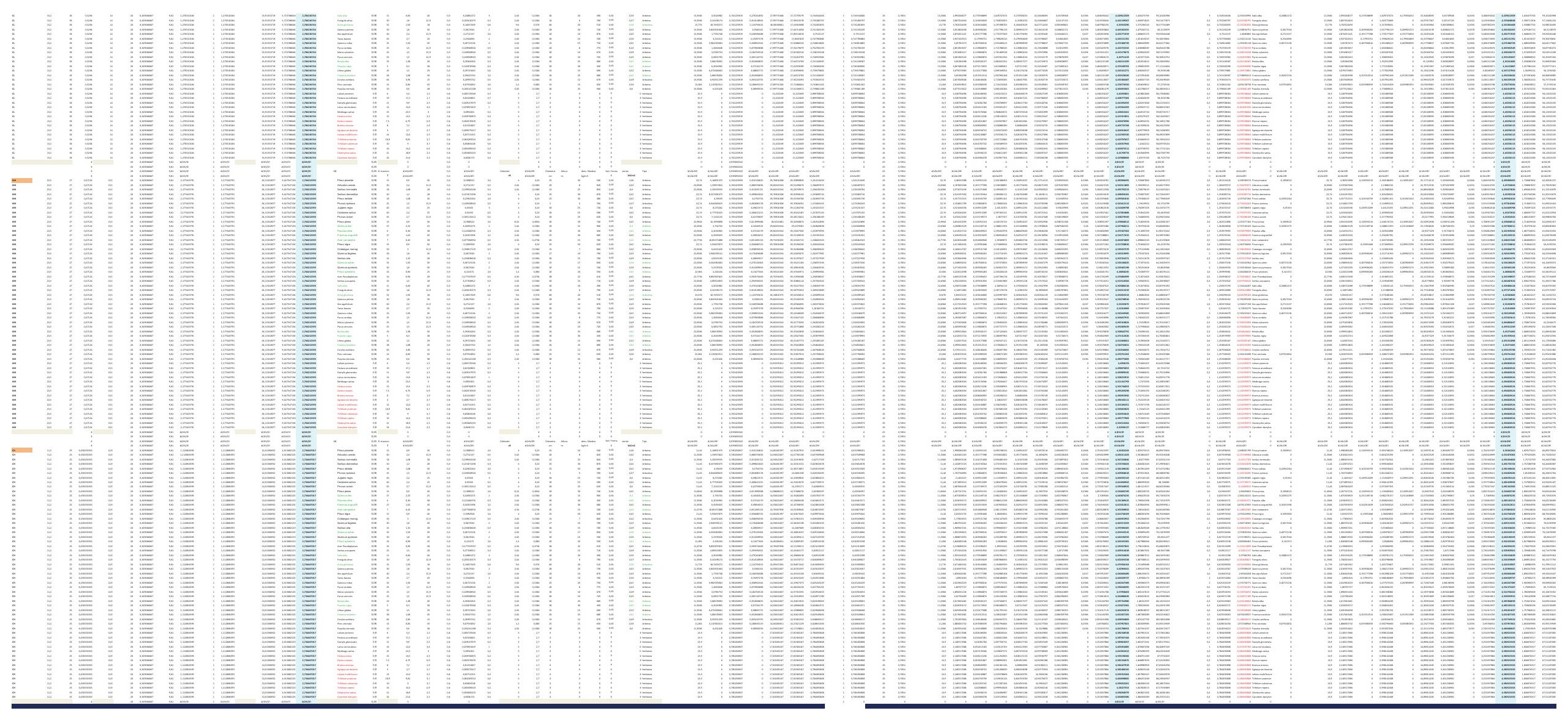



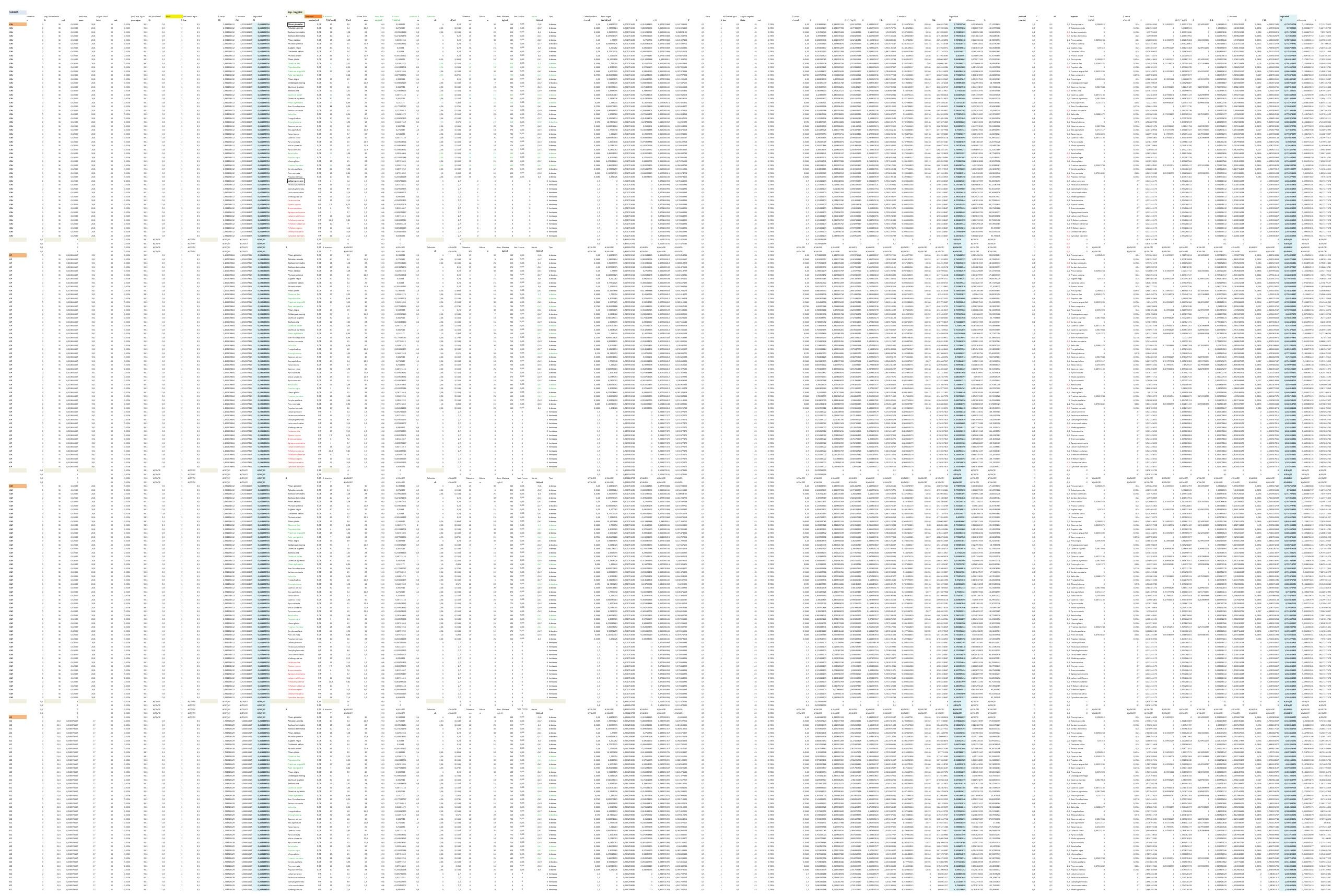

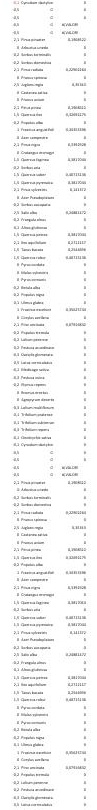

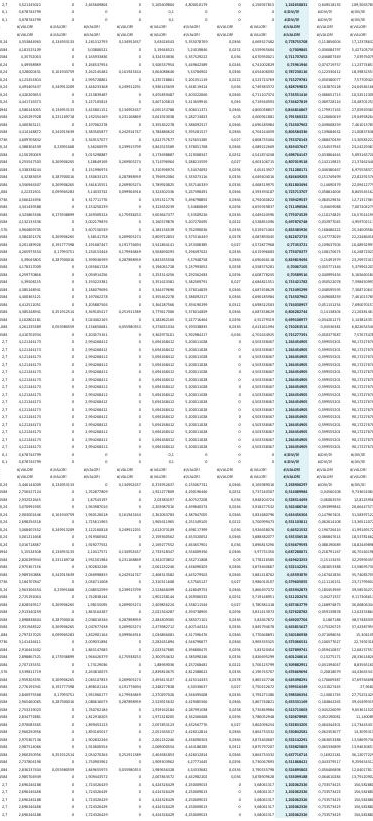




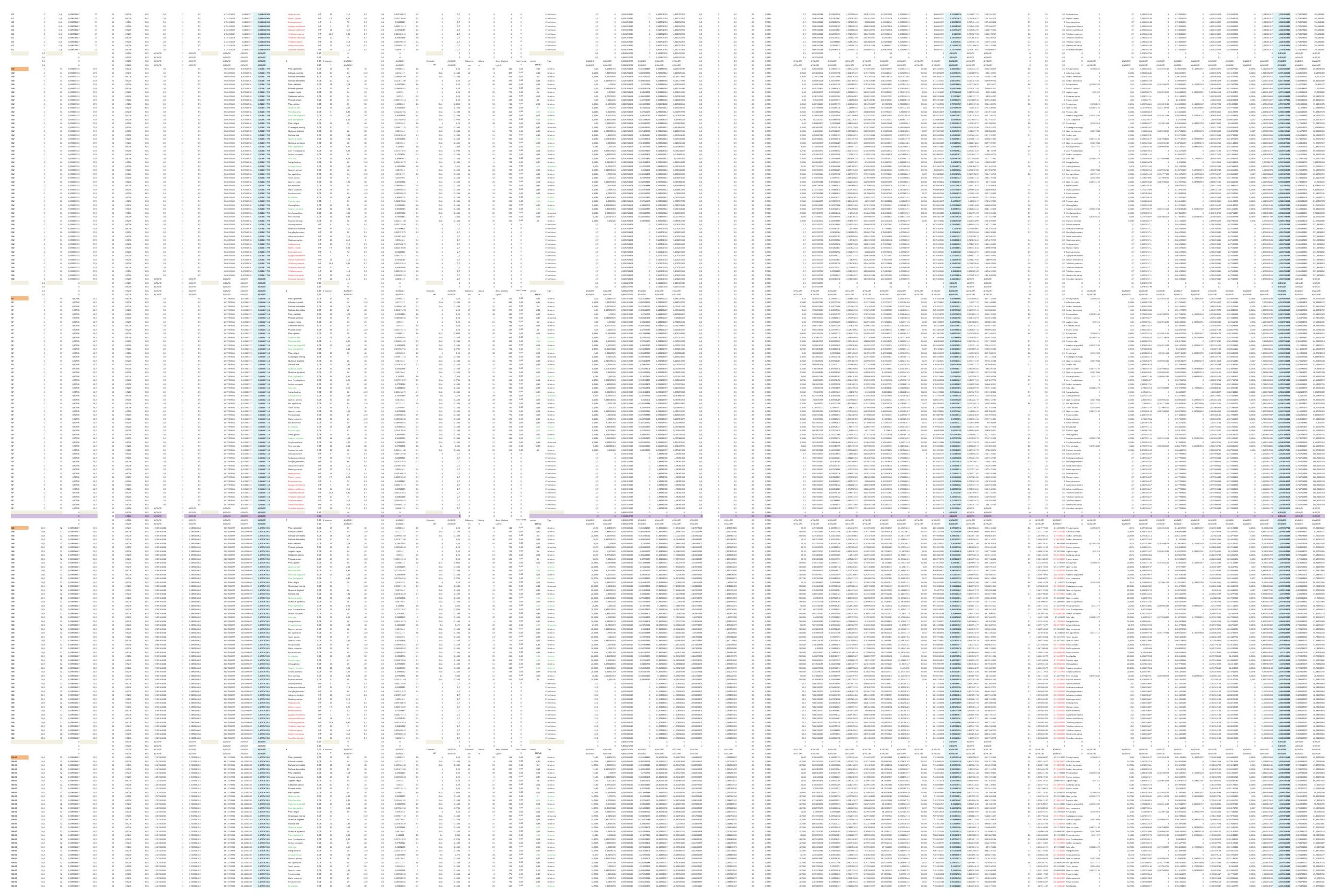



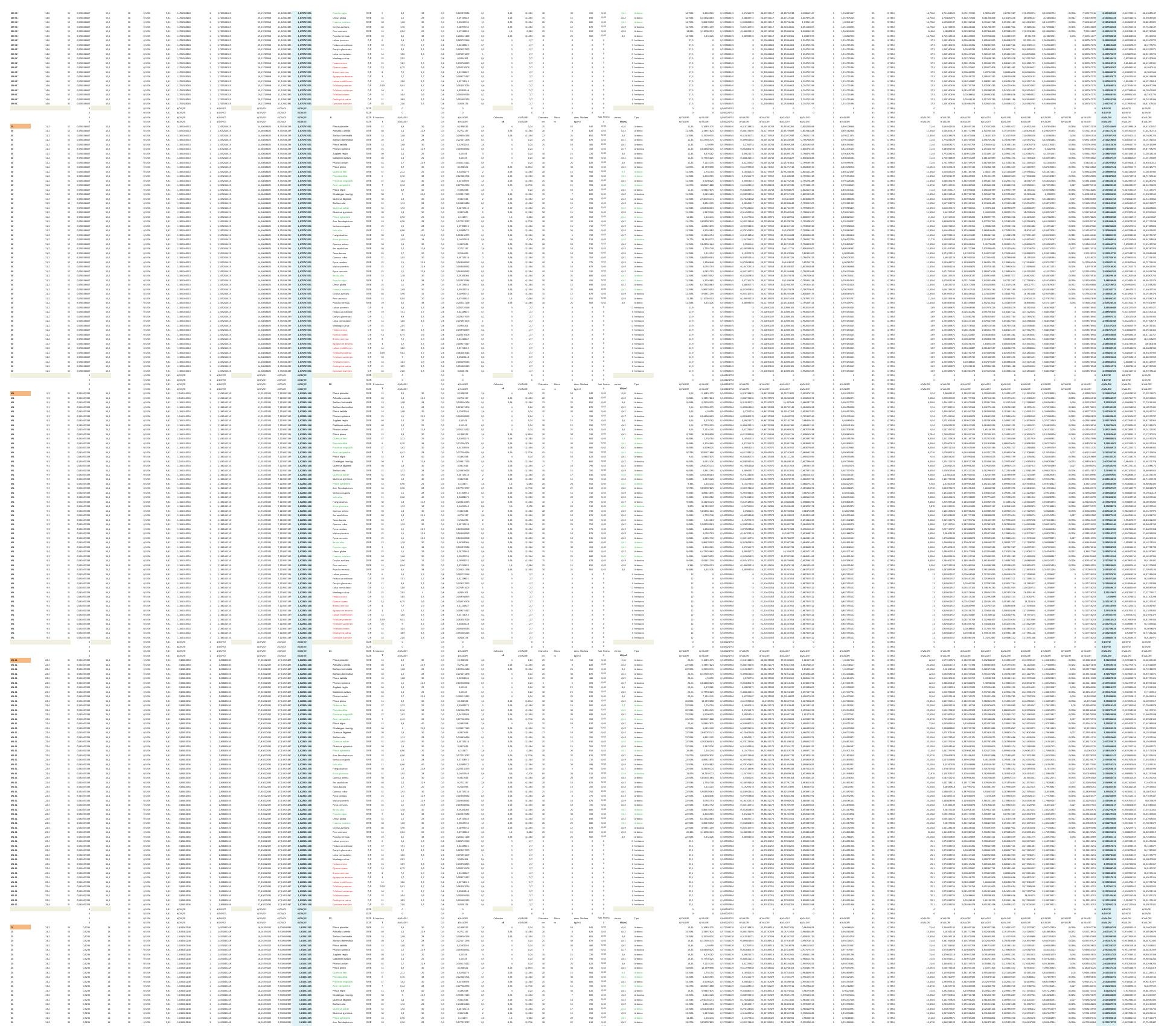

${ }^{\circ}{ }^{\circ} \equiv \equiv$
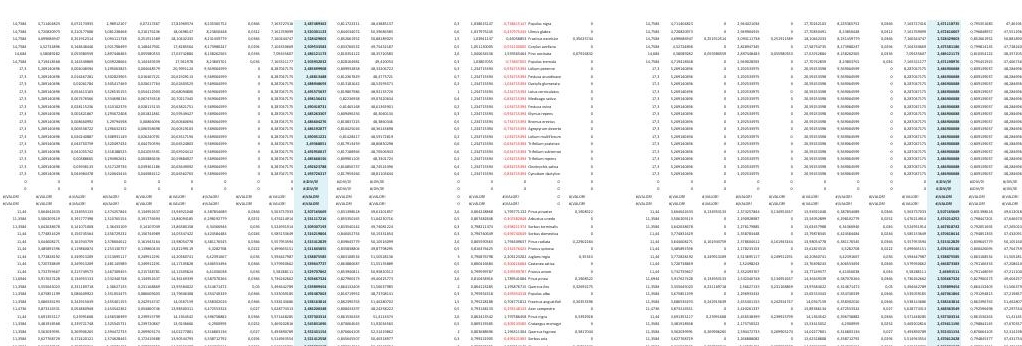

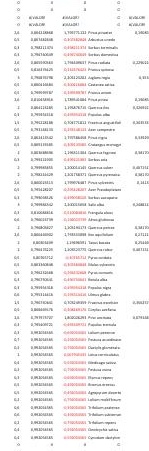
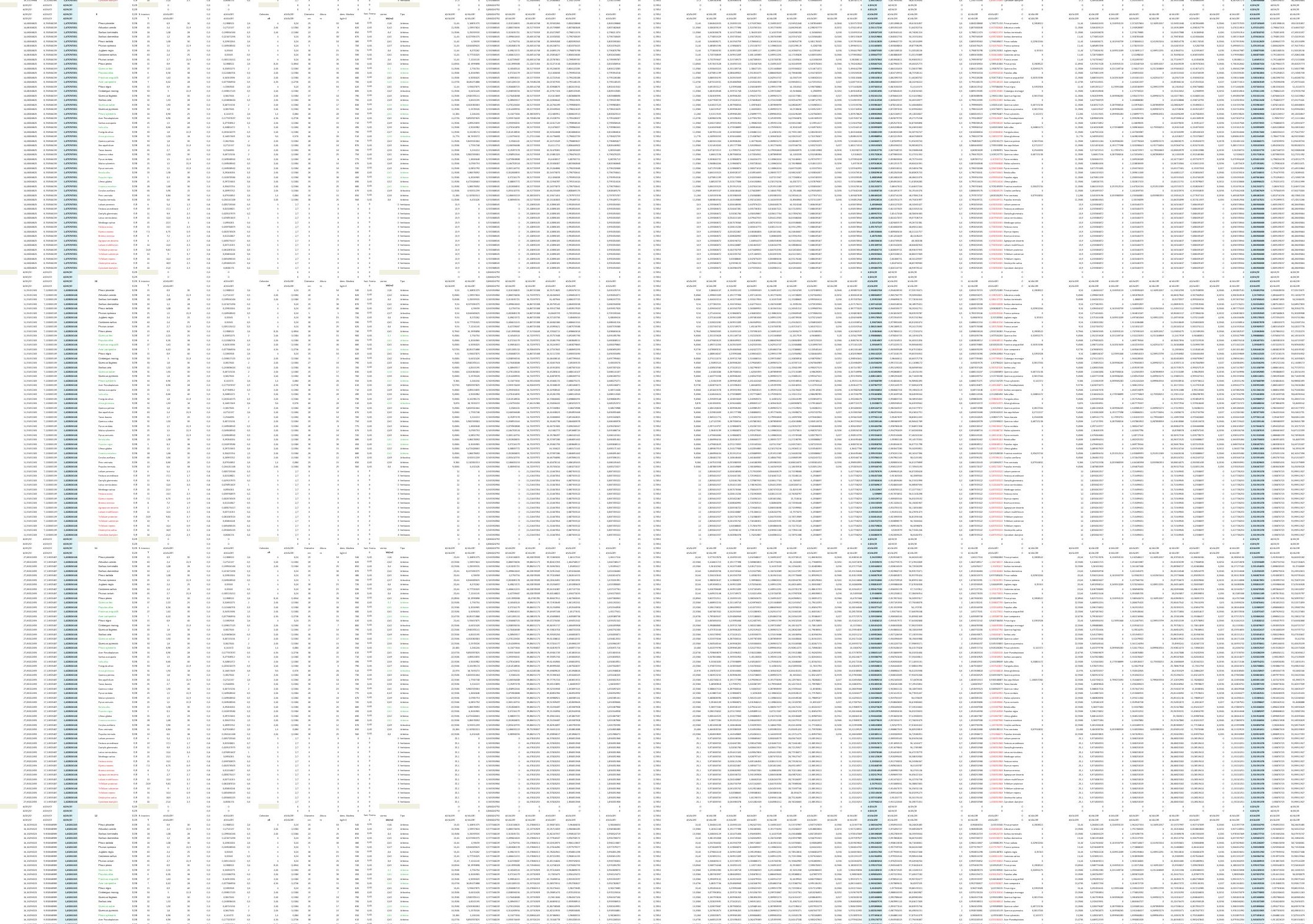


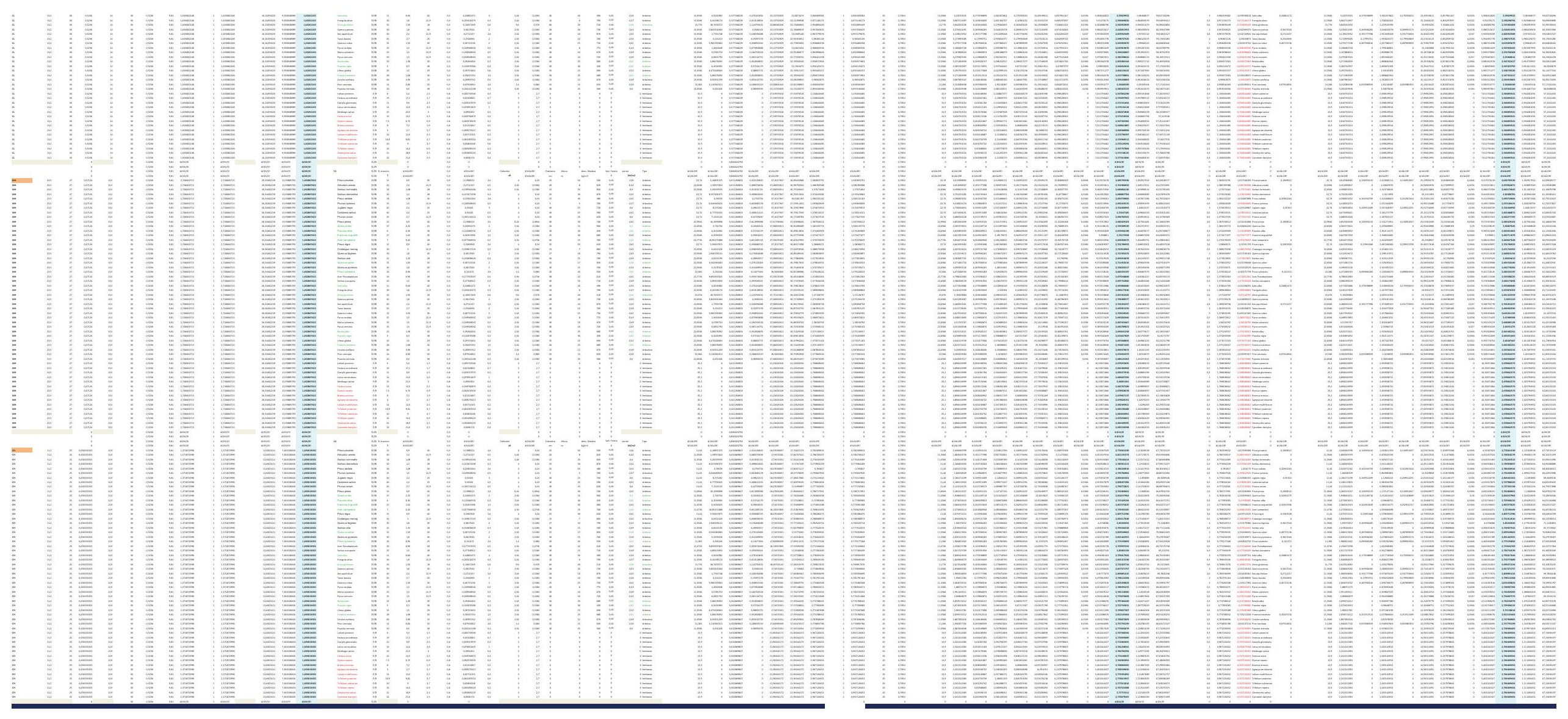



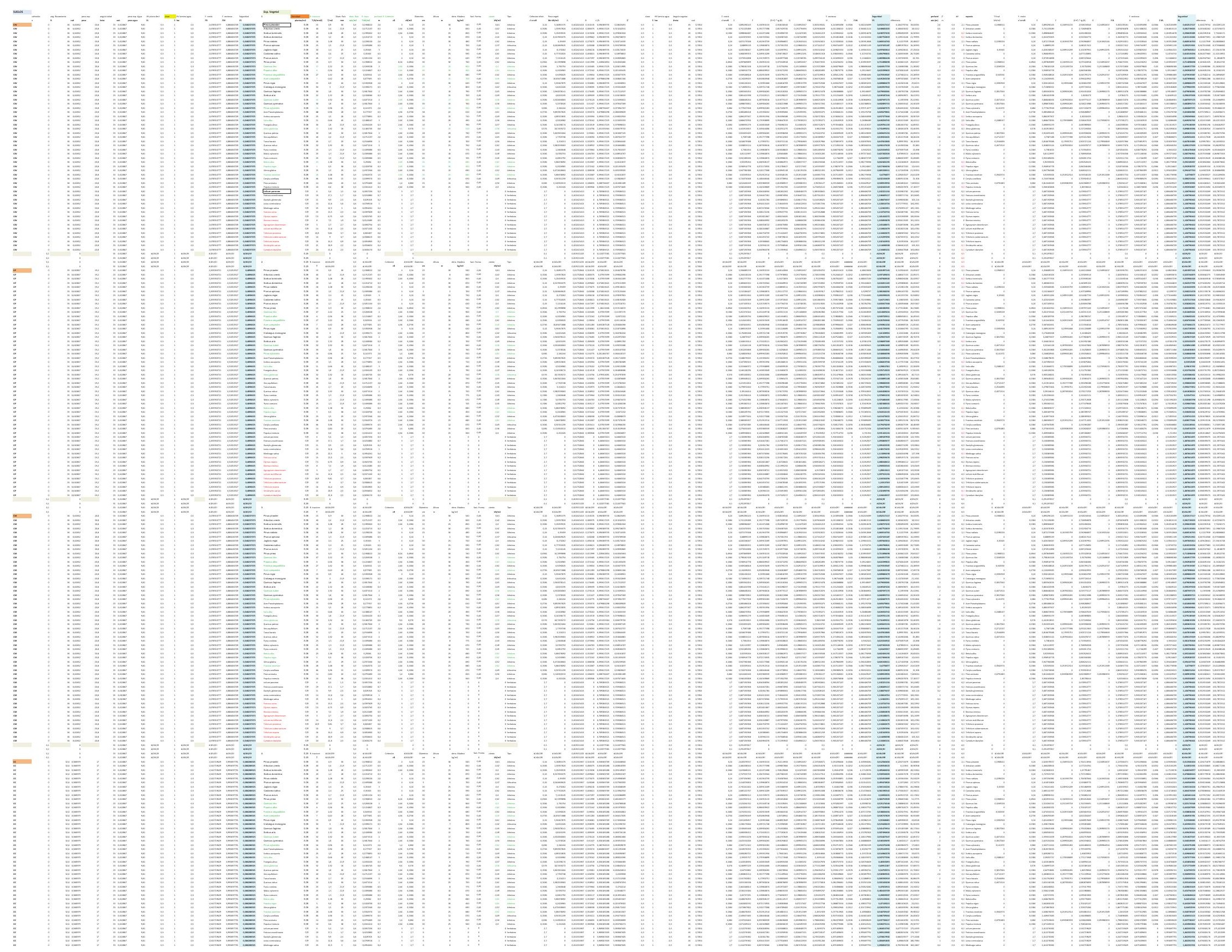


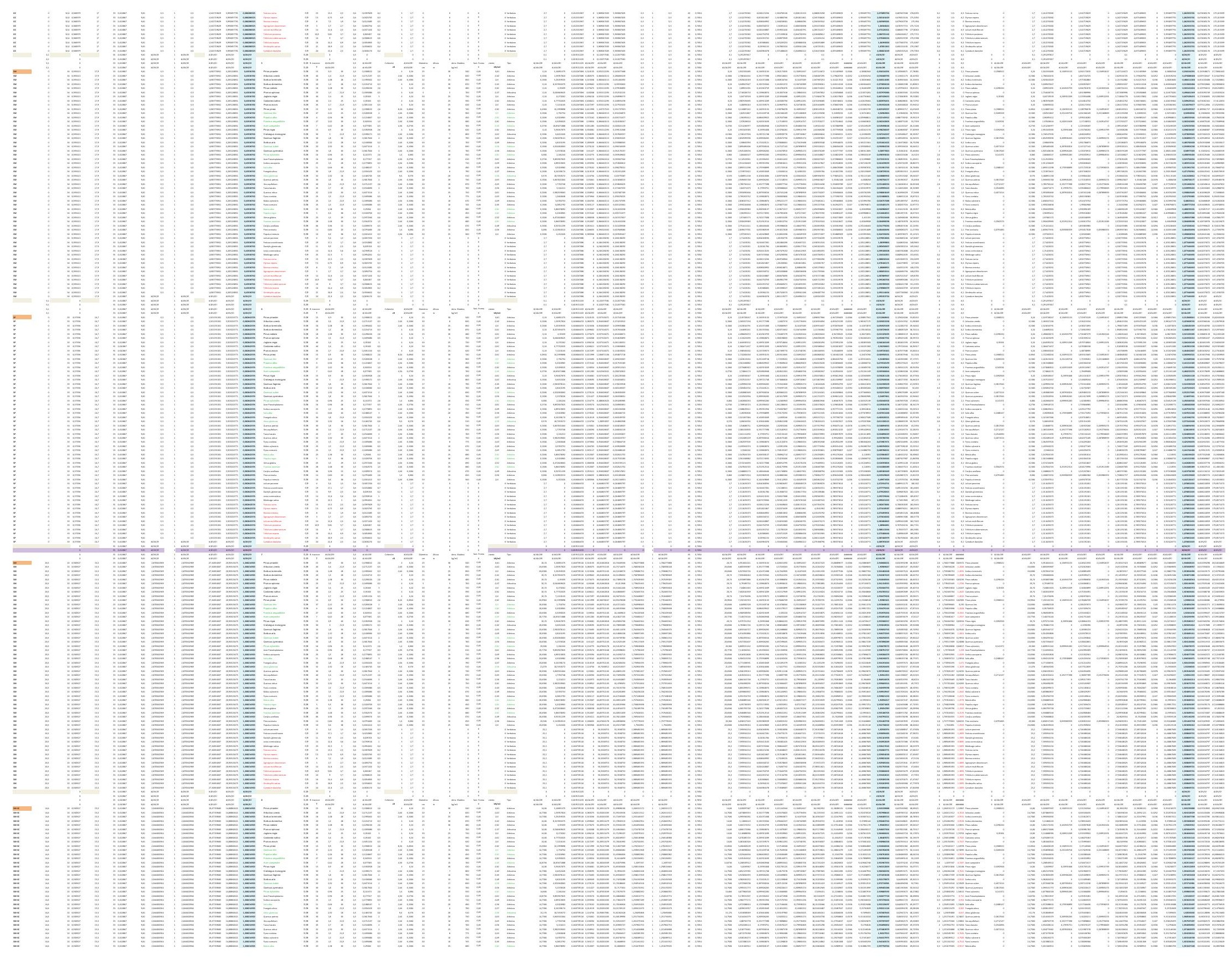



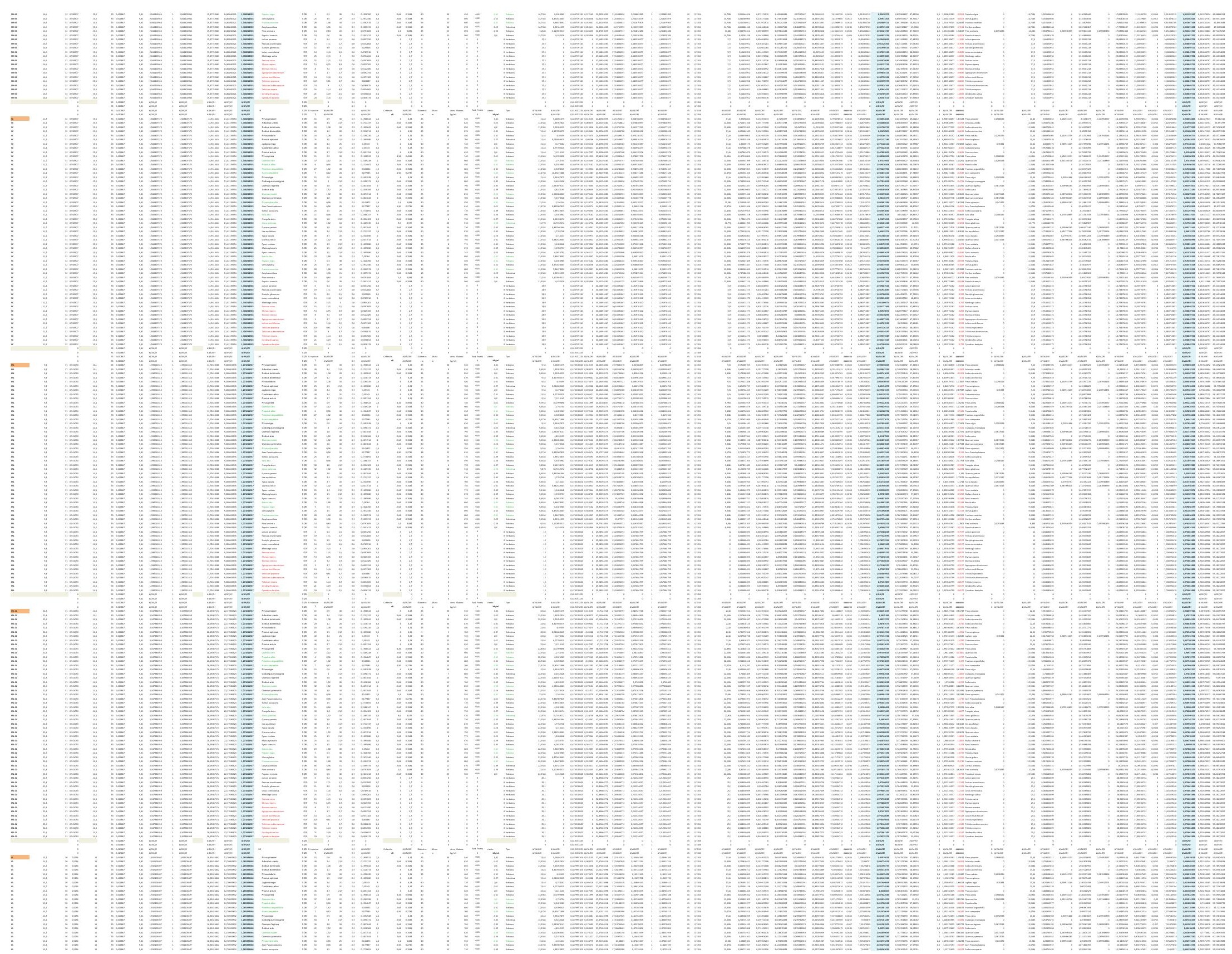

$-$
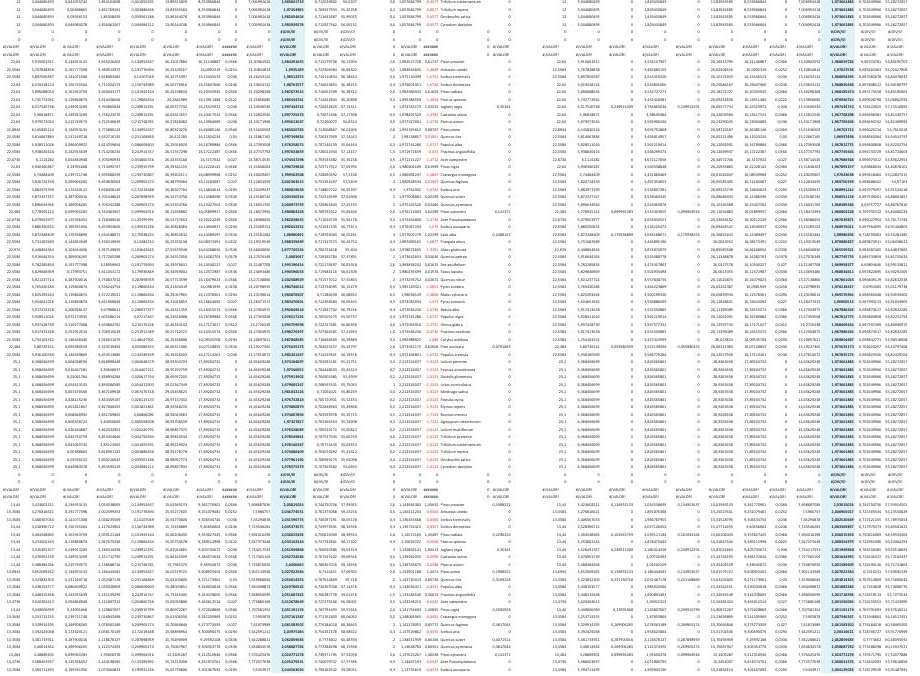


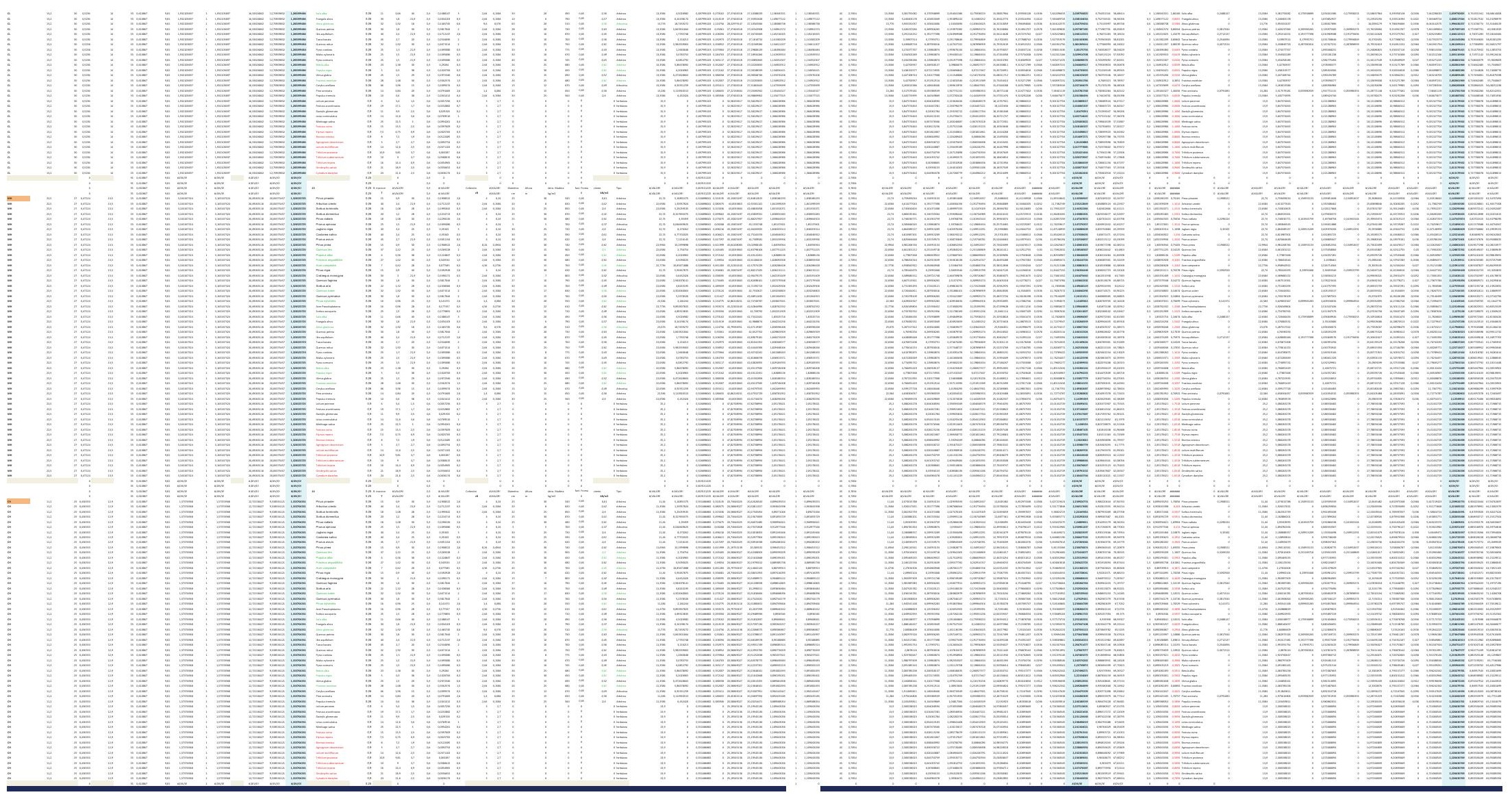



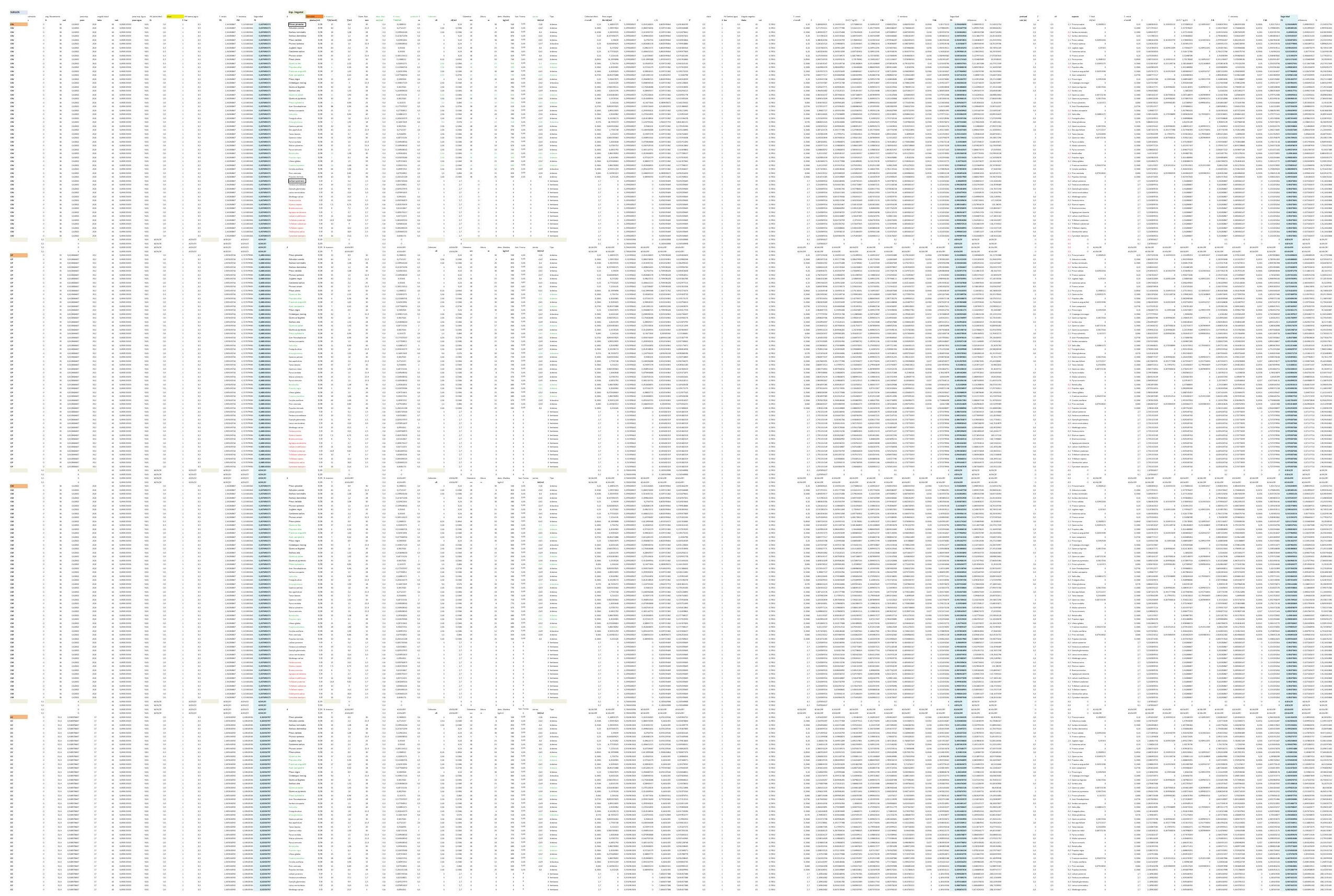


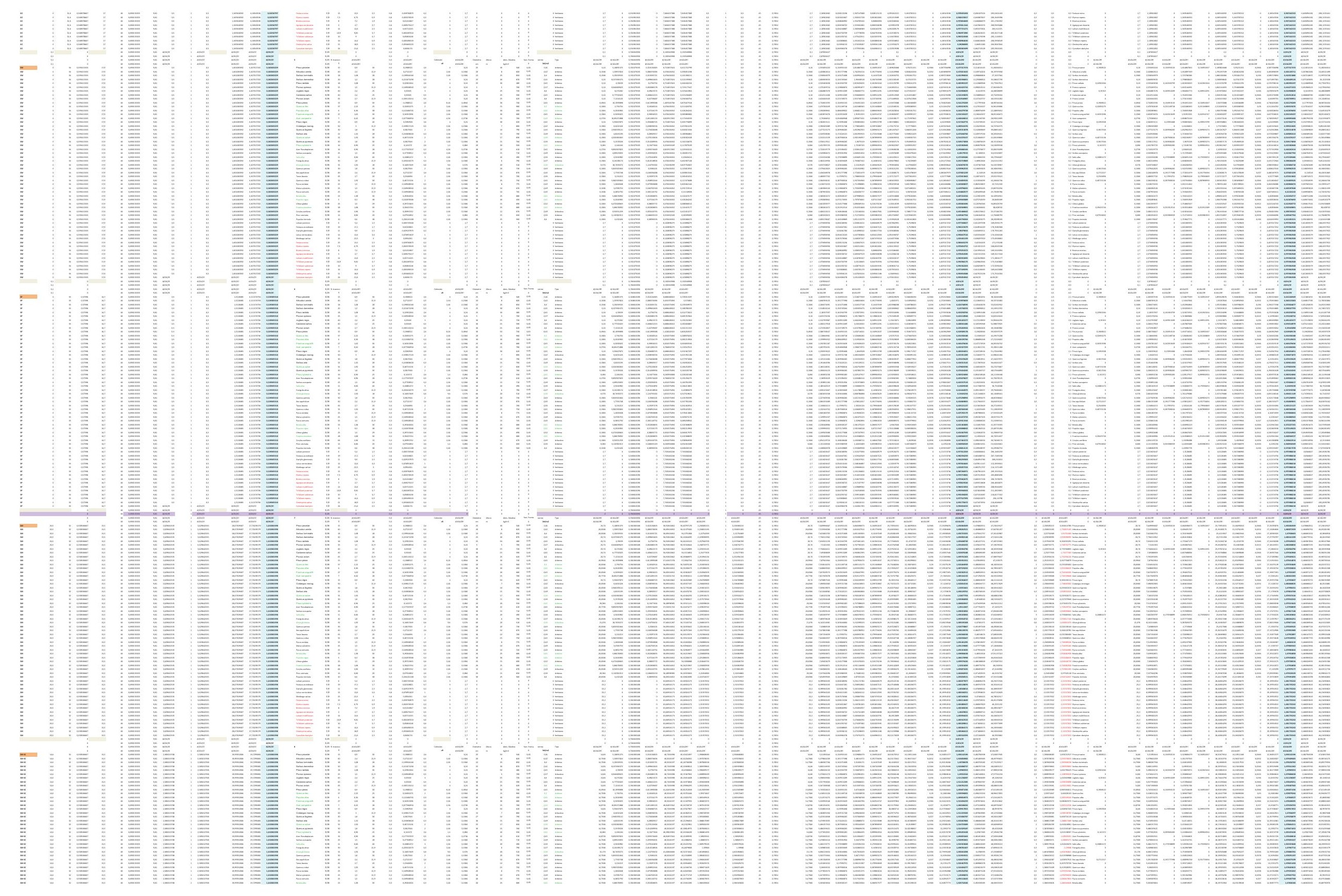



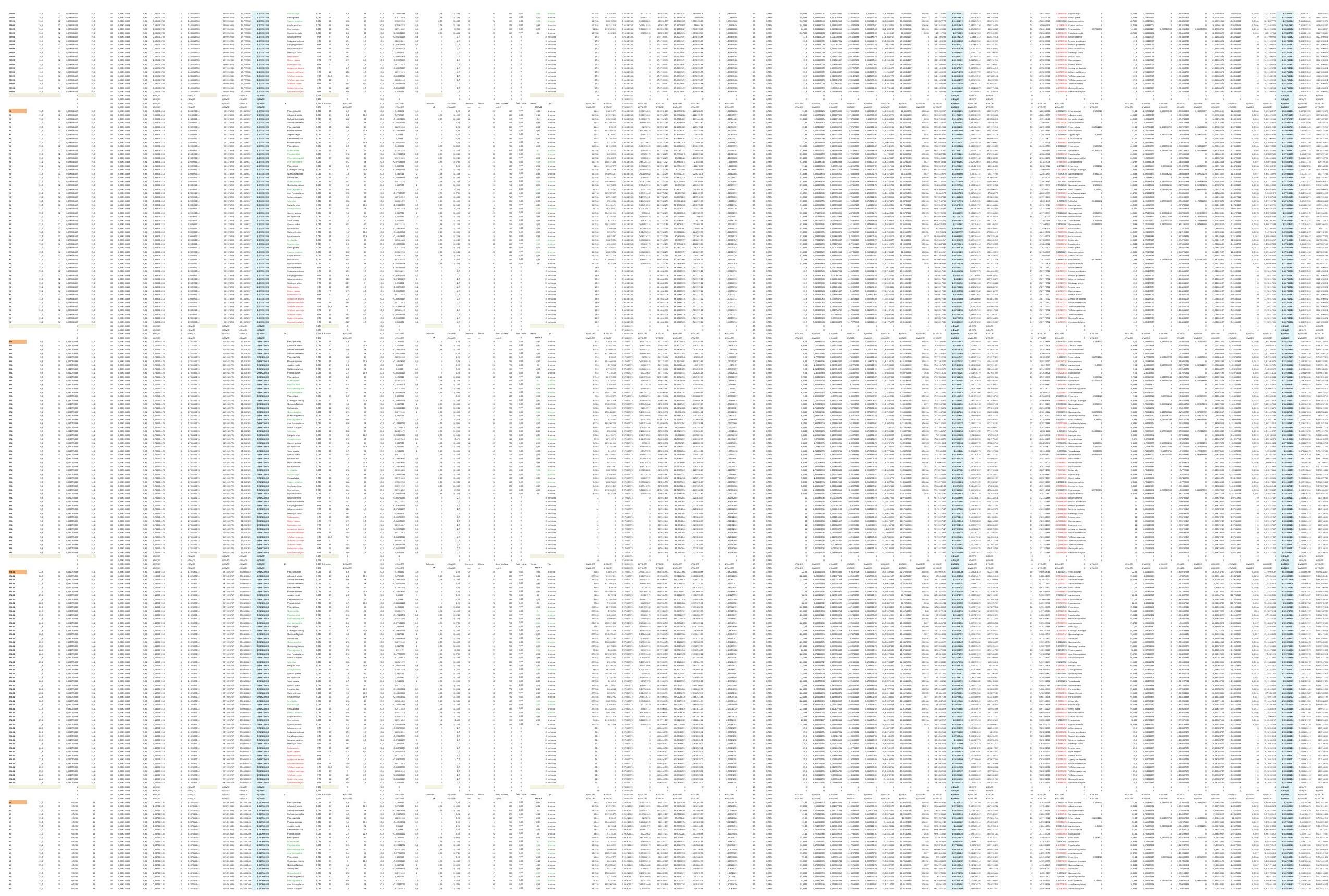


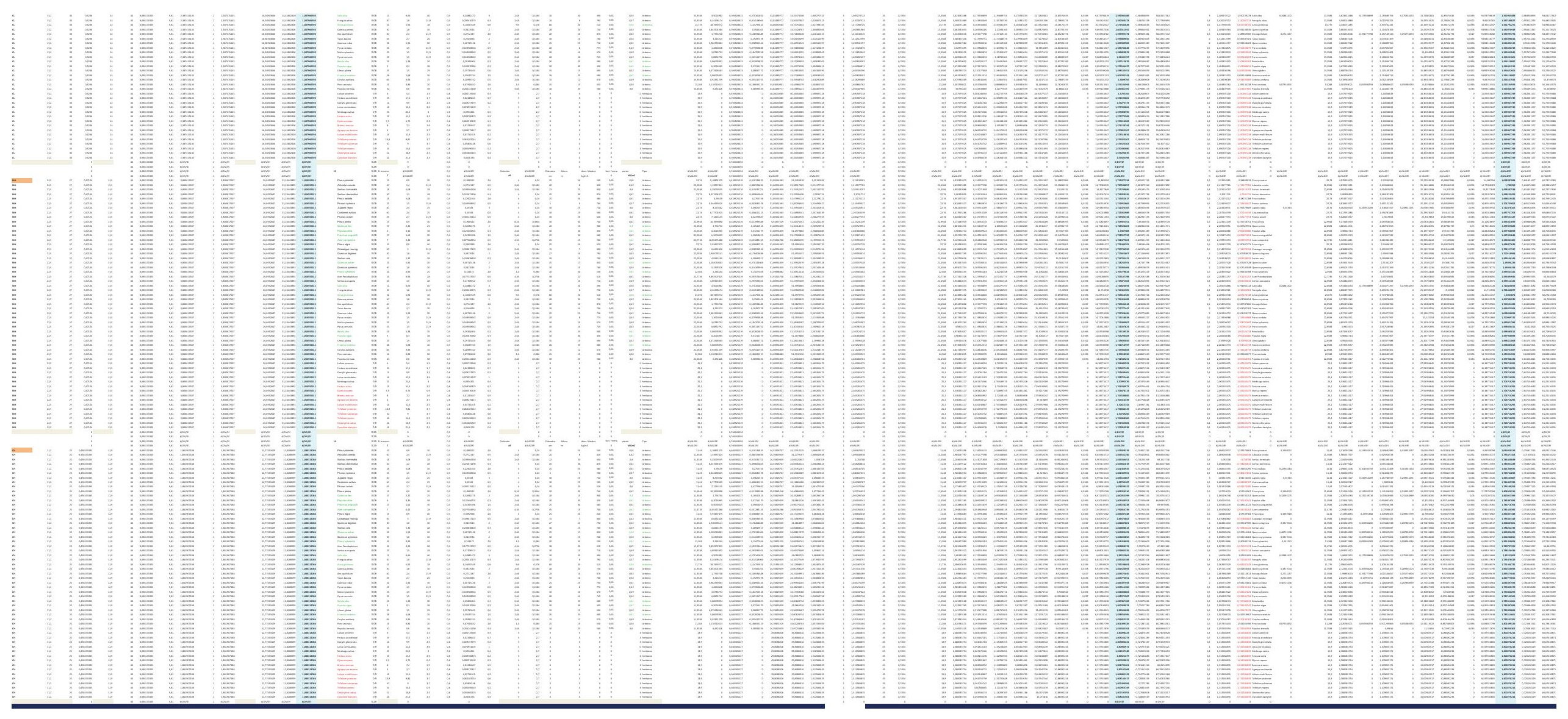



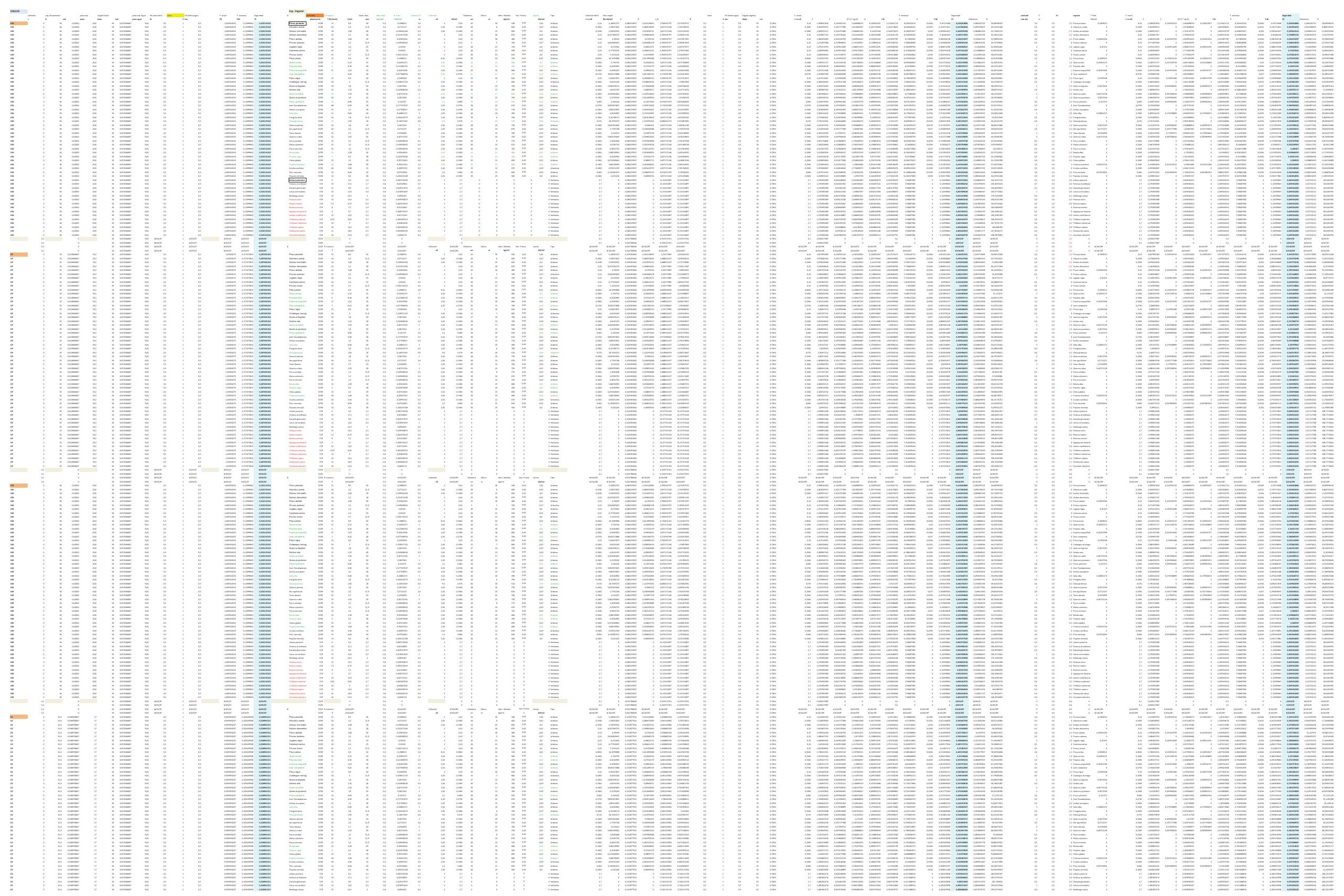


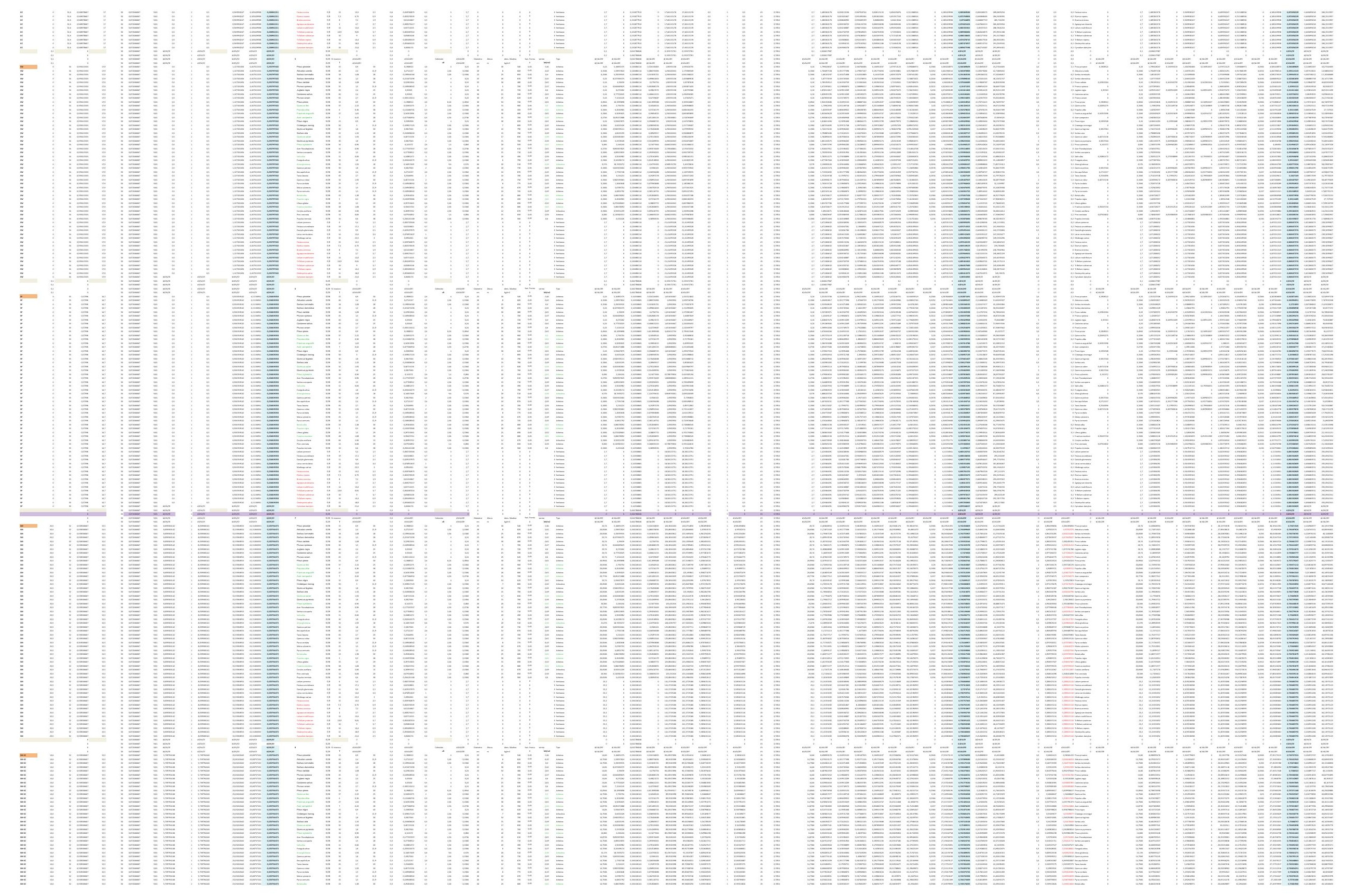



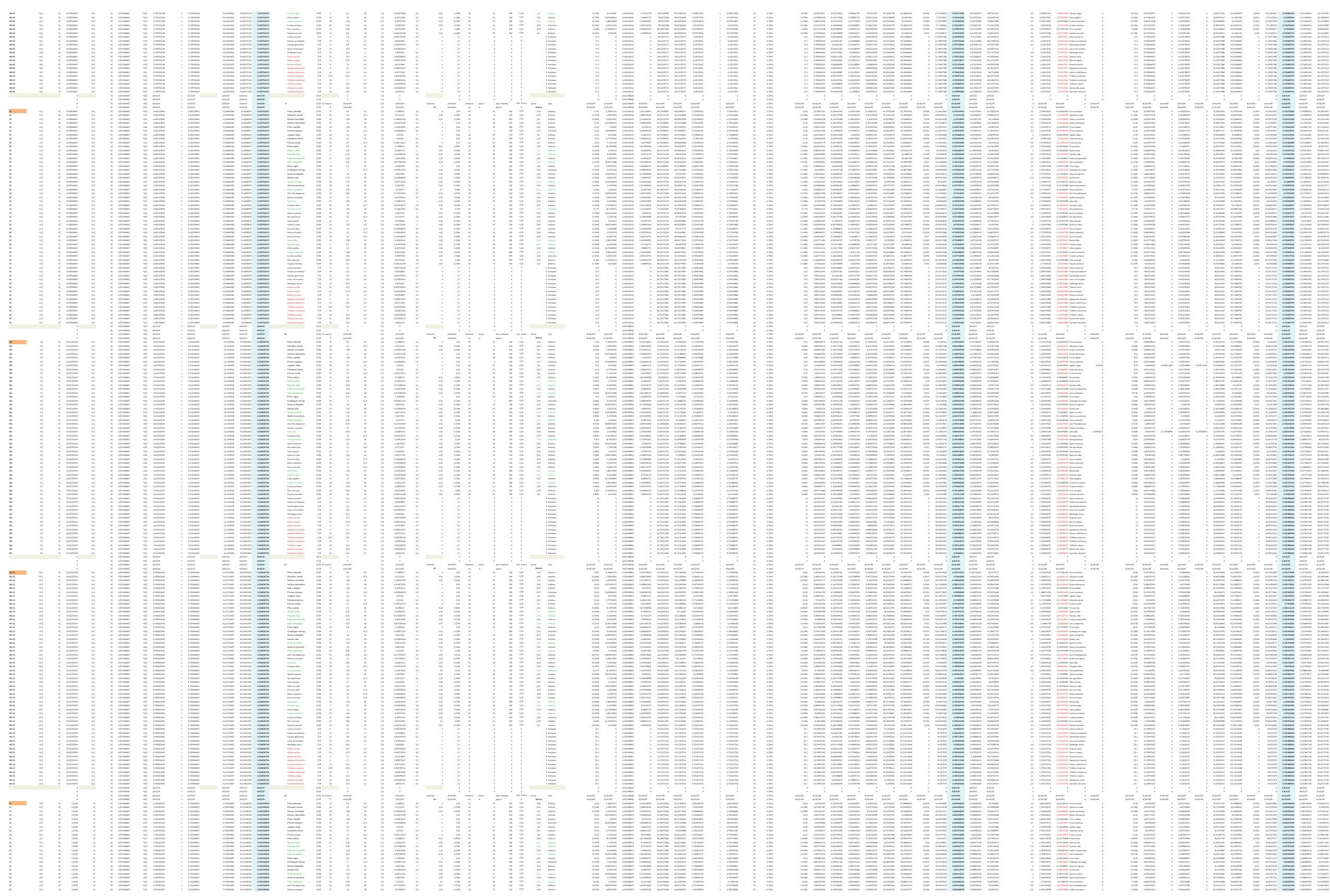


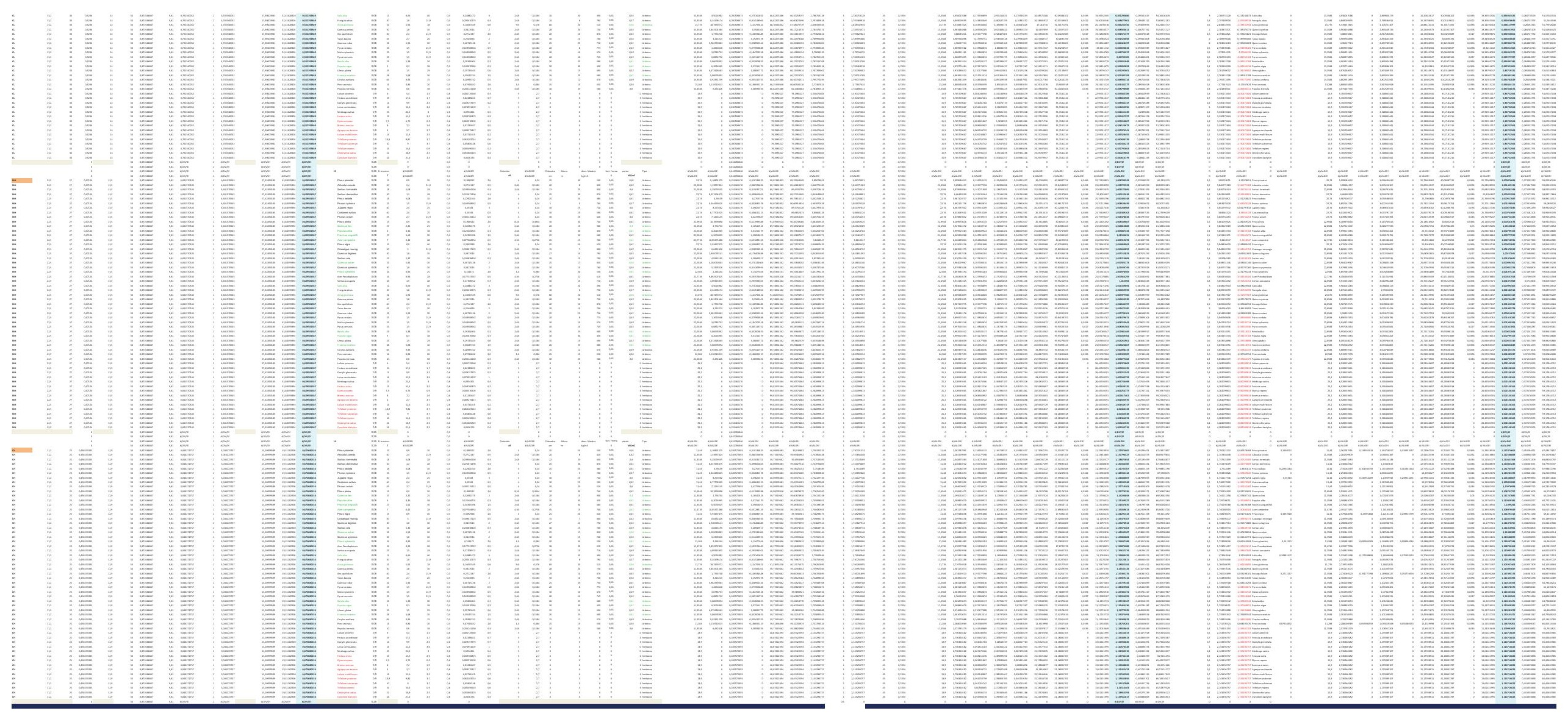



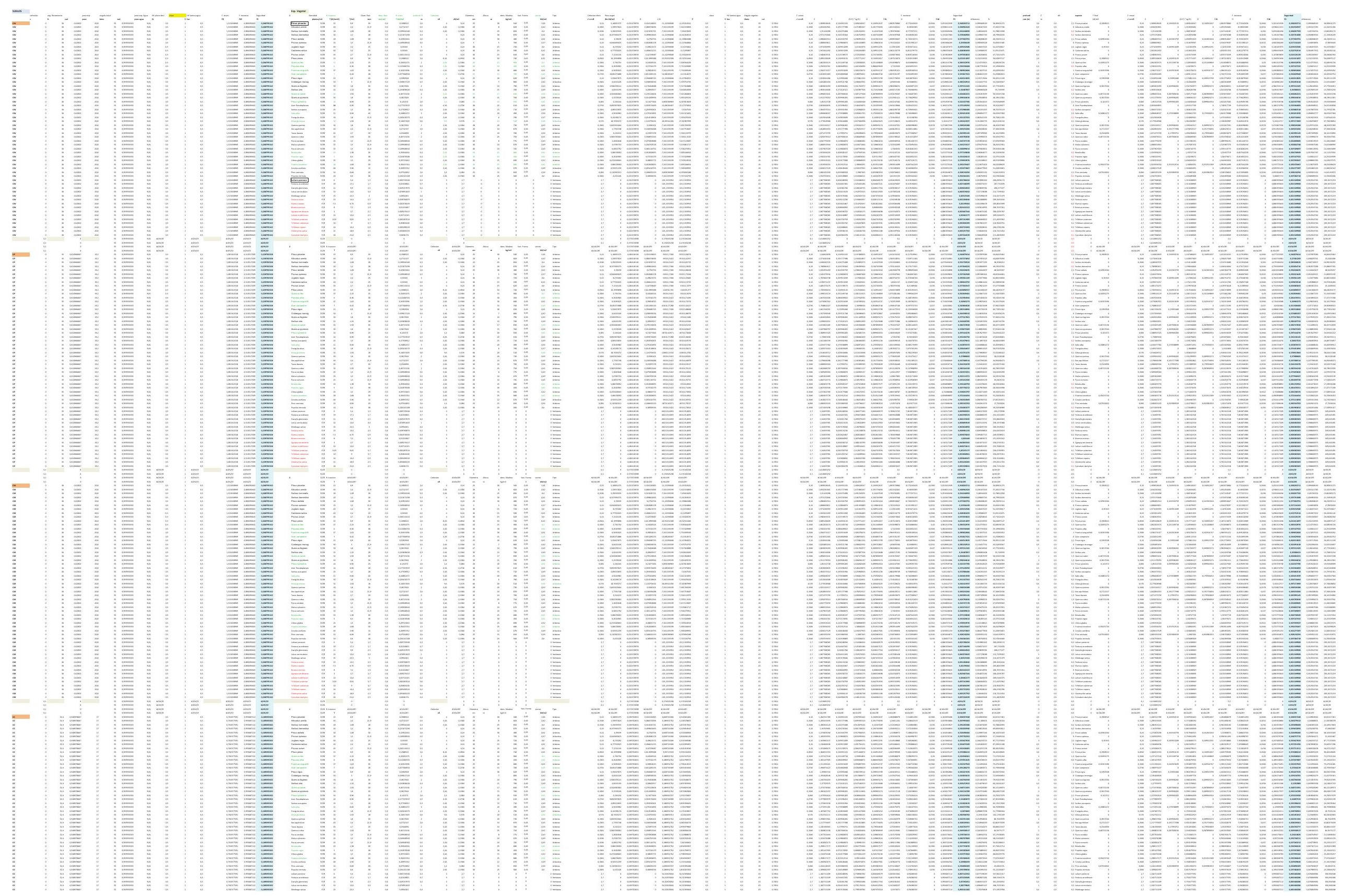


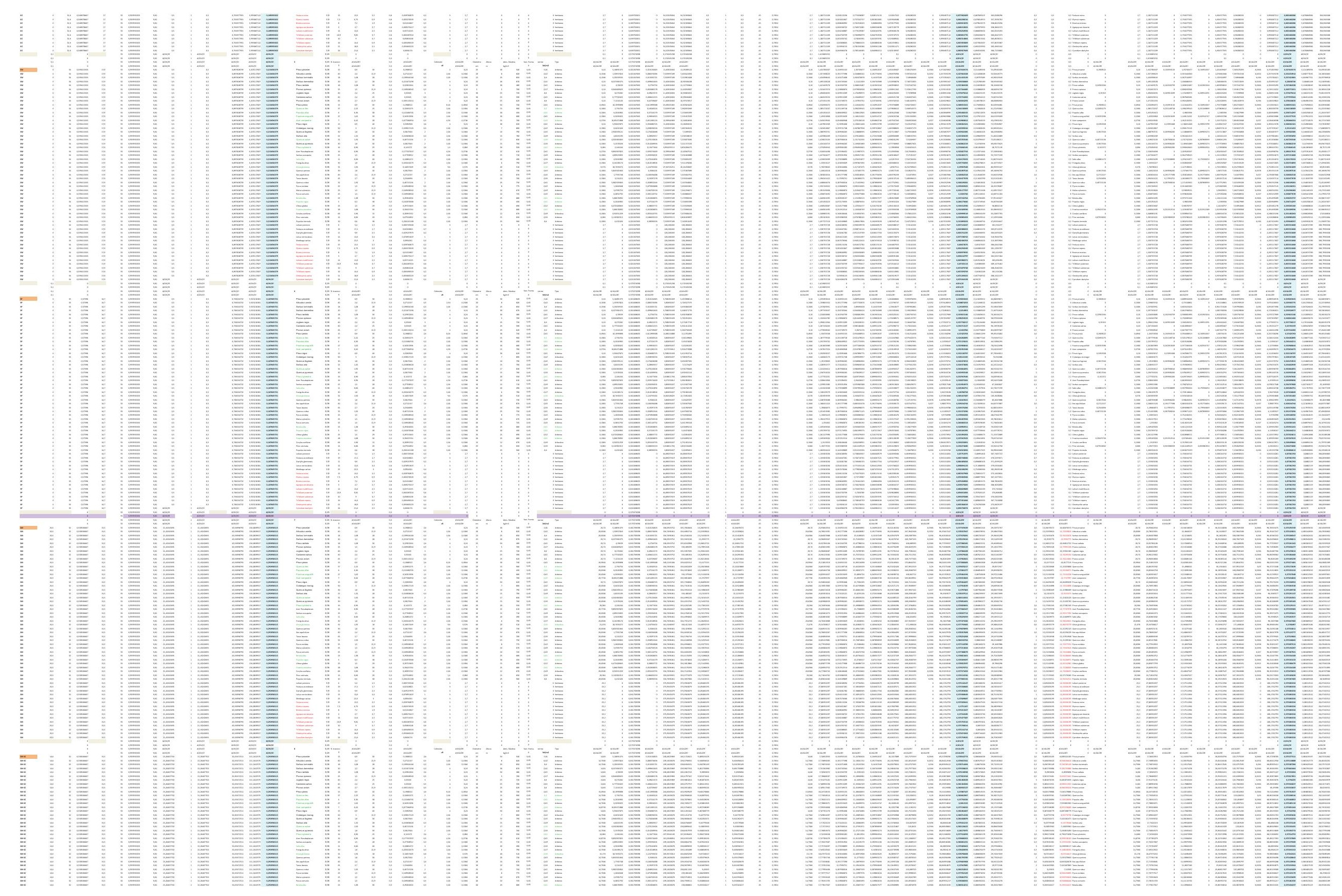



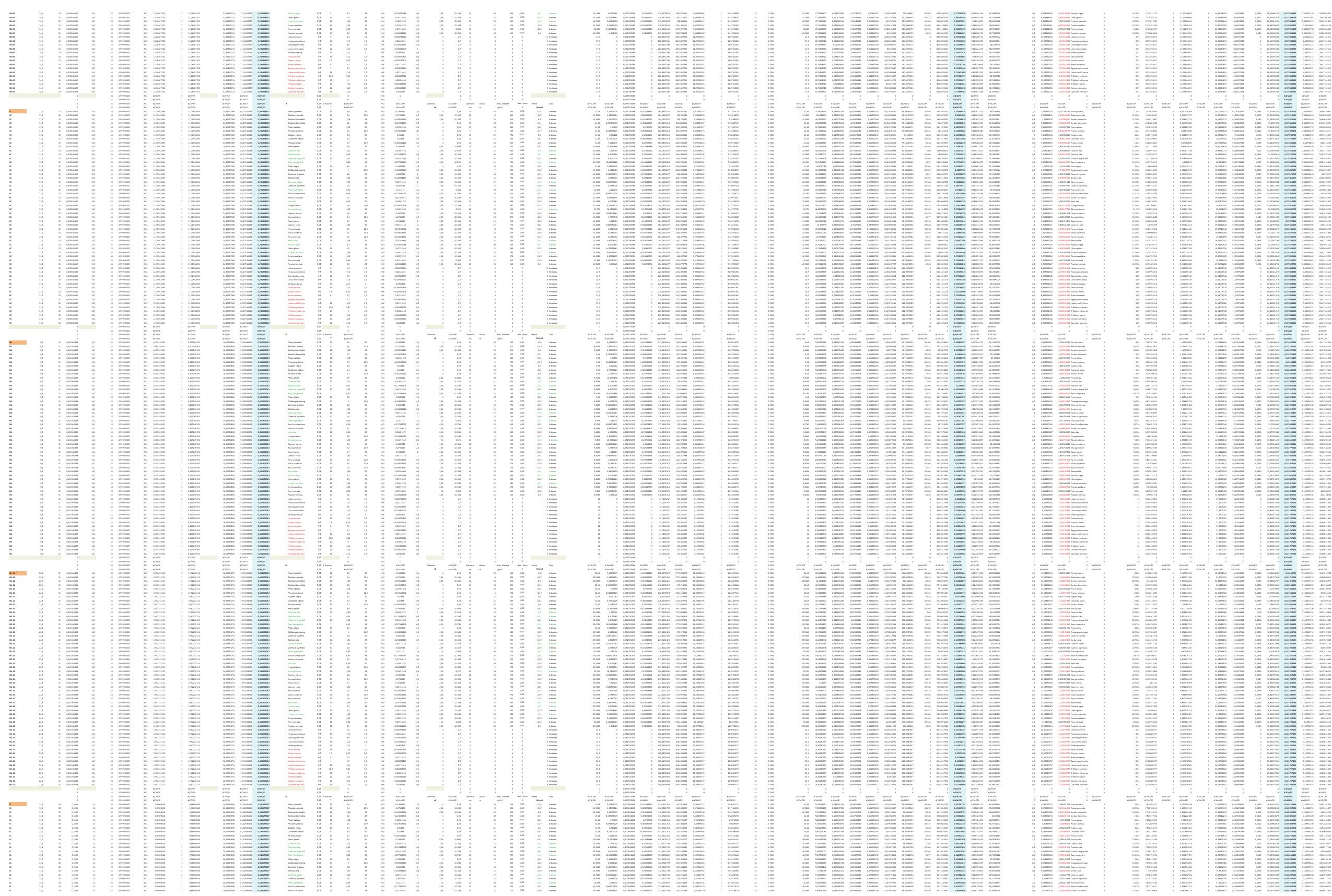


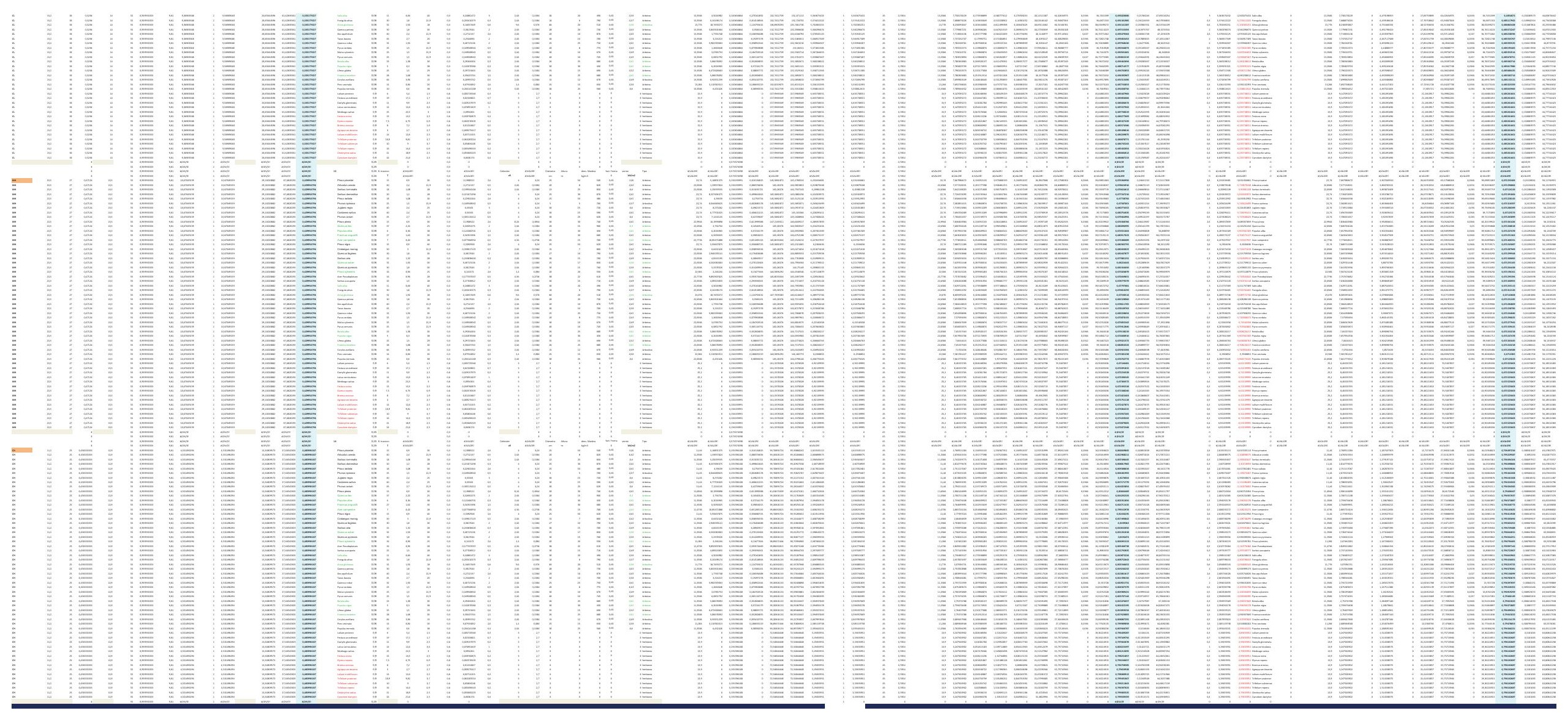



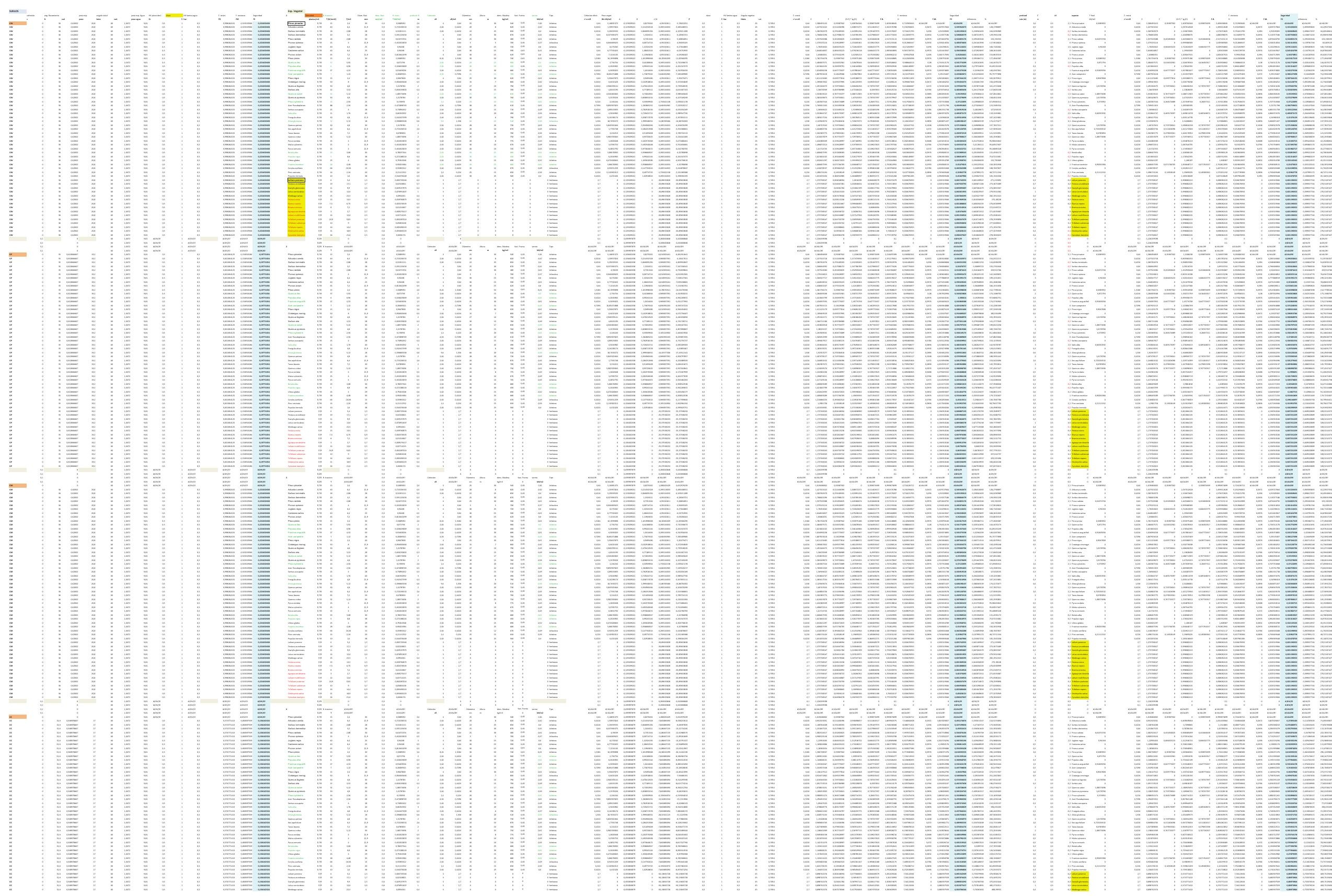

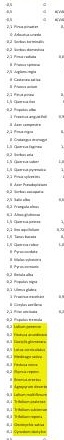
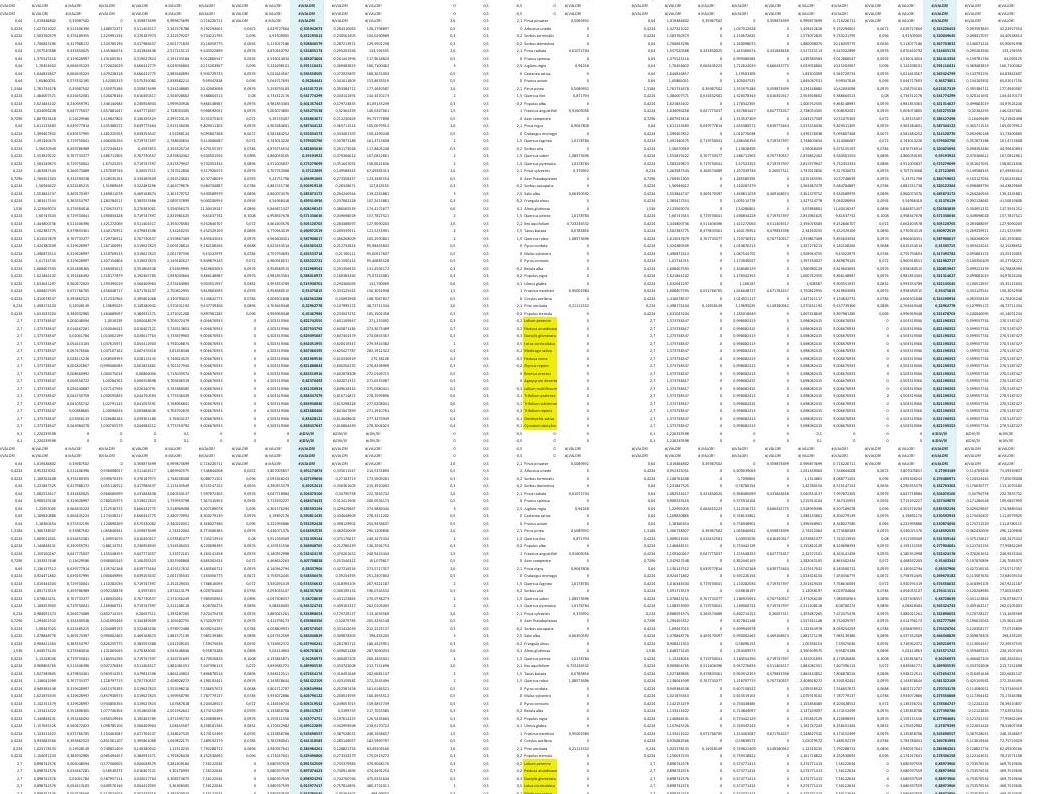

俸

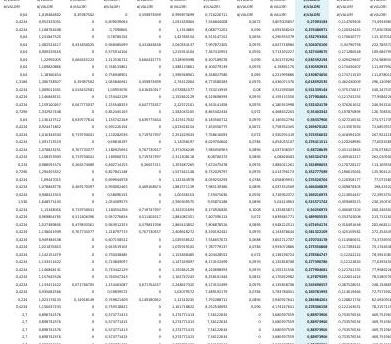




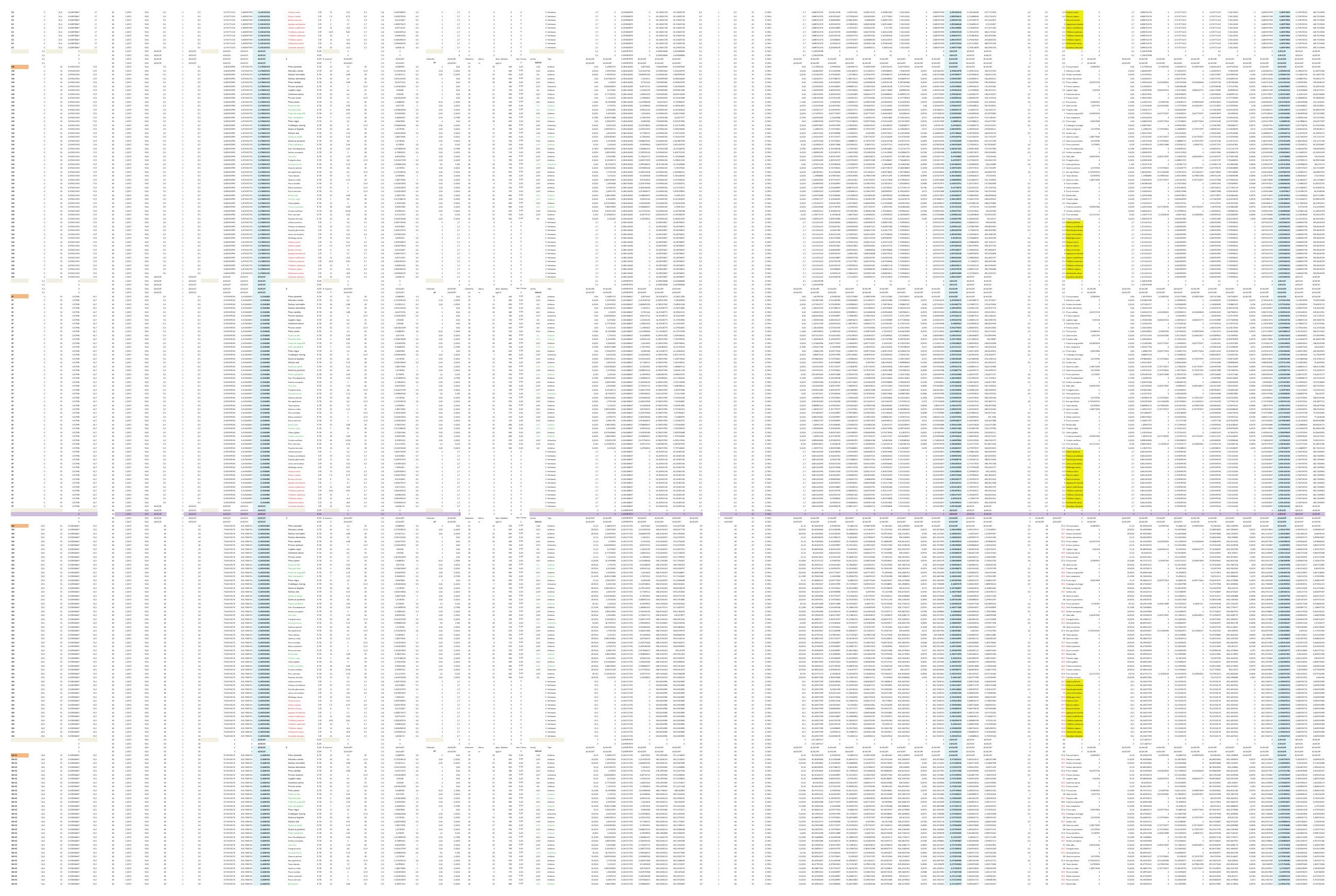



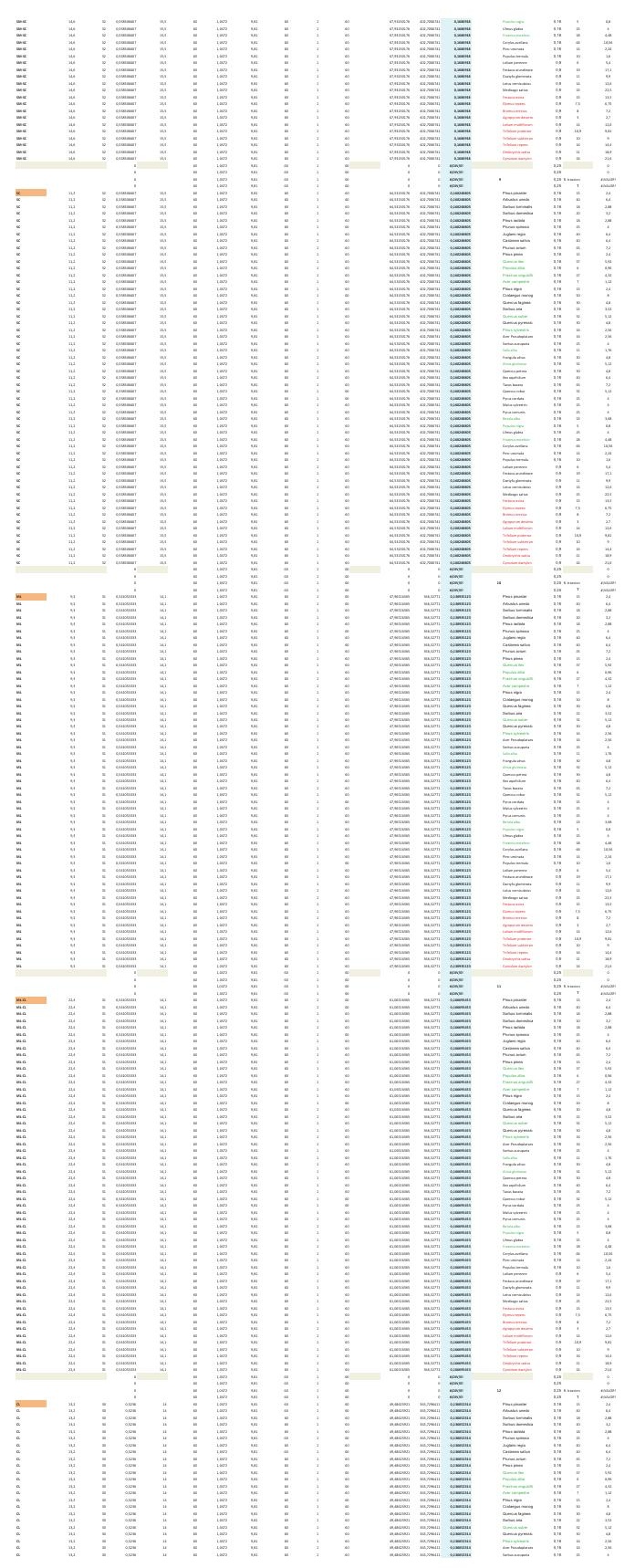

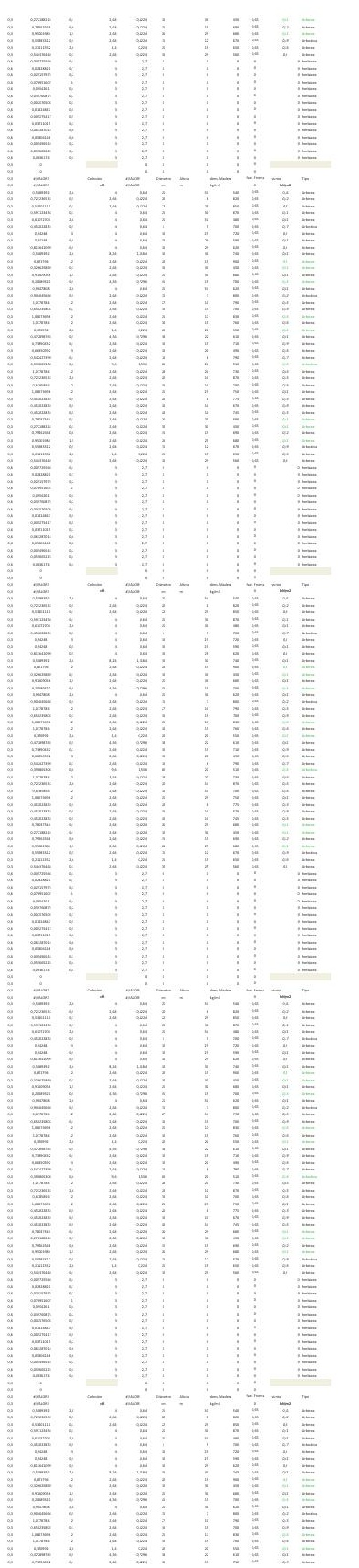

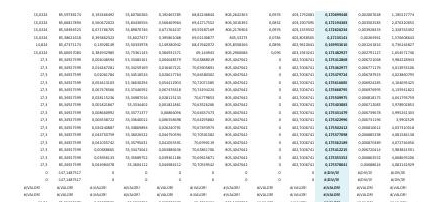
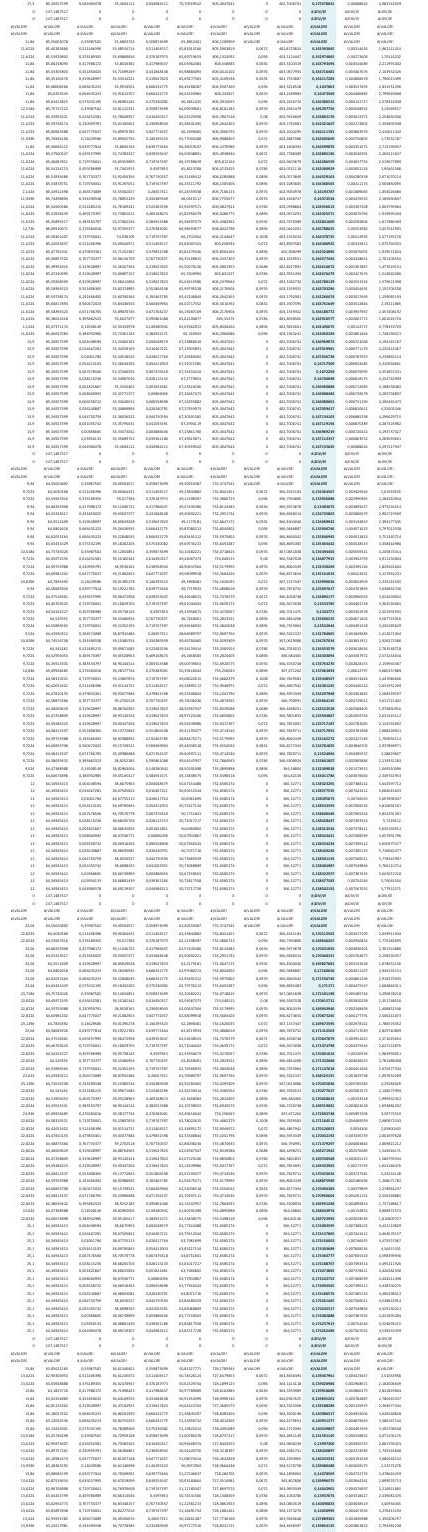

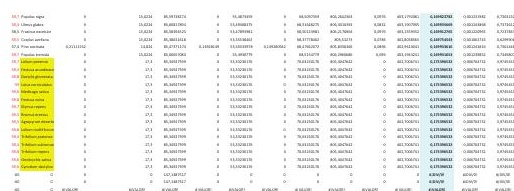

$=$

毫

毫

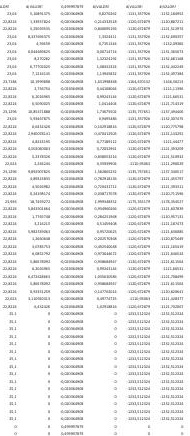

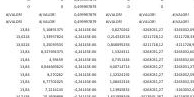

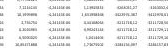

$\sqrt{\mathrm{c}}$

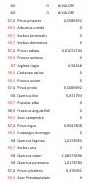
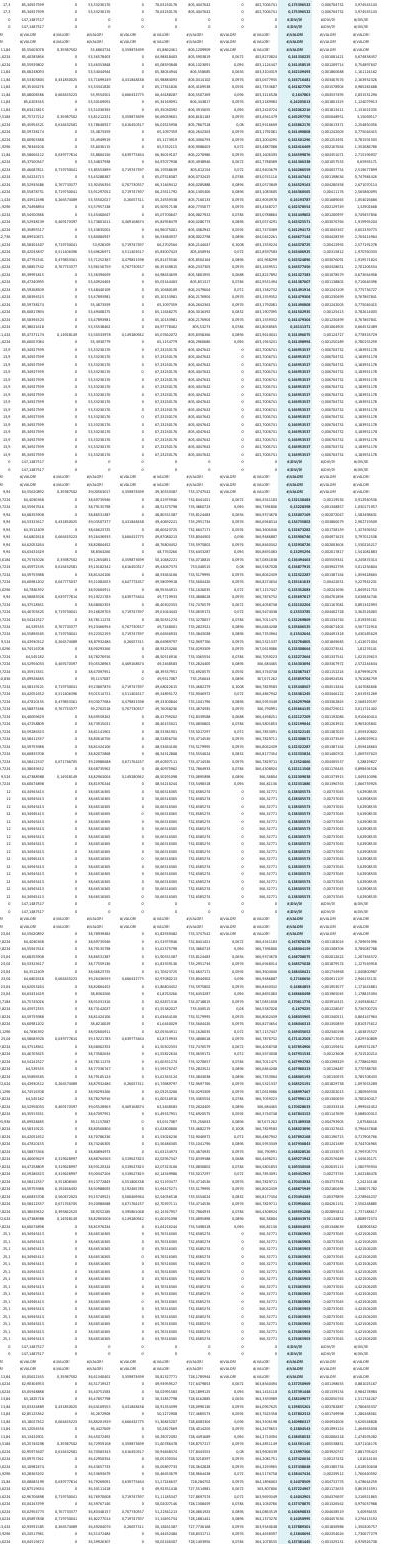


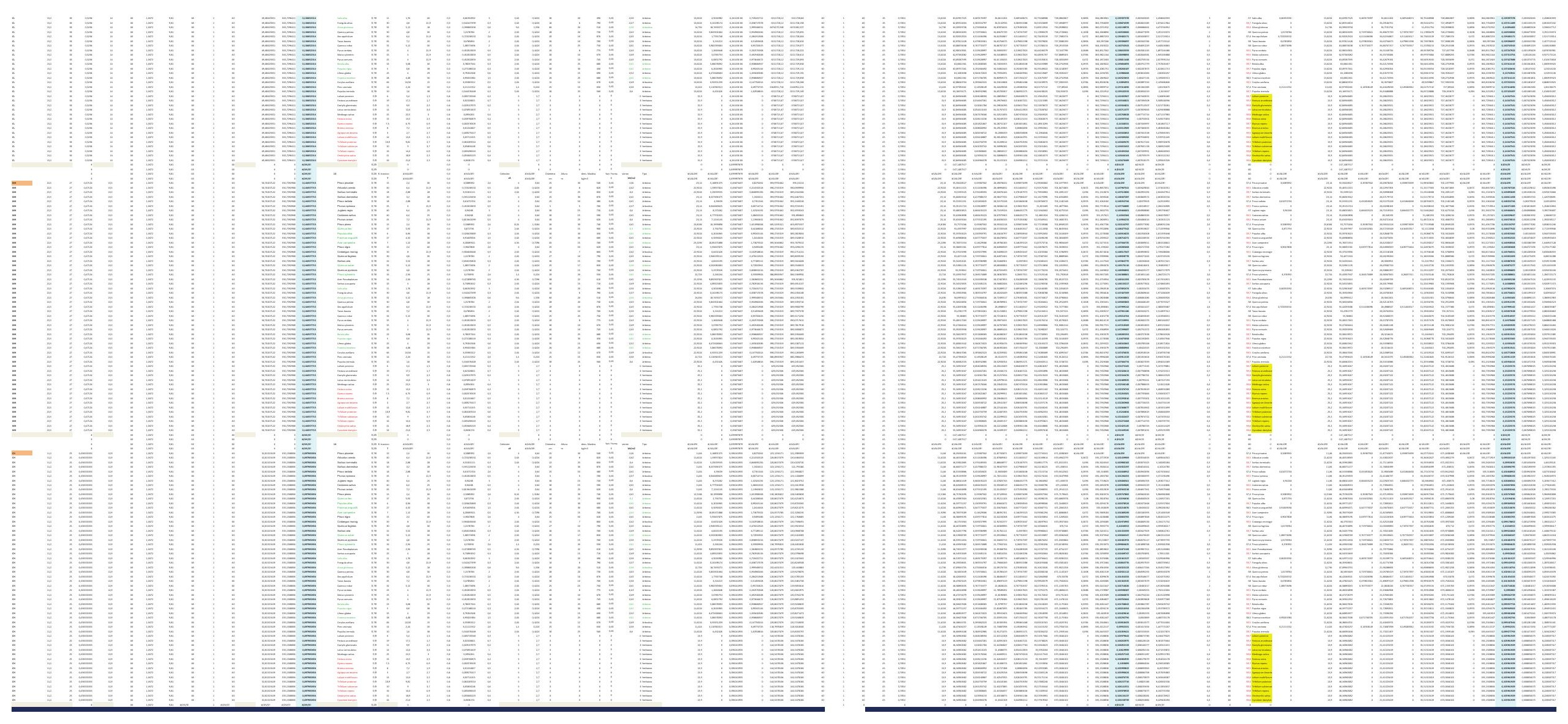



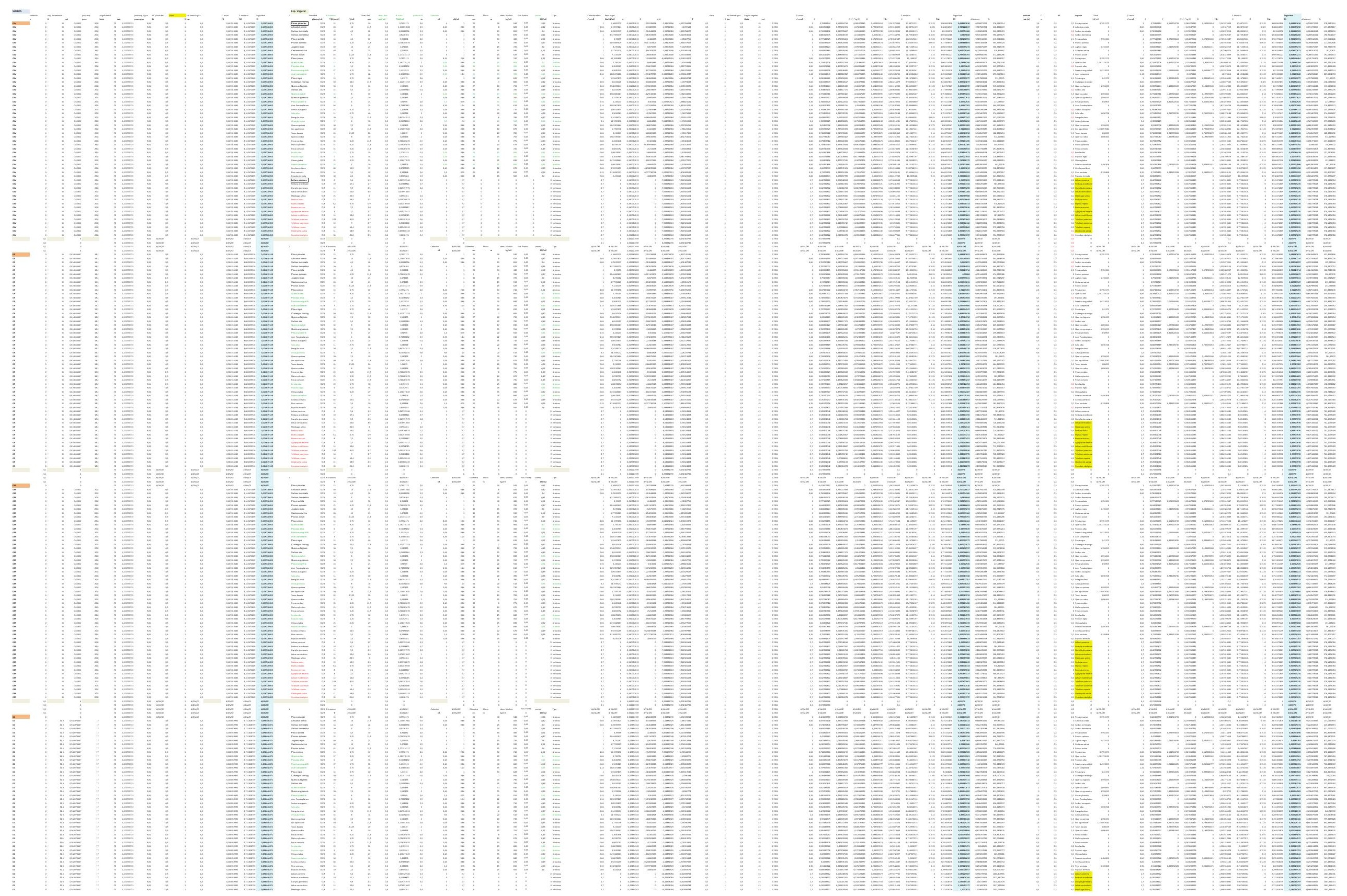

$\vdots$
$\vdots$
$\vdots$
$\vdots$
$\vdots$
$\vdots$
$\vdots$
$\vdots$
$\vdots$

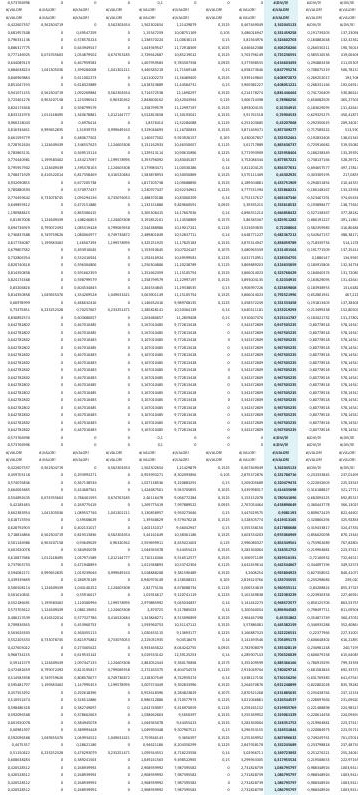




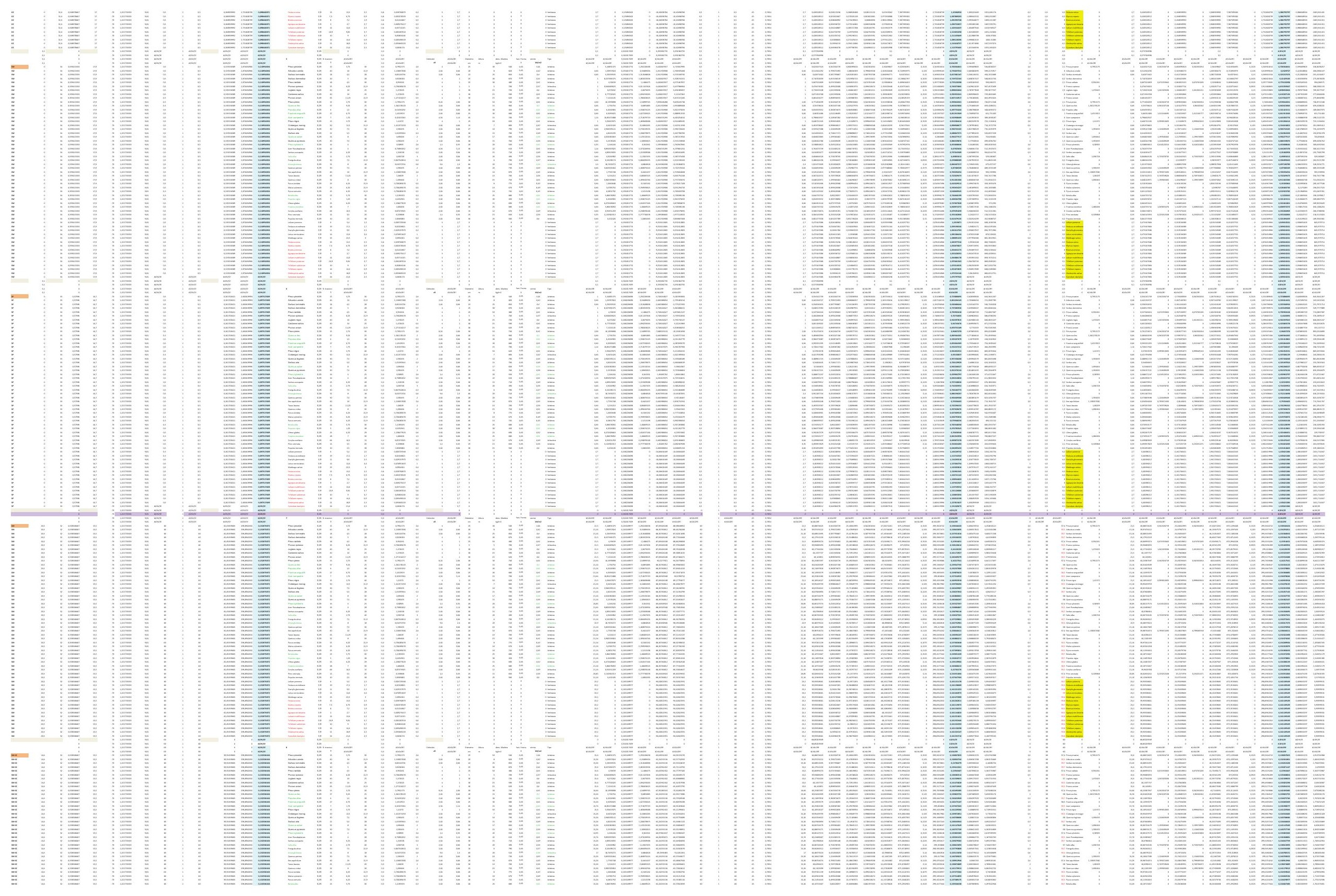



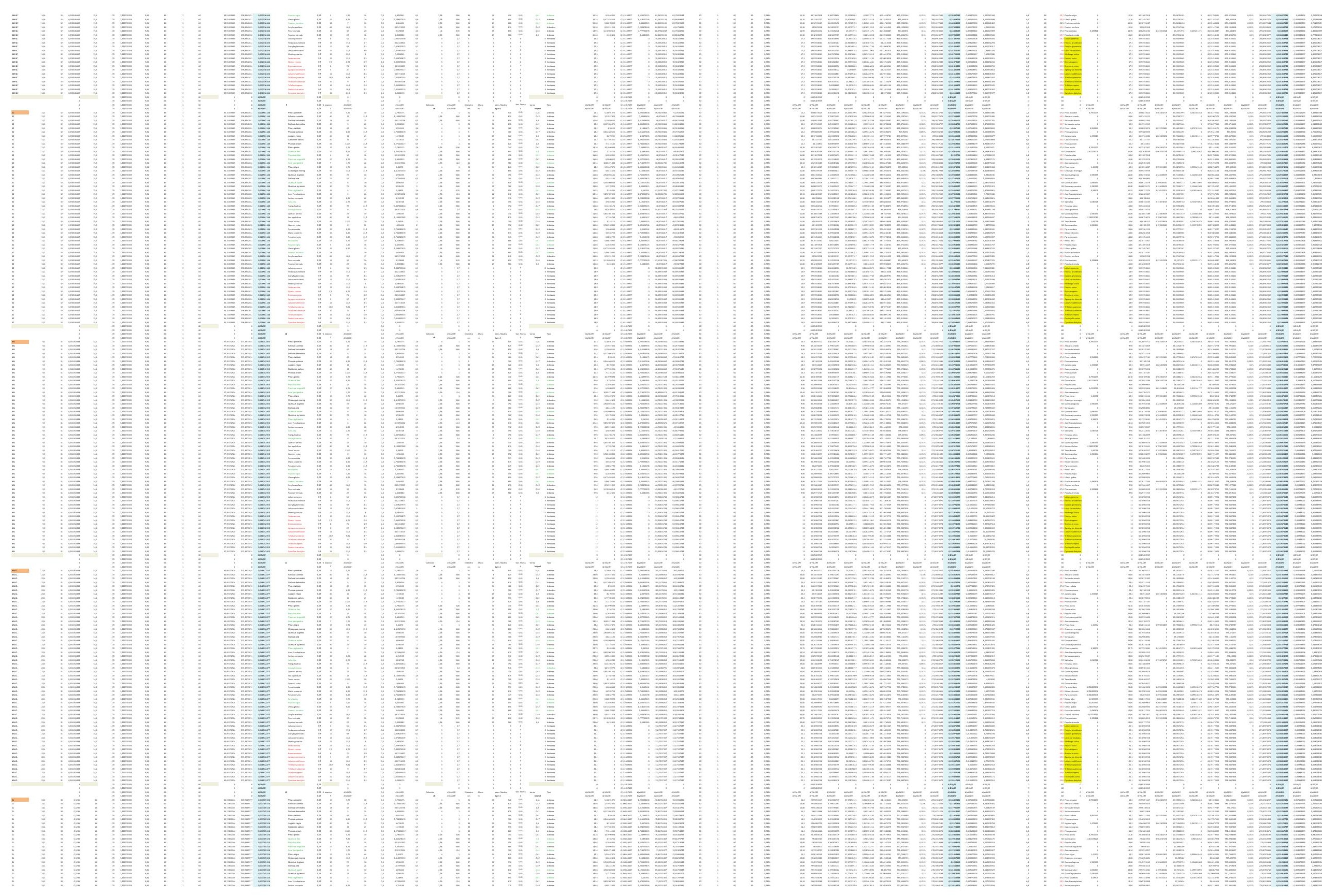

$\vdots$
$\vdots$
$\vdots$ $\equiv \equiv \equiv \equiv \equiv \equiv \equiv$

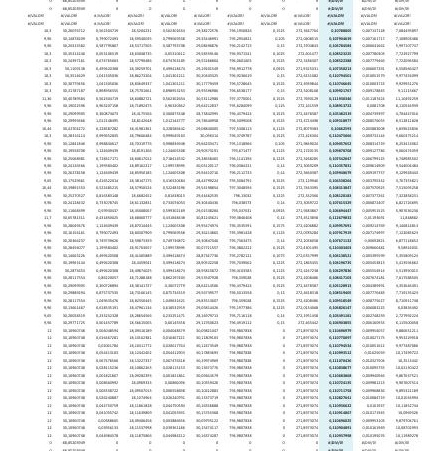

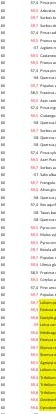

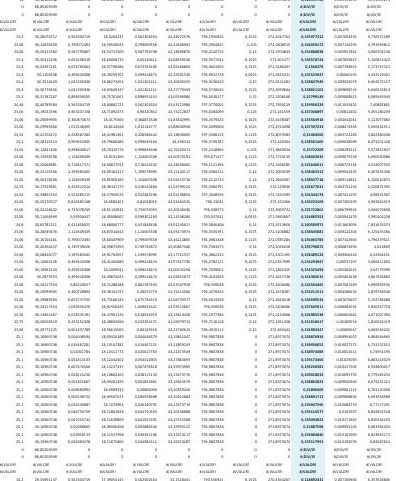

E

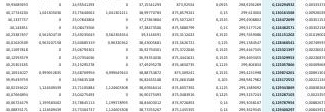

$\equiv \equiv \equiv \equiv \equiv \equiv \equiv \equiv$

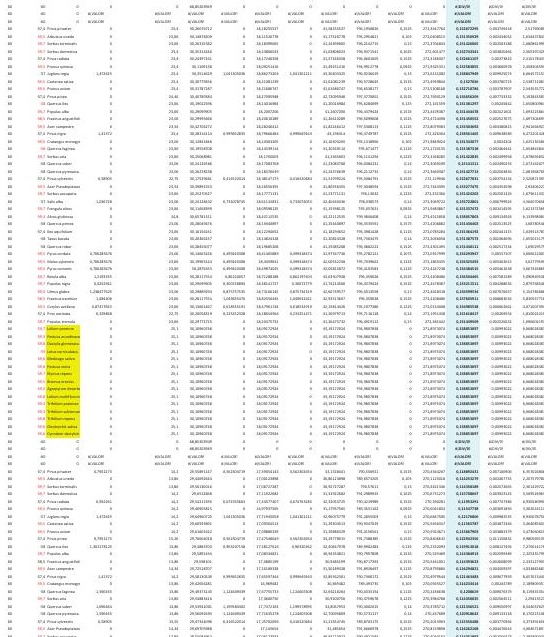




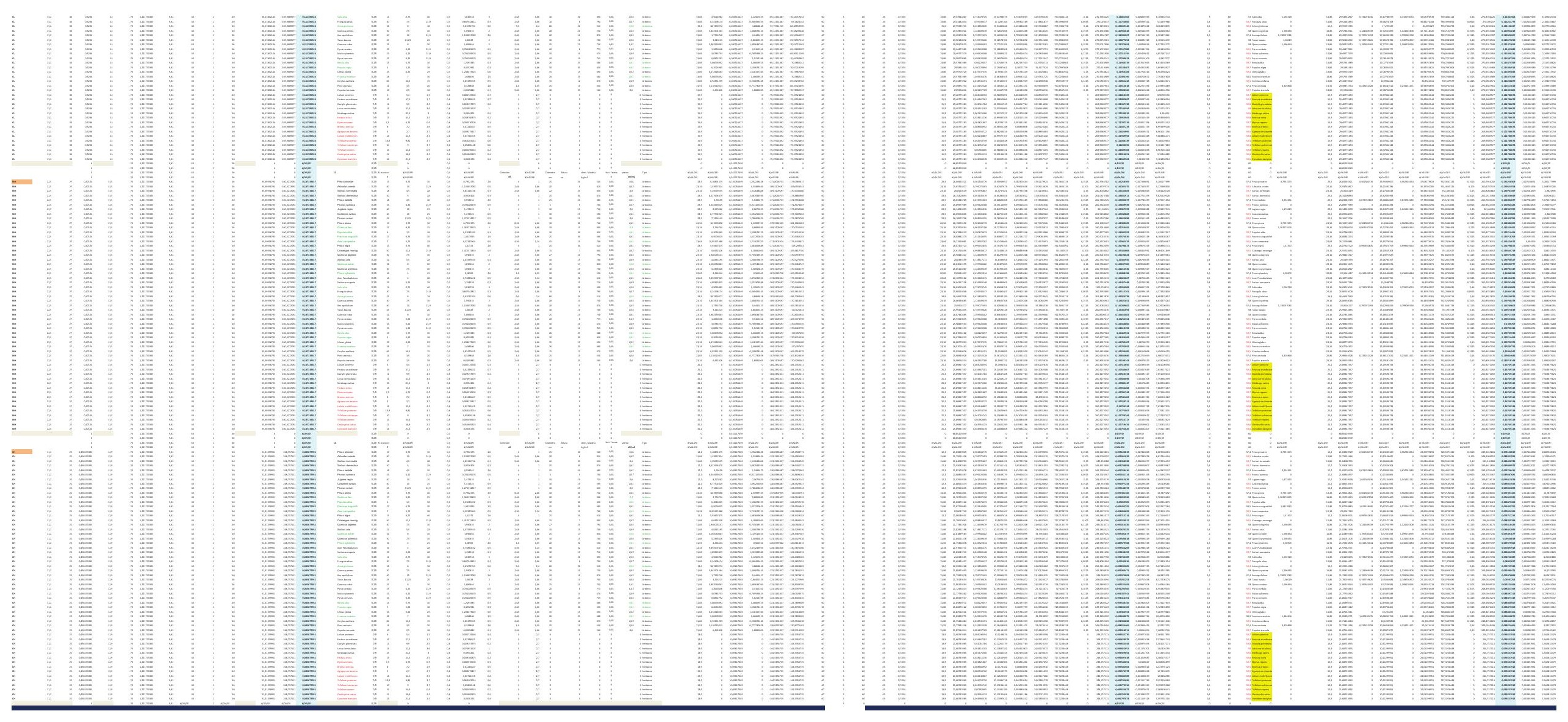



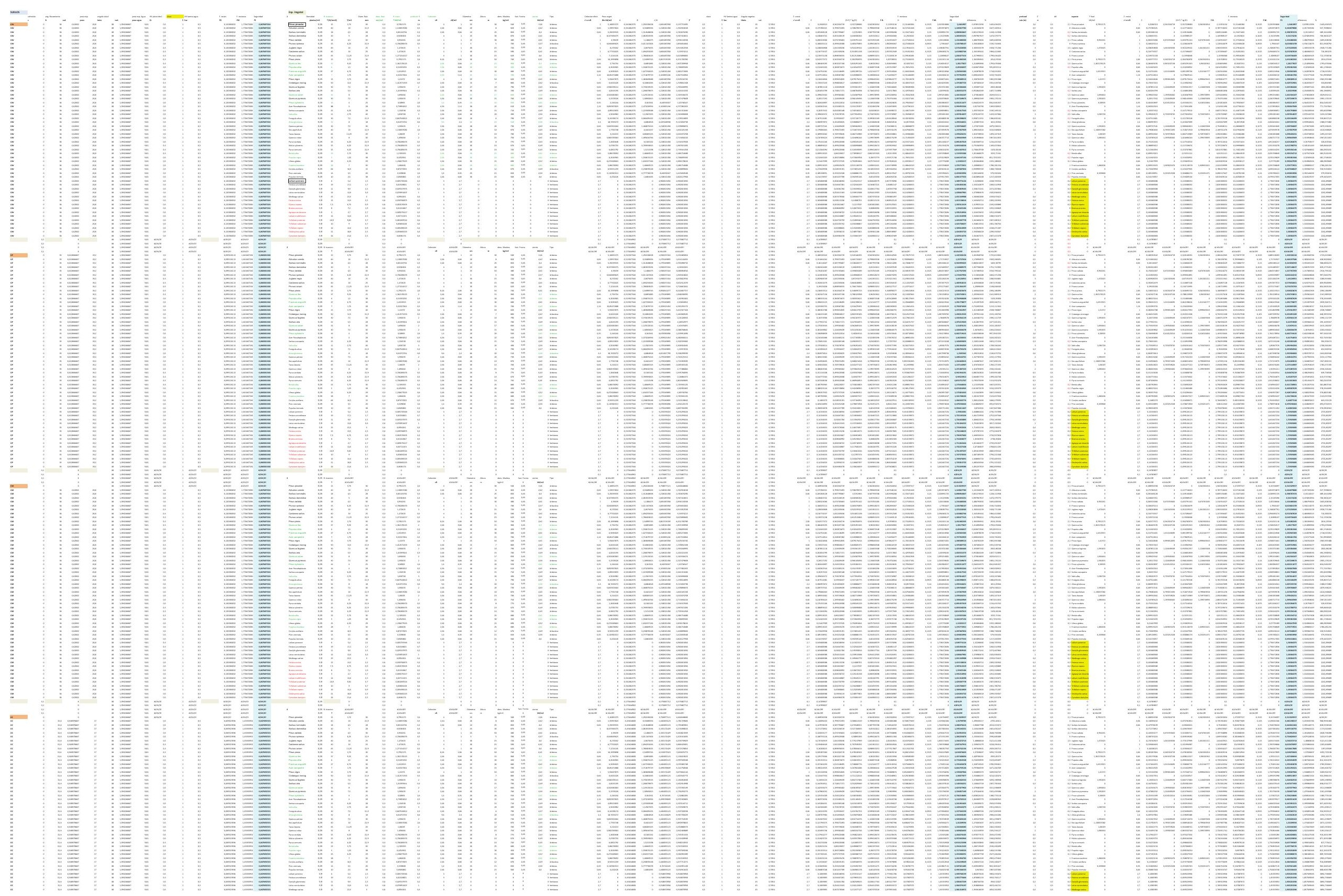

信 $\underline{\bar{E}} \equiv \bar{\equiv} \equiv \equiv \equiv$
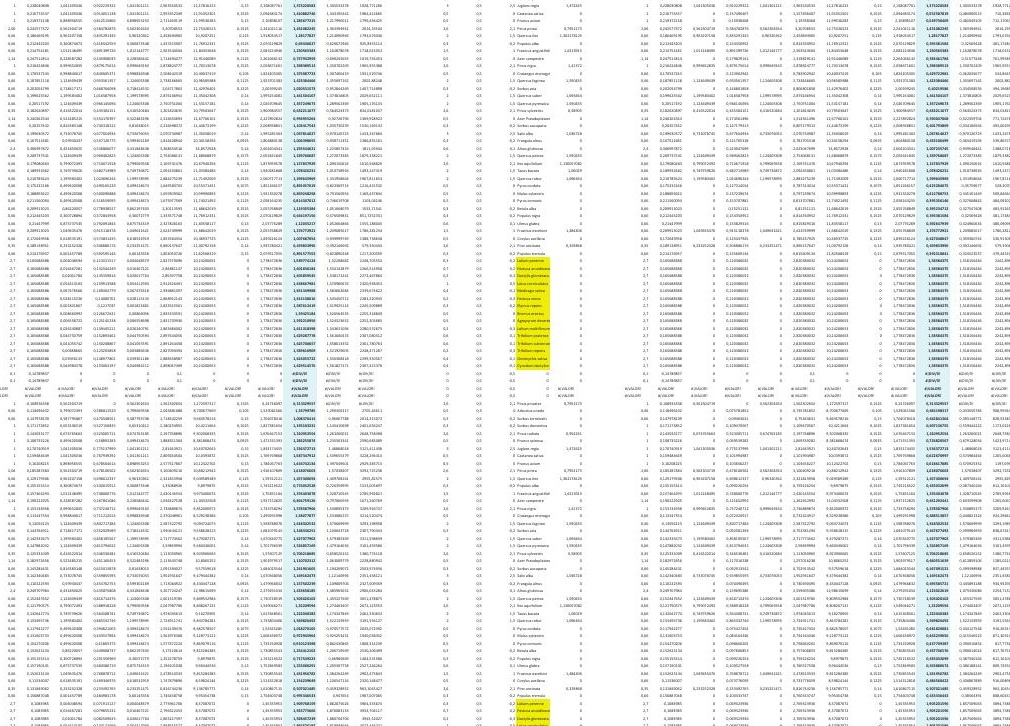

录

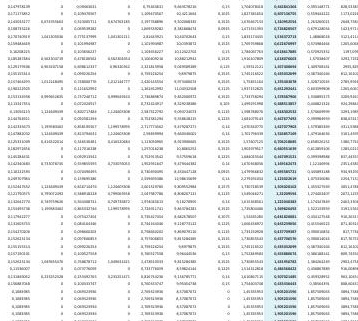




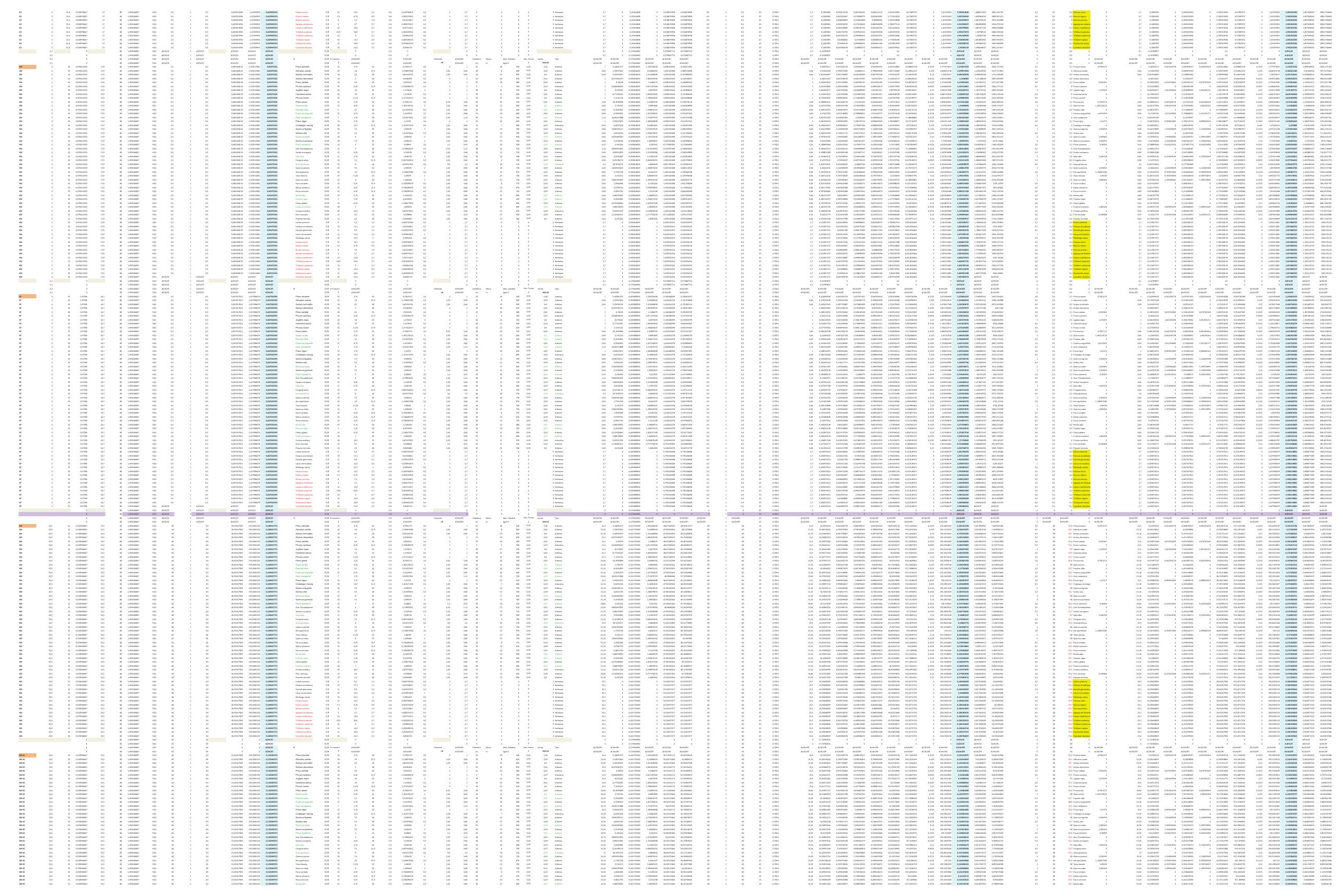



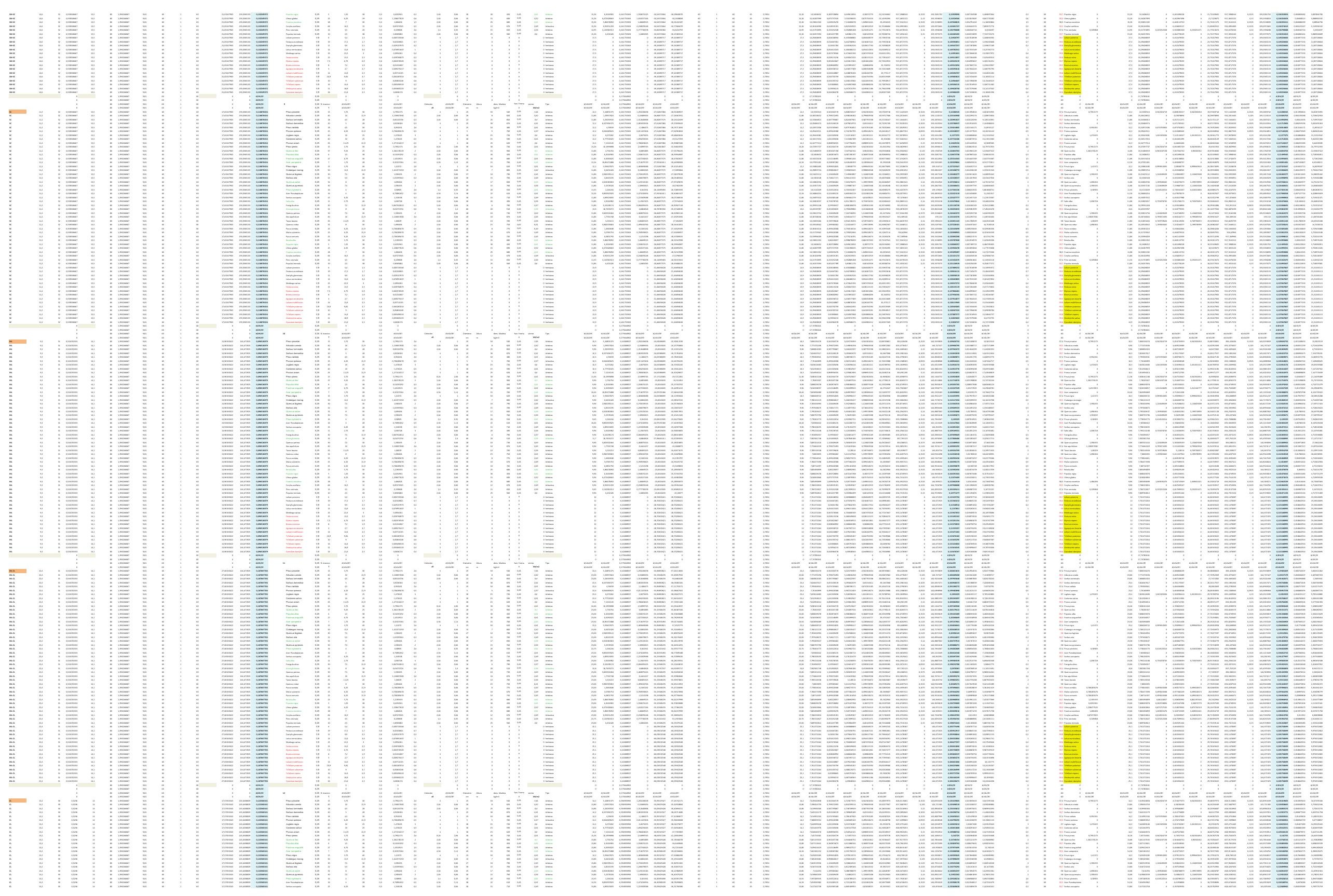


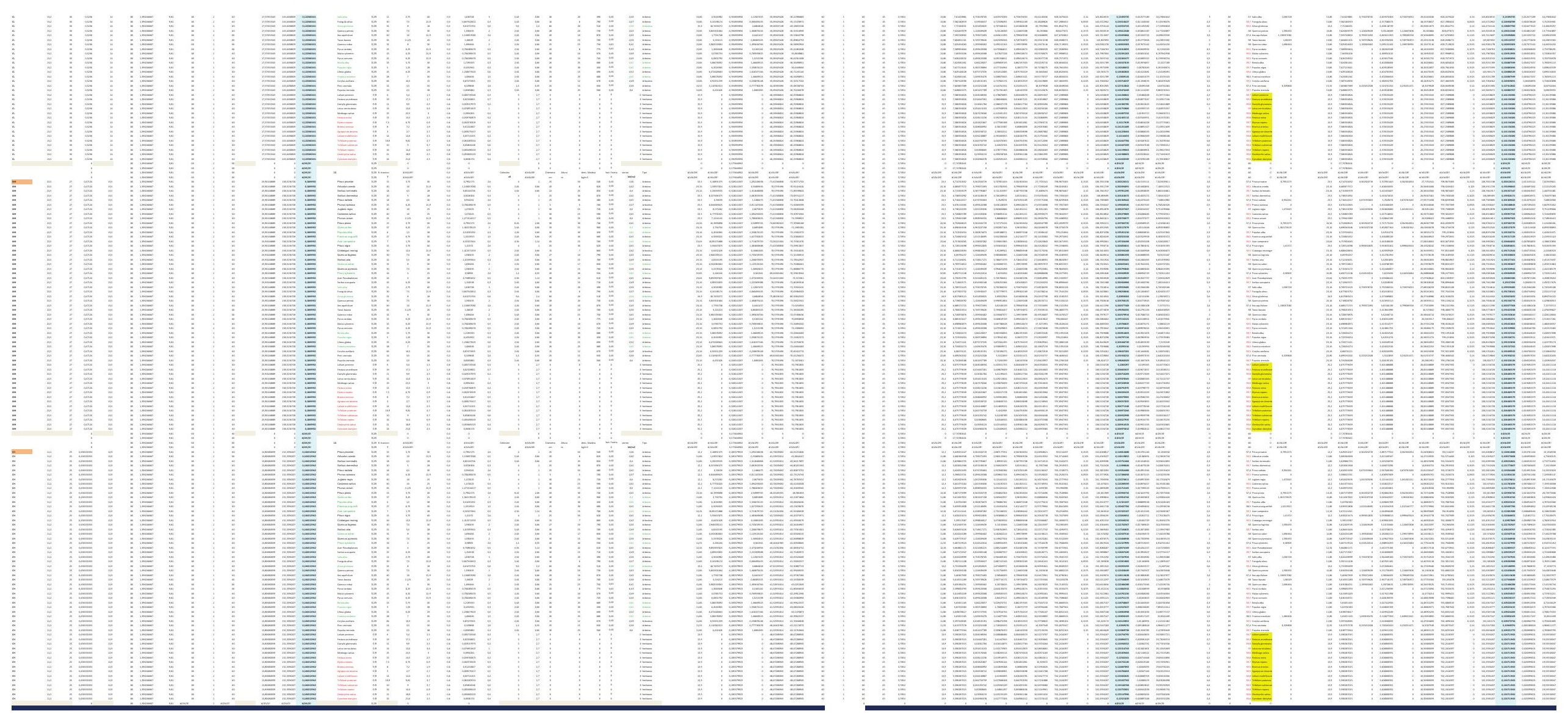


DESARROLLO DE UNA APLICACIÓN IMFORMÁTICA PARA EL CÁLCULO DE SOSTENIMIENTO DE TALUDES MEDIANTE VEGETACIÓN

A02. DENSIDAD DE PLANTACIÓN: 1.600 plantas/ha.

A02-1.POSICIÓN N.F. 1

A02-2.POSICIÓN N.F. 2

A02-3.POSICIÓN N.F. 3

A02-4.POSICIÓN N.F. 4

A02-5.POSICIÓN N.F. 5 
DESARROLLO DE UNA APLICACIÓN IMFORMÁTICA PARA EL CÁLCULO DE SOSTENIMIENTO DE TALUDES MEDIANTE VEGETACIÓN

A02. DENSIDAD DE PLANTACIÓN: 1.600 plantas/ha.

\section{A02-1.POSICIÓN N.F. 1}

INCLINACIÓN DE TALUD 6-100

INCLINACIÓN DE TALUD 10-200

INCLINACIÓN DE TALUD 20-30

INCLINACIÓN DE TALUD 30-40

INCLINACIÓN DE TALUD $35^{\circ}$

INCLINACIÓN DE TALUD 40-50

INCLINACIÓN DE TALUD 50-550

INCLINACIÓN DE TALUD 55-60

INCLINACIÓN DE TALUD 60-700

INCLINACIÓN DE TALUD 70-80 

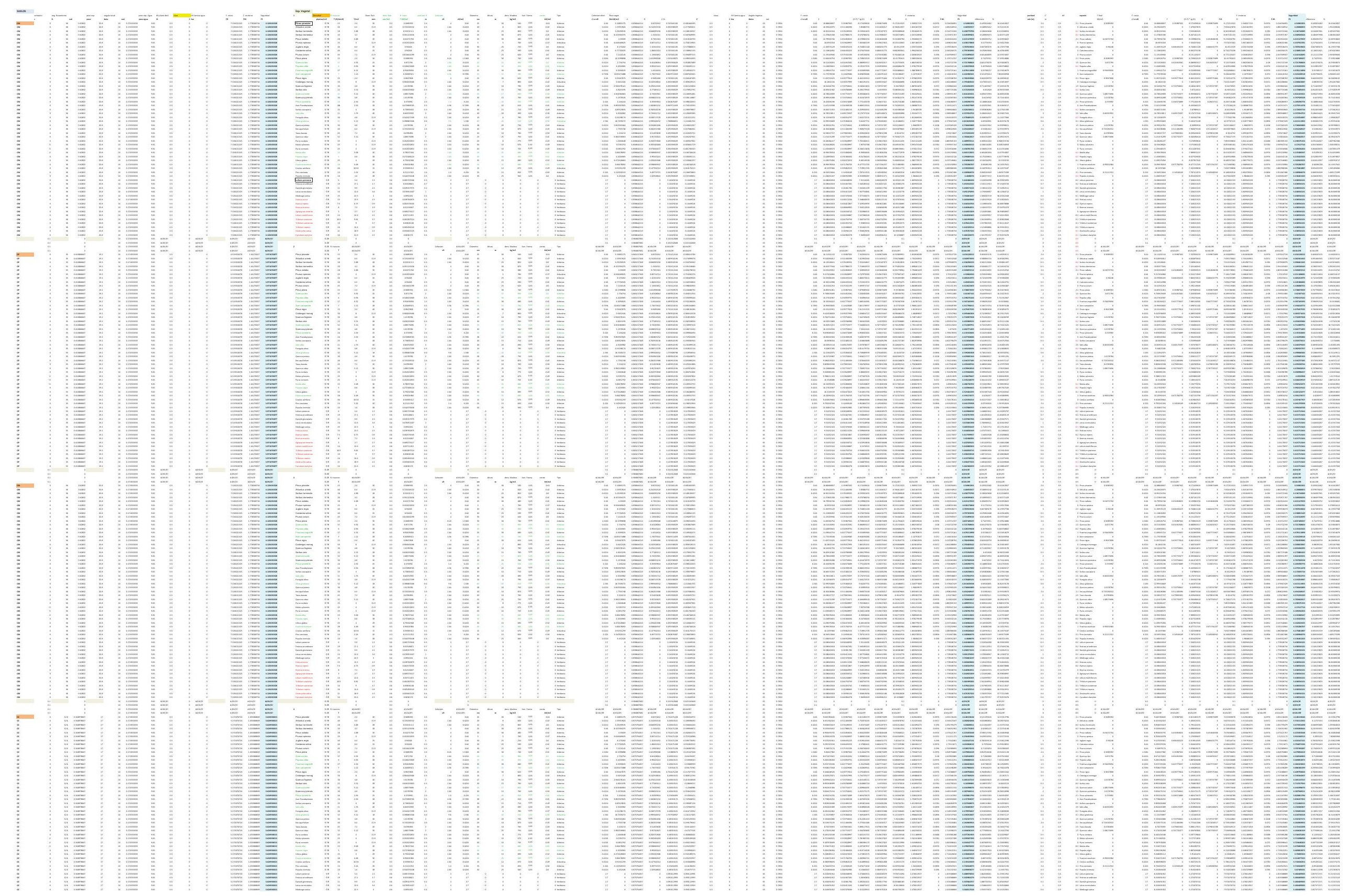


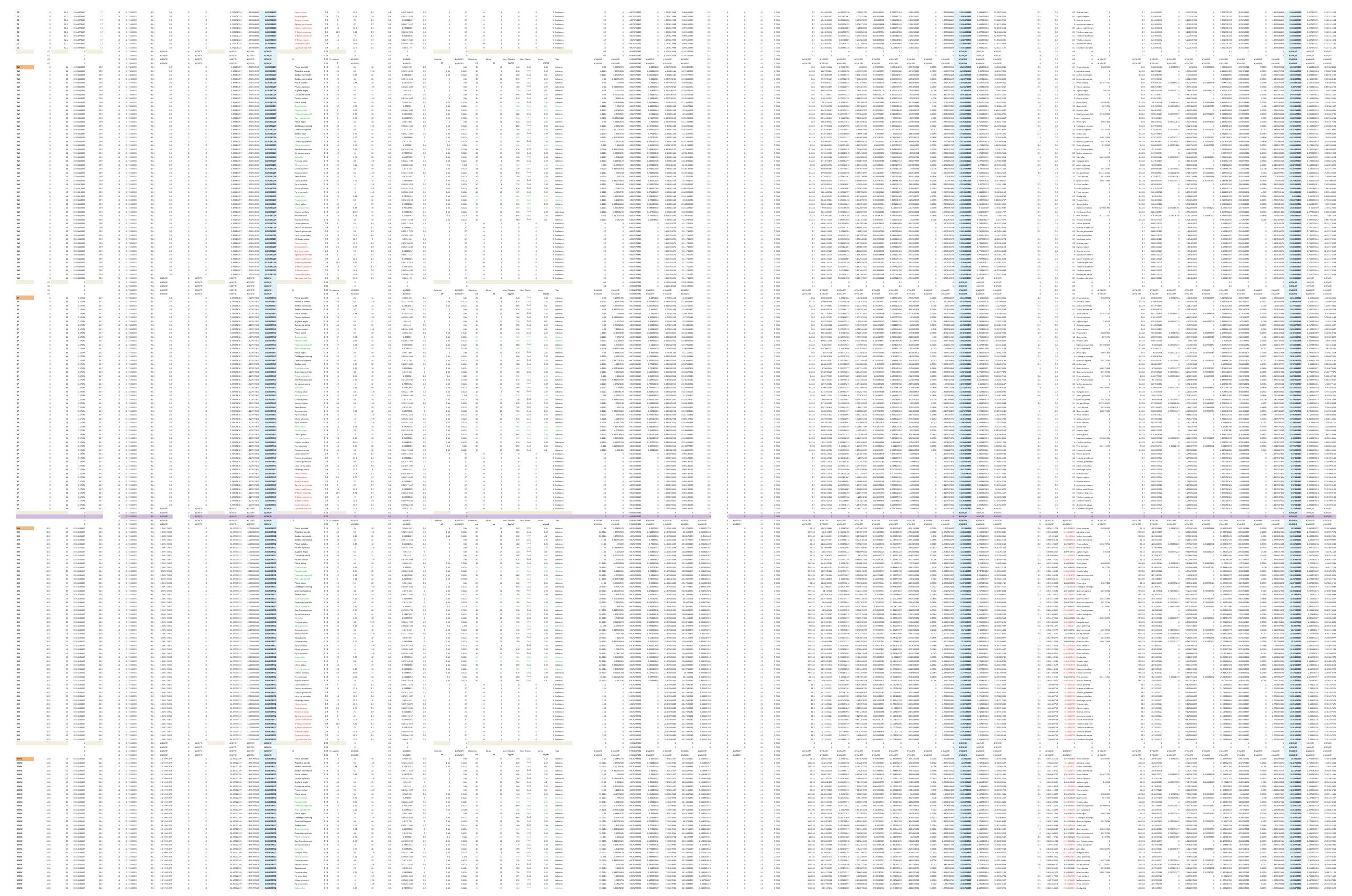



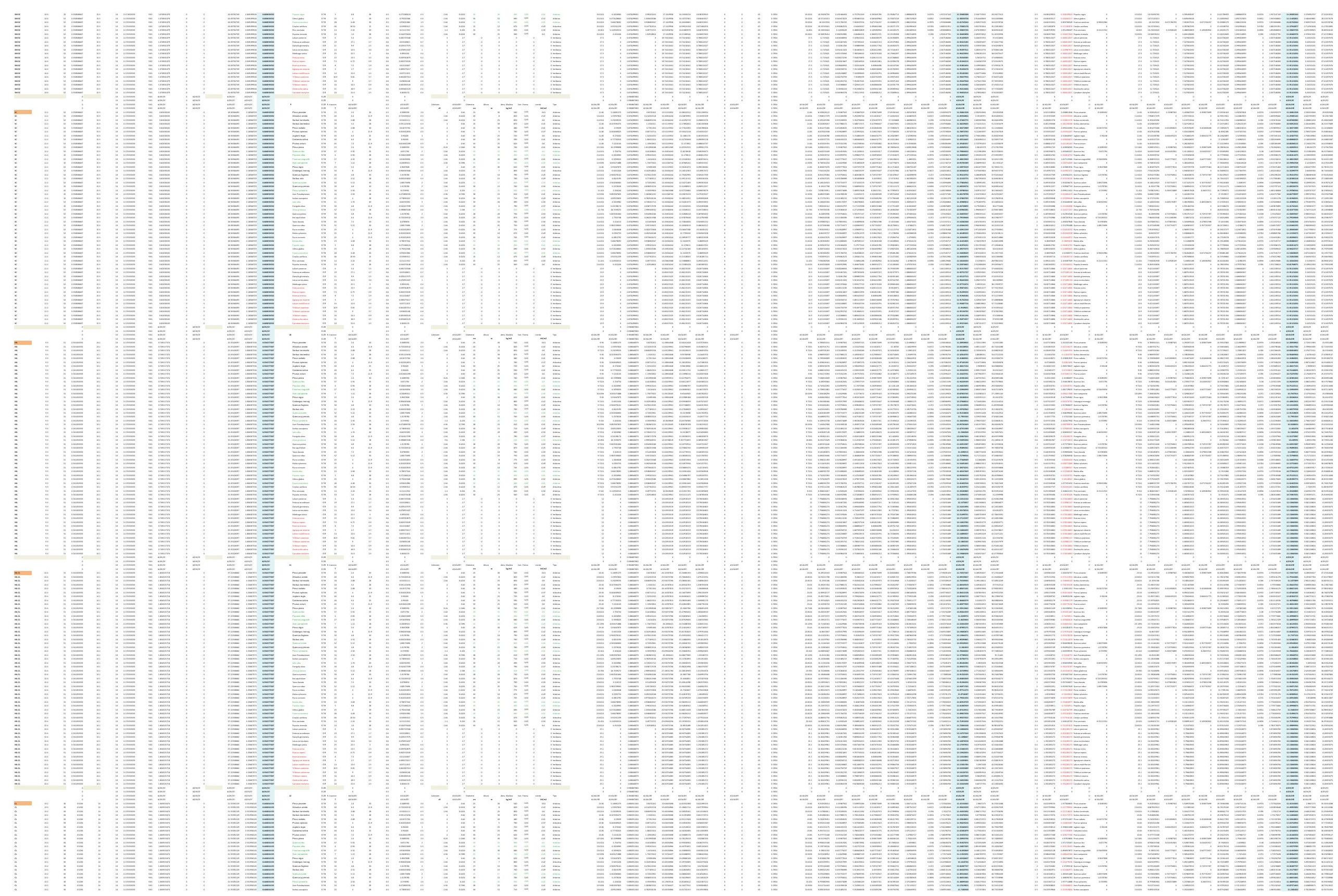

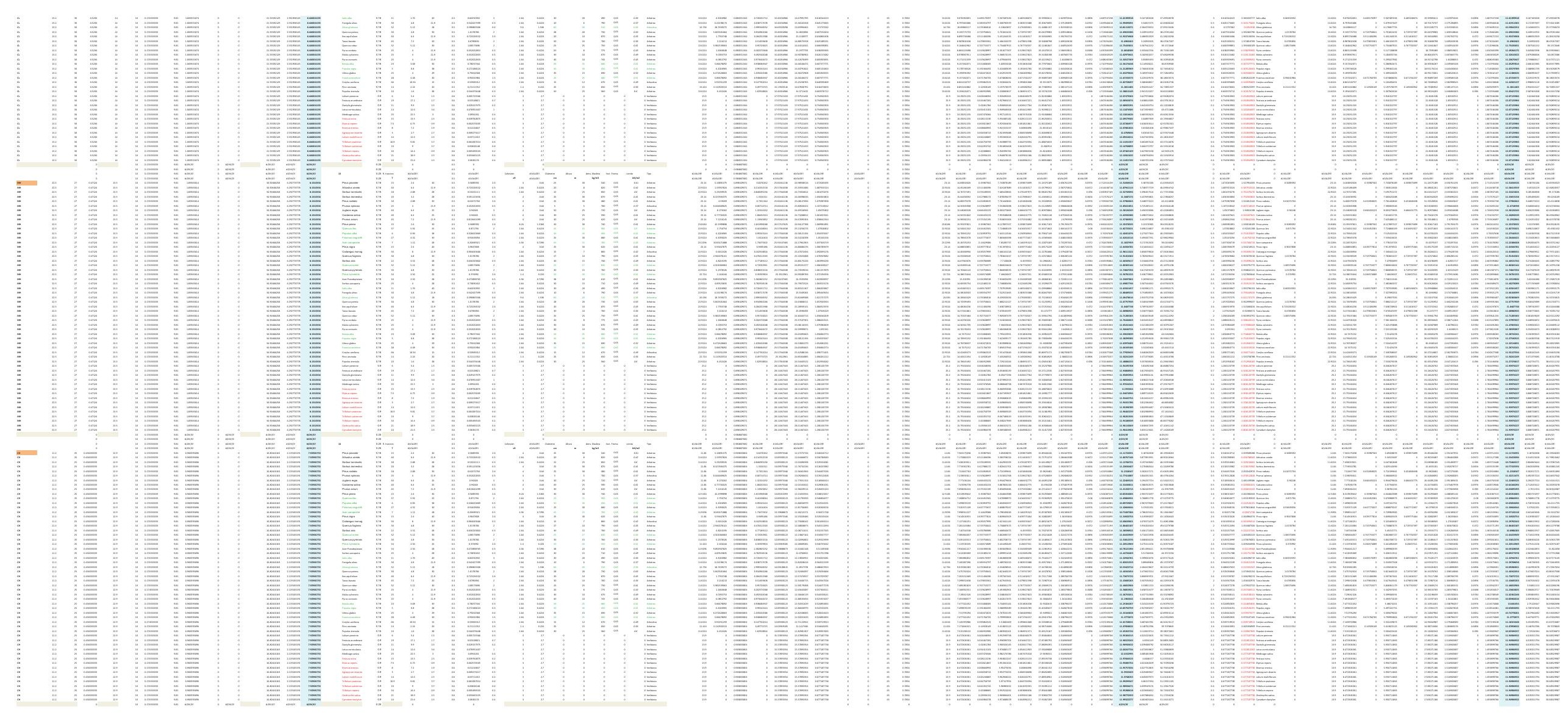

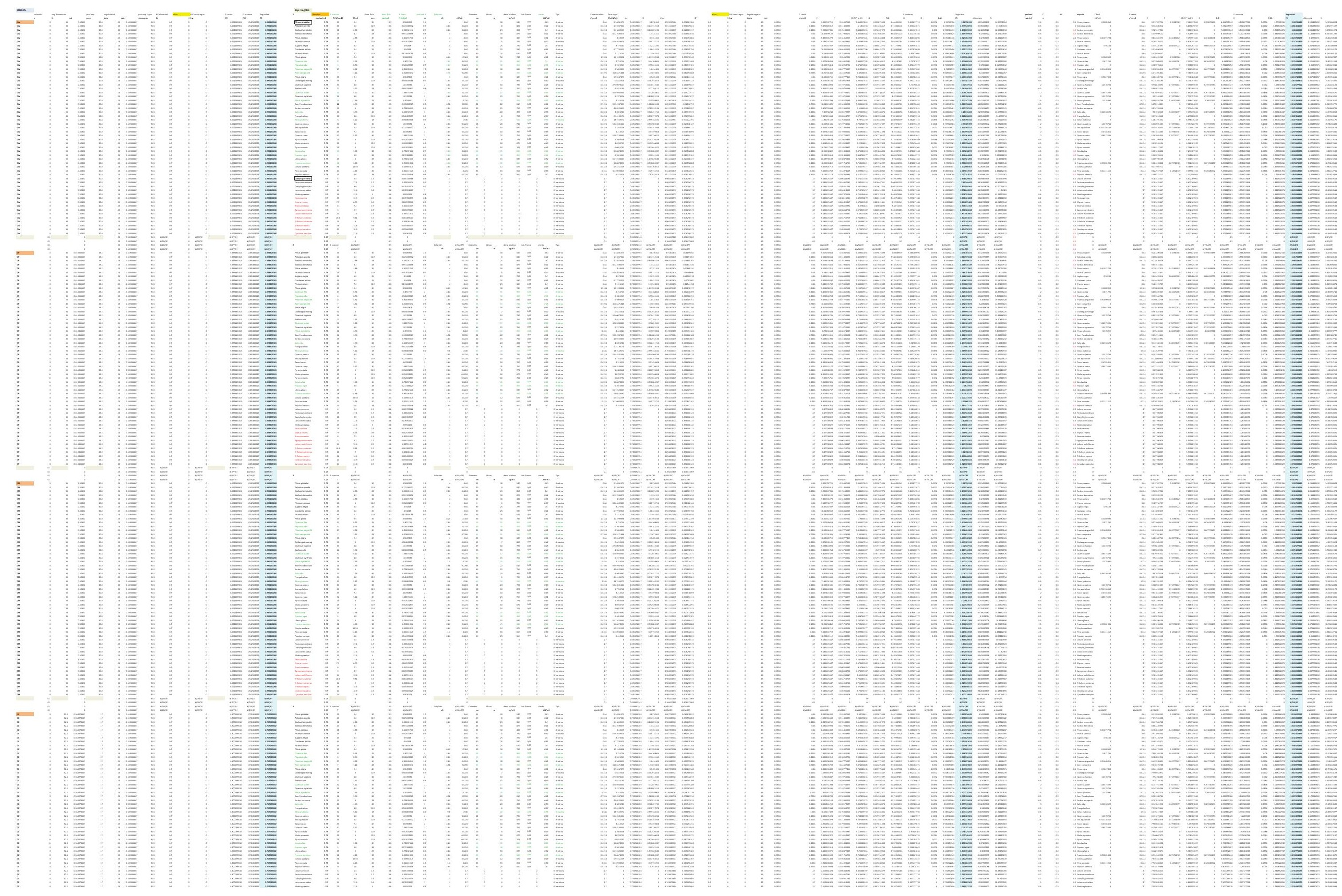


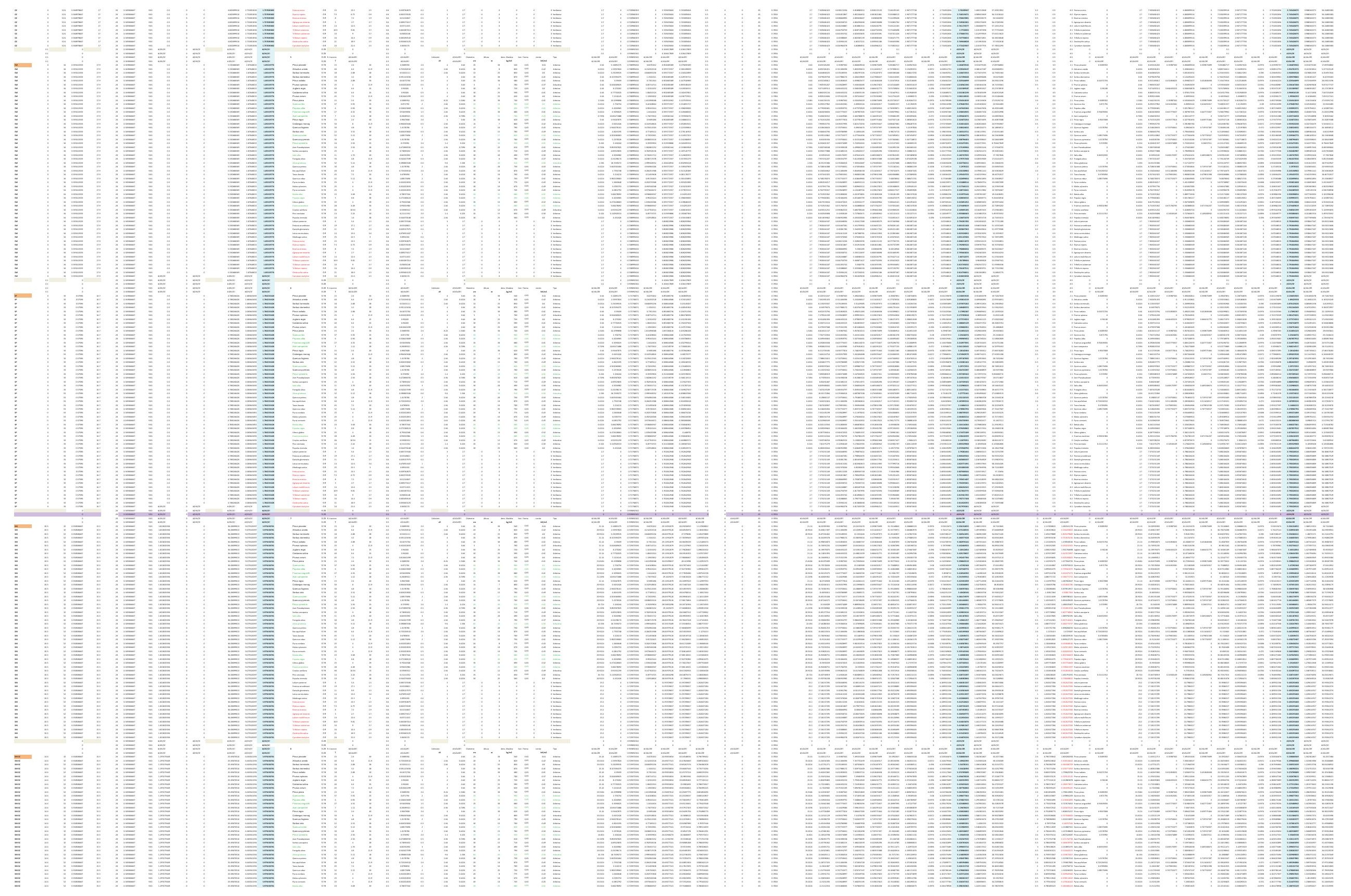



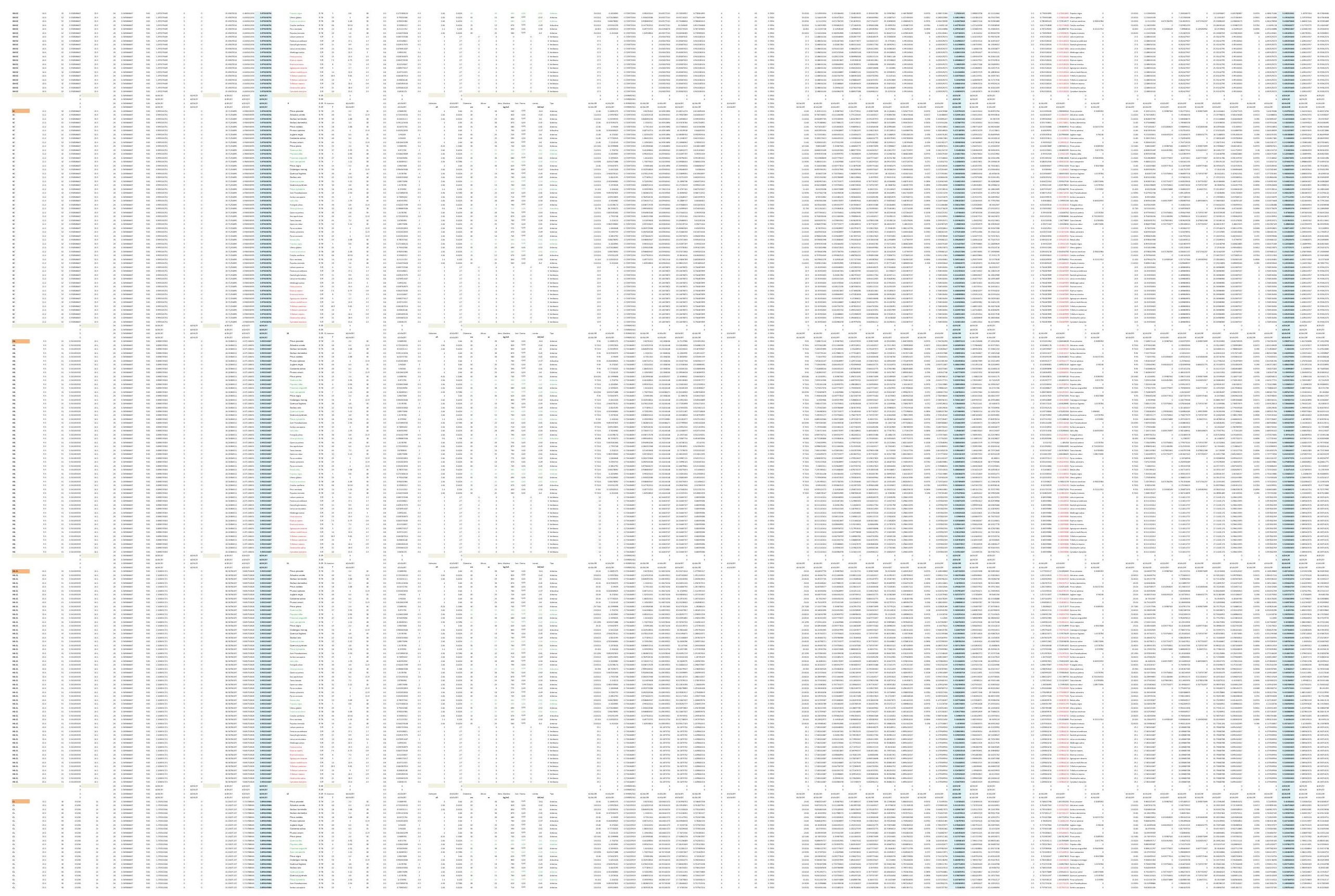


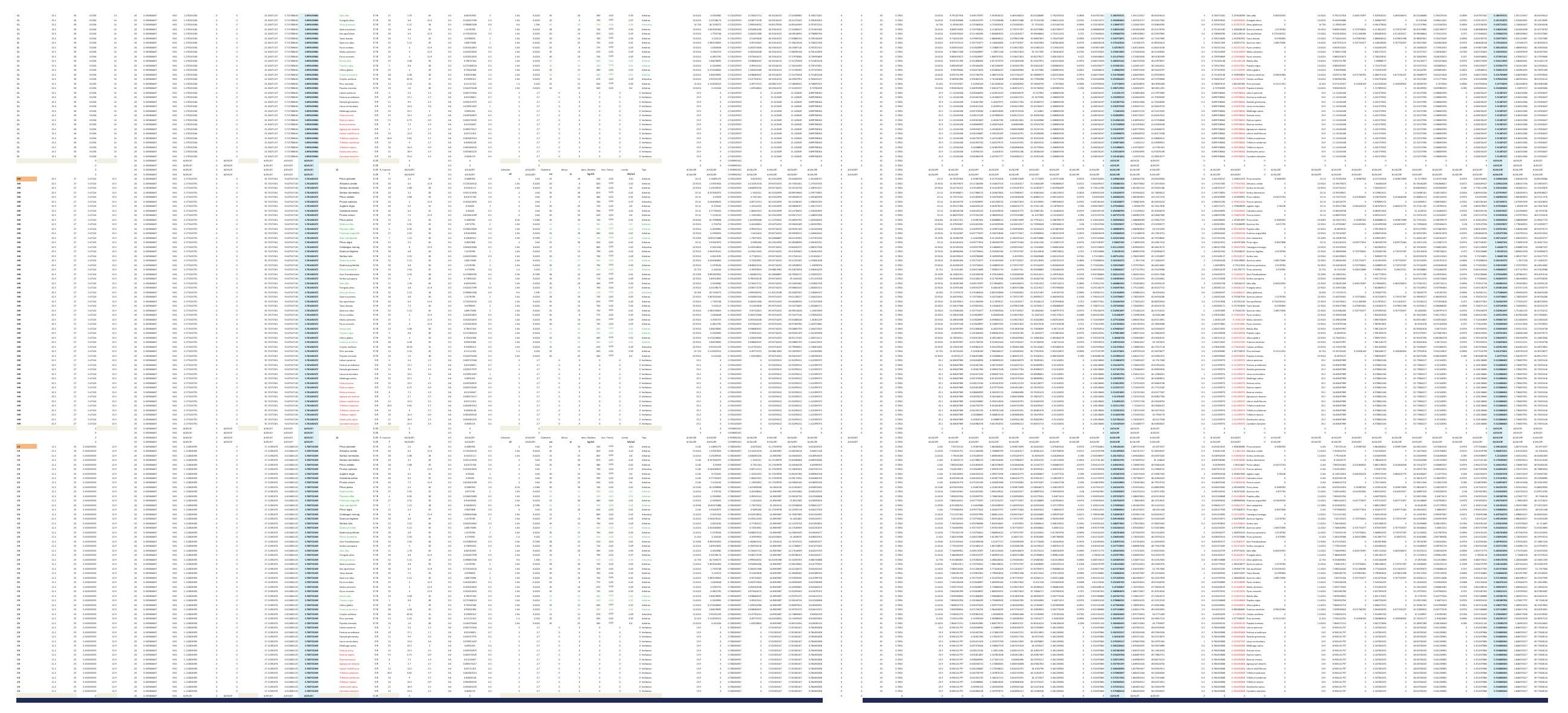



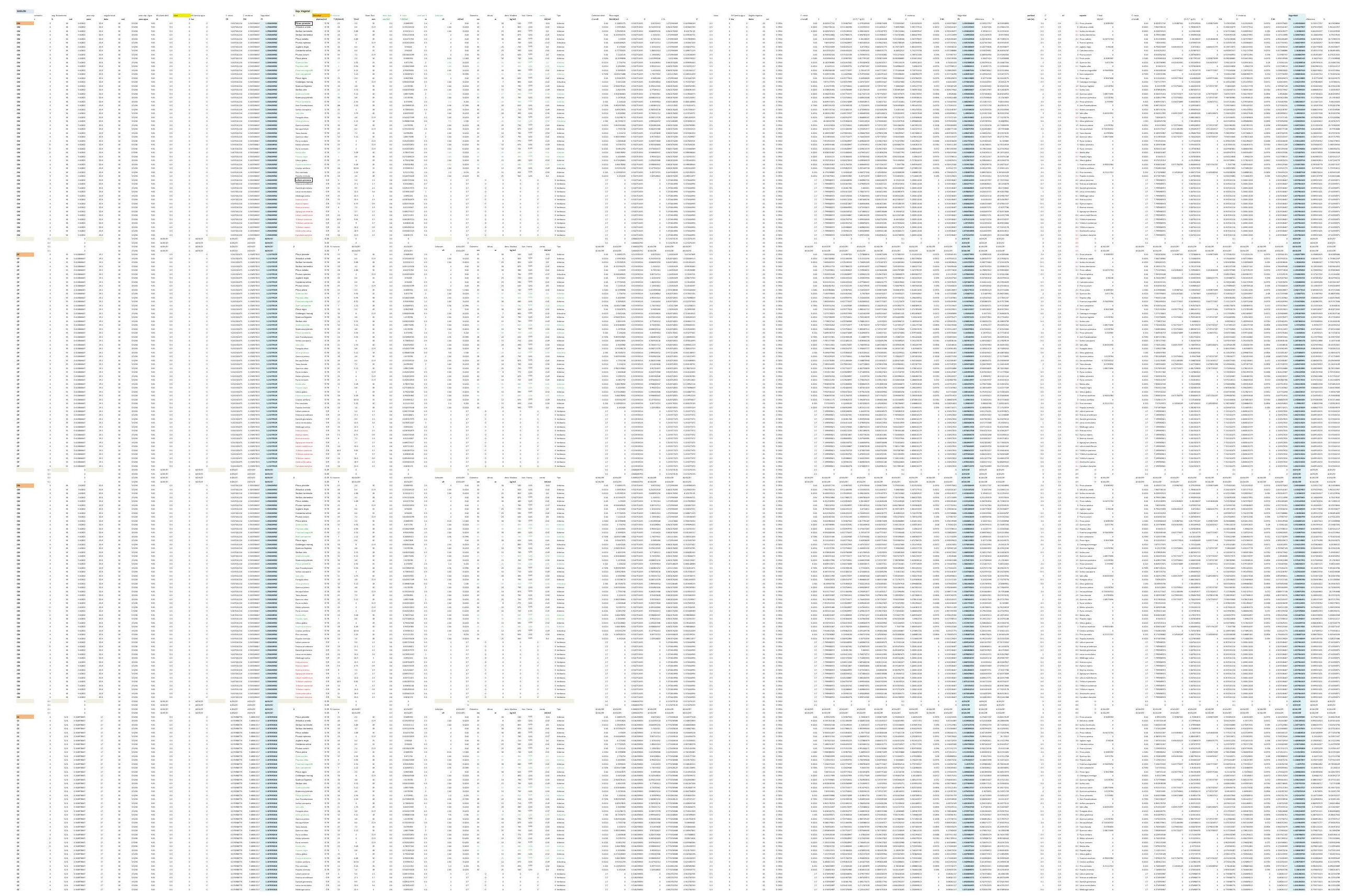


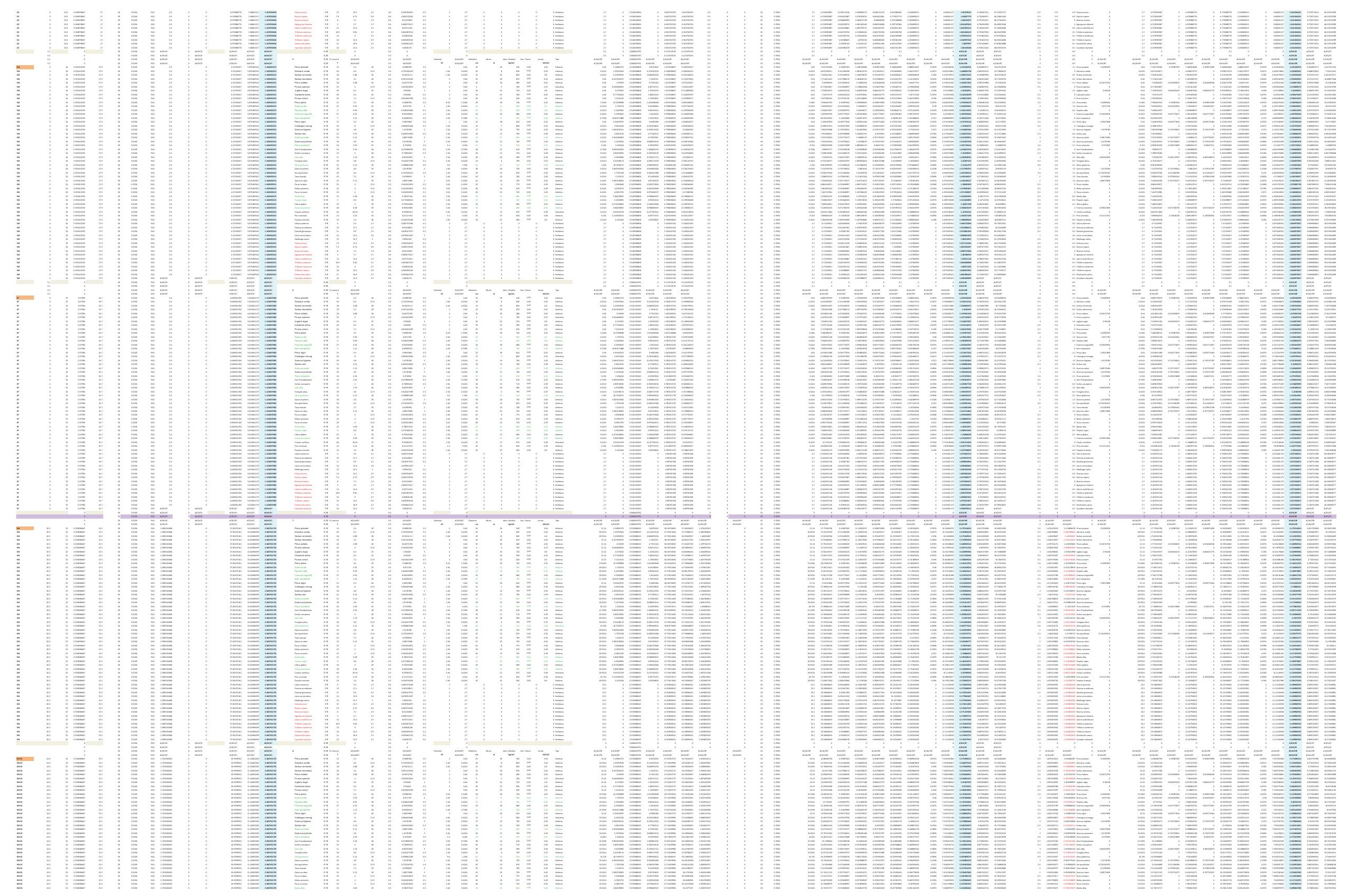



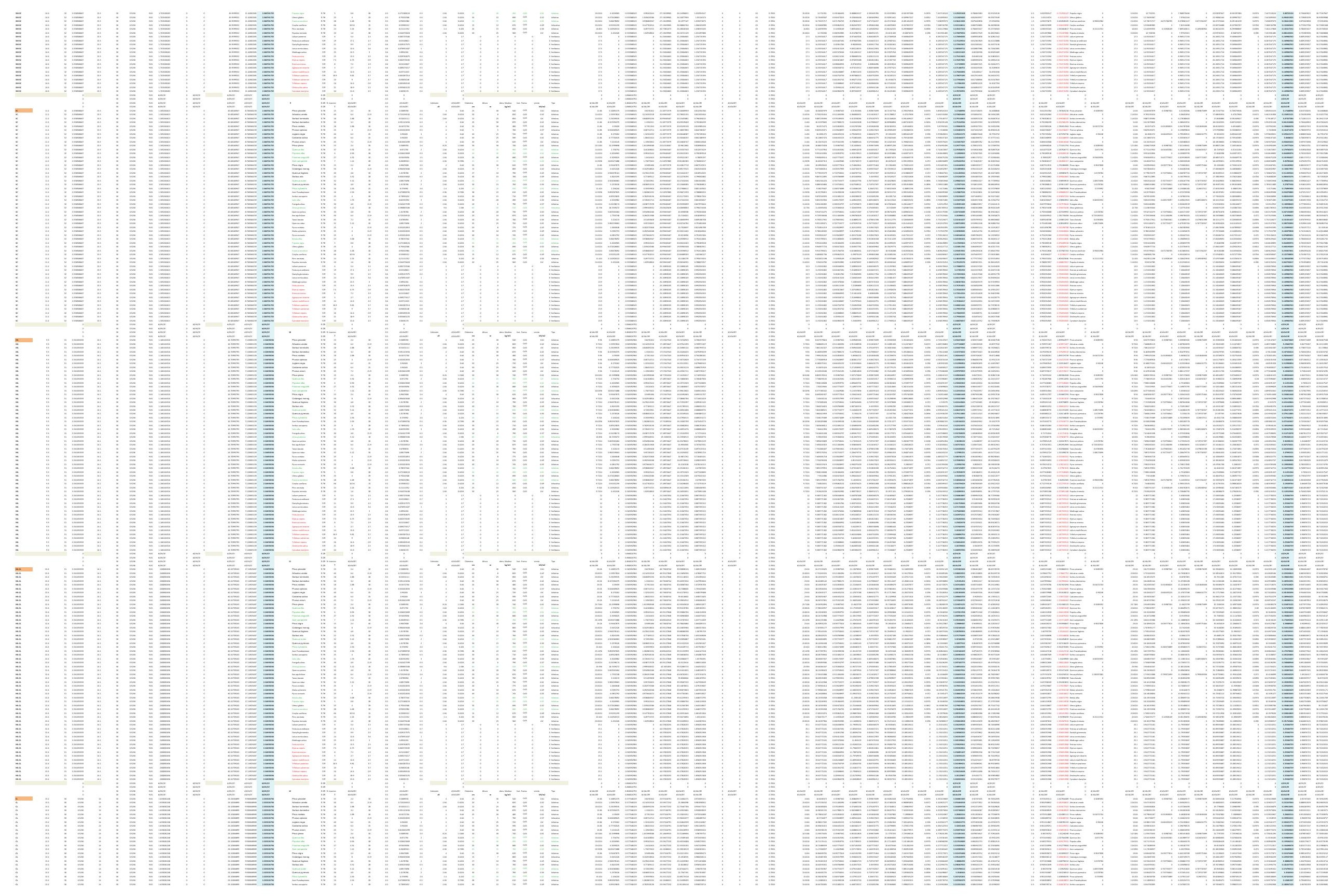


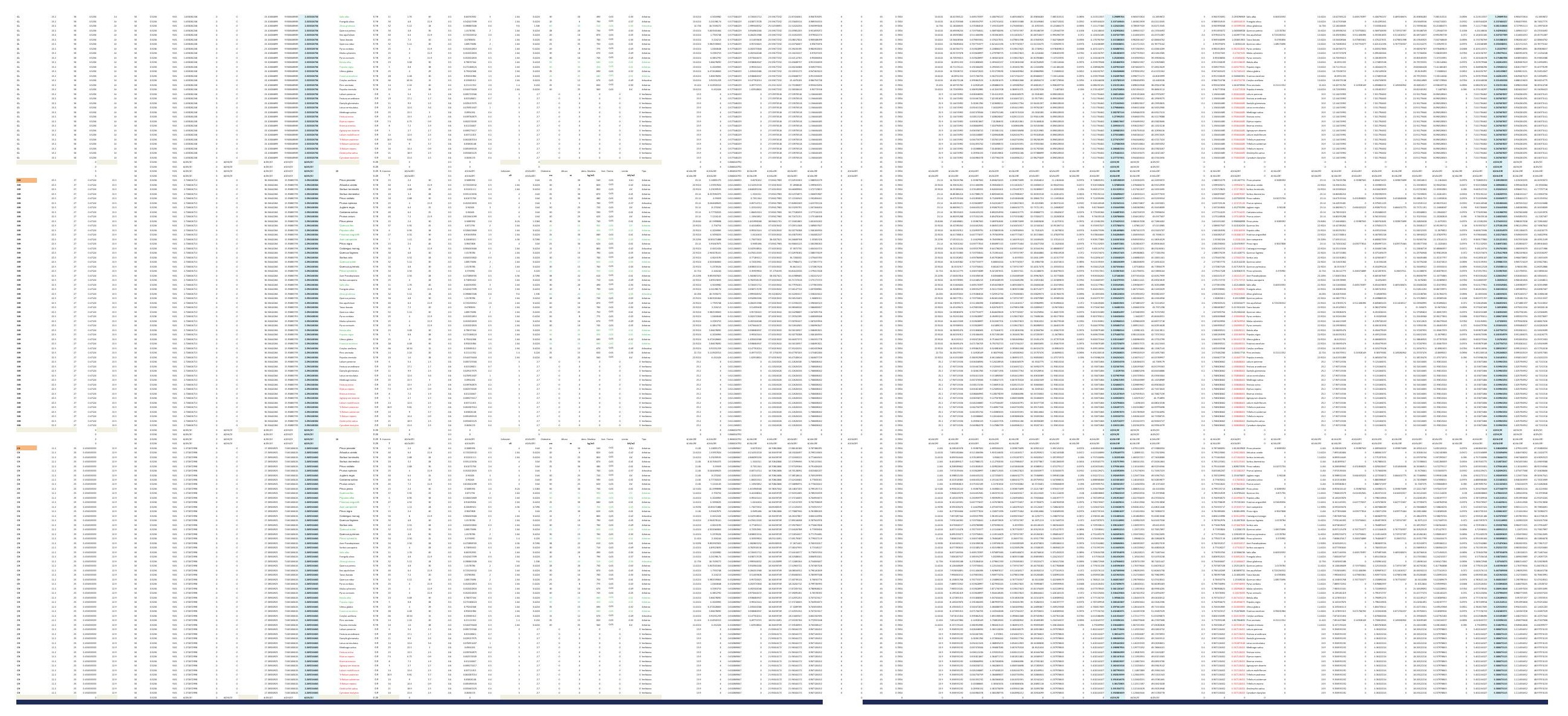



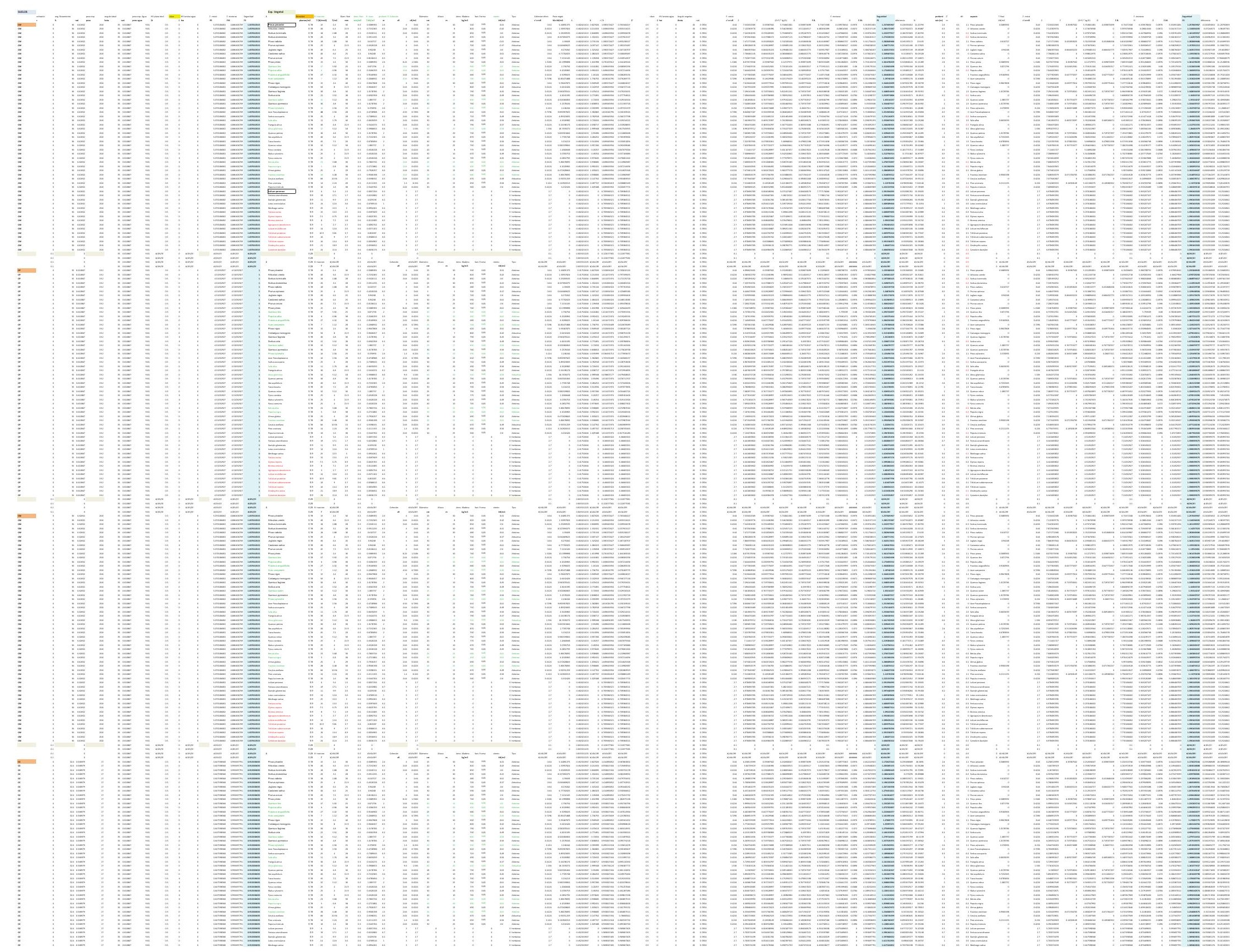


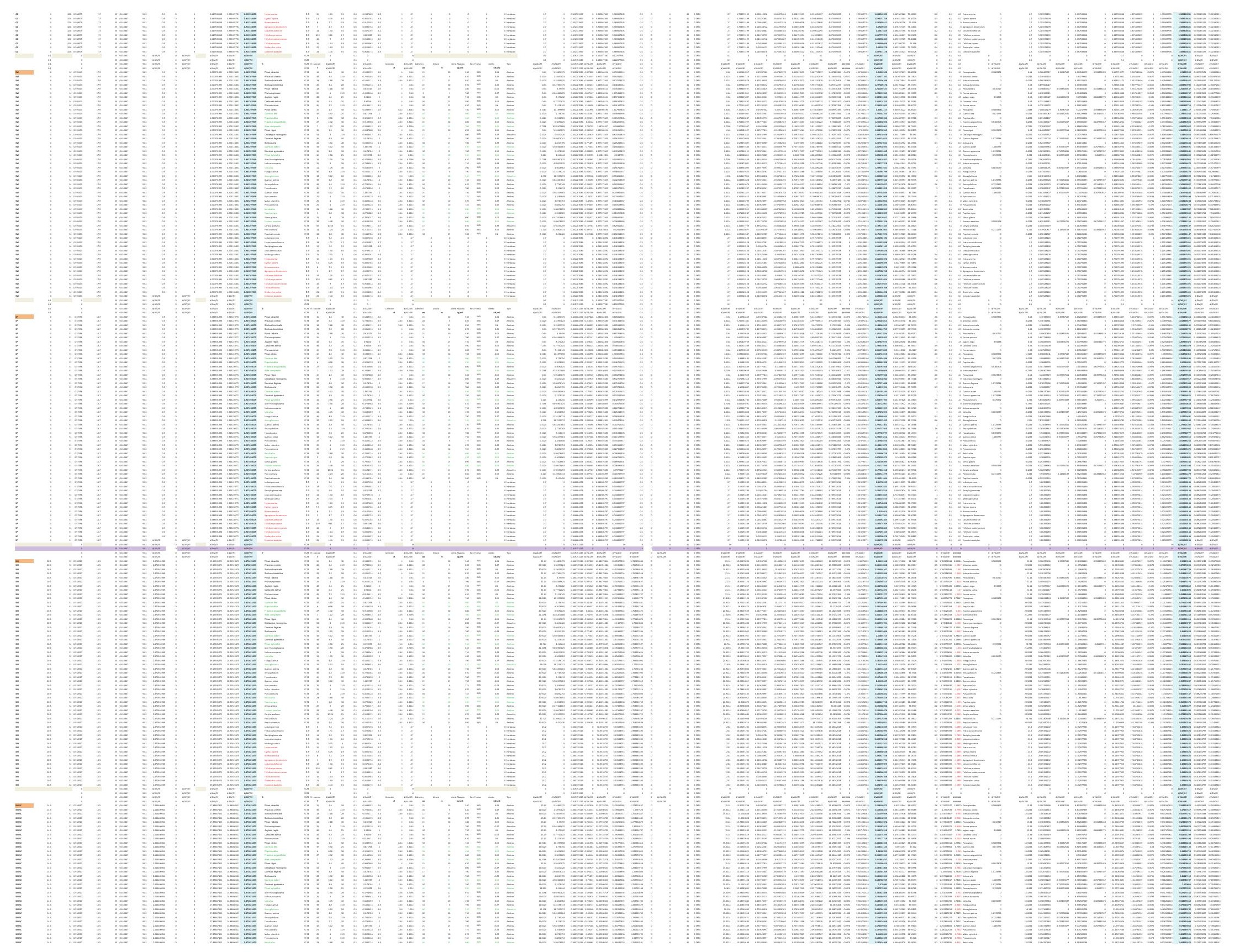



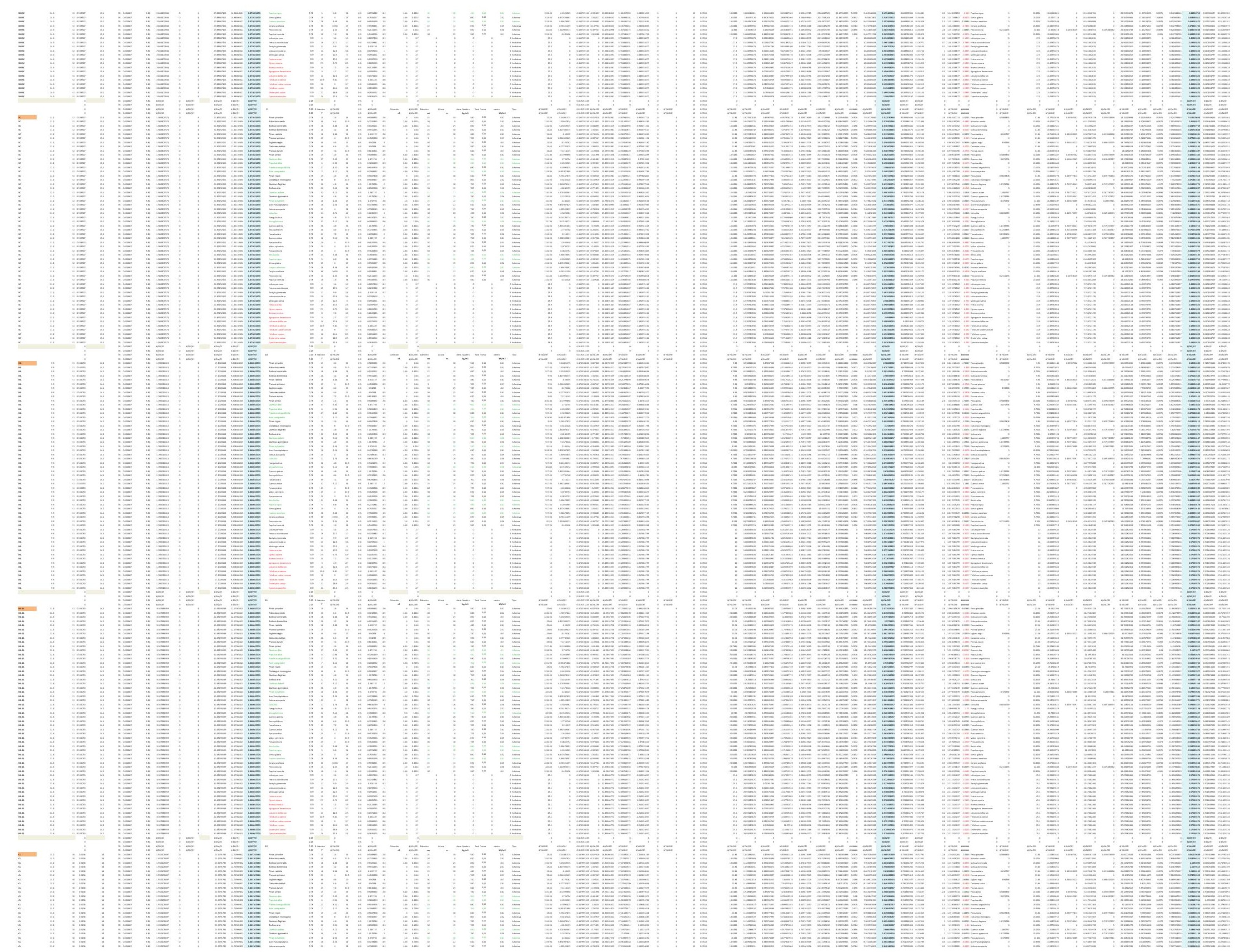


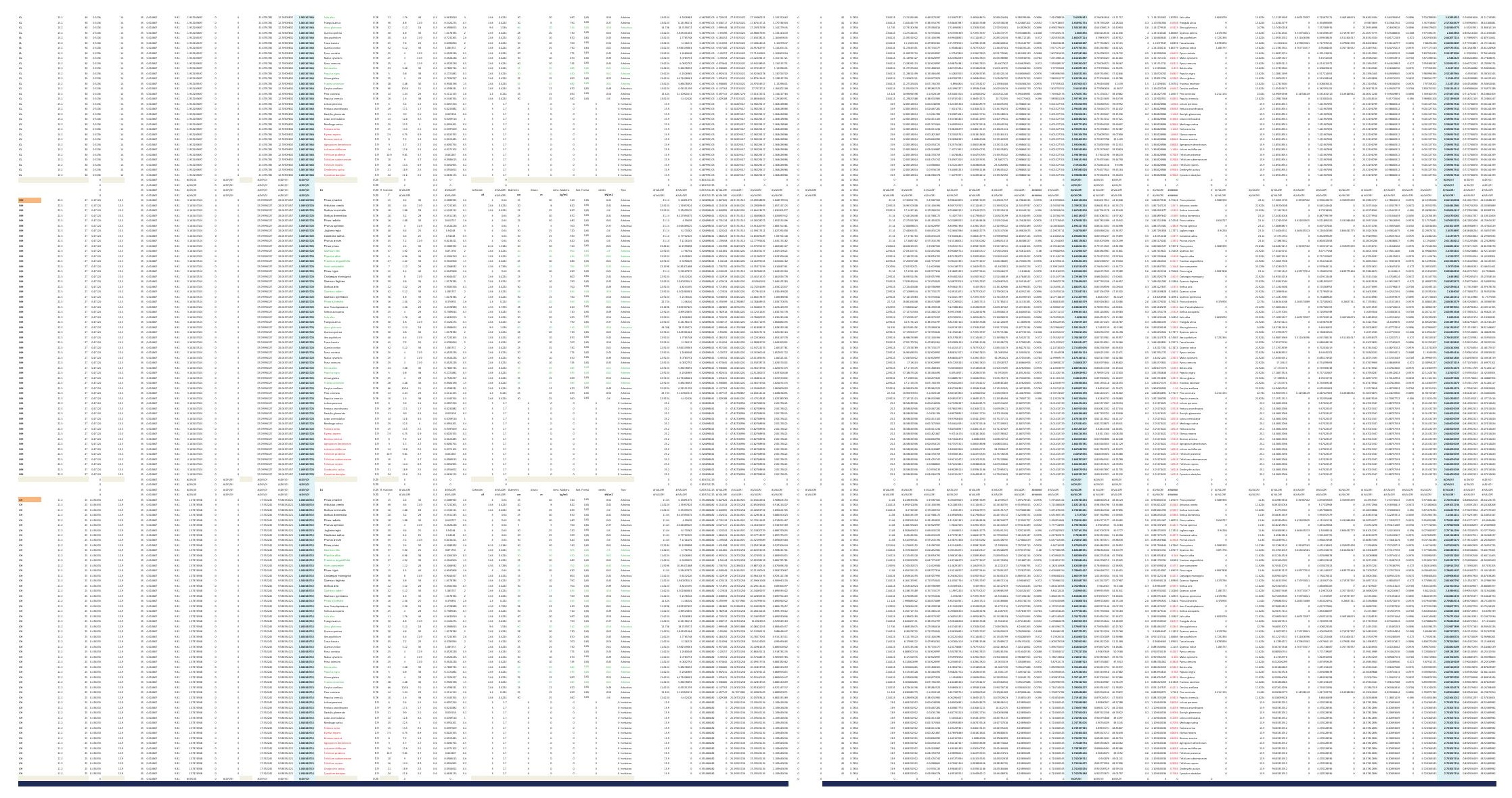



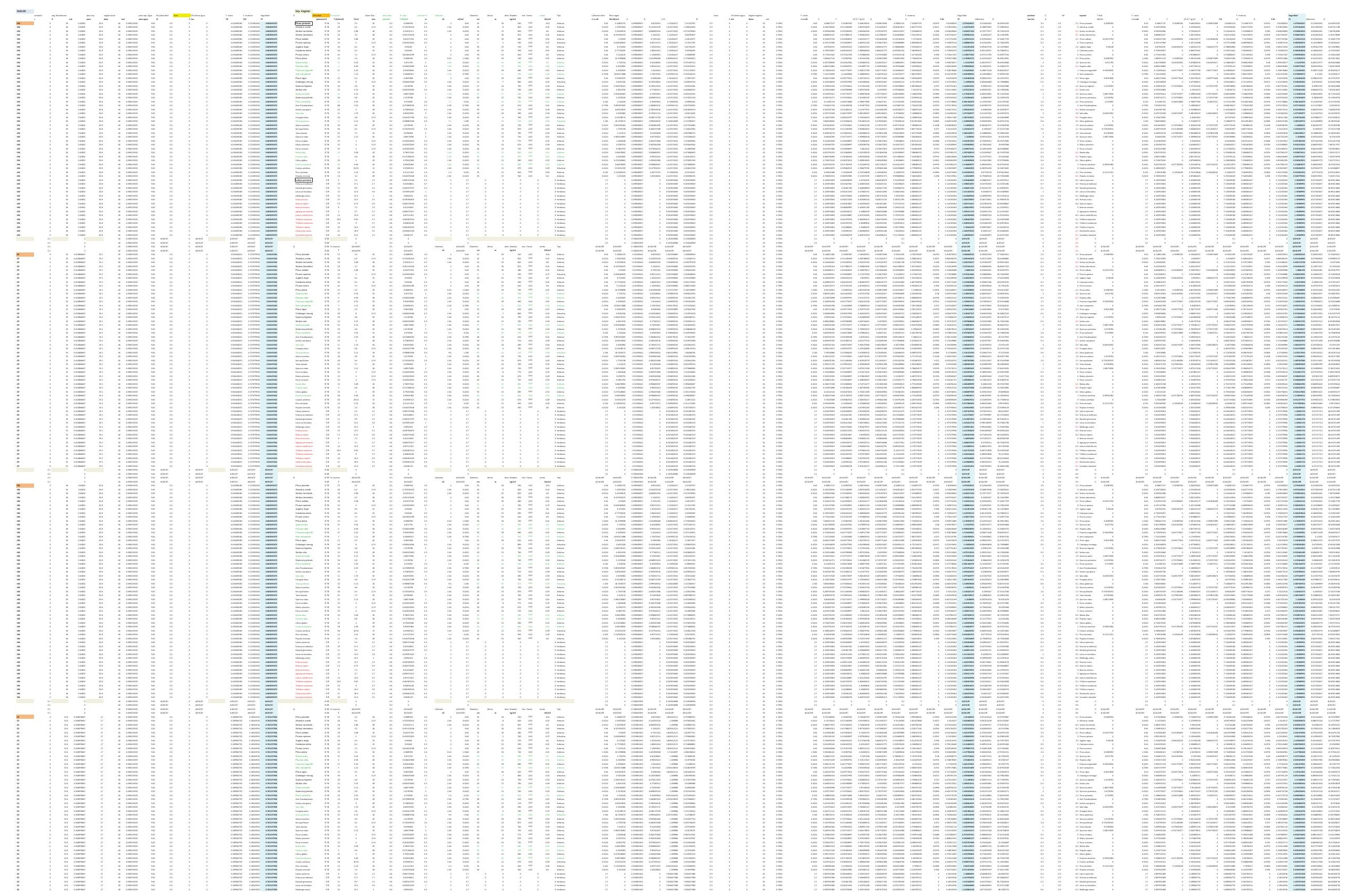


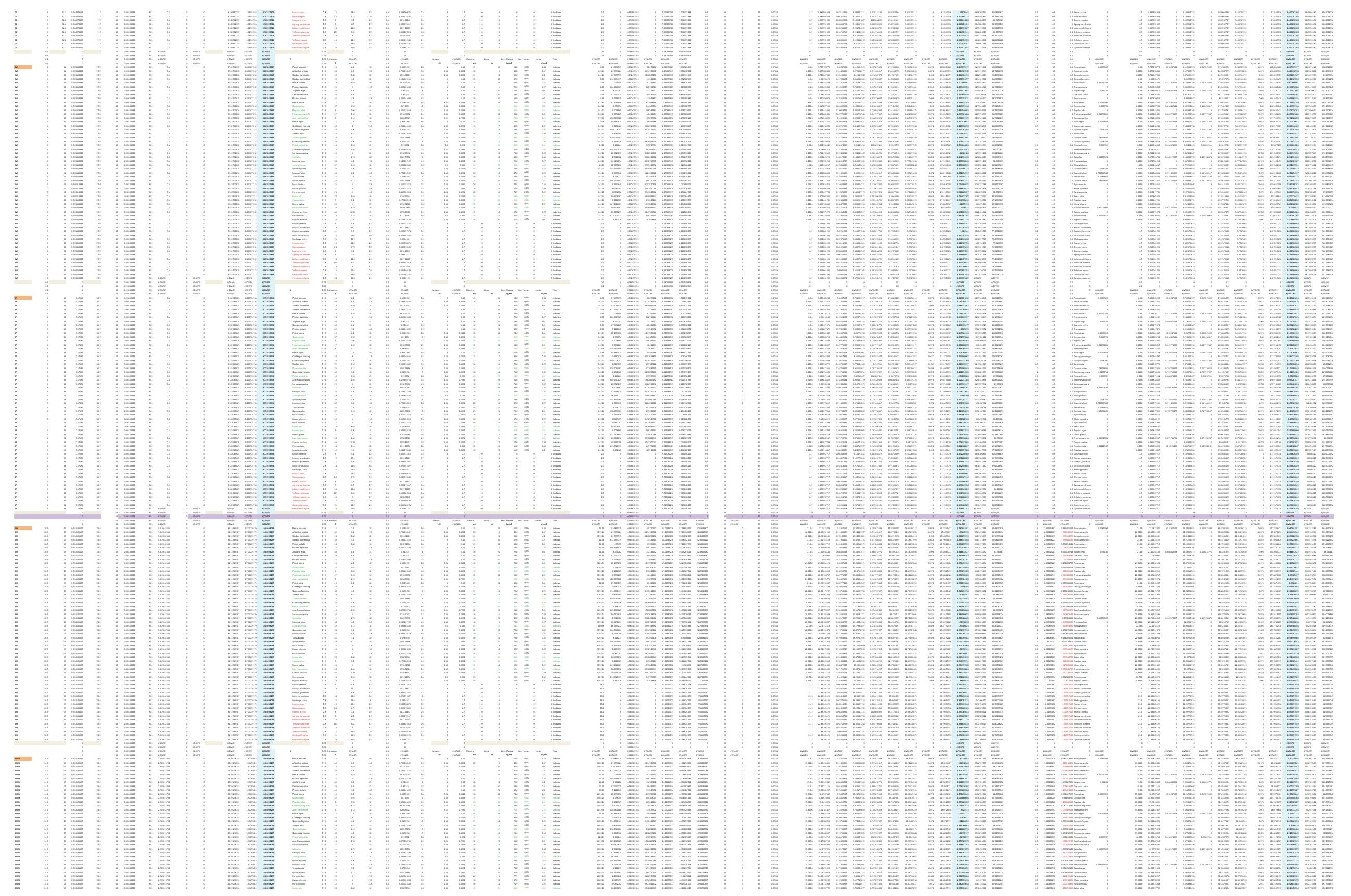



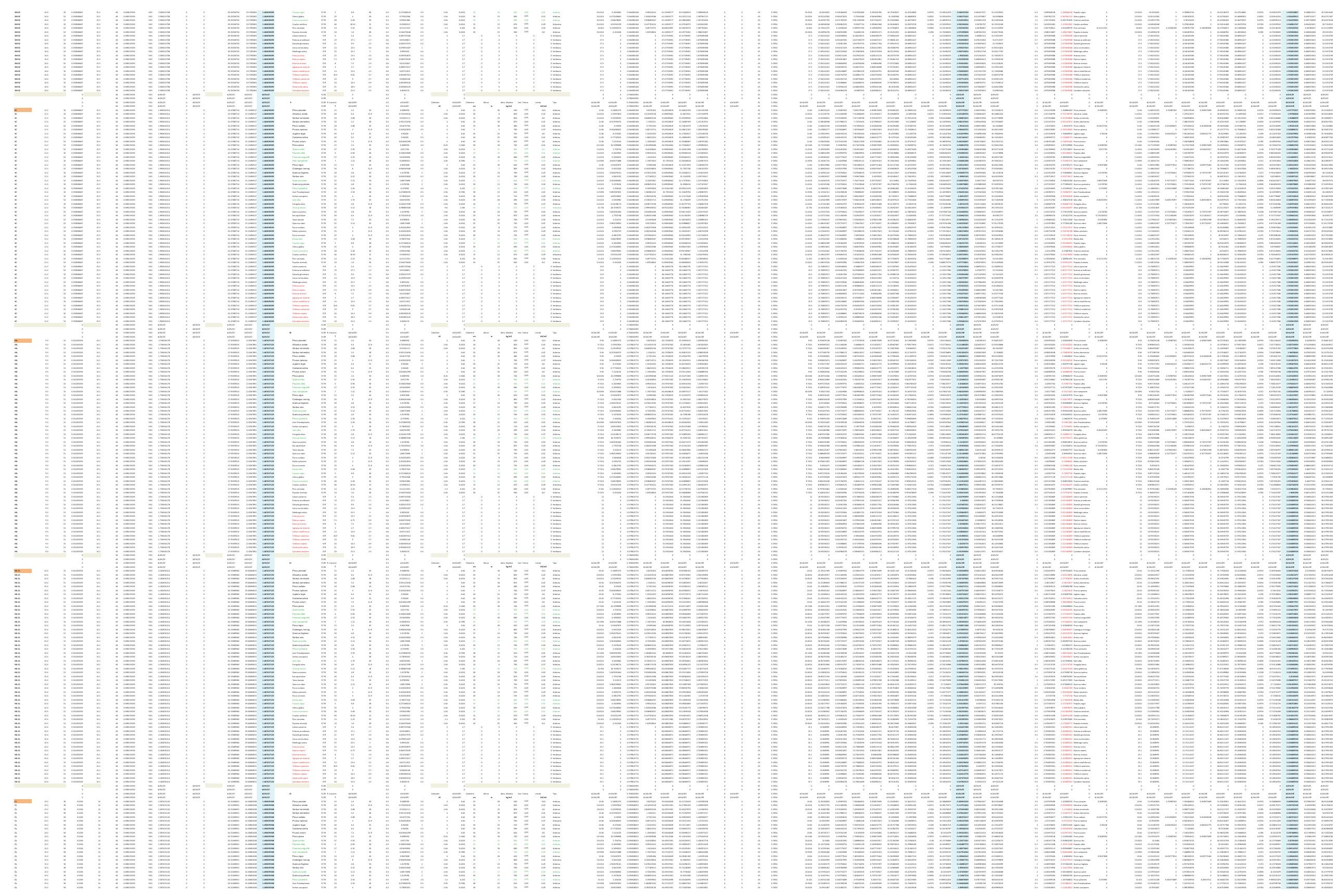


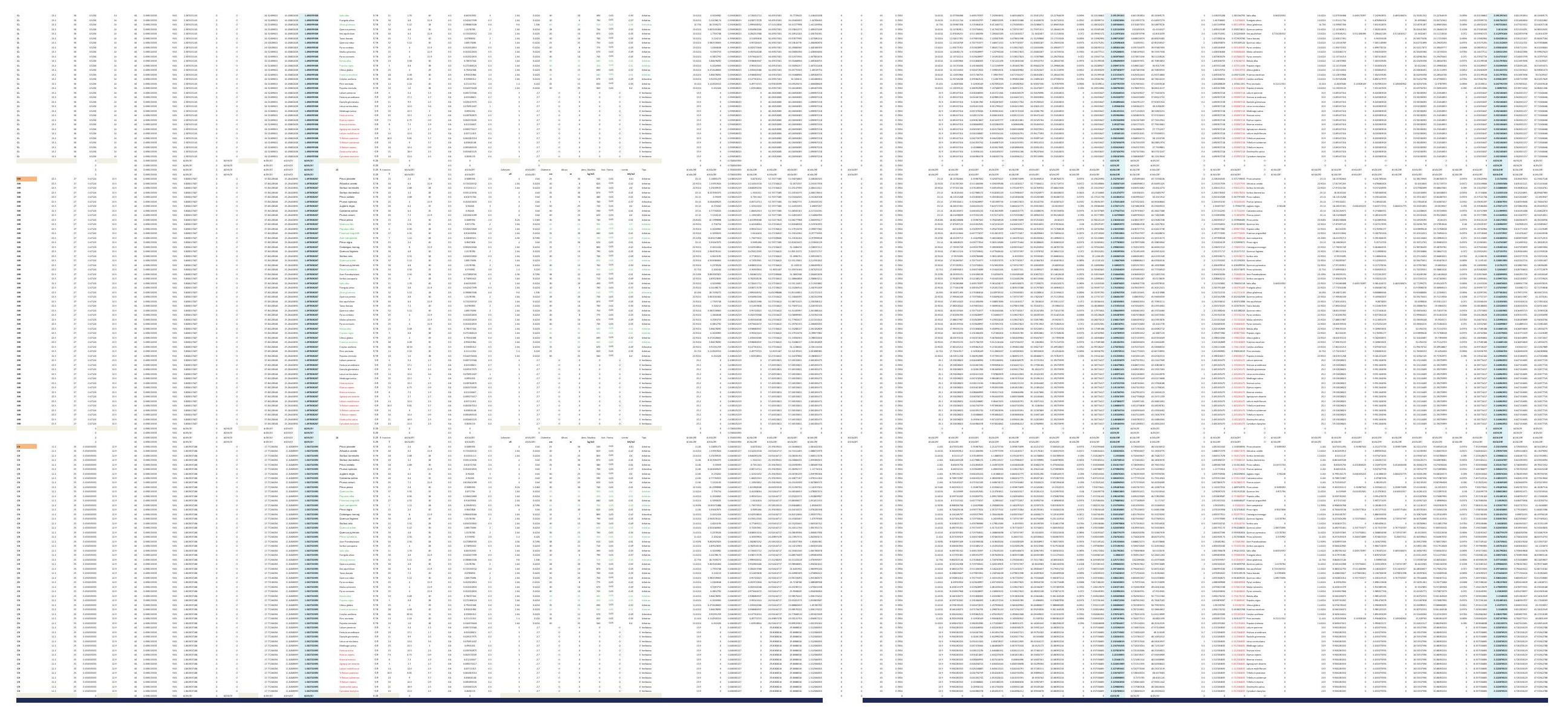



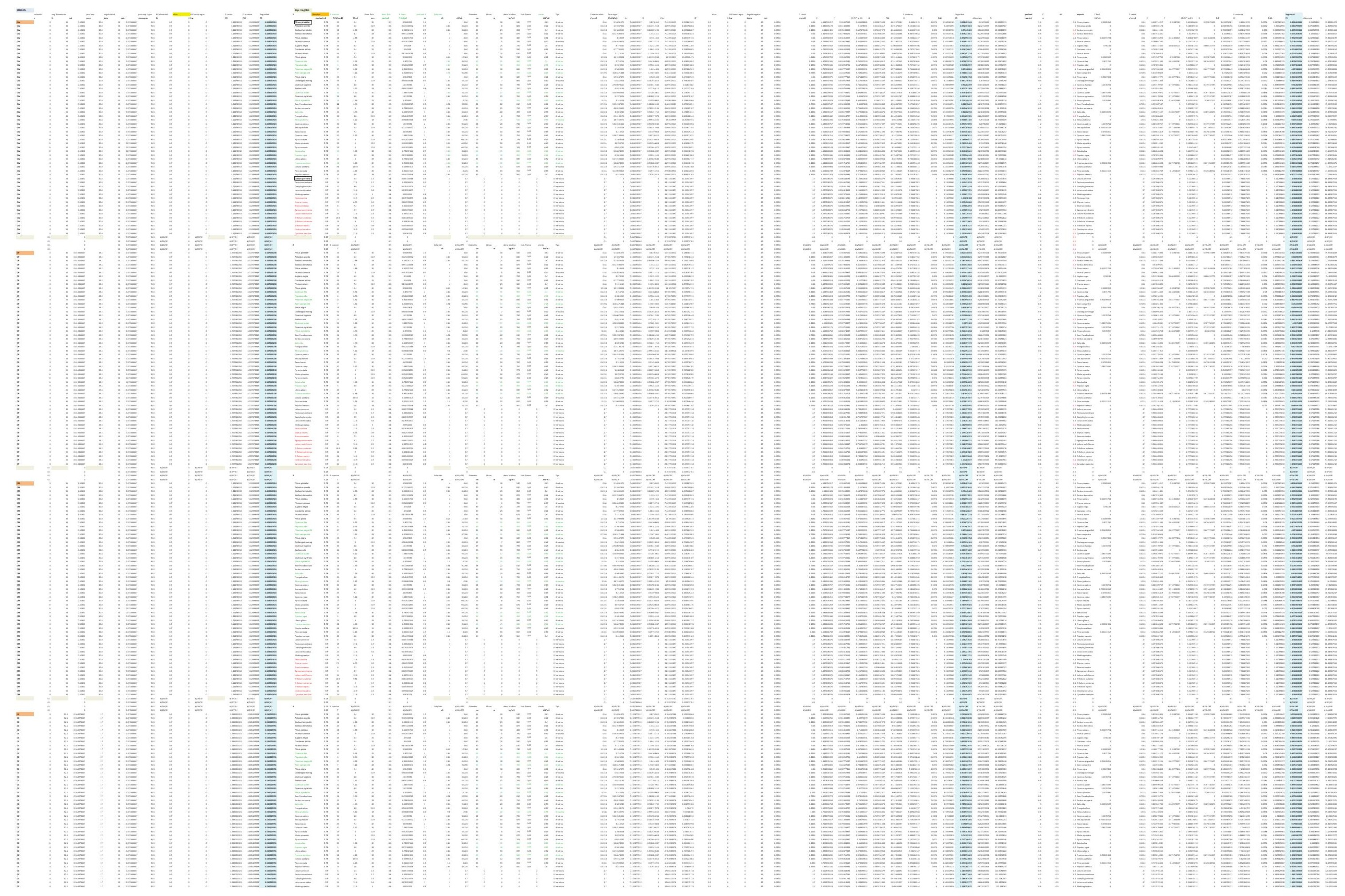


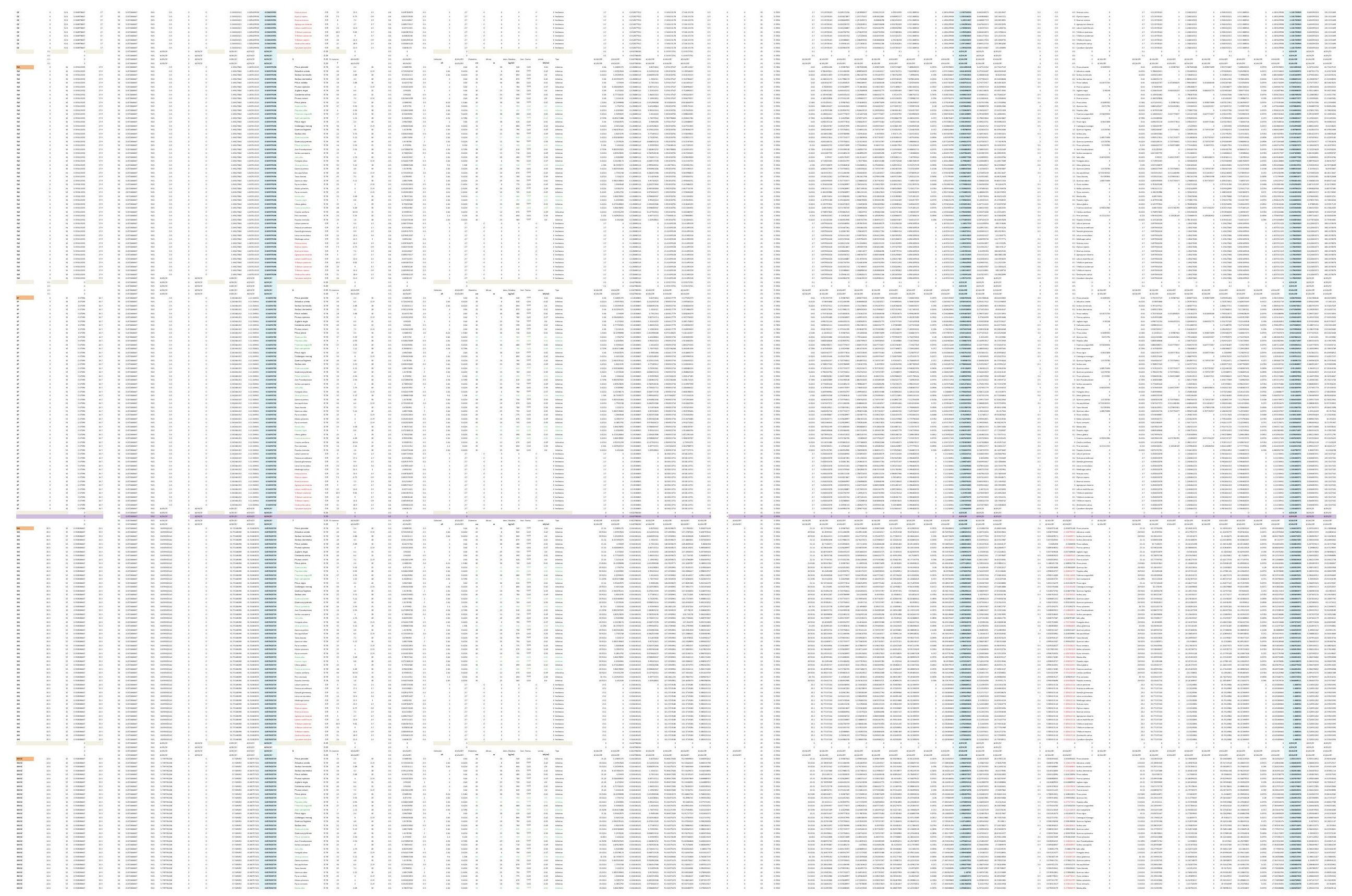



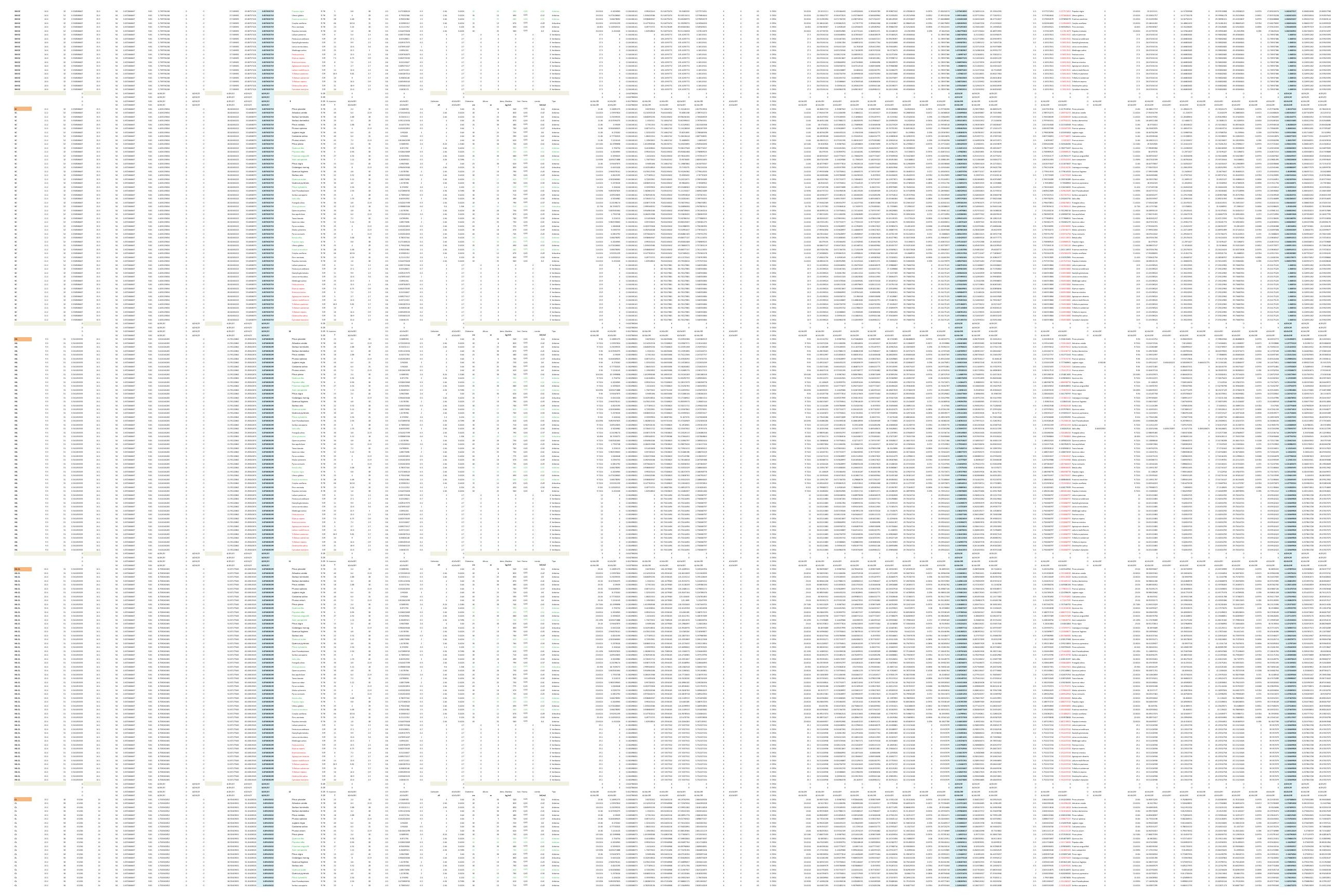


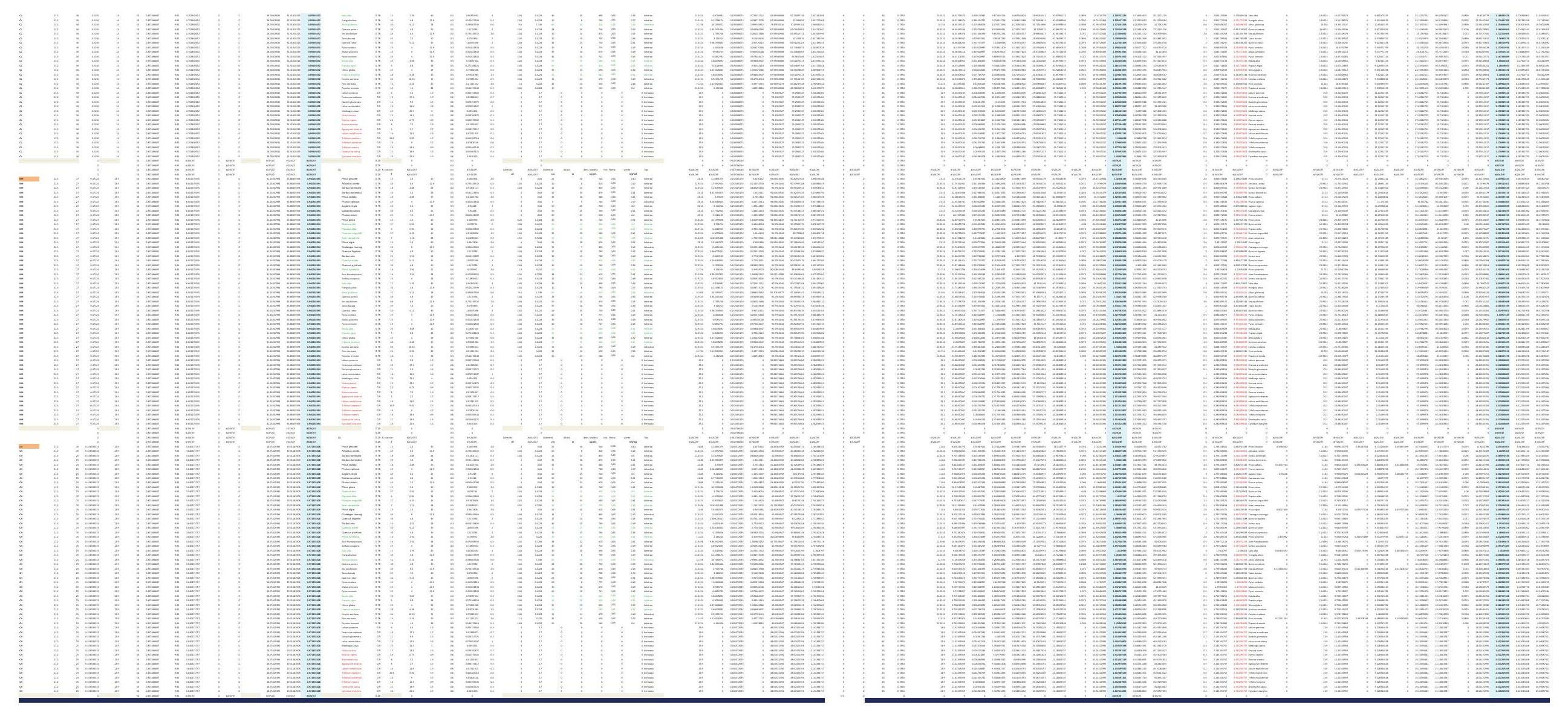



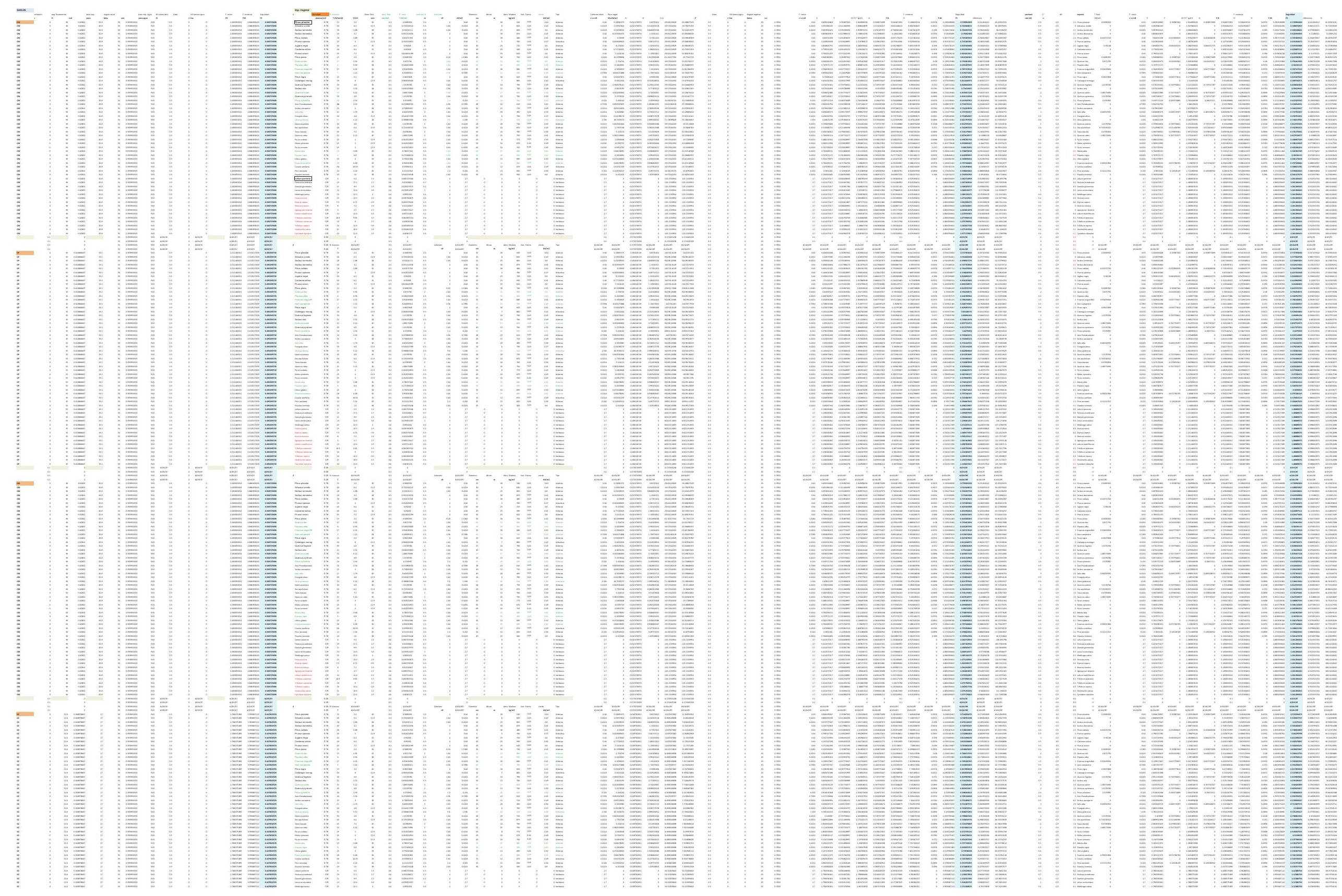


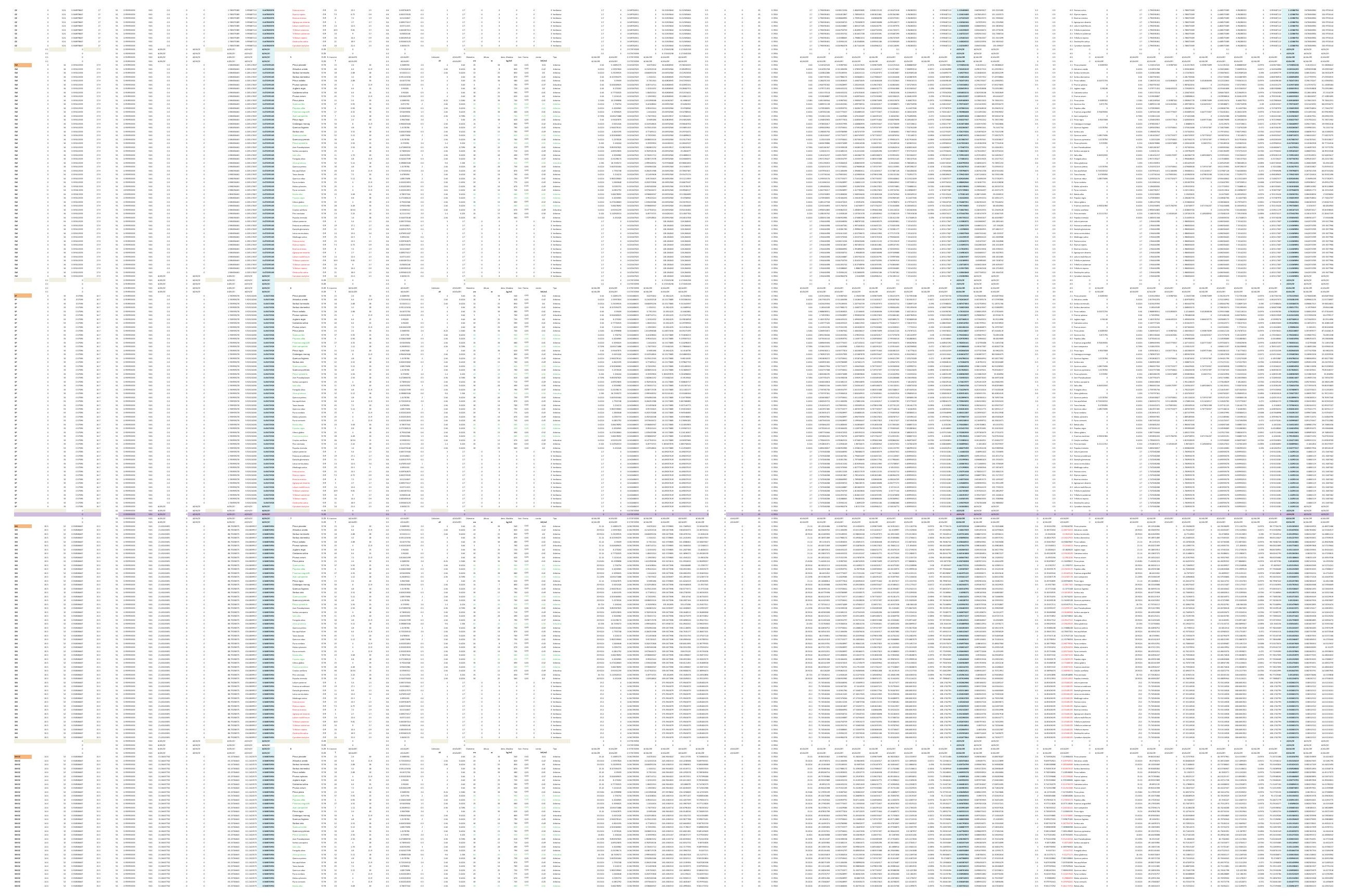



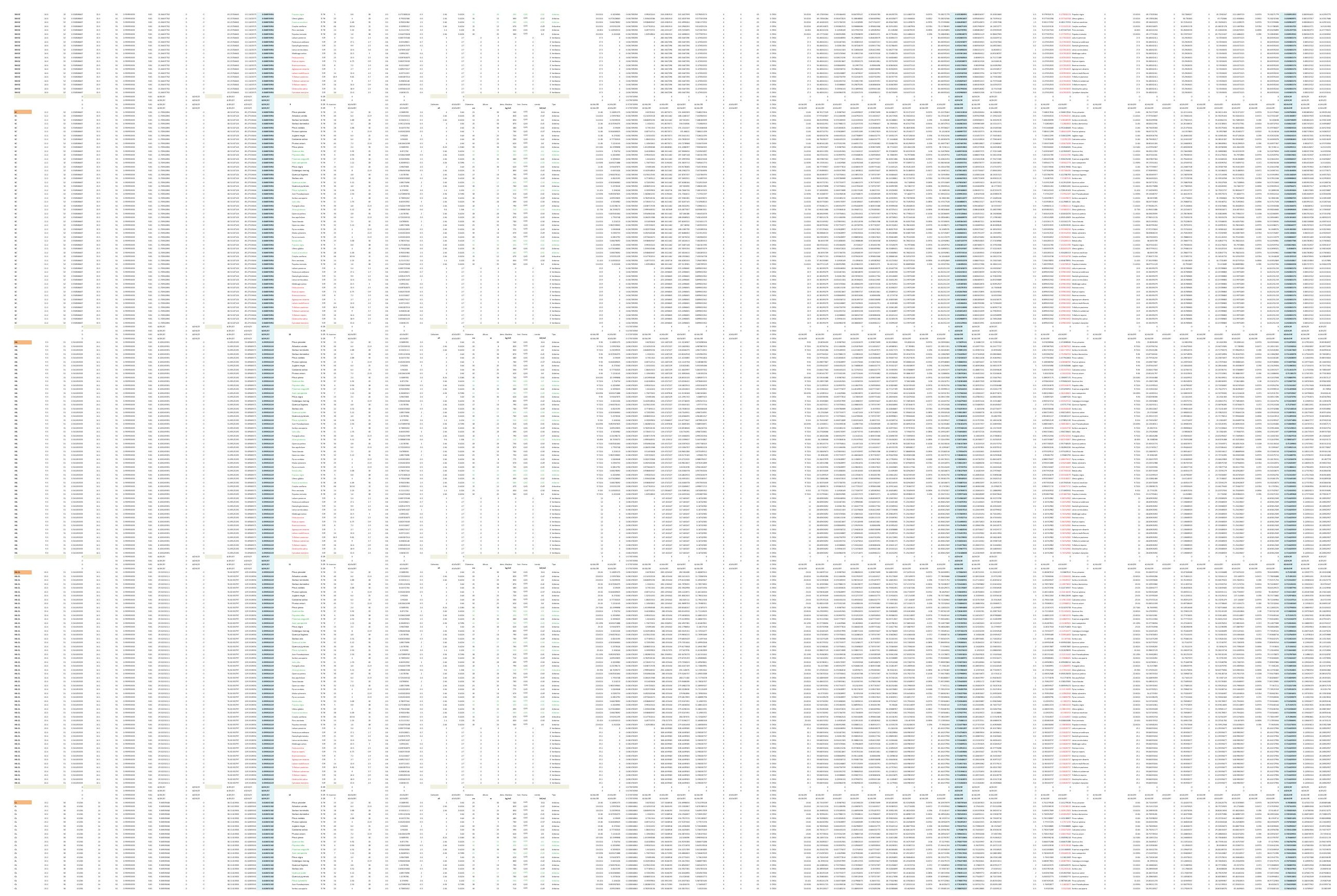


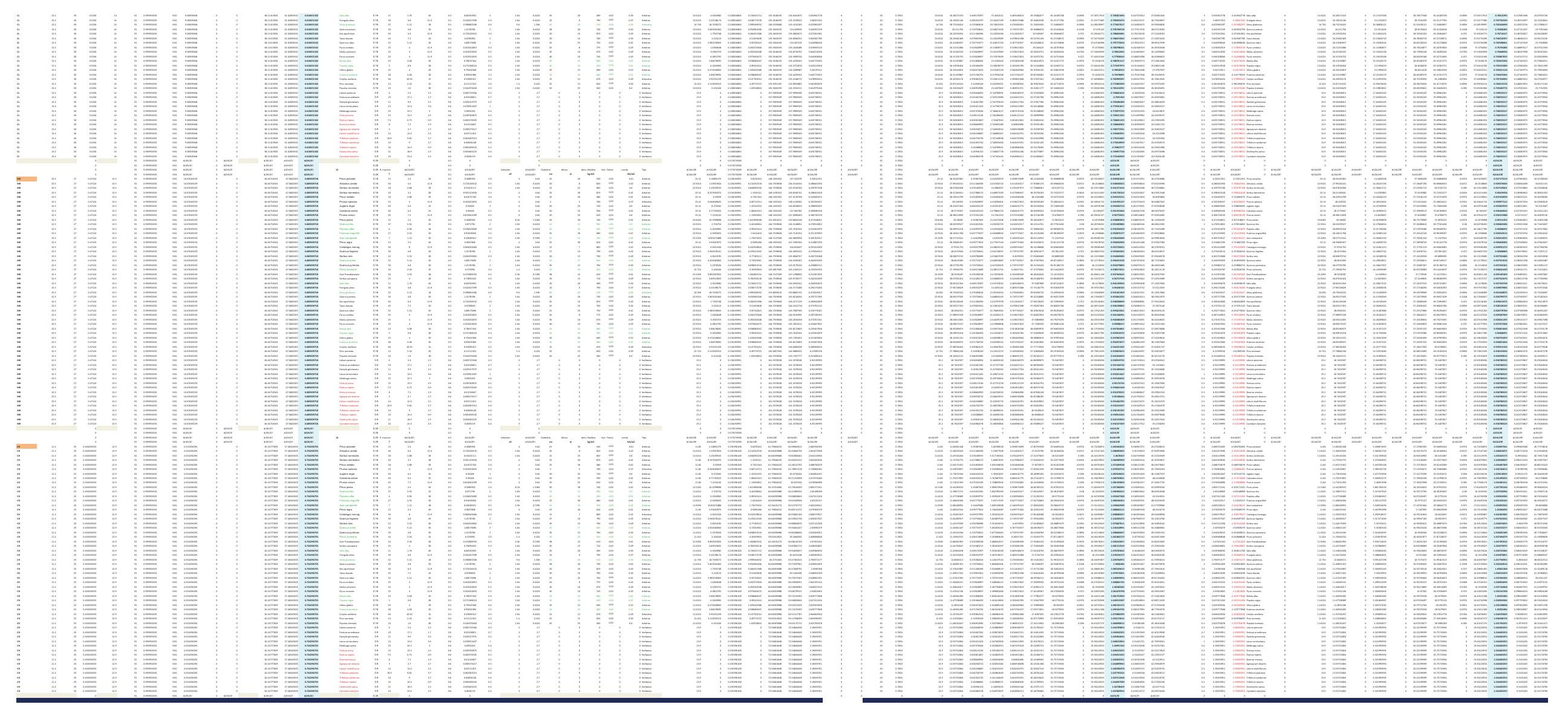



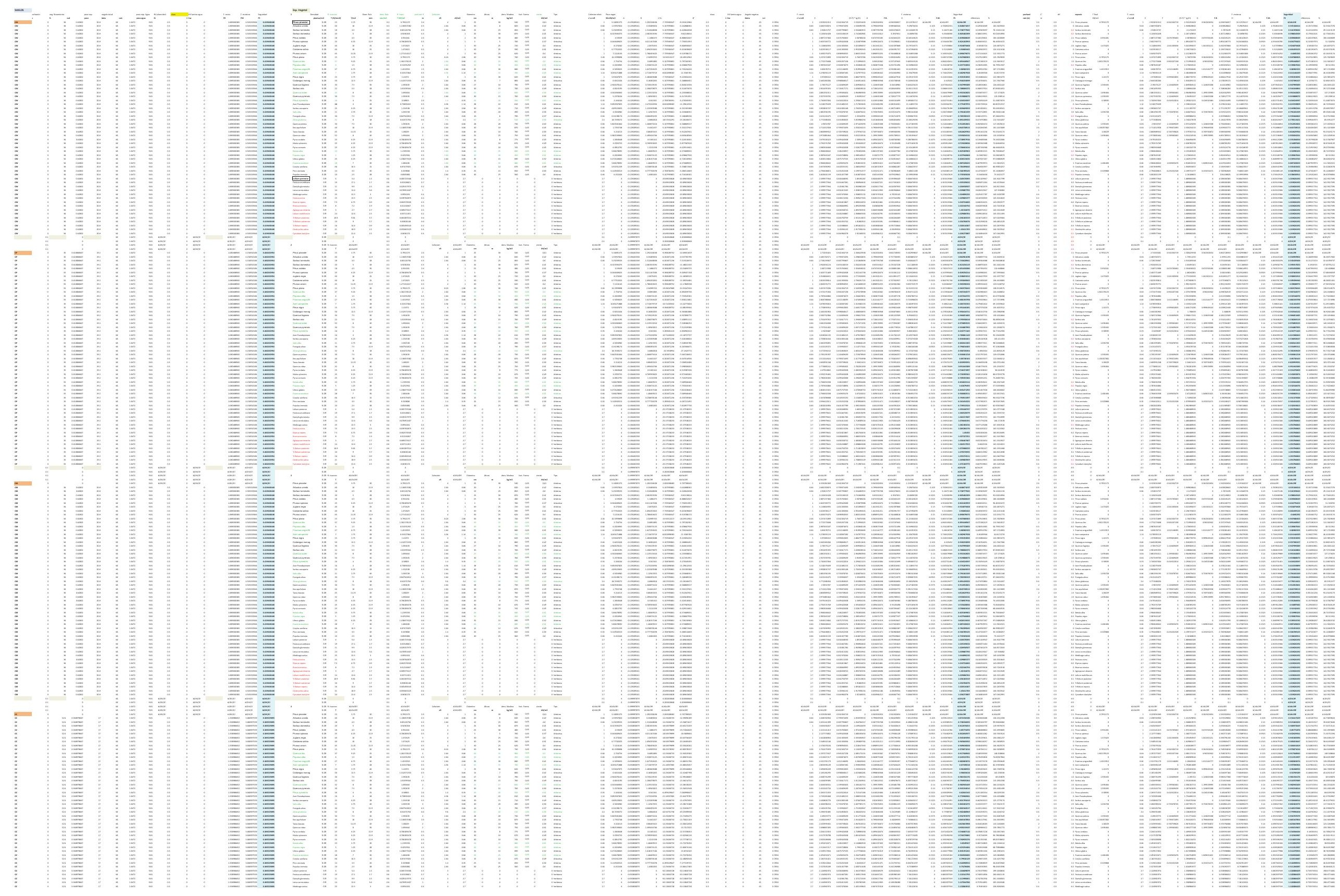


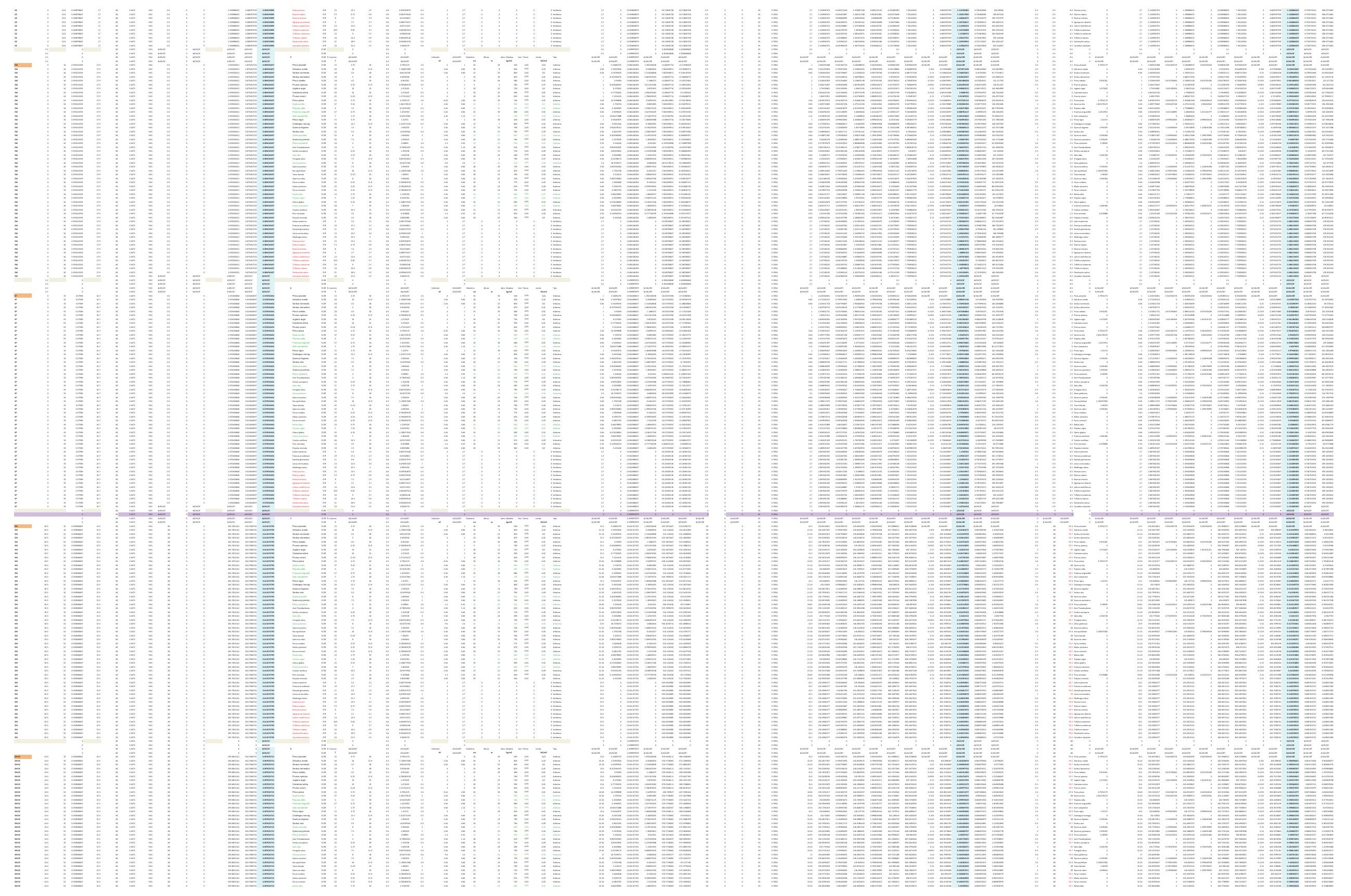



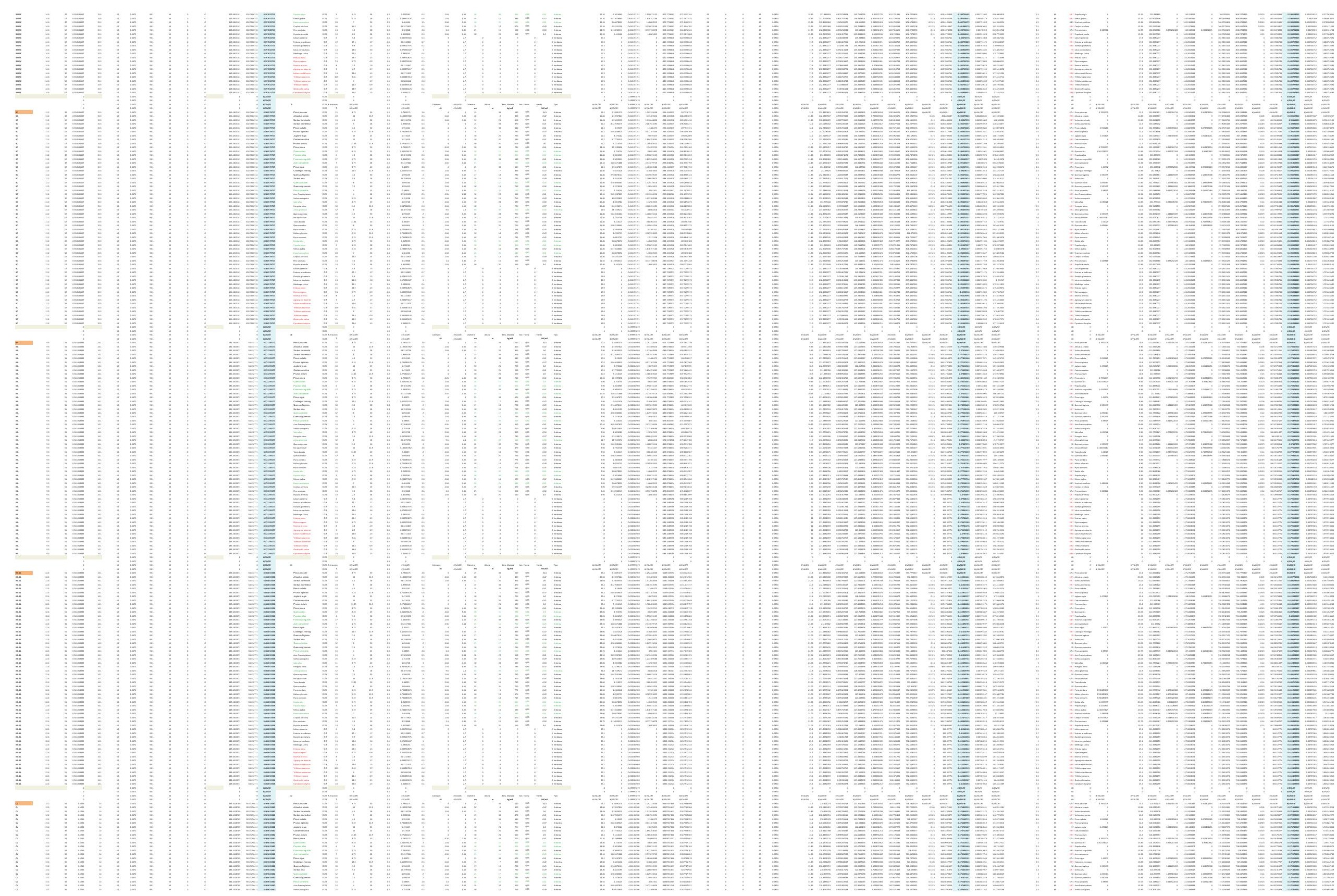


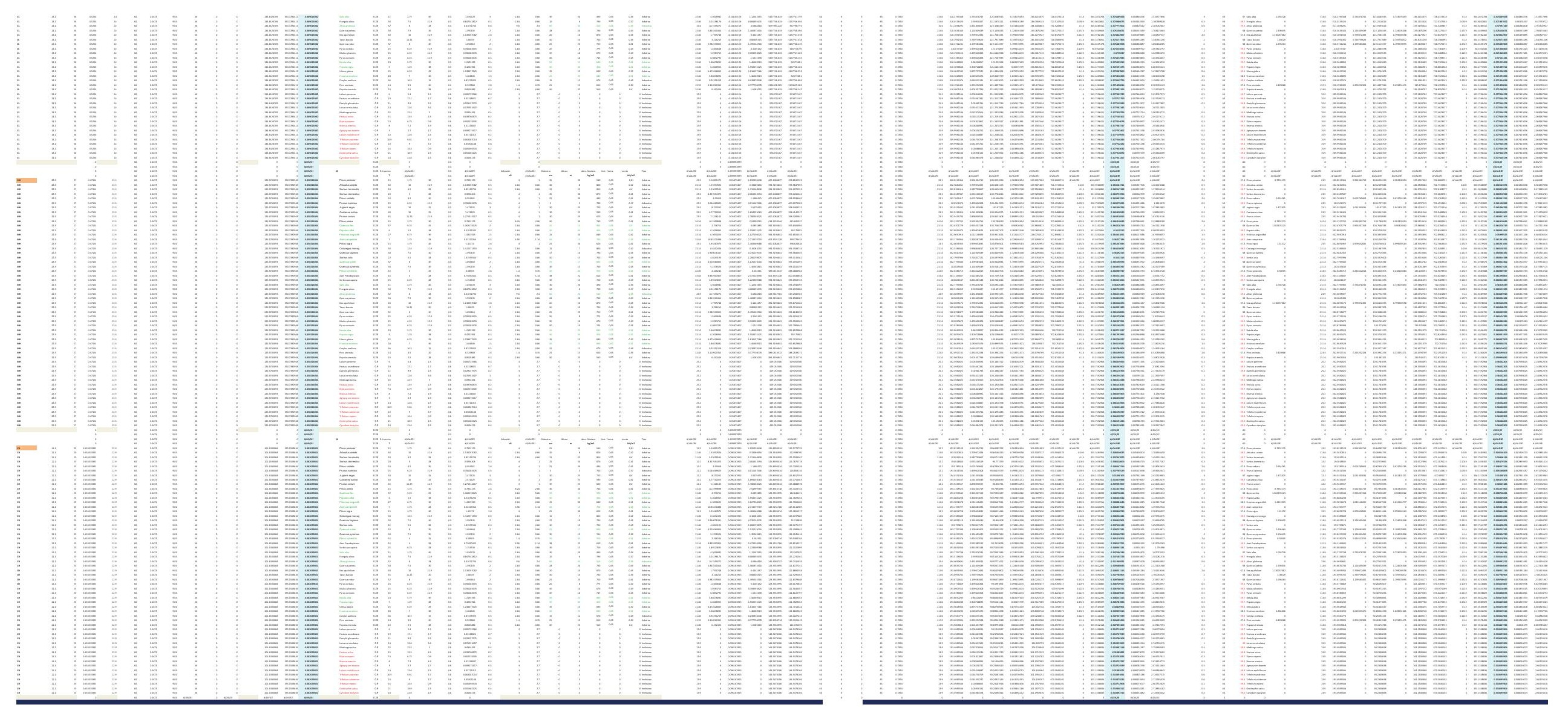



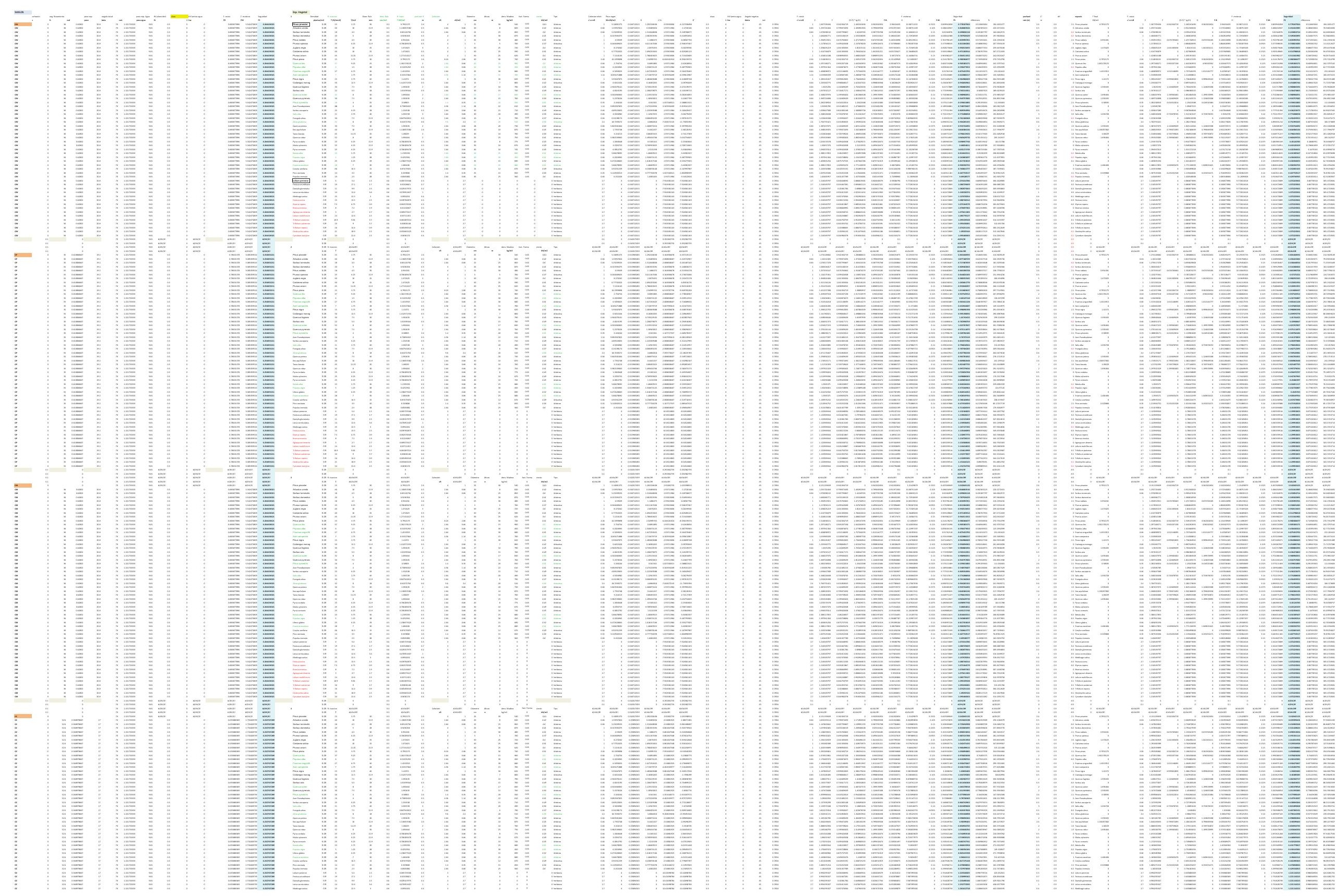


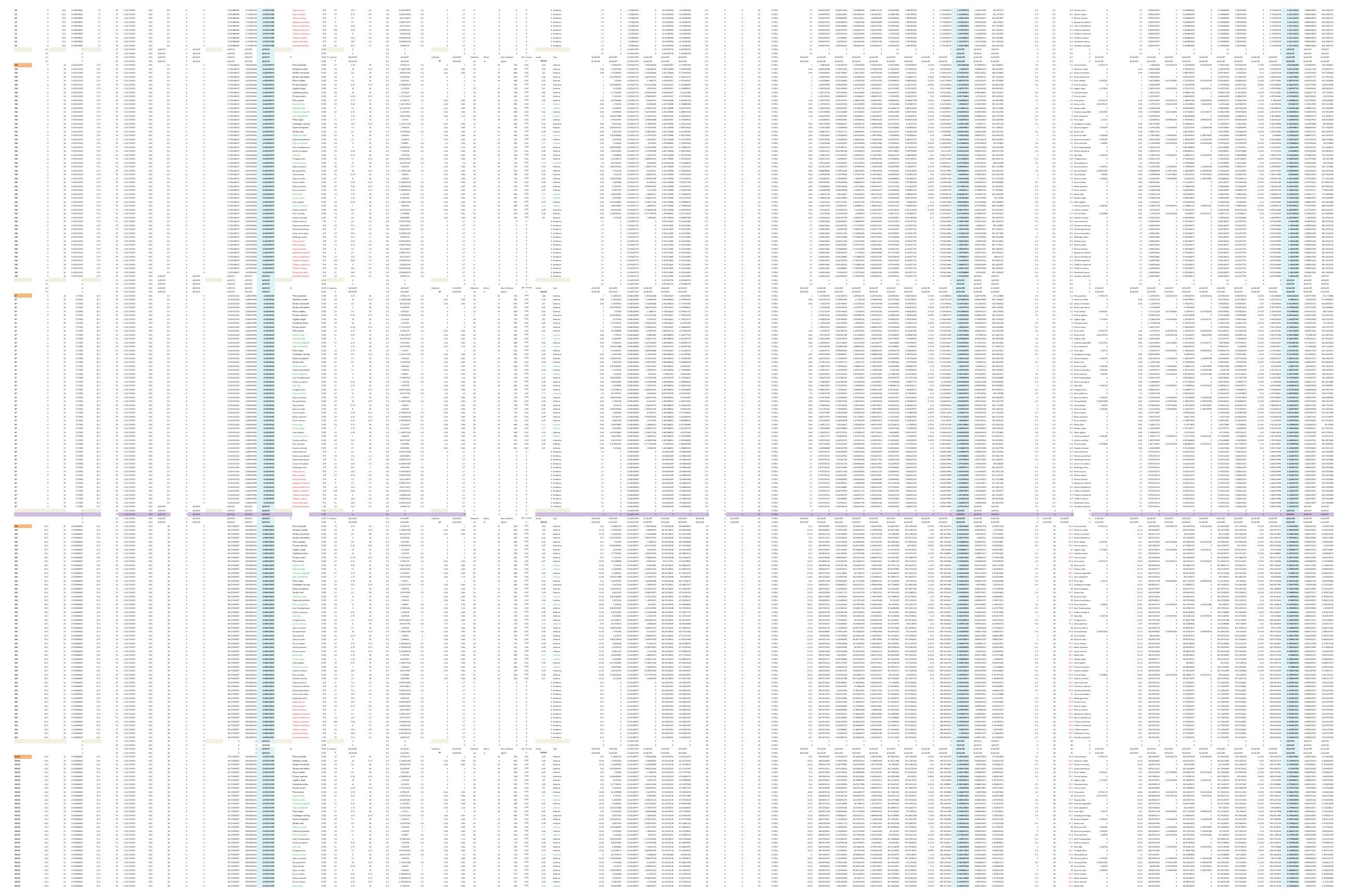



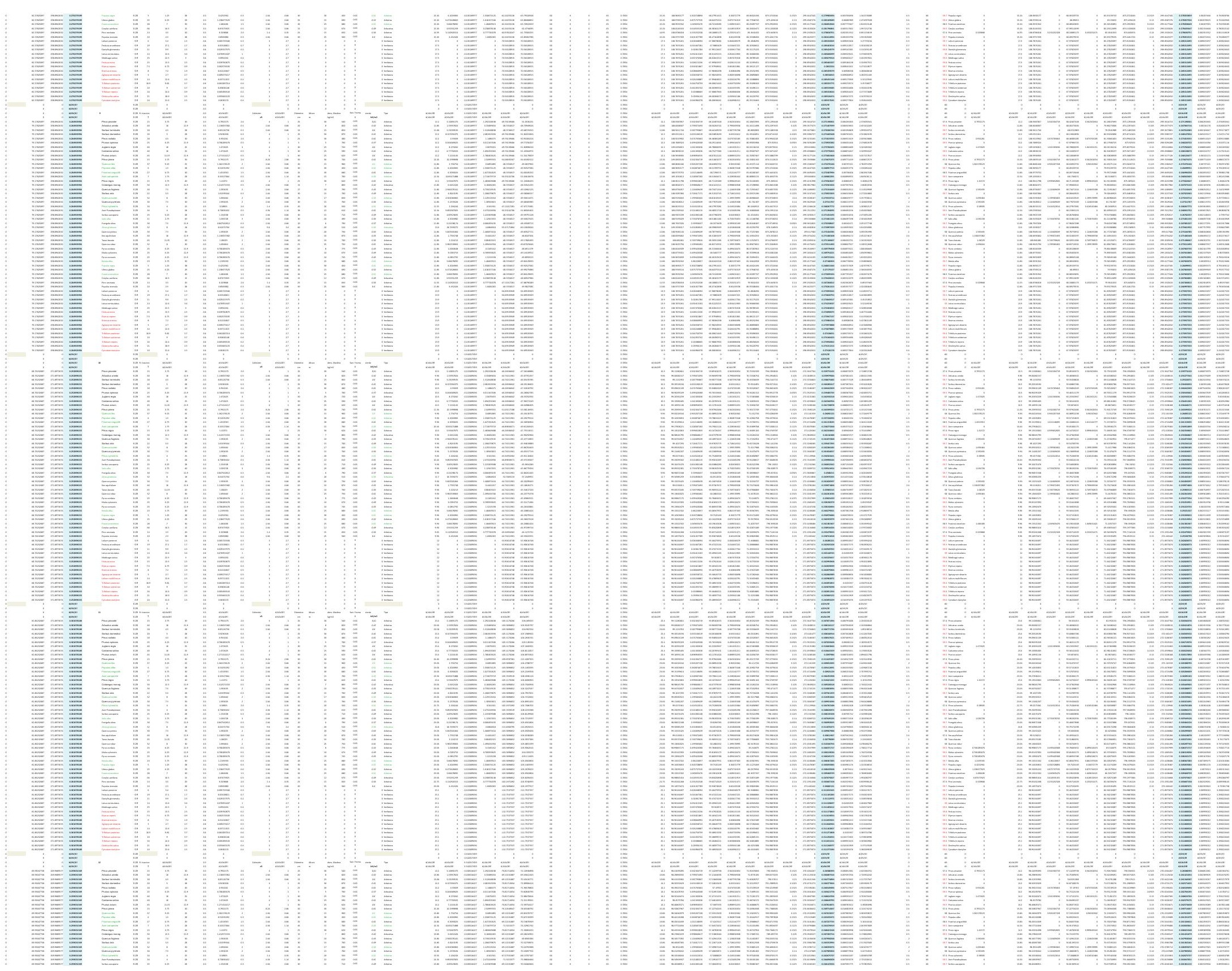


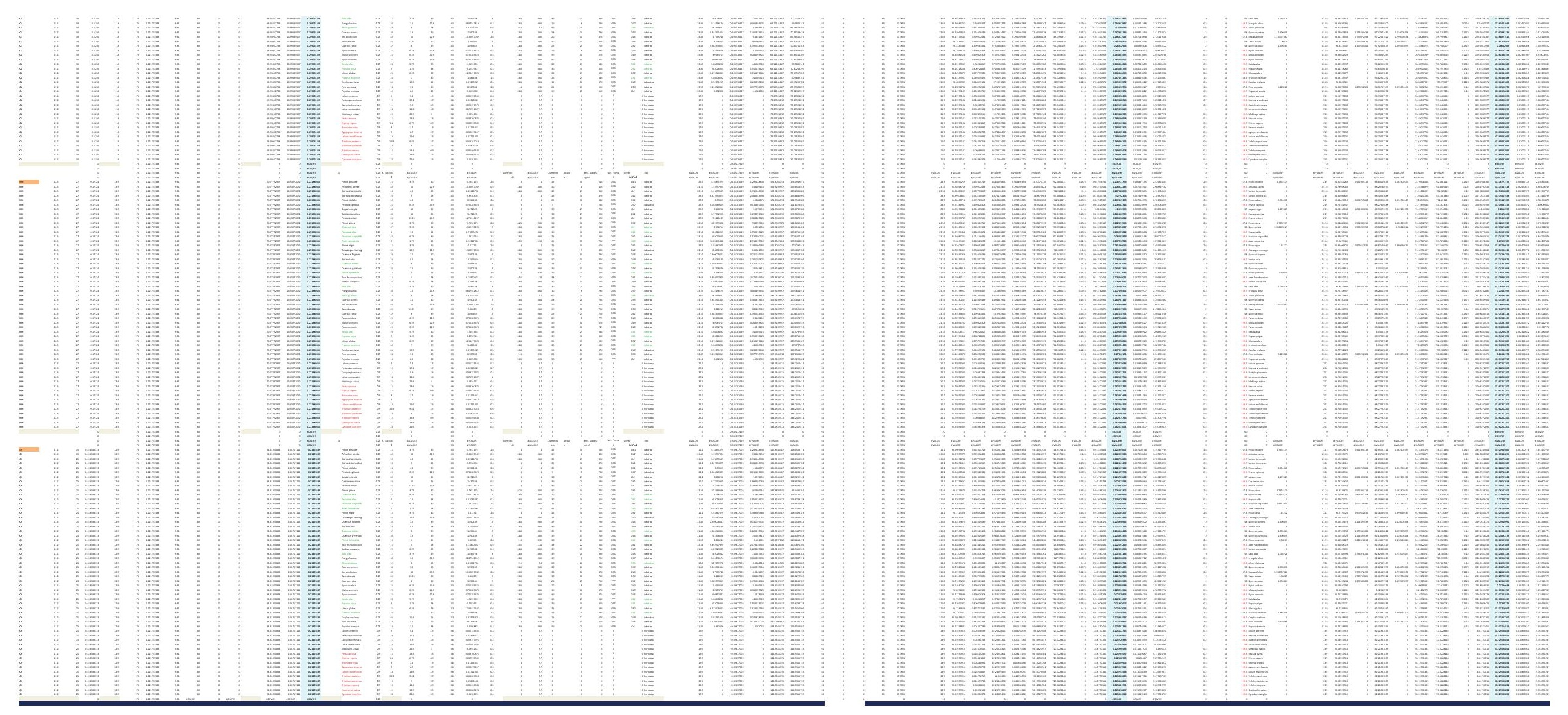



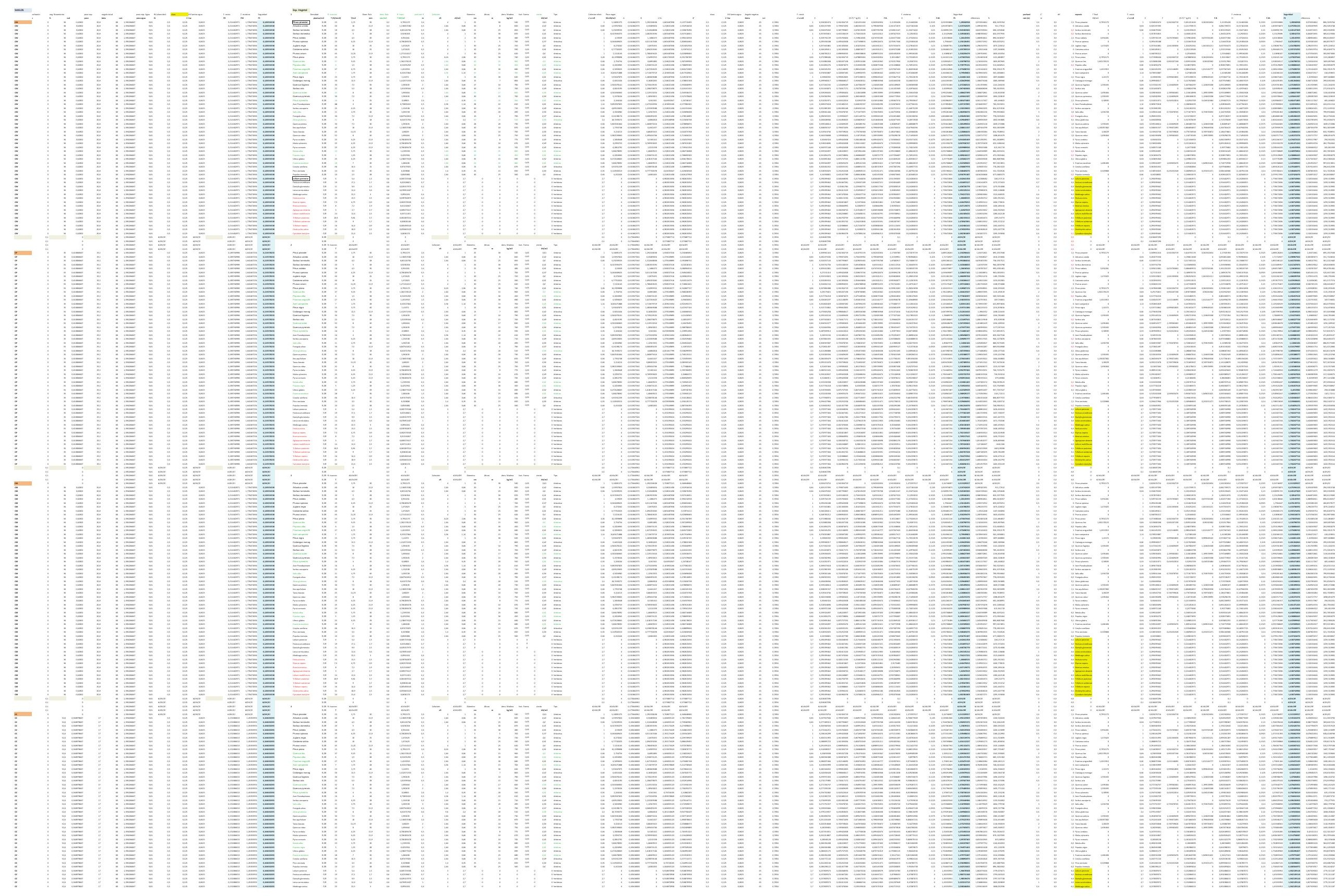


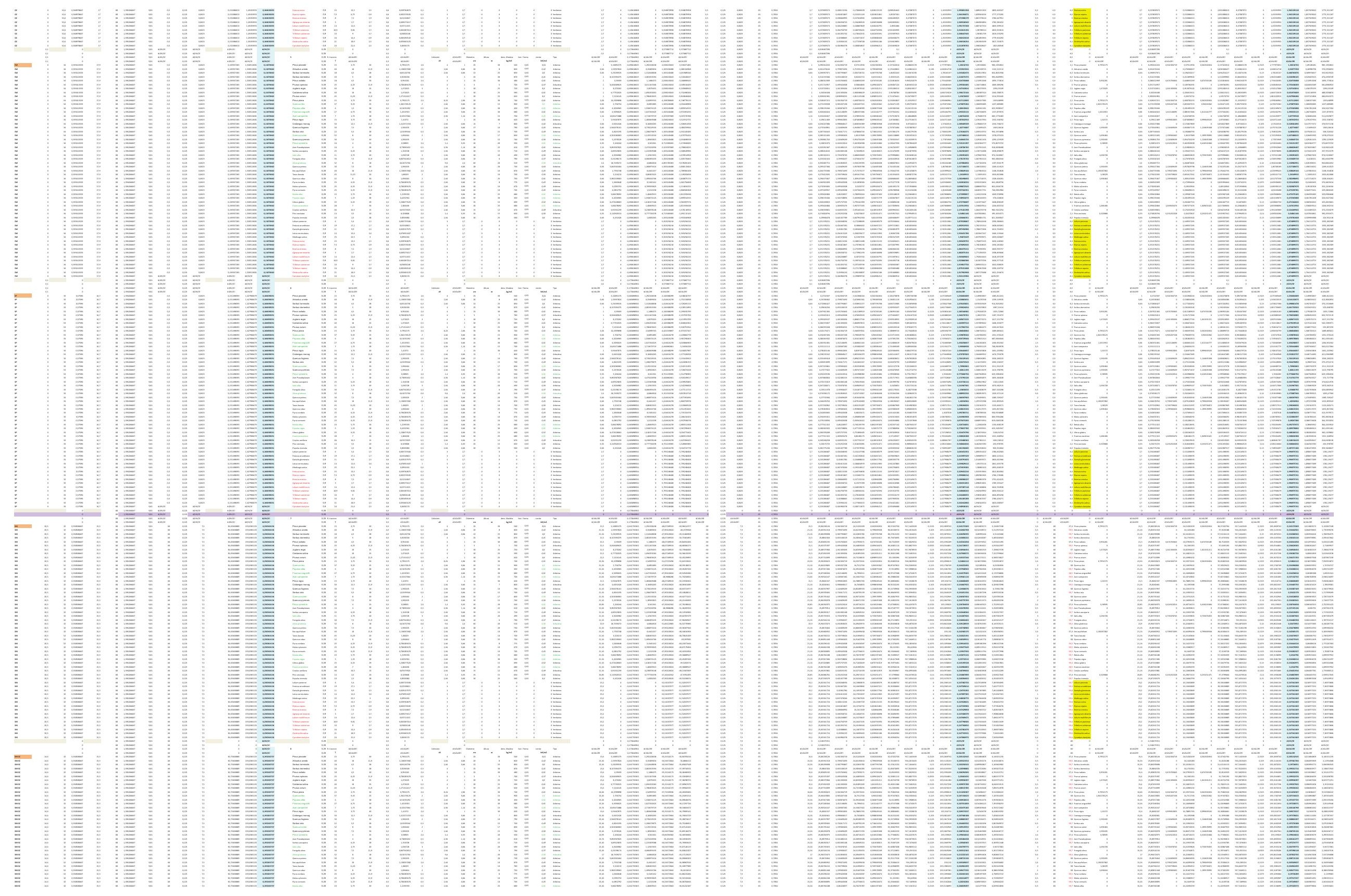




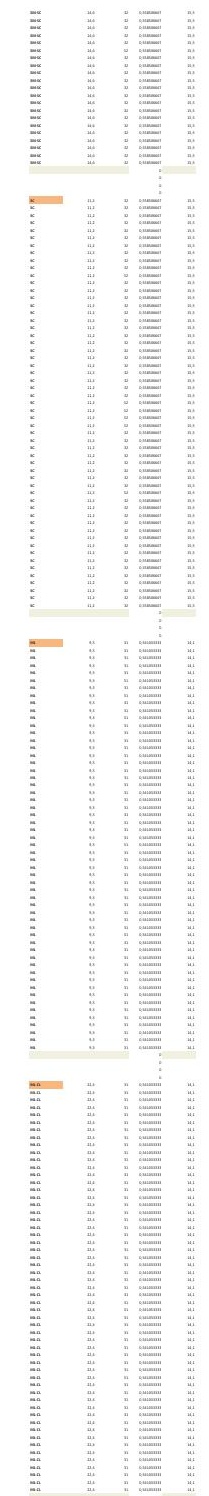

ำ
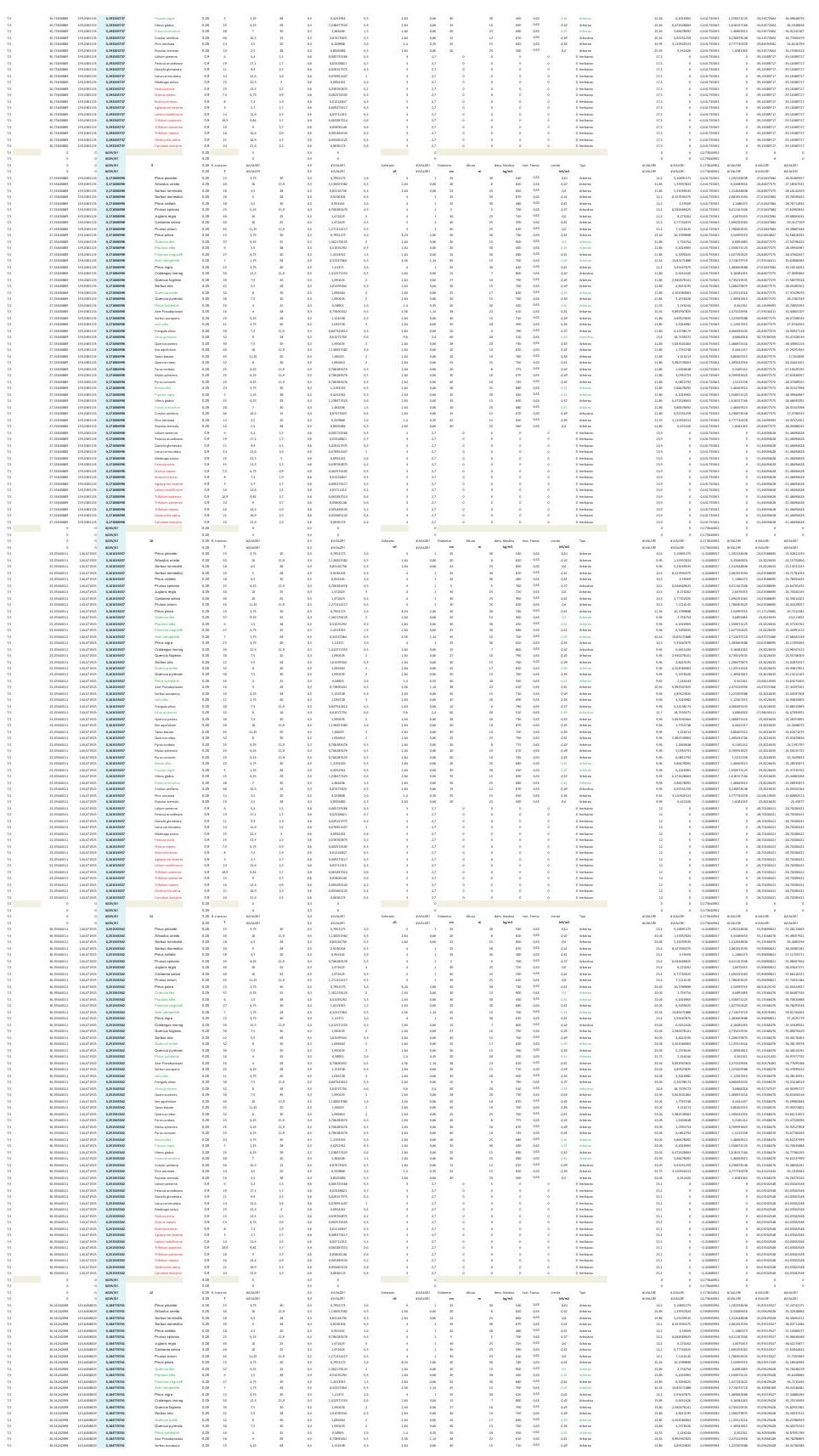
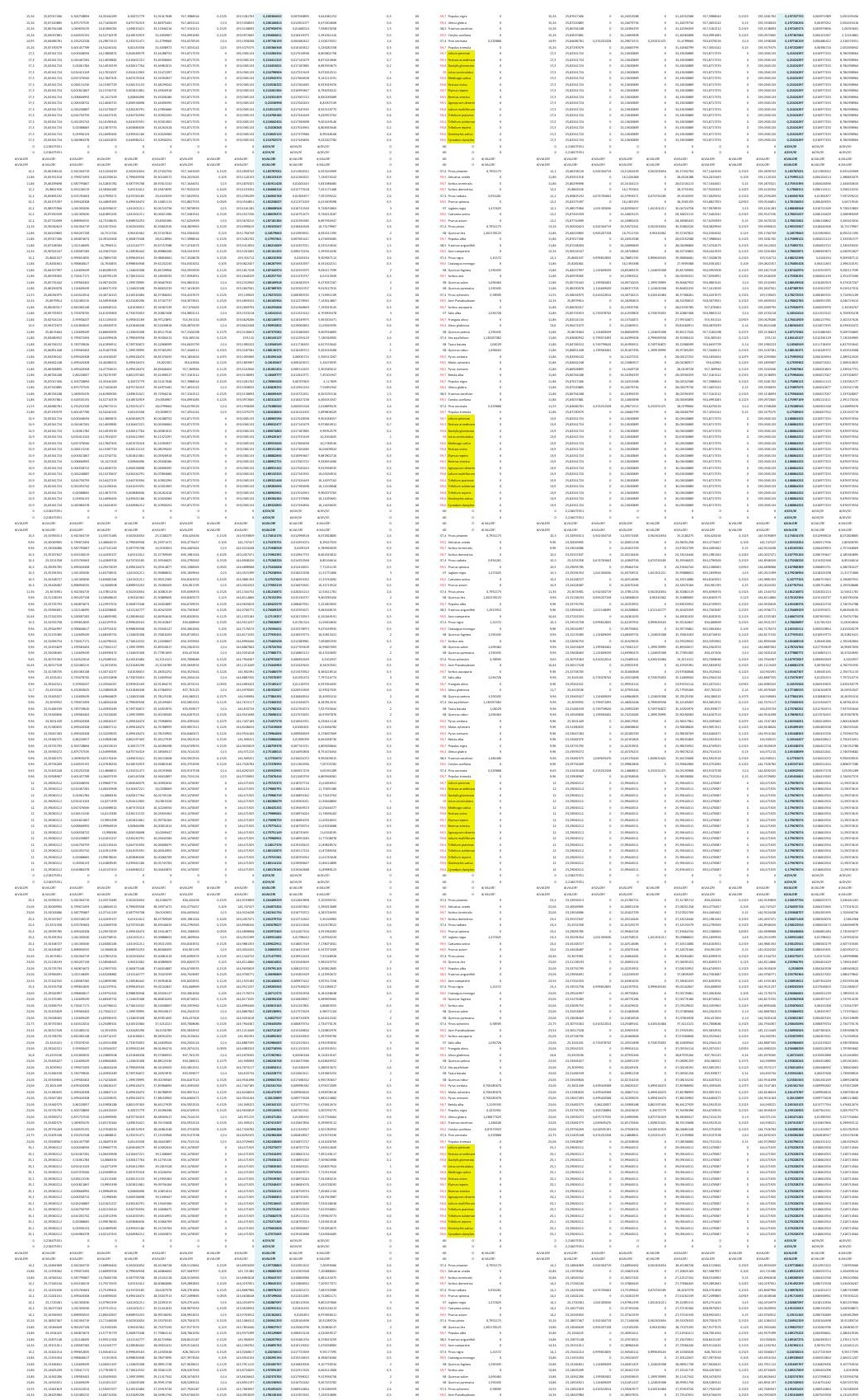

E
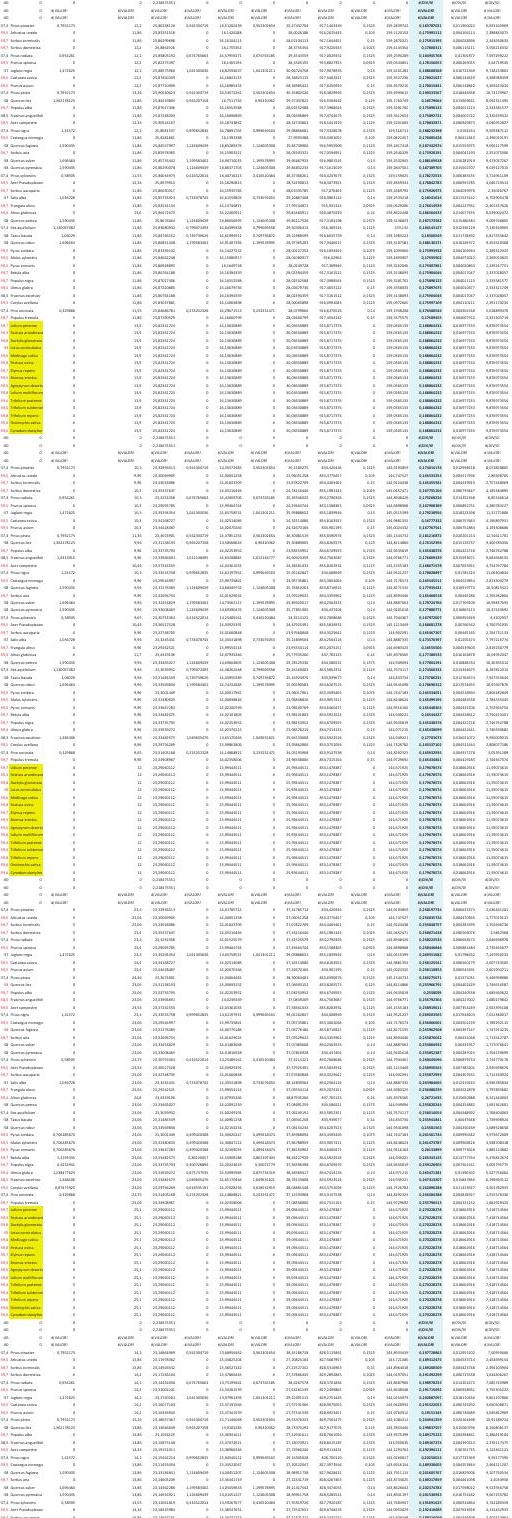


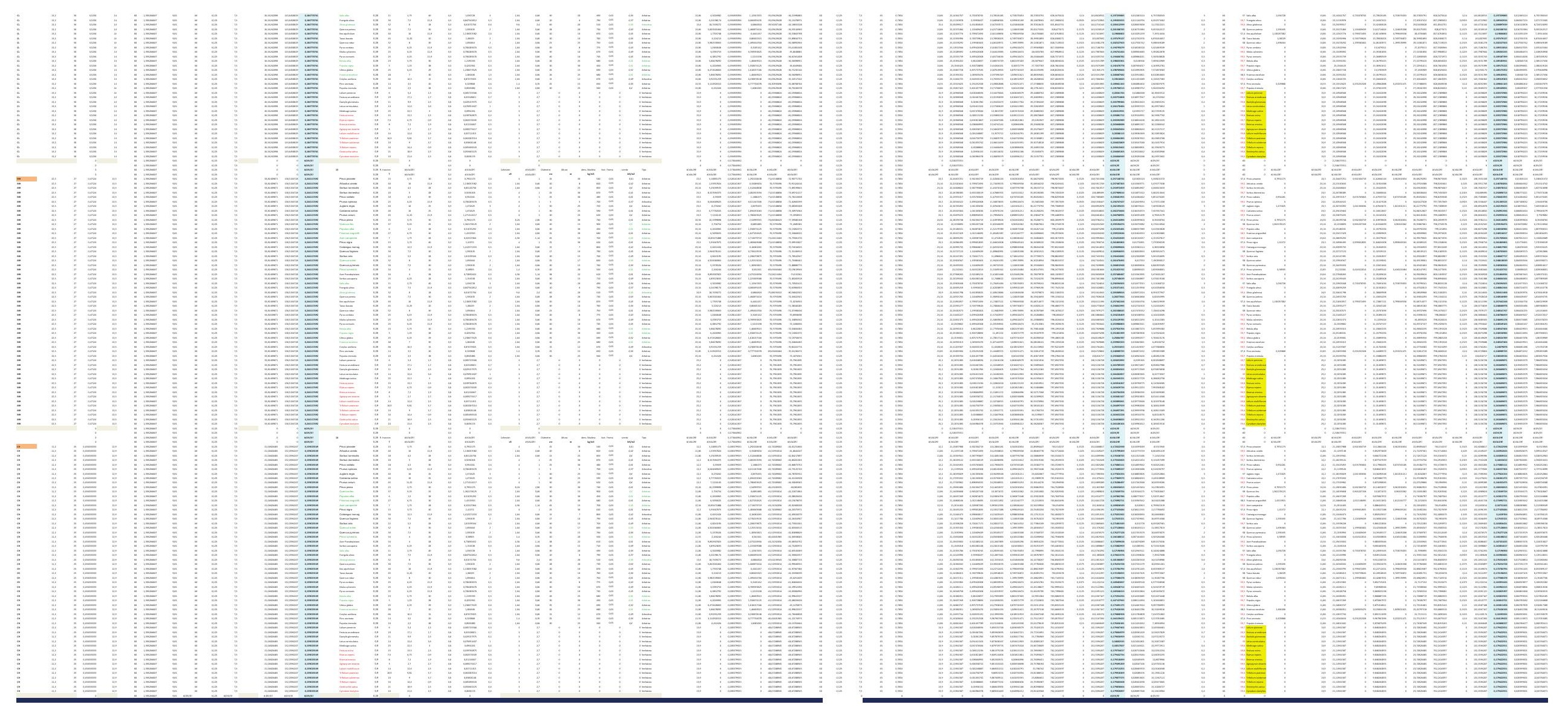


DESARROLLO DE UNA APLICACIÓN IMFORMÁTICA PARA EL CÁLCULO DE SOSTENIMIENTO DE TALUDES MEDIANTE VEGETACIÓN

A02. DENSIDAD DE PLANTACIÓN: 1.600 plantas/ha.

A02-2.POSICIÓN N.F. 2

INCLINACIÓN DE TALUD 6-100

INCLINACIÓN DE TALUD 10-200

INCLINACIÓN DE TALUD 20-30

INCLINACIÓN DE TALUD 30-40

INCLINACIÓN DE TALUD $35^{\circ}$

INCLINACIÓN DE TALUD 40-50

INCLINACIÓN DE TALUD 50-550

INCLINACIÓN DE TALUD 55-60

INCLINACIÓN DE TALUD 60-700

INCLINACIÓN DE TALUD 70-80 

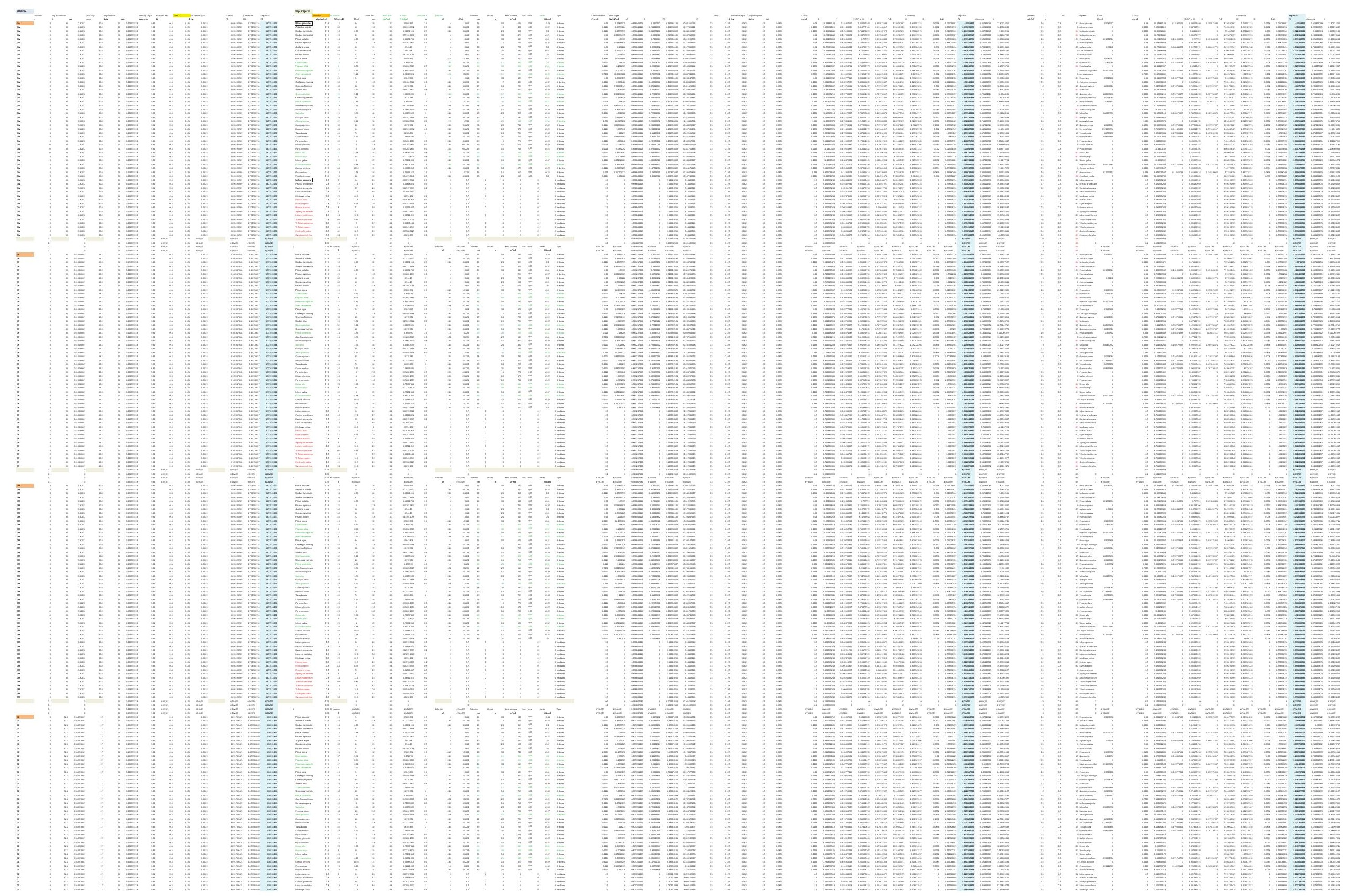


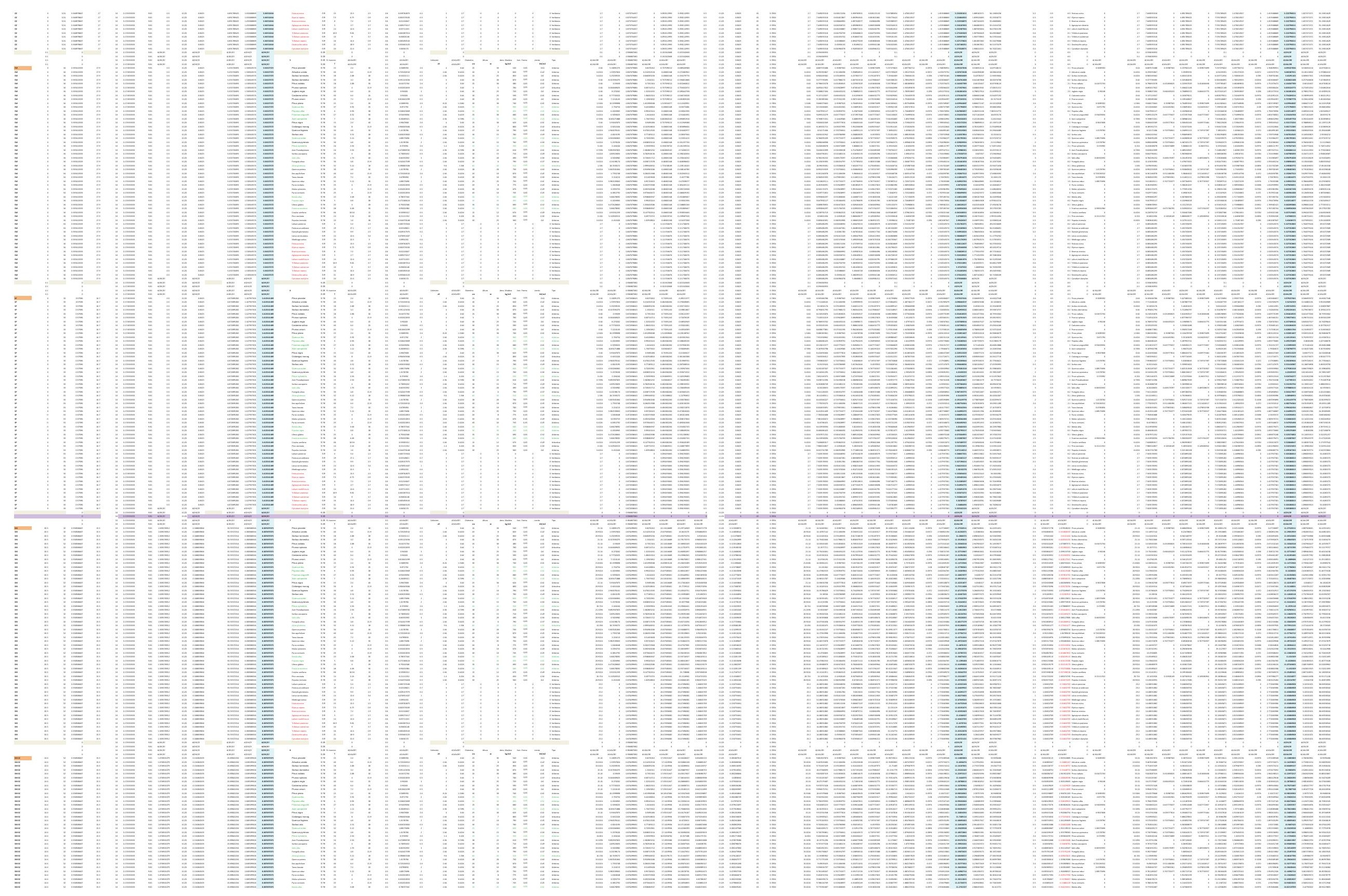



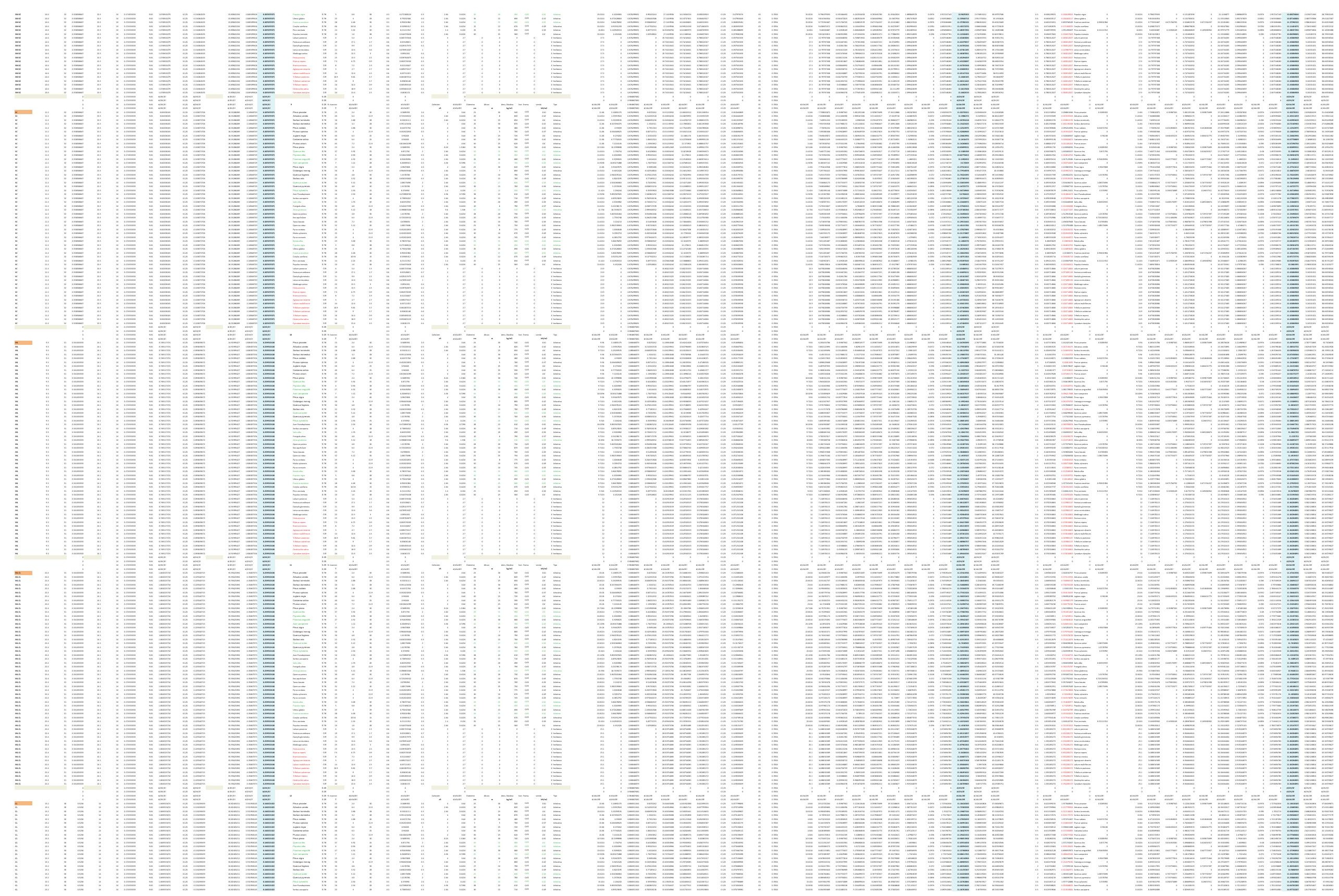


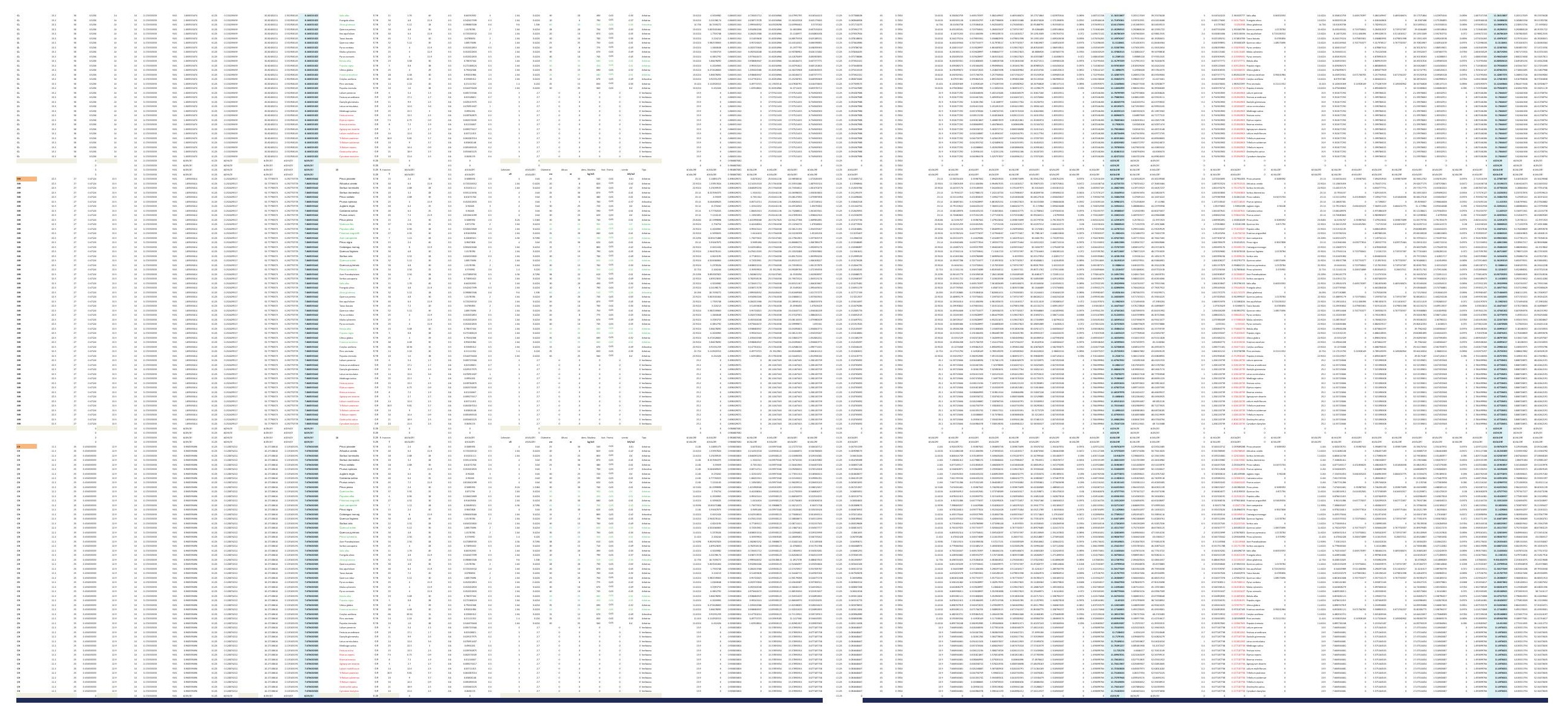



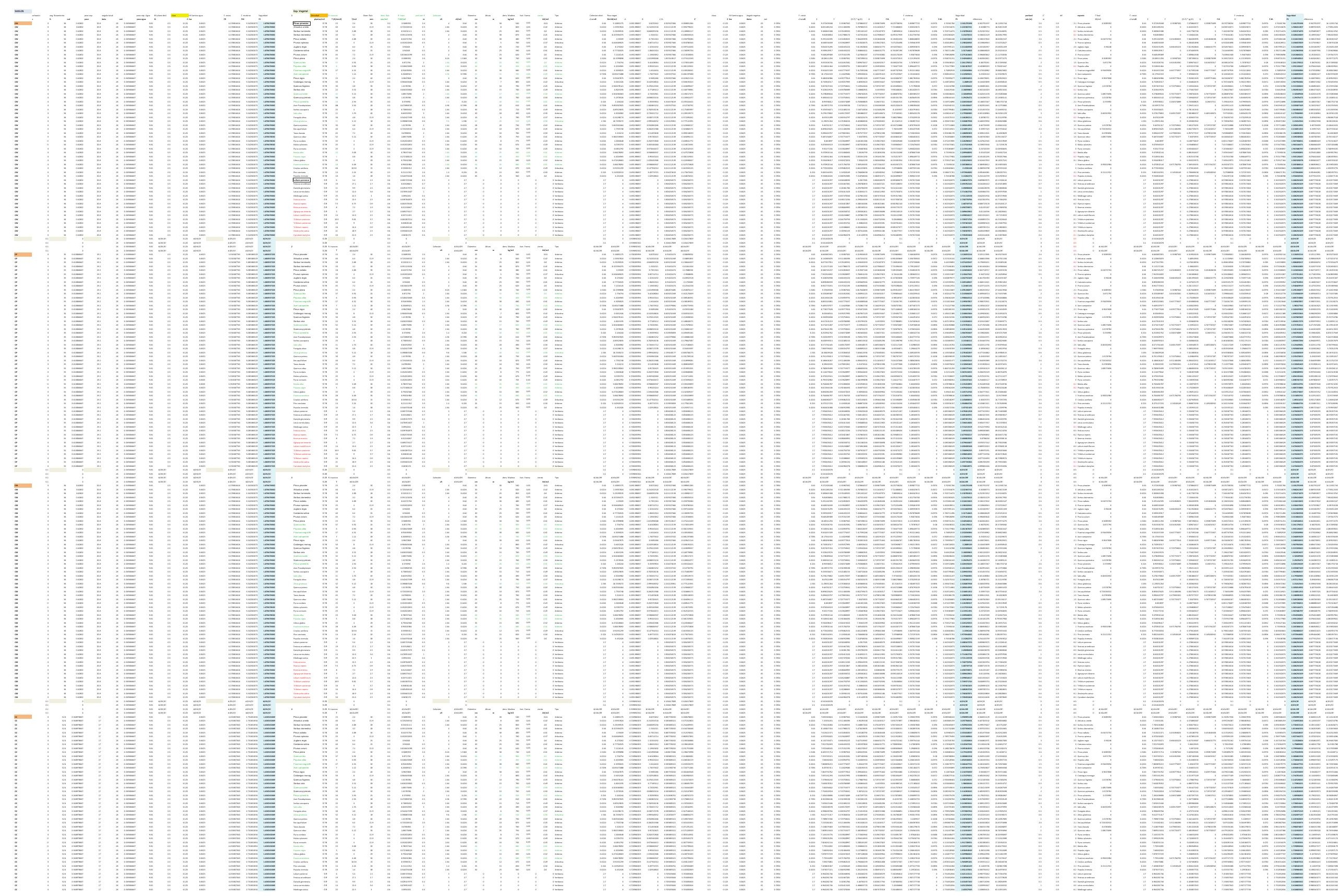


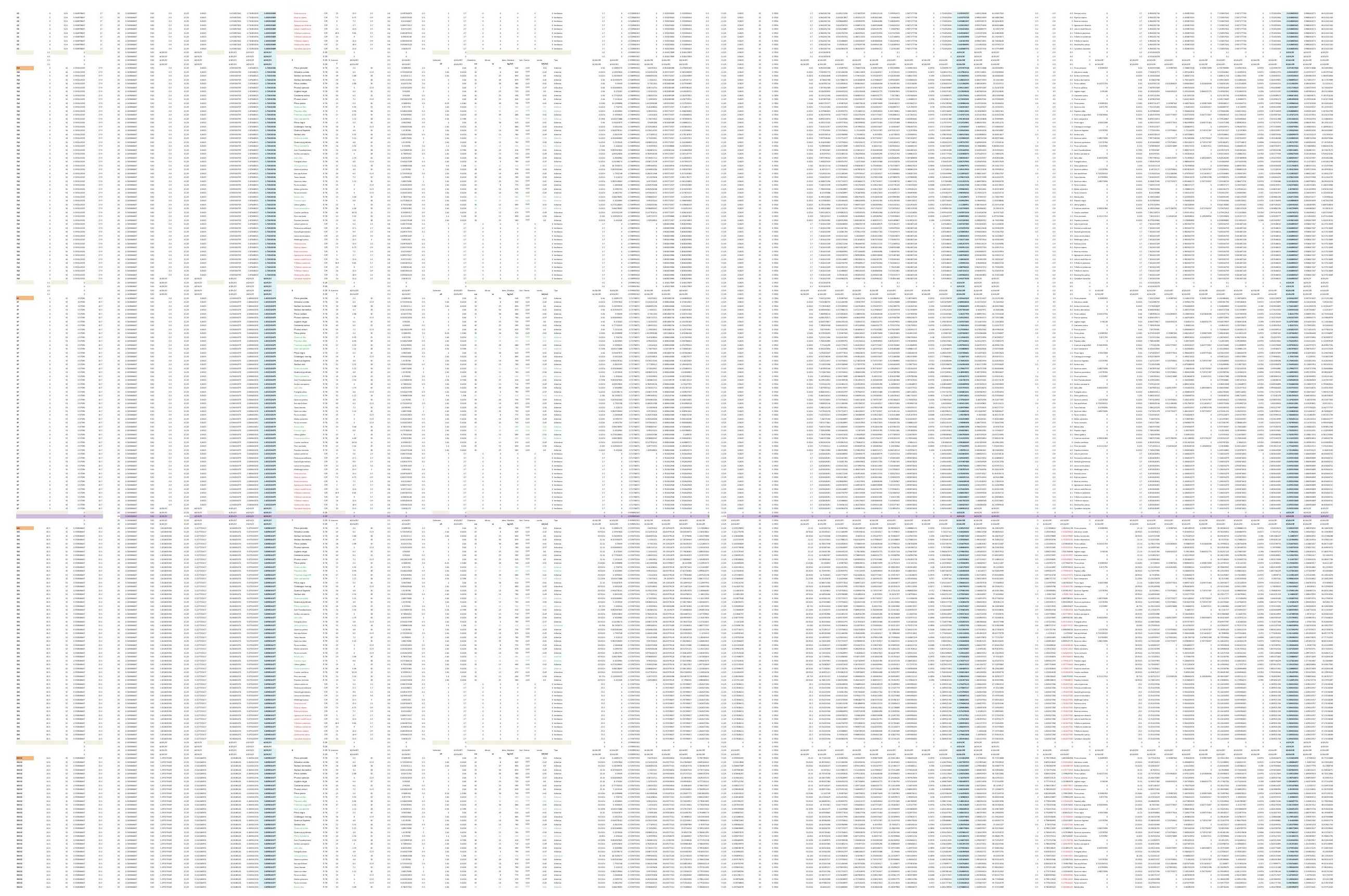



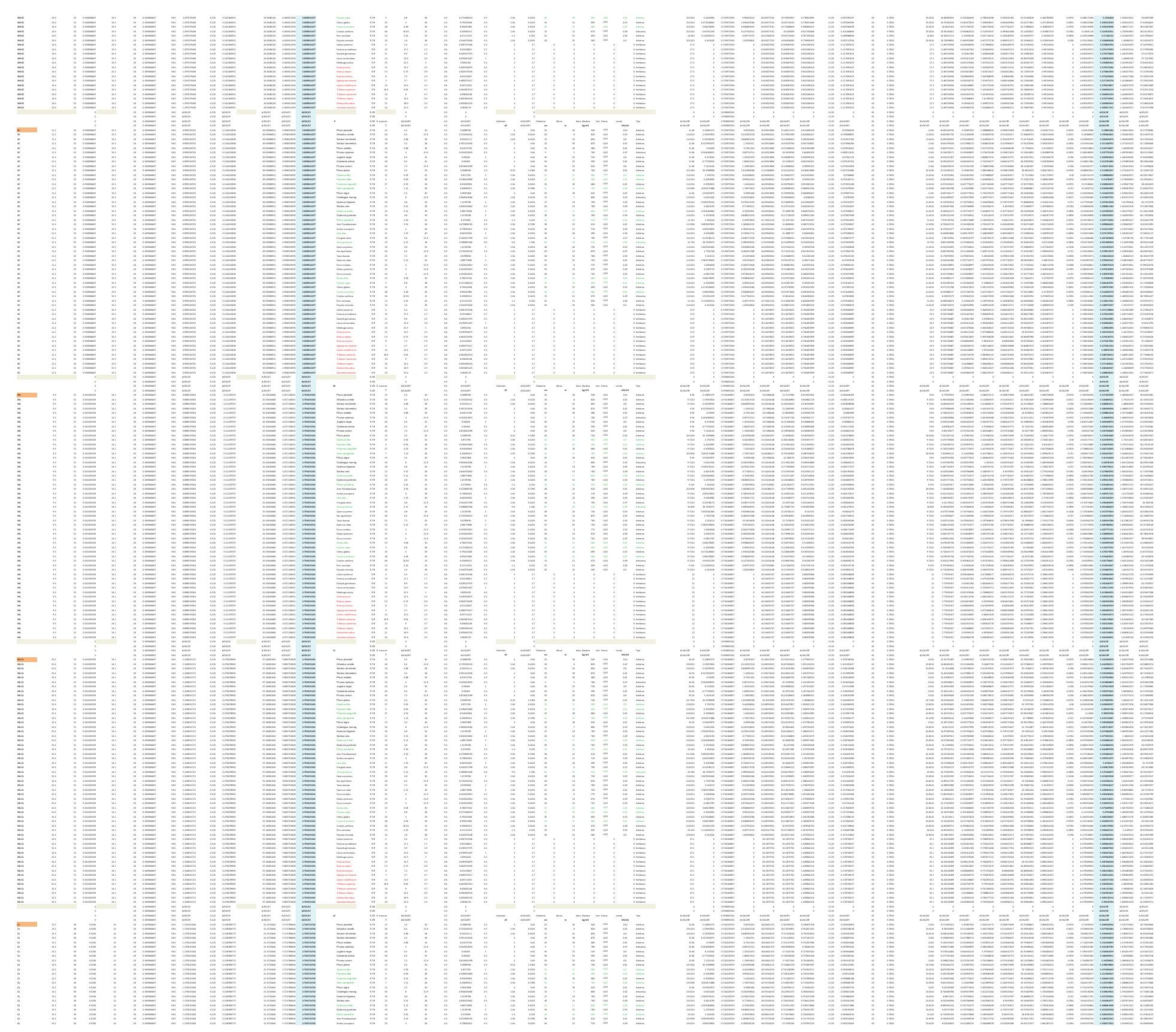

五主
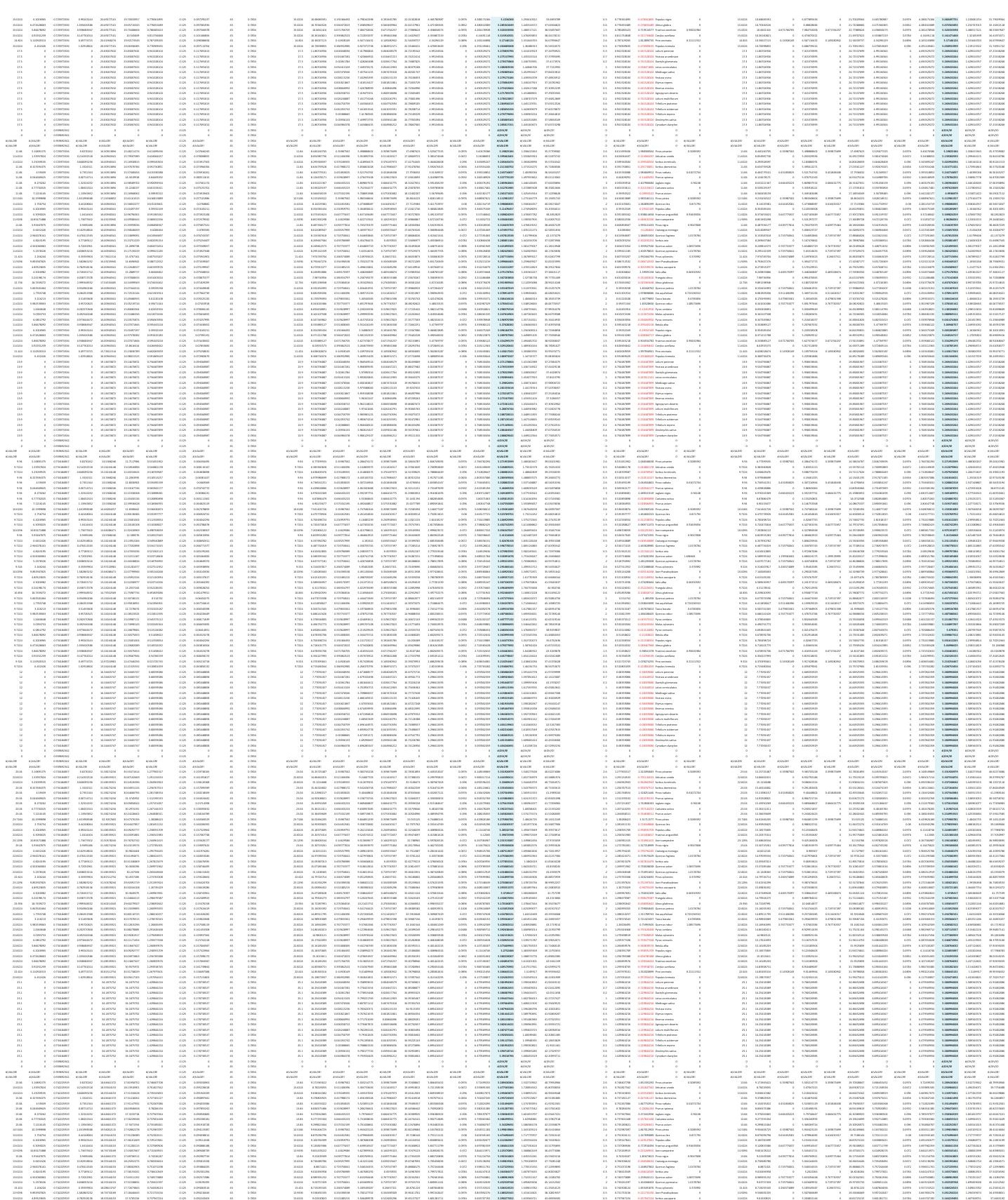


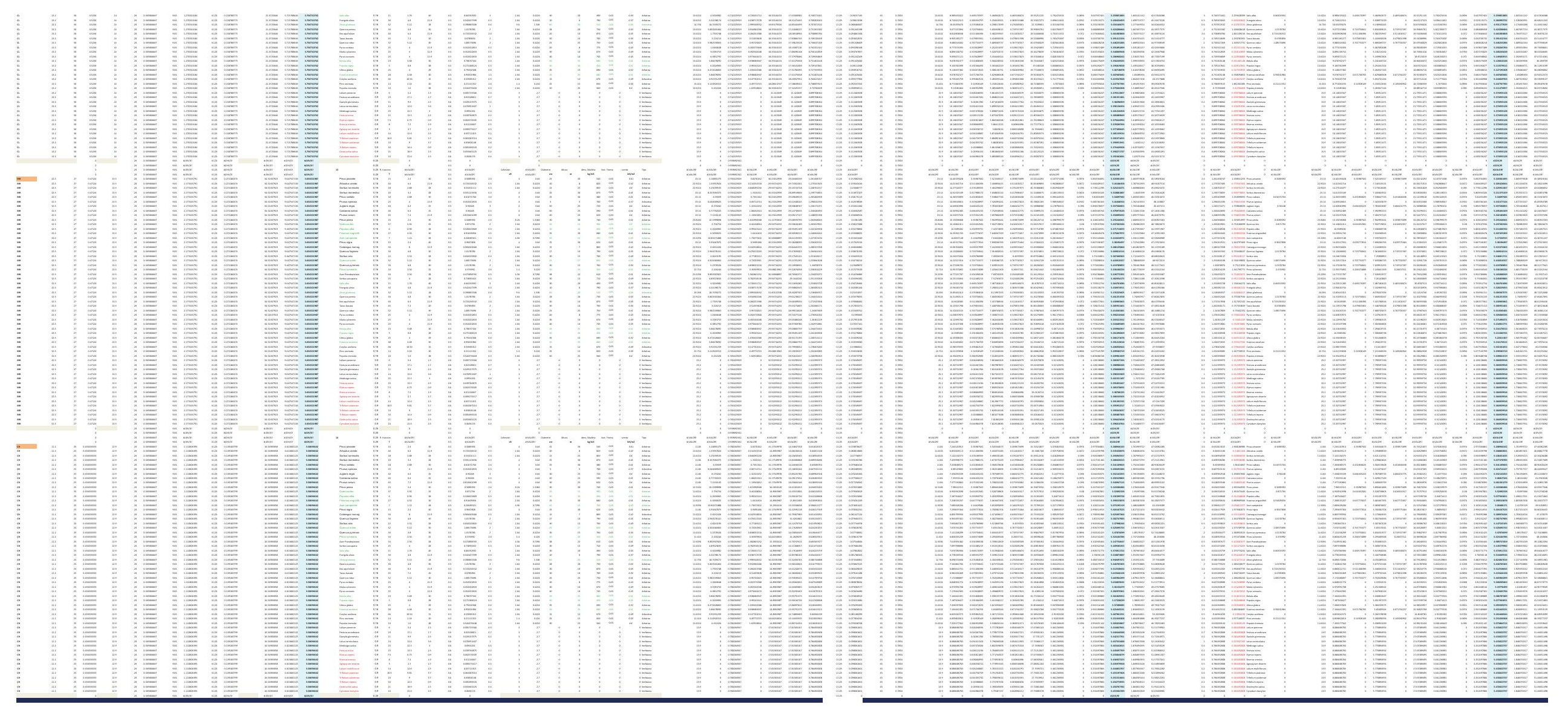



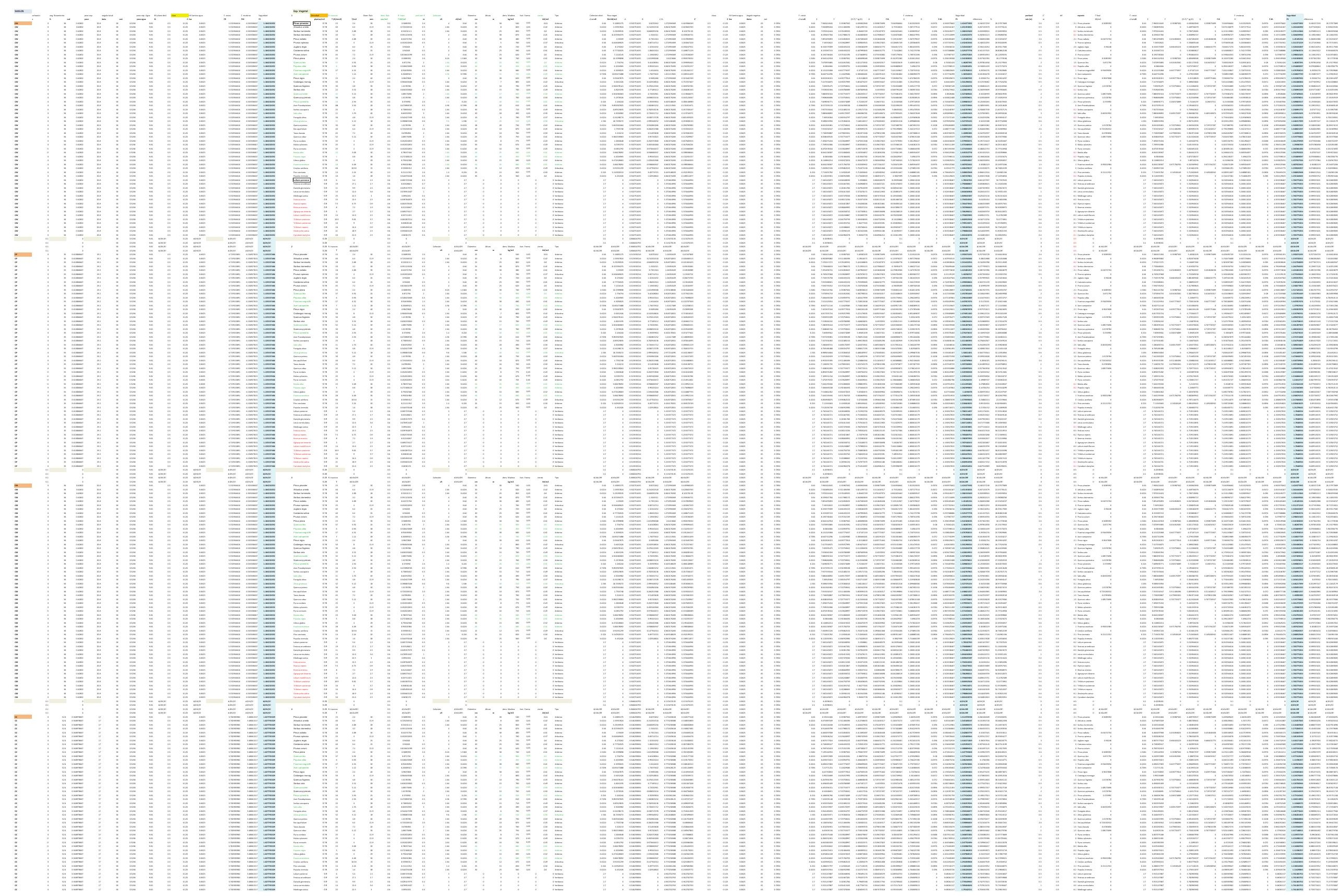


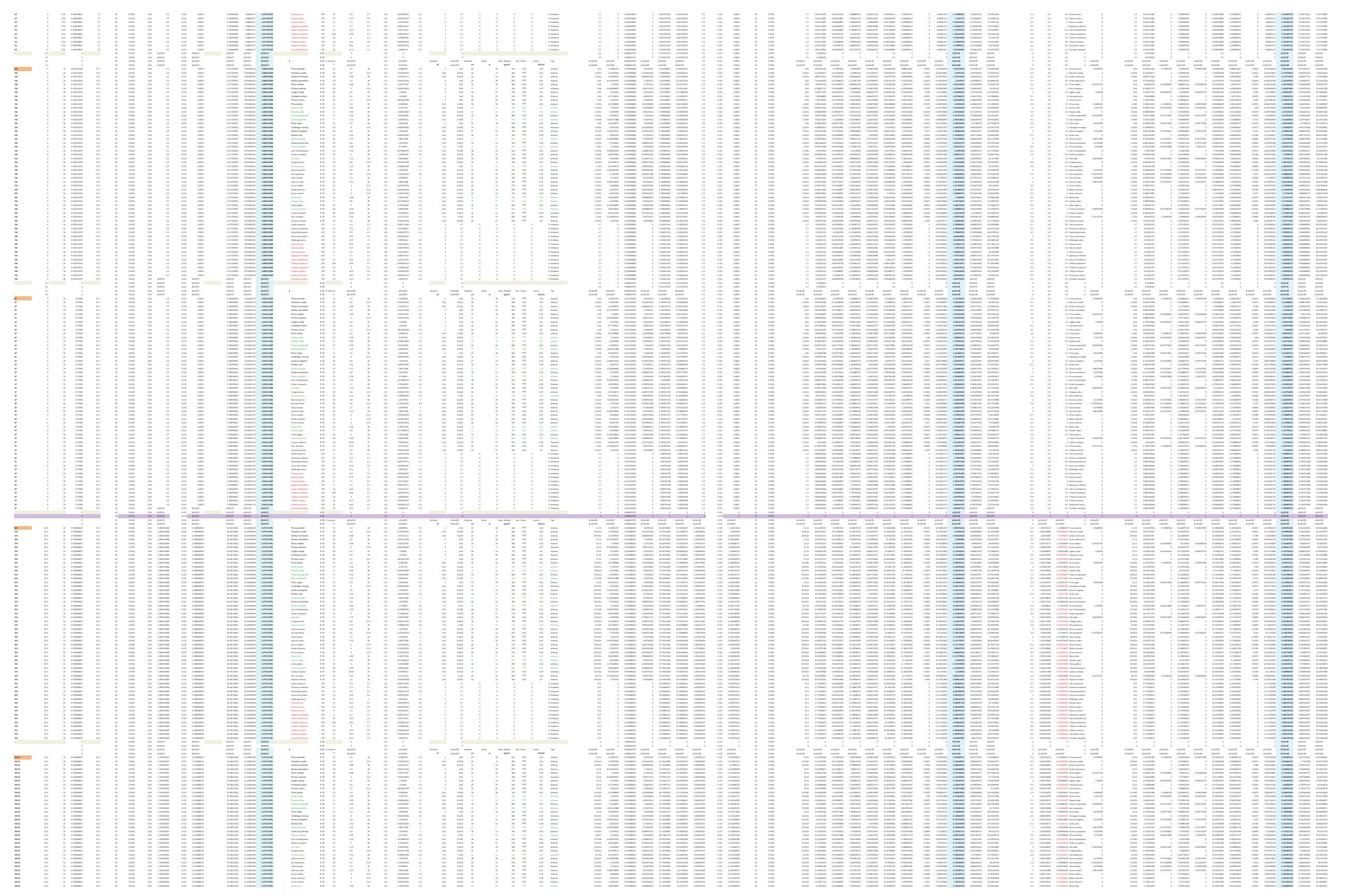



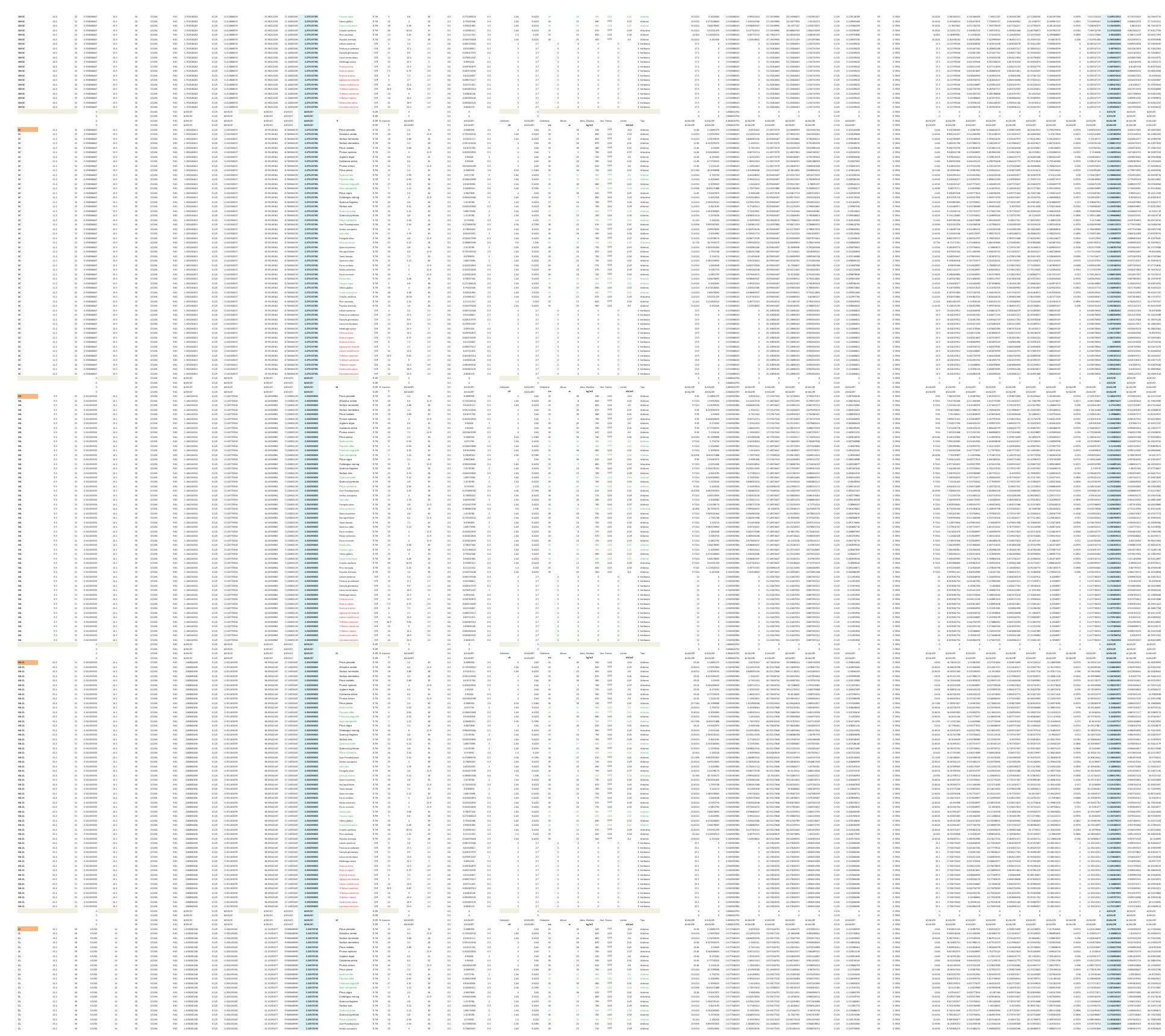

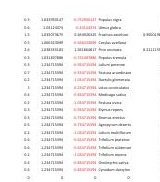
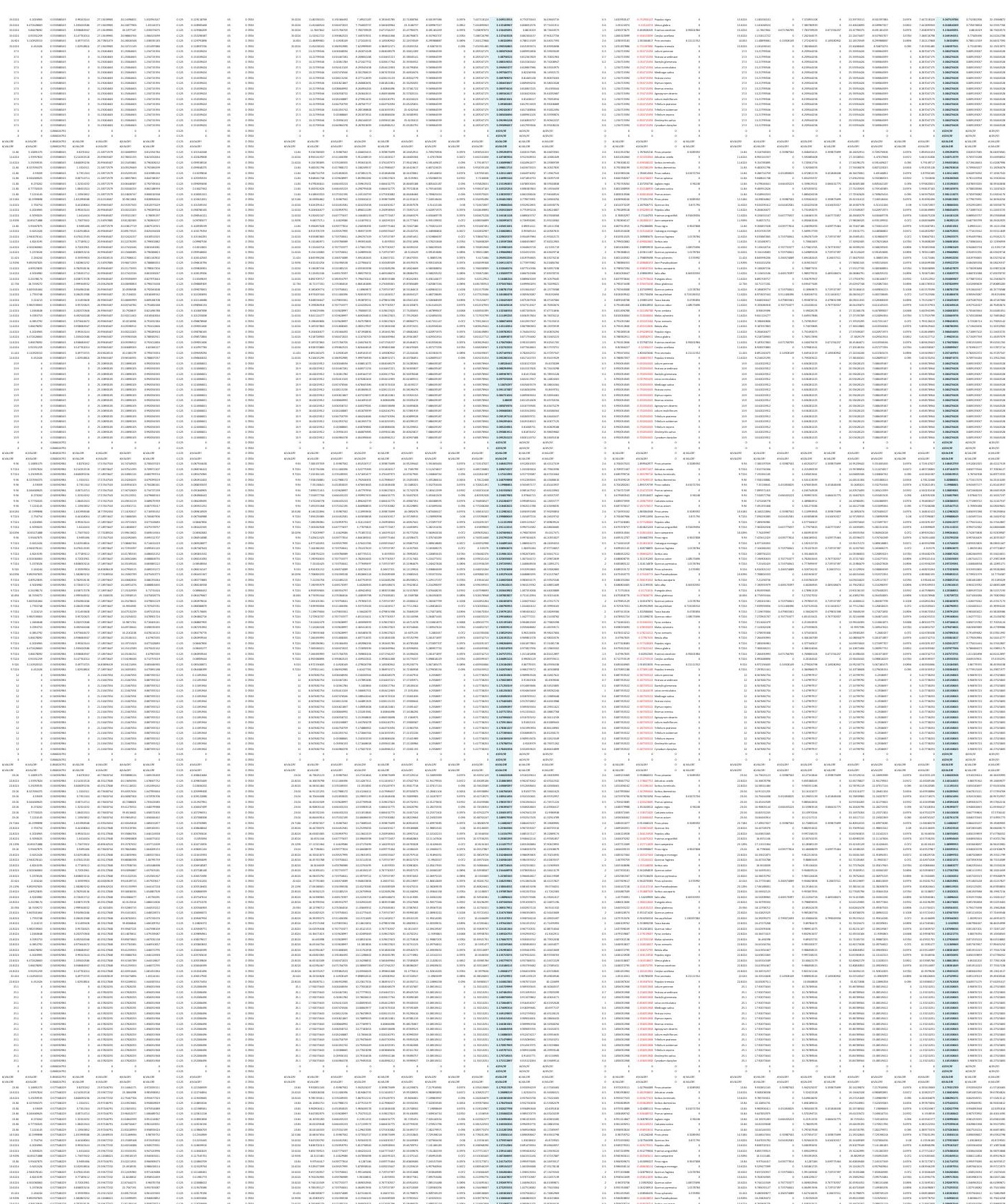


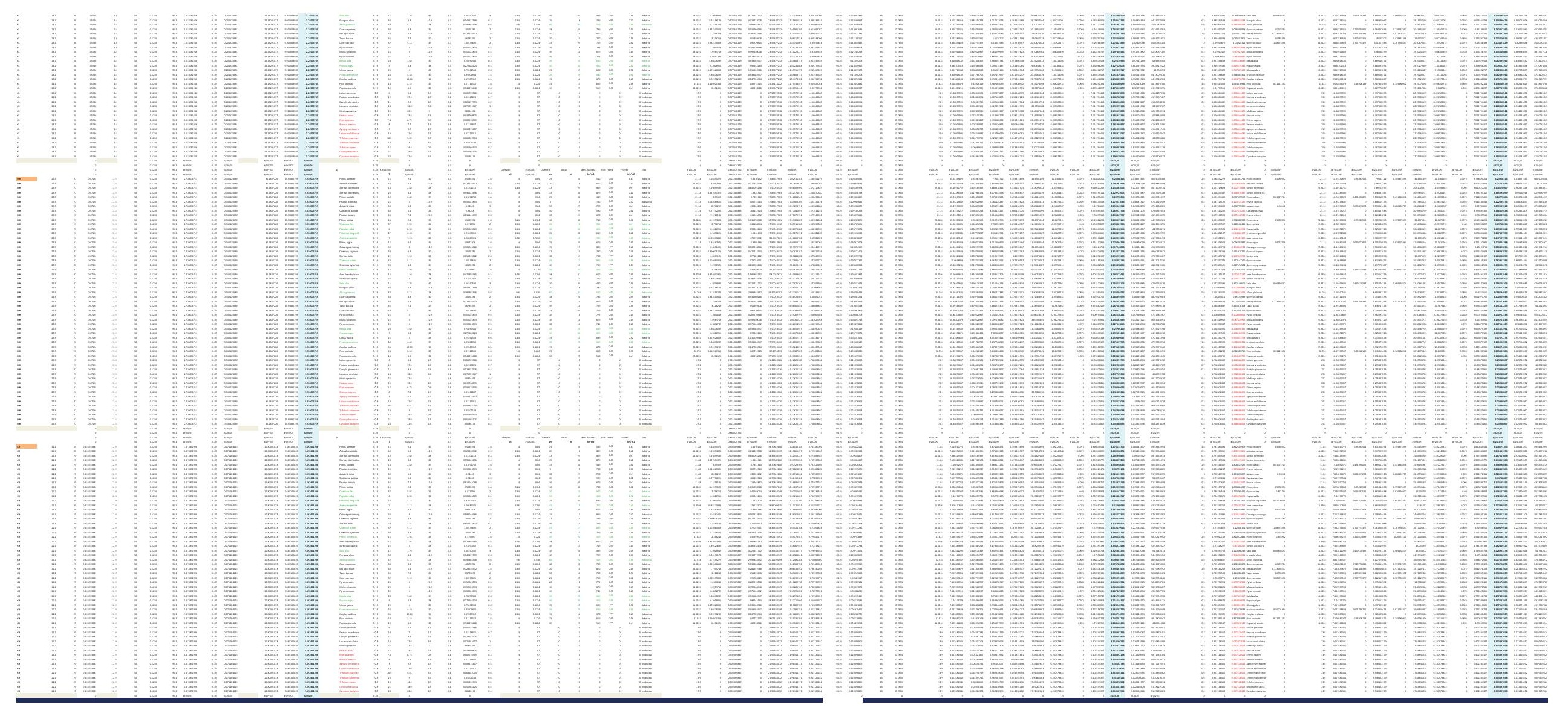



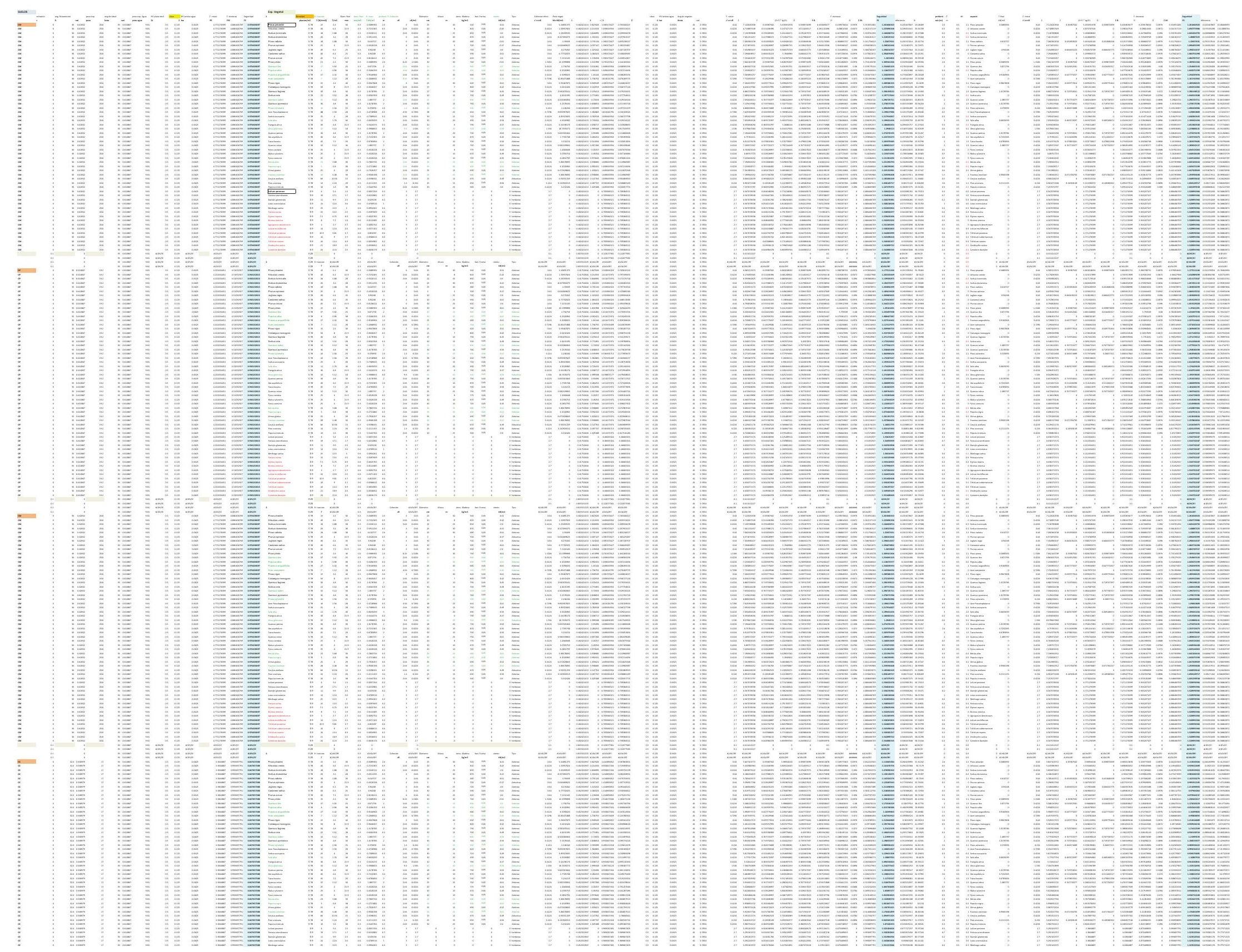

E $={ }^{\prime} \equiv \equiv \equiv \equiv \equiv$

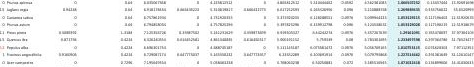

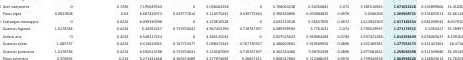

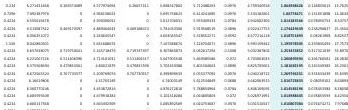

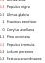

列

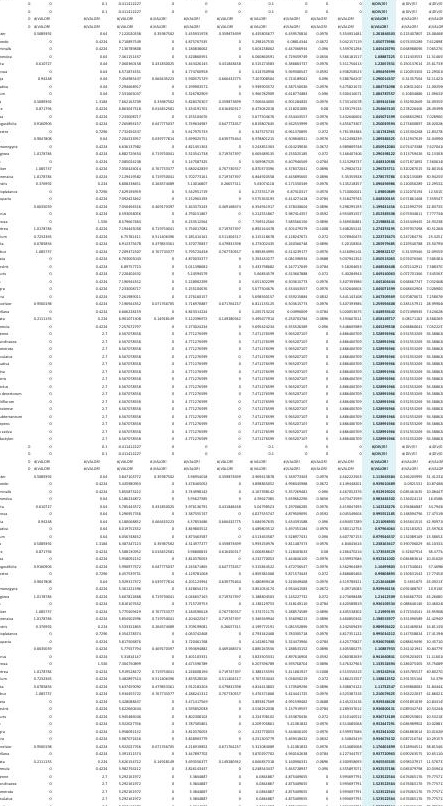




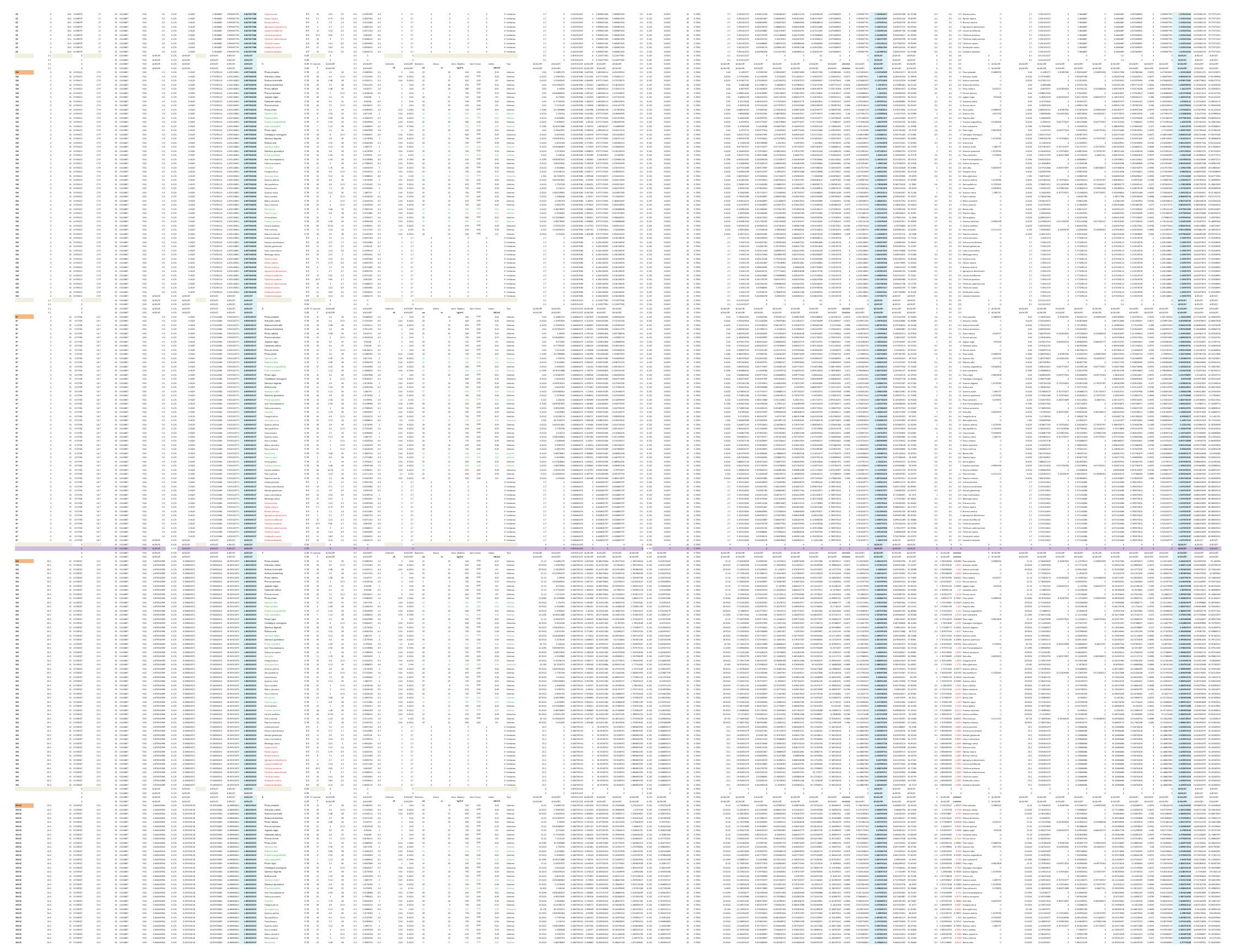



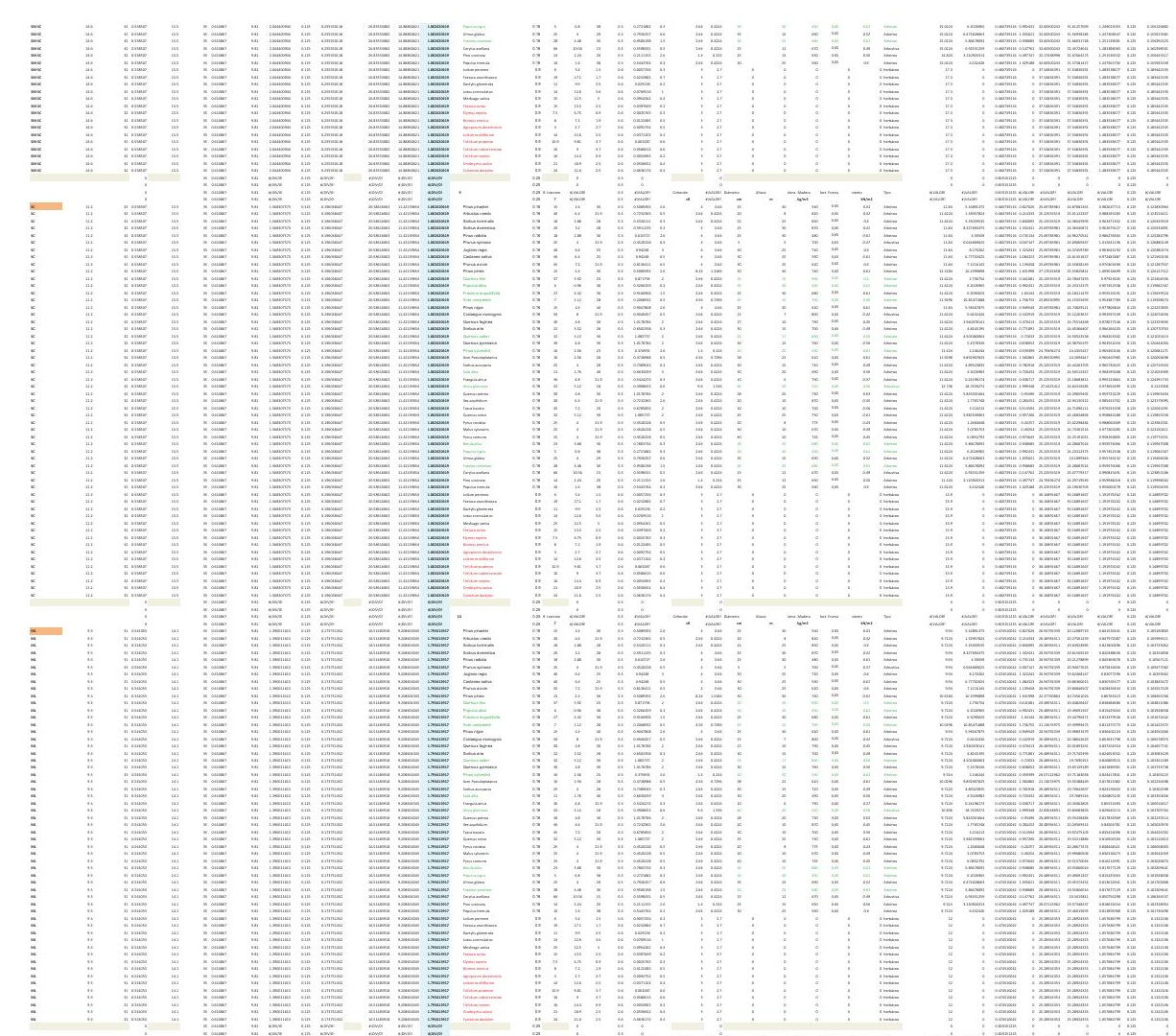

mIIII
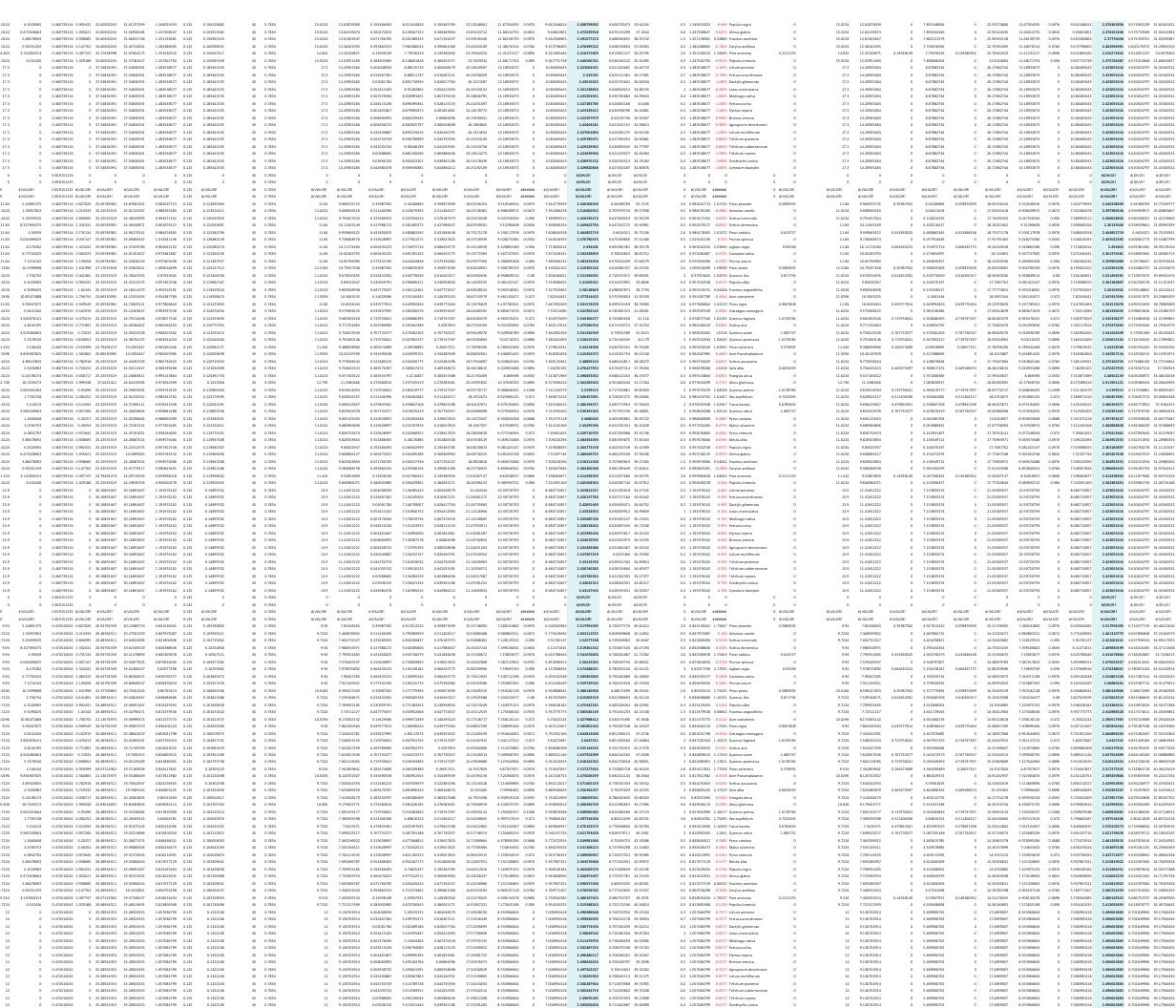

$=\equiv \equiv \equiv \equiv \equiv \equiv \equiv$

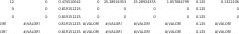
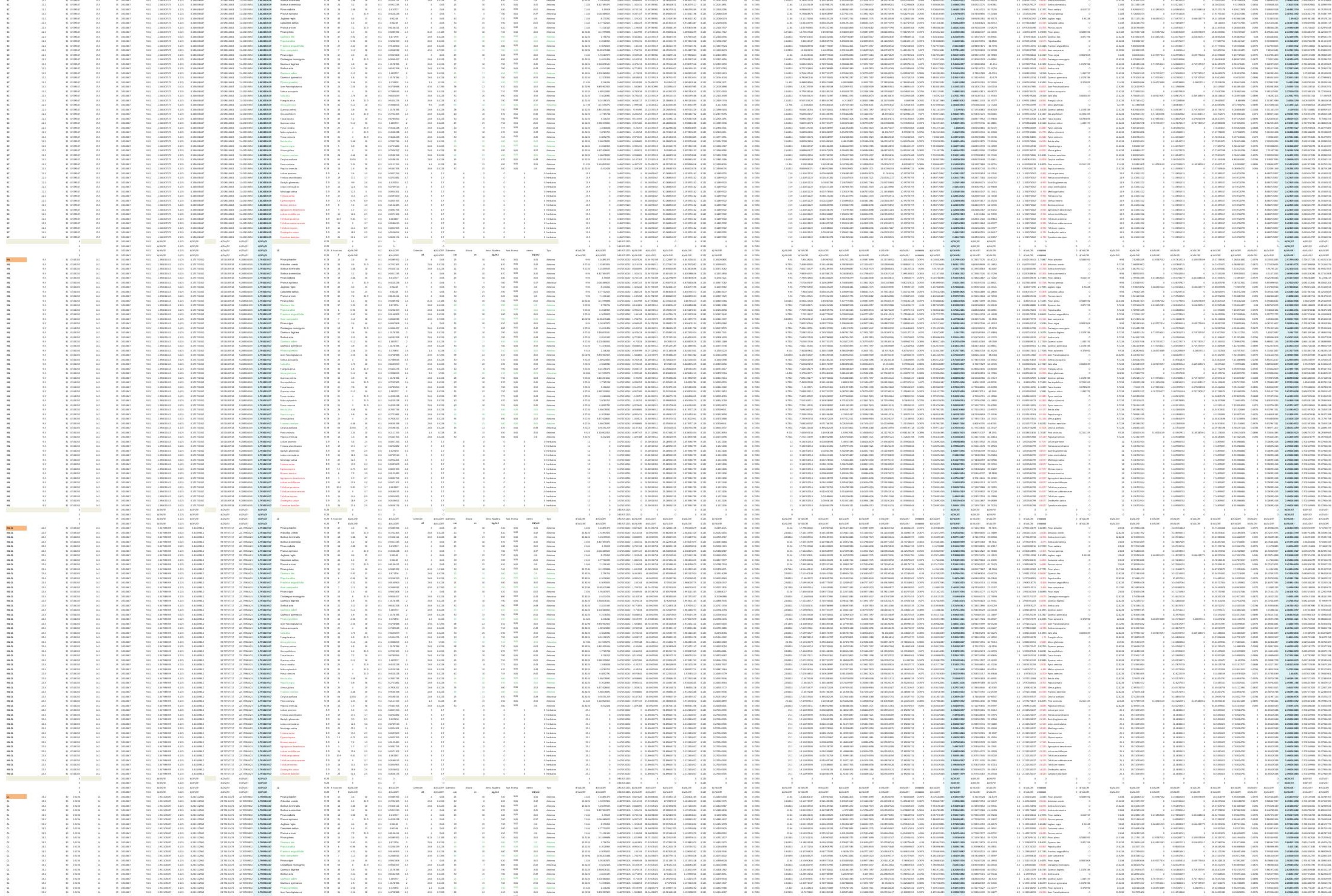


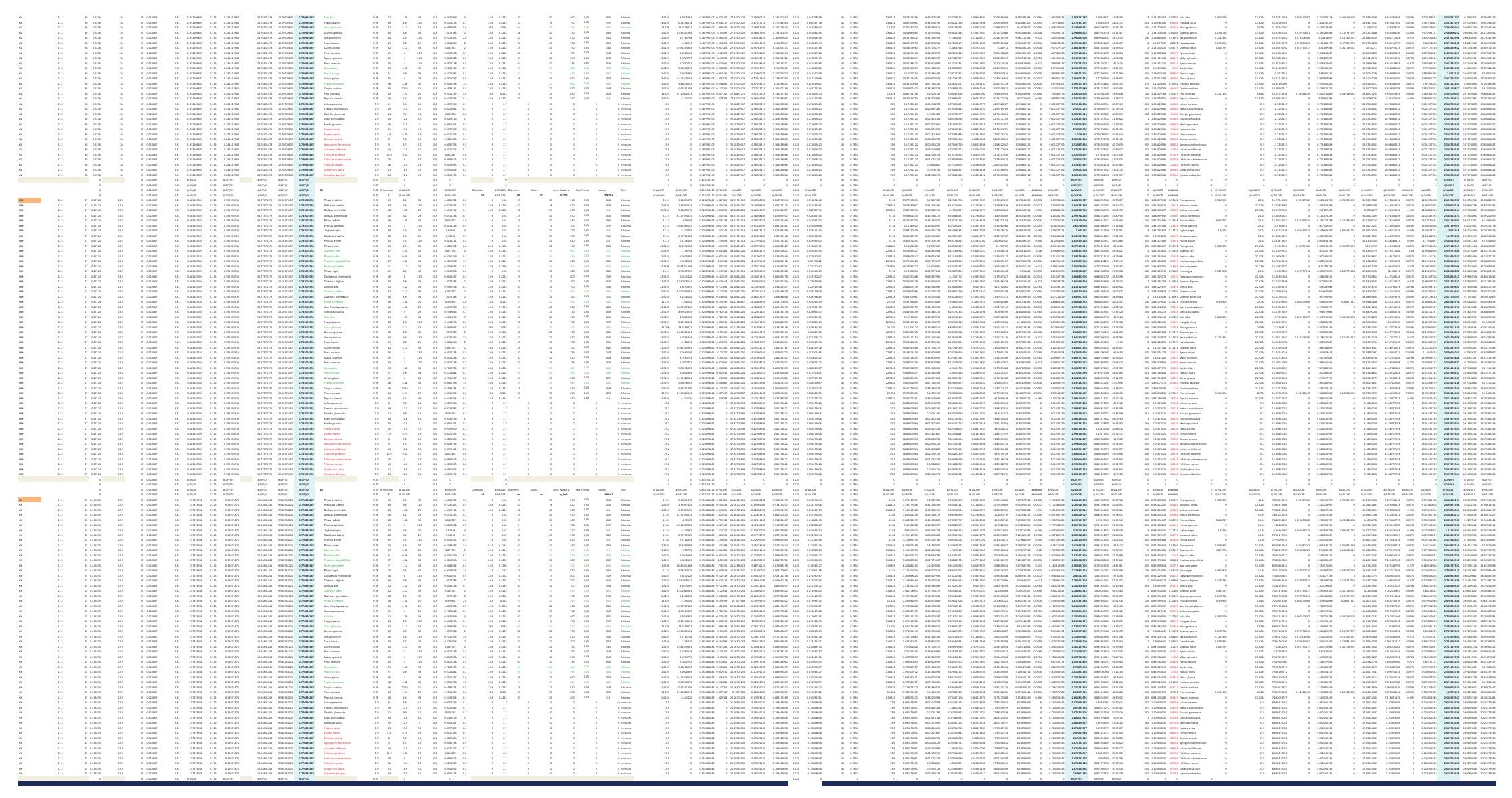



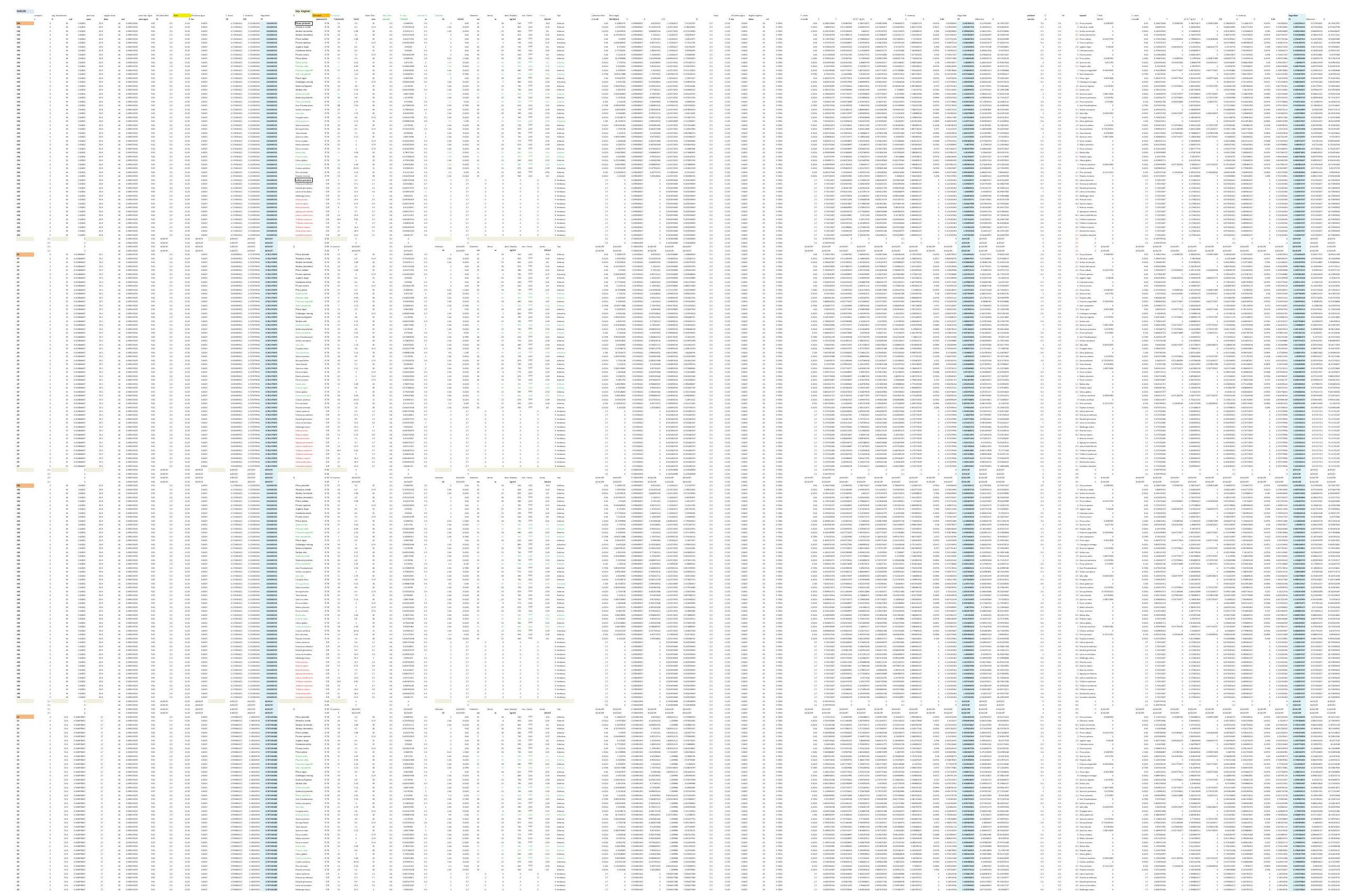


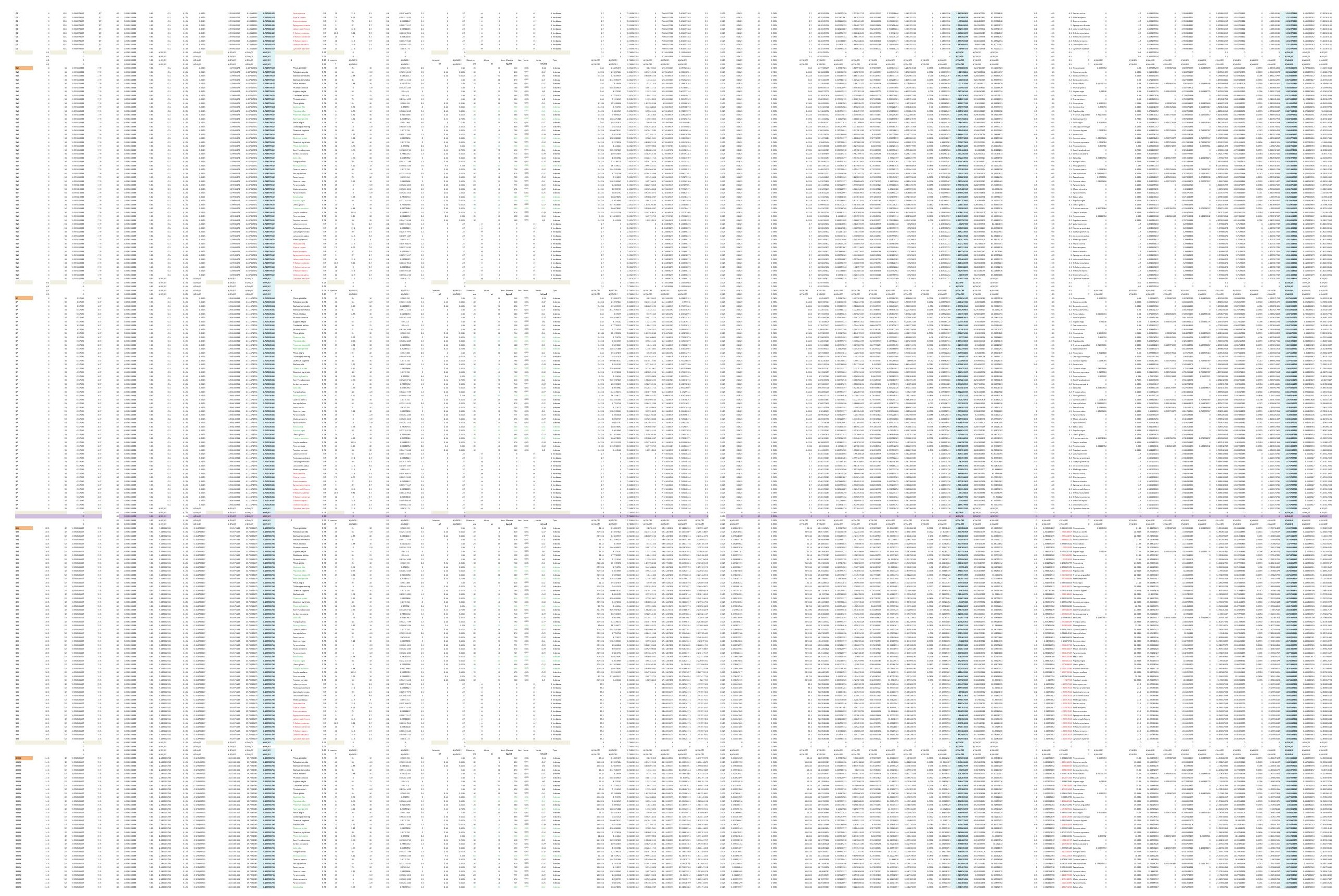



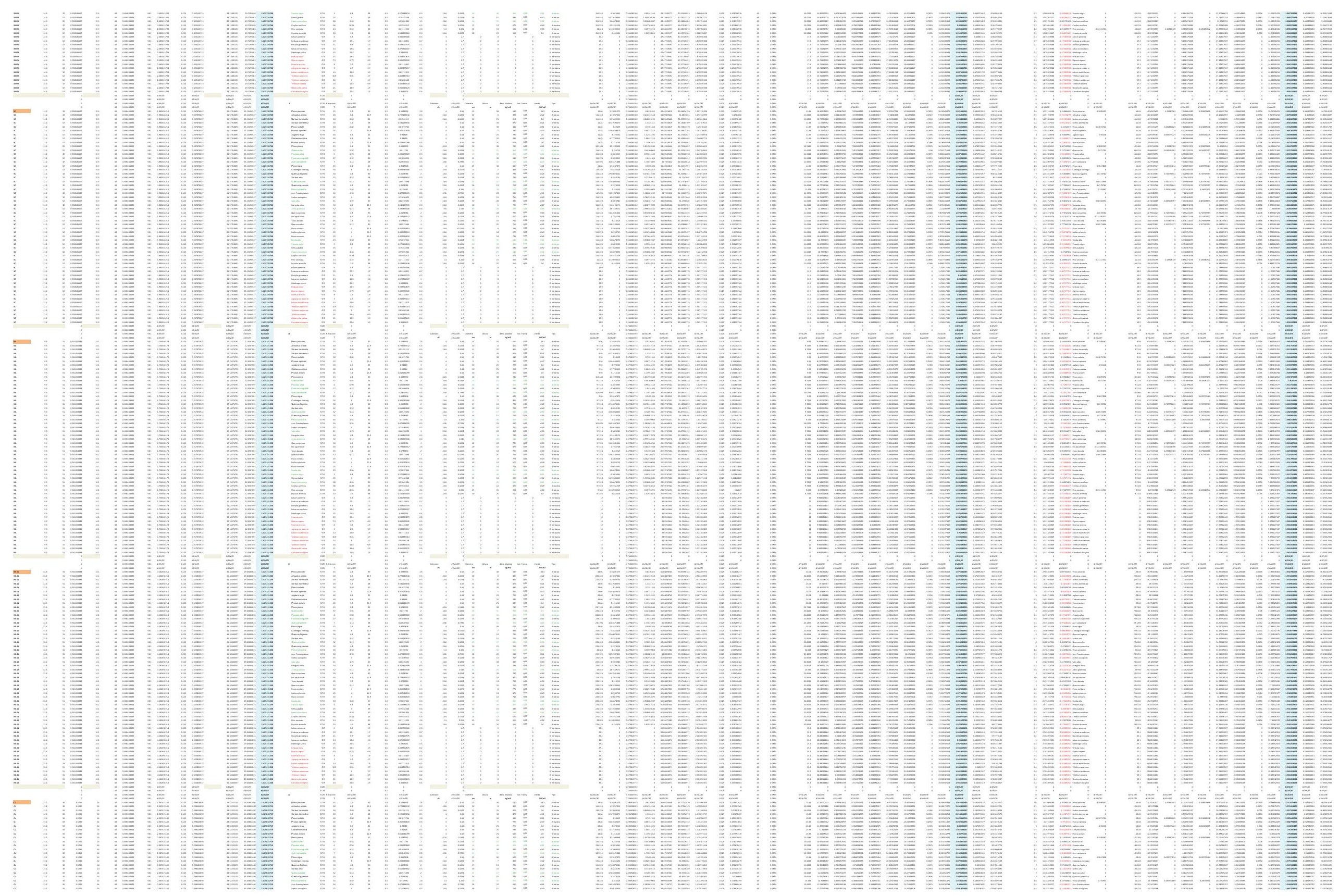


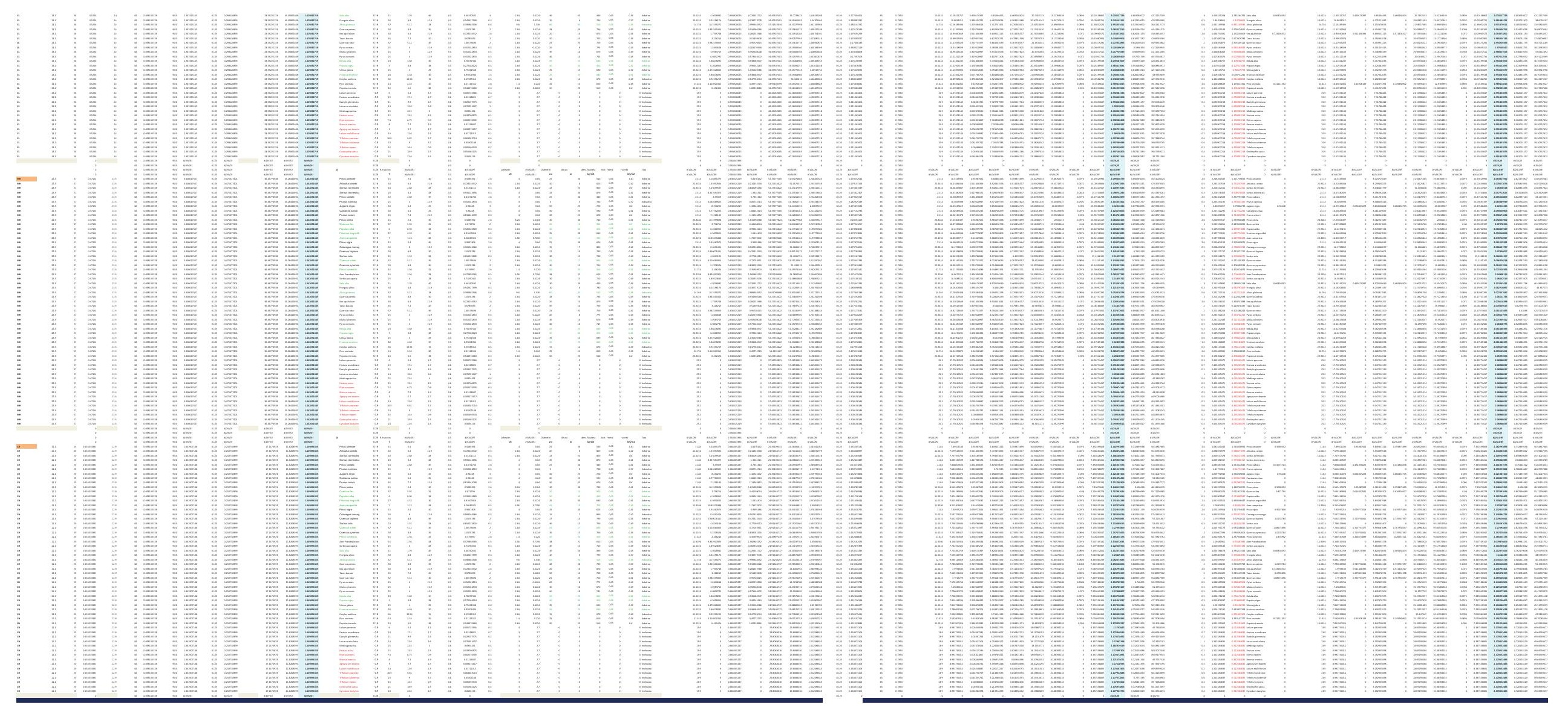



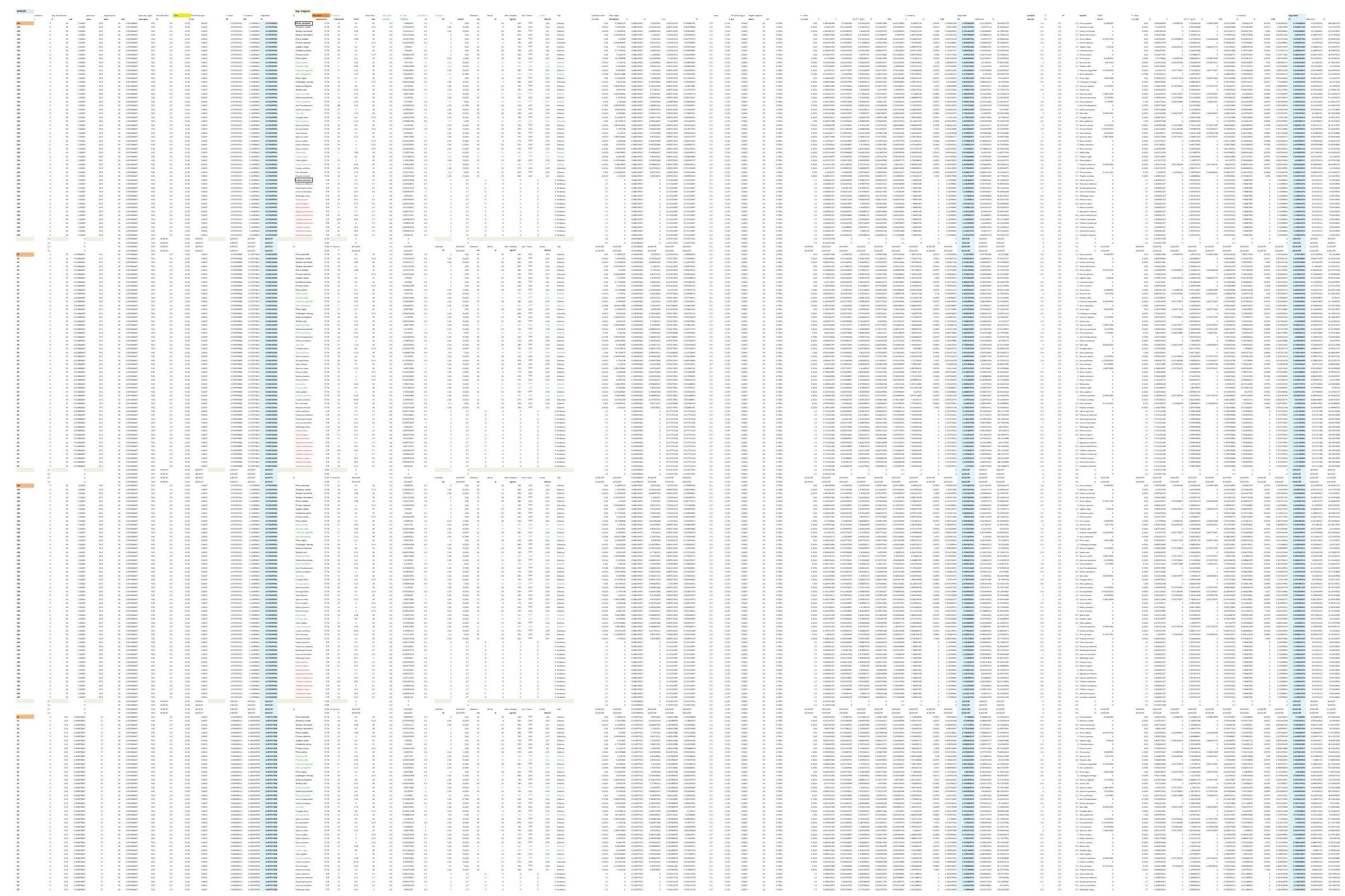


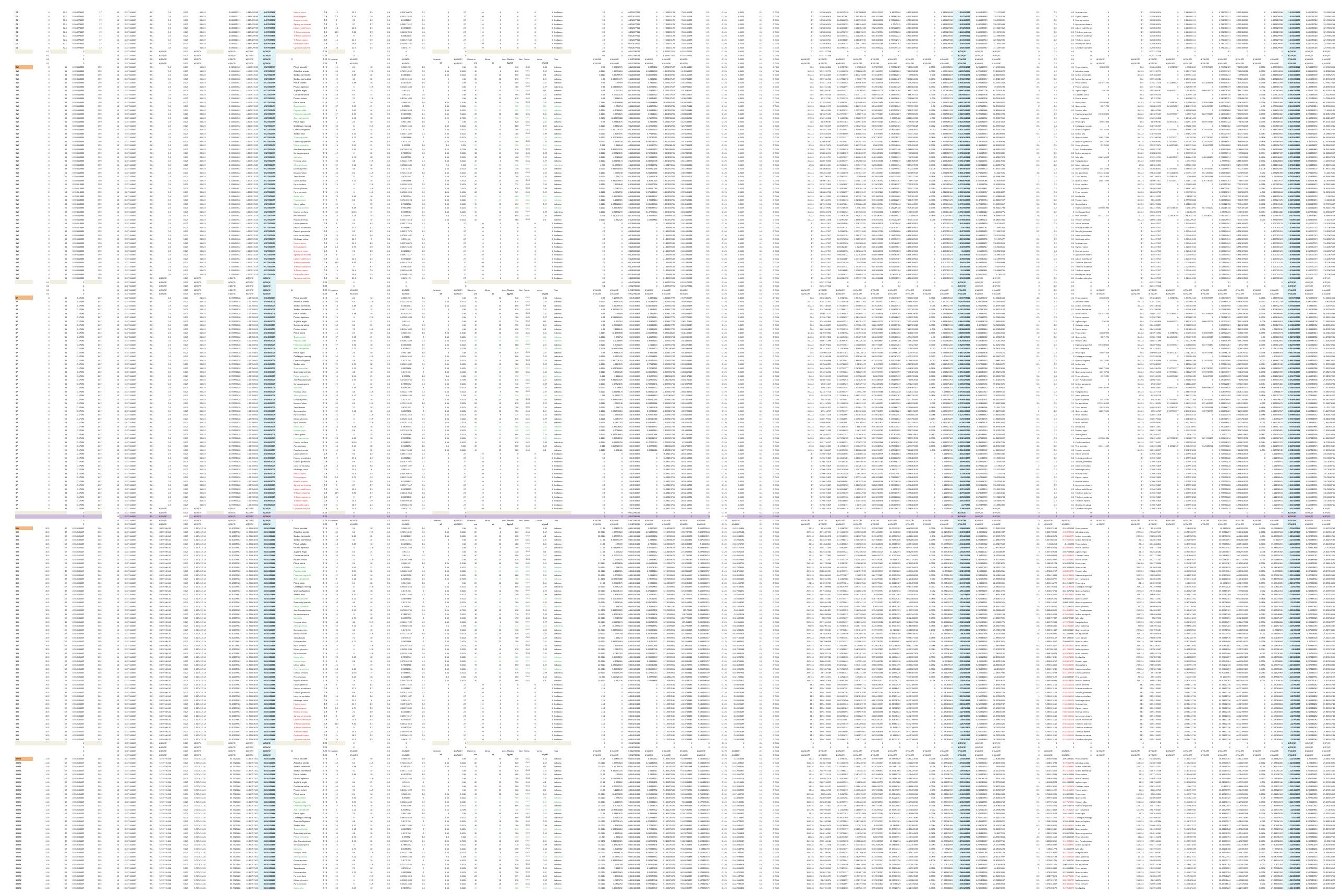




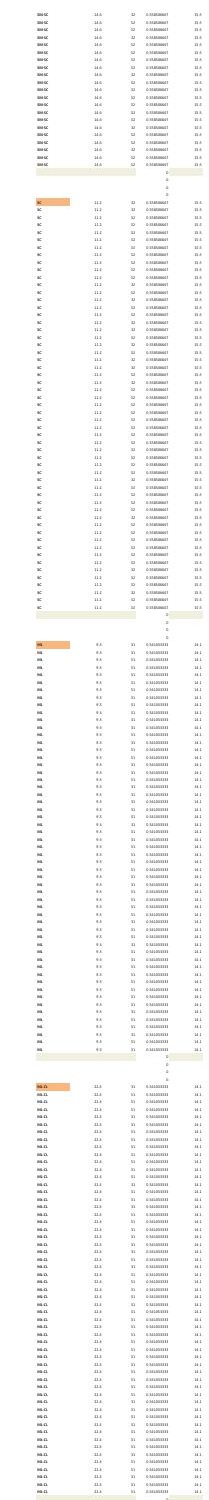

:

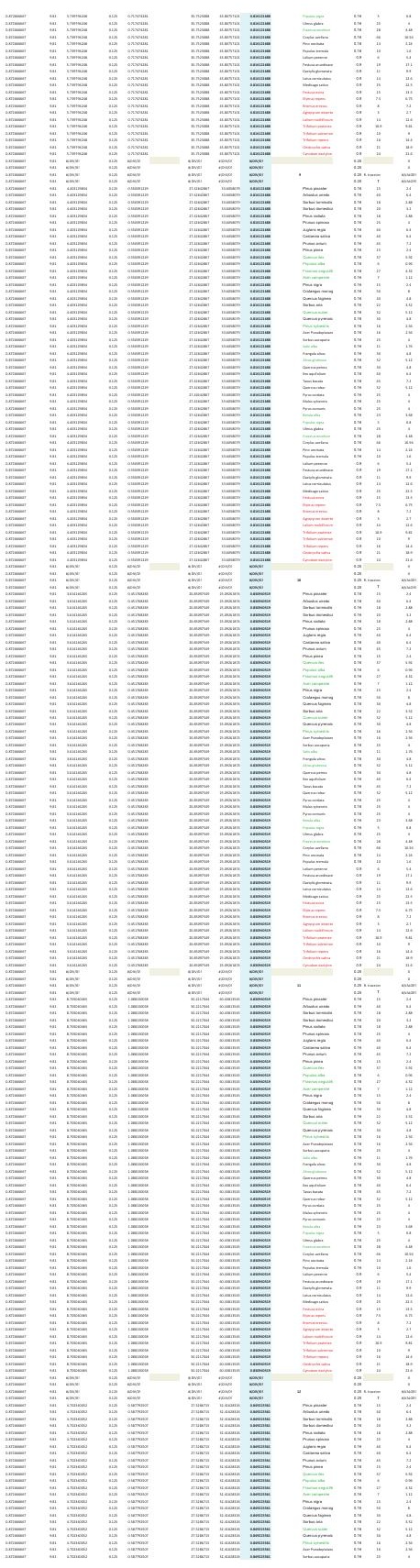

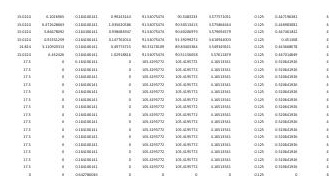
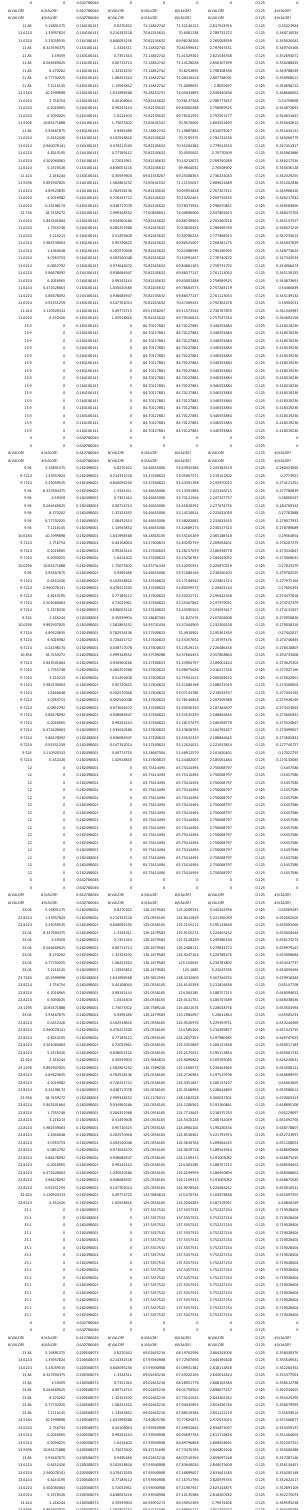

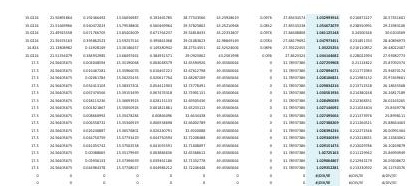

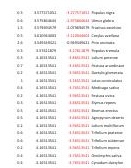

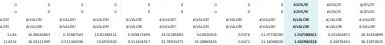

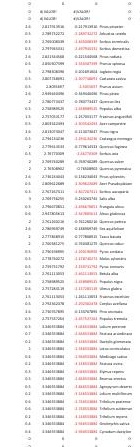
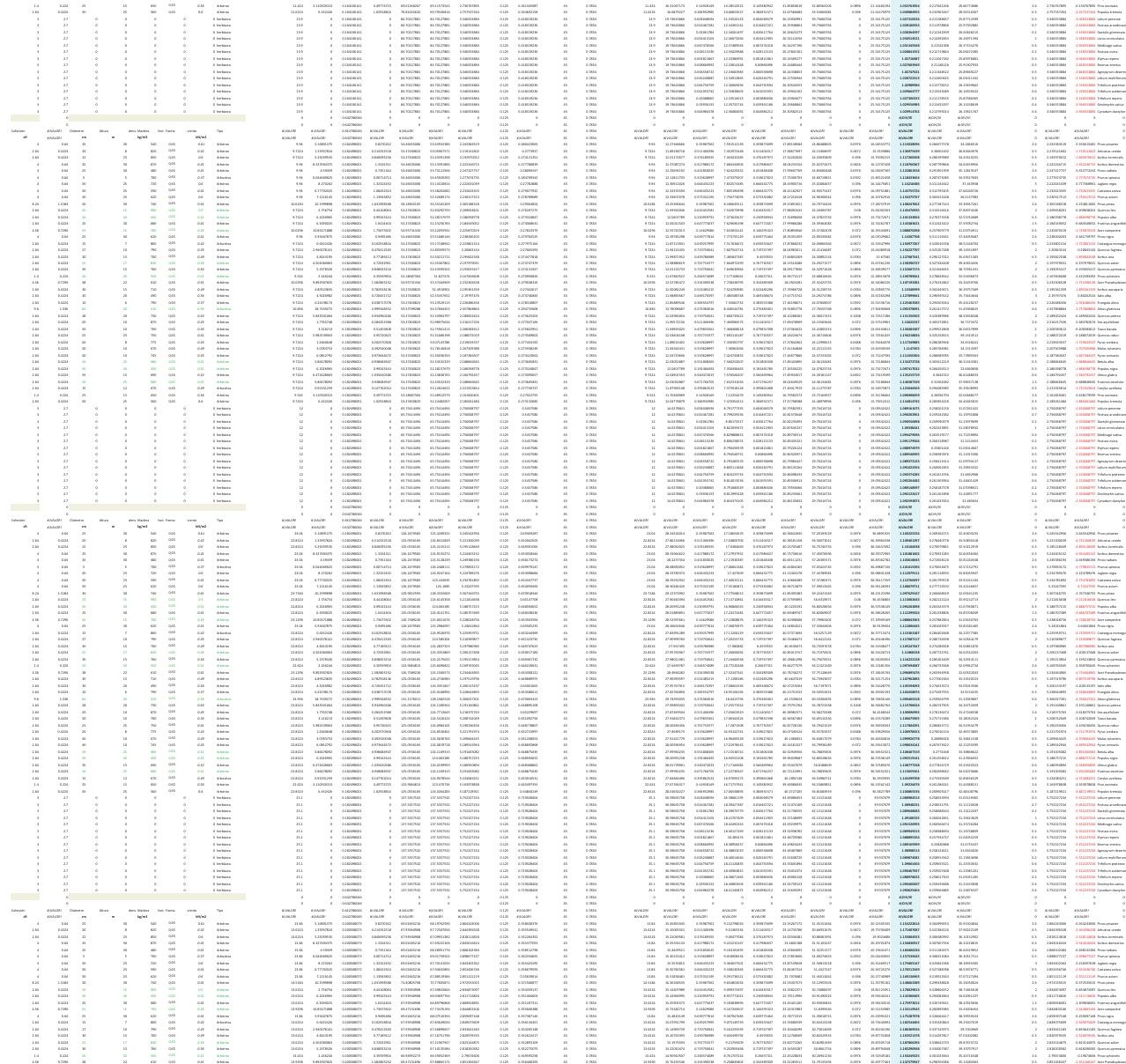
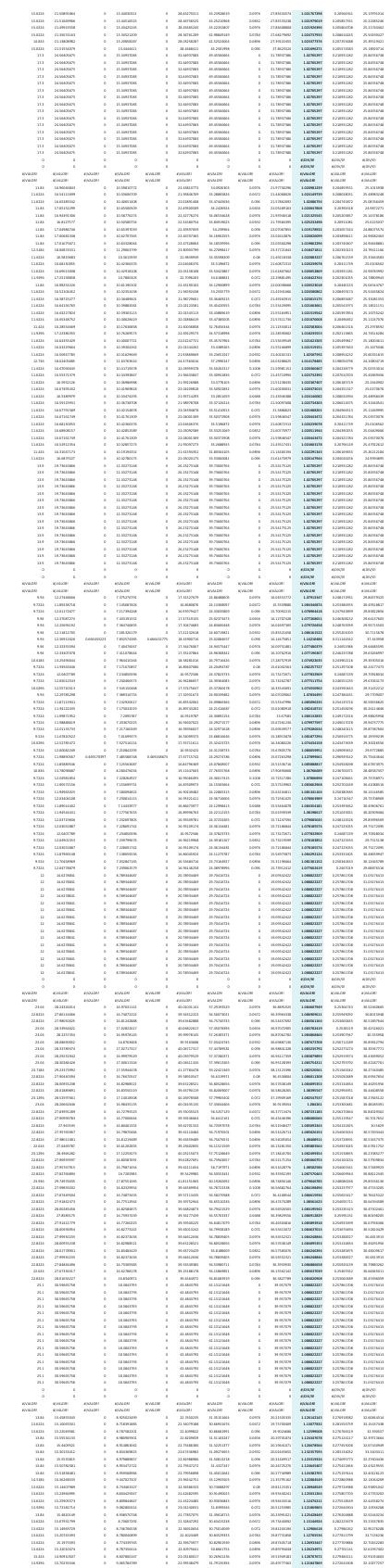


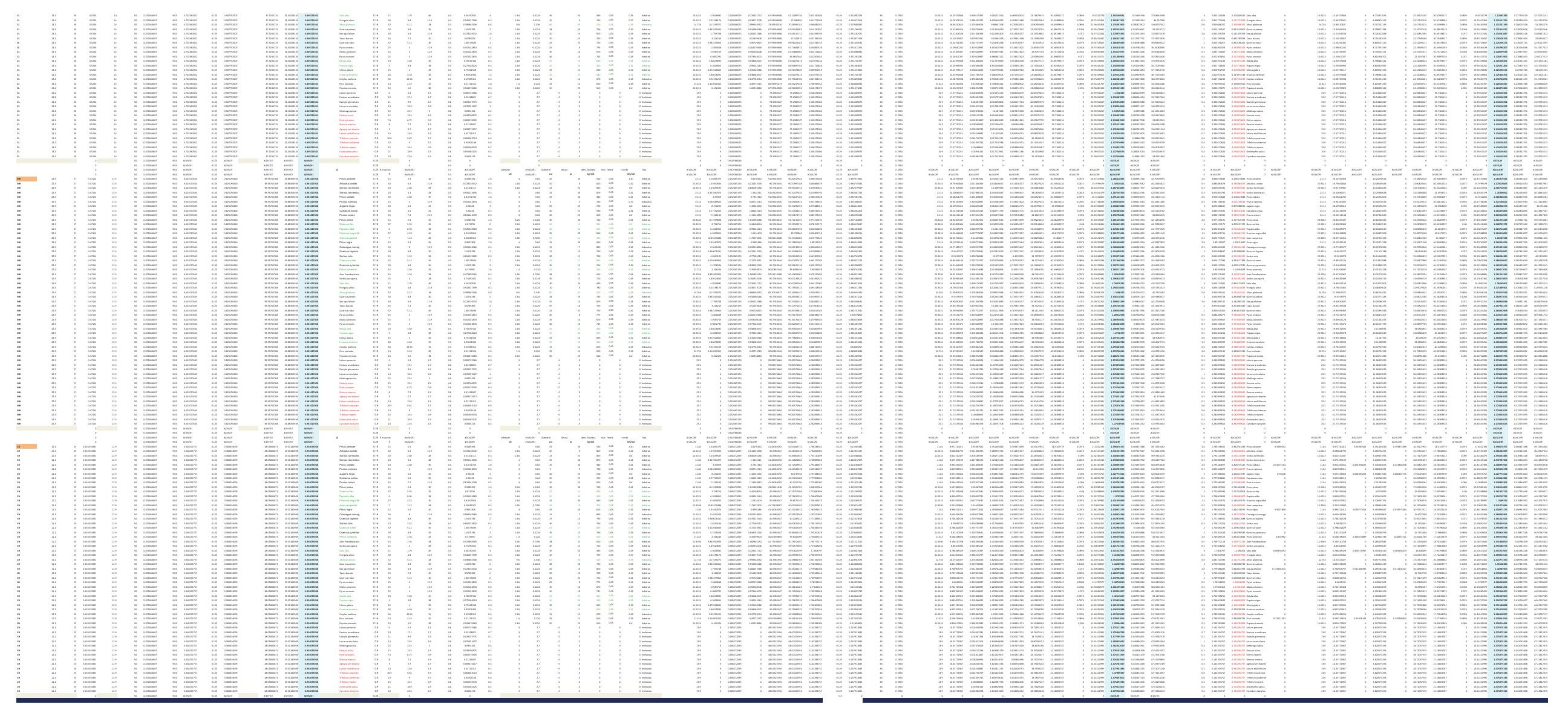



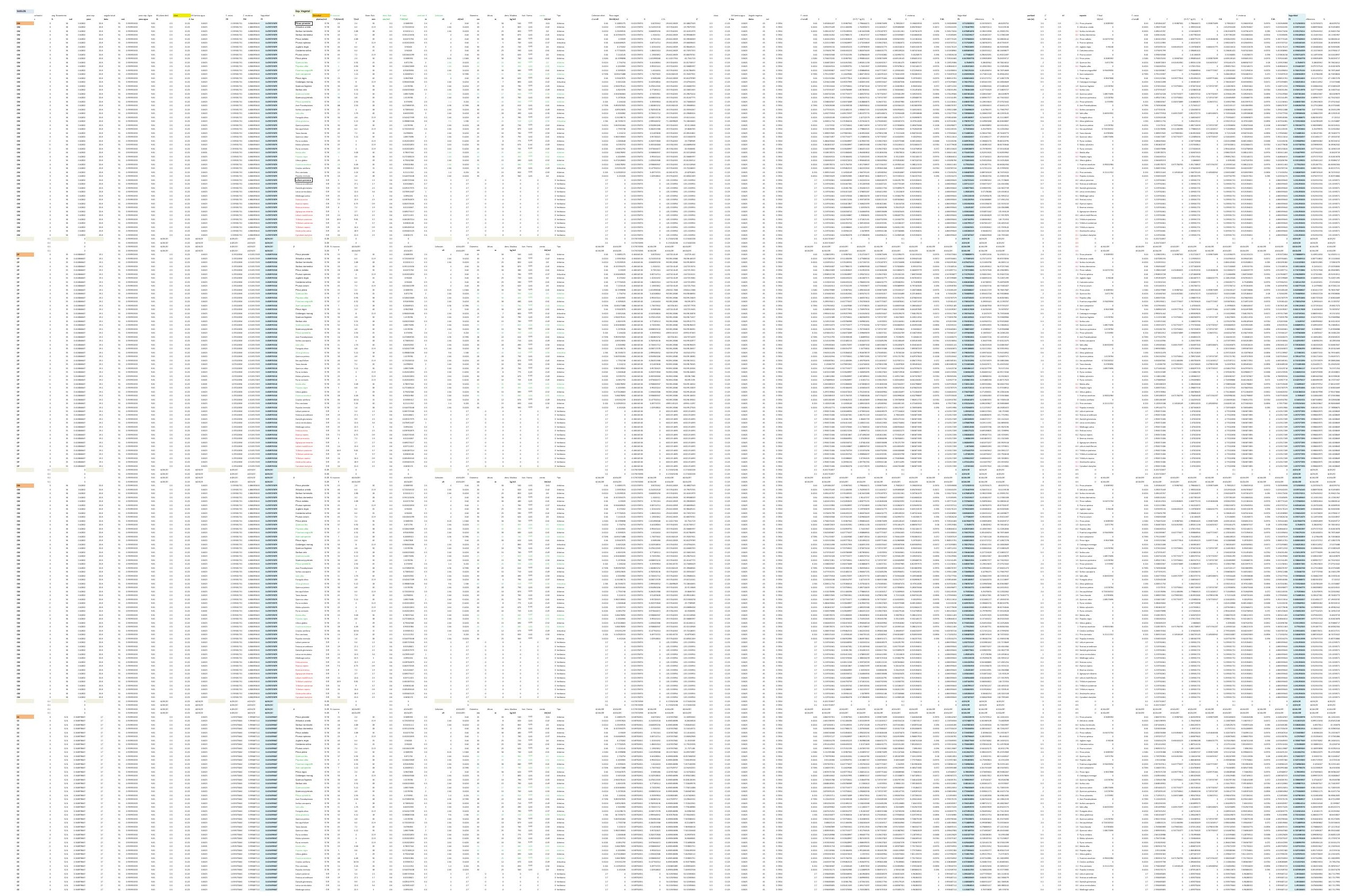


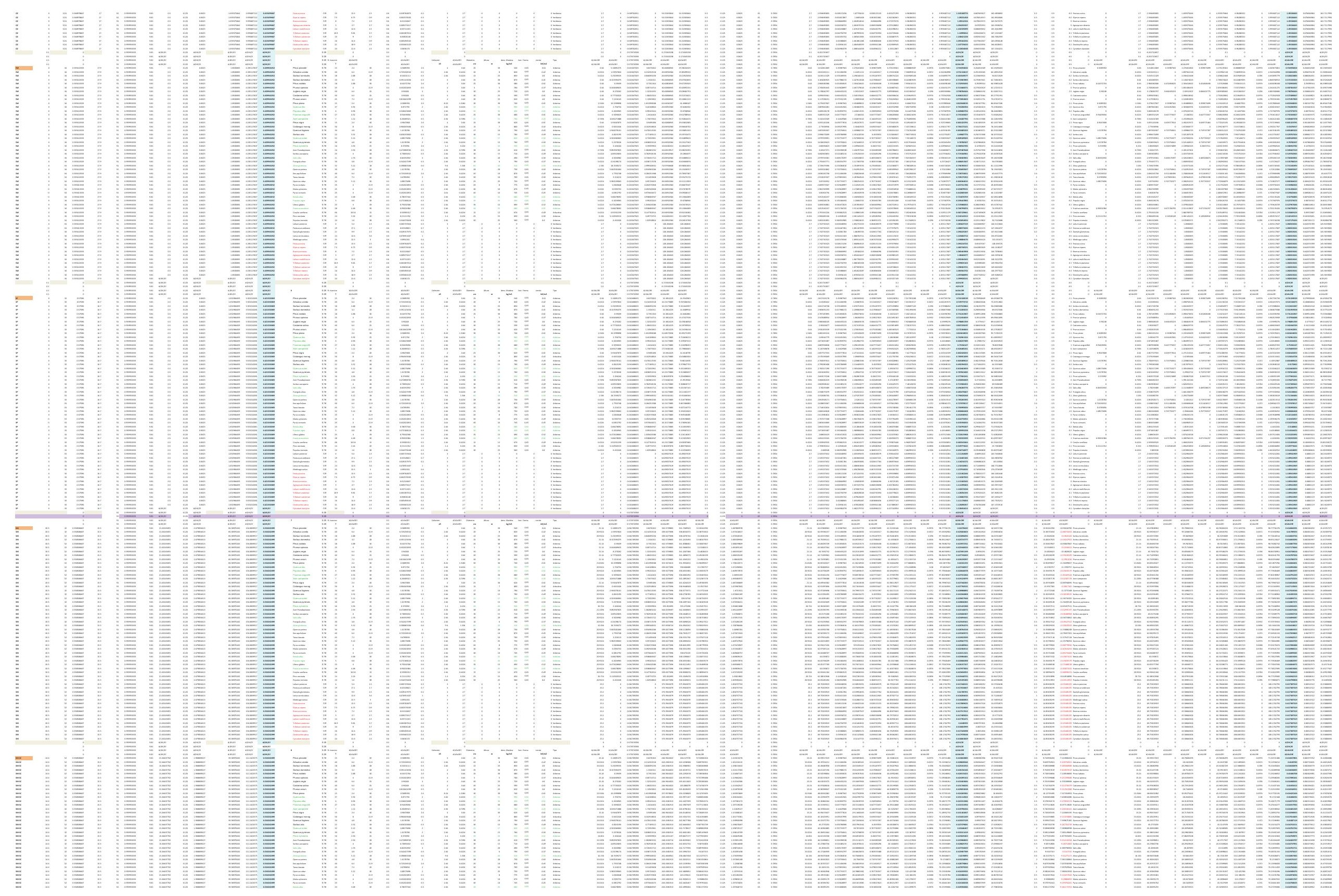



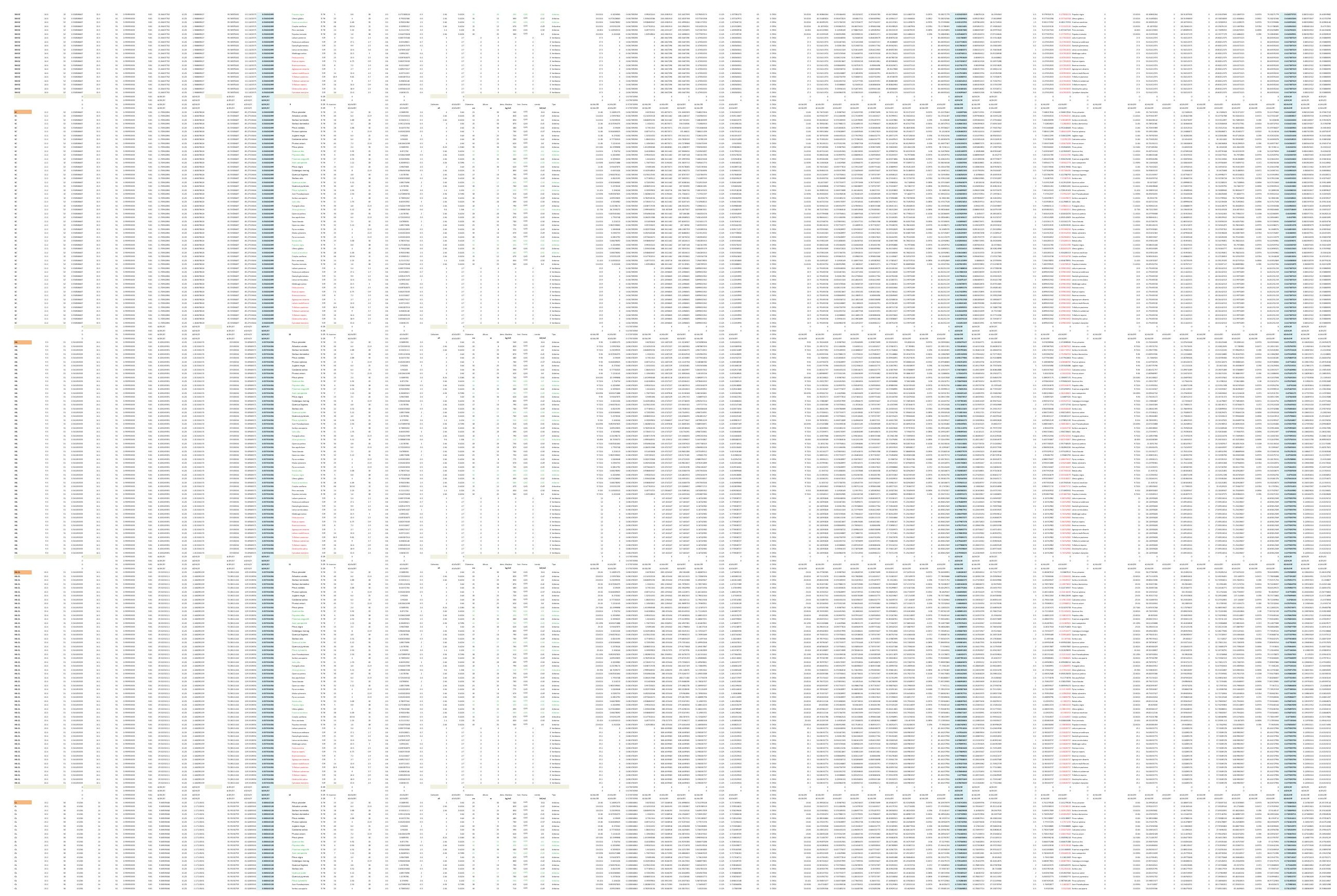


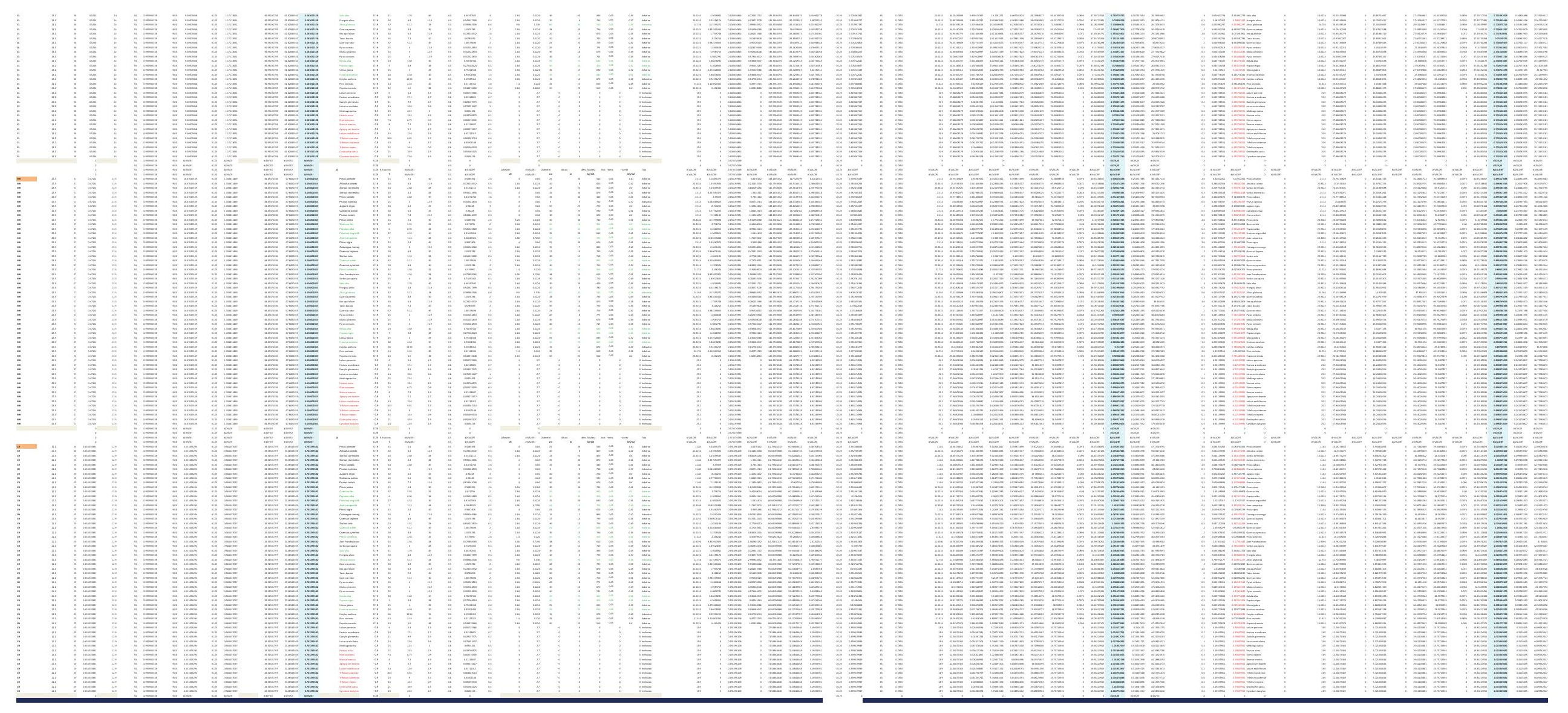



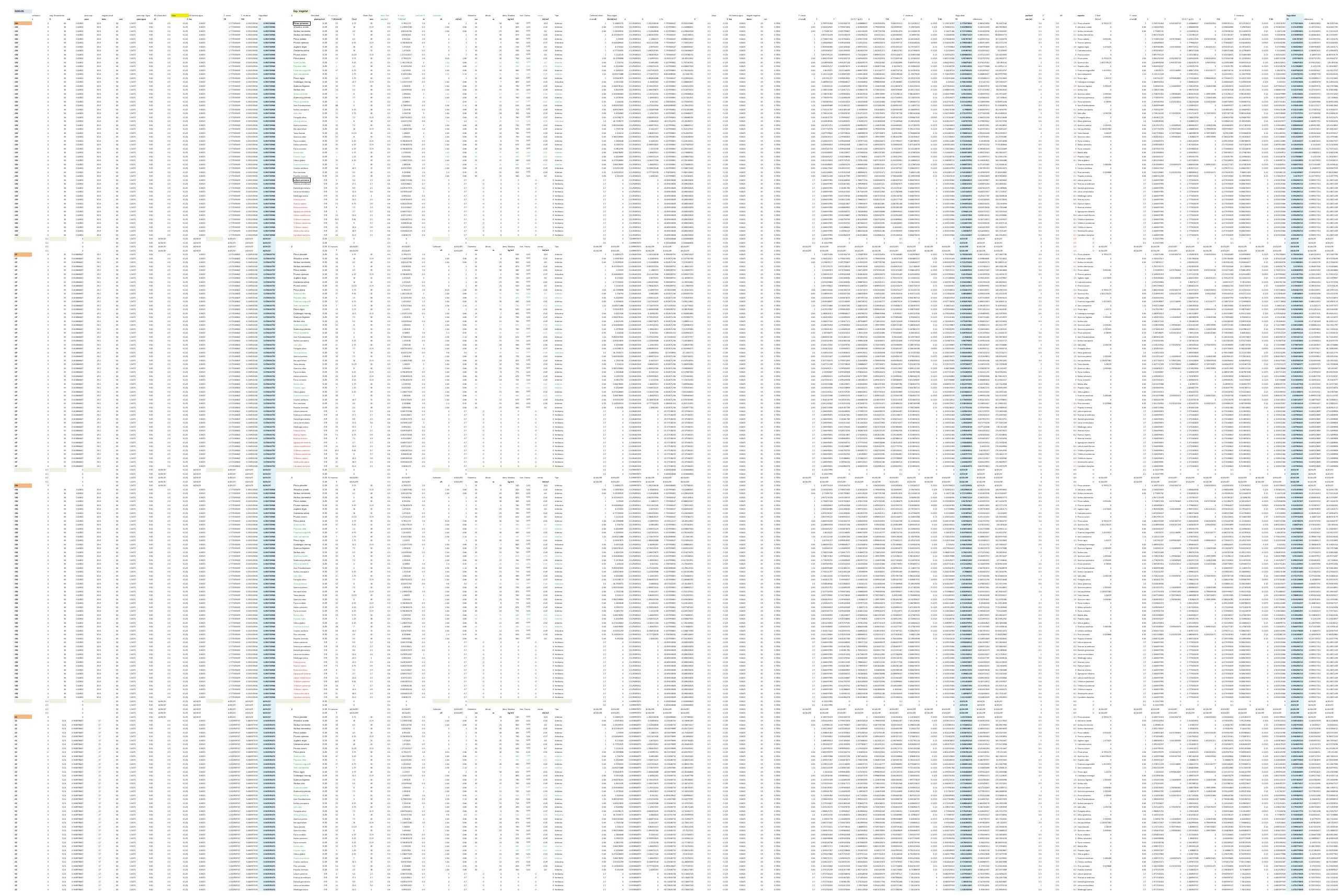


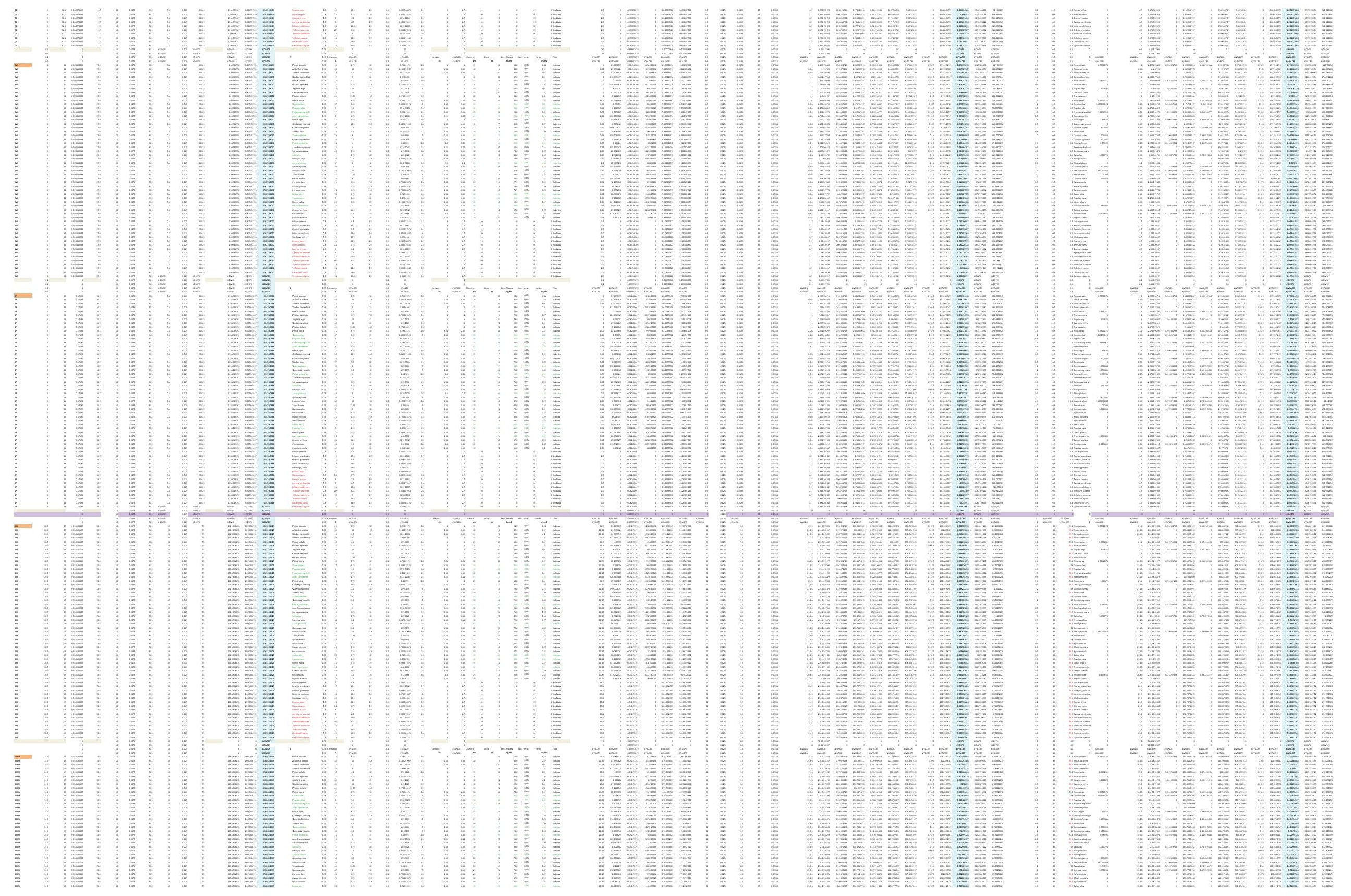



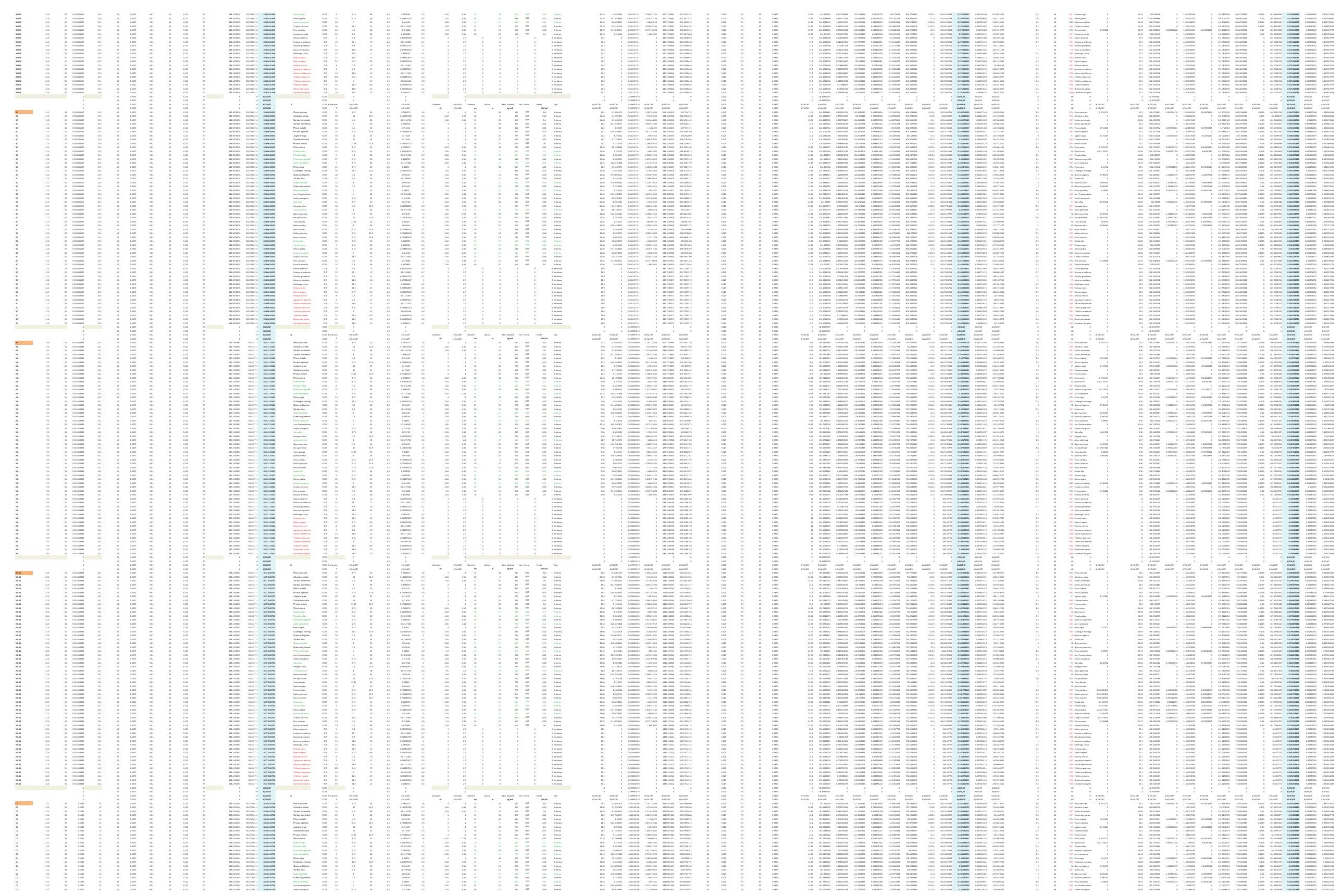


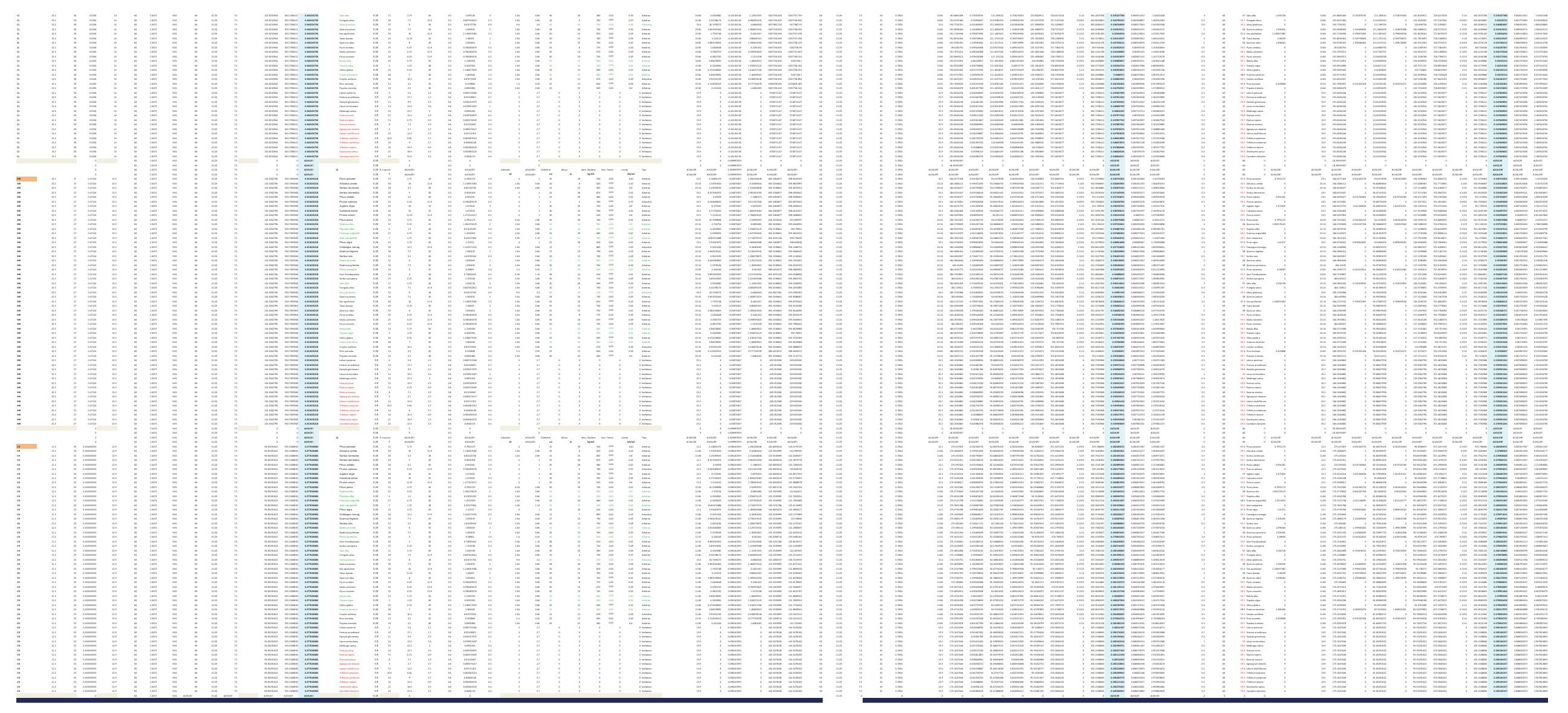



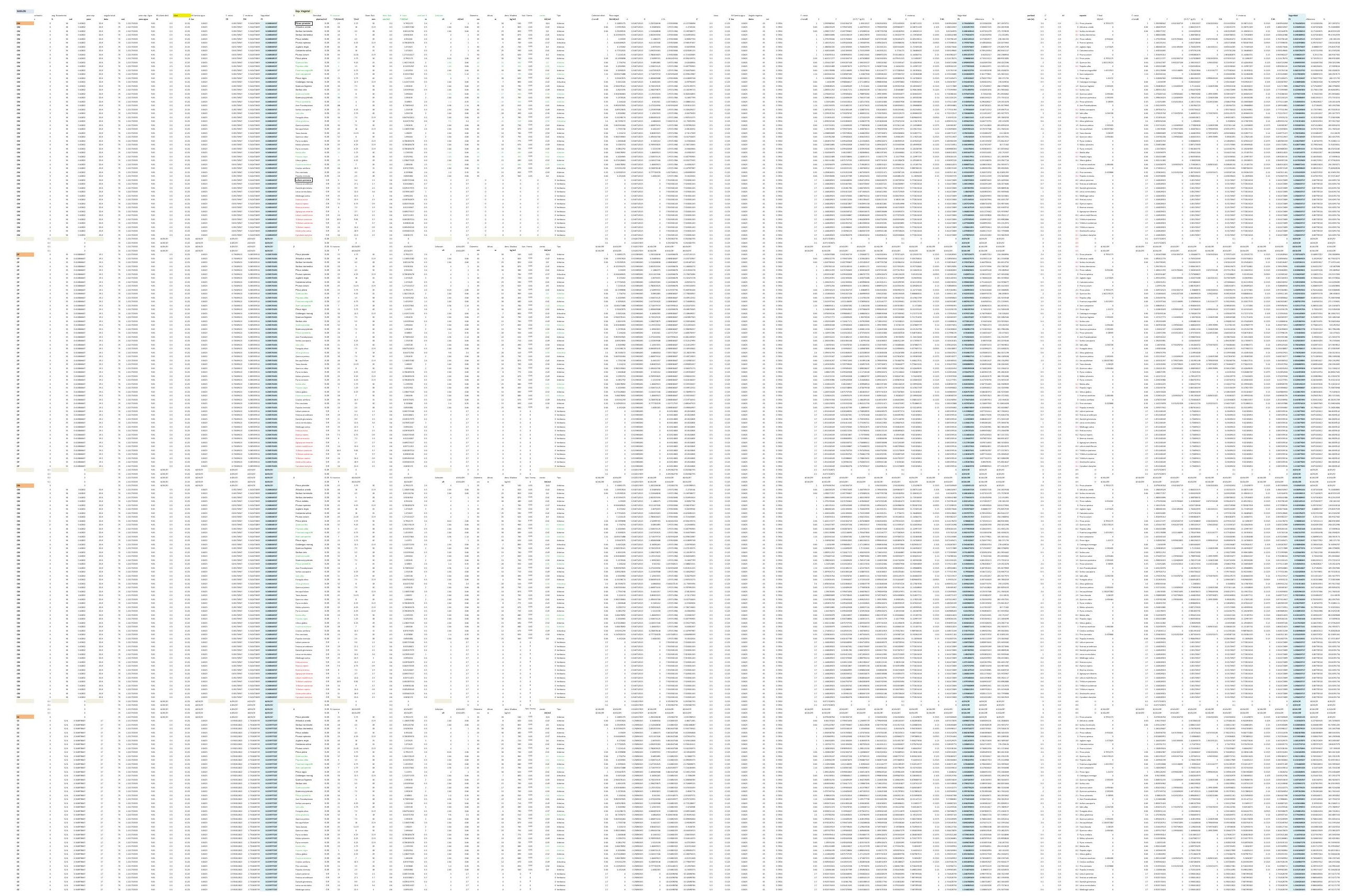


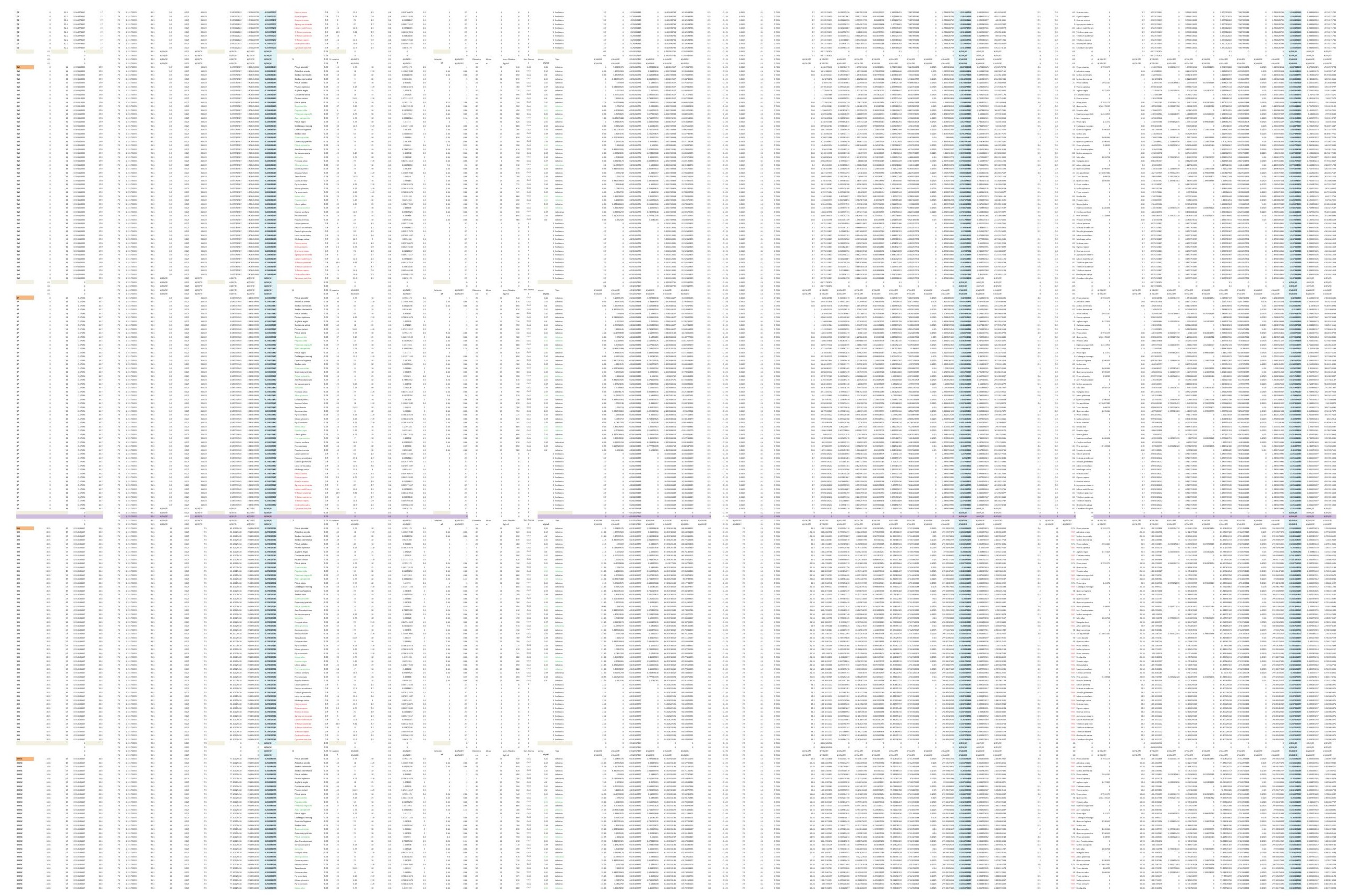




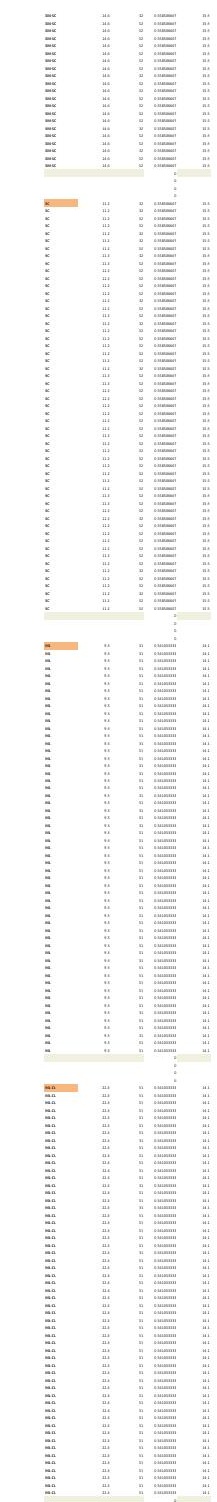

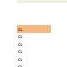

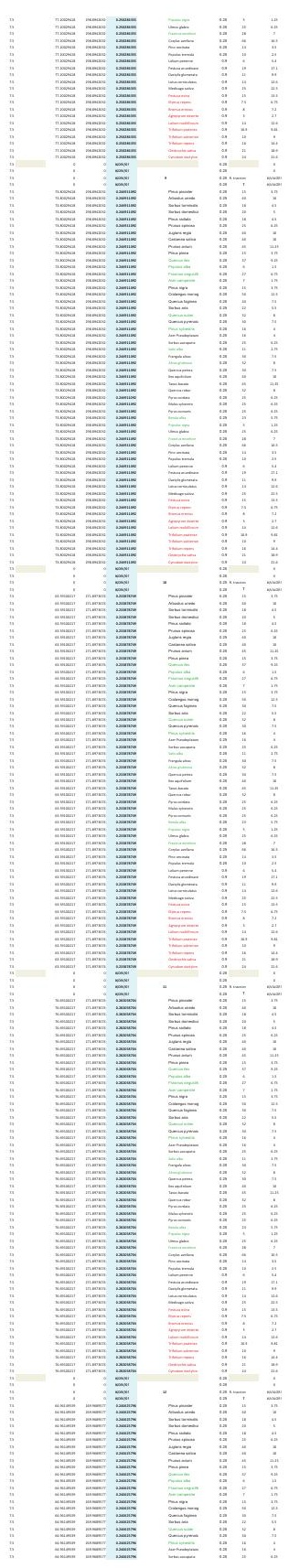

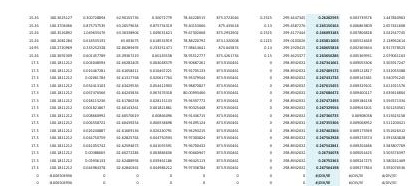
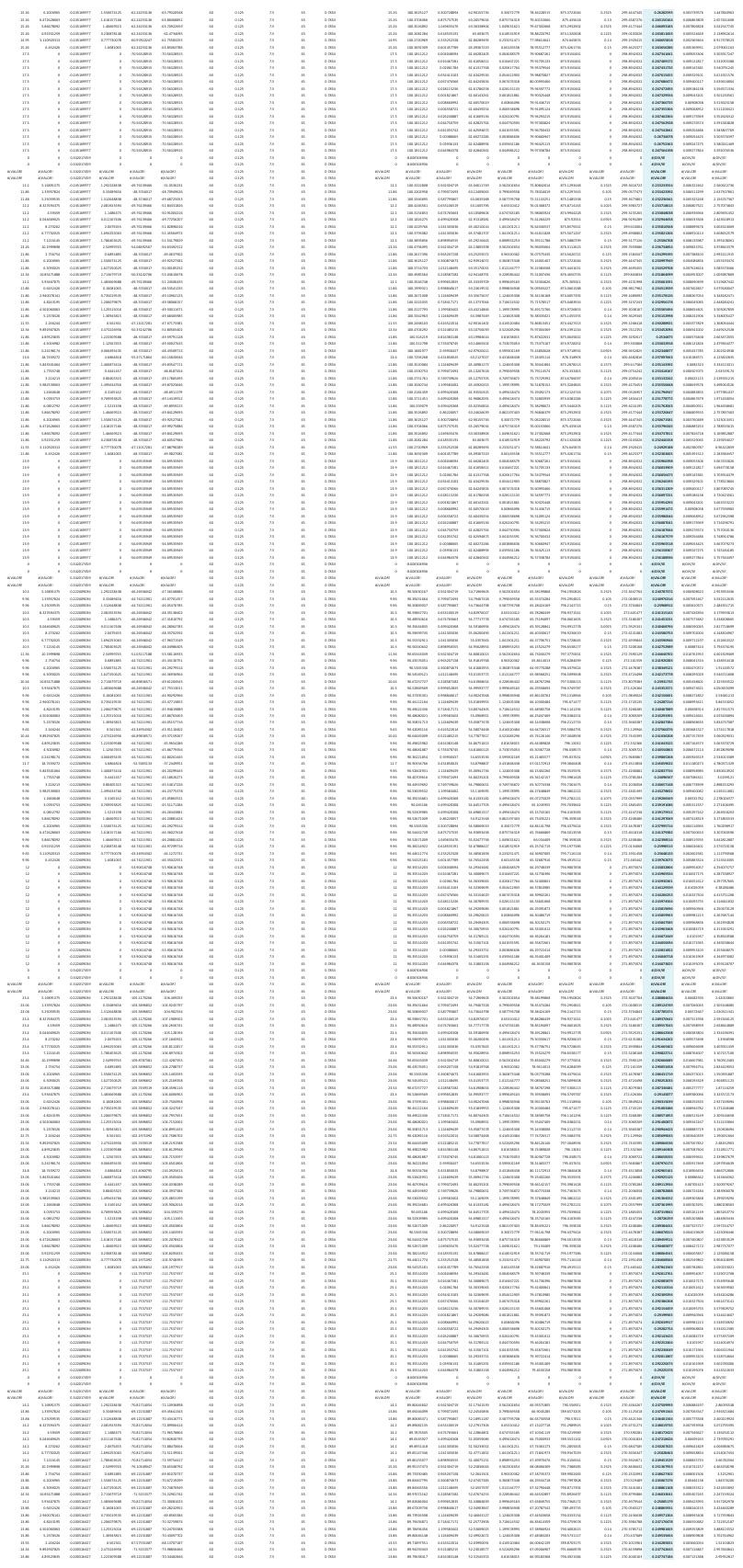

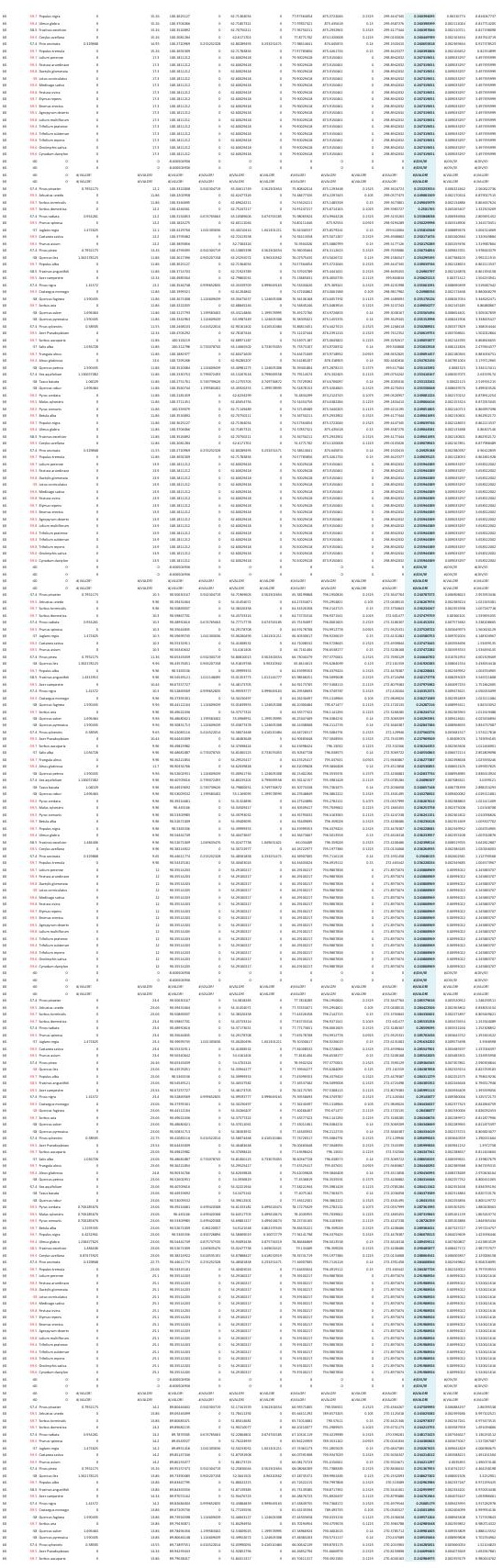




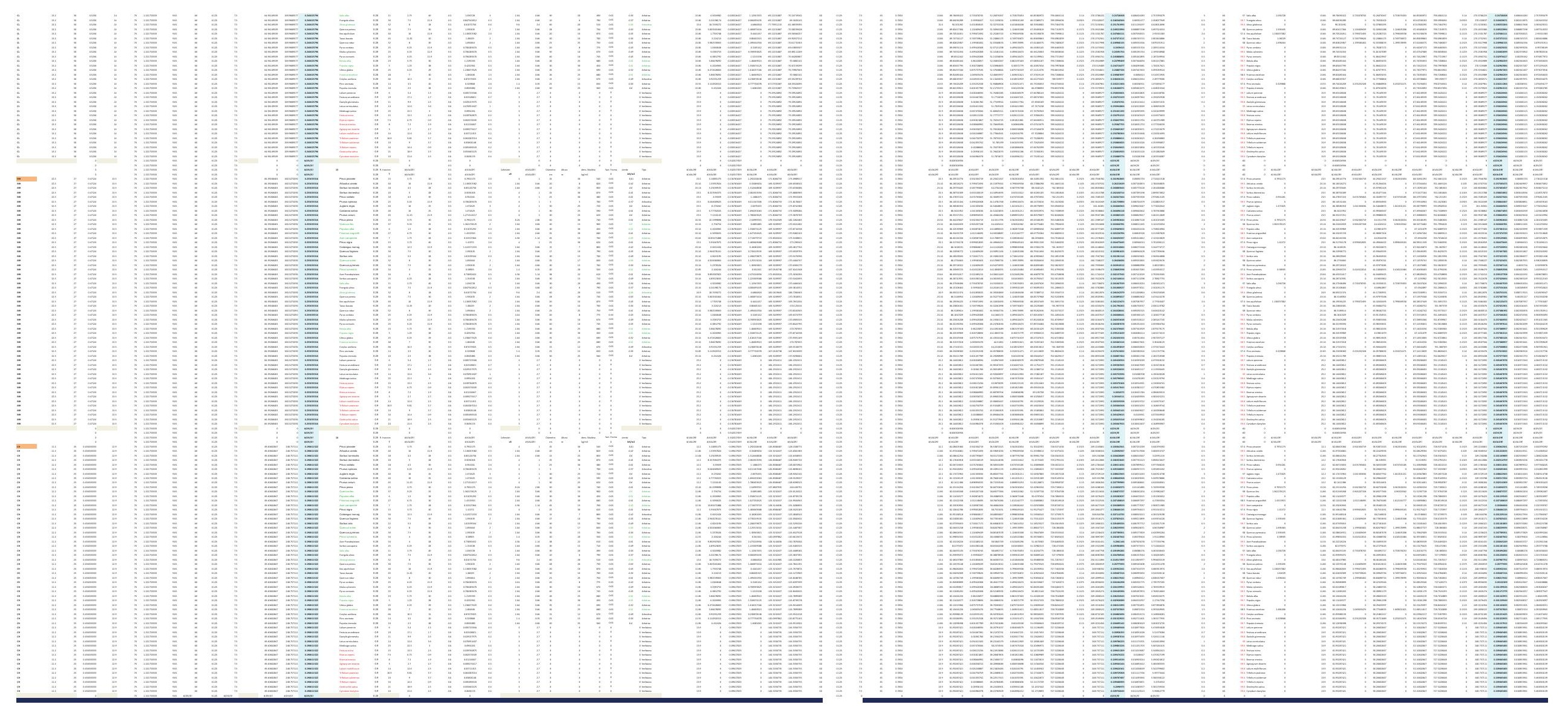



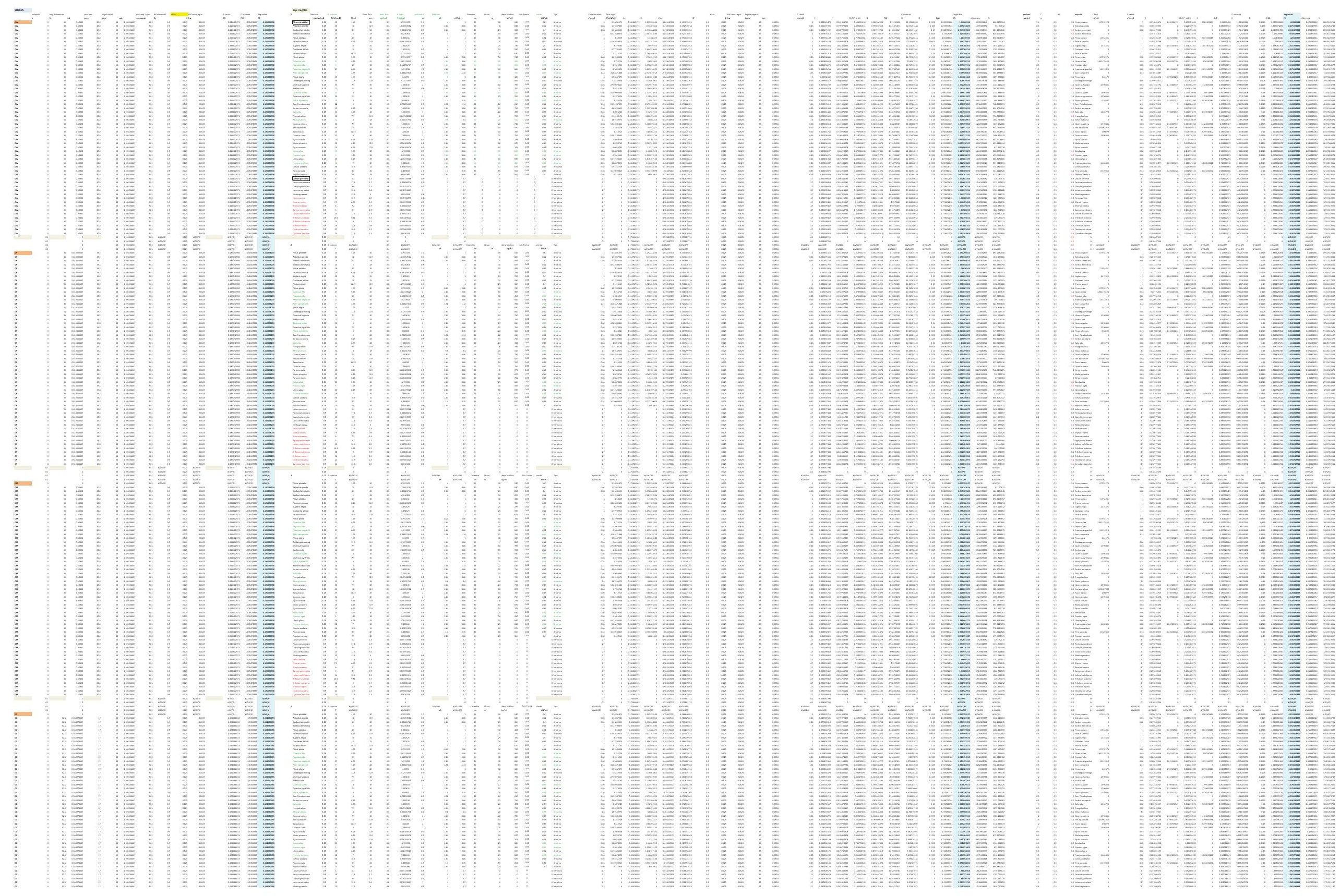


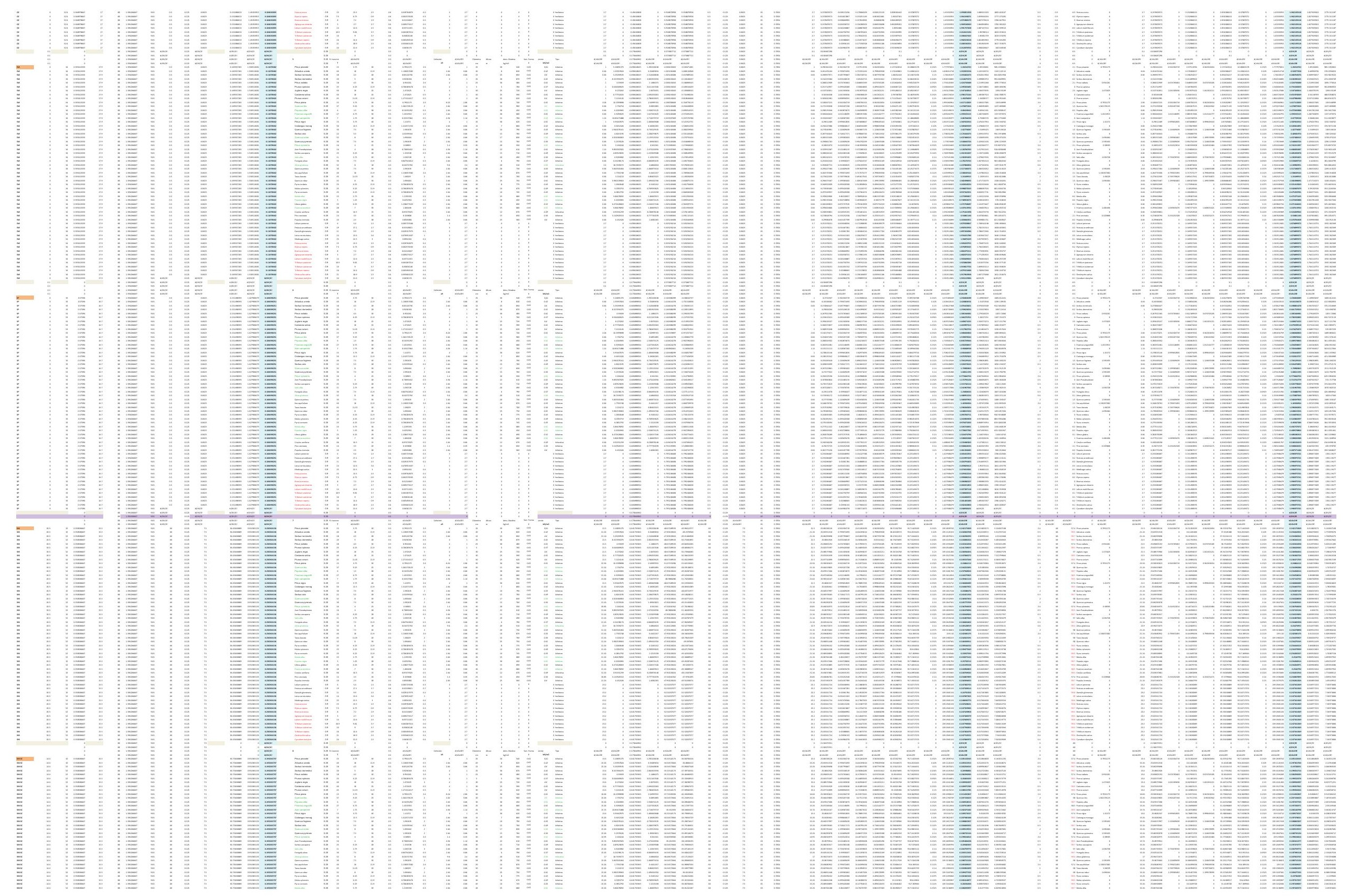




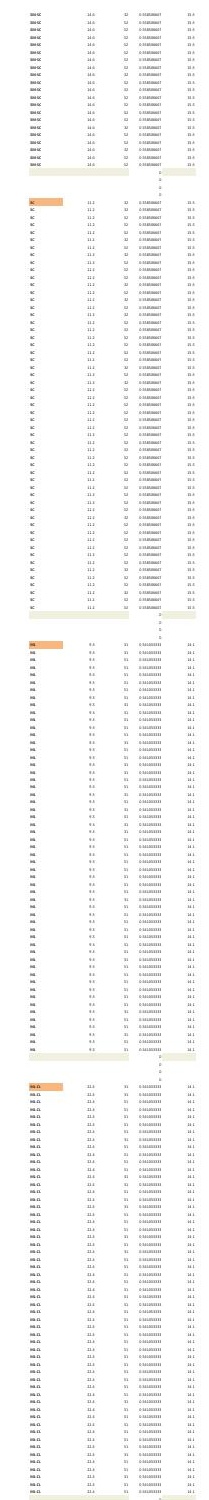

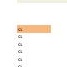
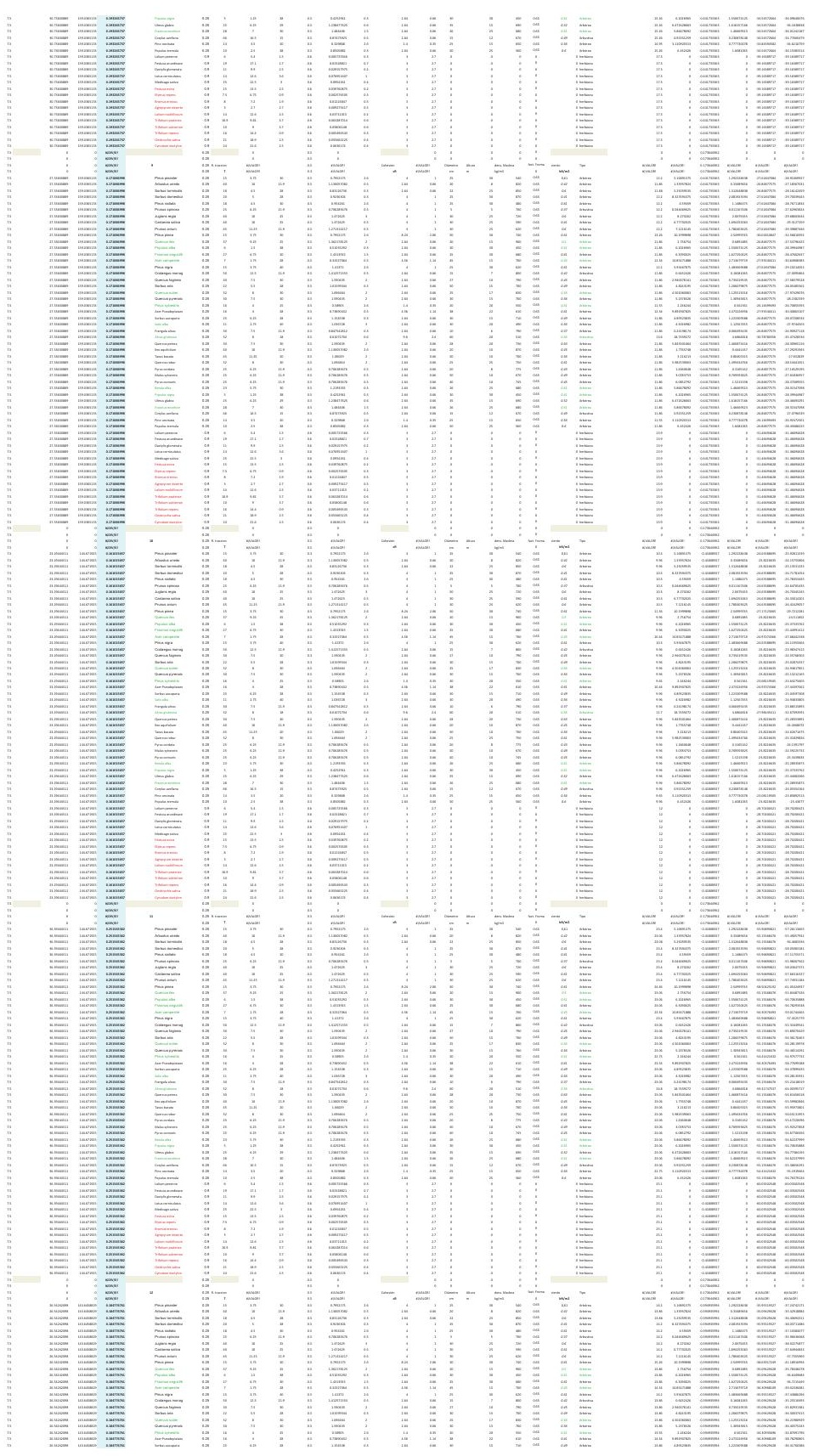
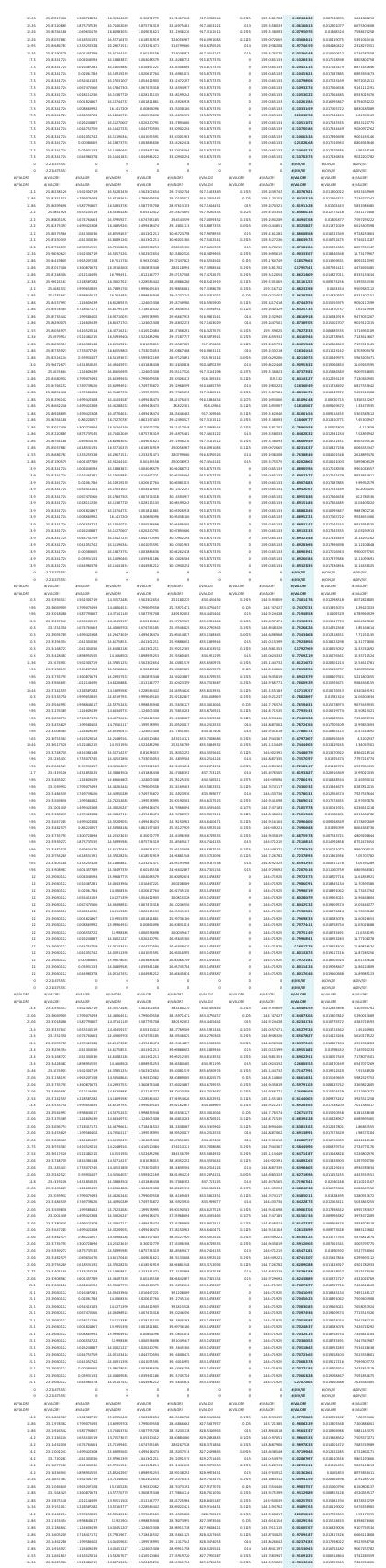

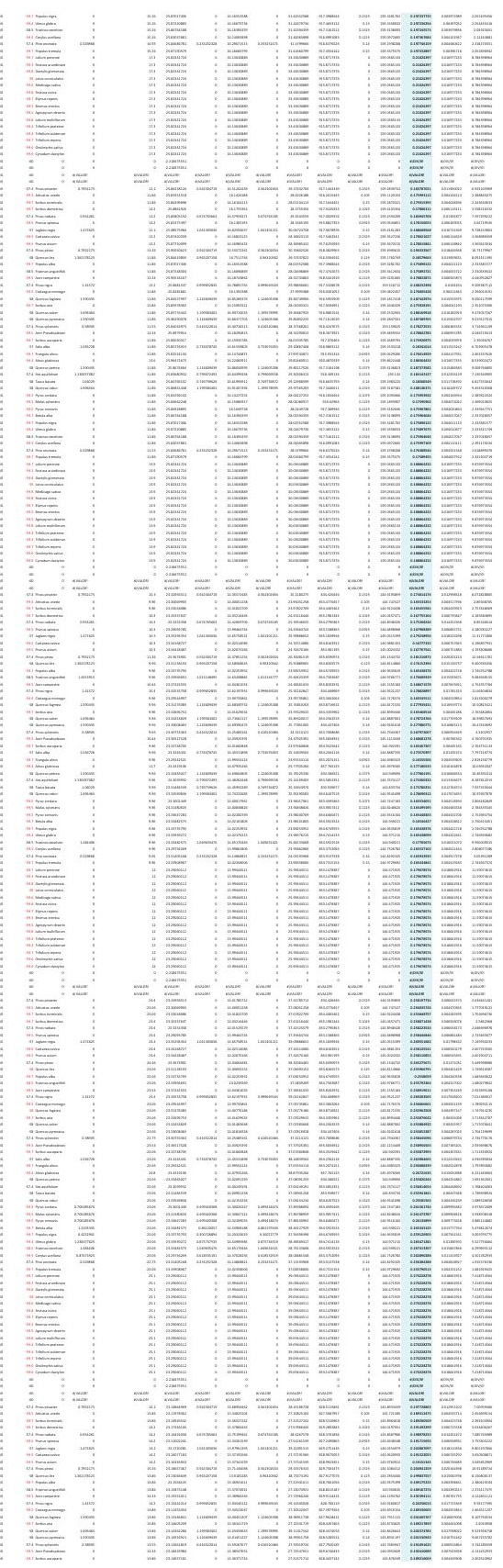




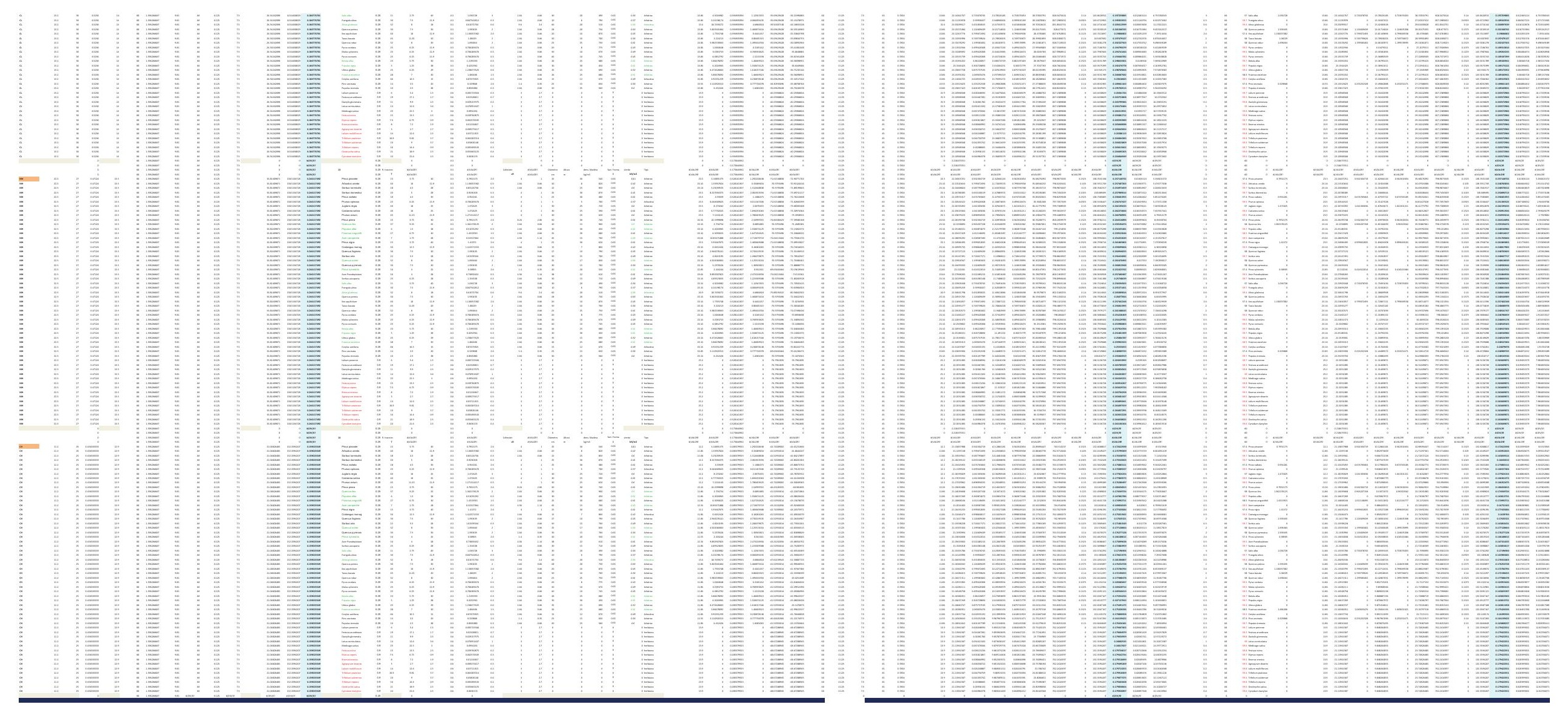


DESARROLLO DE UNA APLICACIÓN IMFORMÁTICA PARA EL CÁLCULO DE SOSTENIMIENTO DE TALUDES MEDIANTE VEGETACIÓN

A02. DENSIDAD DE PLANTACIÓN: 1.600 plantas/ha.

\section{A02-3.POSICIÓN N.F. 3}

INCLINACIÓN DE TALUD 6-100

INCLINACIÓN DE TALUD 10-200

INCLINACIÓN DE TALUD 20-30

INCLINACIÓN DE TALUD 30-40

INCLINACIÓN DE TALUD $35^{\circ}$

INCLINACIÓN DE TALUD 40-50

INCLINACIÓN DE TALUD 50-550

INCLINACIÓN DE TALUD 55-60

INCLINACIÓN DE TALUD 60-700

INCLINACIÓN DE TALUD 70-80 

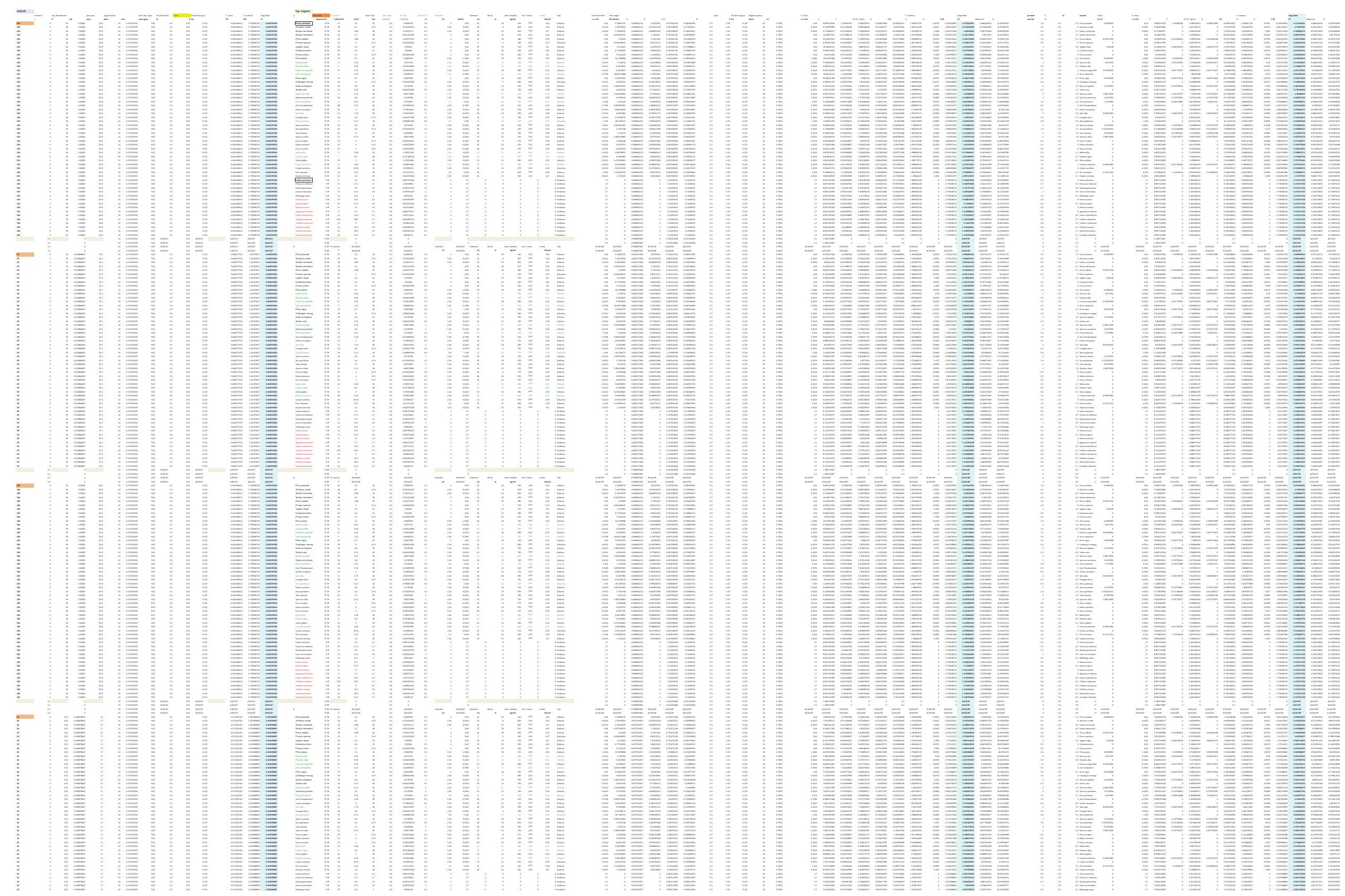


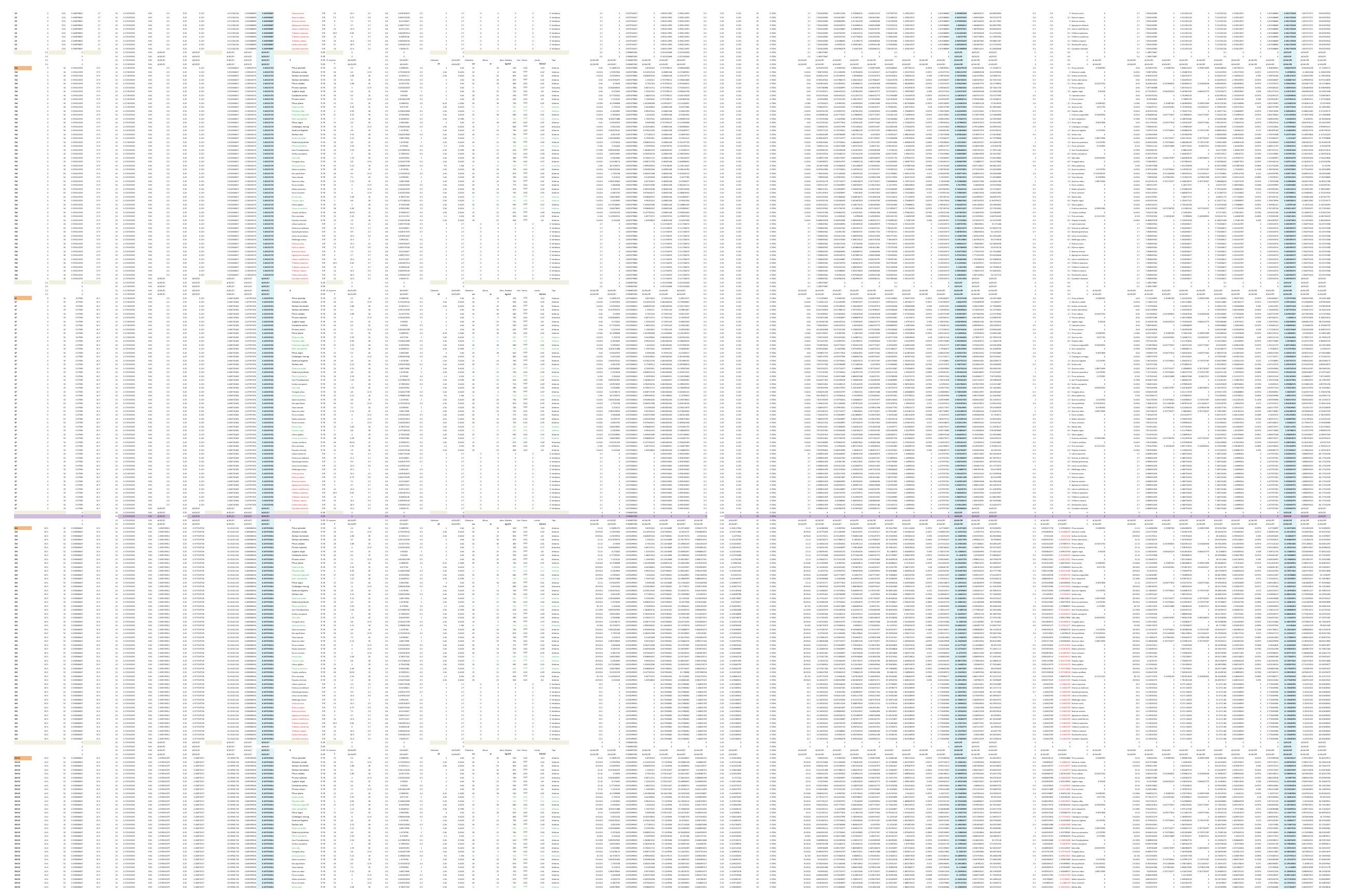



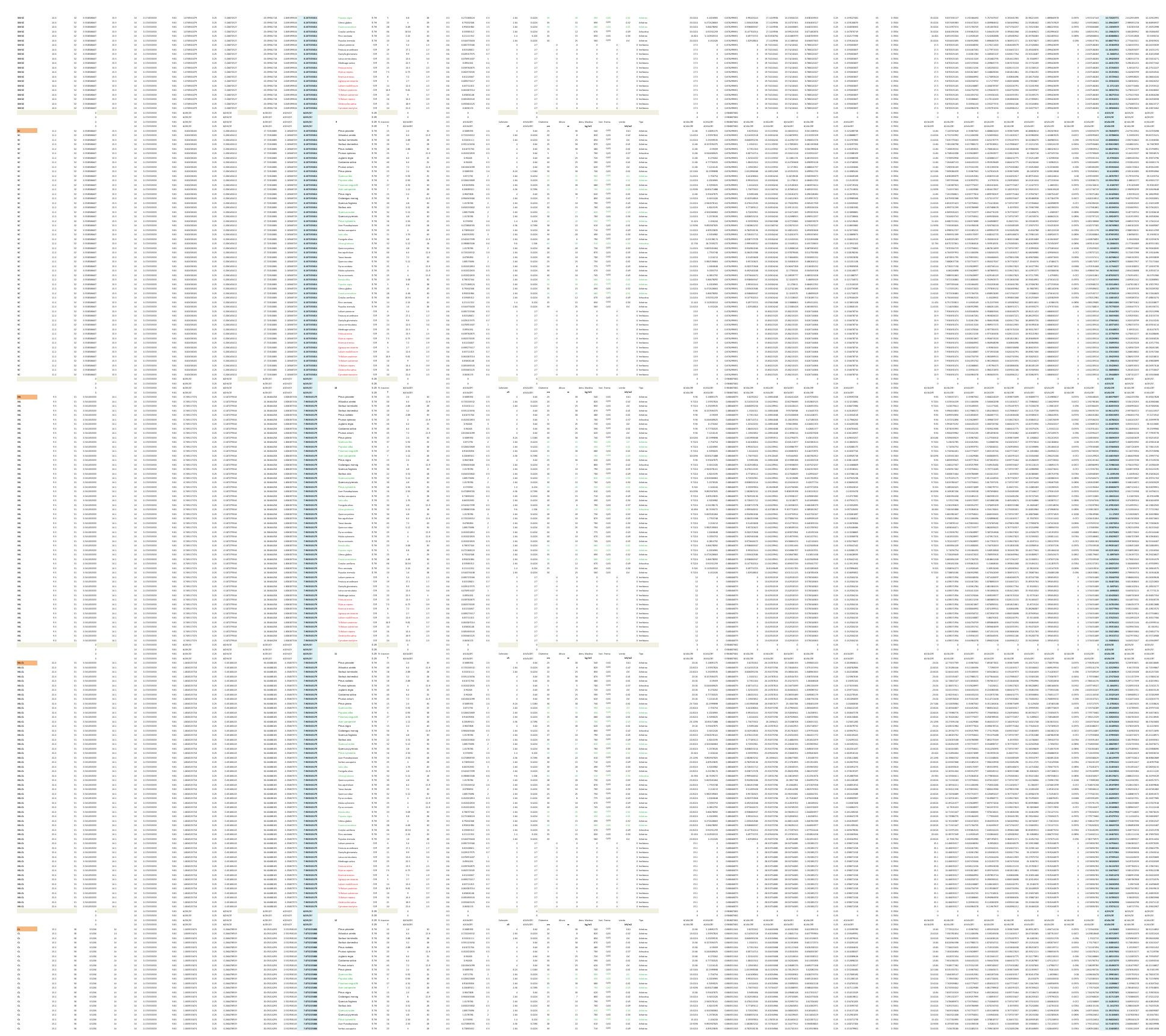

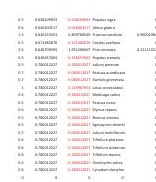
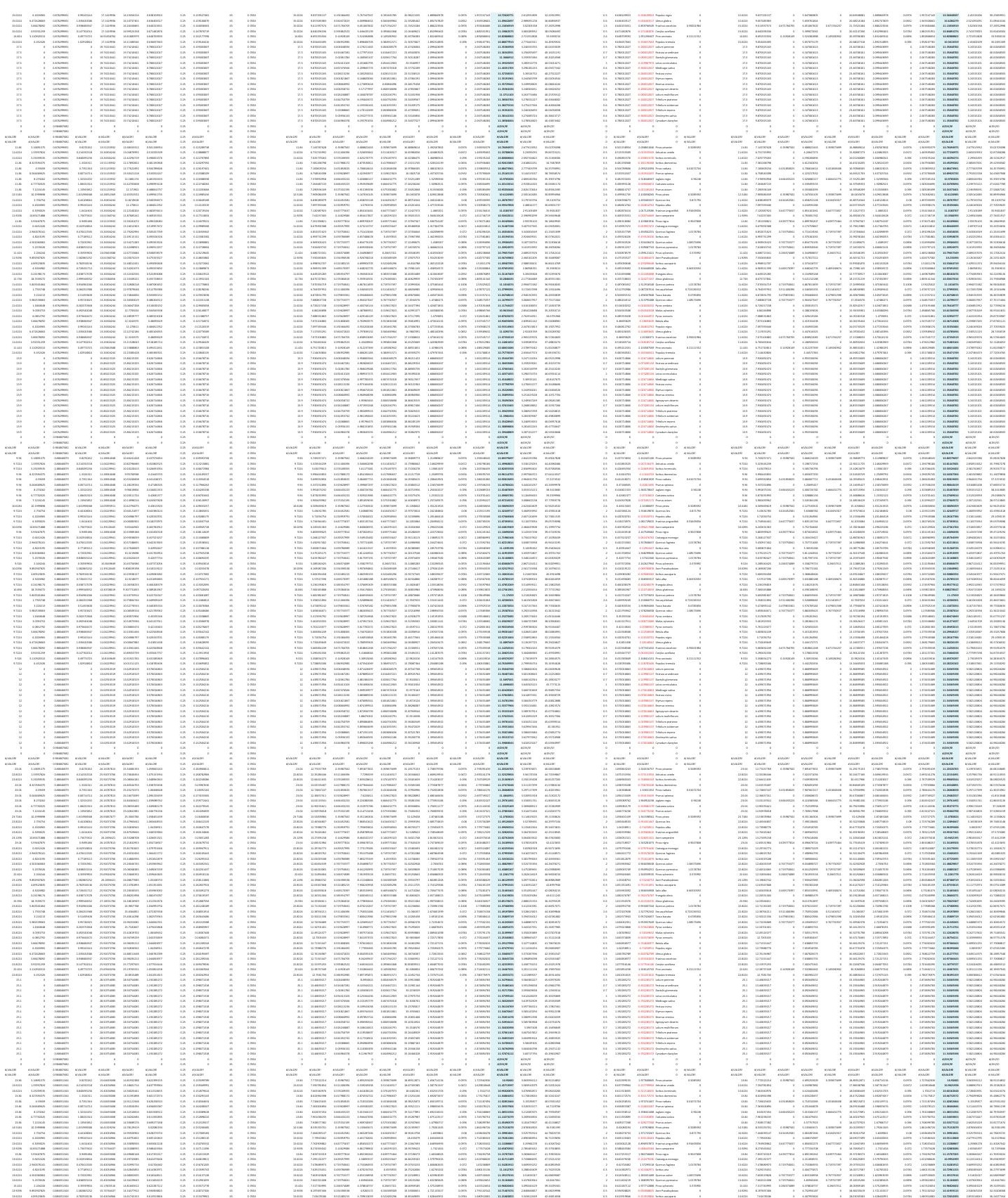


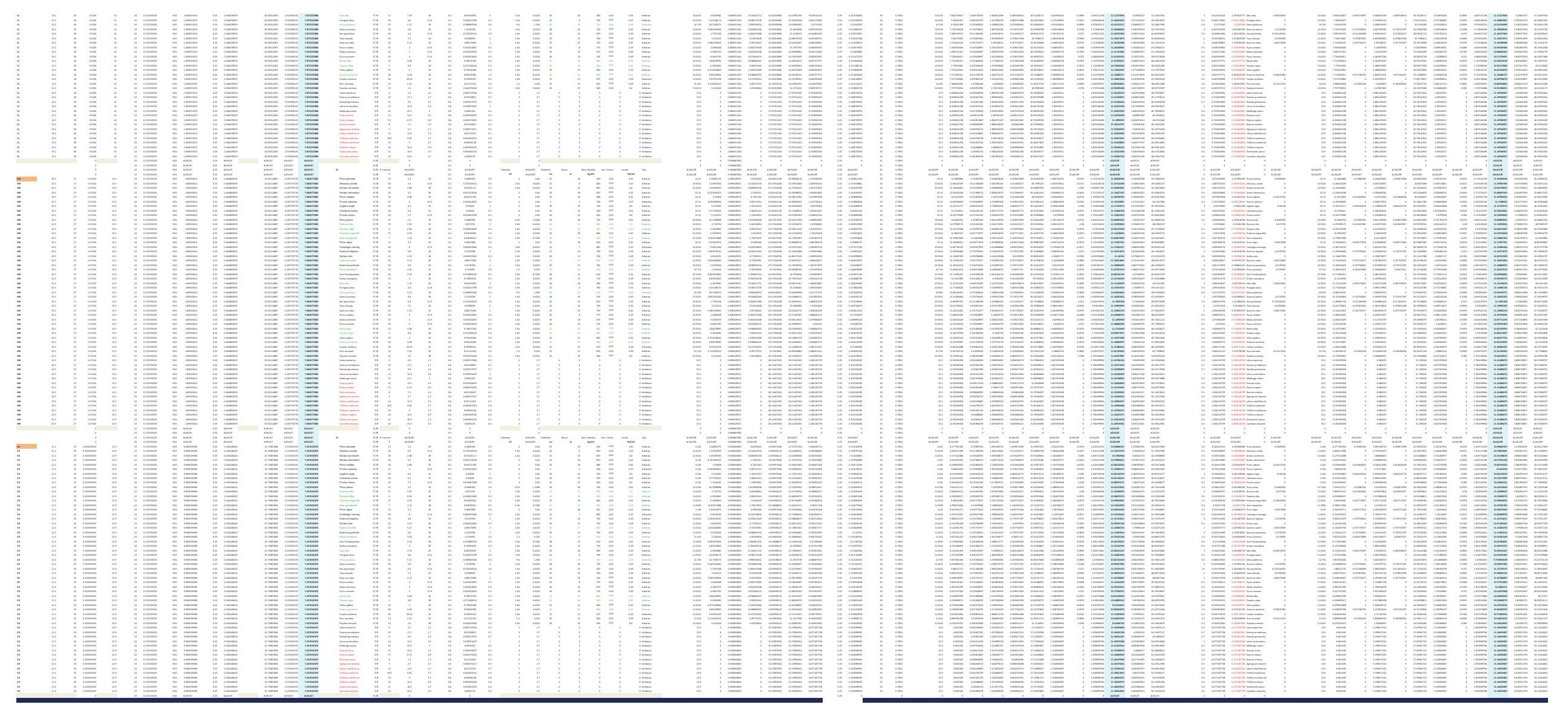



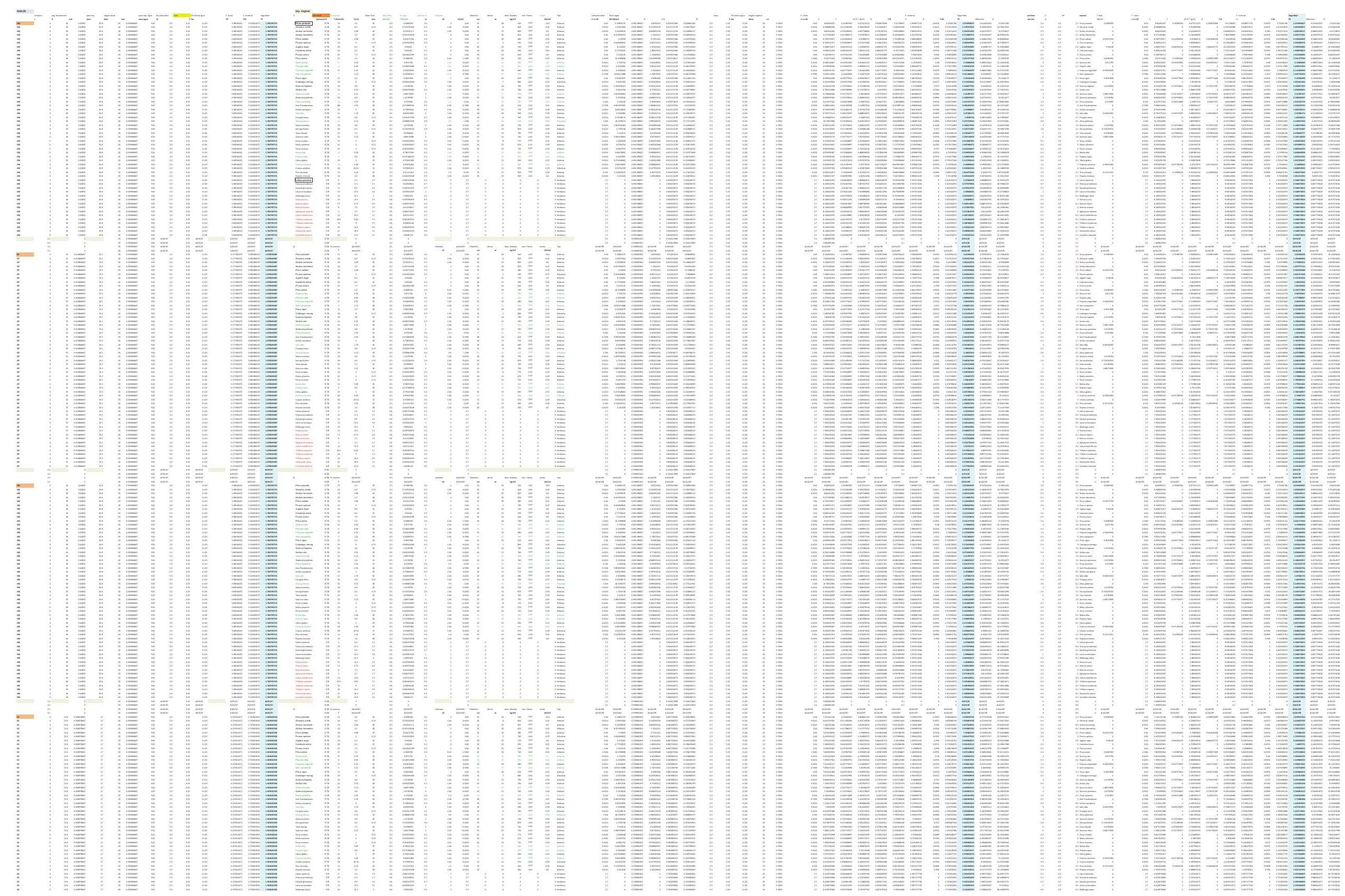


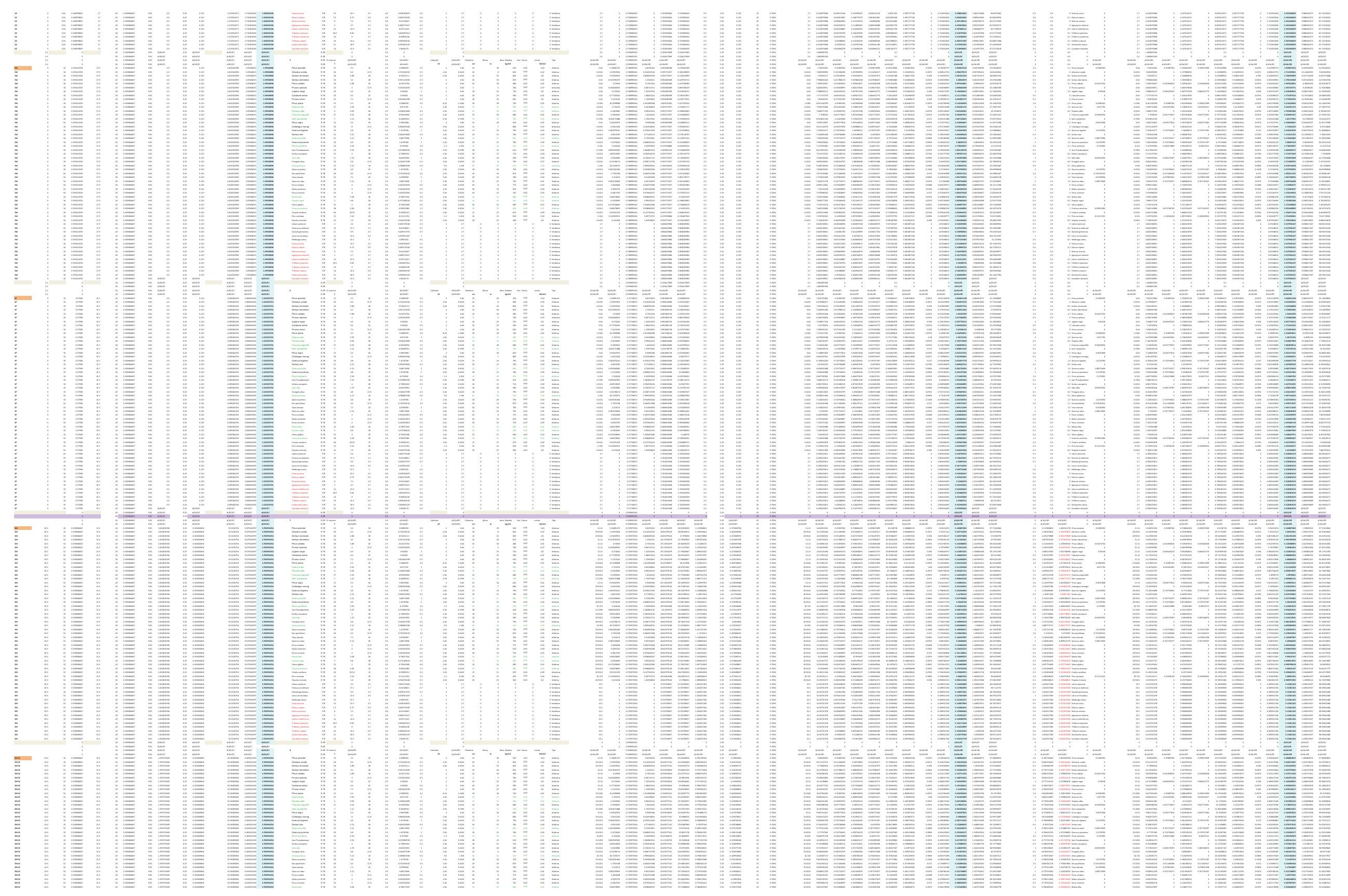



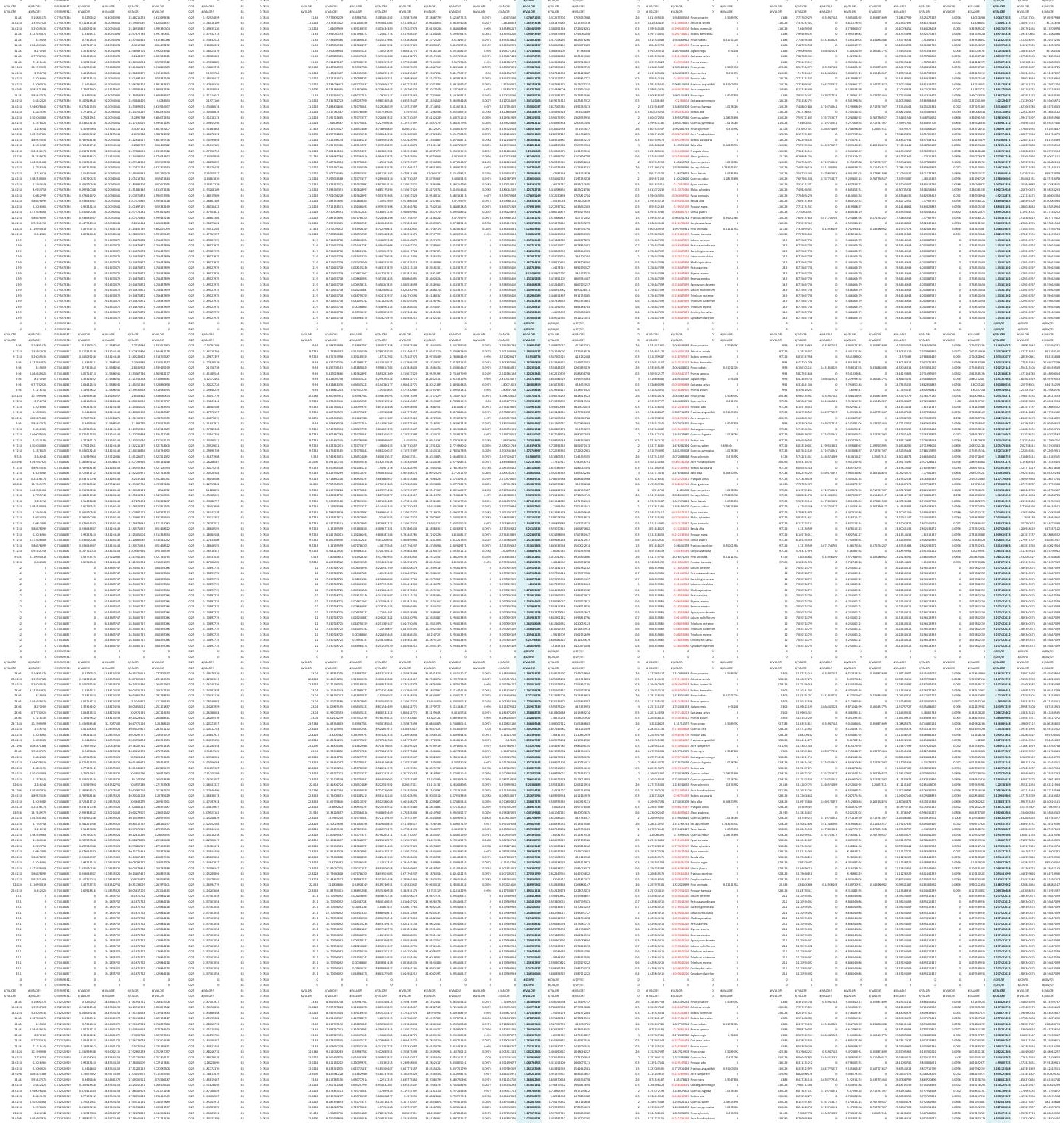


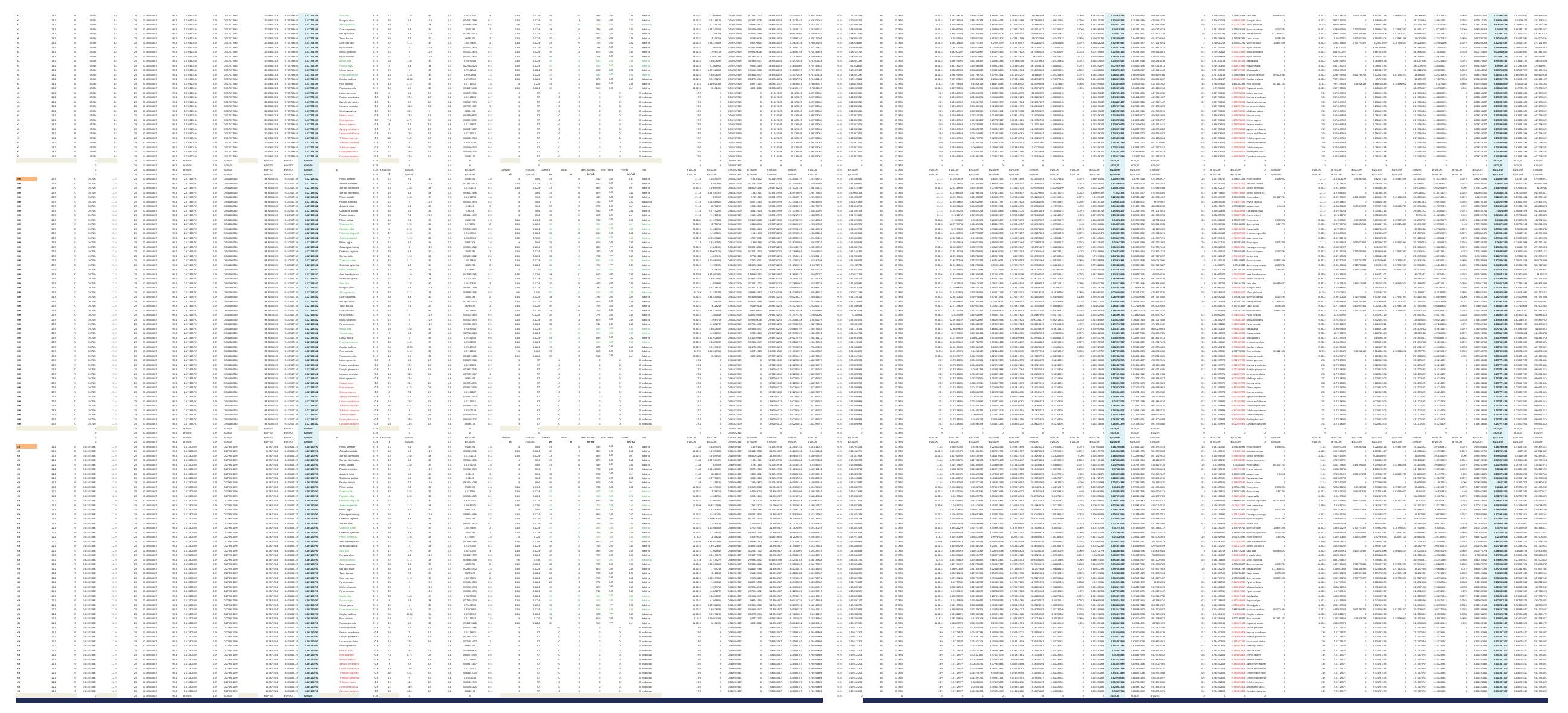



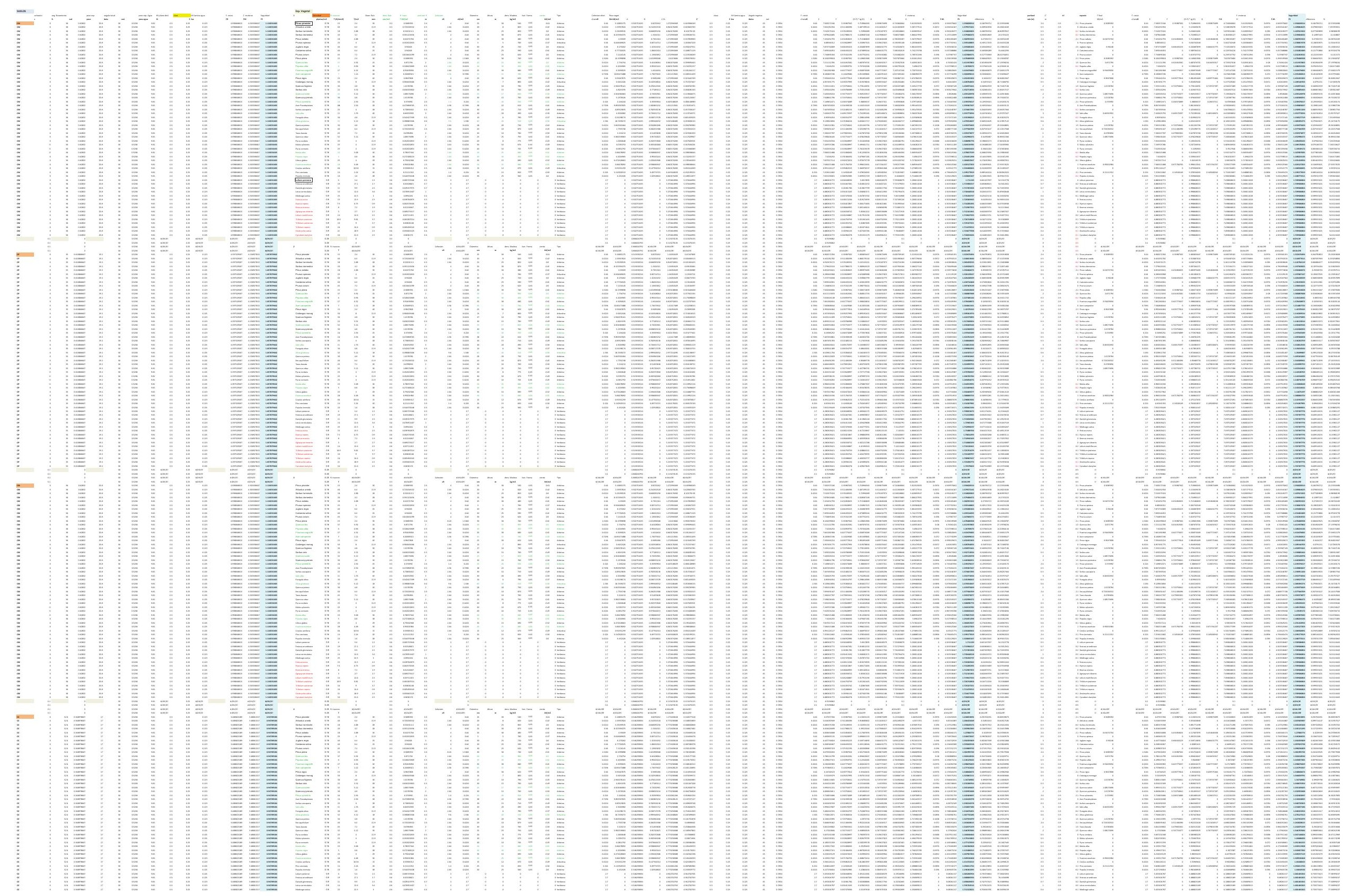


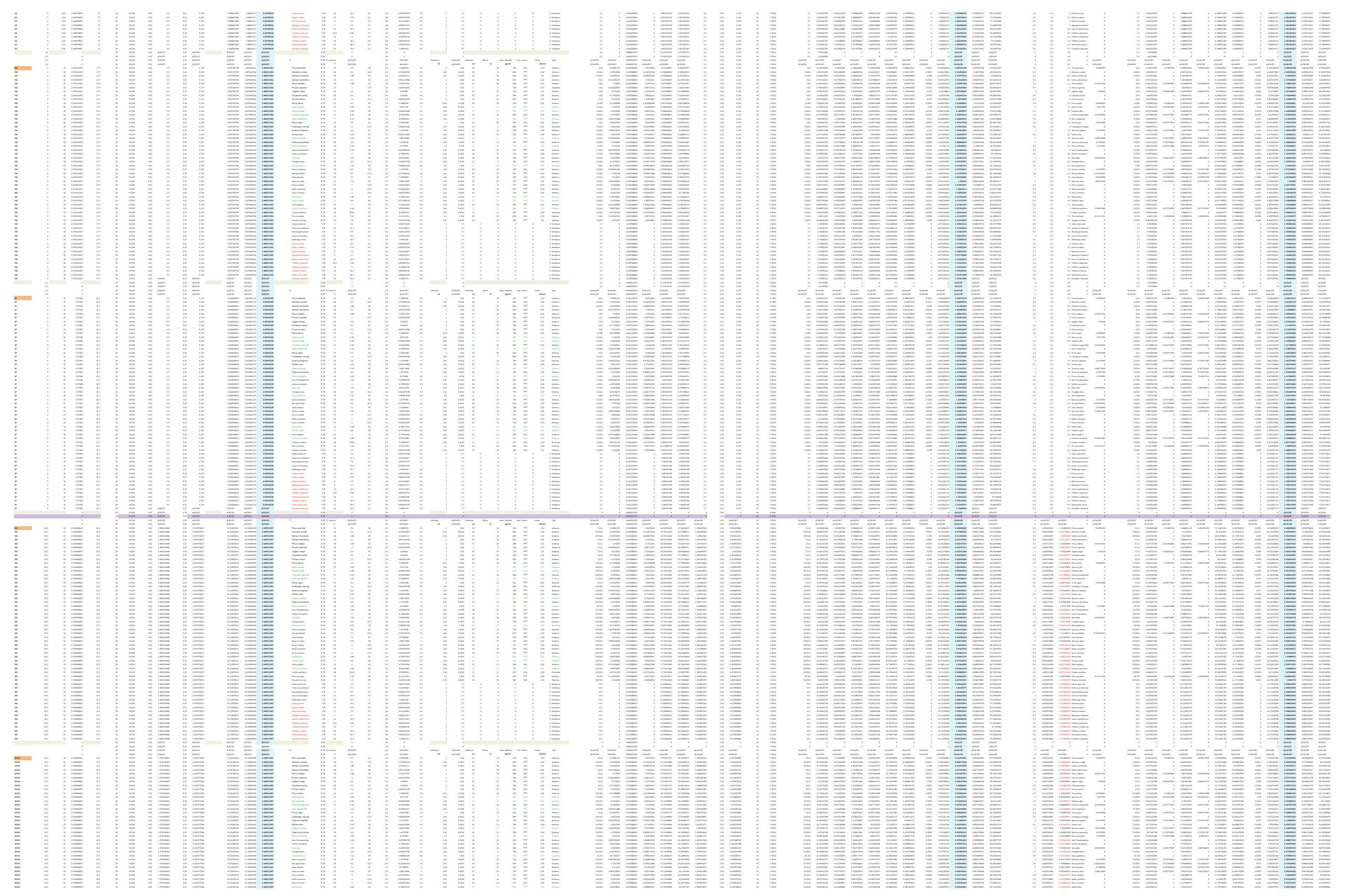



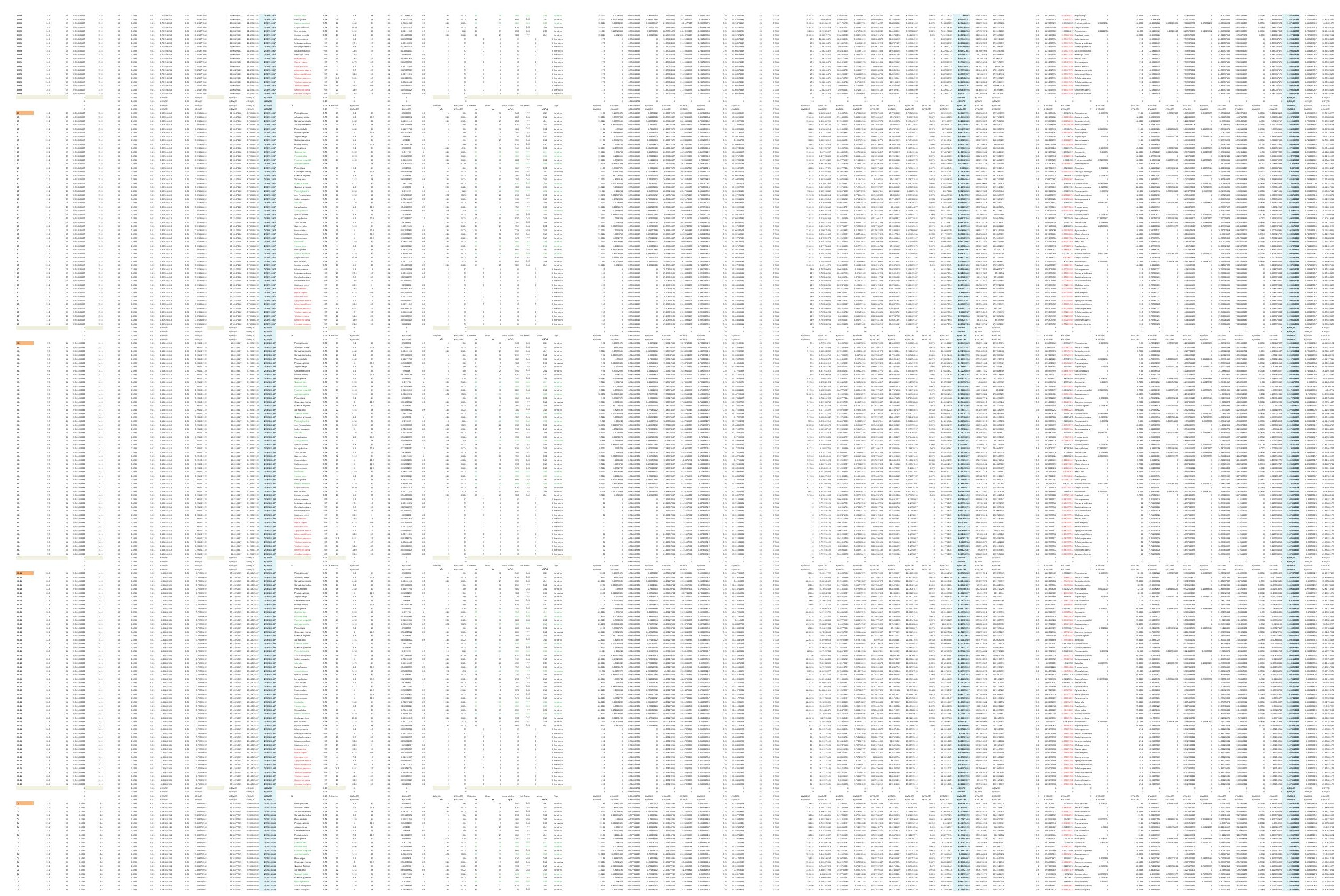


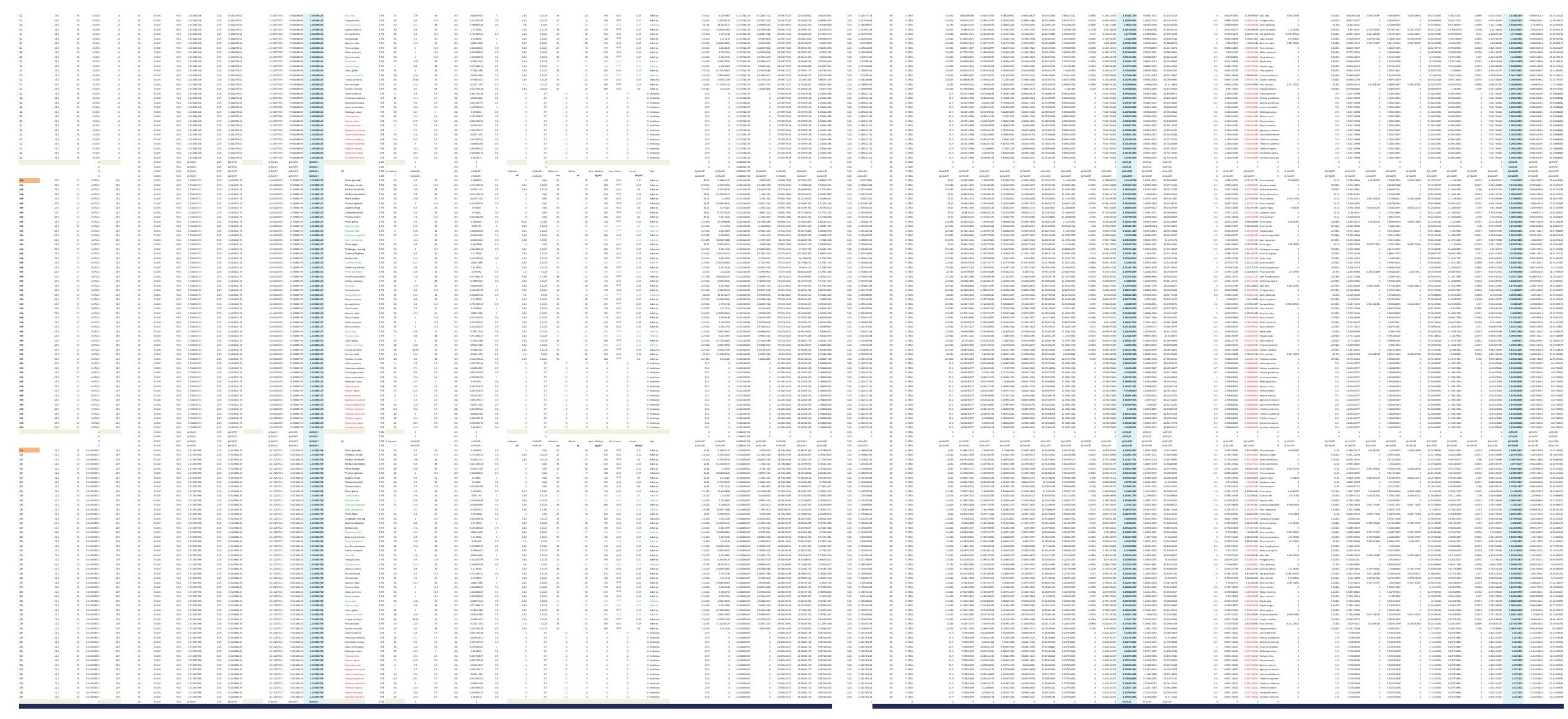



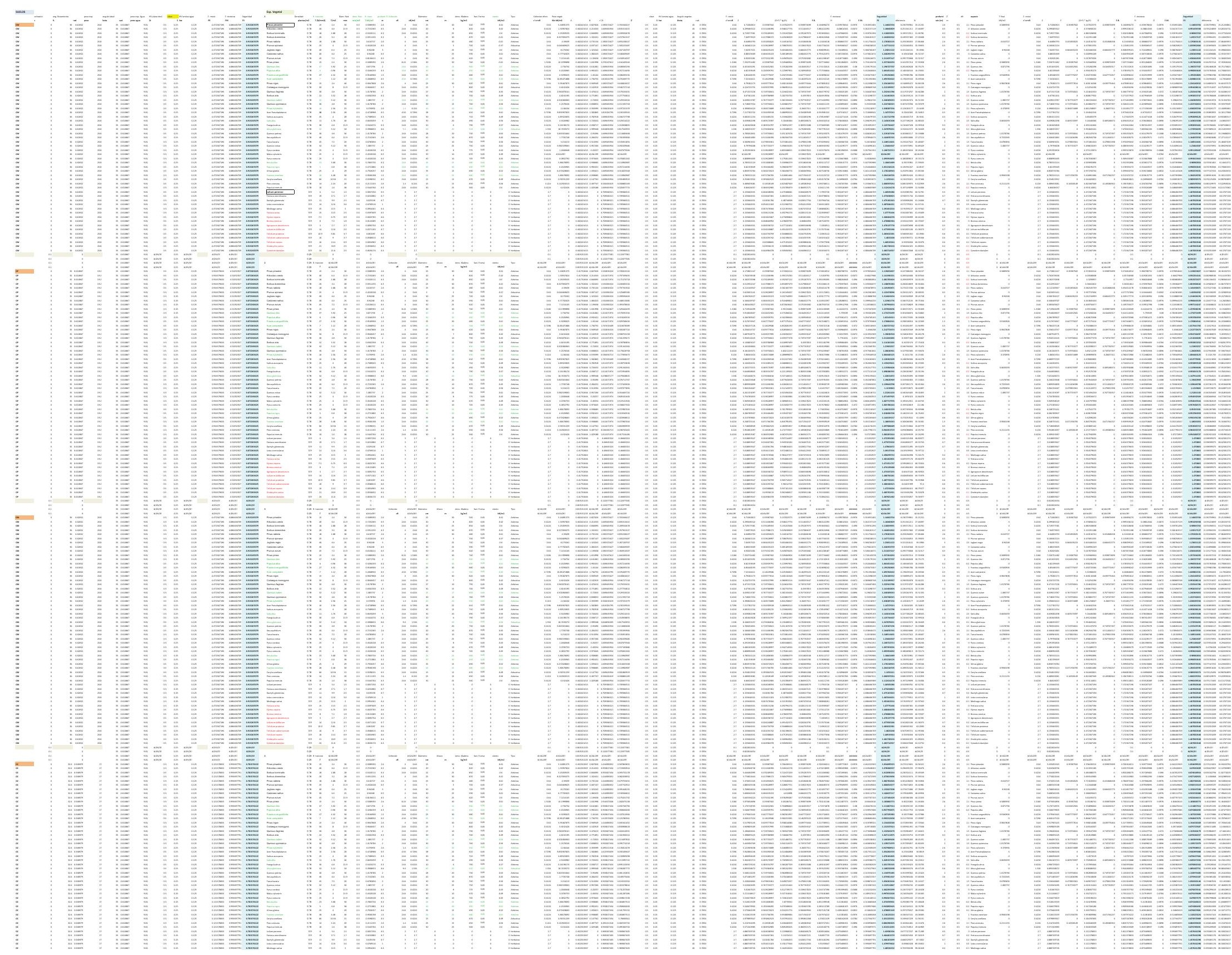


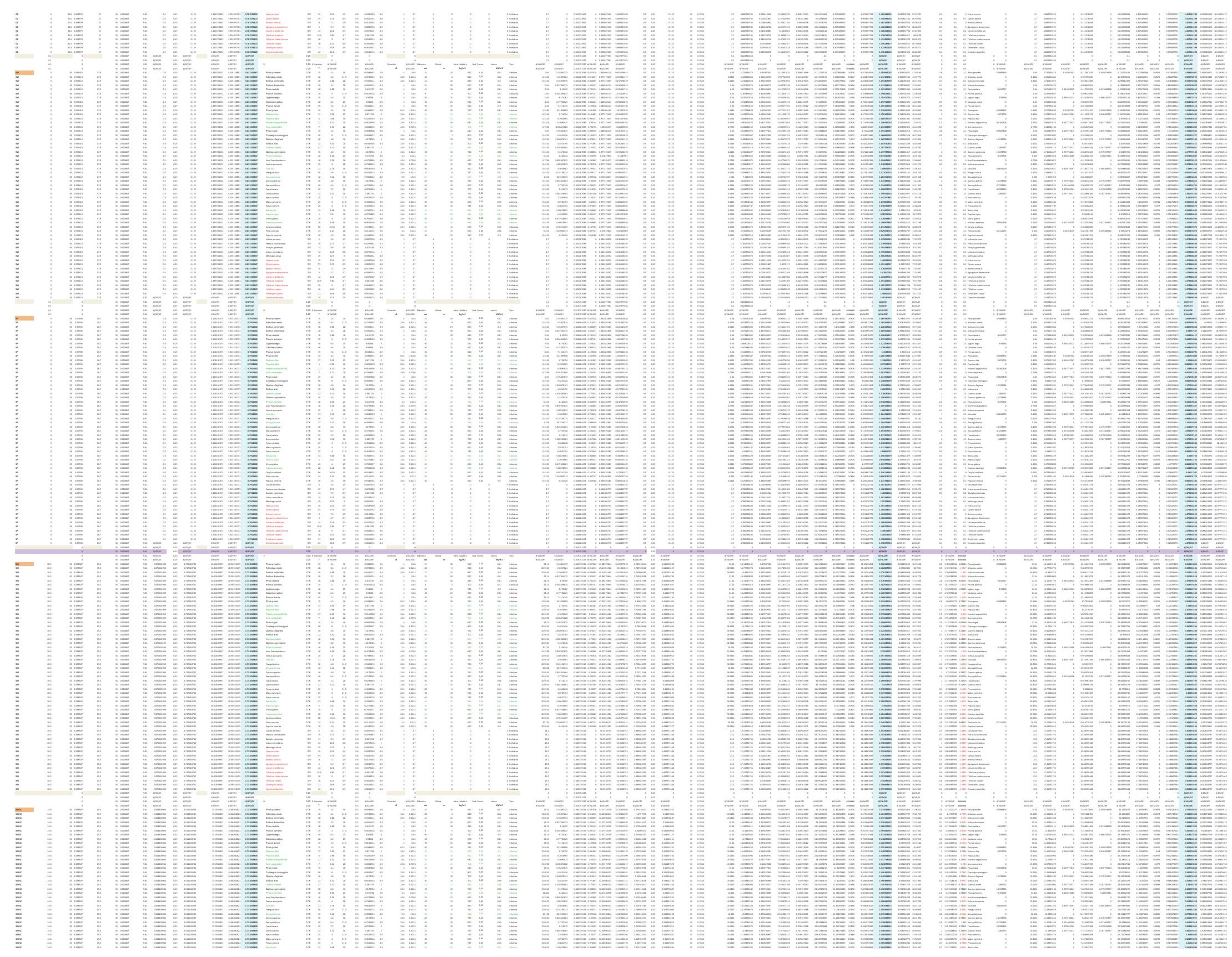



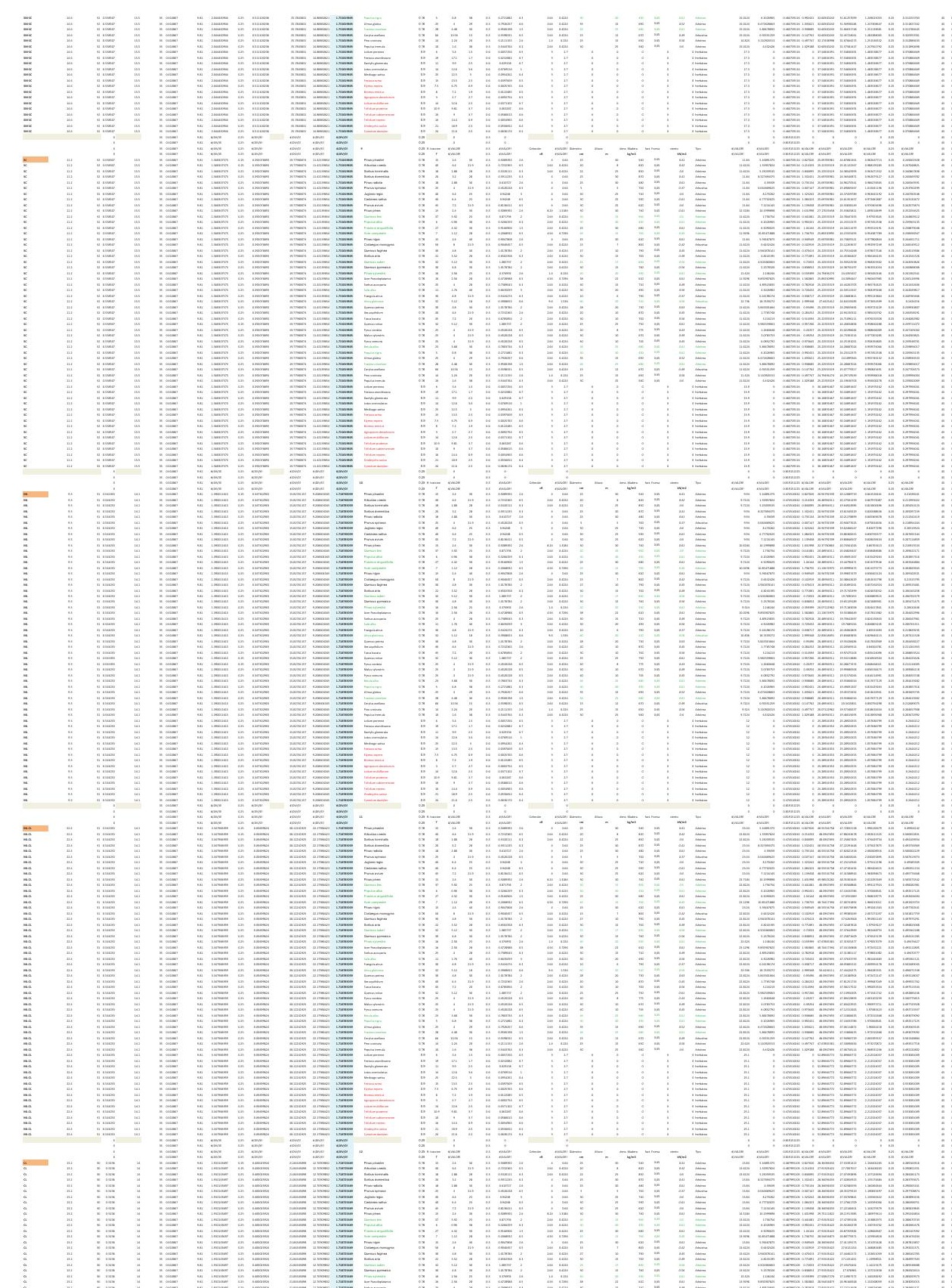

IIIIIIII
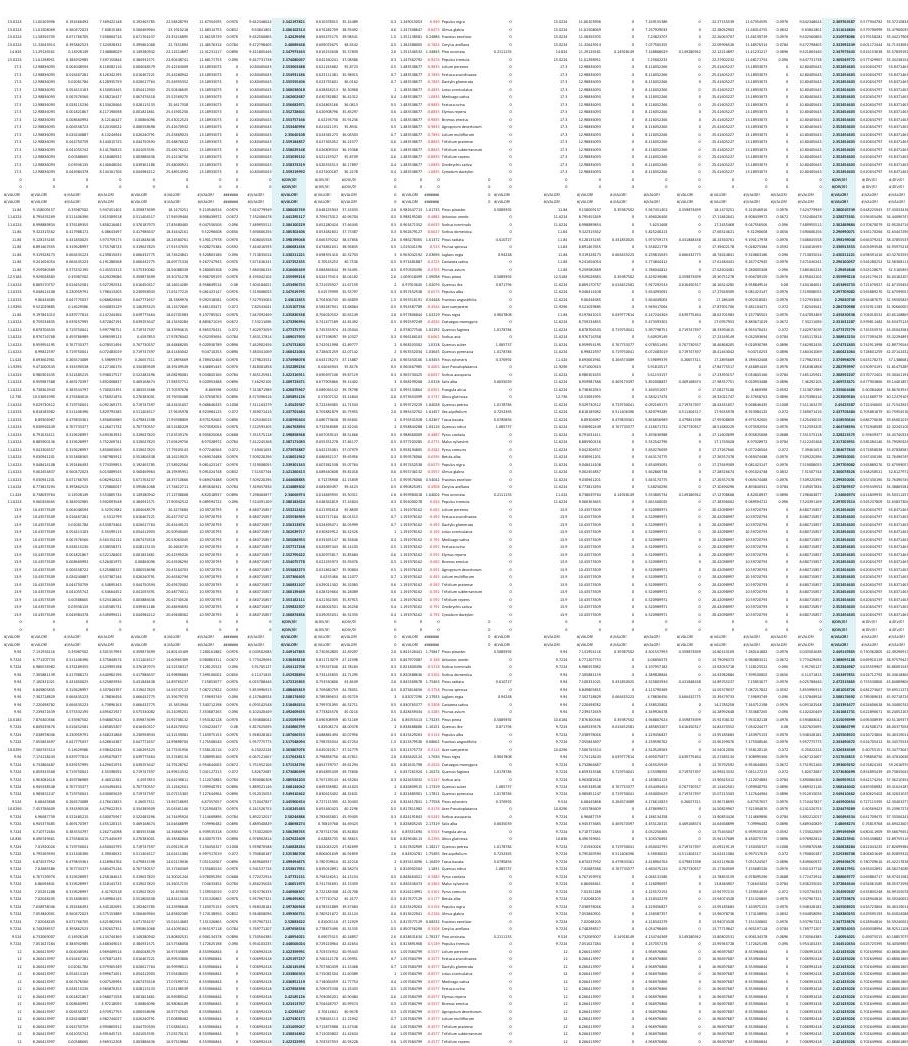

$=\equiv \equiv \equiv \equiv \equiv \equiv \equiv$
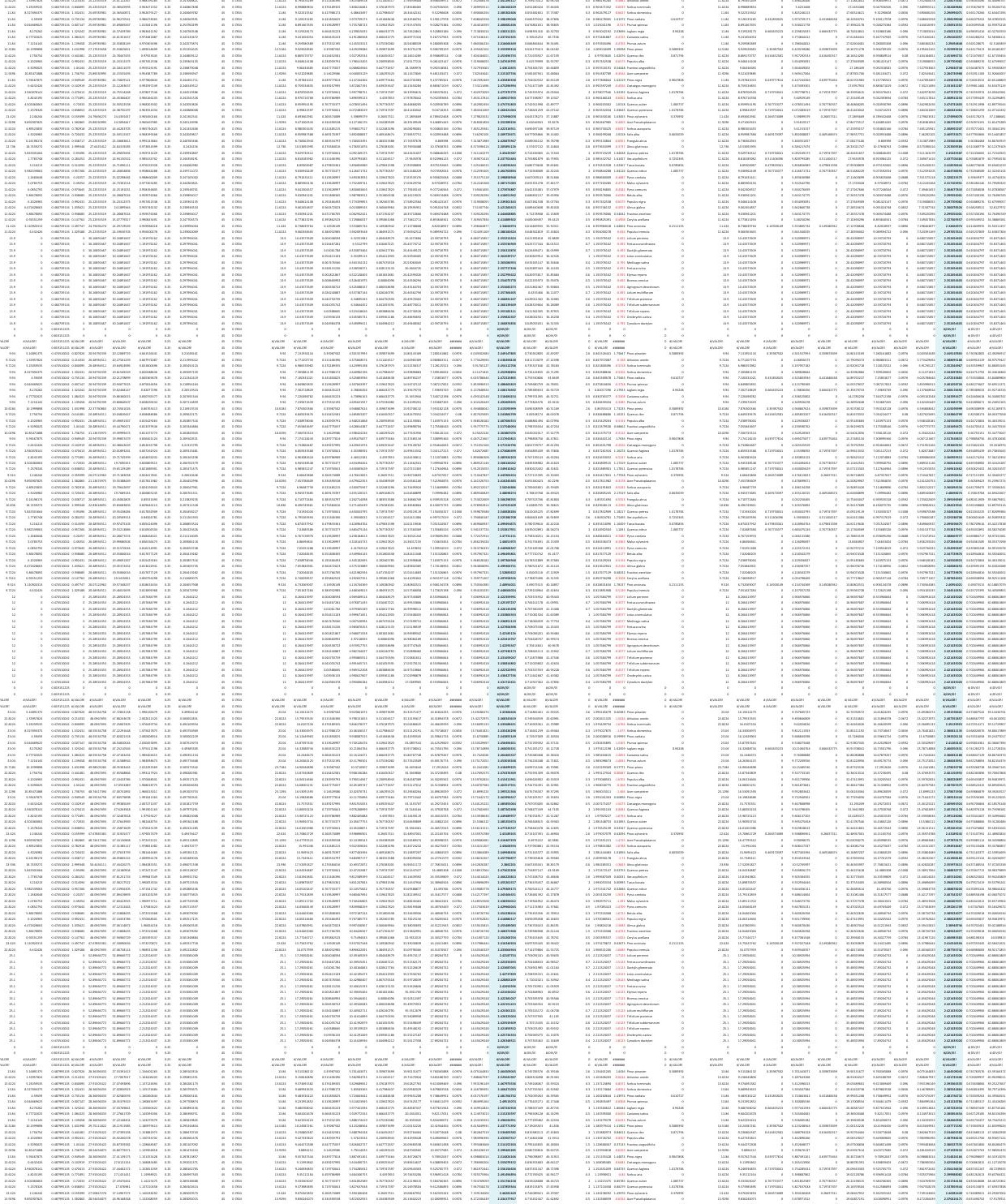


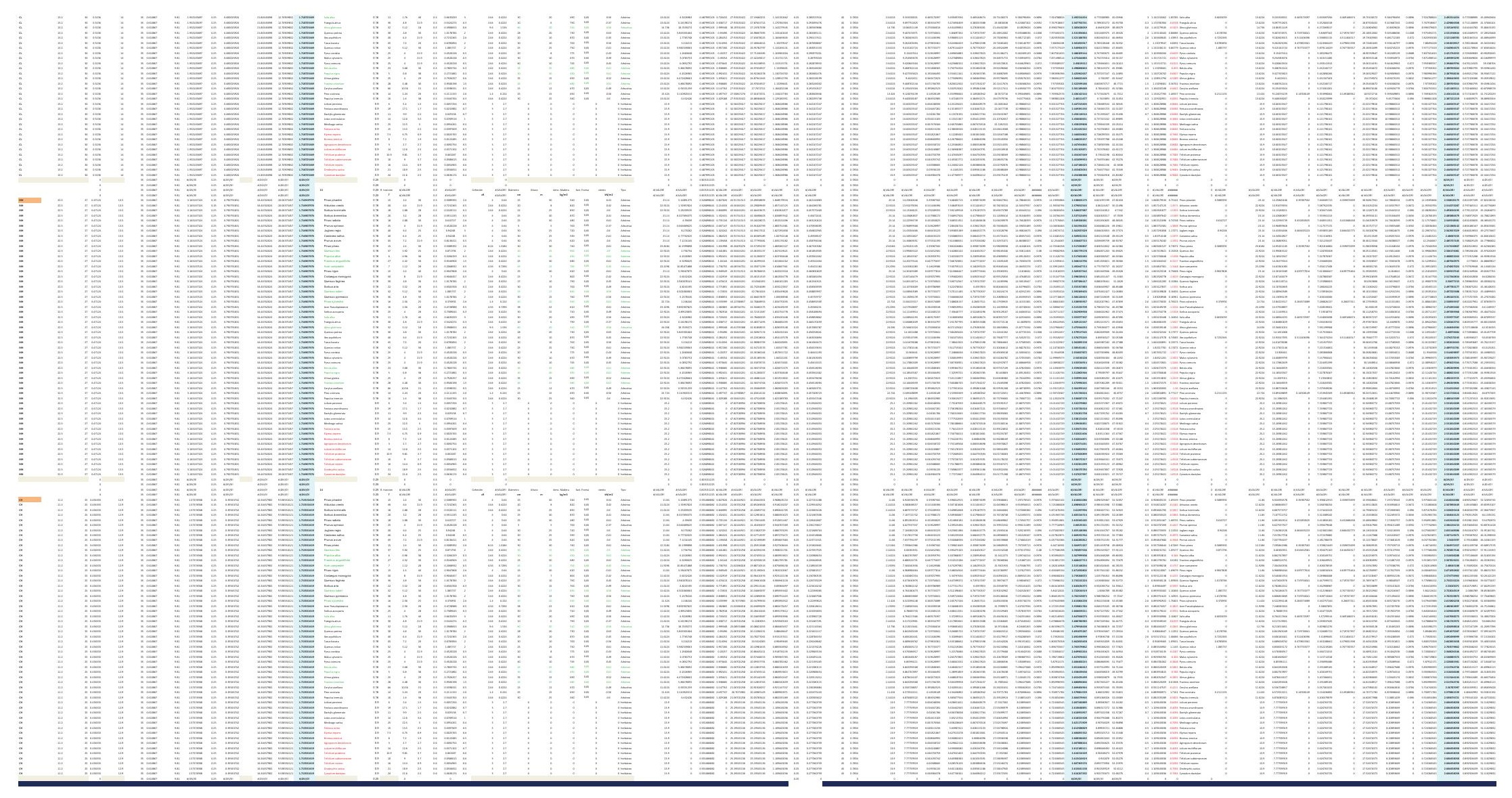



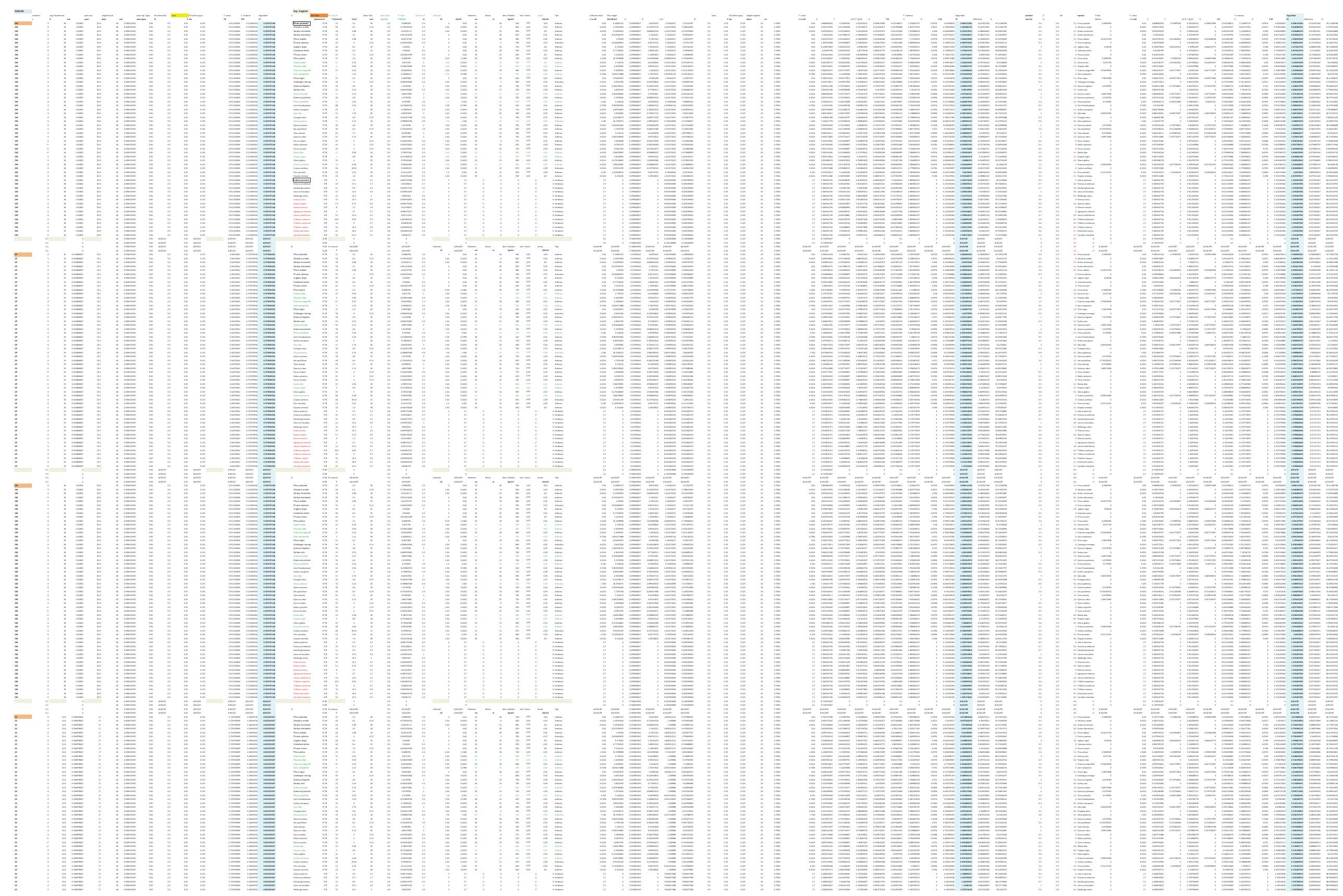


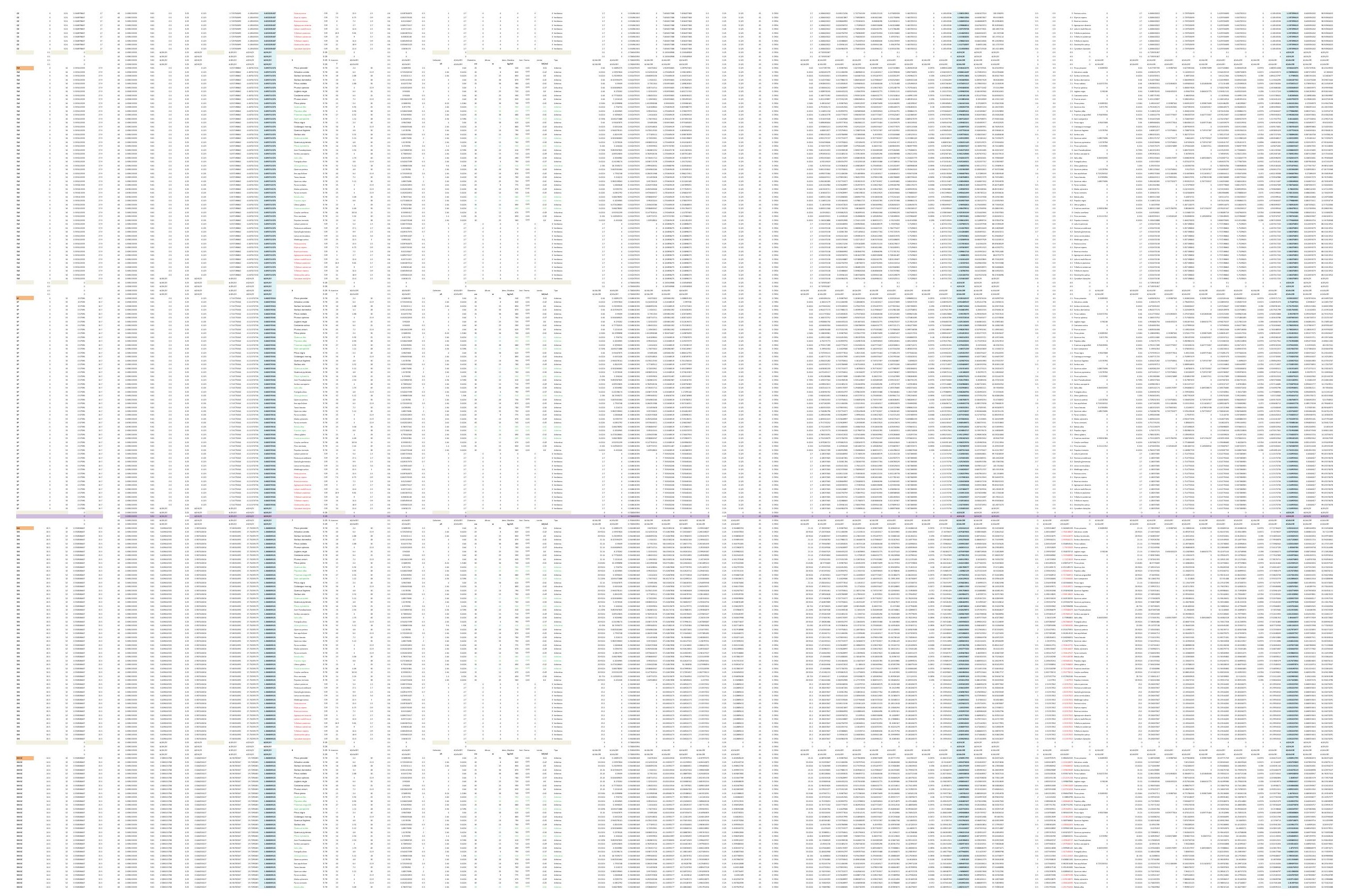



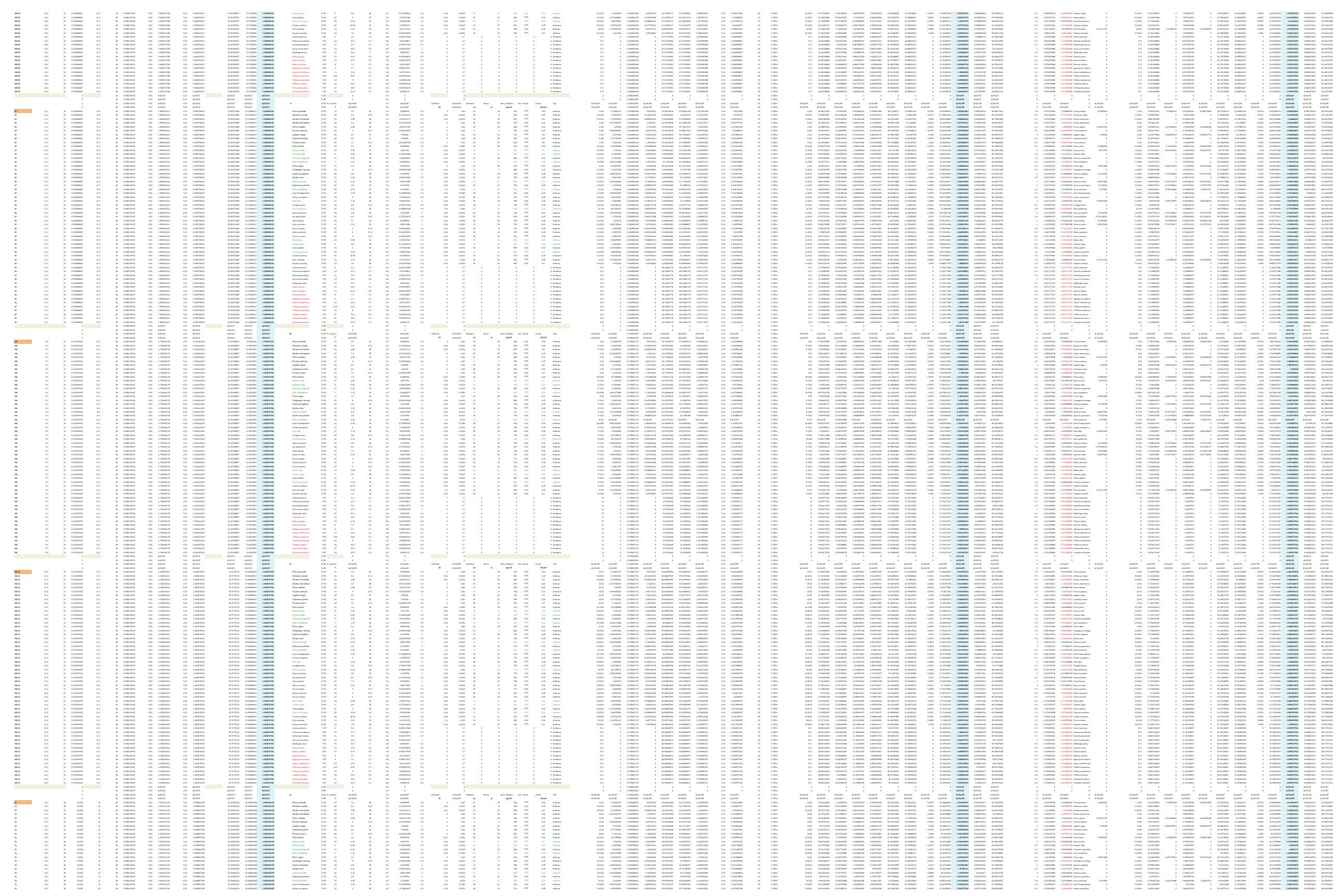


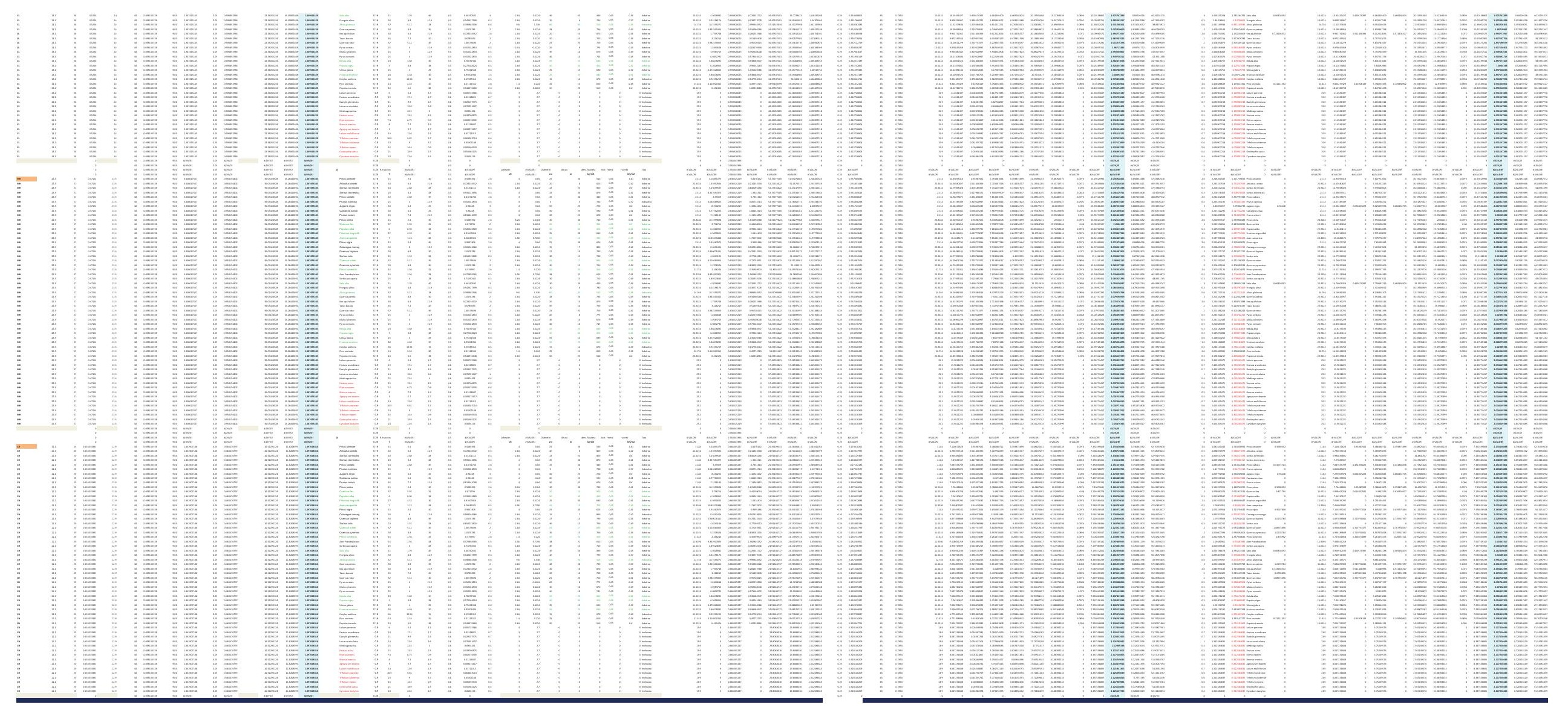



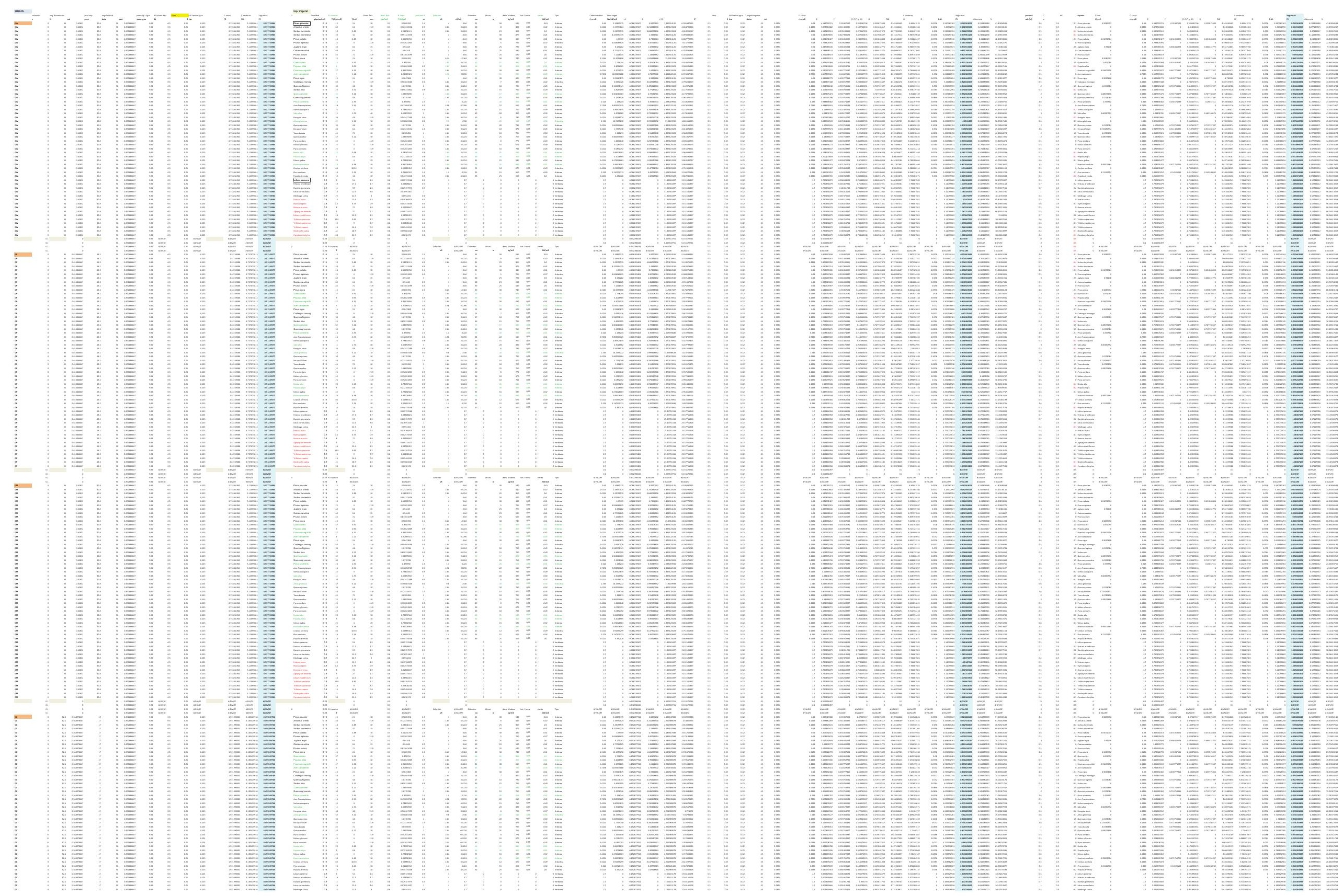


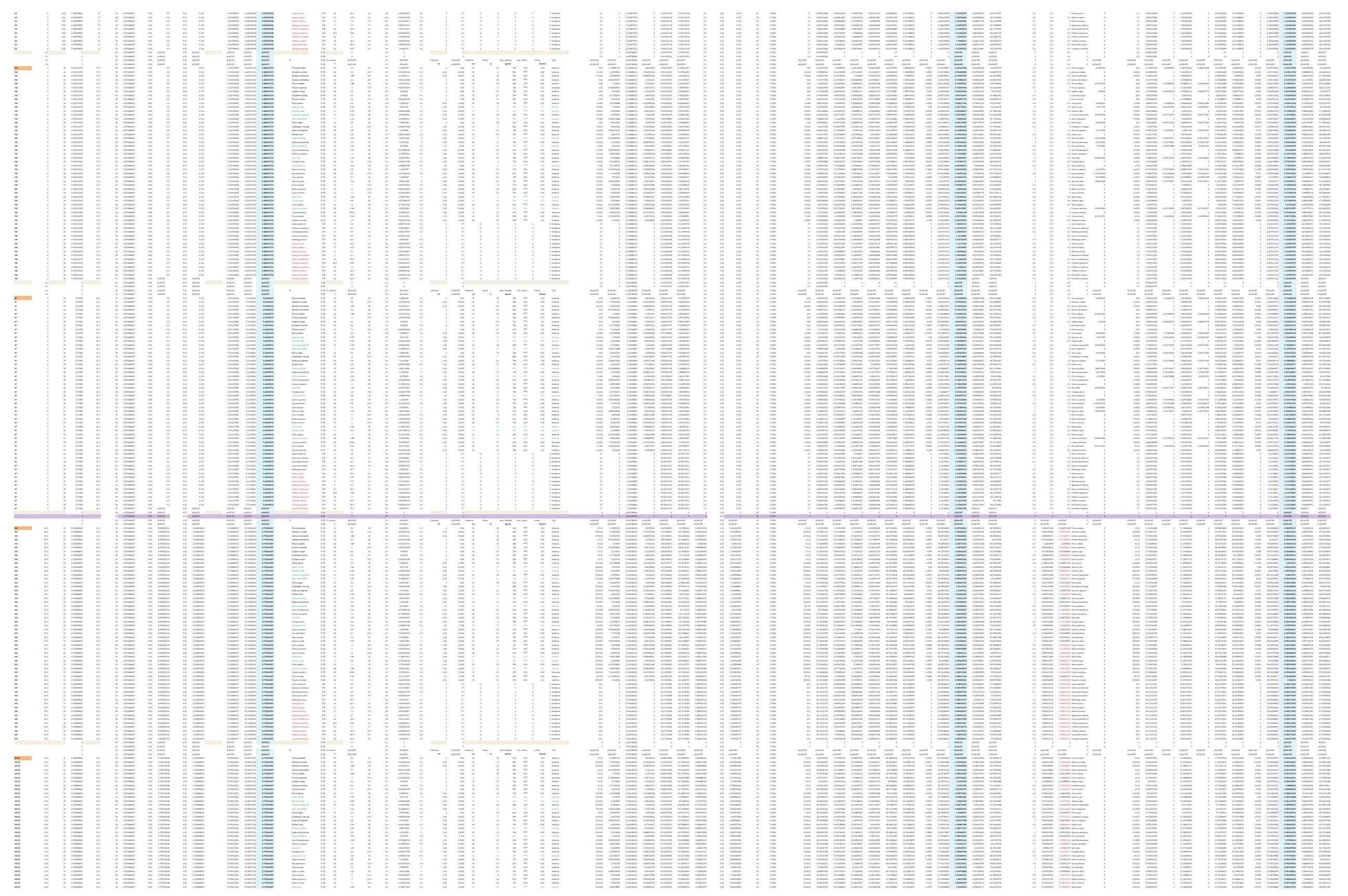



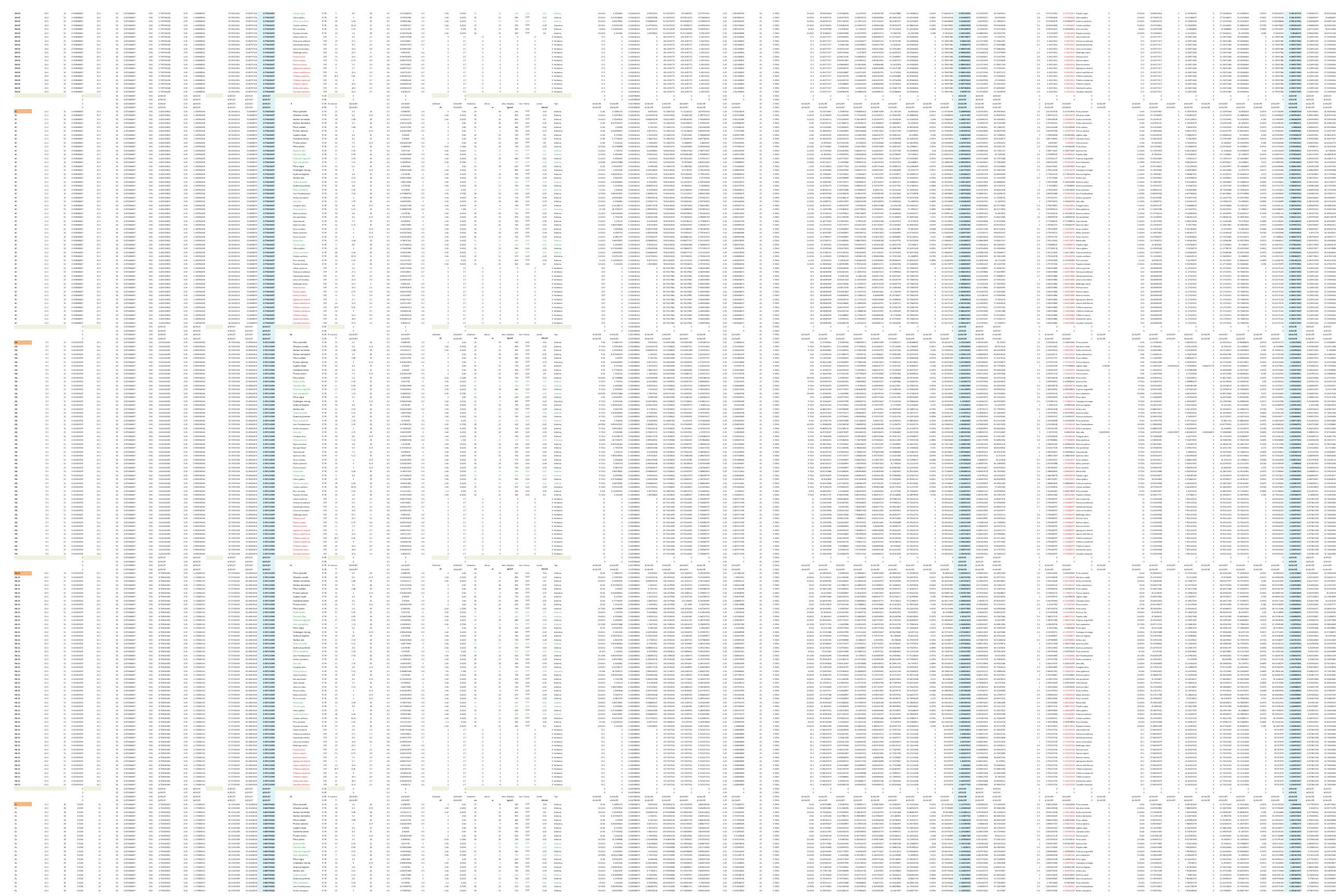


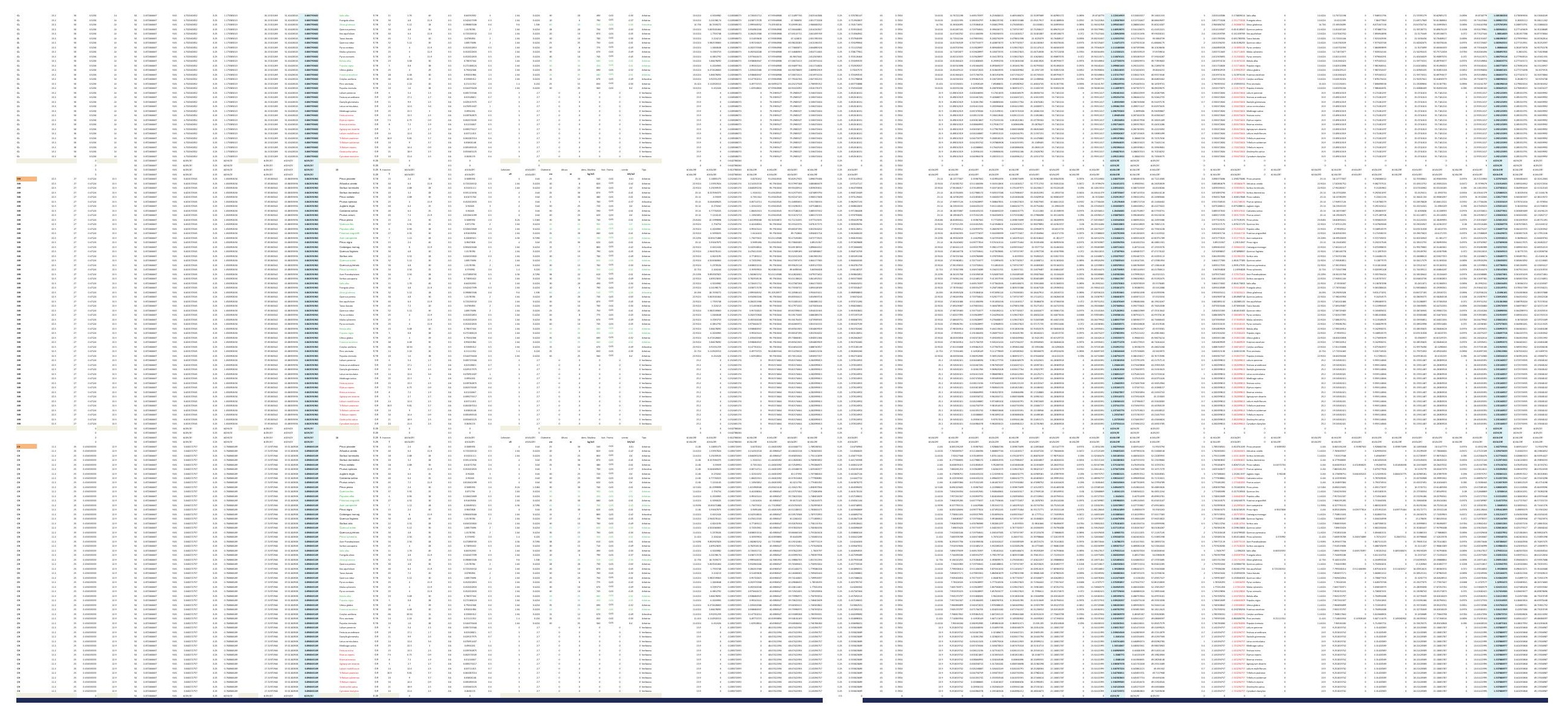



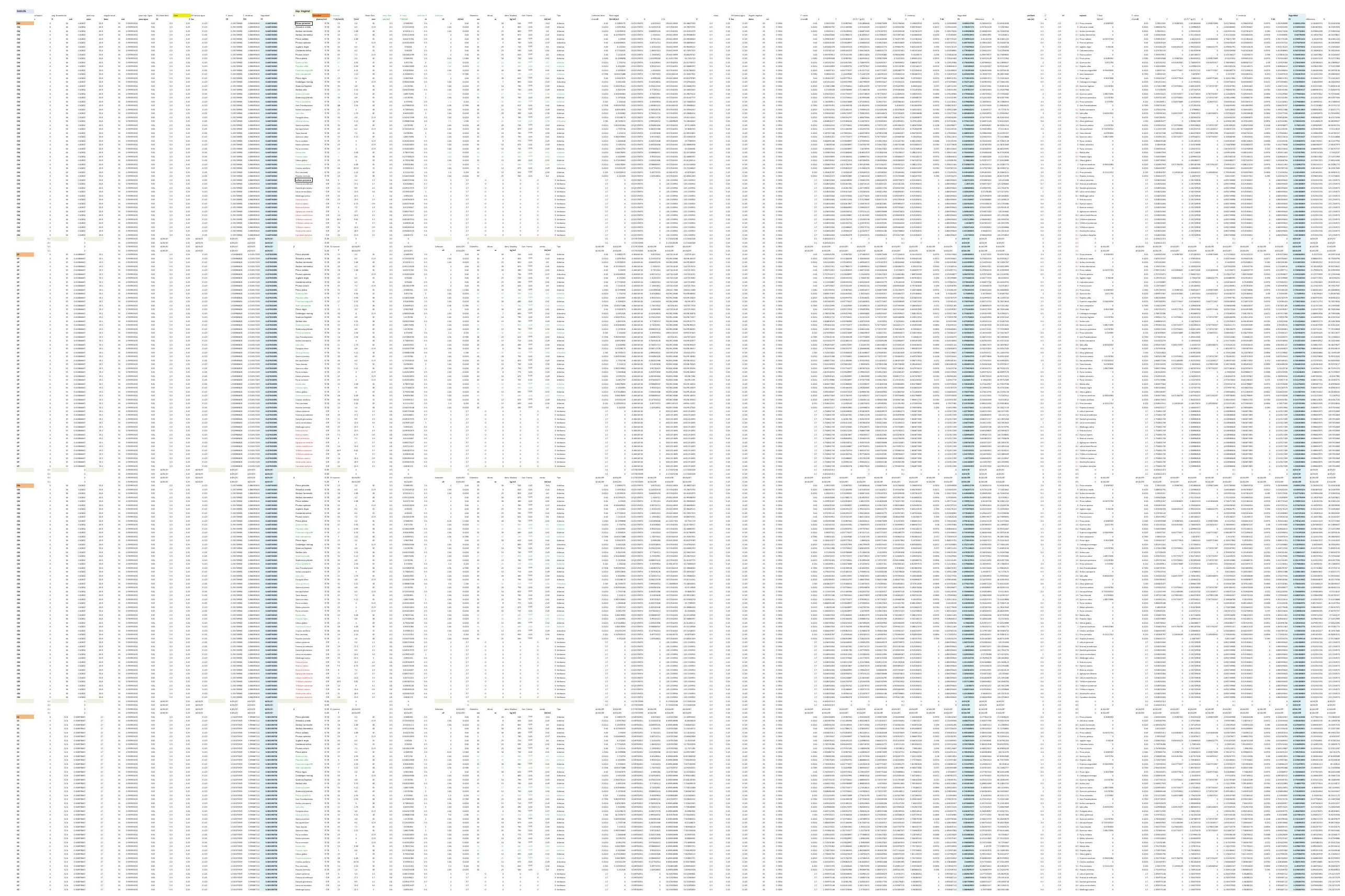


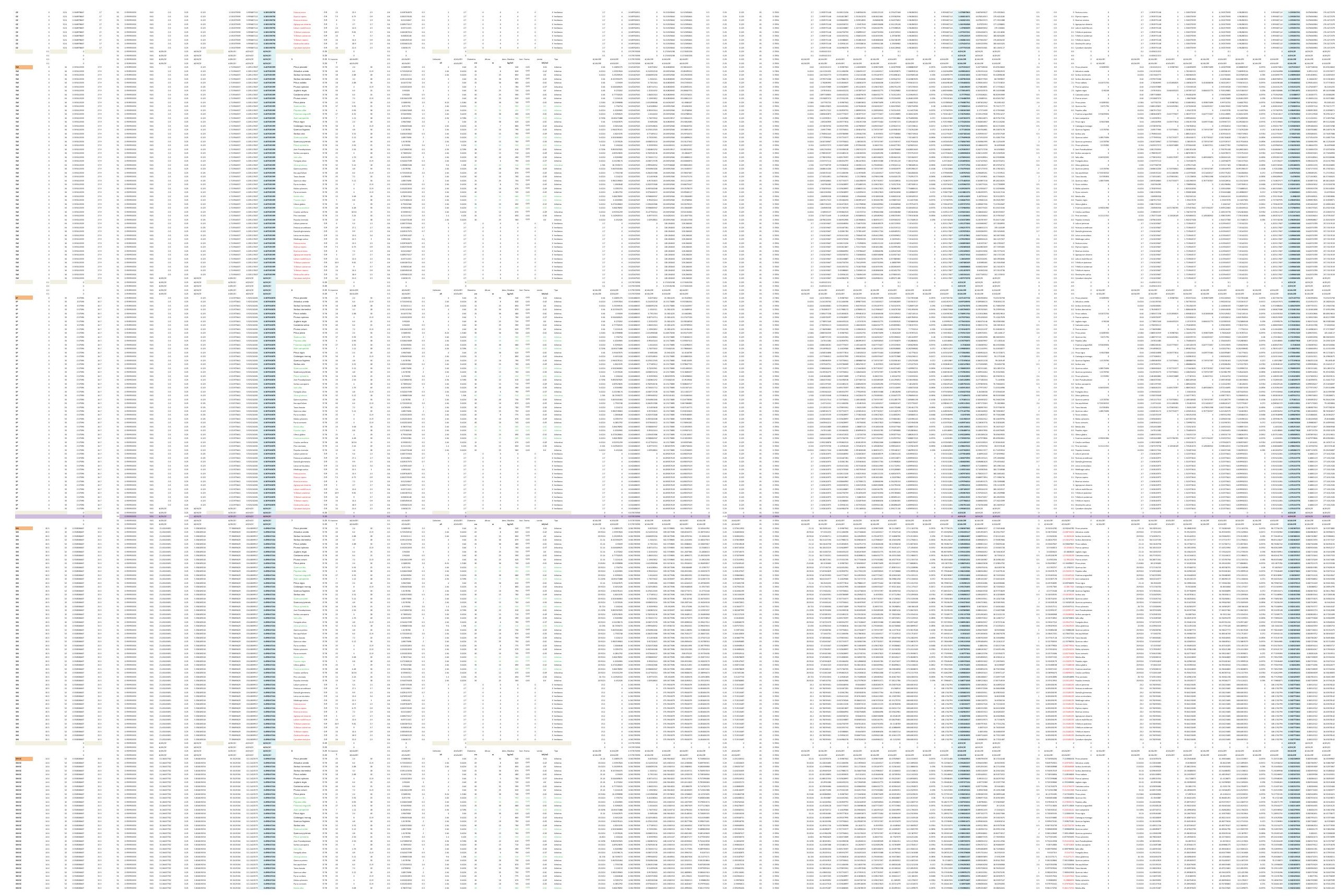



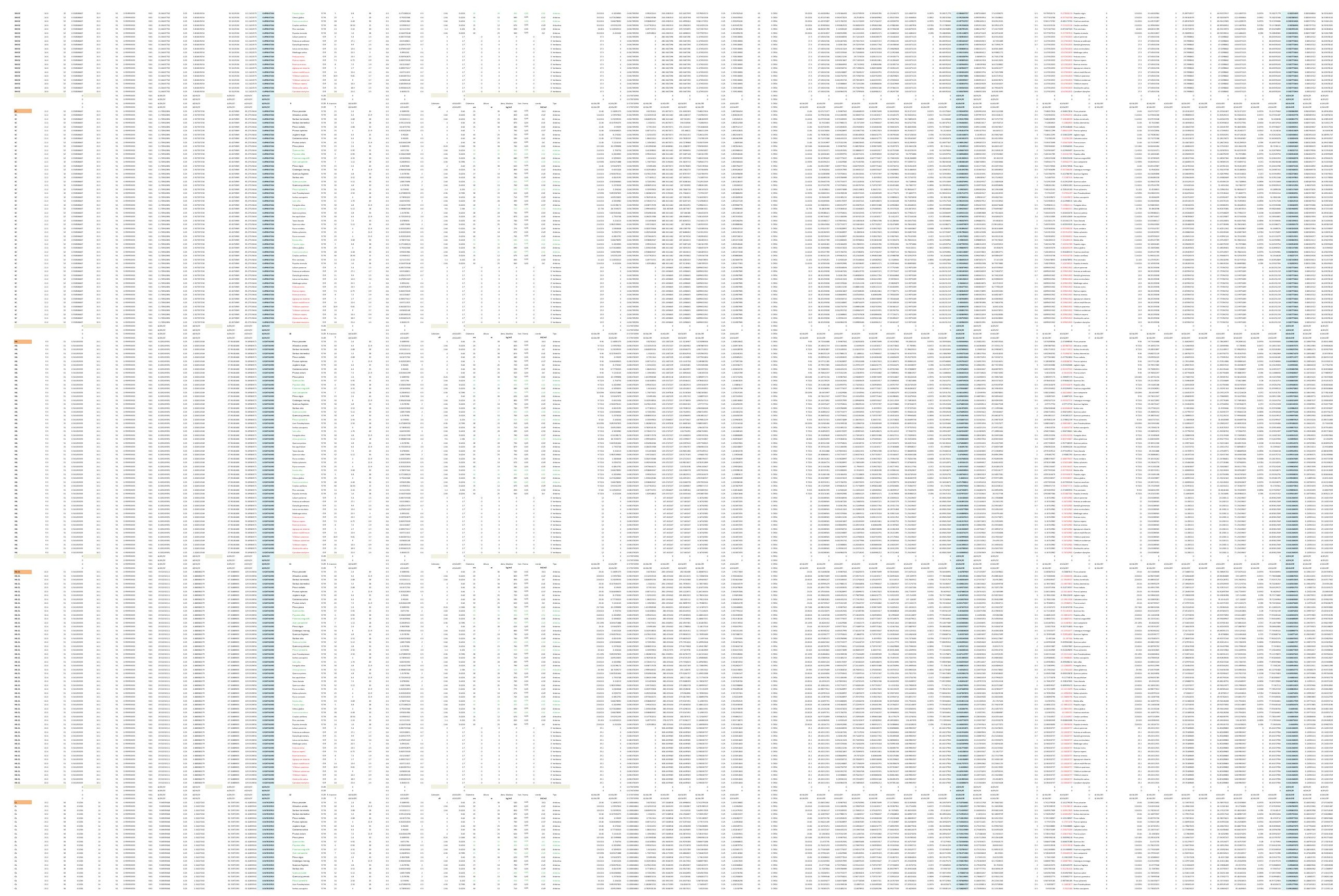


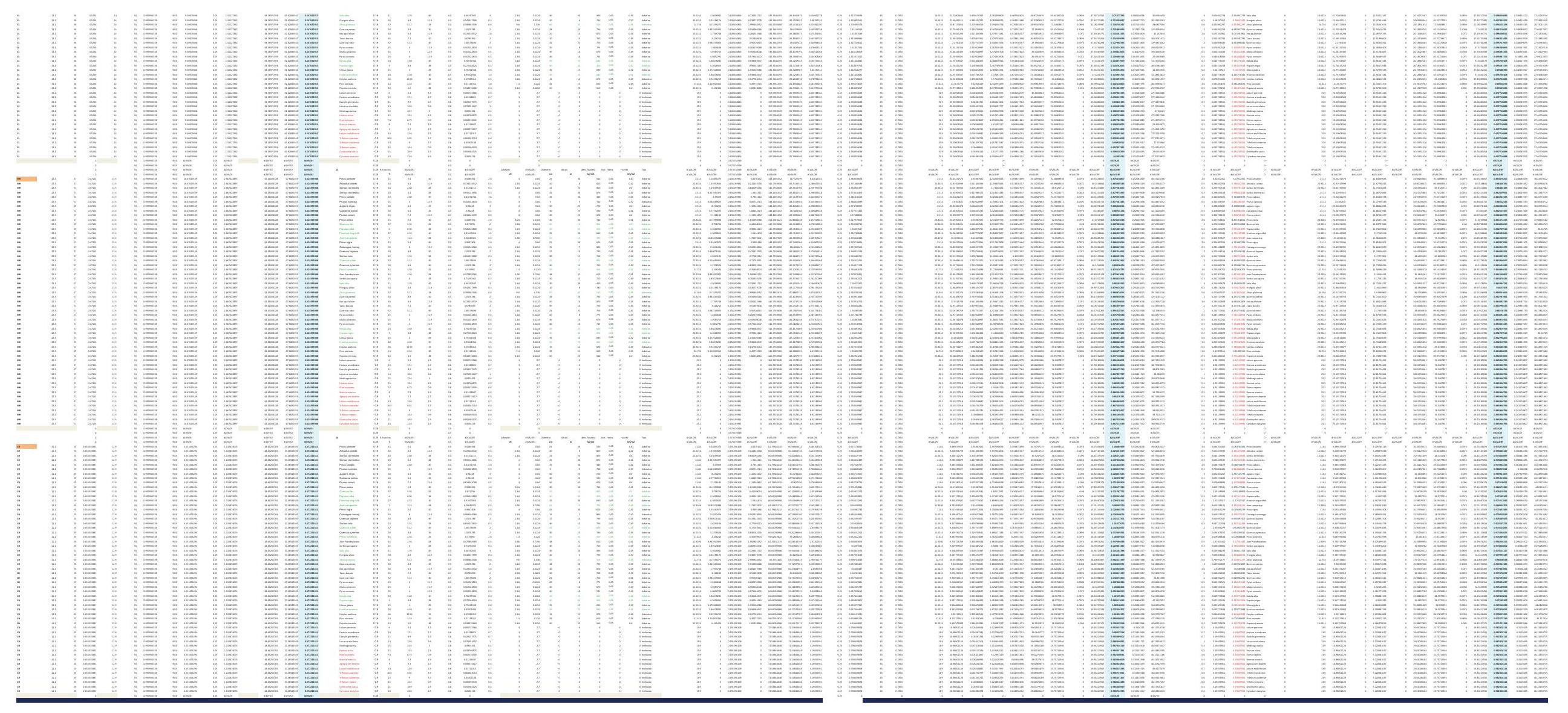



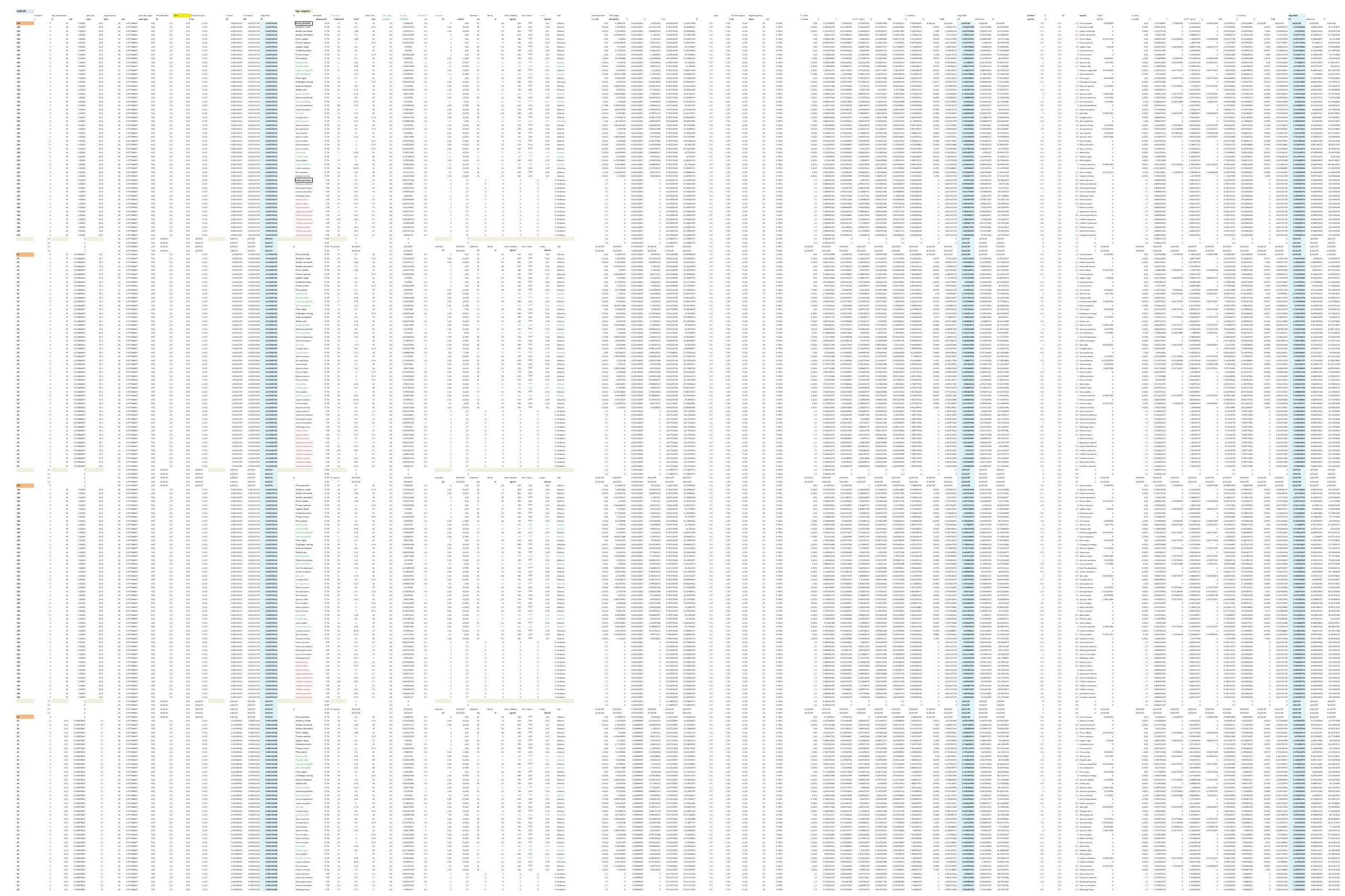


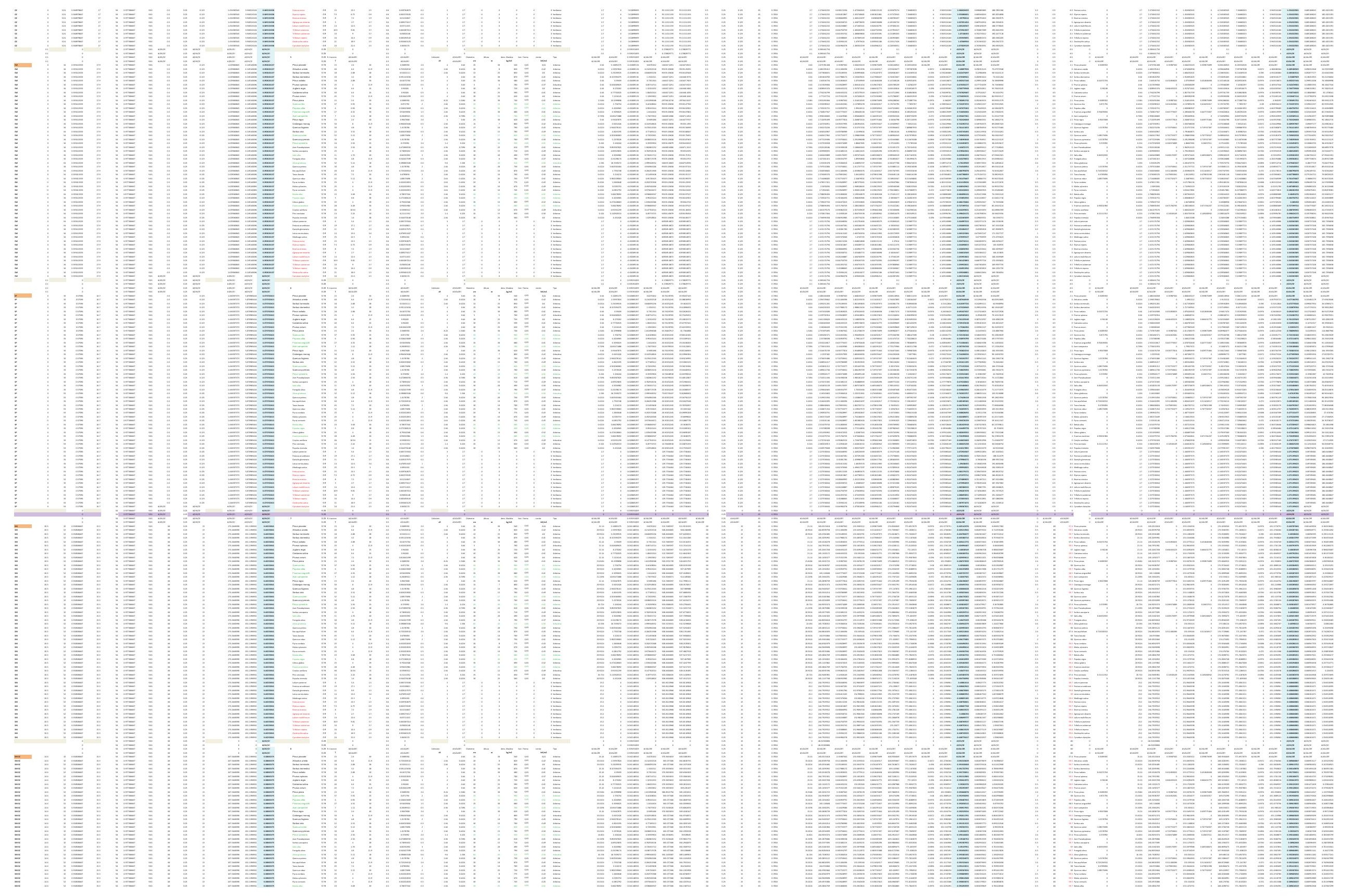



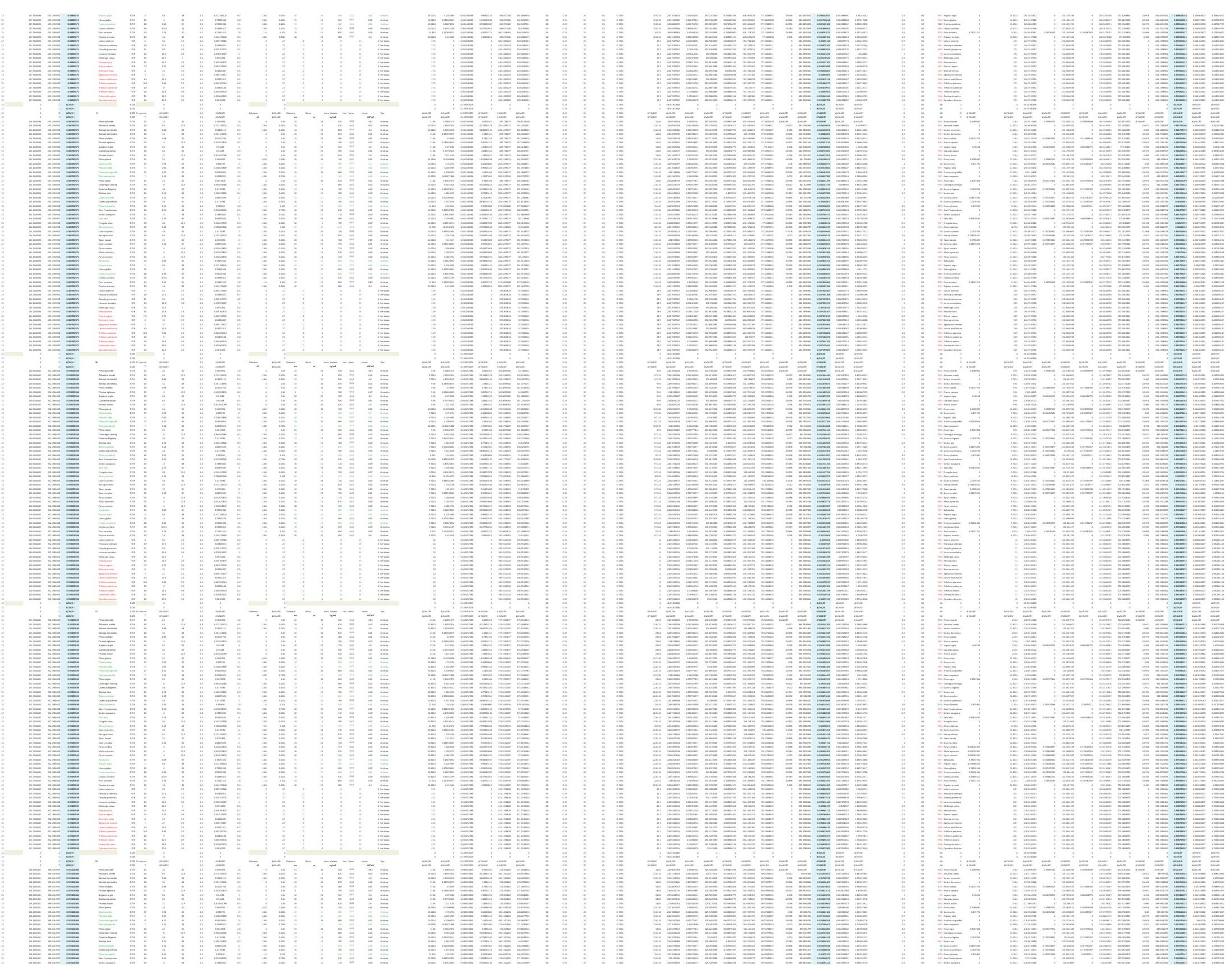


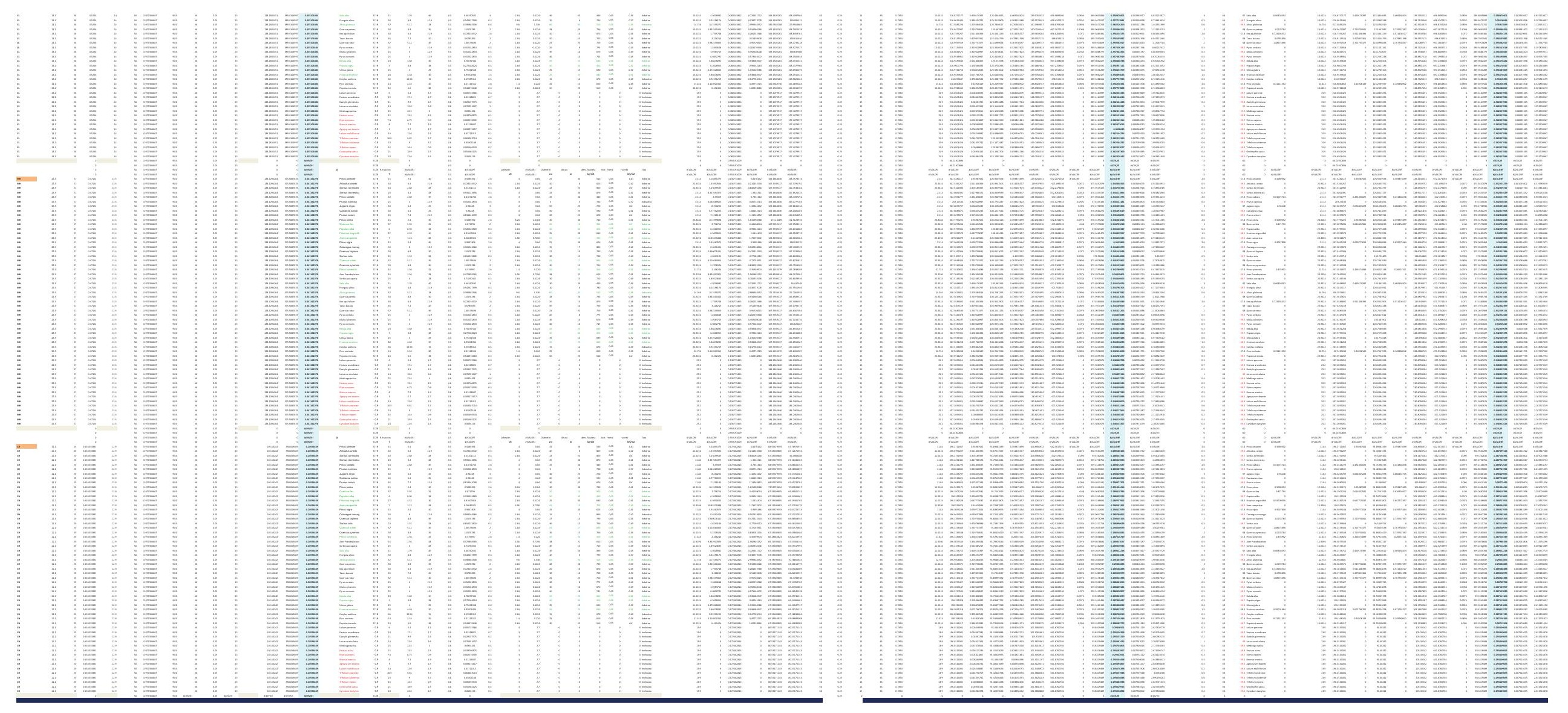



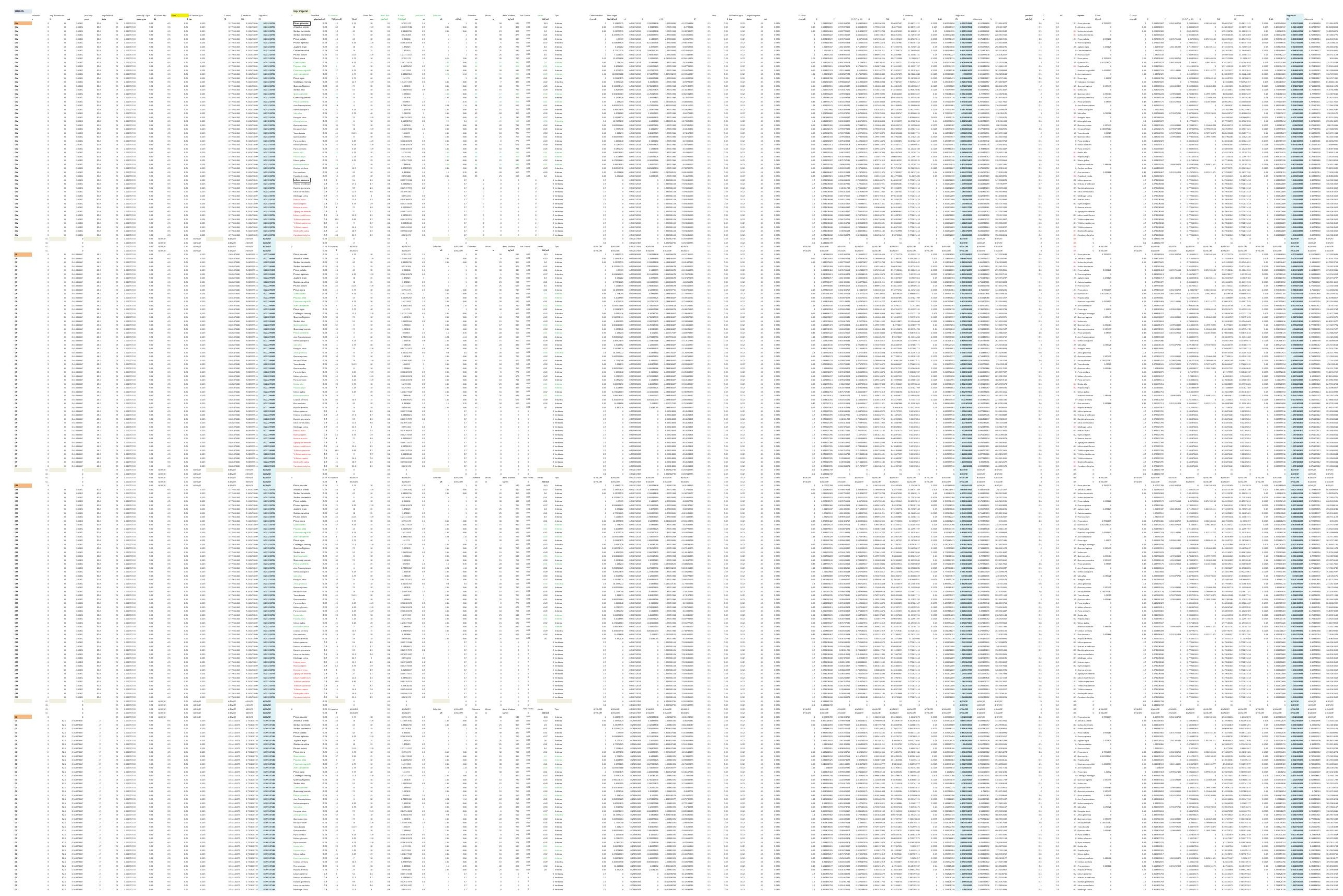


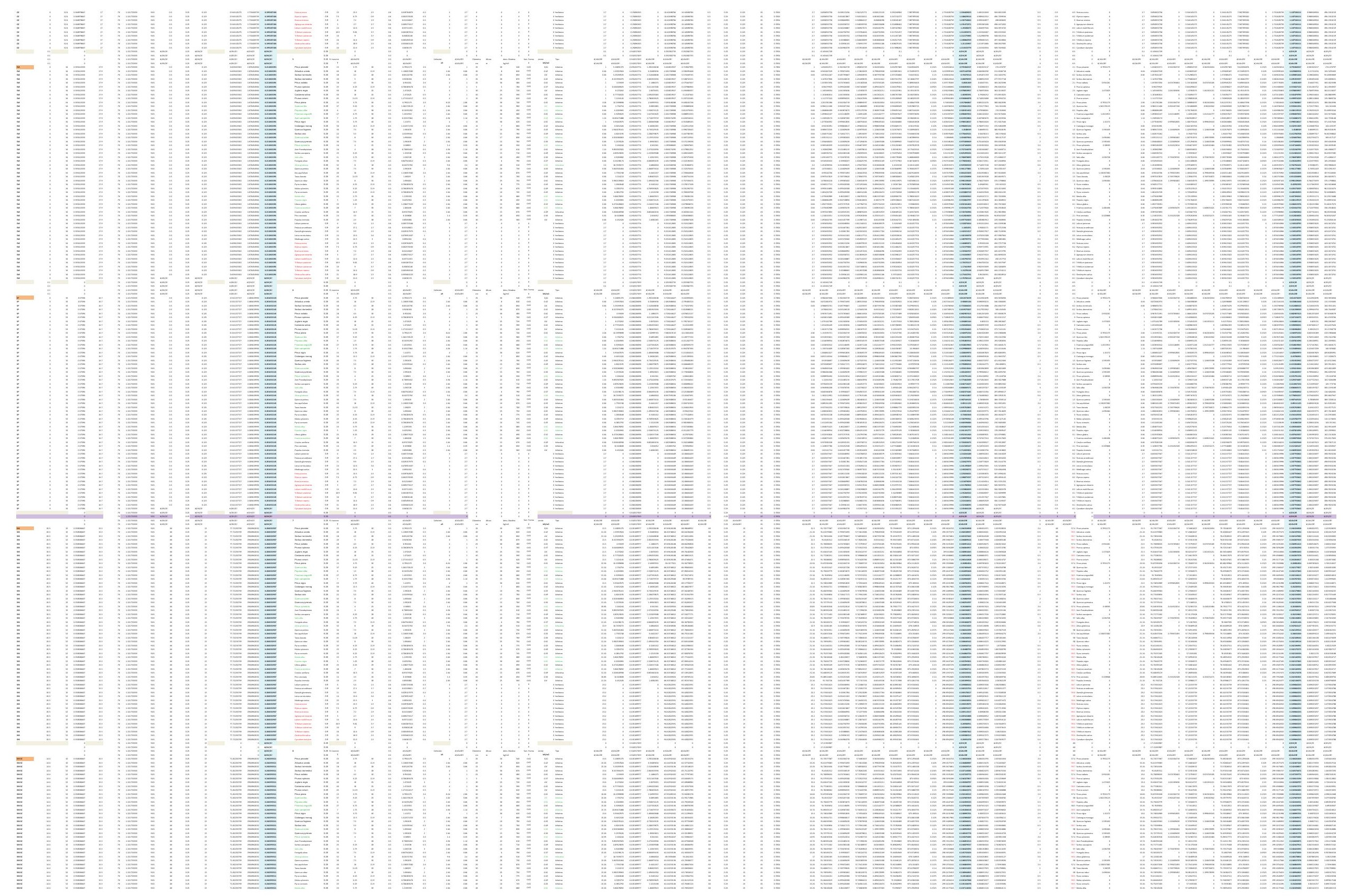



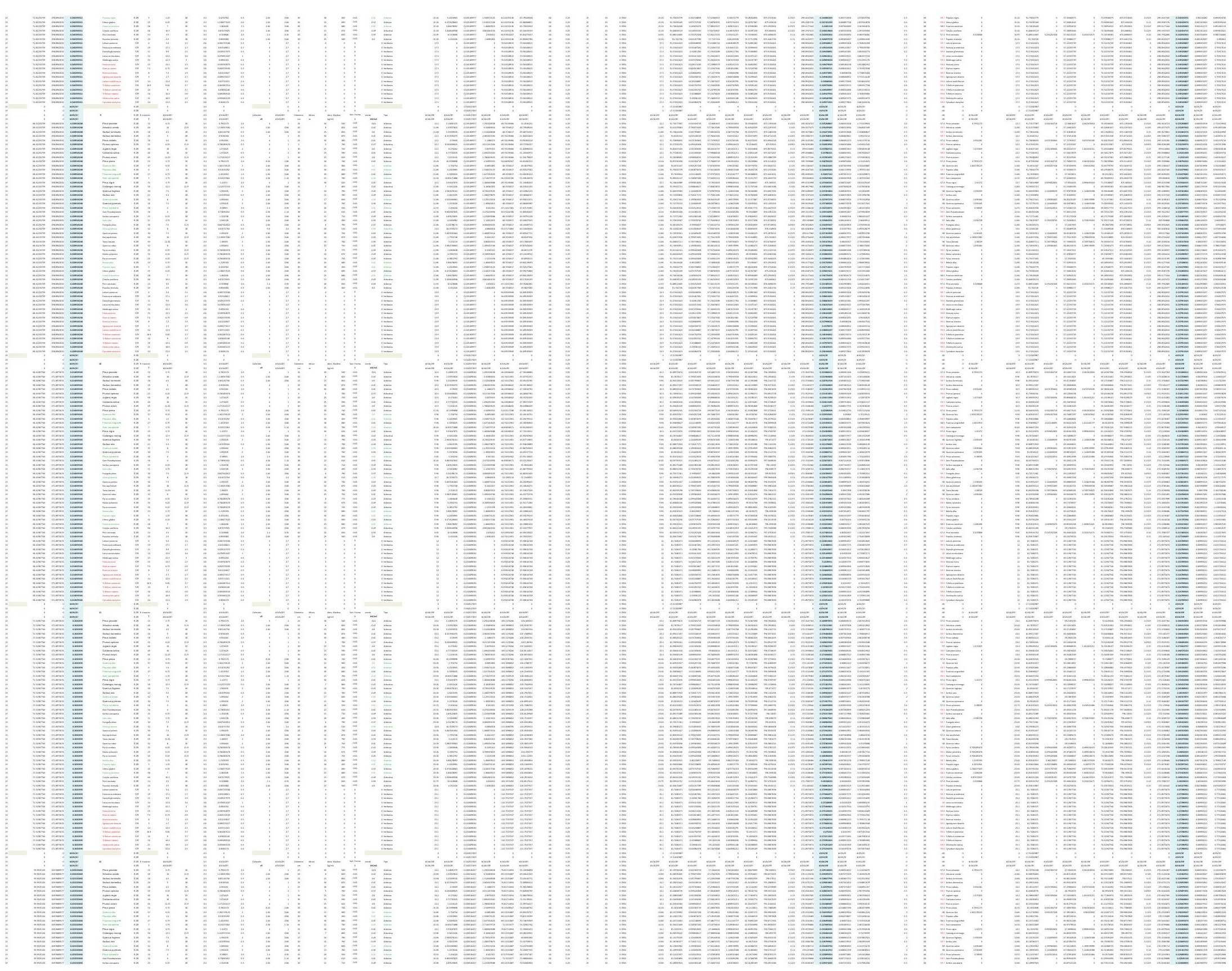


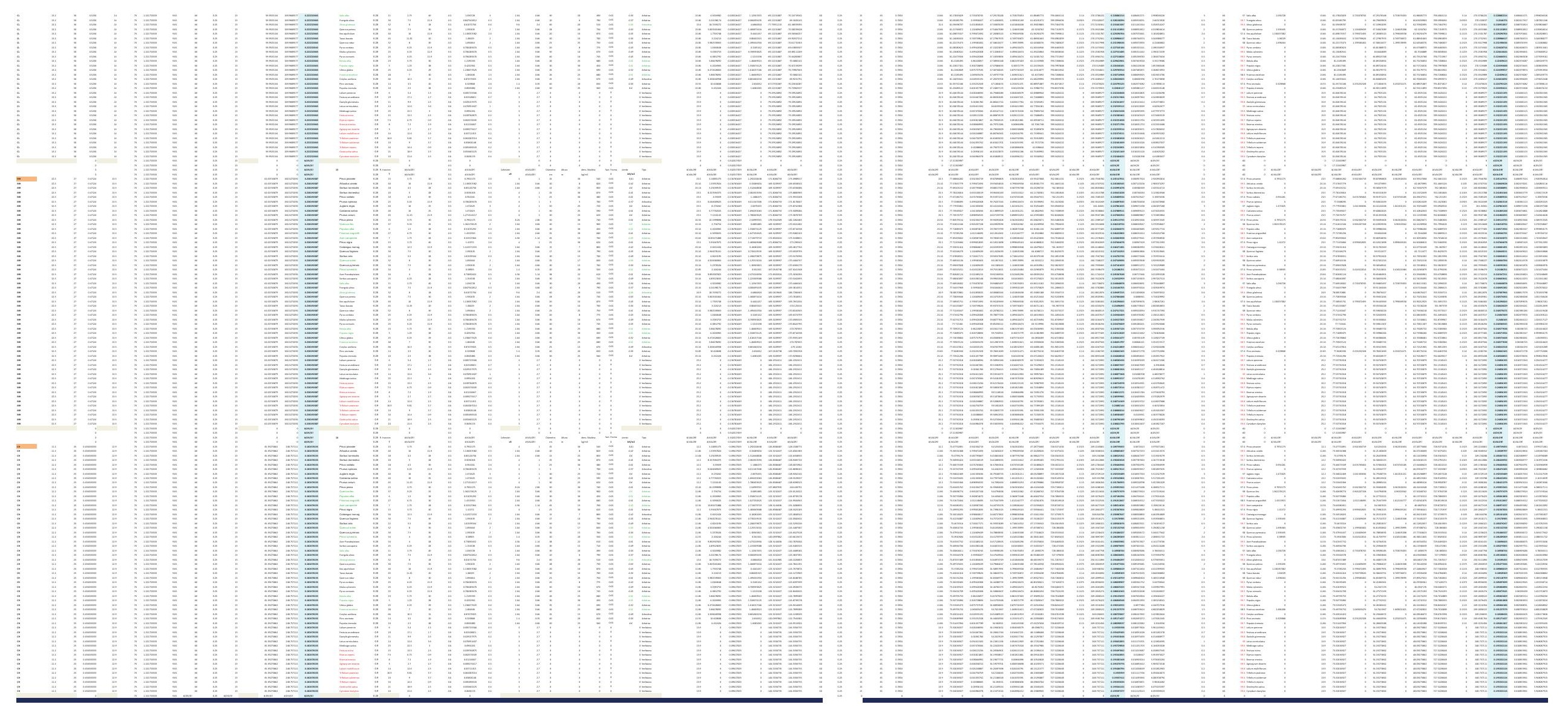



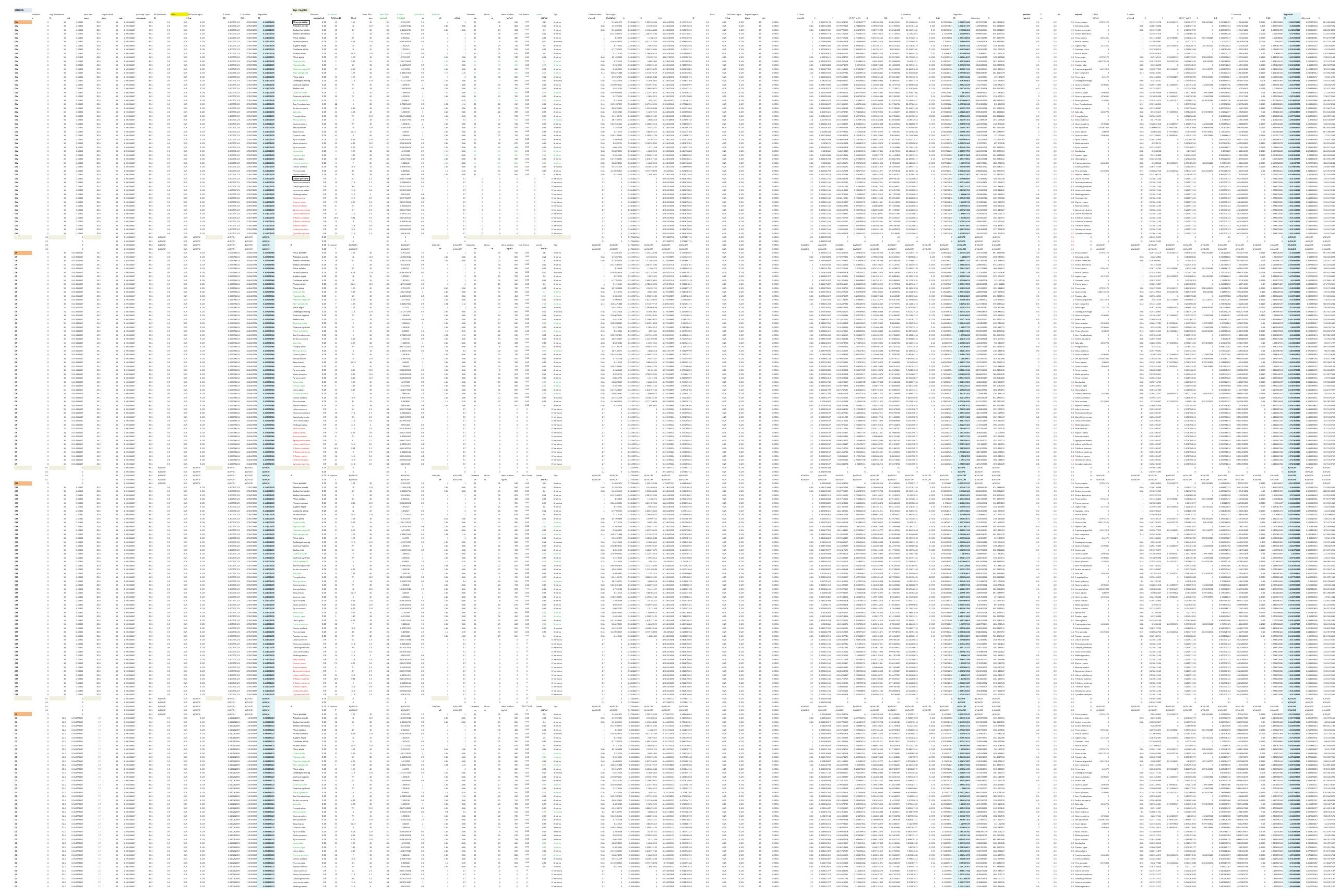


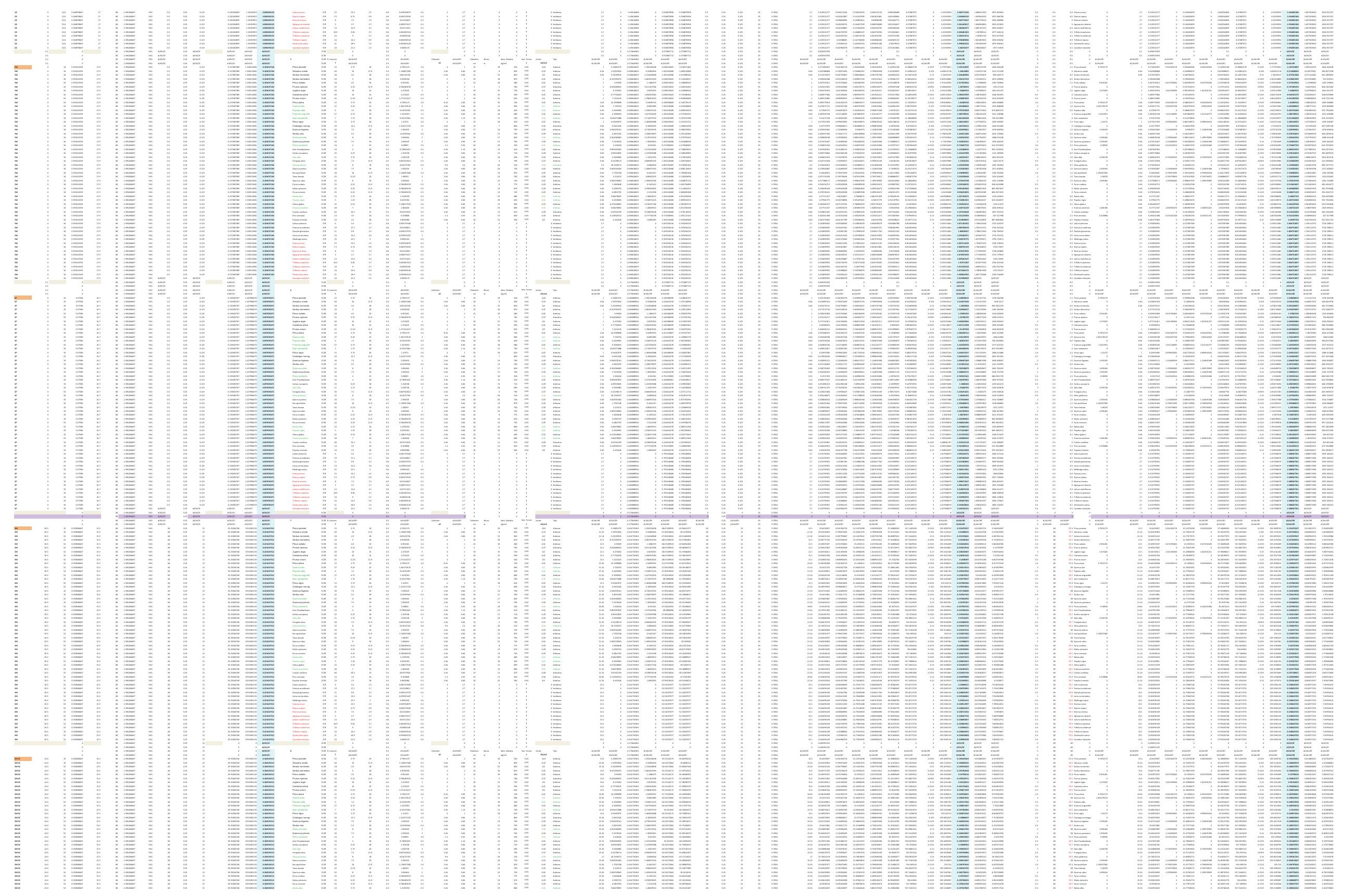



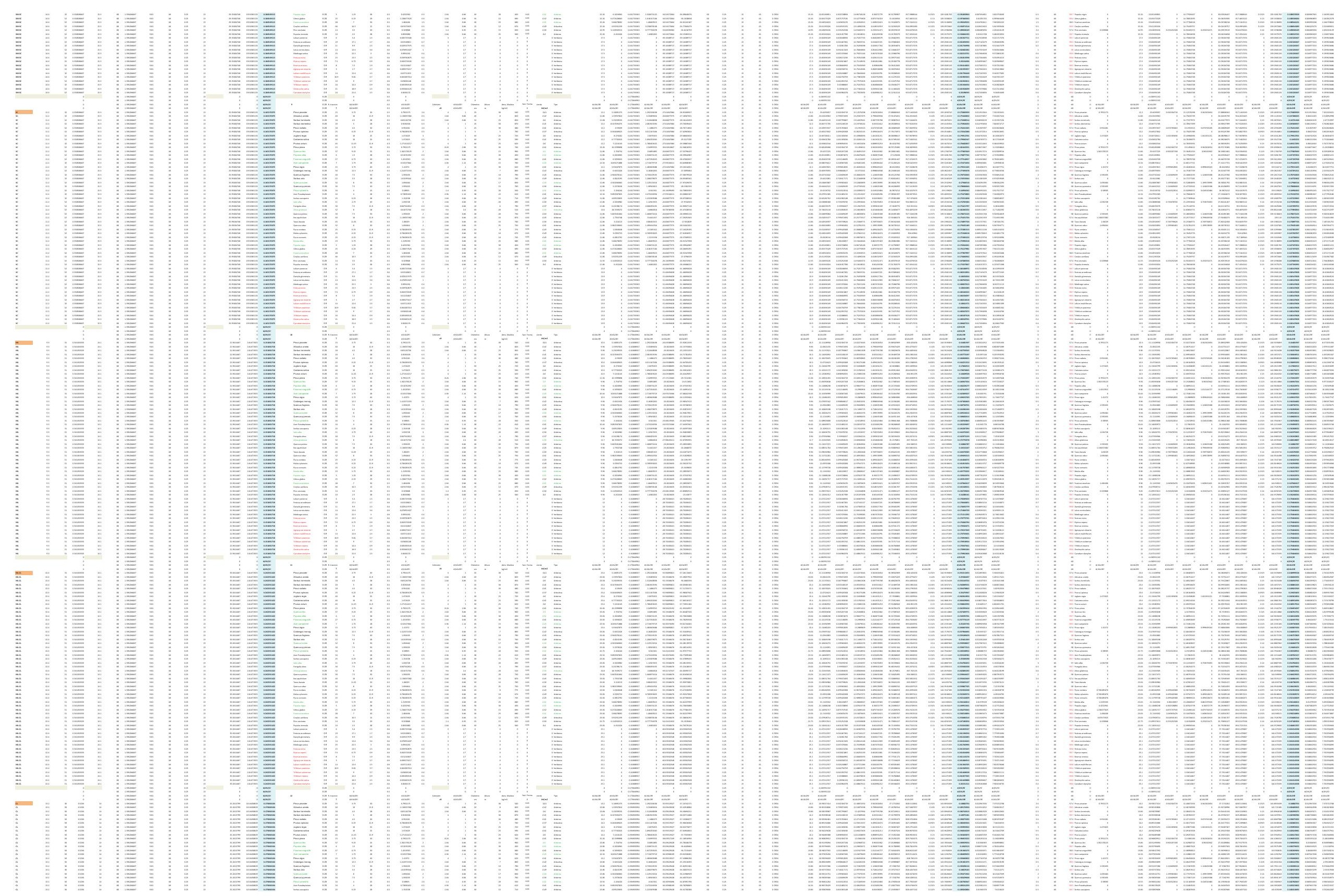


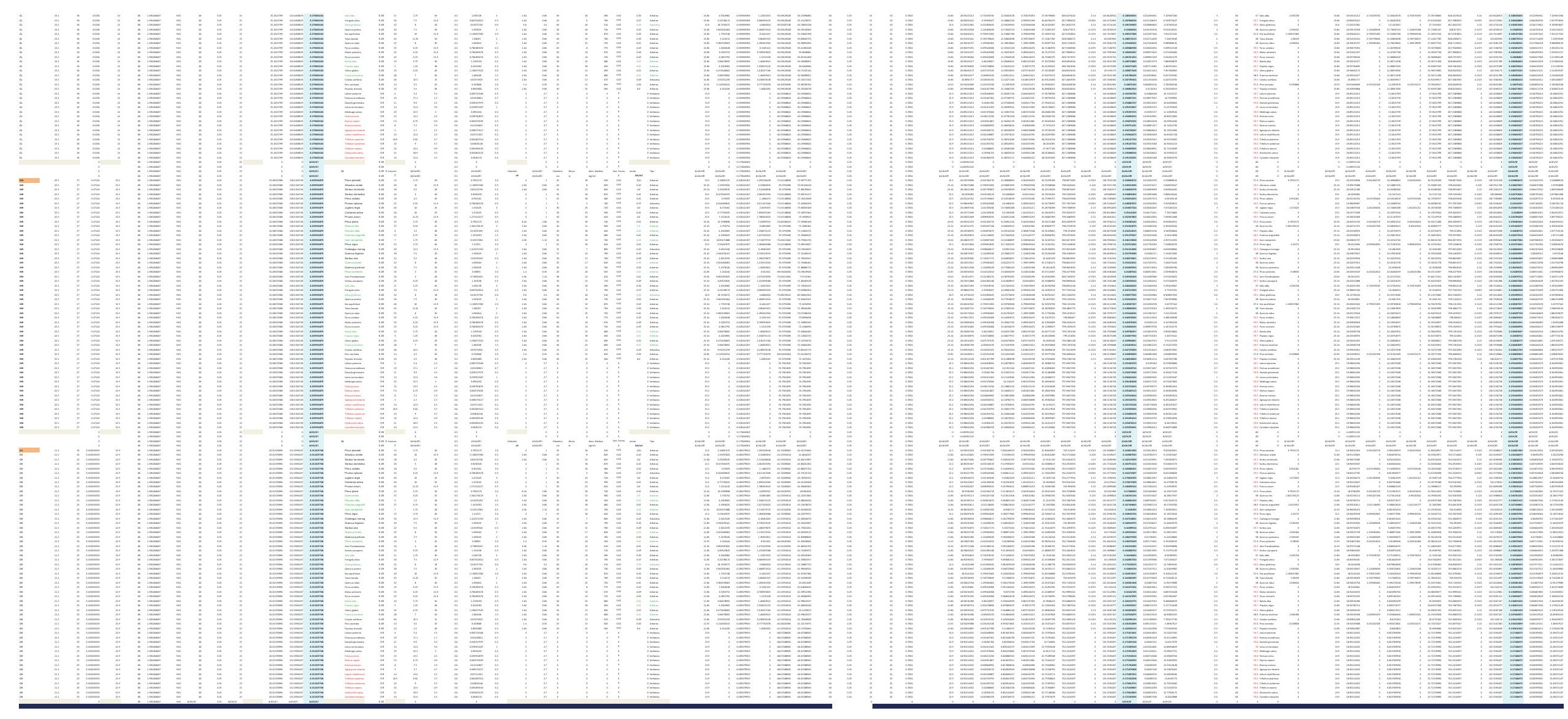


DESARROLLO DE UNA APLICACIÓN IMFORMÁTICA PARA EL CÁLCULO DE SOSTENIMIENTO DE TALUDES MEDIANTE VEGETACIÓN

A02. DENSIDAD DE PLANTACIÓN: 1.600 plantas/ha.

\section{A02-4.POSICIÓN N.F. 4}

INCLINACIÓN DE TALUD 6-100

INCLINACIÓN DE TALUD 10-200

INCLINACIÓN DE TALUD 20-30

INCLINACIÓN DE TALUD 30-40

INCLINACIÓN DE TALUD $35^{\circ}$

INCLINACIÓN DE TALUD 40-50

INCLINACIÓN DE TALUD 50-550

INCLINACIÓN DE TALUD 55-60

INCLINACIÓN DE TALUD 60-700

INCLINACIÓN DE TALUD 70-80 

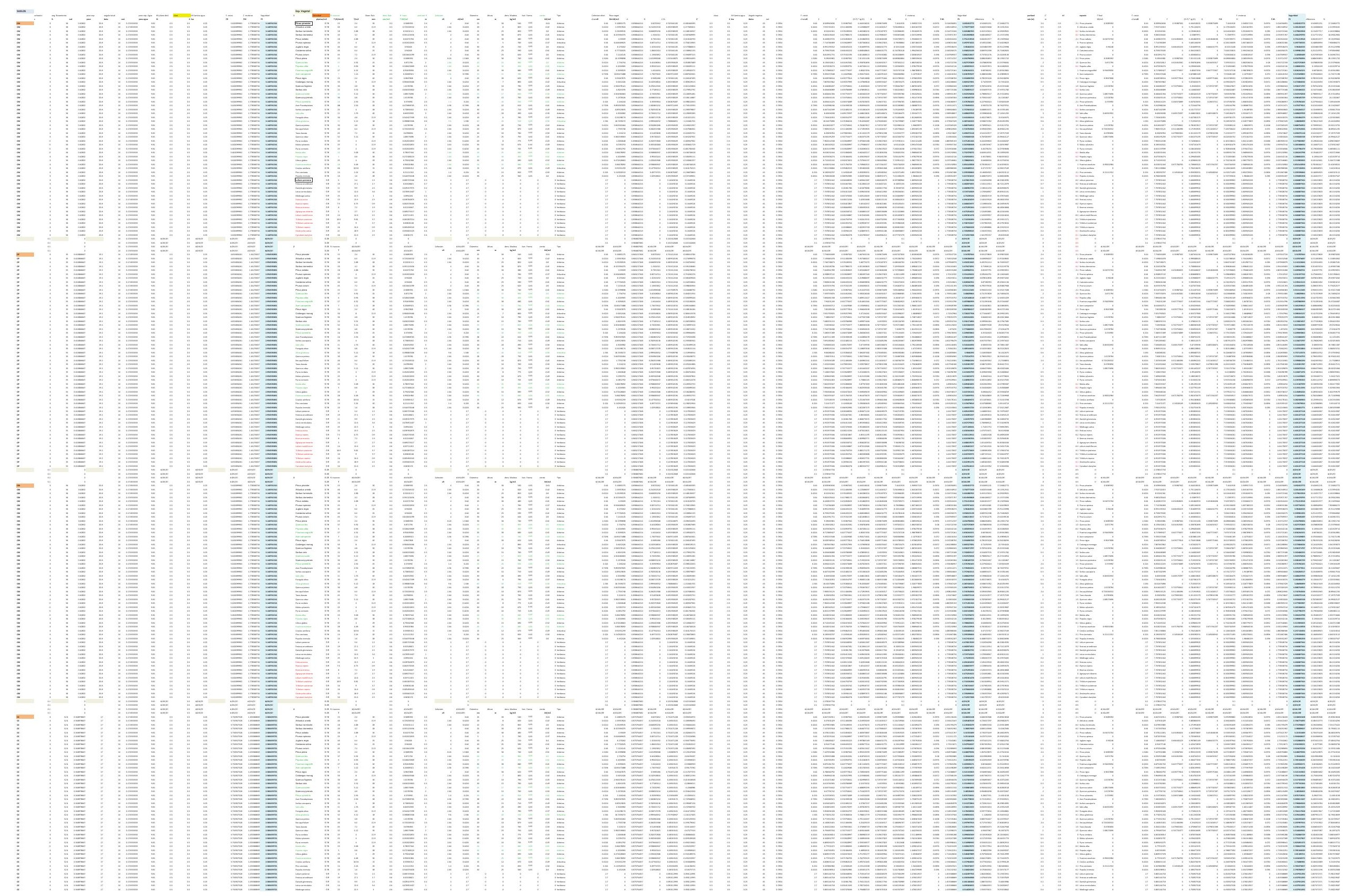


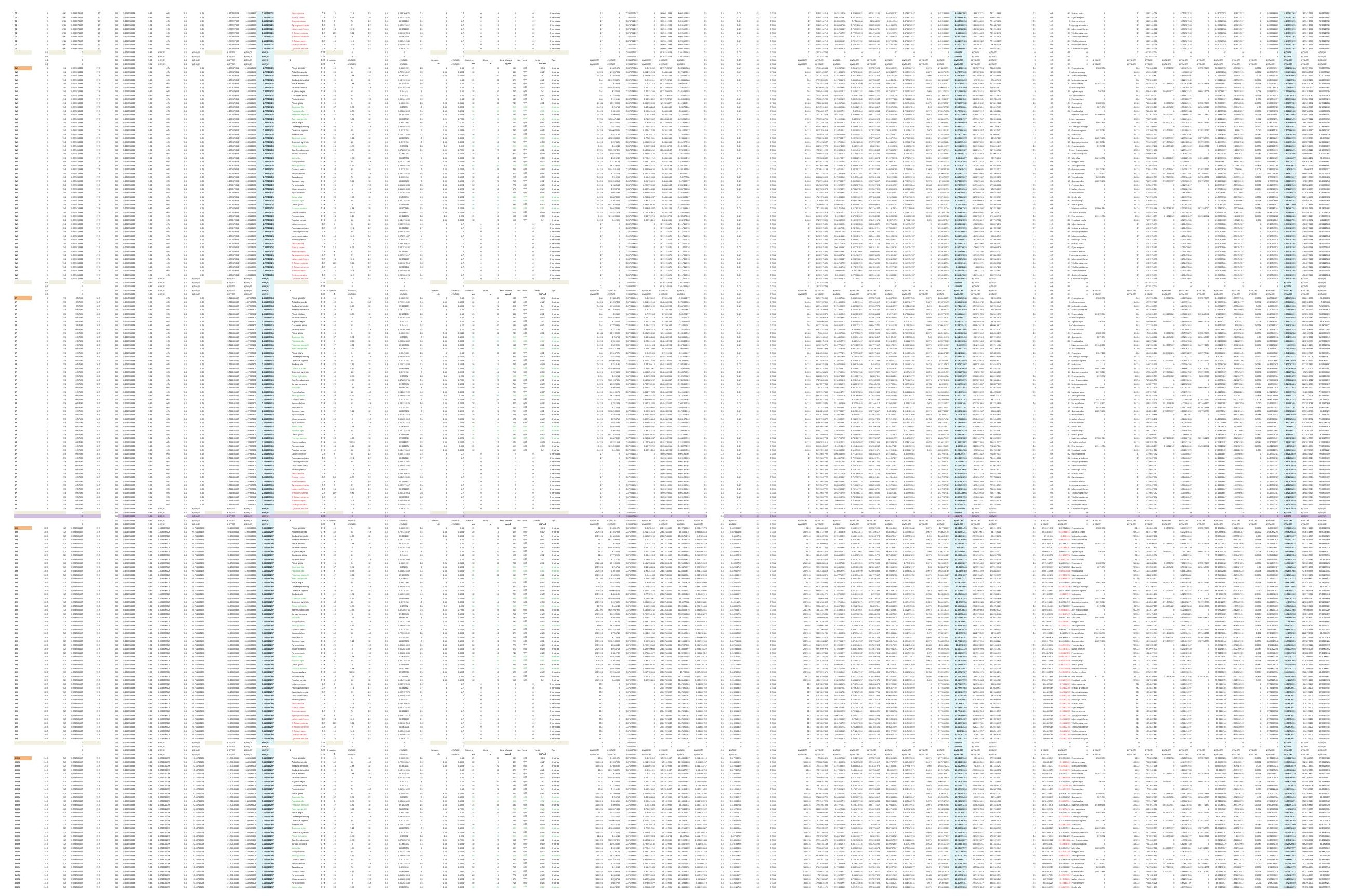



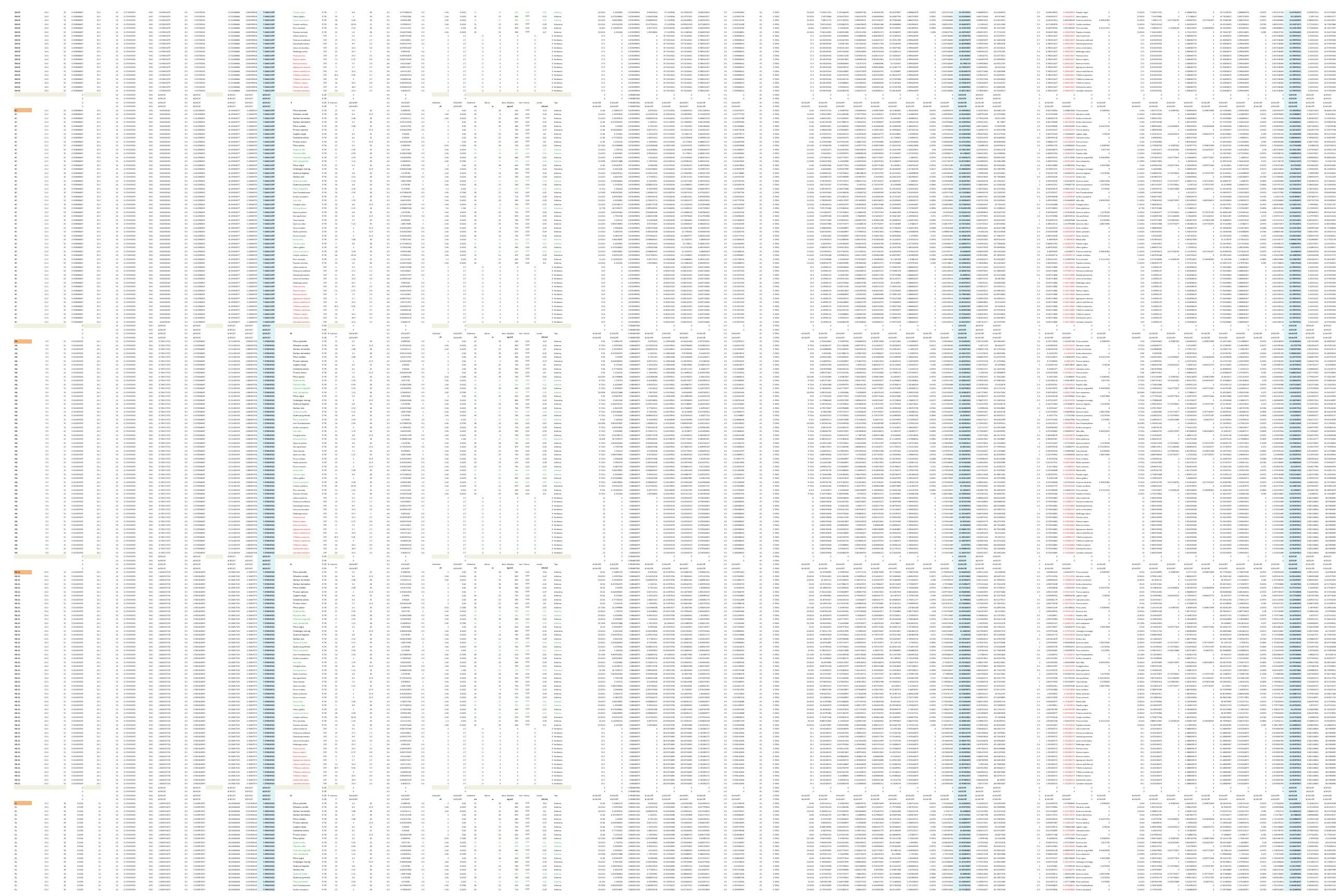


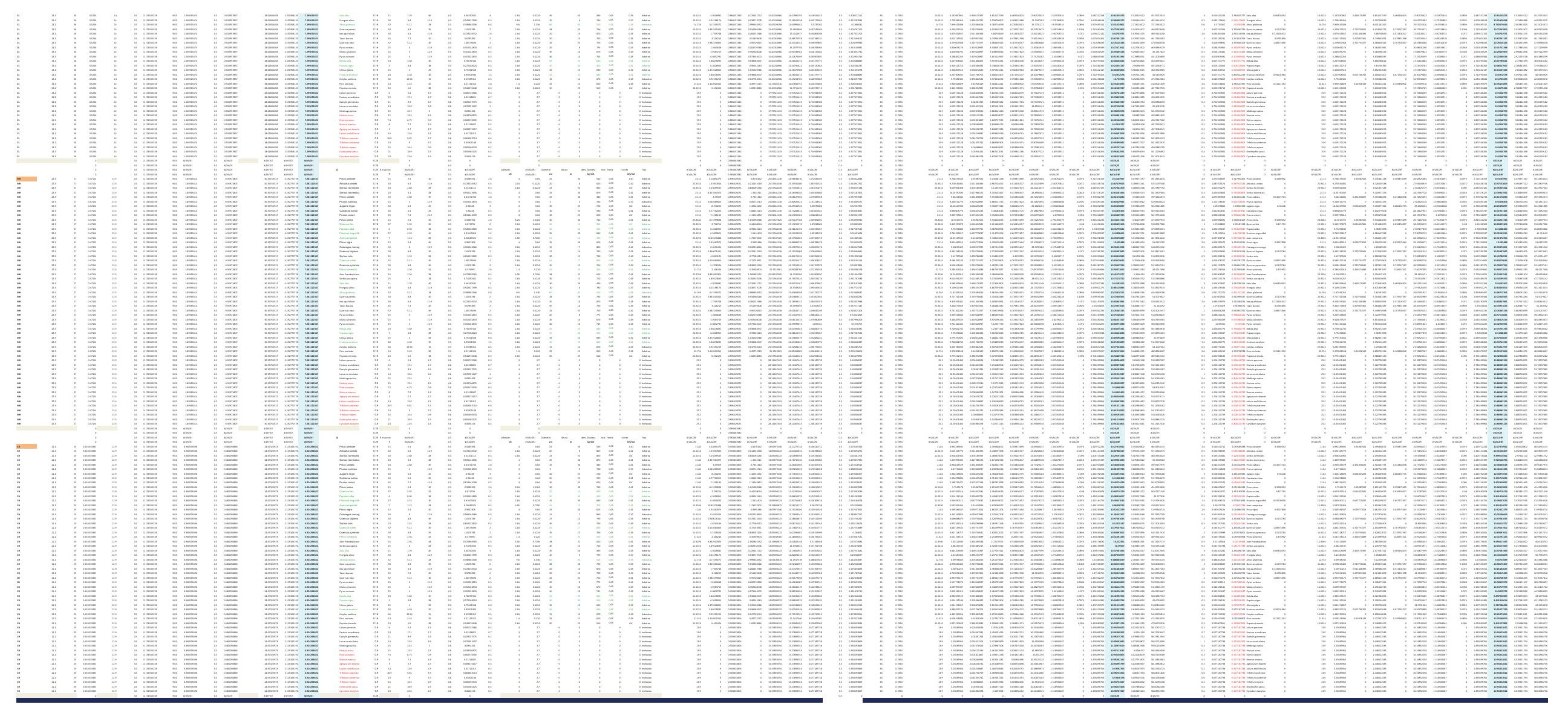



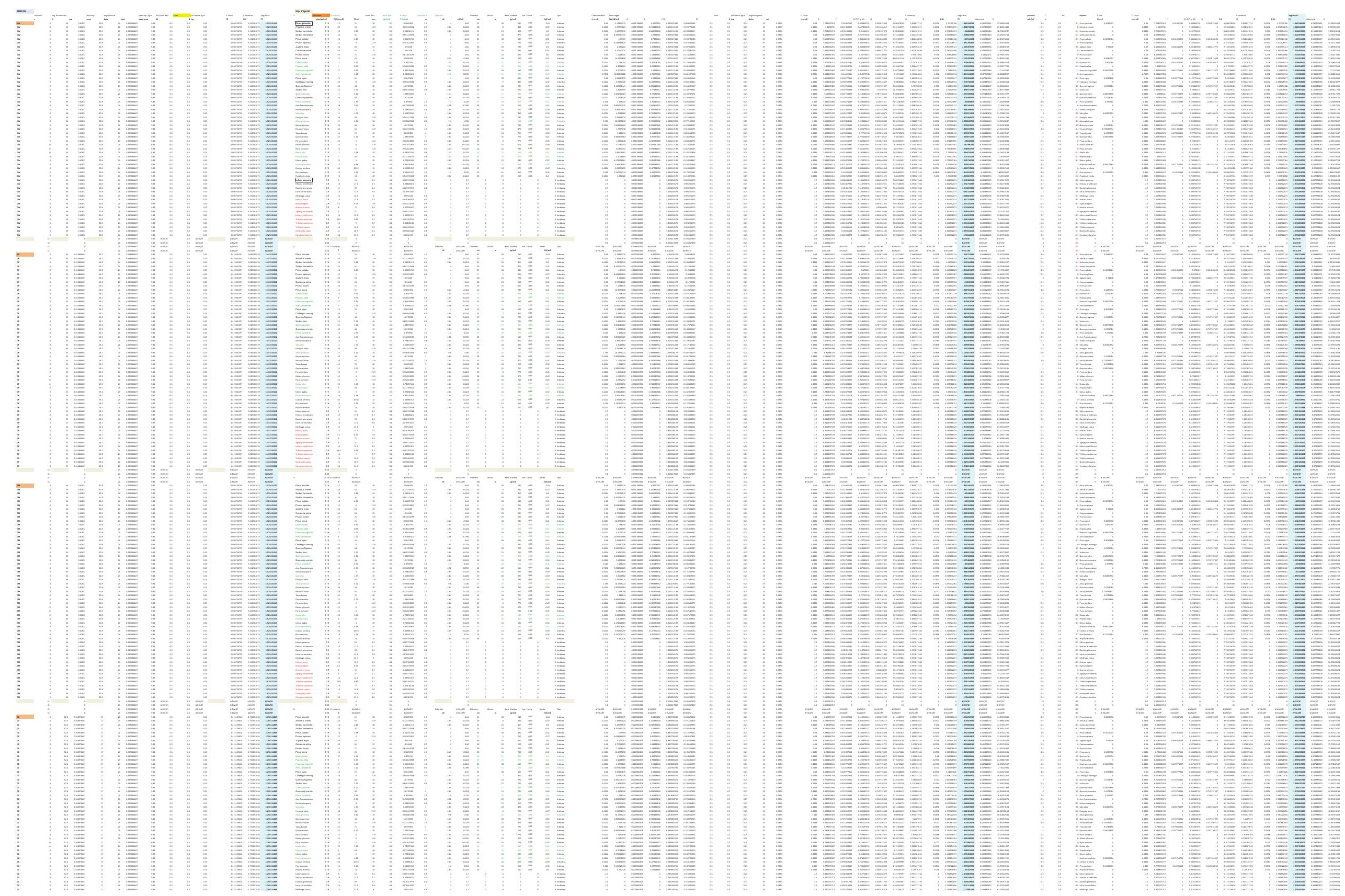


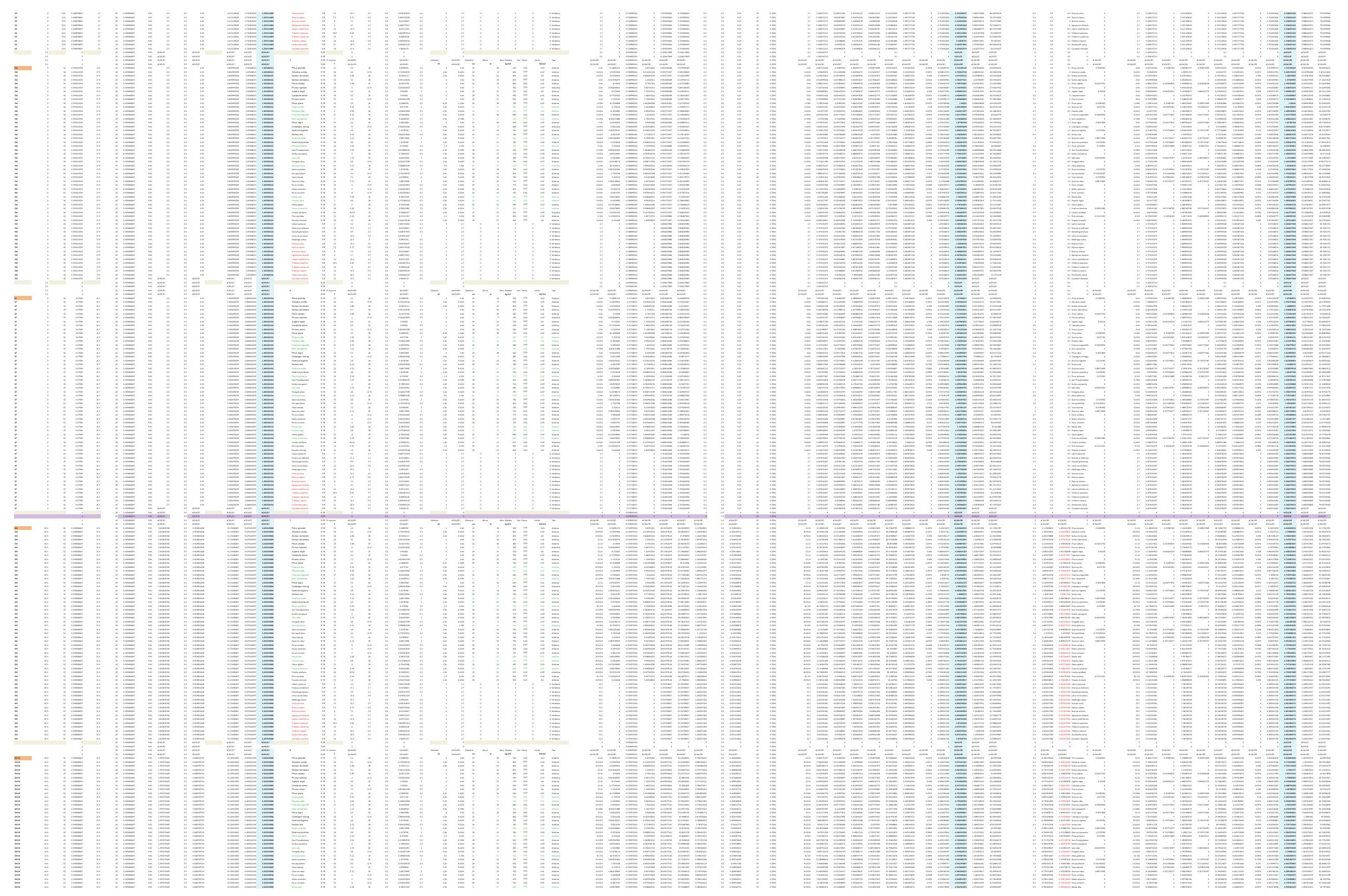



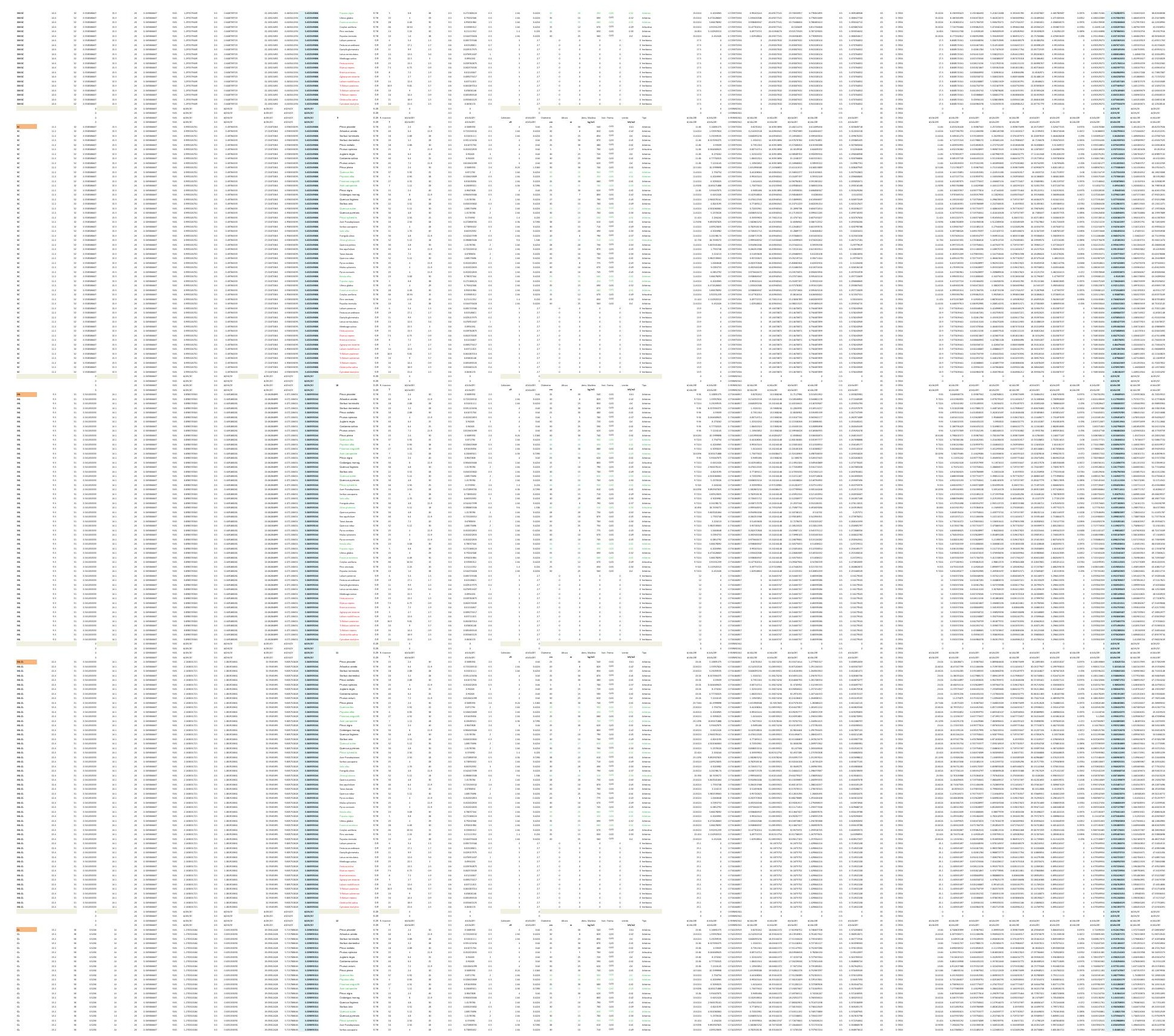

吕E三
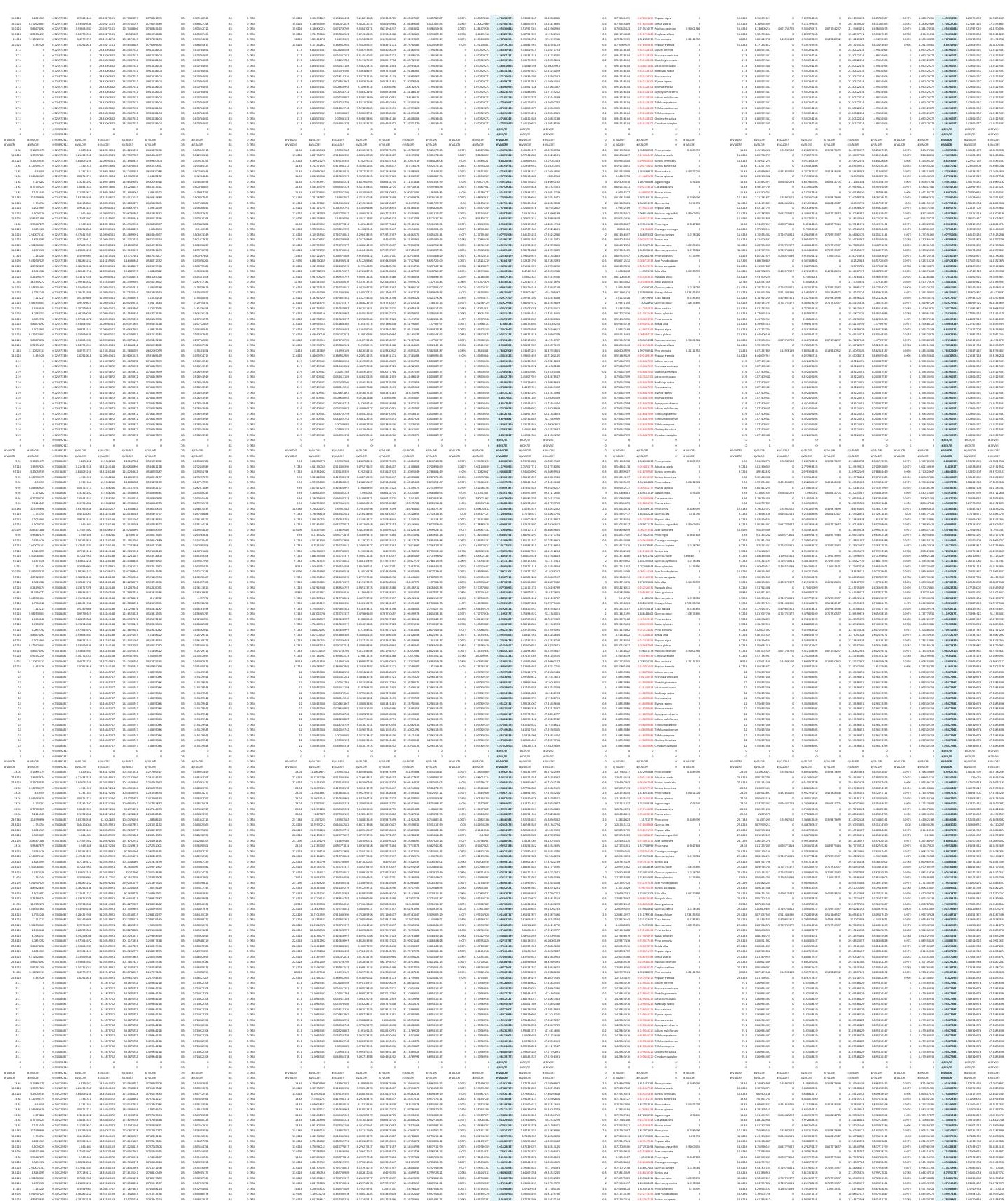


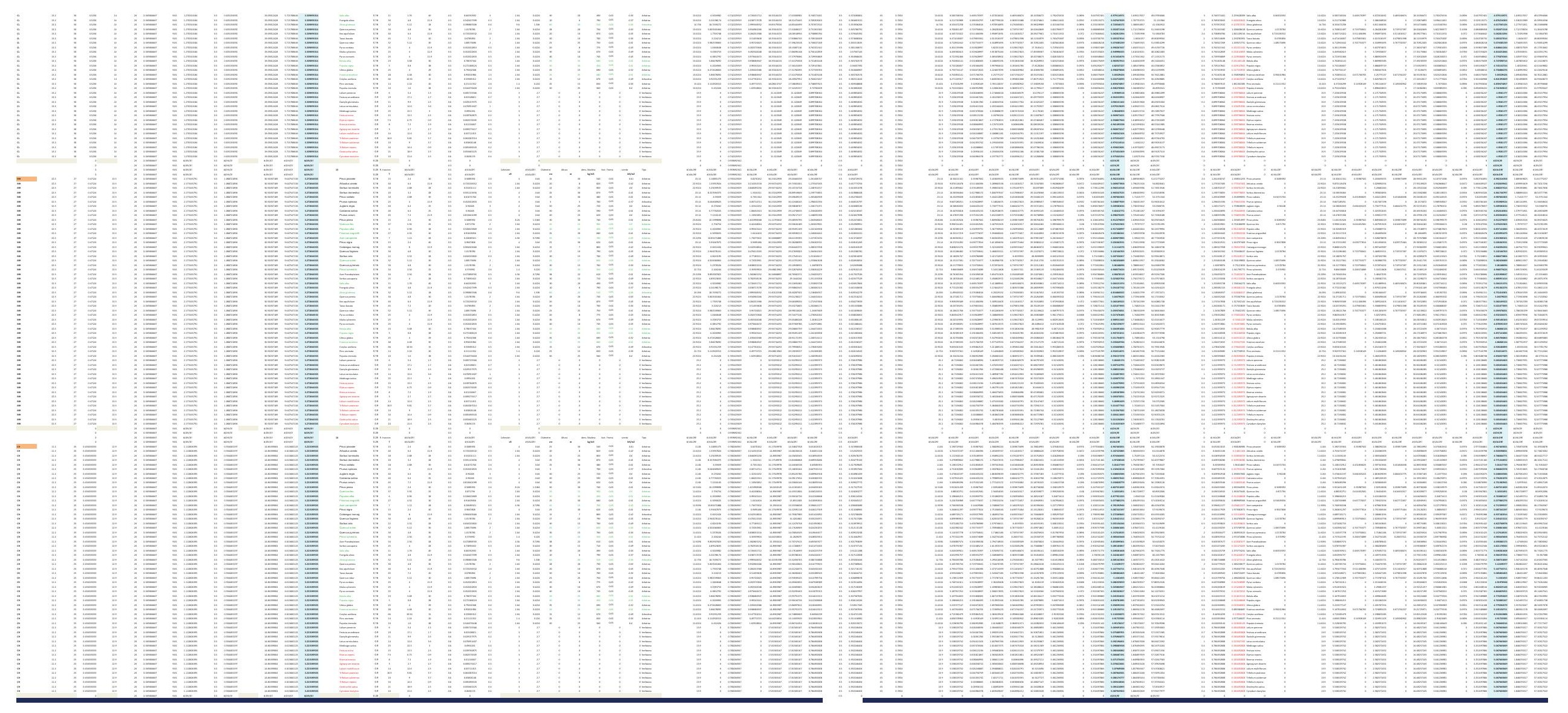



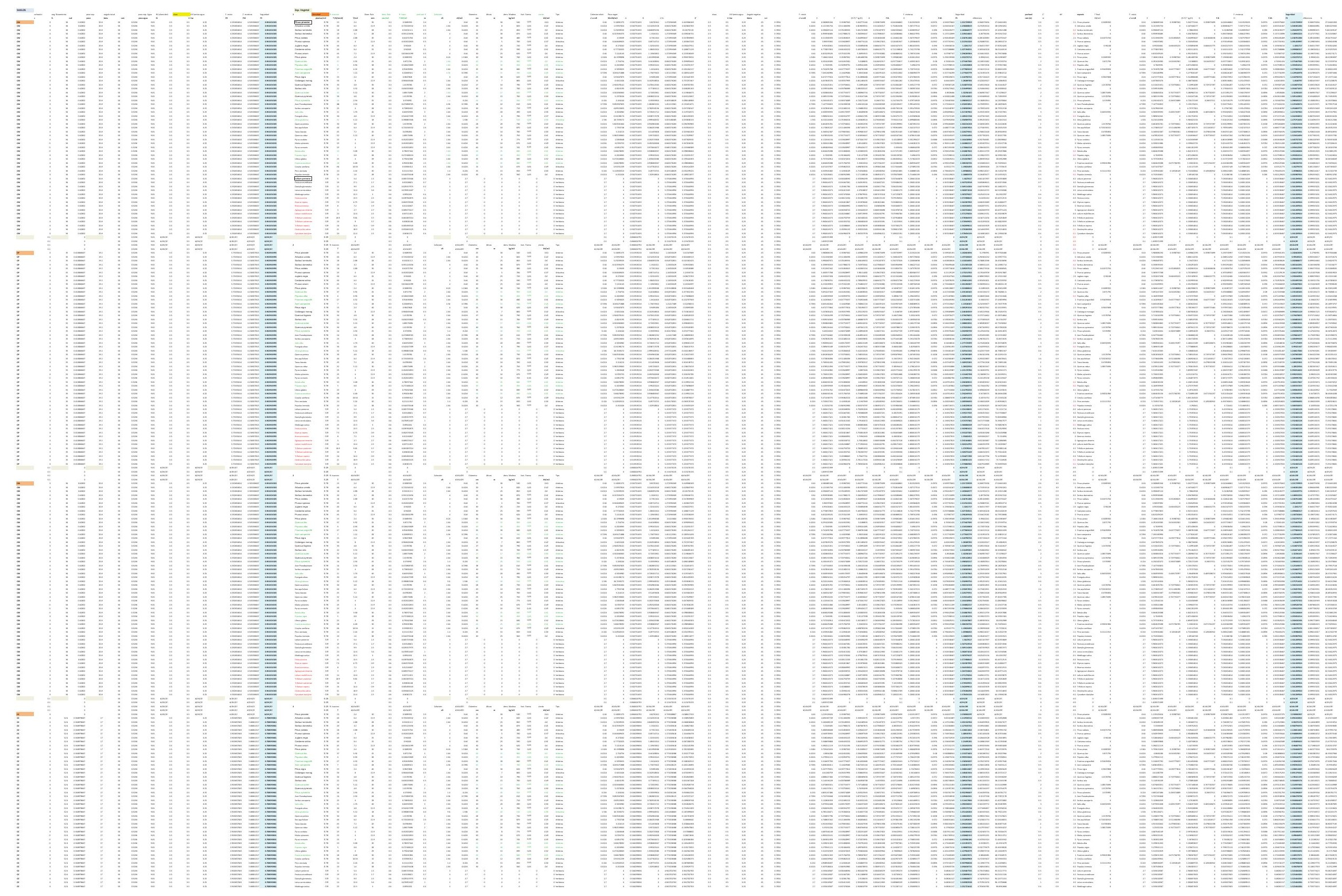


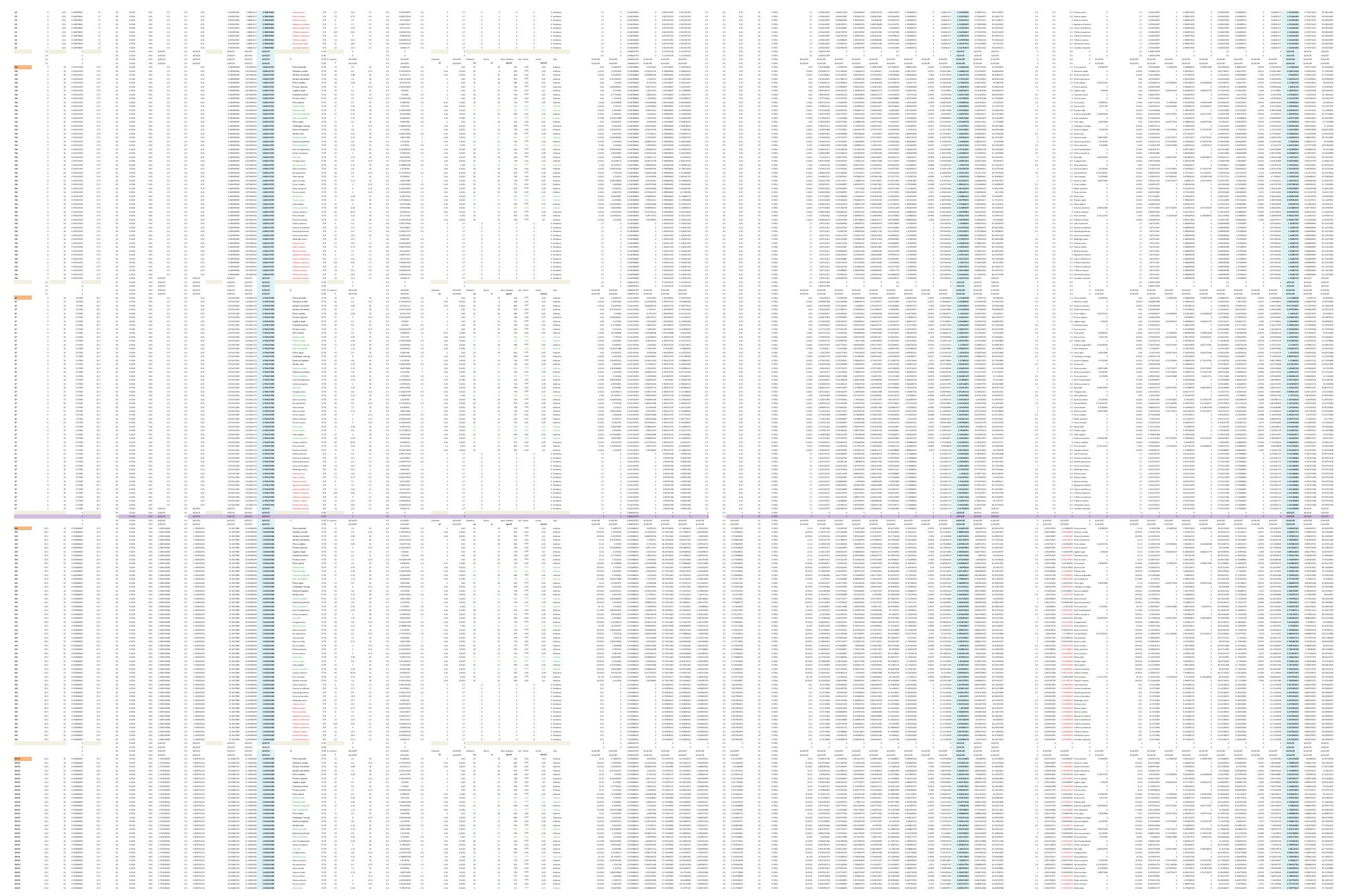



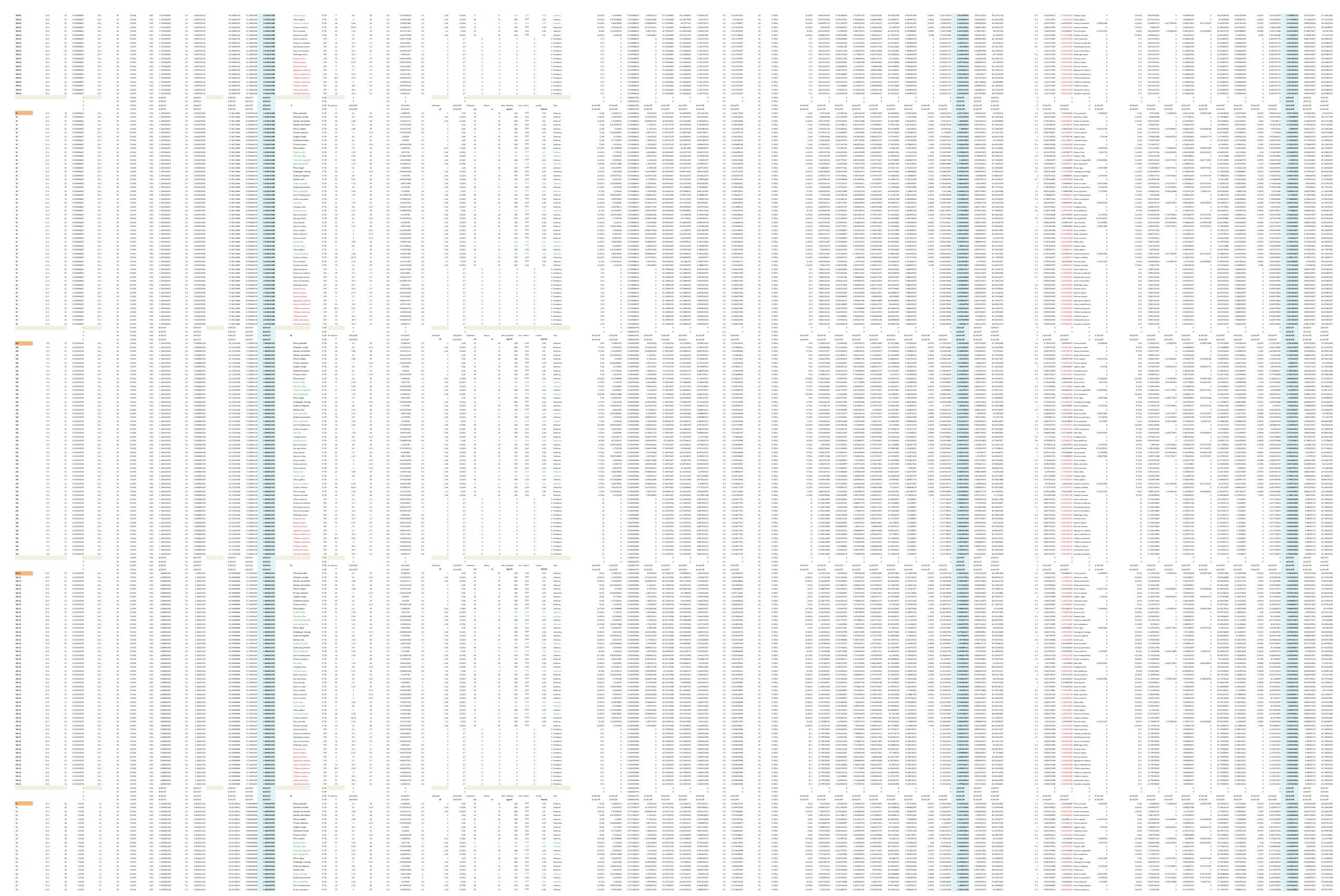


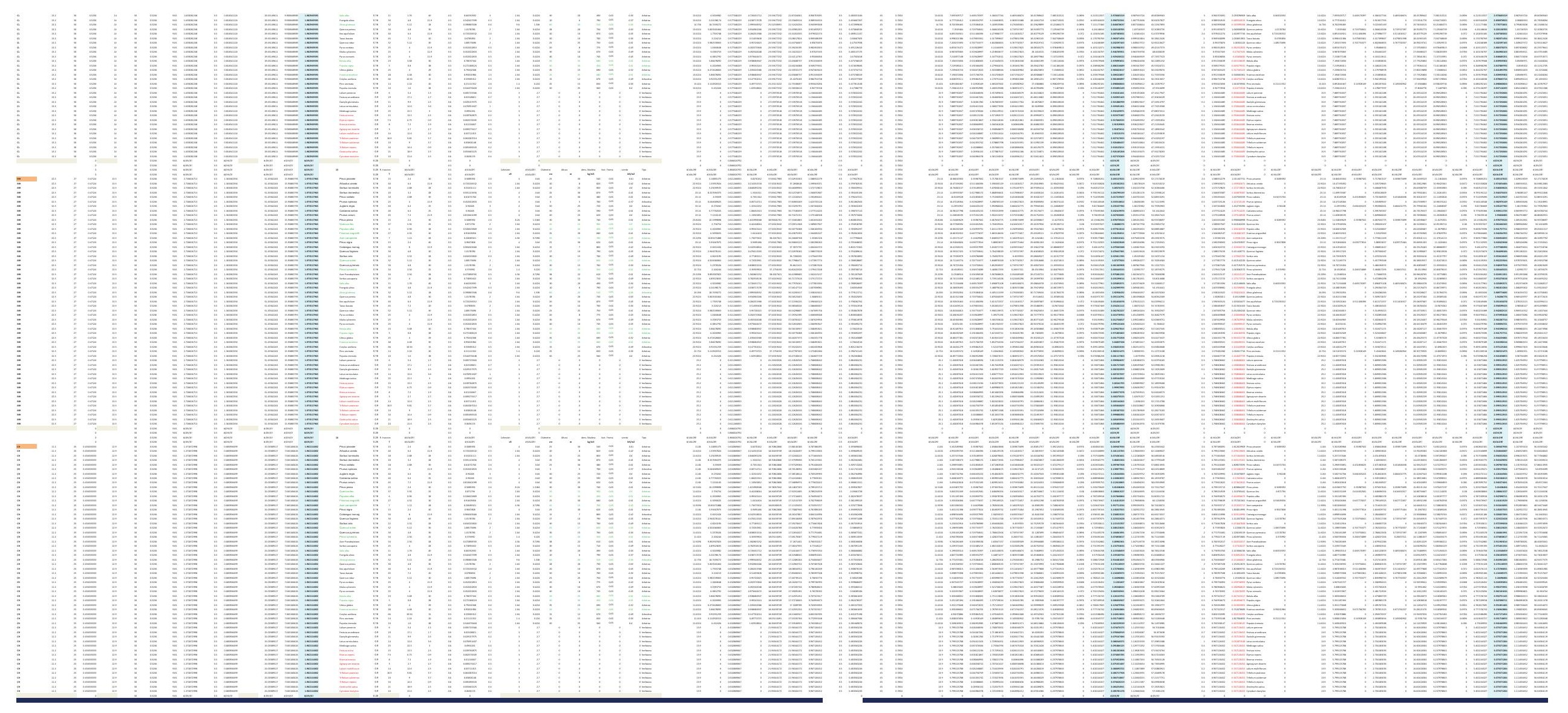



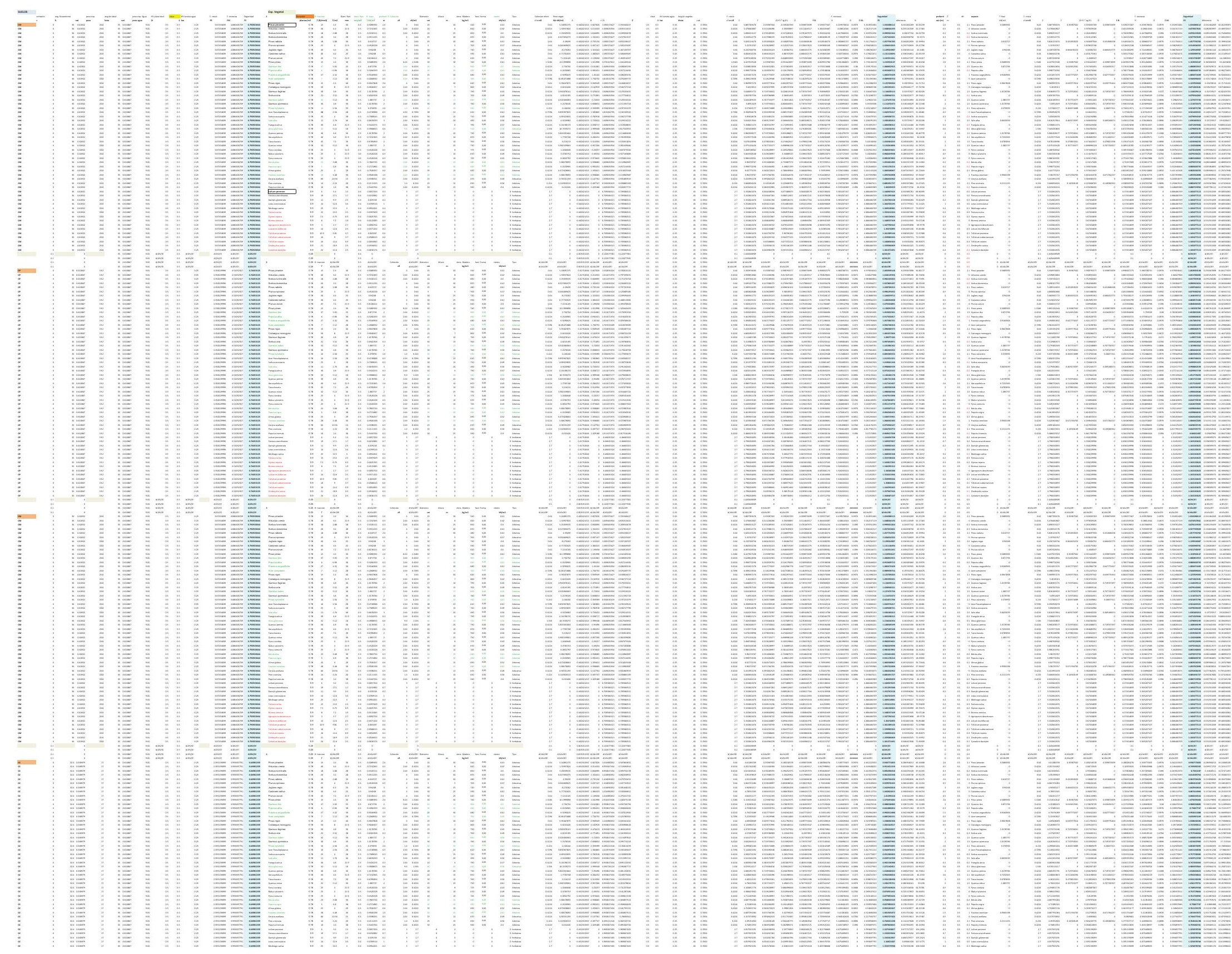


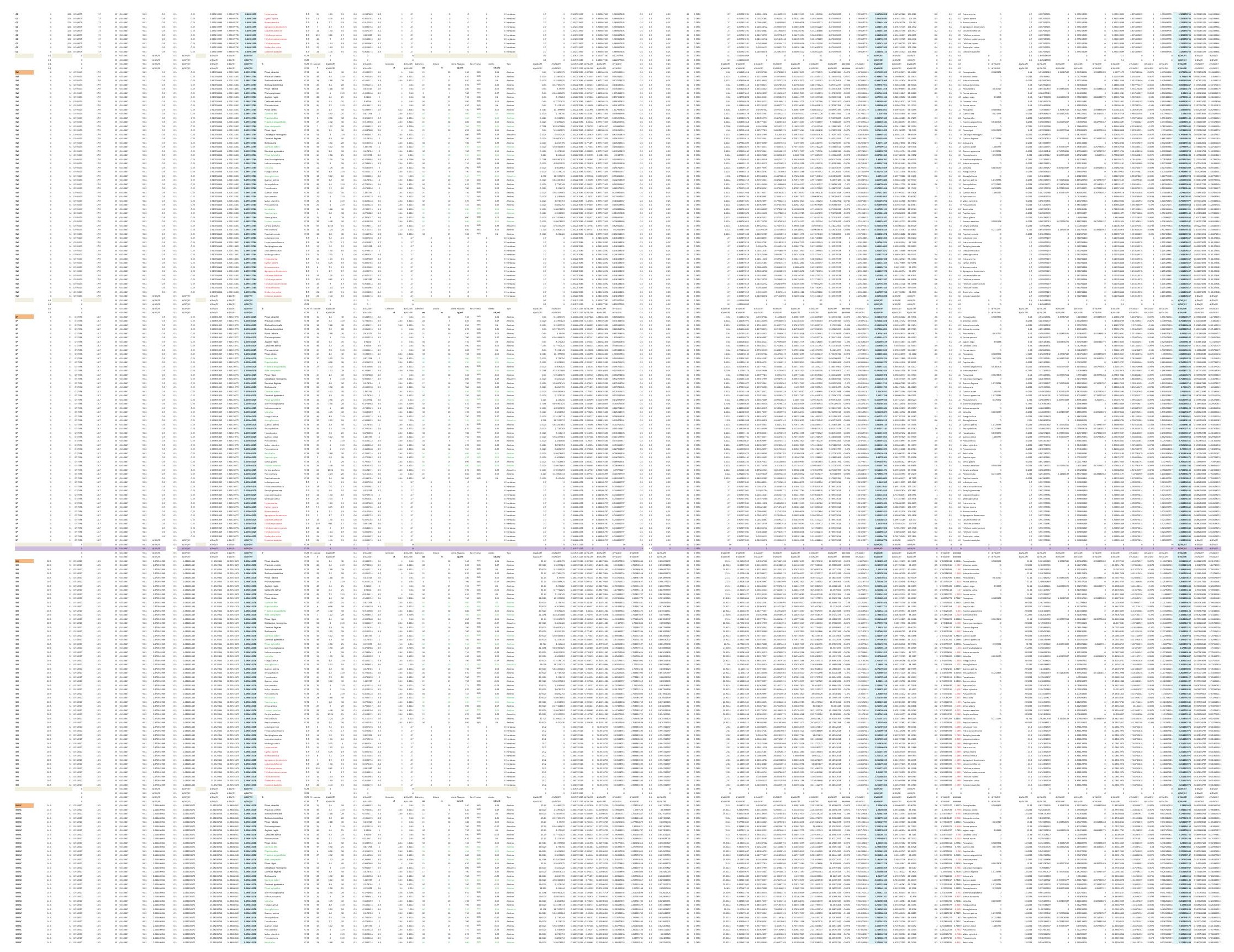



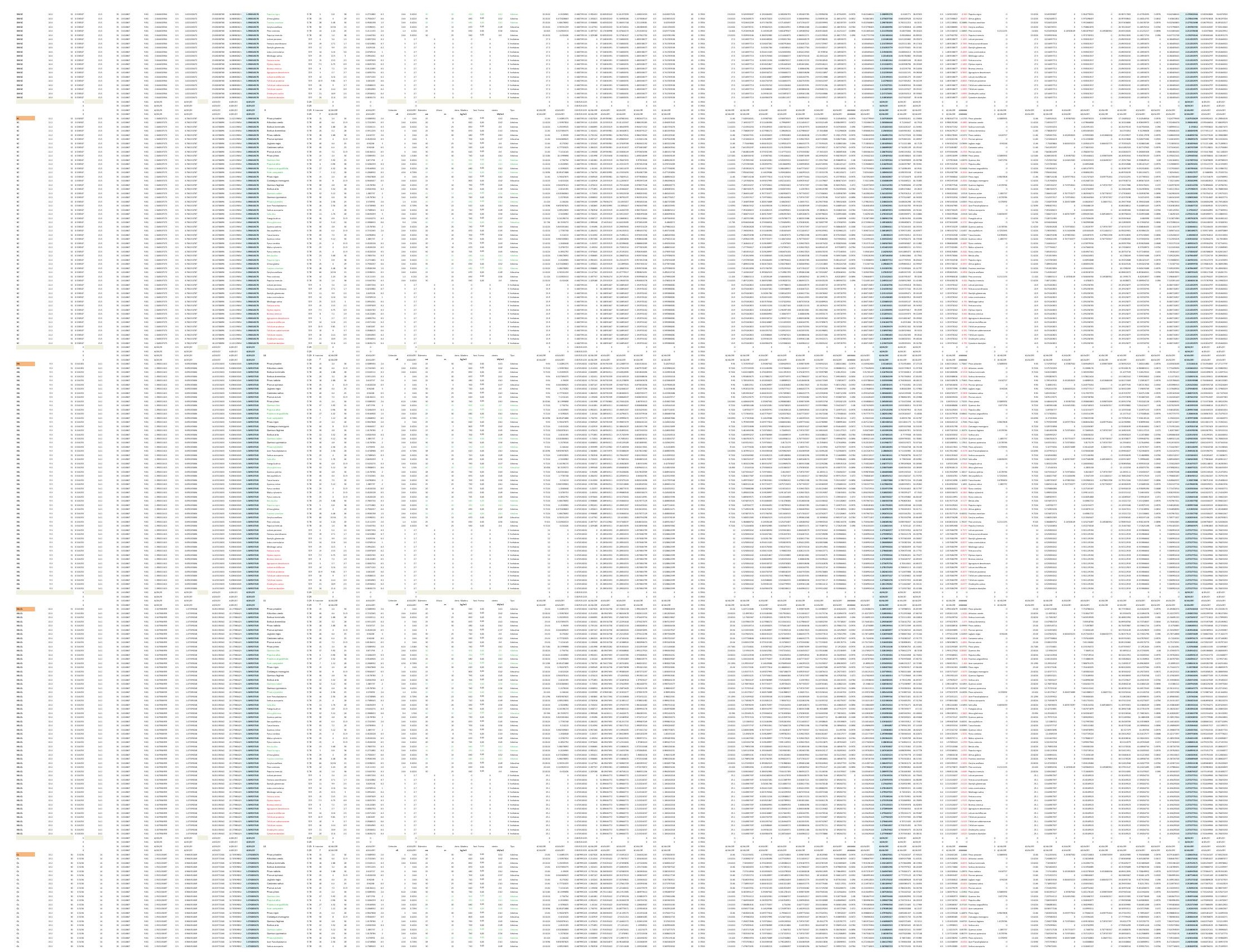


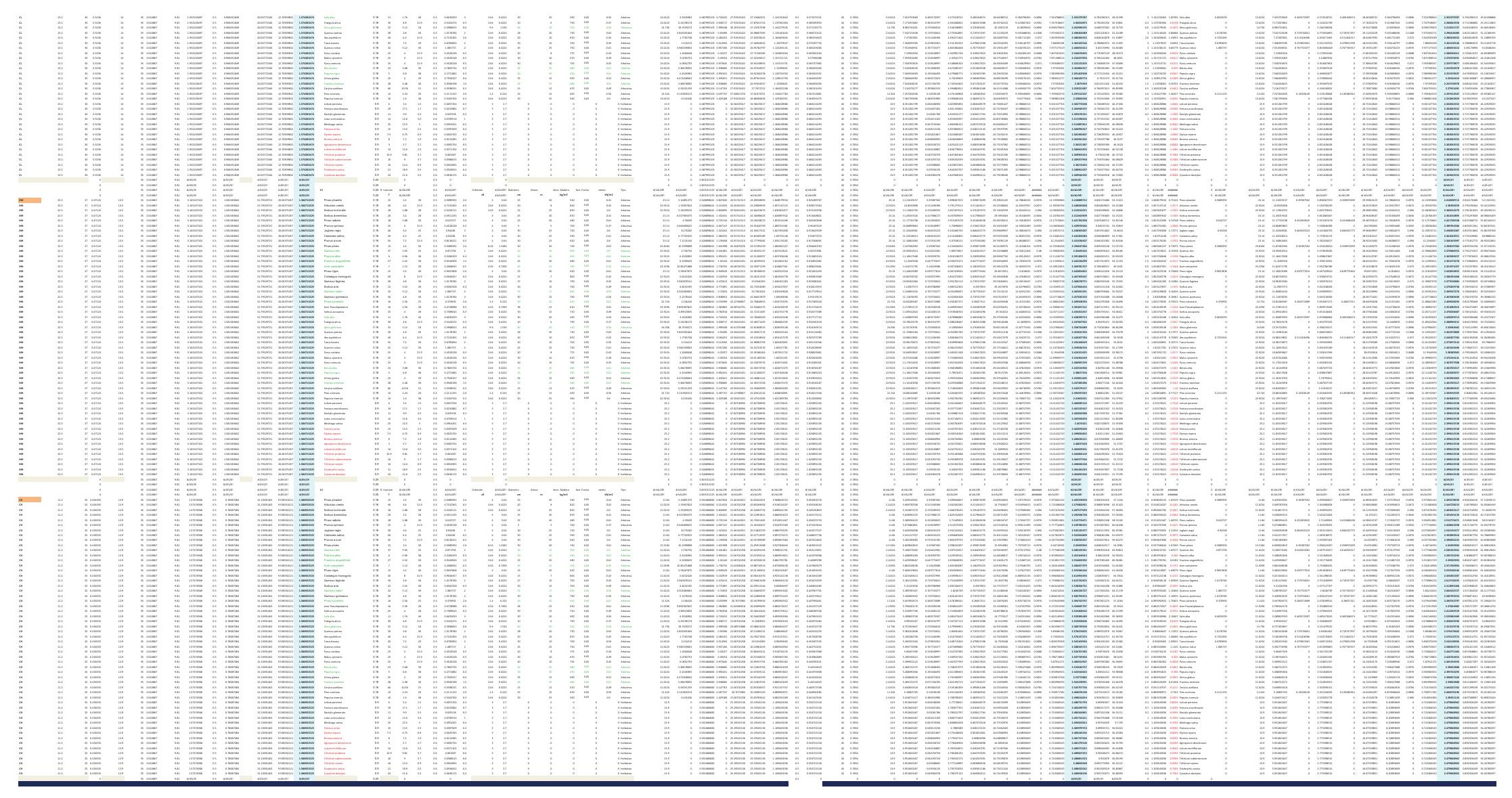



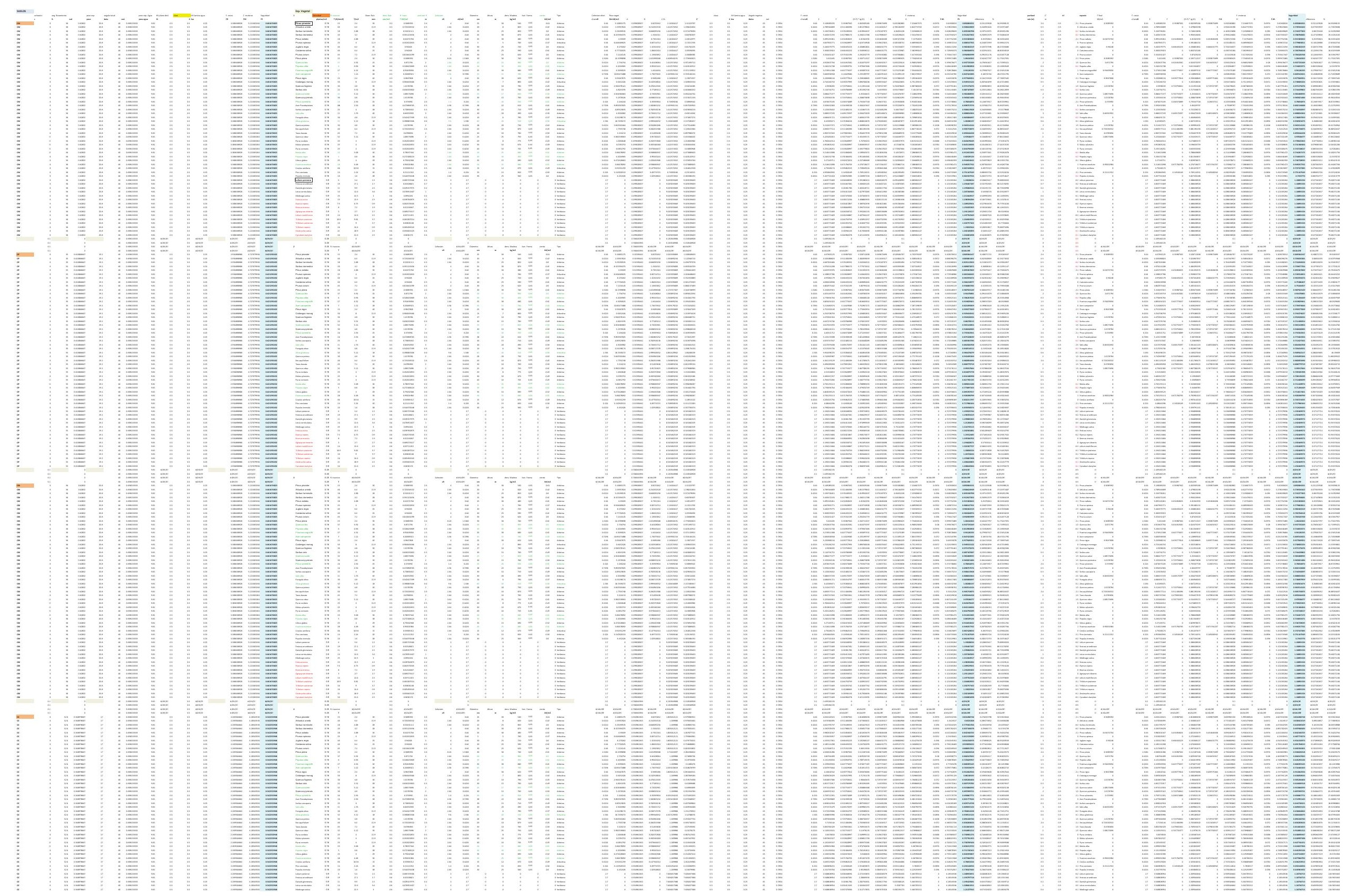


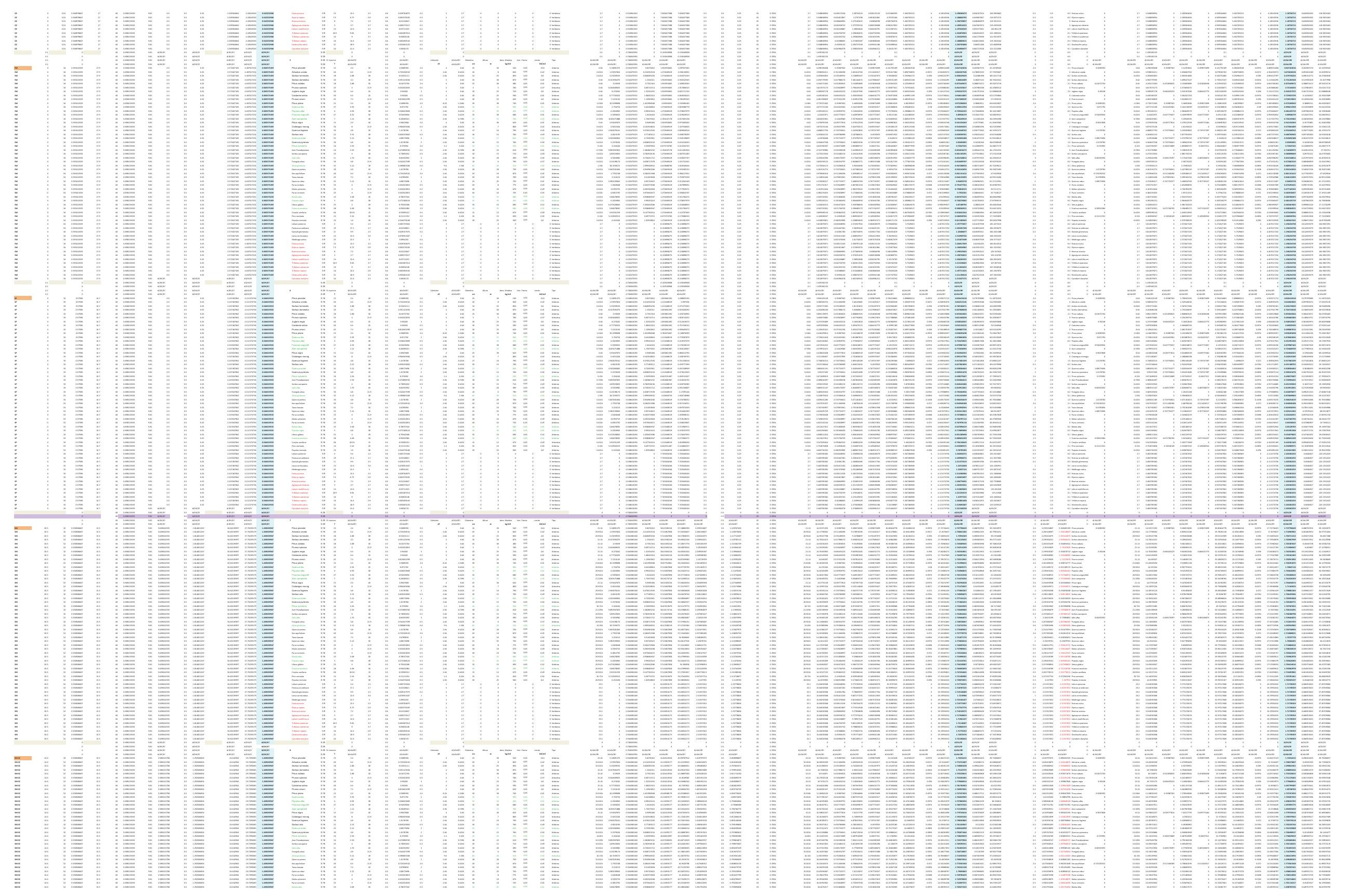



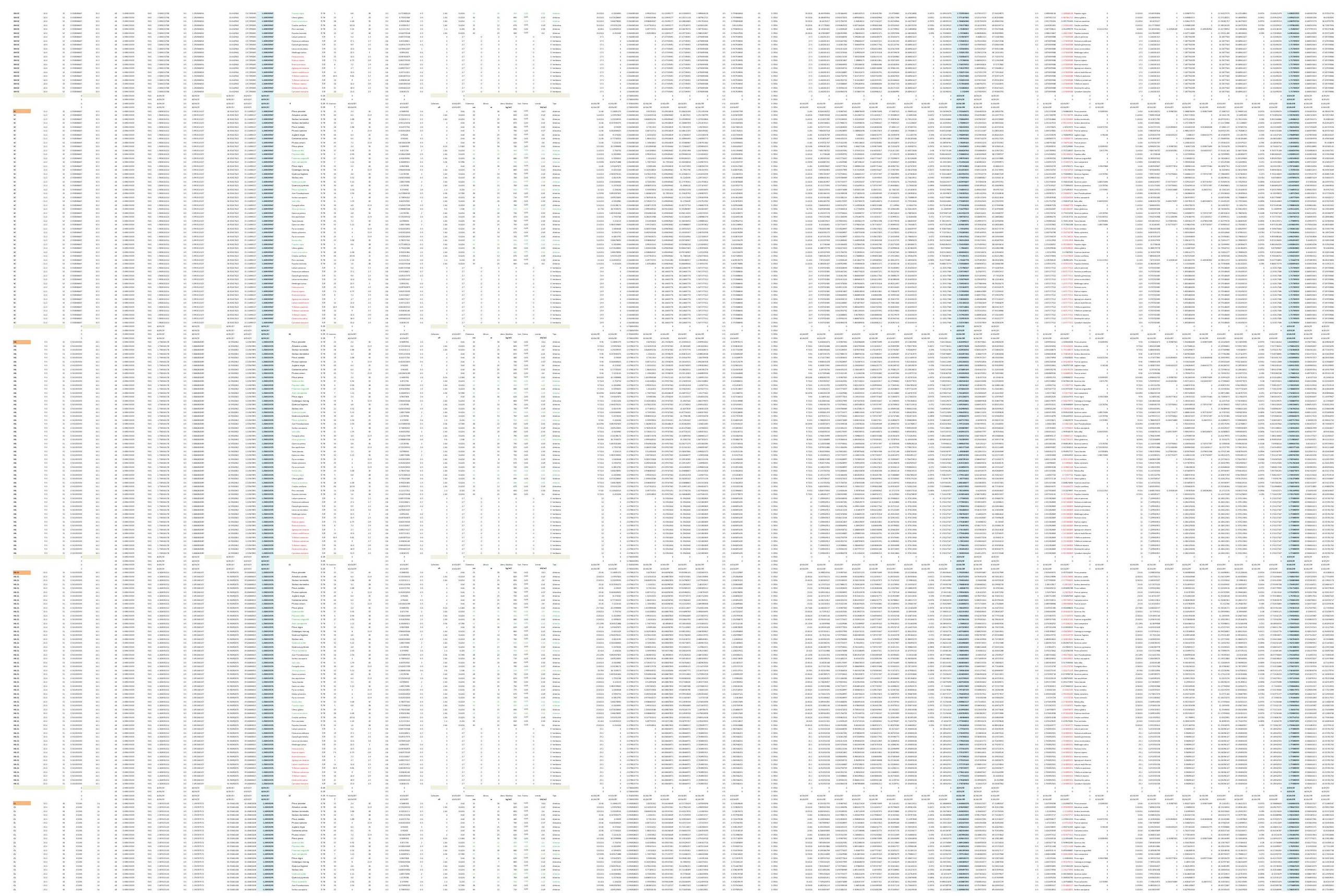


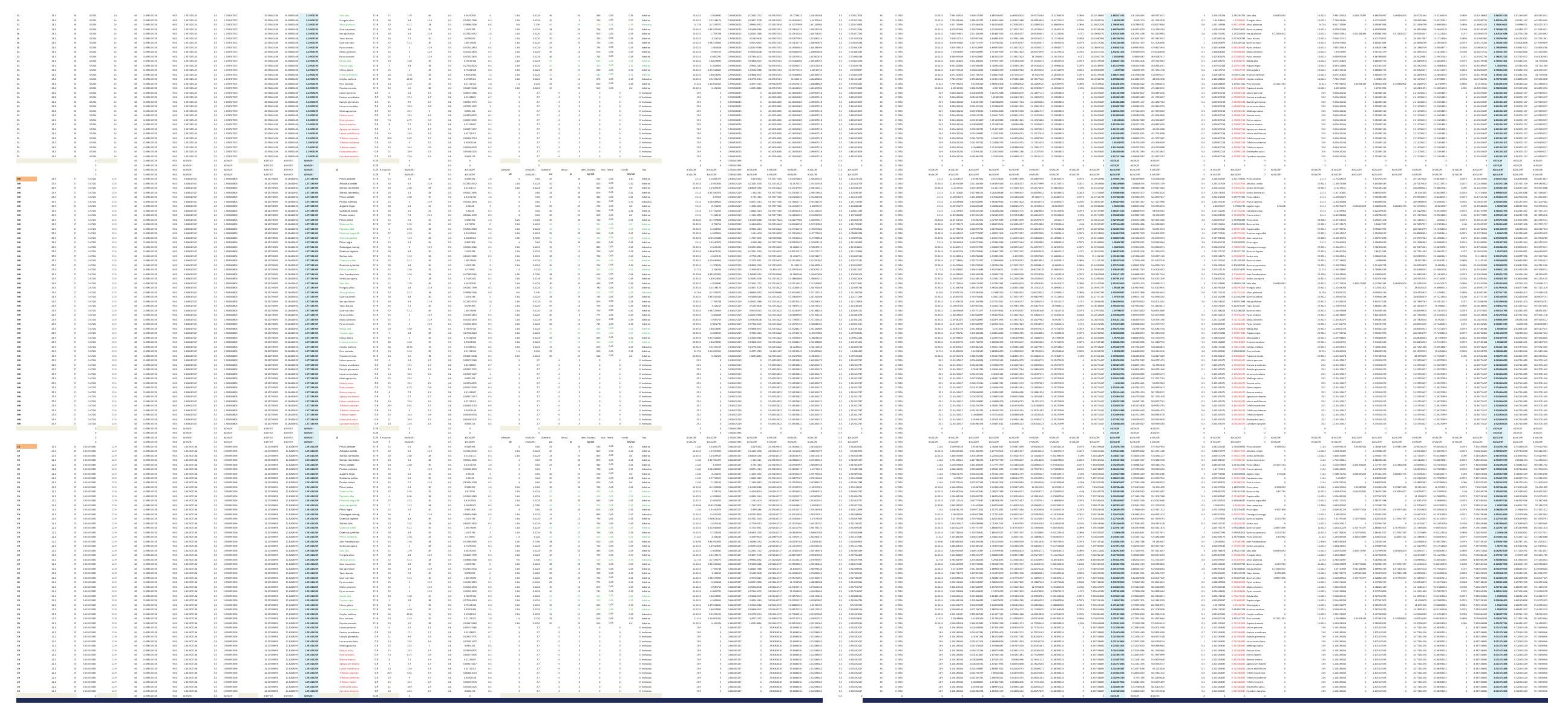



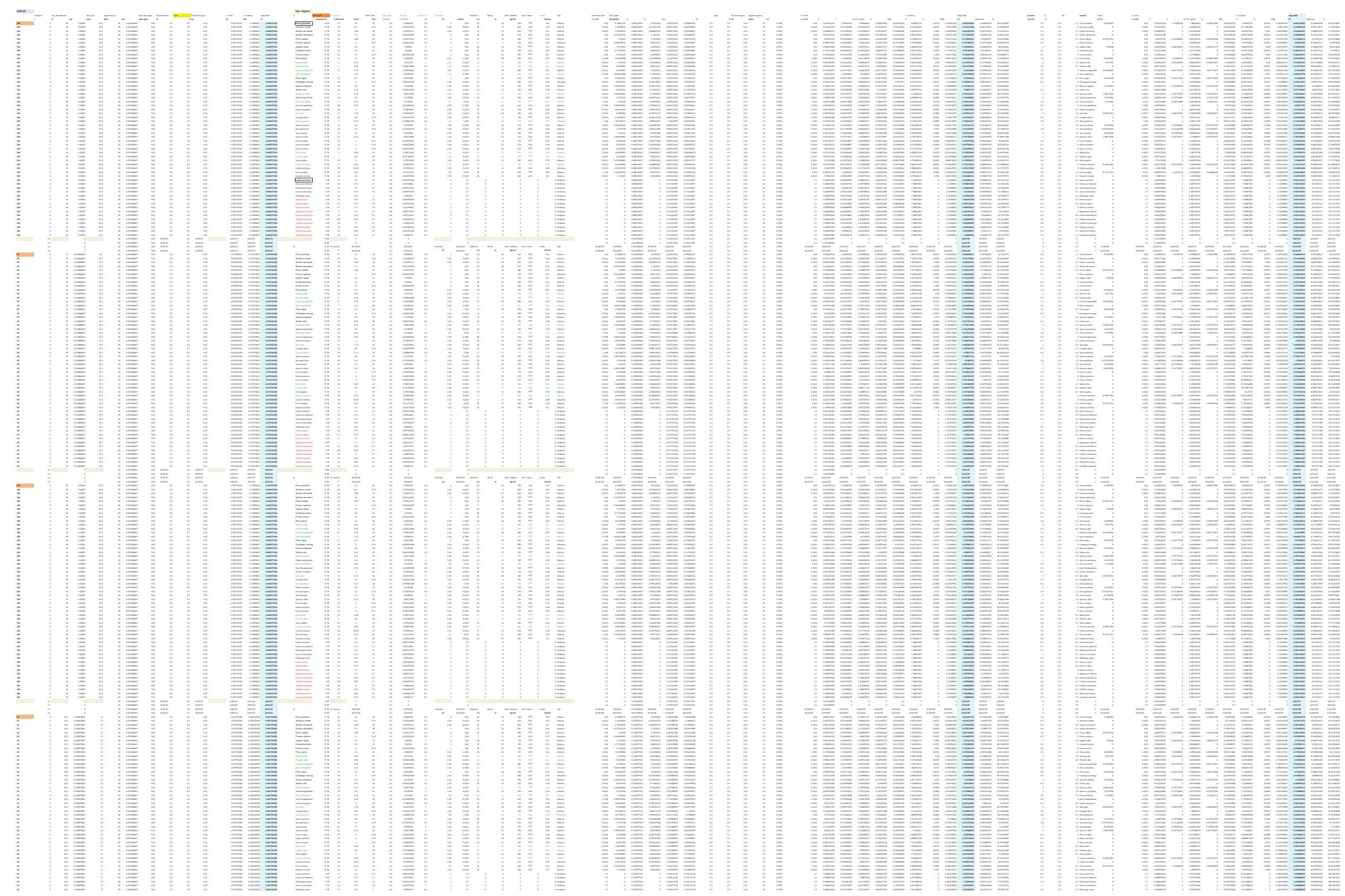


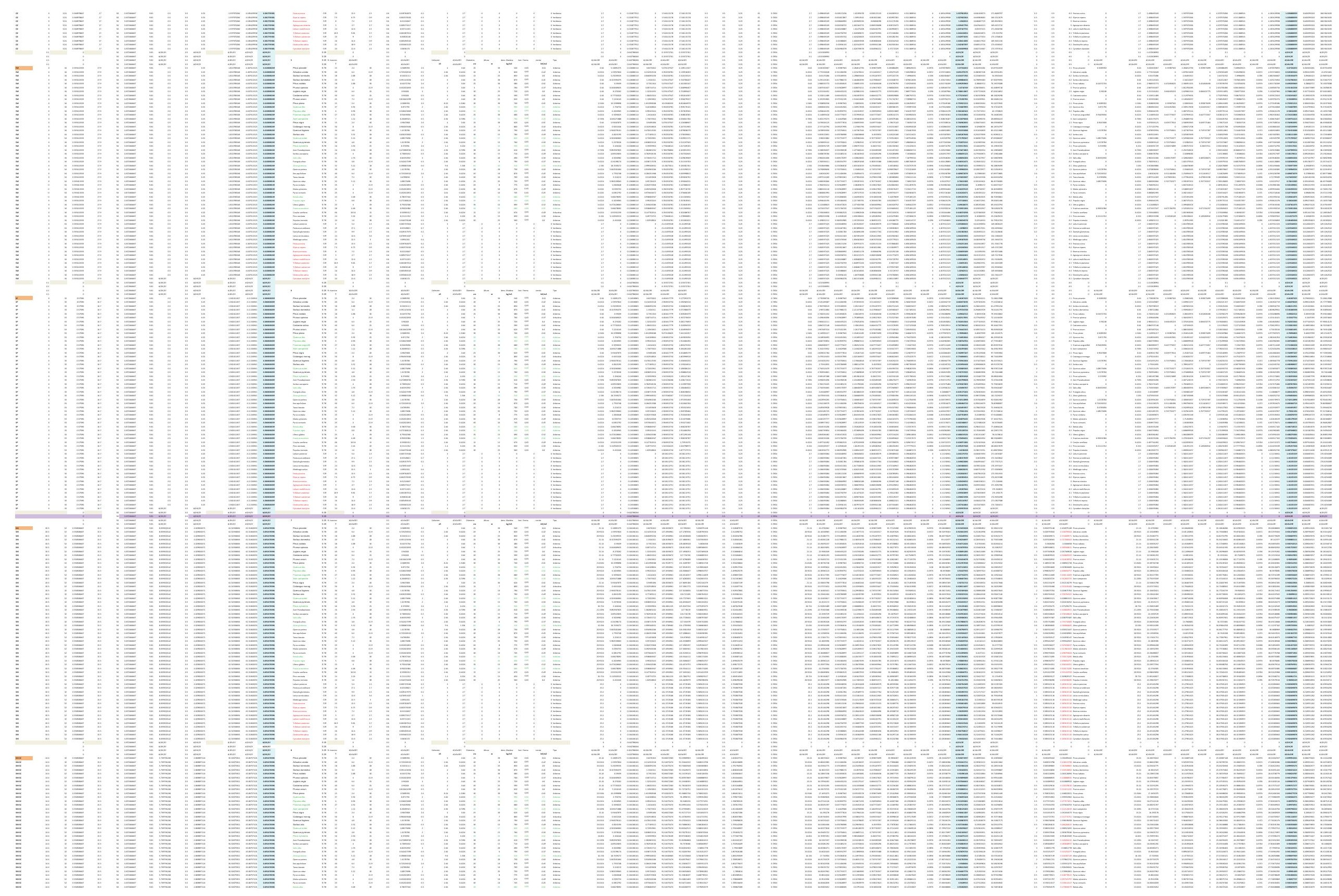



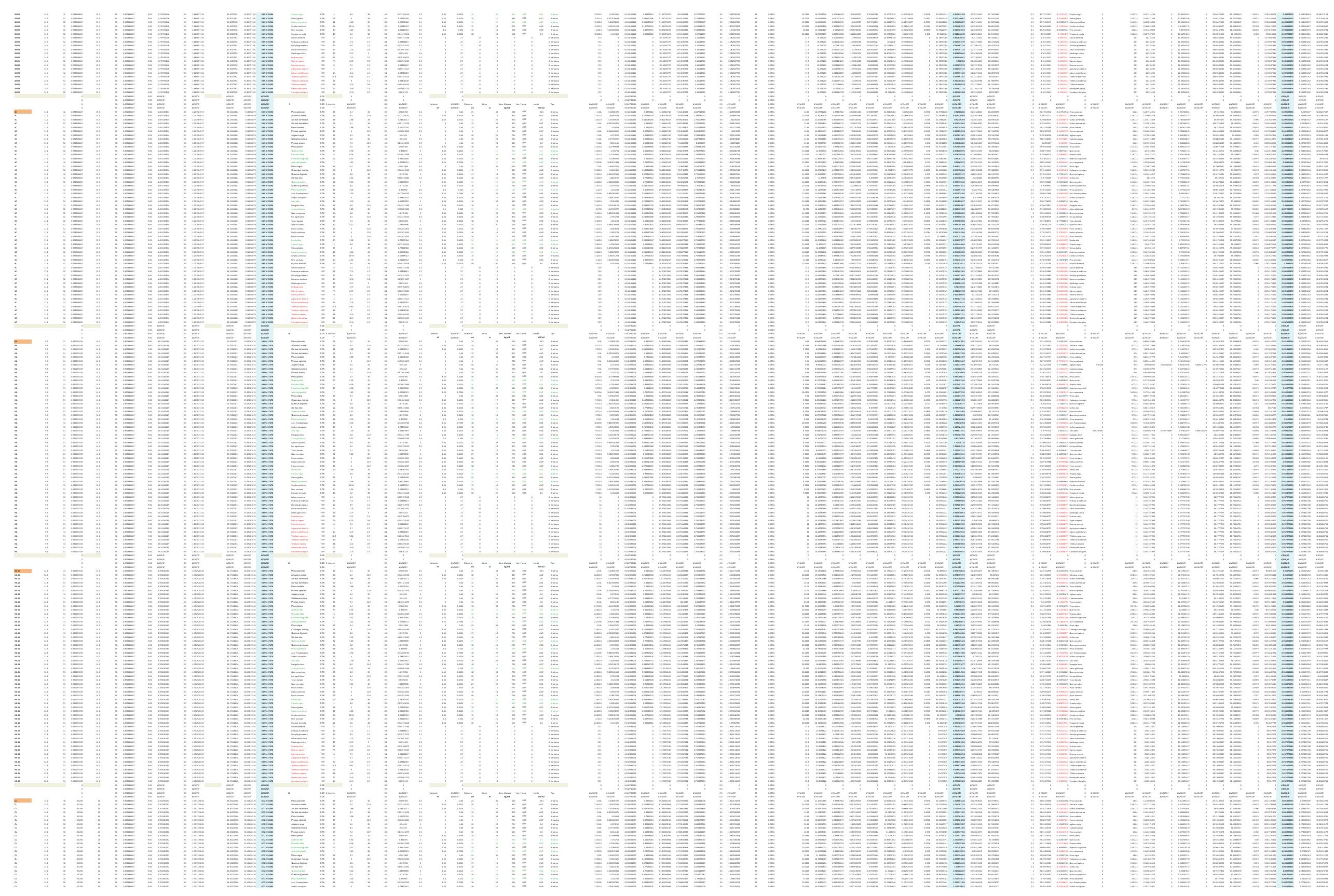


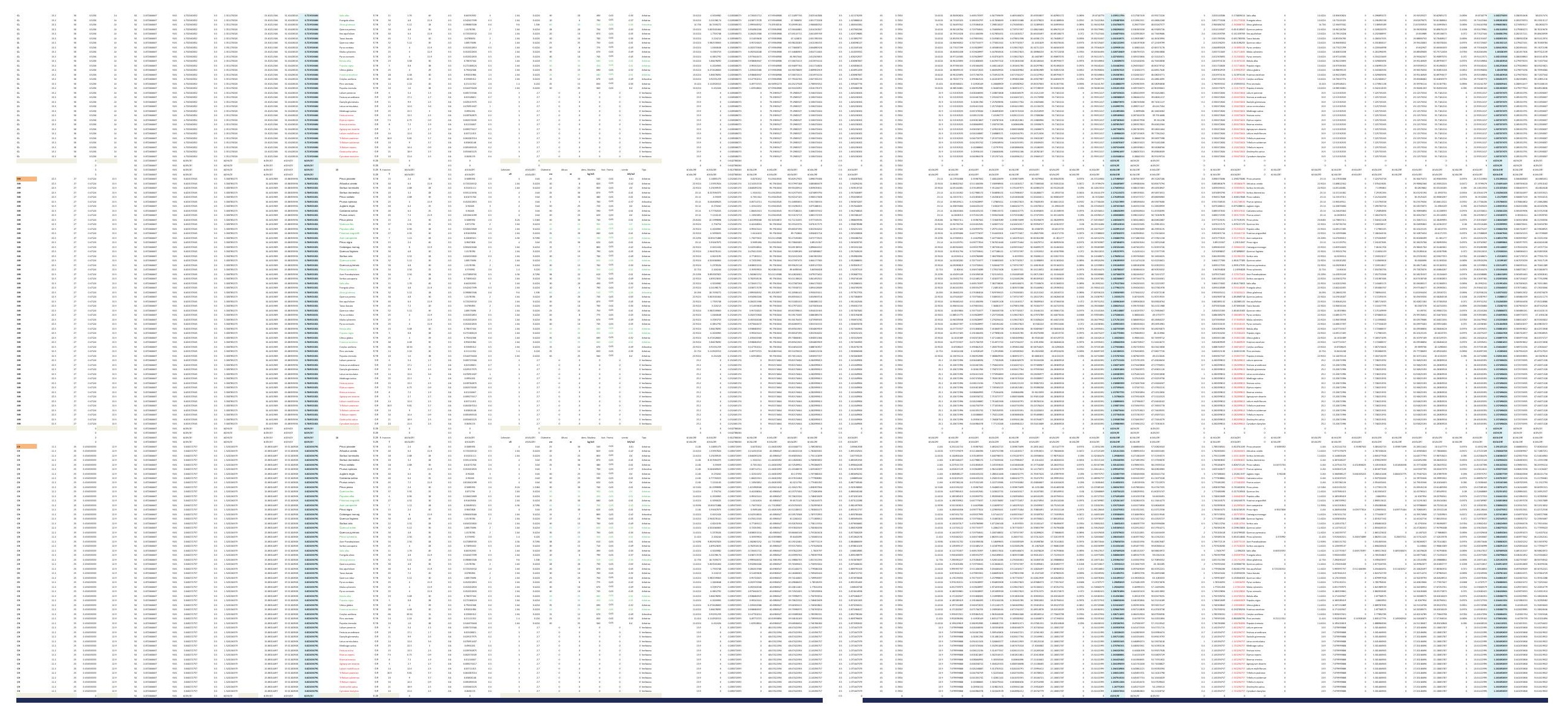



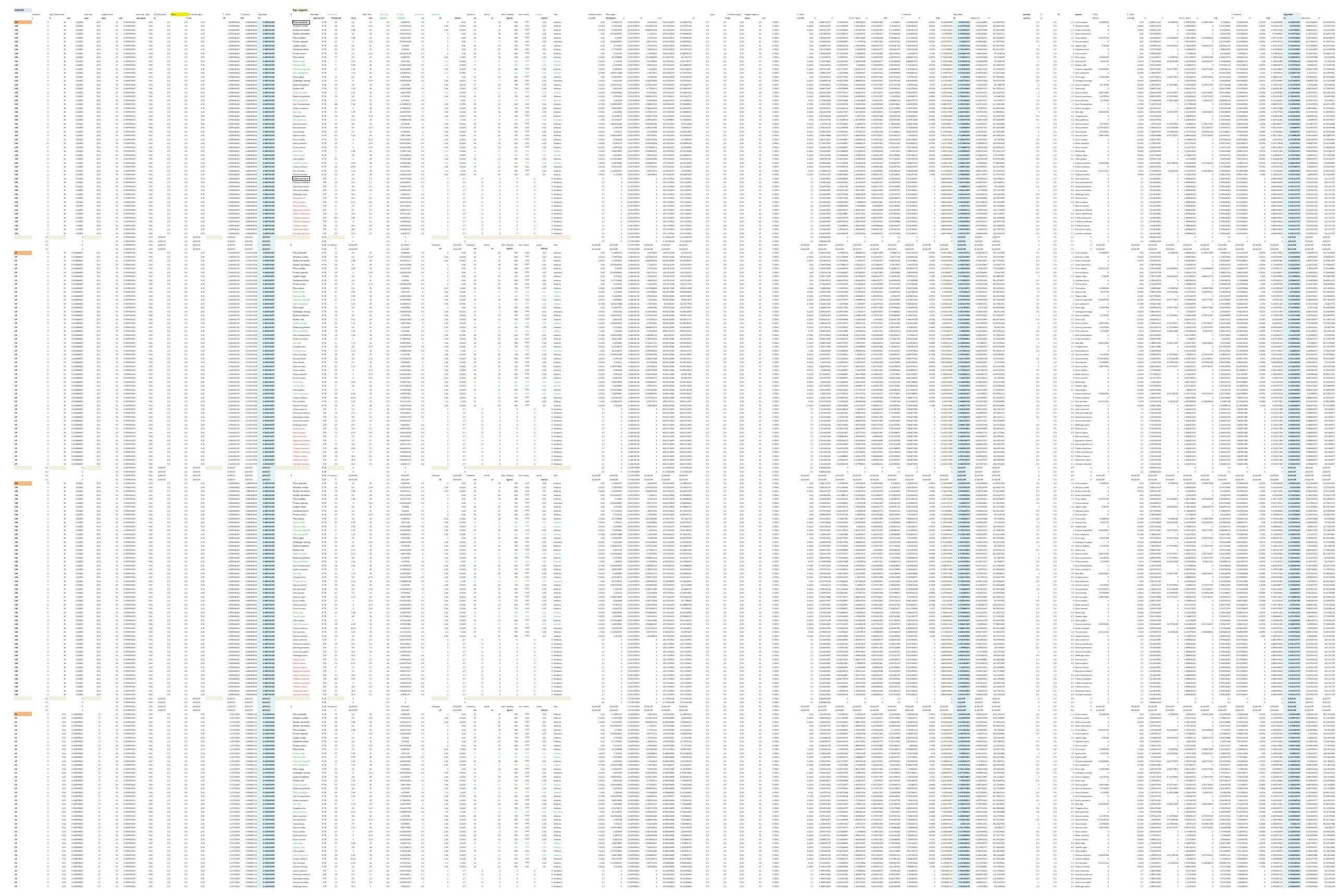


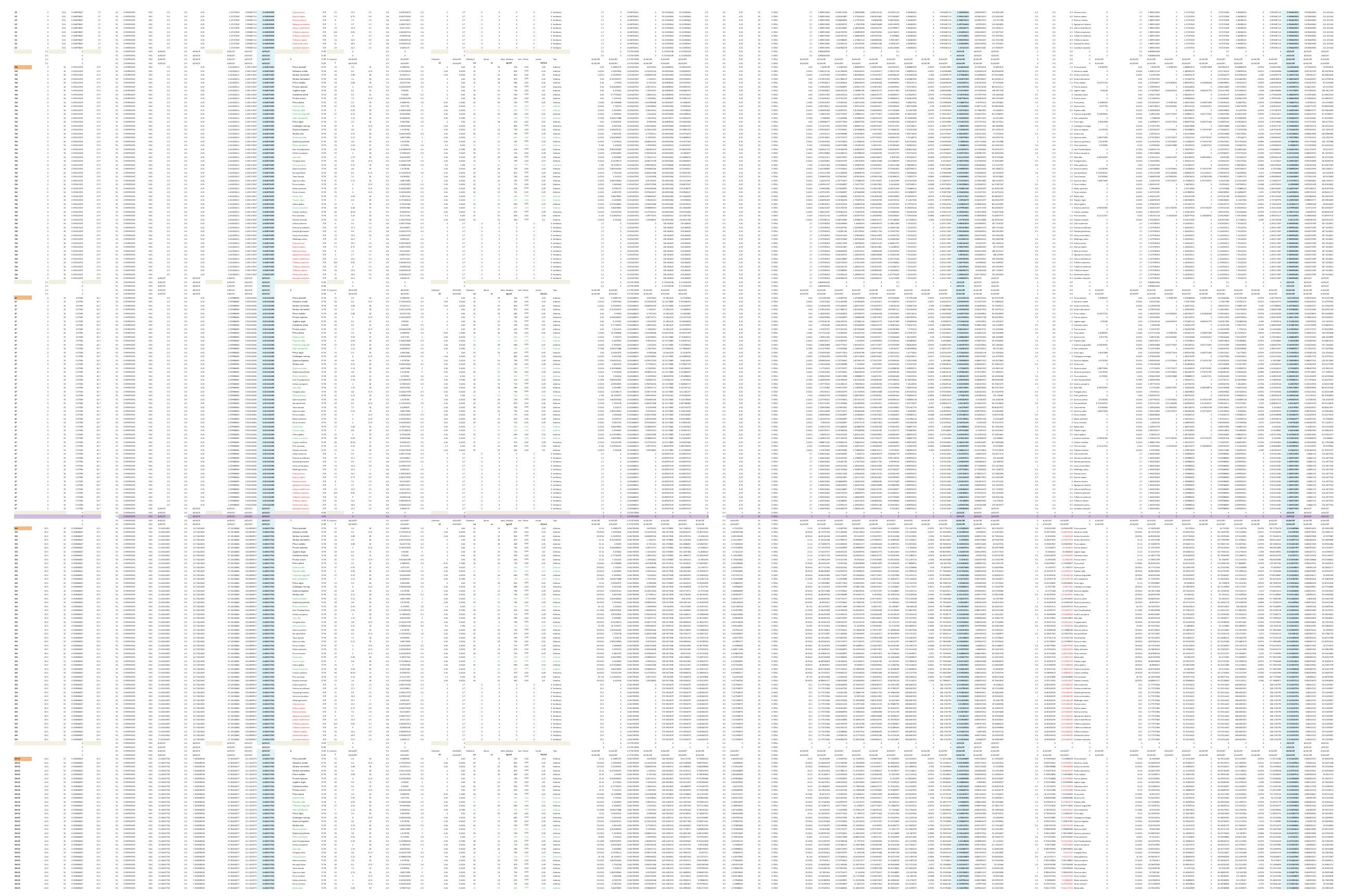



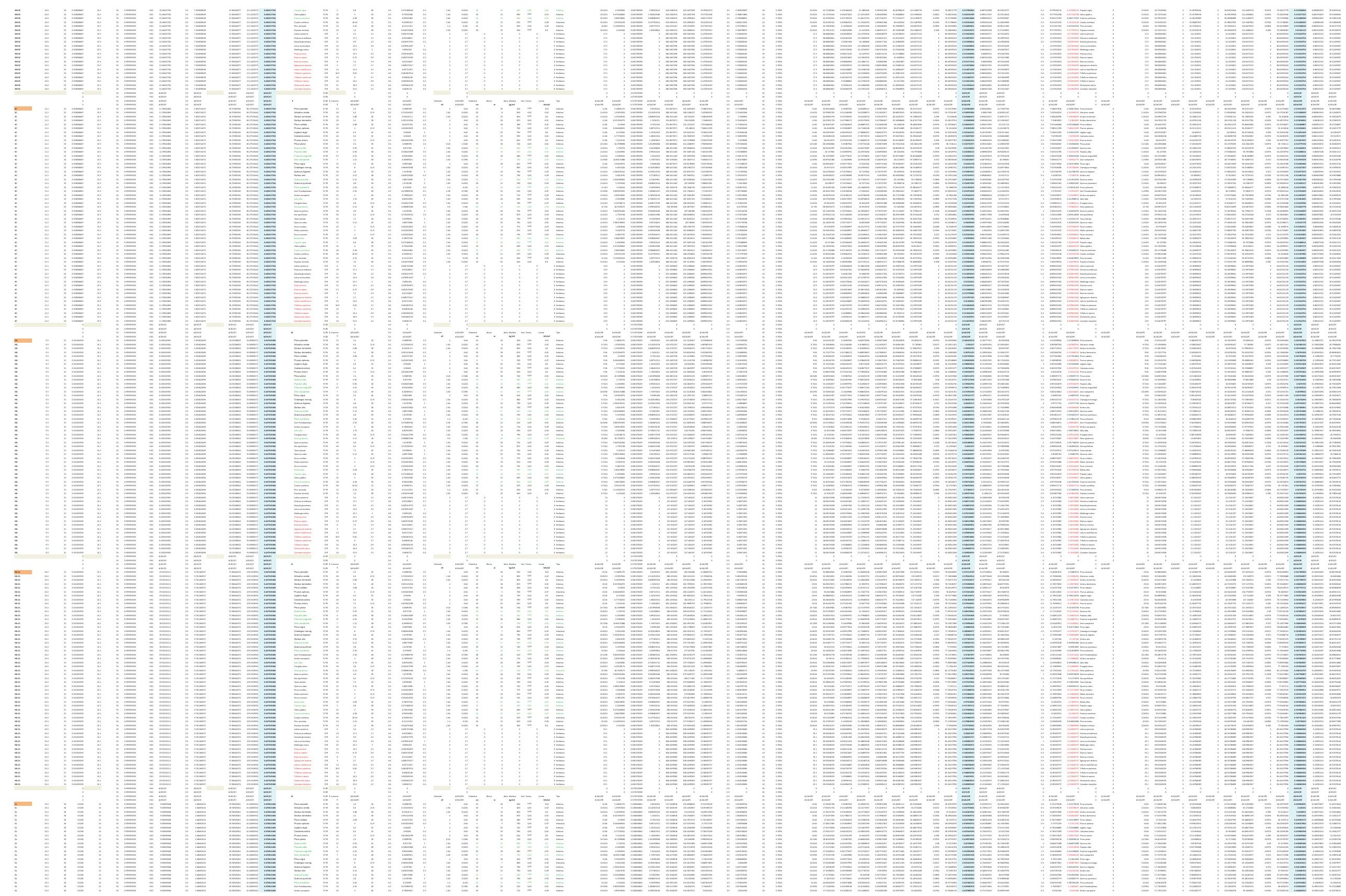


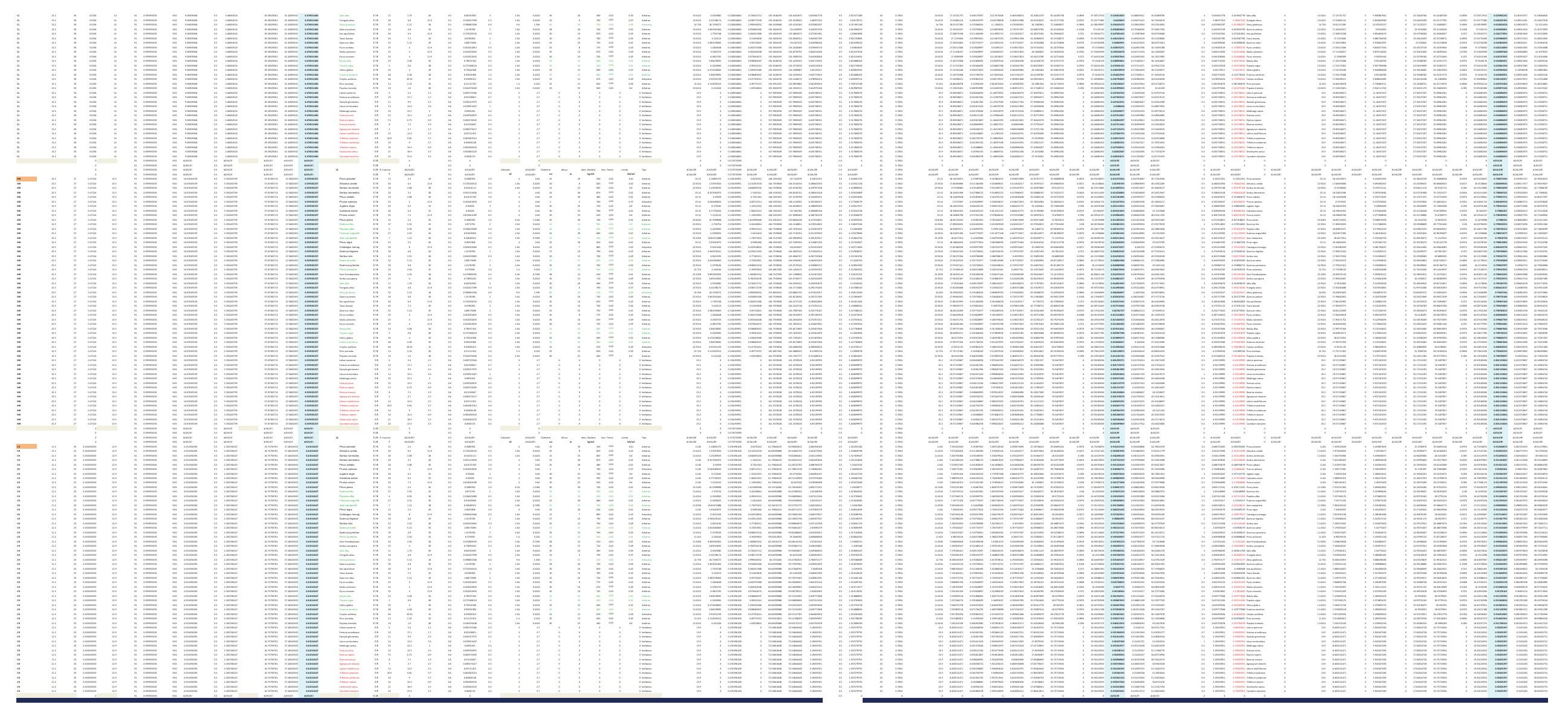



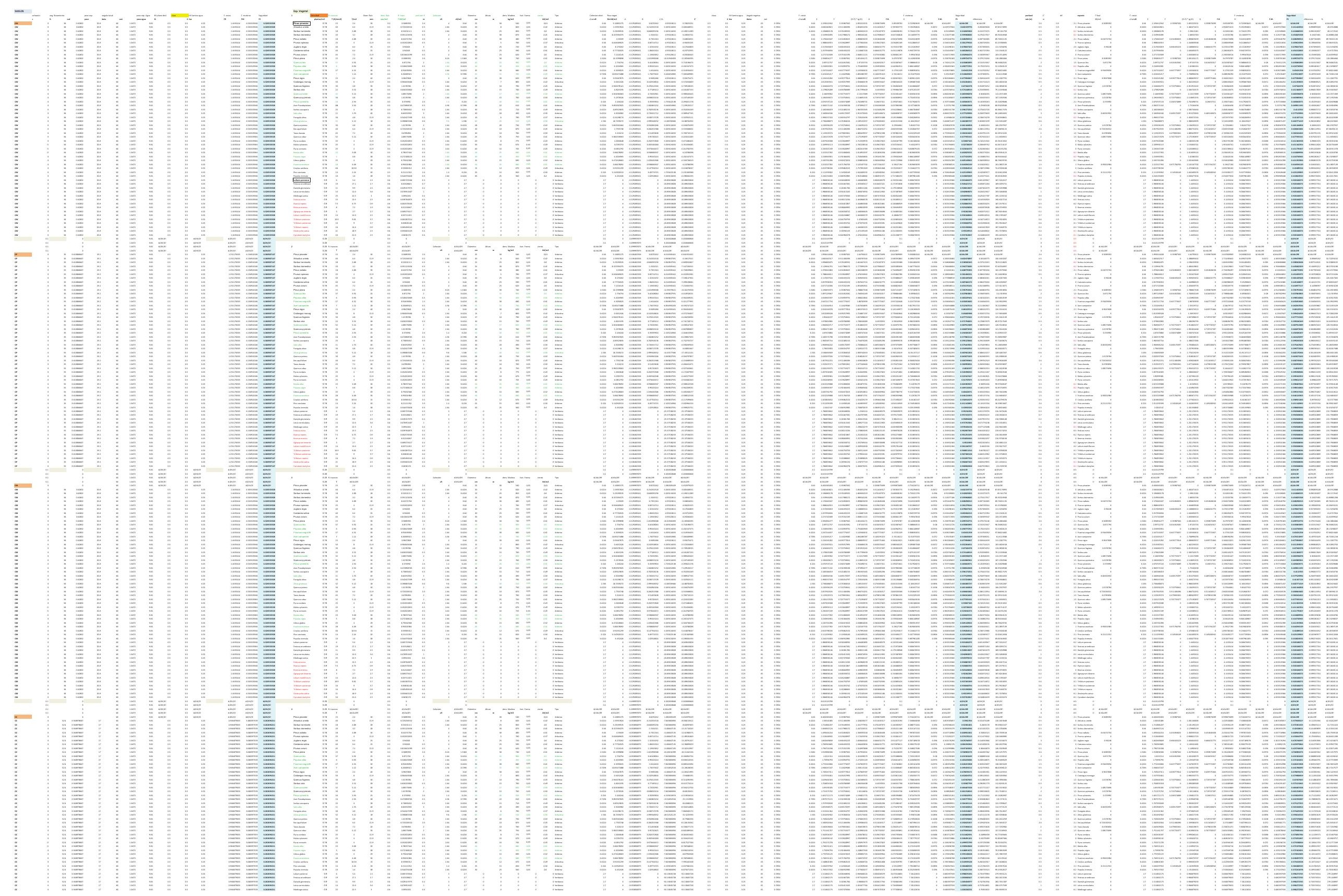


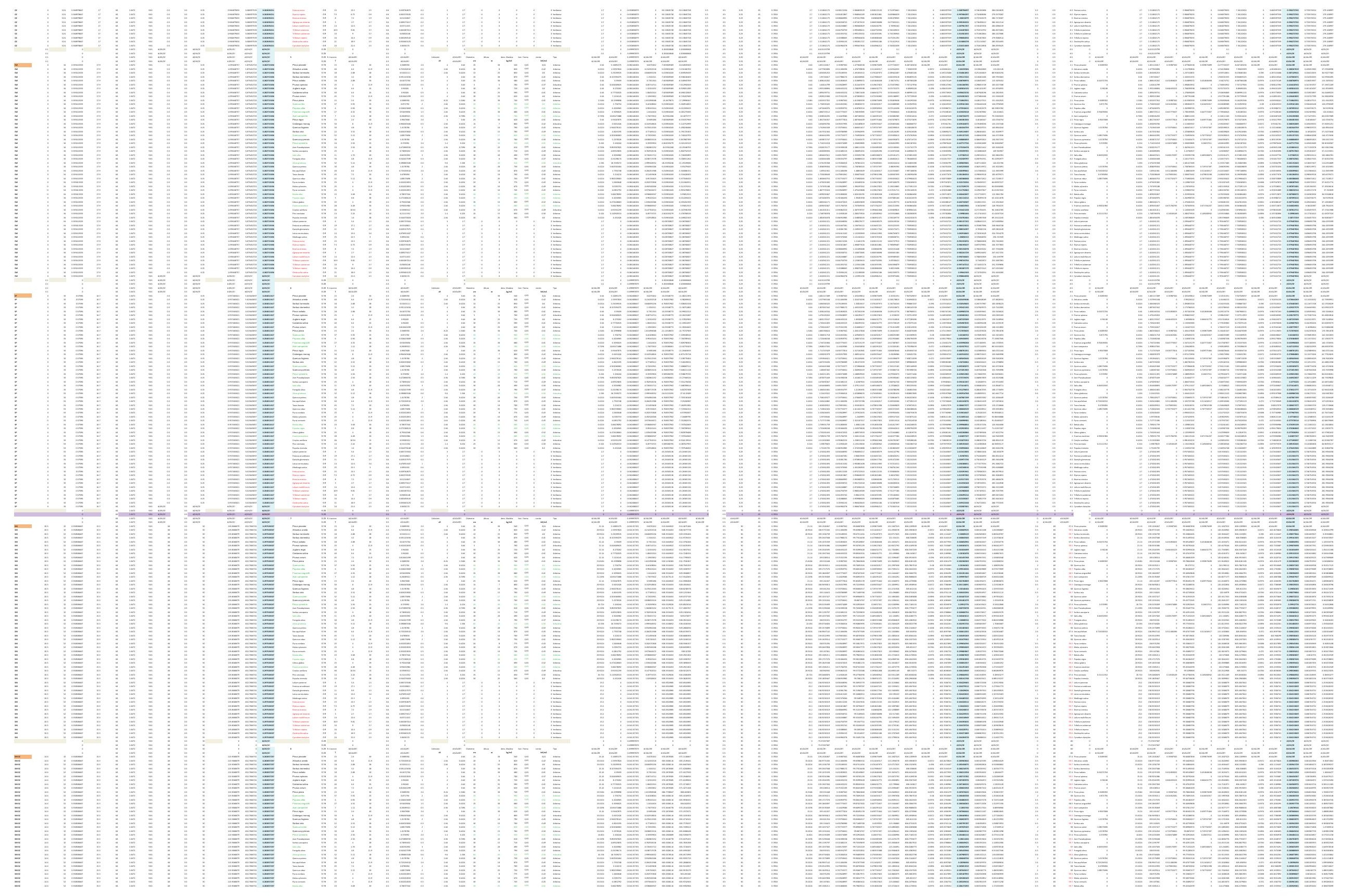



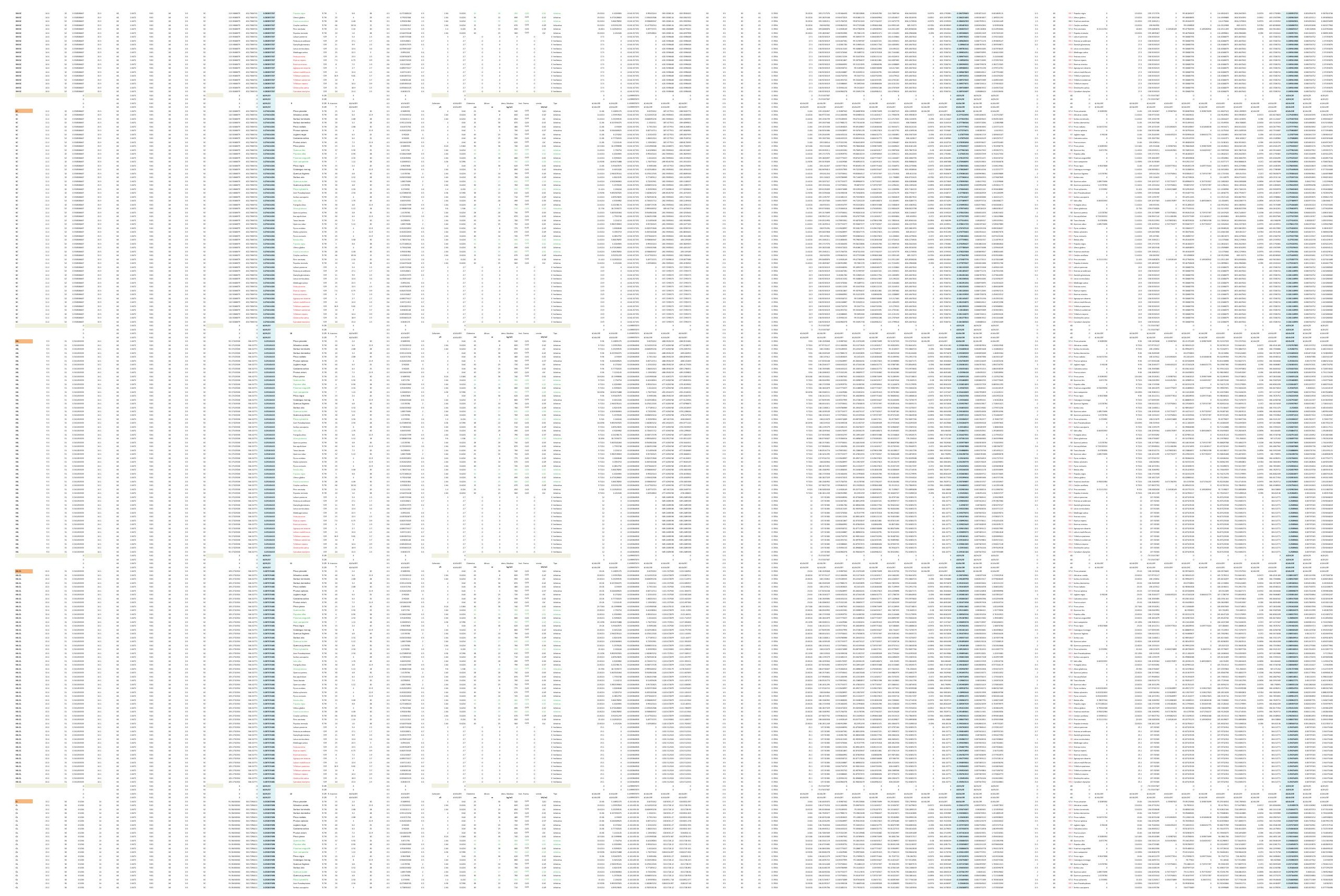


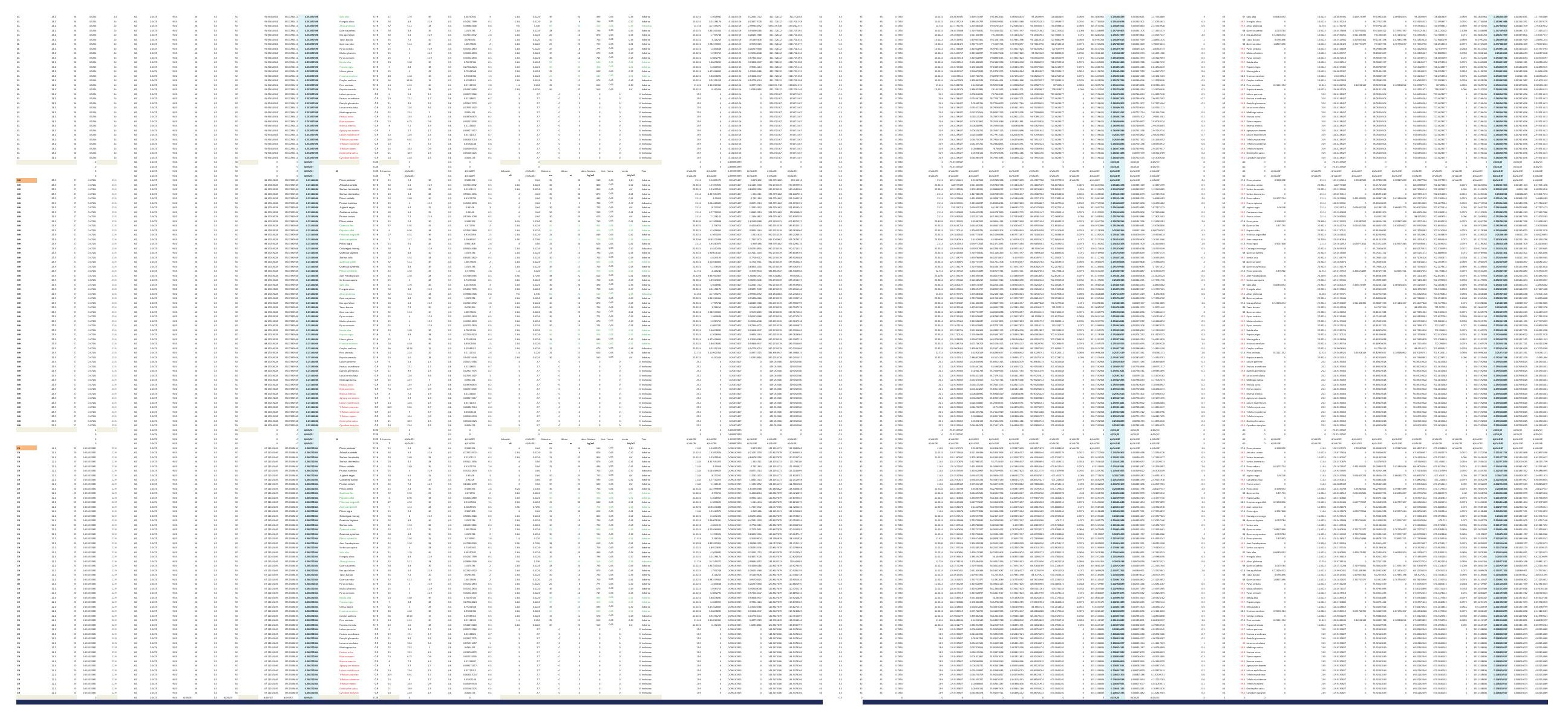



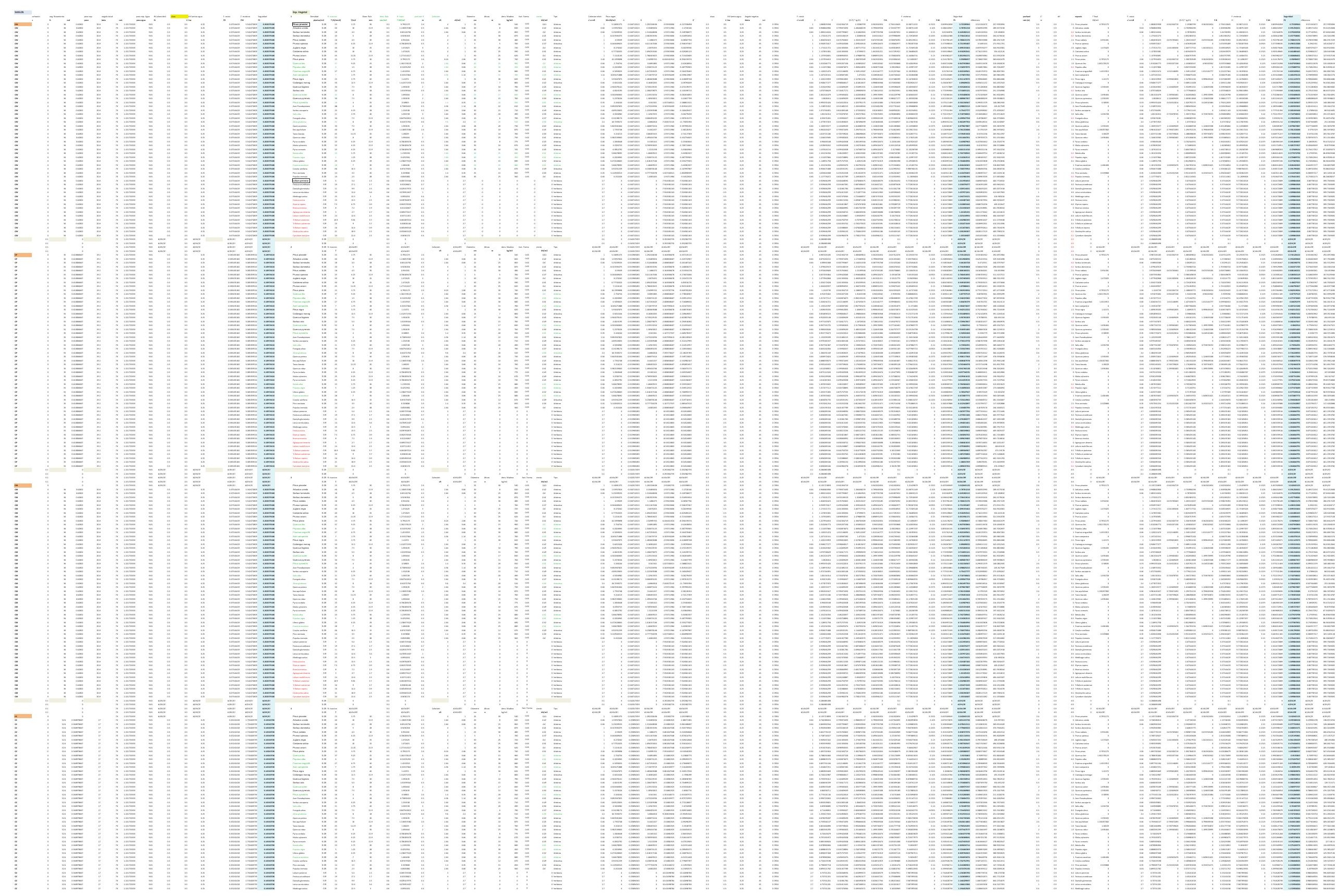


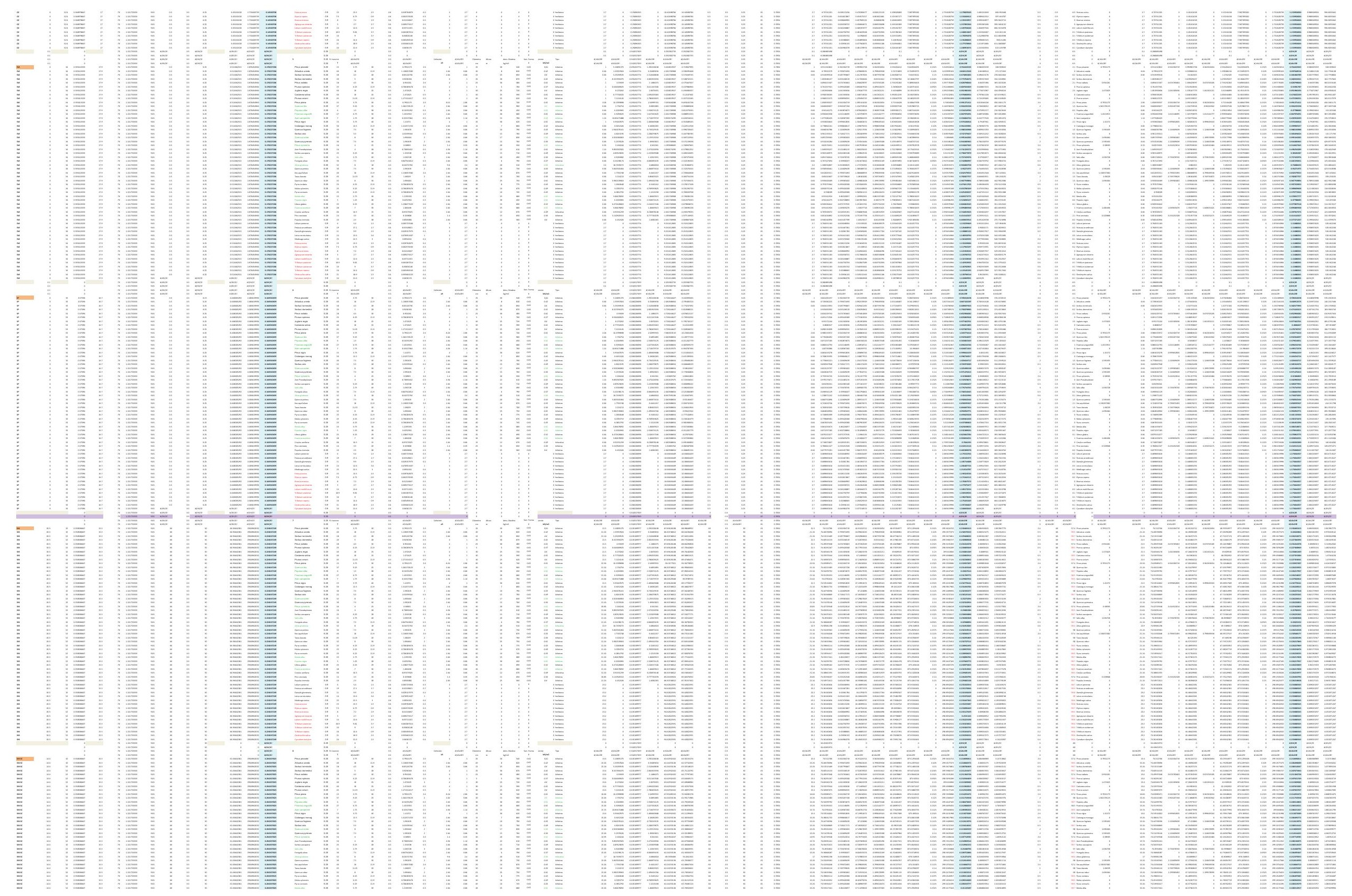




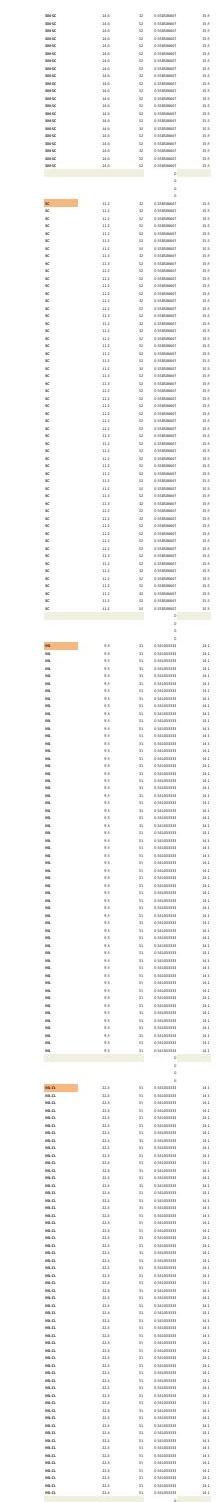

$-$
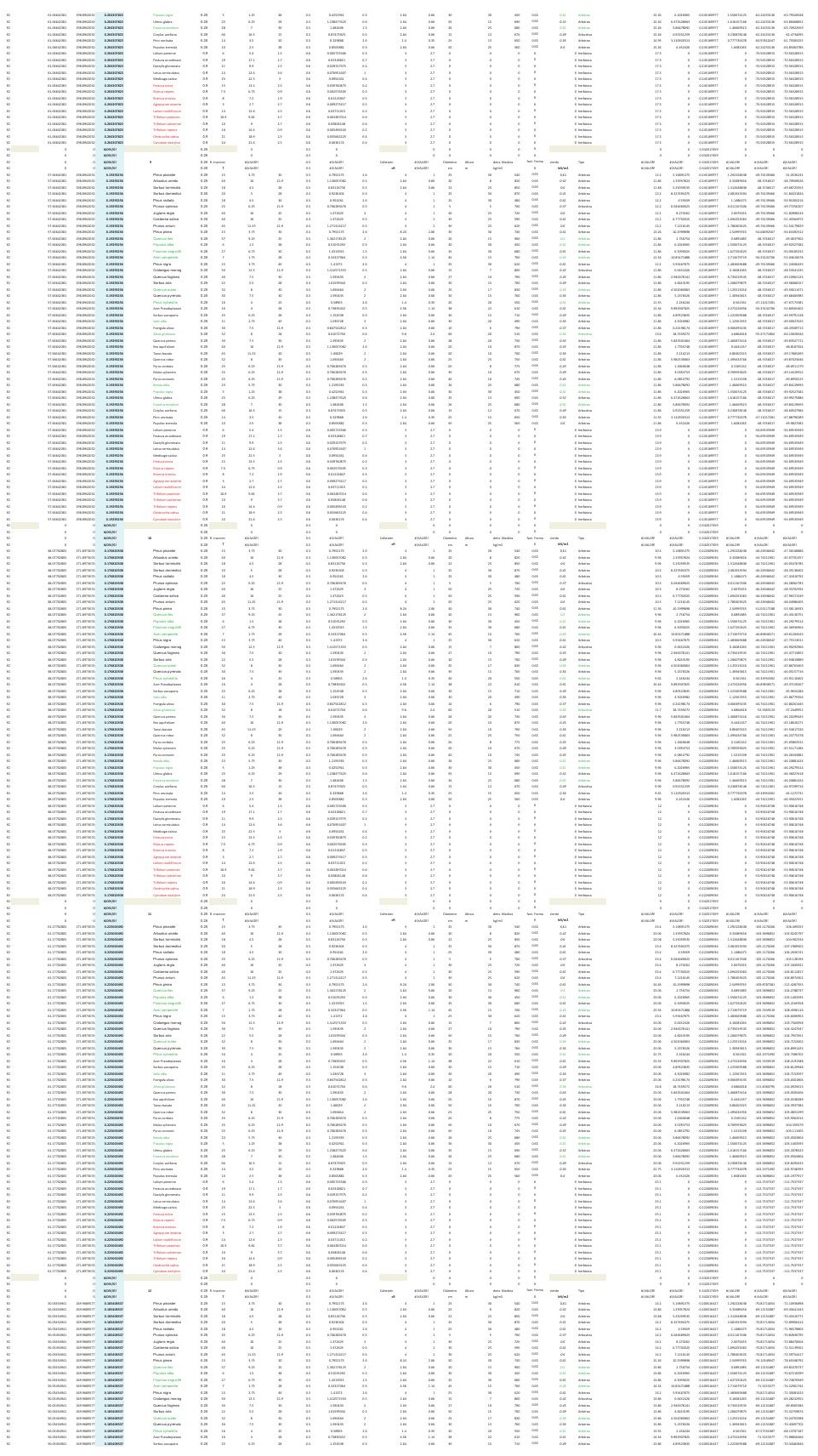
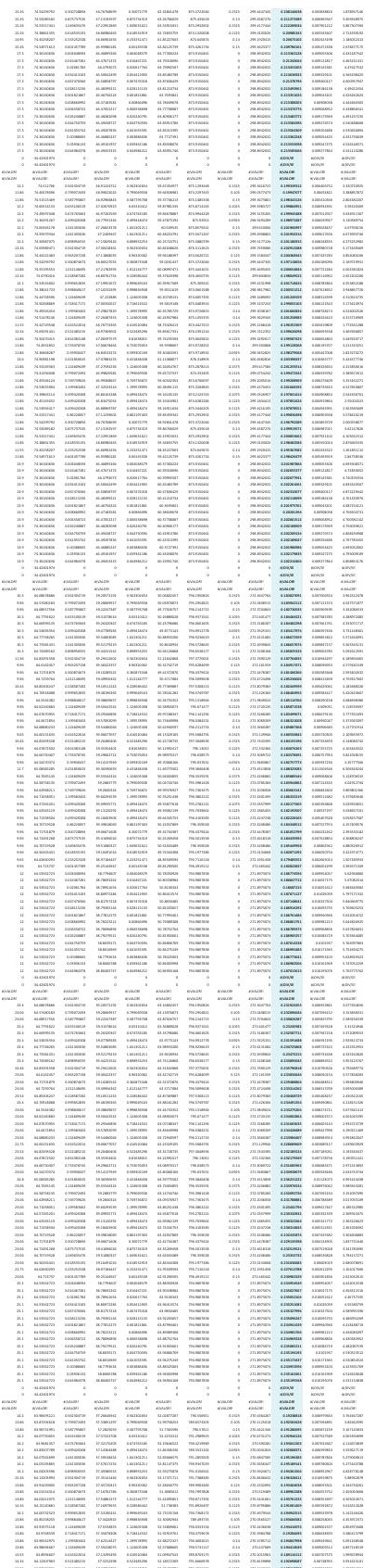

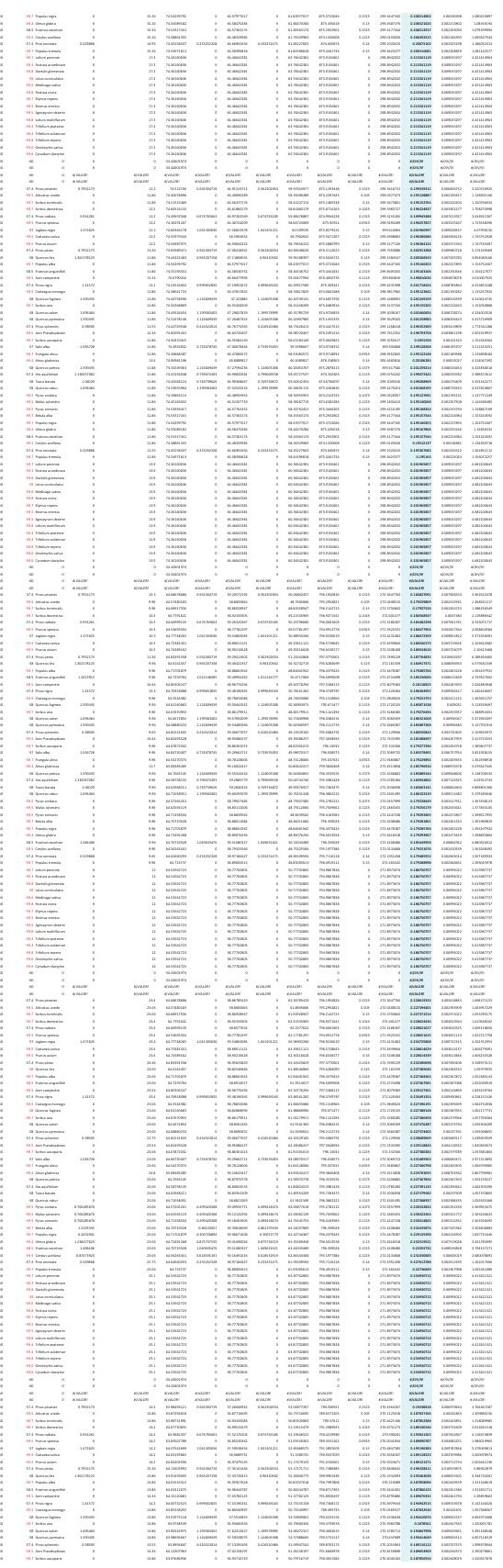




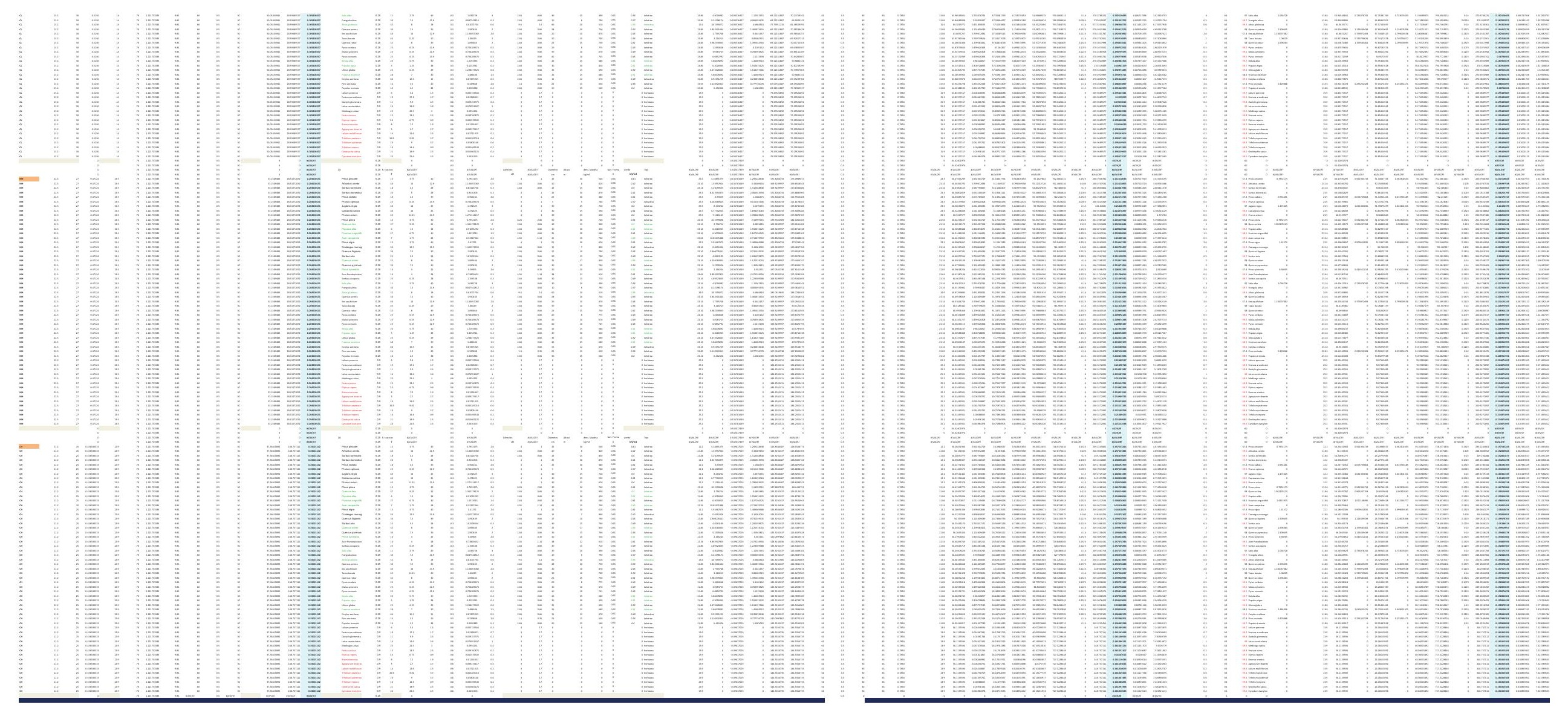



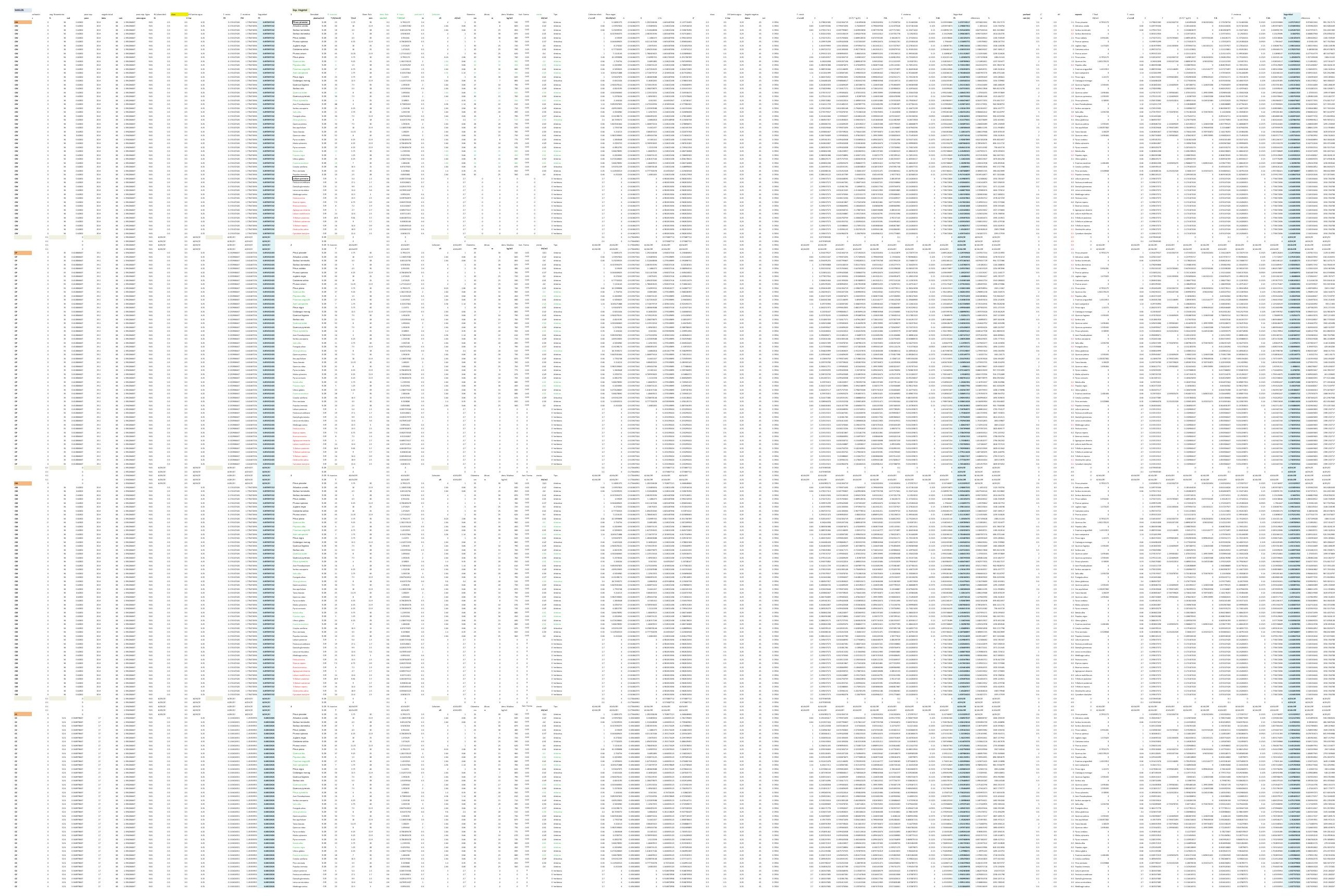


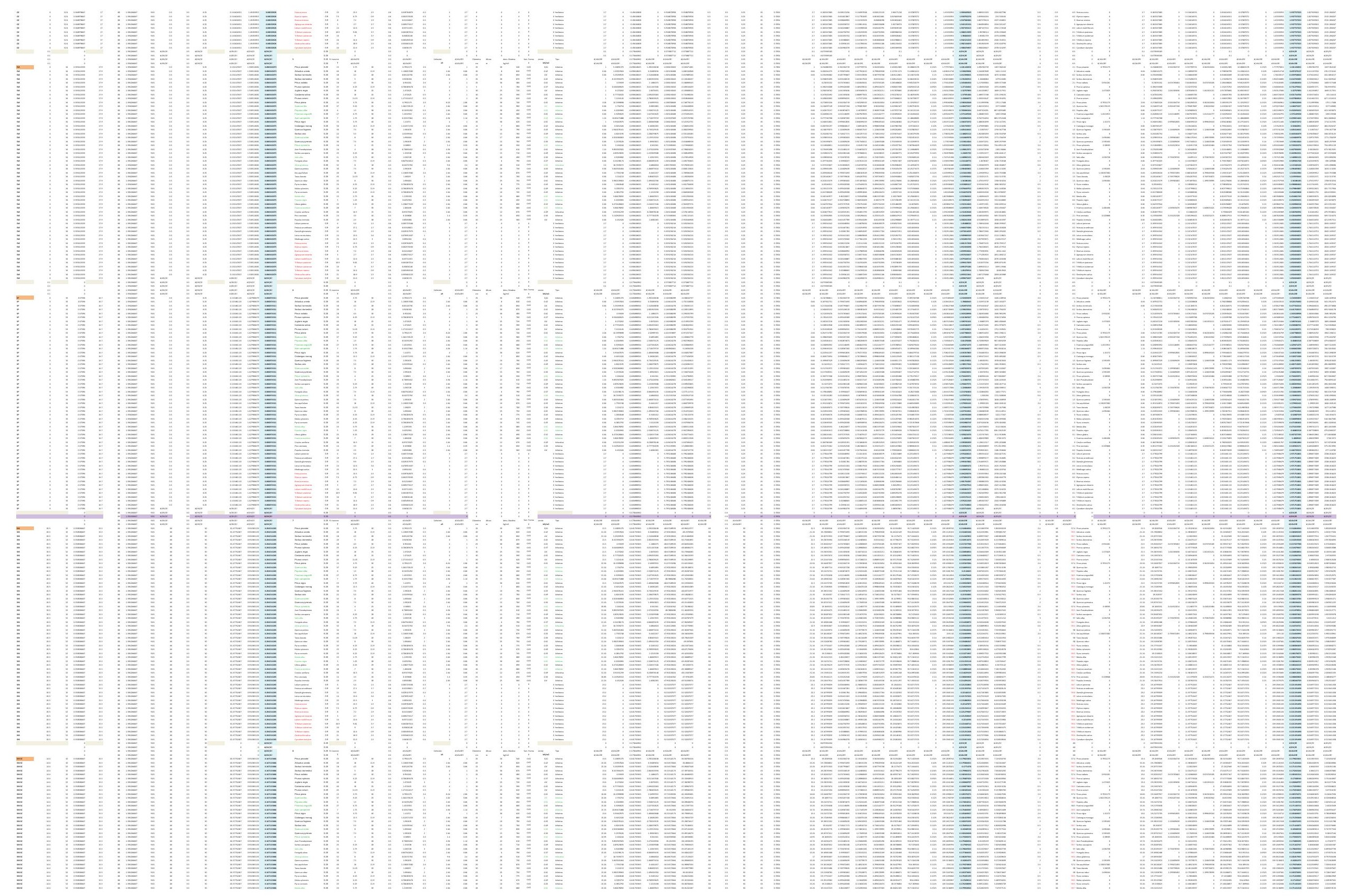



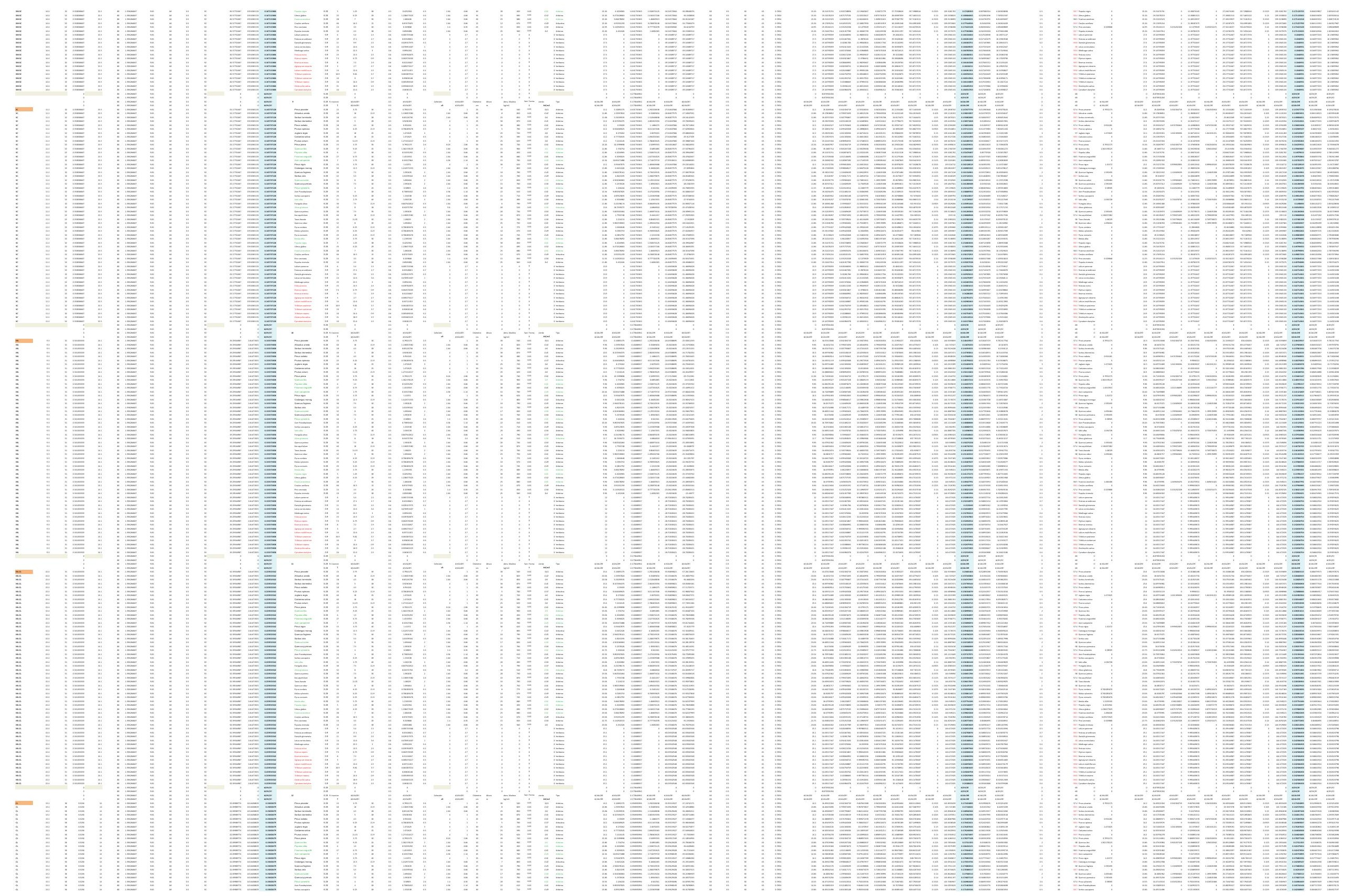


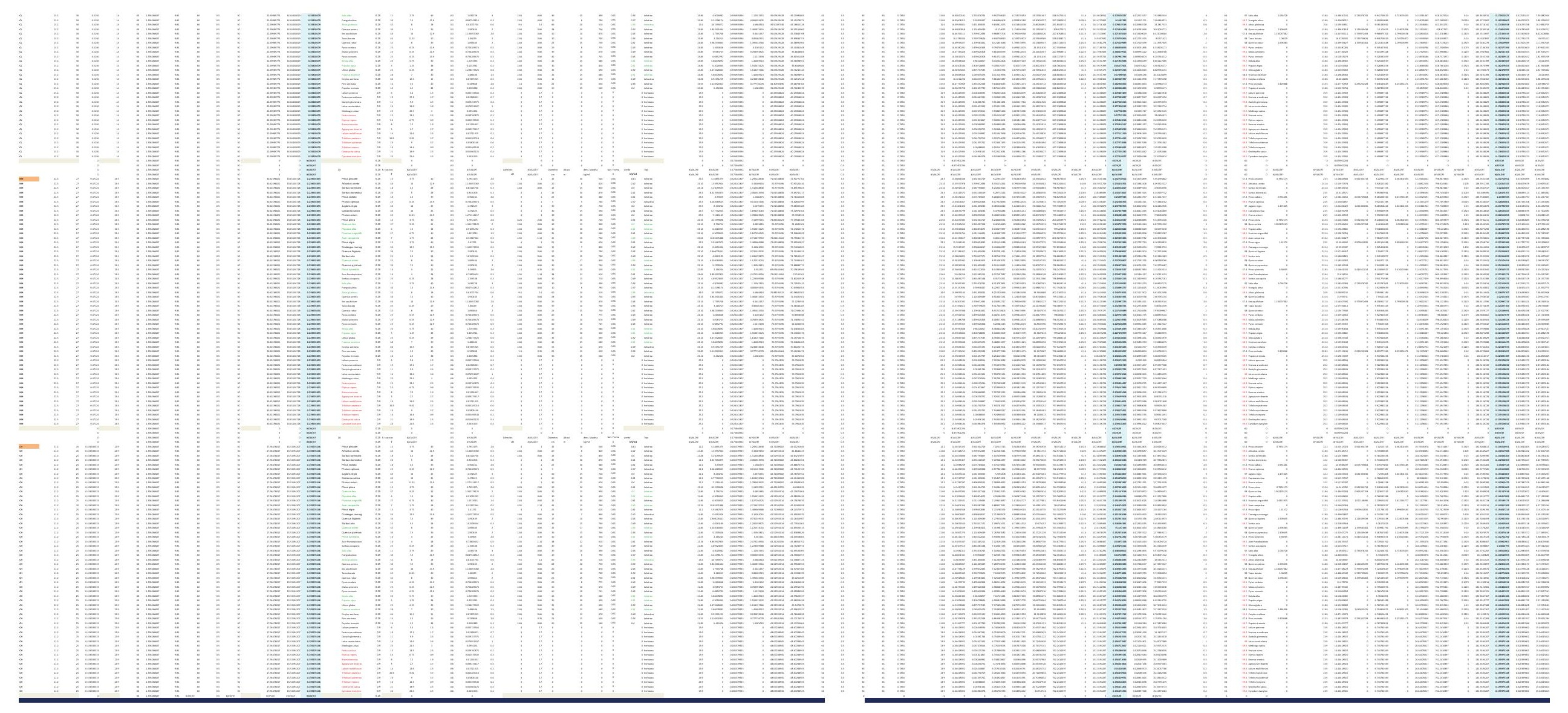


DESARROLLO DE UNA APLICACIÓN IMFORMÁTICA PARA EL CÁLCULO DE SOSTENIMIENTO DE TALUDES MEDIANTE VEGETACIÓN

A02. DENSIDAD DE PLANTACIÓN: 1.600 plantas/ha.

\section{A02-5.POSICIÓN N.F. 5}

INCLINACIÓN DE TALUD 6-100

INCLINACIÓN DE TALUD 10-200

INCLINACIÓN DE TALUD 20-30

INCLINACIÓN DE TALUD 30-40

INCLINACIÓN DE TALUD $35^{\circ}$

INCLINACIÓN DE TALUD 40-50

INCLINACIÓN DE TALUD 50-550

INCLINACIÓN DE TALUD 55-60

INCLINACIÓN DE TALUD 60-700

INCLINACIÓN DE TALUD 70-80 

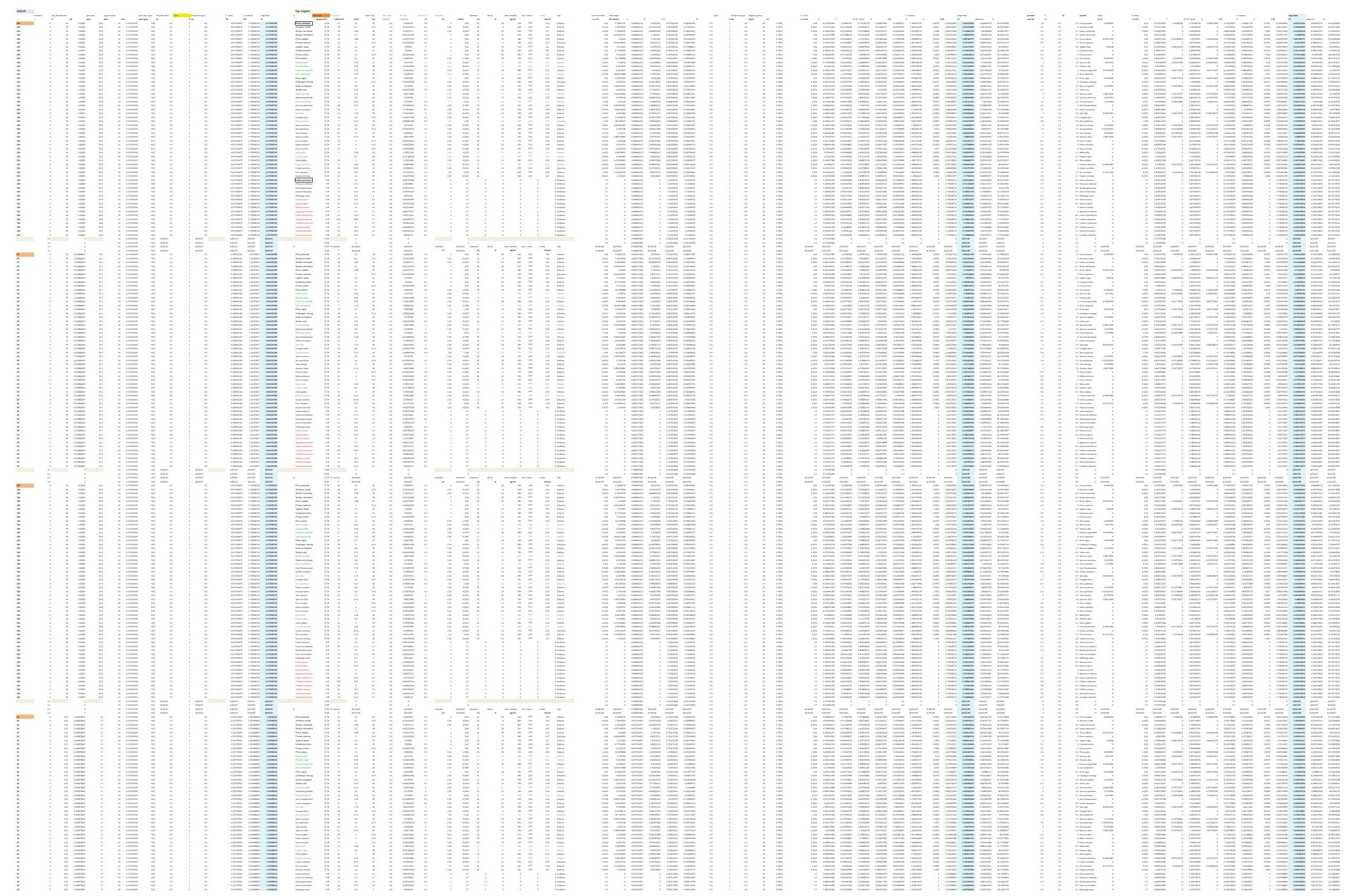


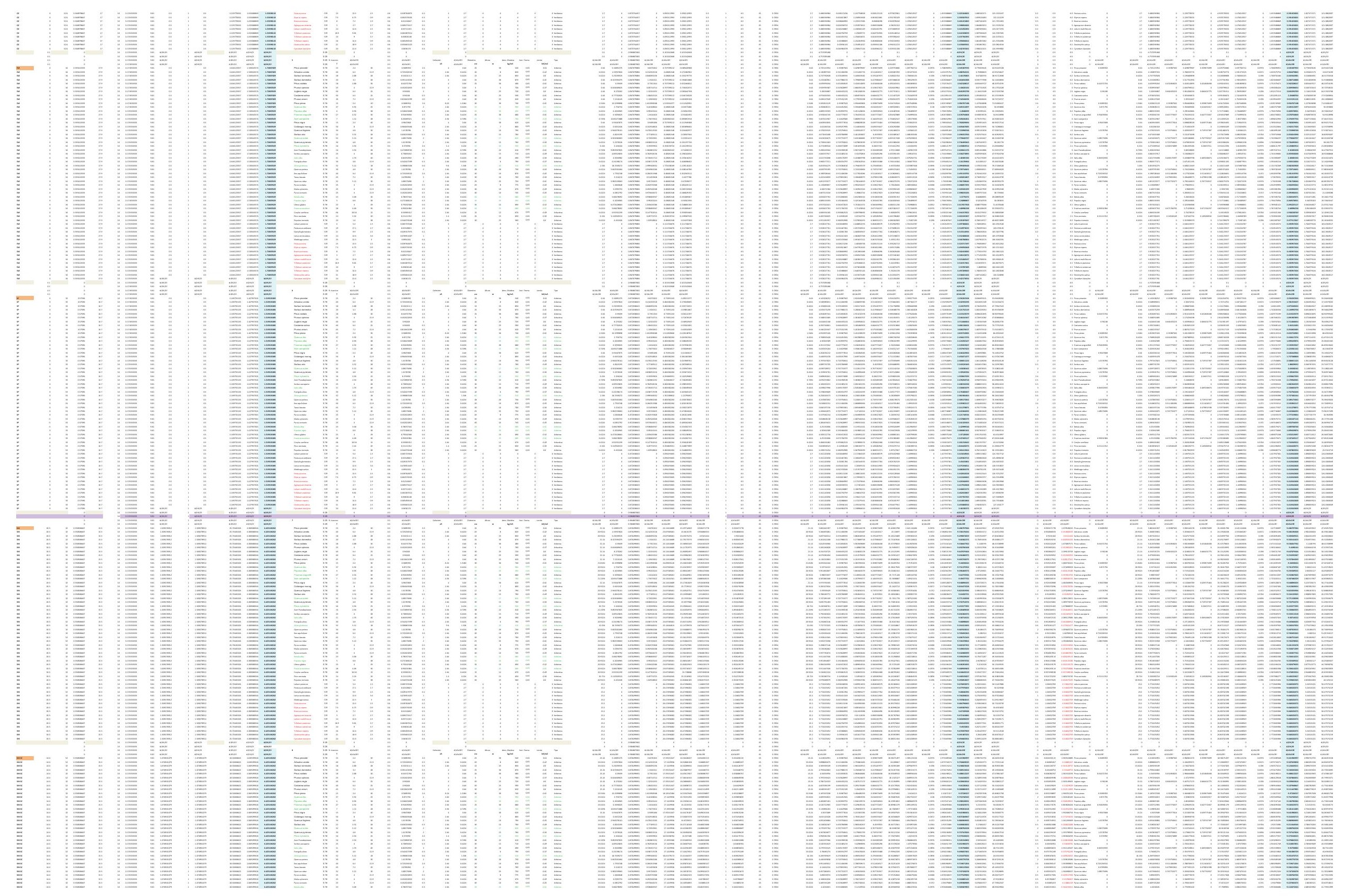



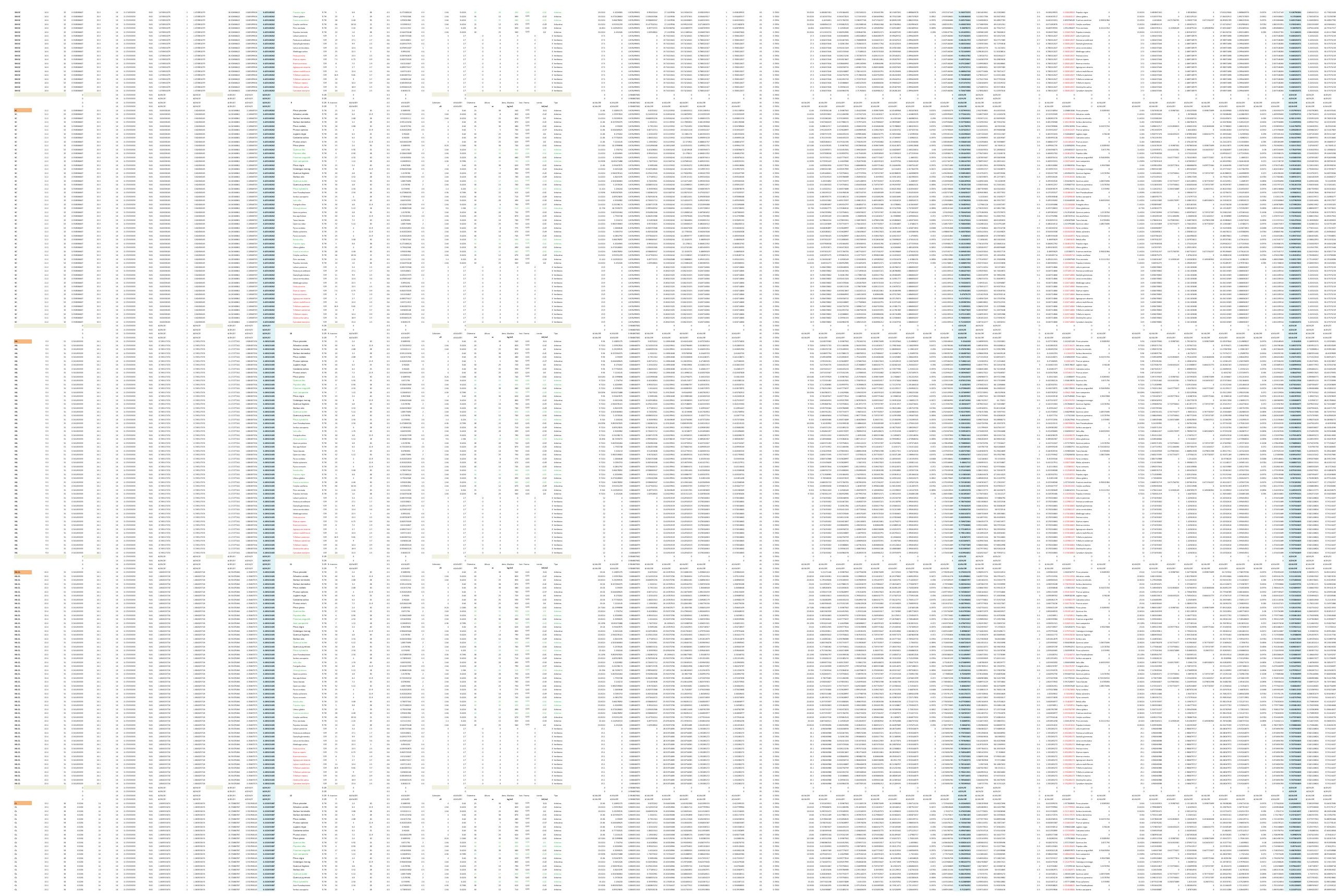


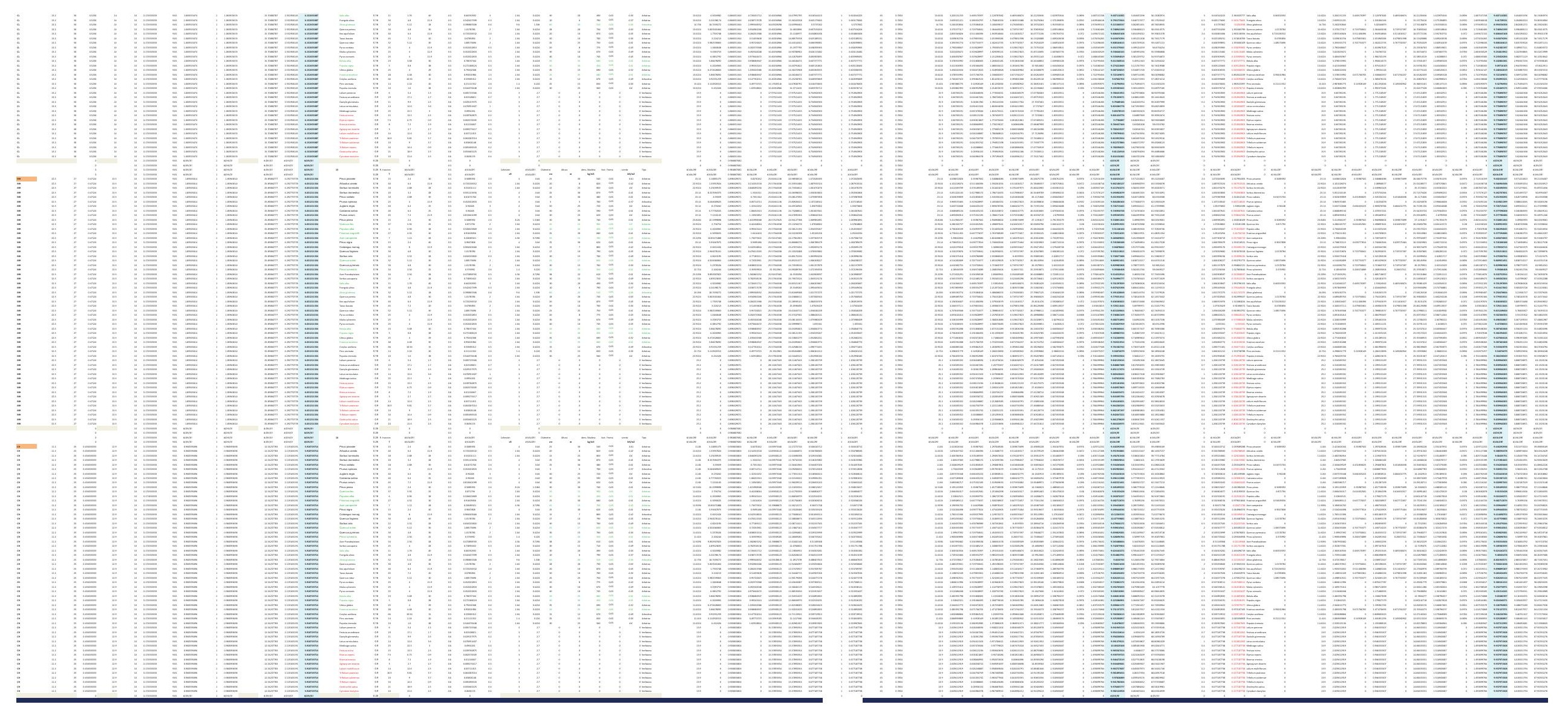



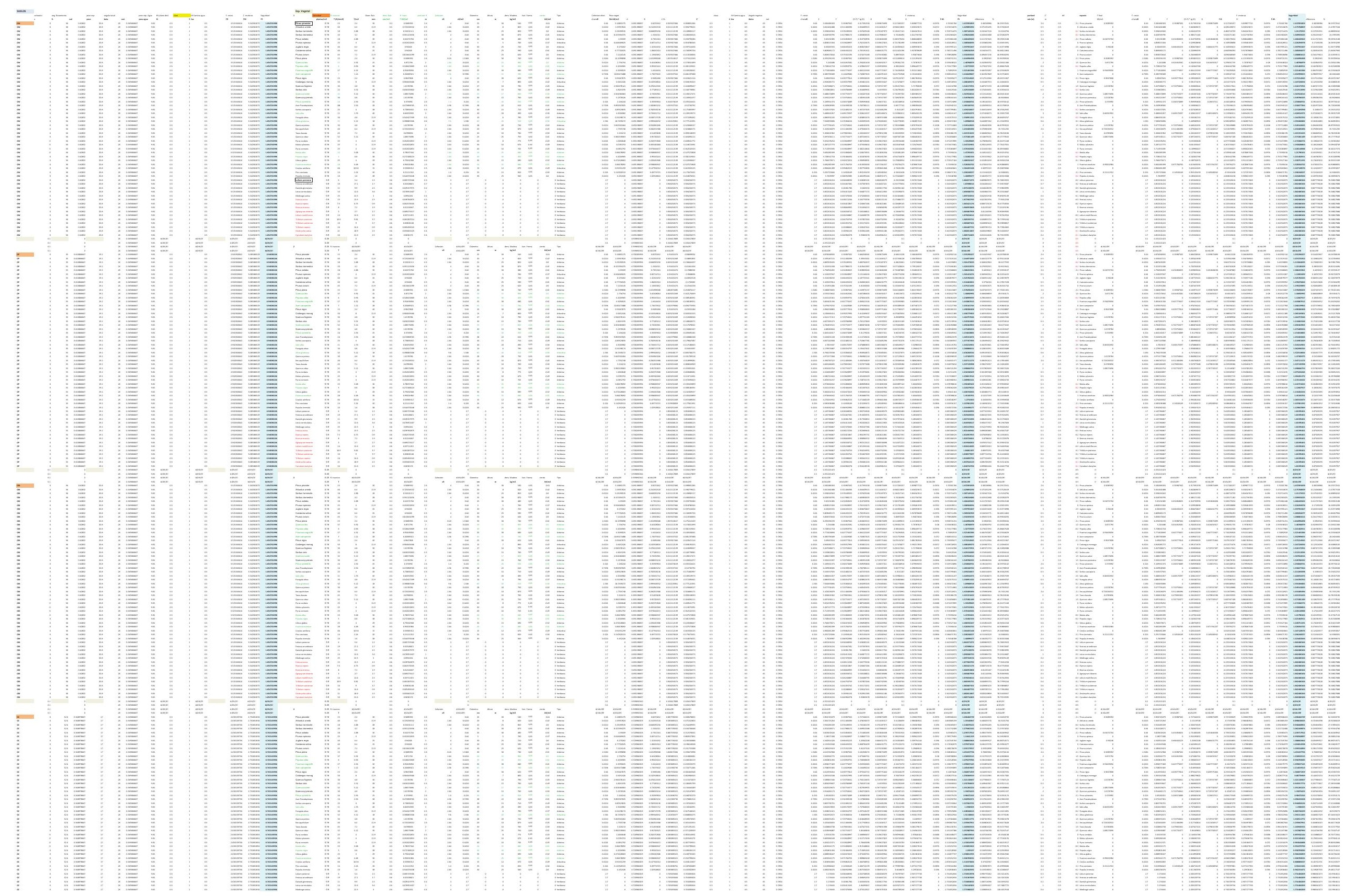


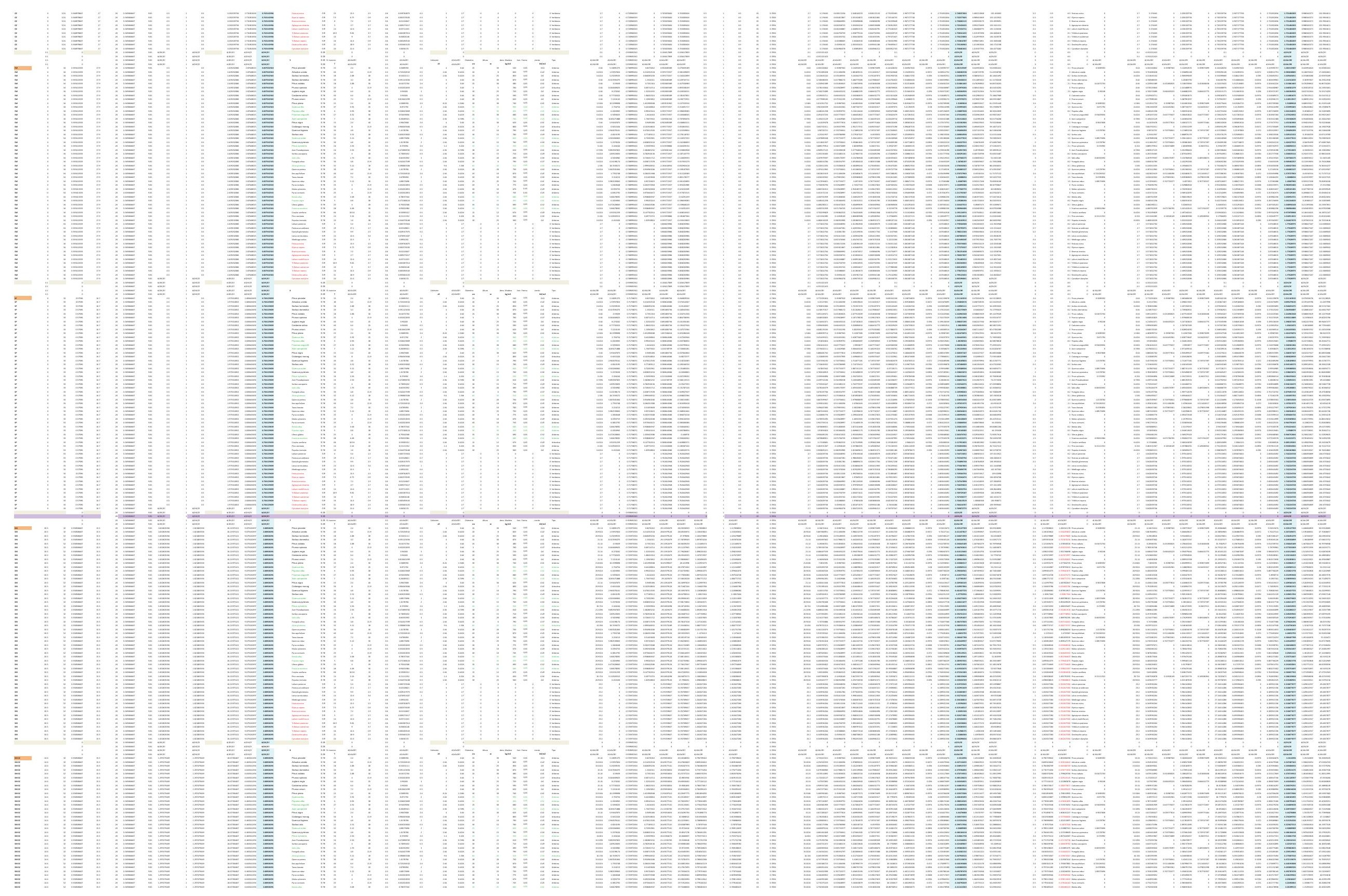



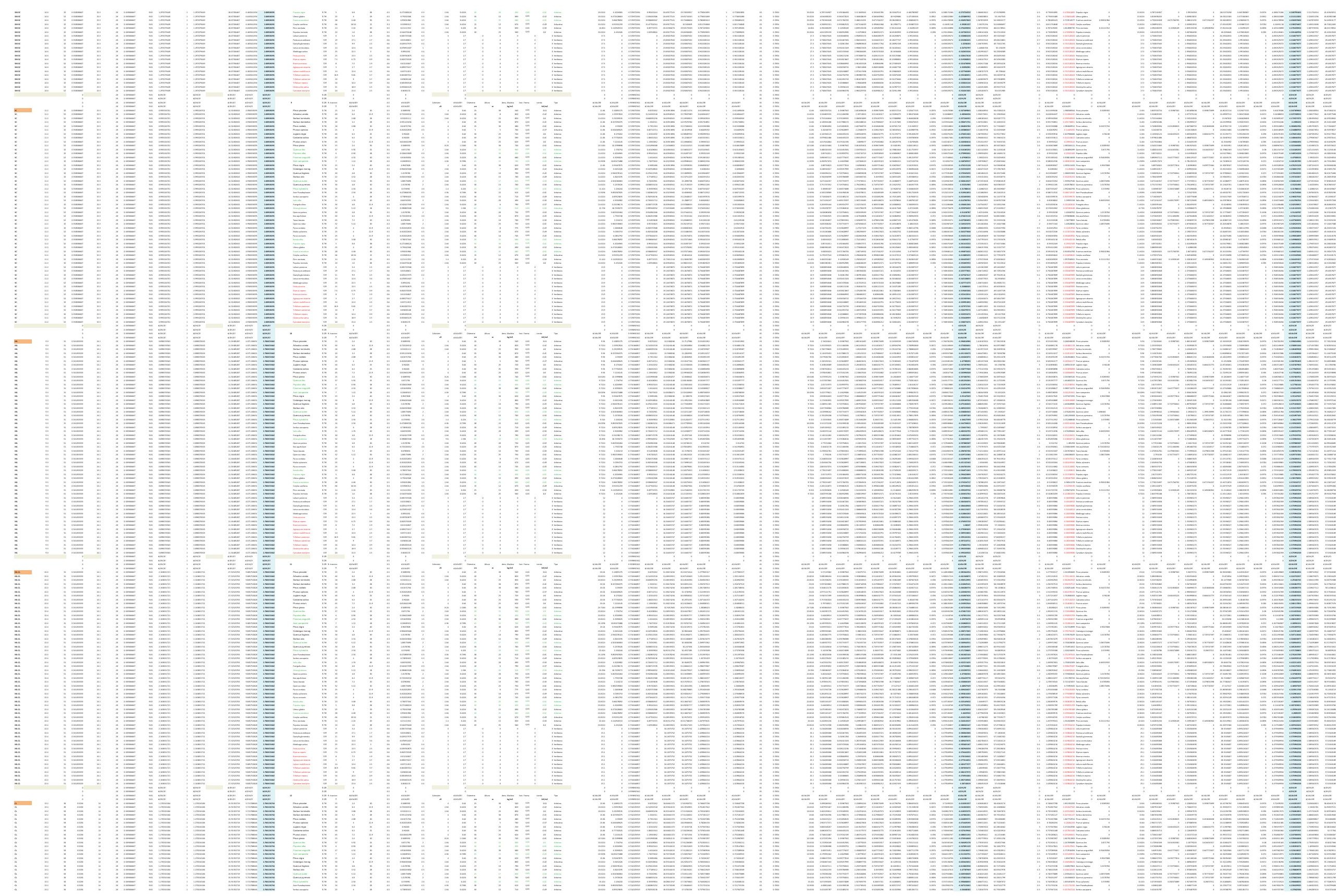


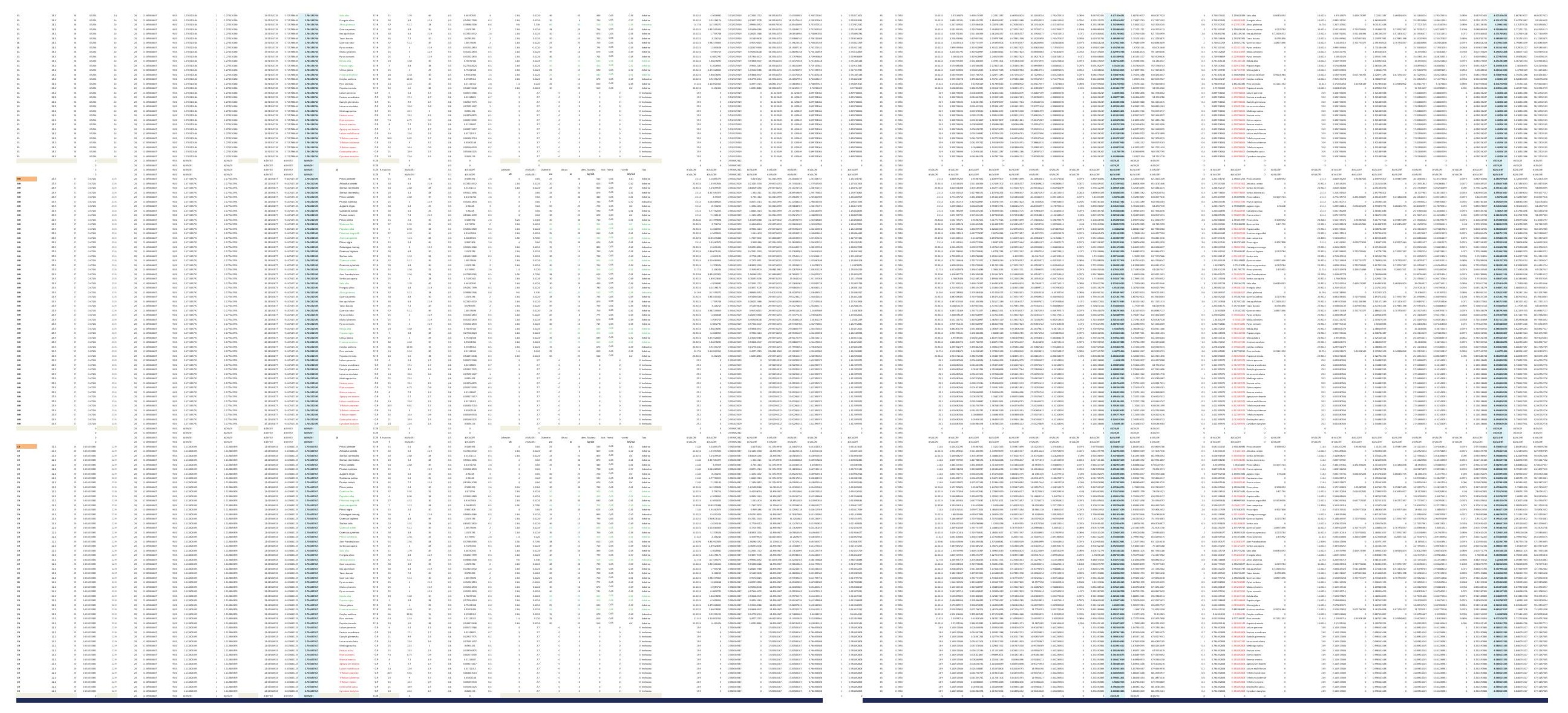



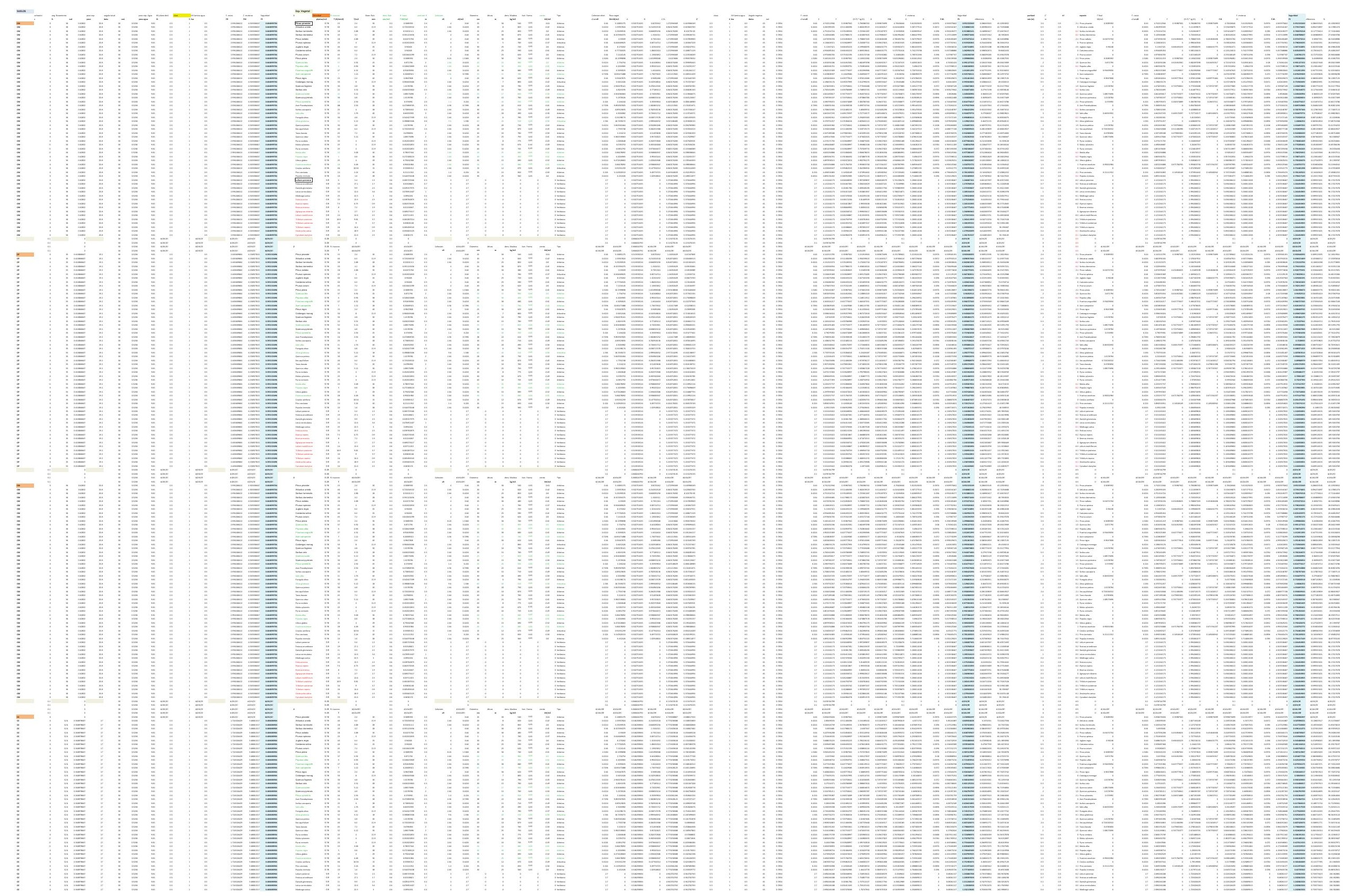


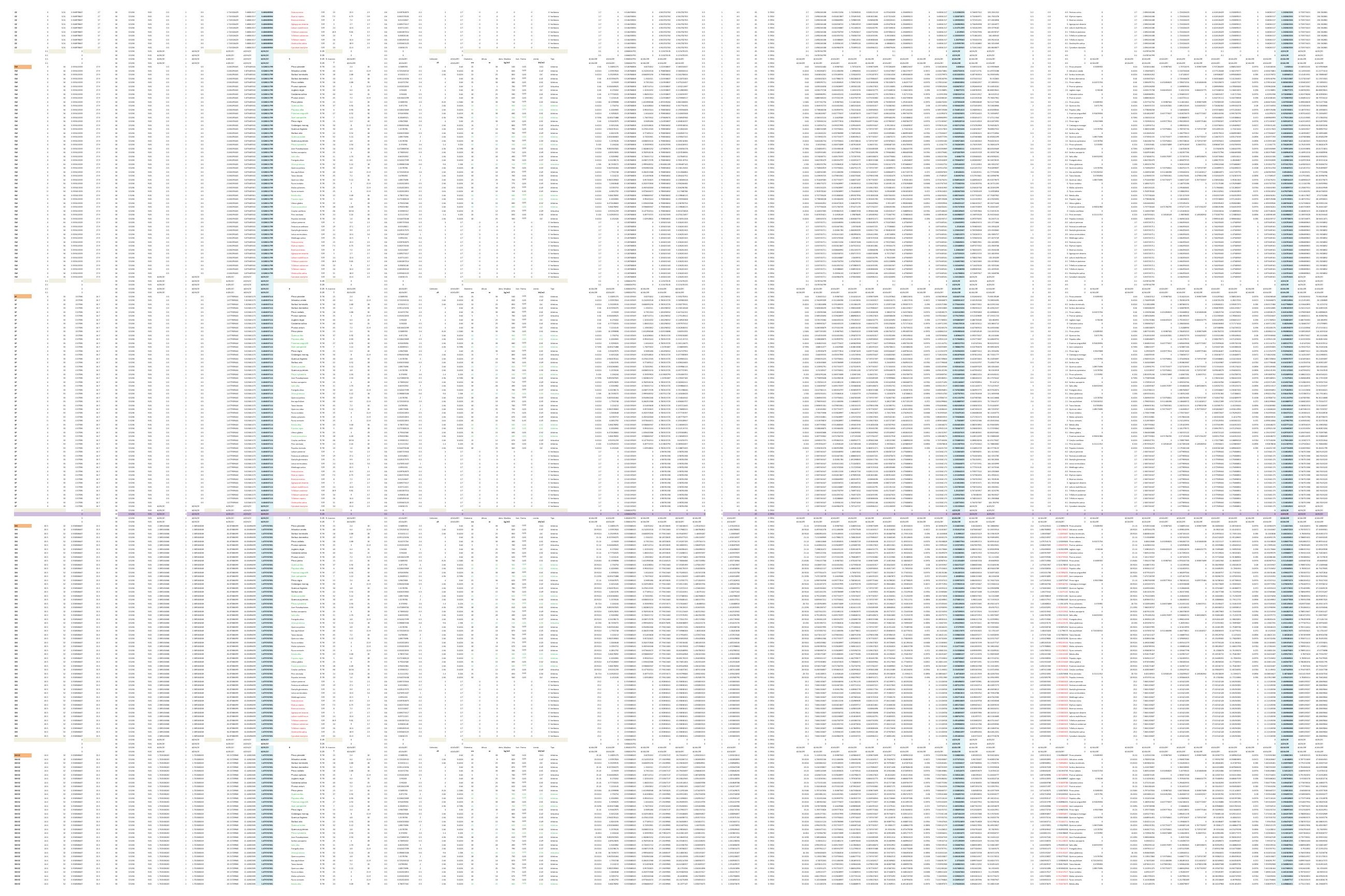



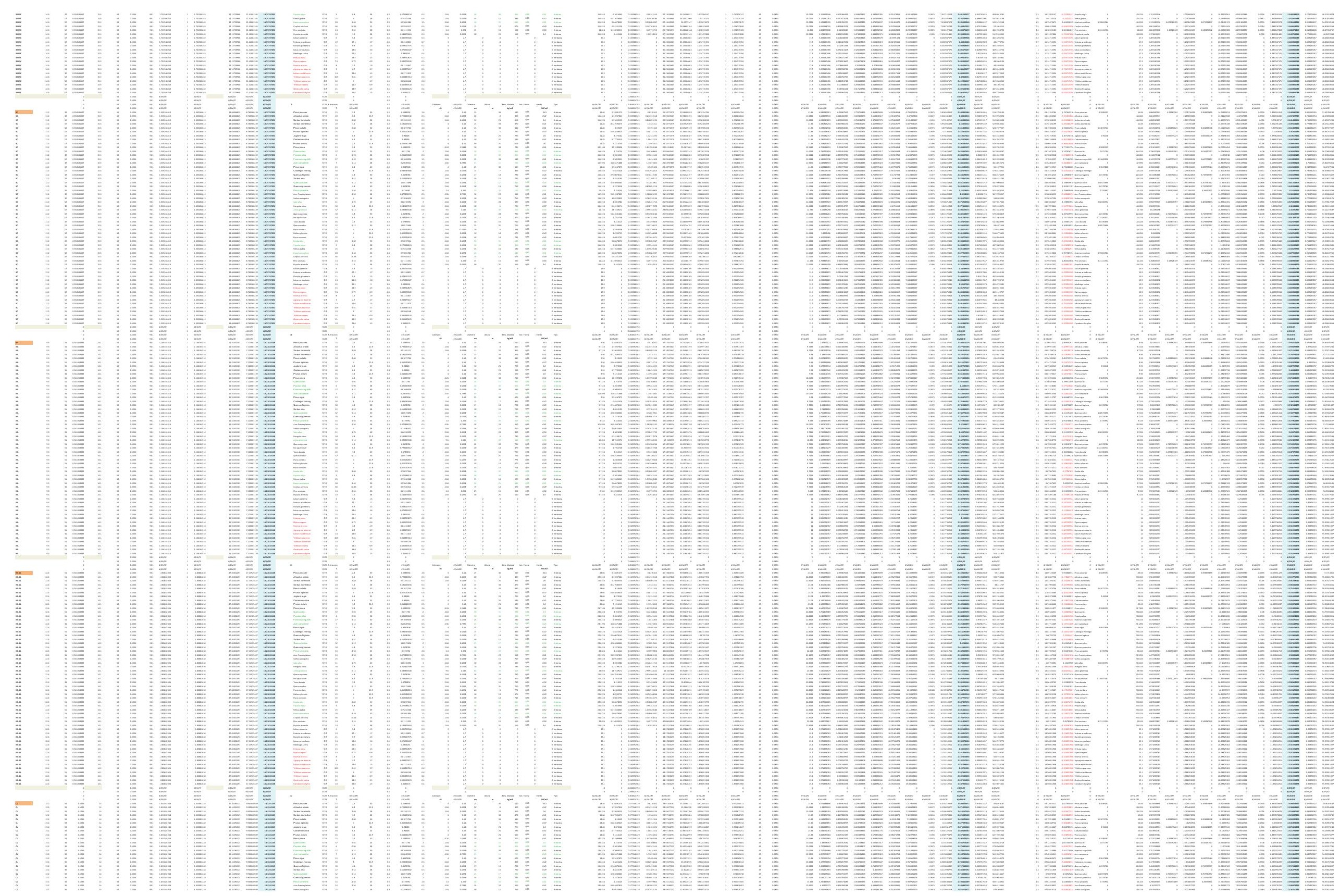


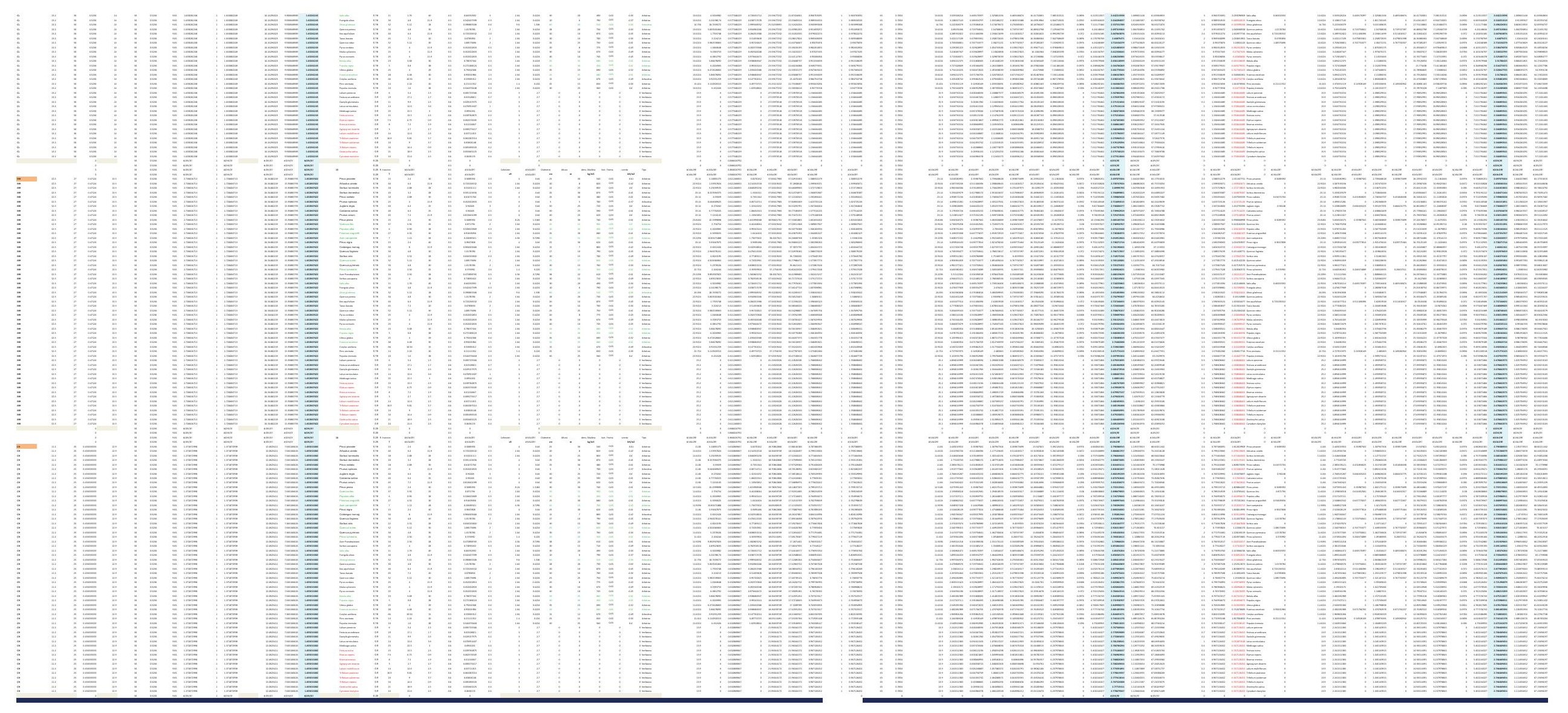



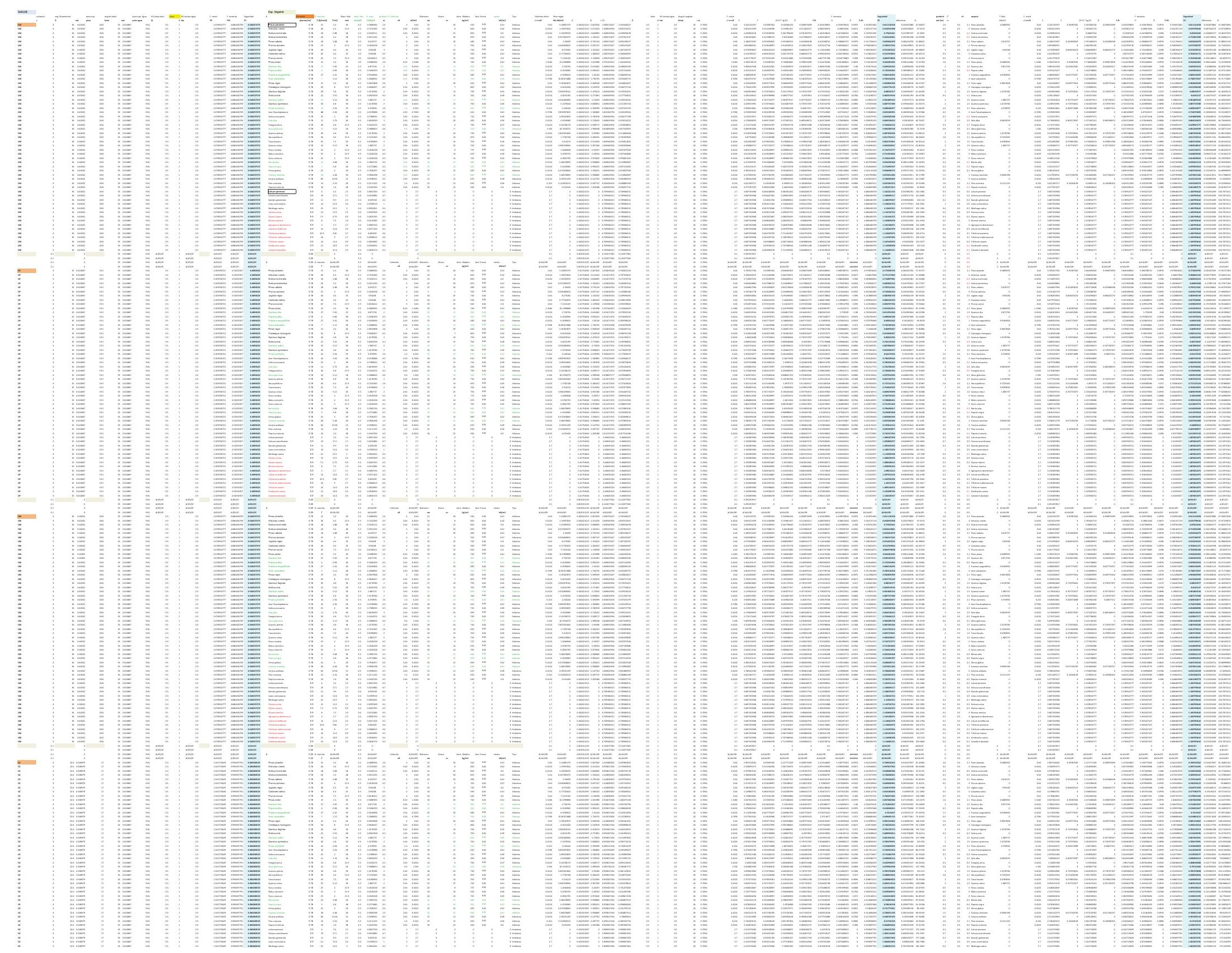


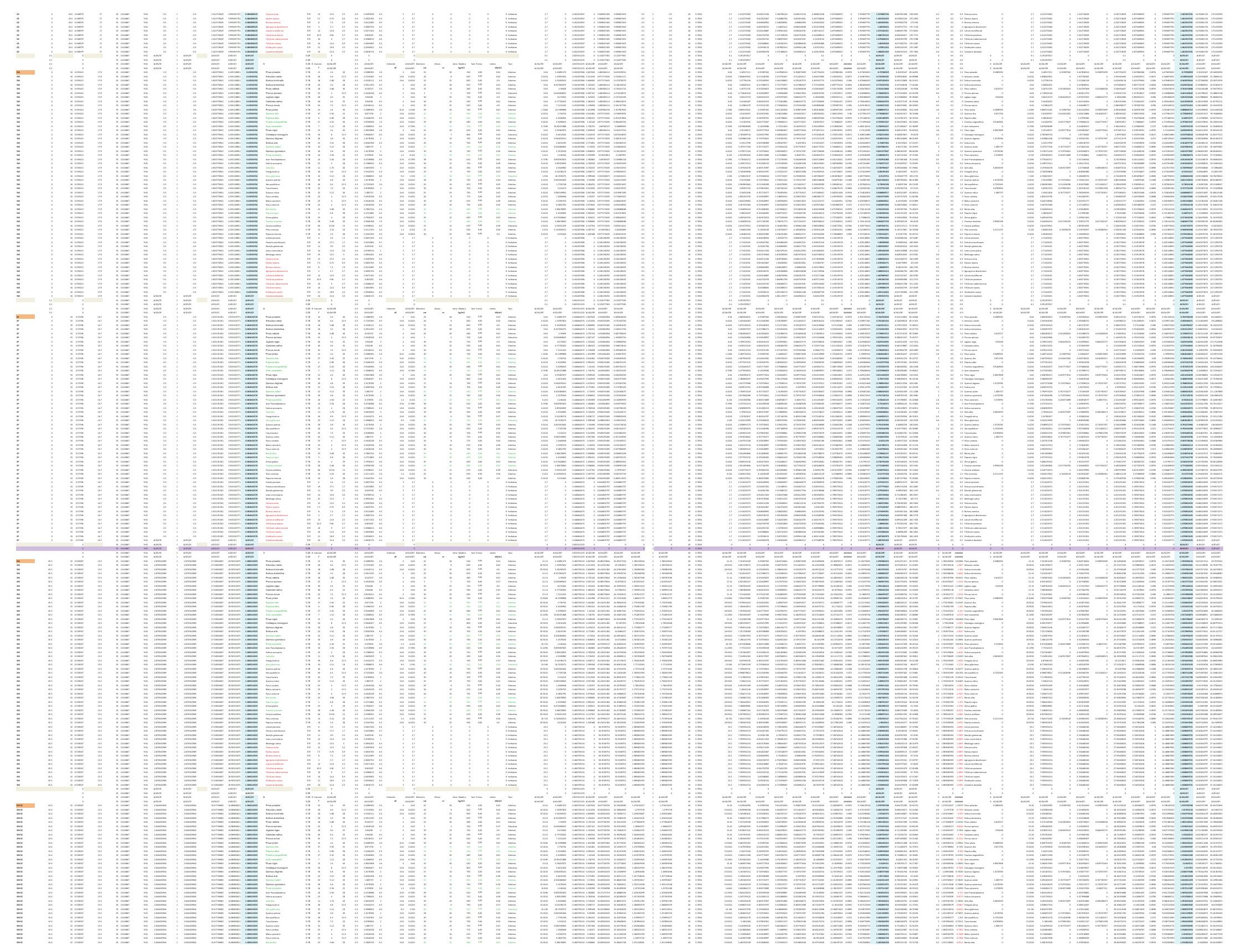



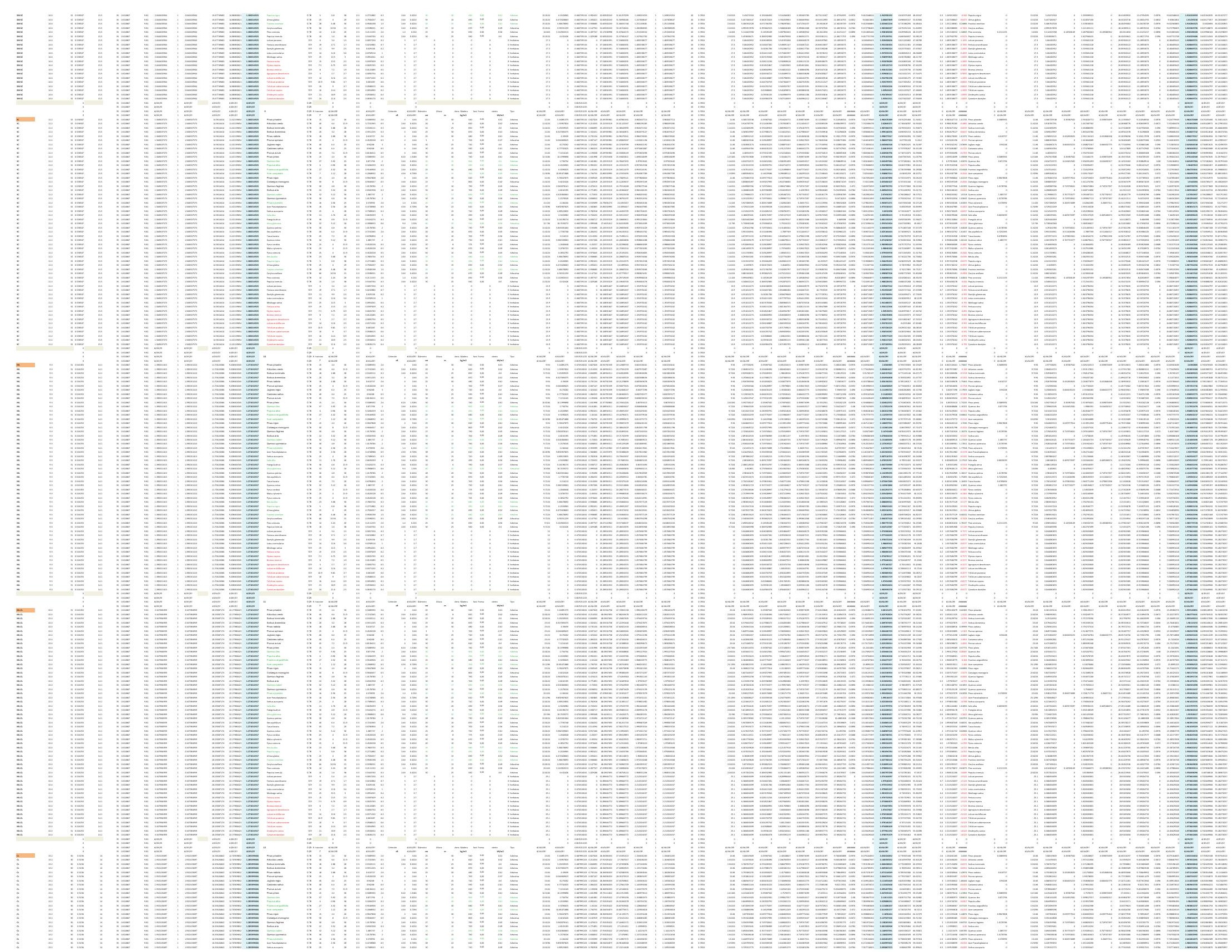


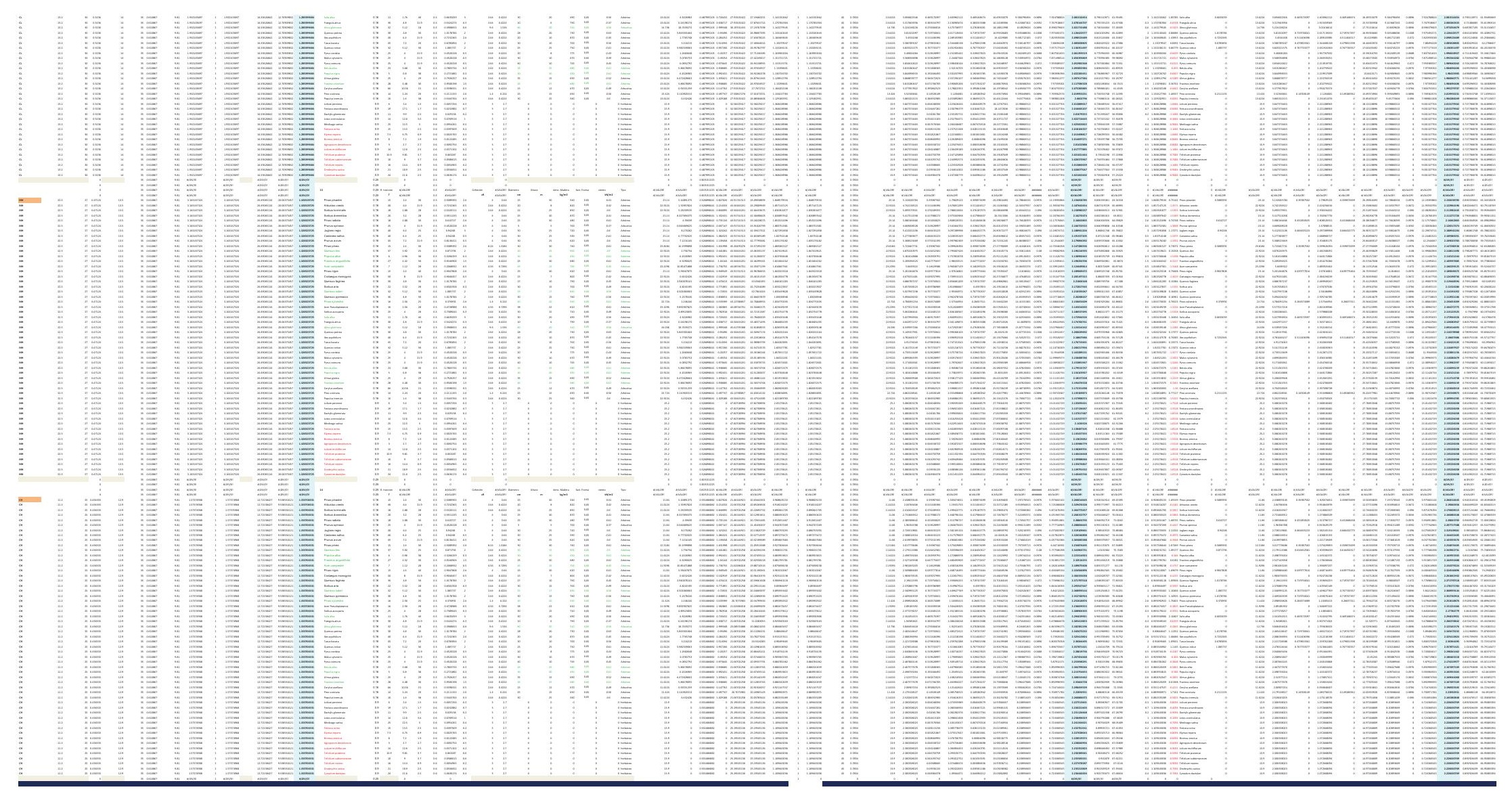



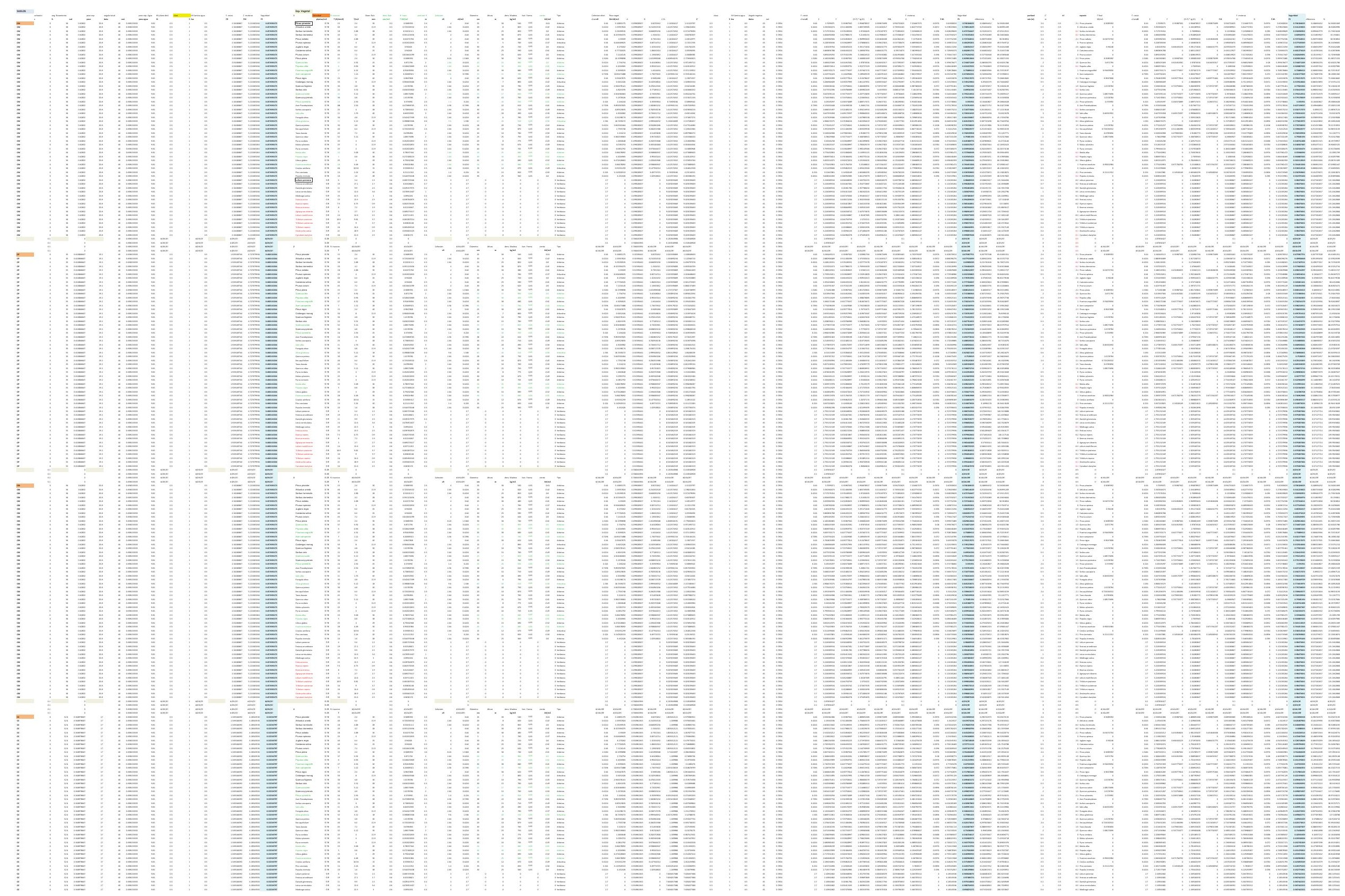


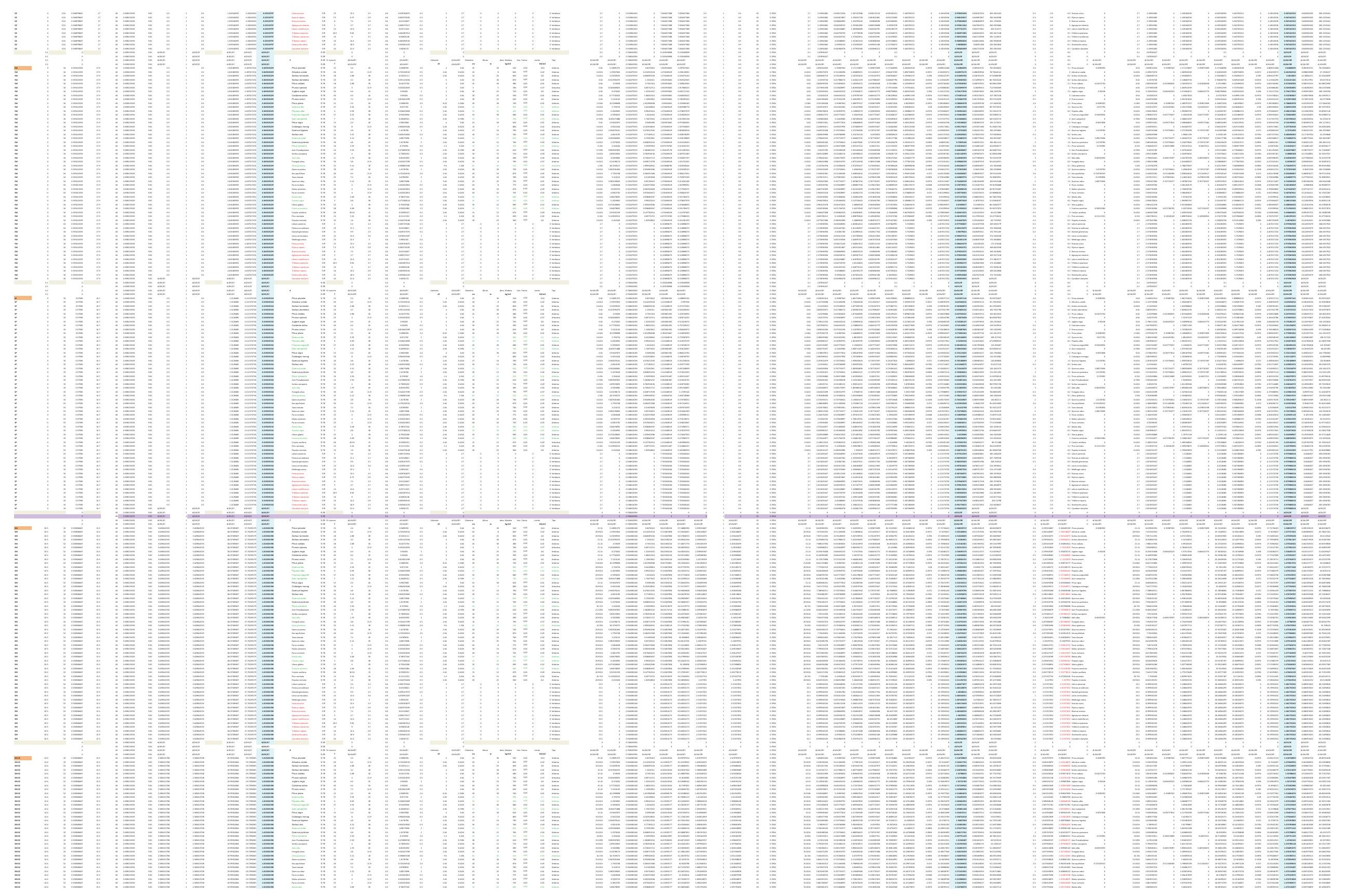



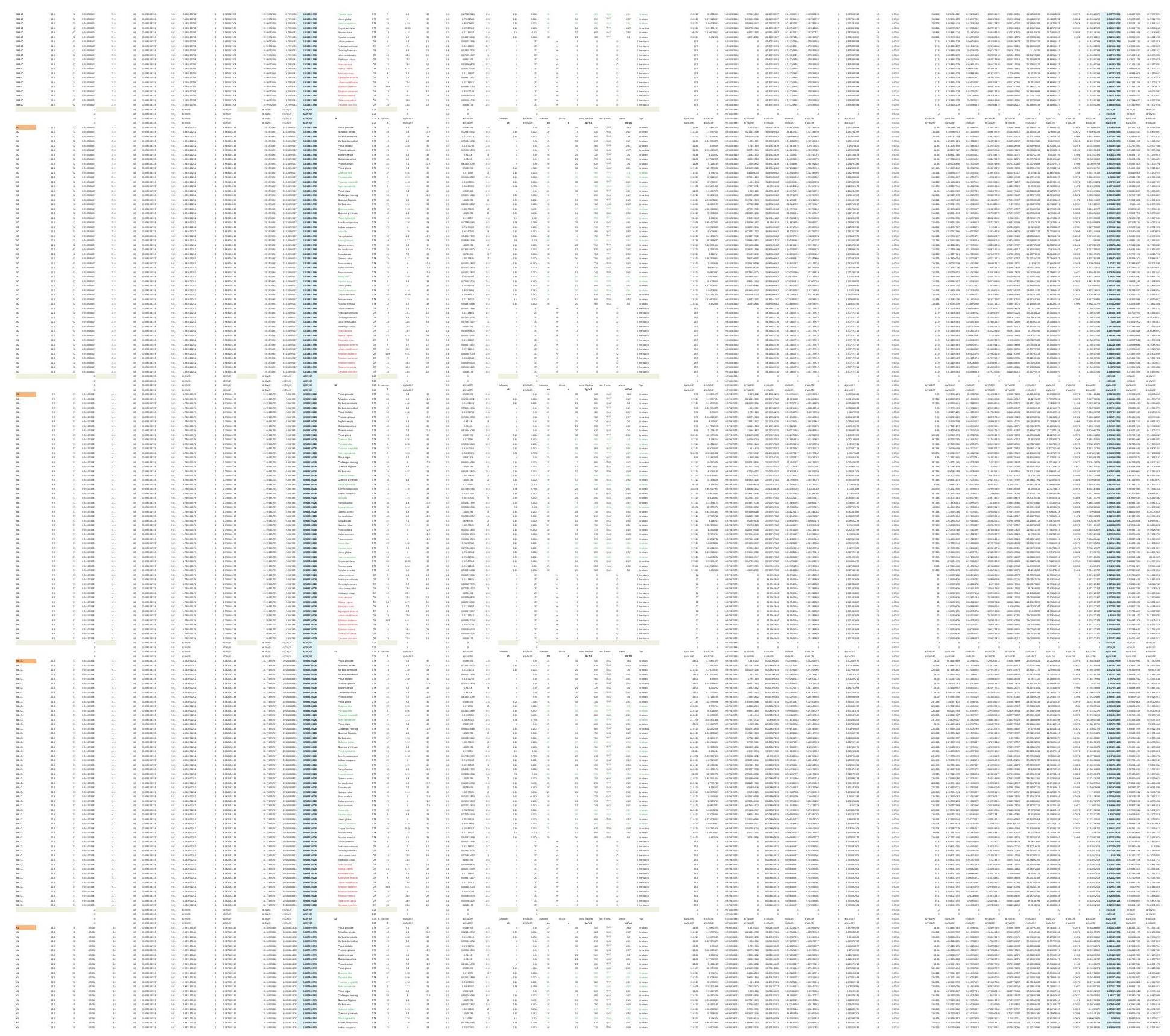

(1)
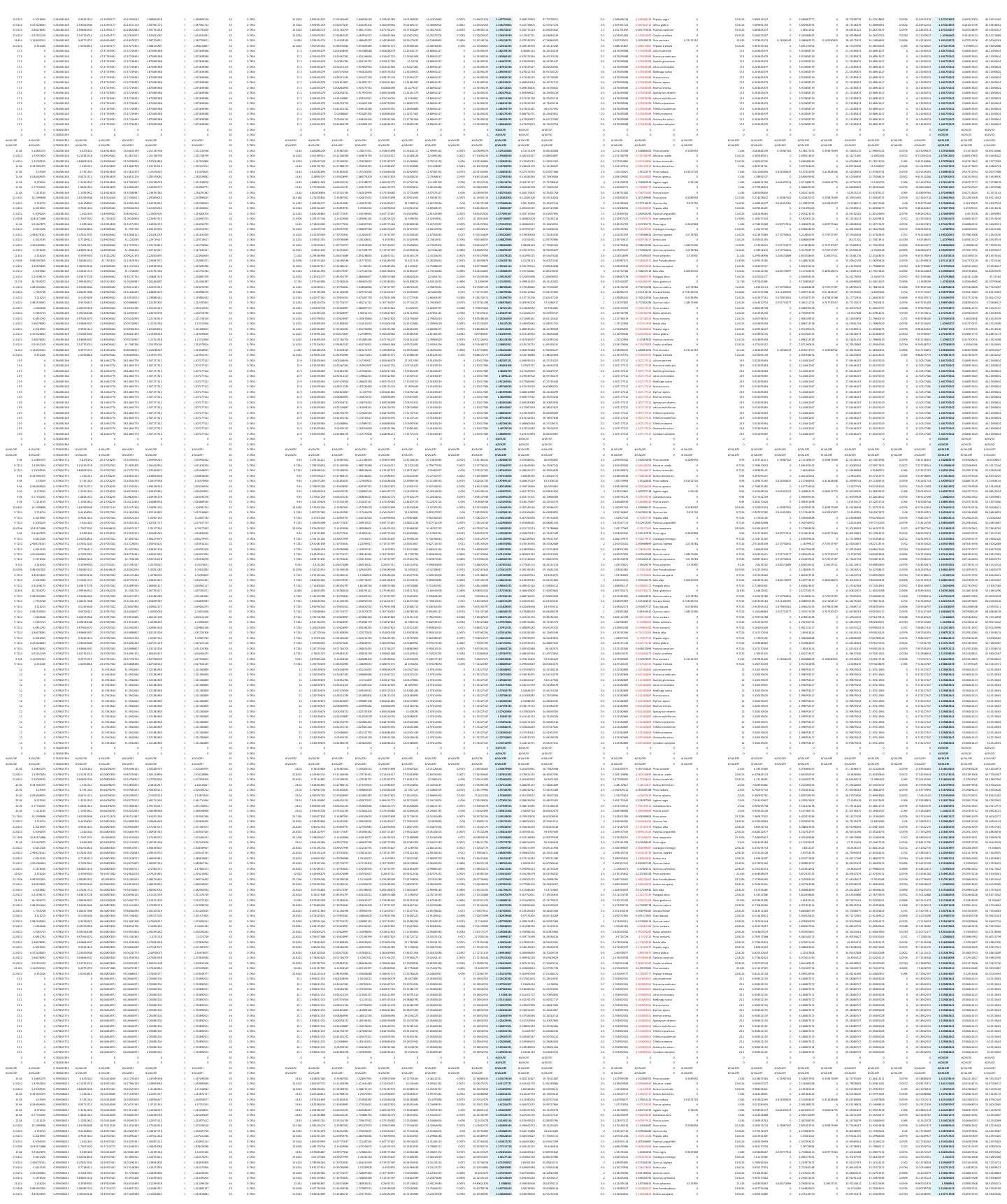


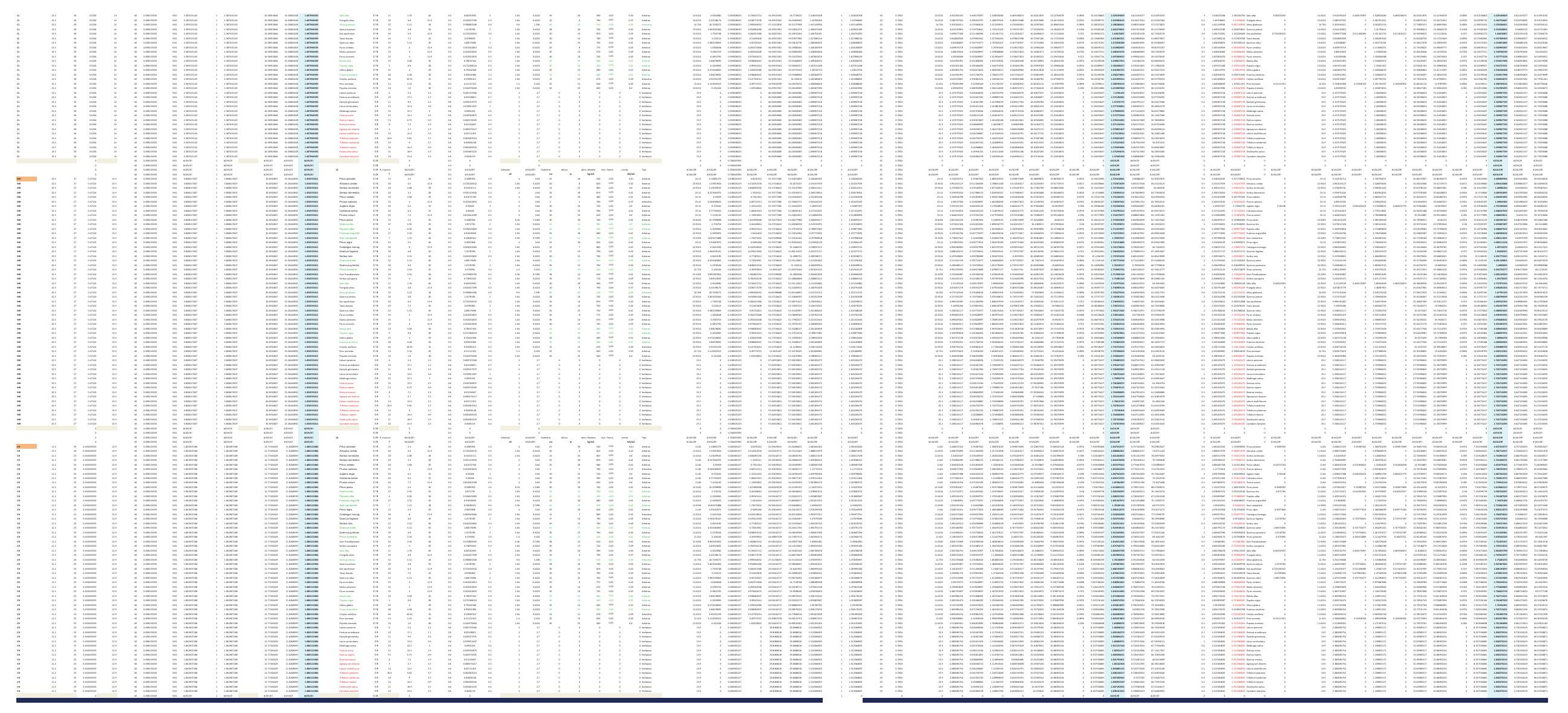



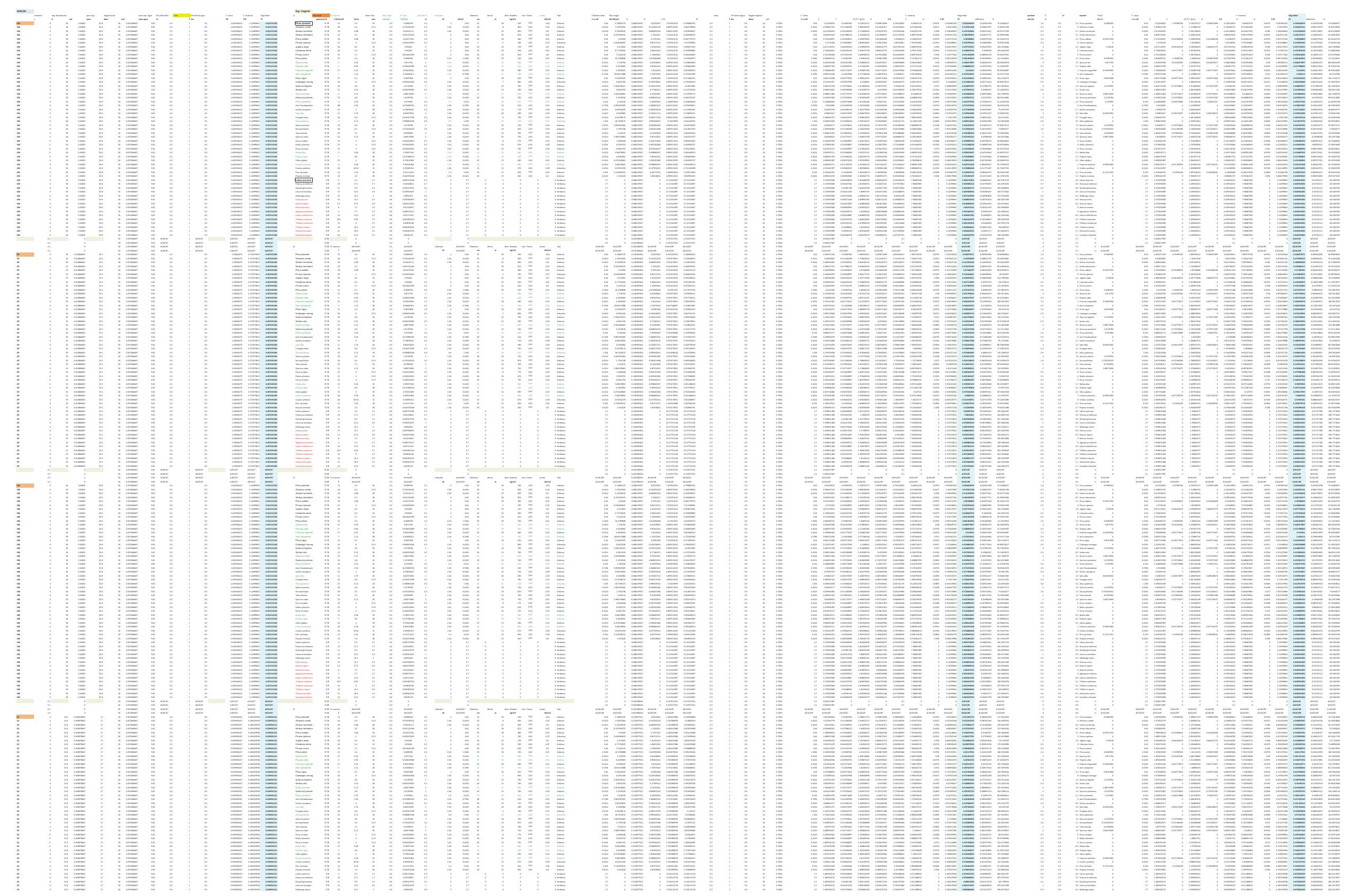


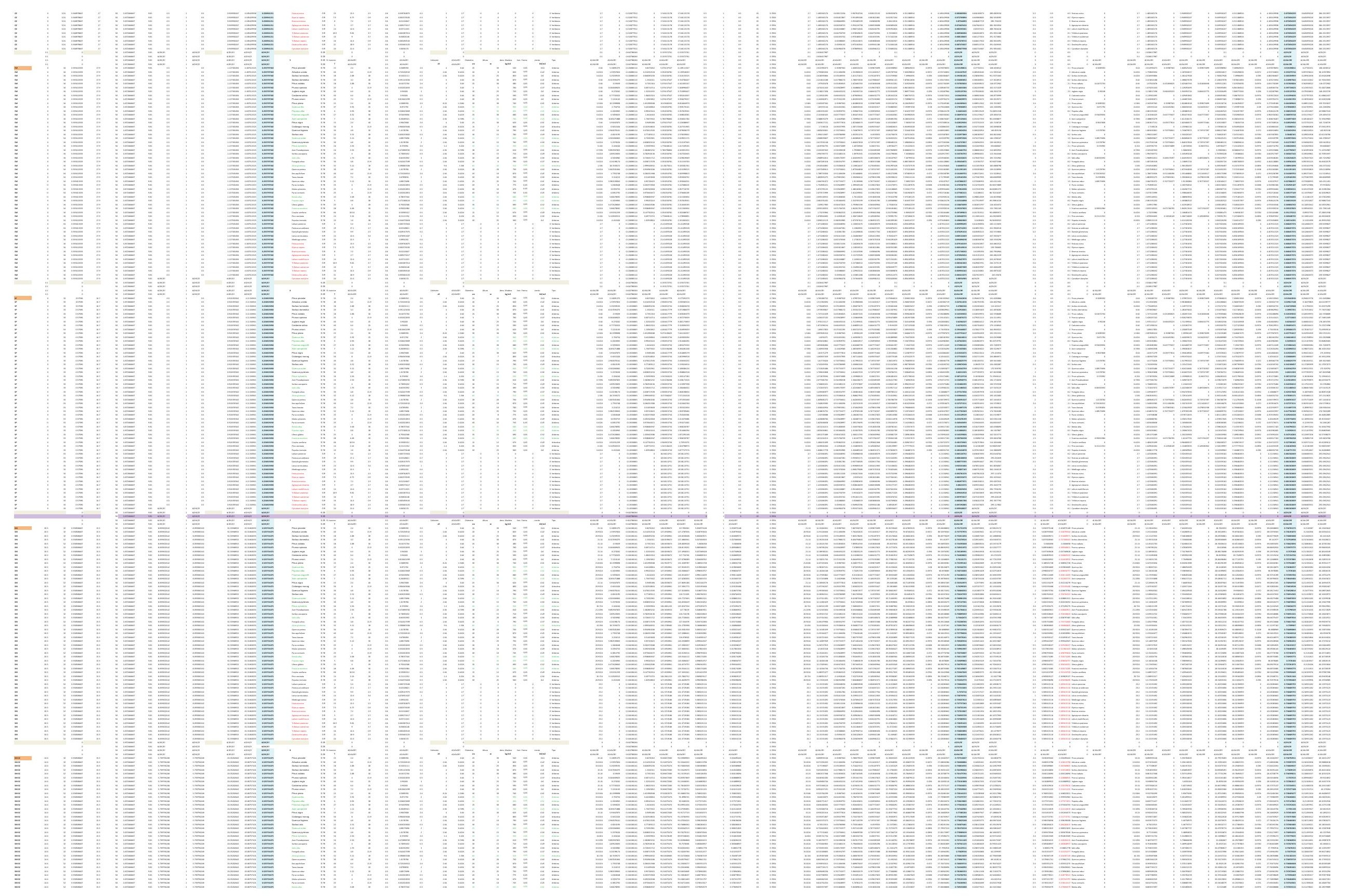




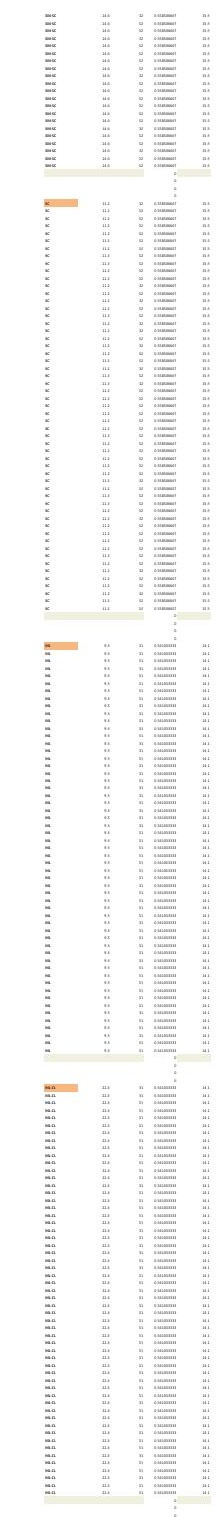

-

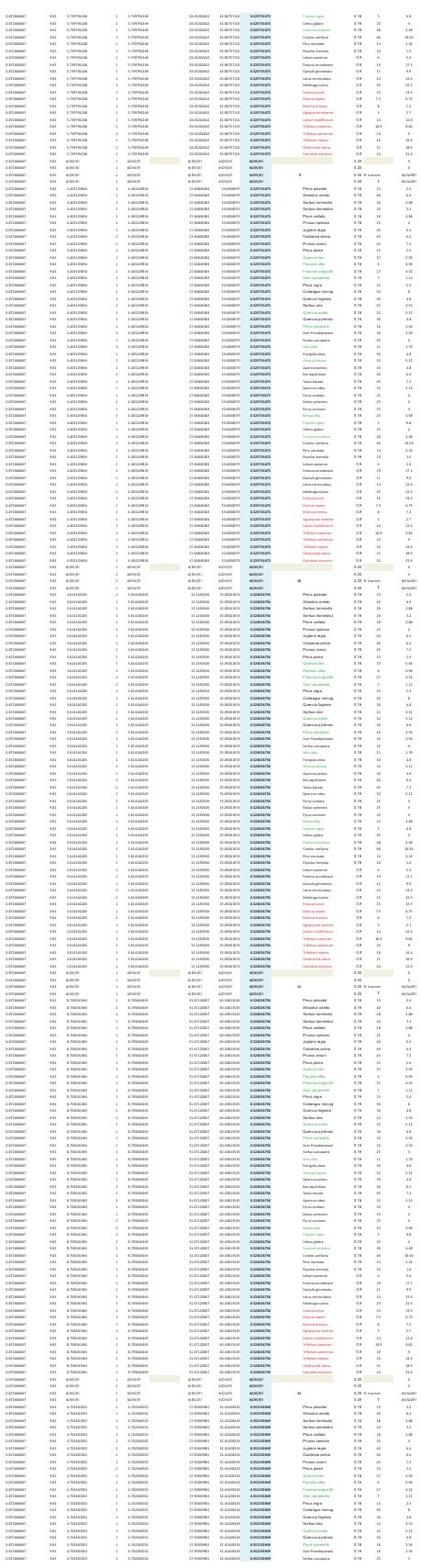

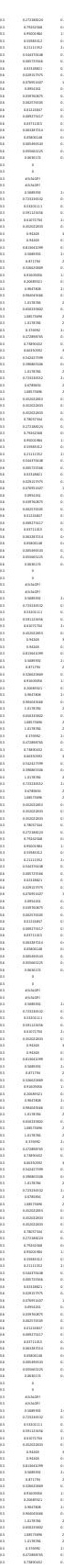

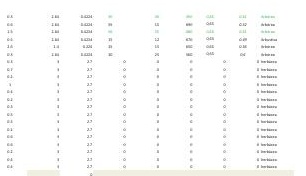

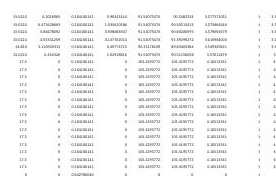
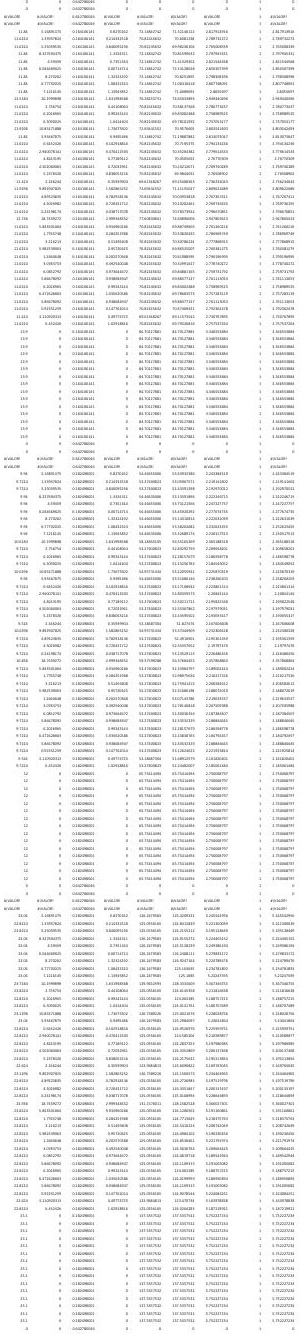

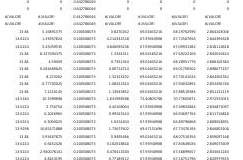

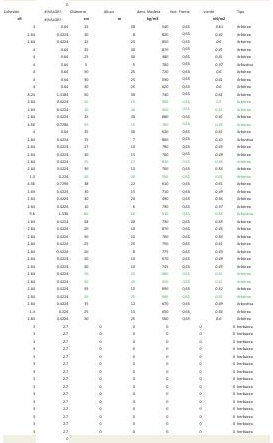

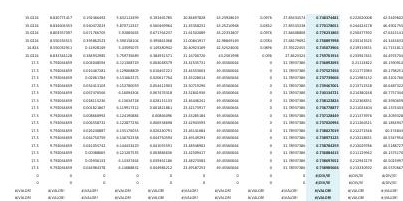

主引E

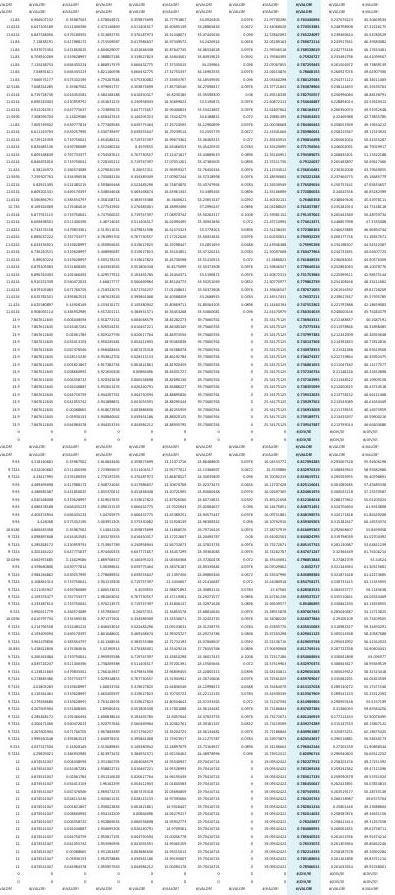

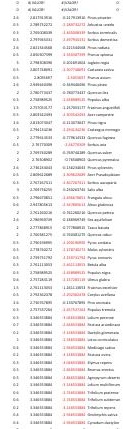
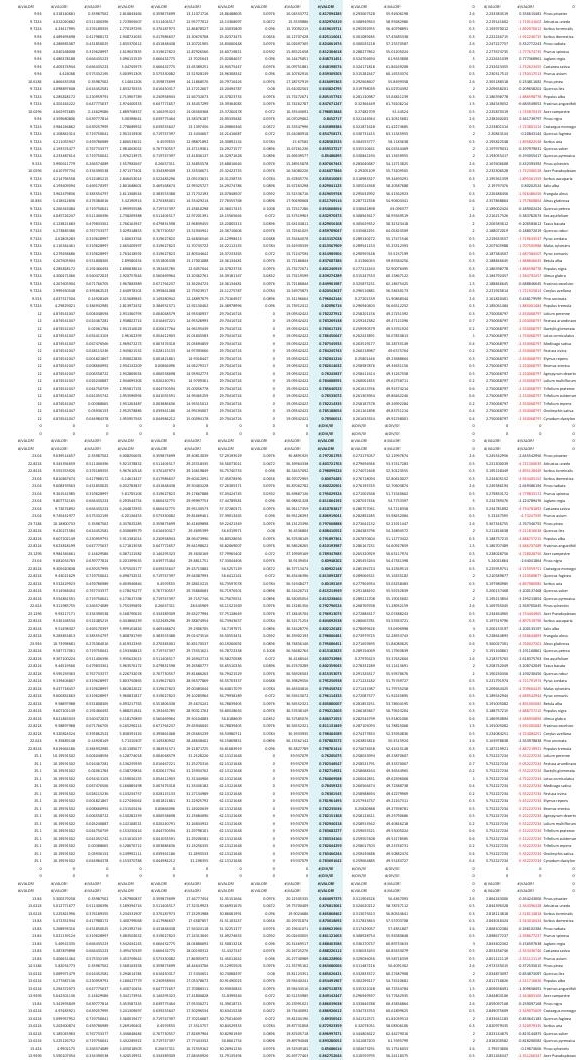
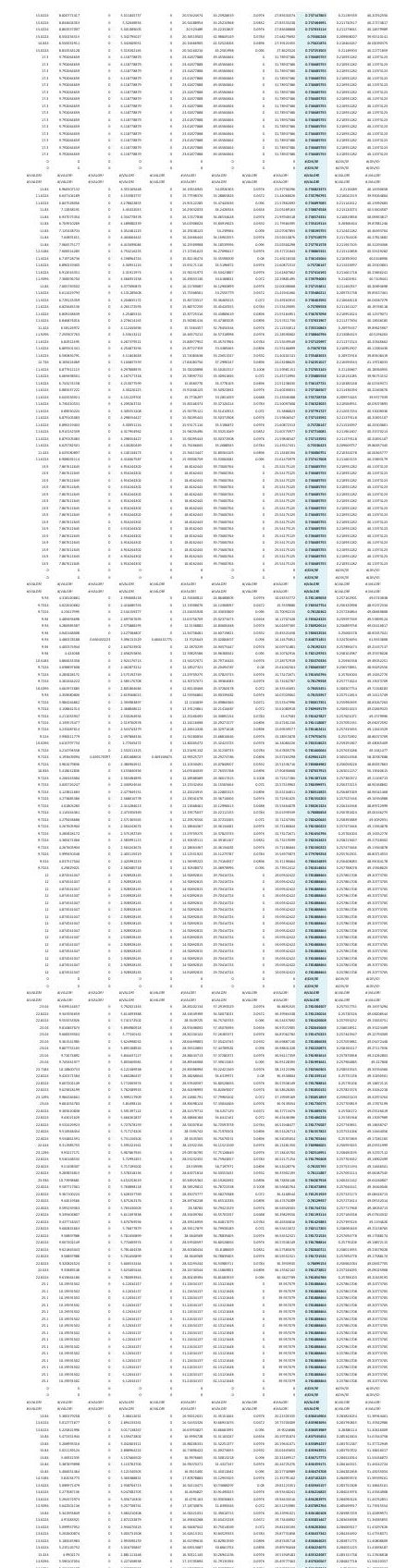


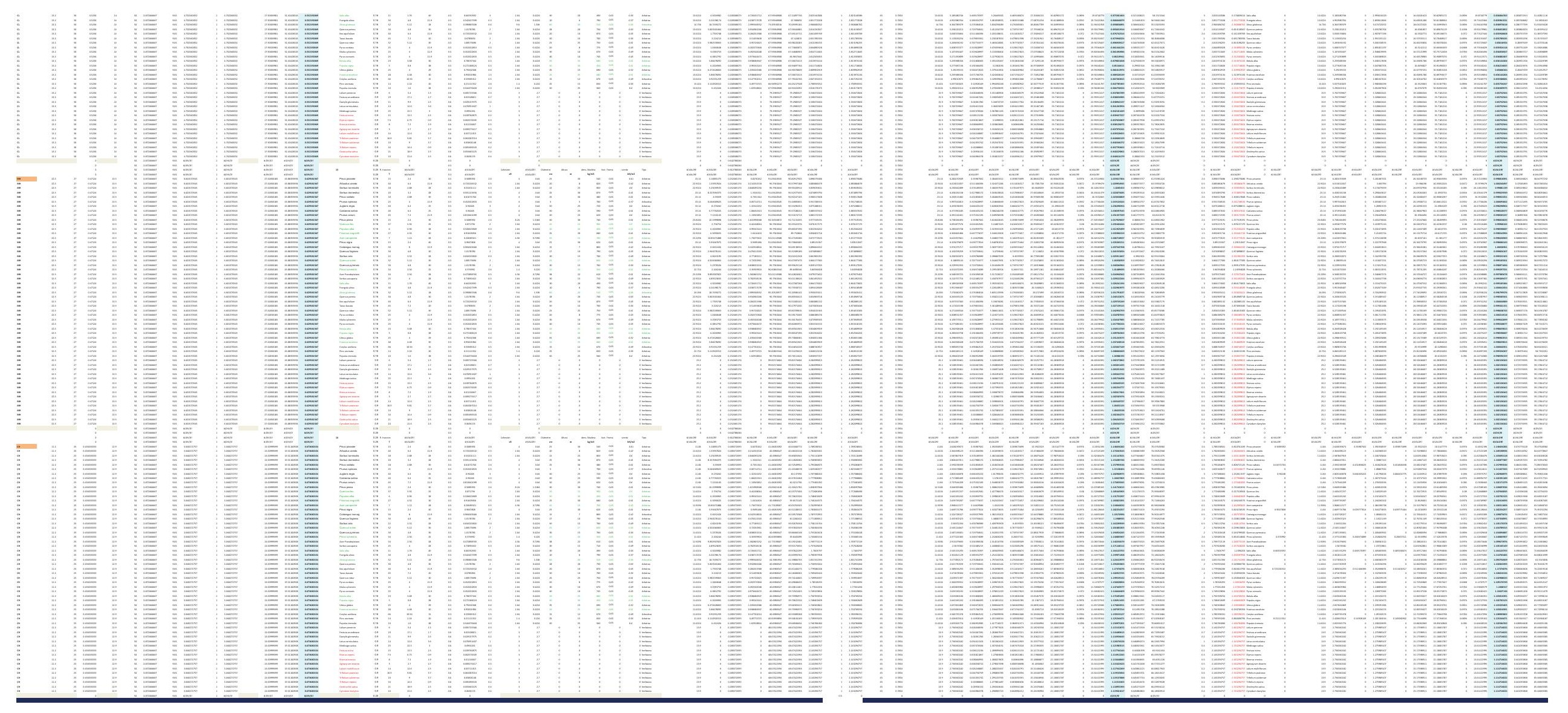



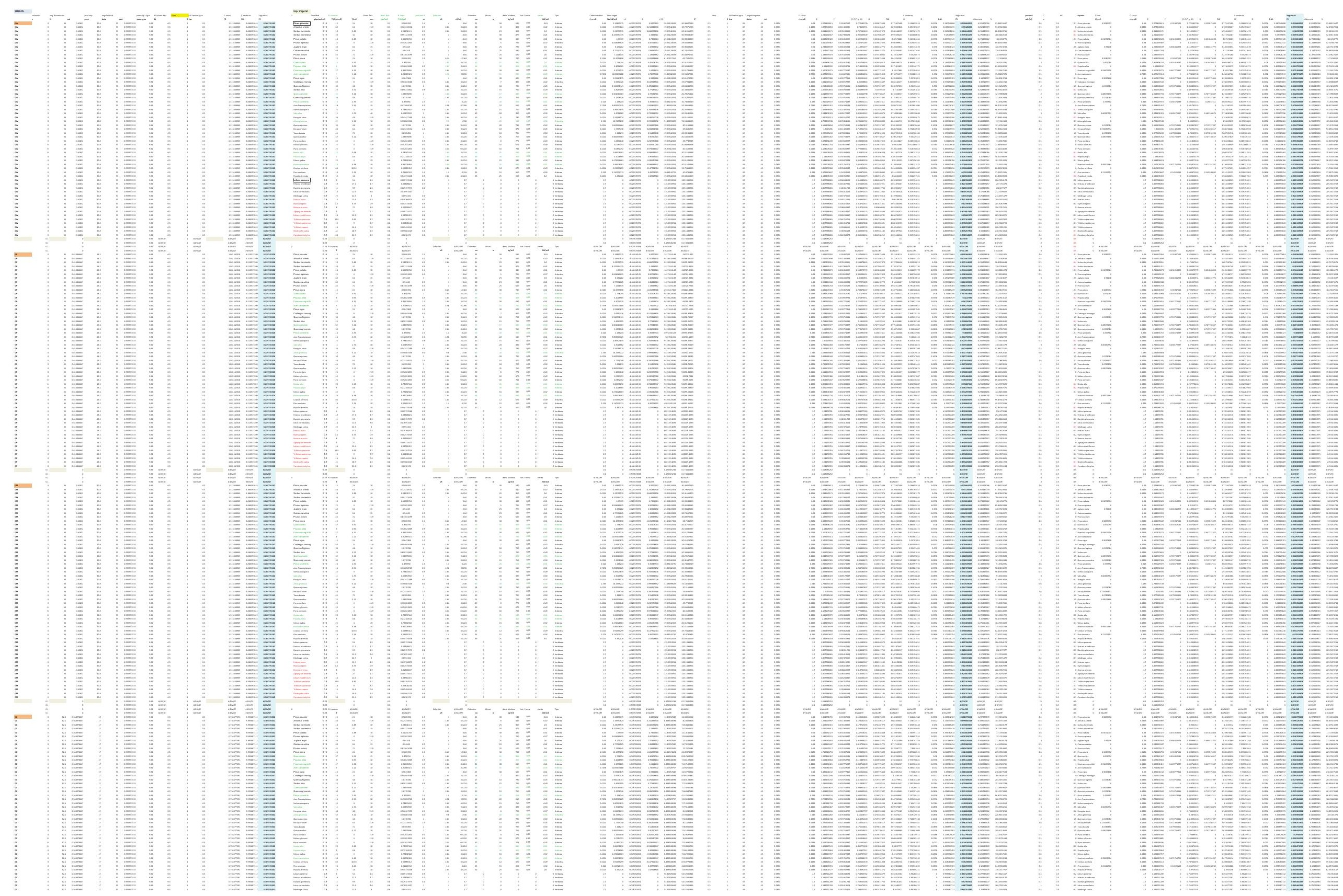


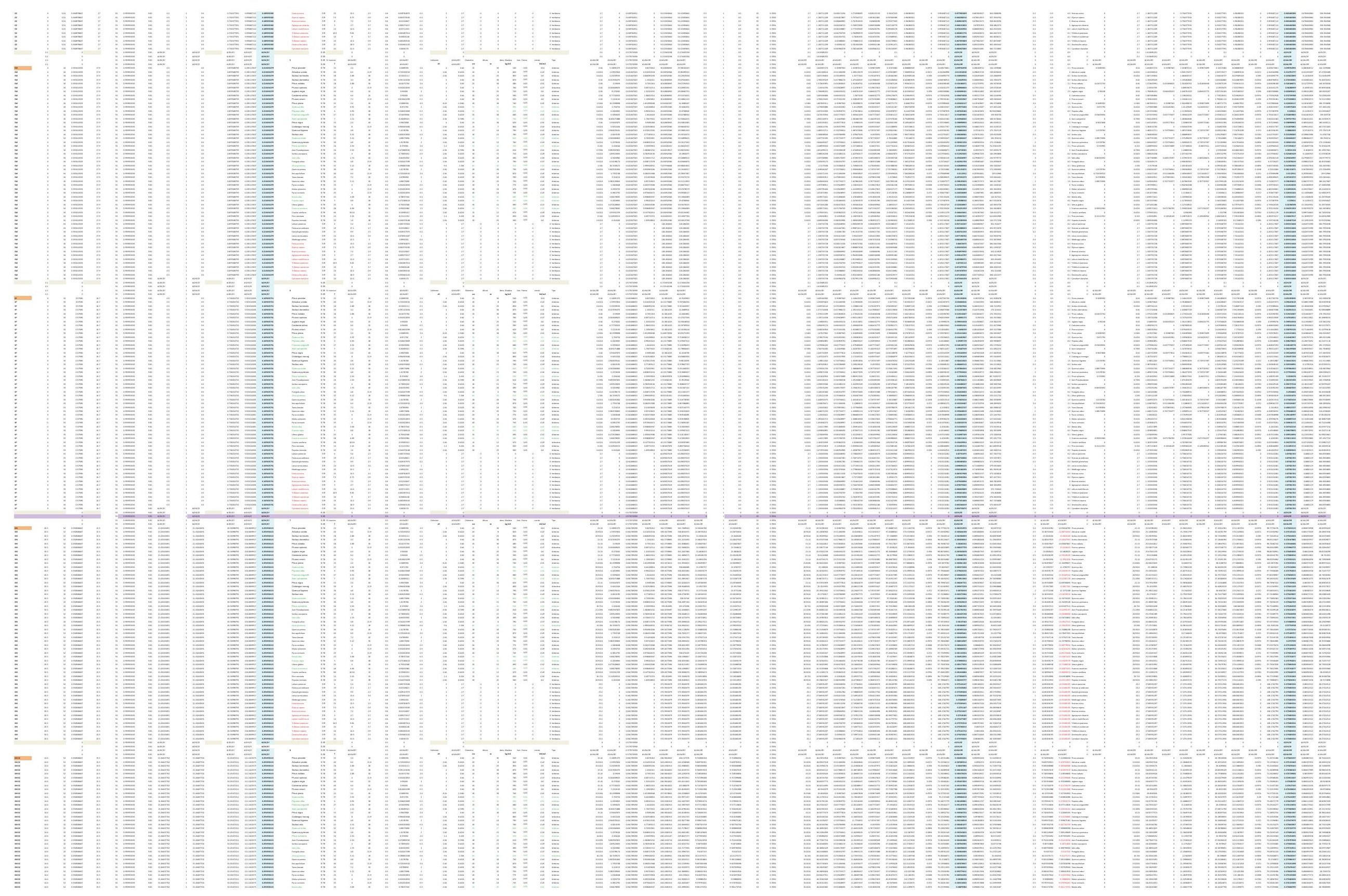



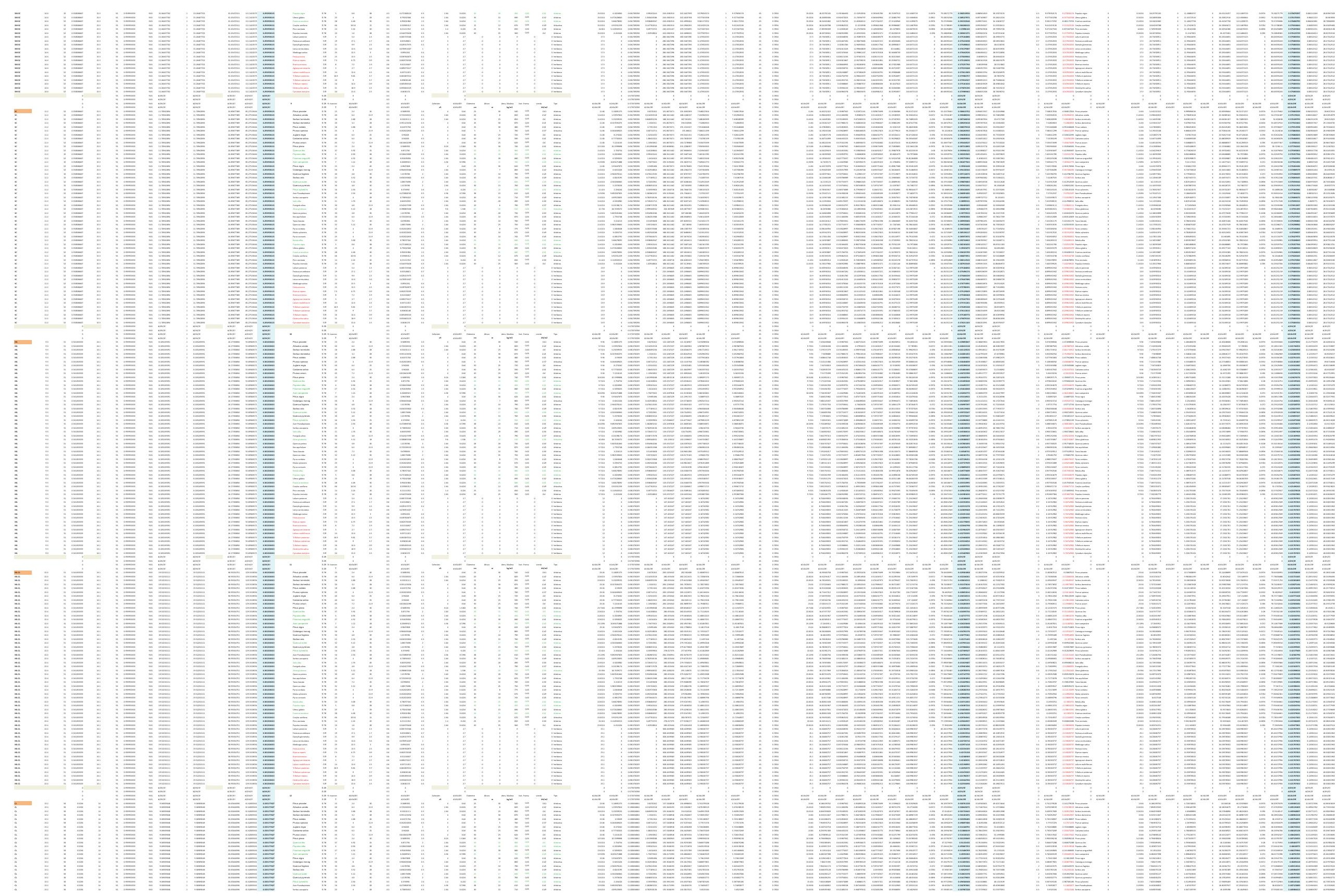


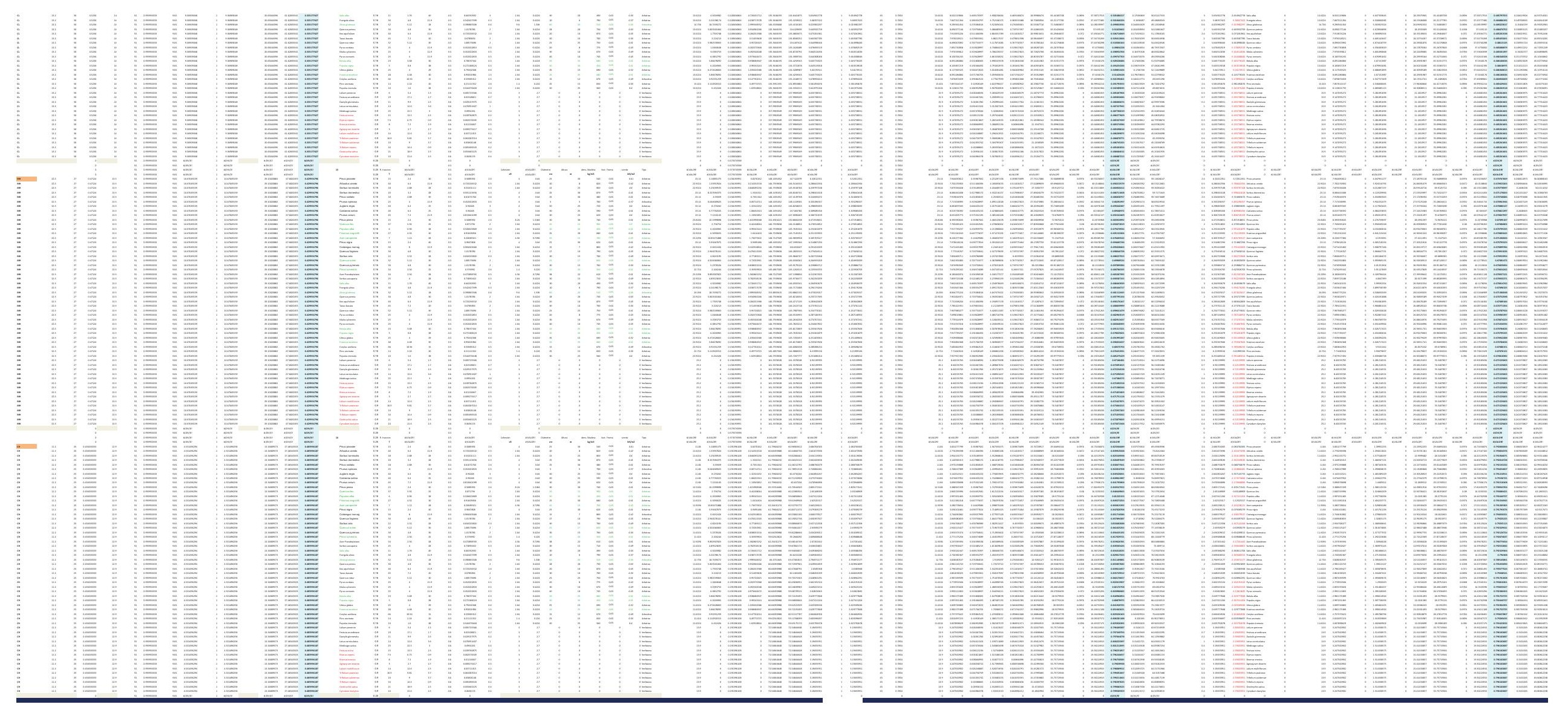



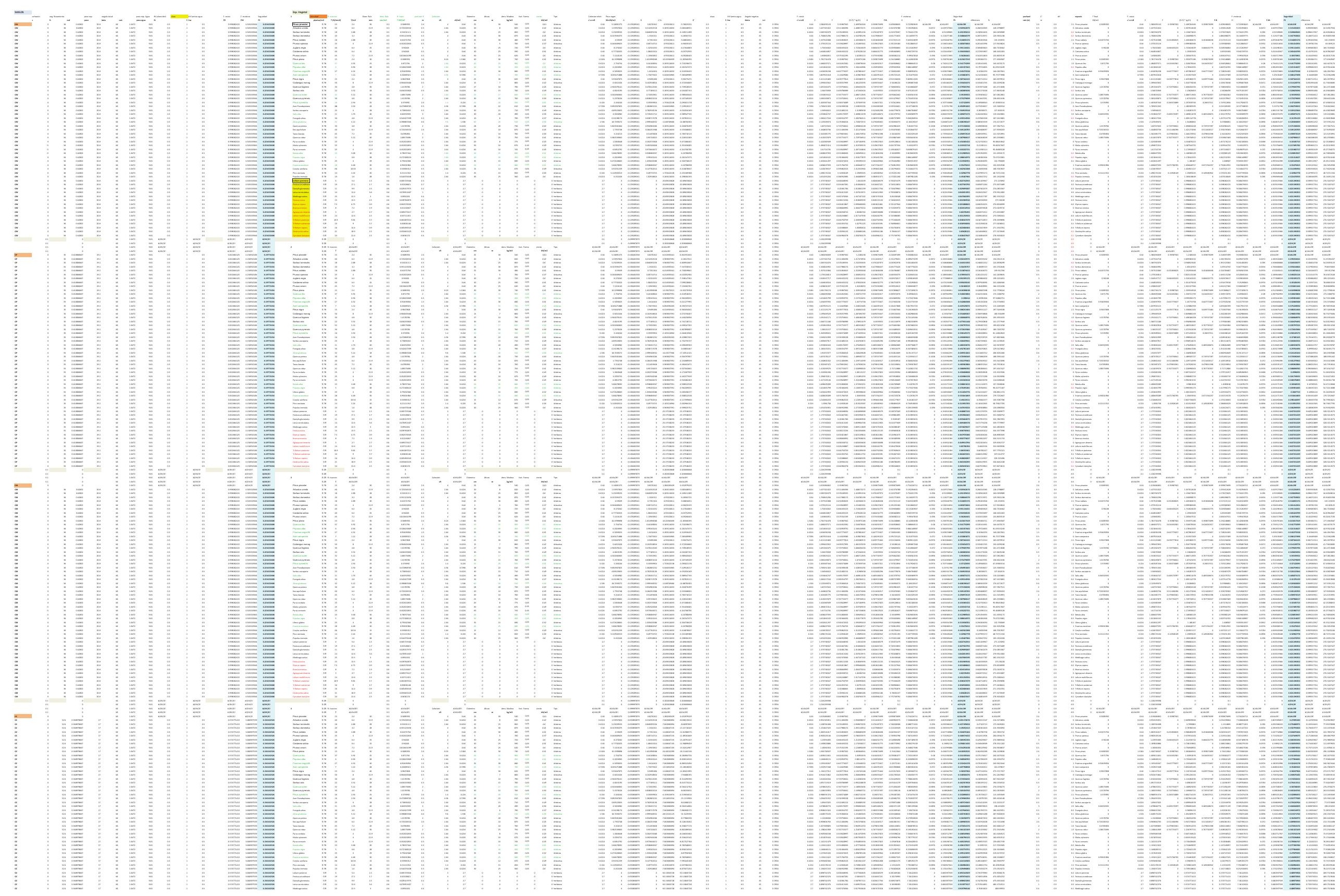


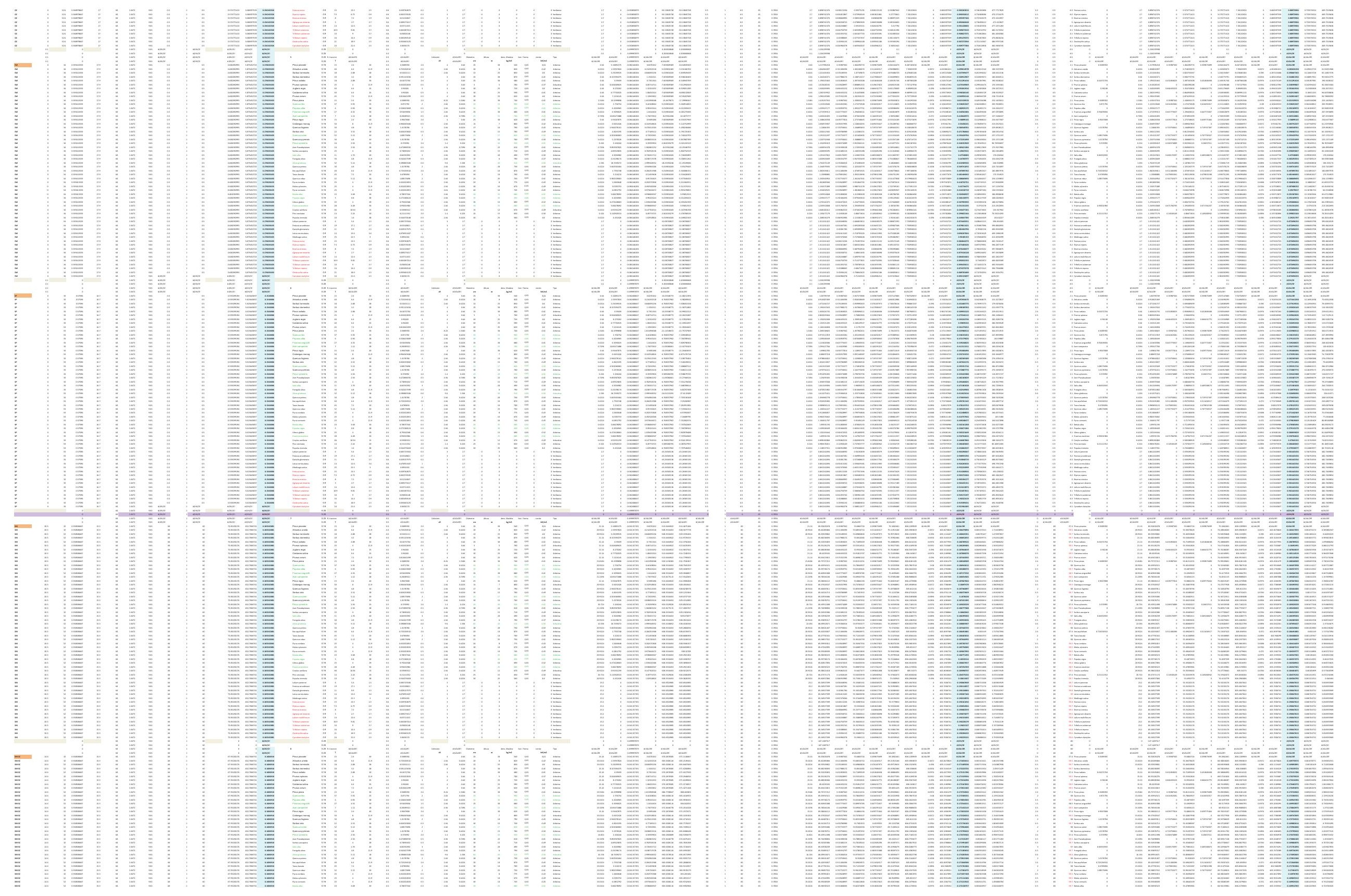



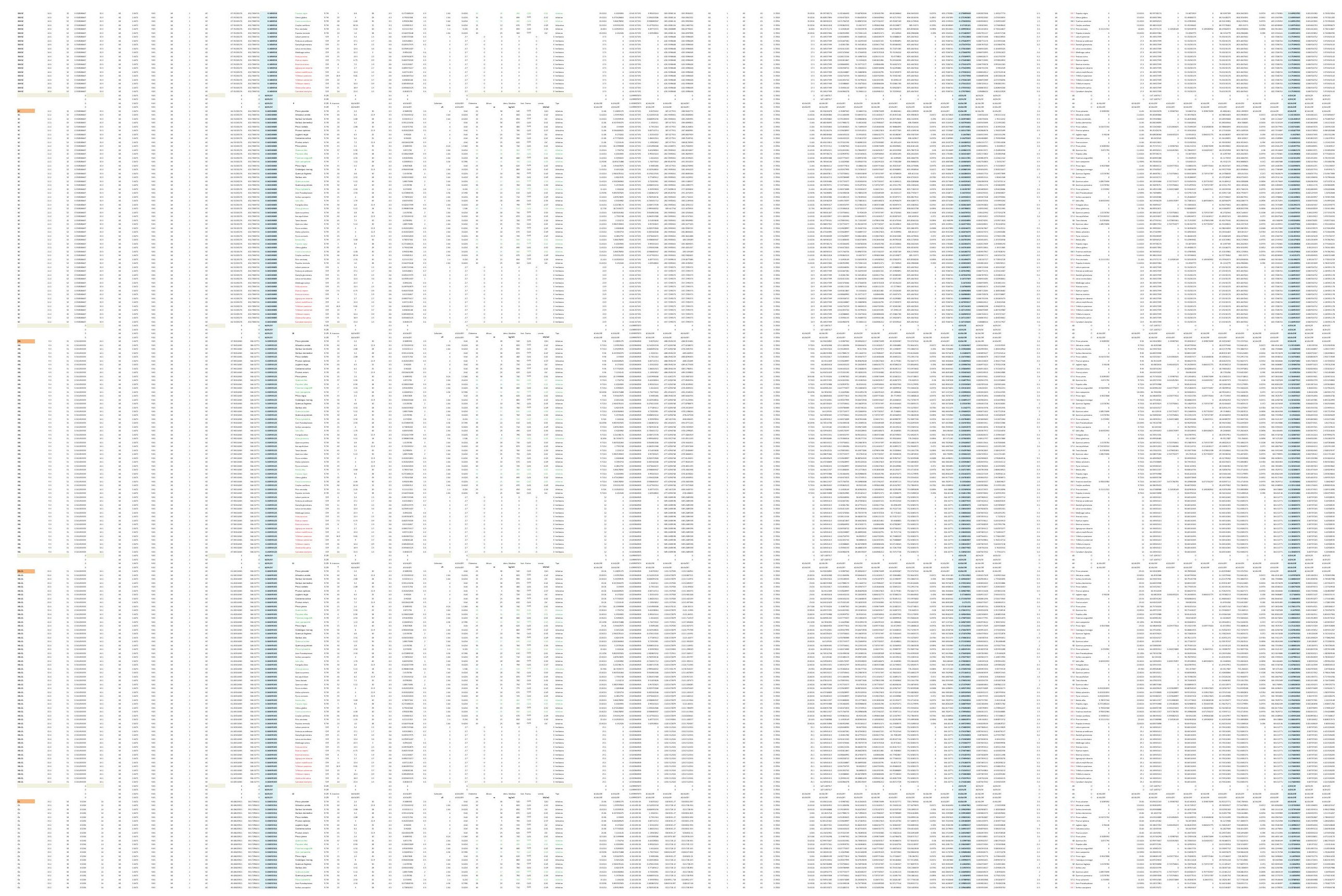

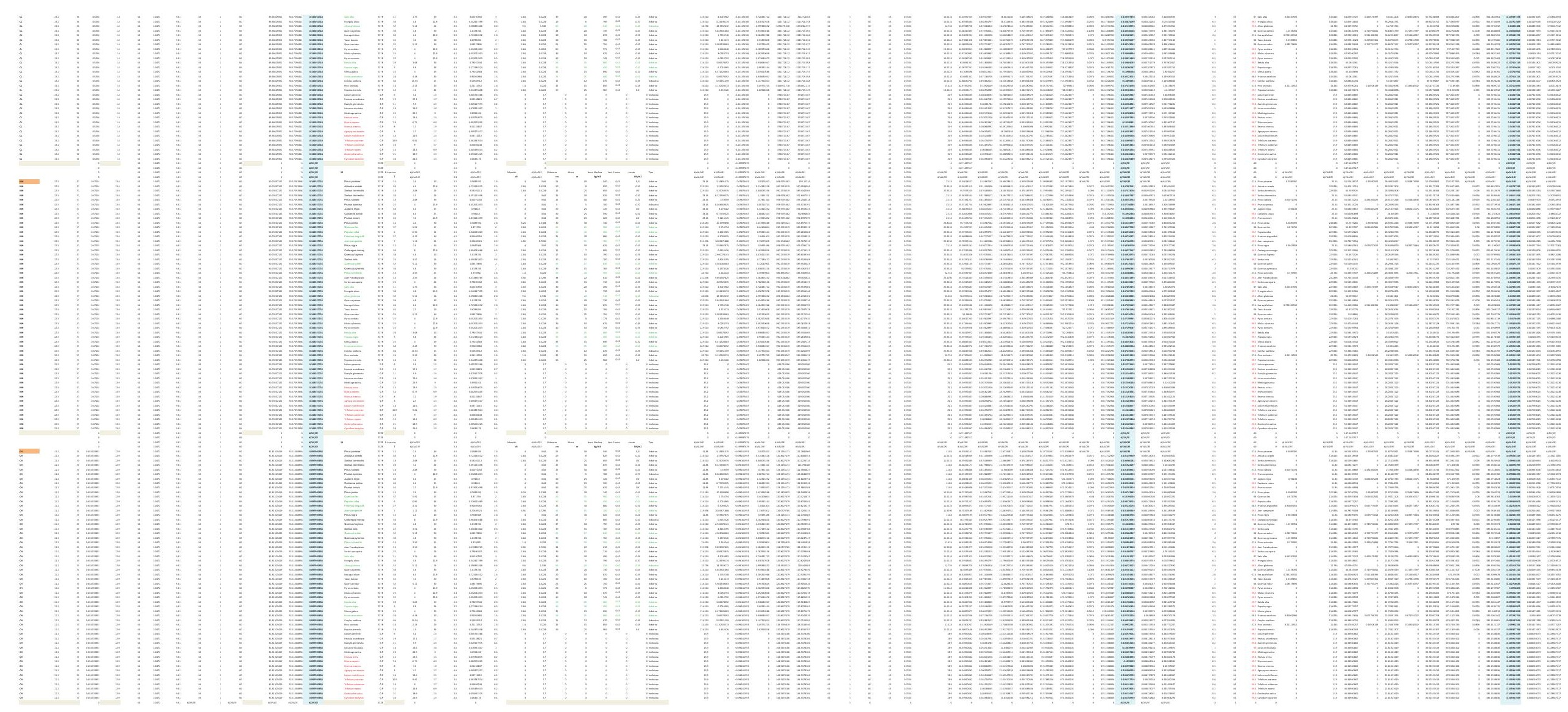

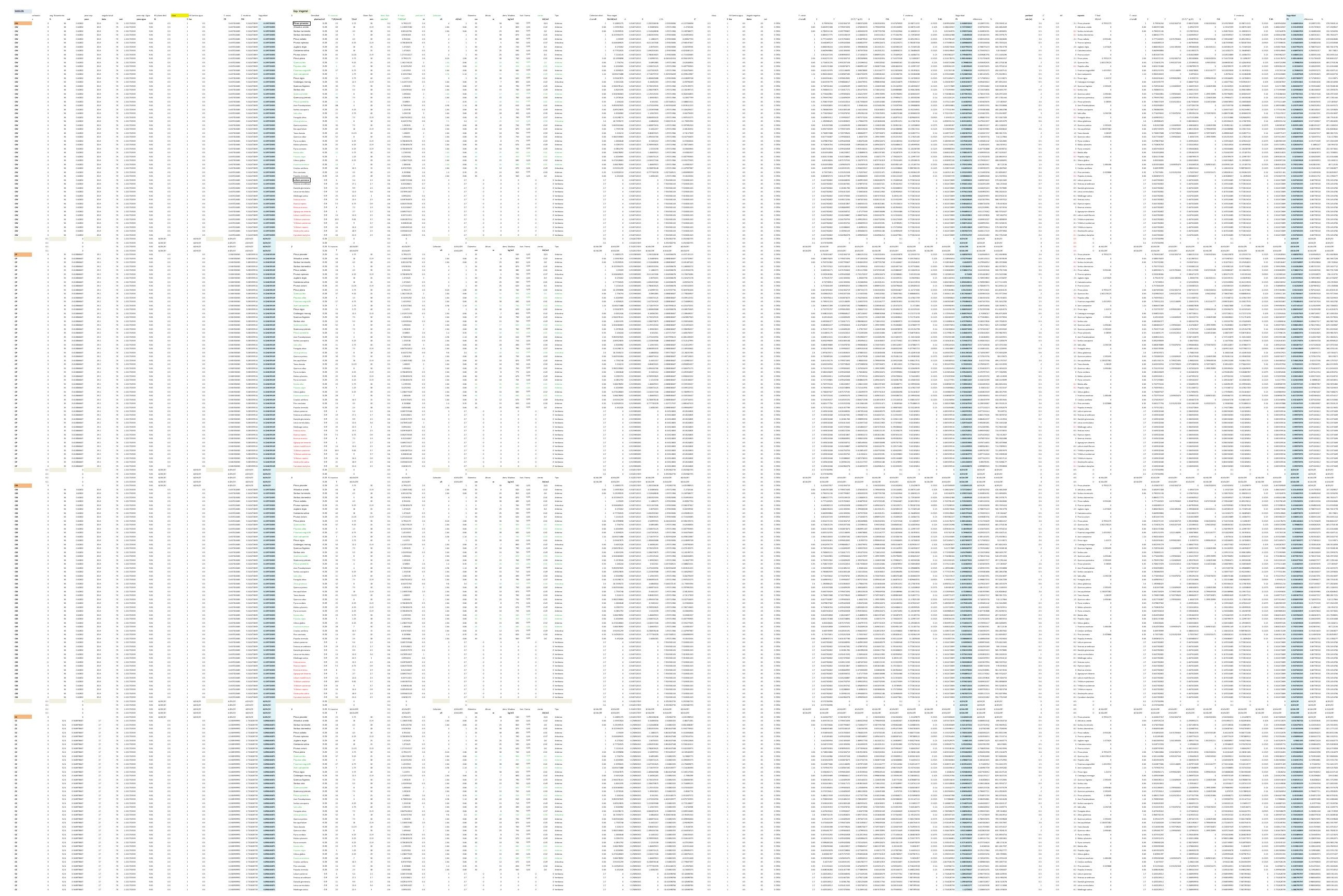


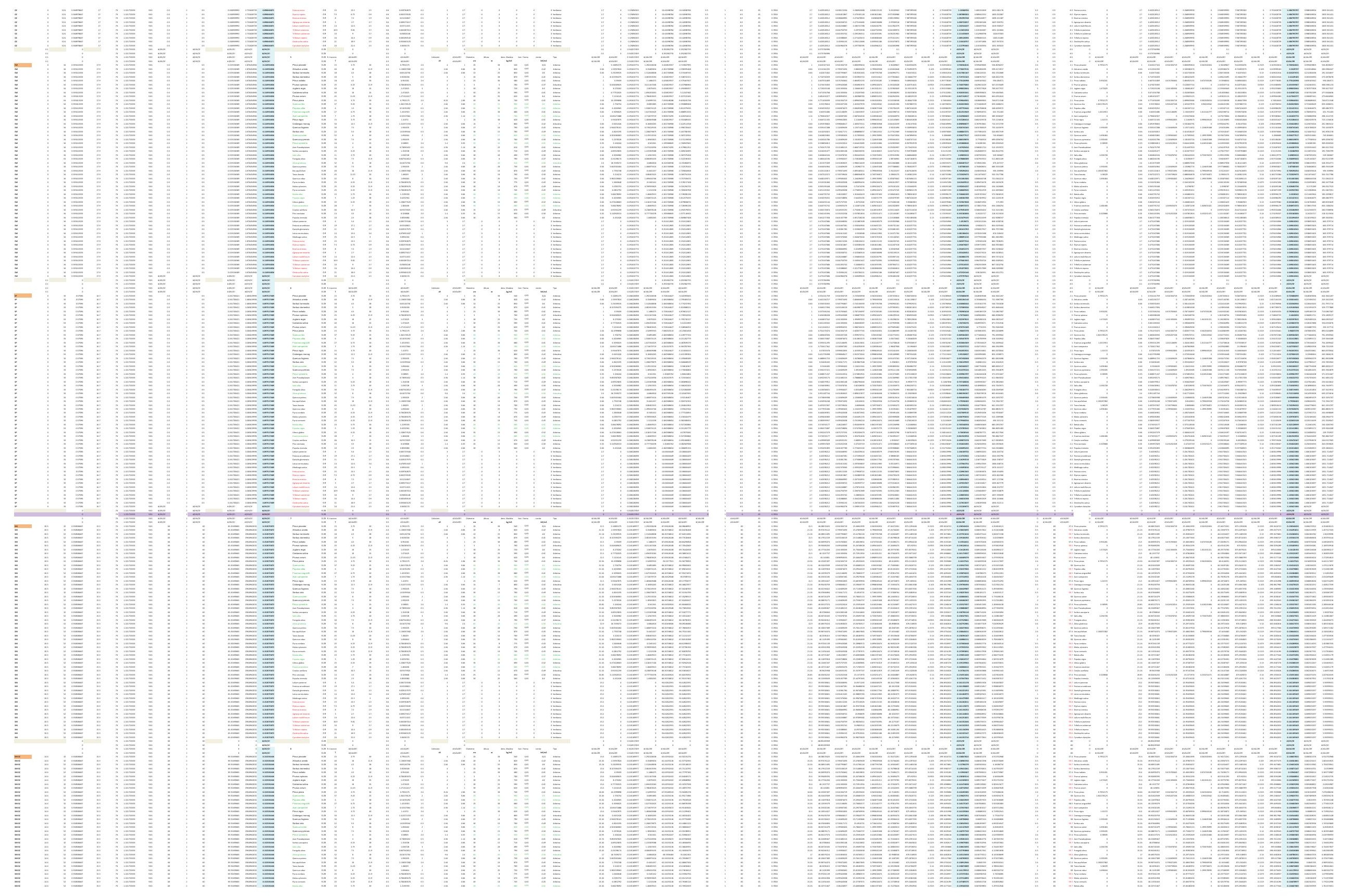




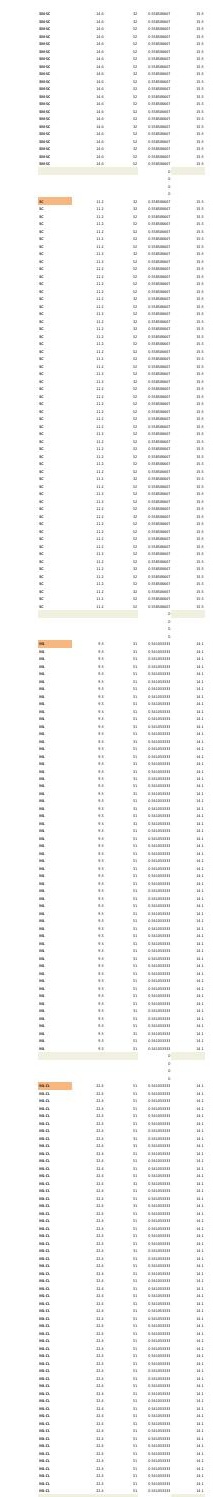

$-$

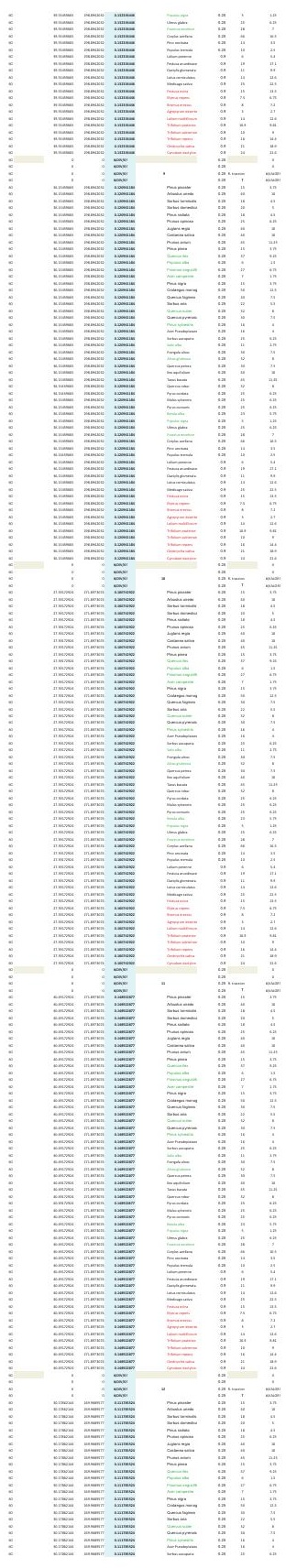

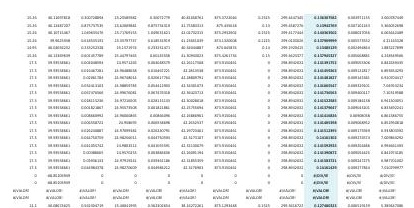

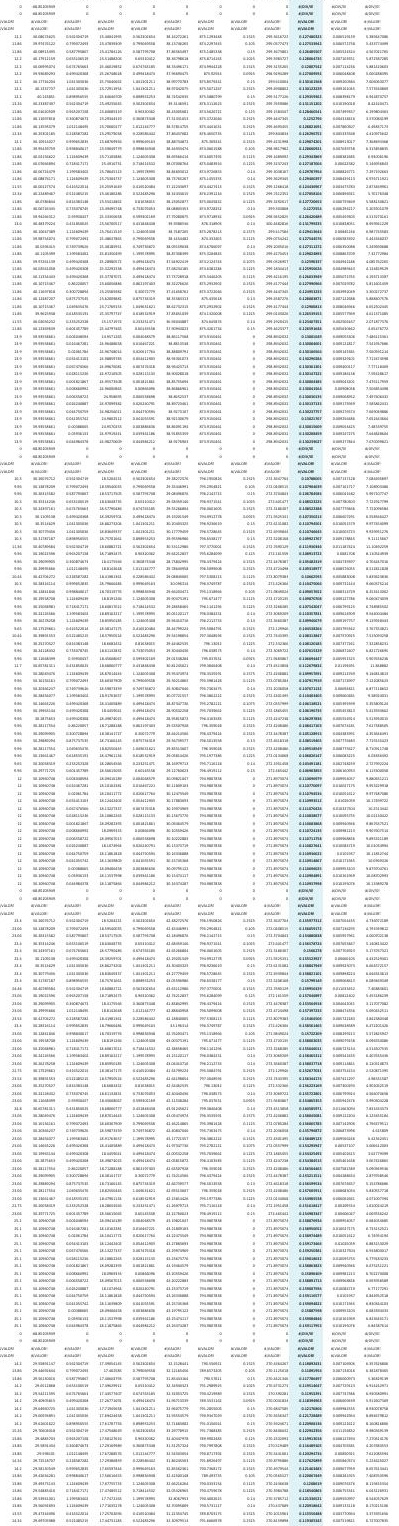

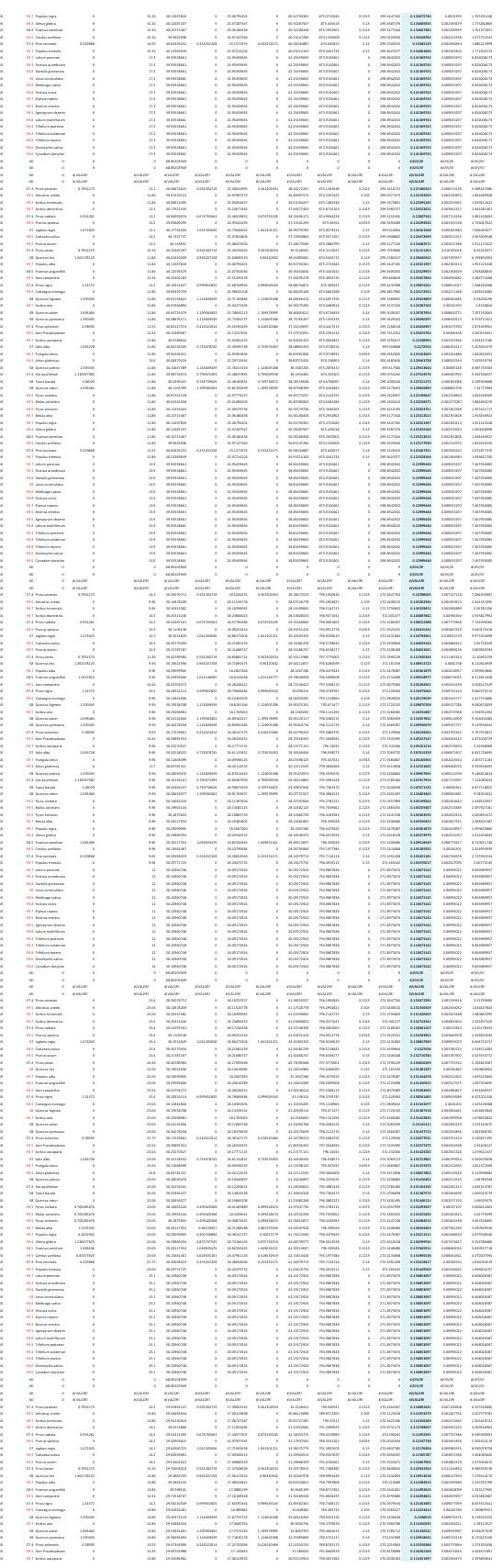




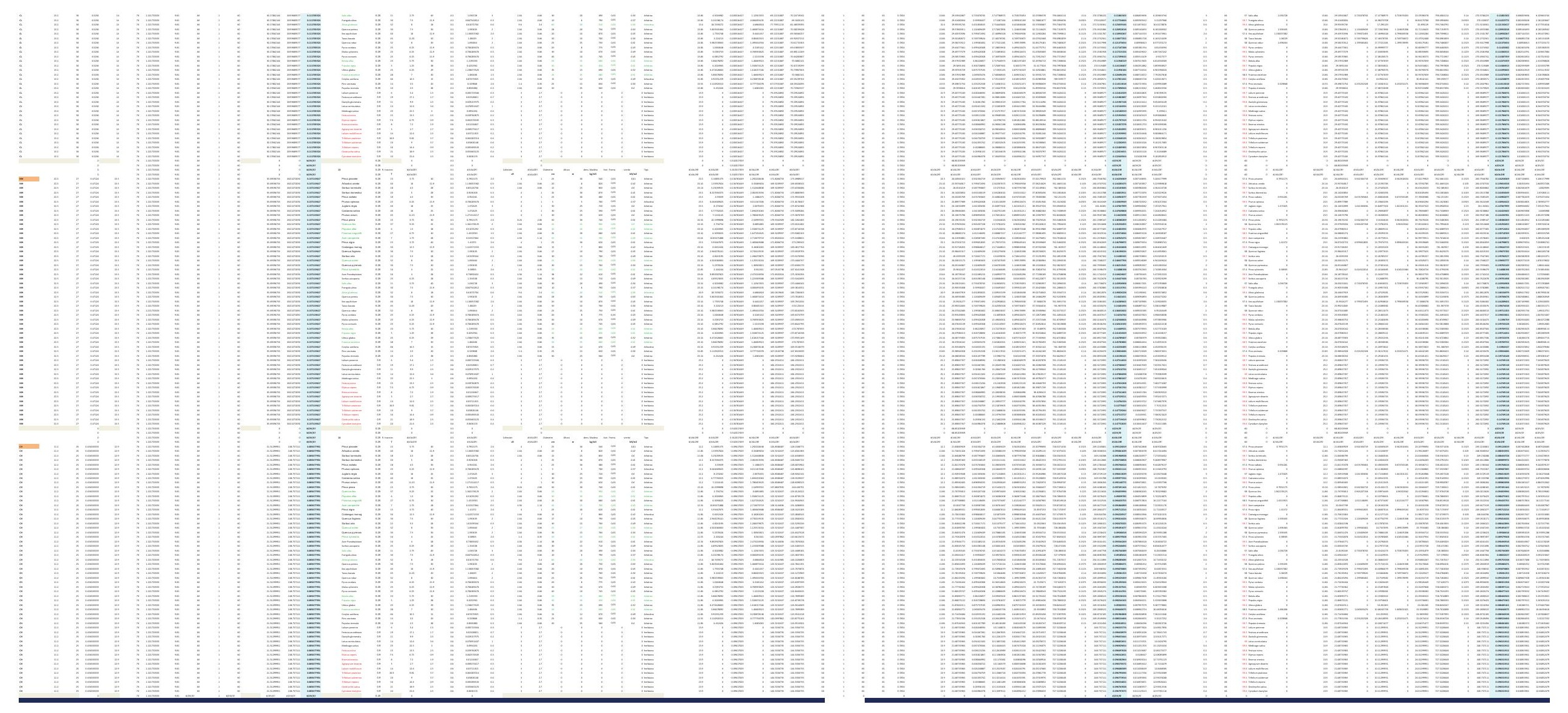



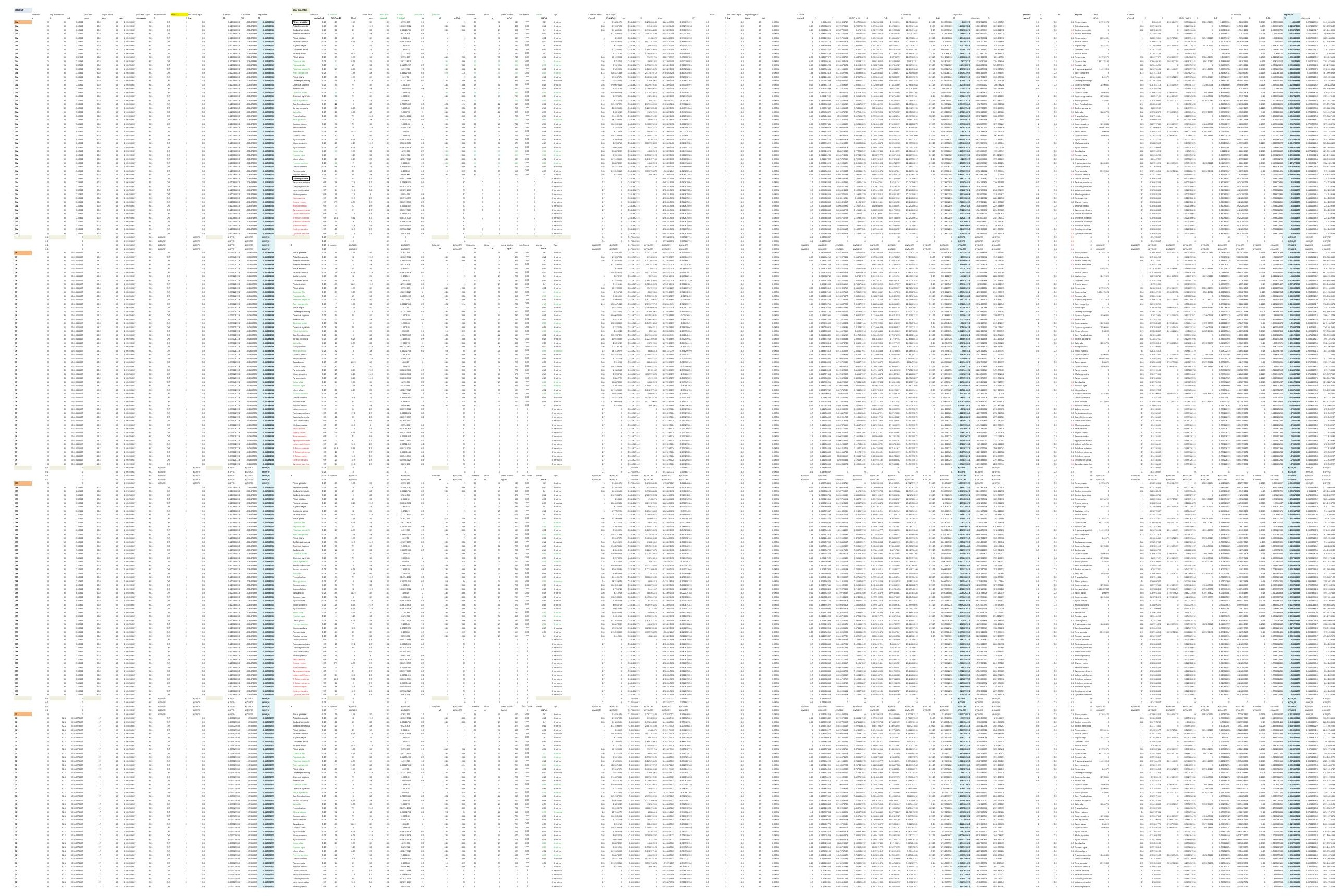


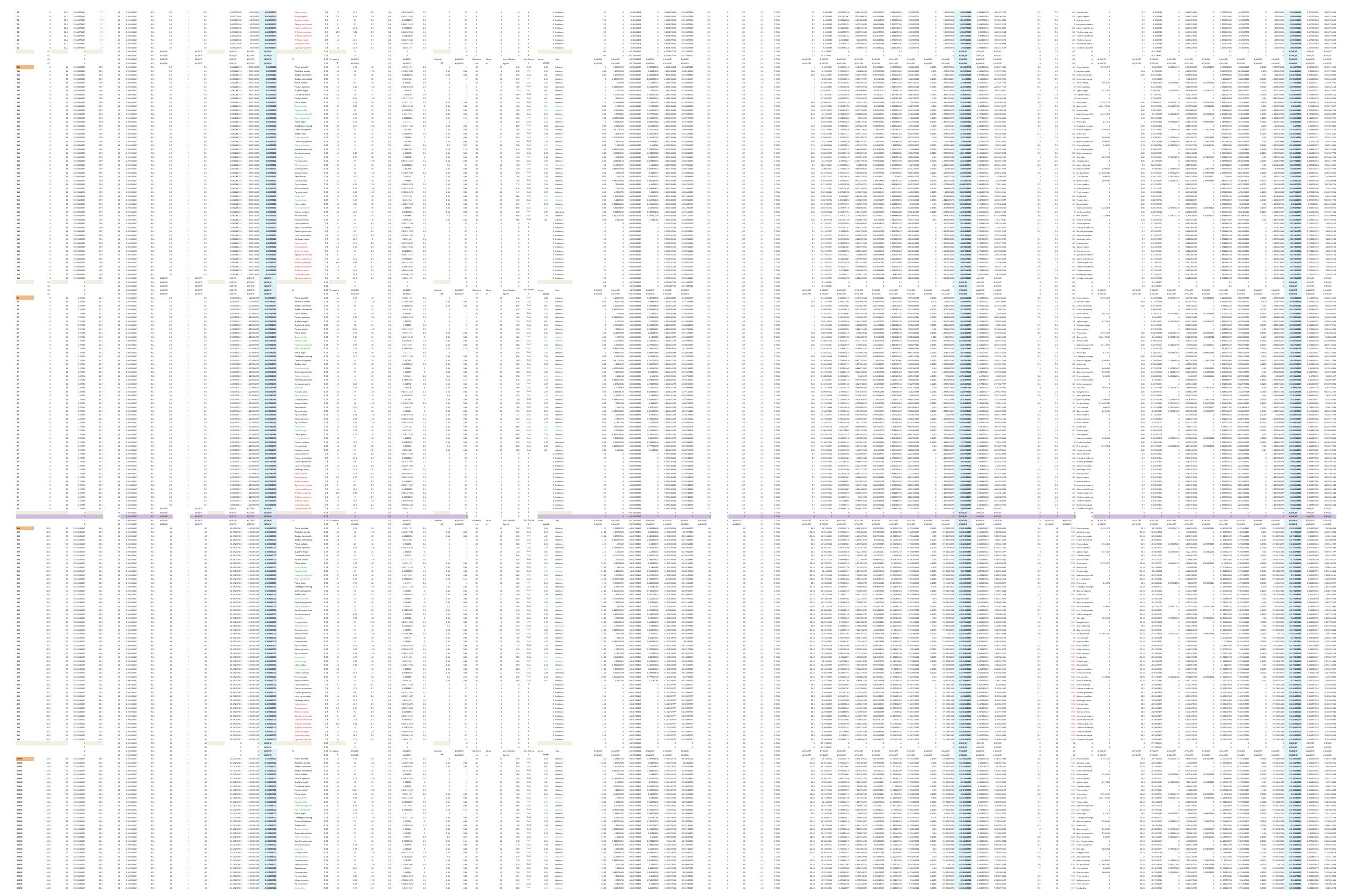




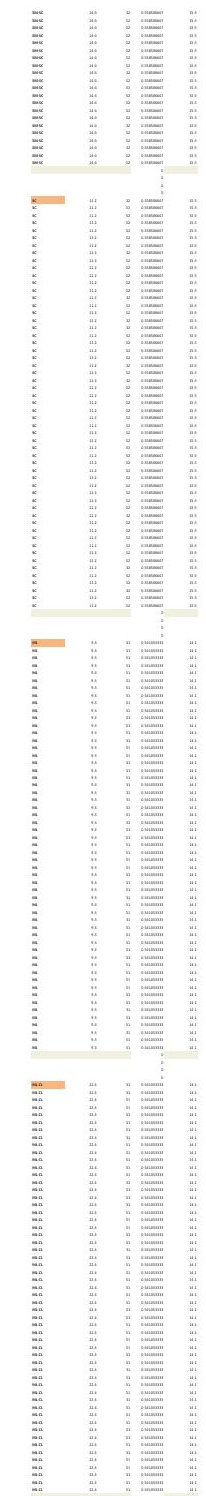

¿
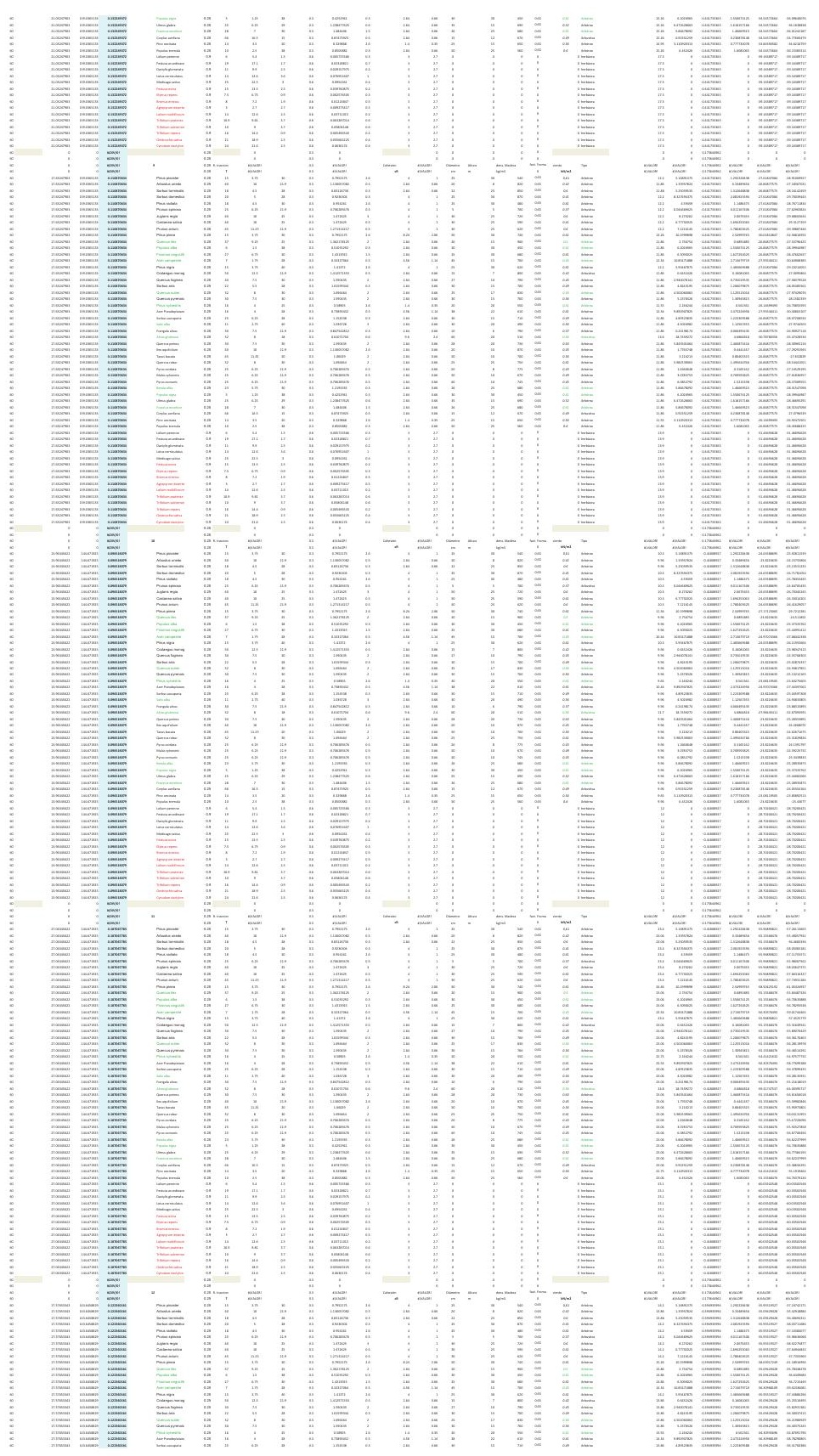
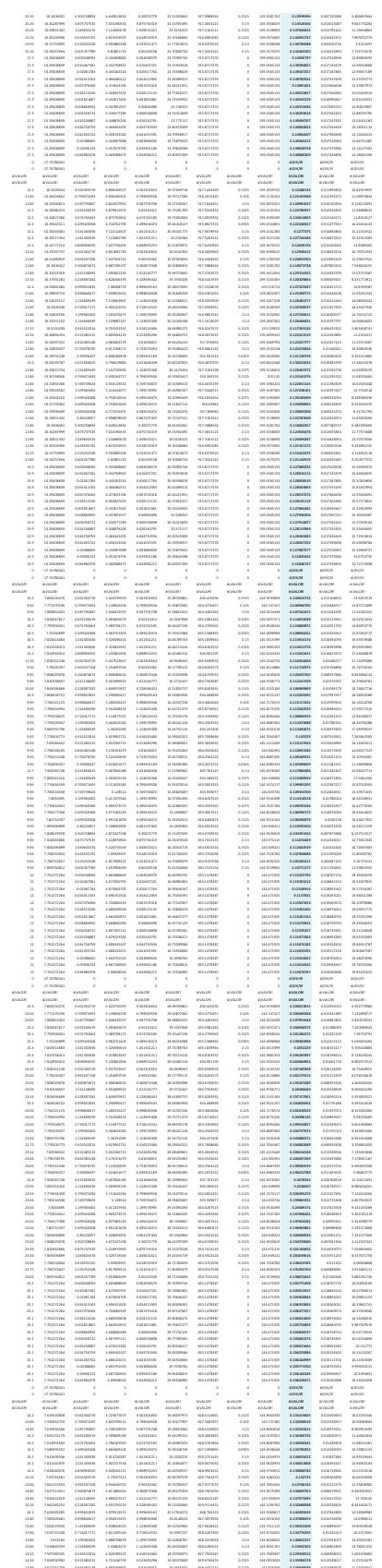

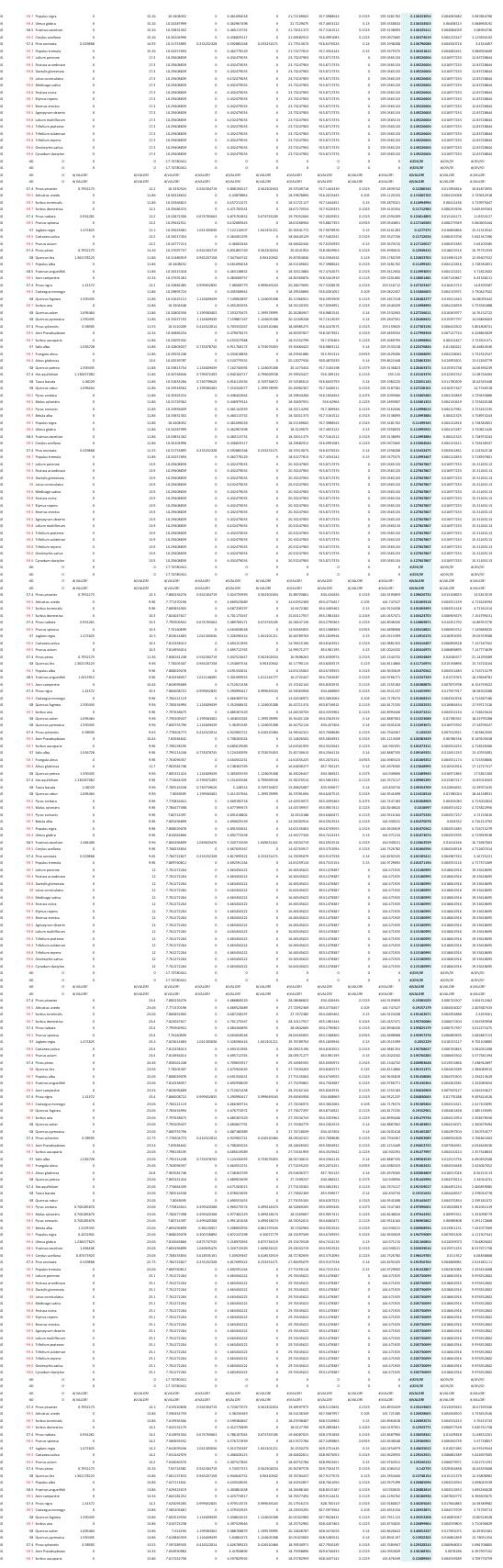




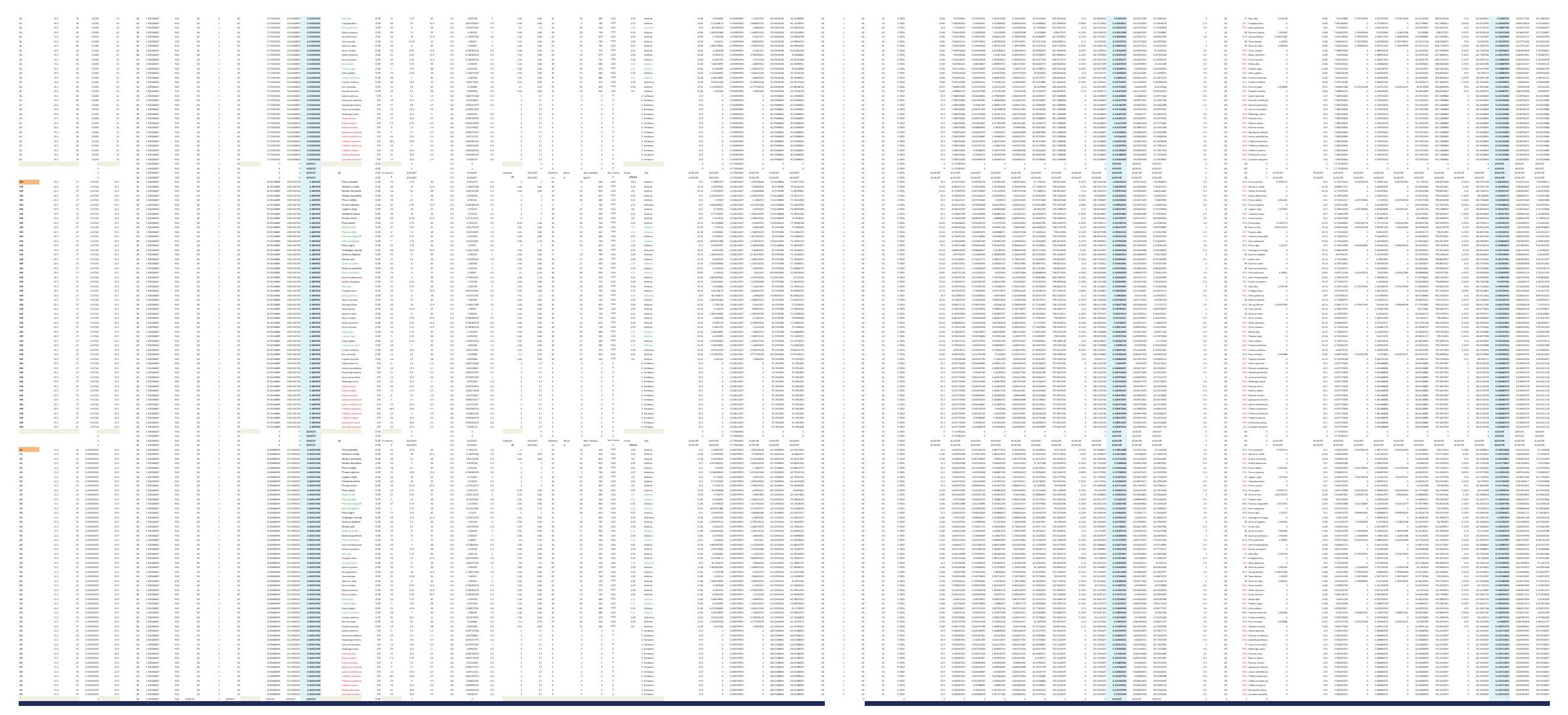


DESARROLLO DE UNA APLICACIÓN IMFORMÁTICA PARA EL CÁLCULO DE SOSTENIMIENTO DE TALUDES MEDIANTE VEGETACIÓN

PRUEBAS DEL MODELO MATEMÁTICO PARA EL CÁLCULO DE ESTABILIDAD DE TALUDES.

A03. DENSIDAD DE PLANTACIÓN: 2.500 plantas/ha.

A03-1.POSICIÓN N.F. 1

A03-2.POSICIÓN N.F. 2

A03-3.POSICIÓN N.F. 3

A03-4.POSICIÓN N.F. 4

A03-5.POSICIÓN N.F. 5 
DESARROLLO DE UNA APLICACIÓN IMFORMÁTICA PARA EL CÁLCULO DE SOSTENIMIENTO DE TALUDES MEDIANTE VEGETACIÓN

A03. DENSIDAD DE PLANTACIÓN: 2.500 plantas/ha.

\section{A03-1.POSICIÓN N.F. 1}

INCLINACIÓN DE TALUD 6-100

INCLINACIÓN DE TALUD 10-200

INCLINACIÓN DE TALUD 20-30

INCLINACIÓN DE TALUD 30-40

INCLINACIÓN DE TALUD $35^{\circ}$

INCLINACIÓN DE TALUD 40-50

INCLINACIÓN DE TALUD 50-550

INCLINACIÓN DE TALUD 55-60

INCLINACIÓN DE TALUD 60-700

INCLINACIÓN DE TALUD 70-80 

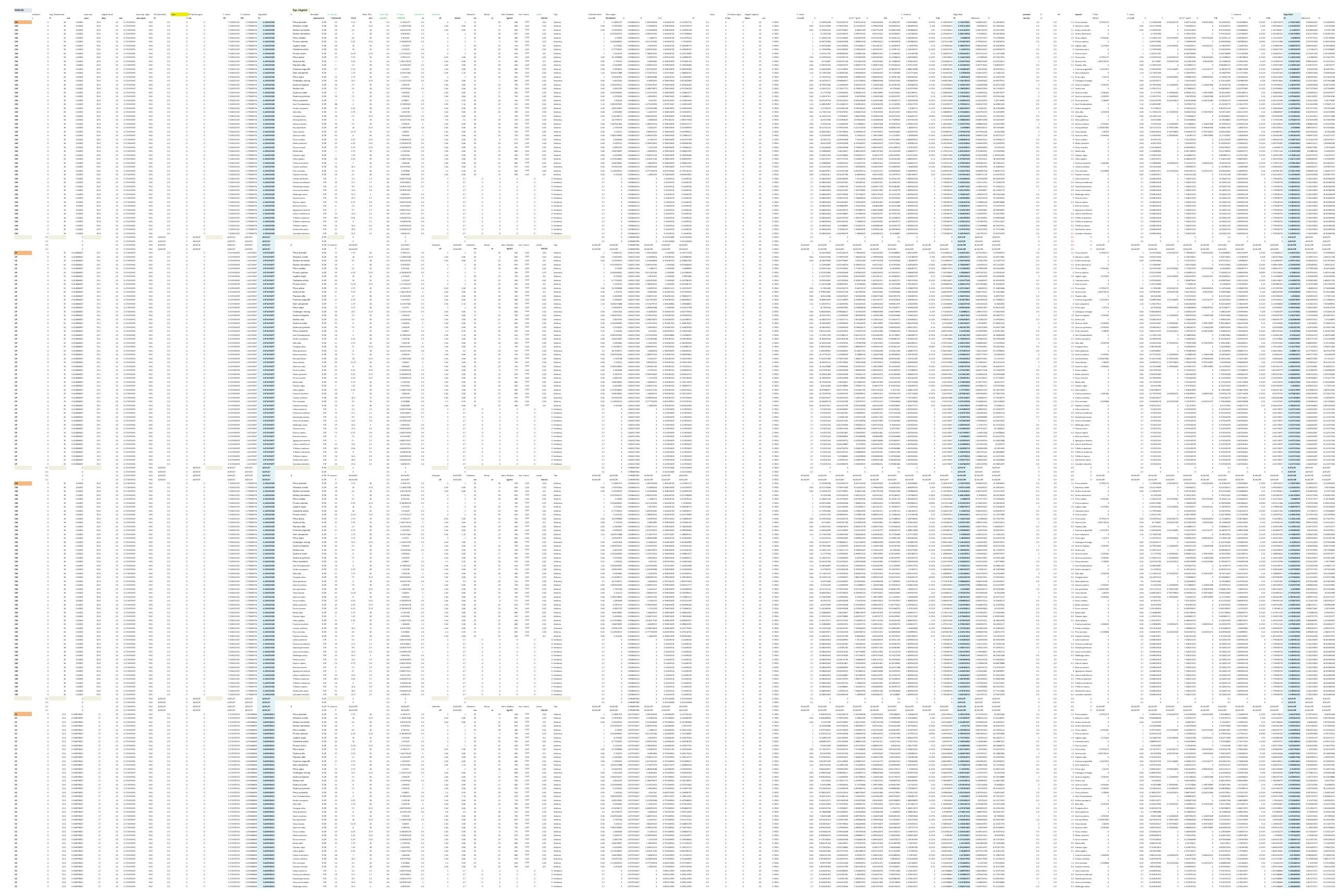


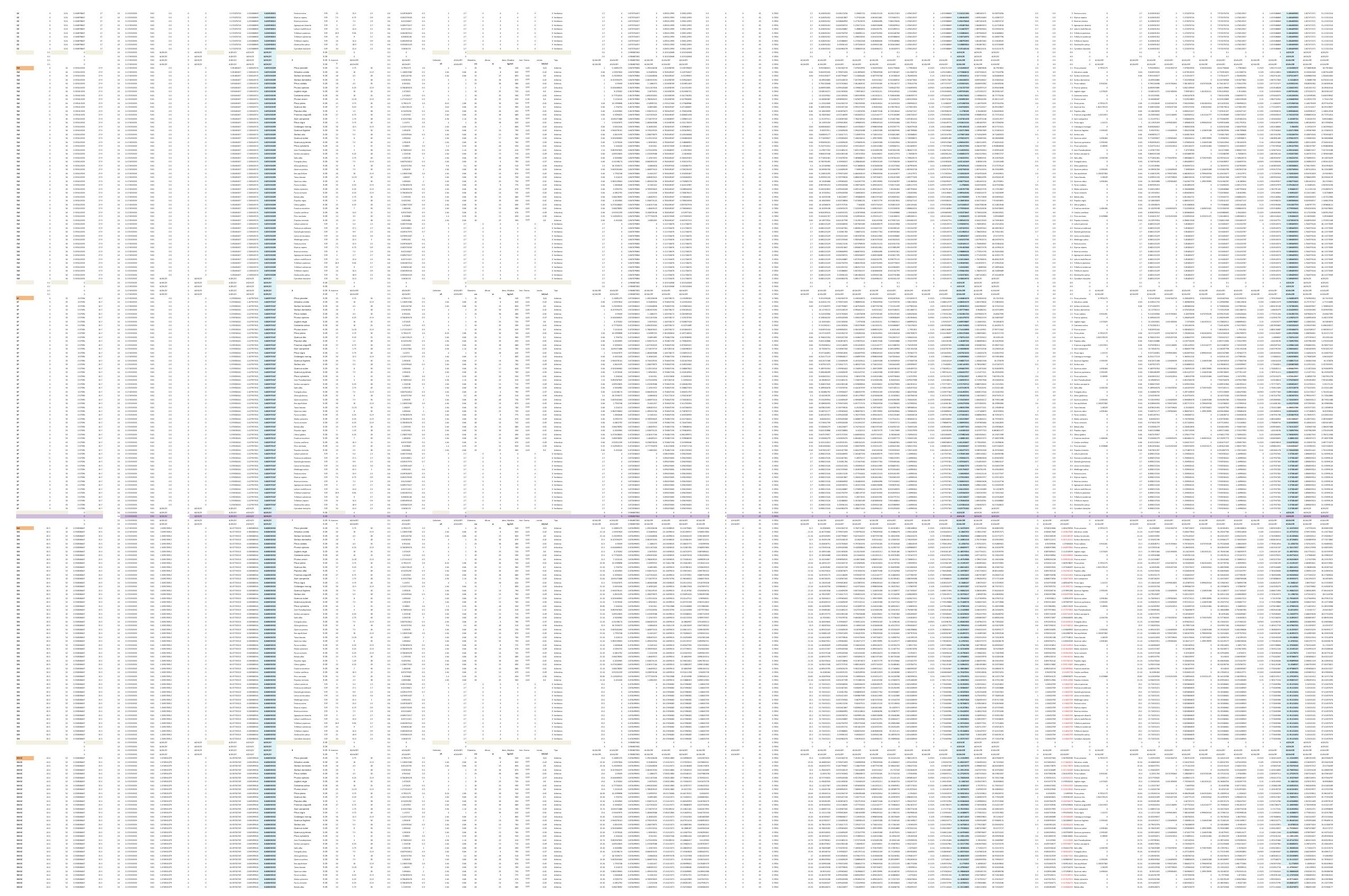



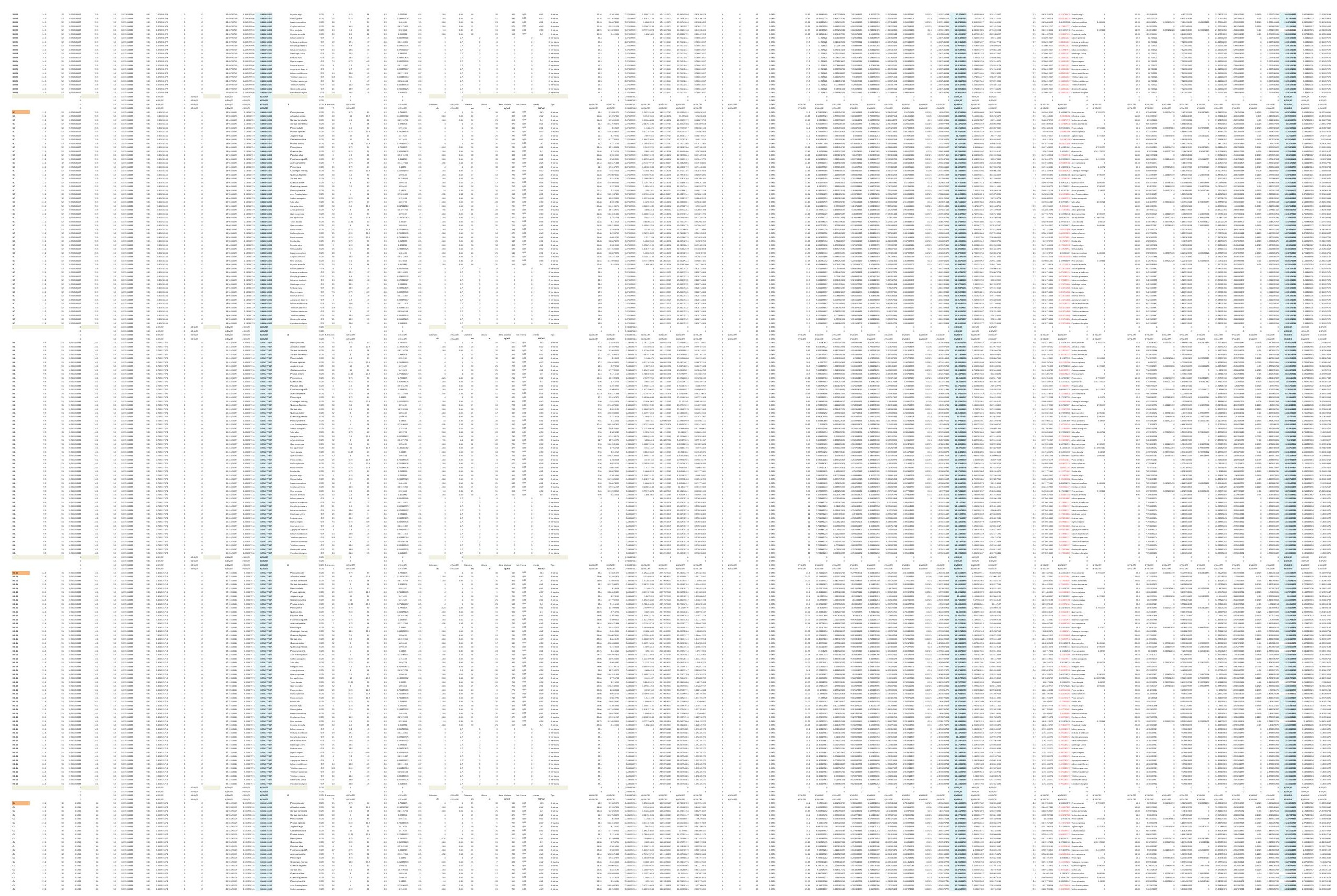


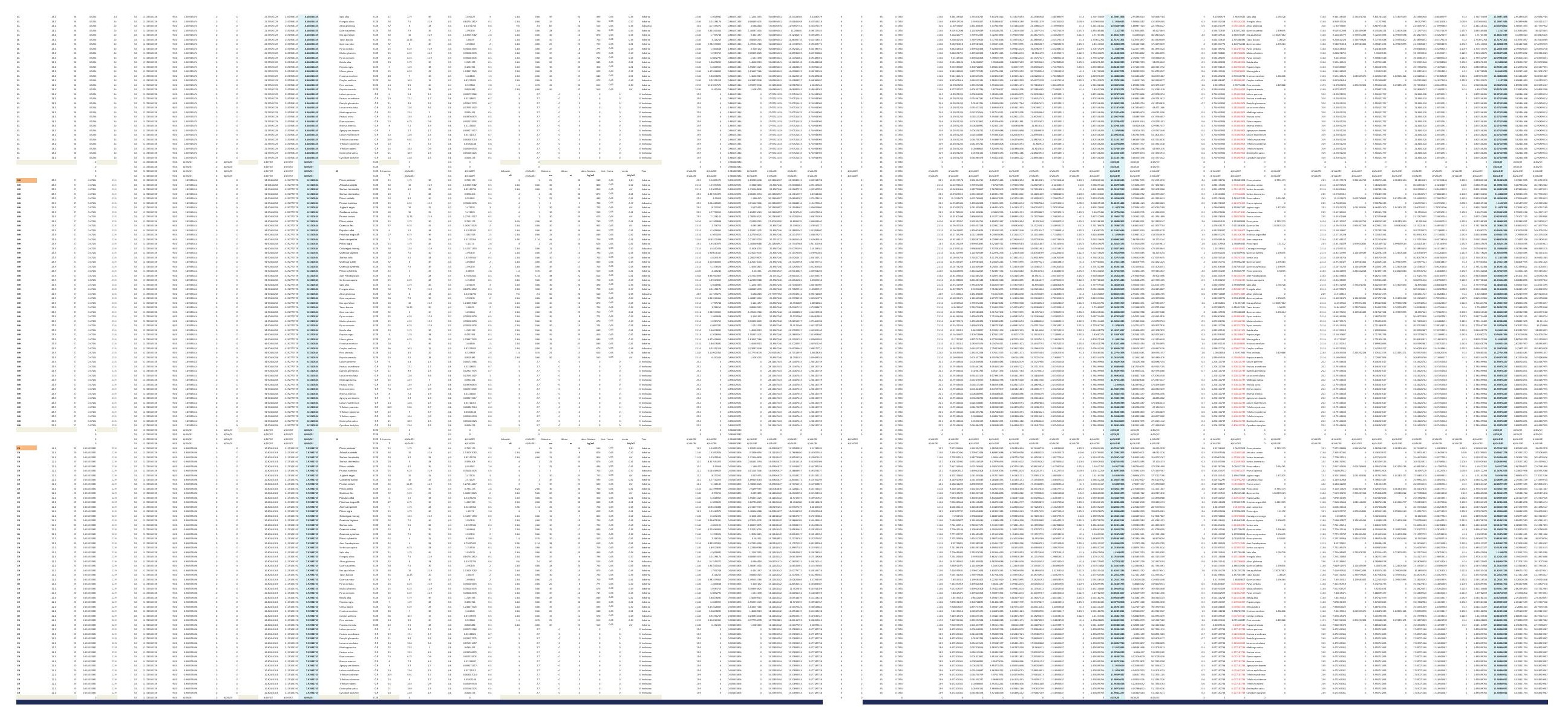



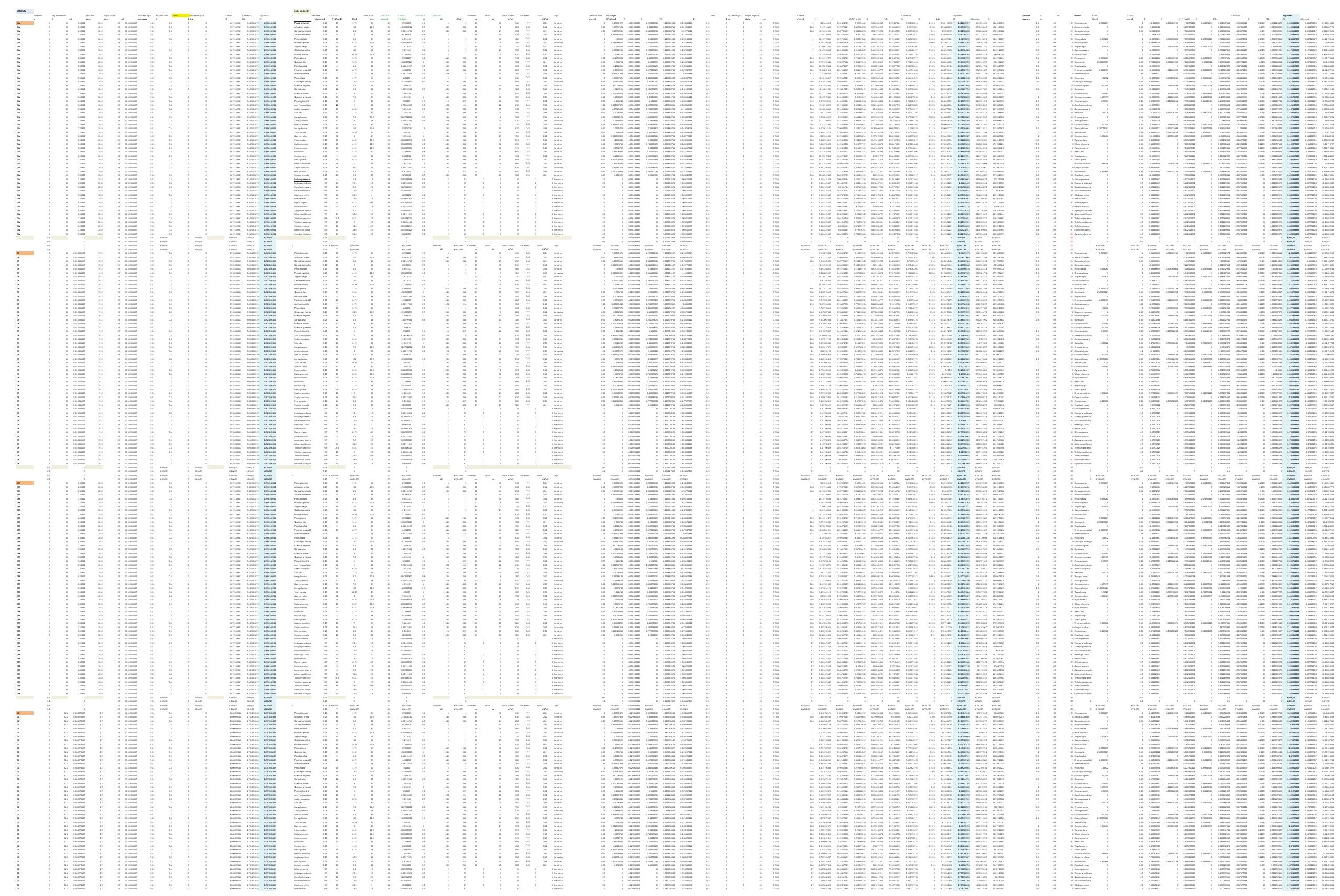


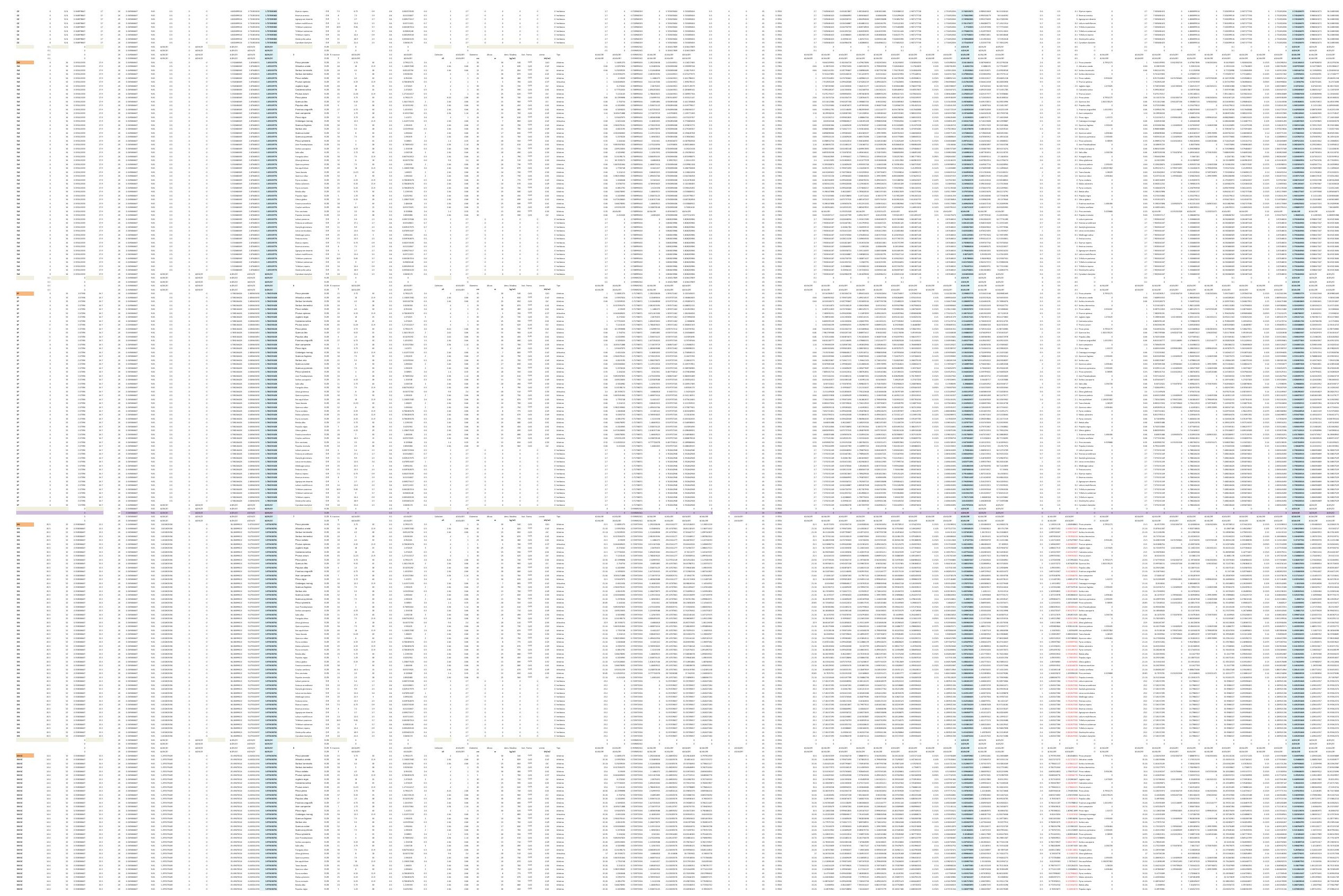



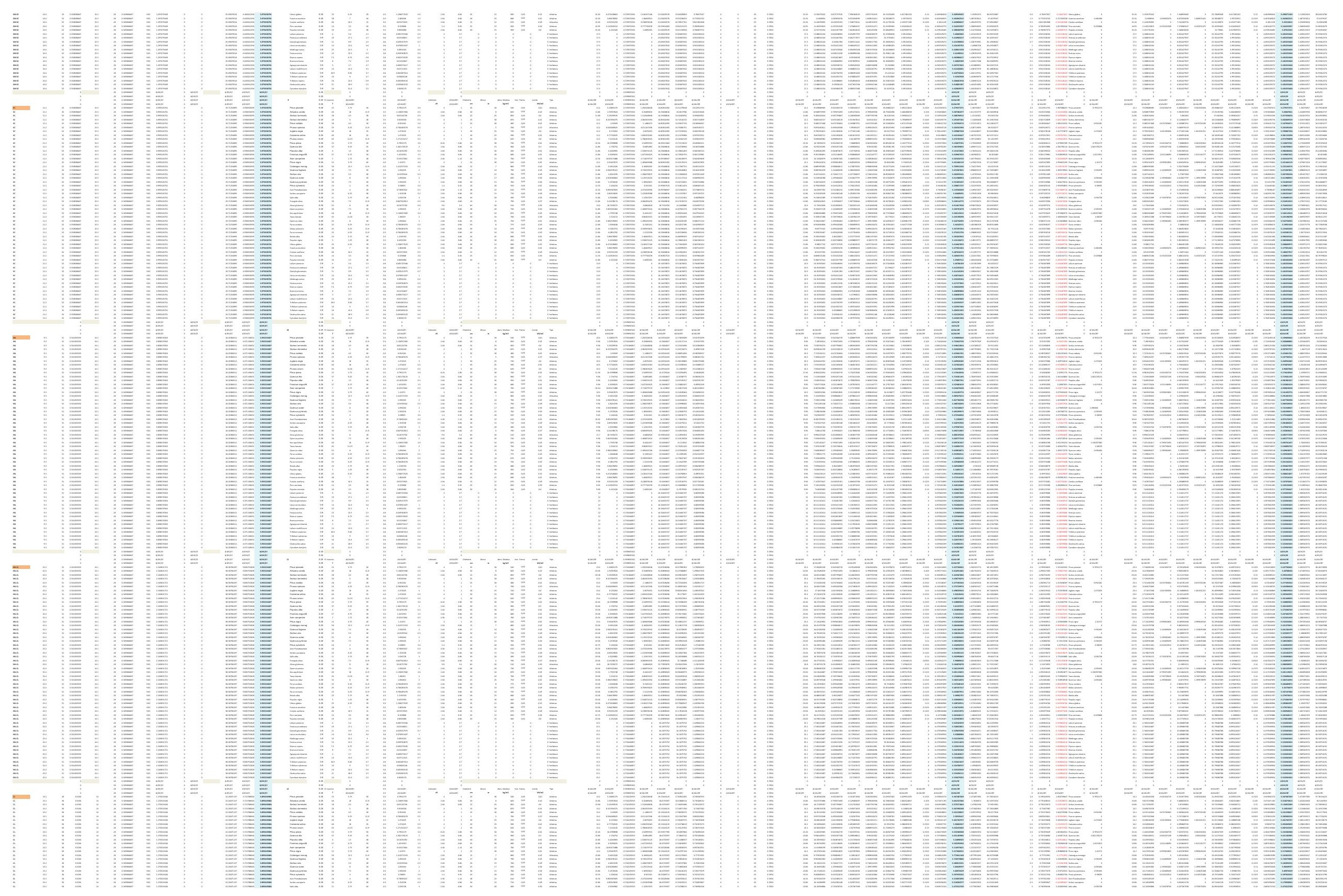


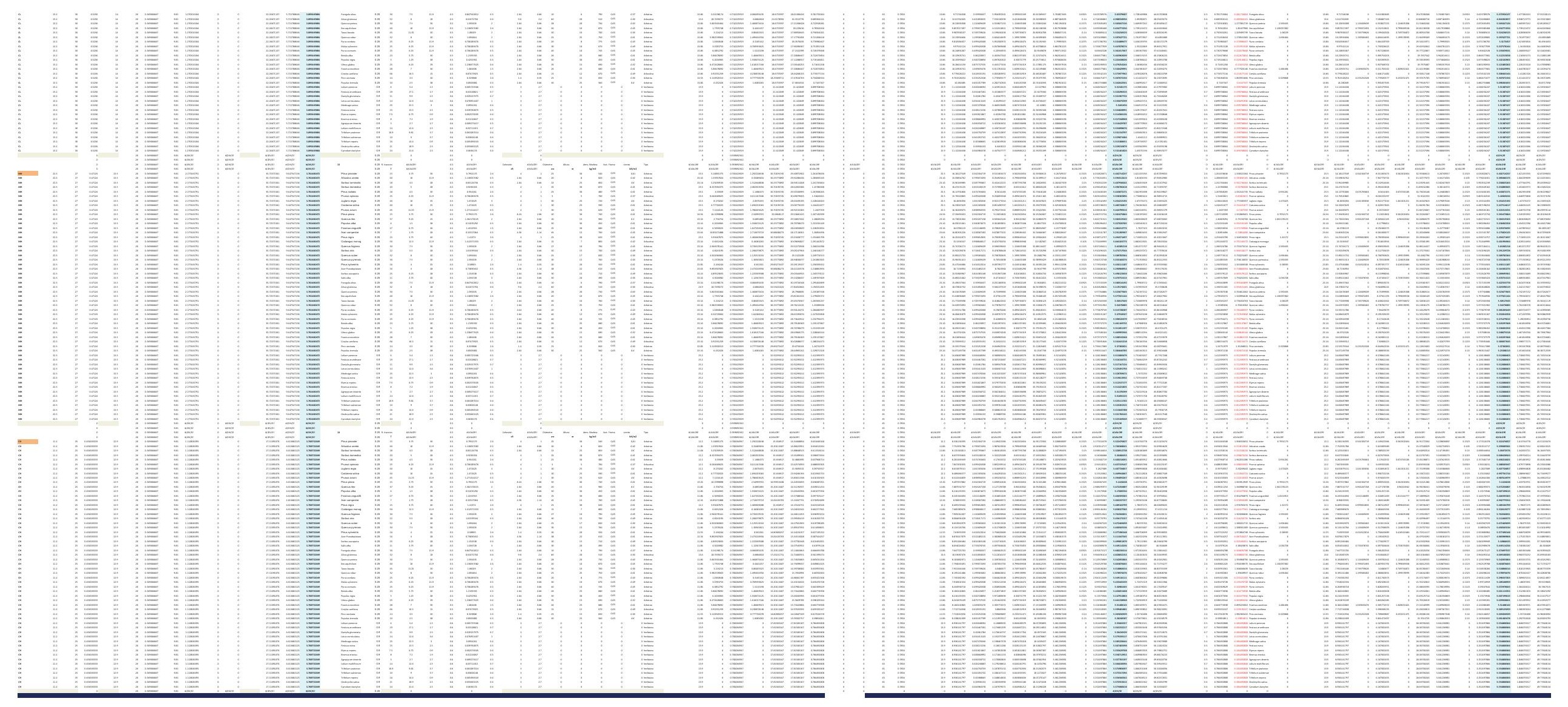



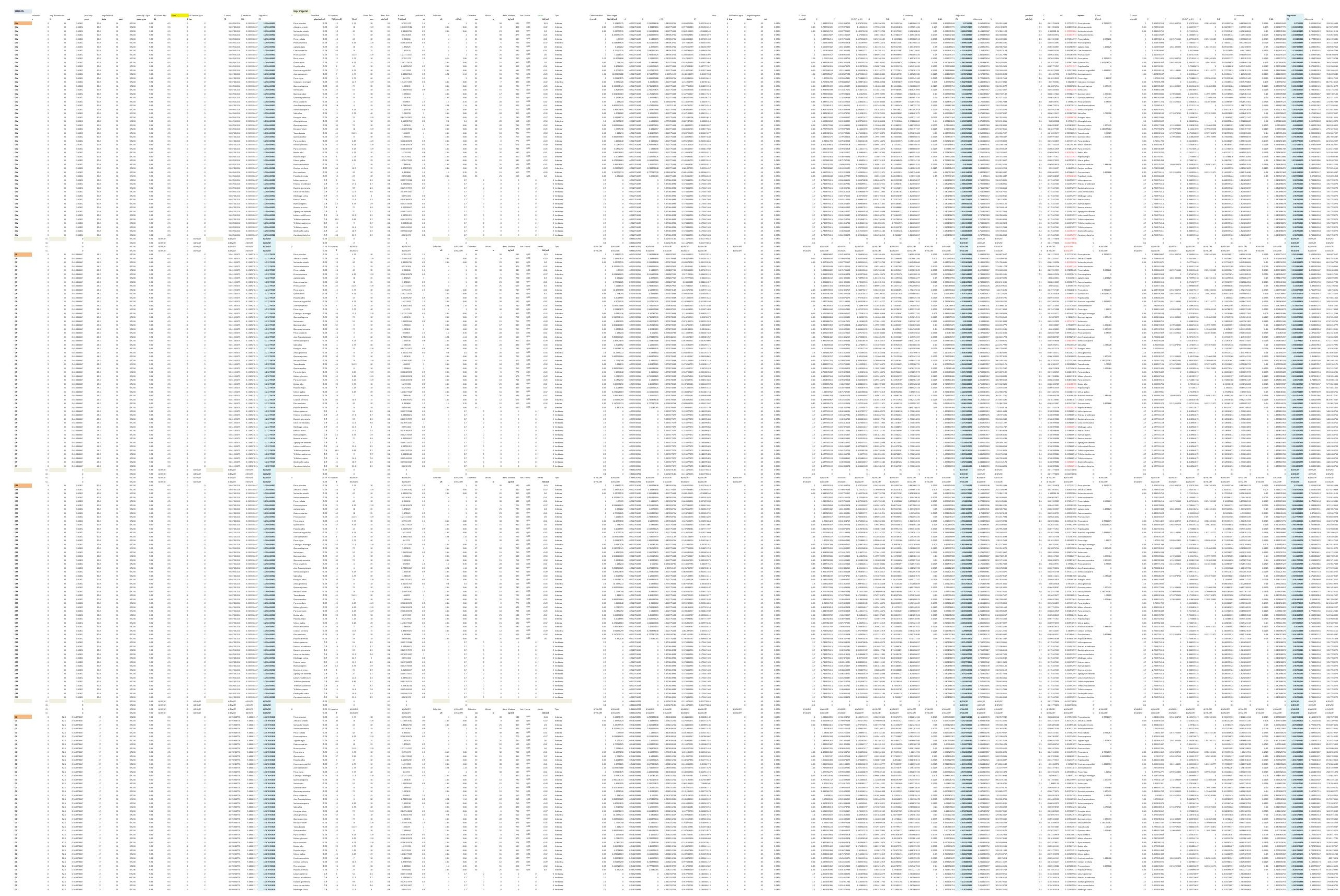


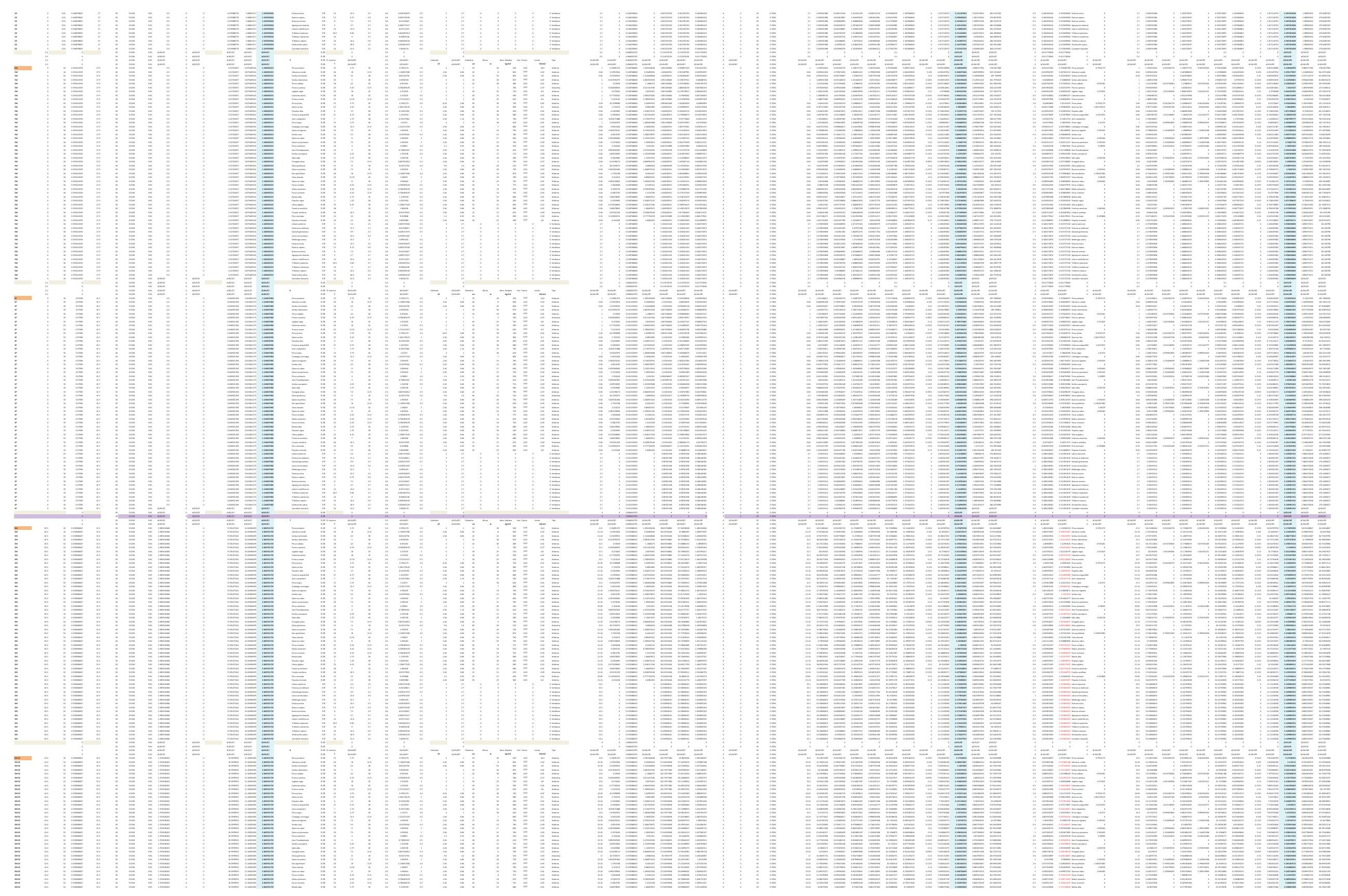



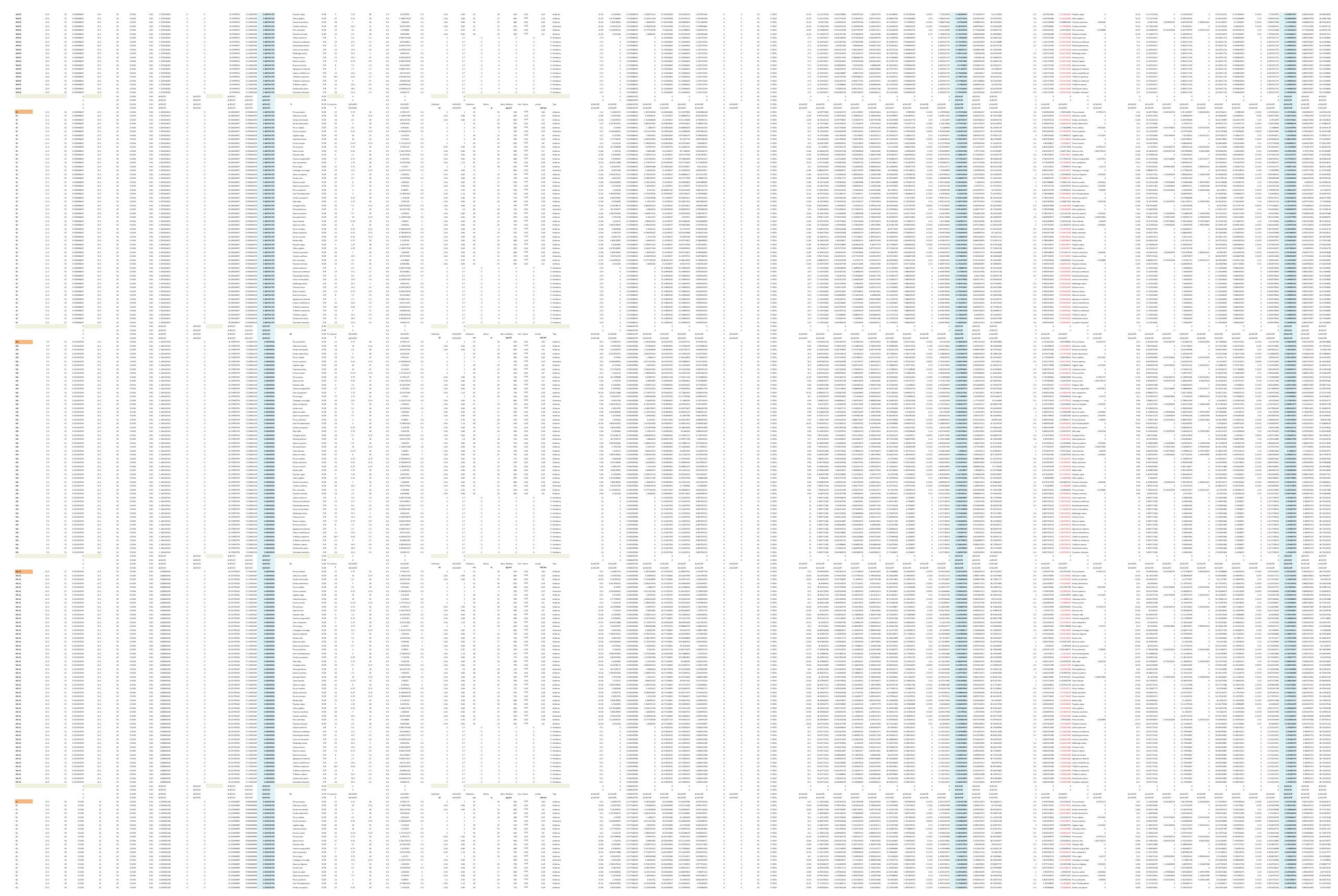


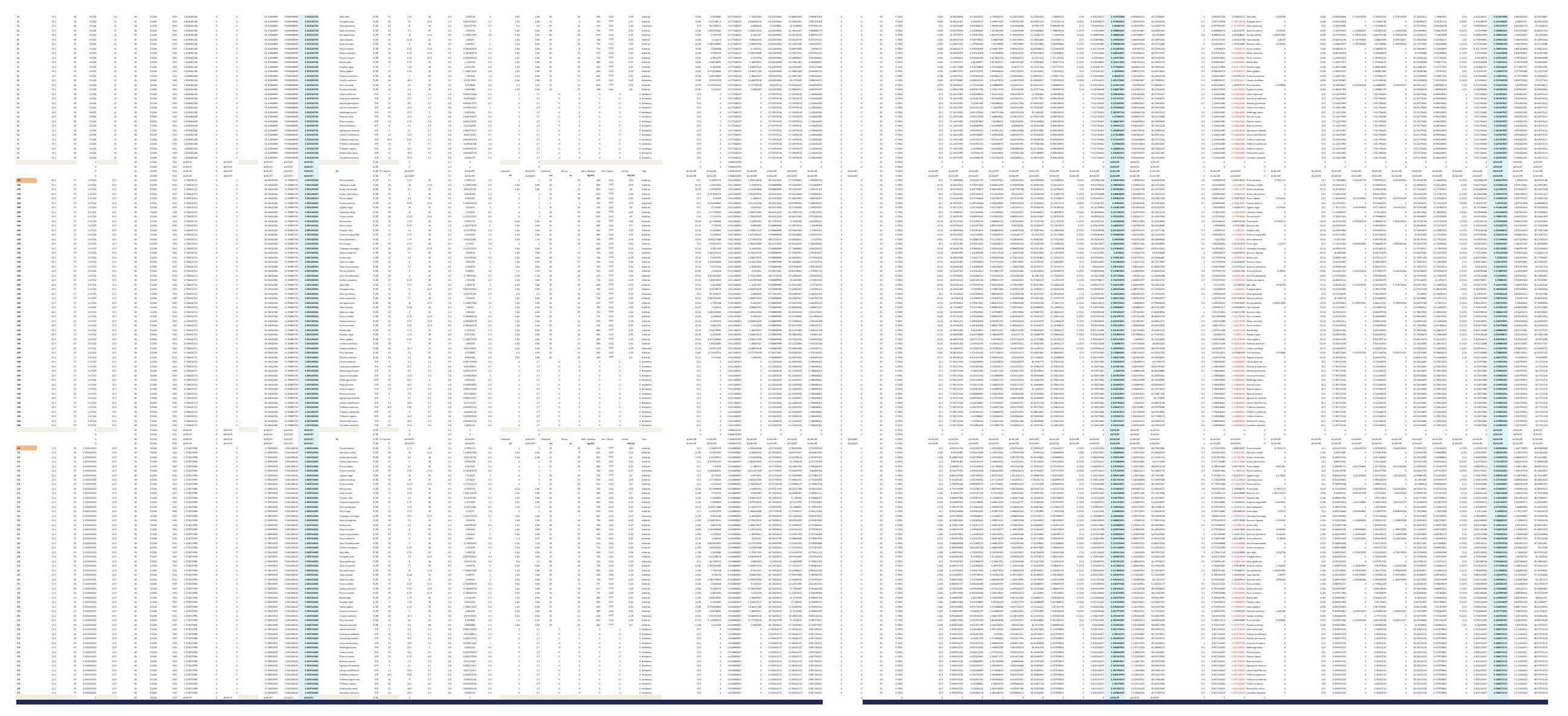



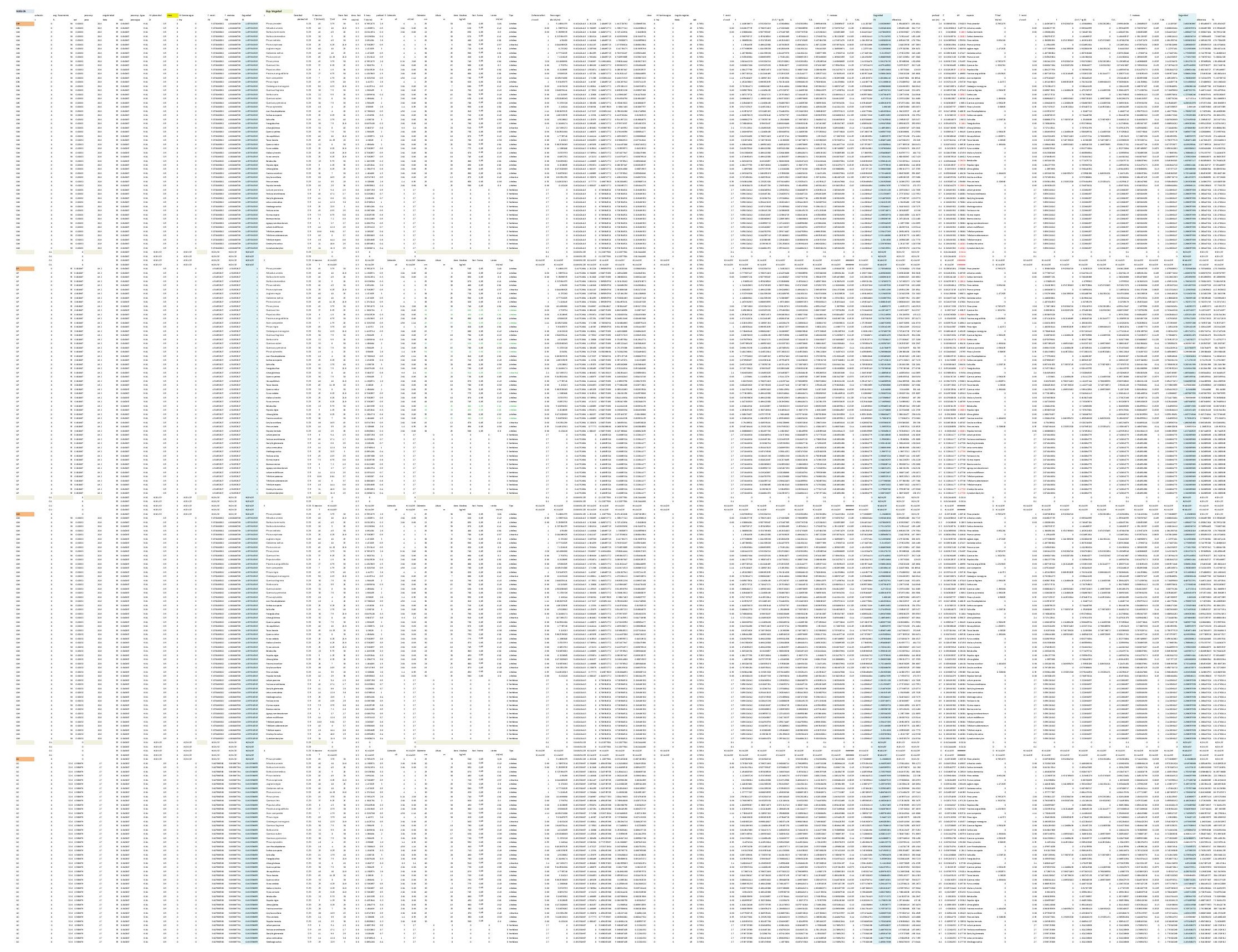


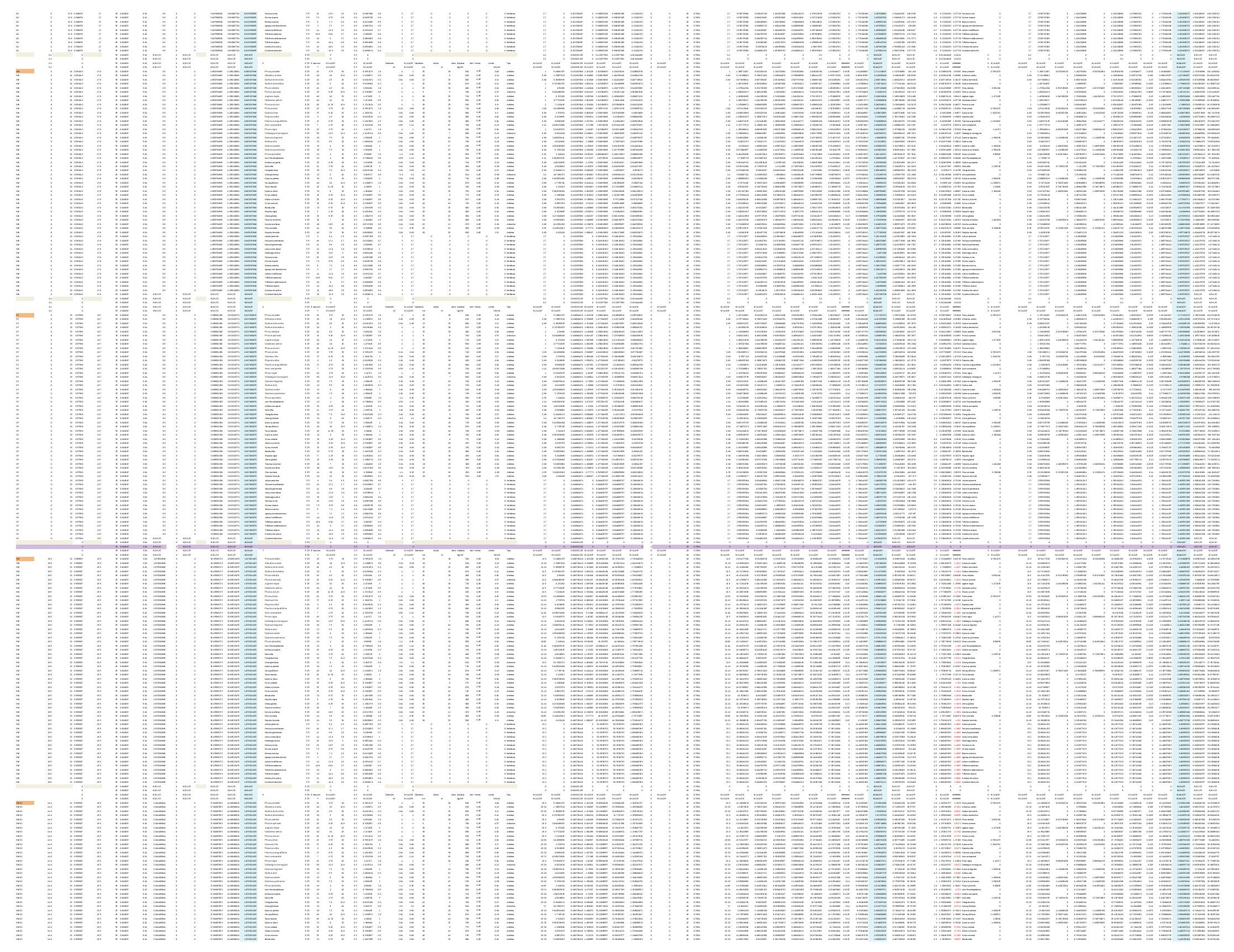



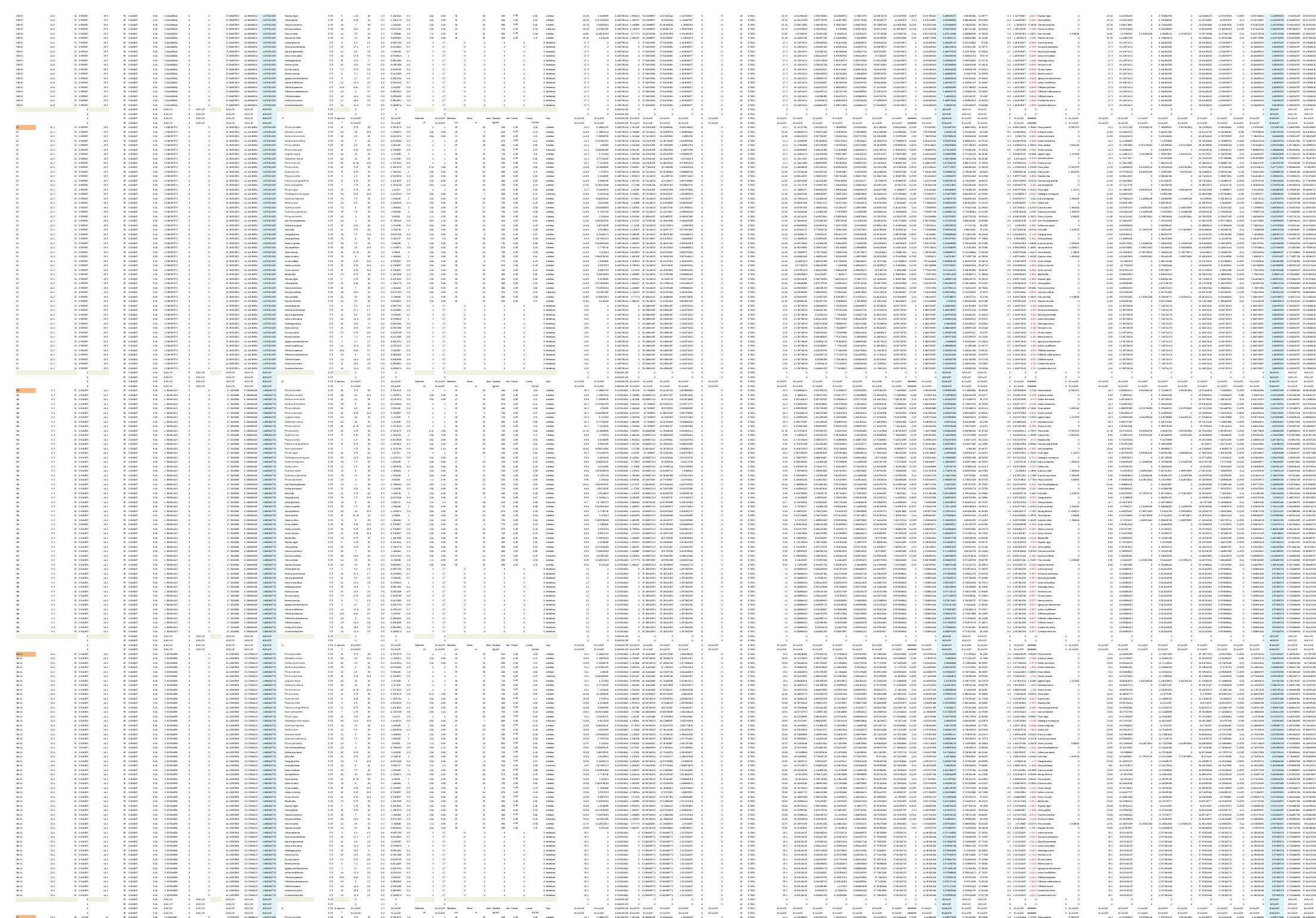

$\because \equiv \equiv \equiv \equiv \equiv \equiv \equiv$
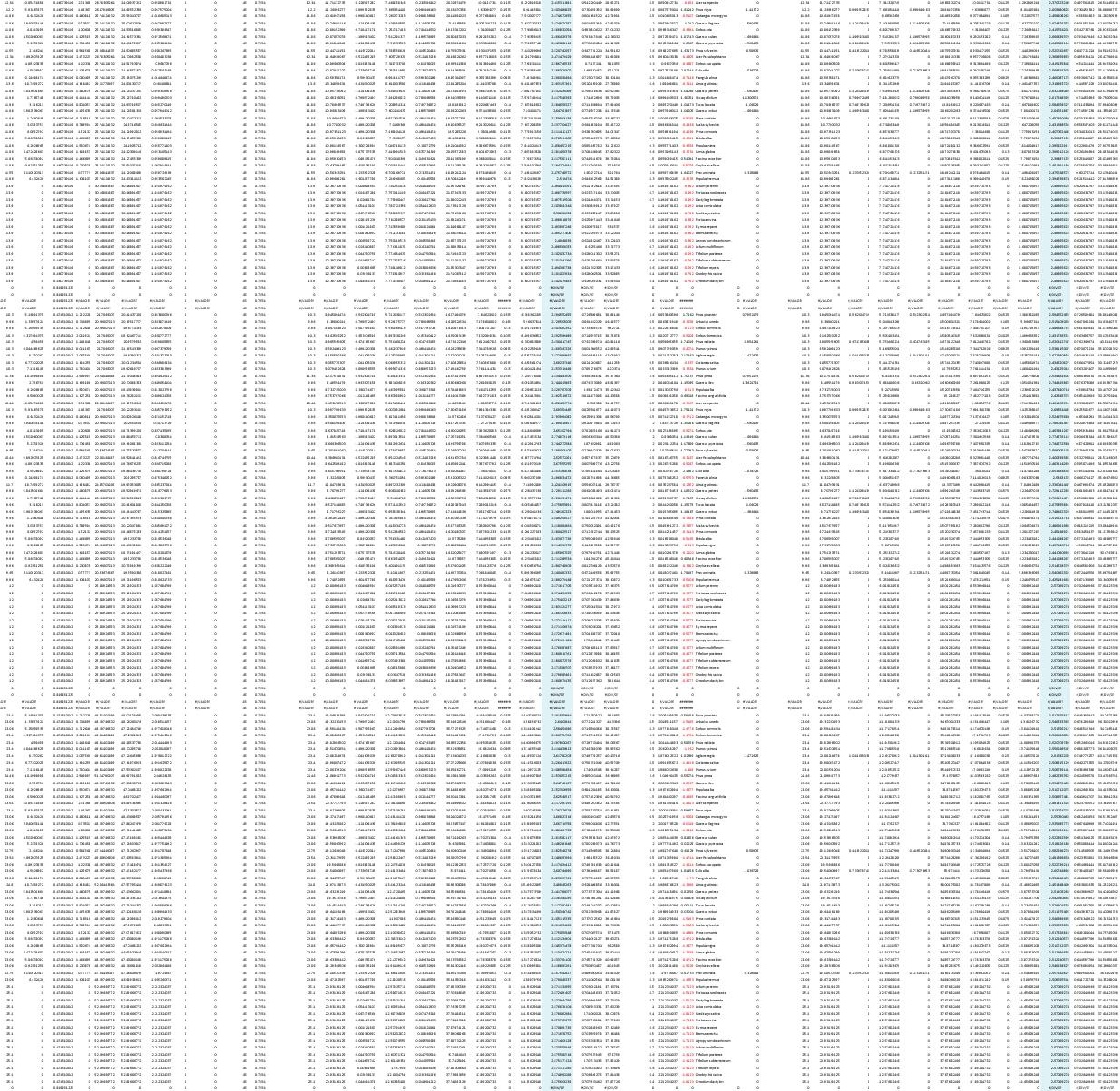

$-$ $=$

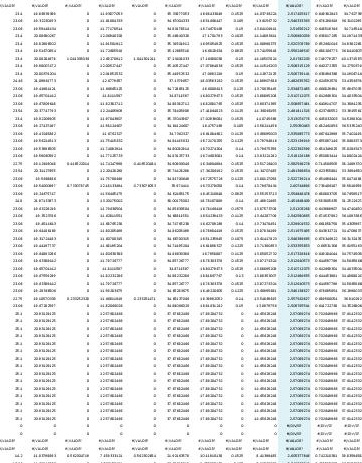

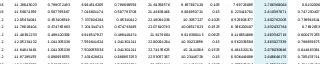

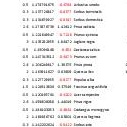

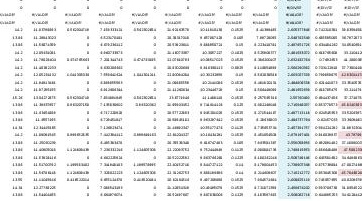




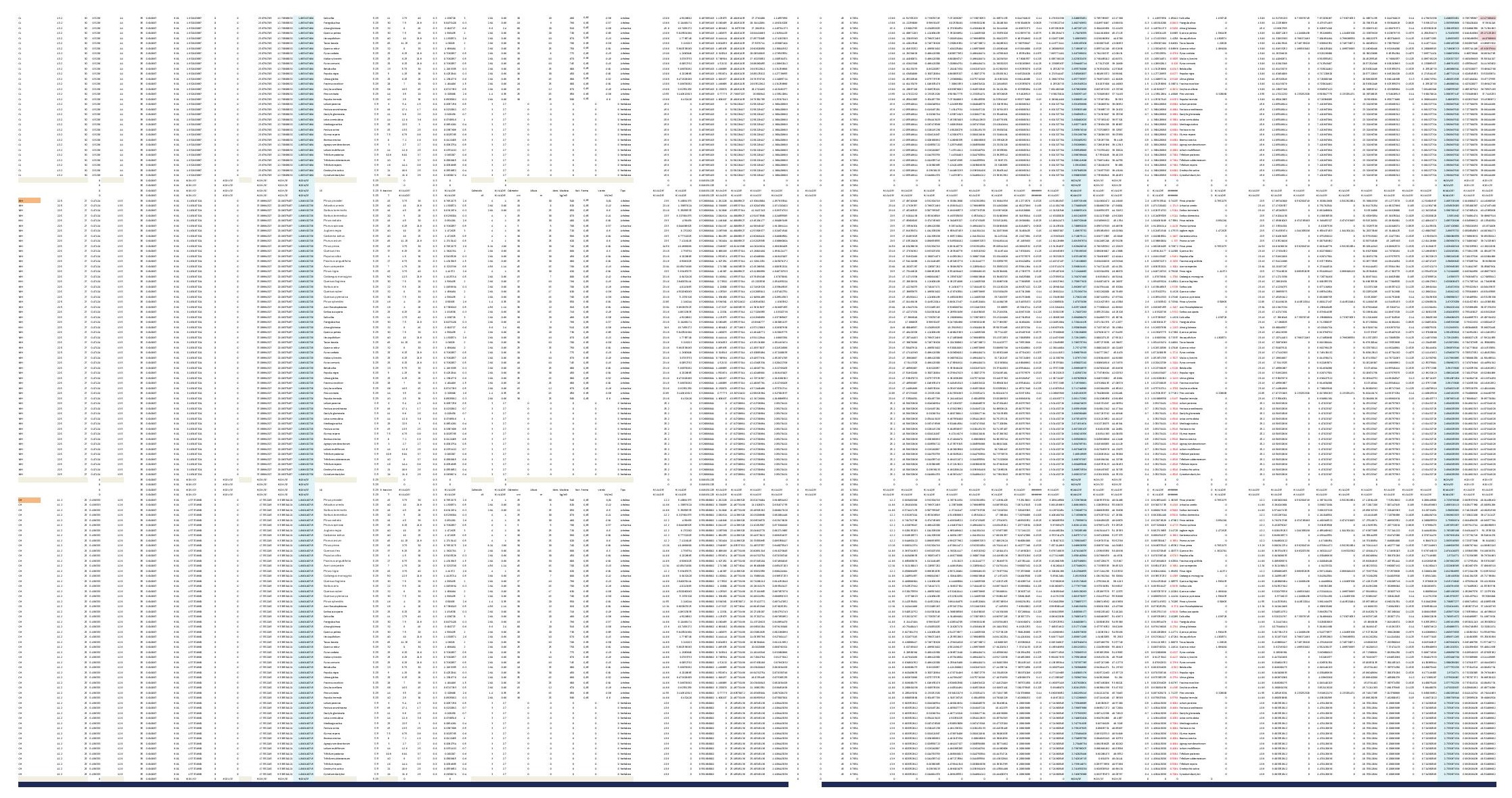



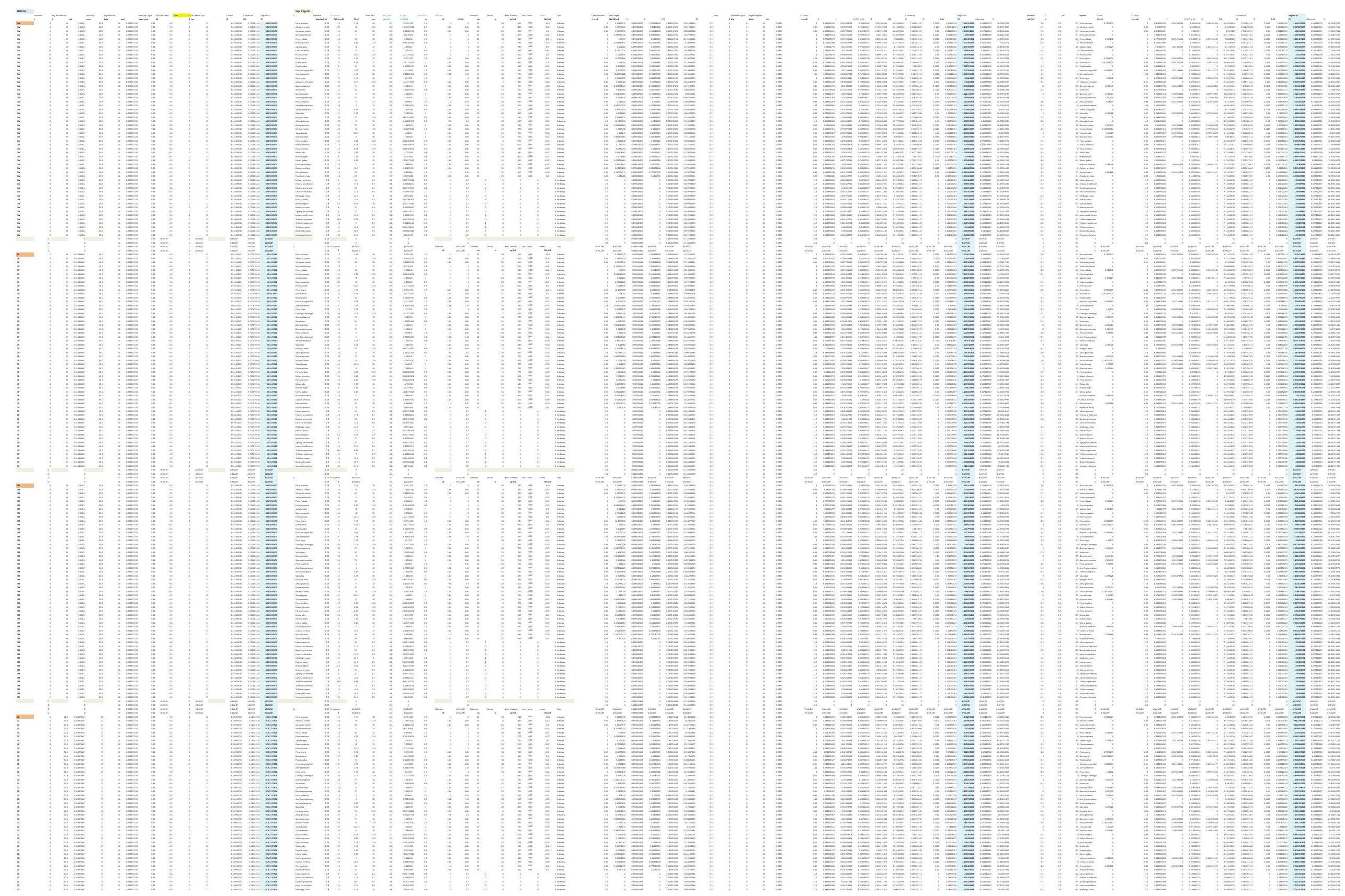


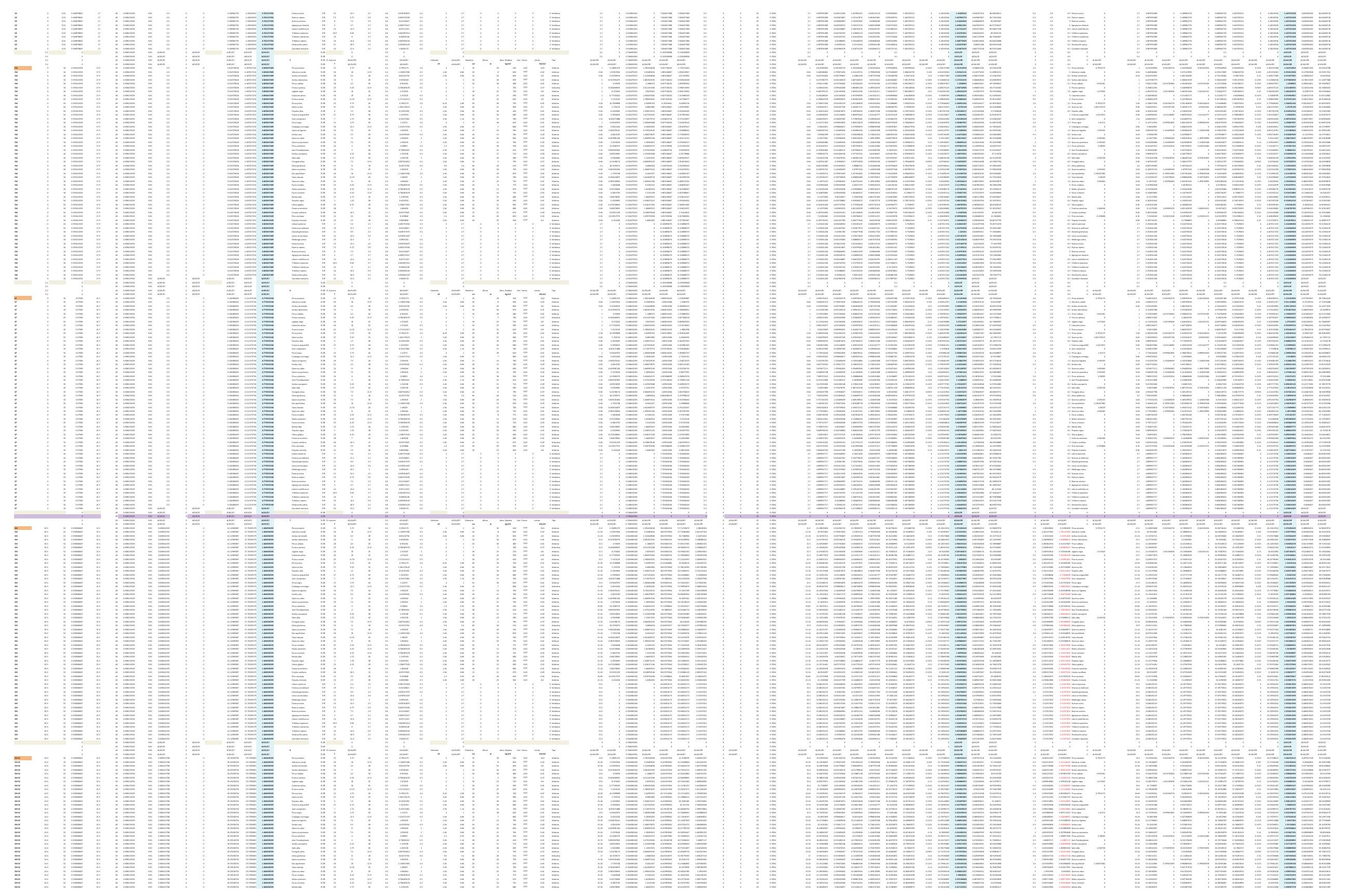



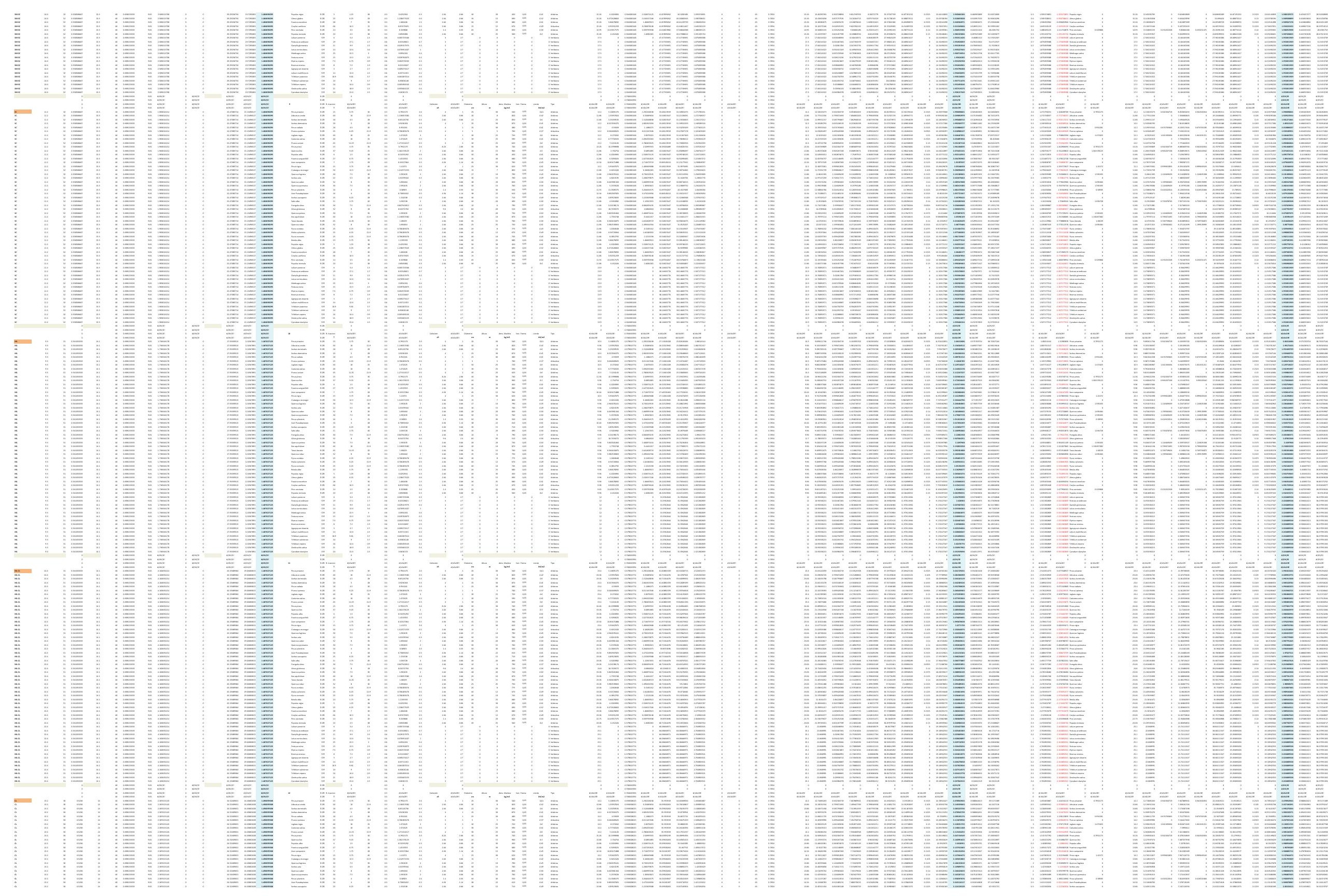


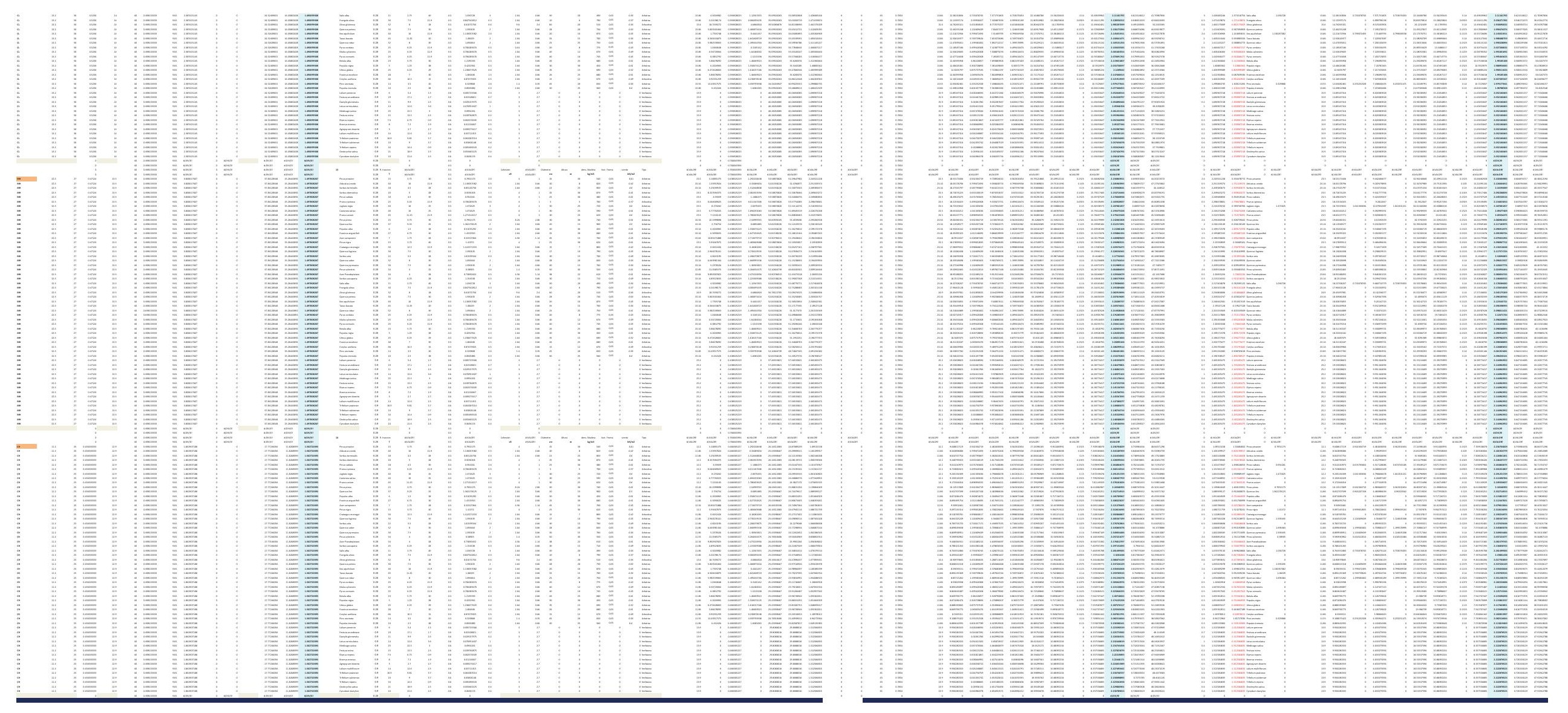



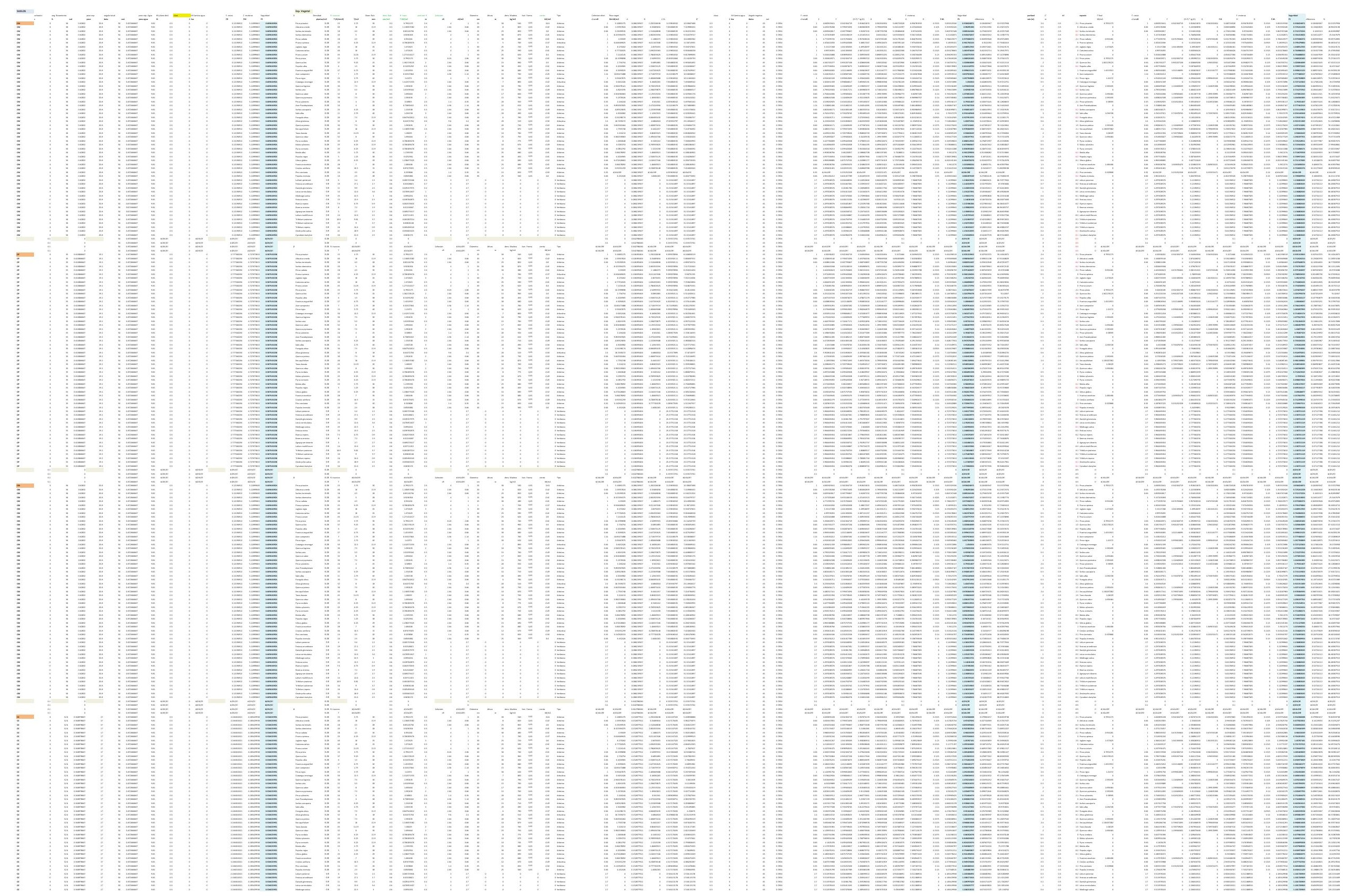


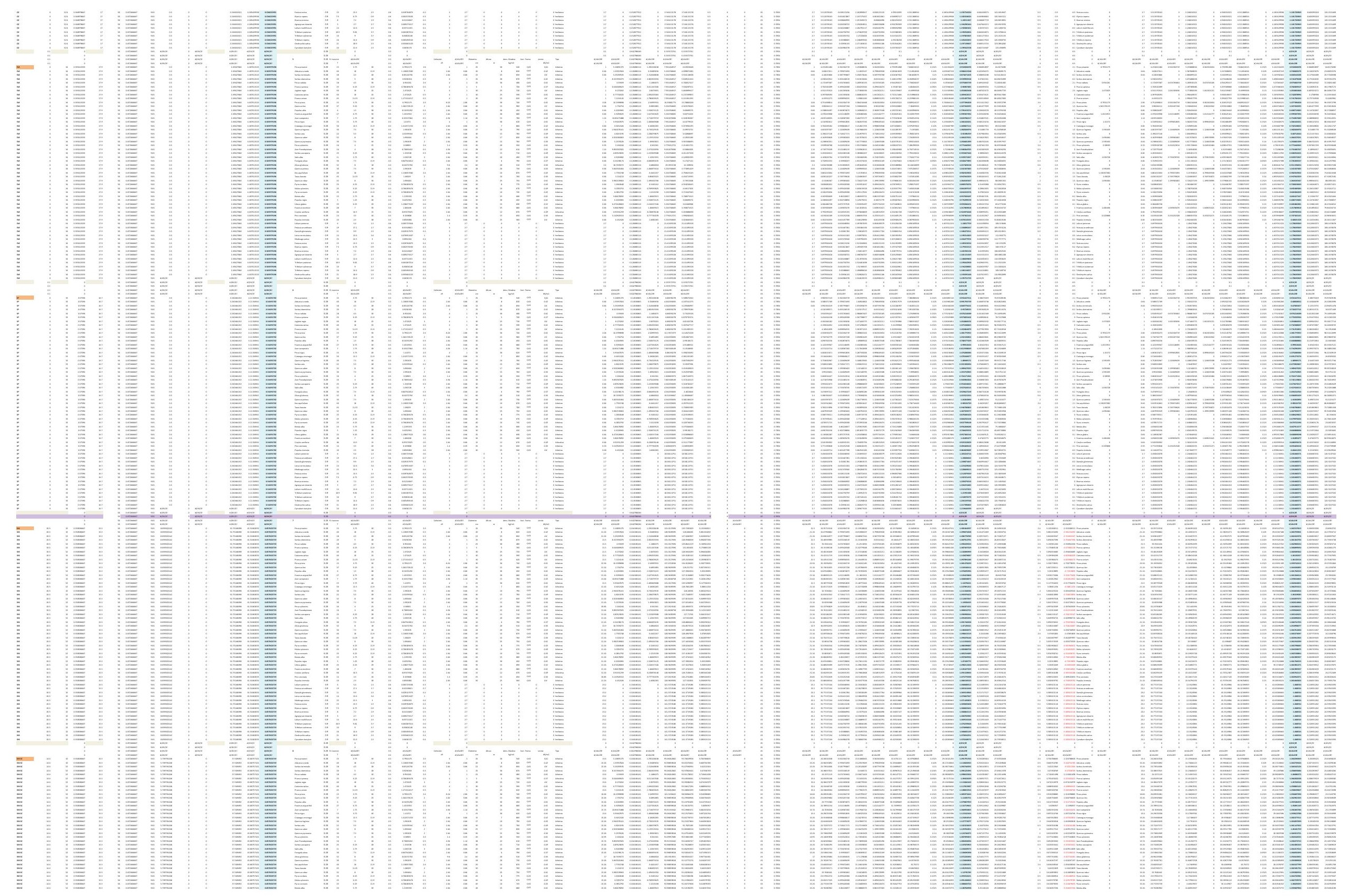



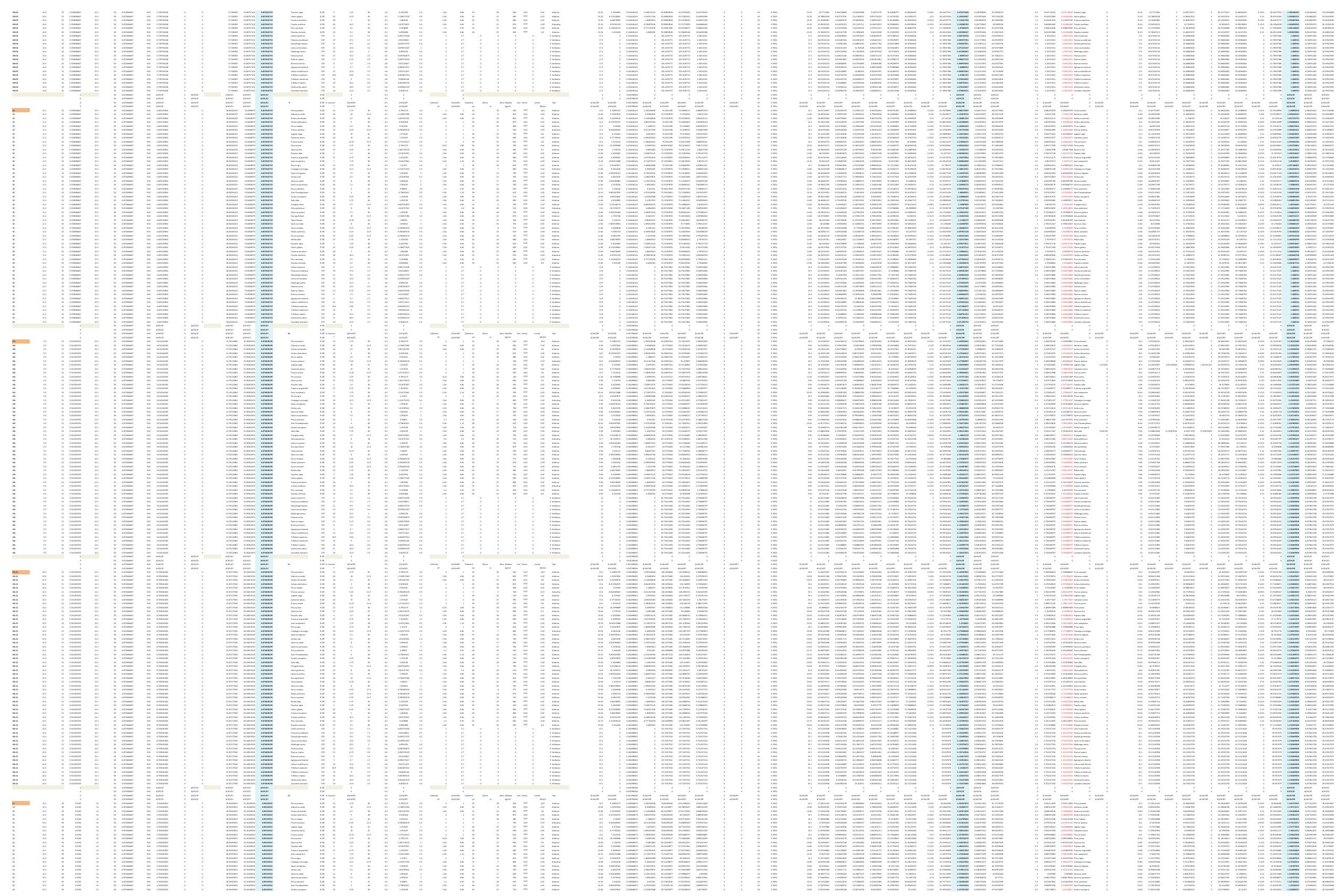


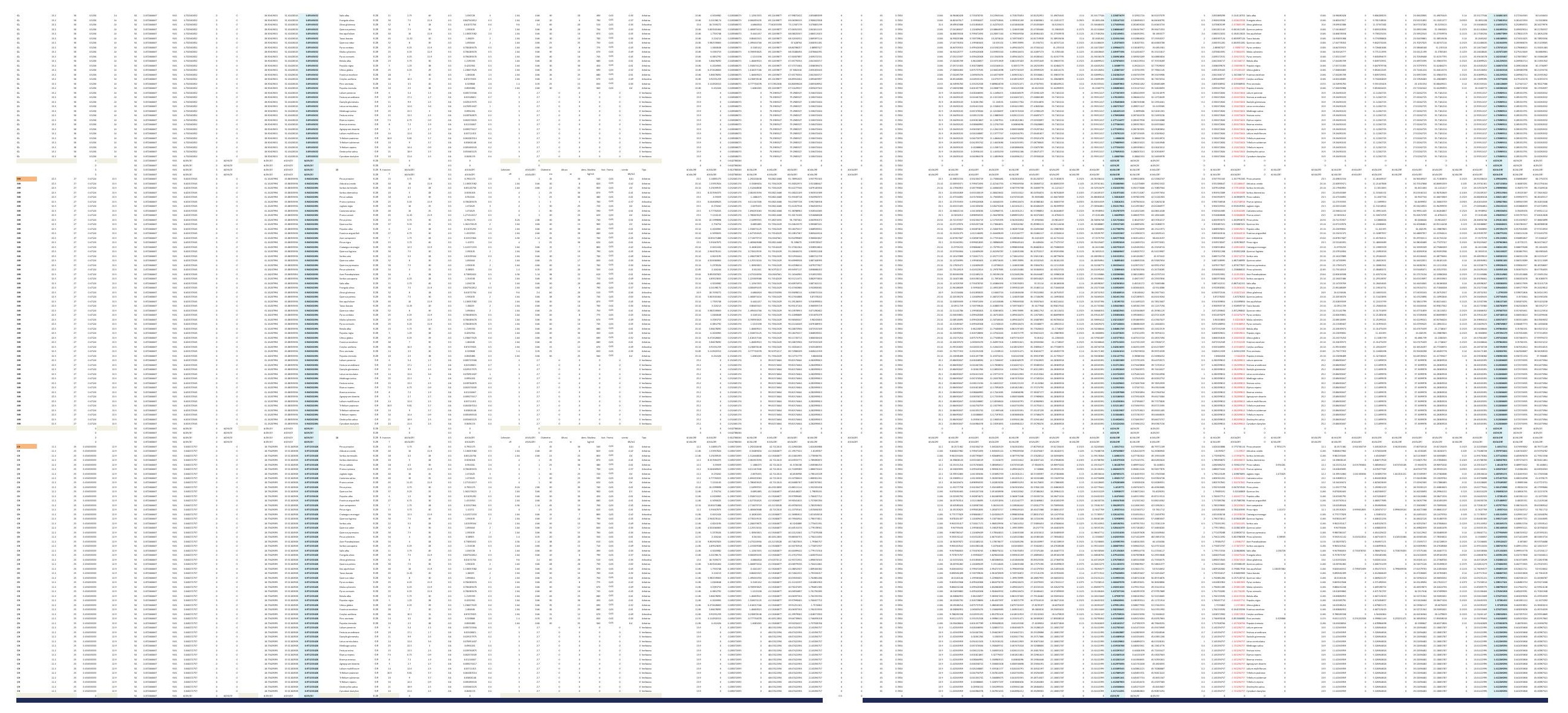



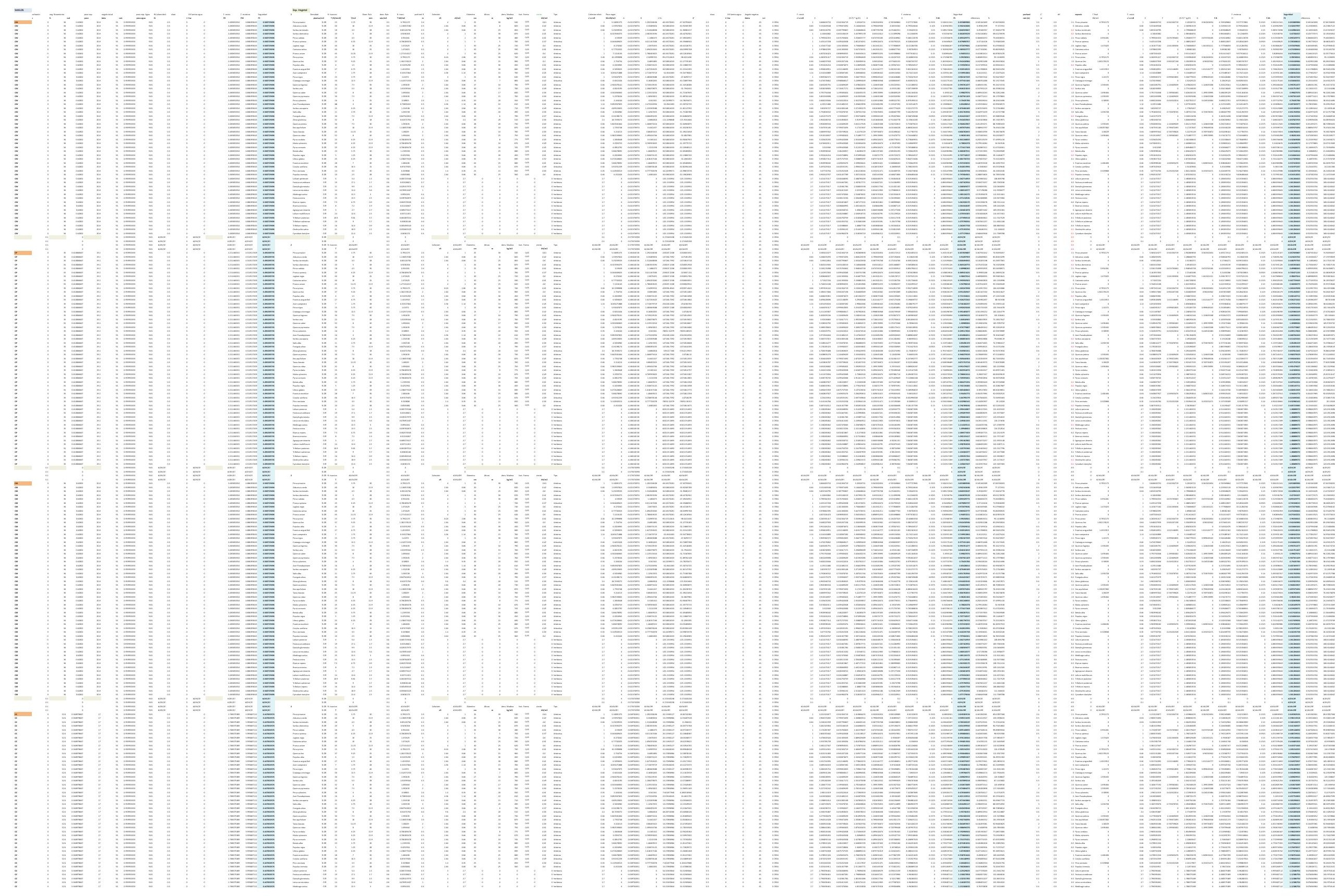


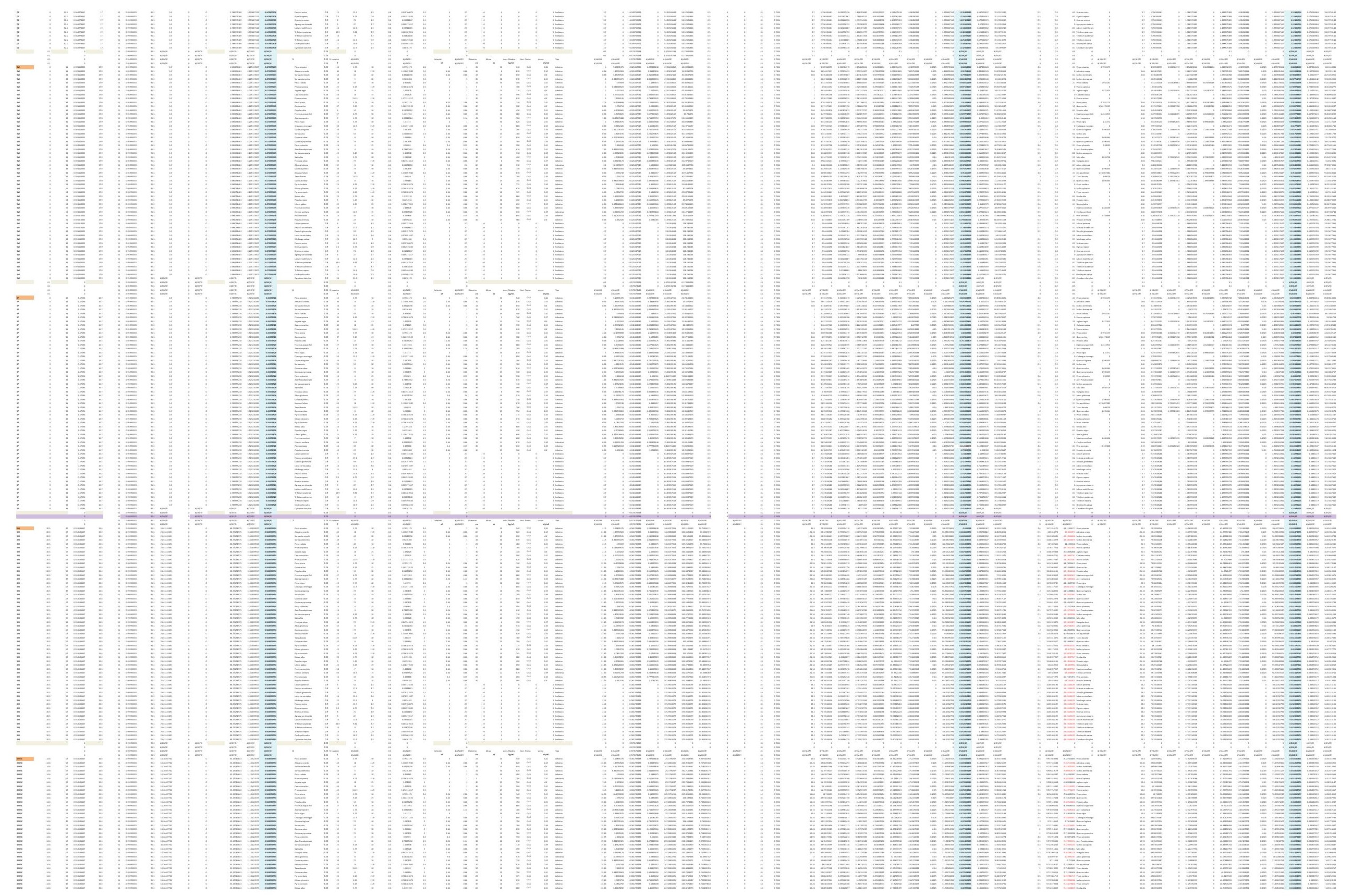



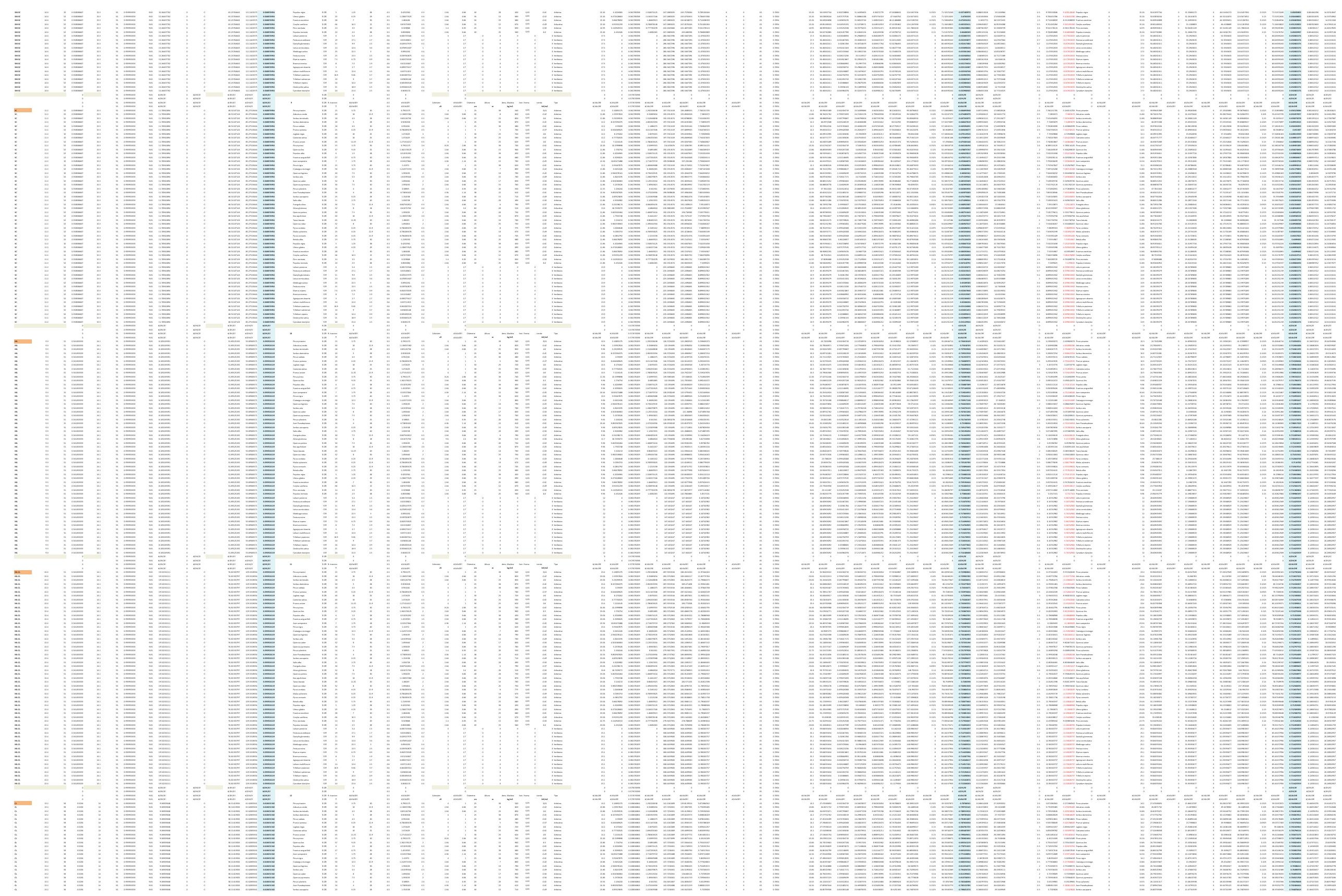


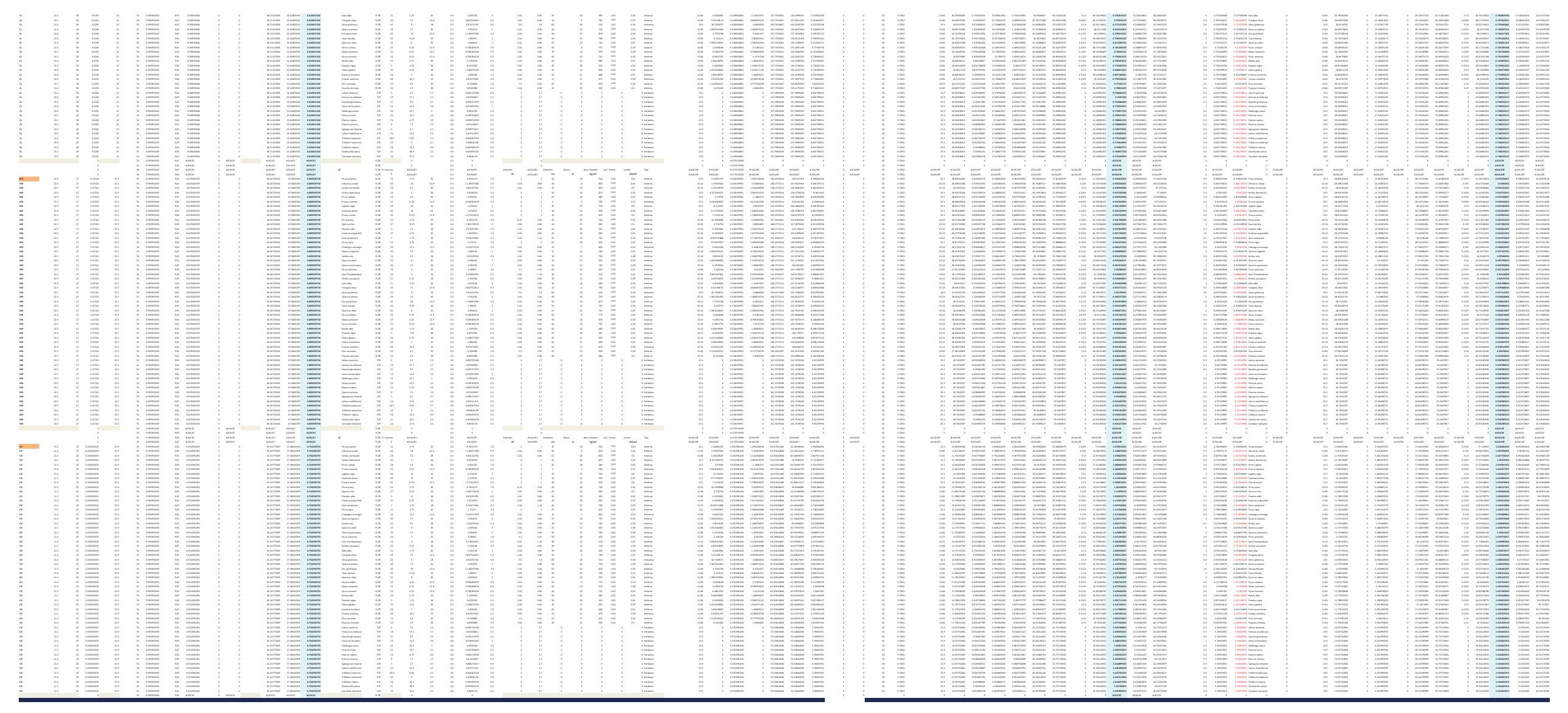



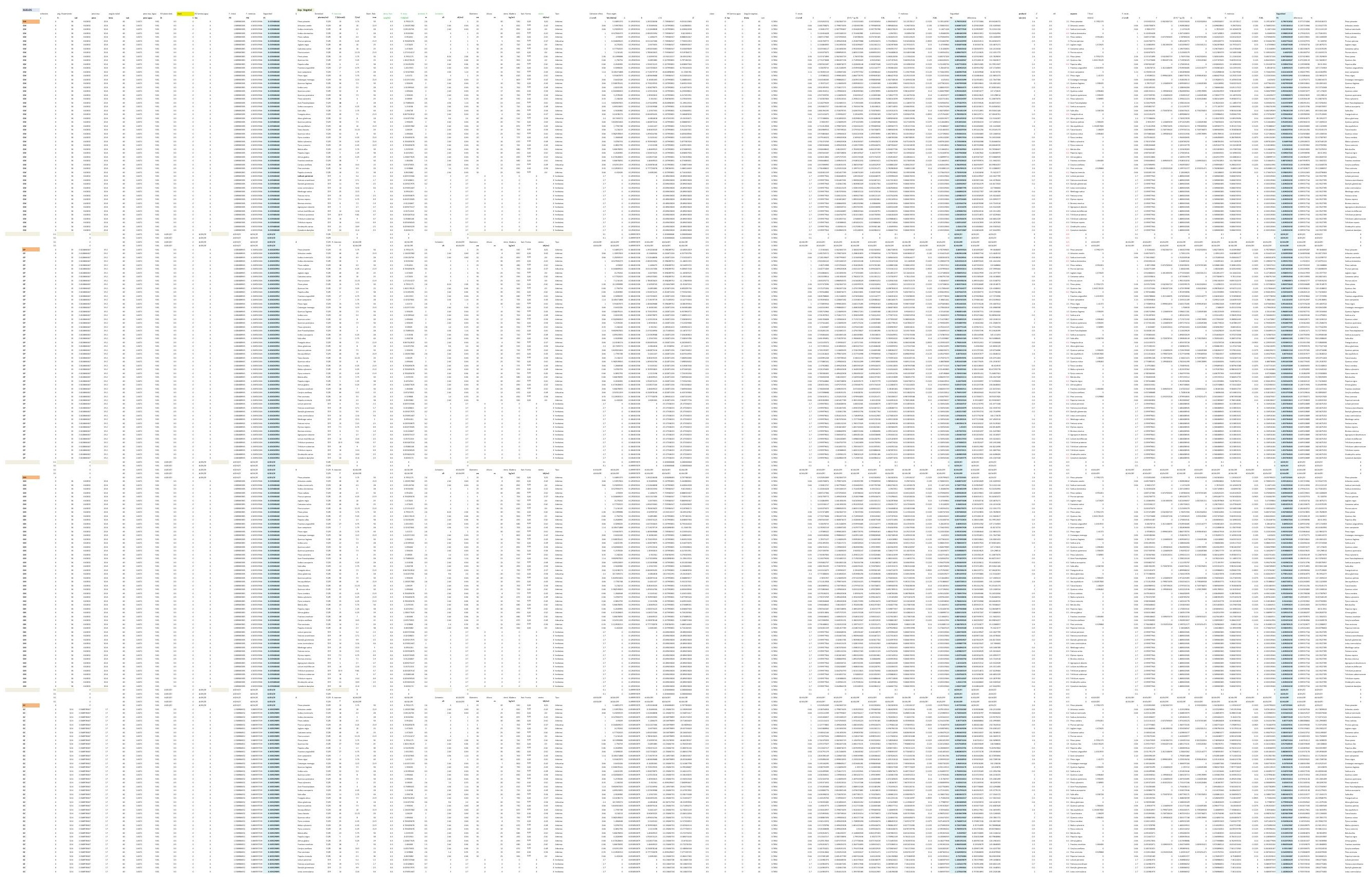


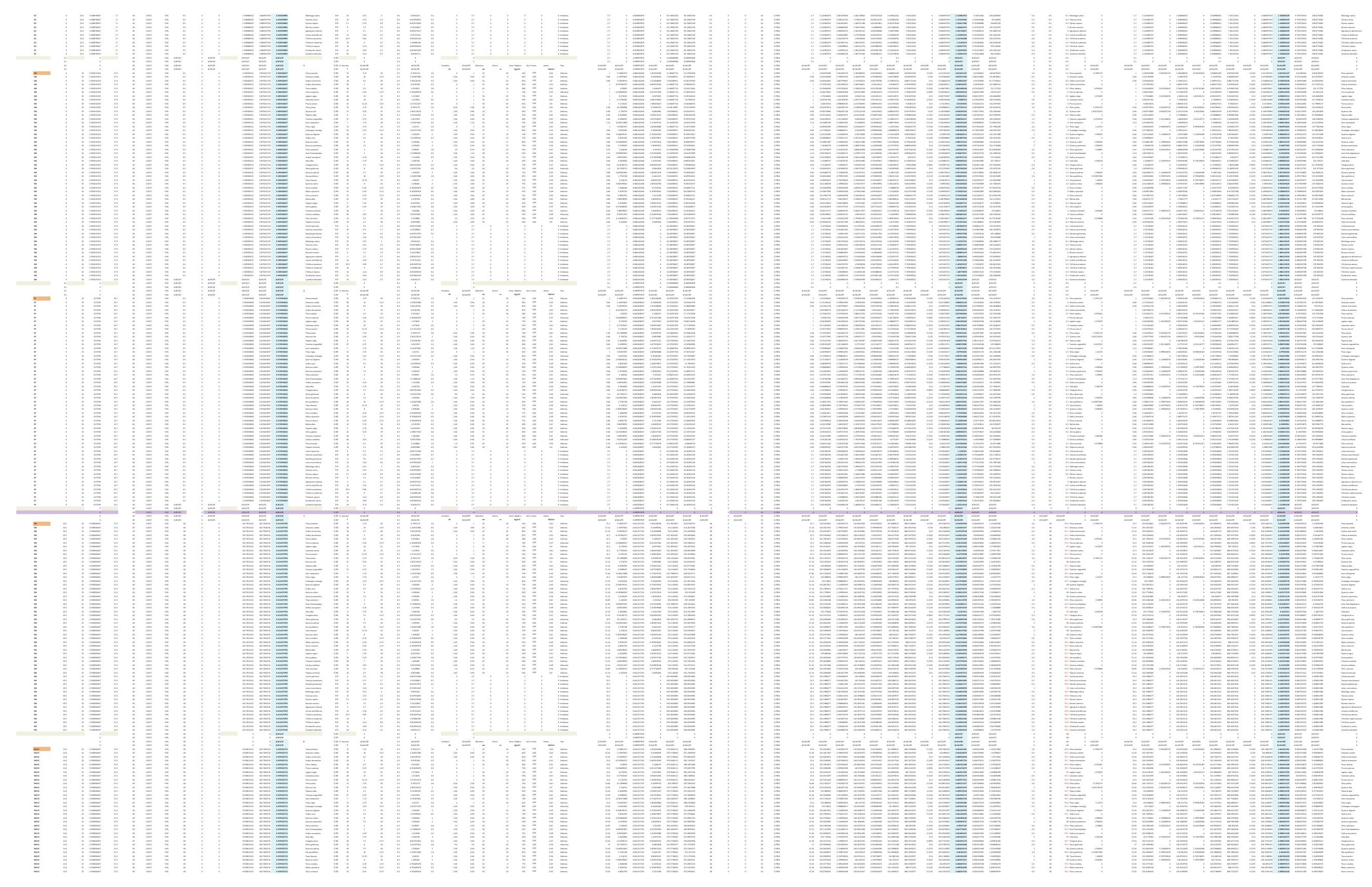



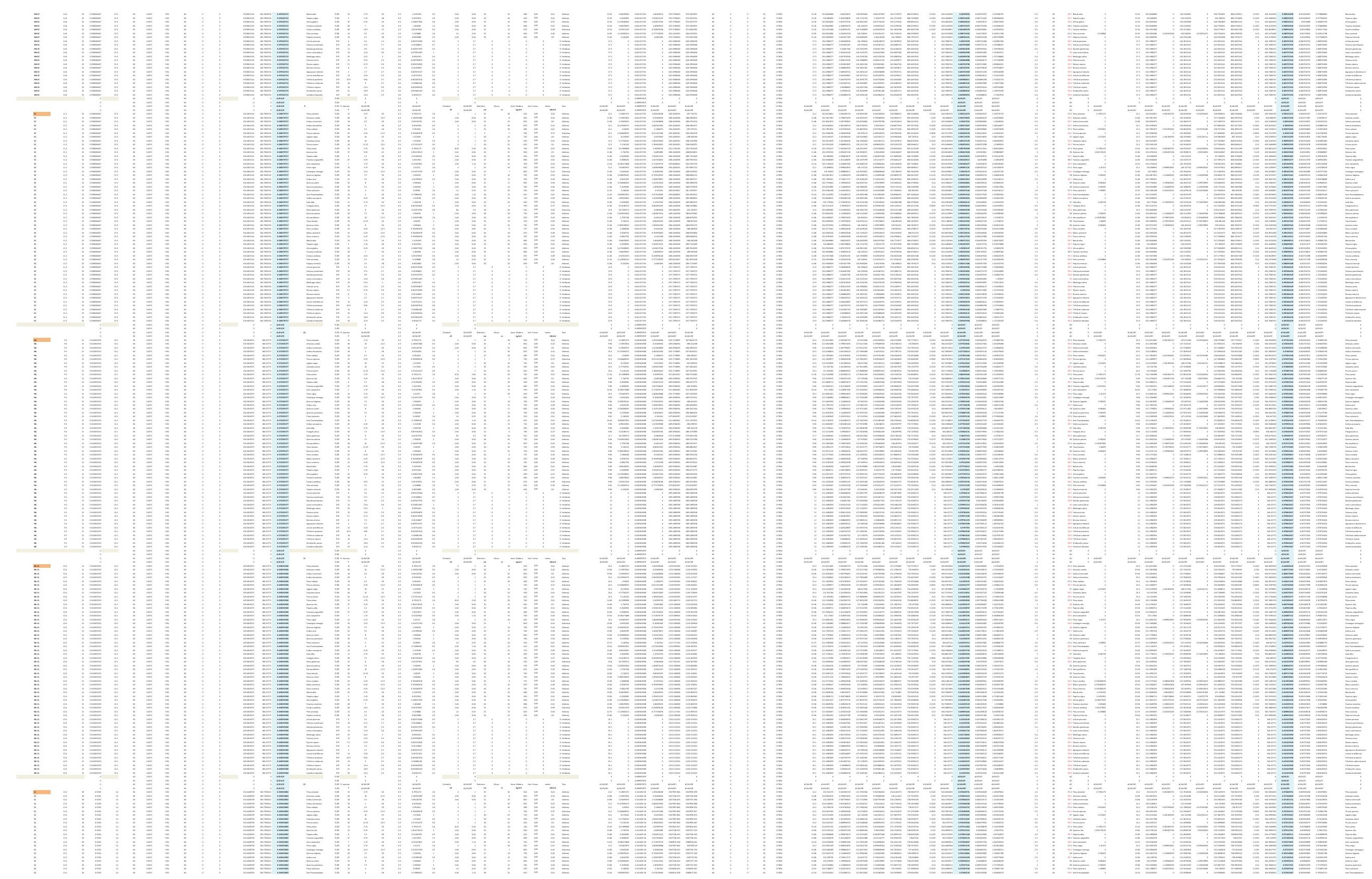

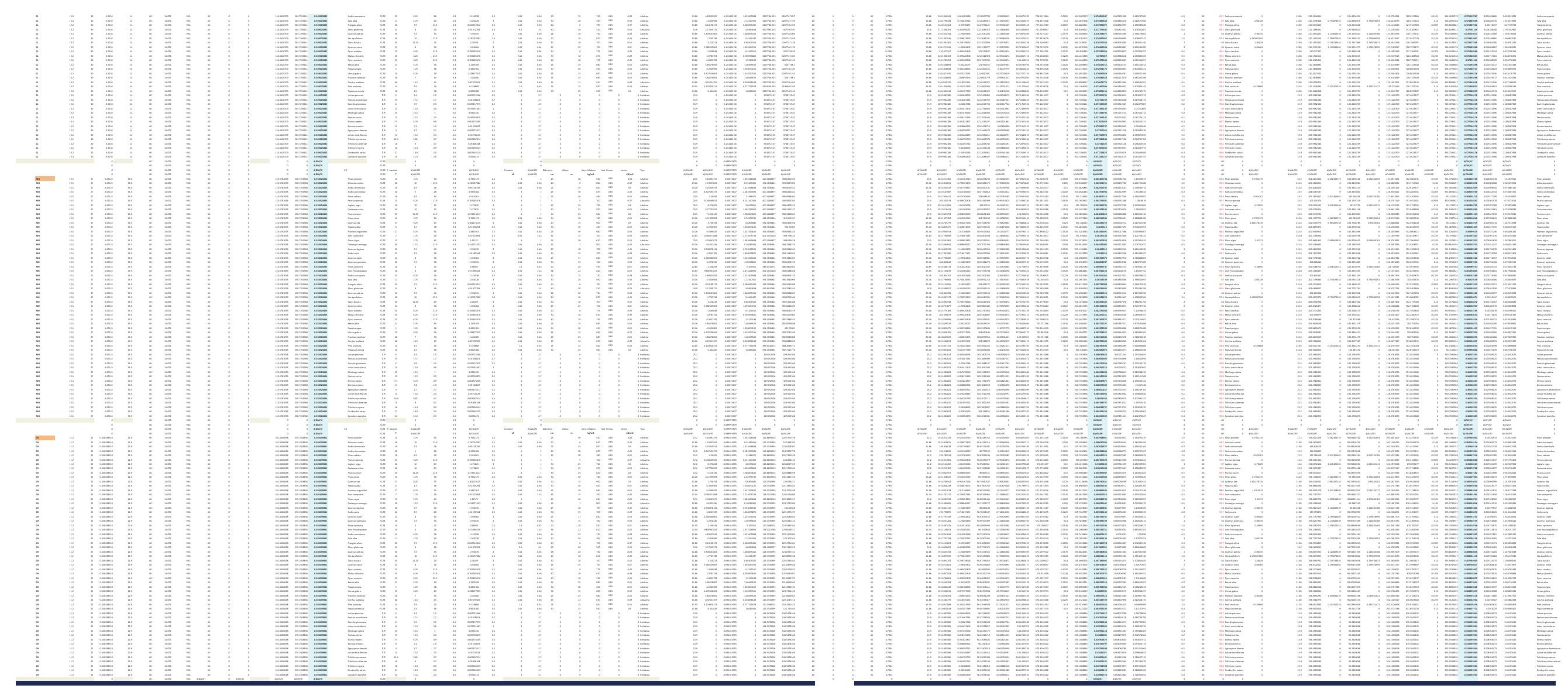

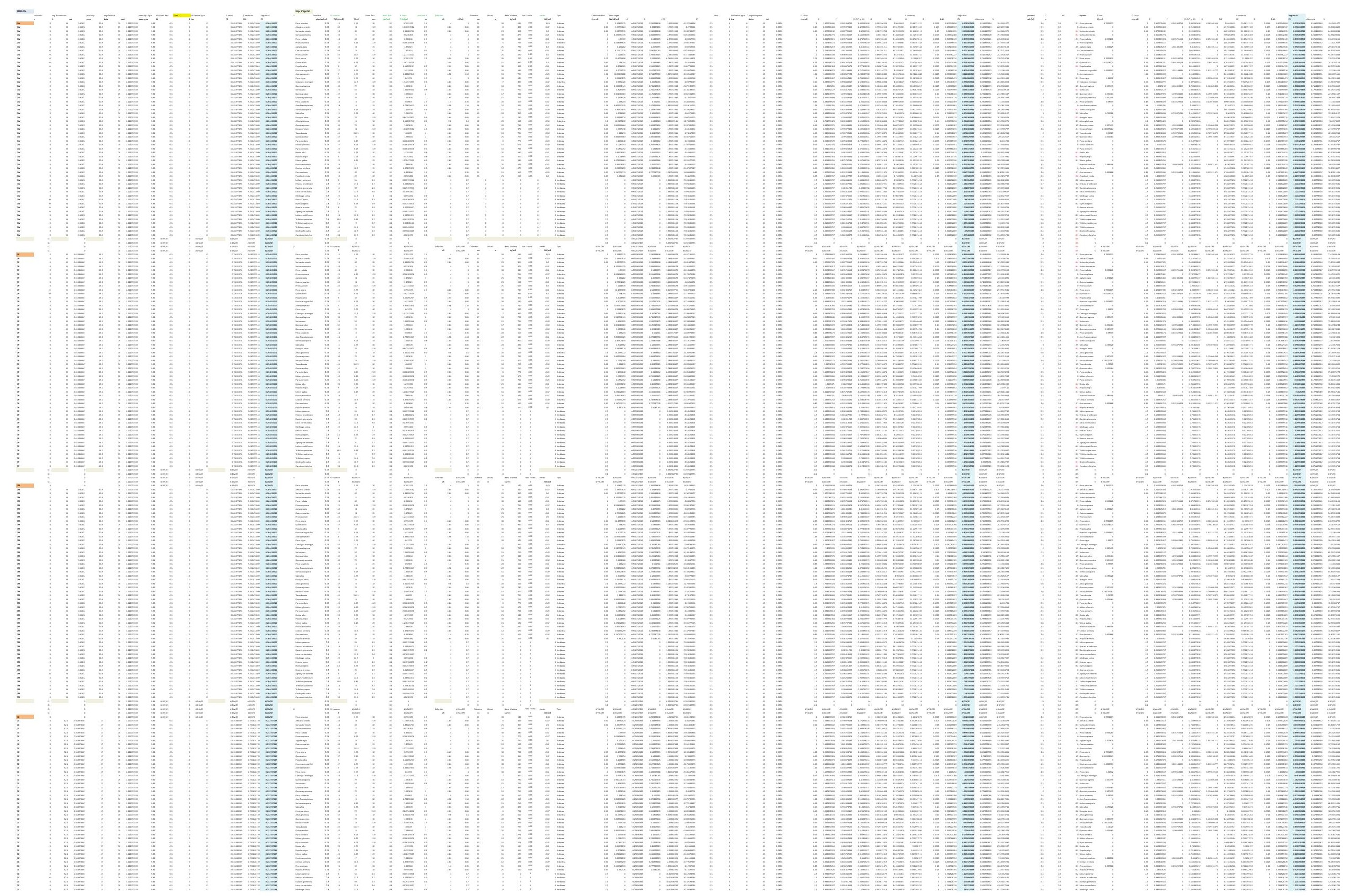


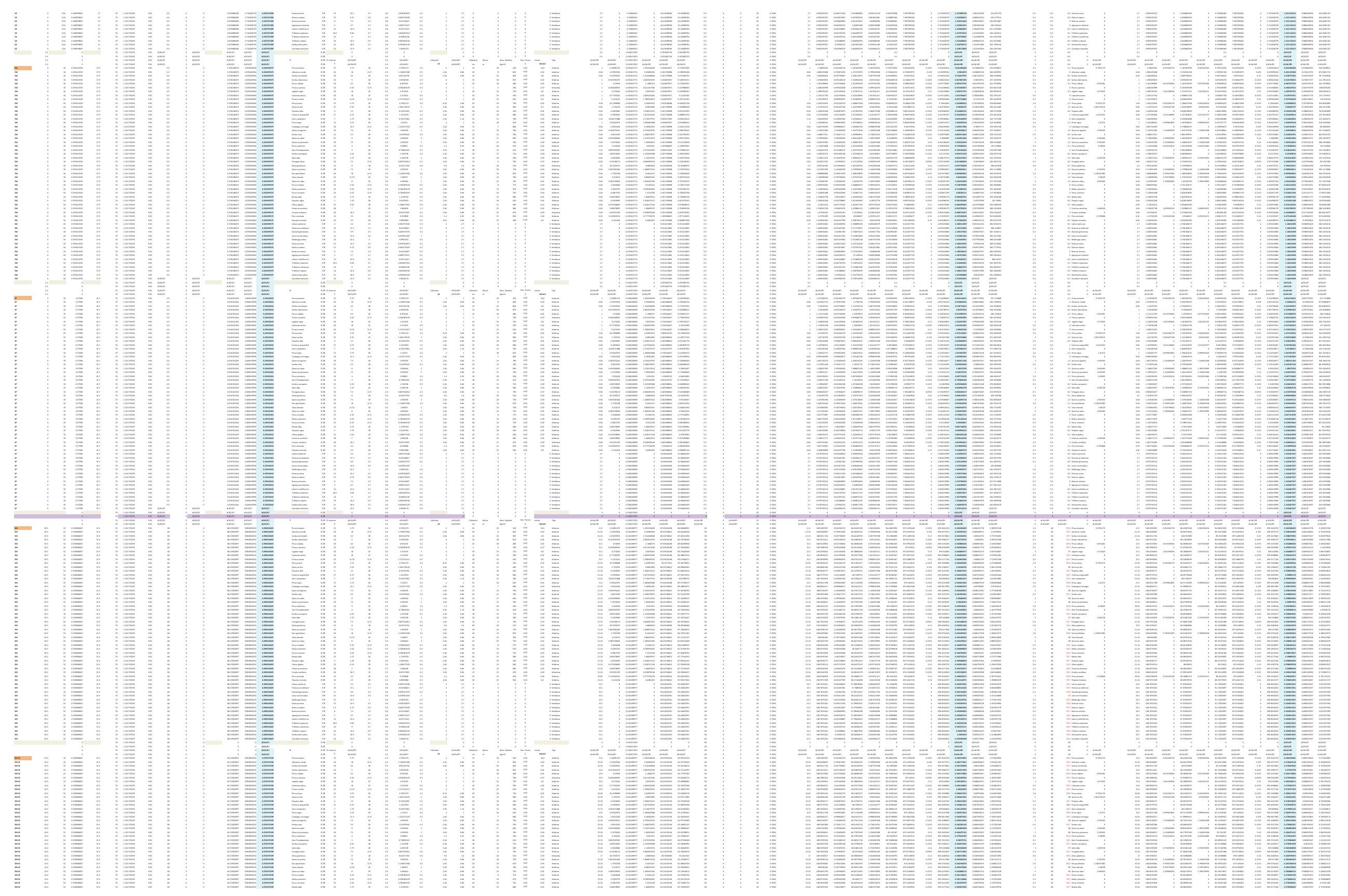



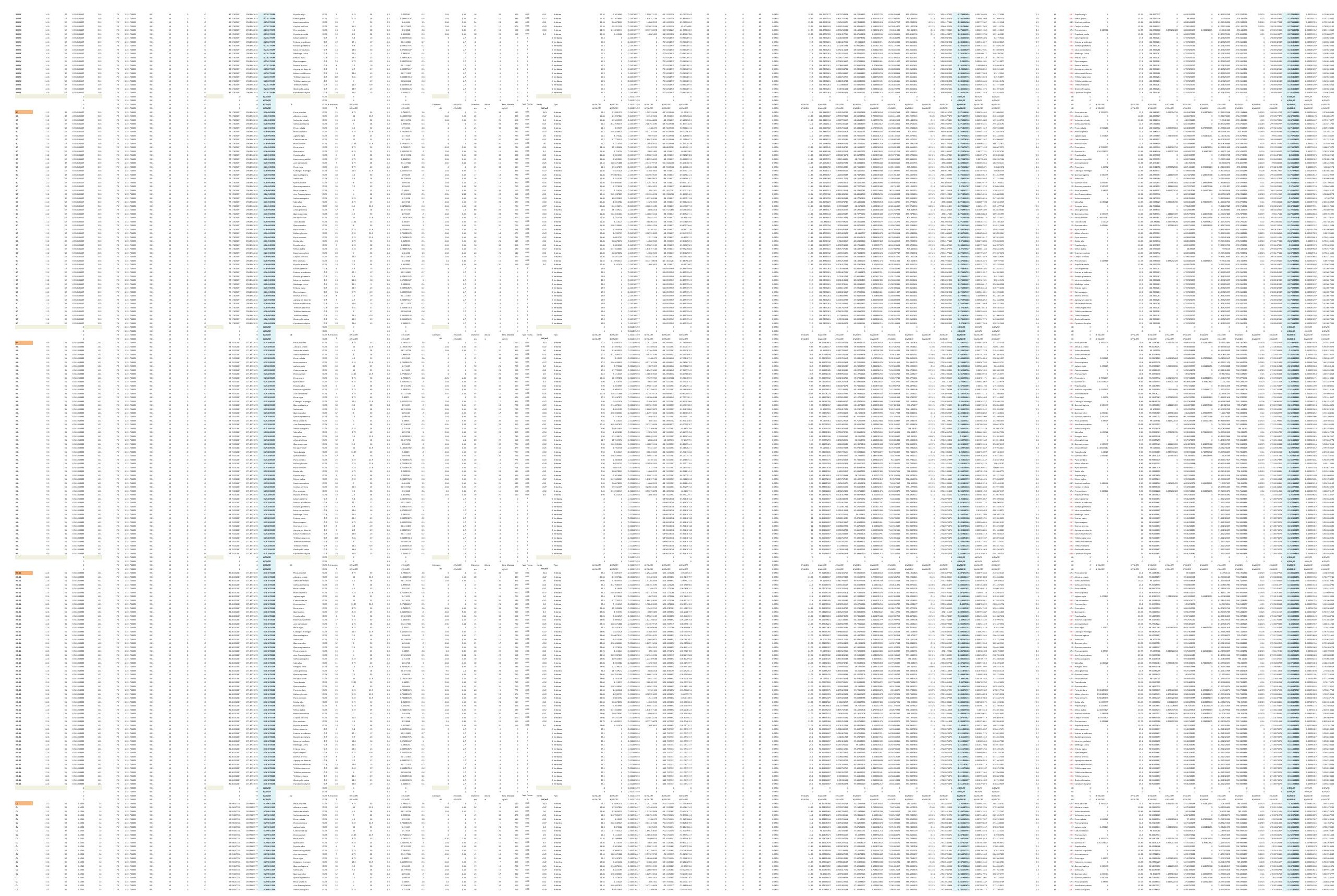


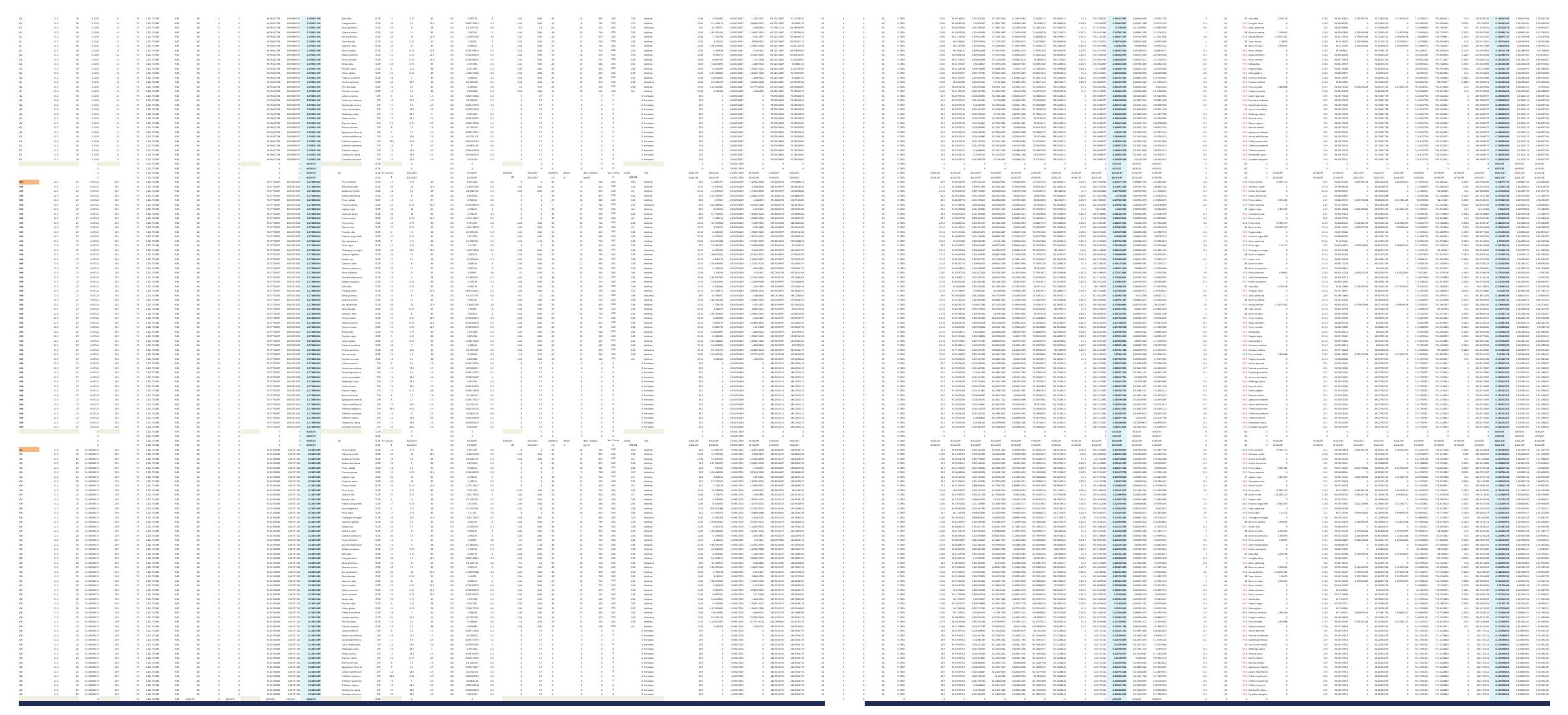



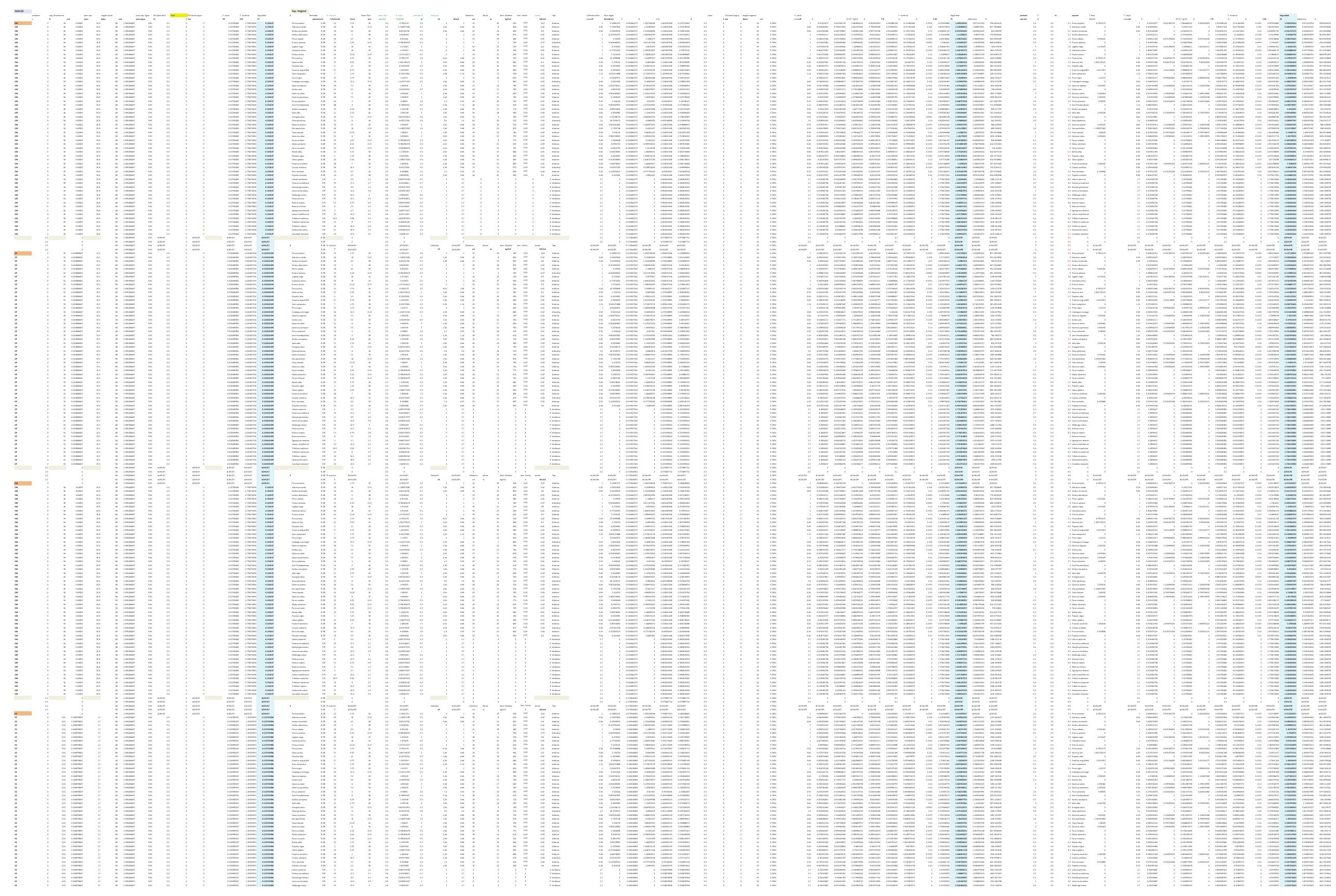


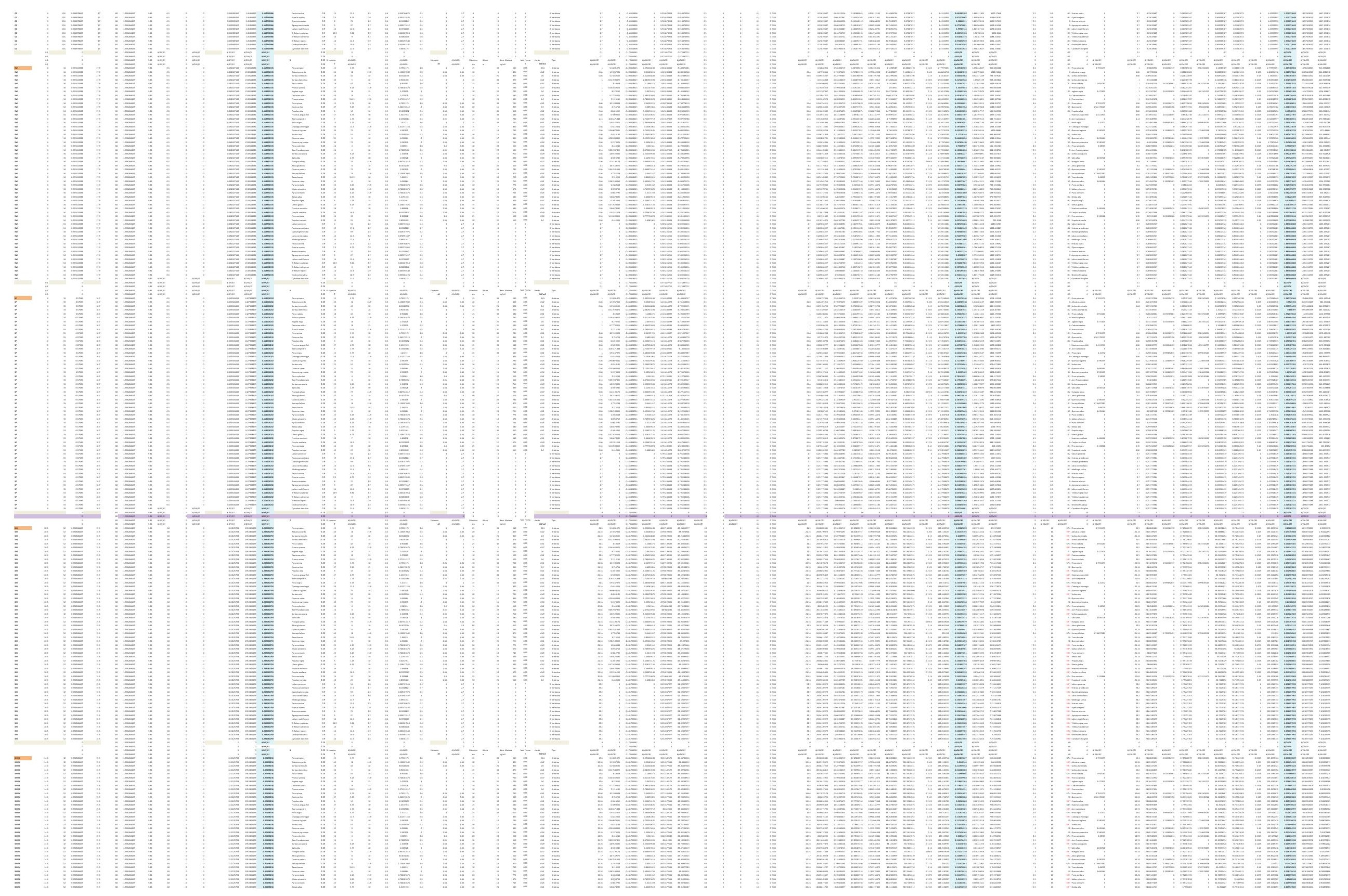




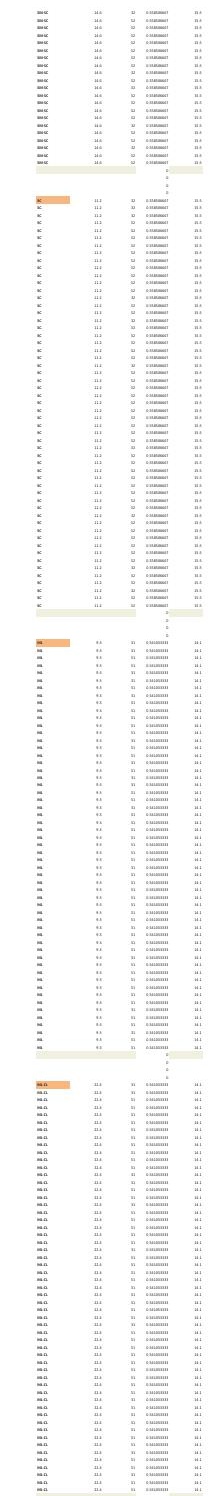

$-$

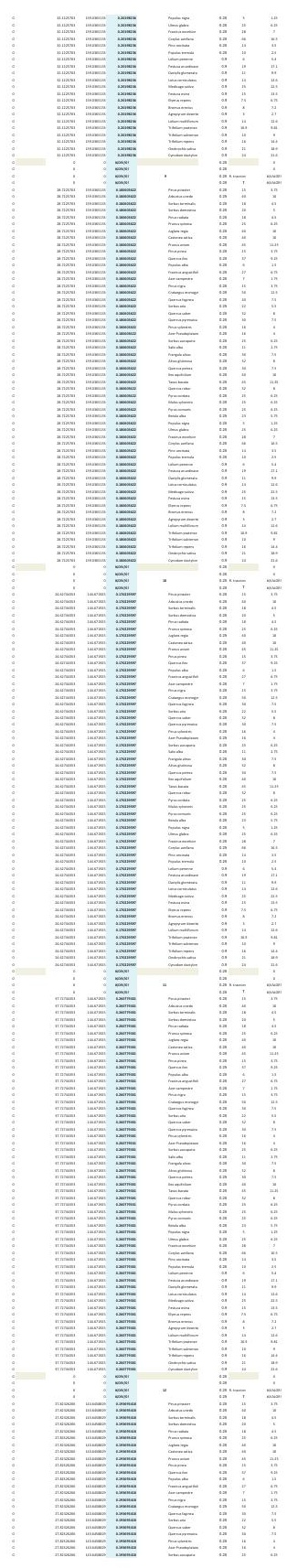

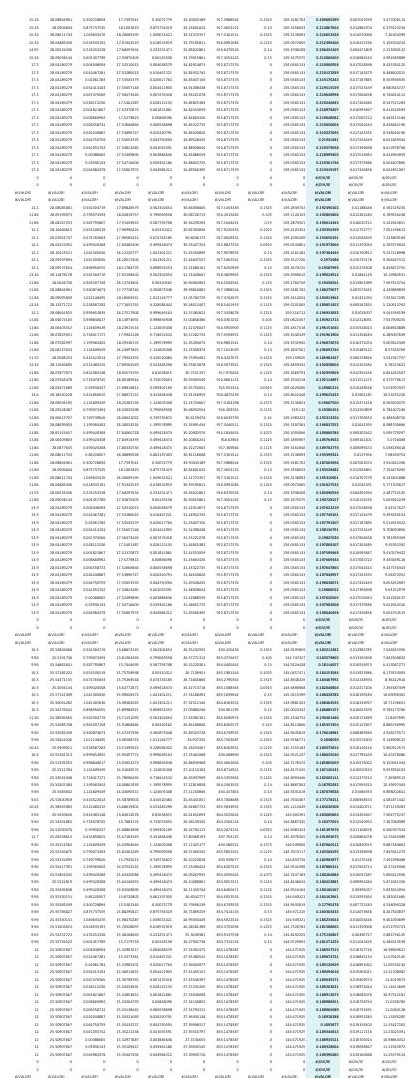

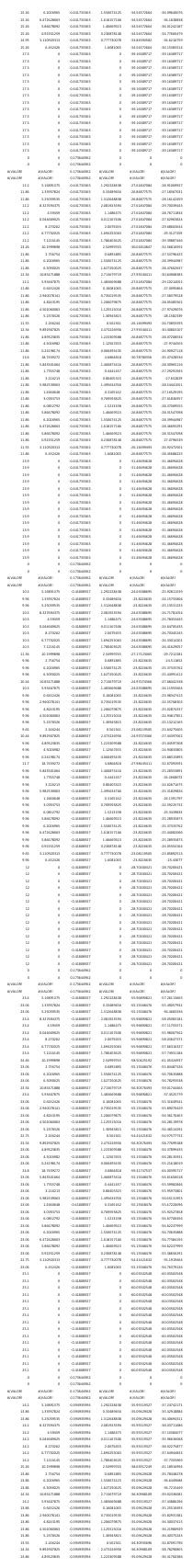

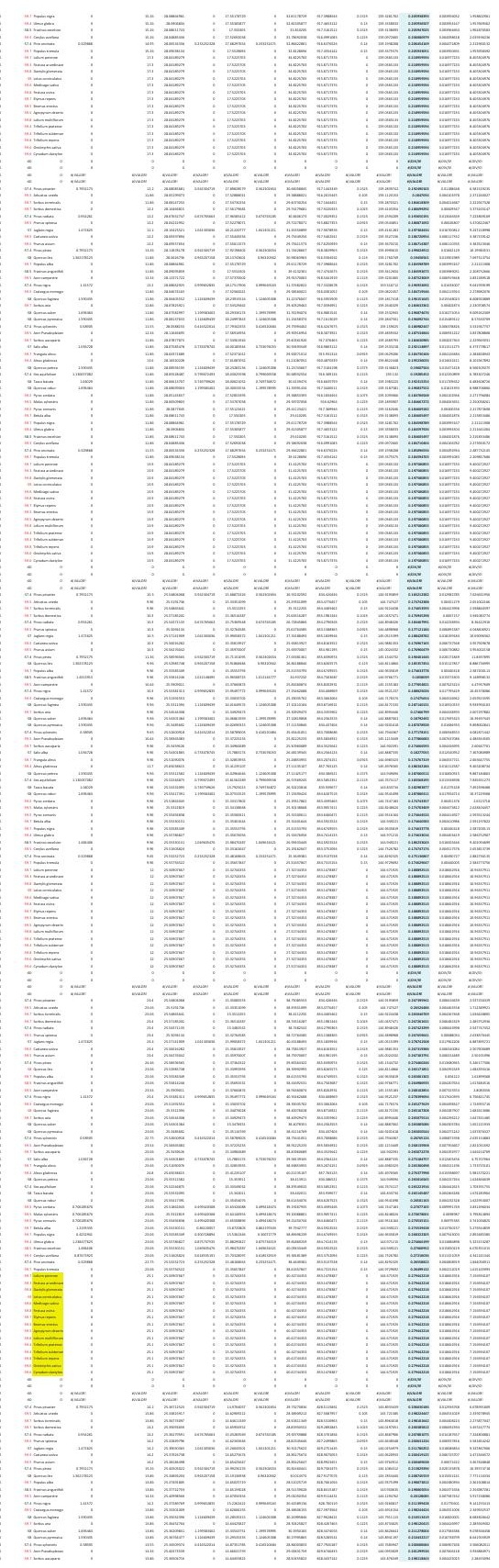




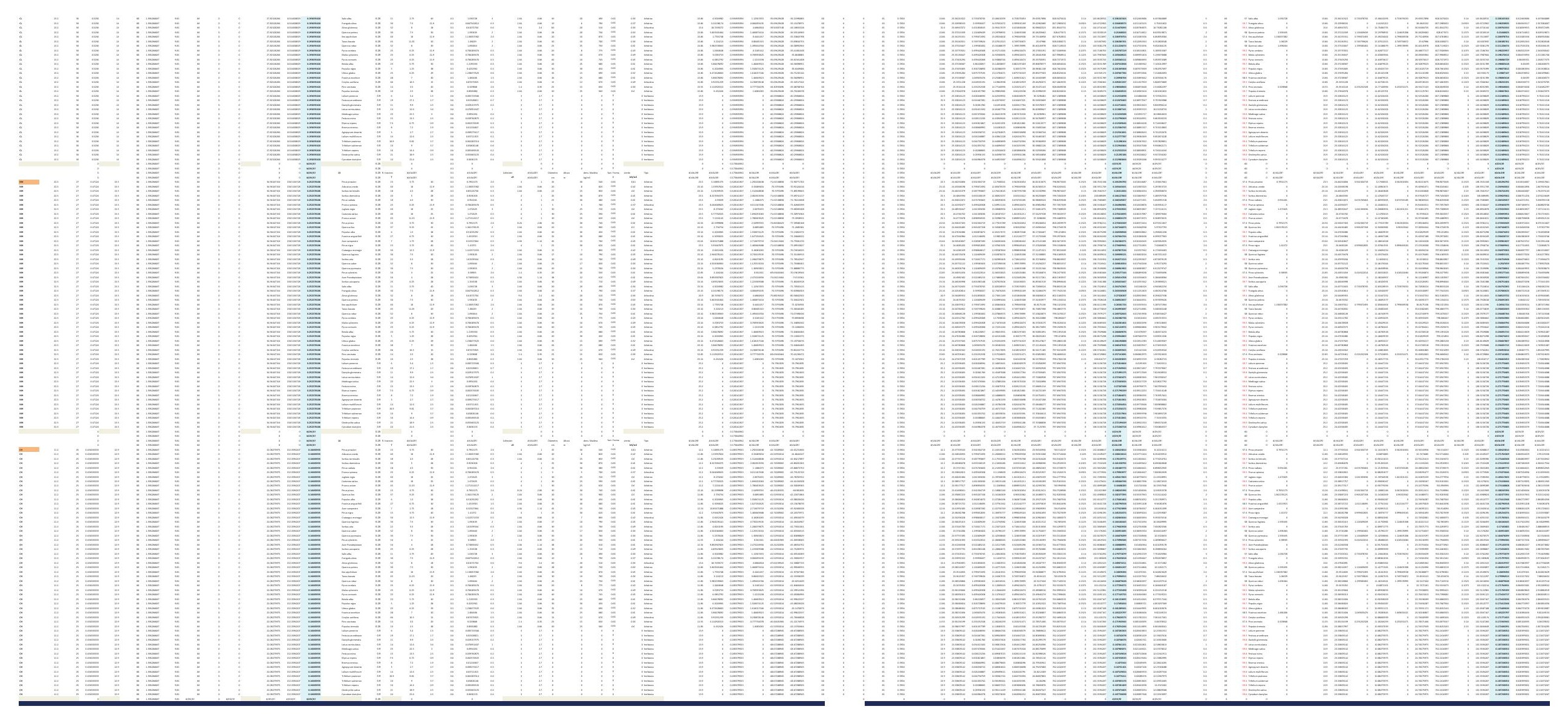


DESARROLLO DE UNA APLICACIÓN IMFORMÁTICA PARA EL CÁLCULO DE SOSTENIMIENTO DE TALUDES MEDIANTE VEGETACIÓN

A03. DENSIDAD DE PLANTACIÓN: 2.500 plantas/ha.

\section{A03-2.POSICIÓN N.F. 2}

INCLINACIÓN DE TALUD 6-100

INCLINACIÓN DE TALUD 10-200

INCLINACIÓN DE TALUD 20-30

INCLINACIÓN DE TALUD 30-40

INCLINACIÓN DE TALUD $35^{\circ}$

INCLINACIÓN DE TALUD 40-50

INCLINACIÓN DE TALUD 50-550

INCLINACIÓN DE TALUD 55-60

INCLINACIÓN DE TALUD 60-700

INCLINACIÓN DE TALUD 70-80 

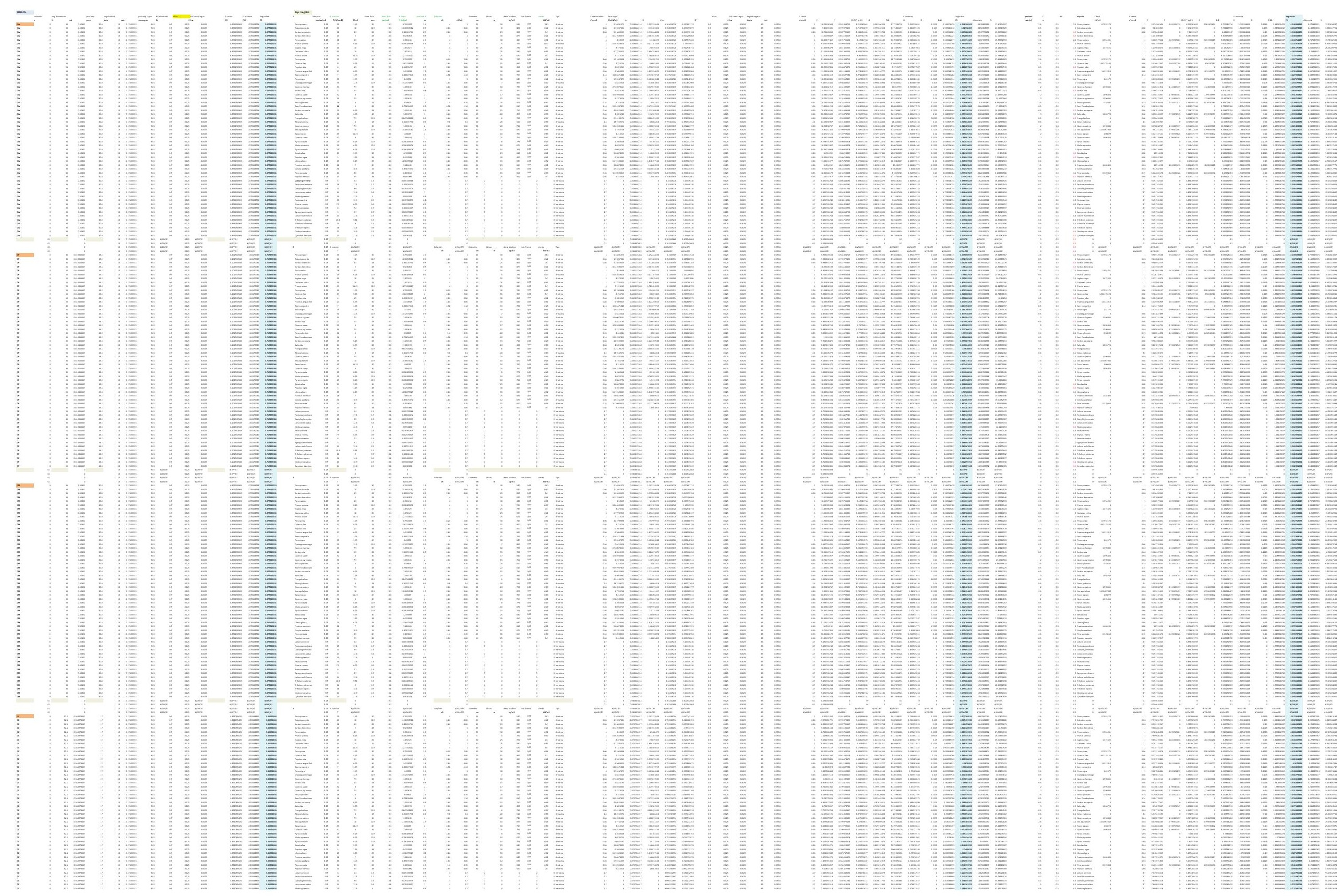


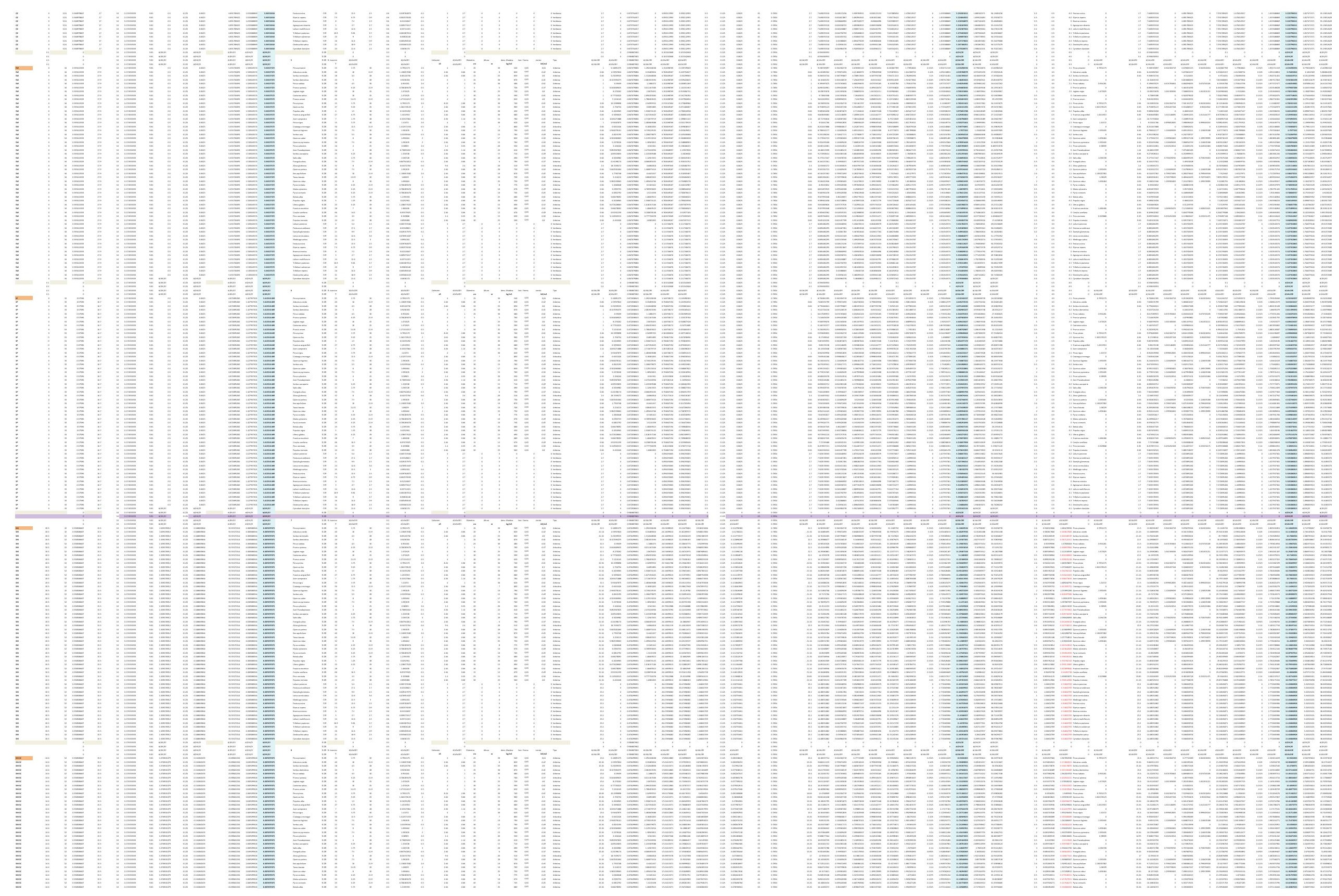



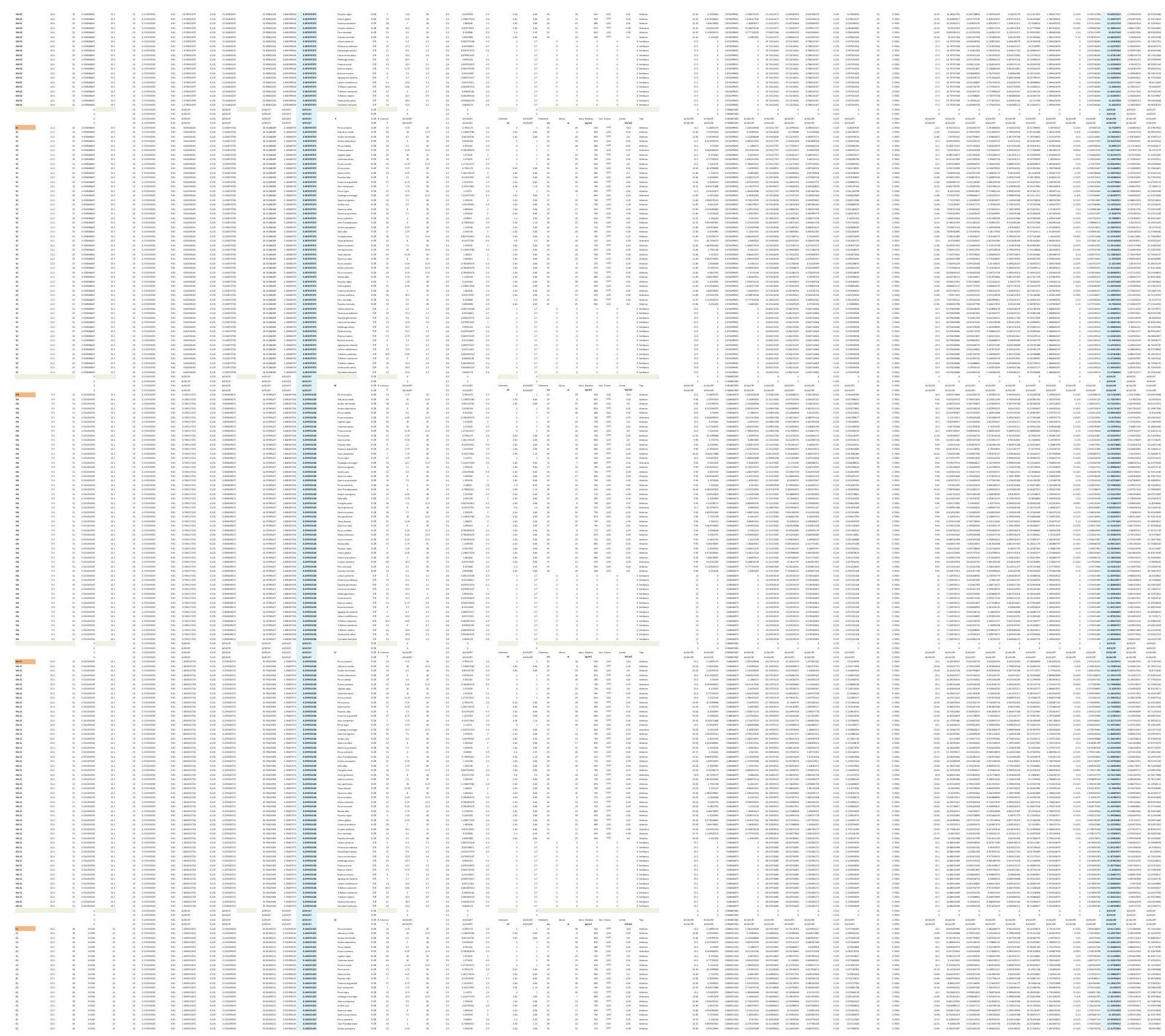

:
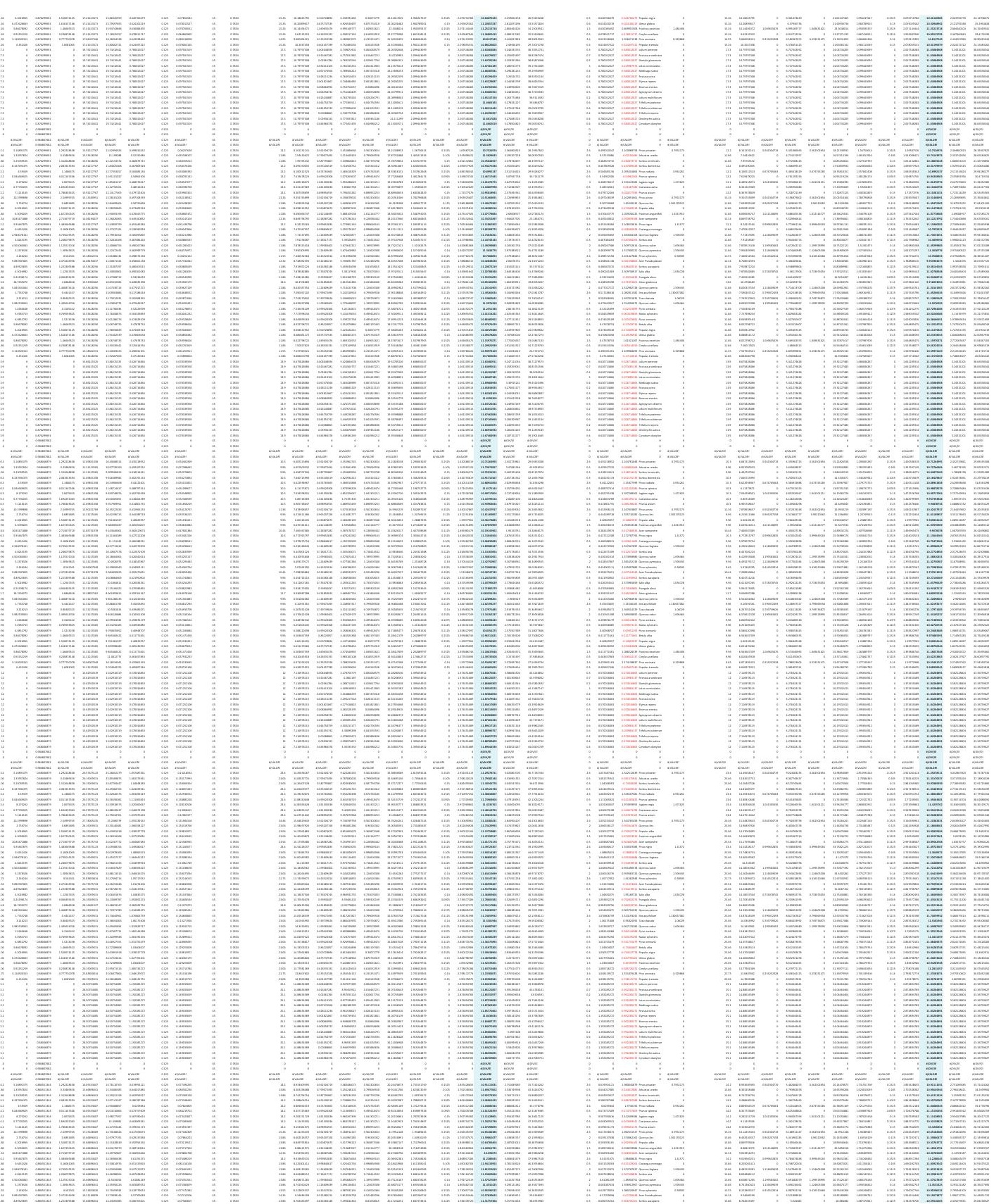


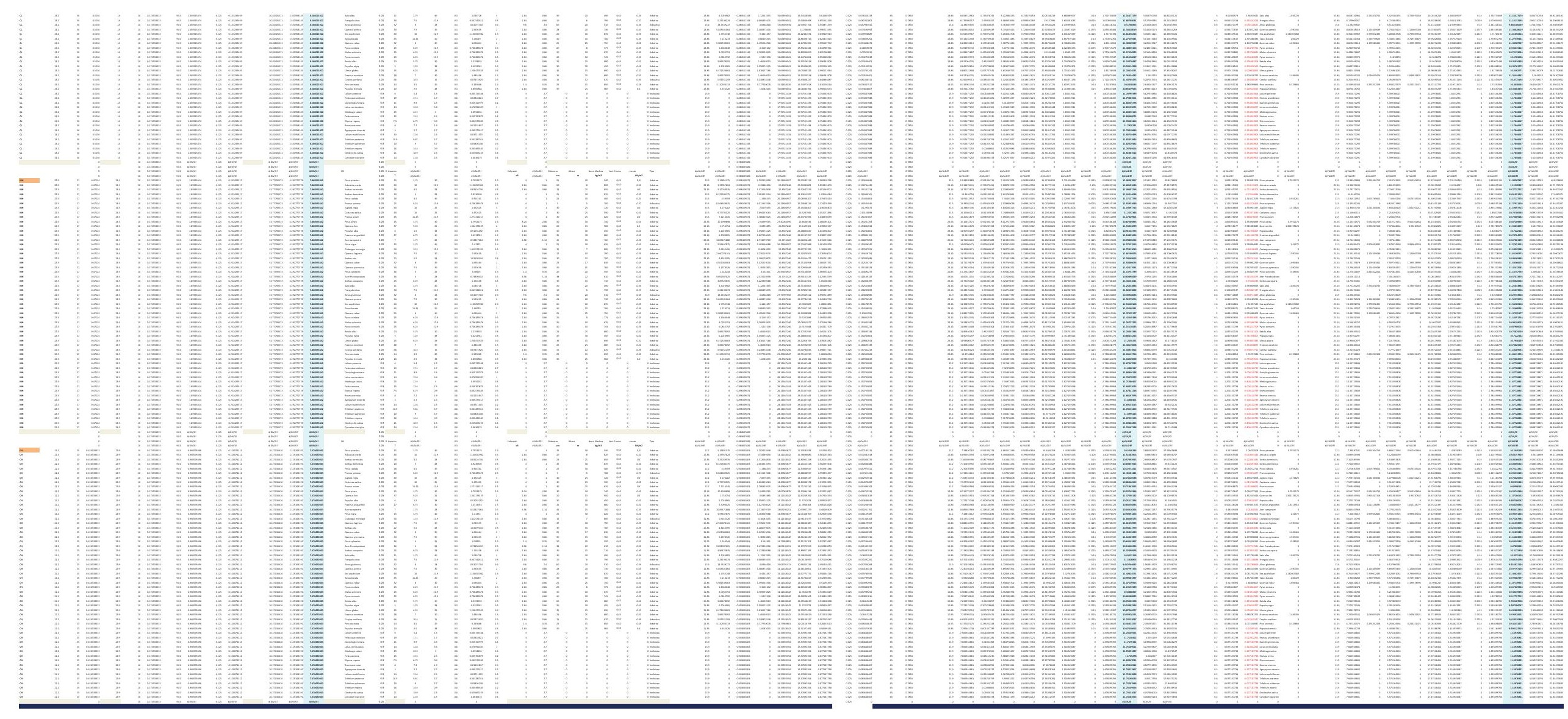



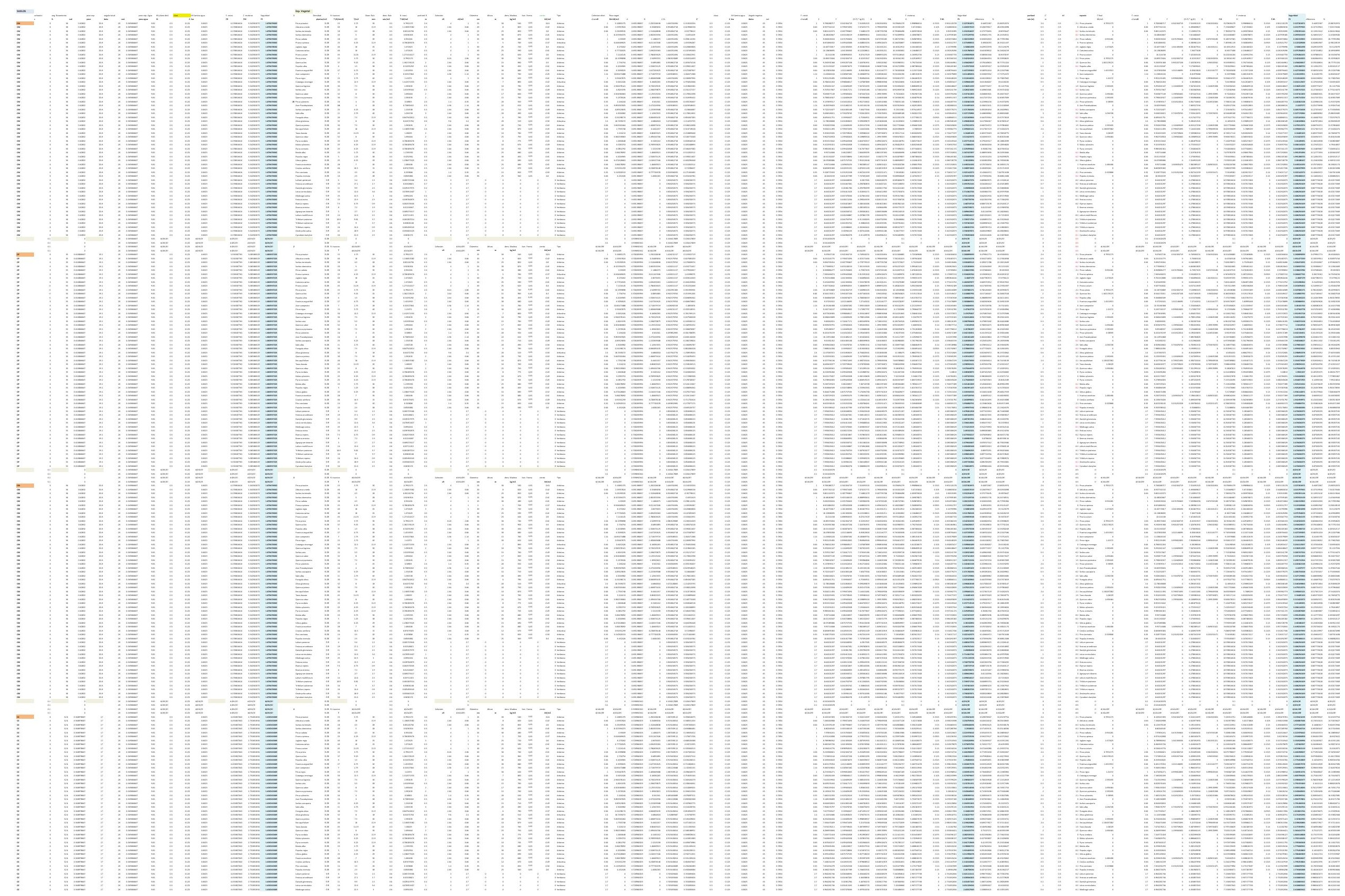


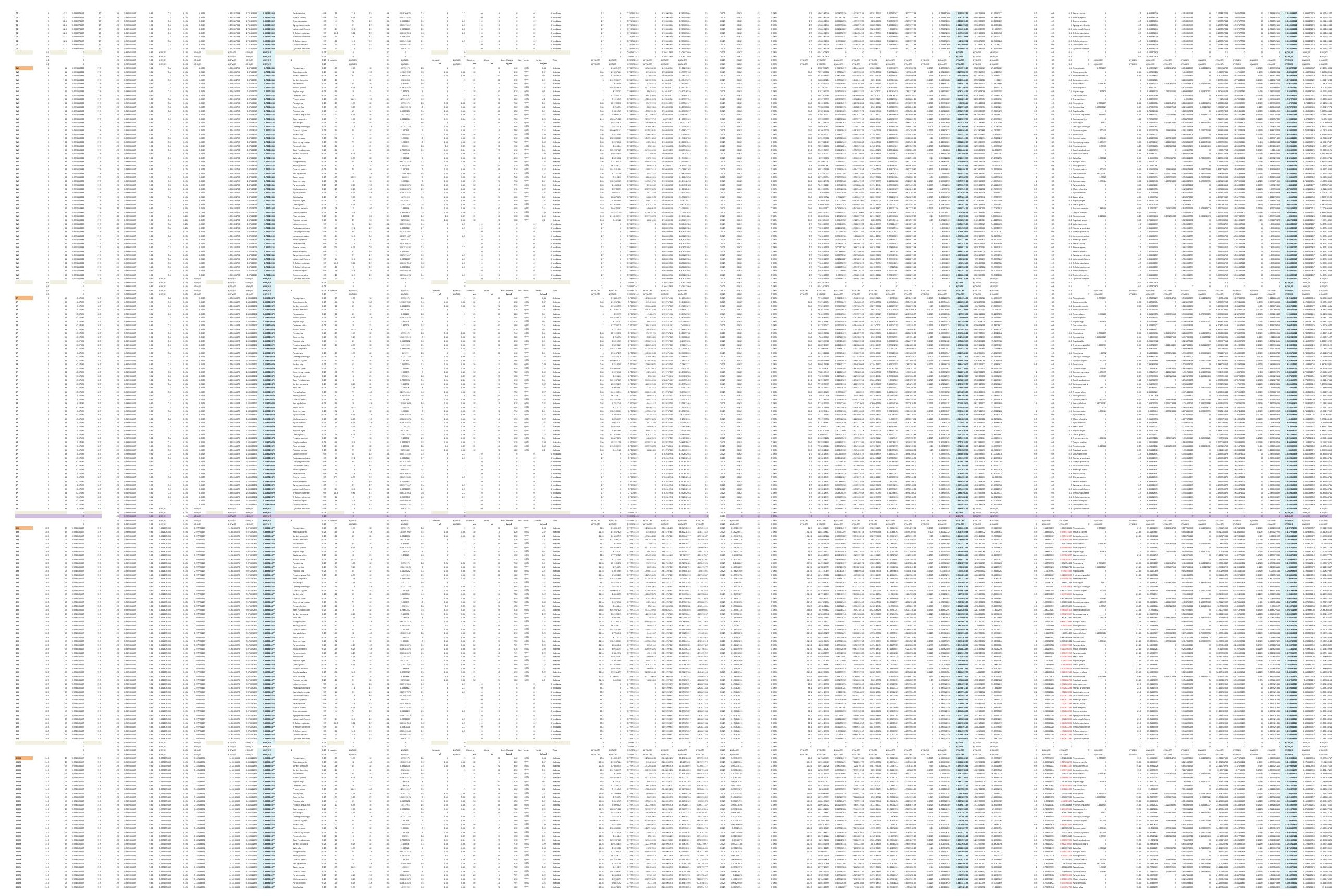



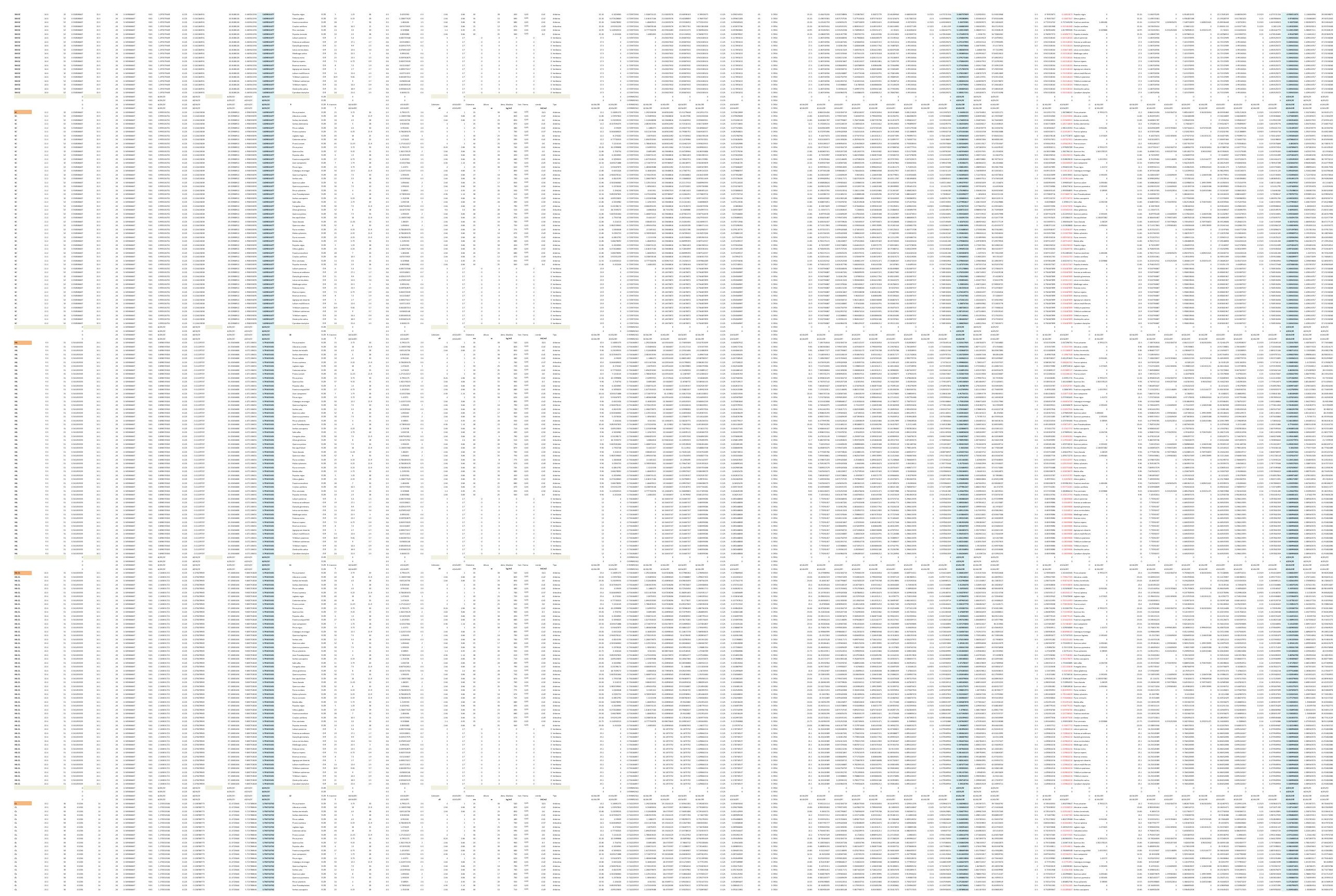


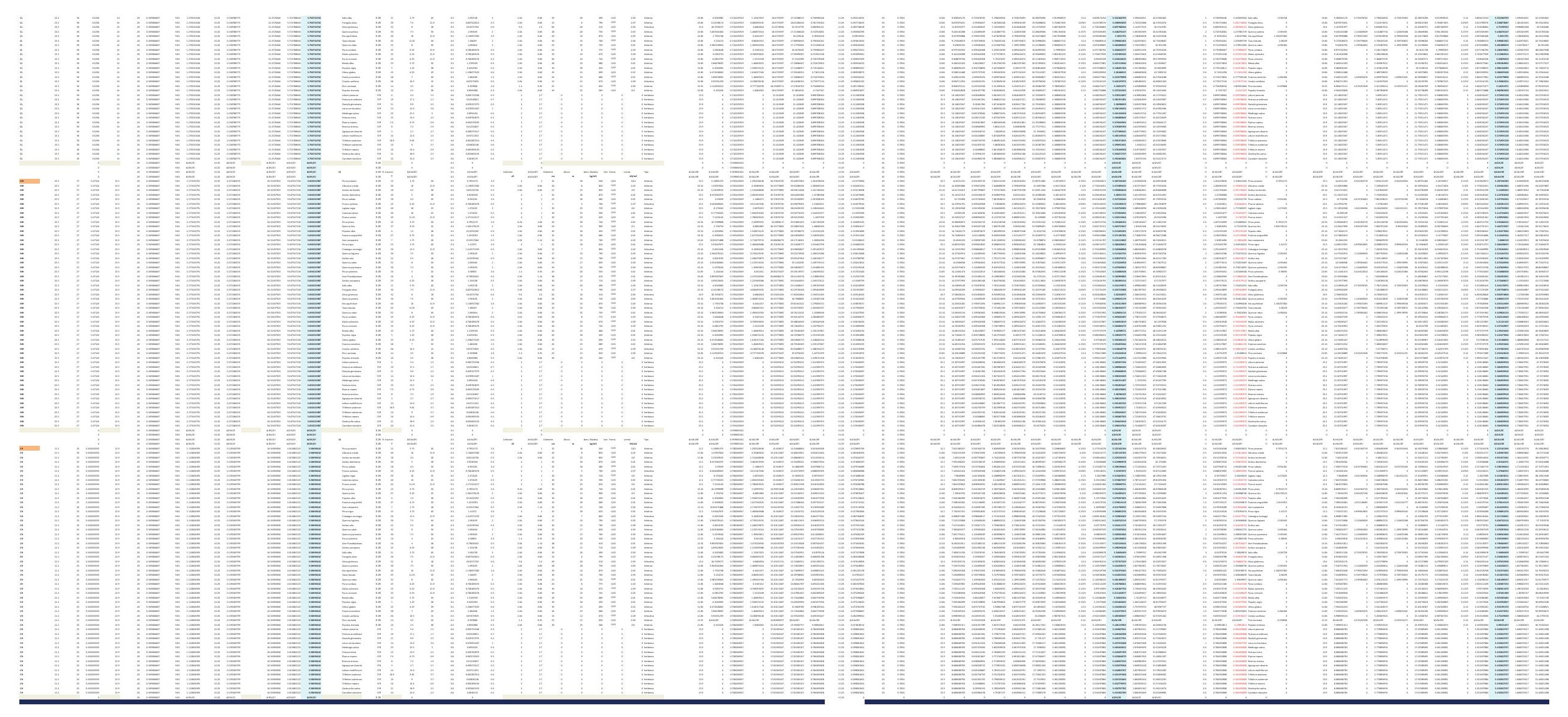



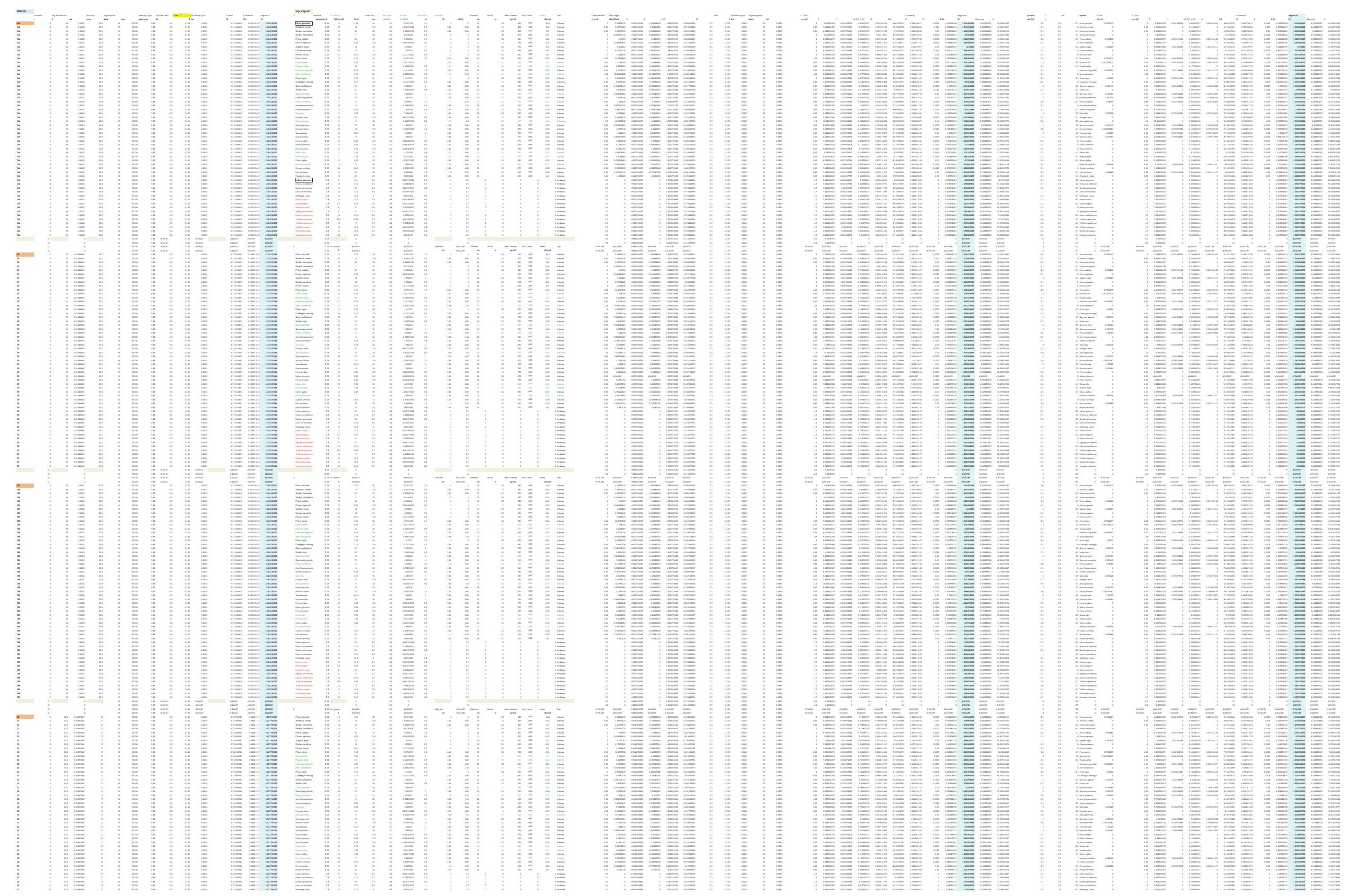


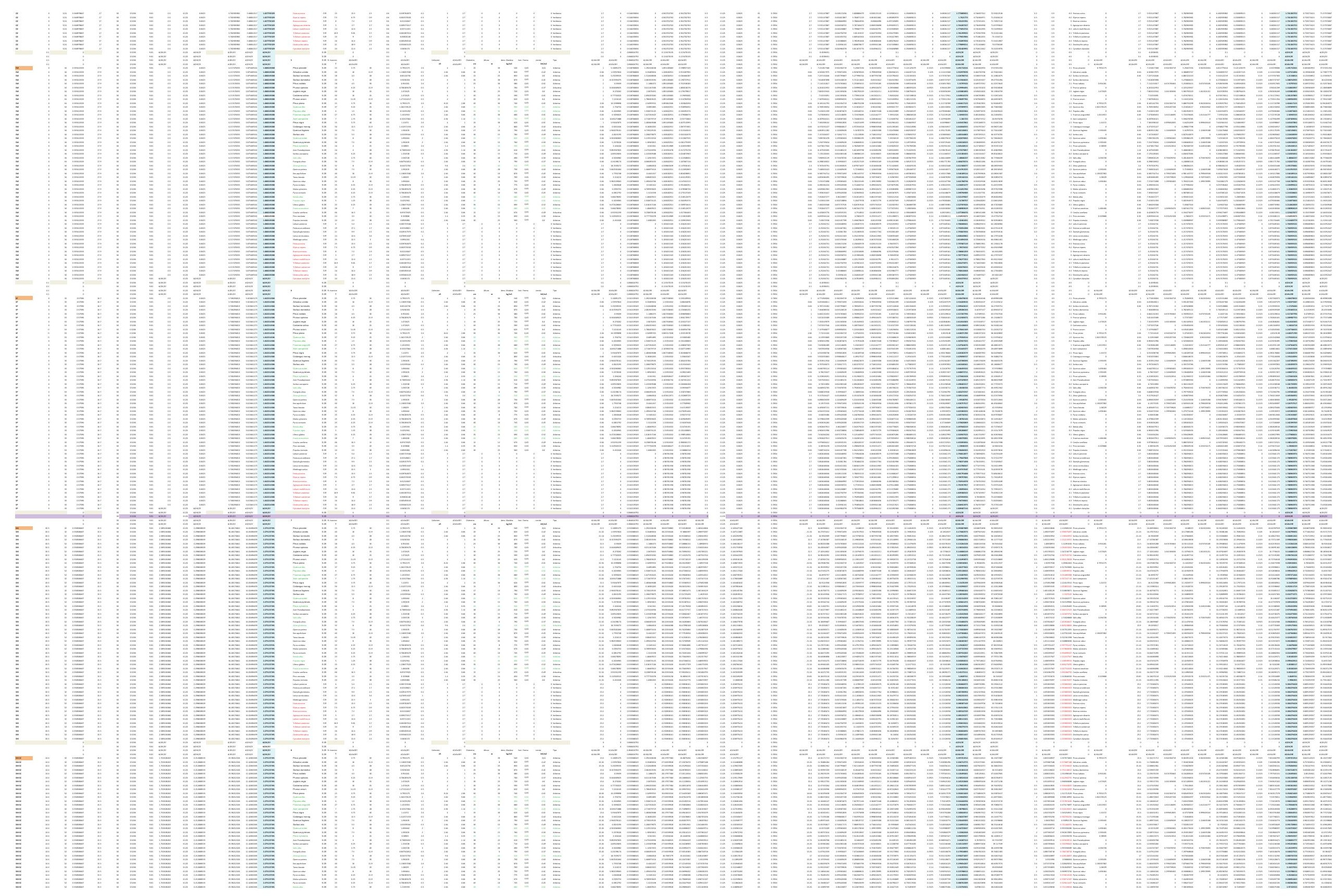



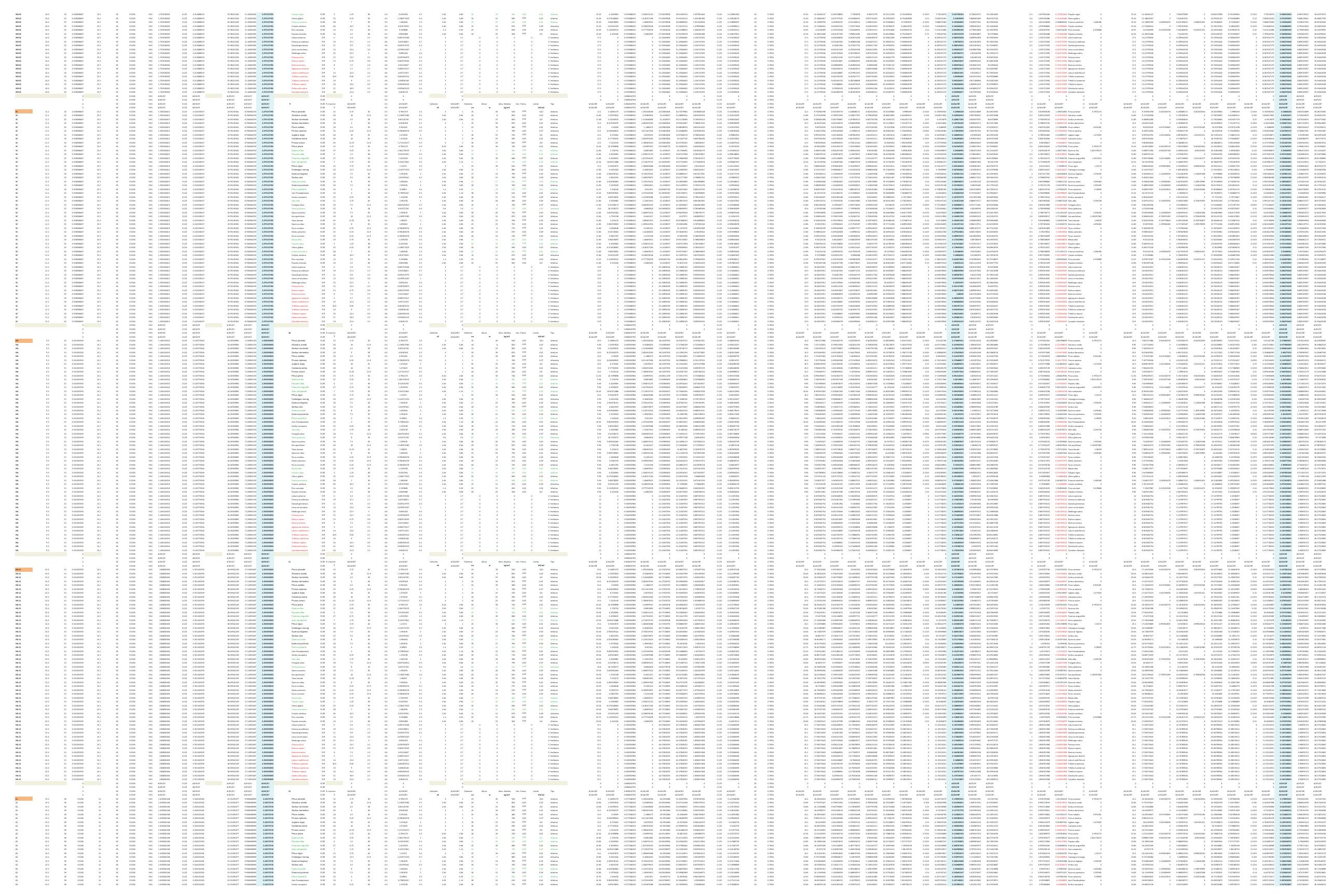


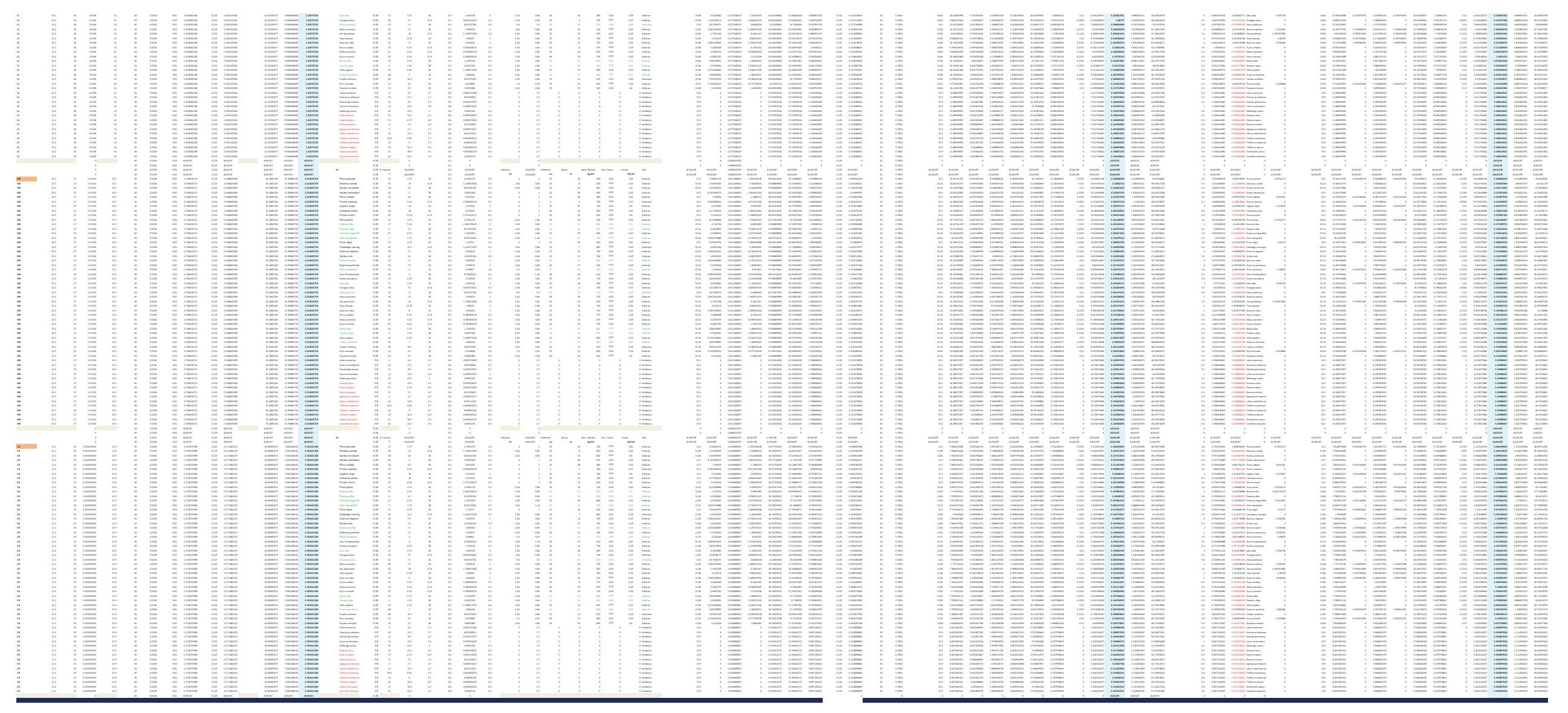



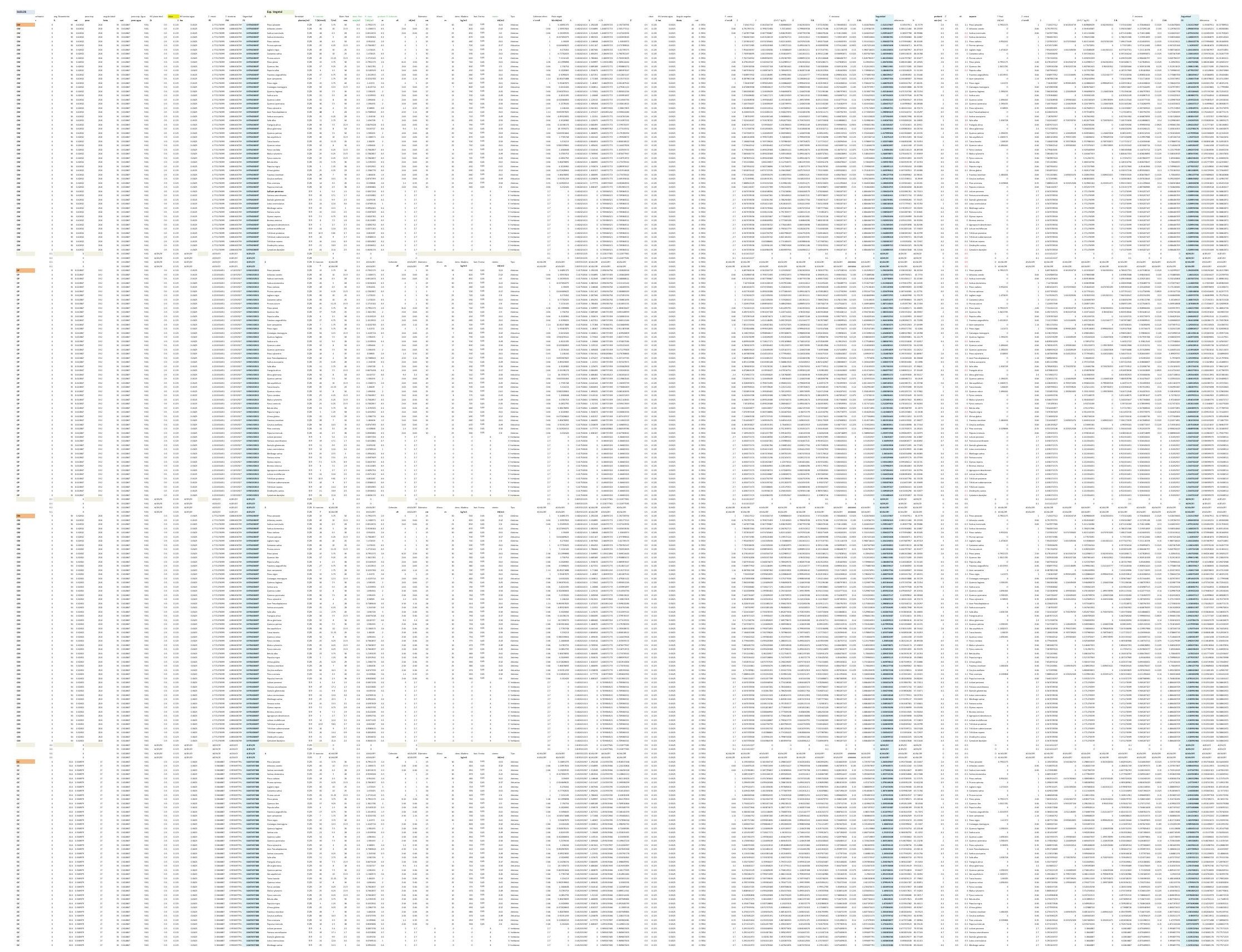


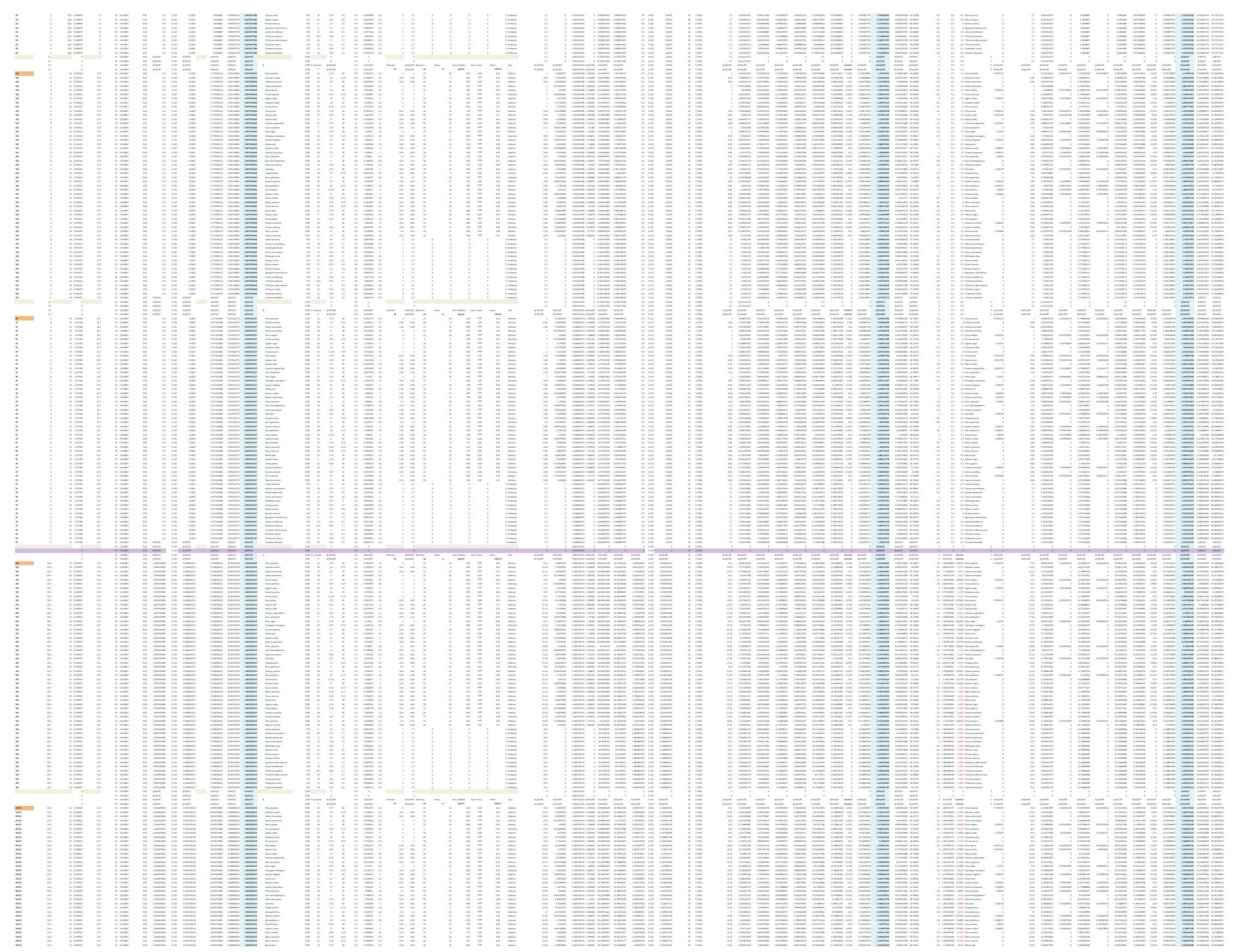



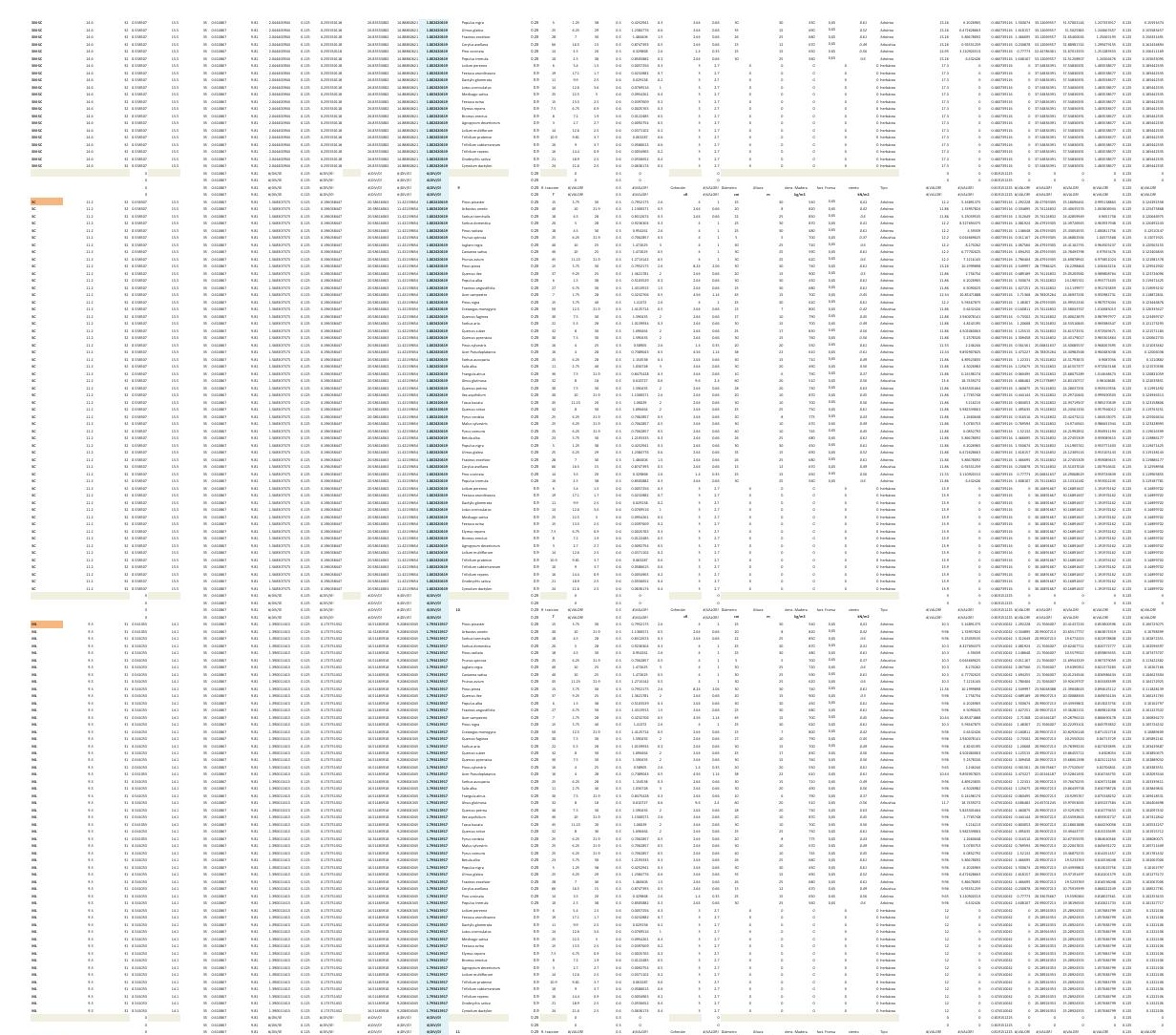

IIEIII
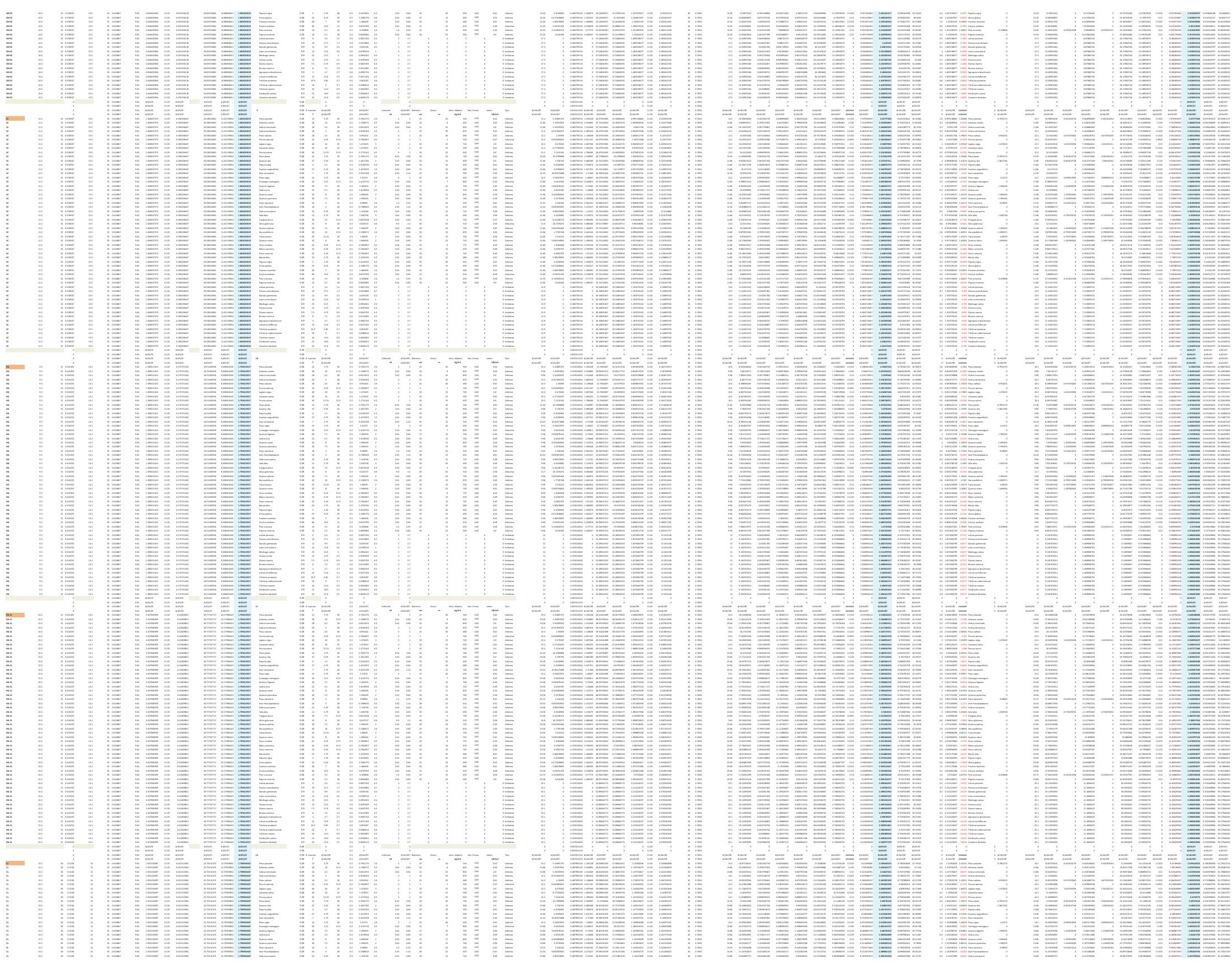


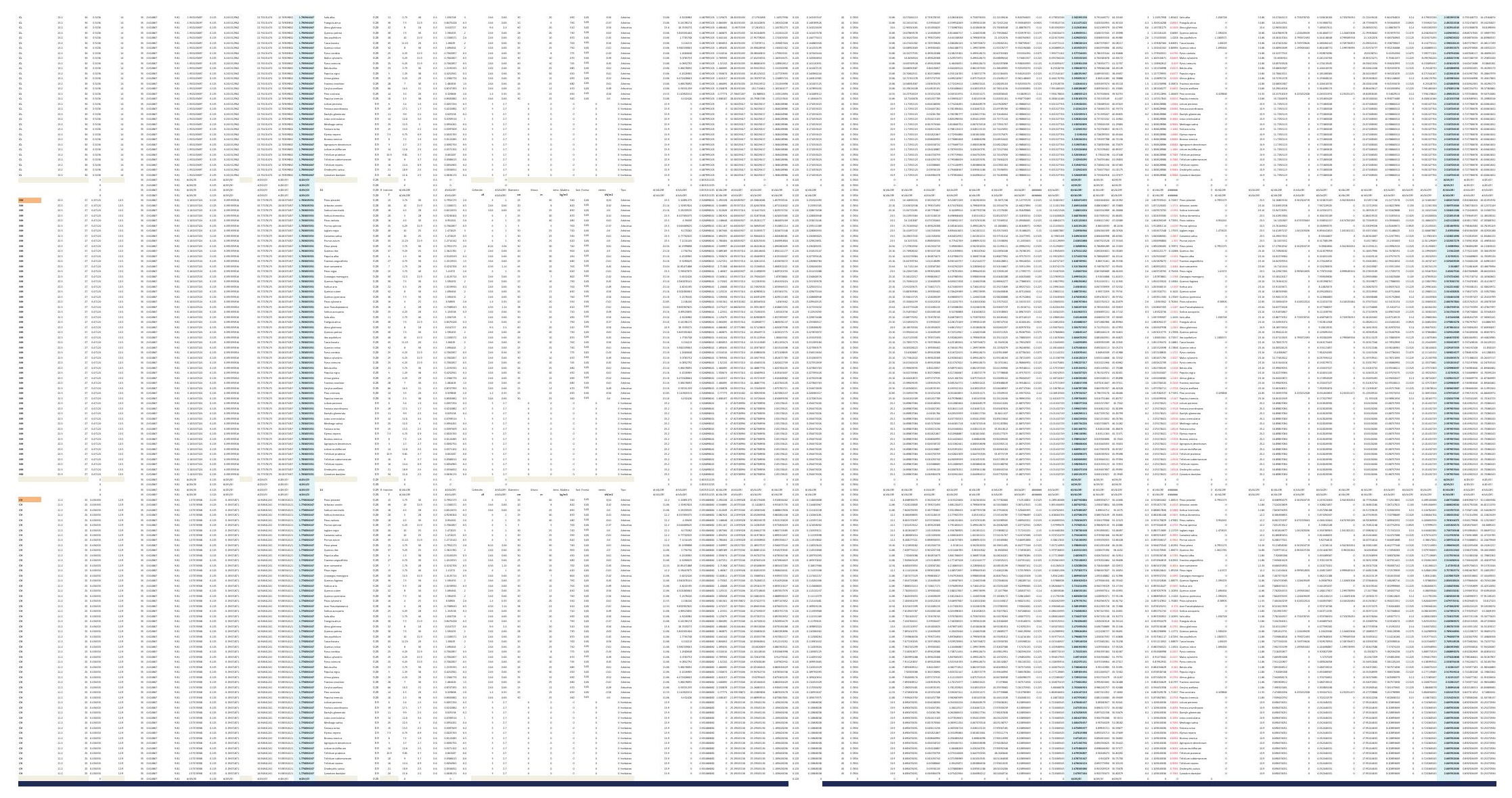



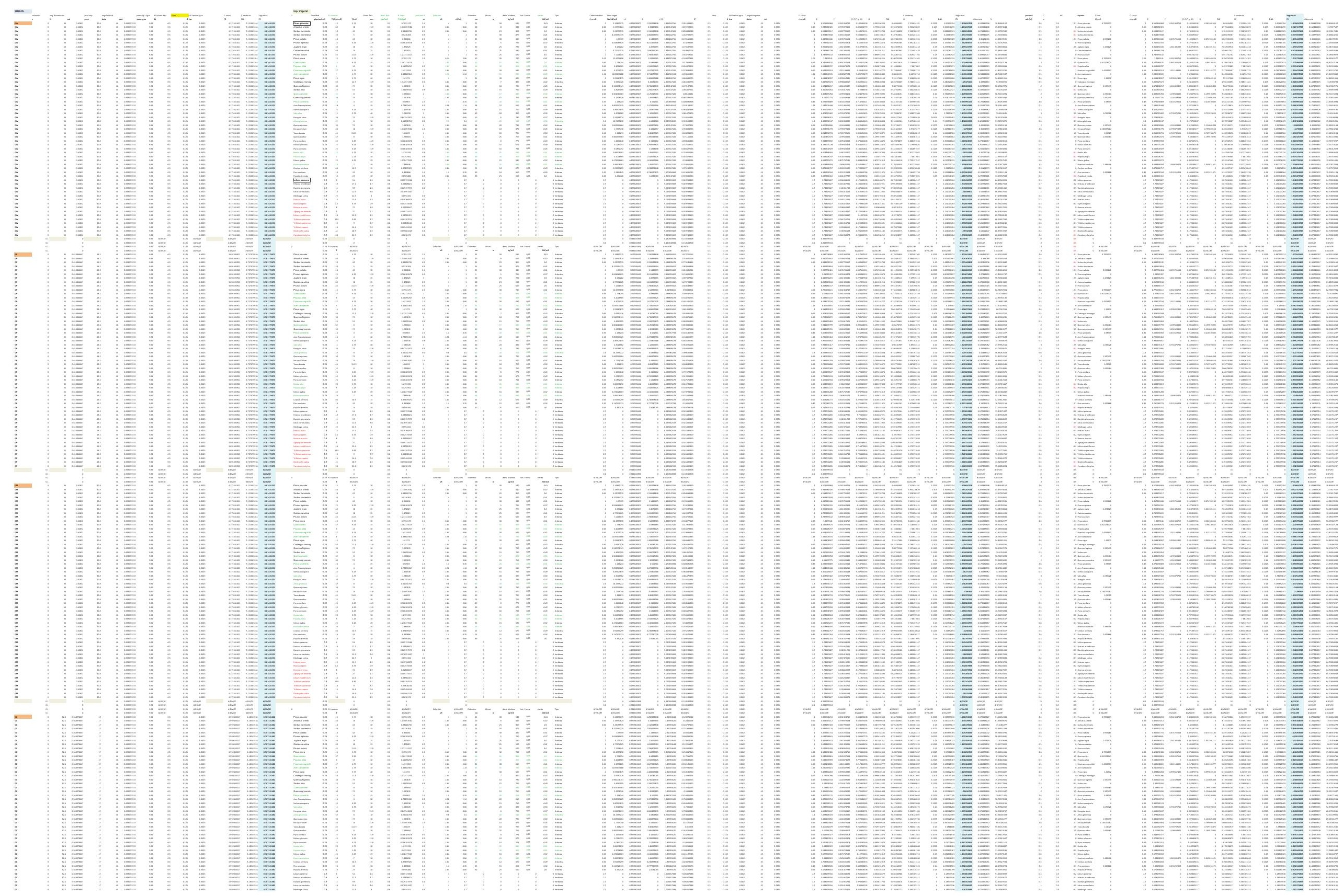


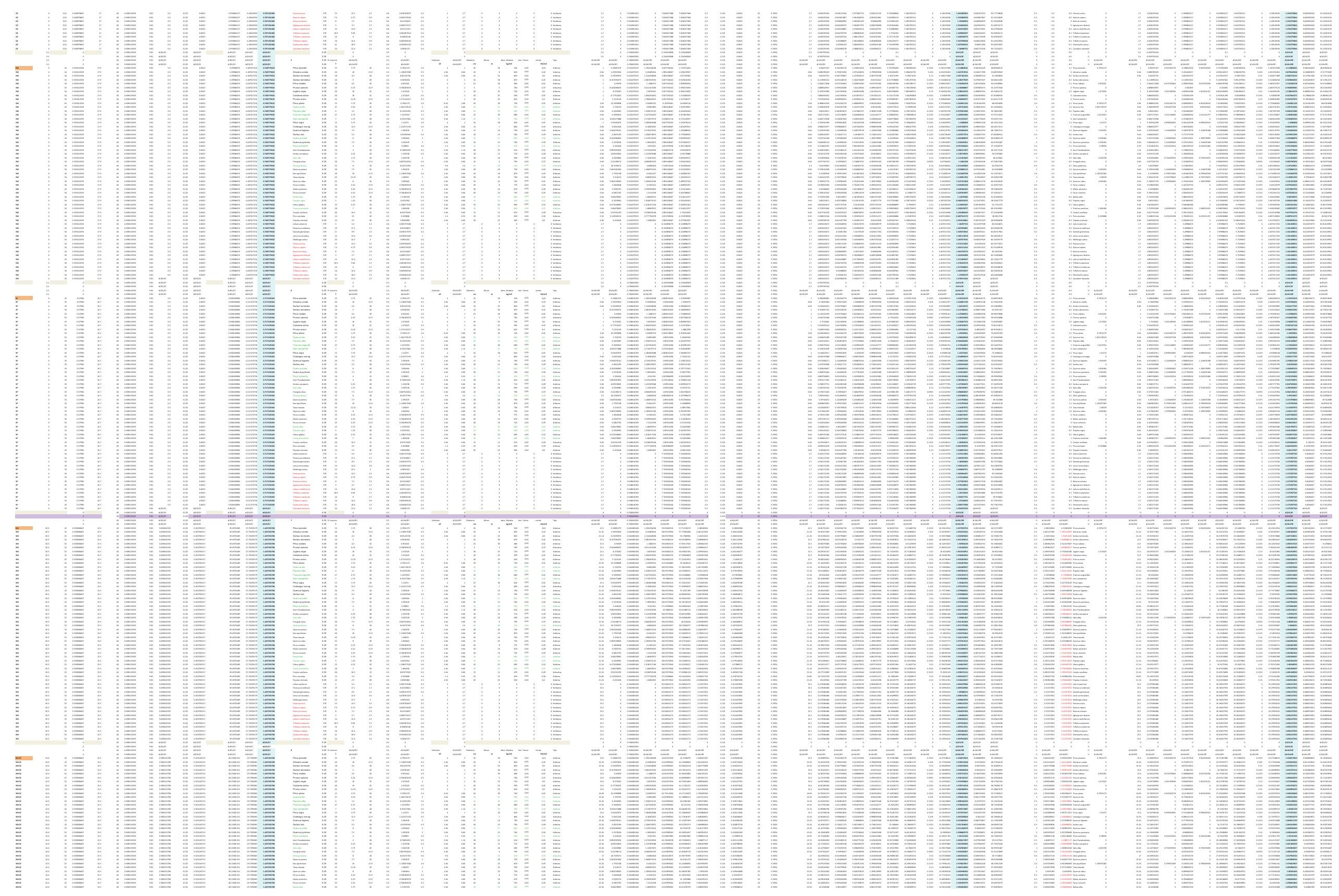



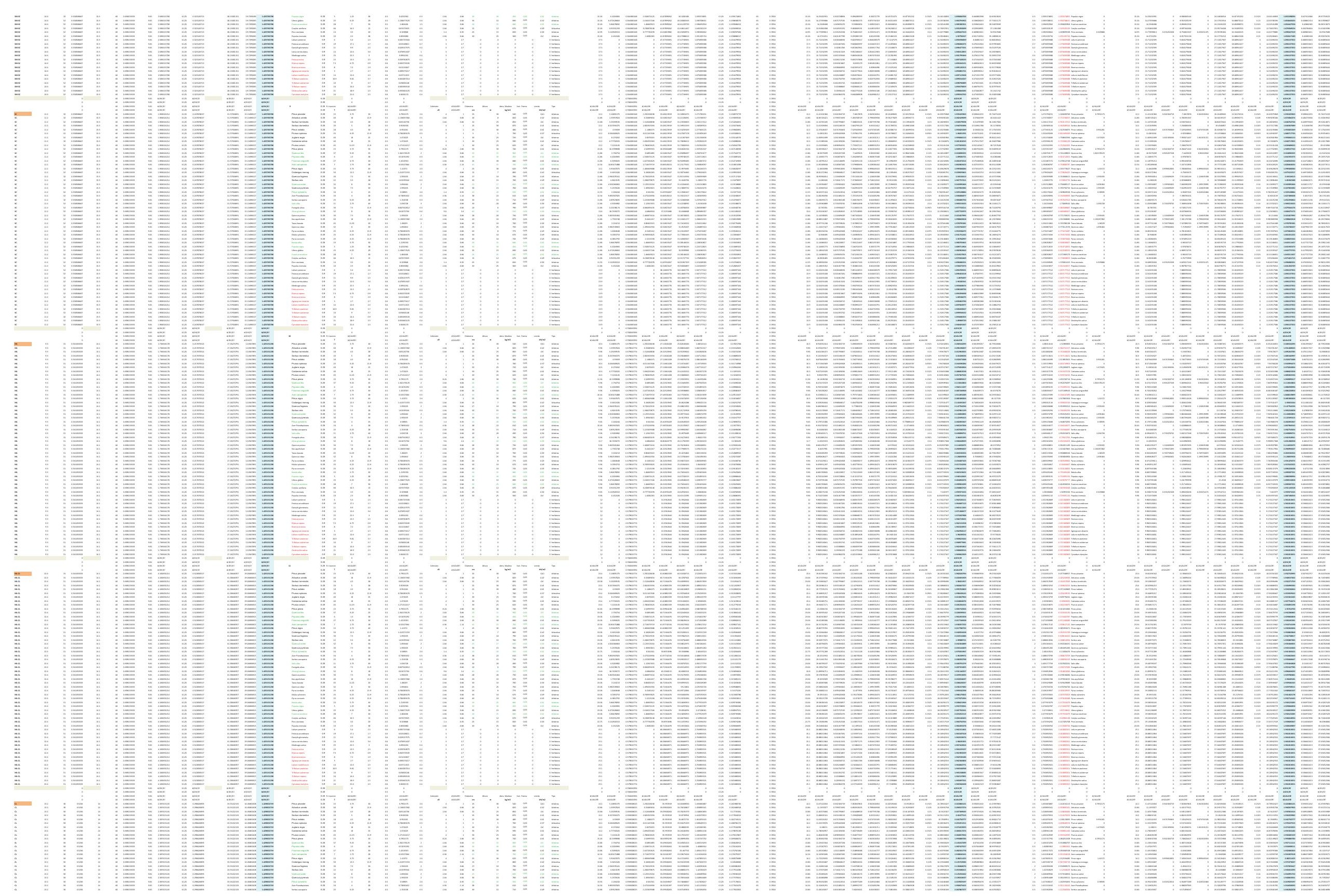


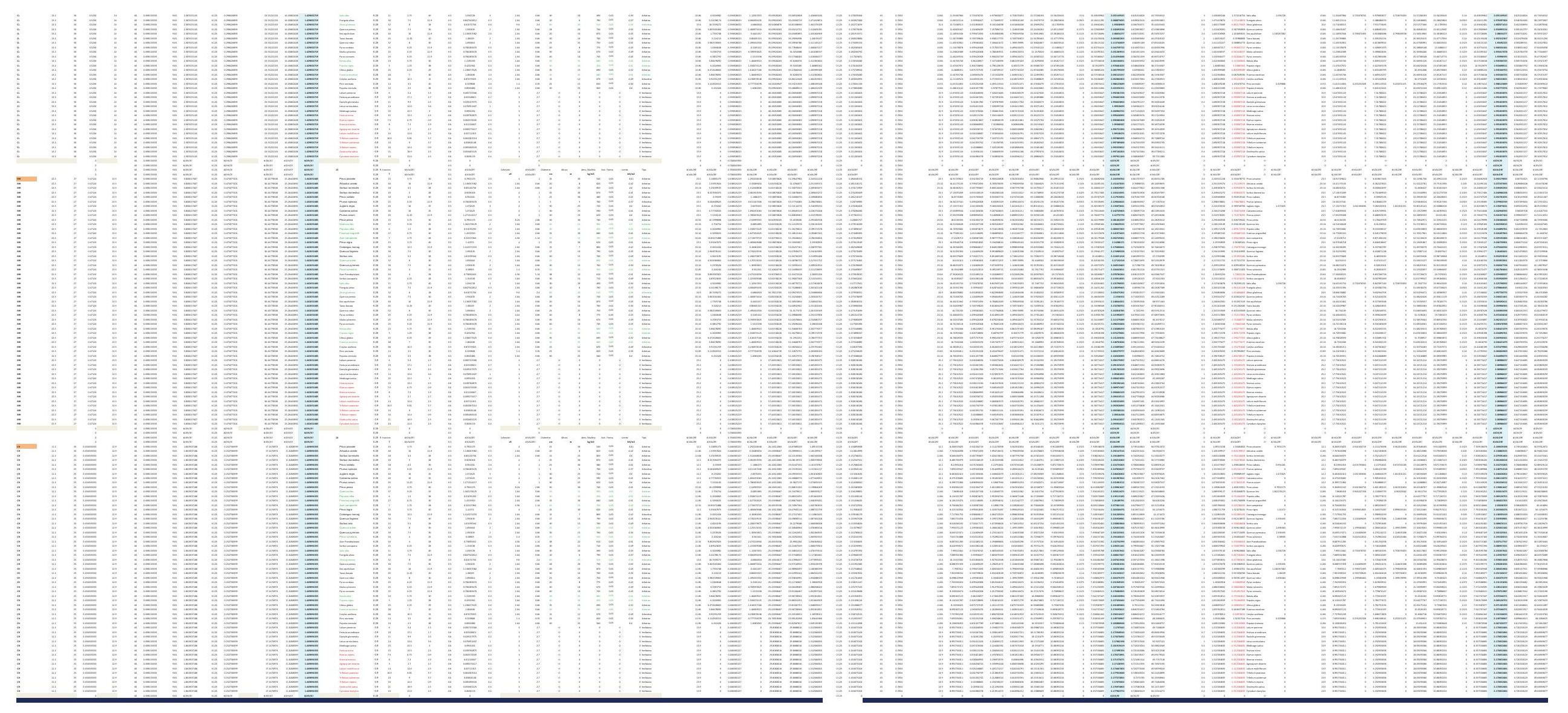



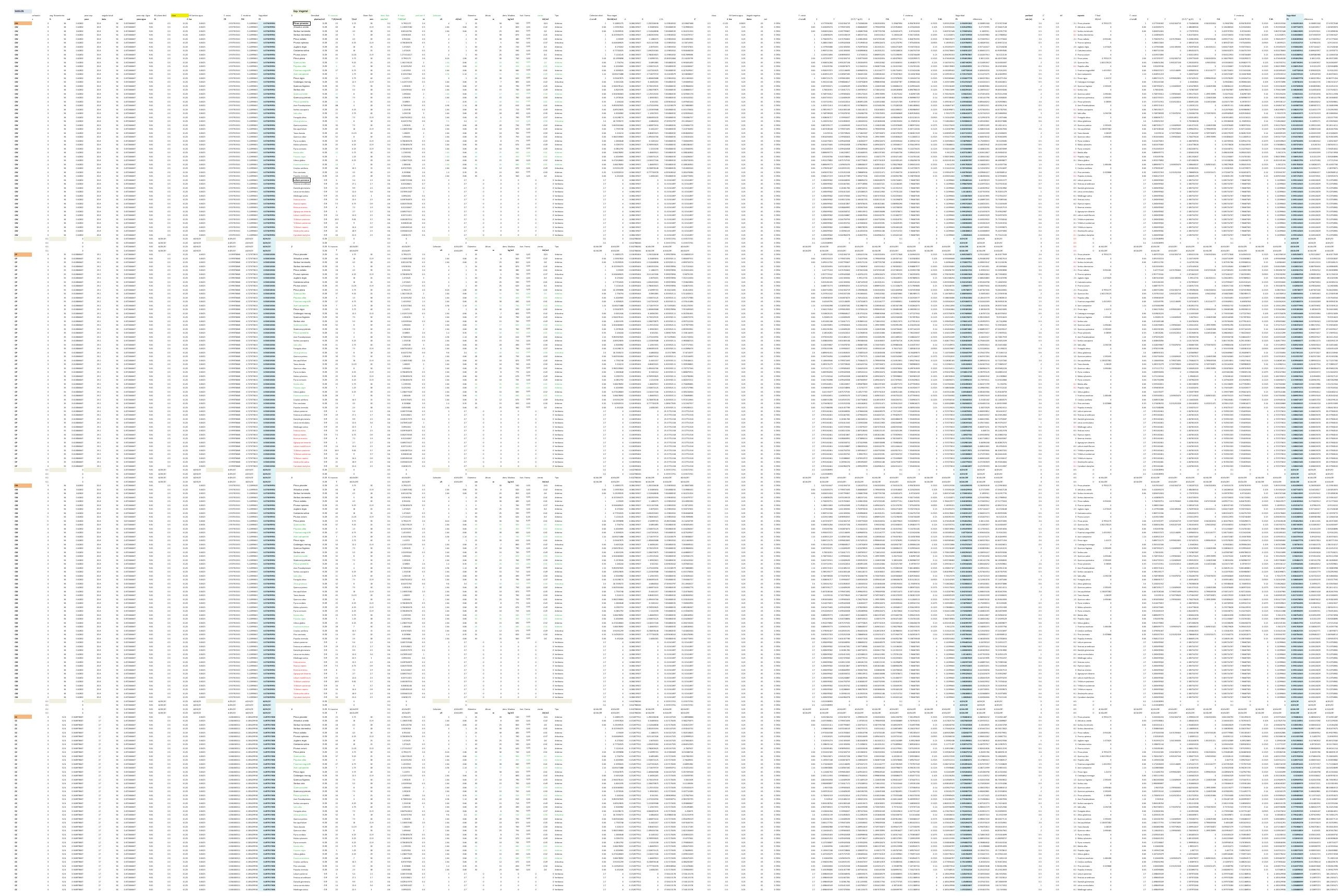


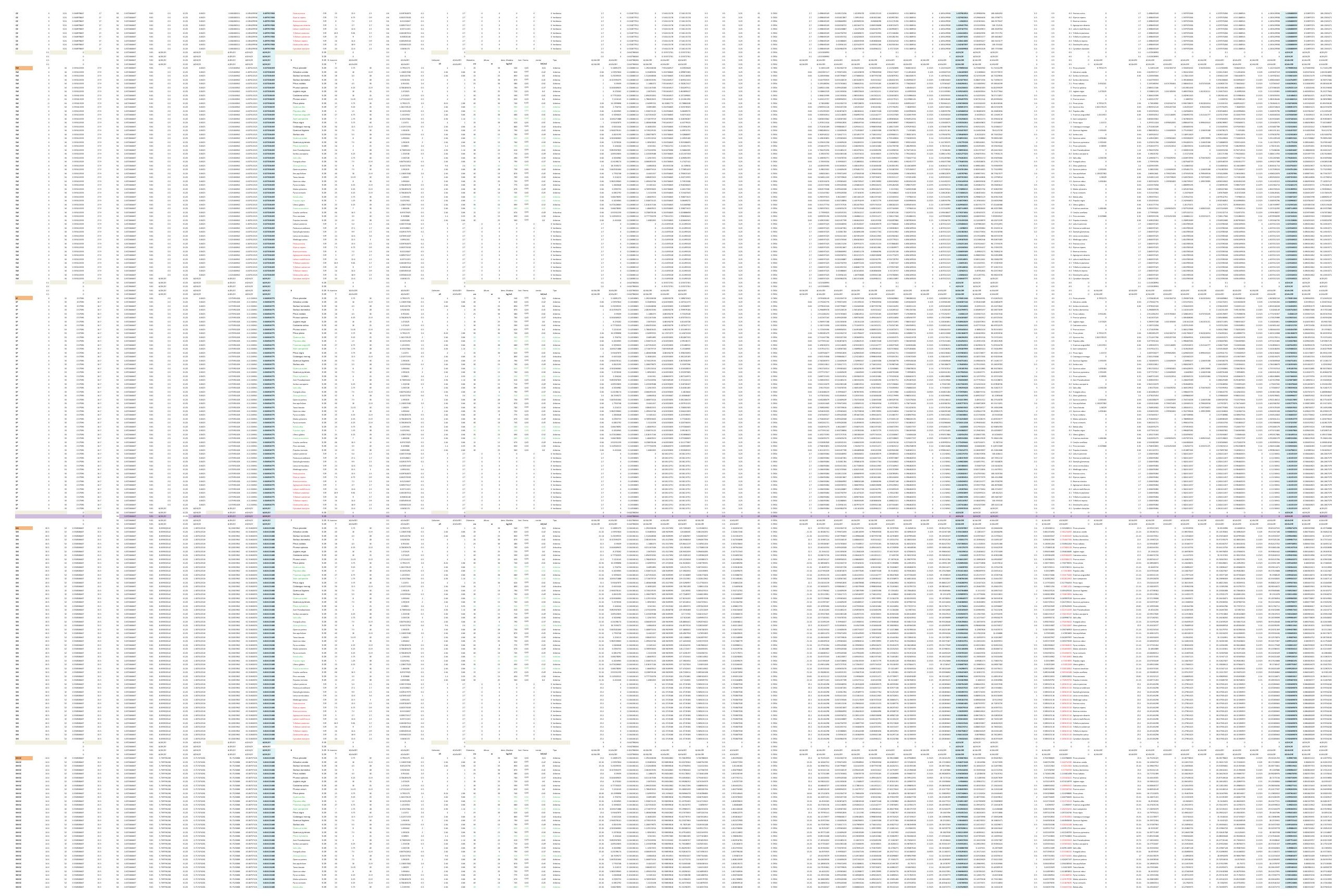



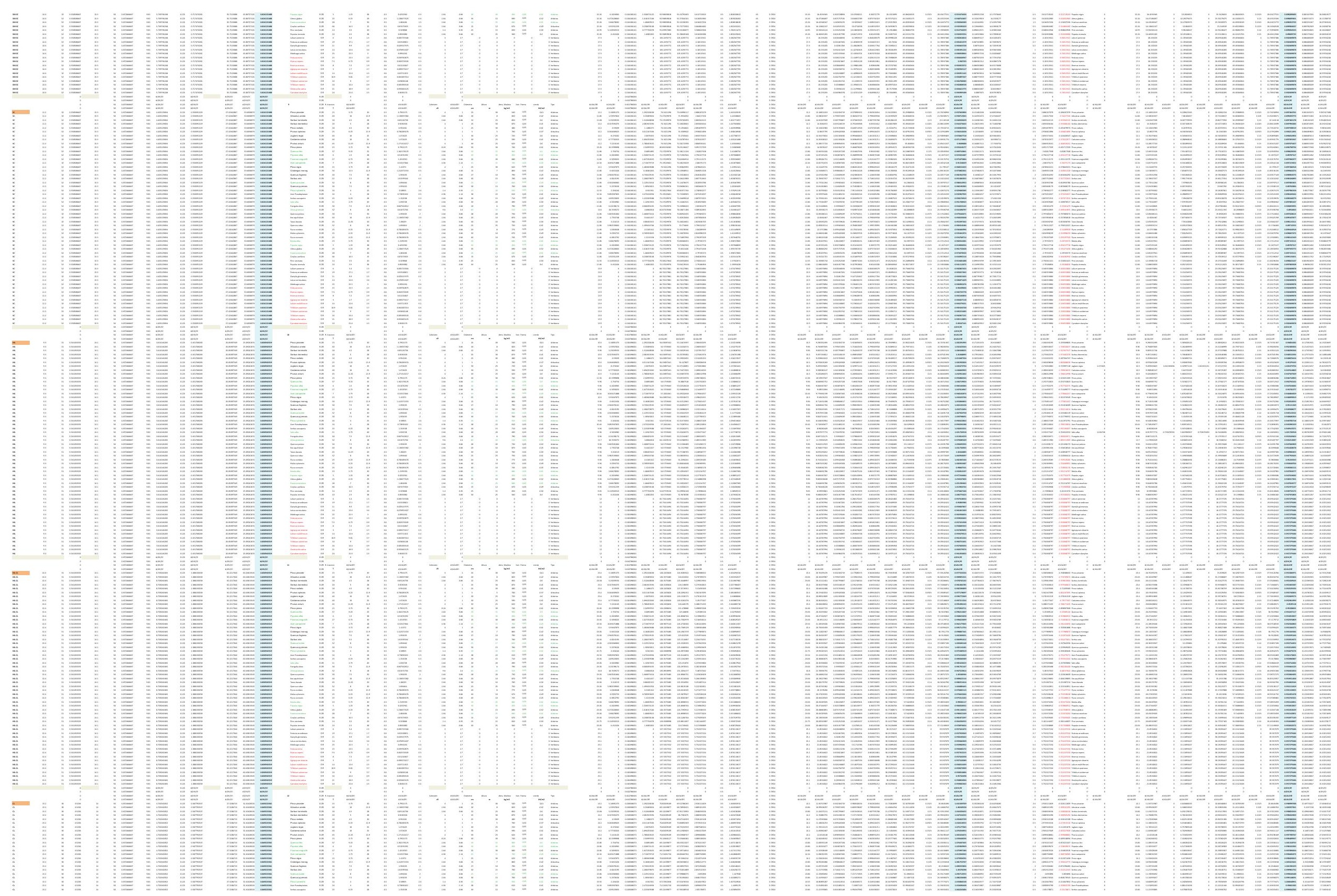


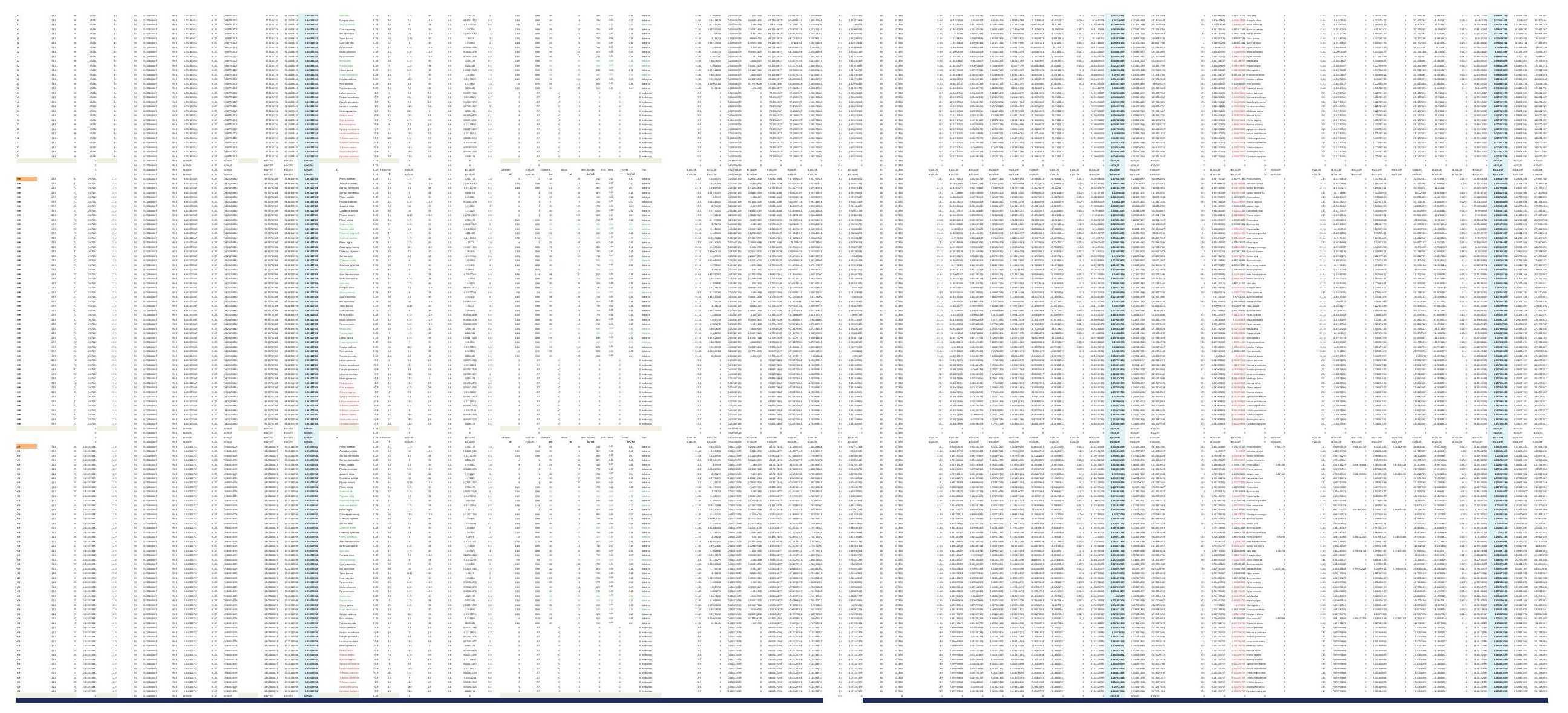



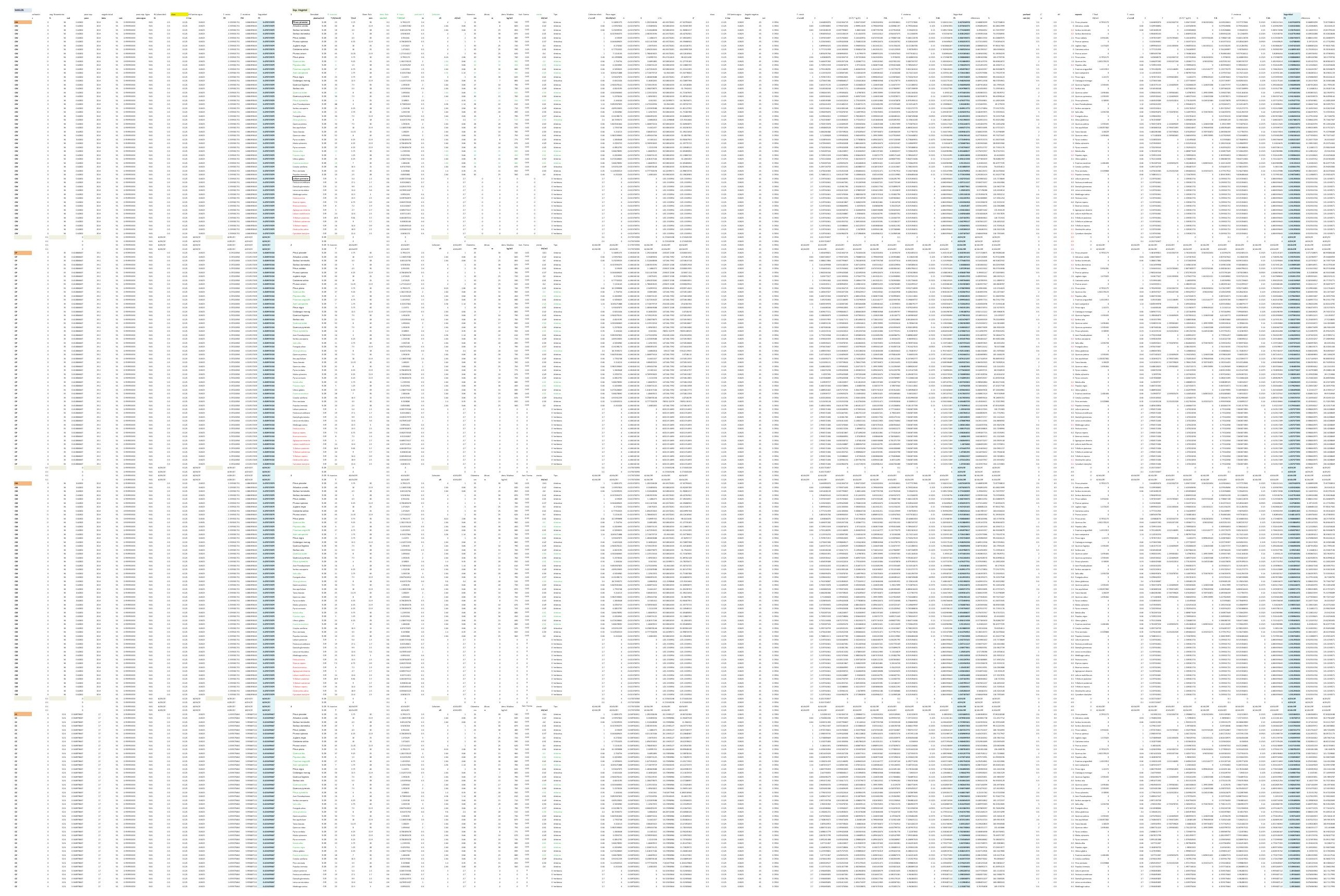


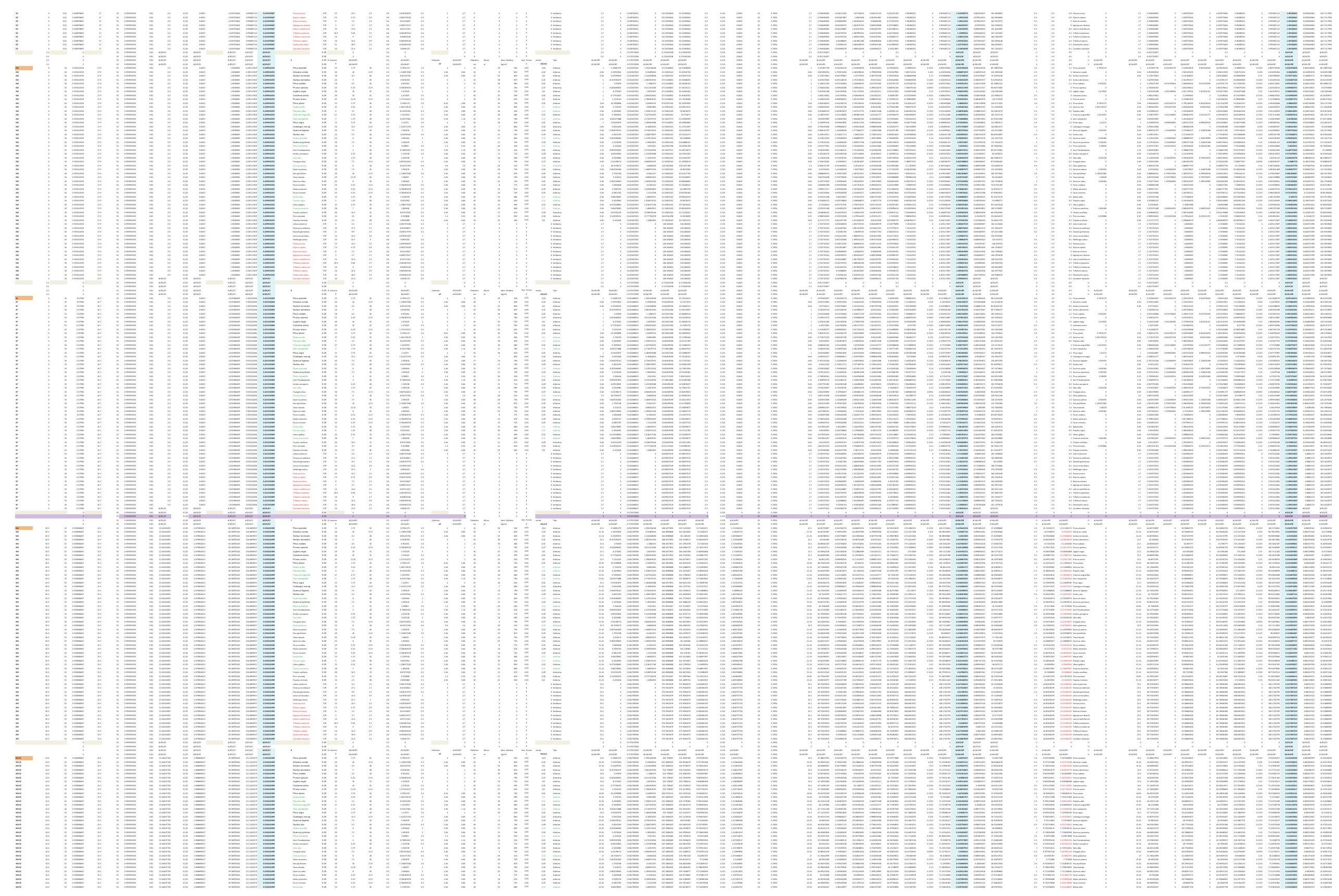



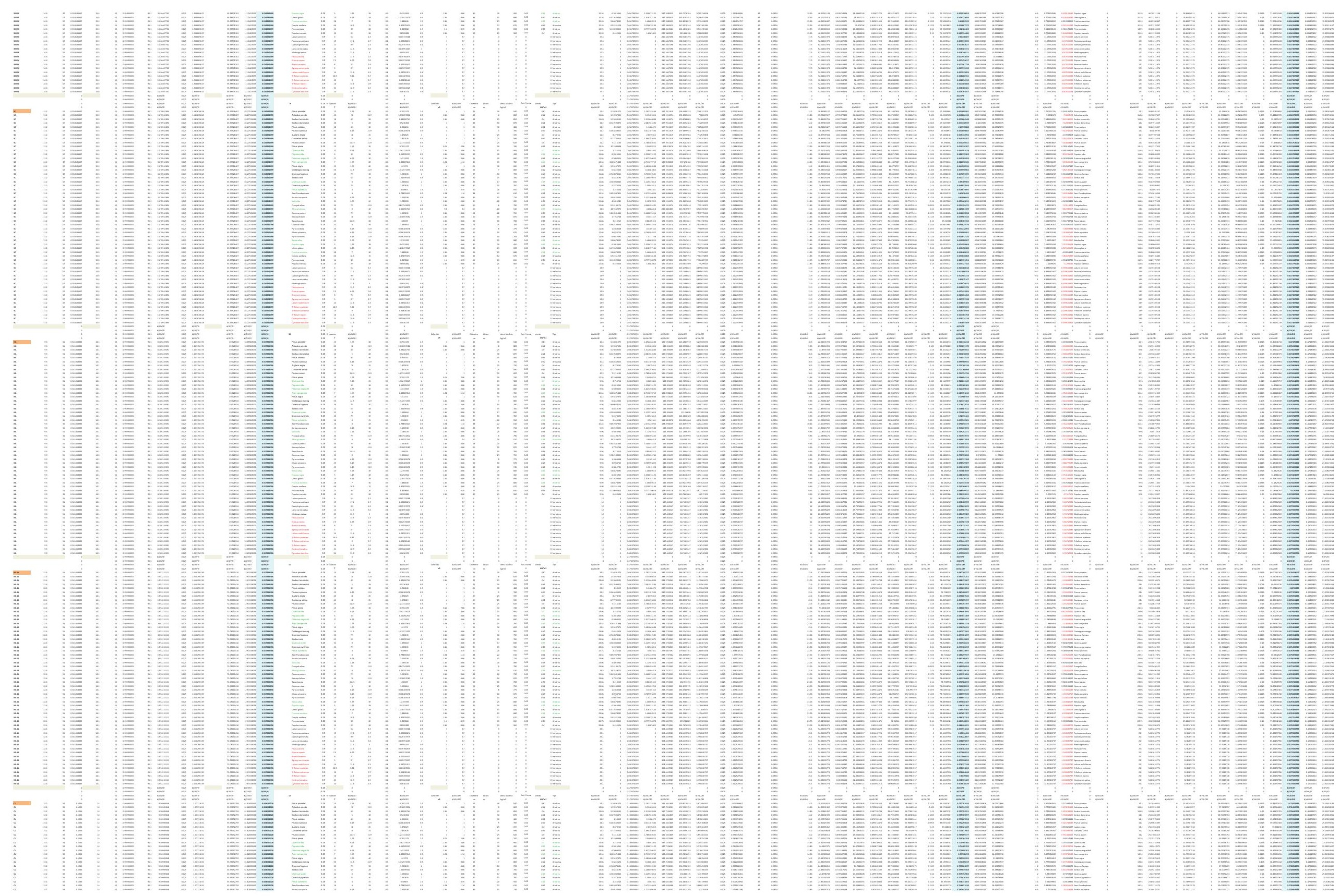


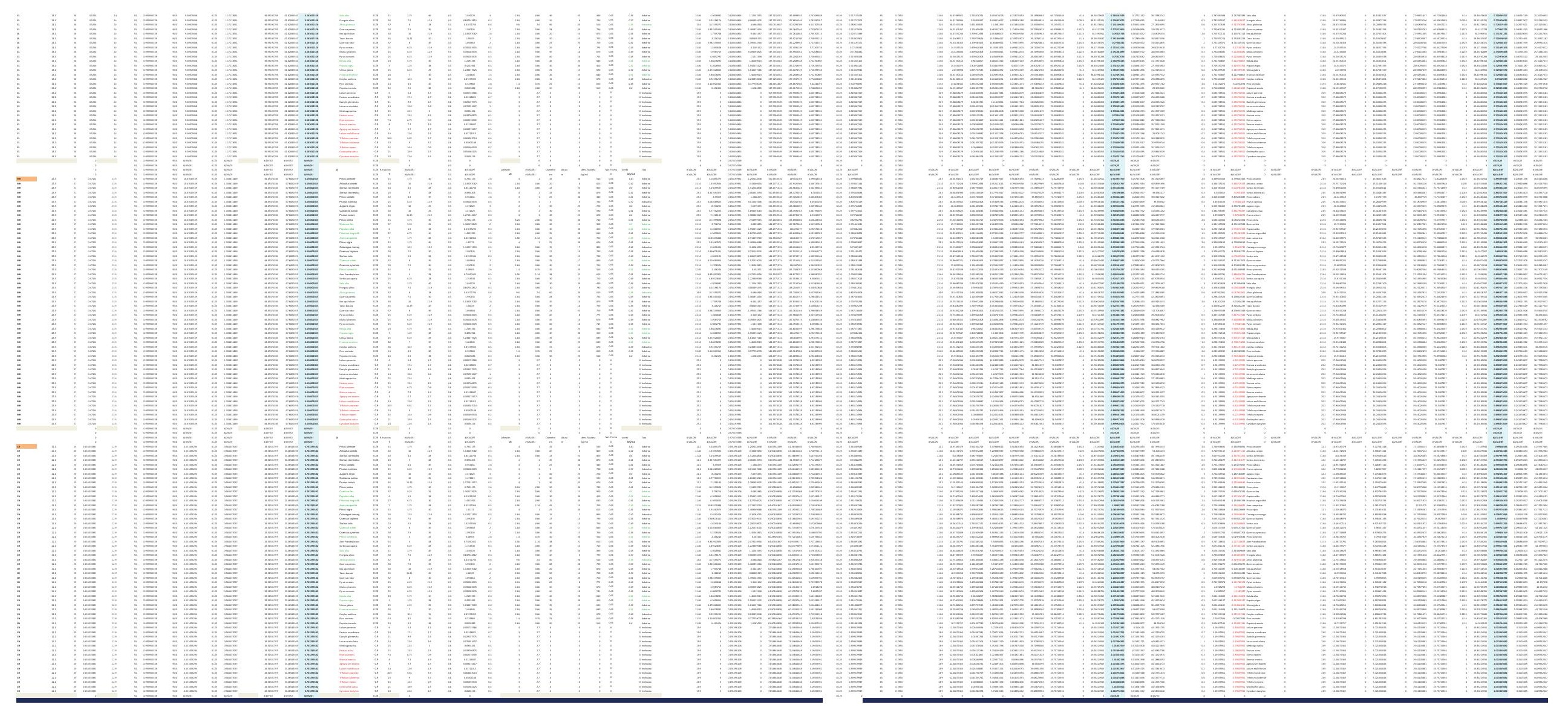



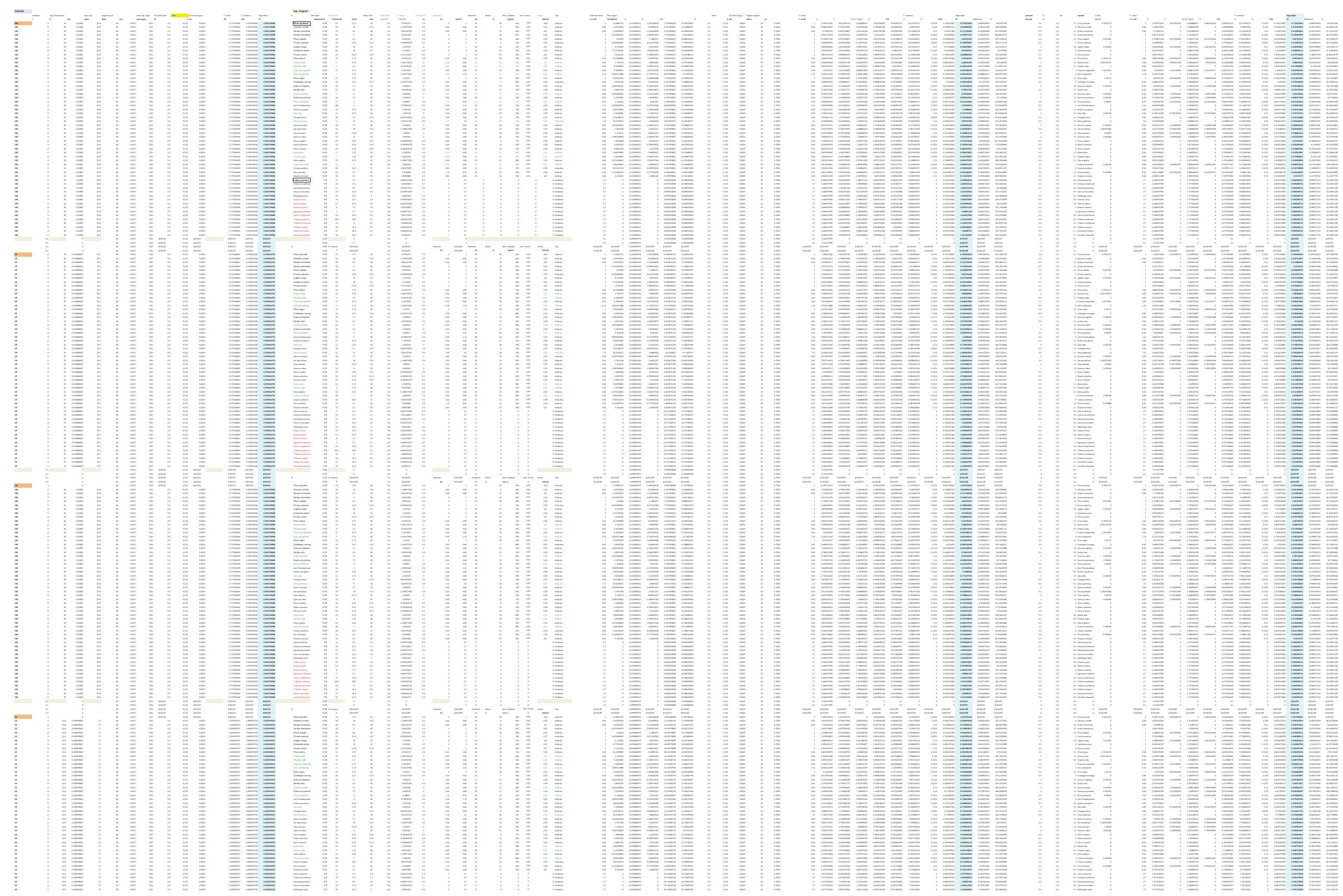


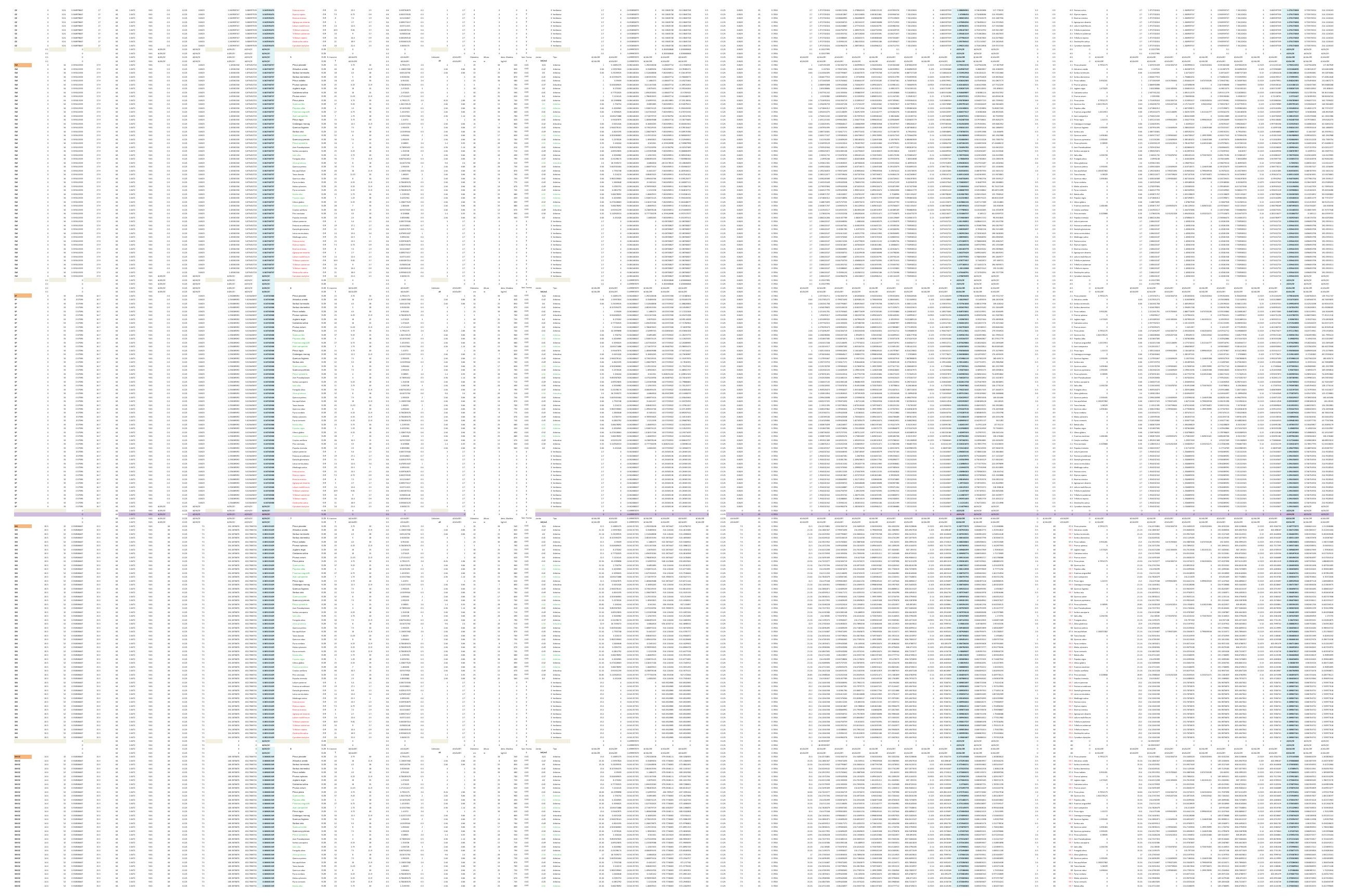



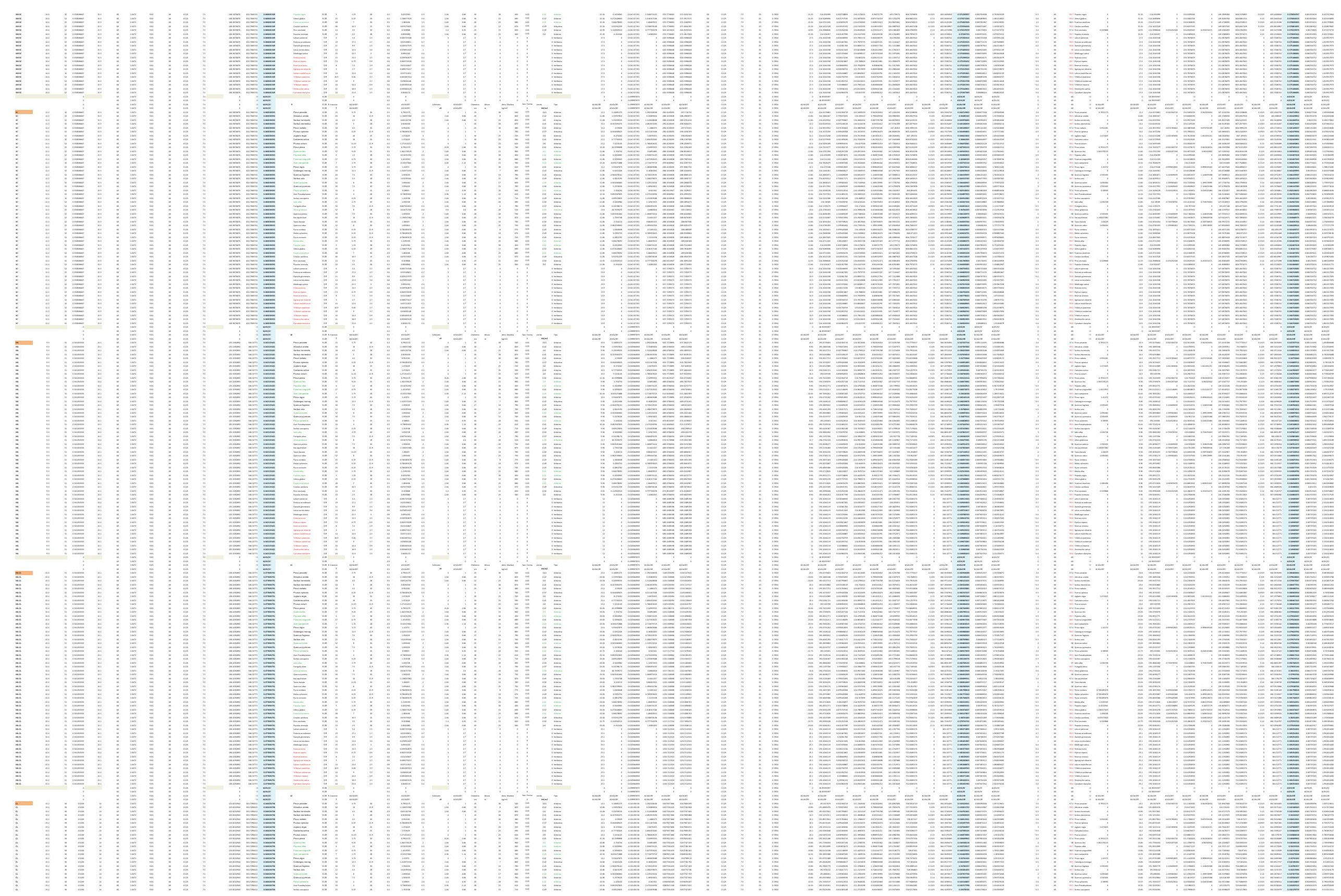


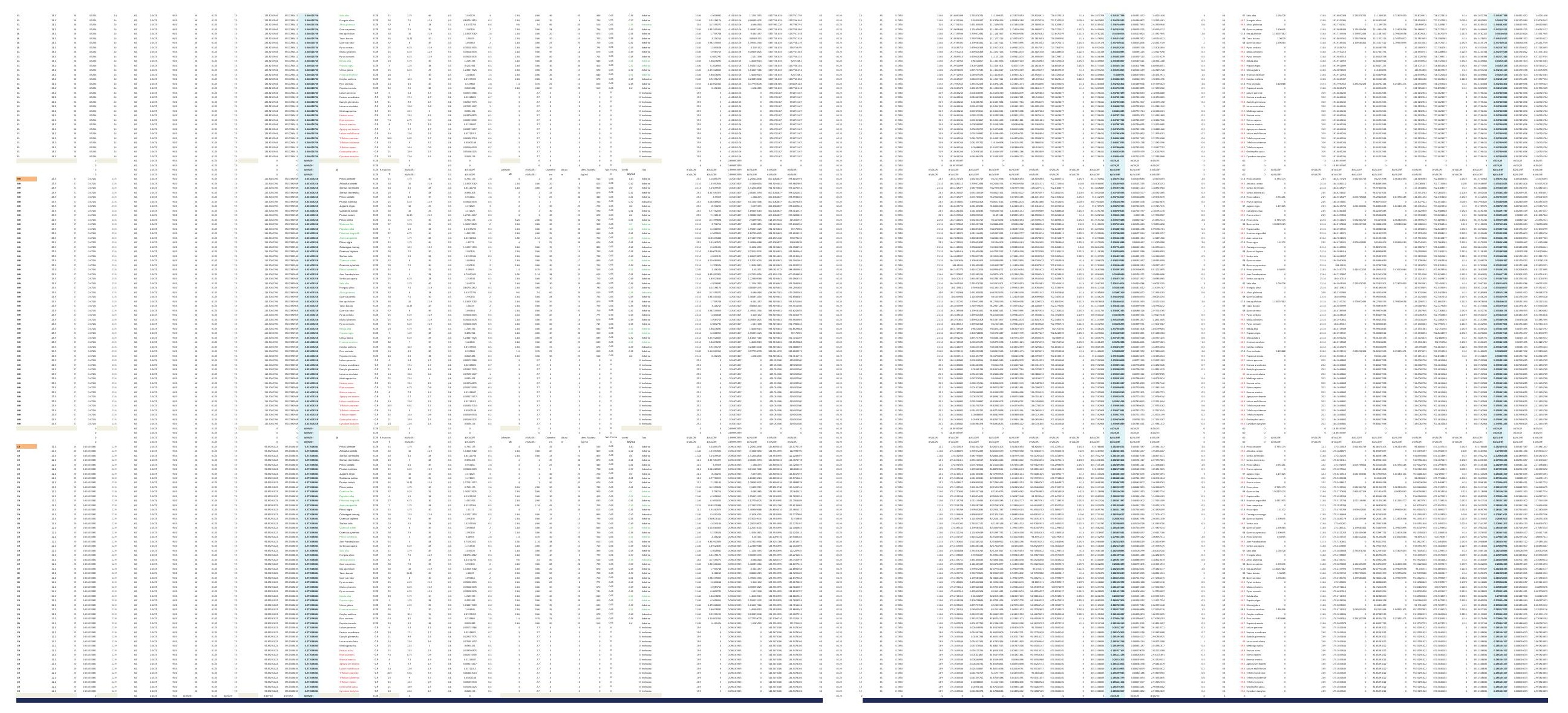



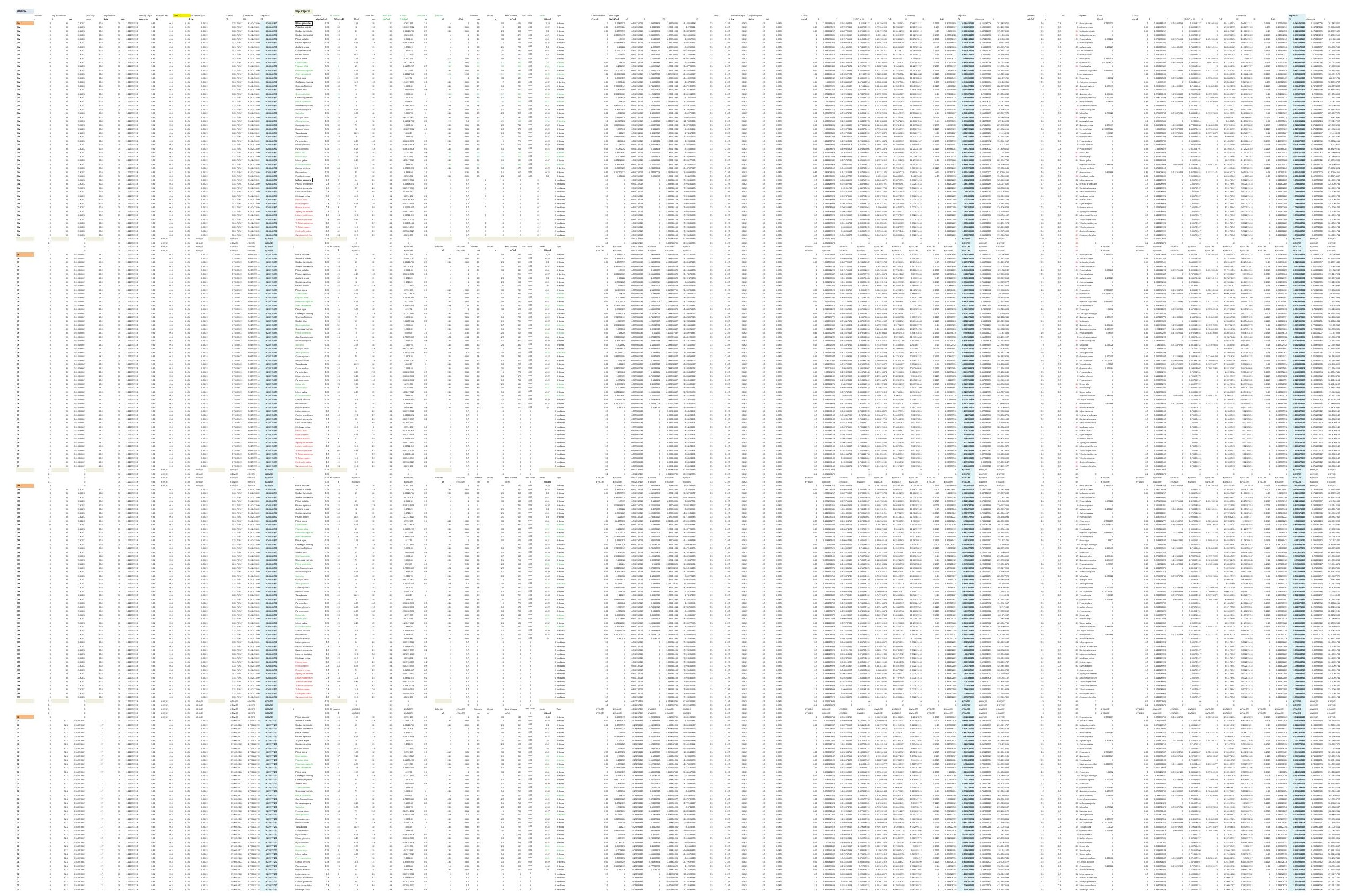


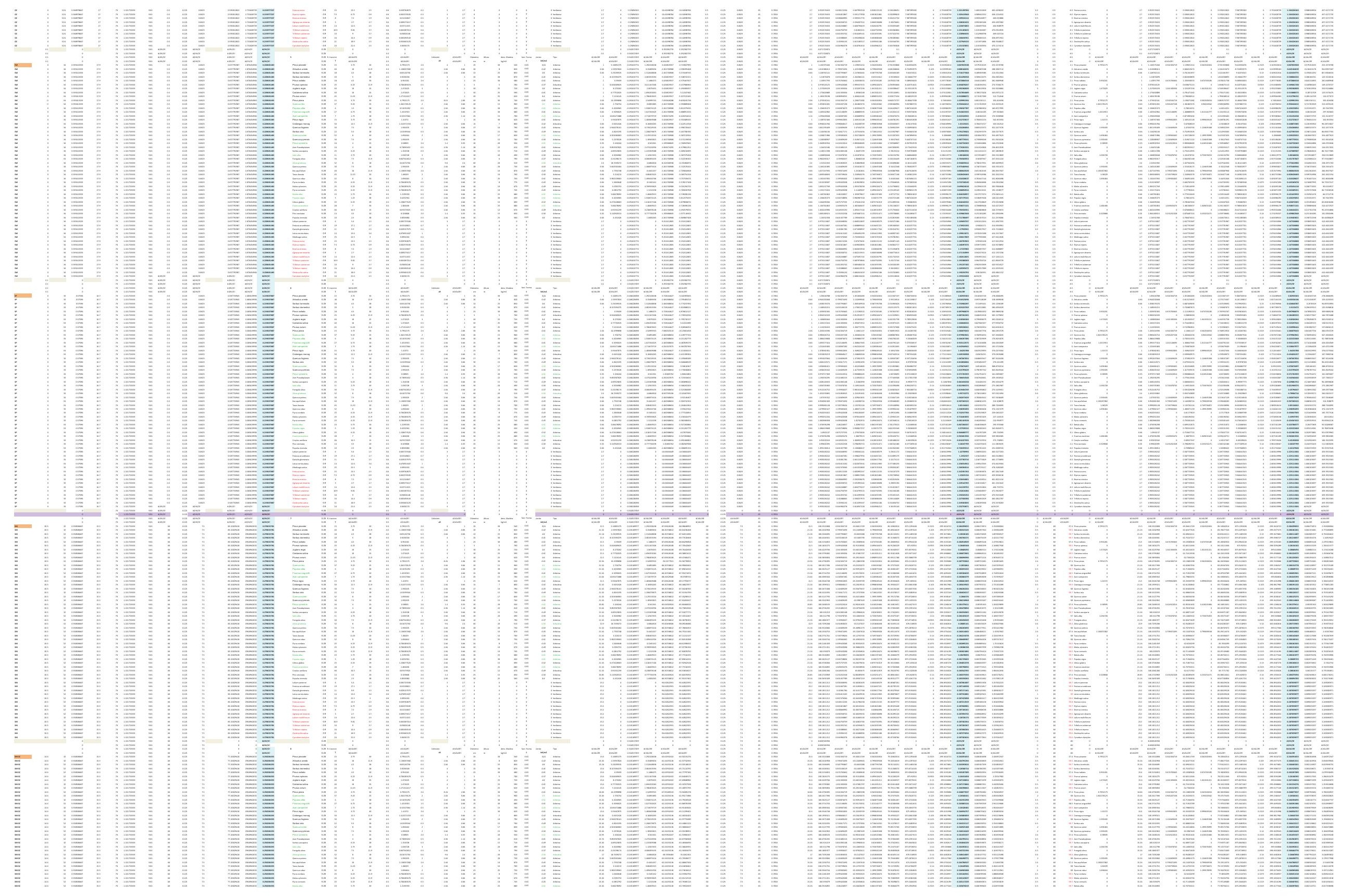




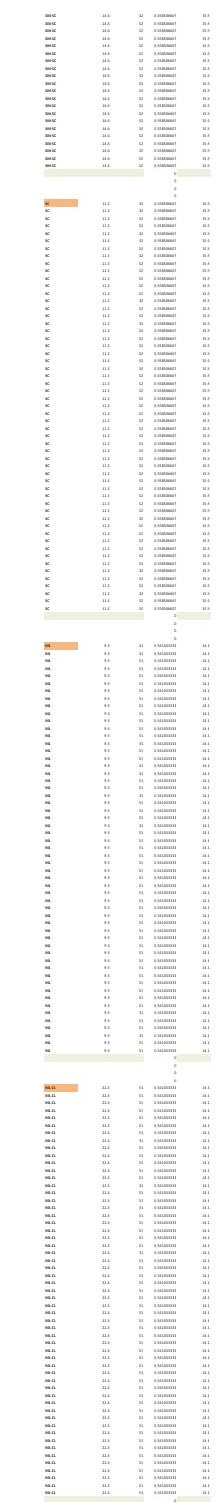

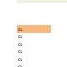

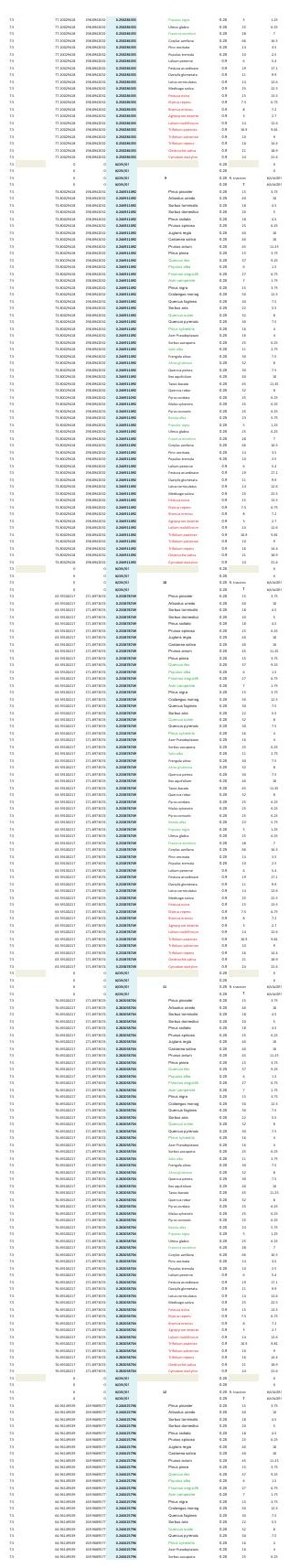

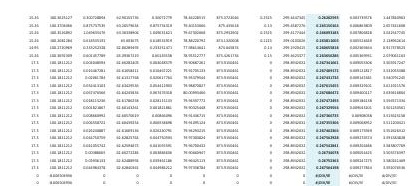
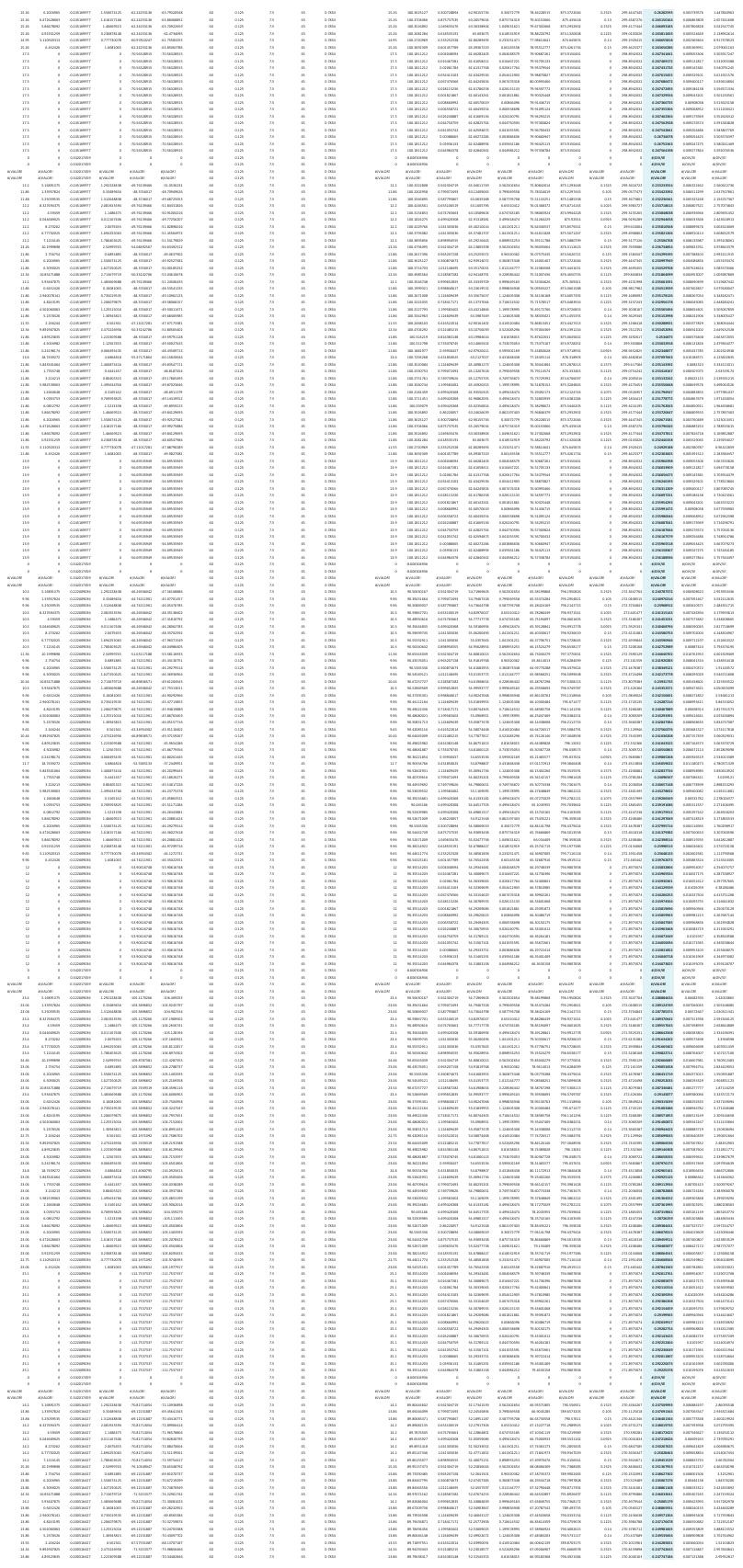

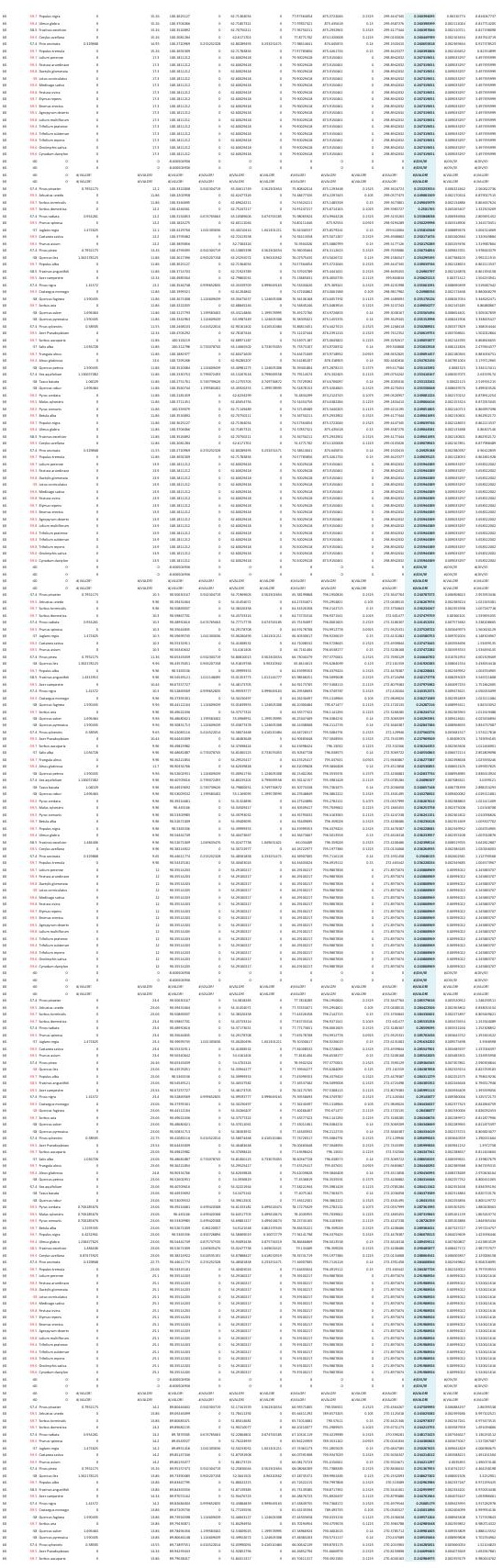




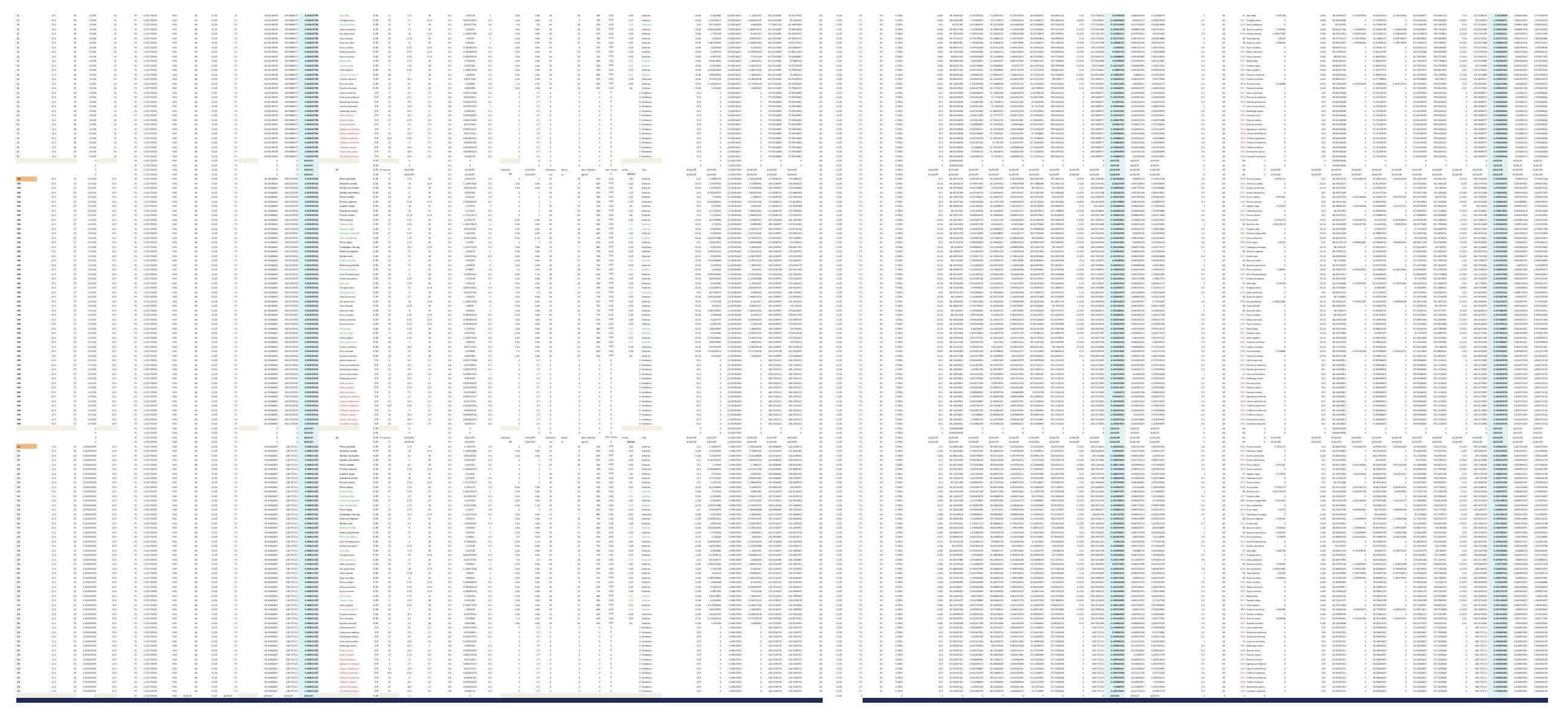



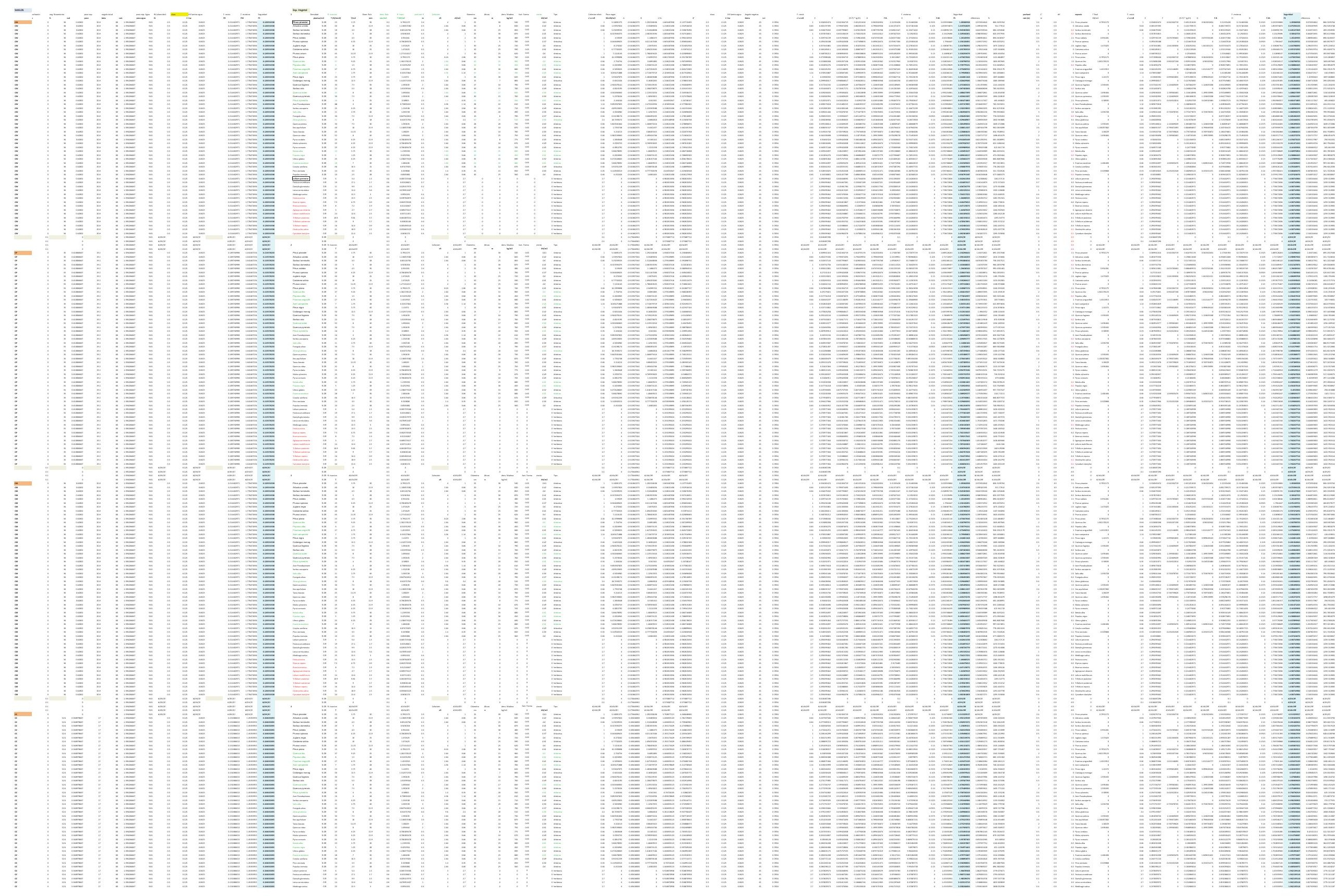


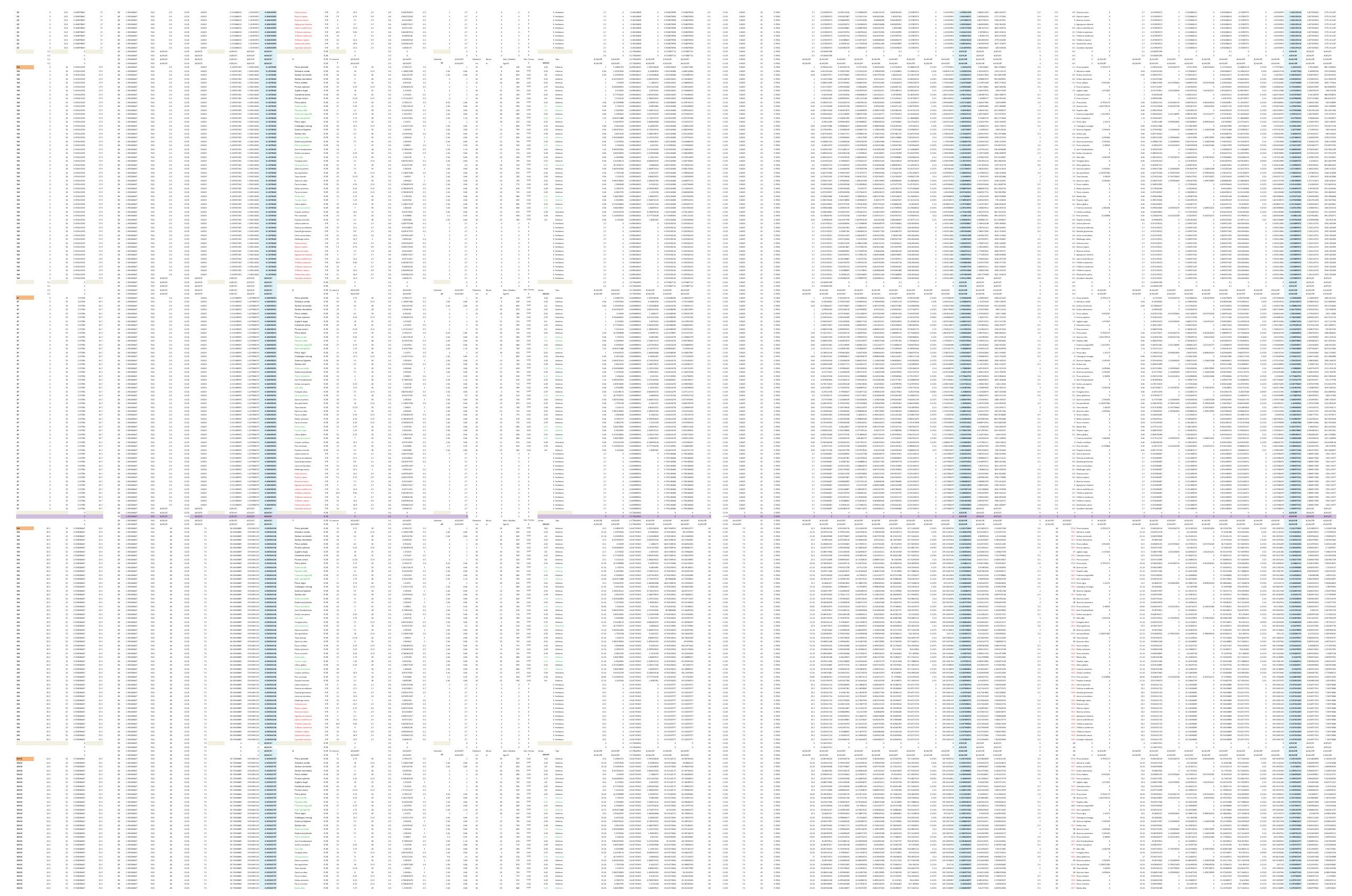




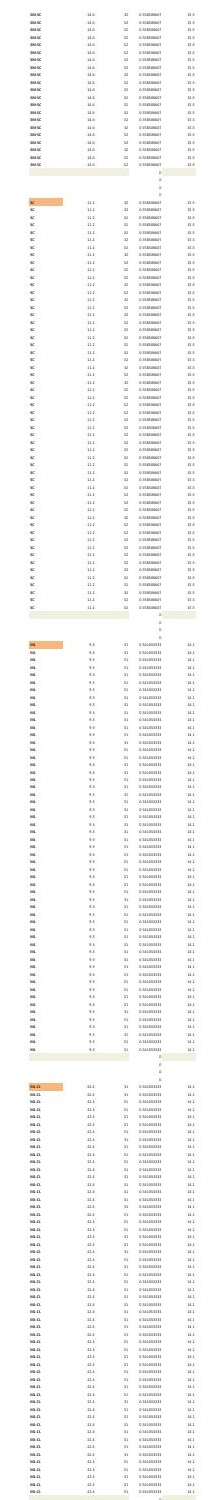

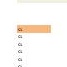
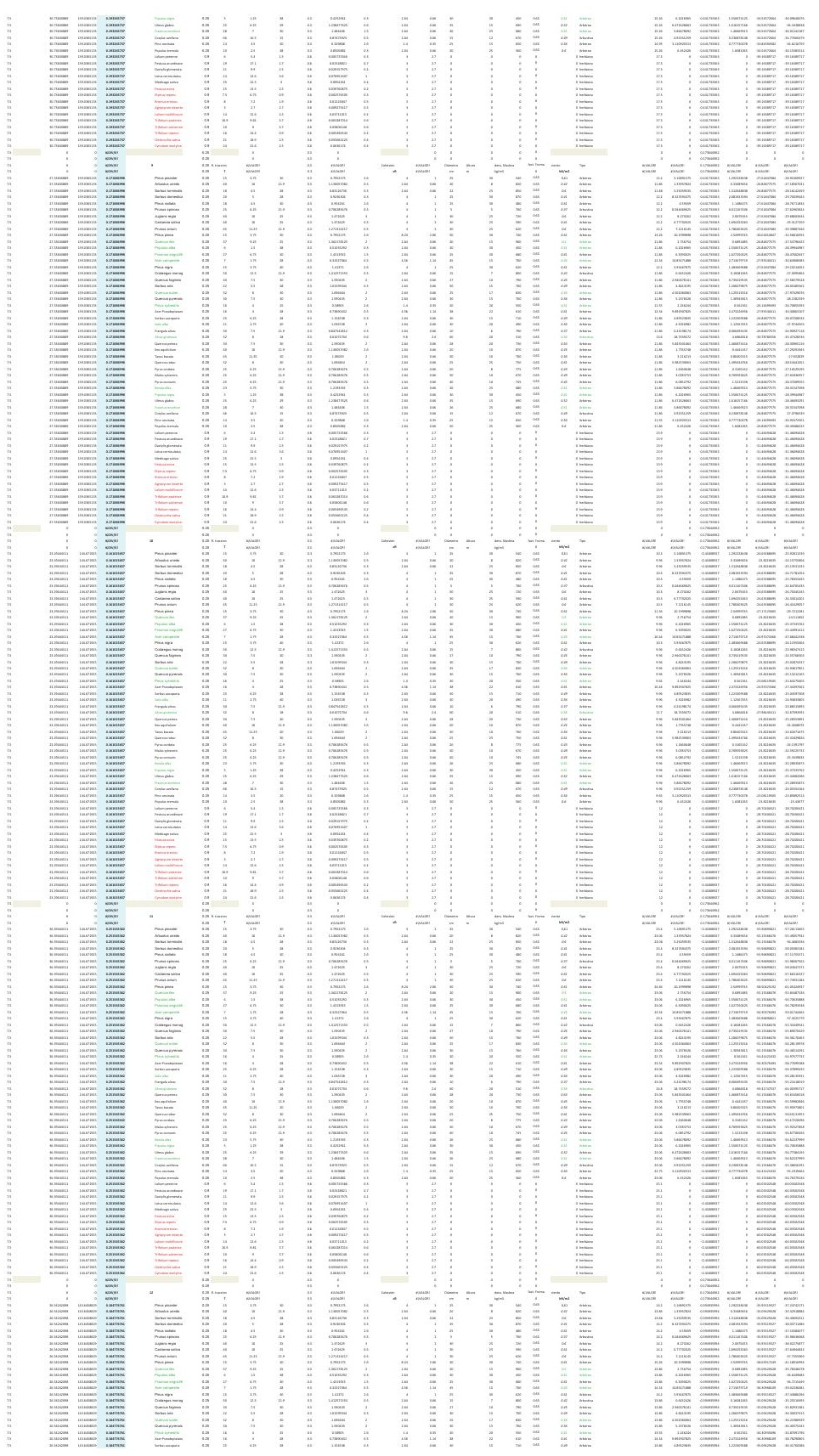
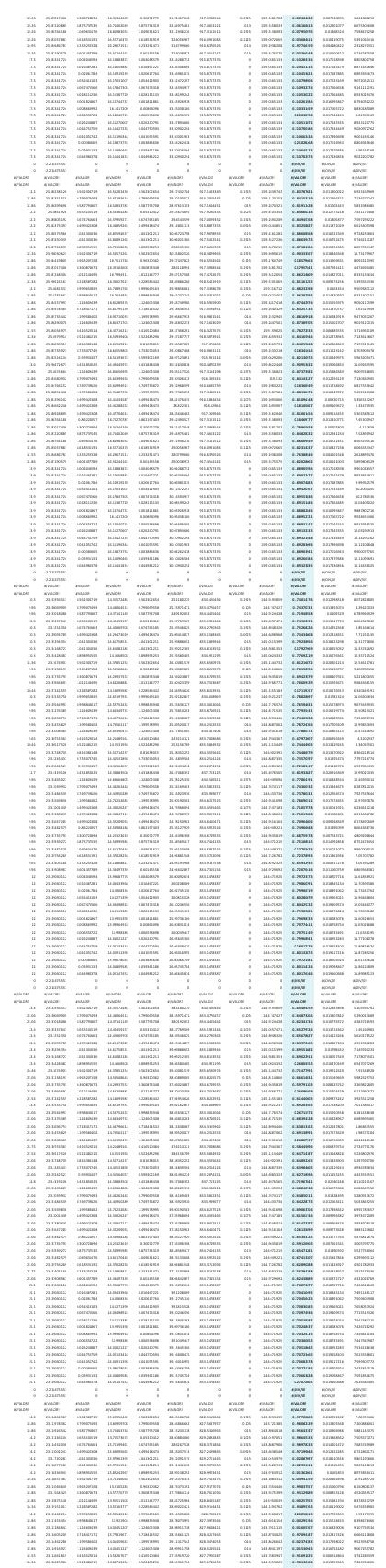

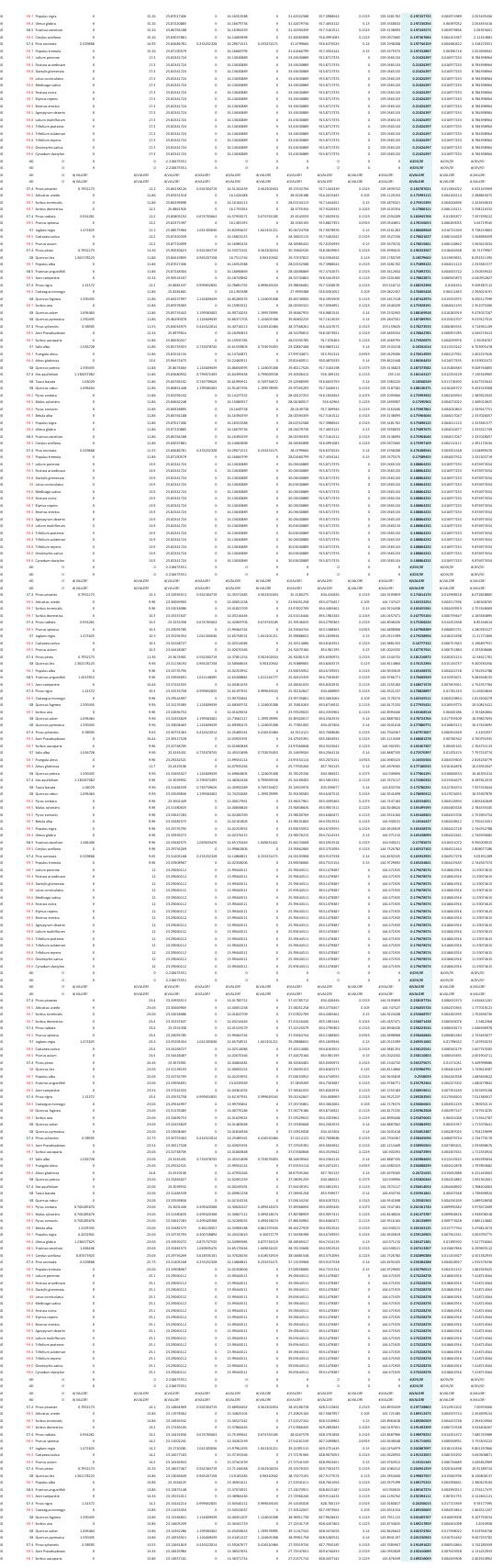




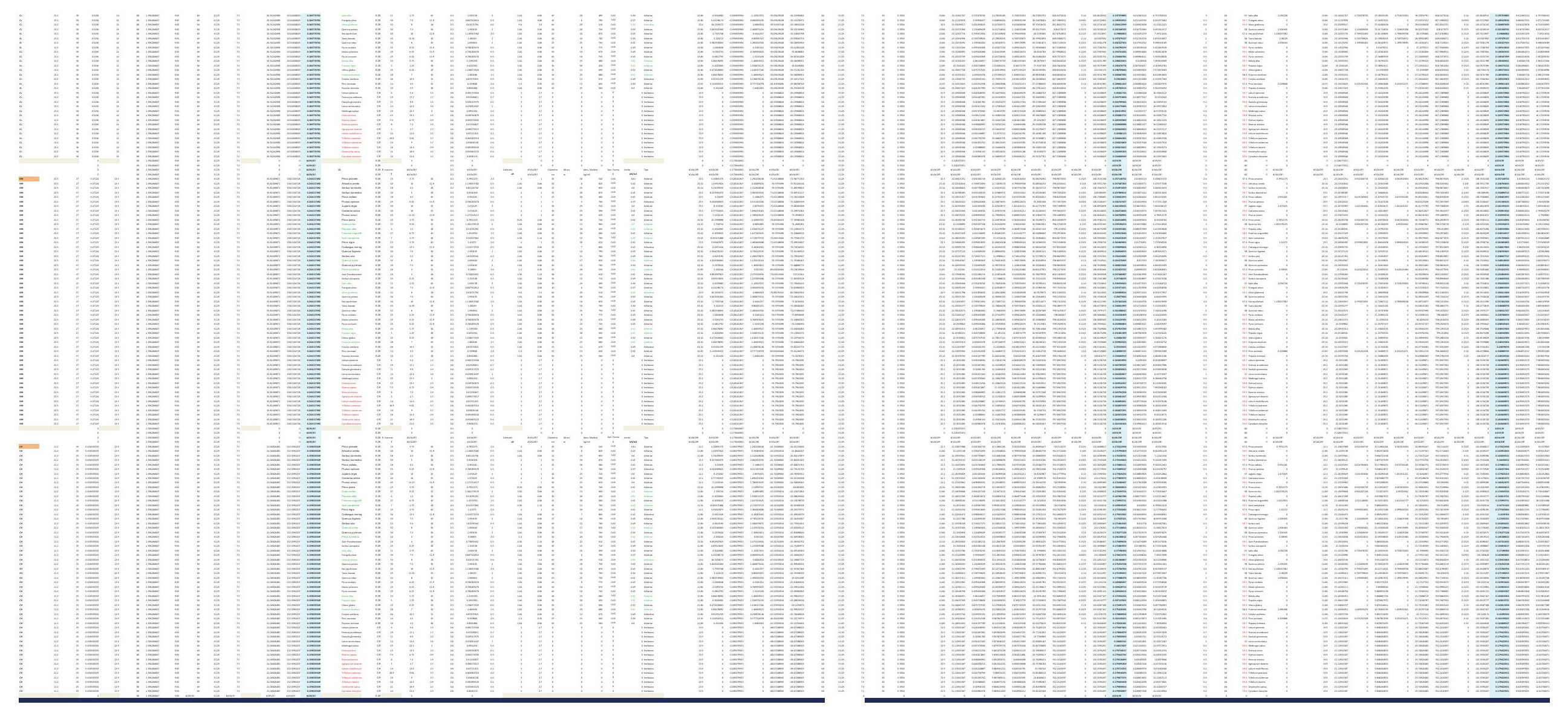


DESARROLLO DE UNA APLICACIÓN IMFORMÁTICA PARA EL CÁLCULO DE SOSTENIMIENTO DE TALUDES MEDIANTE VEGETACIÓN

A03. DENSIDAD DE PLANTACIÓN: 2.500 plantas/ha.

\section{A03-3.POSICIÓN N.F. 3}

INCLINACIÓN DE TALUD 6-100

INCLINACIÓN DE TALUD 10-200

INCLINACIÓN DE TALUD 20-30

INCLINACIÓN DE TALUD 30-40

INCLINACIÓN DE TALUD $35^{\circ}$

INCLINACIÓN DE TALUD 40-50

INCLINACIÓN DE TALUD 50-550

INCLINACIÓN DE TALUD 55-60

INCLINACIÓN DE TALUD 60-700

INCLINACIÓN DE TALUD 70-80 

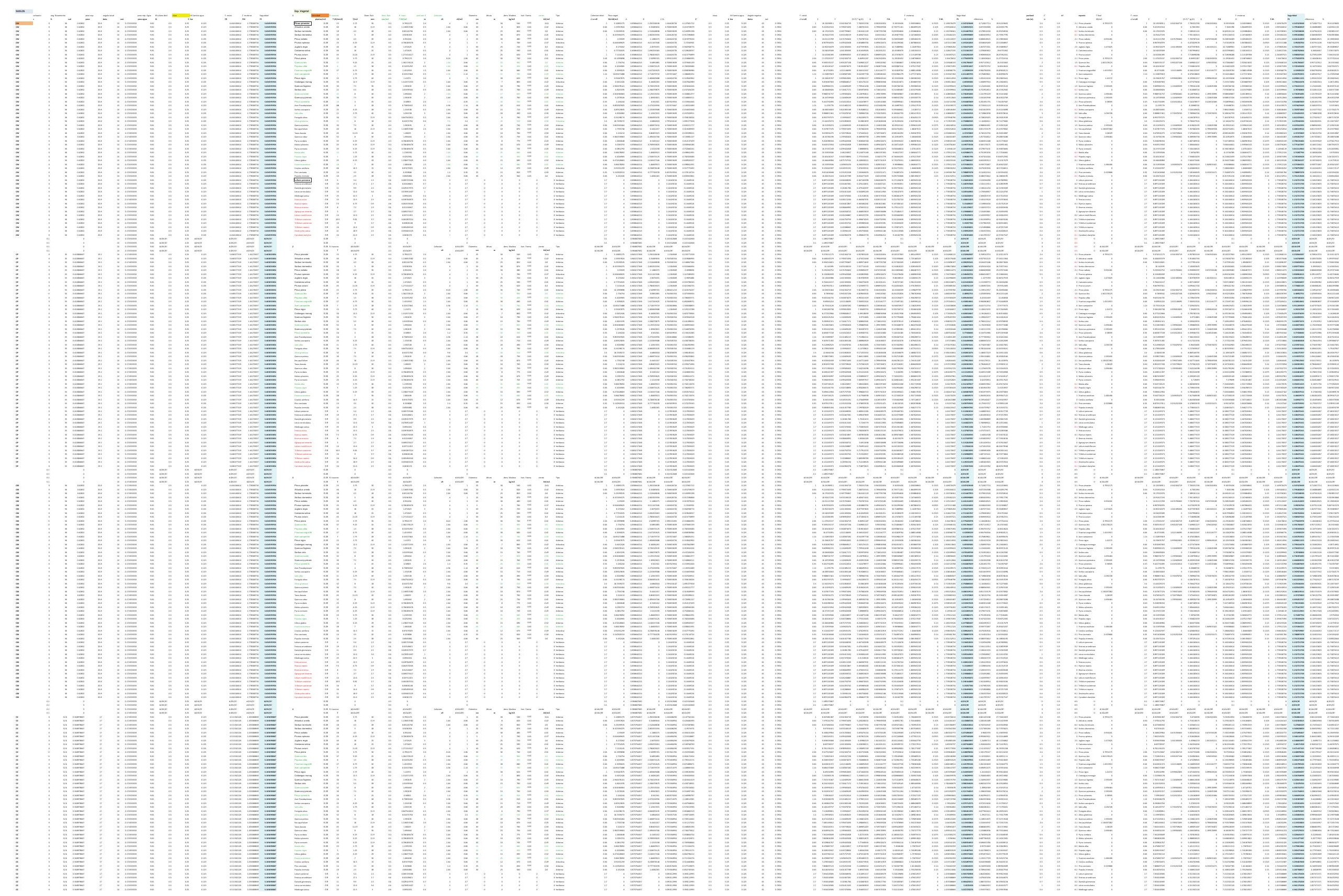

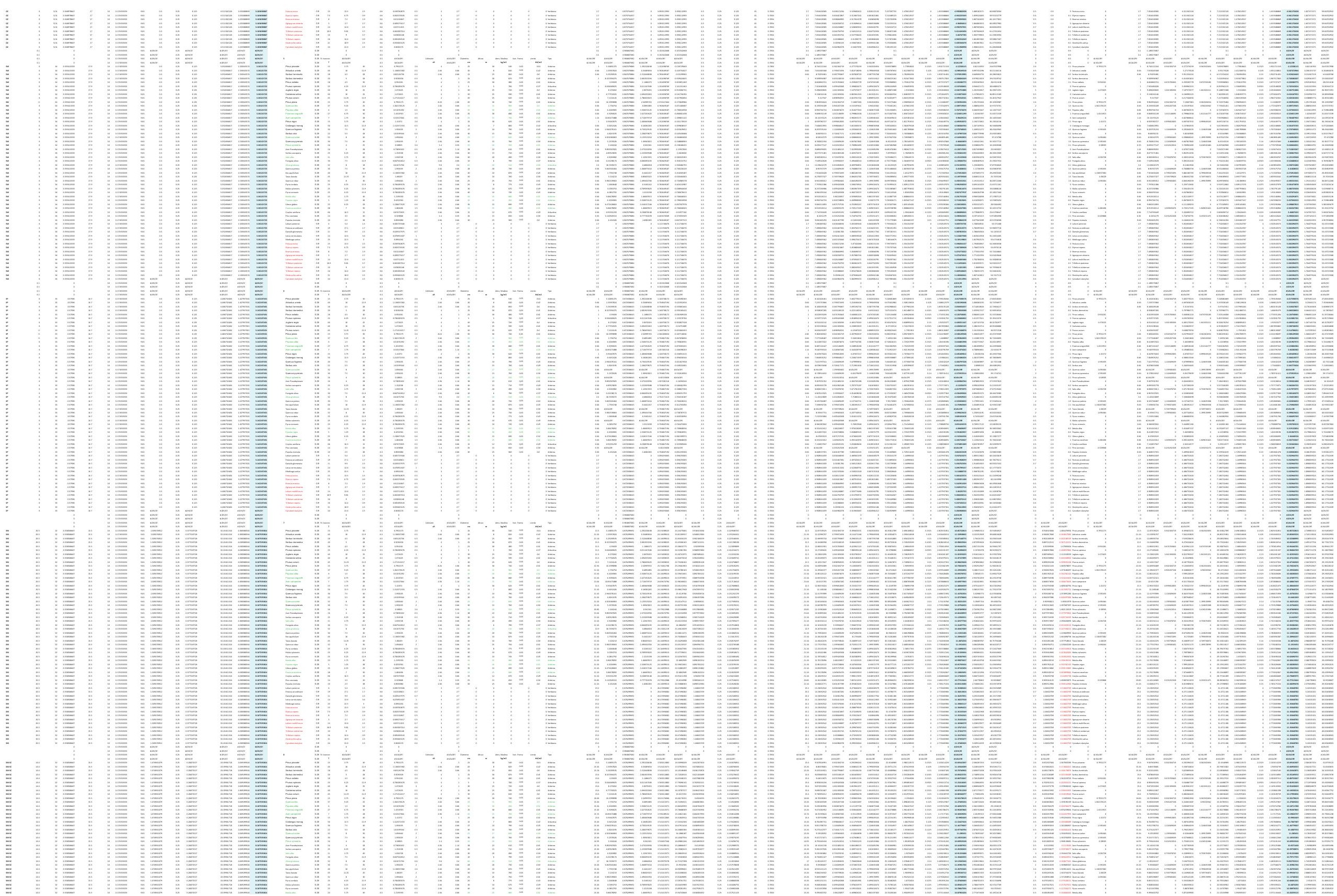


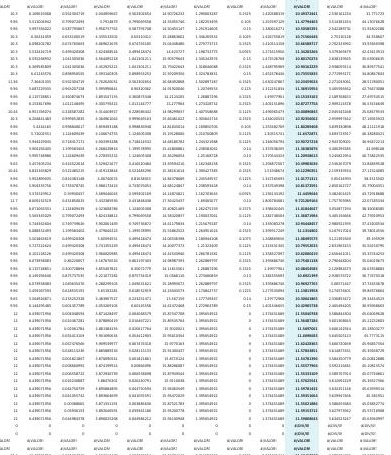

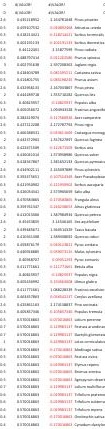
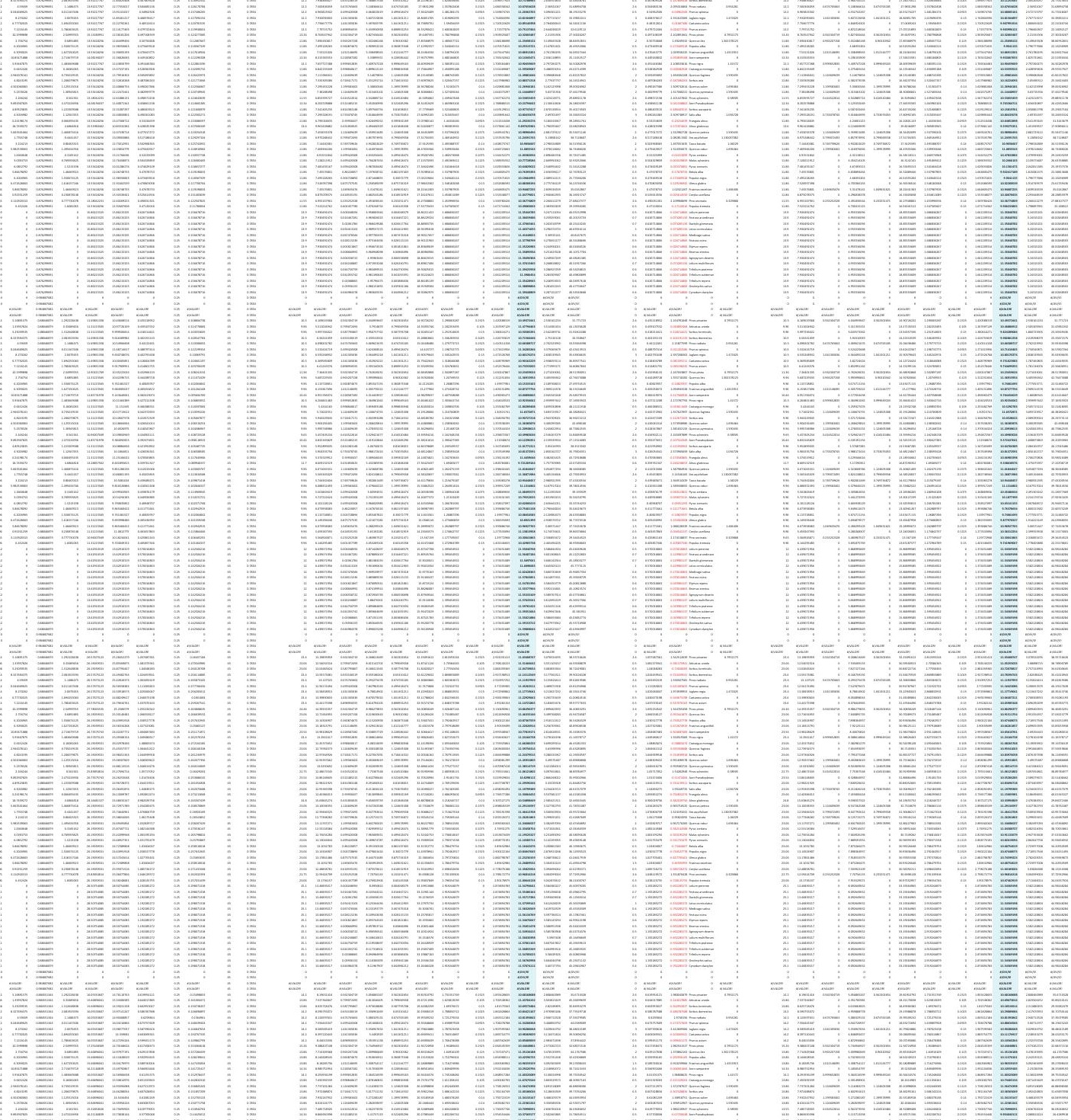


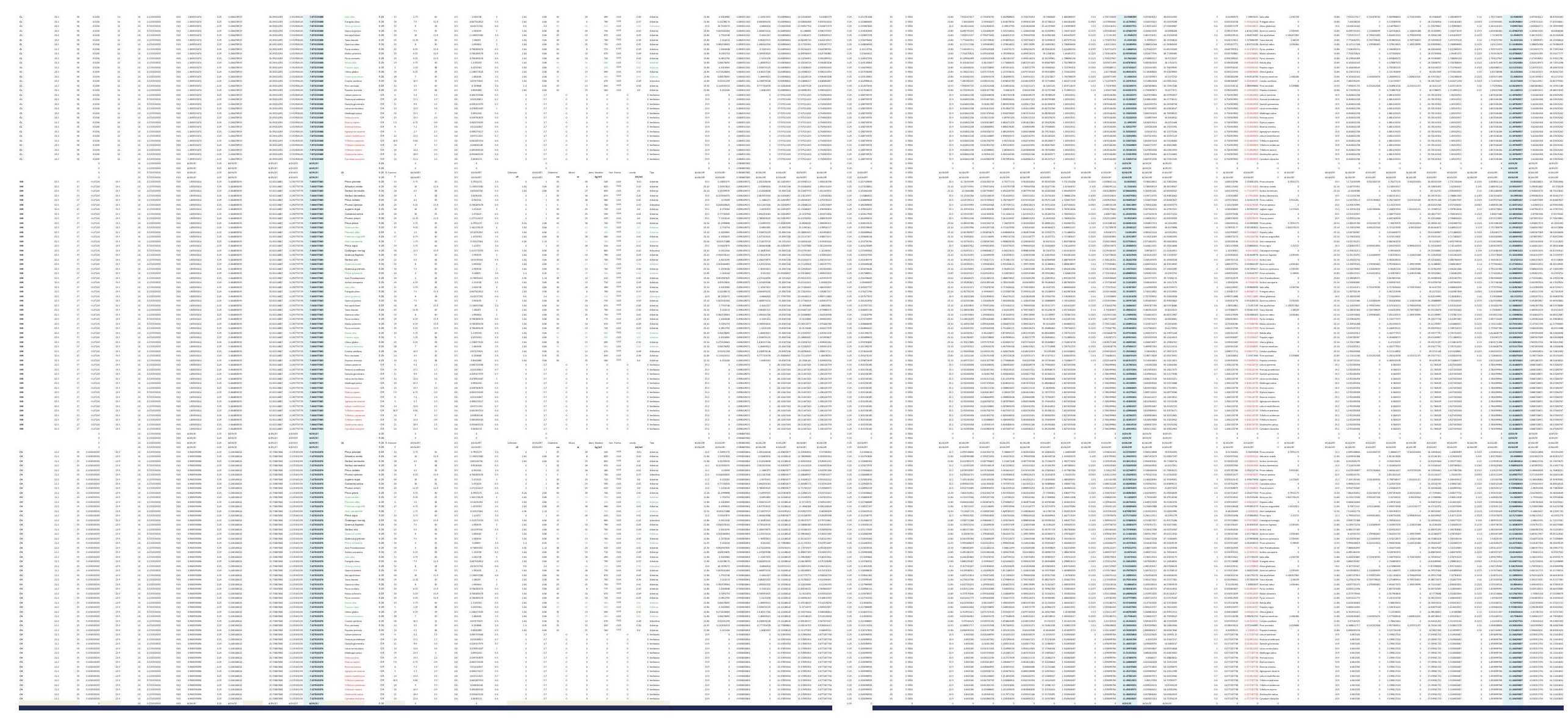



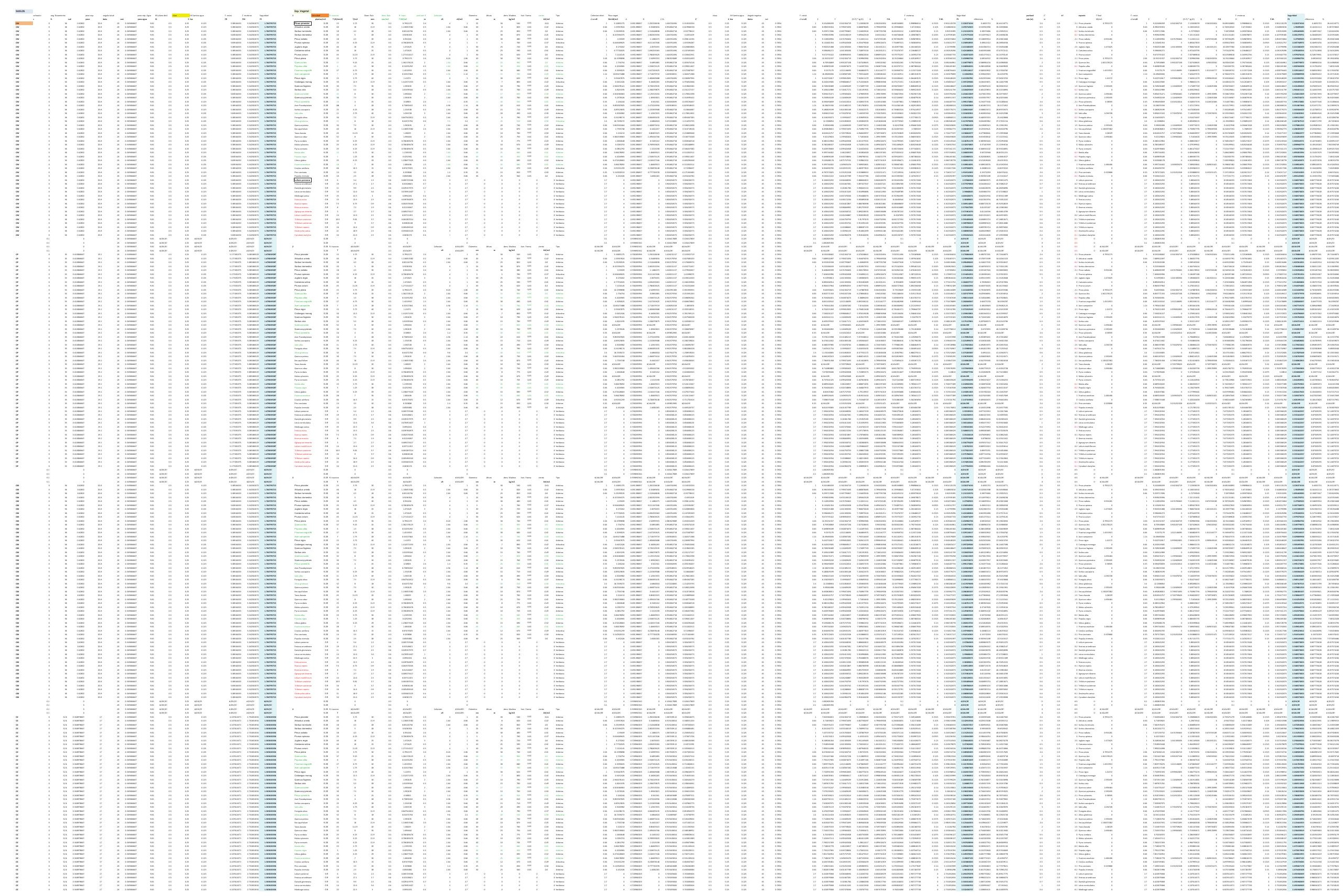

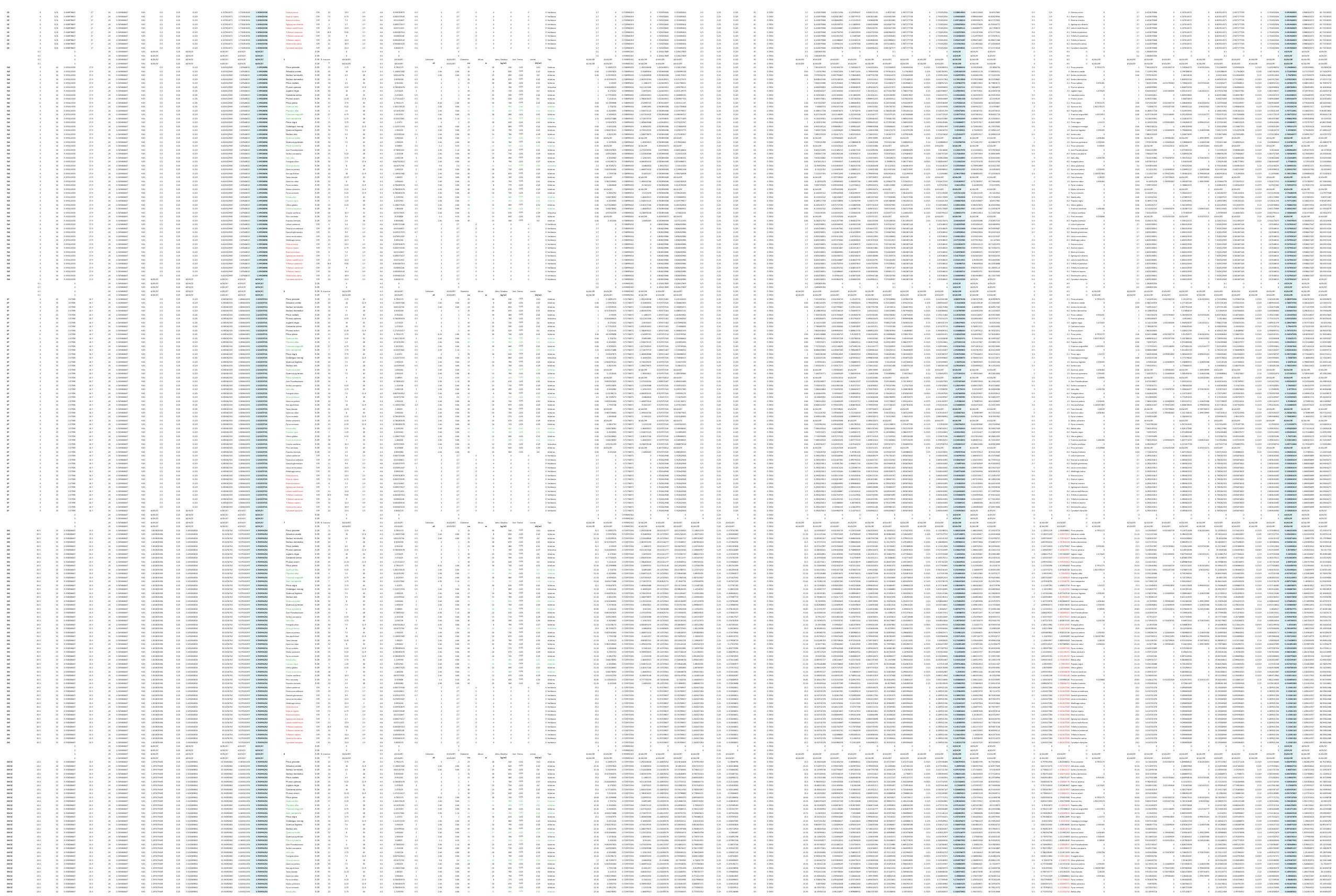

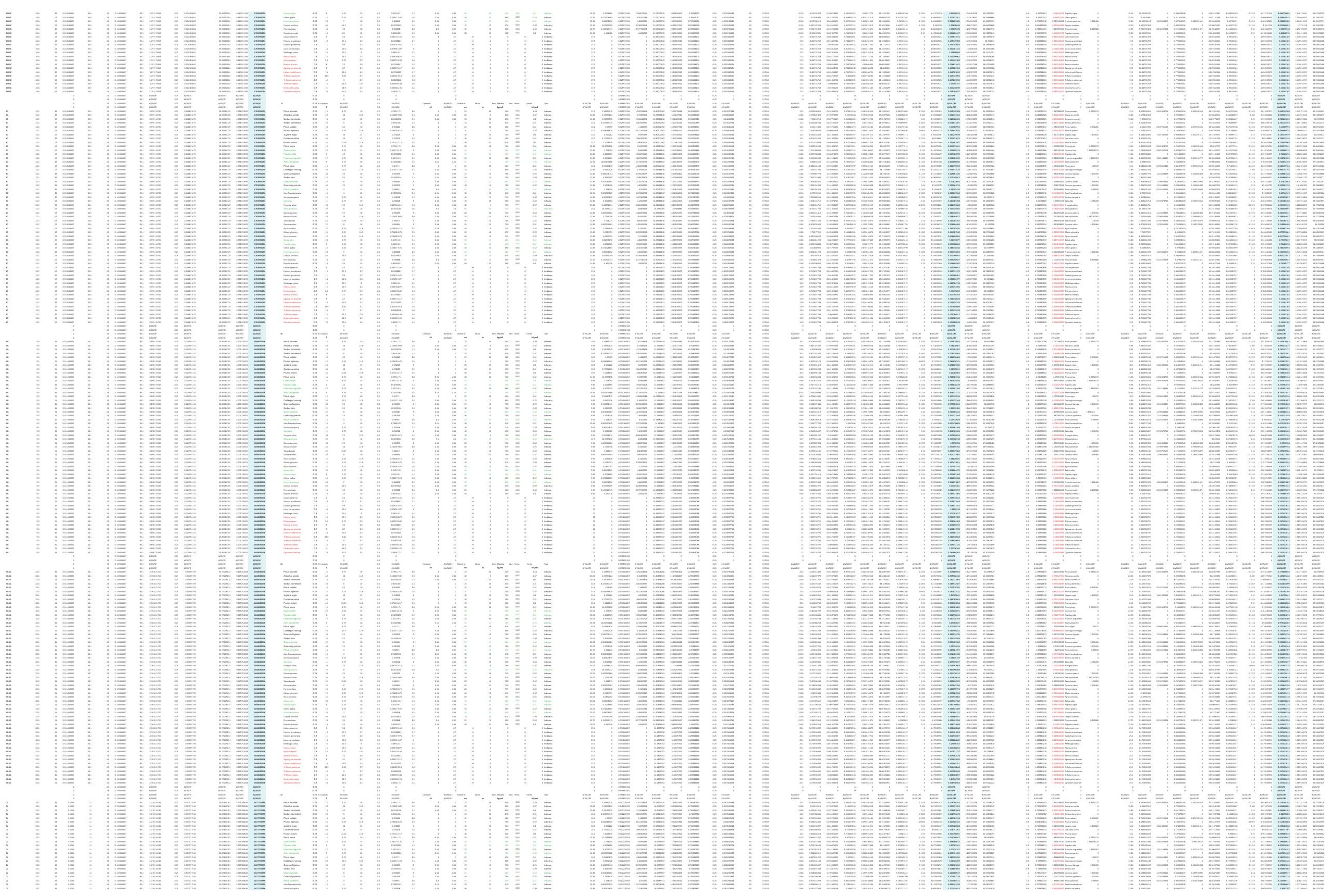


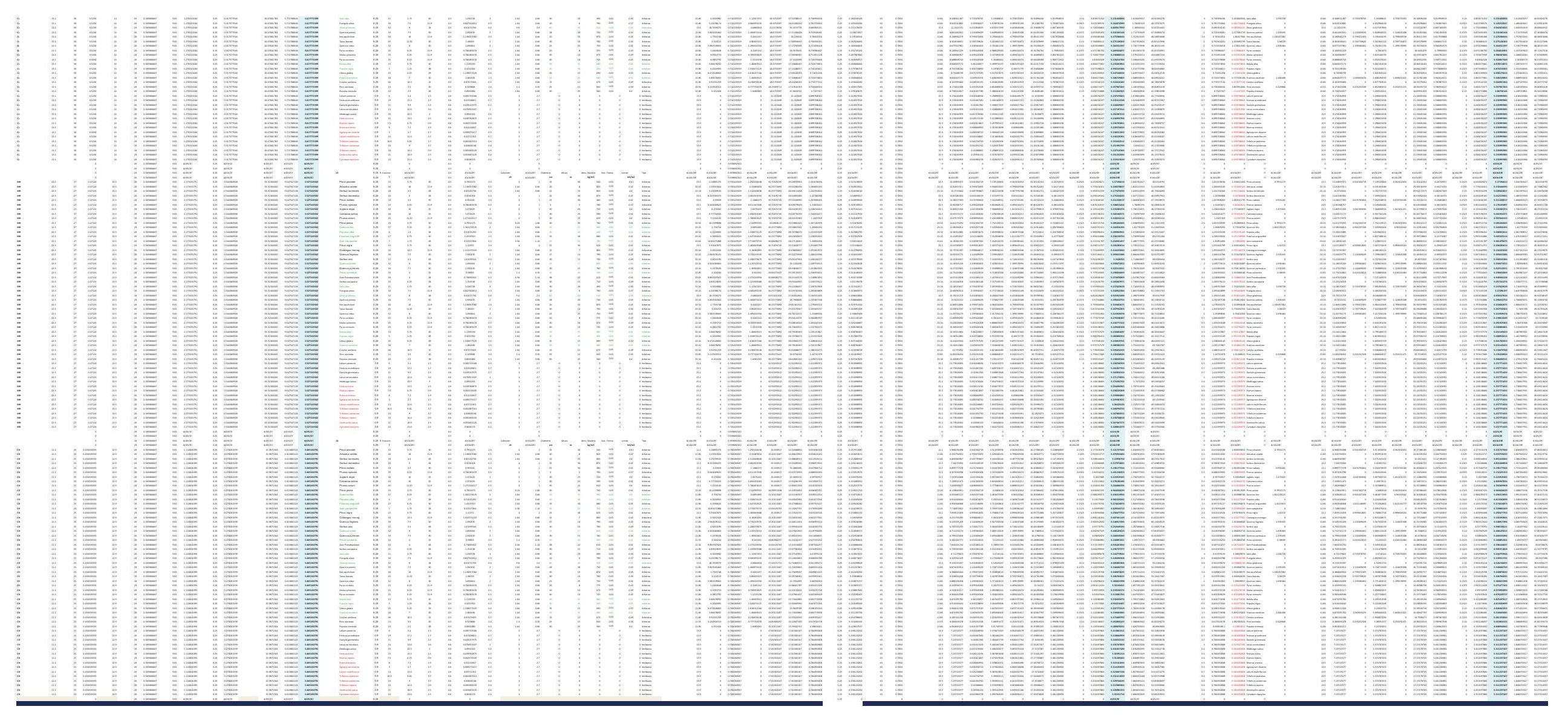



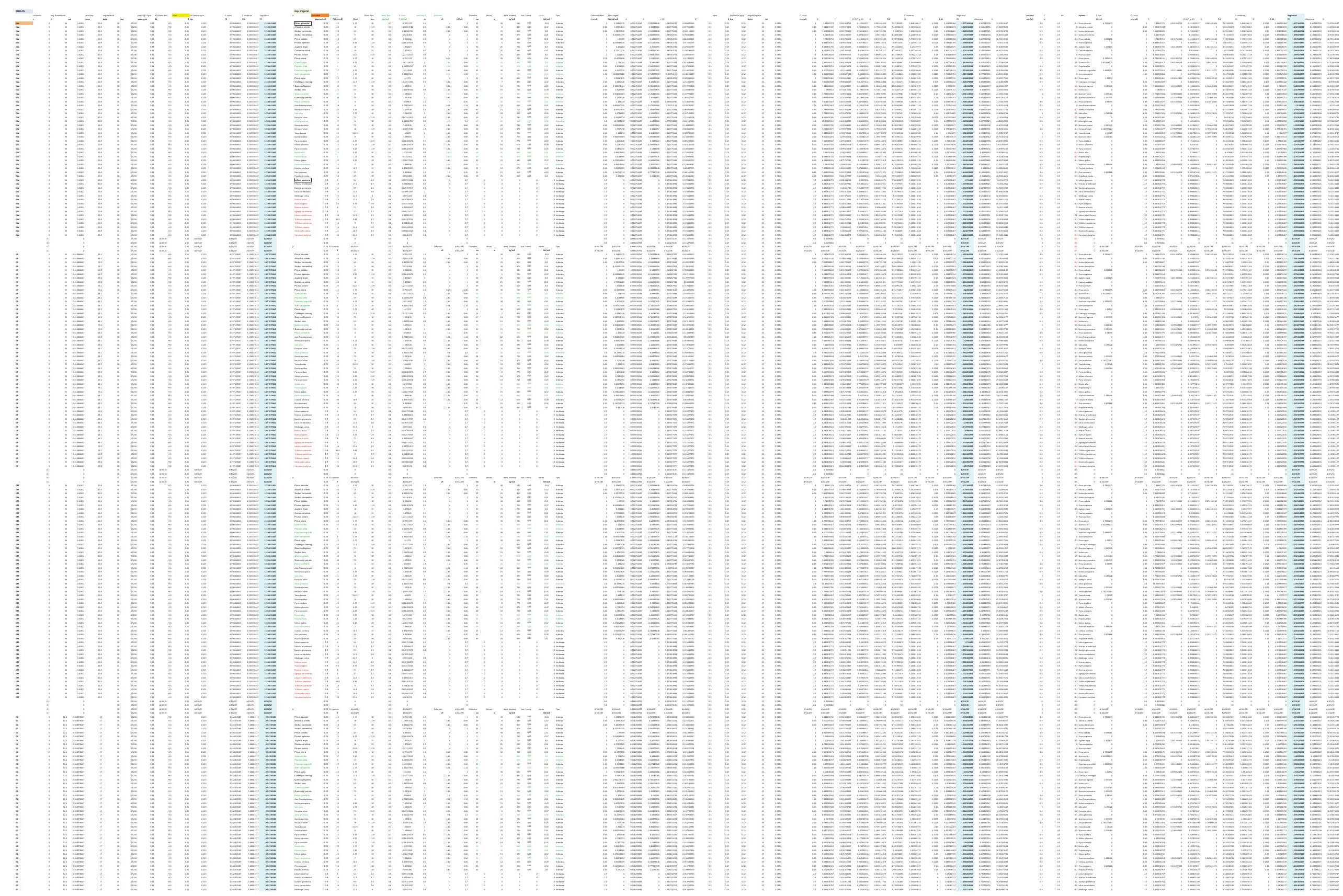

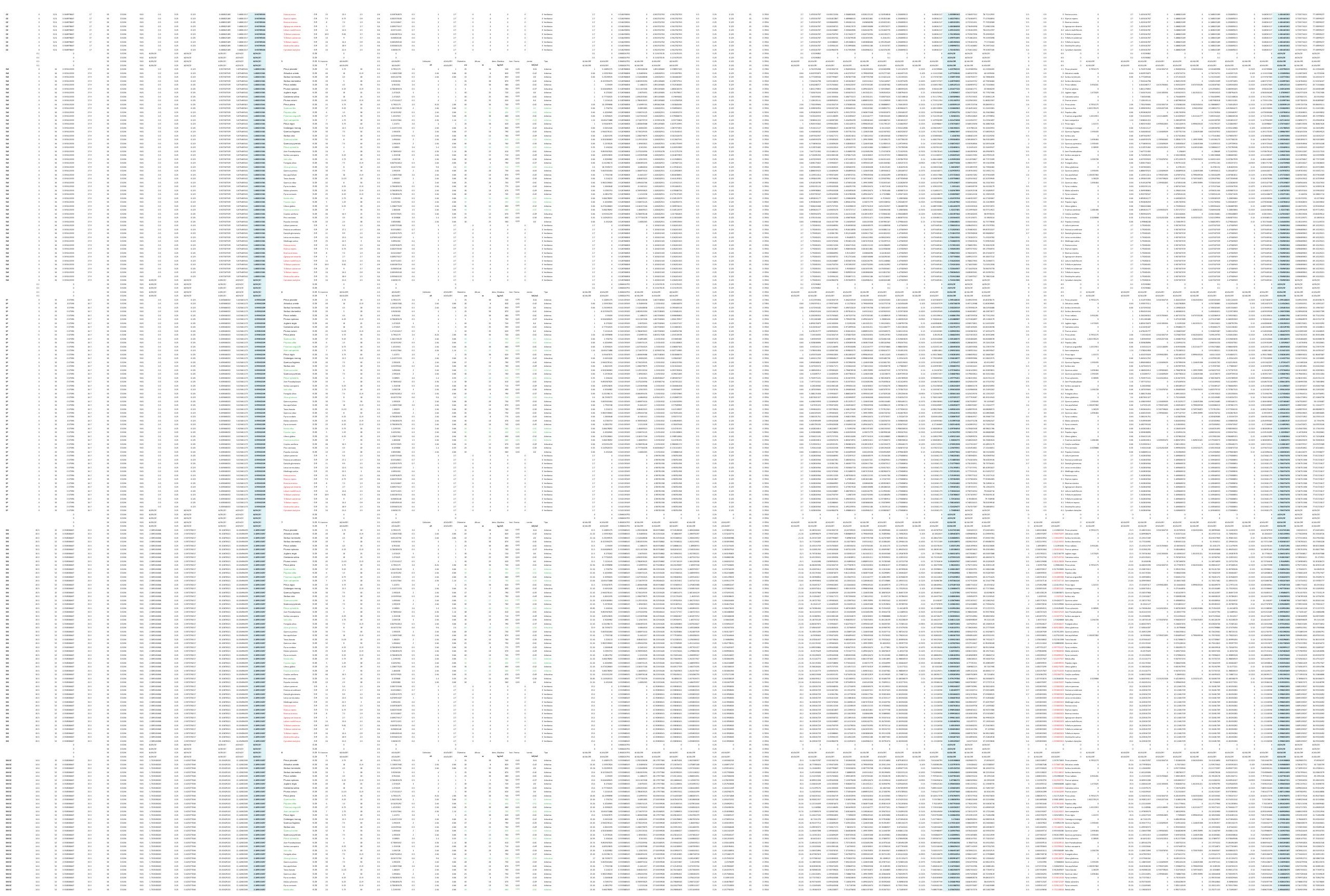

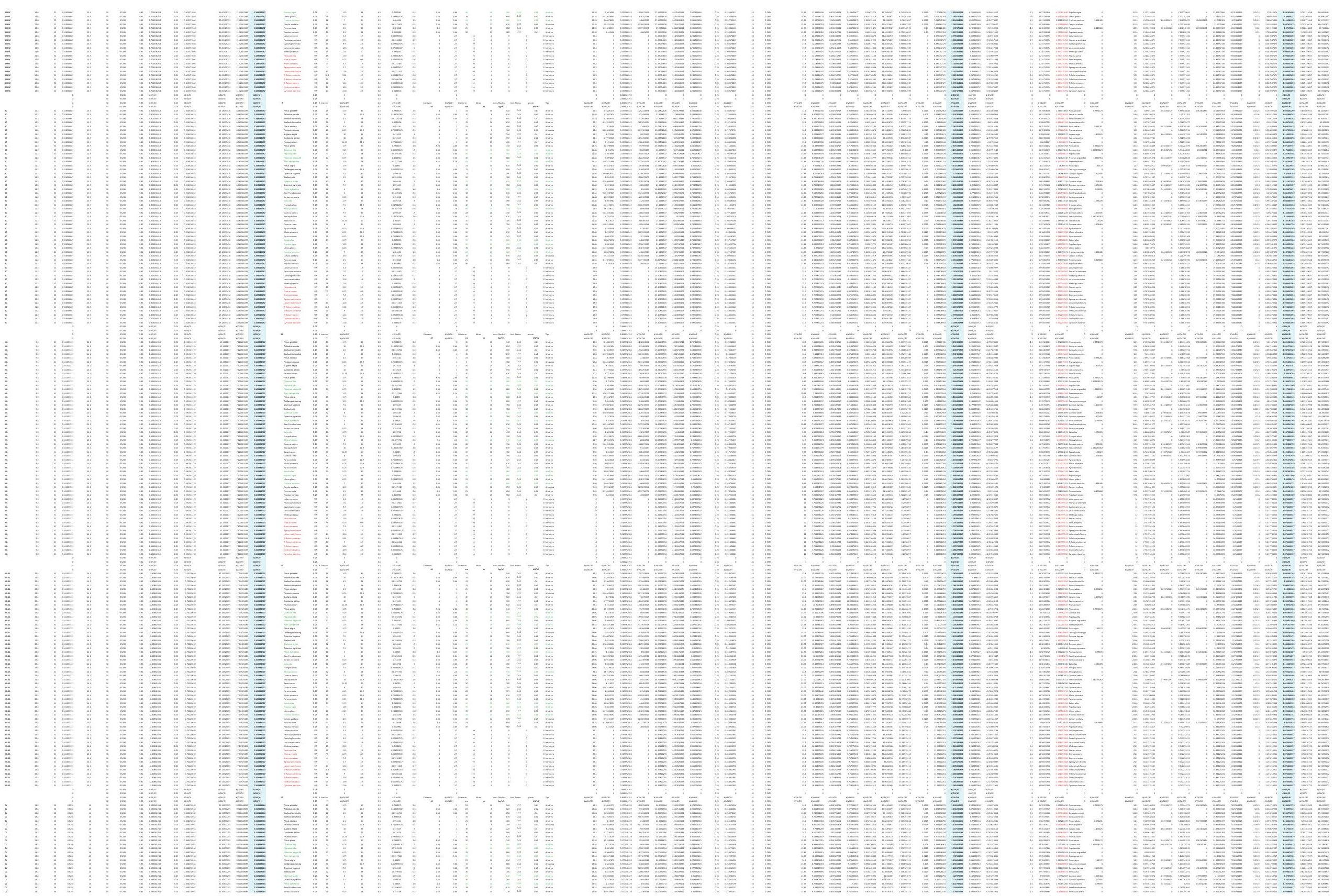


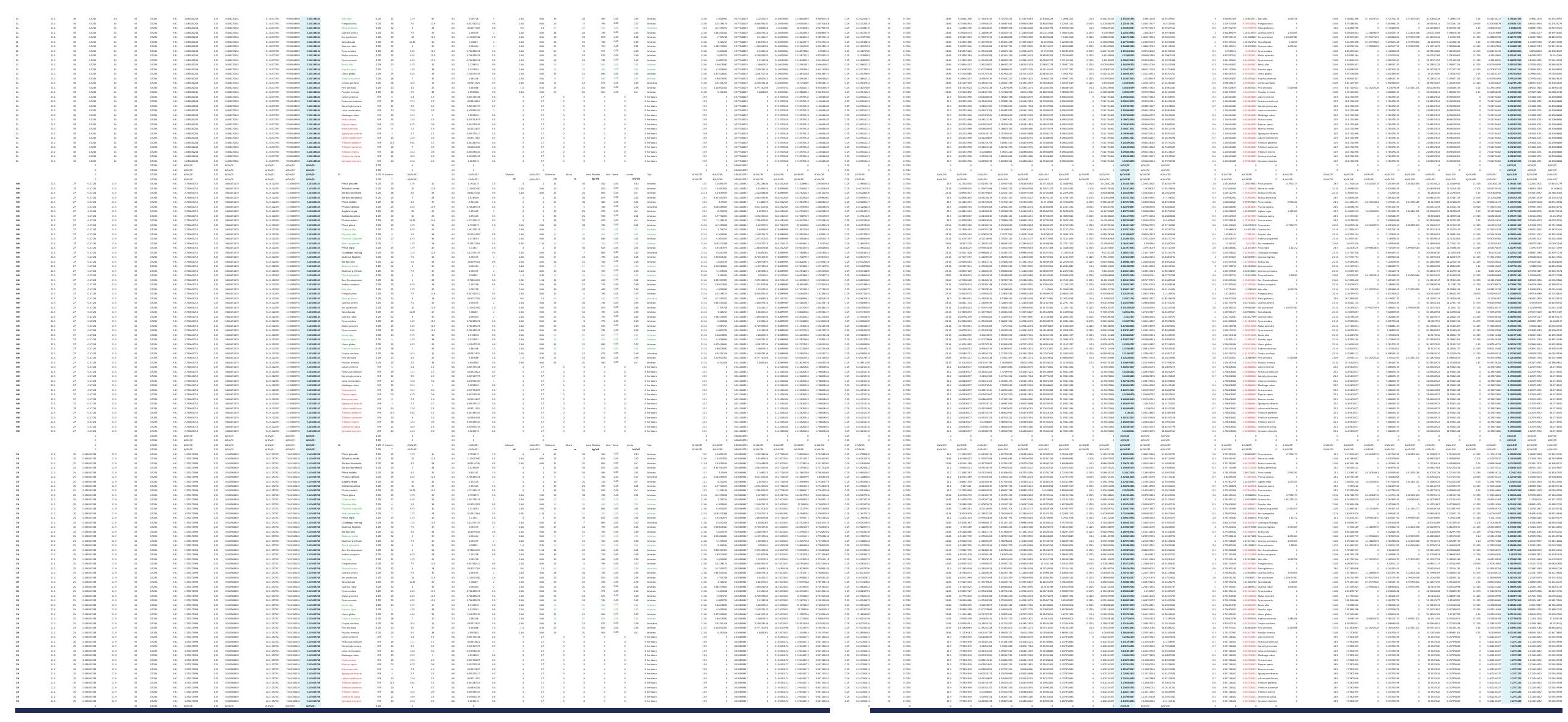



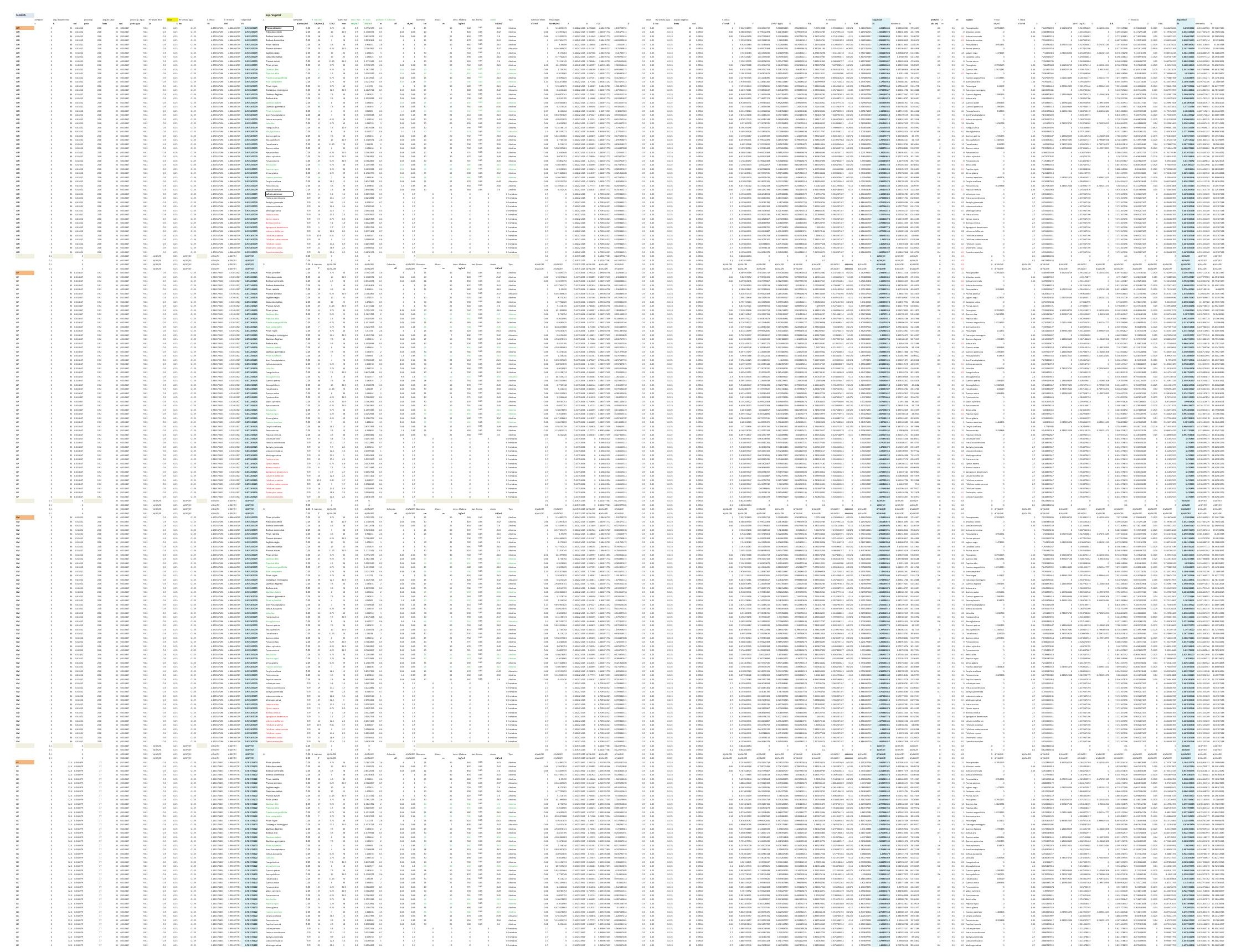


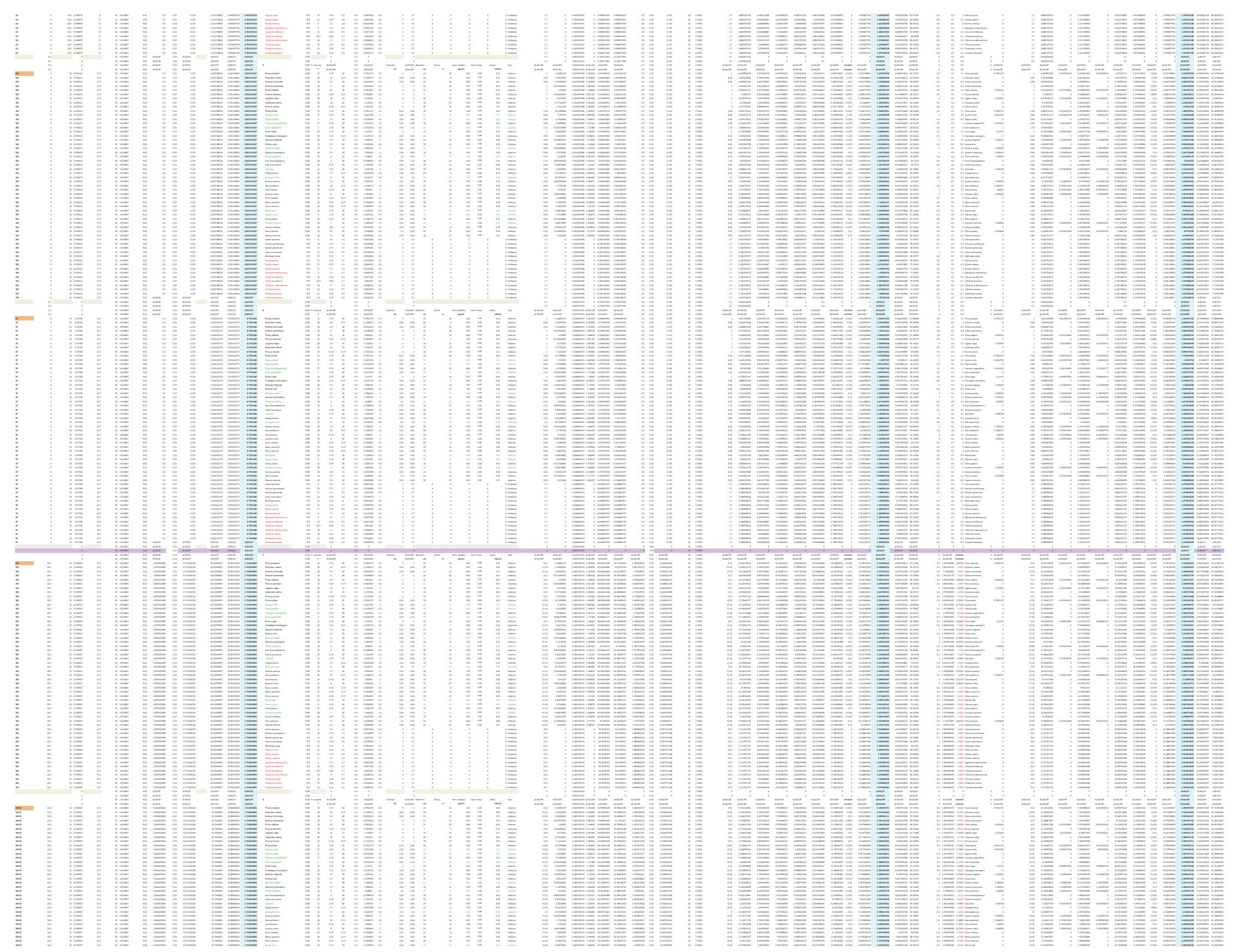



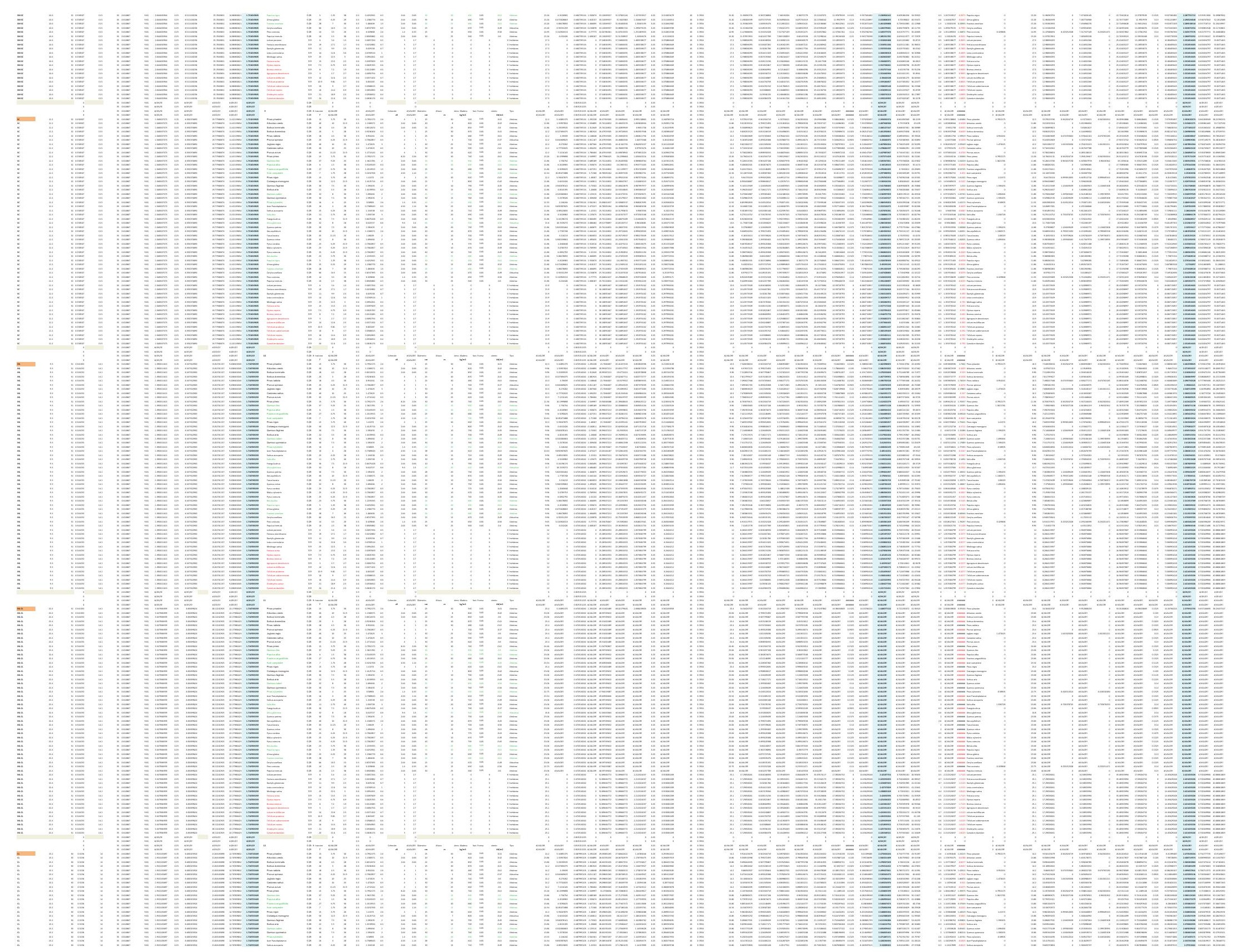


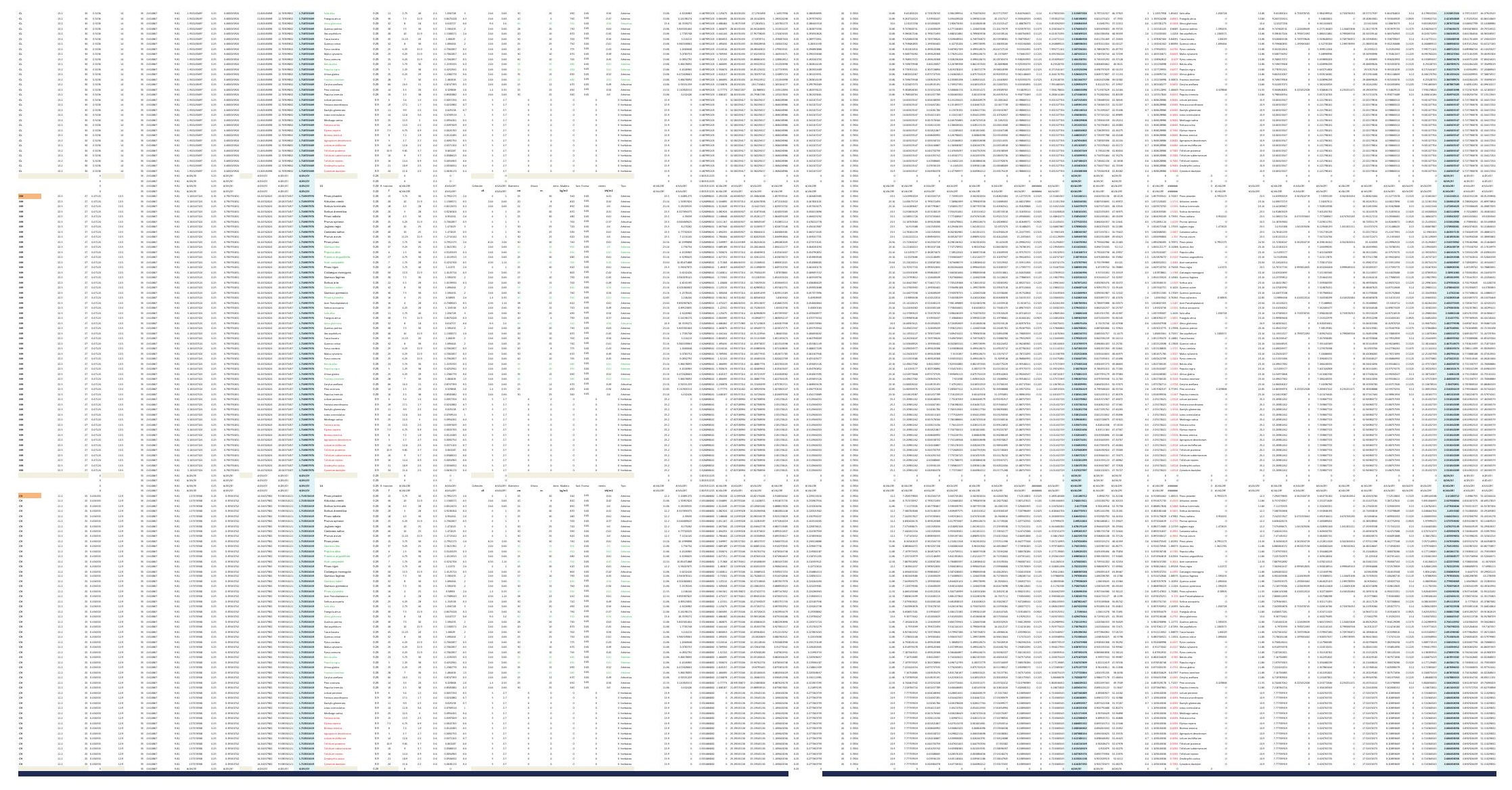



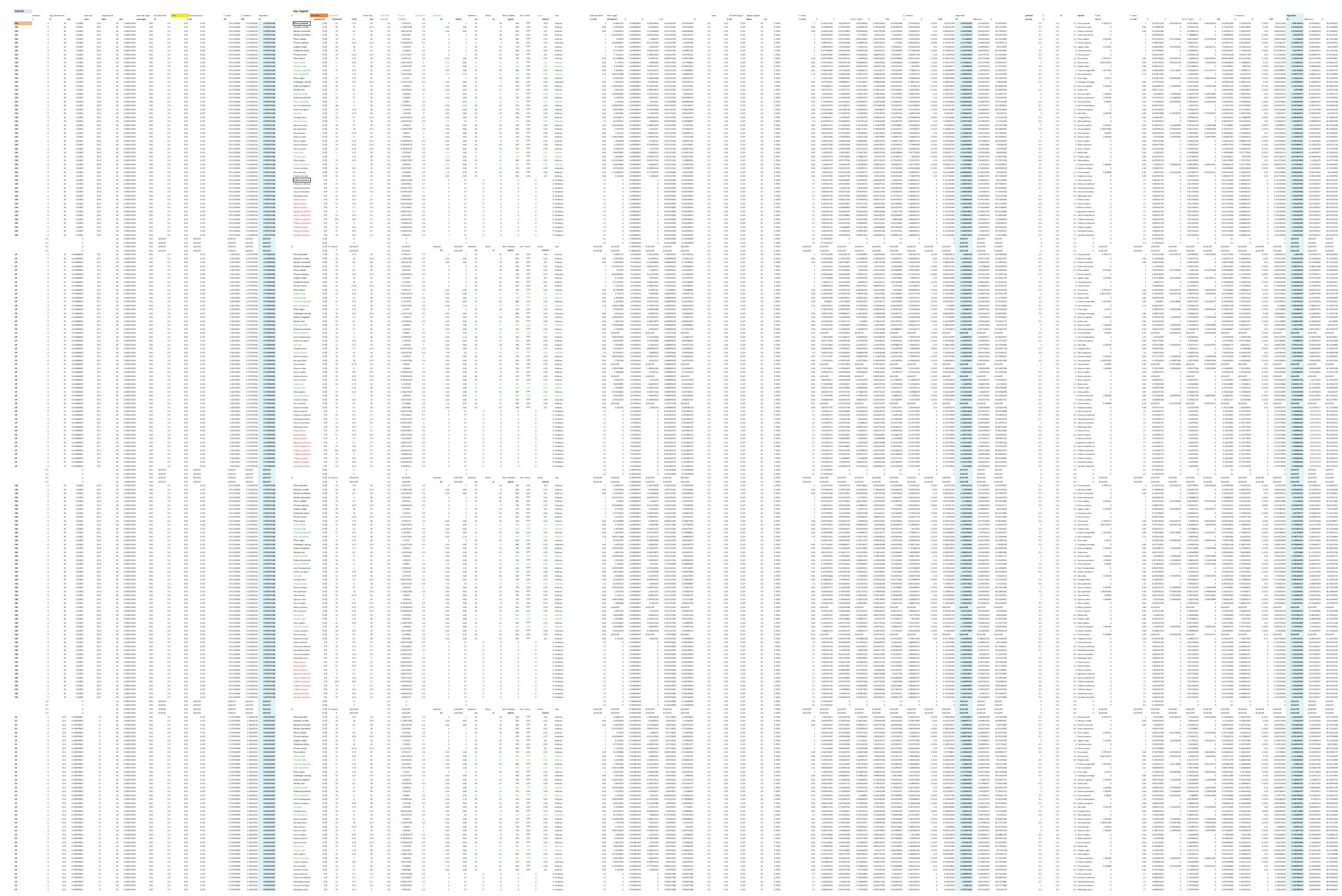

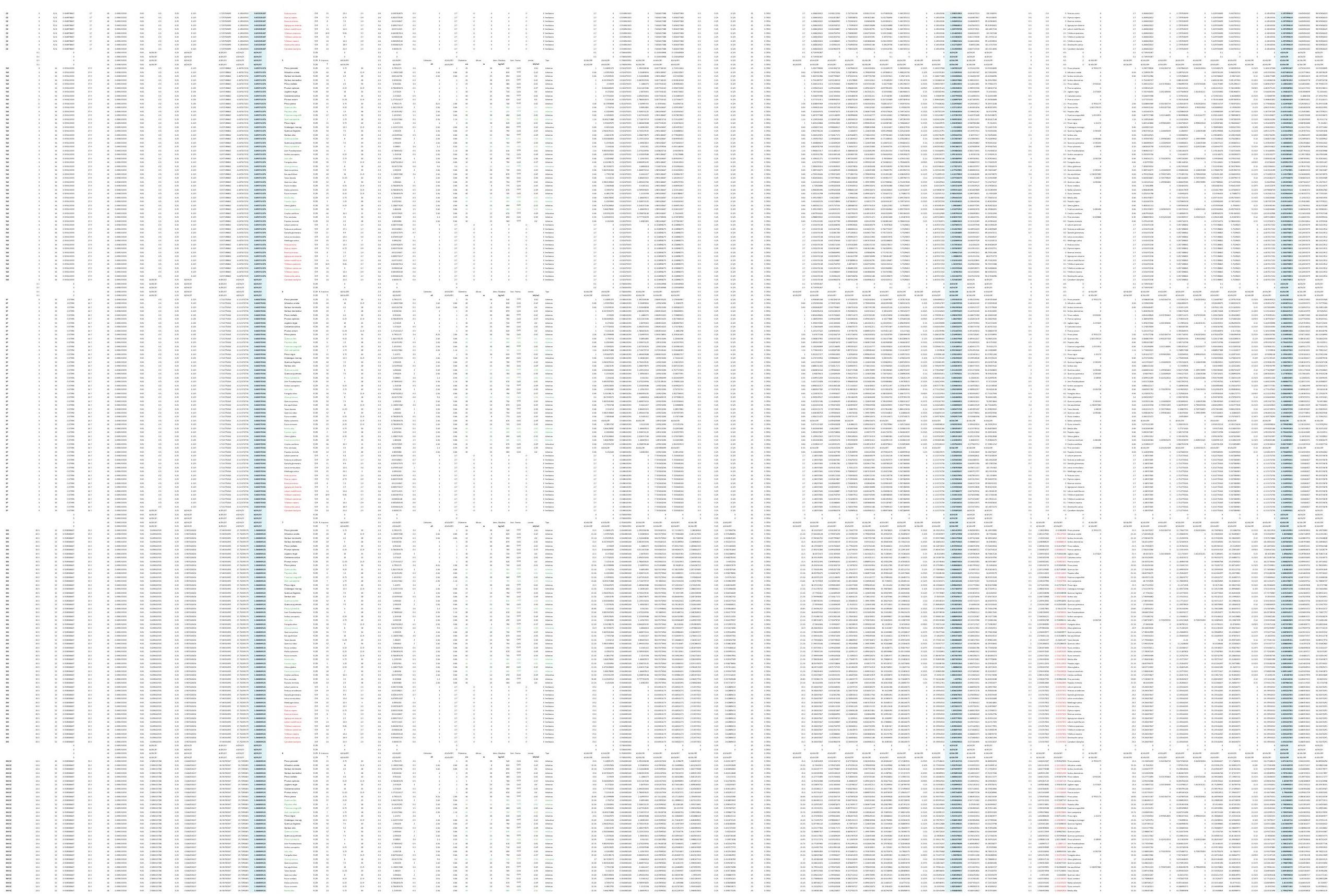

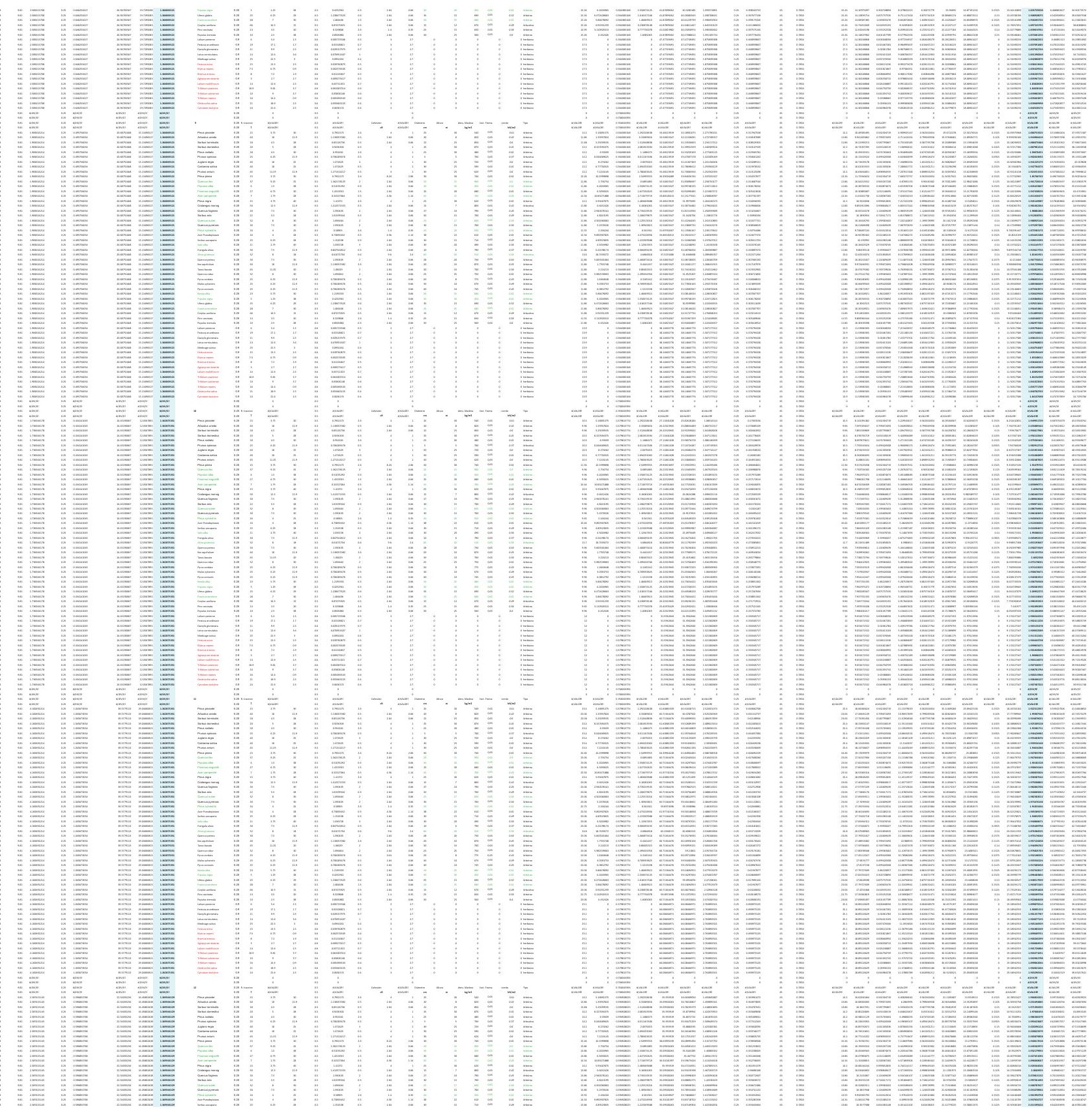

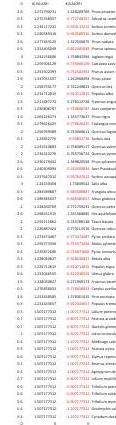
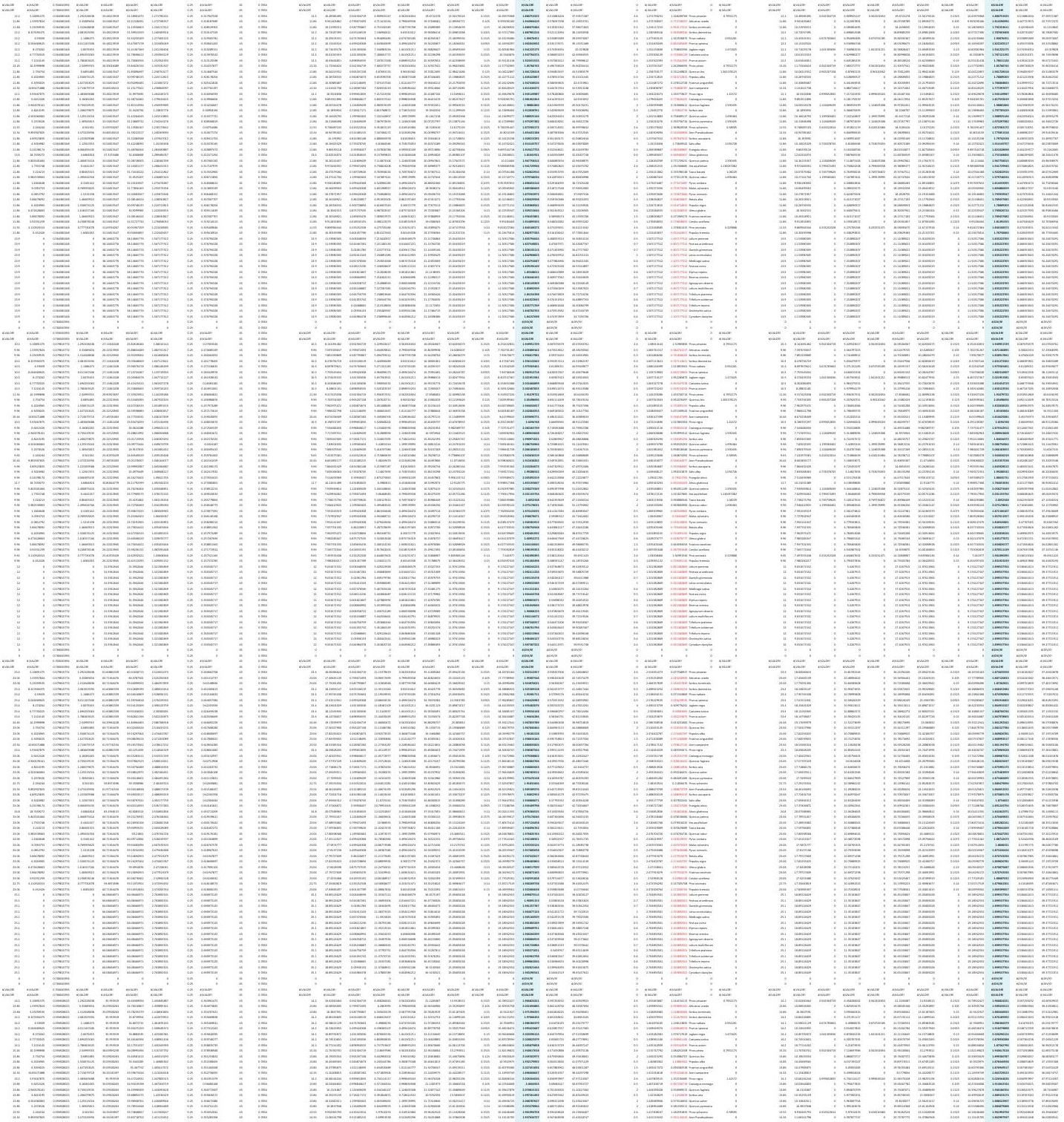


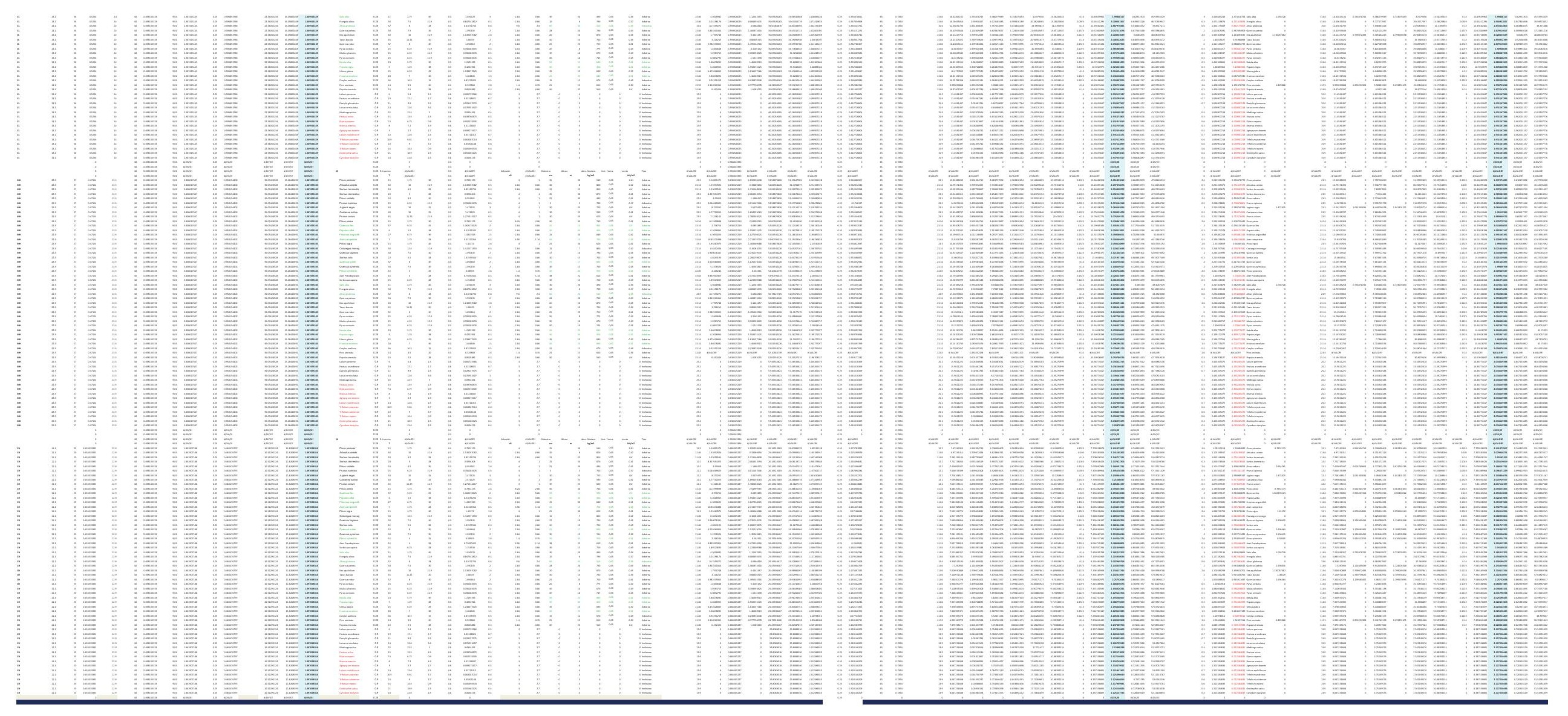



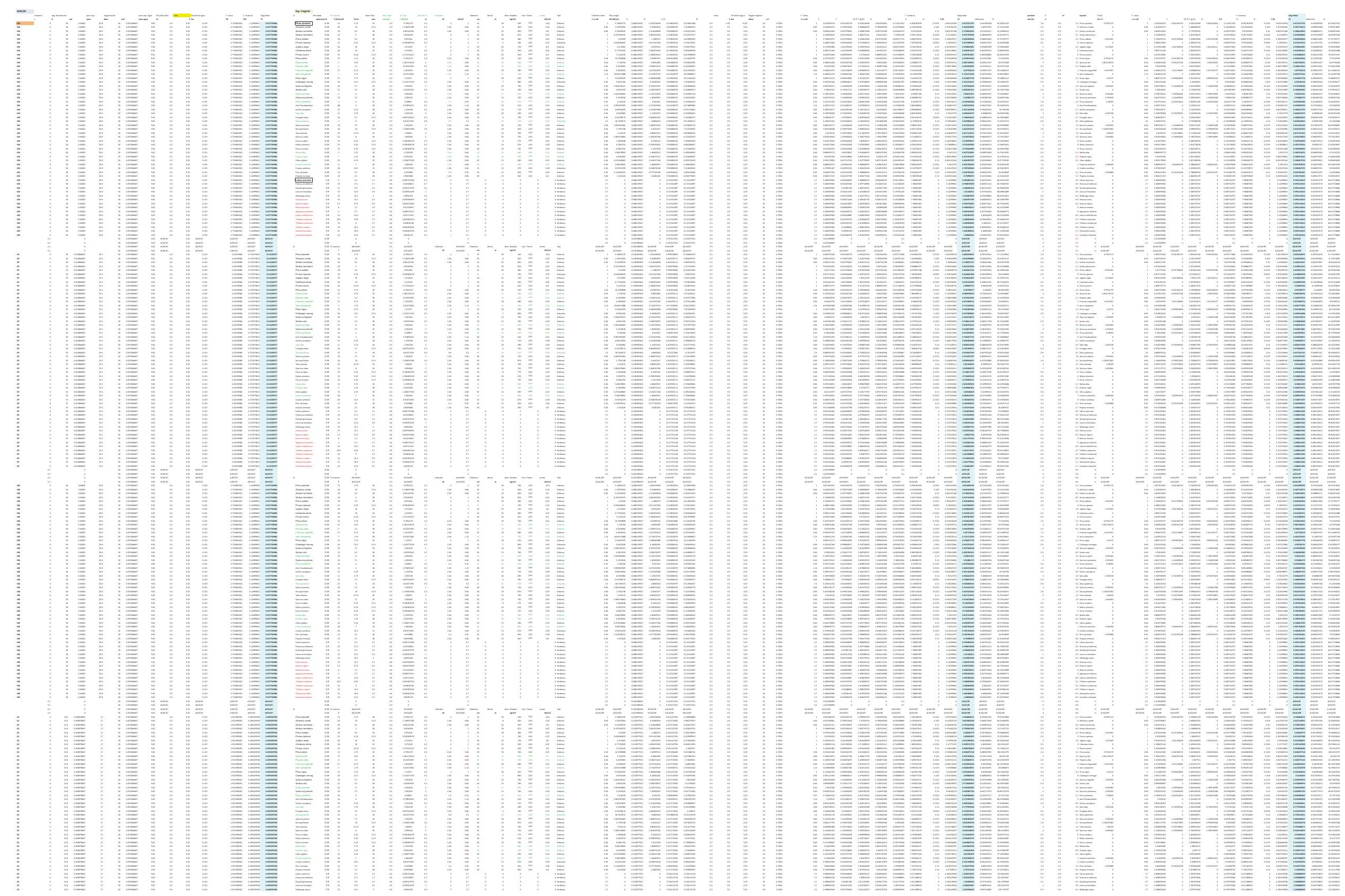

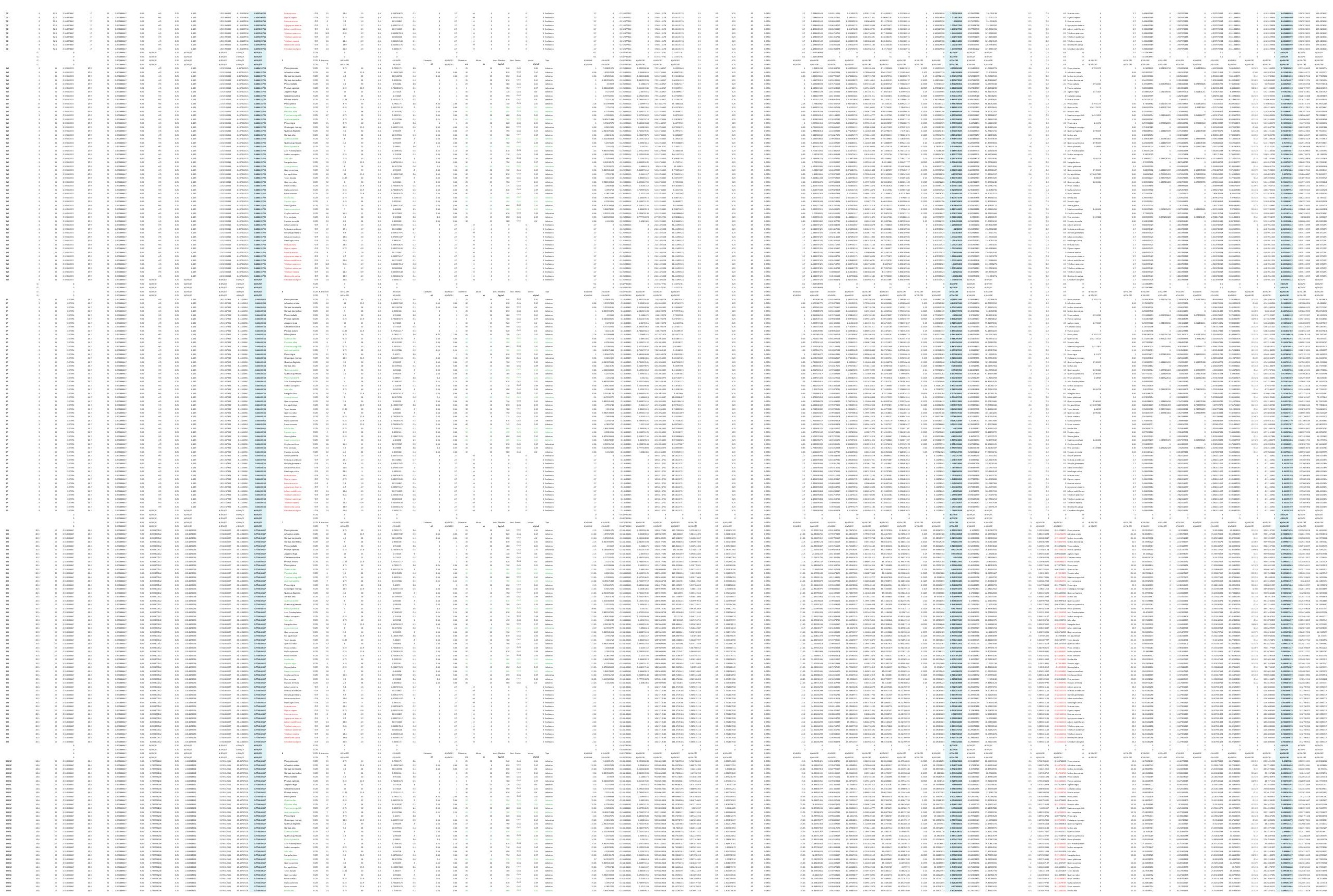

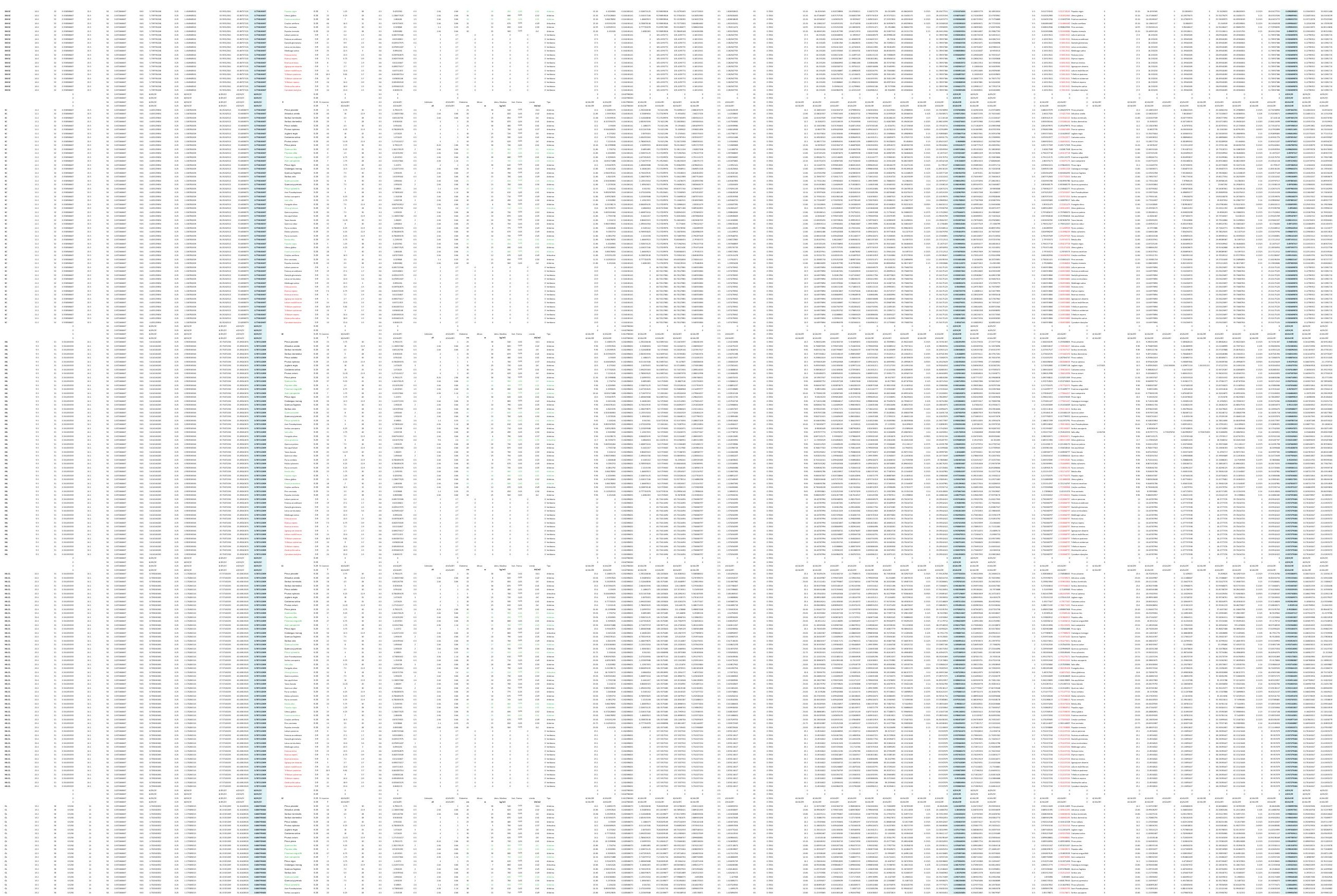


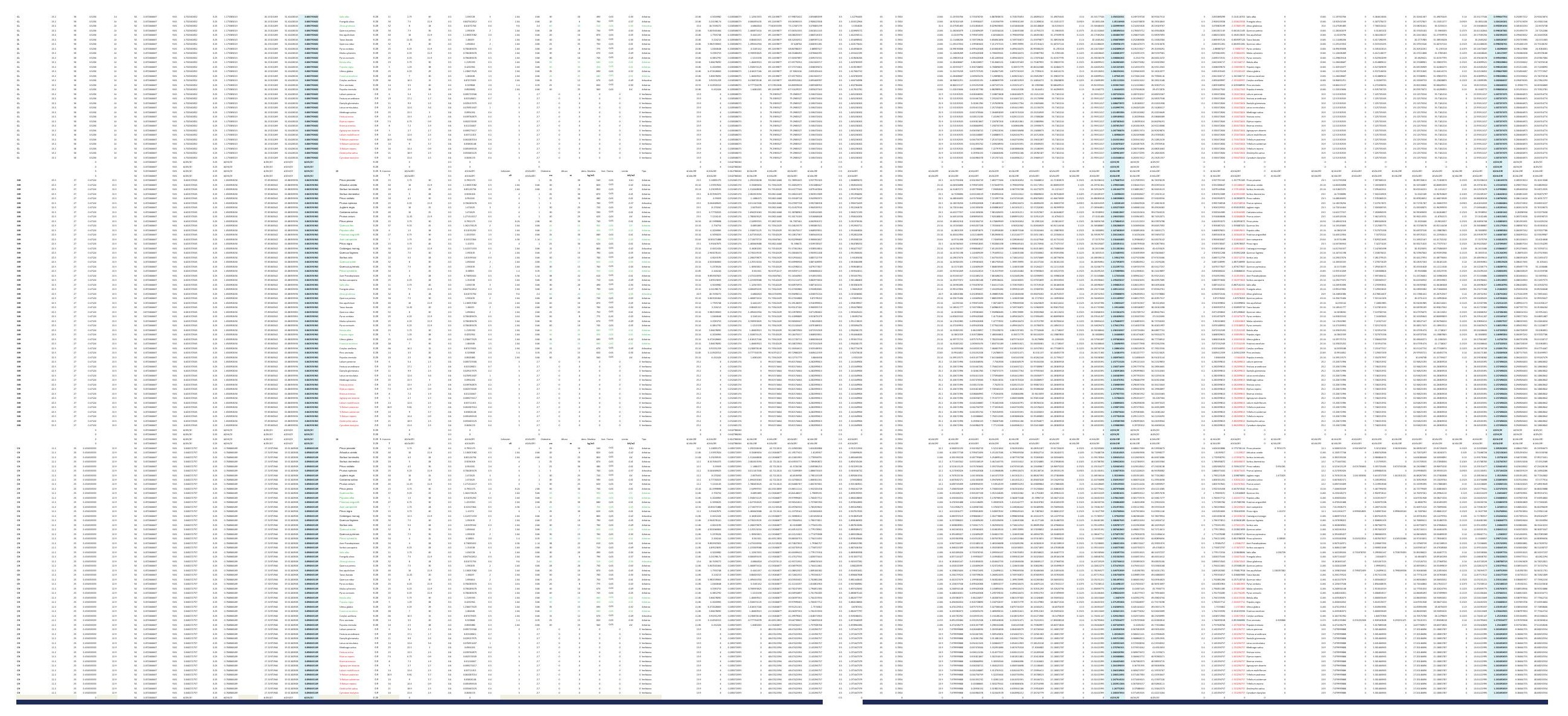



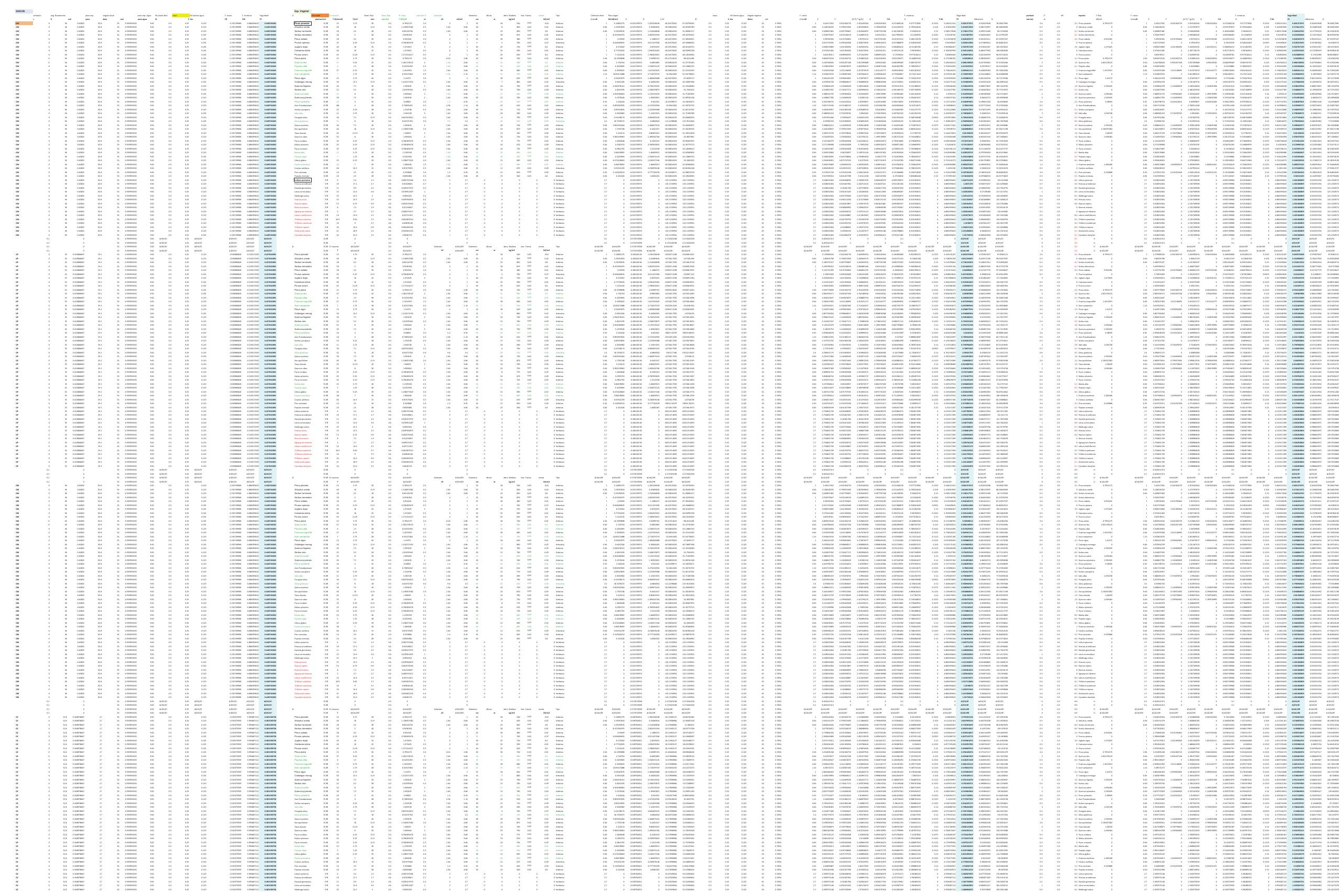


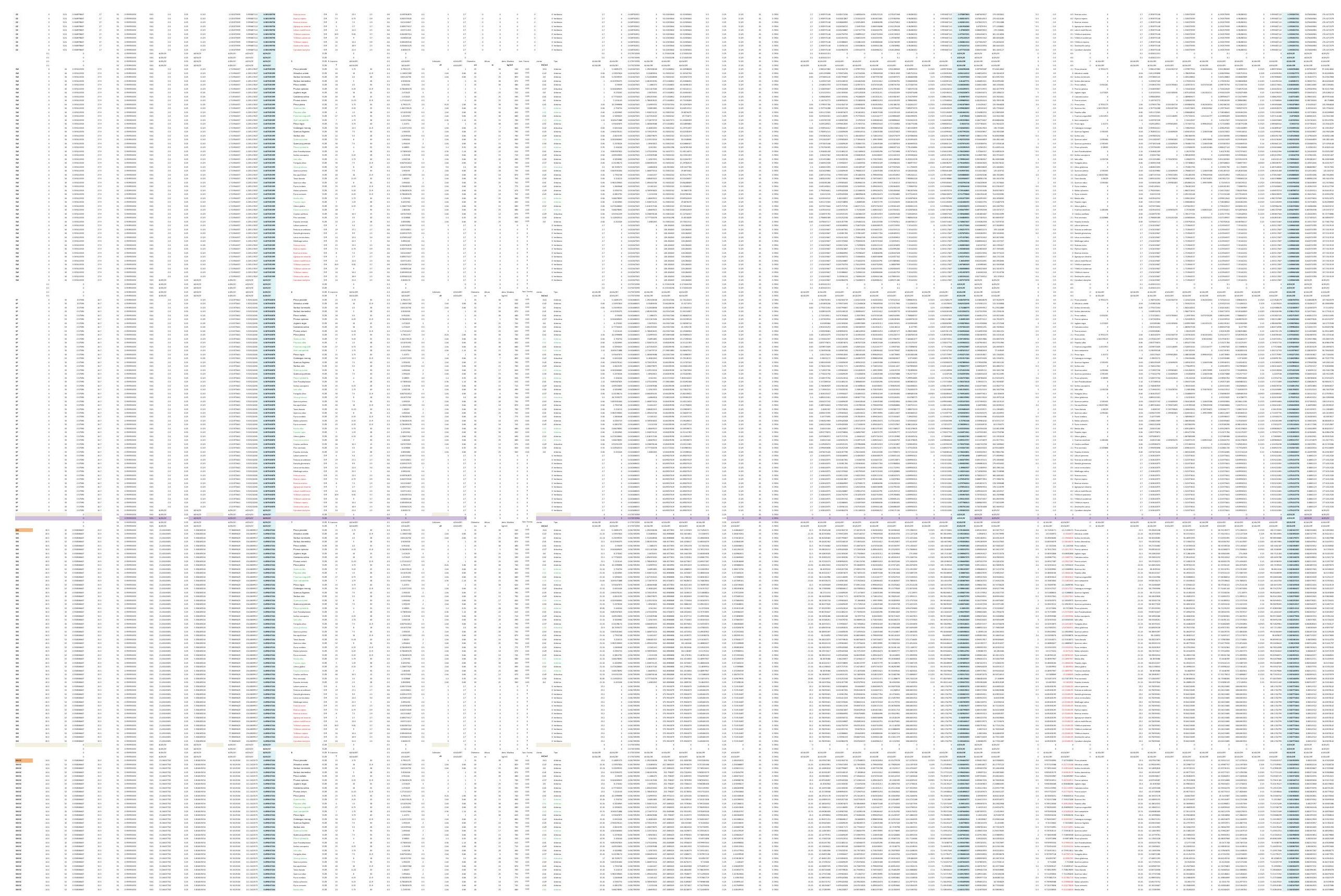



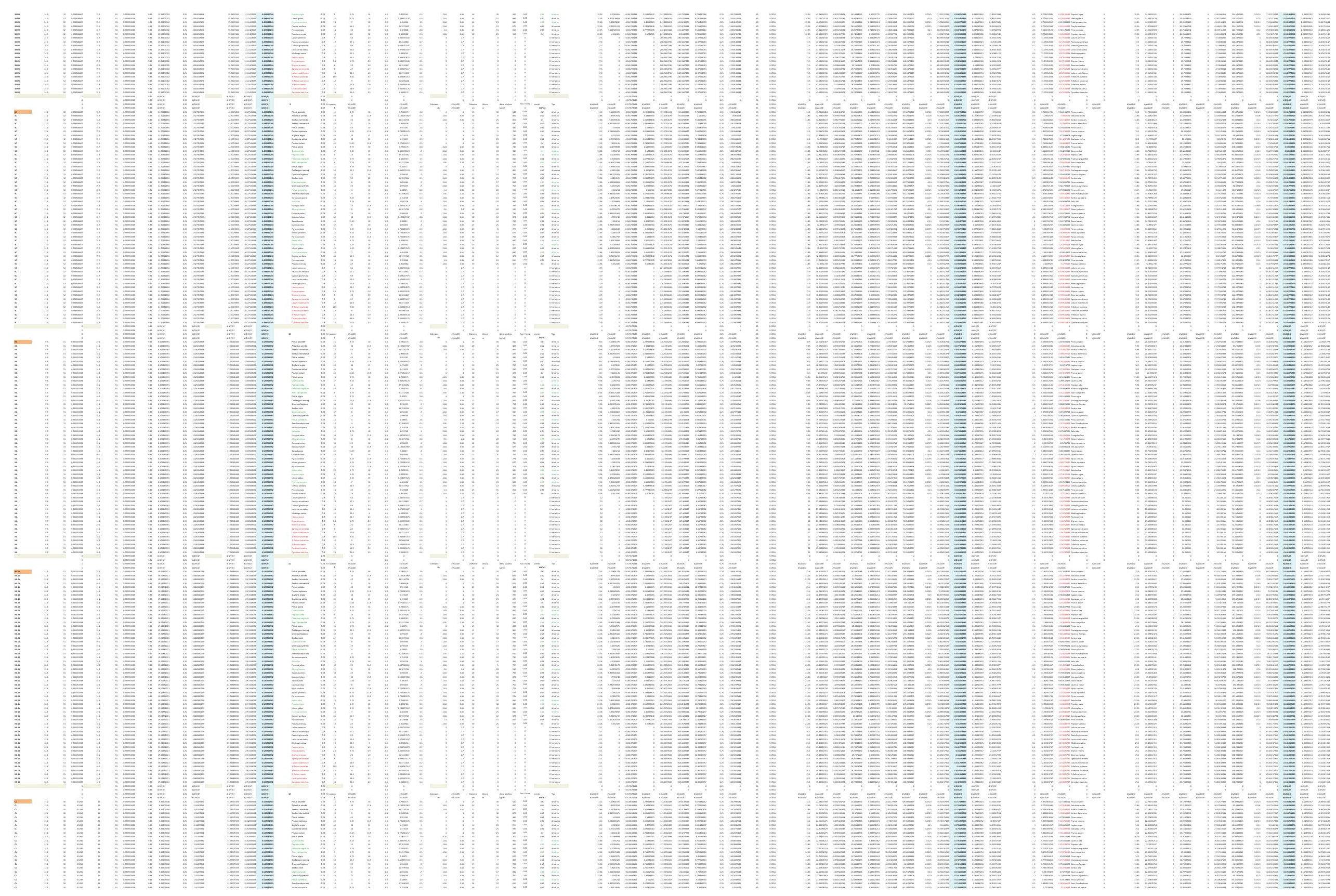


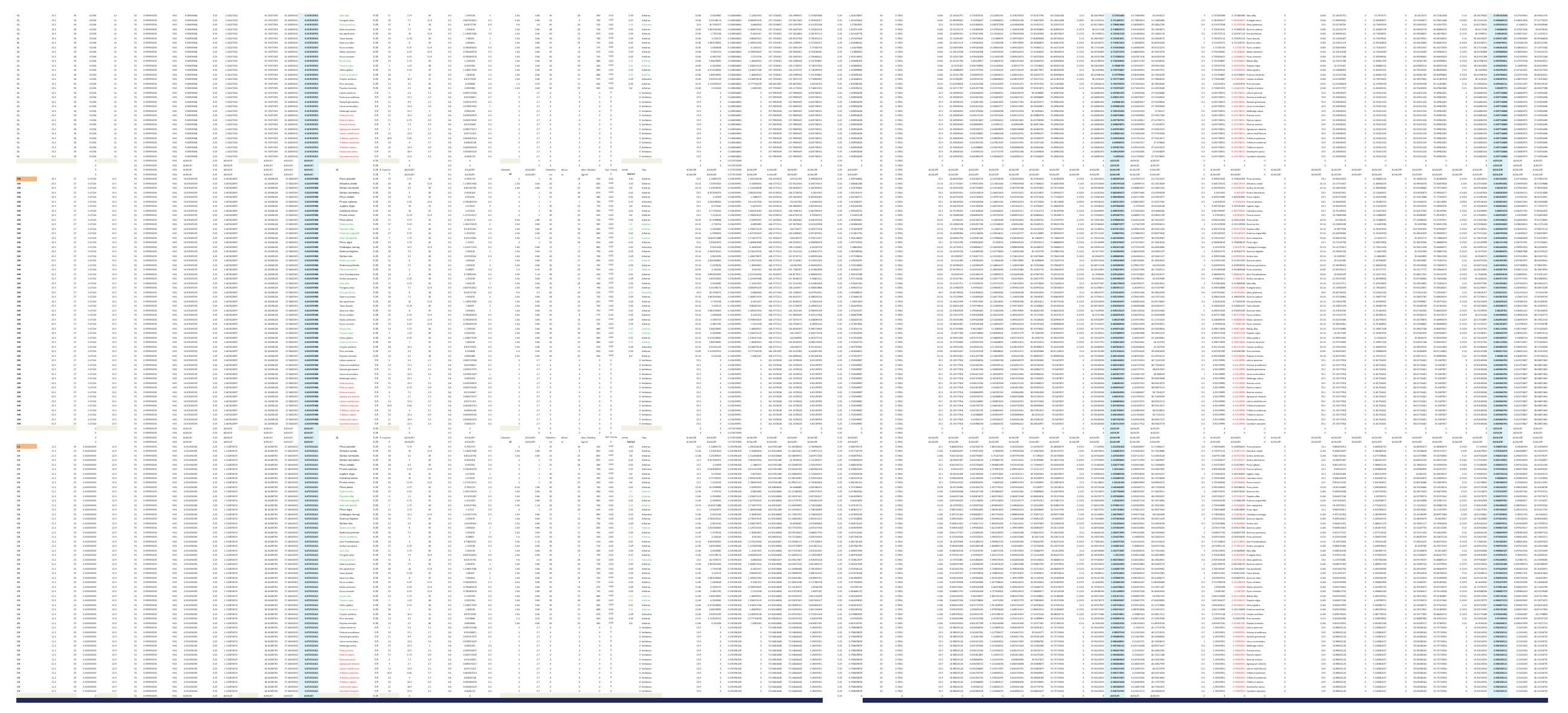



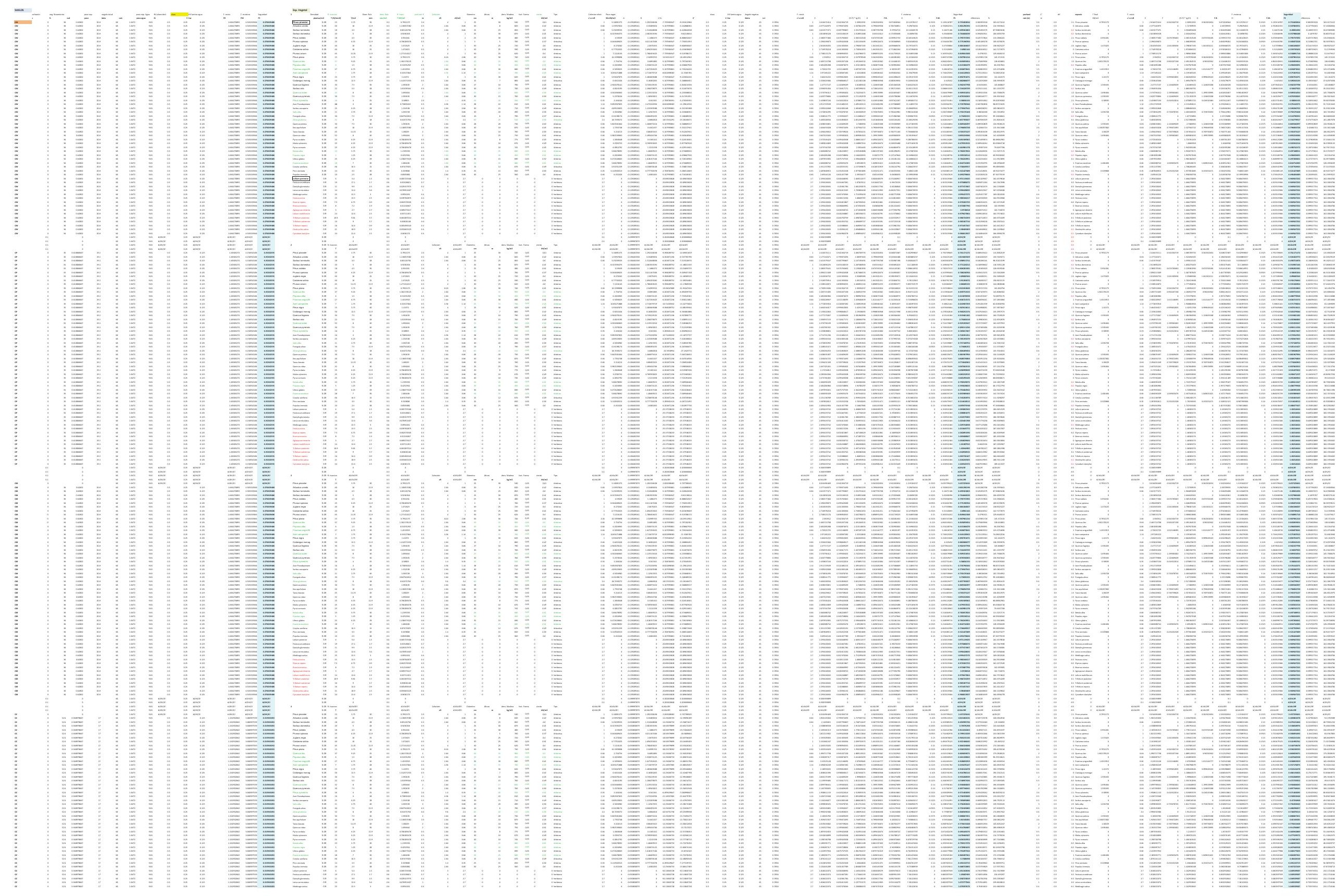

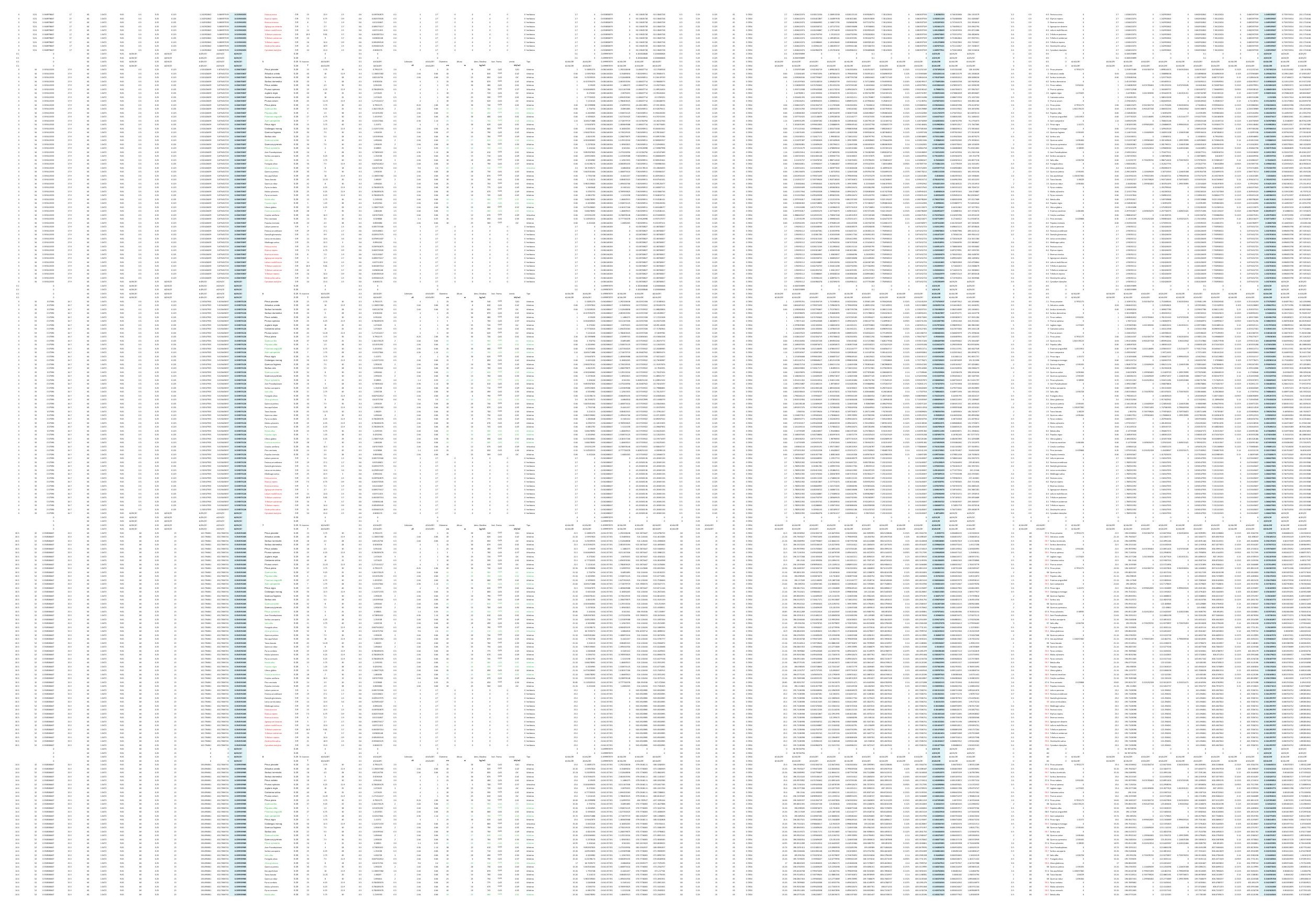

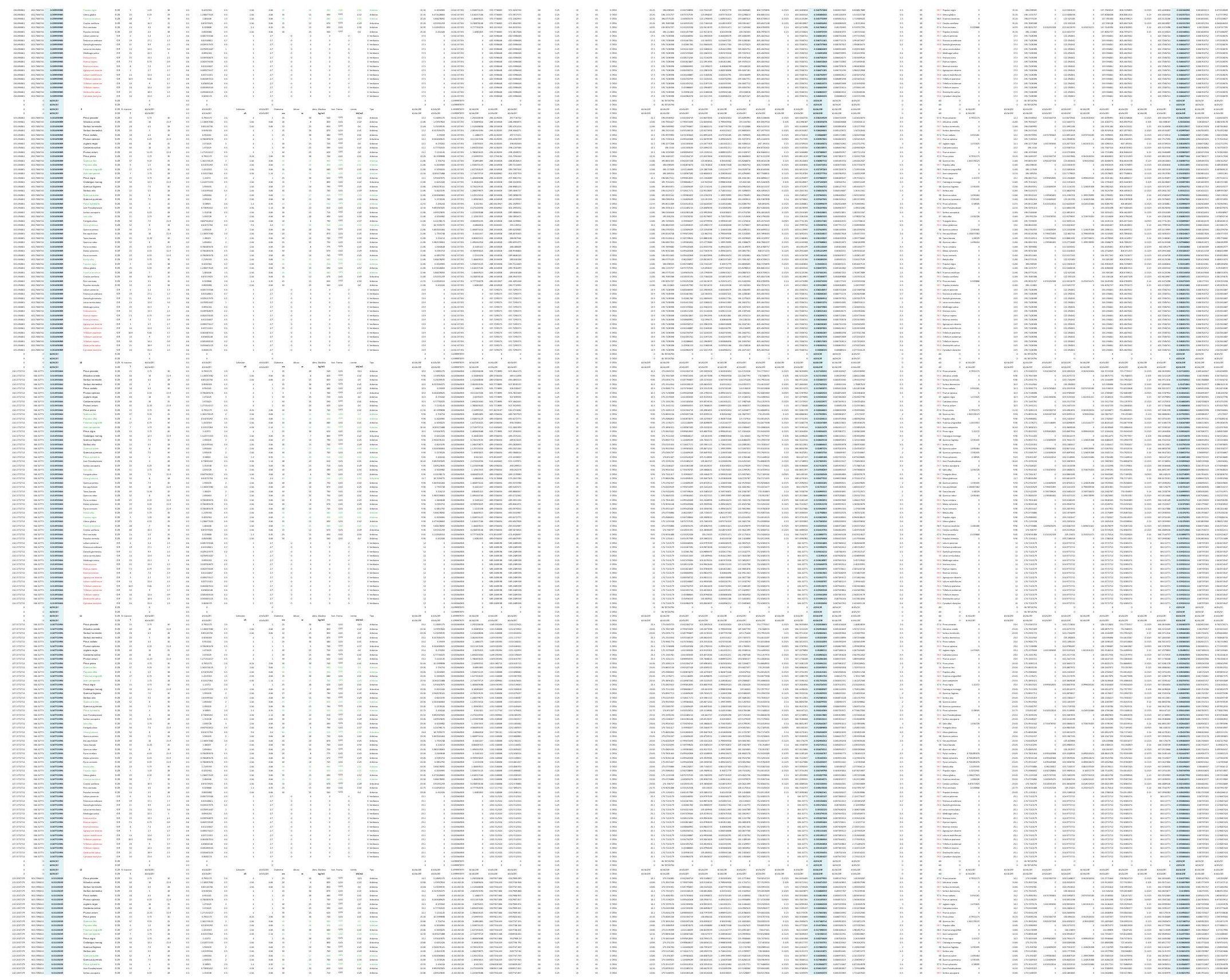


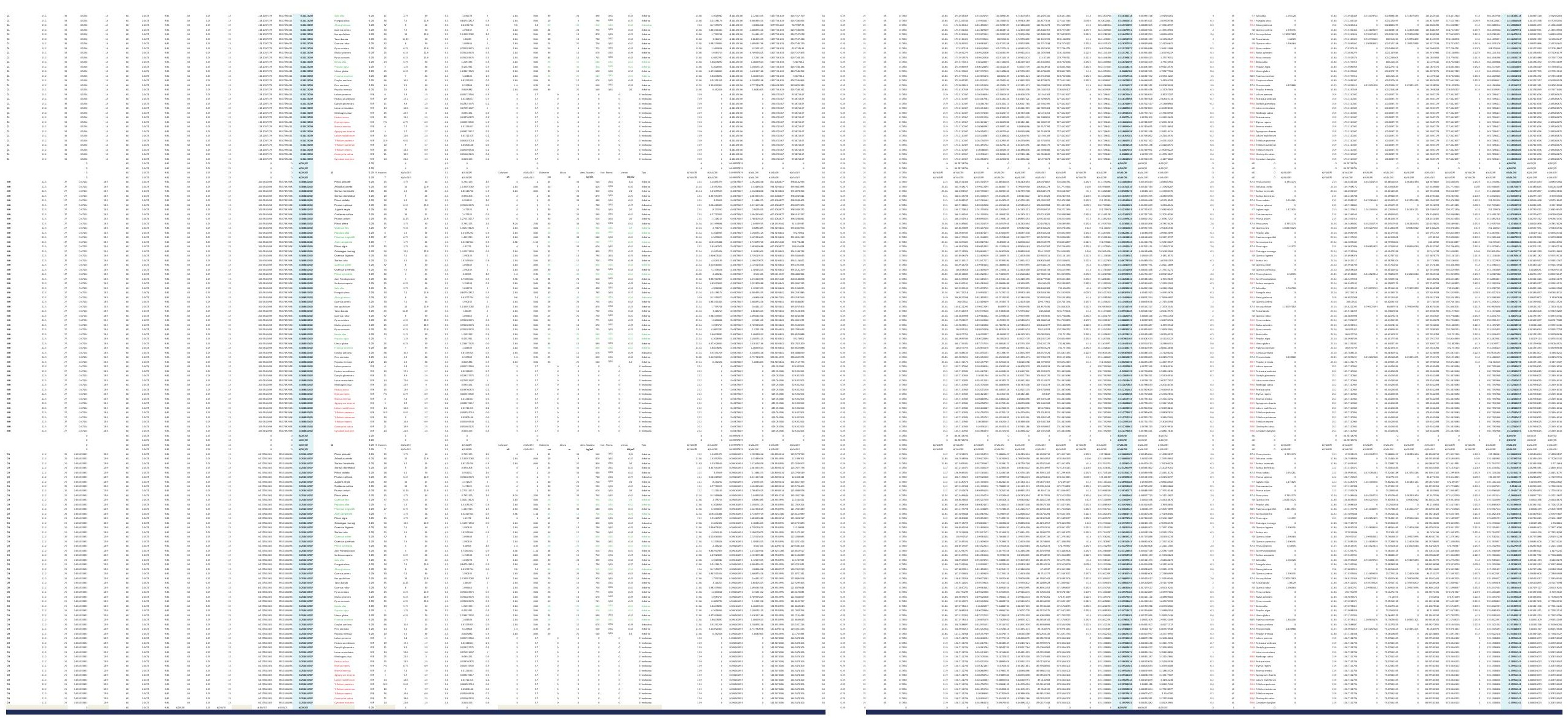



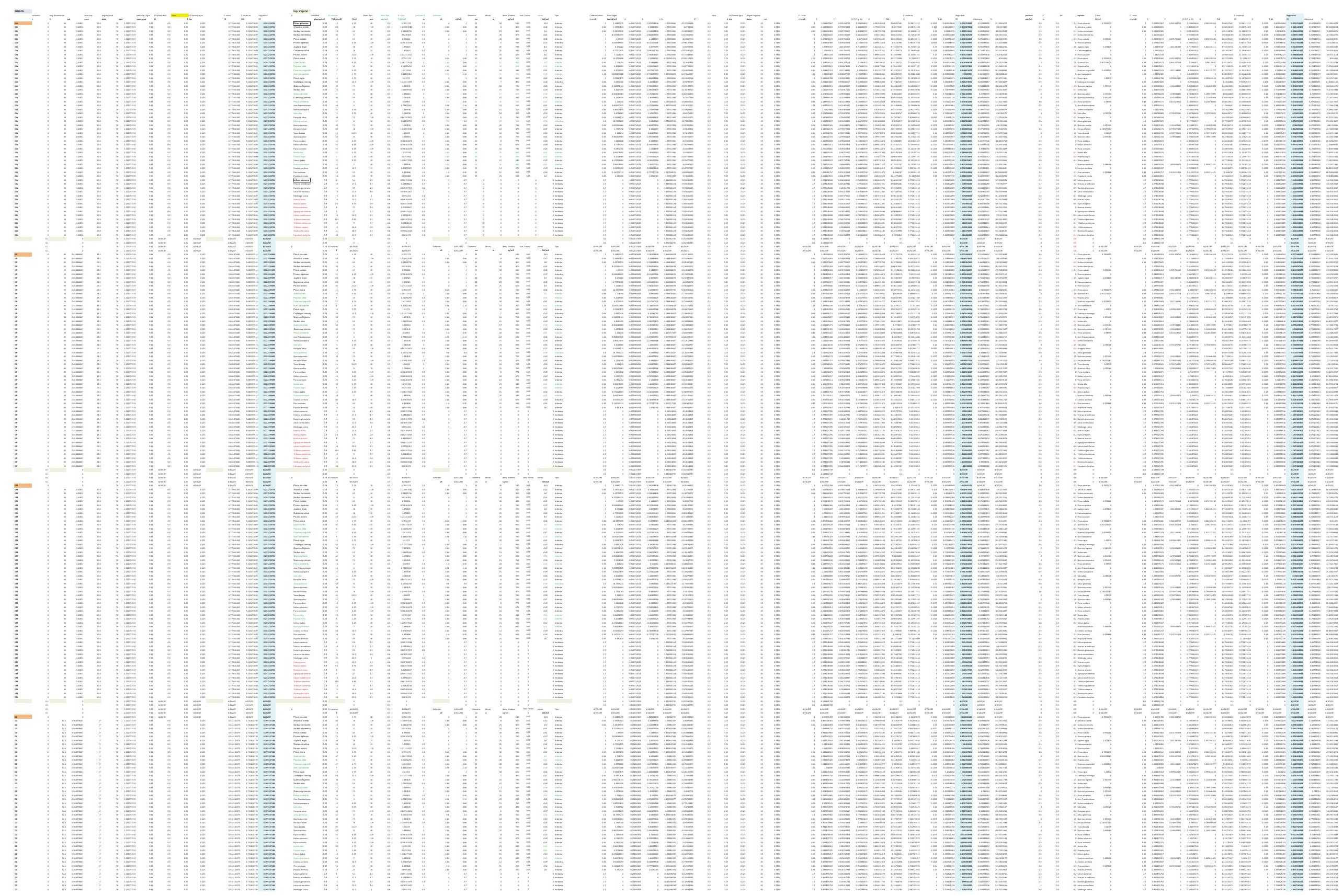


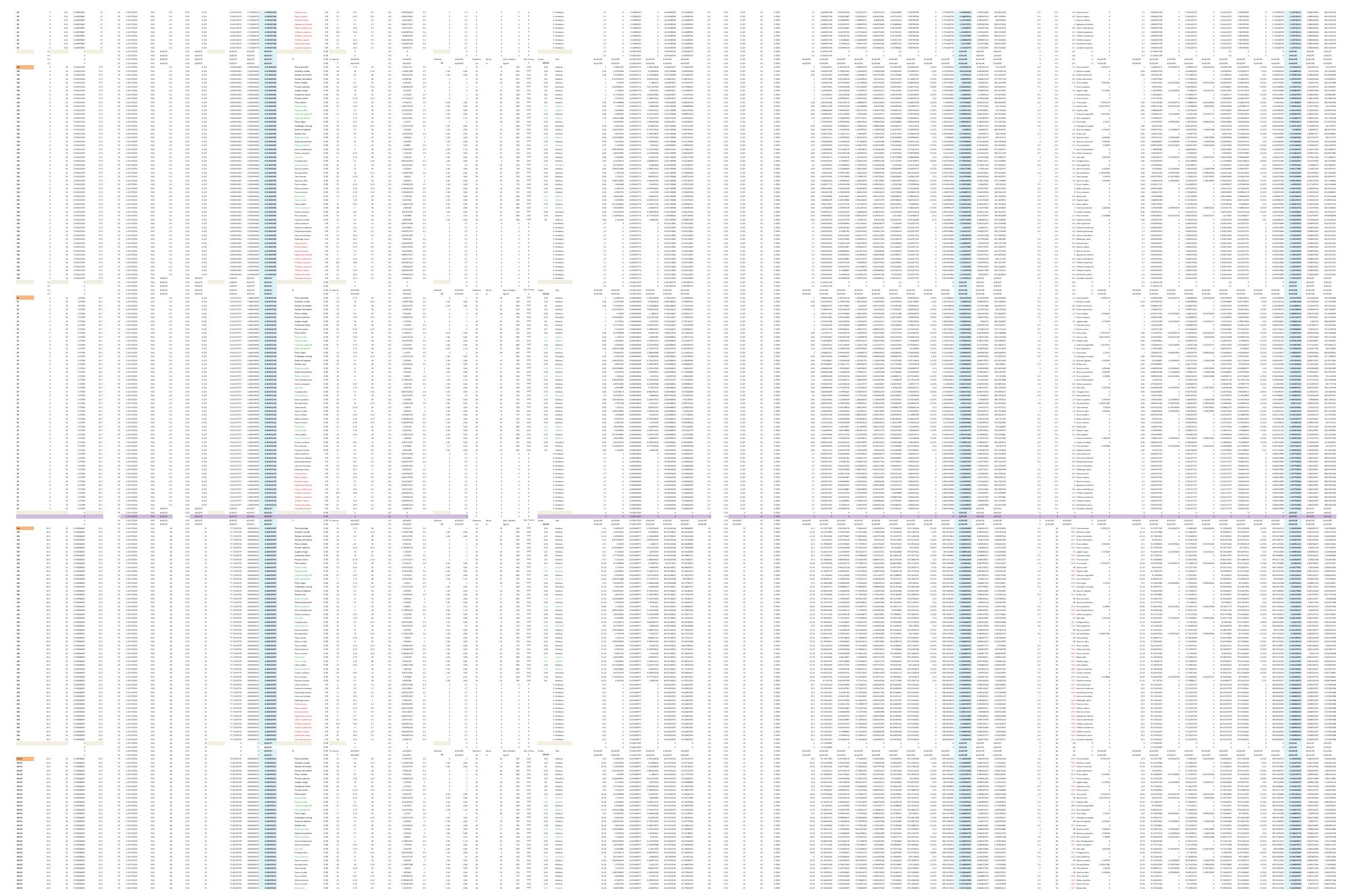



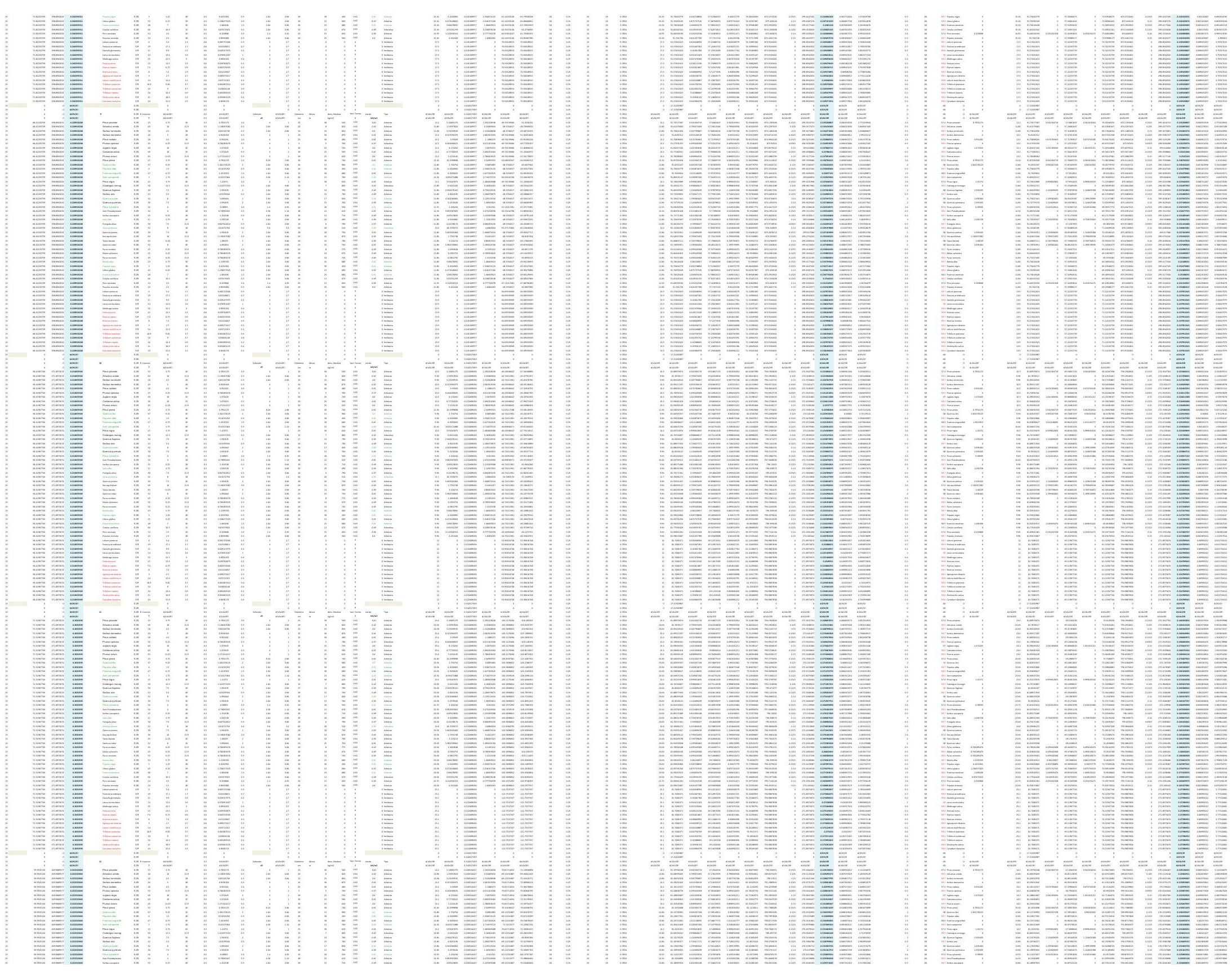


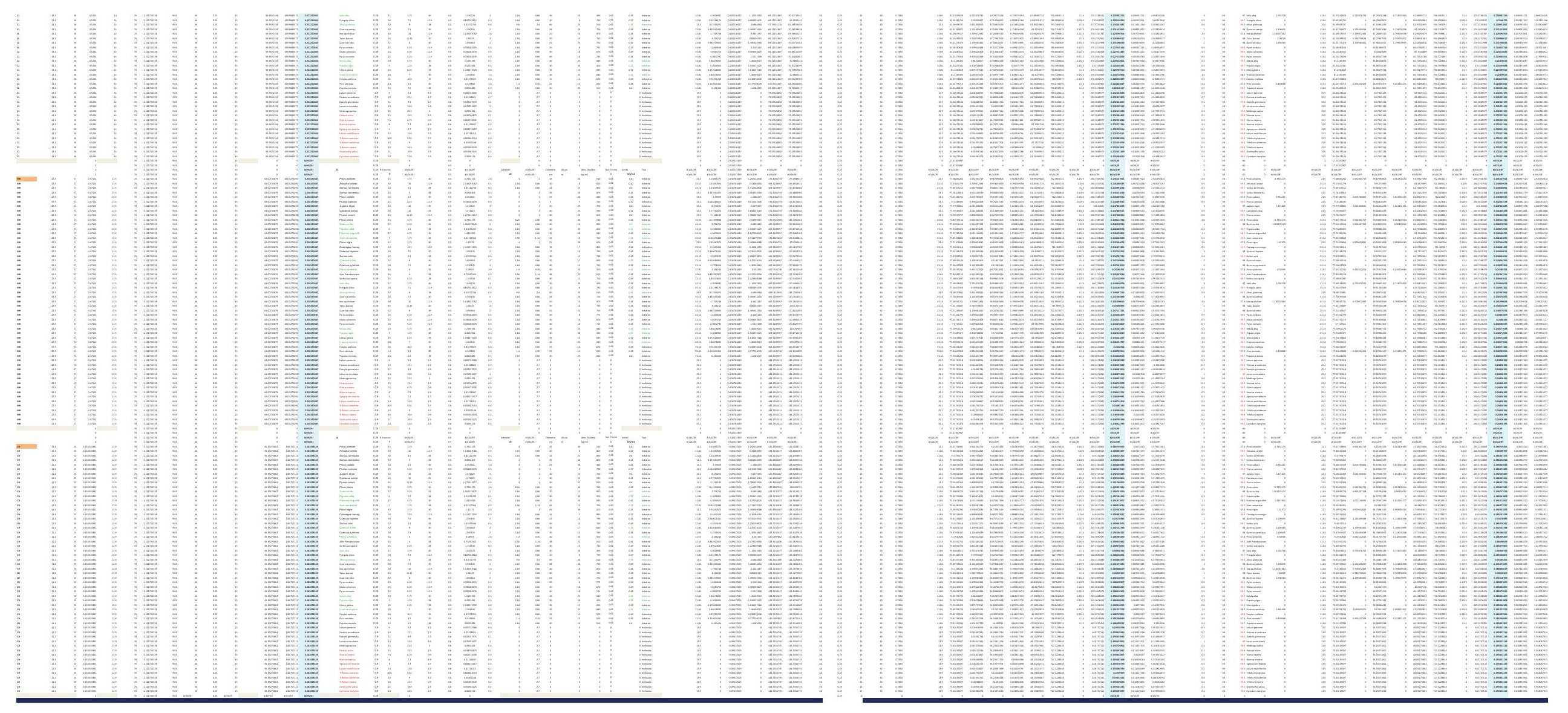



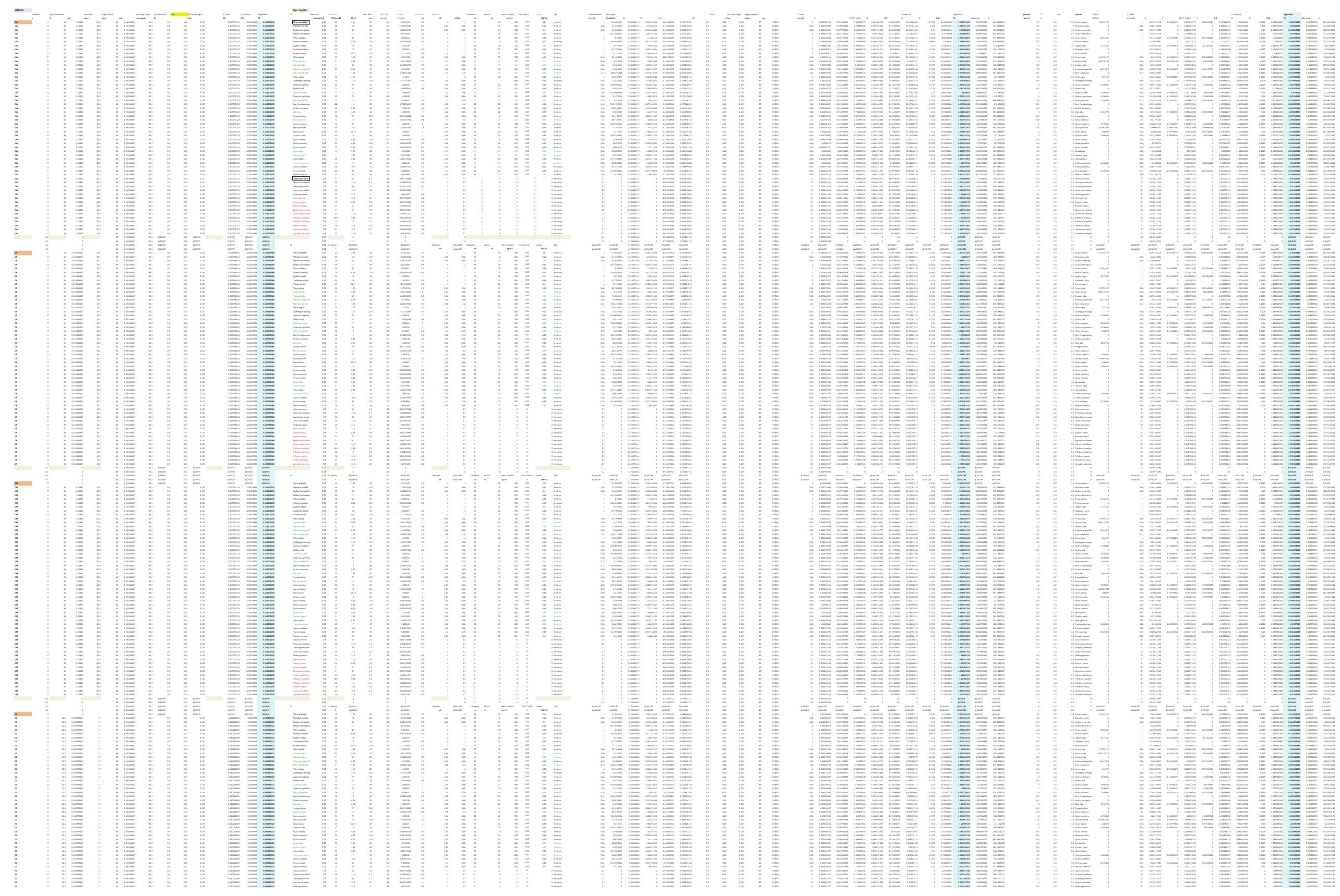


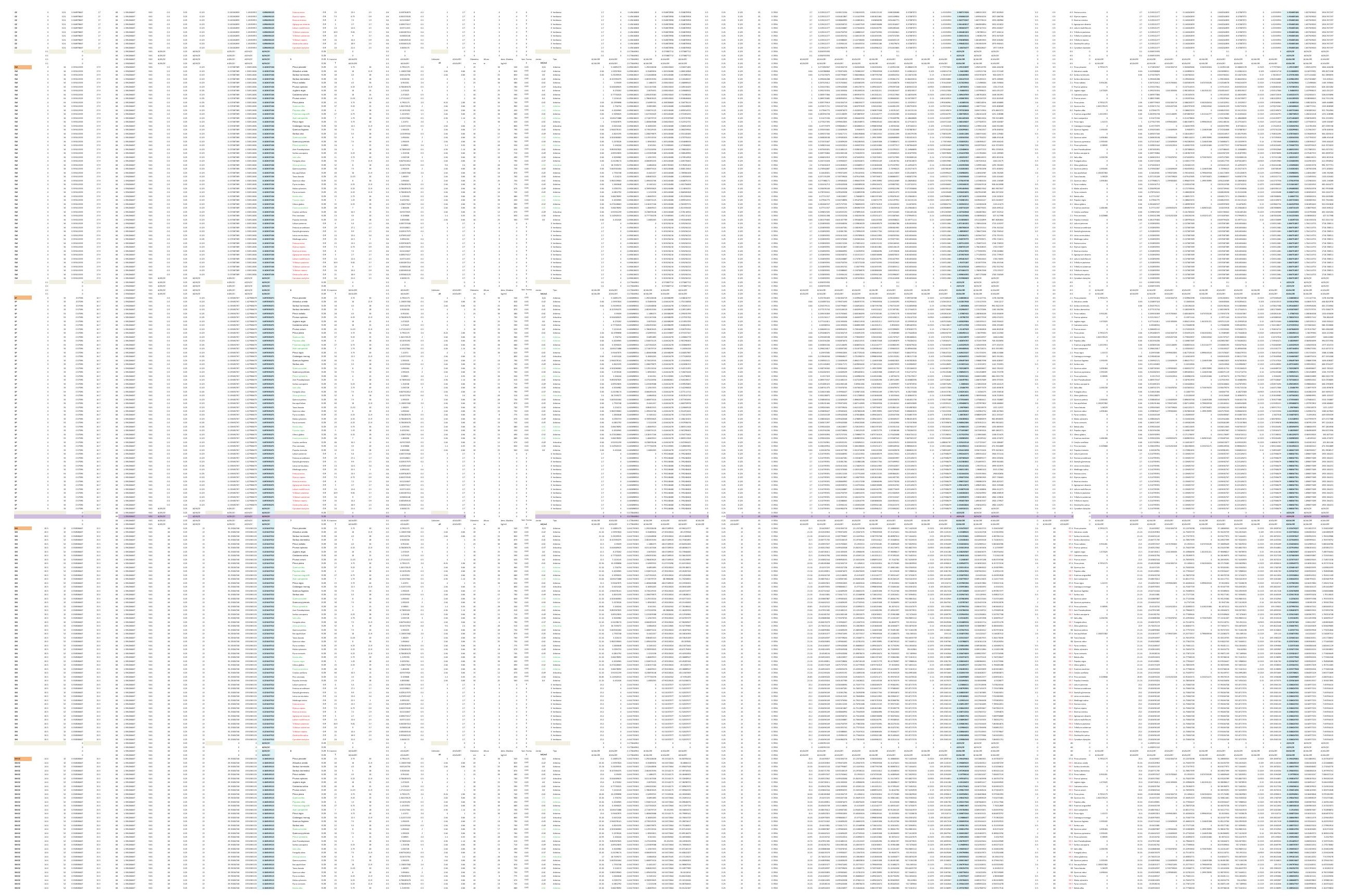



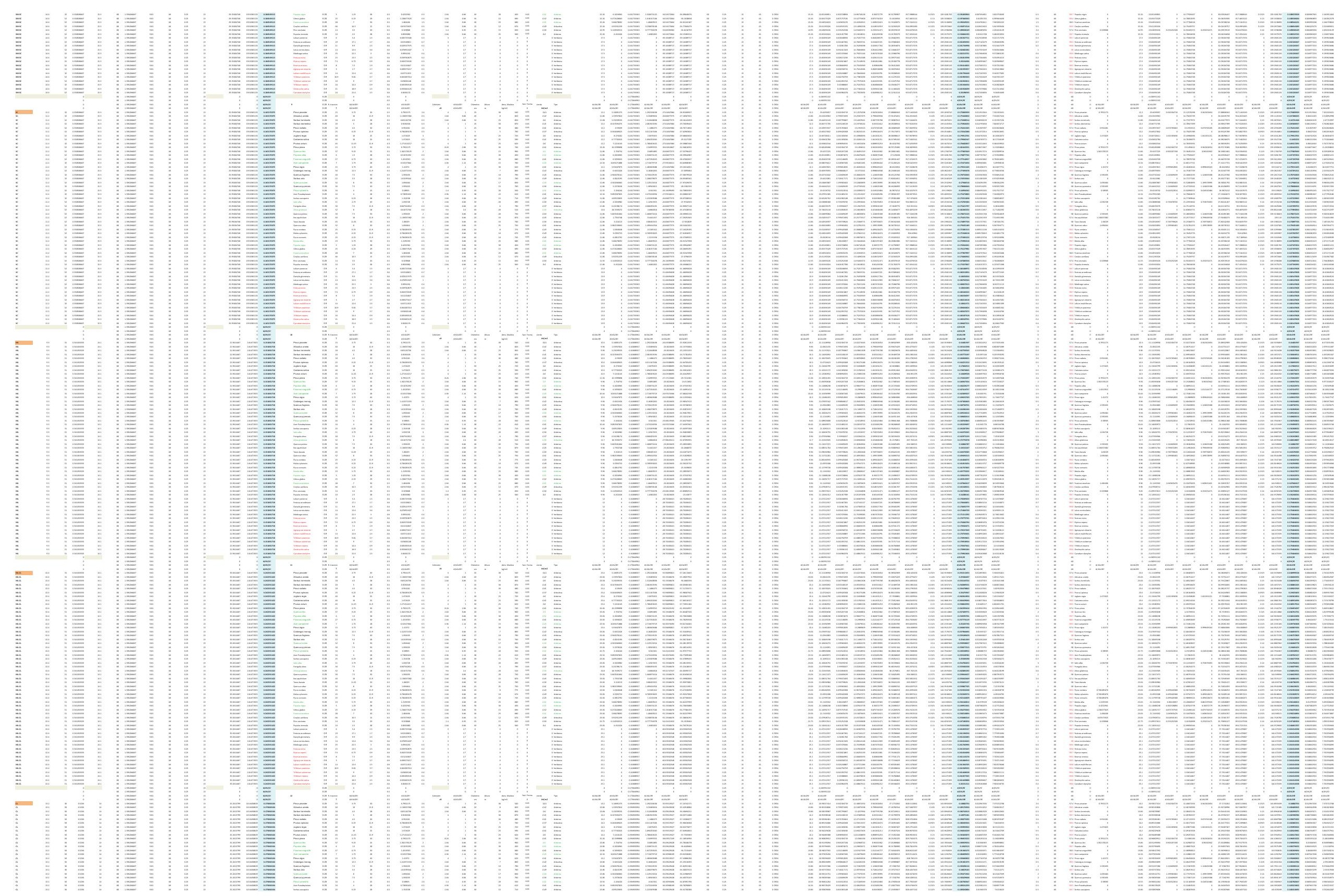


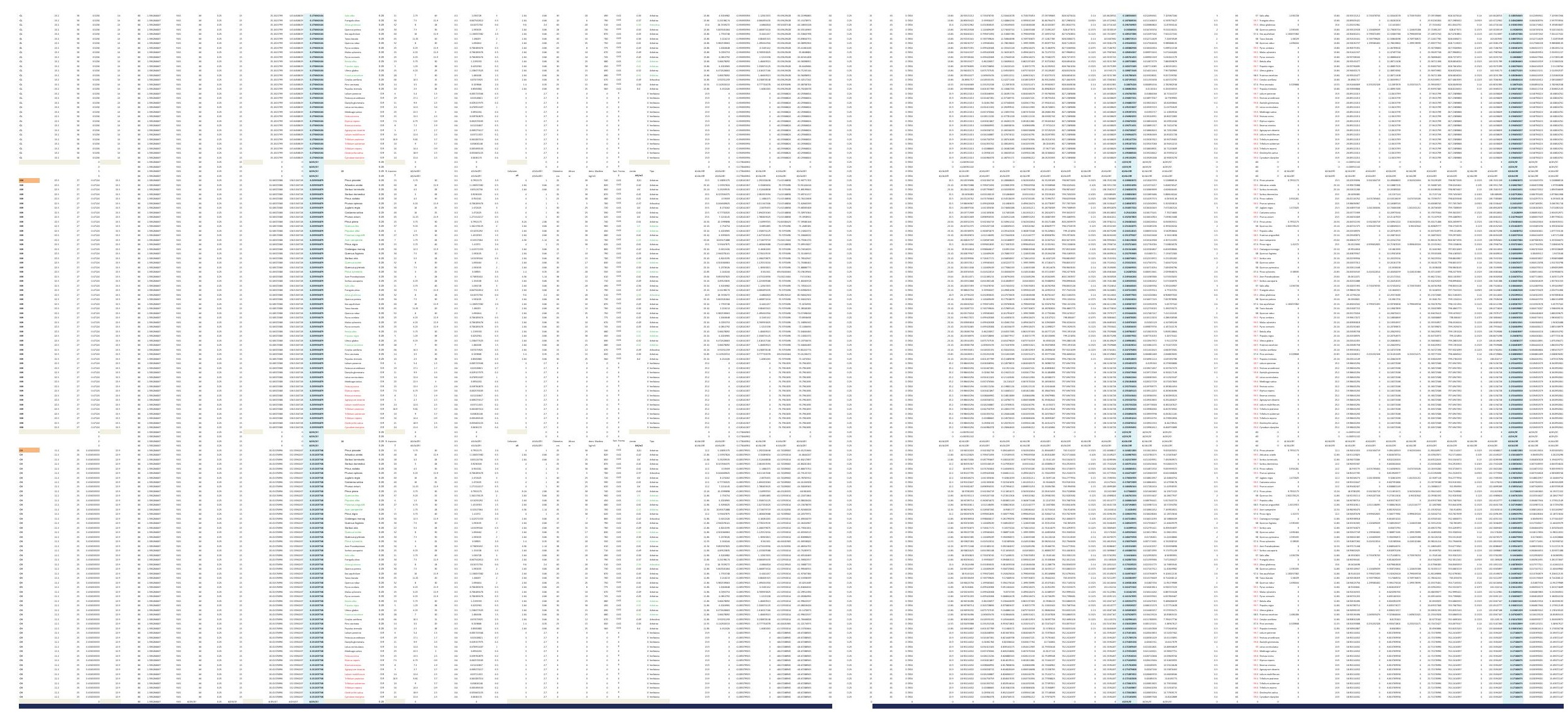


DESARROLLO DE UNA APLICACIÓN IMFORMÁTICA PARA EL CÁLCULO DE SOSTENIMIENTO DE TALUDES MEDIANTE VEGETACIÓN

A03. DENSIDAD DE PLANTACIÓN: 2.500 plantas/ha.

\section{A03-4.POSICIÓN N.F. 4}

INCLINACIÓN DE TALUD 6-100

INCLINACIÓN DE TALUD 10-200

INCLINACIÓN DE TALUD 20-30

INCLINACIÓN DE TALUD 30-40

INCLINACIÓN DE TALUD $35^{\circ}$

INCLINACIÓN DE TALUD 40-50

INCLINACIÓN DE TALUD 50-550

INCLINACIÓN DE TALUD 55-60

INCLINACIÓN DE TALUD 60-700

INCLINACIÓN DE TALUD 70-80 

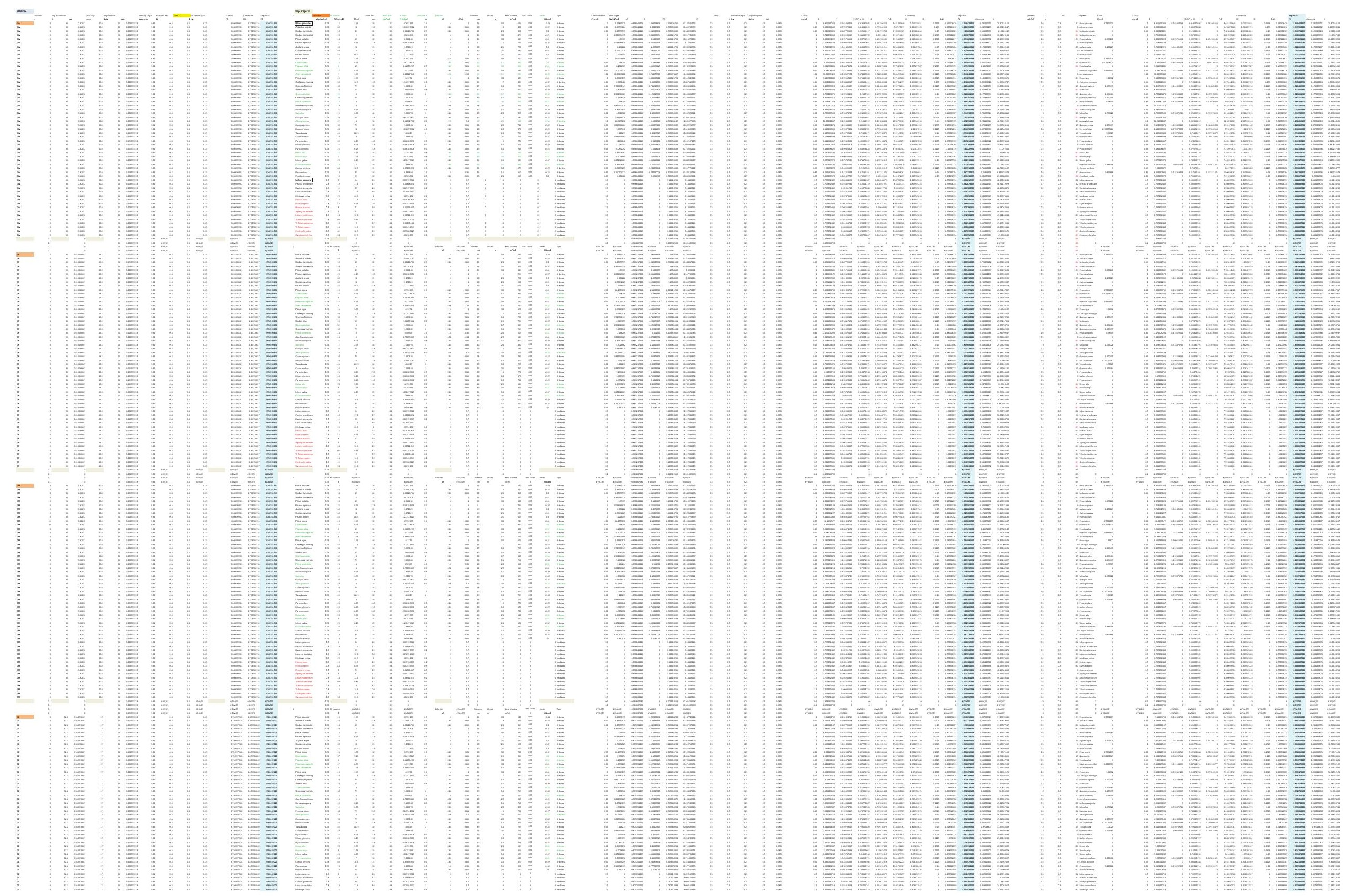


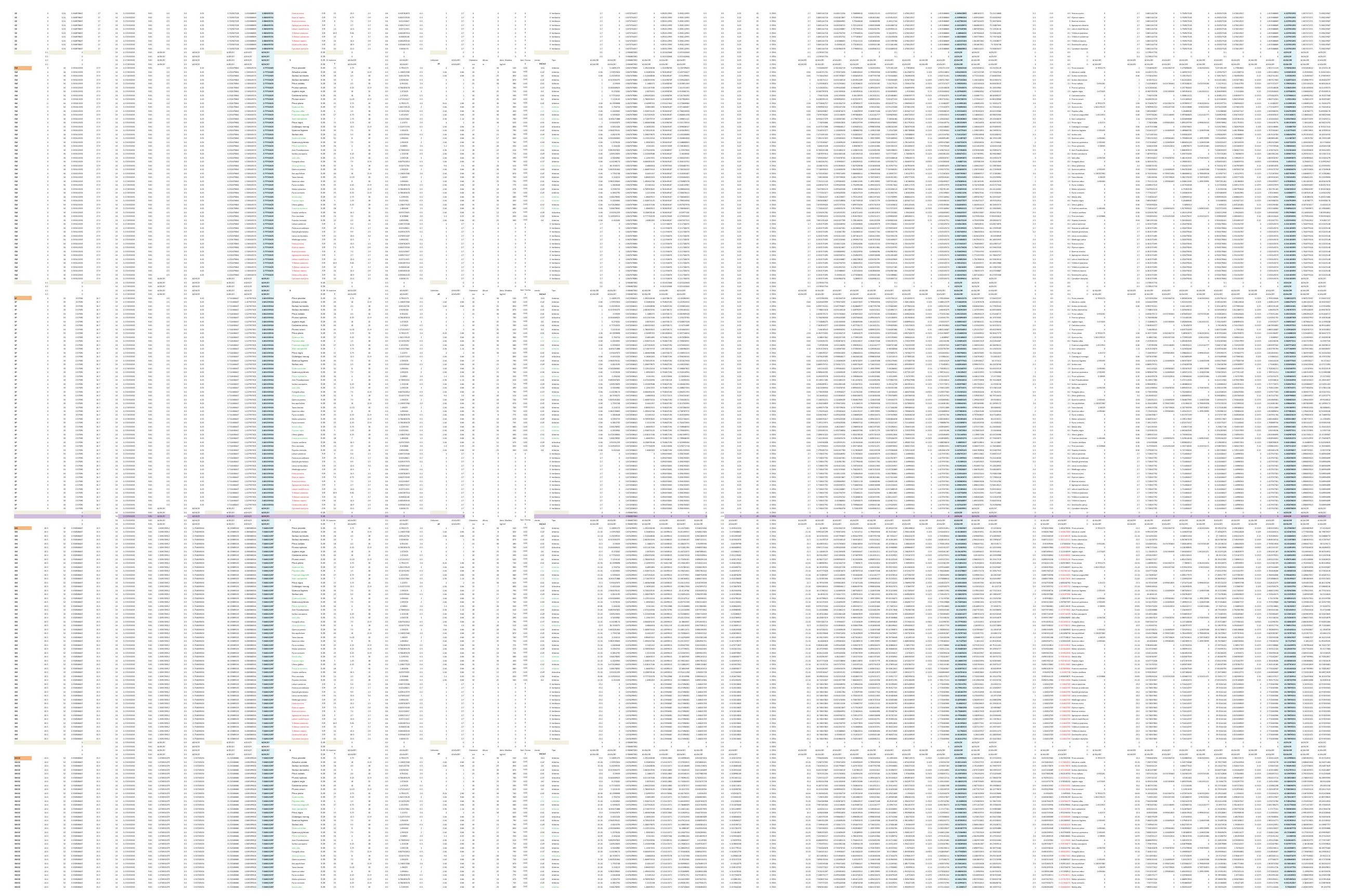



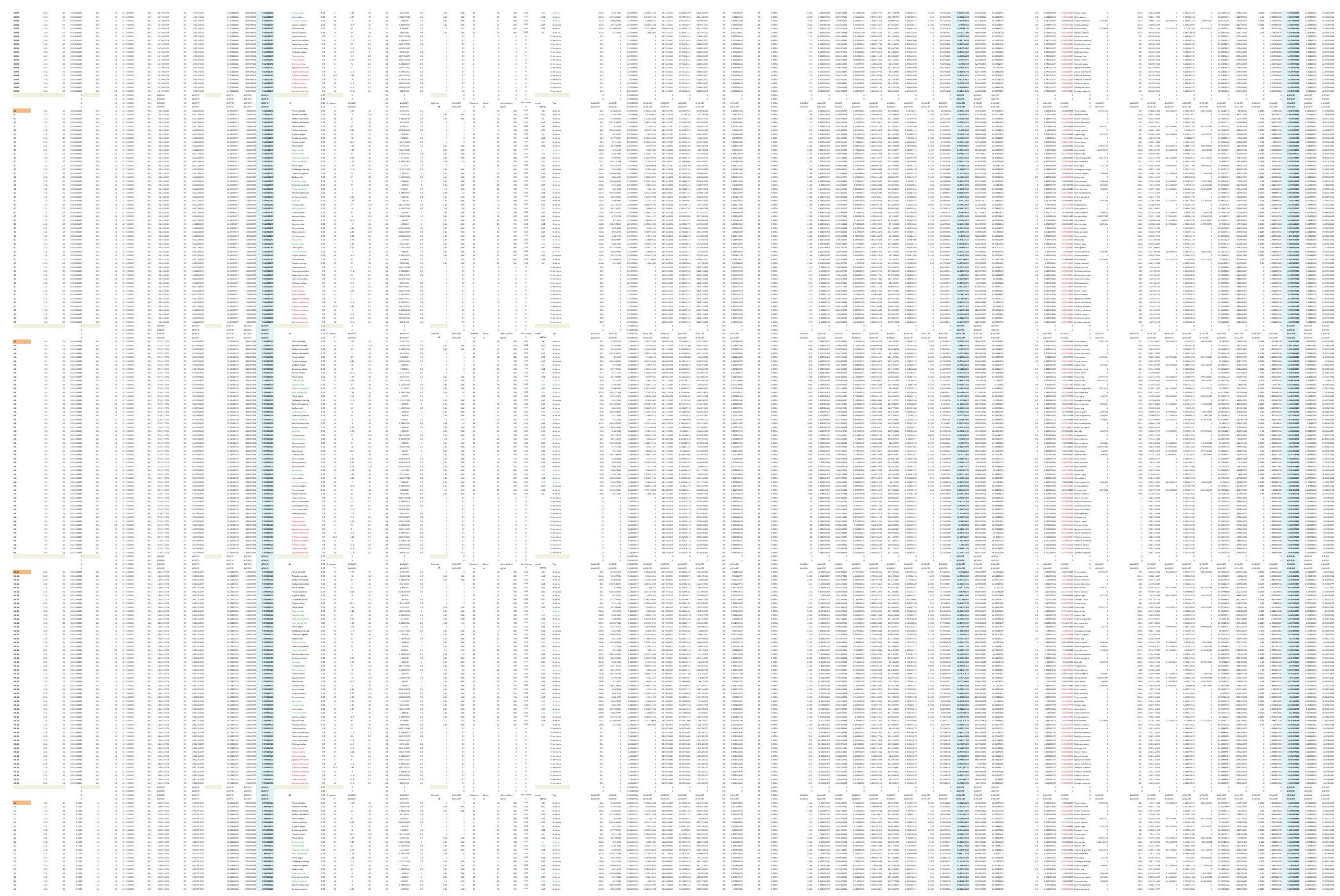


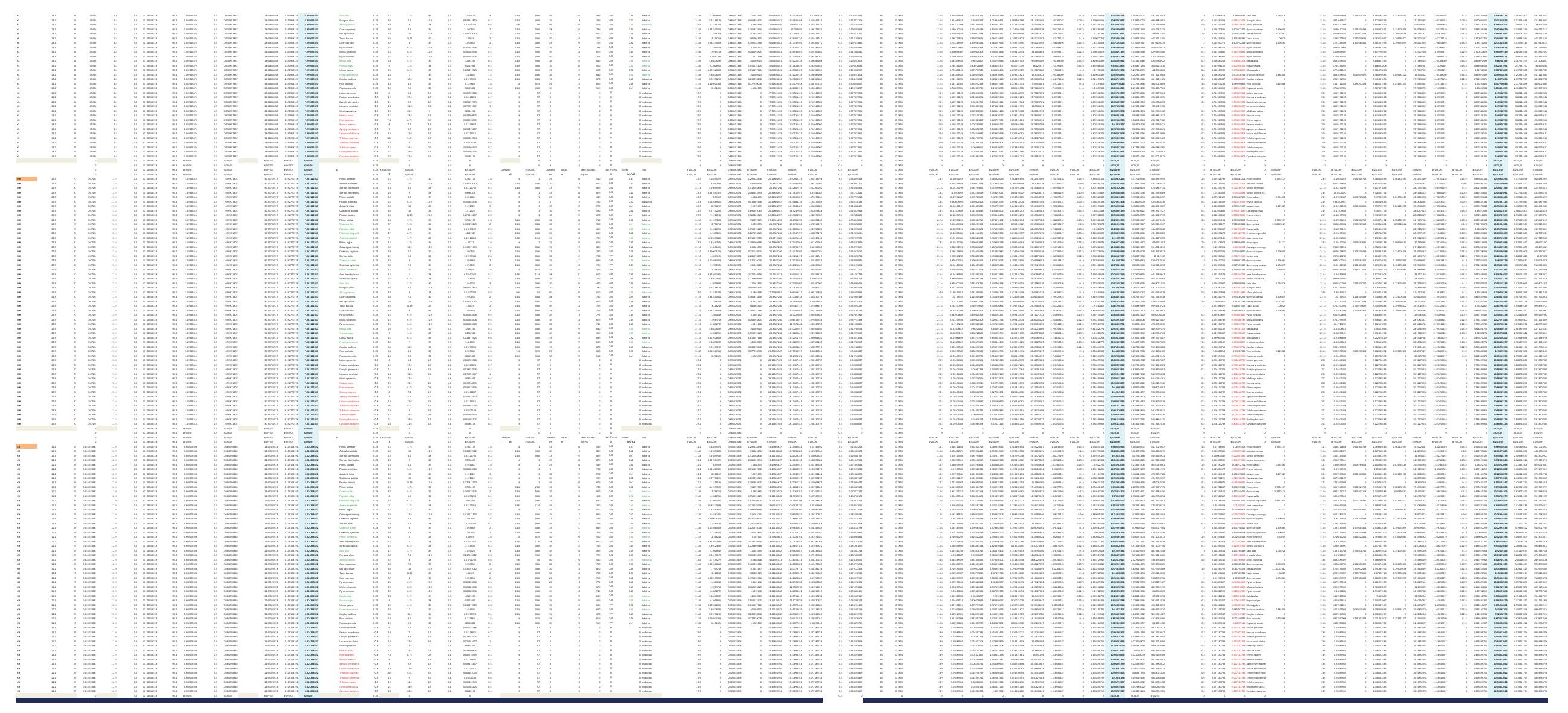



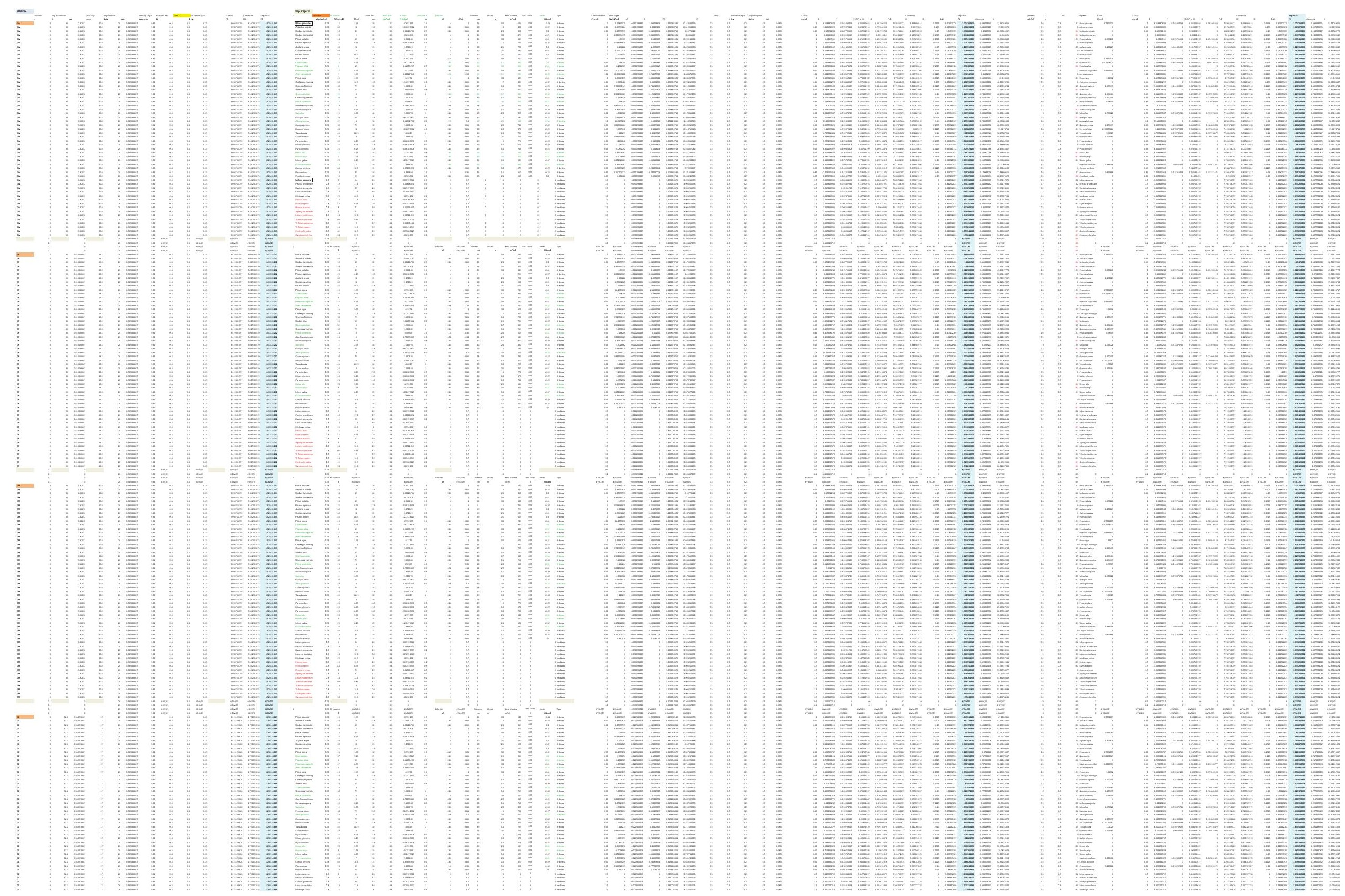


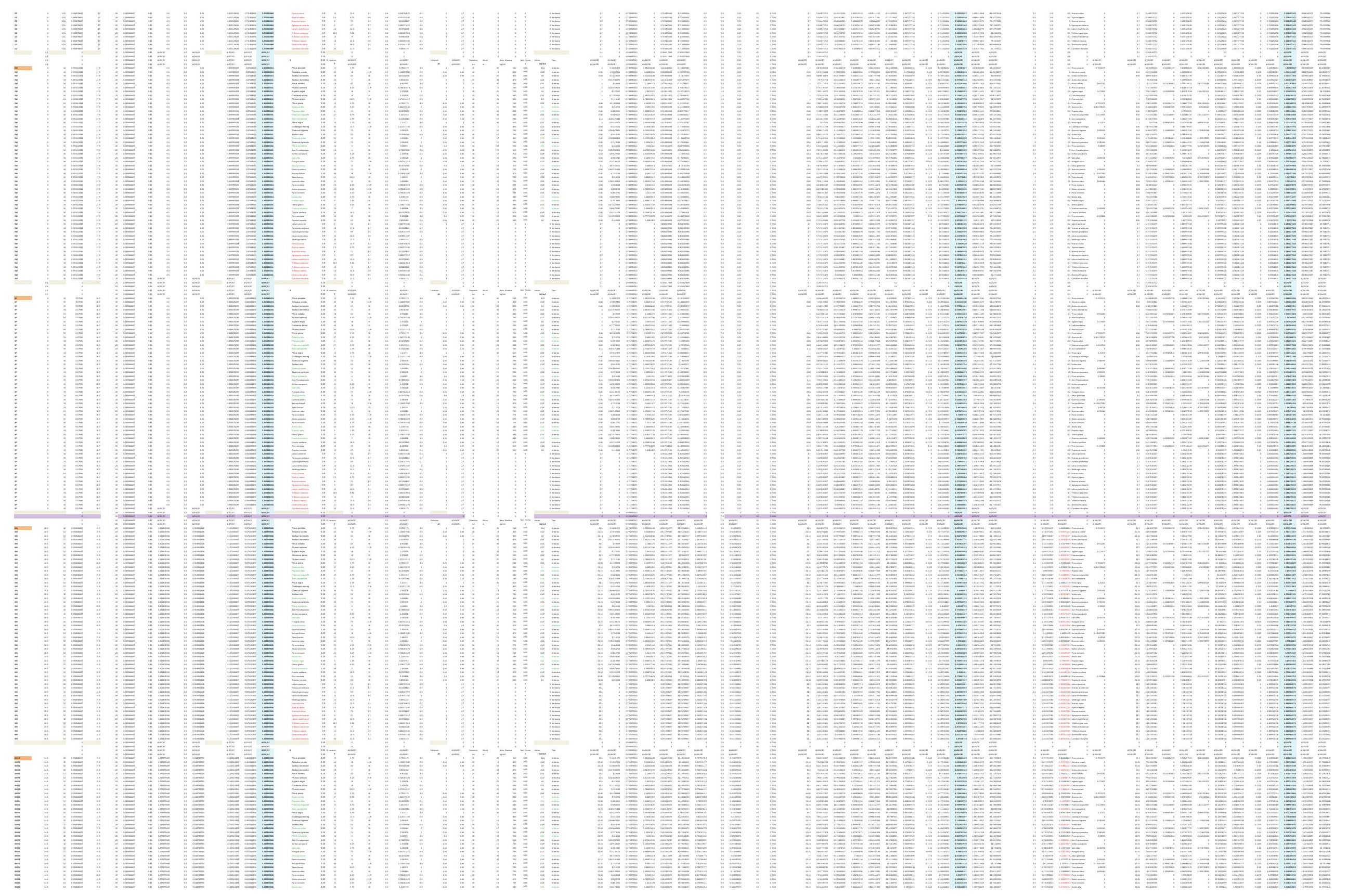



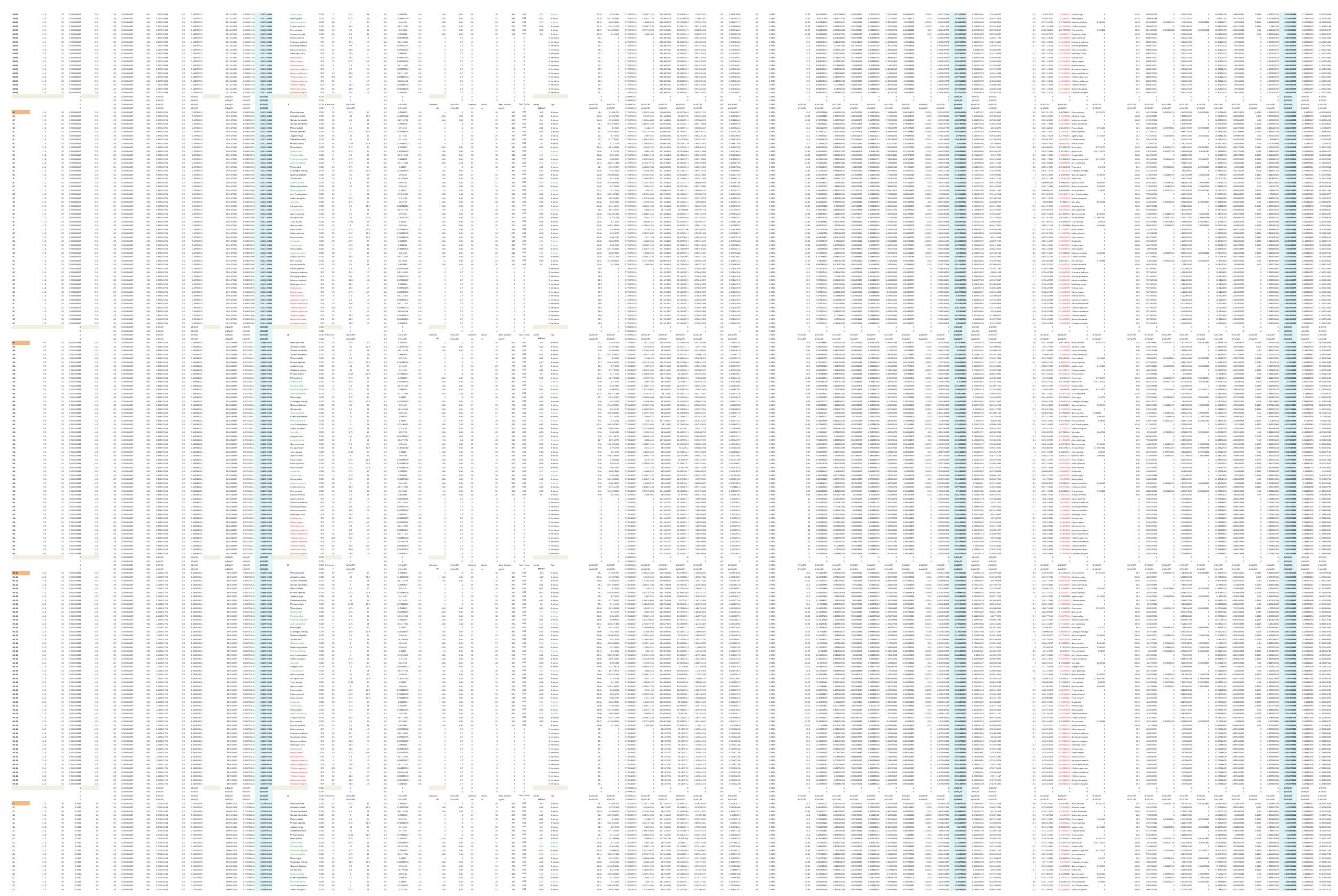


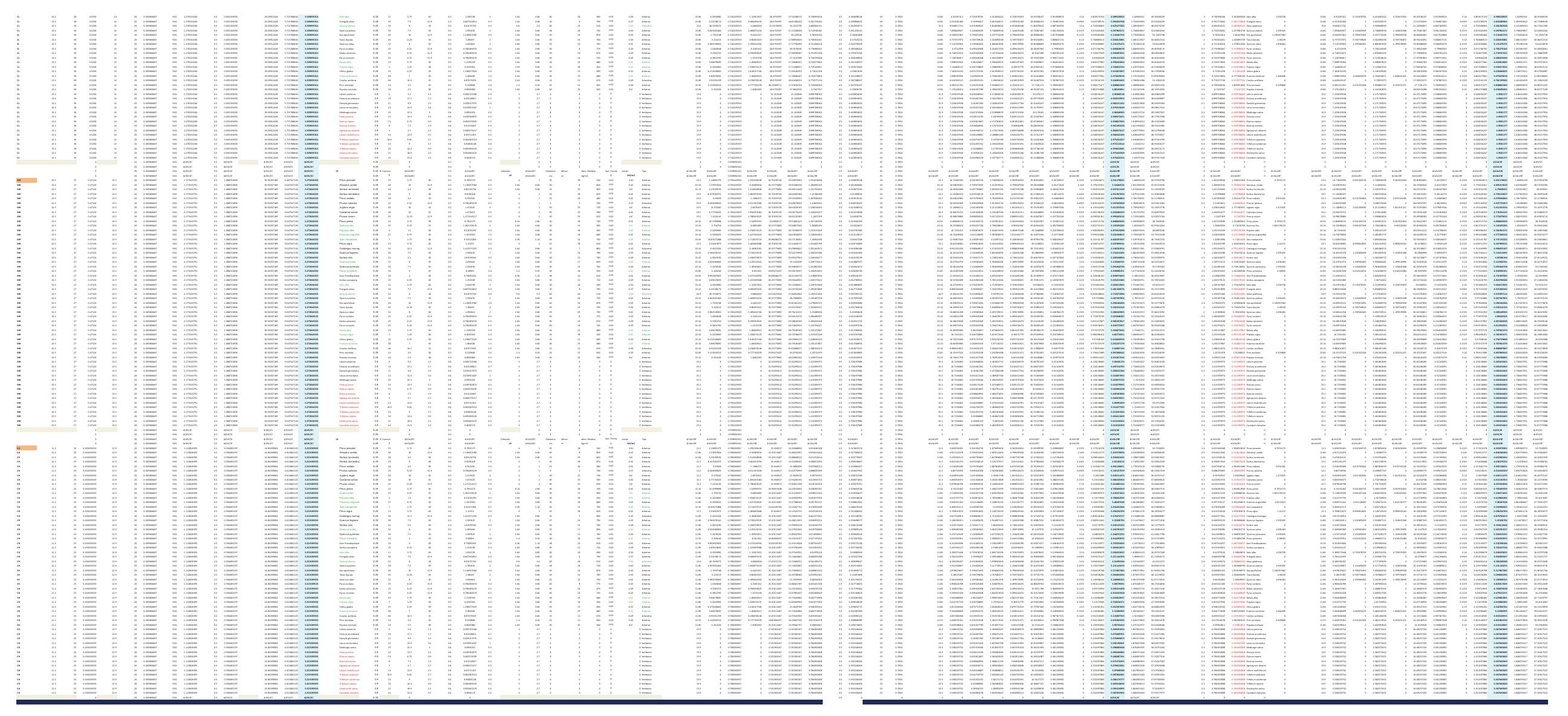



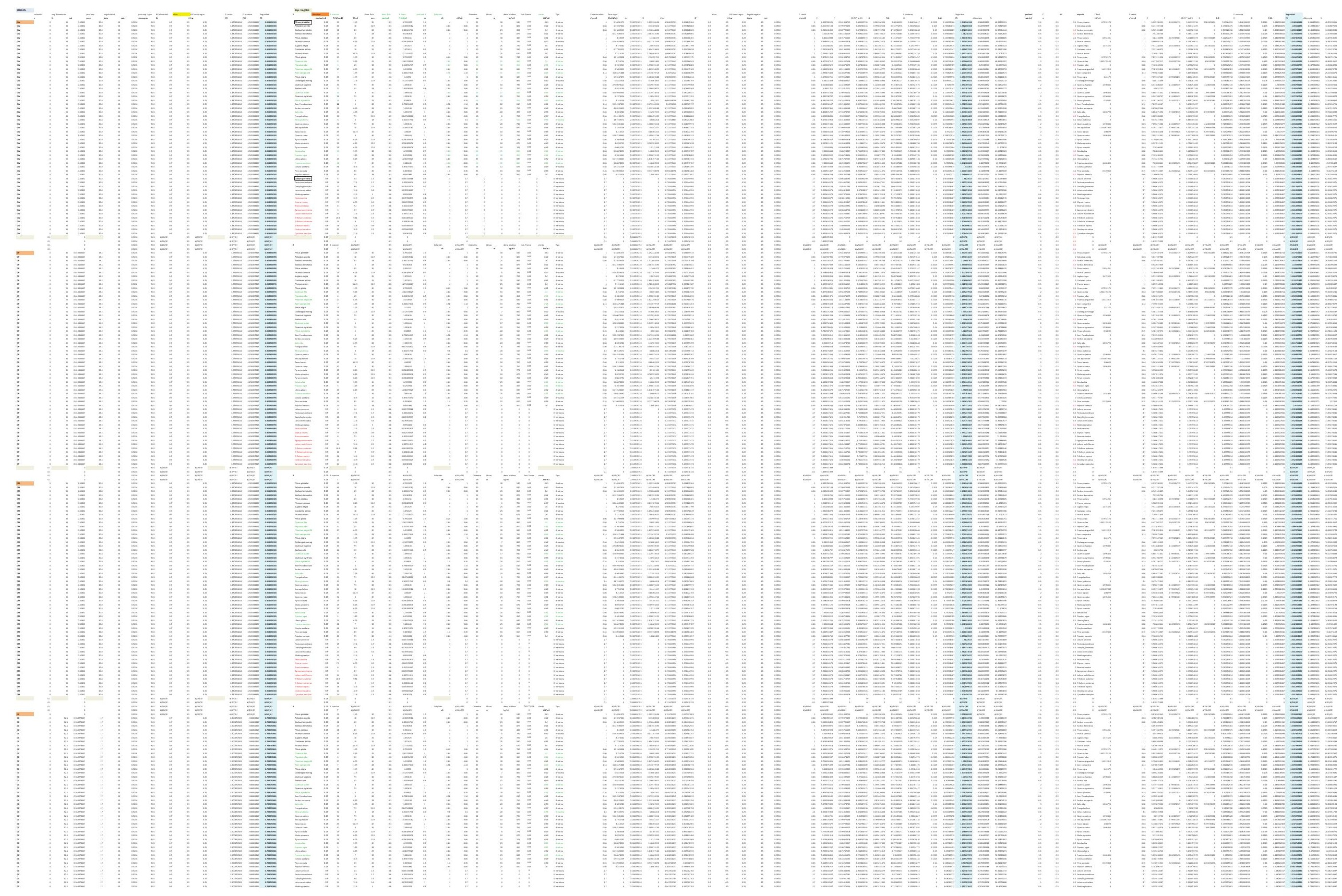


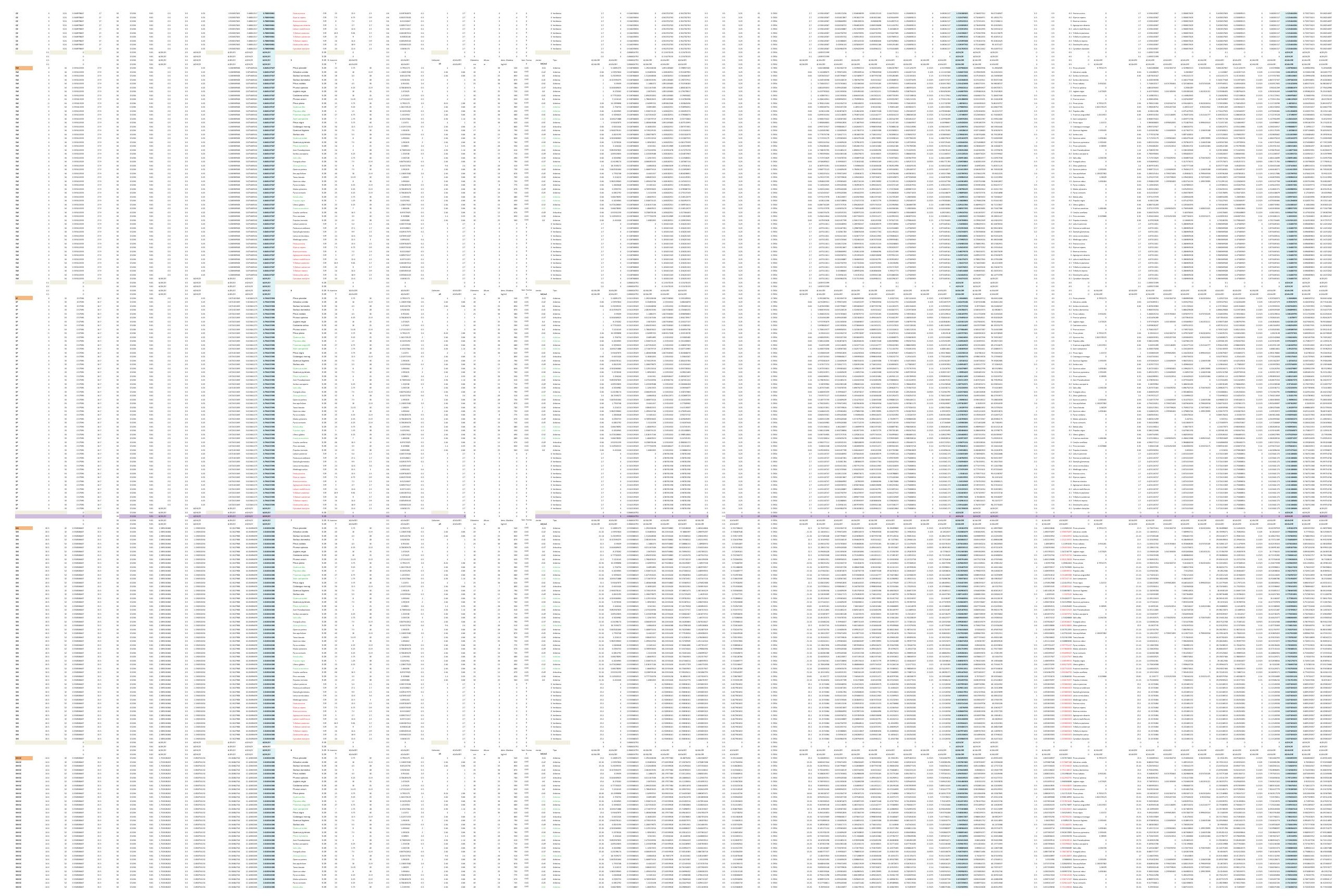



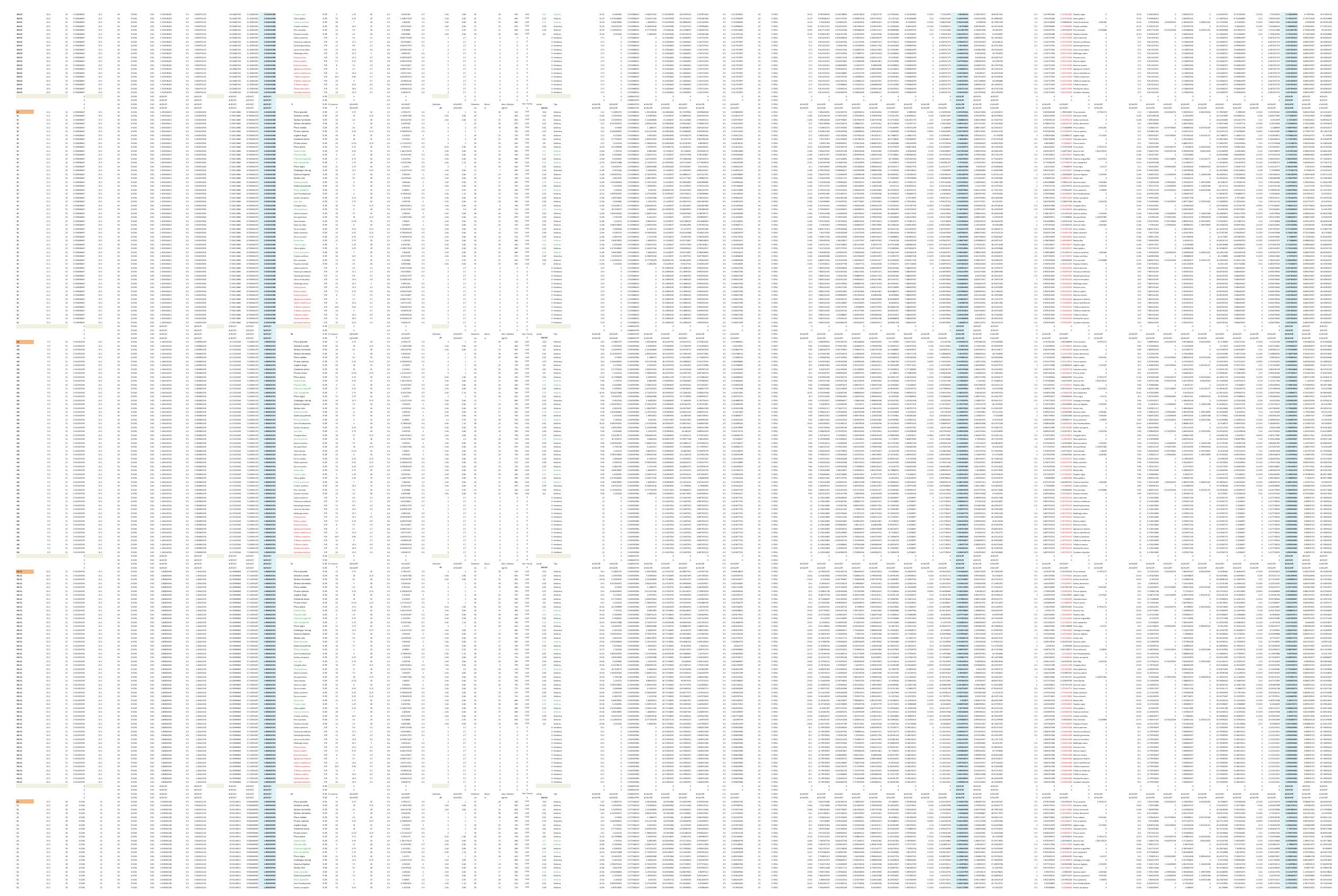


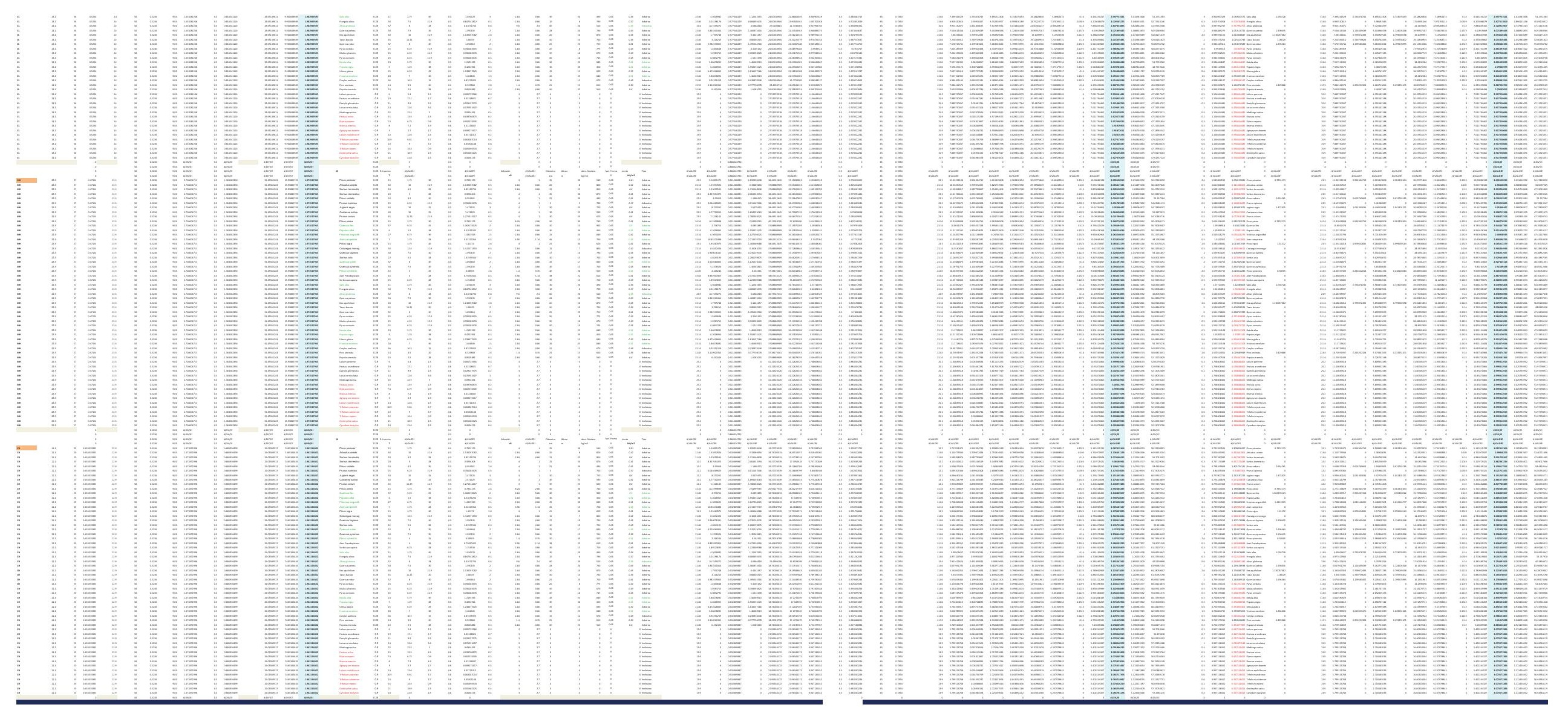



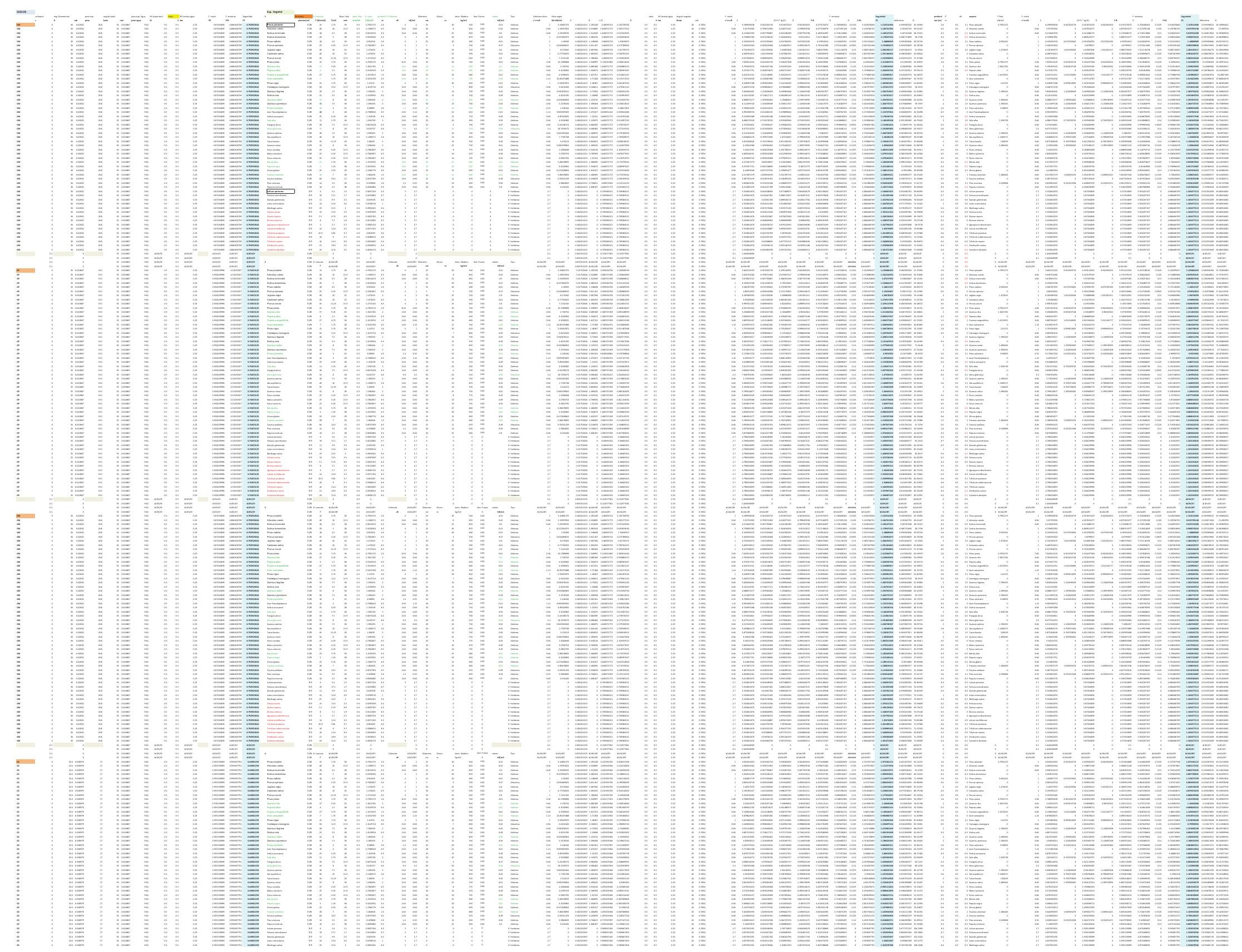


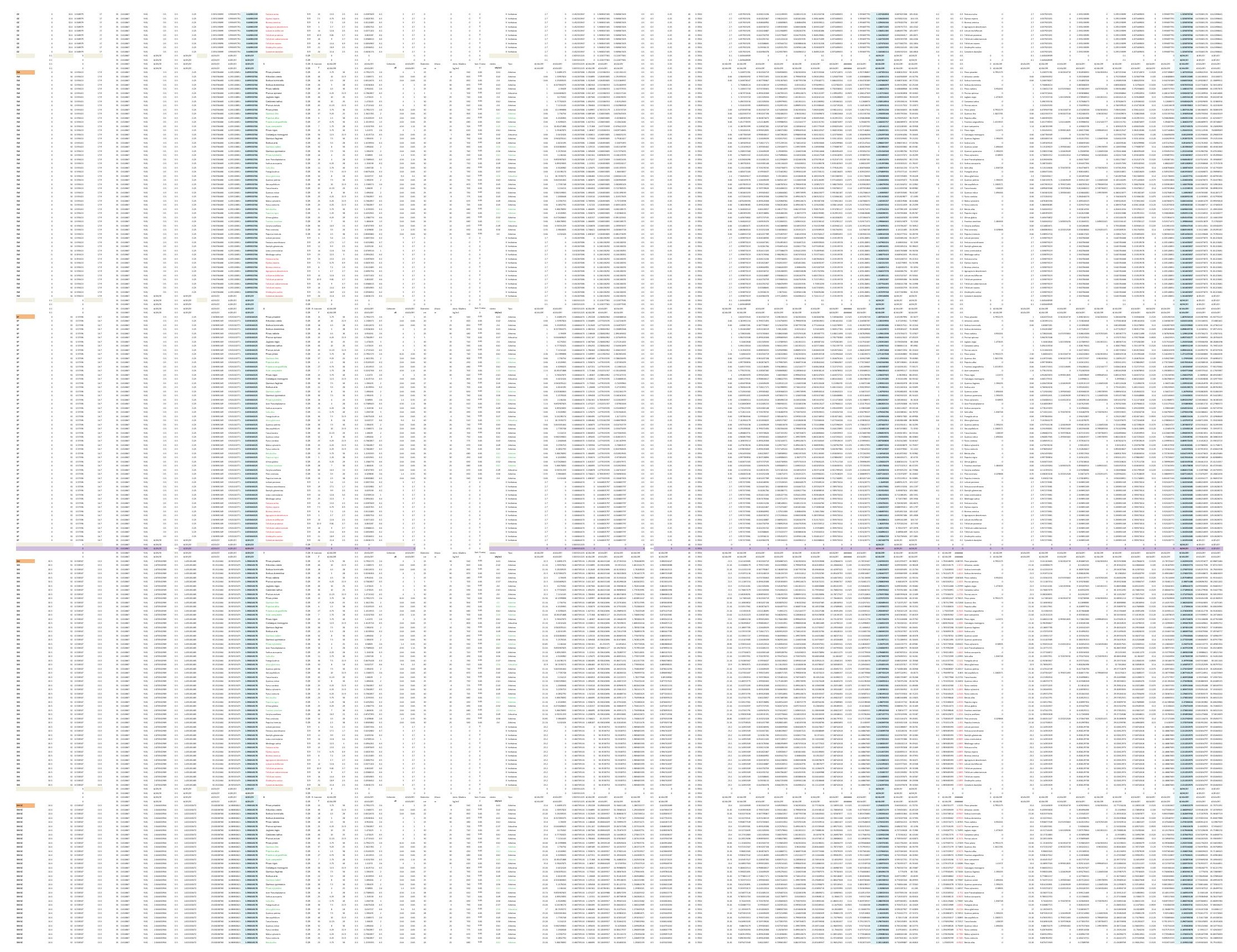



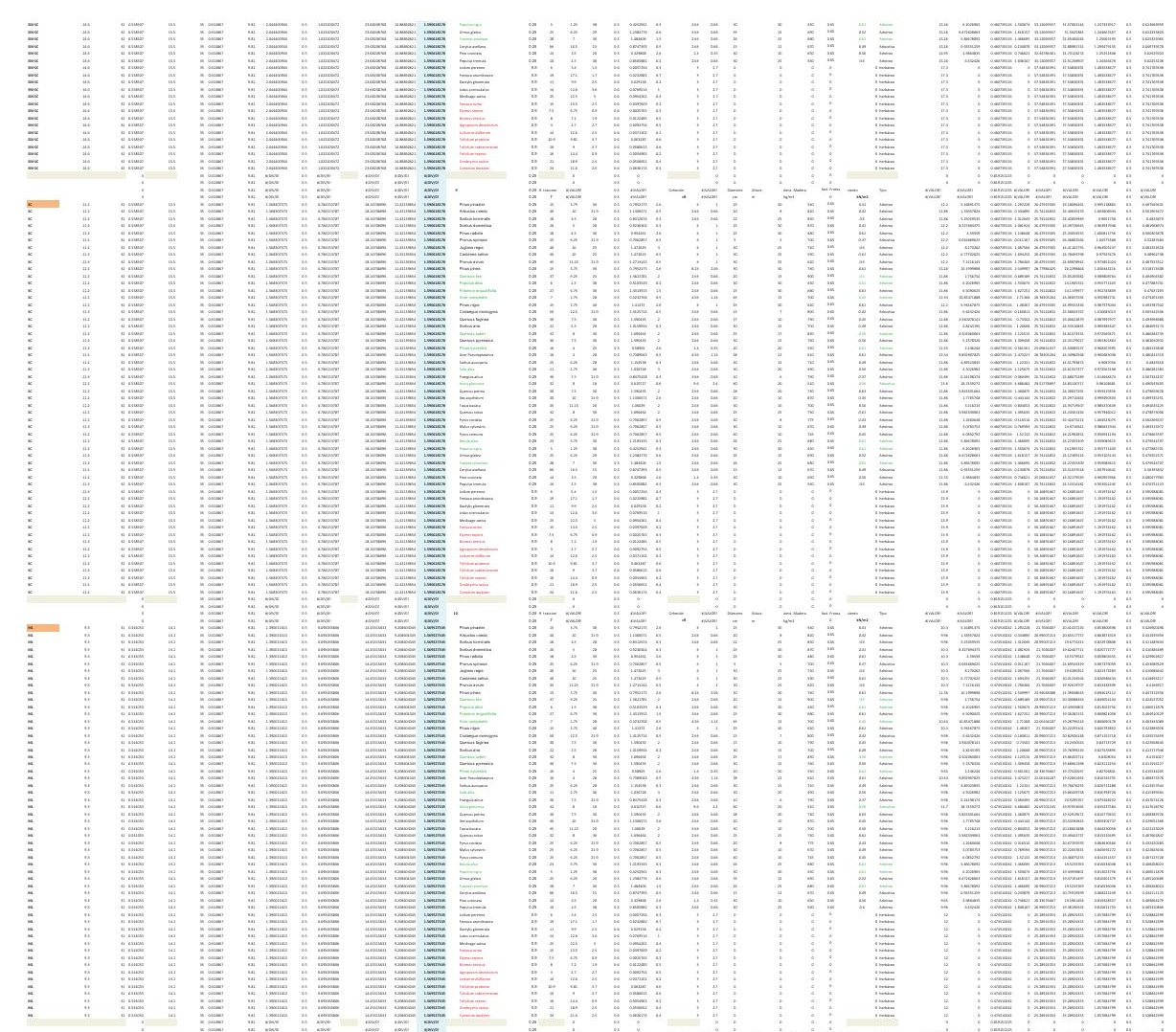

mIIIII
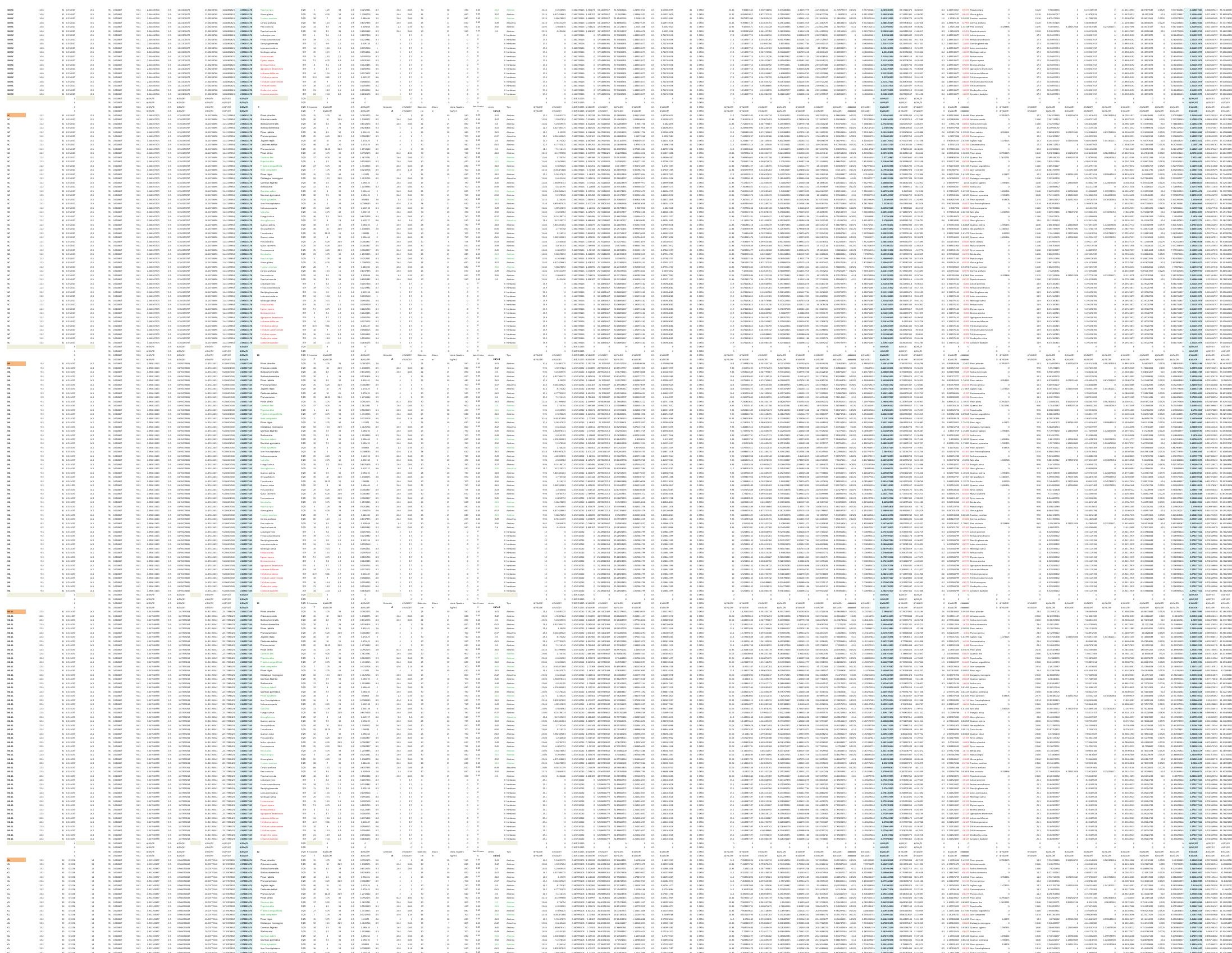


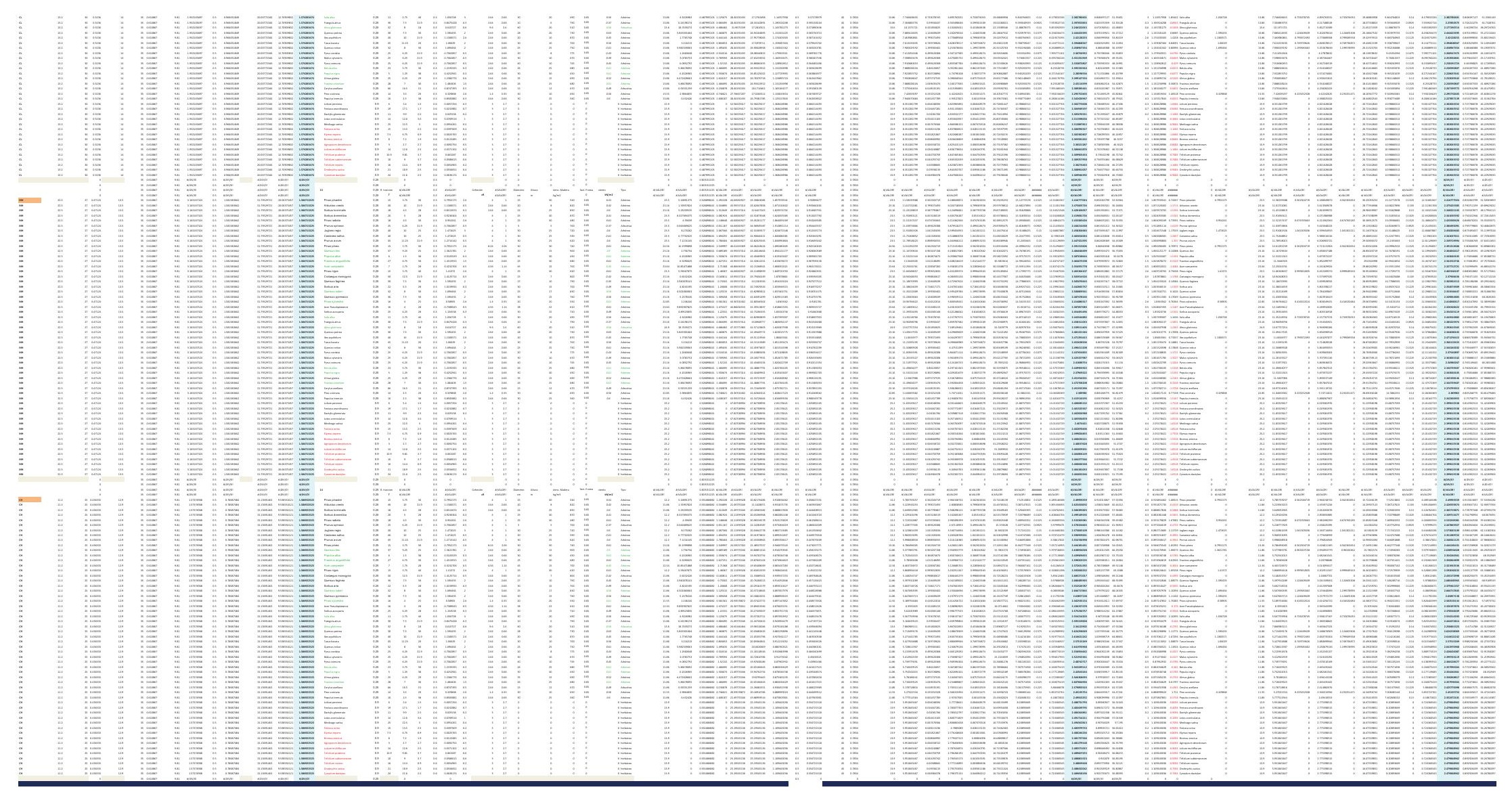



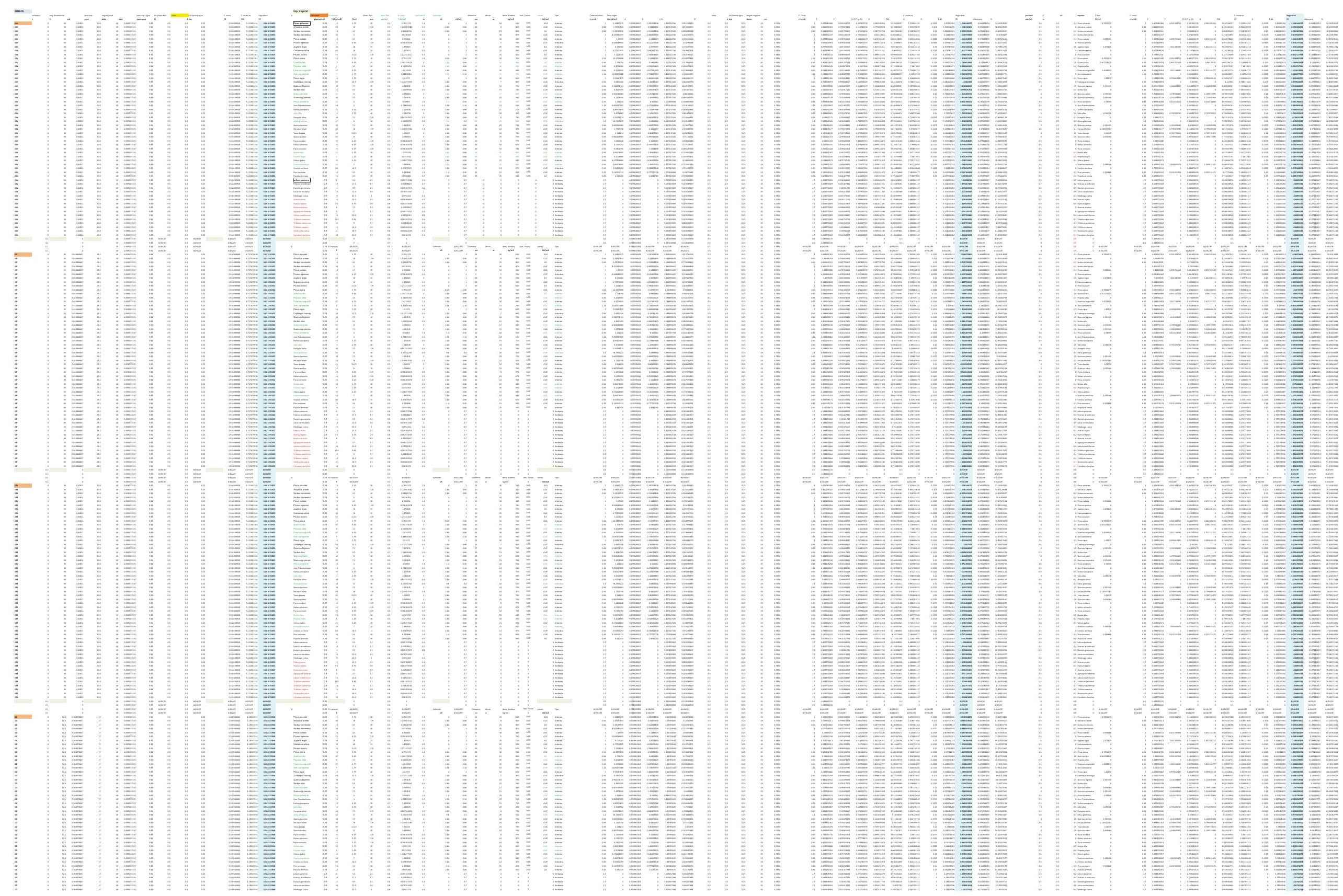


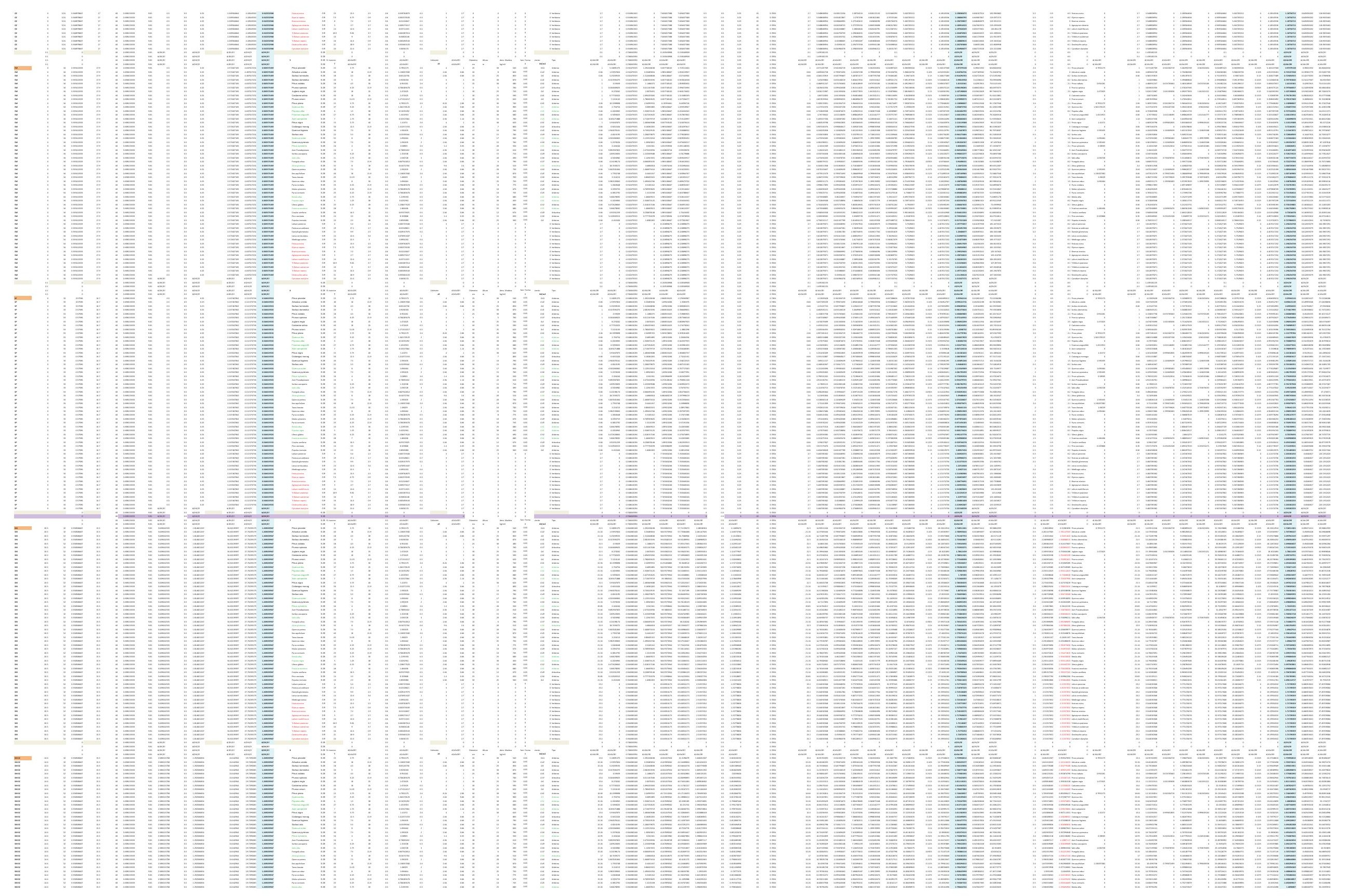



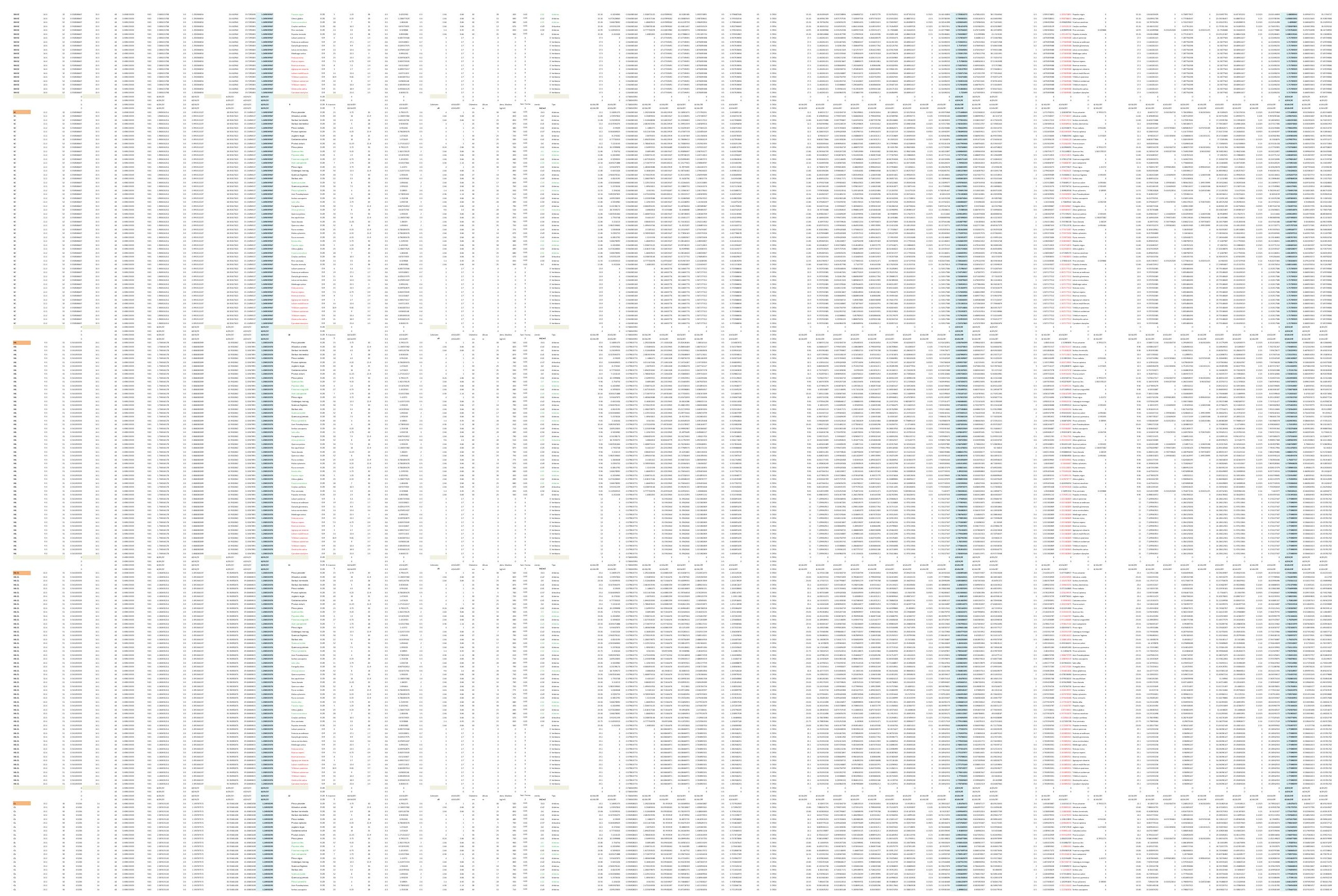


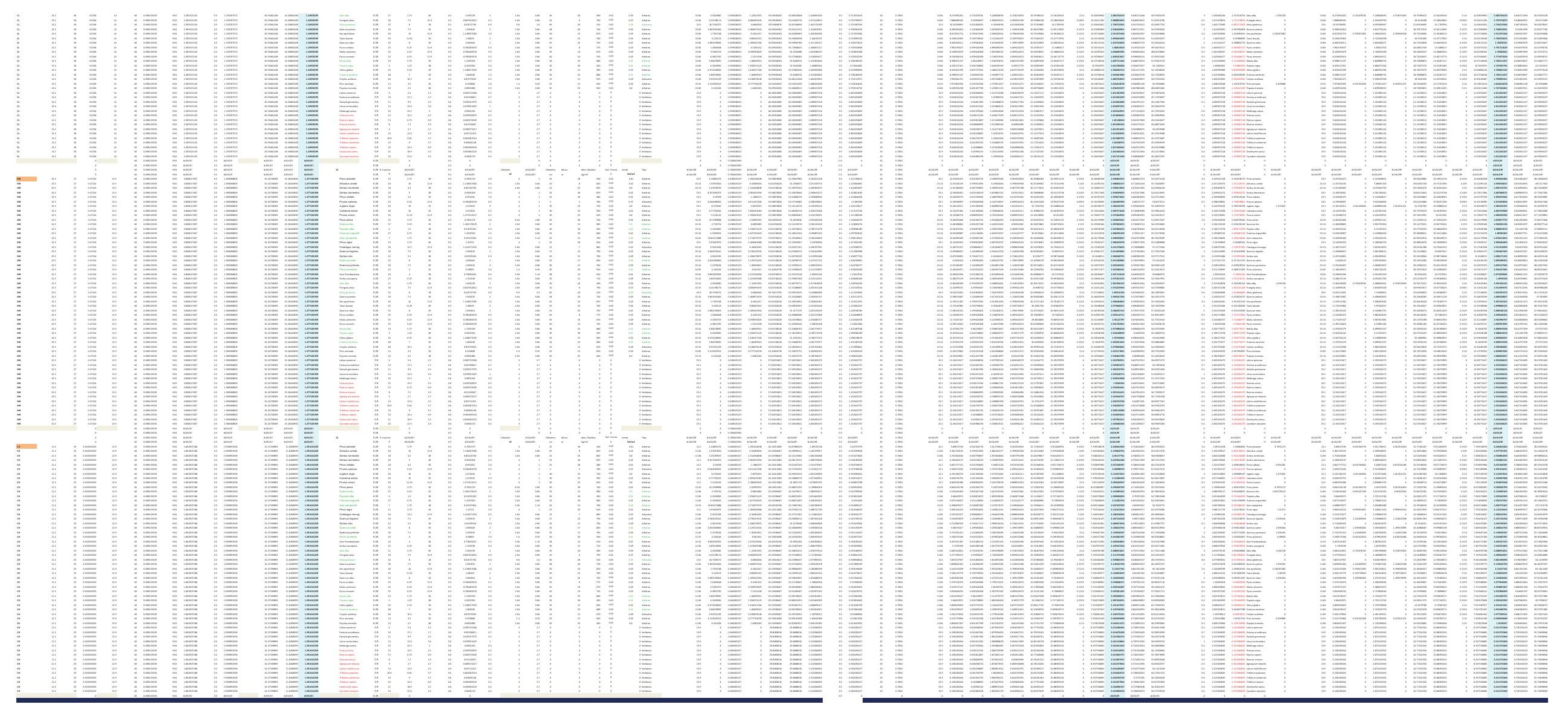



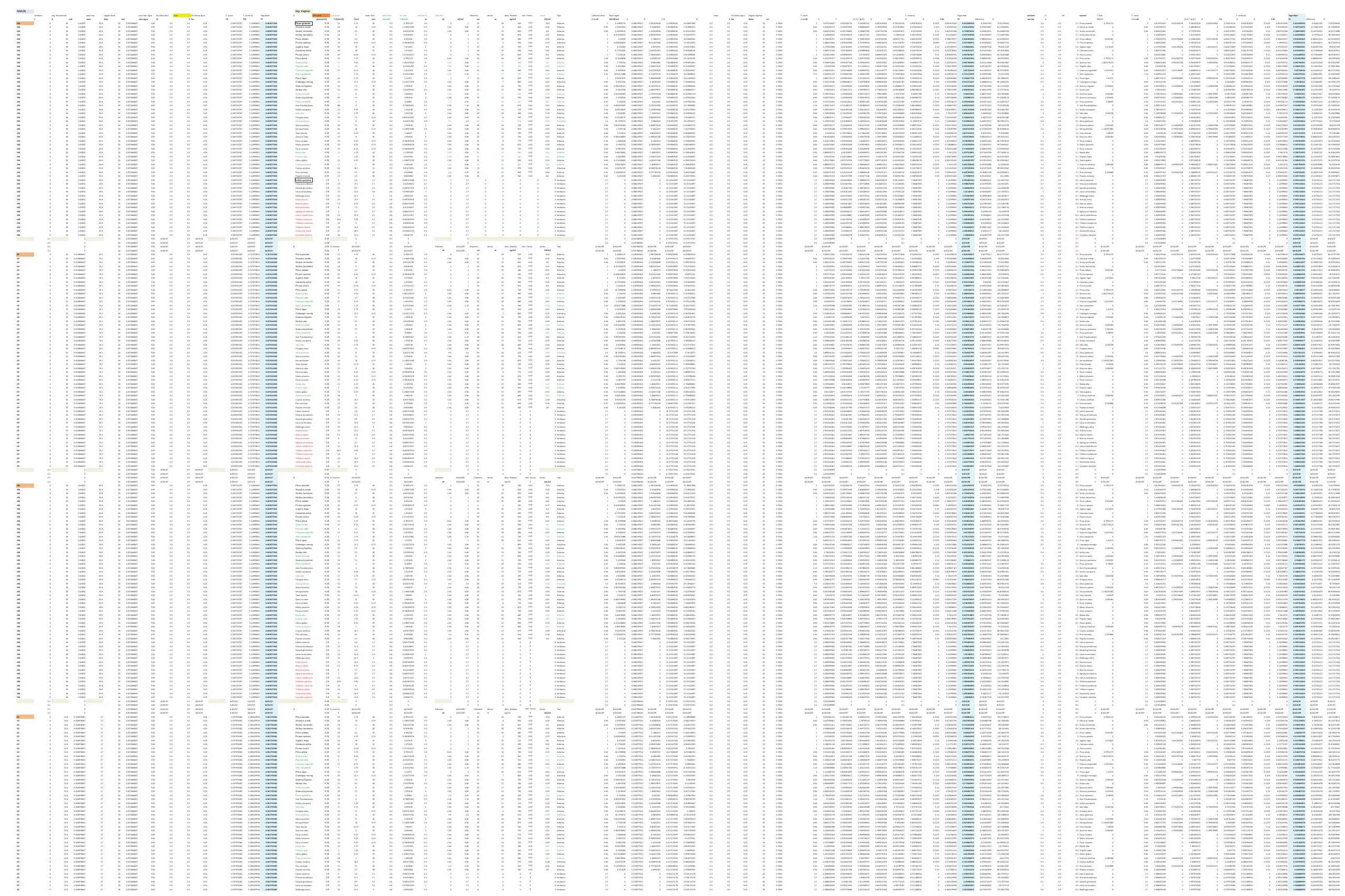


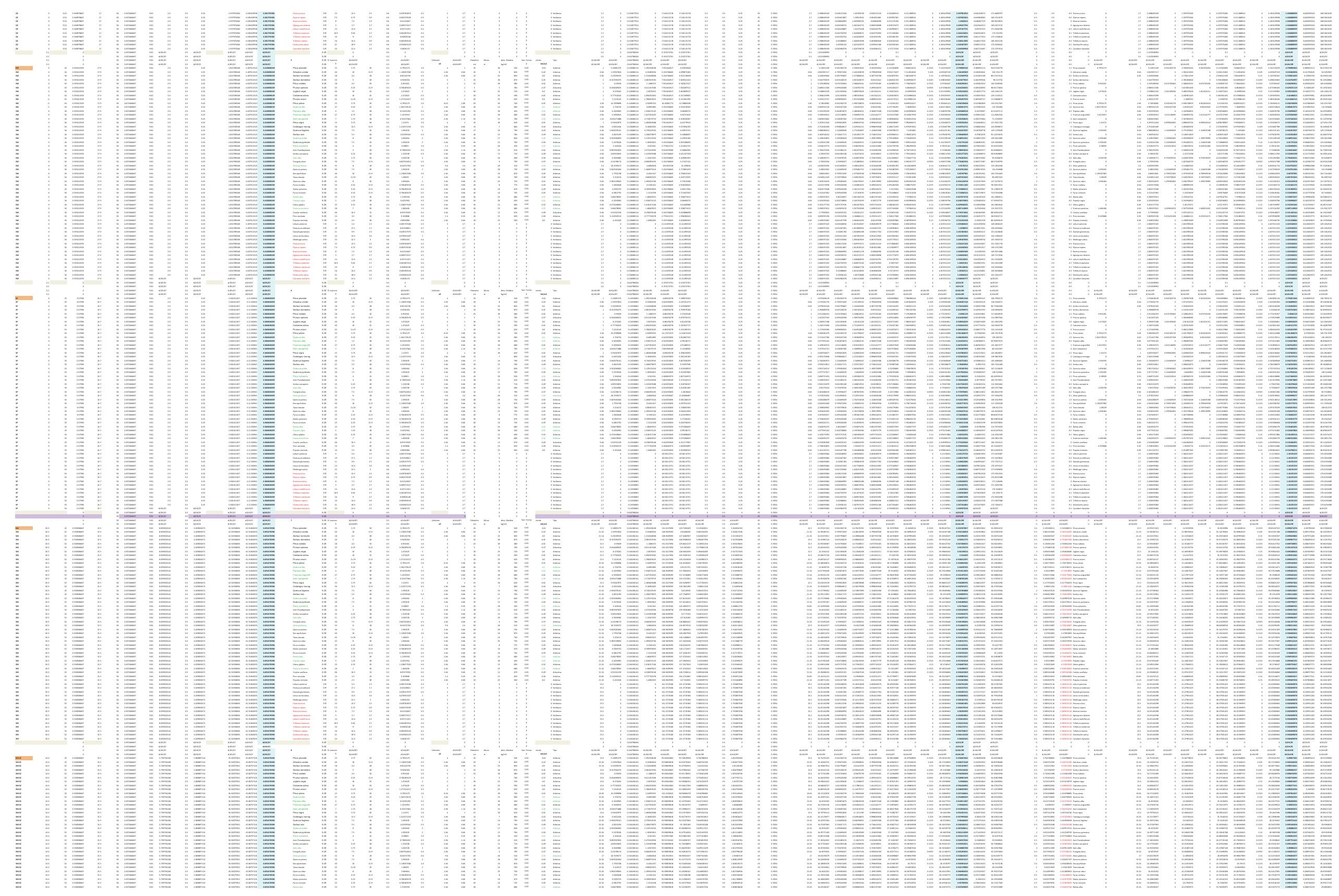



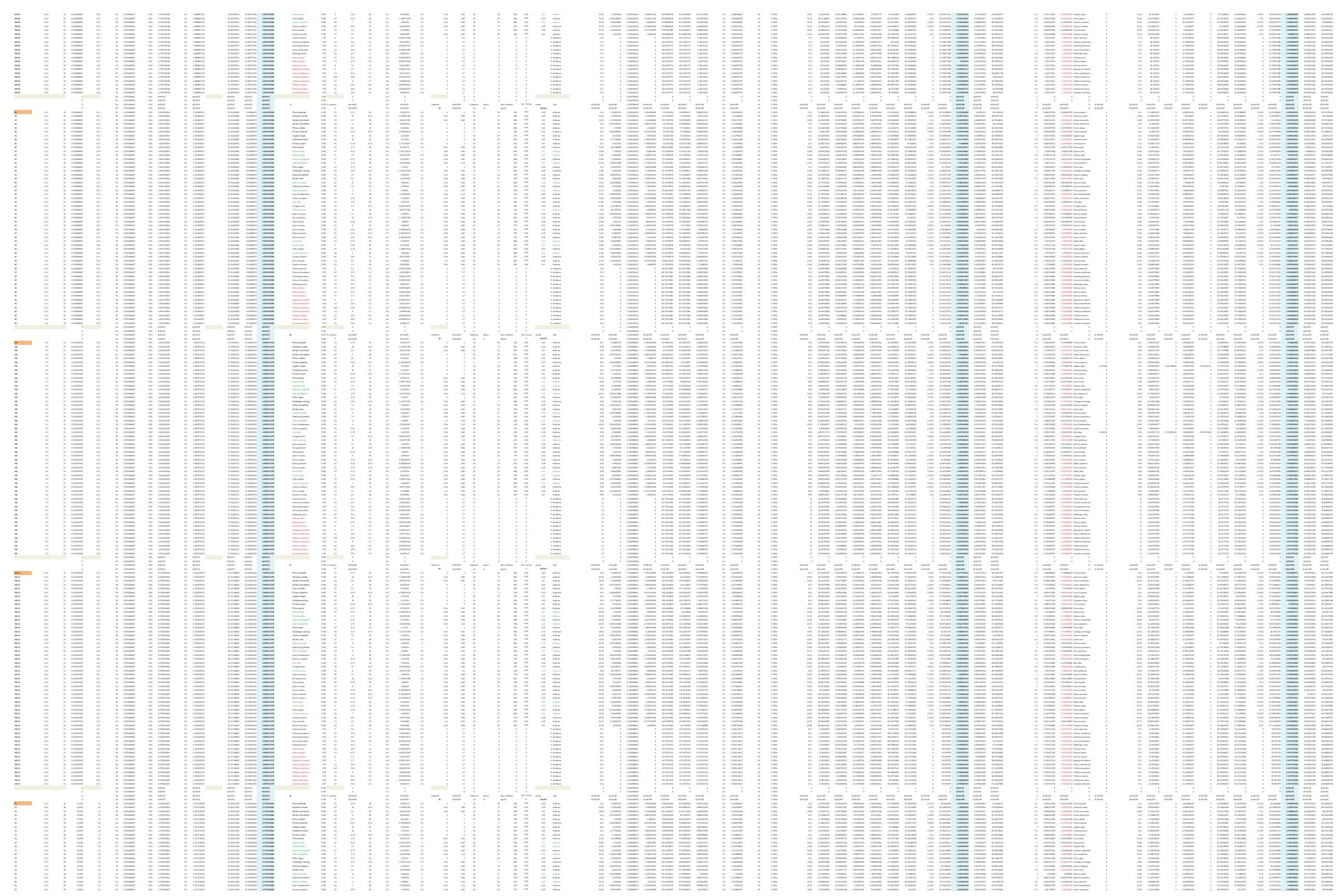


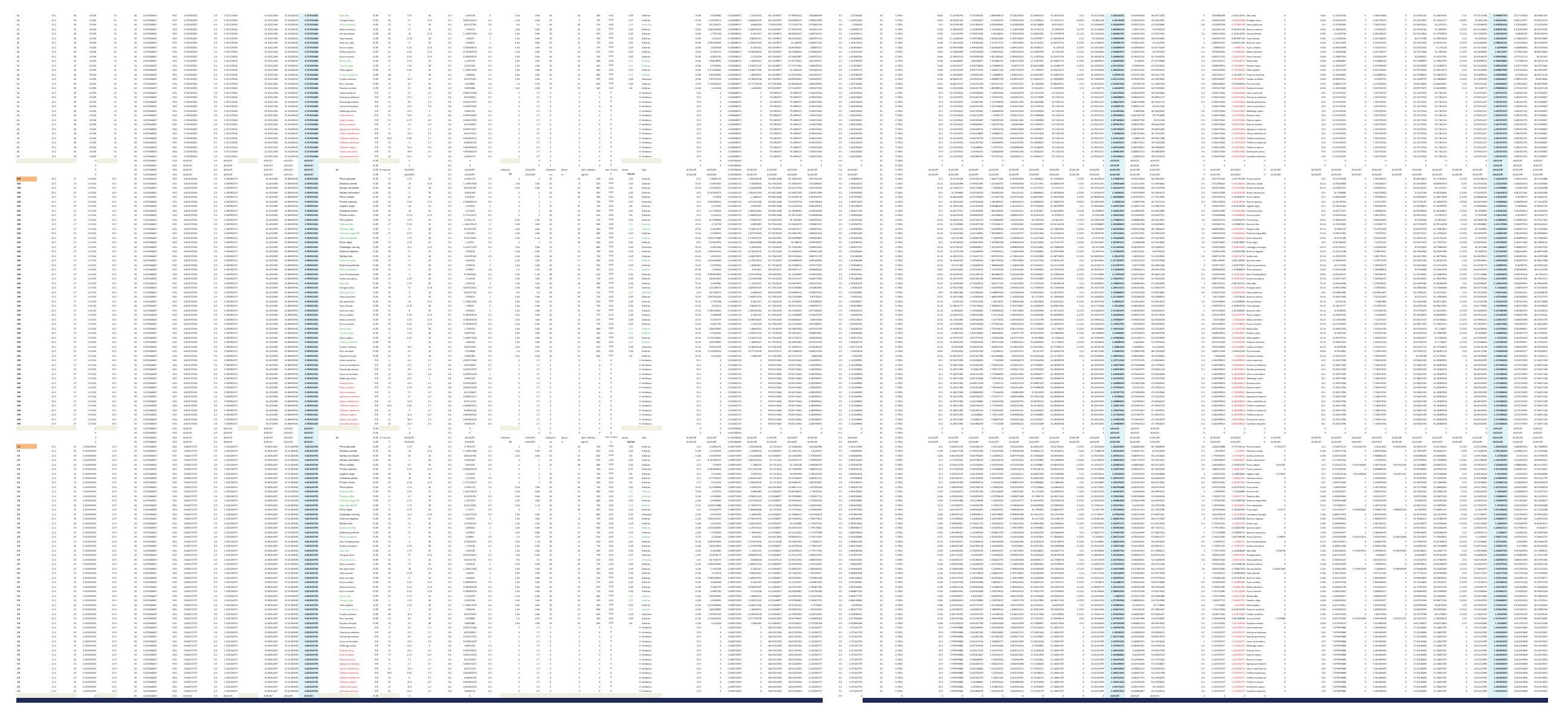



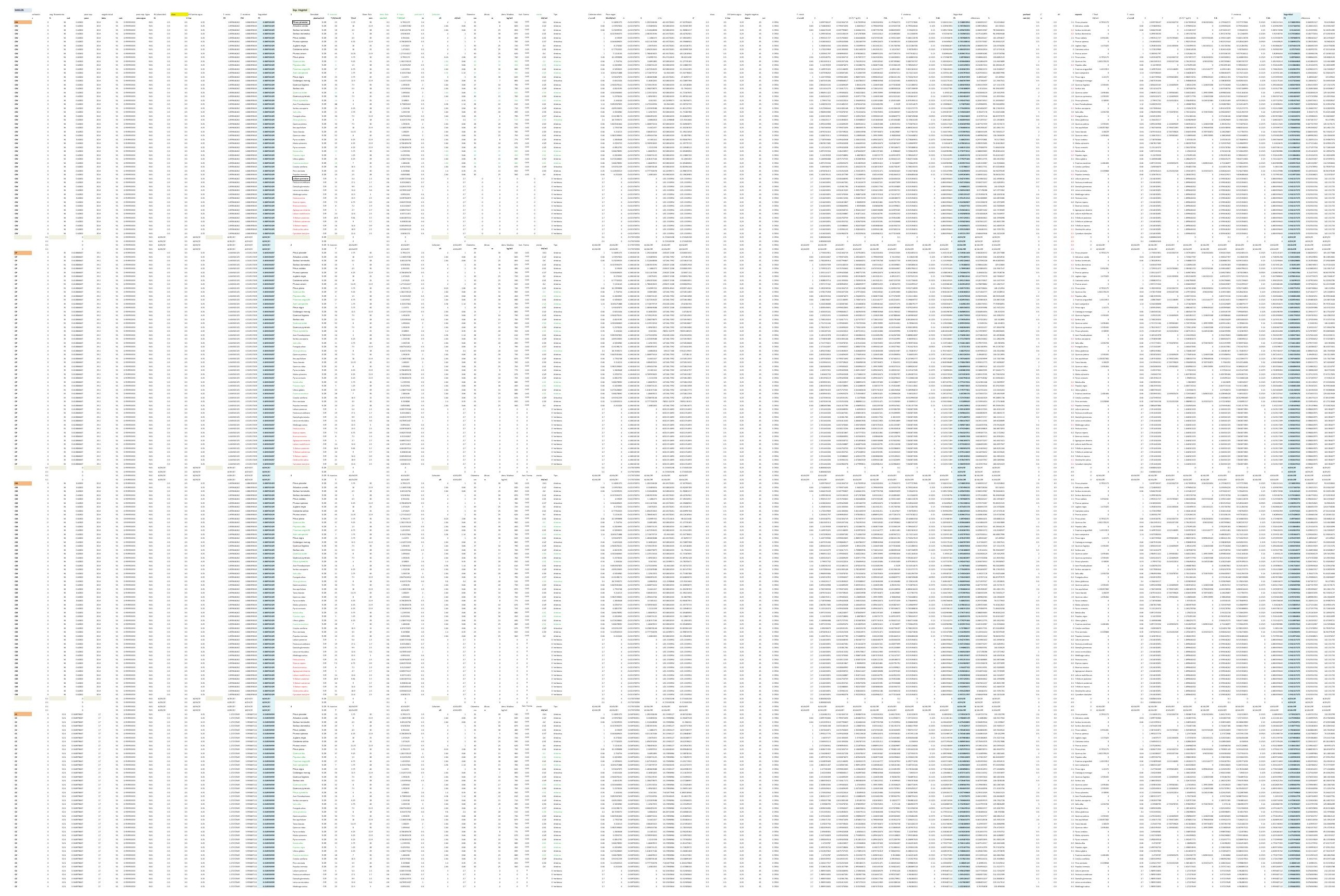


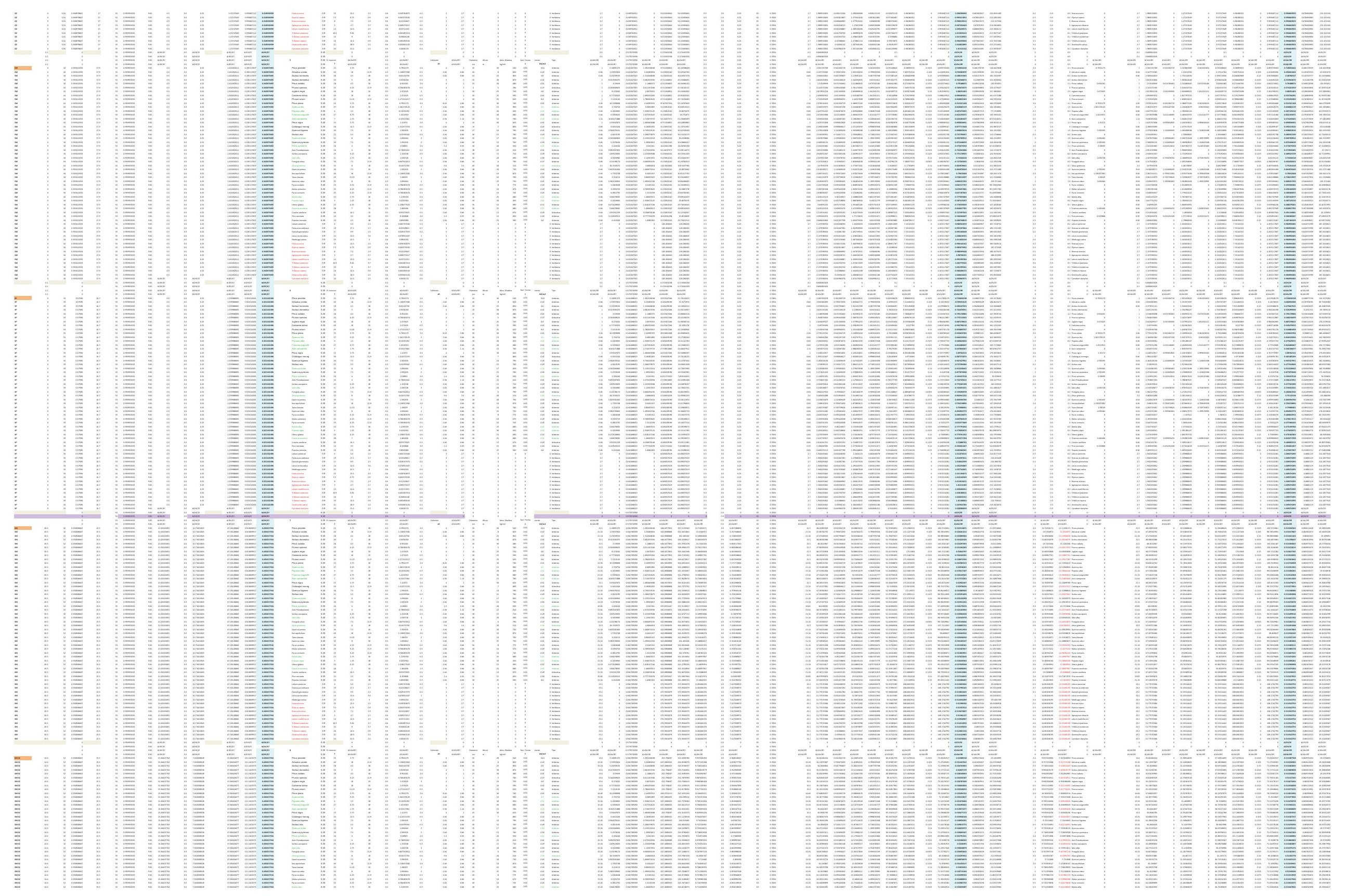



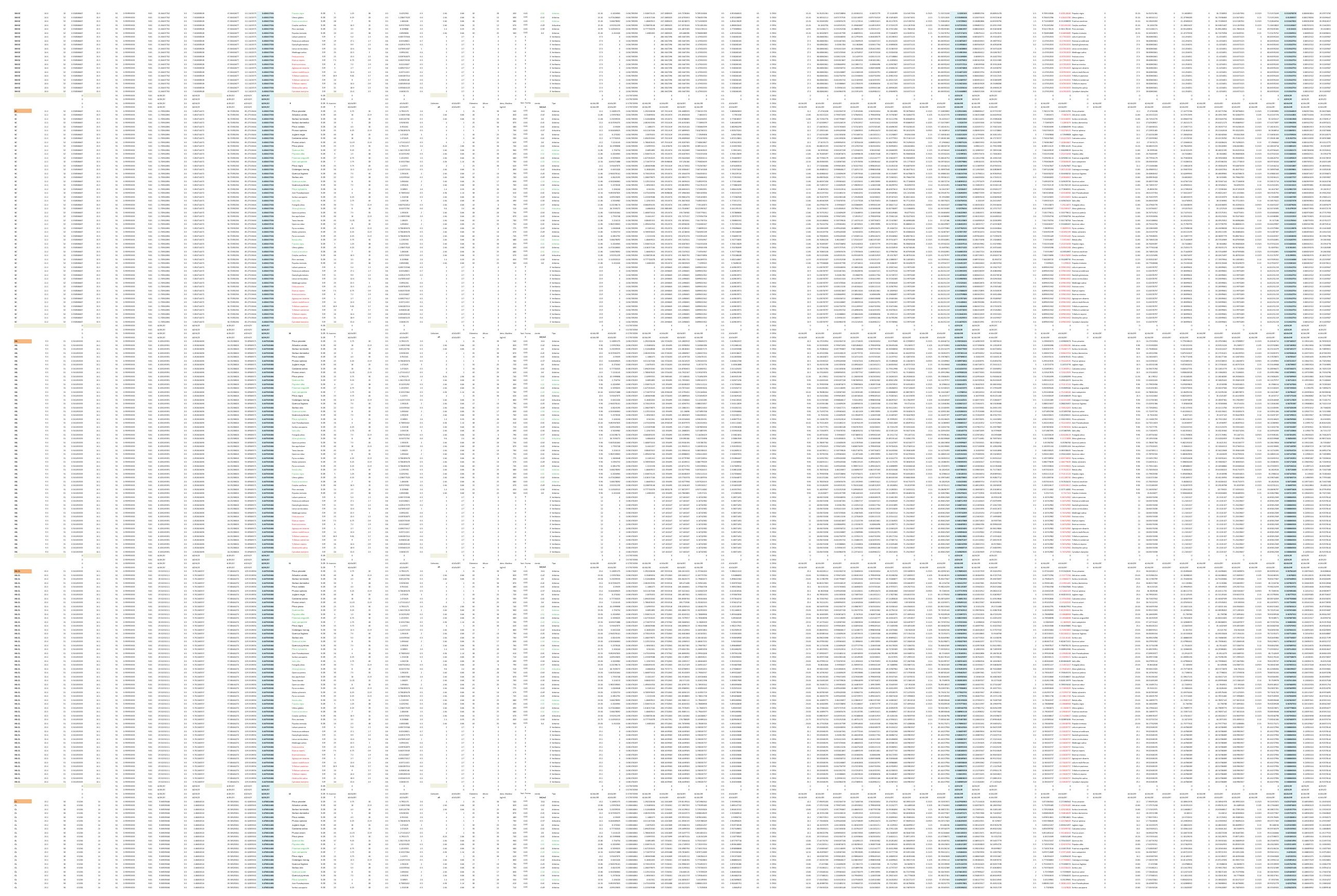


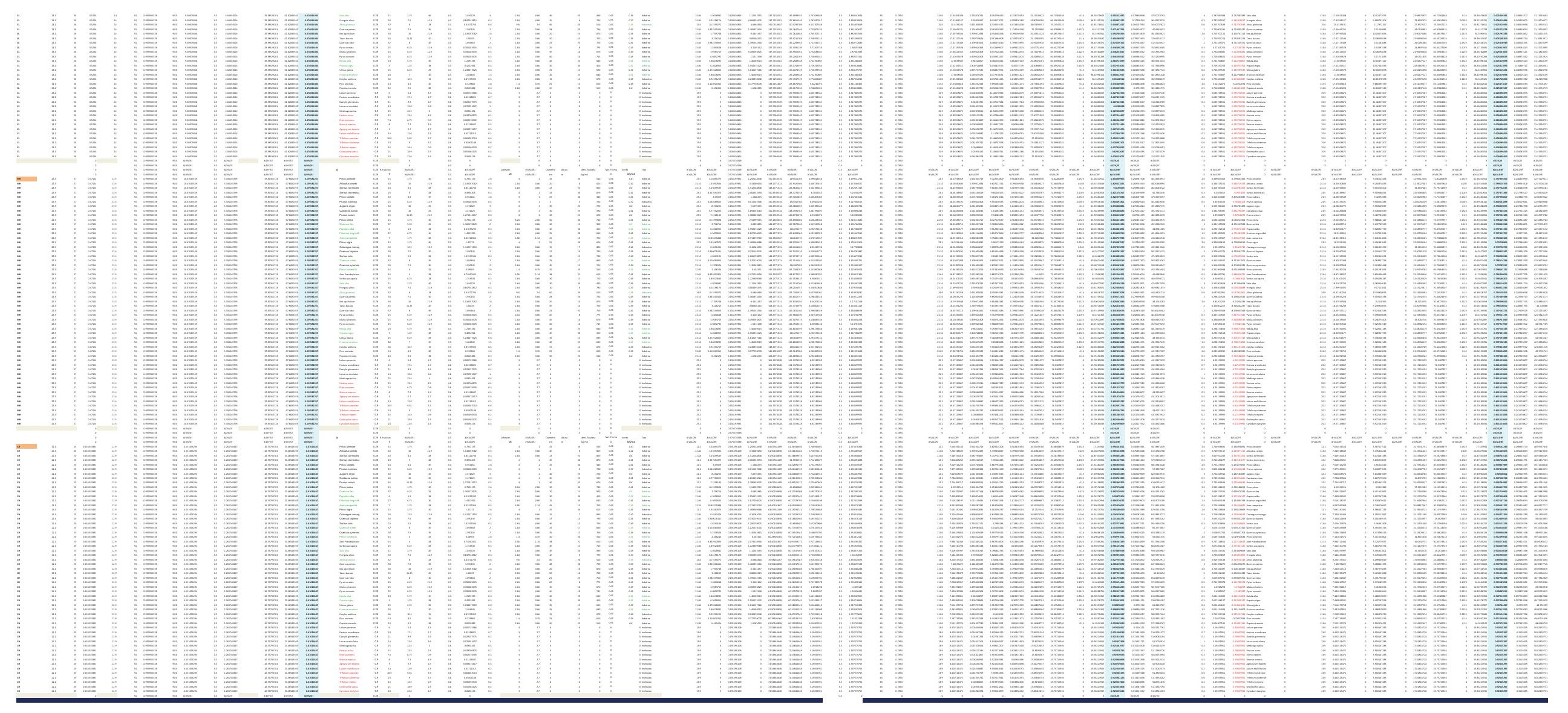



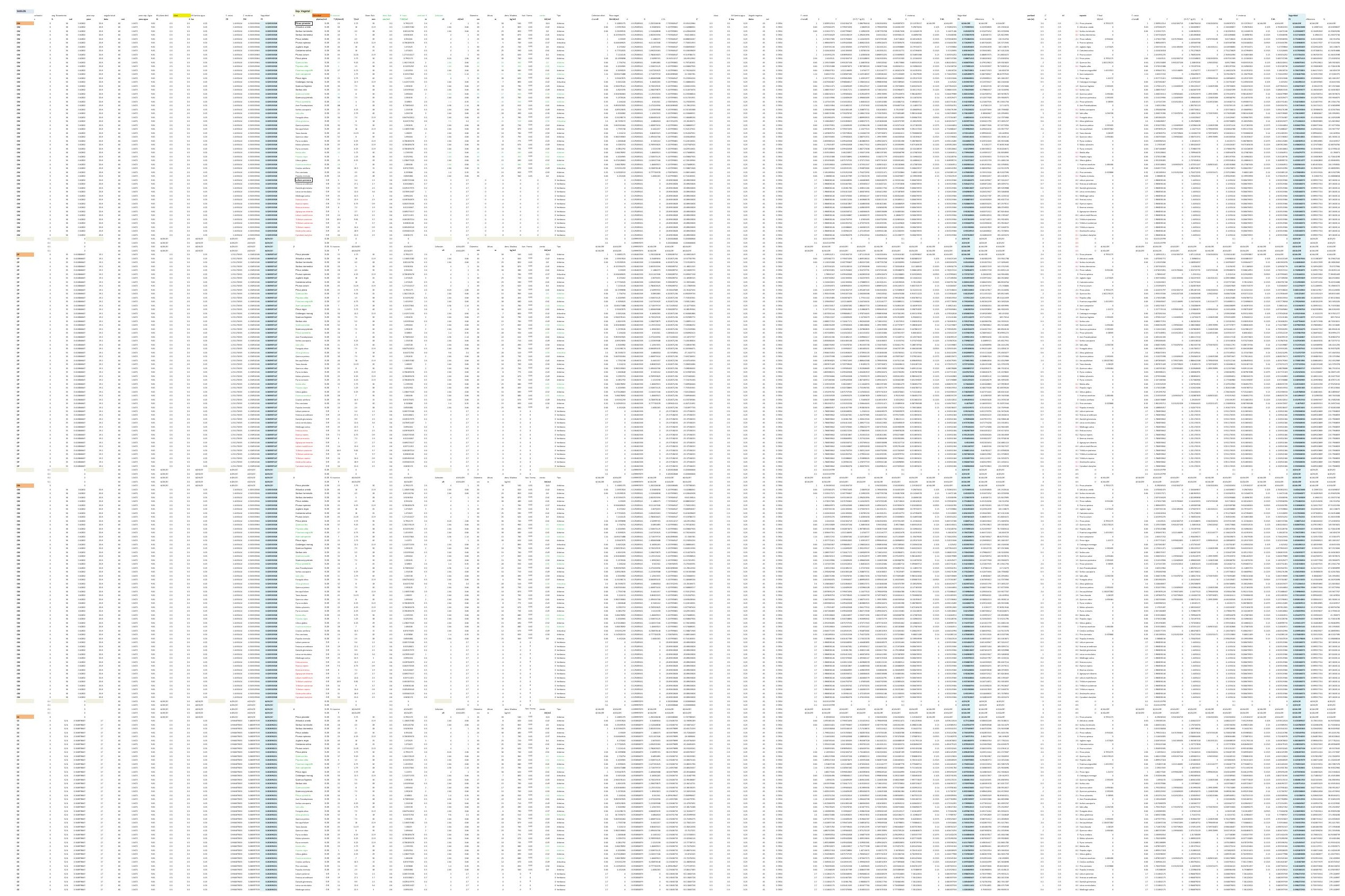


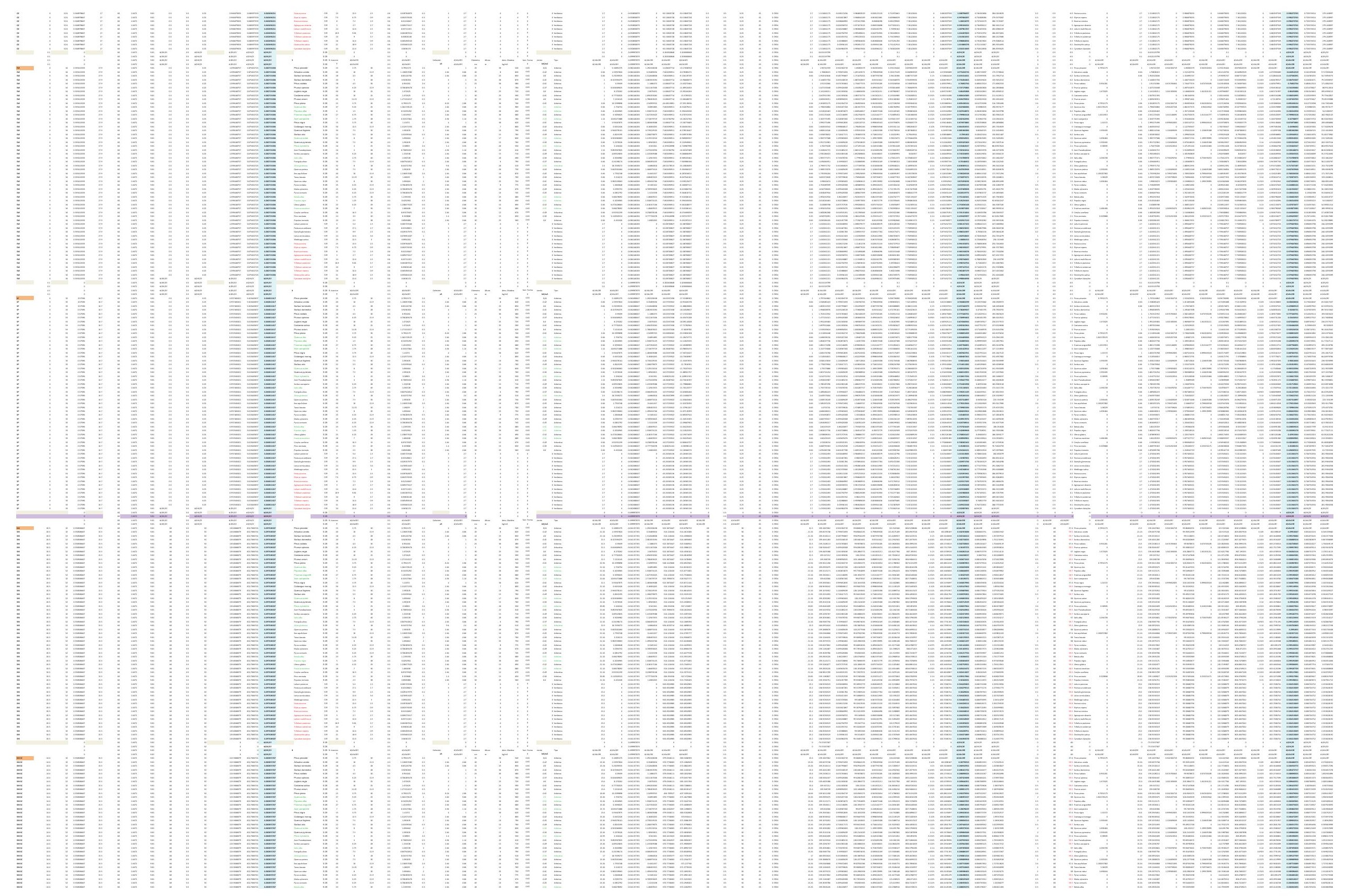



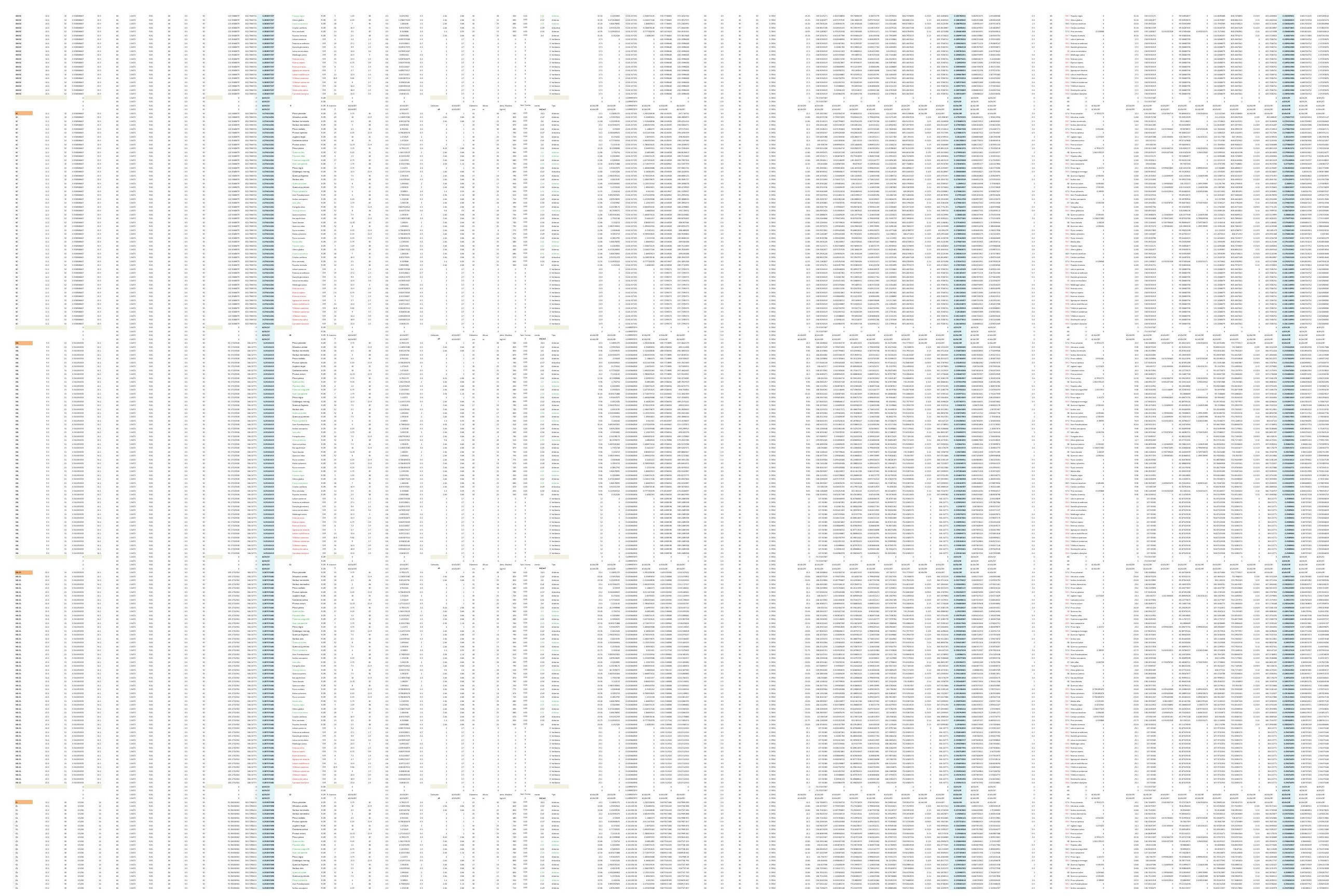


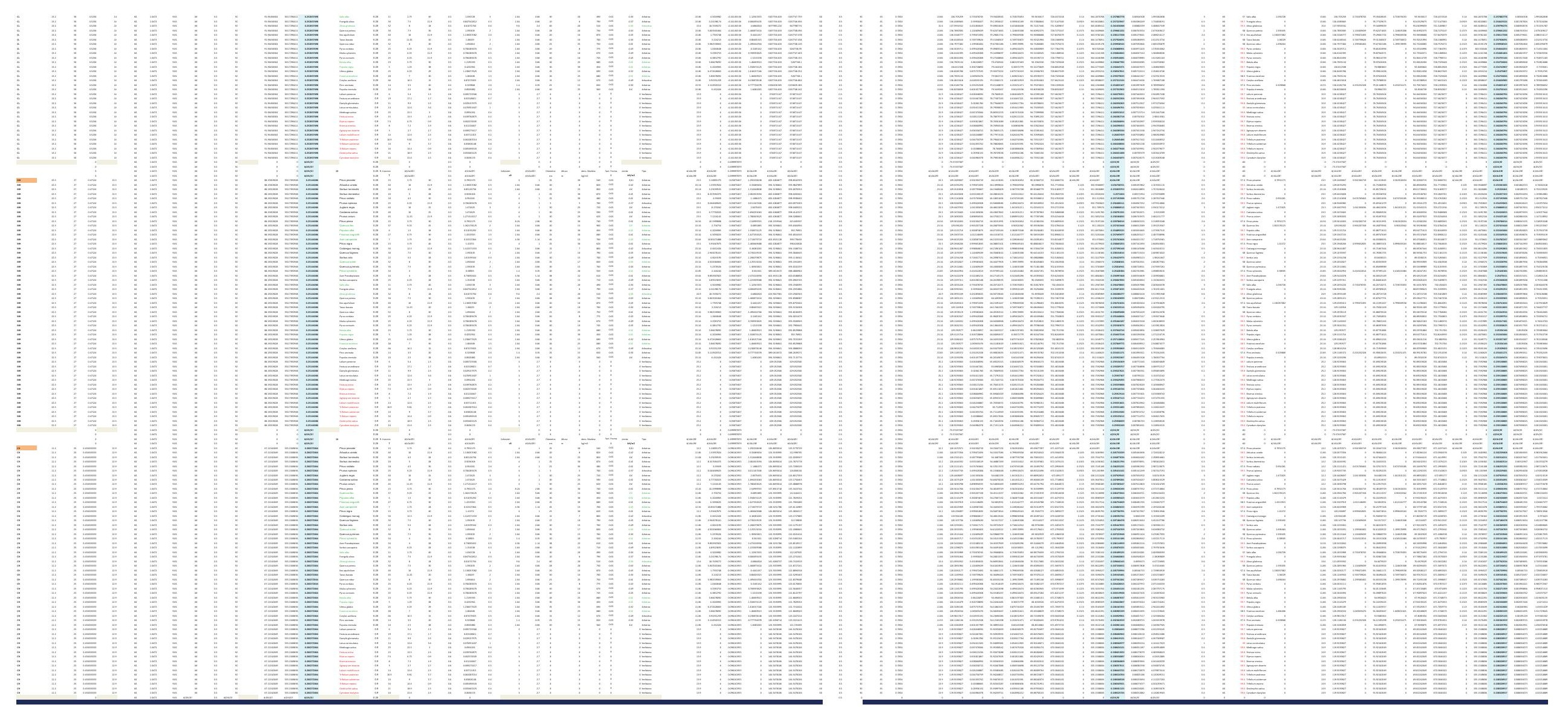



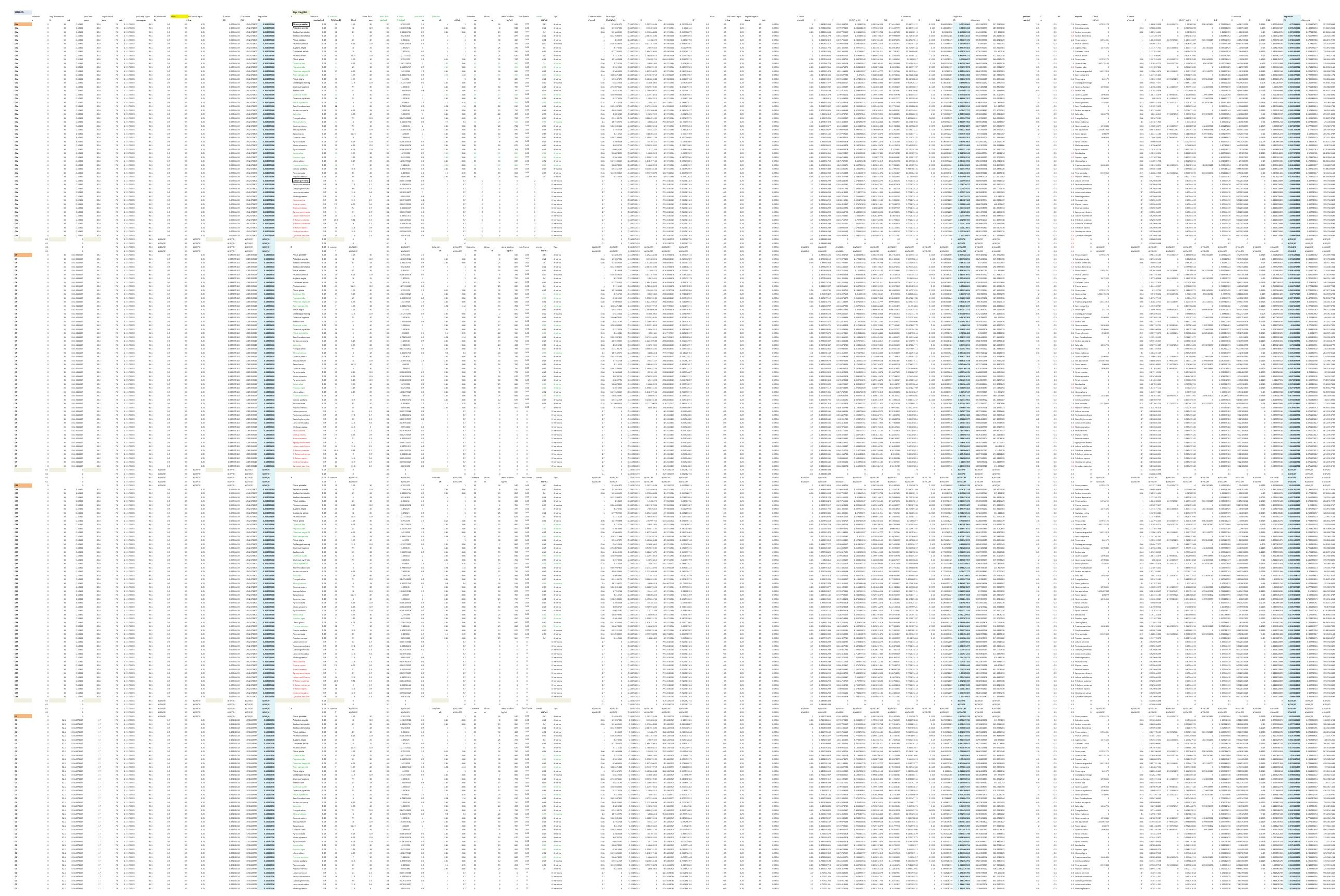


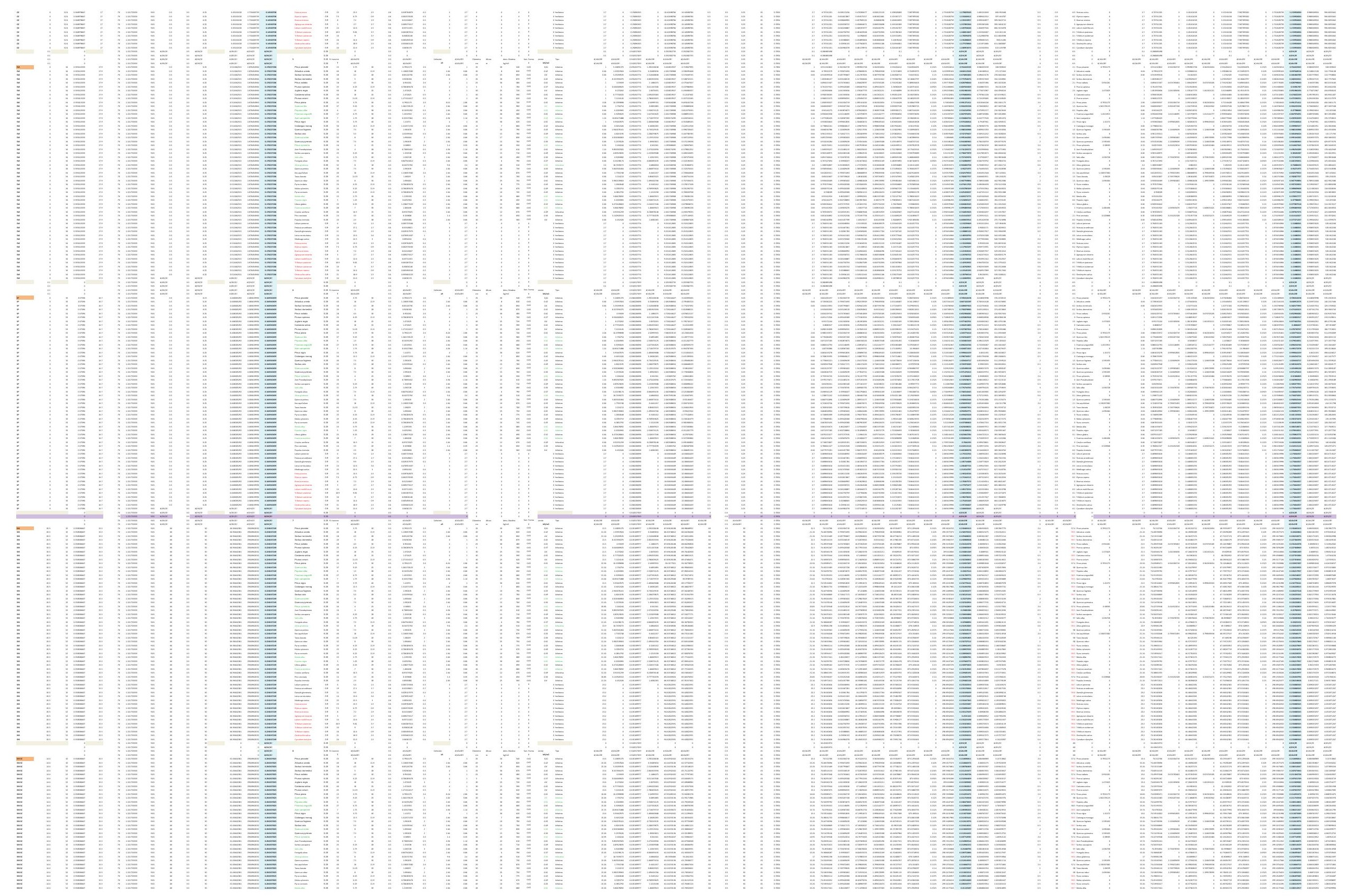




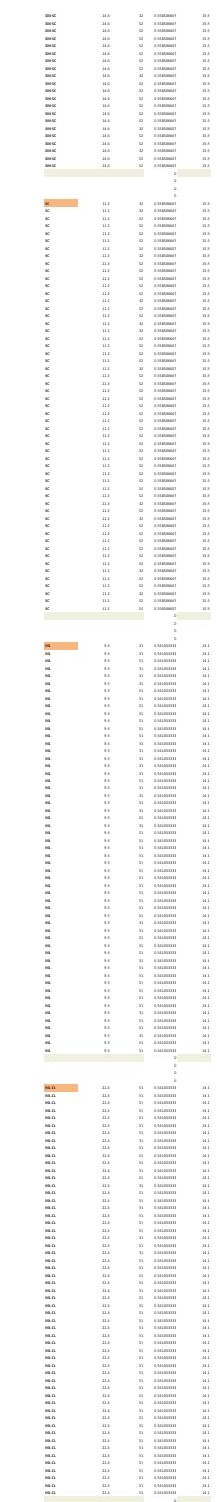

$-$
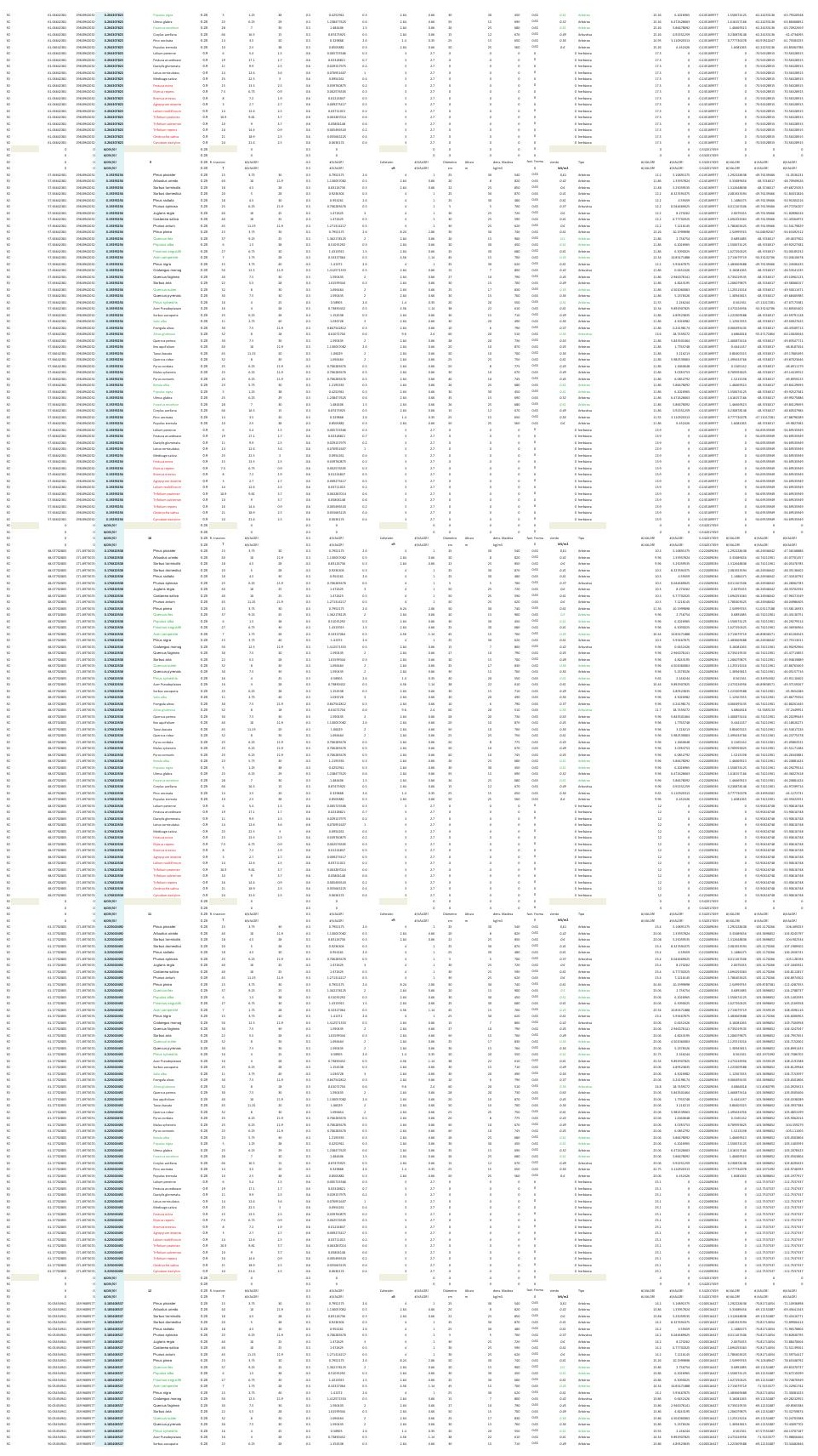
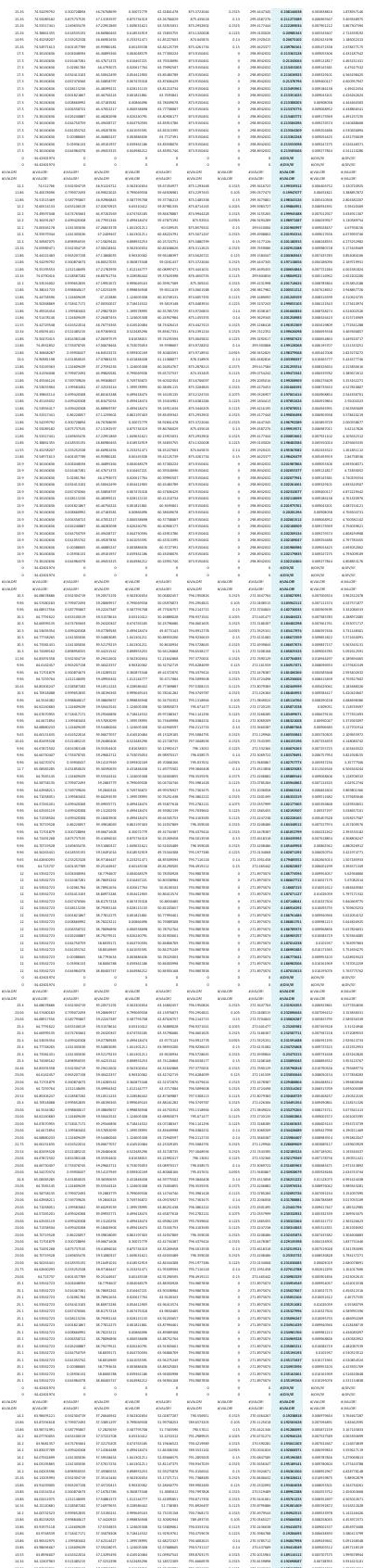

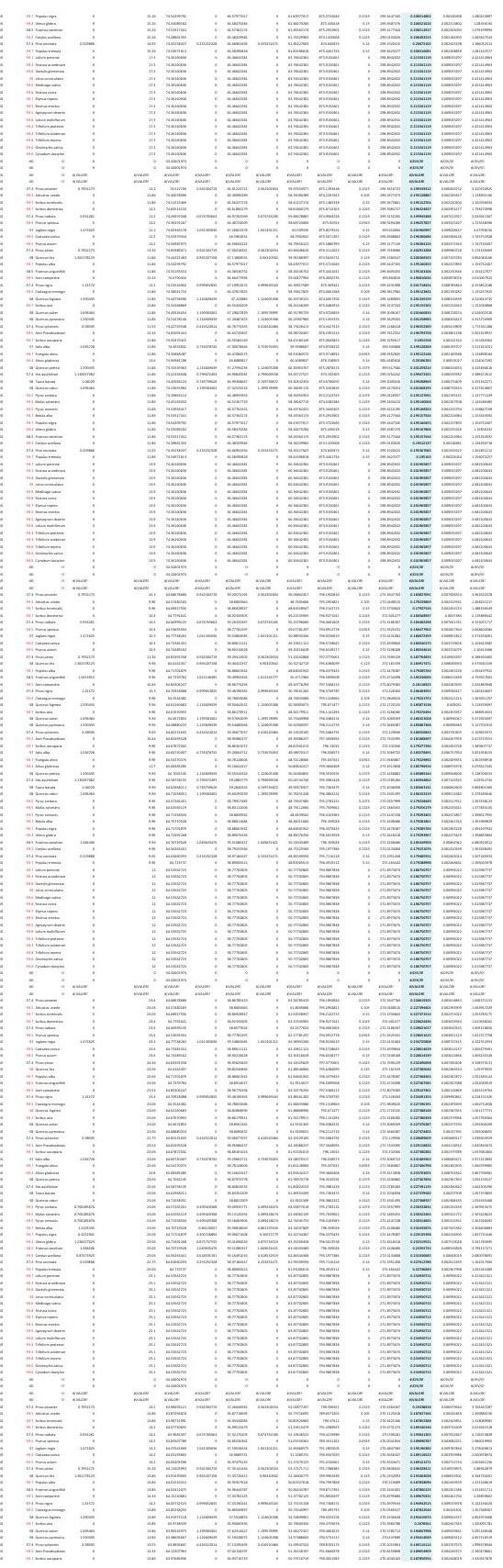




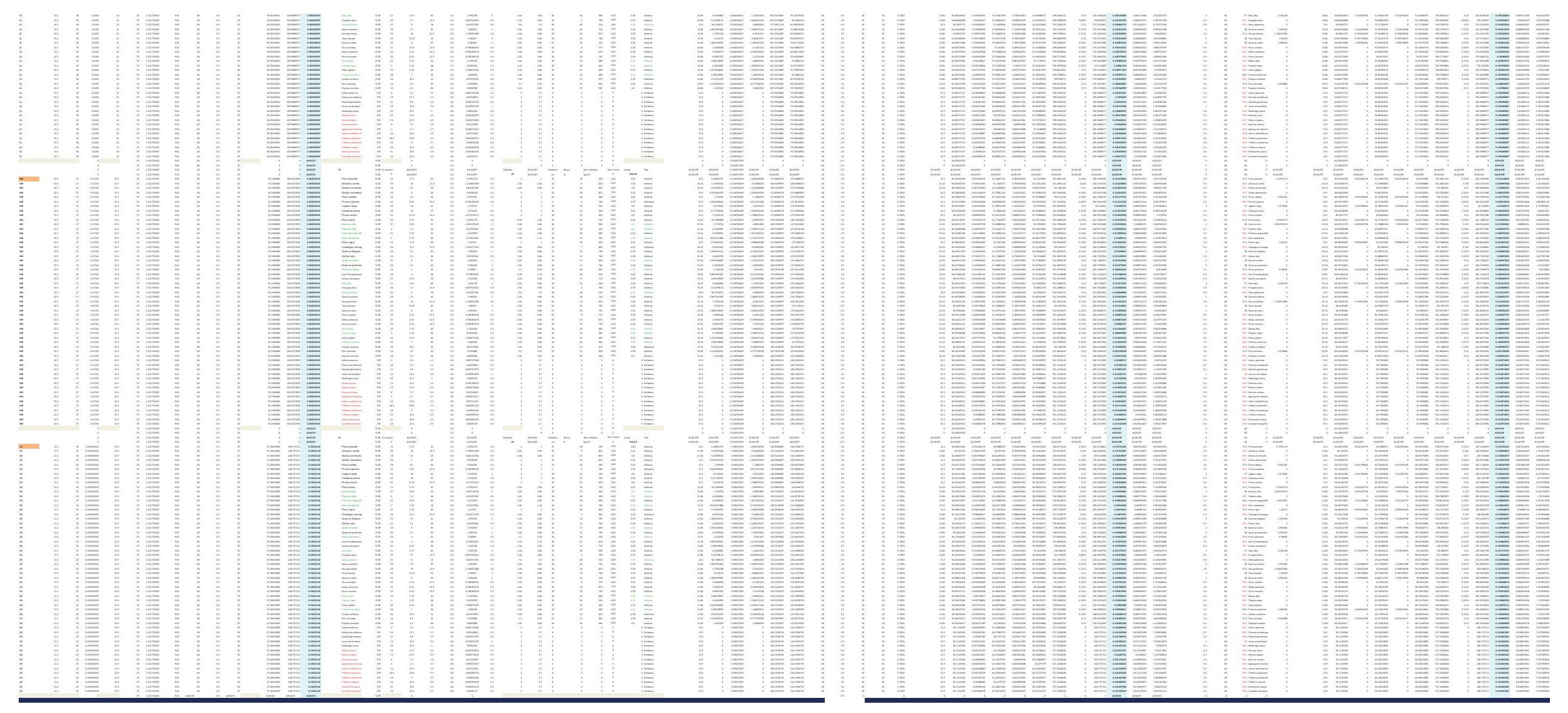



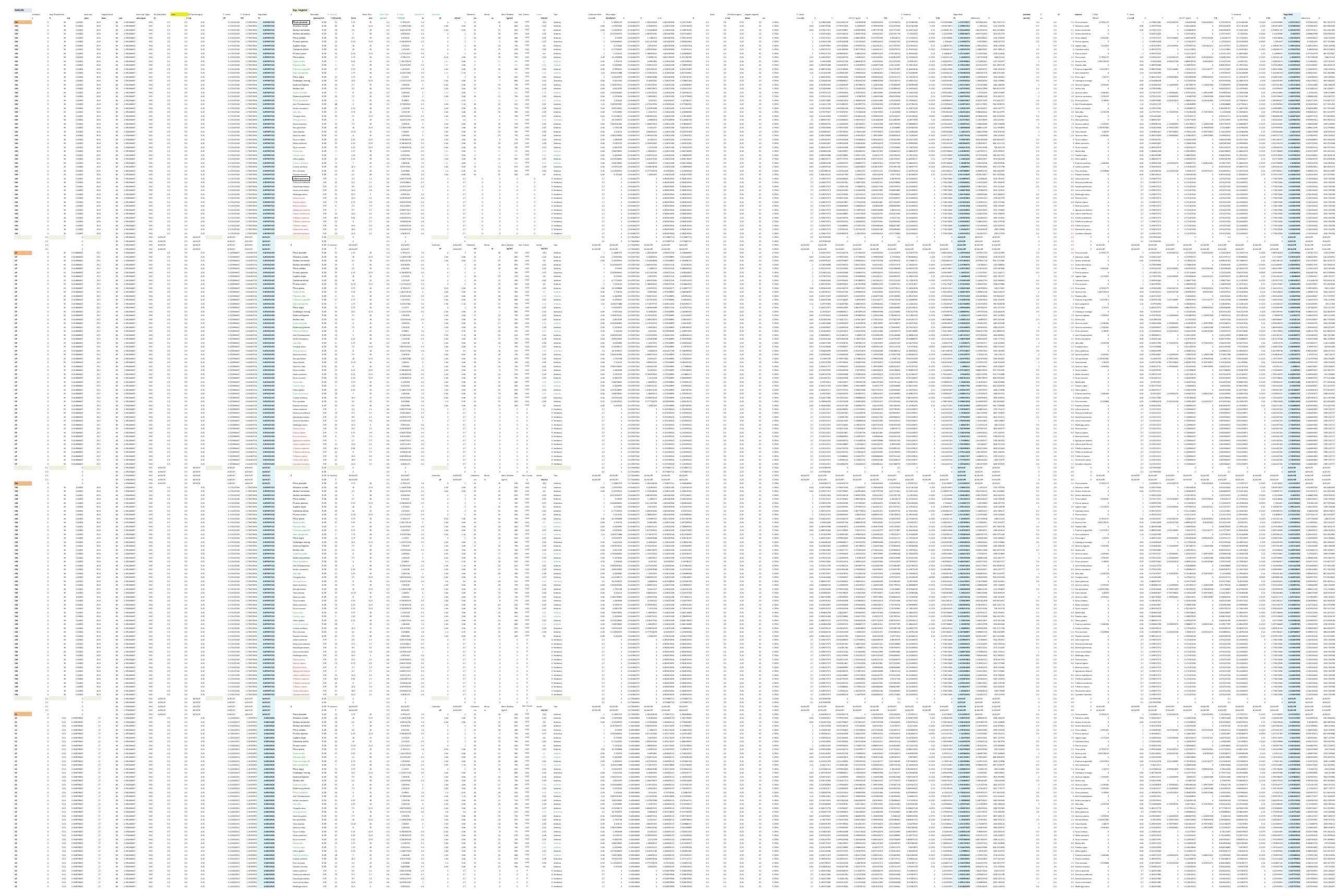


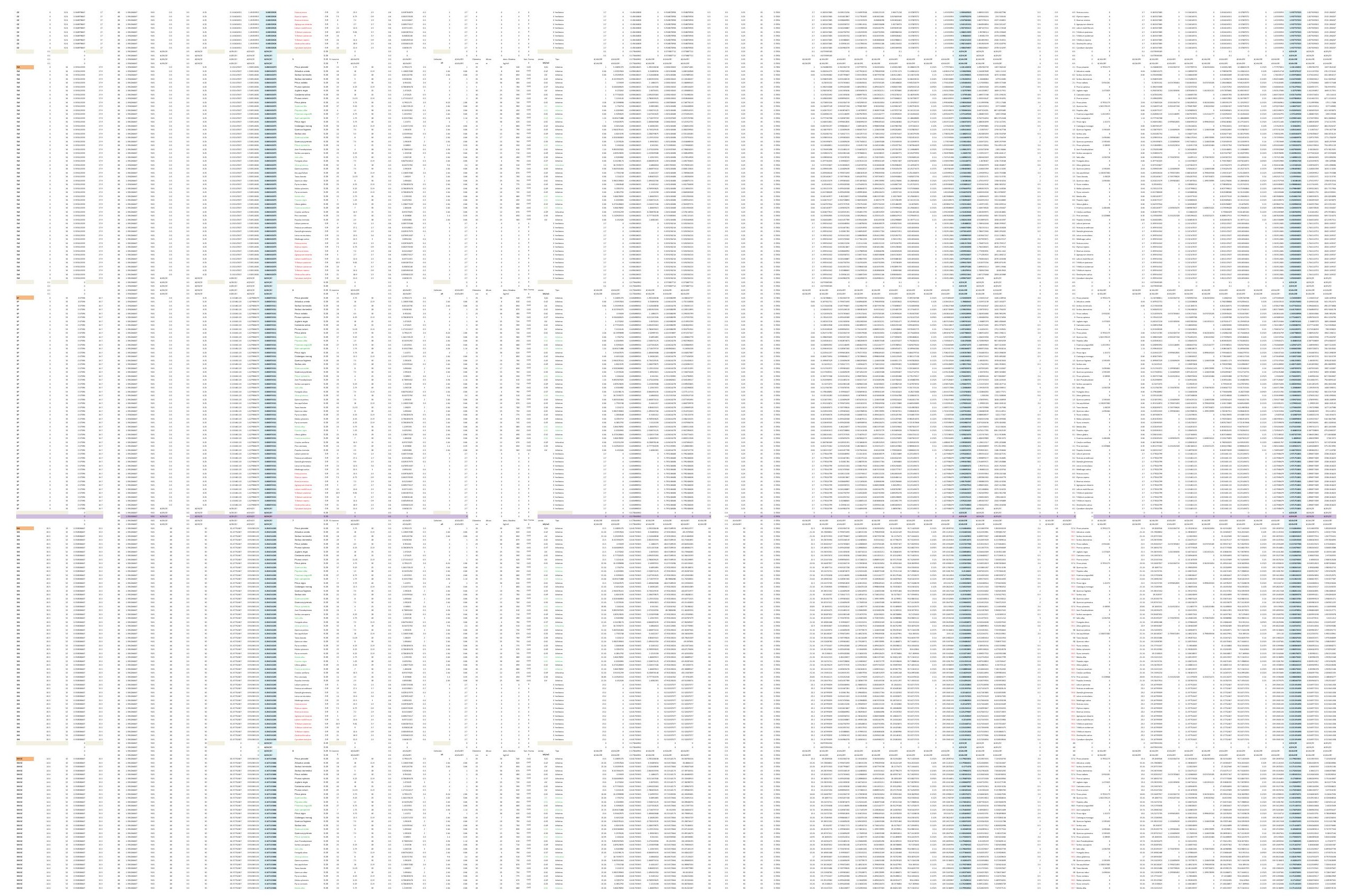



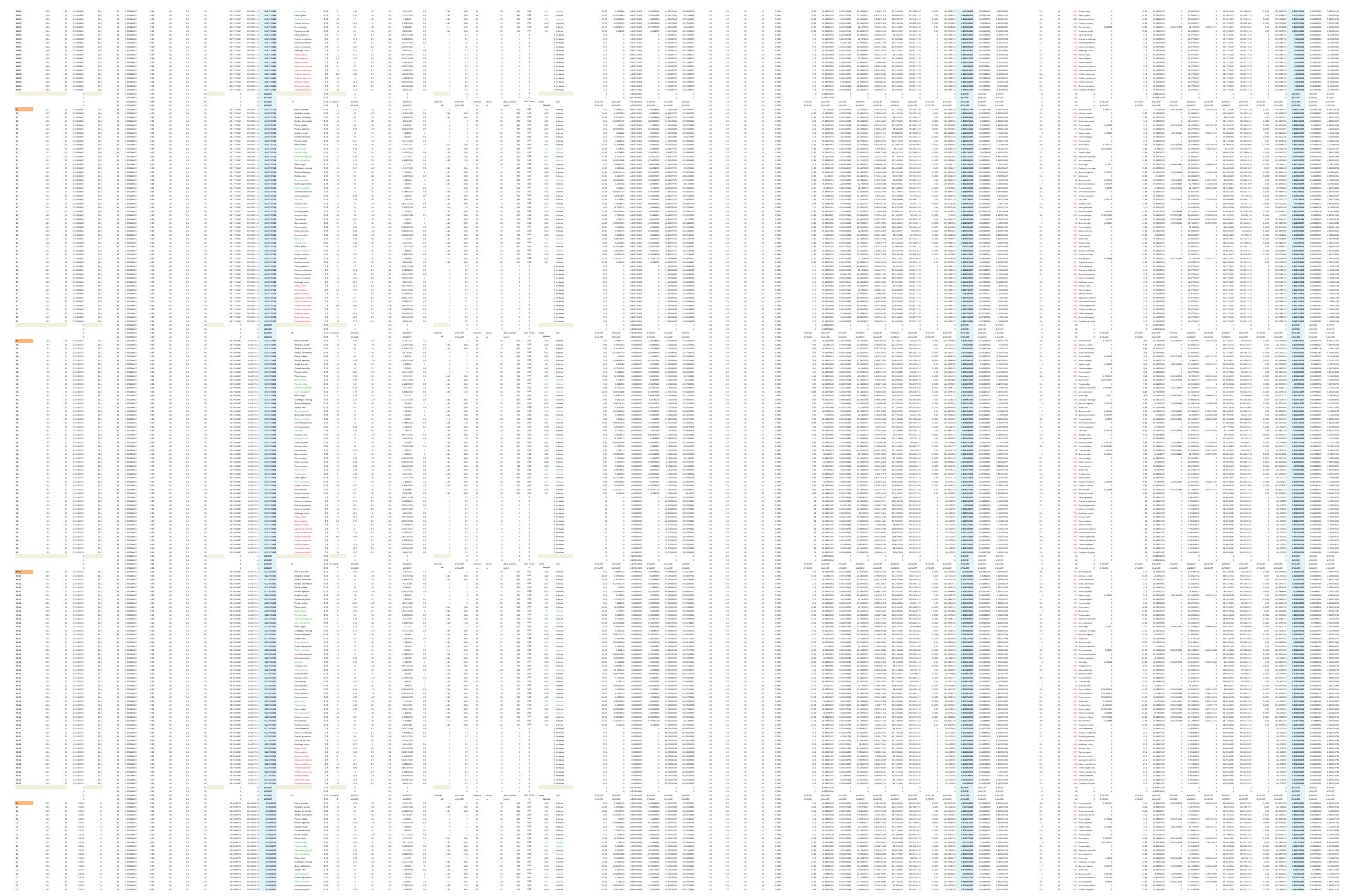


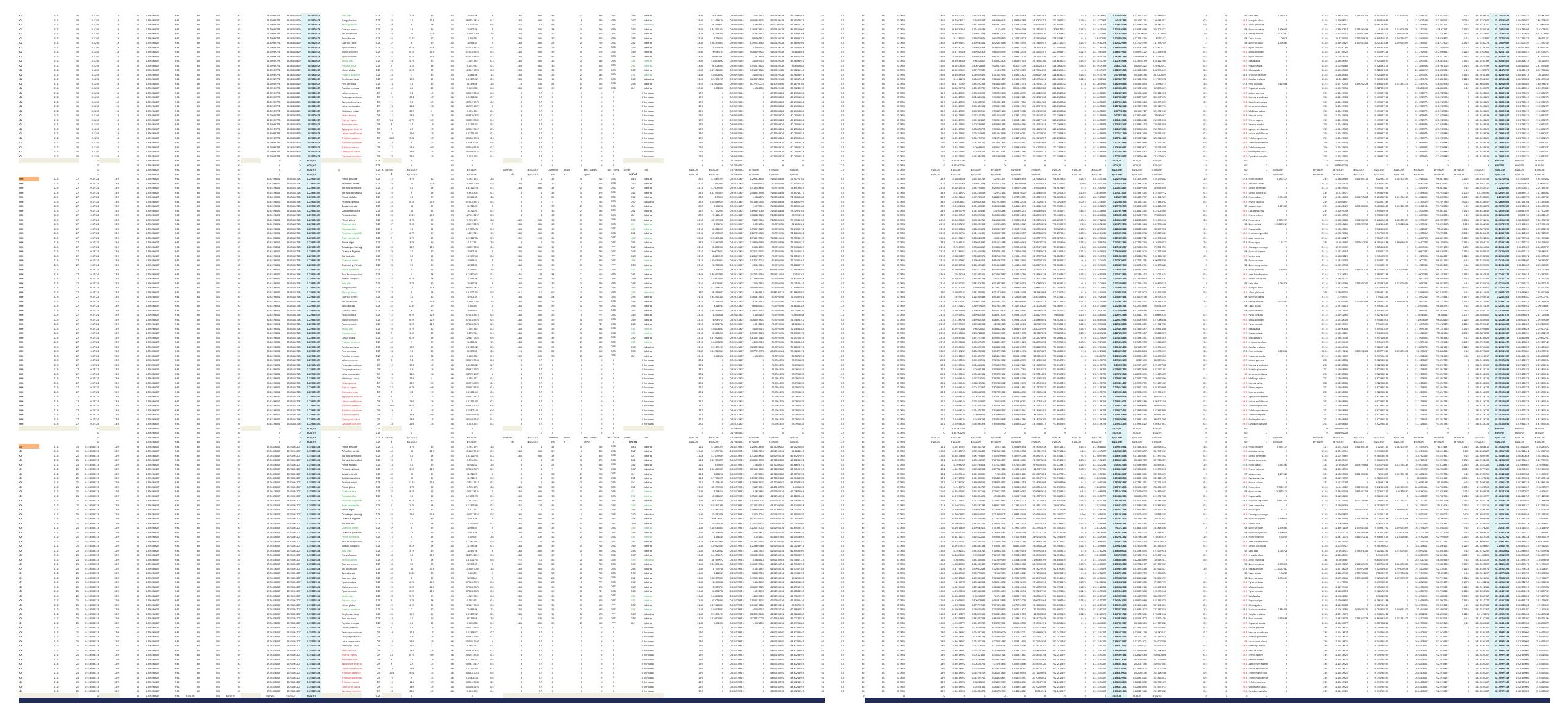


DESARROLLO DE UNA APLICACIÓN IMFORMÁTICA PARA EL CÁLCULO DE SOSTENIMIENTO DE TALUDES MEDIANTE VEGETACIÓN

A03. DENSIDAD DE PLANTACIÓN: 2.500 plantas/ha.

\section{A03-5.POSICIÓN N.F. 5}

INCLINACIÓN DE TALUD 6-100

INCLINACIÓN DE TALUD 10-200

INCLINACIÓN DE TALUD 20-30

INCLINACIÓN DE TALUD 30-40

INCLINACIÓN DE TALUD $35^{\circ}$

INCLINACIÓN DE TALUD 40-50

INCLINACIÓN DE TALUD 50-550

INCLINACIÓN DE TALUD 55-60

INCLINACIÓN DE TALUD 60-700

INCLINACIÓN DE TALUD 70-80 

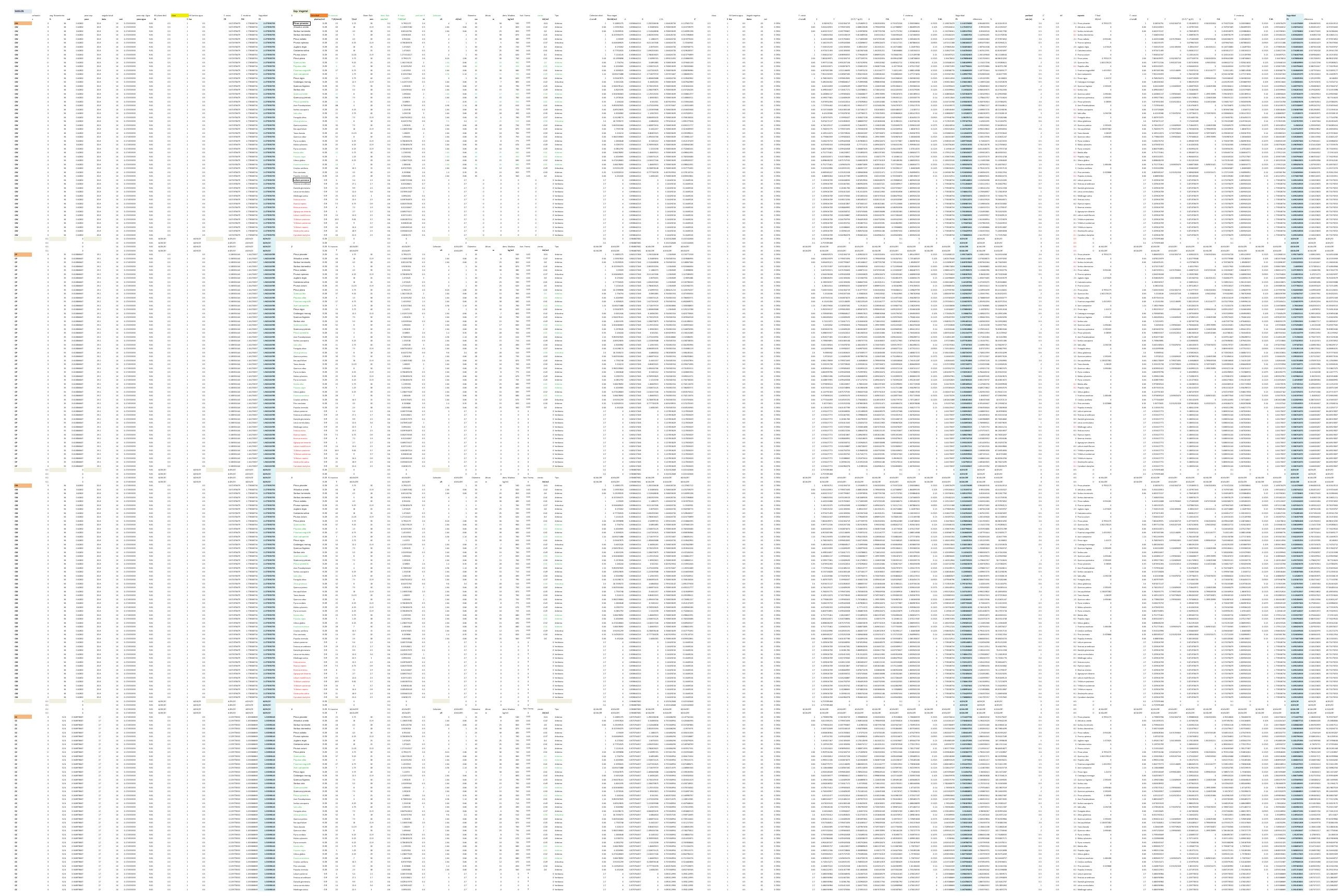


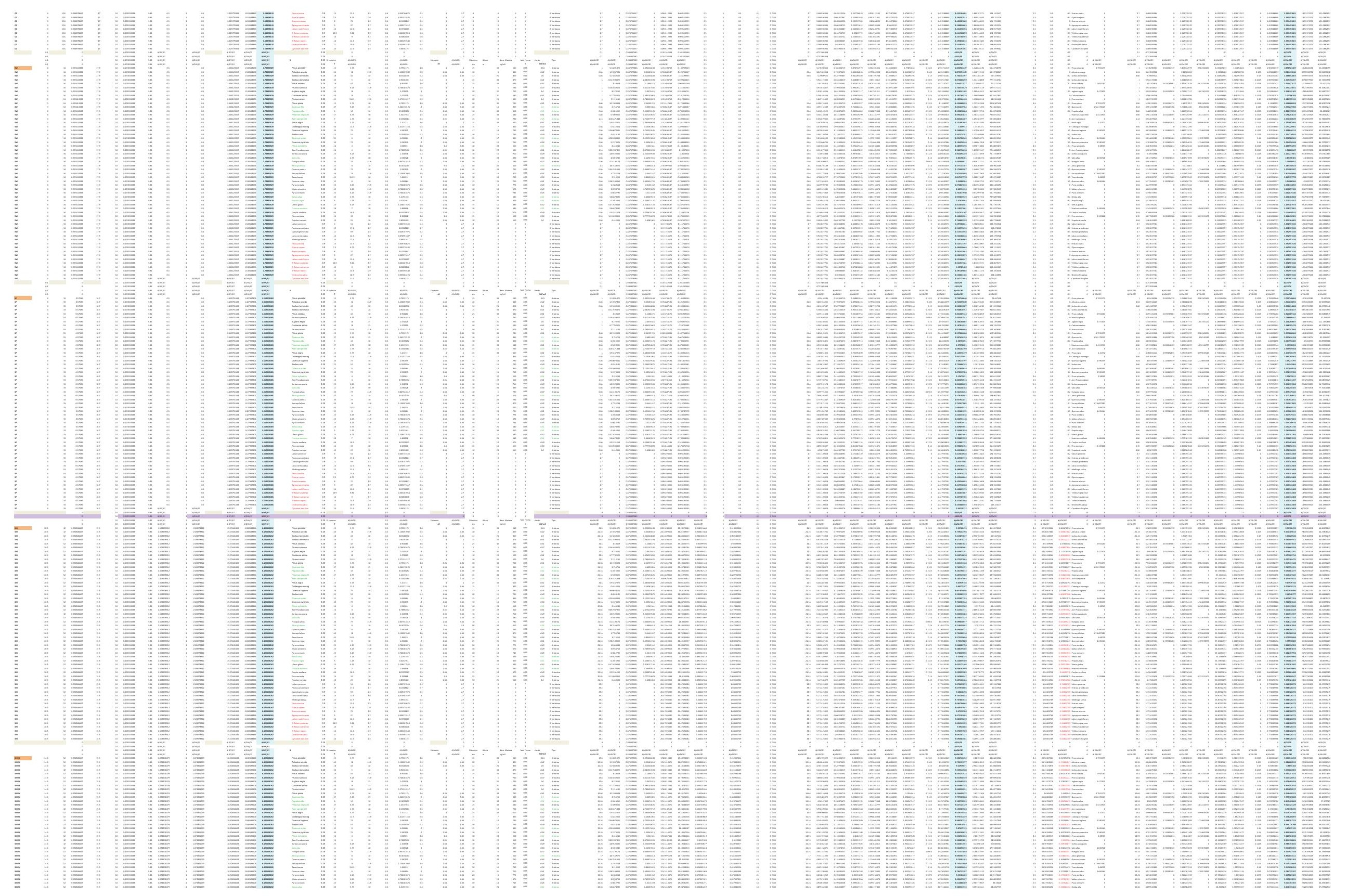



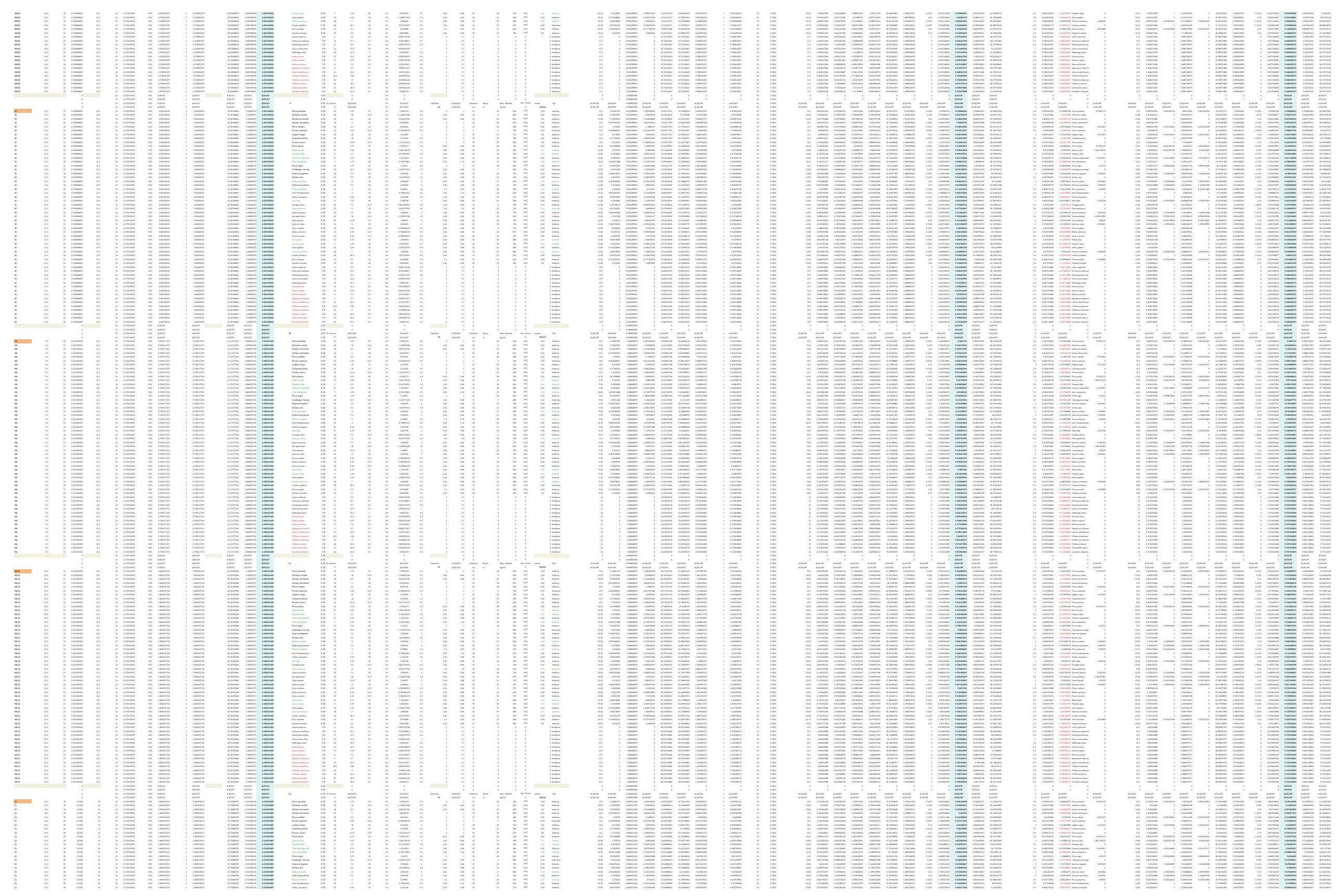


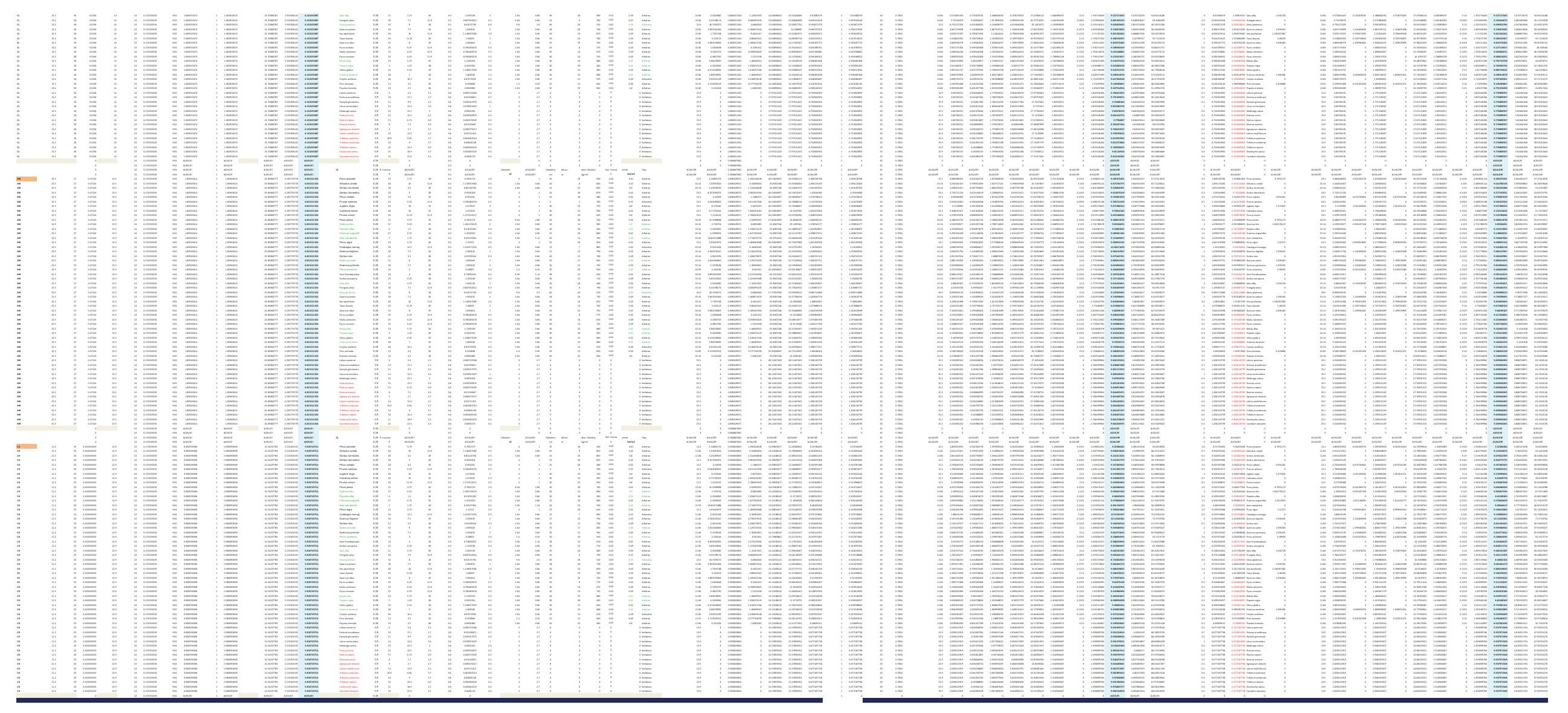



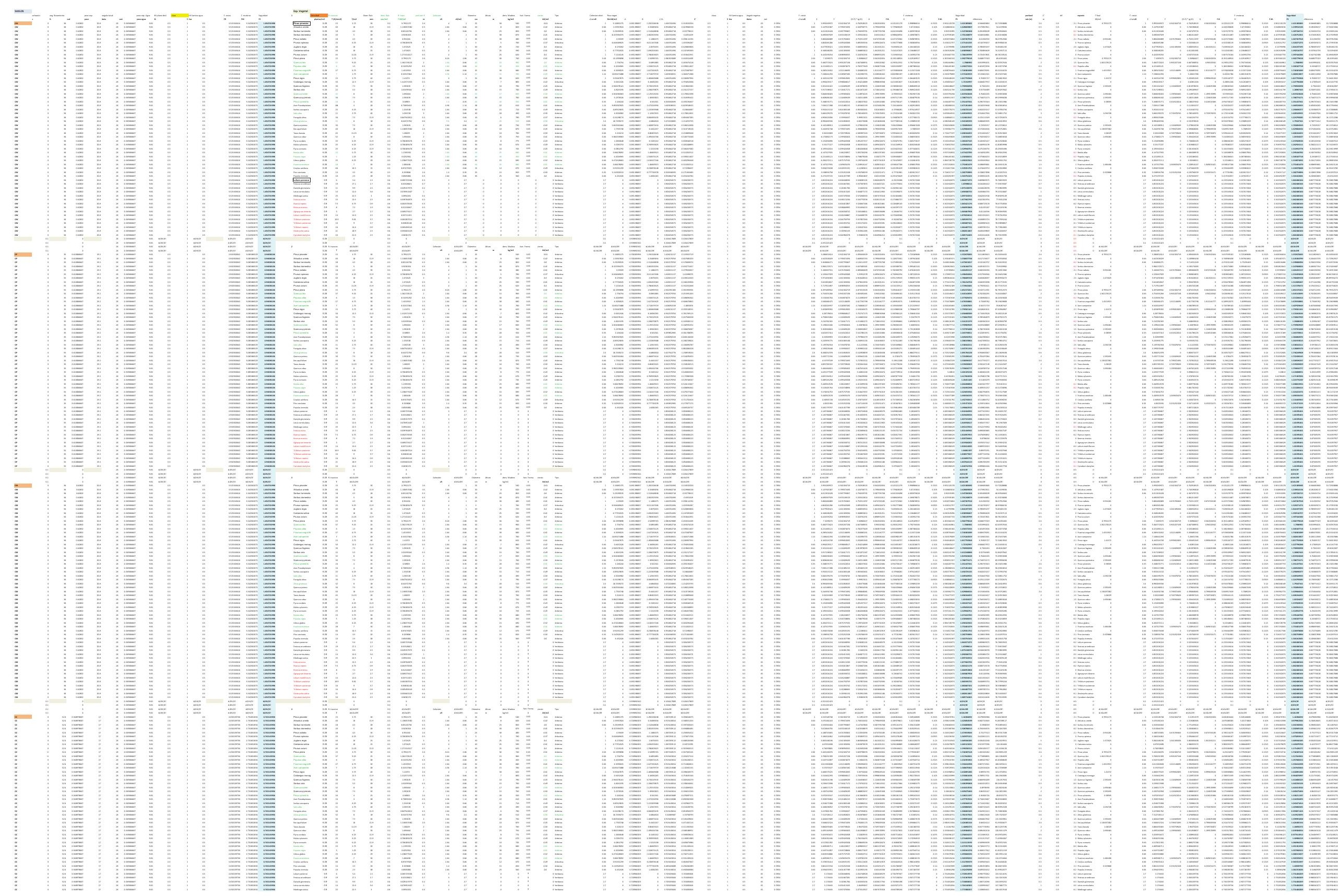


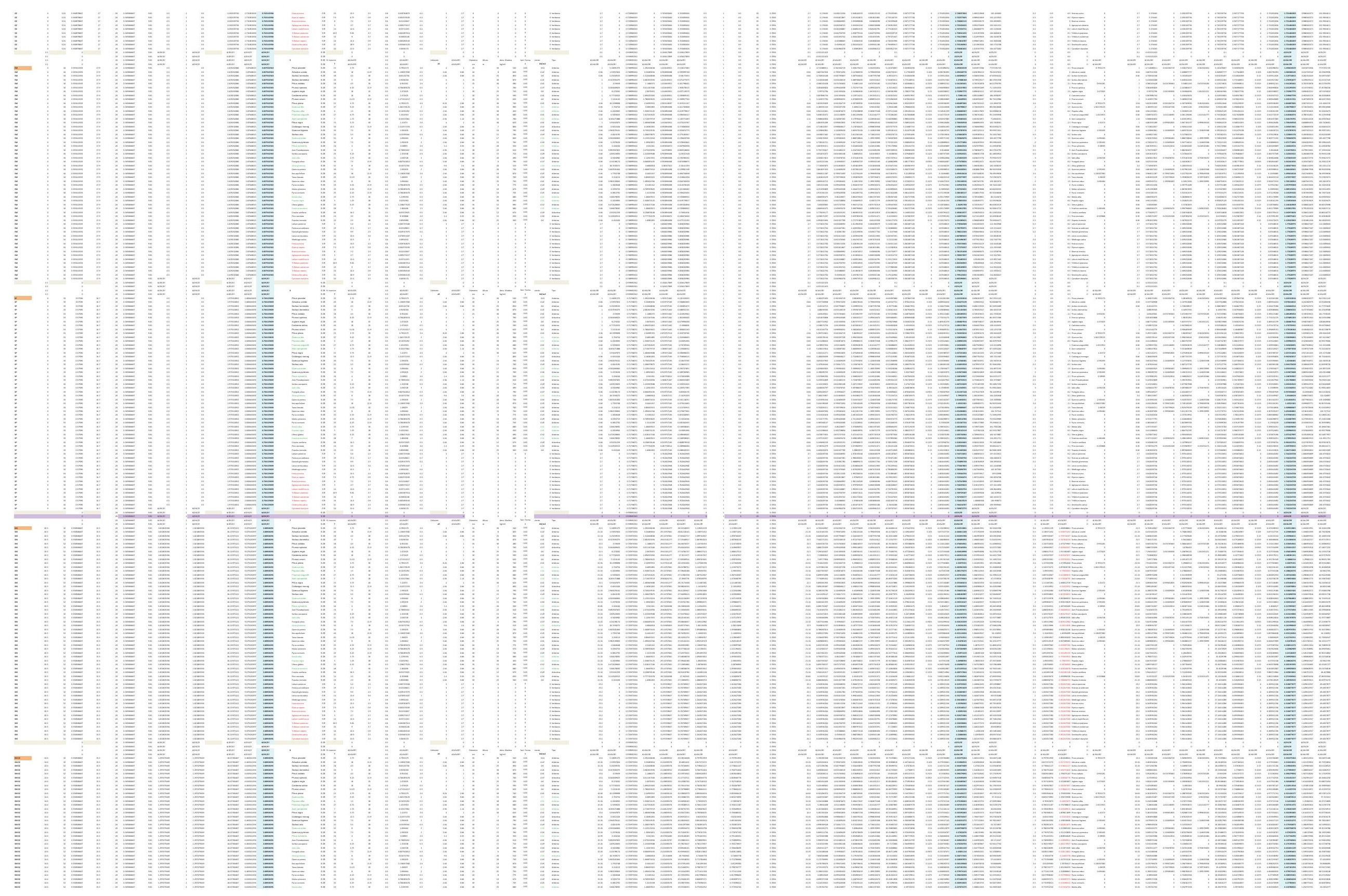



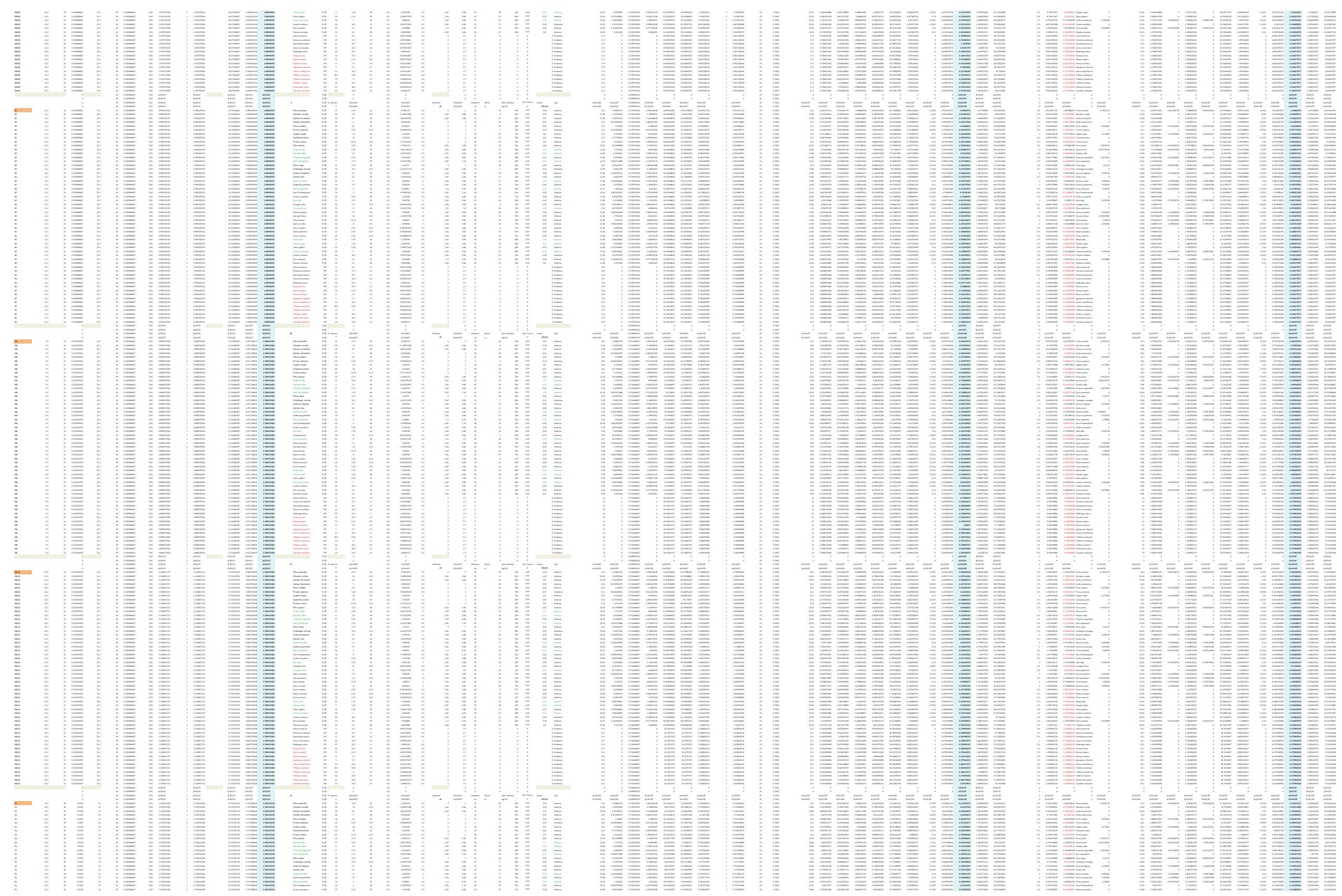


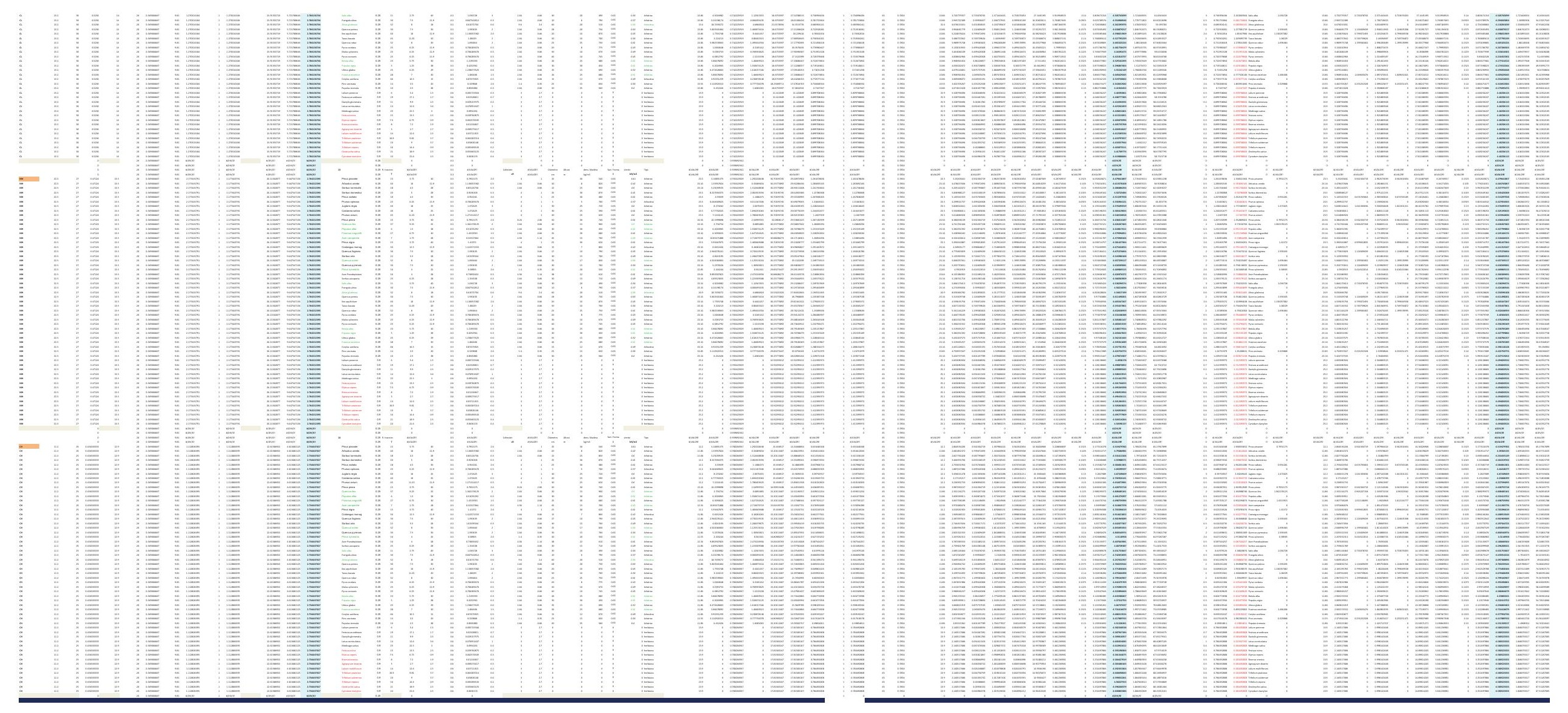



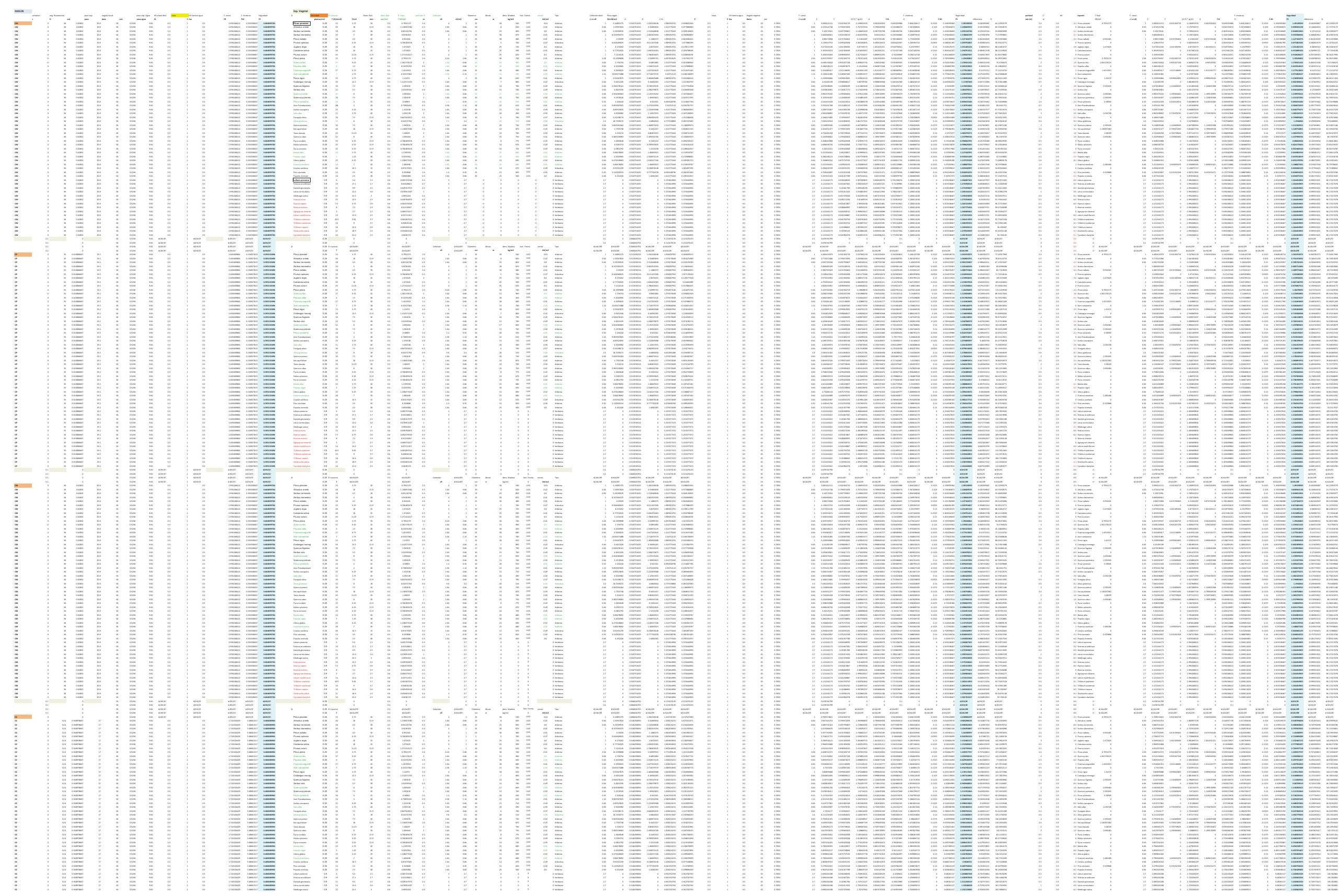


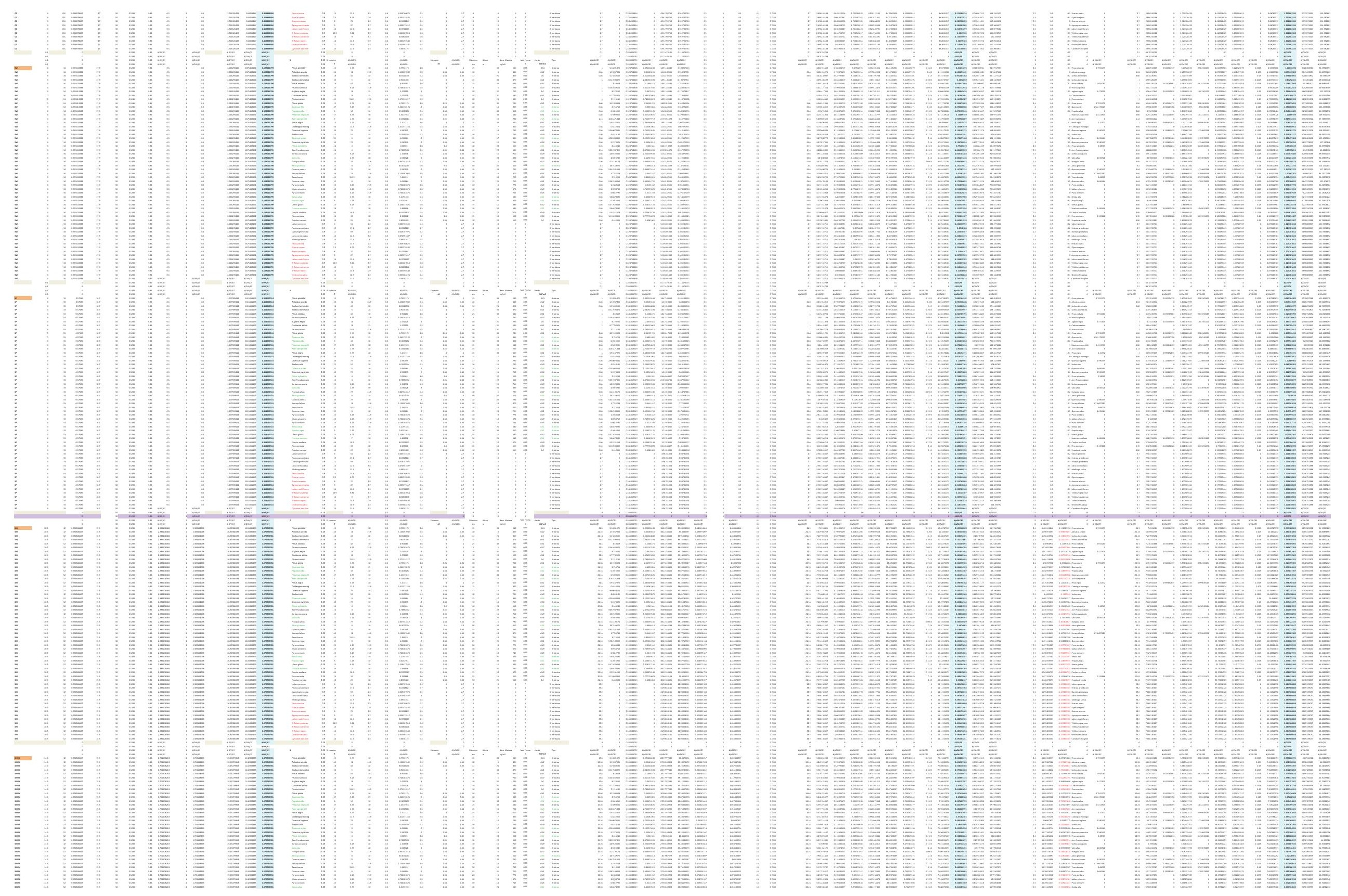



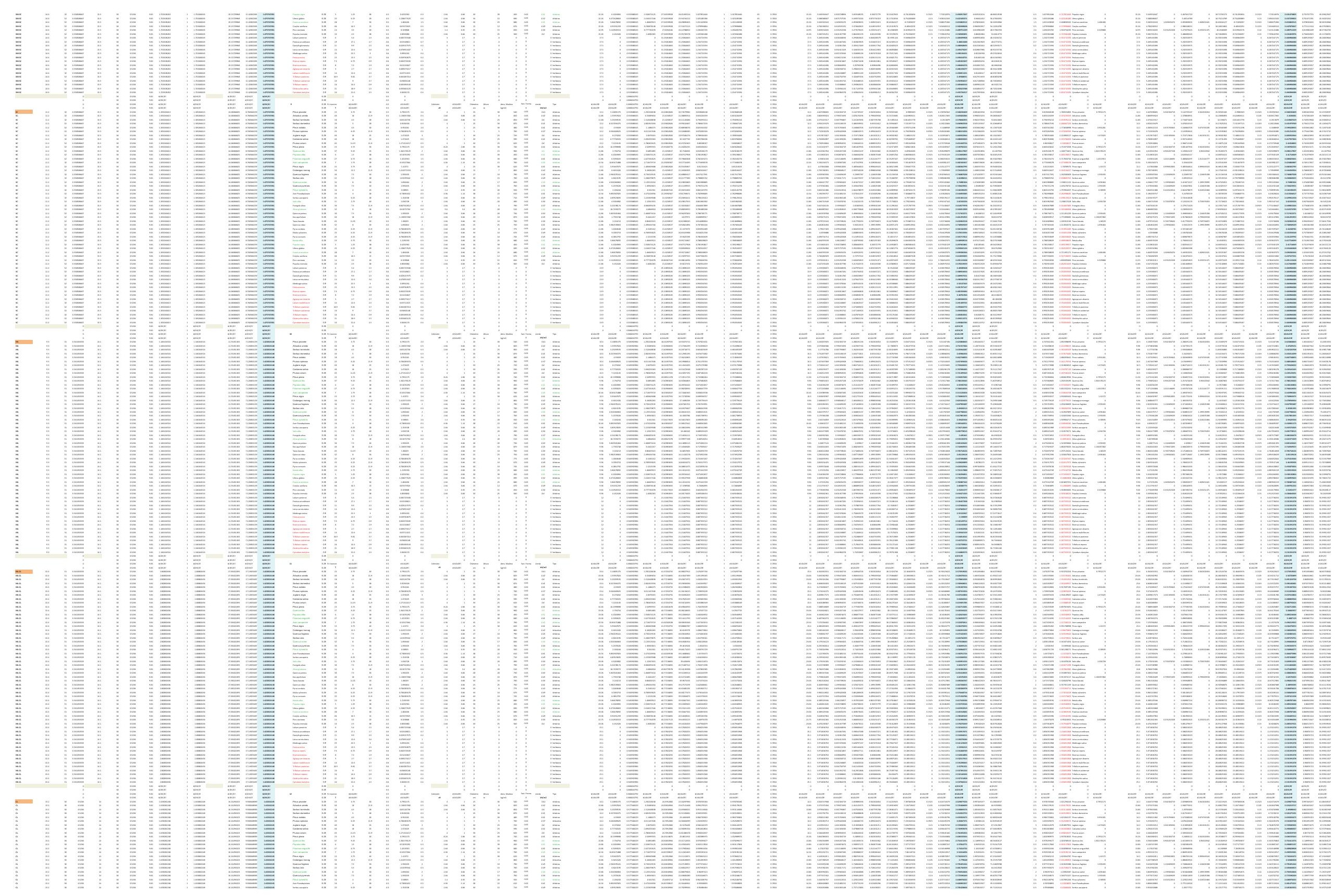


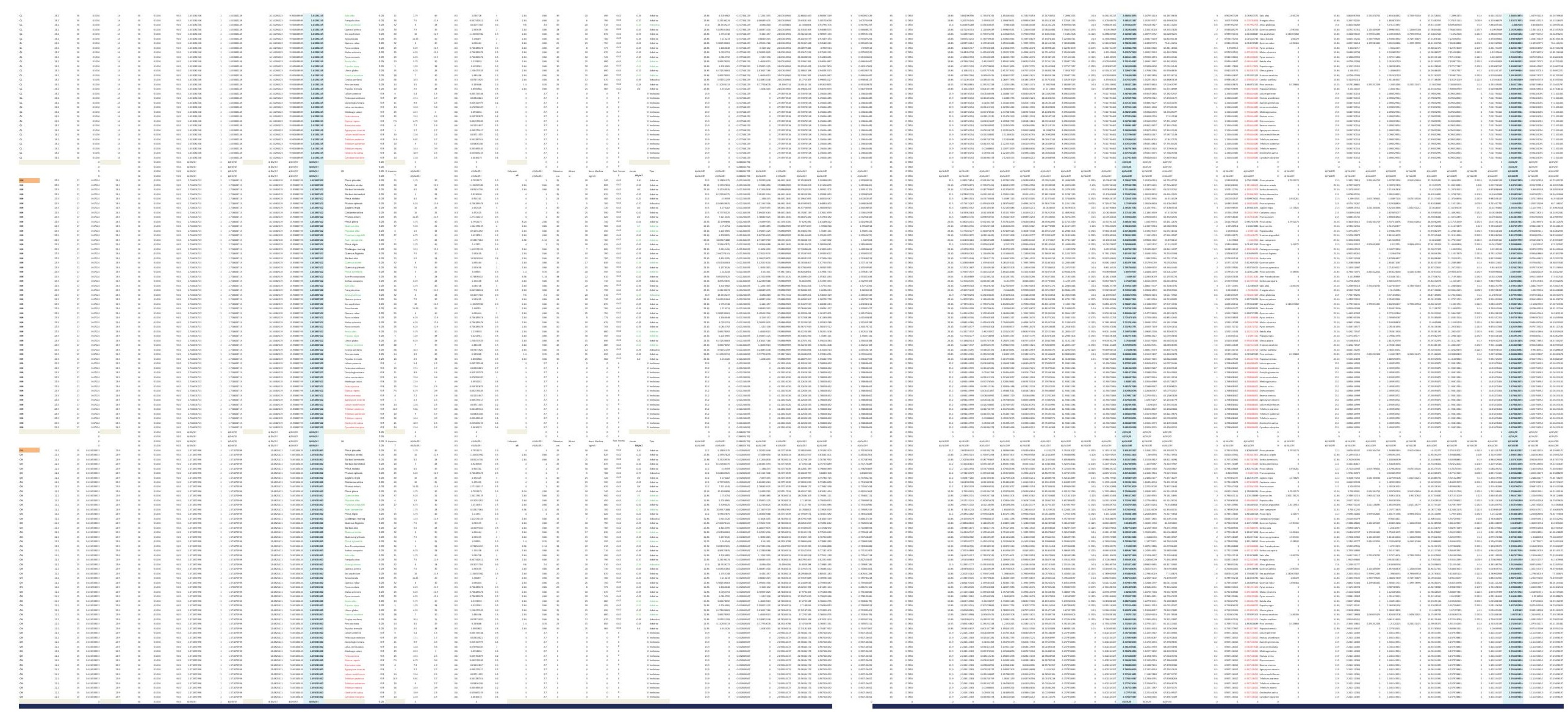



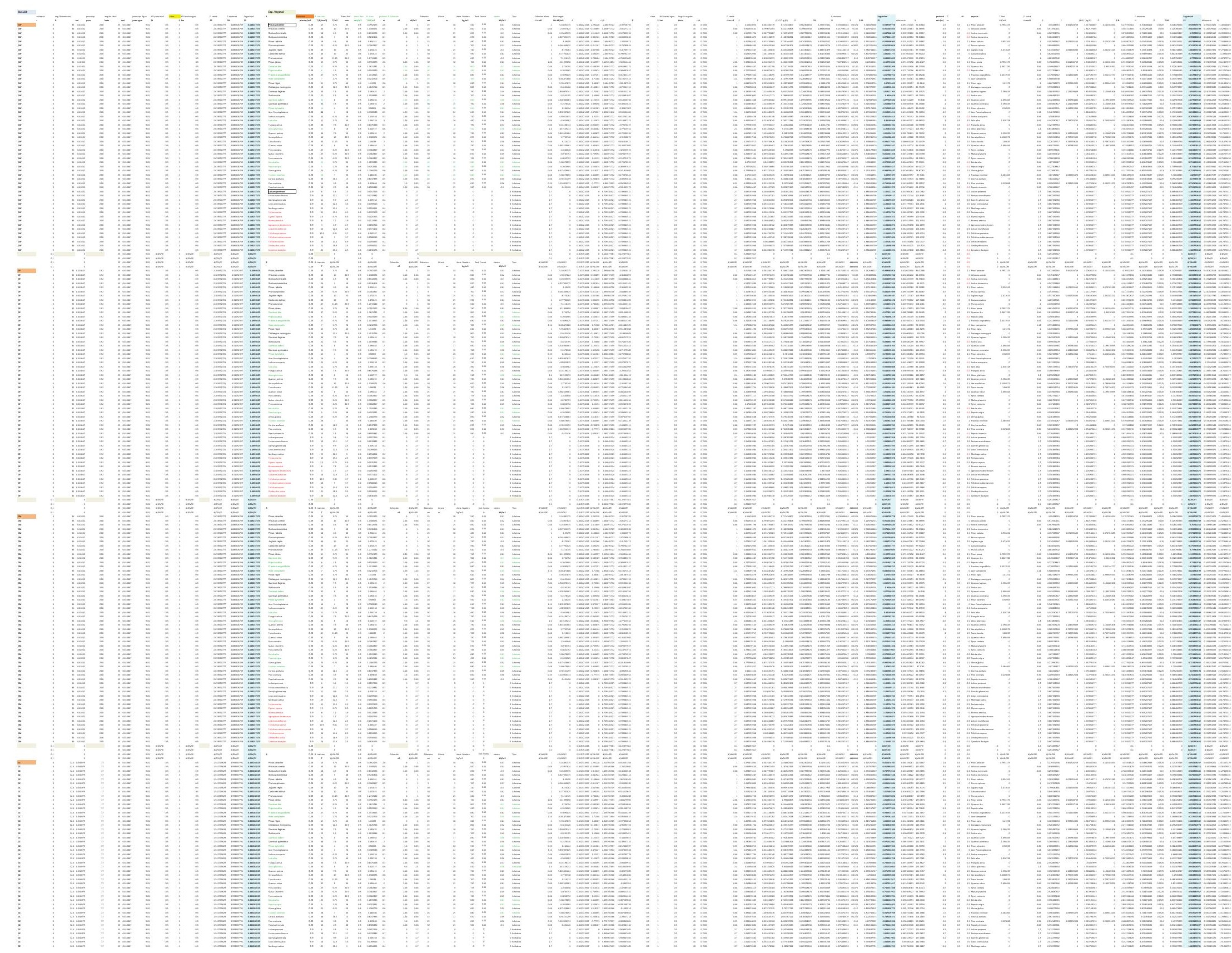


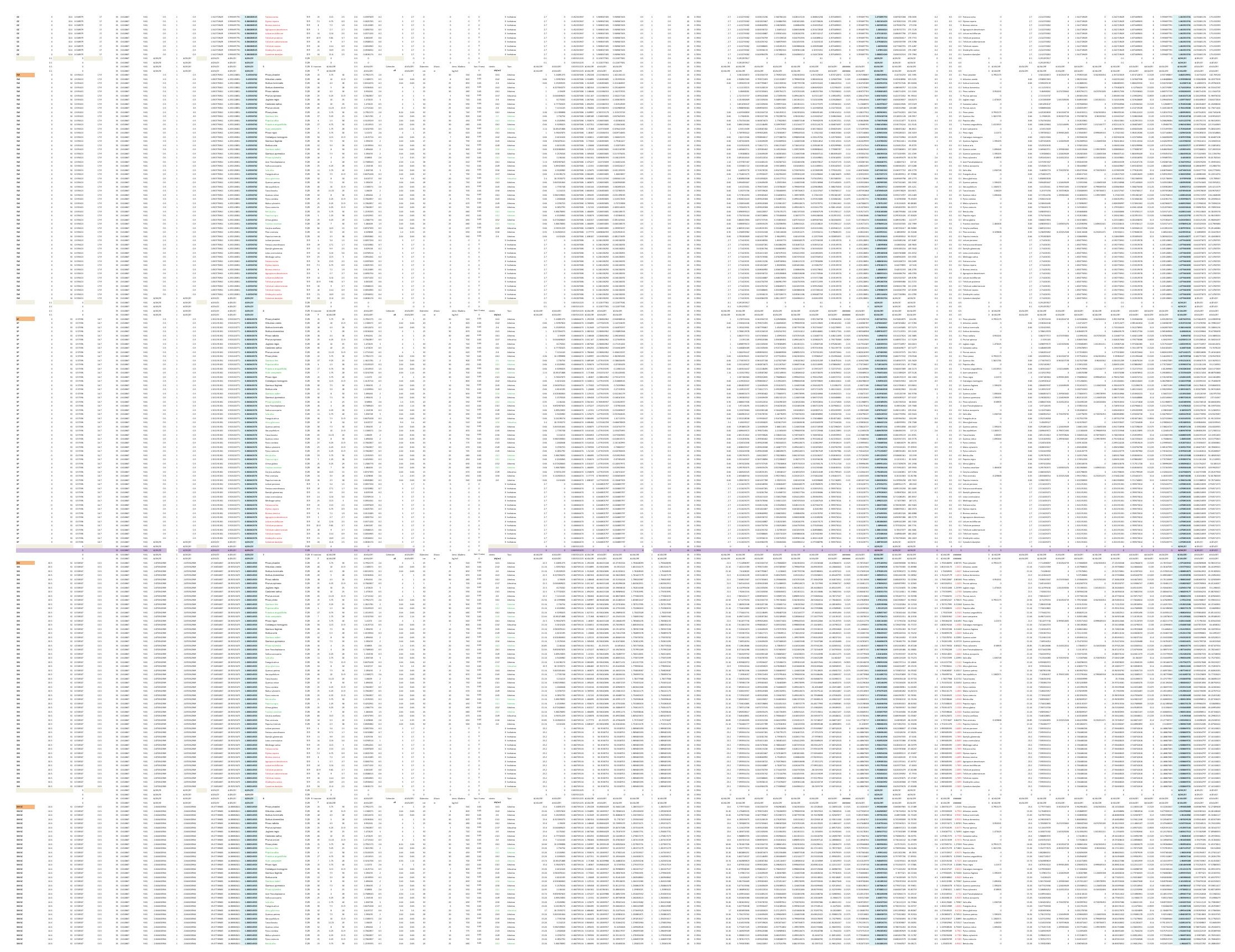



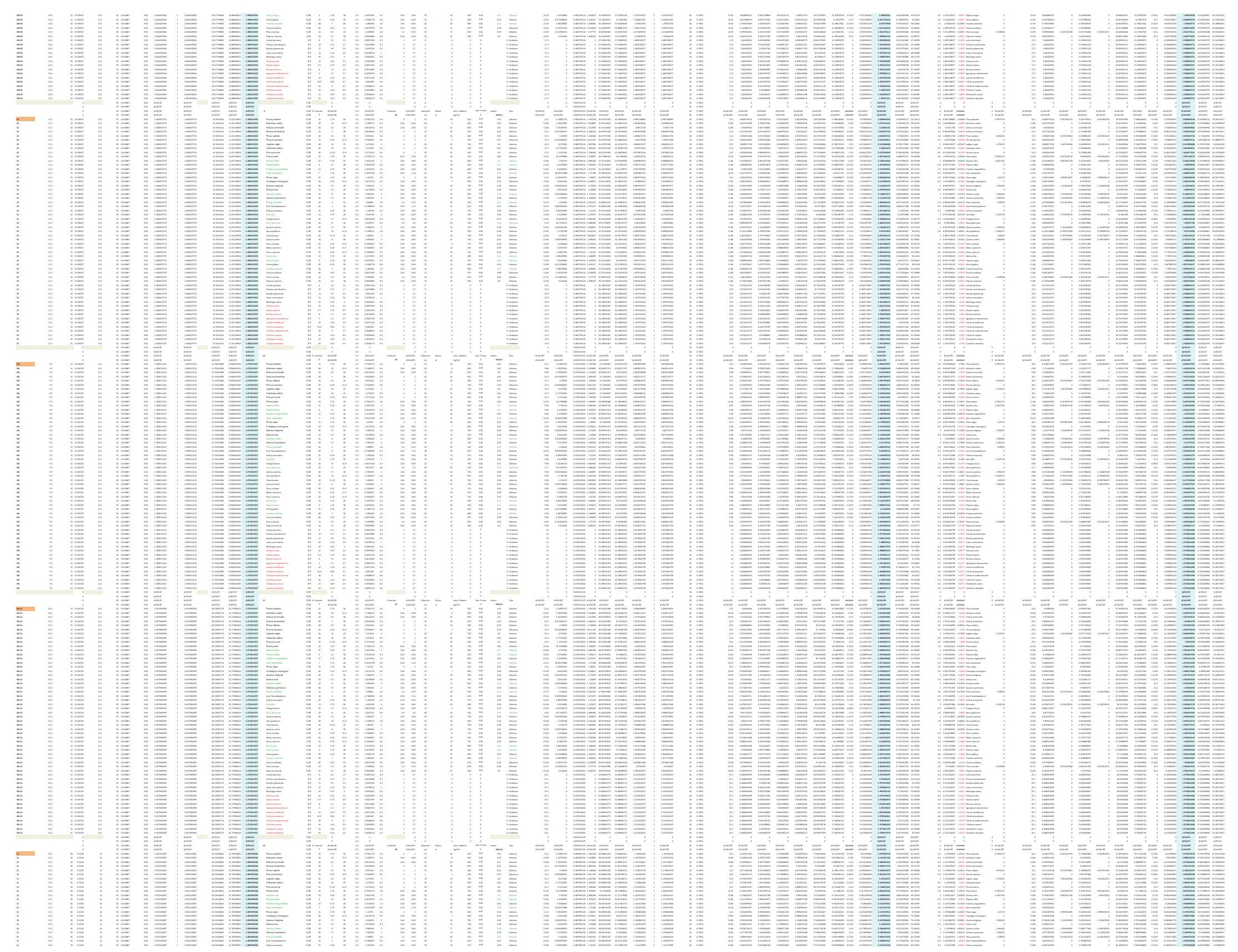


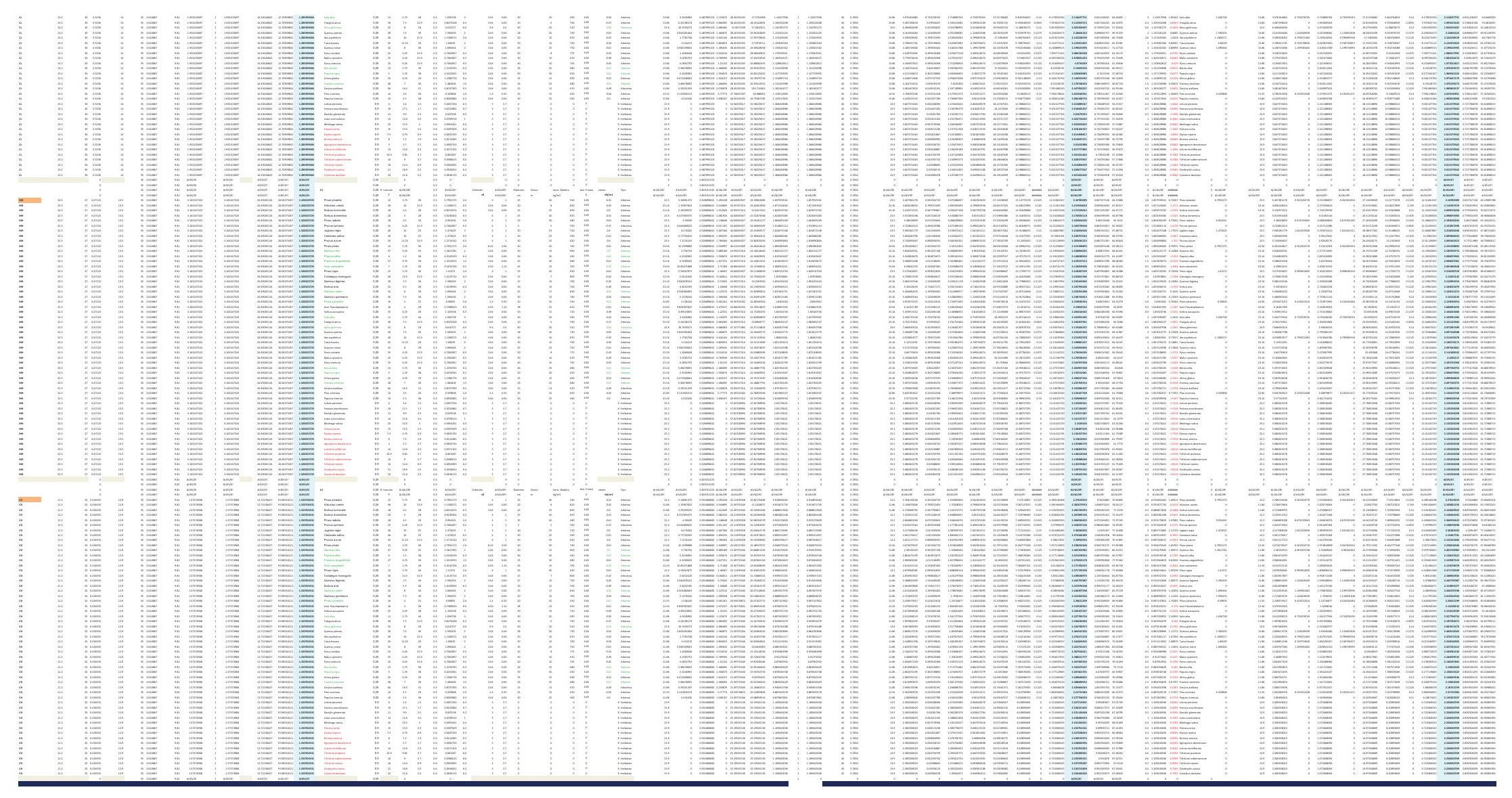



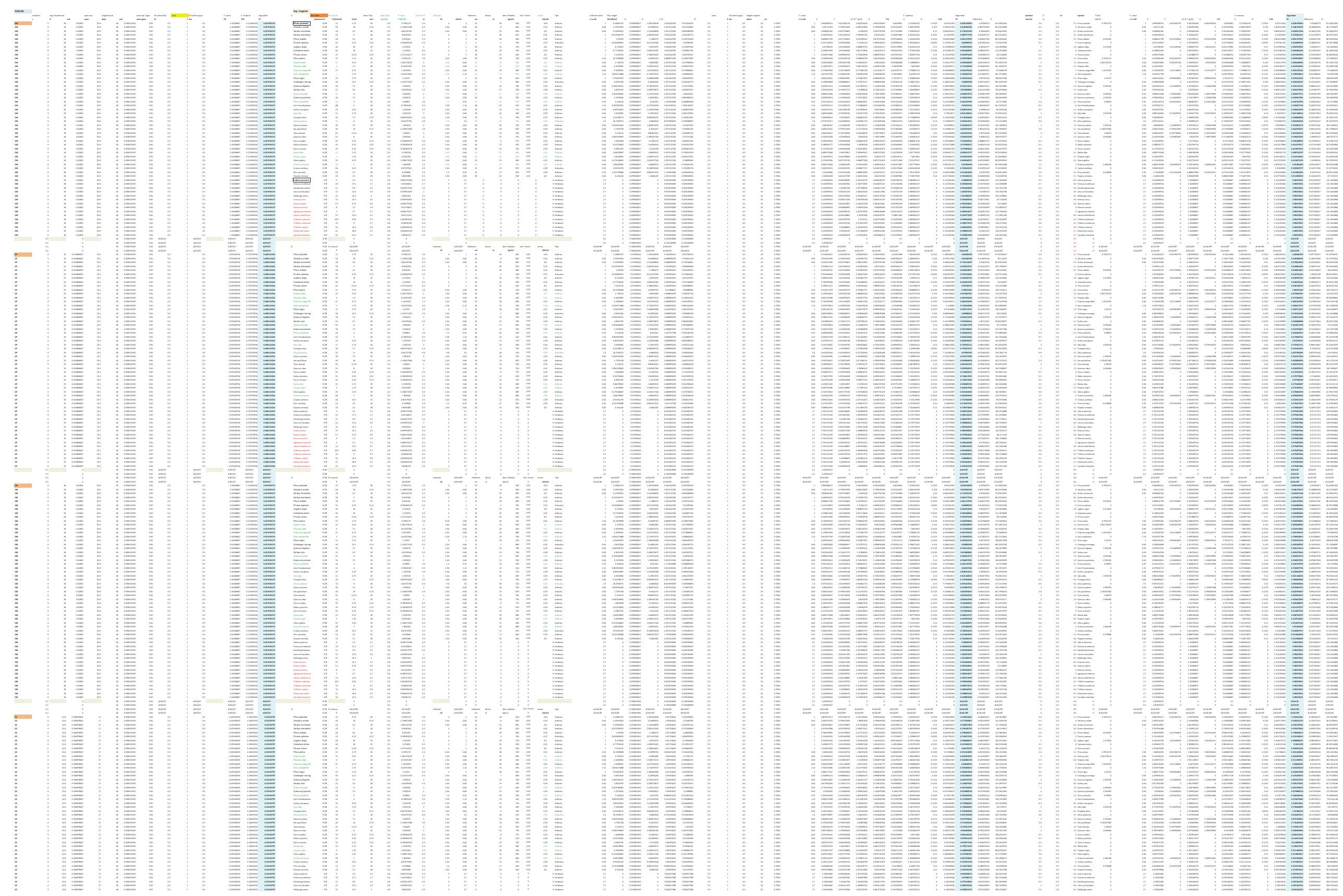


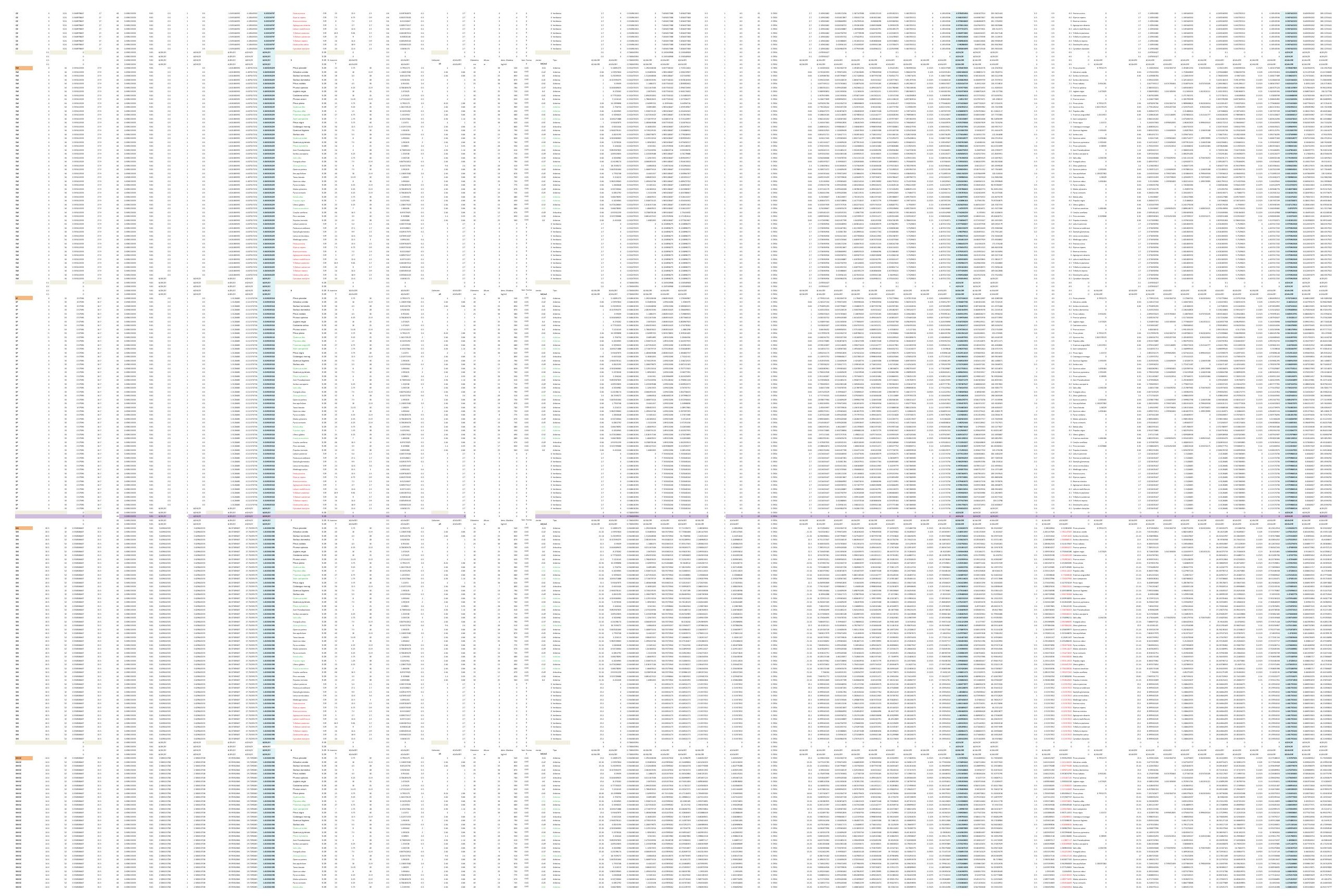



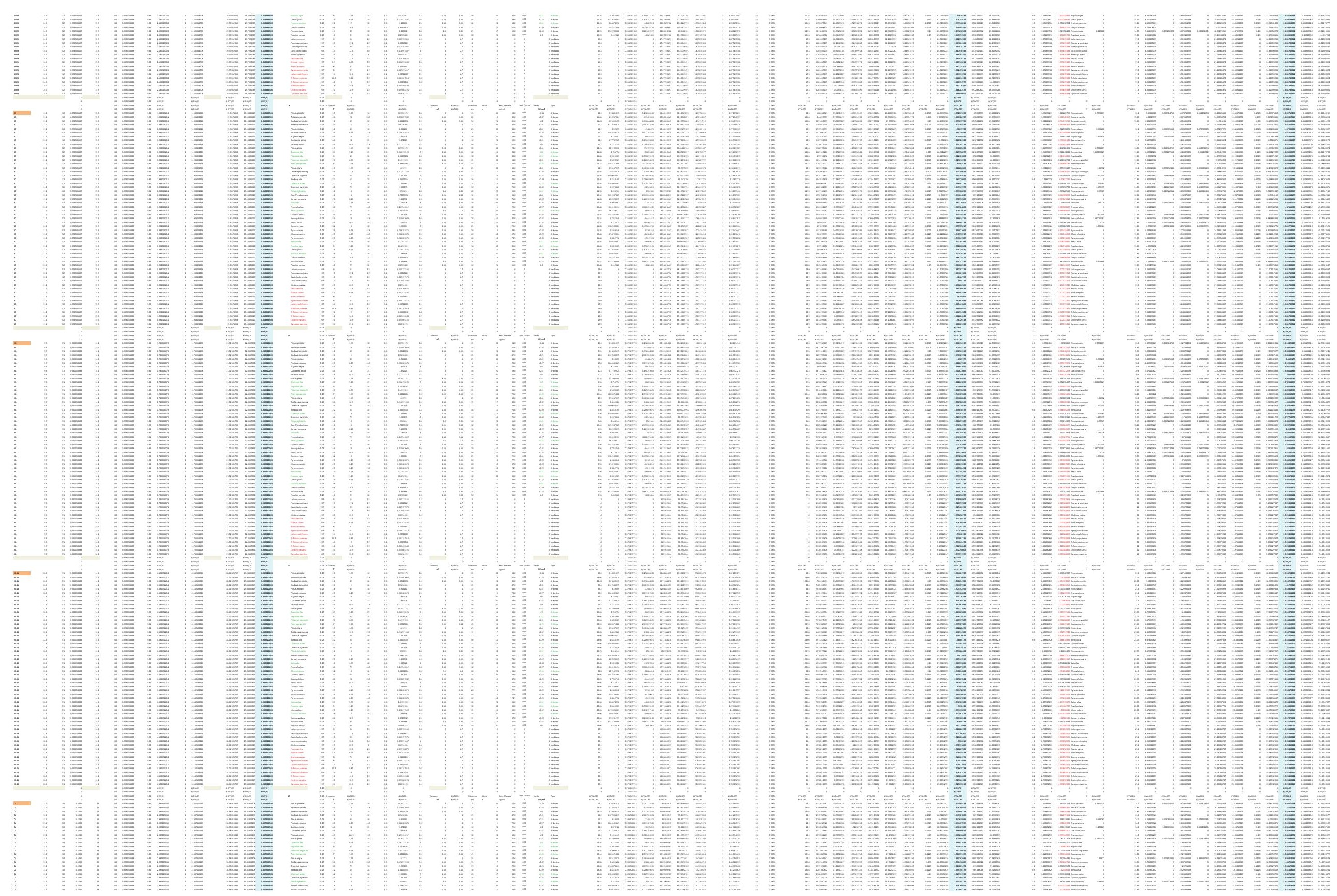


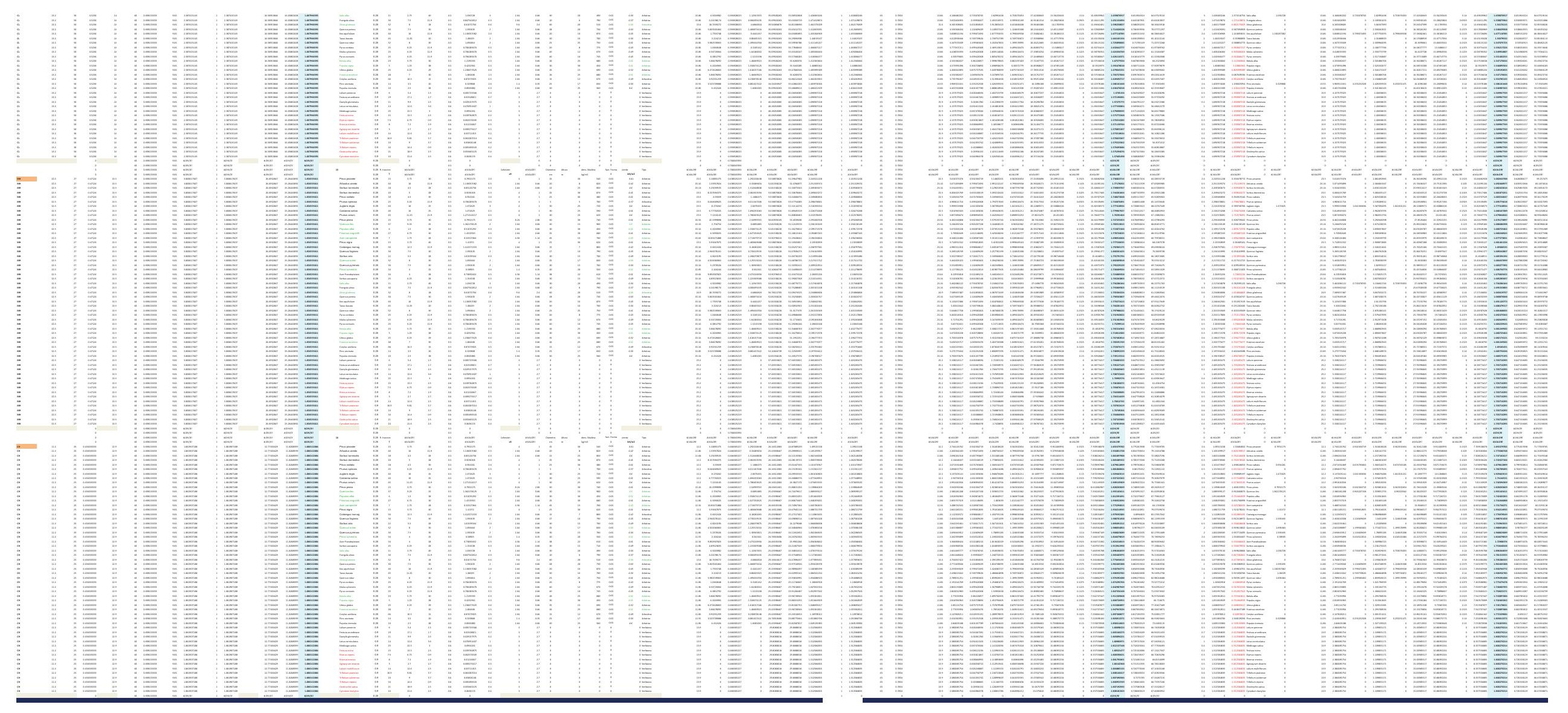



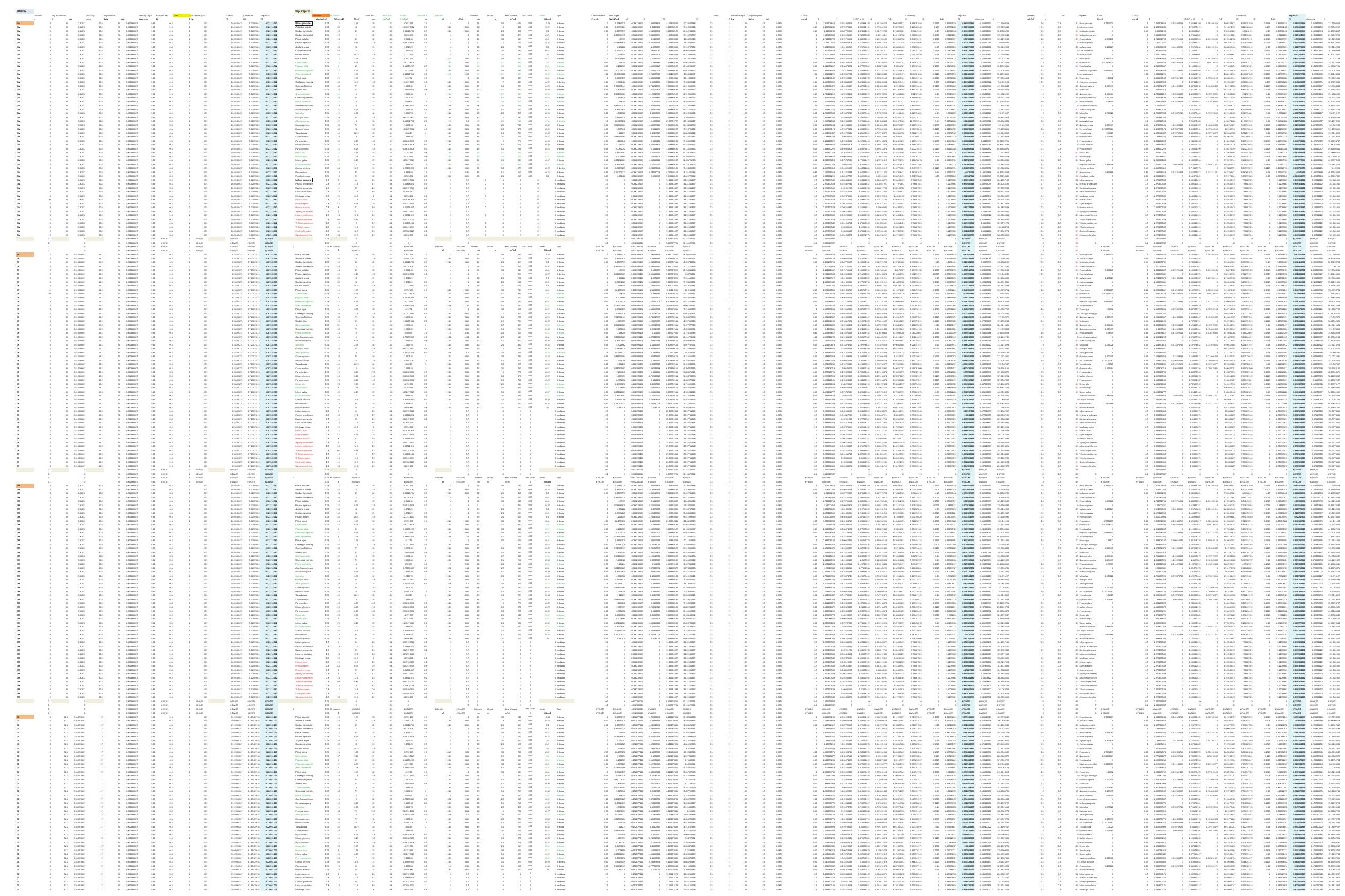


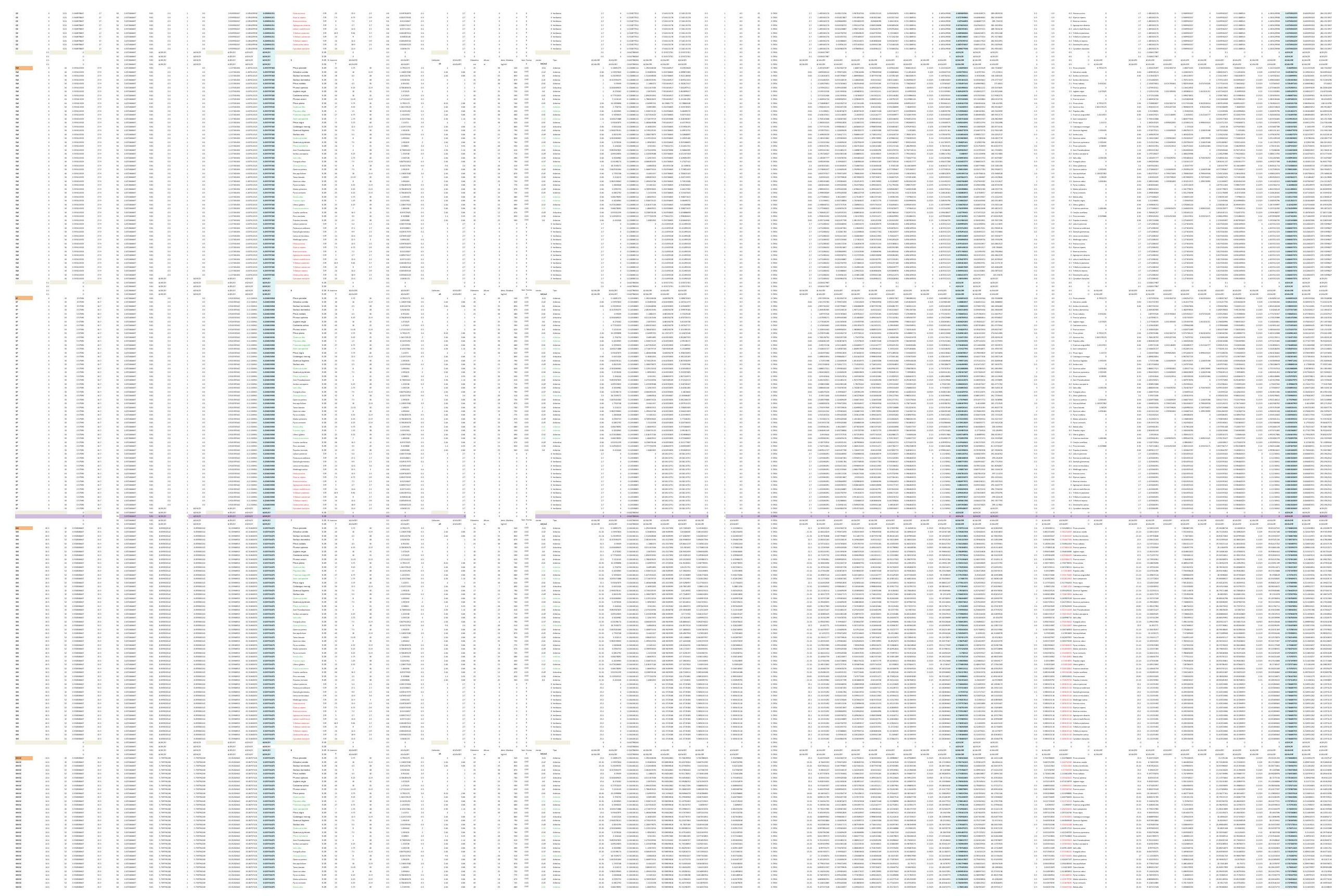



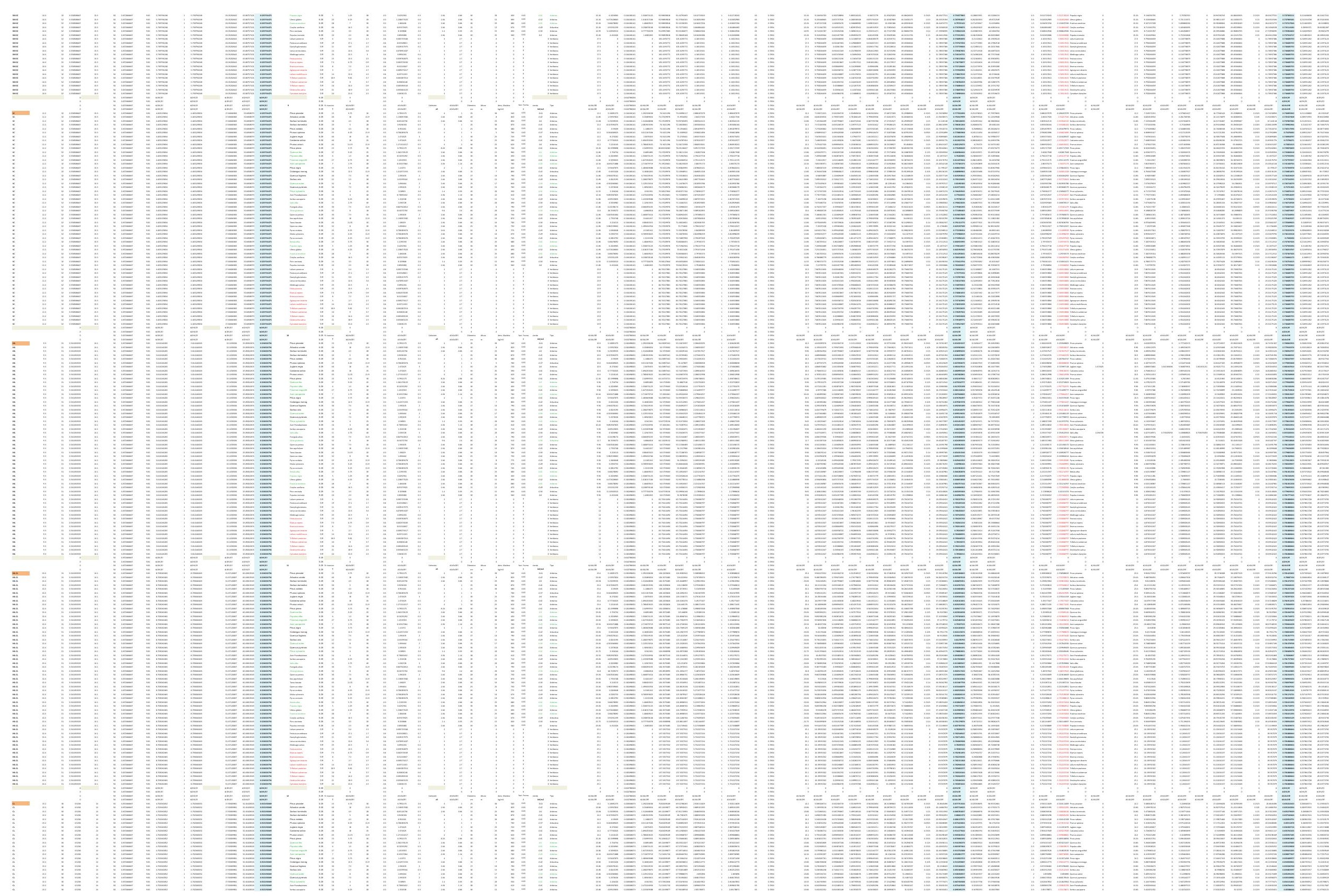


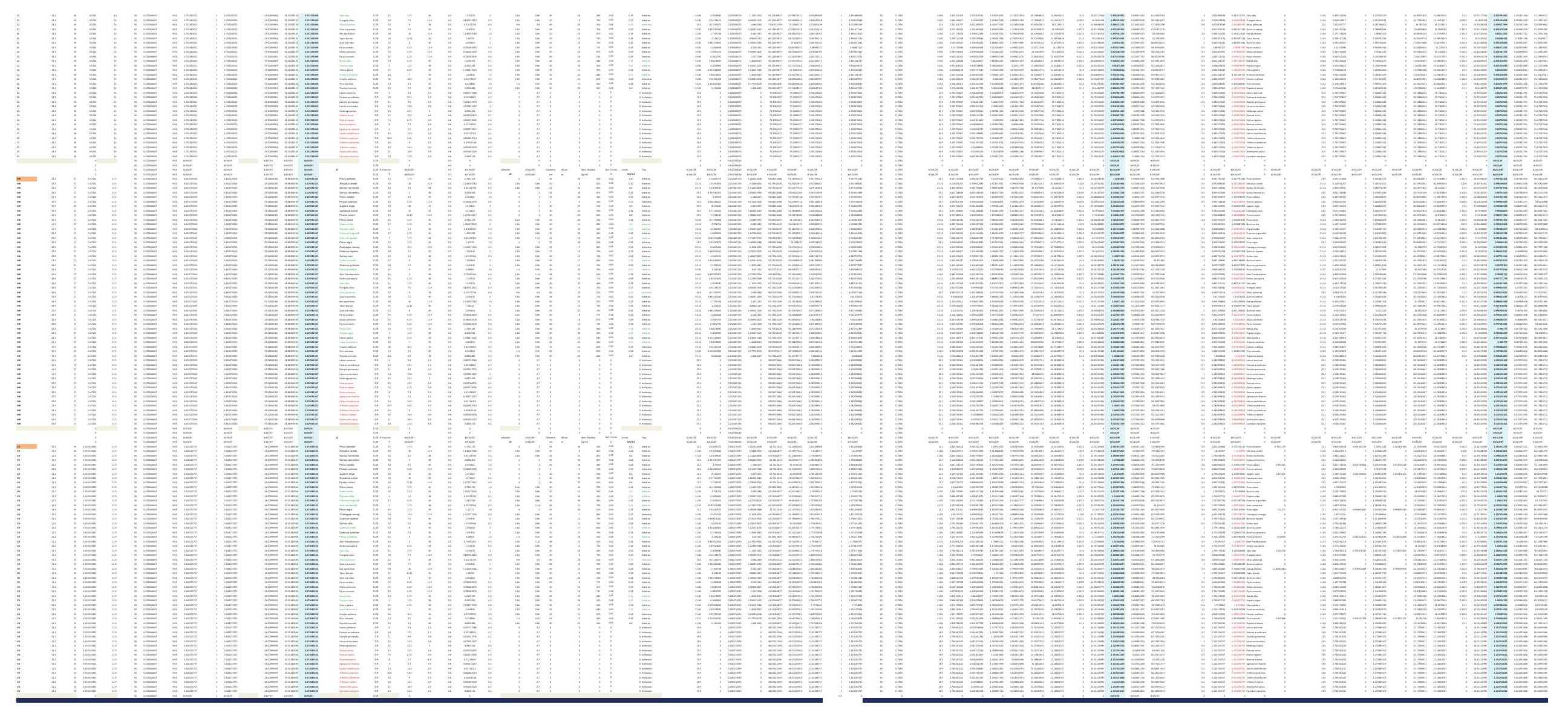



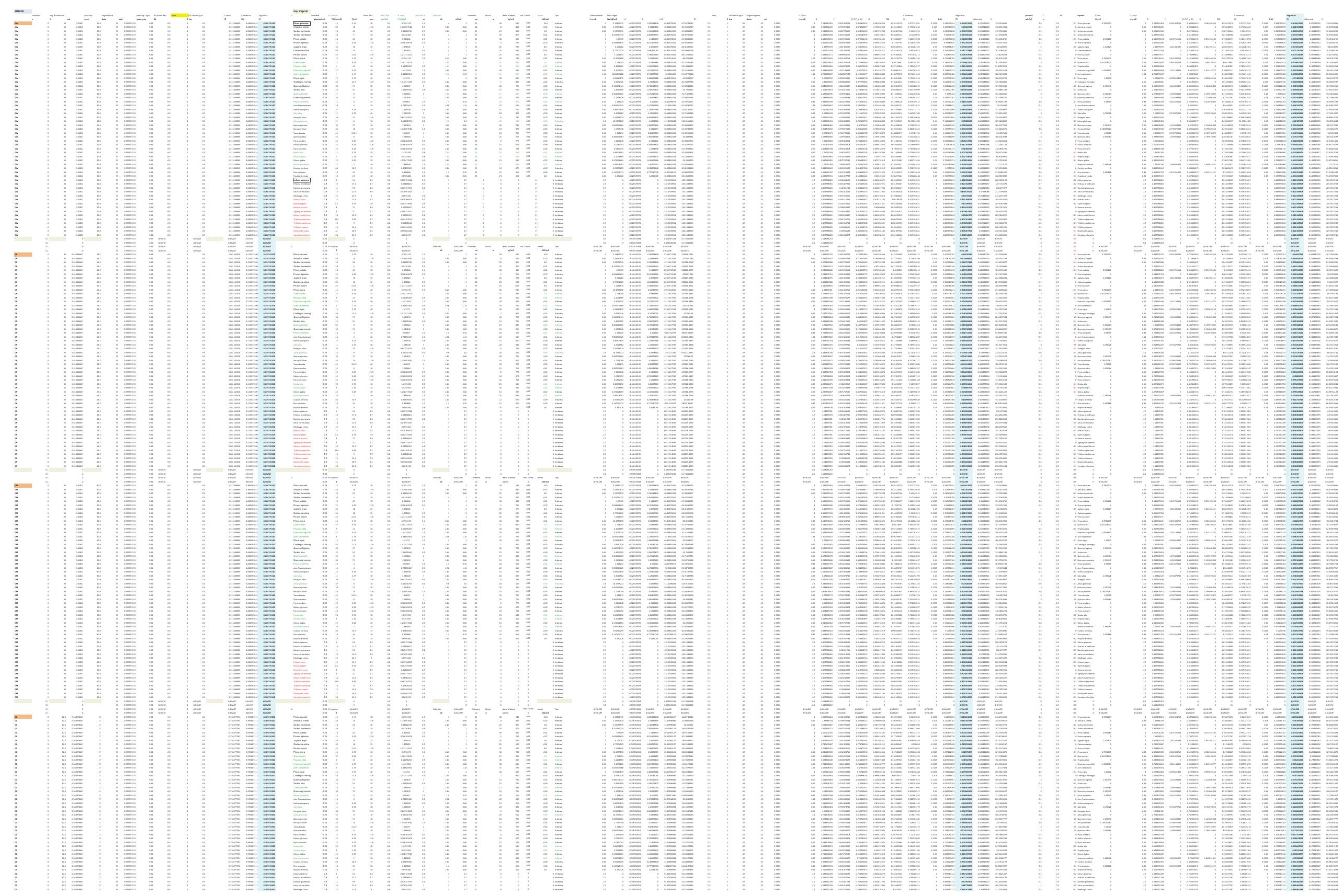


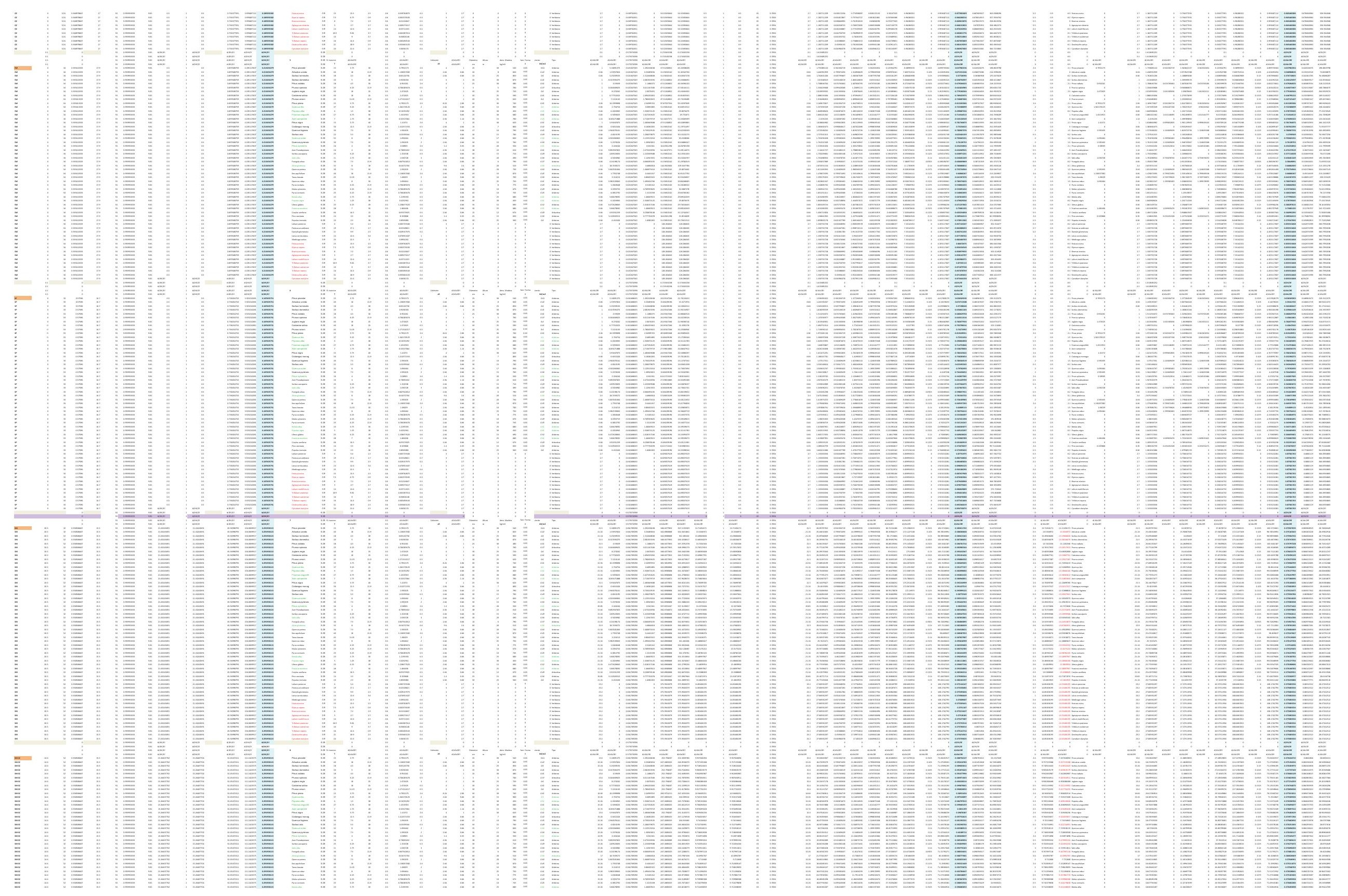



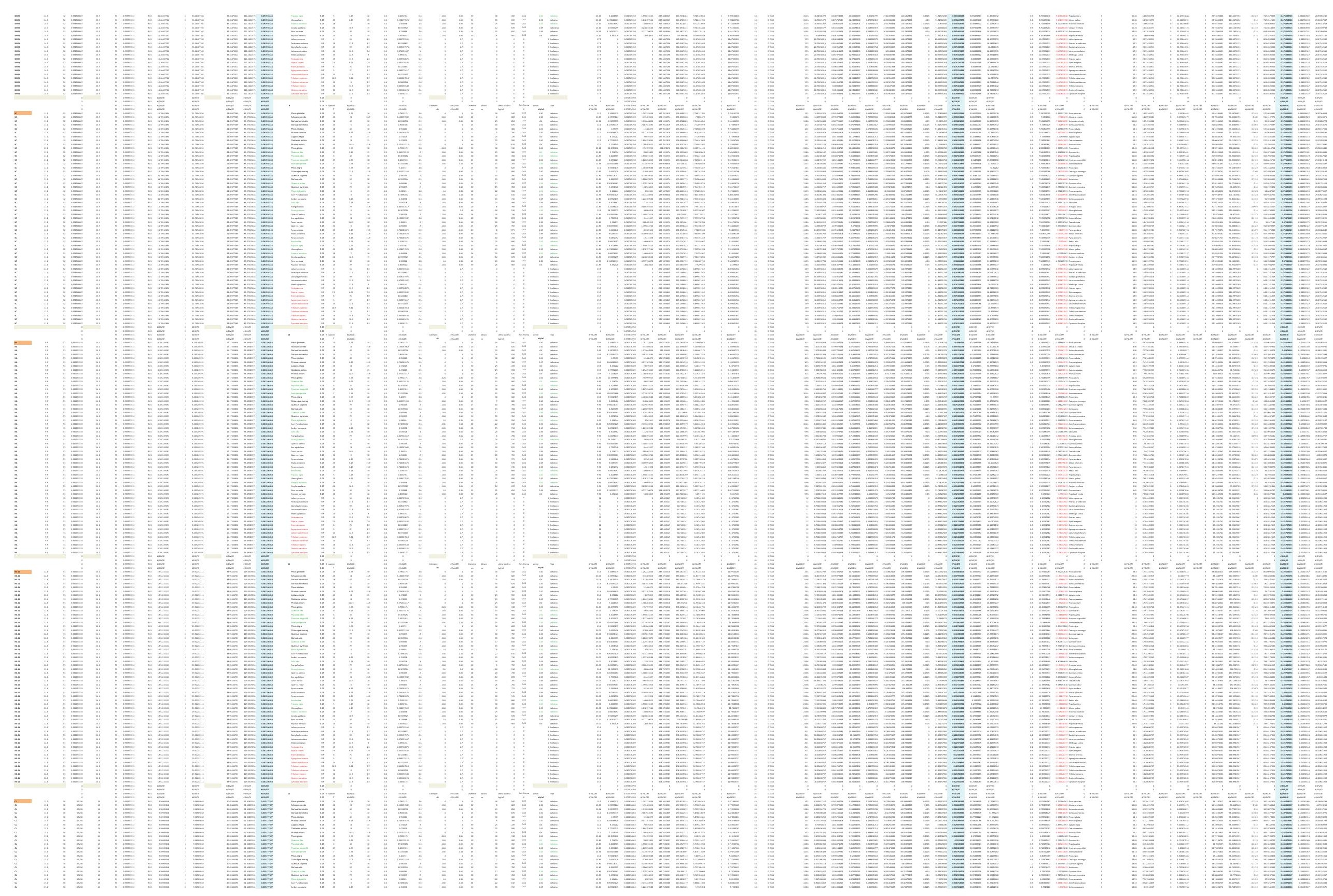


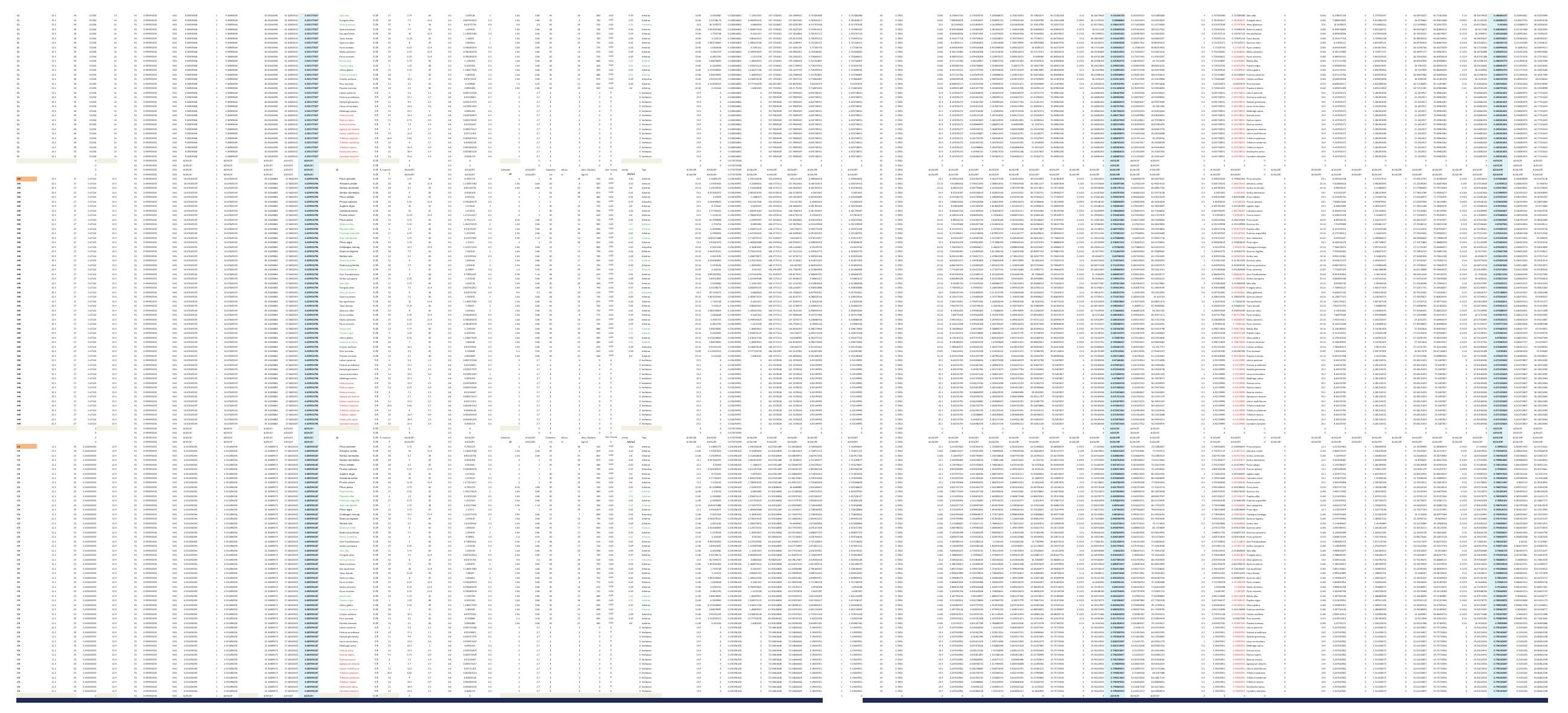



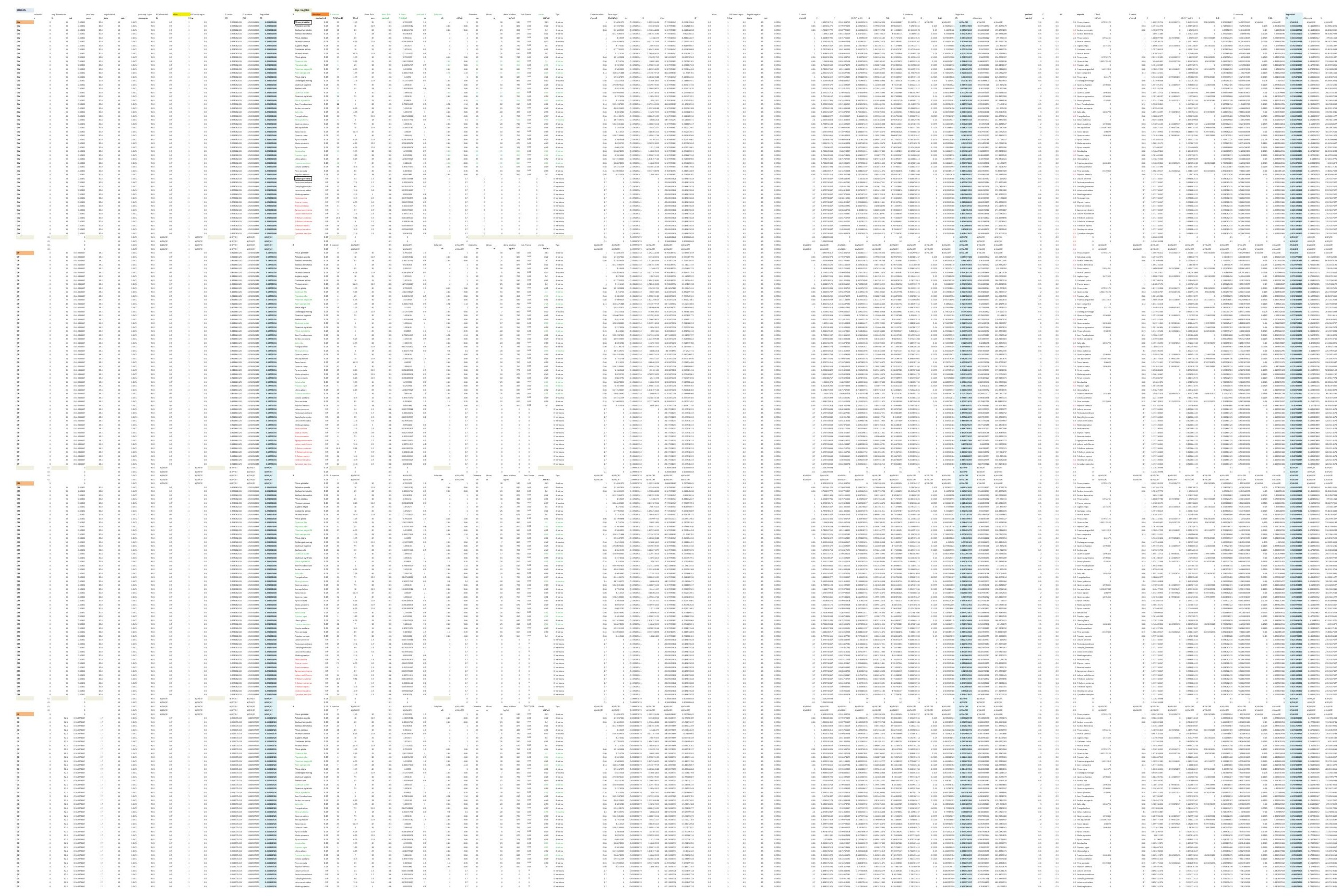


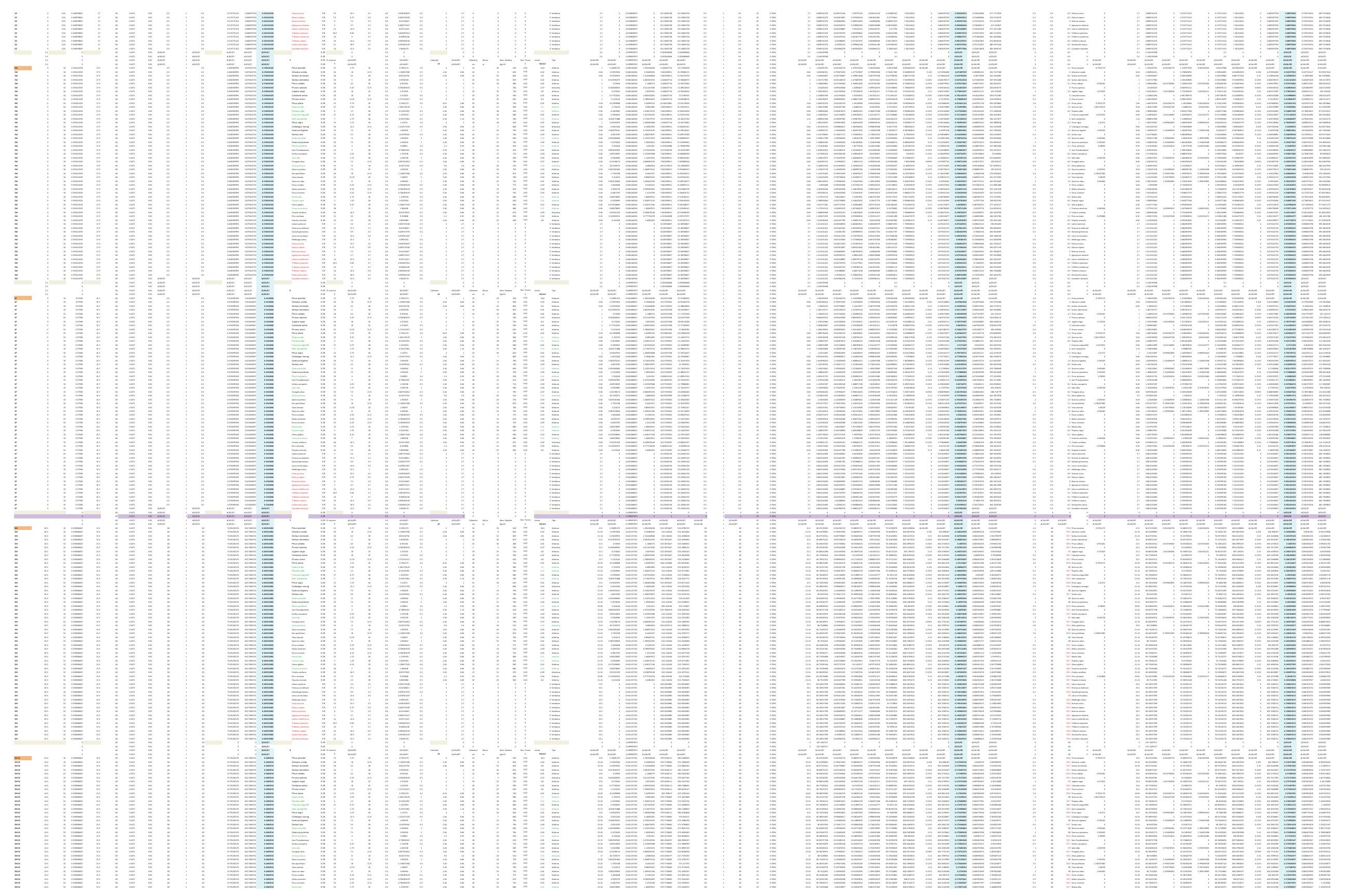



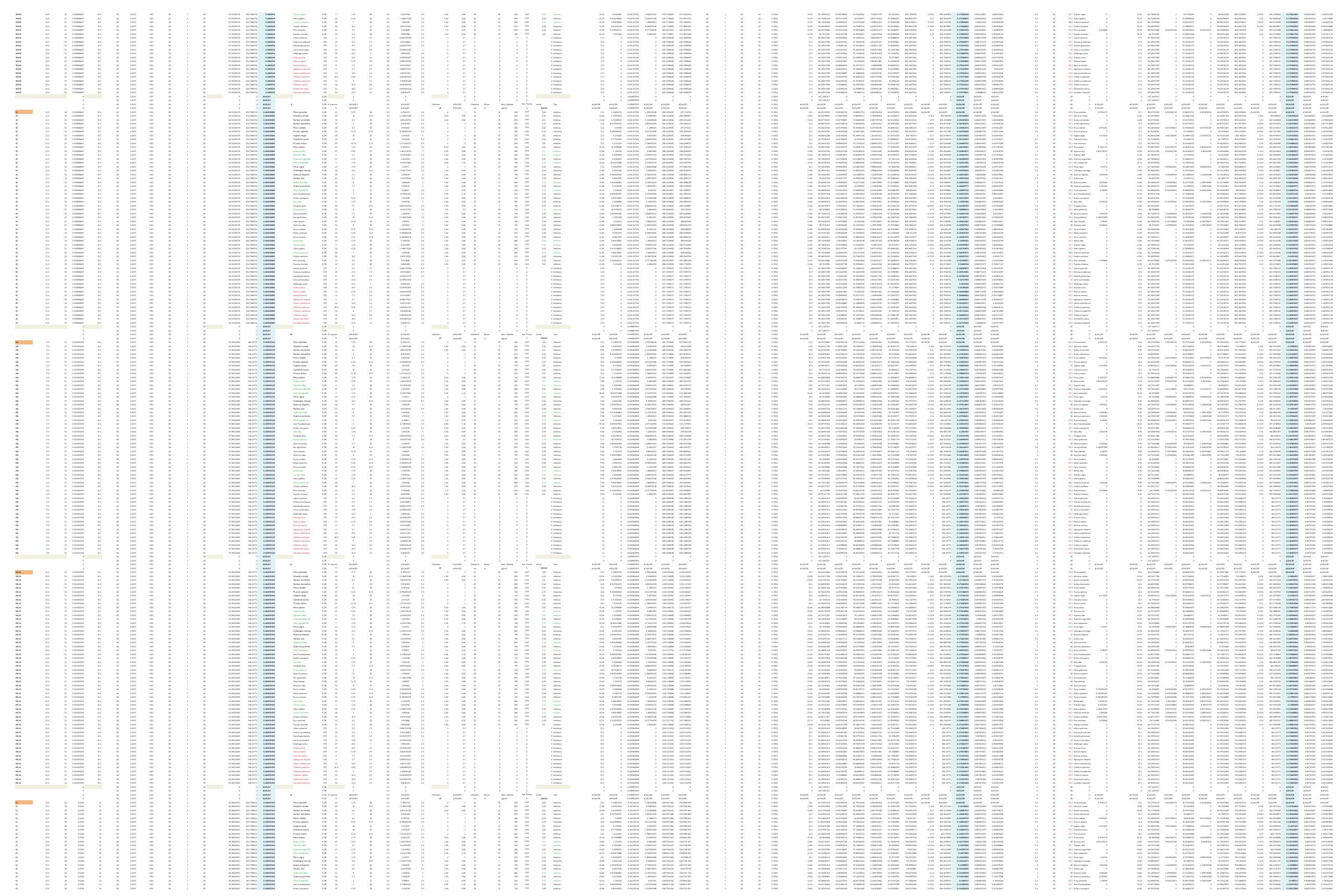


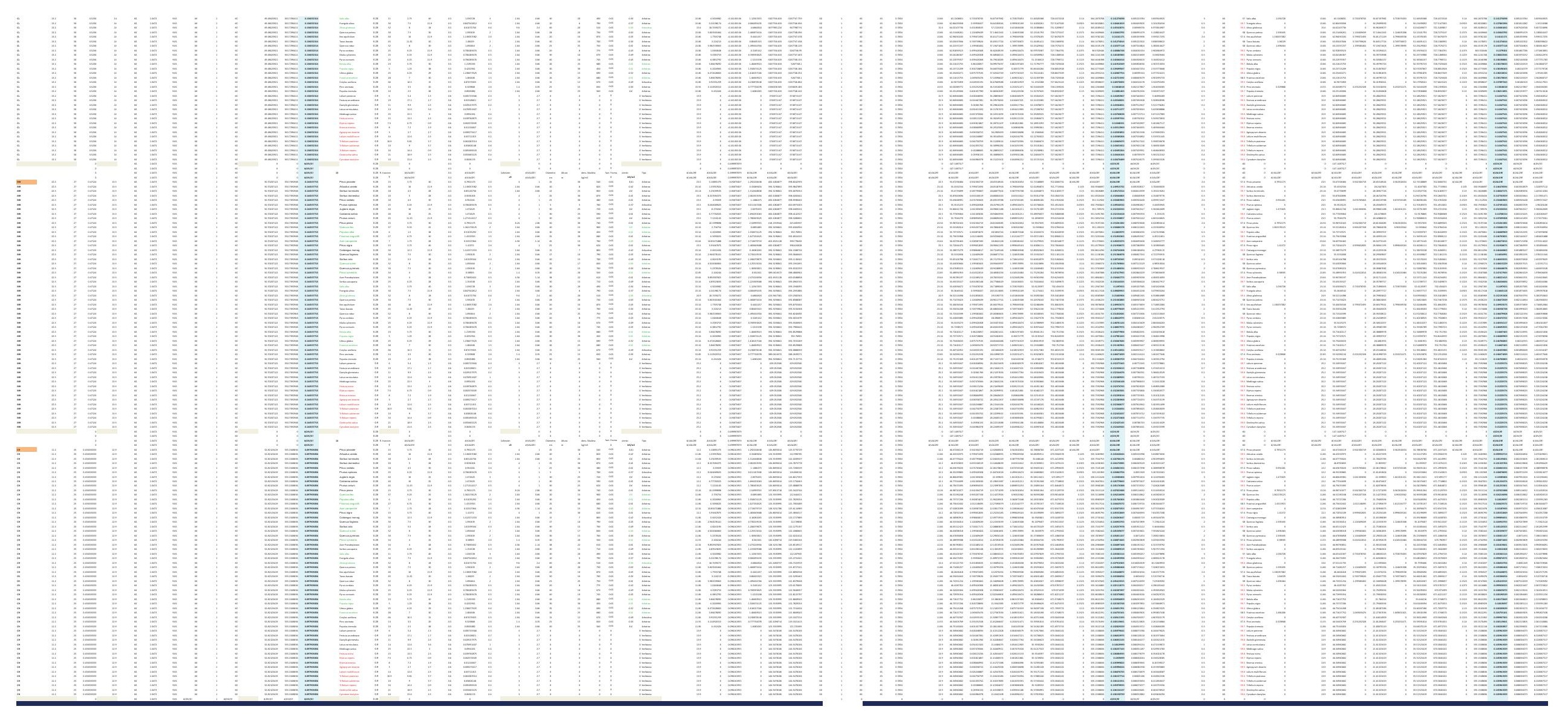



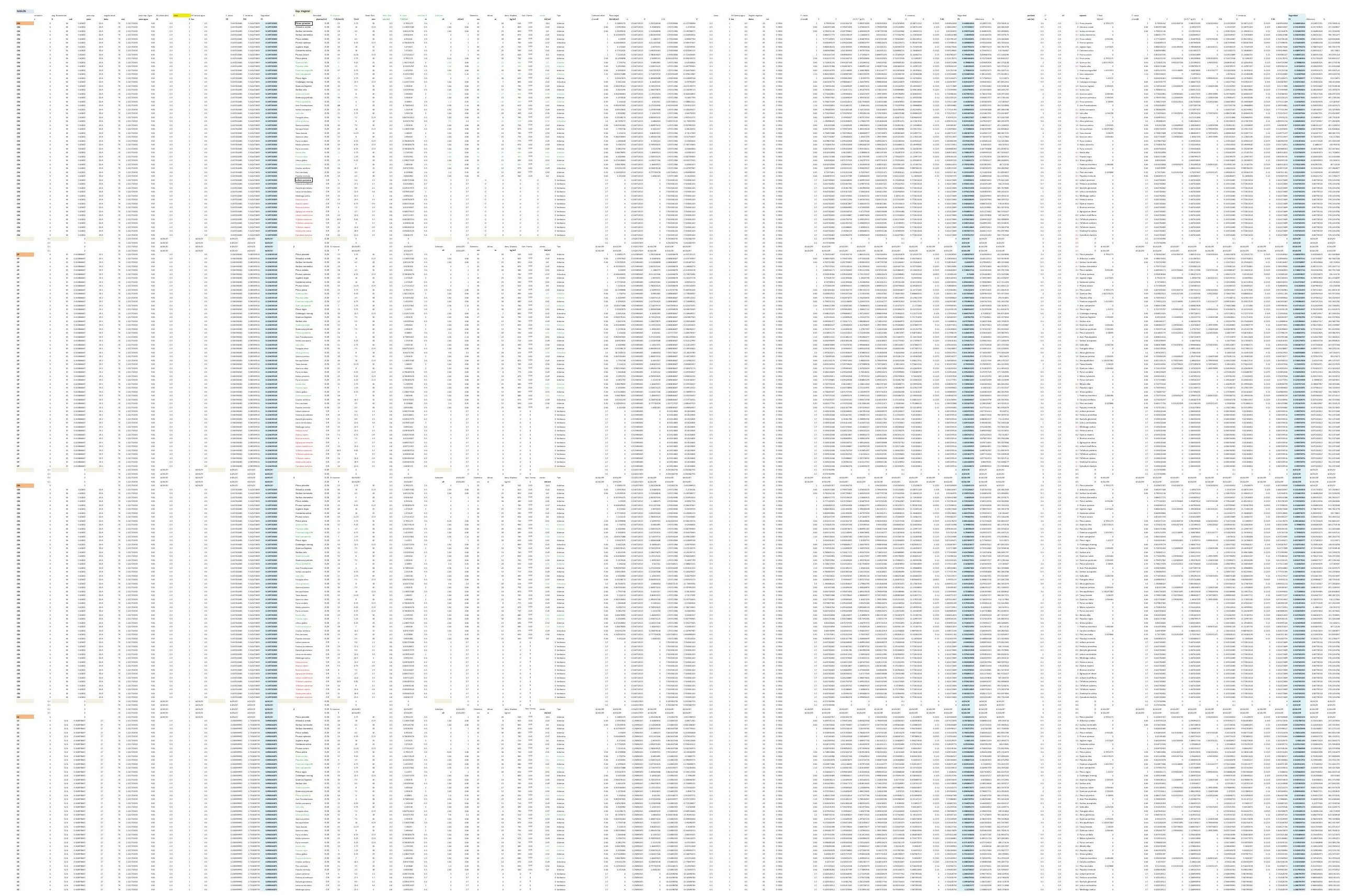


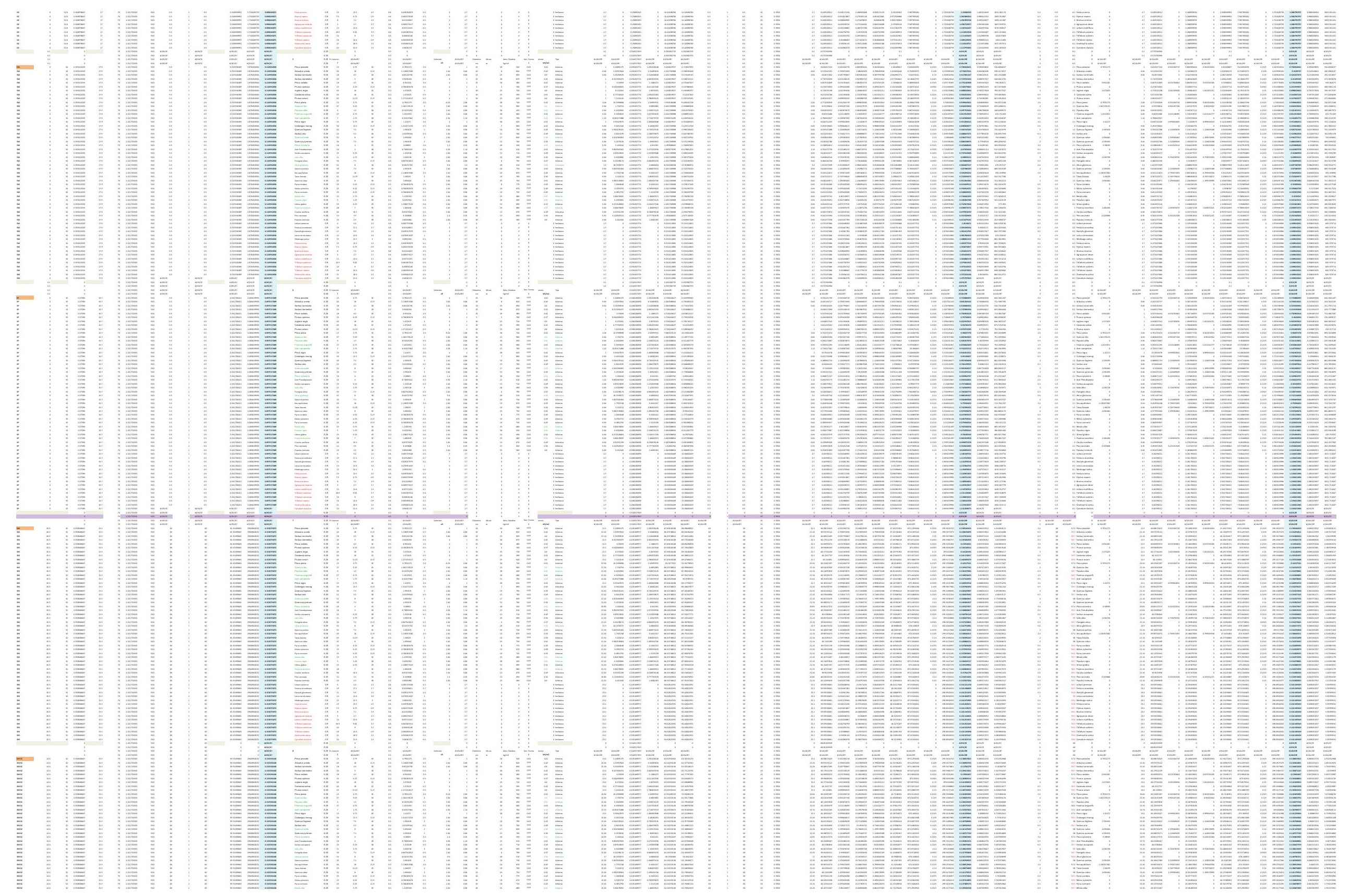



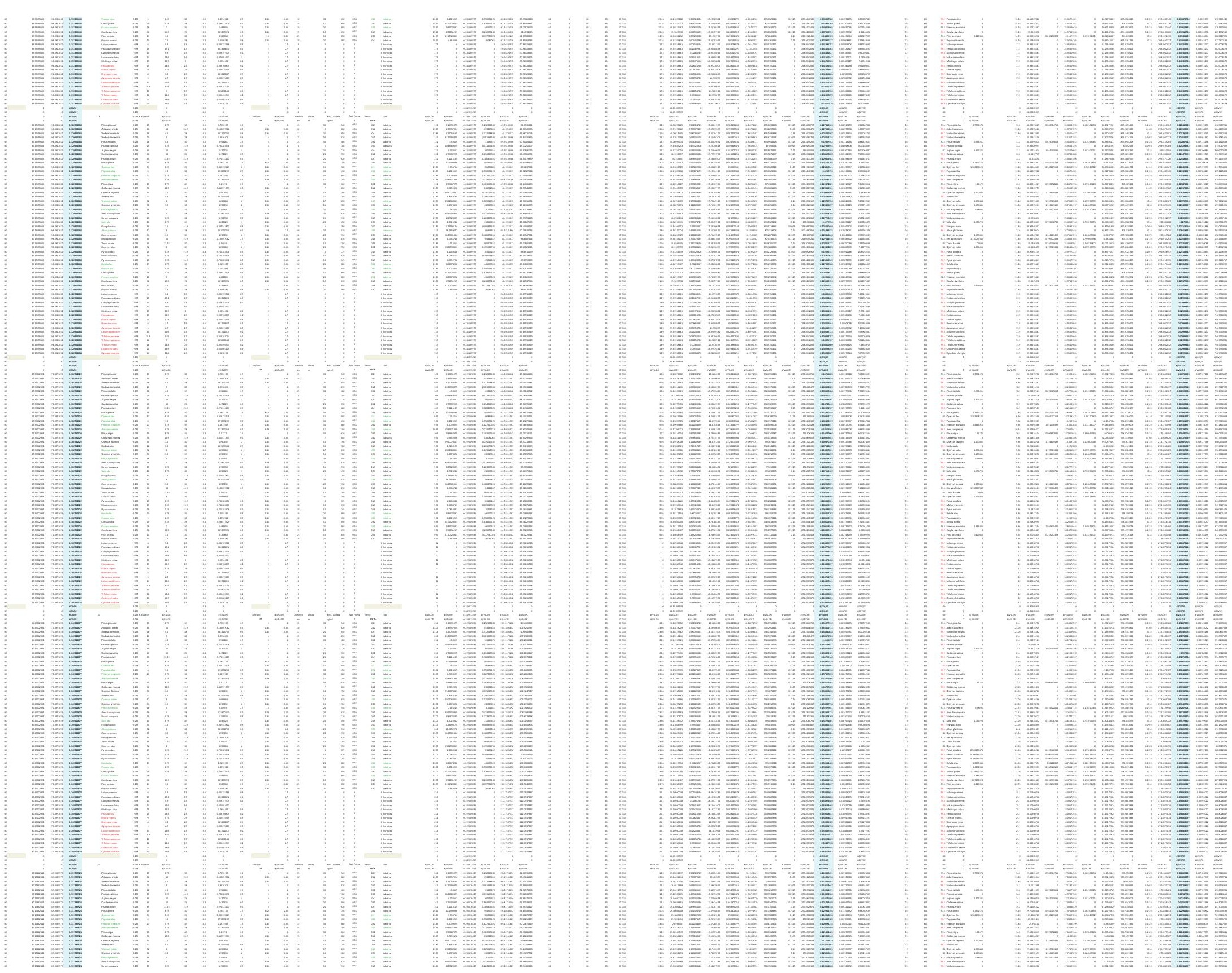


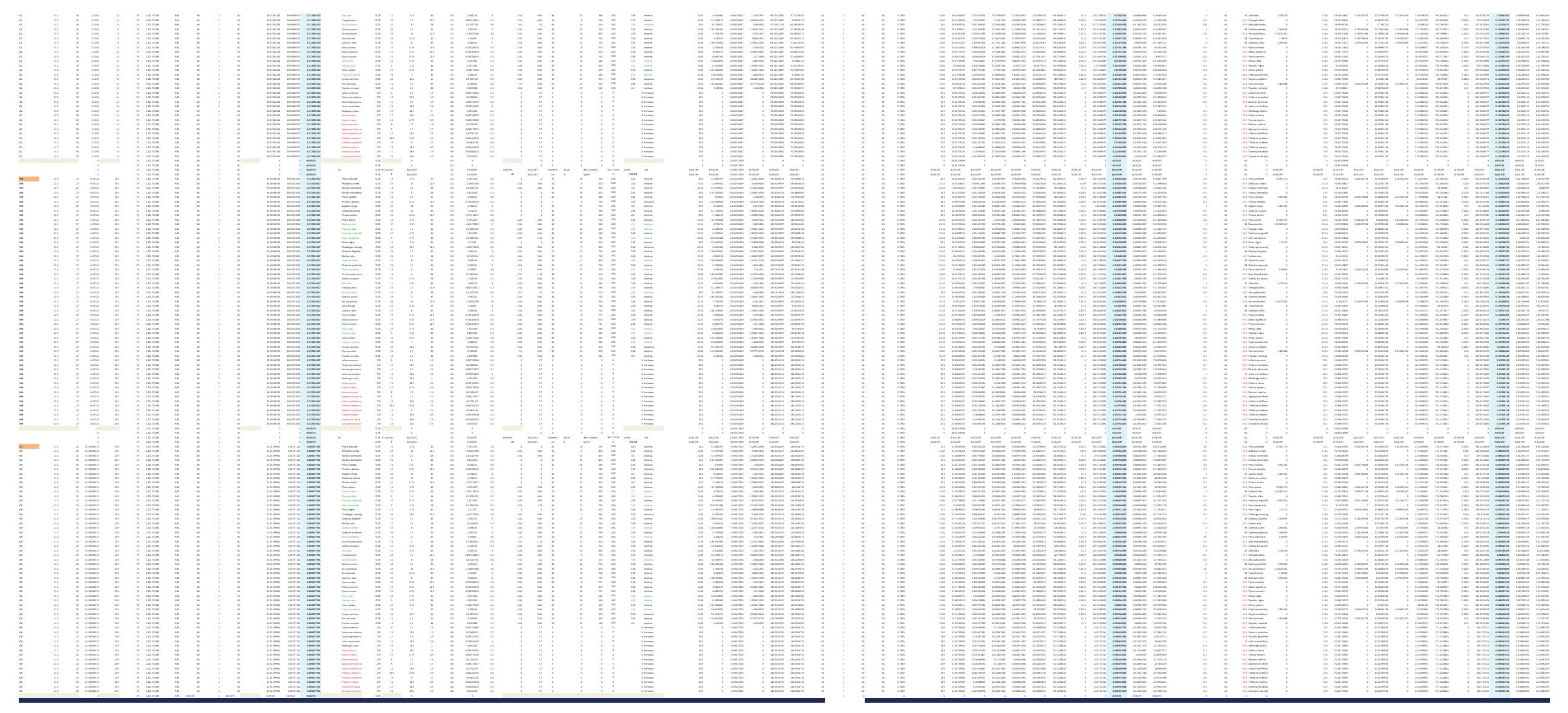



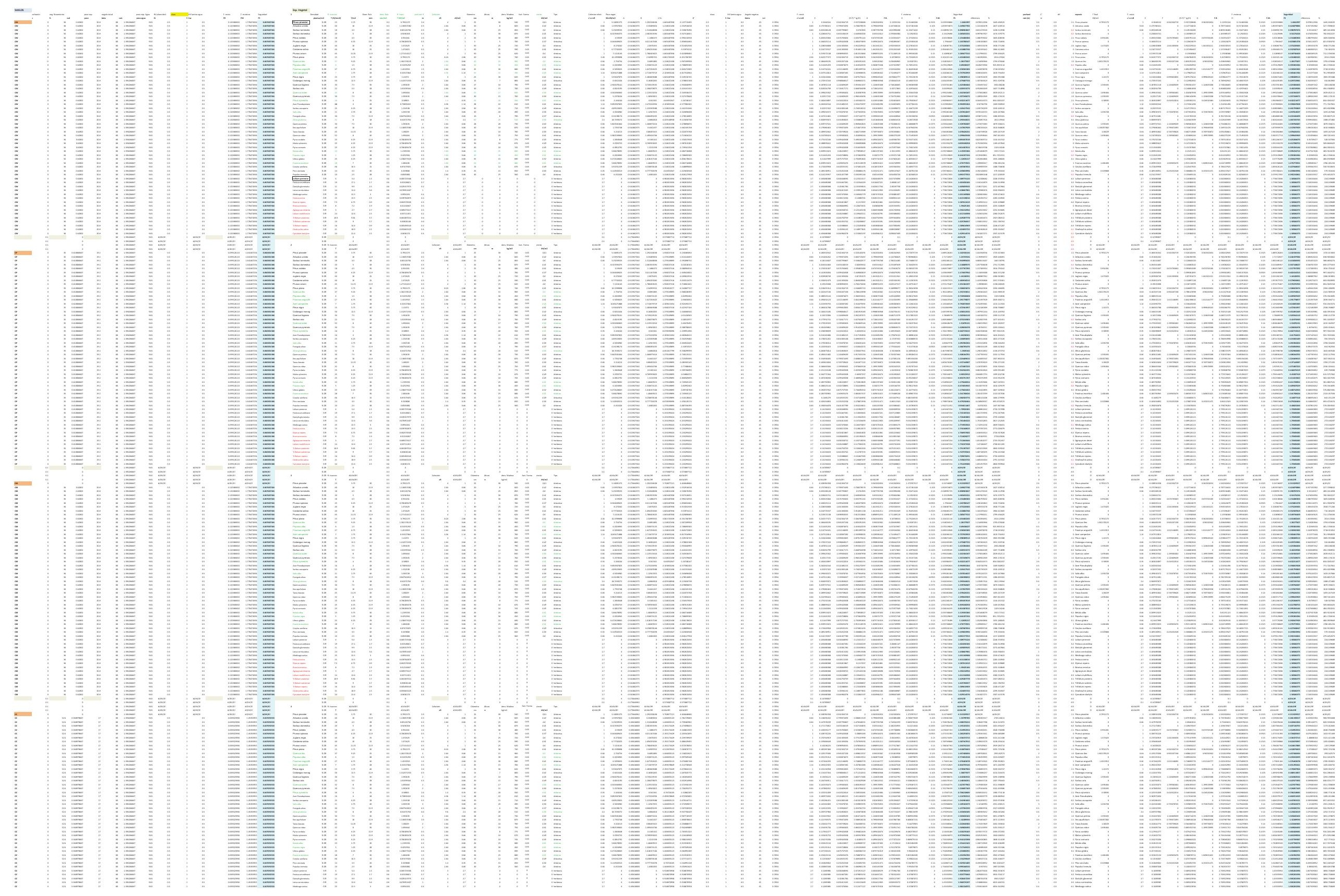


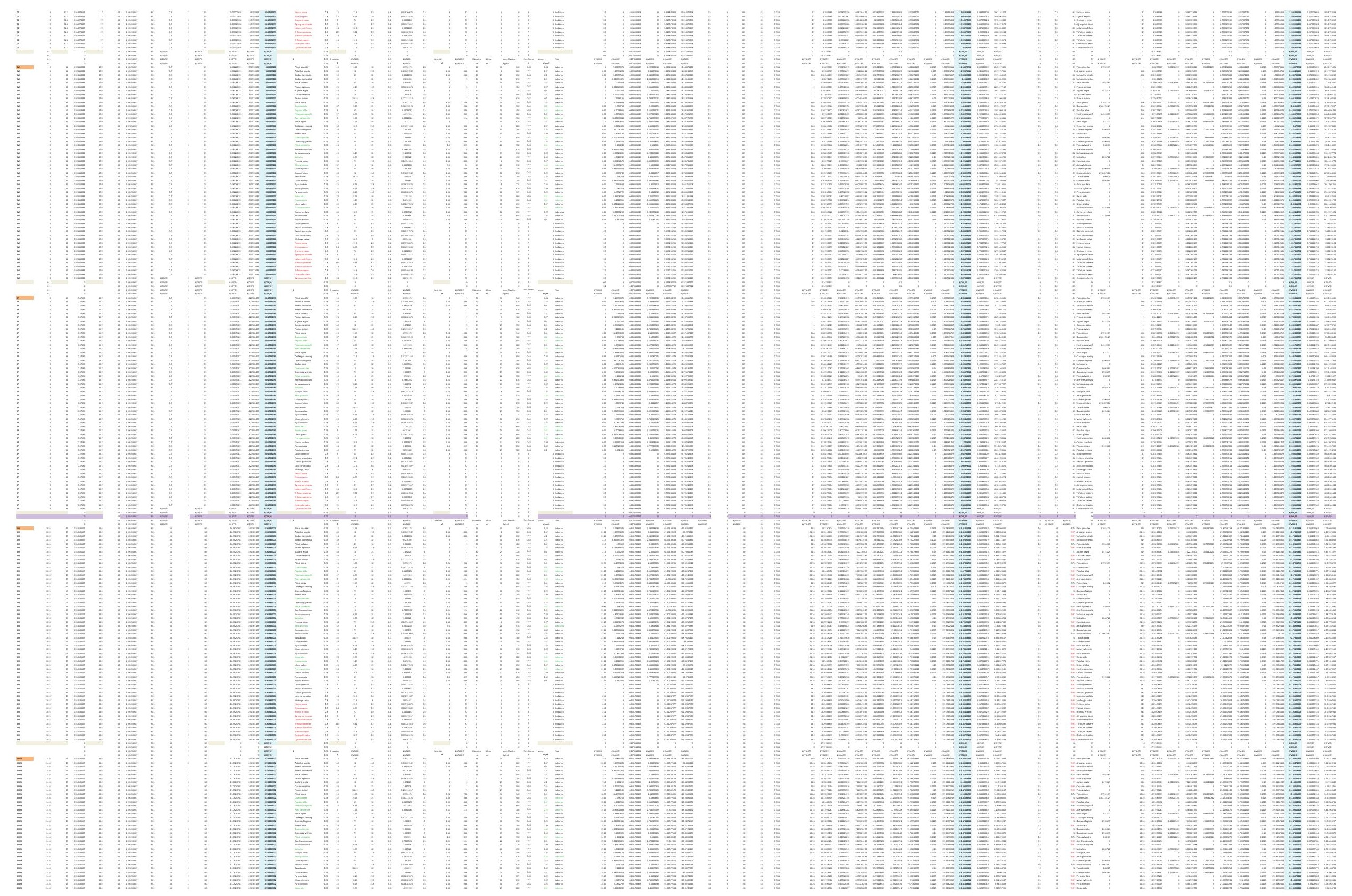




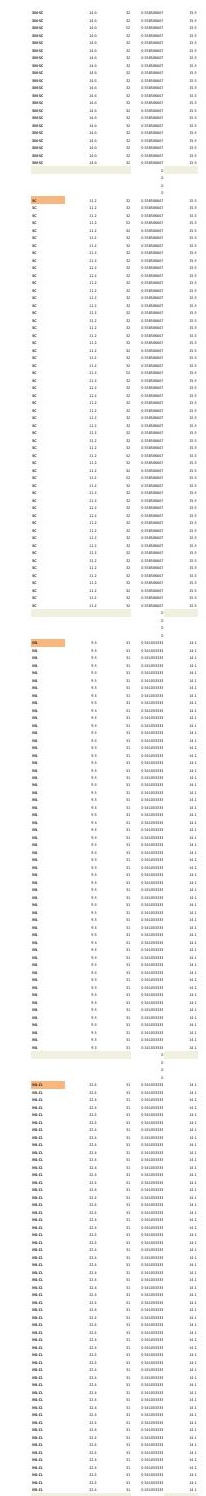

¿-
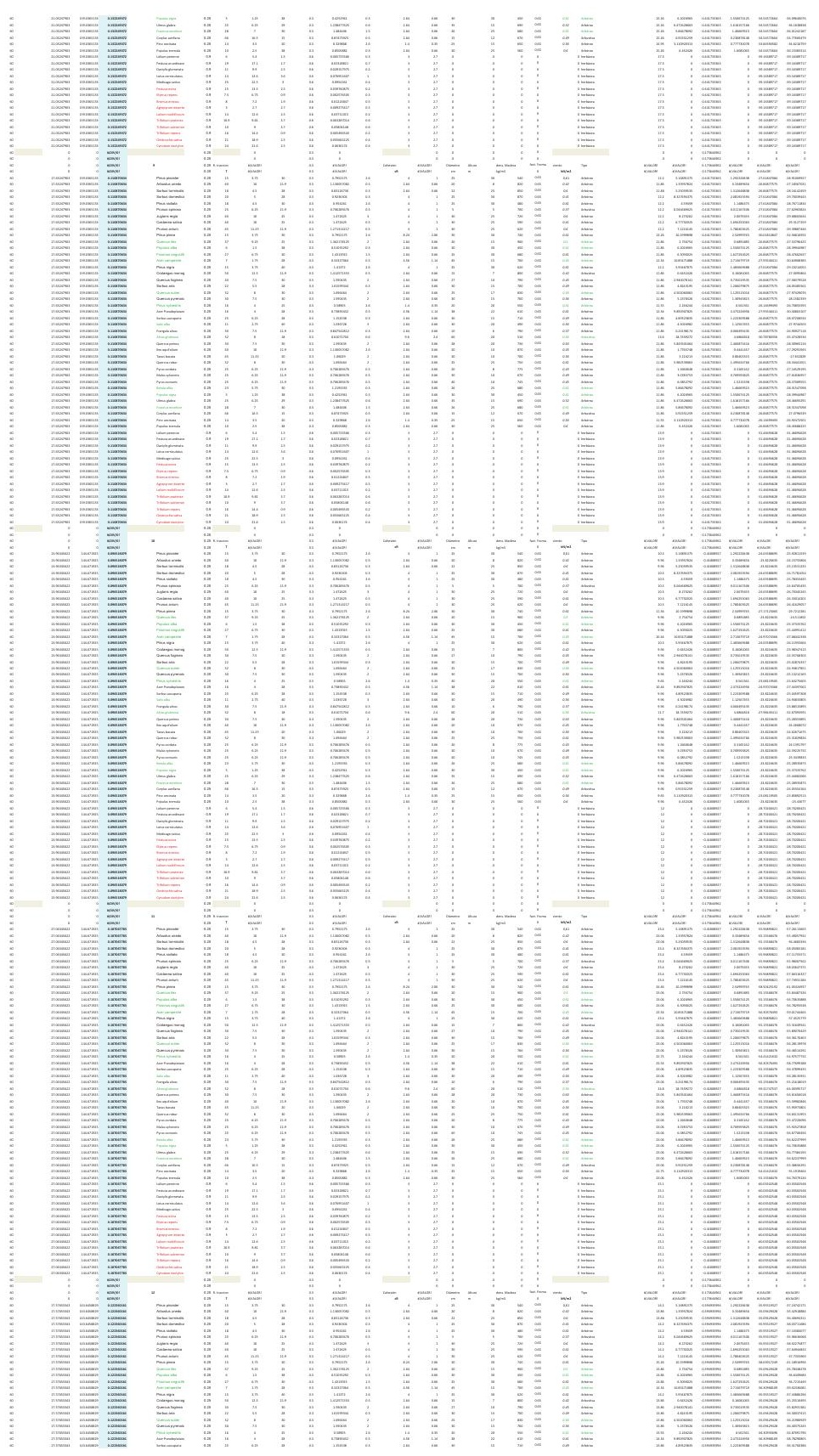
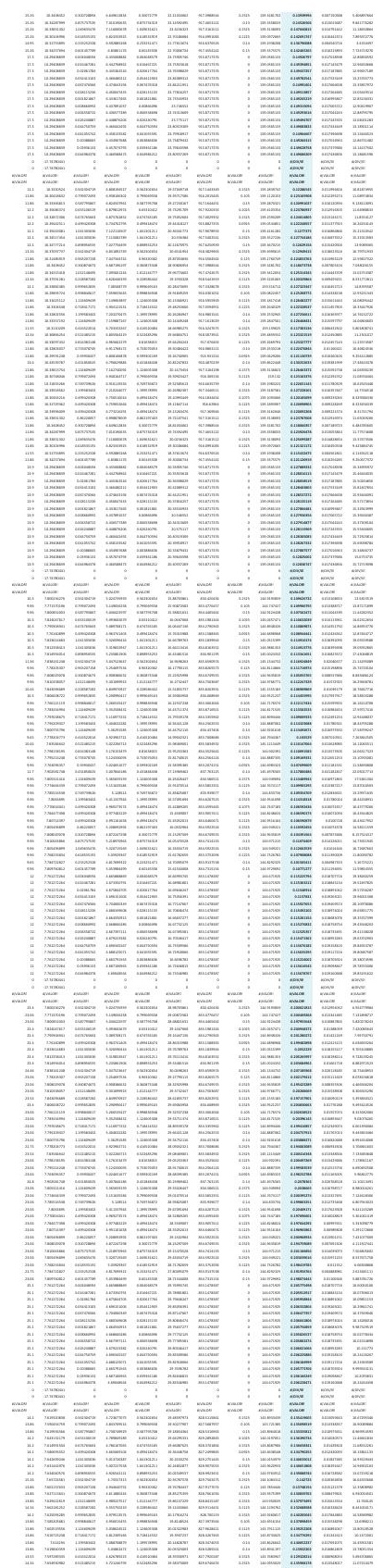

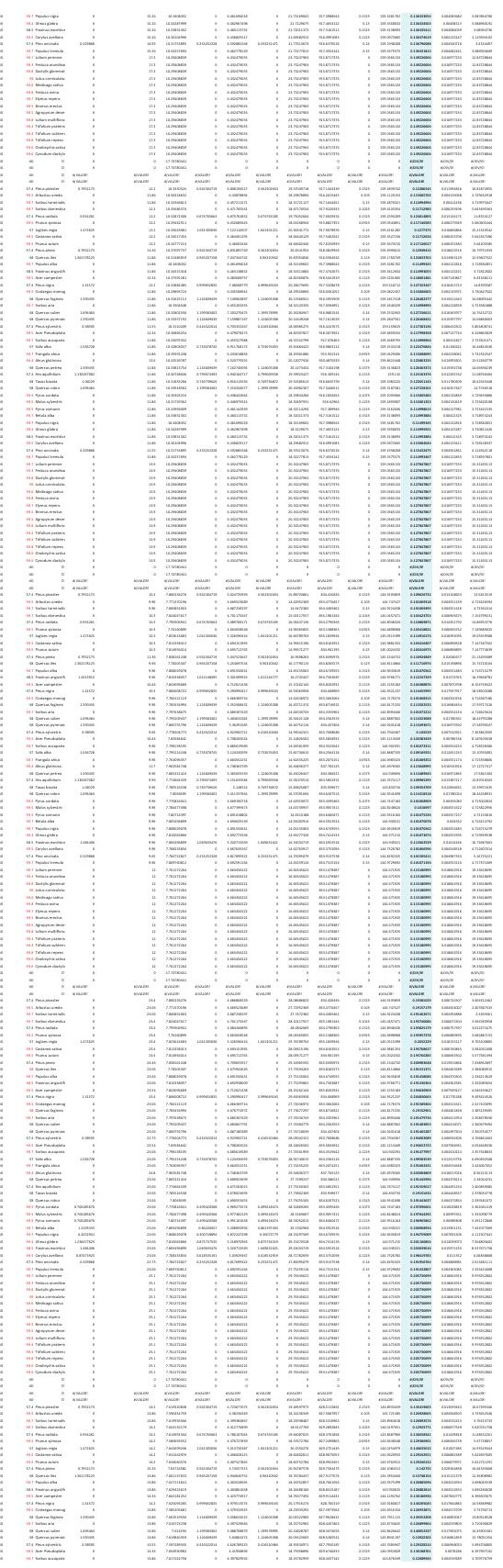




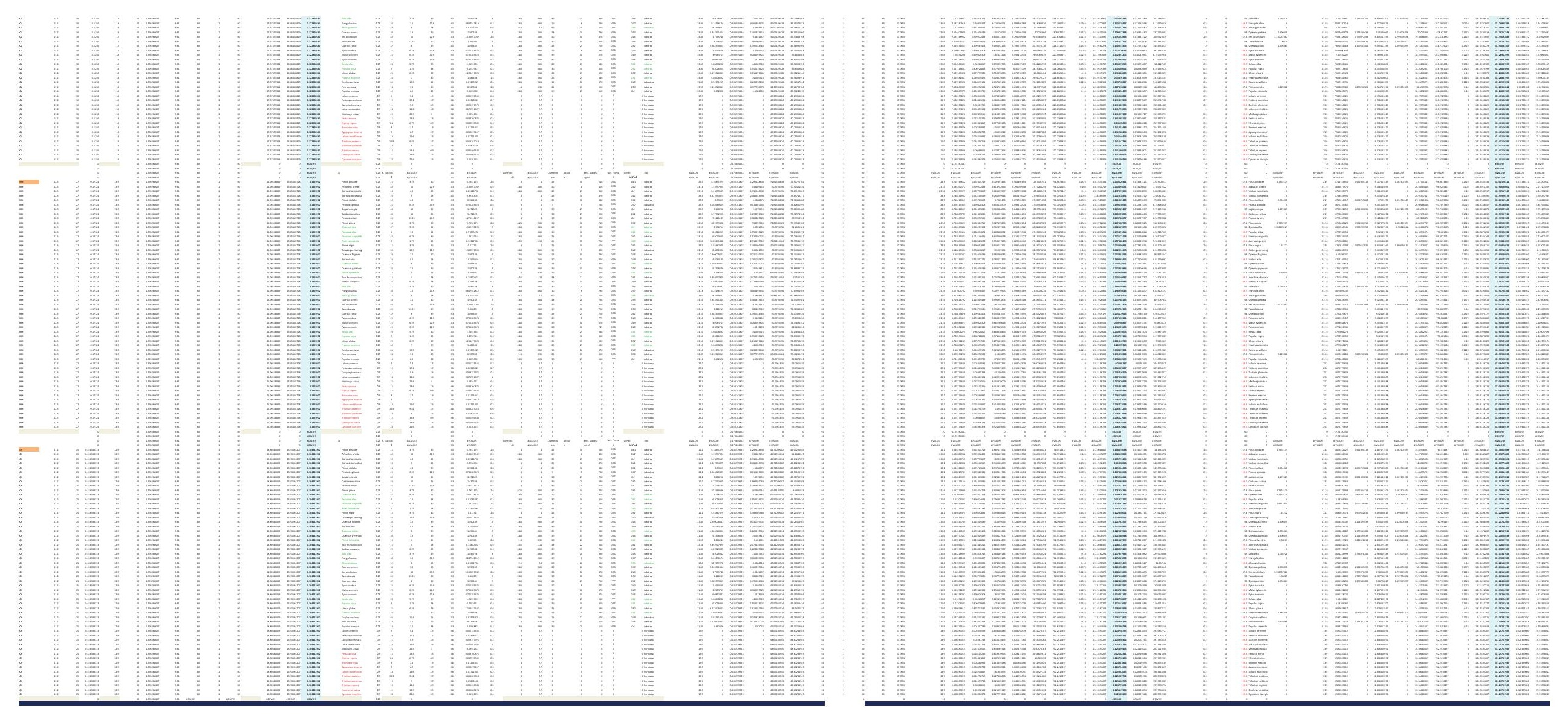


DESARROLLO DE UNA APLICACIÓN IMFORMÁTICA PARA EL CÁLCULO DE SOSTENIMIENTO DE TALUDES MEDIANTE VEGETACIÓN

PRUEBAS DEL MODELO MATEMÁTICO PARA EL CÁLCULO DE ESTABILIDAD DE TALUDES.

\section{PRUEBA B: COMBINACIONES DE ESPECIES}

B01. DENSIDAD DE PLANTACIÓN: 600 plantas/ha.

B01-1.POSICIÓN N.F. 1

B01-2.POSICIÓN N.F. 2

B01-3.POSICIÓN N.F. 3

B01-4.POSICIÓN N.F. 4

B01-5.POSICIÓN N.F. 5 
DESARROLLO DE UNA APLICACIÓN IMFORMÁTICA PARA EL CÁLCULO DE SOSTENIMIENTO DE TALUDES MEDIANTE VEGETACIÓN

B01. DENSIDAD DE PLANTACIÓN: 600 plantas/ha.

\section{B01-1.POSICIÓN N.F. 1}

INCLINACIÓN DE TALUD 6-100

INCLINACIÓN DE TALUD 10-200

INCLINACIÓN DE TALUD 20-30

INCLINACIÓN DE TALUD 30-40

INCLINACIÓN DE TALUD $35^{\circ}$

INCLINACIÓN DE TALUD 40-50

INCLINACIÓN DE TALUD 50-550

INCLINACIÓN DE TALUD 55-60

INCLINACIÓN DE TALUD 60-700

INCLINACIÓN DE TALUD 70-80 


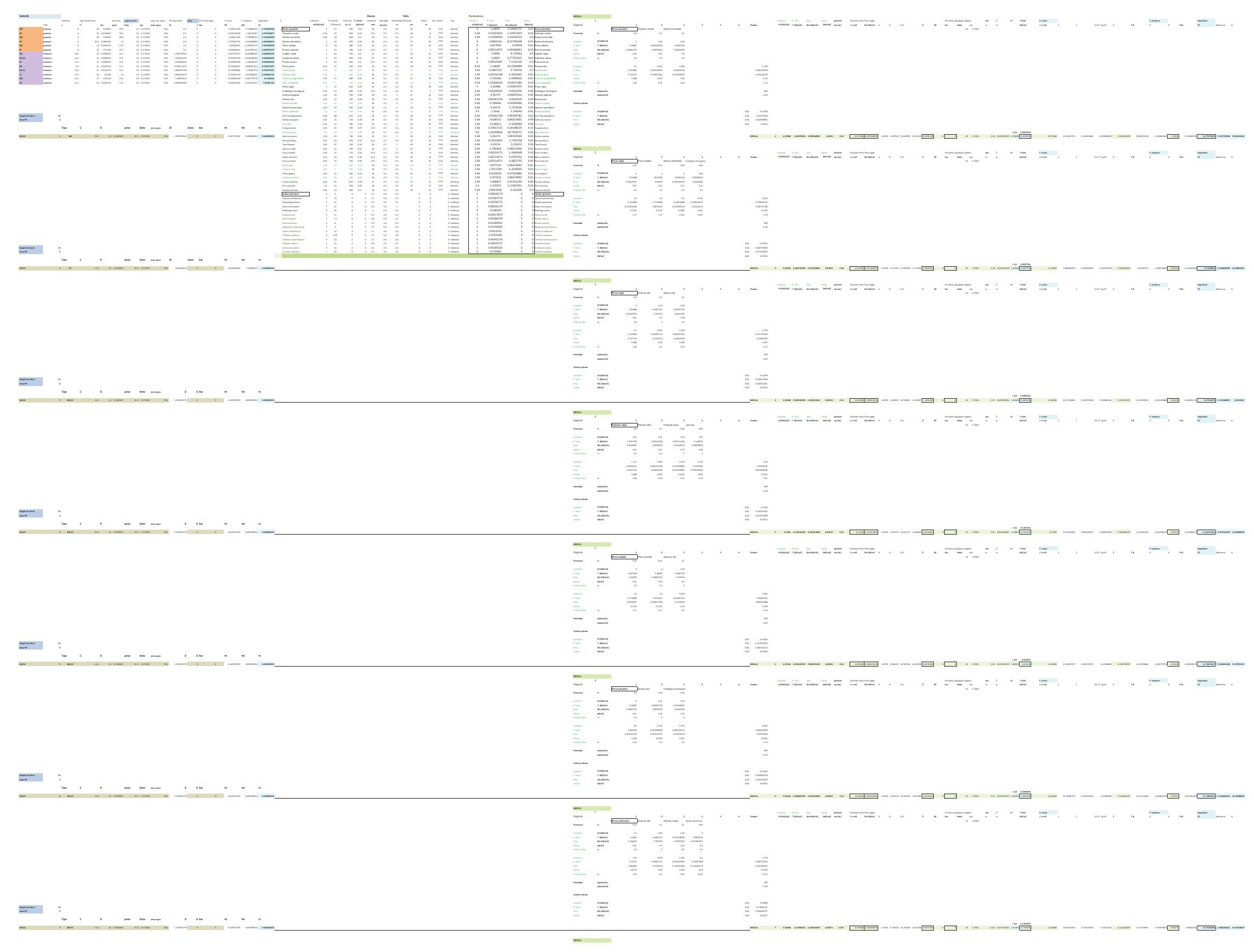




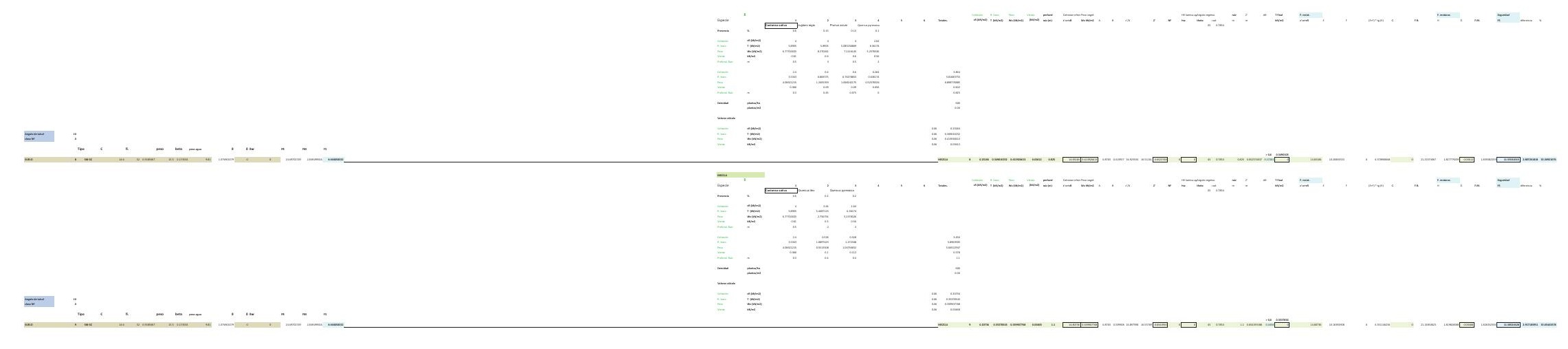




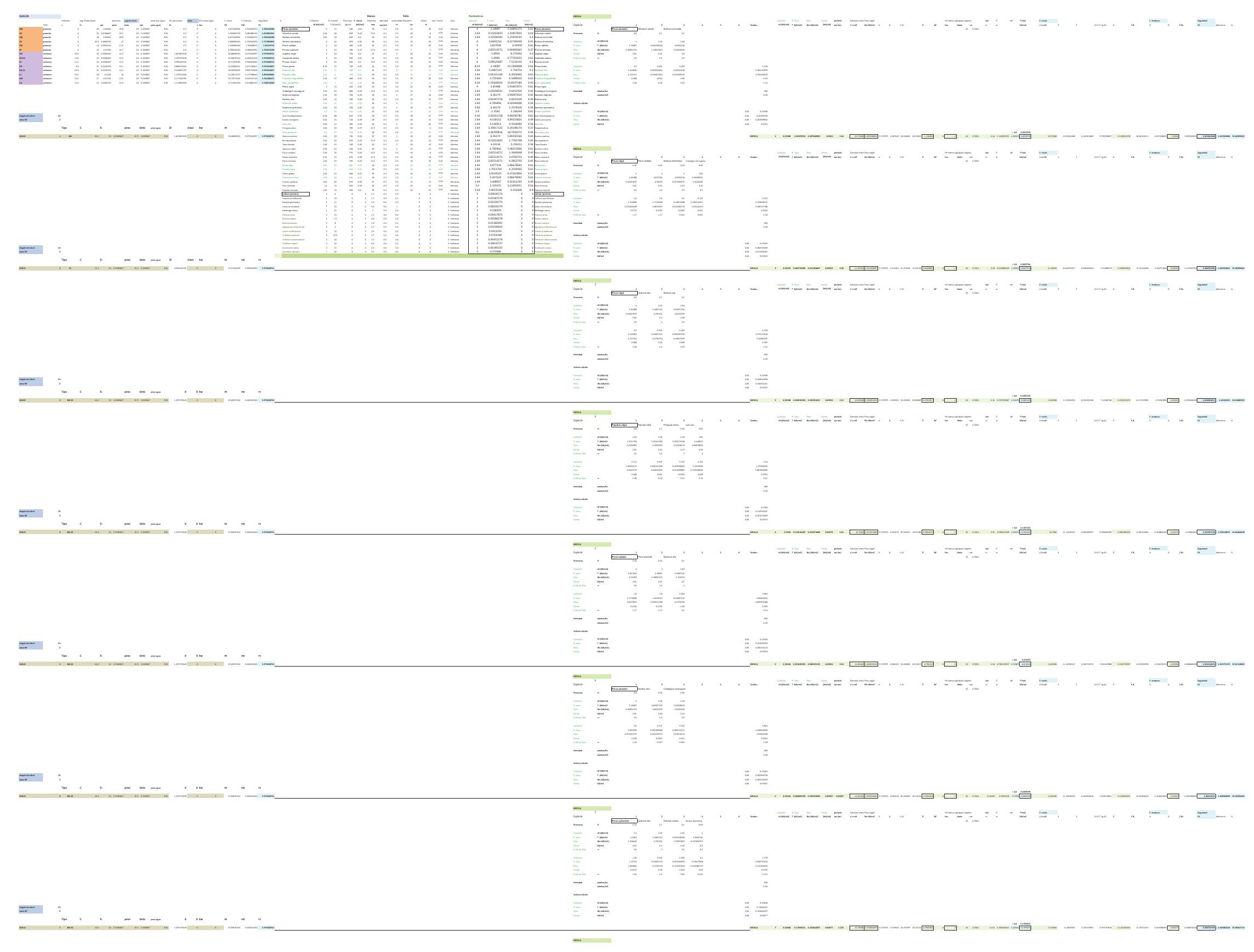




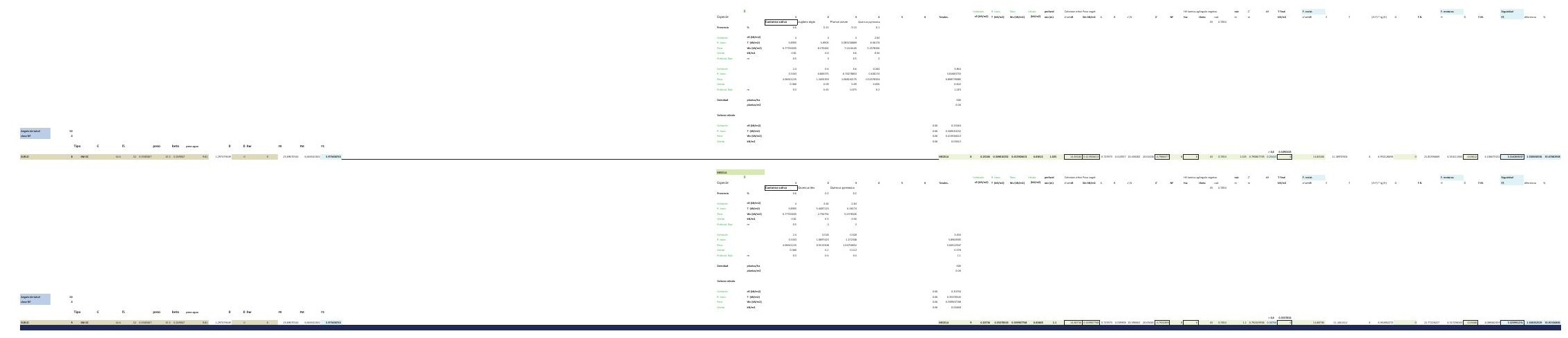




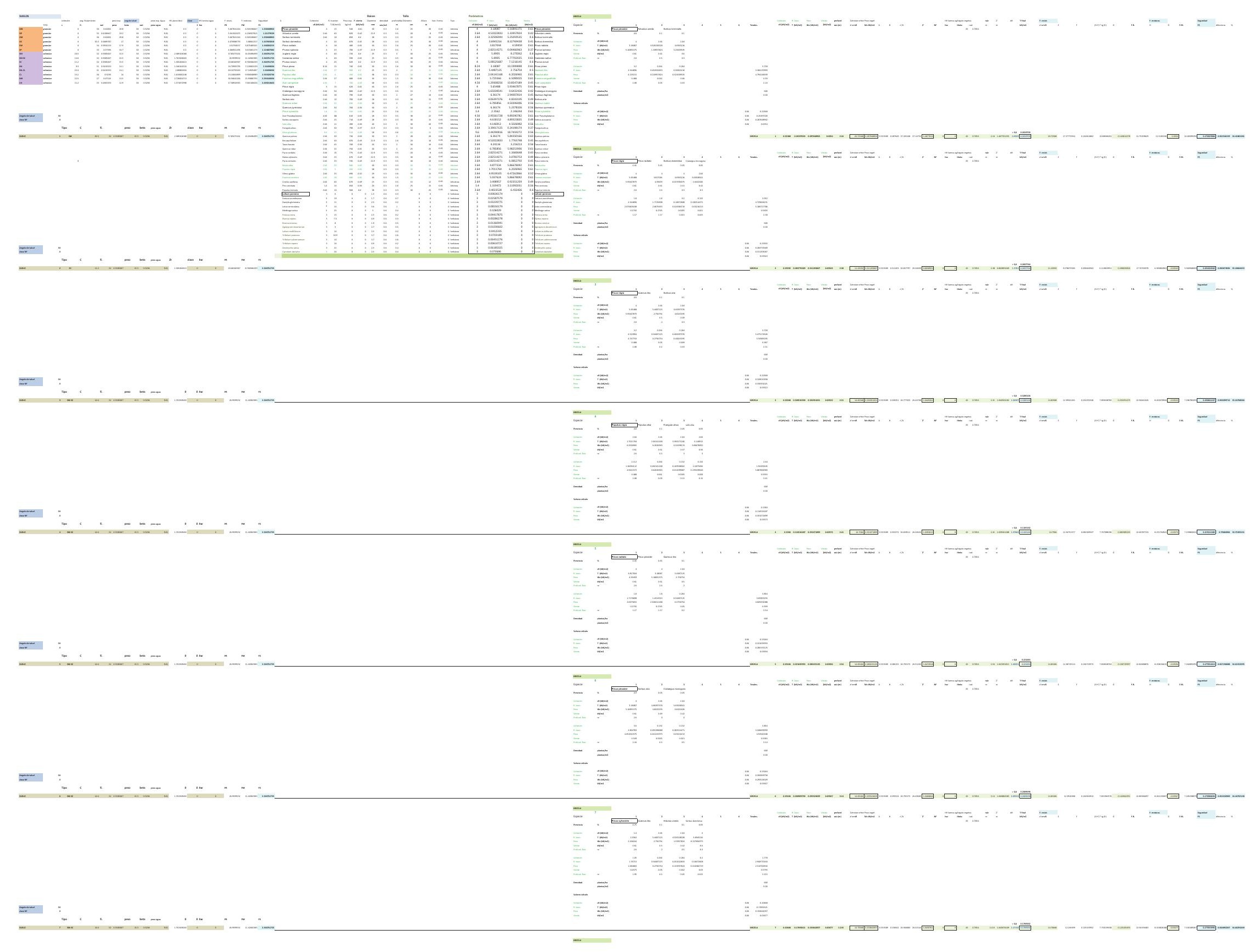




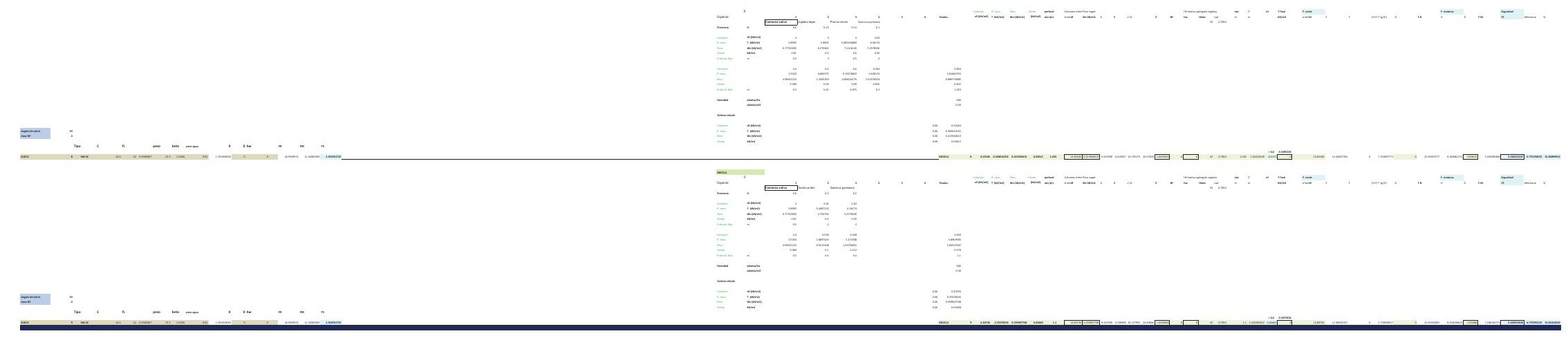




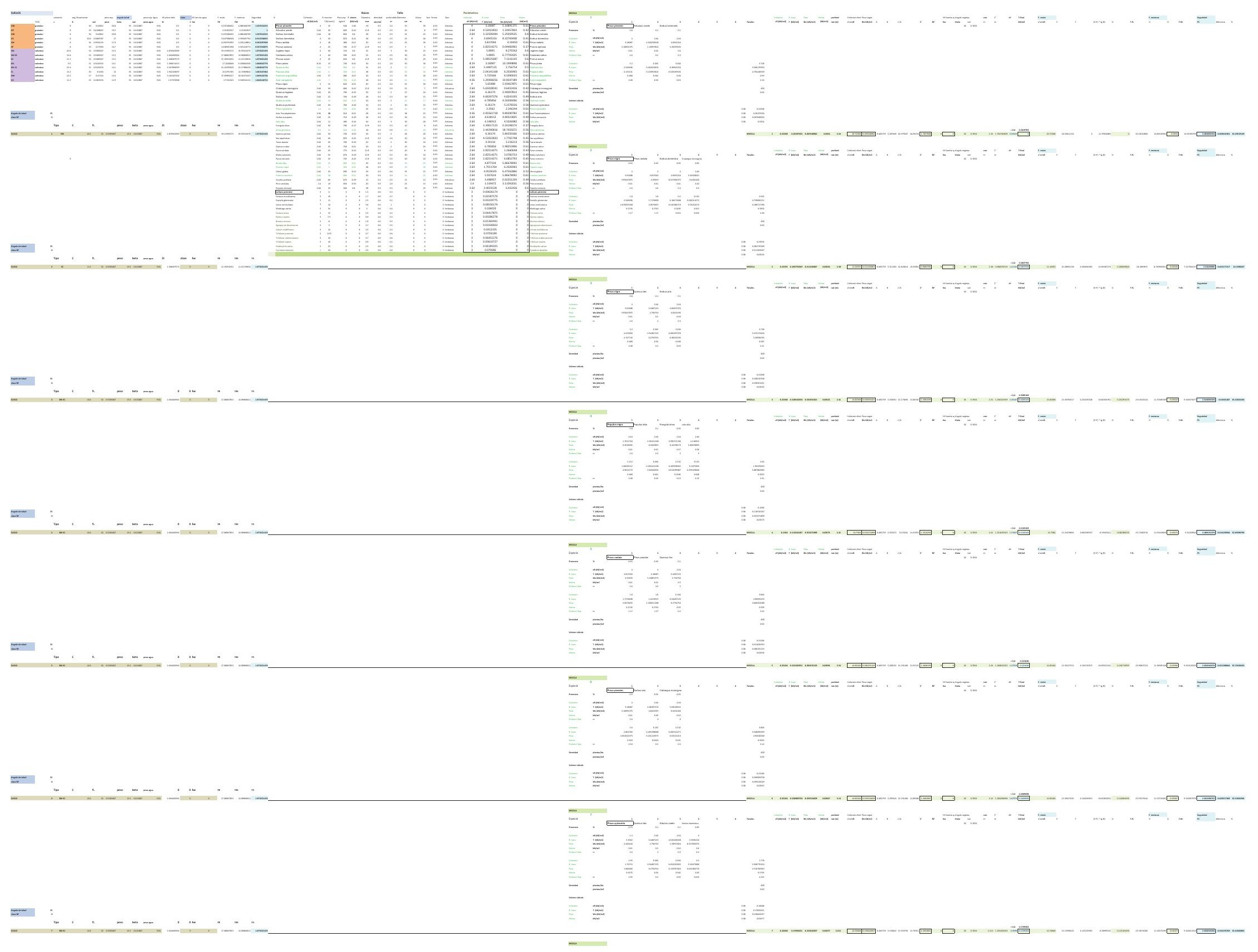




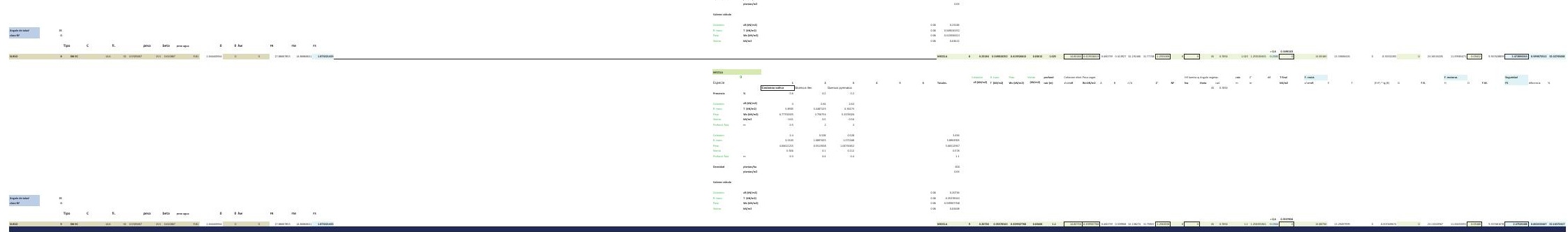




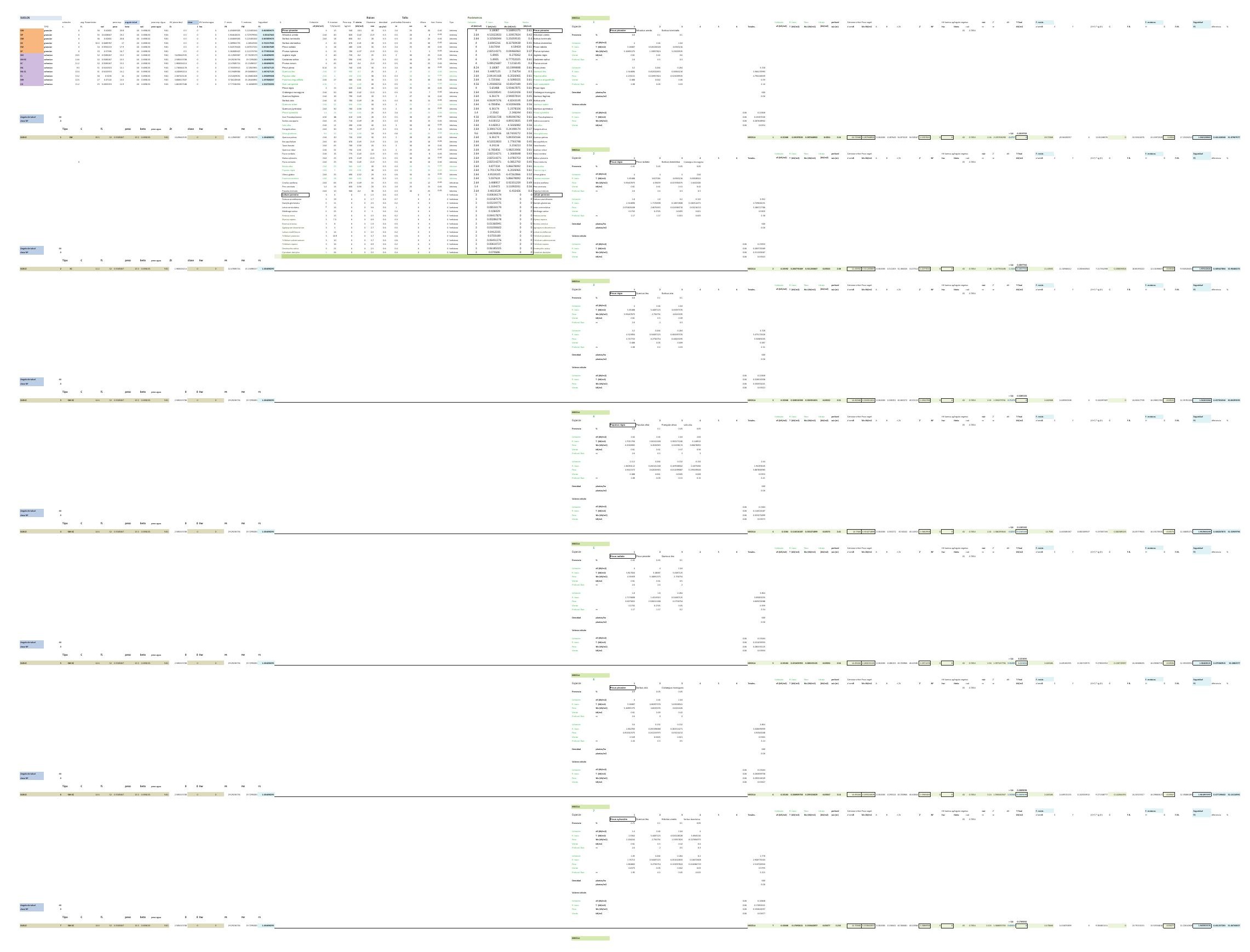




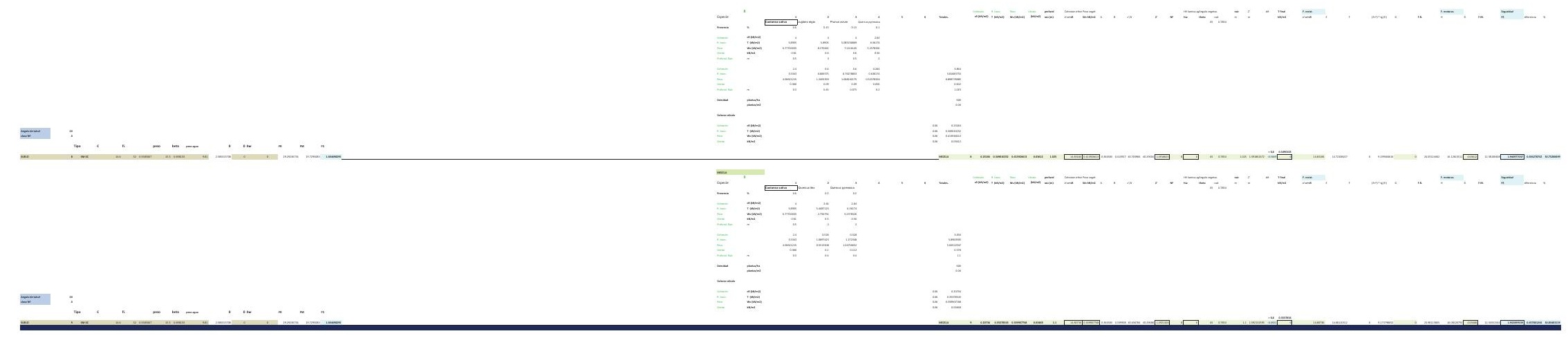




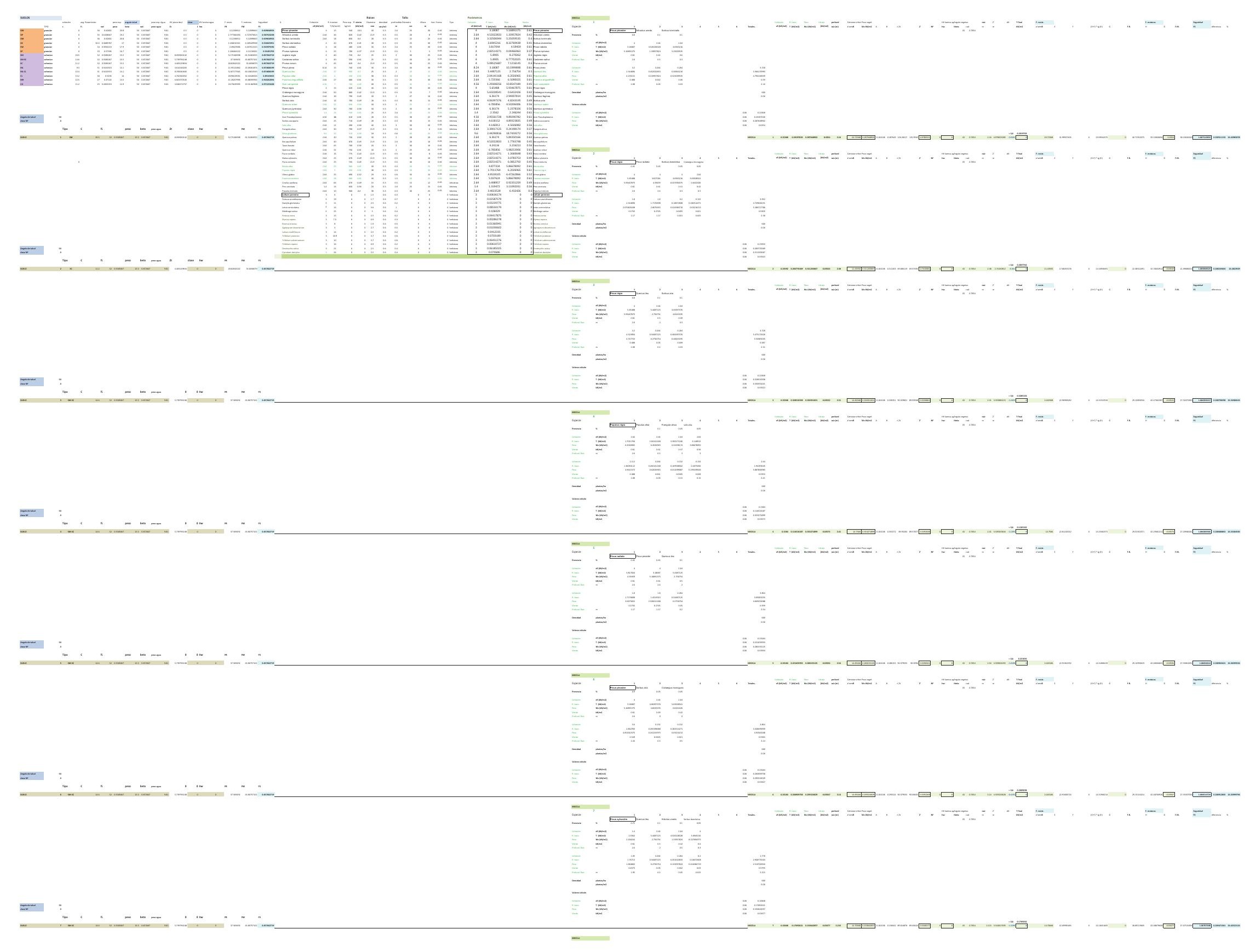




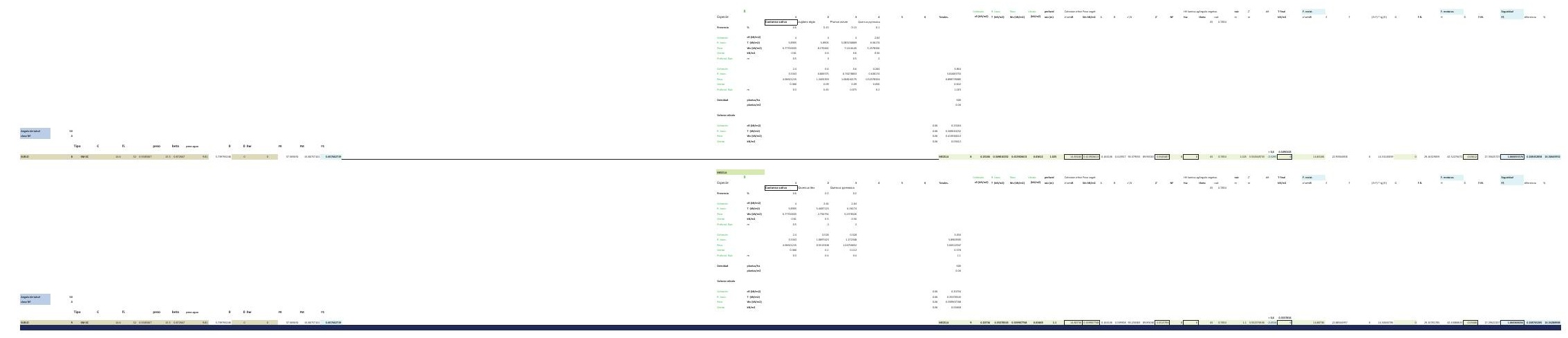




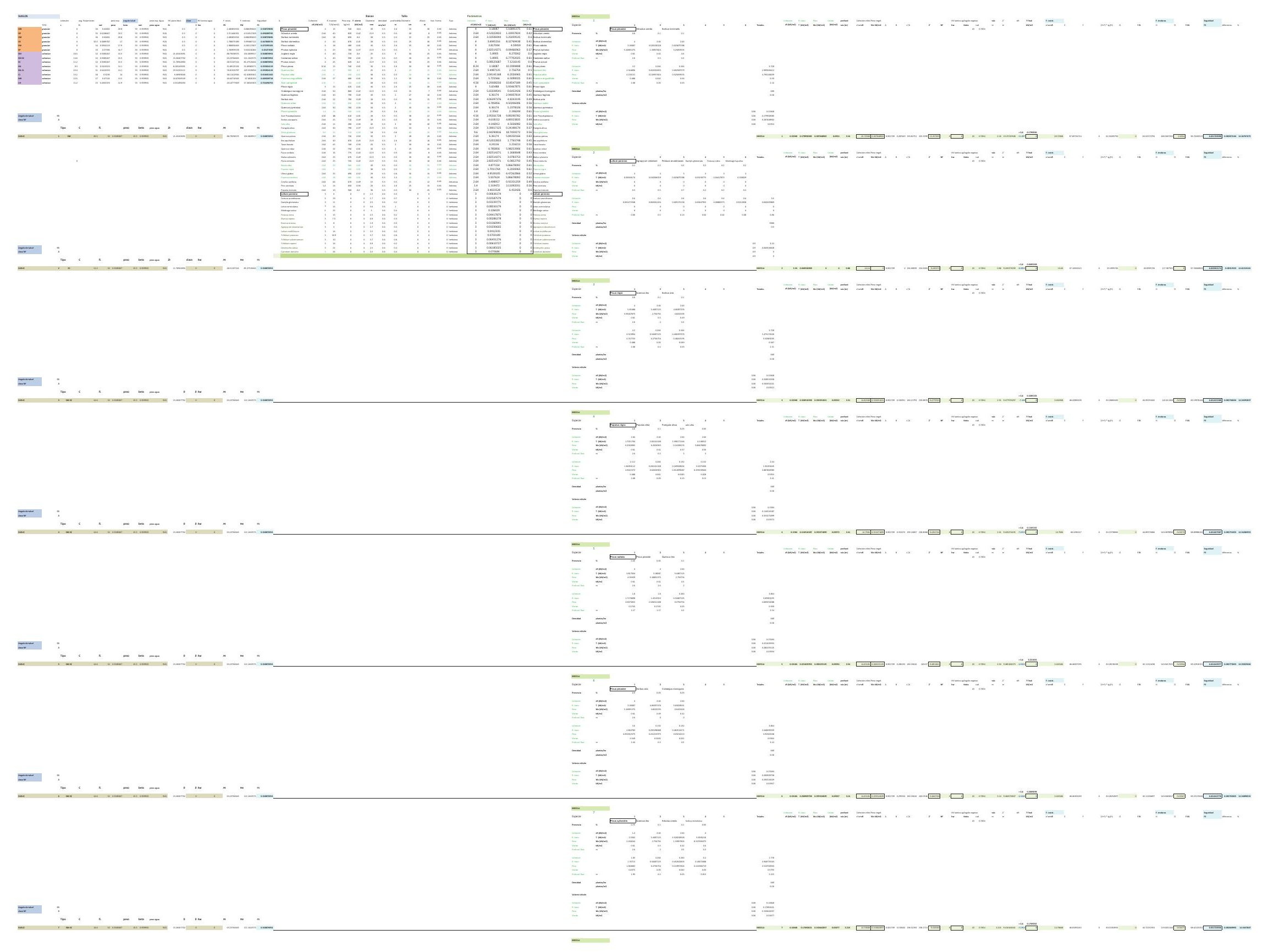




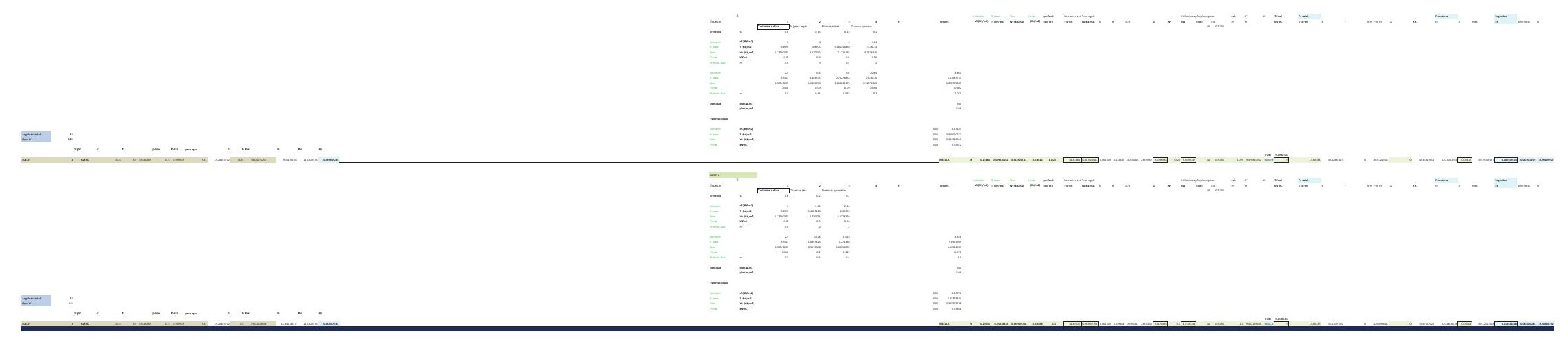




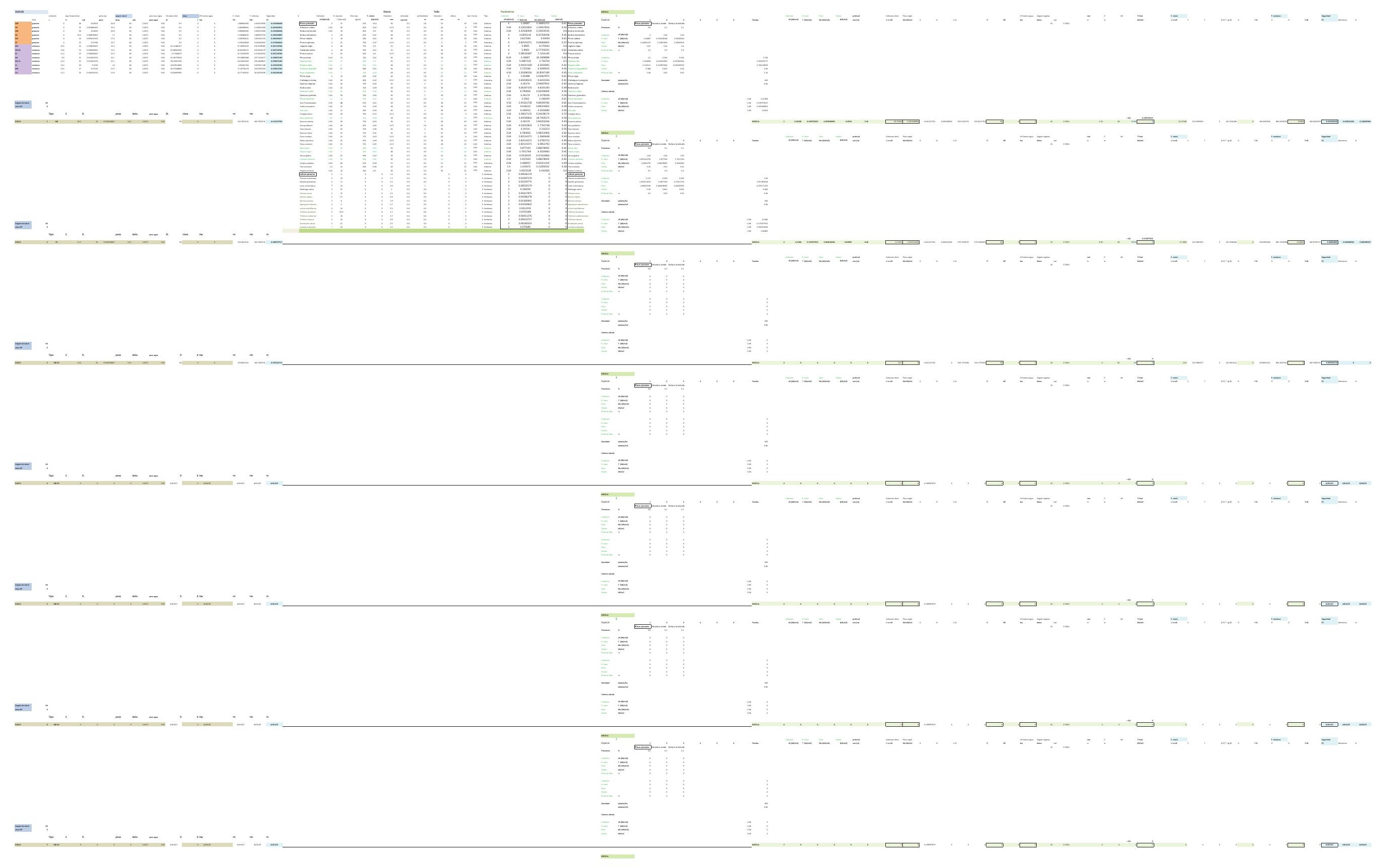




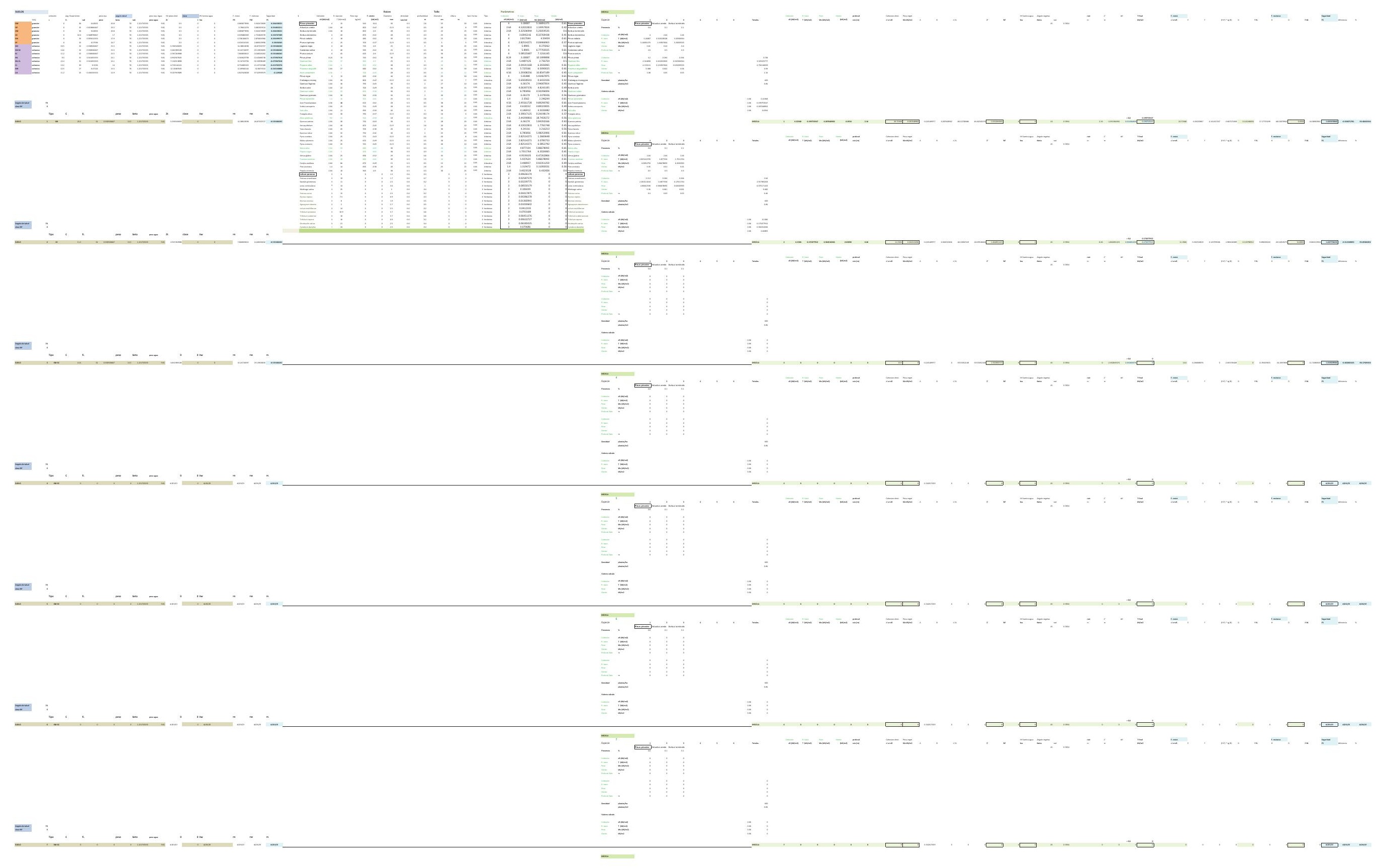




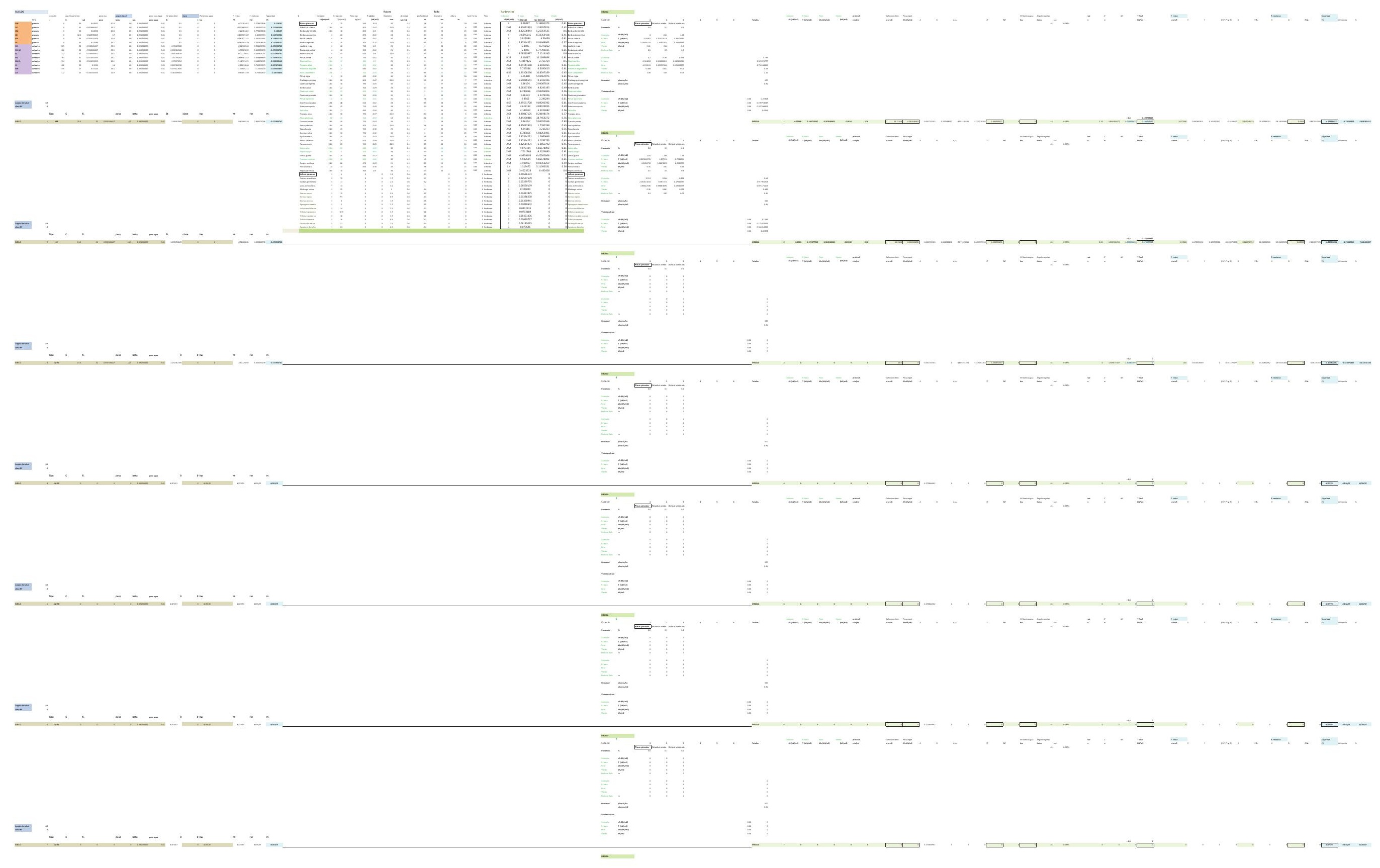


DESARROLLO DE UNA APLICACIÓN IMFORMÁTICA PARA EL CÁLCULO DE SOSTENIMIENTO DE TALUDES MEDIANTE VEGETACIÓN

B01. DENSIDAD DE PLANTACIÓN: 600 plantas/ha.

\section{B01-2.POSICIÓN N.F. 2}

INCLINACIÓN DE TALUD 6-100

INCLINACIÓN DE TALUD 10-200

INCLINACIÓN DE TALUD 20-30

INCLINACIÓN DE TALUD 30-40

INCLINACIÓN DE TALUD $35^{\circ}$

INCLINACIÓN DE TALUD 40-50

INCLINACIÓN DE TALUD 50-550

INCLINACIÓN DE TALUD 55-60

INCLINACIÓN DE TALUD 60-700

INCLINACIÓN DE TALUD 70-80 


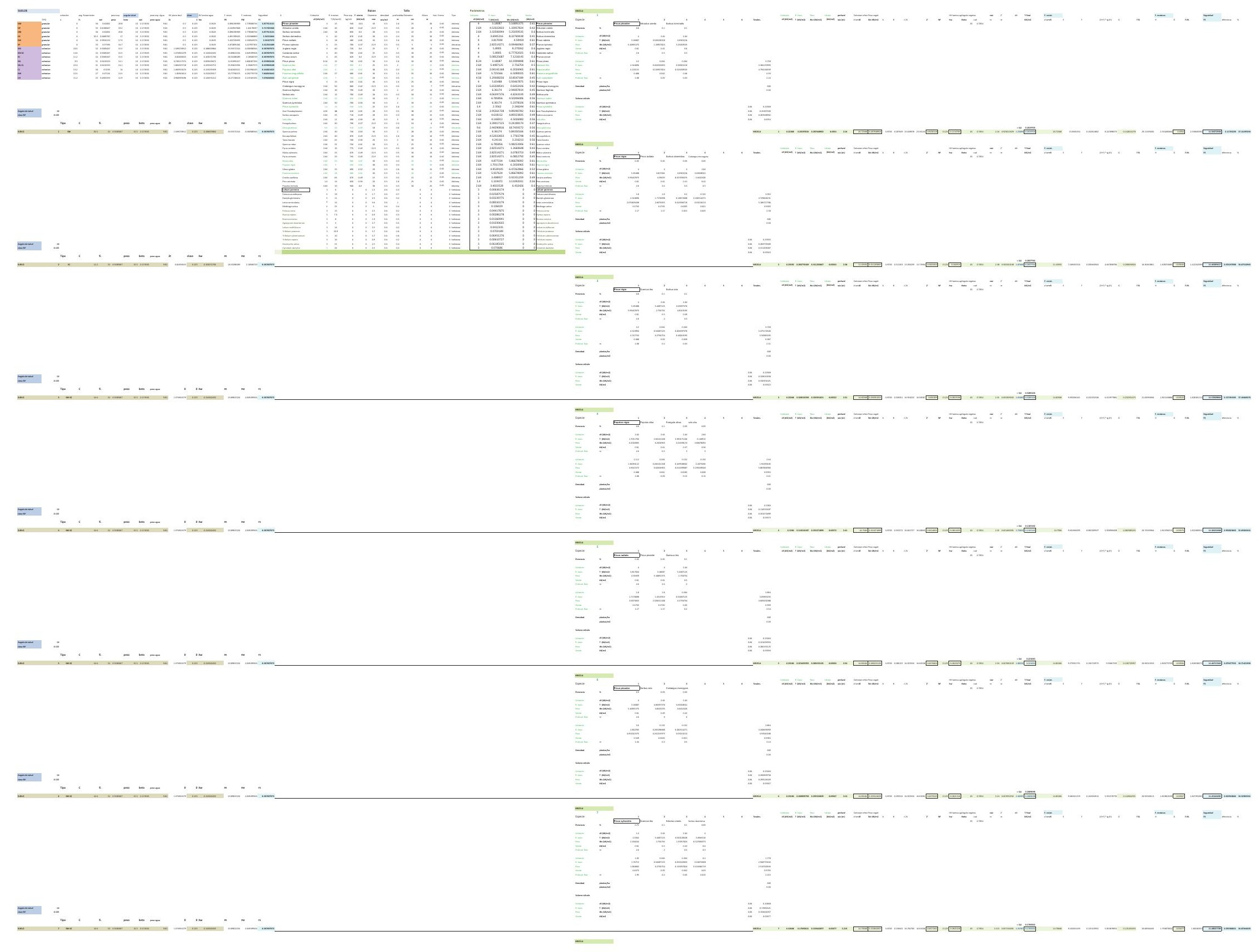




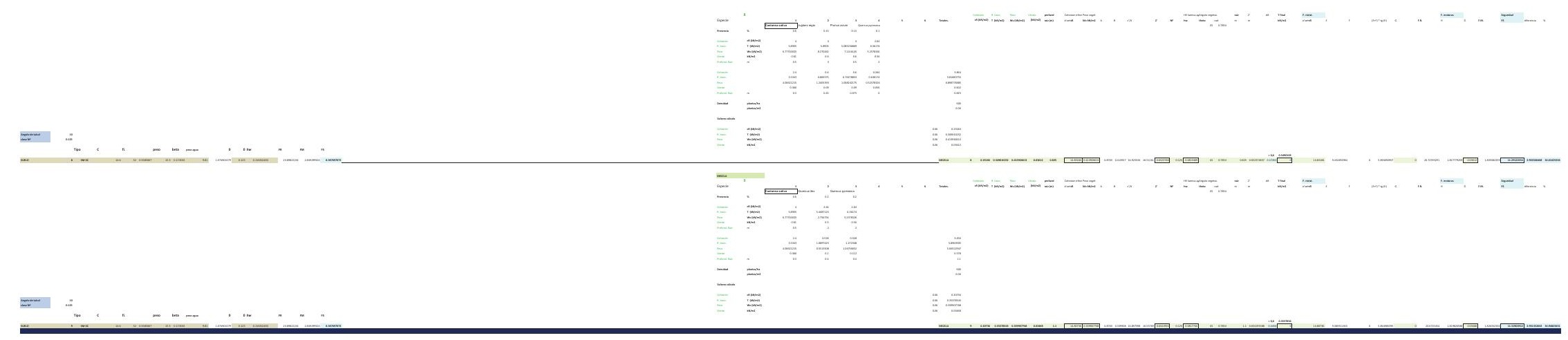




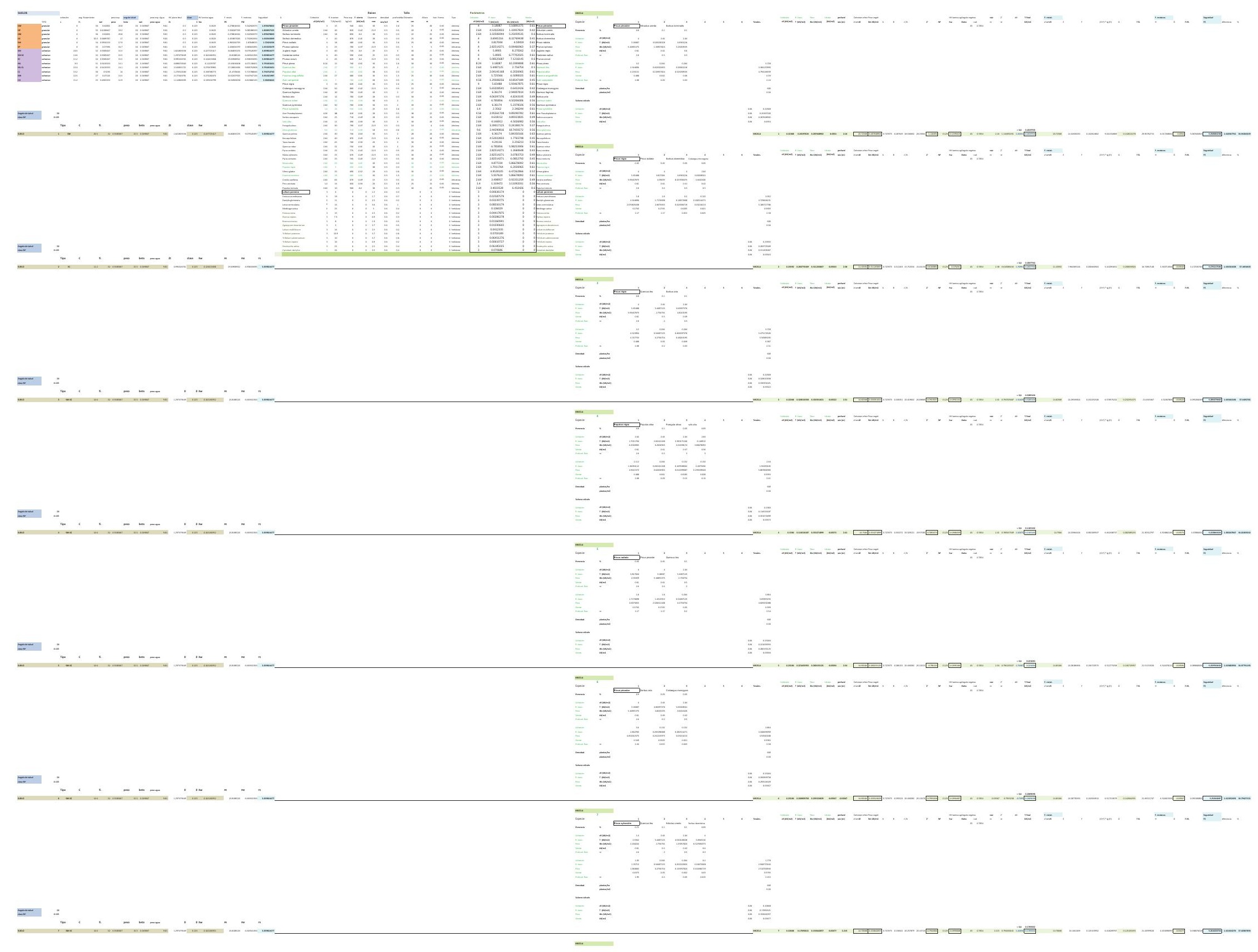




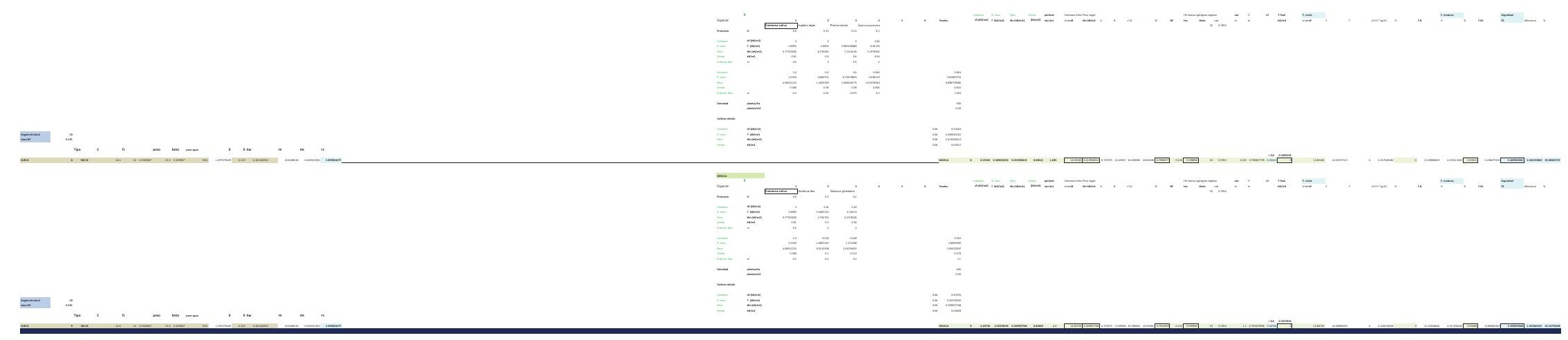




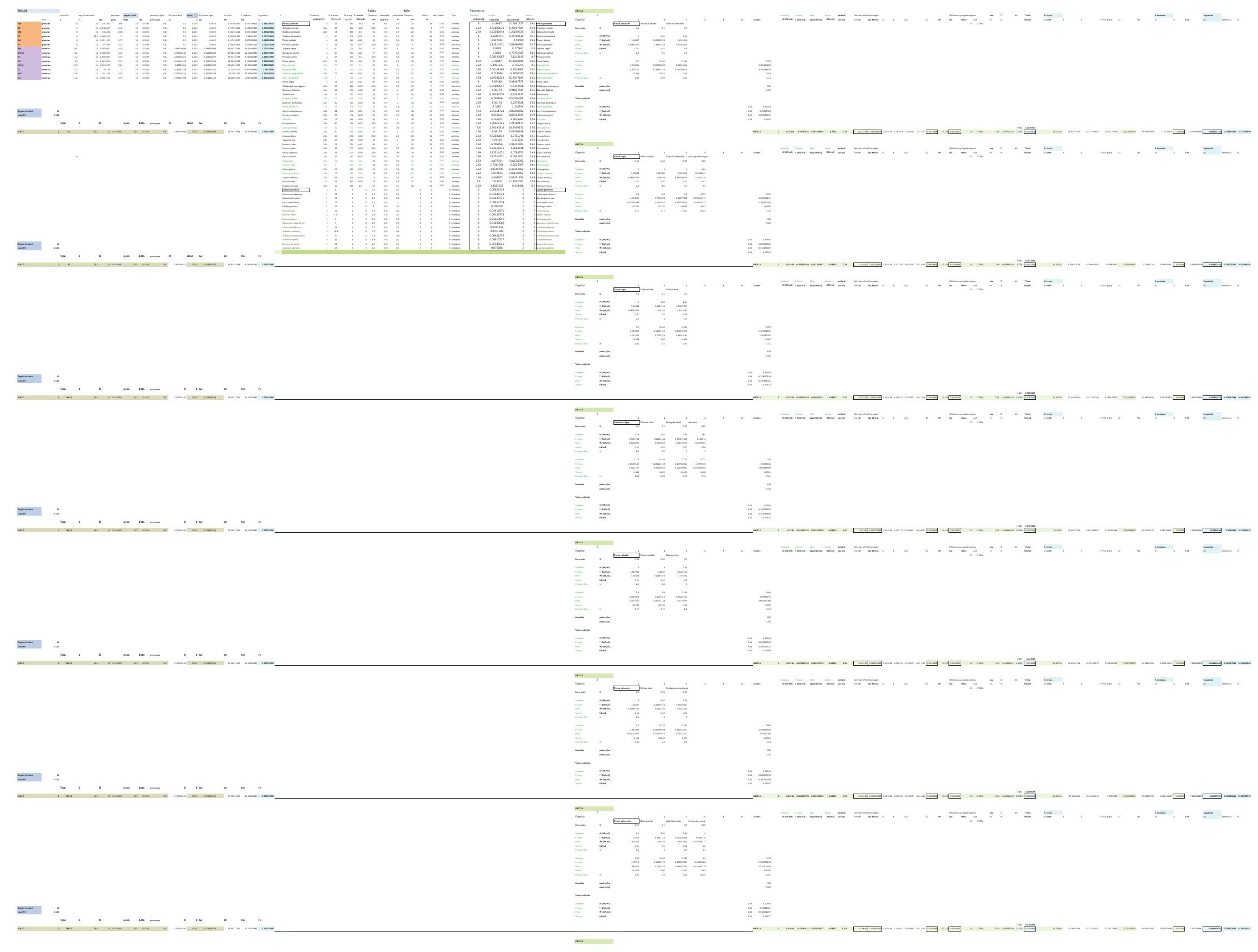




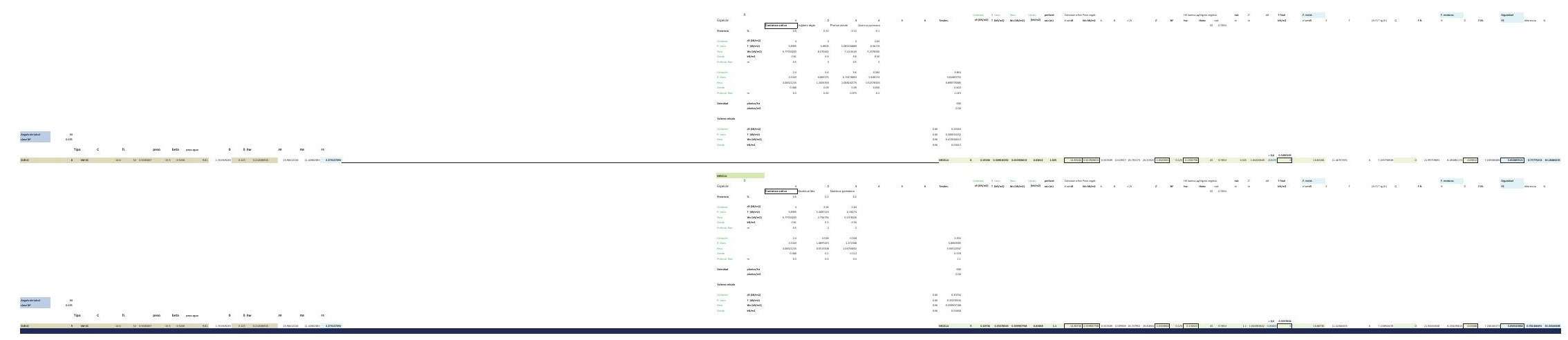




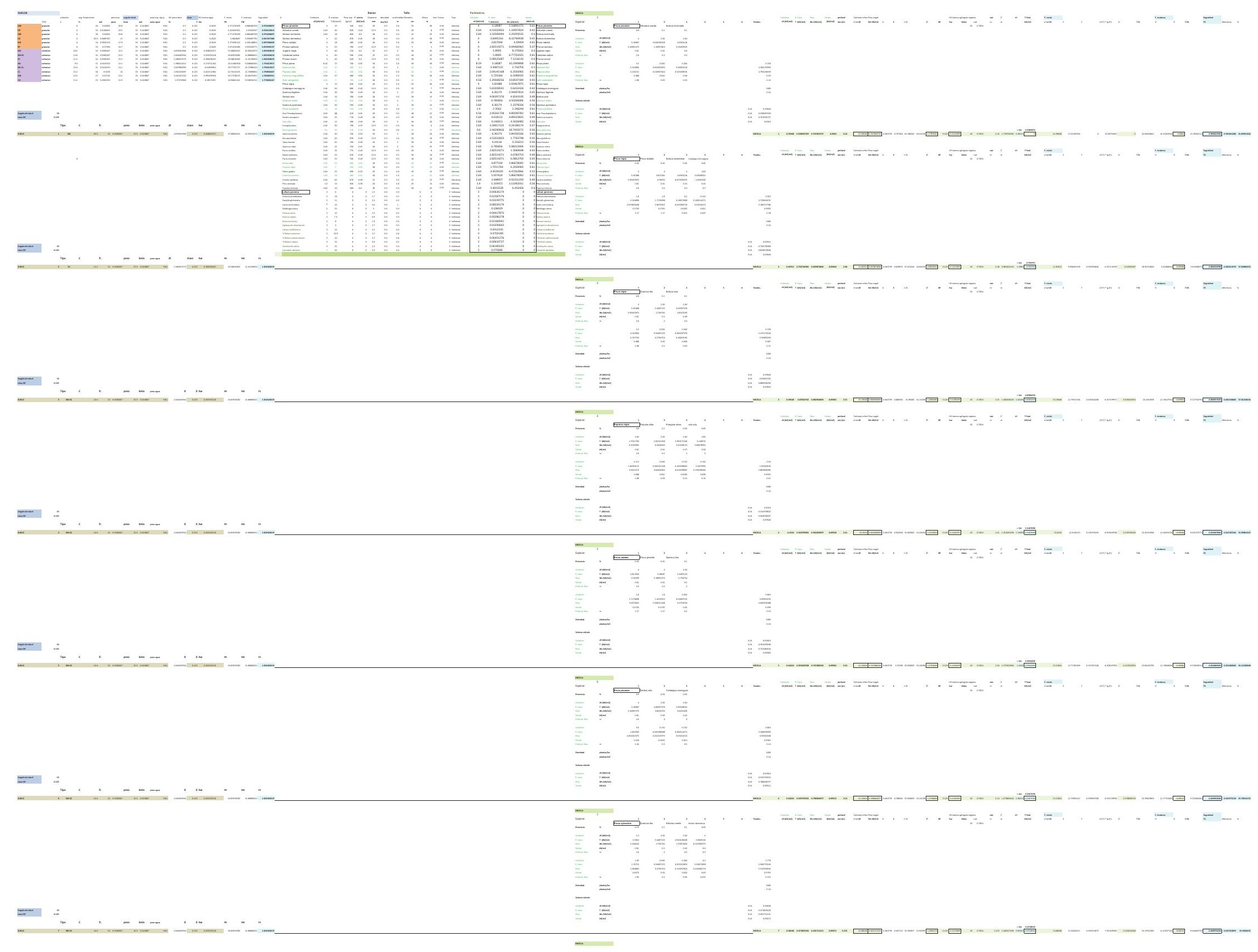




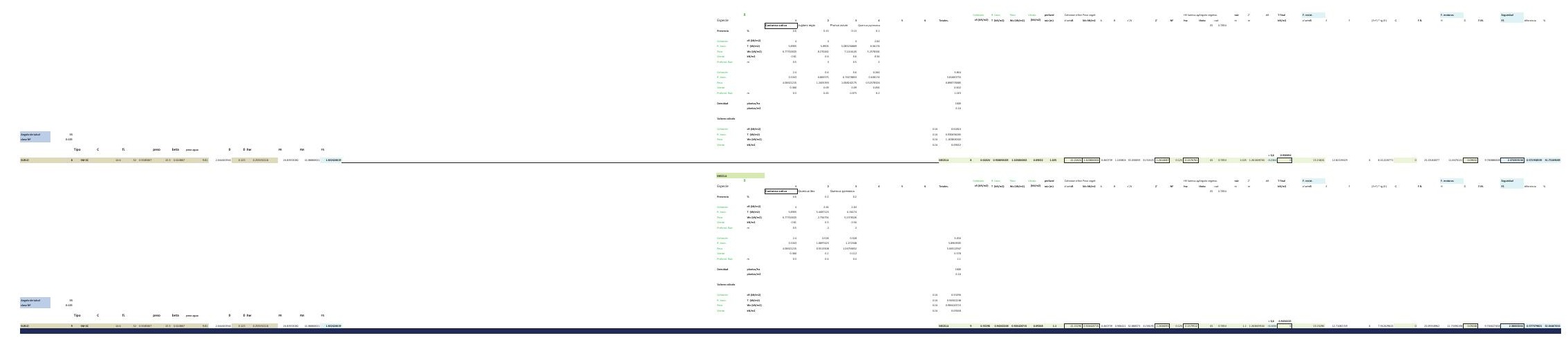




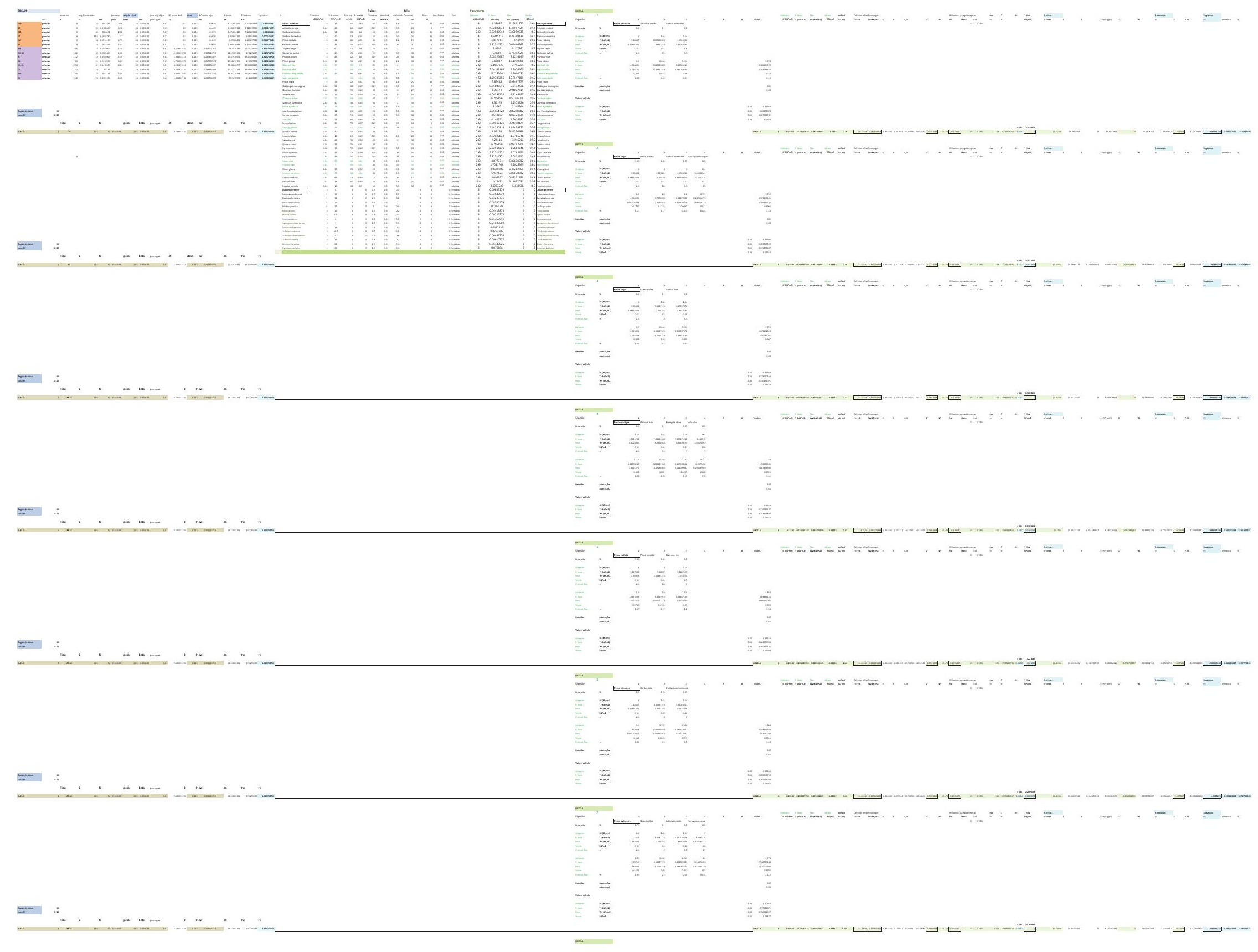




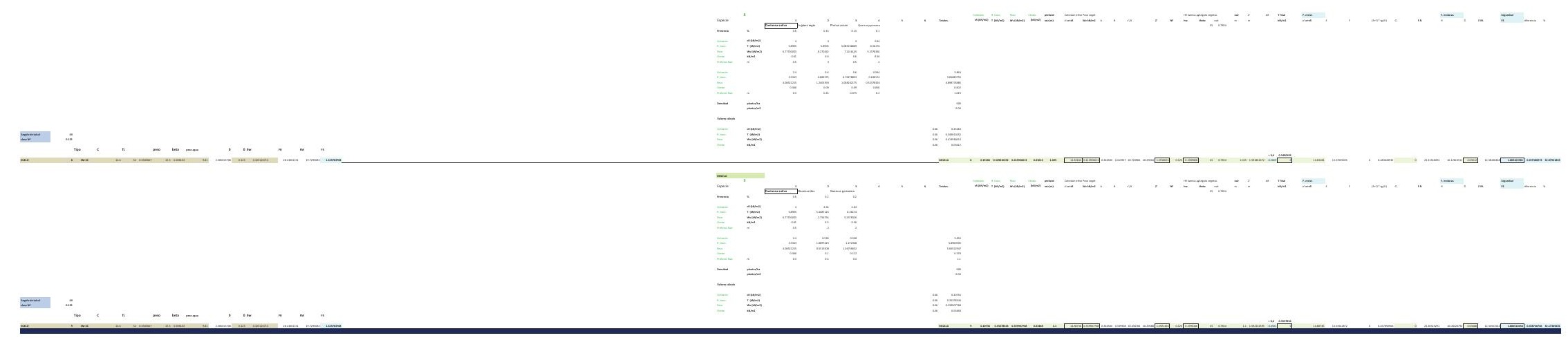




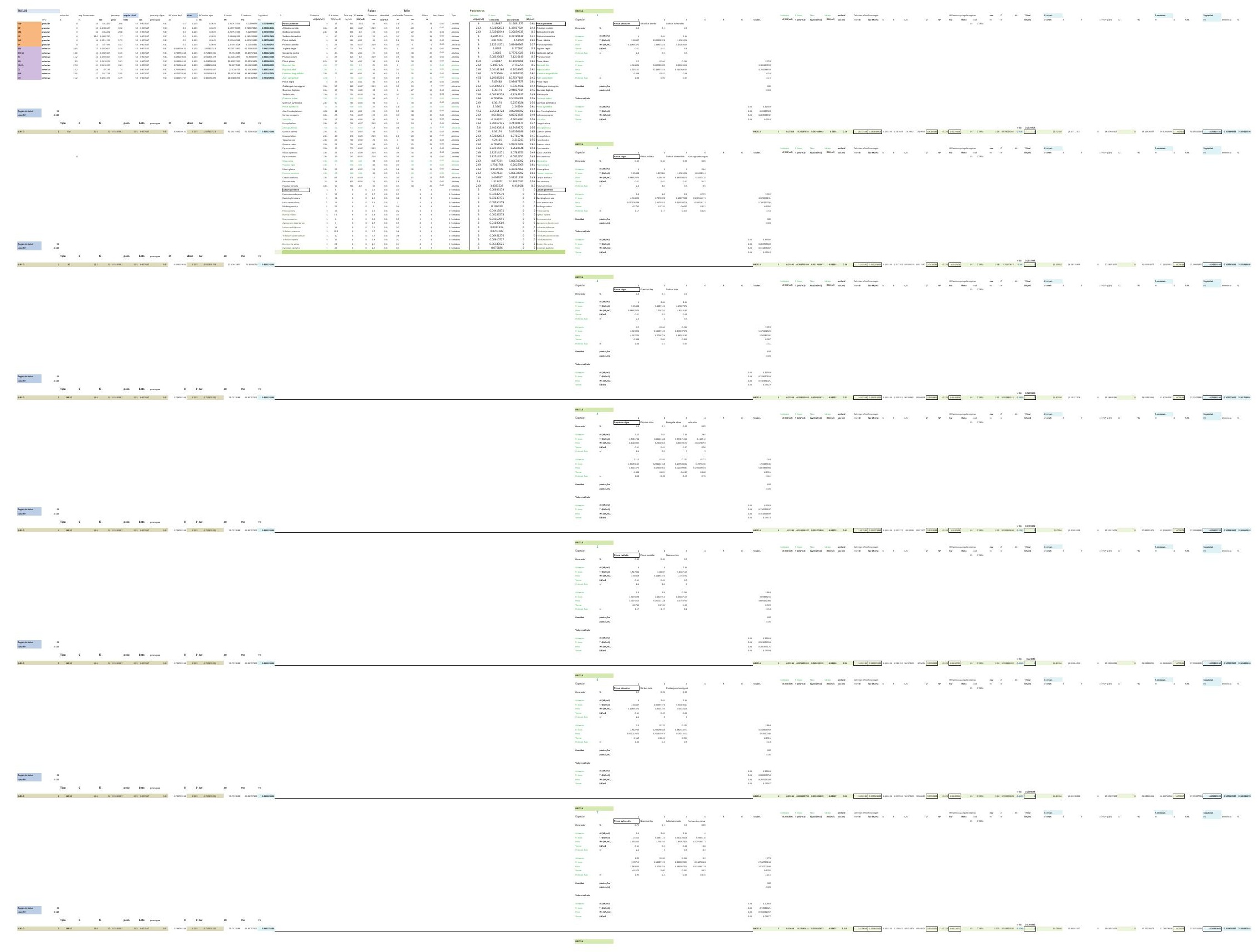




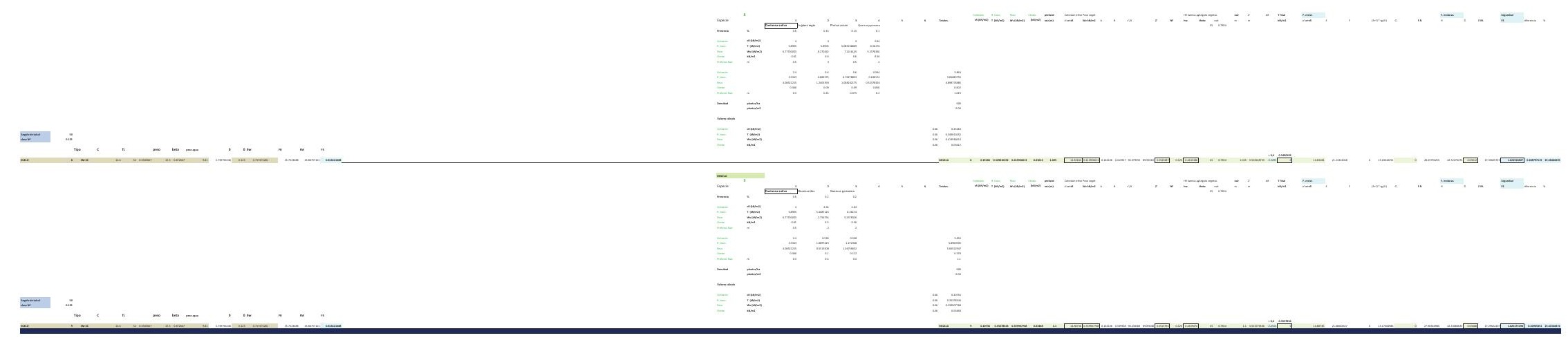




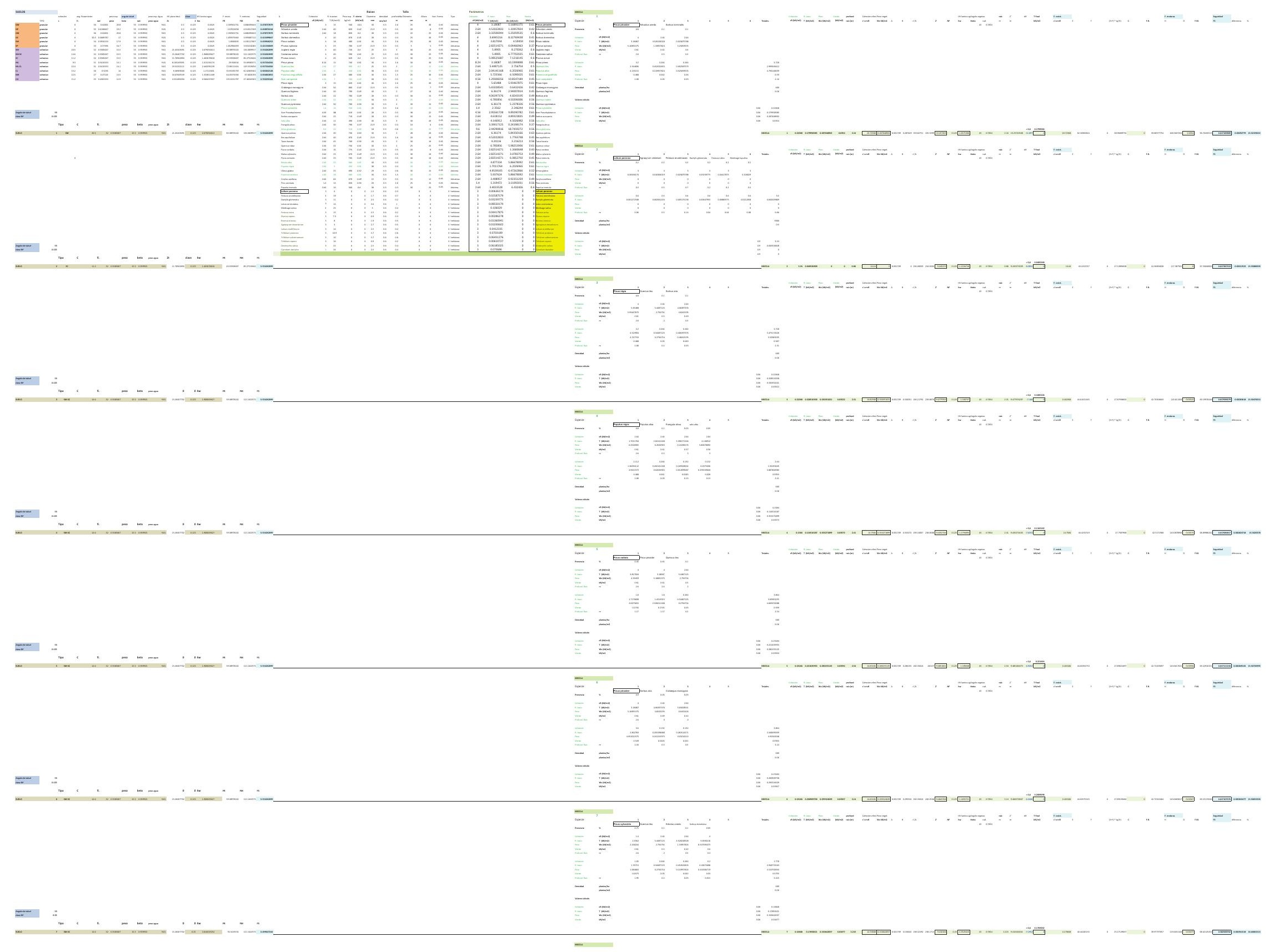




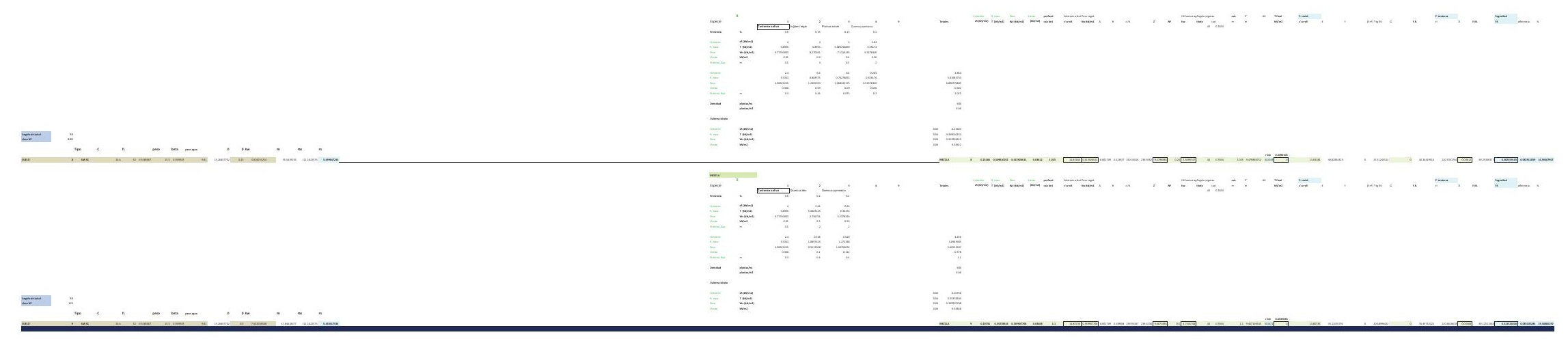




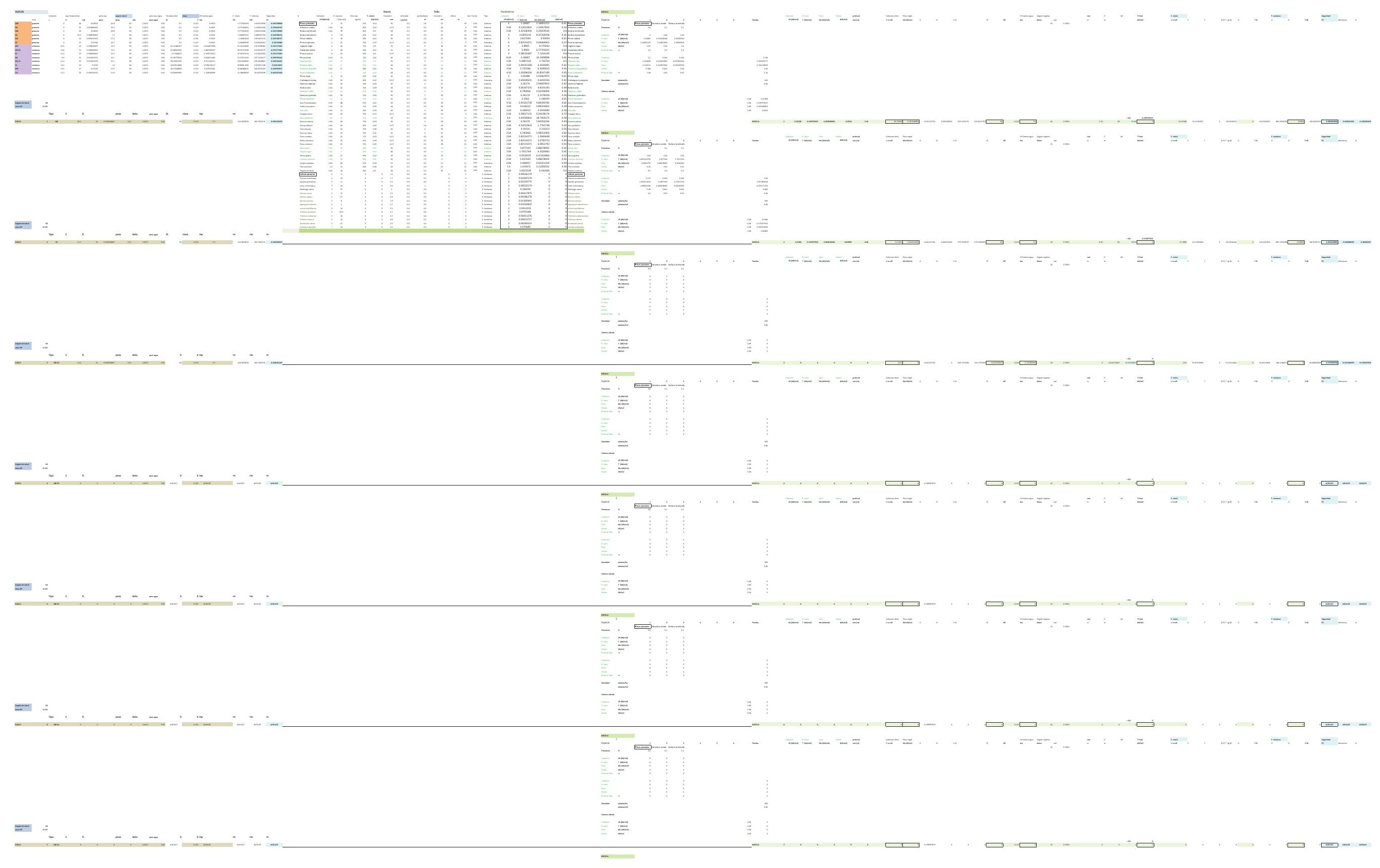


$=$

$\equiv \ldots \ldots \ldots \ldots$

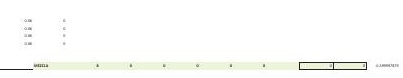

$\equiv \quad:$

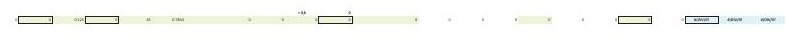

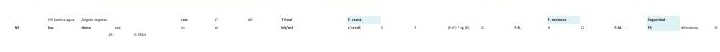




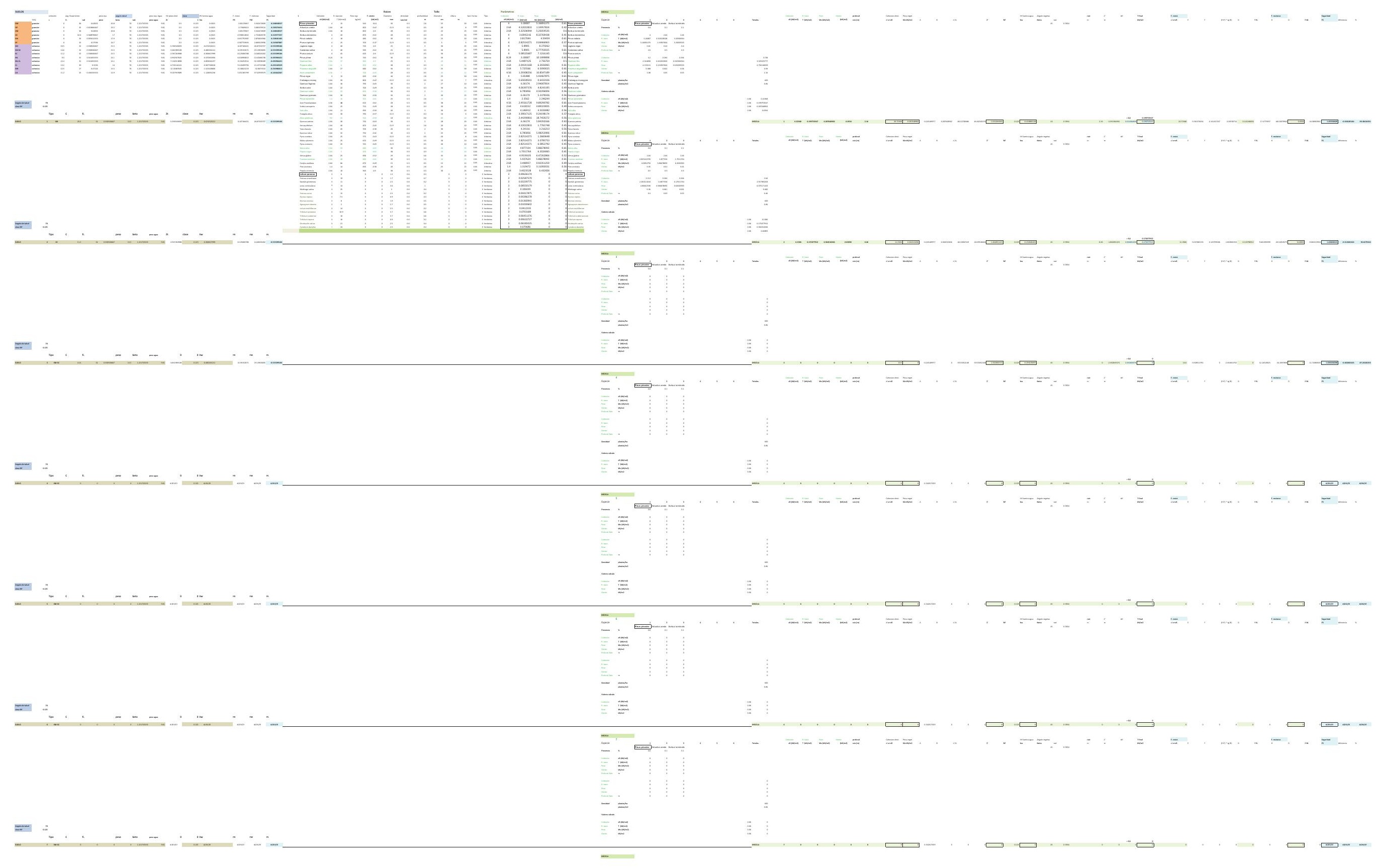




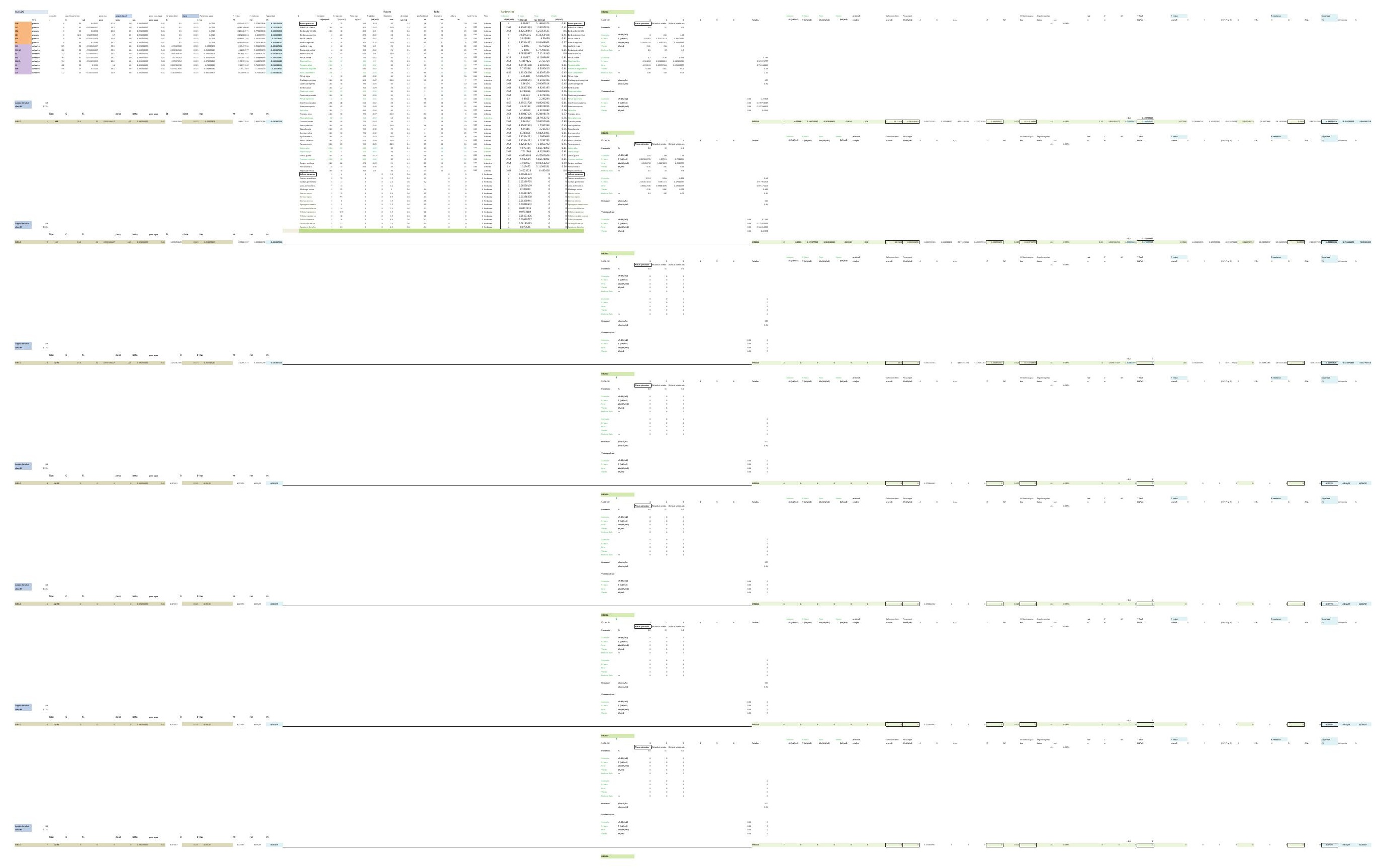


$=$

$\equiv \ldots \ldots \ldots \ldots$

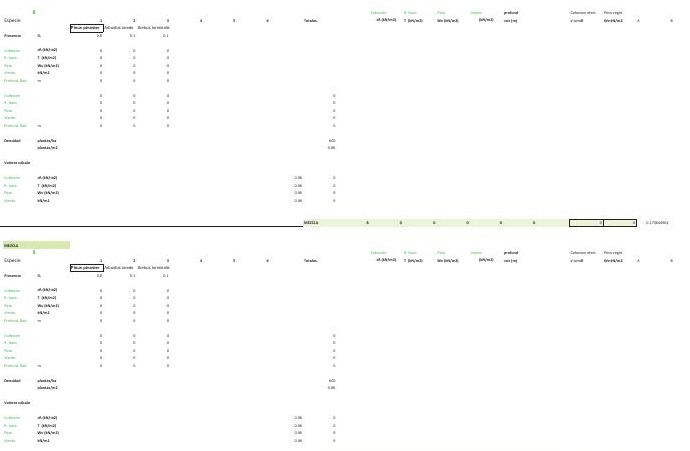

$\square-\square \cdots \cdots$

$\square--$

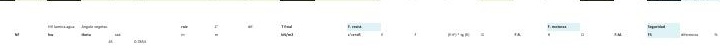


DESARROLLO DE UNA APLICACIÓN IMFORMÁTICA PARA EL CÁLCULO DE SOSTENIMIENTO DE TALUDES MEDIANTE VEGETACIÓN

B01. DENSIDAD DE PLANTACIÓN: 600 plantas/ha.

\section{B01-3.POSICIÓN N.F. 3}

INCLINACIÓN DE TALUD 6-100

INCLINACIÓN DE TALUD 10-200

INCLINACIÓN DE TALUD 20-30

INCLINACIÓN DE TALUD 30-40

INCLINACIÓN DE TALUD $35^{\circ}$

INCLINACIÓN DE TALUD 40-50

INCLINACIÓN DE TALUD 50-550

INCLINACIÓN DE TALUD 55-60

INCLINACIÓN DE TALUD 60-700

INCLINACIÓN DE TALUD 70-80 


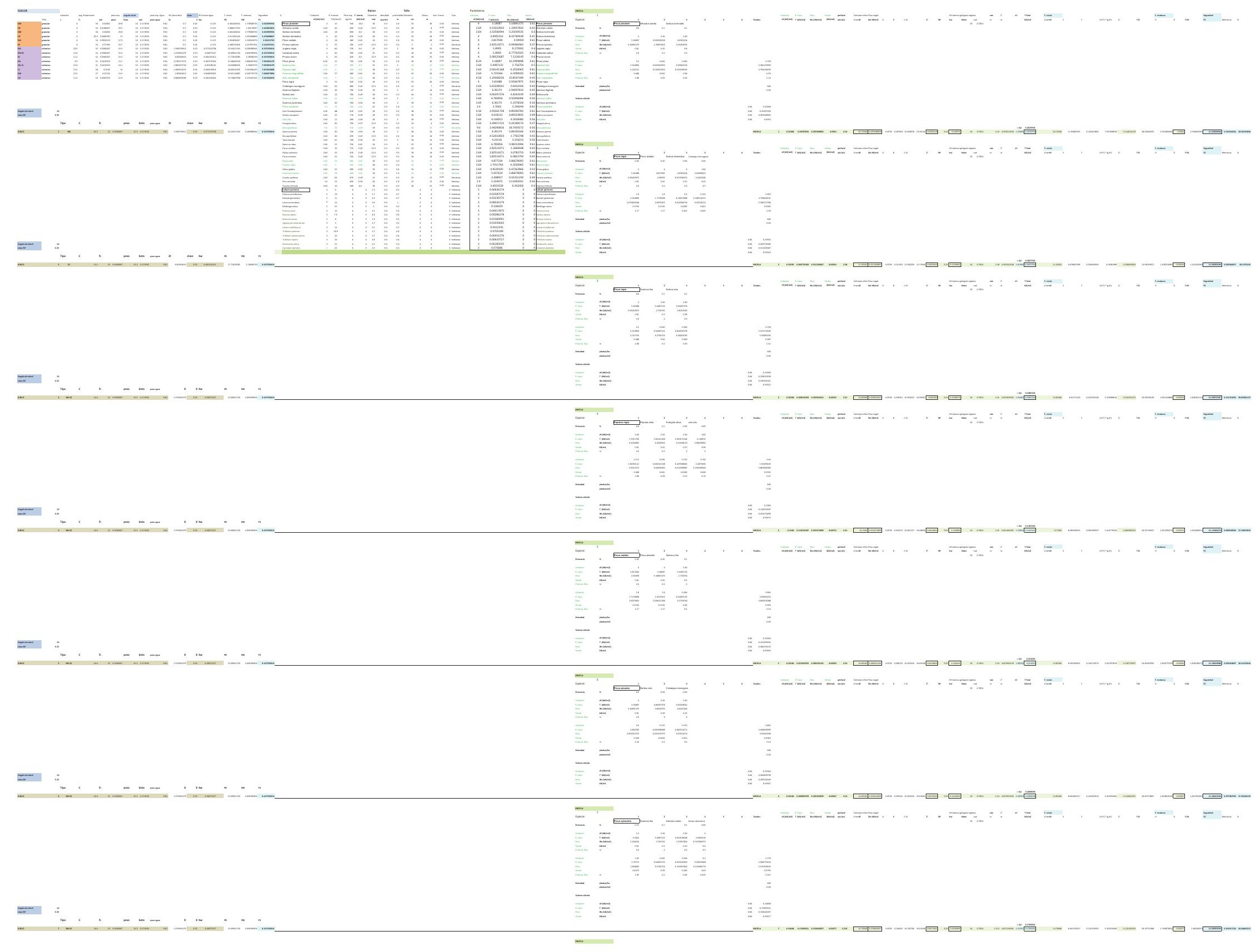




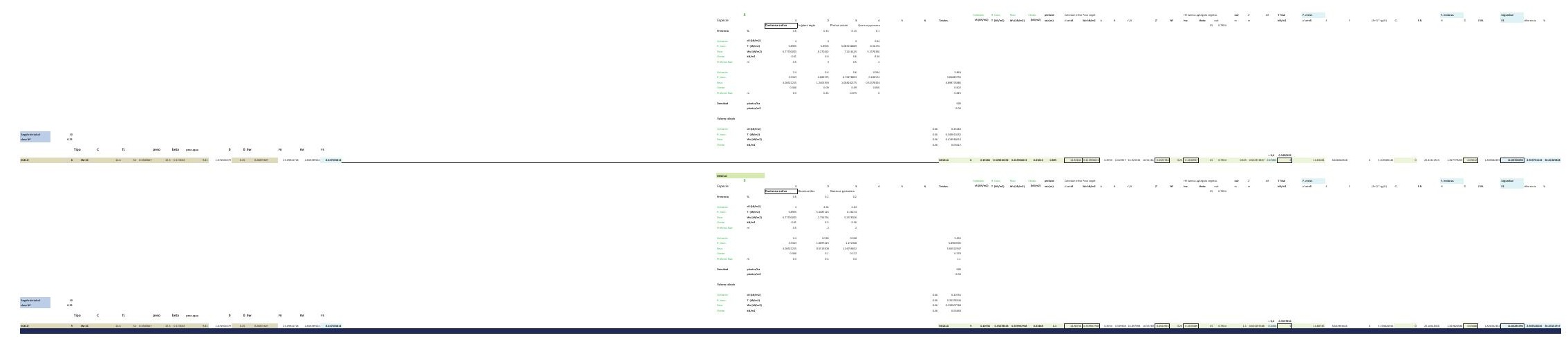




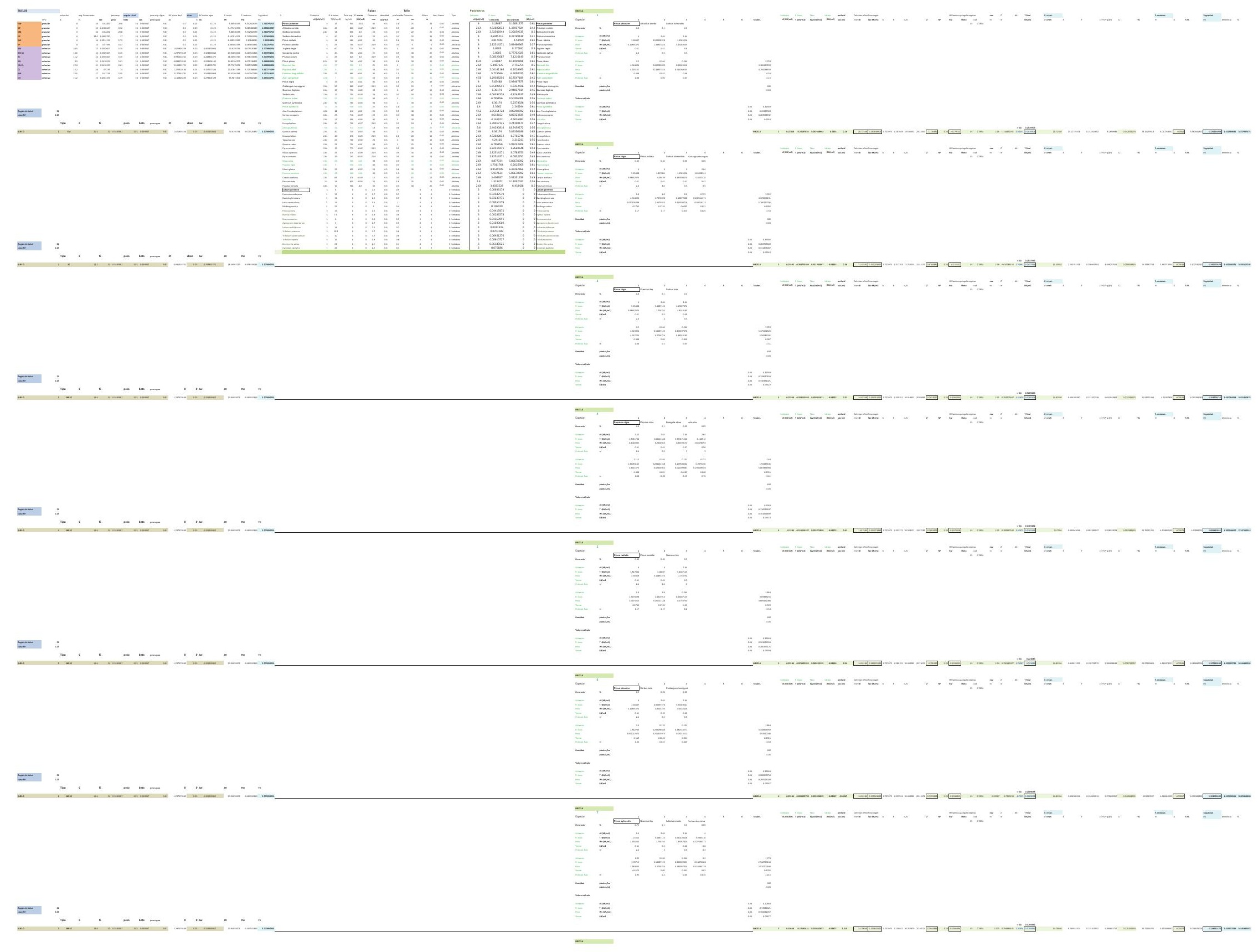




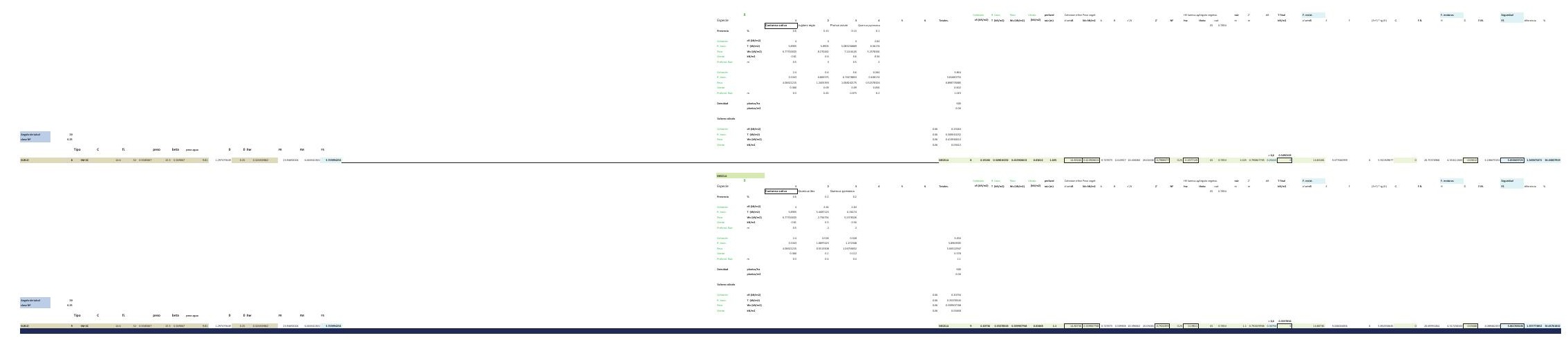




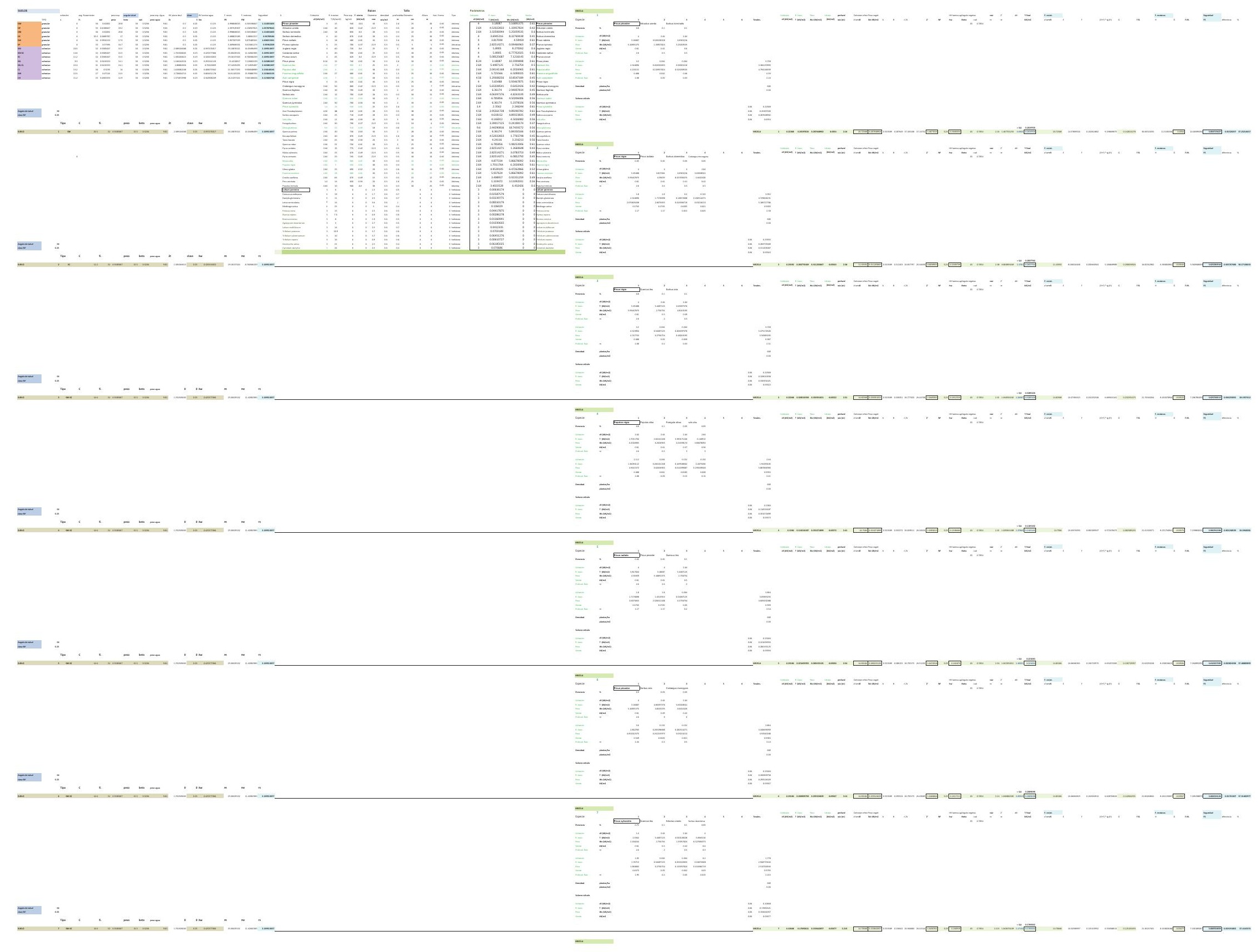




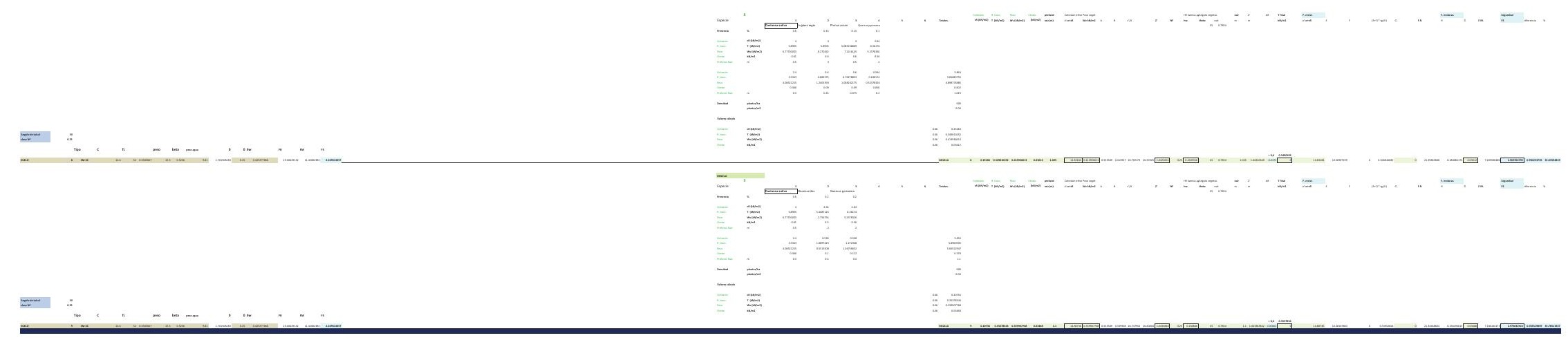




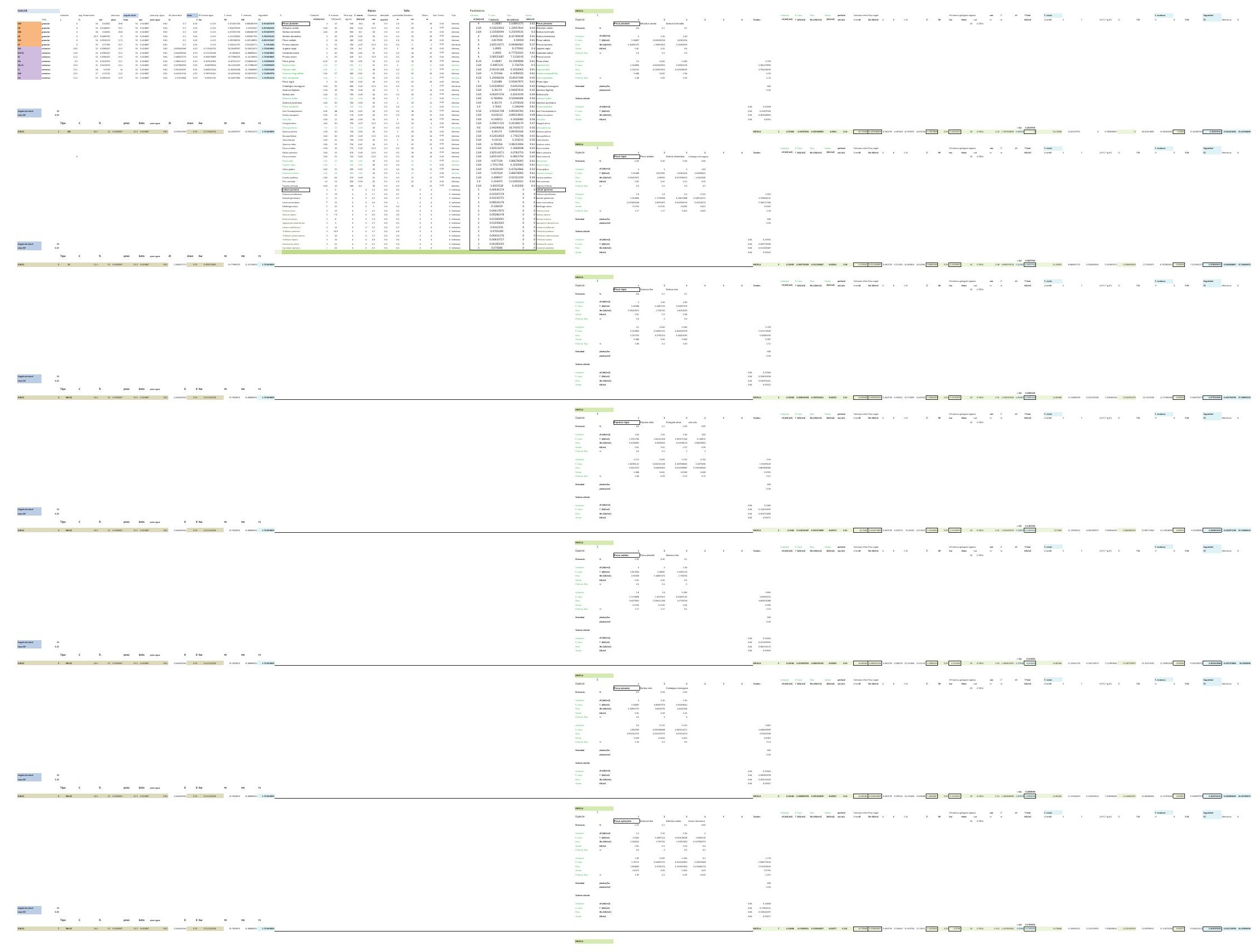




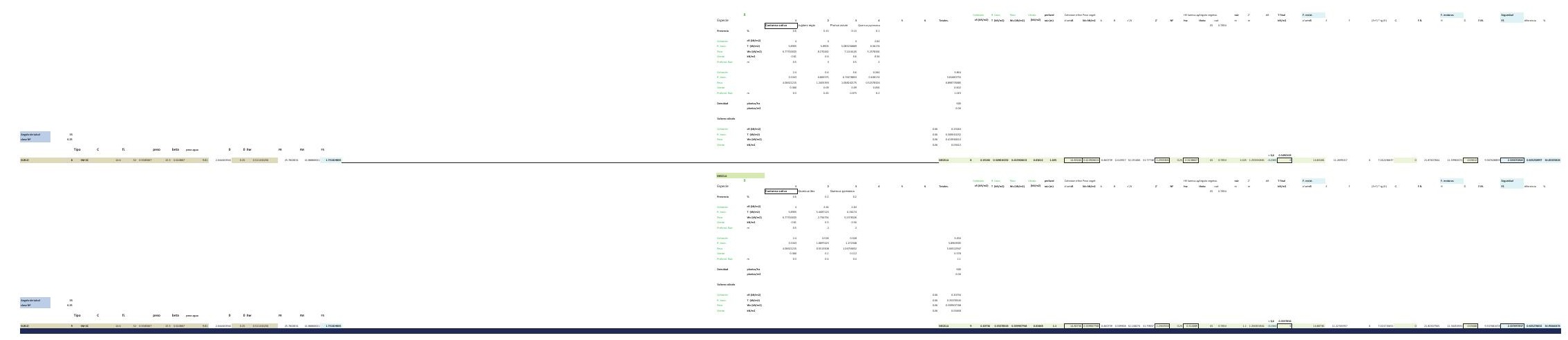




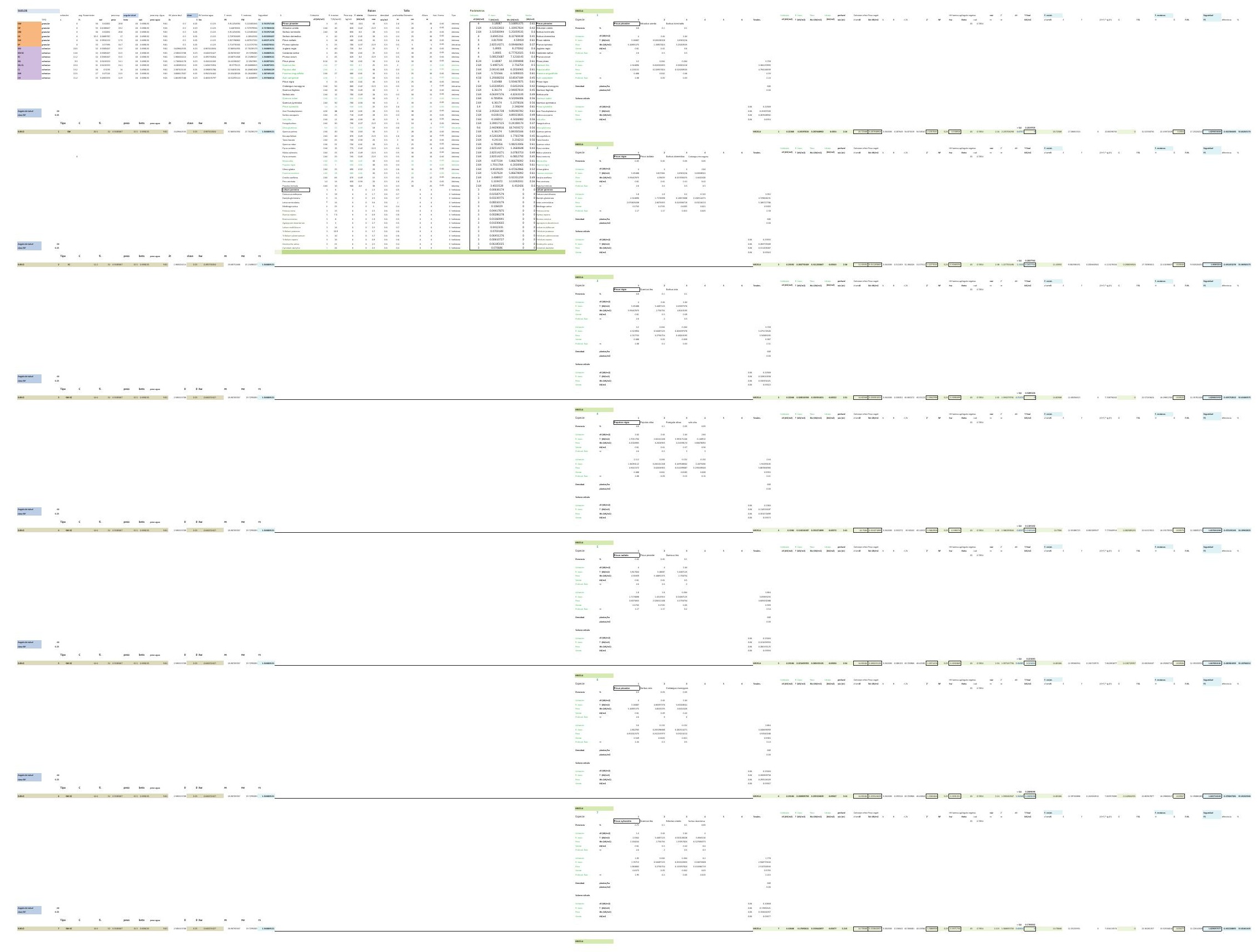




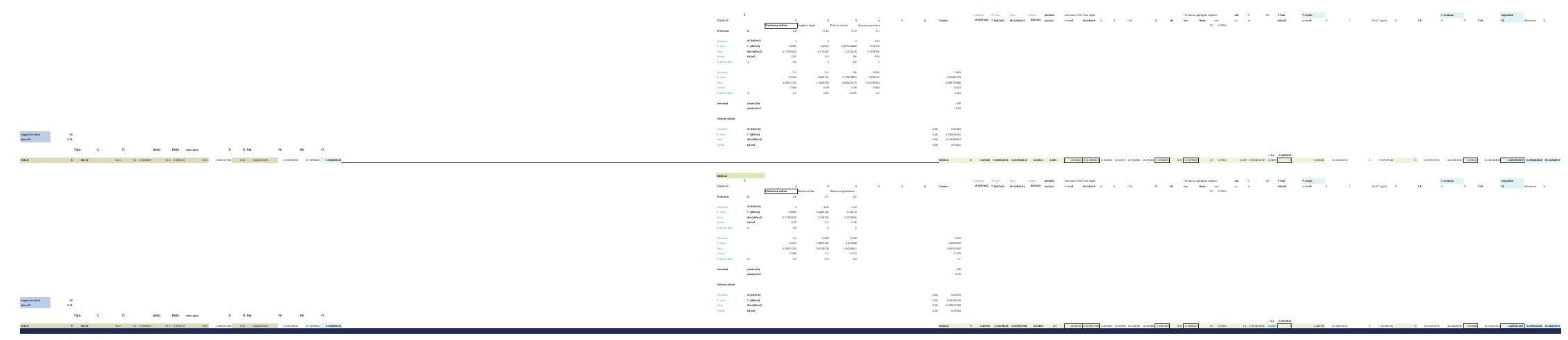




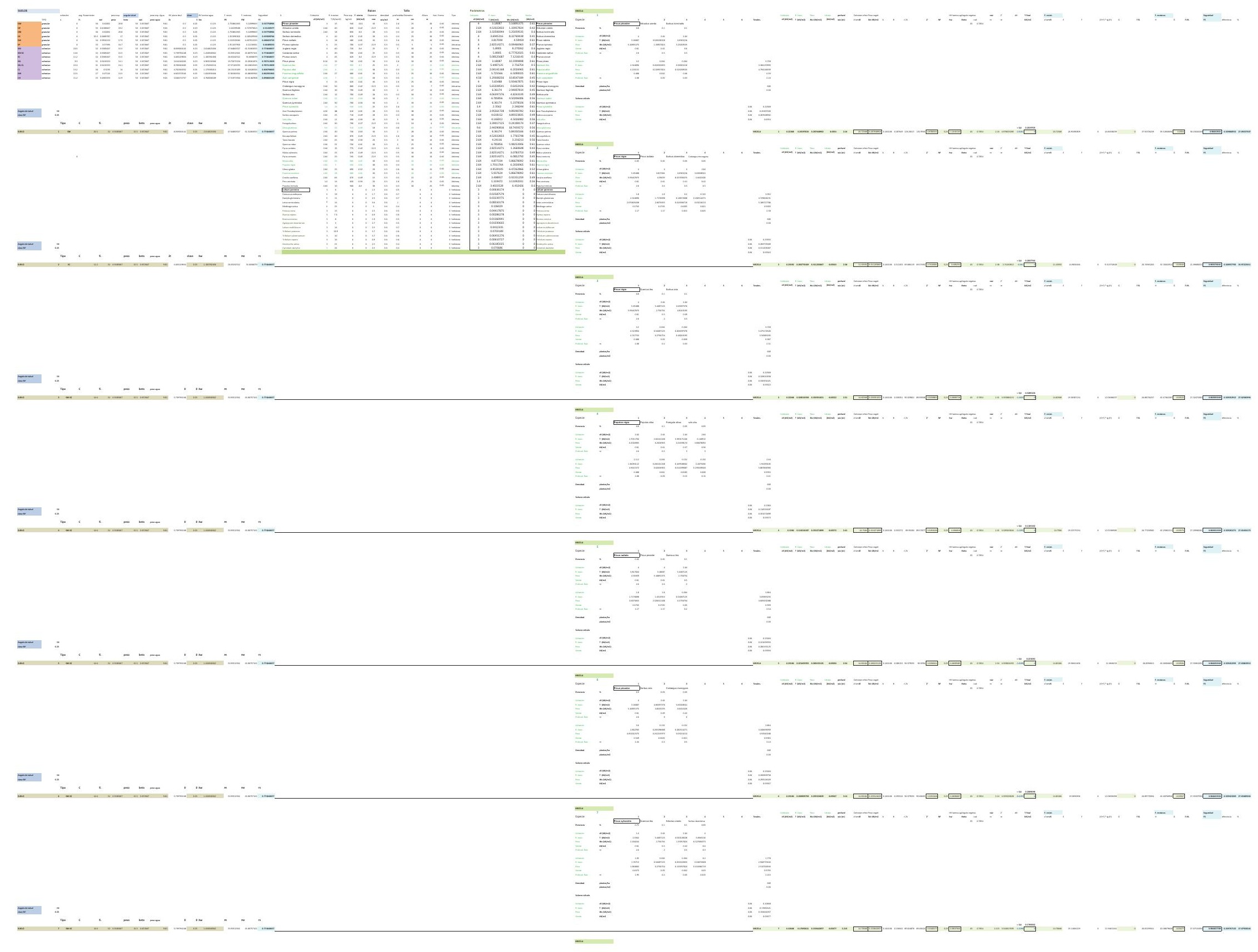




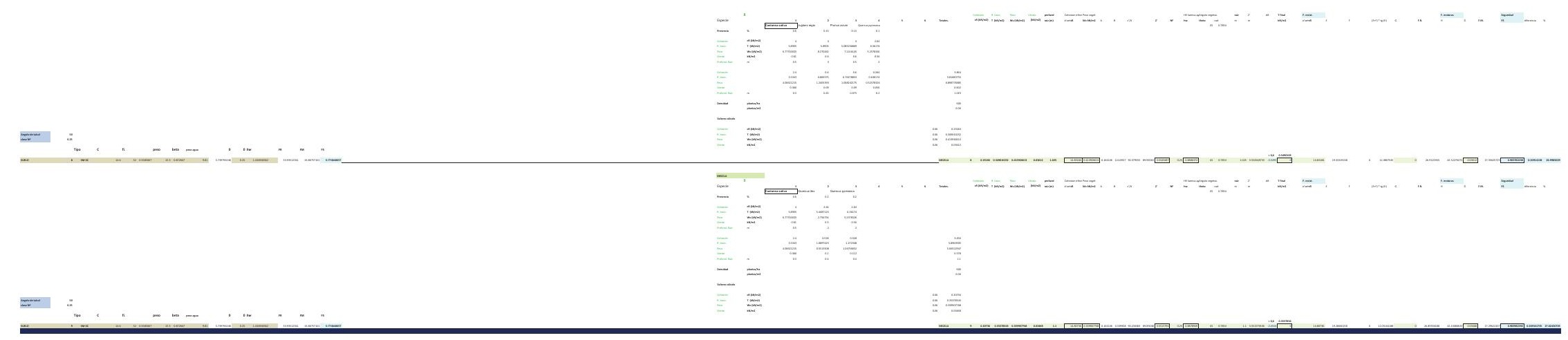




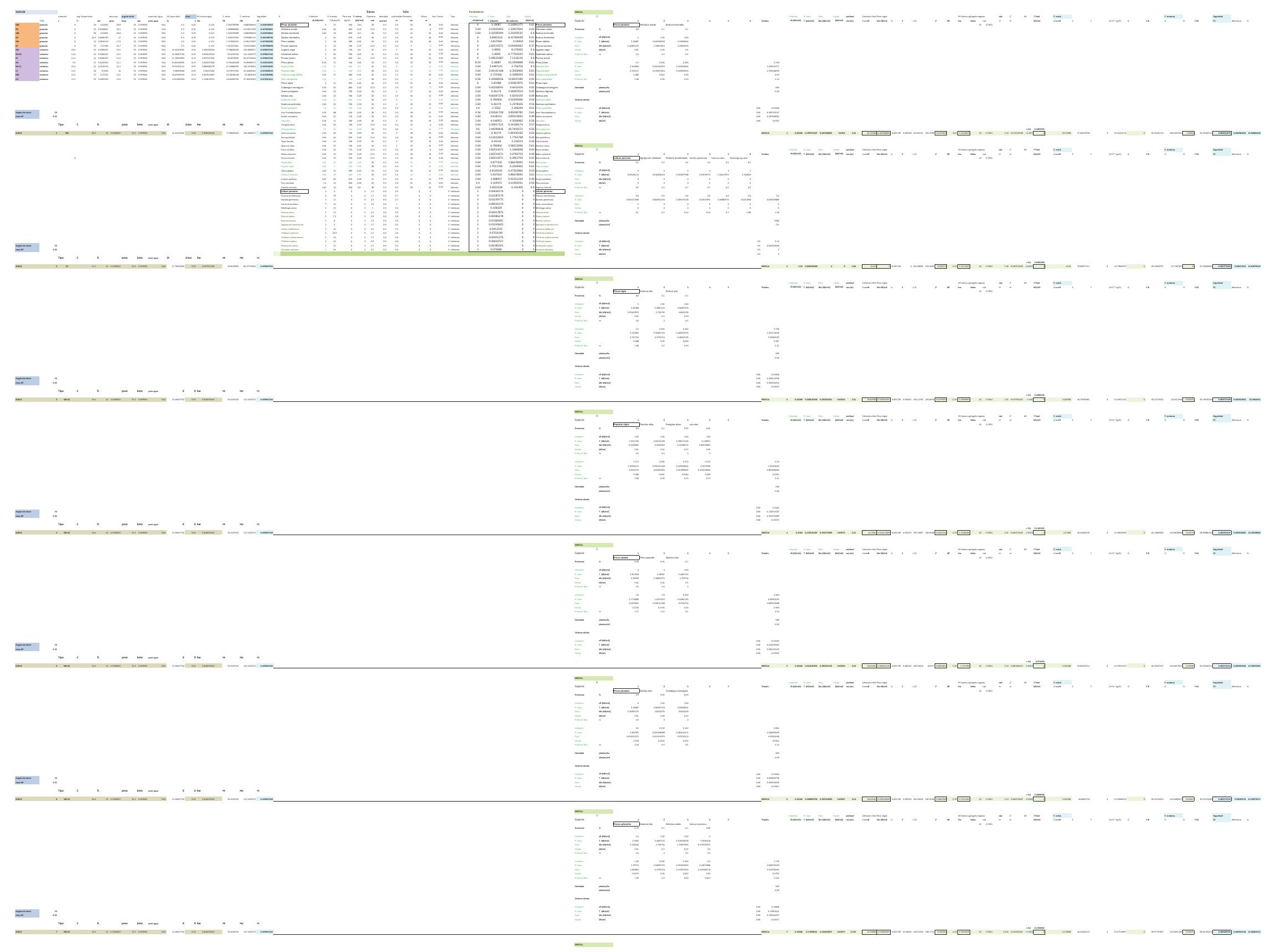




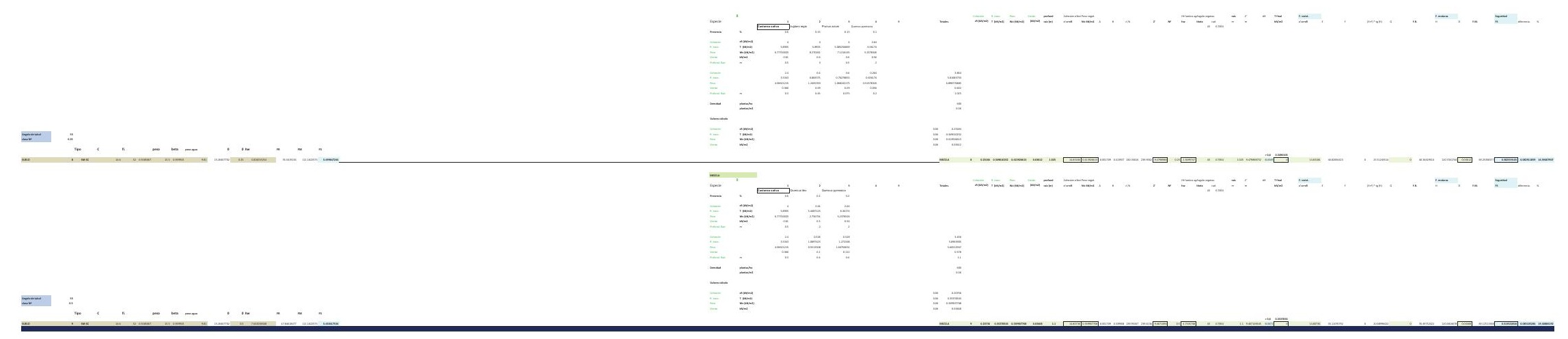




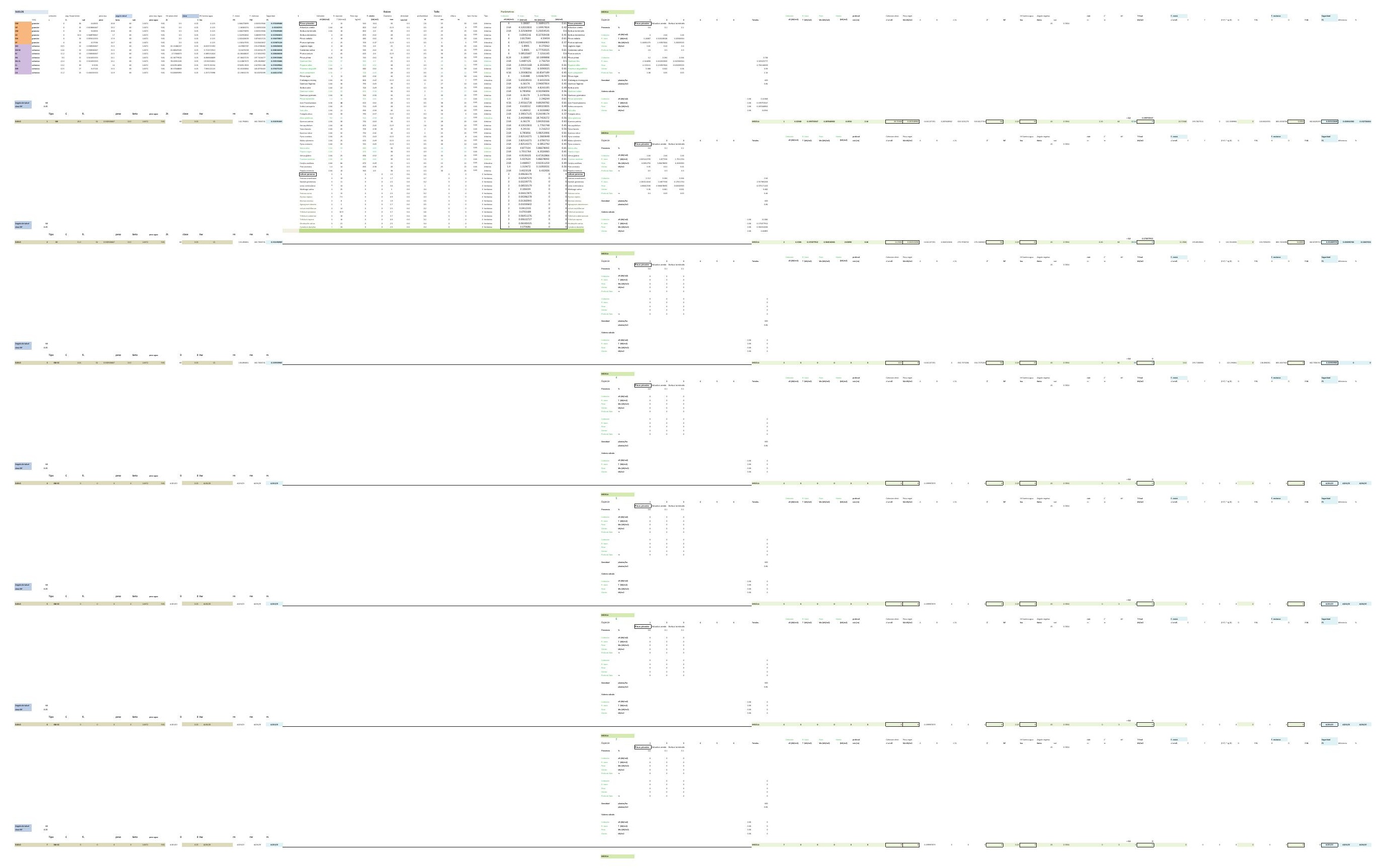




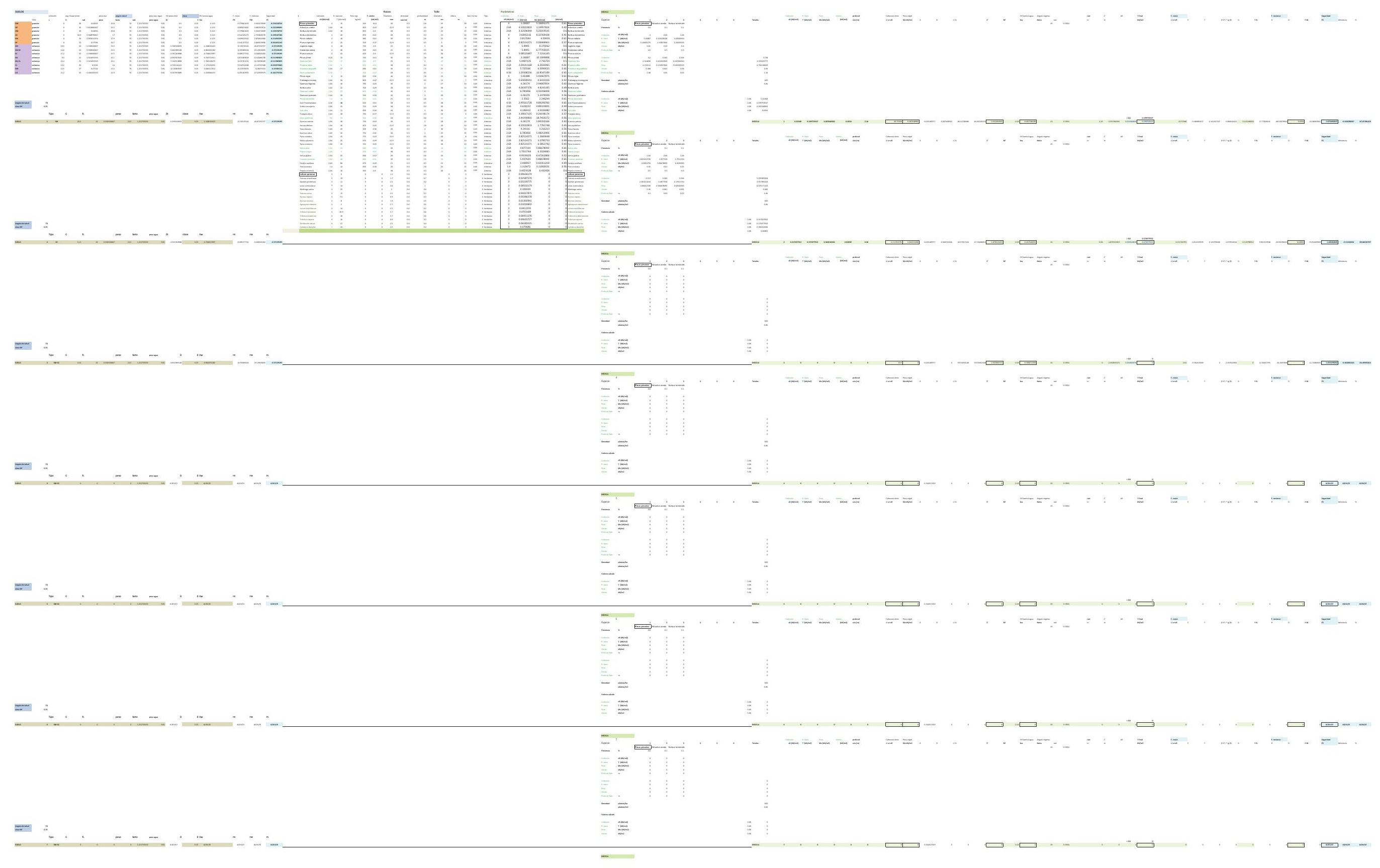




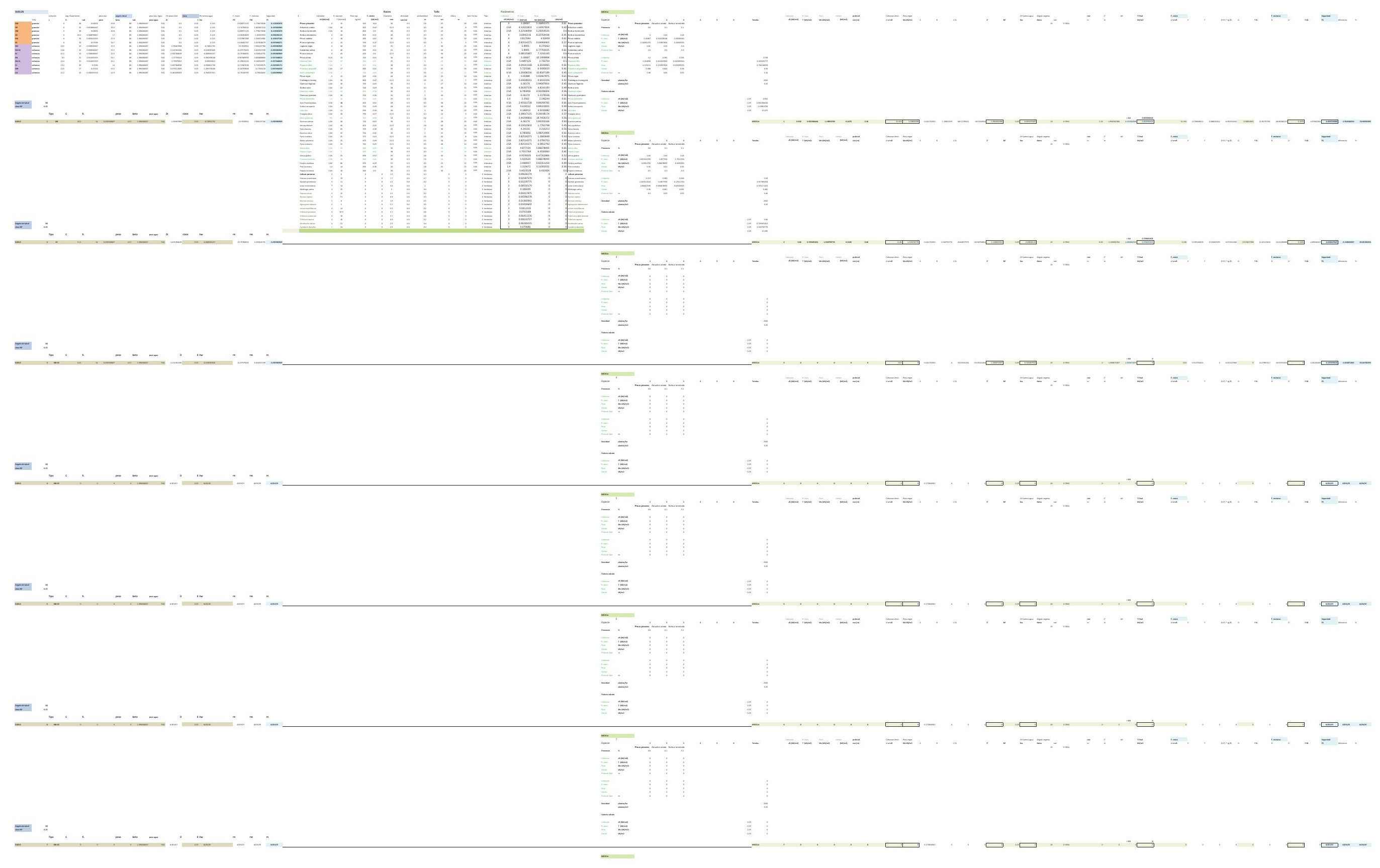


DESARROLLO DE UNA APLICACIÓN IMFORMÁTICA PARA EL CÁLCULO DE SOSTENIMIENTO DE TALUDES MEDIANTE VEGETACIÓN

B01. DENSIDAD DE PLANTACIÓN: 600 plantas/ha.

\section{B01-4.POSICIÓN N.F. 4}

INCLINACIÓN DE TALUD 6-100

INCLINACIÓN DE TALUD 10-200

INCLINACIÓN DE TALUD 20-30

INCLINACIÓN DE TALUD 30-40

INCLINACIÓN DE TALUD $35^{\circ}$

INCLINACIÓN DE TALUD 40-50

INCLINACIÓN DE TALUD 50-550

INCLINACIÓN DE TALUD 55-60

INCLINACIÓN DE TALUD 60-700

INCLINACIÓN DE TALUD 70-80 


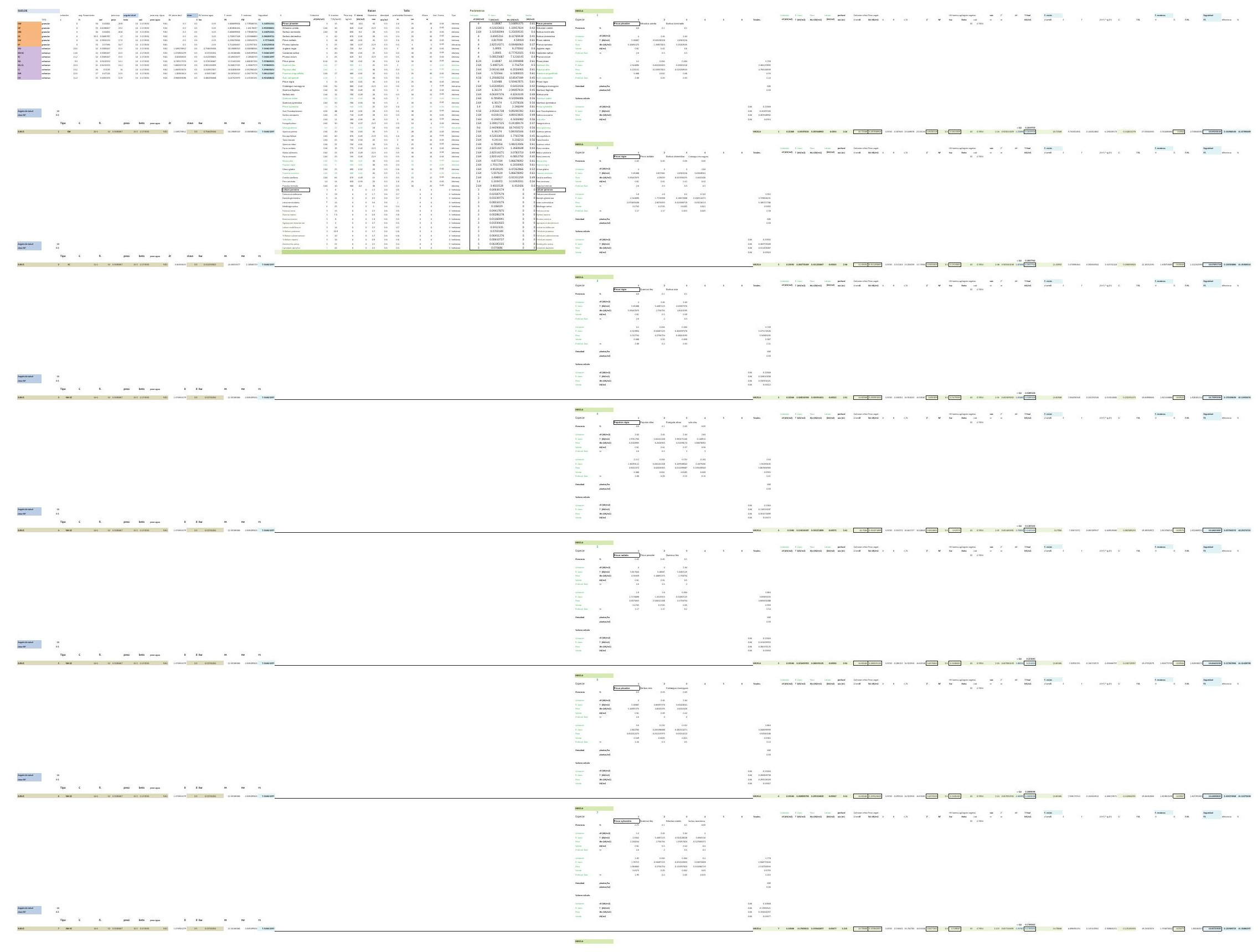




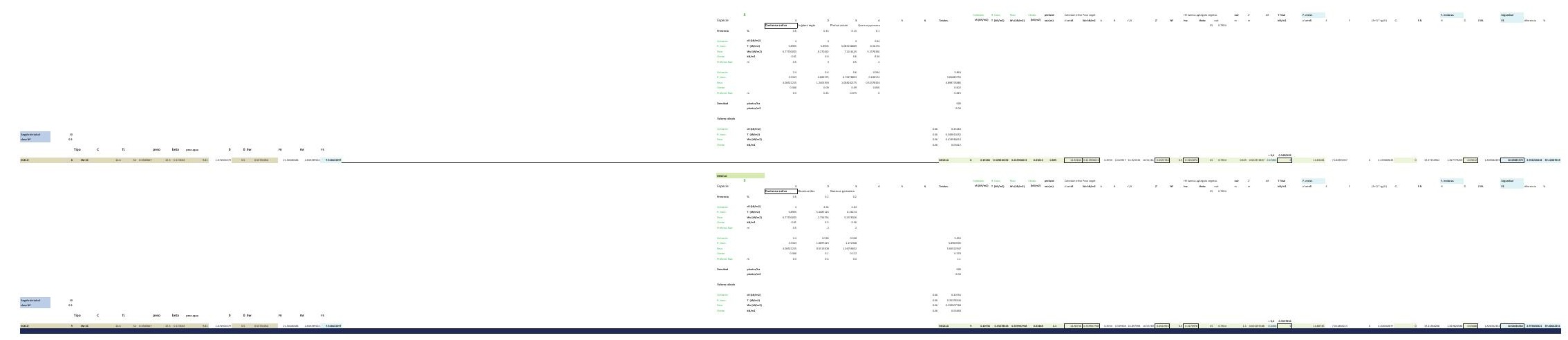




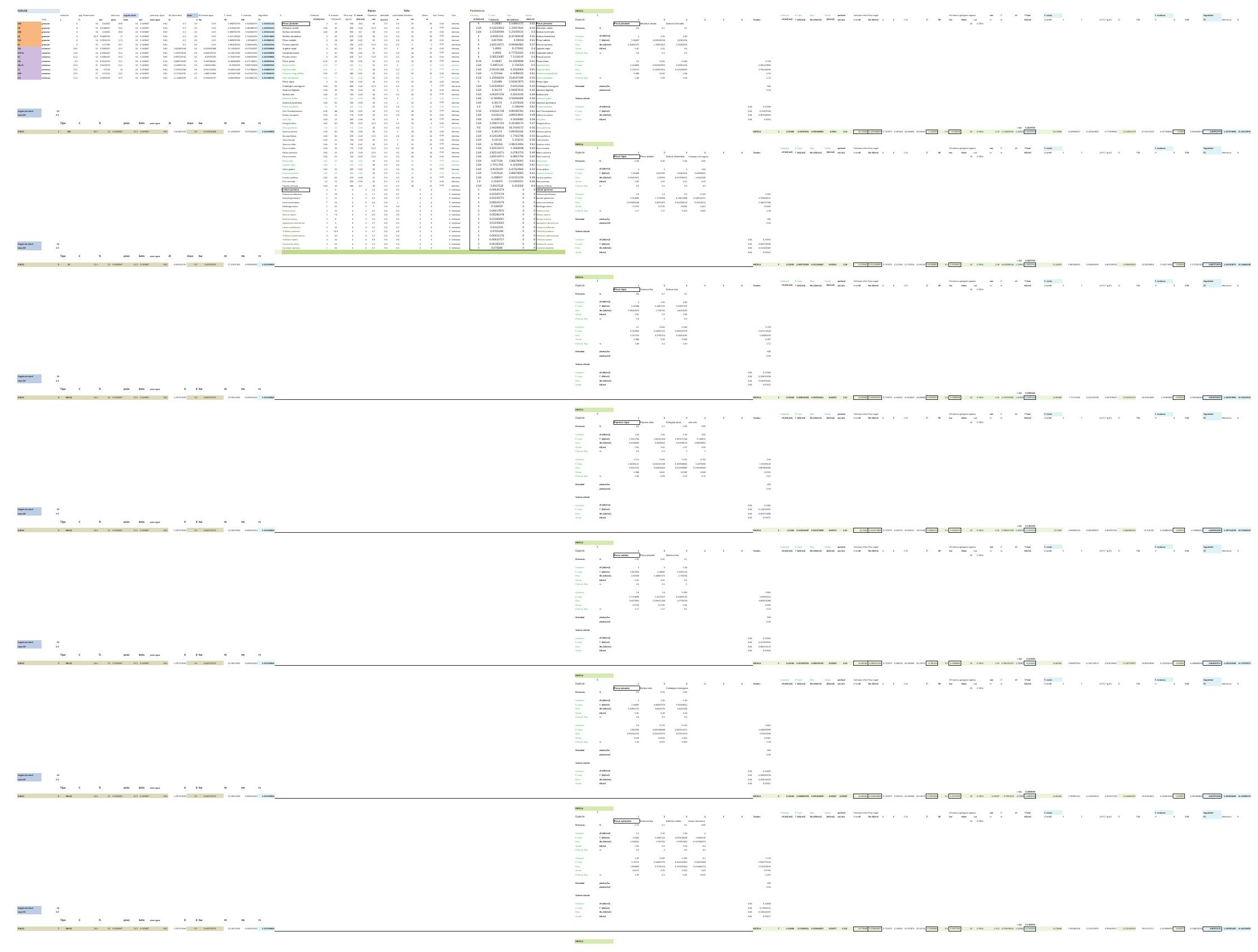




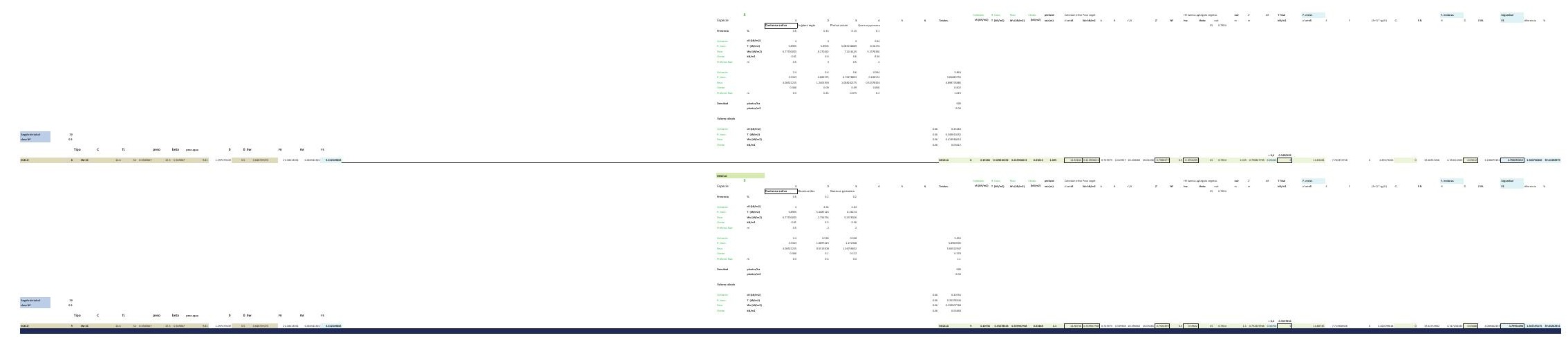




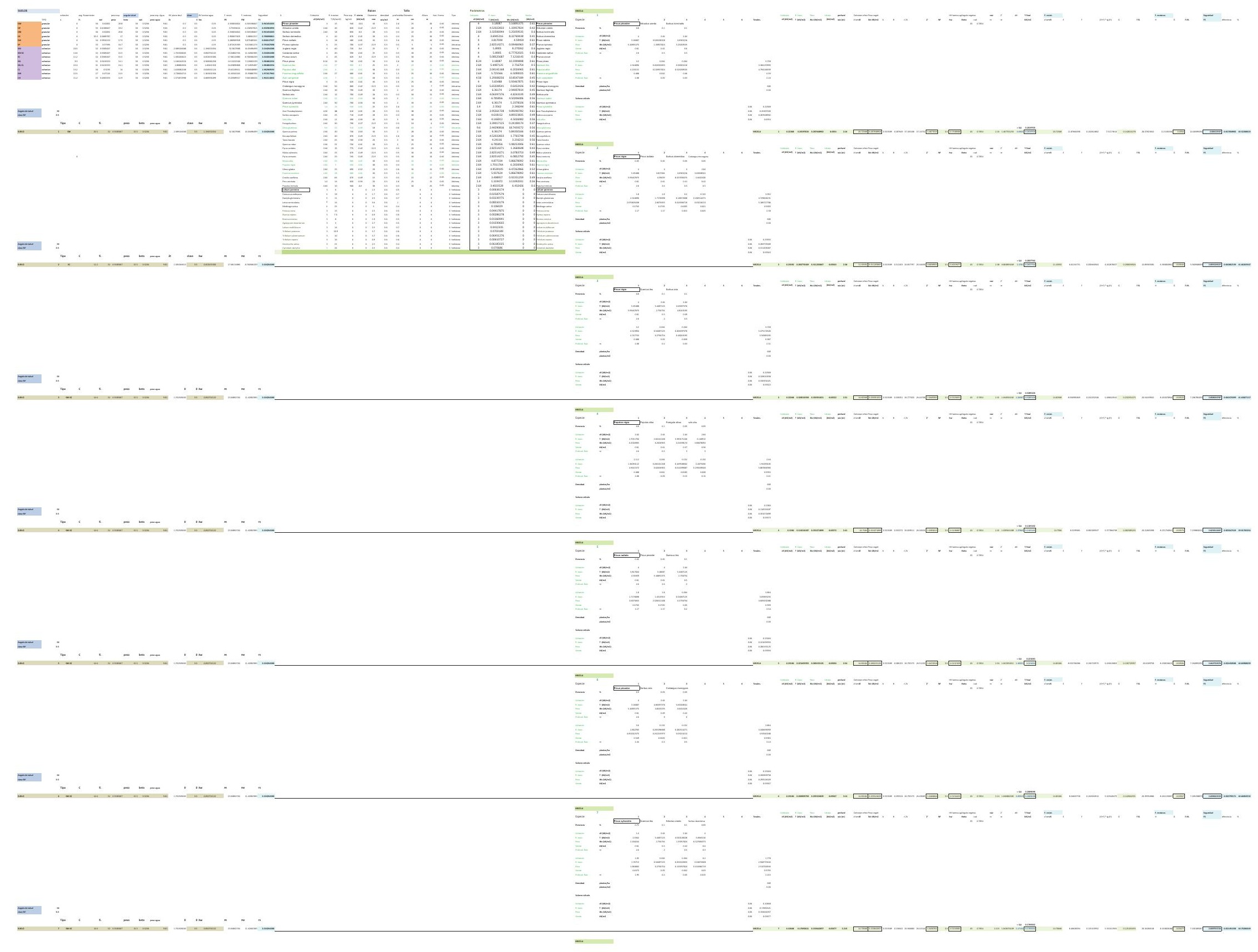




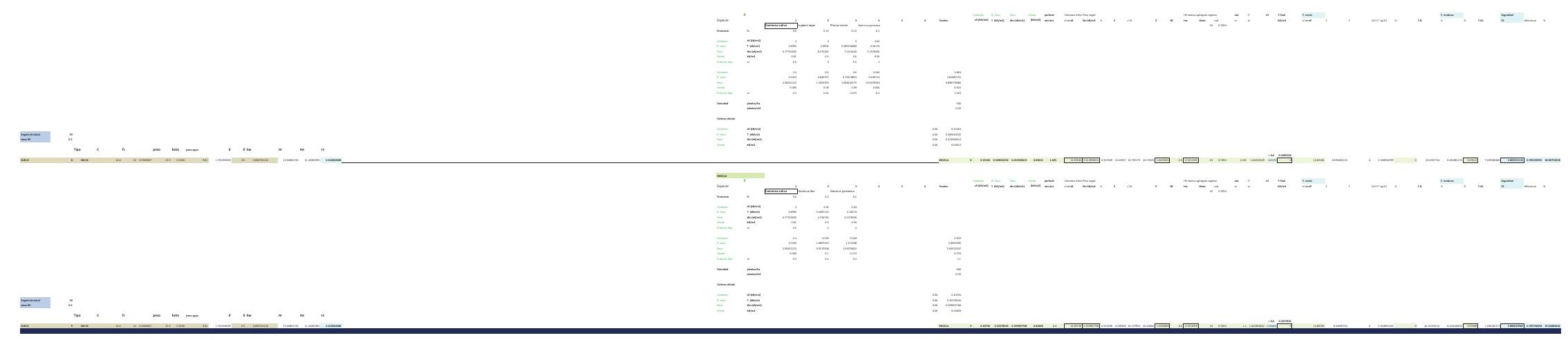




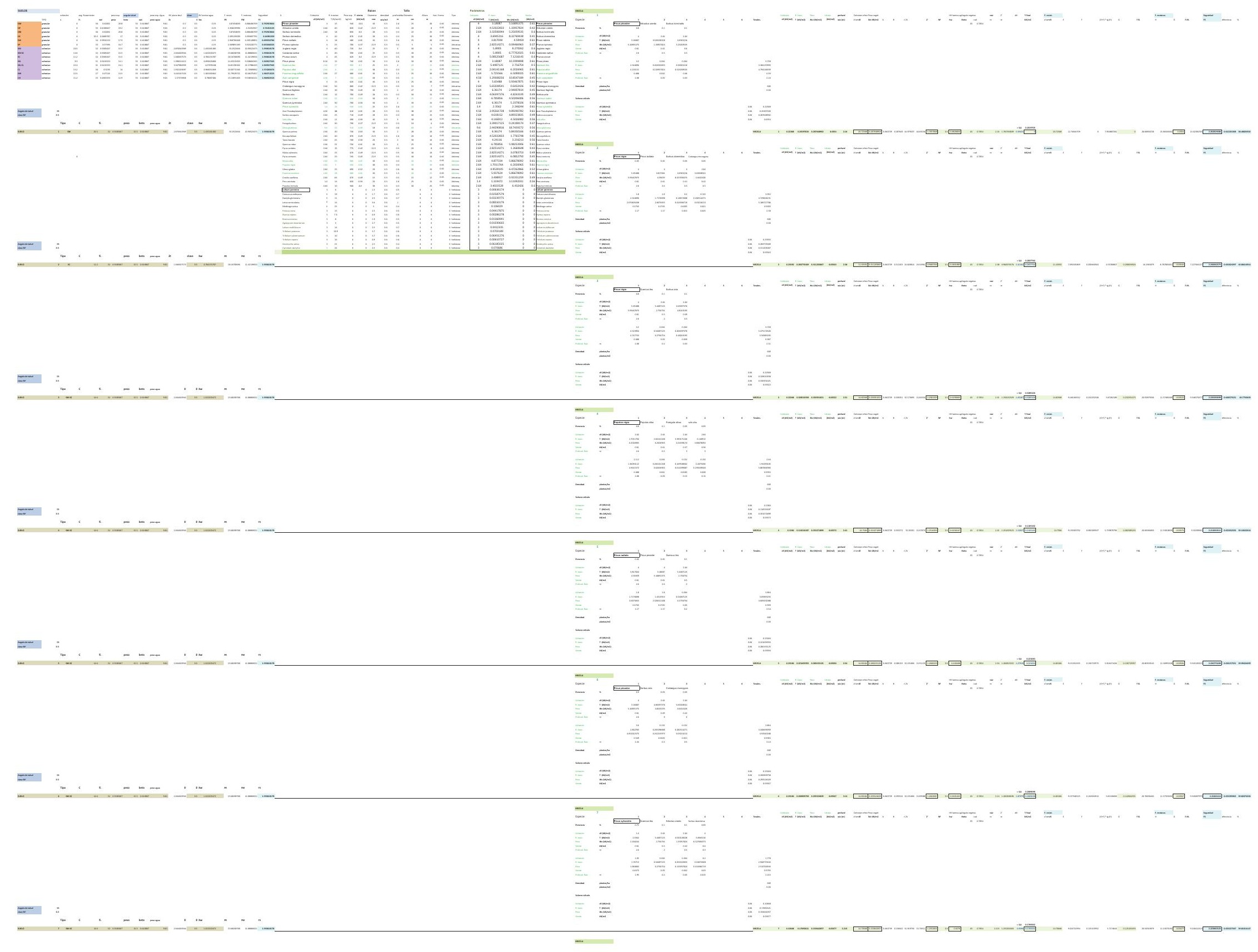




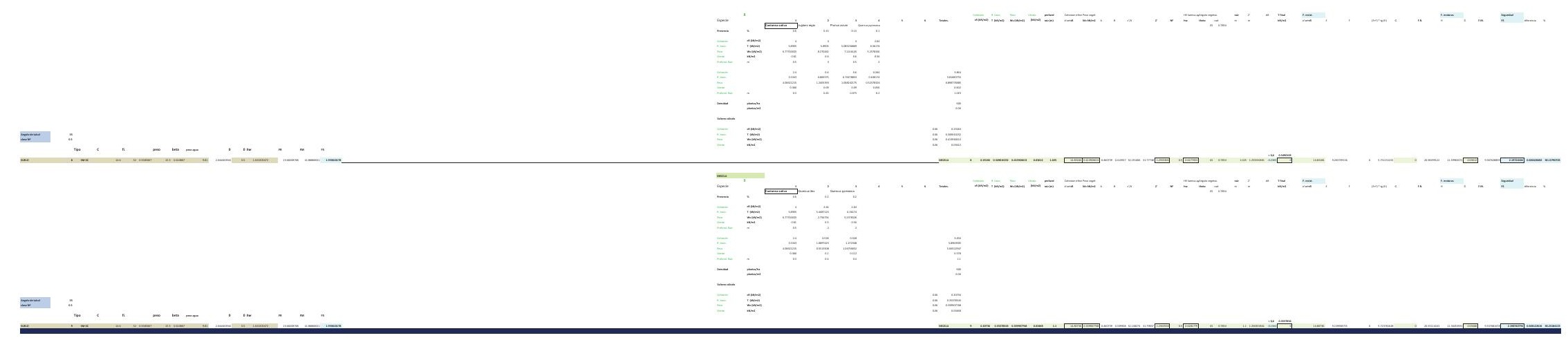




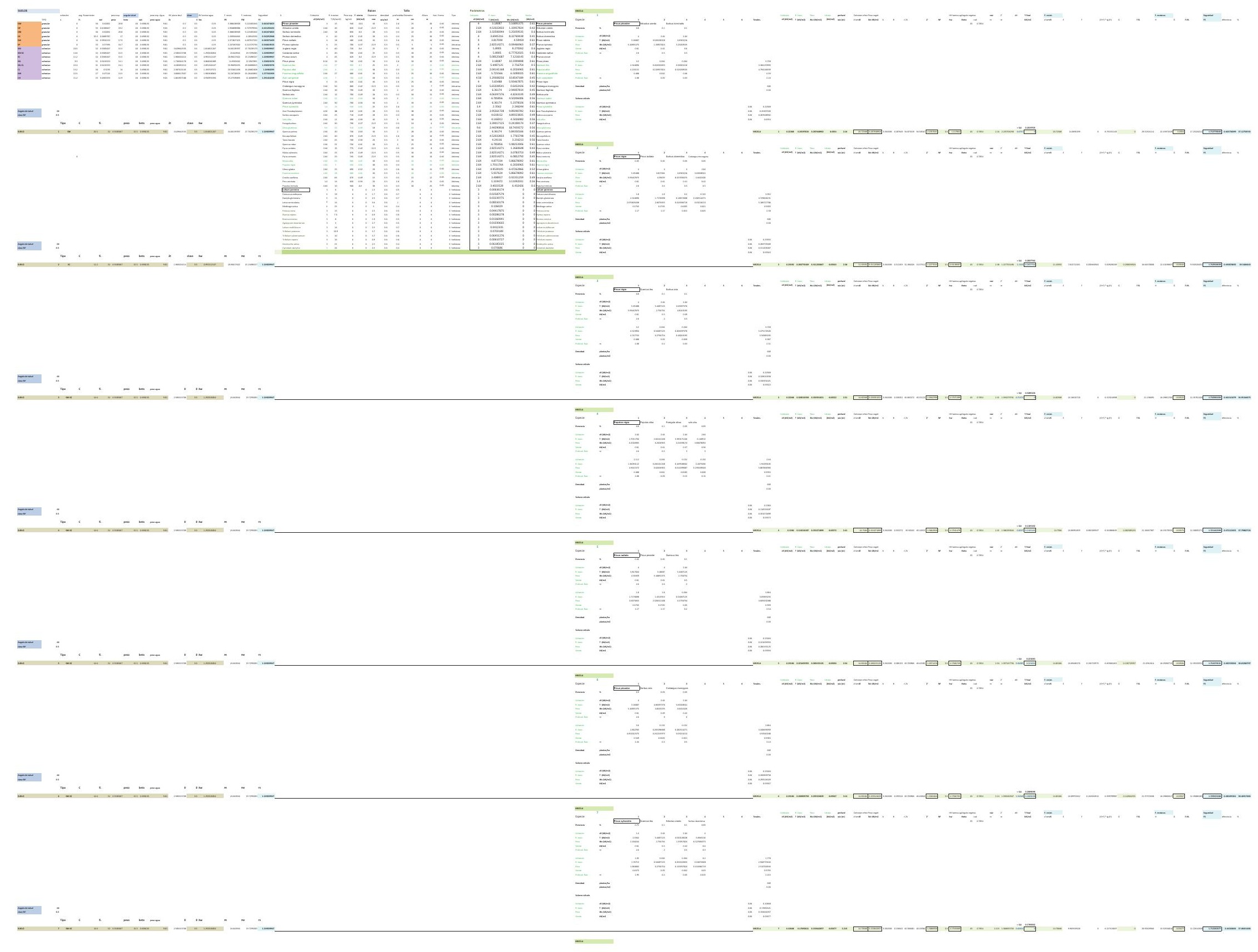




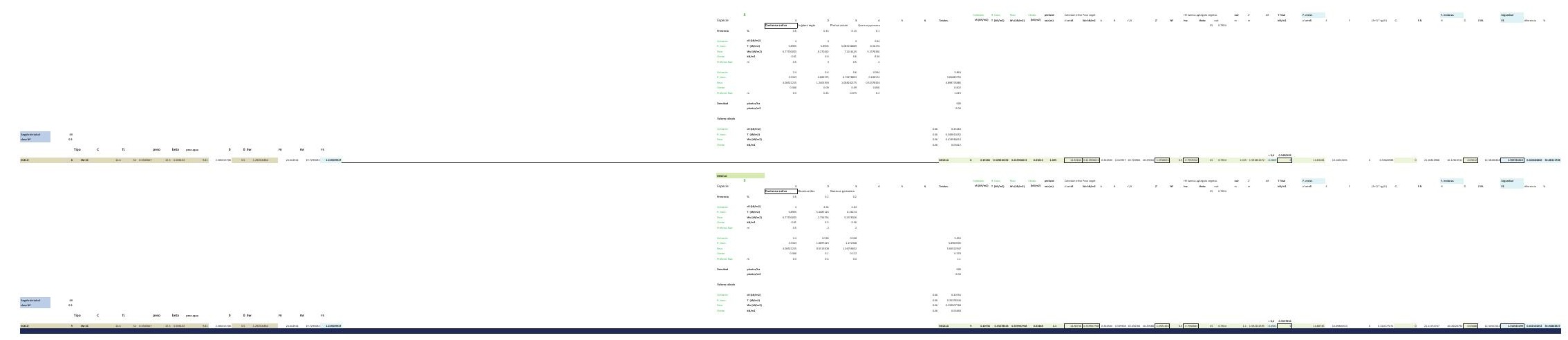




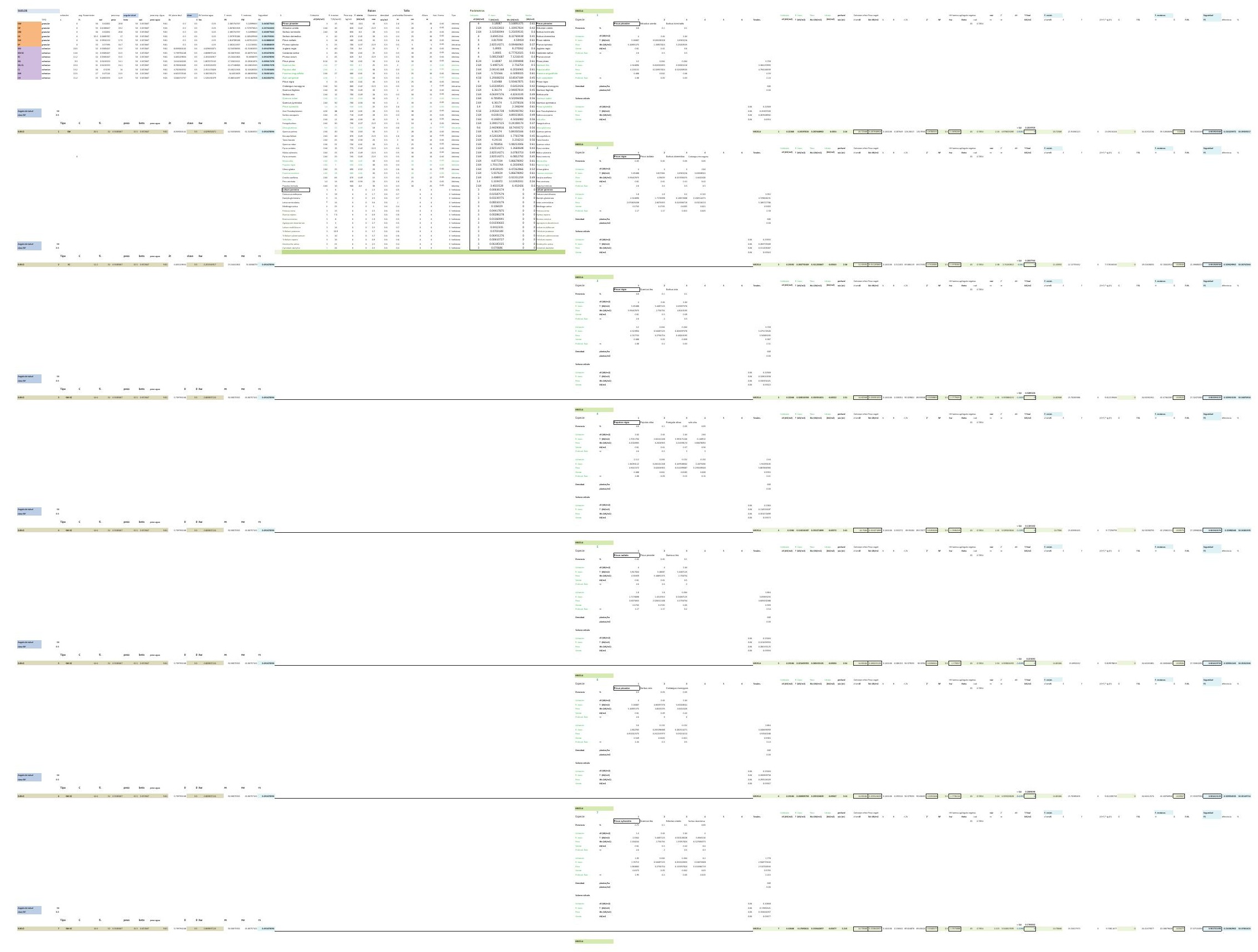




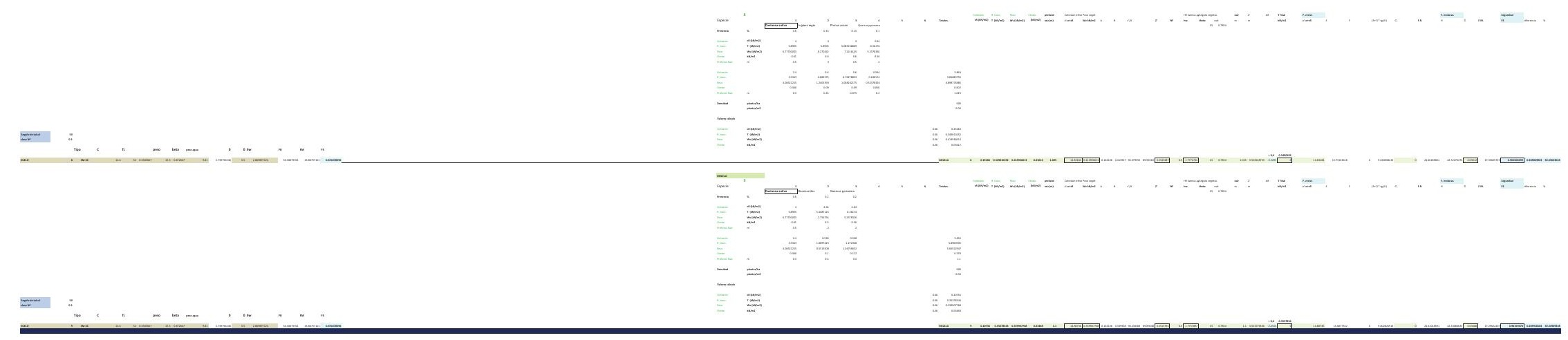




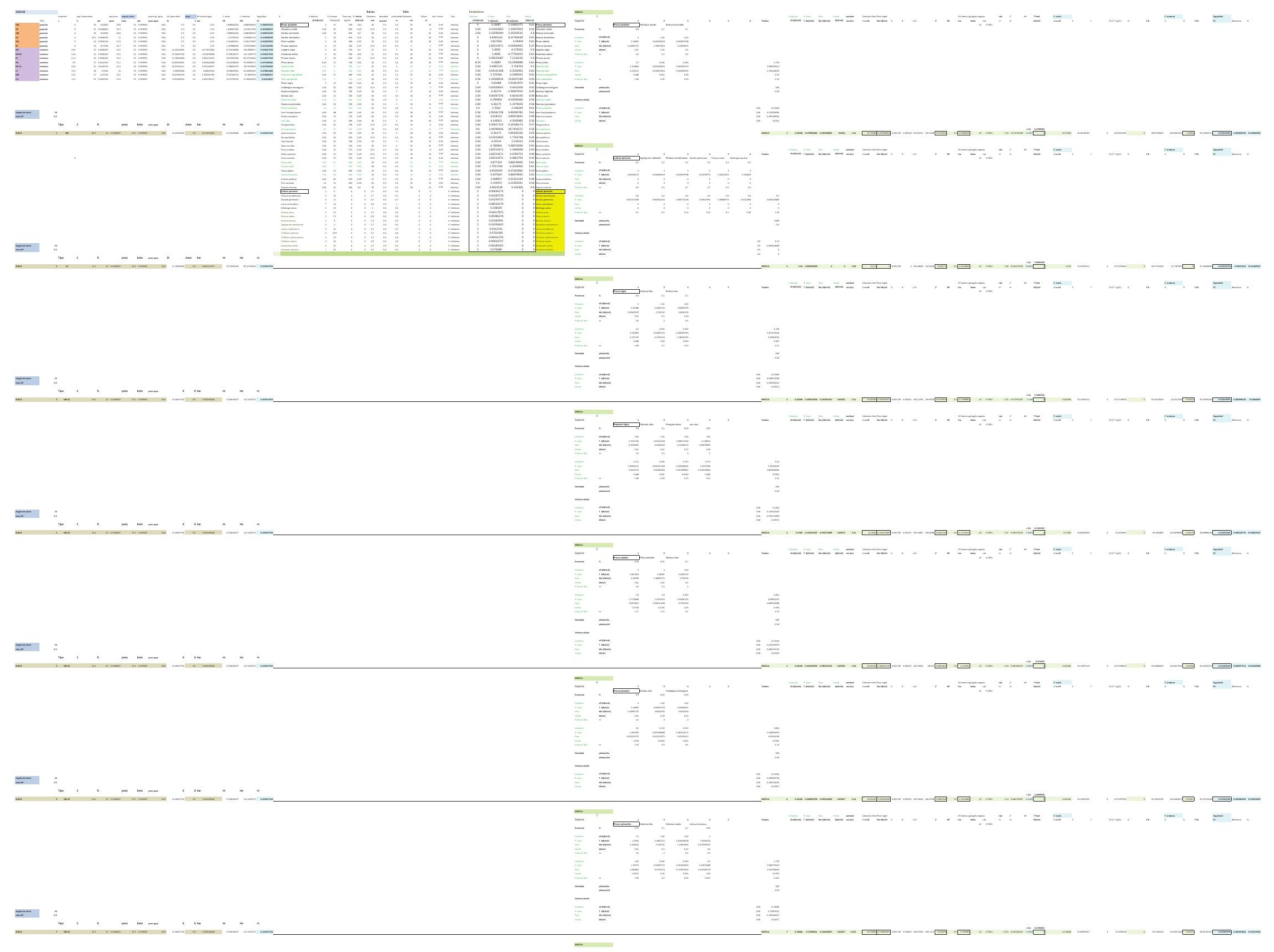




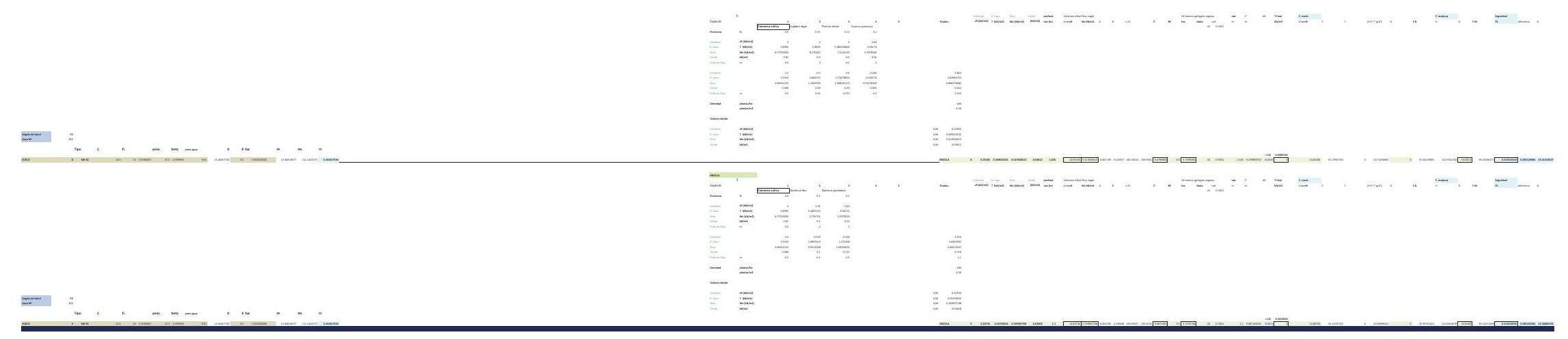




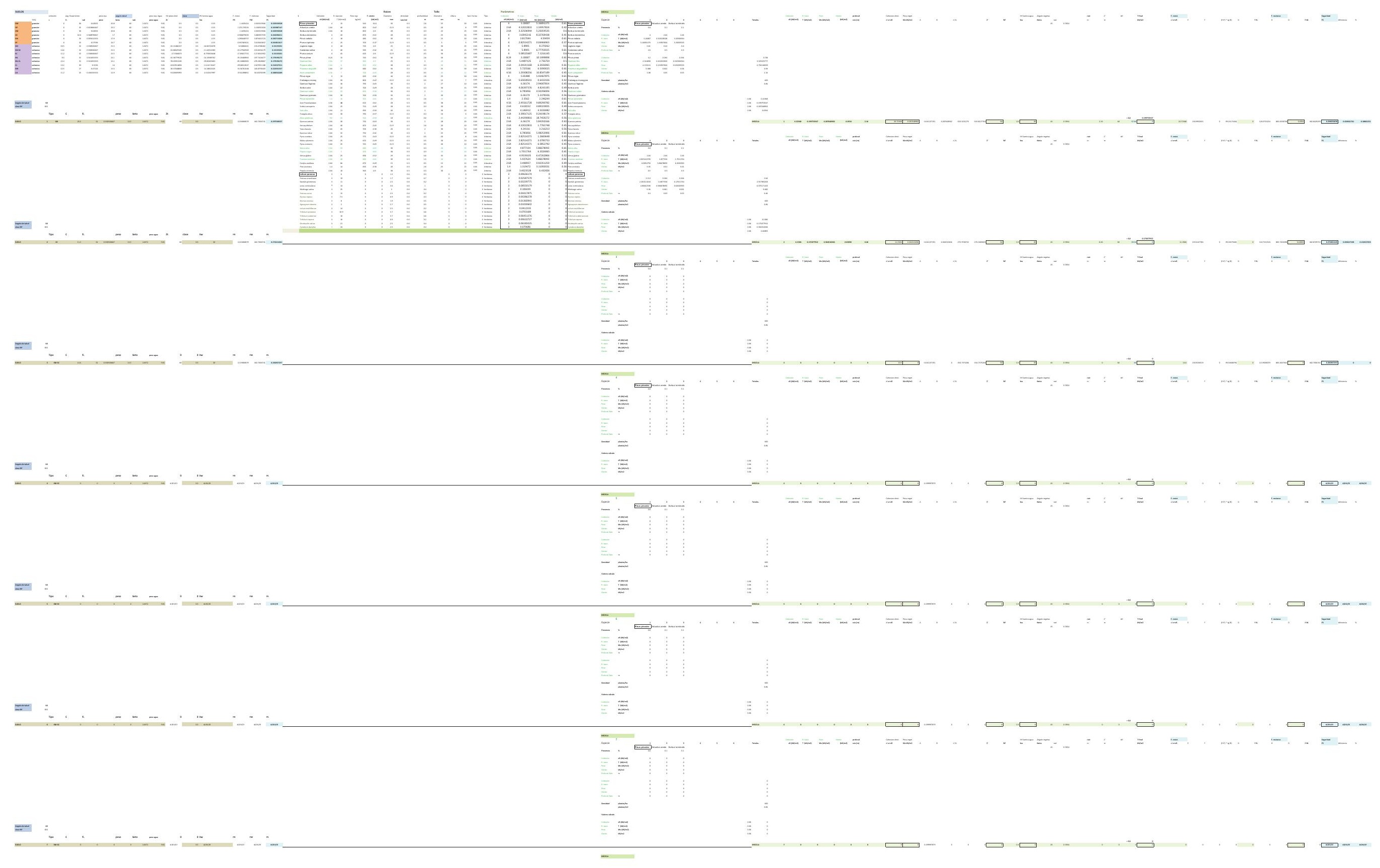




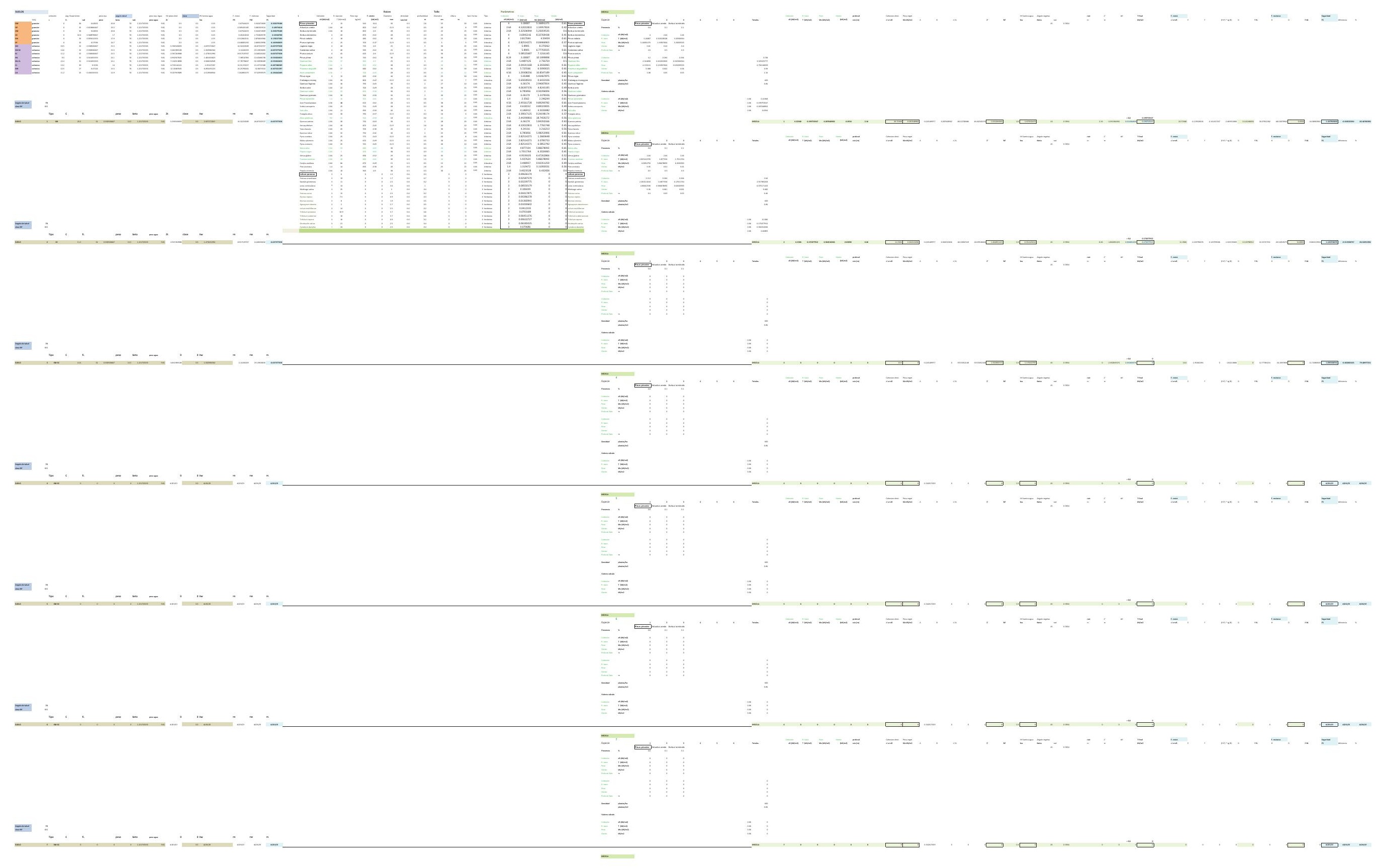




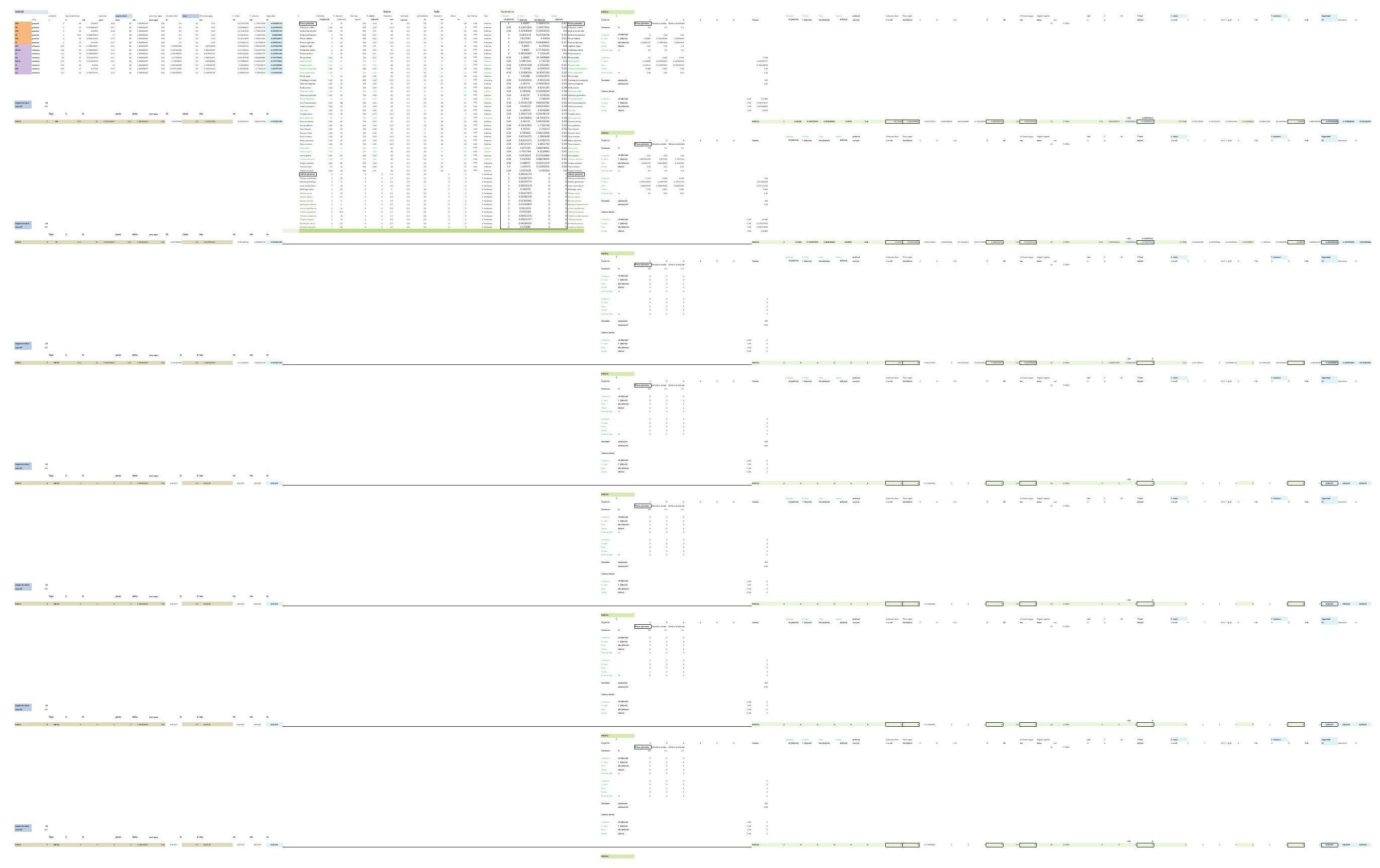


DESARROLLO DE UNA APLICACIÓN IMFORMÁTICA PARA EL CÁLCULO DE SOSTENIMIENTO DE TALUDES MEDIANTE VEGETACIÓN

B01. DENSIDAD DE PLANTACIÓN: 600 plantas/ha.

\section{B01-5.POSICIÓN N.F. 5}

INCLINACIÓN DE TALUD 6-100

INCLINACIÓN DE TALUD 10-200

INCLINACIÓN DE TALUD 20-30

INCLINACIÓN DE TALUD 30-40

INCLINACIÓN DE TALUD $35^{\circ}$

INCLINACIÓN DE TALUD 40-50

INCLINACIÓN DE TALUD 50-550

INCLINACIÓN DE TALUD 55-60

INCLINACIÓN DE TALUD 60-700

INCLINACIÓN DE TALUD 70-80 


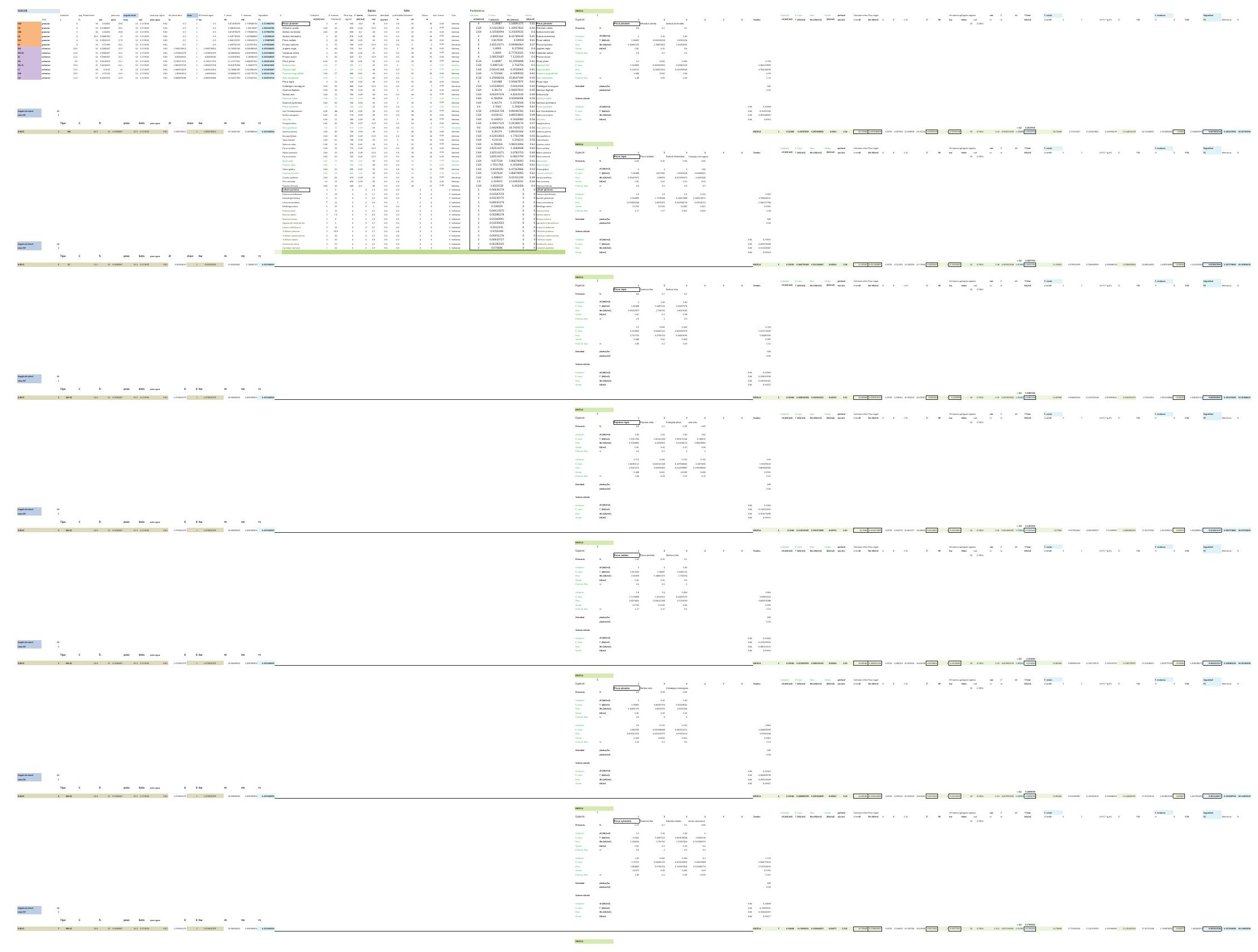




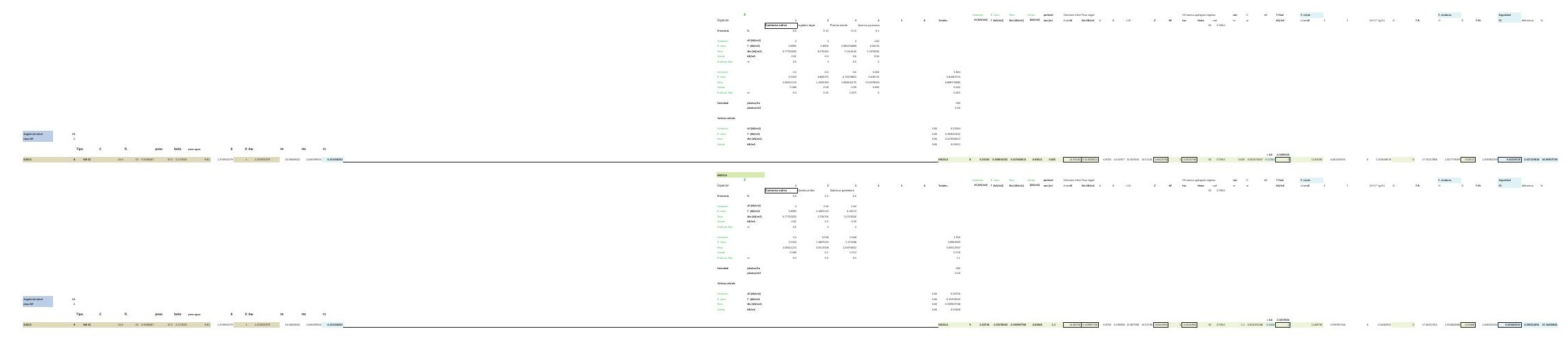




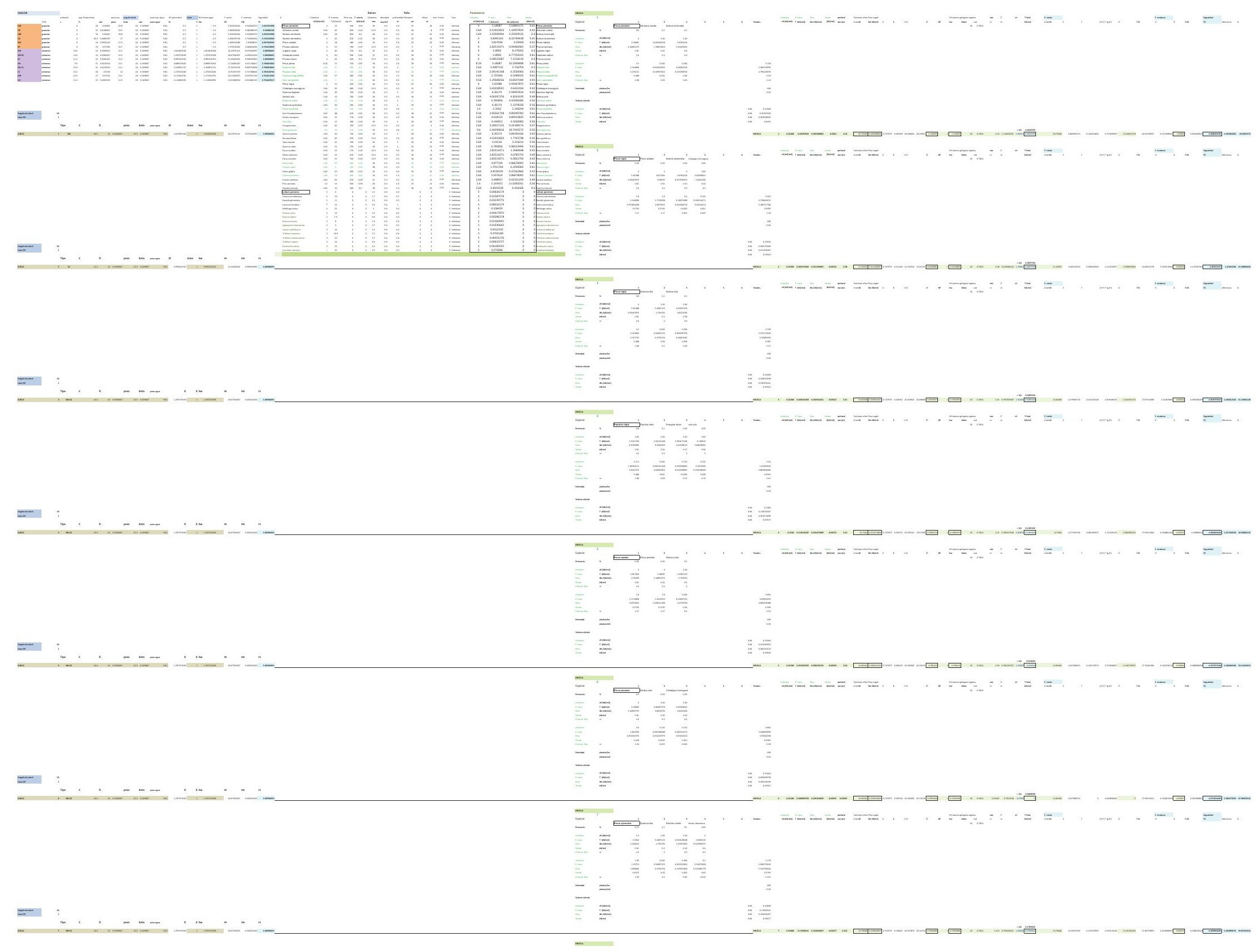




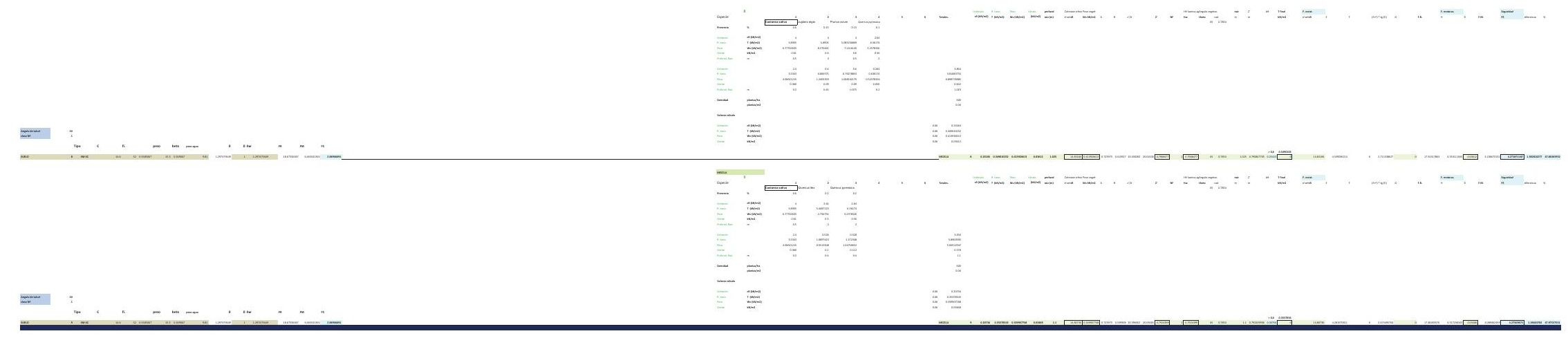




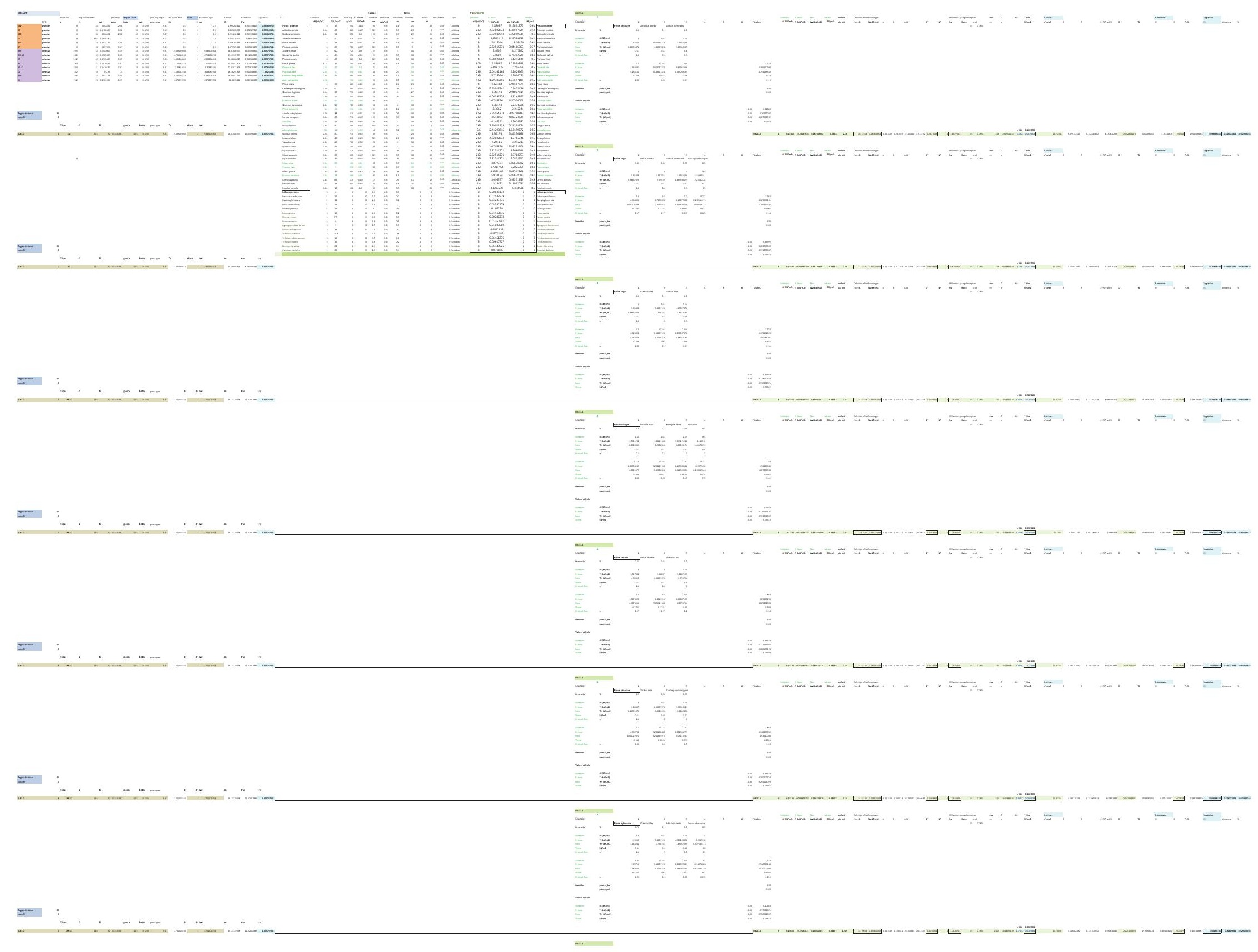




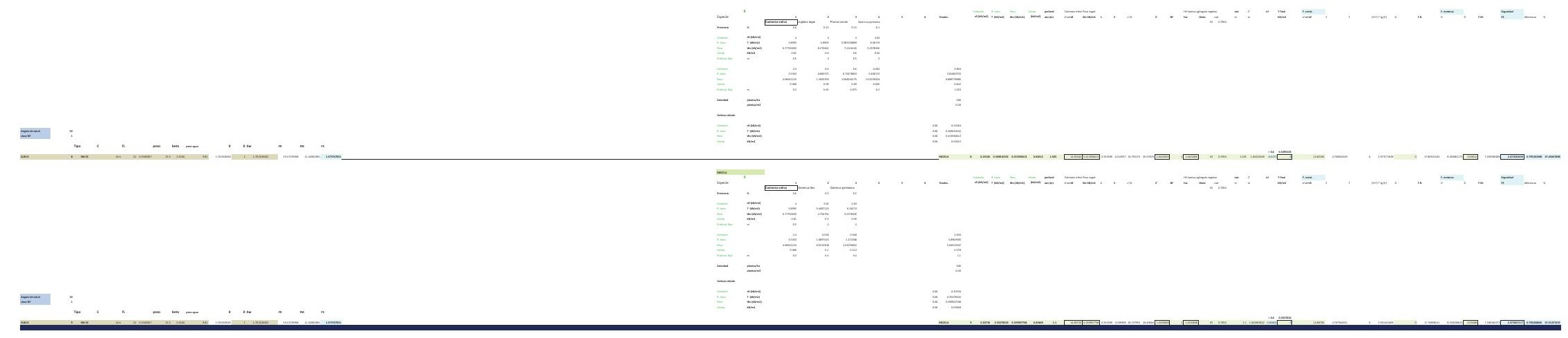




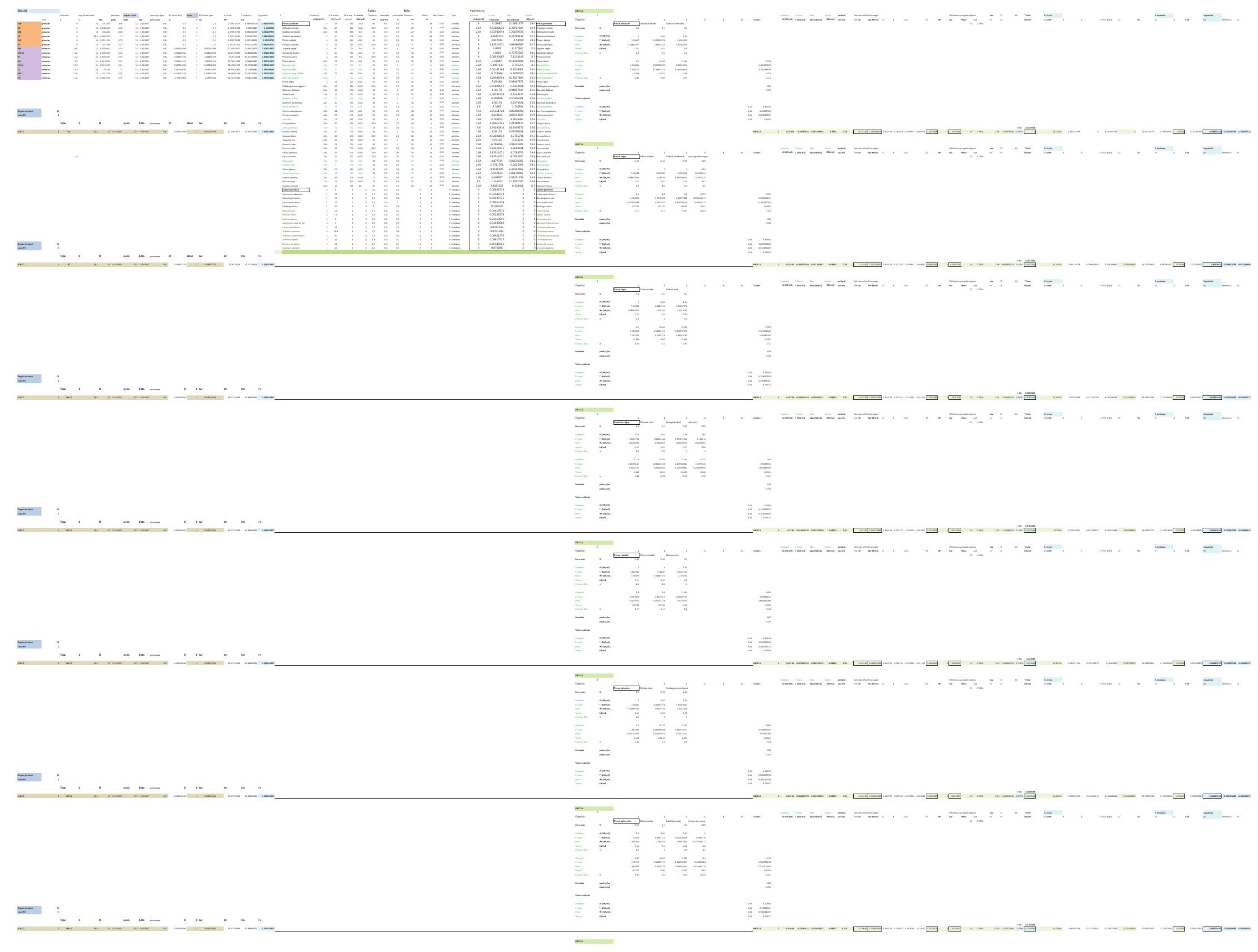




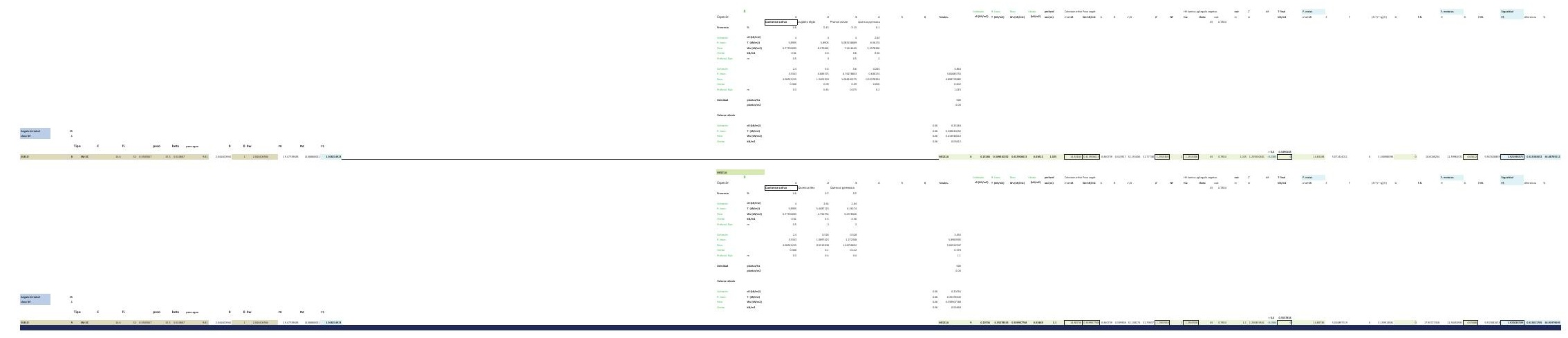




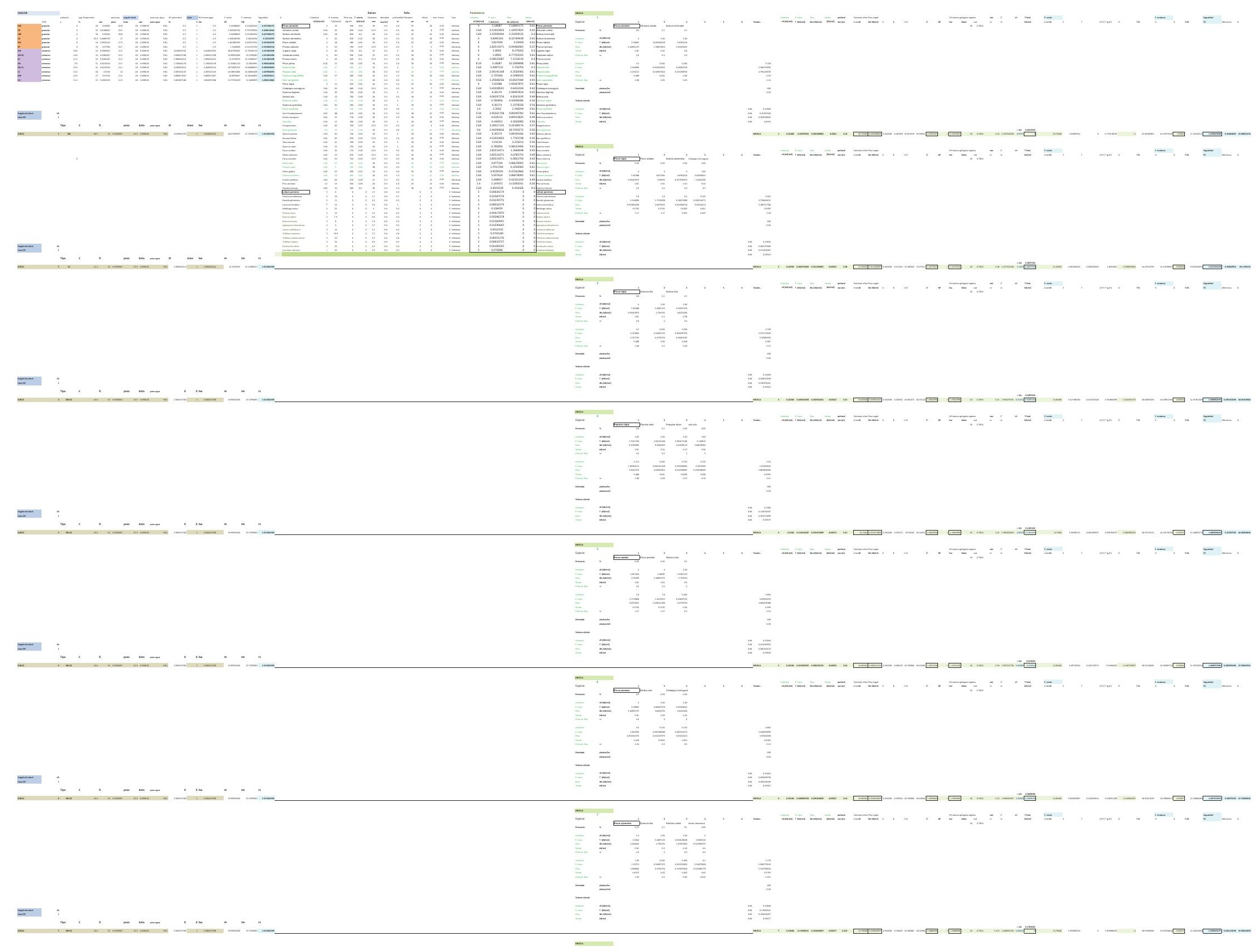




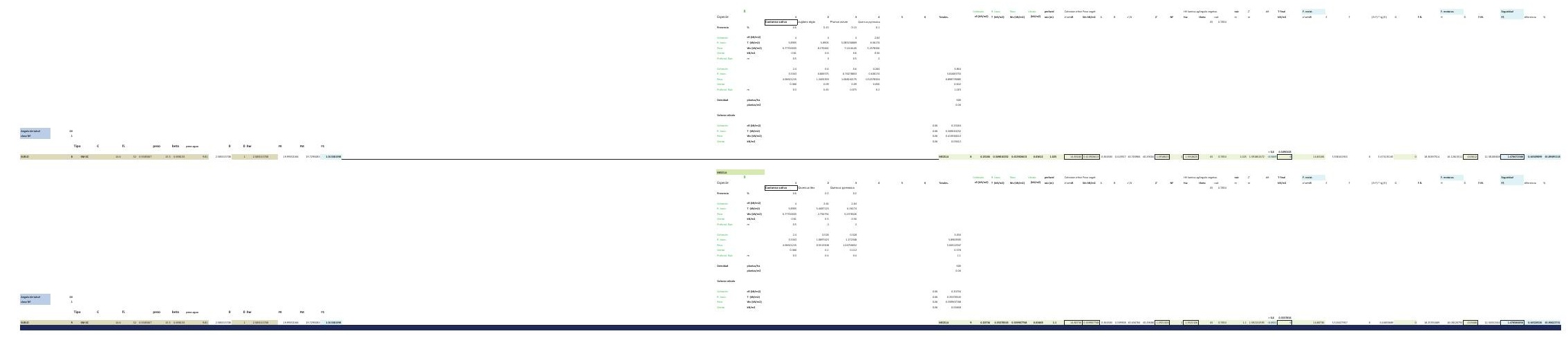




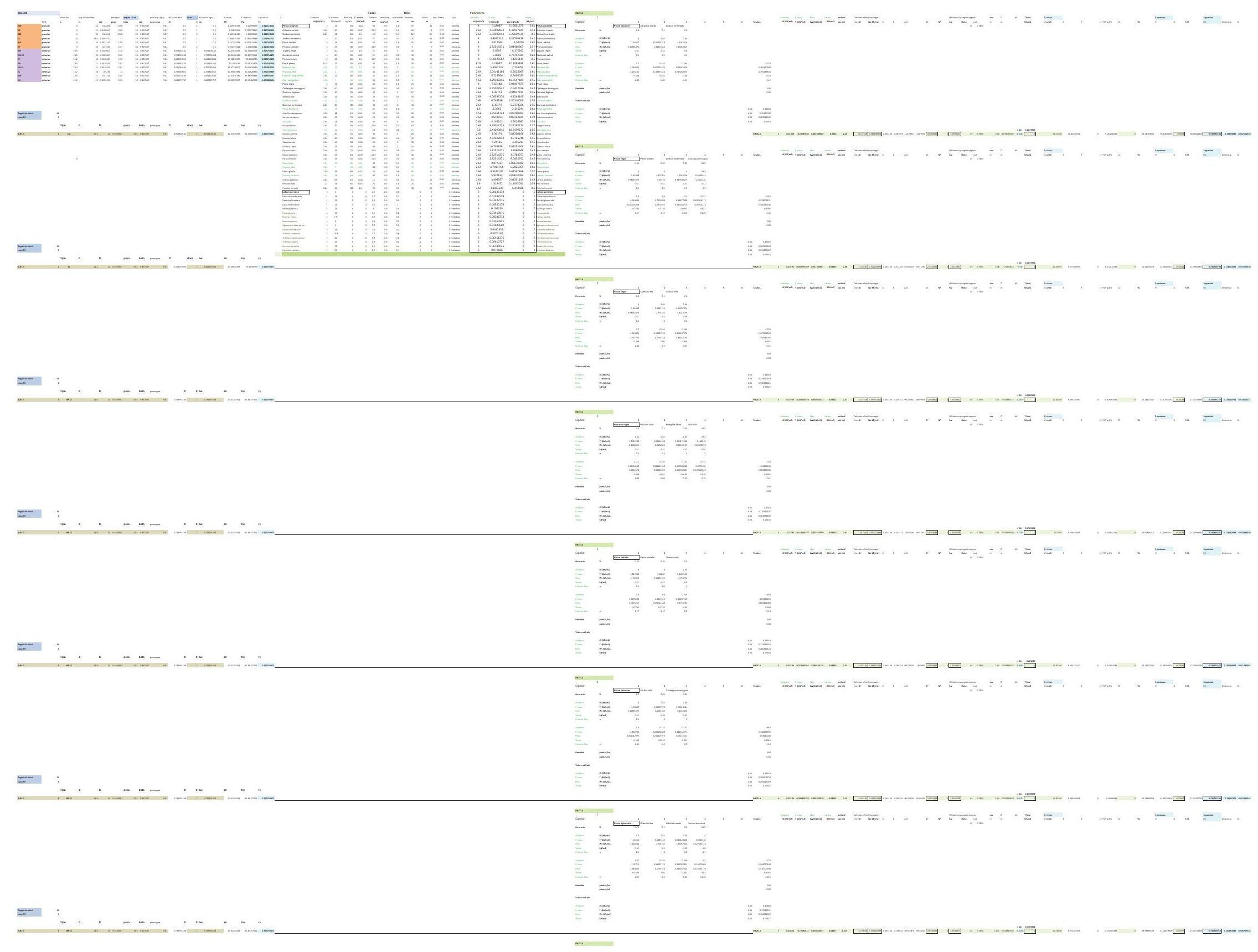




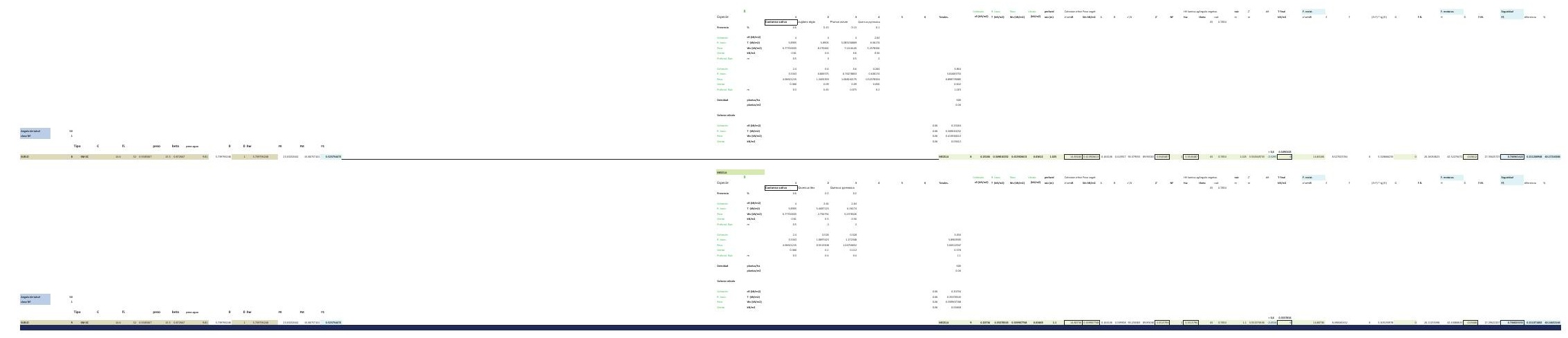




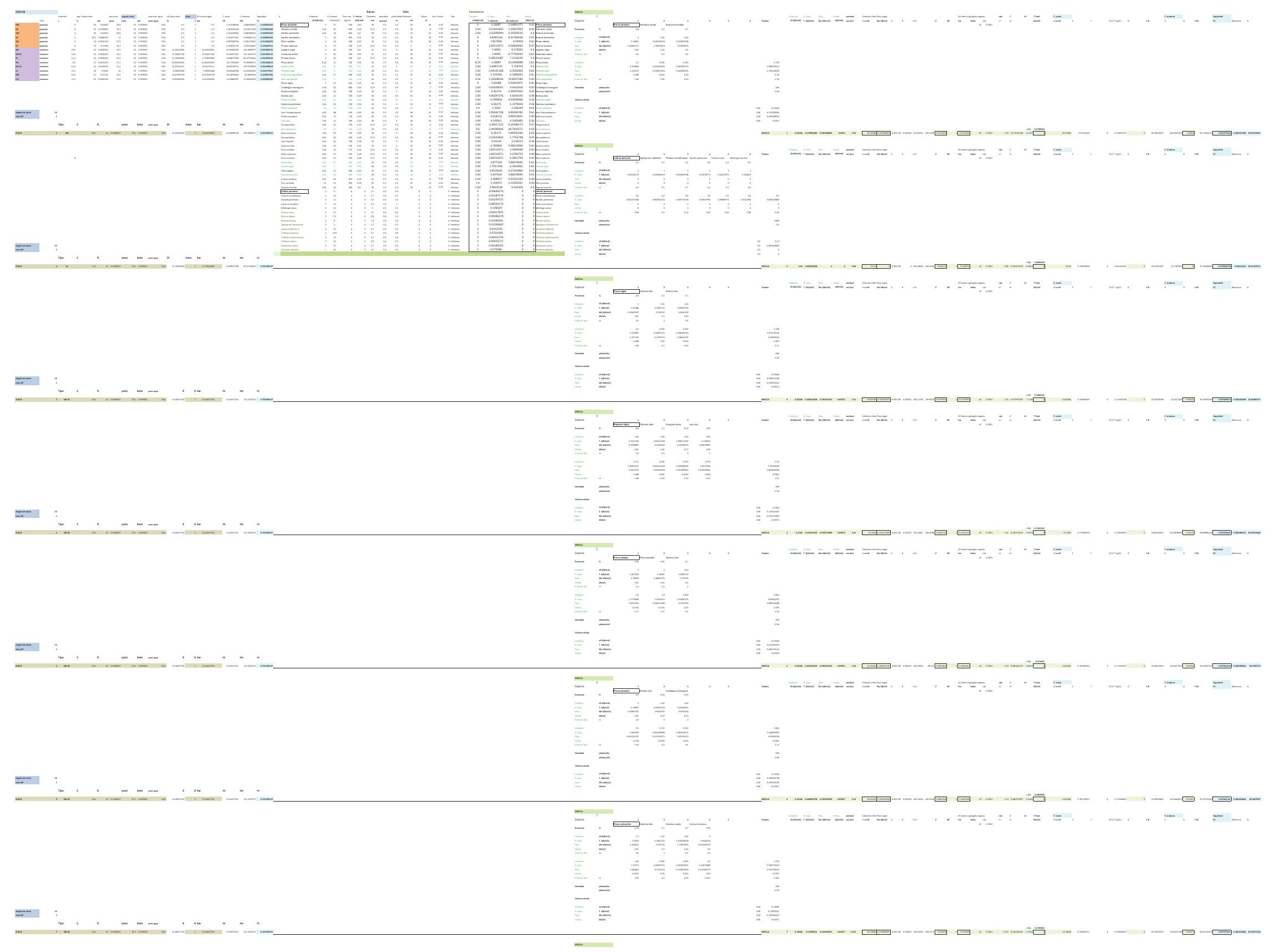


$=$

$=$

-

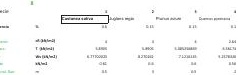

$=\stackrel{\#=}{=}=$

$-$

$\underline{E}$

$\equiv \pm=$

$\therefore=$

$=$
- 


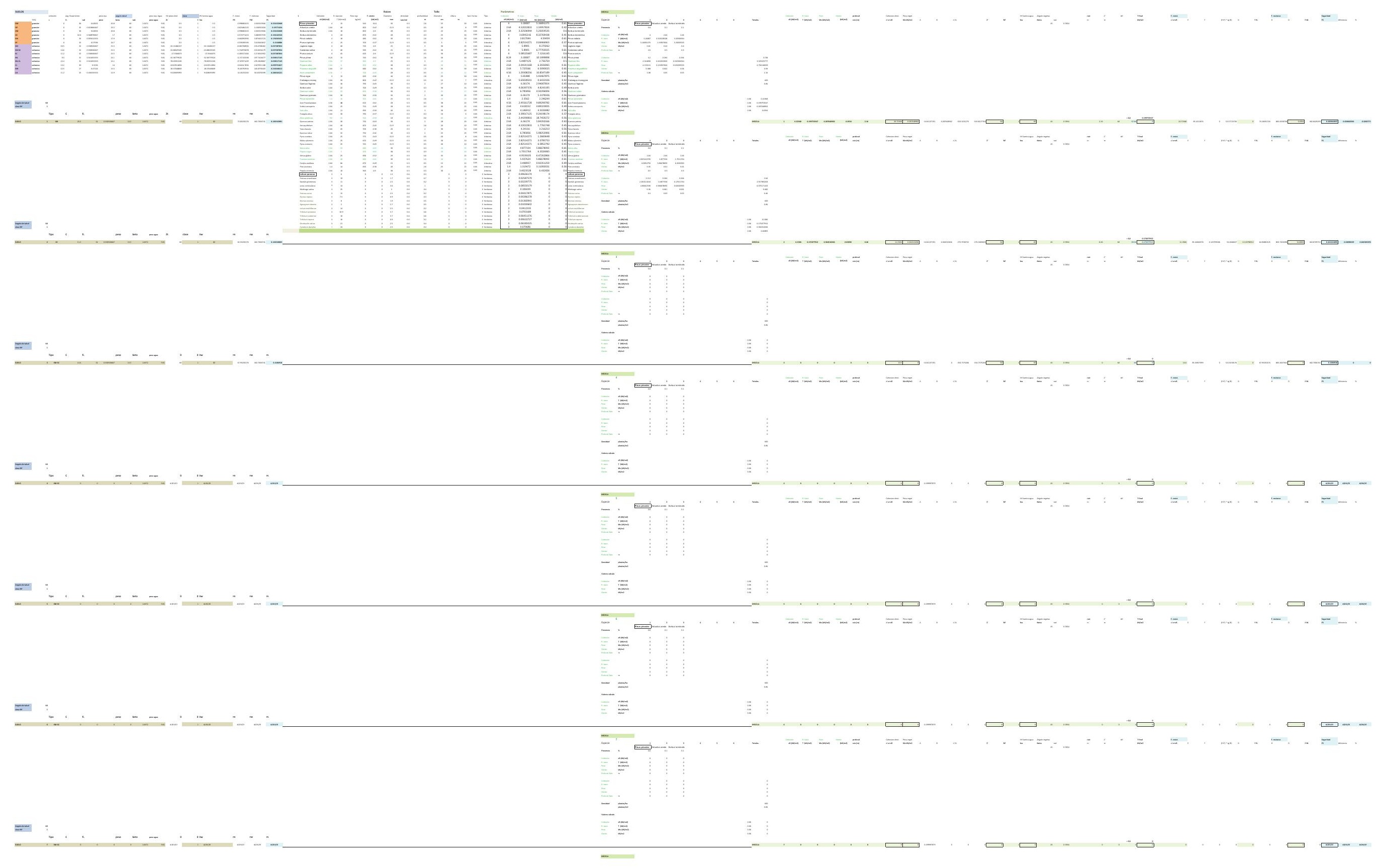




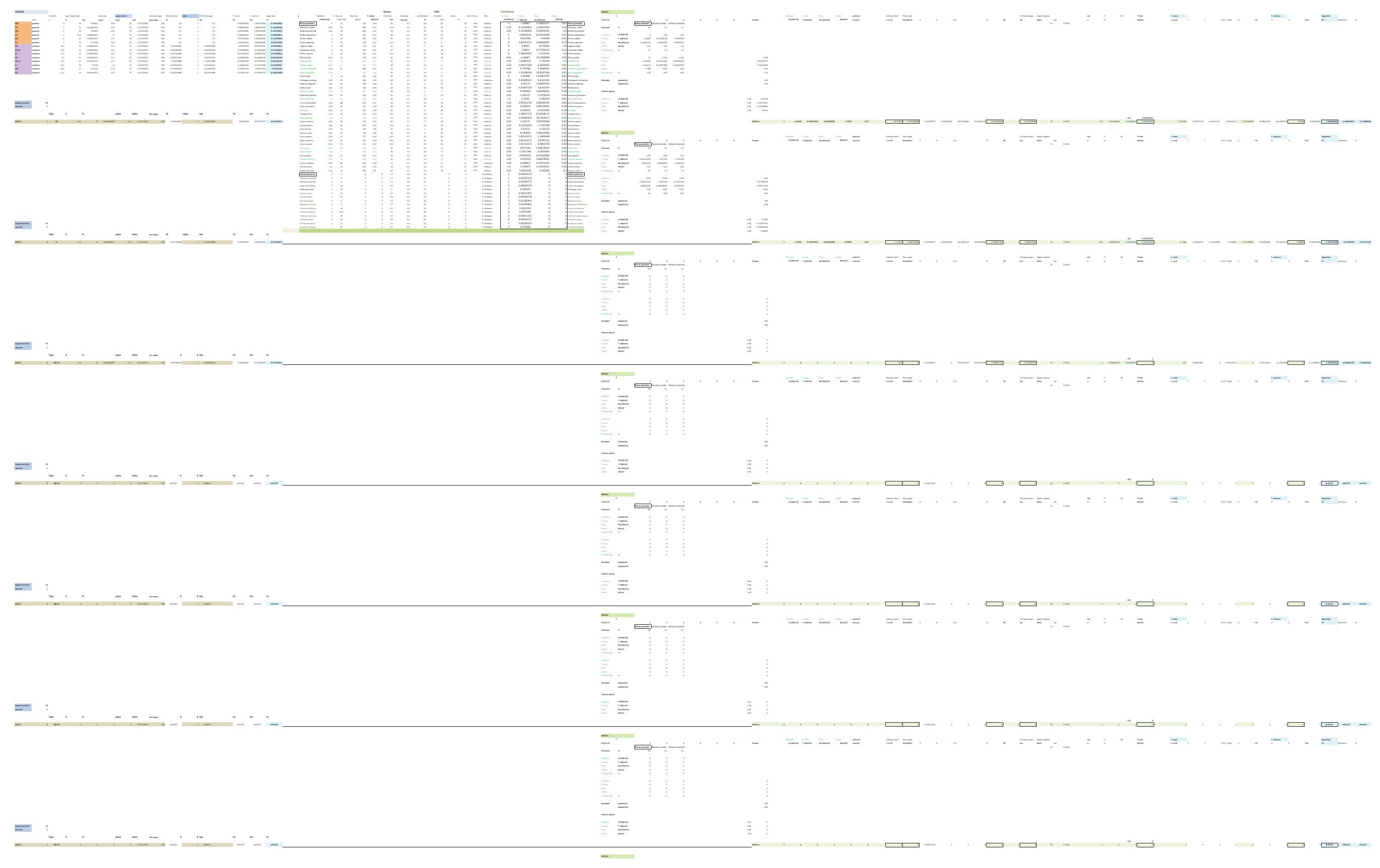


DESARROLLO DE UNA APLICACIÓN IMFORMÁTICA PARA EL CÁLCULO DE SOSTENIMIENTO DE TALUDES MEDIANTE VEGETACIÓN

PRUEBAS DEL MODELO MATEMÁTICO PARA EL CÁLCULO DE ESTABILIDAD DE TALUDES.

B02. DENSIDAD DE PLANTACIÓN: 1.600 plantas/ha.

B02-1.POSICIÓN N.F. 1

B02-2.POSICIÓN N.F. 2

B02-3.POSICIÓN N.F. 3

B02-4.POSICIÓN N.F. 4

B02-5.POSICIÓN N.F. 5 
DESARROLLO DE UNA APLICACIÓN IMFORMÁTICA PARA EL CÁLCULO DE SOSTENIMIENTO DE TALUDES MEDIANTE VEGETACIÓN

B02. DENSIDAD DE PLANTACIÓN: 1.600 plantas/ha.

\section{B02-1.POSICIÓN N.F. 1}

INCLINACIÓN DE TALUD 6-100

INCLINACIÓN DE TALUD 10-200

INCLINACIÓN DE TALUD 20-30

INCLINACIÓN DE TALUD 30-40

INCLINACIÓN DE TALUD $35^{\circ}$

INCLINACIÓN DE TALUD 40-50

INCLINACIÓN DE TALUD 50-550

INCLINACIÓN DE TALUD 55-60

INCLINACIÓN DE TALUD 60-700

INCLINACIÓN DE TALUD 70-80 


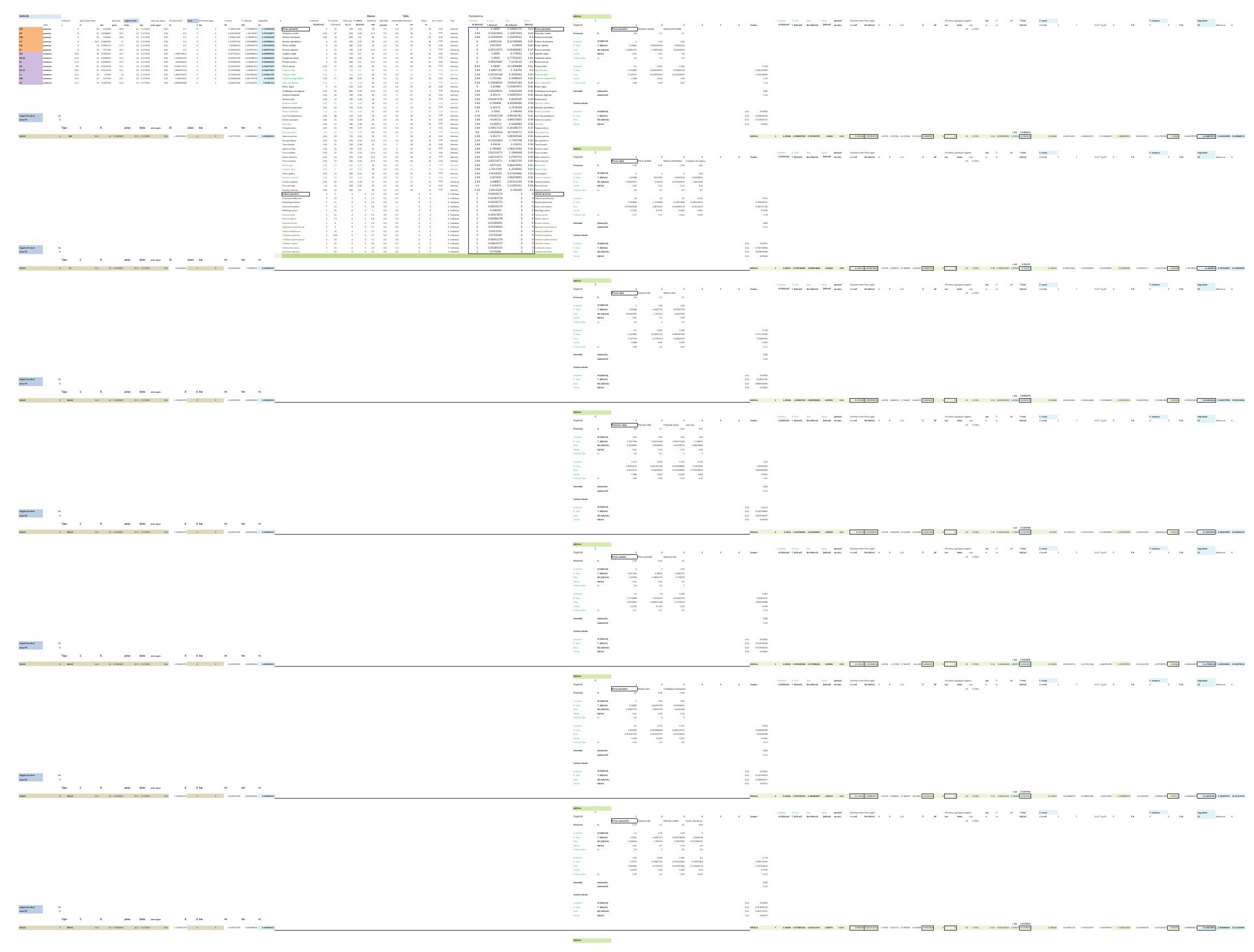




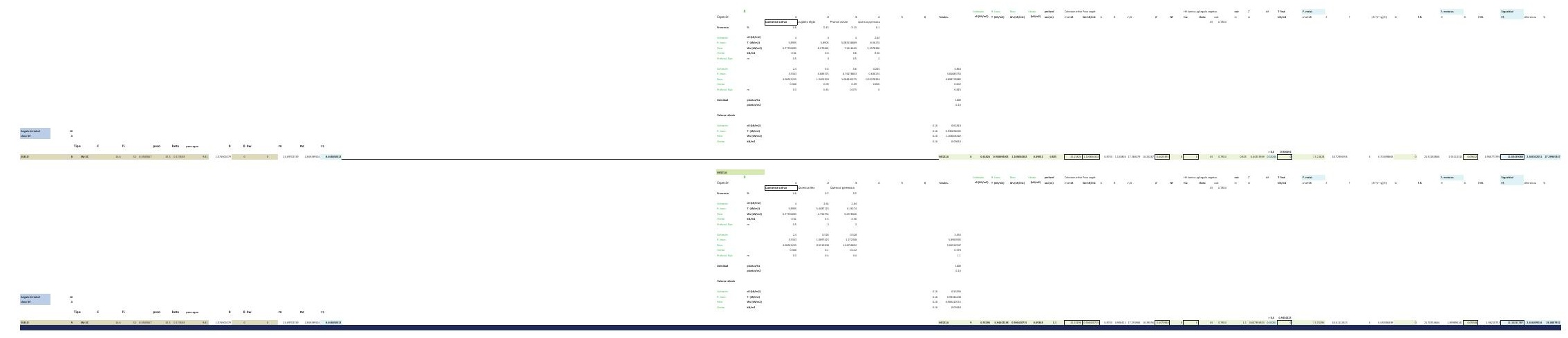




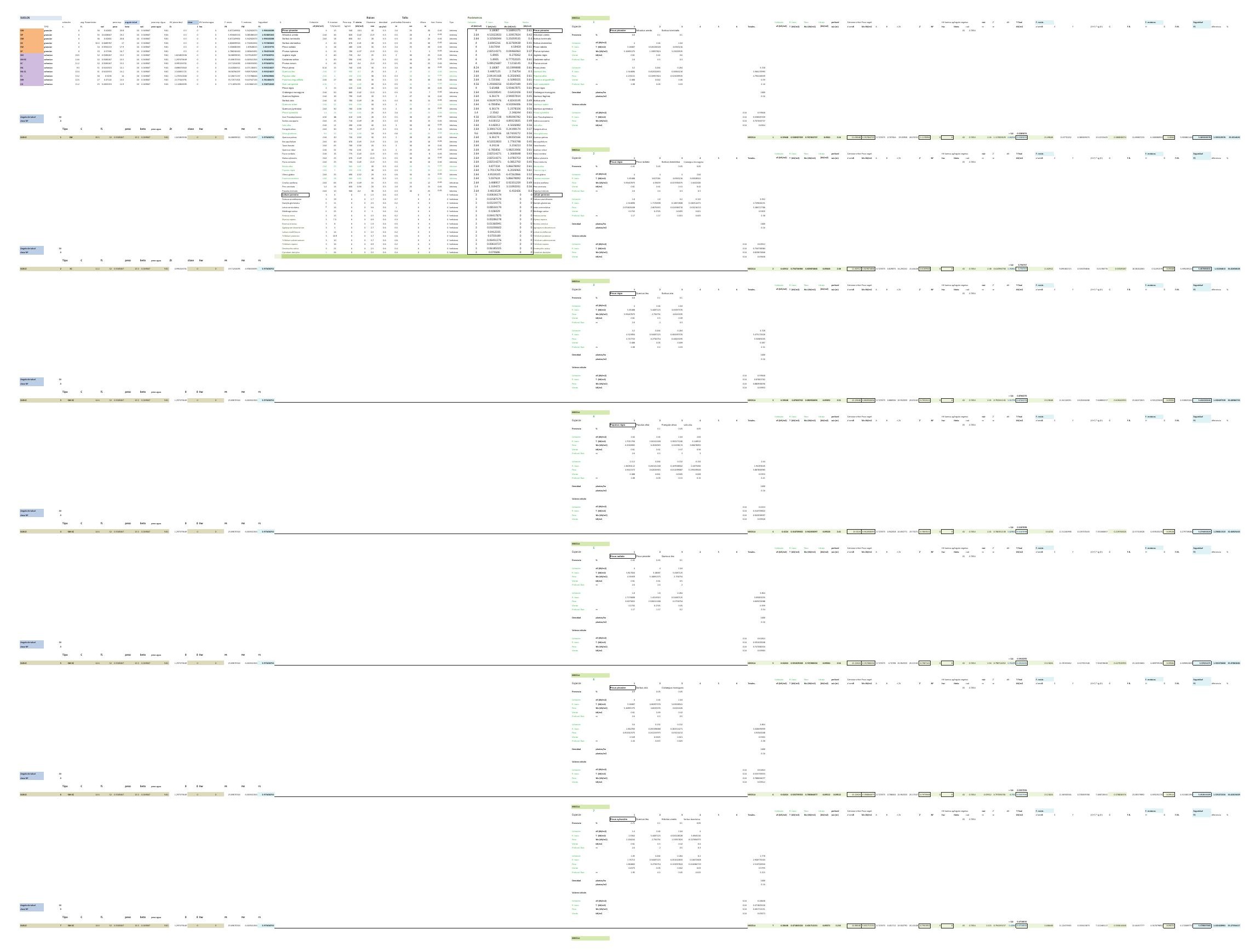




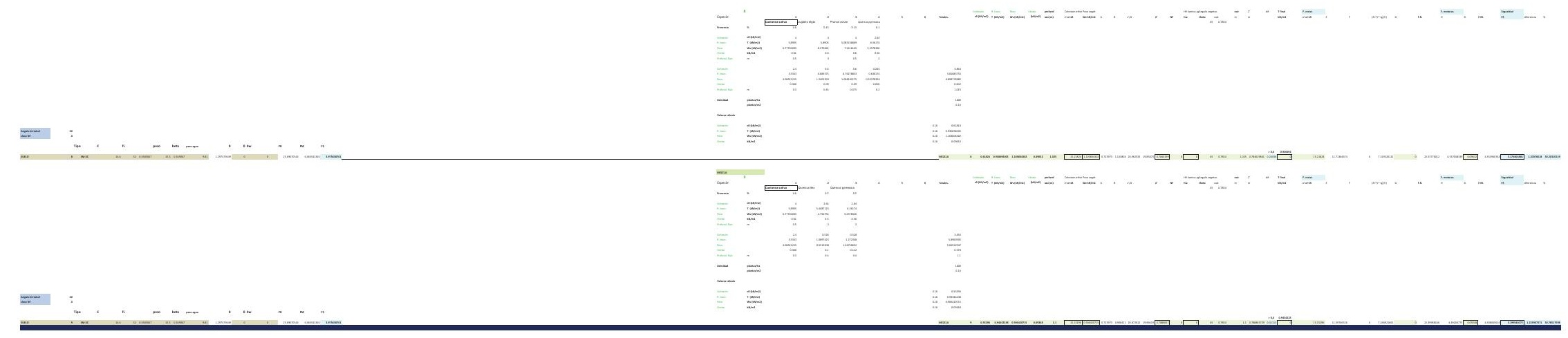




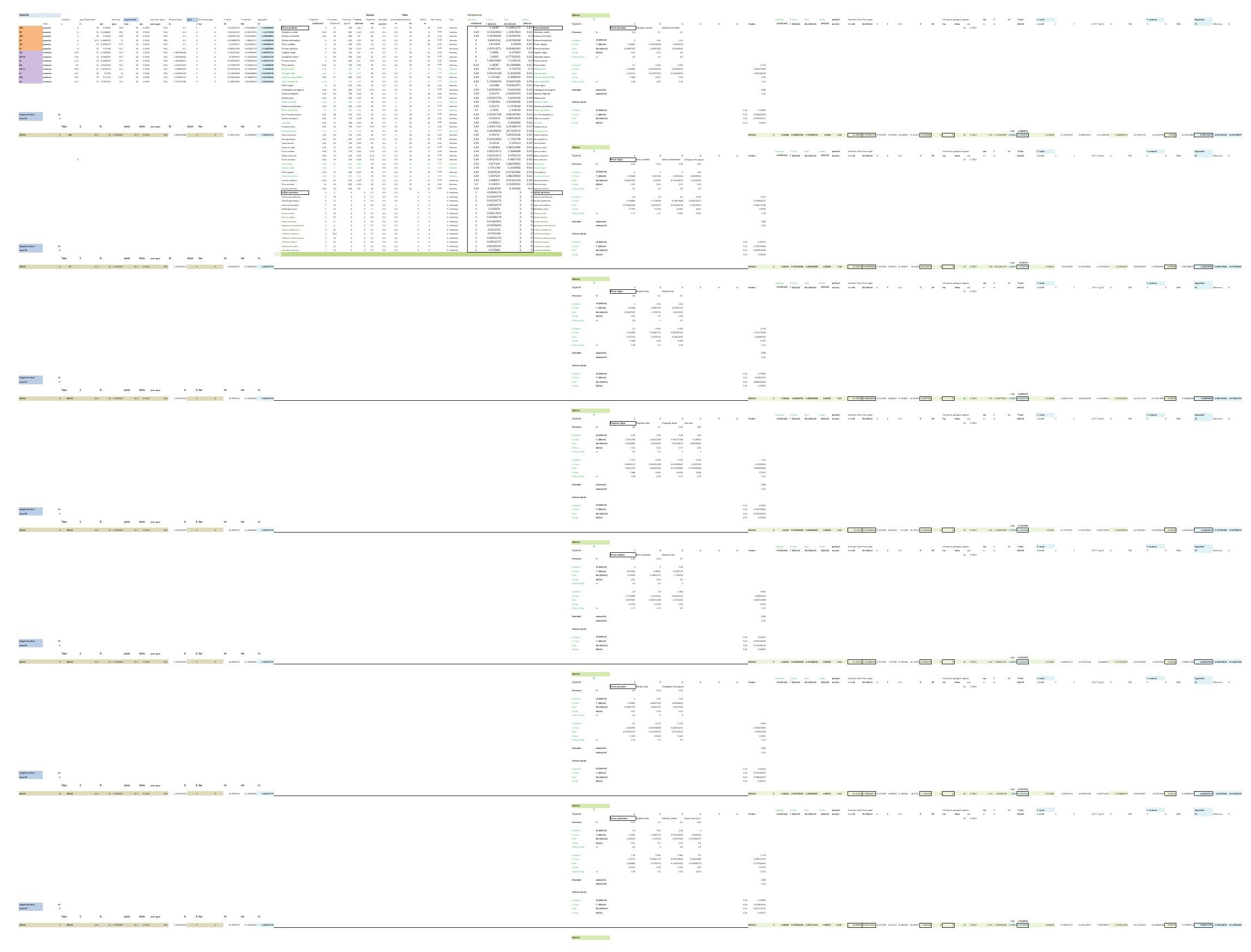




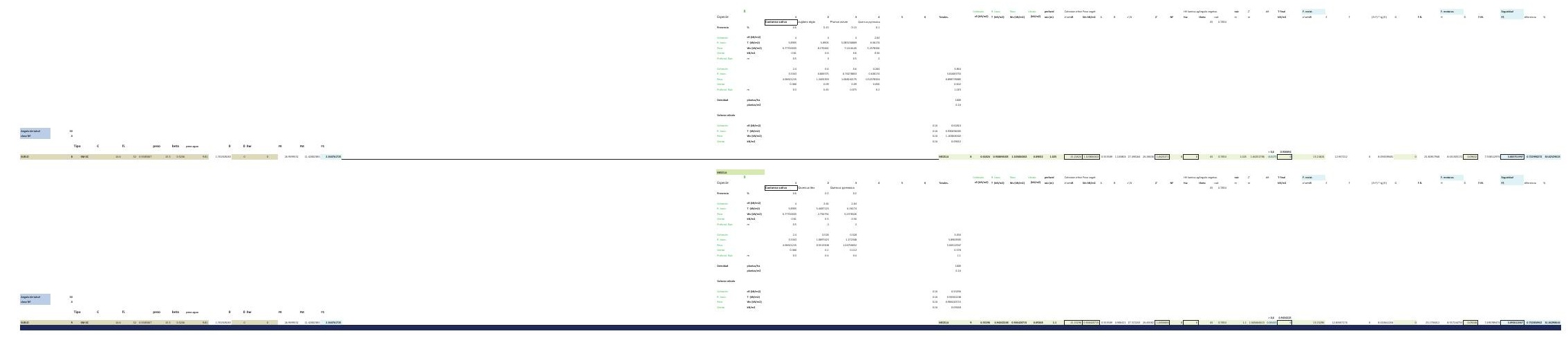




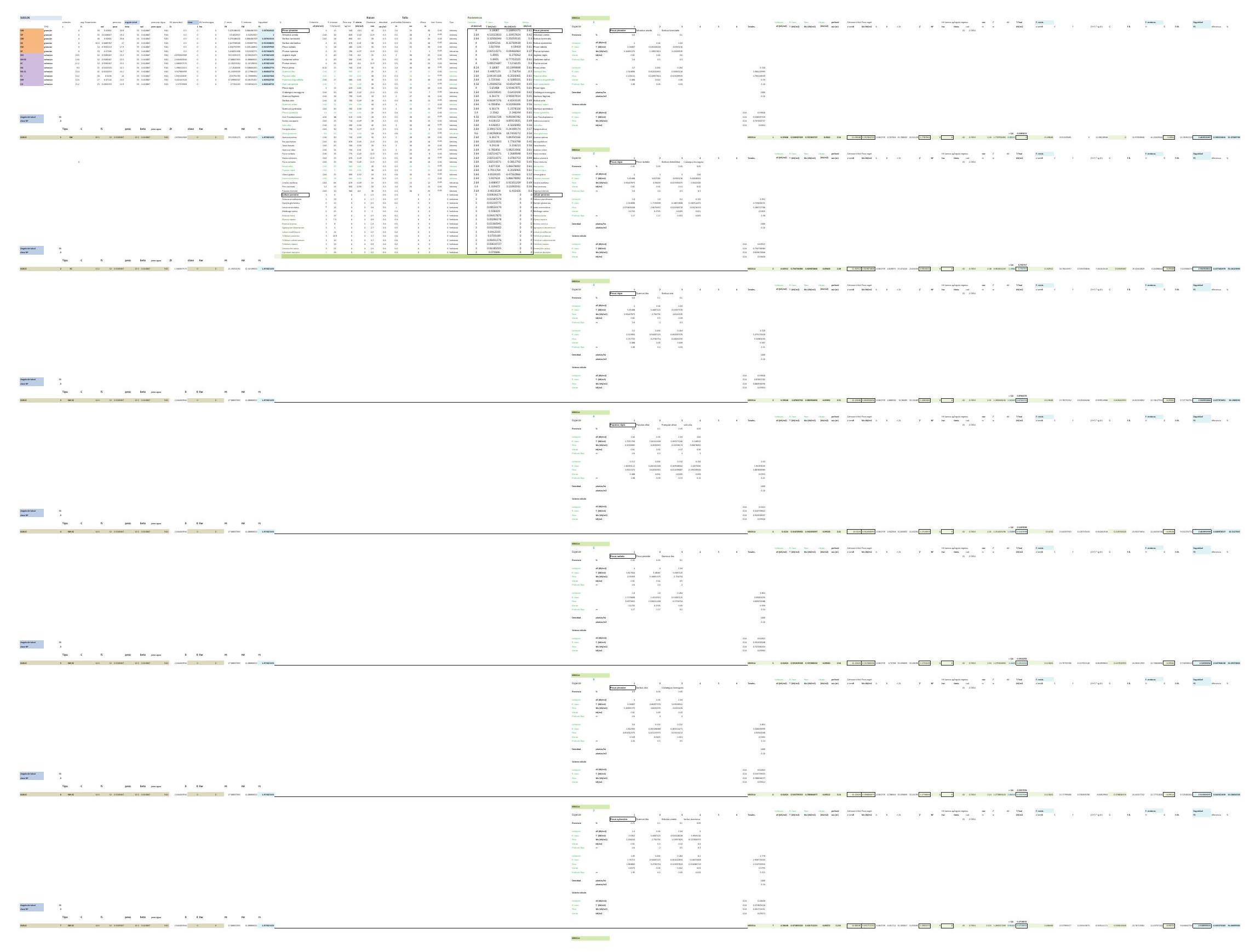




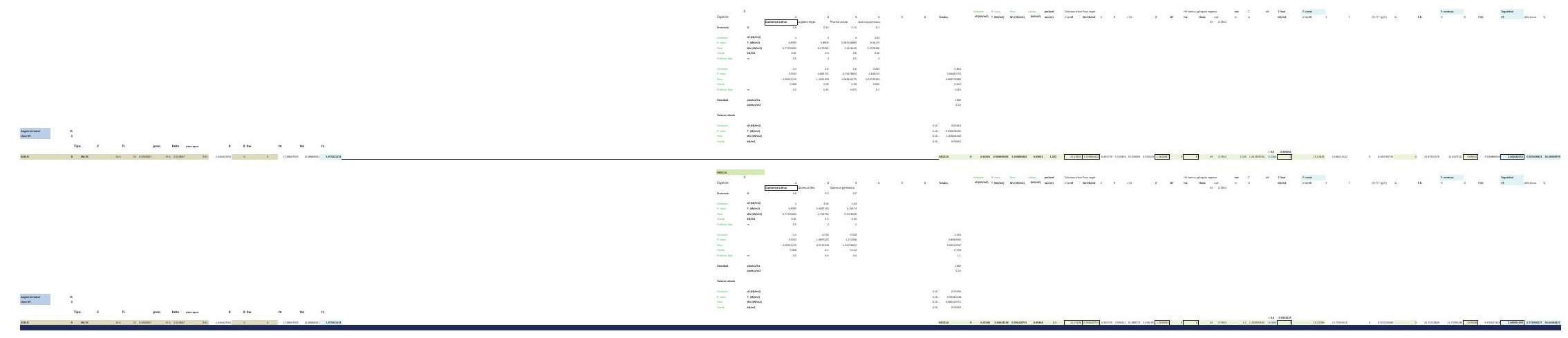




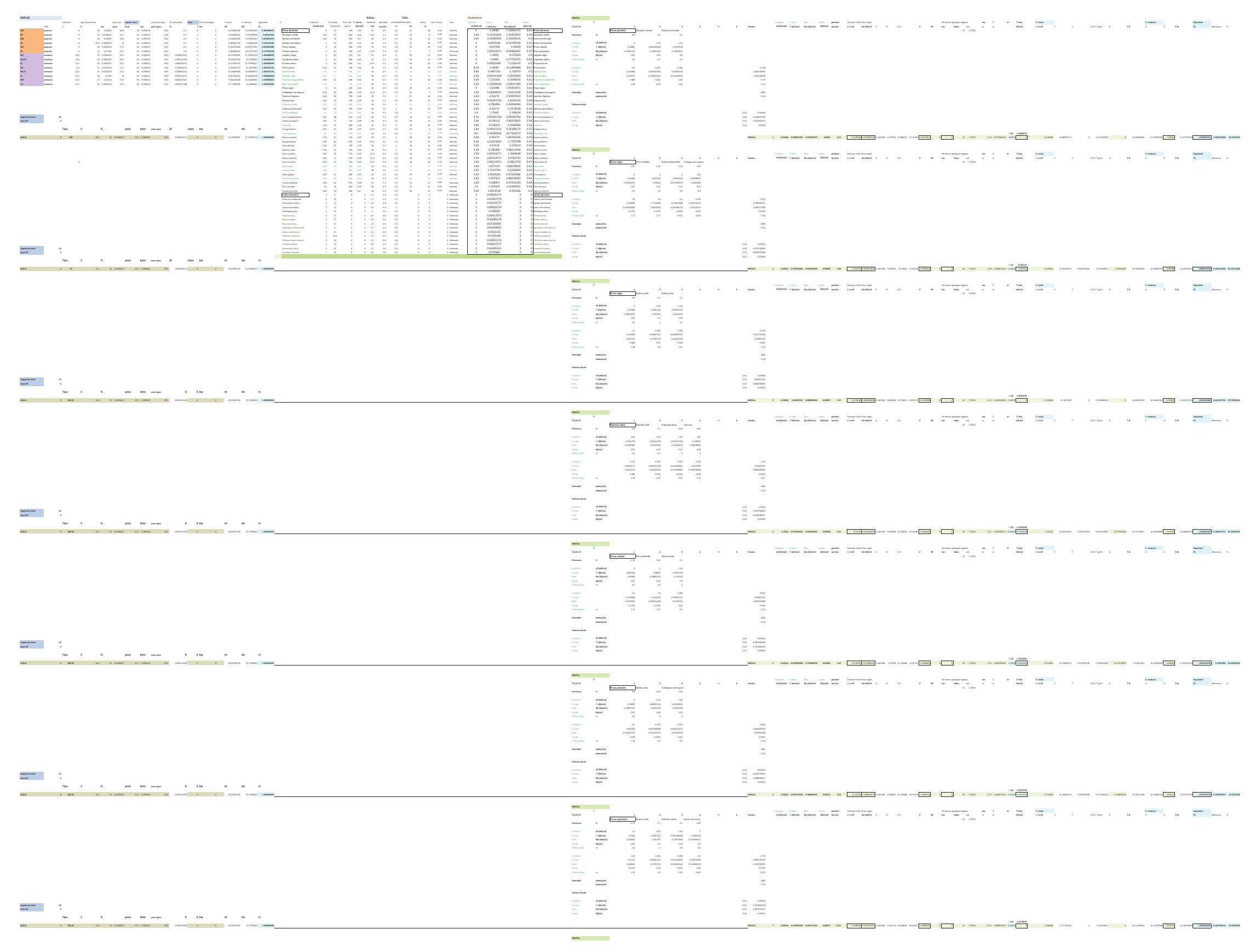




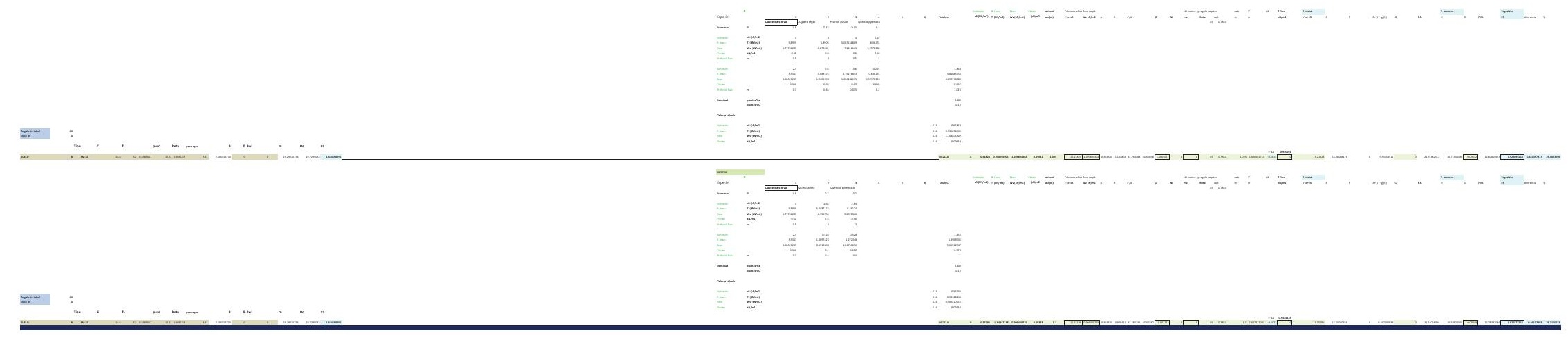




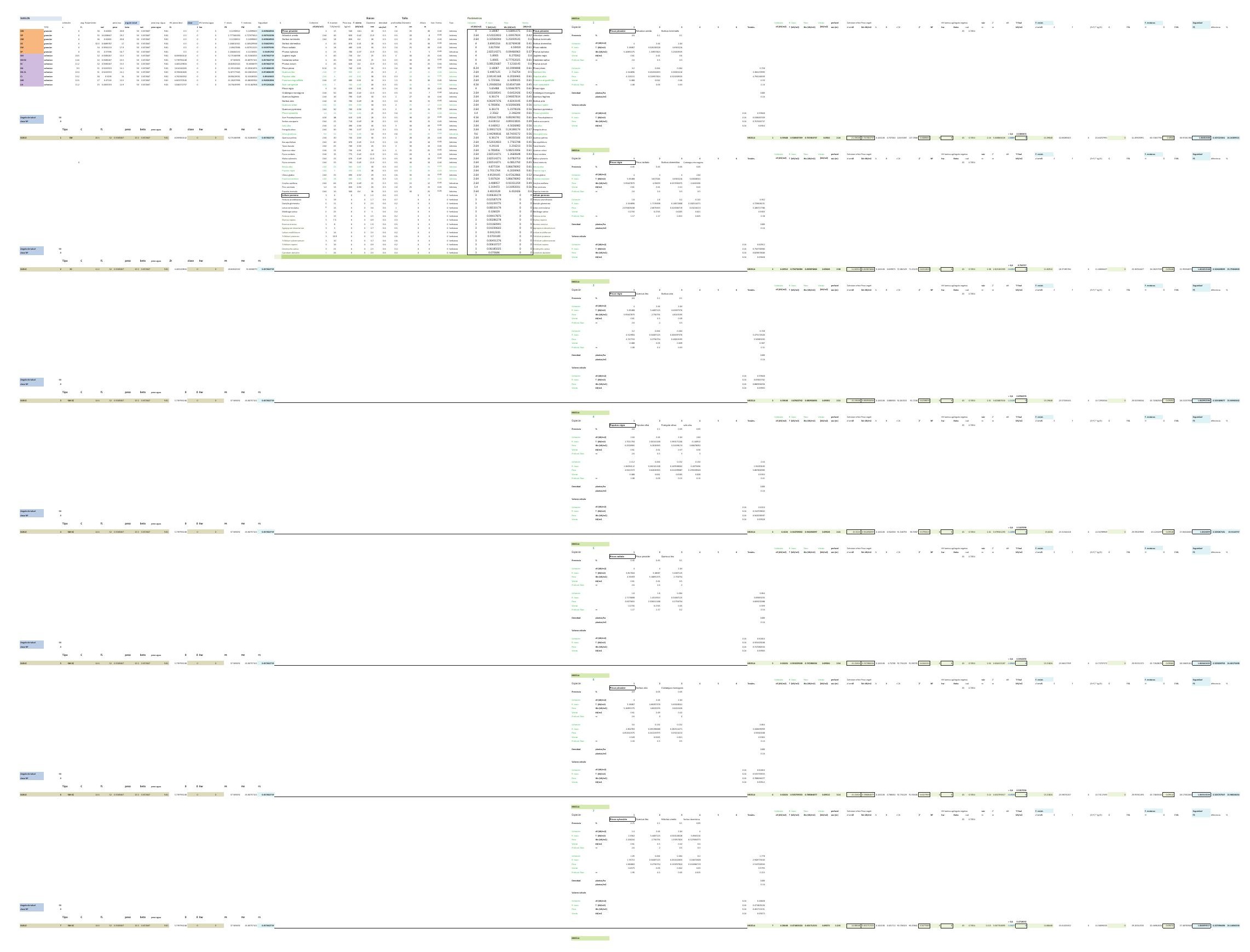




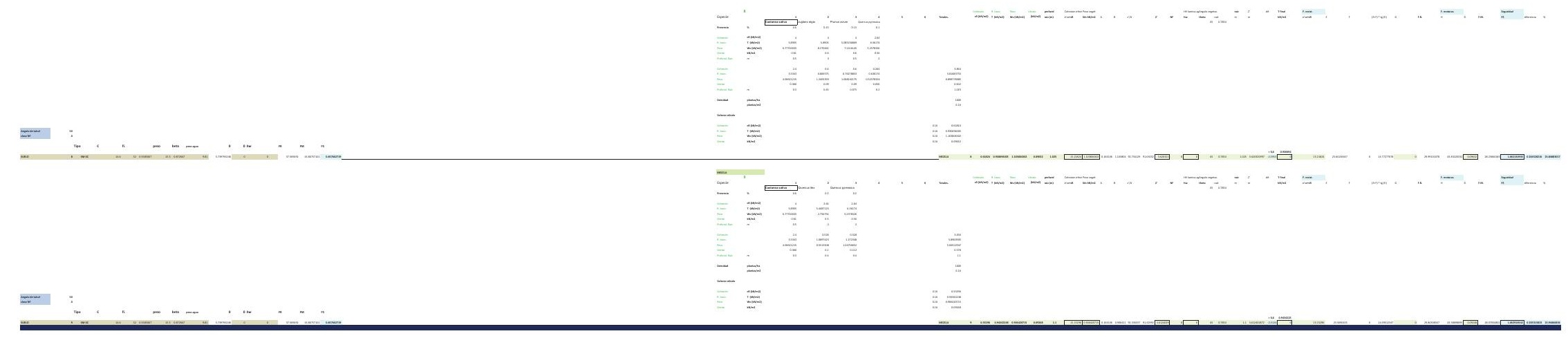




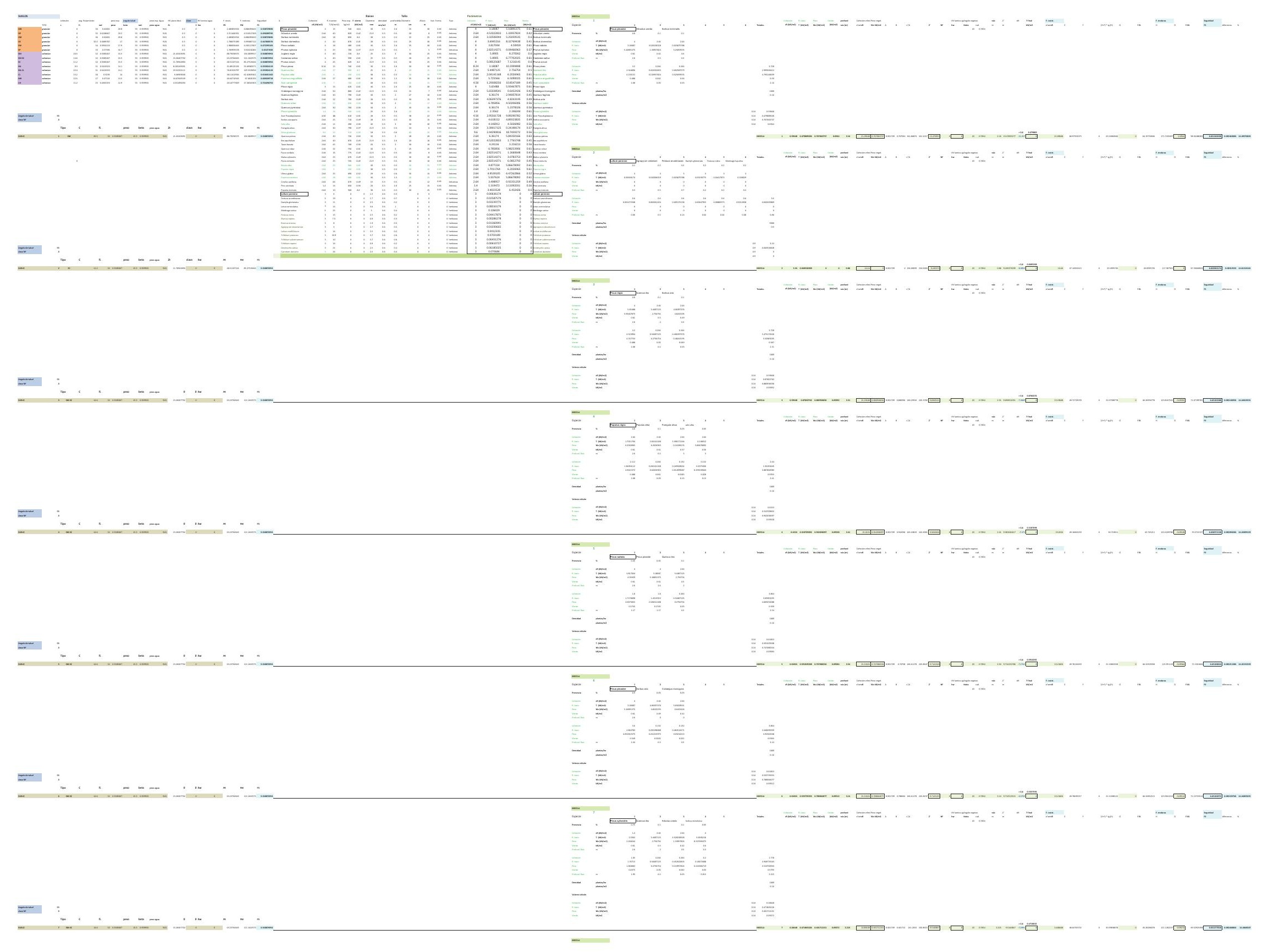




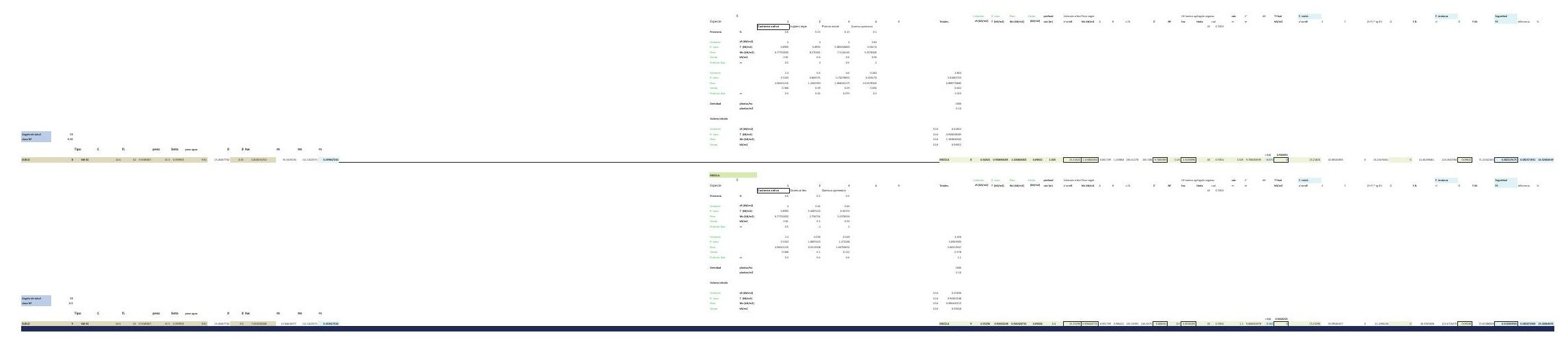




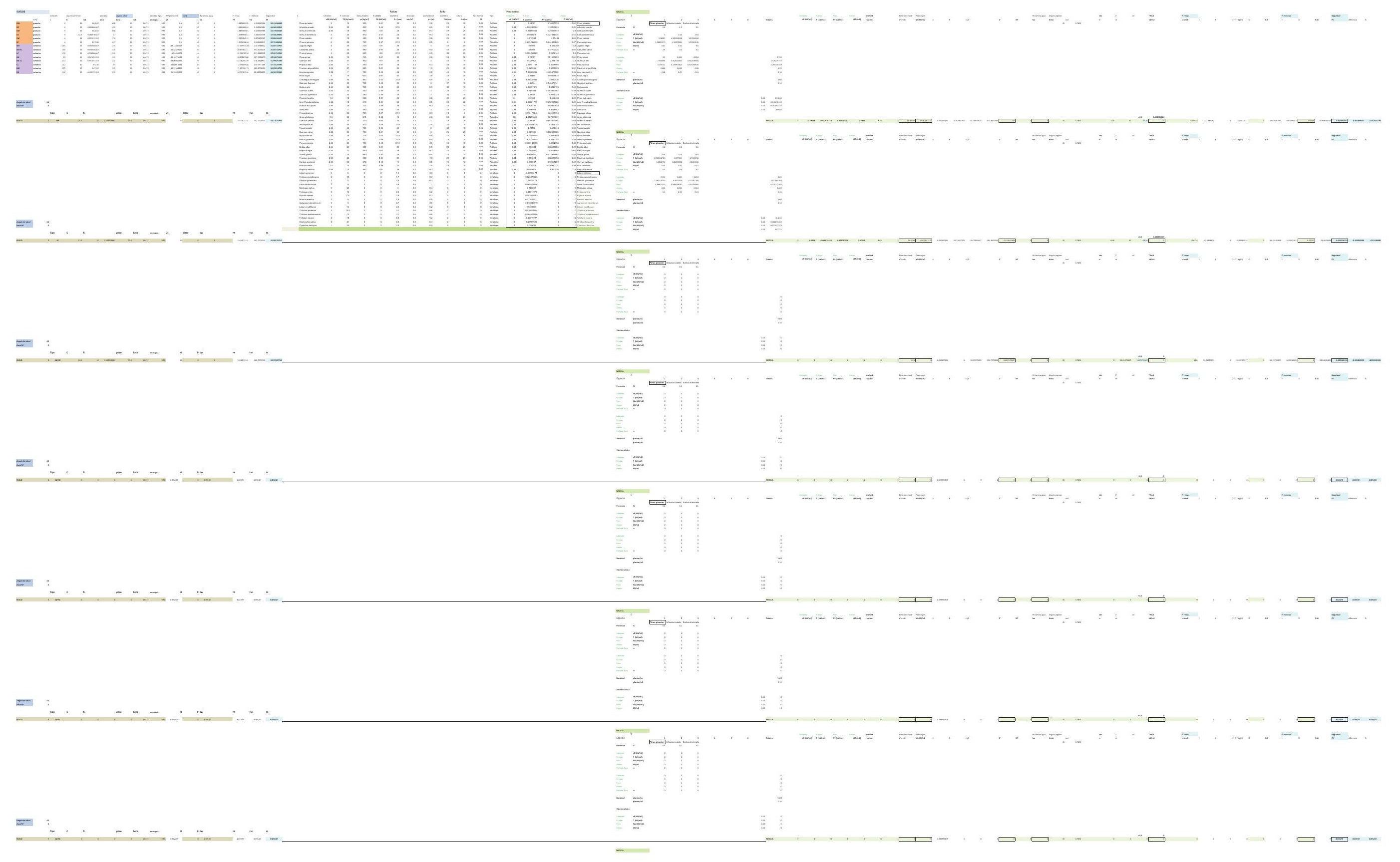




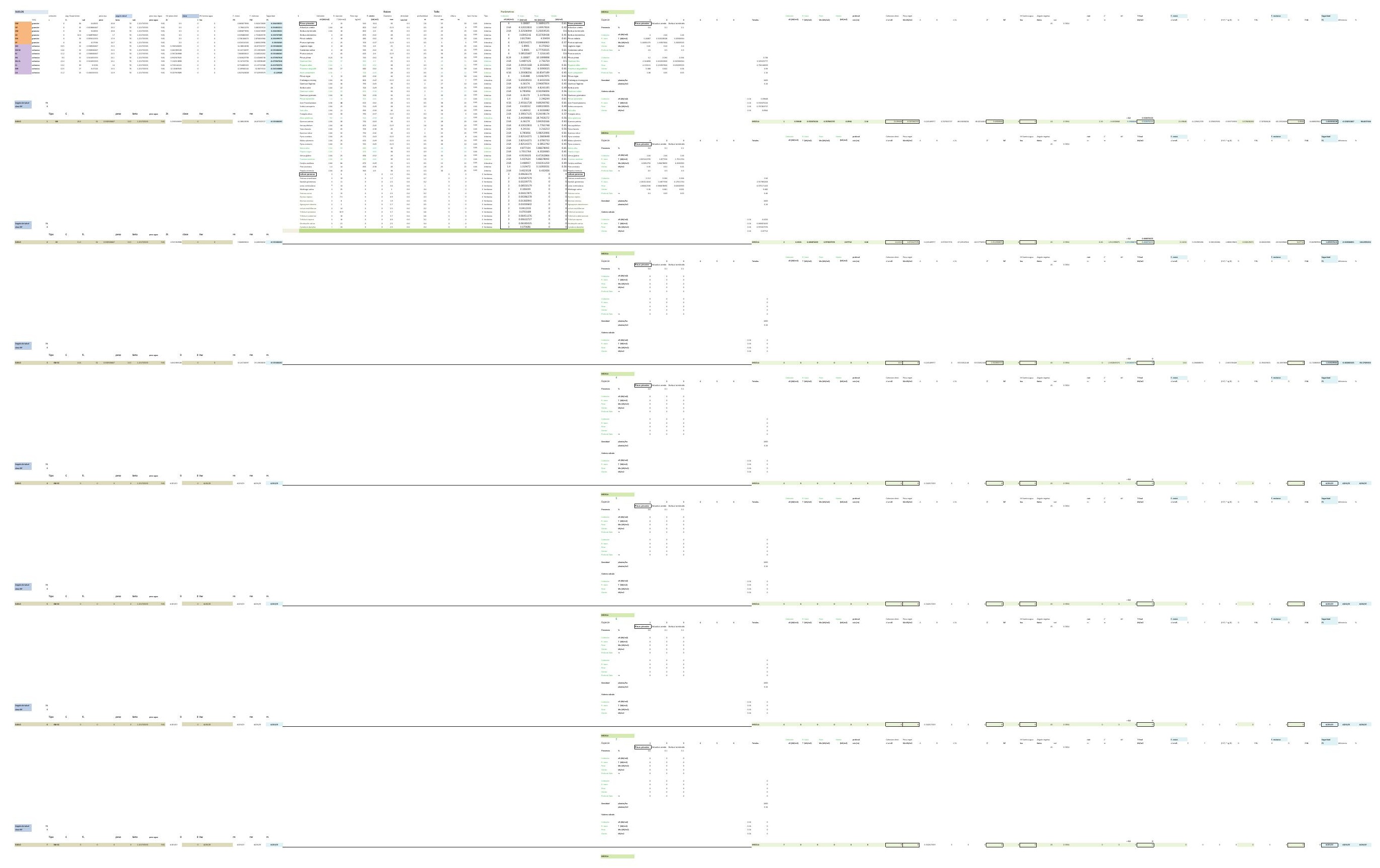




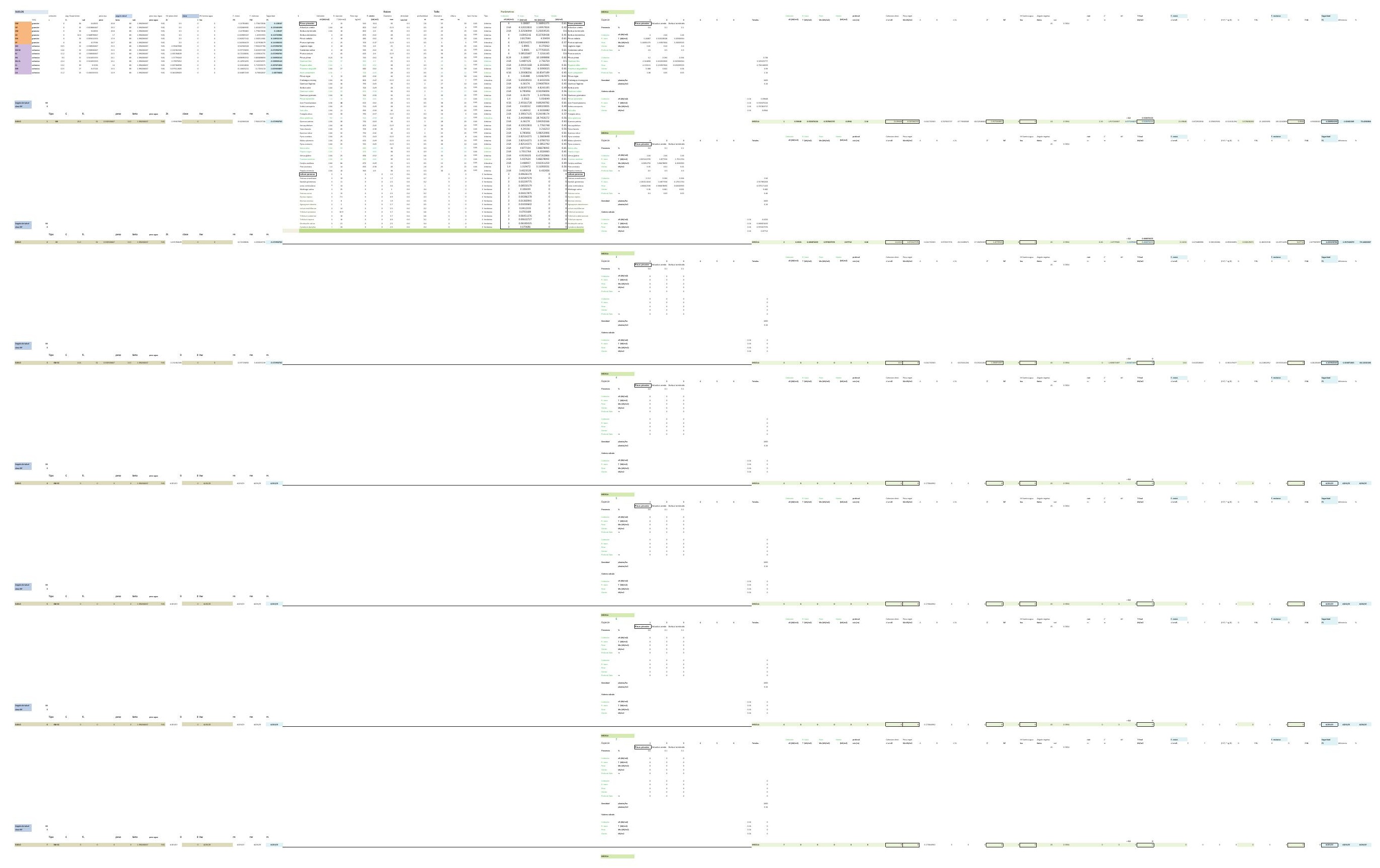


DESARROLLO DE UNA APLICACIÓN IMFORMÁTICA PARA EL CÁLCULO DE SOSTENIMIENTO DE TALUDES MEDIANTE VEGETACIÓN

B02. DENSIDAD DE PLANTACIÓN: 1.600 plantas/ha.

\section{B02-2.POSICIÓN N.F. 2}

INCLINACIÓN DE TALUD 6-100

INCLINACIÓN DE TALUD 10-200

INCLINACIÓN DE TALUD 20-30

INCLINACIÓN DE TALUD 30-40

INCLINACIÓN DE TALUD $35^{\circ}$

INCLINACIÓN DE TALUD 40-50

INCLINACIÓN DE TALUD 50-550

INCLINACIÓN DE TALUD 55-60

INCLINACIÓN DE TALUD 60-700

INCLINACIÓN DE TALUD 70-80 


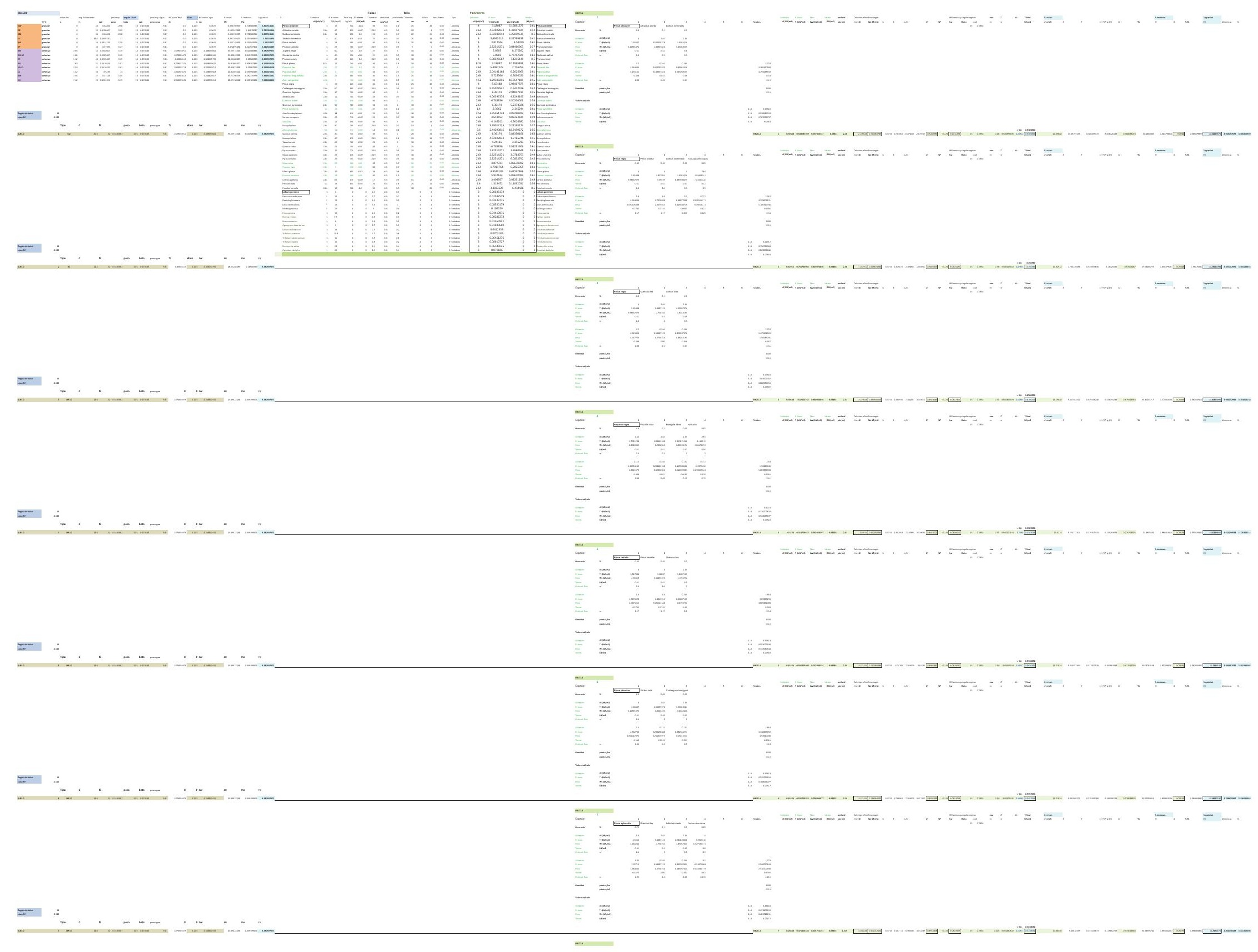




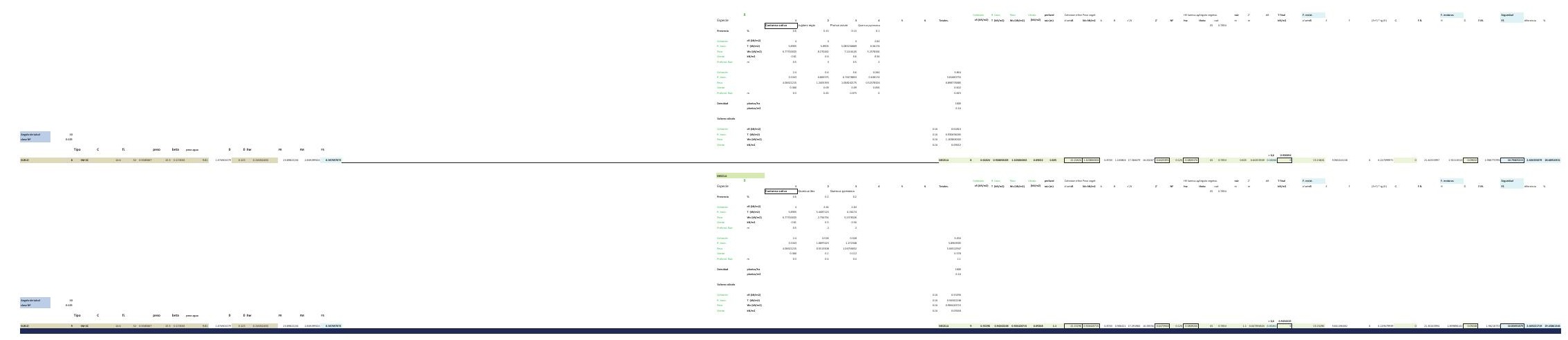




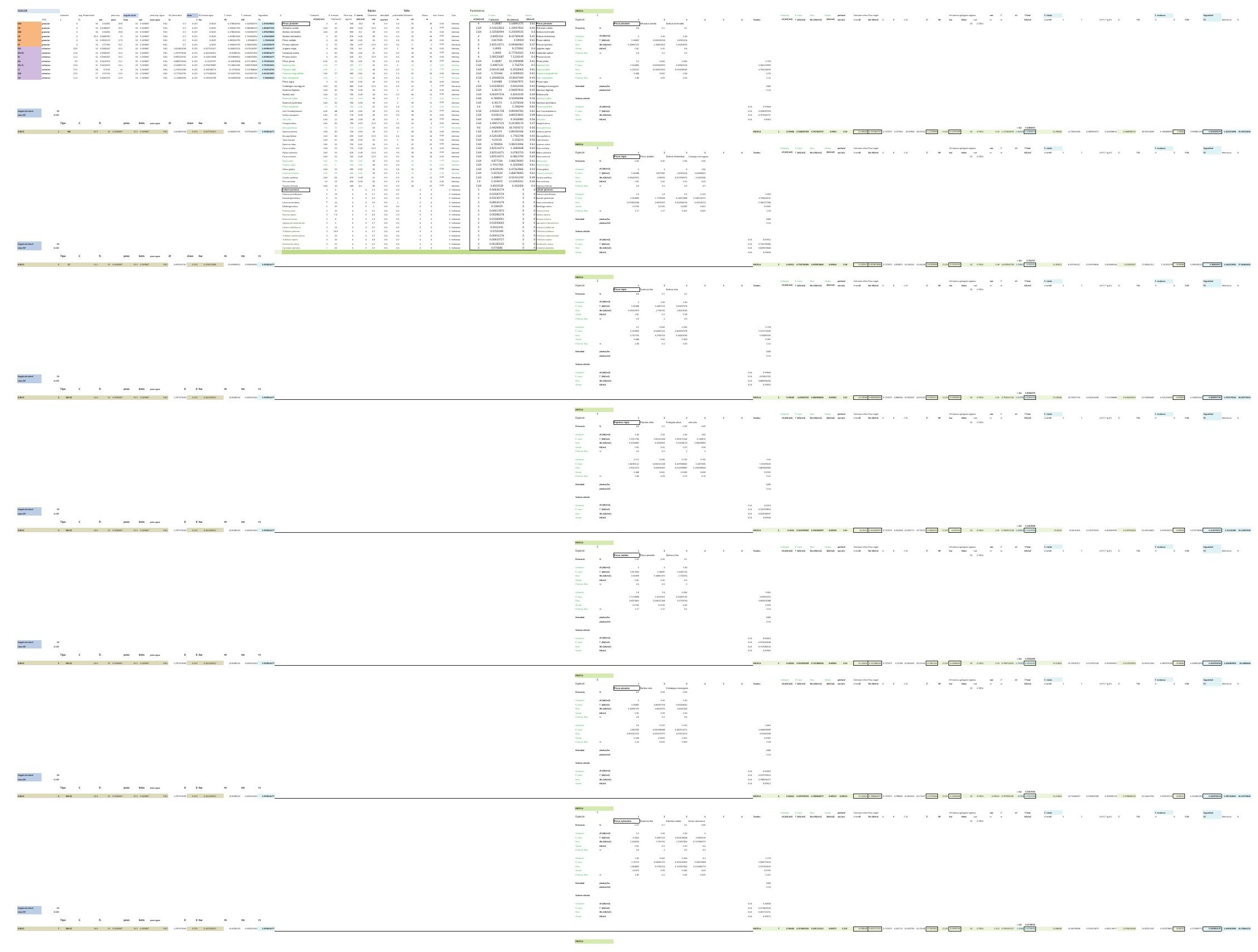




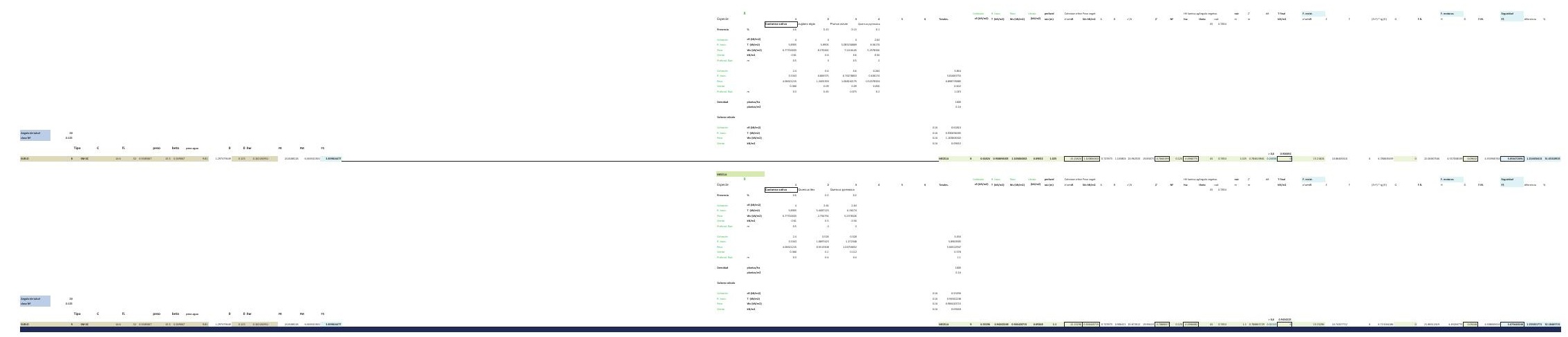




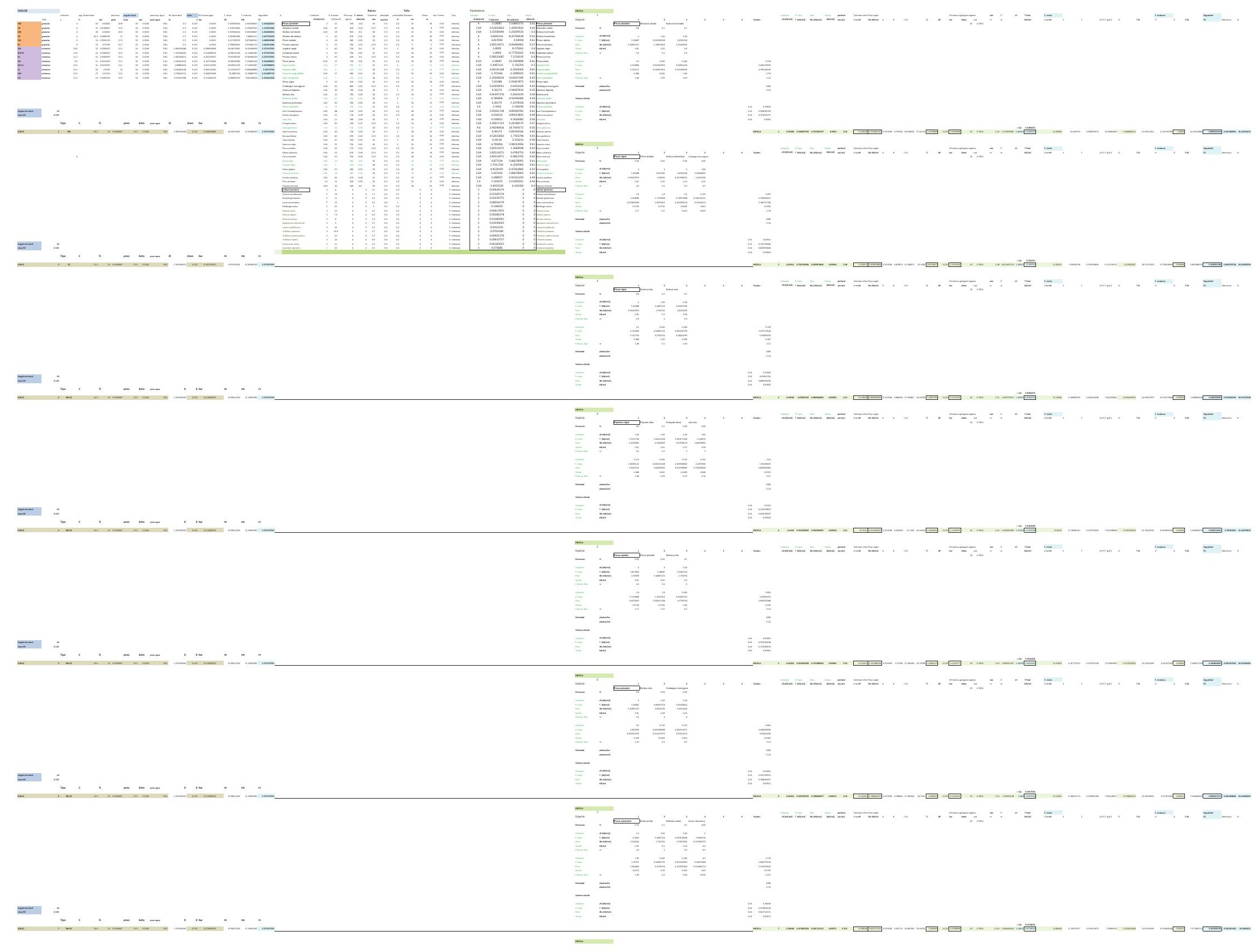




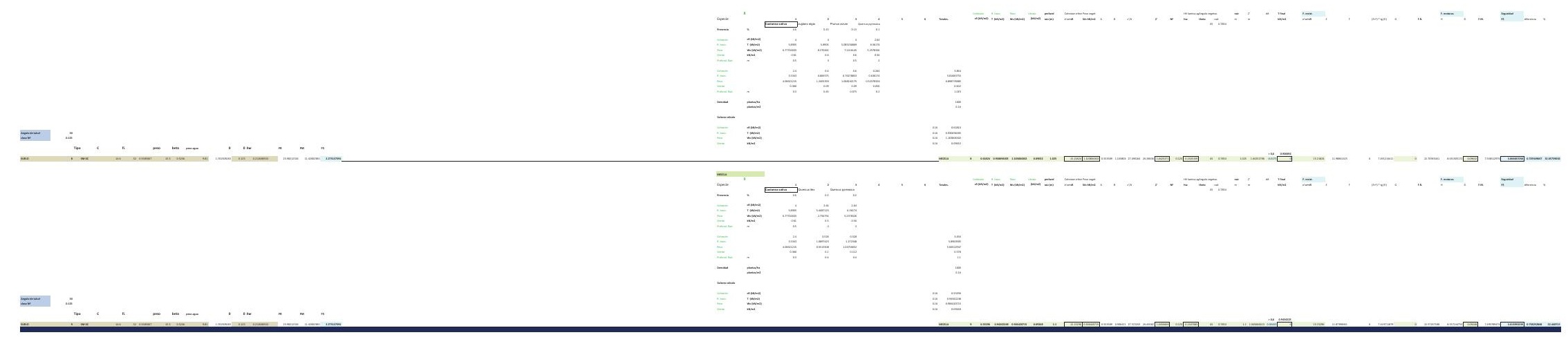




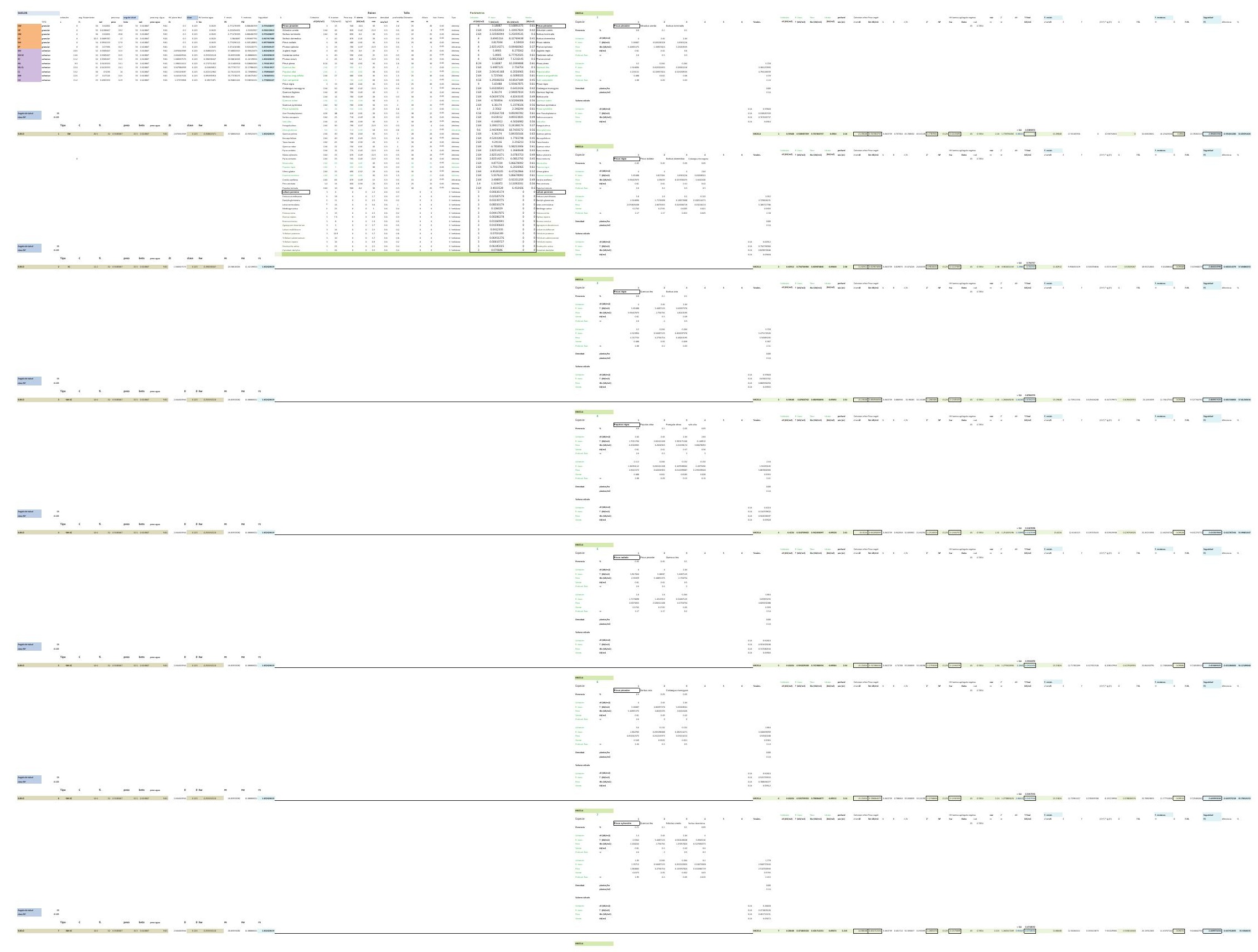




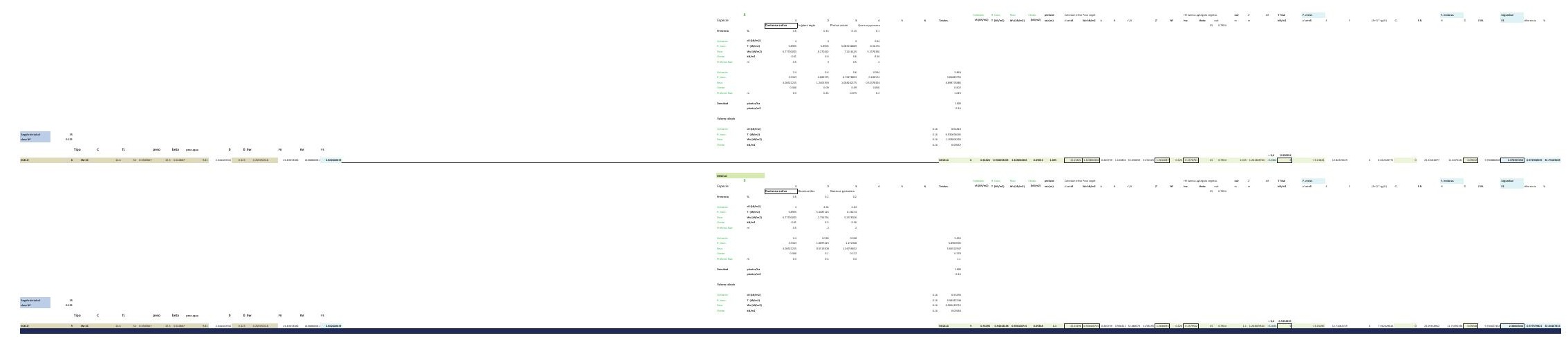




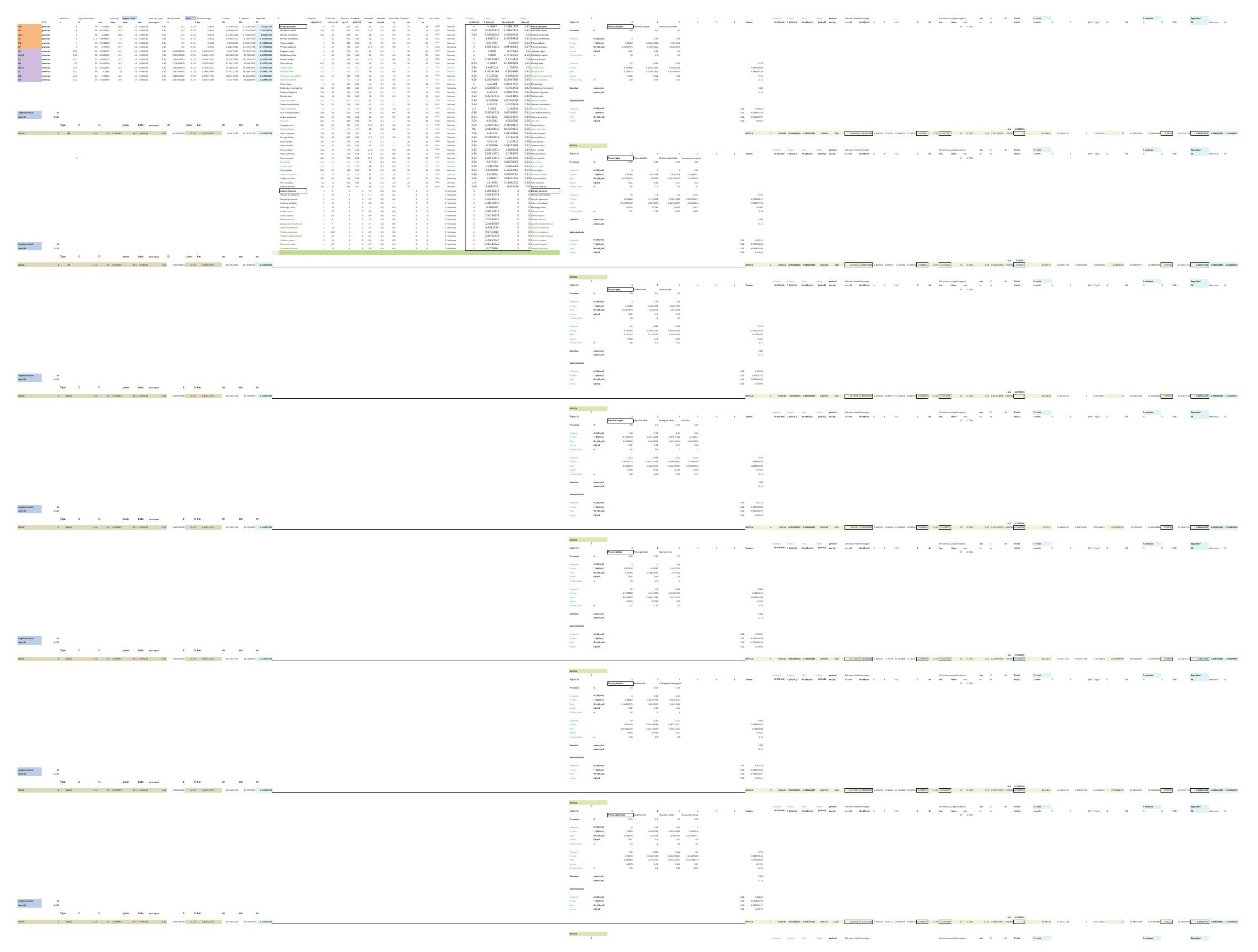




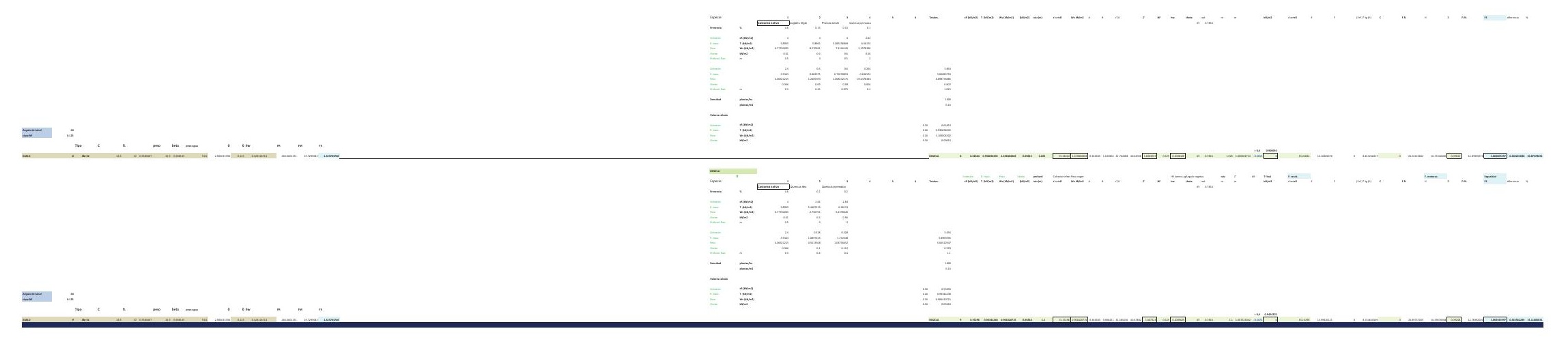




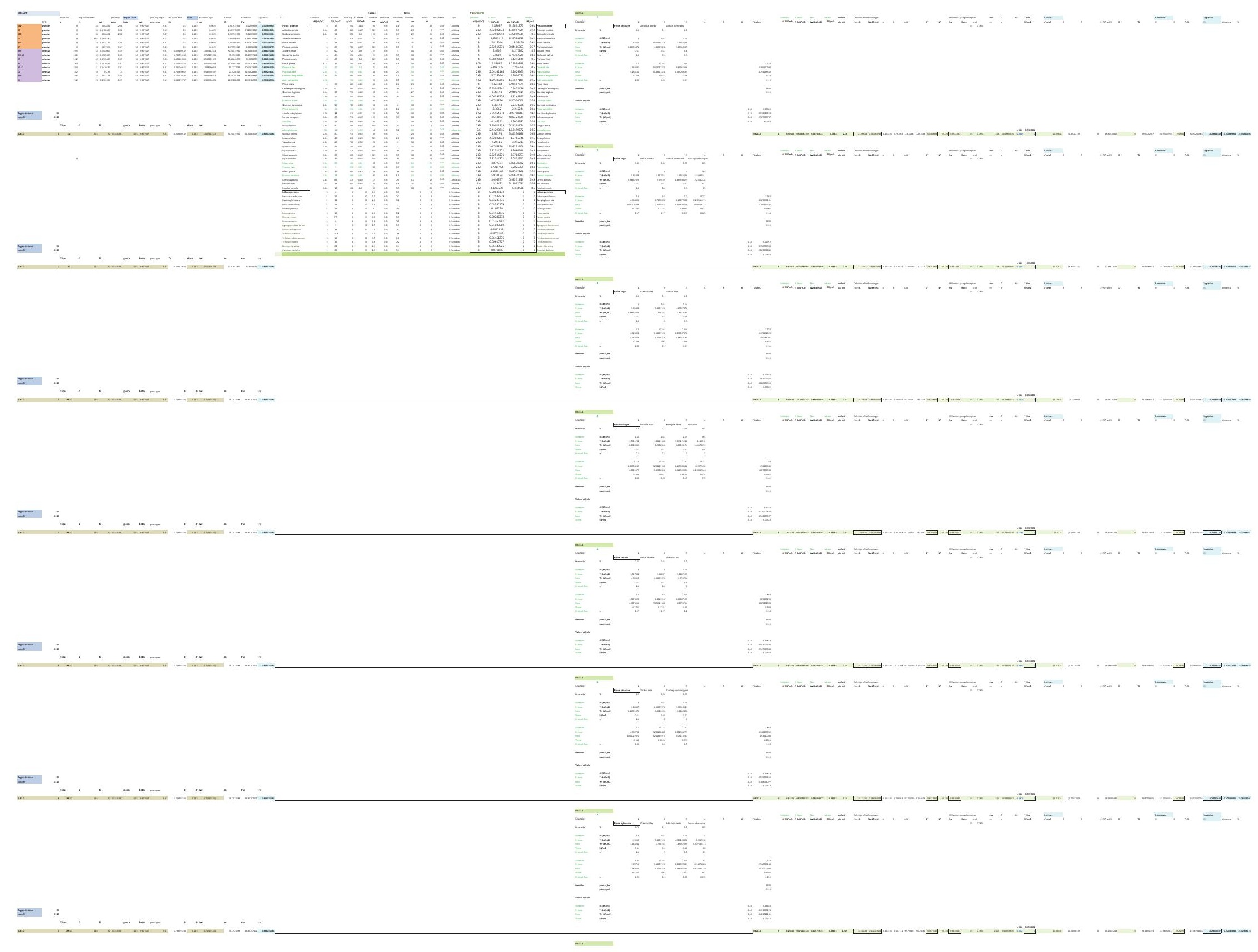




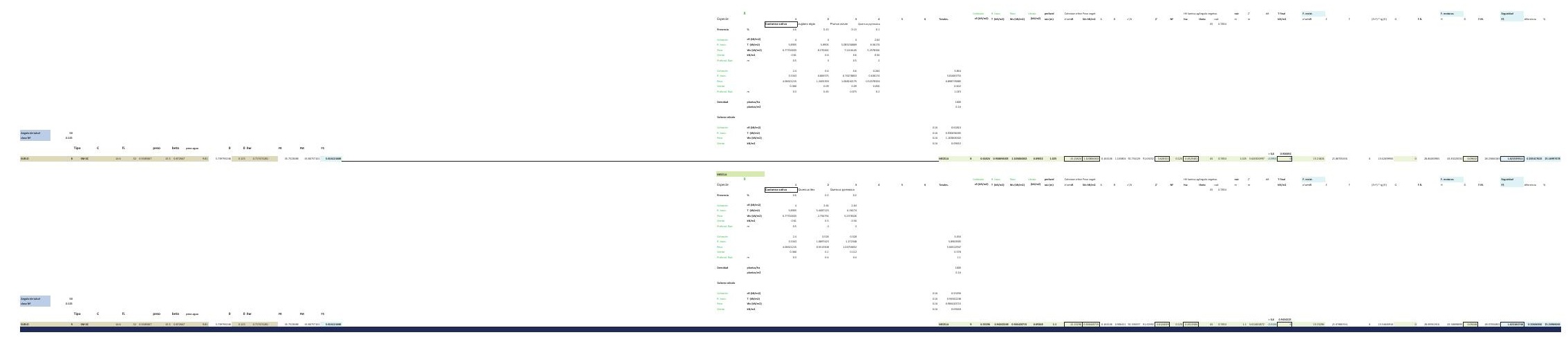




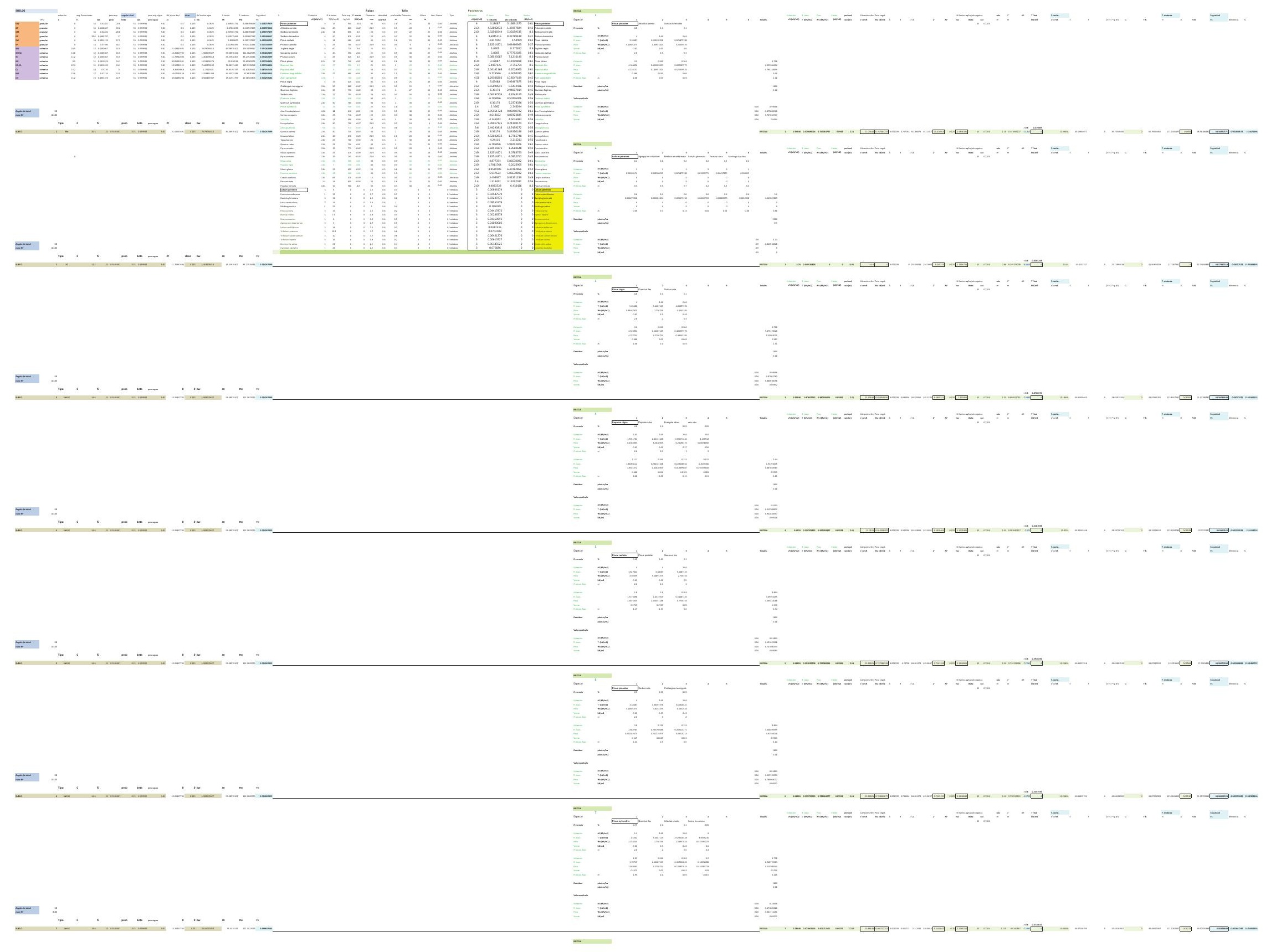




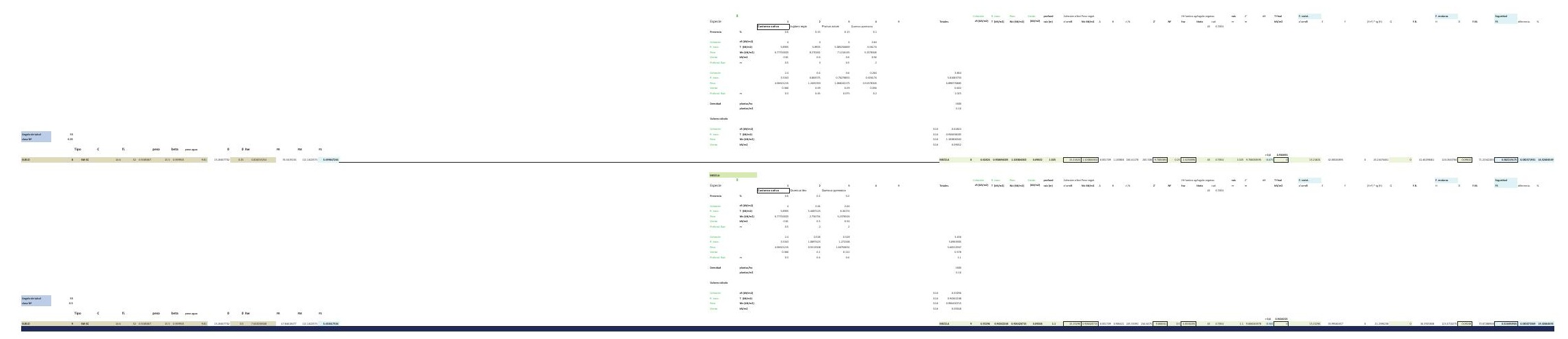




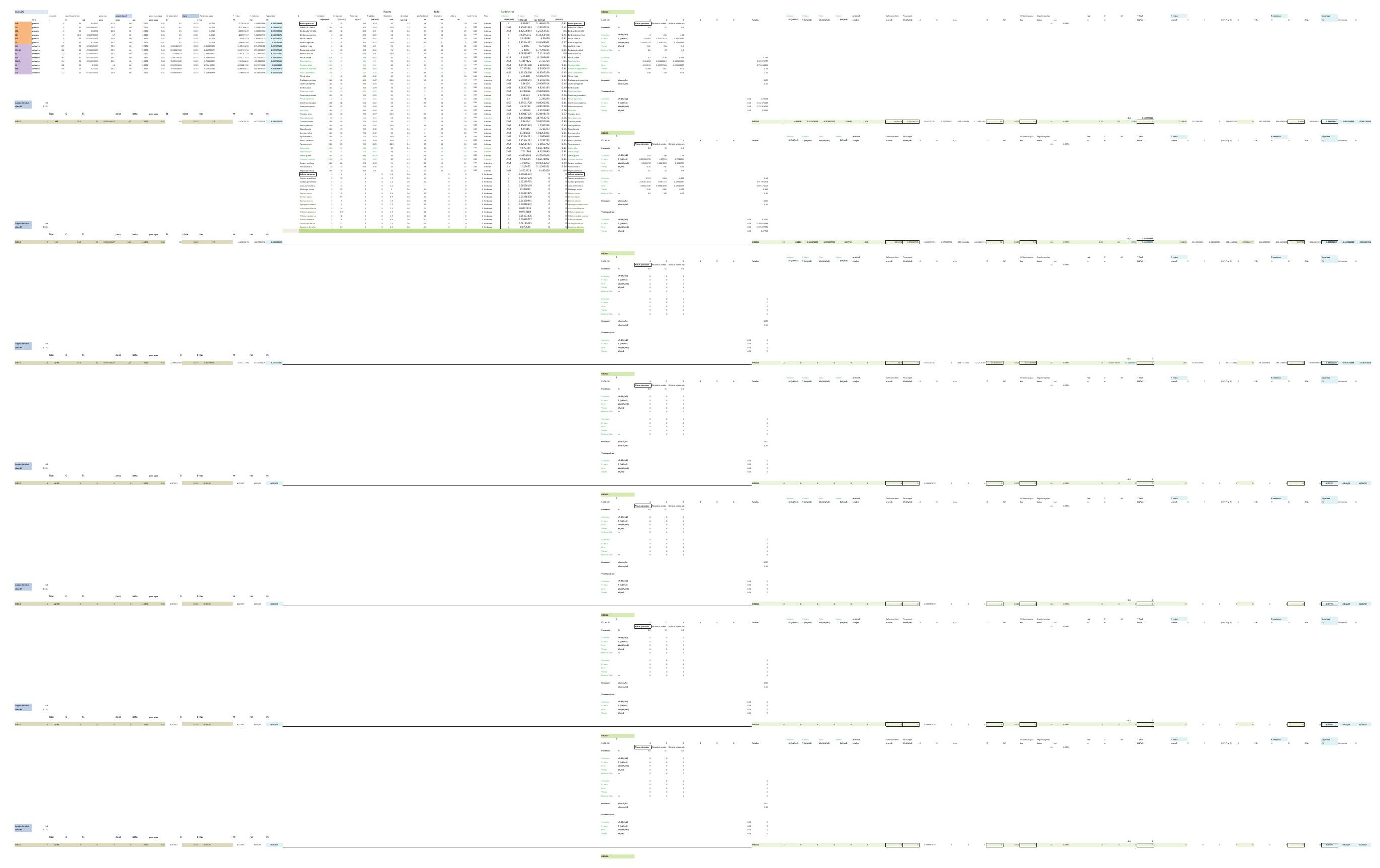


$=$

$$
=
$$

+........

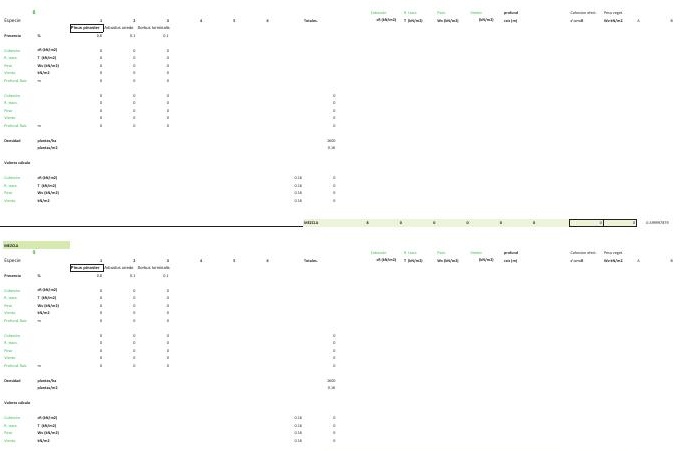

$\square-\square \cdots \cdots$

$\square-\cdots$

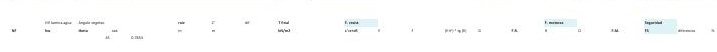




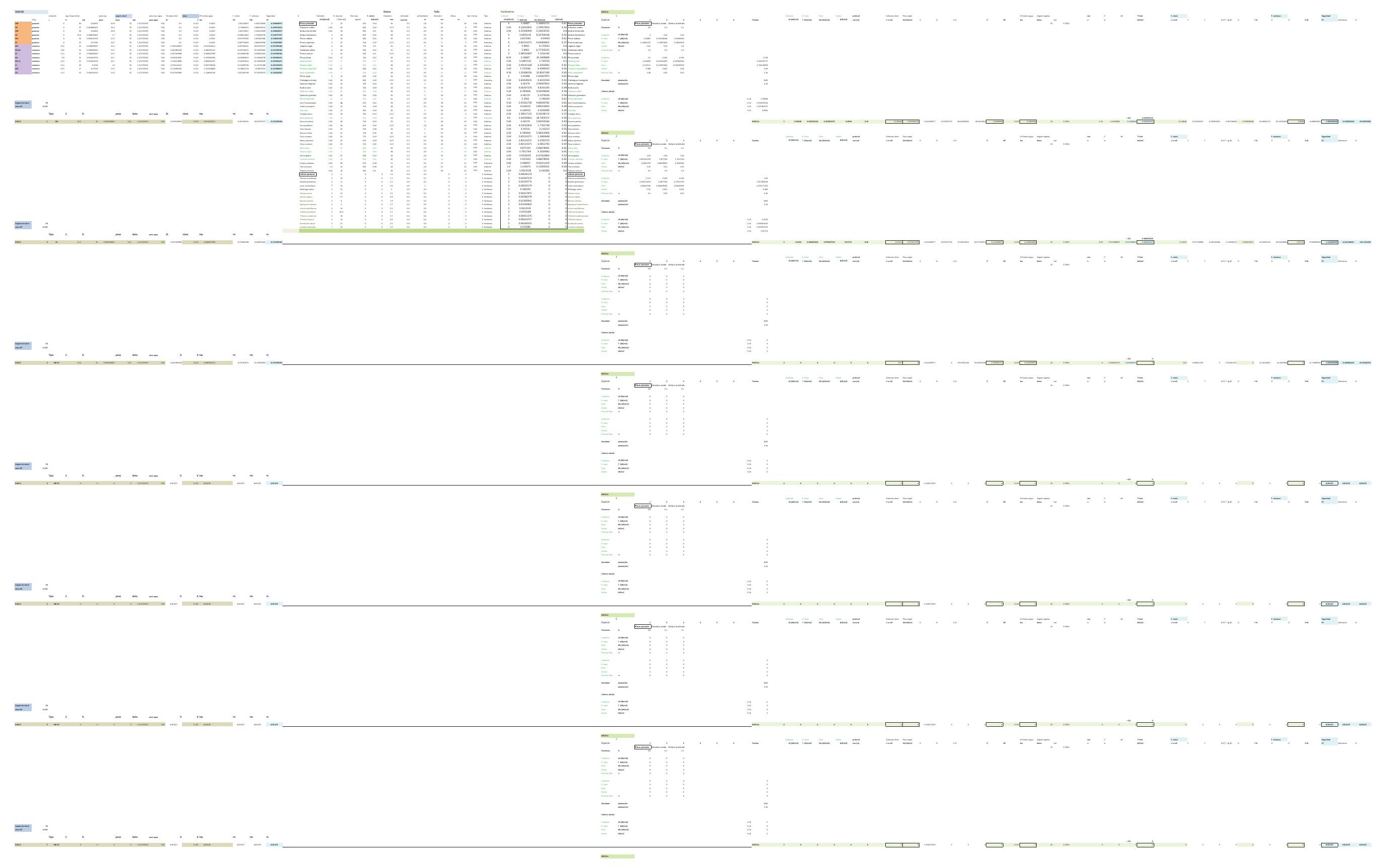




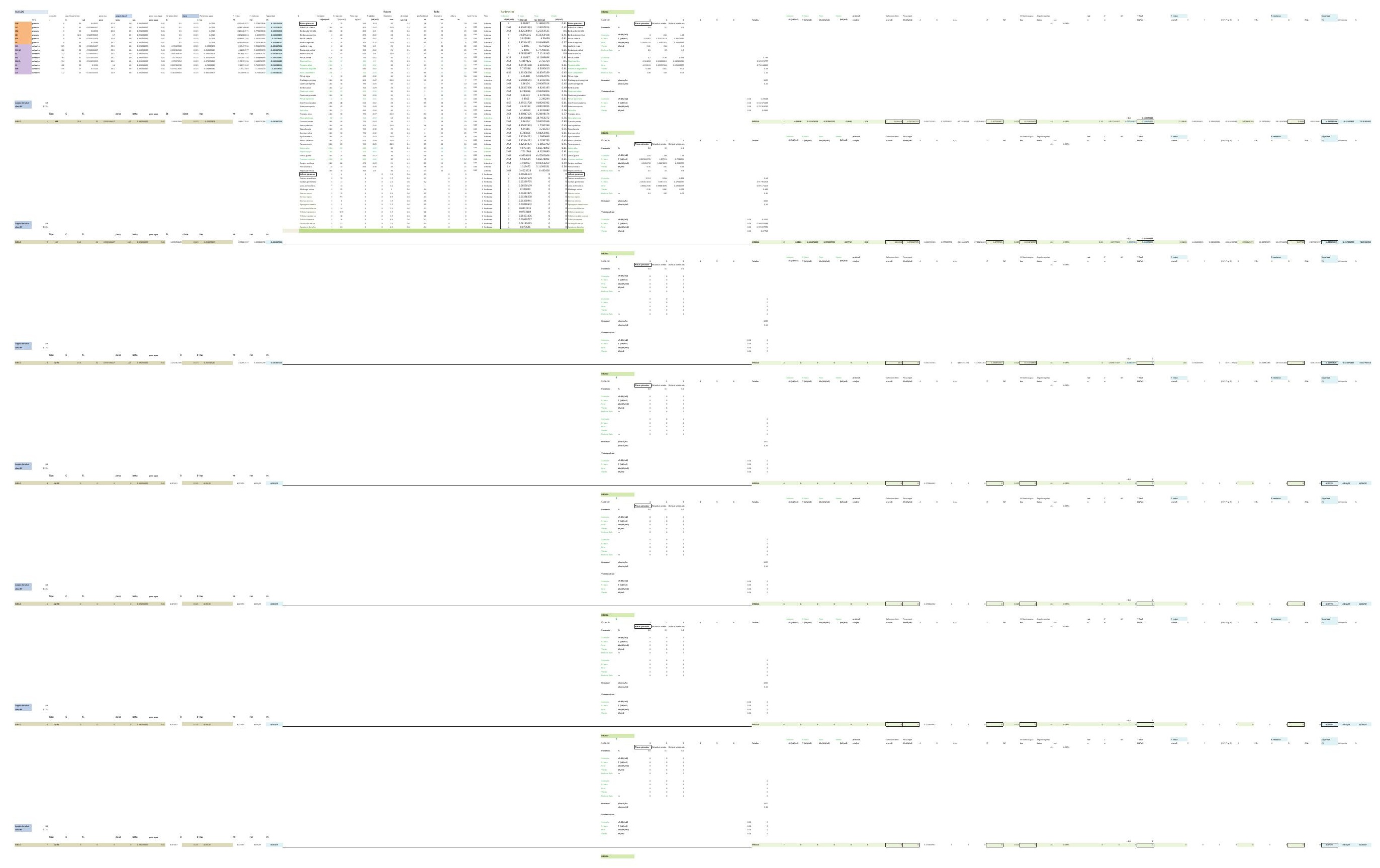


$=$

$\equiv \ldots \ldots \ldots \ldots$

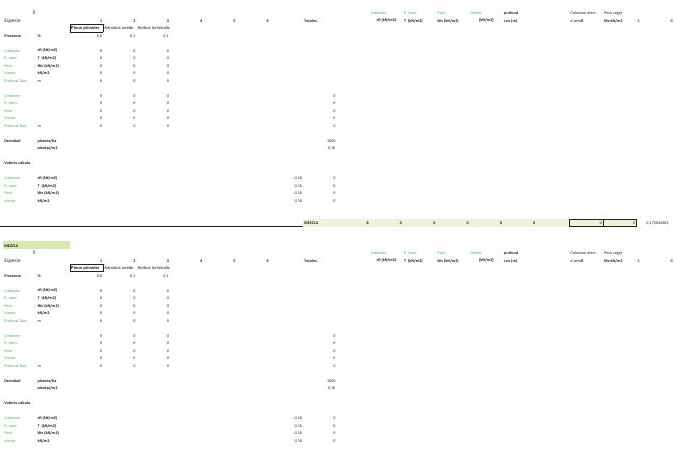

■ $\square-\cdots$

$\square-\cdots$

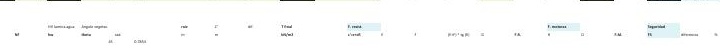


DESARROLLO DE UNA APLICACIÓN IMFORMÁTICA PARA EL CÁLCULO DE SOSTENIMIENTO DE TALUDES MEDIANTE VEGETACIÓN

B02. DENSIDAD DE PLANTACIÓN: 1.600 plantas/ha.

\section{B02-3.POSICIÓN N.F. 3}

INCLINACIÓN DE TALUD 6-100

INCLINACIÓN DE TALUD 10-200

INCLINACIÓN DE TALUD 20-30

INCLINACIÓN DE TALUD 30-40

INCLINACIÓN DE TALUD $35^{\circ}$

INCLINACIÓN DE TALUD 40-50

INCLINACIÓN DE TALUD 50-550

INCLINACIÓN DE TALUD 55-60

INCLINACIÓN DE TALUD 60-700

INCLINACIÓN DE TALUD 70-80 


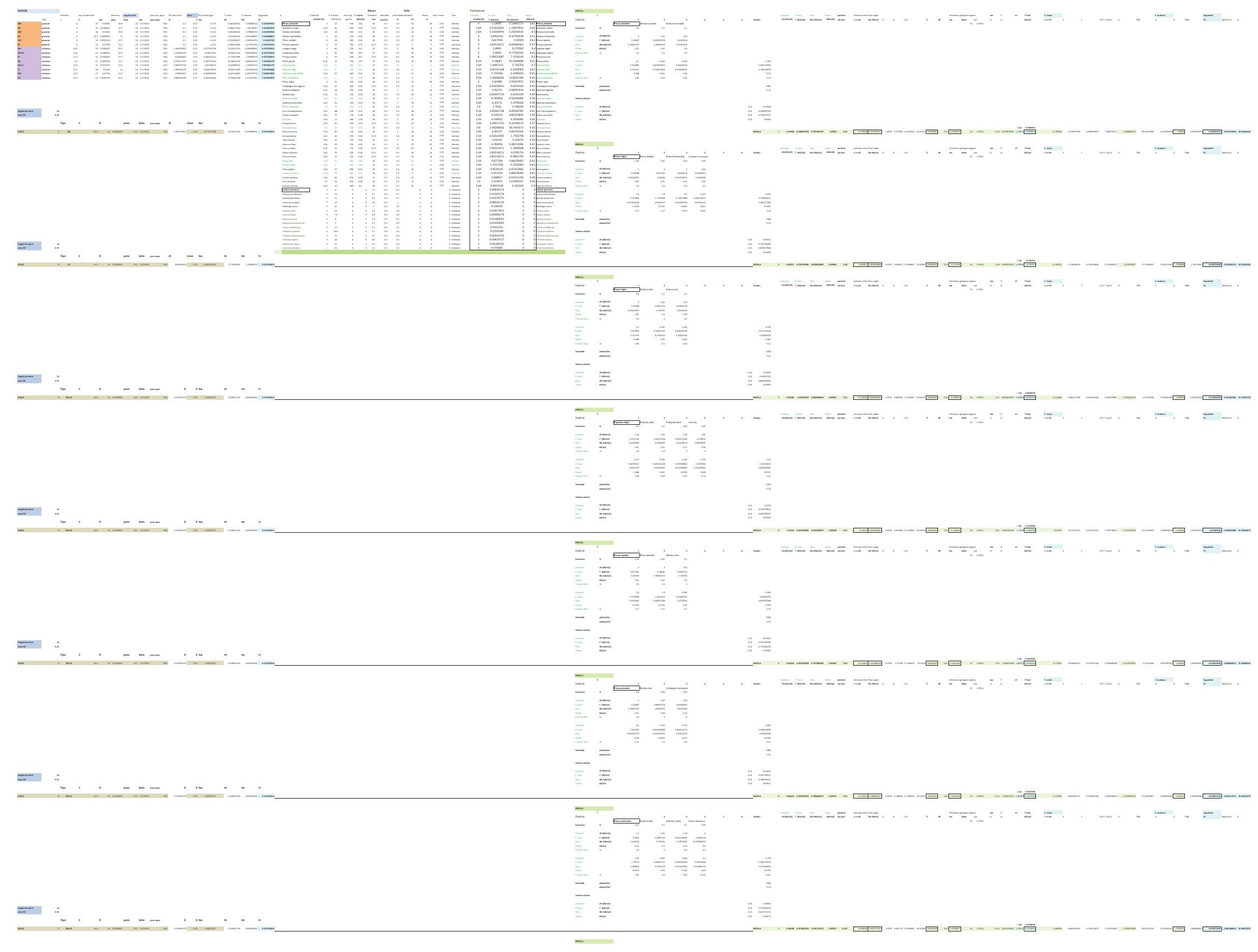




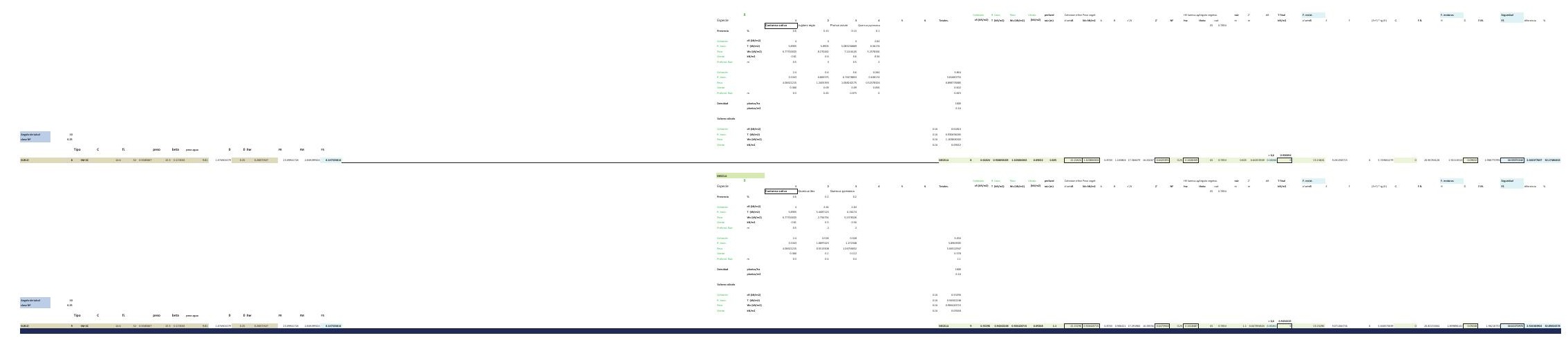




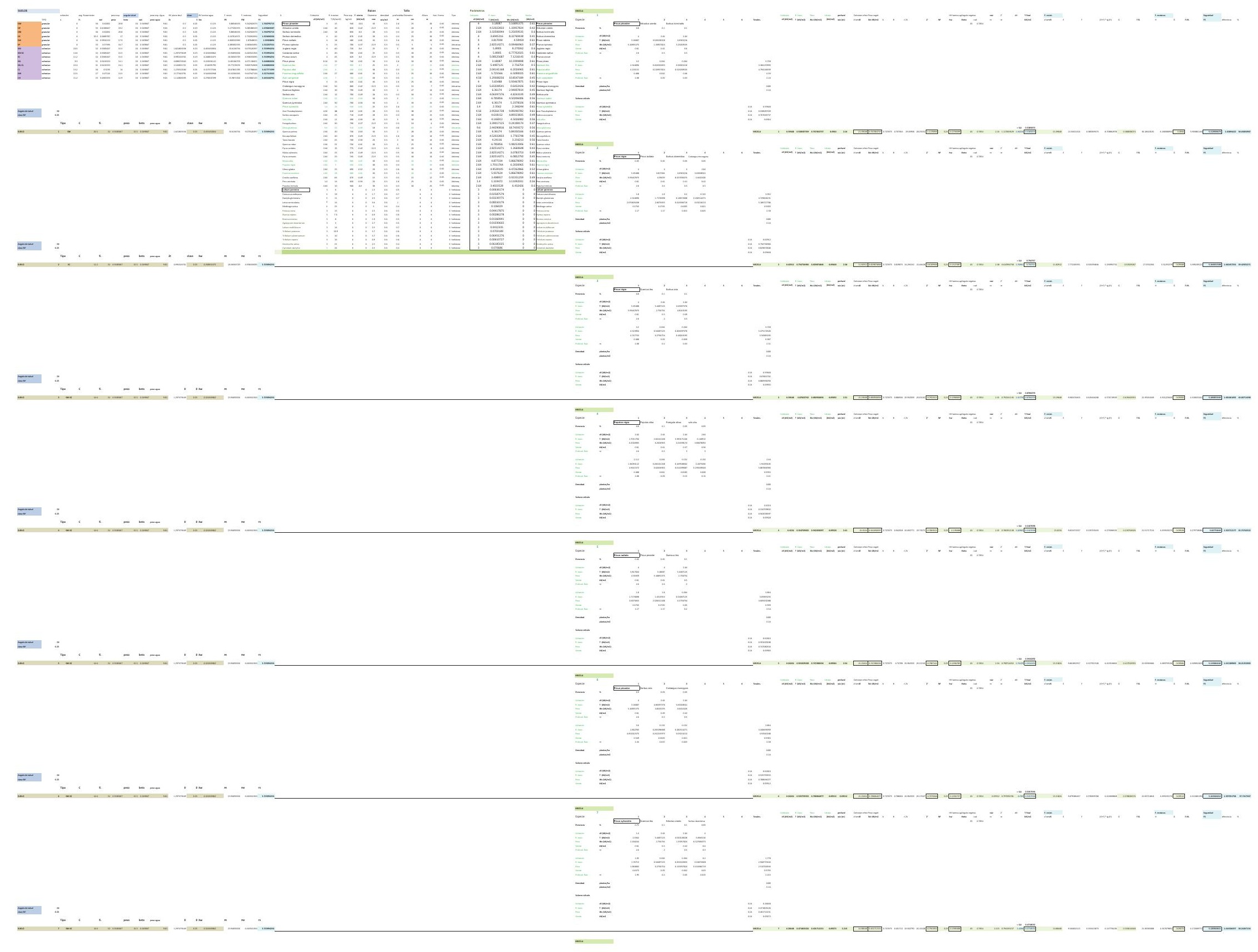




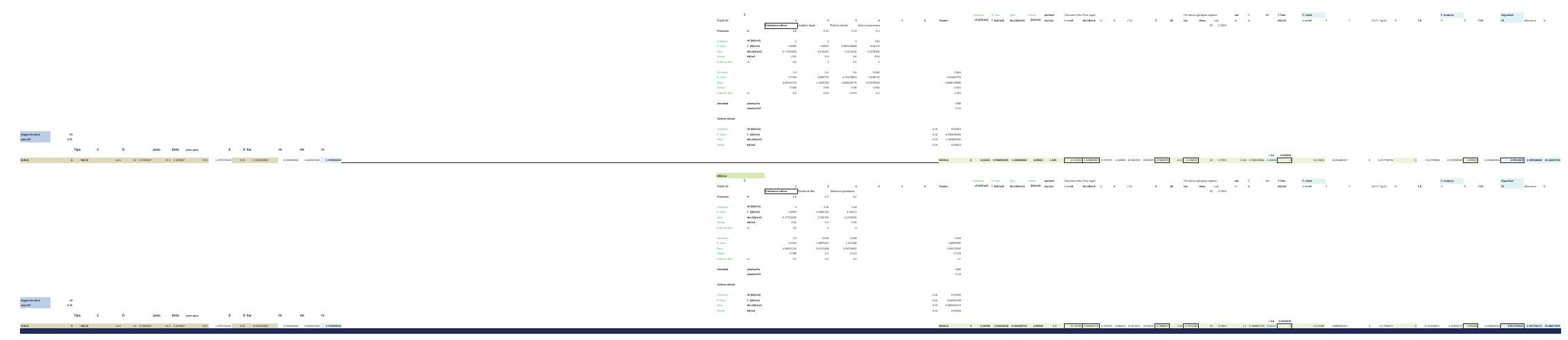




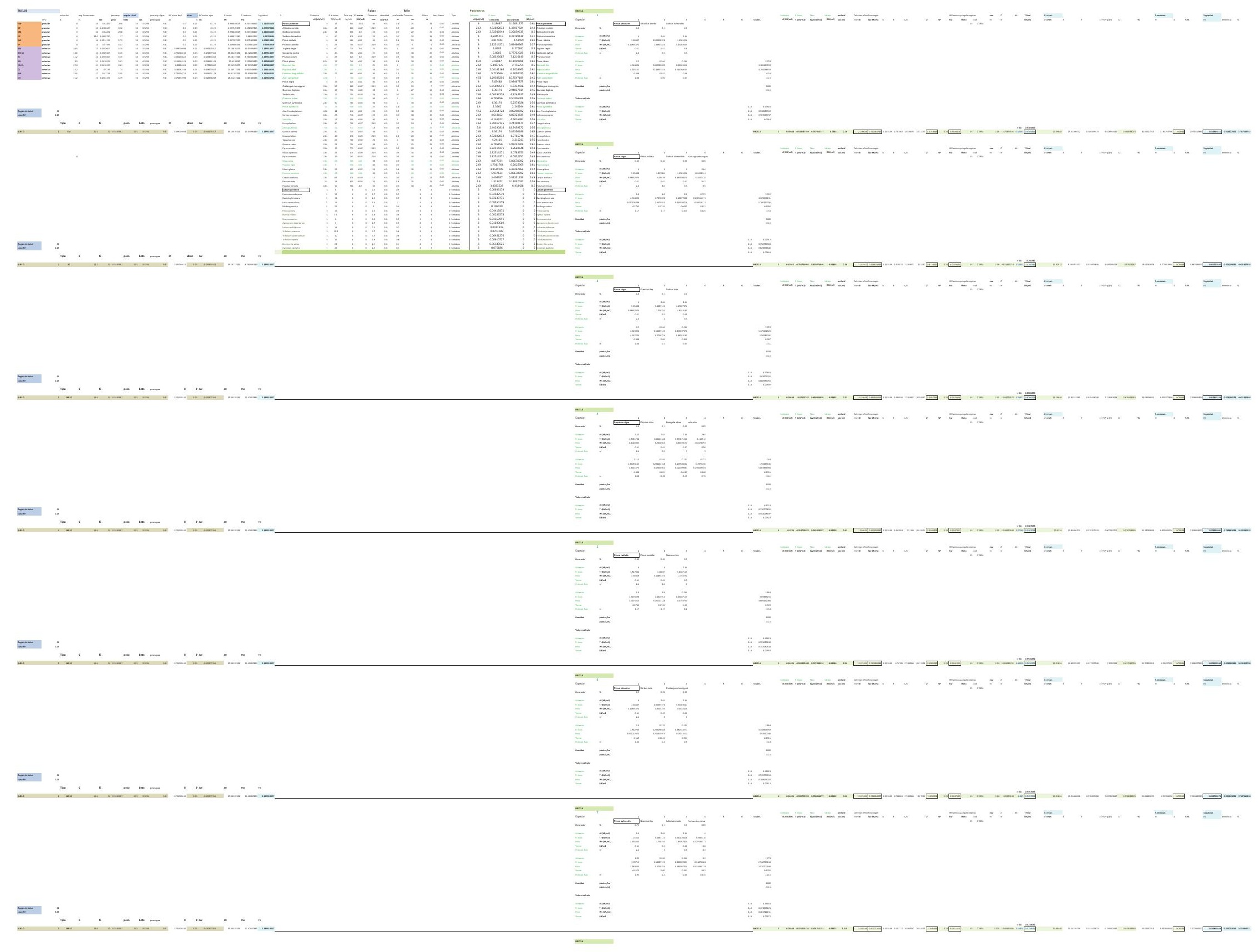




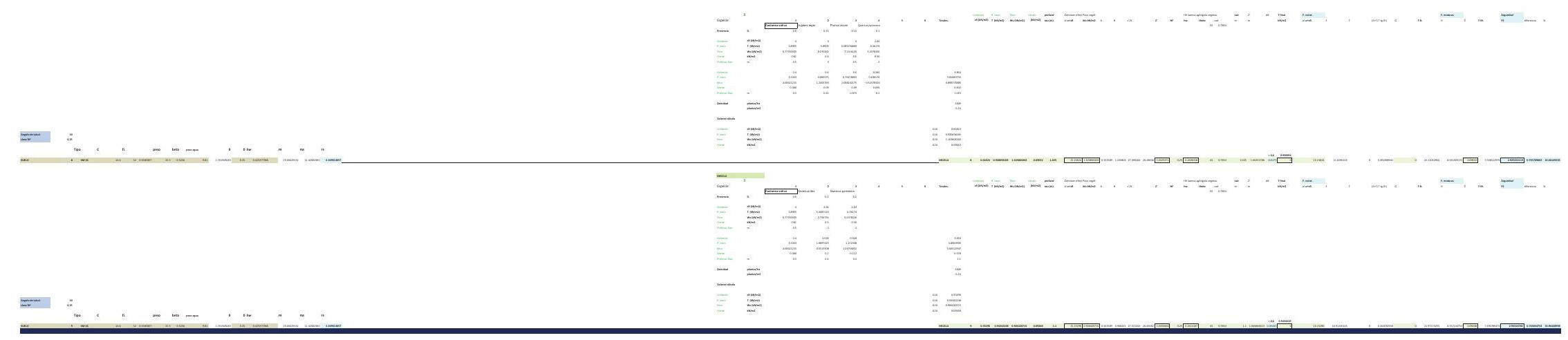




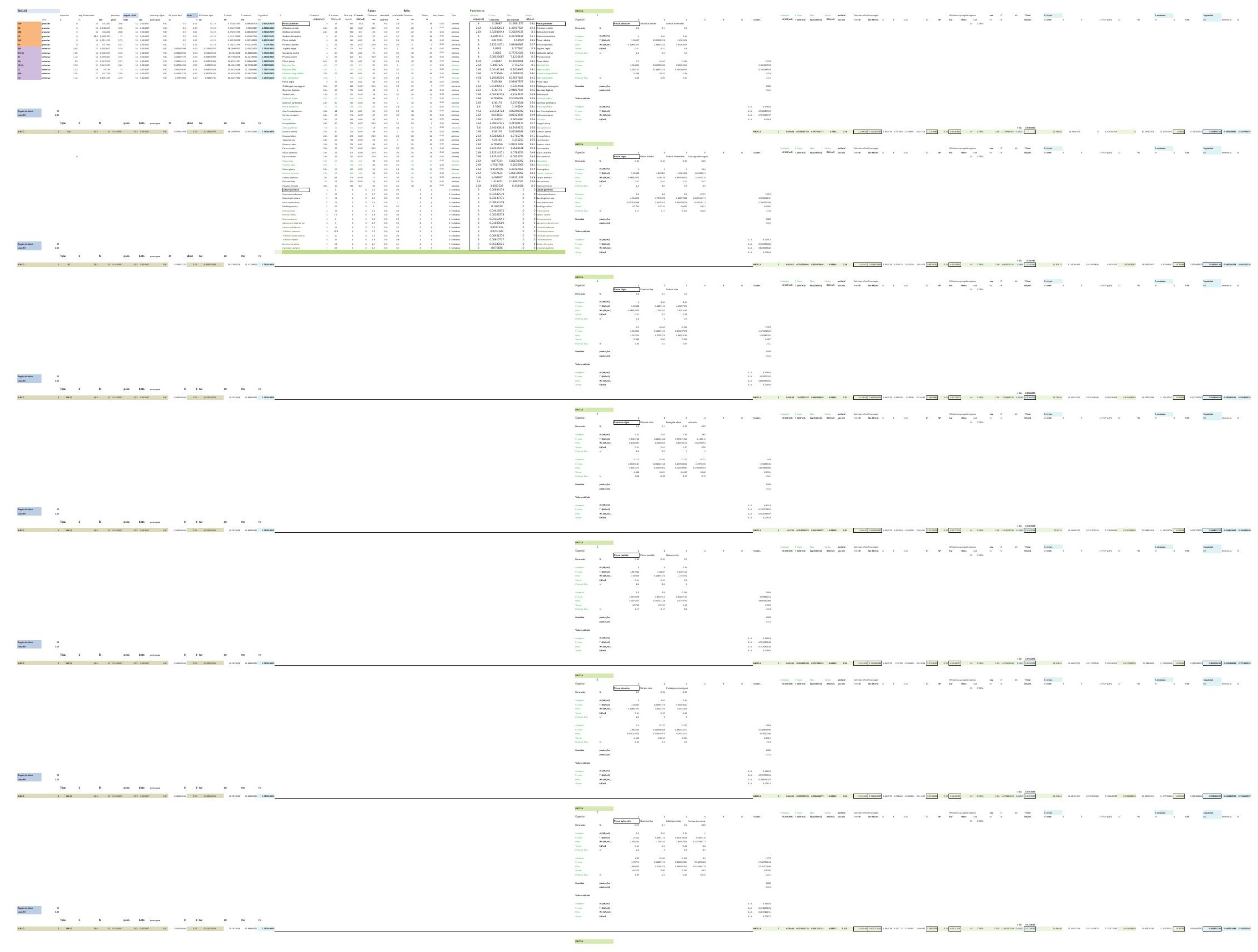




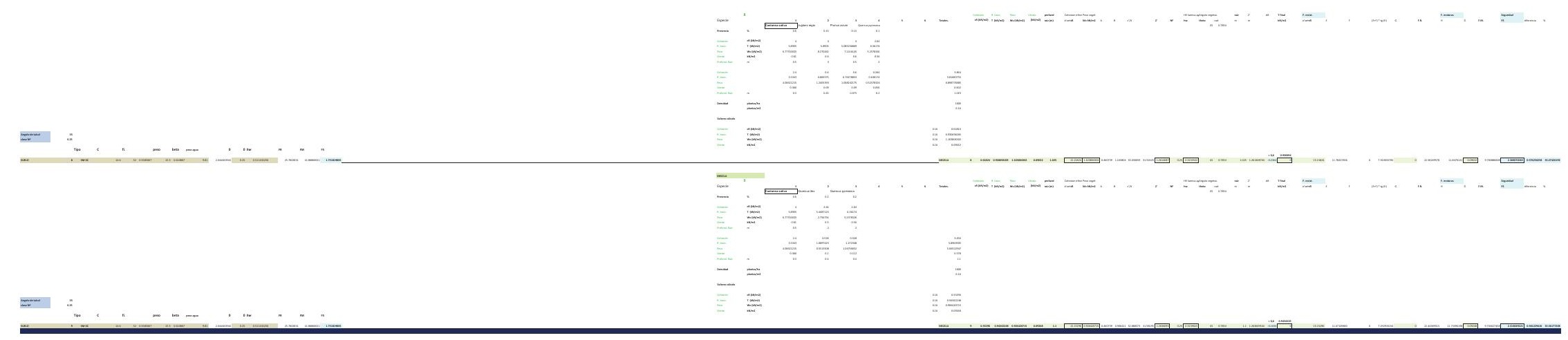




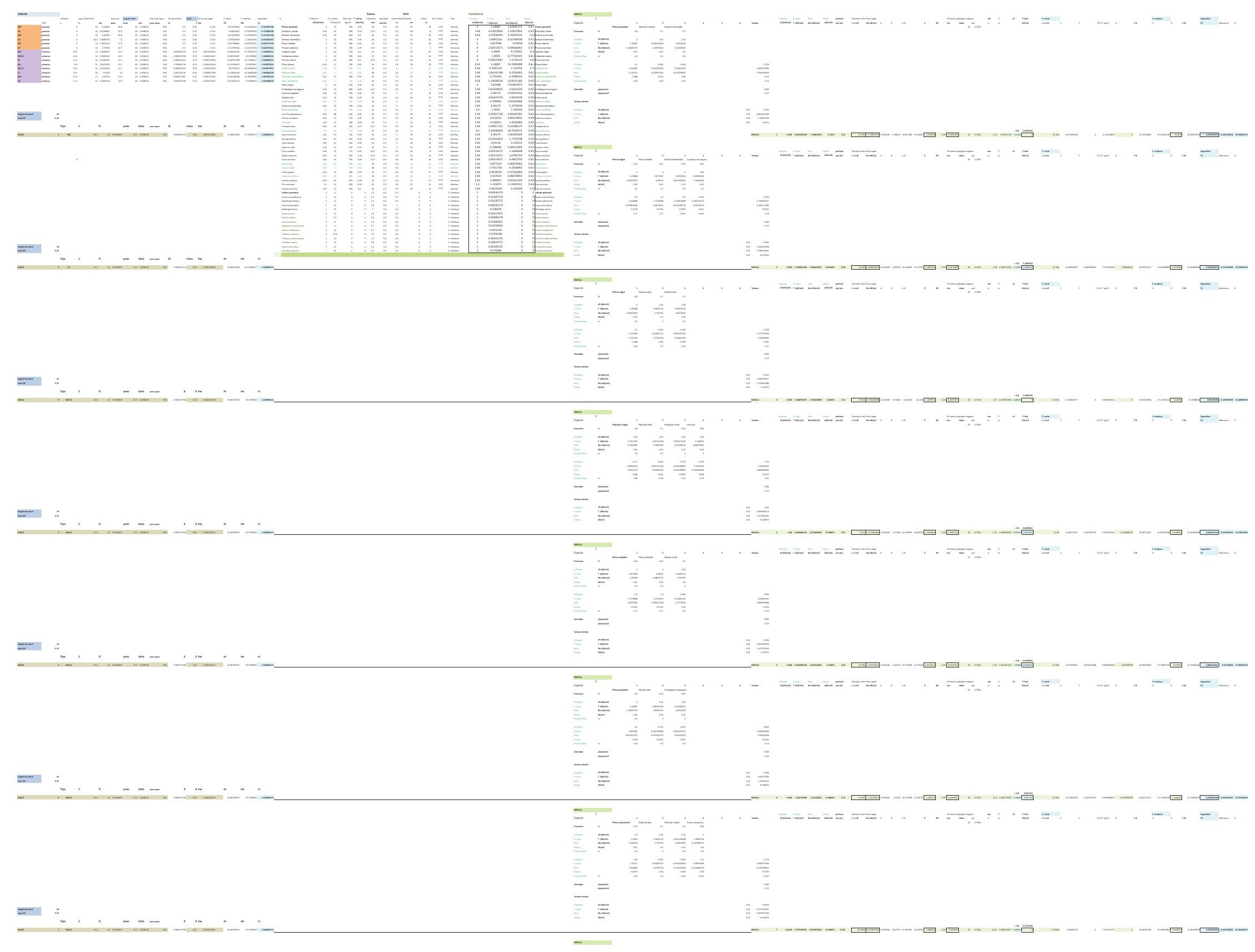


$=$

$=$

$n+\ldots+\cdots+\cdots$ $\pm$

(...

$\equiv=-$

E. $=$

$-$ 


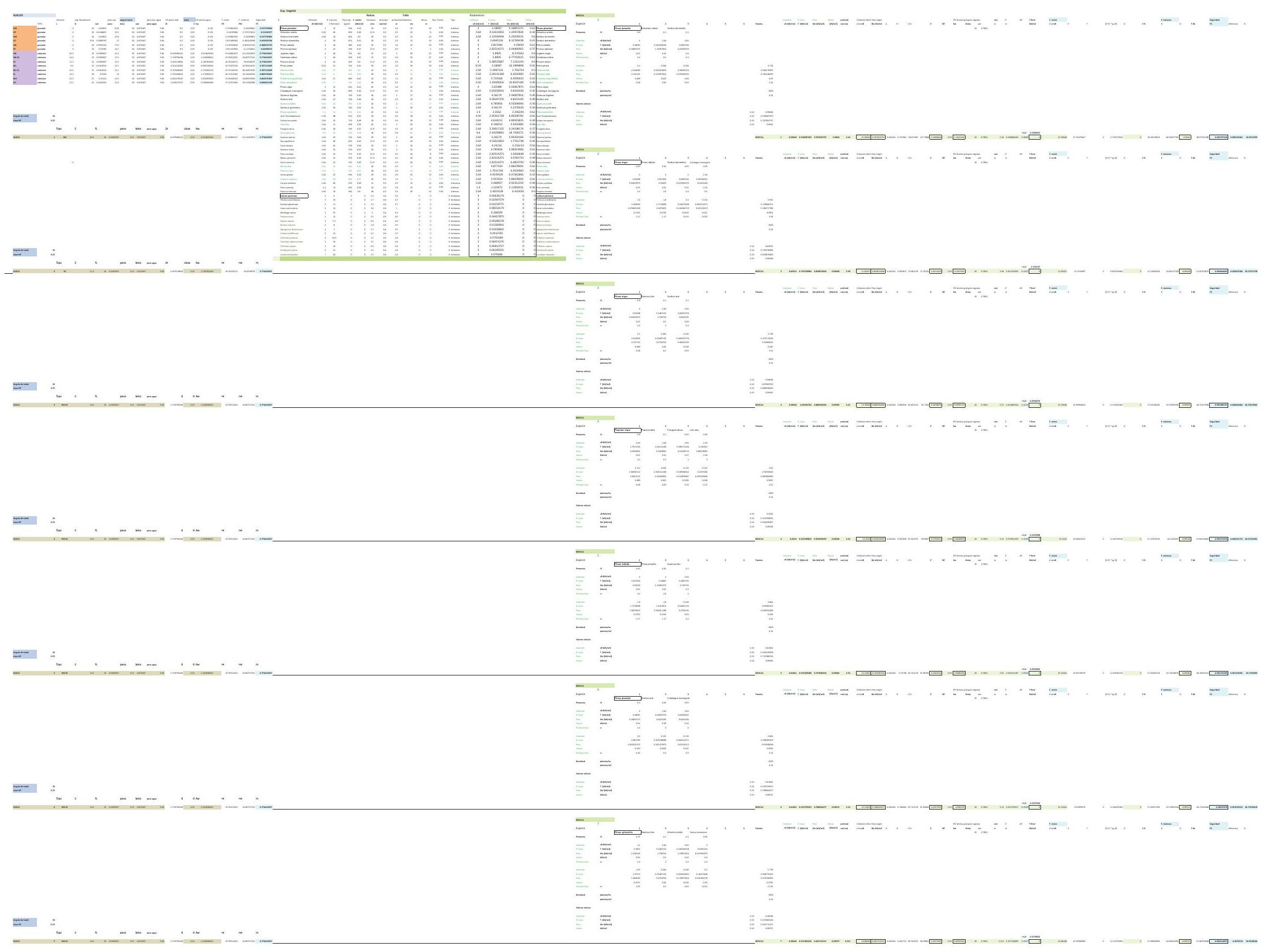




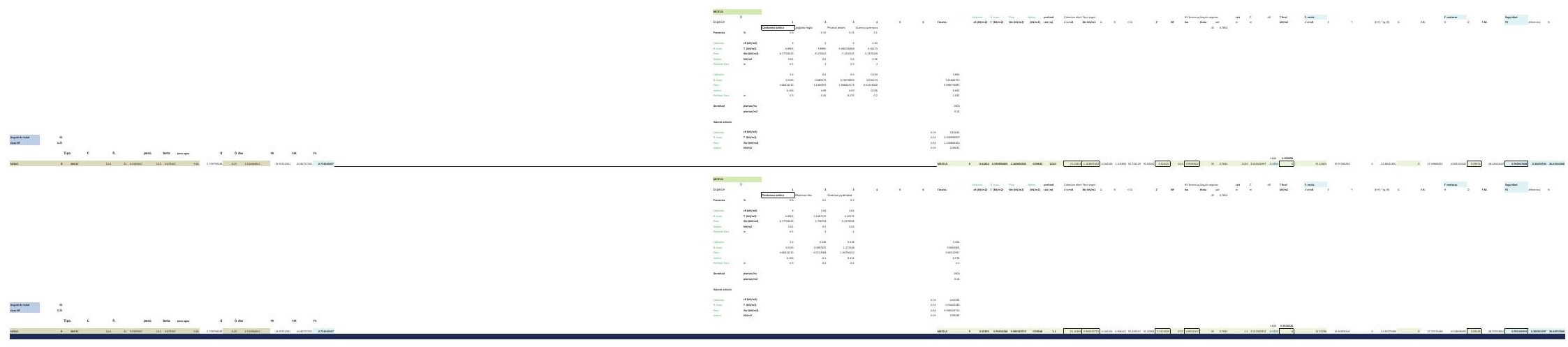




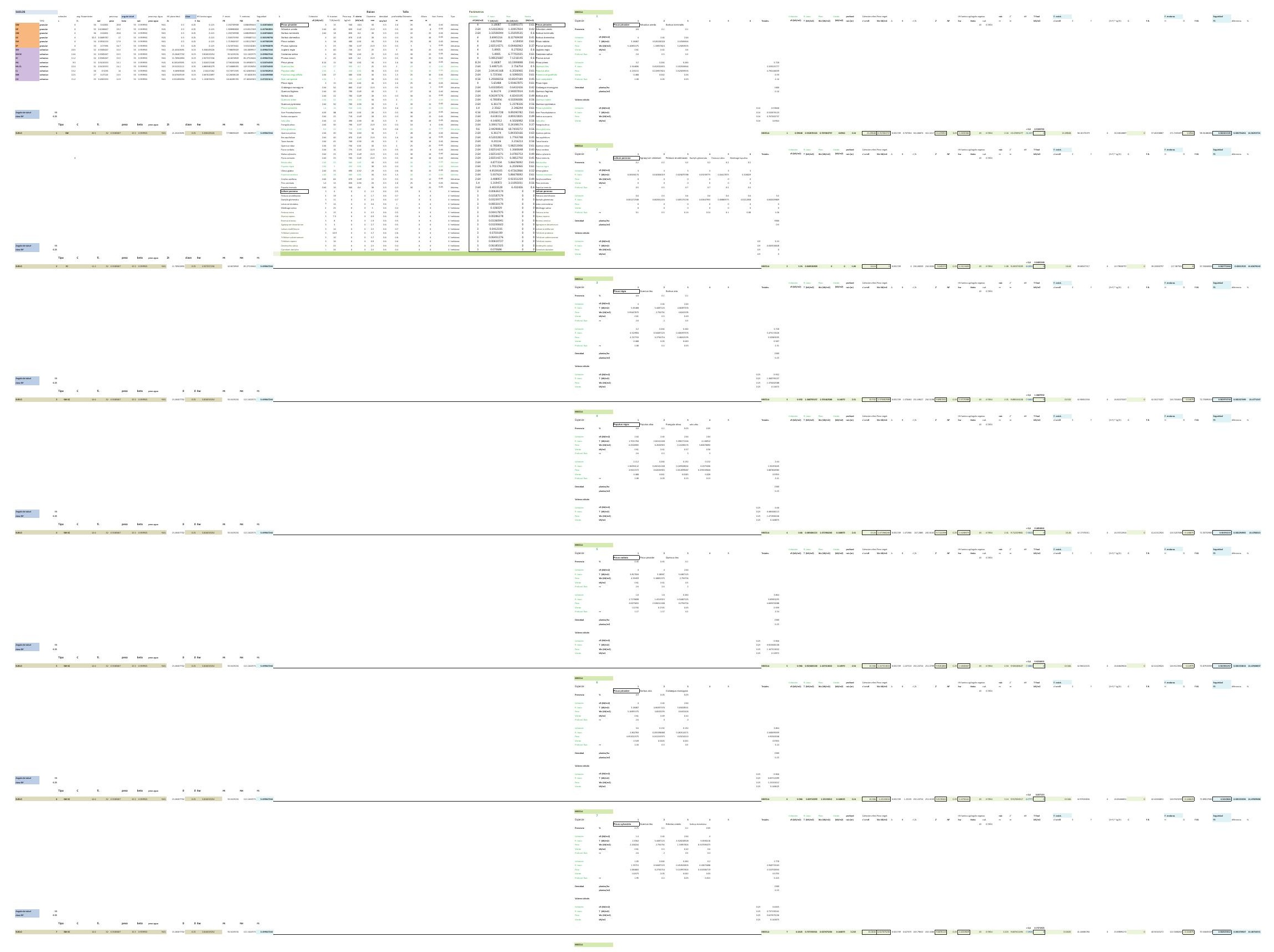




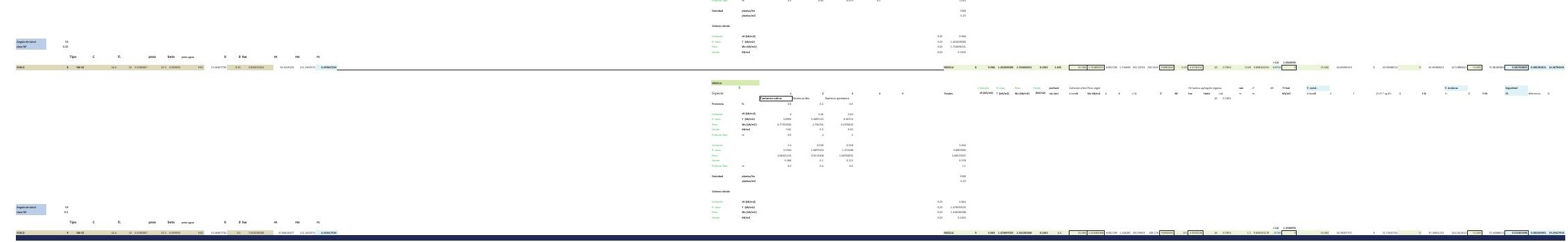




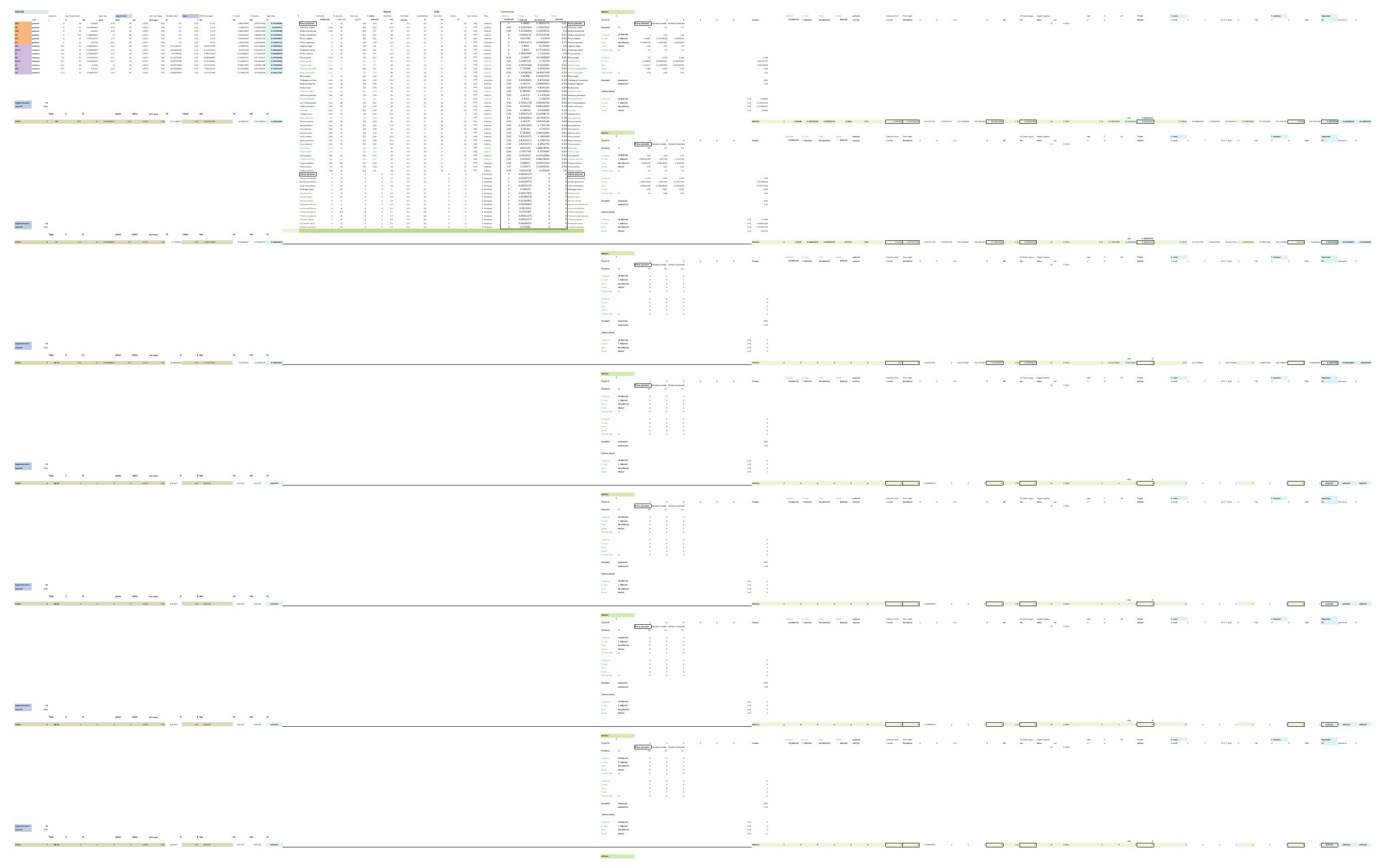




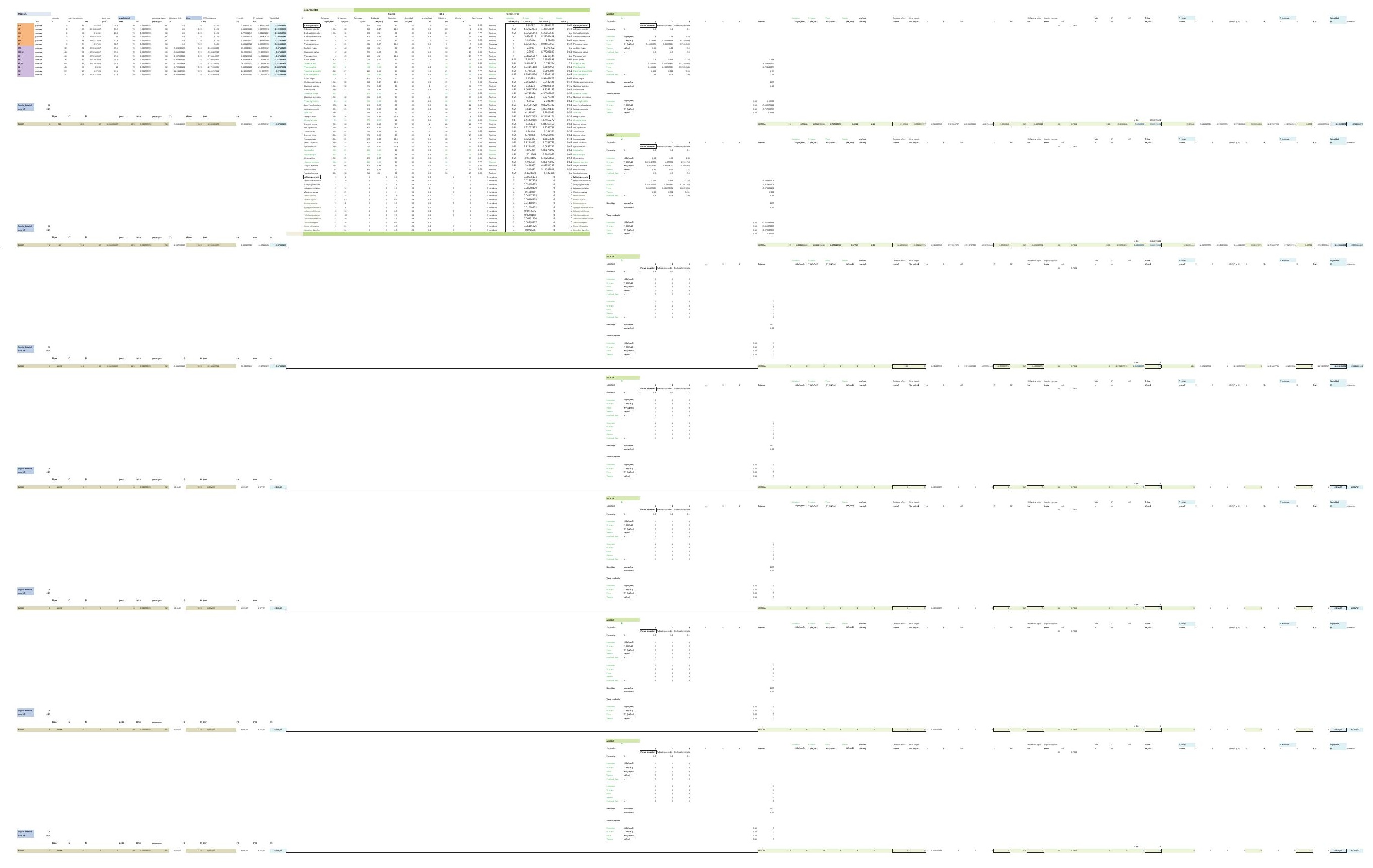




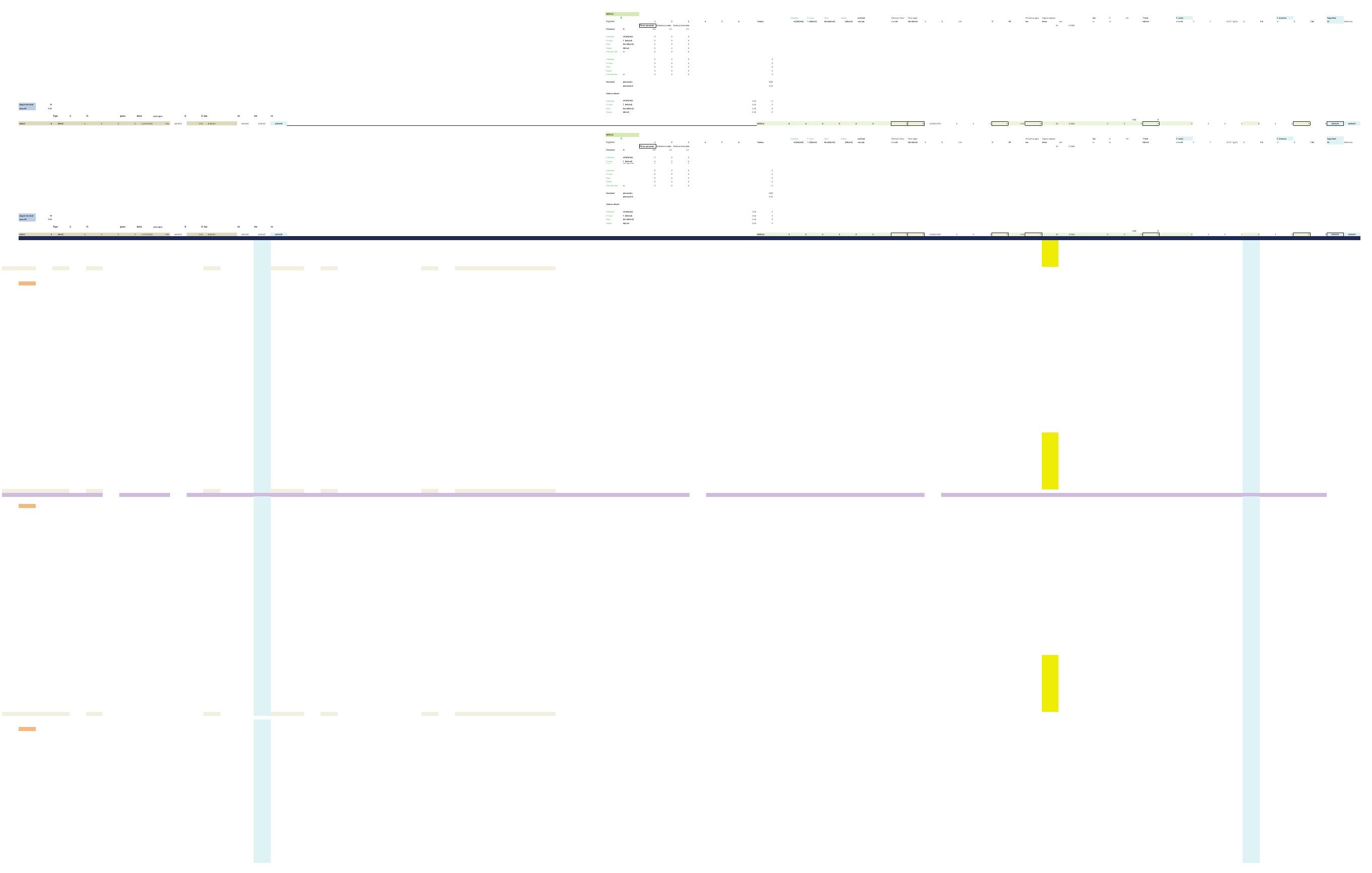




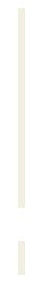




-




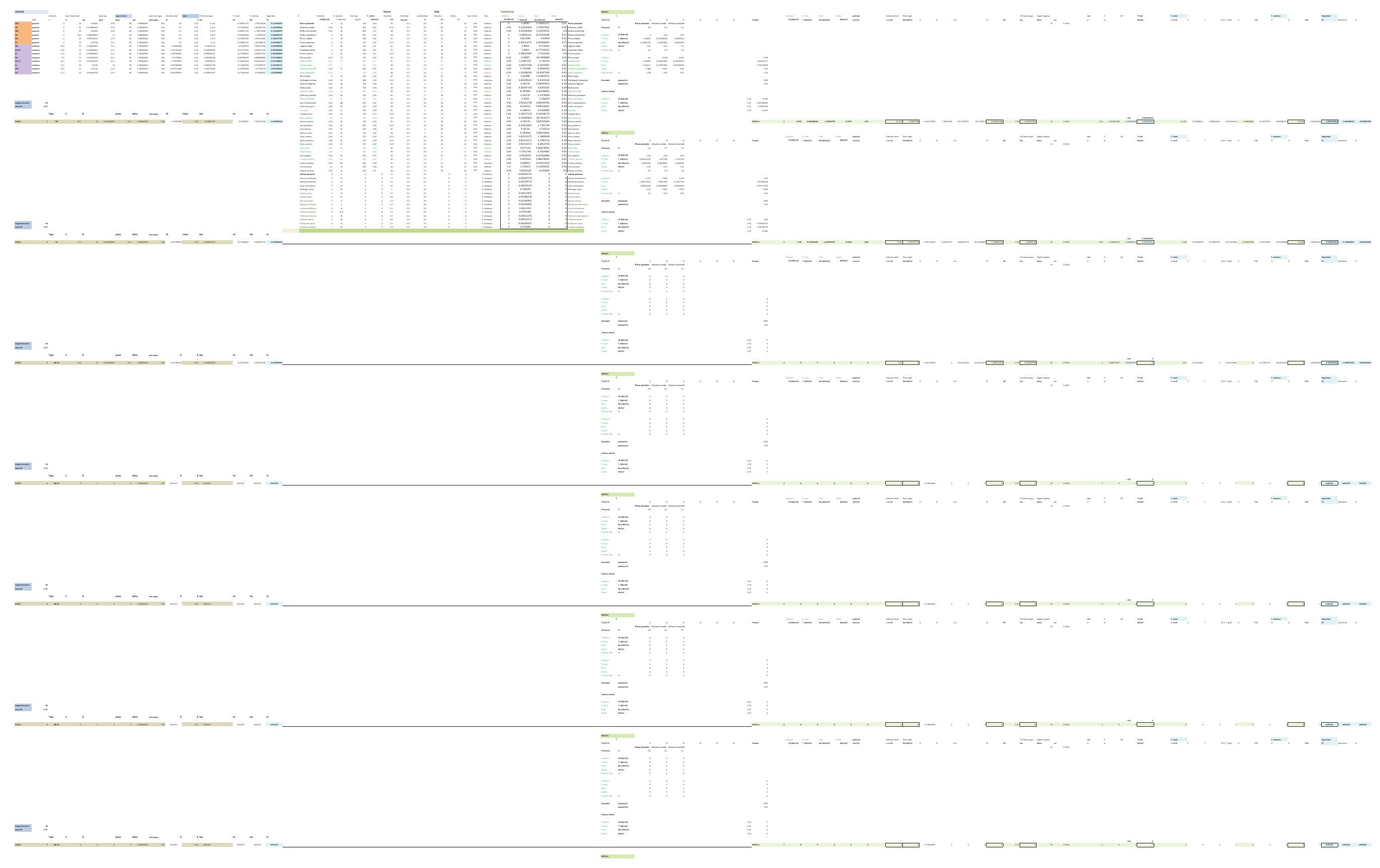


DESARROLLO DE UNA APLICACIÓN IMFORMÁTICA PARA EL CÁLCULO DE SOSTENIMIENTO DE TALUDES MEDIANTE VEGETACIÓN

B02. DENSIDAD DE PLANTACIÓN: 1.600 plantas/ha.

\section{B02-4.POSICIÓN N.F. 4}

INCLINACIÓN DE TALUD 6-100

INCLINACIÓN DE TALUD 10-200

INCLINACIÓN DE TALUD 20-30

INCLINACIÓN DE TALUD 30-40

INCLINACIÓN DE TALUD $35^{\circ}$

INCLINACIÓN DE TALUD 40-50

INCLINACIÓN DE TALUD 50-550

INCLINACIÓN DE TALUD 55-60

INCLINACIÓN DE TALUD 60-700

INCLINACIÓN DE TALUD 70-80 


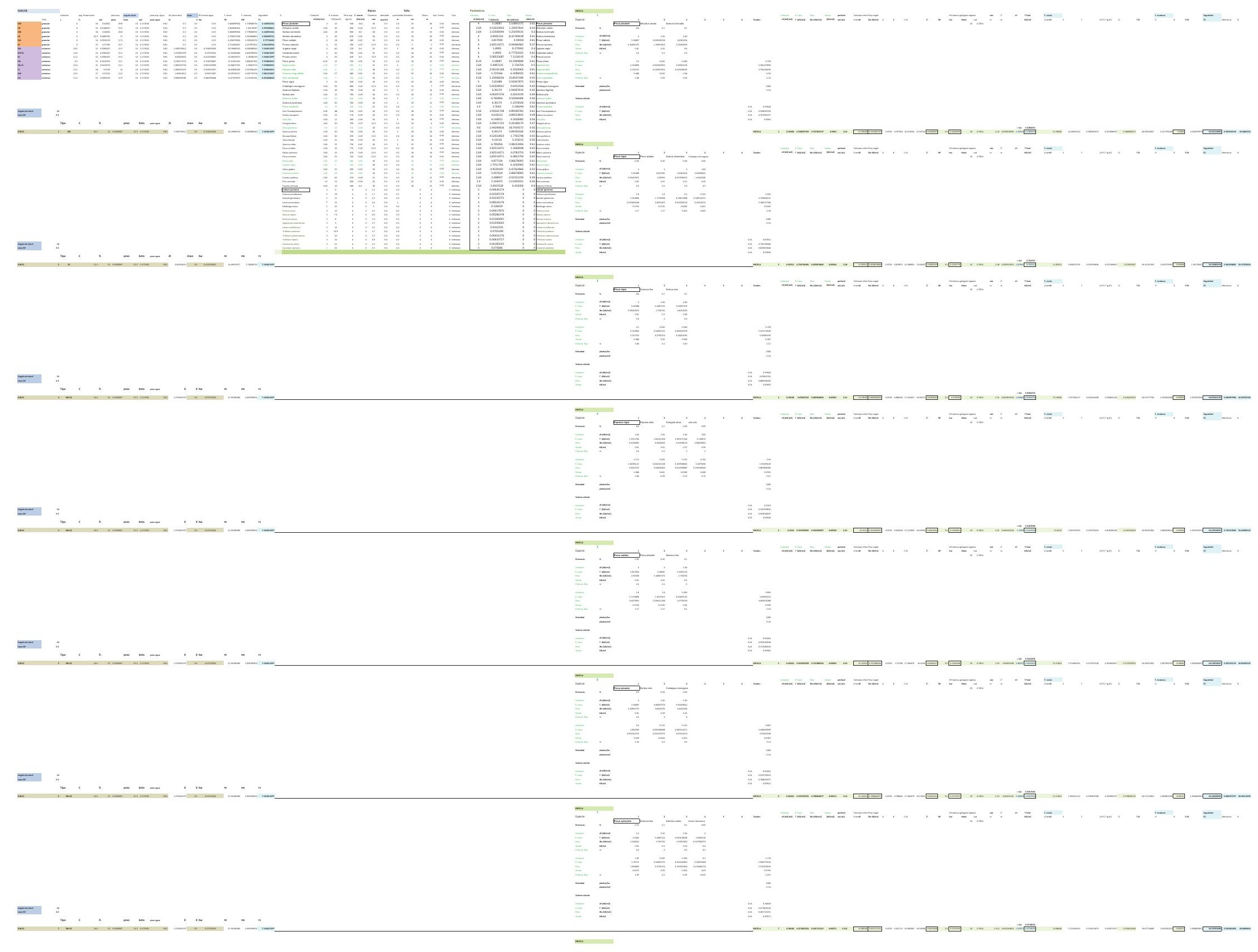




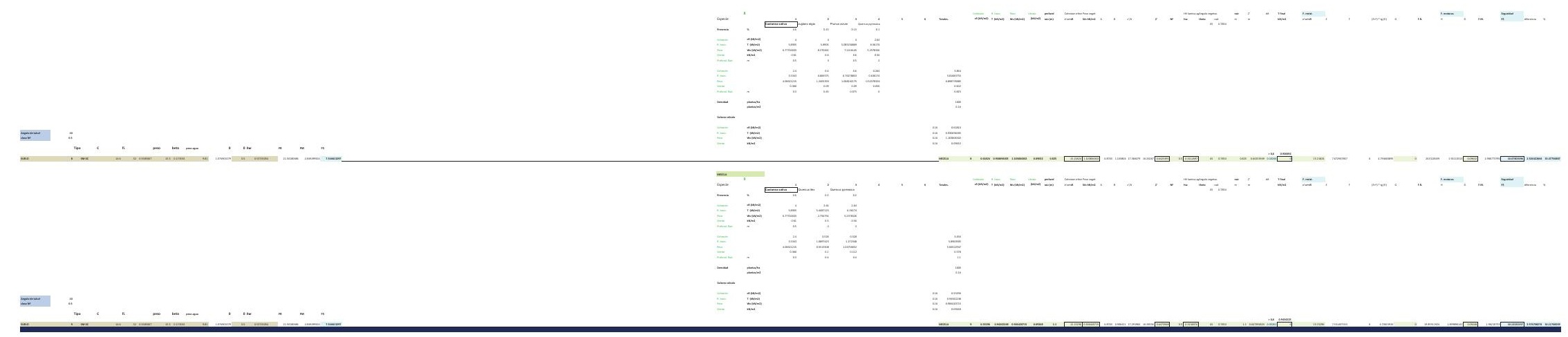




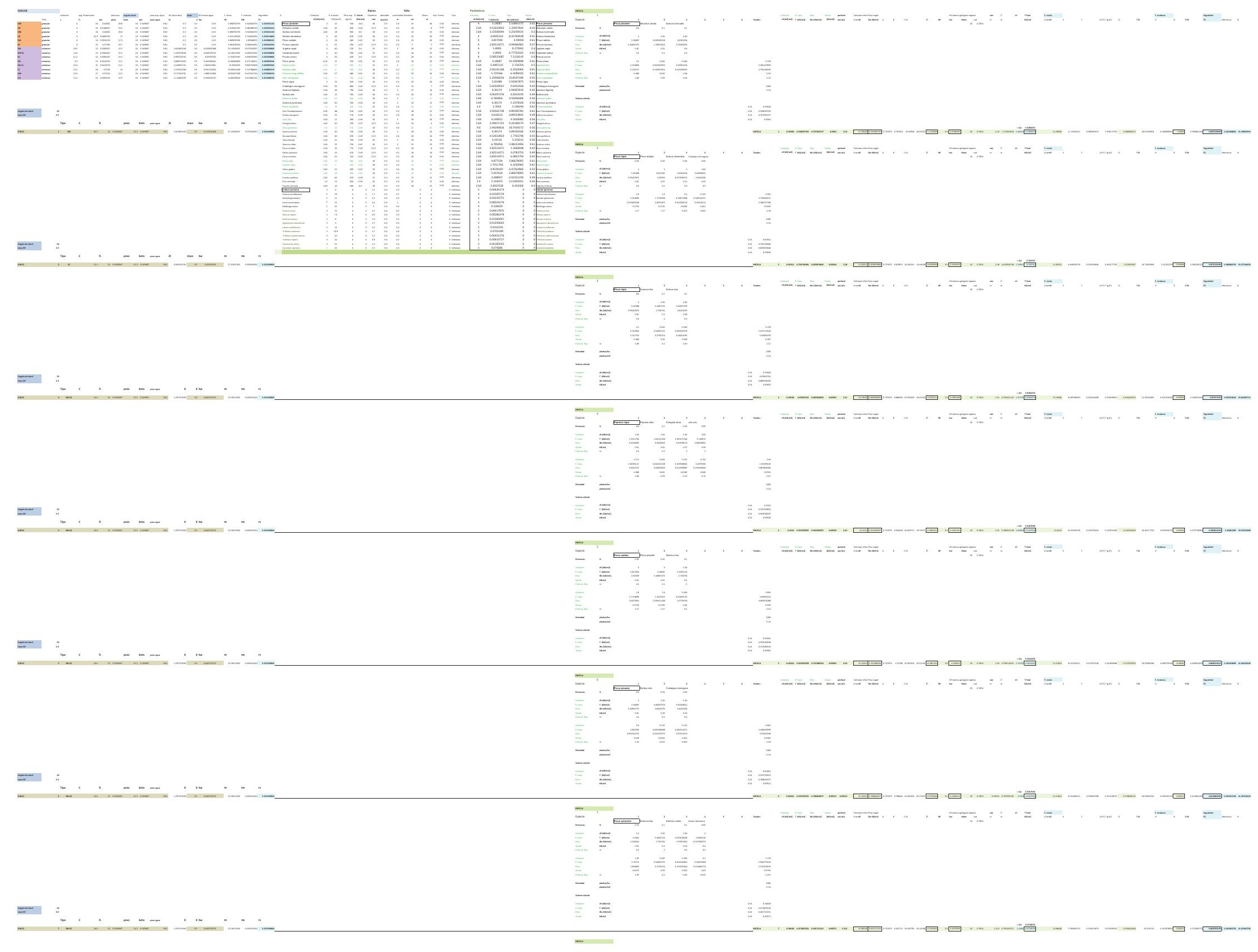




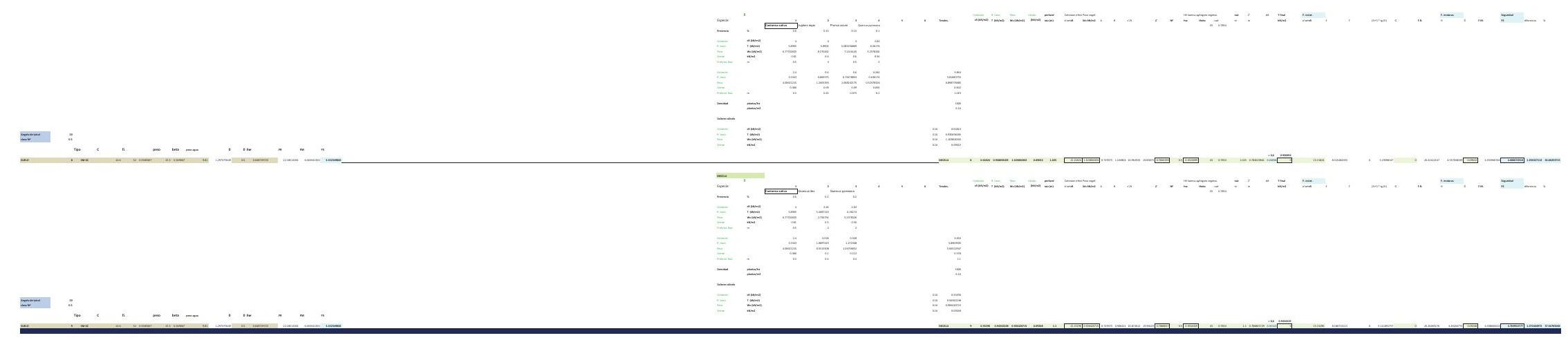




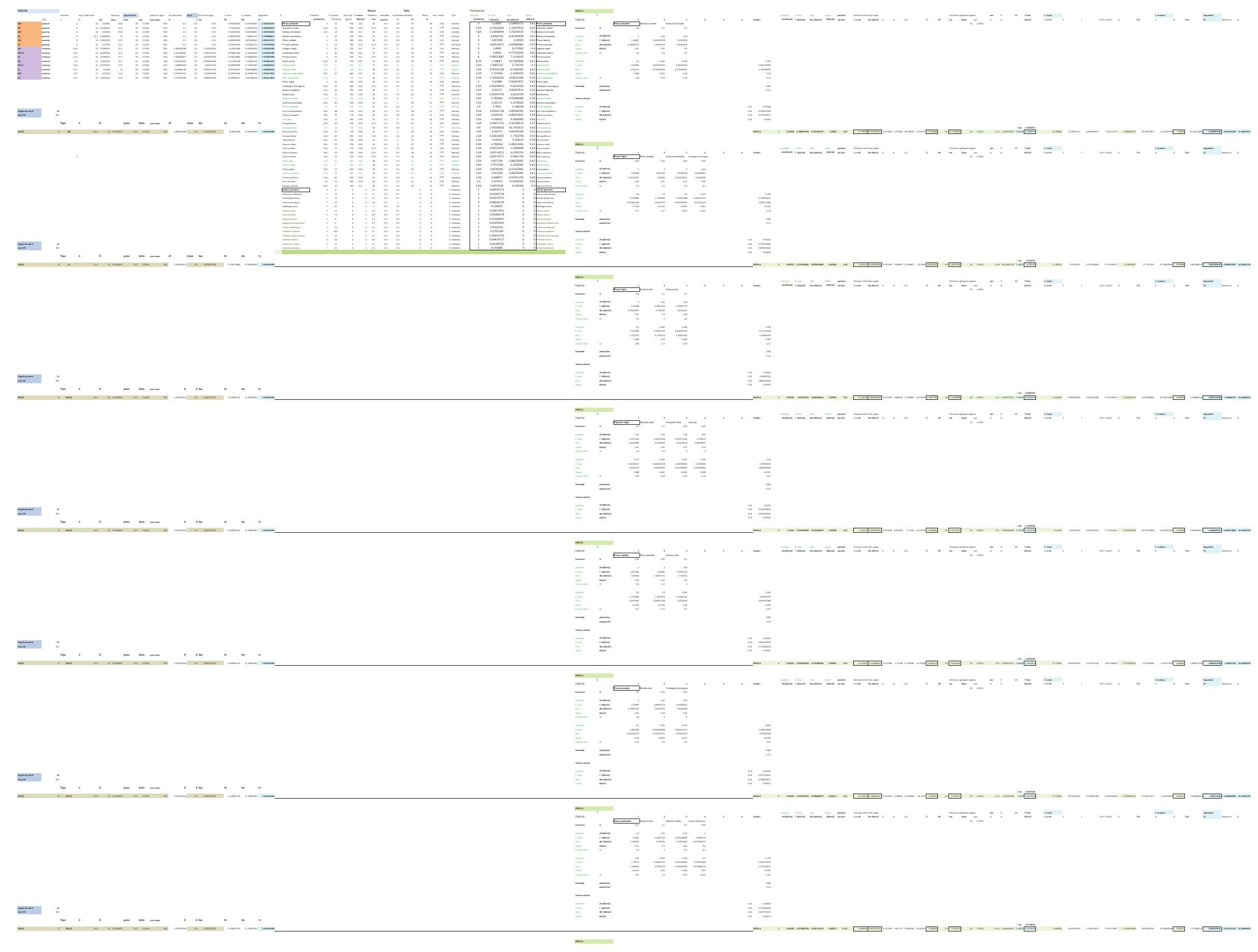




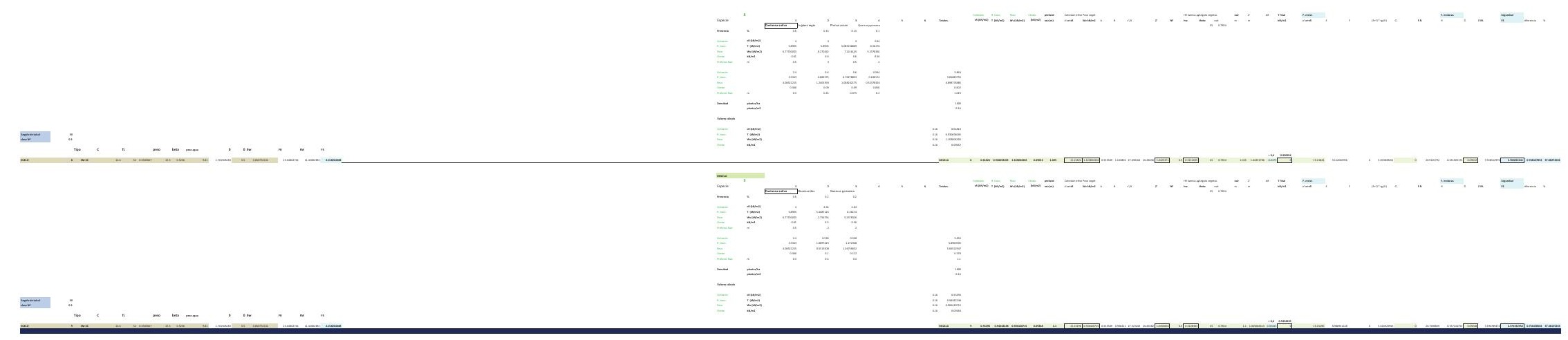




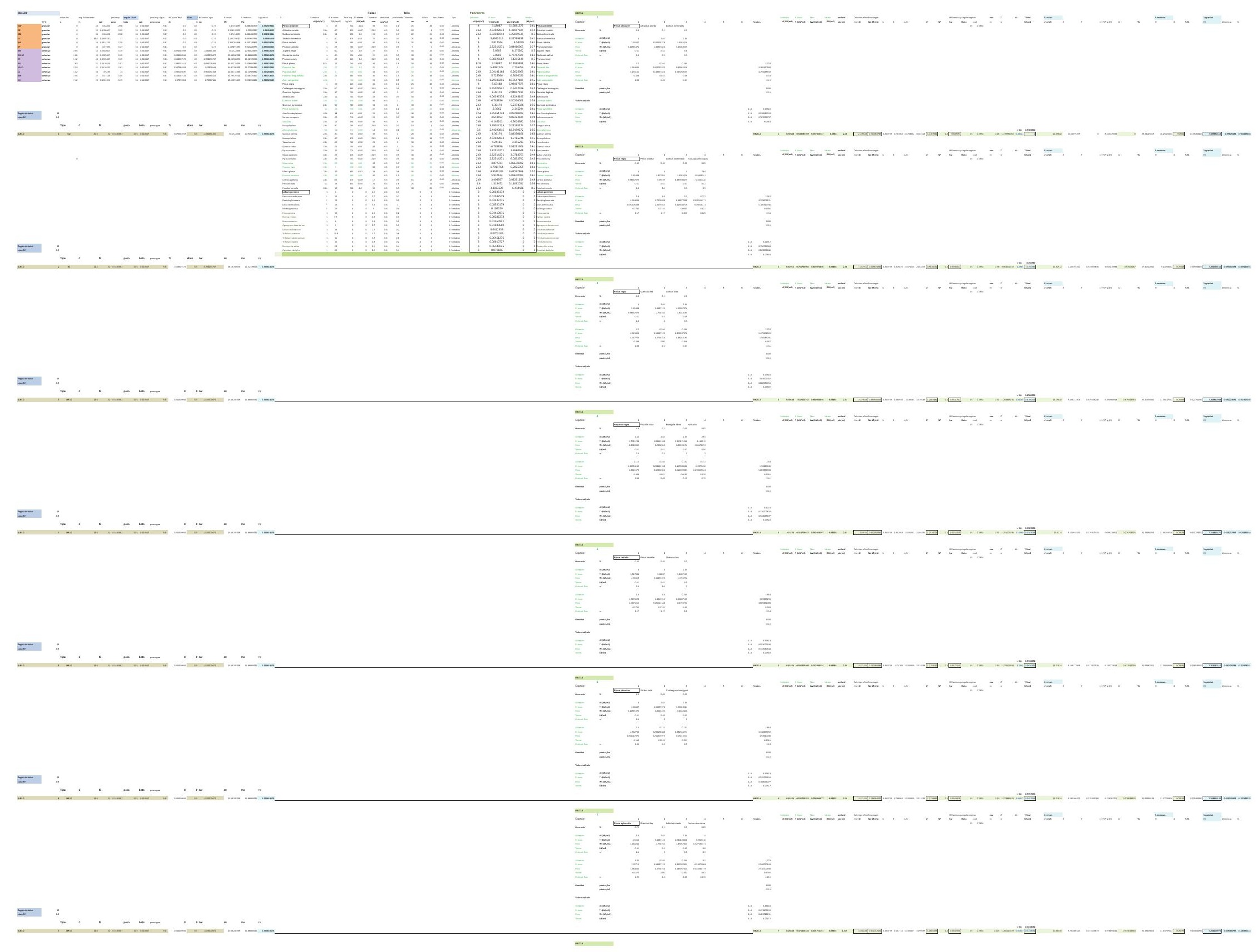




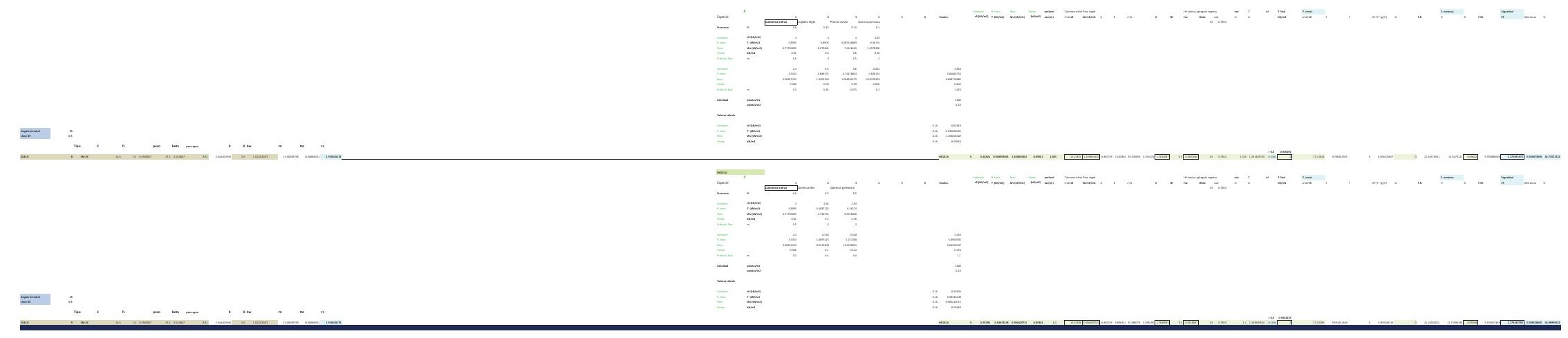




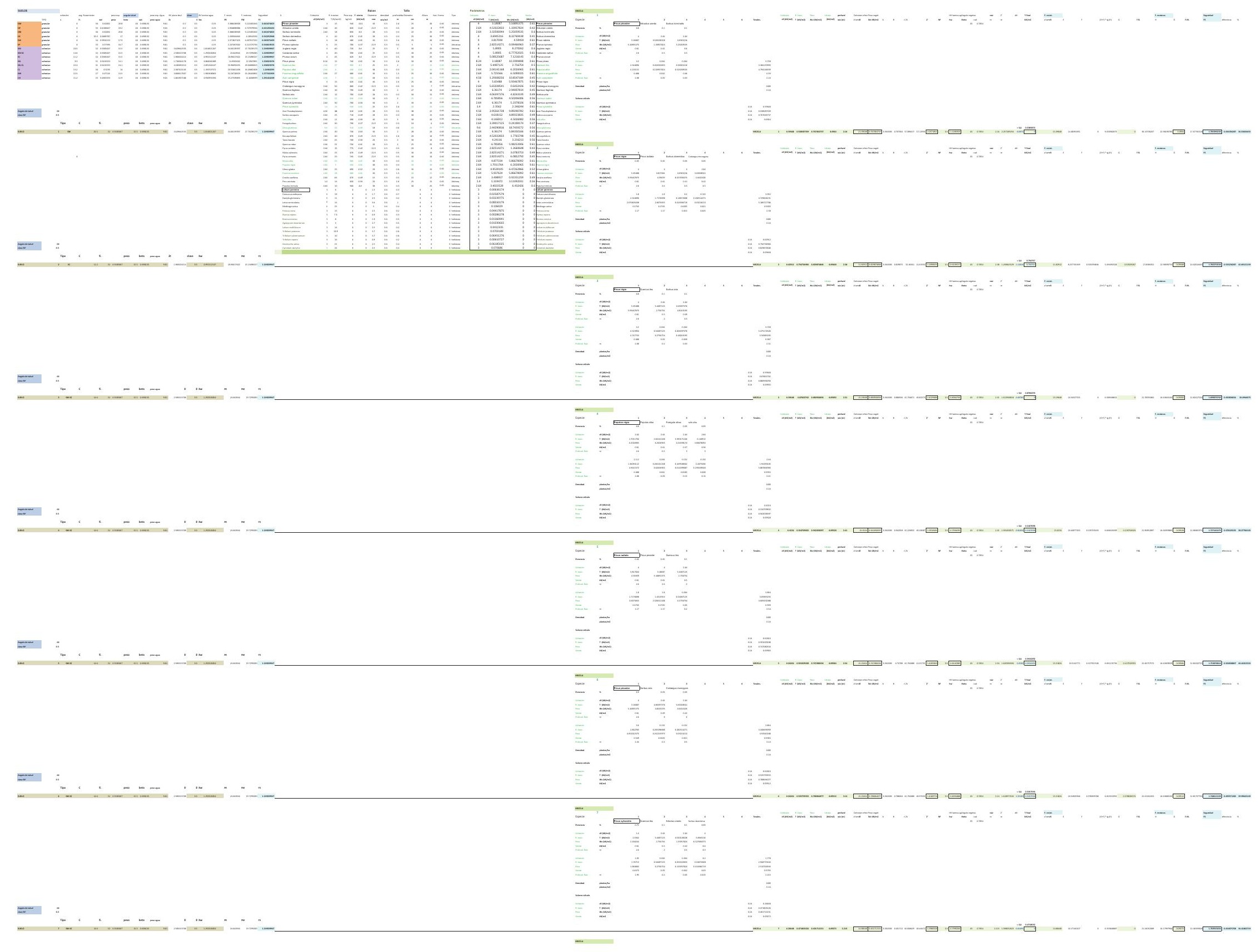




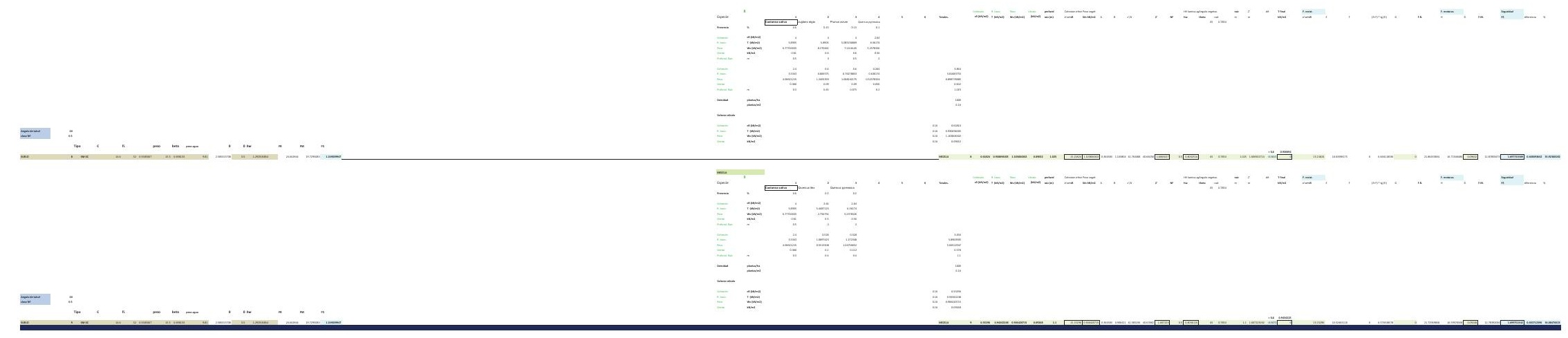




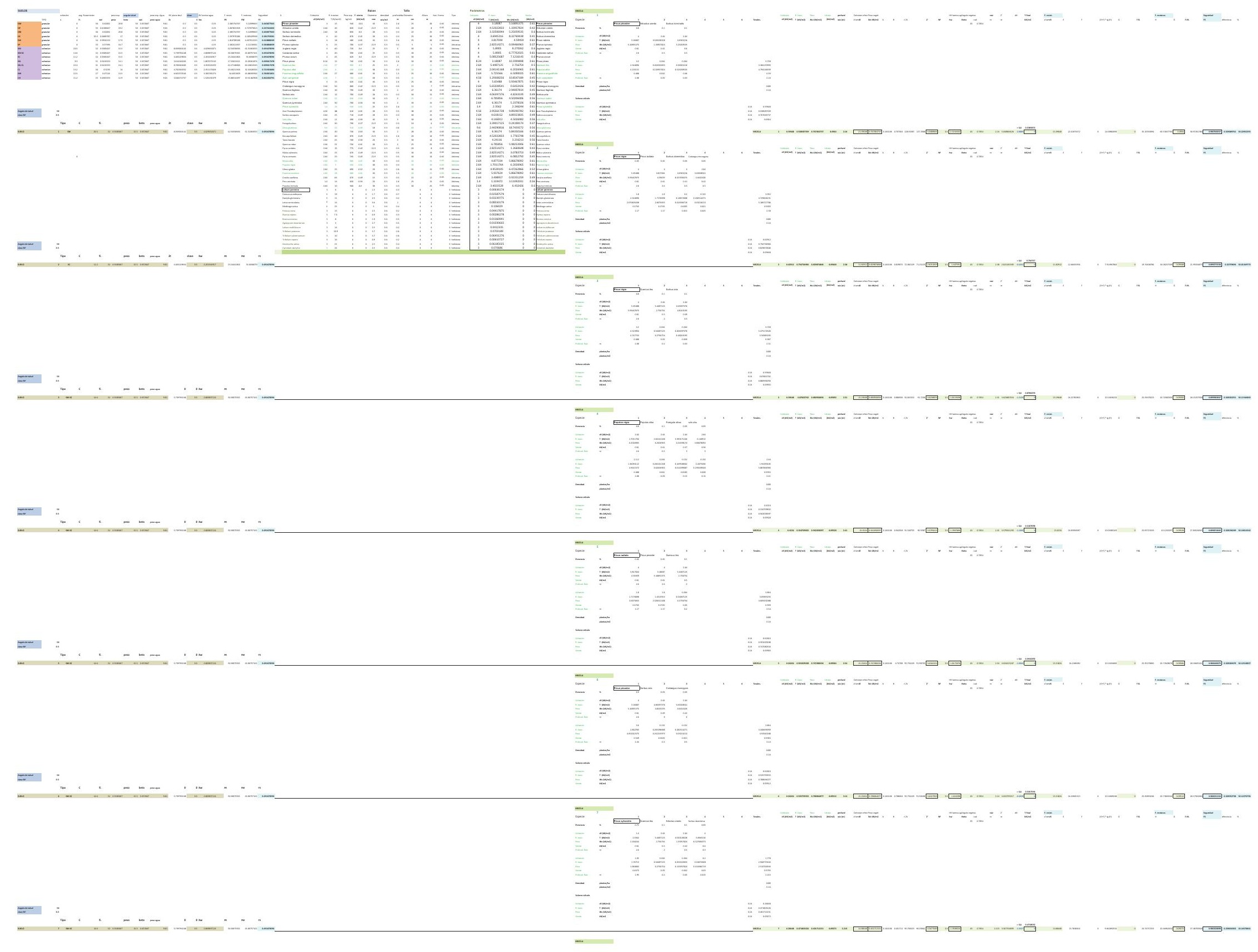




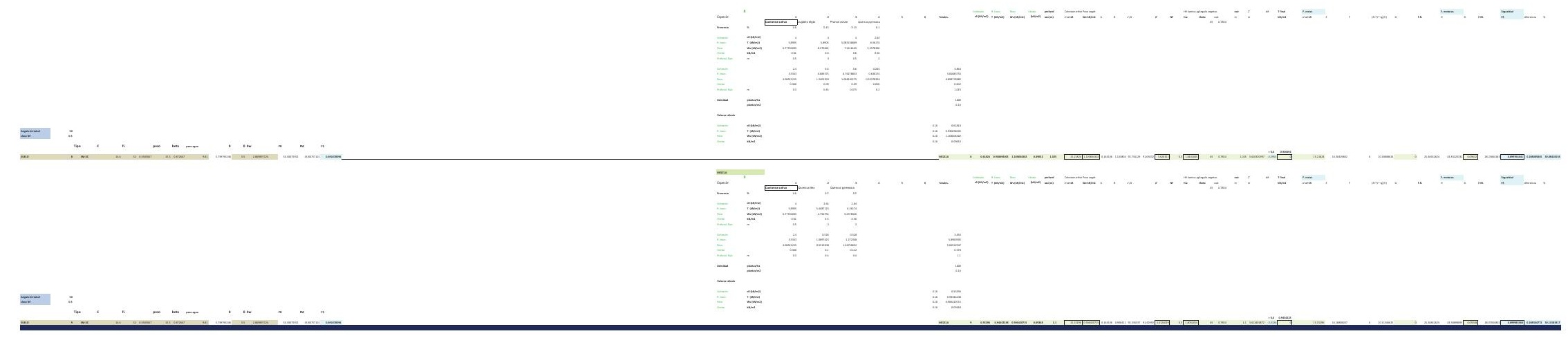




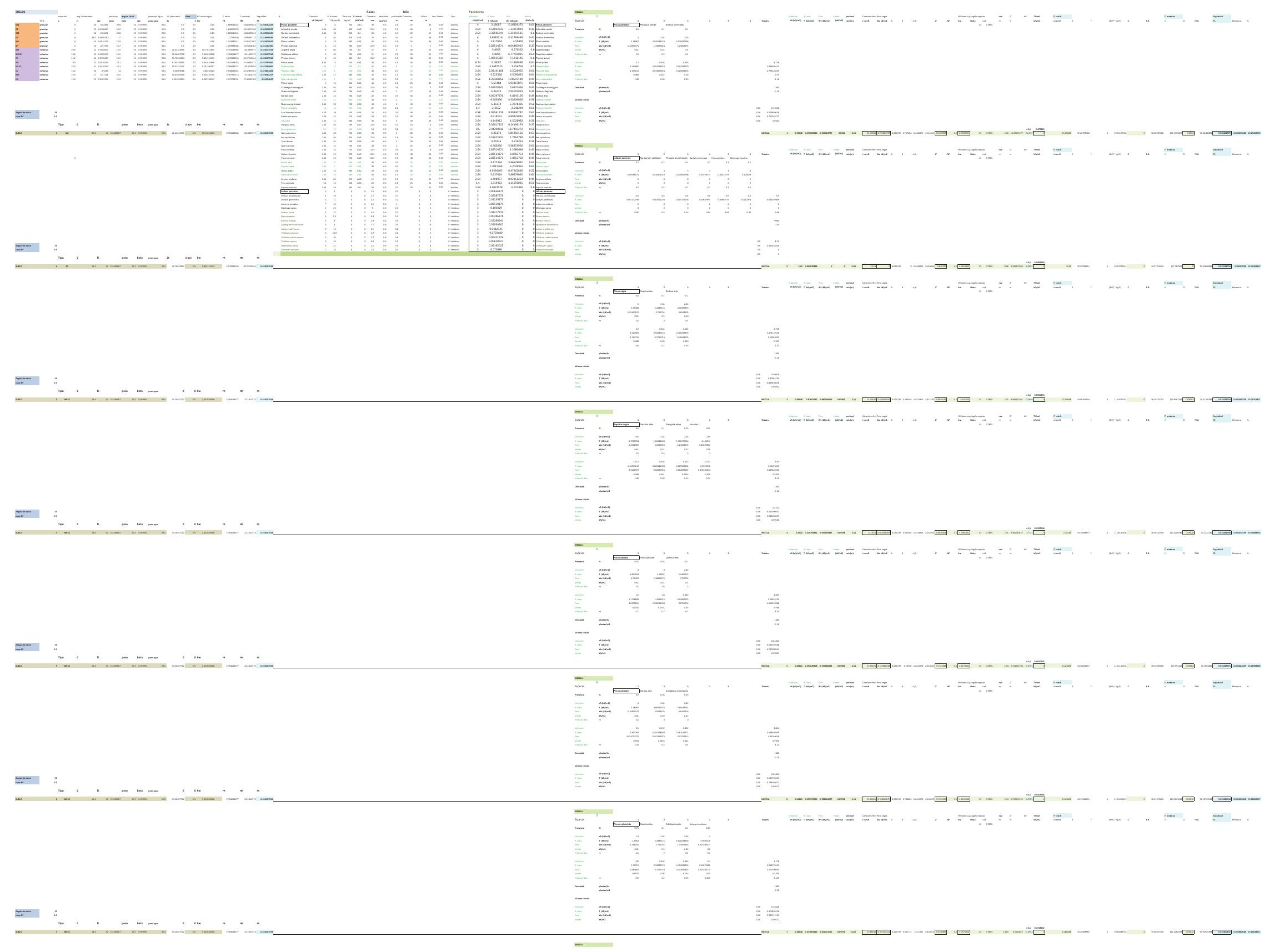




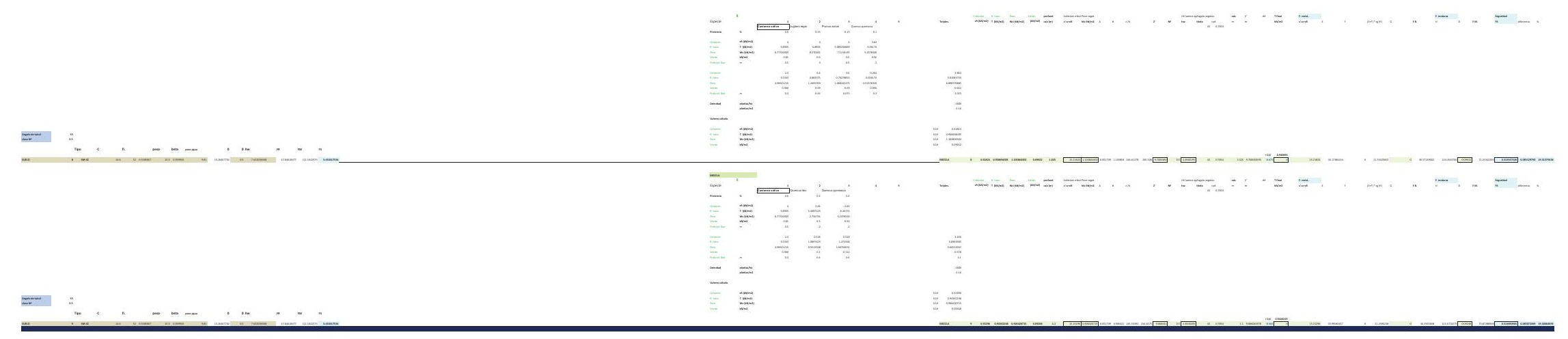




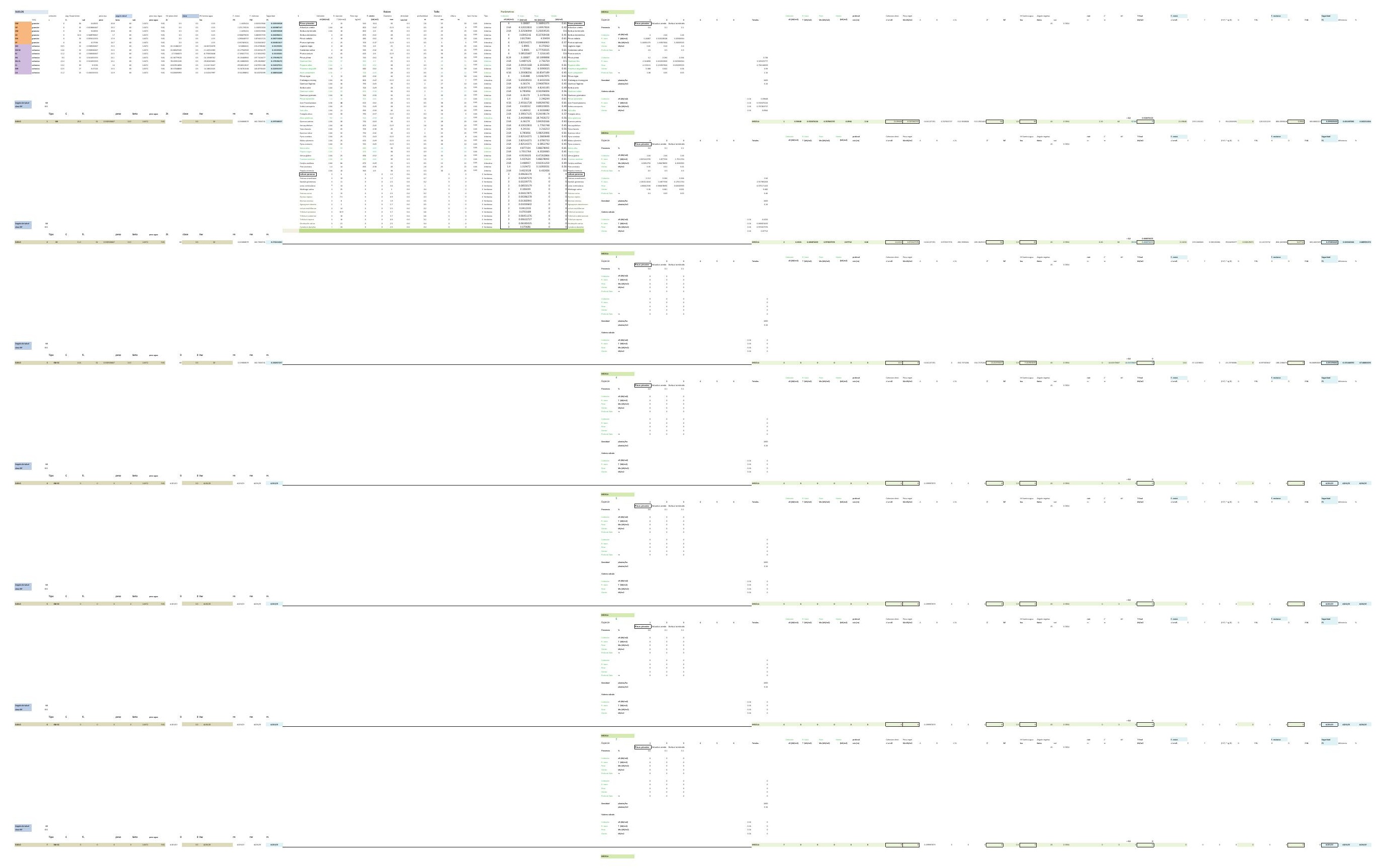


$-\div=\square=$

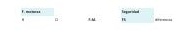




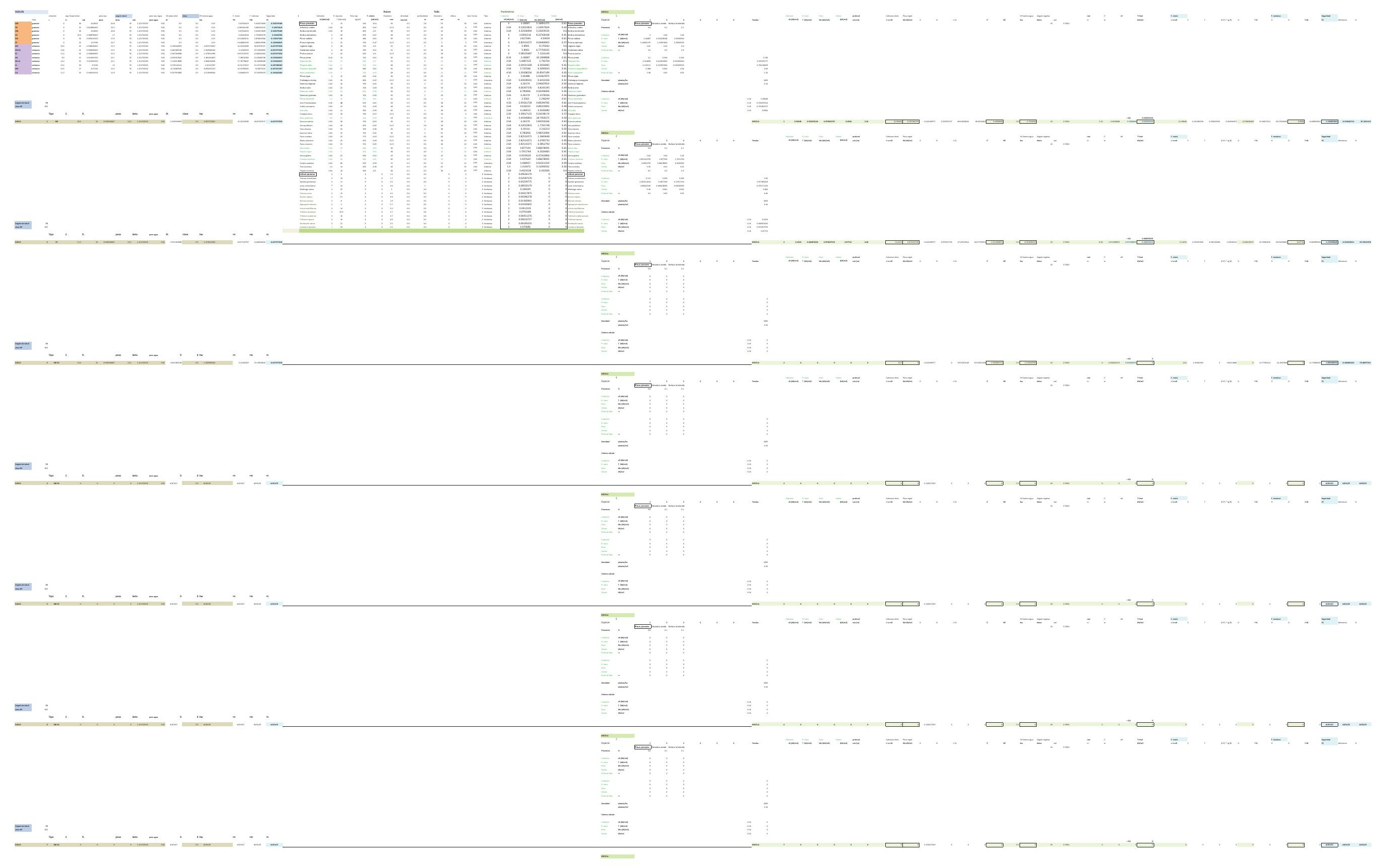


DESARROLLO DE UNA APLICACIÓN IMFORMÁTICA PARA EL CÁLCULO DE SOSTENIMIENTO DE TALUDES MEDIANTE VEGETACIÓN

B02. DENSIDAD DE PLANTACIÓN: 1.600 plantas/ha.

\section{B02-5.POSICIÓN N.F. 5}

INCLINACIÓN DE TALUD 6-100

INCLINACIÓN DE TALUD 10-200

INCLINACIÓN DE TALUD 20-30

INCLINACIÓN DE TALUD 30-40

INCLINACIÓN DE TALUD $35^{\circ}$

INCLINACIÓN DE TALUD 40-50

INCLINACIÓN DE TALUD 50-550

INCLINACIÓN DE TALUD 55-60

INCLINACIÓN DE TALUD 60-700

INCLINACIÓN DE TALUD 70-80 


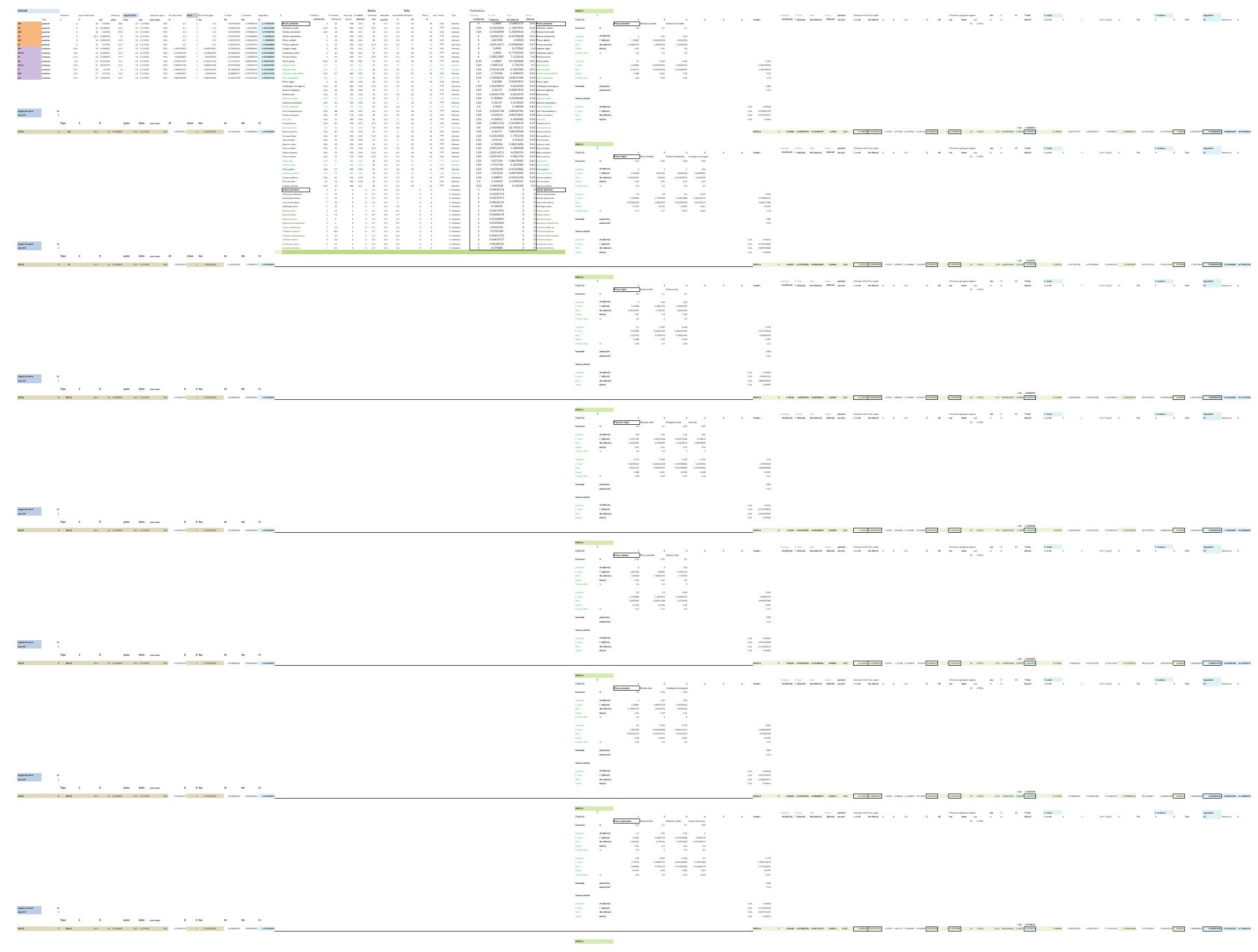




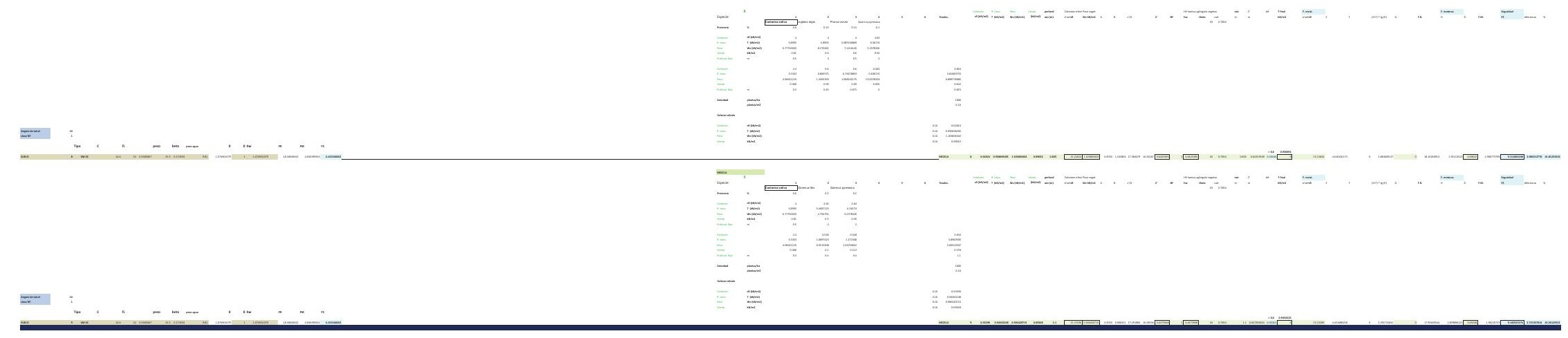




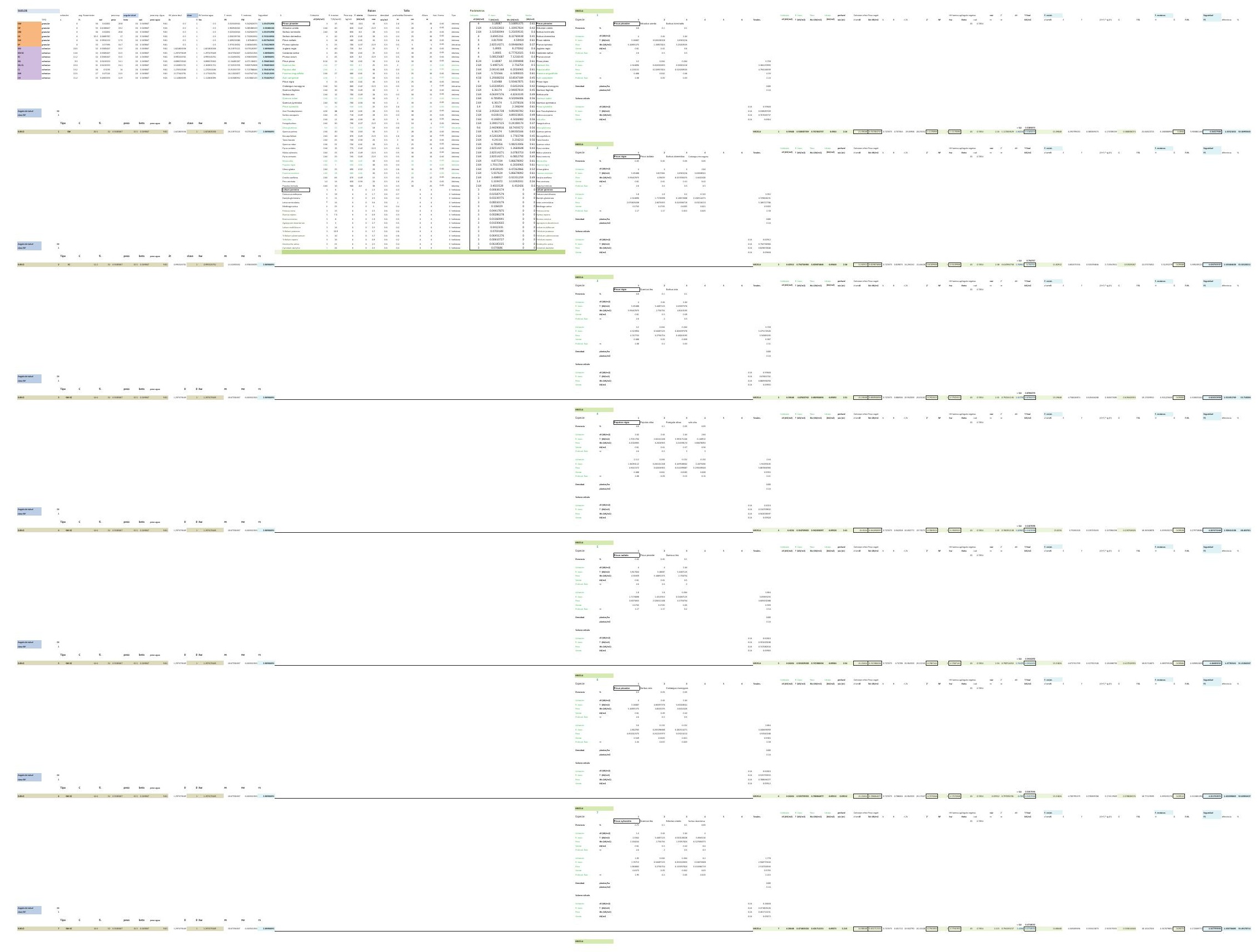




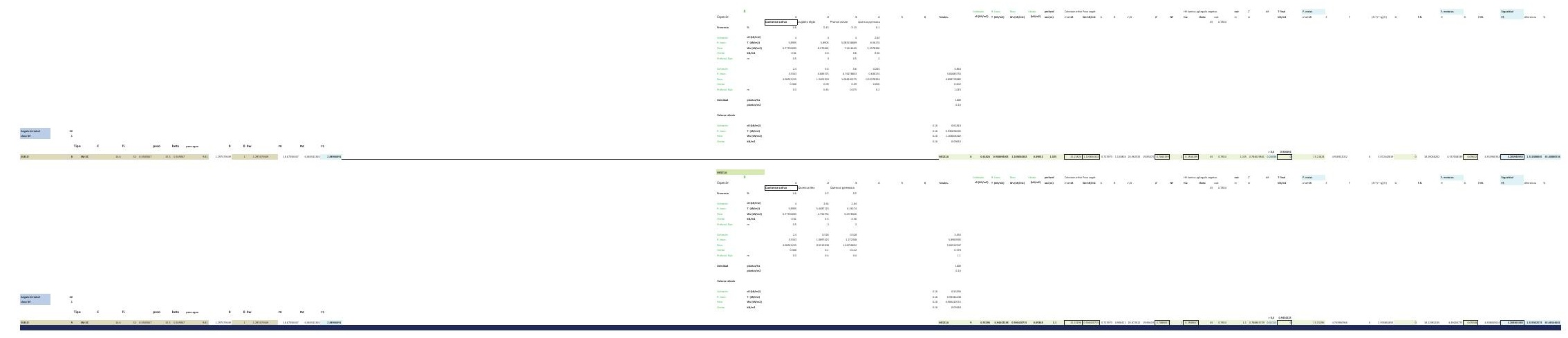




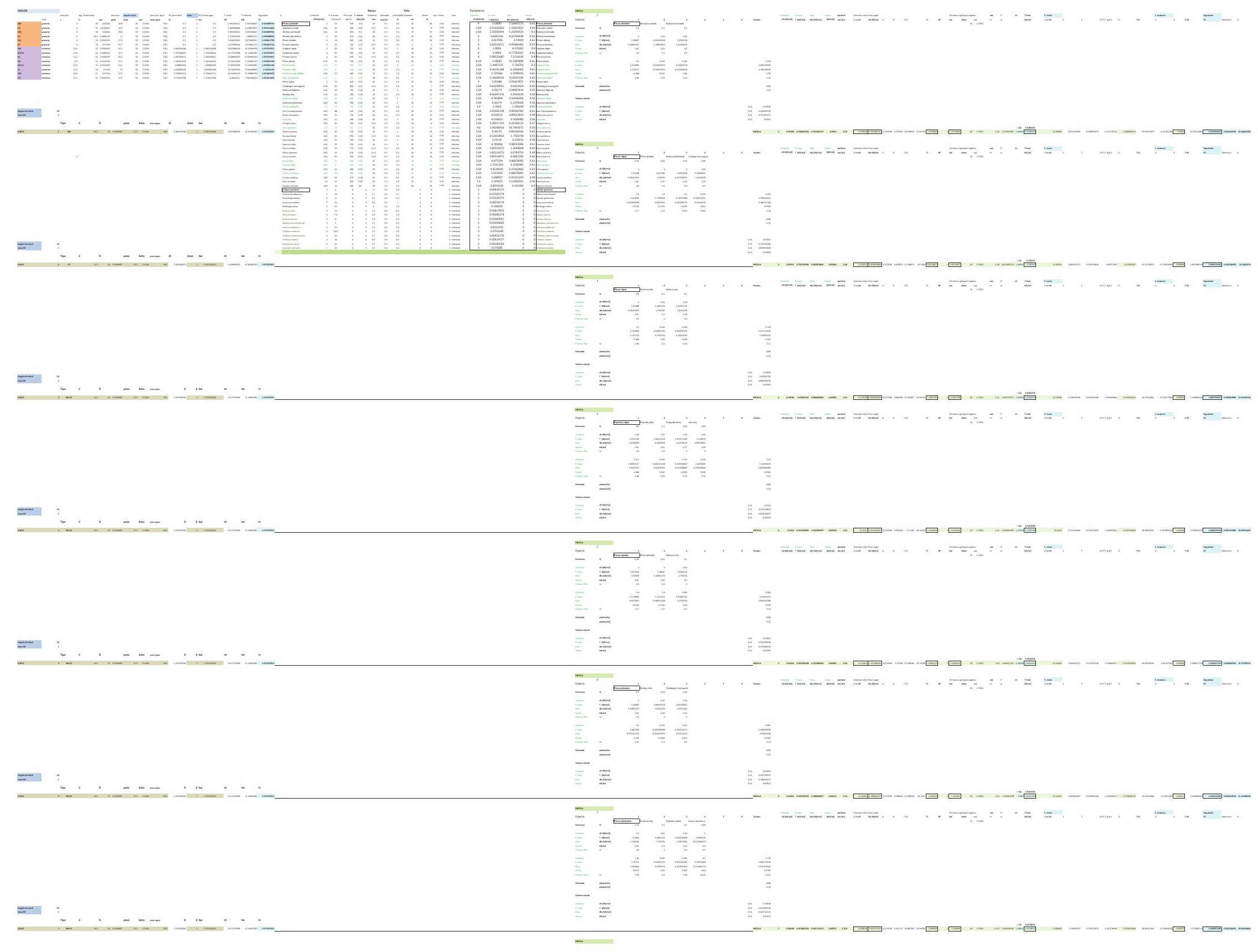




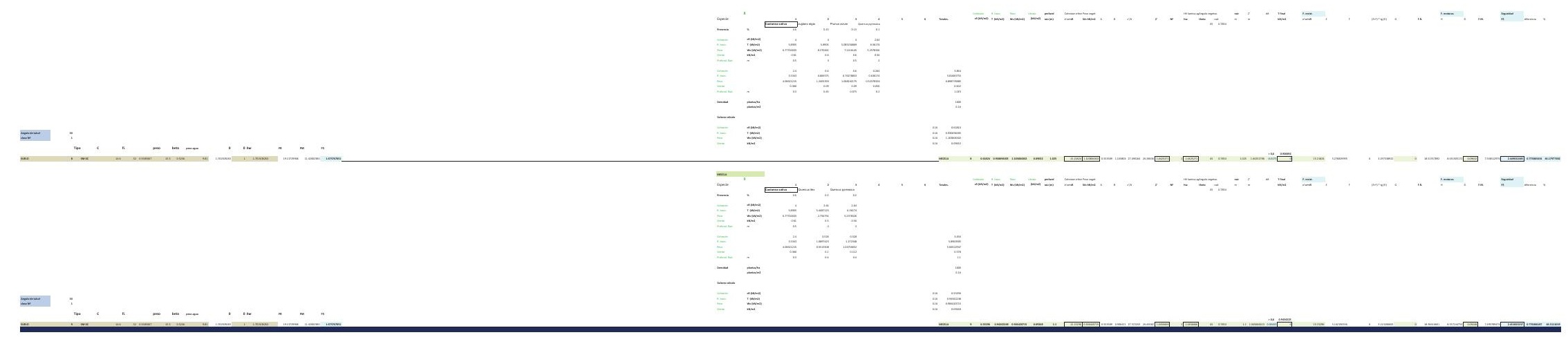




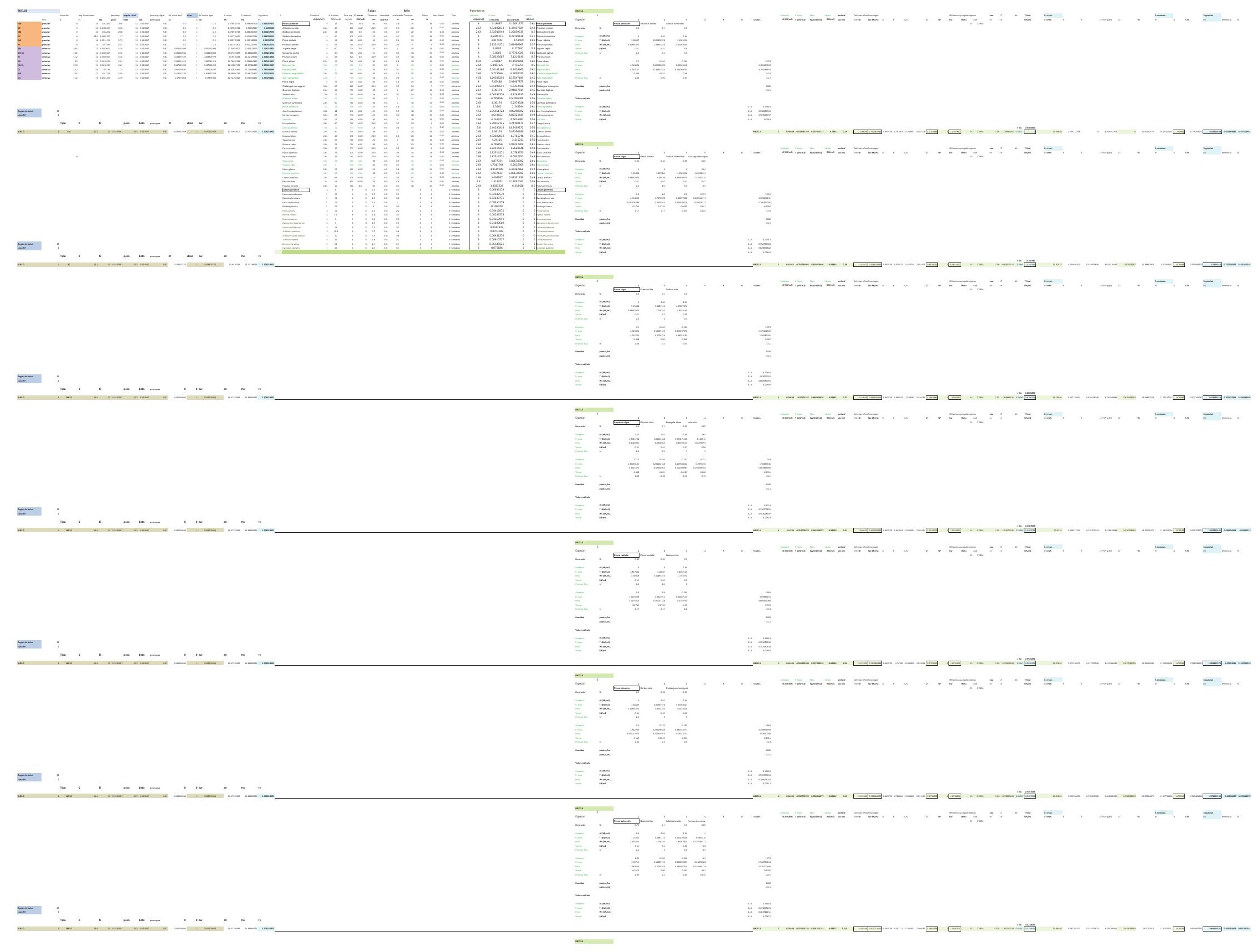




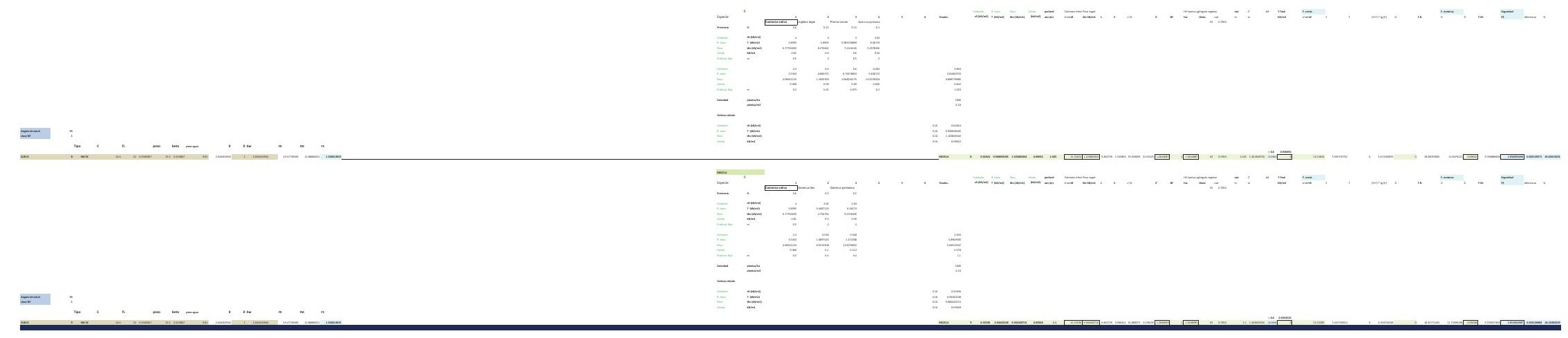




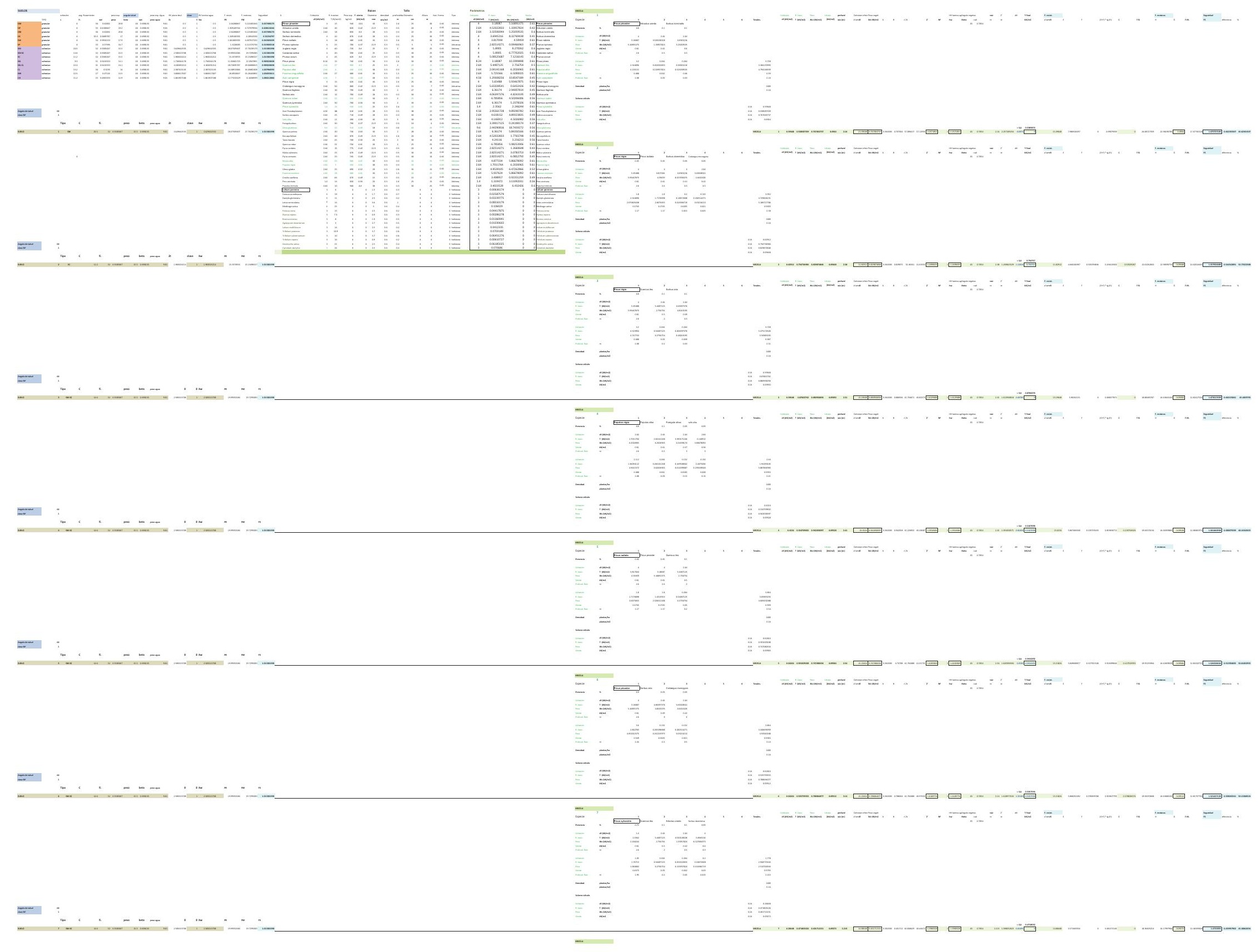




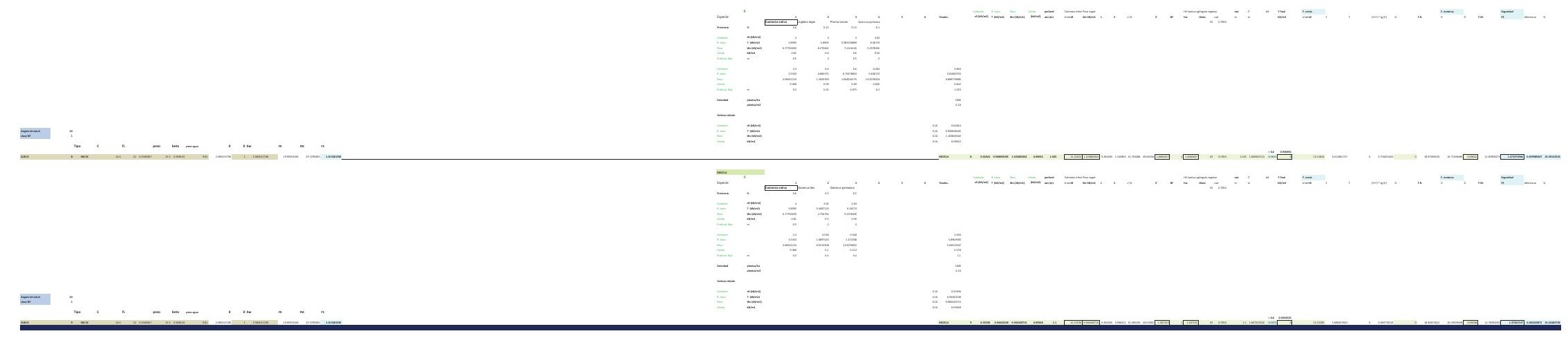




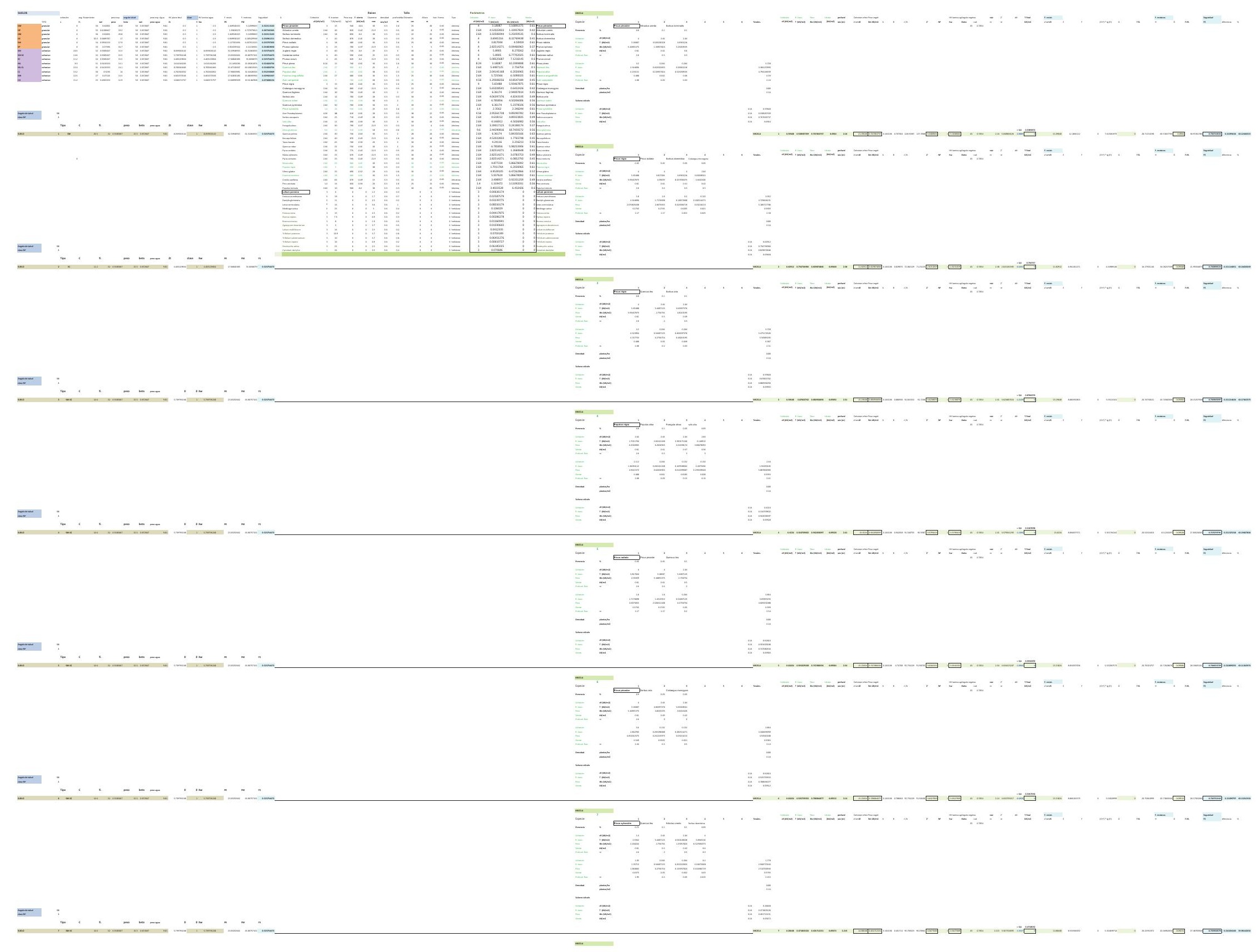




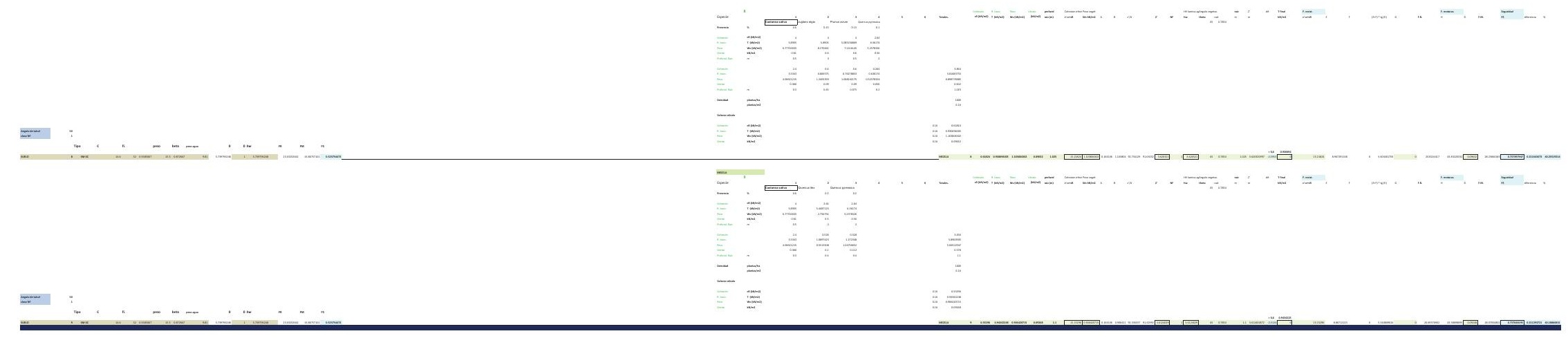




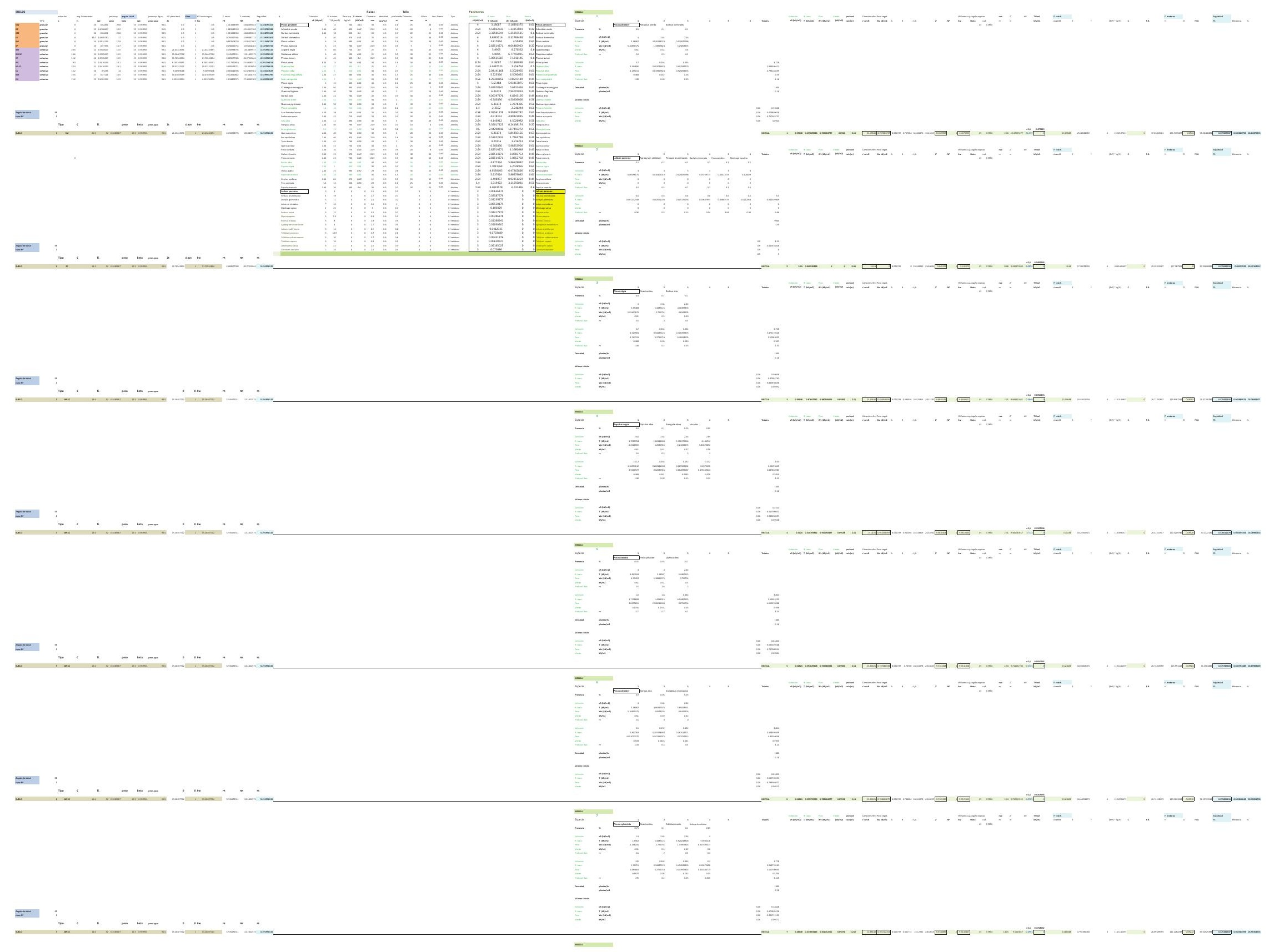


$=$

$=$

-

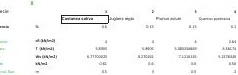

$\stackrel{*}{*}=$

$=$

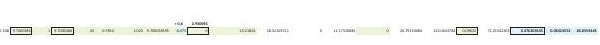

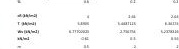

$\pm=$

$\bar{E}=$ 


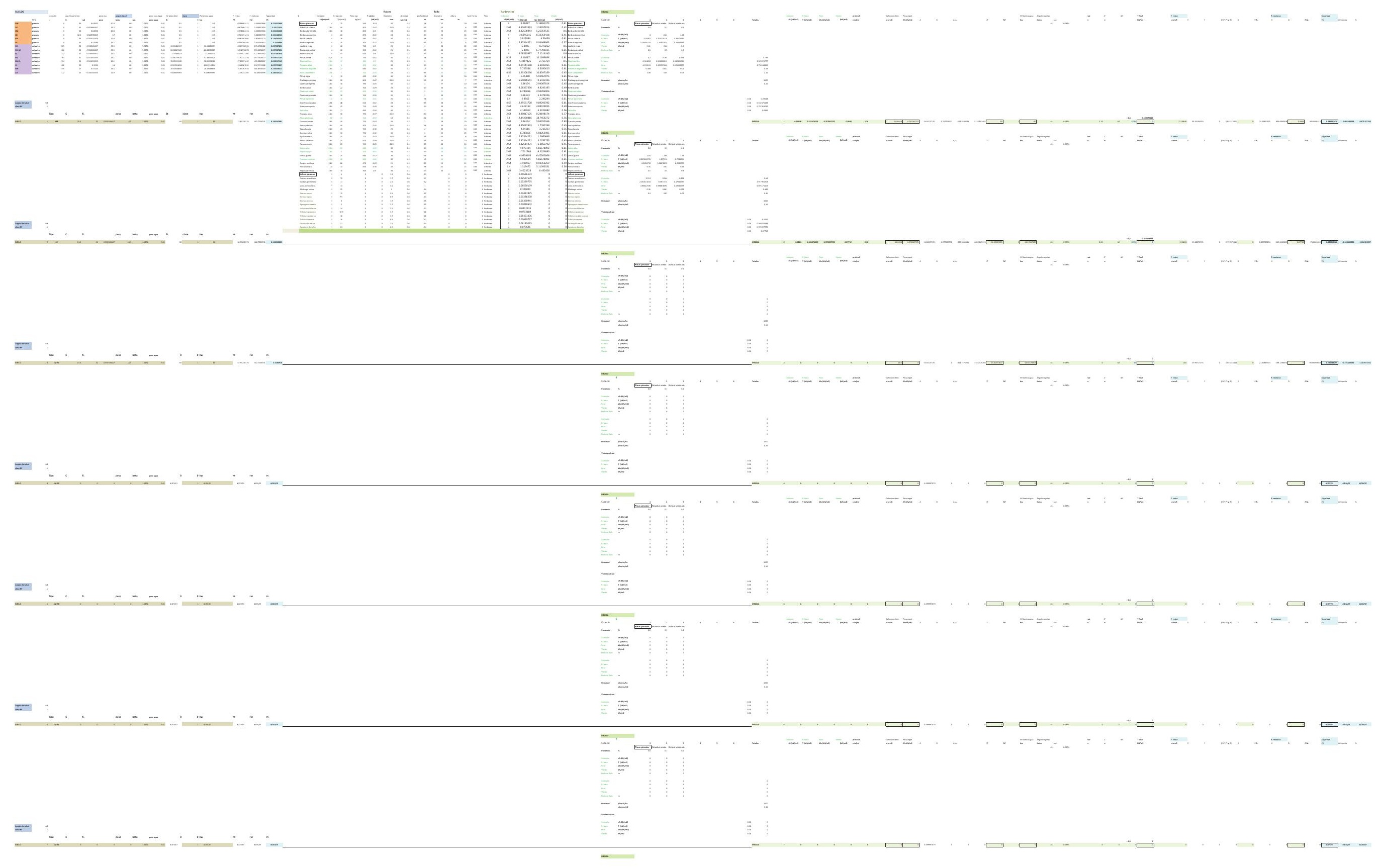




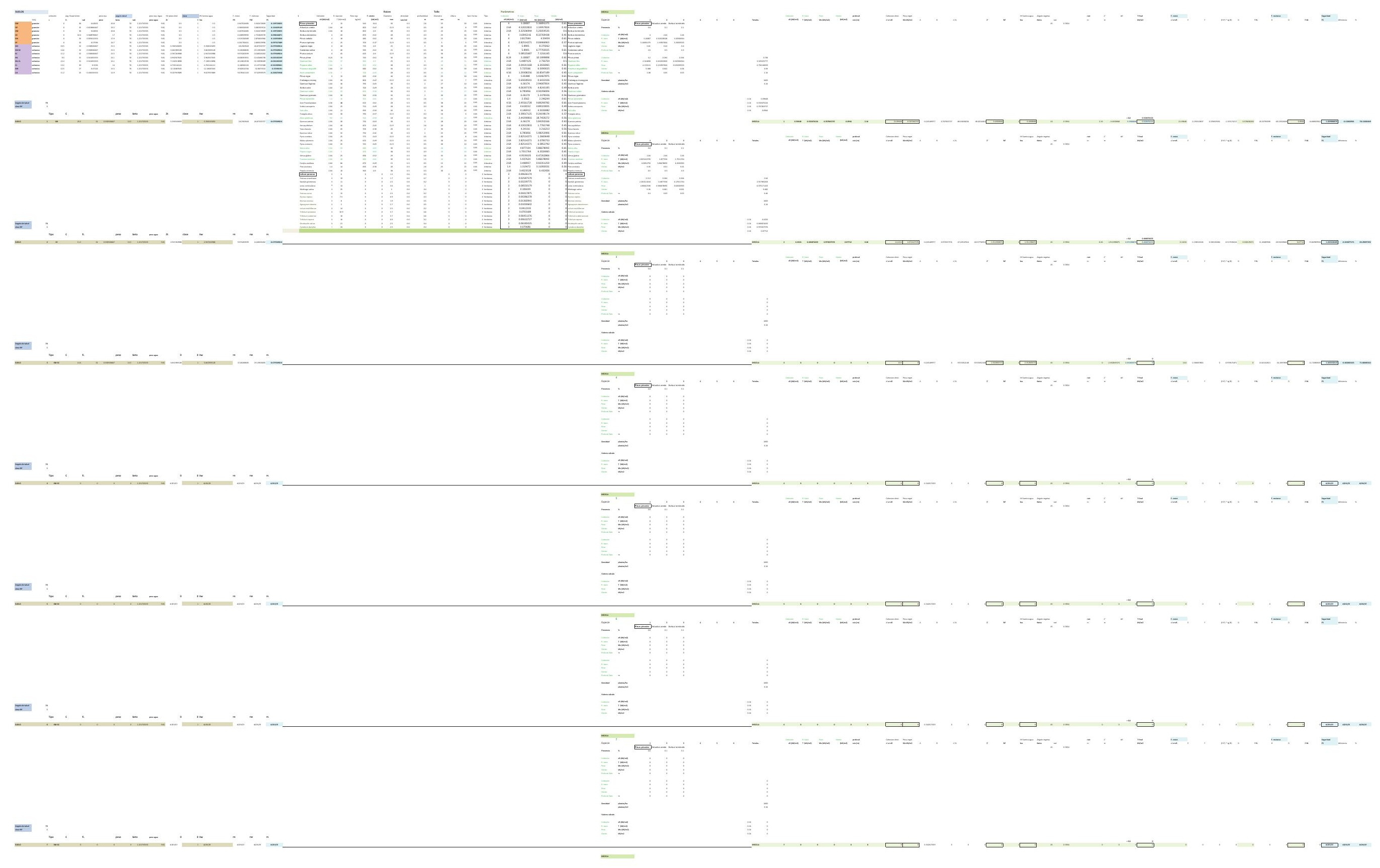




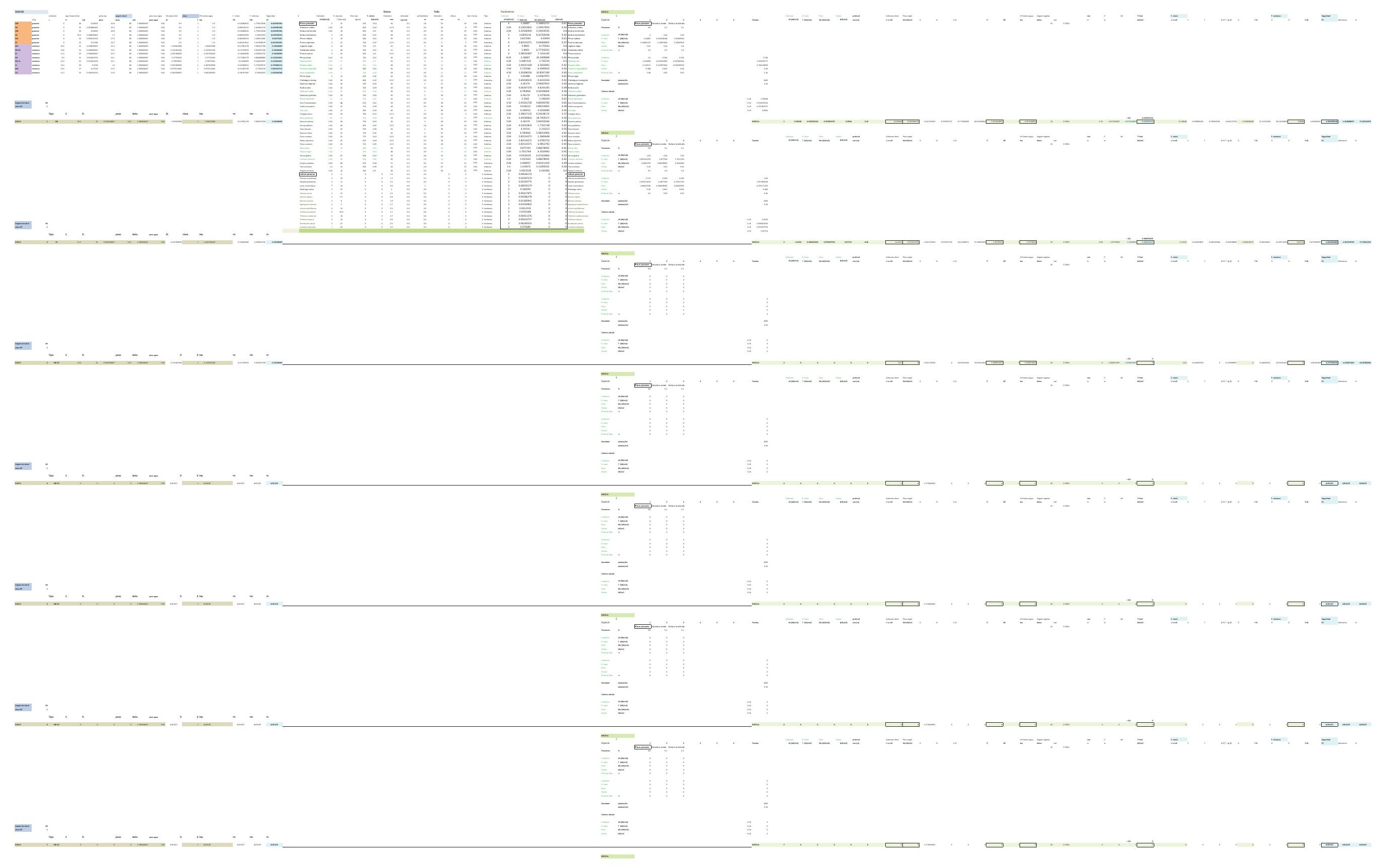


DESARROLLO DE UNA APLICACIÓN IMFORMÁTICA PARA EL CÁLCULO DE SOSTENIMIENTO DE TALUDES MEDIANTE VEGETACIÓN

PRUEBAS DEL MODELO MATEMÁTICO PARA EL CÁLCULO DE ESTABILIDAD DE TALUDES.

B03. DENSIDAD DE PLANTACIÓN: 2.500 plantas/ha.

B03-1.POSICIÓN N.F. 1

B03-2.POSICIÓN N.F. 2

B03-3.POSICIÓN N.F. 3

B03-4.POSICIÓN N.F. 4

B03-5.POSICIÓN N.F. 5 
DESARROLLO DE UNA APLICACIÓN IMFORMÁTICA PARA EL CÁLCULO DE SOSTENIMIENTO DE TALUDES MEDIANTE VEGETACIÓN

B03. DENSIDAD DE PLANTACIÓN: 2.500 plantas/ha.

\section{B03-1.POSICIÓN N.F. 1}

INCLINACIÓN DE TALUD 6-100

INCLINACIÓN DE TALUD 10-200

INCLINACIÓN DE TALUD 20-30

INCLINACIÓN DE TALUD 30-40

INCLINACIÓN DE TALUD $35^{\circ}$

INCLINACIÓN DE TALUD 40-50

INCLINACIÓN DE TALUD 50-550

INCLINACIÓN DE TALUD 55-60

INCLINACIÓN DE TALUD 60-700

INCLINACIÓN DE TALUD 70-80 


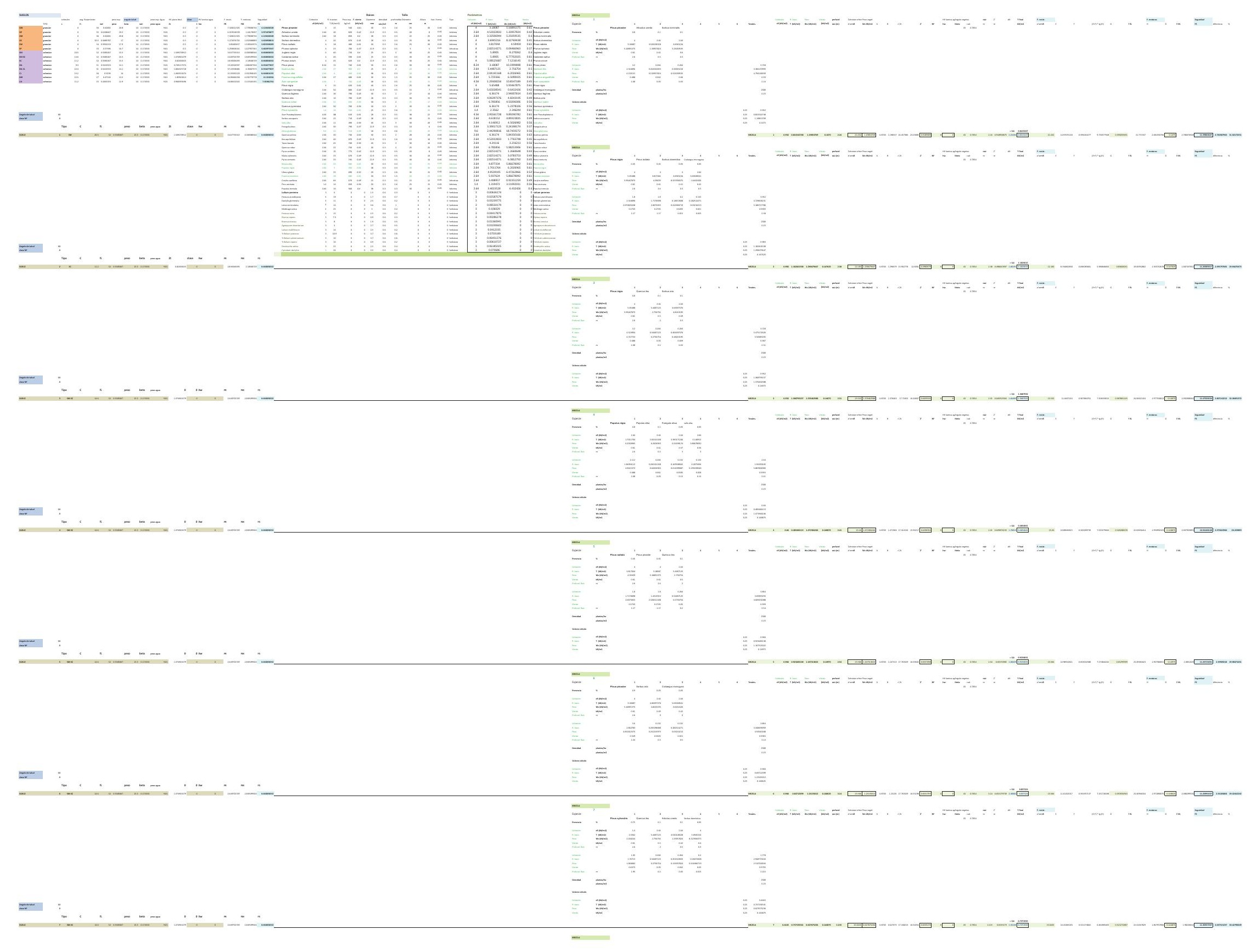


$=$

$=$

$+\cdots+\cdots$ $\pm$

$-\cdots+-\square-$

$\equiv= \pm$

$= \pm=$

$=$ 


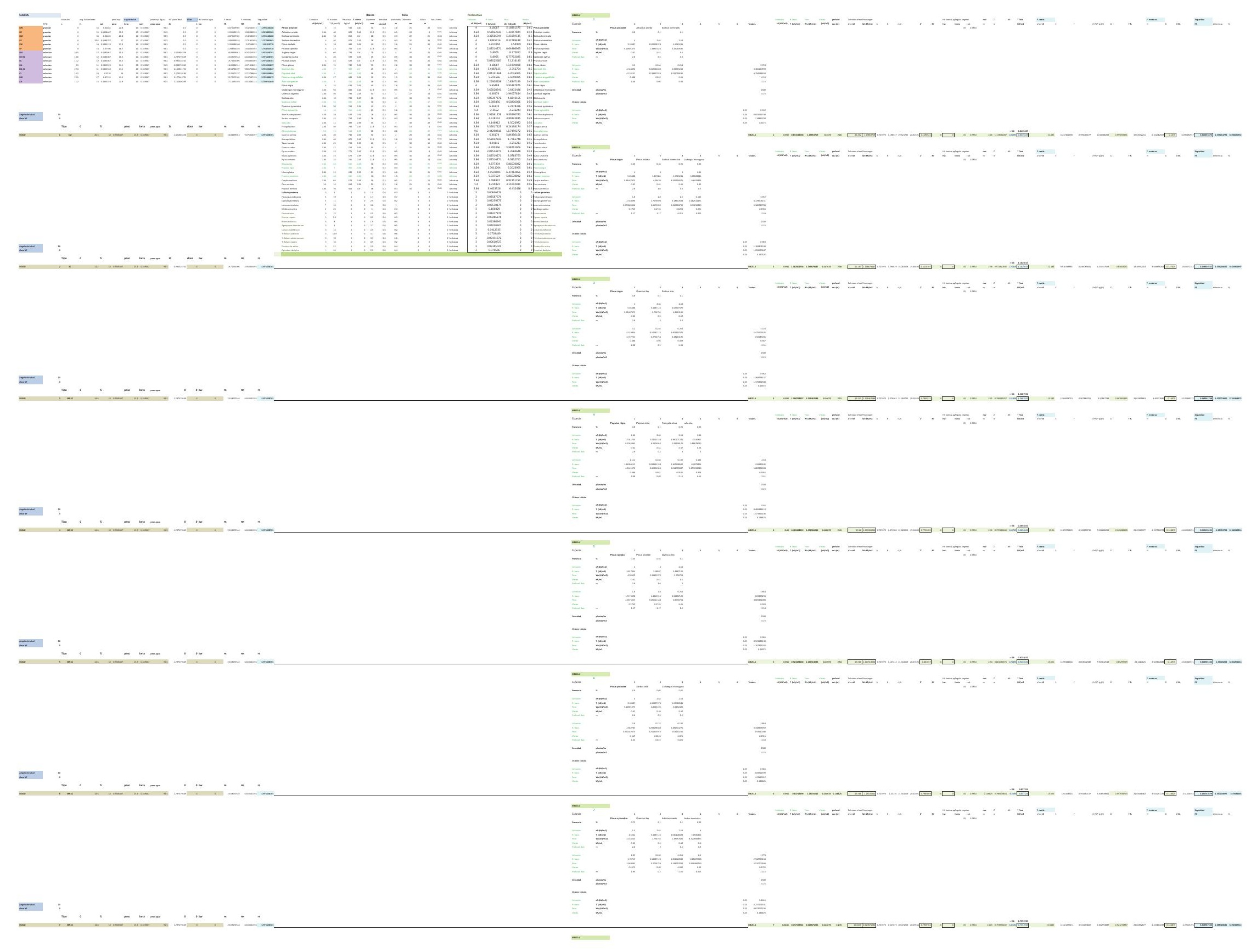


$=$

$=$

- $\pm$

1

$\equiv=-$

E. $=$

$-$

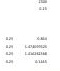




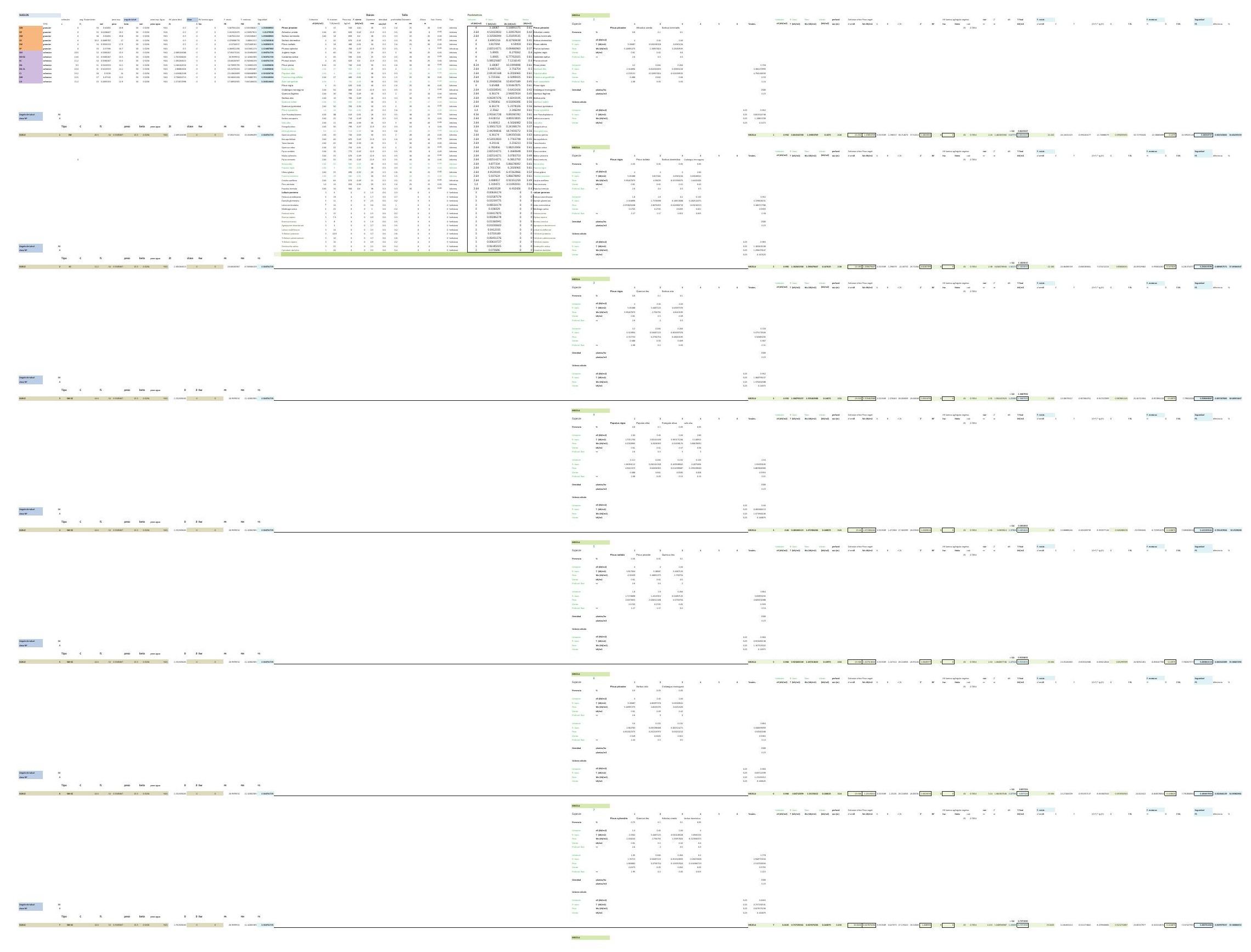


$=$

$=$

- $\pm$

(2.

$\equiv=-$

$= \pm$

$-$

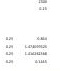




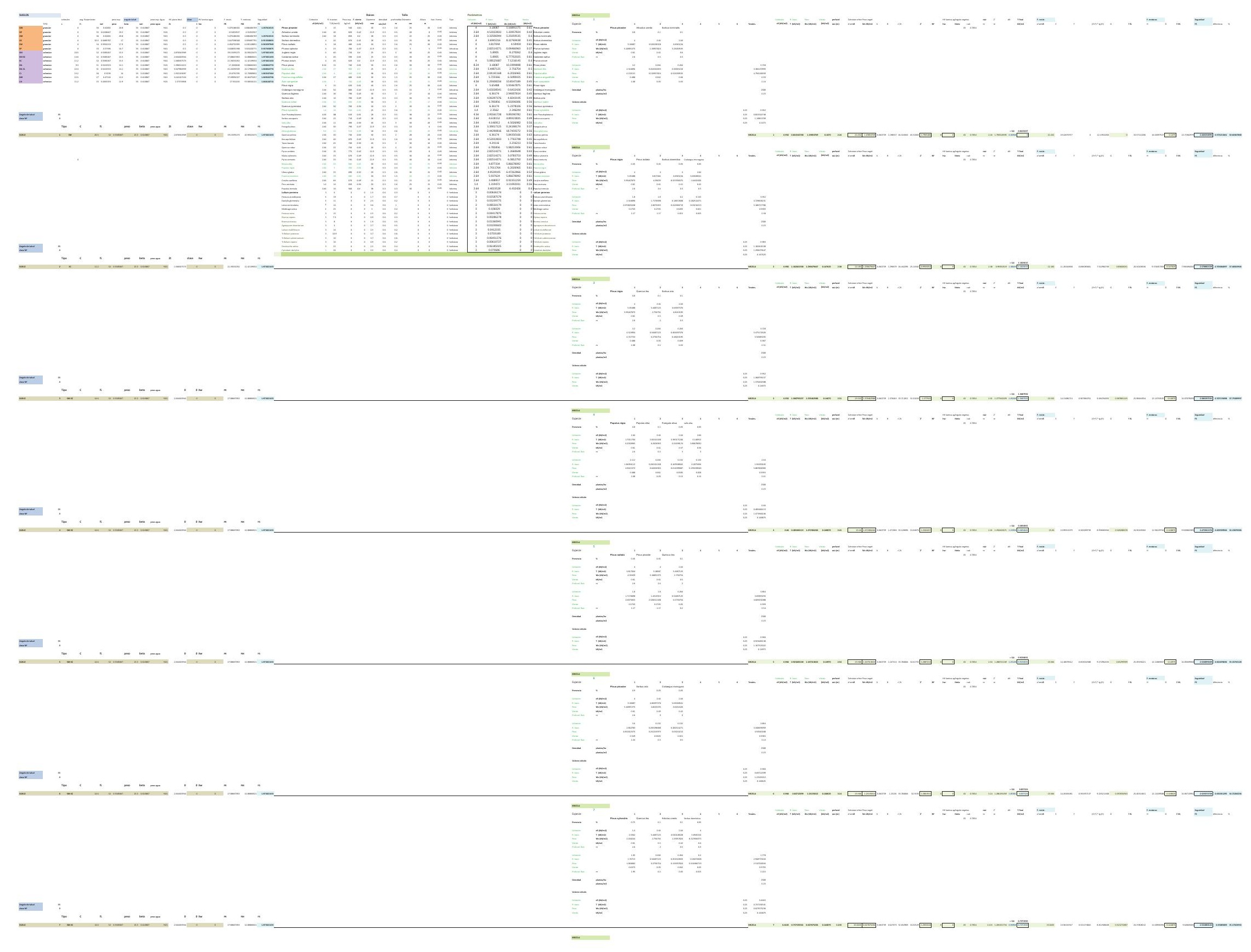


$=$

$=$

- $\pm$

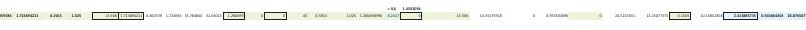

$\equiv=-$

$= \pm$

$-$

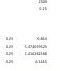




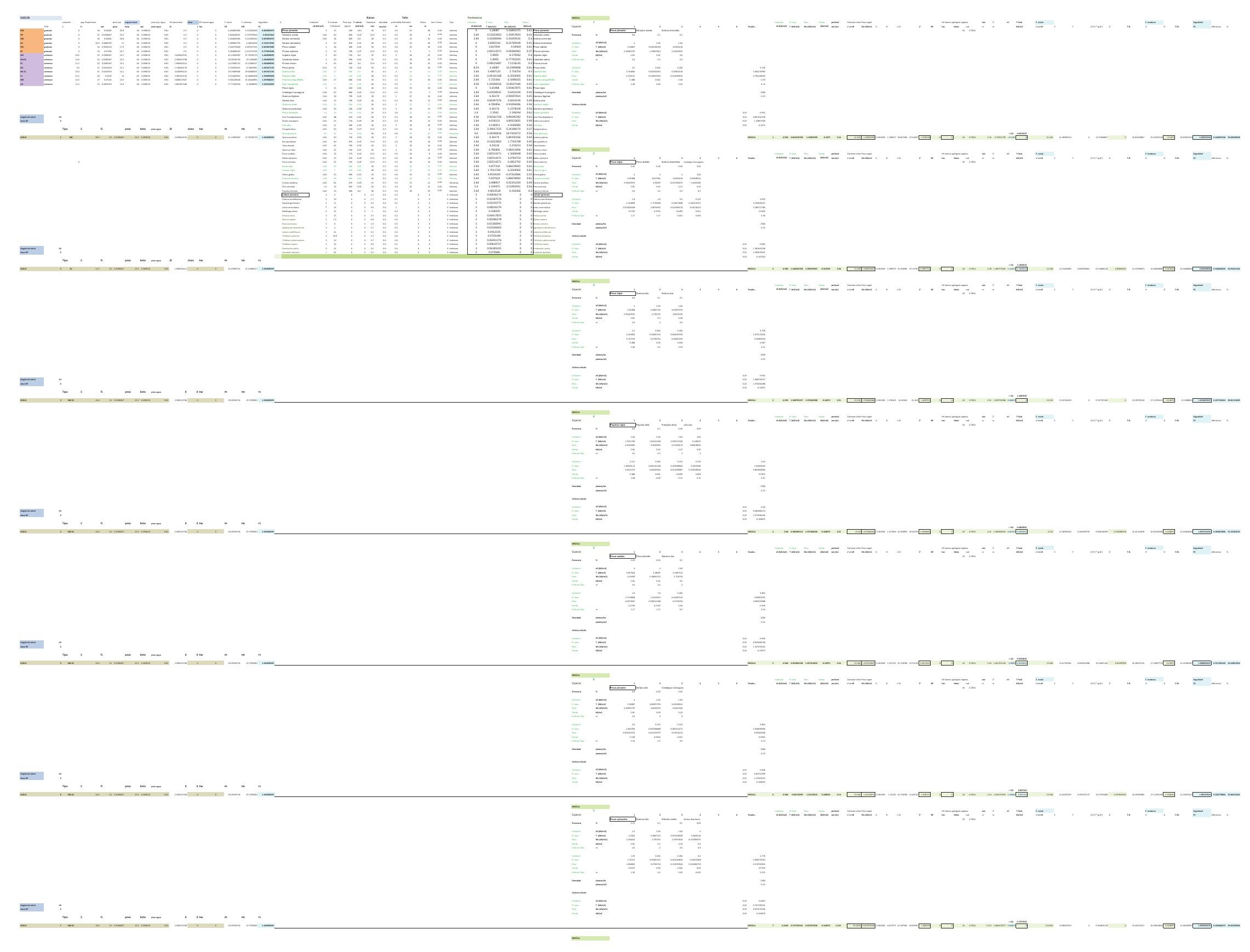




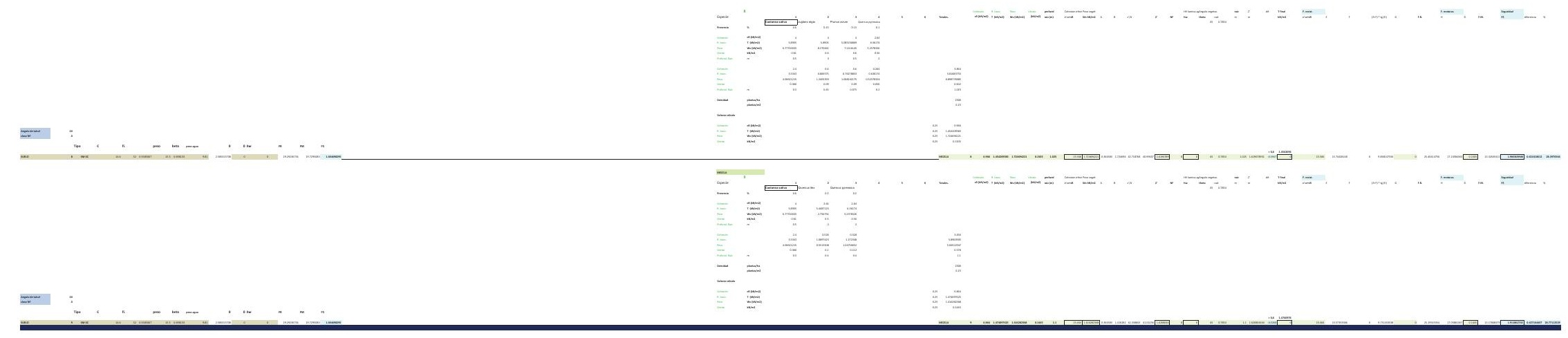




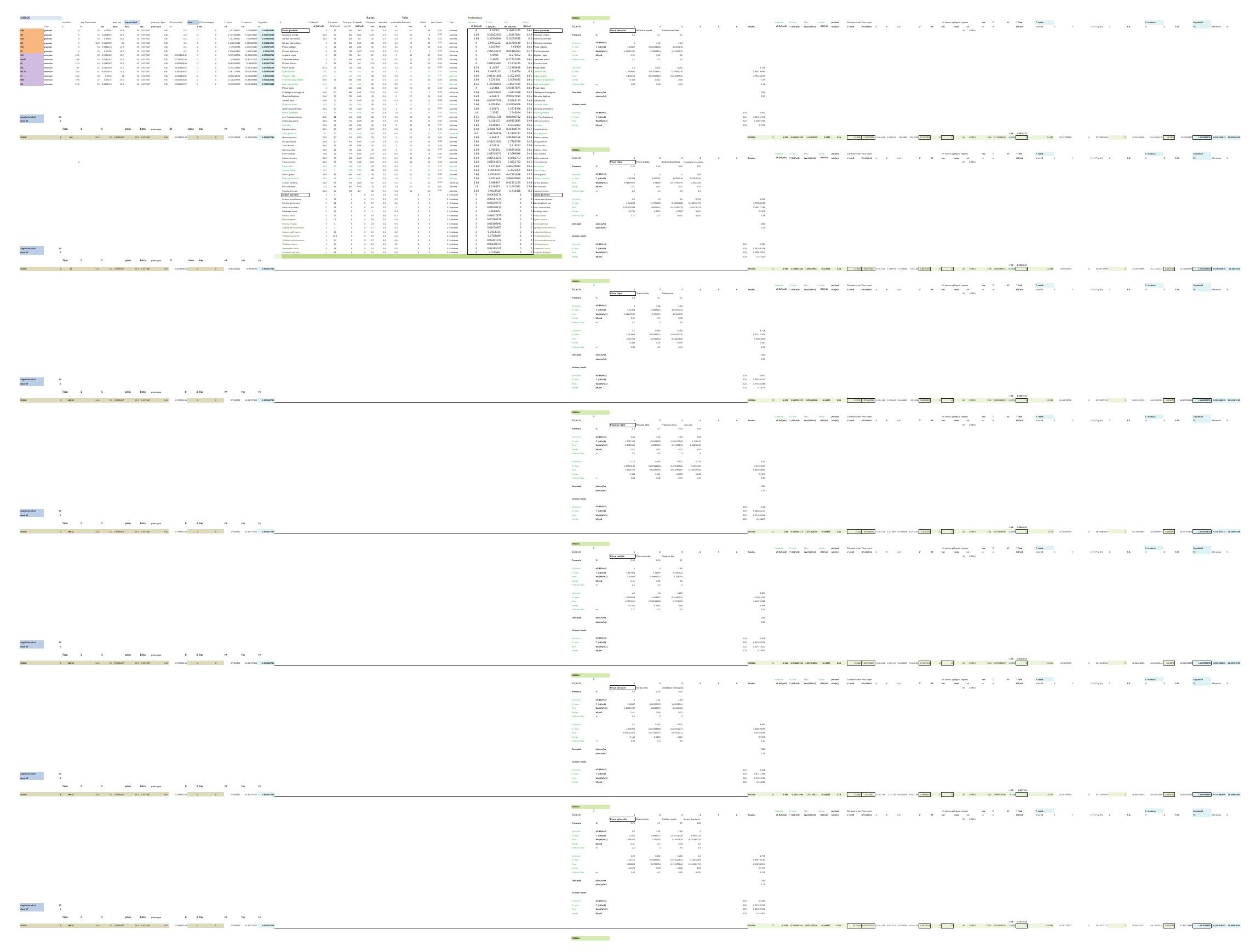




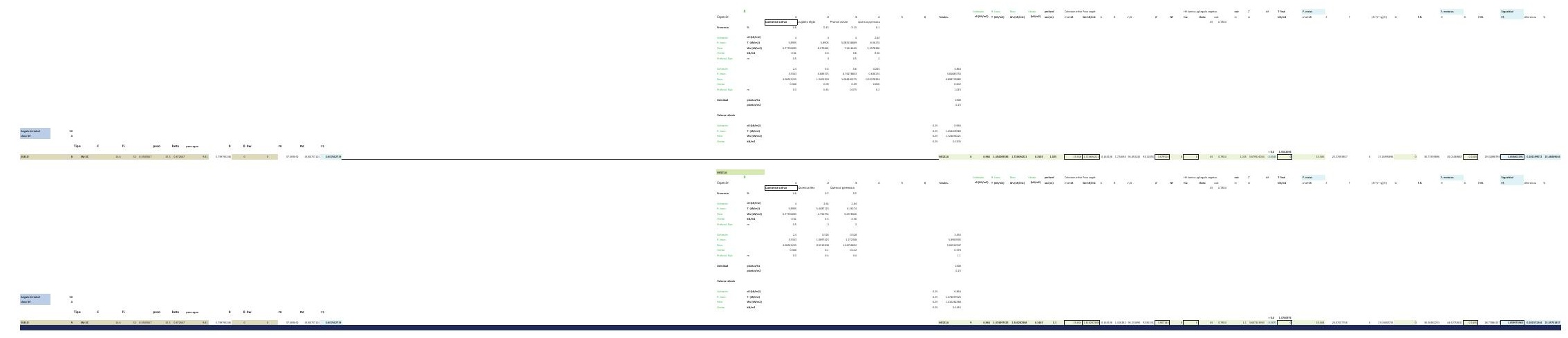




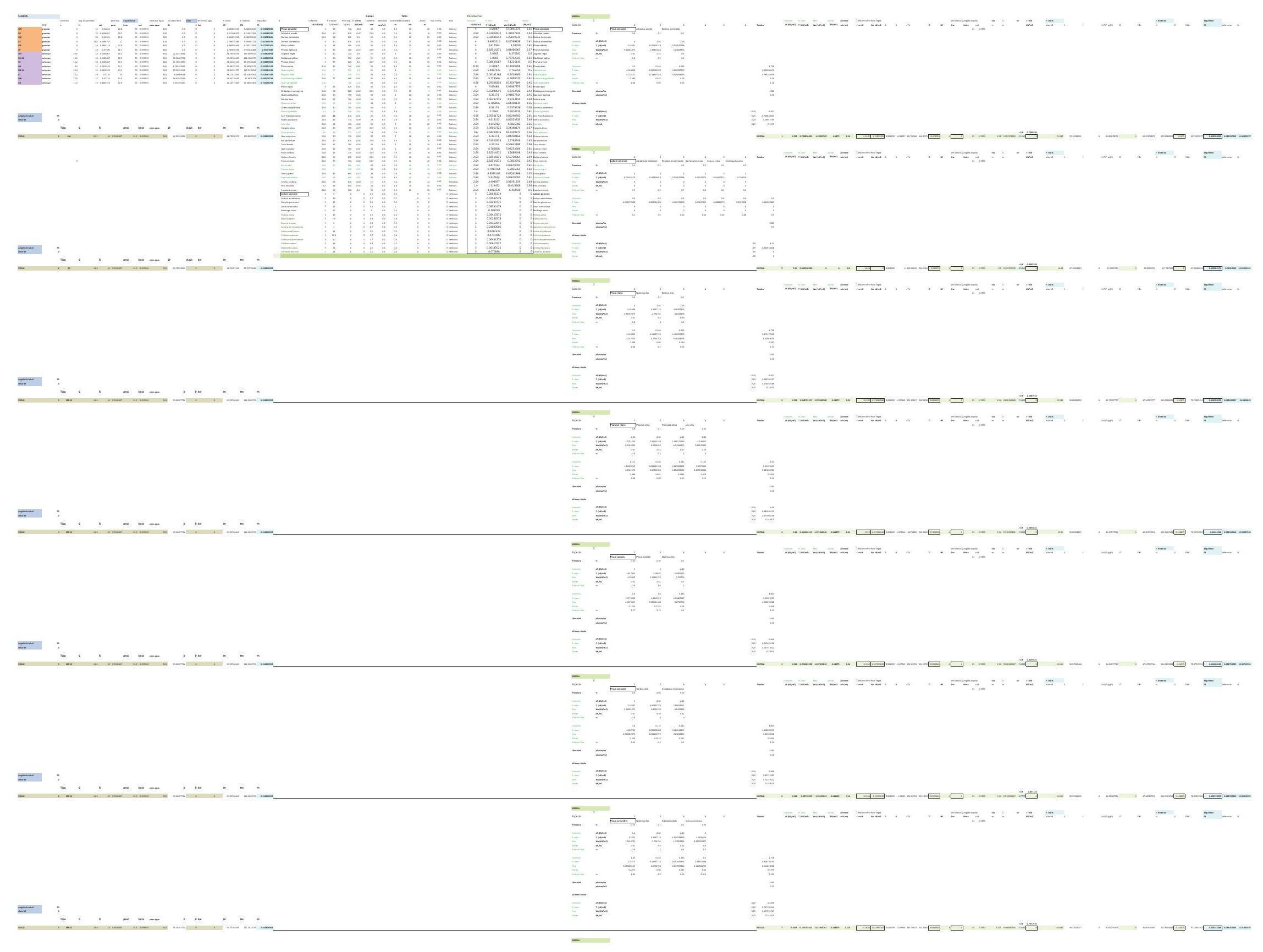




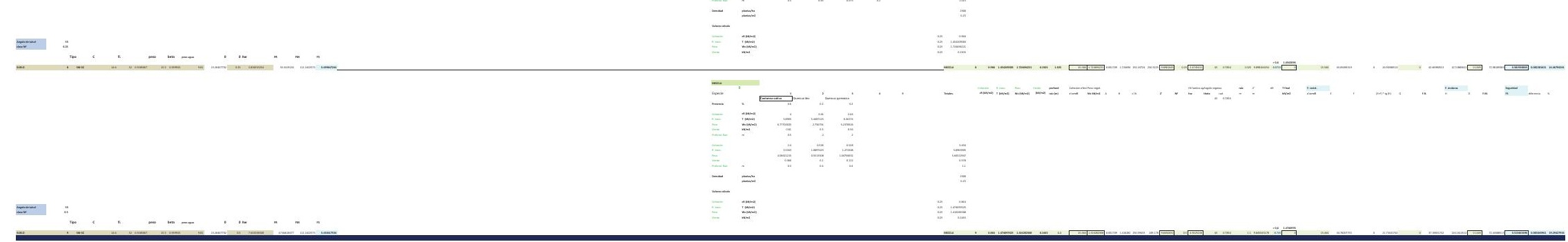




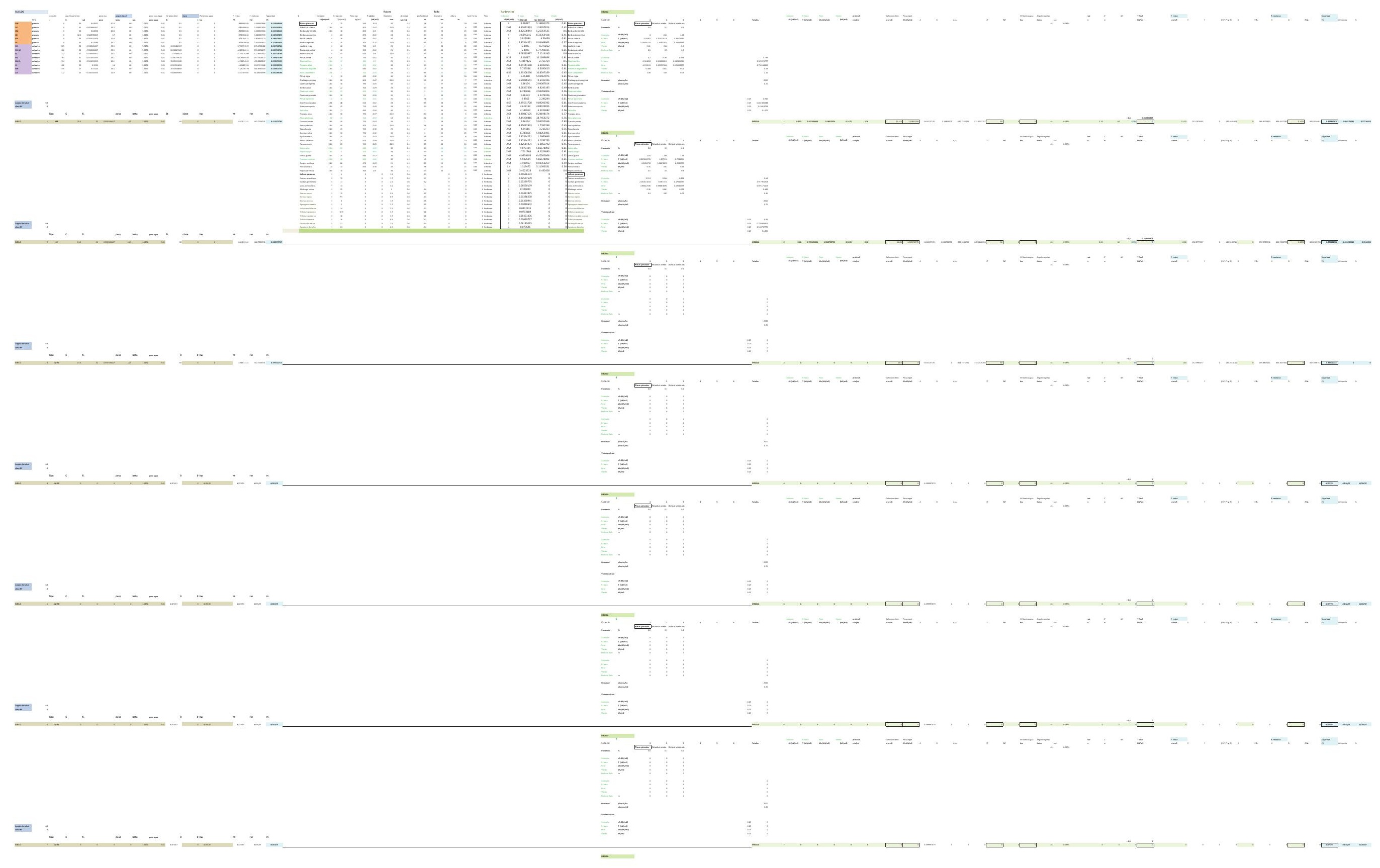




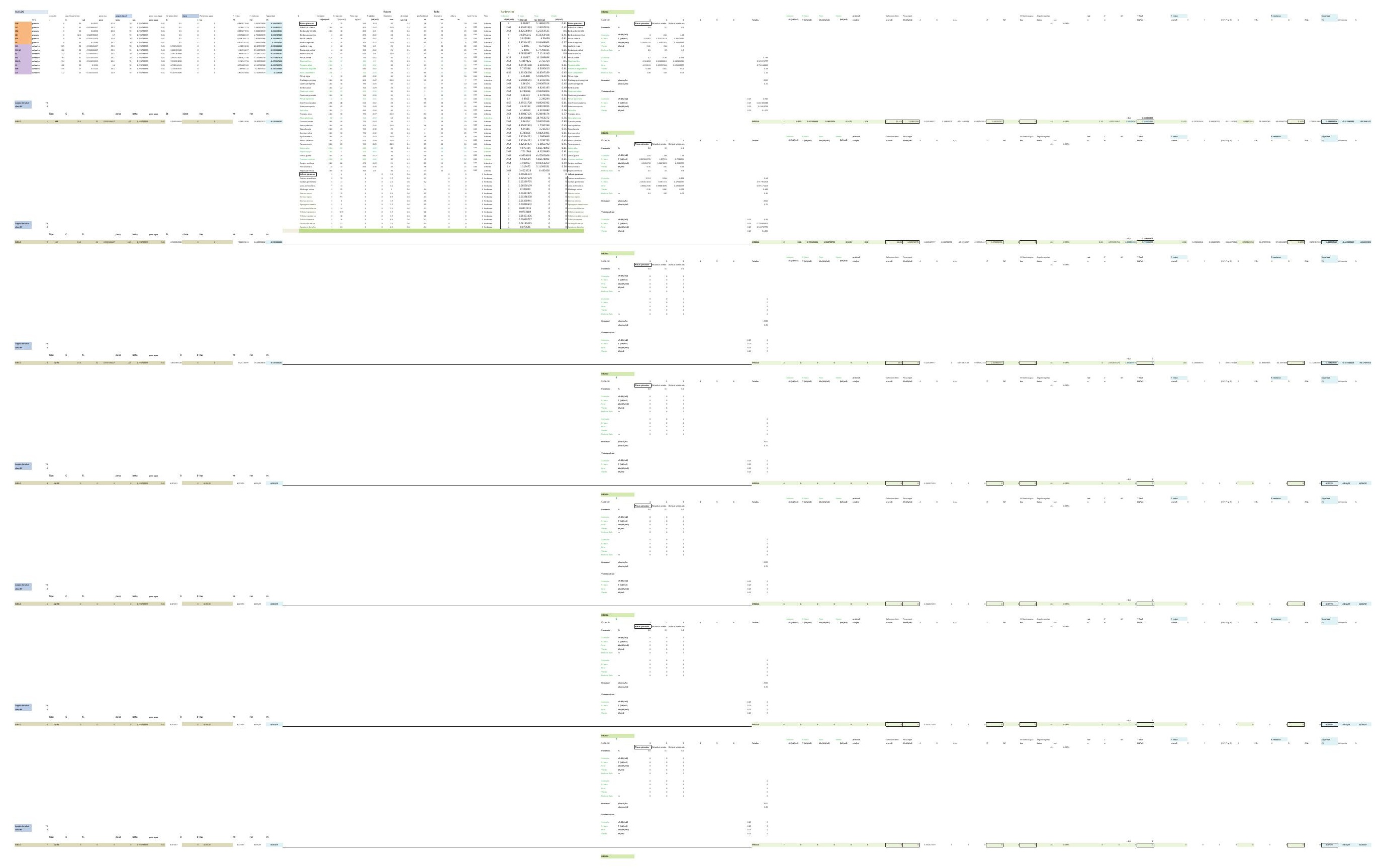




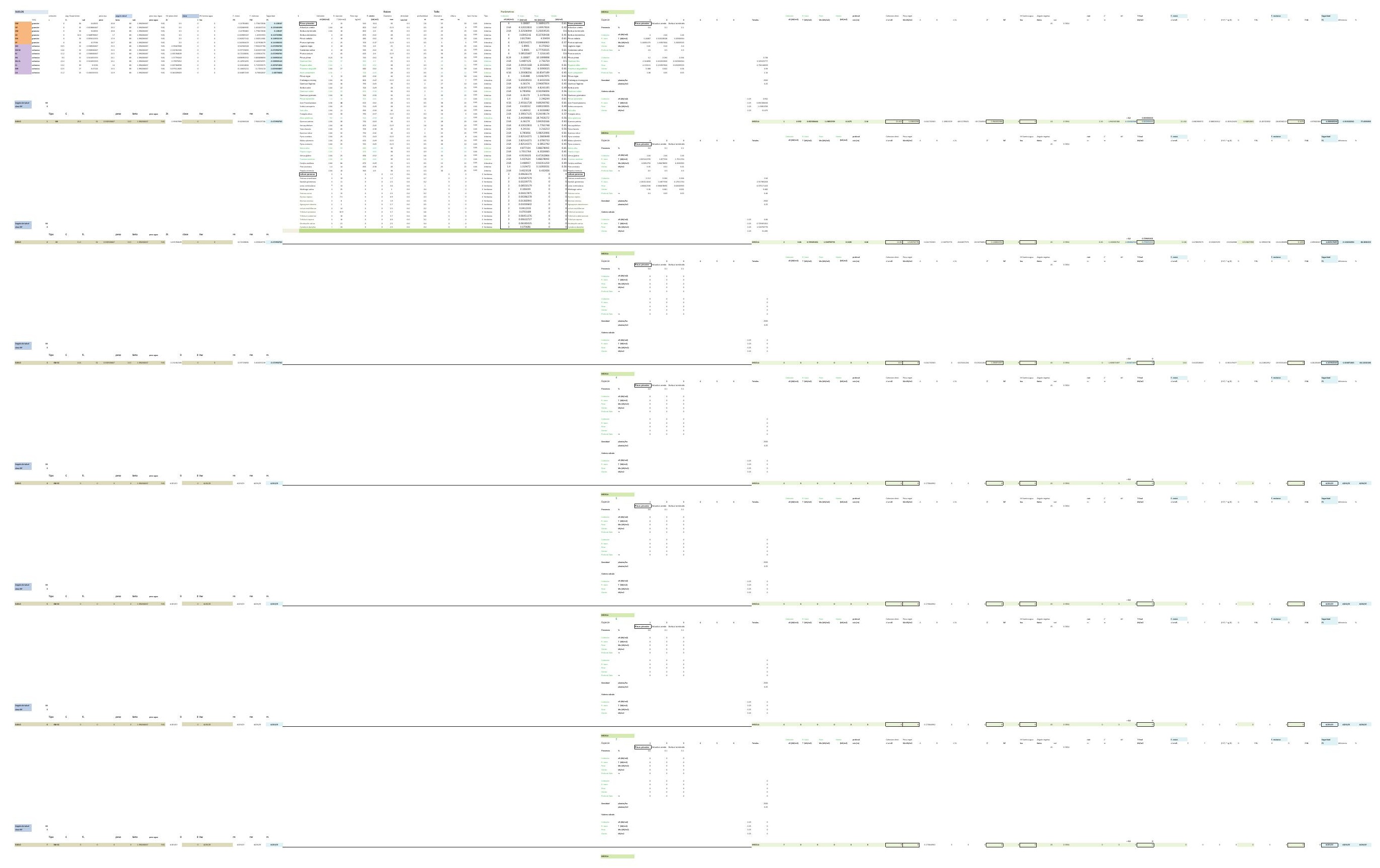


DESARROLLO DE UNA APLICACIÓN IMFORMÁTICA PARA EL CÁLCULO DE SOSTENIMIENTO DE TALUDES MEDIANTE VEGETACIÓN

PRUEBAS DEL MODELO MATEMÁTICO PARA EL CÁLCULO DE ESTABILIDAD DE TALUDES.

B03. DENSIDAD DE PLANTACIÓN: 2.500 plantas/ha.

B03-1.POSICIÓN N.F. 1

B03-2.POSICIÓN N.F. 2

B03-3.POSICIÓN N.F. 3

B03-4.POSICIÓN N.F. 4

B03-5.POSICIÓN N.F. 5 
DESARROLLO DE UNA APLICACIÓN IMFORMÁTICA PARA EL CÁLCULO DE SOSTENIMIENTO DE TALUDES MEDIANTE VEGETACIÓN

B03. DENSIDAD DE PLANTACIÓN: 2.500 plantas/ha.

\section{B03-1.POSICIÓN N.F. 1}

INCLINACIÓN DE TALUD 6-100

INCLINACIÓN DE TALUD 10-200

INCLINACIÓN DE TALUD 20-30

INCLINACIÓN DE TALUD 30-40

INCLINACIÓN DE TALUD $35^{\circ}$

INCLINACIÓN DE TALUD 40-50

INCLINACIÓN DE TALUD 50-550

INCLINACIÓN DE TALUD 55-60

INCLINACIÓN DE TALUD 60-700

INCLINACIÓN DE TALUD 70-80 


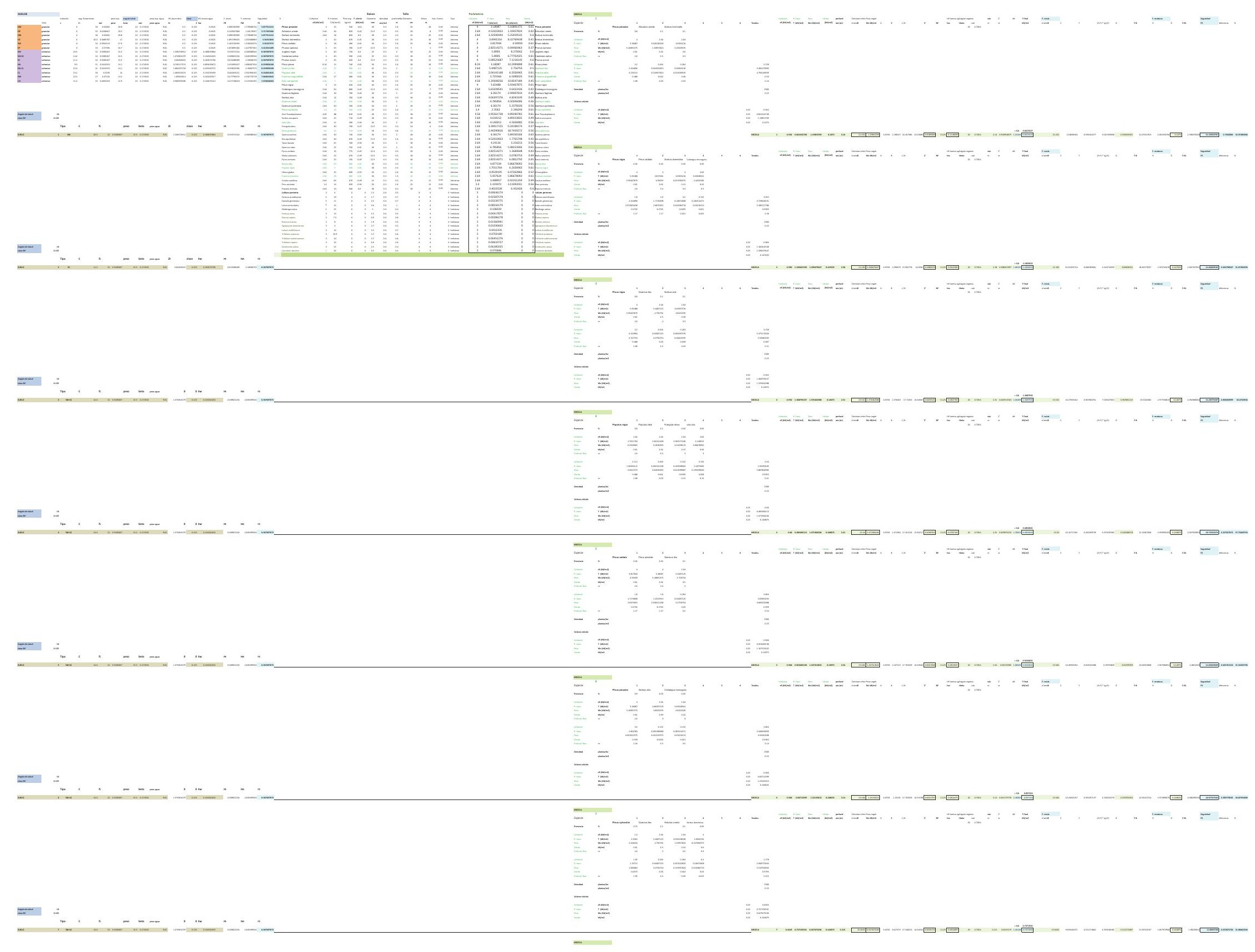


$=$

$=$

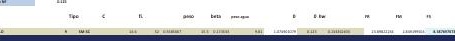

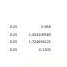

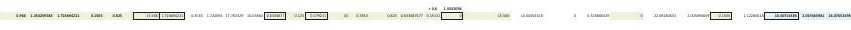

$\equiv=-$

$= \pm$

$-$

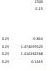




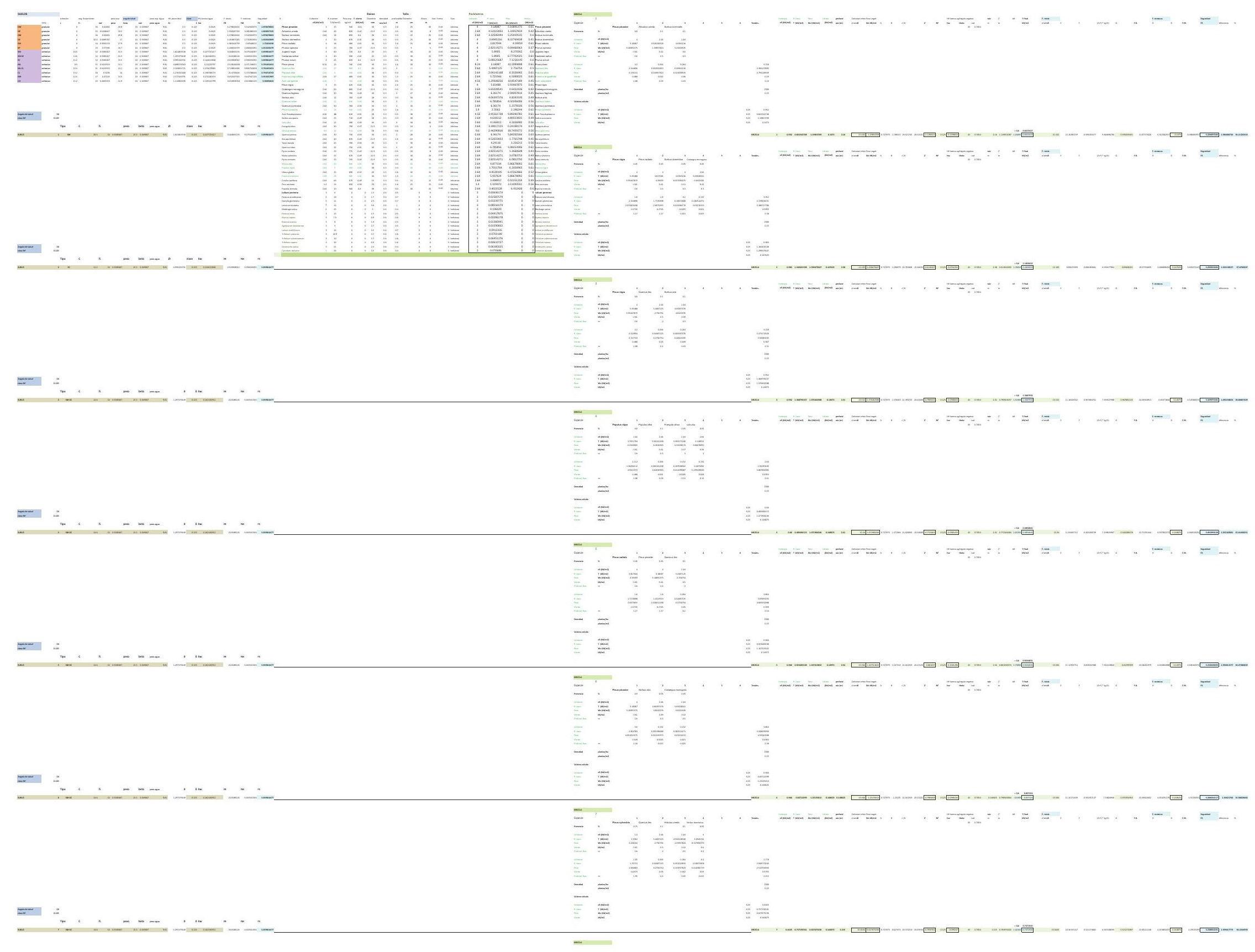


$=$

$=$

$n+\ldots+\cdots$

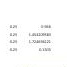

……

$\equiv=-$

$= \pm$

$-$

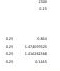




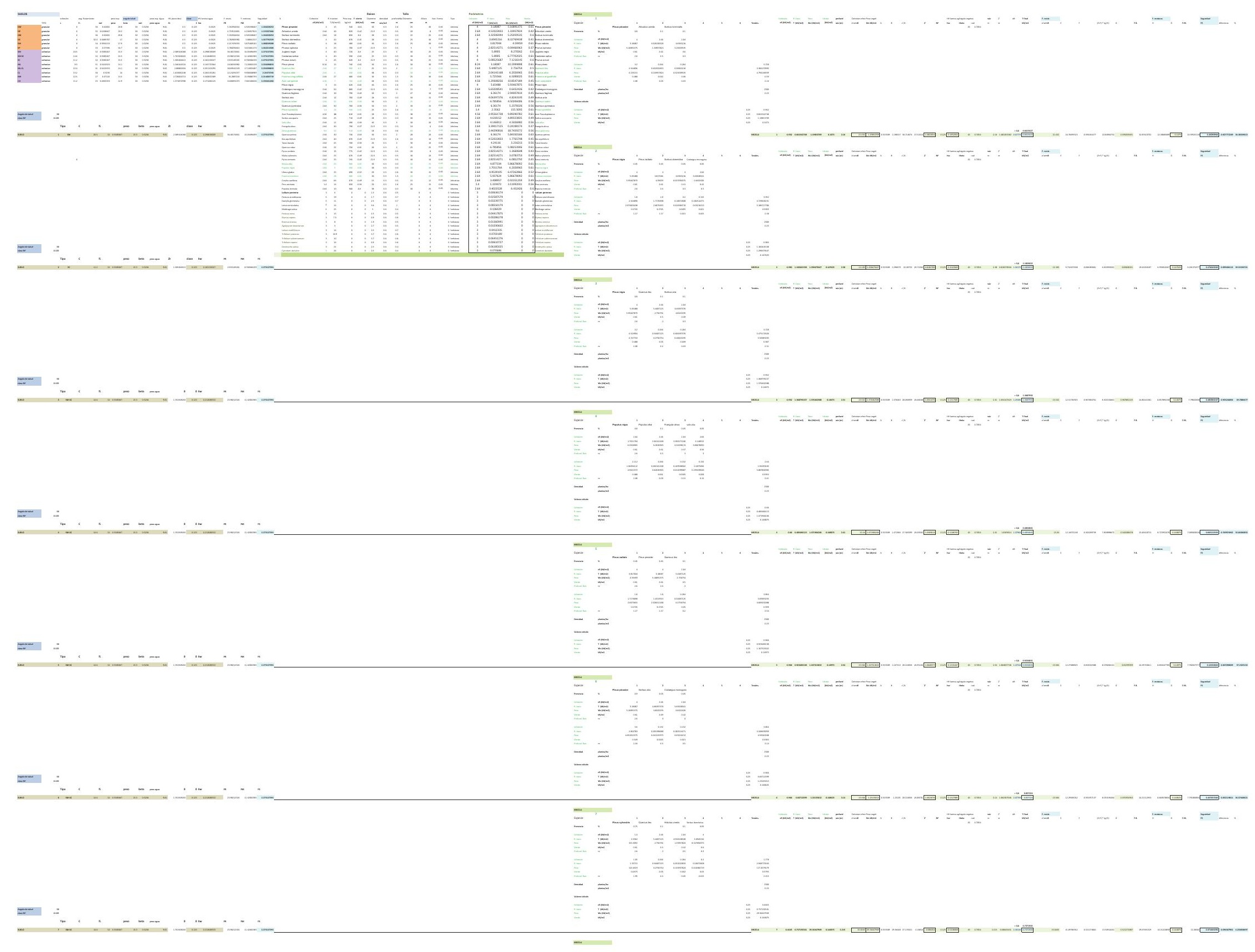


$=$

$=$

$-1+\cdots+\cdots$

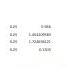

(...

$\equiv=-$

$= \pm$

$-$ 


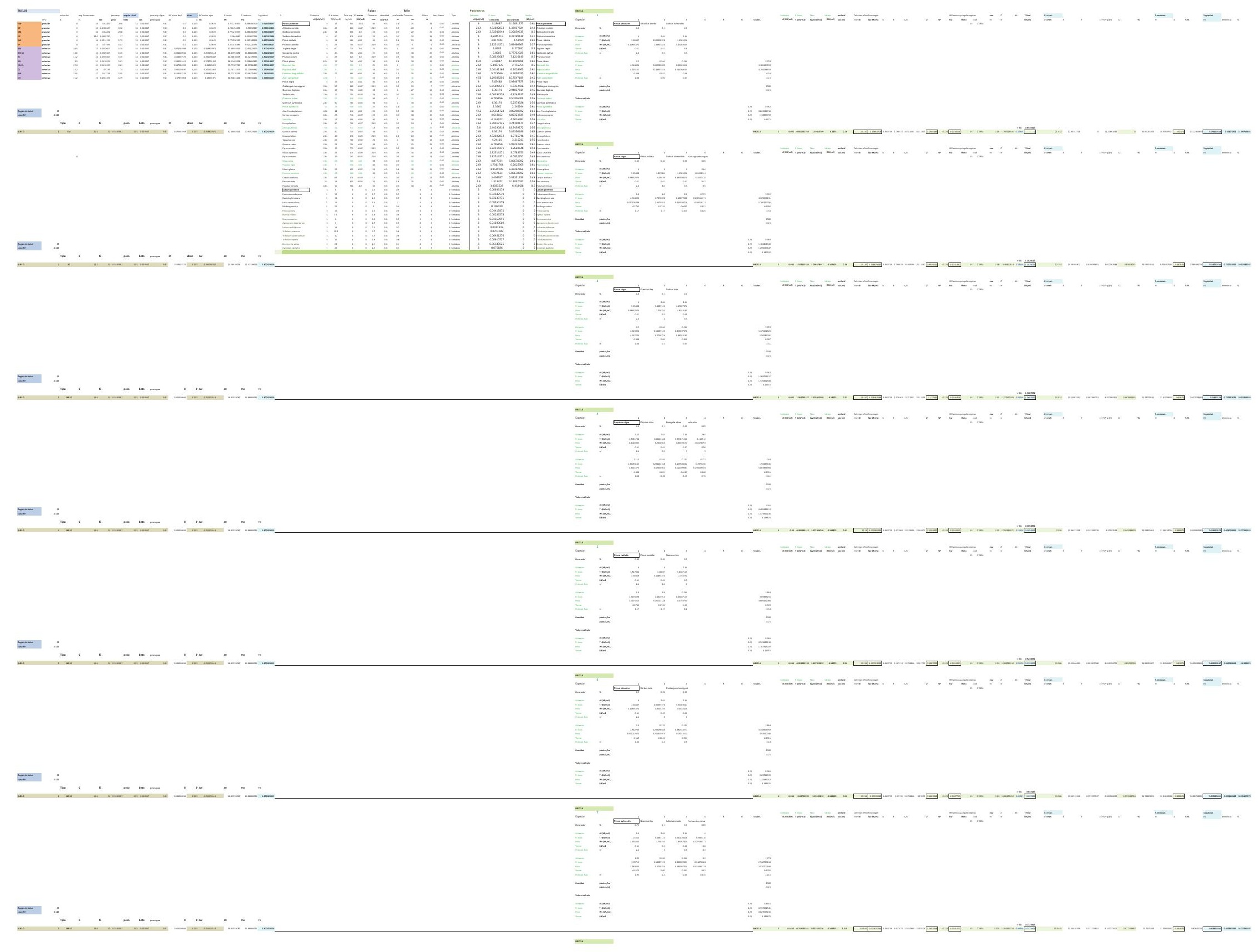




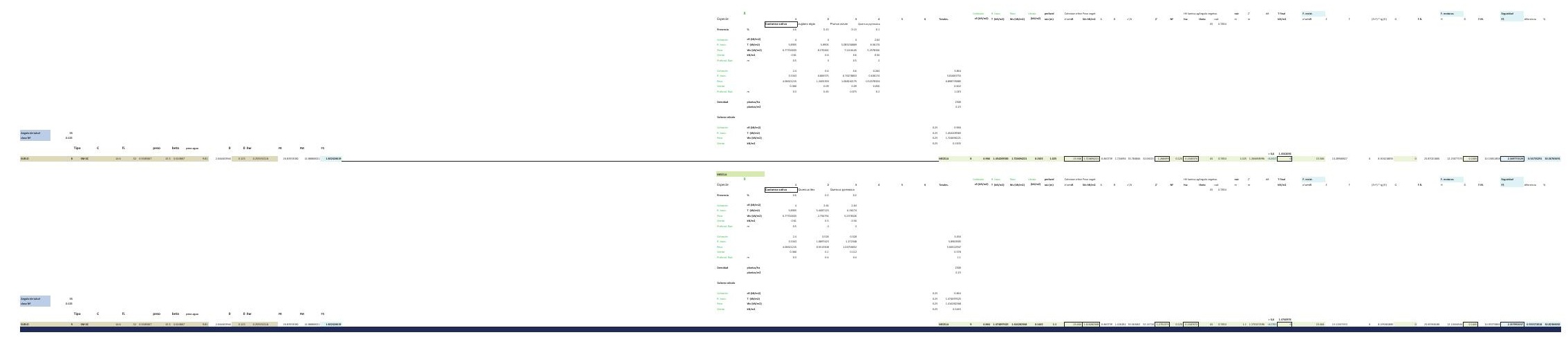




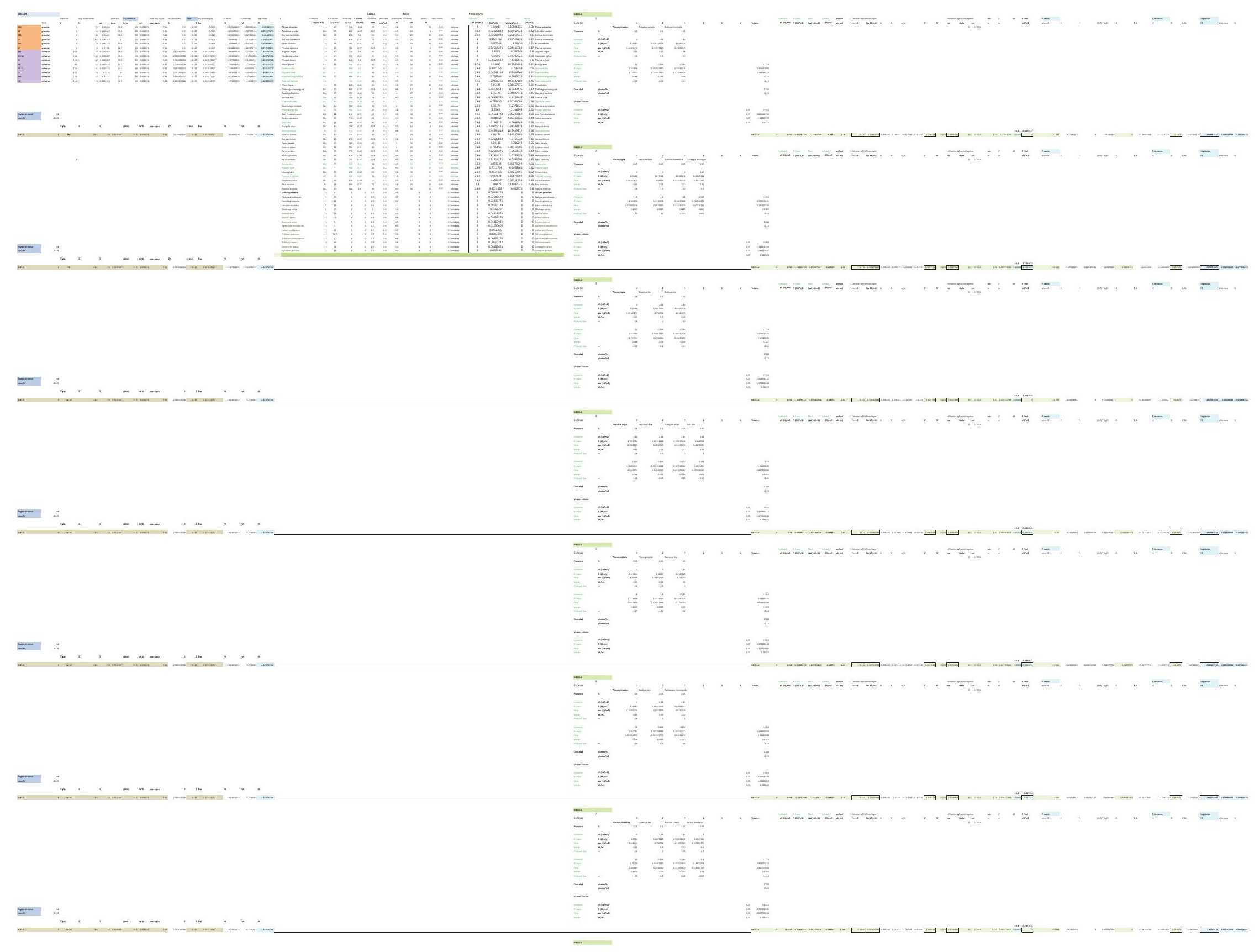


$=$

$=$

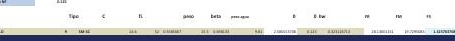

$\pm$

드.

$\equiv= \pm$

$= \pm$

$-$ 


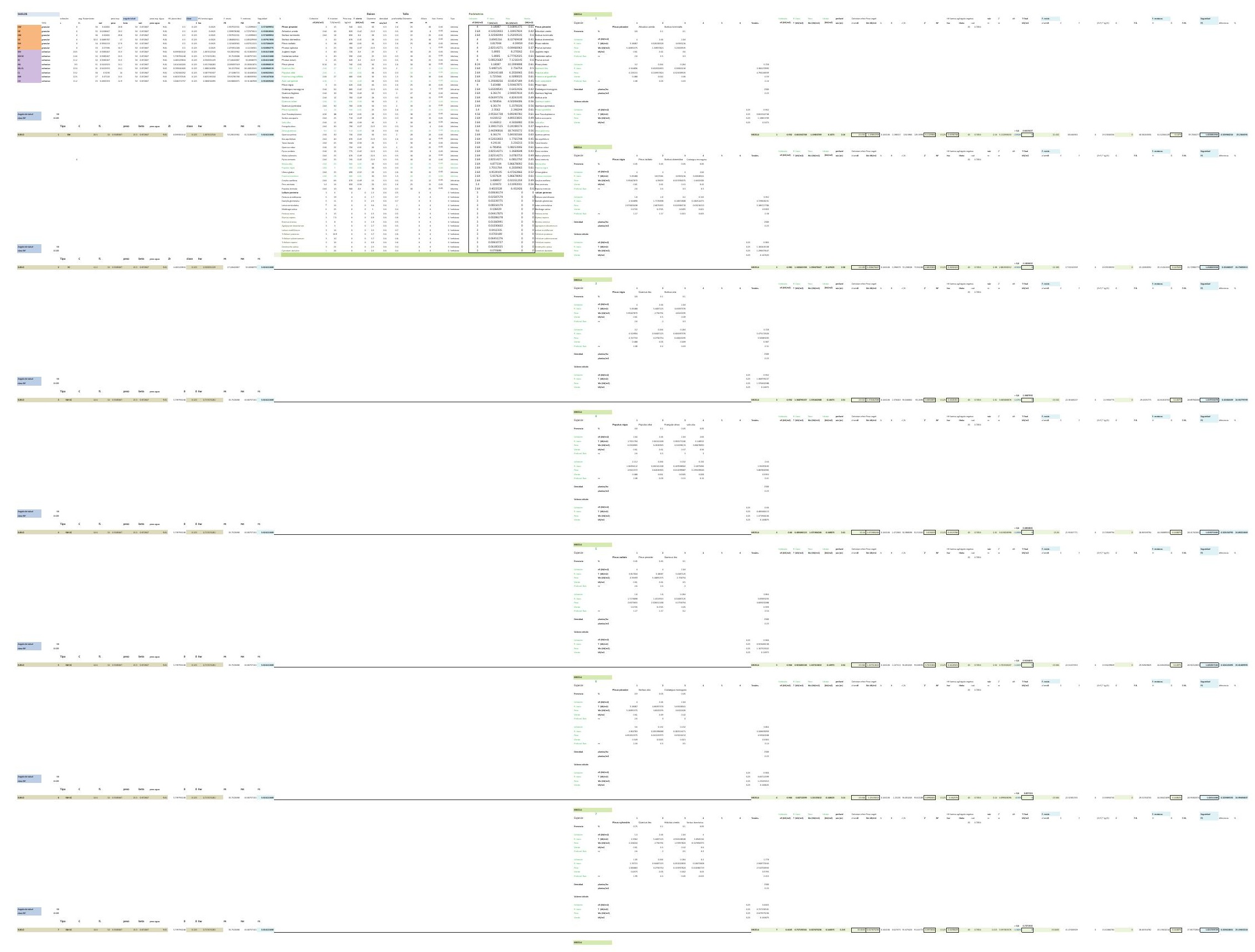


$=$

$=$

- $\pm$

……

$\equiv=-$

$\pm=$

$-$ 


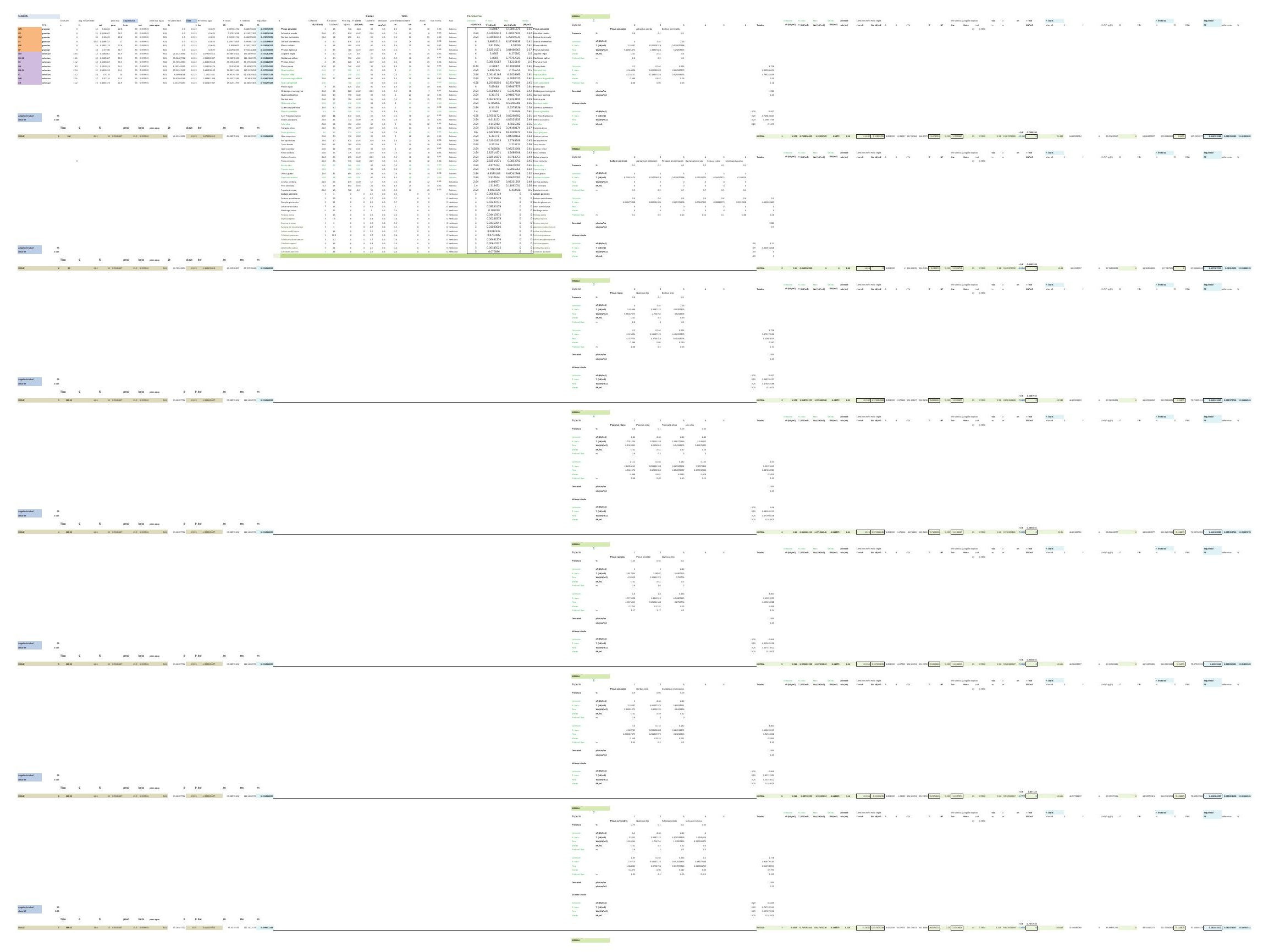


$=$

$=$

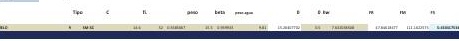

$=$

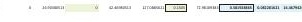

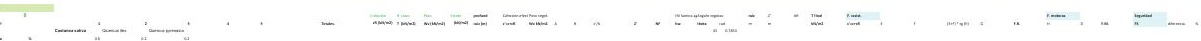

$\equiv= \pm$

$\pm= \pm$

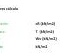




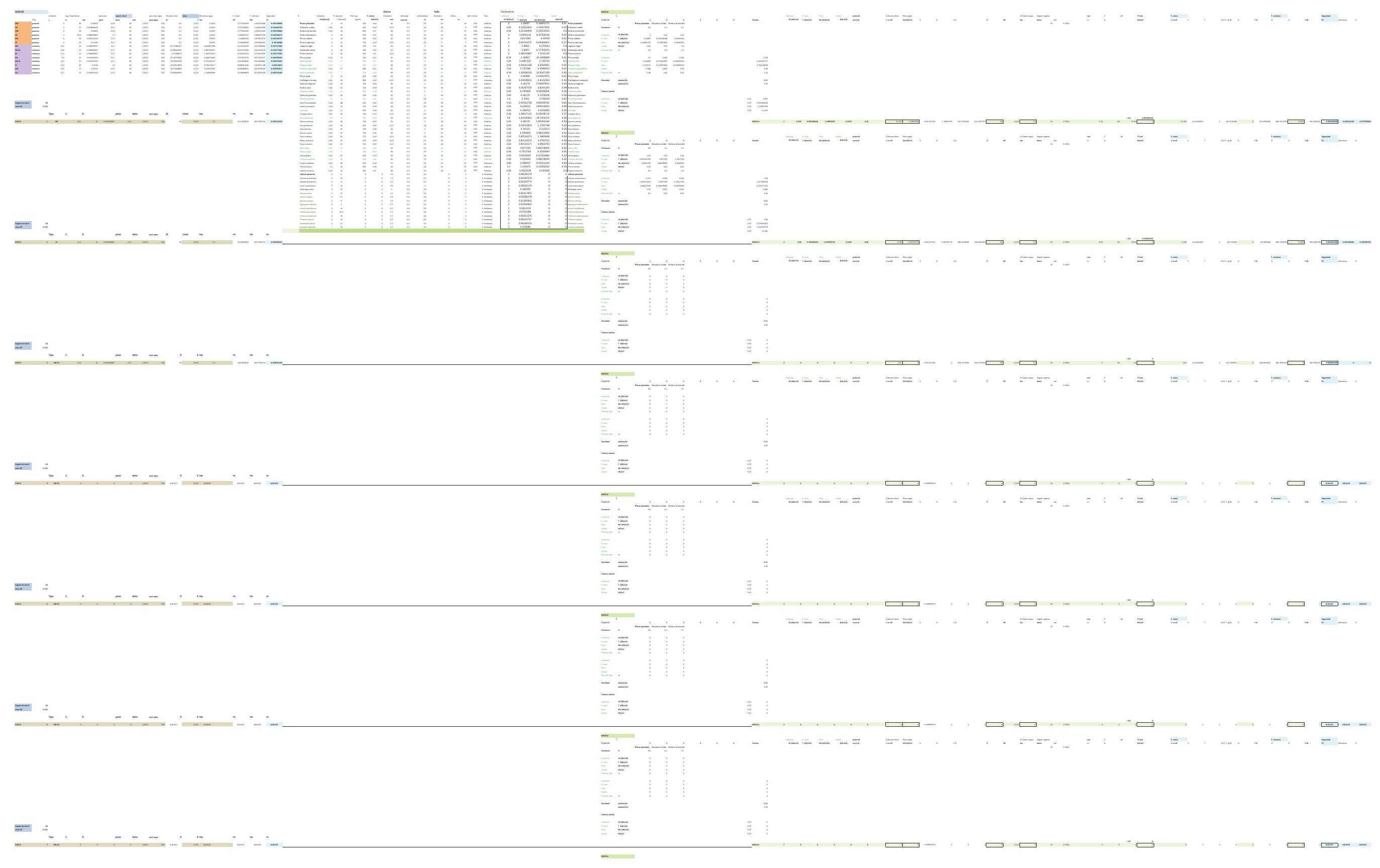




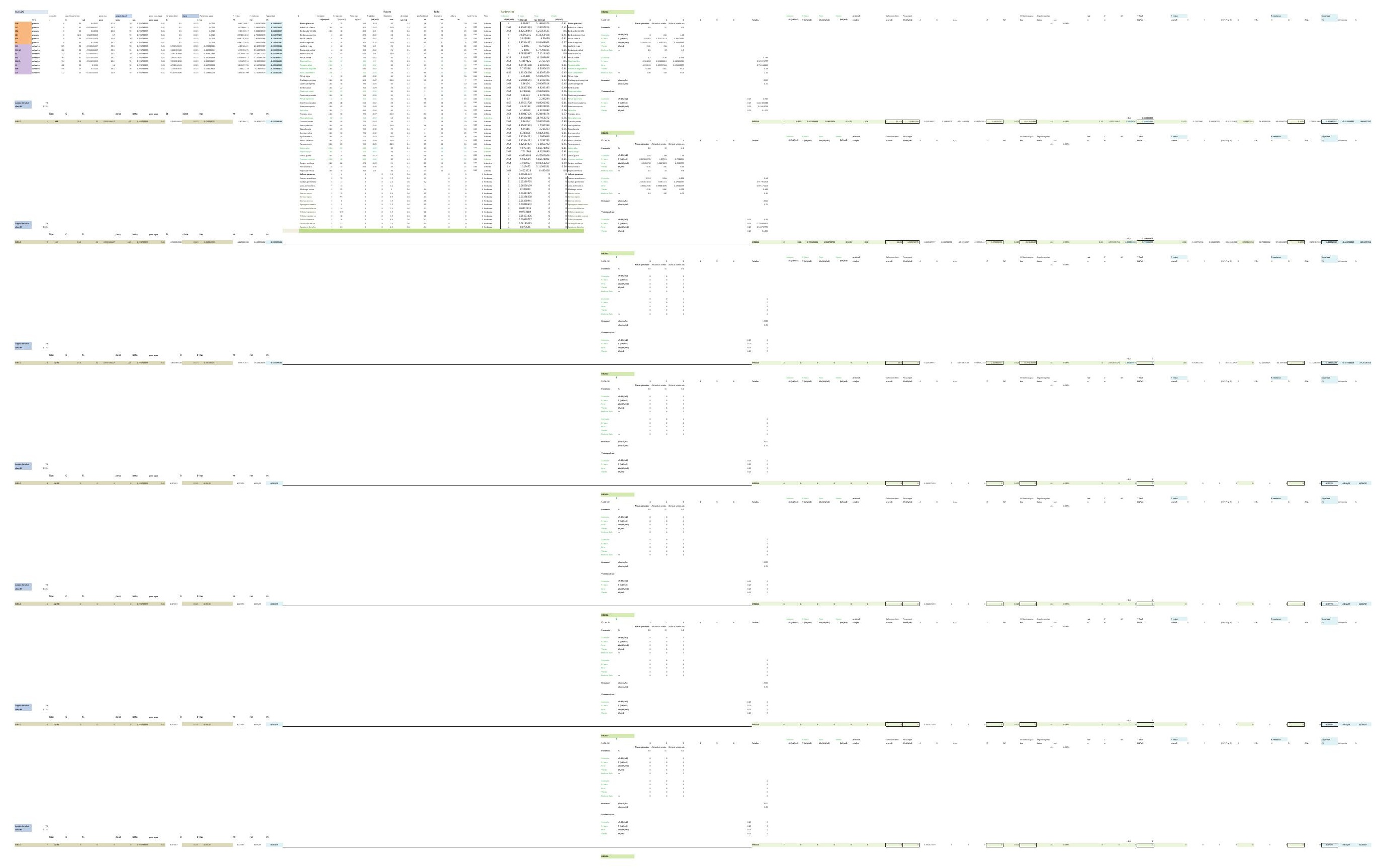




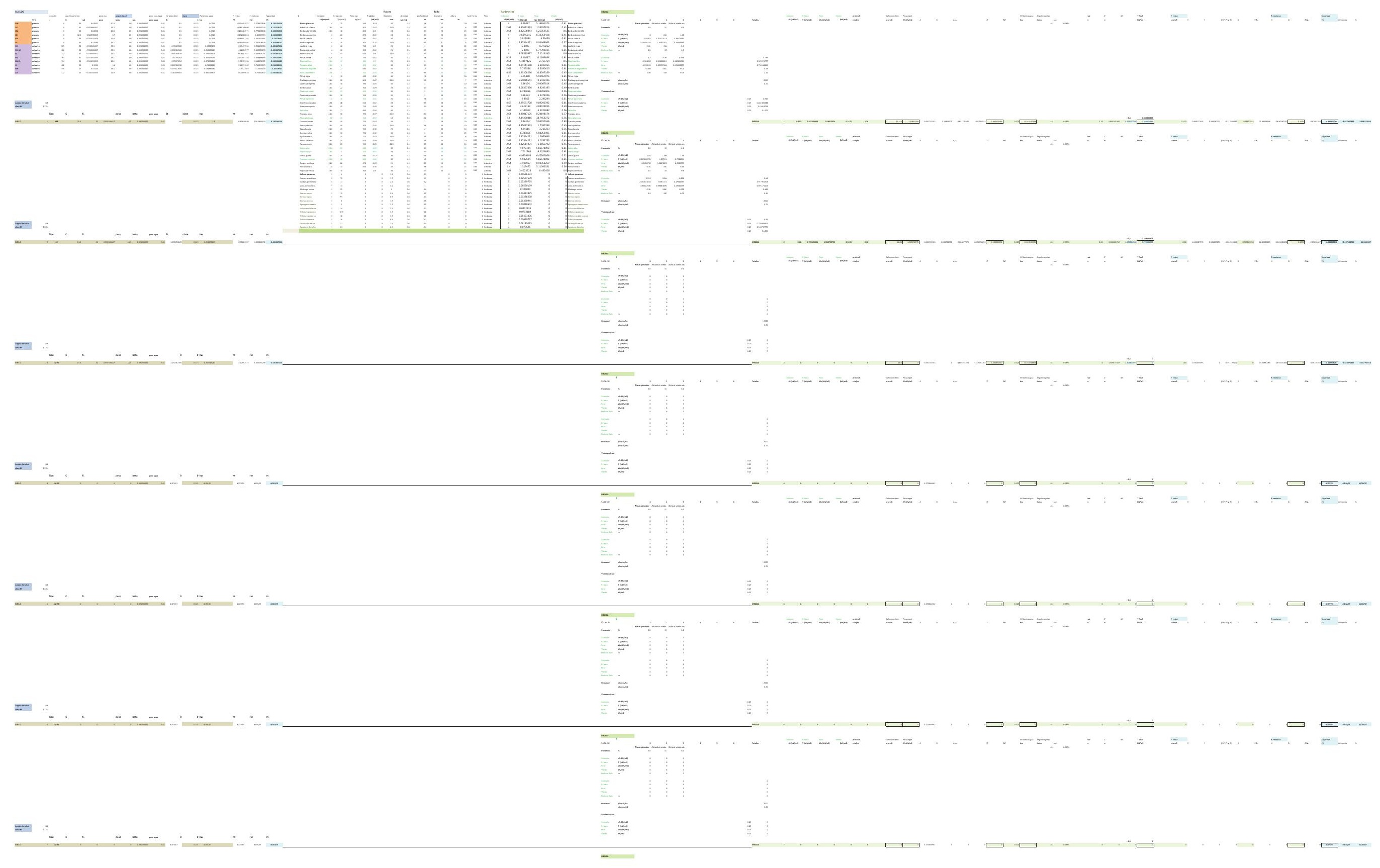


DESARROLLO DE UNA APLICACIÓN IMFORMÁTICA PARA EL CÁLCULO DE SOSTENIMIENTO DE TALUDES MEDIANTE VEGETACIÓN

B03. DENSIDAD DE PLANTACIÓN: 2.500 plantas/ha.

\section{B03-3.POSICIÓN N.F. 3}

INCLINACIÓN DE TALUD 6-100

INCLINACIÓN DE TALUD 10-200

INCLINACIÓN DE TALUD 20-30

INCLINACIÓN DE TALUD 30-40

INCLINACIÓN DE TALUD $35^{\circ}$

INCLINACIÓN DE TALUD 40-50

INCLINACIÓN DE TALUD 50-550

INCLINACIÓN DE TALUD 55-60

INCLINACIÓN DE TALUD 60-700

INCLINACIÓN DE TALUD 70-80 


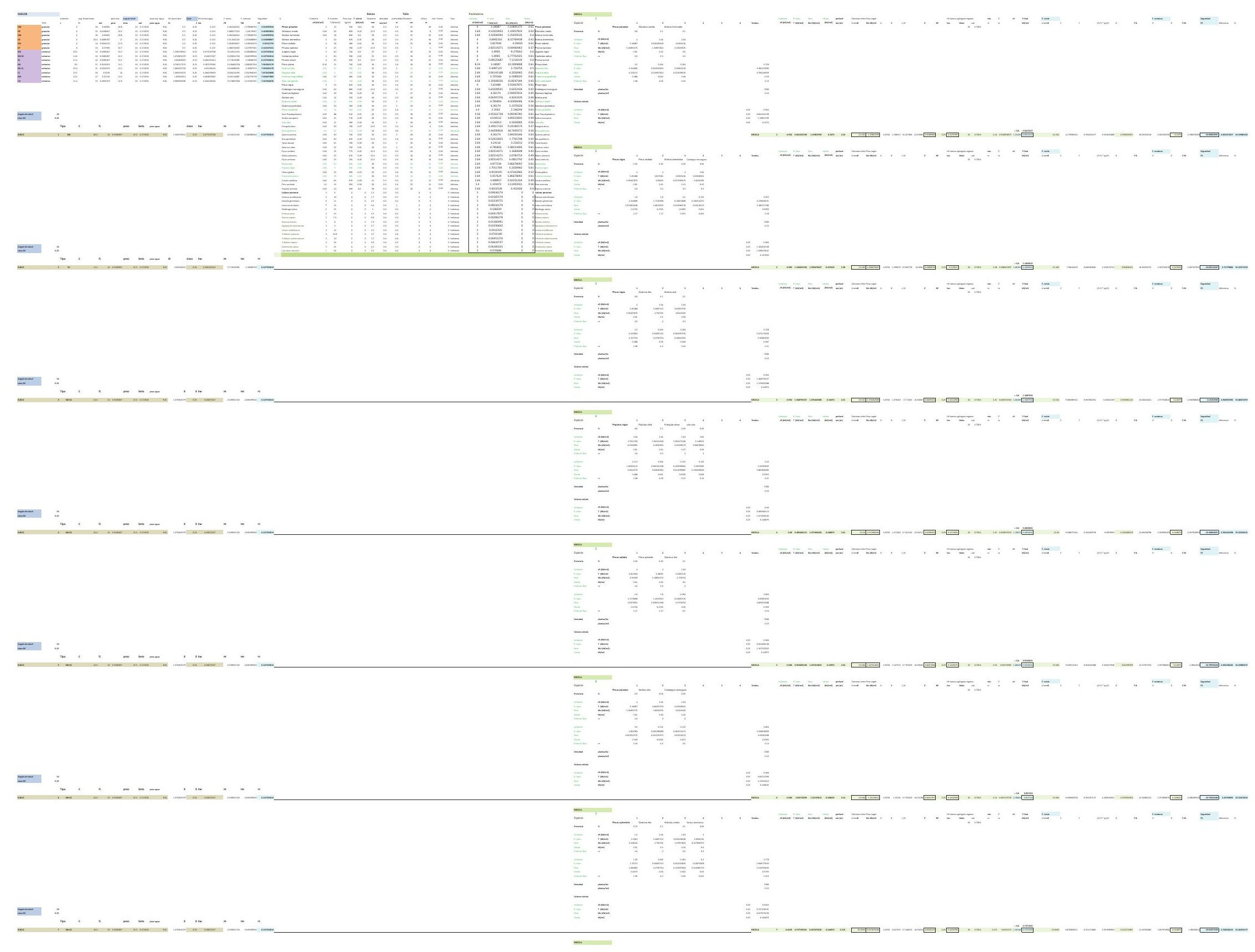


$=$

$=$

-

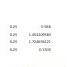

(....

$\equiv=-$

$= \pm \equiv$

$=$ 


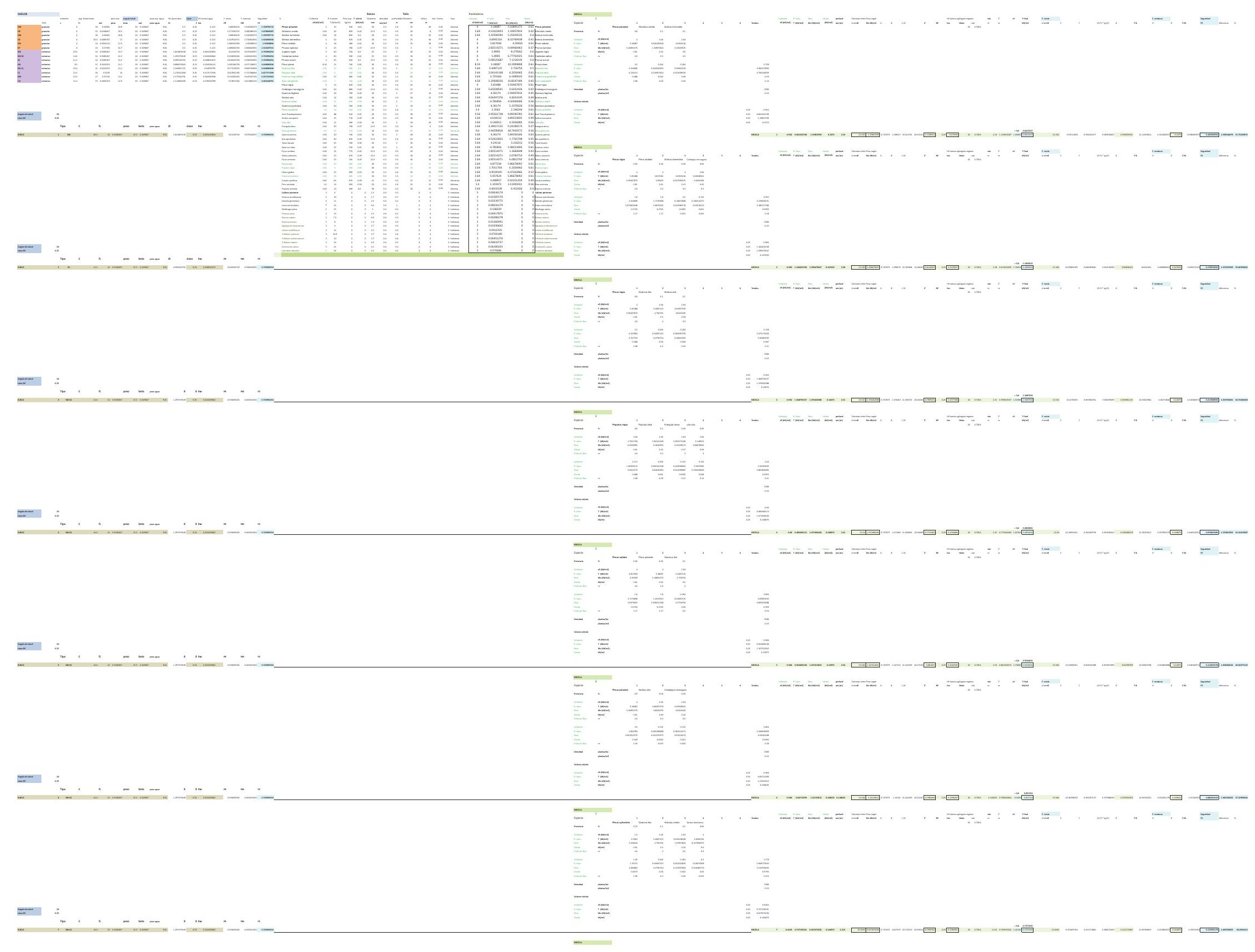


$=$

$=$

- $\pm$

(……

$\equiv= \pm$

E. $=$

$-$ 


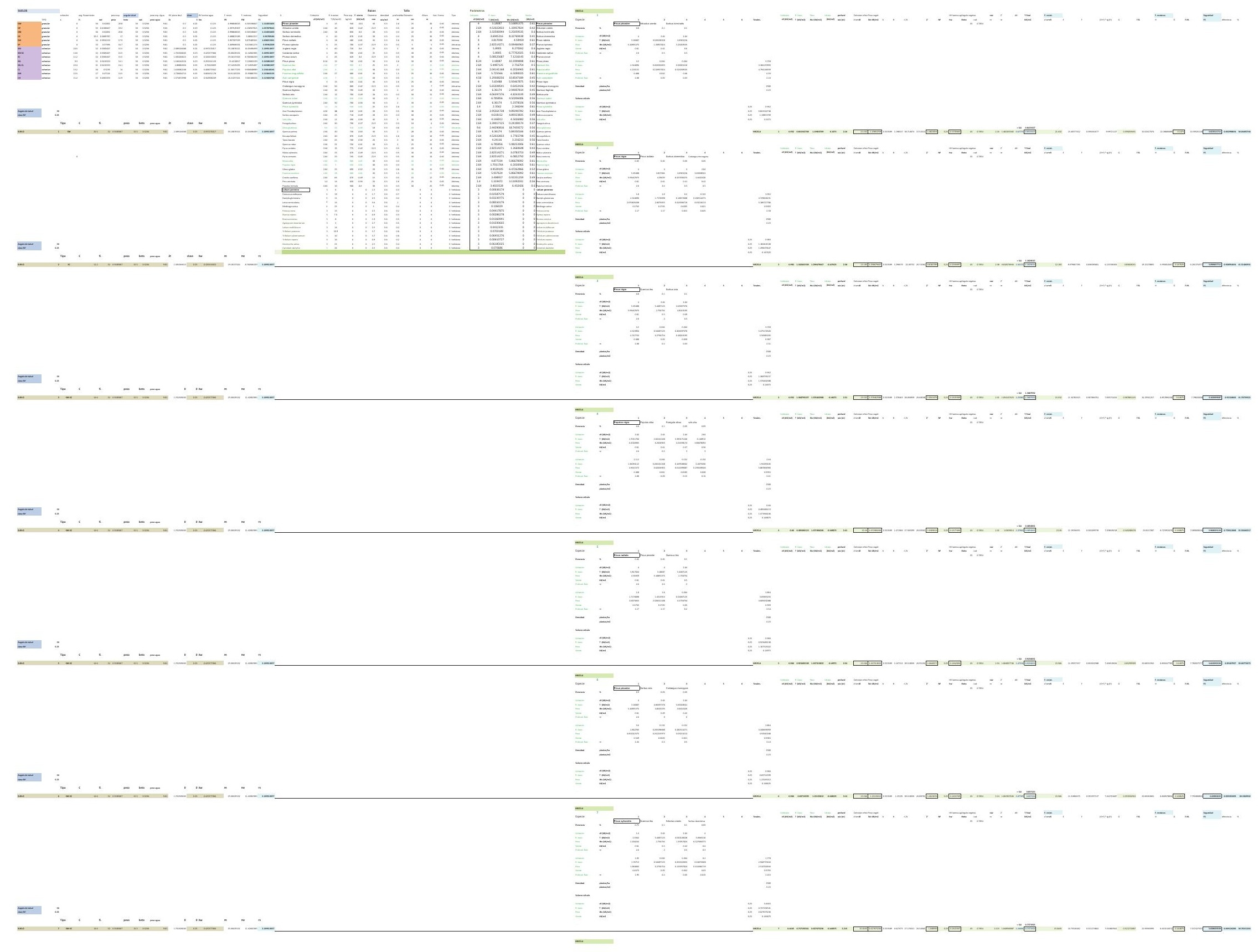




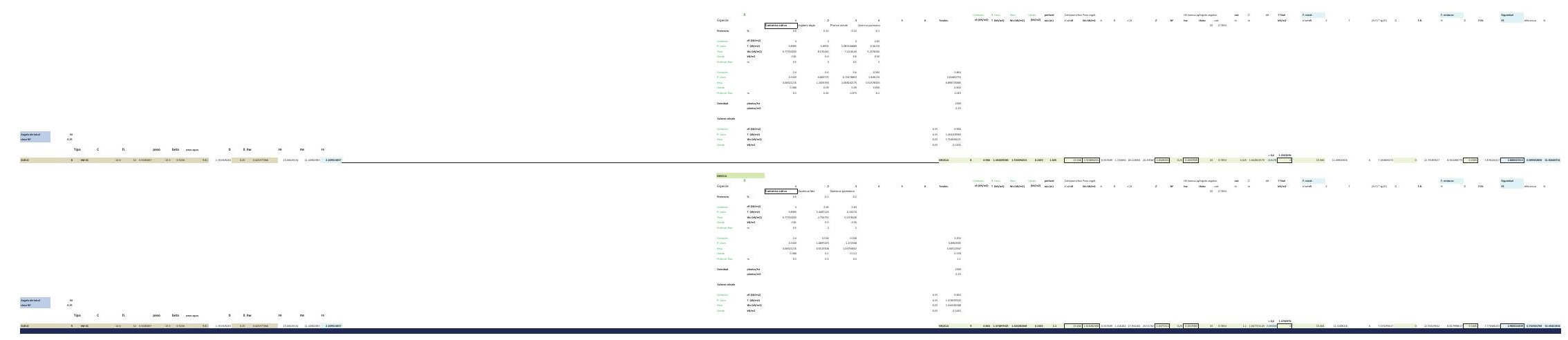




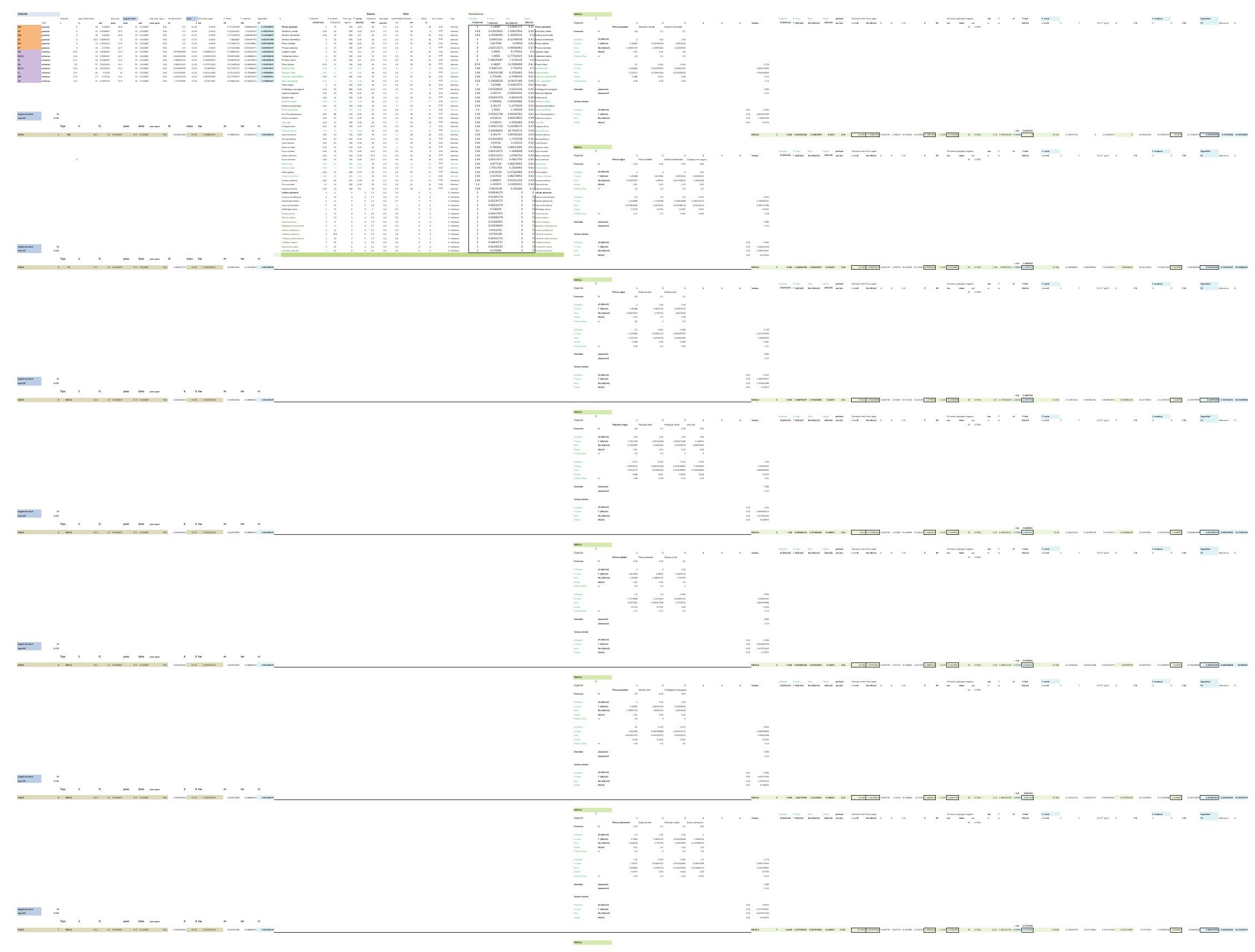


$=$

$=$

$-\ldots+\cdots+\cdots$

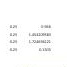

…드.

$\equiv=-$

$= \pm$

$-$ 


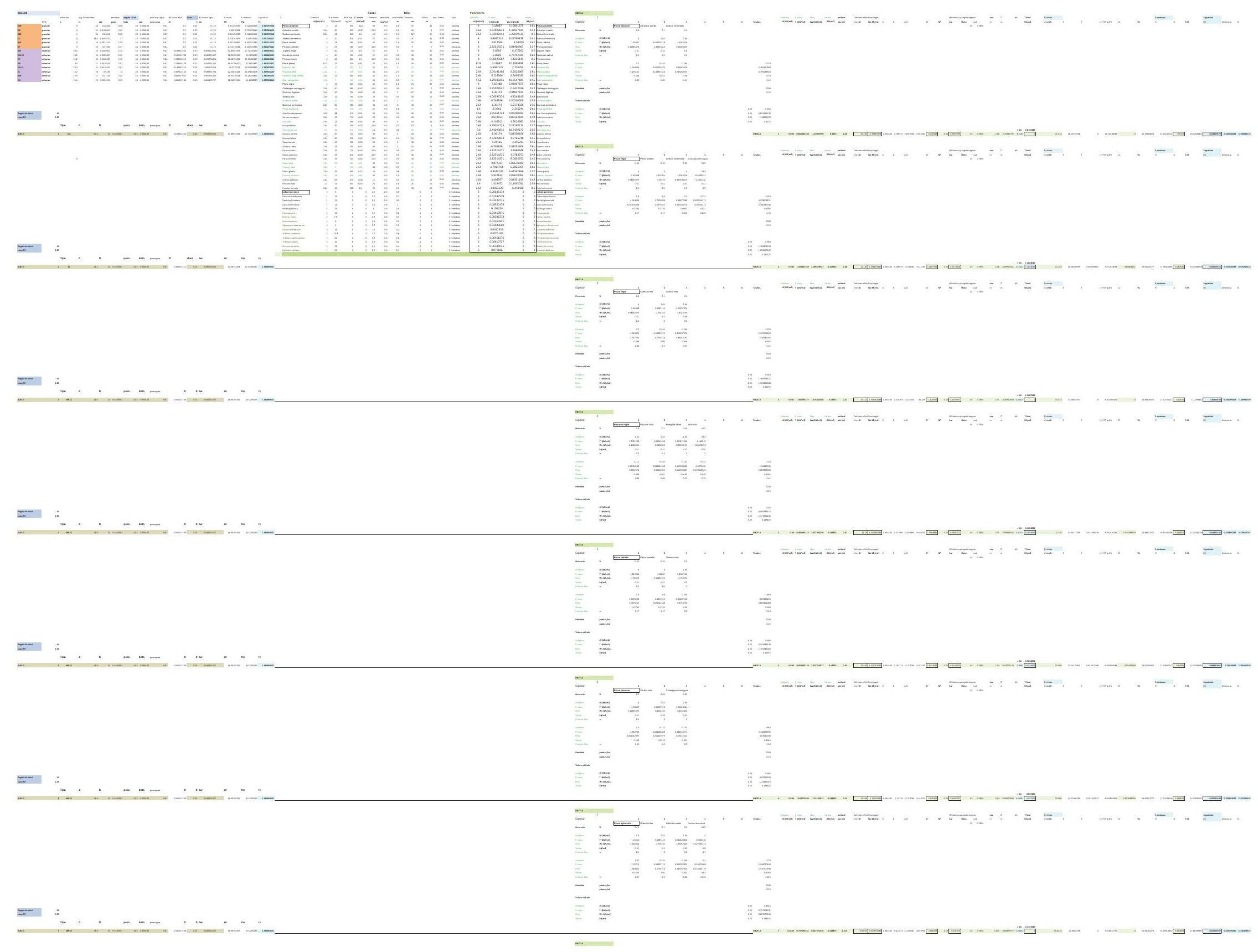




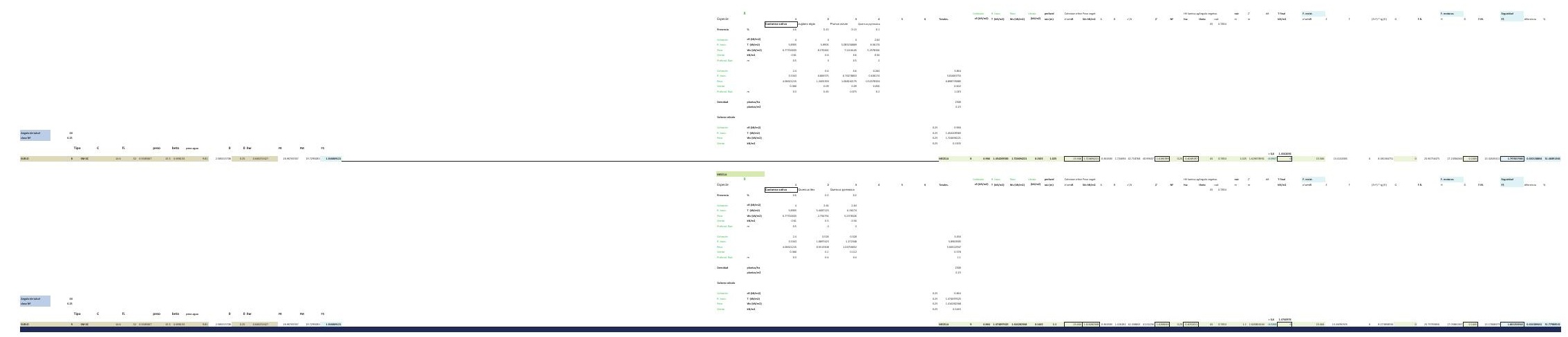




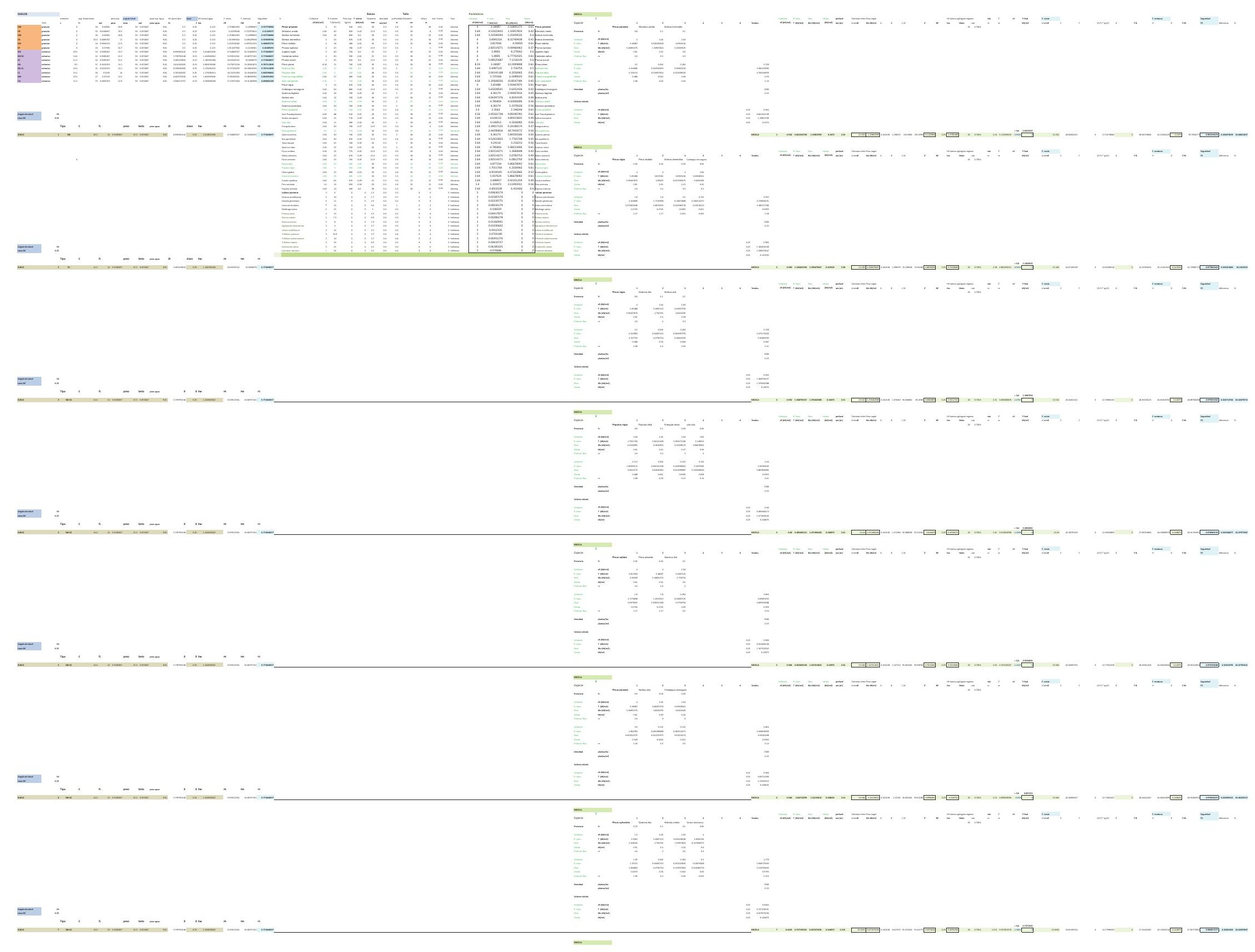


$=$

$=$

-

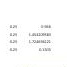

(....

$\equiv=-$

$= \pm$

$-$

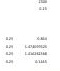




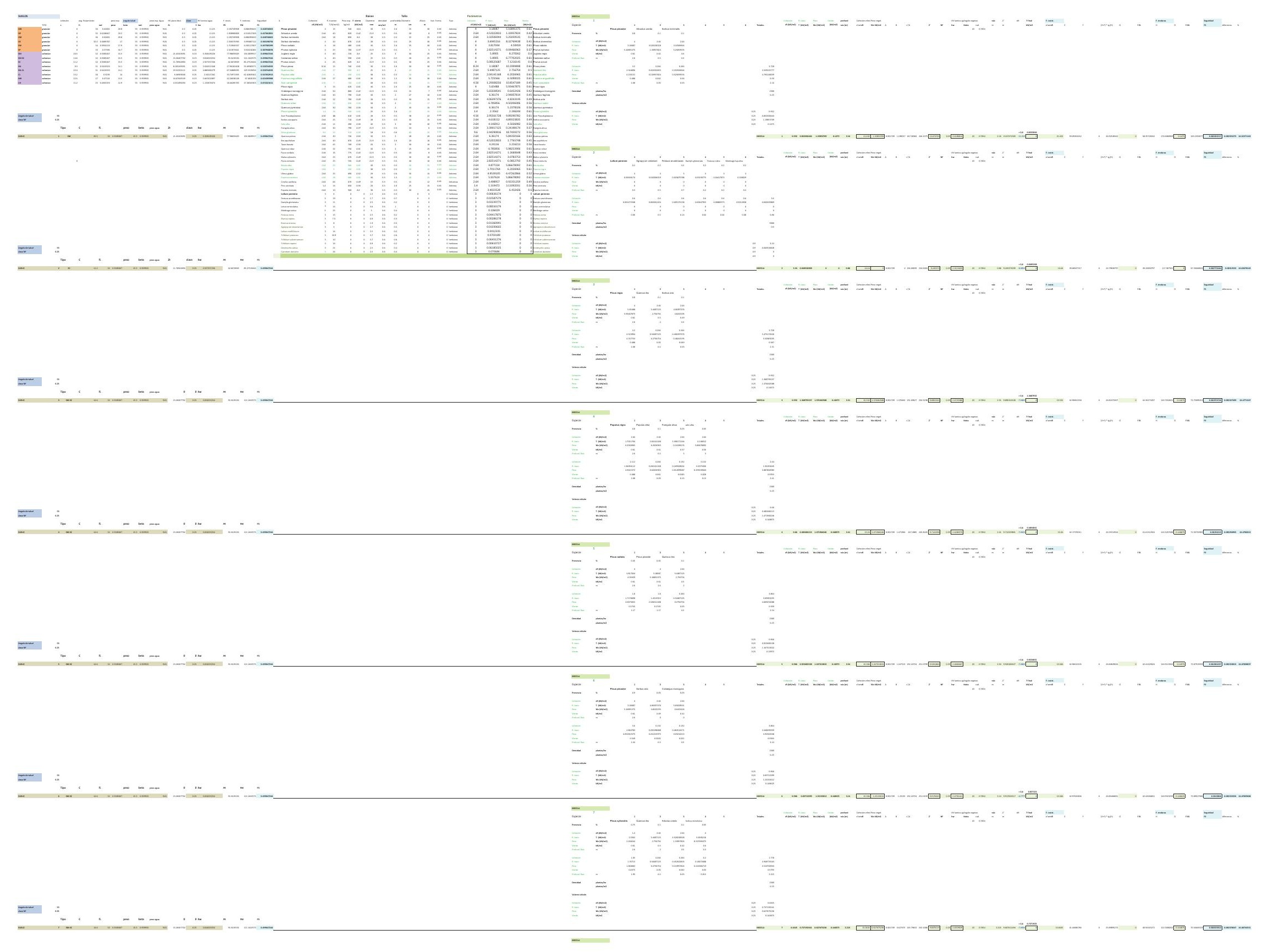


$=$

$=$

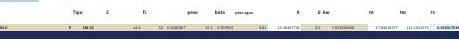

$=$

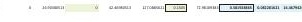

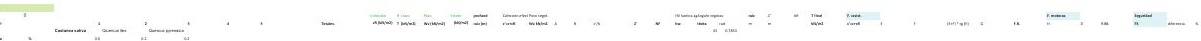

$\equiv= \pm$

$\pm= \pm$

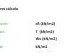




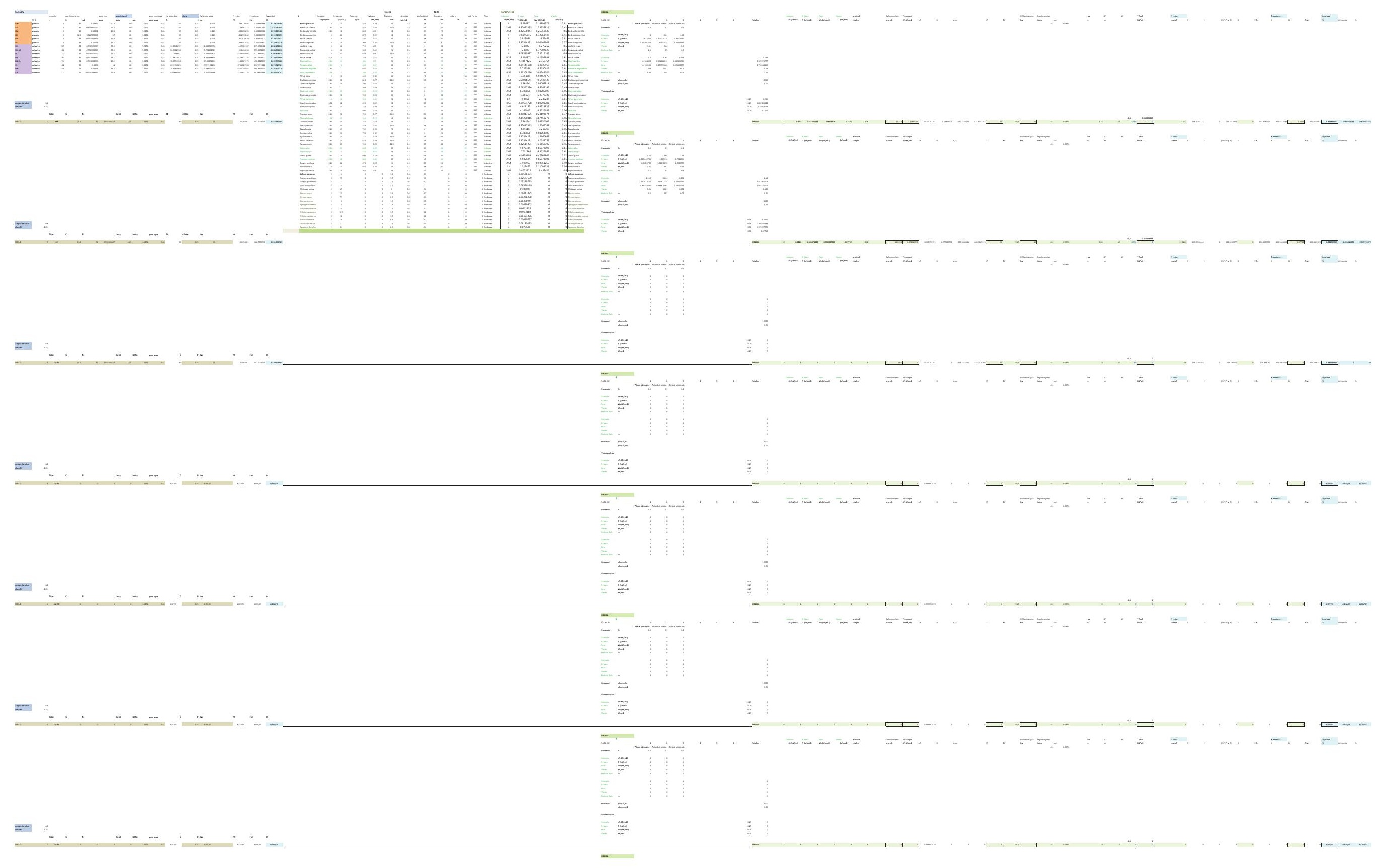




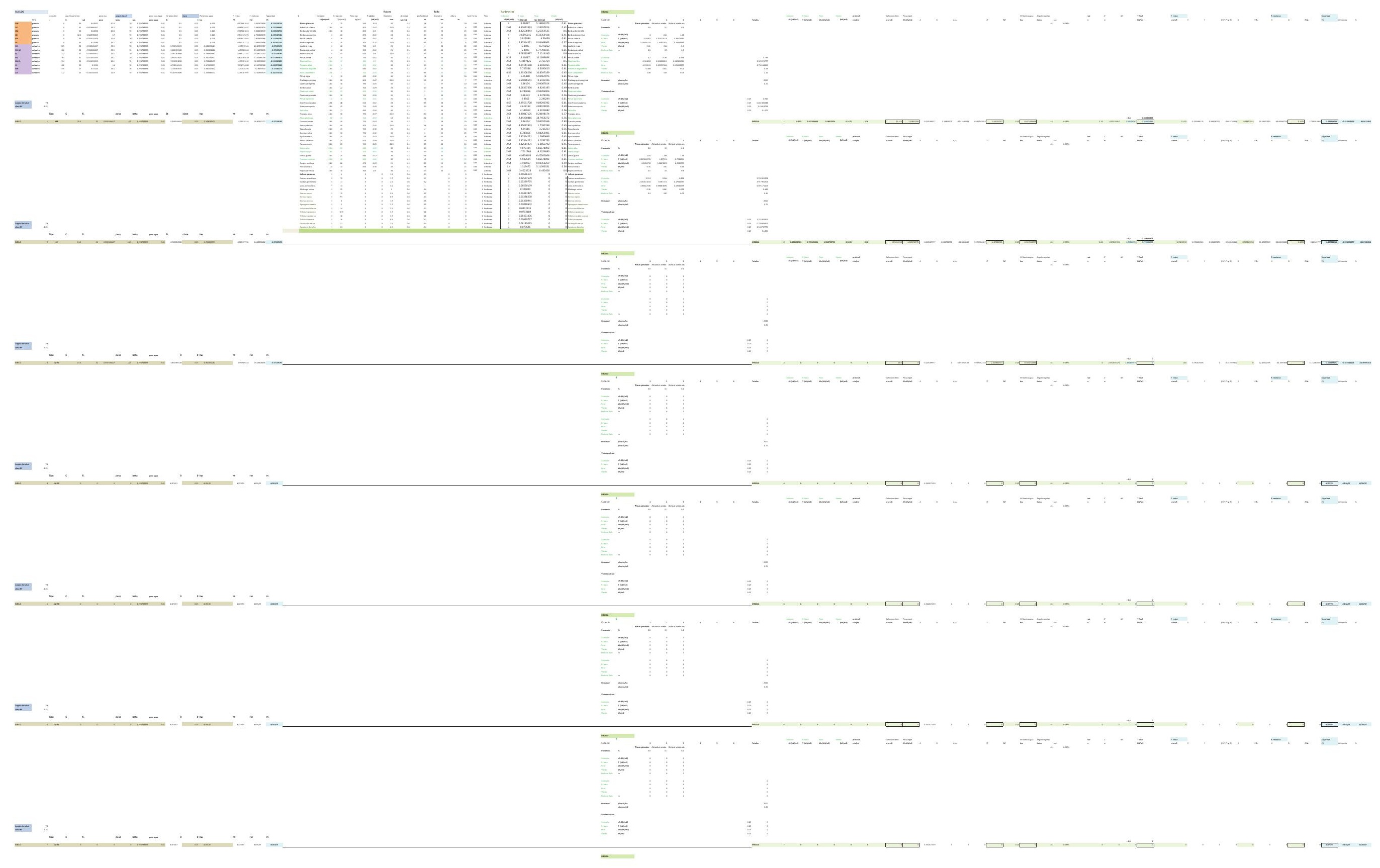




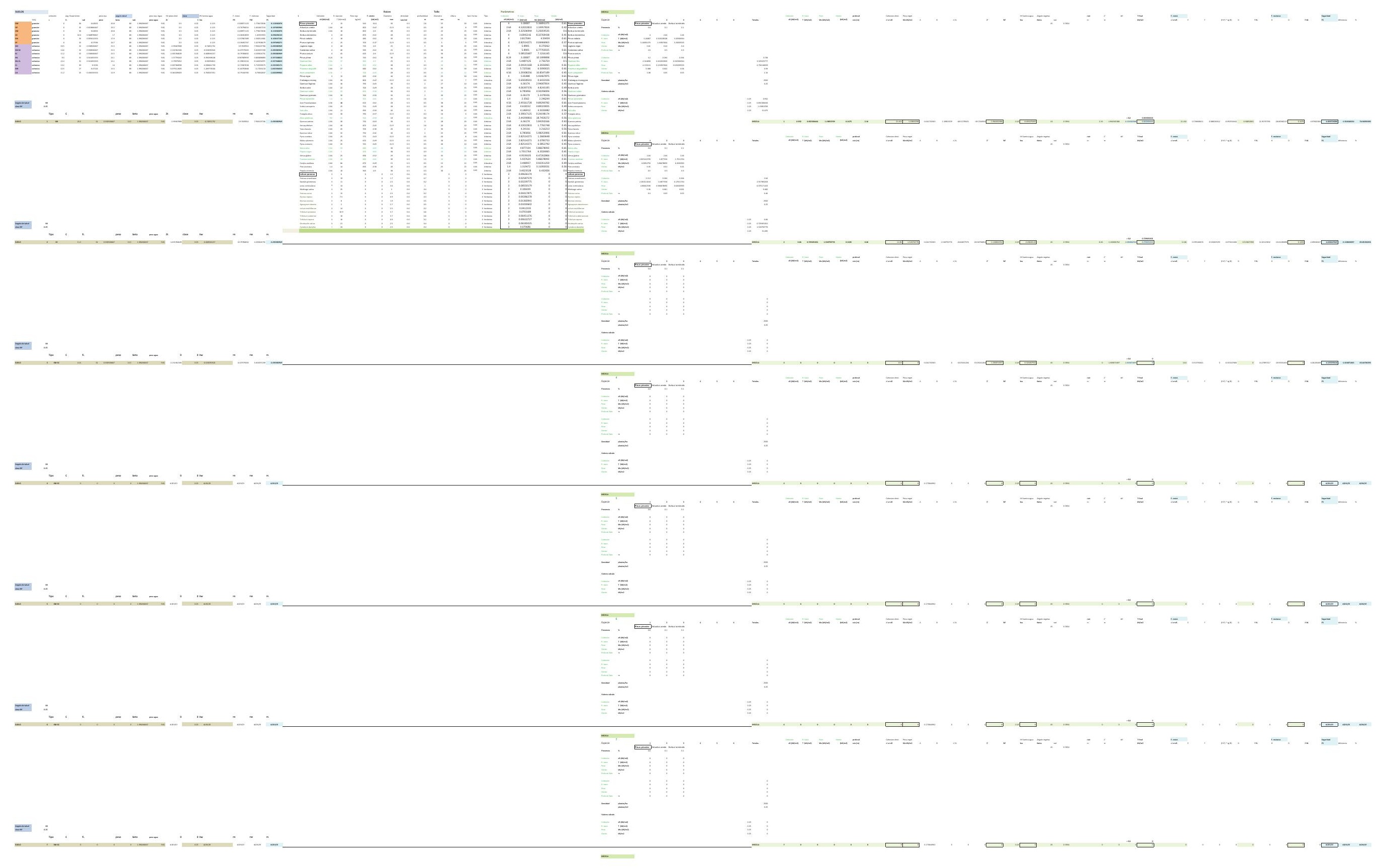


DESARROLLO DE UNA APLICACIÓN IMFORMÁTICA PARA EL CÁLCULO DE SOSTENIMIENTO DE TALUDES MEDIANTE VEGETACIÓN

B03. DENSIDAD DE PLANTACIÓN: 2.500 plantas/ha.

\section{BA03-4.POSICIÓN N.F. 4}

INCLINACIÓN DE TALUD 6-100

INCLINACIÓN DE TALUD 10-200

INCLINACIÓN DE TALUD 20-30

INCLINACIÓN DE TALUD 30-40

INCLINACIÓN DE TALUD $35^{\circ}$

INCLINACIÓN DE TALUD 40-50

INCLINACIÓN DE TALUD 50-550

INCLINACIÓN DE TALUD 55-60

INCLINACIÓN DE TALUD 60-700

INCLINACIÓN DE TALUD 70-80 


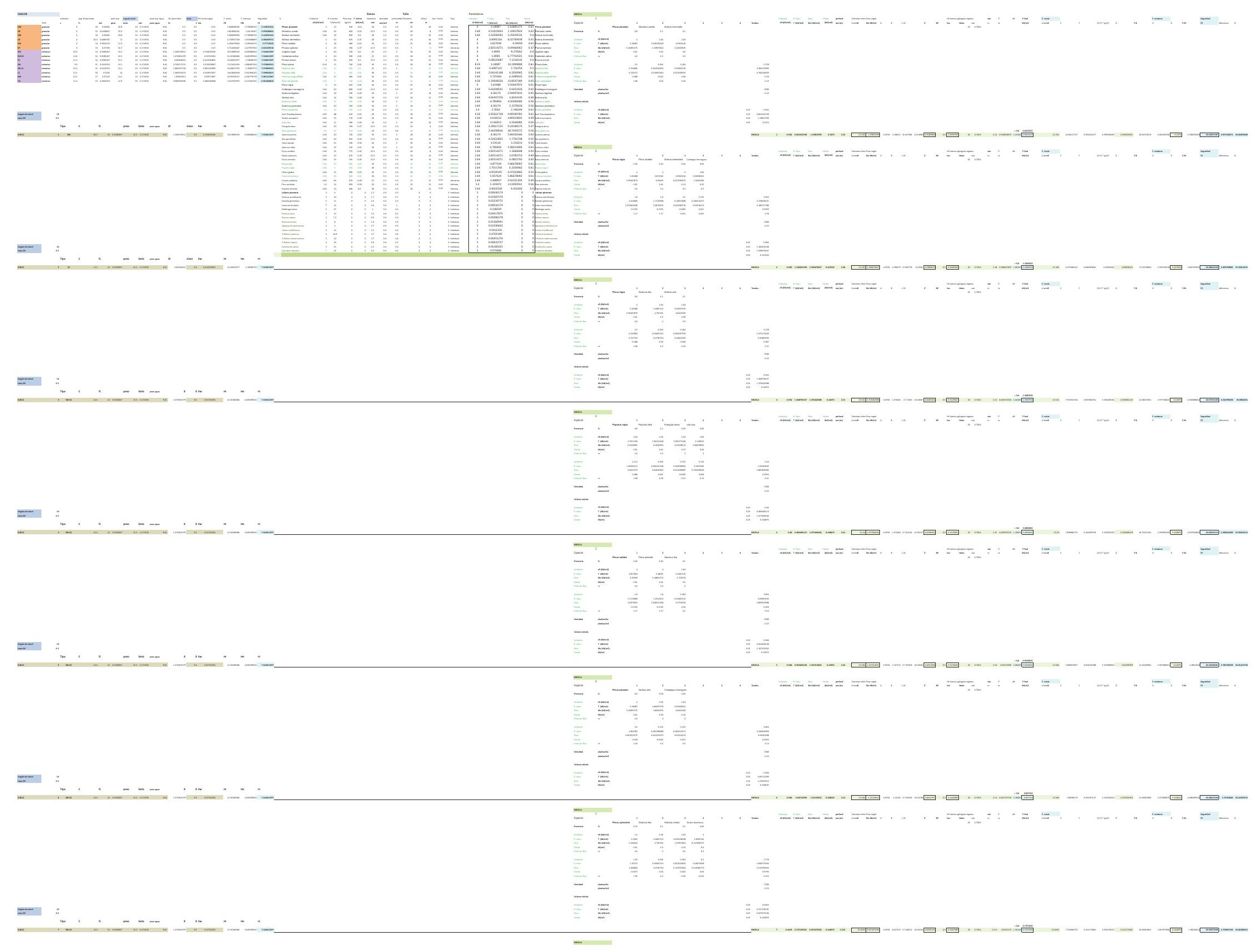


$=$

$=$

-

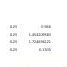

(....

$\equiv=-$

$= \pm=$

$=$ 


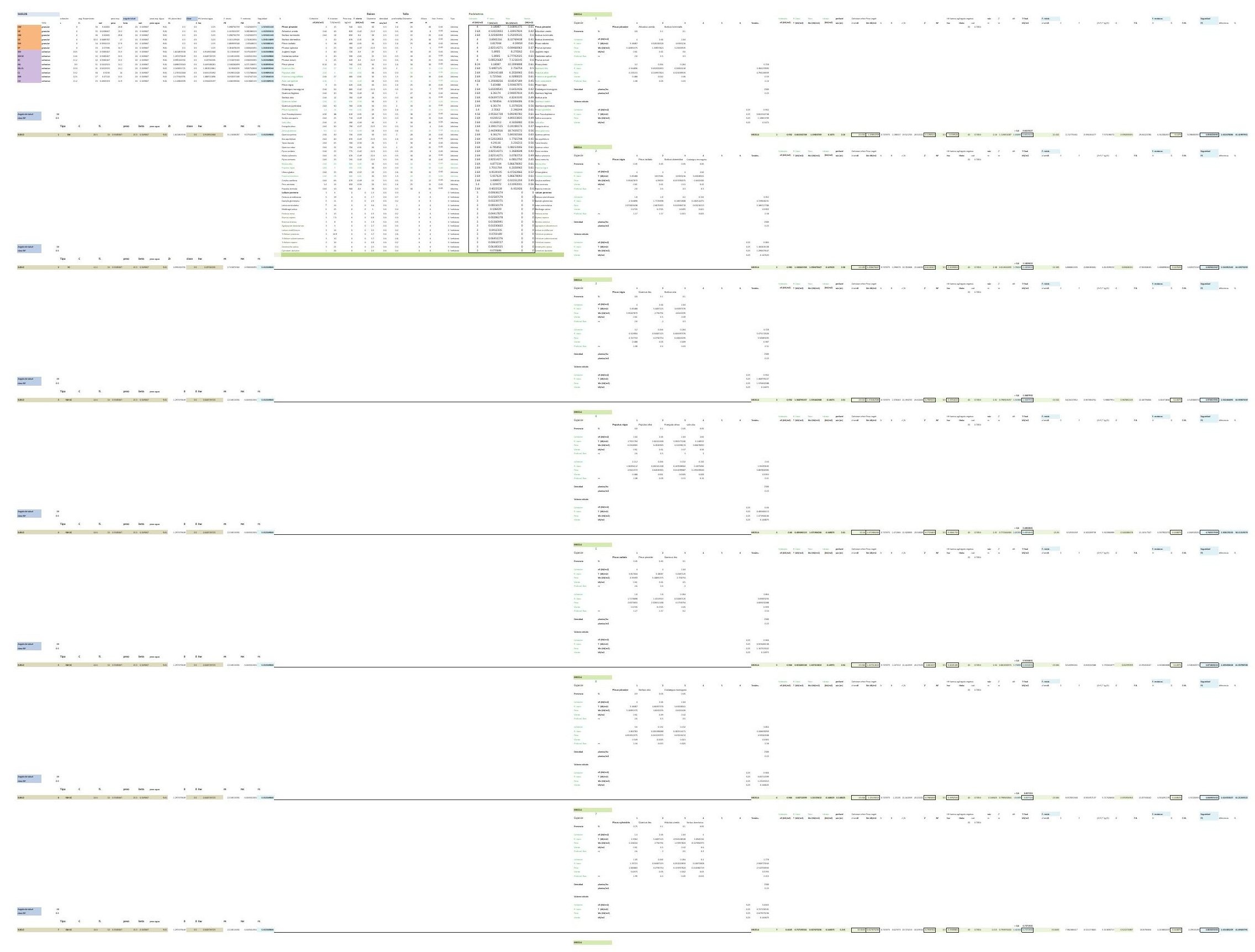


$=$

$=$

-

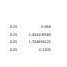

(…ㅁ․

$\equiv=-$

E. $=$

$-$

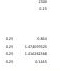




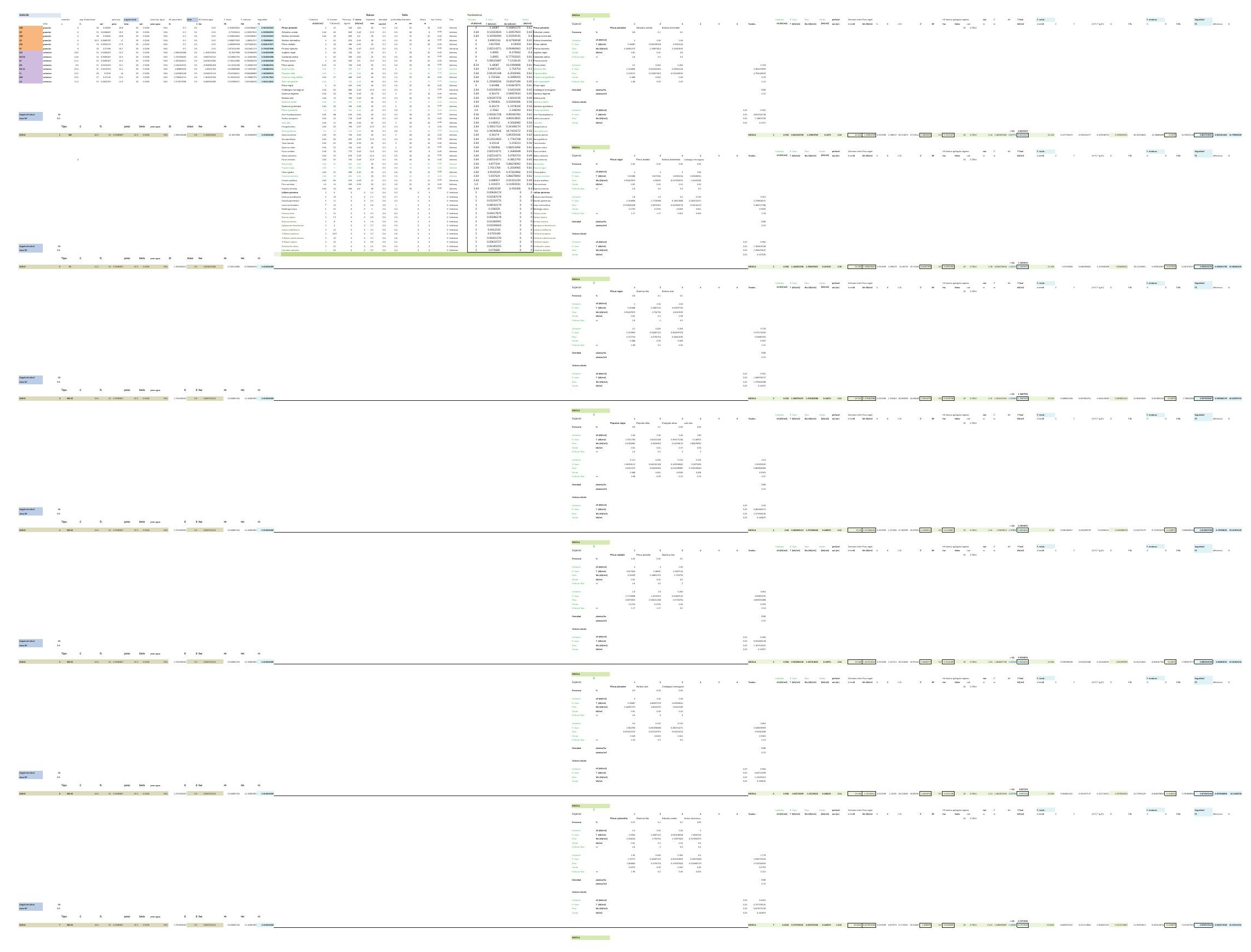


$=$

$=$

-

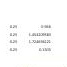

(...

$\equiv=-$

$= \pm$

$-$ 


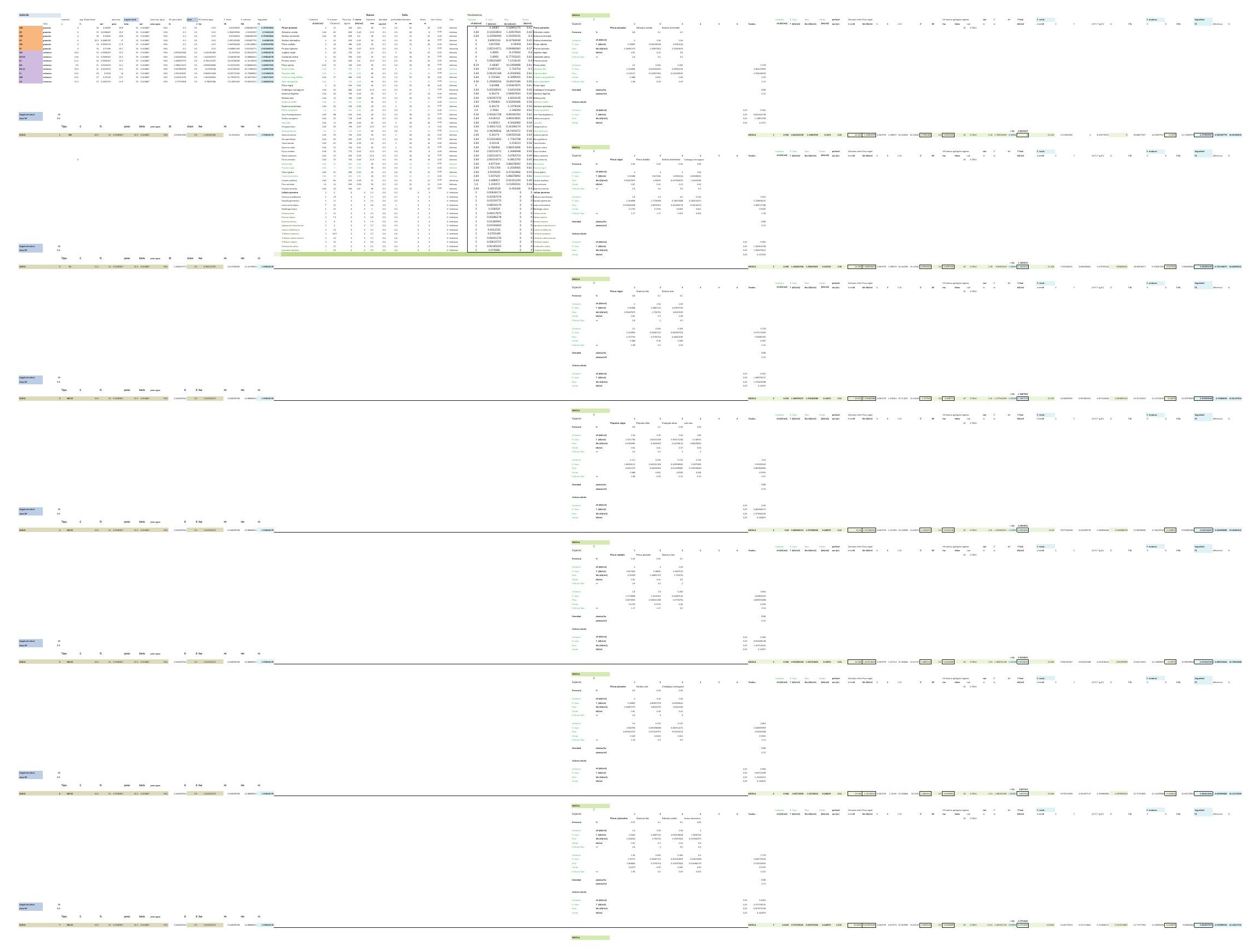


$=$

$=$

(n)

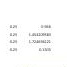

(...

$\equiv=-$

$= \pm$

$-$ 


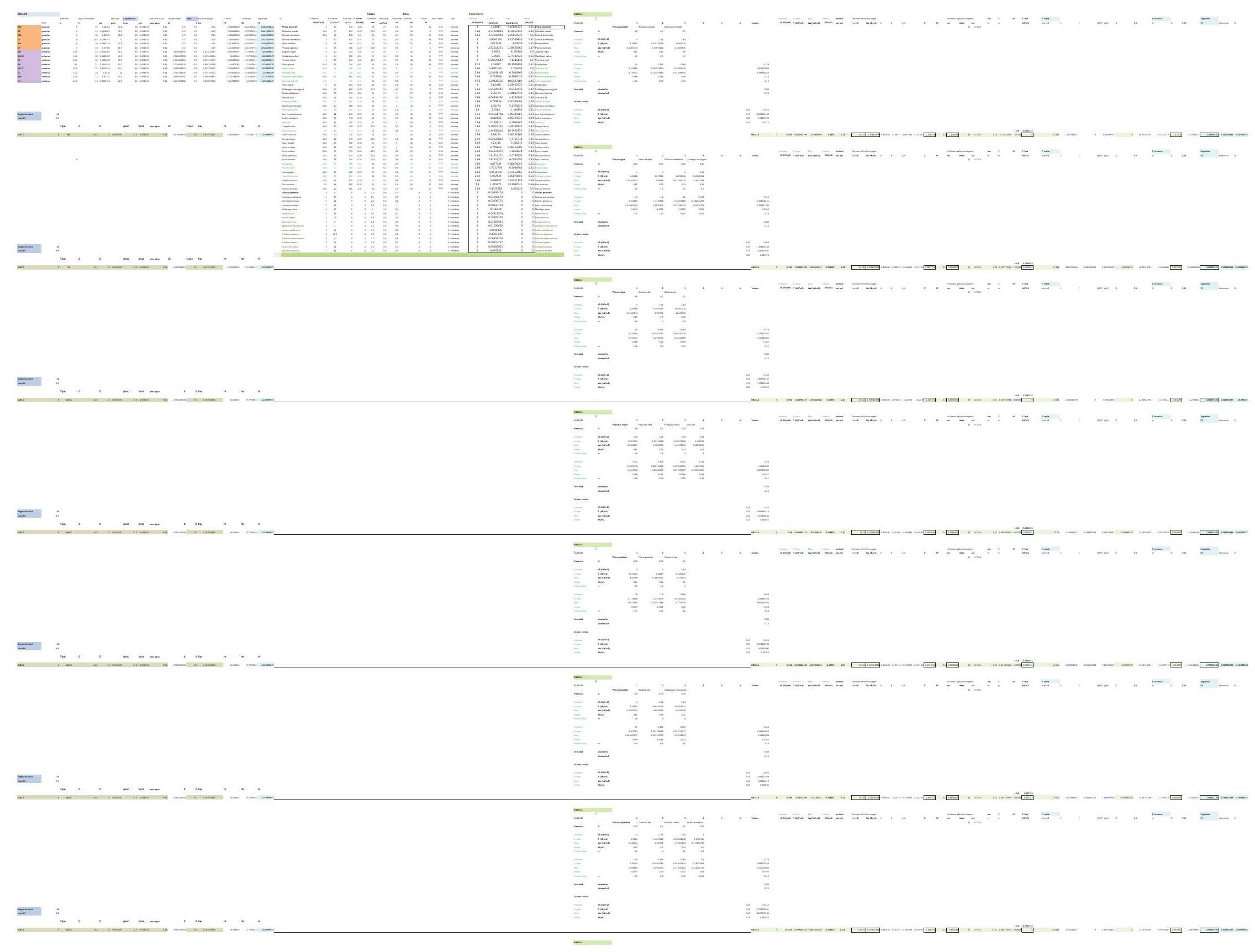


$=$

$=$

-

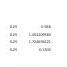

……

$\equiv=-$

$= \pm$

$-$ 


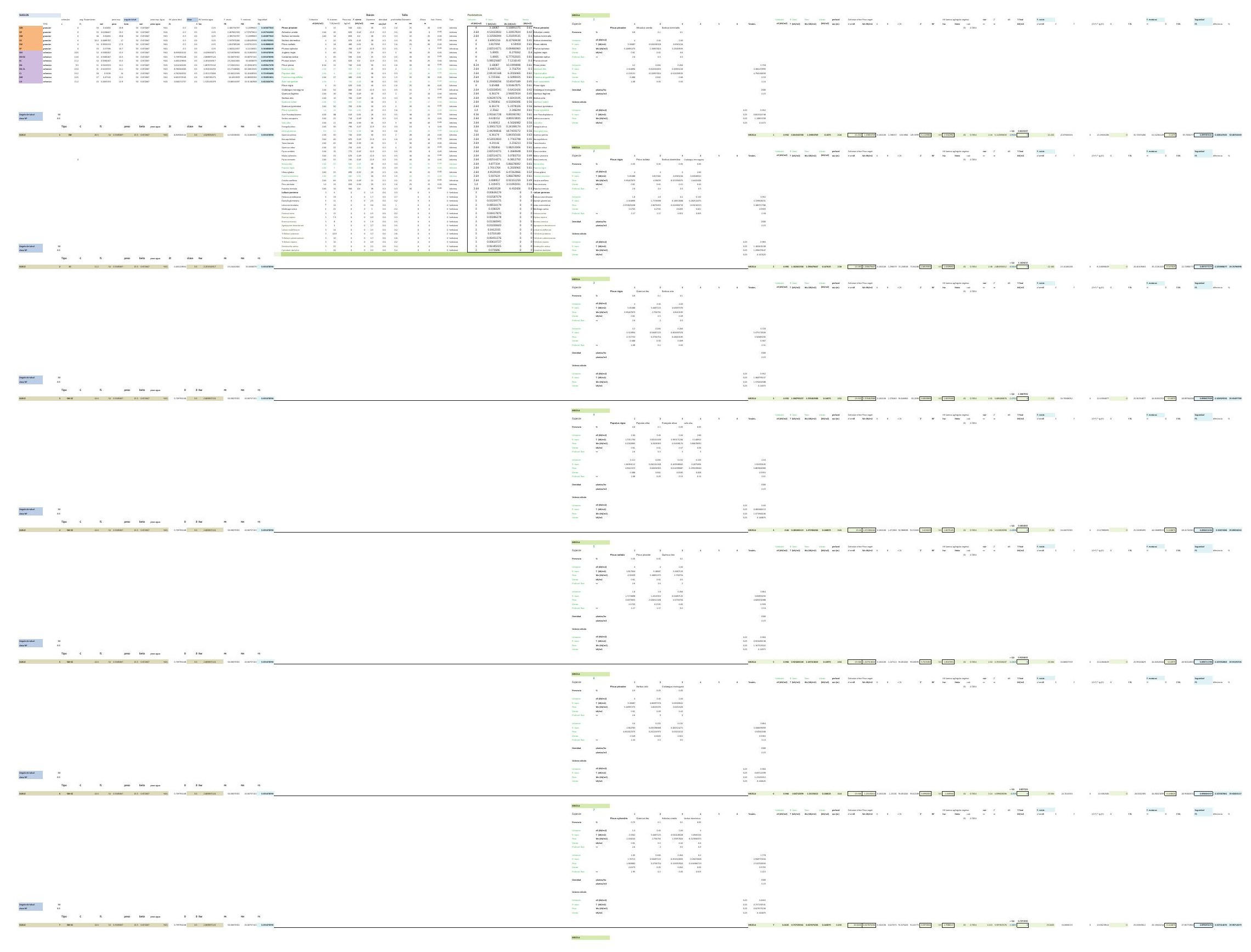


$=$

$=$

-

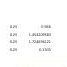

(....

$\equiv=-$

$= \pm$

$-$

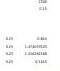




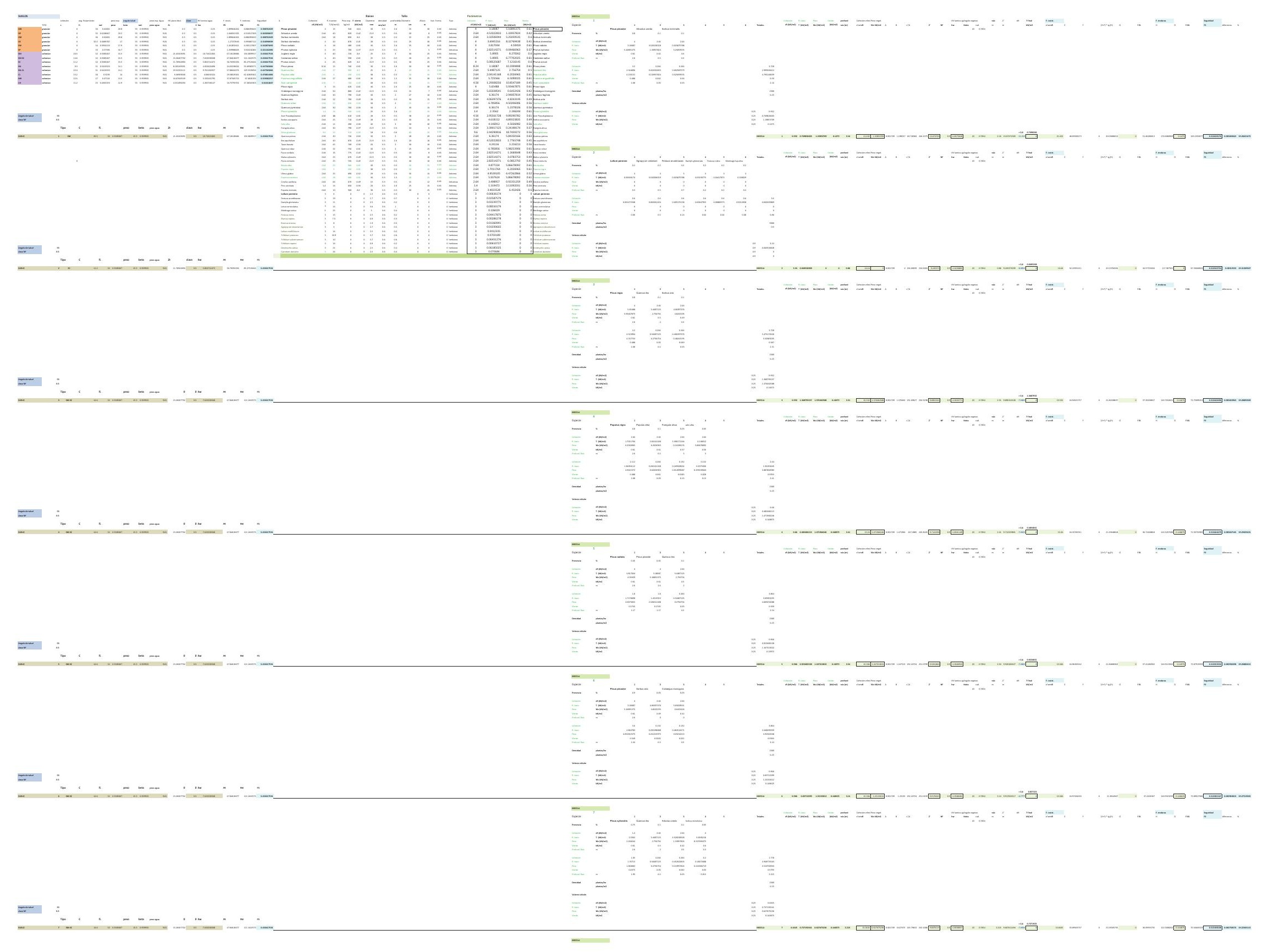


$=$

$=$

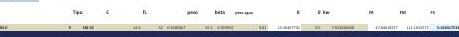

$=$

-

$\equiv= \pm$

$= \pm=$

$=$ 


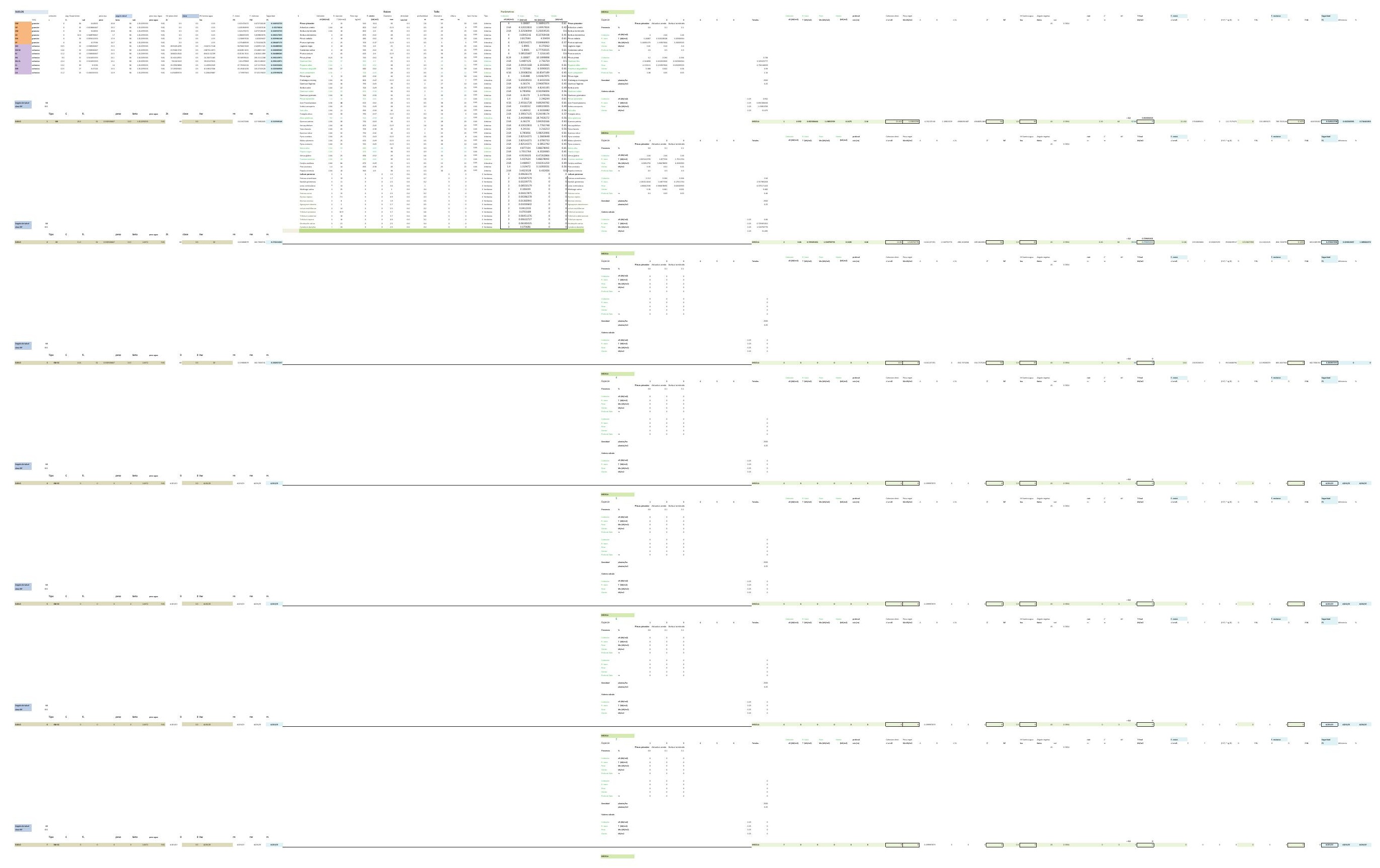




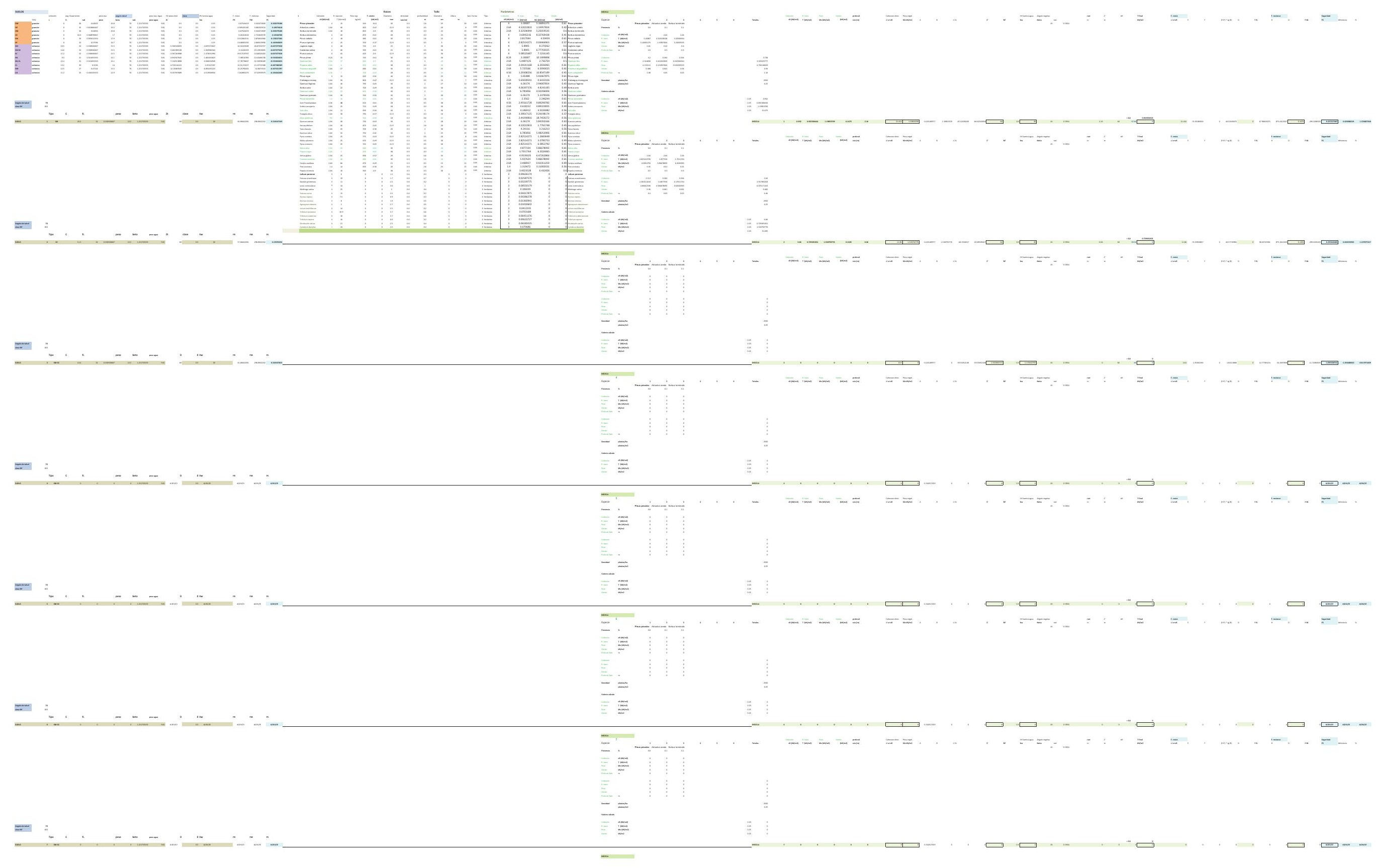




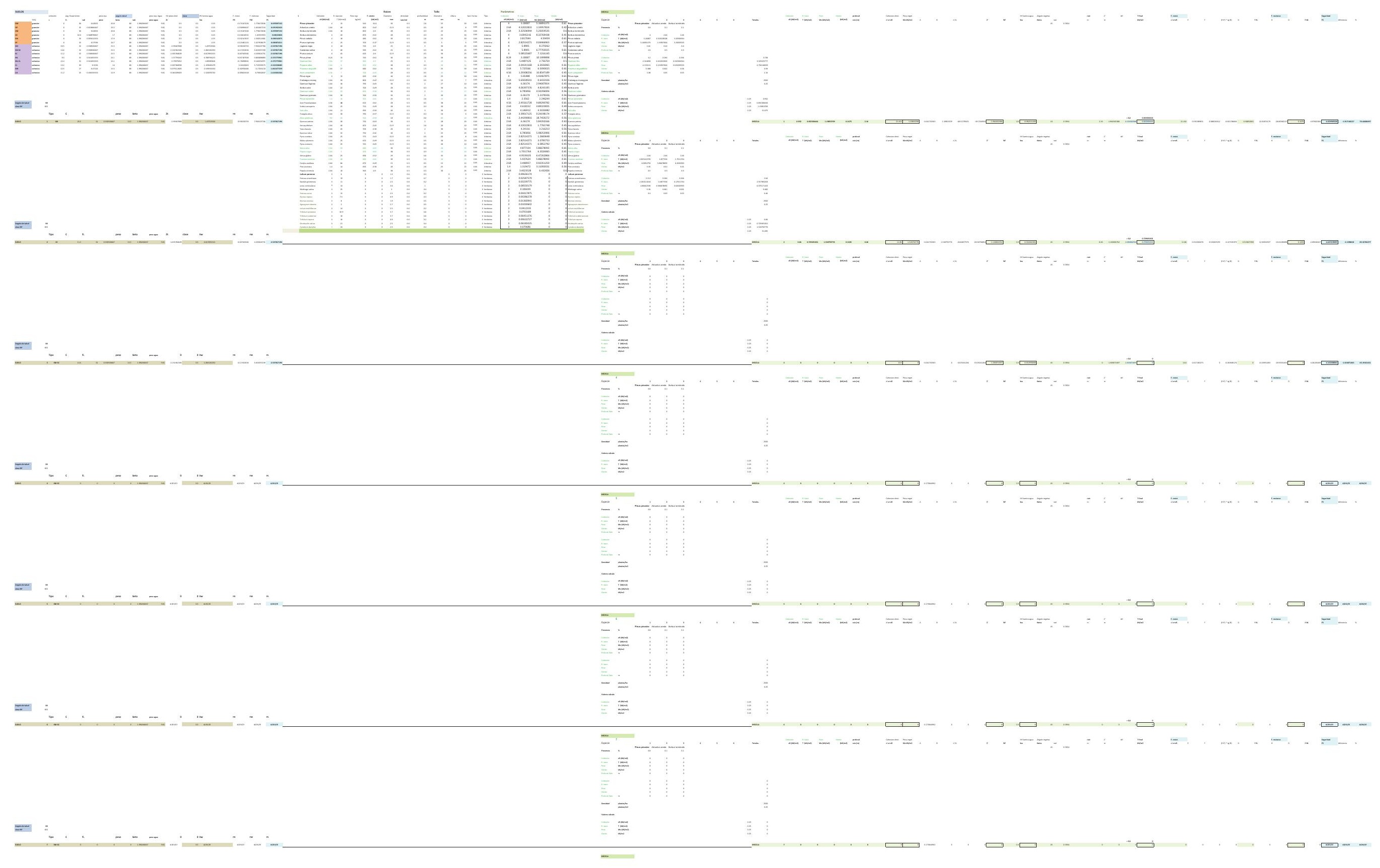


DESARROLLO DE UNA APLICACIÓN IMFORMÁTICA PARA EL CÁLCULO DE SOSTENIMIENTO DE TALUDES MEDIANTE VEGETACIÓN

B03. DENSIDAD DE PLANTACIÓN: 2.500 plantas/ha.

\section{B03-5.POSICIÓN N.F. 5}

INCLINACIÓN DE TALUD 6-100

INCLINACIÓN DE TALUD 10-200

INCLINACIÓN DE TALUD 20-30

INCLINACIÓN DE TALUD 30-40

INCLINACIÓN DE TALUD $35^{\circ}$

INCLINACIÓN DE TALUD 40-50

INCLINACIÓN DE TALUD 50-550

INCLINACIÓN DE TALUD 55-60

INCLINACIÓN DE TALUD 60-700

INCLINACIÓN DE TALUD 70-80 


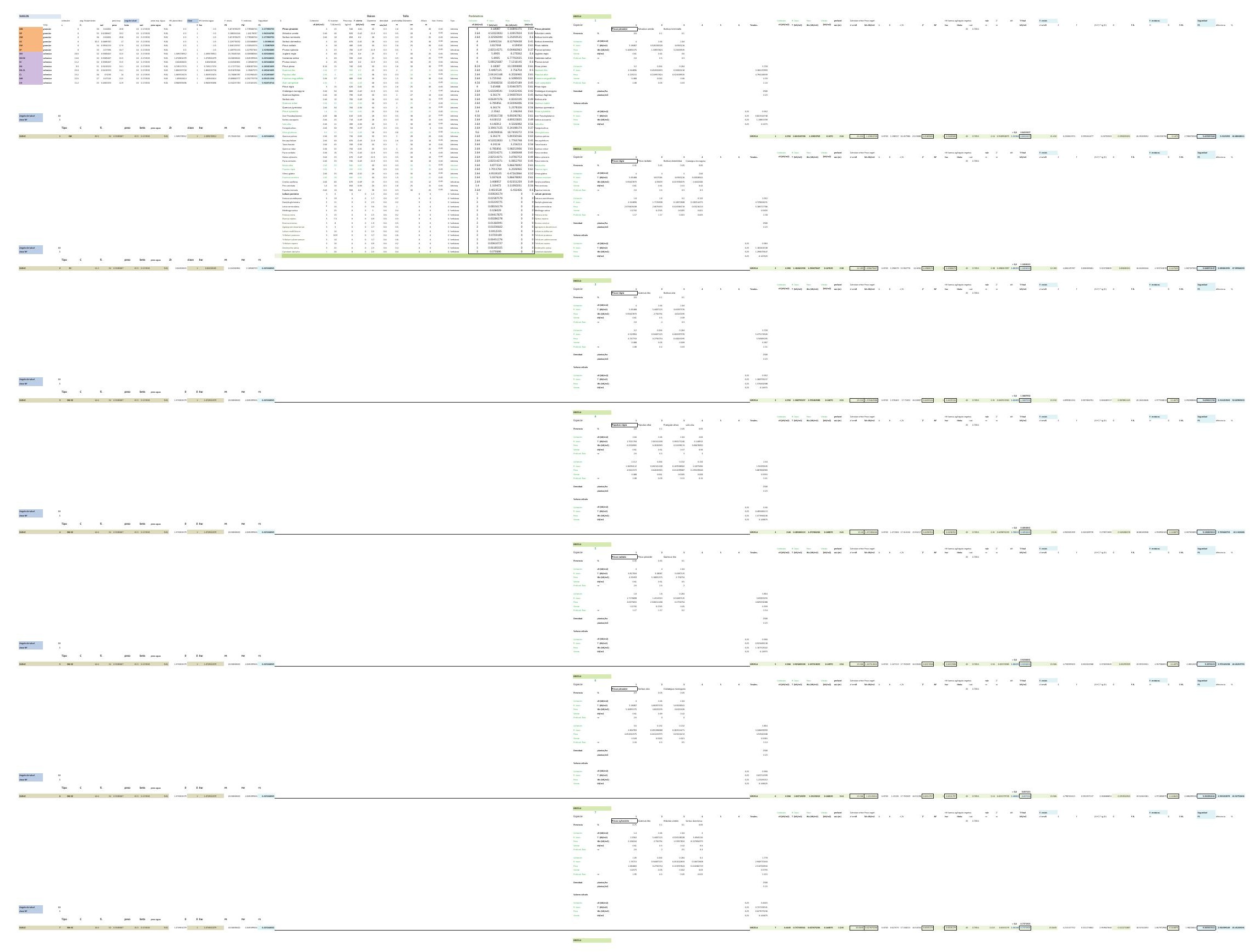




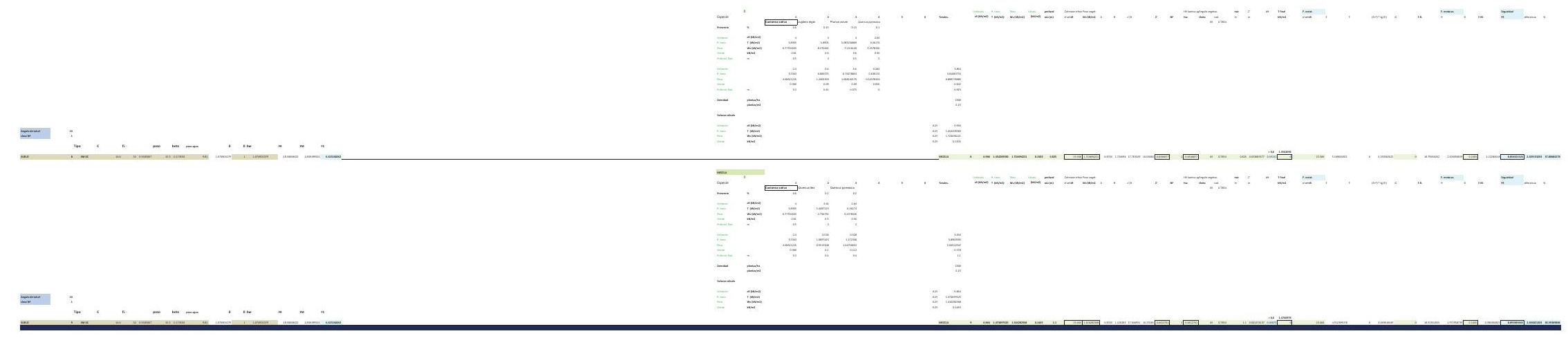




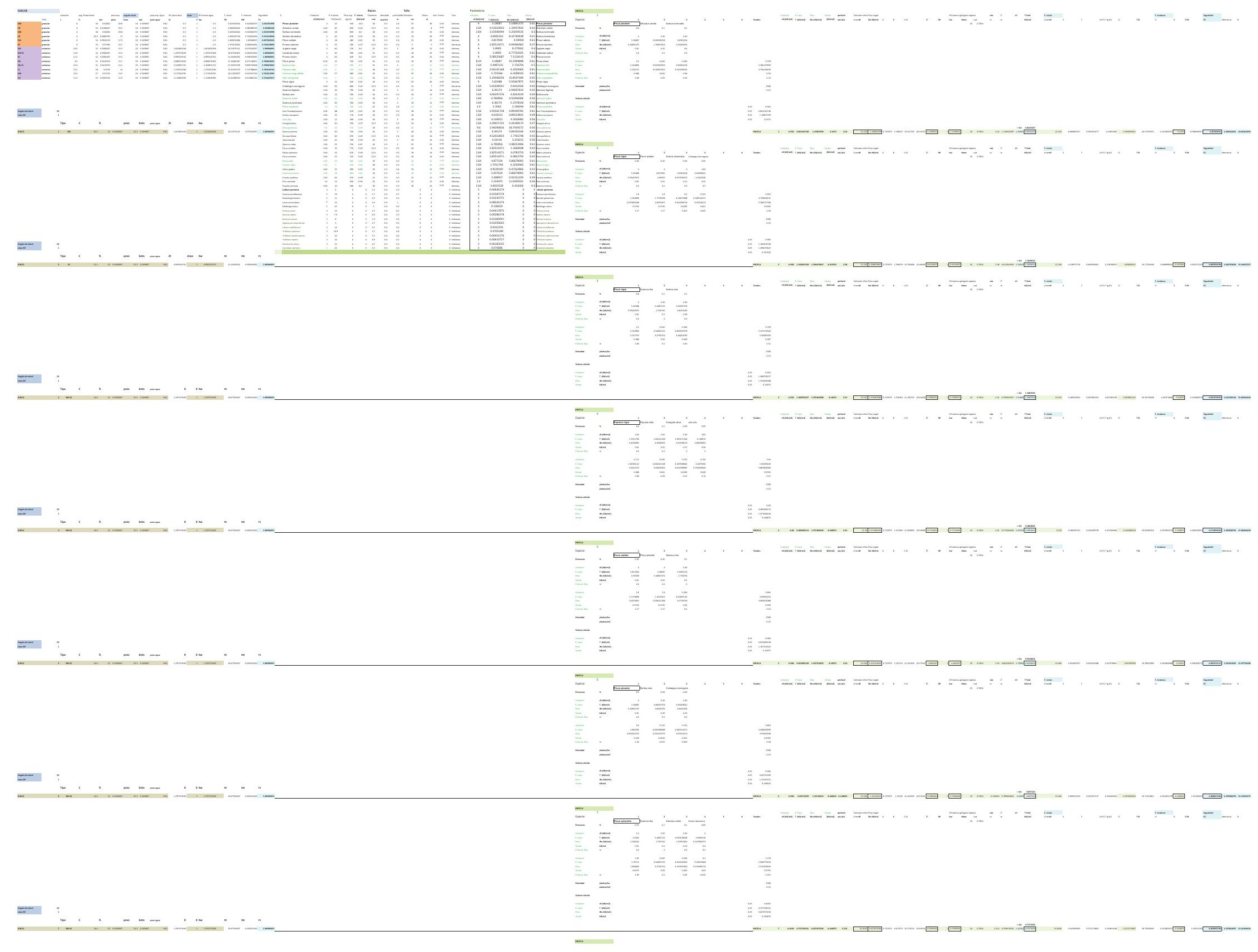




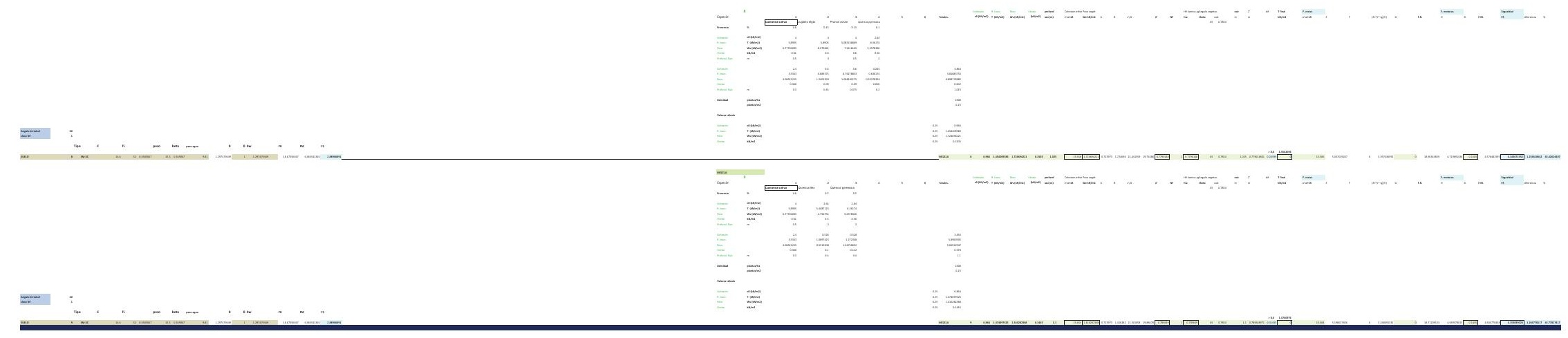




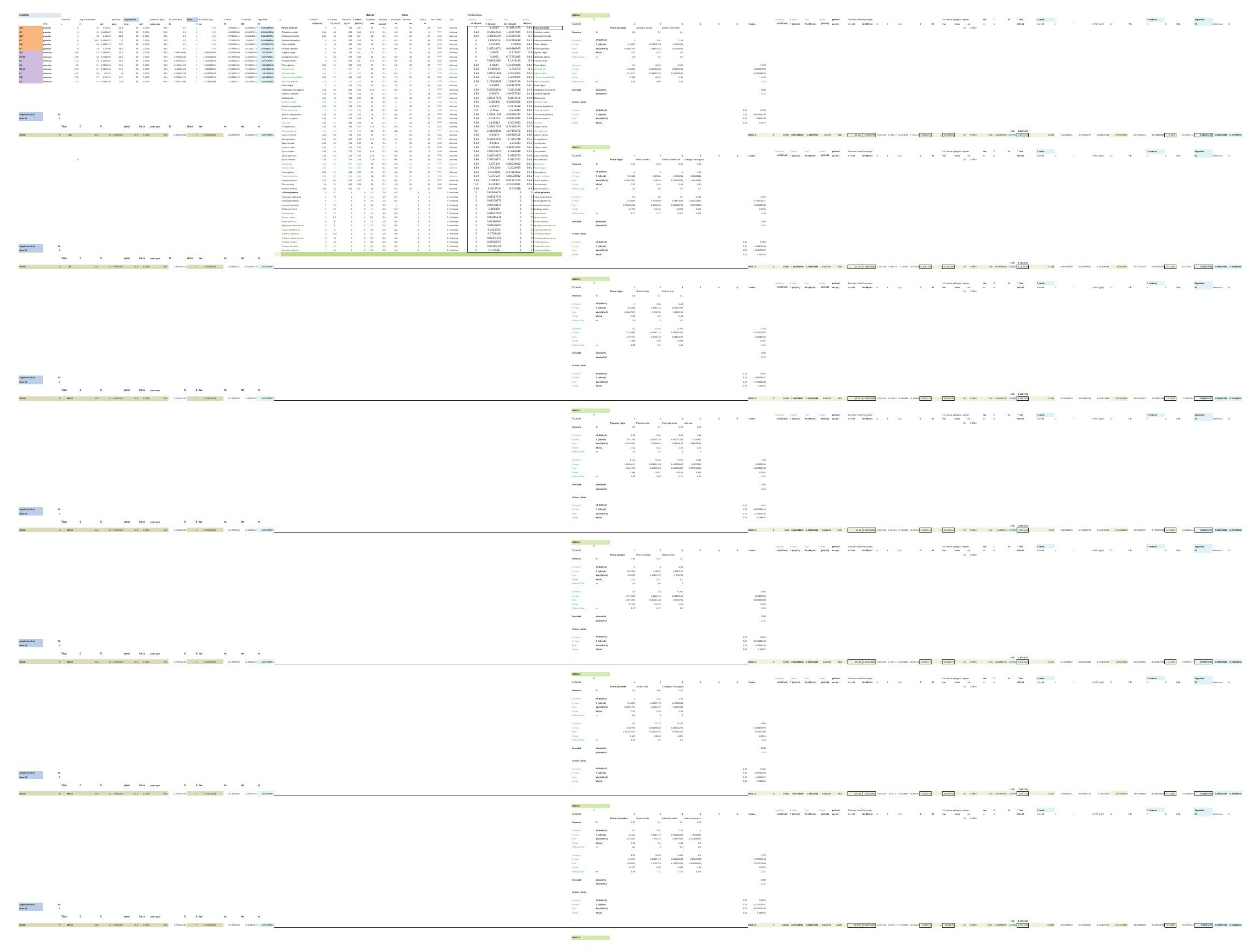


$=$

$=$

(n) $\pm$

(2.

$\equiv=-$

$= \pm$

$-$

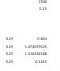




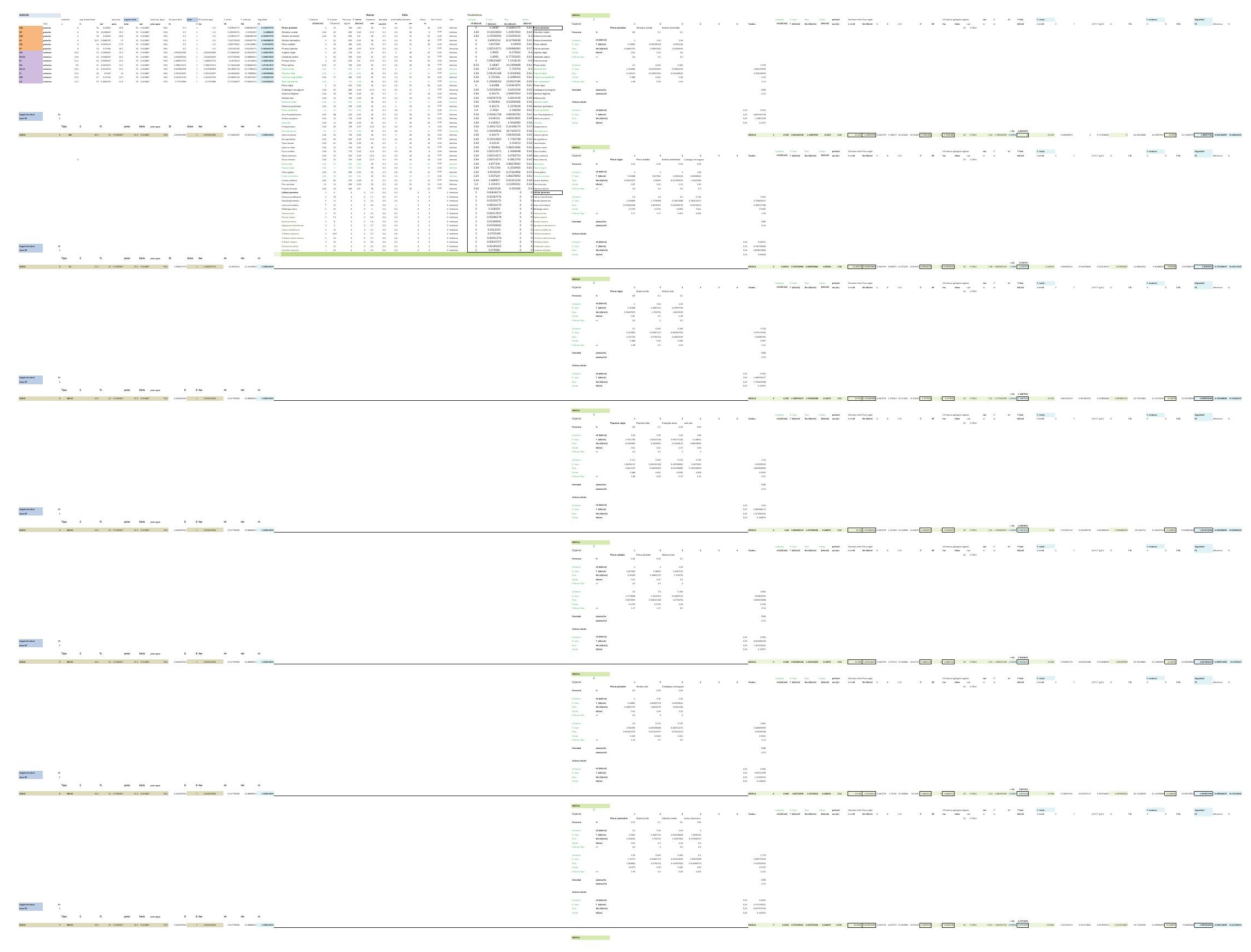


$=$

$=$

- $\pm$

(1)

$\equiv=-$

$= \pm=$

$=$

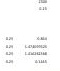




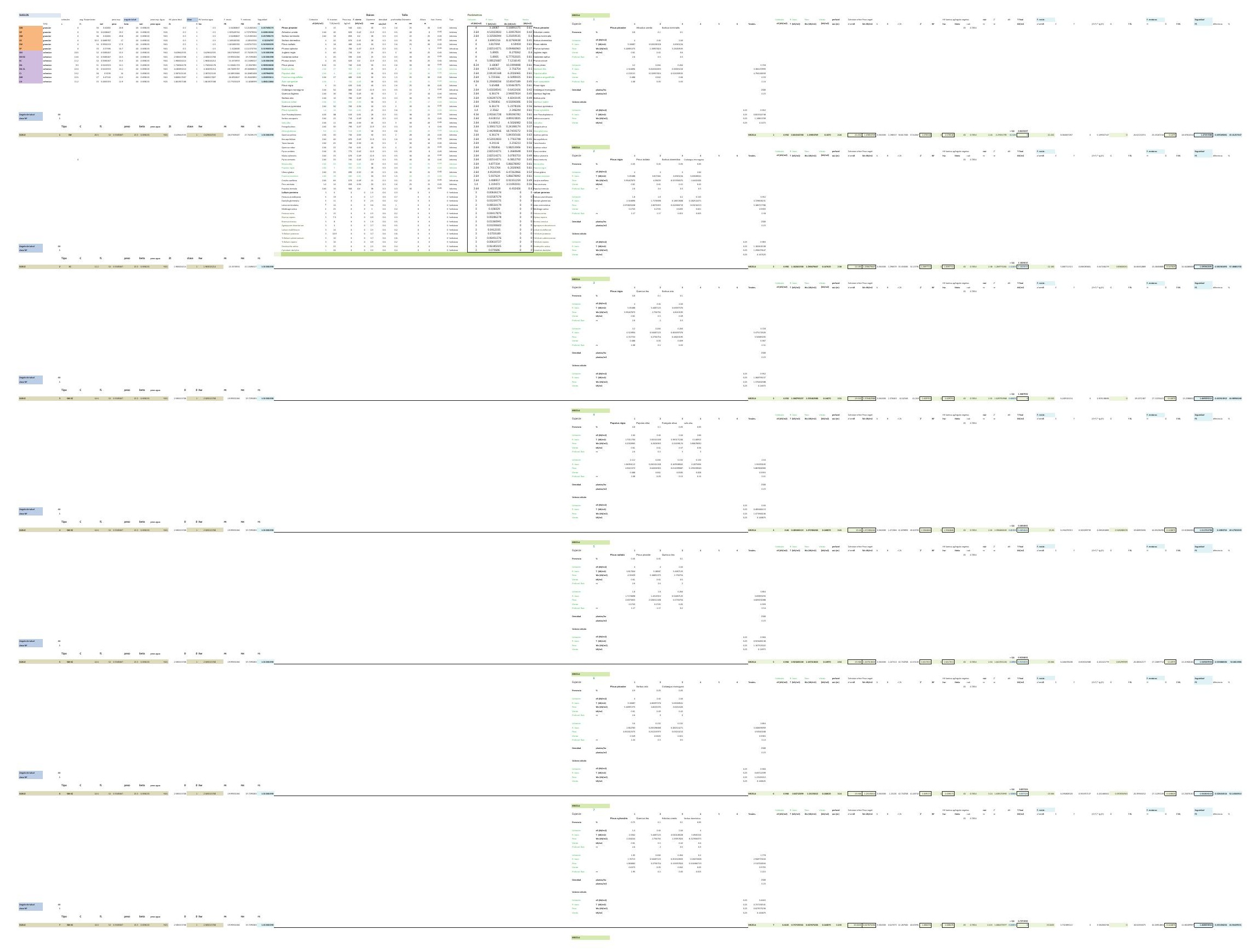


$=$

$=$

(n) $\pm$

1

$\equiv=-$

$= \pm$

$-$

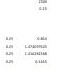




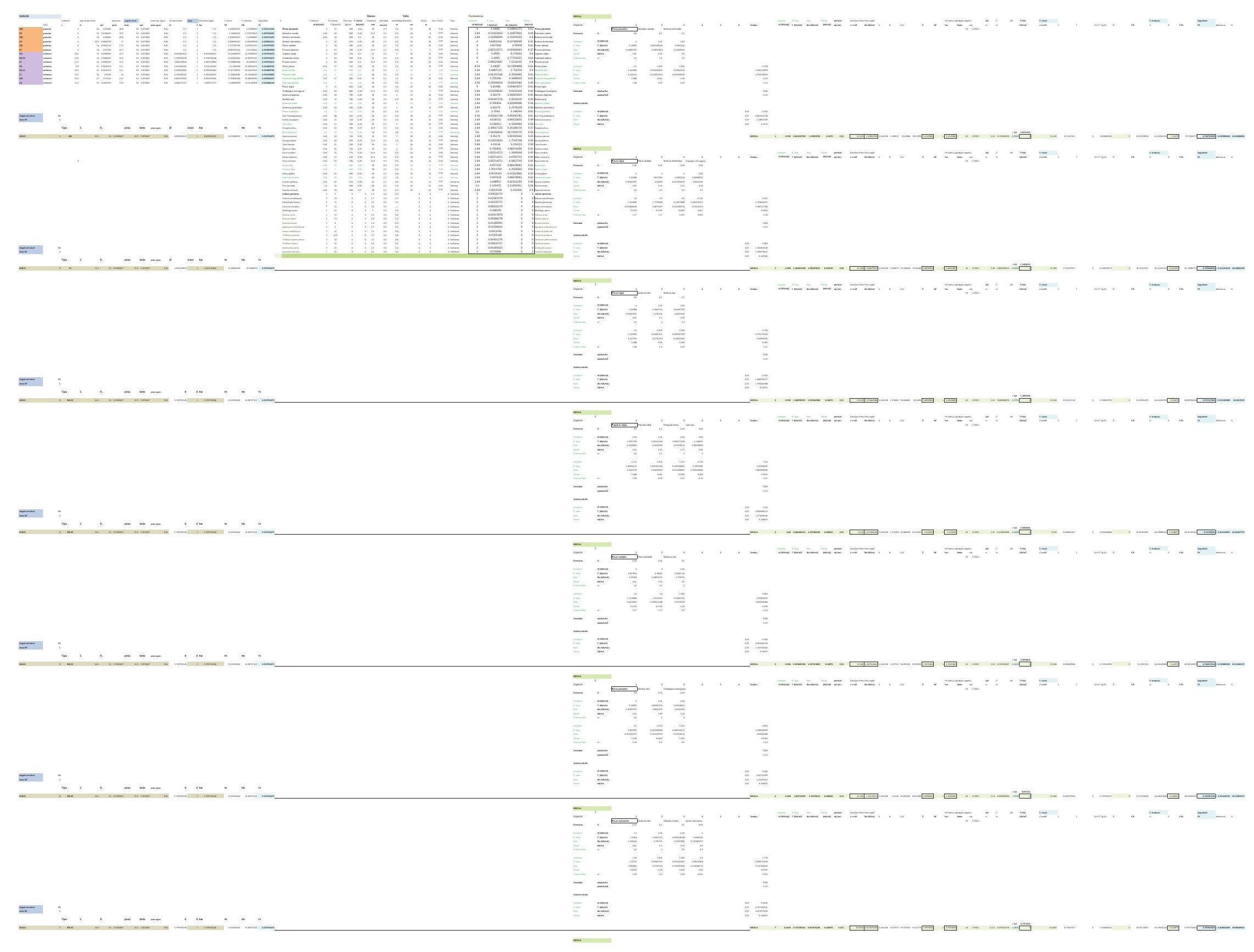




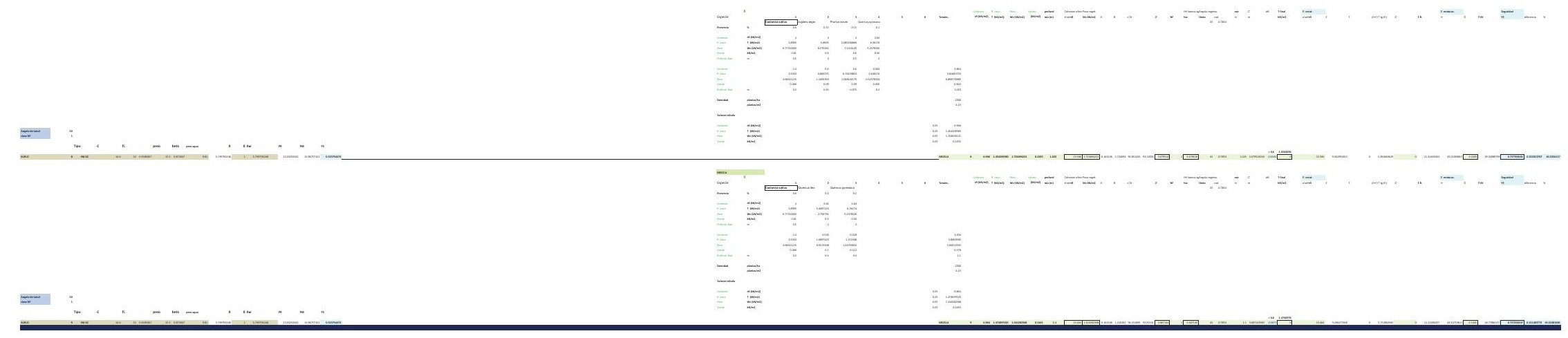




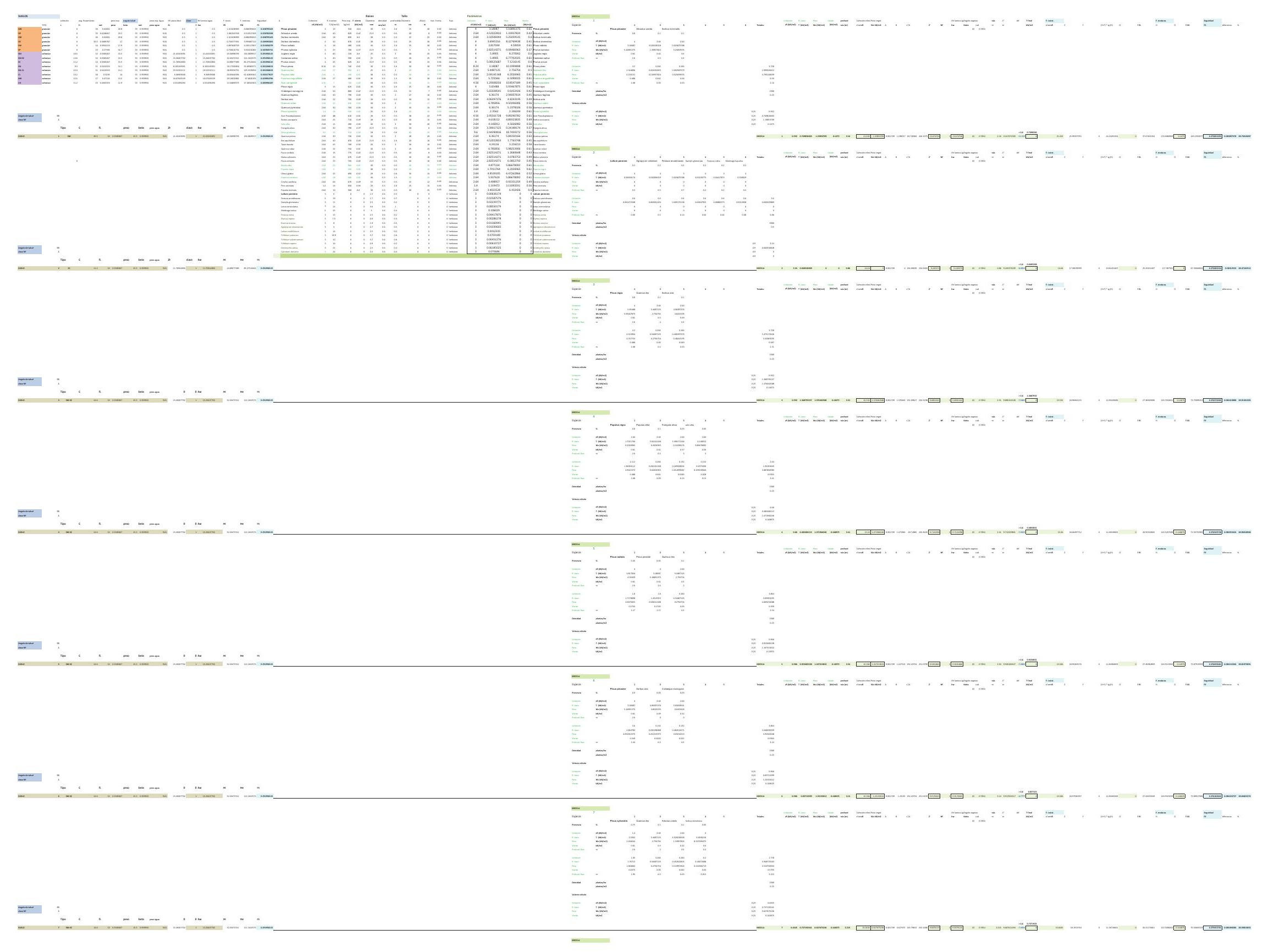


$=$

$=$

$-\ldots+\ldots \ldots$
$=$

-

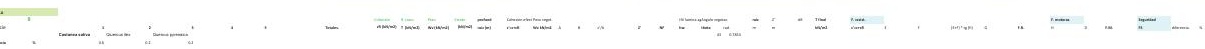

$\equiv=$

$= \pm=$

$=$ 


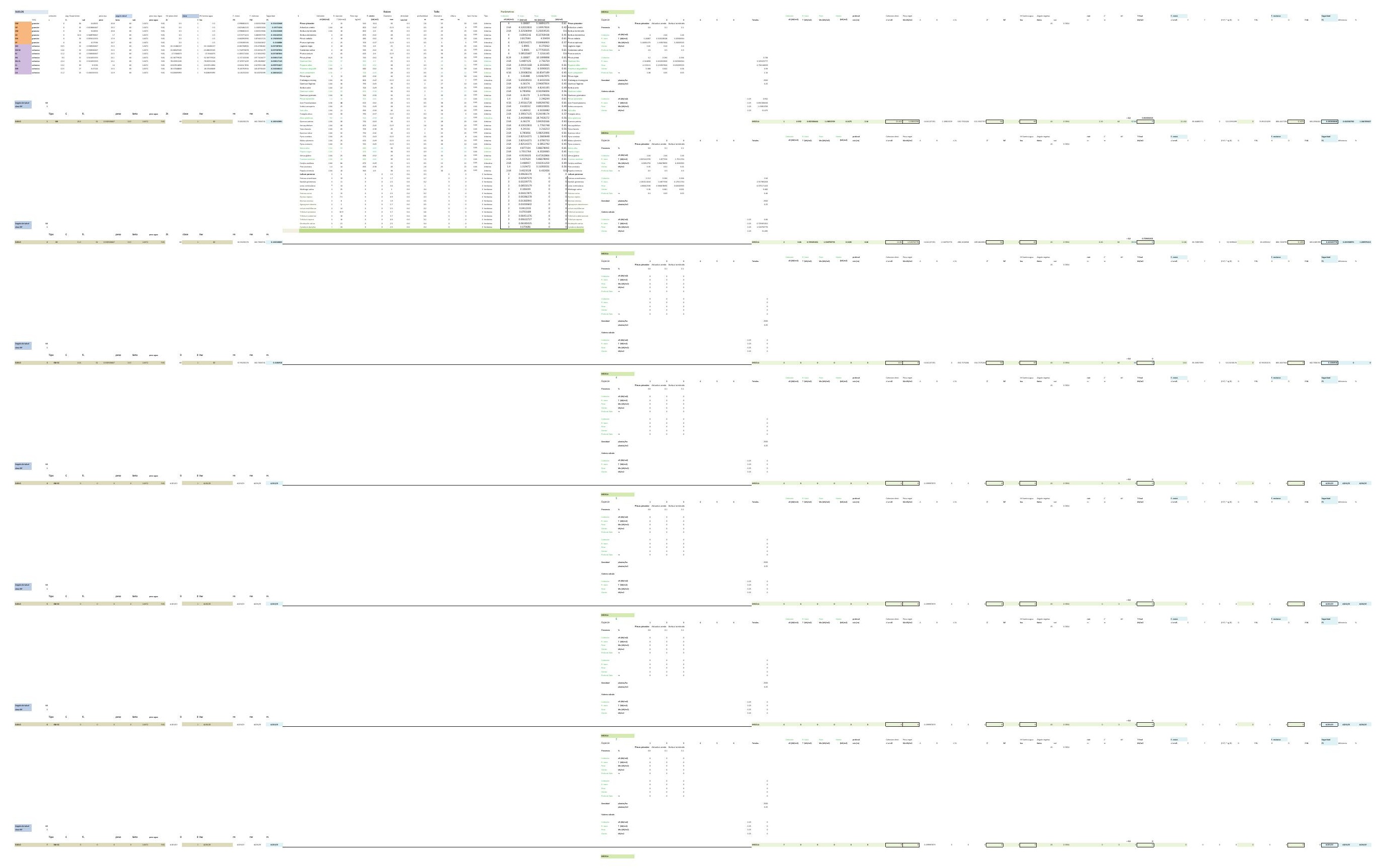




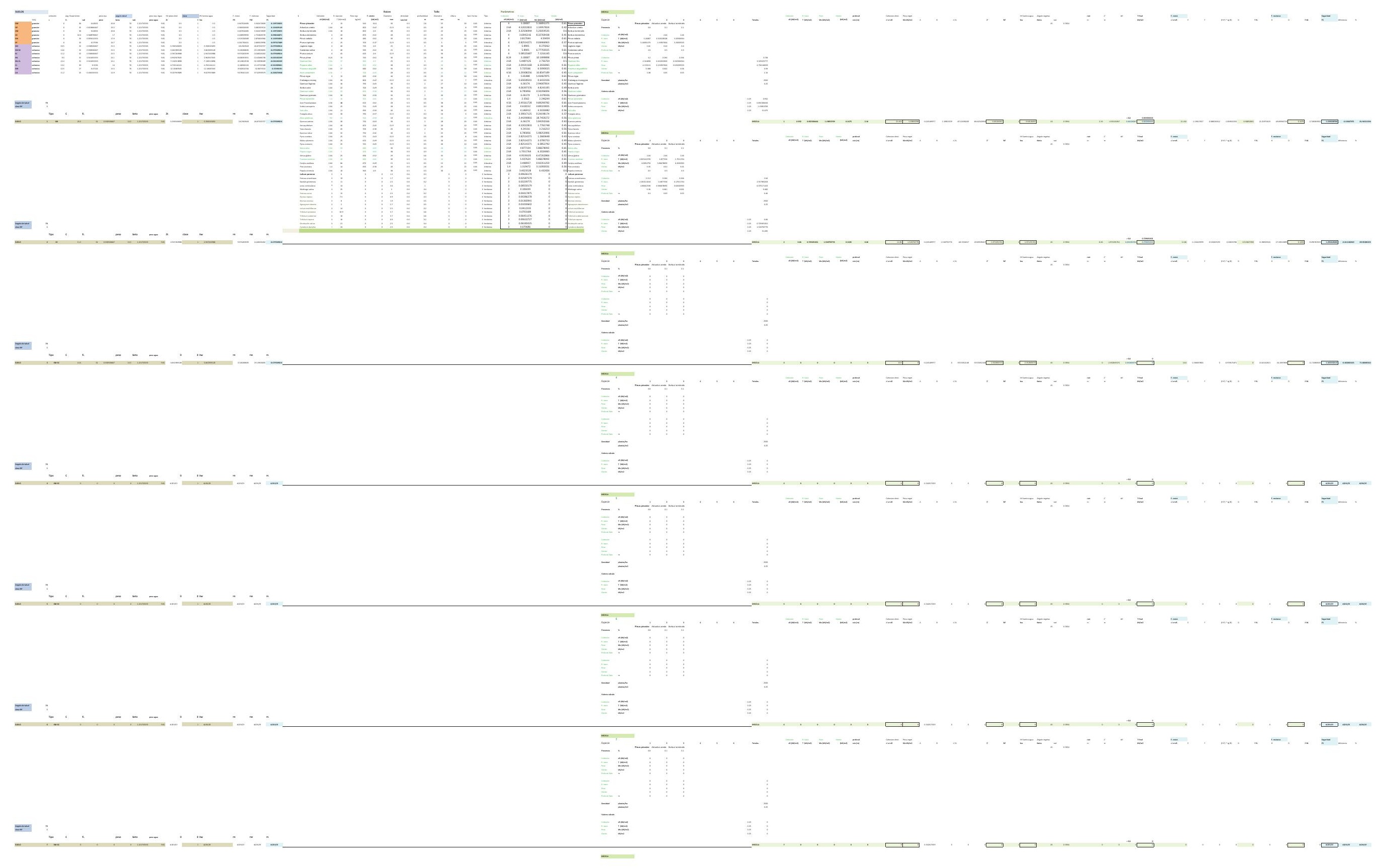




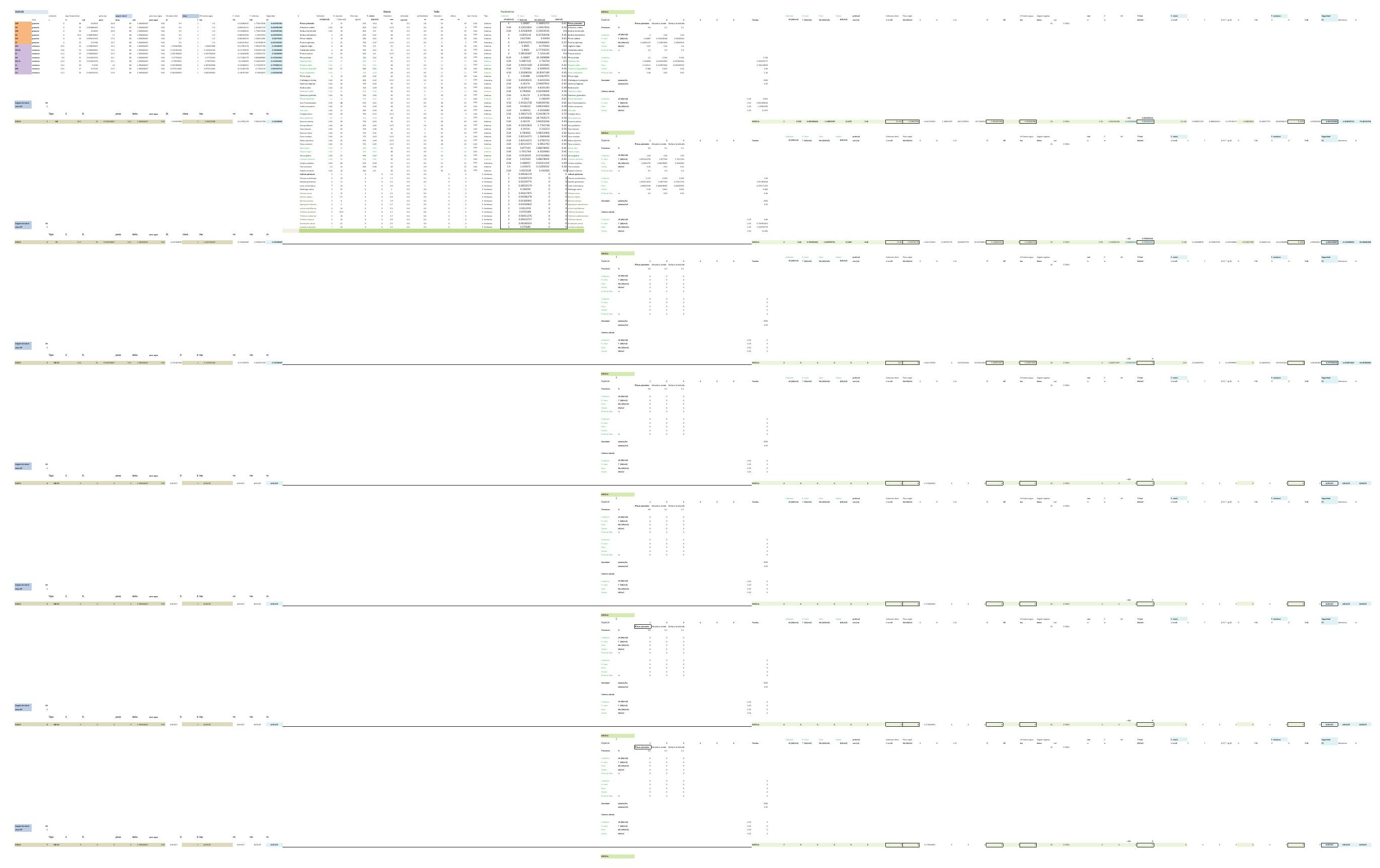


